

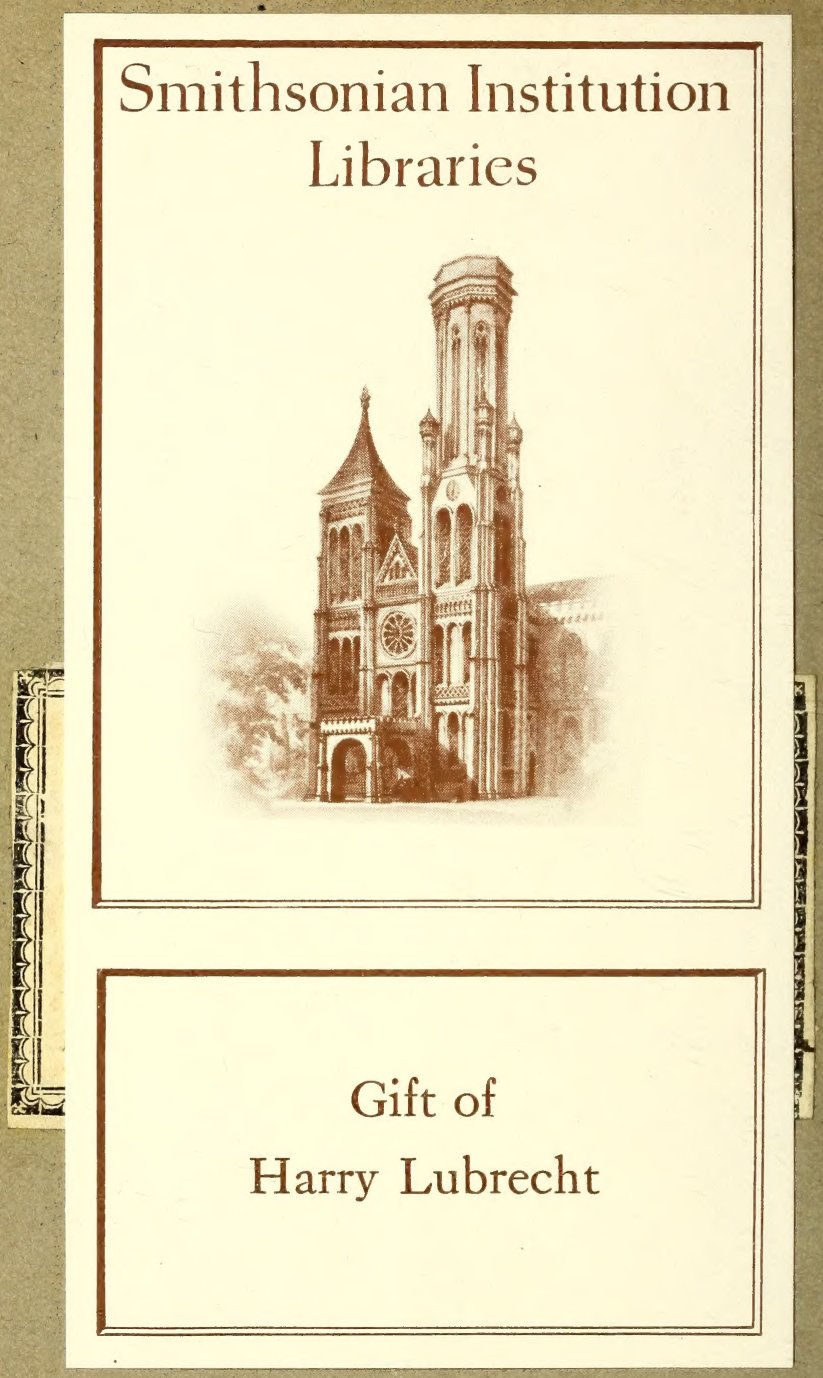


Mo recone

TE

$12 / 68$

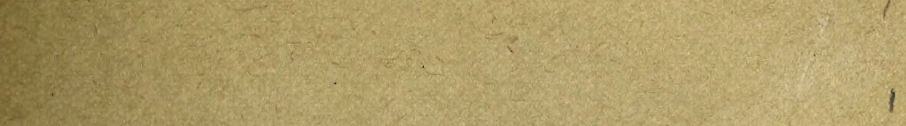

$(7)=$ 



\section{E N C Y C L O P A D I A}

OF

\section{PLANTS;}

COMPRISING

THE DESCRIPTION, SPECIFIC CHARACITR

CULTURE, HISTORY, APPLICATION IN THE ARTS,

AND EVERY OTHER DESIRABLE PARTICULAR RESPECTING

\section{ALL THE PLANTS}

INDIGENOUS, CULTIVATED IN, OR INTRODUCED TO

\section{BRITAIN:}

COMBINING

Át. THE ADVANTAges OF A LINNEAN AND JUSSIEUEAN SPECIES PLANTARUM, AN HISTORIA PLANTARUM, A GRAMMAR OF BOTANY, AND A DICTIONARY OF BOTANY AND VEgETABLE CULTURE.

\section{The wbale in Ënglisth;}

WITH THE SYNONYMES OF THE COMMONER PLANTS IN THE DIFFERENT EUROPEAN AND OTHER LANGUAGES;

THE SCIENTIFIC NAMES ACCENTUATED, THEIR ETYMOLOGIES EXPLAINED;

THE CLASSES, ORDERS, AND BOTANICAL TERMS ILLUSTRATED BY ENGRAVINGS ;

AND WITH

FIGURES OF NEARLY TEN THOUSAND SPECIES, EXEMPLIFYING SEVERAL INDIVIDUALS BELONGING TO EVERY GENUS INCLUDED IN THE WORK.

Edited by J. C. LOUdON, F.L.S. H.S. \&c. THE SPECIFIC CHARACTERS BY AN EMINENT BOTANIST; THE DRAWINGS BY J. D. C. SOWERBY, F.L.S.; AND THE ENGRAVINGS BY R. BRANSTON.

\section{LONDON :}

PRINTED FOR

LONGMAN, REES, ORME, BROWN, AND GREEN, PATERNOSTER-ROW. 
London:

Printed by A. \& R. Spottiswoode, New-Street-Square. 


\section{PR E F A C E.}

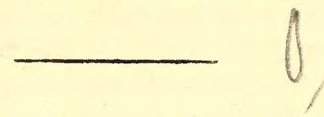

$\mathbf{I}_{\mathrm{N}}$ this Encyclopædia are included all the indigenous, cultivated, and exotic plants which are now found in, or have been introduced into, Britain. The object of the work is to give a natural history of these plants, accompanied by such descriptions, engraved figures, and elementary details, as shall enable a beginner, who is a mere English reader, to discover the name of every plant which he may find in flower, refer it to its proper place, both in the Natural and Artificial Systems of Classification, and acquire all the information respecting it which is useful or interesting. It must be evident to all who are conversant with the present state of botany, and who know the number of plants which have been introduced into Britain, that to accomplish that object within the limits of a volume is a task of no ordinary difficulty; some explanation of the manner in which it has been executed may therefore be required.

The Work is divided into Two Parts. The First Part (page 1.) contains the Linnean or Artificial Arrangement of all the genera and species, with all the details comprehended in botanical description and natural and artificial botanical history, and with engraved portraits of one or more species of each genus. The Second Part (p.1051.) contains the Jussieuean or Natural Arrangement of all the genera, without repetition of the species or any details connected with them: but as the names of the natural orders are added after each genus in the Artificial System, and as each genus in both arrangements is numbered, a direct reference may be had from the second arrangement to the first, and from the first to the second; reference may also be had indirectly, through the medium of the Contents or Index.

An Introduction is given to each system of arrangement (p. 3. and 1051.), and a General Introduction to the whole work (p. 1.), in which its uses are explained. When the beginner has a plant in flower and would ascertain its name, he will turn to the Linnean System, as explained in the Introduction to that system (p. 3.); and, when he has but a small part of any plant, he will turn to the Natural System, as directed in the General Introduction (p. 1.).

All the Technical Terms, or words not usually found in an English dictionary, are explained in the Glossary (p. 1094.); and engravings are given of such of the objects designated as might occasion any difficulty to a beginner. This Glossary and the two Introductions (p. 3. and 1051.) form together a complete Grammar of Botany.

The Table of Synonymes in various languages ( $p .1108$.) may, to a certain extent, be considered as presenting the Popular Floras of the various countries where these names are used; since it is only to the remarkable plants of a country that vernacular names are given.

The signs used for the habits of plants (column 3.), and their duration in the garden (col. 4.), are improvements in botanical description by the Editor*, now applied for the first time. The twenty-three varieties of habit are indicated by

* Originally exhibited in the Encyclopædia of Gardening, 2d edit. 1824, p. 126.

$$
\text { A } 2
$$


figures of the plants themselves; as a grass for a grass, a bulb for a bulb, a plant floating on water for an aquatic, \&c. \&c., to recollect which requires no exertion of memory. A perennial is indicated by a triangle, instead of the old sign, 4 ; an annual remains a circle as before, $O$, because among other reasons gardeners sow patches of annual flowers in circles; and a biennial is a double circle, $\odot$, instead of the old sign, $\hat{\sigma}$. The bark stove is a square, $\square$; the dry stove three sides of a square, $\sqsupset$; the green-house two and a half sides of a square, $\sqcup$; and the frame two sides of a square, - . By combining the signs of duration with habitation, $\triangle \triangle \square[ه$, \&c. \&c., much room is saved in abridged botanical description. Thus in consequence of the single innovation of the triangle and the square, we have simplified and extended the power of indicating the habits and habitations of plants by signs from ten, the usual number in the most complete botanical catalogues, to forty, the number employed in this work.

It is usual, in botanical works enumerating genera and species, to give an Appendix containing the additions discovered or made since the book began to be printed. An Appendix to this Encyclopædia may possibly appear at some future period; but, in the mean time, the Hortus Britannicus, by the same Editor, which contains an enumeration brought down to the end of the year 1828, will serve every purpose of an Appendix, and, in so far as it embraces some reformations in the genera, will be found superior to any Appendix that could be made.

No farther explanation of the nature and uses of this work appearing necessary, it only remains to present the thanks of the Proprietors and of the Editor to Aylmer Bourke Lambert, Esq. F.R.S. V.P.L.S. F.G.S. \&c., for allowing Mr. Sowerby the freest use of his rich botanical library and extensive herbarium, for the selection of subjects to be engraved; and to David Don, Esq. Lib.L.S., Mr. LAmbert's librarian, for his unremitted and unwearied exertions, during upwards of seven years, to facilitate the labours of Mr. Sowerby. To Robert Brown, Esq. F.R.S. V.P.L.S. \&c.; to the Council of the Linnean Society; and, again, to DAvid Don, Esq., in his capacity of librarian to the Linnean Society, the Proprietors are much indebted for similar services; and they beg leave to thank, in a very particular manner, Messrs. Loddiges of Hackney, for original drawings of many species, made from living plants in their unrivalled collection of exotics. Without the Herbarium of Mr. Lambert, and the Hot-houses of Messrs. Lodniges, this work could not have been produced.

It remains only for the Editor to state, that the botanical merits of this publication belong entirely to Professor Linduey, F.R.S. L.S. G.S. \&c., and J. D. C. Sowerby, Esq. F.L.S. \&c. The former determined the genera and the number of species to be arranged under them; prepared the specific characters, derivations, and accentuations; he either wrote or examined the notes; and he corrected the whole while passing through the press : the latter, assisted by Mr. Don and Messrs. Loddiges, sought out the figures, dried specimens, or living plants, necessary for illustration, and made drawings of them on the blocks to be engraved, in that accurate and scientific manner, and with that appropriate taste, for which his late father was long so much distinguished, and for which he himself has not yet been equalled in this or in any country. All that the Editor can deem to be his own is the plan of the work; and if this be found not to have failed in answering those expectations which the state of science, in botany and the compilation of books, might have warranted in 1822 , when this work was commenced, he will have obtained all the approbation to which he is entitled.

\section{J. C. L.}




\section{CONTEN'TS.}

Prefack

List of Books referred to
- iii Abbreviations used in the Linnean Arrangement xvi - vii General Rules for Pronouncing Botanical Names xviii

LINNEAN ARRANGEMENT.

Introduction to the Linnean Arrangement

Table of Linnean Classes

MonANDRIA, genera and their characters Monogynia, genera and specie Digynia, genera and species

DIANDRIA, genera and their character Monogynia, genera and species Digynia, genera and species Trigynia, genera and species

Triandria, genera and their characters Monogynia, genera and species Digynia, genera and species Trigynia, genera and species

TETRANDRIA, genera and their characters Monogynia, genera and species Digynia, genera and species Tetragynia, genera and species

Pentandria, genera and their characters Monogynia, genera and species Digynia, genera and species Trigynia, genera and species Tetragynia, genera and species Pentagynia, genera and species Polygynia, genera and species

Hexandria, genera and their characters Monogynia, genera and species Digynia, genera and species Trigynia, genera and species Polygynia, genera and species

HePtandRIa, genera and their characters Monogynia, genera and species Digynia, genera and species Tetragynia, genera and species Heptagynia, genera and species

OCTANDRIA, genera and their characters Monogynia, genera and species Digynia, genera and species Trigynia, genera and species

ENNEANDRIA, genera and their characters Monogynia, genera and species Trigynia, genera and species Hexagynia, genera and species

Decandria, genera and their characters Monogynia, genera and species Digynia, genera and species Trigynia, genera and species Pentagynia, genera and species Decagynia, genera and species

DoDECANDRIA, genera and their characters Monogynia, genera and species Digynia, genera and species Trigynia, genera and species Tetragynia, genera and species Pentagynia, genera and species Pentagynia, genera and species
Dodecagynia, genera and species

IcoSANDRIA, genera and their characters Monogynia, genera and species Di-pentagynia, genera and species Polygynia, genera and species

PolyandRIa, genera and their characters Monogynia, genera and species Digynia, genera and species Trigynia, genera and species Pentagynia, genera and species Polygynia, genera and species

DIDYNAMA, genera and their character Gymnospermia, genera and species Angiospermia, genera and species

Tetradynamia, genera and their characters

MonadelPHia, genera and their characters Pentandria, genera and species Heptandria, genera and species Octandria, genera and species Decandria, genera and species Dodecandria, genera and species Polyandria, genera and species
DiAdELPHIa, genera and their characters. Pentandria, genera and species Mexandria, genera and species Octandria, genera and species - $\quad-602$ Decandria, genera and species - $\quad$ - 604

Polyadelphia, genera and their characters - 650 Decandria, genera and species - $\quad-650$ Polyandria, genera and species - - $\quad$ - 652

SyNGENESIA, genera and their characters $\quad-660$ AEqatis, genera and species - $\quad-666$ Superflua, genera and species $\quad-\quad$ - $\quad$ - 696 Frustranea, genera and species _ - $\quad$ - 730 Necessaria, genera and species - $\quad$ - 738 Segregata, genera and species - $\quad$ - $\quad 744$

GyNANDRIA, genera and their characters - $\quad 748$ Monandria, genera and species - $\quad-750$ Diandria, genera and species $\quad$ - $\quad$ - 766 Hexandria, genera and species - $\quad$ - 766

MoNocia, genera and their characters - 768 Monandria, genera and species - $\quad$ - 770 Diandria, genera and species $\quad-\quad$ - $\quad 772$ $\begin{array}{lll}\text { Triandria, genera and species } & - & -772 \\ \text { Tetrandria, genera and species } & - & -780\end{array}$

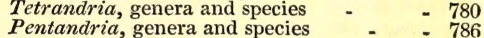
Hexandria, genera and species Polyandria, genera and species $\quad$ - $\quad$ - 790 Monadelphia, genera and species $\quad-\quad$ - $\quad$ - 800

Diœcia, genera and their characters - $\quad$ - 816 Monandria, genus and species $\quad$ - $\quad$ - 820 Diandria, genera and species $\quad$ - $\quad$ - 820 Triandria, genera and species $\quad-\quad-826$ Tetrandria, genera and species - $\quad$ - 328 Pentandria, genera and species - $\quad$ - 832 Hexandria, genera and species - $\quad$ - 836 Octandria, genus and species - $\quad$ - 840 Enneandria, genera and species - $\quad$ - 840 Decandria, genera and species - $\quad$ - 842 Dodecandria, genera and species - $\quad$ - 842 Icosandria, genera and species - $\quad$ - 844 Polyandria, genera and species - $\quad$ - 844 Monadelphia, genera and species - $\quad$ - 846

Polygamia, genera and their characters - $\quad-852$ Monocia, genera and species $\quad$ - $\quad$ - 854 Diocia, genera and species _ _ - $\quad$ - 868

Cryptogamia, genera and their characters - 874 Filices, genera and species - $\quad-\quad$ - 875 Polypodiacece, genera and species $\quad$ - 876 Osmundacec, genera and species - : $\quad$ - 886 Ophioglossea, genera and species $\quad-886$ Equisetacee, genus and species - $\quad$ - 890 Iycopodinea, genera and species - $\quad$ - 892 Marsileacee, genera and species - $\quad$ - $\quad 894$ Musci, genera and species - : - $\quad$ - 894 $\begin{array}{cc}\text { Musci, genera and species - } & \text { - } \\ \text { Evaginulati, genus and species } & -896\end{array}$ Vaginulati Olocarpi, genera and species 896 Vaginulati Schistocarpi, genus and spec. 916 Hepatice, genera and species - - 918 Alga, genera and species - $\quad$ - 924 Diatomea, genera and species - - $\quad$ - 926 $\begin{array}{ll}\text { Diatomea, genera and species } & -\end{array}$ Confervoidece, genera and species $\quad$ - 930 Ulvace $e_{\text {, genera and species - } \quad-940}$ Floridea, genera and species - $\quad$ - 940 Fucoidea, genera and species $\quad$ - $\quad$ - 944

Lichens, genera and species - _ - 948 Idiothalami, genera and species $\quad-950$ Conothalami, genera and species $\quad$ - 956 Homothalami, genera and species - 970 Athalami, genus and species _ $\quad$ - 974 Pseudo-lichenes, genera and species - 974

Fungi, genera and species - - - 978 Hymenomycetes, genera and species - 986 Gasteromycetes, genera and species - 1022 Hyphomycetes, genera and species $\quad-1036$ Coniomycetes, genera and species $\quad-1040$ 
NATURAL ARRANGEMENT.

Introduction to the Jussieuean System

VASCULARES

\section{Dicotyledones.}

Ranunculace

Dilleniacex

Magnoliace

$-\quad-1055$

$-$

Menispermex - - 1055

Berberidea
Podophyllaceæ

Hydropeltider - :

Nymphæaceæ - - - 1055

Papaveraceæ - $\quad-1056$

Fumariaceæ - $\quad-1056$

\begin{tabular}{l} 
Cruciferæ \\
Flacourtianeæ $\quad:-1056$ \\
\hline
\end{tabular}

$\begin{array}{lll}\text { Flacourtianeæ } & - & - \\ \text { Capparideæ } & - & -1058\end{array}$

Violarieæ - - - 1058

Polygaleæ - - - 1058

$-\quad-1058$

Bixineæ - $\quad-\quad-1058$
Cistineæ

$\begin{array}{lll}\text { Cistineæ } & - & - \\ \text { Caryophylleæ } & - & -1058 \\ & - & -1059\end{array}$

Lineæ - - - - 1059

Malvaceæ - - :

Bombaceæ - - - 1059

Byttneriaceæ - $\quad-1059$

Tremandreæ - - - 1060

Tiliaceæ - - - $\quad-1060$

Sapindaceæ - - - 1060

Hippocastaneæ -

Hippocraticeæ - - 1060

Marcgraaviaceæ - : $\quad$ - 1060

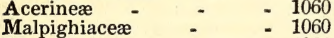

Hypericineæ $\quad-\quad-1061$

Guttiferæ - - - 1061

Viniferæ - - - $\quad-1061$

$\begin{aligned} & \text { Geraniaceæ } \\ & \text { Oxalideæ }\end{aligned}-\quad-\quad=1061$

Balsamineæ -

Zygophylleæ

Meliaceæ

Cedreleæ

Aurantiaceæ

Ternströmiaceæ

Camellieæ

Olacinea

Rutaceæ

Coriarieæ

Ochnaceæ

Simarubace

Celastrine

Rhamnex

Bruniacea

Homaline

Tomalinex

Terebinthace

\section{- Foliacex}

Filices - - - 1090

$\begin{array}{llll}\text { Equisetaceæ } & - & - & - \\ \text { Lycopodineæ } & - & -1090 \\ & & -1090\end{array}$

\section{Rosaceæ \\ Salicariæ - $\quad-\quad: 1067$ \\ Melastomaceæ - $\quad: 1068$}

Myrtaceæ - - - 1068

Passifloreæ - - - 1068

Cucurbitaceæ - $\quad-1068$

Onagrarieæ $\quad-\quad-1069$

Ficoideæ - - - - 1069

Portulaceæ - - - 1069

$\begin{array}{llll}\text { Cacti } & - & - & -1069\end{array}$

Grossulaceæ - - - 1069

Semperviveæ

Saxifrageæ

Philadelpheæ _ - - -

Cunoniaceæ - - - 1070

Araliaceæ

Hamamelideæ

Loranthe

Dipsaceæ - - $\quad-1079$

Calycereæ - $\quad-\quad-1072$

Campanulaceæ - $\quad-1072$

Goodenoviæ - $\quad-1075$

Stylideæ - - $\quad-1075$

Gesnerieæ - - $\quad-1075$

Ericeæ

Syrsine

Symplocacex - - - -1076

Ebenaceæ - - : $: 1076$

Oleinæ - - - - 1076

Jasmineæ - - - - 1076

Apocyneæ - - - 1076

Asclepiadeæ

Bignoniaceæ - - -1077

Cobæaceæ - - = 1077

Polemoniaceæ $\quad-\quad-\quad-1077$

Convolvulaceæ - - - 1077

Boragineæ - - - 1077

Cardiace

Orobancheæ

Scrophularinese-

Labiatæ

Pedalinæ

Myoporineæ

Verbenaceæ

Acanthaceæ

Lentibulariæ

Primulaceæ
Combretaceæ - - - 1068

Halorager - - - $\quad-1069$

Umbelliferæ

Caprifoliaceæ

Valerianeæ

Globularinæ - - - 1080

Plumbagineæ - - 1080

Plantagineæ - - - 1080

yctagineæ - - 1080

Amaranthaceæ - - 108

llecebrea - - - 1080

Chenopodeæ - - 108

Begoniaceæ - - - $\quad-108$

Laurineæ - - - 108

Myristiceæ - - $\quad$ - 108

Proteaceæ - - - 1081

Thymelææ - - - 1089

Santalaceæ - - - 1082

Elæagneæ - - - 108

Aristolochiæ - - $\quad 108$

Euphorbiaceæ - - 1082

Resedaceæ - - - 1083

Calycantheæ - - 1083

Atherospermeæ - $\quad-1083$

Empetreæ - - - 1083

Urticeæ - - - 1083

Amentaceæ - - - 1083

Ulmaceæ - - - $\quad-1083$

Casuarineæ - - - 1083

Coniferæ - - - 1083

Chlorantheæ - - -

Piperaceæ - - - 108

Cycadeæ - : : 1084

MONOCOTYLEDONES

Hydrocharideæ $-\quad-108$

Orchideæ - : : 1084

Scitamineæ - : $: 1085$

Canneæ - - : -1085

Musaceæ - - - 1085

Hæmodoraceæ - $\quad-1085$

Irideæ - - -

Amaryllideæ : - 1086

Hypoxideæ - - - 1086

Dioscoreæ - - - 1086

Hemerocallideæ - - 1086

Asphodeleæ -

Bromeliae - - - 1086

Liliaceæ - - -

Melanthaceæ $\quad-\quad=1087$

Butomeæ - - 1087

Alismaceæ - $\quad-1087$

Commelineæ - $\quad-1087$

Junceæ - - $\quad-1087$

Eriocauleæ - - -

Pandaneæ - - -1087

Naiades - - $\quad-1087$

Restiaceæ - - - 1087

Palmæ - - - $\quad-1088$

Gramineæ - $\quad-1088$

Cyperaceæ - - $\div 1089$

Aroideæ - - - : 1089

CELLULARES.

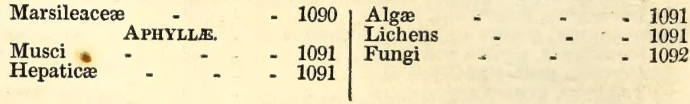

Glossary of Terms

Table of Synonymes in all Languages

General Index of Latin and English Names 


\section{NAMES OF BOOKS REFERRED TO.}

A. ac.pa. 860. Z Mémoires de l'Académie Royale Act. par.

Abb. ins. 780 .

Abel China, 394.

Ac. E. 886 .

Act. bon. 176 Act. helv. 540.
Ac. h. 828. $\begin{aligned} & \text { Acta Helvetica physico-mathema- } \\ & \text { tico-botanico-medica. } 8 \text { vols. }\end{aligned}$ 4to. Basilex, 1757-1777.
4to.

Act. holm. 944. Kongl. svenska vetenskaps academiens Handlingar. 8vo. Stockholm 1739-1816.

Act. petr. 58. Commentarii Academiæ Scientiarum Imperialis Petropolitanæ. 14 vols. 4to. Petropoli, 17281751.

Act. ups. 90. Acta literaria et Scientiarum Upsaliæ publicata. 8vo. $1720-$ 1816.

Allion. 94

Allioni (Carolus). Rariorum Pe. demontii Stirpium Specimen 1 vol. 4to. Taurini, 1755

All. auc. 16. Id. Auctuarium ad Floram Pedemontanam. 1 fasc. 4 to. Tau rini, 1789.

All. ped. 16.

Alp. æg. 196.

Alp. ex. 94 .

4to. Venetiis, 1629. $\left.\begin{array}{l}\text { Amœen. ac. 334. } \\ \text { Am. ac. } 382\end{array}\right\} \begin{array}{r}\text { Linnæi Amœnitates Academicæ, } \\ \text { seu }\end{array}$ seorsim editæ 10 vols $8 \mathrm{vo}$ Holmiæ and Lipsiæ, 1749, et seq.

Am. rut. 14.

Ammann (Johan) Stirpium rariorum in ImperioRutheno sponte provenentium Icones et $\mathrm{De}$ scriptiones. 4to. Petrop. 1739.

And. ger. 578 .

Andrews (Henry) Coloured En gravings of Geraniums. Fol. London.

And. hea. 304 .

Id. Coloured Engravings of Heaths, with botanical descriptions. 3 vols. fol. London, $1802-1809$.

Ann. bot. 4 .

Annals of Bot and J. Sims. 2 vols. 8 vo. London, 1805 and 1806.

Ann. mus. 354. 2 Annales du Muséum d'Histoire An. mu. 88 .

Ard. me. 176. 1802-1813.

Arduini (Pietro) Memoria di Os servazioni e di Sperienze sopra la Coltura e gli Usi di varie Piante. 4to. Padova, 1766.

Ard. spec. 24.

Id. Animadversionum botanica rum Specimen. 4to. Patavii, 1759 .

As. r. 2.

siatic Researches, or the Trans actions of the Society instituted in Bengal. 4to. Calcutta $1788, \& \mathrm{c}$
Asso arr. 556.

Aublet, 16

Aub. guian.

Balb diss 676. 2 Balbis (Joh. Baptist).

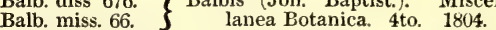

Banks ic. Kæ. 806. Banks (Josephus). Icones selectæ Plantarum quas in Japonia collegit et delineavit $\mathrm{E}$ Kæmpfer, Fol. London, 179!.

Banks r. hous.26. Id. Reliquiæ Houstonianæ. 4to. London, 1781.

Barr. ic. 24. 7 Barrelier (Jacobus). Plantæ per Bar. rar. 204. G Galliam,Hispaniam, etItaliam observatæ. Fol. Parisiis, 1714.

Bartr. trav. 480. 7 Bartram's Travels in North AmeBartr. iter. c. ic. $\}$ rica. 8vo.

Batarra, 990. Batarra (John Ant.). Fungorum Agri Ariminensis Historia 4to. Faventiæ, 1759.

Batsch. cent.988. Batsch (Aug. Joh. Georg. Carl)

Bats. cont. 990. $\}$ Elenchus Fungorum 4to. Elenchus Fungor

Bauh. pin. 672. Bauhin (Caspar). Pinax Theatri Botanici. 4to. Basileæ, 1623

Bauh. prod. 24. Id. Prodromus Theatri Botanici, in quo plantæ supra 600 pro ponuntur. 4to. Franc. Mœen. ponu.

Bea. f.d'Oware, Palisot de Beauv. Flore des 788. Royaumes d'Oware et de Beauv. Ow. 36. \ Benin. Folio. Paris, 1805

Bell. taur. 486. Bellardi (Ludovico). Osservazioni Botaniche, con un Saggio d' Appendice alla Flora Pedemontana. 8vo. Torino, 1788

Ber. ca. 722

Be. c. 288 .

Bergius (Peter Jonas). Descrip Bonæ Spei. 8vo. Stockholm 1767

Berl. mag. 1036. Berlinischer Magazin, oder gesammlte schriften. 4 vols. 8 vo. Berlin, 1765-1767.

Besl. eys. æs, 90, 7 Besler (Basilius). Hortus Eystet B. ey. a. 160 . $\}$ tensis. 2 vols, fol. Nuremberg, 1612 .

Bieb. cent. 278. 7 Bieberstein (Marschall von). Cen-

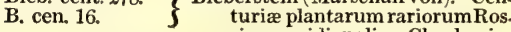
siæ meridionalis. Charkovia. Fol.

Bivon, cent. 676. 2 Bivona Bernardi (Antonin.). SiBiv, cen. sic. 724. $\}$ cularum plantarum Centuria prima. 8vo. Panormi, 1806.

Blackw. 34. 2 Blackwell (Eliz.). A curious herBlackw. hor. 622.$\}$ bal containing 600 cuts of the useful plants. 2 vols. fol. London, 1737.

Bocc. mus, 88. Boccone (Paolo), Museo di Piante rare della Sicilia, Malta, Cor. sica, Italia, Piemonte, et Germania. 4to. Venetia, 1697.

Bocc. sic. 158. IId. Icones et Descriptiones rario rum Plantarum Siciliæ, Melitæ, Galliæ, et Italiæ. 4to. Londini, 1674 .

Boerh. 22.

Boer. lug. 600 .
Index Plantarum qua in Horto Acad. Lugd. Bat. reperiuntur. 8vo. Lugd. Bat. 1710. 
Bolton fung. 986. Bolton (James). A History of Funguses growing about Halifax. 4to. Huddersfield, 1788 -1791 .

Bolton fil. 878

Bot. cab. 2. don, $1785-1790$

The Botanical Cabinet. By Conrad Loddiges and Sons, 14 vols. $12 \mathrm{mo}$, and 4to, published monthly.

Bot. mag. 2

Bot. reg. 2 .

Bot. rep. 4.

Brad, succ. 262

Bre. cent. 184.

Bre. prod. 686 .

Brid. mus. 914

The Botanical Magazine, $8 \mathrm{vo}$, 55 vols. London, 1787-1829.

The Botanical Register. 8vo, 14 vols. London, 1815-1829.

The Botanist's Repository for new and rare Plants. 10 vols. 4to. London, 1797. et seqq.

Bradley (Richard). Historia Plantarum Succulentarum 4to. London, 1716-1727.

Breynius (Jacobus). Exoticarum Plantarum Centuria. Fol.Gedani, 1678 .

Id. Prodromus Fasciculi rariorum Plantarum in Hortis Hollandiæ observatarum. 2 vols. 4to. Gedani, 1680-1689.

Bridel (Samuel Elias). Muscologia. 4to. Gothæ et Parisiis, 1797-1803.

Bro. jam. 100. Browne (Patrick). The Civil and

B. jm. 88 .

Brot. phyt. 556 Natural History of Jamaica. Fol. London, 1756

Brotero (Felix Avellar). Phytographia Lusitaniæ select. Fol. Olyssip. 1801.

Bruce Abys. 856. Bruce (James). Travels to discover the Source of the Nile. 5 vols, 4to Edinburgh, 1790 .

Buchoz ic. 302. Buchoz (Pierre Joseph). Collection des Fleurs. Fol. Paris.

Bulliard, 986, ? Bulliard. Histoire des Champig-

Bull. $\quad$ nons de la France. Fol. Paris, Bull.champ.1022.S 1798

Bull. herb. 154. Id. Herbier de la France, Fol $1780,8 \mathrm{c}$.

Bull. ph. n. 546. Z Bulletin des Sciences par la So-

B. ph. n. 278. $\}$ ciété Philomathique de Paris. 1791-1816.

Bur, afr. 82

Burmann (Johannes) Rariorum Africanarum plantarum Decades 10. 4to. Amstelodami, 1738-1739.

Bur. amer. 150. Id. Plantæ Americanæ a C. Plumier detectæ et a J. Bur$\operatorname{man}$

Bur. ind. 192

Id. Flora Malabarica, sive Index in omnes tomos Horti Malabarici. Fol. Amst. 1769.

Bur. zey. 68.

Bur. zeyl. 90.

Cam. hort. 218

Cat. car. 10.

Cav. diss. 48.

Ca. d. 182.

Cav. ic. 18

Clus. exot. 622 .

Clus. hist. 52.

Co. gott. 90 .

Col, ecph. 34.

Com. hort. 22.

Com. pet. 348. Amst. 1737.

Camerarius (Joachim). Hortus Medicus et Philosophicus. 4to. Franc. Mæn. 1588

Catesby (Marsh). The Natural History of Carolina, Florida, \&c 2 vols, fol London, 1741-1743.

Cavanilles (Ant. Jos.). Monadelphiæ classis Dissertationes. 10 vols. 4to. Paris, 17851789. Madriti, 1790 .

Id. Icones et Descriptiones Plantarum quæ aut sponte in Hispania crescunt aut in Hortis hospitantur. 6 vols. fol $\mathrm{Ma}$ drit. 1791-1800.

Clusius (Carolus). Exoticarum libri x. Fol, Antwerp, 1605.

Id. Rariorum Plantarum historia. Fol. Antwerp, 1601.

Commentarii Societatis regiæ Scientiarum Göttingensis. 4to 1751-1816

Columna (Fabius). Minus cognitarum stirpium Ecphrasis. 4to. Romæ, 1616.

Commelyn (Caspar). Horti Medici Amstelodamensis rariorum Plantarum Descriptio et Icones. 2 vols. folio. Amst. 1703. Commentarii Academiæ Scienti-
Com. præl. 244

Com. rar. 180

Cook it. v. 286.

Cor. can. 88

Crypt. brit. 1008.

Cyrill, ic. 76.

Dalec. lug. 583.

De Asso ar. 552

Dec. diss. 548 .

Dec. ic. gall, 548

Dec. legum. 854.

Del. egyp. 558.

Del. eryng. 210.

Dend. brit 144.

Desf. atl. 46.

\section{Deutschl. fl. 1044.}

Dick. cr. 922

\section{Dil. el. 94.}

D. elt. 132.

D. e. 158.

Dil. Mus. 892.

Dillw. conf. 930 .

Di. co. 926. arum imperialis Petropolitanæ. 14 vols. 4to. Petrop. $1728-1751$. Duh nov.

Eng. bot. 6.

E. b. 926 .
Commelyn (Caspar). 'Præludia Bo. tanica ad publicas Plantarum Demonstrationes. 4to. L. Bat. 1703.

Id. Horti Medici Amstelodamensis Plantæ rariores et exoticæ. 4to. L. Bat. 1706.

Cook (James). Voyage round the World (2d). 2 vols. 4to. 1777. Cornuti (Jacob). Canadensium Plantarum aliarumque nondum editarum Historia. 4to. Paris, 1635.

Greville (Charles Kaye). The British Cryptogamic Flora. 5 vols. 8 vo.

Cyrillo (Domenico). Plantarum rariorum Regni Neapolitani Specimen. Fol. Neapol. 17881792.

Dalechamps (Jacques). Historia generalis Plantarum. 2 vols. fol. Ludg. 1586-1587.

De Asso (Ignatius). Synopsis Plantarum indigenarum Arragoniæ. 4to. Marsiliæ, 1779 .

Decandolle (Augustin Pyramus). Dissertations différens sur la Botanique. Various fascicles, 4to.

Id. Icones Plantarum Galliæ rariorum. 4to. Paris, 1808.

Id. Mémoires sur les Legumineuses. 4to.

Delile (Alire Rafeneau): Memoires Botaniques extraits de la Description de l'Egypte. Fol. Paris, 1813

De la Roche (Francois). Eryngiorum necnon generis novi Alepideæ Historia. Fol. Paris, 1808.

Watson (P. W.). Dendrologia Britannica. 1 vol. 1825.

Desfontaines(René Louiche). Flora Atlantica. 2 vols, 4to. Paris, $1798-1799$.

(Jacob), Deutschlands Flora. 2 vols. 4to. Nurnberg, 1798, \&c.

Dickson (James). PlantarumCryptogamicarum Britanniæ Fasciculi. 3 vols. 4 to. London, 1785-1793.

Dillenius (John Jac.). Hortus Eithamensis. 2 vols. fol. Londini, 1732.

Id. Historia Muscorum, 4to. Oxonii, 1741. 4to. 1802-1814.

Dodar. mem. 636. 3 Dodart (Denys). Mémoires pour Dod. me. 164. $\}$ servir à l'Histoire des Plantes. Fol. Paris, 1676

Dod. pempt. 98. Dodonæus or Dodoens (Rambrot). Stirpium Historiæ pemptades vi. Fol. Antwerp, 1583

Duh. arb. 104. Duhamel du Monceau (Henri Louis). Traité des Arbres et Arbustes qui se cultivent en France en pleine Terre. 2 vols. 4to. Paris, 1755.

Duh. ar. e. n, $\{I d$. The same work, a new ediDuh. ed. $n . \quad\{$ tion, by Michel. 5 vols. folio.

Dun. mon. 480. Dunal (Michel Felix). Monogra. Paris, 1801-1816.

Dun. sol. 156. Id. Histoire naturelle, medicale et économique, des Solanum et des genres qui ont été confondus avec eux. 4to. Montpellier, 1813.

Du Roi, ed. 868. Du Roi (Joh. Phil.). Die Harb. kesche wilde Baumzucht. 2 vols. 8 vo. Braunschweig, 1771-1772.

Edin. phil, journ. $\}$ The Edinburgh Philosophical Journal. Edinburgh. 8vo, pub-

Ehr. pict. 20. $\begin{gathered}\text { lished quarterly. } \\ \text { Ehret (George Dion.). Plantæ et }\end{gathered}$ Papiliones rariores. Fol. London, $1748-1759$.
English Botany, by Sir James Edward Smith, and Mr. James Sowerby. 36 vols. 8 vo. 
Esper fuci. 946. Esper (Eug. Joh. Christ.). Icones fucorum, Abbildungen der Tange. 4to. Nurnberg, 1797 -1799 .

Ex. bot. 12

Exotic Botany, by Sir James Ed. ward Smith. London, 1804 -1808 .

Ex. fl. 626.

The Exotic Flora, by W. J. Hooker. 3 vols. 8 vo. Edinburgh, 1825-1827.

Ferr. hesp. 654. Ferrari (Joh. Baptist). Hesperides, sive de malorum aureorum cul turâ et usu. Fol. Romæ, 1646 .

Feuillée, 844. 7 Feuillée (Louis). Journal des Ob-

Feuill ch.

Feuill. it.

Feuill. per.

Feu. per.

Fl. dan. 16.

servations Physiques, Mathedans l's, et motanide \&c. 4to. Paris, 1714-1725.

Icones Plantarum sponte nascentium in regnis Daniæ et Norvegiæ, \&c. 9 vols. folio. Hafniæ, $1761-1829$

Fl, d'owar. 522. Palisot de Beauvois. Flore des Royaumes d'Oware et de Benin. 2 vols. fol. Paris.

Fl, græc. 6.

Sibthorp (Joh.). Flora Greeca, ed. J. E. Smith. 6 vols, folio. London, 1806-1829.

Fl. lapp. 820 .

Linnæus (Carolus). Flora Lapponica. 8vo. Amstelodami, 1757.

Fl. per. 26.

Ruiz (Hippol.) et Pavon (Jos.). Flora Peruviana et Chilensis. 3 vols. folio. Madriti, 17981799.

Fl. port. 16 .

Hoffmansegg and Link. Flore Portugaise. Fol. Rostoch and Berlin, 1806, \&c.

Forsk, ic. 102. Forskahl (Petrus). Icones rerum naturalium. 4to. Hafniæ, $1775-1776$

Fras. mo. en. ic. 56. Frazer (John). A short History of the Agrostis Cornucopiæ. Fol. London, 1789.

Fries obs. 1032. Fries (Elias). Observationes Mycologicæ. $12 \mathrm{mo}, 2$ vols. Hafniæ, $1815-1818$

Fuchs ic. 160. Fuchs (Leonhard). De Historia Stirpium Commentarii insig. nes. Fol. Basiliæ, 1542-1545.

Gærtn. 688.

Gr. de. fr. 214

G. de f. 628 .

Gært, sem. 104

Gær. s. 380 .

$\left.\begin{array}{l}\text { Garid. aix, 90. } \\ \text { Garid prov. 542. }\end{array}\right\} \begin{gathered}\text { Garidel (Pierre Joseph). His. } \\ \text { toire des Plantes qui naissent }\end{gathered}$ aux Aix, 1715 .

Ger. ema. 90.

Ger. herb. 22

? Gerard (John). The Herbal or General History of Plants. 1 vol. fol. London, 1797. En. larged by Johnson. 1 vol. Fol. 1633.

Ger. prov.

Gmel, it. 14 .

Gerard (Ludovic). Flora Galloprovincialis. 8vo. Paris, 1761

Gmelin (John George). Reise durch Sibirien. 4 vols. 8 vo. Götting. 1751-1753.

Gmel. sib. 54. J Id. Flora Sibirica. 4 vols. 4to.

G. sib. 122 .

Gouan ill. 210. Gouan (Antoine). Illustrationes

Goua. m. 118. Id. Hortus regius Monspeliensis, 8vo. Lugduni, 1762 .

Gre. cryp. fi. 900.? Greville (Charles Kaye). The Gre sc cry. 912 $\}$ Scottish Cryptogamic Flora. Gre. sc. cry. 912. 4 vols. 8 vo.

Hac. pl. al. 118. Hacquet (Balthazar). Plantæ Alpinæ Carniolicæ. 4to. Vienna, 1782.

Hall. helv, 528. Haller (Albert). Historia StirHall. hist. 14. $\quad \begin{gathered}\text { pium indigenarum Helvetiæ. } \\ \text { pium }\end{gathered}$

Ha. h. n.
H. n. h. 52 .

H. in. un. an. 276 3 vols. fol. Berne, 1768.

Hay. trm. 66 .

Hænke (Thadæus), in Usteri's Annalen der Botanik. 6 vols. 8vo. Zurich, 1791-1793.

Botanici Iconibus illustrati. 4to. Berlin, 1799.

Hed. sp. mus. 900. Hedwig (Johannes). Species Muscorum frondosorum 4to. Lipsiæ, 1801.
Her. lugd. 160. Z Hermann (Paulus) Horti Lugduni Batavi Catalogus. 8vo. Ludg. Bat. 1687.

Her, parad, 92. Id. Paradisus Batavus. 4to. Iugd, Bat. 1798.

H. \& L. fl. p. 122. $?$ Hoffmannsegg and Link. Flore Hof, et L. lu. 498. $\} \begin{array}{r}\text { Hoffmannsegg and Link. Flore } \\ \text { Portugaise. Fol. Berlin, } 1806\end{array}$ -1829 .

Hoff. ph. 14. Hoffmann (Georg. Franz.), Phytographische blätter. 8vo. Gottingen.

Hoff. sal. 826. Z Id. Historia Salicum Iconibus H. sal. 820. $\}$ Id. Hillustrata. Fol. Lipsiæ, 1785. Hook. ex. fl. 2. Hooker (William Jackson). The Hooker fi. ex. 18. $\}$ Exotic Flora. 3 vols. 8vo.

Hook. jung. 918. Id. Monograph of the British Jungermanniæ. 4to. London, 1812-1816

Hoo. mus. br. 902. See Musc. Brit

Hor. phys. br. 28. Horæ Physicæ Berolinenses. Fol.

Hort. ber. 66 Berlin.

Willdenow (Car. Lud.). Hortus Berolinensis. Fol. Berlin, 1806 -1810 .

Hort. cliff. 24. Linnæus (Carolus). Hortus Cliffortianus. Fol. Amst. 1737.

Hort. Kew. 704. Aiton (William). Hortus Kewensis. Ed. 1. 3 vols. 8 vo. London, 1789

Hort. trans. 38. Transactions of the Horticultural Society of London. 7 vols. 4 to.

Host. gr. 50 .

Host (Nicol. Thom.). Icones et Descriptiones Graminum Austriacorum. 3 vols. fol. Vindob. 1801-1803.

Hout. pfl. 786. 2 Houttuyn (Martin). Des ritters Houtt. syst. 590. $\}$ von Linné Pflanzensystem Ho. sys. 544. $\}$ nach der anleitung des Houttuynschen werks. 14 vols. 8 vo. Nurnberg, $1777-1788$.

Hum. no. g. 692. Humboldt, Bonpland, and Kunth. Nova Plantarum Genera et Species. 7 vols. 4to. Paris, 1815 to 1825 .

Ic. hor kew. 306. Bauer (Francis). Delineations of Exotic Plants cultivated in the Royal Garden at Kew, publ. by W. J. Aiton. Fol. London, 1796.

Icon. Kæmpf. 152. Icones selectæ Plantarum quas in Japonia collegit et depingi curavit E. Kæmpfer. Fol London, 1791 .

Is. ac. p. 122.

Jac. amer. 34

Isnard in the Acta Parisiensia.

Von Jacquin (Nicolas Jos.). Stirpium Americanarum historia. Fol. 1763 .

Jac. am. pic. 246. $I$ Id. The same work with coloured J. a. ed. pi. 304.$\}$ plates, no date.

Jac. aust. 16. Id. Floræ A ustriacæ icones. 5 vols, fol. Vindob. 1773-1778.

Jac. col. 16. ZId. Collectanea ad Botanicam, \&c

Jc. co. sup. 96.$\}$ spectantia. 5 vols. 4 to. Vin dob. $1786-1796$.

Jac. ecl. gra. 58. ZId. Eclogæ Botanicæ. Fol, 1811Jac. gr. ecl. $64 . \quad\}$ Id. 1816 .
Jac.

Jac. frag. 68.

Id. Fragmenta Botanica. Fol, 1800 -1809 .

Jac. hort. 616. ZId. Hortus Botanicus VindoboJac. hor. vin. 646. $\}$ nensis. 3 vols. fol. Vindob. Jac. vin. $4 . \quad\}$ 1764-1776.

Jac. ic. 4.

Jac. ic. rar. 22.

Jac. pl. rar. 16

Jac. misc. 198

Jac. m. 368.

Jac. obs, 52.

Id. Icones Plantarum rariorum. 3 vols. Fol. Vindob. 17811793.

Id. Miscellanea Austriaca ad Bo. tanicam, \&c., spectantia. vols. 4.to. Vindob. 1778-1781

Id. Observationes Botanicæ. Fol. Vindob. 1764-1771.

Jac. ox. 384.

Jac. schön. 24.

Jacq. schb. 4.

Id. Oxalidis Monographia iconibus illustrata. 4to. Vindob. 1792

Id. Plantarum rariorum Horti Cæsarei Schœnbrunensis. vols. Fol. Vindobonen. 17971804.

Jac. stap. 198. Id. Stapeliæ cultæ. Fol, Vindob. $1806-1815$.

Jour. his. n. 676. Journal d'Histoire naturelle. 4to 2 vols. Paris, 1792.

Jo. of Sc. 244.

Journ. sc. 750.
Journal of Science, edited at the Royal Institution. 8vo, published quarterly. 
Jung. ic rar. 14. Junghans (Phil. Carp.). Icones Plantarum ad vitam impressæ. Fol. Halæ, 1787.

Jus. an, m, 658. Jussieu in the Annales du Museum.

Kæmpfr. 102. ? Kæmpfer (Engelbert). AmœniKæm. am. $\} \begin{array}{r}\text { tates Exoticæ. 4to. Lemgoviæ } \\ \text { tam }\end{array}$ Ka amon. 806. $\} 1712$

Kæmpfr. ic 616. Id. Icones selectæ Plantarum. Fol. London, 1791.

Ker's rev. pl. 252. Ker (John Bellenden). Recensio Plantarum hucusque in Repo. sitorio Botanicorum depicta. rum. 4to. London, 1801.

Knor. del, 614. Knorr (Georg. Wolfgang). Deliciæ naturæ selectæ. 2 vols. fol. Nurnberg, 1766-1767.

Knor. th. 160. ? Id. Thesaurus rei herbariæ hor-

Krock. sil. 16. tensisque univer $1770-1772$

Krocker (Ant. Joh.). Flora Silesiaca renovata. 2 vols. 8 vo Vratislaviæ, 1787-1790.

Kun. nov. g. 688. Kunth (Car. Sigism.). Nova Genera et Species Plantarum. 7 vols, 4to. Paris, 1825.

Kunth mim. 854. Id. Mimoses et autres Plantes Legumineuses du nouveau Continent. Fol. Paris, 1819, \&c.

Lab. ic. pl. sy. 684. Labillardiere (Jac. Jul.). Icones Plantarum Syriæ rariorum Fol Paris, 1791-1812.

Lab. nov. ho. 130. Id. Novæ Hollandiæ Plantarum specimen. 2 vols. fol. Paris, 1804-1806.

Lab. syr. 26.

Id. Icones Plantarum Syriæ rariorum Decades 10. 4to, Paris. 1791-1812.

Lab. voy. 342 .

Id. Relation du Voyage à la recherche de la Peyrouse. Paris, 1798. 2 vols. 8 vo.

Lam. ill. 12. Lamarck (Jean Baptiste Monet de la). Illustration des Genres. 4to. Paris, 1791, \&c.

Lam. cinc. 842. Lambert (Aylmer Bourke). De. scription of the Genus Cinchona. London, 1797.

Lam. pin. 802. ᄀId. A description of the genus

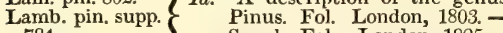
784. Suppl. Fol. London, 1825.

Lapey. fl. 368. 2 Picot de la Peyrouse (Philippe).

La peyr. pyr. 164. 5 Figures de la Flore des Pyrenées. Fol, Paris, 17951801.

Lawr. ros. 442. Lawrence (Miss). A collection of Roses from Nature. Fol. London, 1799.

Lawr. pass. 566. Id. Six numbers of coloured figures of Passion Flowers. Fol. London.

Leers.

3 Leers (John Dan.). Flora Herbo-

Leers. her. 66. $\}$ nensis. 8vo. Colon. Allobr.1789.

Lehm. ic. asp. 120. Lehmann (J, G. C.). Plantæ Asperifoliæ Nucif. 2 vols, 4to. Berlin, 1818

Lehm. nic. 136. Id. Gen. Nicotianarum Historia. 4to. 1818 .

L'Her. ger. 568. L'Heritier (Charles Louis). Geraniologia. Fol. Paris, 1787, 1788.

L'Her. ser.96. Id. Sertum Anglicum sive Plantæ rariores. Fol. Paris, 1788

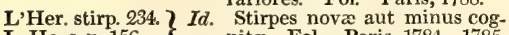
L. He. s. n. 156. \} nitæ. Fol. Paris, 1784-1785. Lightf. fl. scot. 940. Lightfoot (John). Flora Scotica.

Lind. coll. 8. Lindley (John). Collectanea Bo2 vols, 8vo. London, 1777. tanica. Fol. London, 1821.

Lind. dig. 528.

Lind. ros. 442 .

Id. Digitalium Monographia. Fol London, 1821.

Id. Rosarum Monographia. 8vo.

Linnæus (Carolus). In the Trans-

Lin. am ac. 498, Id. Amoenitates academicæ. 10 vols. 8vo. Ed. 1. Holm. et Lips. 1749, \&c.

Lin. fasc. 336. Z Linnæus (Carolus, filius). Plan-

L. fil. fa. 52. $\}$ tarum rariorum Horti Upsaliensis fasc. 1. Fol. Lips. 1767.

Lin. fil, de. 4.62. I Id. Plantarum rariorum Horti

Lin. dec. 120. J Upsaliensis Decas. Fol. Stock. 1762-3.
L hort cliff 844.7 Linnæus (Carolus, filius). Hortus Linn. cliff. 638. $\}$ Cliffortianus. Fol. AmsterLi. h. cl. 166 . $\}$ dam, 1737.

Linn. trans. 16. $\{$ Transactions of the Linnean SoL. t. 182. don, 1791-1829.

Lob. ic. 94. De Lobel, or Lobelius (Mathias). Stirpium Icones, 4to. Antwerp, 1591 .

Lœf. hisp. 744. Z Lœfling(Peter). Iter Hispanicum. Lof. it. rar.
Svo. Stockholm, 1758.

Loes. pruss. 370. Loeselius (John). Flora Prussica. 4to. Regiomonti, 1793.

Lois, fl. gall, 658. Loiseleur Deslongchamps (J, L. A.). Flora Gallica. 2 vols. 12 mo. Paris, 1806-1807.

Lyngb. hydrop. 7 Lyngbye (H. C.). HydrophyLyngb. phyt.dan. $\left\{\begin{array}{c}\text { Lyngye } \\ \text { tologia Danica. 4to. Copen- } \\ \text { hagen. }\end{array}\right.$

Mag. b. mo. 128. Magnol(Petrus). Botanicon MonsMagn. mons. 612. $\}$ peliense. 12mo. Monsp. 1686. Magn. hort. 170. Id. Hortus Regius Monspeliensis. 8vo. Monsp. 1697.

Marc. bra. 512. Marcgravius (Georg.). Historia rerum naturalium Braziliæ. Fol. L. Bat. 1648 .

Mart. cent. 118. Z Martyn (John). Historia PlantaMart. dec. 192. $\}$ rum rariorum. Cent. 1. dec. 1-5. Fol. London, 1728 .

Mass. stap. 198. Masson (Francis). Stapeliæ novæ. Fol. London, 1798.

Meerb. ic. 106. Meerburg (Nicol.). Plantarum selectarum Icones pictæ. Fol. L. Bat. 1798 .

Mem. m. 8. Mémoires du Muséum d'Histoire Naturelle. 4to. Paris, 18151829.

Mem. petr. 20. Transactions of the Academy of St. Petersburgh. 4to. Petersb.

Merian. sur. 626. Merian (Maria Sybilla). De Metamorphosibus Insectorum Surinamensium. Fol. Hagæ, 1726.

Mich, am. 18. Michaux (André), Flora BorealiAmericana. 2 vols. 8vo. Paris, 1803.

Mich. querc. 794. Id. Histoire des Chènes de l'Amerique septentrionale. Folio. Paris, 1801.

Mich. arb. 794. Michaux (André Franc. fils). Histoire des arbres forestiers de l'Amerique septentrionale. 3 vols. 4to. Paris, 1810-1313.

Mich. ge. 166. ? Micheli (Peter Ant.). Nova Plan-

Mic. gen. 50. $\}$ tarum genera. Fol. Florence, Mi. n. g. pl. 640. J 1729. Mil. dic. 796. Miller (Phil.). Gardener's Dictionary. Fol. ed. 8. 1768 ; the best.

Mill, ic. 18.

Id. Figures of Plants described in the Gardener's Dict. $\mathcal{2}$ vols. fol. London, 1760.

Mœnch. m. 132. Mönch (Conrad). Methodus Plantas horti et agri Marburgensis describendi. 8vo. Marburg, 1794

Mönch. weis. 426. Id. Verzeichniss Ausländischer Bäume des lustschlosses Weis senstein, 8vo. Frankf. 1785.

Mor. 6.

Mor, h, 124

M. his. 16 .

M. h. 1. 8 .

M. h. s. 120 .

Mo. ox. s. 538.

Moris. s. 94 .

Mr. s. M. s. 208.

Mor. umb. 224 .

Morison (Robert). Plantarum Historia Universalis Oxoni. ensis. 2 rols. fol. Oxon. 1680 .

Id. Plantarum umbelliferarum distributio nova. Fol. Oxon. 1672 .

Murray 24.

Murr. 22.

Mur. got. 34

Mur. co. got. 98

M. c. g. p. 330 .

Musc. brit. 896 .

Murray (Joh. Andr.). Prodromus designationisStirpium Gottin gensium. 8vo. Gotting. 1770 .

N. ac. ber. 72 .

Hooker and Taylor. Muscologia Britannica. 8vo. London, 1818

Nova acta Academiæ Berolinensis.

Nees crypt. 1008. 2 Nees v. Esenbeck (C. G.). Das

Nees pilze, 998. $\}$ System der Pilze und Nees syst. 1010. $\int$ Schwämme. 4to. Wurtzburg, N. ac. p. 614 . 1817

Nova acta Academiæ Parisiensis. 
N. c. p. 276. N. co. pet. 510 Ort. dec. 192.

'Novi Commentarii Academiæ Cæsareæ Petropolitana.

De Ortega (Cas. Gomez). Novarum aut rariorum Plantarum, Hort. R. Madritensis Decades. 4to. Madrid, 1797, 1798.

Osb. it. 176.

Osbeck (Peter). A Voyage to China, \&c. 8vo. London, 1771 .

Pal, ac. pet. 506. Pallas (Peter Simon), in the PeP. a. p. 216.

Pall. astr. 340 . tersburgh Transactions.

$I d$. Species astragalorum descriptæ et iconibus illustratæ. Folio. Lips. 1800.

Pall, it. 46

P. i. 120 .

Pall. ross. 8.

Park. par. 240.

Id. Reise durch verschiedene provinzen des Russischen Reichs. 3 vols. 4to. Petrop. 1771-1776

Id. Flora Rossica. Fol. Petrop. $1784-1788$.

Pleasant Flowers. Fol. Lon. don, 1629.

Park. thea. 104. Id. Theatrum Botanicum. Fol. London, 1640.

Par. lond. 16

Salisbury (Rich. Ant.). Paradisu Londinensis. 2 vols. 4 to. London, 1805-1808.

Parry's append. Parry (William). A Voyage to discover the North West Passage. 4to. London.

540.

Pass, hort. 242.

Passæus (Crispinus). Hortus flori-

Pater. it. 574. Paterson (William). A Narrative of Four Journeys into the Country of the Hottentots. 4to London, 1789

Pers. disp. 1038. Persoon (Christ. Henr.). Tentamen dispositionis methodica Fungorum 8vo Lips 1797

Pers, ic 994. Z Id. Icones picta specierum rariPers. ic. pict. 996. $\}$ orum Fungorum. 4to. Paris and Strasb. 1803

Pers. syn. 996. Id. Synopsis plantarum s. EnchiridionBotanicum. 2 vols. $12 \mathrm{mo}$ Paris, 1805-1807.

$\mathrm{Pa}$ th. or afr. 764. Aubert du Petit Thouars (Aubert). Histoire des vegetaux recueillies dans les lles Australe d'Afrique. 4to. Paris, 1806.

Pet. gaz. 312

P. gz. 98 .

Petiver (James). Gazophylacium don, 1702-1704.

Pet. h. br. 326. Id. Herbarii Britannici Catalogu

Petiv. fil. 876. Id. Pterigraphia Americana. Fol London.

Pet. mus. 308. Id. Musæi Petiveriani Centurix 10. 8vo, London, 1695.

Ph. tran. 604 .

Transactions of the Royal Society of London, many vols. 4to. London, 1665-1816.

Pic. h. p. 350. Piccivoli (Giuseppe). Hortus Panciaticus. 4to Firenze, 1783.

Pis. bras. 246. Piso (Gulielm). Historia Natu ralis Braziliæ. Fol, Amsterdam, 1648

Plant. grass. 230. De Candolle (Aug. Pyr.). Plantarum Historia succulentarum. Fol, and 4to, Paris, 1799 -1803 .

Pl. rar. hu. 96 Plantarum rariorum Hungariæ. 3 vols. fol. Vienna, 1802-1812.

Pluk. 18.

Pluk. al. 22

Pk. alm. 50

P. al. 36 .

Pl. amal. 512 .

Plk. mt. 50.

PI. man. 82

PI. m. 102

Plk. phyt. 48

$\left.\begin{array}{l}\text { Plumier, 28. } \\ \text { Plum, amer. 514. }\end{array}\right\} \begin{gathered}\text { Plumier (Charles). Description } \\ \text { des Plantes de l'Amerique }\end{gathered}$ des Plantes de l'Amerique. Fol. 1693-1712.

Plum. fil. 878.

Pl. fil. 880

Plu. gen. 350

Pl. r. gen. 804.

Plum, ic. 26.

Pl. ic. 4

Plum. spec. 348.

P1. sp. 688 .

phia s. Stirip \&c. 4 vols 4 to. Lond $-1706$ dus. Fol. Arnheim, 1614

Po. it. ed. ger. 404. Poiret (J. L. M.). Voyage in Barbarie. 2 vols. 8 vo. Strasb. 1789.

Pt. et T. fl. 8. Poiteau et Turpin. Flore Parisienne. Fol. Paris, 1808, \&c.

Pon. bald. 640. Pona (Joh.). Plantæ seu Simplicia quæ in Baldo Monte reperiuntur. 4to. Basiliæ, 1608.

Pursh fl am. 22. Pursh (Frederick). Flora Borea-

Pursh am. 160. 3 lis Americana. 2 vols. 8 vo. London, 1814.

Quer fi. 76.

Quer (Martinez). Flora Espa nola. 4 vols. 4to. Madrid, 1762-1764.

Rauw. ic. 316. Z Rauwolf (Leonh.). Aigentliche

Rauw. it. 822. $\}$ beschreibung der Raiss in den Morganlander. 4to. Laugan. gen, 1582-1583.

Red. lil. 2.

Redouté (P. J.). Les Liliacées. 8 vols. fol. Paris, 18021816.

Red. ros. 448.

Reliq. ho u. 814 Reliquiæ Houstonianæ. 4to. LonR. houst. 18

R. pl. h. 24.

Ren. spec. 276 .

$\int$ don, 1781

Reneaulme (Paul). Specimen Historiæ Plantarum. 4to. Paris, 1611.

Retz. obs. 212. Z Retzius (And. Joh.). ObservaRetz. st. 16. $\}$ tiones Botanicæ. 4to. London, 1774-1791.

Rheede 18.

Rh. mal.

$R$ mal 4 .

Riv. mon. 16

2 Van Rheede (Henricus). Hortus Indicus Malabaricus. $12 \mathrm{vols}$. fol. $1678-1703$

Rivinus (Aug. Quirinus). Ordo Plantarum Flore irregulari monopetalo. Fol. Lips. 1690.

Riv. tetr. 546. Id. Ordo Plantarum flore irregulari tetrapetalo. Fol, Lips. 1699.

Rob. ic. 522.

Roche diss, 42

Robert (Nicolas). Icones Plantarum. Fol. Paris, 1701.

Rœm. arc. 10. de Eryngiis.

Rœmer (Jac. Joh.). Archiv, fûr die Botanik. 3 vols. 4to. 1796 -1799 .

Ro. in. ac. ha. 870. $I d$. In the Copenhagen Transactions, or Acta Hafniensia.

Rottb. gr. 48

Rt. gm. 50 .

\} Rottboll (Christ. Friis.). Descriptiones et Icones Plantarum Roth. abhan. 576. Roth (Alb. Wilh.) Botanische Abhandlungen und Beobachtungen. 4to. Nuremberg, 1787 .

Roxb, cor. 4. Roxburgh (William). Plants of the Coast of Coromandel. 2 vols. fol. London, 1795-1798

Rudg. gui. 86. Z Rudge (Eaward). Plantarum Ru. p. g. 2. Guianæ rariorum Icones et descr. Fol. London, 1805.

Rumph. 2.

Rum 140. Rumphius (George Everh.). Her-

Rum amb. 102. $\}$ barium Amboinense. 6 vols. fol. Amst. 1750.

Sabb. hort. 334. S Sabbati (Liberatus). Hortus Ro Sabb. rom. 158. $\}$ manus. 7 vols. fol. Romæ, $1772-1784$.

Sal. st. ra. 2.

Salisbury (Richard Anthony) Icones Stirpium rariorum. Fol London, 1791.

Sant. itin. 798

Santi (George). Viaggi al Mont Amiata e per la Toscana. 3 vols. 8vo. Pisa, 1795-1806.

Savi pis. 62

Schæffer 986.

Sch. 1002

Sch. br. 16.

Schk. ba. 204.

Schk. bot. 668

Savi (Gaetano). Flora Pisana 2 vols. 8vo. Pisæ, 1798.

Schæffer (Jac. Christ.). Fungorum Bavariæ et Palatınatus Icones. 4 vols. 4to. Ratisbonæ, 17021770.

Schrank (Franz. v. Paula). Baiersche Flora. 2 vols. 8 vo. Munich, 1789 .

Schkuhr (Christ.). Botanisches handbuch. 3 vols. 8 vo. Wit

Schk. fil. 878 tenberg, 1791-1803.

Schk, car.

Sc. ca. 774 .

Schk. hann. 12. Schk, han. 88 .

S. h. 862 ,

Id. Histoire des Carex ou Laiches 8vo. Leipsig, 1802.

Id. Abbildungen der Farrn krauter.

Id. Plantæ Americanæ à C. Plu mier detectæ et a J.Burmanno editæ. Fol, Amst. 1755.
Id. Botanisches Handbuch. 3 vols. 8vo. Wittenberg, 1791-1808. 
Schm, ar. 12

Schm. ic. 176. Schmiedel (Cas. Christ.). Icones

Schmidt (Franz.). Esterreichs Allgemeine Baumzucht.2vols. folio. Vienna, 1792-1794. plantarum. Folio. Norimb.

Schm. mycol, 1038. Schmidt. Historia Mycologica. 8vo Schne. ic. n. 316. Schneevooght (G. Voorhelm) Icones plantarum rariorum. 2 vols. fol. Harlem, 1793.

Schousb. 22. 2 Schousboe (P. K. A.). Iagttagel-

Scho. maroc. 554. $\}$ ser over væxtriget i Marocco. 4to. Kiobenh. 1800.

Schr. ger. 56. Schrader (Henr. Adolp.). Flora Germanica. 8vo. Gottingæ, 1806.

Schr. hal. 206.

Id. De Halophytis Pallasii. 4to Gotting. 1810.

Sch. se. h. 220. ? Id. Sertum Hanoverianum. Fol. Sert han, 364

Sc. v. 14 .

Schr. mon. 88

Id. Cornmentatio de Veronicis spicatis. 8vo. Gottingæ, 1803. Schranck (Fr. v. Paula). Plantæ rariores Horti Monacensis. Fol. Munich, 1817-1819.

Schreb. decad. 638. Von Schreber (Joh. Christ. Dan.). Icones plantarum minus cog. nitarum. Decas 1. Fol. Halæ, 1766.

Schr. gram. 54. Z Id. Beschreibung der græser. Sch. gm. $48 . \quad\}$ vols. fol. Lips. 1769-1779. Schwagr. sup. 896. Schwægrichen (Frid.). Species Muscorum Hedwig suppleMuscorum 4to. Lips. 1811.

Scop. carn. 214. Scopoli (Joh. Ant.). Flora Carniolica. 8vo. Viennæ, 1760.

Scop. del. 24. ? Id. Deliciæ floræ Insubricæ. 3 vols Sco. dl. ins. 92

Scop insub.

Scop.

Seb. mu. 310
Seb. th. 722 .

\} fol. Ticini, 1786-1788.

Seba (Alb.). Locupletissimi rerum naturalium thesauri descrip-
tio. 4 vols, fol. Amst. 1734 tio. 4 vo

Seg. ver. 15. Seguier (Joh. Franc.). Plantæ Veronenses, 3 vols. 8 vo. Ve. ronæ, 1745.

S. fl. i. oc. 870 Swartz (Olof). Flora Indiæ occidentalis. 3 vols. 8vo. Erlangæ, 1797-1806.

Sloane, 68.

Slo. jam. 4.

Slo. hist. 28

Sl. jm. 16.

Smit. ic. fas. 98. S Smith (James Edward). Plan-

Sm. ic. n. 316, $\}$ tarum Icones præs. ex herb. Linnæano. Fol. London, 1789 -1791 .

Smith ic. pict. 526. Id. Icones pictæ plantarum rariorum. Fol. London, 17901793.

Smith n. hol. 142. I Id. A Specimen of the Botany Sm. N. H. 84. $\}^{\text {1d. }}$ of New Holland. 4to. London, 1793.

Smith spic. 154. ? Id. Spicilegium Botanicum. Fol. Sm. spicil. 6. $\quad$ London, 1791-1792.

Sole s mints, c. \{ Sole (William). Menthæ Britanic. 500 .

Sonn. it. 4.

Sowerby, 986.

nicæ. Fol. Bath, 1798

onnerat (P.). Voyage à la Nou. velle Guinée. 4to. Paris, 1776

Sowerby (James). Coloured figures of English Fungi. Fol, Lon. don, 1796-1815, \&c

Spreng, fl. hal. 622. Sprengel (Kurt). Floræ Halensis Tentamen novum. 8vo. Halæ Sax. 1806.

Spr. umb. 210. Id. Plantarum umbelliferarum Prodromus, 4to. Halæ, 1813.

Stackhouse fuci, ? Stackhouse (John). Nereis Britan 042 3 nica Fol Bath, 1795-1797. Sturm's Deuts. 2 Sturm (Jacob). Deutschlands flora flor. 1034 .

Stur. d. f. 374

Sw. ob. 22 .

Sw. syn. fil. 878 . Many volumes $12 \mathrm{mo}$. Nurem. Many volumes 1 .

Swartz (Olof). Observationes Betanica. 8vo, Erlagna, 1791.

nera et species complectens. 8vo. Kiliæ, 1806

Sweet fl. gard. 132. Sweet (Robert). The British Flower Garden. 8vo. London, published in monthly num bers.

Sweet ger. 568. Id. Geraniaceæ. 8vo. published in monthly numbers.
Tab. ic. 94 .

Tabernæmontanus (Jac. Theod.) Eicones Plantarum, cur. N. Bassæo. 4to. Frankf. 1590.

Tenore nap. 544. 2 Tenore (Michel). Flora NapoliTen. fl. nap. 24. $\}$ tana. 4 vols. fol. Neap. 1811, Ten. neap. 132. $\quad$ \&c.

Th, act. haf. 732. Thunberg (Car. Petr.). In the Th. Copenhagen Transactions.

Th. ac. st. 172. Id. In the Stockholm Transactions.

Th. ac. ups. 846. $\{\boldsymbol{I} d$. In the Upsal Transactions.

Thun. ups. 204.

Thunb. diss. 46. \{ Id. Dissertationes Academica Thu. diss. n. 82. $\}$ Upsaliæ sub ejus præsidio habitæ. 3 vols. 8 vo. Gotting. $1799-1801$

Th. eric. 308. ? Id. Diss. de Erica. 4to. Upsal, Thu, eri. n. 314. $\} 1785$.

Th. g. n. $I I d$. Nova plantarum genera. Dis. Thun. G. 172. $\quad$ novem. 1781-1798.

Th. jap. 360. Id. Flora Japonica. 8vo. Lips. 1784

Th. prot. n. 80 . Id. Diss. de Protea. 1781

Till. pis. 92. Tilli (Mich. Aug.). Catalogus Horti Pisani. Fol. Florence, 1723.

Tode fun meckl Tode (Henr, Jul) Fungi Meck 1038.

Tourn. it. 134 . lenburgenses Selecti lenburgenses

Tournefort (Joseph Pitton de) Relation d'un Voyage du Levant 2 vols 4 4to. Paris, 1717

Tra. arc. 864. Trattennick (Leop.). Archiv der Gewächskunde. 4to. Vienn. Gewachskund

Tratt. thes. 544. Id. Thesaurus Botanicus. Fol. Viennæ, 1819 .

Trew. ehret. 144. ) Trew (Christ. Jac.). Plantæ seTr. ehrt. 28. $\}$ lectæ ab Ehret pictæ. Fol. 1750-1773.

Trew. pl. rar. 124. Id. Plantæ rariores, Ed. J. C. Keller, Fol. 1763.

Trium, obs. 680. $\}$ Triumfetti (Joh. Bapt.). ObserTri. ob. 140. $\}$ vationes de Ortu et Vegetatione plantarum. 4to. Romæ, 1685.

Turn. fuci, 938. Turner (Dawson). Historia fucorum. 3 vols. fol. London, 1802 , \&c.

Tur. mus. hi. 914. Id. Muscologiæ hibernicæ specimen $12 \mathrm{mo}$ London, 1804

Vah. symb. 96. Z Vahl (Martino) Symbolæ BoVa. sy. $100 . \quad\}$ tanicæ. Fol. Hafn. 1790-1794. Vail. bot. par. 994 Vaillant (Sebastien). Botanicon Vaill. par. 62. $\}$ Parisiense, operis majoris prodromus, 8vo. L. Bat. 1723.

Vauch. conf. 934. Vaucher (Jean Pierre). Histoire des Conferves d'eau douce. 4to. Geneve, 1803

Vent. cels. 2 Ventenat (Etienne Pierre). De-

Ve. des. pl. n. 772. $\} \begin{array}{r}\text { Ventenat (Etienne Pierre), De- } \\ \text { scription des plantes nouvelles }\end{array}$ ou peu connues du Jardin de J. M. Cels. Fol. Paris, 1800.

Vent. choix, 12. Id. Choix des plantes. Fol. Paris,

Vent. mal. 18. Id. Jardin de la Malmaison. Fol. (803

Vill. dauph. 540. 2 Villars (D.). Histoire des plantes Vill. delph. 202 $\}$ du Dauphiné. 3 vols. 8vo. Vill. de. 824. $\int$ Grenoble, 1786-1788.

Vi. fragm. 64. Viviani (Dominic). Floræ Italica fragmenta. 4to. Genuæ, 1808.

Volck. nori. 700. Volckamer (Joh Georg). Flora Noribergensis. 4to. Noribergæ, 1700 .

Voy. de lab. 86 . (See Labill, voy.)

W. in Rœ, et. 618. Willdenow in Römer's Archiv für der Botanik.

Wah. lap. 544 Wahlenberg (George) Flora Lapponica. 8vo. Berlin, 1812

Wal. \& Kit. 232. 2 Waldstein (Franc.) et Kitaibel W. \& K.hung.92. $\}$ (Paul). Descriptiones et Icones W. \& K. 16. $S$ plantarum rariorum Hun gariz. 3 vols. fol. Vienn. 1802 -1812 .

Walth. hort. 128. Walther (Aug. Frid.). Designatio Plantarum Horti ejus. 8vo. Lipsiæ, 1735

W. am. 322 .

Willdenow (Car. Lud.). Historia Amaranthorum. Fol. Turici, 1790.

Weig. obs. 956.
Weigel (Christ. Ehrenb.). Osservationes Botanicæ. 4to. Gryphiæ, 1772. 
Weinm. 80. J Weinmann (J. Gul.). PhytanWein. phy. 484. 3 thoza Iconographica. 4 vols. fol. Regemb. 1737-1745.

We co. pl 180, $\}$ lectio Plantarum tam exoticarum quam indigenarum.

W. er. 504 . 4to Hannoveræ, 1805, \&c

Wendl, her. 570 .

Id. Ericarum Icones et Descriptiones. 4to. 1798, $8 \mathrm{c}$.

Id. Hortus Herrenhusanus. Fol. $1798, \& c$.

Wer. trans. 900. nactions of the Wernerian

Will, ar. 422

3 Willdenow (Car.Lud.). Berlinische Baumzucht. 8vo. Berlin,

Willd. ber. 26. 2 Id. Hortus Berolinensis. Fol. Ber-
Will.hor. ber. 166.
lin, 1806-1810.

Will.hor. ber. 166

W. ho. br. 190.

Willd. fl. berol.

1032.

Id. Floræ Berolinensis ProdroWil. phy. 138

Wi. ph. 96 mus. 8vo. Berlin, 1787 .

Willd, ach. 696. Society of Edinburgh. 8vo. Willdenow (Car. Lud.). Tractatus de Achilleis et Tanaceto. 8vo. Halæ Magd. 1789.

Zorn ic. 294.

I Id. Phytographia. Fol. Erlangæ, 1797.

Zanon hist. 124. Zanon (Antonio). Istoria Botanica. Fol. Bologna, 1675.

Zorn (Barthol.). Icones Plantarum Medicinalium. 8 vo. $\mathrm{Nu}$ remb. $1779-1784$. 


\title{
LIST OF AUTHORITIES
}

\author{
FOR
}

\section{GENERIC AND SPECIFIC NAMES.}

Abel.

Ach. writer upon Lichens

Ad., Adans. Adanson. A French systematical boAfz. Afzelius. A Swedish professor.

Ag., Agh., Agardh. A Swedish professor, and Agdh.

Ait.

Alb. writer upon A lgæ, \&c.
Aiton. The superintendant of the King's garden at Kew.

Alb.\&Schwe. Albertini and Schweinitz. Writers upon Fúngi

All. Allioni. An Itálian botanist.

Amm. Ammann. An old Russian botanist.

And., Andr., Andrzejowski. A Russian botanist. Andrz.

Ard. Arduini. An Italian botanist.

Aub., Aubl. Aublet. A French traveller in Guiana.

Balb. Balbis. A French professor of botany.

Ban. Banks. A great traveller and patron of science.

Bat. Batard. A writer upon the Flora of France.

Batsch. Batsch. A writer upon Fúngi.

Baumg. Baumgarten. A German botanist.

B. C. Botanical Cabinet. By Loddiges and Sons.

Beauv. Palisot de Beauvois. A French traveller and botanist.

Bell. Bellardi. An Italian botanist.

Berg. Bergius. A Swedish writer upon Cape plants.

Bern,Bernh. Bernhardi. A German botanist.

Bert.,Bertol. Bertolini. A writer upon the Flora of

Bess. Besser. A Russian professor, resident

in the Crimea.

Bieb Bieberstein. A Russian botanist of

Biv. Bivona. A Sicilian botanist.

B. $M$. Botanical Magazine. By Curtis, Sims,
\&c.

Boer. Boerhaave. An old Dutch botanist.

Böhm. Böhmer. A German botanical writer.

Bolton. Bulton. An English writer on Fúngi.

Bon., Bonpl. Bonpland. A French traveller in South America, and botanist.

Bork. Borkhausen. A writer upon the Flora of Hesse Darmstadt.

Bory. Bory de St. Vincent. A French traveller and botanist.

Bosc. Bosc. A French botanist, and traveller in North America.

Bouch. Boucher. A writer upon the French Flora.

B.P. Brown's Prodromus Flora Nove Hol landia.

Br. Robert Brown. A celebrated English botanist, and traveller in New Holland.

Bradl. Bradley. An old English writer upon succulent plants.

B.R.,B.Reg. Botanical Register. By Ker and

B.Rep. Botanical Repository. By Andrews and others.

Brid. Bridel. A German writer upon mosses.

Brot.

Brouss. Broussonet. A French botanist, and
Buch.

Bull.

Buchanan. An English physician, and traveller in Nepal.

Bulliard. A French writer on Fúngi.

Burc, Burch.Burchell. An English botanist, and traveller at the Cape of Good Hope. Burm.,Brm. Burmann. A Dutch editor of other people's works.

Casalp. Casalpinus. A famous old Italian boCa.,Cav. Cavanilles. A Spanish professor and botanist.

Cham. Chamisso. A German traveller round the world

Choisy. A Swiss botanist.

Clus. Clusius. An old French botanist and traveller.

Coleb. Colebrookc. A celebrated English writer upon Indian plants.

Comm. Commelin. A Dutch garden botanist.

Corr., Cor- Corréa de Serra. A Portuguese botanist

rea. and diplomatist.

Crz. Crantz. An Austrian botanist

Curt. Curtis. An English writer upon plants. Cuss. Cusson. A Swiss writer upon Umbelliferæ, whose wife burnt his herbarium.

Cyr. Cyrilli. An Italian botanist.

D. $\dot{C}$., Dec. Decandolle. A celebrated French systematic botanist.

Del. Delile. A French professor, and traveller in Egypt.

Desf. Defontaines. A French botanist, and traveller in Barbary.

Desv. Desvaux. A French professor of botany.

Dicks. Dickson. An English cryptogamic botanist.

Dill., Dillw. Dillwyn. An English writer upon Conférvæ.

Dittm. Dittmarr.

Domb. Dombey. A French traveller in South America.

Donn. Donn. An English gardener and boDufr. Dufresne. A French writer upon Va. Duh. Duhamel. A celebrated French physioDuh. $\quad$ logical botanist.

Dum. Dumont Courset. A writer upon French garden plants.

Dun. Dunal. A French professor of botany.

Duroi. $\quad$ Du Roi. A German writer upon plants.

E.B., E.Bot. English Botany. By Sowerby and Smith.

Ehr. Ehrhart. A German botanist.

Ehrenb. Ehrenberg. A German traveller in Arabia, \&c.

Esp. Esper. A German writer on Fúngi.

Ettl. Ettlinger. A German writer on Sálvia.

Ex. B. Exotic Botany. By Smith.

Fisch. Fischer. A Russian botanist.

Fl. Flügge. A German writer upon Fl. Brit. Flora Britannica. By Sir James Ed-

Fl. Dan. Flora Danica. By Oeder, Hornemann, Fl. Lond. Flora Londinensis. By Curtis and Flocrke. Hooker.

Fl.Per.,Fl.p. Flora Peruviana. By Ruiz and Pavon. Forsk. Forskahl. A Danish naturalist, and traveller in Barbary.
Forsk. Forskahl.
traveller in Arabia 
Forst.

Forster. A traveller in the South Seas with Captain Cook.

Fr.

Fries, A Swedish botanist, and writer upon Fúngi

Frax.

Frazer. A gardener and collector of plants in North America.

Frol.

Frötich. A German writer upon Gentiàna.

Funck. Funck. A German cryptogamic botanist. Gae., Gart. Gartner. A celebrated German carpologist.

Gay. Gay. A French botanist.

Gleditsch. Gleditsch. A German botanist.

Gmel., Gm. Gmelin. A Russian botanist, and traveller in Siberia.

Gouan. Gouan. A French botanist.

Gr., Grev., Greville. An English botanist, and Greville. $\quad$ writer upon cryptogamic plants.

Hal. Hales. A distinguished English writer upon physiological botany.

Hanke. Hanke. A German botanical writer.

Haw. Haworth. An English writer upon succulent plants.

Hayne. Hayne. A German botanist.

Hedw. Hedwig. A German cryptogamic botanist.

Heist. Heister. A German botanist.

Herb.

Herit.

Heister. A German botanist.
Of the Herbarium.

Of the Herbarium.

Hill. Hill. An English compiler of botanical matters.

H. $K$.

Hortus Kevensis. A catalogue of the plants growing in the King's garden at Kew.

Haff, Haffm. Hoffimann. A German writer upon Umbellíferæ, \&c.

Hoimsk. Holmskiold. A Danish botanist.

Hook. Hooker. An English botanist, and professor at Glasgow.

Hoppe. Hoppe. A German botanist, and collector of plants.

Horn., Hor-Hornemann. A Danish botanist and

nem.

Hort. professor.

Host. Host. An Austrian writer upon Grapes and European plants.

H. Par. Of the Paris garden.

Hud., Huds, Hudson. An English writer upon Bri-

tish plants.

Humb. Humboldt. A celebrated Prussian traveller and philosopher.

Jack., Jacks. Jackson. An English botanist.

Ja., Jac., Jacquin. An Austrian traveller in South Jacq. America, and botanist.

Jon. Jones. An accomplished writer upon Indian matters.

atic botanist. Kaulf. Kaulfuss. A German writer upon

Ker. Ker. An English garden botanist.

Kit. Kitaibel. A Hungarian botanist.

Kn.Pr. Knight's Protecicece.

Kon. König. Several German naturalists of

Kunth. Kunth. A Prussian botanist

Kunz. Kunze. A German cryptogamic boLag. Lagasca. A Spanish botanist and pro-

Lam. Lamarck. A French botanist.

La Peyr., La Peyrouse. A French writer upon the

Lap. plants of the Pyrenees.

Lawr: $\quad$ Lawrence (Miss). An English flower painter.

Lax. Laxmann. A German writer on Sibe-

Ledeb. Ledebur. A botanist, and traveller in

Lehm. Lehmann. A German botanist.

L. fil. Linnceus the younger. The son of the

L'Her. $\quad$ L'Heritier. A French botanist.

Lightf. Lightfoot. A writer upon the Scottish Lind., Lindl. Lindley. An English botanist, and pro$r \quad$ fessor in London.

L. $K$. $\}$ Link. A Prussian botanist.

Lik, Link. $\}$ Link.

L.,Linn. Linnaeus. The celebrated Swedish re Lob. former of natural history.

Lob. Lobel. An old writer upon plants. Lodd. $\quad$ Loddiges. English nurserymen and bo-
tanists.

Loe.

Loesel. An old Prussian botanist.
Lois.

Lour.

L. $T$.

Lyngb.

Marcg.

Mart.

Mass.

Mayer.

M. $B$.

Med.

Menz.

Mert.

Mey.

Mi., Mich.

Mik.

Mill.

Mir.

Mohr.

Mol.

Mönch.

Morett.

Moug.

tanist. A German cryptogamic bo-

Muhl., Mhl. Muhlenberg. A North American botanist.

Mur. Murray. A German botanist.

Mutis. Mutis. A Spanish botanist, resident in New Grenada.

Mx. Michaux. See above.

Neck.

Nees.

Nois.

Nor.

Nutt.

Ort.

Otth.

Otto.

Pall.

Panz.

Necker. A German writer upon botanical affairs

Nees $v$. Esenbeck. A German botanist.

Noisette. A French nurseryman.

Noronha. A Spanish botanist who visited Madagascar.

Nuttall. A North American botanist.

Ortega. A Spanish botanist.

Otth. A French writer in Decandolle's Prodromus.

Otto. A Prussian gardener

Pallas. A Russian traveller and naturalist.

$P$ Ae $B$ Pal Panzer. A German botanist.

Patisot de Beauvois. A French botanist,

de Beauv. and traveller in Africa.

Pers. Persoon. A German botanist.

Pet. Petiver. An old English botanist.

Pet. Th. Du Petit Thouars. A French botanist, and traveller in Madagascar.

Ph., Psh. Pursh. A Prussian botanist, and tra. veller in North America.

P. L. Paradisus Londinensis.

Plin. Pliny. An ancient writer upon natural history.

Plu.

Plumier. A French botanist, and traveller in the West Indies.

Poir. Poiret. A French botanical compiler.

Poit. $\quad$ Poiteau. A French botarist and draughts-

Poll. Pollich. A German writer on the plants of the Palatinate.

Pour. Pourret. A French botanist.

P.S. Persoon's Synopsis.

Raddi. Raddi. An Italian cryptogamic botanist, and traveller in Brazil.

Raf., Rafi. Rafinesque Schmalz. A modern writer

upon botanical matters.

R. \& S. Römer and Schultes. German editors of Linnæus's Species Plantarum.

R.B., R. Br., Robert Brown. A distinguished English

R. Brown. botanist, and traveller in New Holland.

Rchb. Reichenbach. A German botanist.

Rebent. Rebentisch. A Prussian botanist.

Red. Redouté. A French botanical draughts-

Relh.

Retz., Rtz. Retzius. A German botanist.

Rich. Richard. A French botanist. 
Risso. Risso. An Italian writer upon Oranges.

Rosc.

Rotb.
Roth, Rth. Rottboll. A Danish botanist.
Roth. A German botanical writer. Redouté's Liliacées.

Roscoe. An English botanist, and writer upon Scitaminex.

Roxb., Rox. Roxburgh. An Indian botanist.

Roy., Royen. Van Royen. A Dutch botanist.

Rudge. Rudge. An English writer upon botanical subjects.

Rudol. Rudolph. A German botanist.

Sab., Sabine. Sabine. An English amateur of botany.

Sal., Salisb. Salisbury. An English botanist.

Salm. The Prince of Salm Dyck. A noble German amateur.

Savi. Savi. An Italian botanist.

Sc., Sch. Schkuhr. A German writer upon Grasses and Ferns.

Schaff. Schaffer. A German writer upon Fúngi.

Schl.,Schlect. Schlechlendahl. A German botanist.

Schleich. Schleicher. A Swiss plant collector.

Schm., Schmidt. A Bohemian botanist.

Schmidt.

Schneev.

Schott.

Schousb.

Schneevoght. A Dutch nurseryman.

Schott.

Schousboe. A writer upon the Flora of Morocco.

Schr.

Schrad.

Schrank.

Schult.

Schum.

Schw.,

Schwagr:

Scop.

Sib.

Sims.

S. $M$.

$\mathrm{Sm}$.

Smith $F l$

Brit.

Sol.

Schreber. A German botanist.
Schrader. A German botanist.

Schrank. A Bavarian botanist.

Schultes. A German botanist.

Schumacher. A Danish botanist.

Schwagrichen. A German cryptogamic botanist.

Scopoli. An Italian botanist.

Sibthorp. An English botanist, and tra. veller in Greece.

Sims. An English garden botanist.

Sole's Monograph of Mints.

Smith. An English botanist, and purchaser of the Linnean Herbarium. panion of Sir Joseph Banks in Cook's

Sowerby. An English botanical draughts-

Spar:

Sparmann. A Swedish travelling botanist.

Spr.,Spreng. Sprengel. A German botanist.

St., Stev. Steven. A Russian botanist.

Steph. Stephan. A Russian botanist.
Stern. Sternberg. A noble German botanist. St. Hil. Auguste St. Hilaire. A French botanist, and traveller in Brazil.

Strauss. $\quad$ Strauss. A German writer on Coffee.

Sturm. Sturm. A German botanical draughts.

Sw., Swz. Swartz. A Swedish botanist, and tra

Ten.

Th., Thunb. Thunberg. A Swedish botanical traveller.

Thuill. Thuillier. A French botanist.

Tode. Tode. A German writer on Fúngi.

Tou. Tourey. A North American botanist.

Trent. Trentepohl.

Trev. Treviranus.

Turner. Turner. An old English herbalist.

Turp. $\quad$ Turpin. A French botanist and draughts man.

Turr., Turra. An Italian botanist.

Turra.

Tuss.

Tussac. A French writer on the Flora of the Antilles.

Va., Vahl. Vahl. A Danish botanist.

Vaill. Vaillant. A French botanist and traveller.

Vandelli. A Portuguese botanist.

Vent., Ven., Ventenat. A French botanist.

Vig. $\quad$ Viguier. A writer upon Poppies.

Vill. Villars. A French botanist.

Viviani. Viviani. An Italian botanist.

W. Willdenow. A German botanist.

Wahl. Wahlenberg. A Swedish botanist

Waldst. Waldstein. A noble German patron of botany.

Wall. Wallroth. A German botanist.

Walt. Walter. A writer on the Flora of

W. \& K. Waldstein and Kitaibel. Authors of the Flora of Hungary.

Wats. Watson. An English writer upon Trees and Shrubs.

W.E.,W.en. Willdenow's Enumeration of the Plants in the Berlin Garden.

Web. Weber: A German cryptogamic botanist.

Weihe. Weihe. A German writer on Rubi.

Wendl., Wnl. Wendland. A German garden botanist.

With. Withering. An English botanist.

Wood. Woodville. An English writer on Me-

Woods. Woods. An English writer on Roses.

Wulf., Wul-Wulfen. A German botanist. 


\section{T A B L E}

\section{ABBREVIATIONS AND REFERENCES}

Used in Columns 3, 4, 5. 7, 8, 9, 10, 11, and 12.

\section{Colums 3. Habit.}

* Deciduous tree.

I Evergreen tree.

平 Palm tree.

Deciduous shrub.

Evergreen shrub.

Deciduous under-shrub.

ziz Evergreen under-shrub.

$\$$ Deciduous twiner, ligneous or herbaceous.

\$ Evergreen twiner, ligneous or herbaceous.

B Deciduous climber, lig. or herb.

月. Evergreen climber, lig. or herb.

* Deciduous trailer, lig. or herb.

i. Evergreen trailer, lig. or herb.

* Deciduous creeper, lig. or herb.

in Evergreen creeper, lig. or herb.

7 Deciduous herbaceous plant.

Evergreen herbaceous plant.

俨 Grass.

¿ Bulbous plant.

* Fusiform-rooted plant.

* Tuberous-rooted plant.

当 Aquatic.

E Parasite

Column 4. Duration and Habitation.

\section{$\triangle$ Perennial \\ () Biennial. \\ O Annual.}

$\square$ Bark, or moist, stove.

$\square$ Dry stove.

Green-house.

Frame.

$\triangle$ Bark stove perennial.

$\triangle$ Dry stove perennial.

$\triangle$ Green-house perennial.

$\triangle$ Frame perennial.

D] Bark stove biennial.

D)] Dry stove biennial.

(ब) Green-house biennial.

Q) Frame biennial.

[0] Bark stove annual.

그 Dry stove annual

Green-house annual.

ل) Frame annual.

Column 5. Popular Character.

ag agricultural.

cl clothing.

clt cultivated

cul culinary.

dy dying plant.

fr fruit-tree

$\mathrm{m}$ medicinal.

or ornamental.

p poisonous

tm timber-tree.

w weed.

spl. splendid.
Column 7. Time of Flowering.

$\begin{array}{ll}\text { ja } & \text { January. } \\ \text { f } & \text { February. } \\ \text { mr } & \text { March. } \\ \text { ap } & \text { April. } \\ \text { my } & \text { May. } \\ \text { jn } & \text { June. } \\ \text { jl } & \text { July. } \\ \text { au } & \text { August. } \\ \text { s } & \text { September. } \\ \text { o } & \text { October. } \\ \text { n } & \text { November. } \\ \text { d } & \text { December. }\end{array}$

Colum 8. Color of the Flower.

Ap apetalous, without petals.

B blue.

Bk black.

$\mathrm{Br}$ brown.

D dark.

G : green

L light.

o orange

$\mathbf{P}$ purple.

Pk pink or rose.

R red.

S scarlet.

St striped or variegated.

W white.

Y yellow.

\section{Column 9. Native Country.}

C. G. H. Cape of Good Hope. E. Ind. E. Indies.

N. Amer. North America.

N. Eur. North of Europe

N. Holl. Nefw Holland.

N. S. W. New South Wales.

S. Amer. South America.

S. Eur. South of Europe,

V. Di. L. Van Dieman's Land.

W. Ind West Indies.

Colums 10. Year of Introduction of Exotics, and Localities of British Species.

al. bogs alpine bogs.

al.b. p. alpine bushy places.

al. hea. alpine heaths.

al. lak. alpine lakes.

al. ma. alpine marshes.

al. me. alpine meadows.

al. riv. alpine rivers.

al. roc. alpine rocks.

a. $r$. tr. alpine rocks and trees.

ba. banks.

bar. gr. barren ground.

bar.he. barren heaths.

bar.pa. barren pastures.

ba.s. p. barren sandy places.

bog. h. boggy heaths.

bog. pl. boggy places.

bo. m. $\}$ bogs on mountains.

bo. me. boggy meadows.

bo. me. boggy meadows.
bor. fi. borders of fields.

br. branches.

bu. fi. bushy fields.

bu. hi. bushy hills.

bu. pl. bushy places.

cal. ba. calcareous banks. cal, ro. calcareous rocks.

ch, ba. chalky banks.

ch. cl. chalky cliffs.

ch. fi. chalky fields.

ch. hil. chalky hills.

ch. pa. chalky pastures.

ch. so. chalky soil.

ch. wo. chalky woods.

clov. fi. clover fields.

clt. gr. cultivated ground.

cor. fi. corn fields.

dit. ditches.

dit. ba. ditch banks.

d.m.pl. dry mountainous places.

dr. co. dry commons.

dr. fi. dry fields.

dr. he. dry heaths.

dr. pa. dry pastures.

dr. wo. dry woods.

d.st pl. dry stony places.

d. st.w. dry stony woods.

dungh. dunghills.

ed.of d. edges of ditches.

gra.ba, gravelly banks.

gra.he. gravelly heaths.

gra.pa, gravelly pastures.

gra. so. gravelly soil.

hea. heaths.

hea.w. heaths and woods,

hed. hedges.

hed. b. hedge banks.

hghl.v. Highland valleys.

hil. pa. hilly pastures.

ir. bog. Irish bogs.

ir. mo. Irish mountains.

ir. roc. Irish rocks.

ir. sho. Irish shores.

ir. thi. Irish thickets.

lak. lakes.

m.al.p. moist alpine places.

mar, marshes.

mar.la. margins of lakes.

m.a.w. moist alpine woods.

m. c. h, moist chalky hills.

m.ch.s. moist chalky soil.

mea. meadows.

me. pa. meadows and pastures.

m. h. $\}$ mountainous heaths.

$\mathrm{m}$. hed. moist hedges.

mic.ro. micaceous rocks.

$\mathrm{m}$, me, moist meadows.

moi. fi. moist fields.

moi.gr. moist ground

moi. h. moist heaths.

moi.pl. moist places.

moi.ro. moist rocks.

moi w, moist woods.

mo. pl. mountainous places.

mos. b. mossy bogs.

moun. mountains.

m. pas. moist pastures.

$\mathrm{ms}$. pas. mountainous pastures.

m. r. h. mountainous rocky heaths.

mrit. r. maritime rocks.

m.r.tr. moist rocks and trees

m. s.pl. moist shady places.

m. thi. mountainous thickets.

$m$. wo. mountainous woods.

mud.d. muddy ditches.

mud.s. muddy shores.

n. of e. north of England

$n$. of s. north of Scotland

old w. $\}$ old walls.

os.hol osier holts.

pas. pastures.

pea. d. peaty ditches.

riv. ba. river banks. 
rivul. rivulets.

ro. sid, road sides.

rub. rubbish.

sa.hea. sandy heaths.

sal. m. salt marshes.

sa. ma. sandy marshes.

san. fi. sandy fields.

san. gr. sandy ground.

san. pl. sandy places.

san.sh. sandy shores.

sa.pas. sandy pastures.

sa.w.d. salt water ditches.

sa.w.p. sandy wet places.

sc. alp. Scottish alps.

sc. bog. Scottish bogs.

sc. isl. Scottish islands.

s. cliffs, sea cliffs.

sc, ma. Scottish marshes.

sc, mo, Scottish mountains.

sc, pas. Scottish pastures.

sc, roc. Scottish rocks.

sc. sh. Scottish shores.

sc. thi. Scottish thickets.

sc.wds. $?$ Scottish woods.

sc. wo. 5

sea co. sea coast.

sea sh. sea shore.

sev. isl. Severn isles.

sha.ba. shady banks.

sha.bo. shady bogs.

sha. la. shady lanes.

sha. pl. shady places.

sh. roc. shady rocks.

s. m.pl. shady moist places.

so. co. south coast.
so. of s. south of Scotland.
sp. bo. spongy bogs.
sta.wa. stagnant water.
st.in w. stones in water.
sto. hi. stony hills.
sto.pa. stony pastures.
sto. pl. stony places.
sto.wa. stones and walls.
sun. hi. sunny hills.
sun.ro. sunny rocks.
thick. thickets.
tr. trees.
tr.\& st. trees and stones.
tru. tr. trunks of trees.
tur. bo. turfy bogs.
tur. he. turfy heath.
unc.gr. uncultivated ground.
unc.pl. uncultivated places.
wa. gr. waste ground.
w.al.h. wet alpine heaths.
w. alp. Welsh alps.
wat.co. watery commons.
wat.pl. watery places.
w. bog. Welsh bogs.
w. co. wet commons.
w. gr. wet ground.
w. lak. Welsh lakes.
w. roc. Welsh rocks.
w.sa.p. wet sandy places.
w. s.gr. wet shady ground.
w.sh.p. wet shady places.
wy.sh.p. watery shady places.
w. thi. wet thickets.

Columa 11. Propagation.

B by budding. cuttings.

division of the plant.

grafting.

inarching.

layers.

leaves.

offsets.

division of the root.

seeds.

suckers.

Column 12. Soil.

aq watery places.

co common garden earth.

c.p. common peat, or bog.

h heavy.

h.l. heavy loam.

l loam.

l.p. loam and peat, most loam.

It light

1t.1. light loam

m.s. moist soil.

p peat.

p.1. peat and loam, most peat.

$r$ rich.

r.m. rich mould.

ru. rubbish.

s sand.

s.l. sandy loam.

s.p. sandy peat.

s.p.1. sand, peat, and loam.

\section{RULES FOR PRONOUNCING BOTANICAL NAMES.}

I might, perhaps, be sufficient to direct the gardener to pronounce Latin vowels as he would English, placing the accent as he may find it marked, and to treat the consonants, with the exception of $c h$, in the same manner; but as many gardeners may not be masters of the correct pronunciation of their mother tongue, for their information, we shall go more into detail.

\section{SYLLABLES.}

In classical words there are as many syllables as there are vowels; except when $u$ with any other vowel follows $g, q$, or $s$, and when two vowels unite to form a diphthong. The diphthongs are $a, a, a i, e i, o i, u i, a u$, $e u$, and ou. These seldom coalesce in final syllables; oo,ee, ea, and other combinations which never occur as diphthongs in classical words, follow, in commemorative names, the pronunciation of their primitives, as Té́dia, Woódsia.

VOWELS.

In this work the accented vowels are indicated by the mark placed over each; but as this only points out the vowel on which the stress is laid, the following observations will be found useful in showing when the vowel is to be sounded long, and when short. In addition to the primary accent, every word of more than three syllables contains a secondary accent, which is regulated by the same rules. The secondary accent must always be at least two syllables before the primary accent, as in Ch€lidonium; for its place the ear is a sufficient guide, and even were it entirely omitted, still, however inharmonious, it would not be incorrect.

Every accented penultimate vowel is pronounced long, when followed by a vowel or a single consonant, as $A$ chillè $a$ tomentòsa; but it is shortened when followed by two consonants or a double one, as Sórbus, Táxus ; except when the first consonant is a mute and the second a liquid, as A 'brus.

Every accented antepenultimate vowel, except $u$, is pronounced short, as Helléborus, Hùmulus; but wher. succeeded by a single consonant, followed by $e$ or $i$ and another vowel, it is lengthened, as Stellaria ; except $i$, which is short, as $T$ ilia.

$A$ unaccented, ending a word, is pronounced like the interjection $a h$, as Stícta $(a h)$.

$E$ final, with or without a consonant preceding, always forms a distinct syllable, as Silènë, $A^{\prime}$ loë; also when

the vowel is followed by a final consonant as Tri-cho-ma-nes, not Tri-cho-manes.

$I$ unaccented, if final, sounds as if written eye, as Spìca vénti (eye); but, when it ends a syllable not final, it

has the sound of $e$, as Méspilus (Mespelus), Smithii (Smithë-eye).

$Y$ is subject to the same rules as $i$.

The diphthongs $e$ and $\propto$ conform to the rules for $e ; e i$ is generally pronounced like eye; the other diphthongs have the common English sounds.

CONSONANTS.

$C$ and $g$ are hard before $a, o$, and $u$, as Córnus, $G$ àlium ; soft before $e, i$, and $y$, as Cetrària, $C$ itrus.

$T, s$, and $c$, before $i a, i e, i i, i o, i u$, and $e u$, when preceded by the accent, change their sounds, $t$ and $c$, into $s h$, as Blètia, Vícia; and $s$ into $z h$, as Blàsia: but, when the accent is on the first diphthongal vowel, the preceding consonant preserves its sound, as aurantiacum.

$\mathrm{Ch}$, before a vowel, is pronounced like $\mathrm{k}$, as Chelidionium (kel), Cólchicum (kolkekum); but in commemorative names it follows their primitives, as Richardsonia, in which the $c h$ is soft.

$\mathrm{Cm}, \mathrm{cn}, \mathrm{ct}, \mathrm{gm}, \mathrm{gn}, \mathrm{mn}, \mathrm{tm}, \mathrm{ps}, \mathrm{pt}$, and other uncombinable consonants, when they begin a word, are pronounced with the first letter mute, as Ptèris (teris), Cnìcus (nikus), Gmelina (melina), Gnídia (nidia); in the middle of a word they separate as in English, as Lap-sàna, Lém-na.

$P h$, followed by a mute, is not sounded; but, followed by a vowel or a liquid, sounds like $f$, as $P$ hlèum (feum).

Sch sounds like $s k$, as Schœ'nus (skenus); in $t l$ and $z m$ both letters are heard.

$S$, at the end of a word, has its pure hissing sound, as Dáctylis; except when preceded by $e$, $r$, or $n$, when it sounds like $z$, as Rìbes (e; $)$.

$X$, at the beginning of a word, sounds like $z$, as Xánthium; in any other situation it retains its own sound, as Táxus, Támarix. (Extractsd from the Gardener's Magazine, vol, v. p. 232.) 


\section{GENERAL INTRODUCTION.}

$\mathbf{T}_{\mathrm{r}}$

HE science of Botany consists of two departments, Phytology and Physiology. This Encyclopædia is exclusively devoted to the former department, and it is limited to the plants in Britain, indigenous and exotic.

Phytology, or the History of Plants, comprehends the knowledge of the external parts of plants, the determination of their names, their classification, their uses, their individual history, and their geography. The object of this work is to convey, in the most convenient manner and in the least possible space, a knowledge of the various particulars which arrange themselves under these heads.

A knowledge of the external parts of plants will be readily and agreeably obtained by turning over the first 700 pages of this work at random, looking at the engravings, and comparing them with the names and descriptions to which they refer; the same process will enable the reader to recognise, at sight, the 10,000 species figured in the 700 pages. In this way, botanical figures supply the place of a botanical garden; and the beginner learns the natures, the technology, and the general appearances of plants, almost as easily and naturally in the one case as he does in the other.

To determine the name of an unknown plant, it is necessary to be furnished with a specimen of it in flower. The parts of the plant including those of the flower being already known by the process above mentioned, its class will be ascertained by the Table of the Linnean System (p. 2.), and its order, genus, species, \&c., by turning to the page referred to at the end of the class. Thus, if you hold in your hand a specimen of $P$ hillyrèa angustifòlia in flower, on counting the stamens and pistils you find it belongs to Class II. Order 1., from which, in the Table in p. 2., you are referred to the details of the class in p. 8.; you there find, under Order 1., the characters of all the genera of that order, and that the flower which you hold in your hand best agrees with the definition given of the genus Phillyrèa, No. 33. But you wish to know the species; and, Phillyrèa being No. 33., you turn to that number in the details of the genera in the subsequent pages. After comparing its leaves with the specific character given of the different species, you find it best agrees with $P$. angustifòlia; and, finding this species numbered 143., you look for that number in the two plates of engravings in the lower parts of the pages, and find a figure which confirms your decision. By reading the abridgements in the line which follows the word angustifòlia, together with the note to the generic name Phillyrèa at the bottom of the page, you find in an abridged form its English name, habit, habitation in the garden, popular character, the height to which it grows, its time of flowering, the colour of its flower, its native country, the year of its introduction into Britain, its propagation, the soil in which it grows, a reference to a work where it is figured and described at greater length, and its uses in the arts, or whatever else is remarkable in its history. You find, also, the natural order to which the genus belongs, the etymology of the name, the French or German name, if the plant has a vernacular name in these languages, and, both generic and specific names being accentuated, you have the pronunciation. On turning to the Table of Synonymous Names (p. 1108.), you will find its vernacular name in the languages of the countries where it is common. If it is not so common in any country as to have received a vernacular name, it will not be found in that list. Finally, if you should not understand any of the terms used in the definition of the specific characters or in the notes, on turning to the Glossary (p. 1094.) you will find them explained, and illustrated where necessary by engravings. 
When the beginner has a leaf or any part of a plant not in flower, he may ascertain, by turning to the Introduction to the Natural System (p. 1051.), to which of the three grand divisions of the vegetable kingdom it belongs, and may learn other particulars, according to circumstances which it is unnecessary to detail. Without the flower, he will not be able by the Natural System to determine the name of a plant; but, what is often much more important, with a very small portion of any part of a plant he will be able to discover something of its nature, an advantage which does not belong to the System of Linnæus.

The classification or arrangement of plants is made by botanists with a view to two objects: the first, to facilitate the discovery of their names, and thus to know them individually; the second, to give general ideas respecting their natures, and thus to know them as belonging to large masses or groups. Hitherto, no system has been discovered which has attained both these objects in an equal degree of perfection; but the Linnean Arrangement has made the greatest advances in teaching how to discover the names of plants, and the Jussieuean in teaching us their natures, and how to recognise them as belonging to certain masses or groups. In order that the student may acquire both these kinds of knowledge, we have given both arrangements. We have begun with the Linnean, not only as being best adapted for beginners, but because it is necessary to know how to discover the name of a plant, as well as to be able practically to recognise a number of plants, before attempting to know their natures, or to combine them in masses or groups.

" The standing objection to botany," says White of Selbourne, " has always been, that it is a pursuit that amuses the fancy and exercises the memory without improving the mind or advancing any real knowledge; and where the science is carricd no farther than a mere systematic classification, the charge is but too true. But the botanist, who is desirous of wiping off this aspersion, should be by no means content with a list of names; he should study plants philosophically, - should investigate the laws of vegetation, - should examine the powers and virtues of efficacious herbs, - should promote their cultivation, and graft the gardener, the planter, and the husbandman, on the phytologist: not that system is by any means to be thrown aside; without system the field of nature would be a pathless wilderness ; but system should be subservient to, and the main object of, our pursuit."

" After all that has been effectcd, or is likely to be accomplished hereafter," Professor Lindley observes, "there will always be more difficulty in acquiring a knowledge of the Natural System of Botany than of the Linnean. The latter skims only the surface of things, and leaves the student in the fancied possession of a sort of information which it is easy enough to obtain, but which is of little value when acquired ; the former requires a minute investigation of every part and every property known to exist in plants, but when understood has conveyed to the mind a store of information, of the utmost use to man, in every station of life. Whatever the difficulties may be of becoming acquainted with plants according to this method, they are inseparable from botany, which cannot be usefully studied without encountering them." *

The History of Plants comprehends every thing relating to their use in the arts, or in any way as connected with man, with animals, or with civilisation. The Geography of Plants relates to the countries in which they are indigenous or acclimated, and to the soils and situations in which they grow or may be grown. Every thing essential in relation to these points will, as we have already stated, be found after the name of each species in the text, after the name of the genus in the notes below, under the natural order to which the genus belongs in the Natural Arrangement (Part II. p. 1051.), in the Table of Synonymes (p. 1108.), or in the Glossary (p. 1094.).

The General Index (p. 1143.) contains not only the names of the genera, and of the classes and orders of both systems, but those of all the remarkable species, and the more important systematic and British synonymes both of genera and species. The various names being included in the same alphabet, this Index may therefore be consulted as a Dictionary of Plants.

* Synopsis of the British Flora, arranged according to the Natural Orders, \&c., pref. p. xi. 


\title{
ENCYCLOPADIA OF PLANTS.
}

\section{PART I.}

\author{
LINNEAN ARRANGEMENT.
}

main object of the artificial system of botanical arrangement is to facilitate the discove of plants. For this purpose some one organ, common to plants in general, is fixed on; and, according to certain conditions in which this organ is found, individual species are referred to their places in the system, as words, by their initial letters, are referred to their places in an alphabetical dictionary.

In the progress of artificial systems different organs have been fixed on by different botanists; but those which have been most extensively employed are the corollas by Tournefort, and the stamens and pistils, by Linnæus. The system of Tournefort has been a good deal employed in France, and may be considered as the artificial system of that country; that of Linnæus bas been employed in most other countries, and is justly esteemed by far the most perfect artificial system which has hitherto been produced. It is, therefore, adopted in this work.

The application of the Linnean system in practice, Sir J. E. Smith observes, is, above all other systems, easy and intelligible. Even in pursuing the study of the natural affinities of plants, this botanist affirms " that it would be as idle to lay aside the continual use of the Linnean system, as it would be for philologists and logicians to slight the convenience, and indeed necessity, of the alphabet, and to substitute the Chinese character in its stead." (Introduct. to Bot.) "The student of the Linnean artificial system," he elsewhere observes, "will soon perceive that it is to be understood merely as a dictionary, to make out any plant that may fall in bis way." (Gram. of Bot.) "If we examine," says Decandolle, "the artificial systems which have been hitherto devised, we shall find the most celebrated of them, that which was proposed by Linnæus, to possess a decided superiority over all others, not only because it is consistently derived from one simple principle, but also because the author of it, by means of a new nomenclature, has given to his terms the greatest distinctness of meaning." (Elements of the Philos. of Plants, by Decandolle and Sprengel.) Whether or not subsequent advances in science may enable botanists to dispense with the Linnean system altogether, it is not for us to affirm; but in the meantime nothing can be more certain than that the Linnean system is the best leading arrangement for such a work as the present, in the existing state of botanical knowledge in Britain. *

According to the Linnean system all plants are furnished with flowers, either conspicuous or inconspicuous. The plants with conspicuous flowers are arranged according to the number and position of their stamens and pistils; those with inconspicuous flowers are arranged according to the situation of the flowers on the plant, or according to other circumstances in the plant itself.

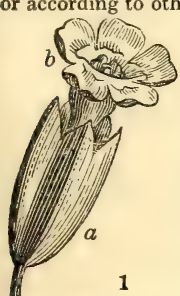

To discover the name of a plant by the Linnean system, therefore, all that is necessary for a beginner is to possess a specimen of it in flower, and to be able to know its different parts by the names given them by botanists. To discover the class, order, and genus of a plant, it is only necessary to be able todistinguish and name the different parts of the flower. These parts are: the calyx or cup (fig 1. a), which is that leaf, or those leaves, by which the flower is usually enclosed when in $a$ bud, and which, when the flower is expanded, appear under it. The corolla (corona, a crown) is the coloured leaf, or leaves, of a flower (fig. 1. b). The stamen (or first principle of any thing) is the thread-like process, or processes, immediately within the leaves of the corolla ( $\mathrm{fg} .2$.$) : it consists of two parts, the filament$ or thread $(a)$, and the anther $(b)$; this anther contains what is called the pollen, or fructifying meal $(c)$. In the centre of the flower is the pistil ( $\mathrm{fig.3}$.): it consists of three parts, the germen, or rudiments of the fruit or seed $(a)$, the style $(b)$, and the stigma or summit $(c)$, which crowns the style, and is destined to receive the fructifying pollen.

The pistil and stamen are the essential parts of a flower. The corolla or the calyx may be wanting, and yet the flower will be termed pertect, because the absence of those parts is no obstacle to reproduction. Even the style and the filament may be absent without preventing the formation or ripening of the fruit; and there are many flowers which have the anther sitting close to the corolia, \&c., without a filament, and the stigma to the germen without a style; but the

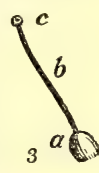
anther, the germen, and the stigma are essential.

The seed is contained in the pericarp, or seed-vessel, which is the germen when grown to maturity. The name of seed-vessel varies according to its form, substance, \&c.; but the word pericarp (peri, about, karpon, a fruit) is applicable to all its varieties. The receptacle is the base or medium which connects the other parts of the fructification. (Magazine of Natural History, vol, i. p. 233.)

The degree of knowledge conveyed by the following Table, and the preceding observations, will enable a beginner to discover the class, order, and genus of any plant which he may find in flower.

* The best work in the English language for acquiring a knowledge of the Linnean system of botany is Smith's Introduction to Botany; there are also various other works nearly as and familiar Introductions to both the Linnean and Jussieuean Systems will be found in the first and second volumes of The Magazine of Natural History. 
First Grand Division. - Plants with conspicuous Flowers (Phanerogàmia).

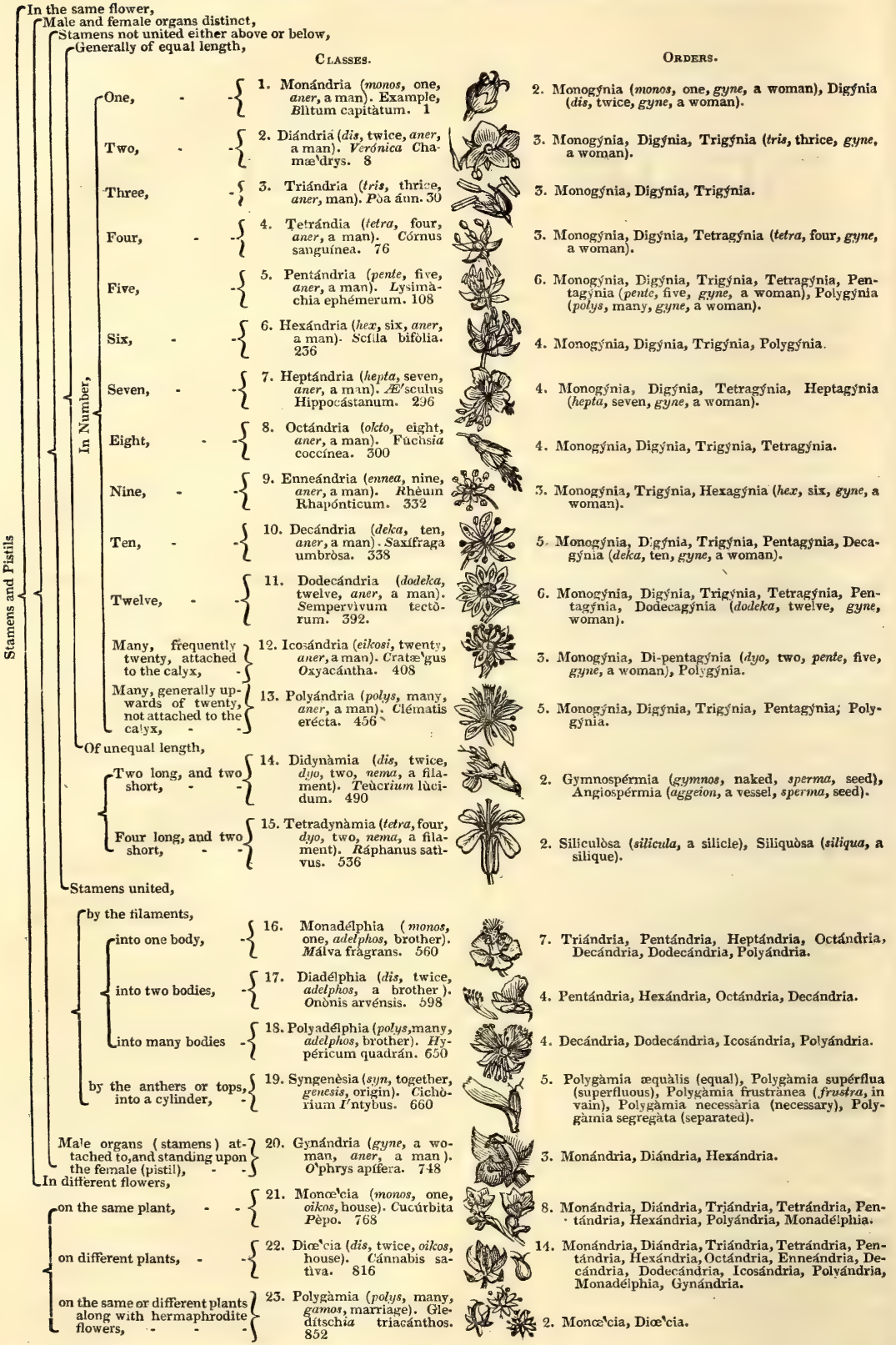

Second Grand Division. - Plants with inconspicuous Flowers (Cryptogìmia).

11. Gonoptérides (gonos, seed, pteris, fern), Stachyoptérides (stachys, a spike, pteris, fern), Poroptérides (poros, a pore, pteris, fern), Filices (, filix, Schisinatoptérides (schisma, a cleft, pteris, fern), Músci (muscus, moss), Hepáticæe (hepar, a liver), $A^{\prime}$ Igæ (alga, sea weed), Lichens (Greek name), Fungi (fungus, a mushroom).

Reproductive organs scarcely visible, so that they have not been dis- cealed, gamos, riage), 874 gavos, maring 
To discover the particular species or variety of a plant it is necessary to become acquainted with the forms and different conditions of the leaves, stems, and other parts of the bodies of plants, as well as with their flowers, and this knowledge, as we have before stated (p.xix.), will be obtained with the greatest facility by turning to the Glossary (p.1094.), and comparing the definitions with the engraved figures.

\section{Crass I. - MONANDRIA. I Stamen.}

THrs class, which is not large, contains chiefly exotic plants, and of these the tribe of Scitaminer is considered one of the most beautiful families of the vegetable kingdom. The useful productions are chiefly the Ginger, Cardamom, and Turmerick, spices highly esteemed, and in general use wherever they are known, and can be procured. The Salicornia, a native of our sea-shores, is burned for kelp, and pickled for culinary purposes. Almost all the plants of this class are aquatics, or grow in marshes. They chiefly thrive best in a sandy loam, from which their roots should be well cleaned every year.

The genera of the Scitamineæ and Canneæ have been remodelled by Roscoe, whose arrangement has received considerable improvement from the hand of the late Dr. Roxburgh. The nature of the floral envelope of those plants has long been a subject of dispute among botanists, some considering the colored inner segments to be true petals and to be variable in numbers; and others, supposing them to be part of the calyx and constant in number, their occasional variation in number being capable of explanation. Persoon (Synopsis, p. 1.) is of opinion that many of the genera of the first section ought to be referred to Gynandria. According to Willdenow and others, the following species belonging to other classes have only one stamen.

Monogynia. Mangifera indica; Alchemilla aphanes, several species of Scirpus, Cyperus, Schœnus, Kyllinga, Cryptostomum monandrum, Chorizandra, Polycnemum monandrum, Hopea.

Digynia. Lacistema, Leersia, Salsola, and many grasses.

\section{Order 1. MONOGYNia. 1 Stamen. 1 Style.}

8 1. Germen inferior, anther simple, style erect, free. Flowers spathaceous.

1. Canna. Anther attached to the edge of the petal-like filament. Style thick, club-shaped. Stigma linear, obtuse.

2. Maranta. Anther attached to the petal-like filament. Style petal-shaped. Stigma three-sided. Flowers panicled.

3. Calathea. Anther attached to the petal-like filament. Style petal-shaped. Stigma cucullate. Flowers in close heads.

4. Thalia. Anther attached to its proper filament. Style depressed. Stigma depressed, perforated, and gaping. 5. Phrynium. Anther attached to its proper filament. Style united to the tube of the corolia, hooked at the end. Stigma funnel-shaped. Seeds with an arillus.

12. Germen inferior, anther double, style inclosed in the furrow formed by the anther. Flowers spathaceous

6. Hedychium. Anther naked. Tube of the corolla long and slender, with both limbs 3-partite, the interior one resupinate. Cansule dry.

7. Roscoea. Anther 2-lobed, incurved, surrounding the style with an appendage split at the base. Outcr limb of the corolla 3-partite, with the upper segment erect and fornicate. Inner limb 2-lipped.

8. Alpinia. Anther not crowned. Interior limb of the corolla with one lip. Capsule berried. Seeds with an arillus.

9. Hellenia. Anther in some marginal. Filament linear, longer than the anther, with a very short rounded entire or 2-lobed appendage. Capsules crustaceous. Seeds with an arillus.

10. Zingiber. Inner limb of the corolla with one lip. Anther with a simple recurved horn at the end.

11. Costus. Interior limb of the corolla nearly campanulate, split at the back. Filament lanceolate. Anther in the centre of it or at some distance from the end. Seeds naked.

12. Kampferia. Tube of the corolla long and slender, with both limbs 3-partite. Anther with a 2-lobed crest.

13. Amomum. Inner limb of the corl. with 1 lip. Anther with an entire or 2-lohed crest. Seeds with an arillus.

14. Curcuma. Both limbs of the corolla 3-partite. Anther with two spurs at the base. Seeds with an arillus.

15. Globba. Inner limb of the corolla 2-lobed or none. Filament hollow at the base, with a wedge-shaped lip Anther with an appendage or none. Seeds attached to 3 parietal placentas.

16. Mantisia. Outer limb of the corolla 3-partite, inner filiform with a double trifid limb. Filament 4-partite at the end.

\section{\$3. Germen superior, corolla irregular.}

17. Philydrum. Calyx 2-leaved colored. Filaments 3 united at the base, the two lateral ones barren and petal-shaped. Seeds numerous, minute.

\$4. Germen inferior, corolla irregular. Flowers naked.

18. Lopezia. Cal. 4-leaved. Cor. 4-petaled, unequal. Filaments two: one antheriferous, the other petalshaped abortive. Caps. 4-valved, 4-celled, many seeded.

\section{Germen inferior, corolla regular, flowers naked.}

19. Boerhaavia. Cal. 1-leaved, ob-conic, inclosing the seed. Cor. plaited, on the end of the calyx.

20. Centranthus. Cor. 5-lobed, regular, spurred. Caps. 1-celled, crowned with the limb of the calyx expanded into a plumose pappus.

21. Pollichia. Cal. 1-leaved, 5-toothed. Seed 1. Fruit upon the heaped, berried scales of the receptacle.

22. Salicornia. Cal. turbinate, entire, fleshy. Stamen inserted into the bottom of the cal. Style 2-fid. Utricle inclosed in the fleshy calyx. Seed vertically compressed.

23. Hippuris. Cal. entire, minute. Style in the hollow of the anther. Germen inferior, one-seeded, crowned by the rim of the calyx.

24. Zostera. Spadix linear in the sheath of the leaf, bearing seed on one side. Stamens opposite the germens and alternate with them, sessile. Caps. one-seeded.

25. Chloranthus. Stamen irregular, fleshy, lobed, fixed to the side of the germen. Stigma capitate. A drupa.

Order 2. DIGYNIA. PU 1 Stamen. 2 Styles.

26. Corispermum. Cal. 2.leaved. Cor. O. Seed one, oval, convex-plane. (Stamens often 5.)

27. Callitriche. Cal, 2-leaved. Pet. O. Caps. 2-celled, 4-seeded.

28. Blitum. Cal, trifid. Cor 0 . Seed one, immersed in a berried calyx.

29. Aspicarpa. Cal. 5-parted. Cor, O. Stamen included, Germen and Stigma 2-lobed. Fruit cartilagi nous, 1-seeded. 
1. CAN'NA. $W$. 1 pátens Rosc. 2 indica Rosc. $\beta$ maculáta

3 coccínea Rosc. 4 lútea Rosc. 5 Lambérti Lind. 6 gigantéa $R$. L.

7 occidentális Rose.

8 limbáta Rosc.

9 variábilis $W$.

10 rúbra $W$

11 rubricáulis $L k$.

12 édulis $B . R$

13 speciósa $B . M$.

14 pedunculáta $B$.

15 fláccida $R o s c$.

16 glaúca
3 rufa

17 iridiflóra Fl, Per

2. MARAN'TA, $W$

18 arundinácea $W$.

19 oblíqua Rudge.

20 lútea Jacq.

21 angustifólia $B . M$.

22 Tónchat $W$.

23 gíbba $L$. $K$.

24 comósa $W$.

3. CALATHE'A. Mey CALATHEA

25 zebrina Lind Marinta zebrina B. M.

4. THA'LIA. $W$. Thalia. 26 dealbáta Rosc. mealy

5. PHRY'NiUm. $W$. Phrynium. 27 capitátum $W$. headed 28 dich'́tomum Roxb. forked

6. Hedy'CHIUM. $W$. Garland Fi 29 coronárium $R o x b$. sweet-scented 30 angustifólium Rox. scarlet 31 elatum $B r$. tall

32 Gardneriánum Wall. Gardner's

33 flavéscens $B$. $C$. pale-yellow

34 spicátum B. M. $\quad$ spiked

35 grácile Roxb. slender

36 flávum Roxb. yellow

37 heteromállum B.R. variable

R.Y Rio Jan. 1778. R x.m Bot. reg. 576

$\mathbf{R}$ India 1570. R r.m Red. lil. 201

R.Y India ... R r.m Hook. ex. fl. 58

S.Y S. Amer. 1731. R r.m Bot. mag. 452

Y E. Indies 1629. R r.m Bot. mag. 2085

S Trinidad 1819. R r.m Bot. reg. 470

R.Y S. Amer, 1809. R r.m Bot. reg. 206

R.Y W.Indies 1822, $R$ rm Bot reg 779

R Brazil 1818. R r.m Bot. reg. 771

$\mathbf{R}$ India 1822. $\mathbf{R}$ r.m

R.x W. Indies 1820 , R r.m

R $\quad$..... 1821. R r.m

R Peru 1820. R r.m Bot. reg. 775

R $\quad$...... 1820. R r.m Bot mag. 2817

O 1820. R r.m Bot. mag. 2329

S. Carol. 1788. R r.m Sal. st. ra. 3. t. 2

S. Amer. 1732. R r.m Ex. b. 2.t. 102

S. Amer. … R r.m Bot. mag. 2309

Peru 1816. R r.m Bot.mag. 1968

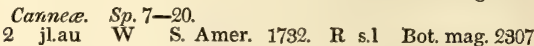

G

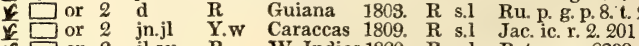

jl.au R W. Indies 1820. R s.l Bot. mag. 2398

jl.au $R \quad$ E. Indies 1819. R s.l Rumph. 4. t. 7

au o E. Indies 1818. R s.l

$$
\text { Cannee. } S p .1-4 .
$$

$\varepsilon \square$ or 2 ja.d R.Y Brazil 1815, R s.p Bot. reg. 385

Cannece. Sp. 1-2.

ـ or 4 jl.au W S, Carol, 1791. R p.l Bot. mag. 1690

$\square$ or 5 Cannece. Sp. 2.

맘 5 or 5 jlau W E. Indies 1807. R 8.1 As.r. 11. t. 8

Scitaminea. Sp. 9-14.

L $\square$ or 5 jn.s Y F. Indies 1791. R p.l Bot. mag. 708

Dor 5 jn.s $\mathrm{S} \quad \mathrm{E}$. Indies 1815. R s.1 Bot. reg. 157

or 5 jn.d Y $\quad$ E. Indies 1818. R s.l Bot. reg. 526

E or 7 jn.au $\quad$ Y $\quad$ E. Indies 1819. R r.s Bot. reg. 771

Y 0 or 6 jn $\mathbf{Y}$ India 1822, R s.l Bot. cab.723

or 3 jn $\mathbf{Y}$ E. Indies 1810. R co Bot. mag. 2300

or 3 jn W Bengal 1823. R s.l

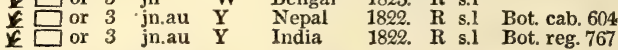

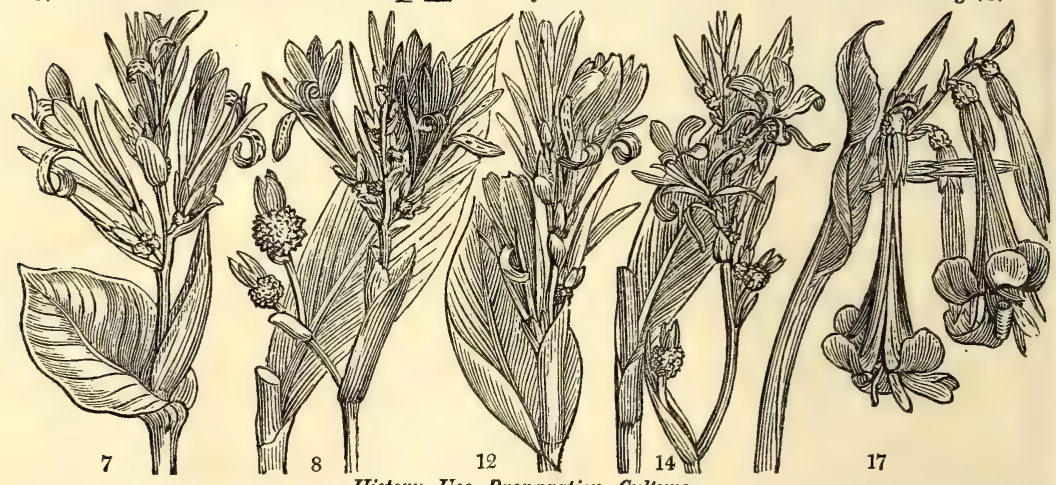

History, Use, Propagation, Culture,

1. Canna. From a Celtic word signifying a cane or mat. Le Balisier, Fr. Blumenrohr, Ger Canna, Ital The first three species are found wild within the tropics on all the continents, and chiefly in moist woods, or spongy woody wastes : in America and the Brazils, they are known by the name of wild plantain, and their leaves are used as envelopes for many objects of commerce; from which circumstance, the French name of the plant (balisier) is said to have arisen; balija being Spanish for an envelope. Clusius says he saw the C. lutea flowering by house-sides in Spain and Portugal, and that the inhabitants there use the seed for making their rosaries : in the East Indies the seeds are sometimes used as shot. The roots of C. edulis are eaten, dressed in various ways, in Peru. The seeds of most of the species are round, hard, black, shining, heavy, and about one sixteenth of an inch diameter. These grow readily, or the plants may be propagated by dividing the roots; Miller recommends rich garden earth; Sweet (Bot. Cultiv. p. 34.) light rich soil for all the species. Most of these, if planted in a warm border early in summer, will flower there during the season.

2. Maranta. So named from Bartholomeo Maranti, a Venetian physician, who wrote three books chiefly to illustrate Diosc. : died 1554. Galangre, Fr. Galgant, Ger. The M. arundinacea is called Indian arrow-root, because its thick fleshy root was thought to extract the poison from wounds inflicted by the poisoned arrows of the Indians. In the West Indies it is used as an alexipharmic, to resist the force of poisons; 
Essential specific Character.

1 Inner limb of the corolla 3-fid, Seg. ovate equal sprdg. with long claws, Lip bifid, rev. Leaves ovate lanc. 2 Inner limb of the corolla trifid, Segments lanceolate acuminate straight

3 Inner limb of the corolla trifid, Segments straight emarginate

4 Inner limb of the corolla bifid

5 Peduncle short inclosed in the upper leaf, Inner limb of the corolla trifid, Segments ovate lanceolate suberect, Lip erect spreading entire

6 Peduncles elong. Inner limb of corolla 3fid, Seg. lanceol. spathul. reflexed spreading, Lip oblong entire

7 Segments of cor. 2 entire ovate unequal, Lip bifid bent down

8 Segments of cor. 3 broad emarginate and crenate : the claws long, Lip. 2-fid bent down

9 Leaves of cal. lanceolate acute, Cor. 5 parted, Leaves ovate.obl. acute at both ends cordate

10 Leaves of cal. oblong obtuse, Cor. 6 parted, Leaves ovate-obl. acute at both ends cordate

11 Leaves sessile ovate with the sheaths and nerves very red, Inner limb 4 parted

12 Leave's smooth and stems colored at the base, Roots tuberous and large, Middle seg. of corolla very short

13 Flowers sessile in pairs, Segments of cor. 2 erect bifid, Lip spotted revolute

14 Flowers on stalks : outer segments reflexed, inner 3 erect, Leaves lanceolate pointed at each end

15 Inner limb of the corolla trifid, Segments flaccid

16 Inner limb of the corolla trifid, Segments ovate straight, Lip three-lobed fringea

17 Stem and Leaves beneath downy, sheaths curled and colored at the edge, Flowers cernuous

18 Culm branched herbaceous, Leaves ovate lanceolate somewhat hairy underneath

19 Leaves ellipt. oblique at end, Spikes elong in fasc. Bract. erect, 2-fid. imbricate acute pubesc.

20 Culm branched knotty ovate smooth, Spikes terminal subternate, Bracteas colored

21 Stem knotty, Leaves lanc. narrow, Panicle wavy, Inner braits colored, Calyx ovate

22 Stem shrubby branching, Leaves ovate smooth

23 Leaves oblong lanc. pubesc. Fl. stalks 2 -fid. Germ very hairy

24 Stemless, Scape naked, Spikes comose, Bracteas reflexed

25 Flowers in dense heads shorter than the leaves which are striped with purple

26 Calyx two-flowered, Culm reedy powdered, Leaves ovate revolute at the apex

27 Stemless, Leaves radical

28 Shrubby, dichotomous, Leaves cordate

29 Leaves lanceolate, Spikes compact imbricated, Segments of the cleft lip of the corolla lunulate

30 Leaves linear lanc. Spikes open, Fasc. of flowers subtern. Seg. of cleft lip obl. the other 5 segs. of cor. lin.

31 Leaves obl. lanc. smooth, Spikes loose, Fascic. tern. 3 fld. Inner segs. of the cor. linear-cuneate, Lip bifid

32 Spike many-fl. loose, Fascicles many-fl. distant, Lip obovate bifid, Filament colored longer than corolla

33 Leaves lanceolate, Spike loose ovate, Petals linear, Lip ovate 2.lob. Fil. the same length as petals

34 Spathes truncate 1-fi. Outer segments of cor. linear, Lip roundish 2-lobed longer than the style

35 Leaves lanceolate, Spike terml. open, Flowers sol. scattered, Lip bifid sessile : stigm. $\frac{2}{2}$-lancenl. Pet. linear 36 Leaves broad, Spike terml. imbricate, Bract. 4-fl. Cor. with linear segm. Lip. obcordate retuse

37 Upper leaves wavy silky beneath, Spike loose conical, Filament much longer than corolla

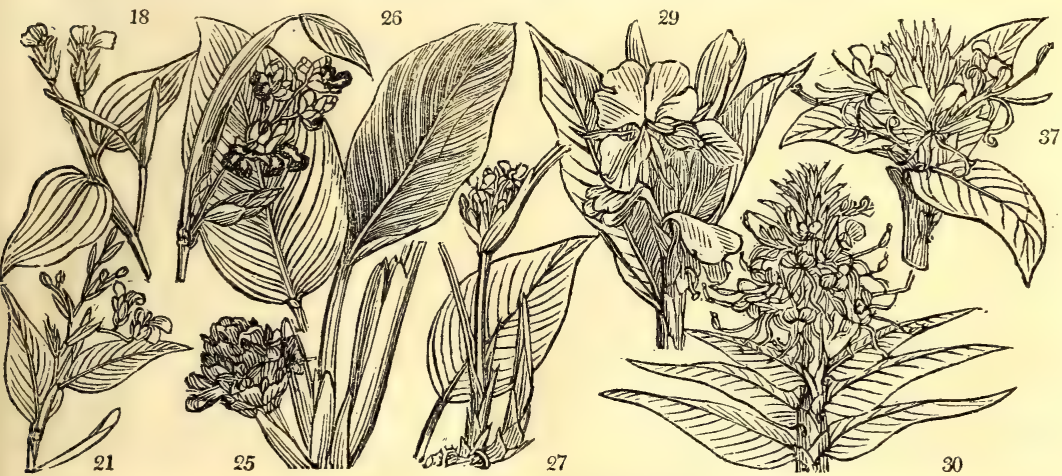

and Miscellaneous Particulars.

washed, pounded, and blanched, it makes a fine powder and starch, and may be used as food, resembling in many respects the salep. A light loamy soil suits all the species, which, though tender, are readily propagated by dividing the root.

3. Calathea. So named by Meyer, probably from the cup-like stigma of the genus. It is much admired on account of its singularly striped foliage, to which the specific name alludes, and its ovate spike of purple flow. ers, about the size of a large pine-cone.

4. Thalia. In memory of John Thalius, a German physician, at Nordhuys, author of Plantæ Hercynæ, 1588 An aquatic, and if planted two or three feet under water, will survive our winters, in the open air. It flowers beautifully.

5. Phrynium. \$evves, a plant which grows in marshes, the habitation of frogs, from 申evyos, a frog. The leaves are used in Malabar and China, for wrapping up cakes in the oven; before expansion they infuse them in spirit of rice or sugar diluted with three times its quantity of water, to make vinegar. Loureiro.

6. Hedychium. From a Greek word signifying sweet, from the grateful odour it emits. This beautiful gerius requires a light rich soil, and large pots to nake the plants flower freely. $\mathrm{H}$. angustifolium deserves a place in every collection. 
7. ROSCO'EA. Sm. 38 purpárea $S \mathrm{~m}$.

8. ALPI'NIA. $W$. 39 comósa Jacq. 40 Galánga $W$.

41 racemósa Ros. 42 occidentális $S w$.

43 nútans Ros.

44 cérnua $\boldsymbol{B} . M$.

45 calcaráta Ros.

46 malaccénsis Ros.

47 mútica Roxb.

48 Cardamómum Roxb.

49 spicáta $R o x b$.

50 tubuláta $B \cdot R$

51 Allúghas $W$.

9. HELLE'NIA $R$.

52 cærúlea $B r$

10. ZIN'GIBER. Rosc.

pandurátum Roxb.

55 officinále Ros.

57 Casumúnar Roxb.

58 purpúreum Rosc.

59 róseum Roxb.

11. Cos'tus. Rosc.

61 arábicus $L$.

63 speciósus Rosc

$\beta$ angustifolius.

64 áfer $B . R$.

$\beta$ hirsutus.

65 spiralis Rox.

Alp. spiralis.

66 villosissimus Jacq.

12. K EMPFE'RIA. $W$ 67 rotánda $L$.

69 angustifólia Jacq.

70 panduráta $B$. Reg.

71 latif́́lia Donn.

72 ovalifólia Roxb.

13. AMO'MUM. Rosc.

$\begin{array}{ll}73 \text { Afzélii Ros. } & \text { sweet-scented } \\ 74 \text { grandifúrum } & \mathbb{N} \text { or } \text { or } 3 \\ \text { large-flowered } & \mathrm{J} \text { or }\end{array}$ 76 Grana Paradisi $W$. grain of parad. $\mathrm{J} N$ clt 1 77 dealbátum Roxb. insipid \$ $\mathbb{N}$ or 3

79 subulátum Roxb. subulate $\$$ L or 3

Alpinia.

close-spiked

clt

clustered

occidental

drooping

upright

petiolate

damoms

spiked

ubular

blue

fiddle-lipped

Japanese $\$$ or

narrow-leaved $\$$ clt 2

broad-leaved $N$ or

downy-leaved $\$ \Delta$ or 2

purple-bracted $\frac{1}{\mathrm{~L}} \mathrm{~N}$ or 2

Costus.

Arabia

spiked

de or

hairy

spiral खे $\Delta$ or 4

villous

$\exists \Delta$ or 6

round-rooted $\neq \mathrm{D} \Delta$ or 1

officinal $\$ \Delta$ clt 1

fiddle-shaped $\mathrm{d} \triangle \mathrm{N}$ or

broad-leaved $\$ \Delta$ or 1

oval $\mathbf{x} \Delta$ or 1

A romur.
54 Mióga Ros.

56 Zerúmbet Ros.

60 squarrósum Rox

68 Galánga $L$. 75 angustifúlium Rox. narrow-leaved $\mathcal{D} \mathrm{N}$ or 8

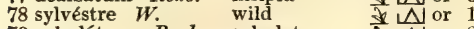

${ }_{1}^{\text {Scitaminea. }} \mathbf{P}$ Sp. ${ }_{\text {Nepal }}^{1-5 .}$

Scitaminea. Sp. $13-19$

rosy $\Delta$ or

Galangale.

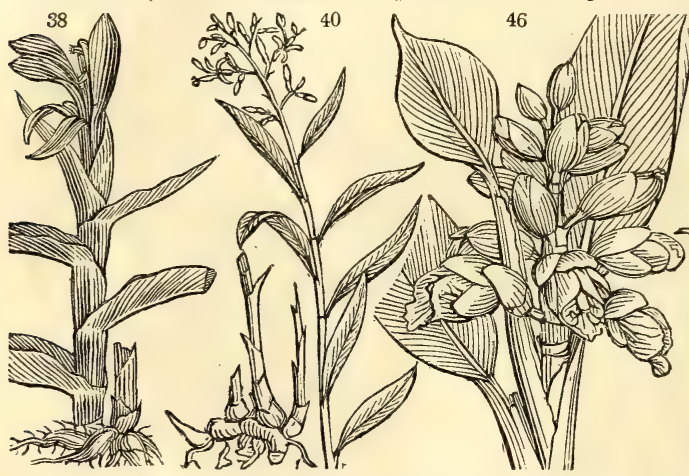

History, Use, Propagation, Culture,

7. Roscoea. Named by Sir J. E. Smith, in honour of W. Roscoe, Esq the accomplished historian of the Medicis, and the first botanist who elucidated the plants of the order Scitaminex. The species are little Medicis, and the first botanist who elucid

8. Alpinia. After Prosper Alpini, an Italian physician and botanist, who practised at Cairo between 1580 and 1584, and died in 1615. Canne de Riviere, Fr. A splendid genus, requiring rich soil, a moist heat, and plenty of room. A. racemosa answers best when treated as an aquatic

9. Hellenia. In honour of C. N. Hellenius, Professor at Abo, who, in 1798, published several academical dissertations. The same culture answers this plant as recommended for Hedychium.

10. Zingiber. From the original Indian appellation. Zingembre, Fr. Ginfer, Ger.; and Zinzer, Ital. Many of the specific names employed in the genus are derived from the vernacular names of the species. The roots of $\mathbf{Z}$. officinale, and zerumbet, much used in the kitchen and in medicine, form a considerable export from our West India Islands. As a medicine, ginger is particularly useful in flatulent colic, debility, and laxity of the system, and in torpid and phlegmatic constitutions, to excite a brisker action of the vessels. The roots of

ger are taken up when the stalks fade, and, being first washed and scalded, are afterwards dried in the sun. This forms black ginger; the white sort is never scalded, but only washed and dried. When the root is to be 
38 Flowers large terminal in the sheaths of the top of the stem, Leaves obl. acute sm.

39 Spike terminal comose, Bracteas colored longer than the flowers, Leaves oblong-ovate pubescent 40 Leaves sessile broad lanc. Panicle terml. Lip obl. unguiculated bifid, Caps. obov. smooth, Seeds few 41 Lip trifid, Leaves ovate-lanc. apex revolute, Caps. striated

42 Lip emarginate, Leaves lanceolate ovate very smooth [and bifid, Caps. sphær. open. on sides, Seeds few 43 Leaves lanc. short stkd. small, Rac. comp. droop. Lip broad 3-lob. lateral incurv. into a tube : external curled 44. Racemes terminal drooping, Lip bifid, Leaves lanc. acumin. Margins rough with little spinous teeth 45 Leaves linear-lanc. polished, Spike compound erect, Lip ovate-obl. apex curled and bifid

46 Racemes spiked, Lip round und. 2-lob. Caps. vill. Leaves obl. villous beneath

47 Racemes compound, Lip 3-lob. no spur, Caps. berried, Leaves narrow shining

48 Scape radical compound flexuose procumbent, Lip 3-lob. calcarate

49 Spike terminal oblong compactly imbricated with narrow sharp bractes

50 Leaves bifar, very remote scape sheathed radical, Bracts dry pointed perm. Cor. tub. Lip included, Anth. sess.

51 Nectary 2-leaved, Capsules spongy, Leaves smooth entire

52 Lip emarg. Leaves and colored capsules smooth, Style hairy

53 Spikes radical, Leaves stalked broad smooth, Ligula large, Lip fiddle-shaped

54 Segments of the corolla concave acute equal, Lip ovate concave

55 Leaves sub-sessile linear-lanceolate smooth, Spikes elevated oblong, Bracteas acute, Lip 3-lobed

56 Stems decl. Leaves bifar. sess. lanc. Spike long-ped. oval close obt. Bract. broad obov. obt. margs. col. Lip 3-lob.

57 Stem erect, Leaves narr. sess. Spikes compact cone-shaped, Bracteas ovate-pointed, Lip 3-lobed

58 Spikes lat. Bracteas ovate col. Segm. of cor. erect, Nect. 2-lob.

59 Spikes lat. Leaves short-stalked lanc. Spikes lax $\frac{1}{2}$ in the earth, Lip entire

60 Spikes lat. squarr. $\frac{1}{2}$ in the earth, Bract. narrow recurv. Lip 3-lobed

61 Nect. ovate entire, Leaves smooth on both sides

62 Nect. wavy sub-3-fid. Leaves pointed entire shining, Spike close

63 Nect. obsol. 3-lob. fringed wavy, Leaves silky beneath

64 Cal, short with 3 grnish. blunt teeth, Fil. sm. at back, Leaves lanc. hairy or sm. Spike turb. close, Br. obt. herb.

65 Nect. concave entire, Leaves long-ellipt. thick shining

66 Leaves rounded and stem very hairy, Flowers crisp

67 Dorsal segments of nectary lanc. acute : frontal 2 part. Segments obovate, Leaves oblong colored beneath 68 Dorsal segments of nect. obtuse obsoletely s lobed : frontal 2-lobed wavy, Leaves ovate pale beneath 69 Dorsal segments of nect. linear obtuse : frontal emarg. Leaves lanc. pale beneath

70 Leaves stalked broad lanc. smooth, Spike cen ral, Cor. with inferior segment very large and panduriform 71 Leaves orbiculate ovate wavy woolly beneath

72 Leaves oval, Spike central, Anther crest jagged

73 Scape very short, Flowers heaped, Leaves distant ovate acum, entire smooth

74. Scape short, Flowers numerous close, Sterile stem simple, Leaves ellipt. lanc. pointed

75 Scape naked very short, Spike capitate, Leaves linear lanceolate

76 Scape branching lax, Leaves ovate

77 Leaves broad villous beneath, Spikes radical, Lip round oval, Crest broad truncated, Caps. 9 winged 78 Scape naked, Spike elong. Bract. inflated, Leaves broad lanceol.

79 Leaves lanceol. smooth, Spikes obovate echinated, Lip oblong

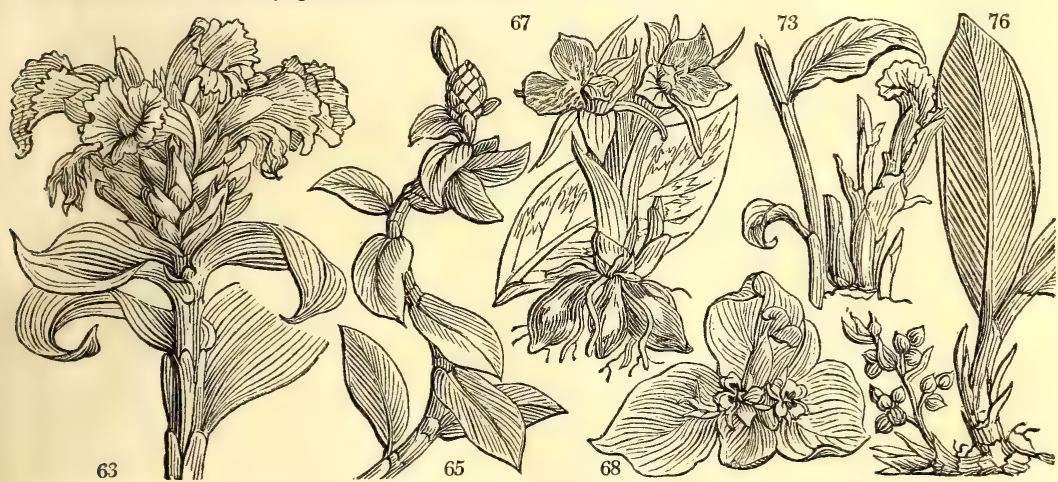

and Miscellaneous Particulars.

preserved in syrup, it is taken up and scalded before fully grown. After steeping and washing in water, it is put in jars, and covered with a thin syrup. (Browne's Jamaica.) Z. zerumbet is used in the East in cataplasms and fomentations, but not as internal medicine.

11. Costus. From its name in Arabic, gosth. Jacquin has shewn that the costus of the moderns is not the same as the plant so called by the ancients. Costwurtz, Ger., and costo, Ital. All the species grow in woods in their native countries, and their roots partake somewhat of the qualities of ginger.

12. Kempferia. In honor of Engelbert Kæmpfer, the Japanese traveller; born in Lemgow in Westphalia in 1651; died in 1716. Zedoaire, Fr. and Grosse Galgant, Ger. This is a curious genus of low stemless plants, 1651 ; died in 1716 . Zedoaire, Fr. and Grosse Galgant, Ger. This is a curious genus of low stemless plants,
with tuberous roots, a pleasant aromatic smell, and sharpish taste. The root is purple without and white within, and is esteemed a stomachic and cephalic. When the plants are not in a growing state, they require little or no water ; otherwise like bulbs which are kept always moist, they will not flower freely.

13. Amomum From $\alpha$, privative, and $\mu \omega \mu \circ$, impurity, it has always been esteemed a powerful counter poison; or perhaps a corruption of phamâmâ, the Arabic appellation of the plant. L'amome des pedes, $\mathrm{Fr}$. poison; or perhaps a corruption of phamama, the Arabic appellation of the plant. Zingiber. 
14. CURCU'MA, $W$. 80 Zedoária Ros.

81 Zerúmbet Roxb. 82 æruginúsa $R o x b$. 83 rubéscens Roxb. 84 cæsia Roxb. 85 comúsa Roxb. 86 eláta Roxb. 87 ferruginea $R o x b$. 88 leucorhiza Roxb. 89 xanthorhiza Roxb. 90 rubricaúlis $L k$. 91 angustifólia Roxb. 92 viridiflora Roxb. 93 petioláta Roxb. 94 Amáda Roxb. 95 lónga Ros.

15. GLOB'BA. Ros. 96 marantína Ros. 97 sessiliflora $B . M$. 98 Careyána Roxb.

16. MANTI'SIA. Sims.

99 saltatíria $B . M$.

17. PHIL girls $\neq \square$ or

18. LOPE'ZIA. Cav:

101 hirsita $H . K$.

102 racemósa $H . K$

103 coronáta $H . K$

104 cordáta Horn.

19. BOERHA A'VIA.

105 erécta $W$

106 diffúsa $W$.

107 hirsúta $W$.

108 scan'dens $W$

109 viscŕsa Lag.

20. CENTRAN'THUS.

110 rúber $D$. $C$.

111 angustifílius $D . C$.

112 calcitrapa Dufr. cut-leaved

21. POLlíchia. $W$. Pollichis

113 campéstris $W$. short-leaved

22. SALICOR'NiA. $W$. Glasswort

114 aŕbica $W$.

115 fruticósa $W$.

116 radicans $\boldsymbol{E}$. $\boldsymbol{B}$.

117 herbácea $W$.

Arabian

rooting

marsh

118 procúmbens $E . B$. procumbent

23. HIPPU'RIS, $W$. Marestail. 119 vulgáris $W$.

common

Scitaminè̀. Sp. $16-18$.

ap.au $\mathbf{R}$ E. Indies 1797. $\mathbf{R}$ r.m Bot. mag. 1546

ap.au Y

F Indies $1807 . \mathrm{R}$ r.m Bot. mag. 2000

ap.au R.Y E. Indies 1807. R r.m

my.s $\mathbf{Y}$ E. Indies 1805. $\mathbf{R}$ r.m

ap.jn $\mathbf{Y}_{\mathbf{Y}}$ Bengal 1819. R s.l

my R.Y E. Indies 1819. R s.l

my $\mathrm{Cr} \quad \mathrm{E}$. Indies 1819. R $\mathrm{s.1}$

my $\quad \mathrm{X} \quad \mathrm{E}$. Indies 1819. $\mathrm{R}$ s.l

my R y E Indies 1819 R s.

my R.

my $\mathbf{R}$ Amboyna 1819. $\mathbf{R}$ s.

my $\mathbf{R} \quad \mathbf{E}$. Indies 1822. $\mathbf{R}$ s.

jl $\quad \mathbf{Y} \quad$ E. Indies 1822. R s.l

jl.au Y.G Sumatra 1822. R 8.1

au $\mathbf{Y}$ Pegu 1822. R s.

ap.jn R.x Bengal 1819. $R$

au E. Indies 1759. R s.l Jac. vind 3. t.4 Scitaminea. Sp. 3-11.

jl.au $\mathbf{Y}$ E. Indies 1800. R s.l Ex. bot.2. t. 108

$\begin{array}{lllll}\text { au } & \mathbf{Y} & \text { Pegu 1807. R s.l Bot. mag. } 1428\end{array}$

1822, R s.l Bot. cab. 691 Scitaminea. $S p .1$.

jn $P$ E. Indies 1808. R s.1 Bot. mag. 1320

Related to Juncea, R. B. Sp. 1-2.

jn.jl $\mathrm{Y}$ China 1801. C 1.p Bot.mag. 783

Onagraria. $S p .4-5$

光 $\Delta$ clt 1 my.jn Ap Britain dit. $R$ co Eng. bot. 763

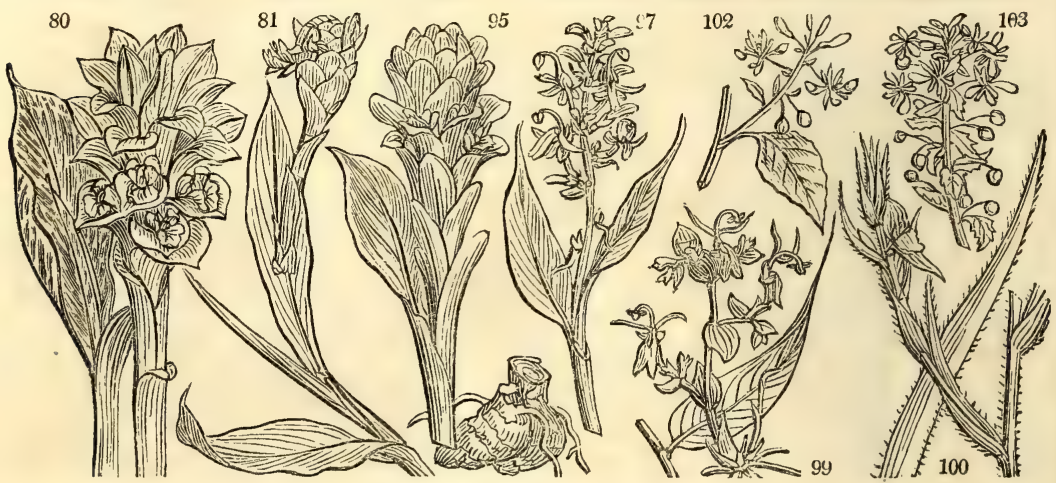

History, Use, Propagation, Culture,

14. Curcuma. From the Arabic kurkum or hercum. Babilonischer safran, Ger. C. longa was formerly much used in cookery to give things a color, and is still so used in the East Indies, for dyeing. The root was reputed aperient and resolvent, and was given in jaundice: it tinges the urine of a deep yellow. The roots of C. zerumbet powdered and mixed with the powdered wood of Casalpinia Sappan is copiously thrown about by the Hindoos during their holidays in March. The tubers of many species yield a very beautiful pure starch like arrowroot, which in some places, especially Travancore, forms a large part of the diet of the inhabitants.

15. Globba. Its Indian name, and that also by which it is known in the Moluccas. Globée, Fr. Most of the species produce spikes of smoky-colored berries about the size of grapes, and which are sometimes eaten.

16. Mantisia. The flowers bear a singular resemblance to some of the insects called mantis. The name of the species is derived from a fanciful notion that the flowers are like a dancing figure attached to a wire.

17. Philydrum. $\Phi$ i $\lambda$ os and vंwe, a lover of water, in allusion to the places in which it grows. A pretty biennial plant, requiring but little protection from frost.

18. Lopexia. Dedicated by Cavanilles to the memory of the licentiate Thomas Lopez, a Spanish botanist, who is said to have directed his attention to the natural history of the New World. The species are chiefly elegant annuals, and well deserving of cultivation.

19. Boerhaavia. So named in honor of the famous Boerhaave of Leyden, born at Voorhoot in 1668 , and died 
80 Spikes lateral, Bulbs small with long palm. tub. yell. Inside, Leaves broad sessile silky beneath all green 81 Spikes lat. Tub. palm. pale straw-col. Leaves gr. stalk. brd. with a pur. cloud down the mid. Fl. short. than brac 82 Spikes lateral, Roots æruginous within, Leaves stalked with a faint rusty cloud beyond their middle above 83 Spikes lat. Roots pearl col. inside, Leaves broad on winged red stalks above the sheaths : rib and scape red 84 Spikes lateral, Roots green inside palmate, Leaves narr. with a rusty cloud in middle

85 Spikes lateral clavate comose, Roots ovate pale yell. inside, Leaves all green

86 Spikes lateral, Tubers large incurved pale yellow, Leaves sessile villous beneath all green

87 Spikes lat. Roots palm. scented pale yell. inside palmd. Leaves and sheath rusty with a pale red spot in mid. 88 Spikes lat. few-flowered comose, Tubers long spreading pale inside, Leaves smooth pure green

89 Spikes lat. Tubers all yellow, Leaves sessile green broad with a purple cloud down the middle

90 Spikes lat. Leaves stalked oblong with red sheaths

91 Spikes lat. Root with pale pendulous tubers, Leaves stalked narrow, Flowers longer than bractes 92 Spikes central, Tubers palmate deep yellow, Leaves long stalked broad-lanceolate, Plant all green 93 Spikes central, Leaves on long stalks cordate, Coma lilac

94 Spikes central few-flowered, Tubers palmate pale yellow inside, Leaves broad smooth on long stalks

95 Spikes central, Roots deep orange inside, Leaves long stalked broad green

96 Leaves lanceolate, Spike terminal sub-sessile cone-shaped bulbiferous, Anther 4-horned

97 Spike whorled, Lateral segments of cor. longest, Appendage cordate, Bractes lanc. withering, Bulbiferous 98 Leaves ovate lanc. villous beneath, Racemes compound term. bulbif. Anther naked roundish

99 The only species

\section{Flowers bright yellow, Leaves hairy}

\section{Leaves ovate villous, Stem round}

102 Leaves ovate attenuate at base, with the 4-cornered stem smooth

103 Leaves shining, Stems angular, from the decurrent stalks, Corymbs leafy at the base

104 Leaves roundish cordate ciliated smooth, Branches angular

105 Stem 4-cornered smooth, Joints clammy, Flowers panicled, Leaves angular dotted with black beneath 106 Stem round pubescent, Flowers in capitate corymbs

107 Stem roundish hairy, Leaves ovate acute sub-repand, Flowers in heads diandrous

108 Stem climbing, Leaves all cordate, Flowers in umbels diandrous

109 Villous viscid, Leaves ovate acute sub-repand, Stem procumbent, Flowers in heads triandrous

110 Leaves entire lanceolate, Stem $\frac{x}{2}$-shrubby at base, Flowers corymbose, Stamens nearly twice as long as cor. 111 Leaves linear, Stem herbaceous, Flowers corymbose, Stamens nearly thrice as long as corolla

112 Rad. leaves ovate cauline pinnatifid, Stem upright smooth, Flowers panicled

113 Stems branching declining, Flowers minute sessile in axillary heads

114. Leaves alternate sheathing obtuse gaping on one side

115 Stem erect shrubby, Joints of the young branches 2-sided, Scales of flowers truncate membranous

116 Stem shrubby procumb. rooting, Joints compressed emarg. cylindr. Spikes obl, Style deeply divided, Stam. 2

117 Herbaceous spreading, Joints emarginate compressed at end, Spikes axillary opp. stalked, Scales blunt

118 Herbaceous procumbent, Joints obconic, Branches simp. Spikes fastigiate, Stamens 2

119 Leaves whorled 10-12 linear acute

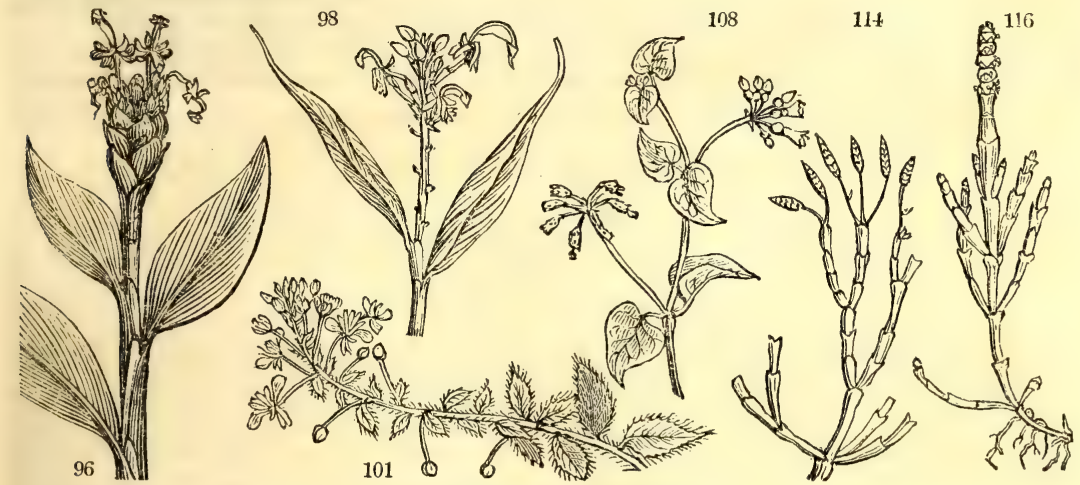

and Miscellaneous Particulars.

in 1758. La Tassole, Fr. He was the first friend and protector of Linnæus. All the plants of this genus are possessed of little beauty.

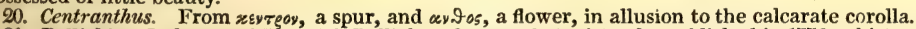

21. Pollichia. In honor of Jean Ad. Pollich, a German botanist, who published in 1776, a history of the plants of the Palatinate. The only species is an obscure herbaceous plant.

22. Salicornia. From sal, salt, and cornu, a horn; saltwort, marsh samphire. Le Christemarine, Fr. Glass schmaltz, Ger., and Erba-cali, Ital. S. herbacea is gathered when in flower, and pickled in salt and vinegar like samphire, for culinary purposes. The whole plant has a saltish taste, and is greedily devoured by cattle. All the species, excepting the S. arabica, abound on the shores of the Mediterranean, and are there burnt for soda, which is much used in the manufactures of soap and glass, especially at Marseilles.

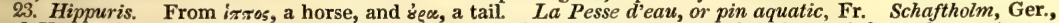
and Hippuride, Ital. The flower of this plant is one of the simplest among perfect plants; it has only one stamen and one pistil, unprotected by either calyx or corolla, and it produces only one seed. The situation of the leaves in whorls is not usual in European plants, excepting in the stellatæ of Linnæus. The flowers in the beginning of summer are mostly hermaphrodite, but in autumn many of them are female. By absorbing a great quantity of inflammable air, this plant is reputed to assist in purifying the putrid air of marshes. It is eaten by wild ducks. 
24. ZOSTE'Ra. $L$. Sea Wrackgrass.

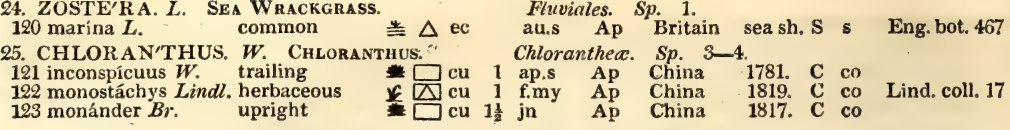

\section{DIGYNIA.}

26. CORISPER'MUM. $W$. TICKSEED.

124 hyssópifólium $W$. hyssop-leaved

125 squarrósum $W$. rough-spiked

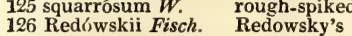

127 intermédium $S c h w$. intermediate

27. CALLIT'RICHE, $W$. WATER STARWORT.

128 aquática $E . B$. common 当 $\bigcirc$

28. BLI'TUM. $\boldsymbol{W}$. STrawberky BltTe. $\begin{array}{ll}129 \text { capitátum } W \text {. } & \text { berry-headed } \\ 130 \text { virgátum } W \text {. } & \text { slender }\end{array}$

130 virgátum $W$.

131 chenopodioídes Lam. goosefoot

29. ASPICAR'PA. Rich. Aspicarpa.

132 úrens Rich.

O
O
Ont.
O or
O or

Chenopodece. 4-9.

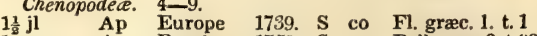

1 au.s Ap Russia 1759. S co Pall, ross.2.t.99

$\frac{x}{2}$ jl.au Ap Siberia 1822. S co

$\frac{3}{3}$ jl.au Ap Poland 1822. S co

Haloragea. Sp. 1.

$\frac{3}{4}$ ap.o W Britain dit. S aq Eng. bot. 722

Chenopodea. Sp.3.

2 my.au Ap Austria 1633. S ru Pt.etT.fi.p.1.t.2

2 my.s Ap S. Europe 1680. S ru Bot. mag. 276

$2 \frac{1}{2}$ my.au Ap Crimea 1797. S co M.h.1.t.32.f.11

Malpighiacea. Sp.1.

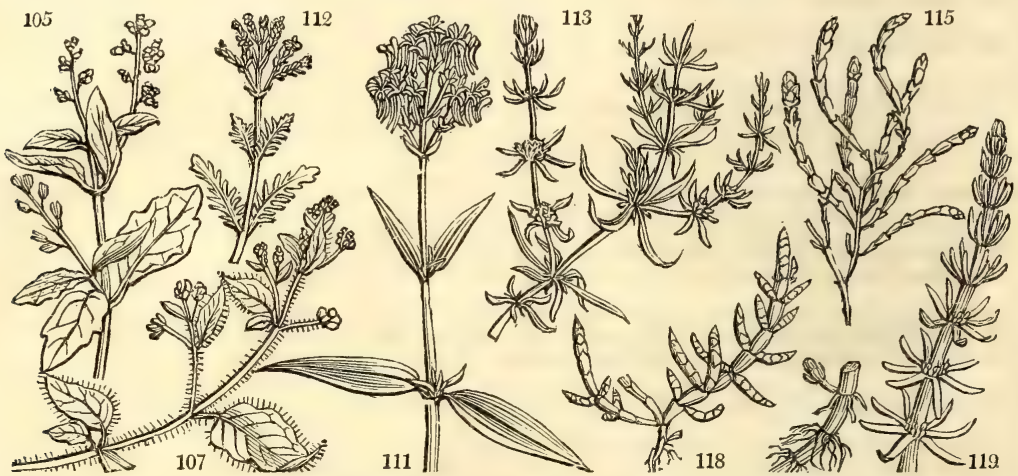

History, Use, Propagation, Culture,

24. Zostera. From ¿ $\omega \sigma \tau \eta \rho$, a riband; the leaves of $Z$. oceanica are a foot long and an inch broad, resembling a riband. La Zostére, Fr., and Seetang, Ger. This plant abounds on the coast of Yarmouth, where it is thrown on shore in such abundance that mounds are made with it to enclose the encroachments of the sea. It is alo us as thatch, and said to endure for upwards of a century; by exposure it bleaches white. In Sweden and Holland it is used as a manure, and is preferred to hay for stuffing beds. Horses and swine eat it, Sweden and Holland it is used as a manure, and is preferred to hay for stuffing beds. Horses and swine
but cows are not fond of it. The rush-like envelopes of Italian liquor-flasks are prepared from this plant.

25 . Chloranthus. So named from $\chi \lambda \omega \rho \circ s$, green, and $\chi^{\lambda} \theta_{0 s}$, a fower, on account of the greenish hue of its inconspicuous inflorescence. The structure of the flower is very curious, and so anomalous, as to render it difficult to tell to what class of Linnæus it is referable. For further remarks upon this subject, see Mr. Lindley's Collectanea Botanica, p. 17.

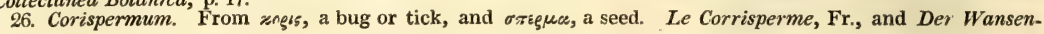

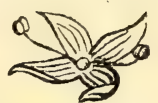

\section{Class II. - DiAndria. 2 Stamens.}

THis class, which is not large, and so entirely artificial that no other characters than those of the Linnæan definition can be assigned to it, contains some elegant and fragrant plants belonging to Jasmineæ, Scrophularinex, and Labiatæ: examples of the two latter orders are Veronica and Salvia, extensive genera chiefly of hardy herbaceous plants. The most useful of the class are the pepper and the olive: the jasmine is used in perfumery; the sage and rosemary in cookery; and the privet and syringa for garden hedges. One or two species are employed in medicine; several are border flowers; but the greater number of the class are plants of curiosity.

Codarium is a leguminous plant, and is widely removed from its natural place, which is Diadelphia; so are Salvia, Monarda, Rosmarinus, Veronica, and many others, which would have been naturally referred to Didy-

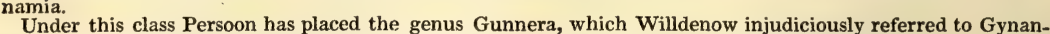
aria. A great variety of diandrous plants are scattered through the other classes of Linnæus; but as such plants are chiefly, with the exception, perhaps, of grasses, diandrous, on account of the incomplete formation of some of their stamens, the rudiments of which are usually obvious, it is scarcely necessary to particularise more

than the following, viz. :- Viola diandra; Salicornia herbacea, virginica; Anychia dichotoma ; several species of
D. MONOGYNIA. Boerhaavia. D. DIGYNIA. Polycnemum salsum; Bufonia tenuifolia. D. TRIGYNIA. Holosteum diandrum.

Order 1. MONOGYNIA.

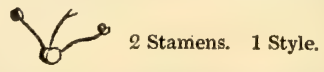

\$1. Flowers complete, inferior, monopetalous, regular.

30. Codarium. Cal. 5-cut, with a persistent tube. Cor. flattish. Legumen one-seeded, filled with a soft fxcula. 31. Maytenus. Cal. 5 lobed. Cor. campanulate, entire. Caps. compressed, 2-valved, with 2 cells, and 2 seeds. 
120 Leaves entire somewhat 3-nerved, Stems nearly round

121 Spikes compound, Stem decumbent

122 Spike simple solitary, Stem upright

123 Spikes 2-4 simple, Stem uplight, Leaves thick

\section{$D I G Y N I A$.}

124. Spikes terminal, Flowers distant, Leaves nerveless and bractes unarmed

125 Spikes axillary, Flowers close imbricat. Leaves nerveless and bractes mucronate pungent

126 Spikes terminal, Flowers becoming remote, Leaves nerveless and bractes pungent, Fruit incurved

127 Spikes terminal and axillary, Flowers imbricate, Leaves and bractes mucronate, Stem villous

128 A small floating-plant resembling Lemna

129 Heads in terminal spikes

130 Heads lateral scattered

131 Heads axillary small not juicy, Stem very branching

132 A stinging twining perennial plant
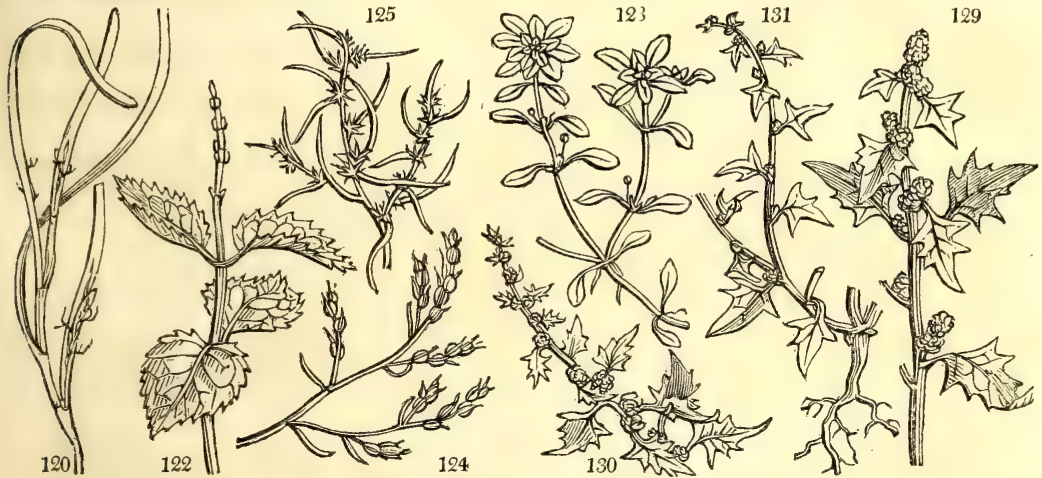

and Miscellaneous Particulars.

same, Ger. The species abound in the south of Russia in marshy steppes with Salsola and Atriplex. Round the Caspian sea they grow six feet high, are red in winter, and eaten by camels.

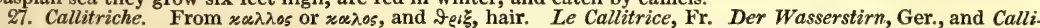
trica, Ital. A little aquatic plant, liable to variation in its appearance; on which account some botanists have divided it into several species.

28. Blitum. From $\beta$ k stov, insipid, or, according to Dr. Theis, from the Celtic blith, which has the same inport. Le Blete, Fr. Die Beermelde, Ger., and Blito, Ital. After the flowers are past, the heads swell to the size of wood-strawberries, and when ripe have the same color and appearance. They are succulent, stain the hands, and were formerly used by cooks for coloring puddings. Some consider the B. virgatum as only a variety of the other.

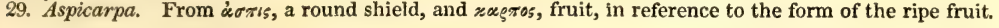

32. Olea. Cor. 4-cleft. Segments subovate. Drupe one-seeded.

33. Phillyrea. Cor. 4-cleft. Berry one-seeded.

34. Chionanthus. Cor. 4-cleft. Segments very long. Drupe one-seeded, with a furrowed nut.

35. Notelaea. Cal. 4-toothed. Cor. 4 short oval petals united by the base of the stamens. Filaments 4-horned. Style O. Stigma bifid. Drupe with a papery putamen.

36. Ligustrum. Cor. 4-cleft. Berry 4-seeded.

37. Syringa. Cor. 4-cleft. Capsule of two cells.

38. Nyctanthes. Cor. 4-cleft. Segments truncated. Caps. with two cells edged. Seeds solitary.

39. Jasminum. Cor. 5 or 8-cleft. Berry with two divisions. Seeds solitary with an arillus.

\section{Flowers complete, inferior, monopetalous, irregular.}

40. Veronica. Cor. 4-cleft: limb flattish; the lowest segment the narrowest. Capsule 2-celled.

41. Galipea. Cor 4 or 5-cleft, hypocrateriform. Stam. 4: 2-sterile.

42. Schwenkia. Cor. nearly equal: the orifice plaited, stellate, and glandular. Stam. 5:3-sterile. Capsule 2-celled.

43. Gratiola. Cor. 4-cleft, 2-lipped, resupinate. Stamens 4: 2-sterile. Caps. 2-celled.

44. Schizanthus. Cal. 5-parted. Cor. 2-lipped resupinate : the upper lip 5-parted, the lower 3-parted.

Stam. 4, 2-sterile. Caps. 2-valved, 2-celled.

45. Elytraria. Cal. 4-5-parted. Cor. 5-cleft, nearly equal. Caps. 2-valved, 2-celled. Seeds attached below to a dissepiment contrary to the valves.

46. Hypoestes. Cal. 5-cleft equal, with a 4-cleft 3-flowered involucrum. Cor. 2-lipped. Stamens 2. Anthers 1-celled. Seeds fixed by little hooks.

47. Justicia. Cal. 5-parted equal. Cor. 2-lipped or ringent: the lower lip divided. Anthers 2-celled. Seeds attached by little hooks.

48. Dicliptera. Cal, 5-parted. Cor, bilabiate. Caps. with two elastic valves, $\frac{1}{2}$ 2-celled, the dissepiment retaining the seeds by its inflexed toothed edge

49. Eranthemum. Cal. 5-parted. Cor. 5-cleft, with the tube curved in the middle. Caps. many seeded.

50. Wulfenia. Cor. 4-cleft: smooth bearded. Cal. 5-parted. Caps. 2-celled.

51. Calceolaria. Cor. ringent, inflated. Cal. 4-cleft. Caps. 2-celled, 4-valved.

52. Pinguicula. Cor, ringent, spurred. Cal. 5-cleft. Caps. 1-celled.

53. Utricularia. Cor. ringent, spurred. Cal, 2-leaved. Caps. 1-celled. 
54. Stachytarpheta. Cal. tubular, 4-toothed. Cor. hypocrateriform, unequal, 5-cleft, curved. Stam. 4: 2 sterile. Seeds two.

55. Lycopus. Cor. 4-cleft, nearly equal, with one segment emarginate. Stamens distant. Seeds naked.

56. Amethystea. Cor. 5-cleft, nearly equal, with the lowest segment concave. Stamens near each other. Seeds naked.

57. Ziziphora. Cal. cylindrical with ten lines, somewhat 2-lipped, 5-toothed, closed with hairs. Cor. 2-lipped. Seeds 4 naked.

58. Cunila. Cal. oblong, 5-toothed, closed with hairs. Cor. 2-lipped. Seeds 4 naked.

59. Hedeoma. Cal. 2-lipped, gibbous at the base. Cor. ringent. Stamens 4: 2 sterile.

60. Monarda. Cor. ringent: helmet linear, wrapping up the anthers. Seeds naked.

61. Rosmarinus. Cor. ringent. Helmet arched, bifid. Stamens curved, with a tooth. Seeds naked.

62. Salvia. Cor. ringent. Filaments stalked cross-wise. Seeds naked.

63. Collinsonia. Cor. somewhat ringent: the lip very finely divided. Seeds naked.

64. Catalpa. Cor. 5-cleft, irregular. Cal. 2-parted. Stam. 3 sterile. Caps. 2-celled. Seeds at each end with a membranous pappus.

65. Ghinia. Cor. ringent. Cal. with 5 bristles. Fruit, a fleshy 4-celled nut.

\section{\$9. Flowers complete, inferior, polypetalous.}

66. Fontanesia. Cor. with 2 petals. Cal. 4-parted. Caps. 2-celled, not opening.

67. Linociera. Cor. with 4 petals. Cal. 4-toothed. Berry with 2 cells

68. Ancistrum. Cal. 1-leaved, armed with barbed spines. Cor. 4 petals inserted into edge of calyx. Stam.

24-5. Stigm. finely divided. Seed one, inclosed in the calyx.

\section{MONOGYNIA.}

30. CODA'RIUM. Vahl. Wild Tamarind. Leguminosa. Sp. 1-2.

133 acutifolium Afz. shining-leaved $\Phi \square$ or 20 G S. Leone 1800. C 1.p Rœ.arc.1.31.t.6 31. MAYTE'NUS. Mol. MaYTENUS. Celastrina. Sp. 1.

134 boária Mol.

32. O'LEA. $W$. OLrve. Oleina. Sp. 8-12.

135 oleáster Hoffm.

136 europæa $W$.

$\beta$ longifólia

$\gamma$ latifólia

Serruginea

$\varepsilon$ obliqua

ל̧ buxifólia

137 capénsis $W$. en.

138 unduláta $W$. .en.

139 verrucósa $W$.

140 americána $W$

141 excélsa $W$.

142 frágrans $W$.

bastard

European olive

long-leaved

broad-leaved $\frac{9}{4} \mathrm{fr}^{15}$ jn.au W

iron-colored

twisted-leaved $\square$ fr 15 jn.au W

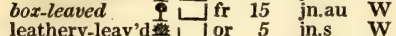

wave-leaved 5 or 6 ap.my W

warted $\quad$ J or 6 ap.my W

American

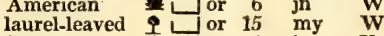

jn.au Y

Portugal 1821. C co

S. Europe 1570. C r.m Flora Græca t. 3

S. Europe ... C $\quad$ C r.m

S. Europe $\ldots$ C.. $\quad$ C r.m

S. Europe $\ldots$ C $\quad$ r.m

S. Europe $\ldots$ C... $\quad$ C $\mathbf{r}_{\mathbf{r}} \mathrm{m}$

S. Europe $\because .$. C r.m

C. B. S. 1730. C p.l Bot. reg. 613

C. B. S. 1730. C p.l Bot. cab. 379

C. B. S. 1814. C p.l

N. Amer. 1758. S s.p Cat. car. 1. t. 61

Madeira 1784. S p.1

China 1771. L p.l Bot. mag. 1552

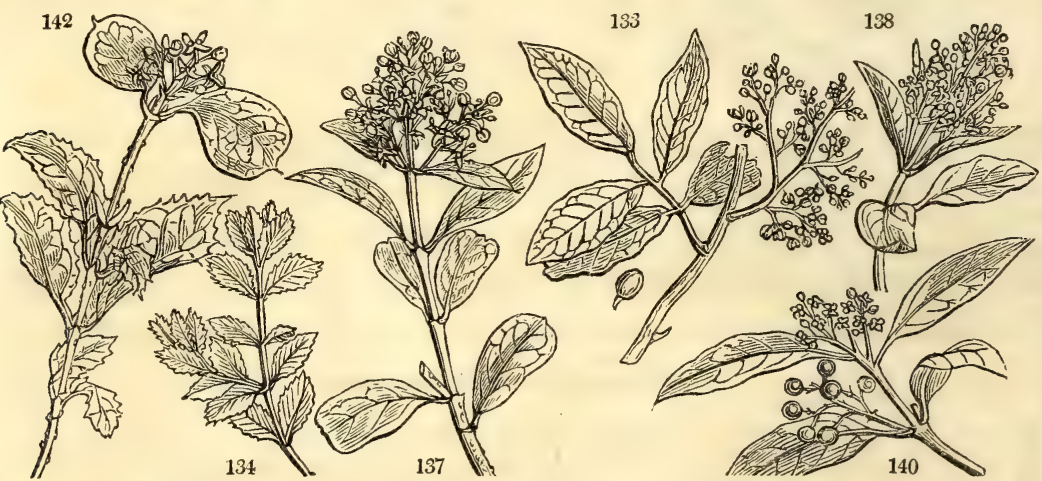

History, Use, Propagation, Culture,

30. Codarium. So named by Dr. Afzelius, from wwiaeroy, a leathern pouch, in allusion to the pods of the tree. These are filled with an abundant pithy fæcula, which is eaten by the inhabitants of the coast of Guinea, where the fruit is called wild tamarinds.

31. Maytenus. The barbarous name of the shrub, and applied as a generic name by Molina. It has the habit of a Rhamnus, and will probably form an hardy inhabitant of our gardens.

32. Olea. From $\varepsilon \lambda \alpha c \infty$, the Greek name for the plant; a word derived in its turn, as De Théis conjectures, from the Celtic olew, oil. Olea is commonly put for the tree; oliva, for the fruit; and oleum, for the juice of the fruit. L'olivier, Fr. Oelbaum, Ger., and Ulivo, Ital. The cultivated olive came originally from Asia, and grows abundantly about Alepno and Lebanon; it is naturalised in different parts of the south of France, Spain, and Italy, and found in hedges and woods; but the fruit of that kind is small and of no use. O. e. var. longifolia, is the variety chiefly cultivated in the south of France and in Italy. O. e. var. latifolia, is chiefly cultivated in Spain; its fruit is near twice the size of the common olive of Provence or Italy, but the oil is so rank of flavor Spain; is too strong for most English palates. The oil and fruit, in a pickled state, are sent chiefly from Languedoc, Leghorn, and Naples to England; the best oil is from Leghorn, and the best pickles from Genoa and Marseilles. The tree seldom exceeds thirty feet in height, is branchy, glaucous, evergreen; and of so great longevity, that some plantations in Italy, as at Terni, are supposed to have existed from the time of Pliny. The tree delights in schistous, calcareous steeps, and does not thrive in elevated situations, or at a distance from the sea. The best oil is produced from fruit grown in calcareous soils. Olive oil may be said to form the cream and butter of Spain and Italy; and the tree has been celebrated in all ages as the bounteous gift of heaven, and as the emblem of peace and plenty.

Olive oil is made by crushing the fruit to a paste, then pressing it through a woollen bag, adding hot water as long as any oil is produced. The oil is afterwards skimmed off the water, and put in tubs, barrels, and bottles for use. The best olive oil is of a bright pale-amber color without smell, and bland to the taste. Kept warm, it becomes rancid, and it freezes at $38^{\circ} \mathrm{Fah}$. It is of the same nature with all mild expressed vegetable oils; of these the most fluid are preferred, and hence the oils of olives and almonds are those chiefly used in medicine. 
6. Ornus. Cal. 4-parted. Cor. of 4 petals. Fruit, a winged Samara of two cells.

10. Flowers complete, superior.

70. Morina. Cal. of the fruit toothed with bristles : of the flower bifid.

71. Circea. Cal. 2leaved. Cor. with two obcordate petals.

79. Fedia. Caps. 3-locular, crowned with the upright (not involute) limb of the calyx. Corolla irregular.

811. Flowers incomplete, with no corolla.

73. Pimelea. Cal, funnel-shaped, with a 4-cleft limb. Stigma capitate.

74. Cladium. Cal. many-valved, 1-flowered: valves glumaceous, imbricated, the exterior smallest. Nut with a double coat.

\section{Order 2. DIGYNIA.}

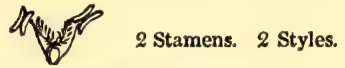

75. Gunnera. Cor. O. Cal. 2-toothed. Seed one, inclosed in a tough coat.

76. Anthoxanthum. Glume membranous, 3-flowered. Lateral florets neuter with one palea bearded; intermediate floret hermaphrodite, much shorter than the lateral ones. Paleæ obtuse, beardless. Seed free.

Order 3. TRIGYNIA.

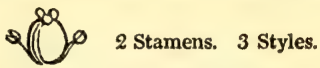
cales.

MONOGYNIA.

133 Leaves unequally pinnate, Leaflets oval acute the inner the smallest

134 Leaves sessile two inches long opposite or alternate oblong smooth serrated

135 Leaves oblong pointed entire : the young ones only hoary beneath, Branches spiny

136 Leaves lanceolate pointed entire hoary beneath, Branches angular not spiny

$\beta$ Leaves linear-lanceolate flat siiky beneath

$\gamma$ Leaves oblong flat hoary beneath

$\delta$ Leaves narrow acute at each end, rusty beneath

Leaves oblong bent obliquely pale beneath

$\zeta$ Leaves oblong ovate, Branches divaricate

137 Leaves oblong, Flowers racemose panicled terminal

138 Leaves elliptical wavy, Stalks of leaves green

139 Leaves lanceolate flat white beneath, Branches warted

140 Leaves elliptic-lanceolate, Bractes all persistent connate ovate, Racemes sub-compound narrow

141 Leaves elliptic acute, Bractes perfoliate: the lower cup-shaped persistent the upper large leafy deciduous

142 Leaves elliptic-lanceolate sub-serrate, Flowers single lateral in bunches

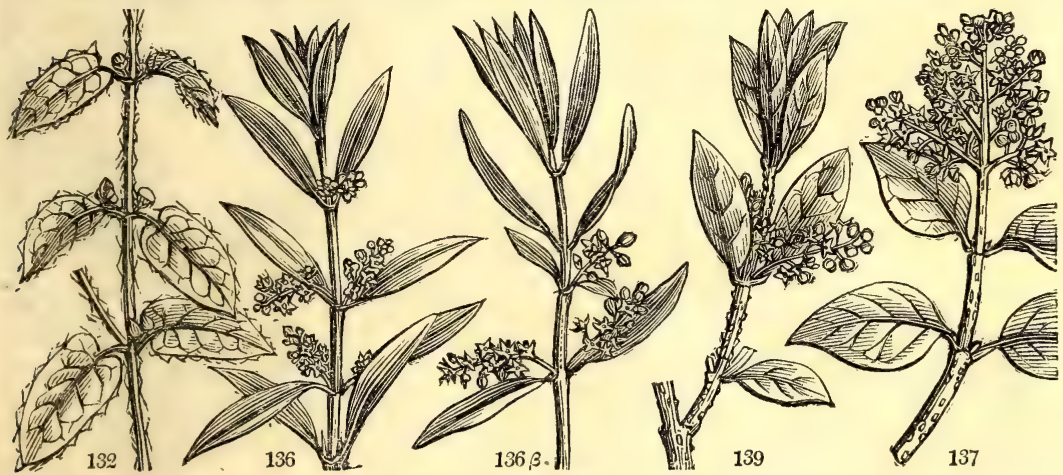

and Miscellaneous Particulars.

nourishment, and medicinally are supposed to correct acrimony, to lubricate, and relax. Olive oil is applied externally to bites and stings of poisonous animals, and to burns alone, with chalk, or in liniments and poultices. The ancients rubbed their bodies with it in dropsies and for various purposes; but it is now little used excepting for coughs and in worm cases.

Pickled olives are prepared from unripe fruit by repeatedly steeping them in water, to which quicklime or any alkaline substance is sometimes added to shorten the operation. Afterwards they are soaked in pure water, and then taken out and bottled in salt and water, with or without an aromatic. They are eaten abroad as a whet before and during the principal meals, and in this country chiefly at the dessert. They are supposed to excite appetite and promote digestion. The finest kind of the prepared fruit is called by the merchants Picholine, after one Picholini, an Italian, who first discovered the art of pickling olives.

The culture of the olive abroad may be said to resemble that of grass orchards in Britain. It is propagated by suckers, large cuttings, or truncheons planted in trenches four feet deep, into which it is still the custom to deposit stones for encouraging moisture about the roots, as described by Virgil. (Georg. ii. 346.) It is also propagated by chips of the stool, in the following manner : An old tree is cut down, and the ceppo, or stock, is cut into pieces of nearly the size and shape of a mushroom, and which, from that circumstance, are called novoli. Care is taken that each novolo shall have a small portion of bark. After being dipped in manure, the novoli are planted thick in a bed and covered with earth to the depth of three inches; they soon throw up shoots, and are transplanted at the end of one year, and in three more are fit to be finally removed to the olive plantation,

The olive in Britain grows readily by cuttings, or may be grafted on the privet. With protection during frost, it may be maintained against a wall in the latitude of London. Some trees so treated, produced a crop in the garden of Camden House, Kensington, in 1719; and in Devonshire, some trees have stood the winter for many years as standards, though without ripening their fruit. Large plants are frequently imported from Genoa, along with orange and pomegranate trees.

O. fragrans is highly odoriferous both in the leaves and blossoms; the plant is much esteemed on that account in China, and the leaves used at once to adulterate and flavor teas. 
33. PHillyre'A. 143 angustifólia $W$. $e$

r brachiáta

144 média $W$. en.

$\beta$ buxifólia

145 virgata $W$. en.

146 péndula $W$. en.

147 oleæfólia $W$. en.

148 lævis $W$. en.

149 ilicifólia $W$. en

150 latifólia $W$. en.

151 obliqua $W$. en.

Phillyrea.

narrow-leaved

rosemary-leav.

brachiate

twiggy

box-leaved

privet-leaved

drooping

olive-leaved

smooth-leaved

holly-leaved

broad-leaved

oblique-leaved

34. CHIONAN'THUS. $W$. Fringe-Tree.

152 virgínica $W$.

153 marítima $P h$.

154 axilláris $B r$.

smooth-leaved

pubescent

axil-flowering 还

35. NOTEL $\mathrm{E}^{\prime}$ A. $\boldsymbol{B}$. $\boldsymbol{P}$. NoteleA.

155 longifólia $B . P$. long-leaved

156 ligustrína Vent.

157 rígida Desf.

36. LIGUS'TRUM. $W$.

158 lúcidum $\boldsymbol{H} . \boldsymbol{K}$

floribúndum

159 vulgáre $W$.

$\beta$ sempervirens

$\gamma$ xanthocárpum

37. SYRIN'GA. $W$.

160 vulgáris $W$.

e violácea

r álba

privet-leaved

rigid

Privet.

wax-tree

flowering

common

evergreen

yellow-berried sh

Lillac.

common

purple

purple
white

Chinese

$\delta$ rothomagénsis Turp. hybrid

162 pérsica $W$.

$\beta$ alba

Persian

white

\% laciniáta

cut-leaved
Oleina. $S p .9$.

or 8 my.jn W

or 8 my.jn W

or 8 my.jn W

or 15 my.jn W

or 15 my.jn W

my.jn W

my.jn W

my.jn W

my.jn W

my.jn W

Oleina. Sp. 3

or 30 my.jl $\mathbf{W}$

or 10 my.jl W

or 7 my.jl W

Oleince. Sp. 3.

3 mr.jn W N.S.W. 1790. C s.p Bot. rep. t. 316

3 jl.au W V. Di. L. 1807. C s.p Vent.choix.25. b

jl.au W V. Di. L. 1821. C s.p

or 8 jn.s ${ }^{\text {W }}$ W China ${ }^{2-4}$ 1794. g.l s.l

or 8 jn.s W China 1794. g.l s.1

or 10 jn.jl W Britain hedg. S co Eng. bot. 764

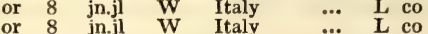

Oleina. $S p .3-4$.

or 8 my B Persia 1597. Sk co Schk, han. 1. t.2

my $\mathbf{P}$ Persia

my W Persia

my.jn V China

mn.jn V China

my P Persia

my W Persia

... Sk co Bot. mag. 183

… L l.p

1640. L s.p Bot. mag. 486

... I s.p

... L 1.p Schm. ar. 2. t. 79

38. NYCTAN'THES $W$ NYCTANTHES

163 arbor tristis $W$.

Jasminea. Sp. 1.

39. JASMI'NUM. $\boldsymbol{W}$. JASMine

164 Sambac $W$

$\beta$ fl. pleno

trifoliátum

65 hirsutum Ex. B Tuscan

166 campanulátum $L k$ hairy Indian

167 laurifólium Roxb. laurel-leaved st

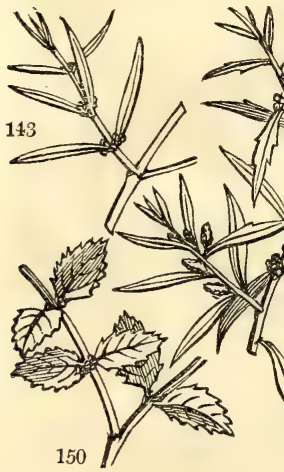

\section{Jasminea, Sp. 18-40.}

6 ja.d W E. Indies 1665. C r.m Bot, reg. 1

6 ja.d W E. Indies 1700 . C r.m Bot. rep. 497

$\begin{array}{lllll}\text { ja.d } & \text { W } & \text { E. Indies } 1730 . & \text { C } & \text { r.m Bot. mag. } 1785 \\ \text { my.au W } & \text { E. Indies } & 1759 . & \text { C } & \text { r.m Ex. bot. 2. t. } 118\end{array}$

1822. C rm

my.s $\ddot{W} \quad$ E. Indies 1819. C r.m Bot. reg. 521

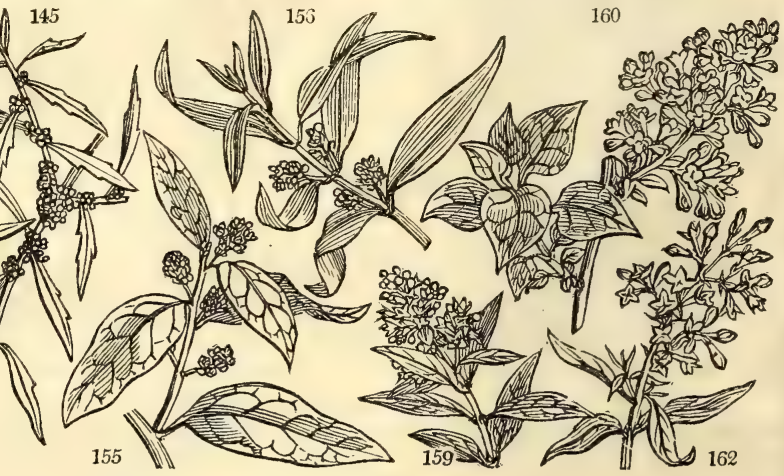

History, Use, Propagation, Culture,

33. Phillyrea. Said to derive its name from $\varphi \nu \lambda \lambda$,, a ledf, an etymology far from satisfactory. The genus consists of ornamental evergreen shrubs, the supposed varieties of which have been considered distinct species by most modern botanists. Some authors have united the genus with Olea; but they have not been followed generally.

34. Chionanthus. From $\chi$ soy, snow, and $\alpha, \theta \circ s$, a flower. Le Chionanthe, Fr. Der Schneeblume, Ger., and Albero de neve, Ital. Both species are highly ornamental shrubs or low trees; their leaves are above half a foot in length, and $1 \frac{1}{2}$ inch in breadth; their flowers white, in numerous long bunches, and their fruit of the size and color of a sloe. They are propagated by seeds or grafting on the common ash.

35. Notelaea. From yoros, south, and $\varepsilon \lambda \alpha \iota \alpha$, olive: the olive of the south. A small ornamental genus of nearly hardy shrubs, which would probably endure the climate of this country in a favorable situation.

36. Ligustrum. From ligare, to tie, on account of its long pliable branches. La Fresillon, Fr. Der Liguster, Ger, and Legustro, Ital. The privet in old authors is called primprivet, as Professor Martyn conjectures, from its patience under the sheers. Few shrubs exceed it as a garden hedge-plant: it will thrive in the middle of coal-burning cities, in the shade, and under the drip of trees; though to flower well it requires an open airy situation. Cows, sheep, and goats eat it, but horses refuse it.

The Sphinx ligustri, L., or privet hawkmoth, and Phalæna syringaria feed on it in the caterpillar state : the blister beetle, Lytta vesicatoria, from which cantharides is formed, is also found on it. Fully grown, the wood is fit for the turner, and a rose-colored pigment may be prepared from the berries, which, with alum, dye wool and silk of a durable green. The berries remain on the tree during winter in elegant purple clusters, and are not eaten by birds excepting in very severe weather, when bullfinches and some others feed on them. Like most plants that have been long in cultivation, the privet varies in its leaves, flowers, and fruit, and in the duration of the former. In its cultivated state it is always evergreen; found wild in woods and hedges, is ge- 


\section{Leaves linear lanceolate entire}

144 Leaves lanceolate entire or serrate in the middle, Leaves 3-nerved

145 Leaves oblong lanceolate sub-serrate in the middle obsoletely veined, Branches erect 146 Leaves oblong lanceolate acute obsoletely serrated at the point veiny, Branches veiny 147 Leaves oblong lanceolate nearly entire obtuse narrowed at the base veiny

148 Leaves elliptic oblong nearly entire veiny somewhat obtuse

149 Leaves ovate oblong rounded at the base veiny serrated, Serratures with stiff points

150 Leaves ovate rounded at the base serrated acute veiny

151 Leaves oblong serrated acute at each end veiny

152 Racemes terminal, Stalks 3-flowered, Petals linear lanceolate, Leaves coriaceous

153 Leaves obovate lanceolate membranaceous pubescent, Panicles very lax, Fruit elliptic

154 Spikes axillary very short, Leaves oblong elliptic acute

155 Leaves lanceolate pointed sub-reclinate, Racemes length of the leaf-stalks

156 Leaves lanceolate acute sub-erect, Racemes as long as the leaves

157 Leaves opposite rigid broad lanceolate entire, Bunches axillary

158 Leaves ovate oblong pointed shining above, Flowers spreading

159 Leaves ellipt-lanceolate smooth, Racemes compound dense

160 Leaves ovate cordate, Branches stiff white colored

161 Leaves ovate-lanceolate, Branches stiff mottled

162 Leaves lanceolate, Branches virgate mottled

163 A delightfully fragrant plant, Leaves cordate, Flowers panicled

164 Leaves opposite sub-sessile oblong or cordate, Calyx with subulate teeth, Berries globular

165 Leaves cordate downy, Umbels terminal sessile many-flowered

166 Branches round pubescent, Leaves ternate oval pointed, Calyx bell-shaped with very short teeth

167 Leaves opp. shining lanc. 3-nerv. Fl. 1.5 ax. and term.Cal. 6.7 toothed,Cor. 9.12 part. Seg. lin. the length cf tuhe

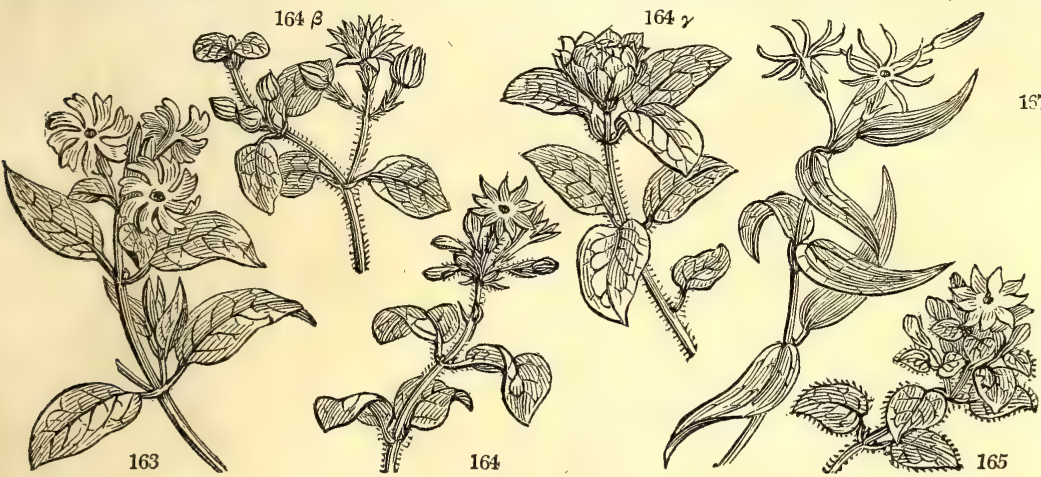

and Miscellaneous Particulars.

nerally deciduous. Sometimes the leaves grow by threes, are enlarged at the base and variegated. The regular number of stamens is two; but sometimes there are three or four in a flower. The berries are usually purple or black, but some have been seen of a white color; and a yellow fruited variety is common in the gardens. A kind of vegetable wax is said to be obtained from $\mathrm{L}$. lucidum in China.

37. Syringa. Some say from $\Sigma_{v e \iota}$, an Arcadian nymph, or, more properly, here, a pipe. The tubes of the finest Turkish pipes are manufactured from the wood of it; but the true root of the word is to be found in sirinx, its native name in Barbary. Lilac is a Persian word signifying a flower. Le Lilas, Fr. Die Syrene, Ger., and Syringa, Ital. All the species are most beautiful flowering shrubs, readily propagated by suckers, which they throw up in abundance. The common lilac seems to have been introduced before or during the reign of Henry VIII.; for in the inventory taken by order of Cromwell of the articles in the gardens of the palace of Nonsuch, are mentioned six lilackes; trees which bear no fruit, but only a pleasant smell. S. persica is well adapted for forcing in pots ; but so treated its flowers are without fragrance.

is well adapted for forcing in pots; but so treated its flowers are without fragrance.
38 . Nyctanthes. From $v v \xi$, night, and $\alpha \nu 0$, f flower, night-flower; its flowers expanding and smelling only in the night. L. Arbor triste, Fr. Der Trauerige baum, Ger. It grows freely in loam and peat soil mixed, but seldom produces its exquisitely fragrant flowers in England. Sweet thinks it is generally kept too warm, and recommends a trial in the greenhouse or open air; but its appearance would probably be little improved by any manner of treatment, as it has but an indifferent aspect in its own country. Cuttings not too ripe, root readily in sand under a hand-glass.

39. Jasminum. From the Arabian jasmin (ysmyn). Linnæus obtained a fancied etymology from ıe, a violet, and $ө \sigma \mu r$, smell. Le Jasmine, Fr. Der Schasmine, Ger., and It Gelsomino, Ital. The flowers of J. sambac are of exquisite fragrance, and in high esteem both in the East and West Indies. It grew in the Hampton Court garden at the end of the 17th century; but being lost there, was known in Europe only in the garden of 
168 grácile $\boldsymbol{B} . P$.

169 glaúcum $W$.

170 trinérve $W$.

171 simplicifólium $W$.

172 paniculátum $R o x b$.

173 undulátum Vahl.

174 auriculatum

175 azóricum $W$.

176 frúticans $W$.

178 odoratíssimum $W$.

179 revolútum $B . R$.

180 officinále $W$.

181 grandiflórum $W$.

40. VERO'NICA. $W$.

182 sibírica $W$.

183 virgínica $W$

$\beta$ incarnáta

184 foliósa $S c h r$

185 crenuláta Vahl.

186 marítima Schr.

187 angustifólia Fisch.

188 spuria Schr.

189 paniculáta

190 complicáta $W$. en.

191 azírea $L k$.

192 polystáchya $L k$.

193 glábra Schr.

$\beta$ alba

194 amethýstina W.en.

195 elátior $W$.

196 acúta Mart.

197 argata Schr.

198 média Schr.

199 persicifólia Schott.

200 austrális $S c h r$.

201 longifólia Schr.

$\beta$ incarnáta

r álba

202 gróssa Mart.

203 ambigua Mait.

204 neglécta $W$. en. 205 incána $S c h r$. 206 rígens Mart. 207 élegans $D$. $C$. 208 brevifólia $L k$. 209 spicáta $S c h r$.

210 clúsii Schott.

211 menthæfolia Schott 212 barreliéri Schott.

213 orchidéa $\mathrm{Cr} z$

214 hýbrida Schr.

215 crassifólia Kit.

216 ruthénica Jacq.

217 Pónæ $W$.

218 villósa Schr.

219 pinnáta Schr

220 incísa Schr.

221 laciniáta Schr.

222 gentianoídes $W$.

223 pállida Hornem.

224 bellidioídes $W$

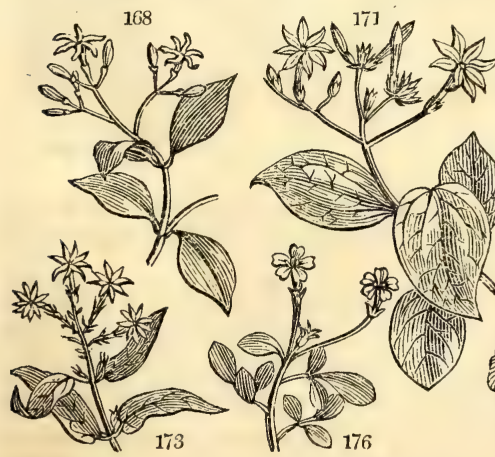

History, Use, Propagation, Culture,

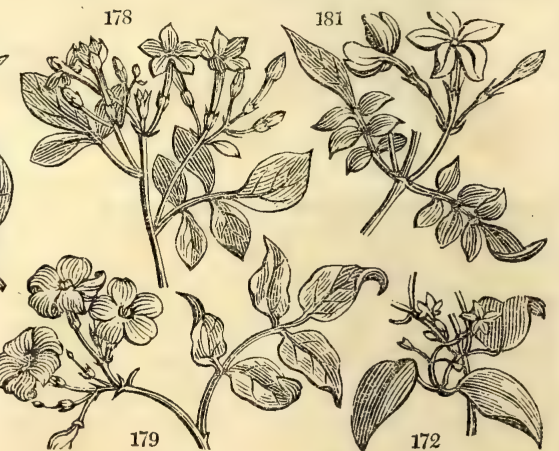

Norfolk 1. 1791. C e.p Bot. rep. 127

Sylhet 1804. C l.p

S.Seas 1800. C r.m Bot. mag. 980

China 1818. C r.m Bot. cab.469

China 1819. C r.m Bot. reg. 436

E. Indies 1790. C r.m Bot. reg. 264

Madeira 1724. C r.m Bot. reg. 89

S. Europe 1570. C r.m Bot. mag. 461

S. Europe 1656. L co Bot. reg. 350

Madeira 1656. C r.m Bot. mag. 285

E. Indies 1812. C r.m Bot reg. 178

E. Indies 1548. $\begin{aligned} & \text { C } \\ & \text { C } \\ & \text { r.m Bot. mag. } 31\end{aligned}$

Sp. 84-136.

Siberia 1779. D co Am. rut. 20. t.

Virginia 1714. D co Hoff. got. 15. t. 1

Hungary 1805 . D co

t. E. 3

co Sc. v. p. 29.t.1. f.1

Siberia - 1822. D co

L.B Siberia 1731. D co Gmel. it. 1. t. 39

Russia 1797. D co

S. Europe 1812. D s.1 Hoff. ph. t. E. f. 4

S. Europe 1804. D co Sc. v. p.25. t.1. f.4

S. ….... D co

S. Gurope 1812.

S. Europe 1808. D co

S. Europe 1812. D co Sc. v. p.22. t.2. f.2

Germany 1804. D co Sc.v. p.23. t.1. f

S. Europe 1823, D co

D co Sc. v p. 24 t 2 f 3

Europe 1731. D co Sc. v. p.24. t.2. f.1

Crimea 1821. D co

Sweden 1823. D co

evanescent $\Delta$ or $1 \frac{1}{2}$ jl.au D.B Siberia 1797. D co Wa. \& K. 3. t.244

hoary $\Delta$ or 2 jl.s $B$ Russia 1759. $D$ co Hoff. got. 15.t. 6

stiff

short-leaved

₹ $\Delta$ or

$\Delta$ or 2 my.jn $_{\mathbf{P k}}$

my.jn Pk

jn.jl

表 $\Delta$ or 1 jil.s

$7 \Delta$ or $\frac{1}{8}$ jl.s

mint-leaved $\Delta$ or 1 jl.s.

Barreliers $\vec{\Delta} \Delta$ or 1 jl.s $B$

orchis-flowrd. $\frac{1}{\Delta}$ or 1 jl.s $\quad$ B

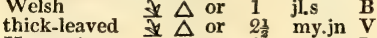

Hungarian $\Delta$ or 2 my.jn $B$

Pona's 方 $\Delta$ or $\frac{\Delta}{2}$ my.jn $B$

wing-leaved $\frac{\text { y }}{2}$ or ${ }^{1 \frac{1}{2}}$ jl.s $\mathrm{B}$

cut-leaved $\frac{\Delta}{\Delta}$ or 2 jn.au $B$

jagged-leaved $\frac{\not}{\Delta} \Delta$ or 2 jn.au $B$

gentian-leaved $\frac{1}{\Delta}$ or 2 my.jn D.B

Russia 1759. D co

S. France 1822. D co

…... 1822. D co

England ch.pa. D co Eng. bot. 2

Hungary 1822. D co

Austria 1823. D co

S. Europe 1823. D co

Europe 1819. D co. Bot. mag. 2210

England moun. D co Eng. bot. 673

Europe 1822. D co

Hungary 1821. D co

Pyrenees 1822. D co

S. Europe 1804. D co Sc. v. p. 31. t.1 f 3

Siberia 1779. D co

Siberia 1780. D co Jung. ic. rar. f. 2

Levant 1748. D co Bot. mag. 1002

Tauria 182I. D co

Titzerl. 1775.
...... 1821, D co

...... ... D co

Siberia 1776. D co Hoff.got. 15. t.10 
168 Leaves opposite simple ovate ellipt. Calyx smooth campanulate: teeth very short 169 Leaves lanceolate mucronate sub-coriaceous, Flowers 3 terminal

170 Leaves polished 3-nerved pointed, FL sol. Cal, 6.7 toothed, Cor. 6.8 part. Seg. filif. longer than the long tube 171 Spreading, Leaves obl. polished, Flowers 3 or many term. Cor. 6.8 part. Segm. linear acute equal to tube 172 Erect every part polished, Leaves ternate oval obtusely acuminate, Panicles terminal

173 Leaves simple cordate obl. shining, Branches and flower-stalks hairy, Racemes 3-flow. Calyx-teeth straight 174 Leaves sub-ternate, Leaflets ovate the pair minute or wanting, Teeth of cal. 5 gland. Cor. 7 part. Berr. glob. 175 Leaves compound ternate ovate and sub-cordate, Calyx campan. smooth, Segm. of corolla equal to its tube 176 Leaves alternate ternate and simple, Leaflets sub-cuneate, Calyx-teeth subulate

177 Leaves alternate acute ternate and pinnate, Branches angular, Calyx-teeth very short

178 Leaves alternate obtuse ternate and pinnate, Branches slender, Calyx-teeth very short

179 Leaves in about 3 pairs ovate lanc. on short stalks, Cym. term. few or many-fl. loose, Anth. mucr. partly exsert. 180 Leaves pinnate acuminate, Buds upright

181 Leaves opposite pinnate exterior 3 or 5 leaflets confluent, Flowers terminal, Buds horizontal

Racemes or Spikes terminal, Leaves whorled and opposite.

182 Leaves 56 or 9 together lanceolate sessile

183 Leaves 45 together lanceolate ovate stalked, Flowers cylindrical

184 Leaves 3 or 4 together ovate or ovate-lanceolate sub-biserrate; serratures unequal

185 Leaves ternate and opposite obl.-lanc. serrate, Cal. acute, Cor. notched. [equal shorter than capsule 186 Leaves 3 or 4 togeth. lin. lanc. from an ov, base acumin. deeply doubly serr. with the stem sub-pub. Cal. nearly 187 Leaves opp. linear narrowed by degrees very acute remotely serrated, Bractes longer than the flower-stalks 188 Leaves 3 or 4 together nearly sessile lanceolate simply serrate; serratures equal

189 Leaves narrow lanc. remotely serr. or lin. and very ent. Bract. much longer than fl.-stalks, Stem ascending 190 Spikes lateral short nodding, Leaves opp. folded together toothed : teeth thick, Segments of corolla entire 191 Leaves lan. lin. narr. by deg. to very end finely serr. the serrat. at base of leaf deep. Bract. longer than flower-st. 192 Leaves sub-sess. ovate acute serrated pubes. Flower bearing branches in bundles, Flow. sub-sess. very small 193 Leaves opp. 3 togeth. sub-cord. lanc. simply serrated with the stem smooth, Serratures remote nearly equal

194 Stem pubes. Leaves opp. and tern. lanc. rather fleshy simply and remotely serrate wedge-shaped at the base 195 All over slightly pubes. Leaves 3 togeth. lanc. acumin. sub-cord. at base doubly serrate : serrat. of base deepest 196 Leaves very long almost coriaceous opp. or 3 together on short stalks cordate at base acutely and unequally dentate serrate hanging down

197 Leaves lanceolate acute simply serrate entire at the end, Serratures distant simple equal

198 Leaves opposite and 3 together lanceolate acute serrate with the stem downy, Serratures near unequal

199 Leaves opp. and tern. lanc. very much lengthened out serrated to the very end, Bract. longer than fl.-stalk

200 Leaves ovate lanceolate simply serrate entire at the end with the stem pubescent, Serratures near unequal 201 Leaves opposite 3 or 4 together cordate lanceolate acuminate doubly serrated with the stem downy

202 Leaves 3 or 4 tog. at base widely cord. lanc. deeply doubly acutely uneq. dent. serr. Serr. sprdg. lowest distant. 203 Leaves 3 or 4 tog. ov. acum. cord. at base doubly acutely and uneq. serr. beneath and with the stem pubesc. Racemes terminal, Leaves opposite.

204 Hoary, Leaves lanceolate serrate acute at the base wedge-shaped and entire, Stem erect 205' Hoary, Leaves lanceolate crenate and nearly entire obtuse, Stem erect

$206^{-L}$ Leaves on short stalks stiffish cordate at the base pointed closely acutely and doubly serrate, Stem pubescent 207 Leaves ovate oblong crenate stalked obtuse with the stem pubescent, Spikes many, Bractes very small 208 Stem simp. pub. Lvs. op. lan. obl. by deg. narr. fr. base point. ser. ent. at end, up. ones sub-ser. Br. lon. than fl.-st. 209 Slightly pub. Lvs. cren. the rad, ov. obl. running down into stalk, Caul. lanc. sess. Fl. spkd. Br. and cal. pilose 210 Toment. with stlkd. glands, Lvs. tooth. rad, ov. runn. down into st. Caul. lan. stlkd. Fl. in spks. Br. \& cal. cil. 211 Vilious, Leaves serr, rad ovate, Caul obl acute stalkd. at base and end entire, Fl in racemes, Bractes linear 212 Villous, Leaves cren, rad ov. Caul, obl. obtuse sub-sess. Flow in racemose spikes, $\mathrm{Br}$. and cal smooth ciliate 213 Slightly pubesc. Leaves crenulate radical oblong ovate running down into stalk, Cauline lanceol. acuminate sub-sessile, Flowers in close spikes

214 Lvs. uneq. tooth serr. with stem pub. rad. stlkd. ov. Caul. sub-sess. ellipt. obl. Fl, in spks. Br. lin. lon. than cal. 215 Leaves opp. ov. ianc. runn. down into st. the lower cren. the upp. ent. Spks. term. or 3 tog. Fl. like an orchis 216 Leaves ov. lan. uneq. ser. Br. lan. as long as cal. Cal. 4 part. uneq. Seg. ov. obl. Caps. smth. rather long. than cal. 217 Leaves cordate ovate sessile very obtuse with the very simple stem hairy, Racemes few-fi. Calyx smooth 218 Leaves oblong ovate cut and serrated with the stem somewhat villous

219 Stem ascending, Leaves in fasc. the lower pinnate, the upper pinnatifid and simp. Leafl. and div. filif. sprdg. 220 Leaves in fasc. stalked pinnatifid lanc. Segm. nearly entire, Racemes several, Seg. of the Calyx lanceolate 221 Leaves in fasc. on short stalks linear pinnatifid: Seg. entire, Raceme nearly sol. Seg. of calyx oblong ovate 222 Raceme corymbose term. Leaves radical obl. connate sheathing cartil. crenate or ent. Stem simp. ascending 223 Stem ascend. feeble, Lvs. lanc. obt. sub-serr.: lower sheathing, Rac. loose, Up. seg. of cor. wider than side ones 224 Leaves obov. cren. with simple ascend. stem pilose, Cauline lvs. remote, Rac. corymb. hairy about 5 -flowered

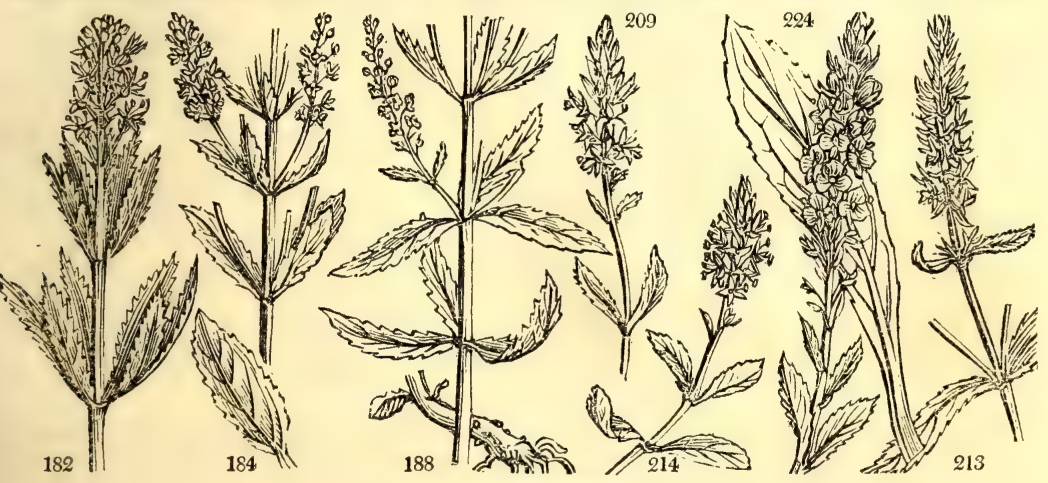

and Miscellaneous Particulars.

rise. All the species thrive in any light loamy soil or loam and peat, and cuttings root freely in sand under a hand-glass.

40. Veronica. A word said to have been altered from Betonica. (See that name.) La Veronique, Fr., and Ehrenfreiso, Ger. $\mathrm{V}$. officinalis has been much recommended in Sweden and Germany as a substitute for tea, than which Professor Martyn says, it is more astringent and less grateful. Withering prefers V. Chamæedrys for

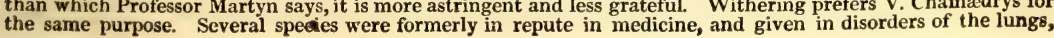


225 fruticulósa $W$. 226 saxátilis $W$.

227 alpína $W$.

$\beta$ integrifólia

228 depauperáta $K i t$.

229 serpyllifólia $\boldsymbol{W}$.

230 hirsúta $L /$.

231 microphýlla Kit.

232 decussáta $W$ 233 aphylla $W$.

234 Beccabúnga $\boldsymbol{W}$.

235 anagállis $\boldsymbol{W}$

236 scutelláta $W$

237 orientális $W$

238 Jacquíni Schott.

239 austríaca Jac.

240 multífida $W$

241 Alliónii $W$.

242 officinális $\dot{W}$

243 prostráta $W$

244 micrántha $H_{0 f f}$.

245 latifólia $W$.

246 Teúcrium $P$. $S$.

247 criníta Kit.

248 Chamæ'drys $W$.

249 urticæfólia $W$

250 montána $W$

251 perfoliáta $B . P$

252 labiáta $\boldsymbol{B}$. $\boldsymbol{P}$

253 polymórpha $W$, en.

254 vérna $W$

255 digitáta $W$.

256 triphýllos $W$.

257 hederifólia $W$.

258 cymbalária Bertol.

259 peregrína $W$

260 filifórmis $W$

261 crista gálli Stev.

262 præcox All.

263 acinifúlia $W$

264 arvénsis $\boldsymbol{W}$.

265 agréstis $W$.

41. GALIPE'A. $A u b$.

266 trifoliáta $W$.

flesh-colored $\mathbf{z}$

blue-rock $\frac{2}{2} \Delta$ or $\frac{1}{\frac{1}{2}}$ jn.au $F$

alpine $\quad \vec{\Delta}$ or ${ }^{\frac{1}{4}} \mathrm{my} \quad \mathrm{B}$

entire-leaved $\vec{\Delta}$ or ${ }^{2}$ my in

impoverished $\frac{}{ \pm} \Delta$ or ${ }^{\frac{1}{4}}$ ap.ji $B$

smooth $\frac{1}{\Delta}$ or $\frac{x}{8}$ ap.jl $\mathbf{B}$

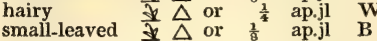

cross-leaved jor 1 jn.au B

naked-stalked $\downarrow \Delta$ or $\frac{1}{4} \quad m y \quad B$

Brook-lime ${ }^{2}$ clt $2^{\frac{1}{4}}$ my.jn B

Brook-lime $\Delta$ clt 2 my.jn

marsh

various-leaved $\Delta$ or $\frac{1}{4}$

Jacquins $\quad$ or 1

I $\triangle$ or 1

fine-cut $\frac{j}{\Delta} \Delta$ or $\frac{1}{4}$

shining-leaved $\frac{b}{\partial} \Delta$ or
officinal

officinal
trailing

small-flowered $\$ \Delta$ or $1 \frac{1}{2}$

broad-leaved $\frac{1}{\Delta}$ or $1^{2}$

rugged-leaved $\vec{\Delta} \Delta$ or 2

long-bracted $\$ \Delta$ or 1

Germander $\frac{\ddagger}{\Delta}$ w $\frac{1}{2}$

nettle-leaved $\not \nabla \Delta$ or 1

mountain

perfoliate

labiated

$\frac{7}{4} \Delta$ or $\frac{1}{2}$

w

iv $\triangle$ or 1

vernal

digitated

fingered

ivy-leaved

twining \$ or $2^{\frac{4}{4} \text { au.my W }}$

O w ${ }^{\frac{1}{8}}$ ap.my B

\begin{tabular}{lllll} 
& $w$ & $\frac{1}{6}$ & jl & B \\
\hline & $w$ & & $\frac{1}{6}$ & ap.my \\
B
\end{tabular}

jn.au F

jn.au L..

jn.au L.B

my.jl L.B

jn.au L.B

ap.jl $\quad$ B

my.jn W

my.jn W.B

jn.au L.B

jl.au B

$\begin{array}{ll}\text { jl.au } & \text { B } \\ \text { jn.jl } & \text { L.B }\end{array}$

jl.au B

jl. au B

ap.jl L.B

w ${ }^{\frac{1}{6}}$ ap.my $B$

or $\frac{1}{3}$ mr.jn W

w $O$ or $\frac{1}{4}$ my L.

early

basil-leaved

wall

field

Galipea.

three-leaved $\begin{gathered}\text { Rutacae. } \\ \text { Galises. } 1\end{gathered}$

V. Schwenckia.

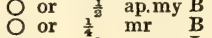

Or $\frac{1}{2}$ ap.my L.B

a $\mathrm{O}$ w

$\frac{2}{4}$ ap.jl B

mr.jl B

Rutace. Sp.

[D] ${ }_{1}^{\text {Primulacea. }}$ au.s Li $^{\text {Sp. } 1-7 .}$ Guian

267 americána $W$.

American

Scrophularina. Sp. $4-45$.

268 officinális $W . \quad$ officinal is $\Delta \mathrm{m} 1$ my.au L. B Europe 1568. D co Fl. dan. 363

269 verónicifólia $W$. speedwell-lvd.

270 virgínica $W$. Virginian $\frac{J}{\Delta}$ or 1 au $\mathbf{Y}$ Virginia 1759. D co

271 quadridentáta Mich. four-toothed $\$ \Delta$ or $\frac{1}{2}$ my.au W N. Amer. 1821. D co Lam. ill. t.16. f.2

44. SCHIZAN'THUS. Fl.per. Schizanthus, Scrophularina. Sp. 2.

272 pinnátus Fl. per. pinnate $\quad$ () or 2 jn.o W.P Chili 1822. S 1.p Hook. ex. fl. 73

273 pórrigens Hook. $\quad$ spreading stalk $\mathrm{O}$ or 2 jn.o $\quad$ W.P Chili 1822 . S 1 Hook. ex.f. 86

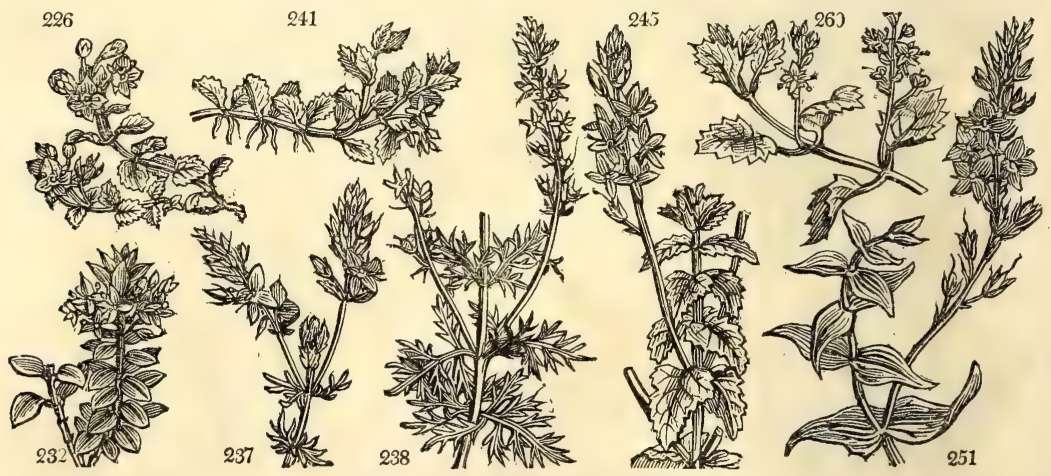

History, Use, Propagation, Culture,

but they are now laid aside by regular practitioners. V. Beccabunga (latinised from bachbunge, its German appellation : bach is a brook; beck, provincial English), is sometimes gathered with watercresses, with which it is often found in limpid streams, and used as a spring salad. Almost all the species thrive in any soil or situation; the tallest are ornamental border flowers; the dwarf spreading sorts are well adapted for rock-work, edgings, or to be grown in pots. A few delight in peat soil, and some in moist situations; all are increased by seed, subdividing at the root, or cuttings: V. decussata will endure the open air if protected from frost.

41. Galipea. A name framed by Aublet from the vernacular appellation of the plant in French Guiana, where it is a native.

42. Schwenckia. John Theodore Schwenck was a professor of medicine at Jena; died in 1671 . There was another Schwenck a professor of botany to the garden at Leyden. The genus is, like the merits of the professors, but little known. One inconspicuous species is occasionally seen in our stoves. The 
225 Upper leaves obl. sub-serr. Stems erect $\frac{1}{2}$ shrubby, Rac. many-fl.Caps. roundish ov. scarcely longer than calyx 226 Upper leaves obl. obov. sub-serr. Caps, ovate larger than calyx, Stems shrubby diffuse, Corymb. term. few-ft. 227 Leaves smth. ellip. ov. ent. or ser. Corymb. term. somew. spiked, Cal. cil. Caps. ob. Stems tufted herb. simple $\beta$ Leaves elliptic ovate obtuse entire

228 Peduncle axillary subracemose few-flow. Leaves obovate obtuse sub-serrated, Fl.-stalks and calyxes pilose 229 Leaves opp. oblong crenate with the calyxes smooth, Racemes elongated, Flowers distant, Stem ascending 230 Glandular hairy, Stem ascending, Leaves oblong acute sub-crenate, Raceme elongated

231 Leaves opp. ovate irregularly crenate, Stem ascending, Bractes scarcely longer than flower-stalks Racemes lateral.

232 Racemes few-flowered, Leaves elliptical perennial entire, Stem shrubby

233 Radical leaves roundish and oblong, Stem naked very short, Flower-stalk like a scape about 3-flowered

234 Leaves elliptical obtuse on short stalks serrulate, Cal. 4-parted, Stem procumbent below rooting

235 Leaves lanceolate serrate stem clasping, Cal. 4-parted, Stem erect

336 Leaves linear lanceol. nearly entire, Flow.-stalks pendułous or spreading, Cal. 4-parted, Stem nearly erect 237 Leaves lin. lanc. lower pectinate pinnatifid, upper entire, Cal. leaves unequal subulate, Stems procumbent 238 Leaves sess. pinnatifid and bipinnatifid, Lower bracte 3-fid longer than fl.-st. Cal. 5-part. Stem nearly erect 239 Leaves sess. lanceol. inciso serrate and pinnatifid, Bracte entire shorter than fl.-st. Cal. 4-part. Stem feeble 240 Leaves bipinnatifid, Segm. lanceol, and lin. Cal. leaves unequal subulate, Stems procumb. woody at base

241 Leaves oblong roundish stiff shining, with the procumbent creeping stem smooth, Flowers in close spikes

242 Leaves obovate or roundish serrate, Cal. 4-parted, Stem rooting at the bottom

243 Leaves sessile oblong obtuse serrated : the upper lanceol. flat, Cal. 4 or 5-part. Flowering stem ascending 244 Stem erect hairy all over, Lvs. sub-sess. oval coarsely and acutely cren. hairy, Cal. 4-part. larger than corolla 245 Leaves somewhat heart-shaped ovate sessile unequally obtusely serrate, Stem erect, Cal. 5-leaved

246 Lower leaves oblong coarsely serrated with the stem villous

247 Leaves sub-sessile ovate lanceolate unequally serrated, Cal. 5-parted, Segm. and bractea linear subulate

248 Lvs. cut serr. the upp. cord. ovate sess. the low. ov. stalk.Cal. 4-part. Stem hairy in 2 rows, Rac. long. than stem 249 Leaves sessile cordate ovate acute serrate, Cal. 4-parted, Stem erect

250 Leaves cord. ovate obtuse coarsely serrated with the stem and stalks hairy, Cal. 4-part. Rac. elong. filiform 251 Racemes lateral stalked many-flow. Leaves entire very smooth ovate acuminate joined together at the base 252 Racemes very long, Leaves elongate lanceolate acuminate unequally serrate

253 Fl.-stalks rather longer than bract.Lvs. lanc. wedge-shaped at base simply and doubly toothed,Stem prostrate Flower-stalks one-flowered.

254. Flowers sub-sess. Leaves finger-parted, the upper undivided, F1.-stalks shorter than the calyx, Stem erect 255 Flowers sessile, Leaves all finger-parted

256 Lower leaves entire : middle finger-parted : upper trifid, Fl.-stalks longer than calyx, Stem erect spreading 257 Leaves as long as stalk cord. rounded 5-lobed : the upper 3-lobed, Segm. of cal, cord, acute, Stem procumbent 258 Leaves cord. rounded with 5 or 9 but generally 7 teeth obtuse a little fleshy, Cal. of fruit spread. Caps. hairy 259 Flowers sessile, Leaves oblong a little serrate longer than calyx, Stem erect

260 Leaves roundish cordate crenate, Flower-stalks very long, Calyx leaves lanceolate

261 Flower-stalks as long as the leaves, Calyx 2-leaved, Leaflets 2 -lobed scrrate

262 Low. lvs. stalk. cord. ov. serr. floral nearly sess. short. than fl.-st. Caps. obov. emarg. turgid, Stem rather upr. 263 Flow. stalked, Low. 1vs. stalked ov. serr. floral s.-sess. as long as fl.-st. Caps. obcord. comp. Stem nearly simple 264 Flow. nearly sess. Low. Jvs. stalked cord. ov. serr. caul. cren. floral lanc. sess. longer than stalk, Cal unequal 265 Leaves stalked cord. ovate serr. Cal. leaves ovate, Stem procumb. Fl,-stalks scarcely shorter than the leaves

266 Leaves alternate stalked, lanceolate entire

267 Stem slender simple, Leaves lanceolate, Cor. thrice as long as calyx

268 Leaves lanceolate serrate somewhat 3-nerved, Flowers on stalks

269 Leaves oblong acutely serrated, Stem creeping, Flowers racemose.

racuminate longer than the calyx 270 Leaves obovate lanc. narrowed below remotely toothed nerved smooth, Fl.-stalk alternate very short, Caps. 271 Leaves lin. lanc. with a few teeth, Fl. -stalks as long as the leaves, Caps. much shorter than the subulate calyx

272 Stalk of fruit on one side deflexed at base

273 Stalk of fruit spreading all ways straightish

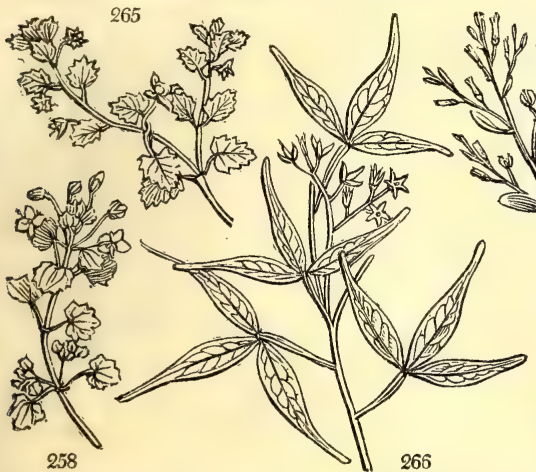

265
269

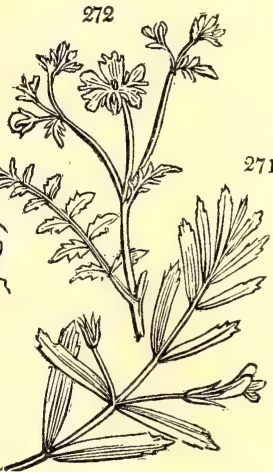

and Miscellaneous Particulars.

appendages to the corolla are very singular, and demand a better explanation of their nature than has yet been affered.

43. Gratiola. From grätia, grace (of God). Matthiolus called it gratia Dei, in allusion to its effects. G. officinalis is so bitter and obnoxious to cattle, that Haller assures us, there are meadows about Yverdun rendered entirely useless by its abundance. It is a powerful cathartic, and was long in use as such, but now laid aside.

44. Schizanthus. So named by the authors of the Flora Peruviana, from $\sigma \chi \zeta^{\zeta} \omega$, to cut, and $\alpha y$. One of the most beautiful of herbaceous genera. Two species or rather varieties are now known, and ornament the green-house with their elegant panicles of lilac and white flowers. They are difficult of cultivation, requirthe green-house with their elegant panicles of lilac and white flowers. They are difficult of cultivation, requir-
ing a very pure and moist atmosphere. They may be propagated by cuttings, but the best plants are raised from seeds, which have not hitherto been obtained, except from flowers artificially impregnated. 
45. ELY'TRA'Ria. $M$. Elytraria. 274 virgáta $M$. 275 crenáta Vahl. Justicia acaulis Roxb.

46. HYPOES'TES. $R$. Br. HYPoEstes. 276 involucráta $R o x b$. involucred 277 purpúrea $W$. purple

\section{JUSTI'CIA. $W$ Justicia.}

278 bicalyculáta $W$

279 Ecbólium $W$ 280 coccínea $\boldsymbol{W}$.

281 quadrífida $\boldsymbol{H} . \boldsymbol{K}$. 282 nígricans Lour.

283 nitida $W$

284 bracteoláta Jacq. 285 picta $W$.

286 paniculáta Vahl.

287 secúnda Vahl.

288 ciliáris $\boldsymbol{W}$.

289 lúcida $\boldsymbol{V a h l . ~}$

290 Gendarússa $W$

291 carthaginénsis. $W$. 292 pedunculósa $M i c h$. 294 comáta $W$.

295 eustachiána $W$.

296 nasúta $W$.

297 pectorális $W$.

298 periplocifólia $\boldsymbol{W}$.

299 furcáta $V a$.

Malabar

\section{long-spiked} scarlet

twiggy

black-striped

glossy

small-

painted

panicled

side-flowering

ciliated

ciliated

Caribean or

N. American $\$$ or procumbent $\bar{x} \mathbb{D}$ or balsam herb $\& \mathbb{N}$ or Eustachian or white-flowerg. $\square \mathrm{m}$ Garden-balsam $\bar{y} \mathrm{~m}$ periploca-leav. 300 lithospermifólia $W$. gromwell-leav.w or

301 caracásana Jacq. 302 adhátoda $W$ 303 betónica $V a$. 304 hyssopifólia $W$. 305 orchioídes $W$.

48. DICLIP'TERA. 306 hexanguláris $W$. 307 scorpioídes $L$. 308 resupináta $W$. 309 pectináta $V a h$ 310 retísa Vahl.

violet 皮 Malabar-nut $\square$ or 1 betony-leaved w $\square$ or

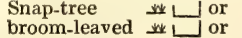

DiCliptera.

chickw.-leaved [0] or scorpion-like w resupinate [0] or small-flowered $\square$ or blunt

$\varepsilon \bar{\nabla}$ o

\section{ERAN'THEMUM. B.P. EranthemuM}

311 spinosum $B . P$.

312 pulchéllum $B . R$

313 bícolor $B . M$

thorny

此 or

业 $\square$ or

50. WULFE'NIA. $\boldsymbol{W}$. WULFENIA.

314 carinthíaca $W$. annual

51. CALCEOLA'RIA. $W$. Slipperwor?

315 pinnáta $\boldsymbol{W}$. wing-leaved

316 scabiosæfólia $R$. \& $S$. scabious-leav.

317 rugúsa $F l$. per

318 integrif́́lia $\boldsymbol{L}$

rugose
Acanthacea. Sp. 2-5.

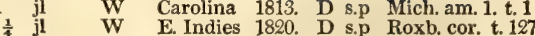

Acanthacee. Sp. 2-10

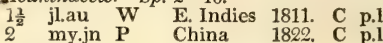

Acanthacea. Sp. 28-137.

$3 \mathrm{au} \mathrm{Li}$ E. Indies 1755. S s.1 Retz.st. 1775. t.9

3 mr.au B E. Indies 1759. C p.l Bot. mag. 1847

f S S. Amer. 1770. C p.l Bot. mag. 432

mr.s S Mexico 1795. C p.l Par.lon. 50

mr.s, W.r China 1819. C p.l

mr.s W W. Indies 1790 C p.l Bot. rep. 570

jl.au P Caraccas 1823. C p.l Jacq. ic. t. 205

jl.au Cr E. Indies 1780. C p.l Bot. mag. 1870

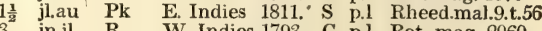

jn.jl $\quad \mathrm{R} \quad$ W. Indies 1793. C p.l Bot. mag. 2060

jl.au W W. Indies 1780. S s.l Jacq. vin. 2. t.104

jl.au Sc W. Indies 1795. C p.1 Bot mag. 1014

jn.jl Li E. Indies 1800, C pl Bot. reg. 635

$1 \frac{1}{2}$ jn.jl Pu Carthag. 1792. C s.p.1 Bot. reg. 797

$1 \frac{x}{2}$ jl.au Li N. Amer. 1759. C s.p.1 Bot. mag. 2367

$\frac{1}{2}$ jl.au Pk E. Indies 1798. L s.p Plk. al. t.56. f. 3

Jamaica 1795. R s.p Sl, jm.1.t.103. f.

$\begin{array}{lllll}\text { au.s } & \text { O } & \text { St. Eustac.1799. C } & \text { s.p } & \text { Bot. reg. } 309\end{array}$

my.jn $\mathbf{P} \quad$ W. Indies 1787. L s.p Bot. reg. 796

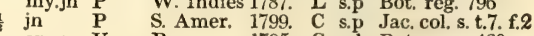

ap.au V Peru 1795. C p.1 Bot. mag. 430

ap.au $\mathbf{P}$ Peru 1796. C p.1 Jac. schön. 1.t.4

my.jn V Caraccas 1822. C p.1 Jac. pl, r. 2, t.206

my.jl P Ceylon 1699. C sl. Bot. mag. 861

my.jl W E. Indies 1737. S p.l Rheede? t.21

mr.au Y Canaries 1690. C pl. Mill.ic.9.t.13

au C.B.S. 1774. C pl. Vent, mal. 51

Acanthacea. Sp. 5-25.

jl $R$ S. Amer. 1733. S s.l Pluk. t. 279. f. 6

11 jl VeraCruz 1802. C p.1 R. Houst. p.3. t.1

1805. S p.1 Cav. ic. 3. t. 203

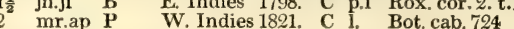

Acanthacee. Sp. 3-14.

jl.au W. Indies 1733. C s.p Jc. am.2.t.2.f.1

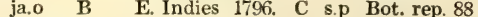

my.au W.r Luconia 1802. C s.p Bot. mag. 1423

Scrophularina. Sp. 1.

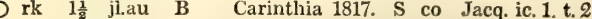
Scrophularina. Sp. $7-55$.

2 jl.s $\quad \mathbf{Y}$ Peru 1773. S s.p Bot. mag. 41

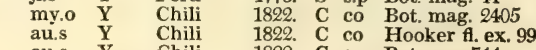

au.s Y Chili 1822. C co Bot. reg. 744
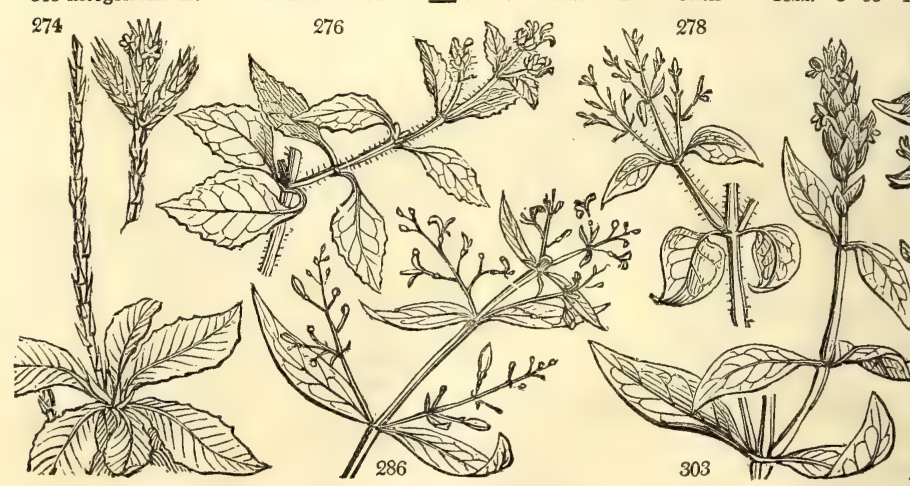

$\rightarrow 0$

History, Use, Propagation, Culture,

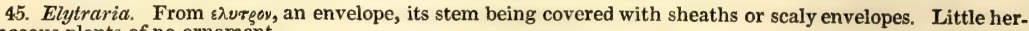
baceous plants of no ornament.

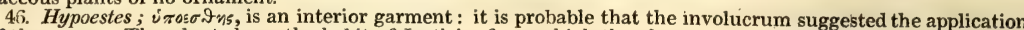
of the name. The plants have the habit of Justicia, from which they have been separated, and are chiefly tropical weeds.

47. Justicia. In honor of James Justice, F.R.S., an eminent Scotch cultivator, author of the Scotch Gardener's Director, published in 1784. J. pectoralis has the smell of new hay, combined with a refreshing
aroma. In Domingo and Martinico the inhabitants make a syrup of it, which they use against disorders of the breast. The bruised leaves are good in wounds, whence the English appellation balsam, and the French name herbe à charpentiére. J. nasuta is said to possess extraordinary aphrodisiacal powers, and milk boiled in the roots is much employed on that account by Indian physicians. Rubbed with limejuice, the roots are used to cure ring-worms. Most of the species are free flowerers, some as J. lucida 
274 Flowering scales ovate villous at edge, Leaves lanceolate smooth entire, Scapes very long, Caps. obtuse 275 Stemless, Flowering scales ovate entire, of the scape lanceolate naked at the edge, Leaves oblong crenate

276 Racemes axillary erect shorter than the leaves which are lanceolate toothed and with the stem hairy 277 Spikes axillary and terminal, Bracteas lanceolate smooth, Branches pubescent

\section{Panicles axillary dichotomous}

Calyx double.

Calyx simple, Flowers labiate.

280 Spikes termal 4-sided imbricated, Bracteas oval, Leaves oblong ovate acuminate, Helmet linear 281 Leaves linear lanceolate, Flowers nearly solitary sessile tubular 4 -cleft

282 Spikes terminal 2-ranked, Bractes setaceous, Leaves linear lanceolate

283 Racemes term. somewhat branched, Cal. whorled smooth, Leaves lanc. elliptic, sharp at both ends stalked 284 Racemes term. comp. Pedunc. 3 or 4-flowered, Bract. lanc. Leaves oblong pointed, Branches square rough 285 Racemes axillary and terminal, Flowers inflated at the throat whorled, Leaves elliptical variegated 286 Stems 4-sided brachiate, Leaves sub-sess. lanc. Flowers 1-sided erect, Lip linear revolute, Flowers downy 287 Racemes terminal compound 1-sided many-flowered, Bract. setaceous, Leaves ovate oblong. acuminate 288 Flowers axillary solitary sessile opposite, Calyx hispid, Leaves lanceolate obtuse ciliated at the base 289 Spikes terminal in heads, Leaves elliptic nerved blistered shining, Upper lip of corolla lanceolate 290 Spikes terminal leafy, Flowers whorled, Leaves elongated

291 Spikes axillary and terminal, Bractes oblong imbricate ciliate obtuse

292 Spikes axillary, Flowers close, Flower-stalks elongated alternate, Leaves lanceolate

293 Spikes lateral and terminal, Calyx 4-leaved linear hairy, Lower lip ovate, Leaves oblong 294 Spikes axillary and terminal filiform, Spikelets whorled

295 Spikes axillary and terminal, Flowers in pairs below single above, Bractes wedge-shaped

296 Upper lip of corolla subulate, Flower-stalks axillary dichotomous, Leaves elliptical entire 297. Panicle terminal dichotomous, Flowers spiked distant

298 Upper lip emarg. reflexed, Flowers axillary solitary sub-scss. opposite : term. in spikes, Lvs. ovate lanceolate 299 Lower lip 3-lob. Flow. axillary solitary and spiked, Lvs. ovate oblong narr. at each end, with stem pubescent 300 Lower lip 3-lobed, Flowers axillary sessile whorled, Bractes linear lanceolate, Leaves lanceolate. Calyx simple, Flowers ringent.

501 Spikes axillary and term. Flowers opposite, Bract. shorter than cal. Stem. and branc. round 6-streak. Leaves 302 Spikes axillary opposite, Bractes ovate acute nerved 303 Spikes terminal, Bract. ovate acuminate netted with veins, Leaves lanceolate ovate stalked

304 Leaves lanceolate entire obtuse, Peduncles axillary 3-flowered 2-edged, Bractes shorter than the calyx 305 Peduncles solitary axillary one-flowered, Leaves lanceolate acute at each end sessile

306 Umbels axillary 3-flowered, Bractes 2 wedge-shaped, Leaves ovate, Flowers in loose spikes 307 Spikes axillary and terminal recurved, Leaves lanc. ovate hairy sessile, Bractes 2, Flowers in loose spikes 308 Flowers axillary rather whorled, Bractes 2-valved subcordate, Leaves ovate

309 Spikes axillary and term. 1-sided villous, Dorsal bractes lanc. 2-ranked with a membran. margin at the base 310 Spikes terminal, Bractes obovate retuse imbricated smooth, Leaves ovate acuminatc

311 Flower-stalks about 1-flowered, Leaves oblong, Spines axillary

312 Spikes axillary and terminal imbricate, Bractes oblong veiny, Leaves ovate acuminate

313 Leaves ovate acuminate repand, Corolla with a long tube white with a purple stain

314 Stemless, Leaves radical very smooth coarsely crenate, Flowers on one side

315 Leaves all pinnate: pinnæ toothed, of the lower leaves pinnatifid

316 Lower leaves pinnate: superior pinnatifid 3-lobed and simple

317 Leaves lanceolate very rugose with spreading teeth, Flowers terminal dichotomous

318 Leaves lanceolate toothed rugose, Flowers terminal dichotomous

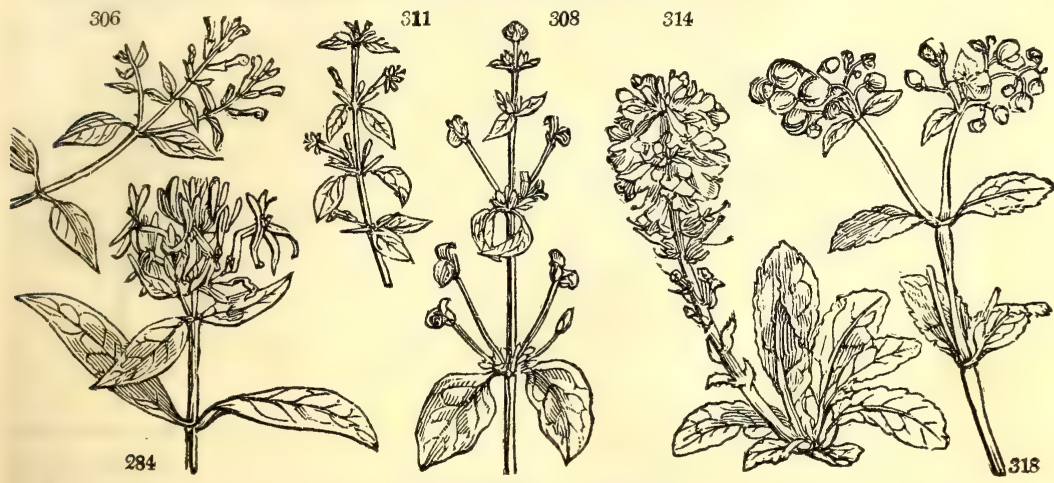

and Miscellaneous Particulars:

are shewy; others are the commonest weeds of the tropics; all are readily propagated by cuttings in heat under a glass.

48. Dicliptera; $\delta \varsigma$, double, and $x \lambda \varepsilon \omega \omega$, to shut. The fruit being compounded of two valves. This genus has been formed like Hypoestes out of the Linnæan Justicia, with which it agrees in habit.

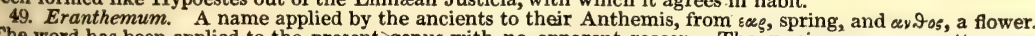
The word has been applied to the present genus with no apparent reason. The species are very pretty orna ments of the stove.

50. Wulfenia. Named after F. X. Wulfen, a German botanist, and author of a work on the plants of Carinhia. A small and very beautiful herbaceous plant

51. Calceolaria. From calceolus, a slipper, in allusion to the shape of the corolla. $C$, pinnata may be raised from seed in a hot-bed in spring, and transplanted to the borders with other tender annuals. The regions of Chili and Peru ahound in many splendid species, some of which have lately been introduced to this country. 
319 corymbósa Cau. 320 parália Cav. 321 Fothergillii $\boldsymbol{W}$. corymbose sea-side Fothergill's

52. PINGUi'CULA. $\boldsymbol{W}$. Butterwort.

322 lusitánica $W$. 323 vulgáris $W$. 324 alpína $\boldsymbol{W}$. 325 grandifúra $\boldsymbol{W}$ 326 lútea $M$.

327 edéntula Hook.

\section{U'TRICULA'RIA.} 328 vulgáris $\boldsymbol{W}$. 329 minor $W$.

330 intermédia $\boldsymbol{P} . \boldsymbol{S}$.

\section{STACHYTA'RPHE'} 331 índica Vahl. 332 jamaicénsis Vahl. 333 orúbica Vahl. 334 mutábilis Vahl. 335 prismática $V a h l$. 336 cayennènsis Rich. 337 hirsutíssima $\boldsymbol{L} \boldsymbol{k}$.

55. LYCO'PUS. $W$ 338 europæus $W$ 339 exaltátus $W$. 340 virginicus $\dot{W}$. 341 intermédius Sch.

56. AMETHYSTEA. 342 cærúlea $W$. 57. ZIZIPH'ORA, $W$. 343 capitáta $W$. 344 hispánica $W$. 345 tenúior $W$.

346 acinoídes $W$ 347 serpyllácea $\boldsymbol{B}$. $M$. 348 média $L k$.

349 dasyántha $W$. en. Pouschkini B. M. 350 taúrica $W$. en. 58. CU'NILA. $P . S$. 351 mariána $P h$. 352 capitáta $\boldsymbol{P} . S$. 59. HEDEO'MA. $P . S$ 253 pulegioídes $P h$. 354 thymoides $P$. S . 60. MONAR'DA. $W$. 355 fistulósa $P h$. 356 média $W$. en 357 mollis $P h$.

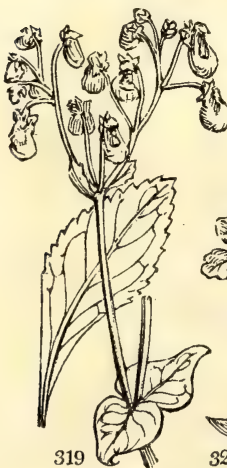
Cayenne hairy common blue-flowering ZIZIPHORA.

Cunila Hedeoma. Monarda. soft pale common $\begin{array}{ll}\text { alpine } & \\ \text { large-flowered } & \Delta \text { cu }\end{array}$ yellow toothless $\triangle \mathrm{el}$

W. Hooded Milfoir common $\triangle \mathrm{cu}$ intermediate * $\Delta$ lesser $\triangle \mathrm{cu}$

\section{1 my.jn $Y$ $1 \quad \begin{array}{lll}1 & \text { my.jn } & \mathbf{Y} \\ \frac{1}{2} & \text { my.au } & \mathbf{O}\end{array}$ \\ Lentibutar}

Chili

Falkl. I. 1822. S co Hook. H. ex. 75

${ }^{\frac{1}{2}}$ jn.jl $\mathrm{Li}$ Britain bogs D m.s Eng. bot. 145 $\frac{1}{2}$ my V Britain bogs D m.s Eng. bot. 70 $\frac{1}{4}$ ap W Germany 1794. D l.p Fl.dan. 453 $\frac{2}{4}$ ap.my B Britain ir. bog. D m.s Eng. bot. 2184 $\frac{2}{4}$ jn.jl Y Carolina 1816. S p.l Bot, reg. 126 $\frac{1}{3}$ ap $\quad$ Y $\quad$ N.Amer. 1823. D s.p Hook. ex. fl. 16 Lentibularia. Sp. 3-63.

$\frac{1}{2}$ jn.jl $\quad \mathbf{Y} \quad$ Britain sta.wa. D aq Eng. bot. 253 $\frac{1}{2}$ jl $\quad Y$ Britain bngs $D$ aq Eng. bot. 254 $\frac{1}{3}$ my.jn $\mathrm{Y}$ Britain bogs D aq Eng. bot. 2489 TA. Vahl. Bastard Vervain. Verbenacea. Sp. 7-13. Indian $\square$ or 2 au.s W Ceylon 1732. S s.p

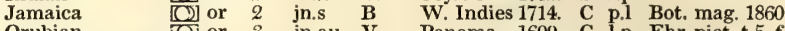
Orubian or 3 jn.au V Panama 1699. C 1.p Ehr. pict.t.5.f.1 chang.-flower. $\square$ or 3 mr.s o $\quad$ S. Amer. 1801. C p.l Bot. mag. 976 Germand.leav. (2) or 2 my.jn B W. Indies 1699. C p.l Jac. ic. 2. t. 208 L $\triangle$ or

ATER Horehound. $\triangle$ ro Virginian $\$ \Delta$ ro intermediate $\neq \Delta$ ro $W$. Amethystea. or oval-leaved 0 or Spanish O or spear-leaved thyme-leaved \& $\triangle$ rk sweet-scented $\Delta r$ intermediate w rk hairy flowering $\Delta$ rk

Taurian $O$ or

mint-leaved \& $\Delta$ or headed के $\triangle$ or pennyroy.-lvd. $\bigcirc$ or thyme-leaved $\mathrm{O}$ or hollow-stalked $₹ \Delta$ or purple-bracted $\frac{D}{2}$ or
3 my.jn $\mathbf{B}$

$1 \frac{1}{2}$ mr.ap B

Labiatce. Sp. 4-6.

$\begin{array}{llll}\text { Cayenna } & 1822 . & \text { C } & \text { p.l } \\ \text { Brazil } & 1822 . & \text { D } & \text { p.l }\end{array}$ B

W Italy 1739. D m.s Fl. græc. 1. t. 12 $\begin{array}{llll}\text { au.s W.P Virginia } & 1760 \text {. D m.s } \\ \text { jl.au W } & \text { Europe } & \text { 1820. } & \text { D m.s }\end{array}$

Labiatce. Sp. 1.

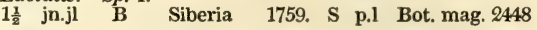

Labiate. Sp. 8-12.

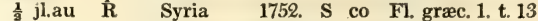

$\frac{1}{2}$ jn $\quad R$ Spain 1759. S co Lam. ill t.18. f.1

$\frac{1}{3} \mathrm{jn} . \mathrm{jl} \mathrm{Li}$ Levant 1752. S co Lam.ill.t. 18.f.2

$\frac{1}{2}$ jl.au $\mathbf{R} \quad$ Siberia 1786. D s.l

jn.au R Caucasus 1822. C co

$\frac{1}{2}$ jn.au R Siberia 1803. C co Bot. mag. 109.3

$\frac{1}{2}$ jls R Tauria 1816. S co Labiatce. Sp. 2-5.

1 jl.s R N. Amer. 1759, D co Mor, h.3.t.19. f.7 jl.au R Siberia 1799. D co Mem. petr.2.t.11 Labiate. Sp. 2-3.

in jn.au $\quad$ B N. Amer. 1777. S co

Labiate. Sp. 13-16.

jn.au $\underset{\mathbf{P}}{\mathbf{N}}$ N. Amer. 1656. D r.m Mill.1c. t.183 f.2 jn.s P. N. Amer. 1656. D r.m

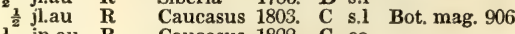

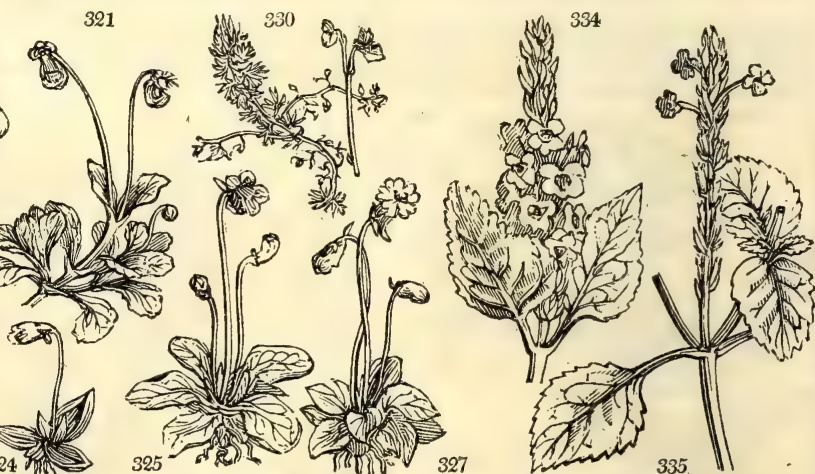

History, Use, Propagation, Culture,

C. corymbosa and paralia, are exceedingly beautiful herbaceous plants of difficult increase. The shrubby and branching herbaceous kinds are easily propagated by cuttings.

52. Pinguicula. From pinguis, fat, on account of the greasiness of its leaves. In P. vulgaris, the structure of the stigma, and its close application to the stamens is very remarkable. Linnæus says, that the warm milk of the rein-deer poured on the fresh leaves, and set aside for a day or two, becomes acescent ; acquires consistence and tenacity, and neither the whey nor the cream separate. In this state it is considered a very grateful food in Sweden and Norway. On cows' milk it acts like common rennet. The plant eaten by sheep has been sup. posed to produce the liver-rot; but a flat apterous insect, the fasciola hepatica or fluke, found adhering to stones and plants in boggy grounds, as well as in the liver and biliary ducts of sheep affected by the rot, is a more likely cause, and the more especially as no animal whatever will feed on the plant. The species (except P. grandiflora) are cultivated with difficulty in artificial shaded morass. P. grandiflora will thrive well on a dry northern bed of bog-mould among North American shrubs.

53. Utricularia. From utricula, a little bottle, from the small inflated appendages to the root. The species are scarcely susceptible of cultivation: they are very numerous in hot countries, and there form the most elegant ornaments of rivulets and pools of water. The flowers are fugacious, and so delicate as not to be capable of preservation as dried specimens, in which state their naturally beautiful colors of purple, pink, violet, or yellow, all change to a dead and uniform black. 
319 Leaves radical ovate and cordate stalked twice-crenate, Cauline cordate half embracing the stem 320 Leaves unequally toothed: the radical cuneate; upper oblong connate with the Capsules tomentose 321 Leaves spatulate entire hairy above, Flower-stalks like a scape 1-flowered

322 Nectarium conical thick at the end, obtuse shorter than the flowers, Scape villous, Capsules globose 323 Nectarium subulate nearly straight as long as the petals, Upper lip 2-lobed : Jower 3-parted, Scape smooth

325 Nectarium subulate straight as long as the flower,Upper lip spreading emarg. very large: lower 3-lobed throat 326 Nectarium subulate recurved shorter than the campan. flower, Throat bearded, Lips toothed, Scape villous 327 Nectarium subulate recurved shorter than the campan. cor. 5-lobed : lobes emarg. entire, Palate prominent,

328 Nectarium conical, Upper lip entire equal to the palate, Leaves very finely divided

[Scape pubescent

329 Nectarium carinate, Upper lip emarg. equal to the palate, Lvs. dichotomously 3-part. Cor. with throat open

330 Nectarium conical, Upper lip entire twice as long as the palate, Leaves dichotomously 3-parted

331 Leaves lanceol. obl. narrower at the base remotely toothed with stem very smooth, Bract. lin. lanceolate 332 Leaves oblong ovate tooth-serrated smooth, Branches hairy, Bractes ovate shorter than calyx

333 Leaves ovate serrate rough rugose, Stem shrubby, Bractes ovate larger than the calyx

334 I eaves serrate ovate rugose with the stem hoary, Bractes lanceolate shorter than the calyx

335 Leaves ovate obtuse serrate, Spikes lax, Bractes subulate shorter than the calyx

336 Leaves ovate crenate serrate smooth very obtuse

337 Leaves ovate acutely crenate with the stem very hairy, Spike very long, Bract. appressd smaller than the cal.

338 Leaves ovate lanceolate villous sinuate serrate

339 Leaves pinnatifid hairy, Lobes oblong somewhat toothed

340 Leaves lanceolate: the lower pinnatifid at the base : the upper remotely serrated, Stem smooth

341 Leaves pubescent ovate pinnatifid, Segments lanceolate : lowest the shortest, deeply cut at the end

342 Leaves opposite stalked 3-parted coarsely serrated smooth

343 Bractes ovate acumin. ciliate, Leaves elliptic lanceolate

344 Flowers in spiked racemes, Bractes obovate nerved acute, Leaves ovate

345 Flowers lateral, Leaves lanceolate

346 Leaves lanceolate naked nerved of one shape entire hoary, Flowers in spikes

347 Heads term. oval, Leaves ovate sub-serrate : those of the flowers nearly of the same shape entire ciliated

348 Leaves ovate acuminate nearly entire nerved, Flowers in heads, Calyx hairy pubescent at base

349 Whorls terminal and axillary close hispid, Leaves ovate sub-ciliate, Stems procumbent hairy

350 Flowers lateral, Leaves lanceolate entire ciliated, Cor. with an inflated throat twice as long as calyx

351 Leaves ovate serrate sessile, Flowers axillary and terminal, Stems erect

352 Leaves ovate acuminate, Flowers in heads, Stem decumbent

353 Pubescent, Leaves oblong serrated, Flowers axillary whorled, Lower lip of calyx with 2 ciliated bristles 354 Leaves oval entire, Flowers whorled, Stem square

355 Leaves obl. lanc. cord. pubesc. remotely and closely ser. Flowers in heads, Involucr. purple stem swollen 356 Leaves ovate oblong cordate pubesc. coarsely serrated, Flowers in heads, Involucr. purple, Stem fistular

357 Leaves obl. cord, pub. remotely serrate : upper entire, Flow. in heads, Invol. pale, Upper lip of cor. bearded
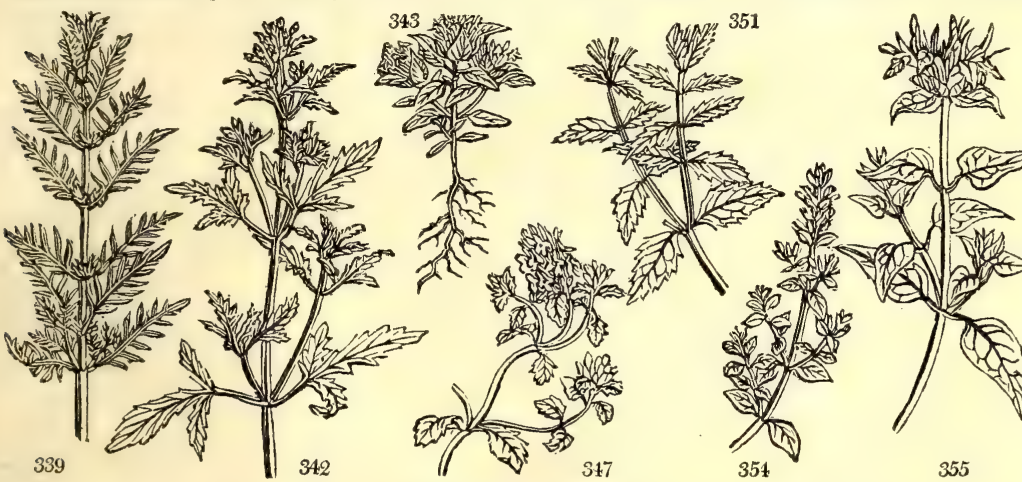

and Miscellaneous Particulars.

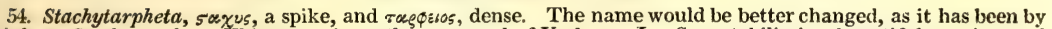
Link, to Stachytarpha. This genus is partly composed of Verbena, $L$. S. mutabilis is a beautiful species, and nearly always in flower. All of them strike readily in heat under glass.

55. Lycopus. From $\lambda v x \circ 5$, a wolf, and $\approx \varsigma_{5}$, a foot, on account of a fancied resemblance between the cut. leaves and a wolf's foot. Le Marrube aquatique, Fr. Der Wolfsfuss, Ger., and Licopo, Ital. L. europæus is common in most parts of Europe in meadows, but is not eaten by cattle. It dyes black, and gives a permanent color mon in most parts of Europe in meadows, but is not eaten by cattle. It dyes black, and gives a permanent color
to linen, wool, and silk. Withering says, gypsies stain their skin with it. According to Adamson, it has two barren filaments; and Pollich remarks, that there are sometimes 82 flowers in a whorl.

56. Amethystea. From $\propto \mu \varepsilon$ iv 50 , the amethyst, alluding to the color of the flower. A pretty annual, not very common in gardens.

57. Ziziphora. Etymolngy uncertain. This genus, and the two following, consist of little herbaceous plants resembling thyme: they are generally pretty, and easily cultivated. It would, perhaps, have been better to unite, with some writers, Ziziphora, Cunila, and Hedeoma, in one genus.

58. Cunila. A Roman name applied by Linnæus to this genus. The plants of Pliny bore some resemblance to those which compose the Linnæan Cunila. (See No. 57.) The leaves of C. mariana are used in decoction for colds.

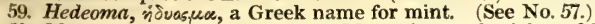

60. Monarda. In honor of Nicolas Monardez, a physician of Seville in the 16th century. Most of the species 
358 oblongáta $P h$. 359 clinopódia $P h$. 360 purpúrea $\boldsymbol{P h}$. 361 altis'sima $W$ 362 rugósa $\boldsymbol{P h}$. 364 didyma $W$. 365 ciliáta $\boldsymbol{P h}$.

366 hirsúta $P h$.

367 punctáta $\boldsymbol{P h}$. 368 officinális $W$. $\beta$ variegáta

62. SA'LVIA. $W$ 370 pomifera $\boldsymbol{W}$. 371 calycina $\mathrm{Sm}$. 372 canariénsis $W$. 373 atrea $W$.

374 dentáta $W$.

375 interrúpta $V a$.

376 pilántha $L \boldsymbol{k}$.

377 pinnáta $V a h l$.

378 hablitziána $W$

379 lanceoláta $\boldsymbol{W}$. en.

380 hirsúta $W$. en.

381 angustifólia $\boldsymbol{C a}$.

382 azurea $P h$.

383 pseúdo-coccinea $W$.

S. amona $B . R .446$.

385 mexicána $W$

386 chamædryoídes $V a$.

387 cæsia $W$. en.

388 hispánica $\boldsymbol{W}$.

389 serotina $W$.

390 dominica $W$.

392 polystáchya $W$

394 formósa $W$.

395 coccinea $W$.

396 pulchélla Dec.

397 amarissima $\boldsymbol{H}$. $\boldsymbol{K}$.

398 glutinósa $W$

400 ægyptiaca $W$.

401 crética $W$.

402 paniculáta $W$

403 africána $W$.

404 coloráta $W$.

405 officinális $W$. 363 kalmiána $\boldsymbol{P h}$.

\section{ROSMARI'NUS. $W$.} 369 chilénsis $W$

384 boosiána Jacq.

391 tiliæfólia $W$.

393 micrántha Vahl.

399 lineatı́fólia $\dot{L} a g$.

long-leaved $\gtrsim \Delta$ or 2 wild-basil-leav. $\frac{1}{\Delta}$ or 2 crimson $\quad \Delta$ or 3 tall $\quad \overrightarrow{ } \Delta$ or 4 white $\quad \forall$ or 4 white $\frac{\partial}{2} \Delta$ or 1 pub. flowered $\$ \Delta$ or 4 Oswego tea $\frac{\downarrow}{\Delta} \Delta$ or 3

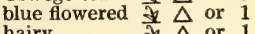
hairy $\pm \Delta$ or 1 spotted $¥ \Delta$ or 2

Rosemary. common variegated Chile

SAGE. : apple-bearing apple-bearing arge calyxed tw or canary or gold,-flowered

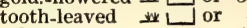
ash-leaved or 4 hairy-flowered or 2 winged-leaved

Siberian

\section{lanceolate}

hirsute

narrow-leaved azure-flowered

pale scarlet

blue Peruvian

Mexican

germander

grey

Spanish

Dominica $\frac{1}{2}$ or $1 \frac{1}{2}$

lime-leaved $\triangle \triangle$ or $4^{\frac{3}{4}}$

many-spiked $\triangle \mathrm{J}$ or 3

small-flowered $\triangle$ or 1

shining-leaved $\mathrm{w}$ L

scarlet-flower'd

pretty $\triangle \mathrm{J}$ or 2

$\begin{array}{ll}\text { bitter } & \Delta \text { or } 2 \\ \text { glutinous } & \Delta \text { or } 3\end{array}$

glutinous $\begin{aligned} & \triangle \text { or } 3 \\ & \text { lime-leaved } \text { or } 3\end{aligned}$

jl.s $\quad \mathbf{P} \quad$ N. Amer. 1761. D r.l

jl P.w N. Amer. 1771. D r.l

jn.au P N. Amer. 1789. D r.1 Bot. mag. 145

jn.au Li N. Amer. 1821. D r.l

jl.s W N Amer. 1761. D r

jn.au P N. Amer. 1813 D p.I Pursh. fl. am.t.1

jn.au R N. Amer. 1752. D r.l Bot. mag. 546

jl B N. Amer. 1798. D r.1 Pluk. al.t.164. f.3

jl.s $\quad$ P N. Amer. 1798. D r.l

jn.o $\quad \mathrm{Br} \quad \mathrm{N}$. Amer. 1714. S s.p Bot. reg. 87

Labiate Sp. ja.ap. 2 . 2.

jl $\quad P$ Chile 1795. C s.l

Labiatc. Sp. 95-170.

jl.au B Candia 1699. C p.1 Fl. græc. 1.t. 15

jl.au Pk Levant 1823. C co

jn.s P Canaries 1697. C l.p Tr. pl, rar. 2.t.19

d.ja

ap.s B

jl.au B

jl $\quad$ P

C. G. H 1731 C .p Tr.

C. G. H. 1774. C p.1

Barbary 1798. C s.l Schousb. 6.t. 1

Ievant 1823. C co

1731. C s.l Boerh.1. t. 167

Siberia 1795. C co Bot. mag. 1429

my.s $B$

my.jn $\mathbf{B}$

jn.jl B

au B

jn au $P$.

mr.ap $\mathbf{B}$

my.jl $\mathbf{S}$

jn.s B

jn.au Pr.

au B

jn.au B.c

o.d B

my.jn B

ap.o $\mathbf{S}$

$\begin{array}{ll}\text { ap.o } & \text { S } \\ \text { o.f } & \text { S }\end{array}$

o.f S

jn.s

...... 1813. S co Jac. ecl. 2. t. 13

1801. S co Jac. sch. 3. t. 252

Carolina 1806. C co Cav. ic. t. 317

S. Amer. 1797. C s.p Jac. ic. 2. t. 209

Peru 1821. C co Jac. ecl.1. t. 47

Mexico 1724. C p.l Cav. ic. 1. t. 26

Mexico 1795. C p.1 Bot. mag. 808

S. Amer. 1813. C p.l

Spain 1739. D p.l Bot. reg. 359

1803. C s.l Jac. ic. rar. 1.t. 3

W. Indies 1759. C s.p Sw. ob.18.t.1. f.1

S. Amer. 1793. C p.1 Jac. sch. 3.t. 254

Mexico 1822. C co Jac. sch. 3.t. 318

Cuba 1823. C co

Peru 1783. C p.l Bot. mag. 376

S. Amer. 1774. C p.l Murr.1778. t. 1

S. Amer, 1821, C co

Mexico 1803. C s.p Bot. reg. 347

Germany 1796. C co Mor.h.3.t.13.f.18

Mexico 1823. C co

Egyptian $\bigcirc$ or $\frac{x}{4}$ jn.jl W Egypt 1770. S co Jac. vind.2.t.108 Cretan or $x^{\frac{1}{2}}$ jn.au V Crete 1760 C co Riv. mon. t. 128 panicled J or 6 jn.au V C. G. H. 1758. C p.l Mill. ic. t.225. f.1

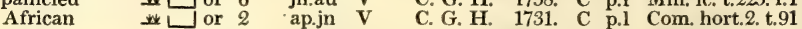
colored calyx $\amalg$ or 6 jl.au B C. G. H. 1758. C s.p Mill. ic. t.225. f.2 garden $\quad$ cul 2 jn.jl R.c S. Europe 1597. C co Ger. herb.623.f.1

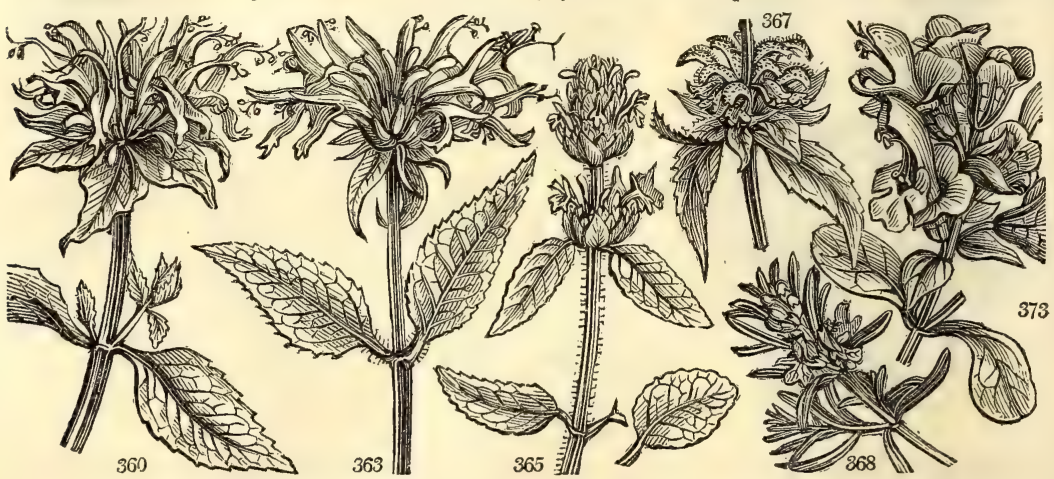

History, Use, Propagation, Culture,

are aromatic, and resemble mint in their habits and mode of culture. The leaves of $\mathbf{M}$. didyma are sometimes used as tea in North America; its flowers are of a very brilliant scarlet.

61. Rosmarinus. Two Latin words signifying dew of the sea. The shrub grows in the southern parts of Europe in the vicinity of the sea. $R$. officinalis yields, by distillation, a light-pale essential oil of great fragrance, which is imparted to rectified spirit. It was formerly recommended for strengthening the nervous system, headaches, \&c. as well as to strengthen the memory. Hence the allusion of the poet, "there's rosemary, that's for remembrance." Rue in former times signified grace; and rosemary, repentance. Rosemary was considered as an emblem of fidelity in lovers; it was worn at weddings and funerals, and on the latter occasions is still in some parts of Wales distributed among the company, who throw the sprigs in the grave along with the corpse. It is the principal ingredient in Hungary water, and is drunk as tea for headaches, and by nervous persons. It prefers a lean dry soil, or rubbish of old buildings; and when it has established itself on a wall, will resist the greatest cold of our winters. Its introduction is beyond record, and was probably by the monks in the dark ages.

62. Salvia. From salvere, to save, on account of its supposed healing qualities. This large and very natural 
358 Leaves oblong lanceolate rounded and narrowed at the base villous flat, Cor. dotted

359 Leaves ovate lanc. rounded and unequal at the base pubesc. remotely serr. Flowers in heads, Bractes pale 360 Smooth, Heads large leafy, Calyx colour. bearded, Cor. long smooth, Lvs. ov. obl. coarsely serr. Stem smooth 361 Leaves ovate acuminate rounded at base and equal hairy coarsely serrated, Flowers in heads, Bractes pale

362 Leaves ovate lanceolate cordate smooth rugose [bright crimson

363 Leaves obl. pointed stalked ovate, Flowers in heads, Bract. smail acute, Stem square pilose, Flowers very long

364 Leaves ovate acum. sub-cordate closely serrated smoothish, Flowers in headed whorls, Involucres purple

365 Leaves ovate attenuated, Stems and whorls hairy, Bractes ovate as long as the calyx

365 Very hairy all over, Flowers small in whorls, Leaves ovate acuminate serrate on long stalks, Stem square 367 Leaves lanceolate remotely serrated smooth, Flowers in whorls, Bractes pale

\section{Leaves sessile}

360 Leaves on stalks

Calyx 3-lobed, enlarged.

370 Leaves ovate lanceolate rugose crenulate undulate, Calyx blunt longer than ovate bracte

371 Leaves ovate crenate flat hoary netted with veins, Calyx 3-lobed dilated retuse with little lips

372 Leaves triangular hastate oblong crenated obtuse

373 Hoary, Lower leaves roundish truncate at base smooth : upper oblong entire, Calyx of fruit large

374 Leaves linear oblong serrate, Whorls 2 -flowered, Calyx obtuse

375 Leaves interruptedly pinnate, Stem shrubby erect

376 Leaves pinnate in 2 or 3 pairs, Leaflets sess. lanceol. obtuse crenulate rugose, hoary beneath, Bract. cordate

377 Hairy viscid, Leaves interruptedly pinnate, Leaflets oblong eroded unequal-sided, Calyx inflated

378 Leaves pinnate entire, Leaflets lanceolate nearly equal : upper generally in pairs

Calyx 3-toothed, sub-cylindrical.

379 Leaves lanc. obt. remotely serrate stalked beneath pub. Spike racemose winged, whorls 2-fl. Bract. lanceolate 380 All hairy, Leaves oblong ovate crenate, Flowers in spiked whorls, Bractes roundish acute

381 Ieaves lanceolate : the lower serrated outwards, with the stem hoary, Lower lip very broad, Calyx acute

382 Leaves linear lanceolate the lower serrated outwards with the stem smooth, Segments of calyx rounded

383 Leaves ovate acute serrated villous on each side, Stem hairy

384 Leaves obl, ov, rugose serr. smooth dotted, Flowers in spiked whorls on one side, Bract. decid. Helmet hairy

385 Lvs. somew. rhom. ov. acum. serr. at base and apex quite ent. beneath dev. above hoary, Bract. decid. hoary 386 I.eaves ovate crenate rugulose hoary, Calyx with stellate hairs, Stem decumbent

387 Leaves ov, acum. serr. beneath hoary, Spikes term. Lower whorls remote, Bract, decid. shorter than calyx

388 Leaves ovate serrate, Leaf stalks with a point on each side, Spikes imbricate, "Bract ovate ciliated narrowed

389 Leaves sub-cordate obtuse unequally bluntly serrated, Calyx viscid villous as long as corolla

390 Leaves cordate obtuse rugose crenated hoary beneath, Calyx villous viscid as long as corolla

391 Leaves cordate rugose crenate equally serrate acute, Calyx smoothish

392 Leaves ov. serr. glaucous beneath, Racemes comp. Flowers on one side, Leaf stalks with 2 glands at base 393 Leaves cordate crenate blistered wavy at edge obtuse smooth, Bractes ovate shorter than calyx

394 Leaves cordate crenate, Flowers axillary whorled, Stem shrubby

395 Leaves cordate acute tomentose serrate, Corolla twice as long and narrower than the calyx

396 Leaves cord. acute smoothish cren. : the upper sess. whorls $6-10 \mathrm{f}$. Helmet hairy entire the length of stamens 397 Leaves cordate crenate : stalks with 2 calli, Stem and calyx clammy with hair, Bractes ovate ciliated 398 Villous viscid, Leaves cordate arrow-headed coarsely serrated acuminated, Helmet entire

399 Leaves cord. ovate acuminate lucid serrat. downy beneath, Spikes numerous axillary and term. very dense Calyx 5-toothed, generally 3-2.

400 Leaves linear lanceolate toothed rugose, Bract. ovate mucronate 401 Leaves linear lanceolate, Flowers nearly digynous, Cal. 2-leaved 402 Leaves obovate wedge-shaped toothletted

403 Lower leaves spatulate serrate truncated at base toothed : upper oblong nearly entire, Cal. hairy

404 Leaves obl. nearly entire hoary, Cal. hairy : of the fruit enlarged veiny with a membranous coloured limb

405 Leaves lanceolate ovate crenulate, Whorls few-flowered, Cal, mucronate longer than bractes

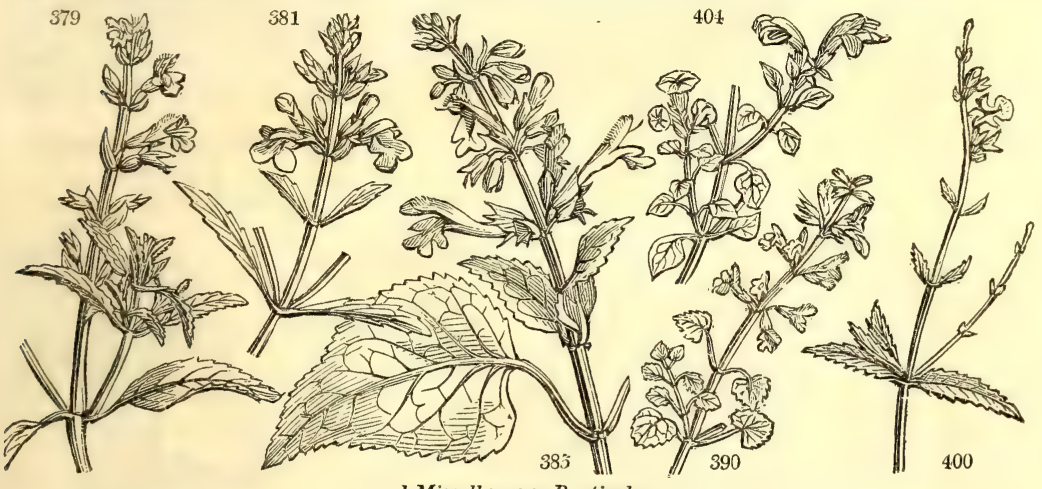

and Miscellaneous Particulars.

genus consists of herl:s or under-shrubs, the leaves of which have generally a rugose appearance, the smell aromatic, and the flowers commonly in spikes, two or three together from a tracte or leaf. They are all of easy culture, and some of them are ornamental as greenhouse plants or border flowers. The Horminum, Salvia, and Sclarea of Tournefort are included in this genus. The Sclarea or clary is derived from $\sigma \approx \lambda$ neos, stiff, and Horminum from ónew, quod ad venerem stimulat. Of $\mathrm{S}$. officinalis there are many varieties, differing in the size, form, and color of the leaves. It was formerly in great repute in medicine as a sudorific, aromatic, astringent, and antiseptic. The Chinese use it as a tonic for debility of the stomach, and strengthening the nervous system, and prefer it for these purposes to their own tea. It is, however, discarded from our pharmacopeiæ, but still used by self-practitioners and herb doctors. In cookery it is used for sauces and stuffings for luscious meats. S. grandiflora is preferred for making tea. S. pomifera produces protuberances as big as oak galls, occasioned like them, by the puncture of an insect. In the isle of Crete, $\mathrm{S}$. officinalis has the same sort of excrescences, and they carry them to market there under the name of sage-apples. S. verbenaca is a native of all the four continents, and very aromatic. A mucilage is produced from its seeds, which, put under the eyelids for a few moments, envelopes any sand or dust there, and brings it out; and hence the name of officinalis christi, clear 
40 ỉ Spielmánni $W$. en. 407 spléndens $K e r$. 408 phlomoides $W$ 409 urticifólia $\boldsymbol{W}$. 410 bulláta $W$. en. 411 rugósa $W$. 412 verticilláta $W$ 413 indica $W$. 414 Tenórii $S p r$. 415 verbascifólia $B i$ 416 odoráta $W$. en 417 compréssa Vahl. 418 móllis Donn. 419 grandiflóra $W$ 420 crassifólia Desf. 421 praténsis $W$.

422 variegáta $W$. en. 423 hæmatódes $W$. 424 viscósa $W$. 425 disérmas $W$. 426 nútans $W$. 427 betonicæfólia $W$. 428 amplexicaúlis $\boldsymbol{W}$.en. 429 austríaca $W$. 430 syriaca $W$. 431 núbia $W$. 432 virgáta $W$. 433 campéstris $W$. en. 434 sylvestris $W$. 435 nemorósa $W$. 436 pátula $W$. en 437 tingitána $W$ 438 Sclárea $l V$. 439 spinósa $\mathscr{W}$ 440 athíopis $W$ 441 argéntea $W$. 442 applanáta $W$ 443 Hormínum $W$ \& violácea $\beta$ rabra

444 víridis $W$ $\$ 45$ truncáta $W$. en. 446 pyramidális $\boldsymbol{P e t}$. 447 verbenáca $W$. 448 oblongáta $V a h l$. 449 tríloba $W$ 450 lyráta $W$ 451 abyssínica $W$. 452 nilótica $W$. 453 Forsköhlii $W$ 454 napifólia $W$. 455 auríta $W$. 455 aurita $W$. 457 Barreliéri Ett 458 laciniáta $W$. 459 runcináta $W$ 460 polymórpha $L k$. 461 clandestína $W$. 462 ceratophýlla $W$ 463 ceratophylloídes $W$. 464 bracteáta $W$.

63 COLLINSO'NIA 465 canadénsis $W$. $\beta$ cordáta r ováta 466 scabriúscula $W$.
Spielman's

splendid -like $\triangle \Delta$ or 2 nettle-leaved $\not \Delta$ or 3 blistered \$ $\Delta$ or 2 wrinkle-leaved $L$ or 2 whorl-flower'd $\downarrow \Delta$ or 3 Indian \& $\Delta$ or Tenore's $\frac{\partial t}{\Delta}$ or 2

mullein-leaved $\$ \vec{\Delta}$ or 3 sweet-scented compressed \& $\triangle$ or 2 soft great-flowered $\frac{j}{\partial} \Delta$ or 2 thick-leaved $\vec{\Delta} \Delta$ or 2 meadow or 4 variegated $\$ \Delta$ or 2 bloody-veined $\overrightarrow{ } \Delta$ or 2 clammy $\vec{x} \Delta$ or 11 long-spiked \$े $\triangle$ or 2 nodding $\frac{\mathrm{D}}{\Delta} \Delta$ or 3 betony-leaved $\not \Delta \Delta$ or 3 Austrian $\$ \Delta$ or 1 Syrian 1 is Nubian $\Delta$ or 2 long-branched $\& \Delta$ or field spotted-stalk'd $\Delta \triangle$ or 2 spear-leaved $\Delta \Delta$ or 3 spreading $\$$ O or 3 common Clary $\$$ (2) cul 4 thorny-calyx $₹$ or 1 thorny-calyx \$ㄴ) or 1 woolly $\quad$ \& 0 or 3

silvery $\quad \not \Delta \Delta$ or 3

flattened $\quad$ \& 0 or $1 \frac{1}{2}$

annual clary $O$ cul $1 \frac{1}{2}$ purple-topped

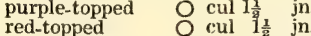
or $1 \frac{1}{2}$ jn.jl $R$ green-topped truncated pyramidal oblongate three-lobed lyre-leaved Abyssinian Nile

Forsköhl's rape-leaved eared-leaved two-coloured Barreliers torn or 1 jl. au Pl jl.au PK my.jn

jn.o $\mathrm{V}$

jn.o B

\& $\triangle$ w 2

O or 11 * $\mathrm{O}$ or 2 $\downarrow \Delta$ or 1 I. $\triangle$ or $1 \frac{1}{2}$ $\mathrm{O}$ or 1

jn.jl $\quad R$

jn.jl L. B jn.jl P Egypt 1780. C l.p Jac. vind. 3. t. 92 jn. au Bk Ievant 1800. C co Bot. mag. 988 jn.jl D.P Italy 1776. D co Jac.vind.2. t.152 my.jn C. G. H. 1795. C p.l jn.jl V.w Barbary 1793. D co Bot. mag. 1774 ap.my B Spain 1821. D co Ten. fl. nap.t. 2 ap.my B 1822. I) co

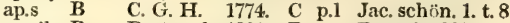

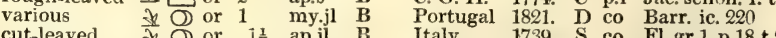

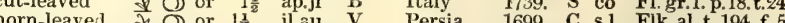
branchy 2 (2) or ${ }^{\frac{1}{2}}$ jn.au V Egypt 1771. C s.l Ard.spec.2.t.2

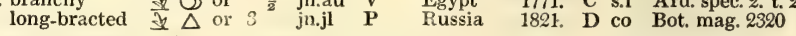
V. Collinsonia. - Labiato, $S p .5-6$. nettle-leaved $\underset{t}{ } \Delta$ or 3 au.o L.B N. Amer. 1735. D p.l Hort. cliff, t. 5 cordate $\quad \vec{y} \Delta$ or 3 au.e L.B N. Amer. $\quad . . \quad$ D p.l

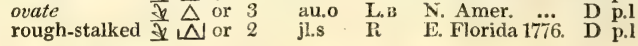

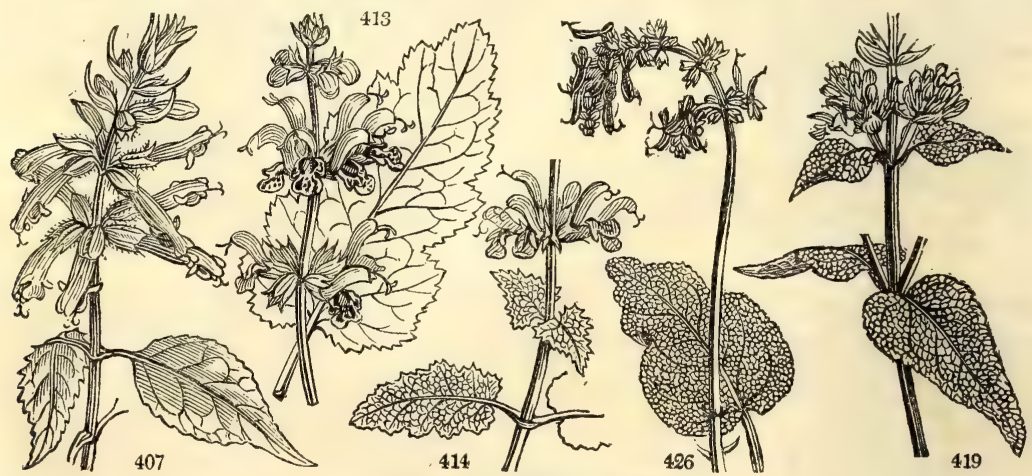

History, Use, Propagation, Culture,

eye or clary. The flowers of S. glutinosa are used in Holland to give a flavor to the Rhenish wines. S. Sclarea has a very strong scent, and was formerly used in medicine. A wine is made from the herb or flower, boiled with sugar, which has a flavor not unlike Frontignac. S. indica is a magnificent species, but rather tender in 
406 Leaves radical obl. sub-cord. bluntly tooth. : cauline tooth cren. Whorls 6-fl. Fl. horizon. a sing. fl.-st. term. 407 Leaves stalked ovate lanceolate flat smooth beneath, Corolla and coloured calyx downy, Style exserted 408 Leaves lanceolate nearly entire with the stem woolly clammy

409 Villous viscid, Leaves ovate oblong toothed running down the stalk

410 Leaves cordate oblong crenated toothed eroded, Stem twiggy, Whorls remote, Helmet linear

411 Leaves cordate oblong lanceolate eroded crenated rugose hairy, Stamens shorter than corolla

412 Leaves cordate crenate toothed, Whorls nearly naked, Style lying on the lip of the corolla

413 Leaves cordate rather lobed at the side : the upper sessile, Whorls nearly naked very distant

414 Leaves sub-cordate oblong crenate naked on each side, Helmet pilose

415 Leaves cord, ovate doubly serr. rugose woolly, Upper whorls sess. Bract. cord. mucronate shorter than calyx 416 Leaves hoary on each side rep. and uneq. tooth. : low. cord. upp. ov. Fl. in panic. Style twice as long as helmet 417 Rather woolly, Leaves toothed : radical cordate-oblong, Bract. roundish cordate unarmed : the upper sessile 418 Leaves cordate ovate acute rugose doubly crenate smooth above pubescent beneath, Branches in bundles 419 Leaves cordate oblong crenate, Whorls many-flowered, Cal. acute shorter than the bracte

420 Stem woolly, Leaves cord. crenulate hoary beneath, Upper whorls dense sessile, Upper lip of cor. abhreviatc 421 Lvs. cord. obl. cren. or cut : the upper stem clasping, Bract. nearly as long as cal. Helm. visc. long. than lip 422 Lvs. cord. obl. rugose tooth cren. : cauline stalked, Spikes twiggy, Bract. short. than cal. Hairs of cal. gland. 423 Leaves cordate ovate rugose tomentose, Cal. hispid, Root tuberous

424 Villous viscid, Leaves cordate oblong rugose acutish crenulate, Bract. cordate roundish acuminate 425 Leaves cordate oblong eroded, Leaf-stalks edged, Stam. as long as corolla

426 Leaves obl. cordate, Stem simple without leaves, Racemes in flowers pendulous

427 Leaves cord. lanc. uneq. cren. Stem 4-corn. Rac. comp. term. nearly naked cernuous, Bract. coloured ciliate 428 Leaves cord. lanc. $\frac{1}{2}$ stem embracing uneq. cren. Bract. cord. acum. shorter than the calyx, Flowers spiked 429 Leaves cordate oblong eroded sinuated, Stem nearly without leaves, Whorls very hairy, Stam. very long 430 Leaves cordate toothed lower repand, Bract. short acute, Cal. tomentose

431 Leaves oblong sub-cordate unequal-sided rugose crenated with a little auricle at the base

432 Leaves oblong cordate rugose crenated, Hairs of the calyx and stem glandular at the end

433 Leaves cord. obl. doubly cren. somewhat repand hairy, Rac. twiggy, Bract. shorter than cal. Fl.-sts. toment. 434 Leaves cord. rugose biserr. Bract. coloured pointed shorter than the flower, Hairs of stem and calyx simple 435 Leaves cordate lanceolate equally serrate, Bract. the length of calyx, Lower lip of corolla reflexed 436 Clammy, Radical leaves cordate toothed sinuated: cauline sessile oblong, Bract. as long as calyx 437 Leaves cordate oblong eroded toothed very rugose, Bract. cordate mucronate ciliated, Cal. spiny 438 Leaves rugose cordate obl. serrate villous, Bract. coloured longer than calyx 439 Leaves oblong repand, Cal. spiny, Bract. cordate mucronate concave

440 Leaves oblong eroded with the whorls woolly, Bract. recurved somewhat spiny 441 Leaves oblong toothed angular woolly, Upper whorls sterile, Bract. concave

142. Lvs, sub-corả. obl. obtuse with spread. teeth, Stem clammy with hairs, Bract. cord. entire equal to spiny cal. 443 Leaves obtuse crenated, Upper bract. sterile large and coloured

444 Lvs. obt. obl. equal, cren. stalk. : those next the fl. stem-embrac. the low. whorls dist. Cal. of the fruit reflex. 445 Leaves obl. obt. cren. stalk. Floral stem-emb. whorls 2 approxim. the term. one having $6 \mathrm{f}$. Cal.of fruit reflexed 446 Lvs. cord. acum. plait. erod. cren. ben. white with hairs, Bract. col. cord. acutelong. than cal, Sp. term. conic. 447 Leaves serrate sinuated smoothish, Corolla shorter than calyx

448 Leaves lanceolate oblong obtuse smooth, coarsely equally bluntly serrated, Cor, narrower than cal

449 Tomentose, Lvs. stalked rugose sub 3-lobed : the intermediate lobe longer and oll. : the lateral obt. ovate 450 Radical leaves lyrate toothed, Helmet very short, Stem with very few leaves hairy downwards 451 Lower leaves lyrate : upper cordate, Flowers whorled, Cal. mucronate ciliated

452 Leaves sinuate angular crenate toothed, Cal. teeth spiny with the angles and edge of the orifice ciliated 453 Leaves lyrate auricled, Stem nearly without leaves, Helmet bifid

454 Lvs. cord, with spread, teeth : the low. hastat. and lyr. Whorls nearly naked, Up. lip of cor. short. cord. edged 455 Villous, Leaves ovate toothed auricled, Flowers in spiked whorls

456 Radic. Ivs. cord. palm. or ent. of the stem arrow-head. lanc. uneq. tooth. Bract. reflex. short. than nodd. cal. 457 Leaves hastate lanceolate unequally serrated, Stem leafy erect

458 Leaves pinnatifid rugose: Segm. lin. unequal crenated obt. Whorls many-fl. Bract. roundish cordate acute 459 Scabrous, Leaves pinnatifid backwards toothed, Flowers in spiked whorls

460 Lower lvs, stalked sinuated pinnatifid rugose smoothish : the upper sessile cord. Bract. short. than flowers 461 Leaves serrated pinnatifid very rugose smooth, Spike obtuse, Cor. twice as long as calyx

462 Leaves very rugose woolly : the radical bipinnatifid cauline pinnatifid, Upper whorls sterile 463 Leaves pinnatifid rugose stalked, Whorls all fertile and very hairy 464 Leaves pinnated hairy, Segments of calyx subulate, Bract. leafy longer than cal. Whorls many-flowered

\$65 Leaves ovate and stem smooth

466 Leaves sub-cordate a little hairy, Stem roughish
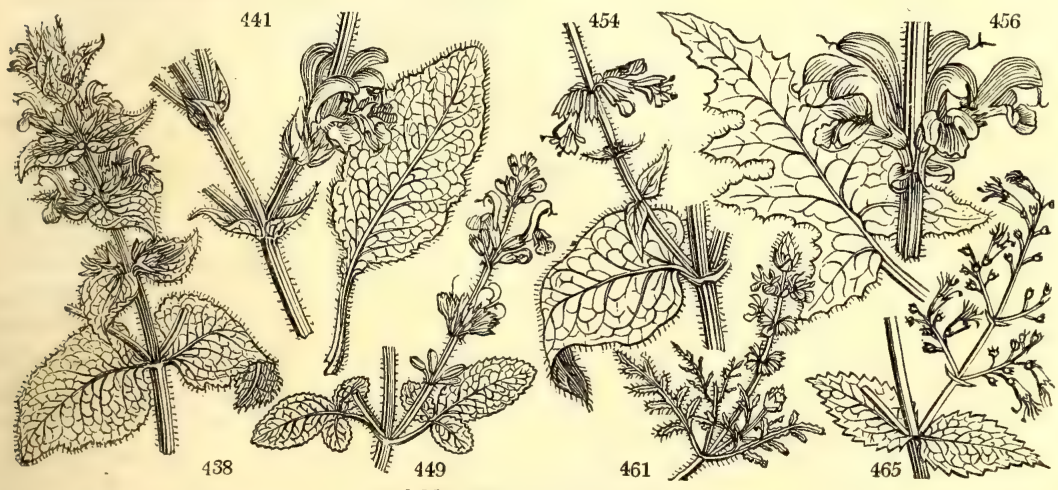

and Miscellaneous Particulars.

severe winters. S. formosa and S. spiendens are very ornamental. Ali the species thrive in light soil, somewhat rich, and are readily propagated by seeds, cuttings, and dividing the roots.

63. Collinsonia. In honor of Peter Collinson, F.R.S., a most distinguished promoter of botany, and a cor- 
467 ovális $P h$.

468 tuberósa $P h$.

469 anisáta $B . M$.

64. CATALPA J

470 syringifólia $H$. $K$.

65. GHI'NIA. $W$.
472 spinósa $W$.

6. Fontanesia

473 phillyræoídes $W$. phillyrea-leav.

67. LINOCIE'RA. B.P. LiNociera.

474 compácta $B . P$. Caribean $\square$ or

68. ANCI'STRUM. I. ANCistrum. 475 latebrósum Vahl. hairy

476 pinnatífidum $F l$.per. pinnatifid

477 ovalifólium Vahl. creeping

478 adscéndens $V a h l$. ascending

479 sanguisórbæ Vahl. Burnet-leaved

480 lácidum Vahl. shining

481 argénteum $F l$. per. silky

482 lævigátum $H . K$. smooth

69. O'RnUS. P.S. Flowering Ash.

483 europæ'a P.S. FLOWERING A

484 rotundifólia $P$. $S$.

485 floribúnda Wall.

70. MORI'NA.

manna

many

486 pérsica $W$. Iorina.

71. CIRCE'A.

488 intermédia

489 alpina $\boldsymbol{W}$.

72. FE'DIA. D. C

490 cornucópiæ D. C. red

73. PIMELE' A. $\boldsymbol{B} . \boldsymbol{P}$.

492 rósea $\boldsymbol{B} . \dot{P}$.

493 drupácea $B r$

494 pauciflóra B. $\boldsymbol{P}$.

74. CLA'DIUM schr

495 germánicum

75. GUNNE'RA.

496 perpénsa $\boldsymbol{W}$.

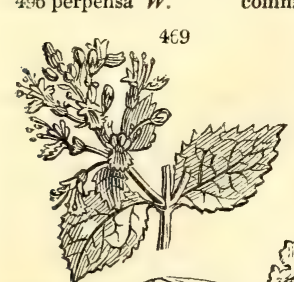

Sanguisorbece.
$\mathrm{N}$ cu 1 ap.jn $\mathrm{G} .8-15$.

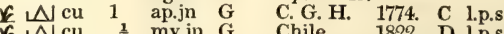

$\triangle \mathrm{cu}^{\frac{1}{2}}$ my.jn $\mathrm{Gu}$

$\triangle \mathrm{cu}^{2}$ my.jn G

f $\triangle \mathrm{cu}$

$\triangle \Delta$ jn G

$\triangle$ cu $2^{\frac{1}{2}}$ my.jn G

₹ $\triangle$ cu $\frac{1}{2}$ jn.au G

Oleince. $\mathrm{Sp}$. 3.

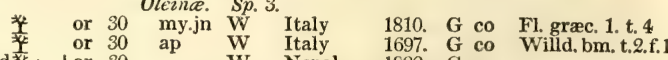

1802. D l.p.s

Magellan 1822. D ip.s

N. Zeal. 1796. D l.p.s Lam, ill. t. 12, f. 1

FalklandI.1777. D 1.p.s Lm. ill.1. t.22. f.3

Chile 1822. D l.p.s Fl. per. 1.t. 103

Magellan 1790. D l.p.

Italy

1822. G co

Dipsacea. Sp. 1.

NChaNTER's Nightshade. Onagraria. Sp. 3.

common $\Delta$ or 1 jn.au $R$. Britain sha. pl. D co Eng. bot. 1056 intermediate $\frac{1}{\mathrm{~N}}$ or $\frac{1}{\mathrm{j} n \mathrm{au}} \mathbf{R}$ Europe 1821. D co Fl. dan.t.256 mountain \& $\Delta$ or $\frac{2}{4}$ jn.s $R$ Britain moun. D co Eng. bot. 1057 Valerianea. Sp. $1-2$.

$\begin{array}{cccc}\text { Valerianea. } & S p .1-2 . \\ \text { jn.jl R } & \text { S. Europe 1796. S co Fl. græc. t. } 32\end{array}$ Thymelace. $S p .4-39$.

Pimelea. flax-leaved w or 2 f.au W N. S. W. 1793. C s.p Bot. mag. 891 rose-coloured $w^{2}$ or $2 \mathrm{mr} . \mathrm{s}$ Pk N. Holl. 1800. C s.p Bot mag 1458 fleshy-fruited w or 2 my W N. Holl 1817 C p few-flowered ${ }^{2}$ or 3 my W. Di. L. 1812. C 1.p Bot. cab. 179

Cladium. Cyperacea. $S p .1-14$.

prickly-sedge 此 $\Delta \mathrm{w} 3$ jl.au Ap Britain mar. D m.s Eng. bot. 950 Urticea. Sp. 1-3.

$$
\text { H. 1683. D m.s Bot. mag. } 2376
$$

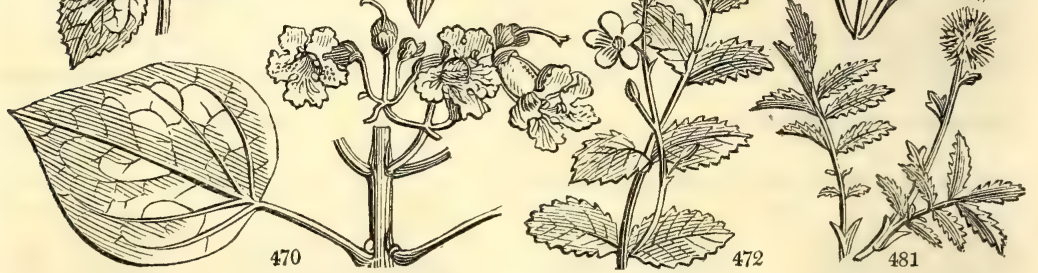

History, Use, Propagation, Culture,

respondent of Linnæus: he died in 17- Horse-weed, Amer. The species are American plants of easy cultivation.

64. Catalpa. The Indian name. Die Trompetenblume, Ger. C. syringifolia, H.K. is the Bignonia catalpa, L. a low-spreading, rather singular looking tree, with succulent shoots easily injured by winds or severe frosts. It requires a sheltered situation and plenty of room. The leaves are large and come out late; the flowers are white, shewy, and are succeeded by long pods, but they seldom appear in this climate. One of the oldest catalpas gant upright tree, known in the West Indies by the name of French oak, and the French call it chêne-noir.

65. Ghinia. In honor of an Italian botanist, named Ghini, who founded several botanic gardens.

66. Fontanesia. So named by Billardiére, in honor of M. Desfontaines, the excellent professor of botany at the Jardin du roi at Paris. It is rather a tender shrub, requiring shelter in severe weather. It grows in common garden soil, and is increased by layers or by cuttings in sand under a hand-glass.

67. Linociera. Narned after Geoffroi Linocier, a French physician. A tropical genus of shrubby plants, propagated by cuttings, and of little beauty in a cultivated state.

68. Ancistrum. From ayzs seo, a hook. Its calyx is terminated by little hooks. These are small herbaceous plants with pretty foliage, but no beauty in their flowers. They are only cultivated as objects of curiosity, and are seldom seen

69. Ornus. In Greek, oøsuys, from ogos, a mountain. The tree grows on mountains. La Frene à fleurs, Fr. Die Blültende Esche, Ger.; and Frassino florido, Ital. O. europæa, P.S. is the Fraxinus ornus, $L$. O. rotundifolia, or the manna ash, abounds in the skirts of the mountains in Calabria. From the middle of June to the end of July the manna gatherers make an incision across the bole of the tree, which they deepen the second day, inserting a maple leaf, so as to form a sort of cup to receive the gum as it distils from the incision. Sometimes bits of reed or twigs are applied, on which the manna oozes out, and drying with the sun, forms tubular 
467 Leaves oblong acute at both ends, Stem smooth, Cal, teeth very short, Flowers terminal naked 468 Leaves sub-rhomboidal ovate, Cal. teeth bristly longer than the tube, Panicle leafy, Stem much branched 469 Leaves ovate cordate rugose, Flowers tetrandrous

470 Leaves cordate flat

471 Leaves oblong undulated

472 Fruit with 4 spines, Leaves smooth

473 Leaves ovate-oblong pointed at each end, Flowers racemose

474 Racemes compound and decompound, Flowers sessile in threes, Petals subulate

475 Leaflets oblong cut, Flower-stalks like scapes, Spikes elongated prickly, Stems half under ground 476 Leaves linear-lanceol. sub-pinnatifid hairy beneath, Spikes cylindrical, Stem erect

477 Leaves oblong,and a little wedge-shaped serrated silky beneath, Spikes globose, Stems creeping

478 Leaflets oblong and obovate serrated smoothish, Spikes round, Stem decumbent

479 Leaves remote, Leaflets wedge-shaped serrated silky beneath, Spikes globose, Stem decumbent

480 Leaves 3-5-parted, Segments linear-villous beneath, Spikes oblong, Stem half under ground

481 Leaflets ovate-oblong serrated silky beneath, Spikes globosc, Stem creeping

482 Leaflets oval crenate and cut smonth above hoary beneath, Spike terminal cylindrical, Stem decumbent

483 Leaves lanceolate attenuated stalked serrated

484. Leaves roundish acute doubly serrated nearly sessile

485 Leaflets oblong tapering acuminate acutely and unequally serrated, Male flowers with a corolla

486 A plant like the Acanthus. Flowers in whorls

487 Stem pubescent erect, Leaves ovate acute denticulate sub-pubescent

488 Stem erect simple nearly smooth, Leaves cordate with spreading teeth acuminate

489 Stem much branched erect smooth, Leaves cordate smooth shining

490 Upper leaves toothed and angular, Flowers in heads

491 Invol, 4-lvd. leafl. broad ov. smth. on both sides much short. than the head, Lvs. lin. -stalk. 1-nerv. Cor. silky 492 Invol. 4-lvd, leafl. lanceol, ovate acute smooth on both sides, Leaves lanceol. lin. Cor. hairy on its lower half 493 Leaves oval-obl. flat pubesc. beneath, Floral lvs. longer than the head, Cor. cylind. deciduous, Fruit berried 494 Lvs. smooth on both sides lin. lanc. twice as narr. as the floral lvs. longer than the few-fl. head, Cor. smooth

495 Culm round, Corymbs dense, Panicle contracted, Flowers in bunches

196 Leaves uniform toothed shorter than the scape in seed, Scape and leafstalks smooth

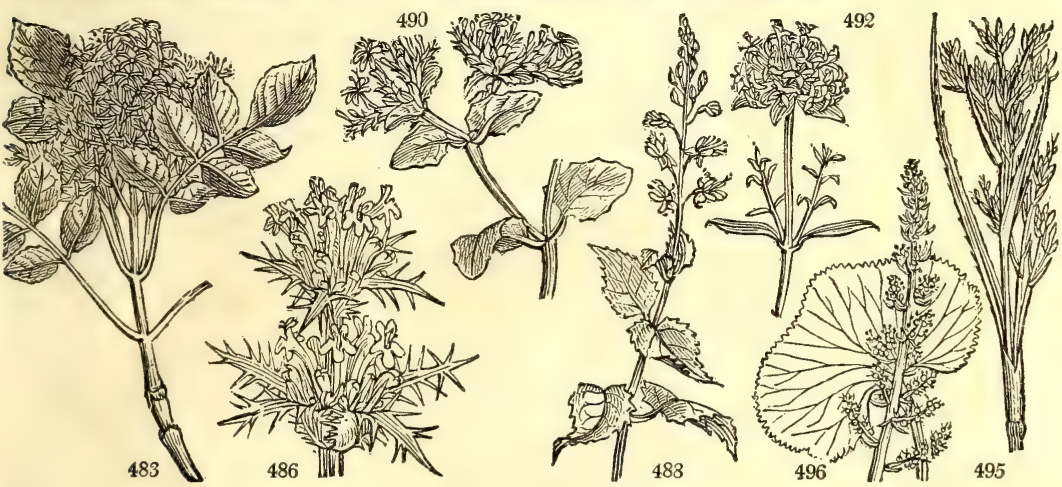

and Miscellaneous Particulars.

pieces called manna in Cannali, which being reckoned more pure, sells higher by one-third than the manna in Tazzeti. Manna is a concrete mucilaginous juice, mild, and slightly nauseous. It seems to have no relation to that which nourished the Hebrews in the desert, being, as Rozier observes (Dict. d'Agr.), much more likely to have purged than nourished them. The Fraxinus virgata, P.S. also affords manna, but from no other species or ornus can it be procured. The Ornus floribunda has lately been discovered in Nepal, where it is called kanga and tahasee.

70. Morina. In memory of Lewis Morin, a French botanist, and son of Peter Morin, a florist celebrated in the 17 th century. This plant is of very rare occurrence. It is not unlike the common acanthus, but more beautiful. Propagated by seeds.

71. Circaa. Poetically named after the enchantress Circe. The genus grows in damp shady places where shrubs fit for incantations may be supposed to be found. The Greeks had a plant named circæa. All the species are easily cultivated, and are curious on account of their singular flowers. C. lutetiana has been found in Nepal.

72. Fedia. A name of Adanson's, which, like many others of the same author, has probably no meaning. The genus has been very properly distinguished from Valeriana by Decandolle, as well as from Valerianella, with which it has recently been again confounded. A weed-like annual is the only species yet in our gardens.

73. Pimelea. From $\pi \iota \kappa \varepsilon \lambda \eta$, fat; but if so, it should be written Pimelæa. A real and extensive genus of plants, natives of the southern hemisphere. Many of the species are from N. Holland, and are chiefly known by the brief descriptions of Mr. R. Brown.

74. Cladium. From $\approx \lambda \propto \delta \circ$, a branch or twig. A tall sedge-like plant, referred by Linnæus and his school to Schœnus. C. germanicum is the only European species; it is the Schœenus mariscus of English botany. The others are chiefly from N. Holland.

75. Gunnera. After Ernest Gunner, bishop of Norway, of which country he published a Flora. A singular plant, cultivated merely as an object of curiosity. It likes a moist peat soil, and the temperature of a cool greenhouse. 
DIGYNIA.

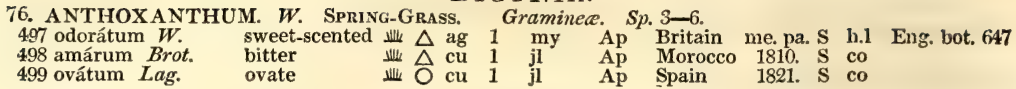

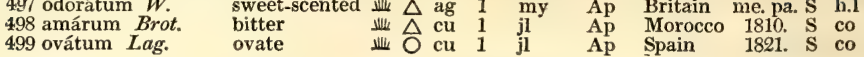

77. PI'PER. $W$. 500 coriáceum Vahl. 501 nítidum $W$. 502 adíncum $\boldsymbol{W}$. 503 mácrophýllum $W$. 504 geniculátum $W$. 505 hispidum $W$. 506 Amalágo $W$ 507 Bétle $W$.

508 nigrum $W$. 509 discolor $W$. 510 reticulátum $W$ 511 decumánum $W$ 512 Siribóa $W$. 513 lóngum $P$. $S$ 514 peltátum $W$. 515 umbellátum $W$ 516 laurifólium Mill. 517 tomentósum Mill. 518 glábrum Mill. 519 racemósum Mill.
Pepper.

Pepper.
leathery

E. Indies 1815. C r.m Bot. cab. 128

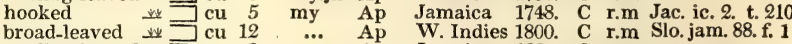
swollen-joint'd $7 \mathrm{cu} 2$ hairy-leaved w cu 6 rough-leaved $\mathrm{cu} 6$ betle clt in clt 6 the great Siriboa peltated laurel-leaved $\mathrm{O}$ cu downy smooth great racemose

... Ap

jl $\cdots$ Ap Jamaica 1823. C r.m C r.m Rheede $7, \mathrm{t} .15$ W. Indies 1821. C r.m Bot. cab. 610 E. Indies 1768. C r.m Rumph. 5. t.117 W. Indies 1748 . C r.m Plumier. W. Indies 1748. C r.m Plumier. 56.t. 74 W. Indies 1748. C 1.p Plumier. W. Indies 1768. C r.m W. Indies 1768 . C r.m Campeac. 1768. C r.m Campeac. 1768. C r.m netted

jl.au Ap Jamaica 1759. C r.m Slo.hist.1.t.87.f.1 E. Indies 1790. C r.m Lam, ill. 79. t. 23 W. Indies 1748. C r.m Plumier. 57. t.75 Carthag. 1768. C r.m Jacq. ic. 2. t. 215 F. Indies 1788. C r.m Rump.5.t.116.f.2

520 brachyphýllum $W$. short-leaved 521 amplexicáule $W$ stem-clasping of $\mathrm{cu}$ 502 magnolicis 523 obtusifólium $W$. obtuse-leaved 524. cuneifolium $W$. en wedge-leaved 525 alátum $P . S . \quad$ winged 526 acuminátum $\boldsymbol{W}$. en acuminate 527 distáchyon $P . S$. 528 maculósum $\boldsymbol{W}$. 529 pellúcidum $W$ 530 pubéscens $\boldsymbol{H}$. $\dot{S}$. 531 húmile $V a h t$. 532 trifólium $P$.S. 533 pulchéllum $\boldsymbol{W}$. 534 pulchellum 534 pereskiæfólium 535 blándum $W_{\dot{1}}$. 537 polystáchion $W$ 538 quadrifólium $W$ 539 inæqualifólium 540 stellátum $\boldsymbol{P} . S$ 541 incánum Haw. 542 subrotúndum Haw. sm. clusia-lvd 543 rubéllum Haw. two-rowed spot-stalked pellucid pubescent low

\section{ree-leaved} small-leaved

cactus-leaved villous red-stemmed many-spiked four-leaved unequal-leav' $d$ dy

\begin{tabular}{|c|c|c|c|}
\hline & & $1^{\frac{1}{2}}$ & \\
\hline & cu & 1 & jn.s \\
\hline & $\mathrm{cu}$ & $1 \frac{1}{3}$ & ja.mr \\
\hline & cu & 1 & ap.jl \\
\hline & $\mathrm{cu}$ & 1 & mr.ap \\
\hline & $\mathrm{cu}$ & 1 & jn.jl \\
\hline & $\mathrm{cu}$ & $1 \frac{1}{2}$ & jn.jl \\
\hline & cu & & $\mathrm{s}$ \\
\hline & cu & $\frac{\pi}{2}$ & ap.s \\
\hline & $\mathrm{cu}$ & & jl.o \\
\hline$\pi$ & $\mathrm{cu}$ & & jn.jl \\
\hline & cu & & jn.au \\
\hline & cu & & jl.o \\
\hline 7 & cu & 1 & my.jn \\
\hline 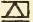 & $\mathrm{cu}$ & & my.n \\
\hline & cu & 1 & my.jn \\
\hline & $\mathrm{cu}$ & $\frac{1}{4}$ & jn.jl \\
\hline & $\mathrm{cu}$ & $\frac{1}{2}$ & jn.jl \\
\hline 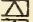 & or & 1 & jl.au \\
\hline & $\mathrm{cu}$ & & my.jl \\
\hline & $\mathrm{cu}$ & 1 & f \\
\hline & $\mathrm{cu}$ & 1 & f \\
\hline & $\mathrm{cu}$ & $\frac{\pi}{2}$ & mr.ap \\
\hline
\end{tabular}

\section{S. Amer, 1818, C r.m} W. Indies 1793 C r.m W. Indies 1739. C r.m Tr. ehrt. 54. t. 96 Caraccas 1809. C r.m Jac. ic. 2. t. 214 S. Amer. 1812, C r.m Fl. per. 31, t. 48 W. Indies 1812 C rm Bot mag 1882 S. Amer. 1793, C rm Plumier. 51. t. 67 St. Domin.1790. C r.m Plumier. 60, t. 66 S. Amer. 1748. C r.m Plumier, 54. t. 72 S. Amer. 1809. C r.m

W. Indies 1768 , C r.m

S. Amer. 1802, C r.m Plumier, 52, t. 68 Jamaica 1778, C r.m Bot. cab. 574

S. Amer 1820 C rm Hook ex fl. 67

Caraccas 1802. C r.m Hook. ex. fl. 21

...... 1822. C r.m Hor, phys. br. t. 8

Jamaica 1775. C r m Hook. ex. fl. 23

S. Amer. 1818. C r.m Hook. ex. fl. 22

Peru 1800. C r.m Fl.per. 1.t. 46 .

Jamaica 1802 C $r m$ Jac vind. 2. t 217

Brazil 1815. C r.m Bot. cab. 503 1812. C r.m W. Indies 1793. C r.m Jac. ic. 2. t. 213

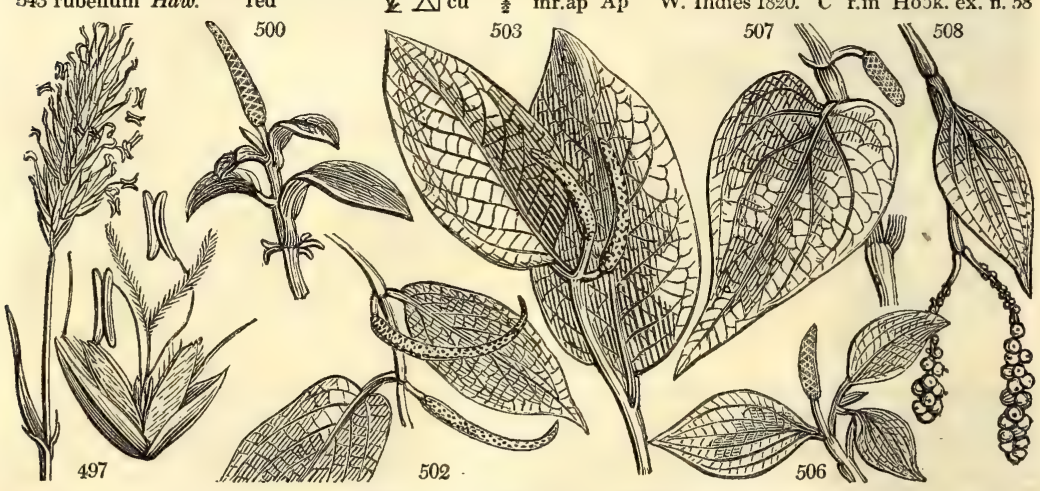

History, Use, Propagation, Culture,

76. Anthoxanthum. From $\alpha y$. 05 , a flower, and $\xi \alpha \nu \theta_{05}$, yellow, the spikes being yellow. This grass has the valves of the calyx sprinkled over with minute yellow dots, similar to those of black-currant berries; hence, possibly, its peculiar scent. It is this grass which gives the peculiar smell to meadow-hay; that made from ray-grass or other sown-grasses having no such odour. It is one of the earliest flowering grasses, grows on any soil, but prefers one moderately dry. Stillingfleet recommends its being sown with a view to improve the flavor of mutton. But its seeds are collected with so much difficulty that they are too costly to be sown in any great quantity.

77. Piper. Undoubtedly from pippul, the Bengalese name of the long-pepper, notwithstanding the learned derivations of authors from $\approx \varepsilon \pi \tau 0, \pi \varepsilon \pi \varepsilon \rho$, to digest. The plants of this genus are mostly succulent, perennial, herbaceous, or frutescent ; often scandent as in that species which furnishes the pepper of commerce ; dichotomous and jointed. P. nigrum furnishes the pepper of commerce. It grows wild in the East Indies, and in Cochin China, and is cultivated in Malacca, Java, and especially in Sumatra. The pepper or seed is distinguished in the shops as black or white; the former is the dried berry in its natural state; the latter, the berry deprived of its skin, by steeping about a fortnight in water, and then drying in the sun. Black pepper is the hottest and strongest. As a spice, pepper differs from most others by its pungency residing not in the volatile parts or essential oil, but in a fixed substance, which does not rise in the heat of boiling water. The culture of the plant in the pepper farms of the East very much resembles that of the hop in England. Holes are made in prepared ground at from six to twelve feet a-part every way; in these from two to six cuttings of the pepper vines are 
DIGYNIA.

497 Spike ovate oblong, Flowers on short stalks longer than the beard spreading, Outer glumes ciliated 498 Panicle spike-shaped sub-lanceolate, Leaves smooth glaucous green, Nect. adnate to the seed, Cor. loose 499 Spike ovate dense, Sheaths smooth, Leaves ciliated

\section{TRIGYNIA.}

\section{Shrubby.}

500 Leaves broad-lanceolate pointed coriaceous, Berries stalked

501 Lvs. elliptic lanc. attenuated very smooth dotted shining above at the base unequal, Spikes recurved at tips 502 Leaves ovate oblong or elliptic acuminate unequal at the base rough on each side, Spikes axillary uncinate 503 Leaves ovate oblong many-nerved acuminate smooth unequal at base, Leaf stalks margined, Joints equal 504 Leaves elliptic oblong acuminate many-nerved unequal at the base, Joints knotty

505 Branches round hairy, Leaves ovate oblong above rough : veins beneath and stalks hispid

506 Leaves ovate oblong 5-nerved rugose on each side smooth equal at the base

507 Leaves ovate attenuated 7-nerved, Stalks 2-toothed

508 Leaves broad ovate acuminate 7-nerved coriaceous smooth, Joints knotted

509 Leaves broad cordate 5-nerved at the base unequal, beneath discoloured, Spikes lax with remote flowcrs

510 Leaves cordate acuminate 5-9-nerved very smooth equal to the leaf stalks

511 Leaves cordate acuminate 9-11-nerved veiny rather villous, Leaf stalks partly winged

512 Leaves cordate oblong acuminate about 7-nerved unequal at the base

513 Lower leaves cordate stalked 7-nerved : upper cordate oblong sessile 5-nerved

514 Leaves peltate round cordate many-nerved obtuse sub-repand, Spikes in umbels

515 Leaves roundish cordate acute many-nerved, Nerves and stalks villous, Spikes in umbels

516 Leaves lanceolate ovate nerved, Spikes short

517 Leaves ovate lanceolate tomentose, Stem arborescent

518 Leaves ovate lanceolate acuminate smooth 3-nerved

519 Leaves lanceolate ovate rugose, Nerves alternate

Stem fleshy.

520 Leaves ovate acute obsoletely 3-nerv. rather folded together at the base, Stalks ciliated, Spikes term. solitary 521 Leaves stem-clasping broad lanceolate narrowed downwards many-nerved, Stem simple erect

522 Leaves obovate very obtuse, Flower-stalks terminal branched, Stem and branches rooting

523 Leaves obovate nearly retuse edged with red, Spike terminal solitary, Stem decumbent rooting

524 Leaves wedge-shaped about 7-nerved, Spikes terminal conjugate, Stem rooting nearly erect

525 Leaves oblong lanceolate attenuated 5-nerved, Spikes axillary, solitary, the terminal in pairs, Stem winged

526 Leaves lanceolate ovate 5-nerved acute at each end, Spikes terminal 2 or 3 together, Stem nearly erect

527 Leaves ovate acuminate 5-nerved, Spikes conjugate erect, Stem branching rooting

528 Leaves peltate cordate ovate acute, Stem creeping

529 Leaves cordate acute, Spikes lateral and terminal, Stem procumbent

530 Leaves oblong nerveless opposite spikes axillary solitary, Stem pubescent upright

531 Leaves oblong acute nerveless opposite with the erect stem villous

532 Leaves ternate roundish, Stem creeping

533 Leaves 4 together sub-sessile oblong nerveless, Spikes terminal, Stem erect

534 Leaves 3 and 4 together oblong 3-nerved smooth coriaceous, Spikes terminal solitary

535 Leaves 3 and 4 together elliptic lanceolate 3-nerved with the upright stems villous

536 St. erect round smth. Lvs,4-6 togeth. ses, lanc, atten. at base 3-nerv. very smth. Sp. ter. very long sol. or double

537 Leaves 3 and 4 together roundish rhomboidal stalked 3-nerved pubescent, Branches erect

538 Leaves 4 together wedge-shaped emarginate sub-sessile, Spikes solitary, Stem erect

539 Very fragrant, Leaves 4,5 , and 6 together sub-sessile reflexed sub-emarginate, Spikes terminal about 4

540 Leaves 3 and 5 together oblong acuminate 3-nerved smooth, Stem erect

541 Hoary with down, Leaves alternate thick round-ovate with a small blunt point, very cordate at the base 542 Leaves obovate rounded stalked very thick green naked

543 Leaves about 4 together roundish convex beneath and coloured, Spikes terminal and axillary sub-solitary

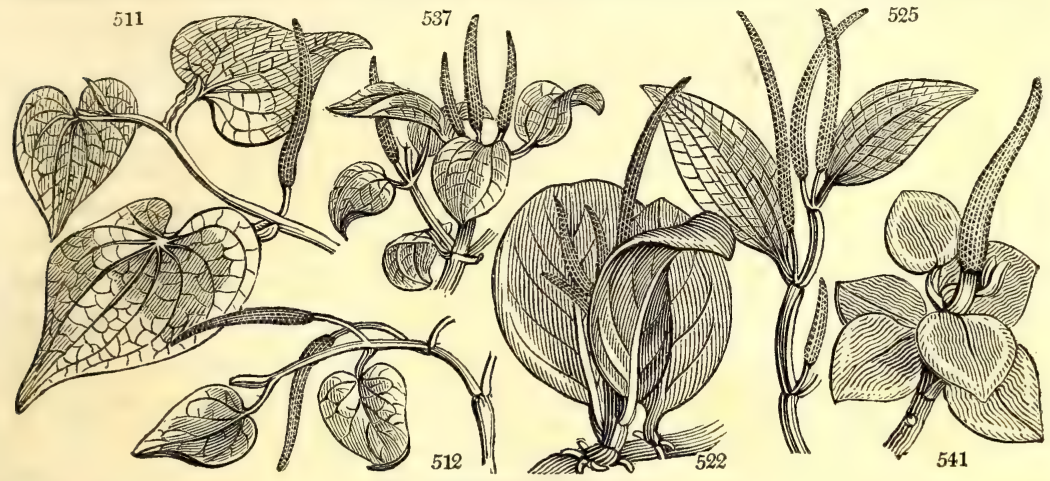

and Miscellaneous Particulars.

planted, and afterwards staked with any rough barked wood, on which the plants climb and attach themselves much in the manner of our five-leaved ivy (Ampelopsis). In Sumatra, Marsden informs us (Hist. 107.), a tree called the chinkareen is planted for the support of the pepper plant, as the common maple and flowering ash is for the vine in Italy. The shoots bear in the third year; the flowers appear in June, and the berries are ripe, and of a blood-red in September. The shoots are then cut down to the ground, and the berries gathered, dried in the

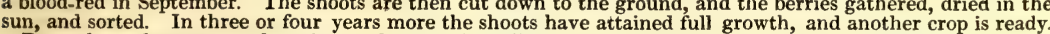
P. amalago, longum, and various other species afford berries differing very little in quality from those of $\mathbf{P}$ nigrum, and sometimes mixed with, or substituted for them.

P. betle affords the betel leaf of the southern Asiatics, which serves to enclose a few slices of the areca nut (thence commonly called the betle-nut), and a little shell lime. This, the inhabitants of those countries chew to sweeten the breath, strengthen the stomach, and ward off the calls of hunger, as the European working classes do tobacco. It is deemed the extreme of unpoliteness in the east to speak to a superior without a quid of betel in the mouth. The teeth of the men in Malabar are ruined by it; but the women preserve theirs to an old age, by staining them black with antimony. Such is the consumption of betel in the east, that it occasions a branch of commerce nearly as extensive as that of tobacco in the west.

All the species of pepper introduced in our stoves grow freely iu loam and peat, require but little water, and are readily propagated by cuttings. 


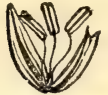

\section{Class III. - TRi ANDRia. 3 Stamens.}

THIs class, which is larger than the two preceding, contains most of the genera of three considerable and very natural orders, the Irideæ, Cyperaceæ, and Gramineæ. The first are ch efly bulbous-rooted sword-leaved plants, with brilliant but transient flowers; the second, sedgy grass-like plants, more curious than useful; and the third, the proper grasses, an order which contributes more extensively and effectually to the support of man and domestic animals than any other, and, unless we except Lolium temulentum, containing no poisonous plant. The genera of the grasses, Sir J. E. Smith observes, are not easily defined. Schreber and Dr. Host among the Germans, and Stillingfleet and Curtis, and more recently, Mr. R. Brown, in this country, have paid much attention to the order; but it is among the French that the greatest improvements have been made in the arrangement and distribution of the genera. The principal graminologists in that country have been Messrs. Desvaux, Palisot de Beauvois, and Kunth, each of whom has divided the Linnæan genera into many others ; the greater part of which have been admitted by other botanists, and are consequently adopted here. It must, however, be confessed, that if much has been done in remodelling the grasses, yet more remains to be effected; and that much more perspicuity and clearness of definition will be required before their arrangement can be said even to approach perfection. In describing the essential characters, the phraseology of the continental botanists has been adopted. This not being very familiar to readers in this country, the following explanation of terms may be useful.

$$
\text { The parts here called Gluma are the Calyx of Linnæus. }
$$

$$
\begin{aligned}
& \text { Palea : : : Corolla. } \\
& \text { Scale : Nectary. }
\end{aligned}
$$

The terms calyx and corolla applied to the floral envelopes of grasses are improper, as they are not analogous to those organs in other plants, but are rather to be considered as a form of Bracteæ, as are also the inner scales, called Nectarium by Linnæus. It has been considered by some writers, proper to place all the grasses in Triandria, without reference to the number of their stamens; but this is manifestly improper, as the whole merit of the artificial system depends upon its principles being closely followed: The grasses not in this class are to be found in Monandria, Diandria, Hexandria, and Polygamia. The grasses, in an ceconominal point of view, have been scientifically experimented on by Sir H. Davy, and Mr. Sinclair, the duke of Bedford's gardener at Woburn.

Galaxia and Ferraria, which Persoon has placed in this class, we have, with Willdenow, placed in Monadel phia. Tigridia will also be found there. The following plants are Triandrous, but as they belong to very na. tural genera, botanists have deemed it better not to separate them.

MONOGYNIA. Narcissus triandrus. Juncus conglomeratus and effusus. Rivina brasiliensis, and some species of Amaranthus, \&c. Galium trifidum, some Asperulas, Melothria, Laurus triandra, Fagara spinosa and acuminata, Hirtella triandra, Tradescantia multiflora.

DIGYNIA. Tripsacum hermaphroditum, some species of Ehrharta, \&c.

TRIGYNIA. Tillæa muscosa, Elatine triandra, Stellaria media, some species of Xanthoxylum, Triplaris americana, \&c.

\section{Order 1. MONOGYNiA. 1 Style.}

1. Flowers with Calyx and Corolla distinct; or with a trifid Corolla only.

78. Valeriana. Cal. very small, finally enlarged into a feathery pappus. Corolla monopetalous, 5-lobed, regular, gibbous at the base. Capsule 1-celled.

79. Patrinia. Cal, very small, finally enlarged into an irregularly and obsoletely toothed rim. Corolla mo. nopetalous, 5-lobed, regular, gibbous at the base. Capsule 3-celled, supported on one side by an oval membra. nous bractea. Stamens variable. (3 or 5 .)

80. Valerianella. Cal, very small, finally becoming a straight rim. Cor. monopetalous 5-fid, regular. Capsule 3-celled.

81. Calymenia. Cal. 5-fid campanulate. Cor. funnel-shaped. Nut 1-seeded, surrounded by the enlarged calyx.

82. Loflingia. Cal. 5-leaved, the leaves 2-toothed at the base. Cor. of 5 petals, which are very minute and connivent. Stigma 3-ple. Caps. 1-celled, 3-valved, many-seeded.

83. Hippocratea. Cal. 5-leaved, very small. Pet. 5 dilated at the base, hooded at the end. Nut fleshy, bearing the stamens. Caps. 3, compressed, 2-valved, opening in the middle, 1-celled, with 2-5 compressed winged seeds.

84. Cneorum. Cal. 3-4-toothed, persistent, small. Pet. 3-4 equal. Stigma 3-fid. Drupes 3 or 4 clustered,

dry. Comocladia Cal. 3-parted. Pet. 3, larger than the calyx. Drupe with 3 spots at the end, and a membranous 1 -seeded nut. (Stamens and petals vary to 4. .)

86. Xyris. Cal. 3-valved, cartilaginous, clustered in a head. Cor. 3-petaled, equal. Caps. 1-3-celled, 3-valved. Stigma 3-fid.

87. Callisia. Calyx 3-leaved. Petals 3. Anthers double. Capsule superior, 2-celled, 2-seeded, compressed. Stigmas 3, finely divided.

88. Commelina. Cal. 3-leaved. Pet. 3. Filaments 3 or 4-sterile, furnished with crossing glands. Caps. 2-3. celled Seeds fixed to the valves.

89. Aneilema. Like Commelina, but no involucrum. Stamens 6. Anthers 3, sometimes 24, dissimilar.

90. Cartonema. Cor. persistent: the 3 outer leaves calycine. Stamens persistent, beardless. Seeds 2.

\section{Flowers with a 5-parted Calyx, and no Corolla.}

91. Ortegia. Cal. 5-leaved. Stigma headed. Caps. 1-celled, 3-valved at the end. Seeds many, affixed to the bottom of the capsule. Stigma 1-3.

92. Polycnemum. Cal. 5-leaved. Seed 1, in an utriculus.

\section{Flowers 6-parted, coloured : the Calyx and Corolla not distinct.}

93. Crocus. Spatha usually 2-valved. Flower funnel-shaped, regular: the outer segments largest. Tube very long, partly under ground. Stigma deeply trifid, with convolute segments.

94. Witsenia. Flower tubular, with a 6-parted limb. Stigma sliglitly trifid or emarginate. Caps. 3-celled, many seeded

95. Ixia. Spatha 2-valved. Flower with a slender tube and regular limb. Stigmas 3, narrow, recurved.

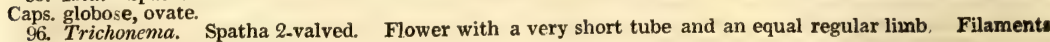

pubescent. Stigmas 3, 2-parted.

97. Geissorhiza. Spatha 2-valved. Flower tubular, with a 6-parted spreading regular limb. Style inclined.

Caps. oval, 3-cornered.

98. Hesperantha. Spatha 2-valved. Flower tubular, with a 6-parted regular limb. Stigmas 3, divided as far down as the tube. Caps. oblong 3-cornered. 
99. Sparaxis. Spatha 2-valved, scarious, membranous, torn at the end. Flower tubular. Stigmas 3, recurved. Caps, oblong, globose.

100. Tritonia. Spatha 2-valved. Flower tubular, with a 6-parted nearly regular limb. Stigmas 3, spreading. Seeds neither winged nor berried.

101. Watsonin. Spatha 2-valved. Flower tubular, with a 6-parted limb. Stigmas 3, filiform, 2-parted, with recurved segments. Caps. cartilaginous, many-seeded.

102. Babiana. Spatha 2-valved, the inner valve 2-parted. Flower tubular, with a 6-parted limb. Stigmas S, spreading. Seeds berried.

1U3. La peyrousia. Flower hypocrateriform. Tube longer than the 6-parted limb. Stigmas 3, 2-parted. Caps. membranous, many-seeded.

10\%. Melasphcerula. Spatha 2-valved. Flower nearly divided into 6 petals : the segments pointed equal. Stigmas 3, recurved. Caps. 3-lobed.

105. Gladiolus. Spatha 2-valved. Flower tubular, with a 6-parted irregular limb. Stamens ascending. Stigmas 3. Seeds winged.

106. Anomatheca. Spatha 2-valved. Flower hypocrateriform. Stigmas 3, 2-parted. Caps. frosted over with little warts.

107. Antholyza. Spatha 2-valved. Flower tubular, with a ringent differently formed limb. Stigmas 3, simple. Seeds nearly round.

108. Xiphidium. Flower inferior, 6-petaled, regular. Caps. 3-celled, many-seeded.

109. Leptanthus. Flower monopetalous, with a very long slender tube, a 6-parted limb, and nearly equal seg-

ments. Stigma simple.

110. Wachendorfia. Flower inferior, 6-parted, irregular. Caps. 3-celled. Seeds solitary.

111 Hemodorum. Flower 6-parted, persistent, smooth. Stamens attached to the base of the inner segments

of cor. Ovarium 3-celled. Cells 2-seeded. Stigma 1. Caps. $\frac{1}{2}$-superior, 3-lobed, 3-celled. Seeds peltate, edged.

112. Aristea. Flower superior, 6-petaled, regular; after flowering twisted spirally and persistent. Caps. 3-celled, many seeded.

113. Dilatris. Flower superior, 6-petaled, regular. One filament shorter than the others, and with a larger anther Stigma simple. Caps, 3-celled. Seeds solitary.

114. Brodiae. Flower inferior, tubular, with a 6-cleft regular limb, and a 3-leaved corona in the orifice Caps. 3-celled, many seeded.

115. Iris. Flower 6-parted : every other division reflexed. Stigmas shaped like petals.

116. Moraa. Flower 6-petaled; after flowering involute above, spirally twisted beneath, finally falling off. Caps. many-seeded.

117. Marica. Flower 6-parted, or of 6 petals : the 3 outer segments largest, the inner connivent and very maller. Stigma like a petal, 3-fid : its segments undivided. Caps. 3-celled.

118. Pardanthus. Flower 6-petaled, regular, equal. Caps. many-seeded. Seeds attached to a central loose receptacle.

\section{Flowers glumaceous.}

$\propto$, Leaves with an entire Sheath. Sedges.

119. Schanus. Spikelets few-flowered, distichous : the lower scales empty, the upper enclosing flowers. No bristles under the ovarium

120. Rhynchospora. Spikelets few-flowered, slender: the lower nearly empty, the upper enclosing flowers. Bristles under the ovarium.

121. Fim'sristylis. Spikelets imbricated in all directions, many-flowered, none of the scales empty. Style jointed at the base, and deciduous. No bristles under the ovarium.

122. Isolepis. Spikelets imbricated in all directions, many-flowered, none of the scales empty. No bristles under the ovarium. Style not jointed at the base, and deciduous.

123. Scirpus. Spikelets imbricated in all directions, many-Howered, none of the scales empty. Bristles under the ovarium. Style not jointed at the base, and deciduous.

124. Elcocharis. Spikelets imbricated in all directions, many-flowered, none of the scales empty. Bristles 124. Elceocharis. Spikelets imbricated in all directions, man.
under the ovarium. Style jointed at the base, and deciduous.

125. Eriophorum. Glumes chaffy imbricated in all directions. Seed surrounded by very long dense wool.

126. Trichophorum. Spikelets nearly ovate, imbricated in all directions. Bristles about the seed usually six, capillary, finally very much lengthened and exserted.

127. Cyperus. Spikelets in two ranks, imbricated; nearly all the scales enclosing flowers. No bristles under the ovarium. Style deciduous, not bulbous.

128. Papyrus. Spikelets many-flowered. Glumes imbricated in two rows, 1-flowered. Style 3-fid. Scales 2, membranous, contrary to the glumes. No bristles beneath the ovarium. Seed 3-cornered.

129. Kyllinga. Spikelets 1-flowered. Glumes 4, imbricated in two rows, compressed: the 2 lower which are smaller and the upper one empty; the intermediate similar to the upper, and including a naked hermaphrodite flower. Style bifid. No bristles under the ovarium. Seed lenticular.

130. Mariscus. Spikelets few-flowered. Glumes imbricated in two rows, the lower empty. Stamens some-

130. Mariscus. Sifid. Neither scales nor bristles below the ovarium. Seed triangular.

Simes 2. Style trifid. Neither scales nor bristles below the ovarium. Seed triangular.
$\beta$. Leaves with a split sheath, and a membranous ligule. True grasses.

131. Remirea. Spikelets 1-flowered, with imbricated scales; the outer ones nerved, the upper which bears the flower enclosed in them and unlike them. No bristles beneath the ovarium. Seed oblong, enclosed in the uppermost scale become thickened and corky.

132. Iygeum. Flowers 2 or 3 together, with two valved glumes, at the base united into a 2-celled villous pericarpium. Involucrum a convolute spatha.

135. Cornucopia. Involucre 1-leaved, cup-shaped or funnel-shaped, many-flowered. Glumes 2-valved, united at base, mitre-formed, equal. Palea 1, bladder-like, split on one side, with a beard below the middle, Stigmas long. Seed not furrowed. Flowers in a head.

134. Cenchrus. Involucrum 1-3-flowered, many parted, bristly without, finally hardened. Glume 2-flowered, a-valved: the outer valve smallest. Florets dissimilar: the outer male or neuter, the inner hermaphrodite. No scales.

135. Pennisetum. Involucrum double, composed of many bristles: the outer unequal, the inner pinnated, bearded. Spikelets 2-3-5. Glume 2-valved, unequal. Lower floret male, upper hermaphrodite, both sessile. Paleæ nearly cartilaginous. Spike compound, with sessile spikelets.

136. Spartina. Glume 3-valved, 1-flowered, unequal, keeled, very acute. Paleæ 2, beardless, bifid, emarginate and toothed, shorter than the glumes. Scales fringed. Style very long. Seed loose, covered with the paleæ. Spikelets 1-sided, inserted in a double row. Spike compound.

137. Nardus. Glume 1-valved, 1-flowered. Palea 1. Stigma simple. Seed covered by the palea

138. Oryzopsis. Glume 2-valved, 1-flowered, membranous, a little longer than the hardened paleæ. Paleæ 2 , the lower villous at the end with a jointed beard, the upper entire. Scales 2, linear, the length of the ovarium, Panicle nearly simple and loose.

\section{Order 2. DIGYNIA. 3 Stamens. 2 Styles.}

1. Inflorescence spiked or panicled. Spikelets either solitary, in pairs, or several together, one or more usually 2-flowered, one of the flowers being steriie or of only one sex. Glumes usually of a thinner texture than the Palea, which are more or less cartilaginous, the lower one half enfolding the upper, and cither beardless or occasionally bearded; neither of them with a keel. (Panicea.)

139. Paspalum. Glume 2-valved, 1-flowercd, closely pressed to the two plano-convex paleæ. Seed coated with the palex. Flowers spiked, attached to onc side of the toothed rachis. 
140. Axonopus. The inflorescence digitate. Spikelets simple. Otherwise, as Paspalum.

141. Milium. Glume naked, beardless, 2-valved: the valves concave, larger than the paleæ, which are two, concave and equal. Seed coated with the indurated palex.

142. Knappia. Glume 1-flowered, 2-valved, truncate, beardless. Palea one, torn, the divisions setigerous and united at the base, enfolding the stamens and pistillum. Flowers alternate in a flexuose rachis. Seed loose. 143. Digitaria. Inflorescence digitate or fascicled. Spikelets 1-sided, flower-stalks 2-, or many-flowered. Glume 2-valved, the lower valve very minute. Of the lower neuter floret the paleæ membranous. Of the upper hermaphrodite floret the paleæ subcoriaceous, hardened. Seed slightly furrowed.

144. Panicum. Glume 3-valved: valves unequal, the outer being very small. Paleæ two, concave, equal, beardless. Seed coated with the hardened palex. Panicle scattered and loose.

145. Setaria. Has the same character as Panicum, except that the panicle is spiked.

145. Echinochloa. Has the character of Panicum, except that the panicle is composed of alternate spikelets, and the third valve of the glume is bearded.

147. Orthopogon. Has the character of Echinochloa, except that both the intermediate and third valves of the glume are bearded.

148. Penicillaria. Involucrum bristly : the bristles equal, pinnated, bearded. Glume 2-valved, very small, membranous. Lower floret male, upper hermaphrodite : the paleæ subcartilaginous and entire. Anthers vil. lous at the end. Spike compound, cylindrical, with stalked involucrated spikelets.

149. Lappago. Glume 2-valved, valves unequal : the lower very minute, membranous, the upper cartilaginous, very large, with soft prickles. Paleæ 2-valved, membranous, shorter than the glume. Scales very small, fringed. Panicle simple spike-shaped; the branches 3-flowered.

2. Inflorescence panicled. Spikelets solitary, 1-flowered. Glumes membranous, the lower Palea coriaceous, bearded, enfolding the upper, which has not two Keels. (STIPACEA.)

150. Stipa. Glume 2-valved, 1-flowered, membranous, longer than the two cartilaginous paleæ, of which the lower is convolute, with a long beard at the apex; upper entire. Beard jointed at the base, deciduous. Scales oblong, entire. Seed furrowed. Panicle almost simple, lax.

3. Inflorescenoe panicled, sometimes contracted into the form of a spike. Spikelets solitary, 1-flowered. Glumes and Palea of nearly similar texture, most usually with a Keel. Lower Palea either bearded or beardless, the upper never with two Keels. (AGROSTIDEA.)

151. Muhlenbergia. Glume 2-valved: valves very minute, fringed, three times as short as the paleæ, the lower of which has a bristle. Scales ovate, obliquely truncate, gibbous. Seed naked, not furrowed. Panicle nearly simple, contracted or spreading.

152. Chaturus. Lower valve of the gluma with a long bristle, upper acute. Paleæ membranous, the lower valve trifid, upper bifid. Flowers spiked, inserted into the elongated teeth of the rachis.

153. Lagurus. Glume 2-valved, 1-flowered, each valve ending in a villous beard. Outer paleæ with two terminal beards, and a third, which is dorsal and twisted back. Panicle spike-shaped, ovate, hairy.

154. Polypogon. Glume 2-valved, 1-flowered: valves nearly equal, obtuse at the end with a long bristle, much longer than the somewhat cartilaginous paleæ. Lower palea below its end, which is entire, with a straight short tender bristle, upper bifid, toothed. Panicle contracted, like a spike.

155. Gastridium. Glume 2-valved : valves ventricose at the base, 3 times as long as the hardened coriaceous paleæ. Paleæ 2, the lower 3-4-toothed with a bristle under the end, the upper bifid, toothed. Panicle compound, contracted like a spike.

156. Agrostis. Glume naked, beardless, 2-valved : valves concave, longer than the paleæ, which are 2 , and enclose the seed

157. Trichodium. Glume Q-valved, 1-flowered. Palea one, shorter than the glumes, bearded, and supported at the base by one or two fascicles of hairs. Seed loose, covered by the palea.

158. Tristegis. Glume naked, 3-valved: valves concave, the outer very small, the intermediate longer than the palex, the third bearded. Paleæ 2, concave, equal, obtuse, beardless. Seed inclosed in the paleæ.

159. Sporobolus. Glume naked, beardless, 2-valved: valves concave, much shorter than the paleæ, which are two, concave, nearly equal, beardless. Seed not inclosed in the paleæ.

160. Airopsis. Glume 2-flowered : valves nearly equal, navicular, longer than the florets. Lower paleæ trifid at the end, upper entire. Seed loose, not furrowed. Panicle contracted, compound.

161. Cinna. Glume naked, beardless, with 2 concave valves shorter than the paleæ, which are 2 , nearly equal, concave, with long points : the outer one being bearded or beardless. Seed enclosed in the paleæ.

162. Psamma. Glumes nearly beardless. Palee under the end emarginate, mucronate, shorter than the glumes. Scales 2, subulate. Style 3-parted. Seed turbinate. Spike compound, erect, cylindrical.

163. Crypsis. Glume 2-valved, I-flowered, compressed, unequal. Palece \&, unequal, longer than the glume Seed loose, covered by the palea.

164. Alopecurus. Glume 2-valved, 1-flowered: valves somewhat equal, connate, distinct. Paleæ united into a bladder-like glume split on one side, below the middle (generally), bearded. Scales linear, entire. Spike compound, contracted, without involucrum, branches very small, branching.

165. Phleum. Glume 2-valved, naked, with a point or little beard out of the nerve at its back: valves navi cular, including the paleæ, which are 2, navicular and beardless. Beard of the glume lengthened. Second floret sessile.

166. Achnodonton. The character of Phleum, except that the beard of the glume is very minute.

166. Achnodonton. The character of Phleum, except that the second floret is stalked.

168. Phalaris. Glume 2-valved, naked, beardless : the valves navicular, inclosing the paleæ, which are two, and navicular also, beardless and naked at the base, but supported by hairs or accessory glumes.

4. Inforescence panicled. Spikelets solitary, 2 or many-flowered. Glumes with a keel. Palea of nearly the same texture as the glumes, the lower carinate or concave, always bearded, the upper with two keels. (BRomEA)

169. Corynephorus. Glume 2-flowered. Valves membranous, longer than the florets. Lower palea entire having at its base a beard, jointed in the middle, woolly, twisting and small below, clavate above ; upper bifidtoothed. Panicle compound.

170. Aira. Spikelets slender. Glume 2-flowered, rarely 3-flowered, beardless, 2-valved, equal to the fiorets or shorter. One of the florets on a stalk. Paleæ 2, equal, enclosing the seed when ripe.

171. Avena. Glumes membranous, 2-7-flowered, longer than the florets. Lower palea twice torn, or, with the upper, bifid-toothed, sometimes eroded, having at the back a plaited twisted beard. Scales ovate. Seed coated, furrowed. Panicle compound, loose.

172. Trisetum. Lower palea with 2 bristles and a tender flexuose beard above the middle of its back. Scale lanceolate. Other characters of Avena.

173. Danthonia. Lower palea 2-toothed, with a plaited twisted beard from between the teeth, upper obtusely truncated. Seed loose, not furrowed. Panicle simple. Other characters of Avena.

174. Gaudinia. Glume unequal, obtuse. Lower palea bifid-toothed, bearded at the back above the middle: the bearded twisted and plaited. Upper palea 2-4-toothed. Seed coated, furrowed. Spikelets sessile, alternate, with 9-11 2-ranked flowers.

175. Arundo. Glume naked, beardless, 2-valved : the valves wrapping up the paleæ which are 2-bearded and surrounded by bristles. Seed inclosed in the paleæ.

176. Chrysurus, - Neuter spikelet. Glume linear, subulate, with remote florets. Paleæ 1, sterile. Herma. phrodite spikelet, 1-flowered. Glumes subulate, linear. Floret stalked. Lower palea below its end, which is entire, setigerous, the upper entire. Seed with two beards, not furrowed. Panicle compound, branching.

177 Sesleria. Common involucrum many-leaved: the leaflets sometimes deciduous. Glume 3.4-flowered. 
Valves unequal, shorter than the stalked Horets. Lower palea irregularly 2-toothed, setigerous. Scales longer than the ovarium, subulate. Spike compound.

178. Cynosurus. Involucrum 1-leaved, with pinnatifid divisions, containing two spikelets. Glume 4-5flowered, shorter than the florets. Lower palea very acute, upper bifid-toothed. Scales hairy. Seed coated, furrowed. Spike compound.

179. Köleria. Spikelets compressed. Glume 2 or 3-flowered, beardless, 2-valved: the valves shorter than the lowest floret. Paleæ 2, the outer beardless or bearded under the point.

180. Dactylis. Many spikelets heaped in a head, 1-sided. Glume 2-7-flowered. Lower palea under the end, which is emarginate, setigerous, upper bifid, toothed. Scales hairy. Seed loose, not furrowed. Panicle compound with short branches.

181. Glyceria. Spikelet slender. Glume 5-7-flowered. Valves 2, truncate, with transparent membranous edges, shorter than the florets. Lower palea eroded or many-toothed, navicular, embracing the upper, which is bifid-toothed. Scales connate. Seed furrowed. Panicle nearly simple.

182. Festuca. Glume beardless, 2-valved : valves nearly equal, shorter than the lowest floret. Paleæ 2, the outer one bearded at the end. Seed inclosed in the paleæ.

183. Mygalurus. Glume 1 or 2-valved, many-flowered, shorter than the spikelet: one valve very small. Palea 2 , one of them bearded near the end. Seed inclosed in the paleæ.

184. Bromus. Glume 3-20-flowered. Valves shorter than the florets, which are imbricated in two rows. Lower palea cordate, emarginate below the end, sometimes torn in two, with a straight beard. Scales ovate, smooth. Seed coated, furrowed. Panicle compound.

185. Brachypodium. Spikelets stalked, alternate in each tooth of the rachis. Stalks broad and thick. Glume 3-15-flowered. Valves shorter than the florets. Paleæ entire, lower setigerous at the end, upper bluntly truncated, generally edged with stiff reflexed hairs. Scales pilose. Seed coated, furrowed.

186. Uniola. Spikelets compressed. Florets imbricated in two rows, the lower only abortive. Glume 3-20-flowered, shorter than the florets. Lower palea navicular at the end, abruptly cut off and $\mathrm{m}$. cronate between the lobes, the upper subulate, somewhat bifid-toothed. Scales bifid. Seeds turbinate, with twe horns, not furrowed. Panicle compound, loose.

187. Tricuspis. Glume 5-7-flowered. Valves navicular, shorter than the florets. Lower palea bifid-toothed, between the teeth and on each side mucronate: the upper truncate, almost emarginate. Seed 2-horned.

188. Diplachne. Glume 7-9-flowered: the upper valve mucronate at the end. Lower palea twice torn, with a bristle beneath the divisions, upper sub-truncate, emarginate. Seed not furrowed. Panicle simple, much branching. Branches alternate, filiform.

189. Ceratochloa. Glume 12-18-flowered. Valves shorter than the florets. Paleæ bifid-toothed : the lower mucronate between the teeth. Ovarium 3-horned. Seed coated, furrowed, 3-horned. Panicle nearly simple Spikelets compressed. Florets imbricated in two rows.

190. Schismus. Glume 3-6-flowered. Valves the length of the florets, or longer. Lower palea cordate, emarginate, its rib extended between the lobes into a filiform mucro, the upper entire. Seed obtuse, nearly furrowed. Panicle simple, contracted, spike-shaped.

191. Triodia. Glume 3-5-flowered. Valves navicular, longer than the florets. Paleæ bifid-toothers: lower with a thick tooth-shaped mucro between the teeth. Scales lanceolate, smooth. Ovarium with a bifidurverging beak.

192. Beckmannia. Spikelets 1-sided, 3-5-flowered. Glumes unequal, navicular, with a little stalk at the base, obtuse at the end, spatulate, nearly the length of the florets. Paleæ nearly equal. Scales lanceolate. Seed loose, not furrowed. Spike compound. 3 spikelets in each tooth of the rachis.

193. Melica. Glume unequal, 2-5-flowered, membranous, nearly the length of the florets, of which the upper are incomplete, abortive and stalked. Scales truncate, fringed. Seed loose, not furrowed. Panicle simple or compound.

194. Molinia. Glume 2-4-flowered, unequal. Paleæ conical, lanceolate, acute, much longer than the glume, the upper barren and abortive, or often in its place, a formless rudiment. Scales subtruncate. Seed with two points from the remains of the style, with a broad furrow. Panicle compound. Spikelets slender.

195. Briza. Glumes navicular, compressed, nearly cordate at the base, many-flowered (3-14), shorter than the florets which are imbricate in two rows. Lower palea cordate at the base, embracing the upper, which is nearly round and much shorter. Seed with two short filiform beaks. Panicle compound, loose, branches pendulous.

196. Poa. Glume 2-20-flowered. Valves shorter than the florets. Paleæ sometimes woolly at the base, the upper bifid-toothed. Scales smooth. Seed furrowed. Panicle more or less branching or scattered.

197. Eragrostis. Glume 4-10-flowered. Valves shorter than the paleæ, which are imbricated in two ranks, Upper palea reflexed, its edges folded back, shell-shaped, entire, fringed, persistent. Seed loose, 2-horned, not furrowed. Panicle compound, more or less scattered.

198. Megastachya. Spikelets elongated: the florets imbricated in two rows. Glume 5-20-flowered. Valves shorter than the florets. Lower palea emarginate, with a point between the divisions, upper bifid-toothed. Seed loose, not furrowed. Panicle compound

5. Inflorescence spiked. Spikelets solitary, seldom many-flowered, with the upper flower abortive and differently formed. Glumes with a keel, not opposite. Lower palea generally bearded, seldom beardless, the upper with two keels. (CHLORIDEA.)

199. Sclerochloa. Glume 3-5-flowered. Valves obtuse, shorter than the florets. Lower palea cordate, emarginate, obtuse, upper entire. Scales emarginate. Seed with a bifid beak. Spike simple. Spikelets 1-sided or dichotomous.

200. Eleusine. Glume 5-7-flowered. Valves obtuse. Paleæ obtuse, upper bifid-toothed. Scales truncate, fimbriate. Seed inclosed in a separate membrane, broadly and deeply furrowed. Inflorescence digitate. Spikelets 4-5, erect, 1-sided.

201. Dactyloctcnium. Spikelets 1-sided. Glume 5-7-flowered. Lower valve with a falcate spine-shaped mucro. Lower palea navicular, ventricose, subulate, upper bifid-toothed. Scales truncate, fringed. Seed square, warted, obtuse, loose. Spikelets digitate, 4-5, erect or horizontal.

202. Leptochloa. Glume 3-5-flowered. Valves lanceolate, acute, nearly as long as the florets. Lower palea navicular, acute, upper bifid-toothed. Seed loose, furrowed. Panicle simple. Branches alternate, simple, with nearly 1-sided spikelets.

203. Cynodon. Spikelets 1-sided in a simple row. Glumes membranous, persistent, shorter than the florets, and only embracing them at the base. Fertile floret with the upper palea bifid-toothed. A rudiment of an abortive floret, stalked, smooth, ciavate. Scales truncate. Seed loose, not furrowed. Spike digitate. Spikelets 4-5-filiform, simple, slender.

204. Dinebra. Glume 2-5-flowered. Valves subulate. Paleæ bifid, emarginate, the lower setigerous under the end. Scales truncate, or somewhat lanceolate. Inflorescence spiked, acuminate, the point of the rachis protruding beyond. Spike simple or compound. Spikelets 1-sided, alternate, remote, pendulous.

205 Echinaria. Spikelets close together. Glume 2-4-flowered. Valves mucronate, shorter than the florets. Lower palea truncate, fringed, terminated by 5 lanceolate unequal bristles, upper cordate, emarginate, with two similar bristles. Scales truncate. Seed loose, gibbous, not furrowed, with two diverging beaks. Spike simple, capitate.

6. Inflorescence spiked. Spikelets solitary, in pairs, or several together, 1-flowered, or many-flowered. Glumes opposite, equal. Lower palea bearded or beardless, upper with two keels. (CEREALIA.)

206. Triticum. Glume 2-valved, many-flowered, shorter than the spikelet : the valves nearly equal, beardless, or with one beard enclosing the florets. Paleæ 2, one of them being bearded from the end Seed inclosed in the paleæ, rarely otherwise. 
207. Lolium. Spikelets sessile, to the lowest a glume of one valve, to the uppermost of two opposite valves. Lower palea with a mucro or bristle at the end, upper membranous, bifid-toothed. Scales with two unequal teeth. Seed furrowed.

208. Elymus. Spikelets in each tooth of the rachis two or more, 3-9-flowered. Glume 2-valved, nearly equal, rarely (as in E. Hystrix) absent or nearly so. Lower palea entire with a bristle which is sometimes very short, upper somewhat bifid-toothed. Scales ovate, hairy. Seed furrowed. Spike simple.

209. Secale. Spikelets in each tooth of the rachis solitary, 2-3-flowered, the two lower florets fertile, sessile, opposite, the upper abortive. Glumes subulate, opposite, entire, shorter than the florets. Lower palea entire, with a very long bristle, upper bifid-toothed. Scales obovate, hairy. Seed coated, furrowed.

210. Hordeum. Spikelets 1-flowered, three together, the two lateral often barren. Glumes 2, subulate. Paleæ 2, the lower bearded. Scales 2. Stigmas feathery. Seed coated with the paleæ.

211. Microchloa. Spikelets 1-flowered. Glumes 2, membranous, beardless. Paleæ 2, much shorter than the glumes, villous. Stigmas very firely divided.

212. Ophiurus. Glumes cartilaginous, half immersed in hollows of the rachis, longer than the floret. Paleæ membranous, transparent. Ovarium cordate. Spike simple.

213. Monerma. Spikelets half immersed in hollows of the rachis. Glume 1-valved, cartilaginous, furrowed. Paleæ membranous, transparent. Scales lanceolate, entire, smooth. Spike simple. Rachis jointed, toothed.

7. Inflorescence spiked, or panicled, jointed. Spikelets generally in pairs, 1 or 2-flowered, the one sessile, the other stclked, and usually of one sex only. Glumes of a stouter texture than the palea, neither keeled nor opposite. Palea very delicate and membranous, not with a keel, the lower commonly bearded. (SACCHARINA.)

214. Perotis. Glume 2-valved : valves with a long bristle at the end. Palea 1, nearly as long as the calyx. Spike nearly simple, involucrated at the base, with woolly hairs.

215. Saccharum. Glume 2-valved, 2-flowered, enveloped in long wool. Lower floret neuter with one palea, upper hermaphrodite with two palea, the upper of which is very small or obsolete.

216. Imperata. Glume 2-valved : valves herbaceous, at the lower part of the back clothed with very long hairs the length of the paleæ, which are two, and beardless, the lowest only half the size of the other. Scales none. Stamens 2-3.

\section{MONOGYNIA.}

78. VALERIA'NA. $W$. VALERIAN. 544 dioica $W$. 545 officinális $W$. $546 \mathrm{Phu} W$. 547 tripteris $W$. 548 montana $W$. 549 céltica $W$. 550 tuberósa $W$. 551 saxátilis $W$. 552 elongáta Ja. 554 sambúcifolia 555 supína $V a h l$. 9. PATRI'NIA. 556 sibirica $W$. 557 ruthénica $W$ dicecious great wild garden three-leaved mountain mount celtic tuberous-root rock elongated heart-leaved elder-leaved prostrate Patrinia. Siberian

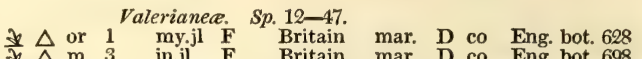
$\$ \Delta \mathrm{m} \quad 3 \quad$ jn.jl $\mathbf{F}$ Britain mar. D co Eng. bot. 698 \ $\Delta$ or 3 my.jl $\underset{W}{W}$ Germany 1597. D co Blackw. t. 250 J $\Delta$ or 1 mr.my W Switzerl. 1752. D co Jac, aus. 3.t. 268 $\$ \Delta$ or 1 jn.jl L.R Switzerl. 1748. D co Bot. cah. 317 \& $\triangle$ or $\frac{1}{2}$ jn W Switzerl. 1748. D co Jac. coll. 1. t. 1

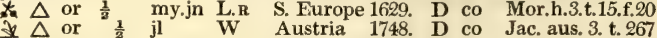
D $\triangle$ or $\frac{1}{2}$ jn.jl $Y$ Austria 1812. D co Jac. aus. 3. t. 219 $\downarrow \Delta$ or 3 my.jn Pk Scotland sc.wo. D co Eng. bot. 1591. I $\triangle$ or 1 my.jn Pk Germany 1810 1t $\triangle$ or $\frac{1}{4}$ my.jn Pk S. Europe 1822. D co Jac. mi.2.t.17.f.2 Valerianea. Sp, 2 .

T or 1 jn Y Siheria 1801 D co Bot. mag. 80. VALERI ANE'LLA. LAMB'S LETTUCE. 558 echináta $W$. 559 olitória $W$. 560 dentóta $W$ 560 dentáta $W$. 561 vesicária $W$. 562 coronáta $W$. 564 carináta $D$. $\dot{C}$. 565 eriocárpa $\dot{D}$. $C$ 566 rádiata Vahl. 567 dasycárpa $M$. $B$ 568 uncináta $M . B$. prickly capsul common oval-fruited bladdery crowned discoid keeled woolly-fruited radiate thick-fruited hook-fruited

$\mathrm{O}$ or 1 my.jn $\mathbf{Y}$ Siberia

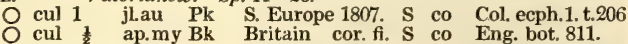

O $\mathrm{W}^{\frac{1}{2}}$ ap.jn B Britain cor. fi. S co Eng. bot. 1370

O w 1 ap.my W Candia 1739. S co Fl. græc. 1. t. 34

O $w$ t ap.jn Pk Portugal 1731. S co Col. ecph. 1.t.209

$\mathrm{O}$ w ${ }_{\frac{1}{2}}$ ap.jl. B Italy 1731. S co Mor.h.3.t.16.f.29

W ${ }^{\frac{1}{3}}$ ap.my B France 1819. S co

O w $1^{\frac{1}{g}}$ ap.my Li France 1821. S co

W 1 ap.my Pk N. Amer, 1821 S co

Mor.h.3.t.16.f. 33

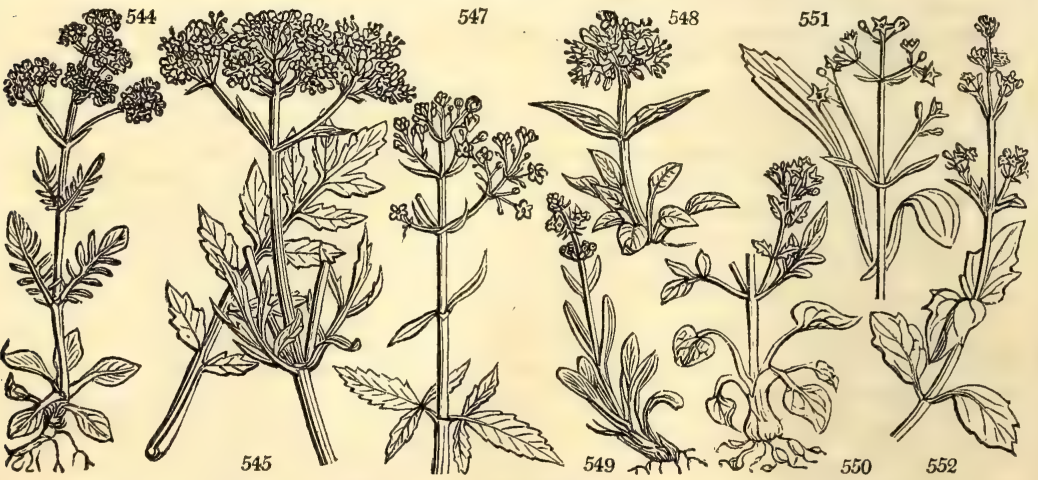

History, Use, Propagation, Culture,

78. Valeriana. A word of uncertain import. Linnæus derived it from a certain king Valerius. De Théis thinks it altered from the verb valere, on account of its medicinal qualities. The species are generally ornamental border plants, of easy culture in common earth, and preferring shady moist situations, V. dioica has usually the stamens and pistils in separate flowers, situated on different plants, This species and V. officinalis are considered medicinal, and prescribed in hysterical cases and habitual costiveness. Cats are delighted with the roots, which are said to smell like the true Teucrium marum; and rat-catchers employ them to draw the rats together, as they do oil of anise. V. Phu has something of the same qualities. V. tripteris derives its name from $\tau \rho \xi \xi$, three, and $\pi \tau \rho \rho \xi$, a wing, in allusion to the ternary position of its leaves. 
8. Inflorescence panicled. Spikelets solitary, 1-flowered. Lower palea cartilaginous, compressed, keeled. Stamens frequently more than 3. (ORYZA.)

217. Leersia. Spikelets 1-flowered. Glumes O. Paleæ 2, beardless, keeled, compressed. Scales 2. Stamens 3.6. Stigmas very finely cut. Seed loose, inclosed in the paleæ.

9. Shrubby. Inflorescence panicled. Spikelets many-flowered. Upper palea with two keels. (BamBusacEa.)

218. Diarrhena. Glume 2-valved: valves navicular, rigid, the lower smalier, shorter than the florets. Lower palea navicular, rigid, upper membranous, the edges broad, folded back. Scales 2, ovate, entire. Ovarium with a hood. Seed furrowed, hardened, shining, loose.

219. Arundinaria. Glume 5-7-flowered, Valves unequal, with stalked florets. Lower palea very acute, upper bifid-toothed. Scales 3, smooth. Stigmas 3, feathery. Styles 3.

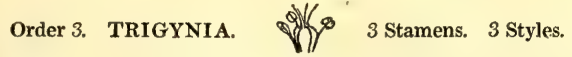

220. Holosteum. Cal. 5-leaved. Petals 5. Caps. sub-cylindrical, 1-celled, opening at the end, 6-va.ved, many-seeded.

221. Polycarpon. Cal, 5-leaved, 5-cornered. Petals 5, very small, ovate. Caps. 1-celled, 3-4-valved : valves lanceolate, twisted inwards. Seeds many.

222. Lechea. Cal. 3-leaved. Petals 3, linear. Caps. 3-celled, 3-valved, and as many inner valves. Seed 1.

223. Eriocaulon. Common calyx an imbricated head. Petals 3 , equal. Stamens above the ovarium.

224. Montia. Cal. 2-3-leaved. Cor. monopetalous, irregular, 5-parted. Caps. 1-celled, 3-valved, 3-seeded.

225. Mollugo. Cal. 5-leaved. Cor. O. Caps. 3-celled, 3-valved.

226. Minuartia Cal. 5-leaved. Cor. O. Caps. 3-celled, 3-valved. Seeds a few.

227. Queria. Cal, 5-leaved or 5-parted. Cor. O. Caps. 1-celled. Seed 1.

228. Kónigia. Cal. 3-leaved. Cor. 0 . Seed 1, ovate, naked.

\section{MONOGYNIA}

544 Radical leaves spatulate ovate undivided ; cauline pinnatifid, Stem erect, Flowers panicled diœcious 545 Leaves all pinnate : pinnæ lanceolate-toothed, Stem hollow furrowed, Flowers corymbose 546 Cauline leaves pinnate, radical undivided, Stem smooth slender, Flowers corymbose

547 Leaves toothed radical cordate simple, cauline ternate ovate oblong, Leaflets lateral lanceol. Stem erect 548 Leaves oblong rather toothed ; lower obtuse, upper acute, Stem erect, Flowers panicled

549 Leaves undivided entire obt. radical cuneate obl. cauline linear, Stem smooth ascending, Flowers racemose 550 Radical leaves lanceolate oblong entire, cauline pinnatifid, Stem smooth, Flowers pink corymbose

551 Leaves undivided, radical elliptical 3-nerv. entire and toothed, caul. linear, Stem erect, Corymbs racemose 552 Radical leaves ovate, cauline cordate sessile cut halbert shaped, Flowers racemose

553 Leaves cord, uneq. toothed : lower simple, upper ternate and pinnate, Stem striated, Flowers corymbose 554 Radical lvs. pinnated, Leaflets ovate coarsely toothed, caul. pinnated downwards, Segm. lanceol. toothed 555 Leaves simple ciliated, radical obovate, cauline lanceolate, Flowers panicled

556 Leaves membranous pinnatifid, Segm. lanceol. : the terminal very large, Stem smooth, Flowers corymbose 557 Yeaves rather fleshy pinnatifid, Segm. entire obt. of nearly one shape, Stem hairy in 2 rows, Flowers corymb.

558 Caps. linear 3-toothed: the outer larger recurved, Stem smooth, Flowers in dichotomous spikes 559 Caps. naked globose compressed, Stem weak, Flowers in heads

560 Caps. polished ovate, Limb of the calyx short 3-5-toothed crowned, Stem smooth, Flowers corymbose 561 Caps, ovate villous, Limb of the calyx bladdered crowned, Stem a little villous, Flowers nearly in heads 562 Caps. villous, Limb of cal. 6-10-tooth. crowned, Crown camp. Teeth long straight, Stem puhesc. Fls. in heads 563 Caps, vill. Limb of cal 10-12-rayed crowned, Crown rotate, Teeth long acute, Stem smooth, Flow, in heads 564 Caps. naked smooth cleft-keeled elongated, Stem weak, Flowers nearly in heads 565 Caps. ovate angular hairy irregularly toothed, Stem angular, Flowers corymbose 566 Caps. pubescent naked at the end, Leaves spatulate oblong nearly entire 567 Stem scabrous, Fruit ovate acute 1-toothed at the end pubescent

568 Caps. linear 6-toothed, Teeth hooked loose, Stem and radical leaves spatulate, cauline pinnatifid pubescent

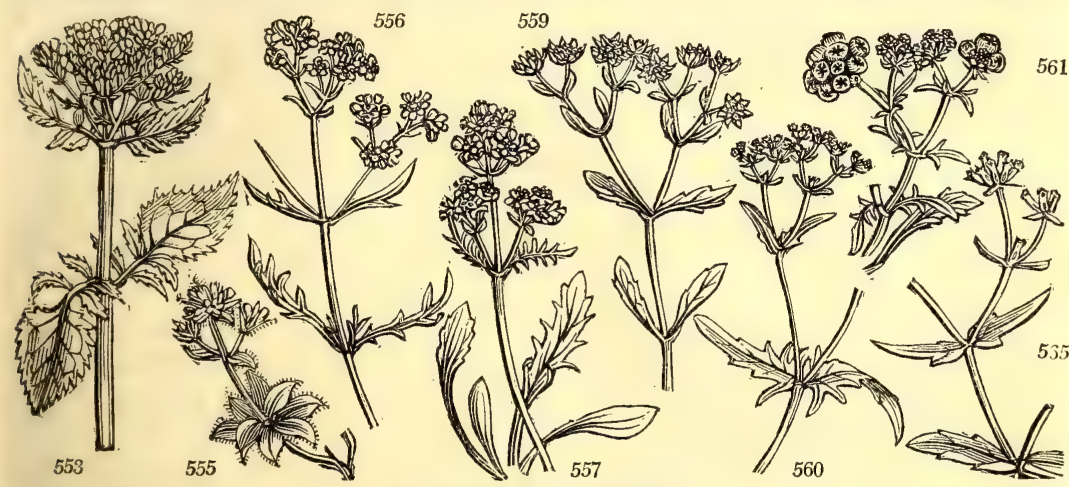

and Miscellaneous Particulars.

Phu is the Arabic name of the species so called.

79. Patrinia. Named by M. Jussieu in honor of M. Patrin, an assiduous French botanist, who travelled in Siberia, where all the species of the genus are found, and whence he sent home collections.

80. Valerianella. A diminutive of Valeriana, from which the genus has been divided. V. olitoria (Valeriana locusta, $L$.) Mache salade de prêtre, Fr., corn salad or lamb's-lettuce, from its appearing in corn fields about the time when lambs are dropped; furnishes an agreeable salad, the leaves tasting little inferior to young lettuce. To have it early, it should be sown in autumn on a warm border. All the species are of as easy culture as those of Valeriana. 
81. CALYME'NIA. 569 viscósa $W$. 570 aggregáta $\mathrm{Cav}$. 571 glabrifólia $W$. en.

UMBRELLA-WORT.

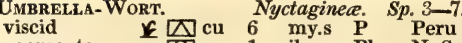

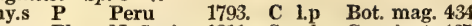
smooth-leaved 5 jl.au Pk N. Spain 1811. S s.1 Cav. ic. t. 437 82 . $W$ I I $\mathrm{cu}$

83. HiPPOCRATE'A. Hrppocratea. 573 volúbilis $W$.

84. CNEO'RUM. $W$. WIDOW-WAIL 575 pulveruléntum $V e n$. powdery

85. COMOCLA'DiA. $W$. Maiden-Plum 576 integrifoli 577 dentáta $W$. 578 ilicifólia $W$. 86. XY'RIS. $L$. 579 operculáta $\boldsymbol{B} . \boldsymbol{P}$ 580 brevifólia $\boldsymbol{P} . S$. 581 lævis $\mathrm{Br}$.

87. CALLI'SIA $W$. 582 répens $W$. 88. COMMELI'NA 583 commúnis $W$. 584 caroliniána $\boldsymbol{W}$. 585 africána $W$. 586 bengalénsis $W$ 587 erécta $W$. 588 virginica $W$. 589 longicaúlis $\dot{W}$. 590 móllis $W$ 591 tuberósa $W$. en. 592 coléstis $W$. en.

89. ANEILE/MA. $B \cdot P$ 593 biflórum $\boldsymbol{B r}$. 594 ambíguum Beauv. 595 sínicum $\mathrm{Ker}$.

90. CARTONE'MA. 596 spicátum

91. ORTE'GIA 597 hispanica $W$. 598 dichótoma $\boldsymbol{W}$. 92. POLYCNE'M . Polycnemu 600 recúrvum Lois. 3. $\mathrm{CRO}^{\prime} \mathrm{CUS}$ Ker 601 vérnus $E$. $B$. 602 albiflórus $K$ it

entire-leaved tooth-leaved holly-leaved Xrris. rush-leaved short-leaved smooth

Callisia. creeping

o ${ }^{1}$ Caryophyllea. Sp. $1-3$. $\square$ or 20 Acerina. Sp. $1-10$. Terebintacece. $S p .2$

$\begin{array}{lllllll}\text { or } & 6 & \text { ap.s } & \text { Y } & \text { S. Europe 1793. C p.1 Lam. ill. t. } 27\end{array}$ Terebintacee. Sp. 3-4.

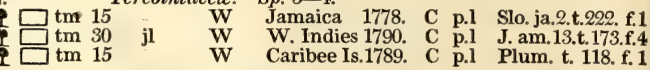
Juncea. Sp. 3-26.

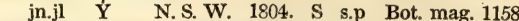
$\frac{1}{2}$ jn.au $\mathbf{Y}$ Carolina 1812. S s.p

$\frac{1}{2}$ jn.au Y N. Holl. 1819. Commelinea. $\mathrm{Sp}$. $1-3$.

jn.jl $B \quad$ W. Indies 1776, $R$ s.p Jac. am.11, t. 11 Commelinea. $S p$. 10-60.

MMELINA. common

Carolina

African

Bengal

upright

Virginian

long-stalked

soft

齿

2. $\square$

2 $O$ or 2 jn.jl P.B America 1732. S co Red. lil. 206

\& $\triangle$ or 2 jn.jl P.B America 1732. D r.m

2 $\mathbb{N}$ or 1 my.o $Y \quad$ C. G. H. 1759. R r.m Bot. mag. 1431

2 1 or 3 jn B Bengal 1794 R s.p Mur got. 18

$\checkmark$ or 1 aus $B$ Virginia 1732

$\checkmark$ or 1 au.s

$\triangle$ or

Virginia 1732. R s.p Di. el.94.t.77.f. 88

Virginia 1779. R s.p P.al.135.t.174.f.4

Caraccas 1806. $R$ s.p Jac. ic. 2. t. 294

Caraccas 1804. R s.p Jac. ic. 2. t. 293

Mexico 1732. R r.m Bot. rep. 399

sky-blue $\frac{D}{\Delta}$ or $1 \frac{1}{\mathrm{a}}$ jn.jl $\mathrm{B}$

ANeILEMa. creeping

doubtful

Chinese

Cartonema

spear-leaved

Commelinece. Sp. 3-12.

$2 \mathbb{N}$ or 1 jl.au $\mathbf{B} \quad$ N. Holl. 1820. R co

E $\square$ or 3 V S. Leone 1822. D r.m Beauv, Ow, t. 15

vor

Commelinere. $\mathrm{Sp} .1$.

$\frac{1}{2}$ jl.au B E. Indies 1783. S s.p

Caryophyllea. Sp. 2.

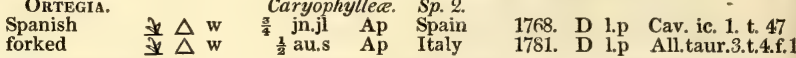
Chenopodece. $S p .2-12$

$\begin{array}{lllll}\frac{1}{4} & \text { jl Ap S. Europe 1640. S } & \text { s.l Jac. aus. 4. t. } 365\end{array}$ trailing * $\mathrm{w}$ recurved w Iridea. Sp. 17.

$\begin{array}{llllll}\text { spring } & \delta & \text { or } & \text { f.ap } & \text { P England mea. O co Eng. bot. 344 }\end{array}$

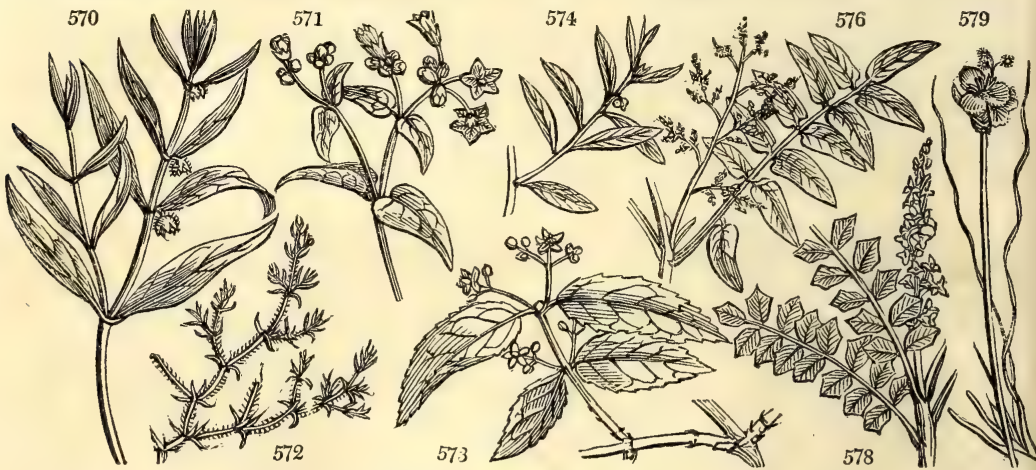

History, Use, Propagation, Culture,

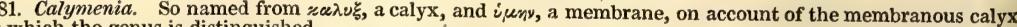
tenus is distinguished.

82. Laflingia. In honor of P. Lœefling, a Swedish botanist, who published a volume of travels in Spain, \&c. These are plants of no beauty, and are only cultivated in botanic gardens.

83. Hippocratea. In honor of the celebrated Hippocrates, the father of physicians, born in the island of Cos, who flourished 450 years before the vulgar ara. Plumier, who first fixed the genus, called it Coa, which Linnæus changed to its present name.

84. Cneorum. Kyeweov is a plant described by Theophrastus, as resembling the olive. This is a low yellowish evergreen shrub, which like Veronica decussata, will endure our winters in the open air, with protection during frost. It grows naturally in hot dry barren and rocky soils; thrives well in an artificial state in any light earth ; ripened cuttings will root in sand under a hand-glass, or it may be raised from seeds, which it produces in abundance.

85. Comocladia. Koun, hair, and $x \lambda a \delta \circ$, a branch. The branches are tufted at the top of the tree. C. integrifolia is a handsome tree with an erect trunk, dividing into few branches, adorned with pinnated smooth leaves, like a frond ; flowers numerous, fruit a deep red, shining, eatable, but not inviting. The wood is hard, of a fine grain, and reddish color. If $\mathrm{C}$. dentata be ever so slightly wounded, it emits a strong smell of dung: it grows in Cuba, where the natives have a notion that it is dangerous to sleep under its shade. This genus is not frequent in British collections : it thrives in loam and peat, and may be propagated by ripened cuttings placed under a hand-glass in moist heat. 
569 Villous viscid, Leaves cordate, Flowers racemose, Stamens longer than the corolla

570 Leaves lanceolate, Peduncles aggregate axillary solitary, Calyxes 3-flowered, Stem ascending

571 Leaves cordate ovate smooth, Peduncles terminal heaped, Stamens shorter than the corolla

572 Flowers triandrous monogynous, Leaves very small : lower linear, upper subulate

573 Leaves oblong-ovate lanceolate or elliptical serrated, Capsules oval

574 Smooth, Flowers axillary

575 Hoary, Leaves flower-bearing powdery, Petals and stamens 4

576 Leaflets stalked ovate-lanceolate entire

577 Leaflets stalked ovate-lanceolate prickly-toothed

578 Leaflets sessile angular-spiny

579 Leaves linear-subulate, Head globose many-flowered, Petals alternate pencil-shaped

580 Scape slender, Head globose

581 Culm 2-edged and leaves smooth very narrow, Head subovate, Scales imbricate on each side, Keel of the glumes ciliate

582 Leaves ovate-lanceolate sessile, Stem procumbent, Flowers axillary sessile

583 Leaves ovate-lanc. nearly sessile acute with the creeping stem smooth, Involucr. cordate doubled together 584 Flowers uneq. Involucres cord. folded together at base with sheaths ciliated, Leaves lanc. sess. Stem decumb. 585 Leaves lanceolate sessile with the decumbent stem smooth, Involucr. cordate doubled together

586 Leaves ovate stalked obtuse, Involucres cordate hooded turbinate

587 Leaves ovate-lanceolate rough, Involucres hooded turbinate, Stem erect

588 Leaves lanceolate stalked rough above, Sheaths rusty, Stem erect simple

589 Leaves linear-lanceolate sessile rather hairy, Involucres ovate doubled together, Stem creeping

590 Villous, Leaves ovate stalked, Involucres half round folded in at the edge, Stem creeping

591 Leaves ovate-lanceolate sessile ciliated, Involucres cordate folded together, Stem erect

592 Involucres cord. acumin. folded together, Pedunc. pubesc. Pedicels smooth, Lvs. obl. lanc. Sheaths ciliated

593 Smooth, Stem creeping, Leaves lanceolate, Flower-stalks 2-flowered

594 Stem solid woody with distant leafy knots, Leaves long ovate acuminate fascicled villous

595 Stem branched diffuse, Leaves ligulate acuminate, Racemes alternate about 7 placed in a panicle form, 3 Stamens bearded 3-naked

596 Leaves lanceolate, Flowers panicled

597 Stem branching, Branches and branchlets opposite, Flower-stalks many-flowered

598 Flower-bearing hranches dichotomous, Flowers solitary

599 Leaves subulate prismatic, Spiny at the end

600 Leaves subulate scattered spreading distinct somewhat recurved, Cal. nearly as long as capsules

\section{Vernal.}

601 Mouth of flower closed by hairs, Segments obtuse, Stigmas dilated, Flowers large early

602 Segments of flower quite entire obt. Anthers twice as long as the stigmas, Mouth of flower closed by hairs

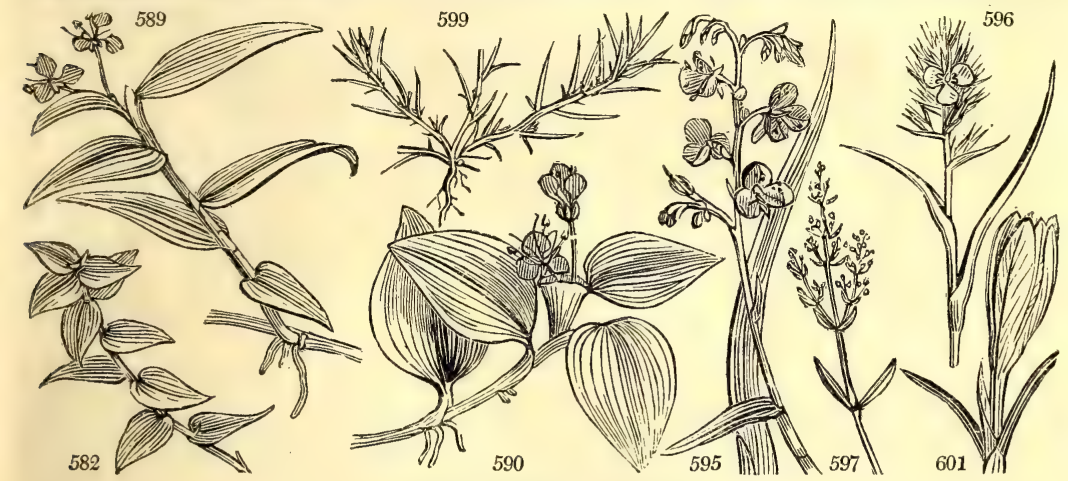

and Miscellaneous Particulars.

86. Xyris. Xegos, acute. Its leaf terminates in a sharp point. Under this name a plant is described by Pliny, which resembles an iris. Pretty little rush-like plants with yellow flowers; uncommon in collections, but easily cultivated, though rarely flowering.

87. Callisia. From $x \propto \lambda \circ 5$, pretty; a name aptly given to this plant, which is easily known by its shining leaves edged with purple.

88. Commelina. So named by Plumier, in honor of the brothers, John and Gaspar Commelin, botanists and Dutch merchants. Some of the species, such as C. cœlestis and tuberosa, are very showy herbaceous plants; others are mere weeds. They are all easily cultivated in wet places in the stove or greenhouse, and propagated by the rooting joints of their stem or by division of the roots, or by cuttings.

89. Aneilema. From $\alpha y \leqslant i \lambda \varepsilon \omega$, to evolve, the flowers being evolved, as it were, from the spatha. A genus resembling Commelina, from which it is chiefly distinguished by not having its flowers enclosed in a spatha.

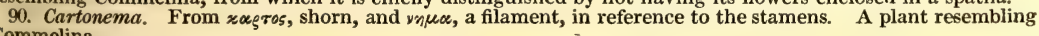
Commelina.

91. Ortegia. In honor of Casimir Gomez de Ortega, a Spanish botanist, and professor of botany at Madrid. An insignificant herbaceous plant.

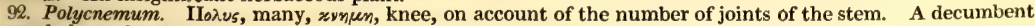
annual plant of no beauty.

98. Crocus. A name given by Theophrastus. The story of the youth Crocus being turned into this flower, may be read in Ovid's Metamorphoses. This is an ornamental genus of great value in the flower-garden, on 
603 minimus Red. 604 versícolor $H . K$ 605 biflórus $H$. $K$. 606 pusillus $T e n$. 607 susiánus $H . K$. 608 reticulátus $M . B$ 609 striátus $L k$. 610 sulphúreus $H$. $K$. $\beta$ flávus

611 lúteus Lam.

612 lagenæflorus Salisb.

$\beta$ flávus

$\gamma$ penicillatus

613 stellaris Haw.

614 sativus $W$. 615 serotínus $H$. $K$. 616 nudiflórus $\boldsymbol{H} . \boldsymbol{K}$.

617 Pallásii $M . B$.

94. WITSENIA. Ker. 618 maúra $H . K$ 619 corymbósa $H . K$

95. I'XIA. Ker. 620 lineáris $\boldsymbol{H} . \boldsymbol{K}$. 621 capilláris 622 aúlica $W$. 623 fucáta Ker 624 pátens $W$. 625 leucántha $P . S$ 626 flexuósa $H$. $K$. 627 hybrida Ker 628 cónica $H$. $K$. 629 monadélpha $H . K$. $\beta$ cúrta Andr. 630 columelláris $H, K$ 631 amæna $L k$. 632 maculáta $W$. $\beta$ ochroleúca 633 capitáta $P$. $S$ 634 viridiflóra $\boldsymbol{P}$. $S$ 635 erécta $H$. $K$. 636 crateroídes $H$. $K$. least

party-colored

Scotch

Neapolitan

cloth of gold

netted vernal

striped vernal

sulphur-colored

pale-yellow

common-yell.

golde

pale

starry-yellow

$\frac{\Delta}{8}$ or $\quad \frac{1}{8}$ f.mr

5 $\triangle$ or $\frac{1}{4}$ f.mr

$\triangle$ or $\frac{1}{6}$ f.mr

$\triangle$ or $\frac{1}{4}$ f.mr

$\Delta$ or $\frac{1}{4}$ f.mr

$\triangle$ or $\frac{1}{2}$ f.mr

$8 \Delta$ or ${ }^{\frac{1}{4}}$ f.mr

\% $\triangle$ or $\frac{2}{4}$ f.mr

\% $\triangle$ or $\frac{1}{4}$ f.mr

$\triangle$ or $\frac{2}{4}$ f.mr

to $\Delta$ or ${ }_{\frac{1}{4}}^{\frac{1}{4}}$ f.mr

saffron

f. $\triangle$ or $\frac{3}{2}$ s.o

late autumnal $\frac{8}{\Delta}$ or $\frac{1}{2}$ s.n

naked autumn. $\delta \Delta$ or $\frac{1}{2}$ o.n

Russian autum. $\delta \Delta$ or

Witsenia.

$\mathrm{N}$ or $4 \mathrm{nja}$

corymbose

IxIA.

slender

capillary

rose-colored

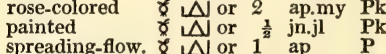

$\checkmark \Delta$ or $\frac{1}{2}$ ap.s

P 1629. O co

Li S. Europe 1629. O co Bot. mag. 1110

W Crimea 1629. O co

Y.br Naples 1824. O co

B Crimea $\ldots$ O co

W $\quad \cdots 1 . . .120$. O co

Y S. Europe 1629. O co

P.T S. Europe 1629. O co

$\begin{array}{llll}\text { Y Turkey 1629. } & \text { O co } \\ \text { D. } & \text { Greece } & \end{array}$

P. $x$ Greece $\quad \ldots$ O co

P.X $\quad$...... $\quad \ldots$ O

... O co

England mea. O s.l

S. Europe 1629. O co Bot. mag. 1267

England mea. O co
Bot. mag. 845

Bot. mag. 652

Bot. mag. 938

Bot. mag. 1384

Bot. mag. 45

græc.1. t.35

Hor, trans. 1, t. 6 Yp. ${ }^{2-4 .}$ C. G. H. 1790, C s.p Bot. reg. 5 P.B C. G. H. 1803. C s.p Bot. mag. 895

C. G. H. 1796. O s.p.l Bot. mag. 570

C. G. H. 1774. O s.p.1 Bot. mag. 617

C. G. H. 1774. O s.p.l Bot. mag. 1013

C. G. H. $\quad$.. O s.p.l Bot. mag. 1379 prite flowered \& 1 or 1 ap $\quad \mathbf{P}$ bending-stalked $\delta$ or 2 ap.my $\mathrm{Pk}$

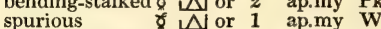
orange-colored $\frac{\delta}{\Delta}$ or 1 ap.my $O$ monadelphous $\frac{6}{\Delta} \Delta$ or $\frac{1}{3}$ ap.my $B$ short

variegated pretty of $\triangle \mathrm{N}$ or $1^{\frac{1}{3}}$ ap.my $R$ t $\triangle$ or 1 my.jn W.br cream-colored of $\triangle$ or 1 my.jn P.Y headed $\triangle \mathrm{d}$ or 2 my.jn $\mathbf{L m}$ green-flowered

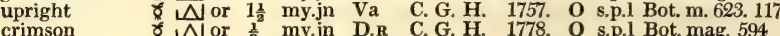

C. G. H. 1779. O s p.l Bot. mag. 522

C. G. H. 1779 . O s.p.l Jac. ic. 2. t. 278

C. G. H. 1757. O s.p.l Bot. mag. 624

C. G. H. 1757. O s.p.1 Bot. mag. 127

C. G. H. 1757. O s.p.1 Bot. mag. 539

C. G. H. 1792. O s.p.l Bot. mag. 607

C. G. H. 1792. O s.p.l Bot. mag. 1378

C. G. H. 1790. O s.p.1 Bot. mag. 630

C. G. H. 1822. O s.p.1

C. G. H. 1780. O s.p.1 Bot. rep. 196

C. G. H. 1780 . O s.p.l Bot. mag. 1285

C. G. H. 1780 . O s.p.1 Bot. rep. 159

C. G. H. 1780 . O s.p.l Bot. mag. 549

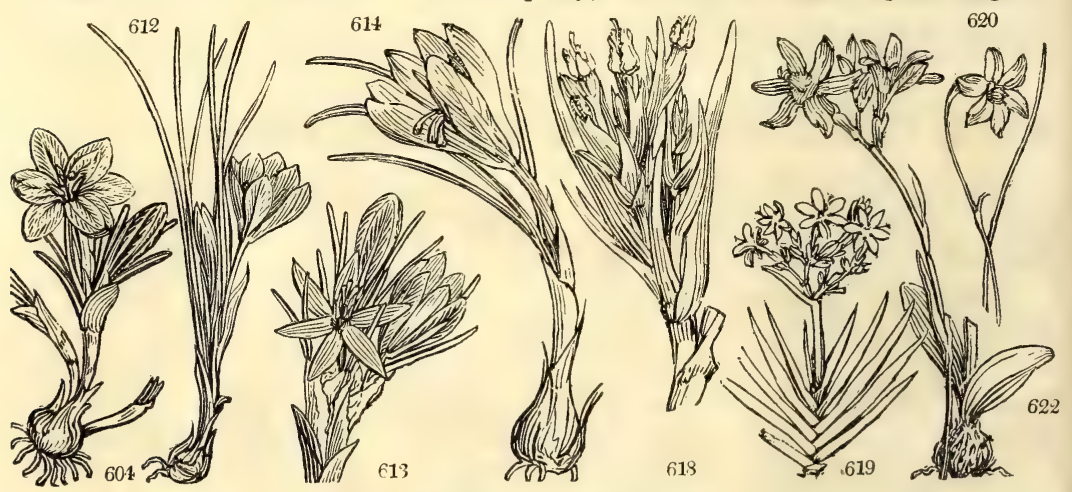

History, Use, Propagation, Culture,

account of the early season of flowering, and the brilliancy of the flowers. Haworth, who has for thirty years paid particular attention to the Crocus, (Hort. Trans. i. 122.) and raised many varieties from seed, found that the blue, purple, and white flowered kinds, ripened their seeds much more readily than the yellow, and that the leaves of the latter were narrower through all the species and varieties. When this genus is in flower, the germen is situated underground almost close to the bulb, but some weeks after the decay of the flower, it emerges on a white peduncle, and ripens its seeds above ground. This extraordinary mode of semination is peculiarly conspicuous in $\mathbf{C}$. nudiflorus, which flowers without leaves in autumn, and throws up its germen the following spring like the Colchicum. Though some species of Crocus are, or appear to be, naturalized in a few places, yet they cannot be considered as aboriginal natives. Allioni affirms the C. sativus (the saffron) is indigenous in Savoy; but Ray says nothing is certain as to its native country. Professor Martyn considers Asia as its native country, saffron having there first acquired that high reputation in medicine, which it has now almost lost in Europe. The Arabic name Z'afarân, and the Moorish and Spanish terms Azafran and Safra, seem to confirm this opinion. C. vernus, the saffran printanier, Fr., is a native of Switzerland and Italy, and is commonly found with white flowers and a purple base. Some botanists consider it and C. sativus as the only distinct species of the genus. Miller describes four, Willdenow four, Sir J. E. Smith three, as natives of Britain, and Haworth (Hort. Trans. i. 132.) no fewer than thirteen species. Parkinson certainly cultivated many varieties which are not now known in collections. Crocus vernus and versicolor, produce by cultivation varieties of singular beauty, both as to size, color, and marking. C sativus, the saffron. Saffran, Fr. and Ger., and Zafrano, Ital., is said to have been first brought into England in the time of Edward III., and introduced to Walden in Essex, to which town it afterwards gave the prænomen. It was abundantly cultivated there, and in Cambridge, Suffolk, and Herefordshire, in the beginning of the 17th century; but the article is now so little in repute, or so much cheaper in foreign markets, that at present the culture of saffron is confined to a few parishes round Saffron Walden. The bulbs are planted in July in a well pulverized soil, not poor nor a very stiff clay; they are placed in rows six inches apart across the ridges, and three inches bulb from bulb in the row. The purple flowers are gathered in September and carried home, where their yellow stigmas and part of the style are picked out and dried on a kiln between layers of paper, and under the pressure of a thick 
603 Segments of flower acute, Stigmas small, Flowers small late, Mouth of throat closed by hairs 604 Stigmas convolute hooded lobed as long as the anthers

605 Leaves longer than flowers, Stigmas but little longer than the anthers

606 Stigma inclosed trifid longer than stamens, Lobes filiform cucullate risp, 607 The three outer segments of flower revolute

608 Stam. as long as the truncate torn stigmas, Leaves supporting the flowers, Bulbs coated with net-work 609 Leaves longer than the flowers, Spathes 2 inner narrowest, Limb of cor. funnel-shaped, Stigma length or 610 Stigmas unequal much longer than the anthers [anthers flattish jagged

611 Filaments hairy, Anthers longer than the stigma

612 Stigma enclosed trifid, Lobes somewhat linear toothed, Coat of the roots membranous

$\beta$ Pale cream-coloured flowers

$\gamma$ Pale cream-coloured flowers, with 3 sky-blue lines on the tube

613 Leaves upright-spreading : their keel blunt: sides nerveless, Flower in the sun campanulate stellate

614 Stigmas very long reflexed crenate at the end

615 Stigmas erect much divided, Leaves coming out with the flowers

616 Stigmas erect much divided, Leaves later than the flowers

617 Bulbs with a thready skin, Leaves later than the f. Stam. as long as the truncate stigmas, Flower large

618 Flowers spiked, Outer segments of flower downy without

619 Flowers corymbose smooth

620 Leaves linear very narrow convex, Scape simple erect

621 Leaves with a cartilaginous edge, Racemes 1-7-flowered

622 Leaves ensiform, Tube of the flower turbinate

[Anthers diverging

623 Leaves grassy, Spike 1-2-flowered, Flower hypocrateriform, Tube clavate straight, Filaments columnar 624 Tube filiform, Limb bell-shaped spreading, Stigmas longer than the anthers

625 Leaves linear ensiform, Flowers 1-sided, Spathes toothed shorter than the tube

626 Tube slender a little enlarged, Limb below bell-shaped contracted, Segments spreading

627 Leaves slender, Raceme flexuose many-flowered

$628 \mathrm{Limb}$ spreading spotted at base, Stigmas not divided lower than the base of the anthers

629 Filaments united in a tube

630 Filaments united at base

631 Leaves lanceolate, Spathe toothed much shorter than the filiform tube, Segments lanceolate

632 Limb campanulate spreading spotted at base, Stigmas divided as low as the tube

633 Smooth with stalked bulbs, Leaves linear ensiform, Flowers in spiked heads, Tube shorter than segments 634 Leaves linear ensiform edged, Scape many-spiked many-flowered, Flowers spotted at base 635 Limb spreading not spotted, Stigmas divided as low as the tube

636 Limb hemispherical campanulate, Stigmas longer than anthers
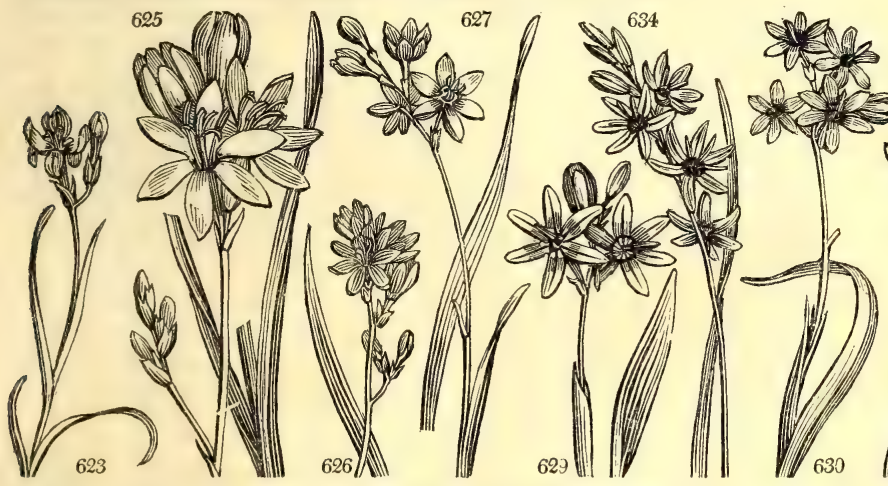

and Miscellaneous Particulars.

board to form the mass into cakes. Two pounds of dried cake is the average crop of an acre after the first planting, and twenty-four pounds for the two next years. After the third crop the roots are taken up, divided, and transplanted.

The uses of saffron in medicine, domestic economy, and the arts, were formerly very various. It is now

employed by painters and dyers, and enters into sauces, creams, biscuits, conserves, liqueurs, \&c.

As a garden-flower, the C. vernus is the parent of many varieties, and these may be increased at pleasure by propagating from seeds. Haworth directs to sow these immediately after being gathered in light earth, in a shady, but open situation. Sift over them half an inch of earth the first autumn, and the second take them up and immediately replant them. Add another half inch of earth the third autumn, and the following spring most of the plants will show flowers in the midst of their fourth crop of leaves. Afterwards they may be treated like old bulbs, and planted in the open borders or shrubbery, in patches, rows, or as fancy may direct. The bulbs of crocus being renewed every year, and the new bulb formed on the top of the old one, it follows, that at whatever depth they may have been planted, they will in a short time rise to the surface, unlike the tulip and the bulbous iris, whose new bulbs being formed under the old ones, soon sink the plants, unless growing on a hard subsoil. Crocus bulbs should be taken up every third year, after the leaves decay, dried in the shade, parted, and replanted three inches deep, and not later than michaelmas. The longer they are kept out of the ground after this period they become the weaker and flower the later. In this way, and by preserving them in an icehouse, they may be retarded so as to flower at midsummer or later; and they may be accelerated by heat or blown in water-glasses, or on fancy pots called cats, hedgehogs, \&c. common in the seed-shops. The yellow-flowered species force better than the blue ones.

94. Witsenia. In honor of Mr. Witsen, a Dutch consul in India, a patron of botanical science, and of Thunberg. This genus and all the succeeding, as far as Pardanthus, consist of handsome herbaceous and bulbous plants, flowering for the most part in the spring and not distinguished from each other by very distinct characters. The bulbous sorts are easily cultivated in pots, are nearly all natives of the sandy wastes of the Cape of Good Hope, and are capable of succeeding well in a warm open border. To make them flower well in pots, they should have no water while they are dormant. 
637 retúsa $H, K$. 638 scilláris $H . K$. 639 críspa $H . K$.

96. TRICHONE'MA. Ker. Trichonema.

641 cruciátum $H$. 642 cauléscens $B . M$. 643 pudícum $B$. $M$. 644 speciósum $B$. $M$ caulescent blush crimson $\stackrel{\Delta \text { or }}{\Delta}$ $\triangle \mathrm{N}$ or $\checkmark$ or rose-coloured

97. GEISSORHI'ZA. Ker. TILE-Root. 646 rochénsis $\boldsymbol{H} . \boldsymbol{K}$. 647 júncea $L k$. 648 setácea $B$. $M$. 64.9 obtusáta $\boldsymbol{H} . \boldsymbol{K}$ 650 secúnda $H . K$ 651 excísa $H . K$ 652 ciliáris $S a l$. plaid $\Delta$ or or or $1^{\frac{3}{4}}$ my bristle-leaved o 1 or 1 jnjil one-sided of or 1 my W short-leaved $\mathrm{N}$ or $\frac{1}{2}$ ap.my W ciliated

* $\triangle$ or $1^{\frac{1}{2}}$ ap.my mr.ap R $\frac{1}{2}$ my B $\frac{1}{2}$ au $\mathrm{mr}$.ap $\mathbf{R}$ yellow-flowered 8 or 1 my

Ly. C. G. H. 1793. O s.p.l Bot. mag. 629 $\begin{array}{llll}\text { ja.f } & \text { Va } & \text { C. G. H. } & \text { 1787. O } \\ \text { ap.my } & \text { B } & \text { C. G. G. H. } & \text { 1787. Oot. mag: } 542 \\ & & & \end{array}$

Iridea. $S p .6$. C. G. 1758 O s.p.l Bot. mag. 575 C. G. H 1810. O s.p.l Bot. mag. 1392 C. G. H. 1808. O s.p.l Bot. mag. 1244 C. G. H. 1808. O s.p.l Bot. mag. 1476 C. G. H. 1808. O s.p.l Bot. mag. 1225 Iridece. Sp. 7 .

98. HESPERA'NTHA. Ker. Evening-Flower. Iridea. Sp. 5. 654. piliata $H . K$. 6.54 pilosa $B . M$. 655 graminifólia Sweet. grass-leaved 656 falcáta $H . K$ sickle-leaved 657 cinnamómea $H . K$. curled-leaved 99. SPARA'XIS. Ker. SparaXIS.

XIS Ker. SparaXIS.
three-coloured

$\beta$ sanguineo-purpurea various-colored

y violaceo-purpurea dark-colored light-colored

or

$\frac{1}{2}$ ap.jn V $\frac{1}{2}$ ap.my V

$\frac{x^{2}}{2}$ au.s. V

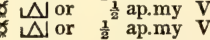

\section{Iridece. Sp. 4.}

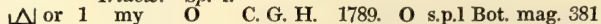

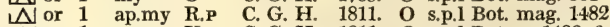
$\mathbb{N}$ or 1 ap.my V.P C. G. H. 1811. O s.p.1 Bot. m. 1482. f. 2

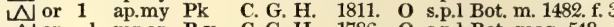
659 bícolor $\boldsymbol{H} . \boldsymbol{K}$. 660 grandiflóra $H, K$

$\beta$ striata

o liliago

661 bulbifera $H . K$. 1 mrap B.y purple-flowered 8 iv or streak-flowered $\mathbb{N}$ or $\frac{2^{4}}{4}$ ap $\mathrm{St}$ lily-flowered of $\mathrm{N}$ or ${ }^{3}$ ap $\mathrm{W}$ bulb-bearing \& $\mathrm{N}$ or

100. TRITO'NIA. Ker 662 críspa $H . K$ 663 viridis $H . K$ 664 rósea $H . K$. 665 capénsis $B . M$ 666 longiflóra $H . K$. 667 tenuiflóra Vahl.

$\beta$ cóncolor Sweet.

r rochénsis $\mathbf{B}$. M.

pállida Ker. 668 lineáta $H$. $K$ 669 securígera $H . K$. 670 fláva $H . K$. 671 squálida $H$. $K$. 672 fenestráta $H . K$. 673 crocáta $\boldsymbol{H}$. $\boldsymbol{K}$. 674 deústa $\boldsymbol{H} . \boldsymbol{K}$. 675 miniáta $H . K$. 676 refrácta $\mathrm{Ker}$.

Tritonis.

Iridere. Sp. 15. green-flowered rosy

Cape

long-flowered slender-tubed self-colored bending-flower $r$. pale-flowered pencilled

copper-colored yellow

sweet-scented open-flowered crocus-flowered spotted

C. G. H. 1786. O s.p.l Bot. mag. 548

C. G. H. 1758. O s.p.l Bot. mag. 541

C. G. H. 1758. O s.p.l Bot. mag. 779

W C. G. H. 1758. O s.p.l Bot. reg. 252

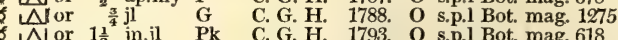

6 $\triangle$ or $1 \frac{1}{2}$ jn.jl Pk C. G. H. 1793. O s.p.l Bot. mag. 618

C. G. H. 1811. O s.p.l Bot. mag. 1531

f or 1 ap.jn $\mathbf{Y}$ C. G. H. 1811 O s.p.l B.m.1502. f. maj.

N or 1 ap.jn $Y$ C. G. H. 1811. O s.p.1 B.m.1502. f.min

$\checkmark \mathrm{N}$ or 1 au $\mathrm{Y}$ C. G. H. 1811. O s.p.1 Bot. mag. 1503.

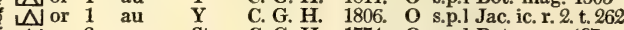

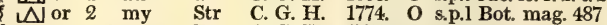

\begin{tabular}{llll}
\hline or & $\frac{1}{2}$ my & Br & C. G. H. 1774. O s.p.l Bot. mag. 383
\end{tabular}

$\begin{array}{llll}\text { Nor or f.mr } & \text { Y } & \text { C. G. H. } 1780 \text {. O s.p.l Bot, reg. } 747\end{array}$

C. G. $\mathrm{H} 1801$ S s.p. Bot mag. 581

C. G. H. 1758. O s.p.l Bot. mag. 184

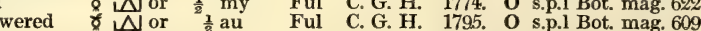
reflexed $\triangle \cup$ or 1 my.jn $Y \quad$ C. G. H. 1815. O s.p.l Bot. reg. 135

Iridea. Sp. 12.

101. WATSO'NIA. Ker. Watsonia. 677 spicáta $H . K$. hollow-leaved 678 plantagínea $\boldsymbol{H}$. $\boldsymbol{K}$. fox-tail 679 puncta 679 punctáta $H$. K. $\beta$ variegata $B . M$ 681 margináta $H . K$ $\beta$ minor

f $\mathrm{N}$ or $2^{\frac{1}{2}}$ jn.jl W dotted-flowered $\delta \mathbb{N}$ or 1 ap.my $P$ two-colored $\triangle$ or 1 jl.au $\mathrm{Pk}$ variegated $\delta \mathrm{N}$ or 1 jl.au St $\begin{array}{lllll}\text { broad-leaved } & \mathbb{N} \text { or } & 3 & \text { jn } & \\ \text { shining-leaved } & \mathbf{P k} \text { or } & 3 & 0\end{array}$
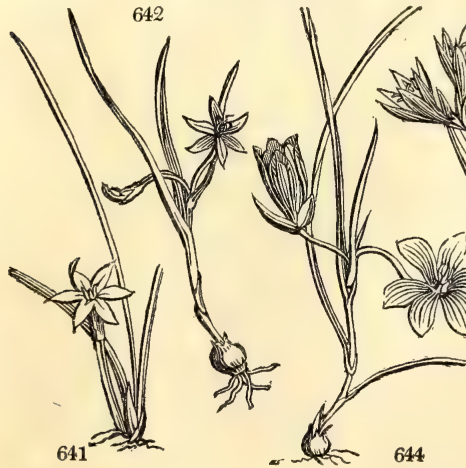

648

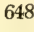

C. G. H. 1791. O s.p.1 Bot. mag. 523

C. G. H. 1774. O s.p.l Bot. mag. 553

C. G. H. 1800. O s.p.1 Bot. rep. 177

C. G. H. $\quad \ldots \quad$ O s.p.l Bot. mag. 537

C. G. H. … O s.p.l Bot. mag. 1198

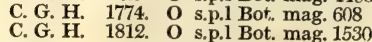

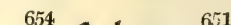

History, Use, Propagation, Culture,

95. Ixia. Derived from $1 \% \omega$, to fix, in allusion to the viscid nature of the roots of some species.

96. Trichonema. From $\theta \rho \iota \xi$, hair, and $\eta_{\eta} \mu \alpha$, a filament; the filaments being hairy.

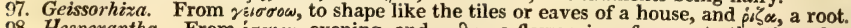

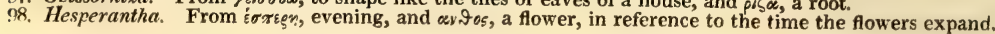


637 Tube twice as long as spathe, Segments oblong, Stigmas split gaping

638 Tube the length of the spathe, Segments spatulate concave, Stigmas funnel-shaped

639 Leaves curled

640 Leaves linear channelled

641 Leaves linear nerved thickened at the edge

642 Radical leaves with 4 furrows, Outer valve of spathe convolute rigid, Flower turbinate, Segments lanc.

643 Leaves twisted, inflated at base, Flower very large spreading, Segm. with a black mark at the base, Stamens bearded at base, Anthers connate

644 Leaves linear, very long, Flowers veiny, spreading on long stalks, Edge of spathe membranous

645 Leaves filiform, Scapes 1-flowered, shorter than the campanulate flower

646 Leaves radical linear acute, Stem smooth, a little honey-pore at the base of the divisions of the flower 647 Leaves filiform, Stem few-flow. smooth, spathes scarious much longer than tube, Segments of flower obl. 648 Stem simple few-flowered, Radical leaves bristly

649 Radical leaves ensiform-linear obtuse

650 Radical leaves linear-acute, Stem villous

651 Radical leaves ovate oblong

652 A doubtful species, known only by name

\section{Leaves fistulous}

654 Leaves linear hairy, Stem smooth

655 Leaves linear with stem smooth

656 Radical leaves falcate smooth

657 Radical leaves falcate curled

658 Spathes spotted, Limb of flower regular

659 Spathes spotted, Limb of flower bilabiate

560 Spathes lined, Limb of flower regular: segments ovate-oblong

661 Spathes lined, Limb of flower regular: segments elliptical

662 Leaves waved curled, Segments of flower flat

663 Scape 3-cornered: angles membranous

664 Outer valve of the spathe cuspidate, Tube of the flower very long, Upper segment largest

665 Spathe lanceolate pointed, Flower striped : Upper segment erect largest, the rest linear oblong

666 Outer valve of the spathe obtuse 3-toothed, Tube very long, Segments of the limb equal

667 Leaves ensiform, Flowers in two rows, Spathes membranous shorter than tube, Segm. of the limb linear

668 Ujper segment of flower largest, outer retuse

669 Outer valve of spathe obtuse 3-toothed at end, Three lower segments of the limb with a stalked perpendicular callus at base

670 Outer valve of spathe cuspidate, Three lower segments of limb with a stalked perpendicular callus at base 671 Limb campanulate: segments approximated, transparent at the edge towards the base

672 Limb infundibuliform; segments distant, transparent at the edge towards the base

673 Limb campanulate transparent at the base

674. Three outer segments gibbous within, at the base spotted and carinate

675 Leaves ensiform, Scape many spiked, Base of the flower lined not transparent

676 Spikes reflexed one-sided, Flowers infundibuliform, Spathes very short, Leaves linear ensiform

677 Leaves fistular slender

678 Upper leaves linear ensiform ; lower fistular compressed

679 Leaves linear very narrow

680 Leaves linear ensiform, Anthers as long as throat, Corolla funnel-shaped with elliptical pointed segments

681 Leaves ensiform thickened at the edge, Spikelets several appressed, Flower funnel-shaped

663

666

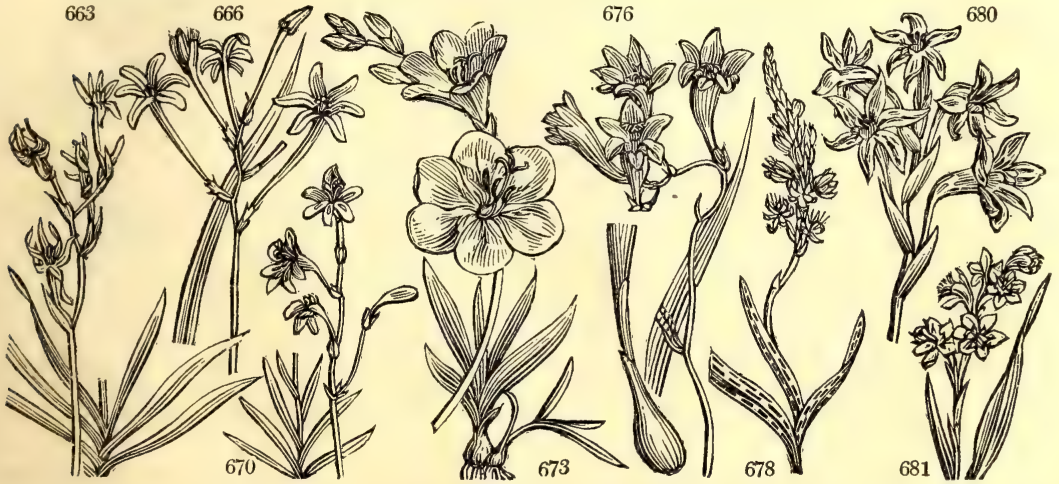

and Miscellaneous Particulars.

99. Sparaxis. Frem $\sigma \pi \propto \rho \propto \sigma \sigma \omega$, to tear. The generic distinction consists in the lacerated spathas.

100. Tritonia. Named by Mr. Bellenden Ker, from Triton, understood, as he informs us, in the sense of a vane or weathercock, in allusion to the variable direction of the stamens in different species.

101. Watscnia. Named by Miller in honor of Dr. Wm. Watson, his friend, W, brevifolia has its blossoms 
682 strictiflóra $\boldsymbol{B} . \boldsymbol{M}$. 683 rósea $H . K$.

684 brevifólia $H . K$.

685 iridifólia Jacq.

$\beta$ fúlgida Sal.

686 meriána $H . K$.

687 húmilis $H . K$.

688 aletroídes $H . K$.

$\beta$ variegata

102. BABIA'NA. Ker.

689 Thunbérgii $\boldsymbol{H} . \boldsymbol{K}$.

690 ríngens $H$. $K$.

691 tubifióra $W$

ß tub̄áta W.

692 spathácea $H . K$.

693 sambucina $\boldsymbol{H}$. $\boldsymbol{K}$.

694 disticha $B$. $M$

695 plicáta $H$. $K$.

696 stricta $H . K$.

697 sulphárea $H . K$.

698 villósa $H . K$.

699 rubro-cyánea $H . K$.

700 corymbósa $\boldsymbol{H}$. $\boldsymbol{K}$. level-topped

701 fissifólia $B . M$.

104. MELASPH无'RUIA

702 gramínea $D$. C.

703 iridifólia $D$. C.

Ker. Melaspherula.

grass-leaved
iris-leaved

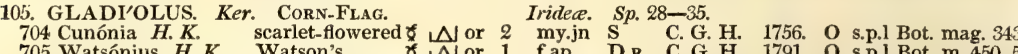
705 Watsónius $\boldsymbol{H}$. $\boldsymbol{K}$. Watson's \& $\mathbb{N}$ or 1 f.ap D.r C. G. H. 1791. O s.p.1 Bot. m. 450.569 706 quadranguláris $\boldsymbol{H} . \boldsymbol{K}$. four-channelled $\delta \mathrm{V}$ or $2 \mathrm{mr}$.ap $\mathrm{Y} \quad$ C. G. H. 1799. O s.p.l Bot. mag. 567 707 viperátus $H . K$. perfumed \& $\mathbb{N}$ or $\frac{1}{6}$ ap.my Br.y C. G. H. 1787. O s.pl. Bot. mag. 688 708 elátus $H . K . \quad$ winged-flower. $\triangle \mathbb{N}$ or $\frac{3}{4}$ my.jn O.G C. G. H. 1795. O s.p.i Bot. mag. 586 709 namaquénsis $H . K$ helmet-flower. o 1 or ${ }_{3}$ my.jn O.G C. G. H. 1800 o s.p.l Bot mag 592 710 revifólius $H . K$. hhort-leaved 0

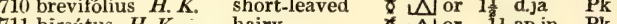
711 hirsútus H.K. hairy $\quad$ o or $1 \frac{1}{2}$ ap.jn $\mathbf{P k}$ 712 versicolor $H . K$. various-colored $\triangle \mathrm{N}$ or $1 \frac{1}{\frac{1}{2}}$ my.jn $\mathrm{Br}$ B binérvis B. M.

713 édulis Ker.

714 hastátus $B . M$.

715 tristis $B . M$.

$\beta$ cóncolor Sal

two-nerved

eatable

spade-spotted

( $\mathrm{N}$ or $1 \frac{1}{8}$ my.jn $\mathrm{Pk}$

$\checkmark \Delta$ cul 12 my.jn W

C. G. H. 1802. O s.p.l Bot. m. 727. 992

C. G. H. 1795. O s.p.l Bot. mag. 574

C. G. H. 1794. O s.p.l Bot. mag. $\propto 1042$

C. G. H. 1806. O s.p.l Bot. mag. $\varepsilon 1042$

C. G. H. 1816. O s.p.1 Bot, reg. 169

C. G. H. 1816. O s.p.l Bot. mag. 1564

square-leaved $\mathbf{N}$ or 1 my.jn Br.Y C. G. H. 1745. O s.p.1 Bot. mag. 272 self-colored

716 trichonémifólius $b . m$ violet-scented 717 grácilis $H . K$. 718 recúrvus $H$. $K$.

719 cárneus $H . K$

720 cuspidátus $H$

701 blsmdus $H . K$. tall

722 campanulátus $P$. S. bell-flowered

723 angústus $\boldsymbol{H}$. $\boldsymbol{K}$. narrow-leaved

involítus $\mathrm{Ker}$.

725 undulátus $H$. $K$

726 floribúndus $H . K$.

727 Milléri H. $K$.

728 cardinális $H . K$

729 byzantínus $\boldsymbol{H} . K$.

730 commúnis $H$. $K$

731 ségetum $H . K$.

732 irncea wave-flowered

large-flowered

Miller's

superb

Turkish
$\Delta$ or 1 my.jn $Y$

C. G. H 1790 O s.pil Bot. mag. 272

\$ $\triangle$ or $1 \frac{1}{2}$ my.jn $Y$ C. G. H. 1810. O s.p.1 Bot. mag. 1483

$8 \mathrm{~N}$ or 2 mr.ap F.w C. G. H. 1800. O s.p.l Bot. mag. 562

$8 \mathrm{~N}$ or 2 ap.my si C. G. H. 1758. O s.p.l Bot. mag. 578

$8 \mathrm{i}$ or 2 my.jn $\mathrm{B} \quad$ C. G. H. 1796. O s.p.l Bot. mag. 591

( $\Delta$ or 11 ap.my W.Br C. G. H. 1795. O s.p.l Bot. mag. 589

\& $\Delta$ or $1 \frac{1}{2}$ jn L.F C. G. H. 1774. O s.p.1 Bot. mag. 625

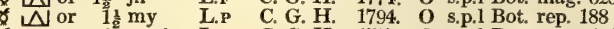

* $\mathbb{N}$ or 2 my.jn L.Y C. G. H. 1757. O s.p.1 Bot. mag. 602

o $\mathbb{N}$ or $1 \frac{1}{2} \mathrm{my} . j n$ Pk C. G. H. 1757. O s.p.1 Roche. diss.2. t.3

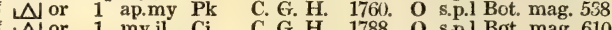

Nor 1 my.jl Ci C. G. H. 1780 O s.p.l Bot. mag. 610

N or $1 \frac{1}{2}$ ap.my $V$ C. G. H. 1751. O s.p.l Bot. mag. 632

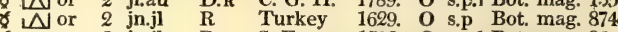

6 $\mathbb{N}$ or $\quad \stackrel{a}{j n . j 1} \quad \mathrm{R} \quad$ S. Europe 1596. O s.p.1 Bot. mag. 86 8 or 2 jn.jl

Iridere. Sp. 1

S. Europe 1596. O s.p.1 Bot. mag. 710

\section{CA.}

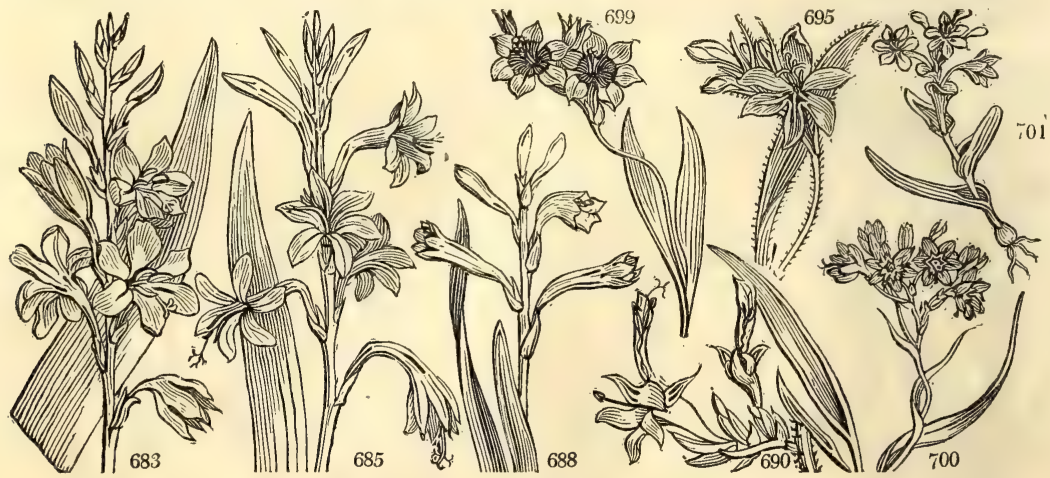

History, Use, Propagution, Culture,

of a micacious hue, glittering in the sun, and not to be represented by art. W. iridifolia is a shewy border flower of a month's duration. W. mexicana is also very shewy, and has kidney-shaped bulbs.

102 Babiana. A name barbarously derived by Mr.J.B. Ker from the name babianer, which the Dutch colonists at the Cape have given to the plant, because its roots are the favourite food of baboons. B. ringens has dark-red bulbs.

103. Lapeyrousia. So named by Mr.J.B. Ker, in honour of Lapeyrouse the celebrated and unfortunate French navigator. 
682 Stem upright many spiked, Leaves linear-lanceolate smooth edged with red

683 Leaves ensiform thickened at the edge, Spikelets several close together, Limb campanulate, Throat naked 684 Leaves ensiform very short, Limb spreading ; inner segments widest

685 Flowers recurved, Tube the length of the spathe, Segments of limb acute

686 Flowers recurved, Tube longer than the spathe, Limb with obtuse segments 687 Flowers recurved, Tube the length of the spathe, Limb with acute segments 688 Flowers recurved, Throat nearly 4 times as long as the segments of the limb

689 Leaves villous, Flowers ringent

690 Leaves smooth, Flowers ringent

691 Tube filiform clavate three times as long as the irregular limb: Upper segment divaricating

692 Tube filiform twice as long as the regular limb; Segments obtuse alternate with a point

693 Segments longer than the throat marked with a darker linear longitudinal spot

694 Leaves stiffish subvillous plaited, Flowers distichous, Segments alternately curled

695 Segments length of the tube nearly equal, the alternate ones wavy : the upper convolute at the end 696 Flowers funnel-shaped, regular; Segments scarcely longer than the tube, flat

697 Segments of flower thrice as long as the tube

698 Tube filiform the length of the regular campanulate limb : alternate segments obtuse with a point 699 Limb much spreading, Segments rhomboidal spotted at the base

700 Flowers corymbose, Stamens much spreading 701 Flowers solitary

702 Tube very short, Segm. nearly equal aristate, Scape panicled, Leaves linear rather shorter than the scape 703 Many spiked, Scape weak, Spikes capil. flexuose, Leaves sword-shaped smooth dist. shorter than scape

704 Leaves linear ensiform, Upper segment of flower very long, lower very small

705 Leaves linear ensiform with 3 ribs on each side, Throat of the flower cylindrical, longer than segm. of limb 706 Leaves 4-cornered 4-furrowed, Upper segment of flower very long, lower very small subulate

707 Upper segm. of flower spat. divar. incurv. lat. rhomb-shaped ovate spread. lower spat. acute hanging down 708 Upper segm. of fl. obov. recurved, lateral rhomb-shaped ovate spread. lower spat. acumin. hanging down 709 Upper segm. of fl. vaulted, lat. rhomb-shaped ovate spread. lower hanging down spat. obtuse with a point 710 Sterile bulb with a single linear pubescent leaf, Flowering bulb leafless, Flowers subringent 711 Leaves linear-ensiform pubescent, Flowers nearly regular

712 Leaves linear-ensiform 3-ribbed on each side, Segments of flower longer than the throat

713 Ieaves very long linear glaucous : nerves prominent on both sides, Segments of flower cordate

714 Tube of the campan. fl. shorter than the spatha, Segments ovate obtuse : the 3 lower with a hastate spot 715 Leaves 4-cornered 4-furrowed, Segments of flower nearly equal

716 Leaves 3 slender upright 4-cornered, Spike 2-3 fld. 1-sided, Fl. funnel-shaped nearly equal somewhat nodd. 717 Leaves linear the edge on each side ribbed, middle nerve nearly obsolete

718 Leaves linear with a rib on each side in the middle, Sheaths radical spotted

719 Tube ingr. than spathe, Up. seg. wider than rest, convol. and recurv. at end ; lowest very narrow hang. down 720 Tube twice as long as the segments of the limb which are acuminate wavy and reflexed

721 Tube shorter than the spatha, Limb campan. subringent: upper segm. concave; the lower narr. spotted 722 Leaves lanceolate smooth, Scape about 3-flowered longer than the leaves, Flower nearly campanulate

723 Leaves linear with a rib on each side in the middle, Tube longer than the spatha, the lower segments with a stalked 3-angular spot

724. Flowers ringent remote in two rows, Tube shorter than spatha, Segm. lanc. the lat. rolled inwards at edge 725 Flowers erect funnel-shaped, Segments wavy, three lower nearly half as short as the others

726 Flowers erect turbinate campanulate, Segments equal in length, upper widest

727 Flowers erect campanulate, Segments equal in length : upper narrower than the lateral ones

728 Spikes several one-sided, three lower segments marked with a white lanceolate spot

729 Spike 2-rowed, Upper seg. covered by lateral ones; the 3 lower marked by a white edged linear lanc. spot 730 Spike 1-sided, Upper seg. covered by lat. ones; 3 lower marked by a white lin.-lanc. spot, lowest very large 731 Spike 1-sided, Upper segm. divaricating, 3 lower nearly equal, marked with a white edged lin. .lanc. spot

732 Leaves broad lanceolate rather wavy

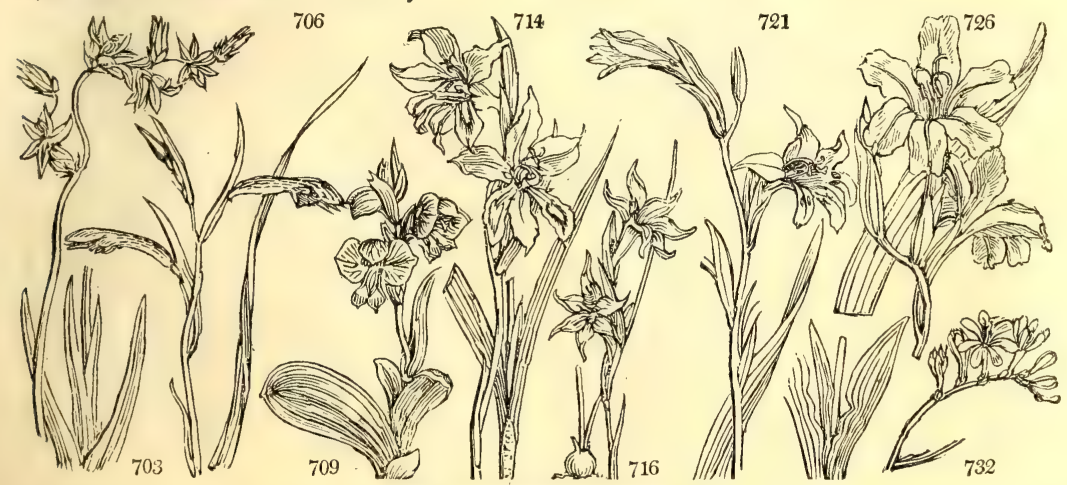

and Miscellaneous Particulars.

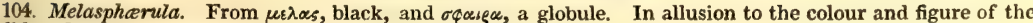
bulblets figured by Jacquin in his representation of the plant.

105. Gladiolus. From the Latin gladius, a sword, in allusion to the shape of the leaves. G. communis is a shewy border flower, of which there are several varieties in general cultivation. G. cardinalis is a splendid plant, with scarlet flowers spotted with white.

106. Anomatheca. From two Greek words (avores and 2 n\% $)$ signifying a singular capsule. The capsule of the genus is remarkable for being, as it were, frosted. 
107. ANTHOLY'ZA. Ker ANTHolYza. 733 rthiópica $H$. $K$ flag-leaved $\beta$ vittígera 108. XIPHI 735 cerúleum $W$ blue 736 renifórmis $\boldsymbol{M}$. kidney-leaved 737 gramineus Vahl. grassy UM. $W$

109. LEPTAN'THUS. Mich. LEPTANTHU

Iridea. Sp. 1-4.

\ $\mathrm{N}$ or 3 my.jn o C. G. H. 1759. O s.p.l Bot. mag. 561 $\triangle \mathrm{V}$ or 2 ja.f $\mathrm{O} \quad$ C. G. H. $\quad \ldots \quad$ O s.p.l Bot. mag. 1172 Hemodoracea. Sp. 2 .

$\mathbb{D}$ or $1 \frac{1}{3} \quad \ldots \quad$ W $\quad$ W Indies 1787 . R s.p

$\triangle$ or $1 \frac{1}{2} \quad \ldots$ B Guiana 1793, R s.p Aub.gui. 1. t. 11 Fluviales. Sp. $2-3$.

$\frac{1}{4}$ jn.jl G N. Amer. 1812. D aq Fl. per. 1. t. 71 jn.au Y N. Amer. 1823, D aq Hook. ex. fl. t.

110. WACHENDOR'FIA. Ker. WACHENDORFIA. Hamodoracea. Sp. 5-6.

738 thyrsiflóra $W$. tall-flowered $\Delta$ J or 2 my.jn Y C. G. H. 1759. D r.m Bot. mag. 1060

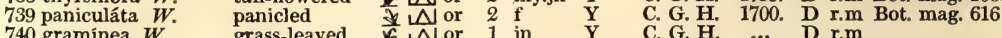
740 gramínea $W$. 741 hirsúta $W$ 742 brevifólia $H . K$ grass-leaved hairy or $12 \mathrm{jn}$

$1 \frac{2}{2}$ jn $\quad$ V

C. G. H. $\quad$... D r.m

111. HEMODO'RUM. Sm. HEMODORUM.

743 planifólium $\boldsymbol{B}, \boldsymbol{P}$ plain-leaved

112. ARISTE'A. Ker.

744 cyánea $H$. $K$.

745 capitáta $H . K$.

746 spirális $H . K$.

747 melaleúca $H$. $K$.

748 pusilla $B$. $M$.

Aristea.

woolly-headed tallest

spiral-flowered Hemodoracea. Sp. 1-6.

$\Delta$ or $1 \frac{1}{2}$ jl.n $\mathrm{O} \quad \mathrm{N}$. S. W. 1810. S s.p Bot. mag. 1610 Iridea. $S p .5$

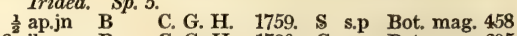
$3^{2}$ jl.au B C. G. H. 1790. C s.p Bot. mag. 605 1 ap.my P.Bl C. G. H. 1795. C s.p Bot. mag. 520 1 my.jn P.Bl C. G. H. 1786. C s.p Bot. mag. 1277 $\frac{1}{4}$ jn.jl B $\quad$ C. G. H. 1806. C, s.p Bot. mag. 1231 Hamodoracea. Sp. 3-4.

113. DILA'TRIS, Ker. Dilatris. 749 corymbósa $W$. 750 viscósa $W$. 751 Heritiéra Pers.

114. BRODI $\mathbb{E}^{\prime}$ A. $S \mathrm{Sm}$ 752 ixioídes Sims.

115. I'RIS. Ker. 753 susiána $W$

754 florentína $W$. 755 germánica $W$ 756 pállida $W$ 757 flavéscens Red. 758 orientális $W$. 759 sambucína $W$ 760 lûrida $W$

761 squálens $W$. 762 variegáta. $\dot{W}$. 763 neglécta Horn.

764 Swértii Lam. aphýlla B. M.

765 biflóra $W$

766 sub-biflóra $H . K$. 767 cristáta $W$. 768 chinénsis $W$. 769 arenária $W_{\text {. en }}$ 770 lutéscens $W$. 771 flavíssima $W$ 772 púmila $\boldsymbol{H} . \boldsymbol{K}$. 773 dichotoma $W$ 774 hungárica $W$. en 775 ibérica $s t$.

776 pseud-ácorus $\boldsymbol{W}$. 777 foetidissima $W$. 778 versicolor $W$. clampetalled dyers

Brodiea.

Ixia-like

IRIS.

Chalcedonian Florentine German pale Turkey yellowish red-leaved elder-scented dingy

brown-flowere variegated neglected

Swert's

two-flowered

two-flowered crested Chinese sand

pale-yellow bright-yellow dwarf

forked reflexed
Hungarian

my $P$ C. G. H. 1790 . S s.p Ex. bot. 1. t. 16 Nor 13 B $\quad$ C. G. H. 1795. S s.p Lam. ill. $t .34$

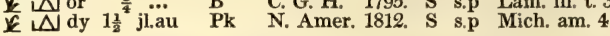
Iridea. $S p .1-4$.

* $\Delta$ or 1 o $\mathrm{Li}$ Chili 1822. O s.p Bot. mag. 2382

Irides. Sp. 63-92.

ฟ $\Delta$ or 2 mr.ap St Levant 1596. R s.l Bot. mag. 91 文 $\Delta$ or 2 my.jn $W \quad$ S. Europe 1596. $R$ p.l Bot. mag. 671 \} \triangle \text { or } 3 \text { my.jn } B \text { Germany 1573. R co Bot. mag. } 6 7 0

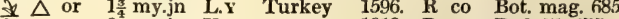
j $\triangle$ or 2 my.jn $Y$ 1818. $R$ co Red. lil. 375 J $\Delta$ or 1 my.jn L.B China 1790. R co Bot mag 1604

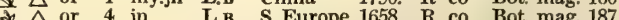
₹ $\Delta$ or 2 ap $\mathrm{Br}$ S. Europe 1758. R co Bot.mag.669.986 $\not \mathbf{z}$ or 2 jn $\quad$ St $\quad$ S. Europe 1768. $\mathbf{R}$ co Bot. mas. 787 \ $\Delta$ or 2 my.jn St Hungary 1597. R s.1 Bot. mag. 16 $\pm \Delta$ or 2 my.jn P.Bl ...... ... R co Bot. mag. 2435 $\downarrow \Delta$ or $1 \frac{1}{2}$ ap.my $W$ 1819. $R$ co Bot. mag. 870

yellow-water $\$$ or 3 jn $\quad Y \quad$ Britain moi.pl. R p.l Eng. bot. 578 Gladwyn $\quad \Delta$ or $1 \frac{1}{4} \mathrm{jn} \quad$ Ld Britain sha. pl. R p.l Eng. bot. 596 various-colored $\frac{1}{\mathrm{t}} \Delta$ or 1 my.jn St N. Amer. 1732. D s.1 Bot. mag. 21

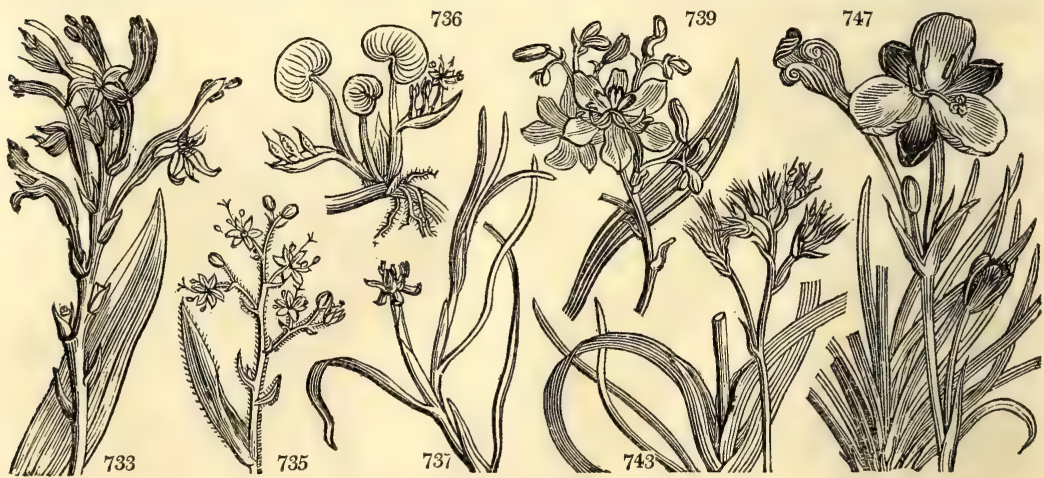

History, Use, Propagation, Culture,

107. Antholyza. From ay $v_{5}$, a flower, and $\lambda \nu \sigma \sigma \alpha$, rage. A metaphorical name. The flower has some resemblance to the mouth of an animal, which by the aid of a little imagination, may be supposed ready to bite. 108. Xiphidium. A name of a similar import with Gladiolus, being derived from $\xi_{\diamond}$ os, a sword, in allusion to its stiff and sword-shaped leaves.

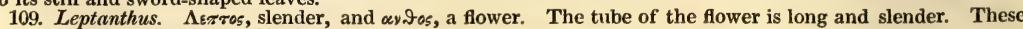
are aquatic floating plants of little beauty.

110. Wachendorfia. In memory of E. J. Wachendorf, a Dutchman, and professor of botany at Utrecht.

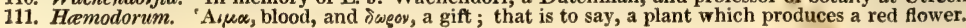


733 Leaves ensiform nerved, Upper segment longest stretched forward, the others recurved.

734 Leaves smooth, Petals linear-lanceolate

735 Leaves hairy, Petals ovate

736 Leaves roundish reniform, Spathes oblong acuminate many-flowered

737 Leaves all linear

738 Scape nearly simple, Panicle contracted, Leaves ensiform 5-nerved perennial plaited smooth 739 Scape many spiked, Panicle spreading, Leaves sword-shaped 3-nerved annual plaited smooth

740 Scape many-spiked, Panicle spreading, Leaves sword-shaped channelled smooth

741 Scape many spiked, Panicle spreading, Leaves linear sword-shaped 3-nerved plaited villous

742 Leaves elliptic sword-shaped hairy

743 Corymbs compound, Branches spreading, Leaves flat

744 Flowers headed, Spathes many-parted torn

745 Heads of flowers alternate, Spathes entire

746 Flowers alternate, Segments of flower equal

747 Flowers alternate, three of the segments less than the rest

748 Scape about 1-flowered, Leaves linear-lanceolate a little falcate

749 Petals ovate oblong, Corymb level-topped hairy

750 Petals linear, Corymb level-topped villous viscid

751 Leaves ensiform, Scape villous above, Flowers spiked one-sided

752 Leaflets of the crown subulate

1. Flowers bearded.

753 Stem 1-flowered longer than the leaves, Smaller petals deflexed

754. Stem 2-flowered longer than the leaves, Flowers sessile

755 Stem many-flowered longer than the leaves, lower flowers stalked, Spathes colored

756 Stem many-flowered longer than the leaves, Flowers sessile, Spathes white

757 Leaves lanc. rather plaited, half as short again as the branching stem, Spathes leafy, Tube length of germen 758 Stem about 2-flowered the length of the leaves, Germens 3-cornered

759 Stem many-flowered longer than the leaves, Petals emarginate : the outer flat

760 Stem many-flow. longer than the leaves, Outer petals revolute, inner nearly upright, wavy and inflexed

761 Stem many-flowered longer than the leaves, Deflexed petals folded back upright emarginate

762 Stem many-flowered as long as the leaves, Deflexed petals emarginate, erect oblong

763 Stem many-flowered longer than the leaves, Erect petals entire, deflexed rather emarginate

764 Leaves shorter than the 3-flowered stem, Larger petals undulate reflexed, smaller emarginate

765 Scape round about 3-flowered longer than the leaves, Deflexed petals narrower than the erect ones

766 Scape about 1-fl. scarcely shorter than ensiform leaves, Tube of corolla about equal to the 6-streaked germen

767 Stem compressed about 1-fl. the length of leaves, Petals about equal, Beard crested, Germens 3-cornered 768 Scape compressed many-flowered, Stigmas jagged

769 Scape 2-flowered shorter than the ensiform leaves, Upper flower abortive

770 Scape very short about 1-flowered, Spathe erect the length of the tube

771 Scape 2 -fiowered longer than the leaves, Spathes the length of the tube

772 Scape very short 1-flowered, Spathes shorter than the tube, Reflexed petals narrower than the erect ones 773 Nearly stemless, Scape panicled round, Branches 2-4-flowered

774 Leaves ensiform smooth somewhat falcate nearly equal to the many-flowered scape, Spathes inflated

775 Leaves ensiform falcate smooth, Scape 1-flowered, Petals obovate

776 Leaves flat, Inner petals less than the stigma 2. Flowers beardless.

777 Stem one-angled many-flowered longer than the leaves

778 Stem round flexuose equal to the leaves, Germens nearly 3-cornered

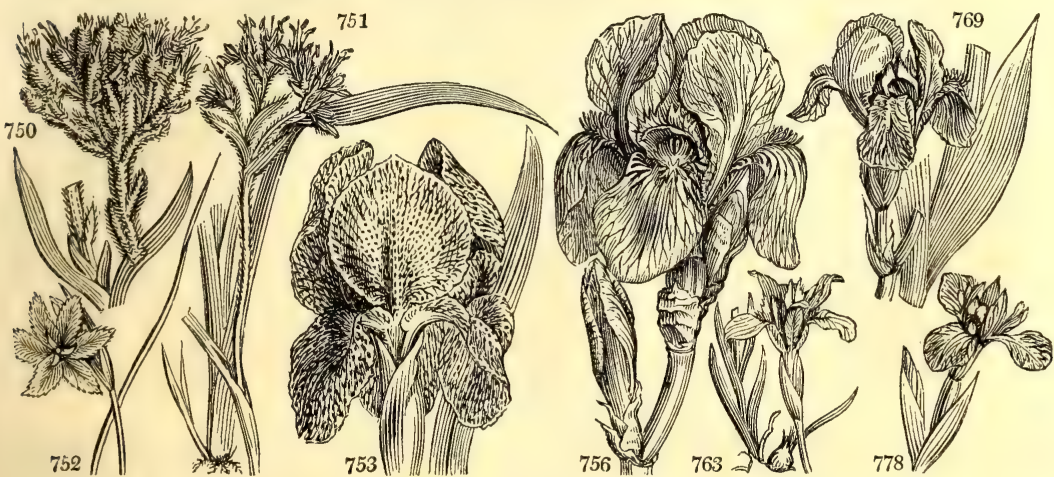

and Miscellaneous Particulars.

112. Aristea. From arista, a point or beard. The leaves are bearded.

113. Dilatris. A name not satisfactorily explained.

114. Brodica. Named in honor of Mr. Brodie, of Brodie House, a Scotch gentleman, who paid great attention to the botany, especially Cryptogamia, of his own country.

115. Iris. The name given by Theophrastus, Dioscorides, and Pliny, from the variety of its colors. According to Plutarch, the word iris signified, in the ancient Egyptian tongue, eye: the eye of heaven. This Ing to Plutarch, the word iris signified, in the ancient Egyptian tongue, eye: the eye of heaven. This beantiful genus abounds in Europe, but is rare in America. Some are bulbous, but the greater part tuber-
ous rooted, of easy culture, and propagation by seed or division of the root. The roots of I. florentina, ger- 
779 cúprea $P h$. 780 virginica $W$. 781 spúria $W$.

782 ochroleúca $W$. stenogyna B. Mag.

783 Guldenstádtii $W$.en.

784 halóphila $W$.

785 aláta Lam.

786 xiphium $\boldsymbol{W}$.

787 xiphioídes $W$.

788 lusitánica $\boldsymbol{H}$. $K$.

789 tenuifólia $W$.

790 pérsica $W$.

791 vérna $W$.

792 ventricósa $\boldsymbol{W}$.

793 sibirica $W$.

794 prismática $P h$.

795 gramínea $W$.

796 humilis Bieb.

797 ruthénica Ker.

798 tuberósa $W$.

799 reticuláta $A d$.

800 spathuláta

801 caucásica Hoffm.

802 furcáta Bieb.

803 triflóra $W$.

804 brachycúspis $B . M$.

805 Pallásii $B$. $M$.

116. MOR纴A. Ker.

806 flexuósa $H . K$

807 collina $\boldsymbol{H} . \boldsymbol{K}$.

$\beta$ miniata $\mathbf{B} . \mathbf{R}$.

808 pavónia $\dot{H}$. $\boldsymbol{K}$.

809 tripétala $\boldsymbol{H}$. $\boldsymbol{K}$.

810 angústa $B . M$.

811 tricuspis $\dot{H} . \dot{K}$.

812 ténuis $\boldsymbol{H} . \dot{K}$

813 unguiculáta $H . K$.

814 édulis $H . K$.

815 longiflóra $H$. $K$.

816 spicáta $B . M$

817 tristis $H . K$

818 crispa $H . K$

819 bituminósa $H . K$.

820 viscária $H$. $K$.

821 ramósa $H$. $K$.

822 villósa $\boldsymbol{H} . \boldsymbol{K}$.

823 ciliáta $H . K$.

$\beta$ barbigera Sal.

824 bearded

825 papilis

82 papilionácea $\boldsymbol{H} . \boldsymbol{K}$. butterfly

826 spathácea $W$.

827 iridioídes $\boldsymbol{H} . \boldsymbol{K}$.

828 lúrida $B, R$.

117. MA'RICA. Ker. sheathed 6 $\mathbb{N}$ or ${ }^{\frac{3}{4}} \mathrm{jl}$ Y lurid

Marica. Iridece. Sp. 14

spring

ellied

ew-Jersey

low

nake's-head $\frac{1}{6} \Delta$ or ${ }^{\frac{3}{4}} \mathrm{my}$ mrap G.B

netted $\frac{j}{\Delta}$ or $\frac{1}{4} \mathrm{mr}$.ap $B$

Caucasian $\frac{\$ 2}{\Delta}$ or 1 jl.au $P$.

forked $\quad \downarrow \Delta$ or ${ }^{\frac{1}{2}} \mathrm{mr}$

or $1^{\frac{1}{2}}$ jn.jl

Pallas's

MoraA.

equal-flowered

spot-flowered

trident-petalled $\delta$ or 1 jn $G$

long-clawed \& $\mathbb{N}$ or 1 my.jn Va

o $\mathbb{N}$ or $\frac{1}{2}$ my.jn $\mathbf{Y}$

\& $\mathrm{N}$ or $1 \frac{1}{2} \mathrm{my} . j \mathrm{n}$

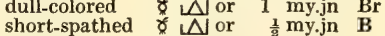

clammy

bird-limed of $\mathbb{N}$ or 1 jn $\mathbf{L i}$

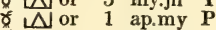

N. Amer. 1812, R p.l Bot. mag. 1496 N. Amer. 1758. R s.l Bot. mag. 703 Siberia 1759. R co Bot mag. 875 L.Y Levant 1757. $\mathrm{R}$ co Bot. mag. 1515

Siberia 1757. $\mathbf{R}$ co Bot. mag. t. 61 Siberia 1780. R co Bot. mag. 1131 Algiers 1801. O co Desf, atl 1, t. 6 Spain 1596 O co Bot mag. 686 B.Y Spain 1591. O co Bot. mag. 686

B.Y Spain 1571. O co Bot. mag. 68

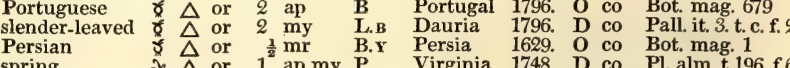

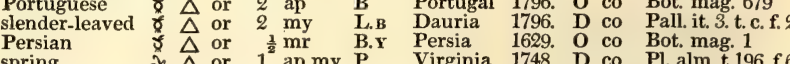

long-leaved $\delta \mathrm{d}$ cul 4 my.jn $\mathbf{L i}$

Dauria 1800. D co Pall it. 3.196. f.6

Siberia 1596. $\mathbf{R}$ co Bot.mag.50.1163

N. Amer. 1812. R p.I Bot. mag. 1504

Austria 1597. R co Bot. mag. 681

Caucasus 1812. R co Bot. mag. 1123

Siberia 1804. D co Bot. mag. 1393

Levant 1597. O s.p Bot. mag. 531

Iberia 1821. $\mathbf{R}$ co

Germany 1759. $\mathbf{R}$ co Bot. mag. 58

Caucasus 1821. R co

Tauria 1822. R co Bot. mag. 2361

Italy - 1821. R co

Siberia 1819. R co Bot. mag. 2326

Tartary 1820. R co Bot. mag. 2331

Sp. 23-26.

C. G. H. 1803. D s.p Bot. mag. 695

C. G. H. 1768. D s.p Bot. mag. 1033

C. G. H. 1768. D s.p Bot. rep. 404

C. G. H. 1790. D s.p Bot. mag. 1247

C. G. H. 1802, D s.p Bot. mag. 702

C. G. H 1790 D s.p Bot mag. 1276

C. G. H. 1776. D s.p Bot.mag.696.779

C. G. H. 1807. D s.p Bot. mag. 1047

C. G. H. 1802. D s.p Bot. mag. 593

C. G. H. 1792. D s.p B. mag. 613.1238

C. G. H. 1801. D s.p Bot. mag. 712

C. G. H. 1785. D s.p Bot mag. 1283

C. G. H. 1768. D s.p Bot. mag. 577

C. G. H. 1803. D s.p Bot. mag. 1284

C. G. H. 1787. D s.p Bot. mag. 1045

C. G. H. 1800. D s.p Bot. mag. 587

C. G. H. 1789. D s.p Bot. mag. 771

C. G. H. 1789. D s.p Bot, mag. 571

C. G. H. 1587. D s.p Bot. mag. 1061

C. G. H. D s.p Bot mag. 1012

S. Europe 1597. D s.p Bot. mag. 1407

C. G. H. 1795. D s.p Bot. mag. 750

C. G. H. 1798. D s.p Thunb. diss. t. 1

C. G. H. 1758. D s.p Bot. mag. 693

C. G. H. 1817. D s.p Bot. reg. 312

829 Northiána $\boldsymbol{H} . \dot{K} . \quad$ broad-stemmed $\triangle$ or 4 ap.au Y.B Brazil 1789. D s.p Bot. mag. 654

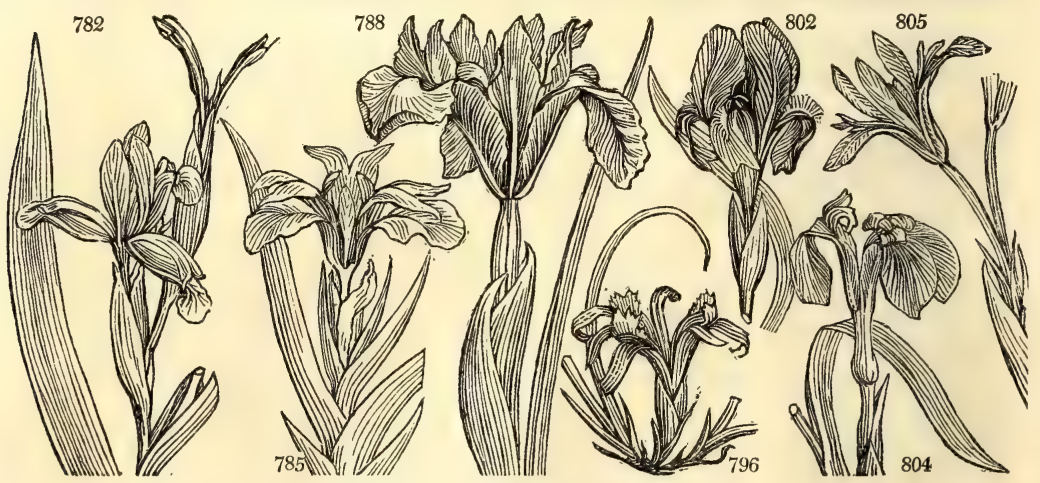

History, Use, Propagation, Culture

manica, and pseud-acorus are used in medicine; those of the first are remarkable for communicating an odor like that of violets, and are the orrice-root (iris-root) of the shops. The root of I. pseud-acorus, in powder, usea as snuff, produces a great heat in the mouth and nose, and occasions discharge from the nostrils: it is astringent, and used instead of galls in making ink or dying black. The fresh juice of the root is one of the most powerful cathartics, and in that way has cured inveterate dropsies. I. germanica possesses similar qualities, and the root of either species suspended in wine or beer, keeps the latter from growing stale, and communicates a pleasant taste and smell to the former. The leaves and roots of $I$ foetidissima are steeped in beer by the country people in some places as a purge. I susian flowers well in a warm border and loamy soil briata is rather tender ; t requires a rich light soil, and to make it flower frel it must be planted in a pot, and have the suckers removed from tho ront and pot, and have the suckers removed from the roots as soon as they appear. I. orientalis requires a similar treatment, and with the two preceding species requires the protection of a green-house to make it flower in perfection. Of I. xiphioides there are numerous varieties procured from seeds, which are treated much in the same way as those of crocus. This species, and I. tuberosa are very ornamental; they thrive best in a light 
779 Stem round flexuose as long as leaves, Petals all emarginate obovate, the inner shortest, Capsules very large 780 Stem 2-edged many-ilowered longer than the leaves

781 Leaves linear, Scape round, Germens 6-cornered, Stigmas acute, Petals rounded

782 Leaves linear, Scape about 3 -flowered round, Germens hexagonal, Petals ovate longer than their claw

783 Leaves ensiform, Scape nearly round, Germens hexagonal, Petals erect oblong

784 Radical leaves very long, Stem higher than the leaves, Germens hexagonal

785 Stemless, leaves channelled, Three erect petals very small, Tube very long

786 Leaves channelled subulate, Stem 2 flowered, Petals nearly as narrow as stigmas, Germen round

787 Leaves channelled subulate, Stem 2 -flowered, Petals much wider than stigmas, Germen acutely angular 788 Leaves channelled, Scape 2-flowered, Inner petals emarginate

789 Stemless, Leaves filiform very long, Scape very short 2-flowered, Tube of the corolla filiform

790 Leaves linear subul. channelled longer than the very short 1-flow. scape, Inner petals very short spreading 791 Leaves flat, Scape 1-flowered shorter than the leaves, Petals nearly equal

792 A little caulescent, Stem about 2-flowered shorter than the leaves, Spathes ventricose, Gcrmens 3-angular 793 Stem about 3-flowered fistulous longer than the leaves, Germens 3-angular

794. Stem solid round as long as the leaves, Leaves very narrow long, Capsules long pointed at each end

795 Stem about 2-flowered 2-edged shorter than the leaves, Germens hexangular

796 Leaves linear-ensiform very much longer than the 2-flowered very short scape, Petals acuminate

797 Leaves linear longer than the 1-flowered scape, Alternate petals smaller

798 Leaves 4-cornered

799 Scape 1-flowered shorter than the 4-cornered leaves, Tube filiform, Root bulbous

800 Outer petals spatulate, Stem branched at the base shorter than the leaves

801 Leaves lanceolate falcate edged, Stem about 2-flowered

802 Leaves ensiform shorter than the 3-flowered 2-forked scape, Germen 3-angular 3-cornered

803 Leaves linear acute length of the 3-fl. scape, Spathes withered with a long point, Flowers close together

804 Leaves linear-lanceolate very long, Inner petals very short, Stigmas spirally revolute

805 Leaves ensiform doubled together striated incurved at end, Ovaries very long cylindrical, Stigmas keeled serrated at end

806 Segments of the flower nearly equal oblong spreading, Filaments united at base 807 Segments nearly equal obovate very spreading, Filaments united in a cylinder

808 Segments spotted and dotted at base, The three inner half as short as the others and much narrower erect 809 Inner segments linear, sometimes absent

810 Leaf filiform erect with 1-flowered scape smooth, Spathes obtuse

811 Outer segments very spreading bearded, Inner small 3-toothed at the end : the middle tooth the longest 812 Outer segm. deflexed bearded, Inner very small 3-toothed at end : the middle tooth longest and involute 813 Outer segments beardless; Inner very small 3 -toothed at the end

814 Lower leaf longest of all, All the segments of the flower very spreading : the alternate ones small

815 Tube filiform very long: All the segments reflexed

816 Beardless, Flower uniform nearly equal, Stigmas petal shaped

817 Leaves very smooth, Stem branches and peduncles villous

818 Leaves about the length of the scape, All the segments of the flower spreading; the alternate ones smaller 819 Lower leaf spirally twisted, Stem smooth, Branches viscid

820 Leaves straightish, Stem and branches viscid

821 Stem panicled much branching, Segments nearly equal deflexed

822 Bearded, Leaves on the inside villous in lines, Stem pubescent, Invol, very smooth, Alternate segments of flower very small 3-toothed

823 Leaves ciliated, Inner segments erect

824 Tube filiform very long, Segments alternate erect

825 Leaves pubescent, all the segments spreading

826 Leaves slender dependent, Flowers terminal in close heads

827 Leaves perernial equitant, Segments of flower sprearing : alternate ones much the largest

828 One-flowered a little bearded, Leaves about 3 linear, Stem simple, Outer segments of flowers rounded : inner very narrow entire

829 Scape winged sword-shaped, Common spathe 2-leaved, partial 2-flowered, Flower stalks simple

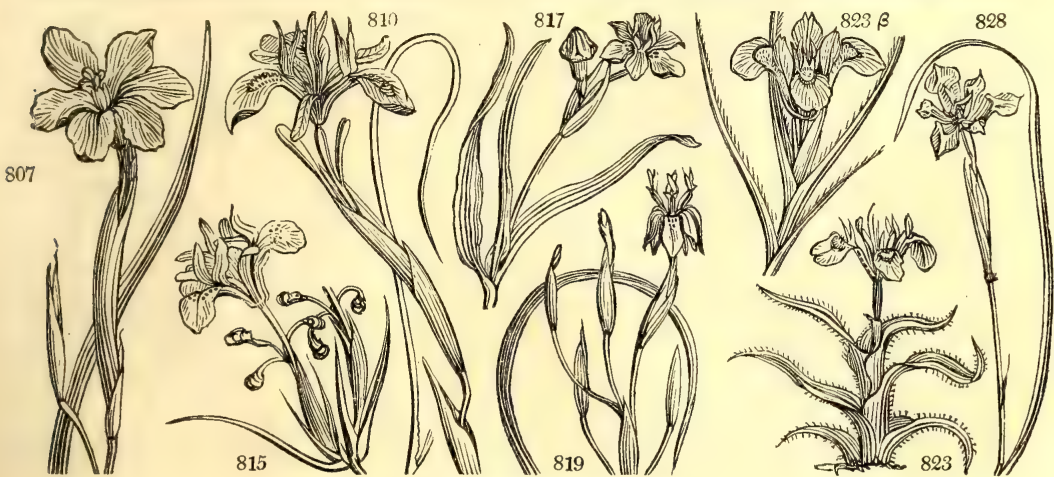

and Miscellaneous Particulars.

sandy soil and eastern exposure; the bulbs are taken up every other year, but must not be kept longer out of ground than a month. I. persica is highly odoriferous; it is propagated by separating the bulbs, or from seeds ; but by the latter mode no new varieties have hitherto been obtained. I. susiana and persica bear forcing well: supplies of them, and of $I$. xiphioides are annually imported from Holland. In a deep and loose soil the roots of the tuberous and bulbous species of this genus are apt to run down when they cease to flower, and getting gradually weaker and weaker, are at last lost. To prevent this, Miller advises to form a stratum of rubbish about a foot and a half under the surface.

116. Morea. So named by Miller, in honor of Robert Moore, of Shrewsbury, a distinguished botanist, of whom there exists a memoir in the Philosophical Transactions. M. pavonia is one of the most elegant species of the genus. The bulbs of M. edulis are eaten at the Cape of Good Hope, both by men and monkeys; and those of M. sisyrinchium are eaten in Spain. Sweet recommends, as the best soil for these plants, " a mixture of sandy loam."

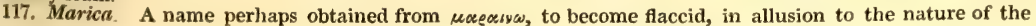


830 martinicénsis $\boldsymbol{H}$. $\boldsymbol{K}$. Martinico

831 gladiáta B. Reg. Cape

832 paln marsh

833 califórnica $B . M$

834 palmifólia $W$. M. plicáta B. M.

835 striáta $B . M$.

836 ánceps $W$.

837 micrántha Cav.

838 Bermudiána $\boldsymbol{W}$.

839 convolúta $W$.

840 tenuifólia Red.

841 cærúlea Ker.

yellow

palm-leaved

\&

«

Nor 1 my s

streaked or 2 aps

two-edged

2 $\triangle$ or 1 jn.jl

small-flowered $\triangle \triangle$ or $1 \mathrm{jn} . \mathrm{jl}$

Iris-leaved $\mathbb{N}$ or 1 jn.jl

convolute $\mathrm{N}$ or $\frac{1}{2} \mathrm{my} . \mathrm{jn}$

slender-leaved $\mathbb{N}$ or ${ }^{\frac{1}{2}}{ }^{2} \mathrm{my} . j n \mathrm{Y}$ blue

semi-apérta Lodd. half-ope

118. PARDAN'THUS. Ker. P

843 chinénsis $H . K$ Chinese Prdanthus.

119. SCHOE'NUS. Vahl. BOG-RUSH.

844 mucronátus $W$. clustered

845 nigricans $W$ black

846 rúfus $E . B$. brown

847 monoicus $E$. $B$. moncecious

848 ferrugíneus $S c h$.

849 compréssus $\mathrm{Sm}$.

rusty

compressed

star-headed

${ }_{2}^{\text {Iridea. }}$ Sp. 1.

Cyperacea. Sp. 7-79

业 $\Delta$ w 1 ap.my Ap S. Europe 1781. D co Fl. græc. 1. t. 43 业 $\Delta$ w 1 jl Ap Britain sp. bo. D co Eng. bot. 1121 业 $\Delta w^{\frac{1}{2}} \mathrm{jl} \quad$ Ap $\quad$ Scotland sc. bog. D co Eng. bot. 1010 业 $\Delta \mathrm{w} 1 \mathrm{i}$ jl.au Ap England bogs. $D$ co Eng. bot. 1410 业 $\Delta$ w $\frac{1}{4}$ ap.my Ap Europe 1781. D co Sch. gm.1.t.1.f.4

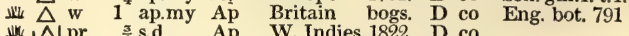
业 $\Delta p$

120. RHYNCHOS'PORA. Va. RhYNChOSPORA. 851 álba $H_{\text {. }} K$. 852 fúsca $H . K$ white-headed 业 $\Delta$ 853 comáta $L k$ brown-headed

121. FIMBRIS'TYLIS. 854 dichótoma $V$.

Vahl. Fimbristylis dichotomous 址 $\mathrm{W}$

122. ISOLE'PIS. R. Br. ISOLEPIS. 855 flúitans $R$. Br. floating 856 setácea $R$. Br. bristle-like 857 Holoschœ'nus $\mathrm{Sm}$. $\beta$ románus W. $\gamma$ australis $\mathrm{L}$ $\begin{array}{ll}\text { cluster-headed } & \text { 业业 } \Delta \mathrm{w} \\ \text { Roman } & \mathrm{w} \\ \text { southern } & \mathrm{U}\end{array}$

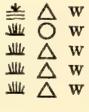

123. SCIR'PUS. R. Br. Curb-Rush. 858 multicaúlis $E, B$. many-stalked 859 cespitósus $W$ 860 pauciflórus $E$. $B$. 861 lacústris $W$. 862 lacústris $W$. glaúcus $E$. 863 tríqueter $W$. 864 mucronátus $W$. 865 carinátus $E . B$. 866 marítimus $W$. 867 Lúzulæ $W$. 868 sylváticus $W$. many-stalked chocolate-head, 亚 $\Delta$ w tall $\Delta \mathrm{ec}$ glaucous 业 $\triangle$ triangular 业 $\Delta \mathrm{w}$ sharp-pointed 业 $\Delta$ blunt-edged 业 $\triangle$ salt-marsh 歱 $\Delta w$ clustered 业㐫 $w$ clustered
wood
Martinico 1782. D s.p Bot. mag. 416 C. G. H. 1816. D s.p Bot. reg. 229 Guiana 1792. Sk s.p Bot. mag. 646 California 1796. Sk s.p Bot. mag. 983 Brazil 1779. Sk s.p Bot. mag. 655

Mexico 1788. Sk s.p Bot. mag. 701 N. Amer. 1693. D co Bot. mag. 464 . A co Cv. diss. t.191. S. Amer 1816. I co Red lil t 47 S. Amer. 1816. D co Bot. mag. 2313 Brazils 1818. D co Bot. reg. 713 Brazils 1820. D co Bot. cab. 68
1 au Ap Britain bogs. D co Eng. bot. 985 au Ap Britain bogs. D co Eng bot. 1575

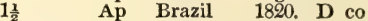

Cyperacea. $S p, 1-65$.

jn.jl Ap E. Indies 1819. D co Rottb.gr.t.13.f.1 Cyperacee. Sp. 3-46.

At. jl.au Ap Britain dit. D co Eng. bot. 216

$\frac{1}{4}$ jl.au Ap Britain bogs. S co Eng. bot. 1693

3 jl Ap England sea sh. Sk co Eng. bot. 1612

3 jl Ap Austria ... Sk co Jacq. aust. 5.448

$\begin{array}{lllll}\text { Ap } & \text { S. Europe } & \ldots & \text { Sk co } & \text { Plk. pht. t.40. f.5 }\end{array}$

Cyperacea. Sp. 11-96.

$\frac{1}{2}$ ji Ap Britain tur. bo. Sk co Eng. bot. 1187

$\frac{1}{2}$ jl Ap Britain tur. he. Sk co Eng. bot. 1029

$\frac{1}{4}$ au Ap Britain bgs. m. Sk co Eng. bot. 1122

6 jl.au Ap Britain rivers. Sk co Eng. bot. 666

2 jl.au Ap England sal. m. Sk co Eng. bot. 2321

3 au Ap England mar. Sk co Eng. bot. 1694

2 au Ap Eur. Asia Sk co

3 jl.au Ap England riv. ba. Sk co Eng. bot, 1983

2 jl.s Ap Britain sal.m. Sk co Eng bot 549

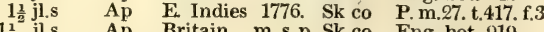

Ap Britain m. s.p. Sk co Eng. bot. 919

\section{Cyperacea. Sp. 3-26.}

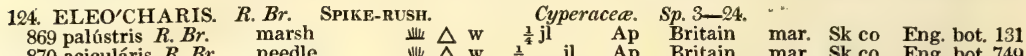

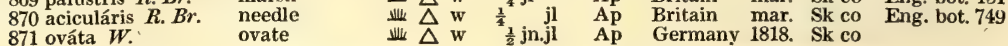

841

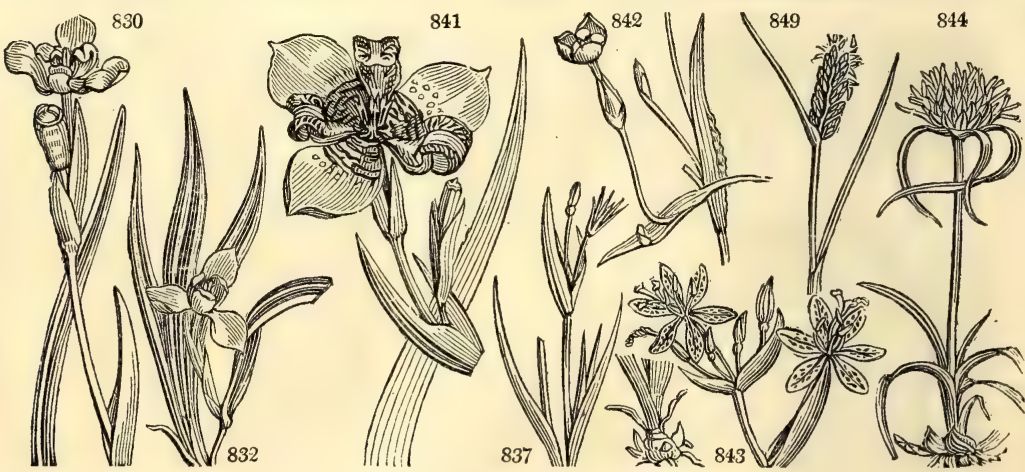

IIistory, Use, Propagation, Culture,

flowers. M. northiana has beautiful and transient flowers, like the rest of the species, all of which grow freely in a rich light soil, and are readily increased by parting the roots or from seeds.

118. Pardanthus. Named by Mr.J.B.Ker,from $\pi \alpha \rho \delta \circ 5$, a leopard, and $\alpha \nu .-05$, a flower, on account of the spot. ted flower.

119. Schcenus. From xosvos or $\sigma$ xosvos, a cord, in Greek. From plants of this kind the first cordage is supposed to have been made. All the plants from this genus to Mariscus, No.130, are sedgy plants of similar habit, of value in an œconomical point of view, but not cuitivated for ornamental purposes.

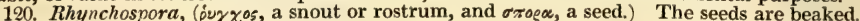

121. Fimbristylis. So named by Vahl. The word is constructed from the Latin fimbria, a fringe, and stylus, the style.

122. Isolepis. From $6 \sigma^{\circ}$, , equal, and $\lambda s \pi \iota s$, a scale, on account of the relative form of the scales which constitute the inflorescence. 
830 Beardless, leaves linear, Petals with glandular spots, Ovaries 3-cornered 831 Flower-stalks lateral nearly equal to the one-leaved involucrum

831 Flower-stalks lateral nearly equal to the one-leaved involucrum

833 Leaves linear-ensate flat, Scape simple leaf-like winged, Flowers opened out, Fil, united at base 834 Scape 2-edged, Flowers in spikes, Leaves sword-shaped nerved-plaited

835 Scape 2-edged leafy, Flowers in spikes, Petals roundish ovate acute, Leaves linear sword-shaped 836 Scape 2-edged simple nearly leafless, Spathe about 4-flowered unequal longer than the flowers, Pet. muc. 837 Scape 2-edged branchy leafy, Spathe about 3-flow, unequal, Pet. linear acuminate, Leaves grassy channelled 837 Scape 2-edged branched leafy, Spathe about 4-flow. shorter than the flowers, Pet. muc. Leaves sword-shaped 839 Scape 2-edged branched leafy, Spathe 3-flowered shorter that the flower, Leaves sword-shaped

840 Scape 2-edged ascending leafy, Spathe 3-flowered, Caps. hairy, Leaves capillary

841 Stigmas united petal shaped, Scape many-flowered erect, Spathe not viviparous

842 Leaves linear-lanc. nerved a little wavy at back, Fl.-stalks nearly as long as spathe, Flowers campanul.

\section{Flowers spotted with orange}

844 Culm round naked, Spikelets bundled in a roundish head, Involucr. 3, 6-leaved very long reflexed 845 Culm naked round, Spikelets in headed bundles, Invol. 2-leaved longer than the valves, Setæ none 846 Culm round leafy, Leaves channelled, Spike compound 2-ranked longer than the bractea 847 Culm round naked, Spike compound, Flower monœecious, Leaves channelled rough 848 Culm round, Spikelets 2-3, Outer valve of involucrum as long as spikelets, Setæ several 849 Spike distichous, Spikelets many-flowered, Involucre 1-leaved, Culm roundish 850 Involucres very long white. (Dichromena, Vahl.)

851 Culm leafy 3-angular, Leaves linear keeled, Root creeping 852 Culm 3-angular, Leaves bristly channelled, Root creeping

853 Leaves flat glaucous with hairy sheaths, Invol. longer than the contracted panicle, Spikelets oblong, Scales oblong carinate mucronate

854 Spikes ovate oblong, Involucre about 3-leaved decompound longer than the umbel

855 Culms branched leafy flaccid, Spikelets few-flowered, Floating

856 Culm bristle-shaped, Spikelets lateral sessile

857 Culm round naked, Heads terminal globose clustered, Leaves channelled

858 Stem round sheathing at the base, Spike ovate terminal, Glumes obtuse equal, Root fibrous

859 Stigmas 3, Spike enclosed in a 2-leaved involucrum, Lower glumes very large as hig as the spike, Culm round, Sheaths bearded

860 Glumes unequal obt. ovate, one larger but shorter than the 2-valved spike, Culm round, Sheaths not bearded 861 Culm round, Inner sheaths ending in a short leaf, Cyme terminal decompound with 2-4-leaved involucrum Spikelets ovate smooth

862 Top of the 3-angular stem straight, Upper sheaths leafy, Panic. lateral under the end, Spikel. sess. \& stalked 863 Culm straight naked pointed, Lateral spikes sessile or stalked, Stigma bifid

864 Top of the 3-cornered culm bent down at end, Sheaths leafless, Spikel. lateral sess. clustered naked, Stigmas 3 865 Culm naked, upwards 3-cornered, Panicle cymose terminal, Bract. pungent, Stigma bifid 866 Panicle globose terminal, Glumes mucronate torn bifid

867 Spikes roundish headed, Heads umbelled globose proliferous, Invol. many-leaved, Culm 3-angular 868 Culm 3-cornered leafy, Cyme term. supra-decompound surrounded with a many-leaved invol. Gl. mucronate

869 Spike oval naked, Scales lanceol. acute, Culms roundish, Sheaths leafless beardless lanceol. acute, Stigmas 2 870 Spike ovate naked, Two lower scales scarcely larger than the rest, Culms 4-cornered setaceous

871 Spike ovate naked, Scales oblong obtuse, Stigmas 2, Culms sub-compressed, Sheaths leafless, Root fibrous

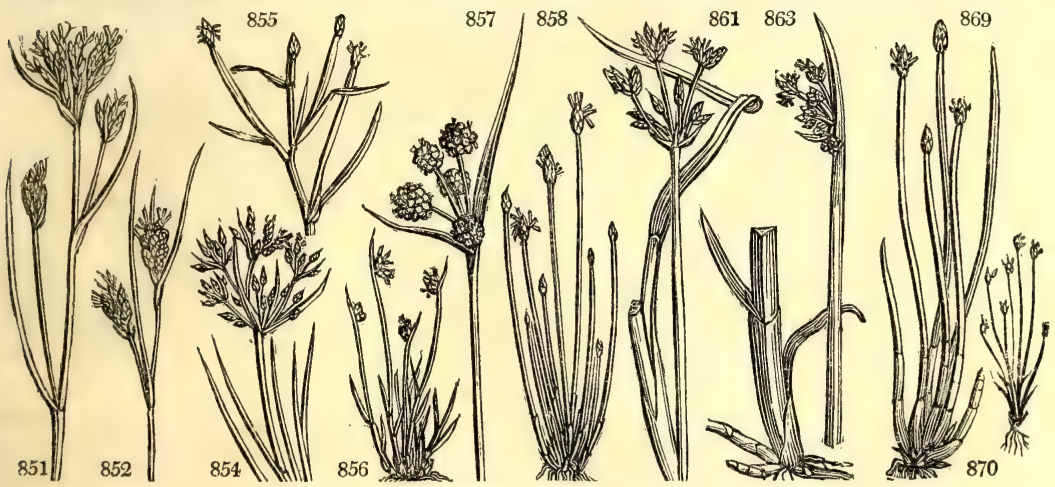

and Miscellaneous Particulars.

123. Scirpus. From cirs, a Celtic word for rushes, which is, in the singular, cors, whence the Latin chorda. $\mathbf{S}$. caspitosus is the principal food of cattle and sheep in the Highlands of Scotland in March and till the end of May. S. lacustris, the bull-rush, is used to bottom chairs : cut at one year old, it makes the finer bottoms; at two years, the coarser sort; still older, and mixed with the leaves of Iris pseud-acorus, it makes the coarsest bottoms. Cottages are sometimes thatched, and pack-saddles stuffed with it, and in severe seasons cattle will eat it. Of S. maritimus there are several varieties, natives of the salt marshes of Europe, Barbary, and Siberia, greedily eaten by cattle; and the roots, which are large, Withering says, have been ground and used instead of flour in times of scarcity. The Pi-tsi or water-chestnut of the Chinese, is a species of this genus (Scirpus tuberosus). It has not yet been introduced to our gardens. In China it is cultivated in tanks, the bottoms of which are manured and exposed for a time to dry in the sun. The tubers are eaten either boiled or raw, and are esteemed both as food and medicine.

124. Eleocharis. A name not explained by Mr. Brown, its author, the meaning of which is not obvious. 
125. ERIO PHORUM. $P$. $S$. CotTON-GRass. 872 vaginátum $W$. Hare's-tail 873 polystáchion $W$. 874 angustifólium $W$. 875 virgínicum $W$.

876 grácile $P, S$.
877 capitátum E. $B$

Cyperacea. $\quad S p .6-7$.

$\frac{1}{2}$ mr.ap Ap Britain moors. D co Eng. bot. 873 $1^{2}$ jn.jl Ap Britain bogs. D co Eng. bot. 563 $\frac{1}{2}$ ap Ap Britain bogs. D co Eng. bot. 564 1 my au Ap N Amer 1802. D co Pk alm 299.4 1 my.au Ap N. Amer. 1842. D co Pk. alm.t.299.f. $\frac{3}{4}$ au.s Ap Scotland sc. mo. D co Eng. bot. 2387

Cyperacee. Sp. 2

126. TRICHO'PHORUM $\boldsymbol{P} S$ TRICHOPHORUM 878 cyperínum $\boldsymbol{P}$. S. cyperine 879 alpinum $P . S . \quad$ Alpine $\quad$ ill $\triangle \mathrm{cu}$

127. CYPE'RUS. $W$. 880 dábius $W$.

881 tenéllus $\dot{V} a h l$. 882 conglomerátus $R$ 883 pannónicus $W$. 884 Lúzulæ $W$. 885 distans Vahl. 886 viscósus $W$. 887 fastigiâtus $W$. 888 erubes'cens $L k$. 889 paniculátus $V a h$. 890 glomerátus $W$. en. 891 elegans $W$. 892 flavéscens $W$. 893 fúscus $W$. 894 strigósus $W$. 895 vegétus $W$ 896 esculéntus 896 esculentus 897 lóngus $W$

Cyperus. bulbous-rooted $* \square \mathrm{cu}$ slender ill $\mathrm{iO} \mathrm{cu}$ Cyperacea. Sp. 22-250.

Cyperacea. my.jn Ap 1 my.s Ap dwarf 业 $O$ cu 1 jl.au Ap compact-flower. 亚 $\mathrm{cu} 2$ my.s Ap distant clammy 业 $\triangle \mathrm{Ju} 2 \mathrm{cu}$ my.au Ap lofty $\quad$ ill $\mathbb{D} \mathrm{cu} 1 \mathrm{my} . \mathrm{au} \mathrm{Ap}$ pink 此 $\triangle \mathrm{Cu} 1 \mathrm{my}$.jn Ap panicled round-headed Ille $_{\mathrm{H}} \mathrm{O} \mathrm{cu} 2$ my.au Ap elegant yellow 此 D cu 1 jn.s Ap brown smooth $\Delta \mathrm{cu}$ ill my.s Ap Rush-nut $\quad$ cul 1 jl sweet tall $\quad$ 业 $\triangle \mathrm{D}$ cu $1 \frac{1}{2} \mathrm{jl}$ Ap

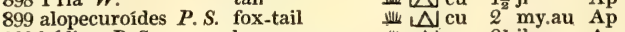
900 bádius $P . S . \quad$ brown $\quad$ 业 $\triangle \mathrm{N}$ cu $2 \frac{1}{2} \mathrm{jl}$ Ap 901 alternifólius $W$

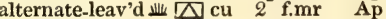

E. Indies 1802. S co C. G. H. 1819. S co Arabia 1820. D co Hungary 1781. Sk co W. Indies $\ldots$ Sk co W. Indies 1820 , D co Jamaica 1781. Sk co E. Indies 1800. Sk co 1820. D co Italy. D co Italy . 1804. S co Germany 1776 . S S co Europe 1777. S co W. Indies 1786. Sk co America 1790. Sk co S. Europe 1597. Sk co England mar. Sk co E. Indies 1802. Sk co C. G. H. 1804. Sk co Algiers 1800 . Sk co Madagasc.1781. Sk co

Plk.mt. t.419. f.3

Rot.gr.20.t.4. f.5 Pk.al, t.300, f.4.5

Host. gr. 3. t. 20 Rott, gr, t. 13. f. 3 Jacq. ic. t. 299 Jac. ic. 2. t. 295 Rt. gm.32.t.7.f.2

Slo.ja. 1.t. 75, f.1 Host. gra. 3. t. 72 Host. gra. 3. t. 73 Rt. g. 40.t.11. f'3 Jac. vind. 3, t. 12 Host. grm.3. t.75 Eng. bot. 1309

Rheede. 12 . t. 56 Rott. g.38.t.8. f. 2 Desf. at.1. t.7. f.2 Cyperacea. $\quad$ Sp. 1-3.

128. PAPY'RUS. $L k$. PAPYrUS 902 antiquórum $L k$. ancient

129. KYLLIN'GA. $W$. 903 monocéphala $W$. 904 polycéphala $L k$. 905 uncinata $L$ 906 triceps $W$.

当 [ $]$ or $10 \mathrm{jl} . \mathrm{s}$ Ap Egypt

1803. D co Mic, gen.44.t.19

KYLLINGA. one-headed many-headed hooked three-headed

\section{Cyperacea. Sp.4-12.}

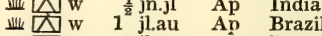

1793. Sk co Rott. gr. t. 4. f. 4 业 $\mathrm{W}$; ${ }^{4}$ s.n Ap India

130. MARIS'CUS. Vahl. Mariscus 907 umbellatus $W$. en. umbelled 908 elátus $\boldsymbol{W}$. en. 909 confléxus $L k$. tall 910 aggregatus $W$.

contracted aggregated

Cyperacea. Sp. 4-28.

910 aggregatus

911 marítima $A u b$. sea

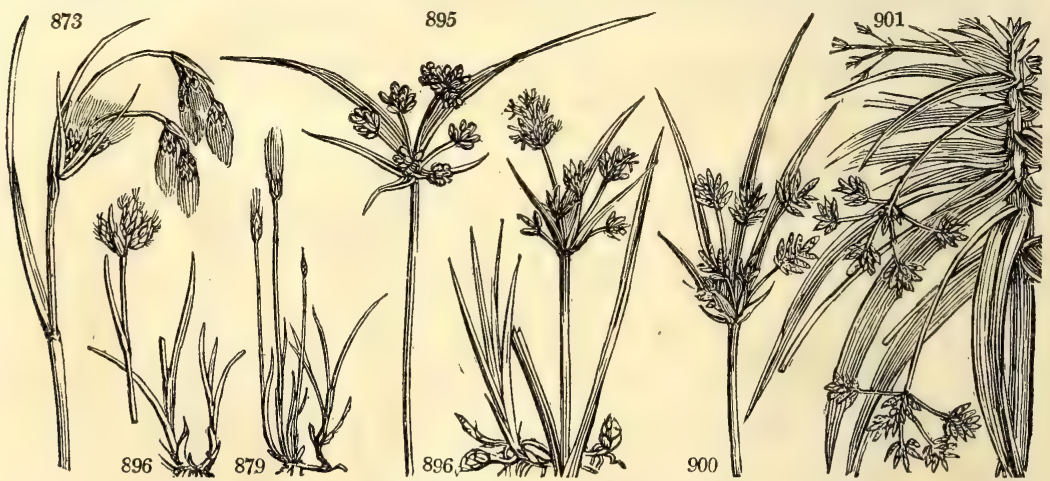

History, Use, Propagation, Culture,

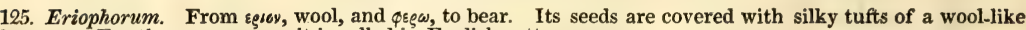
substance. For the same reason it is called in English cotton-grass.

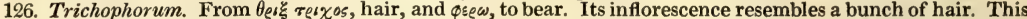
genus and Eriophorum grow in peat bogs, and have their seeds clothed at the base with a white or brown silky down or cotton-like substance, from which specimens of cloth have been made, paper, and wicks for candles; and in Sweden, pillows stuffed. Of these genera, and of the Cyperacea in general, it has been observed by Villars, that being mostly natives of bogs, marshes, and watery places, they have a tendency to raise and dry such spots. The roots and base of the stems rot and become peat, and thus are useful as firing or manure.

127. Cyperus. The roots of some species of this genus have eatable roots, and are considered aphrodisiacal in a high degree. It is, therefore, probable that the word derived its origin from Cypris, a name of Venus. This is a genus of sub-aquatic or marsh sedgy plants, more injurious than useful, and of little or no beauty. The root of $\mathrm{C}$. longus is agreeably aromatic, warm, and bitter: those of $\mathrm{C}$. esculentus (souchet comestible, Fr.) produce round tubercles about the size of peas, which are eaten in some places in France and Spain; and when boiled, taste something like chestnuts.

128. Papyrus. A word of obscure origin. P. antiquorum yields the substance used as paper by the ancient Egyptians. In Syria it is called babeer, and hence, probably, the words papyrus and paper. The flower-stalk rises about ten feet from a long horizontal thick root, the lower part clothed with long hollow sword-shaped leaves 
872 Spike solitary, Culm very smooth, Sheaths inflated

873 Spikes several, Culms 3-cornered, Leaves broadish keeled

874 Spikes several, Culms 3-cornered, Leaves very narrow setaceous

875 Spikes several, Culms round leafy, Spikes sessile clustered shorter than the involucrum

876 Spikes several, Culms 3-cornered, Leaves nearly filiform 3-cornered, Peduncles rough, Flowers erect 877 Spike solitary, Culms round spongy soft, Sheaths not inflated

878 Umbel compound, Culm branched

879 Spike solitary, Culms simple 3-cornered roughish

880 Head globose, Spikelets oblong convex about 8-flowered, Involucr. 4-leaved, Leaves channelled lax 881 Spikelets solitary and in pairs sessile, Involucr. 1-leaved, Culm setaceous

882 Spikelets ovate much clustered, Culm rather 3-cornered, Leaves channelled

883 Stem 3-cornered leafless ascending or decumbent, Spikelets about 5 oblong obtuse very shortly stalked 884 Heads simple and clustered ovate, Spikelets oblong, Involucr. very long

885 Spikes distichous, Spikelets spreading filiform, Florets distant, Umbel upright

886 Spikelets aggregate ovate rather squarrose in heads, Involucr. longer than umbel, Lvs. and involucr. rough 887 Umbels many rayed compound, Spikes elongate, Spikelets linear-lanceolate, Involucr. 4-leaved long

888 Lvs. linear shorter than the 3-cornered culm, Invol. 3-leaved, outer leaf very long, Spikel. lanc. Scales obtuse 889 Spikelets linear-lanceolate, Umbels corymbose fascicled, Involucr. about 6-leaved

890 Culm 3-cornered naked, Umbel 3-leaved supra-decompound, Spikes clustered rounded, Spikelets subulate 891 Spikelets about 3 linear, Valves obcordate mucronate distinct spreading, Umbel loose

892 Spikelets linear-lanc. alternate clustered, Glumes obtuse, Involucr. 3-leaved longer than the trifid umbel 893 Spikelets linear-lanc, alternate very close, Valves acute, Invol, about 3 or 5-leaved very long, Umbel 3-5-fid. 894 Spikes oblong loose, Spikelets subulate alternate capitate, Invol. very long spreading, Rays of umbel altern 895 Spikelets lanceolate roundish headed compact, Valves ovate 1-nerved, Involucr. longer than the umbel 896 Spikelets lin.-lanc. distant acute, Rays of the umbel about 7 terminal shorter than the 3-5-leaved involucrum 897 Spikes corymb. Spikel. lin.-lanc. flattened, Invol. and rays of umbel very long corymbose with leafy stem 898 Spikes corymbose, Spikelets linear, Valves remote obtuse obovate spreading in fruit, Umbels loose 899 Spikes nearly sessile imbricated round, Spikelets ovate oblong spreading

900 Spikelets in corymbose fascicles, Spikelets linear-lanceolate dense, Invol. 3-leaved, Leaves very rough 901 Umb. 6-7-rayed compound, Heads many-spiked, Spikel. lin. many-flowered, Invol, 3-leaved reflexed rough

902 Stem tall terminated by a reflexed involucrum of many very long narrow leaves

903 Head globose sessile solitary, Involucr. very long

904 Umbel rather contracted, Invol. very long, Spikelets clustered, Valves ovate carinate acute 905 Head 1 or 3 sessile round, Invol. many leaved long, Valves carinate hooked

906 Heads about 3 sessile clustered, Spikelets very dense rather imbricated

907 Umbel compound, Spikes cylindrical imbricated backwards, Involucres many-leaved

908 Umbel compound, Spike cylindrical, Spikelets very spreading, Bractes longer than the spikelets

909 Leaves shorter than the 3-cornered culm rough at edge, Umb. contracted, Invol. many-leaved, Spikel. subreflexed, Scales keeled striated

910 Spikes cylindrical sessile, Spikelets oblong, Bract setaceous longer than spikelets, Invol. many-leaved

911 Common peduncle shorter than the spikes

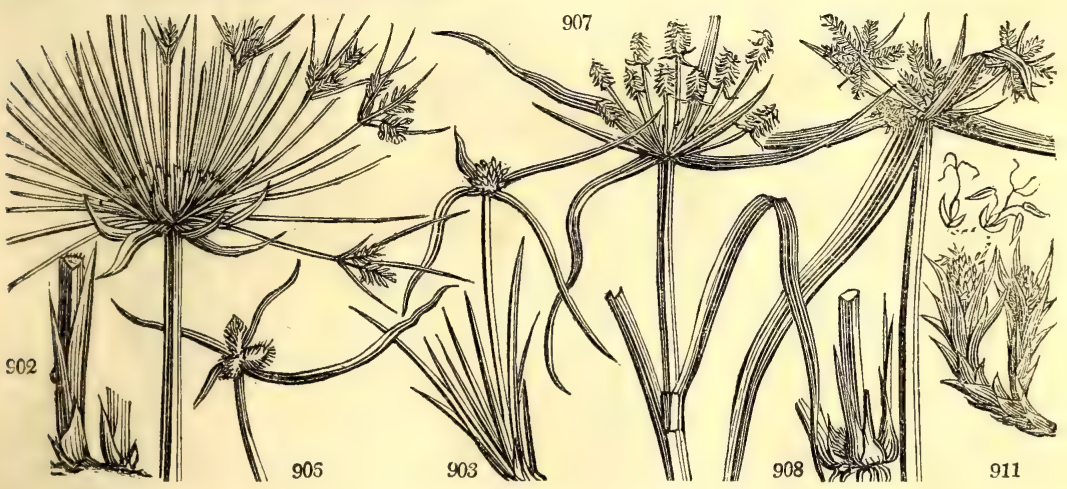

and Miscellaneous Particulars.

of a brown color. The ancients made their paper from the pellicle found between the flesh and bark of the thick part of the stalk; ribbons of which were united till they formed the size required, and then pressed and dried in the sun. The top of the stalk, with the umbel of flowers, adorned the temples, and crowned the statues of the gods. Antigonus used the stalks for ropes and cables to his fleets, before the use of spartum (Lygeum spartum, still used on the coast of Provence for small vessels, and also in Spain) was known. Pliny says, the whole plant was used for making boats ; and Bruce says, they have no other boat in Abyssinia. That traveller found it growing in the rapid course of the river Jordan, and he there remarked that it constantly opposed one of the angles of its stem to the current, as if to elude the violence of the waves. Perhaps, if the observation were applied to similar plants in our own rivers, the same result would be obtained. The root was chewed for its juice, which is also practised in Abyssinia with various species of cyperus, and with those of maize. The papyrus is indigenous in Calabria as well as in Ethiopia and Egypt, in stagnant water; but only in the calishes or swamps of the Nile, and never in the stream as has been supposed. To thrive in our stoves, it requires to be placed in a cistern of water with rich mud at the bottom. Plants so treated, at White Knights, near Reading, have attained a large size, and flower freely.

129. Kyllinga. In memory of P. Kylling, a Danish botanist, who died in 1696.

130. Mariscus. A word derived from the Celtic mar, a marsh, in allusion to the situations in which it is found.

131. Remirea. The Guiana name of the plant. 
132. LYGE'UM. $W$. 912 Spártum $W$.

133. CORNUCO'PI 913 cucullátum $W$

Lygeum. rush-leaved

Cornucopis.

134. CEN'Chrus. $P$. S. Cenchrus.

914 lappáceus $W$.

915 echinátus $W$

916 tribuloídes

Bur

rough-spiked spinous

917 cenchroídes Rich. ciliated

136. SPARTI'NA. $W$.
918 stricta $W$.
$\begin{gathered}\text { Spartina. } \\ \text { upright }\end{gathered}$

918 strícta $W$.

919 cynosuroídes Rich. Dog's-tail

920 polystáchya $P h$. many-spiked

921 júncea $P h$.

137. NAR'DUS. $W$ 922 strícta $W$.

spreading

138. ORYZOP'SIS. Mich. ORYZOPSIS. 923 asperifólia $\boldsymbol{M}$. rough-leaved

139. PAS'PALUM $W$ PASPaLUM. 924 scrobiculátum $W$. punctur 925 paniculátum $W$. 926 stoloníferum $W$ 927 distichum $W$. punctured purple

two-spiked decumbent

140. AXo'NOPUS. $P$. de B. Axonopus 929 cimicinus $\boldsymbol{P}$. de $\boldsymbol{B}$. spotted

141. MI'LiUM. $W$. Millet-grass. 930 effúsum $W$. $W$ common 931 paradóxum $W . \quad$ black-seeded 934 frutéscens $L k$. shrubby

142. KNAP'PIA. E. $B$. KNAPPIA 935 agrostídea $E . B$. small

143. Digita'RIA. $P, S$. Finger-grass 936 sanguinális $P$. S. slender-spiked 937 villosa $P$. $S$. 939 cilíris $P$. 940 margináta $L k$. villous Egyptian ciliated divaricate

144. PAN'ICUM. B. $P$. PANIC-GRASS. 941 colónum $W$. 942 brizoídes $W$. 943 fasciculátum $W$ 944 prolíferum Lam. purple purple friza-l fascicled proliferous
135. PEnNise'TUM. Rich. Pennisetur. 028 sertinim 933 crulescens Desf. blueish 938 ægyptíaca W.en.

Graminea. Sp.1.

$1 \frac{1}{2}$ my.jn Ap Spain

Graminea. Sp.1.

$\frac{1}{2} \mathrm{au}$ Ap Levant 1788. S co Fl. græc. 1. t.51

Graminea. $\quad S p .3-21$.

此 $\mathrm{O}$ cu $1 \mathrm{jl}$ Ap India 1773. S co Beauv, t.14.f.7

业 $\mathrm{cu} 2$ au.d Ap W.Indies 1691. S co C. ic.5. p.39.t.469 O cu 1 my.au Ap N. Amer. 1818. S co C. ic. 5. t. 461 Graminece. Sp.1-8.

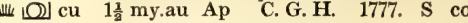
Graminea. Sp. 4-8.

步 $\Delta$ cu 1 au Ap Britain sal. m. D co Eng. bot. 380 业 $\triangle$ cu 3 au.s Ap N. Amer. 1781. D co L.fil.fa.1.p.17.t.9 耑 $\mathrm{cu} \quad 6$ au.s Ap N. Amer. 1781. D eo

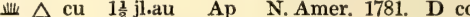
Graminea. Sp. 1-2.

业 $\triangle \mathrm{cu} 1 \mathrm{jn} . \mathrm{jl}$ Ap Britain moi.h. D m.s Eng. bot. 290 Graminea. $S p .1$.

业 $\Delta$ cu 3 jl.au Ap N. Amer. 1822. D co

\section{DIGYNIA.}

Graminea. Sp. 5-82.

啮 $\triangle \mathrm{cu} 1 \frac{1}{2} \mathrm{jl} . \mathrm{s}$ Ap E. Indies 1778. S co H.n.h.13.t.89.f.3 步四 cu 3 jl.s Ap Jamaica 1782. S co Sl. hist.1. t.72, f.2 业 $\triangle \mathrm{J}$ cu 2 jl.s Ap Peru 1794. S co Jacq. ic. 2. t. 309 典 7 cu 11 jl Ap Jamaica 1776. S co Sw.obs.35.t.2.f.1 Cu 12 jlau Ap N. Amer 1804, S Graminea. Sp. 1-4.

O cu 1 jl.s Ap India 1788. S co Graminee. Sp. 5-14.

进 $\Delta \mathrm{w} \quad 3$ jn.jl Ap Britain m.s.p. S m.s Eng. bot. 1106 业 O cu 3 jn.jl Ap France 1771. S co Host. gr. 3. t. 23

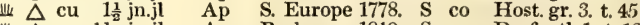
业 $\triangle$ cu $1 \frac{1}{2} \mathrm{jn} . \mathrm{jl}$ Ap Barbary 1819. S co Desf. atl.1. t. 12 业 $\triangle$ cu 1 ... A Ap Crimea 1822. S co Graminea. Sp. 1.

业 $\mathrm{O}$ cu $\frac{1}{4} \mathrm{mr}$.ap Ap Wales san.pl. S s Eng. bot. 1127 Graminee. $S p$.

业 $\mathrm{O}$ ag $2 \mathrm{au}$ Ap Britain fields. S co Eng. bot. 849 业 $\mathrm{O}$ w $1 \frac{1}{2} \mathrm{jl.s}$ Ap N. Amer, 1781. S co

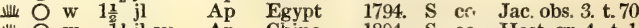
进 $\mathrm{W}$ w $1 \frac{1}{2}$ jl.au Ap China 1804. S co Host. gr. 4. t. 15 业 $\mathrm{O}$ w $\frac{2}{2} \mathrm{jl}$ Ap Brazil 1822. S co Graminea. Sp. 18-185.

业 $\mathrm{O}$ ag $\frac{1}{2}$ jl.au Ap E. Indies 1699. S co Ehr.pic. t. 3. f.3 业 业 $\mathrm{O}$ cu 2 jn.jl Ap Jamaica 1801. S co 址 $\triangle \mathrm{cu} \frac{3}{4} \mathrm{jn}$.au Ap N.Amer. 1820. S co

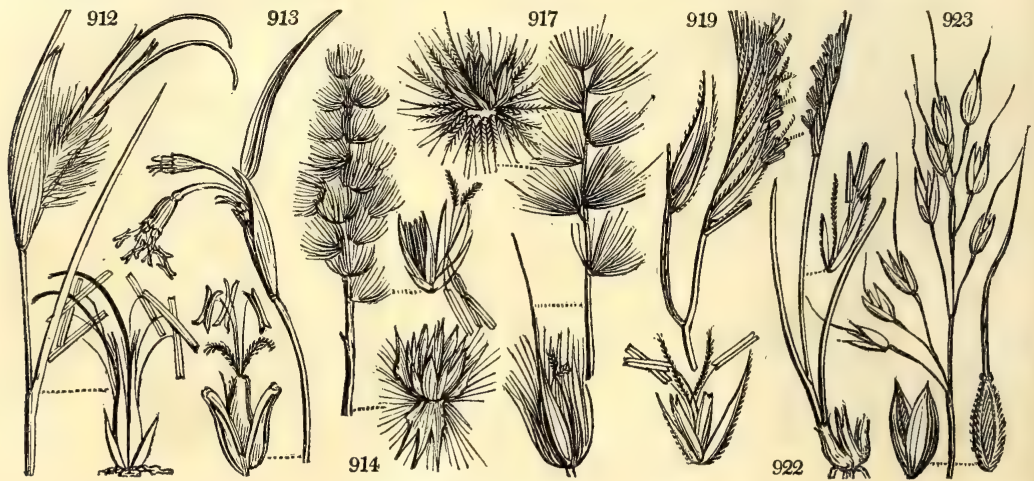

History, Use, Propagation, Culture,

132. Lygeum. From durow, to bend, in allusion to its flexibility. This plant is used in Spain, Provence, and other places for making ropes, baskets, nets, and for filling their paillasses or lower mattrasses. Ropes were made of it by the Romans. Esparto (spartum) is the Spanish appellation of this and other grasses used for similar purposes.

133. Cornucopice. The spike inclosed in the involucrum peculiar to the genus, resembles the " $\bar{H}$ Horn of Plenty." The leaves and flower of C. cucullatum, Sir J. E. Smith observes, are perhaps of all grasses the most singular and uncommon. It is a native of the vales about Smyrna, whence it was sent to England by Sherard, and is preserved in the Chelsea garden and at Kew.

134. Cenchrus. Kev £ $\rho_{05}$ is the Greek name of the millet; by which, it is probable, that Setaria italica was intended. C. echinatus is the most common grass in the pastures of Jamaica, and is looked on as a wholesome and pleasant food for horses and cattle.

135. Pennisetum. From penna, a pen, and seta, a bristle; a feathery bristle, referring to the nature of the involucrum

136. Spartina. A word altered from spartum, the specific appellation of Lygeum; the plants being similar to the latter in habit. The origin of the word spartum has not been satisfactorily explained. The Spaniards call this, and similar tough grasses, useful to them in making ropes, esparto.

137. Nardus. The term voédos was applied by the Greeks to a substance possessing a peculiar per- 


\section{The only species}

913 The only species

914 Branches of the panicle simple, Paleæ hispid backwards, Glumes 3-valved 2-flowered (Centotheca. Desv.) 915 Spikelets approximated, Involucres 10-parted villous 916 Spike with alternate spikelets, Involucres entire spiny

917 Culm jointed, Invol. altern. twice as long as flowers, one of the setæ bristle-chaffy longer than the others 918 Spikes terrn. about 2, Spikelets one-sided loosely imbricated Paleæ longer than glume, Leaves involute 919 Spikes altern. remote, Rachis ang. wavy, Glumes twice as long as paleæ, Leaves very long glaucous flat 920 Leaves broad flat, Spikes many turned all ways linear, Keels aculeate

921 Leaves distichous shortish bristly convol. Spikes few remote spreading, Glumes acuminate, Keels rough

922 Spike bristly straight one-sided

923 The only species

\section{DIGYNIA.}

924 Spikes few altern. Rachis flat straight as long as spikel. Glumes roundish obtuse smooth, Upper lvs. naked 925 Spikes very num. Rachis 3-sided smooth twice as narr. as spikel. Glumes roundish obv, blunt pub. 3-nerv. 926 Spikes numerous scattered, Rachis undulated broader than spikelets, Glumes oblong corrugated, Leaves

927 Spikes 2 close together, Rachis flat narrower than spikelets, Glumes ovate obtuse polished length of palex 928 Spikes 5 close together, Rachis flat rather broader than spikelets, Glumes elliptic lanc. acute pubescent

929 Panicles umbelled, Racemes about 4, One glume fringed

930 Panicles diffuse, Florets beardless ovate dispersed

931 Pan. spreading lax few-flowered, Flowers bearded, Each glume at least 3-nerved (Piptatherum. P. de B.) 932 Panicles spreading many-flowered, Flowers bearded, Outer glume 3-5-nerved

933 Flowers panicled bearded, Beard shorter than glume

934 Stem shrubby at base, Panicle whorled, Lower rays sterile

935 The only species. The least of grasses

936 Spikes digitate erect spreading 4, Leaves and sheaths pilose, Florets oblong pubescent at edge 937 Spikes many setaceous, Leaves and sheaths very hairy

938 Spikes digitate erect 7, Leaves and sheaths hairy, Florets oblong acute smooth

939 Spikes digitate erect spreading 8, Leaves and sheaths hairy, Florets lanceolate ciliated

940 Stem decumbent, Sheaths hairy at end, Spikes divaricate, Paleæ fringed at end

941 Spikes alternate one-sided beardless ovate rough, Rachis roundish

942 Spikes alternate sessile one-sided, Glumes two much shorter than paleæ retuse, The third as long as they 943 Spikes panicled alternate erect in bunches, Spikelets one-sided roundish

944 Very smooth, Panicles oblong erect, Glumes striated largish, Stem branching

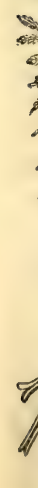

996

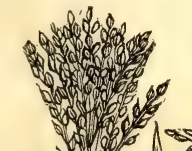

930
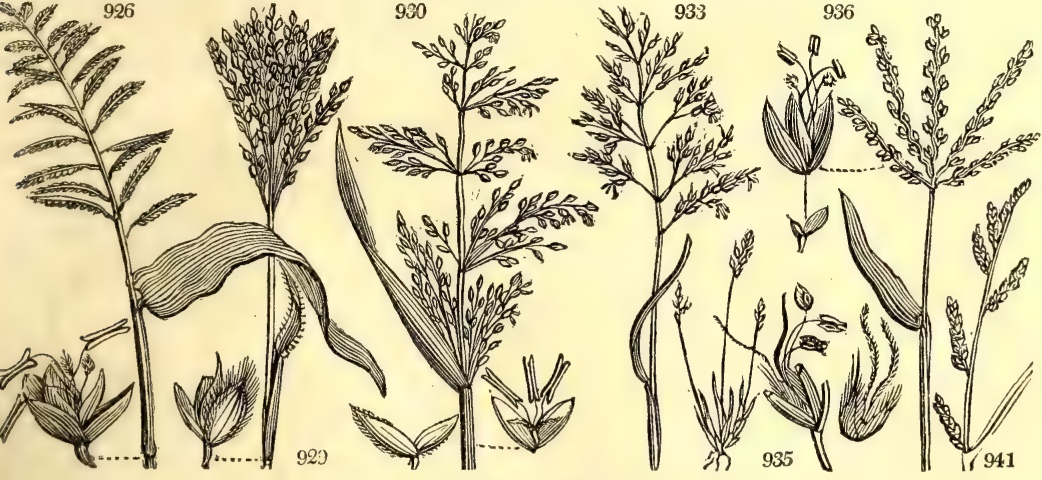

and Miscellaneous Particulars.

grasses.

138. Oryzopsis. Oryza, rice, and o ${ }^{\prime 5}$, appearance. The plant resembles rice.

139. Paspalum. One of the Greek names for millet, $\pi \propto \sigma \tau \kappa \lambda$.

140. Axonupus. From áçy, axis, and $\pi \varepsilon_{5}$, a foot, because the chief difference between this genus and Paspalum consists in the spikes being separately placed, as it were, upon little stalks or feet.

141. Milium. Derived by some from mille, a thousand, on account of its numerous grains; by others, from mil, the Celtic for a pebble, in reference to the hard shining nature of the grains. M. effusum is admired for the elegance of its panicle. M. paradoxum resembles the Arundo.

142. Knappia. Named after Mr. Knapp, an author of an illustrated work upon British grasses, not much esteemed. A minute plant, resembling an agrostis.

143. Digitaria. From digitus, a finger, on account of the singular manner in which the heads are divided; or, as the botanists express it fingered. D sanguinalis has its specific name, not from the color as might be supposed, but from an idle trick which the boys in some parts of Germany have of pricking one another's nossupposed, but from an idle trick which the boys in some parts of Germany have of pricking one another's nos-
trils with its spikelets till they bleed. It abounds by the road sides in Poland and Lithuania, where its seeds are collected and boiled whole like rice, with milk, and highly esteemed

144. Panicum. Pliny says, so called, from its flowers being in a panicle; but others derive the name from E 3 

y49 muricátum $W$ 9.58 palmifólium 961 víridis $P$. de $B$. 968 macrochæ'ta $L k$.
945 hispídulum $W$. 946 colorátum $\boldsymbol{W}$. 947 répens $W$.

y48 miliáceumi $W$ 950 capilláre $W$.

951 latifolium $\boldsymbol{W}$. 952 clandestínum $W$ 953 arboréscens $\boldsymbol{W}$. 954 virgátum $W$. 955 pátens $\boldsymbol{P}$. $\boldsymbol{S}$. 956 brevifólium $W$ 957 divaricátum $W$. 45. SET'A'RIA. $P$. de $B$. Setaria. 959 verticilláta $P$. de $B$. rough 960 glaúca $P$. de $B$. glaucous o6 itálica $P$ de $B$. yoj setósa $P$. de $B$ $96+$ sericea $\dot{P}$. de $B$. 965 germánica $P$. de $B$ 966 geniculáta Horn. 967 púmila $L k$. 969 áspera $L k$. glaucous Italian Italian silky German knee-jointed dwarf long-spiked rough

hispid coloured slender

prickly hair-panicled broad-leaved

hidden-flor

tree

tronicled spreading hort-leaved raddling

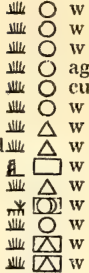
jl.au $1 \frac{3}{2}$ jl.s jn.au au.s $50^{1 \frac{1}{2} \mathrm{jl}} \mathrm{mr}$. 1 au.s 1 jl.au $1 \frac{1}{2}$ jl.au 5 jl.au

6 jl.au Gramine 此 O w $1 \frac{1}{2}$ jl. au Ap 业 $O$ w $1 \frac{1}{2}$ jl.au. Ap 垱 $O$ w $1 \frac{1}{2}$ jlau Ap 此 $O$ ec $1 \frac{1}{2}$ jl.au Ap 业 $O$ w $2 \frac{1}{2}$ jl.au Ap 此 $O$ w $1 \frac{2}{2}$ my.s A 阱 $\bigcirc$ ag $1 \frac{1}{2} \mathrm{jl} \quad$ Ap

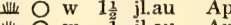
业监 $O$ w 1 jl.au $A_{1}$ 此 O w 2 jl.au Ap 业业 $\triangle$ w 2 jl.au Ap

146. ECHinochlo'A. $P$. de $B$. Prickly-grass. Graminece. 970 stagnina $\boldsymbol{P}$. de $\boldsymbol{B}$. pond 业 $\mathrm{O}$ w 3 jl.au Ap 971 crus córvi $P$. de $B$. crow's-foot 齿 $\bigcirc$ w 1 jl.au $A p$ 972 crus gálli $P$. de $B$. loose Pánicum E. $\mathrm{B}$.

147. ORTHOPO'GON. $B . P$. ORthopogon. 982 capilláta $W$ 973 hirtéllus $B$. $P$. hairy
974 undulatifúlius $R . \& S$. wavy-leaved

148. Penicilílaria. $\boldsymbol{P}$. de $\boldsymbol{B}$. Penicillaria. 975 ciliáta $W$. 976 spicáta $W$

149. LAPPA'GO. 977 racemúsa $W$

150. ST'I'PA. $W$ 978 pennáta $W$. 979 húmilis Cav. 980 júncea $W$. 981 sibírica $P, S$. 983 tenacíssima $W$

Graminea. Sp. 2-6.

1 jn.jl Ap W.Indies 1795. S co 1 jn.jl Ap S. Europe 1795. S co Graminea. Sp.2.

2 ils Ap Jamaica 1748 S co Pl al t 90 f 5 2 jn.jl Ap India 1592. S co Pl. al. t.32. f. 4 Graminea. Sp.1.

$\frac{1}{2}$ jl.au Ap S. Europe 1771. S co Host. gr. 1. t. 36

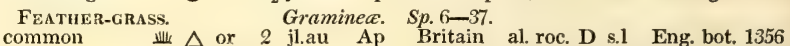

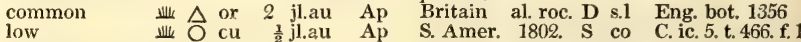
rush-leaved 业 $\triangle \mathrm{cu} 3^{2} \mathrm{jl}$ Ap France 1772. D co Fl.græc. 1. t.85 Siberian 此 $\triangle \mathrm{cu}$ 3.jl.au Ap Siberia 1777. D co Gmel. sib.1.t.22 capillary 址 cu 2 jl.au Ap Europe 1815. D co Host. gr. 3. t. 5

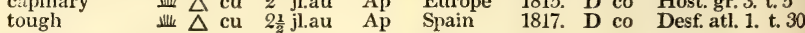

151. MUHLENBER'GIA. Schr: MuHLenberGiA. 984 diffúsa $S c h r$. spreading 齿 $\triangle \mathrm{w}$

152. CHETU'RUS. L $k$. Cheturus. 985 fásciculátus $L k$. bundled : 业 $\bigcirc \mathrm{W}$

153. LAGU'RUS, $W$. HARE'S-TAIL-GRASS. 986 evátus $\boldsymbol{W}$.

Graminee. Sp. 1

$\frac{1}{2}$ my.jn Ap N. Amer. 1816. S co Schr.gram. t. 51 Graminea. Sp. 1-2.

$\frac{1}{2}$ jl.s Ap Spain 1816. S co

Graminea. Sp.1.

Host. gr. 3. t. 52
Jac. ic. 1. t. 58

Host. gr. 2. t. 20

Host. gr. 4. t. 16

Pl. al. 176. t. 189 Eng. bot. 874

Host. gr. 2, t. 16

Rump. 5. t.76. f. 2

Host. gr. 2. t. 15

Host. gr. 3. t. 51

Eng. bot. 876
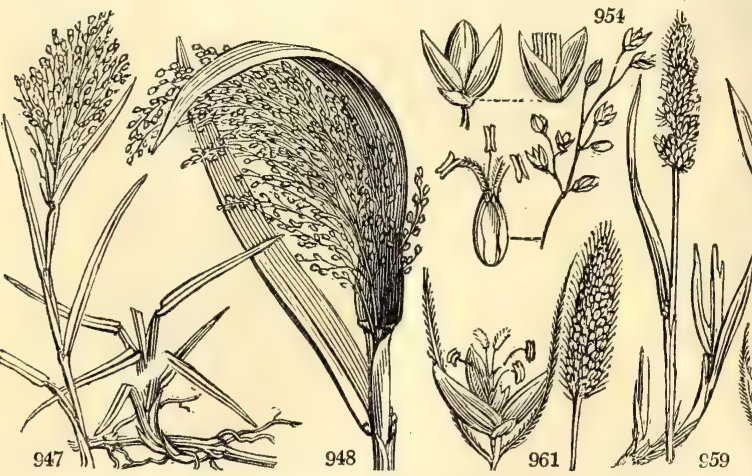

$\$ 59$

972

Eng. bot. 1334

History, Use, Propagation, Culture,

panis, bread, because of its uses as such. Of P. miliaceum there are two varieties, the brown and yellow. They are sometimes sown in this country for feeding poultry, and for having the husk taken off, to be used as rice; but the ample supplies received from the shores of the Mediterranean, render the culture of the plant unnecassary P. arborescens, is said, by Linnæus, to contend for height with the loftiest trees in the East Indies, though the culm is scarcely thicker than a goose quill. This culm resembles that of Commelina, and shoots up through the branches of trees in woods and jungles.

145. Setaria. From seta, a bristle, on account of the bristles of the involucrum. S. italica is frequently called millet, and its seeds are used for the same purposes. S. germanica is cultivated in Hungary as food for horses, for which it is preferred before all other grasses. The seeds may be used as millet. Sparrows are remarkably fond of the seeds of S. viridis; and, according to Curtis, this and the two preceding genera, when cultivated in gardens, require to be protected from them from the time they come into flower.

146. Echinochloa. From $\varepsilon \chi^{\prime \prime} 05$, a hedge-hog, and $\chi \lambda$ on, a grass, on account of the prickly appearance of the heads of flowers. $\mathrm{E}$. crus-galli is a coarse grass which grows thick and close, and stands dry weather better than most others. 
945 Spikes 2-3 together erect, Glumes hispid with two beards

946 Panicles spreading, Stamens and pistils coloured, Stem branching

947 Panicles twiggy, Leaves divaricating

948 Panicles lax nodding, Spikelets beardless, Leaves lanceolate pilose, Sheaths hirsute, Valves mucronate 949 Panicles spreading, Flowers solitary'muricated, Stem rooting ascending

950 Panicles capillary erect spreading, Pedunc. straight, Glumes acuminate smooth, Sheaths very hairy

951 Panicles with simple lateral racemes, Leaves ovate lanceolate hairy at the neck.

952 Panicles few axillary, Stem dichotomous, Sheaths dotted

953 Panicle much branched, Leaves ovate oblong acuminate, Shrubby

954 Panicles branched diffuse, Glumes acuminate smooth gaping, Leaves reedy

955 Panicles oblong flexuose capillary spreading, Glumes two-flowered, Leaves linear-lanc. Stem creeping 956 Panicled, Sheaths of the leaves ciliated lengthwise

957 Pan. short beardless, Stem much branched divaricating, Flower-stalks 2-flow. one shorter than the other 958 Panicles simple upright, Spikelets appressed, Leaves oblong lined plaited, Sheaths pubescent

959 Pan. spiked whorl. Invol. 1-fl. with hairs in bundles toothed hispid, teeth reversed, Herm. paleæ smoothish 960 Raceme spiked cylind. Invol. 2-fl. with hairs in bundles, hispid above, Herm. paleæ wavy crosswise 961 Pan. spiked cylind. Invol. 2-fl. with hairs in bundles, hispid above, Herm. paleæ smoothish, Sheaths downy 962 Spike comp. interrupted at base nodding, Spikelets heaped, Invol. setaceous much longer than flower 963 Spike comp. Spikelets panicled in bundles, Bristles mixed with the florets very long, Pedunc. smoothish 964 Spike round, Involucres setaceous villous 1 -flowered as long as florets, Leaves flat

965 Spike compound contracted, Spikelets heaped, Invol. setaceous longer than the flowers, Rachis hairy 966 Spike elongated cylind. Invol. 2-fl. bristly, Herm. paleæ smoothish, Stem ascending, Sheaths smooth 967 Stem branched, Sheaths pubescent, Spike dense short, Setæ none, Paleæ smooth

968 Spike compound erect, Clusters remote, the lowest sessile, Setæ 8 times as big as florets

969 Sheaths very rough, Spike simple with naked setæ longer than florets

970 Spikes one-sided alternate, Glumes 2-fl. bearded hispid

971 Spikes alternate one-sided, Spikelets subdivided, Glumes bearded hispid, Rachis triangular

972 Spikes alternate and in pairs, Spikelets subdivided, Glumes bearded hispid, Rachis 5-angular

973 Spike compound, Spikelets appressed alternate, Glumes torn, All the valves bearded outer largest

974 Bundles about ten, Rachis very hairy, Glumes bearded smooth a little fringed, Leaves ovate acum. wavy

975 Joints of the stem smooth, Involucres ciliated

976 Joints of the stem villous, Involucres rough

977 The only species

978 Beard feathered

979 Flowers panicled spiked nearly included in the sheaths, Beard feathered

980 Beard naked straight, Glumes longer than the seed, Leaves smooth inside

981 Panicled, Beards naked twice as long as glumes, Seeds woolly

982 Bearil naked rough twisted in various directions

983 Beard hairy at base, Panicle spiked, Leaves filiform

984 Panicles branched compressed, Leaves linear smooth, Stem diffuse

985 The only species. A plant looking like a Polypogon

986 The only species

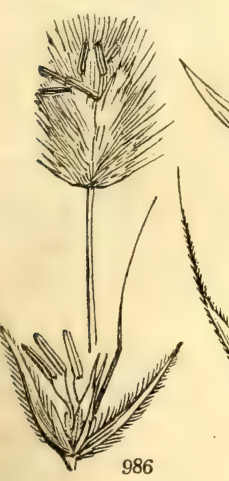

985

(t)

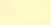
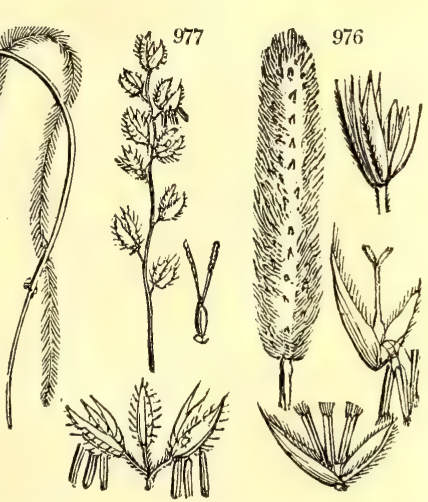

c84

and Miscellaneous Particulars.

147. Orthopogon. O O $\mathrm{O}_{0 \varsigma}$, straight, and $\pi \omega \gamma \omega \nu$, a beard, because the beards of the flower are straight, and not jointed. This plant is cultivated in the low and marshy lands of Jamaica as fodder.

148. Penicillaria. From penicillus, a pencil, in allusion to the soft hairy appearance of the spikes.

149. Lappago. The flowers are rough, with little prickles like Lappa or Burdock.

150. Stipa. From $5 \cup \pi \eta$, silky or feathery material. S. pennata has beautifully feathered beards which distinguish it from all other grasses. Gerarde says, they were worn in his time by "sundry ladies instead of feathers." S. tenacissima is used in Spain for the same purposes as Lygeum spartum, and like it, is called Es. parto. It is supposed by some to be the plant so called by the ancients.

151. Muhbenbergia. Named in honor of Dr. Muhlenberg, an eminent North American botanist. A North American genus of grasses.

152. Cheturus. From $\chi \alpha i \tau \alpha$, a head of hair, and $\& \rho \alpha$, a tail. So named by Link, from the silky appearance of the panicles.

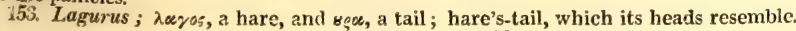


154. POLYPO'GON. W.en. Poly pogon.

987 monspeliénsis Desf. panic-grass_like llth

155. GASTRI'DIUM. $P$. de B. Gastridium. 988 lendigerum Milium E. B.

989 múticum Spr.

156. A GROS

990 Spic BENT-GRAss.

991 retrofrácta $W_{\text {. en. }} \quad$ silky broad-leaved

992 littorális $E . B$.

993 vulgáris $\boldsymbol{E} . \boldsymbol{B}$.

994 híspida $W$.

995 stolonifera $W$

996 álba $W$.

997 verticilláta $W$

998 sylvática $L$.

999 calamagróstis $W$.

157. TRICHO'DIUM.

sea-side

fine

hispid

Fiorin

marsh

whorl-flowered

wood

reedy

i. Trichodium.

1000 decúmbens $M i$.

1001 canínum $W$. en.

1002 rupéstre $S c h r$.

decumbent

brown

rock

bristly

1003 setáceum $R$. \& $S$.

loose-flowered

158. TRIS'TEGIS. Nees. Tristegis.

1005 glutinósa Nees

159. SPORO'BOLUS. $\boldsymbol{B} . \boldsymbol{P}$. SPorobolus.

1006 indicus $B . P$. Indian

1007 tenacíssimus $W$. tough

160. AIROP'SIS. Desv. Airopsis.

1008 involucráta Cav. involucred

161. CIN'NA. P. de B. CinNa.

1009 mexicána $W$. Mexican

1010 arundinácea $L$. reedy

162. PSA M'MA. P.de B. Mat-grass.

1011 arenárium

Arundo E. B.

163. CRYP'SIS. $W$. CRYPSIS.

1012 aculeáta $W$ prickly

1012 schœenoídes Lam. $\begin{aligned} & \text { prickly } \\ & \text { rush-like }\end{aligned}$

164. ALOPECU'RUS. $\boldsymbol{W}$. Fox-TAIL-Grass

1014 bulbósus $W$.

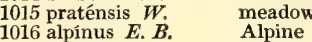

Alpine

slender

Graminece. Sp. $1-8$.

jl.au Ap Britain ways. S co Eng. bot. 1704

Graminea. Sp. 2.

$\frac{1}{4}$ jl.au Ap Britain san. fi. S co Eng. bot. 1107

ille w Iin jl.au Ap Sicily 1819. S co

Gramince. Sp. 10-110.

Illik $\mathrm{W} \quad 4$ jn.jl Ap England san. fi. S s.l Eng. bot. 951

* $\triangle$ w 2 jl.au Ap N. Holl. 1806. S s.1

sal. m. S $1 \quad$ Eng. bot. 1261

$\Delta w^{\frac{1}{2}}$ jl.au Ap Britain me.pa. S 1 Eng. bot. 1671

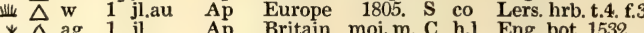

光 $\Delta$ w 1 $_{\frac{1}{2}} \mathrm{jl} \quad$ Ap $\quad$ Britain mar. S m.s Eng. bot. 1189

正 $\mathrm{O}$ w 1 jn.jl Ap S. Europe 1800. S co

$\Delta \mathrm{w}$ 光 jn.jl Ap Britain woods $\mathrm{S}$ m.s Lers. hrb. t.4. f.3

$2^{2} \mathrm{jl}$ Ap Britain dit. S co

Graminea. Sp. 5-16.

业业 $\Delta$ ag 2 jn.jl Ap N. Amer. 1786. S co Fras. mo. cu. ic.

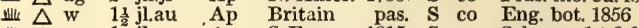

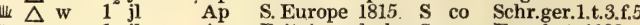

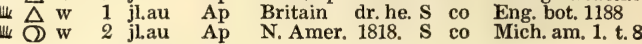

Graminea. Sp. 1.

业 $\Delta \mathrm{cu} \quad \frac{1}{2} \mathrm{jn} . \mathrm{jl}$ Ap $\quad$...... 1822. S co Hor. ber. $t .7$

Graminea. Sp. 2-10.

齿 $\mathrm{O}$ cu 2 au.o Ap India 1773. S co Slo.jam.1.t.73.f.1

$\frac{1}{2}$ au.s Ap E. Indies 1801. S co Jacq. ic. rar. t.16

Graminea. Sp. 1-6.

业 $\bigcirc$ w 1 jn Ap Spain 1820. S co Cav.ic. t.44. f. 1

Graminece. Sp. 2 .

亚 $\Delta$ w 1 jn.s Ap America 1780 S 1p

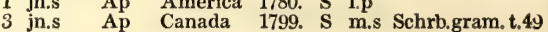

Graminea. Sp. 1-2.

业业 $\triangle$ w 2 jn.jl Ap Britain seaco. S \& Eng. bot. 520

\section{Graminece. Sp. 2-8.}

Graminea. Sp. 2-8.
$\mathrm{au}$ Ap

$\frac{1}{8}$ au Ap S. Europe 1783. S co Host. gra.1.t. 30

Graminea. Sp. 8-21.

亗 $\Delta$ w 1 jl Ap England sal. m. S m.s Eng. bot. 1249

業 $\Delta$ ag 2 my Ap Britain mea. S h.l Eng. bot. 759

此 $\Delta{ }^{\frac{1}{2}}$ my.jn Ap Scotland sc. mo. S s.1 Eng. bot. 1126

业 $\mathrm{O}$ w $1 \frac{1}{2}$ jl.au Ap Britain ro. sid. S s.1 Eng. bot. 848

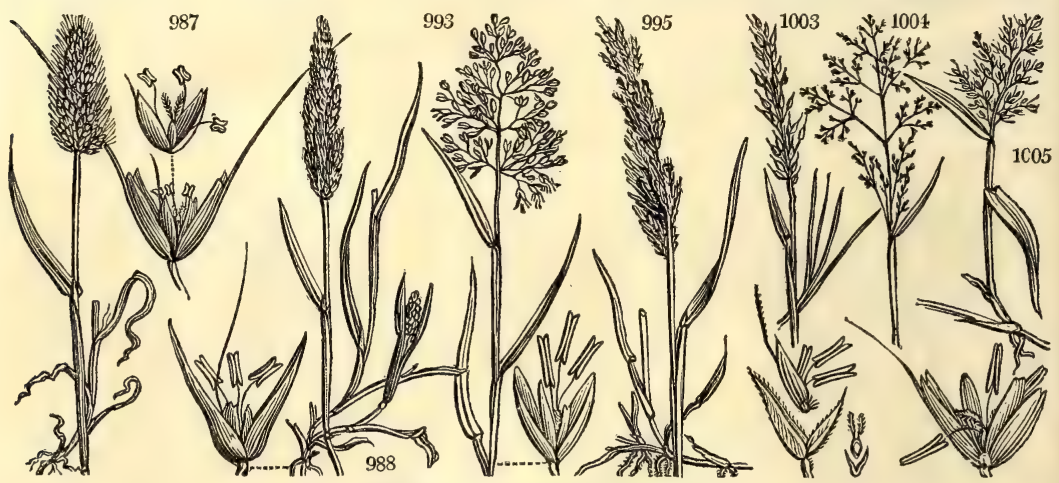

History, Use, Propagation, Culture,

154. Polypogon. Named by M. Desfontaines from $\pi 0 \lambda v$, much, and $\pi \omega \gamma \omega v$, beard, in allusion to its bearded heads.

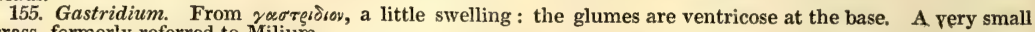
grass, formerly referred to Milium.

156. Agrostis. Derived from áreos, a field. Agrostis was the name given by the Greeks to all grasses. Of this genus the most remarkable species is the A. stolonifera or fiorin, so much recommended by Dr. Richardson; but respecting which the opinion of practical men is still unsettled, and, on the whole, rather unfavorable than otherwise. It seems to suit the climate and soil of Ireland, and to be more productive and nutritive there than any where else. In the account of the Woburn experiments on grasses, it is observed of fiorin, tbat it appears to possess " merits well worthy of attention, though, perhaps, not so great as has' been supposed, if the natural place of its growth and habits be impartially taken into the account." It is called squitch, quick, \&c. like the common couch-grass, from the length of time it retains its vital power. Like other plants, which propagate themselves abundantly by extension of their parts, it rarely bears seeds, and is therefore propagated by cuttings of the stems laid along drills an inch deep, and slightly covered with soil. A. vulgaris, which in dry arable land is called the black quitch, is the most common and earliest of the bents, but inferior to several in produce, and the quantity of nutritive matter it affords. The bents are generally rejected by the agriculturist on account of their lateness of flowering; but this circumstance, as Sinclair observes (Davy's Agr. Chem. App. Ixxv.) does not always imply a proportional lateness of foliage. A. vulgaris is in leaf by the middle of April. A. stolonifera is two weeks later, and A. nivea, and repens, three weeks later. In the south of France and Italy, the poor people collect the stolons of different species of agrostis by the roadsides and hedges, and cxpose them for sale in the market places in small bundles, as food for horses. 
987 Panicle contracted, somewhat spiked, Glumes somewhat pubescent with a smooth edge

988 Panicle spiked ventricose at base, Glumes acuminate shining, Flowers bearded

989 Flowers beardless

990 Panicle whorled spreading, Beard very long below the end of the outer paleæ (Apera P. de B.)

991 Panicle much spreading, Beard bent inwards, Paleæ hairy, Culm ascending branched at the base

992 Glumes linear-lanc. bearded, Paleæ nakèd, Beard nearly term. straight, Culm decumbent (Vilfa P. de B.) 993 Branches of pan. smoothish, Branchlets at the time of flow. divar. Ligula very short trunc. (Vilfa P. de B.) 994 Branches of pan. hispid, Fl. purple, Branchlets much spreading rather lax, Ligula oblong (Vilfa P. de B. 995 Pan. contracted, Culm branched creeping, Flowers clustered, Glumes equal lanc. pubesc. (Vilfa P. de B.) 996 Branches of pan. hispid, Fl. white, Branchl. much spreading rather lax, Ligula oblong (Vilfa P. de B.) 997 Whorls of the pan. approxim. closely covered all over with flowers, Florets beardless (Vilfa P. de B.) 998 Panicle contracted beardless, Glumes equal, Flowers viviparous (Vilfa P. de B.)

999 Beard term. curved, Hairs longer than paleæ, Panicle diffused, Glumes acumin. (Achnatherum P. de B.)

1000 Pan. very branching, Branches trichot. much sprdg. hispid, Glumes acute, Paleæ beardless, Stem decumb. 1001 Branches of panicle di-trichotomous roughish, Glumes acute, Leaves of stem wider than those of root 1002 Branches of panicle nearly 3-chotomous roughish, Glumes acuminate, Paleæ with two short beards at end 1003 Glumes lanceolate, Paleæ with a jointed beard at their base, Radical leaves setaceous 1004 Culms erect, Leaves narrow short, Sheaths roughish, Panicle very capillary and loose

1005 A little agrostis-like plant. The only species

1006 Panicle contracted beardless, Racemes lateral erect alternate

1007 Pan. elong. contr. nearly spiked, Florets beardless, Glumes uneq. twice as short as paleæ which are uneq.

1008 Panicle spreading, with a setaceous involucre, Florets beardless

1009 Panicle contracted beardless, Flowers acuminate often monandrous, Leaves flat rough 1010 Panicle much branched oblong close, Branches erect, Paleæ beardletted, Ligula torn

1011 Panicle spiked, Glumes acute, Hairs 3 times as short as paleæ, Leaves involute

1012 Stems branched compressed, Panicle spiked hemisphærical surrounded by a leafy involucre, Diandrous 1013 Stems branched compressed, Panicle spiked oblong sheathed at base, Triandrous

1014 Stem erect, Spike very simple attenuated, Glumes distinct villous, Root bulbous

1015 Stem erect smooth, Pan. subspiked cylindrical obtuse thick, Glumes fringed connate below the middle

1016 Stem erect smooth, Spike ovate, Glumes villous bearded nearly as long as the beard of the paleæe

1017 Stcin generally erect roughish upwards, Panicle spiked cylind. acute, Glumes connate below the middle

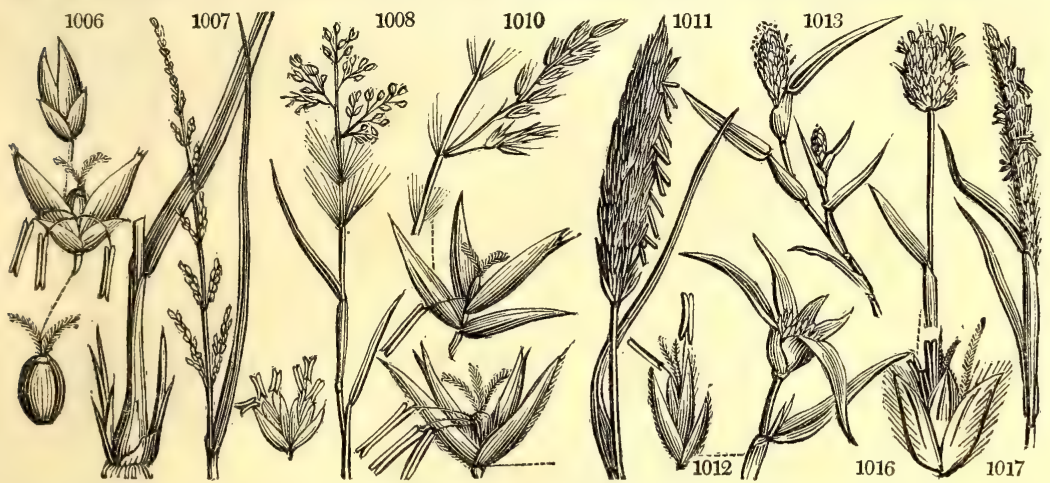

and Miscellaneous Particulars.

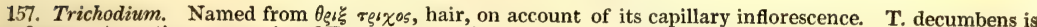
the famous Agrostis cornucopiæ of Frazer, respecting which so much was said some years ago; but which upon trial did not prove so valuable an agricultural grass as it was represented to be.

158. Tristegis. From $\tau \rho \varepsilon s$, three, and $s^{\prime} \varepsilon \eta \eta$, a covering, on account of the three glumes or valves of the calyx.

159. Sporobolus. From $\sigma$ rogos, a seed, and $\beta \alpha \lambda \lambda \omega$, to cast forth. Its grains are loose, and easily fall out of their husks.

160. Airopsis. A word formed by M. Desvaux, from Aira, and $\circ \% \iota$, like. The genus resembles Aira in appearance.

161. Cinna. An ancient name used by Dioscorides, who ascribes heating and stimulating qualities to this grass when eaten by cattle, whence the name (from $\approx \varepsilon \omega$, , to heat). Linnæus applied it to this genus of American grasses.

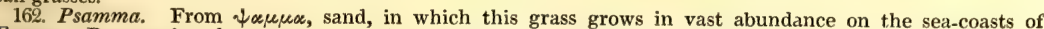
Europe. P. arenarium has a strong creeping perennial root with many tubers at the joints, the size of a pea. It is planted and encouraged on the coast of Norfolk to aid in fixing the sand against the action of the wind and tides, which it effects in a surprising manner. The marrum, as it is called, is considered of so much importance that there are severe laws to prohibit its being destroyed. Mats are made of it, and it is used as thatch.

163. Crypsis. From z the leaves.

164. Alopecurus. A $\lambda \omega \pi \eta \xi$, a fox, and $\boldsymbol{\varepsilon} \propto$, a tail : fox-tail. A. pratensis is one of the best of meadow-grasses, possessing the three great requisites of quantity, quality, and earliness, in a superior degree to any other. It is 
1018 geniculátus $W$. 1019 fúlvus $E$. $B$.

1020 utriculátus Pers.

1021 nigricans Horn.

165. PHLE'UM. $W$.

1022 praténse $W$.

1023 alpinum $W$.

1024 nodósum $\dot{W}$

1025 felínum $\mathrm{Sm}$.

1026 Michélii W.en.

floating

$\stackrel{*}{*} \mathrm{w}$

orange-spiked 娄 $\Delta$ w 1 my.au Ap

bladdered ill $\mathrm{O}$ w 1 jl.au Ap

blackish 制 $\triangle W$

Cat's-TaIl-Grass. Graminece.

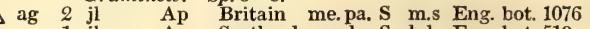

Alpine $\quad$ 㫜 $\triangle$ w 1 jl Ap Scotland sc. alp. S h.l Eng. bot. 519

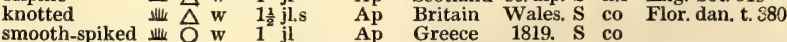

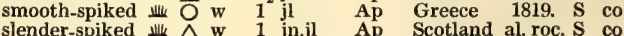

slender-spiked 制 $\Delta$ w 1 jn.jl Ap Scotland al. roc. S co Eng. bot. 2265

166. ACHNODON'TON. P. de B. Achnodonton. Graminea. Sp. 2.

1027 Bellárdi $P$. de $B$. bulbous $\quad$ 輊 $\triangle$ w $\frac{1}{2}$ jn.jl Ap Spain 1798. S co

1028 ténue $R . \& S$. slender 进 $\mathrm{O}$ w $1^{\frac{1}{2}}$ jn.jl Ap Mesopota.1804. S co Barr. ic. t.14. f.1

167. CHIlochlo'A. $\boldsymbol{P}$, de $\boldsymbol{B}$. Снilochlos. Graminea, Sp.3-6.

1029 Bœhméri Schr. Phalaris-like

1030 arenária $\mathrm{Sch}$. Phalaris E. B.

1031 áspera Schr.

Phleum paniculatum $\mathbf{E}$ B.

168. PHA'LARIS. W. en. Canary-grass

1032 arundinácea $P$ S reed like

1033 canariénsis $W$. . common

1034 aquática $W$. water

1035 capénsis $W$.

1036 cæruléscens Desf. blue

1037 paradóxa $W$. bristle-spiked

1038 seminéutra $R$.\& $S$. half-barren

1039 bulbósa $W$

half-bar

bulbous

制 $\mathrm{O}$

$\frac{1}{2}$ jl.au Ap

England sea co. S co Eng. bot. 222

silli $\mathrm{O}$ w 1 jl.au Ap

England hea. S co Eng. bot. 1077

Graminea. Sp. 8-23.

此 $\triangle w^{4}$ jl Ap Britain dit. S co Eng. bot. 402

些 $\bigcirc$ ag 2 jn.au Ap Britain unc.pl. S r.m Eng. bot. 1310

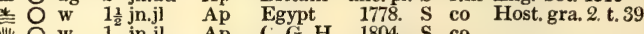

IIII O W 1 jn.jl Ap C. G. H. 1804. S co

Ill O w 1 jn.jl Ap Spain 1818. S s.l Buxb.cent.4.t.53

业 $\mathrm{O}$ w $\frac{1}{2} \mathrm{jnjl}$ Ap Levant 1687. S co Host. gra.2. t.40

业 $\triangle$ w $2^{\frac{1}{2}}$ jn jl Ap Hungary 1813. S co

此 $\triangle$ w 1 jn.jl Ap Spain 1798. S co Cav. ic. 1.t. 64

CORYNE'PHORUS, $P$. de $B$. Club-grass. Aira E B.

170. AI'RA. $W$.

1041 aquática $W$.

1042 cæspitósa $W$

1043 lævigáta $L$. T.

1044 truncáta $W$.

1045 média Gouan.

1046 pulchélla $W$

1047 flexuósa $W$.

1048 caryophýllea $W$

171. AVE'NA. P. $S$.

1049 brévis $W$.

1050 orientális $W$.

\section{Hair-grass.}

water

turfy

Graminea. Sp. 1-2

$\frac{1}{2}$ jl.au Ap England san.sh. S s.l Eng. bot. 1190

Graminea. Sp. 8-25.

$1 \frac{1}{2}$ my.jn Ap Britain pools. S m.s Eng. bot. 1557

3 au Ap Britain m.s.p. S m.s Eng. bot. 1453

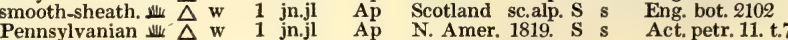

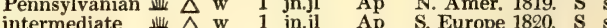

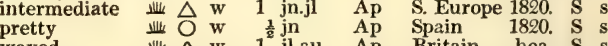

pretty 制 $\mathrm{O}$ w

waved 此 $\Delta$ w

1 jl.au Ap Britain hea. S s.1 Eng. bot. 1519

$\frac{1}{4} \mathrm{jl}$ Ap Britain sa.pas. S s.1 Eng. bot. 812

Graminea. Sp. $9-34$

OAT-GRASS.

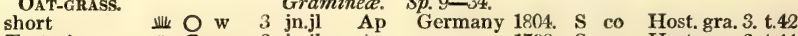

Tartarian $\quad$ 业 $O$ ag $S$ jn.jl Ap ...... 1798. S co Host.gra.3. t.44

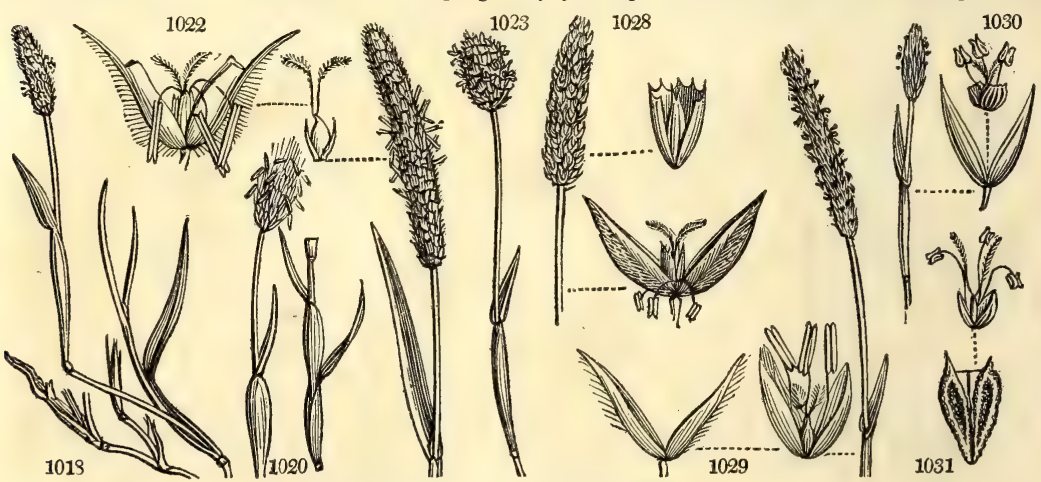

History, Use, Propagation, Culture,

often fit for the scythe by the middle of May; it flowers twice a-year, and gives more bulk and weight of hay than any other grass. At Woburn the produce was nearly three-fourths greater from a clayey loam than from a sandy soil, and the grass from the latter was of comparatively less value in the proportion of four to six. What is almost peculiar to this grass, Poa pratensis and Anthoxanthum odoratum, the value of the grass of the latter math considerably exceeds that of the crop at the time of first flowering. A. geniculatus, and most of the other species of this genus (A. agrestis excepted) are valuable grasses both for hay and pasture.

165. Phleum. We have no information as to what the $\varphi \lambda \varepsilon 05$ of the Greeks was. The name being unoccupied has been applied by Linnæus to this plant. Some think the plant of the ancients was our Typha. $\mathbf{P}$. pratense, the timothy-grass (so named from Timothy Hanson, who brought it from New York and Carolina about 1780), varies much in size according to soil and situation, and the root becomes bulbous in very dry grounds. Opinions are different as to its merits. Dr. Walker (Rural Econ. Hebrides, ii. 27.) thinks it may be introduced into the Highlands with good effect. W. Salisbury says, it is coarse and late. At Woburn, its "comparative merits were considered very great. It produces abundance of fine foliage early in spring, which, as it flowers late, may be cropped till an advanced period of the season without injury to the crop of hay." Unlike the Alopecurus pratensis, the value of the grass as hay when the seed is ripe is to that when it is in flower as 10 to 23. P. nodosum has gibbous joints, which might have been expected to be sugary like those of Fiorin, which, however, is not the case, as Sir H. Davy found them to be less nutritive than those of P. pratense, in the proportion of 8 to 28 .

166. Achnodonton. From $\chi_{\chi \eta}$, a chaff or husk, and $\delta 8 s$, a tooth, in allusion to the toothed paleæ or inner valves of the flower.

167. Chilochloa. A genus formed by M. de Beauvois, to contain certain grasses referable to both Phalaris

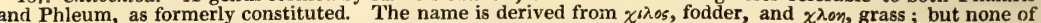
the species are remarkable for their qualities as grasses useful in husbandry. 
1018 Stem ascending knee-jointed, Panicle spiked cylindrical obtuse, Glumes connate at base obtuse 1019 Stem ascending knee-jointed, Spike compound cylindrical, Glumes obtuse fringed, Anthers orange col, 1020 Stem ascend. Raceme spiked ov. Glumes with a hairy keel beyond the mid. dilated, Upper sheath inflated 1021 Stem erect, Pan. spiked cylind, atten. at base, Glumes vill. fringed, Beards of paleæ twice as long as glumes

1022 Raceme spiked cylindrical, Glumes truncate mucronate with a fringed keel, Beard shorter than glume 1023 Raceme spiked ovate oblong, Glumes truncate mucronate with a fringed keel, Beard as long as glume

1024 Like P. pratense, but stems lower, Raceme shorter, Root knotty. A mere variety

1025 Spike ovate, Beard longer than glume divaricate angular rough, Root fibrous

1026 Panicle hairy spiked cylindrical, Glumes lanceolate acuminate with a fringed keel

1027 Glumes keeled smooth membranous at edge

1028 Outer glume a little prickly at the back

1029 Panicle spiked cylindrical smooth, Glumes lanceolate mucronate obtuse roughish

1030 Panicle spiked oblong ovate, Glumes lanceolate acute with a fringed keel, Stems ascending

1031 Panicle spiked cylindrical, Glumes wedge-shaped mucronate rough

1032 Panicle spreading heaped, Outer paleæ pencilform, inner shining

1033 Panicle spiked ovate, Glumes navicular entire at the end, Outer paleæ 2

1034 Panicle spiked oblong ovate, Glumes navicular toothed at end, Outer palea 1

1035 Panicle spiked oblong, Glumes navicular nearly entire, Outer palea 1, Stem knee-jointed

1036 Stem naked upwards, Spike slender lax, Glumes keeled acute

1037 Pan. spiked cylindrical, Intermediate floret hermaphrodite acuminate, the rest imperfect bitten off

1038 Panicle diffuse, Glumes acute shorter than florets, One floret hermaphrodite, one neuter

1039 Panicle beardless cylindrical spiked, Paleæ 2 smooth, Root bulbous

1040 Pan. spreading afterwards contracted, Florets less than glume, Beard clavate less than glume

1041 Pan. diffuse, Glumes obtuse, Florets longer than glumes (Catabrosa P. de B.)

1042 Panicle diffuse, Florets as long as glumes, Beard straight short, Leaves flat (Deschampsia P. de B.)

1043 Pan, contr. Glumes bearded villous at base, Rachis smooth very short, Leaves flat (Deschampsia P. de B.)

1044 Beardless, Panicle lanceolate lax erect, One floret stalked the other sessile, Leaves pubescent

1045 Leaves bristly, Stem naked, Panicle lax, Florets hairy at base, Beard nearly terminal shorter

1046 Pan. divar. Branches trichot. Flor. 3-f. larger than glumes, Beard jointed longer than glumes, Leaves set.

1047 Bearded, Pan. spreading trichot. Pedunc. wavy, Florets scarcely longer than glume, Leaves setaceous

1048 Bearded, Pan. trichot. divar. Florets less than glume, Beard dorsal jointed longer than glume

1049 Pan. one-sided, Spikelets short 2-flowered, Florets as long as glume obtuse 2-toothed at end, Root fibrous 1050 Pan. 1-sided contracted, Spikelets 2-fl. less than glumes, One floret beardless, Root fibrous

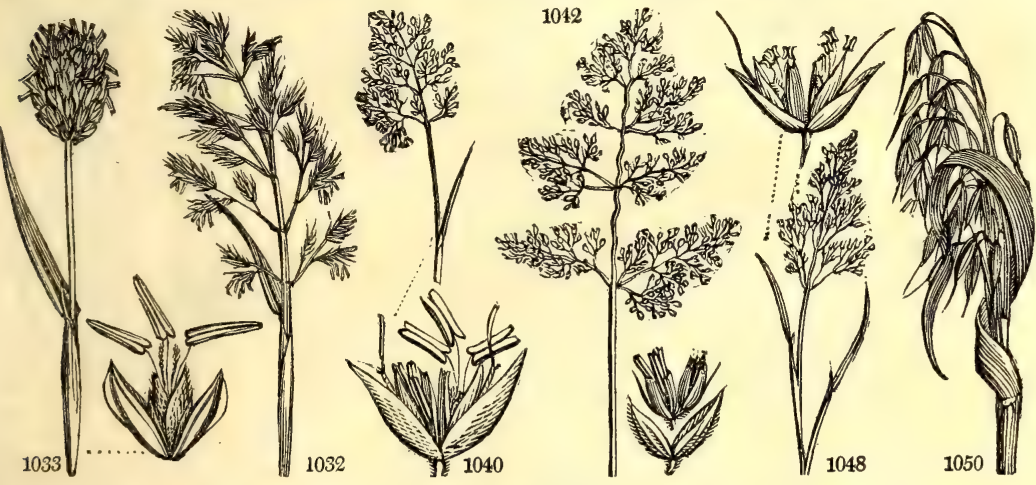

and Miscellaneous Particulars.

168. Phalaris. An ancient name said to have arisen out of $\varphi \propto \lambda_{0}$, brilliant, because the plant had shining grains. P. canariensis is cultivated for the seeds, which are given to singing birds, and more especially the canary. It requires a loamy soil, well manured, clean, and in good tilth. The grain is sown in February, in drills, six inches apart, and the plants are thinned to two inches distance in the rows. The growth of canary grass is slower than that of the common weeds, with which it is in consequence liable to be overrun, if they are not kept under by hoeing and hand-weeding. The culture of this grass is chiefly carried on in the isle of Thanet, where the chaff is esteemed as a horse food; but the straw being short, it produces little fodder or manure.

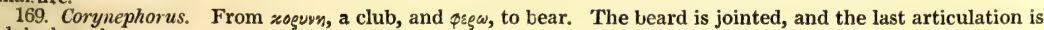
club-shaped.

170. Aira, is the name applied by the Greeks to the Lolium of the Romans, our Lolium temulentum. It signifies "something deadly," in allusion to the dangerous effects of that plant; but the name has no reference to any species of the genus to which it has been applied by Linnaus. A. aquatica is relished by cattle, and water-fowl are fond of the young shoots and seeds. It is introduced in decoys, by throwing plants in the water with a weight tied to them. A. cæspitosa is common in marsh-meadows, and occasions those excrescences called tussocks or hassocks which interrupt the progress of the scythe. Though cows eat the grass, horses will not. The stiff erect stalks frequently bear viviparous flowers.

171. Avena. A name of obscure origin. De Théis thinks it has been derived from the Celtic word aten, which comes from etan, to eat; and whence our common word ait, oat, has been obtained. A. sativa is the common cultivated oat, and A. nuda and tartarica are also sometimes cultivated. Of the first species there are numerous varieties, some more permanent, as the white and black; others temporary, as the potatoe oat, Angus nat, \&c. No botanist has been able to ascertain satisfactorily the native place of this or any other of our cultivated grains. A. fatua is accounted a distinct species; but some think the naked, tartarian, common, 
1051 sativa $W$.

1052 núda $W$

1053 fátua $W$.

1054 stérilis $W$

1055 praténsis $W$

1056 præ'cox $P$. de $B$. Aira E. B.

1057 hirsúta Roth.

172. TRISE'TUM. P.S.

1058 striátum $P$.S.

1060 flavéscens $R . \& S$ Avéna E. B.

1061 pensylvánic. $P$. de B. Pennsylvanian

1062 pubéscens $R$ \& $S$. Pennsylva Avena E. B.

1063 planicúlme Avena E. B.

Stichophyllum $S c$. fan-leaved

1065 airoídes $P$. de $B$. Aira-like

173. DANTHO'NiA. $P$. de B. Danthonia.

1066 strigósa $P$. de $B$. meagre Avena E. B.

174. GAUDI'NIA. $P$. de B. Gaudinia.

1067 frágilis $P$. de $B$. brittle

175. ARUN'DO. With. REED.

1068 epigéjos $W$

1069 stricta $E$. $\dot{B}$.

1070 sylvática Schr

1071 Dónax $W$.

$\beta$ versicolor

1072 phragmites $W$.

REED

wood

wild

cultivated

striped

common

176. CHRYSU'RUS. $P . S$. Chrysurus. 1073 aúreus $\boldsymbol{P}$. de $\boldsymbol{B}$. golden-spiked 1074 echinátus $P$. de $B$. rough

177. SESLE'RIA. $P$. $d e B$. Sesleria 1075 elongáta Host. long-spiked

1076 cærúlea Schr. Cynosurus E. B.

1077 tenélla blue

weak

1078 sphærocéphala Ard. round-headed

\begin{tabular}{|c|c|c|}
\hline & ag & 3 jn.jl \\
\hline & ag & 2 jn.jl \\
\hline tille & w & $4 \mathrm{au}$ \\
\hline 业 & $\mathrm{cu}$ & 4 jl.au \\
\hline 业步 & ag & 1 jn.jl \\
\hline 齿保 & w & $\frac{2}{2} \mathrm{my} \cdot \mathrm{jn}$ \\
\hline
\end{tabular}

Graminea.

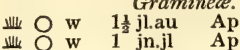

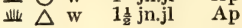

$6 \mathrm{jl} \quad \mathrm{Ap}$

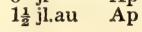

$1 \frac{1}{2}$ jn.s

$1 \frac{1}{2}$ jn.s

$\frac{1}{2}$ jn.jl

Gramir

3 jn.jl
... S r.m Host. gra. 2. t. 59

... S r.m Host. gra. 3. t. 43

ritain cor fi S co Host gra 2, t. 58

Barbary 1640. S co Host.gra. 2.t.57

Barbary 1640. S co Host. gra. 2.t. 57
Britain me.pa. S

Britain hea. S co Eng. bot. 1296

Barbary 1798. S co

Sp. 8-30.

S. Europe 1804. S co Lrs. herb. t.9. f.3

Spain 1770. S co Cav.ic.1.t.45.f.1

Britain $\quad \ldots$ S co Eng. bot. 952

N. Amer. 1785. S co

Britain ch. pa. D s.1 Eng. bot. 1640

Britain sc.alp. D co Eng. bot. 2141

Ap Switzerl. 1796. D co Host. gra. 2. t.53

Ap Switzerl 1800. S co Host. gra 2 t. 45 p. $1-15$.

Graminea. Sp.1.

业 $\Delta \mathrm{w} 1 \frac{1}{2} \mathrm{jn}$.au Ap Spain 1778. D co Host.gra. 2.t. 54 Graminea. Sp. 5-33.

址 $\triangle$ w 2 jl Ap Britain moi.w, S m.s Eng bot. 403

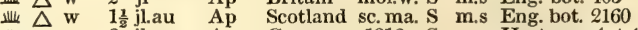

此 $\triangle$ w 3 jl.au Ap Germany 1813. S m.s Host. gra.4. t.49

此 $\triangle$ ec 10 jl.au Ap S. Europe 1648. S co Host. gra. 4. t.38

此 $\triangle$ or 3 jl.au Ap S. Europe 1648. S co Mor. h.3.t.8.f.9

此 $\triangle$ ec 6 jl.s Ap Britain dit. S m.s Eng. bot. 401

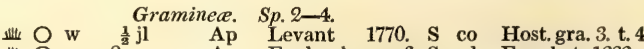

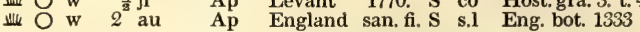

Graminea. Sp. 4-11.

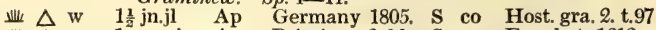
此 $\triangle$ w 1 my.jn Ap Britain fields. S co Eng. bot. 1613

址 $\triangle$ pr $\frac{x}{2}$ ap.my Ap Switzerl. 1819. S co Host. gra2.t.100 Switzerl. 1819. S co Host. gra.2.t.100
Switzerl. 1819. S co Host. gra. 2. t.99
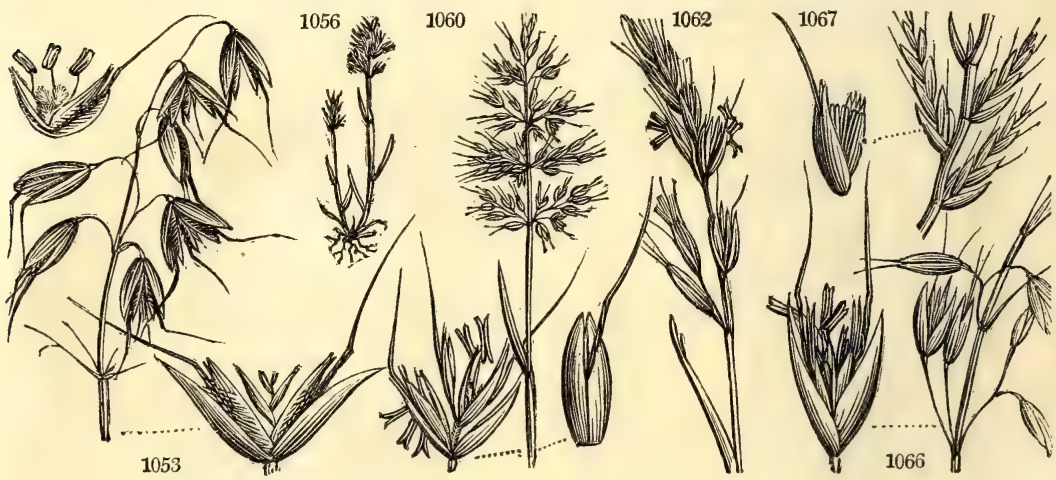

History, Use, Propagation, Culture,

and wild oat originally the same. The wild oat is remarkable for the length of time the grain will lie in the soil, and retain its vegetative powers; its awns are sometimes used as hygrometers, and its seeds as artificial flies in fishing. Where it abounds naturally it is an inveterate weed.

The oat, in an agricultural point of view, is a grain only calculated for cold climates. In Italy and France, and even in the southern counties of England, the ears are small and husky, and afford little meal ; the panicle is open, and the foot-stalks of the ears small ; and in July and August the heat dries them up, and obstructs the progress of the sap to the grain. On the other hand, this naked airy panicle is better for drying after rains and dews than the close spikes of wheat and barley, which, while they serve to guard the ears from the extremes of heat in warm climates, are apt to rot or become mouldy (covered with fungi) in cold moist countries or seaof heat in warm climates, are apt to rot or become mouldy (covered with fungi) in cold moist countries or sea-
sons. The grain of the oat, though chiefly used as food for horses, is also more or less a bread corn in every country where it is generally cultivated. Fourteen pounds of grain yield eight pounds of meal; in some places, as Yorkshire and Aberdeenshire, this meal is ground nearly as fine as flour; in others, as at Edinburgh, it is made of a coarser quality. The kernel freed from the husk, and entire, is used for gruels, and forms an article of commerce with Embden, Bremen, and some towns where the grains are grown to a large size on the variety known as the Friesland oat. The fine powder which is produced by the operation of husking the corn, or making grist, forms a jelly, the sowins of the Scotch, and frumerty of the Irish, an agreeable and wholesome food. Water-gruel from a coarse oatmeal, is esteemed a cooling laxative drink.

A. nuda, the naked, or hill-oat, or peel-corn, when ripe drops the grains from the husks. It was generally cultivated in Worlige's time " in the north of England, Scotland, and Wales, because the kernel threshes clean out of the husk, and need not be carried to the mill to be made into meal or grist." It was made into meal by the lower classes, by drying on the hearth, and bruising in a stone mortar, as still practised in the Highlands of Scotland, in Lapland, Ceylon, China, and in every country under certain circumstances of civilization. In the low country of Scotland, the quern mills, as they were called, now no longer in use, may be seen neglected or dilapidated, by the doors or about the gardens of cottages and villages, where they were formerly in use.

Avena sterilis is sometimes grown as an object of curiosity, under the name of the animal oat, on account of its singular hygrometrical properties. After the seeds have fallen off, their strong beard is so sensible of alter- 
1051 Pan, equal, Spikelets 2-fl. Florets smaller than glumes at the base naked 1-bearded, Root fibrous 1052 Pan. equal, Spikelets 3-f. longer than glumes, Florets naked at base, Root fibrous

1053 Pan. equal, Spikelets 3-fl. Florets less than glumes, hairy at base, all bearded, Root fibrous [fibrous 1054 Pan. 1-sid. Spikel. 5-fl. Florets less than glumes lower bearded and hairy upper beardless and smooth, Root 1056 Pan. sub-spiked, Florets nearly equal to the glume, Beard jointed longer than glume, Leaves setaceous

1057 Pan. spread. Glumes 3-fl. Florets linear 2-bearded at end very hairy below the middle, Beard dorsal jointed

1058 Pan. equal, Spikelets about 3-fl. Florets longer than the glume the lower with a beard under the end 1059 Pan. contracted 1-sided, Spikelets 2-fl. Outer glume bifid 2-bearded, Dorsal beard reflexed

1060 Pan. lax, Outer glume bifid, Spikelets 3-fl. Ligula truncate obsolete, Lower sheaths pubesc. Root creeping

1061 Pan. slender, Glumes 2-fl. Seeds villous, Beard twice as long as glume

1062 Pan. sub-spik. equal, Spikelets about 3-fl. Florets longer than cal. hairy at base, Lvs. pubesc. Rootcreeping

1063 Pan, erect nearly simp. Glumes about 5-fl. Recept. bearded at end, Leaves serrulate naked, Sheaths rough

1064 Pan. equal, Spikel. 3-fl. Flor. as long as glume, Lvs. distichous smth. Mouth of sheaths hairy, Root creeping 1065 Panicle nearly spiked, Beard at length reflexed longer than glume

1066 Panicle one-sided, Spikelets 3-flowered, Florets 3-bearded as long as glume, Root fibrous

1067 Spike jointed brittle 3 or 4 inches long, Leaves flat slightly hairy

1068 Pan. upright sprdg. Glumes acum. Dorsal beard straight shorter than the hairs which are as long as glume 1069 Pan. upright spreading, Glumes acute, Dorsal beard straight as long as palea which is longer than hairs 1070 Panicle spreading, Glumes acute, Hairs very short, Dorsal beard jointed longer than glume 1071 Glumes about 3-5-flowered, Florets as long as the glume, Stem woody at base (Donax. P. de B.)

1072 Glumes 5-flowered, Florets very little longer than glumes

1073 Stems erect, Sheaths very smooth, Ligulas large elongated, Panicle close many-flowered 1074 Pan. contr. ovate, Spikelets bearded, Leaves lanceolate, Bractes pinnate scarious with very long beards

1075 Raceme spiked cylindrical, Spikelets 3-flowered, Outer palea 3-5-bearded, Root stoloniferous 1076 Raceme spiked subovate oblong, Bractes entire, Spikelets 2-3-flow. Outer palea 3-5-bearded, Leaves flat

1077 Raceme spiked ovate nearly naked, Spikelets 2-flowered, Bractes toothletted, Outer palea 5-bearded 1078 Raceme in a round head, Outer palea with one beard, Leaves fine keeled

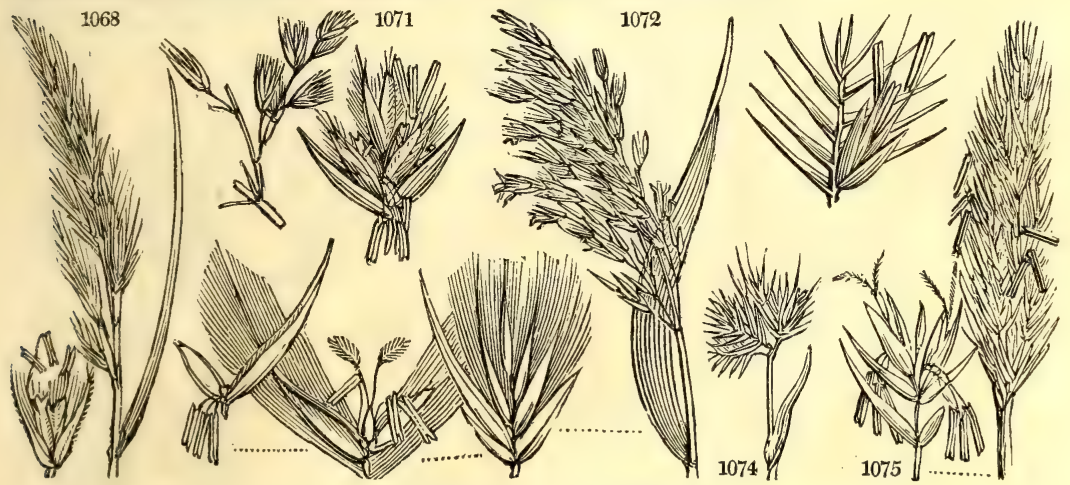

and Miscellaneous Particulars.

ation in the atmosphere as to keep them in an apparently spontaneous motion, when they resemble some grotesque insect crawling on the ground.

172. Trisetum. (Three bristles); on account of the three beards or awns of the flower. Trisetum pubescens, according to the Woburn experiments (vii.), possesses several good qualities, which recommend it to particular notice. It is hardy, early, and more productive than many others which affect similar soils and situations. It appears well calculated for permanent pasture on rich light soils. Trisetum flavescens is also a useful grass; but the most valuable as a grass is the Avena elatior, $L$ the Holcus avenaceus of Eng. Bot., which will be noticed hereafter in its proper place. (In Polygamia monœcia, under Arrhenatherum).

173. Danthonia. A genus containing some incongruous species of Avena, and named after M. Danthoine, a French botanist.

174. Gaudinia. Named in honor of M. Gaudin, a Swiss botanist, who paid great attention to the study of grasses, and who published an Agrostographia Helvetica in 1811, still a work of reputation.

175. Arundo. An ancient name of doubtful origin; perhaps, as a recent author conjectures, from $a r u$, the Celtic word for water. Phragmites is derived from 申e⿻ Rohr, Ger, and Canni di Giardini, Ital. is common in the south of France and Italy, where it is cultivated as fence-wood, for supporting the vine, for fishing-rods, and a great variety of purposes. In Spain and Portugal it forms an article of commerce, and supplies materials for the looms, fishing-rods, \&c. of this country. The striped-leaved variety (gardener's garters) used formerly to be a common inhabitant of gardens.

A. phragmites, Roseau de Marais, Fr. Gemeine Rohr, Ger.; and Canna palustre, Ital, is used for thatching, for protecting embankments or sea-dykes, for ceilings to cottages, verandahs, and rustic buildings; to lay across the frame of wood work as the foundation for plaister floors, and for screens and hot-bed covers in kitchen gardens. The panicles will dye wool green; and the roots, it is said, are good in liver complaints, like those of Triticum repens.

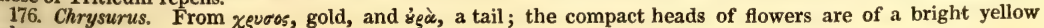
color.

177. Sesleria. A genus named by Scopoli, after Leonard Sesler, a physician and botanist, who contributed to 
178. CYNOSU'RUS. $P$. S. DOG'S-TAIL-Grass, 1079 cristátus $W$. 179. KOELE'RIA. $P . S$. Kogleria. 1080 cristáta $P$ S 1081 tubers $P$. S . cred 1082 pubéscens $\boldsymbol{P}$. de $B$. pubescent 1083 phleoídes $P$. S. cat's-tail 1084 hispida $D . C$. hispid 180. DAC'TYLIS. W.en. Cock's-Foot-Grass. 1085 glomerata $W$. 1086 hispánica W. en 1087 glaúca Rth. 1088 répens Desf. 1089 pátens $H$. $K$ 181. GLYCE'RIA. $\boldsymbol{R} . \boldsymbol{B r}$. Glyceria. 1090 fluitans $B . P$ 182. FESTU'CA. W 1091 tenćlla $P h$. 1092 ovina $W$. 1093 vivipara $\boldsymbol{E} . \boldsymbol{B}$. 1094 rúbra $W$. 1095 duriúscula $W$. 1096 amethýstina $W$ 1097 cæ'sia $E$. $B$. 1098 dumetórum $W$. 1099 calamária $E . B$. 1100 triflóra $E$. $B$. 1101 spadicea $W$. 1102 praténsis $\boldsymbol{E}, \boldsymbol{B}$. 1103 vagináta $W . e n$. 1104 mexicána Donn. 1105 pubéscens $W$. en 1106 flavéscens Bell. 1107 pannónica $W u l f$ 1108 decídua $E$. $B$. 1109 elátior $W$. 1110 diándra $\dot{P} h$. 1111 loliácea $W$. 1112 grandiflora $P h$. 1113 rúbens $P$. $S$. 1114 glaúca $P$. $S$. 1115 ciliáta $P . S$ 1115 ciliáta $P$. $S$.

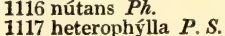
rough Spanish glaucous creeping floating Fescue-Grass. slender sheep's viviparous creeping creeping hard grey bushy reed-like three-flowered brown meadow sheathed Mexican downy yellowish Hungarian deciduous tall

diandrous spiked large-flowered Spanish glaucous glaucous nodding 此 $\triangle \mathrm{w} \quad 3^{\mathrm{j} n . \mathrm{j}}$
Graminea. Sp. 1-8.

2 au Ap Britain pas. S 8.l Eng. bot. 316

Graminee, $S p$.

址 $\Delta$ w 1 jn.au Ap Britain pas. S co Eng. bot. 648

业 $\triangle$ w 1 jl.au Ap Europe 1802. S co Lam. ill.t.45. f.4

1 jn.j1 Ap S. Europe 1800. S co Ger. prov. t. 1

1 jl.au Ap Portugal 1802. S co Desf. atl. 1. t. 23

$\frac{3}{4}$ jl.au Ap Mediterr. 1819. S co Savi, pis. t. 1.f.5

Graminece. Sp. 5 -19.

jn.jl Ap Britain mea. S h.l Eng. bot. 335

jn.jl Ap Spain 1814. S co

2 jn.jl Ap Saxony 1800. S co

$\frac{3}{4}$ jn.jl Ap Barbary 1821. S co Desf. atl 1. 15

Graminea. Sp. 1.

$\Delta$ w 11 my.au Ap Britain ponds. S m.s Eng. bot. 1520 Graminea. Sp. 27-65.

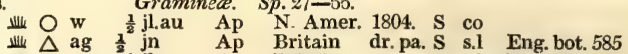
llik $\triangle$ ag $\frac{1}{2}$ jl Ap Britain sc. mo. S s.l Eng. bot. 1355 此 $\mathrm{W}$ 1 jl Ap Britain me pas h.l Eng bot 2056 Illik ag 1 jn Ap Britain me pa S s l Eng bot 470

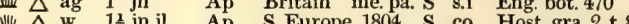

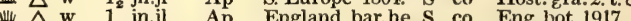
III $\Delta$ w 1 jn.jl Ap England bar.he. S co Eng. bot. 1917 Ap Europe ... S co Fl, dan, t. 700

3 jl.au Ap Scotland m.wo. S m.s Eng. bot. 1005

2 jlau Ap Britain woods. S m.s Eng bot. 1373

Italy 1775. S co Host gra 3 t 20

Britain me.pa. S h.l Eng. bot. 1592

Hungary 1804. S co

Mexico 1805. S co

Hungary 1822. S co

Savoy 1804. S co

Hungary 1804, S co Host gra, 4, t. 62

England m.wo. S m.s Eng bot. 2266

Britain m. me. S m.s Eng. bot. 1593

N. Amer. 1810. S co Mich. amer, t.10 England moi.p. S m.s Eng. bot. 1821

N. Amer. 1812. S co

S. Europe 1776. S co Fl. grac, t. 83

S. Europe $\ldots$ S co Lam.ill.1.t.46.f.3

Portugal 1802. S co Host. gra. 4. t.65

Ap Portugal 1802. S co

Ap N. Amer. 1805. S co

Ap France 1812. S co Vaill.par.t.19.f.6

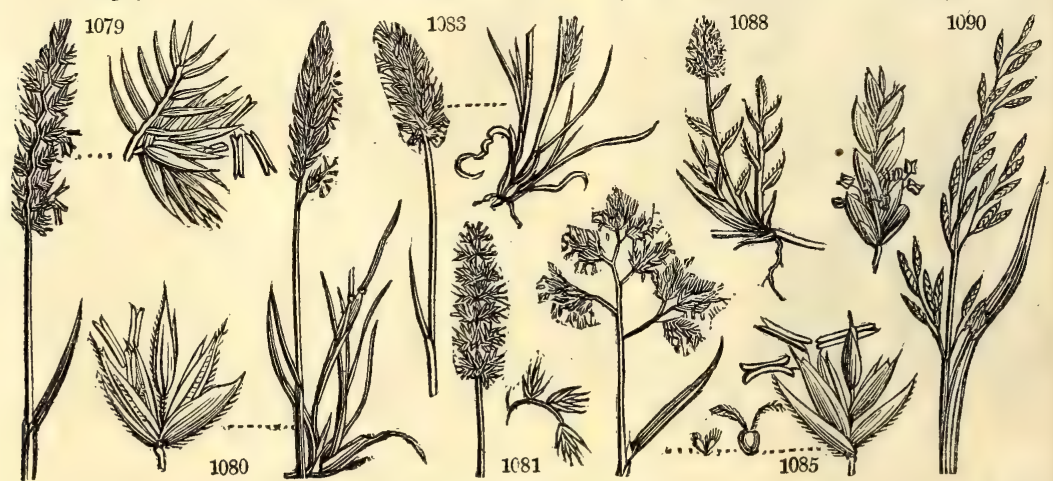

History, Use, Propagation, Culture,

Vitaliano Donati's Natural History of the Adriatic sea, published in 1750. The species were formerly part of Cynosurus.

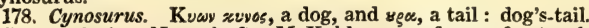

179. Koeleria. Named after M. Kohler, a professor of natural history at Mayence, and author of some works upon grasses. A pretty genus of grasses, with elegant silky heads.

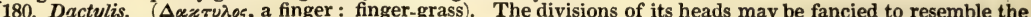
fingers, and the large cluster at the bottom the thumb of an animal. D glomerata is a coarse grass of early and rapid growth, and considered valuable as a pasture grass on light soils from the quantity of herbage it affords. It comes in from the time turnips are over, till the meadows are fit for grazing; but old and dry, or made into hay, neither horses nor cattle are fond of it. To reap the full benefit of this grass, it must be kept closely cropt. It has been of late strongly recommended by Mr. Coke of Holkham.

181. Glyceria. (From rivzus, sweet, in allusion to the herbage). This is the Festuca fluitans of $\mathrm{L}$. it is found in stagnant water, and its long narrow leaves float on the surface. Horses, cattle, and swine are fond of this grass, which produces abundance of seeds, which are eaten greedily by geese, ducks, and fish, especially the trout (Salmo fario). These seeds are very nourishing, and are collected in some parts of Germany and Poland, under the name of manna seeds, and used in soups and gruels. The plant will not thrive unless on land that is constantly under water.

182. Festuca. In Celtic, the word fest signifies pasture, food. We may be satisfied with this explanation in want of a better. This genus affords some valuable hay and pasture grasses, F ovina has a fine short sweet foliage, well adapted to the masticating organs of sheep, and for producing delicate mutton: it is totally unfit for hay, and according to Sir H. Davy's experiments, it does not possess the nutritive powers generally ascribed to it. It is an excellent grass for lawns, requiring little mowing, and forming so thick a turf as to suffer few intruding plants. It should be sown about the middle of August, on ground nicely prepared, open, and not too light or dry. The same remarks will apply to $\mathrm{F}$. rubra and amethystina. 
1079 Raceme spiked linear, Spikelets beardless, Bractes pinnatifid, Leaves linear

1080 Pan. spikeshaped at the base interrupted and smoothish, Spikelets 3-4-flow. nearly beardless very acute 1081 Pan. closely spiked, Spikel. 2-3-fl. acum. beardless, Glumes fringer at back, Lower leaves conv. setaceous 1082 Pan. spiked oval cylind. Spikelets 2 flowered villous at back acumin. Outer glume bearded under the end 1083 Panicle spiked cylind. Spikel. 2-5-8-flowered, Outer glume rough outside, with a soft beard under the end 1084 Panicle spiked ovate cylind. Spikelets 3-4-flowered, Outer glume hairy with a stiff' beard under the end

1085 Panicle one-sided heaped, Leaves keeled

1086 Panicle one-sided headed spiked, Spikelets 3-flowered, Leaves keeled glaucous

1087 Panicle equal before and after flowering contr. spiked, Spikelets 4-fl. beardless, Glumes with a rough kee 1088 Stem creeping, Branches in bundles, Leaves villous subulate stiff, Flowers in spiked one-sided heads 1089 Spikes scattered one-sided few, Flowers closely imbricated, Leaves much spreading, Stem decumbent

1090 The only species is a floating creeping plant very common in ponds

1091 Panicle simple one-sided, Spikelets about 9-flow. bearded, Leaves setaceous, Culm upwards 4-comered 1092 Panicle contracted, Spikelets ovate 4-flowered, Paleæ roundish, Leaves very narrow rough 1093 Panicle one-sided contracted, Florets compressed beardless pubescent, Leaves setaceous smooth 1094 Pan. one-sided erect spreading, Florets roundish longer than beard, Leaves pubes. above, Root creeping 1095 Panicle erect spreading, Florets longer than beard, Root fibrous

1096 Pan. sprdg. Spikel. obl. nearly beardl. Outer valve of glume and paleæ ciliated, Lvs. setac. rigid, Lig. 2-eared 1097 Glaucous, Pan. 1-sided contracted, Florets cylind. bearded, Stem square, Leaves compound channelled 1098 Panicle spike-shaped pubescent, Leaves filiform

1099 Panicle one-sided erect branching contracted, Fiorets oblong angular beardless, Leaves ensiform striated 1100 Panicle spreading, Spikelets 3-flowered with long beards

1101 Panicle erect, Spikelets ovate 4-5-flowered, Glumes acum. beardless, Leaves setaceous smooth pungent 1102 Panicle spreading branched, Spikelets linear beardless many-flowered, Leaves linear, Root fibrous

1103 Pan. sprdg. one-sided, Spikel. about 6-fl. Florets blunt beardless, Leaves lin. conv. glauc. Stem round erect 1104 Panicle spike-shaped, Spikelets slender 11-flowered bearded, Sheaths rough

1105 Culm ascending angular, Leaves rolled together smooth, Pan. nodding close, Spikelets 9-10-flow. pilose 1106 Pan. erect contracted, Spikelets 4-5-fl. rery smooth, Paleæ margined membranous, Leaves setaceous 1107 Pan. one-sided oblong, Spikel. 7-fl. bearded, Outer glume and paleæ fringed, Leaves setac. Root fibrous 1108 Panicle one-sided erect branching, Florets ternate oblong angular beardless, Leaves linear striated

1109 Pan. spreading much branched, Spikelets ovate lanc. somewhat bearded 4-5-fl. Leaves linear lanceolate

1110 Pan. close, Branches simple scattered, Spikelets linear 5-f. Flowers acum. 2-androus, Stem very rough

1111 Raceme spiked elongated, Spikelets remote beardless afterwards spreading, Root fibrous

1112 Panicle simple erect, Spikelets very few about 7-flowered, Florets acute distant

$1113 \mathrm{Par}_{\text {icle fascicled, Spikelets subsessile villous, Beard erect }}$

1114 Panicie one-sided spike-shaped, Spikelets 5-fl. smooth somewhat bearded, Leaves glaucous rigid subulate 1115 Culm ascending, Leaves subconvolute, Spike racemose, One glume very small, Outer paleæ fringed 1116 Panicle one-sided erect nodding at the end, Spikelets 5 -flowered obtuse beardless

1117 Panicle loose spreading nodding, Radical leaves very slender and long, Root creeping

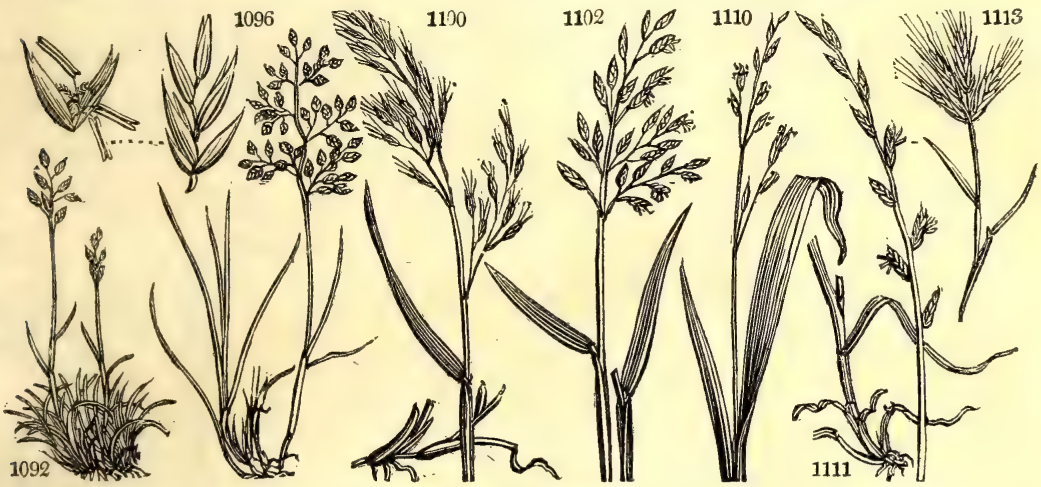

and Miscellaneous Particulars.

F. duriuscula, is a good grass either for hay or permanent pasture : hares are remarkably fond of it: its pro duce in the spring is not very great, but the quality is fine, and the quantity is considerable at the time of flowering. F. calamaria is subject to the disease in the grain called clavus, in which the seed swells to three times the usual size, and the kernel is wanting.

F. pratensis is one of the six grasses (Anthoxanthum odoratum, Alopecurus pratensis, Poa pratensis and trivialis, Cynosurus cristatus, and the F. pratensis) which Curtis recommends kefore all others for laying down meadows or pastures, on soil either moist or moderately dry. According to the Woburn experiments, the dalue advantage of cutting almost all grasses when in flower rather than later. W. Salisbury says, "if land intended for meadow could be laid down with one bushel of $F$. pratensis, one of Alopecurus pratensis, three pounds of Anthoxanthum, a little Bromus mollis, with white clover, the farmer ill seek no farther"

F. elatior differs little from F. pratensis, but in being larger in every respect. According to the Woburn extion of 8 to $6 . "$ " "the produce is nearly that of the former, and the nutritive powers superior in the propor-

F. loliacea greatly resembles the rye-grass in habit and place of growth: " it has excellencies which make it greatly superior to that grass, for the purposes either of hay or of permanent pasture. It improves in proportion to its age, which is directly the reverse of rye-grass." (Wob. exp. xxxiii.)

F. glauca, cut at the time of flowering, exceeds in value the same grass cut when the seeds are ripe in the proportion of 6 to 12, a strong proof of the value of the leaves and culm in grasses intended for the scythe, and the loss, as we have before observed, of leaving them for the sake of the seed when they become dry and wiry. After this grass, and indeed most others, are in flower, "the root leaves neither increase in number nor in size but a total suspension of increase appears in every part of the plant, the roots and seed-vessels excepted."
(Wob exper, xii.) 
183. MYGALU'RUS. $L k$, Mouse-TaiL.

1118 caudátus $L k$. Festuca Myurus E. B.

1119 bromoides $L k$. Festuca E. B.

1120 stipoídes $L k$. 1121 delicátulus $L k$.

$1122 \underset{\text { uniglumis }}{\text { Festuca E. B. }}$

184. BRO'MUS. $W$.

1123 secalínus $W$. 1125 móllis $W$.

1126 lanceolátus $W$

1127 squarrósus $W$.

1128 Alopecúrus $W$.

1129 púrgans $W$.

1130 inérmis $W$

1131 ásper $W$.

1132 praténsis $E . B$.

1133 stérilis $W$.

1134 arvénsis $E$. $B$.

1135 eréctus $E . B$.

1136 tectórum $W$.

1137 altíssimus $\boldsymbol{P h}$.

1138 racemósus $W$.

1139 máximus Roth.

1140 madriténsis $W$.

1141 gigantéus Sch

Festuca E. B. wall

barren 业 $O \mathrm{w}$

fine-leaved

fhe-leaved 业 $O \mathrm{w}$ delicate

\section{Brome-grass} smooth-rye

downy-rye

soft

spear-leaved

corn

Fox-tail

purging

awnless

hairy wood

meadow

barren

field

upright

nodding

tallest

smooth

great

wall

giant
Graminea. Sp. 5.

$\frac{1}{2} \mathrm{jn}$ Ap Britain ways. S co Eng. bot. 1412

$\frac{1}{2}$ my.jn Ap Britain walls. S co Eng. bot. 1411

1 jn.jl Ap Majorca 1793. S co Barr. ic.t.76. f.1

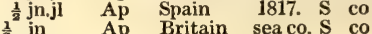

Ap Spain

Graminea. $\quad S p .19-66$.

2 in.au Ap England cor. fi. S co Eng. bot. 1171

2 jn.au Ap Britain ... S co Eng. bot. 1884

jn.au Ap Britain walls. S co Eng. bot. 1078

3 jn.au Ap Crimea 1798. S co

3 jn.au Ap England cor. fi. S co

2 jn.au Ap Barbary 1799. S co

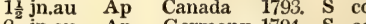

2 jn.au Ap Germany 1794. S co

4 jn.au Ap England m.s.p.S co

2 jn.au Ap $\quad$ England cor.fi. S co

3 jn.au Ap Britain cor.fi. S co

3 jn.au Ap England ch.pa. S co

1 jn.au Ap Europe 1776. S co

8 jn.au Ap N. Amer. 1812. S co

2 jn.au Ap

England me. S h.

Morocco 1804. S h.1 Desf. atl. 1.t. 26

Britain walls. S h.l Eng. bot. 1006

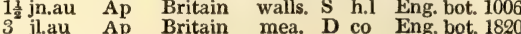

185. BRACHYPO'DIUM. P. de B. BRAchy Podium. Graminea. Sp.9-25.

1142 ciliátum $W$. ciliated 业 $\Delta w_{2} 2$ jn.au Ap Canada 1802, $S$

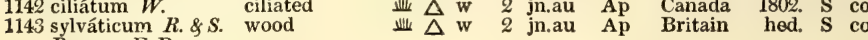
Bromus E. B.

1144 pinnátum $P$. de $B$. spiked heath Bromus E. B.

1145 distáchyon $R . \& S$. two-spiked

1146 tenéllum $W$. slender

1147 loliáceum $R$.\& $S$. Darnel-like Triticum E. B.

1148 unioloídes $L k$.

1150 unilaterále $R$ \& \&S. $\quad$ one-sided

Eng. bot. 729

业 $\Delta$ w 3 jn.au Ap

Britain hea. S co

Eng. bot. 730

进坚 $\triangle$ w 1 jn.au A

S. Europe 1772. S co

Host. gra. 1. t.20

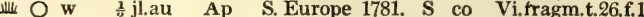

业 O W 1 jn.jl Ap Britain seaco. S co Eng.bot. 221

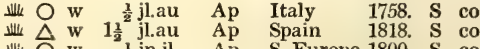

Jacq. ic. 2. t. 303

S. Europe 1800. S co

185. UNI'OLA. W.

1151 latifólia $P h$.

1152 paniculáta $P h$.

1153 spicáta $W$.

SEA-SIDE-OAT.

broad-leaved

panicled

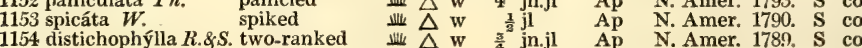

Graminea.

Graminea. Sp. $4-7$.
jn.jl Ap N. Amer. 1809. s co

187. TRICUS'PIS. $P$. de $B$. TRIcUspis 1155 quinquéfida $P$. de $B$. five-cleft 业业 $\Delta \mathrm{w} \quad \frac{\mathrm{s}^{2}}{4} \mathrm{jn} . \mathrm{jl}$

Ap N. Amer. 1789 , S co

Cates. car. 1. t.32

Graminea. Sp. 1-3.

188. DIPLACH'NE $P$. de B. DiplachNe. Graminea. Sp. 1-2.

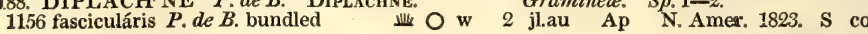

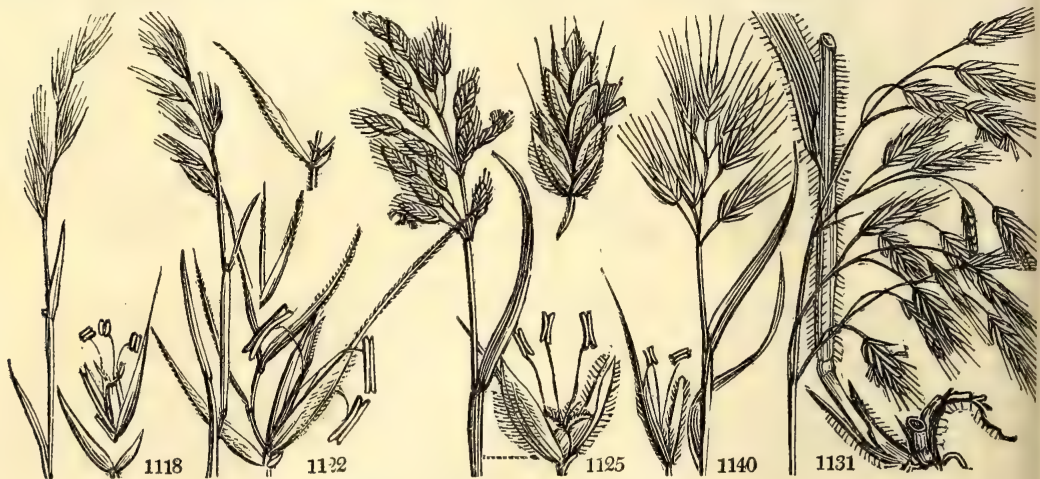

History, Use, Propagation, Culture,

183. Mygalurus. Named by Link, from $\mu \nu \gamma \propto \lambda \eta n$, a mouse, and \& $\dot{\rho} \alpha$, a tail. An alteration of the previous specific name of one of the species, Festuca myurus, L. A natural genus, better distinguished by natural than by artificial characters.

184. Bromus. Beweos is the name given by the Greeks to a sort of wild ont. Most of the species of this genus are of a coarse quality, and being strictly annuals are of little value as pasture, and as hay produce no after math. Sir $\mathrm{H}$. Davy found that the nutritive powers of the straws and leaves of most of the species were greatest when the plant is coming into flower; because, like all other plants strictly annual, or which do not shoot up again from the root the same season, when left till the seed is ripe, the leaves and straws become dried up. B. secalinus is often found among rye and wheat crops; the seeds when ground among the flour are said to impart a bitter taste to bread, and to have similar narcotic qualities as Lolium temulentum. In Scania, the panicles are used to dye green; and there, as formerly in Britain, rye was supposed to degenerate into this grass. The seeds of $\mathrm{B}$. mollis are said to bring on giddiness in the human species and quadrupeds, and to be fatal to poultry. B. asper is the tallest of British grasses; it has had many names, but is distinguished from all 
1118 Panicle one-sided nodding elongated, Florets rough at end, Leaves setaceous keeled very short

1119 Panicle one-sided erect, Florets rough at the end, Leaves setaceous shorter than their sheath

1120 Panicle nearly erect, Flower-stalks ensiform dilated

1121 Panicle one-sided spiked lanceolate, Spikelets spreading 5-flowered, Leaves inear setaceous

1122 Panicle one-sided erect nearly simple, Florets subulate compressed, One glume very short

1123 Panicle in seed nodding at end, Spikelets ovate oblong compressed naked, Florets at last distinct, Beard wavy shorter than glume, Leaves nearly smooth

1124 Pan. nodding at end, Spikelets lanc. compr. naked, Beard straight longer than glume, Leaves villous

1125 Pan. erect contr. Spikelets oblong ovate roundish pubes. Outer paleæ bifid, Beard straight, Leaves soft

1126 Pan. nearly erect, Spikelet lanc. somew. compr. Flor. closely imbr. smooth, Beard straight afterwards sprdg.

1127 Pan. lax nodd. at end, Spikel. lanc. somewhat compr. Florets closely imbr. Beard at length very much sprdg.

1128 Panicle close erect, Spikelets oblong pubescent 12-15-flow. nearly sessile, Beards below spirally twisted

1129 Pan. nodd. Spikelets lanc. slender, Florets bearded hairy, Beards straight, Leaves smooth, Sheaths hairy

1130 Pan. erect, Spikes lin. slenderish naked, Florets imbr. nearly beardless, Leaves smoothish, Root creeping

1131 Pan. nodd. one-sided, Spikel. lin. lanc. compr. pubesc. Beard straight shorter than glume, Leaves vill. rough

1132 Panicle spreading branching, Spikelets ovate turgid 10-flowered, Florets elliptical 3-nerved on each side

1133 Pan. spreading nodding at end, Spikelets rough lin. lanc. Beard straight longer than glume, Leaves pubesc.

1134 Pan. at length nodding, Spikelets lanc. compr. naked, Beards straight as long as glume, Leaves villous

1135 Pan. erect, Spikel. lin. lanc. compr. Florets imbr. Beard shorter than glume, Leaves tufted very narrow cil,

1136 Pan. nodding at end, Spikelets compressed and leaves pubescent, Beard straight about length of glume

1137 Pan. nodd. Spikelets oblong 6-fl. pubesc. Outer glume with a short beard, Leaves sheaths and stem smooth

1138 Pan. erect, Spik. obl. ov. compr. nak. Flor. imbr. Outer pal. undiv. Beard straight as long as glume, Lvs. pub.

1139 Leaves villous, Panicle spreading erect, Beards long straight, Rachis pubescent

1140 Pan. erect, Spikel. rough lin. lanc. Flor. diandr. Beards straight about length of glume, Lvs, nearly smooth

1141 Pan. nodd, at end one-sided, Spikel. lanc. compr. naked, Florets imbr. Beard flexuose longer than glume

1142 Panicle loose capillary pendulous, Spikelets 6-fl. compr. Outer palea with a short beard villous at edge

1143 Raceme spiked distich. simple somew. nodd. Spikel. rem. erect, Upper beards longer than glume, Root fibr.

1144. Spike sim. distich. erect, Spikel, altern. pub. bearded, Beard shorter than its valve, Lvs. pub. Root creeping

1145 Spikes in pairs terminal oblong, Florets lanceolate distichous bearded, Culm 2-knotted smooth equal

1146 Spikelets many-flowered 5-9-flowered beardless, Glumes and paleæ obtuse, Leaves setaceous

1147 Glume many-fl. Spike simple compressed, Spikelets ovate unilateral, Glumes 3-nerved, Florets beardless

1148 Spike distichous compressed, Spikelets lanceolate oblong sessile

1149 Stem branching creeping rough, Leaves convol. obtuse rigid smooth, Alternate spikel. bearded smooth

1150 Glumes one-sided alternate beardless

1151 Panicle lax, Spikelets ovate with long stalks, Glumes 3-valved, Florets 1-androus, Keel pubescent 1152 Panicle long, Spikelets subsessile, Glume many-valved, Florets 3-androus, Keel smooth, Leaves convol. 1153 Nearly spiked, Leaves involute rigid

1154 Raceme spiked branching erect, Spikelets 5-9-flowered beardless smooth, Leaves involute subulate

1155 Panicle large, Stem firm, Spikelets lanceolate 6-8-flowered, Leaves and stem smooth

1156 Panicle erect contracted oblong, Branches chiefly simple numerous setaceous, Spikelets appressed oblong slender 8-10-flowered, Leaves very long smooth
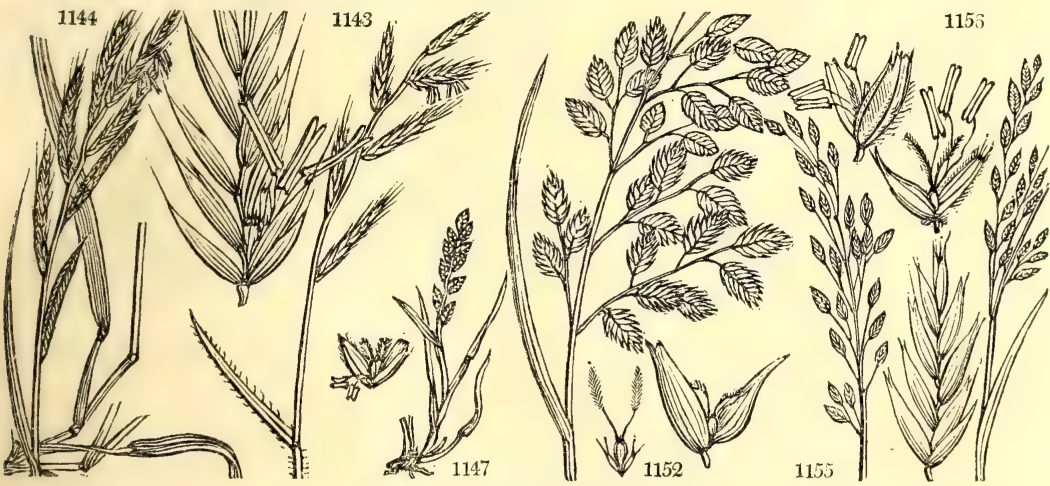

and Miscellaneous Particulars.

others by the hairyness of its stalks. It is found in copsewood in clayey moist soils. Bromus giganteus partly resembles it.

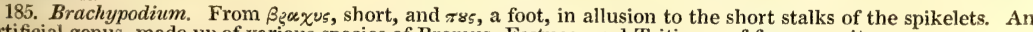
artificial genus, made up of various species of Bromus, Festuca, and Triticum of former writers.

186. Uniola. Named by Linnæus, on account of the union of the glumes. A fine N. American genus, resembling a gigantic Bromus or Festuca. It is chiefly found upon the sands of the sea-coast.

187. Tricuspis. A word signifying three points, in allusion to the structure of its flower. This grass is called Red-top in the southern státes of N. America. Pursh says, " a most excellent grass, I have seen mountainmeadows in Pennsylvania where they mow this grass twice a-year, producing most excellent crops cach time without manure or any other trouble than the mowing, lasting for the space of sixteen years without the least decline in the crops, the soil at the same time being a very indifferent one."

188. Diplachne. $\Delta \leqslant \pi \lambda_{05}$, divided, $\alpha_{x} \eta$, chaff. The outer palea is divided at the end, and bearded between the divisions. 
180. CEE ATOCHLO'A $P$ de $B$ HORN-GRASs. 1157 unioloídes $P$. de $B$. large-spiked $\quad$ ill $O$ w 190. SCHIS'MUS. $\boldsymbol{P}$. de $\boldsymbol{B}$. Scmisuus. 1158 marginátus $P$. de $B$. margined 191. TRIO'DIA. R. Br: Trionia. 1159 decúmbens $R . B r$. decumbent

192. BECKMAN'NiA. Host. Beckmannia. 1160 erucæfórmis W.en. linear-spiked $\mathbf{l l}$. $\mathrm{O}$ 193. ME'LICA. $W$. 1161 ciliáta $W$.

1162 Bauhíni $W$.en.

1163 nútans $W$.

116 uniflóra $W$.

1165 pyramidális $P . S$.

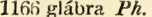

1167 altíssima $W$

Melic-gifass.

ciliated
Italian

mountain

wood

pyramidal

smooth

tallest

194. MOLI'NiA. P. $d e$ B. Molinia.

1168 cærúlea $P$. de $B$. purple Melica E. B.

195. BRI'ZA. $W$. 1169 minor $W$. 1170 vírens $W$.

1171 média $W$

1172 máxima $W$

196. POA. $W$.

1173 aquática $W$.

1174 alpina $W$.

1175 flexuósa $E . B$.

1176 láxa $W$.

$1177 \mathrm{cæ}^{\prime}$ sia $\boldsymbol{E}$. $B$.

1178 vivípara $W$.en.

1179 triviális $W$.

1180 praténsis $W$.

$\beta$ angustifólia W.

1181 húmilis $E . B$.

1182 ánnua $W$.

1183 badénsis $W$.

1184 sudética $W$.

1185 cenísia $W$. en.

1186 fláva $W$.

1187 serotína $W . e n$.

1188 festucæfórmis $W$. en

1189 abyssinica $W$.

1190 capilláris $W$

1191 Mlolinéri Balb.

\section{Q МAKING-GRASS}

small

green

common

greatest

MEadow-Grass.

water

Alpine

zigzag

sea-green

viviparous 跰 $\Delta$ w

common

smooth-stalked illik $\Delta$

norrou-leaved $\Delta$

narrow-leaved illi $\triangle$ ag

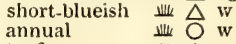

turfy

soft 迕 $\Delta$

palc-yellow $\Delta w$

palc-yellow

Festuca-like 业业 $\Delta$ w

smooth-upright $\frac{\Delta}{\mathrm{O}} \mathrm{w}$

hair-panicled 业 $\mathrm{O}$ w

dwarf-glaucous ille $\triangle$ broad-leaved 址 $\Delta w$
Gramince. $S p .1-2$.

$1 \frac{1}{9} \mathrm{jl}$ Ap N. Amer. 1788. S co Hort. ber. 1.t. 3

Graminea. Sp. 1.

$\frac{1}{2}$ jn.jl Ap Spain 1781. S co Lam.ill.t.46.f.1

Graminea. Sp. 1-10.

jlau Ap Britain

Graminea. Sp. 1.

2 jl Ap Europe 1773. S co Host. gra. 3. t. 6 Graminere. Sp. 7-24.

ji 1771. S s.l Host gra 2 t.19 jn.jl Ap Italy 1806. S co Host.gra. 4. t.23 $1 \frac{1}{2}$ jn.jl Ap Britain moun. S s.l Eng. bot. 10.59 my.jn Ap Britain groves. S m.s Eng. bot. 1058 3 jn.jl Ap Barbary 1804. S co Barr. ic. t.96. f.1 3 jn.jl Ap N. Amer. 1812. S co Mor. h.3.t.7. .51 4. jl.au Ap Siberia 1770. S co Host. gra.2. t.9 Graminea. Sp. 1.

au Ap Britain bogs. S p.m Eng bot. 750

Graminea. Sp, 4-9.

$\frac{1}{2}$ jl.au Ap England cor.fi. S co Eng. bot. 1316 jl.au Ap Spain 1800. S co Hay.trm.t.25.f.6 $\frac{1}{2}$ my.jn Ap Britain pas. S co Eng. bot. $3+0$ Graminea. Sp. 34-1+2.

Ap Britain dit. S m.s Eng.bot. 1315

$\frac{1}{2}$ jn.jl Ap Scotland sc. alp. S s.! Eng. bot. 1003

Ap Scotland sc. alp. S h.l Eng. bot. 1193

4 jn.j Aermany 1800. S co Host. gra.3. t.1

A Ap Scotland sc.mo. S s.l Eng. bot. 1719

$\Omega_{\text {jn au Ap }}$ Switzerl. 1800. S co Fl. dan. t. 807

$1 \frac{1}{2}$ my.jn Ap Britain me.pa. S s.l Eng bot. 1073

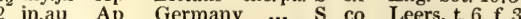

$\frac{1}{2}$ my.jn Ap Britain me.pa. S s.1 Eng. bot. 1004

$\frac{3}{4}$ mr.o Ap Britain pas. S h.l Eng. bot. 1141

$\frac{1}{4} \mathrm{jl}$ Ap Baden 1800. S co Host. gra. 2. t.66

jlau Ap Germany 1802. S co Host. gra. 3. t.13

1 jl.au Ap Mt. Cenis 1791. S co Host. gra. 3 , t. 16

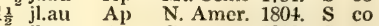

N. Amor. 180t, S co

Germany 1800. S co Lers. her. t.6. f.4 Dalmatia 1800. S co Host. gra. 3. t.17 Abyssinia 1775. S co Jac. ic. 1. t. 17

N. Amer. 1781. S co Mor, h.3.t.6. f.33

in.jl

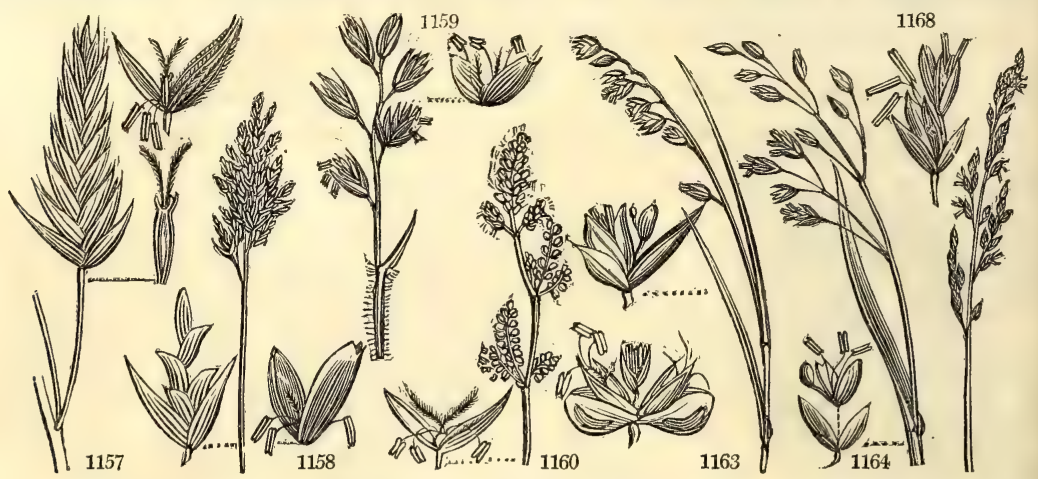

History, Use, Propagation, Culture,

189. Ceratochloa. The seed having three little horns, the name has been contrived in reference to that circumstance : zse⿻s, a horn, and $\chi \lambda$ on, grass.

190. Schismus. From $\sigma^{\sigma} \chi \sigma \omega n$, a cleft. The outer palea is emarginate or cleft.

191. Triodia. Tৎ६ı, three, odov5, teeth, on account of the three teeth of the palea.

192. Beclcmannia. In honor of M. Beckmann, the celebrated author of the History of Inventions, and of a Lexicon Botanicum, published in 1801, besides other works.

193. Melica. A name applied in Italy to the Holcus sorghum, $L$., the pith of which is like mel, honey. M. ciliata and nutans are curious grasses, deserving a place in botanic parterres.

194. Molinia. In honor of Giovanni Ignatio Molina, who wrote an account of the plants of Chile, published in 1782. Of M. cærulea, the fishermen of the isle of Sky make ropes for their nets, which they find will bea the water well without rotting. None of the species are cultivated.

195. Briza. From $\beta_{\rho} \rightarrow \omega$, to balance, the spikelets being continually in a state of balance or suspension in the air. This is an ornamental or curious genus, of little value in agriculture. The perennial species indicate a poor soil, and are bitter in taste. B. maxima is sometimes sown as a border annual.

196. Poa. Inon is the Greek name of herb. This genus affords several valuable pasture, and some good hay grasses. P. aquatica is one of the tallest of British grasses, with a powerful creeping root, a native of most parts of Europe, and very common in the fens of Cambridgeshire and Lincolnshire, where it not only affords rich pasturage in summer, but forms the chief winter's fodder. It is sometimes cut thrice in one season. It grows not only in very moist ground, but in deep water; and with cat's tail, burr-reed, \&c. soon fills up ditches, and occasions them to require frequent cleansing. In this respect it is a formidable plant even in slow rivers. In the is of Ely they cleanse these by an instrument called a bear, which is an iron roller with a number of piece of iron like small spades fixed in it; this is drawn up and down the river by horses walking along the bank, 
1157 Panicle nodding spreading, Spikelets compressed 6-8-flowered, Sheaths of leaves bearded at end

1158 Panicle contracted, Spikelets linear, Glume longer than florets, Leaves bearded at base

1159 Panicle nearly simple contracted few-flowered, Spikelets oblong ovate 3-4-flow. Glume as long as florets 1160 The only species

1161 Outer paleæ of lower floret fringed, Panicle subspicate equal, Spikelets erect at length spreading 1162 Branches of panicle erect or spreading, Spikelets 3-flowered, Outer glume of lower floret hairy at edge 1163 Ligula nearly none, Panicle almost simple, Spikelets nodding beardless, Glumes obtuse 1164 Paleæ beardless, Panicle branching one-sided, Spikelets ovate erect 2 -flowered one imperfect 1165 Ligula half-linear, Panicle branching, Spikelets nodding smooth, Glumes acute

1166 Panicle lax few-flowered, Branchlets simple, Flowers obtuse naked, Stem erect smooth

1167 Paleæ smooth, Panicle spiked branching, Spikelets 3-flowered third flower imperfect

1168 A small purplish grass common on moors with a very narrow smooth spikelike panicle

1169 Panicle erect, Spikelet 3-angular 5-7-flowered, Glume larger than florets 1170 Spikelets ovate, Glume equal to florets, Upper leaf involute

1171 Panicle erect, Spikelets finally cordate, about 7-flowered, Glume less than florets

1172 Panicle nodding at end, Spikelets oblong cordate 13-17-flowered

1173 Pan. equal erect diffuse much branched, Spikel. lin. 5-9-fl. Florets obtuse smooth 7-nerved, Root creeping 1174. Panicle diffuse, Spikelets ovate 5-fl. Ligule of the stem-leaves lanceolate acute, of the rest obtuse 1175 Panicle zigzag, Spikelets 3-flowered, Glumes ovate villous at base, Ligules lanceolate

1176 Panicle contracted erect or nodding, Leaves and stems lax, Ligule oblong

1177 Panicle diffuse, Spikelets ovate 5-flowered, Glumes lanceolate rather silky loose, Ligules very short 1178 Panicle equal diffuse, Spikelets ovate 2-4-flowered at length viviparous

1179 Pan. equal diffuse, Spik. obl. ov. about 3-fl. Flor. vill. at base 5-nerved, Stem and sheaths roughish, Lig. obl.

1180 Panicle diffuse, Root creeping, Upper leaves much shorter than their sheaths, Ligule short truncated

$\beta$ Panicle divaricating, Radical leaves very narrow and long

1181 Panicle diffuse, Spikelets ovate about 3-flowered, Glumes acute villous at base, Ligule very short obtuse

1182 Panicle one-sided divaricating, Spikelets oblong ovate 5-7-flowered, Stem subcompressed

1183 Panicle spreading, Spikelets ovate compressed acute, Outer paleæ pubescent at back

1184 Panicle equal diffuse, Spikel. ovate lanc. 3-fl. Flor. few, Sheaths loose 2-edged, Ligule short, Root creep.

1185 Panicle diffuse nodding, Spikelets oblong 5-7-ff. Florets villous at base, Ligule short

1186 Panicle diffuse, Spikelets ovate oblong shining

1187 Panicle equal diffuse narrowed one-sided spreading when in seed, Root nodose

1188 Pan. equal sprdg. Spikel. lanc. 9-fl. Flor. vill. at base obtuse 5-nerved, Lvs. rough, Ligule obl. Root creep.

1189 Pan. equal capill. lax erect sprdg. Spikel. 4-5-fl. smooth lin. lanc. Lvs. smooth convol. at end, Stem procumb.

1190 Panicle lax much spreading capillary, Leaves hairy, Stem much branching

1191 Panicle contracted, Spikelets 7-9-fl. cordate lanceolate shining, Glumes green lax

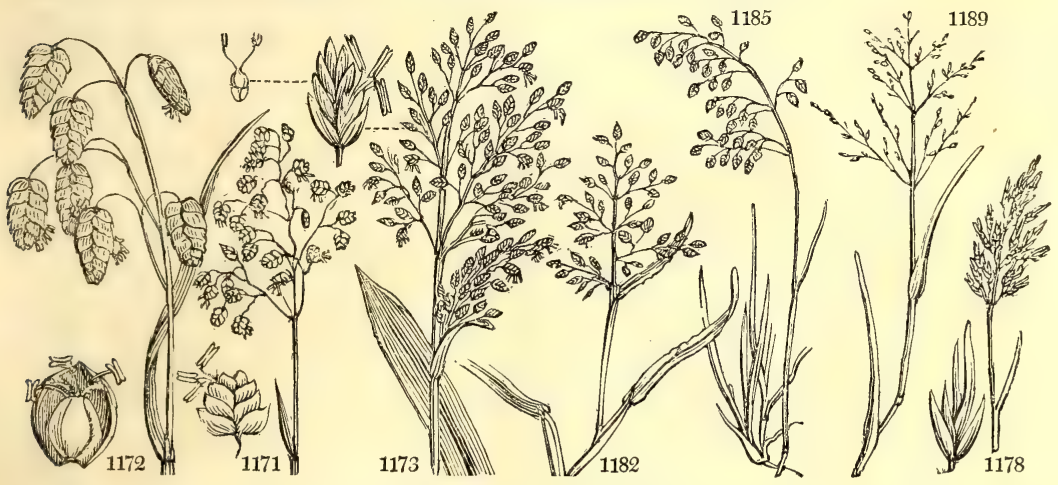

and Miscellaneous Particulars.

and tears up the plants by the roots, which float, and are carried down the stream. (Curtis.) W. Salisbury says, " it is highly ornamental, and might be introduced into ponds for the same purposes as Arundo phragmites, or planted with Festuca elatior, Poa sudetica, and Phalaris arundinacea in pits and water-holding excavations, where it would be useful as fodder, and form excellent shelter for game." (Bot. Comp. ii. 11.)

P. alpina, in common with many alpine grasses which live almost constantly in a moist vapour, is frequently viviparous. Linnæus says, it is the rudiment of the germen which grows and forms the young plant ; Sir J. E. Smith, that the glumes change into leaves, and at length the fictification into a bud.

P. trivialis Curtis considers one of our best meadow and pasture grasses, especially for moist soils and sheltered situations ; on dry exposed situations it is not productive, and, as Sinclair observes, dies off in the space of four or five years. Contrary to what is the case in almost all other grasses, the hay of this species is of most value cut when the seed is ripe. It and $P$. annua are almost the only grasses that will thrive in grass plats in towns and small confined situations.

$P$. angustifolia is a valuable grass for permanent pasture, being of rapid and early growth; but the stalks and leaves being subject to the rust, it is obviously unfit for hay. P. pratensis assumes a beautiful verdure very early in spring; but as it sends up flower-stalks only once in a season, it is less adapted for hay than for early and permanent pasture. Cultivated by itself, it becomes so much matted by its creeping roots as to be unproductive, unless on water meadows, for which it is one of the best of grasses. P. annua is a diminutive plant, the most common in all temperate climates, and perhaps in the world. P. sudetica is a tall aquatic. P. glauca is ornamental from its glaucous hue. P. maritima Sir H. Davy found to be one of the best grasses for producing latter-math. P. fertilis (P. serotina) ranks as one of the most valuable of grasses. According to the Woburn experiments it produces the greatest abundance of early foliage next to P. angustifolia. It prefers a clayey soil, and flowers late. 
1192 stérilis $M . B$.

1193 angustáta $R$. Br.

1194 ténax $L k$.

1195 marítima $W$.

1196 compréssa $W$

1197 glaúca $E$. $B$.

1198 nemorális $W$.

1199 amboinénsis $W$.

1200 bulbósa $W$.

1201 distans $W$.

1202 retrofléxa $\boldsymbol{E}$. $\boldsymbol{B}$

1203 ægyptíaca $W$. en

1204 peruviána $W$

1205 nerváta $W$.

1206 digitáta $R . B r$.

197. ERAGROS'TIS. $P$. de $B$. Live-GRA

$\begin{array}{ll}1207 \text { pilósa } P \text {. de } B . & \text { pilose } \\ 1208 \text { tenélla } P . d e B & \text { small }\end{array}$

1209 purpuráscens $S p r$. purple

198. MEGASTA'CHYA.

1210 Eragróstis P. de B. Love-gr. Meg

1211 amábilis $P$. de $B$. purple

1212 rígida $P$. de $B$. hard Poa E. B.

1213 elongáta $P$. de $B$. long-panicled

1214 ciliáris $P$. de $B$. ciliate

199. SCLEROCHLO'A. $\boldsymbol{P}$. de $\boldsymbol{B}$. Hard

1216 procúmbens $P$.de $B$. procumbent Poa E. B.

1217 dúra $P$. de $B$

coarse

200. ELEUSI'NE. $R$. Br. EleUsine.

1218 coracána $P$. S. $\quad$ thick-spiked

1219 índica P.S.

Indian

201. DACTYLOCTE'NIUM. $\boldsymbol{P}$. de $\boldsymbol{B}$.

1220 ægyptíacum $P$. de $B$. creeping

202. LEPTOCHLO' A. P. de B. IEPTOCHLOA

1201 virǵta $P$ de $B$. $P$. de $B$. Cander.

1222 tenérrima $R . \& S$. $\quad$ very-slender

1223 domingénsis $L k$. close-spiked

1224 filifórmis $\boldsymbol{P}$. de $\boldsymbol{B}$. Chinese Poa chinénsis

203. CY'NODON P.S. CYNODON.

1225 Dáctylon $P$.S. $\quad$ creeping

1226 lineáris $W . e n$. linear-leaved

204. DINE'BRA, $P$. de B. Dinebra.

1227 arábica Jacq. reflexed

1228 Líma $P$. de $B$. imbricated

205. ECHINA'RIA. Desv. Echivaria.

1229 capitáta Desv. headed

206. TRI'TICUM. $W$. WhEAT.

1230 æstívum $W_{\text {. }}$ summer

1231 hybérnum $W . \quad$ Lammas

1199

1199

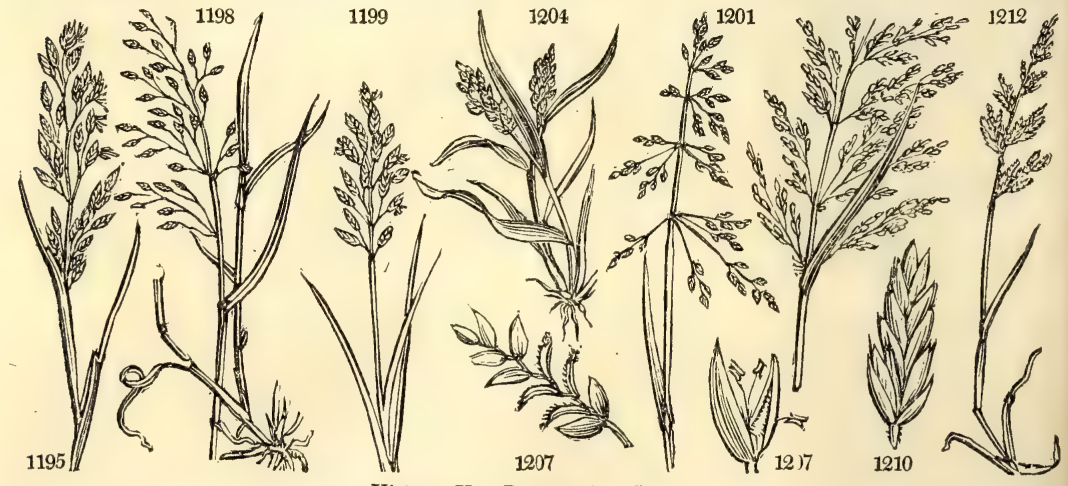

1 jn.jl

$\frac{1}{2} j$ ja.f

$2^{\frac{1}{2}}$ jl.au

1 jn.jl

1 jn.au

jn. au

2 jn

1 jn.jl

$1 \mathrm{jl}$

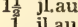

1 jl.au

$\frac{2}{2}$ jl.au

$1 \frac{1}{2} \mathrm{jl}$.au

jl.au

Graminea.

$1 \frac{1}{2} \mathrm{jl}$.au

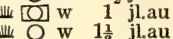

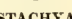

Graminece.

业 $O$ or $2 \mathrm{jl} A \mathrm{p}$

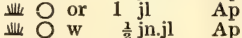

E Indies 1699. S co Host. gra. 2. t. 69 E. Thdies 1802. S co Lam, ill, t.45. f.2

प] $\mathrm{w} 2$ jl.au Ap E. Indies 1812. S s.l Jac. ecl gra t

$1 \frac{1}{2}$ jl.au Ap Jamaica 1776. S s.l Jacq. ic. 2. t. 304

Graminece. Sp. 3.

业 $\mathrm{O}$ w $\frac{1}{2}$ jl.au Ap S. Europe 1802. S co Gou. ill.4.t.2.f.1

w $\frac{2}{2}$ jl.au Ap Britain seaco. $\mathrm{S}$ h.s Eng. bot. 532

业 $\mathrm{O}$ w $\frac{1}{2} \mathrm{jn} . \mathrm{jl}$ Ap Europe 1822. S co Host. gra. 2, t.73 业 $\mathrm{O}$ w 4 jls

w 2 jls Ap India

1714. S co Rheede. 12, t. 69

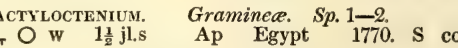

Graminea. Sp. 4-5.

Graminea. Sp. $4-5$.

$\begin{array}{llll}3 \text { jl.au Ap } & \text { W. Indies 1727. S co } \\ 1 \frac{1}{2} \mathrm{jn} & \text { Ap } & \text { China 1820. S } & \text { co }\end{array}$

3 jn Ap W. Indies 1820. S co

W 2 jlau Ap China

$\therefore$ w 1 Graminece. Sp. 2-10.

Graminea. Sp. 2-5.

业 $\mathrm{O}$ w $\frac{1}{2} \mathrm{jn} . \mathrm{jl}$ Ap E. Indies 1804. S co Jac.frag.t.121.f.1

业 $\mathrm{O}$ W $\frac{\mathrm{x}^{2}}{2} \mathrm{jl}$.au Ap Spain 1776. S co Cav. ic. 1.t.91

Graminea. Sp. 1.

业 $\bigcirc$ w $\frac{1}{2}$ my.au Ap S. Europe 1771. S co Host. gra. 3. t. 8 Graminea. Sp. 16-28.

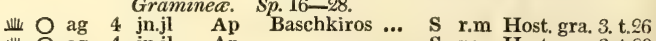

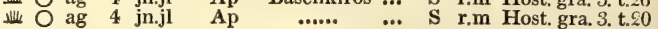

History, Use, Propagation, Culture,

P. abyssinica is grown as a bread-corn in Abyssinia, and furnishes the teff bread; that made from wheat being used only by the superior ranks. The dough is allowed to turn sour, and by generating carbonic acid gas, answers instead of yeast; it is then baked into circular cakes, which are white, spongy, of a hot disagreeable sourish taste, but light of digestion. The same bread, well toasted, and infused in water for some days, fur. nishes the bouza or common beer of the country, like the quas (sour, Rus.) of Russia.

197. Eragrostis. An elegant appellation derived from z९os and argosis, Love-grass. The pretty dancing spikelets are the delight of children, and remembered by men long after many of their other innocent pleasures have ceased to retain their charm. The plants resemble the Briza or quaking-grass.

198. Megastachya. From $\mu \varepsilon \gamma \alpha s$, large, and $\tau_{\alpha \chi \nu}$, a spike, on account of the large panicles of the genus.

199. Sclerochloa. Hard-grass ( $\sigma * \lambda \eta \eta^{\circ} \circ$, rigid, and $\chi^{\lambda}$ on, grass). A genus of hard worthless grasses.

200. Eleusine. Eleusis was one of the appellations of Ceres, the goddess of grasses. E. coracana, according to Thunberg, is cultivated in Japan for its edible seeds. 
1192 Pan. attenuated, Branches very short, Spikel. 3-fl. acute smooth, Leaves short, of the stem distich. sprdg. 1193 Pan. simple contracted linear lanceolate, Spikelets 4-5-fl. Lower glume shortest, Paleæ eroded at end

1194 Lvs. flat striat. rough, Lig. short, Branches of pan. quite sim. Spik. obl. with distant flor. Pal. acute smooth 1195 Pan. branching contr. Spikelets about 5-flow. Spikel. obtuse slenderish obsoletely 5-nerved, Root creeping 1196 Pan. one-sided diffuse, Spikel, obl. ovate 5-7-fl. Florets villous at base, Stem oblique compr. Root creeping 1197 Pan. attenuate erect, Spikelets ovate 3-flowered, Paleæ retuse villous at base, Stipule very short

1198 Ligules nearly none, Leaves plaited at base broader and longer than sheath, Panicle elong. Paleæ nerved 1199 Panicle contracted one-sided, Stem round

1200 Panicle equal diffuse, Spikelets ovate 4-5-fl. Florets villous at base, Stem and bundles of leaves bulbous 1201 Pan. equal at length divar. Branches in seed bent down, Spikel, linear about 5 -fl. Florets smooth obtuse 1202 Same as Poa distans

1203 Pan. equal diffuse, Spikel. lin. 9-15-ff. Florets smooth, Ligule trunc. ciliated, Stem much branched ascend. 1204 Pan. spiked, Spikel. 5-fl. ovate, Flor. smooth acute, Inner paleæ cil. at back, Stem procumb. and lvs. hairy 1205 Pan equal diffuse, Spikelets ovate 5 -fl. Florets smooth 7-nerved obtuse, Stem furr. ang. Root somew, creep. 1206 Spikes fingered numerous, Spikelets imbricated 7-flow. Outer glume obtuse 3-nerved rather silky at base

1207 Pan. equal, in fl. contr. in seed diffuse, Low. bran. at base and rami. hairy, Sp. lin. 7-9-fl. Flor. sharpish smth. 1208 Panicle oblong capillary whorled, Florets 6-flowered very minute nodding

1209 Panicle erect, Flower-stalks stiff, Leaves smooth about the mouth of the sheaths

1210 Panicle equal spreading, Lower branches at base and ramifications hairy, Spikelets 15-25-flowered I211 Panicle spreading, Spikelets 18-flowered linear

1212 Pan. distichous one-sided contr. hard, Spikelets linear acute 5-11-fl. Florets smooth obsoletely 5-nerved

1213 Pan. elong. Branc. sprdg. distant abbrev. Spik. lin. 7-11-fl. close press. Flor. smooth acute 3-nerv. Lvs. glauc 1214 Panicle closely spiked, Spikelets ovate oblong 6-10-flowered, Florets smooth acute, Inner paleæ fringed

1215 Panicle divaricating, Flower-stalks thickened, Spikelets 4-flowered, Leaves filiform 1216 Panicle lanceolate contracted one-sided rough, Rachis round, Florets obtuse nerved

1217 Panicle one-sided broad contracted stiff, Spikelets lanceolate obtuse 3-5-flowered

1218 Spikes about 7 digitate at length incurv. Rachis membranac. Stem compr. erect, Leaves close together 1219 Spikes digitate erect 5-9 on a linear rachis, Stem compressed declining branching at bottom

1220 Spikes fingered 4-5 obtuse much spreading mucronate, Stem ascending, Leaves opposite

1221 Panicle with simple branches, Flowers sessile 6-flowered, the last sterile, lower bearded

1222 Spike alternate very slender, Spikel. distich. beardless, Leaves rather hairy, Sheaths compressed smooth

1223 Pan. branched fringed, Branches simple, Spikelets 5-fl. subsess. Florets all bearded (Rhabdochloa. P.)

1224 Panicle much branched contracted, Branches simple filiform, Spikelets alternate 2-4-flowered beardless

1225 Stolones creeping, Glume much spreading rough, Leaves fringed at edge

1226 All over hoary, Spikes digitate 4 , Glume erect, Leaves naked rough at edge

1227 Spikes altern. 1-sided panicled, Glumes equal, Spik. 2-fl. Flor, stalked beardl. herm. Stems prost. Lvs. flat 1228 Spike one-sided simple, Spikelets many-flowered

1229 The only species

1230 Spike paral. compr. bearded, Glumes gibbous bearded trunc. at base contr. with a nerve runn. thinner upw. 1231 Spike par. compr. nearly beardl. Glumes gibb. trunc. mucron. at base contr. with a nerve runn. thinner upw.

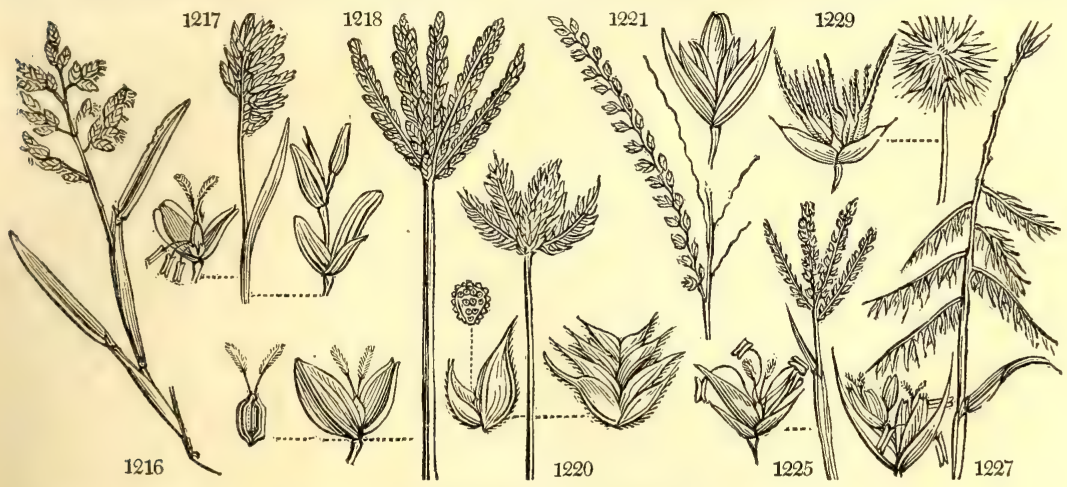

and Miscellaneous Particulars.

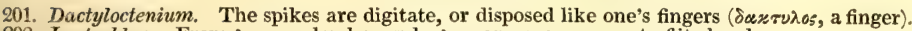

202. Leptochloa. From $\lambda \varepsilon \pi \tau \circ$, slender, and $\chi \lambda$,

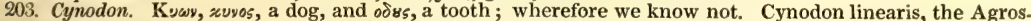
tis linearis of König., is the famous durva grass of the Hindoos, for which, see Lambert in the Linn. trans, vii. No. 22 .

204. Dinebra. Its Arabic name.

205. Echinaria; '́xivos, a hedge-hog: the prickly round heads may be fancied to resemble little hedgehogs.

206. Triticum. According to Varro, was so named from its grain being originally worn down (tritum) in making it eatable. This is by far the most important genus of the Graminex, as including the wheats, the flour of which is universally allowed to make the best bread in the world. For what is man upon rice or potatoes? 
1232 compósitum $W$. 1233 túrgidum $W$. 1234 polónicum $W$ 1235 Spélta $W$.

1236 monocóccum $W$. 1237 squarrósum Roth. 1238 junceum $W$.

1239 répens $W$.

1240 canínum $E . B$

1241 rígidum $W$. en.

1242 cristátum Sclır.

1243 Zéa Host.

1244 villósum $P$. de $B$.

1245 elongátum Host.

207. LO'LIUM. $W$.

1246 perénne $W$.

1247 ténue $W$

1248 temuléntum $W$

1249 arvénse $E . B$.
Egyptian

turgid

Polish

Spelt

one-grained

Porcupine

rushy

Couch-grass

bearded

rigid

crested

maize-like

villous

long-spiked

Darnel.

Rye-grass

slender

bearded

beardless

\begin{tabular}{|c|c|c|c|}
\hline & ag & 3 & $\mathrm{jn} . \mathrm{j}$ \\
\hline & & 3 & jn.jl \\
\hline & ag & 4 & jn.jl \\
\hline & $\mathrm{ag}$ & 3 & jn.jl \\
\hline & ag & 3 & jn.j1 \\
\hline & w & 7 & jn.jl \\
\hline & $\vec{\lambda}$ & $1 \frac{1}{2}$ & jn.jl \\
\hline & $\Delta$ & & jl.au \\
\hline & $\Delta$ & & jl.au \\
\hline & $\Delta \mathrm{w}$ & & jn.j \\
\hline & w & & jl.au \\
\hline & & & \\
\hline & & & \\
\hline & & & \\
\hline
\end{tabular}

Ap Egypt

1799. S r.m Mor. h. 3,t.1. f.7

Ap $\quad$...... $\quad . .$. S r.m Host. gra. 3. t.28

Ap $\quad \ldots . . .1$ 1692. S r.m Host. gra. 3. t.31

Ap $\quad$...... $\quad \ldots \quad$ S $\quad$ r.m Host. gra. 3. t.30

Ap $\quad$..... 1648. S r.m Host. gra. 3. t.32

Ap Egypt 1800. S co Host. gra. 3. t.32

Ap England sea. sh. S co Eng. bot. 814

Ap Britain rub. S m.s Eng. bot. 909

Ap Britain ch.wo. S s.l Eng. bot. 1372

$\begin{array}{llll}\text { Ap } & \text { Britain ch. Wo. S } & \text { s.I } & \text { Eng. bot. 1372 } \\ \text { Ap } & \text { Germany 1805. S } & \text { co } & \text { Host. gra. 2. t.29 }\end{array}$

Ap Britain hed. S co Eng. bot. 2267

Ap Austria 1815. S r.m Host. gra. 3. t.29

Ap S. Europe 1790. S co Fl. græc. 1. t.97

Ap Germany 1805. S co Host. gra. 2. t.23 Graminece." Sp. 4-10.

此 $\triangle$ ag 3 my.jn Ap Britain me.pa. S co Eng. bot. 315

此 $\triangle$ w 3 jl.au Ap S. Europe 1590. S co

业 $\mathrm{O}$ p 4 jl.au Ap Britain cor,fi. S co Eng bot. 1124

will $\mathrm{O}$ ag 4 jl

England cor, fi. S co Eng. bot. 112

1235
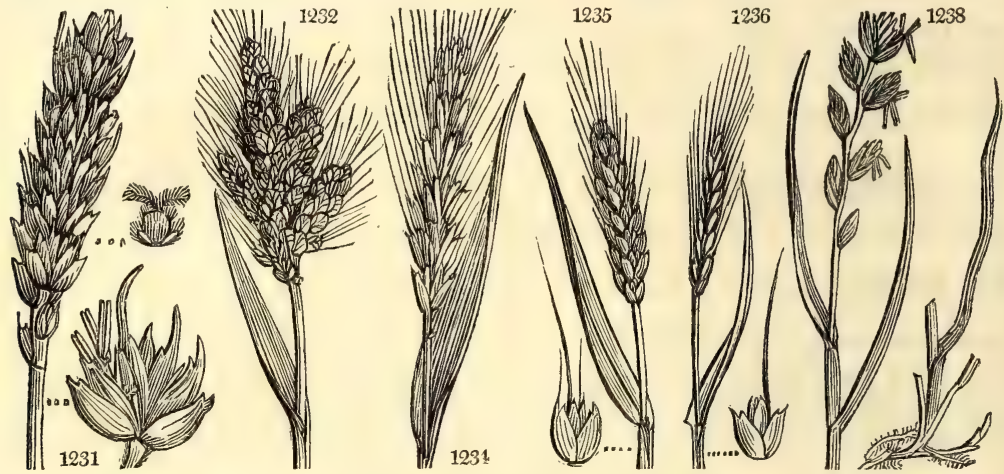

History, Use, Propagation, Culture,

T. æstivum, and the five following sorts, are most probably variations of the same species. It is certain that winter-wheat sown in spring will ripen the following summer, though the produce of succeeding generations of spring-sown wheat is found to ripen better. White, red, awned, and beardless wheat change and run into each other on different soils and in different climates; and even the Egyptian wheat is known to change in this country to the single-spiked common plant. There is a sort of summer-wheat apparently a distinct species from those which have been mentioned; the agricultural treatment of which, as well as the general appearance, is similar to that of barley. The straw is short and soft, the ears awned, small, and easily threshed, and the grain may be sown in May and reaped in August or September. It is very subject to the black disease, and though it has been tried in a number of places has never come into general cultivation. A variety from India, called " hill-wheat," and another from the Cape of Good Hope, have also been tried with no better results. But the hill-wheat, and, we believe, the hill-barley, also, of the northern provinces of India has been cultivated with success in Germany, under the direction of the Archduke John of Austria. T. monococcum grown in Switzerland, is of similar appearance.

T. spelta appears a distinct species, and more hardy than common wheat; it has a stout straw almost solid, with strong spikes and chaff adhering firmly to the grain. The grain is light, yields but little flour, and makes but indifferent bread. It is grown in Switzerland in elevated situations, where common wheat would not ripen : also in Bavaria and other parts of Germany. It is sown in spring, and ripens in July and August.

Of the common wheat there are many varieties, but the most permanent are the red and white grained, and the spring-wheat, which is generally red. The Hertfordshire reds and whites, woolly eared, awned, and nearly fifty other names are merely sub-varieties of the red and white. Wheat answers best when treated as a biennial, though it does not remain above one year in the ground. Provided the soil be well prepared and dry, and the grain sown in time, the plants do not suffer from the greatest cold of our climate, or even that of Russia. In the latter country, and in the northern counties of Britain, the fields are covered with snow, which retaining a temperature of from 30 to 32 degrees, the plants are found to vegetate and establish their roots firmly in the soil. The snow is not thawed off till the weather is decidedly warm in spring, when the plants make rapid progress, apparently more so than in warmer climates. Wheat, like all culmiferous plants, may be said to have two distinct sets of roots; the seminal or tap-root, and the coronal or surface-root, the former proceed. ing from the embryo, and the latter from the first joint of the stem. The former seem intended to nourish the plant while young, to fix it to the soil, and to penetrate into the sub-soil for water; the latter to search along the surface among the lighter materials of the soil for nutritive particles. There is in the Banksian museum, a stalk of wheat of ordinary length with a tap-root six feet long, which had penetrated into a sub. soil of limestone brush, and was taken up in digging a drain. It grew on the estate of J. Fane, Fsq. at Wormley in Oxfordshire, in 1818. M. Sageret, a scientific French agriculturist, found that when wheat or any of the other grains were etiolated immediately after germination, by growing too rapidly or being sown too thick, the first joint from which the coronal or surface roots proceed is raised above the ground, and in consequence either throws out no roots at all, or so few as to nourish it imperfectly, in which cases it either dies before it comes into flower, or before the grains are matured. This accurate statement of what takes place, is well calculated to show the bad effects of sowing winter-wheats too early, or spring-corn too late, and grasses in general too thick. Animal substances, and especially bones and urine, are the best manures for wheat, as containing much gluten, a substance found in a greater proportion in that grain than any other. Next to animal manures lime is important, as tending to the same effect by chemical combinations. Wheat is almost every where cultivated, both in the temperate and torrid zone, to the 45th degree of north latitude, and the height of 2000 feet vated, both in the temperate and torrid zone, to

The insects and diseases which attack wheat are various. The grubs of chaffers and beetles, as well as the wire-worm (the larva of different species of Tipula), attack the roots; the wheat-fly (Tipula tritici) the ears; the smut or black the grains; and the mildew, rust, or blight, different names for the same disease, the whole plant. The mildew Sir J. Banks determined to be produced by the growth of a minute fungus on the straws and chaff of the plant, and Dr. Cartwright (Phil. Mag. Oct. 1820.) ascertained it might be destroyed by watering with salt and water. The smut converts the farinaceous part of the grain into a black powder, and is sup. posed to be prevented or lessened by steeping the grain previously to sowing in any strong saline mixture. It 
1232 Spike compound at the base, Spikelets 3-flowered ventricose imbricated, Terminal floret beardless neuter 1233 Spikelets 4 -flowered ventricose pubescent imbricated bearded, Terminal floret barren, Glumes obtuse 1234 Spikelets 4-flowered ventricose roughish, Two middle florets sterile, Paleæ unequal outer fringed 1235 Spikelets 3-flowered ventricose roughish, Intermediate floret barren, Glumes ovate

1236 Spikel. 2-fl.ventr. imbr. bearded, Barren floret with a short, fertile with a very long beard, Glumes 3-toothed 1237 Spike distich. Spikelets 4-flowered approxim. Two middle florets sterile, Glumes lin. lanc. Stem ascending 1238 Glumes 9-nerved obtuse 4-5-flowered, Florets beardless, Rachis smooth, Root creeping 1239 Root creeping white jointed proliferous

1240 Glumes shortly bearded 3-nerved 5-flowered, Florets bearded, Root fibrous

1241 Spike interrupted, Rachis hispid, Leaves rolled in at edge, Root creeping

1242 Glumes 4-flowered bearded, Spikes lanceolate imbricated, Stems pubescent

1243 Spikelets 4 -flowered remote, Two joints of the hairy rachis longer than the spikelet

1244 Spikelets 3-flowered, Ríbs of glumes fringed in tufts, Leaves downy

1245 Spikelets lanceolate 8-flowered beardless, Glumes truncate naked, Leaves nerved

1246 Spike beardless, Spikelets longer than glume

1247 Culm slender, Leaves narrow, Spikelets 3-4-flowered

1248 Spike bearded, Spikelets less than glume, Culm rough upwards

1249 Spike nearly beardless, Spikelets as long as calyx
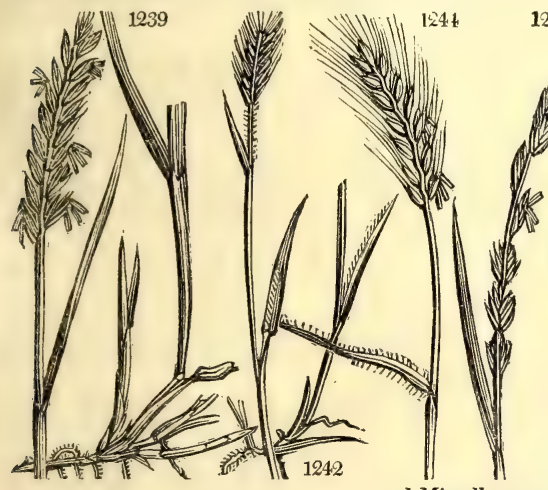

and Miscellaneous Particulars.

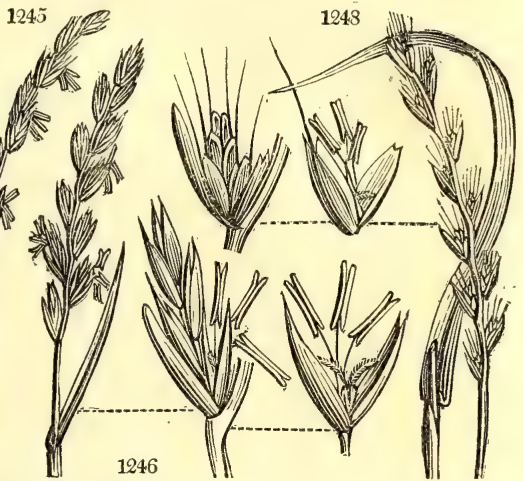

is not easy, however, to cure diseases in the vegetable kingdom, and therefore the grand object of the culti. vator ought to be to procure healthy seed, and apply judicious culture.

The uses of wheat are well known. The grain yields a greater proportion of flour than every other; for, while $14 \mathrm{lbs}$. of barley yield $12 \mathrm{lbs}$. of flour, and of oats $8 \mathrm{lbs}$., the same quantity of wheat yields $13 \mathrm{lbs}$. It is also more nutritive, 1000 parts of barley yielding 920 , of oats 743 , and wheat 955 soluble parts. Of these, the gluten of wheat is 90 , of barley 60 , and of oats 87 . (Davy. Ag. Chem. 138.) Gluten is so essential an ingredient in bread that the pannary fermentation cannot go on without it, and hence the inferiority of that article in wet seasons, when wheat is blighted or ill ripened, and the advantage of having a stock of old grain, or of grain from the south of Europe, especially of the Mediterranean isles and coasts.

Wheat starch is made from wheat, by steeping it, and afterwards beating it in hempen bags. The mucilage being thus mixed with the water produces the acetous fermentation, and the weak acid thus formed, renders the mucilage white. After settling, the precipitate is repeatedly washed, and then put in square cakes. In drying, the cakes separate into flakes as found in the shops. Starch is soluble in hot water, but not in cold; and hence, ground down, it makes an excellent hair powder. Its constituents are carbon 43.55 ; oxygen $49^{\circ} 68$; hydrogen $6 \cdot 77=100$.

The straw of wheat, from dry chalky lands, is manufactured into hats, for which purpose the middle part of the tube above the last joint is taken, and being cut into lengths of 8 or 10 inches, these pieces split in two are used to form the plait. The operation of plaiting is performed by females and children, who plait it into ribbons of from one to two inches broad, and these are afterwards sown together on blocks or moulds, beginning at the crown, in various shapes according to fancy or fashion. The best straw is produced on the chalky soil about Dunstable, where plaiting is a common occupation. Other grasses afford culms which have also been used and manufactured into much finer and expensive work that those of wheat or rye. Leghorn hats are made from the straw of a bearded variety of wheat not unlike rye. It is grown on poor sandy soils on the banks of the Arno, between Leghorn and Florence, expressly for this manufacture. It does not grow above 18 inches in length, is pulled green, and bleached like flax on the gravelly bed of the river. The straws are not split as in England, which renders the plait tougher and more durable. The value of wheat-straw for thatching, litter, and other purposes, need not be mentioned.

$\mathrm{T}$. junceum grows in loose sand on the sea-coast, and by its tough creeping roots and numerous fibres coorerates with Carex arenaria, Elymus arenarius, and Festuca rubra, in keeping them stationary, accumulating more, and eventually rendering drifting sands fit for agricultural purposes.

T. repens, couch, white couch, twitch, dog-grass, quickens, \&c. is common in most parts of Europe, and even in Siberia. It is one of the worst weeds in arable lands and gardens, and in the former is only to be destroyed by fallowing or fallow crops, or laying down to grass; and the latter by hand-pickirg or very deep trenching. The roots are sweet and nourishing, and are greedily eaten by horses and cattle. Sir $\mathrm{H}$. Davy found them to contain nearly three times the nourishment of the stalks and leaves.

207. Lolium. Loloa is the Celtic name of this grass. L. perenne is the fausse ivraie (see L. temulentum) of the French, from which our term ray-grass is derived, the Dauerende Lolch, Ger., and Loglio vivace, Ital. This appears to be the first grass which was taken into cultivation in Europe, but when is uncertain. Gerarde, Parkinson, Plattes, and even Blythe in Cromwell's time, take no notice of it. It is first mentioned by Dr. Plott in 1677. "They have lately sown," he says "ray-grass, Gramen loliaceum, to improve cold sour clayey weeping ground unfit for saint-foin." It was first sown in the Chiltern parts of Oxfordshire, and afterwards by one Eustace at Islip in the same county. There are two varieties of this grass; the perennial, which is of shorter growth than the other, and on sound dry soils will last four or five years, and on rich soils longer; and the annual, or rather biennial, which is tall and larger in all its parts than the perennial, and after producing one bulky crop dies at the root, or, at least, sends up no latter math. After all that has been affirmed of other grasses, none appear so well adapted as the annual rye-grass for producing a bulky crop of hay, with or without red clover; or better adapted than the perennial variety for sowing down with white clover, to afford three or more years pasture in the rotations of what is called convertible husbandry, or the alternate corn and grass culture. Cock's-foot grass and woolly grass (Holcus) may afford a greater lulk on poor soils, but are far inferior to the ray-grass in regard to nutritive qualities. Sir H. Davy found the value which 
208. E'LYMUS. $W$.

1250 arenárius $W$.

1251 geniculátus $E . B$.

1252 sabulósus $W$. en

1253 gigantéus $W$

1254 sibiricus $W$

1256 philadélphicus $W$.

1257 canadénsis $W$.

1258 virgínicus $W$.

1259 striátus $W$

1262 crinítus Sch.

1263 Cáput-Medúsæ $W$

1264 júnceus Fisch.

1265 hýstrix $L$.

209. SECA'LE. $W$.

1266 ceréale $W$.
1267 orientále $W$.

210. HOR'DEUM. $W$.

1268 vulgáre $W$.

1269 hexástichon $W$.

1270 dístichon $W$.

1271 Zeócriton $W$.

1272 bulbósum $W$.

1273 murinum $W$.

1274 praténse Roth.

1275 marítimum $W$.

1276 jubátum $\boldsymbol{H} . \boldsymbol{K}$.

211. MICROCHLO'

LYME-GRASS. upright-sea

pendulous

glaucous

gigantic

Siberian

tender

Philadelphian

Canadian

Virginian

striated

villous

wood

long-awned

Portuguese

rush

Porcupine

RYe.

common

hairy-spiked

Barley.

spring

winter

common

battledore

bulbous

wall

meadow

sea

long-bearded
1255 téner $W$.

1260 villósus $P h$.

1261 europæ'us $W$.

1277 setácea $R$. Br.

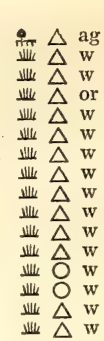

Graminea. Sp. 16-24.

ap.jn Ap Britain seaco. S s Eng. bot. 1672

4 jl Ap England sea sh. S s Eng. bot. 1586

4 jn.jl Ap Siberia 1806. S co

5 jl.au Ap Mexico 1790. S co

6 jn.jl Ap Siberia 1758. S co

2 jn.jl Ap Siberia 1801. S co

4. jl.au Ap N. Amer. 1790. S co

4 jl.au Ap N. Amer, 1699. S co

$2 \frac{1}{2} \mathrm{jn} . \mathrm{jl}$ Ap Virginia 1781. S co

2 jn Ap N. Amer. 1790. S co

2 jn.j Ap N. Amer. 1809 S co

2 jn.j Ap N. Amer. 1802. S co

2 jn.jl Ap England woods. S

1 jn.jl Ap Smyrna 1806. S co

jn.j

2 jn.jl

Ap Siberia 1806. S co

Graminea. Sp. 2

此 $O$ ag 3 jn.jl Ap Crimea ... S s.1 Host.gra. 2, t. 48

a 3 jn.jl Ap Levant 1807 . S co N ac.ber. 2.4 .48

Graminece. $S p .9-12$

the ag 3 jl Ap Sicily $\quad \ldots . \quad$ S r.m Host. gra. 3. t. 34

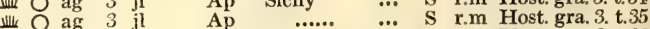

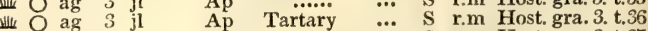

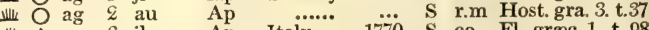

址 $\triangle \mathrm{W} \quad 3 \mathrm{jl}$ Ap Italy 1770. S co Fl. græe. 1. t. 98

llle $O$ w $1 \frac{1}{2}$ ap.au Ap Eritain sal.m. S s.l Eng. bot. 1971

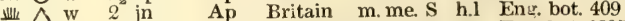

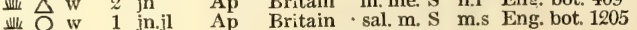

址

Graminece. $S p .1$

$\frac{1}{4} \mathrm{jl}$ Ap E. Indies 1806. S co Rox.cor. t.132

Graminece. Sp. 3-4.

$\frac{3}{4} \mathrm{jl}$ Ap Britain seaco. S m.s Eng. bot. 760

12. OPHIU'RUS. $P$. de B. IIARD-GRass.

1278 incurvátus $P$. de $B$. sea

1279 filifórmis $P$ de $B$ filiform

1280 pannónicus $P$. de $B$. two-flowered

213. MONER'MA. P. de B. Monerma.

1281 monándrum $P$.de $B$. monandrous

1282 subulátum $P$, de $B$. subulate

Ap Britain seaco. S m.s Eng. bot. 760 1

$\frac{1}{2} \mathrm{jl}$ Ap Hungary 1804. S co Host. gra.1. t.2.

Granince. Sp. 2-3.

捗 $\mathrm{O}$ w Ap Spain 1804. S co Cav. ic. t. 39. f. 1
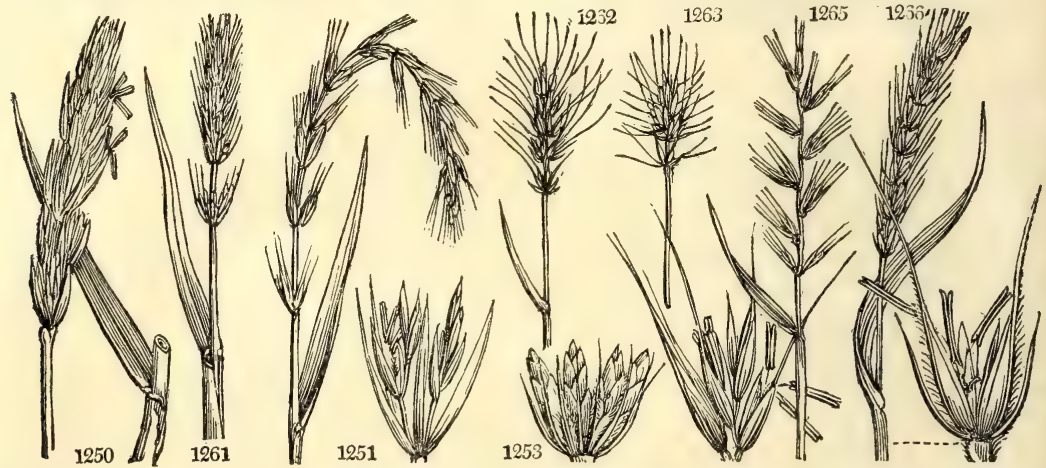

History, I'se, Propagation, Culture,

this grass cut at the time it is coming into flower bears to that when the seed is ripe, to be as 10 to 11 . Pacey's perennial ray-grass, a variety raised in Staffordshire, has long been in repute, and there has lately been a new variety raised in Bedfordshire, known as the Russel ray-grass.

208. Elymus. Linnæus derives the name from $\varepsilon \measuredangle \lambda \varepsilon \omega$, to cover, because the leaves of his Elymus maritimus are formed into a coarse sort of fabric. The Elymus of the ancients was evidently a sort of corn. E. arenarius is a strong rough glaucous plant common on sandy shores, and like Calamagrostis arenaria and others, which have been mentioned (genus Lygeum, Stipa, Arundo), prevents, by its matted roots, the shifting of loose sand thrown up by the tides. In analyzing the soluble matter afforded by this grass, Sir H. Davy found it to contain more than one-third of its weight of sugar. It is not, however, eaten by any of our domestic animals.

209. Secale. An ancient name, supposed to have been derived from seco, to cut, which word is said to have been formed from the Celtic sega, a sickle. This grain, of which there is probably only one species, affords a grain next in value to the wheat for making bread, and is generally used for this purpose, alone or mixed with wheat, throughout Germany and the north of Europe. It is hardier and earlier than wheat. Like it, it will ripen if sown in spring, but better if treated like a winter-wheat. In Britain it is little sown. Its grain yields $792-1000$ parts of soluble matter, of which 645 are mucilage, 190 gluten, and 38 sugar.

210. Hordeum. Bodæus à Stapel derives this word from hordus, heavy, because bread made with barley is very heavy. Bara is the Celtic for bread, whence the English words barn and barley ; as beer is a slight alteration of the appellation of barley in that tongue, Bere. Hexastichon ( $\xi \xi$, six, $\sigma \varangle \xi \sigma \tau i \chi 05$, row) signifies grain growing in six rows; distichon, in two rows. Zeocriton is derived from ' $\varepsilon$, which is supposed to have been Spelt, and $x$ probably, sub-species, are cultivated as barleys. H. vulgare or two rowed barley, is that in gencral cultivation, probably, sub-species, are cultivated as barleys. H. vulgare or two rowed barley, is that in gencral cultivation,
and of this the rath-ripe and Thanet are preferred as varieties. H. hexastichon is the bear or bigg chiefly cultivated in the north of Scotland, and in Denmark and Sweden. $\mathbf{H}$. distichon has thin husks, and is preferred for malting. H. zeocriton or sprat barley has short broad ears, long awns, and short coarse straw, and is not much cultivated. The native country of barley is unknown. It was cultivated by the Romans as a horse-corn, and also for the army, and the gladiators were called Hordiarii from their feeding on this grain. In the south of Europe they have sometimes two crops in one season; one sown in autumn and cut in May, and another 
1250 Spike erect close, Spikel. 3-fl. pubesc. Lower and upper in pairs middle in 3s rather shorter than fring. glume 1251 Spike loose erect, Spikel. 3-fl. pubesc. lower remote shorter than the smooth glumes, Leaves involute rigid 1250 Spike erect close, Spikel. 4-fl. from middle to base pubesc. shorter than smooth glume, Leaves involute rigid 1253 Spike erect close, Spikel. 6-7-fl. pub. in 6 s upper in 3s or pairs shorter than smooth glumes, Lvs. invol. rigid

1254 Spike pendulous close, Spikelets 2 together longer than the glumes

1256 Spike pendulous spreading, Spikelets 6-flowered bearded in threes, Leaves flat

1257 Spike nodding spreading, Spikelets 6-flowered bearded the lower in threes upper in pairs, Leaves flat

1258 Spike erect, Spikelets 3-fl. bearded smooth in pairs, Glumes lanceol. nerved as long as spikelets, Leaves flat $1059 \mathrm{Sp}$. erect, Spt. 2-fl. beard. hispid in pairs, Gls. lin. nerv. beard. as long as spikel. Lvs. flat and sheaths smooth 1260 Spike erect, Spikel. 3-fl. villous bearded in threes, Glumes bearded longer than spikel. Leaves flat

1261 Spike erect, Spikel. in 3s 1-2-fl. bearded rough, Glms. linear subul. bearded as long as spikel. Sheaths hairy, 1262 Spikelets 1-fl. rough, Involucres erect

1263 Spikelets 2-fl. Involucres setaceous spreading

1264 Lvs, short involute curved, Spike erect rough, Spikel. in 3s 2-fl. longer than the bearded very narrow invol 1265 Spike erect, Spikelets spreading, Involucr. none

[Outer glume with a short beard

1266 Glumes and beard rough, Paleæ smooth toothed at the end

1267 Stem procumbent at base, Uppermost leafsheath tumid, Glumes and paleæ subulate bearded

1268 All florets hermaphrodite bearded, Seeds in 4 rows, Stems erect

1269 All florets hermaphrodite bearded, Seeds in 6 rows

1270 Lateral florets male beardless hermaphrodite in 2 rows bearded

1271 Lateral florets male beardless hermaphrodite in 2 rows, Spike shori, Seeds angular spreading

1270 All florets fertile in threes bearded, Involucres setaceous ciliated at base

1273 Intermediate glumes linear lanceolate ciliated outer setaceous rough

1274 Lateral florets male with a short beard, All the glumes setaceous rough

1275 All the glumes rough, Inner glume of the lateral florets semi-lanceolate the rest setaceous

1276 Beards and involucres setaceous very long

\section{The only species}

1278 Spike slender subulate incurved

1279 Spike subulate somewhat compressed erect, Leaves channelled

1280 Spike subulate erect, Leaves flat

1281 Spike subulate erect, Glume minute, Florets bearded

1282 Spike subulate erect, Glume ensiform acuminate appressed

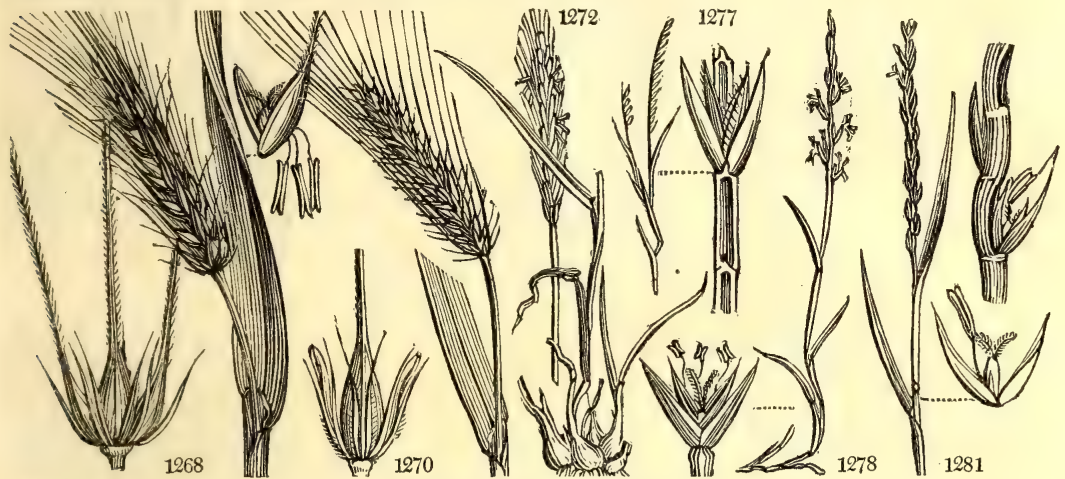

and Miscellaneous Particulars.

sown in spring and cut in autumn. In Lapland two months, and in England nine weeks elapse between the sowing and cutting of this grain.

Malt is the chief purpose for which barley is cultivated in Britain, but it is also made into flour, and pot and pearl barley. In order to understand the process of malting, it may be necessary to observe, that the cotyledons of a seed before a young plant is produced, are changed by the heat and moisture of the earth into sugar and mucilage. Malting is only an artificial mode of effecting this object, by steeping the grain in water, and fermenting it in heaps, and then arresting its progress towards forming a plant by kiln drying, in order to take advantage of the sugar in distillation for spirit, or fermentation for beer. The chemical constituents of mucilage and sugar are very nearly alike: in the process of malting a part of the mucilage or starch is converted into sugar, so that the total quantity of sugar, and consequently the source of spirit, is increased.

Of pot-barley there are two sorts, pearl and Scotch, both produced by grinding off the husk, and the former variety by carrying the operation so far as to produce roundness in the kernel. It is used in soups, gruels, and medicinal drinks.

Barley-flour is ground like flour, and forms a light pudding or pottage, which, spread out in thin cakes and slightly toasted, forms a breakfast bread much esteemed in some parts of Scotland. It is brought to table hot from the baking plate, and eaten with butter and honey, or cream and sugar.

H. murinum, squirrel-tail-grass, is common by way-sides, and its awns or heads are so injurious to the gums of horses in the isle of Thanet, that one of the greatest recommendations of an inn is having " hay without any mixture of squirrel-grass."

H. pratense resembles rye, and to this, Professor Martyn observes, the name of rye-grass belongs, and not to Lolium perenne, which is ray (from ivraye, Fr.) grass.

211. Microchloa. From usxeos, small, xion, grass, on account of its size.

212. Ophiurus.: A name constructed by Gærtner from ó 65 , a snake, and søa, a tail, from a fancied resemblance in the spikes of the genus to the tail of a viper. This is the genus Rottböllia of English botanists : but no true species of that genus have yet been cultivated in this country.

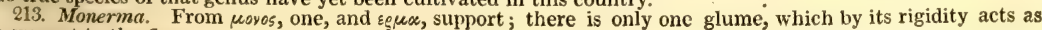
a support to the flower. 


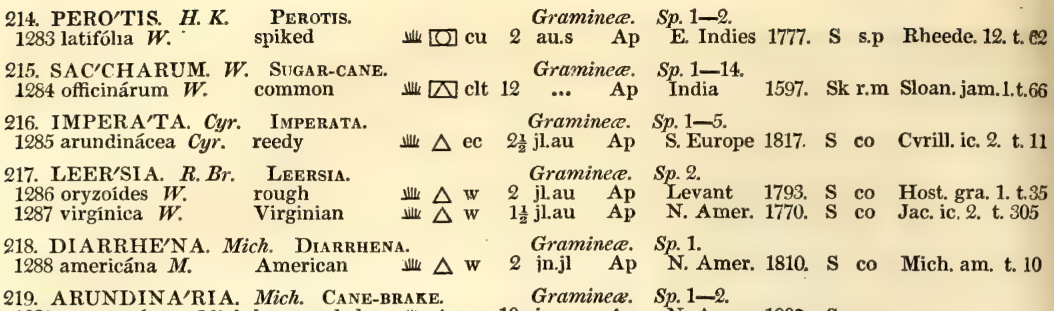

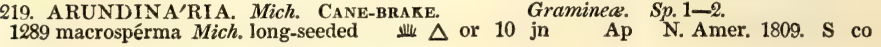

\section{TRIGYNIA.}

220. Holo'steUM. $\boldsymbol{W}$. Holosteum. 1290 umbellátum $\boldsymbol{W}$. umbelliferous 1291 cordátum $W$. cordate

221. POLYCAR'PON. $W$. ALI, SEED. 1292 tetraphýllum $W$. four-leaved 222. LECHE'A. $W$. 1293 májor $W$. LECHEA. greater 1294 mínor $W$. lesser

Caryophyllea. Sp. 2-5.

O pr $\frac{1}{4}$ jl.au Pk England oldwa. S co Eng. bot. 27 [0] $\mathrm{pr} \frac{1}{4}{ }_{\mathrm{jn}} \mathrm{W}$ Jamaica 1814. S co Lam.ill.t.51.f2 O $\quad$ Caryophyllere. $S p, 1-3$.

O w $\frac{1}{2}$ jl W England san.pl. S co Eng. bot. 1031 Caryophyllea. Sp. 2.

† $\Delta \mathrm{w} 3$ jl.au W Canada 1780. D co Lam.ill.1.t.52. $\mathrm{W} 2$ iv $\triangle$ w $\frac{1}{2}$ jl.au W Canada 1802. D co Lam.ill.t.52.f.1

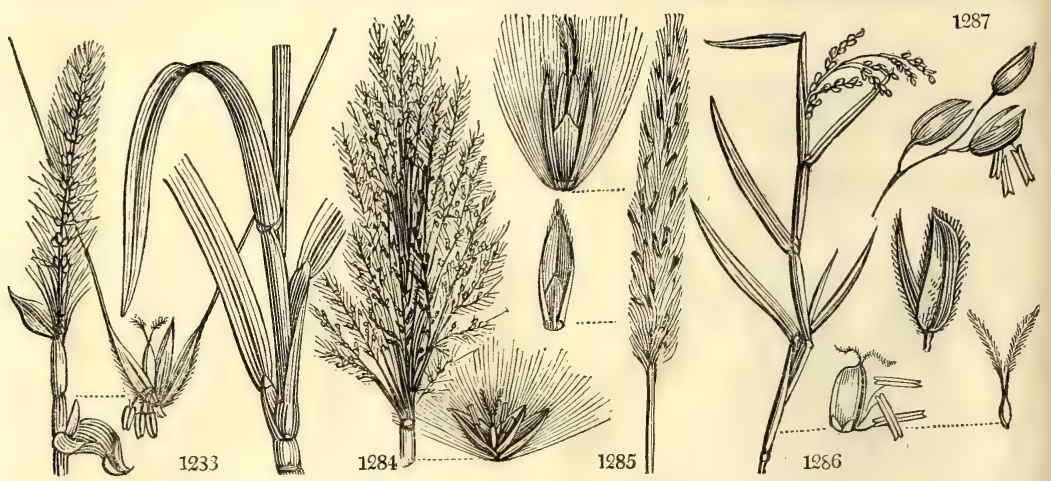

History, Use, Propagation, Culture,

214. Perotis. From aneos, deficient, some parts of the flower being absent

215. Saccharum. From its Arabic name soukar, from which the Greeks formed $\sigma \propto \chi \chi \alpha \rho$, and modern European nations sugar. Sucre, Fr. Sucker, Ger., \&c. This grass or reed, though unknown to the ancients, has become of immense importance in modern times. There are many varieties or species both wild and cultivated, natives of the banks of rivers and meadows in both the Indies, China, Africa, the South Sea islands, and South America. It is cultivated in a zone extending from 35 to 40 degrees on each side of the equator Where it was first cultivated is unknown ; in all probability, in India, for the Venetians imported it from thence by the Red Sea prior to 1148. It is supposed to have been introduced into the islands of Sicily, Crete, Rhodes, and Cyprus by the Saracens, as abundance of sugar was made in these islands previously to the discovery of the West Indies in 1492 by the Spaniards, and the East Indies and Brazil by the Portuguese in 1497 and 1500 the West Indies in 1492 by the Spaniards, and the East Indies and Brazil by the Portuguese in 1497 and 1500. in these provinces. (Townsend and Jacob.) In the 15th century the cane was introduced to the Canary islands by the Spaniards, and to Madeira by the Portuguese, and hence to the West India islands and the Brazils. The Dutch began to make sugar in the island of St. Thomas, under the line, in 1610, and the English in Barbadoes in 1643, and in Jamaica in 1644. The culture of the cane has since become general in warm climates, and the use of sugar being universal, it forms one of the first articles of commerce throughout the world. Sugar is described by Pliny and Galen as a sweet salt, and from the former it appears to have been used only in medicine. Actuarius, a physician, who wrote in the 10th century, or later, was the first to substitute sugar for honey in medicinal compositions. It was called Indian salt, and a small piece was recommended to be kept in the mouth to moisten it in fevers. Different medical men have written for and against the use of sugar, as they have against tea, coffee, wine, and all with similar success. The enjoyment derived from these articles to all mankind who enjoy them, is too great to be left off in deference to the opinions of a few. Dr. Mosely is the greatest advocate for sugar. For the last two centuries it has been an ingredient in the popular diet of is the greatest advocate for sugar. For the last two centuries it has been an ingredient in the popular diet of
Europe. It was in use in England in 1466, but chiefly in feasts and as a medicine, till it was brought from the Brazils about 1580 to Portugal, and imported from thence. The quantity consumed in Britain has always kept increasing; the consumption of England alone in 1790 amounted to $166,573,344 \mathrm{lbs}$. ; which, taking the population at eight millions, gives each individual at an average about $20 \mathrm{lbs}$. a-year.

The cane, as a stove plant, is of easy culture in soft moist soil with a good heat ; it grows seven or eight feet high, but it never flowers. It was grown in abundance in the stoves of the Paris gardens, and a small sugar loaf was made from the canes, and presented to the Empress Josephine. In the botanic gardens of Toulon and Naples it stands the winter in the open air.

The cane in the West Indies is propagated by cuttings from the root end, planted in hills or trenches in spring or autumn, something in the manner of hops. The cuttings root at the joints under ground, and from those above send up shoots, which in eight, twelve, or fourteen months are from six to ten feet long, and fit to cut down for the mill. A plantation lasts from six to ten years. Sugar mills are merely iron rollers placed vertically or horizontally, between which the canes are passed and repassed. The juice thus squeezed out, is collected and boiled with quick-lime, which being an alkali, imbibes the superfuous acid, which would otherwise impede crystallization: impurities are skimmed off, and the boiling is continued till a thick syrup is pro- 
1283 Culm simple, Leaves very smooth, Joints smooth

1284 Flowers panicled, Leaves flat

1285 Pan. spiked cylindrical, Leaves convolute, Joints smooth, Flowers generally diandrous

1286 Pan diffuse sheathed, Florets 3-androus spreading, Keel of the glumes fringed 1287 Pan. diffuse, Branches horizontally spreading, Florets 3-androus, Keel of the glumes fringed 1228 The only species

1289 Smooth, Leaves linear-lanceolate distichous, Flowers panicled

\section{TRIGYNIA.}

1290 Leaves elliptical glaucous smooth, Flowers umbelled, Common peduncle viscid 1291 Leaves cordate

1292 Stem branched 4-leaved prostrate

1293 Leaves ovate lanceolate, Flowers lateral scattered 1294 Leaves linear-lanceolate, Flowers panicled
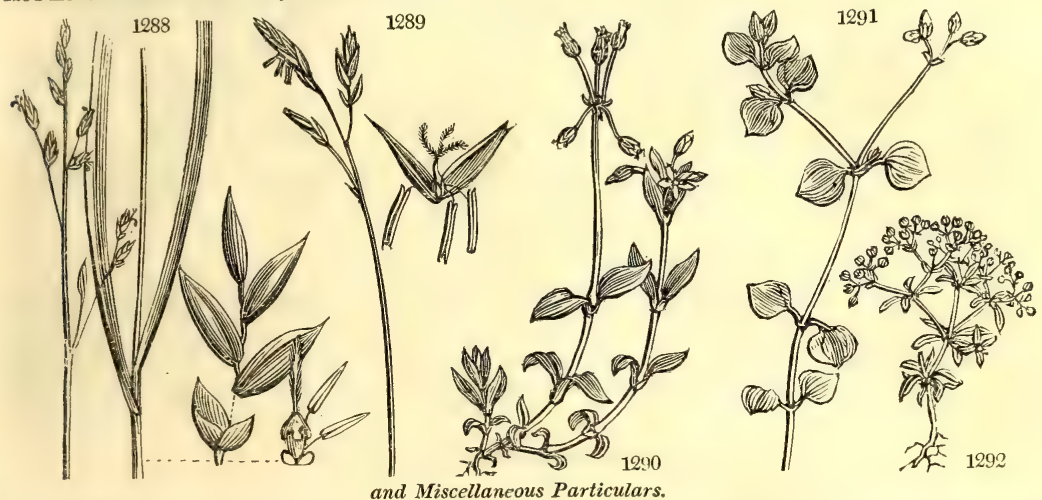

and Miscellaneous Particulars.

duced, when the whole is cooled and granulated in shallow vessels. It is now the raw or Muscovado sugar of corther purification is effected by dissolving it in water, boiling, skimming, adding lime, and or Wh the vel a conical shape, with a a scum. When boiled to a proper consistency it is put into unglazed earthen vessels of a conical shape, with a hole at the apex, but placed in an inverted position, and the base, after the sugar is poured in, covered with clay. When thus drained of its impurities, it is taken out of the mould, wrapped in paper, and dried or baked in a close oven. It is now the loaf sugar of the shops, and according to the number of operations it undergoes, is called single or double refined. The operation of refining is seldom or never performed by the growers ; but in Europe, at least, generally forms a separate branch in the mother country of the colony.

Sugar candy, Shukur and khand, Indian names for sugar in general, is formed by dissolving loaf sugar in Sugar candy, Shukur and khand, Indian names for sugar in general, is formed by dissolving loaf sugar in
water over a fire, boiling it to a syrup, and then exposing it to crystallize in a cool place. This is the only sugar esteemed in the east.

Barley sugar is a syrup from the refuse of sugar candy, hardened in cylindrical moulds.

Rum is distilled from the fermented juice of sugar and water.

Sugar as a chemical compound is described as a neutral salt, consisting of the acetic acid, united to a small suntity of oil and charcoal, carbonated hydrogen, and carbonic acid gas. Besides its use in medicine, dietetics, and distillation, it is employed to preserve animal and vegetable substances from putrefaction, and to communicate a gloss to ink, varnishes, and pigments. When very cheap, it has been successfully employed to fatten caitle. Most plants contain sugar, and it has been extracted in considerable quantities from the beet, parsnip, maple, birch, grape, \&c., but the cane is preferred as affording it in greater abundance.

216. Imperata. The derivation or application of the idea not explained. The plants resemble in their noble port and waving silky heads the plumes of a cap of state.

217. Leersia. Named after J. D. Leers, an author of the Flora Herbornensis, the first edition of which, in 1789 , is very valuable on account of its rarity: but its merits have been extolled much beyond reality by Sir James Smith. One species, L. lenticularis, which has not yet been introduced to this country, has the power of catching flies by the singular structure of its corolla, which resembles the leaves of Dionæa muscipula.

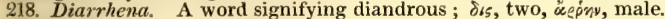

219. Arundinaria. An alteration of the word Arundo, to which genus this may be compared with reference to its large size.

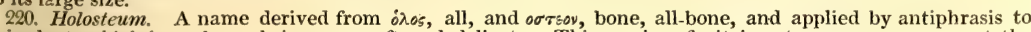
this plant, which is no-bone, being very soft and delicate. This species of wit is not uncommon even at the present day, but applied to men, not plants. The abuse of M. Decandolle in the Botanical Register, p. 729. must be considered a modern instance of the use of this figure of speech; for we find the gentle editor eating his words a few months afterwards, p. 791. in a most satisfactory and complacent manner.

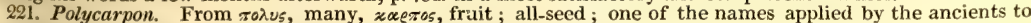
the Polygonum aviculare, and sufficiently applicable to this plant.

222. Lechea. In memory of G. Lecheo, a Swede, professor of natural history at Abo, and author of observations on rare plants; died in 1764 . The genus consists of small N. American plants of no beauty. 
223. ERIOCAU'LlON. $W$. Pipewort. 1295 septánguláre $E . B$. jointed 1296 austrále $R B$. 224. MON'TIA. $: W$. 1297 fontána $W$

1298 rivuláris Gmel. 225. MOLLU'GO. W. 1299 verticilláta $W$ 1300 triphýlla $L k$.

226. MINUAR'TIA. $W$. 1301 dichótoma $W$ 1302 campéstris $W$ 1303 montána $W$. 227. QUE'RIA. $W$ 1304 hispánica $W$. 228. KOENI'GIA. W 1305 islándica $W$. jointed water

Mollugo. whoried three-leaved

W. Minuartia. forked field mountain QUeria. Spanish Chickwerp.

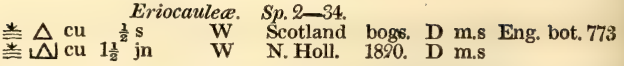

Portulacea. Sp. 2

O w $\frac{2}{4}$ ap.my W Britain springs. $\mathrm{S}$ aq Eng. bot. 1206 Caryophyllee. $\quad$ Sp. 2-7.

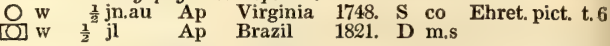

Caryophyllea. Sp.3.

O w $\frac{1}{4}$ jn.jl Ap Spain 1771. S co Ac.st.1758.t.1.f. W 1in jn.jl Ap Spain 1806, S co Ac.st.1758.t.1.f O w $\frac{1}{8}$ jn.jl Ap Spain 1806. S co Loef.it.rar.t.1.f.4 Caryophyllea. Sp. 1-2.

O w 1in my.s Ap Spain 1800. S co Quer.fl.6.t.15. f.2 Polygonece. Sp. 1.

$\mathrm{O}$ cu $\frac{1}{8}$ ap Ap Iceland 1773. S co Lam. ill. t. 51

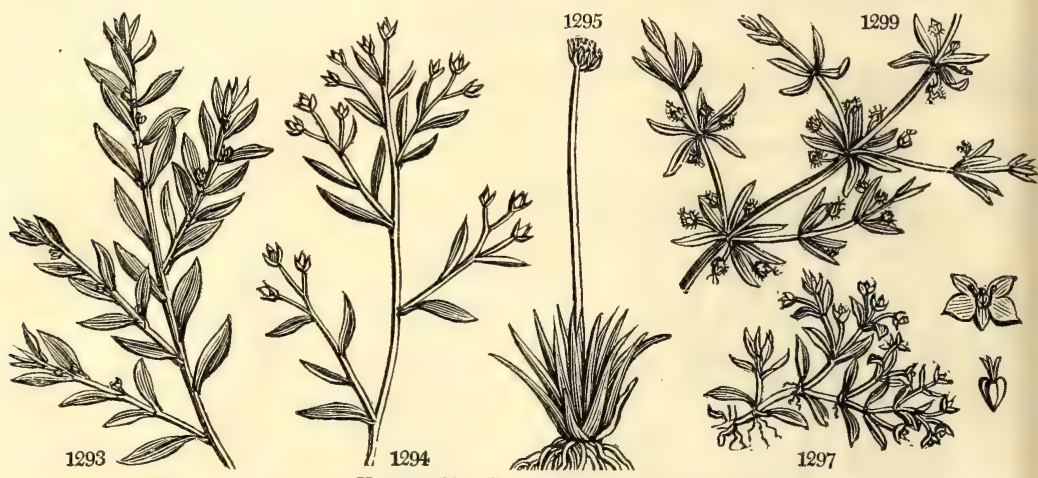

History, Use, Propagation, Culture,

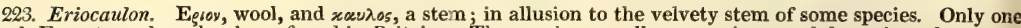
kind, E. septangulare, has been found in Britain. The species are all very curious, and deserving of more attention than they have received at the hands of cultivators.

224. Montia. In honor of Joseph de Monti, professor of botany and natural history at Bologna in the beginning of the 18th century. The plants are small inconspicuous weeds.

225. Mollugo. The Roman name of what is supposed to be our Galium mollugo, which the present plant resembles in its whorled leaves and inconspicuous appearance.

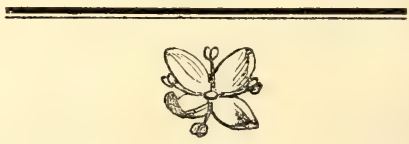

\section{Class IV. - TETRANDRIA. 4 Stamens.}

THIs class is neither so large nor so important as the last. It is composed chiefly of ornamental or curious plants, mostly shrubs, of which the Proteaceæ hold the first rank. Among the few plants used in the arts which it contains, may be mentioned the madder (Rubia), Fuller's thistle (Dipsacus), the holly (Ilex), one of the best evergreen hedge plants; and some foreign timbers and dyes, as the sandal-wood and chayroot.

The Proteaceæ, of which the first section of the class partly consists, are natives chiefly of the Cape of Good Hope and New South Wales; and there is this singular circumstance connected with their geographical distribution, that those two continents do not possess any one genus in common; a singular fact, and of the more difficult solution, as the genera of the order are strictly natural. They have been described by Mr. Brown, in a long and learned memoir, in the Transactions of the Linnean Society, vol. x., where much information respecting them may be found. It has been impossible to state the natural height or color of flower of many of the New Holland kinds, as Mr. Brown says nothing upon these two points : and he is the only author who has seen the plants in their native country, where alone many of them have flowered. In the conservatory they are mostly shrubs of from four to seven feet in height.

The principal part of the fourth section of Monogynia consists of the Stellatæo or Crossworts, which are com. mon weeds all over Europe.

Many of the genera in the sixth section, such as Ixora, Pavetta, Catesbæa, are beautiful ornaments of the conservatory. The wood of Curtisia in the seventh section furnishes the Caffres with materials for the shafts of their hassagays.

With the exception of Proteacex, the class is made up of a miscellaneous assemblage of species, with few characters in common. The genera have not been combined in any other than a purely artificial manner, and among them are to be found plants belonging to almost all the natural orders of Dicotyledonous plants of the older French botanists. Pothos, Potamogeton, and Ruppia are among the rare instances of a quaternary division of the flower in Monocotyledonous plants.

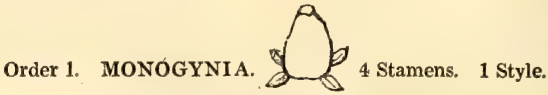

1. Flowers incomplete, (no corolla), inferior.

229. Petrophila. Cal. 4-cleft, all deciduous. Style persistent at base. Stigma spindle-shaped, narrowed at end. Scales beneath the ovary none. Cone ovate. Nut lenticular, comose at one end. 
1295 Stem 7-angled, Leaves acuminate cellular, Male f. monopetalous tetrandrous 1996 Stem 7-angled, Leaves flat hairy much shorter than the stem, Scales of the head powdery

1297 Stem erect divaricating, Leaves connate-sessile oblong ovate 1298 Stem weak dichotomous, Leaves opp. sessile obtuse lanceolate fleshy

1299 Leaves whorled wedge-shaped acute, Stem divided decumbent, Pedunc. 1-flowered 1300 Stem erect, Leaves whorled three larger than the rest, Pan. terminal and lateral

1301 Leaves filiform dilated at base, Branches terminal capitate corymbose, Flowers axillary 1502 Leaves capillary, Flowers terminal stalked alternate longer than bracteæ 1303 Leaves capillary, Corymbs leafy axillary stalked, Flowers shorter than bracteæ

1304 Leaves opposite filiform, Flowers terminal heaped, Bracteæ squarrose

1305 The only species

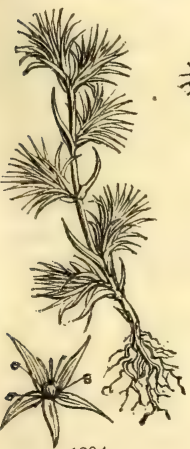

1304
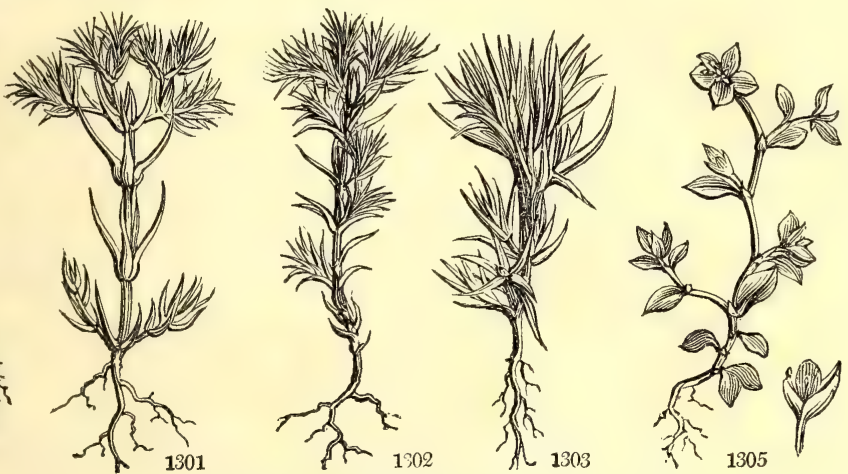

and Miscellaneous Particulars.

226. Minuartia. In memory of John Minuart, a Spanish botanist, and correspondent of Linnæus. He published some Opuscula in 1739.

227. Queria. In memory of Joseph Quer, a Spanish botanist, who published a Flor Espagnol in 1762, in six volumes, quarto, held in no estimation. The plant is Spanish, and worthless also.

228 Kenia. In honor of Emanuel Konig, professor of botany at Bale, and called the modern Avicenna he died in 1731. He published several works now forgotten. The plant is a curious inconspicuous annual, occasionally seen in botanic gardens.

230. Isopogon. Cal. 4-cleft, with a slender tube, persistent for a long time. Style wholly deciduous. Stigma spindle-shaped or cylindrical. Scales beneath the ovary none. Nut sessile, ventricose, comose on all sides.

231. Protea, Cal, bipartible, unequal, with the stamen-bearing divisions of the broader lip cohering. Style subulate. Stigma narrowly cylindrical. Nut bearded on all sides, with the remains of the persistent style. Common receptacle with short persistent scales. Involucrum imbricated, persistent.

232. Leucospermum. Cal. irregular, labiate, with three of the segments (rarely all) cohering at the base, the stamen-bearing divisions distinct. Style filiform, deciduous. Stigma thickened, smooth, sometime unequal-sided. Nut ventricose, sessile, smooth. Head indetinitely many-flowered. Involucrum many-leaved, imequal-side

233. Mimetes, Cal. 4-parted, equal, with distinct divisions. Style filiform, deciduous. Stigma cylin. drical, slender. Nut ventricose, sessile, smooth. Common receptacle flat, with narrow deciduous scales. Involucrum indefinitely many-leaved, imbricated.

234. Serruria. Cal. 4-cleft, nearly equal, with distinct claws. Stigma vertical, smooth. Scales 4 , hypogynous. Nut shortly stalked, ventricose. Head indefinitely many-flowered, with persistent imbricated

235. Nivenia. Cal. 4-cleft, equal, wholly deciduous. Stigma clavate, vertical. Nut ventricose, shining, sessile, entire at the base. Involucrum 4-leaved in a simple series, 4-flowered, when in fruit indurated. Receptacle flat, without scales.

236. Sorocephalus. Cal. 4-cleft, equal, wholly deciduous. Stigma vertical, clavate. Nut ventricose on very short stalk, or emarginate at base. Involucrum 3-6-leaved in a simple series, definitely few-flowered or 1-flowered, in fruit not altered. Recept. without scales.

257. Spatalla. Cal. 4-cleft, wholly deciduous, the inner segment usually largest. Stigma oblique, dilated. Nut ventricose on a short stalk. Involucrum 2-4-leaved in a simple series, 1-flowered, or definitely manyflowered. Recept. without scales.

238. Persoonia. Cal. 4-leaved, regular, the segments having the stamens in their middle, recurved at end, and deciduous. Stamens exserted. Glands 4, hypogynous. Ovary stalked, 1-celled, 1-2-seeded. Stigma obtuse. Drupe berried, with a 1-2-celled nut.

239. Grevillea Cal irregular, with the segments 1-sided, bearing the stamens in their hollow ends. An thers immersed. Gland 1, hypogynous, halved. Ovary 2-seeded. Stigma oblique, depressed (sometimes nearly vertical and conical). Follicle 1-celled, 2-seeded, with a cell in the middle. Seeds edged, or with a very short wing at the end.

240. Hakea. Cal. 4-leaved, irregular, with the segments on one side. Stamens immersed in the concave ends of the calyx. Gland 1, hypogynous, halved. Ovary stalked, 2-seeded. Stigma nearly oblique, with a conical point from a dilated base. Follicle 1-celled, woody, with a cell out of the centre, falsely 2 -valved. Seed with a wing at the end longer than the nut.

24.1. Stenocarpus. Cal. irregular, segments distinct, at one side. Stamens immersed in the concave ends 241. Stenocarpus. Cal. irregular, segments distinct, at one side. Stamens immersed in the concave ends
of the cal. Gland 1, hypogynous, half-annular. Ovary stalked, many-seeded. Style deciduous. Stigma oblique, orbicular, flattened. Follicle linear. Seeds winged at base.

242. Lambertia. Cal. tubular, 4-cleft, the segments spirally revolute. Stamens inserted in the segment3. 
Scales 4, hypogynous, distinct or united in a sheath. Ovary 2-seeded. Stigma subulate. Follicle 1-celled, coriaceous. Seeds emarginate. Involucrum 1-7-flowered, imbricated, deciduous. Receptacle flat, without chaff.

243. Xylomelum. Cal. 4-leaved, regular, the segments revolute at the end. Stam. inserted above the middle of the segments. Glands 4, hypogynous. Ovary 2-seeded. Style deciduous. Stigma vertical, clavate, obtuse. Follicle thick, woody, 1-celled : the cell out of the centre. Seeds winged at end.

244. Telopea. Cal, irregular, on one side irregularly divided, on the other 4-toothed. Stam. immersed in the concave ends of the calyx. Gland none. Ovary stalked, many-seeded. Stigma oblique, orbicular, dilated. Follicle cylindrical. Seeds winged at end. Involucrum none.

245. Lomatia. Calyx irregular, with distinct 1-sided segments. Stamens immersed in the concave ends of the calyx. Glands 3, hypogynous on one side. Ovary stalked, many-seeded. Style persistent. Stigma oblique, dilated, roundish, flat. Follicle oval. Seeds winged at ends.

246. Rhopala. Cal, 4-leaved, regular, segments recurved at end. Stamens inserted above the middle of the segments. Scales 4, hypogynous, distinct or connate. Ovary 2-seeded. Style persistent. Stigma vertical, cla. vate. Follicle 1-celled, woody. Seeds winged at both ends.

247. Banksia. Cal. 4-parted. Stamens immersed in the concave ends of the segments. Scales 4, hypogy. nous. Ovary 2-celled, with 1-seeded cells. Follicle 2-celled, woody. Dissepiment loose, bifid.

248. Dryandra. Cal. 4-parted or 4-cleft. Stamens immersed in the concave ends of the segments, Scales 4, hypogynous. Ovary 2-celled, with 1-seeded cells. Follicle 2-celled, woody, with a loose bifid dissepiment. Common receptacle flat.

249. Struthiola. Cal. tubular, having 8 glands at the mouth. Berry without juice, 1-seeded.

250. Opercularia. Common calyx 1-leaved, campanulate, 3-6-flowered, 6-9-toothed, proper none. Seeds solitary, immersed in a closing receptacle, which is operculiform, deciduous.

251. Cryptospermum. Common calyx 6-leaved : leaflets spreading, unequal ; proper, 3-leaved from the chaff of the receptacle. Recept. globose, chaffy. Capsules 1-celled, united into a sub-globose receptacle, opening lengthwise in the middle.

252. Pothos. Spathe 1-leaved. Spadix cylindrical, simple, covered with flowers. Cal. 4-leaved. Stamens next the ovary. Berry 2 -seeded.

253. Rivina. Cal. 4-leaved, persistent. Berry 1-seeded, with a lentiform rough seed.

254. Camphorosma. Calyx urceolate, with two opposite and alternate teeth very small. Caps. 1-seeded. Stamens exserted.

255. Alchemilla. Cal. 8-cleft, the alternate segments smallest. Style from the base of the ovary. Seed 1, naked, covered with the calyx.

256. Sanguisorba. Cal. coloured, 4-lobed, with 2 scales at the base. Caps. 4-cornered, enclosed in the calyx, 1-2-celled.

257. Dorstenia. Common receptacle 1-leaved, fleshy, dilated, spreading, orbicular, or angular, in which the solitary seeds nestle.

\section{Flowers incomplete, superior.}

258. Isnarda. Cal. campanulate, adhering to the ovary, 4-cleft. Caps. 4-celled, surrounded by the calyx, 4-cornered, many-seeded.

259. Elaeagnus. Cal. 4-8-cleft, campanulate on the outside rugose, inside colored, deciduous. Filaments very short between the segments of the calyx. Style short. Drupe ovate, with an oblong 1-seeded nut.

3. Flowers monopetalous, 1-seeded or dicoccous, inferior.

260. Globularia. Common calyx imbricated : proper tubular, 5-toothed. Cor. with the upper lip 2-, the lower 3-parted. Seed 1, enclosed in the calyx. Recept. chaffy.

261. Houstonia. Cal. 5-toothed. Cor. tubular. Caps. 2-celled, 2-valved, 2-seeded.

\section{Flowers monopetalous, 1-seeded or dicoccous, superior.}

DIPSACEE.

262. Dipsacus. Common calyx many-leaved, proper superior. Cor. tubular, 4-cleft. Seed 1, crowned by the calyx. Recept. conical, chaffy. Pappus cross-shaped, entire.

263. Cephalaria. Common calyx sub-globose, with scales more or less scarious, proper double, pappus shaped, variously split. Receptacle chaffy.

264. Scabiosa. Common calyx many-leaved, proper double pappus-shaped, variously split. Receptacle chaffy.

265. Knautia. Common cal. many-leaved, cylindrical, oblong, simple, 5-flowered, proper simple, superior. Corolla irregular. Seed 1 , crowned by the calyx. Receptacle naked.

\section{STELLATA.}

266. Galium. Cal, an obsolete superior edge, Cor. rotate. Seeds 2, globose.

267. Rubia. Cal. an obsolete superior edge. Cor. rotate, sub-campanulate. Berries 2, 1-seeded. Stam. 4-5. 268. Asperula. Cal. an obsolete edge, 4-toothed. Cor. monopetalous, funnel-form. Seeds 2 , globose, not crowned by the calyx.

269. Sherardia. Cal. a 4-toothed edge. Cor. monopetalous, funnel-form. Seeds 2, 3-toothed, crowned by the persistent calyx.

270. Spermacoce. Cal. a 4-toothed edge. Cor. monopetalous, funnel-form. Caps. 2-celled, not divisible in two, with 2 cells, 2-toothed. Seeds with their edge rolled together over their side

271. Crucianella. Cal. 2-3-leaved. Cor. monopetalous, funnel-form, with a filiform tube and an unguiculate limb. Seeds 2 , linear.

\section{Flowers monopetalous, many-seeded, inferior.}

272. Callicarpa. Calyx 4-toothed. Corolla tubular, campanulate, 4-cleft. Stamens exserted. Berry 4-seeded.

273. Witheringia. Cor. sub-campanulate, with a tube having 4 projections. Cal, very small, obsoletely 4-toothed. Pericarp 2-celled, berried. Anthers conniving, opening laterally.

274. Egiphila. Cal. 4-toothed. Cor. 4-cleft. Style semi-bifid, filiform. Berry 2-celled. Cells 2-seeded.

275. Cephalanthus. Common cal. none ; proper, as well as corolla, 4-toothed, tubular funnel-form. Receptacle globose. Caps. 2-4-celled, not splitting. Seeds solitary by abortion, oblong.

276. Scoparia. Cal. 4-parted, equal. Cor. 4-parted, rotate, with a hairy throat, regular. Stamens equal.

Stigma obtuse. Capsule nearly round, 2-celled, 2-valved, with a dissepiment from the inflexed margins of the valves.

277. Centunculus. Cal. 4-cleft. Cor. 4-cleft, tubular, with a spreading limb. Stamens short. Caps. 2-celled, cut round, many-seeded.

228. Plantago. Cal. 4-cleft. Cor. quadrifid, with a reflexed limb. Stamens very long. Caps. 2-celled, cut round.

279. Buddlea. Calyx and corolla 4-cleft. Stamens from the incisures. Caps. 2-furrowed, 2-celled, manyseeded.

280. Exacum. Cal. 4-leaved. Cor. somewhat bell-shaped, 4-cleft, with a globose tube. Caps. compressed, 2-furrowed, 2-celled, many-seeded, splitting at the end.

281. Sebra. Cal. 4-5-parted, the sepals keeled on winged. Cor. 4-5-cleft, withering. Stamens exserted, 
the anthers bursting lengthwise after flowering with a recurved callus at the end. Stigmas 2. Caps. with the valves inflexed at the edge, inserted in a central placenta, which finally becomes loose.

282. Frazera. Cal. deeply 4-parted, spreading. Cor. much larger than the calyx, very deeply 4-parted, spreading, the segments oval, bearded with a gland in the middle. Stamens shorter than corolla, with anthers 글-divided at the base. Stigmas 2, thick, glandular. Caps. oval, much compressed, 1-celled, 2-valved at the edge. Seeds 8-12, elliptical, with a membranous edge.

283. Penaea. Cal. 2-leaved deciduous. Cor. campanulate. Style quadrangular. Stigma 4-lobed. Caps. 4-cornered, 4-valved, 8-seeded.

284. Blcria. Calyx 4-parted. Corolla 4-cleft, somewhat campanulate. Seeds inserted into a receptacle, Caps. 4-celled, many-seeded, opening at the angles.

6. Flowers monopetalous, 2 or many-seeded, superior.

285. Chomelia. Cal. 4-parted, tubular, with unequal segments. Cor. hypocrateriform, 4-parted. Drupe oval, inferior, with a 2-celled, 2-seeded nut. Stigmas 2, thickish.

286. Adina. Cal, 4-5-cleft, with an occasional toothlet between the divisions. Corolla infundibular. Filaments inserted into the mouth of corolla. Stigma turbinate. Seeds 2-3 in each cell. Flowers in heads.

287. Bouvardia. Cal. 4-leaved, with some teeth between. Corolla tubular. Anthers included. Caps. 2-partible, many-seeded. Seeds edged.

288. Ixora. Cal. 4-parted. Cor. monopetalous, funnel-shaped, long. Stamens above the throat. Berry 4-seeded.

289. Catesbaa. Cal. 4-toothed, very small. Cor. funnel-shaped, very long. Stamens within the throat. Stigma simple. Berry 2-celled, many-seeded.

290. Pavetta. Cal. 4-toothed. Cor. monopetalous, funnel-form. Stigma thickened, incurved. Berry 1-2-seeded, 1-celled.

291. Ernodea. Cal. 4-parted. Cor. hypocrateriform. Style simple. Berry 2-celled. Seeds 2, solitary.

292. Siderodendrum. Cal. small, 4-toothed. Cor. hypocrateriform, 4-cleft, with an incurved tube. Stigmas 2, revolute. Berry 2-coccous, 2-celled, dry, with a contrary dissepiment. Seeds 2, solitary.

293. Coccocypsilum. Cal. 4-parted. Cor. funnel-shaped. Berry inflated, 2-celled, many-seeded. Style half 2-cleft.

294. Mitchella. Cal, 2, on one ovary, 4-parted. Cor. funnel-shaped, hairy within. Stigmas 4. Berry bifid, 4-seeded

295. Oldenlandia. Cal. 5-toothed, persistent. Cor. of 5 petals inserted into the calyx.

296. Manettia. Cal. 8-leaved. Cor. quadrifid, tubular. Caps. 2-valved, 1-celled. Seeds imbricated, orbiculate, with a central point

\section{Flowers polypetalous, inferior.}

297. Epimedium. Cal, 4-leaved, caducous, opposite the petals. Nectaries 4 , cup-shaped, incumbent upon the petals. Pod 1-celled, 2-valved, many-seeded.

298. Ptelea. Cal. 4-parted. Pet. coriaceous. Stigmas 2. Samara roundish with a 1-seeded centre, or 2-celled, 2-secded.

299. Monetia. Cal, 4-cleft, urceolate. Pet. 4, revolute, linear. Berry 2-celled, with 2-seeded cells, one of which is usually abortive.

300. Curtisia. Cal. 4-parted. Petals 4, obtuse. Drupe roundish succulent. Nut 4-5-celled.

301. Hartogia. Cal. 4-5-cleft. Petals 4, spreading. Drupe not juicy, ovate. Nut rather fleshy, 2-seeded.

302. Ammannia. Cal. 1-leaved, campanulate, plaited, 8-toothed. Pet. 4, inserted in the calyx, or very often none. Caps. 2-4-celled, many-seeded.

303. Fagarg Cal 4-5-cleft. Corolla of 4-5 petals, which are shorter than the stamens. Cal. 2-valved, 1-2-celled, 1-seeded, simple or compound. Stam. 4-5.8.

304. Zieric. Cal. 4-cleft. Cor. of 4 petals. Stam. 4, smooth, with filaments inserted into a gland. Style simple. Stigma 4-lobed. Caps. 4, connivent. Seeds with an arillus.

\section{Flowers polypetalous, supcrior.}

305. Cissus. Cal. 1-leaved, nearly entire. Berry 1-seeded, rarely 3-4-seeded, surrounded by the calyx.

306. Cornus. Involucre 4-leaved in some. Cal. 4-toothed. Pet. 4. Drupe with a 2-celled nut.

307. Santalum. Cal. $\frac{1}{2}$-superior, campanulate, 4-cleft. Pet. 4, squamiform. Berry 1-seeded. Embryo inverse, albuminous.

308. Trapa. Cal. 4-parted. Nut with 2 opposite spines proceeding from the leaves of the calyx, 1-celled, 1-seeded.

309. Ludwigia. Cal. 4-parted, superior, with long persistent sepals. Cor. 4-petals or O. Caps. 4-cornered, 4-celled, crowned, inferior, many-seeded.

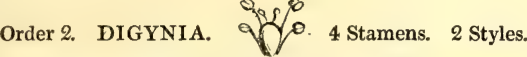

10. Cuscuta. Cor. 4-fid, ovate. Cal, 4-fid. Caps. 2-celled, cut round.

311. Bufonia. Cal, 4-leaved. Pet. 4, shorter than calyx. Caps. 1-celled, 2-valved, 2-seeded

312. Hamamelis. Involucr. 3-leaved. Sepals 4. Petals 4, linear, very long. Nut 2-horned, 2-celled.

313. Hypecoum. Cal. 2-4-leaved. Pet. 4, the two exterior widest. Fruit a silique.

\section{Order 3. TETRAGYNiA. 4tyof 4 Stamens. 4 Styles.}

314. Myginda. Cal. 4-toothed, very small, persistent. Pet. 4, rounded, flat, spreading. Stamens shorter than corolla. Style short. Stigmas 2.4. Drupe globose, 1-celled, with a 1-seeded nut.

315. Ilex. Cal. 4-5-toothed. Cal. rotate, 4-cleft. Style O. Berry 4-seeded.

316. Coldenia. Cor. 1-petalous, Cal, 4-leaved. Seeds 2, 2-celled.

317. Potamogeton. Sepals 4. Pet. O. Style O. Seeds 4, sessile.

318. Ruppia. Cal, and Cor. O. Seeds 4-stalked.

319. Sagina. Sepals 4. Pet. 4. Caps. 4-celled, 4-valved, many-seeded.

320. Tillae. Cal. 3-5-parted. Pet. 3-5, equal. Caps. 3-5, 2 or many-seeded, opening inwards. Nectary none.

321. Radiola. Cal, many-cut. Pet. 4. Caps. superior, 4-8-valved, 8-celled, globose. Seeds solitary. 
MONOGYNIA.

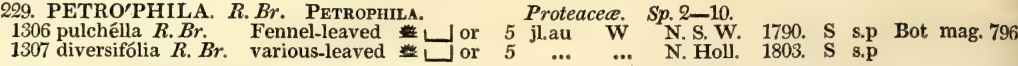

230. ISOPO'GON. $R . B r$. ISOPOGON. 1308 anéthifólius $R$. Br. Dill-leaved 1309 formósus $R . B r$. handsome

1310 anemónifólius $R . B r$. Anemone-leav.

1311 trílobus $R . B r$. three-lobed

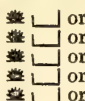

1312 attenuátus $R . B r$ attenuate

Proteacece. Sp. 5-12

231. PRO'TEA. $R$. Br

Protea.

Artichoke-flr

1314 latifólia $\mathrm{Kn}$. Pr.

1315 compácta $R . B r$.

1316 longiflóra $R . B r$.

1317 speciósa $R$. $B$ r

1318 obtúsa $K n$. Pr.

1319 formósa $R . B r$.

1320 melaleúca $R$. Br.

1321 Lepidocárpon $R . B$

1322 neriifólia $R$. Br.

1324 pátens $R$. Br.

ray-flowered

compact

milk-colored

splendid

obtuse

5 mr.jn $\mathrm{Pa}$

N. Holl.

$\begin{array}{lll}4 & \mathrm{mr} . \mathrm{jn} & \mathrm{Pa} \\ 5 & \mathrm{jl} . \mathrm{au} & \mathrm{Y}\end{array}$

N. Holl

1796. S s.p Cav. ic. 6. t. 549

jl.au Y N. Holl. 1791. S s.p

my.jn $\quad \mathrm{Pa}$ N. Holl. 1803 S s.p Bot. mag. 697

... Pa N. Holl. 1822. S $\mathrm{s}$

1325 magnífica $K \boldsymbol{K}$. Pr.

1326 longifólia $R$. Br.

1327 umbonális $K n$. Pr.

1328 ligulæália $\mathrm{Kn}$.

1330 grandiflóra $R$. Br

1331 Scólymus $R . B r$.

1332 mucronifolia $R$. Br. da

1333 inúm $R$. $R$. dagger-leaved

1333 incompta $R$. Br.

1334 nána $R$. $B r$.

1335 péndula $R$. $B$

crown-flowered

black-fringed

crested

wave-leaved

spreading

magnificent

long-leaved

embossed

honey-bearing

great-flowered

dagrer-leaved

bearded

dwarf

pendulous

tough

Proteacea.

1337 canalículáta $R . B r$. channel-leaved

1338 acúmináta $B, M$ sharp-pointed

1339 acaúlis $R$. Br.

a glatis short-stalked

W \begin{tabular}{lll} 
or & $1 \frac{1}{2} \mathrm{mr} . \mathrm{n}$ & $\mathrm{Pu}$ \\
\hline
\end{tabular}

$S p .36-55$

$\begin{array}{llllll}7 \text { jl.s } & \text { Pu } & \text { C. G. H. 1806. S } & \text { s.l } & \text { Bot. mag. } 770 \\ 6 & & \end{array}$

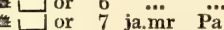

C. G. H. 1810. C s.l.p

C. G. H. 1795. C s.l.p Ex. bot. 2. t. 81

C. G. H. 1786. S s.l Bot. mag. 1183

or 10 Re C. G. H. 1786. C s.l.p Bot. rep. 110

6 my.jn Re C. G. H. 1789. S p.l Bot. mag. 1713

6 mr.jl D.pu C. G. H. 1786. C s.l.p Bot. rep. 103

6 mr.jl D.pu C. G. H. 1806. S s.l Bot. rep. 301. 2

f.ap W C. G. H. 1806. C s.l.p Bot. reg. 208

2 mr.jn W.pu C. G. H. 1789. C s.l Bot. rep. 543

$6 \mathrm{mr.jn}$ W C. G. H. 1789. S s.l Bot. rep. 438

2 mr.au Pu C. G. H. 1798. S s.1 Bot. reg. 47

7 mr.au W.bk C. G. H. 1798. C s.l.p Bot. rep. 144

7 mr.au Pu C. G. H. 1798. C s.l Bot. rep. 133

6 my.d Pa.Y C. G. H. 1774. S s.l Bot. mag. 345

8 my.jn W $\quad$ C. G. H. 1787. S p.l Bot. reg. 569

3 my.jn Pu $\quad$ C. G. H. 1780. C s.l Bot. mag. 698

jl.d W C. G. H. 1803. C s.1 Bot. mag. 933

3 ap.my W C. G. H. 1822. C s.l.p

2 ap.jl Pk C. G. H. 1787. C s.l.p Ex. bot. 1. t. 44

mr.jn $\ldots$ C. G. H. 1806. C l.p

$\begin{array}{llll}\text { f.my } & \mathbf{Y} & \text { C. G. H. 1801. C 1.p Par. lond. } 70\end{array}$

f.d $\quad$ Pk $\quad$ C. G. H. 1800. S s.l Bot. rep. 437

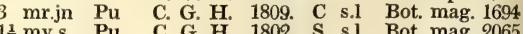

$\begin{array}{llllll}1 \frac{1}{2} \text { my.s } & \underset{G}{\text { Pu }} & \text { C. G. H. 1802. S } & \text { s.l } & \text { Bot. mag. } 2065 \\ \text { Par. lond. } 11\end{array}$

1340 l'vis $R . B r$ Kn. P. glaucous-leaved

1341 scábra $R$. B

1342 répens $R$. B

rough-leaved

creeping

1343 túrbiniflóra $R$. Br. turfy

1344Scolopéndrium R.Br. Hart's-tongue

1345 cordáta $R$. Br.

heart-leaved

1346 amplexicaúlis $R . B r$. stem-clasping

1347 húmilis $R . B r$. low-flowering

1348 acerósa $R, B r$

Pine-leaved

232. LEUCOSPER'MUM.

1349 lineáre $R$. Br.

1350 tóttum $R$. Br.

R.Br. LeUcospermum.

$\frac{1}{\frac{1}{2}} \quad \ldots \quad G$

C. G. H. 1806. C 1.p Bot. mag. 2439

C. G. H. 1809. C l.p

C. G. H. 1800, C s.1 Weinm, t. 897. a

$\frac{1}{2} \ldots . .$.

C. G. H. 1803. C 1.p Par.lond. 108

C. G. H. 1802. S s.1

C. G. H. 1790. S s.l Bot. rep. 289

C. G. H. 1802. S p.l Par. lond. 67

C. G. H. 1802. S s.1 Bot. rep. 532

C. G. H. 1803. C s.1 Bot. rep. 577

ja.mr $\mathrm{Pu}$

3 mr.my $\mathrm{Pk}$

Proteacea.

Sp. $12-18$.

1351 médium $R . B r$. oval-leaved $\bigsqcup_{\text {or }}$ or my.jn o

c. G. H. 1774. S $\mathrm{p}$.

C. G. H. 1794. C 1.p Bot. rep. 17
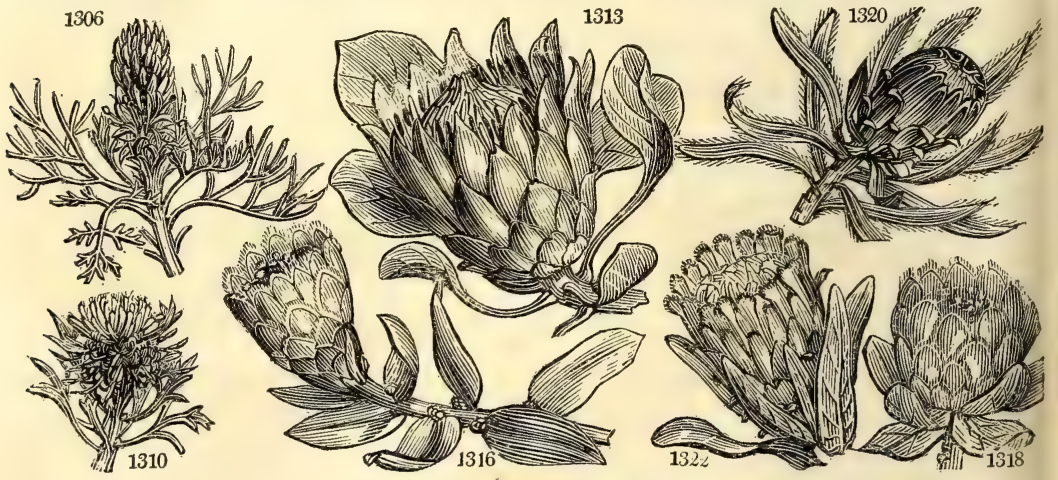

IIistory, Use, Propagation, Culture,

229. Petrophila. From $\pi \varepsilon \tau \rho \circ$ and $\phi i \lambda \varepsilon \omega$, to love rocks, in allusion to the places in which it is found growin in a wild state. Stiff shrubs, with smooth leaves of various kinds. Heads of flowers ovate or oblong, terminal or axillary. Ripened cuttings root in sand under a hand-glass.

230. Isopogon. This genus consists of stiff shrubs, with smooth, flat or filiform, divided or entire leaves. Heads terminal or rarely axillary. Flowers sometimes closely imbricated in a globose cone, sometimes clustered in a common flat receptacle which is somewhat involucrated ; they thrive best in a soil composed of onethird loam, a third of peat, and a third of sand. The pots must be well drained, and ripened wood may be chosen for cuttings which will root in sand and a little earth under a hand-glass. They must be uncovered fre quently, and the glass wiped, as they are liable to damp off if kept too close. (Sweet.)

231. Protea. A mythological name of Proteus the son of Ocean and Thetis, who assumed various forms upon various occasions, to whom this genus, once equally variable in its forms, has been likened. It, as Sweet observes, thrives best in a soil composed of "s light turfy loam, mixed with rather more than one-third of fine sand; the pots must be well drained with broken potsherds to prevent them from getting soddened with too much water; the roots are also very fond of running amongst the small bits of sherds. Care must be taken not 


\section{MONOGYNIA.}

1306 Leaves trifid bipinnate, Segments erect, Flowers silky their segments tomentose at end 1307 Leaves bi-tri-pinnatifid plain, Segments mucronate, Flowers bearded, Cones axillary stalked

1308 Leaves pinnatifid and bipinnatifid filiform furrowed above, Segments erect, Branches smooth 1309 Leaves bipinnatifid somewhat triternate filif. chan. above, Segments divaricating, Branchlets tomentose 1310 Leaves trifid pinnatifid or bipinnatifid, Leaves linear flat spreading erect smooth beneath 1311 Leaves wedge-shaped flat 3-lobed attenuated at base stalked lobes entire, Branchlets tomentose 1312 Leaves elongate oblong mucronate attenuate at base, Branches and involucres smooth

Flowers terminal.

1313 Leaves roundish stalked, Invol. silky, Inner bractes acute beardless, Style pubescent below the middle 1314 Leaves broad ovate $\frac{1}{9}$ cordate sessile, Invol. silky toment. Inner bractes narr. dilated at end and bearded 131.5 Leaves ovate oblong cordate edged the callus of the end prominent, Invol. silky fringed beardless 1316 Leaves ov. obl. sessile subcord. or simple, Branches toment. Invol. silky, Inner bracte elong. fringed silky 1317 Leaves ov. obl. narr. at base with branches smooth, All the bracteæ sim. inn. dilat. at end and beard. in mid. 1317 Leaves ov, obl. narr. at base with branches smooth, All the bracter sim. inn. dilat. at end and beard. in mide 1319 Leaves narr. oblong veiny oblique simple at base, the edges and branches downy, Involucre ciliated 1320 Leaves linear ligulate edged ciliated, Branches hairy, Invol. long turbinate, Bract. fringed with white 1321 Leaves linear ligulate edged roughish shining with the branches smooth, Inner bract. of invol. spatulate 1322 Ieaves linear ligulate smooth opaque at base outside with the branches downy, Invol. fringed with black 1323 Leaves linear ligulate edged shining roughish, Branches little downy, Invol. fringed with black

1324 Leaves narrow oblong rather wavy attenuated at base, Invol. hemisph. inner bearded with black and puxple 1325 Leaves broad long elliptical edged the old ones pubescent wavy, Bractes pale yellow, the upper fringed 1326 Leaves elong. lin. atten. at base, Inv. turb. Bractes smooth acute beardl. Beards of cal. longer than segm 1327 Leaves long ligulate, Head broad convex embossed in middle, Upper bractes spatul. the length of flower 1328 Leaves long ligulate, Head broad not convex, Upper bractes spatulate longer than flowers

1329 Leaves lanc. ligul, attenu, at base, Inv, turb. Bractes smooth beardl, viseid, Beards of flow. woolly white 1330 Leaves obl. sessile and branches smooth, Invol. hemispherical beardl. naked, Fl. toment. Style smooth 1331 Leaves lin. lanceolate acute submucr. attenuated at base, Invol. hemispherical, Bractes smooth obtuse 1332 Leaves lanc. lin. mucr. pungent with an obtuse base, Bractes lanc. mucr. smooth, Stem erect many-flow. 1333 Leaves ligulate oblong the upper and the branches hairy, Inner bracteæ with a round and bearded end 1334 Ieaves subulate mucronate, Invol. nodding hemispherical, Bract. smooth obtuse

1335 Leaves linear lanceolate mucronate, Flower-bearing branches recurved, Bract. obtuse at length smooth 1336 Leaves lin. lanc. flat attenuated at base roughish at edge, Branches decumbent, Invol. hemisph.

1337 Leaves linear veinless smooth concave above, Branches smooth decumbent, Invol. obtuse

1338 Leaves lin. lanc. acute flat veiny above, Bractes obtuse pubesc. and conc. at end, Branches wavy colored 1339 Stems short with depressed branches, Leaves obov. obl. edged veiny attenuat. at base, Invol. hemispher. $\beta$ Leaves more glaucous and narrow

1340 Stems dwarf decumb. Leaves elong. lin. smooth veinless recurved at edge, Invol. hemispherical 1341 Stems dwarf, Leaves elong. lin. scrabrous obsoletely veiny recurv, at edge, Invol. turbinate hemispher. 1342 Stems decumb. dwarf, Leaves elong. lin. roughish revol. at edge, Invol. turb. Bractes obtuse tomentose 1343 Stems dwarf, Leaves elongate lanc. edged subundulate smooth, Invol. turb. Bractes tomentose obtuse 1344 Stems dwarf, Leaves elongate lanc. edged smooth, Invol. turbinate, Bractes lanceolate acuminate

1345 Leaves cordate roughish nerved, Bractes smooth Flowers lateral.
smooth

1346 Leaves cordate ovate, Stem clasping divaricate recurved at the end, Bractes pubescent 1347 Leaves linear acute, Receptacle conical, Paleæ acute 1348 Leaves subulate, Receptacle convex, Paleæ obtuse

1349 Style longer than the hairy flower, Stigma gibbous on one side, Invol. downy, Leaves linear entire 1350 Style a quarter longer than the hairy flow. Stigma gibb. on one side, Leaves lin. obl. veiny ent. obt. at base 1351 Style nearly twice as long as hairy flow. Stigma gibb. on one side, Leaves lin. obl. entire or 2 or 3-toothed

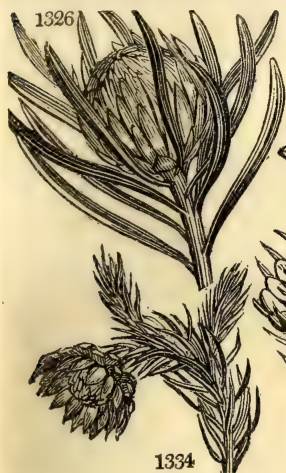

1334

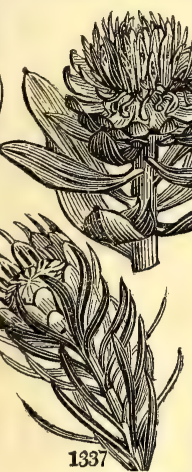

1330
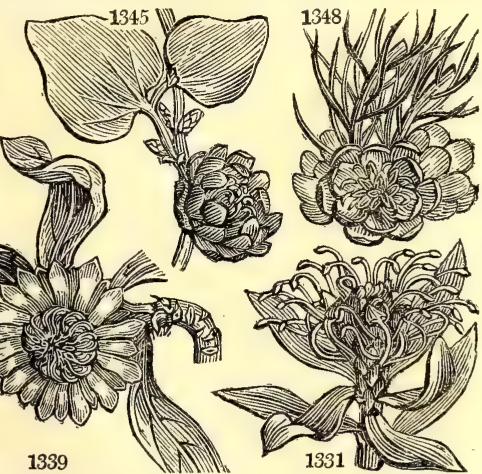

1339

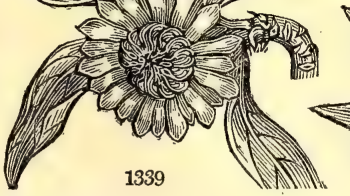

to let them droop for want of water, as the young roots are of a very fleshy substance, and soon suffer by too much drought, as well as by too much wet, so that they seldom recover if suffered to flag much ; they also like to be placed where they may have a free circulation of air, as they cannot bear to be crowded like some more rigid-growing plants. Ripened cuttings taken off at a joint, and pared quite smooth, will strike root if planted thinly in pots of sand placed under a hand-glass, but not plunged: the glasses must be often taken off to give them air, as they are very liable to get the damp amongst them, which soon spreads if not cleaned off, and destroys them; water them regularly whenever they want it, but not over the leaves, and let them get a little dry before the glasses are placed over them again. Some of the kinds root very soon, others are a long time

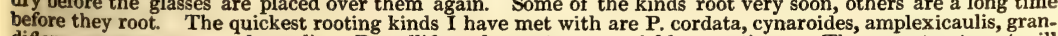
diffora, acerosa, nana, and acaulis. P. mellifera also roots very quickly sometimes. The same treatment will agree with several other genera belonging to this family, as Leucospermum, Spatalla, Sorocephalus, Leucam dendron, and Aulax. (See Bot. Mag. No. 1717. Bot. Cult,244.) There are several kinds in cultivation, and published in Knight's Proteeæ, which have not been retained here; because, as they are not acknowledged by Mr. R. Brown, it is probable that they are not distinct from some which are here enumerated." 
1352 formósum $K n$. Pr. handsome 1353 ellipticum $\boldsymbol{R}$. Br. elliptic 1354 conocárpum $R$. $B r$. many-toothed 1355 grandifiórum $R$. Br. great-flowered 1356 púberum $R, B r$. downy-leaved 1357 tomentósum $\boldsymbol{K} n . P r$. cottony 1358 párile $\boldsymbol{K} n . \mathbf{P r}$. matched 1359 cándicans $B . R$. Rose-scented 1360 Hypophýllum $R . B r$ r trifid-leaved 233. MIME'TES. $R . B r$. MrMetes. 1361 hírta $R . B r$. 1362 palústris $K \boldsymbol{K}$. $\mathbf{P r}$. mars 1363 cuculláta $R . B r$. three-toothed 1364 divaricáta $R . B r$. divaricate 1365 vaccíniifólia Sweet. Vaccinium-lvd. 1366 purpúrea $R . B r$. Heath-leaved 234. SERRU'RIA. $R . B r$. Serruria.

1367 abrótanifólia $K n, \boldsymbol{P}$. Southernw..lvd 1368 mill 1368 millefolia Kn. P. Thousand-leav'd 1369 artemisiæfólia $K \boldsymbol{n} . \boldsymbol{P}$. wormwood-lvd. 1370 pinnáta $R$. Br. 1371 arenária $\boldsymbol{R}, \mathrm{Br}$. 1372 cyanoídes $R . B r$.

1372 cyanoídes $R . B r$ r. trifid-leaved 1374. Nivéni $R$. Br 1375 ciliáta $R$. $\mathrm{Br}$. 1376 phylicoídes $\boldsymbol{R} . \boldsymbol{B r}$. $1377 \mathfrak{x}^{\prime}$ mula $R$. Br. 1378 párilis $\boldsymbol{K} n . P$. 1379 odoráta Sweet.

1380 emargináta Sweet. Serruria arenária

1381 glomeráta $R . B r$. 1382 decípiens $R$. $B r$ 1383 Roxbúrghi $\boldsymbol{R}$. $\boldsymbol{B r}$ 1384 Burmánni $R$. Br. 1385 triternáta $R$. Br. 1386 elongáta $R$. Br.

235. NIVE'NIA. $\boldsymbol{R} . \boldsymbol{B r}$ 1387 Scéptrum $R$. Br. 1388 spathuláta $R, B r$. 1389 spicáta $R$. $B r$ 1390 crithmifólia $\boldsymbol{R}$. $\boldsymbol{B r}$. $\square$ or sand woolly-heade decumbent ciliated Phylica-flower. grey-branched matched sweet-scented emarginated Kn. Prot. many-headed deceptive Roxburgh's Burmann's silvery-flower'd long-stalked

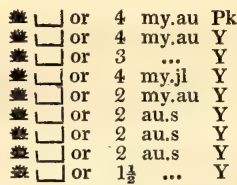

Proteacea

$3 \frac{1}{\mathrm{a} n \text {.au R }}$ jn.au Pu 1 in... $\mathrm{s}$ $1 \frac{1}{2}$ jn.s 2 n. $\ddot{d} \quad P u$

Proteacec. 4 jn au Pk 4 jn.au Pu 5 jn.au Pu 1 jn.au Pk 1 jn.au $\mathrm{Pu}$ $1 \frac{1}{2}$ jn,au $\mathrm{Pu}$ 7 jn.au $\mathrm{Pu}$ $\frac{1}{2}$ jn.au Pu jn.au Pu jn.au Pu jn.au Pk jn.au Pk 2 jn.au Pk $\begin{array}{lll}4 & \text { jn.au } & \mathrm{Pu} \\ 4 & \text { jn.au } & \mathrm{Pu}\end{array}$ jn.au W $7^{\frac{2}{2}}$ jn.au W 1즐 jn.au Pu

Proteacea. NIVENIA. ceptre-like jor 2 my.jn W maiden-hair-lv. $\mathbb{N}$ or $2 \frac{1}{2}$ jl.au $\mathrm{Pu}$ spiked or $2 \frac{1}{2}$ jn.au Pu

C. G. H. 1784. S p.l Bot. rep. 469 C. G. H. 1803. C 1.p C. G. H. 1774. S s.I Pl. pht.t.200.f.2 C. G. H. 1800. S p.1 Par, lond. 116

C. G. H. 1774. C s.l

C. G. H. 1789. S p.I

C. G. H 1789. C lp

C. G. H. 1790. S p.1 Bot. rep. 294

C. G. H. 1787. S p.l Pl. man.t. $440 . f .3$ Sp. 6-13.

C. G. H. 1774. C s.l W.ph.4.t.899.f.a C. G. H. 1802. C 1.p B. lgd.2.p.194.c.t C. G. H. 1789, S s.1 P.al.212.t.304.f.6 C. G. H. 1795. C s.1

C. G. H. 1800 , C 1.p

C. G. H. 1789, C s.l

Sp. $20-46$

C. G. H. 1803. C $1 \mathrm{p}$ Bot. rep. 522

C. G. H. 1803. C 1.s.p Bot. rep. 337

C. G. H. 1789. C 1.p Bot. rep. 264

C. G. H. 1803. S p.1 Bot. rep. 512

C. G. H. 1803. C s.p

C. G. H. 1803. S p.l Pl.m.61.t.345.f.6

C. G. H. 1789. C p.l.s Bot. rep. 264

C. G. H. 1800. C s.p.1 Bot. rep. 349

C. G. H. 1803. C s.1

C. G. H. 1788. S p.1 Bot. rep. 507. f. 4

C. G. H. 1803. C 1.p

C. G. H. 1803. C p.l Bot. rep. 507

C. G. H. 1803. C p.1 Bot, rep. 545

C. G. H. 1800. C p.1 Bot. rep. 536

C. G. H. 1789. S p.I Bur, afr.t.99. f.2

C. G. H. 1806. C l.p

C. G. H. 1786 C l.p Bur afr, t. y9. 2

C. G. H. 1802. S p.1 Bot. rep. 447

C. G. H. 1800. C l.p

Sp. 5-12.

C. G. H. 1790 . S p.l

C. G. H. 1790. C s.1 Thu.dis.n.58. t.5

C. G. H. 1786. S p.1

$2 \frac{1}{2}$ jn.au Pa.pu C. G. H. 1797. S p.l Bot. rep. 243

C. G. H. 1803. C s.p Bot. rep, 234

Proteacea. Sp. 6-10.

236. SOROCE'PHALUS. $\boldsymbol{R}$. Br. SoRocephalUS.

1392 imbérbis $R . B r$ s smooth J or

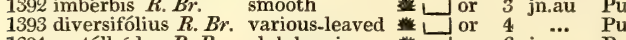

or 3 jn.au Pu

1395 tenuifolius $R$. Br. slender-leaved

1396 lanátus $R . B r$. woolly

1397 imbricátus $\boldsymbol{R} \cdot \boldsymbol{B r}$. imbricated

237. SPATAL/LA. $R . B r$. Spatalla.

1398 prolín $R$. $B r$.

1398 prolifera $R$. Br.

1399 ramulosa $R$. B

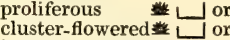

incurved-leav'd e

3 jn.au Pu

2 jn.s $\quad \mathrm{Pu}$

Proteacea.

$1 \frac{1}{2}$ jn.au Pu

3 au.s Pu

$2 \frac{1}{2}$ my.jn $\mathbf{P u}$

C. G. H. 1806. C s.p

C. G. H. 1803. C 1.p

C. G. H. 1803. C s.p

C. G. H. 1802, C 1,p

C. G. H. 1790. C 1.p Thu. dis.n.30.t.3

C. G. H. 1794. S p.1 Bot. rep. 517

Sp. 4-16.

C. G. H. 1800. C s.1 Thunb.dis.27.t.4

C. G. H. 1787. C 1.p

C. G. H. 1789. S s.1 Bot. rep. 429

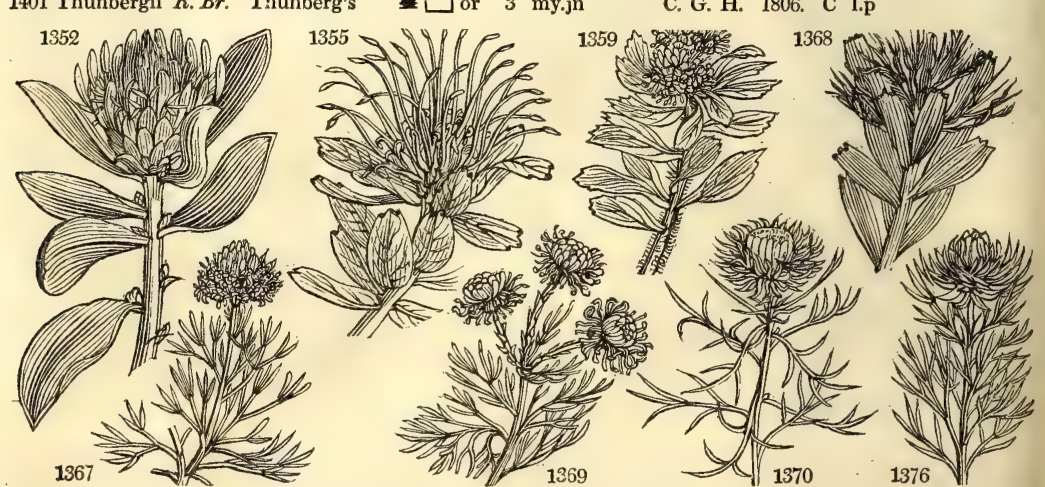

History, Use, Propagation, Cuiture,

232. Leucospermum, From $\lambda$ svzos, white, and $\sigma$ rseuc, seed, in allusion to the color of the seeds The genus is chiefly composed of low shrubs, which are usually downy or hairy. Leaves entire, or with callous teeth at the end. Heads terminal. Flowers yellow. The culture as for Protea

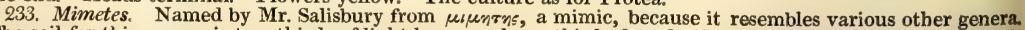
The soil for this genus is two-thirds of light loam, and one third of sand. In other respects, the treatment is the same as for Isopogon.

234. Serruria. Named by Burmannus after Professor Joseph Serrurier, an obscure botanist, of whom little is

known. The species flower freely, and make handsome bushy shrubs. The soil best adapted to them is onethird light loam, a third of peat, and a third of sand, with well drained pots. "They also require an airy situation, as they are so crowded with leaves that the branches are liable to damp and canker if any wet settles 

238. PERSOO'NIA. $\boldsymbol{R} \cdot \boldsymbol{B r}$. Persoonia. 1404 lanceoláta $\boldsymbol{R} . B r$. spear-leaved 1405 salicína $R$. Br. willow-leaved 1406 latifólia Andr. 239. GREVILLEA. 1408 sericea $R$. $B r$. 1409 punicea $R . B r$ 1410 juniperina $R . B r$. 1411 linearis $R . B r$. 1412 ripária $R$. $B r$.

1413 arenária $\boldsymbol{R} . \mathbf{B r}$. 1414 acumináta $R$. Br. 1415 stylósa $K n$. $P$. 1415 stylósa $K n$. $P$. $\quad$ long-styled 1417 cinérea $R$. $B r$.

1418 buxifólia $R . B r$. Box-leaved 1419 collína $K n$. $P$. hill pine-leaved silky jurple linear-leaved river-side

sand acute-leaved 1407 pinifolia $R$. $B r$

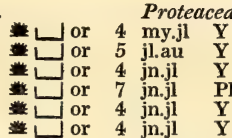

R. $\boldsymbol{B} r$. Grevillea . Proteacee. 6 ap.s Pk

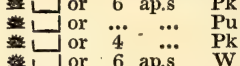
L ${ }^{2}$ or 4 ap.s $\quad$ Pk

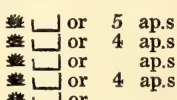

ap.s

4 ap.s

輩

蒌

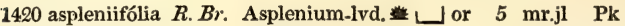
240.! HA'KEA, $R, B r$. HAKEA.

1421 pugiónifórmis $R . B r$. dagger-fruited 1422 párilis $K n . P$. 1423 obliqua $R$. $B$ r. 1424 gibbósa $R$. Br. 1425 aciculáris $R$. $B r$. 1426 suavéolens $R$. $B r$. 1427 microcárpa $R$. Br.

1428 flórida $R . B r$. 1429 ilicifólia $R, B r$. 1430 nítida $R$. $B r$. 1431 amplexicaulis $R \cdot B r$. stem-clasping 1432 prostráta $R$. $B r$. 1433 ceratophýlla $\boldsymbol{R}$. Br. horn-leaved 1434 acanthophýlla $L k$. prickly-leaved 1435 unduláta $R$. $B r$.

1436 óleifólia $R . B r$.

1437 salígna $R$. $B r$. 1440 elliptica $R$. $B r$. oval-leaved

241. STENOCAR'PUS. $R, B r$. STENOCARPUS

1441 salignus $R$. B

242. LAMBER'TIA. $\boldsymbol{R}, \boldsymbol{B r}$. LAMBERTIA. 1442 formósa $R . B r$. handsome

243. XYLOME'LUM, $\boldsymbol{R}$. $\boldsymbol{B r}$. XYLOMELUM 1443 pyrifórme $R$. Br. pear-fruited 244. TELOPE'A. $R$. $B r$. WarRatah. 1444 spéciosíssima $R$. $B r$. splendid 245. LOMA'TIA, $\boldsymbol{R}, \boldsymbol{B r}$. Lomatia. 1445 siláifólia $R$. Br. cut-leaved 1446 longifólia $\boldsymbol{R} . \boldsymbol{B r}$. long-leaved

Proteacea.

6 my.jn W my.jn W 6 ... W my.jn W ja.n W 4 my.jn W

5 my.jn W 4 jl.s W jn.jl W W $1 \frac{1}{3} \quad \cdots \quad W$ my.jn $\mathrm{Br}$ a... Proteacece. jn.ji $\dddot{w} \quad$ N. Holl. 1803. $\mathbf{L}$ s.p jni.ji W N. Holl. 1794. S s.p Bot. rep, 215 jn N. S. W 1790. S s.p

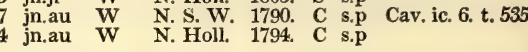

N. Holl. 1794. C s.p Sp. 1-2.

N. Holl. 1819. C s.l Bot. reg. 441 Proteacea. Sp. $1-2$

4. jn.au Re N. S. W. 1788. C s.p Bot. rep. 69 Proteacea. Sp. 1.

1 or 14 Proteacea. $\quad$... $\quad$... N. S. W. 1789. S s.p Cav. ic. 6. t. 536

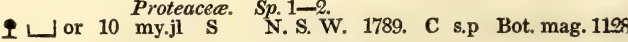
Proteacece. $S p .2-8$.

늘 or 2 jn.au O N. S. W. 1792. C s.p Bot. mag. 1272 N. S. W. 1816. C l.p Bot. reg. 442

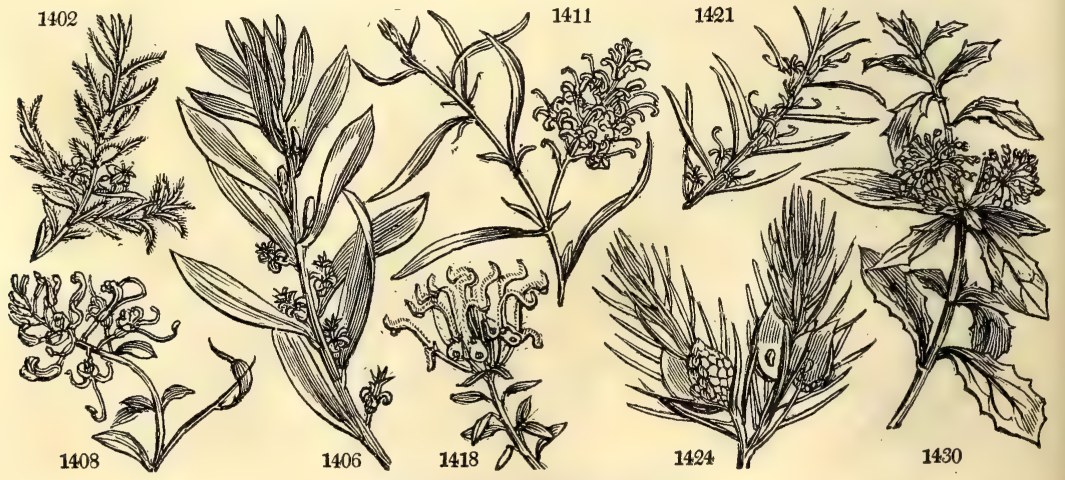

History, Use, Propagation, Culture,

238. Persoonia. So named by Sir J. E. Smith, in honor of C. H. Persoon, the celebrated author of Symopsis Plantarum and other esteemed works : he is still living, and about to publish a new edition of his most useful Synopsis.

239. Grevillea. So named by Mr. R. Brown, after the Right Honorable Charles Francis Greville, a great promoter of natural history. He was one of the vice-presidents of the Royal Society. Some species ripen abundance of seeds; all of them thrive in an equal mixture of sandy loam and peat, and strike roots freely in sand under a hand-glass.

240. Hakea. Named by Schreber after Baron Hake, a patron of the botanic garden at Hanover. This genus thrives in equal parts of loam, peat, and sand well drained; and cuttings root readily in sand under a hand-glass. 
1402 Leaves linear hairy scabrous recurved at edge, Flowers axillary, Ovary one-sided silky

1403 Leaves oblong linear mucronate rather villous, Flowers axillary solitary

1404 Leaves lanceolate or elliptical mucronate glabrous smooth, Peduncle axillary 1-flowered, Flower silky

1405 Leaves lanceolate oblong unequal-sided, Flowers smooth, Stem arborescent, Bark scarious in layers

1406 Leaves obovate acute smooth on both sides without ribs thick, Flowers axillary remote on long stalks

1407 Leaves filiform lax, Spike leafy elongated pyramidal, Floral leaves abbreviated Style smooth, Follicle ribless.

1408 Leaves ellipt. or obl. obt. mucr. broken back at the edges, Flower branches erect, Racemes abbrev. recurv. 1409 Leaves elliptical oblong attenuate at base broken back at edges, Flower bearing branches recurved 1410 Leaves subulate fascicled divaricating broken back at the edge, Branches villous rounded

1411 Leaves linear lanceolate acute mucr. broken back at edges, Rac. abbreviate erect, Style very smooth at end 1412 Lvs, elong. linear broken back at edges smooth, Inner beard of flower very dense, Stalks longer than ovary Style hairy. Follicle ribbed.

1413 Leaves oblong obtuse mucronate, Racemes recurved few-flowered, Pistils tomentose

1414 Leaves lanc. sub-acum. mucr. above dotted scabrous beneath cinereous, Branc. pubes. Rac. few-fl. recurved

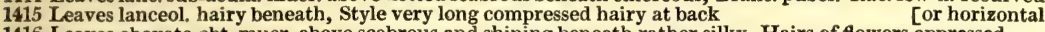
1416 Leaves obovate obt. mucr. above scabrous and shining beneath rather silky, Hairs of flowers appressed 1417 Leaves elliptical and obovate mucronate above roughish beneath cinereous Pistil woolly. Follicle ribless.

as recurved appendage 1418 Leaves elliptical above dotted scabrous beneath cinereous with close tomentum, Stig. orbic. scarcely as long 1419 Leaves elliptic lanceolate little revolute at edge, Flowers scarcely higher than leaves Raceme thyrsoid. Leaves pinnatifid. (True Grevillea, Br.)

1420 Leaves elongate linear pinnatifid cut or entire beneath tomentose, Racemes 3 times as short as the leaf Leaves filiform.

1421 Leaves smooth, Flowers silky or hairy, Caps. lanceolate acuminate straight crested on both sides 1422 Leaves smooth with bloom not channelled, Petals woolly

1423 Leaves terete, Branches toment. Gland attached to oblique end of stalk, Flow. silky, Caps. gibbous nodose 1424. Lvs. ben. with an obsol. furr. at base and branc. s.-pub. Branchl. and fl-stks. hairy, Caps. gibb. with cav. inside 1425 Leaves smooth beneath below the middle with an obsolete furrow the length of fruit, Caps. gibbous rugose 1426 Leaves furrowed above pinnatifid occasionally undivided, Flowers racemose smooth, Caps. gibbous

$1427 \mathrm{Lvs}$, of upper branches filif. of lower flat, Perianths very smooth, Caps. with 2 spurs umbelled much shorter Lenves flat, toothed, or entire.

than leaf

1428 Leaves narrow-lanceol. prickly toothed minutely dotted a little rough at the edge, Caps. 2-spurred convex 1429 Leaves oval opaque sinuate-toothed prickly stalked, Caps. 2-spurred ovate gibbous compressed at end

1430 Lvs. lanc. or obl. attenu. at base with a few prickly teeth or entire shining veiny with branches very smooth 1431 Lvs. sinu. tooth. shining veiny stem clasp. with a dilated cord, base, Stem prost. Bran. smooth, Caps. spurl. 1432 Lvs. angul. tooth. dil, at end and cuneate at base cord. stem clasp. Stem prost. Branc. pubes. Caps, spurless 1433 Leaves pinnatifid and bipinnatifid linear, Capsules spurless

1434 Leaves pinnatifid the anterior segments 1 inch long the posterior $1 \frac{1}{4}$ inch and more

1435 Leaves obovate 3-nerved reticulated wavy prickly toothed, Caps. spurless ventricose

1436 Leaves lanc. entire and nerved obsoletely veined prickly at end upper pubesc. Caps. term. 2-spurred gibbous 1437 Lvs, elongate-lanc. entire 1-nerv. acute withered at end with hran. very smooth, Caps. keeled on both sides 1438 Lvs. lin.-lanc. elongate entire 3-nerv. obsoletely veined rough. wither. at end, Bran. downy, Caps. lanceol. 1439 Leaves entire 3-nerved veiny obovate-oblong or linear lanceolate reversed, Branches angular, Bark warted 1440 Leaves entire 5-nerved reticulated elliptical or oval pointless, Stalks and flowers smooth, Bark shining

1441 Leaves elongate lanceolate 3-nerved at base

1442 Involucres 7-flowered, Leaves linear-lanceolate cuspidate

1443 The only species

1444 Leaves wedge-shaped oblong toothed veiny smooth

1445 Leaves bipinnatifid very smooth, Segments wedge-shaped or lanceolate cut

1416 Leaves linear lanceolate elongate smooth remotely serrate

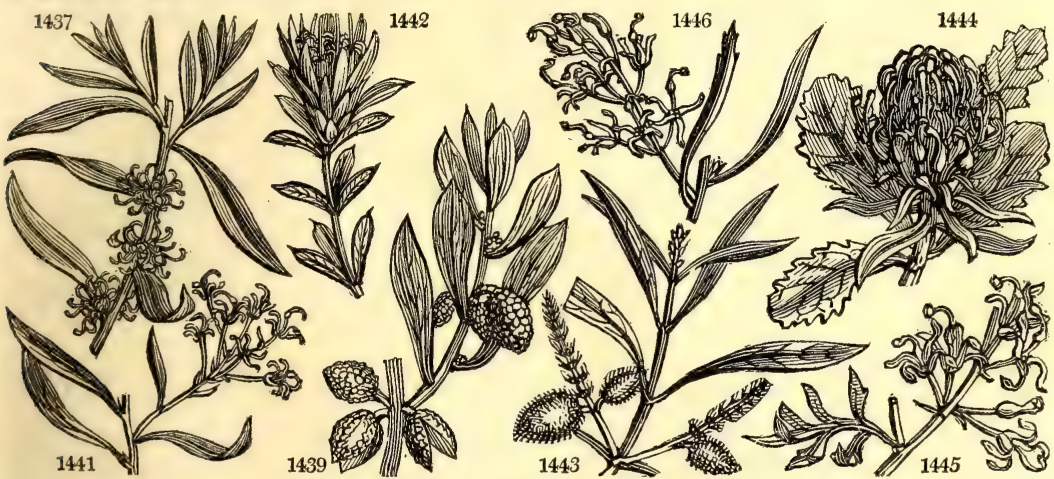

and Miscellaneous Particulars.

241. Stenocarpus. A handsome genus. The name is derived from $\sigma \tau \varepsilon v{ }^{2}$, narrow, and raeros, fruit.

242. Lambertia. In honor of A. B. Lambert, Esq. F. R. S., vioe-president of the Linnæan Society, and possessor of a rich Herbarium. This handsome plant thrives well in loam and peat not over watered. Cuttings must be taken off at a joint before they begin to push, and planted thinly in sand under a glass, and guarded from damp.

243. Xylomelum. A name derived by Sir J. E. Smith from the remarkable fruit of the plant which resembles

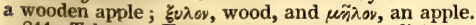

244. Telopea. From snd $^{2}$ aros, seen at a distance, in allusion to the brilliant crimson blossoms which decorate the plant, and make it a conspicuous object in its own country, as well as in our conservatories.

245. Lomatia. From n.we⿰, an edge, on account of the winged edge of the seeds. 
246. RHOPA'LA. $R \cdot B r$, RHOPALA.

1447 dentáta $R$. Br. tooth-leaved

1448 séssilifólia $R . B r$. sessile-leaved

247. BANK'SIA. $R$. Br. BANKSIA.

1449 pulchélla $R . B r$. small-flowered

1450 sphærocárpa $R . B r$. round-fruited

1451 nútans $R . B r$, nodding-flower

1452 erícifólia $R$. Br: Heath-leaved

1453 spinulósa $R$. Br.

1454 collina $R$. $B r$.

spiny

1455 occidentális $\dot{R}$.

1456 littorális $R$. $B r$.

1457 margináta $R . B r$.

1458 austrális $R$. $B r$.

1459 intégrifólia $R . B r$.

1461 coccínea $R . B r$.

1462 paludósa $R$. $R$ r

1463 oblongifólia $R$. B .

1464 latifólia $R . B r$

1465 marcéscens $R$. $B$

1467 attenuáta $R$. $B$.

1468 serráta $R$. $B r$.

$1469 æ^{\prime}$ mula $R$. $B$ r

1470 quercifólia $R . B r$

1471 dentáta $R$. Br

1472 speciósa $R$. $B r$.

1474 répens $R . B r$.

west-coast

sea-side

various-leaved

southern

entire-leaved

verticillate

marshy

oblong-leaved

broad-leaved

short-leaved

Island

smooth-flower.

saw-leaved

deeply-sawed

oak-leaved

toothed

long-leaved

great-flowered

creeping

Proteacea. $\mathrm{Sp} .2$

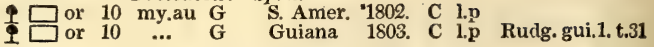

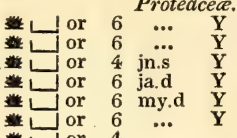

Sp. 26-35.

N. Holl. 1805. C 1.p

N. Holl. 1803. C $\begin{array}{lll}\text { N.1 } \\ \text { N. Holl. }\end{array}$

N. S. W. 1788. C $\begin{array}{llll}\text { N.p } & \text { Bot. mag. } 738\end{array}$

N. S. W. 1788. C s.p Bot. rep. 457

N. S. W. 1800 . C s.l

N. Holl. 1803. C 1.p

$\because \quad \ddot{0} \quad$ N Holl 1803 C

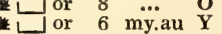

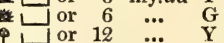

N. S. W. 1804. G s.p Bot. mag. 1947

N. S. W. 1822. C. s.p Bot. reg. 787

N. S. W. 1788. C 1.p Cv.ic.6.t. 545,546

N. Holl. 1794. C s.p Hook. ex. fl.96

N. Holl. 1803. C 1.p

N. S. W. 1805. L s.p Bot. cab. 392

N. S. W. 1788. C 1.p Bot. cab. 241

N. S. W. 1802. S s.p Bot. mag. 2406

N. Holl. 1794. C s.p Bot. rep.258

N. S. W. 1822. C s.p

N. Holl. 1794. L s.p

N. S. W. 1788. S s.p Bot. rep. 82

N. S. W. 1788, C 1.p Bot. re 688

N. Holl. 1805. C 1.p

N. S. W. 1822. C s.p

N. Holl. 1805. C l.s.p

N. Holl, 1794. S s.p

N. Holl, 1803. C 1.s.p Voy.de lab.1.t.23

248. DRYAN'DRA, $R \cdot B r$. DRYandra

1475 floribúnda $R . B r$. many-flowered

1476 cuneáta $R$. Br.

1477 armáta $R$. $\boldsymbol{B r}$.

1478 formósa $R$. Br.

1479 plumósa $\boldsymbol{R}$. $\boldsymbol{B r}$

1480 obtúsa $R$. Br.

1481 nivea $R$. $B r$.

1482 longifólia $R$. $B r$. wedge-leaved acute-leaved splendid

feathered

obtuse-leaved

white-leaved.

long-leaved

fine-leaved

249. STRUTHI'OLA. $\dot{W}$. Strúthibla. 1484 juniperina $W$.

1485 erécta $W$. en

1486 ováta $W$

1487 imbricáta $H . K$

1488 tomentósa $\boldsymbol{H} . \boldsymbol{K}$.

1489 virgáta $\boldsymbol{H}$. $K$.

1490 ciliáta $A n d r$.

1491 pubéscens $H_{\text {. }} K$

drooping

upright

oval-leaved

tiled-leaved

downy-leaved

twiggy

ciliated

downy

hoary

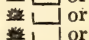

....

Proteacea. Sp. 9-13.

L or 3 ja.d Y N. Holl. 1803. S s.p Bot. mag. 1581

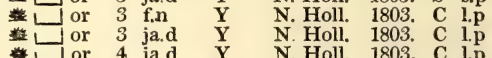

Lin.tran. 10.t. 3

N. Holl 1803, C lp

N. Holl 1803, C 1.p Voy.delab.1.t.24

N. Holl. 1805. S s.p Bot. mag. 1582

N. Holl. 1803. S s.p

mr.my $Y$

Thymelace.

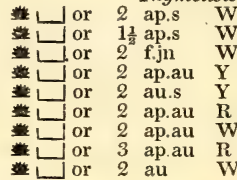

Sp. 9-18.

C. T. H. 1758. C 1.p Bot. mag. 222

C. G. H. 1798. C s.p Bot. mag. 2138

C. G. H. 1792. C s.p Bot. rep. 119

C. G. H. 1794. C s.p Bot. rep. 113

C. G. H. 1799. C s.p Bot rep. 334

C. G. H. 1779. C s.p Bot. rep. 139

C. G. H. 1779. C s.p Bot. rep. 149

C. G. H. 1790. C s.p Bot. mag. 1212

C. G. H. 1817. C s.p Bot. cab. 11

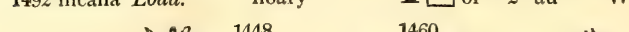

1464

1468

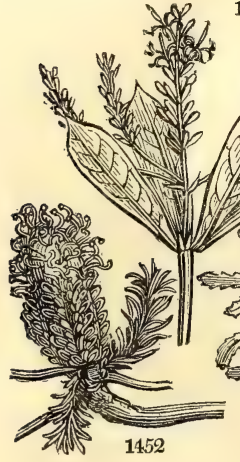

1460 
1447 Leaves alternate ovate lanceolate complicate toothed attenuated at both ends

1448 Leaves 4 together subsessile wedge-shaped oblong entire

1149 Leaves acerose entire not pointed, Claws of flower woolly, Segments smooth, Stigma a depressed head 1450 Leaves acerose entire mucronate, Flower all hairy, Stigma subulate, Cones globose

1451 Leaves acerose entire mucronate, Flower houds nodding, Flowers silky

1452 Leaves acerose emarginate 2-toothed entire, Flower heads long, Flowers silky, Stigma capitate

1453 Leaves acerose 3-toothed at end, the middle tooth longest prickly or entire at the edge, Stigma subulate

1454 Leaves linear prickly toothed; the terminal tooth shortest

1455 Leaves linear beyond the middle prickly toothed beneath veinless, Stem shrubby, Branches smooth

1456 Leaves long lin. prickly toothed atten. at base veinless beneath, Stem arborescent, Branchlets tomentose

1457 Leaves linear truncate mucronate entire or toothed; veins beneath inconspicuous, Ends of branches hairy

1458 Leaves linear truncate mucronate recurved at edge entire beneath netted, Ends of branches tomentose

1459 Leaves whorled oblong lanc. entire mucronulate with conspicuous netted veins beneath, Stem arboreous

1460 Leaves whorled lingulate oblong obtuse unarmed beneath veinless white, Stem arbortous

1461 Leaves altern. wedge-shaped obovate or obl. toothed truncated ribbed reticulated at the base transverse

1462 Leaves somewhat whorled wedge-shaped obl. subtrunc. attenuated at base beyond middle toothed serrate

1463 Leaves scattered narr. obl. trunc. toothed serr. beneath ribbed and veiny, Footstalks and branchl. toment.

1464 Leaves obovate oblong prickly serrate acute at base beneath ribbed reticulated cinereous

1465 Leaves wedge-shaped flat scattered truncate beyond the middle toothed serrate at the base acutish

1466 Leaves linear or wedge-shaped oblong rounded mucronulate scattered or whorled beneath netted

1467 Leaves elongate lin. trunc. at the base attenuate beyond the middle serrated beneath ribbed retic. toment.

1468 Leaves broad linear elongate truncated serrate beneath reticulated smoothish at the base attenuated

1469 Lvs. broad lin. elong. truncated deeply serrate beneath reticulated smoothish, Stig. bearded not furrowed

1470 Leaves oblong wedge-shaped subtruncate smooth cut serrate mucronate, Segments of flower awned

1471 I eaves wedge-shaped oblong truncate sinuate toothed undulated acute at base beneath ribbed veiny snowy

1472 Leaves linear pinnatifid, Lobes triangular half ovate mucronate beneath snowy obsoletely nerved

1473 Leaves pinnatifid, Lobes triangular ovate acute flat beneath nerved smoothish, Flowers smooth

1474 Leaves pinnatifid, Lobes sinuate or toothed, Stem prostrate

1475 Leaves wedge-shaped cut serrate, Bractes of involucre striated outer smoothish

1476 Leaves wedge-shaped sinuate toothed prickly stalked, Bractes all smooth silky

1477 Lvs, pinnatifid, Lobes trians, that divaricating straight prickly pointed the term. longer than those next it

1478 Lvs, elongate linear pinnatifid, Lobes triangular pointless flat snow-white beneath, Involucres tomentose

1479 Leaves elongate lin. pinnatifid, Lobes an equal-sided triangle mucron. recurved at edge beneath snow-white 1480 Leaves lin. pinnatifid longer than decumbent tomentose stem, Lobes triangular obtuse snow-white beneath 1481 Leaves lin. pinnatifid as long as smooth stem, Lobes triang. acute mucr. beneath white with recurved edge 1482 Lvs. lin. pinnatifid very long acute beneath ashy at base attenuated and entire, Lobes triang. ascend. decur. 1483 Leaves linear elongate pinnatifid sub-truncate white beneath, Lobes triangular decurrent divaricating

1484 Leaves linear acute spreading, Flowers naked, Anthers included

1485 Leaves linear and 4-cornered branches smooth

1486 Leaves ovate and branches rugose smooth

1487 Leaves ovate furrowed quadrifarious ciliated at edge, Glands of flower 4

1488 Leaves ovate tomentose, Glands of flower 12

1489 Leaves lanceolate ciliated, Bractes the length of germen

1490 Leaves lanceolate mucronate ciliate concave incurved at end

1491 Leaves lineax ciliated, Bractes longer than germen

1492 Leaves all over hoary

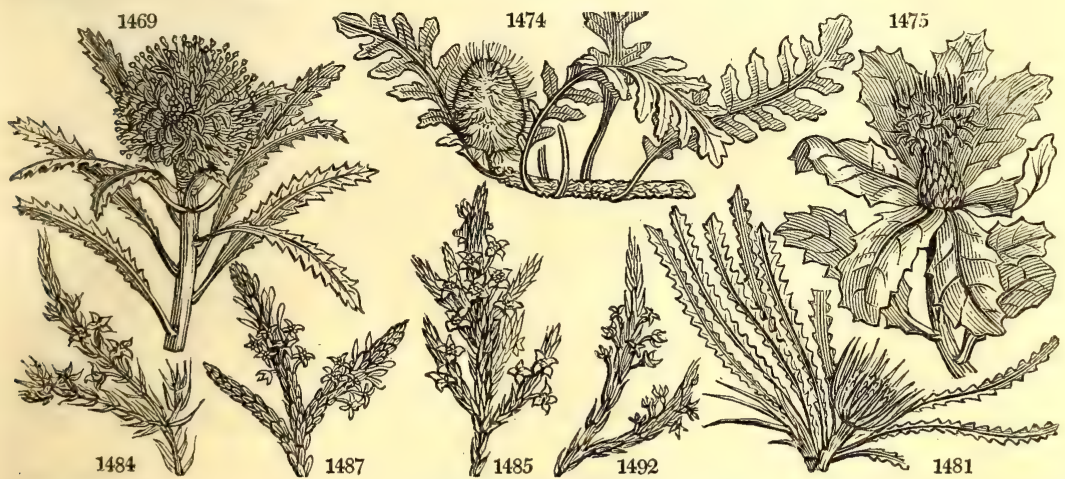

and Miscellaneous Particulars.

heat; the glasses must be frequently taken off to give them air and dry them, or they are apt to damp off; when they are rooted, the sooner they are potted off in little pots the better, as the sand is liable to canker their roots if left too long in it; when potted off, they should be placed in a close frame, but not on beat, as a bottom heat will destroy their roots, when they must be hardened to the air by degrees. Plants raised in this way have better roots, grow faster, and flower sooner than plants raised from seeds. In raising them from seeds they should be sown in the same kind of soil as the plants are grown in, and placed in the green-house ; or if it is in summer they will come up sooner if placed out in the open air ; they will soon make their appearance, when they should be potted off in small pots, for if left in the seed-pots too long they are apt to die, and are more difficult to move with safety." (Bot. Cult. 147.)

248. Dryandra. Was named by Mr. R. Brown after the famous Jonas Dryander, whose catalogue of the Banksian library would alone be a monument of talent and industry, if his high botanical acquirements had been unknown. This genus is allied in character and habits to Banksia. It thrives best in very sandy loam and peat in well drained pots. Cuttings made from ripened wood taken off at a joint before they begin to push, planted in sand without shortening any of the leaves, and covered with a glass, wiil root without difficulty. 'The pots should not be plunged, and as soon as the cuttings are rooted they must be potted off, as the sand is apt to injure their roots. Place them afterwards in a close frame or under hand-glasses till they strike root afresh, and then harden them by degrees. (Sweet.)

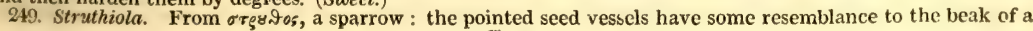


250. OPERCULA'RIA. $W$. OPERCUlaria 1493 áspera $W$. 251. CRYPTOSPER 1494 Youngii $P$. S . 252. PO'THOS. $W$. 1495 acaúlis $W$. 1496 lanceoláta $W$. 1497 violácea $W$ 1498 cannæfólia $H . K$. 1499 crassinérvis $W$. 1500 cordáta $W$. 1501 sagittáta $B$. $M$. 1502 macrophýlla $W$. 1503 obtusifólia $\boldsymbol{H}, \boldsymbol{K}$ 1504 foetida $\boldsymbol{H}, \boldsymbol{K}$. 1505 palmáta $W$. 1506 pentaphýlla $W$. 253. RIVI'NA. $W$. 1507 húmilis $W$. $\beta$ canes'cens W. 1508 purpurásce 1509 læ'vis $W$. 1511 octándra $W$.

254. CAMPHOROS'M 1512 monspelíaca $W$.

255. ALCHEMIL'LA. 1513 vulgáris $W$. en. 1514 montána $W$. en. 1515 pubéscens $W$.en. 1516 serícea $W$. en. 1517 alpina $W$. 1518 pentaphýlia $W$. 1519 A'phanes $W$.

256. SANGUISOR'BA. 1520 officinális $W$.
$\beta$ auriculáta 1521 cárnea Fisch. 1522 tenuifólia Fisch. 1523 média $W$ 1524 canadénsis $W$.

257. DORSTE'N1A $W$. 1525 brasiliénsis $W$ 1526 Houstóni $W$. 1527 Contrajérva $W$. 1528 arifolia Lam. rough-seede W $\mathrm{w}$ sp $1-12$ M. P.S. Cryptospermum Valerianere. Sp. 1. Pothos. stemless lance-leaved blue-fruite sweet-scented thick-nerved heart-leaved arrow-leaved large-leaved blunt-leaved Scunkweed palmated five-leaved Riviva. downy hoary

purple

smooth wave-leaved climbing

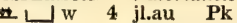
Aroidea. Sp. 12-28.

K $\square$ cu 1 ap.jl Ap W. Indies 1790. Sk s.p Jac.am.240.t.153 KD cu 11 ap.jl Ap Barbadoes1790. Sk s.p Plum am.47.t.62 F $\mathrm{cu} 2$ ap.jn Ap Jamaica 1793. Sk s.l Hook. ex. fl. 55  Eu 21 ... Ap

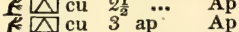
KD cu 3 ap है cu 3 my.jn Ap \& $\mathbb{D}$ cu 2 my.jn Ap * 1 cu 1 mrap Ap E $\mathrm{A}$ cu 3 jn.jl Ap E Chenopodea. w $\square$ or 2 ja.o 2 W -

or $2 \mathrm{fs}$ Pk

t $\square$ or 2 fis $\quad$ in.jl

2. $\square$ or 20 my.jn $\quad$ W

W. Camphorosma

Chenopodea.
$1 \frac{1}{2}$ au.s Ap hairy t. W Indies 1789. Sk.I Hook. ex. H. 55 S. Amer. 1796. Sk s.p Jac. ic. 3. t. 609 America 1770. Sk s.p Plum. ic. 26. t.38 W. Indies 1800. Sk p.l Bot. mag. 1584 W. Indies 1794. Sk s.p Jac. ic. 3. t. 610 Barbadoes1790. Sk p.1

N. Amer. 1735. Sk p.l Bot. mag. 8.36 S. Amer. 1803. Sk p.l Plum.am.49.t.64 Cayenne 1803. Sk p.l Bot. mag. 1375 Sp. $5-7$.

W. Indies 1699. S r.m Bot. mag. 1781 W. Indies 1804. C I.p

W. Indies 1815. C 1.p Brazil 1790. C l.p W. Indies 1752. C p.1 B.jm.149.t.23.f.2 Sp. 1-5.

S. Europe 1640. C p.l Schk. han.1. t.26 LADIES-MANTLE.

common \ $\triangle$ or 1 jn.au G Britain me.pa. D co Eng. bot. 597 mountain $\quad \vec{y}$ or 1 jn.au $G$ pubescent $\quad \frac{\$}{\Delta} \Delta$ or $\frac{1}{2} \mathrm{jn} . \mathrm{au}$ G silky silvery or $i^{\frac{1}{2}} \mathbf{j l} \quad$ G Parsley-piert $\frac{\$}{*} \mathrm{O}$ w $\frac{1}{4}$ ap.jn

Britain moun. D co Mill. ic. t. 18 Caucasus 1813. D co Hort. ber. 2. t.79 Caucasus 1813. D co Britain rocks. D co Eng. bot. 244 Switzerl. 1784. D co Bocc mus, 1. 1 Britain $\quad .$. D co Eng. bot. 1011 W. GREAT-BURNet

Sanguisorbea. Sp. 5 officinal $¥ \triangle$ ag 2 jn.au Pk Britain me.pa. $\mathbf{S}$ co Eng. bot. 1312 eared $D \Delta$ or 2 jn.au Pk Italy ... $\quad$ Bocc.mus.19. t.9 flesh-colored $\frac{\downarrow}{\nabla} \Delta$ or 2 jn.au $R \quad$...... 1823. $\quad$ D co Schr.mon.t. 69 fine-leaved short-spiked Canadian

Dorstenia. Brazilian

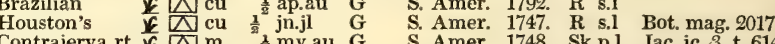
Contrajerva-rt. $\triangle \mathrm{m} \quad \frac{1}{2}$ my.au $\mathrm{G} \quad$ S. Amer. 1748. Sk p.l Jac. ic. 3. t. 614 arum-leaved $\mathbb{E} \mathrm{cu} \frac{\frac{1}{2}}{2} \mathrm{my} . \mathrm{jl}$ G Brazil 1822. R s.l Bot. mag. 2476

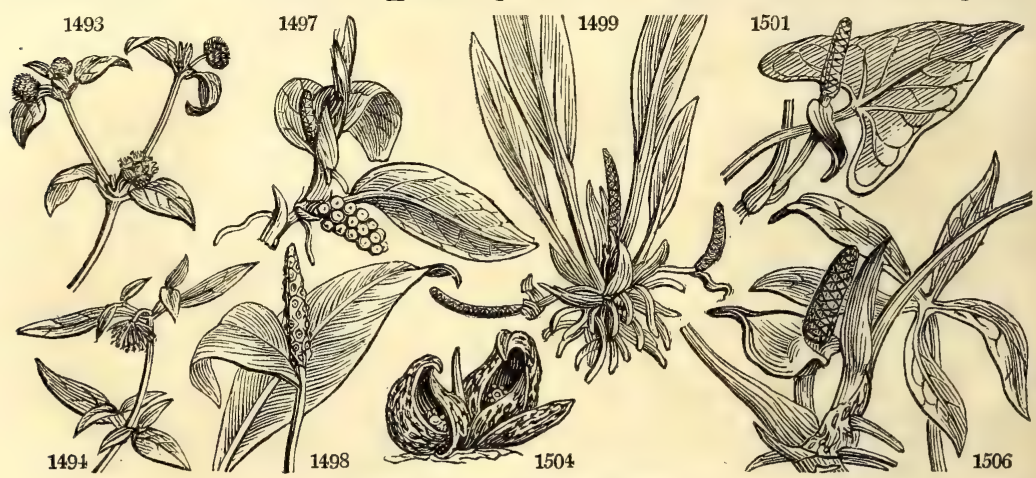

History, Use, Propagation, Culture,

sparrow or other small bird. The species are all slender, hardy, green-house plants, of pretty appearance, and easy cultivation.

250. Opercularia. From operculum, a lid, in allusion to the manner in which the calyx is closed. Plants of no beauty.

251. Cryptospermum. From « hidden in the involucrum. Weeds of some tropical countries.

252. Pothos. From potha, the native name of this plant in Ceylon. Most of the species are sub-parasitic, and found climbing, like ivy, on the trunks of trees in the West Indies and America. In our stoves most of the species will thrive planted in old bark and moss, and plunged in heat. P. palmata has leaves upwards of three feet long, with a foot-stalk nearly four feet long, palmate, as thick as strong parchment, smooth, with a midrib of a deep green above, and the fructification on spikes more than a foot in length. The species are cultivated for the sake of their foliage, which is always of an agreeable green color, and not liable to discoloration by damp or other accidents of a hot-house.

253. Rivina. In memory of A. Q. Rivinus, a native of Saxony, born in 1652, and died in 1722 . He was for a long time professor of botany and medicine at Leipsig, and left behind him some valuable botanical works ; and among them a very ingenious attempt at a classification of plants by the corolla ; from which some modern botanists have profited more than they have acknowledged. The name, as Linnæus observes, with his usual neatness, has been given to a shrub always covered with leaves and fruits, in allusion to the merit of the works of Rivinus. R. octandra, the Hoop-withy of Jamaica, and liane a baril of Martinique, has a very long tough fexile stalk an inch or more in diameter, and sometimes made into hoops in the West Indies. Theberries con- 
1493 Leaves opposite ovate rough, Flowers capitate, Heads stalked axillary

1494 Stem erect 4-cornered and leaves lanceolate entire smooth

1495 Leaves lanceolate entire nerveless

1496 Leaves lanceolate 3-nerved veiny entire, Scape 3-cornered at the end

1497 Leaves ovate lanceolate entire nerved dotted

1498 Leaves obovate lanceolate pointed at both ends ribbed, Spathe oblong acuminate flat stalked

1498 Leaves obovate lanceolat pointends veiny entire, Middle rib convex on both sides with 3 keels at its base

1499 Leaves obl. attenuated imbricated, Spathe flat, Scape rounded

1501 Leaves cordate acute, Lobes spreading, Spathe reflexed as long as the erect spadix

1502 Leaves cordate lobes divaricating, Spadix much shorter than the spatha

1503 Leaves cordate very obtuse

1504 Leaves cordate acute, Spadix subgiobose

1505 Leaves palmated, Lobes 9 or 10 lanceolate obtuse

1506 Leaves digitate quinate ovate acuminate

1507 Leaves pubescent

1508 Leaves ovate smooth ciliated, Petioles pubescent

1509 Leaves ovate acuminate smooth flat, Stem round

1510 Ieaves ovate wavy rugose, Stem furrowed

1511 Flowers octandrous and dodecandrous

1512 Tufted tomentose hoary, Stems ascending simple

1513 Leaves reniform plaited serrated, Stem and petiole smoothish, Flowers dichotomous corymbose

1514 Leaves reniform 9-lobed beneath with the stem and petioles silky, Flowers fastigiate clustered sessile

1515 Leaves reniform 7-lobed toothed silky beneath, Corymbs terminal

1516 Leaves digitate in sevens lanceolate acute, from the middle to the end deeply serrated silky beneath

1517 Leaves digitate in fives or sevens lanceolate cuneate obtuse serrated or toothed at the end silky beneath

1518 Leaves three together, Leaflets ciliated multifid smooth

1518 Leaves three parted, Segments trifid pubescent, Flowers clustered monandrous

1520 Spike ovate, Stamens shorter than the cor. Cal. and leaves smooth, Leaflets ovate subcordate

1521 Leaflets cordate lanceolate crenate toothed quite smooth, Stamens shorter than corolla

1522 Leaflets subsessile ovate-lanceolate finely serrated, Spikes cylindrical, Stamens longer than corolla

1523 Spikes cylindrical, Stamens longer than corolla, Cal. somewhat ciliated

1524 Spikes cylindrical very long, Stamens much longer than corolla

1525 Leaves cordate oval obtuse crenulate, Receptacles orbicular

1526 Leaves cordate angular acute, Receptacles quadrangular

1527 Leaves cordate or pinnatifid palmate serrated, Receptacles quadrangular

1528 Leaves cordate sagittate undulated toothed large, Receptacles oval

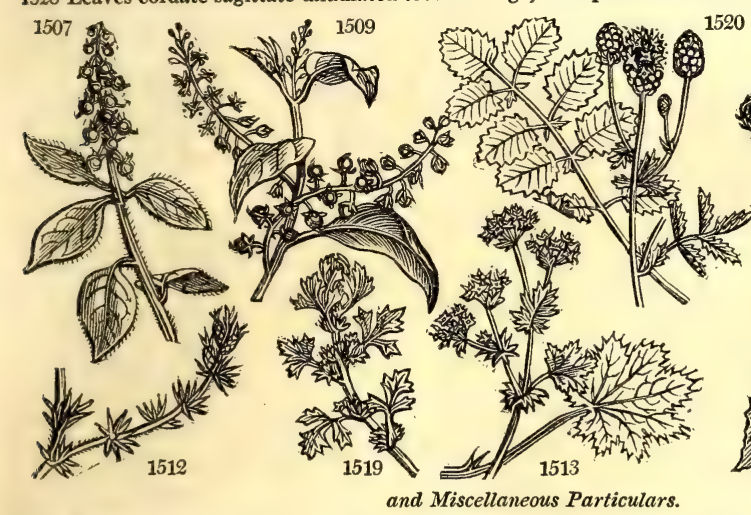

1520

stitute the principal part of the food of the American thrush or nightingale ; they contain a very oily seed, and after the bird has swallowed many of them he frequently flies to the next bird-pepper bush (Capsicum), and picks a few pods : instinct directing him to what is necessary to promote the digestion of that oleaginous heavy food. 254. Camphorosma. Barbarously named from two words, the one Latin (camphora), and the other Greek $(\sigma \sigma \mu \eta)$, signifying a smell of camphor. The plant abounds with a volatile oily salt, and is warm and stimulating; but its appearance has nothing to recommend it.

25.5. Alchemilla. Named, as Linnæus asserts, from its supposed alchymical purposes; but, as others maintain, from its Arabic appellation âlkêmelyeh. (J. de Souza, p. 52.) A. vulgaris is eaten readily by horses, sheep, and goats, and is considered a good herbage-plant where it abounds in upland pastures. A. alpina is an elegant species, common on many of the Highland mountains, and supposed by Lightfoot and others to aid considerably in giving the peculiarly excellent flavor to Highland mutton. A. aphanes is a worthless weed.

256. Sanguisorba. From sanguis, blood, and sorbere, to absorb. The plant has passed for an excellent vulnerary. This genus greatly resembles Poterium (Monocia Polyan.), and Professor Martyn observes, that it is certainly a defect in the Linnæan system that two genera so similar in habit should be placed so far apart. A profound remark, and quite worthy the professor of botany of Cambridge. Alas! poor Linnæus! if he could profound remark, and quite worthy the professor of botany of Cambridge. Alas! poor Linnæus ! if he could
rise from his grave he would have little cause to congratulate himself upon the aid of those who call themselves his champions, and the expounders of his system.

257. Dorstenia. In memory of Theodore Dorsten, a German, author of a work entitled Botanicon, printed in 1740. Its flowers, says Linnæus, are like the works of Dorsten, they have little to recommend them. The roots are imported under the name of Contrayerva roots, and used both in medicine and dying. 
258. ISNAR'DA. $W . \quad \begin{aligned} & \text { IsNarda. } \\ & \text { marsh }\end{aligned} \quad$ palústris $W$. 259. EL 1530 anguG NUS. $W$. OLEASTER. 1530 angustifólia $W$. 1531 argéntea $P h$. 1532 orientális $W$. 1533 latifólia $W$.

1534 acumináta $L k$.
260. GLOBULA'RIA. $W$ narrow-leaved silvery oriental broad-leaved acuminated

1535 longifólia $W$. 1536 A'lypum $W$ 1537 vulgáris $W$. 1538 spinósa $W$.

1539 cordifólia $W$. 1540 nudicaúlis $\dot{W}$. 261. HOUSTO'NIA.

1541 cærúlea $W$.

1542 purpúrea $W$. 262. DIPSA'CUS. $W$. 1543 fullónum $W$ 1544 sylvéstris $W$ 1545 laciniatus $W$. 1546 Gmelni Bieb. 1547 inérmis Wall. 1548 pilósus $W$. iongularia. long-leaved L pr i 3 jl.au W common $\quad \Delta$ pr $\frac{1}{2}$ my.jn $B$ prickly-leaved
wedge-leaved wedge-leaved
naked-stalked $\frac{\mathrm{pr}}{\mathrm{p}}{ }^{\frac{1}{2}} \mathrm{jn}_{\mathrm{jn} . \mathrm{jl}} \quad \mathrm{B}$

Houstovia. Houstonia.
blue-flowered Rubiacea. Sp.2-15. purple-flower'd $\Delta$ pr 1 my.au $\mathrm{Pu} \quad \mathrm{N}$. Amer. 1800. D co

Teasel. clothier's wild cut-leaved intermediate unarmed small 263. CEPHAla'Ria. Schr. Cephalaria.

1549 alpina $W$. Alpine 1549 alpína $W$. 1550 albéscens $W$. en. 1551 rigida $W$.

1552 attenuáta $W$.

1553 transylvánica $W$. 1554 syriaca $W$.

1555 leucántha $W$.

1556 tatárica $W$.

1557 uralénsis $W$.

1558 lævigáta $W . \& K$. $\beta$ corniculáta

1559 cretácea Bieb.

1560 Vaillantii Schott.

1561 pappósa $W$.

264. SCABIO'SA. $W$. 1562 dichótoma $W . e n$. 1563 Succísa $W$. 1564 integrifólia $W$ 1565 arvénsis $W$. 1567 longifólia $P$. 1568 ciliâta $\mathrm{Spr}$. whitisi stiff-leaved $\neq \Delta$ or 2 jn.jl narrow-leaved or 2 jl Transylvanian $O$ or Syrian $\quad 0$ or white-flowered $₫ \triangle$ or Tartarian \& 0 or Uralian $\mathrm{O}$ or smooth horned chalky

Vaillant's Elaagnea. Sp. 5-10.

or $15 \mathrm{jl}$ Ap S. Europe 1633. C co Pall. ross. 1. t. 4 or 10 jl.au Ap N. Amer. 1813. C co N. Amer 1748. Coll ross 1 t. 5 E. Indies 1712. L p.l Bm. zeyl. t.39.f.2 ...... $\quad .$. C co

Sp. $6-13$.

Madeira 1775. L p.1 Bot. reg. 685

S. Europe 1640. I p.l Garid. aix. t. 42 Europe 1640. C p.l Bot. mag. 2256 Spain 1640. C l.p

Germany 1633. C 1.p Jac. aus. 3.t. 245 Germany 1629. C p.l Jac. aus. 3.t. 230

Dipsacea. Sp. 6-10.

\$2 (D.ag 6 jl Pu Britain hedg. S 1 Eng. bot. 2080 $\$$ w 4 jl Pu Britain m.hed. S m.s Eng. bot. 1032 () $w 4$ jl.au Pu Germany 1683. S m.s Jac. aus.5. t. 403 3 jl.au B Caucasus 1820. S m.s au $\cdots$ W Nepal 1823. S m.s Dipsacece. Sp. $13-30$.

downy-headed $O$ or $1 \mathrm{jl}$ W $\mathrm{S}$. Europe 1739. S co Scabious. $\quad$ Dipsacea. Sp. 33-103.

forked $¥ \mathrm{O}$ or 1 jn.au Pk Sicily $\neq 1804$. S co Bocc. mus.t.120 Devil's-bit \$ $\triangle$ or 1 au.o V Britain pas. D co Eng. bot. 878 red-flowered $\mathrm{O}$ or $1 \frac{1}{2} \mathrm{jn}$.au $\mathrm{R}$ France 1748. S co field $\downarrow \Delta$ or 2 jl.o Pu Britain cor. fi. S co Huc. aus. 4, t. 362 W. et Kit. t. 5 ciliated $\quad \mathrm{s} \Delta$ or 2 jl.au W Germany 1802. D co

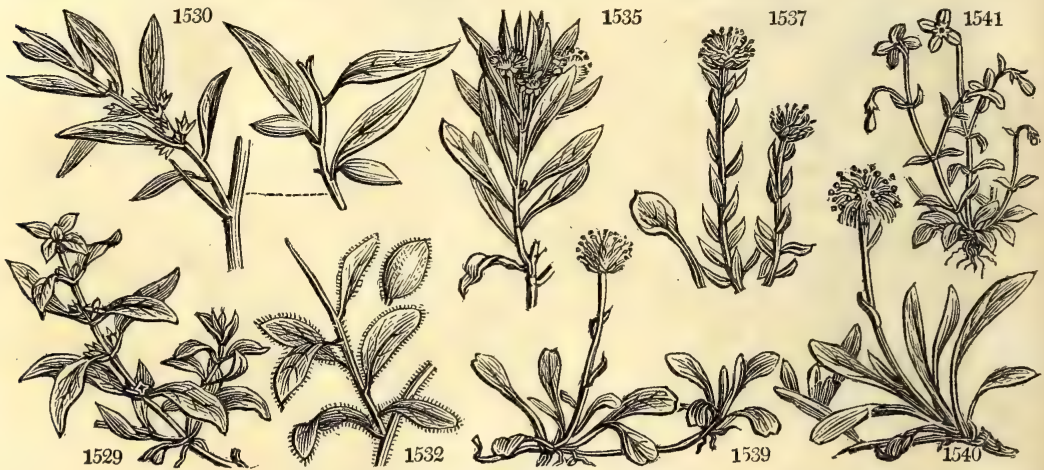

History, Use, Propagation, Culture,

258. Isnarda. Antoine Tristan Danti d'Isnard was a French botanist, professor at the Jardin du Roi, and member of the Academy of Sciences, to which he communicated many memoirs upon plants from 1716 to 1724 . An obscure marsh plant.

259. Elaeagnus. From $\varepsilon \lambda \alpha s \alpha$, an olive: the tree having a striking resemblance to the olive tree. E. angustifolia is a low tree with elegant silvery leaves and a brown bark, but not of long duration. All the hardy species are commonly propagated by layers; but according to Sweet and Haynes, "cuttings will strike if taken off at a joint in ripened wood, and planted in a sheltered situation early in autumn," The green-house and stove species strike in sand under a bell-glass.

260. Globularia. From the flowers being packed in globose heads. The species called Alypum has been so named from $\alpha$, privative, and $\lambda \nu \pi \eta$, pain ; used by way of antiphrasis, according to Dalechamp, because it is a dangerous purgative. Bauhin even calls it Frutex terribilis ; but Clusius says, it was used by the Spanish quacks of his day as a cure for venereal diseases. It is however doubtful whether the Alypon of the old botanists is the same with the plant so called by the moderns. Cuttings of the shrubby green-house species, taken off before they begin to make new shoots, root freely in loam and peat under a bell-glass, and in moderate bottom heat. The hardy and herbaceous kinds may be propagated from seeds, or divided like daisies. Miller says, they prefer a shady situation herbaceous kinds may be propagated from seeds, or divided like daisies. Miller says, they prefer a shady situation 261. Houstomia. Named after Dr. Wm. Houston, the friend and correspondent of Miller: he died in 1733 . The plants are small, elegant in their habits, and very fit for pots or rockwork. 
1529 Leaves stalked ovate acute

1530 Leaves lanceolate

1531 Leaves oblong acute at each end silvery, Flowers solitary nodding

1532 Leaves oblong ovate opaque

1533 Leaves ovate

1534 Leaves ovate acuminate wavy

1535 Stem shrubby, Leaves lanceolate linear entire, Flowers axillary subsessile solitary

1536 Stem shrubby, Leaves lanceolate 3-toothed and entire, Heads terminal

1537 Stem herbaceous, Radical leaves about 3-toothed much longer than the stalk, Cauline lanceolate

1538 Radical leaves crenate acuminate, Cauline entire mucronate

1539 Radical leaves wedge-shaped retuse toothed at end the intermediate tooth very small

1540 Stem naked, Leaves entire lanceolate

1541 Leaves radical ovate, Stem compound, First peduncles 2-flowered

1542 Leaves ovate lanceolate, Corymbs terminal

1543 Corona obsolete, Head cylindrical, Bractes recurved, Leaves connate entire subcoriaceous

1544 Corona obsolete, Head cylind. Bractes straight, Invol. weak longer than head, Lvs. conn. entire or jagged

1545 Leaves of involucre linear-lanceolate rigid about as long as the head, Leaves usually sinuately jagged

1546 Corona membranaceous, Head ovate, Involucre weak deflexed

1547 Leaves oblong serrate villous stalked sublobate, Cauline connate, Heads globular villous

1548 Corona obsolete, Head globose; Involucre deflexed not quite so long as bracteæ

Corollas 4-cleft.

1549 Corona with 8 nearly eq, awned teeth, Anth. strip, with green at time of open. Br. acum. pub, Corol radiant 1550 Corolla equal, Cal. imbr. Radical leaves pinnated, Leaf. lanc. cut toothed ciliat. Caul, tern. and sim. lin. 1551 Corollas 4-fid unequal, Scales of calyx obtuse, Leaves oblong serrated scabrous

1552 Corollas equal, Scales of calyx oblong obtuse, Leaves linear smooth entire trifid and at base pinnatifid

1553 Corona with 8 equal short teeth, Bractes awned, Awns purplish black

1554 Corona with 8 teeth of which 4 are awned and the other 4 very short, Br. awned, Awns rufous, Corol. equal 1555 Coroll. sub-equal, Scales of calyx ovate, Leaves pinnatifid

1556 Corona with 8 awned nearly equal teeth, Anth. str. with green at time of op. Br. acum. pub. Corol. radiant 1557 Coroll, radiant, Radical leaves simple, Cauline decurrent pinnated, Paleæ arid reflexed at end

1558 Corona with 4-8 obsolete teeth, Bractes awnless yellowish white the outer obtuse the inner acuminate $\beta$ Teeth of the corona distorted

1559 Coroll. radiant, Calyx imbricated, Leaves coriaceous smooth lanceolate entire: the upper lyrate

1560 Coroll, equal, Calyx and paleæ awned, Stem simple smoothish, Leaves lanceolate almost smooth

Corollas 5-cleft.

1561 Coroll. unequal, Stem herbaceous erect, Leaves pinnatifid, Seeds bearded and feathery pappose Corollas 4-fid.

1502 Coroll, nearly equal, Stem dichotomous, Leaves oblong cauline entire subsessile radical toothed stalked 1563 Cor. equal, Stem simple, Branches approximated, Leaves lanc. ovate pubescent, Caul. lin. nearly entire 1564 Cor. radiant, Leaves undivided, Radical ovate serrated, Cauline lanceolate

1565 Coroll. radiant, Leaves entire pinnatifid and cut, Stem hispid

1566 Coroll. radiant, Leaves all undivided ovate oblong serrated, Stem hispid

1567 Coroll radiant, Leaves oblong lanceolate entire, Stem below smooth above pilose

1568 Coroll. sub-radiant, Stem and leaves ovate hispid the lower leaves stalked entire auric. or pinn. Calyx cil.

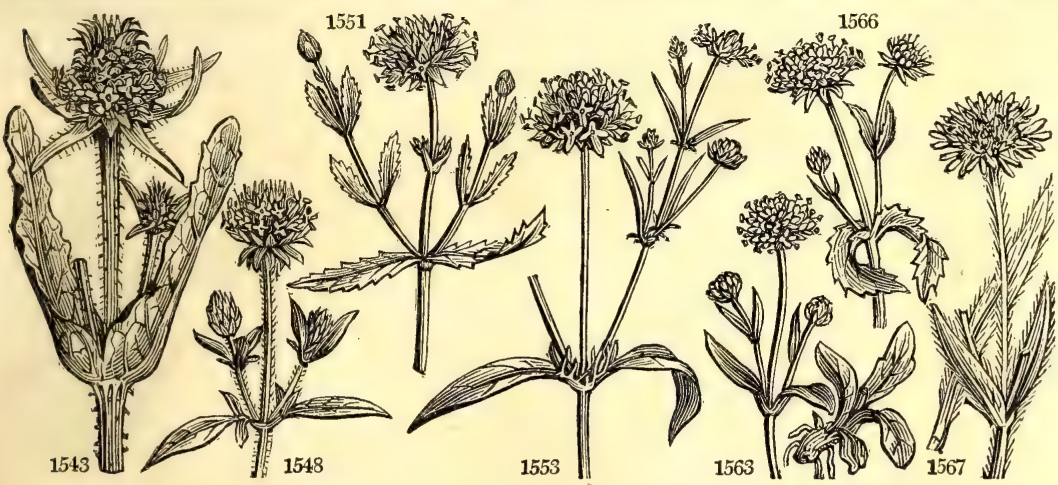

and Miscellaneous Particulars.

262. Dipsacus. From $\delta$ w $\alpha \omega$, to thirst. At the axillæ of the leaves is usually a quantity of limpid water, which may be acceptable to people who are thirsty. This water once had reputation as a cosmetic Chardon a Foulon, Fr. Kardendestel, Ger.; and Dissaco, Ital. D. fullonum is cultivated in the west of England for raising the nap upon woollen cloths, by means of the crooked awns or chaffs upon the heads, which in the wild Teasel are not hooked. For this purpose they are fixed round the circumference of a large broad wheel, which is made to turn round, and the cloth is held against them. The seeds are sown in March, on well prepared strong clayey loam, broad-cast, and at the rate of one peck to the acre. They are hoed, like turnips, to a foot distance; and the second year, in August, the heads are fit to cut. They are sold by the bundle or stave, twenty-five in each, and the ordinary produce is 160 staves per acre. In Essex, carraway is often sown along with teasel, and the second year after the latter is pulled, the former is mown or reaped. (Young's Annals, vol, xxi. p. 53.)

D. pilosus is the handsomest species; the seeds are eaten by small birds, and the flowers trequented by moths in great numbers.

263. Cephalaria. From $\approx \varepsilon \propto \alpha \lambda \eta$, a head, in reference to the manner in which the flowers grow. A mere artificial division of the genus Scabiosa, from which it differs in no natural characters whatever.

264. Scabiosa. From scabies, leprosy. The sudorific qualities of this plant are said to be useful in cutaneous diseases. This is a vigorous-growing coarse-looking genus. S. succisa is one of the few examples of radix prremorsa or bitten-off root; an appearance, as Keith states, owing to the point or top of the seminal root 
1569 canéscens $P$. $S$. 1570 gramúntia $W$.

1571 columbária $W$.

1573 lucida $P$. S.

1574 síoula $W$.

1575 rutæfólia $P$. S.

1578 holosericea Bert.

1580 prolífera $W$.

1581 atropurpúrea $W$

1583 urceoláta $P$. S.

1585 nítens $R$. \& $S$. Scabiósa lu

1587 graminifólia $W$.

1588 caucásea $\boldsymbol{B} . \boldsymbol{M}$.

1589 lyráta $W$

1591 iseténsis $W$.

1592 ucránica $W$.

1593 ochroleúca $W$. en

1594 banática $P$. $S$.

265. KNAU'TIA. $W$.

1596 propóntica $W$.

266. GA'LIUM. $W$.

1597 rubioides $W$.

1599 Witheringii $E$. $B$.

1600 austríacum $W$

1603 pusillum $\boldsymbol{W}$.

1604 vérum $W$.

1605 Mollágo $W$.

1606 sylváticum $W$.

1608 rigidum $W$.

1609 aristátum $W$.

1611 glaúcum $W$.

1613 rábrum $W$

1614 spúrium $E . B$.

1615 uliginósum $W$.

1616 ánglicum $E . B$.

1617 saxatile $W$.

1618 tricórne Sm.
1576 marítima $W$.

1577 Webbiána $B . R$.

1579 stelláta $W$.

1584 africána $W$.

1590 palæstína $W$.

1598 palústre $W$.

1602 eréctum $E . B$.

1607 linifólium $W$.

1610 tyrolénse $W$.en.

1612 purpáreum $W$. hoary

\& $\Delta$ or 1 jl.au

fine-leaved $\underline{\Delta} \Delta$ or 1 jl.au

shining ered or jn.s

Sicilian

Rue-leaved

sea

Webb's

silky

starry

sweet

silvery

jagged

Masson's

Cretan

grass-leaved

Caucasian

lyrate-leaved

Palestine

Siberian

Ukraine

pale-flowered

Hungarian

Knautia.

red-flowered

purple-flower'

BED-straw.

marsh

rough

Austrian

Boccone's

upright

least

Cheese-rennet

great-hedge

wood

Flax-leaved

rigid

rigid

Tyrolese

glaucous

purple

red

spurious

marsh

wall

smooth beath

three-horned $¥ \Delta \mathrm{O} w$

7 or $\triangle$... jn, au

m

ap or 1 jl.au

₹

z $O$ or 1 jl.au

O) or $1 \mathrm{jl}$.au

t $\Delta$ or 1 s

or 1 jl.au cut-leaved or 1 jl.au

Madder-leaved

Li Hungary 1802. D co W.\&K.hun. t.53

L.B S. Europe 1597. D p.1 Ger. herb.582.f.2

Pu Britain dr.pa. S co Eng. bot. 1311

W Barbary 1804. S co Sco.dl. ins.3.t.14

B Dauphiny 1800 . D co

Sicily 1783. S co Jac. vind. 1.t. 15

Sicily 1804. D co Bocc. sic. t. 52

Sicily 1804. D co Bocc. sic. t. 52
Italy 1683 . D co Mor.h.6.t.15.f. 29

Mnt. Ida 1818. D co Bot. reg. 717

Pyrenees 1818. D co

Spain 1596. S co Clu. hist.2.p.1.ic

Egypt 1683. S co Her. parad.t.125

...... 1629. S co Bot. mag. 247

Levant 1713. D co Ann.mus.11.t.24

Barbary 1804. S co Moris.6.t.13.f.24

Africa 1690. S p.l Herm. par. t.219

t) $\triangle$ or 3 jlau

3 jl.au

Dipsacea. $S p .2-6$.

$O$ or 1 jn.s $R$ Levant 1713. $S$ co Schk han.1.t.29

Crete 1596. S p.1 Mor.h.3.t.15.f.31

Switzerl. 1683. D p.l Bot. reg. 835

Caucasus 1803. D p.1 Bot. mag. 886

Turkey 1799. S s.1

Palestine 1771. S s.1 Jac. vind. 1. t. 96

W Siberia 1801. S s.1 Gmel. sib.2. t.88

L.Y Ukraine 1795. C s.1 Gmel. sib.2. t.87

Germany 1597. D s.1 Jac. aust.5, t.439

Hungary 1800. D co W. \& Kit.10. t.12 jn.au $\mathbf{P u}$ Levant

Rubiacea. Sp. 26-160.

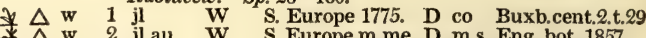

类 $\mathbf{w} \quad 2$ jl.au $\quad$ W $\quad$ S. Europe m.me. D m.s Eng. bot. 1857

\& $\mathrm{w}$ 这 jn.jl W England hea. D s.p Eng. bot. 2206

W 1 jn.jl W Europe 1804. D co Jac. aust. t. 80

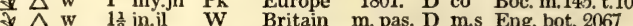

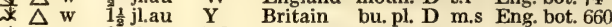

* $\Delta$ w 2 jl.au W Britain hedg. D co Eng. bot. 1673

* $\Delta$ w 3 jl.au W $\quad$ S. Europe 1658. D co Flor, dan. t.609

$\$ \Delta W \quad 1 \frac{1}{2}$ jn.jl W $\quad$ S. Europe 1759. D co Barrel, ic. 583

\$ $\Delta$ w 1 jn.jl W $\quad W$.... 1778. D co

Italy 1699, D co Boc. mus.83. t.75

Tyrol 1801. D co

S. Europe 1710. D co Jac, aust. 1. t. 81

Switzerl. 1731. D co

Italy 1597. D co Ger. herb.967.f.3

Britain cor. fi. S co Eng. bot. 1871

Britain mar. D m.s Eng bot. 1970

${ }_{\frac{2}{2}}^{\frac{2}{2} \text { jl.au }}$ Y England Wales. D s.l Eng. bot. 384

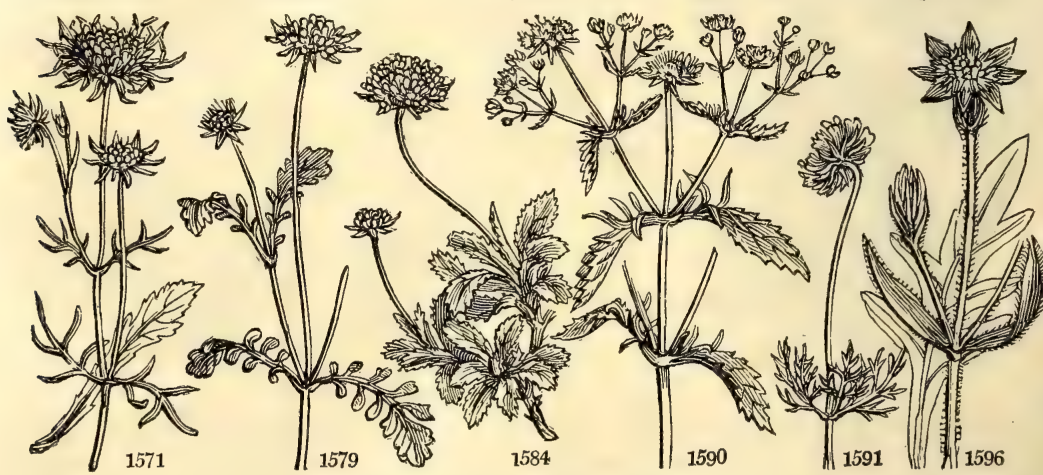

History, Use, Propagation, Culture,

dying off, in consequence of which horizontal roots naturally protrude themselves. Why it should rot off is another matter, but readily accounted for by ascribing it to a bite from the devil. The same appearance is found in Plantago, Trifolium, and some other plants with subfusiform roots. A decoction of S. succisa is an empirical specific for the gonorrhœe.

$S$. atropurpurea is the handsomest species, and is cultivated as a border annual and biennial. It has been so long in cultivation that its native country is unknown. Linnæus and Miller consider it a native of India ; Professor Martyn of the south of Europe.

265. Knautia. So named by Linnæus in honor of Christopher Knaut, physician at Halle in Saxony : born in 1636; died in 1694. Another Knaut (Christian) published a system of plants in 1705, which has nothing to recommend it.

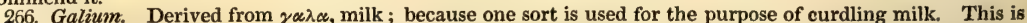
a very natural genus; the roots of most of the sorts dye red, and the herb, like madder, colors the bones of animals that feed on it. The stems of all the species are four-cornered, and the leaves in whorls; the flowers ge- 
Corollas 5-fid.

1569 Hoary, Coroll. radiant, Stem many-flowered, Radical leaves ovate lanceolate entire, Cauline pinnatifid 1570 Calyx very short, Cauline leaves bipinnate filiform

1571 Coroll. radiant, Radical leaves ovate or lyrate pubescent crenate, Cauline pinnate setaceous

1572 Coi oll. radiant, Radical leaves oblong crenated, Caul. pinnatifid: the pinnæ linear lanceolate spreading

1573 Coroll. radiant, Leaves smooth, Radical ovate oblong serrate or lyrate, Caul. pinnate : the segm. lin. cut

1574. Coroll. equal shorter than calyx, Leaves lyrate pinnatifid hairy, Stem branched divaricating

1575 Leaves pinnate: the upper linear, Calyces 1-leaved 5-cleft

1576 Coroll. radiant shorter than calyx, Leaves pinnated the upper linear entire

1577 Silky, Lower lvs. stalked roundish or cuneate rugose cren. upper pinnat. Florets uniform longer than invol.

1578 Hoary very soft, Radical leaves obl. crenated upper caul, pinnatifid with ovate or lanc. crenated segm.

1579 Coroll. radiant, Lvs. cut, Recept. of fruit roundish, Outer limb of calyx broad membran. Stem branched

1580 Coroll. radiant, Flowers subsessile, Stem dichotomous, Leaves oblong lanceolate nearly entire pubescent

1581 Coroll. radiant, Leaves cut, Receptacles of the flower subulate

1582 Coroll. radiant, Leaves pinnatifid, Segments linear, Peduncles very long, Stem rounded

1583 Calyx multifid urceolate, Coroll. radiant, Leaves fleshy pinnatifid with linear stiff pinnæ

1584 Coroll. equal, Stem shrubby, Leaves simple erect

1585 Coroll. radiant, Leaves undivided elliptical serrated shining stalked

1586 Coroll. radiant, Leaves lanceolate nearly entire, Stem shrubby

1587 Coroll. radiant, Leaves linear lanceolate entire, Stem herbaceous 1-flowered

1588 Coroll. radiant, Radical leaves lanceolate stalked entire, Cauline pinnated, Stem 1-flowered

1589 Coroll. radiant, Segments entire, Lower leaves oblong coarsely serrated upper pinnatifid at base

1590 Coroll radiant, all the segmenrs trifid, Leaves undivided subserrate the upper pinnatifid at base

1591 Coroll. radiant longer than calyx, Leaves bipinnate longer than stem

1592 Coroll. radiant, Radical leaves pinnatifid, Cauline linear fringed at base

1593 Coroll, radiant, Radical leaves bipinnate with linear leaflets, Cauline pinnate with perfoliate stalks

1594 Coroll. radiant, Radical leaves lyrate, Cauline sub-bipinnate, Calyxes as long as disk

1595 Leaves cut, Cor. 5 longer than calyx

1596 Upper leaves lanceolate entire, Cor. 10 as long as calyx

Fruit smooth.

1597 Leaves 4 ovate lanceolate 3-nerved beneath scabrous, Stem erect simple

1598 Leaves 4 obovate unequal obtuse, Stems diffuse

1599 Leaves 5 reflexed lanceolate awned ciliated, Stem erect simple scabrous

1600 Leaves linear smooth mucronate, Stems 4-cornered diffuse

1601 Leaves 6 linear mucron. roughish, Peduncles trichot. Stems prostrate diffuse 4 angular winged branched

1602 Leaves 8 lanceolate prickly serrate forwards, Panicles trichotomous, Stems smoothish flaccid

1603 Leaves 8 hispid lanceolate linear acuminate subimbricate, Peduncles twice dichotomous

1604 Leaves 8 linear furrowed with stem smooth to the touch, Branches flexible, the flow.-bearing ones short

1605 Leaves 8 elliptical lanceolate obtuse mucronate at the edge rough horizontally spreading, Stem flaccid

1606 Leaves 8 smooth lanc. scabrous beneath, Floral in pairs, Panicle term. Ped, capill. Stem rounded smooth

1607 Leaves 8 linear lanceolate very smooth, Peduncles panicled capillary, Stem rounded

1608 Leaves whorled linear above scabrous, Panicle divaricating, Stem erect rounded pilose roughish

1609 Leaves 8 lanceolate smooth mucronate, Panicle capillary, Petals awned, Stem 4-cornered weak

1610 Leaves 8-6 ohovate lanc. mucr. rough at edge, Peduncles 3-flow. Petals awned, Stem 4-cornered smooth

1611 Leaves whorled linear, Peduncles dichotomous flower-bearing from the top of the stem which is smooth

1612 Leaves whorled linear setaceous, Peduncles capillary longer than the leaves

1613 Leaves whorled linear spreading, Peduncles very short

1614 Leaves 6 lanceolate keeled rough aculeate backwards joints simple

1615 Leaves 6 or 8 lanceolate prickly serrate backwards mucronate stiff, Cor. larger than fruit

1616 Leaves 6 linear lanceolate mucronate thin, edges and the stem scabrous, Peduncles bifid, Fruit granular Fruit rough or hispid.

1617 Leaves 4-6 oblong with short point rough at edge, Panicles close, Stem weak short smooth

1618 Leaves 8 lanc. at edge and stem aculeate backwards, Peduncles axillary 3-fl. Fruit granular nodding

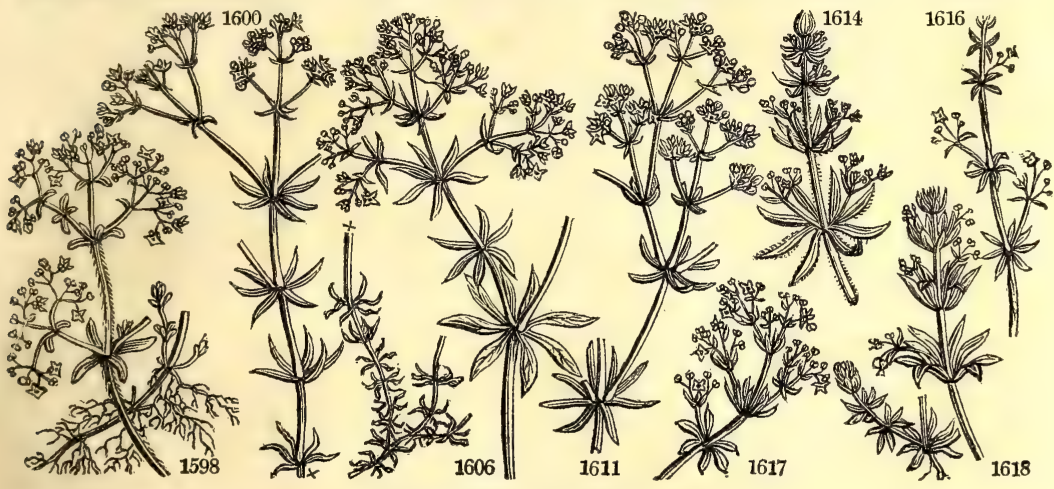

and Miscellaneous Particulars.

nerally axillary, but sometimes panicled. G. verum, petit Muget, Fr. is called bed-straw, from the verb to strew, strow, or straw; being one among a variety of odoriferous herbs which were formerly used to strew beds with. The bruised plant is sometimes put in milk intended for cheese to give it a flavor and color. Boiled in alum-water, the flowering stems dye a good yellow color, and the roots a red equal to madder. 'They were once cultivated like that plant, at the recommendation of the Committee of Council for Trade, and yielded $12 \frac{1}{\mathrm{cwt}}$. of dried roots per acre. G. mollugo, of which there are several varieties, and G. sylvaticum and boreale have similar qualities, though in a less degree.

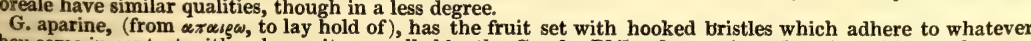
they come in contact with, whence it was called by the Greeks Philanthropon (man-lover), and by us cleavers, catch-weed, scratch-weed, \&c.; and from being a favorite food or medicine with geese, goose-grass, \&c. Linnæus informs us, that they use the stalks in Sweden as a filtre to strain their milk through Dioscorides relates, that the shepherds made the same use of it in his time; and certainly it is no bad thing to take hairs from milk, where a sieve is not at hand. It is reckoned to purify the blood, and for that purpose the tops are 
1 ì19 boreáie $W$. 1620 Aparine $\boldsymbol{W}$. 1621 pilósum $W$. 1622 græ'cum $W$. 267. RU'BIA. $\boldsymbol{W}$. 1623 tinctórum $W$. 1624 peregrína $W$. 1625 lúcida $W$. 1626 fruticósa $W$. 1627 angustifólia $W$. 1628 cordifólia $W$. 268. ASPE'RULA. $W$. 1629 odoráta $W$ 1630 arvénsis $W$. 1631 hirta $P . S$. 1632 hirsúta Desf 1633 taurina $W$. 1634 crassifólia $W$. 1635 aristáta $L$.

1636 scábra $L k$.

1637 tinctória $W$.

1638 cynánchica $W$

1639 supina Bieb.

1640 arcadiénsis $\boldsymbol{B} . \boldsymbol{M}$.

1641 lævigáta $W$.

1642 montána $W$. en.

269. SHERAR'DIA. 1643 arvénsis $W$.

$16+4$ murális $W$.

1645 tenúior $W$.

$16 \pm 7$ strigósa $B . M$.

1648 radicans $W$.

$16+9$ verticilláta $W$

1650 hispida $W$.

1651 rúbra Jacq.

1652 stricta $L$.

1653 stylósa $L k$

1654 cornifólia Fisch.

1655 Fischéri $L k$.

1656 suffruticósa Jacq.

1657 mucronáta Nees.

271. CRUCI A NELLA.

1658 angustifólia $W$.

1659 latifólia $W$. cross-leaved

Cleavers

hairy

Candian

Madder.

dyer's

wild

shiring

prickly-leaved

narrow-leave

heart-leaved

WOODROOF. sweet-scented

field

hairy

hirsute

broad-leaved

thick-leaved

awned

rough

narrow-leaved

small

supine

Arcadian

shining

mountain

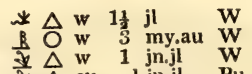
츠 $\triangle$ cu $\frac{1}{2}$ jn.jl Pu Rubiacere.

* $\Delta$ ag 4 jn

* $\Delta$ w $\quad 2$ jl

L W 2 J

*

* $\Delta \mathrm{cu}$

1.4 or

w $\frac{1}{2}$ my.jn w

$\neq \Delta p \quad \frac{1}{4} \mathrm{jn} . \mathrm{jl} \quad \mathrm{Pu}$

* $\Delta$ pr $\frac{1}{2}$ my.jn W

$\frac{1}{\partial} \Delta$ pr $1_{\frac{3}{4} \text { ap.jn }} \quad W$

$\downarrow \Delta$ pr 1 jl.au

म $\triangle$ pr 1 jnjl

$\frac{1}{2} \Delta$ pr $\frac{3}{4} \mathrm{jn} . \mathrm{jl}$

$\$ \Delta \mathrm{pr}$

$\$ \Delta$ pr

$\gtrsim \Delta p r$ से $\Delta$ pr

Field-madder. wall

$\begin{array}{lll}\text { pr } 1 & \text { ju.jl Pk }\end{array}$

Rubiacea.

$\frac{1}{4}$ ap.s $\mathrm{Sp} .2$.

$\frac{1}{4}$ jn.au Y Italy

Rubiacea. Sp. 13-65.

jn.au Pk W. Indies 1732 S co Sch, hand 1.29

2 ji W Guiana 1803. S s.l Aublet. t. 19. f.1

1 jl.au W W. Indies 1760. S $\begin{array}{llll}\text { S } & \text { s.1 } & \text { But. mag. 1558 }\end{array}$

$\frac{1}{2} \mathrm{jl}$ W Guiana 1803, S s.l Aublet.1.t.20.f.

$2^{2}$ jn.au W Africa 1732. S s.p Dii.el.t.277.f.358

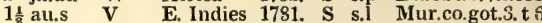

1 jn.au Pu 1804 S s.l Jac.schon. t.256

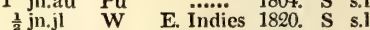

$1^{\frac{1}{2}}$ my.jn W Manilla 1819. S s.

1 my.jn R Brazil 1819. S s.

1 my.jn W Jamaica 1821. S s.

$\frac{1}{2}$ jn.au F

suffruticose $\square$ w

ate $y$

W. Cross-wort

narrow-leaved

broad-leaved

○ cu $\begin{array}{r}\text { Rubiaceg. } \\ \frac{1}{2} \text { jn.jl }\end{array}$ Y $9-16$.

Jamaica 1829. D

Jac.schœn. t. 322

France 1658. S co Ex. bot. 2.t. 109

Grance 1633, S co Barr. ic. t. 520

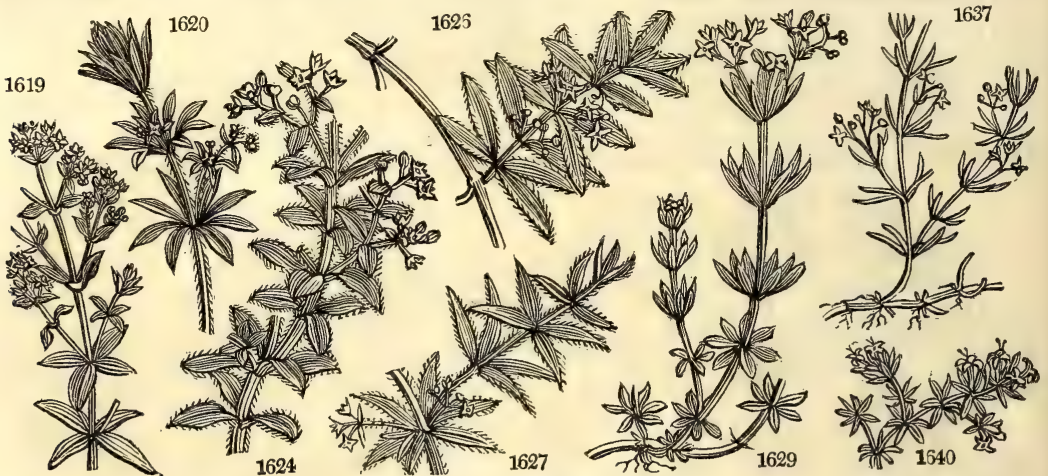

History, Use, Propagation, Culture,

an ingredient in spring-broth. The expressed juice of the herb, taken to the amount of four ounces or a quar. ter of a pint night and morning, during several weeks, is very efficacious in removing many of those cutaneous eruptions, which are called, though improperiy, scorbutic. The seeds have been substituted for coffee. The roots, like those of most of the species, will dye red; and, eaten by birds, tinge their bones of that color. It is a very troublesome weed, particularly in young hedges, but being an annual is easily eradicated.

G. tuberosum is cultivated in China for the roots, which are eaten boiled, either whole or in meal, and Lou. reiro says, are esteemed salubrious. It has not yet been introduced.

267. Rubit. From ruber, red. R. tinctorum has an annual stalk, which trails or climbs, supporting itself in the latter case by its leaves and prickles. Its root is composed of many long thick succulent shoots nearly half an inch in diameter, striking deep into the ground, and growing to the length of three or four feet. From them is procured a well-known red and scarlet dye used by clothiers and callico-printers, and employed to a great extent, though chiefly from foreign roots. England was formerly supplied with this article exclusively from Holland, and as in times of political derangement the price was greatly increased, its dearness induced some patriotic individuals, who had recently set on foot the Society of Arts, to attempt its culture in England. Miller paid great attention to the subject about 1758, publishing separately, as well as in his Dictionary, the Dutch practice as observed by him while in Holland. A. Young, in his "Annals," details several trials; the result of which, and especialiy those of J. Arbuthnot in 1765, proves, that it could be grown here to as great perfection as in Holland, but not sold at so low a price. Its culture was not therefore encouraged, and we are now supplied from Holland, France, Italy, and Turkey, and the cochineal is very generally in use as a substitute. Like others of the natural order of Bubiaceæ, madder tinges with a florid red color the milk, urine, and bones of the animals that feed ou the plant. The hardest part of the bones receives the color first, which gradually extends through the whole substance; but if the plant be alternatelv given and inter- 
1619 Leaves 4 lanceolate 3-nerved smooth, Stem erect, Fruit hispid

1620 Leaves 8 lanc. keels and edge scab. acul. backw. Stem flaccid, Joints vill. Fruit covered with hooked hairs 1621 Leaves 4 subovate pilose nerveless, Fruit hairy

1622 Hairy leaves about 6 linear lanceolate, Stems woody

1623 Leaves 6 lanceolate smooth above : their edge and keel beneath scabrous, Stem herbaceous aculeate 1624 Leaves 4 perennial lanceolate above shining smooth their edge and rib beneath scabrous

1625 Leaves perennial 6 elliptical shining, Stem smooth

1626 Leaves perennial elliptical at the edge and keel very prickly, Stem rough shrubby

1627 Leaves perennial linear above scabrous

1628 Leaves perennial 4 cordate oblong stalked 3-nerved above and at the edges scabrous

1629 Leaves 8 lanceolate, Corymbs terminal stalked, Seeds echinate

1630 Lower leaves 4 obovate, upper 5-6-8, Flowers terminal sessile aggregated, Involucres ciliated

1631 Leaves hairy acute 6 longer than the joint, Flowers terminal aggregate sessile longer than involucrum

1632 Leaves 6 linear acute toothletted : the lower hirsute, Flowers aggregate terminal

1633 Leaves 4 ovate lanceolate 3-nerved, Flowers fascicled terminal

1634 Leaves 4 together oblong: the lateral revolute obtuse pubescent

1635 Leaves linear fleshy : the lower 4 , Flowers 3 awned

1636 Cauline leaves 4 linear the lower elliptical the upper in pairs all rough awned, Cor. rough

1637 Leaves linear the lower 63 -nerved, the middle 4, the upper opposite, Stem flaccid, Cor. smooth 3-fid

1638 Lower leaves 4 lanceolate upper linear very unequal in pairs, Stem erect, Fruit smooth tubercled

1639 Leaves 4 linear the lower imbricate, Stem much branched at base procumbent, Flowers 4-fid

1640 Hispid, Leaves 6 oblong-ovate acute revolute at edge, Stems decumbent

1641 Leaves 4 elliptical obsoletely nerved smooth glabrous at edge, Fruit scabrous

1642 Leaves linear the lower 6 , middle 4, upper opposite, Stem flaccid, Cor. 4-fid scabrous outside

1643 Lower leaves 8 and 4, Flowers terminal, Stem and branches scabrous, Involucres naked

1644. Leaves 6 linear: floral in pairs opposite, Branches simple, Flowers two, Fruit hispid subsessile

1645 Smooth, Leaves lanceolate, Stamens included, Flowers whorled, Seeds hairy

1646 Smooth, Leaves ovate, Stamens exserted, Flowers whorled ciliated

1647 Leaves and bractes oblong ovate hispid, Stalks stem-clasping, Flowers capitate, Stamens exserted

1648 Smooth, Leaves subsessile lanceolate acute, Flowers whorled small, Stem procumbent rooting

1649 Smooth, Leaves lanceolate, Whorls globose

1650 Hispid, Leaves obovate oblique, Flowers axillary in pairs

1651 Hairy, Leaves ovate the upper four together, Heads terminal

1652 Leaves linear-lanceolate lined

1653 Stem decum. rounded smooth, Lvs. obl. lanc. atten. at base, Stipules setose, Fl. whorled, Style exserted 1654 Stem erect slightly downy, Leaves stalked oblong acute rough and pubescent at edge, Stamens exserted 1655 Stem erect 4-cornered hairy, Leaves acute entire lined pubescent with very short hairs, Flowers termina 1656 Stem ascending very smooth 4-cornered, Leaves stalked ovate acuminate thin, Flowers whorled

1657 Resembles Sp. verticillata, but the leaves are shorter and obtuse with a point, at the edge and back rough

1658 Erect, Leaves 6 linear, Flowers spiked

1659 Procumbent, Leaves 4 lanceolate, Flowers spiked

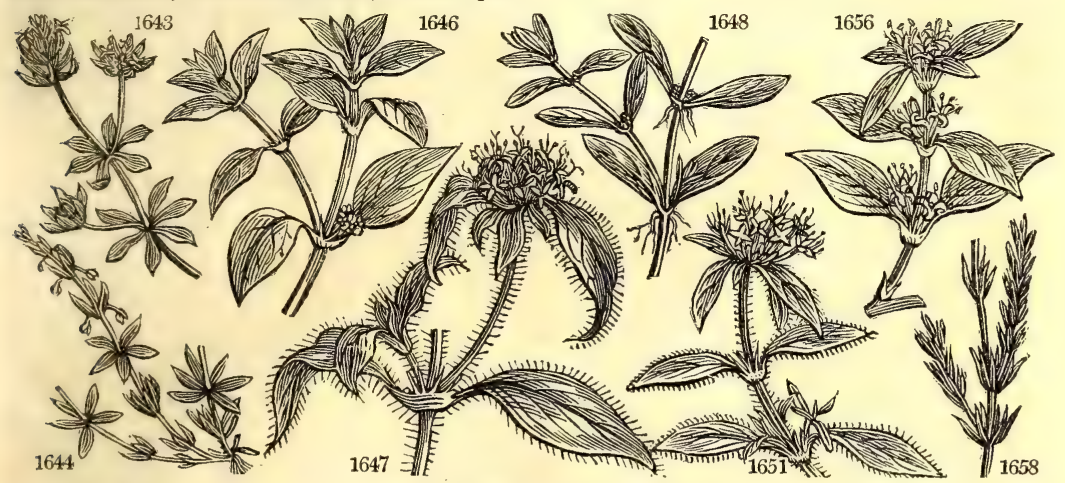

and Miscellaneous Particulars.

mitted, the bones are found to be colored in concentric circles. In medicine, madder was formerly used in complaints of the kidnies.

To cultivate the madder, choose a deep sandy loam, and prepare it by trenching or very deep ploughing. Plant cuttings of the roots in rows, eighteen inches by one foot in the row, in March, and the third year they may be taken up in September. The roots are next kiln-dried, and afterwards threshed to clean them from earth and dust. They are then drie a second time, and immediately afterwards pounded or stamped in a mill. It is cultivated extensively in Zealand, and especially in the isle of Schowen : round Avignon and in Lombardy it is grown on narrow ridges, and irrigated by directing water along the furrows.

268. Asperula. From asper, rough. The species cynanchica is so called from *vy๘r $x_{\varepsilon i v}$, to choak, it being a specific in cases of squinancy. The inglish name of this genus is supposed to be a corruption of the word wood rowel, the whorls of leaves, according to Turner, representing certain kinds of " rowelles of sporres," All the species, excepting arvensis and cynanchica, will thrive in the shade and drip of trees in a moist soll. A. odorata has a pleasant scent like Anthoxanthum : it imparts a grateful flavor to wine, an agreeable perfume to clothes, and preserves them from insects. It is eaten by cattle and horses, and from containing an acid principle, with much fixed alkaline salt, has been thought useful in obstructions of the liver and biliary ducts. The roots of A. tinctoria are used in Gothland to dye wool a red color.

269. Sherardia. So named in honor of the famous Sherard, of whose noble garden at Eltham Dillenius's Hortus Elthamensis is a living monument, and whose herbarium is still one of the few things which recommend Oxford to the notice of a botanist. This is a little insignificant weed, by no means worthy to be consecrated to the memory of so celebrated a man.

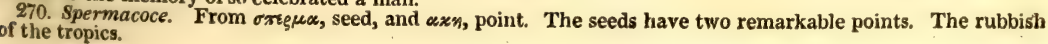


1660 ægyptiaca $W$.

1661 pátula $W$.

1662 pubéscens $W$.

1663 ciliáta $W$.

1664 marítima $W$.

1665 monspeliaca $W$.

Egyptian spreading

pubescent

ciliated

Montpelier

1666 molluginoídes $\boldsymbol{W} . e n$. Mollugo-like

272. CAllicar'Pa. $W$. Callicarpa

1667 americána $W$. American

1668 cána $W$.

1669 lanáta $W$.

1670 macrophýlla $W$.

1671 ferrugínea $W$.

hoary

woolly

rusty

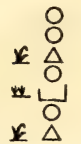

$\frac{1}{2} \mathrm{jn}$.

$\mathbf{Y}$
$\mathbf{Y}$
$\mathbf{P u}$
$\mathbf{Y}$

1 jl.au Pu Candia

$1^{\frac{1}{2} \text { jl.au }}$ jl.au

$\begin{array}{ll}\frac{1}{2} \text { jl.au } & \text { Y } \\ \text { jl.au } & \text { G }\end{array}$

Verbenacee.

6 jn.jl R N. Amer. 1724. C s.p Cat. car. 2. t. 47

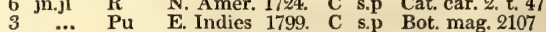

4 jn.jl Pu E. Indies 1788. C $1 . p$

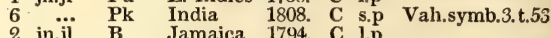
Solanacea $S p .1-12$

273. WITHERIN'GIA. $W$. Witheringia

1672 solanácea $W$. yellow-flower'd $\square$

274. ÆGI'PHILA. $W$. REIPHILA.

1673 martinicénsis $W$. Martinique

1674 fo'tida $W$.

1675 diffúsa $A n d r$.

1676 obováta $A n d r$.

foetid

diffuse

oval-leaved

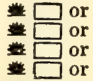

275. CEPHALAN'ThUS $W$ ButTon-wood.

1677 occidentális $W$. American

276. SCOPA'RIA. $W$. SCOPARIA.

1678 dúlcis $W$. sweet

策 or

cu

277. CENTUN'CULUS. $W$ BASTARD-PIMPERNEI 1679 mínimus $W$. least

278. Plantágo. $W$. Plantain.

1680 májor $W$.

1681 críspa Jacq.

1682 asiática $W$.

1683 máxima $\dot{W}$.

1684 média $W$.

1685 virgínica $W$.

1686 altissima $W$.

1687 lanceoláta $W$.

1688 capénsis $W$.

1689 Lagōpus $W$.

1690 túmida $L k$.

1691 mexicána $L k$.

1692 kamtchática $L k$.

1693 tenuiflóra $W . \& K$

1694 sálsa Pall.

1695 lusitánica $W$.

1696 álbicans $W$.

1697 patagónica $W$.

1698 hirsúta $W$.

1699 villosa $\boldsymbol{P}$.S. .

1700 alpina $W$.

1702 Bellárdi $W$.

1703 crética $W$.

greater

broad-leaved

hollow-leaved

hoary

Virginian

tall

Rib-grass

Cape

round-headed

swelling

Mexican

Kamtchatka

slender-flower.

grassy

Portuguese

woolly

Patagoniam

hairy

villous

Wulfen's

Alpine

Alpine

Bellardi's
Cretan

$\mathrm{O} \mathrm{cu}$

1 my.s Y

Verbenacea. Sp. 4-12.

$\begin{array}{lllll}6 \mathrm{n} & \mathrm{W} & \text { W. Indies 1780. } & \mathrm{S} & \text { p.l Jac. obs. 2. t. } 27\end{array}$

2 jn.jl Li W. Indies 1800. C l.p

2 jl.au $\quad \mathbf{Y} \quad$ W. Indies 1804. C 1.p Bot. rep. 578. f. 1

2 jl.au $\quad$ Y W. Indies 1804. C l.p Bot. rep. 578. f. 2 Rubiacee. Sp. 1-10.

7 au W N. Amer. 1735. S s.l Schm. arb.1.t.45 Scrophularine. Sp. 1.

jn.s W Jamaica 1730. S s.l Herm, par.t.241

\section{Primulacea. $S p .1-4$.}

jn.jl F Britain moi.h. S p.l Eng. bot. 531

\section{Plantaginea. Sp. 42-115.}

$7 \Delta \mathrm{w} 1 \mathrm{my} . \mathrm{jn} \mathrm{W}$ Britain me. pa. D co Eng. bot. 1558

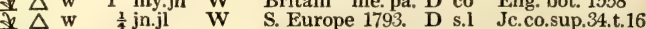

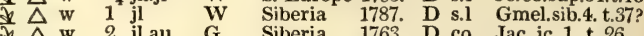

\$ $\Delta$ w 2 jl.au $\quad G \quad$ Siberia 1763. D co Jac. ic. 1. t. 26

$\Delta$ w 11 my.jl G Britain me.pa. D co Eng. bot. 1559

$\downarrow \Delta \mathrm{w} \quad 3 \mathrm{jn.jl} G$ Italy 1774, S co Jac. obs. 4. t. 83

\ $\triangle$ ag $\frac{1}{2}$ my.jl G Britain me.pa. S co Eng. bot. 507

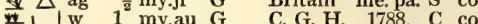

C. G. H. 1788. C co

Spain 1683. S co W.ph.4.t.\$20.f. 2

1 jn.j1

1 jn.jl G Chiii 1819. S co

Mexico 1820. D co

$\begin{array}{llll}\frac{1}{4} j n . j l & \text { G } & \text { Kamtsch. 1819. D co } \\ \frac{2}{4} \text { jn.jl } & \text { G } & \text { Hungary 1802. S } & \text { S.l }\end{array}$

Hungary 1802. S s.l Pl. rar. hn.1. t.59

${ }^{4}$ jl.s G Siberia 1804 D s.l

娄 jl.s G Spain 1781. D s.1

1781. D s.1 Bar. ic.119. t.745

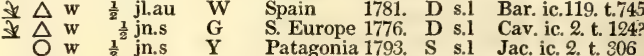

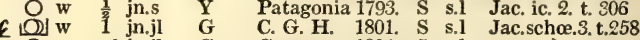

w 1

Germany 1804. S s.l

Germany 1802. D co

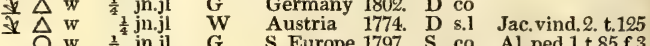

G S. Europe 1797. S co O w $\frac{1}{4} \mathrm{jn} . \mathrm{jl}$

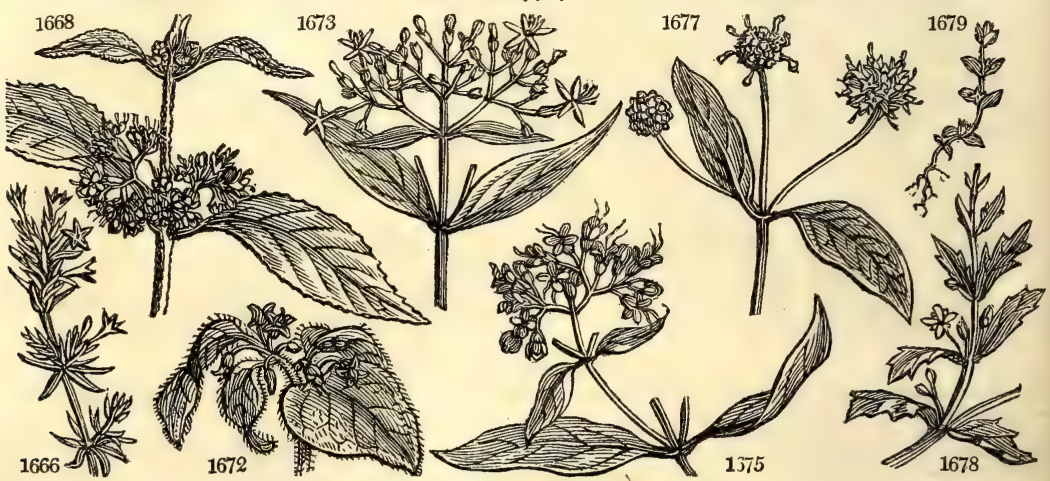

History, Use, Propagation, Culture,

271. Crucianella. A diminutive of crux, a cross; some of the roots having their leaves in whorls of four. These are small herbaceous plants of little beauty, natives of the south of France, and rarely seen in this country except in botanic gardens.

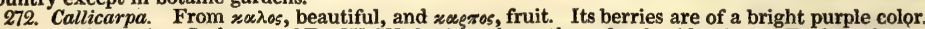

273. Witheringia. In honor of Dr. W. Withering, the author of a classification of English plants, which has been one of the most popular of our English botanical works, and deservedly so, although it has now yielded to

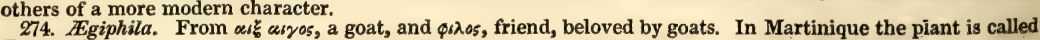
Bois de Cabri.

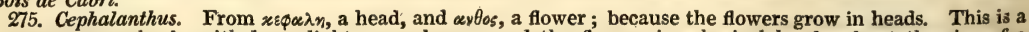
low evergreen shrub, with large light green leaves, and the flowers in spherical heads, about the size of a musket bullet. It has a good effect on lawns in scattered groups, or in the front ranks of shrubberies. Sweet says, " soil that has some peat in it suits them best," and that they are readily propagated by layers, or ripened cuttings under a hand-glass. Miller, in whose time the art of striking cuttings was not nearly so well understood as at present, recommends a moist light soil, and propagating from seeds. 
1660 Leaves 4 sublinear, Flowers spiked 5-cleft

1661 Diffuse, Leaves 6 revolute at edge, Bract. linear subulate roughish, Flowers scattered

1662 Erect, Leaves 6 linear pubescent, Heads stalked axillary and terminal

1663 Diffuse, Leaves 4 or 2 lin. keeled, Bract. ciliated loosely spiked, Seeds oval covered with obtuse tubercles 1664 Procumbent suffruticose, Leaves 4 mucronate, Flowers opposite 5-cleft

1665 Procumbent, Leaves acute, of the stem in $4 \mathrm{~s}$ ovate, of the branches 6 linear, Flowers spiked

1666 Erect, Leaves whorled 8-12 linear lanc. scab. Fascic. of flowers stalked term. and axillary, Cor. 5-cleft

1667 Lvs. ovate acum. uneq. obtusely toothed at base wedge-shaped atten. entire beneath and branches toment. 1668 Leaves ovate toothletted running down the petiole beneath hoary villous, Panic. dichotomous

1669 Leaves ovate rounded at base entire somewhat toothletted rugose above beneath with the branches woolly 1670 Leaves ovate lanc. serrulate reticul. hoary beneath, Corymbs axillary dichotomous longer than petioles 1671 Leaves broad lanceolate serrate roughish beneath, Cymes terminal and axillary

1672 Stem hairy herbaceous angular, Leaves ovate lanceolate pilose, Stalks 1-flowered umbelled axillary

1673 Leaves ovate lanceolate acuminate smooth, Branches diffuse, Panic. terminal and axillary, Cal. smooth 1674 Leaves ovate lanceolate beneath and the stalks hairy, Peduncles axillary solitary

1675 Leaves ovate lanceolate with a long point smooth on both sides, Pan. diffuse axillary and terminal

1676 Leaves obovate acuminate smooth on both sides, Pan. axillary and terminal, Stalks and calyxes less pub.

1677 Leaves opposite and ternate oblong oval acuminate

1678 Leaves 3 together, Flowers stalked

1679 Leaves alternate ovate, Flowers sessile

1680 Lvs. ovate smoothish generally shorter than footst. Scape rounded, Spike cyl. slender, Caps. many-seeded 1681 Leaves ohovate shining undulated fleshy sessile, Scape compressed below, Flowers imbric. remote at base 1682 Leaves ovate smooth somewhat toothed, Scape angular, Spike with distinct flowers

1683 Leaves ovate subdenticulate 9-nerved pubescent, Spike cylindrical imbricated, Scape rounded

1684 Leaves ovate pubescent longer than the footstalk, Scape rounded, Spike short cylindrical, Filam. lilac

1685 Leaves lanceolate ovate pubescent toothletted, Spikes cylindrical pubescent, Scape angular

1686 Leaves lanceolate 5-nerved toothed smooth, Spike oblong cylindrical, Scape angular

1687 Leaves lanceolate acuminated both ways, Spike short ovate cylind. Scape angular, Caps. 2-seeded 1688 Leaves elliptical, Spike with distinct flowers

1689 Leaves lanceolate somewhat toothed, Spike ovate hairy, Scape rounded

1690 Leaves linear lanceolate toothletted silky, Scapes ascending with appressed hairs, Caps. tumid 1691 Leaves lanceolate linear entire, Hairs scattered, Scapes erect rounded, Spike cylindrical dense 1692 Leaves oblong toothed 5-nerved hairy, Scapes ascending angular hairy, Spike cylindrical dense 1693 Leaves linear nearly entire obtuse fleshy, Scape rounded, Spike erect, Flowers distant

1694 Leaves linear convex beneath a little toothed smooth, Scape rounded hirsute, Spike cylindrical smooth 1695 Leaves broad lanceolate 3-nerved a little toothed pilose, Scape angular, Spike oblong hairy

1696 Leaves lanceolate oblique villous, Spike cylindrical erect, Scape rounded

1697 Leaves lanc. lin. somew. chan. ent. woolly; Scape rounded hirsute, Spike cyl. Stam. not longer than flower 1698 Leaves linear ciliated, Spike cylindrical, Stem hirsute

1699 Subcaulescent, Lvs. lin. lanc. obsol. 3-nerv, toothl. hoary, Spike roundish, Br. winged keeled shorter than f. 1700 Leaves linear attenuated both ways flat 3-nerved, Scape rounded

1701 Leaves lin. atten. remotely toothed, Scape rounded hairy, Spike obl. acute, Br. ovate membranous at edge 1702 Leaves linear lanceolate hairy longer than the rounded hairy scape, Spike ovate erect, Bractes lanceolate 1703 Leaves linear, Scape rounded very short woolly, Spike roundish nodding

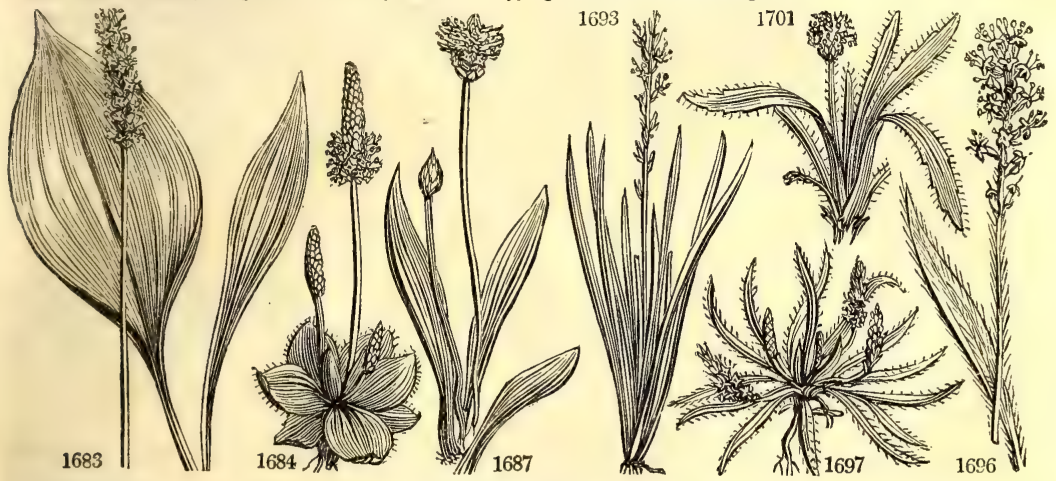

and Miscellaneous Particulars.

276 Scoparia. From scopa, a broom. In the Antilles brooms are made of the twigs. This plant is treated as a tender annual, and after being raised in the hot-house or hot-bed, is potted off, and kept in the greenhouse, or planted out in the flower borders.

277. Centunculus. A name given by the Romans to a small plant found in cultivated lands. The present is a little mean weed of no use or beauty.

278. Plantago. A name of which no satisfactory explanation has been given. Of the species, Psyllium is derived from $\psi v \lambda \lambda_{0}$, a flea, in allusion to the appearance of its little seeds. Lagopus, from $\lambda \propto \gamma_{05}$, a hare, and $\pi 85$, foot; its velvety or silky spike resembling the foot of such an animal foot; its deeply-cut leaf having been compared to a bird's foot. Cynops, signifying dog's-eye, is the name of a plant of Pliny, and one of his plantains. This is a genus of little beauty, and no great utility. Like all other plants known to our botanical forefathers, they were said to have their medical virtues; but that is nothing, or at least but little guide to their absolute use in the arts. P. Janceolata (rib-grass) has been employed in agriculture as a herbage plant, but to which it appears to have no great claim. Where it abounds naturally, it is a certain indication of a dry soil. Haller attributes the richness of the milk in the alpine dairies to this plant and Alchemilla vulgaris, but Linnæus says cows refuse it. This every shepherd knows to be the case as far as 
1704 marítima $W$. 1705 graminea $P . S$. 1706 recurváta $W$. 1707 subuláta $W$. 1708 macrorhiza $\boldsymbol{W}$. 1709 Serrária $\boldsymbol{W}$. 1710 Corónopus $W$. 1711 Loeffingii $W$. 1712 Cornúti $W$. 1713 amplexicaúlis $W$. $171+$ Psyllium $W$. 1715 arenária $\boldsymbol{P} . \dot{S}$. 1716 squarrósa $W$. 1717 indica $W$. 1718 strícta $P$. S. 1719 púmila $W$ 1720 Cýnops $\boldsymbol{W}$. 1721 áfra $W$.

279. BUD'DLEA. $W$. 1722 globósa $W$ 1723 Neem'da Buch. 1724 salvifólia $W$. 1725 salígna $W$. en. 280. EX'ACUM. $W$. 1726 viscósum Sm. 1727 spicátum Vahl. 1728 filifórme $W$. 281. SEB $E^{\prime} A, R, B r$. 1729 cordáta $R$. $B$

282. FRASE'RA. Walt 1730 carolinénsis $P$. $S$. 283. PENA'A. $W$. 1731 mucronáta $W$ 1732 squamósa $W$. 284. BLE'RIA. $W$. 1733 ericoídes $W$. 1724 articuláta $W$. 173.5 purpúrea $W$. 1736 muscósa $W$. 1737 ciliáris $W$.

285. CHOME'LIA. $W$ 1738 spinósa $W$. 286. A DI'NA. Sal. 1739 globiflóra Sal. 287. BOUVAR'DI $17+0$ triphýlla $H . K$ $17+1$ versicolor $B . R e g$

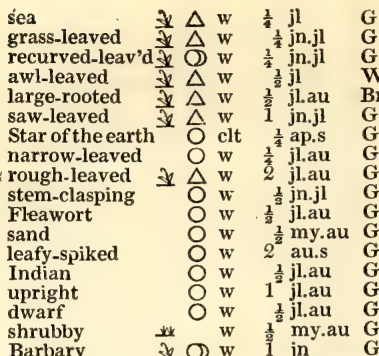

Britain seaco. S co Eng. bot. 175

France 1804. D co Dod. pempt. 108 S. Europe 1799. S s.1 M.co.go.1780. t.6 S. Europe 1596. D s.l Lob. ic. 439

Morocoo 1798. D s.l Mor. h.3.t.17,f 2 Barbary 1640. D s.1 Col.ecphr. t. 259 Britain seash. S s.1 Eng. bot. 892 Britain seash. S s.1 Eng. bot. 892
Spain ...... 1801. S co

Spain 1797. S co Cav. ic. 2.t. 125 S. Europe 1562. S co Mor.h.3.t.17.f.4 Hungary 1804. S co W. \& Kit. t. 51 Egypt 1787. S co Jac. ic. 1. t. 28 India 1780. S co Morocco 1804. S co Sch.mar.1.ic.145 S. Europe 1790. S s.l M.co.go.1778.t.5 S. Europe 1596. C s.1 W.ph.4.t.837.fa Sicily 1640. S s.1 Mor.h.3.t.17.f.4 Scrophularince. Sp. 4-26.

Buddea. round-headed Indian Sage-leaved

Willow-leaved Exacum. clammy spiked

least

Sebea. heart-leaved 跣 or 15 my.jn Or Chili 1774. C co Bot. mag. 174 Nepal 1824. C 1.p

C. G. H. 1760. C s.l Jac.schœen.1.t.28 C. G. H. 1816. C 1.p Jac.schœen.1.t.29 au.s C Gentianea. 5̃p.3-18.

2 jn.jl Y Canaries 1781. S p.1 Smit.ic.fas.3.t.18

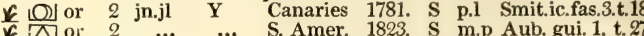

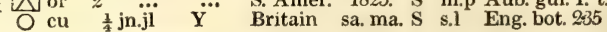
Gentianea. Sp. 1-4.

O or $\frac{1}{2}$ jl.au $\mathbf{Y}$ C. G. H. 1815. S co Bur. afr. t.74. f.5 Gentianea. Sp. 1.

Carolina

PenaA.

heart-leaved

scaly

BLERIA.

heath-leaved jointed

purple-flowered

Moss-leaved

ciliated

Chomelia. spiny

AdrNa.
globe-flowered Epacridea? Sp. 2-14.

1795. S co Bart. m. bot.t.35

* J or 2 jn.jl R $\quad$ C. G. H. 1787. S p.l Vent. mal. 87 C. G. H. 1787. S p.l Bot. reg. 106 Ericea. Sp. 5-13.

- $J$ or 2 au.o Pu C. G. H. 1774. C s.p P.gz.471.t.2.f.10

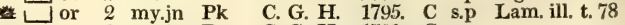
my.jn Pu C. G. H. 1791. C s.p C. G. H. 1774, C l.p

2 jn.au W C. G. H. 1795. C s.p Wend.col.2.t.49 Rubiacea. $S p, 1-2$. Rubiacee $S p$

Rubiacea. Sp. 2.

$K$. Bouva RDIA.

three-leaved

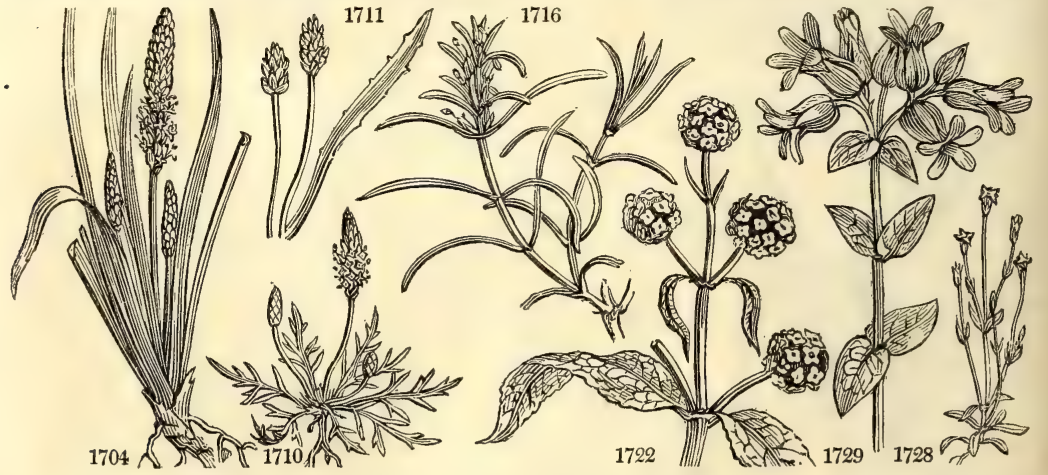

History, Use, Propagation, Culture,

respects the flower-stalks. Zappa of Milan, and A. Young, speak in high terms of it; but the general feeling and practice of scientific agriculturists is against it, and it is now seldom sown.

P. major is a native of most parts of Europe and of Japan, and always by way-sides, whence its name of waybread or way-bred. The seeds afford food to linnets, finches, and other small birds, and the leaves are a common application to wounds and cutaneous sores. An American negro once received a reward from an assembly of South Carolina for a cure for the bite of the rattle-snake; and in the receipt, it is said by Woodville (Med Bot.), plantain was a principal ingredient. There are several varieties of this species to be met with in rich pastures and in botanic gardens, such as the rose $\mathbf{P}$., in which the flower appears changed into a tuft of leaves expanded like a rose, and the besom $\mathbf{P}$., in which the spike-leaves are imbricate and pyramidal.

P. maritima varies in size and situation more than most plants. Its leaves are sometimes scarcely an inch, and at other times more than a foot in length ; and the number of flowers in the spike varies extremely. Like Statice armeria and Sambucus nigra, it is found on the summits of the highest mountains, in the clefts of rocks, on the sea-shore, in salt marshes, and muddy banks.

P. coronopus is a singular-growing plant, with recumbent stems pressing closely on the ground. The leaves have a very peculiar flavor, and are rather disagreeable, but were formerly used in salads. $\mathbf{P}$. psyllium is sometimes imported from the south of France in a dried state for the druggists.

279. Buddlea. In honor of Adam Buddle, a name well known to the English botanist as authority for many rare British plants, B, globosa is a very handsome shrub, and though rather tender, flowers freely in warm situations, or against a wall, with protection in very severe winters. Its leaves are long, narrow, pointed, 
1704 Leaves semicylindrical entire woolly at base, Scape rounded

1705 Leaves lin. flat somew, toothed smooth at base, Spike cyl. Scape rounded hairy scarcely longer than leaves 1706 Leaves linear ahannelled recurved naked

1707 Leaves linear channelled entire beneath with rigid ciliæ hairy at base, Scape rounded pubescent

1708 Leaves spatulate cut-toothed, Teeth imbricated mucronated, Scape rounded hairy

1709 Leaves lanceolate 5-nerved toothed serrate, Scape rounded

1710 Leaves linear pinnate toothed, Scape rounded

1711 Leaves linear sub-toothed, Scape rounded, Head ovate, Bractes keeled membranous

1712 Leaves ovate entire fleshy rough woolly at base, Capsules 4-seeded

1713 Stem erect simple short, Leaves lanceolate fleshy entire stem-clasping hairy, Heads oblong leafless

1714 Stem branched herbaceous, Leaves somewhat toothed recurved, Heads leafless

1715 Hoary, Stem erect branched herbaceous, Leaves nearly entire, Heads leafy and sepals ovate

1716 Herbaceous, Stem branched diffuse decumbent, Leaves linear entire, Heads squarrose

1717 Stem branched herbaceous, Leaves linear entire reflexed, Heads leafy

1718 Stem branched herbaceous erect, Leaves linear channelled entire, Heads leafless

1719 Stem branched herbaceous weak, Leaves subulate entire, Heads leafy

1720 Stem branched suffruticose, Leaves entire filiform straight, Heads somewhat leafy

1721 Stem branched shrubby, Leaves lanceolate toothed, Heads leafless

1722 Leaves lanceolate acuminate crenulate beneath hoary, Heads globose stalked

1723 Leaves lanceolate subserrate hoary underneath, Spikes terminal lengthening with flowers threefold

1724 Leaves lanceolate cordate crenate rugose beneath tomentose, Flowers panicled

1725 Leaves linear lanceolate entire revolute at edge tomentose beneath, Corymbs terminal

1726 Leaves oblong nerved stem-clasping, Bractes cordate perfoliate longer than calyx

1727 Flowers spiked whorled and ternary, Leaves ovate lanceolate, Stem nearly simple

1728 Limb spreading, Stem filiform branched, Radical leaves roundish, Cauline subulate

1729 Flowers 5-cleft, Sepals cordate striated membranous keeled, Stem dichotomous, Leaves cordate

1730 A singular plant found in morasses in North America, and resembling Swertia

1731 Flowers terminal, Leaves cordate acuminate smooth

1732 Leaves rhomboidal wedge-shaped fleshy smooth, Flowers terminal

1733 Anthers exserted awnless, Cal. 4-leaved, Bract. 3 length of cal. Leaves 4 oblong acerose hairy imbricated 1734 Anthers exserted awnless, Leaves 4 ovate smooth, Flower-heads cernuous

1735 Anthers included awnless, Leaves 4 ovate subciliated, Flowers umbelled, Stem flexuose erect

1736 Anthers subexserted awnless, Cal. 1-leaved pilose, Cor. campanulate pilose above, Flowers axillary

1737 Leaves 4 smooth, Calyx lacerated ciliated

\section{Leaves ovate acuminate entire, Peduncles axillary}

\section{The only species}

1740 Leaves ternate lanceolate, Stamens included

1741 Leaves opp. Cor, clavate, Tube smooth inside

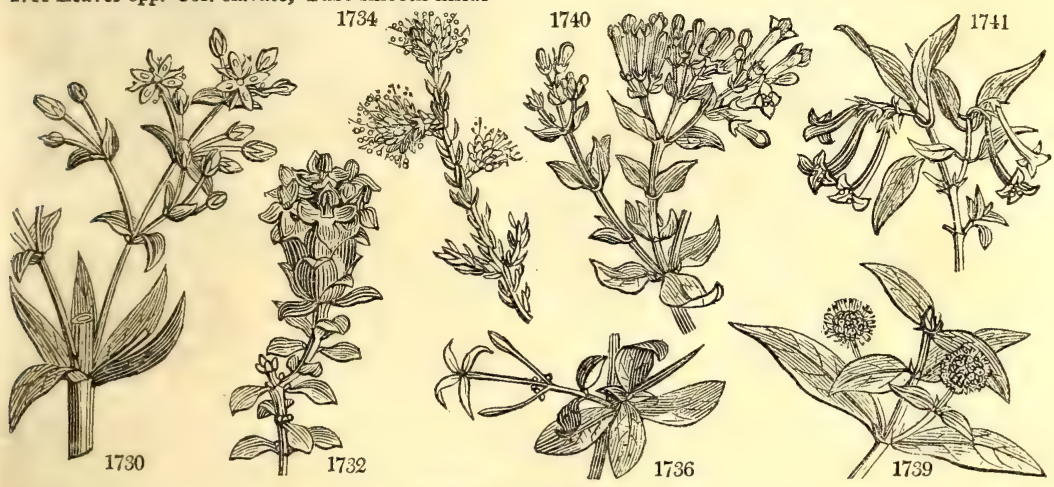

and Miscellaneous Particulars.

rugose, of the color of the common sage, and the flowers are very fragrant. It is commonly propagated by layers; but cuttings of the young wood of all the species root freely in common earth under a hand-glass. Buddlea Neemda is one of the most beautiful plants of India.

280. Exacum. The ancient name of a plant nearly related to Centaurium; said to have been derived from $\xi_{\xi}$ and $\alpha \gamma \omega$, to conduct out, on account of its properties of expelling poison taken into the stomach.

281. Sebaa. A genus nearly related to the last, named after the famous Albert Seba, whose museum was once one of the wonders of Europe.

282. Frasera. After Mr. John Frazer, an indefatigable collector of plants in North America.

283. Pencea. In honor of P. Pena, who published Adversaria Botanica, 1570, in conjunction with Lobel. A handsome genus, readily propagated by cuttings in sand under a hand-glass. Many of the finest species remain to be introduced from the Cape of Good Hope.

284. Bicria. In honor of Patrick Blair, who practised physic at Boston in Lincolnshire, and was one of the fellows of the Royal Society. He published Botanical Essays in 1778. The species resemble some kinds of heaths, and require the same treatment.

285. Chomelia. Named after Pierre Jean Baptiste Chomel, a French botanist, physician to Louis XV.; he died in 1740. Culture as for Siderodendrum.

286. Adina. From adivos, clustered, its flowers being in heads. A small Chinese plant, with flowers looking

like those of a Cephalanthus. It is probably not different from Cephalanthus.

287. Bouvardia. Named after Dr. Charles Bouvard, formerly a superintendent of the Jardin du Roi at H 2 
288. IXO'RA. $W$.

1742 crandiflóra $B . R$ 1743 Randhúca Roxb. 1744 coccínea $W$. 1745 barbáta Roxb. 1746 parviflóra $W$. 1747 rósea Wall.

1747 rósea $W$ álba $W$.

1748 álba $W$ strícta Roxb. 1750 blánda B. Reg. 1751 cuneifólia Roxb. 1752 crocáta $B . R$

289. CATESB更A. $W$. 1753 spinósa $W$

1754 parviflóra $P . S$.

290. PAVET'TA. $W$.

1755 indica $W$.

291. ERNO'DEA. Swz

1756 montána Sm.

209 SIDERODEN'DRU

1757 triflórum $W$

293. COCCOCYP'SILUM

294. MITCHELLA. $W$.

1760 umbelláta $W$.

1761 corymbósa $W$

296. MANET'TIA. $W$. MANETTIA.

1762 coccínea $W$.

297. EPIME'DIUM. $W$. BARREN-WORT:

1763 alpinum $W$.

298. PTE'LEA $W$

1764 trifoliáta $W$

299. MONE'TIA. $W$.

1765 barlerioides $W$.

300. CURTI'SIA. $W$

1766 fagínea $W$

301. HARTO'GIA. $W$ 1767 capénsis $W$.

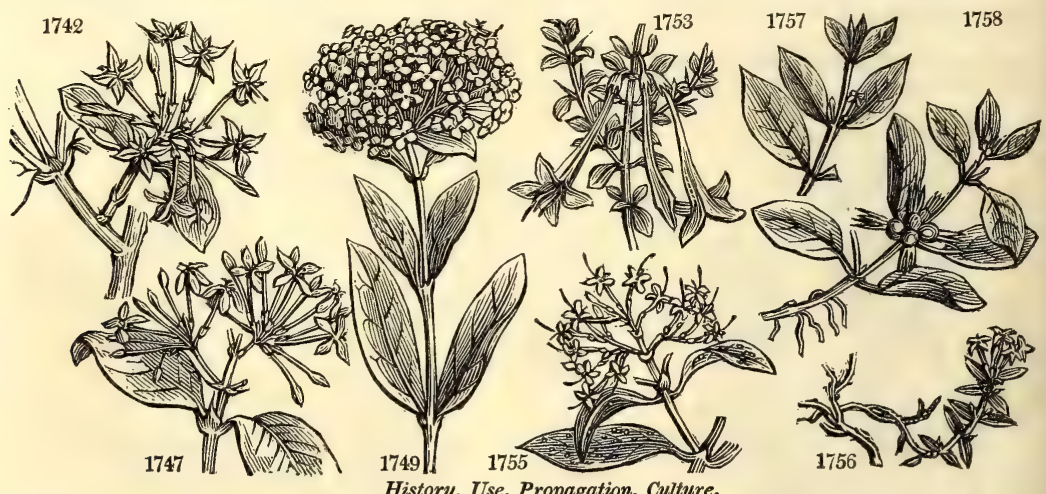
Alpine $\quad$ *

SHRUBBY-TREFOIL.

three-leaved

Monetia.

four-spined

Hassagay-Tree. Beech-leaved $1 \mathrm{tm} 30$ Incerta. $S p .1$.

Rubiacea. $S p .11-16$.

au Or E. Indies 1814, C 1.p Bot. reg. 154

jl F E. Indies 1815. C p.1 Bot. reg. 513

jl.au $\mathrm{S}$ China $\ldots$ C p.l Rhed. mal.2.t.12

jn.jl W E. Indies 1823. C p.l Bot. mag. 2505

au.o W E. Indies 1800. C p.1 Va.sy.3.p.11.t.52

Bengal 1819. C p.l Bot. reg. 540

E Indies 1768 . C

Moluccas 1690. C p.1 Bot. mag. 169

E. Indies $\ldots$ C p.1 Bot. reg. 100

E. Indies 1822. C p.1 Bot. reg. 648

3 jl.au s

3 jn.jl S

$\square$ or 12 Rubiacea. $S p$. my.s Y I. Provid. 1726. C s.p Bot. mag. 131 Rubiacea. Sp. 1-13.

4 au.o W E. Indies 1791. C p.l Bot. reg. 198

Rubiacee. $S p .1$ - 3

$\frac{1}{4}$ jn.jl R Sicily 1820. D rk Bot. mag. Rubiacea. Sp. 1.

... Pk W. Indies 1793. C p.l Jacq.am.t.175. f.9 Rubiacee. $S p .1-5$.

Indies 1793. D s.p Bro. jam, t.6. f. 1 Rubiacere. Sp. 1.

$\frac{1}{4}$ jn W N. Amer. 1761. L s.p Cat. car. 1. t. 20 Rubiacea. $S p .2-3$.

$\frac{2}{2}$ jl.au W F. Indies 1792. R s.p Roxb. cor. 1. t. 3 jn.o W Jamaica 1739. S s.I Eh.pic.t.2.f.1.t.4 Rubiacee. Sp. $1-8$.

$\square$ or $20 \mathrm{my} . \mathrm{jl} \quad \mathrm{Pk}$ Guiana 1806. C l.p Bot. reg. 693

Berberidea. Sp. 1.

$\frac{3}{4}$ ap.my Bd England m. thi. C p.l Eng. bot. 438

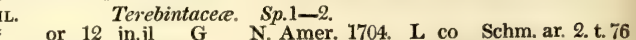

${ }_{3}^{\text {Incerta. }}{ }_{\mathrm{jl}}^{S p .1}$ E. Indies 1758. C s.p L'Her. st.n.1. t.1

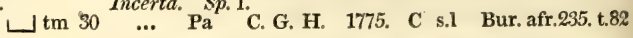
Hartogia. Terebintacece? Sp. 1.

* or $6 \underset{\text { jn.jl }}{\text { G }} \quad$ C. G. H. $\quad \ldots$ C s.l Lam. ill. t. 76

History, Use, Propagation, Culture,

Paris. B triphylla is a beautifu, and not very tender plant, which flowers great part of the year; var. $\beta$ has smooth shining leaves, and flowers of a deeper scarlet than the other. B. versicolor requires the warmest part of the green-house, and the cuttings require bottom heat, with the same soil as the plants.

288. Ixora. A name of doubtful origin. Iswara is the name of an Indian divinity. According to Sweet, the species of this beautiful genus " require to be kept in a moist heat to thrive well; but not plunged in tan, as that is almost certain to injure their roots. A mixture of sandr loam and peat is the best soil for them. Care must be taken to keep them clean and free from insects, or iney will not thrive. Cuttings root very freely in sand under a hand-glass.

289. Catesbrea. So named by Gronovius, in honor of Mark Catesby, author of the natural history of Carolina, and who discovered the first species of this genus. It is very ornamental. C. spinosa has flowers about six inches long, in the form of a Roman trumpet, and succeeded by fruit the size of a pullet's egg; the skin smooth and yellow, and the pulp like that of a ripe apple, with an agreeable taste. It does not flower very freely, but strikes root readily in sand under a bell-glass, and in moist heat.

290. Pavetta. The name of the plant in Malabar. A small genus nearly related to Ixora, with flowers usually white, as those of Ixora are red.

291. Ernodea. From eevwins, branching, in allusion to the habit of the plant.

292. Siderodendrum. From $\sigma i \delta \varsigma \rho \circ$, iron, and $\delta \varepsilon \nu \delta \rho o v$, a tree. Wood, compared for hardness to iron. This tree may be noticed on account of an anomaly which occurs in the corolla, which is often changed, perhaps by some insect, into an oblong bag, half an inch in length, fleshy, and hollow within, and ending in a point at top like a fruit. Cuttings of ripened wood root in sand under a hand-glass.

293. Coccocypsilum. From $\approx 0 \% \%$ s fruit, and $\approx \nu \psi \varepsilon \lambda \pi_{n}$ a vase, its berry being surmounted by a corona resembling a little cup. Cuttings root freely in sand under a bell-glass.

294. Mitchella. Named after John Mitchell, an Englishman, who travelled in Virginia, and left some papers upon North American plants behind him. This is one of those plants which Humboldt (De Distrib. Plant.) calls 
1742 Shrubby spreading, Lvs. oval stem-clasping, Corymbs crowded, Segm. of cor. ovate obt. Berries crowned

1744 Leaves elliptical acute cordate at base sessile, Umbels terminal aggregate, Segm. of cor. ovate acute

1745 Corol. long bearded at mouth, Lvs. opp. obl. entire smooth shining, Floral lvs. round cord. sess. Pan. open

1746 Leaves subsessile oblong smooth, Panicles ovate oblong decussated, Pet. oval, Style hairy

1747 Leaves obl. acute with a contr. emarg. base pubesc. beneath subsessile, Corymbs large, Pet. cuneate acute 1748 Leaves sessile broad lanceolate, Corymbs decompound dense, Pet. obovate reflexed

1749 Shrubby straight, Lvs. subsess. obl. Corymbs dense, Pet. round spreading, Anthers round bristle-pointed 1750 Leaves ovate-lanceolate, Cyme trichotomous contracted

1751 Leaves wedge-shaped lanceolate acuminate, Corymbs terminal, Sepals conical

1752 Leaves coriaceous oval lanc. Cymes decompound close, Petals wedge-shaped obovate, Anthers sessile

1753 Tube of corolla very long, Berries oval

1754 Tube of corolla 4-cornered short, Berries roundish

1755 Leaves smooth entire, Panic. fastigiate axillary and terminal, Style twice as long as corol. Stigma entire

1756 Leaves in 4 s oblong obtuse smooth, Stem shrubby

1757 The only species. Branches 4-cornered, Leaves 5-6 inches long elliptic lanceolate

1758 Stem herbaceous creeping, Leaves ovate, Flowers clustered axillary sessile

1759 A little creeping plant with flat round leaves and little scarlet berries

1760 Umbels naked lateral alternate, Leaves linear

1761 Pedunc. many-flowered, Leaves linear lanceolate

1762 Leaves ovate acuminate, Racemes many-flowered, Stem twining shrubby

1763 The only species

1764 Leaves on long stalks ternate, Fruit with two wings

1765 A small prickly shrub, Leaves opposite ovate acute entire. The only species

1766 The only species. Leaves ovate oblong acute serrated opposite

1767 Leaves opposite elliptical obtuse emarginate serrated

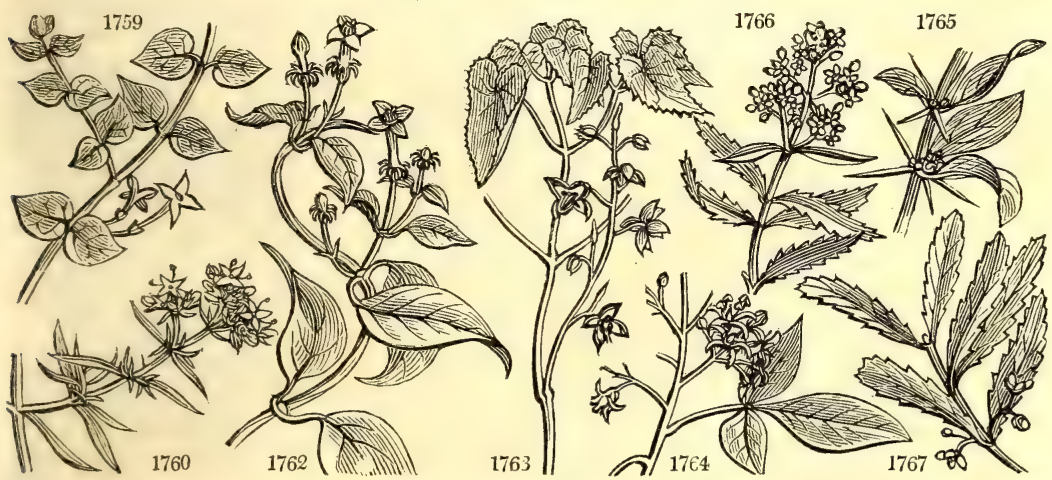

and Miscellaneous Particulars.

social, being always found in quantities. Barton says, it is the plant most extensively spread in North America, covering the surface from the 28 th to the 69 th degree of north latitude.

205. Oldenlandia. In honor of H. B. Oldenland, a Dutch naturalist, who travelled in A frica, where he died about the end of the 17th century. O. umbellata, the chay-root, grows on light sandy ground near the sea, and is much cultivated on the coast of Coromandel for dyeing red, purple, brown, and orange, and to paint the red figures on chintz. The coloring matter resides in the bark, which gives it out to water. The Malabar physicians say that the roots cure poisonous bites, colds, and cutaneous disorders, and warm the constitution.

296. Manettia. In honor of Xavier Manetti, an Italian, and professor of botany at Florence. Some of the species are rather pretty, but they are seldom seen in collections.

297. Epimedium. A name of Dioscorides, applied to this little elegant alpine plant, without any assignable reason.

298. Ptelea. The Greek name of the elm. It is derived from $\pi \tau$ rew, to fly, in allusion to the winged seedvessels. A hardy shrub of North America, not unlike a laburnum in foliage, but with small green fowers.

29'. Monetia. So named by L'Heritier, in honor of the Chevalier Jean Baptiste Monet de la Marck, a celebrated French botanist, now dead ; who, unfortunately for botany, many years ago diverted his attention from that science to conchology. Cuttings root in sand under a bell-glass, and in bottom heat.

-300. Curtisia. Named in honor of W Curtis, lecturer on botany, author of the Botanical Magazine and other works; he died in 1799. This is one of the largest trees of Africa, from which the Hottentots and Caffres make the shafts of their javelins. It has fine broad leaves, but small flowers, which, however, have not yet appeared in this country.

301. Hartogia. Named after John Hartog, a Dutchman, who travelled in Southern Africa and Ceylon, The plant called by this name in the gardens is probably only a variety of the common laurel, and nearly as hardy as it. The flowers grow in axillary racemes like bunches of currants. 
302. AMMAN'NIA. $\boldsymbol{W}$. AmMannia. 1768 latifolia $W$ 1768 latifolia $W$. 1770 cáspica Ledeb. 1771 baccífera $L$. 1772 ramósior $W$ 1773 sanguinolénta $W$. 303. FAGA'RA. $\boldsymbol{W}$. 1774 Pteróta $W$ 1775 Piperita $W$. 1776 tragódes $W$.

304. ZIE'RIA. Sm 1777 Smithii Sm.

305. CIS'SUS. $W$. 1778 vitiginea $\dot{W}$ 1779 antárctica $\dot{V}$ ent 1780 heterophýlla $L k$. 1781 glandulósa Horn. 1782 sicyoídes $W$. 1783 quadranguláris $W$. 1784 capénsis $W$. 1785 crsia $R, B$. 1786 5-folia $B$. $M$ 1787 ácida $W$ 1788 trifoliáta $W$. 1789 pentaphýlla $W$. 1790 quináta $\boldsymbol{H}, \boldsymbol{K}$ 306. COR'NUS. $W$. 1791 suécica $W$ 1792 canadénsis $W$ 1793 flórida $W$ 1794 máscula $W$.

1795 sanguínea $W$. 1796 álba $W$ $\beta$ ros'sica 1797 sericea $W$ 1798 circináta $W$ 1799 stricta $\boldsymbol{W}$ 1800 paniculáta $W$. 1801 alternifólia $\boldsymbol{W}$

broad-leaved

cluster-flowered Caspian berry-bearing branching

Fagara.

Lentiscus-leav. ash-leaved prickly-lea

\section{Zieria.}

Smith's

Cissus. vine-leaved five-leave acid

Pensylvanian

vine-leaved $\square$ or 0 Kanguru-vine various-leaved $\square$ or 10 glandular naked-leaved $\square$ or 10 square-stalked $\mathrm{H}$ or 30 Cape $\quad \square$ or 30 Sier. Leo. grape 8 or 15 ... S. Leone 1822 D co three-leaved $\square$ or $6 \quad \ldots$. five-leaved or 6 ap.s wedge-leaved f $10 \mathrm{jl}$

Salicaria. $\quad S p .6-20$.

1 jl.au W W. Indies 1733. - S s.1 Slo.jam.1.t.7.f.4 1 jl.au Pu E. Indies 1778. S s.l

$\frac{1}{2}$ jl.au Ap Astracan 1821. S s.l

jn.jl Ap India 1820. S s.1 Lam, ill, t.77. f.5 jl.au Pu Virginia 1759. S s 1 Bocc. mus, t. 104 $\frac{1}{2}$ jl.au $\mathrm{R}$ Jamaica 1803. S s.l

Terebintacea. Sp. 3-18.

au.s G Jamaica 1768. C p.1 Bro.ja.146.t.5.f.1 . W W. Indies 1759. C 1.p Jac. am. 21. t. 14 Rubiacea. $S p .1$

\section{Sarmentacece. Sp. 13-50.}

... G India 1772, C p.l Pl.m.27,t $337 . \mathrm{f}$ jus $\ldots \mathrm{G}$

Dogwood. dwarf

Canadian

great-flowered

Cornel.-cherry

common

white-berried Russian

blue-berried upright

panicled

alternate-leav'd

SAndal-woon. true

Caprifolia. $S p .11-14$.

307. SAN'TAIUM. $W$ 1802 álbum $W$.

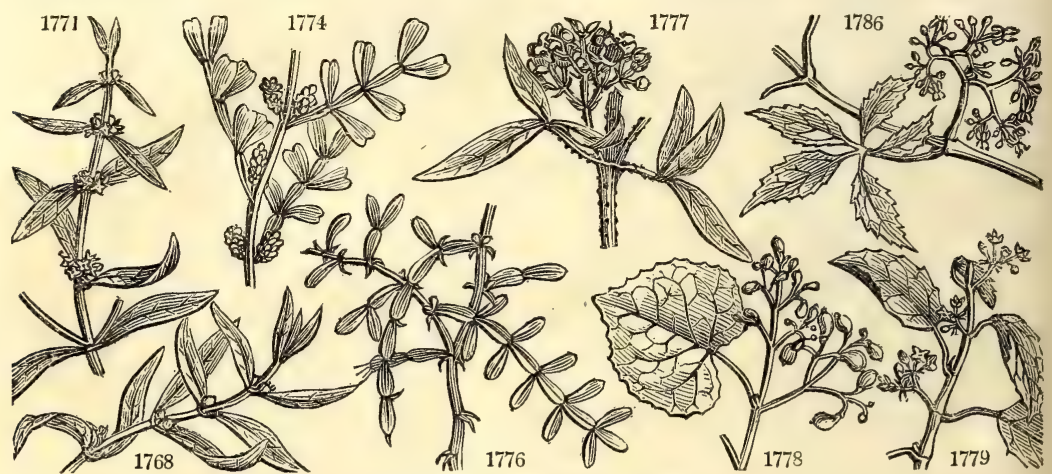

History, Use, Propagation, Culture,

302. Ammannia. Named in nonor of John Ammann, a native of Siberia, who was a physician and professor of botany at St. Petersburg. He published a work upon the plants of Finland, and some papers in the Transactions of the Academy at St. Petersburg. None of the species have any beauty. They may be treated like balsams and other tender annuals.

303. Fagara. The name of an aromatic plant mentioned by Avicenna. The foliage of the present plant has a strong smell of turpentine. Cuttings root readily in sand under a hand-glass.

304. Zieria. So called by Sir J. E. Smith, in honor of his friend Mr. Zier, of whom nothing more is known than that he was " a learned and industrious botanist." The species is a pretty greenhouse plant.

305. Cissus. The Greek name of the ivy. The Latin name hedera having been retained for the real plant the Greek word was given to this genus, which climbs like the ivy. The species greatly resemble Vitis in generic character. None of them are ornamental, with the exception of C. quinquefolia, justly admired for its quinquefid leaves, and the different tints of yellow, red, and purple which these take in autumn. It grows rapidly in any soil, and is well adapted for covering naked walls, decorating old unsightly elevations of houses, ruins, cottages, bowers, \&c. All the species root freely by cuttings in any soil.

306. Cornus. From cornu, a horn: the wood being thought to be as hard and durable as horn. Its value as a material for warlike instruments has been celebrated by Virgil -Bona bello cornus. The larger species of this genus are very ornamental and hardy shrubs, not only from their flower and berries of different colors, but by their green, red, purple, or striped barks, which have a fine effect in winter, especially among evergreens. C. florida blossoms early, but does not bear berries in this country. C. mascula, the Cormier of old authors, blossoms still earlier, and bears handsome fruit, which were formerly made into tarts and rob de cornis : the wood is very hard; and Evelyn says, made into wedges, it will last like iron. C. sanguinea, alba, and sericea, 
1768 Leaves stem-clasping, Stem square, Branches erect

1769 Leaves lanceolate attenuated at base, Stem branched, Flowers fascicled axillary, Caps. 2 Leaves sessile lanceolate attenuated at base, Flowers axillary clustered, Sepals rigid acute

1771 Leaves somewhat stalked, Caps. larger than calyx colored

1772 Leaves half stem-clasping, Stem square, Branches much spreading

1773 Leaves half stem-clasping linear lanceolate cordate at base, Pedunc. very short many-flowered

1774 Leaves pinnated, Leaflets obovate emarginated, Common footstalk margined jointed unarmed 1775 Leaves pinnated, Leaflets oblong unequal at base crenate

1776 Leaves pinnated, Leaflets wedge-shaped emarginate, Common stalk winged jointed prickly beneath

1777 The only species. It may be known by the stamens being inserted into large glands

1778 Leaves cordate roundish 3-5 lobed angular repand beneath ferruginous

1779 Leaves ovate loosely serrated smoothish, Nerves glandular at base, Petioles and branches pubescent

1780 Branches rounded subpubesc. Petioles with a pubesc. line, Lower lvs. simple, middle tern., upper quinate

1781 Leaves ovate serrate toothed, Pedicels and cal. hispid glandular

1782 Leaves ovate cordate smooth thickish bristly serrated, Serratures appressed, Branches rcunded

1783 Leaves cordate ovate serrated fleshy, Stem 4-cornered winged

1784 Leaves 5 angular toothed beneath ferruginous, Flowers headed

1785 Leaves cordate serrated, Branches very glaucous

1786 Ieaves in fives, Leaflets narrowed each way acuminate stalked, Branches rounded knotted smooth

1787 Leaves ternate obovate wedge-shaped fleshy smooth toothed at end entire at base

1788 Leaves ternate rounded hairy toothed, Branches with membranous angles

1789 Leaves quinate, Leaflets undivided ovate serrated

1790 Leaves quinate, Leaflets obovate wedge-shaped serrated above

1. Flowers in umbels with an involucrum.

1791 Herbaceous, Branches binate, Umbel axillary stalked, Nerves of leaves distinct

1792 Herbaceous, Branches none, Upper leaves whorled stalked veiny

1793 A tree, Involucr. very large colored, Leaflets obcordate

1794 A tree, Umbels as long as involucrum

2. Flowers in naked cymes.

1795 Branches upright, Leaves ovate whole-colored, Cymes depressed flat

1796 Branches recurved, Branchl. smooth, Leaves broad ovate acute pubesc. hoary beneath, Cymes depressed

1797 Branches sprdg. Branchl. woolly, Lvs. ovate acum. beneath ferrugin. Cymes depr. woolly, Nuts compr.

1798 Branches warted, Leaves orbicular beneath hoary, Cymes depressed

1799 Branches upright, Leaves ovate whole-colored naked, Cymes panicled

1800 Branches erect, Leaves ovate acuminate smooth hoary beneath, Cyme panicled

1801 Leaves alternate, Stem dichotomously forked

1802 Leaves oblong

1803 Leaves lanceolate

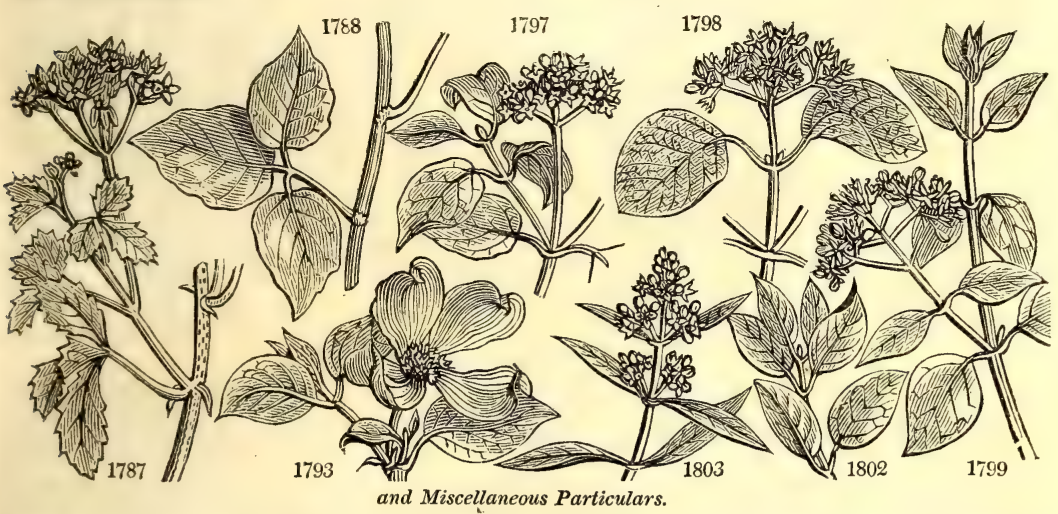

have fine red twigs; the wood of the first is equal to that of the cornel for hardness, and makes excellent mill cogs, bobbins for lace, toothpicks, and butchers' skewers. An oil may be extracted from the berries, by boiling and pressing. C. sericea from its large leaves, whitish underneath, and its terminating branches of white flowers, is valuable for the shrubbery or lawn. All the species may be propagated by seeds, layers, suckers, or cuttings; the second is the most common mode.

C. sanguinea is very common in woods, and after a smothered combustion, affords a charcoal esteemed the best for entering into the composition of gunpowder. It grows in the shade and drip of other trees, and is therefore a valuable plant for thickening strips of plantations which have become naked below.

C. suecica is called by the Highlanders Lus-a-chrasis, or plant of gluttony, from its berries, which are eaten by the children, being supposed to create an appetite. This plant is difficult to preserve in gardens : a bed of peat in a shady situation, and kept moist, is the most suitable for it ; or it may be planted in small pots of peat, and treated as an alpine.

307. Santalum. From its Persian name Sundul-sufed. It is a low tree in habits; leaves and inflorescence a good deal resembling the privet. It produces the white and yellow sandal wood of the materia medica, formerly thought to be the produce of different trees. But in India, as in a certain degree in every other country, most trees when large and old, become colored towards the centre, and when the sandal tree becomes large, its centre acquires a yellow color, and great fragrance and hardness; while the exterior part of the same tree that covers the colored part is less firm, white, and without fragrance. It is only the yellow part that is in use, being in universal esteem for its fragrance. According to Wathen (Voy. to China, 1812, p. 116.), it sells so high that the tree is seldom allowed to grow more than a foot in diameter. It is manufactured into musical instruments, small cabinets, escrutoires, boxes, and similar articles, as no insect can exist, or iron rust (as it is 
3C8. TRA'PA. IV. 1804 nátans $W$. 1805 bicórnis $\dot{W}$. 309. LUDWI'GIA. $W$ 1806 alternifólia $W$. 1807 hirsúta $P h$.
WATER-CALTROPS. European $\mathrm{v}$ clt Chinese $\triangle$ clt

\section{Ludwigia.} large-capsuled hairy
Hydrocharidece, $S p .2-3$.

jn.au W.P Europe 1781. S co Bot. reg. 88

... W China 1790. S co Gært.sem.2.t.95

Onagrarice. $S p .2-16$.

1 jn.jl Y Virginia 1752. S co Lam. ill. 1. t. 77

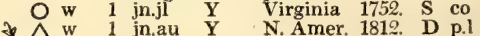

\section{DIGYNIA.}

310. CUS'CUTA. $W$.

1808 europæ' a $\boldsymbol{W}$. 1809 Epithymum $W$. 1810 chinénsis 1811 chilénsis $B$. $M$. 1812 verrucósa Sweet. 311. BUFO'NIA. $W$. 1813 tenuifólia $W$. 312. HAMA ME'LI 313. HYPE'COUM. 1815 procum'bens $W$. 1816 péndulum $W$ 1817 eréctum $W$.
DodDER. common lesser Chinese Chili

Bufonia.

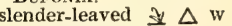

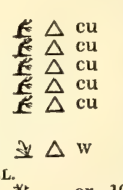

Convolvulacece. Sp. 5-10.

jl W Writain hea. D par Eng. bot. 378 jl W W Britain hea. D par Eng. bot. 55 au.s W China 1803. D par

ja.d W Chili 1821. D par Bot. reg. 603 ap.o W Nepal 1821. D par Scot. fl. gard. 6. Caryophyllea. Sp. 1-2.

$\frac{1}{2}$ jn W England sea co. S co Eng. bot. 1313 Berberidea. Sp. 1-2.

Virginian $*$ or 10 my.n W N. Amer. 1736. L p.l Duh. arb.1.t.114 Hypecoum. Papaveracea. Sp. 3-6. procumbent $\quad$ w $\bigcirc$ or 1 jn.jl Y S. Europe 1596. S co Schk. han.1.t.27 pendulous $*$ or or $\frac{1}{8}$ jn.jl Y $\quad$ S. France 1640. S co Par. thea.372. f.2 erect $\$$ O or $\frac{1}{2}$ my.jn $Y$ Siberia 1759. S co Am, ruth.58, t.9

\section{TETR AGYNIA.}

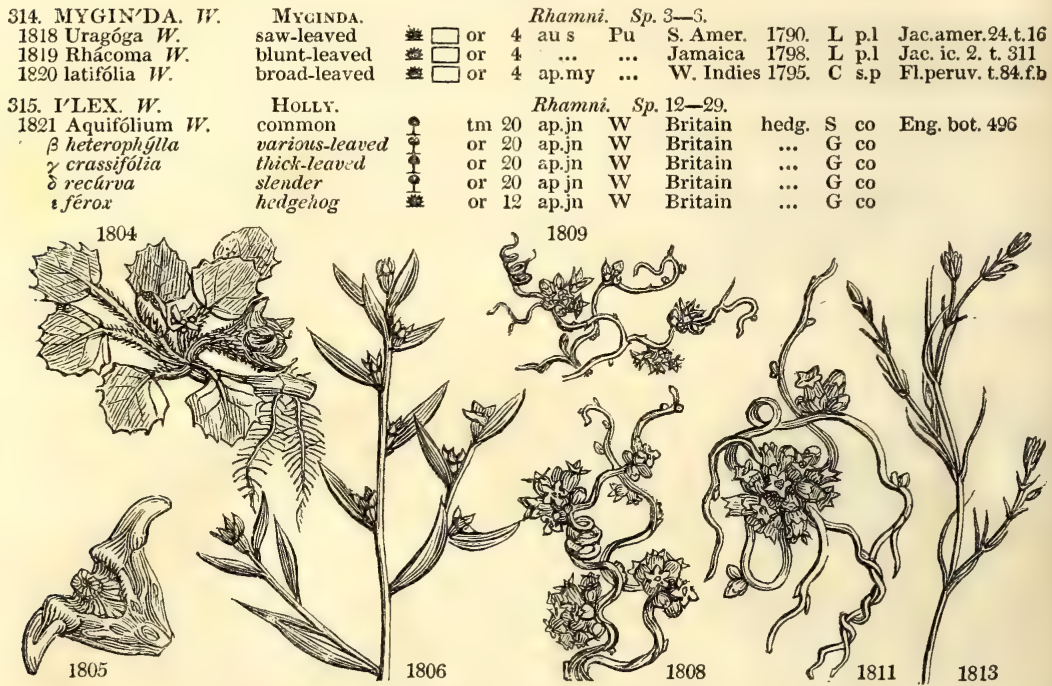

History, Use, Propagation, Culture,

Rhamni. Sp. 3-

aw-leaved

Holly.

common

varions-leaved

hedgehog

... $\quad \ldots \quad$ Jamaica 1798. L p.l Jac. ic. 2. t. 311

ap.my $\quad \ldots \quad$ W. Indies 1795 . C s.p Fl.peruv. t.84.f.b

9 $\operatorname{tm} 20$ ap.jn W Britain hedg. S co Eng. bot. 496

or 20 ap.jn W Britain $\quad \ldots \quad$ G co

or 12 ap.jn W Britain ... $\quad$ G co

said) within its influence. It is of the dust of this wood that the Bramins form the pigment which they use in giving the tilac or frontal mark to the God Vishnoo: and the oil used in their ceremonies is obtained from the shavings, or at least scented by them. Cuttings root readily in a pot of sand under a bell-glass.

The true sandal wood is the Santalum album, found chiefly on the coast of Malabar, and in the Indian Archipelago.

Santalum myrtifolium, which has been confounded with it, is the kind which grows upon the Circar mountains, the wood of which is of little value. An amusing specimen of German critical puzzling upon this subject may be seen in Messrs. Römer and Schultes, Species Plantarum, vol, iii. p. 328.

308. Trapa. Abridged from calcitrapa, the Latin name of a dangerous instrument called caltrops, furnished with four spines, which was formerly used in war to impede the progress of cavalry. The fruit of this plant is hard, and has four spines also. T. natans is a curious aquatic, with long brown and green roots and floating leaves, with petioles inflated into a tumour, as in the marine algæ. The seed is larger than the kernel of the filberd, with two cotyledons, one large, and the other very small, and not increasing in size during the germination. Hence, Gærtner considers this plant like the Nelumbium, as in a sort of middle state between the mo nocotyledoneæ and dicotyledoneæ. The nuts are farinaceous, and are esteemed nourishing and pectoral. The skin with the spines being removed, there is a white sweet kernel within, somewhat like a chestnut. They are sold in the market at Venice under the name of Jesuits' nuts. They are also much eaten in Switzerland are sold in the market at Venice under the name of Jesuits' nuts. They are also much eaten in Switzerland
and the south of France. Some of the canals at Versailles are covered with the plant; and Neill informs us (Hort. Tour.), that the nuts are sometimes served up like chestnuts. Pliny says that the Thracians made them into bread; and Thunberg states that they (the seed of Trapa bicornis) are commonly put into broth in Japan. In this country the plant is generally kept in a cistern in the stove, and so treated, was fruited by A. B. Lambert, Esq. in 1815, and specimens of the fruit sent to the Horticultural Society.

$T$. bicornis is cultivated by the Chinese in marshes; and the nuts used as food.

309. Ludwigia. So named by Linnæus, in honor of C. G. Ludwig, professor of botany at Leipsic, in the middie of the last century. He left behind him several works which are now almost forgotten. The species are of no beauty.

310. Cuscuta. This is a genus of parasitical plants, which fasten themselves to, and draw their nourishment from others. The seed does not split into lobes, but opens and puts forth a little spiral body, which is the em- 
1804 Nuts 4 horned, Spines spreading

1805 Nuts 2 horned

1806 Erect branched smooth, Leaves altern. lanc. hoary beneath, Caps. large crowned with the col. lvs. of cal. 1807 Leaves alternate lanceolate, Flowers axillary solitary subsessile, Stem rounded diftuse.

\section{DIGYNIA.}

1808 Flowers sessile, Orifice of cor, naked, Stigma acute

1809 Flowers

1810 shoots short white

1811 Flowers 5-cleft, Segments oblate rounded, Anthers sessile, Stigmas pileate

1812 All over warted, Color dull brown, Shoots very long

1813 Stem branched at end, Branches erect, Calyx scariose at edge

1814 Leaves obovate acutely toothed cordate with a small sinus

1815 Pods jointed compressed arcuate, Pet. 3-lobed the outside smooth at the back

1816 Pods knotty rounded pendulous, Petals smooth the 2 outer ovate oblong pendulous 2 inner 3 -parted

1817 Pods not jointed erect compressed, Pet. smooth outer wedge-shaped about 3-lobed inner trifid the lateral lobes 2-lobed the middle one small

\section{TETRAGYNIA.}

1818 Leaves ovate and subcordate acuminate subserrated pubescent

1819 Leaves lanceolate ovate obtuse crenated, Flowers monogynous, Style quadrifid

1820 Leaves elliptical crenated subcoriaceous, Stigmas 2-4 sessile

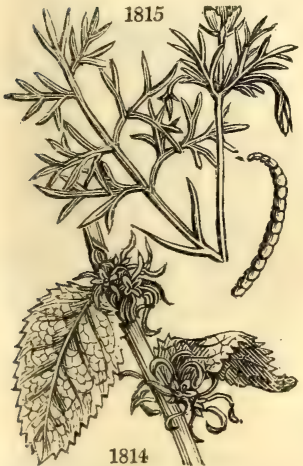

1814

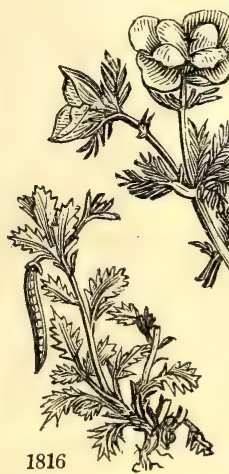

and Miscellaneous Particulars.

1817

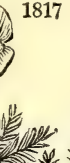

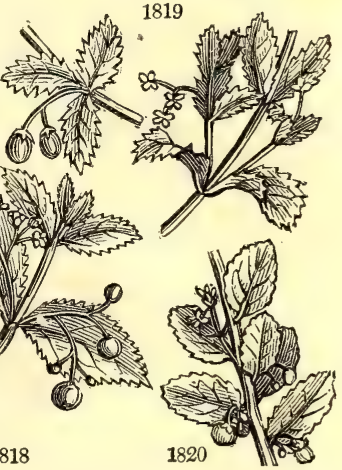

1818

1.3

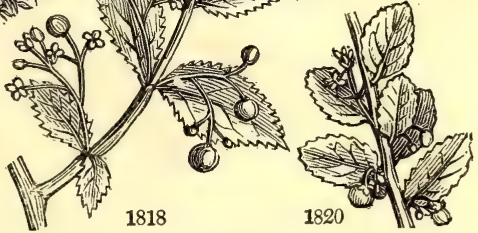

bryo. The stalk twines about some other plant, contrary to the sun's apparent motion, or from right to left, sending out from the inner surface a number of little vesicles which attach themselves to the bark of the supporting plant. By degrees, the longitudinal vessels of the stalk shoot from their extremities, and insinuate themselves so intimately with it, that it is easier to break than to disengage them. Plants raised from seed soon die when they have no plant to which they can attach themselves. They adhere to the ground by the original root, and draw a part of their nutriment from thence at first; but the original root withers away as soon as the young stem has tixed itself to any other plant.

C. euro ra may be sown in peat soil by the sides of other plants; in a wild state it is common $y$ found in hedges, and on hops, brambles, woody nightshade, fern, thistles, hemp; as also on flax, nettles, clover, grass, \&c.

C. epithymum will thrive well on any small shrub when once it has got hold. According to Sweet, " it will flower freely, and be very handsome."

C. chinensis may be treated like C. europæa.

311. Bufonia. So named after the celebrated Count de Buffon. It is slender, like the botanical acquirements of that illustrious naturalist. Some say that Linnæus slily dropped an $f$ in the name.

312. Hamamelis. Homomelis is the name under which Athenæus describes a fruit like an apple. This is another of the not very commendable freaks of gentlemen who name genera; the present plant being more like a hazel-nut than an apple-tree. In New England this tree has ripe fruit and fresh blossoms at the same time.

313. Hypecoum. From $i \pi, \chi \varepsilon \omega$, to rattle, on account of the noise the seeds make in the pods. It is not impossible that Hypecoum procumbens is the Hypecoon of Pliny : the wild Cumin of Gerarde. The juice of all the species is yellow, like that of celandine, and is said to have the same effect as opium.

314. Myginda. So named by Jacquin, in honor of Counsellor Mygind of Vienna; a botanical amateur and patron. A tree resembling some kind of Ilex.

315. Ilex. A word upon which much ingenuity and learning have been tortured in vain. De Théis derives it from $e c$ or $a c$, a point in Celtic; but that explanation applies better to the specific name acquifolium. I. aquifolium is one of our most beautiful shrubs or low trees, displaying either character, according to situation, age, and application by art. It is found in most parts of Europe, and in North America, Japan, Cochin- 
¿flava

ท álbo-margináta

จ aúreo-margináta

- medio-picta

1822 chinénsis $B . M$.

1823 laxiflóra $P h$.

1824 opáca $W$.

1825 crócea $W$

1826 Perádo $\boldsymbol{W}$.

1827 Prinoídes $W$.

1828 Cassine $P h$.

1829 Dahóon $P l$.

1830 augustifólia $W$. en.

1831 vomitória $W$.

1832 canadénsis $\boldsymbol{P} h$.

316. COLDE'NIA. $W$.

1833 procúmbens $W$.

317. POTAMOGE'TON.

1834 nátans $W$.

1836 heterophýllum $W$

1837 perfoliátum $W$.

1838 den'sum. $W$

1839 lúcens $W$.

1840 crispum $W$.

1841 compréssum $W$.

1842 pectinátum $W$.

1843 lanceolátum $E$. $B$

1844 gramineum $W$

1845 pusillum $W$

1846 setáceum $W$.

318. RU'PPIA. $W$.

1847 maritima $W$

319. SAGI'NA. W

1848 procum'bens $W$

1849 cerastoídes $W$. yellow-berried silver-edged gold-edged painted

Chinese

loose-flowered

Carolina

African

thick-leaved

deeiduous

br.-Iv.-Dahoon

Dahoon

Myrtle-leaved

South Sea Tea

Canadian

Coldenia.

railing

W. Pond-weed. broad-leaved ong-leaved

arious-le

close-leaved shining

curled

flat-stalked

fennel-leaved

spear-leaved

grass-leaved

small

bristle-leaved

RUPPIA.

sea

Pearlwort procumbent tetrandrous

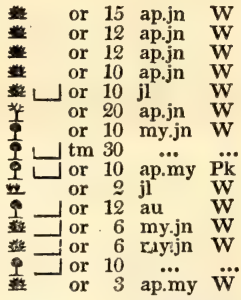

Boraginece.

* $\mathrm{O}$ or 2 jlaginea

Alismacea.

au $\mathrm{G}$ Britain

jl.au R Britain

jl.au $\mathbf{G}$ Britain

jl.au P

my.jl G

jn.jl G

Britain

Britain

Britain rivul. D co Eng. bot. 418

Britain dit. D co Eng. bot. 323

$\begin{array}{lllll}\text { jn.jl } & \text { Ol } & \text { Britain dit. } & \text { D co } & \text { Eng. bot. } 323 \\ \text { jl.au } & \text { Ol } & \text { England w.lak. D co } & \text { Eng. bot. } 1985\end{array}$

jl.au G Britain dit. D co Eng, bot. 2253

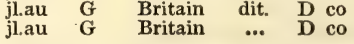

Fluviales. Sp. 1.

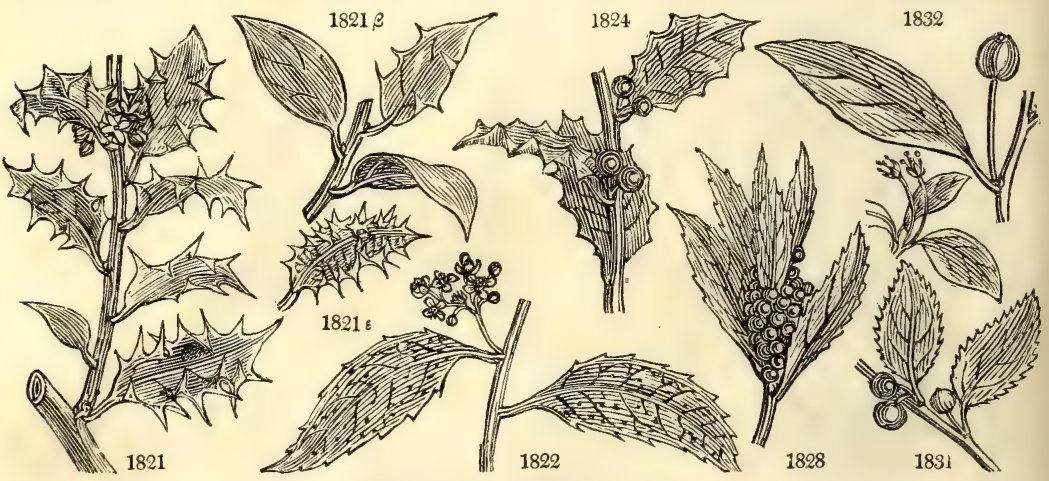

History, Use, Propagation, Culture,

China, \&c. In Britain, it is found congregated in natural woods and forests. Some of the finest in England, are in Medwood forest, in Staffordshire, and in Scotland, in the woods of Dumbartonshire, about Luss and Lochlomond. Professor Martyn's father first discovered the difference of sexes in the holly; some being male, others female, and others hermaphrodite. It is a tree of great longevity, and will grow in any soil not very wet, but best in a dry deep loam; such is the soil of Medwood forest. By culture alone, a hundred varieties and subvarieties have been produced, differing in the variegation, margin, and size of the leaves, and in the color of the fruit. These make gay and elegant shrubs for lawns and small groups, and form an important furniture in the general shrubbery. The common green prickly-leaved holly makes the best of all hedges, whether we regard its qualities for defence, shelter, duration, or beauty. It has one fault, it is very slow of growth unless carefully cultivated, and for this reason hawthorn is preferred. It was a very general custom about the end of the 17th century to divide gardens by hedges of this tree, and to keep them exactly shorn. Evelyn's impenetrable holly hedge at Deptford has been much celebrated. It was 400 feet long, 9 feet high, and 5 feet broad. Gibson, (Arch cologia Brit. \&c.) who mentions Evelyn's hedge, made a tour of the principal gardens near London, and states, as next in grandeur, that of Sir M. Decker at Richmond: of neither does there exist a single plant. The largest holly hedge in Scotland is at Tynningham near Dunbar, planted by a former earl of Haddington, author of a Treatise on Fruit Trees. It has for many years past been left uncut, and now presents a noble phalanx of deep shining green leaves, and numerous spiry tops with spikes of coral berries.

In cultivating the holly, the kernel or stone of the berries is divested of its skin and glutinous pulp, by mixing with sand in heaps in the open garden, and turning over frequently. The berries being gathered in November, may be rotted in this way till the October following, and then sown in beds, and covered three quarters of an inch with fine mould; or they may remain on the trees till spring, then gathered and mashed in a tub of water to separate the pulp, after which they may be sown. In general, the stones do not vegetate till the second year from the gathering; some will occasionally germinate the first year, and a number not till the third. In transplanting and pruning the holly, the months of October and April are to be chosen : the oftener young plants are removed before planted in the final site the better, as it has naturally but few roots, and those chiefly ramose and descending. Miller recommends cutting holly hedges with a knife, as clipping renders them unsightly. The variegated and other curious sorts are generally propagated by budding and grafting on the common green. Evelyn says he raised some of the variegated sorts by sowing the seeds, and Miller always found the hedgehog variety continue the same when so propagated. Some raise them by layers, and Sweet says all of them "will root freely by cuttings taken off at a joint in ripened wood, and planted in sand under a hand-glass in a shady situation." 
1892 Leaves ovate oblong edge with little cartilaginous scarcely pungent teeth, Corymbs pedunc. dichotomous 1822 Leaves ovate sinuate-toothed slightly spiny, Stipules subulate, Pedunc. lax divided

1824 Leaves ovate acute spiny smooth flat, Flowers scattered at the base of the older branches

1825 Leaves oblong serrated, Serratures prickly-ciliated

1826 Leaves ovate with a point unarmed nearly entire

1827 Leaves elliptic-lanceolate acute deciduous serrated, Serratures unarmed

1828 Leaves alternate distant evergreen lanceolate attenuated both ways serrated at the end

1890 Teaves lanceolate elliptical nearly entire reflexed at the edge, Rib villous beneath

1830 Leaves alternate distant evergreen linear lanceolate shining serrated at end, Rib smooth beneath

1831 Leaves alternate distant oblong obtuse crenated serrated, Serratures not prickly

1832 Leaves oblong acuminate subserrated at the end, Pedunc. long axillary 1-flowered

1833 Leaves wedge-shaped stalked shorter on one side coarsely sawed and plaited

1834 Leaves all elliptical stalked floating, Lower petioles submersed leafless

1835 Laves alloting lanceolate ovate narrowed at both ends

1836 Upper leaves stalked elliptical narrowed at both ends the lower close together sessile linear

1837 Leaves cordate stem-clasping all immersed

1838 Leaves ovate acuminate opposite close, Stem dichotomous, Spike 4-flowered

1839 Leaves ovate-lanceolate flat narrowed into the stalks, Spike many-flowered contracted

1840 Leaves lanceolate alternate wavy serrated

1841 Teaves linear obtuse, Stem compressed

1842 Leaves setaceous parallel close together in two rows

1843 Leaves lanceolate membranous flat entire, Spike ovate dense few-flowered

1844 Leaves linear lanceolate alternate sessile broader than their stipule

1845 Leaves linear opposite and alternate narrower than their stipule spreading at base, Stem rounded

1846 Leaves lanceolate opposite acuminated

1847 The only species

1848 Branches procumbent smooth, Petals very short

1849 Stem diffuse dichotomous, Leaves spatulate and obovate recurved, Fruit-stalks reflexed

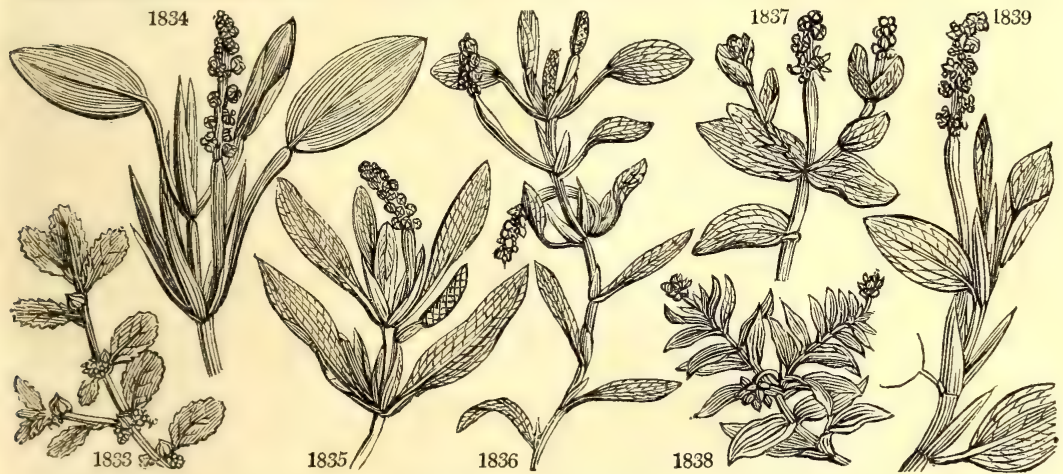

and Miscellaneous Particulars.

I cassine and vomitoria have bitter leaves, of which the N. American Indians make a tea, which is almost their only physic. At a certain time of the year they come down in droves from a distance of some hundred miles, to the coast, for the leaves of this tree, which is not known to grow at any considerable distance from the sea. They make a fire on the ground, and putting a great kettle of water on it, they throw in a large quantity of these leaves, and setting themselves round the fire, from a bowl that holds about a pint they begin drinking large draughts, which in a very short time occasion them to vomit easily and freely : thus they continue drinking and vomiting for the space of two or three days, until they have sufficiently cleansed them selves; and then every one taking a bundle of the tree to carry away with him, they all retire to their selves; and

516. Coldenia. So named by Linnæus, in honor of Cadwallader Colden, an English naturalist, who published in 1742 , an account of the planis of New York.

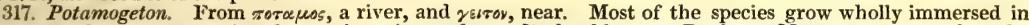
water, but ine most aquatics, flower above its surface. It should seem, Professor Martyn observes, that the respiration of such truly-aquatic vegetables must be as different from those which inhale atmospheric air, as the breathing of fishes is from that of beasts and birds. Accordingly, they are, as Haller remarks, of a different texture, pellucid, like oiled paper, very vascular, harsh, and ribbed, but often very brittle; and their surface, like that of aquatic animals, destitute of hair or down of any kind. The leaves of aquatic plants afford shade and spawning places to fish, and habitations for aquatic insects and worms for their nourishment. The roots of P. natans are a favorite food of the swan, and that bird is in consequence erroneously considered as keeping ponds and lakes clear of all aquatics. Ducks eat the seeds and leaves of $\mathbf{P}$. crispum. Haller informs us, that in the Swiss lakes P. serratum grows from ten to twenty fathoms long, forming, as it were, immense woods in the midst of these immense reservoirs. Most of the species may be considered as ornamental in a botanic garden, when kept within bounds or in pots. They are readily propagated by seeds or by dividing their long roots, and for the most part, grow best on a clayey bottom.

318. Ruppia. Named after Henry Bernard Ruppi, a German. He published in 1718, a Flora Jenensis. It is remarked by Dr. Goodenough, that the flower-stalk of this plant is spiral, like that of Valisneria, and relaxes or contracts itself according to the depth of the water. The truth is, the flower and leaf-stalks of all aquatics have a power of accommodating themselves to the depth of the water, so as just to emerge above its surface ; but the singularity in Ruppia and Valisneria appears to be the employment of a flower-stem for that purpose. (See Valisneria.)

319. Sagina. This plant, says Linnæus, is so called for its qualities. In Latin, sagina expresses something 
1850 apétala $W$. 1851 maritima $E . B$ 1852 erécta $\mathrm{Sm}$.

320. TILLE'A. $\boldsymbol{W}$. 1853 muscósa $W$. 321. RADI'OLA. Sm 1854 millegrána $\mathrm{Sm}$. small-flowered sea-side glaucous

TILLEA. mossy

RaDiola. all-seed

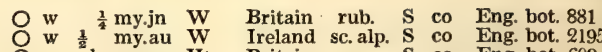
Ireland sc. alp. S co Eng. bot. 2195 $\begin{array}{llll}\text { Britain } \quad . . & \text { S } & \text { co } & \text { Eng. bot. } 609\end{array}$ Sempervive. Sp. $1-4$.

O cu $\frac{1}{4}$ jn.o Pl England sa.he. $\mathrm{S}$ co Eng. bot. 116 Caryophyllea. Sp. 1.

O w $\frac{1}{\mathrm{~g}}$ jl.au W Britain san. pl. s co Eng. bot. 893

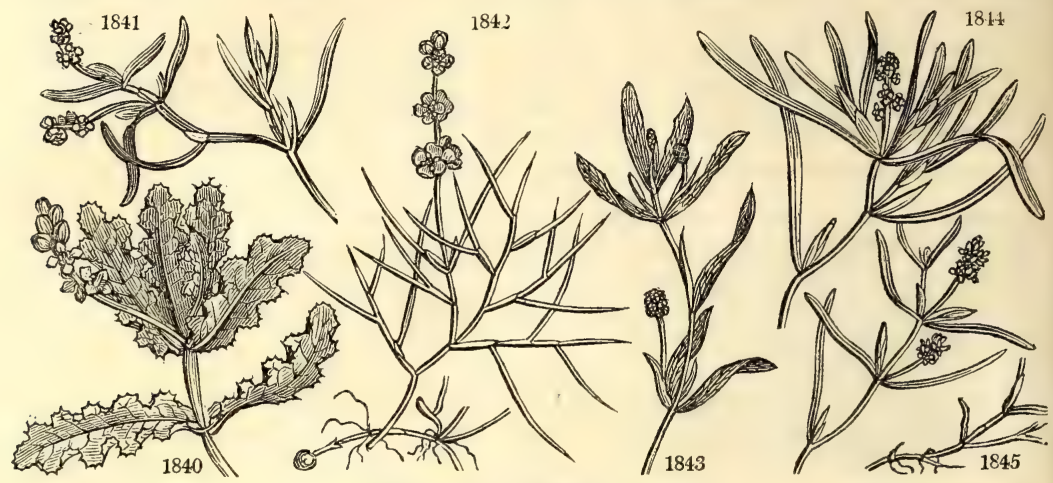

History, Use, Propagation, Culture,

nourishing. The species are very common in dry pastures, where they are valuable for sheep-food. S. procumbens is a small but troublesome weed in shaded garden-walks and paved courts, and with S. apetala, seeds the whole summer. Curtis remarks, that the latter species ripens its seeds more rapidly than almost any other plant.

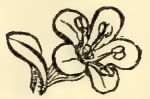

\section{Class V. - Pentandria. 5 Stamens.}

- ONE of the most extensive of the Linnæan classes, and containing about a fifth part of all phænogamous plants. It includez the whole of the Boragineæ or Asperifoliæ, Asclepiadeæ, A pocyneæ, and Umbelliferæ, nearly all Primulaceæ, and portions of a great variety of other natural orders, among which many are ornamental, and others valuable on account of their relation to medicine and the arts.

The Boragineæ are, in many instances, ornamental plants; a few, such as Anchusa tinctoria are applied to economical purposes; but the principal part are weeds of northern latitudes. They have been recently described and re-arranged in a scientific manner by M. Lehmann, whose Monographia Asperifoliarum should have a place in every botanical library.

The curious genus Stapelia is a part of the Asclepiadeæ, which order was in so unsettled and confused a state as to be a reproach to the science until it was remodelled by $\mathrm{Mr}$. Brown, who first determined the just limits of its genera. The A pocyneæ contain, among some poisonous plants, such as Echites venenata, the Oleander remarkable for the beauty of its flowers, and the Cream fruit and Picimmons of Sierra Leone, which are said to be excellent fruit-trees.

Umbelliferous plants contain numerous species, some of which, like the Cicuta virosa, Conium maculatum, \&c. are dangerous poisons, and others which are useful to mankind either as luxuries or necessaries. The seeds of caraway, coriander, \&c. are commonly used by the confectioner, of dill and anise by the distiller; the blanched stems of celery and sweet fennel, and the roots and leaves of many others are among the best of British vegetables. The gum grlbanum of the shops is said to be the produce of a plant of this tribe. Great difficulty exists in ascertaining upon what principles the genera should be divided. Linnæus, contrary to his usual practice, attempted taining upon what principles the genera should be divided. Linnæus, contrary to his usual practice, attempted
to derive their characters from the absence or presence of the involucrum; Hoffman, Link, and Sprengel from peculiarities in the fruit, or, as it is familiarly called, in the seeds. The characters of Sprengel, who has, as it were, grown old in the study of Umbelliferæ, are certainly deserving of attention; but botanists are much divided in opinion upon their merits; and, it is to be feared, that notwithstanding the labours of the learned men who have directed their study particularly to the consideration of the order, little real progress has been made in its final arrangement. In this work the arrangement of Sir James Smith has been adopted, as being the most simple of all that has been published, and the most easy of application.

The plants belonging to Primulaceæ are beautiful border-flowers, or pretty alpine plants. In the same artificial section with these, are found the elegant families of Convolvulus and Ipomæa, one or several species of which produce the jalap of the shops; the various kinds of Epacris, which in New Holland rival the heaths of Southern Africa, and the splendid genus Azalea.

Other sections include the teak wood of the East Indies; the Sapodilla plum, and the Star apple, fine fruits of the West Indies; solanum, well digested by Dunal ; the Jesuit's bark (Cinchona), of which no species has yet been brought alive to Europe; the coffee tree, and many others.

Pentandria Digynia contains little beyond the Asclepiadeæ and Umbelliferæ, already mentioned. The Sumack, Guelder Rose, and Elder are contained in Trigynia ; in Tetragynia the paradoxical and curious Parnassia ; in Pentagynia, Crassula, Linum, and Statice, all ornamental genera; and a few obscure weeds make up the last order, Polygynia. 
1850 Stem erect pubescent, Flowers alternate apetalous

1851 Stems erect divaricating smooth, Leaves obtuse blunt, Petals obsolete

1852 Stem erect about 1-flowered, Sepals acute, Petals entire

1853 Procumbent, Flowers trifid

1854 The only species
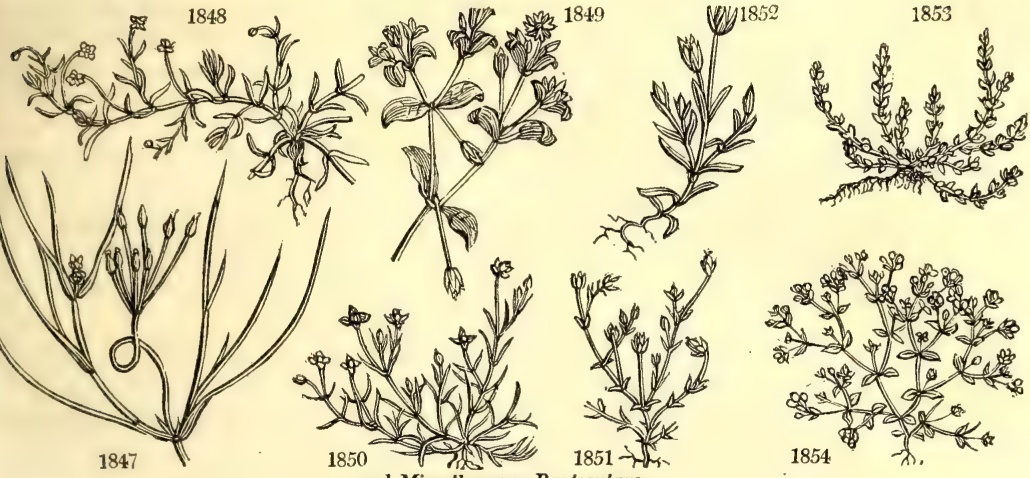

and Miscellaneous Partzculars.

320. Tillea. From Mich. Ang. Tilli, an Italian, born in 1653, died in 1740. He was a foreign member of the Royal Society of London, and published a Catalogus Horti Pisani, in one volume, folio.

321. Radiola. A diminution of radius. A little insignificant weed, formerly referred to the same genus with common flax.

\section{Order 1. MONOGYNia. 1 Style.}

1. Flowers monopetalous, inferior. Seed 1, naked.

922. Mirabilis. Nut below the corolla, which is funnel-shaped. Stigma globose, a little warted.

323. Abroma. Cor. funnel-shaped, with cordate segments, above the germen contracted, at the orifice in. flated. Stigma simple.

324. Plumbago. Seed 1. Stamens inserted into the valves. Corolla funnel-shaped. Stigma 5-cleft.

2. Flowers monopetalous, inferior. Seeds 2 or more, naked.

325. Heliotropium. Cal. 5-parted. Cor. hypocrateriform, orifice without teeth, limb 5-cleft, sinuses plaited, simple, or toothed. Stamens included. Stigma peltate. Nuts 4, cohering without a common receptacle.

326. Myosotis. Cal. 5-parted. Cor. hypocrateriform, closed with scales. Limb 5-parted, obtuse. Stamens included. Anthers peltate. Stigma capitate. Nuts 4, distinct, perforated at the base

327. Echinospermum. Cal. cor. and other parts as in Myosotis. Nuts united to a central column, prickly, compressed, closed at the base.

328. Mattia. Cal. 5-parted, spreading. Cor. tubular, funnel-shaped at the orifice with 5 scales as long as the tube. Anthers sagittate, conniving, exserted. Style longer than stamens. Stigma simple. Seeds winged.

329. Tiaridium. Cor. hypocrateriform, with an angular tube, the orifice contracted with 5 rays. Style very short. Stigma capitate. Nuts 4, 2-celled, mitre-formed, cohering, closed at base. No common receptacle.

330. Lithospermum. Cal. 5-parted, persistent. Cor. funnel-shaped, with a half 5-cleft obtuse limb, and an open orifice. Anthers included. Stigma obtuse, bifid. Seeds 4, hard, smooth, closed at the base.

331. Batschia. Cal. deeply 5-parted. Cor. hypocrateriform, with a hairy ring at the base inside, an open orifice, and rounded segments. Stigma emarginate. Seeds hard, shining.

332. Onosma. Cal. 5-parted, erect. Cor. campanulate, funnel-shaped, with a ventricose tubular 5-toothed limb, and an open orifice. Anthers sagittate, connected at base by their lobes. Stigma obtuse. Seeds ovate, shining, stony, closed at base.

333. Anchusa. Cal. 5-cleft, persistent. Cor. funnel-shaped, with a half 5-cleft spreading limb, orifice closed with 5 prominent scales. Anthers included. Stigma emarginate. Seeds gibbous, with a sculptured surface.

334. Symphytum. Cal. 5-parted, acute. Cor. cylindrical, campanulate, with a short tube and a tubular inflated limb, orifice with 5 subulate rays conniving into a cone. Stigma simple. Seeds gibbous, not pierced at base.

335. Onosmodium. Cal deeply b-parted. Cor. oblong, campanulate, with a ventricose halt 5-cleft limb, the edges of which are inflated, orifice open. Anthers sagittate, included.

336. Cynoglossum. Cal. 5-parted. Cor. short, funnel-shaped, with a 5-parted obtuse limb; orifice closed by scales. Stamens included. Stigma capitate. Nuts depressed, attached to a central column.

337. Omphalodes. Cal. deeply 5-parted. Cor. rotate, shorter than the tube of the calyx, with 5 short scales crossing over the anthers, which are inserted into the base of the tube. Style short. Stigma thick. Seeds urceolate, toothed at the edge.

338. Pulmonaria. Cal, prismatic, 5-cornered, 5-toothed. Cor, funnel-shaped, with a cylindrical tube, open orifice, and obtuse 5 -lobed limb. Stigma obtuse. Seeds 4 , obtuse, rounded.

389. Cerinthe. Cor. tubular, ventricose. Nuts 2, each 2-celled, open at the base.

340. Borago. Cal. 5-parted. Cor. rotate, with acute segments; orifice crowned. Filaments couniving. Seeds rounded, closed at base, rugose, inserted lengthways into an excavated receptacle. 
341. Trichodesma. Cor. rotate, with a naked orifice and subulate segments. Stamens exserted. Anthers villous at back. Nuts half immersed in the 4-winged column.

342. Asperugo. Cal. 5-parted, irregular. Cor. funnel-shaped, with a short tube, orifice closed by convex scales. Stigma obtuse. Seeds oblong, compressed, not perforated.

343. Nonea. Cal. at length inflated. Cor. funnel-form, with a 5-cleft short limb, and straight naked tube. Stamens included. Orifice nearly open. Seeds 4 , with parallel streaks.

344. Lycopsis. Cor. funnel-shaped, 5-lobed, with a covered tube and obtuse limb. Scales at the orifice. Stigma emarginate. Nuts hollowed at base.

345. Echium. Cal. 5-parted, subulate. Cor. campanulate with unequal obtuse segments, the 2 upper the longest; orifice open. Filaments unequal, declinate. Stigma obtuse. Seeds roundish, warted, not open at base.

346. Tournefortia. Berry 2-celled, cells 2-seeded, perforated at end. Cor. hypocrateriform or rotate, naked at the orifice.

347. Nolana. Cal. turbinate. Cor. campanulate, plaited. Nuts 5, 2 or 4-celled.

3. Flowers monopetalous, inferior. Seeds in a capsule or dry drupe. (Vestia, which has a berry, is an exception, but is placed here on account of its relation to other genera.)

348. Aretia. Caps. 1-celled. Corolla hypocrateriform, contracted at the orifice. Stigma globose.

349. Androsace. Caps. 1-celled. Corolla hypocrateriform, contracted at the orifice. Stigma globose.

350. Primula. Caps. 1-celled. Corolla funnel-shaped, pervious at the orifice. Stigma globose.

351. Cortusa. Caps. 1-celled, oblong. Corolla rotate. Stigma somewhat capitate.

352. Soldanella. Caps. 1-celled. Corolla torn. Stigma simple.

353. Dodecatheon. Caps. 1-celled, oblong. Corolla reflexed. Stigma obtuse.

354. Cyclamen. Caps. 1-celled, pulpy within. Corolla reflexed. Stigma acute.

355. Hottonia. Caps. 1-celled. Corolla with the tube below the stamens. Stigma globose.

356. Lysimachia. Caps. 1-celled, 10-valved. Corolla rotate. Stigma obtuse.

357. Anagallis. Caps. 1-celled, cut round. Corolla rotate. Stigma capitate

358. Diapensia. Caps. 3-celled. Corolla hypocrateriform. Cal. 8-leaved.

359. Pyxidanthera. Cal. deeply 5-parted. Cor, campanulate, much shorter than the tube of calyx, segments 5 ,

spatulate. Anthers with an appendage at their base. Style thick. Stigmas 3.

360. Coris. Caps. 1-celled, 5-valved. Corolla irregular. Stigma capitate.

361. Galax. Caps. 1-celled, 2-valved. Corolla hypocrateriform. Stigma roundish.

362. Menyanthes. Caps. 1-celled. Corolla villous spreading. Stigma bifid. Cal. 5-parted.

363. Villarsia. Caps. many-seeded, 2-valved. Cor. rotate, limb spreading, 5-parted, flat, bearded or scaly at

the base. Glands 5, hypogynous.

364. Chironia. Caps, ovate, seeds numerous small. Cal. 5-parted erect. Cor. equal, with a 5-parted limb of ovate equal segments. Filaments from mouth of tube. Anthers, after bursting, spiral. Style declinate

365. Eustoma. Cal. deeply 5-cleft. Tube of cor. funnel-shaped, contracted. Filam. short, regular, inserted about the middle of the tube. Stigma large, deeply 2-lobed. Seeds scurfy.

366. Erythraa. Caps. linear. Cal. 5-cleft. Cor. funnel-shaped, with a short limb withering. Anthers, after bursting, spiral. Stigmas 2.

367. Sabbatia. Cor. with an urceolate tube, and limb 5-12-parted. Stigmas 2-parted, with spiral divisions.

Anthers at length revolute.

368. Logania. Caps. 2-parted. Cor. subcampanulate, with a villous throat, and 5-parted limb. Stigma clavate.

369. Phlox. Caps. 3-celled. Corolla hypocrateriform, with a curved tube. Stigma trifid.

370. Polemonium. Caps. 3-celled. Corolla 5-parted. Stamens placed on the valves.

371. Vestia. Berry. Cor. funnel-shaped, 5-parted, with a hairy throat. Stamens exserted. Stigma nearly entire.

372. Hydrophyllum. Caps. 1-celled, 2-valved. Corolla with 5 nectaries. Stigma bifid.

373. Phacelia. Caps. 2-valved, 4-seeded. Cal. persistent. Cor. campanulate, 5-cleft, with 5 furrows inside the base. Stam. exserted. Style short. Stigmas 2, long.

374. Ramondia. Caps. 2-valved, valves bent in at edge, septiferous. Cor. rotate, rather unequal, Stamens approximated, perforated at end. Stigma round.

375. Verbascum. Caps. 2-celled. Corolla rotate. Stigma obtuse. Stamens declinate.

376. Datura. Caps. 2-celled, 4-valved. Corolla funnel-shaped. Calyx deciduous.

377. Brugmansia. Caps. unarmed. Cal. bursting at side, persistent. Cor. funnel-shaped. Anthers glued

together. Stigma or line running down each side of style.

378. Lisianthus. Caps. 2-celled, many-seeded. Corolla funnel-shaped, ventricose. Style persistent.

379. Spigelia. Caps. 2-celled, double. Corolla funnel-shaped. Stigma simple.

380. Nicandra. Berry without juice, 3-5-celled, covered by the calyx, which is inflated. Cor. campanulate.

Stamens incurved, distant.

381. Hyoscyamus. Caps, 2-celled, with a lid. Corolla funnel-shaped. Stigma capitate

382. Nicotiana. Caps. 2-celled. Corolla funnel-shaped. Stigma emarginate.

383. Ipomae. Caps. 3-celled. Corolla funnel-shaped. Stigma capitate.

384. Convolvulus. Caps. 2-celled, 2-seeded. Cor. campanulate. Stigma 2-cleft.

385. Argyreia. Berry rounded, juiceless, 4-celled. Cal. colored, persistent, the outer sepals largest. Cor.

5-parted, with a short thick tube surrounding the nectary. Stamens in the mouth of tube thickened, at base

hairy. Anthers sagittate.

386. Nemophila. Ovary 1-celled, with 2 parietal placentas, each bearing 2 distant ovules. Capsule 1-celled, with fleshy placentas fixed to a longitudinal dorsal axis, otherwise loose, bearing the seeds on their inner surface.

387. Calystegia. Ovary half 2-celled, 4-seeded. Cal. 5-parted, inclosed in two leafy bractes. Cor. campanulate, 5-plaited. Stamens nearly equal, shorter than the limb. Stigmas 2, obtuse.

388. Cobcea. Caps. obovate, 3-5-celled, 3-5-valved. Seeds imbricated, edged. Cal. 5-cleft, campanulate,

5-cornered, winged. Cor. campanulate, with 5 blunt lobes. Stamens declinate, filaments spiral.

389. Cantua. Caps. 3-celled, 3-valved. Seeds winged. Corolla funnel-shaped. Stigma trifid.

390. Hoitzia. Caps, of Cantua. Seeds not edged. Cal. double, inner 1-leaved, tubular, outer of $4-8$ leaves.

Cor. funnel-shaped, 4-5 times as long as calyx, a little incurved. Stamens inserted into base of tube.

391. Retzia. Caps, 2-celled. Corolla cylindrical, villous on the outside. Stigma bifid.

392. Lubinia. Caps. many-seeded, mucronate, when pressed of 2-4 valves. Cal. 5-parted. Cor. hypocrateri-

form, with a flat 5-parted equal limb. Filaments attached to middle of tube. Stigma obtuse.

393. Epacris. Caps. with placentas attached to a central column. Cal. colored, with many bracteæ. Cor.

tubular, with a beardless limb. Stamens on the petals. Scales 5, hypogynous.

394. Styphelia. Drupe juiceless, with a solid bony putamen. Cal. 5-parted, with many bracteæ. Cor. in a long tube, having within 5 bundles of hairs, and bearded reflexed segments. Filaments exserted.

395. Lissanthe. Drupe berried, with a bony solid putamen. Cal. with 2 bracteæ or more. Cor. infundibuliform, not bearded. Ovarium 5-celled.

396. Astroloma. Drupe juiceless, with a solid bony putamen. Cal. with 4 or more bracteæ. Cor. ventricose, twice as long as calyx, with 5 bundles of hairs inside, and a short spreading bearded limb. Filaments linear included.

397. Sprengelia. Caps, with placentas attached to a central column. Cal. colored. Cor. 5-parted, rotate,

beardless. Stamens hypogynous. Anthers connate or not. No hypogynous scales.

398. Andersunia. Caps. of Sprengelia. Cal. colored, with 2 or more leafy bractex. Cor. the length of the 
calyx, the segments of the limb bearded at the base. Stamens hypogynous. Scales 5 , hypogynous, sometimes

connate. 399. Lysinema. Caps. of Sprengelia. Cal, colored, with many bractex. Cor. hypocrateriform, with a tube
sometimes 5-partiole, with beardless segments bent to the right. Stamens hypogynous. Scales 5 , hypogynous. sometimes 5 -partible, with beardless segments bent to the right. Stamens hypogynous. Scales 5, hypogynous.
400. Monotoca. Drupe berried. Cal, with 2 bractex. Cor. funnel-shaped, with the limb and throat beardless. Ovary 1-seeded.

401. Leucopogon. Drupe berried or juiceless, sometimes crustaceous. Cal. with 2 bracteæ. Cor. funnelshaped, with a spreading limb bearded lengthwise. Filaments included. Ovary 2-5-celled.

we Stenanthera. Drupe juiceless, with a solid bony putamen. Cal, with many bracteæ. Cor. tubular, longer than the calyx, ventricose, with a short spreading half-bearded limb. Filaments included, fleshy, broader than the anthers.

403. Azalea. Caps. 5-celled. Corolla campanulate. Stigma obtuse.

404. Chamaledon. Caps. 2-celled, opening at the end. Cal. 5-parted, equal. Cor. campanulate, 5-cleft, unequal. Stamens inserted into the base of cor. equal, straight, included. Anthers opening lengthwise. Style straight.

405. Brexia. Cal, short, with 5 rounded lobes. Petals ovate, spreading, rounded. Filam. dilated at base. Bristles shorter than the stamens, about the ovarium.

406. Ophiorhiza. Caps. 2-celled, 2-parted. Corolla funnel-shaped, villous at mouth, with acute segments. Stigma bifid.

407. Allamanda. Caps. 1-celled, lens-shaped, 2-valved, the valves being boat-shaped. Seeds imbricated. 408. Theophrasta. Caps. 1-celled, very large, Corolla campanulate. Stigma acute.

409. Clavija. Caps. 1-celled, very large. Corolla rotate, with 5 prominences in the centre. Filaments 5 , united into a tube at the base of the corolla.

\section{Flowers monopetalous, inferior. Seeds in a follicle.}

410. Vinca. Cal. 5-cleft. Cor. hypocrateriform, plaited at the orifice, with flat segments, truncate at the end. Filaments at the end dilated into concave scales. Glands 2 at base of ovary.

411. Nerium. Cor. hypocrateriform, crowned at the mouth with little lacerated appendages, segments of cor. twisted. Filaments inserted into middle of tube. Anthers sagittate, adhering to the stigma by the middle. Little teeth at the base of the calyx outside the corolla.

412. Wrightia. Cor. hypocrateriform. Mouth crowned by 10 divided scales. Stam. exserted. Filaments inserted into throat. Anthers sagittate, adhering to the stigma by the middle. Scales 5-10, inserted into base of calyx outside of corolla, some hypogynous.

413. Echites. Cor. hypocrateriform, with segments of the limb unequal-sided. Ovaries 2. Style 1, filiform. Follicles slender.

414. Ichnocarpus. Cor. hypocrateriform, with segments of limb halved. Ovaries 2. Style 1, filiform. Stigma ovate, acuminate. Filaments 5 , hypogynous, alternate with the stamens.

415. Plumieria. Cor. funnel-shaped, with a flat limb, and ovate-oblong oblique segments. Filaments from the middle of tube. Anthers conniving. Styles scarcely any.

416. Strophanthus. Cor. funnel-shaped, with segments caudate, mouth crowned with 10 entire scales. Stam inserted into middle of tube. Anthers sagittate, aristate, or mucronate. Style filiform, dilated at end. Stigma cylindrical.

417. Cameraria. Cal, very small. Cor. funnel-shaped or hypocrateriform, with a long tube inflated at both ends, and a flat limb, with 5 lanceolate oblique segments. Filaments in the middle of tube. Ovaries, with appendages at their sides. Styles scarcely any.

418. Tabernamontana. Cor. hypocrateriform. Stamens included. Anthers sagittate, Ovaries $2 . \quad$ Style 418. Tabernamontana. Cor. hypocrateriform. Stamens inc
filiform. Stigma dilated at base, bifid. Seeds immersed in pulp.

419. Amsonia. Cor. funnel-shaped, closed at the orifice, with a 5-lobed limb. Stigma capitate, surrounded by $a$ membranous angle. Seeds obliquely truncate, naked.

\section{Flowers monopetalous, inferior. Seeds in a drupe or berry.}

420. Cerbera. Cal persistent, 5-parted. Cor. funnel-shaped, with a clavate tube and 5-cornered throat, with 5 scales, segments of limb oblique obtuse. Stigma fringed, bifid. Drupe bony, 2-celled, 4-valved. Seeds 1-2, covered with a fleshy skin.

421. Tectona. Cal. campanulate, with 5.6 lobes. Cor. funnel-shaped, the length of calyx, with a short tube, and 5-6-parted crenulate limb. Stamens under the throat of corolla. Drupe globose in the inflated calyx, s-4-celled.

422. Caldasia. Cal. tubular. Cor. tubular, 2-lipped, with emarginate segments. Filaments declinate. Drupe 3-angular, 3-valved, 3-seeded.

423. Bumelia. Cal, 5-parted, very small. Cor. campanulate, 5-cleft, or hypocrateriform, with teeth between the divisions of limb. Nectary a 5-leaved crown, adhering to the tube of the corolla. Drupe ovate or globose 424. Chrysophyllum. Cal. 5-parted, small. Cor. campanulate, short. Filaments on the tube connivent. Style very short. Stigma obtuse, 5-cleft. Berry 10-celled, with solitary shining seeds.

425. Sideroxylon. Cal. 5-toothed. Cor. 5-cleft. Scales of nectary five. Stigma simple. Berry 5-seeded.

426. Jacquinia. Cal. 5-leaved. Cor. with a campanulate ventricose tube, and 10-cleft limb. Stamens hypogynous. Anthers hastate. Stigma capitate. Berry roundish, 1-celled, 1-seeded.

427. Achras. Cal. 5-6-parted. Cor. ovate, 5-6-cleft, with as many scales on the throat. Berry or apple teated, 1-celled. Seeds solitary, with a marginal hilum, and a claw at the end.

428. Cordia. Cal. tubular, 4-5-toothed. Cor. funnel-shaped, 4-5-cleft. Style dichotomous. Stigmas 4 Drupe covered by the calyx, 1-4-celled. Cotyledons plaited.

429. Varronia. Cal. tubular, 5-toothed. Cor. tubular, with a 5-cleft, spreading, plaited limb. Style dichoto:nous. Stigmas 4. Drupe 4-celled, 4-seeded.

430. Ehretia. Cal. deeply 5-cleft. Cor. funnel-shaped, with a naked throat. Stamens exserted. Style semibifid. Berry 2-celled, 2-seeded.

431. Bourreria. Cal. campanulate, half 5-cleft, very small. Cor. longer than calyx, with a plaited limb. Stam, as long as cor. Stigma obtuse edged. Berry roundish, 1-celled, with 4 convex seeds.

432. Ellisia. Cal. 8-parted. Cor. funnel-shaped. Stam. inserted in base of corolla. Stigma simple or bifid. Berry dry, scrotiform, 2-valved, 2-celled, in an enlarged stellate calyx. Seeds globose, black, dotted.

433. Sersalisia. Cal. 5-parted. Cor. 5-cleft. Stamens 5, sterile, scale-like, with as many alternate fertile ones. Ovary 5-celled. Stigma undivided. Berry 1-5 seeded. Seeds with a crustaceous skin, and longitudinal
hilum.

434. Manglilla. Cal. very small, 5-parted. Cor, rotate, 5-parted. Scales of nectary none. Drupe or berry 1-celled, 1-seeded.

435. Ardisia. Cal. 5-parted. Cor. hypocrateriform, with a reflexed limb. Anthers large, erect. Stigma simple. Drupe fleshy, superior, 1-seeded.

436. Arduina. Cor, funnel-shaped, curved. Stigma bifid. Berry 2-celled. Seeds solitary, oblong.

437. Strychnos. Cor. tubular, 5-cleft. Berry 1-celled, with a woody coat. A Contorta. 438. Carissa. Cal. short. Cor. tubular. Stamens included. Berry 2-celled. Cells 1-2 or many-seeded. A
Contorta.

433. Pcederia. Cal. 5-toothed. Cor. infundibuliform, 5-lobed, hairy within. Style bipartite. Berry brittle, shining, 2-seeded.

440. Gelsemium. Cal. 5-toothed. Cor. infundibuliform. Limb spreading, 5-lobed, nearly equal. Caps. compressed, flat, 2-partible, 2-celled. Seeds flat, attached to the marrins of the valves.

41. Rauwolfia. Cor, tubular, globose at base. Berry succulent, \& seeded. A Contorta. 
442. Vallesia. Cal. very small, 5-fid. Cor. hypocrateriform, or infundibuliform, with a long slender tube, an inflated throat, and a flat limb with 5 lanceolate spreading segments. Stamens inserted in the throat. Drupes 2, 1-celled, 1-seeded. Nut fibrose, striated.

443. Baobotrys. Cor. tubular, 5-cleft. Calyx double, superior: outer 2-leaved, lower campanulate, 5-toothed.

Berry 1-celled, many-seeded.

444. Solandra. Cal. bursting. Cor. clavate, funnel-shaped, very large. Berry 4-celled, many-seeded.

445. Cestrum. Cal. funnel-shaped. Segments acute, edged. Stamens with or without a tooth. Anthers

4-cornered. Berry 1-2-celled. Seeds few, angular.

446. Atropa. Cor. campanulate. Stamens distant. Berry globose, 2-celled, sitting on the calyx.

447. Mandragora. Cal. turbinate. Cor. campanulate. Filaments dilated at base. Ovary with 2 glande. Berry fleshy, solid. Seeds reniform.

448. Physalis. Cor. campanulate, rotate. Stamens conniving. Berry within the inflated calyx, 2-celled.

449. Saracha. Cor, rotate, campanulate. Berry 1-celled. Receptacle fleshy.

450. Lycium. Cor. tubular, with a closed orifice. Filaments bearded. Berry 2-celled, many-seeded.

451. Solanum. Cal. persistent. Cor. rotate or campanulate, 5-lobed, plaited. Anthers in some degree united, opening by a double pore at the end. Berry 2-celled, many-seeded.

452. Nycterium. Cal. 4-5-cleft. Cor. rotate, unequal. Anthers declinate, conniving, the lowest longest. Berry 2-celled, many-seeded.

453. Capsicum. Cor. rotate. Berry without juice.

454. Leea. Cor. monopetalous. Nectary 1-leaved, placed on the tube of the corolla, 5-cleft, erect. Berry 5-seeded, inferior.

6. Flowers monopetalous, superior. Seeds in a capsule.

455. Spermadictyon. Caps. inferior, 1-celled, 5-valved. Seeds 5, with a netted coat. Cor. funnel-shaped. Stigma 5-cleft.

456. Dentella. Cal. 5-parted, superior. Cor. funnel-shaped, with 3-toothed divisions. Caps. 2-celled, manyseeded.

457. Macrocnemum Cal. campanulate, cup-shaped. Cor. campanulate or funnel-shaped. Caps. 2-celled. Seeds imbricated.

458. Exostemma. Cal. campanulate, 5-toothed. Cor. funnel-shaped. Limb 5-parted, usually hairy. Caps. oblong, rounded, 2-celled, 2-partible. Seeds numerous, with a membranous edge.

459. Burchellia. Heads of flowers in an involucrum. Cor. clavate, funnel-shaped, with a 5-cleft short limb and a beardless orifice. Segments before expansion twisted together. Stamens inserted above the middle of the tube. Anthers subsessile, included. Stigma clavate. Berry crowned by the deeply 5-cleft calyx, 2-celled, many-seeded.

460. Rondeletia. Cor. funnel-shaped. Tube ventricose at top. Segments rounded, flattish. Caps. round, crowned, 2-celled. Seeds several or solitary.

461. Coutarca. Cal, 6-leaved. Cor. large, funnel-shaped, 6-cleft, with an incurved ventricose tube. Filaments inserted at base of tube. Caps. 2-celled, 2-valved, many-seeded. Seeds with a membranous edge.

462. Portlandia. Cal. 5-leaved. Cor, clavate, funnel-shaped. Segments spreading, deflexed. Caps. 5-cornered, retuse, crowned, 2-celled, 2-valved. Valves doubled, 2-cleft, many-seeded.

463. Campanula. Cor. campanulate, closed at bottom with staminiterous valves. Stigma 3-5-cleft. Caps. inferior, opening by lateral pores.

464. Lobelia. Cor. with the tube split on one side, the limb 2-lipped, 5-parted. Stigma 2-lobed, sometimes entire. Caps. 2-3-celled, 2-valved at end.

465. Phyteuma. Cor, at first rounded conical, afterwards 5-parted with linear weak segments. Stigma 2 or 3-cleft. Caps. 2-3-celled, inferior.

466. Trachelium. Cor. funnel-shaped. Style long. Stigma globose. Caps. 3-celled, inferior.

467. Roella. Cor. funnel-shaped, closed at bottom with staminiferous valves. Stigma 2-fid. Caps. nearly 2-celled, cylindrical, inferior.

468. Goodenia. Cor. labiate, 5-cleft, waved, longitudinally split, pushing forth the stamens. Anthers linear. Stigma urceolate, ciliated. Caps. 1-2-celled, 2-valved, many-seeded. Seeds imbricated.

469. Euthales. Cal tubular, 5-cleft, equal. Cor. split at the end, with a 2-lipped limb. Anthers distinct.

Style undivided. Stigma 2-lipped. Caps. 4-valved, 2-celled at base.

470. Dampiera. Cor. 2lipped. Tube split on one side. Segments of upper lip with an auricle upon tne inner edge. Anthers cohering. Covering of stigma naked.

471. Samolus. Cor. hypocrateriform, 5-cleft, with scales between the divisions. Stamens inserted into the tube. Caps. 1-celled, 5-toothed, many-seeded.

472. Velleia. Cal. 3-5-leaved, unequal. Tube split at end with a 2-lipped limb. Anthers distinct. Style undivided. A gland between the two front stamens.

7. Flowers monopetalous, superior. Seeds in a drupe or berry.

473. Scavola. Cor. 1-petalous, with the tube divided lengthwise. Limb 5-cleft, lateral. Drupe inferior,

1-seeded. Nect. 2-celled.

474. Caprifolium. Cal. 4-5-toothed or entire. Tube of cor. long, with a 5-cleft, regular, or 2-lipped limb. Stamens length of cor. Stigma globose. Berry distinct, 3-celled, many-seeded.

475. Lonicera. Cal. 5-toothed. Cor. tubular, 5-cleft, irregular. Berry inferior, 2-3-4-celled, many-seeded.

476. Symphoria. Cal. 4-toothed. Cor. trifid, nearly equal. Berry crowned, 4-celled, 4-seeded, 2 cells sometimes abortive.

477. Diervilla. Cal, oblong, 5-cleft. Cor, twice as long, funnel-shaped, 5-cleft, spreading. Caps. oblong,

4.celled, many-seeded.

478. Triosteum. Cal. 5-cleft. Cor. scarcely longer, tubular, 5-lobed. Berry 3-celled, 3-seeded, inferior.

479. Coffea. Cal, increasing, 5-toothed, teeth deciduous. Cor. hypocrateriform. Stamens above the tube.

Anthers sagittate. Berry 2-seeded. Seeds with an arillus, on one side convex, on the other flat.

480. Chiococca. Cor. funnel-shaped, equal. Berry compressed, double, 2 seeded. Seeds oblong, compressed.

481. S. "issa. Cor. funnel-shaped, fringed at the throat, with segments of the limb 3-lobed. Berry 2 -seeded.

482. Canthium. Cal. 5-cleft. Cor. 5-cleft, spreading. Style elevated. Stigma capitate. Berry coated,

2-celled, 2-seeded. Seeds on one side convex, on the other flat, with a longitudinal furrow. Prickly.

483. Psychotria. Cal. 5-toothed, crowning. Cor. funnel-shaped. Berry globose or oval. Seeds 2, furrowed, bony.

484. Hamelia. Cor. 5-cleft. Berry 5-celled, many-seeded. Racemes divided. Flowers 1-sided.

485. Posoqueria. Cal. turbinate. Cor. hypocrateriform, with a long cylindrical curved tube which is dilated at end, with long narrow reflexed segments. Stamens exserted.

486. Vanguiera. Cor. campanulate, globose, with a hairy throat. Stigma of 2 lips. Berry apple-shaped,

4-5-celled, 4-5-seeded.

487. Gardenia. Segments of the cal. vertical or oblique. Cor. at first trisisted, funnel-shaped, 5-9-cleft, with a tube usually long. Style elevated. Stigma 2-lobed. Berry 2-celled, many-seeded. Seeds in a double row.

488. Genipa. Cal, tubular or turbinate, entire. Cor. hypocrateriform, with a large 5-parted limb. Anthers sessile in the throat, exserted. Stigma clavate, entire, or simple. Berry large, fleshy, truncated at the end, 2-celled, many-seeded.

489. Oxyanthus. Cal. contracted at top. Cor. funnel-shaned, with a verv long rounded tube, and a 5-parted limb, with very acute lobes. Anthers exserted.

490. Randia. Cal. 5-parted, with linear-lanceolate, twisted sepals. Cor. hypocrateriform, tube not much longer than calyx. Stigma 2-lobed, with oblong unequal lobes. Berry half 2-celled, with an incomplete par. tition; crowned with the tubular calyx. Seeds many. 
491. Mussanda.' Cor. funnel-shaped. Stigmas 2, thickish. Berry oblong, 2-celled, many-seeded. Seeds in 4 rows. Stamens in the inside of the tube.

492. Pinckneya. Sepals unequal, one or two of them foliaceous. Cor. a long tube. Filaments in the base of the tube. Caps. 2-valved, valves bearing the divisions in the middle.

403. Erithalis. Cal. urceolate. Cor. 5-parted, with recurved segments. Berry 10-celled, 10-seeded.

494. Webera. Cor. funnel:shaped, spreading. Stamens included. Stigma clavate. Berry rounded, two-

celled.

495. Plocama. Cal. 5-toothed. Cor. campanulate, 5-cleft. Berry 3-celled, with 1-seeded cells.

496. Morinda. Flowers collected in a globe above a spherical receptacle. Cal. 5-toothed. Cor. funnelshaped, 5-cleft, spreading. Berries aggregate, on account of their mutual compression angular.

497. Cephaelis. Flowers headed in an involucrum. Cal. 5-toothed. Cor. tubular. Stigma 2-parted. Berry

2-seeded. Receptacle chaffy. Involucrum 1-5-leaved.

498. Sarcocephalus. Flowers in a naked head, 5-parted. Stigma clavate. Fruit united into a great fleshy tessellated berry.

8. Flowers polypetalous, inferior. Seeds in a drupe, berry, or berried capsule.

499. Hirtella. Pet, 5. Filam, very long, persistent, spiral. Berry 1-seeded. Style lateral.

500. Triphasia. Flowers with their parts ternary. Stamens distínct. Anthers sagittate. Berry 3-celled 3-seeded.

501. Vitis. Petals cohering at the end like a calyptra, withering. Berry 5-seeded.

502. Ampelopsis. Cal. entire. Petals cohering at the end, withering. Stigma capitate. Ovary immersed in the disk, 2-4-seeded.

503. Rhamnus. Cal. campanulate, 4-5-cleft. Cor. scales protecting the stamens, inserted into the calyx. Stigmas 1-2-5-cleft. Berry 3-4-seeded.

504. OEnoplia. Cal, urceolate, 5-cleft. Petals 5. No fleshy discus. Drupe juicy, 2-celled, one cell being usually abortive, 1-seeded.

505. Paliurus. The flowers of Zizyphus. Styles 3. Drupe dry, 3-celled, surrounded by a membranous orbicular wing.

506. Zixyphus. Cal, spreading, 5-cleft. Petals 5. Discus fleshy, orbicular, surrounding the ovary. Styles 2.

Drupe with a 1 or 2-seeded nut. Flowers axillary.

507. Celastrus. Cor. 5 petals, spreading. Caps. 3, angular, 3-celled. Seeds with an arillus.

508. Senacia. Cal. very small, 5 -toothed. Cor. 5 petals. Caps. spherical, stalked, 2-valved, 4-seeded. Seeds angular, naked.

509. Euonymus. Pet. 5. Caps. 5-cornered, 3-celled, 3-valved, colored. Seeds with an arillus.

510. Ceanothus. Pet. 5, bagged, vaulted. Berry dry, 3-celled, 3-seeded.

511. Staavia. Flowers aggregate. Stamens inserted into the calyx. Styles 2, united. Berry 5-seeded, coated. Rereptacle chaffy, villous.

512. Pomaderris. Cal, turbinate. Petals arched, scale-like, sometimes none. Style 3-cornered. Stigmas 3, capitate. Caps. of 3 papery divisions.

513. Mangifera. Pet. 5. Drupe reniform.

514. Schrebera. Drupe dry, with a 2-celled nut. Nectary an elevated edge.

515. Billardiera. Petals 5, alternate with the sepals. Nectary O. Stigma simple. Berry many-seeded

516. Elcoodendrum. Sepals 5-10, with round concave scales. Cor. 5-parted. Segments ovate, lanceolate, concave. Nect. linear, subulate, petal-like. Drupe dry, with a 2 or 3-celled nut. Putamen thick, hard, furrowed.

9. Flower polypetalous, inferior. Seeds in a capsule.

517. Diosma. Cal. 5-parted. Petals and stamens inserted in the calyx. Nect. of 5 plaits. Ovary crowned. Caps. 5-valved. Each end with an elastic arillus.

518. Adenandra. Cal. 5-parted. Pet. and stamens inserted in the calyx. Stamens 10, of which every other one is sterile. Anthers with a gland at end.

519. Baryosma. Cal. 5-leaved. Petals 10, unequal, inserted in the receptacle. Nect. a 5-lobed gland inserted on the receptacle.

520. Agathosma. Cal. 5-parted. Petals 10, unequal, inserted in the calyx. Nect. 5-lobed, inserted in calyx.

5k1. Nauclea. Cal, about 5-toothed. Cor. funnel-shaped. Caps. 3-cornered, 2-celled, many-seeded. Flowers in a globose head upon a common pilose receptacle.

52\%. Pittosporum. Cal. deciduous. Petals 5, conniving in a tube. Caps. 2-5-celled, 2-5-valved. Seeds pulpy.

523. Lasiopetalum. Cal. 5-leaved. Petals minute, gland-like. Filaments 5, separate. Anthers opening by two pores inwards. Stipules none.

524. Thomasia. Cal persistent, veiny. Pet. 5, very small or 0 . Filam. united at base. Anthers opening laterally. Stipules leafy.

525. Seringia. Cal, withering. Pet. O. Filam. 10, every other one barren. Anthers opening at their back.

Stipules small, deciduous.

526. Buttneria. Pet. 5. Nect. 5-leaved. Filaments inserted into the end of the nectary. Caps. of 5 divisions, muricated.

527. Ayenic. Cal. 5-parted. Pet. 5, connected at end into a star, with their claws slender, bent into the form of a crown. Glands 5, stamen-shaped. Nectary cup-shaped. Caps. depressed, 5-furrowed, 5-celled, 5-valved. Valves bifid.

528. Calodendrum. Cal. 5-parted, short. Petals lanceolate, stalked. Stam, 5, sterile, petal-shaped. Caps.

5-angular, 5-celled, 5-valved, with 2-seeded cells.

529. Toddalia. Cal. 5-cleft. Petals 5. Stigma capitate. Caps. berried, 5-celled. Cells 2-seeded.

530. Bursaria. Cal, inferior, 5-toothed. Pet. 5, linear. Stigma simple. Caps. cordate, compressed, 2-part ble, 2-seeded. Seeds reniform.

531. Cedrela. Cal. withering. Cor. of 5 petals, funnel-shaped, at base united $\frac{1}{3}$ with the receptacle. Caps. woody, 5-celled, 5-valved. Seeds with a membranous wing.

532. Hovenia. Cal. 5-parted. Pet. 5, convolute. Stigma 3-fid. Caps. 3-celled, 3-valved. Cells 1-seeded.

533. Brunia. Flowers aggregate. Cal, superior, 5-parted. Filaments inserted into the claws of the petals.

Stigma 2-fid. Caps. small, 2-celled.

534. Brossaea. Cal. fleshy, superior. Cor. conical, truncated. Caps. 5-furrowed, 5-celled, covered by the persistent calyx, with 5 -fissures

535. Itca. Cal. 5-cleft, campanulate. Pet. 5, linear, reflexed, inserted into calyx. Stigma capitate, 2-lobed Caps. 2-celled, 2-valved, with the valves bent inwards.

536. Cyrilla. Cal. very small, turbinate, 5-parted, superior. Pet. 5, stellate, stiffish. Styles 2-fid. Berry dry, 2-celled. Seeds solitary, attached by a little cord.

537. Claytonia. Cal. 2-valved. Pet. 5. Stigma 3-fid. Caps. 3-valved, 1-celled, 3-seeded.

538. Impatiens. Cal. 2-leaved. Pet. 5, irregular, with one cucullate. Anthers at first subconnate. Caps. superior, 5-valved.

539. Sauvagesia. . Pet. 5, fringed. Sepals 5. Nectary 5-leaved, alternate with the petals. Caps. 3-celled, 3-furrowed, 3-valved, with the edges bent inwards.

540. Viola. Sepals 5. Petals 5, irregular, connate behind. Anthers adhering at the end by a membrane, or distinct. Caps, 3-valved, 1-seeded.

541. Ionidium. Sepals 5, produced at their base. Cor. 2lipped, without a spur. Anthers usually distinct, Stigma simple. Caps, 1-celled, 3-valved. 
10. Flowers polypetalous, superior.

542. Phylica. Cal. 5-parted, turbinate. Pet. O. Scales 5, protecting the stamens. Caps. 3-coccous, inferior.

543. Plectronia. Cal. turbinate, 5 -toothed, persistent, closed by 5 villous scales. Pet. 5 , inserted in the throat of calyx. Berry 2-celled, 2-seeded.

544. Conocarpus. Pet. 5 or $\mathbf{O}$. Seeds naked, solitary. Flowers in heads.

545. Cyphia. Cal. 5-cleft, turbinate. Petals linear, dilated at base, connivent, spreading at end. Filaments hairy, cohering. Anthers distinct. Stigma cernuous, hollow, gibbous.

546. Lightfootia. Sepals 5. Petals thin, bottom closed by stamen-bearing valves. Stigma 3-5-cleft. Caps. 3-5-celled, 3-5-valved, $\frac{1}{3}$-superior.

547. Jasione. Flowers in heads. Common involucrum 10-leaved. Petals 5, erect. Anthers cblong, cohering at base. Stigma bifid.

548. Lagoecia. Umbel simple. Common involucre about 8-leaved, partial 4-leaved, finely pinnated. Cal. 5-cleft, with many-cut fine segments. Petals 2 -fid. Seeds crowned by the calyx.

549. Hedera. Petals 5, oblong. Berry 5-seeded, surrounded by the calyx.

550. Ribes. Petals 5, and stamens inserted into the calyx. Style 2-fid. Berry many-seeded, inferior.

551. Gronovia. Petals 5, and stamens inserted into the campanulate calyx. Berry dry, 1-seeded, inferior.

\section{Flowers incomplcte, inferior.}

552. Achyranthes. Sepals 5. Scales 5, connate at the base into a tube, at the end fringed and alternate with the stamens. Stigma 2-fid. Seed solitary, crowned by the conniving sepals.

553. Philoxerus. Sepals 5, irregular. Stamens 5 , united at the base into a little cup shorter than the ovary. Anthers 1-celled. Style 1. Utricle 1-seeded, without valves.

554. Desmochata. Sepals 5. Stamens 5, united at base with a very small cup with neither teeth nor chaff between. Stigma capitate. Utricle 1-seeded.

555. Illecebrum. Sepals 5, vaulted at the end. Pet. O. Stigma simple or bifid. Caps. 5-valved, 1-seeded.

556. Alternanthera. Sepals 5. Stamens 5, united into a little cup, with or without intermediate teeth, one or more of the stamens usually abortive. Anthers 1-celled. Stigma capitate.

557. Paronychia. Cal, nearly 5-parted, colored inside. Scales or petals 5, linear. Style 2-fid. Stigmas 2.

Caps, 1-celled, 5-valved.

558. Chenolea. Cal. globose, fleshy, concave. Cor. O. Filam. inserted into the base of calyx. Stigmas 2 , spreading. Caps. round, depressed, 1-celled, 1-seeded.

559. Anychia. Cal. connivent, with oblong segments, bagged at the end. Pet. O. Filam. distinct, with no setæ between. Stigmas 2, oblong. Caps. an utricle, not opening. Seed 1, reniform.

560. Arua. Sepals 5, with 2-3-bracteæ, oblong; on the outside white, hairy ; inside smooth. Stamens 10 , alternately barren, inserted into a little cup at the base. Style larger, filiform. Stigma bifid.

561. Lestibudesia. Sepals 5. Stamens 5, united into a little cup without teeth. Anthers 2-celled. Ovary many-seeded. Style short or none. Stigmas 3-4, filiform, recurved. Caps, opening transversely.

562. Rhagodia. Flowers polygamous. Perianth 5-parted. Stamens 5 or fewer. Style bifid. Grain depressed, fleshy, surrounded by the perianth

563. Deeringia. Perianth 5-parted. Stamens united at base into a small cup. Anthers 2-celled. Style

3-parted. Berry many-seeded.

564. Trianthema. Sepals oblong, colored inside. Stamens 5-10-12, with capillary filaments. Ovary half-superior. Style 1 or 2 , filiform. Stigmas simple. Caps. oblong, truncate, cut round.

565. Celosia. Sepals 3, like a 5-petalous corolla. Stam. united at base by a plaiter nectary. Caps. horizon tally opening. Style 2-3-cleft.

566. Gomphrena. Sepals 5, colored : outer 3 conniving, keeled. Pet. 5, rude, villous. Nect. cylindrical, 5-toothed. Caps. cut round, 1-seeded. Style half-bifid.

567. Moltia. Sepals 5. Pet. 5, emarginate. Style simple. Caps. 3-cornered, 1-celled, 3-valved, manyseeded.

568. Glaux. Cal. 1-leaver, colored, 5-lobed. Cor. O. Caps. 1-celled, 5-valved, 5-seeded, surrounded by a calyx.

\footnotetext{
12. Flowers incomplete, superior.
}

569. Thesium. Cal. 1-leaved, into which the stamens are inserted. Nect. inferior, 1-seeded, surrounded by the persistent calyx

570. Heliconia. Spathes universal and partial. Cal. O. Cor. 3 petals, superior. Nect. 2-leaved. Stigma 1. Caps. 3-celled, with 1-seeded cells.

571. Strelitzia. Spathes universal and partial. Cal. O. Cor. superior, 3 petals, the larger segments hastate.

Nect. 3-leaved, surrounding the stamens. Stigmas 3. Caps. 3-celled. Cells many-seeded.

\section{Order 2. DIGYNIA. 2 Styles.}

1. Flowers monopetalous, inferior. Fruit a follicle or capsule. (Asclepiadere.)

572. Apocynum. Cor. campanulate. Filaments 5, alternate with the stamens. Style none. Stigma broad. Follicles long, linear.

573. Melodinus. Cal campanulate, 5-toothed. Cor. hypocrateriform. Limb spreading, with falcate, crenulate segments. Corona 5-cleft, with short, stellate, torn divisions. Stigmas 2. Fruit a fleshy globose, 2-celled, many-seeded berry.

574. Periploca. Anthers bearded at back. Pollen-masses solitary, made up of 4 confluent ones. Stigma blunt. Follicles cylindrical, divaricating, smooth. Seed comose.

575. Cryptostegia. Cor. funnel-shaped. Tube with two included bifid scales, alternate with the divisions of the limb. Stamens included, inserted in the base of the tube. Filaments distinct. Anthers cohering with the stigma by their base. Glands 5 , spatulate. Pollen granular, simple.

576 . Hemidesmus. Cor. with 5 blunt scales under the sinuses. Anthers free from the stigma, simple at end. stigma blunt. Follicles cylindrical, much spreading, smooth. Seeds comose.

577. Secamone. Corona 5-leaved. Pollen-masses 20, smooth, erect, fixed by fours to the point of each corpuscle of the stigma. Stigma contracted at end.

578. Microloma. Tube of cor. inflated, angular, shorter than the limb. Scales inserted into the middle of the tube below the sinuses. Anthers terminated by a membrane, sagittate. Pollen-masses compressed, pendulous. Stigma with a little point.

579. Sarcostemma. Cor. rotate. Pollen-masses pendulous. Stigma blunt. Seeds comose.

580. Damia. Cor. rotate, with a short tube. Outer corona 10-parted, short. Pollen-masses yendulous, compressed. Stigma blunt. Seeds comose.

581. Cynanchum. Cor. rotate, 5-parted. Pollen-masses inflated. Stigma with a little point. Follicles smooth.

582. Oxystelma. Cor. spreading, rotate, with a short tube. Columna exserted. Crown 5-leaved, with compressed, acite, undivided leaflets. Pollen-masses compressed, pendulous, fixed by a narrow end. Stigma pressed, acute, undivided seeds comose.

583. Gymnema. Cor. 5-cleft. Scales or little teeth of the orifice 5, inserted in the sinuses. Crown none. Masses of pollen erect, fixed by the base. Follicle slender, smooth. 
584. Calotropis. Cor. with an angular tube: the angles saccate inside. Crown with carinate leaflets, united lengthwise to the tube of the filaments. Pollen-masses pendulous, fixed by the narrow end. Stigma blunt. 555. Dischidia. Cor. urceolate, 5-cleft. Corona with subulate, spreading, recurved segments. Pollenmasses erect, fixed by the base. Stigma blunt. Follicles smooth. Seeds comose.

masses erect, fixed by the base. Stigma blunt. Follicles smooth. Seeds comose.
586. Xysmalobium. Cor. 5-cleft, spreading. Corona 10-parted in a 'single row : the 5 divisions next to the anthers fleshy, round, simple within, the 5 others small. Pollen-masses pendulous, with lax connecting processes. Stigma blunt.

587. Gomphocarpus. Corona 5-leaved, the segments simple within. Pollen-masses compressed, pendulous, fixed by a fine end. Stigma depressed, blunt. Follicles ventricose, covered with innocuous spines. Seeds comose.

588. Asclepias. Corona 5-leaved, with a process on the inside. Pollen-masses fixed by a fine end. Stigma depressed, blunt.

589. Gonolobus. Cor. rotate, 5-parted. Corona shield-shaped. Anthers opening across, terminated by a membrane. Stigma flat, depressed.

590. Pergularia. Cor. hypocrateriform, with an urceolate tube. Pollen-masses erect, fixed by their base. Stigma blunt. Follicles ventricose, smooth. Seeds comose.

591. Marsdenia. Cor. urceolate, 5-cleft, sometimes rotate. Pollen-masses erect, fixed by the base. Follicles smooth. Seeds comose.

593. Hoya. Cor. 5-cleft. Pollen-masses fixed by the base, conniving, compressed. Stigma depressed, with an obtuse wart. Follicles smooth. Seeds comose.

593. Ceropegia. Outer corona short, 5-lobed; inner 5-leaved, with ligular undivided leaflets. Pollen-masses fixed by their base with simple edges. Stigma blunt. Follicles cylindrical, smooth. Seeds comose.

594. Stapelin. Cor, rotate, 5-cleft, fleshy. Column of fructification exserted. Pollen-masses fixed by the base. Stigma blunt. Follicles cylindrical, smooth. Seeds comose.

595. Piaranthus. Cor. fleshy. Outer corona none. Pollen-masses fixed by the base, with one edge cartilaginous, pellucid. Stigma blunt.

596. Huernia. Accessory segments of cor. tooth-like. Leaflets of the inner corona from a gibbous base subulate, undivided, alternate with the outer segments. Pollen-masses fixed by the base, with one edge cartilaginous, pellucid. Stigma blunt. Follicles cylindrical, smooth. Seeds comose.

597. Brachystelma. Cor. campanulate, with angular recesses. Column included. Crown 1-leaved, 5-cleft, with the lobes opposite the anthers, simple at back. Anthers without a membrane at the end. Pollen!masses erect, inserted by the base.

598. Caralluma. Cor. rotate, decply 5-cleft. Cal. of fructification exserted. Pollen-masses erect, fixed by the base with simple edges. Stigma blunt. Follicles slender, smooth. Seeds comose.

\section{Flowers monopetalous, inferior. Fruit a capsule.}

599. Swertia. Caps. of 1 cell. Cor. wheel-shaped, with 2 nectariferous pores at the base of each segment.

600. Gentiana. Caps. of 1 cell. Cor. tubular at the base, destitute of nectariferous pores

601. Hydrolea. Caps. 2-valved, 2-celled. Cor. rotate, campanulate. Stamens inserted in the tube.

602. Falkia. Cal. inflated, 5-parted, 5-angular. Cor. campanulate, emarginate, crenate. Styles spreading. Stigma globose, woolly. Seeds 4, globose, with an arillus in the bottom of the calyx.

603. Dichondra. Cal. 5-parted, with spatulate segments. Cor. short, campanulate, 5-parted. Stigma peltate, capitate. Caps. compressed, 2-celled, 2 -seeded. Seeds round.

\section{Flowers pentapetalous, inferior.}

604. Velezia. Cal. slender, 5-toothed. Cor. of 5 small petals. Caps. 1-celled, at the end 4-valved. Seeds many, attached to a filiform central receptacle.

605. Bumalda. Cal. 5-parted. Petals 5. Styles villous. Caps. 2-celled, with 2 bractes.

606. Heuchera. Petals 5. Caps. 2-celled, with 2 bractes.

607. Cussonia. Invol. O. Cal. 1-leaved, truncated, crenated. Pet. 5, oblong, acute. Fruit twin, 2-celled, crowned by the calyx and styles.

608. Anabasis. Cal. 3-leaved. Pet. 5. Berry 1-seeded, surrounded by the calyx.

609. Salsola. Caps. ciosed, imbricated in the fleshy calyx. Seed with a spiral embryo.

610. Kochia. Cal. 1-leaved, campanulate, in the fruit expanding into a leafy rim resembling 5 petals. Cor.

o. Stigmas 2-3, long. Caps. 1-celled, 1-2-seeded. Seed incurved.

611. Chenopodium. Seed lenticular, truncated, superior.

612. Beta. Seed kidney-shaped, imbedded in the fleshy calyx.

613. Bosea. Cal. 5-leaved. Cor. O. Berry 1-seeded.

614. Herniaria. Caps. closed, membranous, invested with the calyx. Stam. with 5 imperfect filaments.

615. Ulmus. Caps. closed, membranous, compressed, bordered, superior.

616. Planera. Cal membranous, subcampanulate, 4-5-cleft. Cor. O. Stigmas 2, oblong, glandular, spreading. Caps. globose, membranous, 1-celled, not opening, either smooth or scaly, not winged, 1 -seeded. Stamens 4-6. Polygamous.

4. Flowers pentapetalous, superior.

617. Phyllis. Cal. 2-leaved. Pet. 5. Stigmas hispid. Seeds 2, oblong, fixed to a filiform axis.

\section{Flowers pentapetalous, superior. Seeds 2. (UмBELLIFERE.)}

A. Fruit of a single or double globe.

618. Coriandrum Fruit a single or double globe, smooth, without ribs. Cal. broad, unequal. Petals radiant. Floral recept. none.

\section{B. Fruit beaked.}

519. Scandix. Beak much longer than the seeds, fruit somewhat bristly. Cal, none. Pet. unequal, undivided. Floral recept. 5-lobed, colored.

620. Anthriscus. Beak shorter than the seeds, even. Fr. rough, with scattered prominent bristles. Cal. none. Petals equal, inversely heart-shaped. Fl. recept. slightly bordered.

621. Charophyllum. Beak shorter than the seeds, angular. Fr. smooth, without ribs. Cal. none. Pet. inversely heart-shaped, rather unequal. Fl. recept. wavy.

\section{Fruit solid, prickly, without a beak.}

622. Eryngium. Fr. ovate, clothed with straight bristles. Cal. pointed. Pet. oblong, equal, inflexed, undivided. FL. aggregate. Common recept. scaly.

623. Sanicula. Fr. ovate, clothed with hooked bristles. Cal. acute. Pet. lanceolate inflexed, nearly equal. Fl. separated, dissimilar.

624. Echinophora. Fr. ovate, imbedded in the enlarged armed receptacle. Seed solitary. Cal. spinous. Pet. inversely heart-shaped, unequal. Fl. separated.

625. Daucus. Fr. elliptic oblong, compressed transversely. Seeds with four rows of flat prickles, and rough intermediate ribs. Cal. obsolete. Pet. inversely heart-shaped, unequal. Fl, separated.

626. Caucalis. Fr. elliptic oblong, compressed transversely. Seed with 4 rows of ascending, awl-shaped, hooked prickles, the interstices prickly or rough. Cal. grooved, acute, unequal. Pet. inversely heart-shaped, unequal. Fl. imperfect, separated.

627. Torilis. Fr. ovate, slightly compressed laterally. Seeds villous, rough, with scattered prominent, 
ascending, rigid prickles. Cal. short, broad, acute, nearly equal. Pet. inversely heart-shaped, nearly equal. Fl. united.

628. Oliveria. Leaflets of the involucres 3-parted. Umbels fascicled, as long as the involucres. Petals split to the base. Fr. ovate, hispid, with three streaks.

629. Ledeburia. Involucres $\mathbf{O}$. Fr. ovate, with spreading bristles. Bases of styles 2, conical, connate at base. Styles persistent.

630. Myrrhis. Fr. deeply furrowed. Cal. none. Pet. inversely heart-shaped, rather unequal. Fl. recept. none. Flowers imperfectly separated.

631. Bunium. Fr. slightly ribbed. Cal. small, acute, unequal. Pet. inversely heart-shaped, equal. Fl. recept. none. Flowers imperfectly separated.

\section{Fruit solid, nearly round, unarmed, without wings.}

632. Enanthe. Fr. ribbed, somewhat spongy. Cal. large, lanceolate, acute, spreading, unequal. Pet. inversely heart-shaped, very unequal. Fl, recept. dilated, depressed. Fl. separated.

633. Crithmum. Fr. ribbed, coriaceous. Cal. small, broad, acute, incurved. Pet. elliptical, acute, incurved, equal. Fl. recept. none. Fl. united, all perfect.

634. Athamanta. Fr, ribbed, ovate, hairy. Styles short. Cal. lanceolate, acute, incurved. Pet. inversely heart-shaped, broadly-pointed, equal. Fl. recept. none. Fl. imperfectly separated.

635. Pimpinella. Fr. ovate, ribbed, with convex interstices. Styles capillary, as long as fruit. Cal. none. Pet. inversely heart-shaped, nearly equal. Fl. recept. none. Fl. either united or diœcious.

636. Phellandrium. Flowers fertile. Fruit crowned. Fruit ovate, smooth, crowned by the calyx and styles, Involucres partial, not universal.

637. Dondia. Umbels capitate. Involucre 6-leaved, longer than umbel. Petals entire. Fruit ovate, solid, with 4 ribs, and convex intervals.

638. Trachyspermum. Leaves of involucre pinnatifid. Fruit striated, with 5 muricated ribs. Rudiments of calyx 5. Fl, receptacle conical. Style withering

639. Ammi. Involucre pinnate or pinnatifid. Fruit oblong, with 5 obtuse ribs, and convex intervals.

640. Bubon. Involucres 0 . Fruit ovate, solid, hispid, or villous, with 5 ribs, and broadish bands of the intervals and raphe.

641. Cuminum. Involucres 5-leaved. Fruit ovate, prismatic, smoothish, bladdery, with 7 ribs, and bearded intervals.

642. Seseli. Common involucre $O$; partial 5-leaved, sometimes 1-leaved. Fruit ovate, solid, with 5 acute ribs, and furrowed, striated intervals.

643. Thapsia. Fruit narrow, but little compressed, scarcely ribbed, with 2 dorsal and marginal wings.

644. Actinotus. Umbel capitate. Involucre woolly, very large. Cor. 0 . Cal, 5 sepals. Male fowers mixed with hermaphrodite. Fruit ovate, villous, with 5 stripes, crowned by the calyx.

645. Trinia. Flowers dicecious. Involucre few-leaved. Pet. ovate, lanceolate. Seeds roundish, with 5 ribs, with the intervals once-banded.

E. Fruit solid, unarmed, without wings, compressed laterally, the diameter of its juncture being at least twice as narrow as the opposite diameter.

646. Sium. Fr ovate or orbicular, ribbed, furrowed. Cal. small, acute, unequal, or obsolete. Pet inversely heart-shaped or obovate, equal. Styles cylindrical, shorter than the petals. Fl. receptacle none. F1. uniform, united.

647. Sison. Fr. ovate or nearly orbicular, ribbed. Cal. obsolete or blunt. Pet, elliptical or inversely heart. shaped, with an involute point, equal. Styles very short and thick. Fl. recept. none. Fl, uniform, united.

648. Cicuta. Fr. nearly orbicular, heart-shaped at the base, with 6 double ribs. Cal. broad, acute, rather unequal. Pet. ovate or slightly heart-shaped, nearly equal. Style scarcely tumid at the base. Fl. recept. depressed, withering. Fl. uniform, nearly regular, united.

649. Conium. Fr, ovate, with 10 acute ribs, wavy in an unripe state. Cal. obsolete. Pet. inversely heartshaped, slightly unequal. Styles a little tumid at the base. F1. recept. dilated, depressed, wavy, permanent. Fi. slightly irregular, united.

650. Smyrnium. Fr. broader than long, concave at each side, with 6 acute dorsal ribs ; interstices convex. Cal. very small, acute. Pet. equal, lanceolate, incurved or inversely heart-shaped. Styles tumid and depressed at the base. Fl. recept. none. El. nearly regular, partly barren or abortive.

651. Apium. Fr. roundish, ovate, with 6 acute dorsal ribs ; interstices flat. Pet. roundish, with an inflexed point, very nearly equal. Styles greatly swelled at the base, Fl, recept. thin, orbicular, wavy. Fl. nearly regular, united

652. AEgopodium. Fr. elliptic-oblong, with equidistant ribs; interstices flattish. Cal. none. Pet. inversely heart-shaped, broad, a little unequal. Style ovate at the base. Fl. recept. none. F1. united, all perfect, slightly radiate.

653. Meum. Fr. eiliptic, oblong, with equidistant ribs; interstices flattish. Cal. none. Pet. obovate, with an inflexed point, equal. Styles tumid at the base, short, recurved. Fl. recept. none. Fl. united, all perfect, regular.

654. Anethum. Invol none. Pet. involute, yellow. Seeds compressed, with 3 ribs; intervals once-banded.

654. Anethum. Invol. none. Pet. involute, yellow. Seeds compressed, with 3 ribs ; intervals once-banded.
655. Carum. Fr. elliptic, oblong, with equidistant ribs; interstices convex. Cal. minute, acute, often obsolete. Pet. inversely heart-shaped, unequal. Styles tumid at the base, subsequently elongated, widely spreading. Fl. recept. angular, thin, wavy, permanent. Fl. separated, irregular.

656. Cnidium. Fr. ovate, acute, with equidistant sharp ribs ; interstices deep, concave ; juncture contracted. Cal none. Pet. equal, obovate or inversely heart-shaped. Styles hemispherical at the base; subsequently elongated, spreading, cylindrical. Fl. recept. annular, thin, undulated, erect, afterwards depressed. Flower

imperfectly separated, nearly regular.
657 . Bupleurum. Fr. ovate-oblong, obtuse, with prominent, acute, abrupt ribs ; interstices flat ; juncture contracted. Cal. none. Pet. equal, broadish, wedge-shaped, very short, involute. Styles very short, not extending beyond the circumference of their broad tumid bases. Fl. recept. none. Fl. all perfect and regular.

658. Hydrocotyle. Fl. nearly orbicular, rather broader than long, angular, much compressed, juncture very narrow. Cal, none. Pet. equal, ovate, spreading, undivided. Styles cylindrical, shorter than the stamens, tumid at the base. Fl. recept. none. Fl. all perfect and regular.

659. Spananthe. Umbel simple, with few rays. Involucre few-leaved. Fruit ovate, solid, smooth, with the juncture and sides contracted, and 5 ribs at the back.

660. Ulospermum. Involucre few-leaved. Germen oblong. Ribs of fruit membranous, wavy, curled. Calyx scarcely any. Fl. receptacle flattened. Styles withering.

F. Fruit solid, unarmed, compressed transversely, the diameter of the juncture being much greater than the opposite diameter.

661. Athusa. Seeds ovate, convex, with 5 tumid, rounded, acutely keeled ribs ; interstices deep, acute, angular; border none. Cal pointed, very minute. Pet. inversely heart-shaped, rather angular. Fl. recept. gular; border none.

none. Fl. all perfect, slightly radiant. and a dilated, flat, even border. Cal. none. Pet. inversely heart-shaped, very slightly irregular. Fl. recept none. Fl, all perfect, scarcely radiant.

663. Selinum. Scales elliptical, slightly convex, with 3 acute dorsal ribs, and a dilated, flat, even border. Cal. minute, pointed, spreading. Pet. inversely heart-shaped, involute, equal. Fl. recept. obsolete. Fl. perfect, regular, a few occasionally abortive. 
664. Angelica. Seeds elliptic-oblong, convex, with 3 dorsal wings, and a narrow, flat, even border. Cal. none. Pet. lanceolate, flattish, undivided, contracted at each end, equal. Fl. recept. thin, wavy, narrow, permanent. Fl. all perfect,

665. Ligusticum. Seeds oblong convex, with 3 dorsal and 2 marginal equal wings. Cal, small, pointed, erect, broad at the base. Pet. elliptical, flattish, undivided, contracted at each end, equal. Fl. recept. none. Fl. all perfect, regular.

666. Hasselquistia. Involucres various. Flowers radiant. Fruit compressed at edge, flat, roundish. Bark turgid in the circumference with 5 obtuse ribs. Fruit in the middle of the umbel deformed, navicular, torn at edge, with 3 stripes at back.

667 . Artedia. Fruit oblong, compressed, with the marginal wings sinuated, 5 dorsal ribs, and scaly juncture. Flowers radiant. Involucres pinnatifid.

668. Ferula. Fruit compressed, flat, thickened at edge, with 3 obtuse dorsal ribs, and banded intervals and juncture. Flowers polygamous Involucres various.

669. Laserpitium. Fruit oval, somewhat compressed, with the 3 principal ribs acute, the secondary winged. Involucres many-leaved.

\section{G. Fruit thin and almost flat, compressed transversely, without dorsal wings.}

670. Peucedanum. Seeds broadly elliptical, with a notch at each end, a little convex, with 3 slightly prominent ribs, interstices striated, border narrow, flat, even, smooth, and entire. Cal, pointed, ascending. Pet. inversely heart-shaped, all very nearly equal. Fl. recept. none. Flowers regular, imperfectly separated.

671. Pastinaca. Seeds elliptic-obovate, with a slight notch at the summit, very nearly flat, with 3 dorsal ribs and 2 marginal ones; border narrow, flat, thin, even, smooth, and entire. Cal. very minute, obsolete. Pet. broadly lanceolate, involute, equal. Fl. recept. broad, orbicular, wavy, rather thin, concealing the calyx. F1. regular, uniform, perfect.

672. Heracleum. Seeds inversely heart-shaped, with a notch at the summit, very nearly flat, with 3 slender dorsal ribs, 2 distant marginal ones, and 4 intermediate, colored, depressed, abrupt lines from the top; border narrow, slightly tumid, smooth, even, and entire. Cal, of 5 small, acute, evanescent teeth. Pet. inversely heart-shaped, radiant. Fl. recept. wavy, crenate, obtuse. Fl. separated.

673. Tordylium. Seeds orbicular, nearly flat, roughish, without ribs; border tumid, wrinkled or crenate, naked or bristly. Cal. of 5 awl-shaped unequal teeth. Pet. inversely heart-shaped, radiant, variously unequal and irregular. Fl, recept. none. Fl. separated.

674. Astrantia. Umbels fascicled. Involucres as long as umbels. Fruit oblong, surrounded by furrowed, wrinkled, little bladders.

675. Zosimia. Both involucres many-leaved. Petals obcordate, with the little segment involute, acute. Fruit compressed, villous, thickened at edge, at the back with 4 bands, which are jointed and conniving.

\section{H. Fruit with a coarse, corky, or spongy bark.}

676. Rumia. Partial involucre, 3-8-leaved. Cal. 5-toothed. Petals ovate, incurved, with a short crenulate segment. Seeds ovate, fleshy, rugose, scaly.

677. Cachrys. No involucre. Cal. O. Petals ovate, lanceolate, acute. Seed obovate, oblong, rounded, smooth, fungous.

678. Hippomarathrum. Fruit with scaly, rough ribs, covered with a thick bark.

\section{Order 3. TRIGYNIA. Styos 5 Stamens. 3 Styles.}

1. Flowers superior.

679. Viburnum. Cor, 5-cleft. Berry with 1 seed.

680. Sambucus. Cor. 5-cleft. Berry with 3 seeds.

\section{Flowers inferior.}

881. Rhus. Cal. 5-parted Petals 5. Berry 1-seeded.

682. Cassine. Cal. 5-parted. Petals 6. Berry S-seeded.

683. Spathelia. Cal. 5-leaved. Petals 5. Caps, 3-angular, 3-celled. Seeds solitary.

684. Staphylea. Petals 5. Caps. 2 or 3 , inflated.

685. Tumarix. Pet. 5. Caps. of 3 valves. Seeds numerous, feathered.

686. Turnera. Cal. 5-cleft, infundibuliform; the outer 2-leaved. Petals 5, inserted in the calyx. Stigmas many-cleft. Caps. 1-celled, 3-valved.

687. Drypis. Cal. 5-toothed. Petals 5. Caps, cut round, 1-seeded.

688. Alsine. Cal. 5-leaved. Pet. 5 equal. Caps, superior, 1-celled, 3-valved, many-seeded. Receptacle central, free.

689. Telephium. Cal. 5-leaved. Petals 5, inserted in the receptacle. Caps. 1-celled, 3-valved.

690. Corrigiola. Pet. 5. Seed 1, naked, triangular.

691. Pharnaceum. Cal. 5-leaved. Cor. O. Caps. 3-celled, many-seeded.

692. Portulacaria. Cal, 2-leaved. Petals 5. Seed 1, winged, 3-cornered.

693. Basella. Cal. O. Cor. 7-cleft; at length berried, with the two opposite segments larger than the rest.

\section{Order 4. TETRAGYNiA. 5 Stamens. 4 Styles.}

694. Parnassia. Nectaries fringed with bristles bearing globes. Caps. of 4 valves. *

695. Evolvulus. Cal. 5-leaved. Cor. rotate, campanulate, with emarginate lóbes, Styles 2, deeply bifid, Stigma simple. Caps. 2-celled, 4-valved, 4-seeded. Seeds 2.

\section{Order 5. PENTAGYN1A. 5 Styles.}

\section{Flowers superior.}

696. Aralia. Involucre very small. Umbels globose. Cal, very small, 5-toothed. Petals 5, ovate, oblong, spreading, or reflexed. Stigmas nearly round, 5-10. Berry roundish, crowned, 5-seeded. Seeds hard, oblong. 697. Actinophyllum. Cal, an entire rim. Cor. calyptrate, jumping off. Stam. 5-6-8-9. Styles 4-7. Berry with 7 angles and 7 cells. Seeds solitary, bony. Flowers clustered.

\section{Flowers inferior.}

698. Rochea. Cal, 5-parted. Cor, funnel-shaped, 5-cleft. Scales 5, at base of ovary. Caps, 5.

699. Crassula. Cal. 5-leaved. Pet. 5. Scales 5, nectariferous at base of ovary. Caps. 5 .

700. Gisekia. Cal. 5-leaved. Cor. O. Caps. 5, close together, roundish, 1-seeded.

701. Linum. Pet. 5. Capsule of 10 cells.

702. Drosera. Pet. 5. Caps, of 3 valves, with many seeds. 
703. Commersonia. Cal. 1-leaved, bearing the cor. Petals 5. Nectary 5-parted. Caps. 5-celled, echinate. 704. Rulingia. Petals 5, with a cucullate base. Sterile stamens 5, undivided. Ovary 5-celled. Caps. with double septa.

705. Armeria. Cal. 2-leaved, entire, plaited, scarious. Petals 5. Seed 1, superior. Flowers in heads, with a common many-leaved involucrum.

706. Statice. Cal, 2-leaved, entire, plaited, scarious. Petals 5. Seeds 1, superior. Flowers scattered in a panicled or spiked scape.

\section{MONOGYNIA.}

Nyctaginea $S p$

322. MIRA'BILIS. $\boldsymbol{W}$.

\begin{tabular}{|c|c|c|c|}
\hline 322. MIRA'BILI & VE & F & \\
\hline 1855 dichótoma $W$. & forked & * & or \\
\hline 1856 Jalápa $W$. & common & * & or \\
\hline$\beta$ fláva & yellow-flowered & & or \\
\hline rálba & white-flowered & ћ & or \\
\hline ¿ rubro-álba & red and white & * & or \\
\hline 1857 hýbrida $W$. en. & close-flowered & 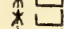 & or \\
\hline 1858 longiflóra $W$. & long-flowered & \# & or \\
\hline $\begin{array}{l}\text { 323. A BRO'NIA. Juss. } \\
1859 \text { umbelláta } \boldsymbol{J} \text {. }\end{array}$ & $\begin{array}{l}\text { Abronia. } \\
\text { umbelled }\end{array}$ & $\varepsilon$ & el \\
\hline 324. PLUMBA'GO. $W$. & LEADWORT. & & \\
\hline 1860 europæ'a $W$. & European & E & or \\
\hline 1861 zeylánica $W$. & cingalese & ti & or \\
\hline 1862 rósea $W$. & Rose-colored & te & or \\
\hline 1863 scándens $W$. & climbing & ne & or \\
\hline 1864 tristis $H . K$. & dark-flowered & 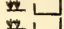 & or \\
\hline $\begin{array}{l}1865 \text { capénsis } W . \\
1866 \text { lapathifólia } W .\end{array}$ & $\begin{array}{l}\text { Cape } \\
\text { Dock-leaved }\end{array}$ & $\frac{12}{x}$ & or \\
\hline 325. $\mathrm{H}$ & Tur & & \\
\hline 1867 peruviánum $W$. & Peruvian & & or \\
\hline $\begin{array}{l}1868 \text { corymbósum } B . M . \\
1869 \text { parviflórum } W .\end{array}$ & large-flowered & 2 & $\begin{array}{l}\text { or } \\
\text { w }\end{array}$ \\
\hline 1870 europæ'um $W$. & European & & or \\
\hline 1871 oblongifólium $L k$. & oblong-leaved & & or \\
\hline $\begin{array}{l}1872 \text { chenopodioides } W . e \\
1873 \text { curassávicum } W .\end{array}$ & $\begin{array}{l}\text { Goose-foot } \\
\text { glaucous }\end{array}$ & E 5 & or \\
\hline 1874 húmile $\mathrm{Lam}$. & & 童 & or \\
\hline 1875 indicum $W$. & Indian & & or \\
\hline 1876 sup & & & or \\
\hline
\end{tabular}
855 dichótoma

J Jáva

r álba

S rubro-álba

\& rubro-fláva

1858 longiflóra $W$.

323. A BRO'NIA. Juss

324. PLUMBA'GO. $W$

1860 europæ'a $W$

1862 rósea $W$.

1863 scándens $W$

1864 tristis $H . K$

1866 lapathifólia $\boldsymbol{W}$

2 jl.au Y Y

jlau $Y$ Mexico

2 in.s

jn.s

jn.s

jn.s

2 jn.s

2 jn.s

2 jn.s W

Nyctaginece. Sp.

$\frac{1}{2}$ ap.my R California 1823. D s.p

Plumbaginea. Sp. 7-11.

$\begin{array}{llllll}\text { s.o } & \text { B } & \text { S. Europe 1596. C p.l Bot. mag. } 2139\end{array}$

ap.s W E. Indies 1731. Sk s.p Rhed. mal.10.t.8

$1 \frac{1}{2} \mathrm{mr} . \mathbf{j l} \mathbf{R} \quad \mathbf{E}$. Indies 1777. Sk r.m Bot. mag. 230

W W. Indies 1699. Sk s.p Slo.im.1.t.133.f.1

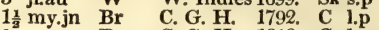

$\begin{array}{llll}\text { C. G. H. } & 1792 . & \text { C } & \text { l.p } \\ \text { C. G. H. 1818. } & \text { C } & \text { l.p } & \text { Bot. reg. } 417\end{array}$

$\begin{array}{lll}\text { C. G. H. 1818. } & \text { C 1.p } \\ \text { Iberia } & \text { 1822. Sk s.p }\end{array}$

\section{Boraginea. $S p .10-77$.}

2 my.s Li Peru 1757. C r.m Bot. mag. 141

4 my.s Li Peru 1808. C r.m Bot. mag. 1609

1 jl.s W W. Indies 1732. C s.l Dil.el.t 146.f.175

$\frac{3}{4}$ jn.o W S. Europe 1562. C s.l Jac, aust.3. t.207

$\frac{s}{4}$ jn.o W S. Europe 1824. S s.1

$\begin{array}{llll}\text { jn.o } & \text { W } & \text { S. Europe 1824. S } & \text { s.i } \\ \text { jn.jl W } & \text { S. Amer. 1823. S } & \text { i.p }\end{array}$

${ }^{\frac{3}{4} \text { jn.jl W W. Indies 1731. C }}$ s.I Mr.s.11.t.31.f.12

1 my.jn W S. Amer. 1752. C s.1 Plum. ic. 227. f. 8

1 jn.au B W. Indies 1713. S s.p Plk. phyt.245. f.4

$\frac{1}{2}$ jn.jl W S. Europe 1640. S co Goua.m.17.c.tab

Boraginea. Sp. 10-29.

326. MYOSO'TIS. $\boldsymbol{B}, \boldsymbol{P}$. ScoRPION-GRASS.

1877 scorpioídes $W$.

1878 arvensis $W$.

1879 nána $W$

1880 obtúsa $\dot{W}$. en.

1881 rupicola $\dot{E}, \boldsymbol{B}$

1882 stricta $L k$

1883 sylvática $\mathrm{E} h \mathrm{r}$. marsh

field

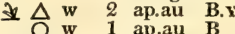

Britain mea. D co Eng. bot. 1973

dwarf $D$ cu 1 jl $B$ Britain dry fi. S co Eng. bot. 480

obtuse-calyxed $\frac{\lambda}{\nabla} \Delta$ w $2^{2}$ jn.jl $\quad$ B Hungary 18̈15. D co Pl.rar.hu.1.t.100

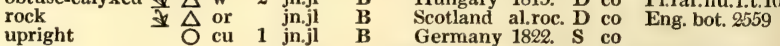

upright $\mathrm{Cu} 1 \mathrm{jn} . \mathrm{j}$ $\begin{array}{lll}\text { Germany } & 1822 . & \text { S co } \\ \text { Europe } & \text { 1823. } & \text { D co }\end{array}$

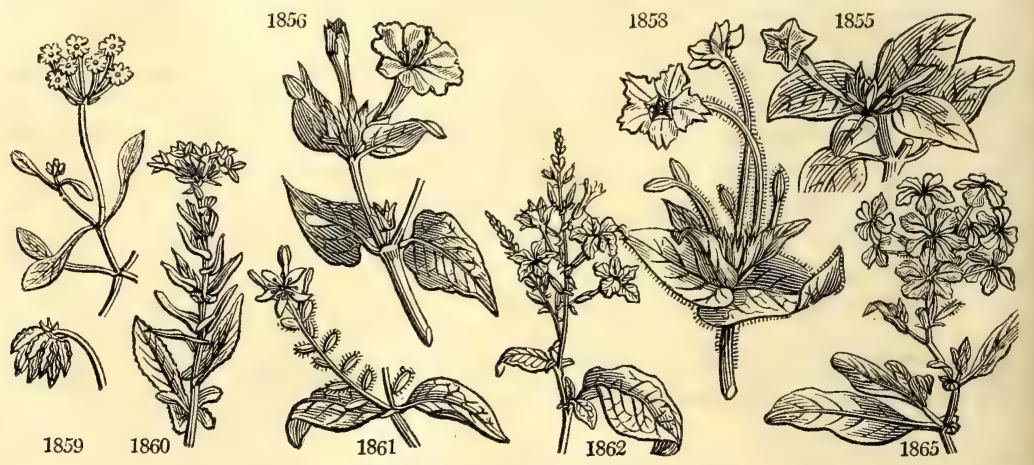

History, Use, Propagation, Culture,

322. Mirabilis, is a Latin word, signifying something wonderful or admirable; and applied with some reason to this, the most fragrant of flowers. Clusius called it Admirabilis. We from the same cause call it Marvel of Peru. The French botanists still call the genus by Van Royen's name, Nyctago ; derived from vez, night, and ago, to act, on account of the flowers expanding at night. M. dichotoma is called the four-0'clock flower in the West Indies, from the flowers opening regularly at that time of the afternoon. M. jalapa is a very ornamental plant in warm borders. When cultivated, it sports into many agreeable varieties. It flowers best when treated as a tender annual, and then planted out ; but if sown at once in the open air, it will flower late in the season in favorable summers. Its large tuberous roots, if taken up and preserved during winter like those of Dahlia, or even covered well with litter in the open garden, will flower perennially. The powder of these roots washed, scraped, and dried, is one of the substances which form the jalap of druggists.

323. Abronia. Derived from $\alpha \beta \rho \circ$, delicate. The little plant produces flowers surrounded by an involucrum of a charming rose color.

324. Plumbago. Pliny says this plant was so called from plumbum, because it possessed the power of curing a disorder in the eyes called by that name, which appears to have been the same as what we call cataract. There 


\section{Order 6. POLYGYNiA. 5 Stamens. Many styles.}

707. Myosurus. Pet. 5, with tubular honey-bearing claws. Seeds naked. Cal. spurred at the base. 708. Ceratocephalus. Cal. 5-leaved, persistent. Petals 5, with a honey pore at base covered by a scale. Seeds several, naked, attached to a bearded receptacle.

709. Xanthorhiza. Cal. O. Petals 5. Nectaries 5, stalked. Caps. 5, 1-seeded.

710. Sibbaldia. Cal. 10-cleft. Petals 5, inserted in the calyx. Styles from the side of the ovary. Seeds 5.

\section{MONOGYNIA.}

1855 Flowers sessile erect axillary solitary

1856 Flowers clustered stalked, Leaves smooth

1857 Flowers clustered somewhat stalked, Tube of cor. 4 times as long as limb, Leaves cordate smooth 1858 Flowers clustered sessile, Leaves pubescent

1859 The only species, resembling Primula farinosa. Very beautiful

1860 Leaves stem-clasping lanceolate rough, Stem erect

1861 Leaves stalked ovate smooth, Stem filiform

1862 Leaves stalked ovate smooth somewhat toothed, Stem with swollen joints

1863 Leaves stalked ovate smooth, Stem flexuose climbing

1864 Leaves obovate retuse smooth

1865 Leaves stalked oblong entire glaucous beneath, Stem erect

1866 Leaves stem-clasping lanceolate smooth, Stem divaricating

1867 Leaves lanceolate ovate, Stem shrubby, Spikes numerous aggregate corymbose

1868 Leaves oblong lanceolate, Stem shrubby, Spikes terminal aggregate corymbose, Sepals long subulate

1869 Leaves ovate rugose scabrous opposite and alternate, Spikes in pairs

1870 Leaves ovate entire tomentose rugose, Spikes in pairs

1871 Leaves stalked oblong obtuse entire rough with scattered hairs

1872 Leaves lanceolate glaucous smooth obsoletely veined opposite and alternate, Spikes in pairs

1873 Leaves linear lanceolate glaucous smooth opposite and alternate, Spikes in pairs or compound

1874 Leaves ovate lanceolate villous, Spikes solitary lateral stalked

1875 Leaves cordate ovate subserrate rugose, Spikes terminal simple solitary, Stem herbaceous

1876 Leaves ovate entire tomentose plaited, Spikes solitary and in pairs

1877 Cal. 5-toothed smoothish, Teeth nearly equal obtuse as long as the tube of cor. Leaves lanceolate obtuse smooth, Limb of cor. more than twice as long as cal 1878 Stem hairy, Calyx with dense spreading hairs hooked at the end

1879 Seeds smoothish sawed at edge, Stem simple few-flowered and objong, Leaves villous

1880 Stem nearly sim. with lanc. nearly acute somew. repand lvs. hispid, Sp. in pairs somew. corym. Cal. very obt. 1881 Seeds naked, Radical leaves stalked, Racemes without bracteæ, Hairs of calyx spreading.

1882 Stem diffuse, Branches and flower-stalks much shorter than cal. Leaves oblong ovate obtuse upright

1883 Cal. spreading 5-parted, Segments unequal acute, Hairs long downy

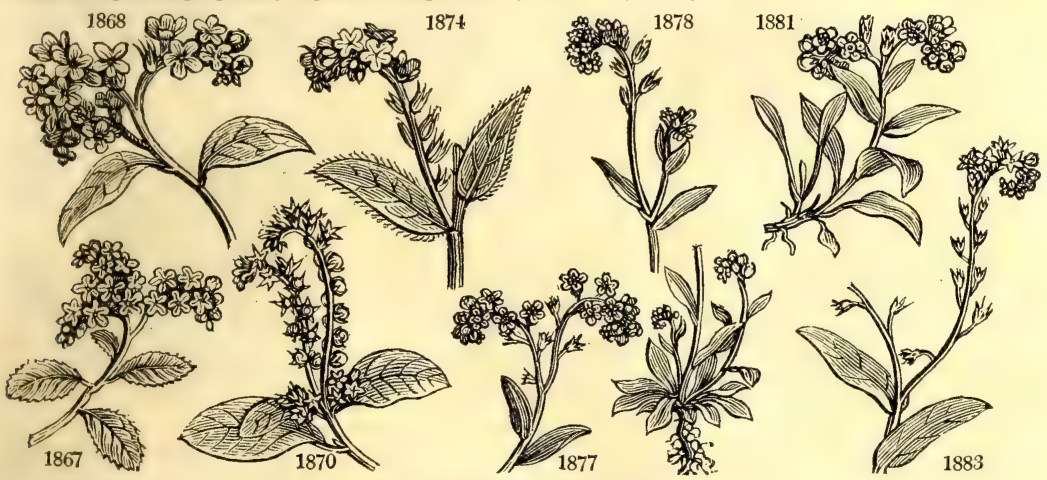

and Miscellaneous Particulars.

is also a modern reason for the application of the name to this genus. $\mathbf{P}$. europæa is called toothwort, and dentelaire, Fr., from its curing the tooth-ach, for which purpose the bruised root is chewed, when it excites by its causticity a healthy salivation, but stains the teeth of a lead color. The species are all pretty, easily cultivated, and almost always in flower.

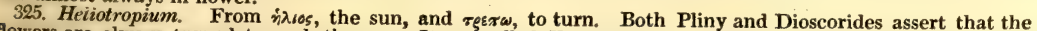
flowers are always turned towards the sun. It was called Verrucaria by the Iatins, because the juice of the leaves mixed with salt was said to be excellent in removing warts, verruca. $\mathbf{H}$. peruvianum and europæum are popular plants, with the smell of new hay: the former is rather tender; but both keep flowering during most of the summer months. Curtis recommends keeping $\mathbf{H}$. peruvianum in a stove during winter.

326. Myosotis. So named from $\mu \nu s$, a rat, and $\dot{\varepsilon} 5$, ózos, an ear. Its oval velvety leaves are like the ear of a rat or mouse. M. scorpioides, Forget-me-not, has its specific name from the racemes of flowers, which, when young, bend in at the top like a scorpion's tail. It is a well known sentimental flower, will grow any where, and varies more than most plants with situation. On dry walls and rubbish, it is dwarfish, rough, and hairy, not rising when in flower more than two or three inches; in muddy ditches it is smooth all over, of a shining light 
1884 suavéolens $\boldsymbol{W} . K$. sweet-scented $₫ \Delta$ or $\frac{1}{2}$ jn.jl B Hungary 1823. D co 1885 sparsiflóra Mik. scattered $\mathrm{O}$ or 1 my.jn $\mathbf{B}$ S. France 1822. S co 1886 pedunculáris Trev. stalked $\cdots \quad \mathrm{O}$ or $1 \frac{1}{2}$ my.jn B

327. ECHINOSPER'MUM. $\boldsymbol{S} w$. Echinospermum. Boraginea. 1887 virginiánum $\boldsymbol{P} . \boldsymbol{S}$. Virginian \& $\mathrm{O}$ or 2 jn.jl W 1888 Láppula $P . S$. common 1889 squarrósum $P . S$. squarrose 1890 barbátum Lehm. bearded

\section{MA'T'TIA. Sch.}

1891 umbelláta Sch. 1892 lanáta Sch. Matria. umbelled woolly

329. TIARI'DIUM, Lehm. TIARIDIUM. 1893 indicum Lehm. Indian

330. LITHOSPER'MUM, $\boldsymbol{W}$. Gromwell. 1894 officinále $W$. officinal 1895 arvénse 1896 ápulum $W$ corn small

1897 purp.-cærúleum $W$. creeping 1898 fruticósum $W$. 1899 dîstichum $P$.S 1900 tenuiflórum $W$ 1901 dispérmum $W$. 1902 orientále $W$. 1903 canéscens Lehm. shrubby two-rowed two-seeded yellow

331. BAT'SCHIA. Mich. Batschia. 1904 Gmelini $P h$. 1905 longiflóra $P h$.

332. ONOS'MA. $W$. 1906 simplicissimum 1907 taúricum $H . K$ 1908 orientále $W$. 1909 echioídes $W$. 1910 seríceum $\boldsymbol{W}$. 1911 arenárium $W, K$ 1912 trinérvium Lehm. 333. ANCHU'SA. $W$.

1913 paniculáta $W$. 1914 capénsis $W$. 1915 officinális $W$ 1916 ochroleúca Bieb. $\beta$ itálica W.

1917 angustifólia $W$ 1918 Barrelieri Dec. 1919 rupéstris $R$. Br 1920 unduláta $W$. 1921 tinctória $W$. 1922 sempervirens $W$ 1923 Milléri W. en.
Gmelin's

long-flowered

Onosma.

linear-leaved

golden-flowered $\frac{\$ 2}{2} \Delta$ or oriental hairy hairy silky-leaved sand

\section{Bugloss.} panicled Cape common pale-flowered Italian narrow-leaved Barrelier's rock waved-leaved dyer's dyer's pink
Virginia 1699. S co

my.j1 Y Carolina 1812. D co
Astracan 1824.

Sp. 4-16. Europe 1656. S co Siberia 1802. S co Tauria 1823. S co or 2 ap.au $\mathbf{B}$ Boraginea. Sp. 2-4.

ve $\Delta$ or 1 my.jn $R$ Hungary 1822. D s.l Pl.rar.hun.t.148 $\mathrm{V}$ or 2 jn $\mathrm{Pk}$ Levant 1800. D s.l Ann.mus.10.t.37 Boraginea. Sp. $1-3$. Lلم or 1 jn.jl B W. Indies 1820. S s.l Plk. phyt.245.f.4 Boraginea. Sp. 10-35. $\triangle$ cu 2 my.au Y Britain ch.hil. D co Eng. bot. 134 w 2 my.jn W Britain cor.fi. S co Eng. bot. 123 O cu $\frac{1}{2}$ jn.jl $\quad$ Y $\quad$ S. Europe 1768. S co Col. ecph.1.t.185 * $\Delta$ or 1 my Pu * or 2 myjn $B$ Nor 11 myjn O or $\frac{1}{2}$ my.jn $B$ O or $2^{\frac{1}{2} \text { jn.jl }} \quad \mathbf{B}$

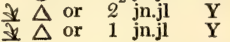

Boraginea, Sp. 2-4.

England ch so. D co Eng bot 117 S. Europe 1683, C co Barr.ic. 1168

Cuba 1806. D co Egypt 1796. S co 1799. S co Linn, dec. 1. t. 7 1713. D co Bot. mag. 515 my.jl Y Missouri 1812. D co

\section{Boraginea. Sp.7-23.}

1 ap.jn Y Siberia 1768. D s.1 Bot. mag. 2248 $\frac{1}{2}$ ap.jn $\quad \mathbf{Y}$ Caucasus 1801. D s.1 Bot.mag. 889 $\frac{1}{2}$ my.jn $Y$ Levant 1752. D s.1 1 mr.jn W S. Europe 1683. D s.I $\frac{1}{2}$ jn.jl $\quad Y \quad$ Levant 1752. D co Jac. aust. 3.t.295 1 ap.jn Y Hungary 1804. D s.1 W.et.K.hu.t.279 S. Amer. 1824, C s.I Lehm ic.asp. t.9

Boraginea. $S p .11-50$.

2 my.jn B Madeira 1777. C p.l Fl. græc. 163 $\frac{1}{4}$ j1 $\quad$ B $\quad$ C. G. H. 1800 . S p.1 Bot. rep. 336 2 jn.o Pu Britain sea co. D co Eng. bot. 662 2 jl.au Pa.Y M.Caucas.1810. D co Bot. mag. 1608 4 jn.o R.Pu S. Europe 1597. S co Bot. reg. 483 2 my.jn Pu S. Europe 1640. D co Bot. mag. 1897 2 my.jn B S. Europe 1820. D co Bot. mag. 2349

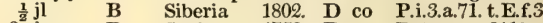
$2^{\frac{1}{2}}$ jn.au B Spain 1752. D co Bot. mag. 2119 1 1 juain 1752. D co Bot. mag. 2119 Montpel. 1596. D Britain rub. D co Eng. bot. 45
Levant 1713. D co

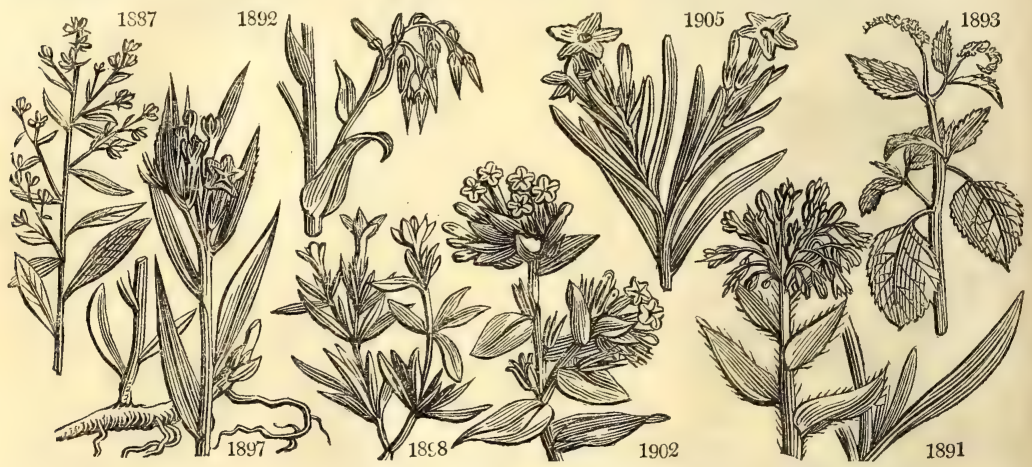

History, Use, Propagation, Culture,

green, and two or three feet high. In common soils, as in a garden or loamy corn-field, it assumes an inter mediate character. Linnæus considers the plant as deadly to sheep. In gardens it does well in pots in the shade, or treated as a bog-plant, than which few better deserve the name of pretty.

327. Echinospermum. Named by Lehmann from $\varepsilon$ ¿vos, a hedgehog, and $\sigma \pi \varepsilon \rho \mu n$, seed, the seeds being very prickly, by which character, and their being compressed, not depressed, and the bracteæ of the inflorescence, the genus is principally distinguished from Myosotis and Cynoglossum.

328. Mattia. A genus divided by Professor Schultes from Cynoglossum, with which it agrees in general character. Named after some unknown botanist.

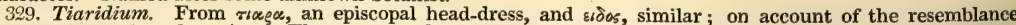
between its seeds and a mitre. Three species have been described, of which one is the H. indicum of Linn., a plant of no beauty or merit.

330. Lithospermum. From $\lambda \sigma \rightarrow \omega_{5}$, a stone, and $\sigma \pi \varepsilon \rho \mu n$, seed, the seeds being hard and shining, like little pebbles. L. officinale has stony, brittle, egg-shaped nuts, exquisitely polished, grey or yellowish; and being considered like a stone, were for that reason used as a cure for the disease so named. The bark of $L$. arvense abounds with a deep red dye, which stains paper, linen, \&c. and is easily communicated to oily substances, like the alkanet root, and hence is called bastard alkanet. The country girls in the north of Sweden stain their faces with the root on days of festivity. 
1884 Stem nearly simple hispid, Leaves lanc. acute hairy ciliated at base, Cal. very spreading

1885. Stem branched diffuse, Lvs. lanc. acute hispid, Racemes simple elongated, Flow. very remote, Cal. acute 1886 Stem branched, Leaves obovate obtuse mucr. Fl.-stalks in fruit much spreading thickened under calyx

1887 Seeds all over prickly, Leaves ovate oblong, Racemes divaricating

1888 Seeds with a double row of marg. prickles, Lvs. lanc. with incumb. hairs, Limb of cor. camp. longer than cal. 1889 Seeds with a single row of marginal prickles, Leaves obl. obtuse with spreading hairs, Cal. as long as cor. 1890 seeds with a doub. row of very short mar. prickl. Lvs. lanc. with incum. hairs, Cor. twice as long as cal. with a flat limb

1891 Stam. as long as cor. Segments of cor. obtuse, Racemes terminal umbelled, Leaves hoary 1892 Cal. woolly, Limb of cor. acute deeply 5-cleft, Racemes cernuous

1893 Stem herbaceous erect hairy, Leaves ovate cordate acute hairy, Tube of cor. twice as long as calyx

1894 Seeds smooth, Cor. scarcely longer than calyx, Leaves lanceolate acute veiny

1895 Leaves lanceolate linear strigose, Cal. the length of cor. spreading in fruit

1896 Leaves linear lanceolate acute, Spikes terminal 1-sided, Bractes lanceolate, Seeds muricated

1897 Seeds smooth, Cor. much longer than cal. Leaves lanceolate acute at each end, Stem herbaceous

1898 Leaves linear hispid revolute at edge, Stamens as long as corolla

1899 Seeds smooth, Cor. twice as long as cal. Lvs. obl. lanc. acute, Spikes leafy distichous term. and axillary

1900 Leaves linear lanceolate strigose, Cal, as long as tube of cor. in fruit conniving

1901 Seeds smooth, Cal. spreading incurved, Leaves linear

1902. Flower branches lateral, Bractes cordate stem-clasping

1903 Stem nearly simple villous, Leaves oblong obtuse hoary, Tube of cor. twice as long as calyx

1904 Hairy, Floral leaves ovate, Cal. long lanceolate

1905 Silky, Leaves linear, Cal. long linear, Corolla crenate, Tube long

1906 Hirsute, Hairs prost. scattered, Fl.-stems simp. aggregate, Lvs. lin. acute, Anthers shorter than filaments 1907 Flowers ventricose, Fruit erect, Leaves lanceolate hispid, Hairs stellulate

1908 Flowers cylindrical acute, Fruit pendulous, Leaves linear hairy

1909 Hispid, Hairs erect scattered, Stem branched, Leaves lanceolate, Anthers as long as filaments

1910 Silky, Hairs prostrate very minute, Stems branched, Leaves spatulate, Anthers as long as filaments

1911 Flowers clavate cylindrical, Leaves oblique the lower lanceolate obtuse, Fruit erect, Seeds smooth

1912 Stem simple leafy, Leaves linear lanceolate very long acute 3-nerved above hispid beneath closely hairy

1913 Leaves lanceolate strigose entire, Panic. dichotomous divar. Flower stalked, Cal. 5-parted subulate

1914 Leaves lanceolate callous villous, Racemes trichotomous

1915 Leaves lanceolate strigose, Spikes 1-sided imbricated, Cal. as long as tube of corolla

1916 Leaves linear-lanceolate coarsely dotted hispid, Calyx in fruit camp. nodding

1917 Racemes nearly naked in pairs

1918 Leaves oblong entire narrowed at both ends with the simple stem hispid, Peduncles trifid

1919 Leaves linear lanceolate villous, Racemes alternate

1920 Strigose, Leaves linear toothed, Stalks less than bracteæ, Cal. in fruit inflated

1921 Leaves oblong, Bractes longer than the 5-parted calyx, Valves of corol. shorter than stamens

1922 Leaves ovate strigose, Racemes somewhat capitate in pairs leafy, 2-leaved at base, Cal. 5-cleft

1923 Leaves obl. toothed hispid the lower stalked the upper sessile, Flowers single lateral, Stems diffuse

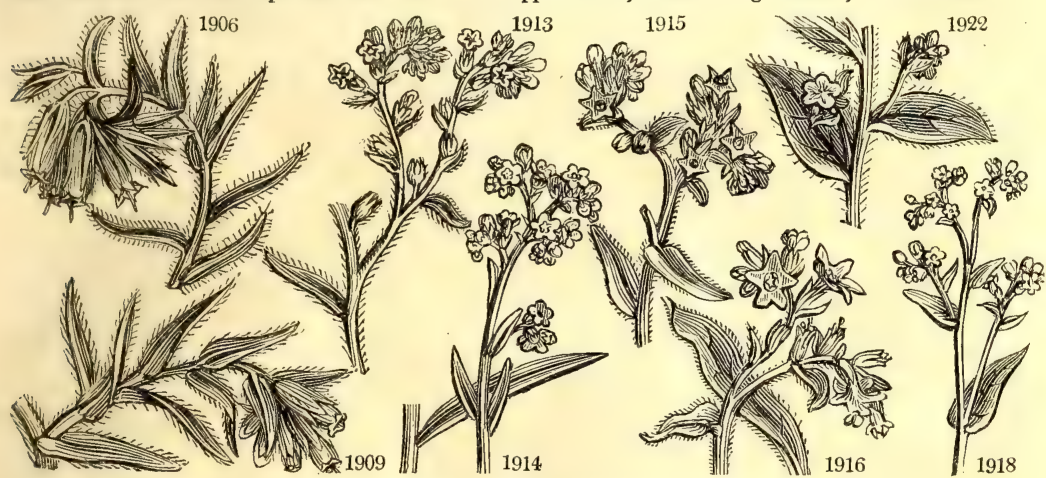

and Miscellaneous Particulars.

331. Batschia. Named in honor of John George Batsch, a German professor of botany in the university of Jena, in the latter part of the last century. His works upon Fungi are still quoted. The three species known are natives of North America, and are very pretty plants.

332. Onosma. An ancient name, the origin of which, from ovos, an ass, and or $\mu$, smell, as being a plant with flowers grateful in their smell to asses, is not very certain. What was intended by Pliny and Dioscorides as Onosma has not been satisfactorily ascertained. It was undoubtedly a plant of this family. This wild state is found chiefly on rocks; and like most temporar ,

333. 333. Anchusa. Derived from ar xov $\%$, paint. In early times, the root of A. tinctoria was used for staining the features when more delicate colors were unknown. The English name Bugloss has been formed from $\beta$ s $s$, an $o x$, and $\gamma \lambda \omega \sigma \sigma \alpha$, a tongue, in allusion to the long rough leaves. A. officinalis is nearly allied in qualities to Borago. The tube of the corolla is melliferous, and very attractive to bees; the leaves are juicy, and the roots mucilaginous, and used in Chin for promoting the eruption of the stances, as and by vintnell as to spirits of wine. It is used chiefly by the apothecaries for coloring plaisters, lip-salves, \&c. and by vintners for staining the corks of their port wine bottles, or for coloring and flavoring the spurious compounds sold as port wine. 
334. SYM'PHYTUM. $\boldsymbol{W}$. CoMfREY.

1924 officinále $W$.

$\beta$ patens Sibth. spreading

$\gamma$ bohémicum Sch. red-flowered

1925 tuberósum $\boldsymbol{W}$.

1926 orientále $W$. en.

1927 tauricum $\dot{W}$. en.

en. blistered

1928 aspérrimum $\boldsymbol{H}, \boldsymbol{K}$. roughest

1929 cordátum $W$.

1929 cordátum $W$. heart-leaved $\$$

1931 mólle $M$.

336. CYNOGLOS'SUM. $W$ Hound's-T

1932 officinále $W$. common

1933 sylvátıcum $E$. B. green-leaved

1934 pictum $W$ Madeira

1935 amplexicaúle $P h$. stem-clasping

1936 cheirifólium $W$. silvery-leaved

1937 apenninum $W$. en. Apennine

1938 hirsútum $W$. hirsute

1939 glomerátum Fraz. clustered to

337. OMPHALO'DES. Lehm. VENUS' NAVEL

$\begin{array}{ll}1940 \text { vérna Lehm. } & \text { blue } \\ 1941 \text { linifólia Lehm. } & \text { common } \\ 1942 \text { nítida Lehm. } & \text { shining }\end{array}$

1942 nitida Lehm, shining

338. PULMONA'RIA. $\boldsymbol{W}$. Lungwort

1943 angustifólia $W$. narrow-leaved

1944 officinális $W$.

1945 davúrica Fisch.

1946 paniculáta $W$.

1947 lanceoláta $P h$.

1948 virgínica $W$.

1949 sibirica $W$.

1950 maritima $\dot{E} . B$.

1951 móllis Wulf.

1952 azúrea Bess.

339. CERIN'THE. $\boldsymbol{W}$.

1953 májor $W$.

1954 áspera $W$.

1955 minor $\boldsymbol{W}$.

1956 maculáta $W$.

340. BORA'GO. $W$.

1957 officinális $W$

1958 orientális $W$.

1959 laxiflóra $B$. $M$

1960 crassifólia Vent.

common

Daurian

spear-leaved

Virginian

Siberian

sea

soft

sky-blue

HoNeXWORT

great

rough

small

spotted

Borage.

common

oriental

bell-flowered

thick-leaved

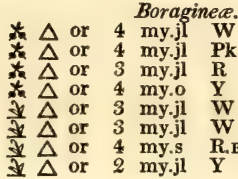

Boraginea.

$\Delta$ or 1 jn $Y$

Boraginea.

2 jn.jl P.R Sp. 8-40

$\neq$ OD or 2 jn.jl P.R Britain rub. S co Eng. bot. 921

3 jn.jl B Britain sha. la. S co Eng. bot. 1649

(D) 1 or 2 au L.B Madeira $1658 . \quad$ Bot. mag. 2134

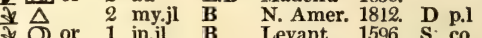

\$ 0 or 1 jn.jl B Levant 1596. S co

Q 6 ap.jl $R$ Italy 1731. D co

1 jl.au L.B C. G. H. 1806. S co

Boraginea. Sp. 3-10.

f $\Delta$ el $\frac{1}{2}$ mr.ap B S. Europe 1633. D co

or 1 jn.au W Portugal 1648. S co

$\downarrow$ or 3 ap.jn W

Boraginea.

Portugal 1810. D co

Sp. $10-19$.

ฟ $\Delta$ or $\frac{3}{4}$ ap.my V Britain woods. D p.l Eng. bot. 1628

₹ $\Delta$ or 1 my Pk England woods. D p.l Eng. bot. 118

$\neq \Delta$ or 1 my Li Dauria 1812. D s.l Bot. mag. 1743

\$ $\Delta$ or $1 \frac{1}{2}$ my.jn L.B

1 my jn Pu Hud. Bay 1778. D p.l

7 or $1 \frac{1}{2} \mathrm{mr} \mathrm{B}$

$\downarrow \Delta$ or $3^{2}$ jn.jl Pu

\& $\triangle$ or $\frac{1}{4}$ jn.jl B

\$1 $\triangle$ or $\frac{3}{4}$ ap.my $B$

\} \Delta \text { or } 1 \frac { 1 } { 2 } \text { ap.jn } B

Boraginea.

O or 3 jl.au Y.P S. France 1596. S co Bot. mag. 333

$O$ or 2 jl.au Y.P S. France 1633. S co Fl. græe. t. 170

O or $1 \frac{1}{2}$ jn.o $\quad \mathrm{Y}$ Austria 1570. S co Jac. aus.2.t. 124

\2 or 2 jn.o Y.R S. France 1804. S co

\section{Boraginea. $S p .4-7$.}

O cul is jn.s B England rub. S co Eng. bot. 36

\& $\Delta$ or 2 mr.my B Turkey 1752. D co Bot. reg. 288

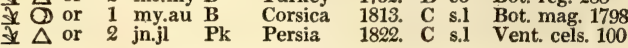

341. TRICHODES'MA. $\boldsymbol{R} . \boldsymbol{B r}$. Trichodesma.

1961 indicum R. Br. Indian

1962 africánum $\boldsymbol{R}$. Br. African

1963 zeylánicum $\boldsymbol{R} \cdot \mathbf{B r}$. Ceylon

1 Boraginea. Sp. 3-4.

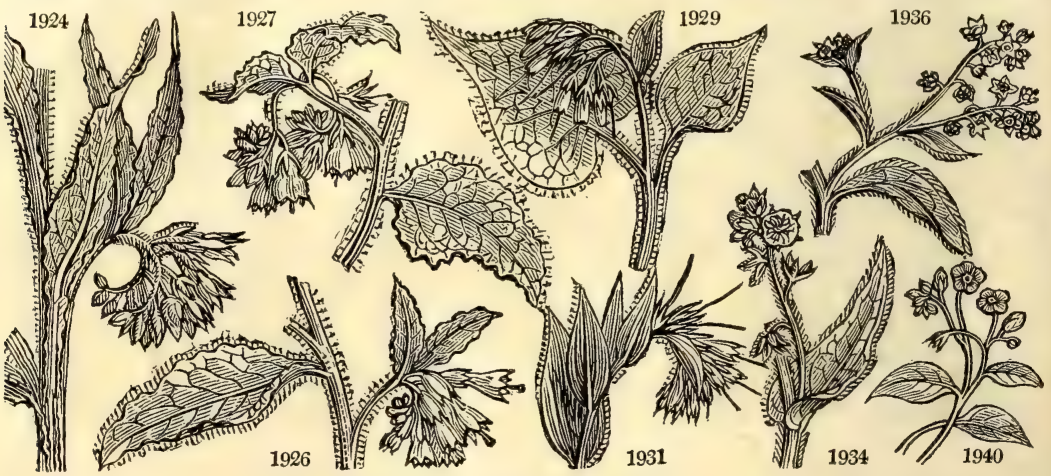

History, Use, Propagation, Culture,

334. Symphytum. Named from $\sigma \nu \mu \varphi v \sigma s$, a union or junction, the plant having for a long time passed for a famous vulnerary. The French name for the plant, Consoude, has the same meaning; but that of the English term Comfrey is obscure. S. officinale abounds in mucilage, and may be substituted for Althæa officinalis. All the species are large, coarse, but showy shrubbery plants, flowering for two or three months together, and $\mathbf{S}$, asperrimum the whole season.

335. Onosmodium. From Onosma and $\varepsilon \delta \circ$, similar to Onosma ; from which it is not very different either in habit or characters.

336. Cynoglossum. From zvwy zuvos, a dog, and $\gamma \lambda \omega \sigma \sigma \alpha$, a tongue. Its long soft leaves have been compared to the tongue of a dog. C. officinale smells like mice, was considered anti-scrophulous, and is disliked by cattle.

337. Omphalodes. From ouф $\lambda_{2 s,}$ a navel, and $\varepsilon \delta \circ$, resemblance; the round seeds, which are depressed in the centre, may be compared to a little navel; for the same cause it is called Navelwort in English. O. linifolia is a common border annual. $O$. verna is a beautiful little plant with blue flowers, like the Forget-me-not, peepiug from among the snow in every cottager's garden in the early spring.

338. Pulmonaria. Derives its name, some say, from the speckled appearance of the leaves resembling diseased lungs; but others think that its name has arisen from the plant having been used with success in pulmonary complaints; whence also, perhaps, the English name Lungwort. It must not, however, be inferred from 
1924 Leaves ovate lanceolate decurrent

1925 Leaves ovate oblong narrowed at base the lower stalked, Segments of flower very short obtuse 1926 Leaves ovate obl. narr. at base hairy the lower stalked the flor. opp. sess. Cal. spread. Segm. of fl. acute 1927 Leaves cordate ovate hairy stalked the floral opp. sess. Segments of flower obtuse, Stem branched

1928 Lvs. cord. ovate or lanc. acumin. stalked very rough, Stem muric. with reversed bristles, Limb of fl. camp. 1929 Leaves cordate ovate acuminate hairy, foral sessile nearly opposite, Stem simple

1930 Hispid, Leaves oval lanceolate acute papillose, Segments of cor. very acute 1981 Hoary, Leaves oblong about 3-nerved, Segments of cor. oval

1932 Leaves broad lanceolate wavy hoary on each side sessile close together, Seeds warted 1933 Leaves spatulate lanceolate shining nearly naked scabrous beneath

1934 Leaves lanceolate tomentose the upper obovate lanceolate cordate stem-clasping, Sepals ovate 1935 Very hairy, Leaves oval the upper' stem-clasping, Corymb. terminal leafless on a long stalk 1936 Leaves villous, Cal. hairy, Stamens longer than corolla

1937 Stamens longer than corolla, Cal, villous, Radical leaves ovate stalked very large

1938 Leaves lanceolate villous, Seeds with hooked prickles

1939 Leaves spatulate obtuse, Flowers heaped

1940 Radical leaves ovate cordate, Cauline ovate stalked, Shoots creeping

1941 Leaves linear lanceolate smooth roughish with little teeth at the edge, Seeds urceolate rugose

1942 Leaves obl. lanc. nerved smooth and shining above pubesc. beneath the lower on long stalks the upper sess,

$1943 \mathrm{Cal}$. length of the tube of the cor. Leaves oblong lanceolate the radical sessile cauline stalked 1944 Cal. length of the tube of the cor. Radical leaves ovate cordate scabrous cauline ovate sessile 1945 Cal. short 5-parted hispid, Radical lvs. ovate cordate stalked, cauline half stem-clasping, Flowers panicled 1946 Cal. short 5-parted hispid, Leaves ovate oblong acuminate hairy

1947 Smooth erect, Radical leaves on long stalks lanceolate, cauline linear oblong, Flowers panicled, Cal, short 1948 Cal. much shorter than tube of cor. which is longer than limb, Radical leaves ovate elliptical cauline ob1949 Cal. short, Rad. leaves cordate

1950 Smooth, Leaves ovate glaucous fleshy, Stem branching procumbent

[ovate lanceolate obtuse

1951 Leaves ovate lanceolate acuminate downy decurrent radical stalked, Cal. longer than tube

1952 Leaves hispid radical obl, lanc. acuminate narr. into the stalk, Cauline decurrent, Cor. campanulate

1953 Cor, obtuse spreading ventricose campanulate at end, Stamens shorter than corolla, Leaves smooth 1954 Cor. obtuse spreading cylindrical, Stamens as long as cor. Leaves rough

1955 Leaves stem-clasping entire, Cor. acute closed whole colored, Segm. of cal, unequal

1956 Leaves stem-clasping entire, Cor. acute closed with a red band in middle, Seg. of cal, uneq. Stems many

1957 Leaves ovate the lower stalked all alternate, Cal. spreading, Pedunc. terminal many-flowered 1958 Leaves cordate stalked, Pedunc. many-flowered, Stamens exserted villous

1959 Leaves alternate oblong sessile, Pedunc. axillary 1-flowered, Cor. campanulate nodding

1960 Glaucous, Stem smooth, Leaves decurrent rough above, Segments of cor. lin. lanc. spreading unequal

1961 Leaves of stem and branches lanc. half stem-clasping, Pedunc. 1-flowered, Sepals auriculated at base 1962 Leaves opposite stalked ovate, Pedunc. many-flowered, Sepals ovate acute erect

1963 Sepals not auriculated, Nuts smooth without an edge, Leaves sessile attenuated at the base

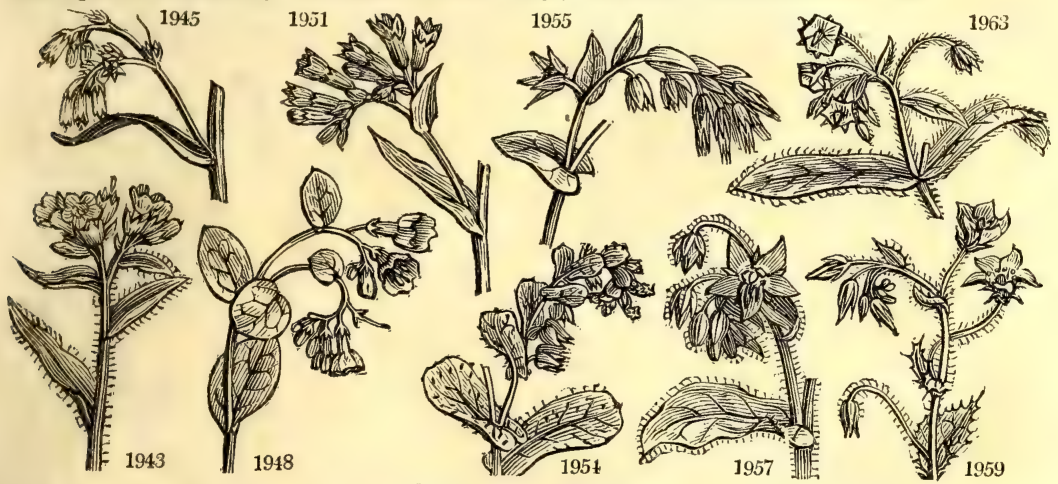

and Miscellaneous Particulars.

Fnglish names of this sort having been applied to plants, either that lungwort was ever used in this country for the lungs, or liverwort for the liver. The truth is, that the old herbalists, or translators of the classical writers upon natural history, made English names after their Latin denominations, without enquiring whether such continued to be applicable or not, and their less informed successors had no difficulty in finding those virtues in the plants which were indicated by the names of the translators. P. virginica, sibirica, and maritima are elegant plants, greatly resembling each other, and considered by some as most probably only varieties. They are among the most elegant ornaments of the flower-garden in dry springs; but they require some care in keeping, unless in a soil almost entirely of sand.

339. Cerinthe. From xmos, wax, and ay. 0 o5, flower, because there is great attraction for bees in the flowers. The French word melinet and the English honeywort have been formed in the same sense c. major is a shewy border annual, much frequented by bees. In Italy and Sicily it is very common, and a biennial.

340. Borago, is said by Apuleius to be an alteration of corago, and to have been named on account of its cordial qualities. Pliny says that wine, with this infused in it, cheers the spirits. B. officinalis was formerly in great repute as a cordial. According to Withering, the young leaves may be used as a salad or as a pot-herb, and the flowers form an ingredient in cool tankards.

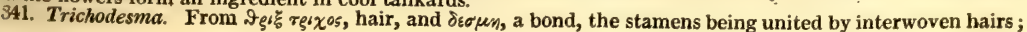


34\%. ASPERU'GO. $W$. 1964 proctimbens $W$.

343. NO'NEA. Mönch 1965 púlla $\mathrm{Dec}$ 1966 lútea $D \varepsilon c$ 1967 rósea $L k$. 1968 nigricans Dec. 1969 violácea Dec. 1970 ciliáta $W$.

\section{LYCOP'SIS. $W$.}

1971 variegáta $W$. 1972 arvénsis $W$. 1973 orientális $\dot{W}$.

345. E'CHIUM. $W$. 1974 fruticósum $W$. 1975 cándicans $W$. 1976 grandiflórum $H . K$. 1977 ferocíssimum $B . R$. 1978 gigantéum $W$. 1979 strictum $W$. 1980 argen'teum $W$. 1981 lævigátum $W$. 1982 glábrum $W$. 1983 fastuósum $\dot{H} . K$. 1984 nervósum $H . K$. 1985 spicátum $W$. 1986 glaucophýllum Jacq. 1987 plantagíneum $W$. 1988 itálicum $\boldsymbol{W}$ 1989 rúbrum $\underset{W}{W}$. 1991 violáceum $W$ 1992 marítimum $W$ 1993 pyrenáicum $W^{\prime}$ en. 1994 créticum $W$. 1995 orientále $W$ 1996 lusitánicum $\boldsymbol{W}$. 1997 parviflórum $H . K$.

German-madwort procumbent $* 0$ Nonea.

Boraginese $S p$ yellow rose-colore black-flowered violet ciliated

WiLd-Bugloss. variegated small oriental

VIPER'S-BUGLOSS. shrubby hoary-tree

\section{* J or} great-flowered

prickly-stalked gigantic upright smooth-stalked sea-green spiked-dwarf

glaucous Plantain-leaved white red common $\quad$ \& 0 or 4 jl.au violet-flowered $\$$ O or 2 jl.au

Pyrenean Cretan oriental Portugal small-flowered or or $1^{\frac{1}{2}}$ jlau $O$ or $1 \mathrm{jl} . \mathrm{s}$

or 3 jl.au or 3 jlau Or 2 jl.au

346. TOURNEFOR'TIA $R, B r$ TOURNEFORTI 1998 Messerchindia $R$. Br.shru 1999 Argúzia $R$. \& $S$ 2000 fotidissima $W$ 2001 cymósa $W$. 2002 bícolor $W$. 2003 suffruticósa $\boldsymbol{W}$. 2004 volubilis $W$.

2005 laurifólia $V$ ent 347. NOLA'NA. $W$. 2006 prostráta $\boldsymbol{W}$. 348. ARE'TIA. $W$ 2007 helvética $W$. 2008 alpina $\boldsymbol{W}$. 2009 Vitaliána $W$

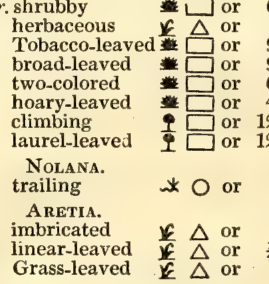
$\frac{1}{2}$ jn.o s jl Boraginea. $\quad$ Sp. 1-7.

Primulacea. Sp. 3-9.

imbricated

linear-leaved

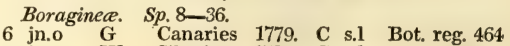

W Siberia 1780. C s.1

Pk Jamaica 1739. C p.l Plu. ic.226. t.230 Pk Jamaica 1777. C p.1 Jac. ic. 1.t. 31 G Jamaica 1812, C p.l

W Jamaica 1759. C p.1 Slo.jm.2.t.162.f.4 G Jamaica 1752. C p.l Slo.jm.1.t.143.f.2 Porto Rico1819. C p.1 Vent. chx. t. 2
$\frac{1}{4} \mathbf{j}$
1761. C p.1 Bot. mag. 731

$\frac{1}{4}$ my.jn W Switzerl. 1775. D s.p Schk. han.1.t.32 my.jn Pk Switzerl. 1775. D s.p Bot. cab. 297
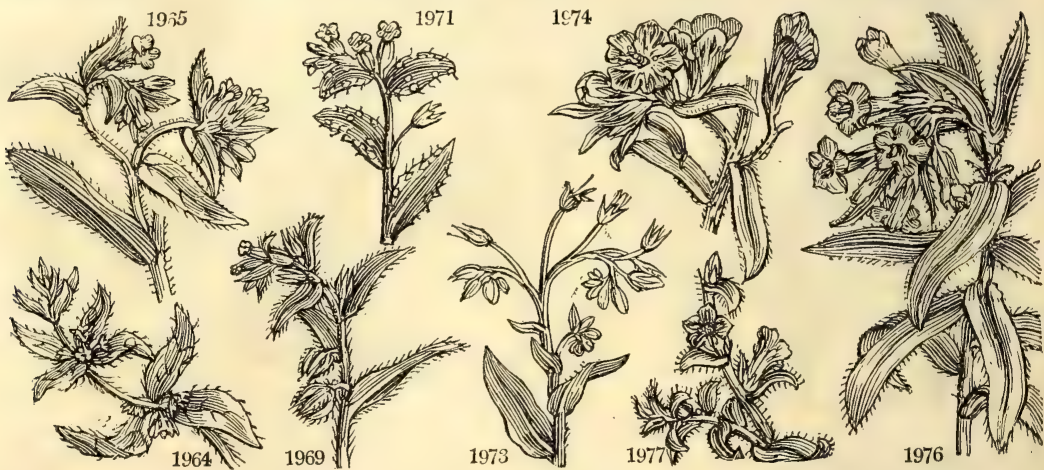

History, Use, Propagation, Culture,

the principal feature in the generic character. This has been separated from Borago by modern botanists; it is a plant of no beauty.

342. Asperugo. So called from its asperity. The only species is a procumbent annual with small blue flow-

ers, founa all over Europe, from Lapland to the Mediterranean. of Lycopsis. The genus was long neglected, but has recently been adopted by both Decandolle and Lehmann. of Lycopsis. The genus was long neglected, the eye. Ingenious people have found a similarity between the 344. Lycopsis. From $\lambda v \approx 05$, a wolf, and o 4 , the eye. All the species are weed-like plants.

small blue flowers of this plant and the eye of a wolf. All the species are weed-like plants. 345. Echium, is an ancient name applied to some plant of this family, and derived from Exss, a viper, from the resemblance between its seeds and the head of a viper. The spotted stem, which may be likened to a snake's skin, affords a reason for the application of the name. All the species are beautiful in their flowers, but rough and un
plants. 
1964 The only species. Stem climbing very rough, Flowers small axillary

1965 Leaves entire, Stem erect, Cal. of fruit inflated pendulous

1966 Leaves obl. lanc. strigose floral cordate longer than the cal. Cal. acute, in fruit inflated pendulous

1967 Cal. 5-cleft, in fruit inflated pendulous, Leaves obl. hispid floral cordate longer than cal. Stems procumb.

1968 Stem procumbent, Leaves entire, Cal. of fruit pendulous, Cor. shorter than calyx

1969 Leaves lanceolate, Stem prostrate, Cal. of fruit inflated nodding 10-angular, Cor. longer than calyx

1970 Leaves lanceolate denticulated hispid ciliated, Cal. of fruit inflated pendulous

1971 Leaves repand toothed callous, Stem decumbent, Corollas nodding

1972 Leaves lanceolate hispid, Cal. always erect

1973 Leaves ovate entire scabrous, Cal, erect

1974 Pubescent, Fl. in loose corymb. Pan. at end of branches, Tube closed by a 5-lobed fringe, Stam. included 1975 Stem shrubby, Leaves lanc. nervose and branches hairy, Sepals oblong and lanceolate acute, Styles hairy 1976 Stem smooth, Leaves lanceolate rough above, Flowers cymose equal, Tube of flower very long

1977 Stem shrubby, Branches and leaves prickly, Flowers in spikes, Corollas nearly equal

1978 Stem shrubby, Leaves lanc. atten. at base hairy, Hairs very short, Bract. and cal. strigose, Stam. exserted 1979 Stem shrubby upright branched, Leaves oblong lanc. hairy, Cor. campanulate small, Stamens exserted

1980 Stem and lanceolate acute leaves silky, Spike terminal nearly simple leafy

1981 Stem smooth, Leaves lanceolate smooth ciliated prickly, Cor. equal

1982 Stem smooth, Leaves lanceolate smooth scabrous at edge

1983 Stem branched, Leaves lanceolate nerved and branches silky, Styles hairy, Racemes cylindrical

1984 Leaves lanceolate nerved and branches silky, Styles hairy, Racemes ovate

1985 Stem villous, Leaves sword-shaped elliptical villous, Spike compound linear oblong

1986 Stem shrubby, Branc. and cal. smooth, Lvs. lanc. glauc. veinl, smooth above with a few coarse hairs at back

1987 Leaves radical ovate lined stalked

towards the end

1988 Stem herbaceous hairy, Leaves linear lanc. strigose hairy lower nerved, Cor. equal, Stamens exserted

1989 Stem erect hispid,. Leaves linear lanceolate hispid, Spike compound terminal, Cor. nearly equal

1990 Stem warted hispid, Cauline leaves lanceolate hispid, Flowers spiked lateral

1991 Cor. as long as stamens, Tube shorter than calyx

1992 Leaves spatulate lanceolate villous, Stam. shorter than corolla

1993 Stem herb. erect panic. hisp. dotted, Lvs. lin. lanc. strigose, Flowers remote, Stamens $\frac{1}{2}$ as long again as cor. 1994 Stem herb. echinate, Lvs. obl. lanceol. hispid little narrowed at base, Stam. as long as cor. Cal. of fr. distant 1995 Stem branched, Cauline leaves ovate, Flowers solitary lateral

1996 Stem nearly simple, Lvs. lanc. rather silky, the radical very long on stalks, Spikes axillary bent backwards 1997 Stamens shorter than cor. Cal. as long as limb, Leaves lanceolate strigose

1998 Stem shrubby, Leaves stalked, Flowers hypocrateriform

1999 Stem herbaceous, Leaves sessile, Flowers funnel-form

2000 Leaves ovate-lanceolate hairy, Peduncles branched, Spikes pendulous

2001 Leaves ovate entire naked, Spikes in cymes

2002 Leaves ovate acuminate smooth above rugose, Spike cymose erect recurved

2003 Leaves nearly lanceolate hoary, Stem half shrubby

2004 Leaves ovate acuminate nearly smooth, Leafstalks hairy, Stem climbing, Cal. 5-parted

2005 Stem climbing, Leaves ovate oblong acute repand smooth, Berry with 4 projections bipartible

2006 Leaves ovate oblong, Cal. pyramidal, Sepals triangular sagittate

2007 Stems rounded, Leaves imbricated, Flowers sessile

2008 Villous, Scapes 1 -flowered

2009 Stem branching, Leaves smooth above, Pedunc. short, Petals conniving

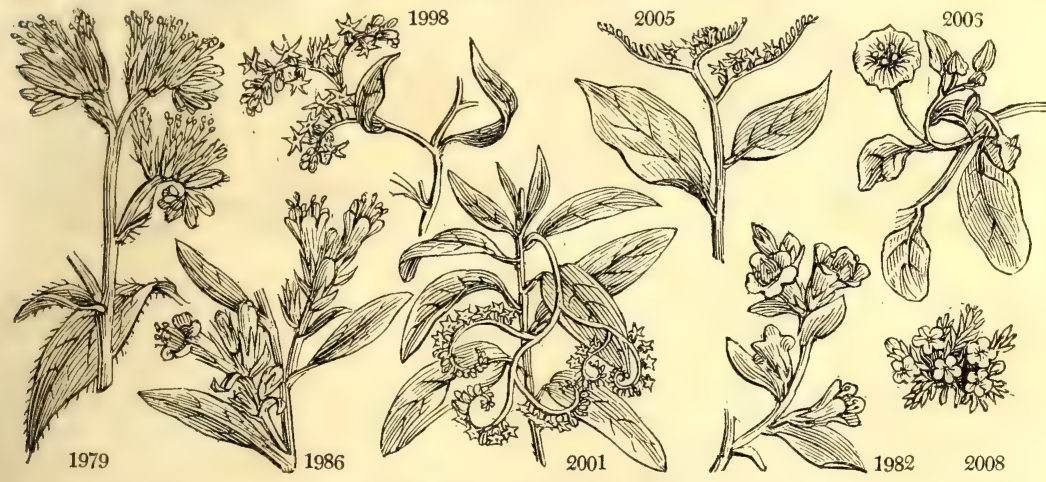

and Miscellaneous Particulars.

346. Tournefortia. So named by Linnæus, after Joseph Pitton de Tournefort, author of an elegant arrangement of plants under the title of Institutiones rei Herbarice, and the father of the French school of botany. The system of Jussieu is founded upon that of Tournefort, or is rather an adaptation of the principles of that botanist to the actual state of the science. The species are by no means handsome either in flowers or foliage, and some cases the latter is even fetid.

347. Nolana. Is a diminution of nola, signifying a bell in low Latin. The name has been applied to this plant on account of its bell-shaped corolla. The species are hardy annuals, of beautiful appearancc when in flower. They may be sown in the spring in the open border, where they will grow without protection.

348. Aretia. In honor of Benoit Aretio, a Swiss, professor in the university of Berne. He died in $1574 . \mathrm{He}$ published a work upon alpine plants, and his name has been applied to a charming alpine genus, said by some, with little reason, not to be distinc from Primula. The species are very delicate, and require good air and skilful cultivation to succeed well. They are peculiarly suitable for rock-work or growing in pots, well drained, and filled with turfy loam and peat. 

2010 máxima $W$. oval-leaved 2011 elongáta $W$ 2012 septentrionális $W$. tooth-leaved 9014 lactifióra Fisch. 2015 Chamæjásme $\boldsymbol{W}$ 2016 láctea $W$. 2017 cárnea $\boldsymbol{W}$. 2018 obtusifólia $W$. 2019 nána Horn.

350. PRI'MULA $W$

2020 vulgáris $\boldsymbol{E}, \boldsymbol{B}$.

Primrose.

plena-álba

S plena-sulpharea

\& plena-rubra

$\zeta$ plena-cuprea

plena-atropurpúrea

จ plena-violáce

2021 elátior $W$

2022 véris $W$.

2023 farinósa $W$.

2024 davúrica Fisch.

2025 cortusoídes $\boldsymbol{W}$.

2026 dentiflóra Andr.

2027 longifólia $\boldsymbol{H}$. $\boldsymbol{K}$.

2028 villósa $W$

$\beta$ flore-albo

2029 nivális $W$

2030 maŕgináta $W$

2031 Auricula $W$.

2032 Palinúri W.en

2033 integrifólia $W$.

2034 finmárchica $\dot{W}$

2035 minima $L$

2036 sinénsis Lindl.

2037 stricta Horn.

2038 scótica Hook.

2039 Pailásii Lehm.

2040 pusilla Hook.

2041 viscósa $W$.

2042 decóra $B$. $M$.
Primulacea. Sp. 10-35.

I mr.jn W Austria 1597. S p.l Jac, aus. 4. t. 331

ap.my W Austria 1776. S p.1 Jac. aus. 4. t. 330

$\frac{1}{3}$ ap.my W Russia 1755. S p.l Bot. mag. 2021

$x^{2}$ jn.jl Pk Pyrenees 1790. D s.p Bot. mag 743

W Wiberia 1806. D s.p Bot mag. 9029

1 jn.s W Siberia 1806. D s.p Bot. mag. 202

1 jn.au Pk Austria 1768. D s.p Bot. cab. 232

青 jn.au W Austria 1752, D s.p Bot. mag. 868

jl.au F $\quad$ Switzerl. 1768. D s.p Bot. cab. 40

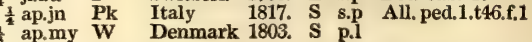

Primulacea. Sp. $23-55$.
Britain woods. D s.I Eng. bot. 4

\begin{tabular}{llll}
$\frac{2}{4}$ mr.my Y & Britain woods. D s.I & Eng. bot. 4 \\
\hline
\end{tabular}

mr.my Pk

$\frac{1}{4}$ mr.my W

mr.my Y

mr.my $R$

$\frac{1}{m r m y ~ O}$

$\frac{1}{4} \mathrm{mr}$.my Pu

$\mathrm{mr} . \mathrm{my} \mathrm{Li}$

mr.my $\mathbf{Y}$

s my.jn $\mathbf{Y}$

jn.jl R

my.jn

my.jl $R$

1 my.jl $R$

$\frac{1}{2}$ ap.my $R$

ap.my $\mathbf{P u}$

$\frac{1}{4}$ ap.my $\mathrm{W}$

$\frac{1}{4}$ mr.ap Pk

$\frac{2}{4}$ ap.my Y

ap.my Y

$\frac{1}{4}$ jn.jl Pk

$\frac{1}{4}$ my.jn V

Britain ... D s.l Bot. mag. 229

Britain $\quad$... $\quad$ D s.l

Britain $\quad \cdots \quad$ D $s .1$

Britain ... D s.l

Britain $\cdots$ D s.l

Britain $\quad \cdots \quad$ D s.1

Britain woods. D s.1 Eng. bot. 518

Britain m. pa. D s.I Eng bot 5

Britain m. pa. D p.l Eng. bot. 6

Siberia 1806. D p.l Bot. mag. 1219

Siberia 1794. D p.l Bot. mag, 399

Siberia 1806. D pl Bot rep. 451

Levant 1790. D p.1 Bot rep.

Switzerl. 1768. D p.l Bot. mag. 14

Switzerl. 1768. D p.l Bot. mag. 1161

Dauria 1790. D s.1 Pal, it. t. G.* f. 2

Switzerl. 1777. D s.l Bot. mag. 191

Switzerl. 1596. D h.1 Jac. aus, 5, t. 415

Naples 1816 D h.l Sweet fl gard 8

Pyrenees 1702 D pl Bot mag 949

Norway 1798. D p.1 Bot. mag. 949

S. Eury 178. D p.l Flor, dan. 188

$\begin{array}{lll}\text { China } & \text { 1820. S s.l } & \text { Sot. reg. } 581 \\ \text { Lind. coll. t. } 7\end{array}$

Denmark 1822. D s.l Fl. dan. t. 1385

Scotland al.hea. D s.l Bot. cab. 652

Altai 1823. D s.l Lehm mon t 3

N. Amer, 1822, D s.l Hook. ex. fi. 68

Piedmont 1792. D p.l All.ped.1. t.5. f.1

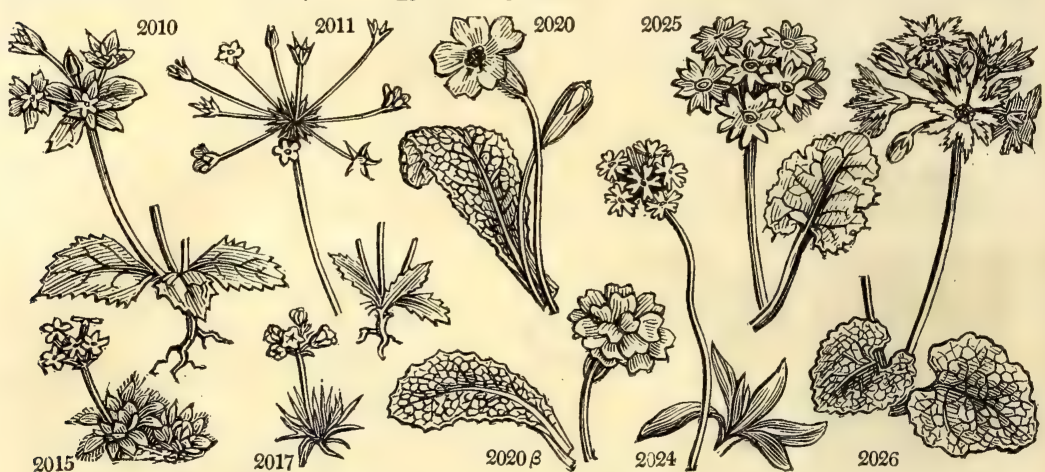

History, Use, Propagation, Culture,

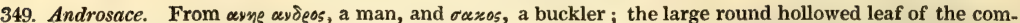
mon Androsace has been compared to the buckler of the ancients. The Androsace of Pliny and others must have been something very different. These are elegant mountaineers which may be treated in all respects as Aretia.

350. Primula, is derived from primus, the first, - to flower; the delicate blossoms of many of the species appearing when all nature is otherwise inert. This genus consists of beautiful dwarf alpine plants, valuable in horticulture, on account of their flowering early in spring, and being prolific in variation.

P. vulgaris is a native of most parts of Europe in woods and hedges on a moist clayey soil. It is generally found with brimstone-colored flowers, and single; but in some places, though rarely, it is found of a white, and again, of a purple hue, and occasionally double. The leaves and roots, which smell of anise, when dried, ground, and used as snuff, act as a sternutatory, and, taken internally, as an emetic. The varieties and subvarieties of this plant are very numerous. Some consider $\mathbf{P}$. veris and elatior as sprung from it, and only more permanent varieties. The Hon. W. Herbert says, he raised from the seed of one umbel of a highly-manured red cowslip, a primrose, a cowslip, and oxlips, of the usual and other colors; a black polyanthus, a hose-in-hose cowslip, and a natural primrose bearing its flower on a polyanthus stalk; and from the seed of the hose-in-hose cowslip he raised a hose-in-hose primrose. (Hort. Trans. iv. 19.) But this requires confirmation, as the circumstance was never before recorded. For distinction's sake we shall consider them as species or subspecies.

The varieties of $P$. vulgaris are arranged by florists in two classes; the first contains all those whose flowers are on separate pedicels, rising from the root upon a common stem, so short as not to be seen without separating the leaves of the plant, and are called primroses. The second class includes all those whose flowers are in umbels on a scape or flower-stalk rising from three to six inches or more, and are called polyanthuses. Of the primroses there are about a dozen beautiful varieties in cultivation; and of the polyanthus an innumerable number, geadily added to by propagation from seed. The names of the varieties, with the exception of the double sorts riven above, are entirely arbitrary. The rules for judging of the beauty or merits of a variety are also wholly artificial, and founded on an inaginary form far removed from ordinary nature. These rules or canons are 
2010 All villous, Leaves ovate oblong and sepals toothed, Involucres very large, Flowers very small 2011 Much branched rough, Branches spreading, Leaves obl. somew, toothed, Sepals lanc. ent. Fl, very small 2012 Roughish erect, Lvs. lanc tooth atten at base, Prop, ped. elong. upright, Cor longer than cal. Pet. ov, ent. 2012 Roughish erect, Lvs. anc. tooth atten. at base, Prop. ped cor longer than the ovate campanulate calyx

2013 Leaves lanceolate entire villous, Umb. few-flowered, Cor longer than the ovate campanulate calyX
2014 Smooth, Lvs. lanc. lin. tooth, at end, Ped. sprdg. elon. Cor. longer than cal. pet. obcord. (A. coronopif. B. M.) 2015 Pubescent, Leaves lanc. nearly entire ciliated, Umb. few-flowered, Cor. longer than the turb. calyx 2016 Caulesc. smooth, Lvs. lin. shining ent. cil. at end, Umb. few-fl. Stalks elong. Cor. longer than turb. calyx 017 Caulesc pubesc. Lvs, scattered lin. subuiate ciliat. Umb. few-fl. Stalks short, Cor. longer than turb. calyx g018 Leaves elliptical lanceolate smooth, Scapes umbellate

2019 Lvs. ov. lanc. from middle to end acutely toothed, Scape lvs. and stalks rather long. than invol. Cor. shorter than angular cal. (A. Bocconi of Gardens.)

2020 Leaves obovate oblong toothed rugose villous beneath, Umb. radical, Flower-stalks as long as lvs. Cor. flat

2021 Leaves toothed rugose hairy on both sides, Umbel many-flowered with outer flowers nodding, Cor. flat 2009 Leaves the rowers all nodding, Cal, angular, Cor. concave 2023 Lvs. tonthed rago rug. cren tooth. powdery, Umb. many-f. Ped. spread. 'Tube gland. at end, Limb flat the 2024 Leaves sessile lanc. spatul. entire smooth on both sides, Outer fl. nodding
2025 Lvs. cordate stalked doubly crenate smooth beneath hairy at the veins, Stalks villous, Umb. many-fl. erect 2026 Leaves cordate erenate-lobed very rugose, Corolla acutely toothed

2027 Leaves oblong spatulate toothed green on each side, Leaves of involucre auricled at base

2028 Leaves obl oval serrulate villous pale green, Scape 2-3-fl. erect rounded, Cal. globose, Tube of cor. villous

2029 Leaves lanc. flat finely toothed smooth, Umb. many-fl. erect, Leaves of invol. connate at base 2030 Leaves smooth on each side crenate powdery at edge, Cal. very short (P. crenata, Lehm.)

2031 Leaves obov. ent. or serr. fleshy, Scape central as long as lvs. Umb. erect, Inv. with short lvs. Cal. powdery 2032 Leaves spatulate serrated smooth, Scape lateral, Umbel nodding, Involucre with large leaves 2033 Leaves elliptical nearly entire thickish cartilaginous at edge, Uinb. 2-3-fl. erect, Cal. tubular obtuse 2034 Laves ovate entire stalked smooth, Umb erect 3-fl. Cal. campanulate, Cor. cyathiform 2035 Leaves wedge-shaped shining many-toothed at end, Scape about 1-fl. Petals half bifid like a Y 2035 Leaves wedge-shaped shining many-toothed at end, Scape about 1-fi.

2036 Leaves stalked ovate cordate rugose, Umbel proliferous, Cal. inflated 2 . 2038 Resembles P. farinosa. Distinguished by its flat corolla, and more robust habit

2039 Leaves obovate oblong close toothed smooth somewhat wavy, Umb. pubesc. Cal. ovate gaping, Cor. flat 2040 Leaves obovate spatulate beneath and scape mealy, Segments obcordate toothed

2041 Leaves obovate tongue-shaped entire vill. viscid, Umb. many-fl. erect, Leaves of inv, ovate short membr. 2042 Leaves flat coarsely serrated acute, Cal, viscid, Pedicels longer than scape

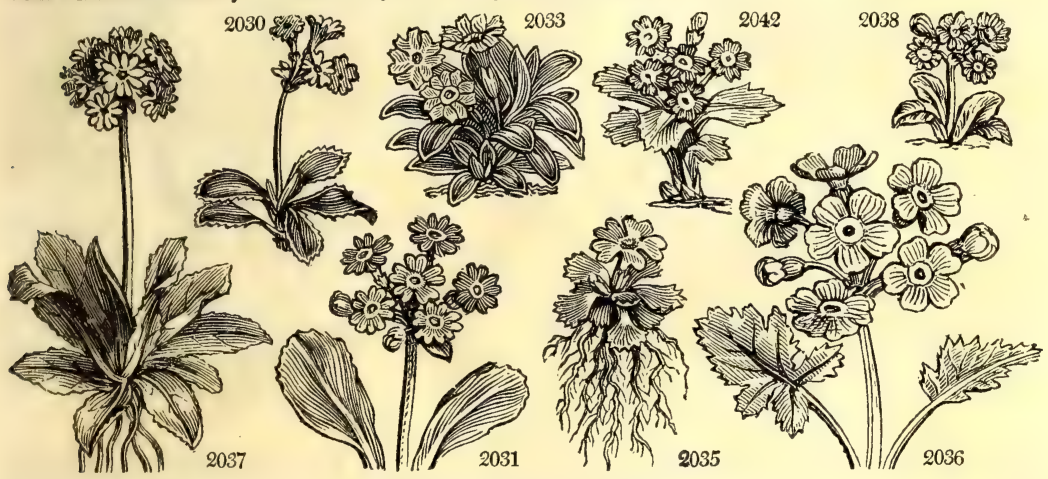

and Miscellaneous Particulars.

agreed on by the general consent of florists; they were first brought forward by the Dutch, and are now to be found in the treatises on florists' flowers of all countries : one of the best in this country is Maddocks's Florist's Directory.

The culture of $\mathbf{P}$. veris as a border flower is abundantly simple, as it will grow any where, but best in a situation shaded from the mid-day sun, and in a loamy soil ; but its culture as a florists' flower, the crossing to procure new varieties, and all the various cares of the florist involve details much too tedious for this work, if they were to be given at such length as to be of real use. We refer to Maddocks, Emerton, and Hogg, and to the Encycloperia of Gardening.

$P$. elatior is found in the same situations as the primrose, but is much less common than either it or P. veris, It has little or no smell. Sir J. E. Smith considers it as probably a hybrid between the cowslip and primrose. There are two or three varieties of oxlip, but they are not considered as florists' flowers.

P. veris smells more strongly of anise than the primrose. Its leaves have been used as a pot-herb, and in salads, and are recommended for feeding silk-worms. The flowers make a pleasant wine, flavored like muscadel, but considered somniferous. Liquors and syrups are sometimes tinctured with the leaves. Having been less cultivated than the primrose, there are but few varieties of this plant in gardens. They may be raised from seed, however, to any extent, as Messrs. Gibbs, of the Brompton nursery, and others, have lately proved.

P. auricula is a well known favorite of the florist. It is a native of the alpine regions of Italy, Switzerland, and Germany, and found also about Astracan. The most common colors in its wild state are yellow and red, sometimes purple, and occasionally variegated or mealy. The cultivated are innumerable, and many of them of exquisite beauty and fragrance. The leaves in different varieties differ almost as much as the flowers, a circumstance which does not take place to the same extent in the variations of $P$. vulgaris or veris. Near circumstance which does not take place to the same extent in the variations of $\mathbf{P}$. vulgaris or veris. Near
most of the manufacturing towns of England, and many in Scotland, the culture of this flower forms a favorite amusement of weavers and mechanics. Lancashire has been long famous for its auriculas : it is no uncommon thing there for a working man who earns, perhaps, from 18s. to 30 s. per week, to give two guineas for a new variety of auricula, with a view to crossing it with some other, and raising seedlings of new properties. 
351. CORTU'SA. $W$. 2043 Matthioli $W$.

352. SOLDANEL/LA. 2044 alpina $W . e n$. 2045 montána $W$.en.

S. Clusii B. M.

353. DODEC 2046 Méadia $W$.

354. CY'CLAMEN. $W$.

2047 cóum $W$

2048 europæ'um $W$.

2049 pérsicum $W$.

2050 héderæfólium $W$.

2051 ver'num Mill.

355. HOTTO'NIA. $W$.

2052 palústris $W$

YOOSE-STRIF

2053 vulgáris $\boldsymbol{W}$. common

2054 Ephémerum $W$.

2056 dúbia $W$

2057 strícta $W$.

2058 thyrsiflóra $W$.

2059 capitáta $P h$.

2060 punctáta $W$

2061 verticilláta $\boldsymbol{P a l l}$

2062 quadrifólia $P h$.

2063 ciliáta $P h$.

2064 longifolia $P h$.

2065 hýbrida $P h$.

2066 Linum-stellát

2067 némorum $\boldsymbol{W}$.

2068 Nummulária $\boldsymbol{W}$. Moneywort

357. ANAGAL'LIS, $W$. Pimpernel.

2069 arvénsis $W$.

2070 cærúlea $\boldsymbol{E}$. $\boldsymbol{B}$.

2071 fruticósa $\boldsymbol{H}$. $\boldsymbol{K}$.

2072 latifólia $W$.

Bear's-ear Sanicle.

\. $\triangle$ or

$\Delta$ or whorled

Primulacea. Sp. 1.

Primulacea. Sp. 2-3.

$\frac{1}{4}$ ap Pu Switzerl. 1656. D p.l Bot. mag. 49

Primulacer. Sp. 1.

1 ap.jn L.Pu Virginia 1744. D p.1 Bot. mag. 12

Primulacea. Sp. 5 .

CYClAMEN. * 4 or 2 ja.ap L.R S. Europe 1596. S s.p Bot. mag. 4

$\Delta$ or ${ }_{\frac{1}{4}}$ au L.R Britain banks. S s.p Eng. bot. 548

Persian $\quad \square$ or $\frac{1}{4}$ f.ap R.w Cyprus 1731. S p.1 Bot. mag. 44

数 $\Delta$ or $\frac{1}{4}$ ap $\quad$ W Austria 1596. S p.l Bot. mag. 1001

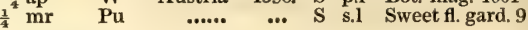

Primulacee. Sp. $1-2$.

jl.au F England dit. S aq Eng. bot. 364

Primulacee. Sp. $16-29$.

3 jl.s Y Britain wat.sh. D co Eng. bot. 761

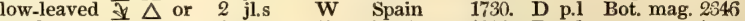
narrow-leaved $\frac{2}{\Delta}$ or $1 \frac{1}{2}$ jl.s $\quad$ Y N. Amer. 1803. D p.l

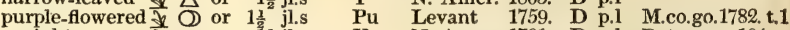

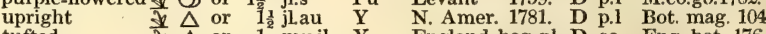
tufted $\quad \frac{\not}{} \Delta$ or 1 my.jl $\quad Y \quad$ England bog.pl. D co Eng. bot. 176 headed $\quad \triangle$ or 1 my.jl $Y$ N. Amer. 1813. D co

dotted $\quad \searrow$ or 11 jl.au Y Holland 1658. D co Jac. aus. 4. t. 366 \ $\Delta$ or 1 jl.au s 4 or 2 jlau Y N Amer. 1794. D p.1 Lm.ill.1.t.101.f.2 four-flowered $\frac{7}{\mathrm{~L}}$ or 2 jl.au $\quad \mathrm{Y} \quad$ N. Amer. 1798. D p.1 Bot. mag. 660 hybrid $\frac{\ddagger}{\Delta}$ or $1 \frac{1}{2}$ jl.au $\quad Y \quad$ N. Amer. 1806. D co

z $\mathrm{O}$ or $\frac{1}{2}$ jn $\mathrm{G}$. Italy 1658. S s.1 Mag.b. mo.t.162

$\neq \Delta$ or $\frac{1}{4}$ my.jl Y $\quad$ Britain m.s.pl. D m.s Eng. bot. 527

2. $\triangle$ or $\frac{1}{4}$ jn.jl $\quad \mathrm{Y}$ Britain m.me. D m.s Eng. bot. 528

Primulacee. Sp. 4-12.

common $\quad$ * $\mathrm{O}$ w $\frac{1}{2}$ jn.s $\mathrm{S}$ Britain cor. fi. $\mathrm{S}$ co Eng. bot. 529 blue $*$ O $w$ s $\frac{3}{2}$ jn.s B Britain cor. fi. S co Eng. bot. 1823 large-flowered 7 (O) or 3 my.jl Ve Morocco 1803. L p.1 Bot. mag. 831

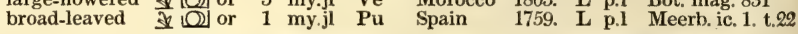

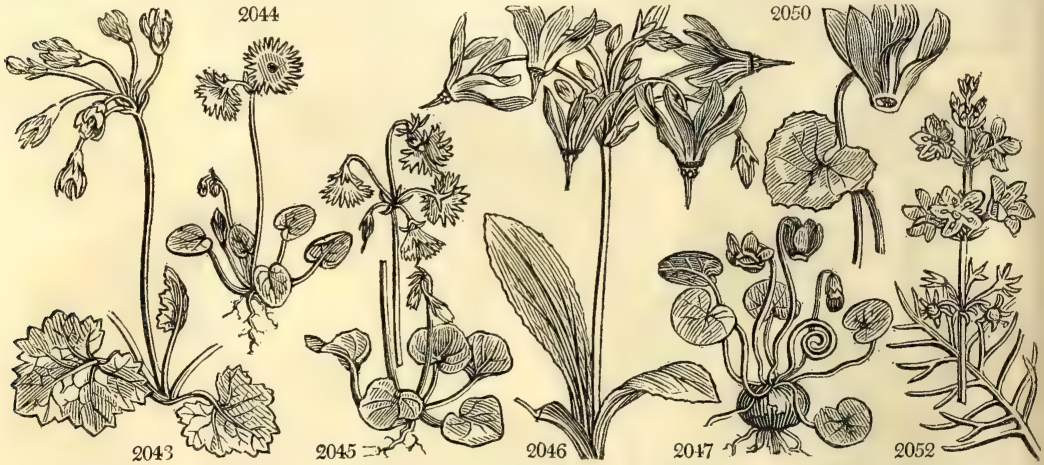

History, Use, Propagation, Culture,

As to the soil proper for auriculas and polyanthuses, much has been written, and some highly artificial compositions of bullock's blood, sugar-baker's scum, night-soil, fuller's earth, \&c. recommended. Many of the most successful growers, however, use nothing more than a loam from an old pasture or hedge-row, kept and turned over occasionally during a year, and then mixed with hot-bed dung rotten to a mould, or with leaf-mould, and some sand to keep it open. The soil and manure must be well mellowed by time before using, and not mixed till it is wanted, as that is said to generate worms. (See Encyc. of Gard. art. Primula.)

P. auricula, helvetica, nivalis, and viscosa, are considered by Herbert as only varieties of one original, for he says he raised a powdered auricula and a $\mathbf{P}$. helvetica from $\mathbf{P}$. nivalis, and a $\mathbf{P}$. helvetica from $\mathbf{P}$. viscosa. (Hort. Trans. iv. 20.) These, and the other species of this genus, are well adapted for being kept in pots of loam and eaf-mould, or loam and peat well drained, and in frosty or wet weather during winter, protected by a frame to imitate their natural covering of snow in alpine regions. Sweet says, " they require to be shifted and parted frequently, for if left too long without these being done, they will dwindle away and die." The best time for parting and shifting is after they have done flowering.

P. scotica, a pretty plant, resembling P. farinosa, has lately been discovered in Scotland by Dr. Hooker, pro. fessor of botany at Glasgow.

351. Cortusa. So named by Mathiolus, in honor of his friend J. A. Cortusus, who first noticed it. This is a handsome little alpine, requiring a similar treatment to the Swiss Primulæ.

352. Soldanella. The diminutive of solidus, a shilling. The round leaves of these plants are very like pieces of money. They are among the least and most beautiful of alpine plants, and remarkable for the manner in which their corolla is cut or lacerated. Culture as in the Swiss Primula.

353. Dodecatheon. A name of the Romans, signifying 12 gods or divinities, applied with singular absurdity by Linnæus to a plant, native of a world the Romans did not know, and resembling in no particular that of their writers. It was originally named Meadia by Mark Catesby, in honor of Dr. Mead, but the name was continued only as a specific appellation by Linnæus. It is very ornamental when in flower; afterwards the leaves die away, and the root only remains till next season. It is not easily kept ; but thrives better in a bed of light loamy soil, in a shady and rather moist situation, than in pots.

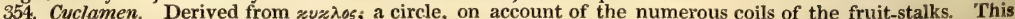
genus consists of humble plants with very beautiful flowers. In the north of Italy wild swine feed on its 
2043 The only species

2044 Cor. funnel-shaped spreading out beyond the middle, Calyx erect, Style shorter than corolla 2045 Cor. cylindrical bell-shaped not cut so far as the middle, Cal, spreading, Style longer than corolla

2046 The only species. Leaves radical flat on the ground, Scape bearing at top an umbel of drooping flowers

2047 Leaves orbicular cordate entire, Segments of cor. ovate

2048 Leaves orbicular cordate crenate or tuothed, Segm, of cor. lanceolate

o049 Ieaves oblong ovate cordate or reniform-cordate crenated, Segm. of cor. oblong obtuse

205 Leaves cordate oblong acuminate angular toothed, Segm. of cor. oblong lanceolate rather acute

2051 Leaves cordate crenulate emarginate, with the base overlapping, Flower short, Style exserted

2052 Flowers vertical stalked, Leaves under water all finely cut

2053 Racemes terminal compound, Leaves opposite 3-4 together oblong lanceolate 20.54 Racemes terminal, Petals obovate spreading, Leaves linear lanceolate sessile

2055 Smooth branching, Leaves opp. or whorled long linear spotted, Raceme terminating a short scape

2056 Racemes terminal, Petals conniving, Stam. shorter than corolla, Leaves lanceolate stalked

2057 Racemes terminal, Petals lanceolate spreading, Leaves lanceolate sessile

2058 Racemes axillary stalked ovate compact, Leaves opp. lanceolate

2059 Smooth, Stem simple spotted, Leaves opp. sess. lanc. acute spott. Flowers in close heads

2060 Leaves 3.4 together ovate lanc. stalked pub. beneath, Ped. axill. whorled, Pet. ovate fringed with glands 2061 Leaves whorled obl. lanc. stalked, Pet. ovate acute glandular, Stem pubescent

2062 Leaves subsessile 4-5 together oval acuminate dotted, Peduncles four, 1-flowered, Petals oval entire

2063 Pub. Lvs. opp. on long stalks cord. ovate, Fl.stalks axill. in pairs, Fi. cernuous, Petals rounded crenulate 2064 Smooth much branched, Leaves linear very long, Segments of cor. serrulate

2065 Smooth, Leaves opp. on long stalks lanc. Petioles ciliated, Fl. cernuous, Cor. shorter than cal. Pet. cren.

2066 Leaves lanc. sessile, Peduncles axillary opp. Stem much branched smooth, Cal. longer than corolla

2067 Leaves ovate acute, Flowers solitary, Stem procumbent, Stamens smooth

2068 Leaves opposite roundish cordate, Pedunc. axillary 1-flow. Stem smooth creeping, Stamens glandular

2069 Stem procumbent, Leaves 3-nerved ovate lanceolate petals dilated at end crenate with glands 2070 Leaves 5-nerved ovate lanceolate, Stem erect a little winged, Petals toothed at end

2071 Leaves lanceolate about 3 together sessile, Stem shrubby at base rounded, Branches diffuse angular 2072 Leaves cordate stem-clasping, Stem brachiate erect

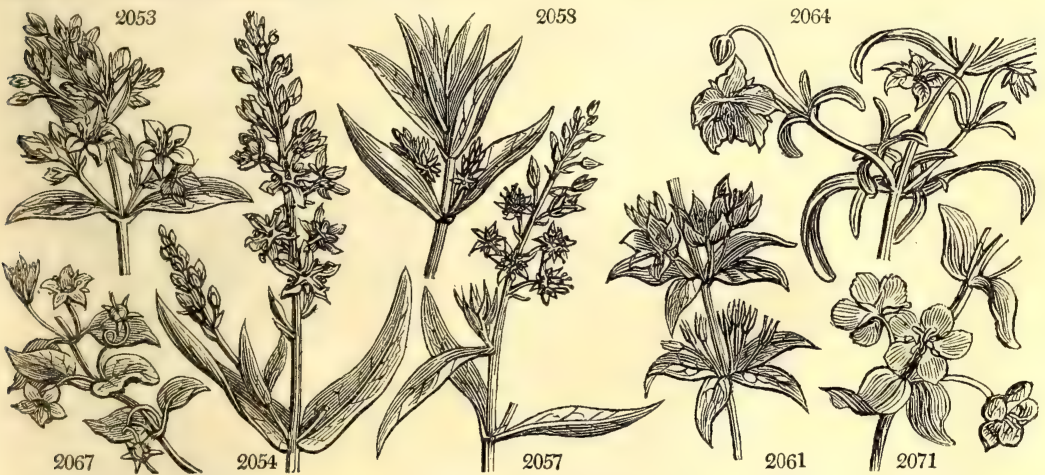

and Miscellaneous Particulars.

bulbs, which are round, flattened, and solid, and as large as pigeons' eggs. When the flowers fade the pedicels twist up like a screw, inclosing the germen in the centre, and, lying close to the ground among the leaves, remain in that position till the seeds ripen. The plant is peculiarly adapted for pots, and for chamber decoration in spring. C. hederæfolium is very scarce, and agreeably fragrant. C. persicum is tender; the others are quite hardy.

355. Hottonia. In honor of Peter Hotton, a professor in the university of Leyden, born in 1648, died in 1709. He wrote several academical dissertations, and published remarks upon medicinal plants, valuable in their day. Plume d'cau, Fr. Wasserviole, Ger., and Miriofillo aquatica, Ital. This singular aquatic has roots consisting of white capillary fibres, which strike deep into the mud. The leaves grow in tufts under the water, and only the upper part of the flowering stem rises above it, producing a showy spike of white and blue flowers. It affords refuge to the fresh-water periwinkle (Turbo Littoreus), and other small shellfish. The seeds being sown in a pond when ripe, the plants will rise in the water the spring following.

356. Lysimachia. From $\lambda \nu \sigma i s ~ \mu \alpha \chi \eta$, of which the English name Loose-strife is a translation; it has been given to this plant from the quality absurdly ascribed to it by the ancients, of quieting restive oxen when put upon
their yokes. Linnæus says it was named after king Lysimachus of Sicily, who first used it, which account is nearly the same as that of Pliny. Most of the species are bog or fen plants, of the easiest culture. L. nummularia is ornamental on moist rock-work or hanging from a pot in a northern exposure. Though one of the hardiest natives, it seldom produces ripe seeds, like most plants which multiply themselves much by the roots or stem. The flowers of $\mathrm{L}$ thyrsiflora come out in lateral bunches from the axils towards the top of the stem, which Linnæus notices as a singular circumstance in an upright plant. L stricta after flowering, throws out bulbs from the axils of the leaves, which, if allowed to lie on a moist surface, will produce young plants the following spring. L. dubia requires to be treated like a tender annual.

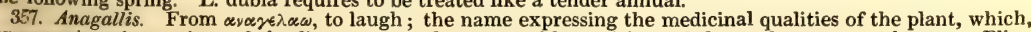
by removing obstructions of the liver, removed a cause of low spirits and despondency; so at least say Pliny asd Dioscorides. A arvensis is a beautiful trailing weed, and one of the Floræ horologicæ, opening its flowers regi larly about eight minutes past seven o'clock in our latitude, and closing about three minutes past two o'clock. It also serves as an hygrometer, for if rain fall, or there be much moisture in the atmosphere, the o cowers either do not open, or close up again. Small birds are very fond of the seeds. A. monelli is a very
fowers. 
2073 Monélli $\boldsymbol{W}$. 2074 liniflia $W$ 2075 tenélla $W$.

358. DIAPEN'SIA, $W$ b

A. Mi. Prxidanthera.

2077 barbuláta $M$

360. CO'RIS. $W$

361. GA'LAX. $W$.

2079 aphýllà $W$.
362. MENYAN'THES. $W$. Buck-BEAN.

2080 trifoliáta $W$. common

363. VILLAR'SIA, $\boldsymbol{R} . \boldsymbol{B r}$. VILLARSIA.

$\begin{array}{ll}2081 \text { nymphoides } \boldsymbol{W} \text {. } & \text { fringed } \\ 2082 \text { lacunósa } \boldsymbol{V} \text {. } & \text { smooth-flower. }\end{array}$

2083 sarmentósa $\boldsymbol{B}$. $\boldsymbol{M}$. running

2084 indica $W$. Indian

2085 parnassiifólia $R . B r$. tall

2086 ováta $\boldsymbol{V}$.

oval-leaved

364. CHIRO'NIA. $L$. Chironia.

2087 jasminoides Thunb. Jasmine-leaved 2088 lychnoídes Thunb.

2089 linoídes $\boldsymbol{W}$.

2090 baccifera $\boldsymbol{W}$

2091 angustifólia $\boldsymbol{H} . \boldsymbol{K}$.

2092 frutéscens $W$.

2093 decussáta $\boldsymbol{H}$. $\boldsymbol{K}$.

365. EUSTOMA. $P, L$.

Lychnis-flower Flax-leaved nerry-bearing shrubby cross-leaved 366. ERYTHR EA. P. S. ERYTHREA. 2095 Centaúrium $P$. $S$. common 2096 pulchella $E$. B. dwarf bramched 2097 littorális $E . B$. 2098 marítima $P . S$. 2099 conférta Pers. dwarf-branched dwarf-simple procumbent

367. SABBA'TIA. P. $\boldsymbol{L}$. SABbatia 2100 grácilis $\boldsymbol{P h}$. 2101 calycósa $P h$. 2102 chloroídes $\boldsymbol{P h}$. 2103 paniculáta $P h$. slender slender chlora-like panicled

\section{LOGA'NIA. $\boldsymbol{R}, \boldsymbol{B} r$. Logania.}

2104 latif6lia $R$ Br $B$ broad-leaved t or 3 Gentianec.

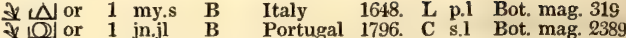

Italy 1648. L p.1 Bot. mag. 319 $\$ \triangle \triangle$ or $\frac{1}{4}$ au.s $\quad$ Pk Britain bog.pl. D l.p Eng. bot. 530 Ericea. Sp. 1.

f.mr Wapland 1801. D s.l Bot. mag. 1108 Ericea. Sp. 1.

$\frac{1}{2}$ jl W Carolina 1806. D l.p Mich. amer.t.17 Primulacece. Sp. 1.

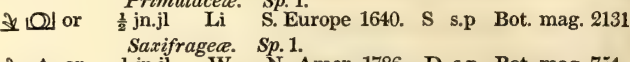

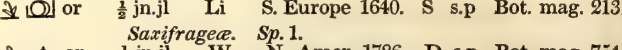
se $\triangle$ or $\frac{1}{2} \mathrm{jn} . \mathrm{jl} \mathrm{W}$ N. Amer. 1786. D s.p Bot. mag. 754 $\Delta$ or 1 Gentianece. Sp. $1-2$.

Britain moi.pl. C p Eng. bot. 495 Gentianece. Sp. 6-12.

* or 1 jn.jl $\quad \mathrm{Y}$ England rivers. S p.l Eng. bot. 217

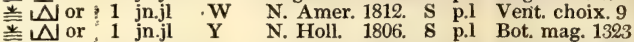
* or 1 my.au W C. G. H. 1792. S p.l Bot. mag. 658 * 1 or 2 jn.o Y N. S. W. 1805. S p.l Bot. mag. 1029 * $\Delta$ or 1 my.jl O C. G. H. 1786. S p.l Bot. mag. 1909 Gentianea. $S p .7-14$.

w or 2 ap.jl Pu C. G. H. 1812. C p.1 Bot. reg. 197

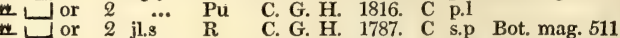

n. $\longleftarrow$ or 2 jn.jl $\quad Y \quad$ C. G. H. 1759. S s.p Bot. mag. 233 w or 1 jn.au $R \quad$ C. G. H. 1800. C s.p Bot. mag. 818 \# or $1 \frac{1}{2}$ jn.s $R \quad$ C. G. H. 1756. C s.p Bot. mag. 37

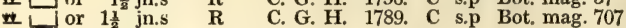

Gentianea. Sp. 1.

or 1 jl W I. Provid. 1804. S s.l Par. lond. 241 Gentinnea. Sp. 5-39.

Or $\frac{1}{2}$ jl.au Pk Britain heaths, S s.1 Eng. bot. 417 $\mathrm{O}$ or $\frac{2}{4}$ au.s Pk England sea co. S s.l Eng. bot. 458 O or $\frac{1}{4}$ jn.jl Pk Britain sea co. S s.1 Eng. bot. 2305 $\tilde{\tau} \Delta$ or $\frac{1}{2}$ jl.au $\quad$ Y $\quad$ S. Europe 1777. S s.l Cav.ic.3.t.296.f.1 $\checkmark \Delta$ or $\frac{1}{2}$ jl.au Pk Spain 1821. S s.l

Gentianee. Sp.4-6.

₹ $\mathrm{O}$ or 1 jl Pu N. Amer. ... C co Par. lond. 32 Dy (D) 1 jn.au Pk N. Amer. 1812. C co Bot. mag. 1600 L 0 or $\frac{1}{2}$ jl.au Pk N. Amer. 1817. S co 5 $\Delta$ or $1 \frac{1}{2}$ my.jn W N. Amer. 1817. C co

\section{Gentianea. Sp. 2-11.}

N. Holl. 1816. C 1.p Lb.nov,ho.1.t.51

N. S. W. 1797. C l.p Bot. rep. 520

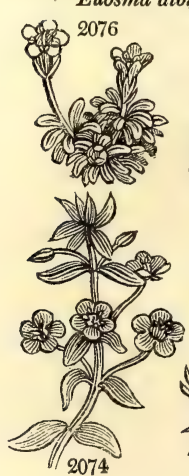

2074

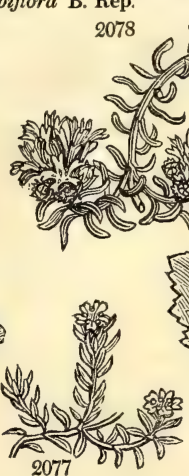

d $ـ$ or 2 ap.my W

\section{N. S. W. 1737.}

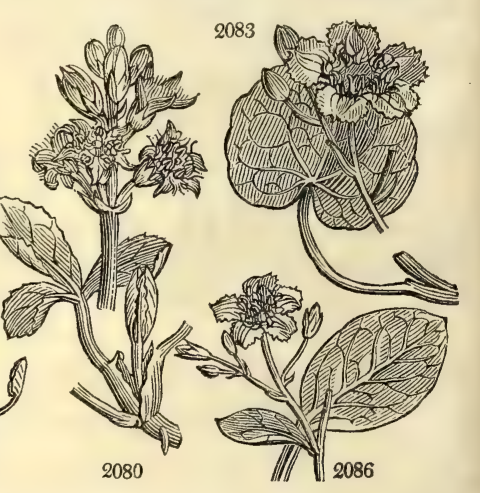

History, Use, Propagation, Culture,

beautiful small plant, and, with $A$. latifolia and linifolia, require the protection of a frame during winter. A. tenella is a delicate bog-plant, but not a very certain tenant of the genus. It is probably botanically distinct.

358. Diapensia. An ancient Greek name of the Sanicle, and signifying a plant which removes pain; the Sanicle being a vulnerary. Linnæus applied the name to this plant, which is neither a Sanicle nor a vulnerary, but a pretty alpine species, requiring the same cultivation as similar things, and retaining its deep green leaves through the severest winters.

359. Pyxidanthera. From $\pi v \xi_{35}$, a box, and dy $9 n \rho \alpha$, an anther, the anthers bursting across like a little box. A small plant resembling Azalea procumbens, with heath-like leaves and minute white flowers. It is found on the White-Mountains of New Hampshire, and in Pine-barrens in other parts of North America, but is very

rare in cultivation. have been unable to provide a meaning. It was given to a plant analogous to Hypericum, and resembling the heath. Tournefort applied the name to this plant, whose fine leaves, and purple or pink flowers, clothe, like the heath, the places where it grows wild.

361. Galax. From roic, milk, in allusion to its milk-white spikes of flowers. This is a neat little plant, and thrives best in a moist situation ; where alone it flowers freely.

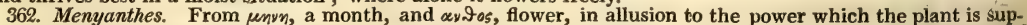
posed to possess of exciting menstruation. Buck-bean or Bog-bean, Eng., Bachsbohne, Ger. An infusion of the leaves is bitter, and is frequently recommended in dropsy and rheumatism. In Sweden the plant is used 
2073 Leaves linear lanceolate opp. or whorled, Stems ascending

2074 Leaves sessile opposite 3-4 together lanceolate 3-nerved, Sepals linear acute, Cor. twice as big as caiyx 2075 Leaves ovate acute, Stem creeping, Stigma acute

2076 The only species. Plant growing in dense tufts

2077 A small plant resembling Azalea procumbens

2078 The only species

2079 The only species. Roots deep red. Flowers in long slender spikes

2080 Leaves ternate

2081 Leaves cordate orbicular floating, Flowers umbelled, Corollas fringed

2082 Leaves reniform subpeltate beneath full of holes floating, Petioles flower-bearing, Corollas smooth

2083 Runners creeping, Leaves cordate roundish repand dotted beneath, Panic. opp. the leaves, Seeds smooth 2084 Leaves cordate roundish nerved floating, Petioles flower-bearing, Corolla hairy within

2085 Leaves radical cordate roundish spreading toothed, Stem long naked, Flowers panicled

2086 Leaves ovate erect, Flowers in panicled racemes fringed

2087 Leaves lanceolate smooth, Stem herbaceous 4-cornered cernuous

2088 Stem simple, Leaves linear-lanceolate

2089 Herbaceous, Leaves linear erect, Branches fastigiate, Peduncles elongated

2090 Leaves linear-lanceolate smooth spreading, Stem much branched shrubby, Fruit a berry

2091 Leaves linear spreading, Cal. ovate closed, Cor. clammy, Segm. cuneate pointed

2092 Shrubby, Leaves lanceolate subtomentose, Calyxes campanulate

2093 Shrubby subtomentose, Leaves close together decussate oblong obtuse, Cal. globose 5-parted

\section{The only species}

2095 Stem herbaceous dichotomously panicled, Leaves ovate lanceolate, Cal. shorter than tube 2096 Flowers stalked, Segments of cal. shorter than tube, Style simple, Leaves ovate

2097 Stem nearly simple dwarf, Flowers clustered sessile, Cal. as long as tube of cor. Leaves lin. lanc.

2098 Herbaceous, Leaves oblong-lanceolate, Stem dichotomous corymbose rounded, Flowers stalked digynous 9099 Dwarf upright much branched, Lvs. oval obtuse, Fl. sessile fasc. clustered, Cal, $\frac{1}{2}$ as long as tube of cor.

2100 Weak, Branches lax elongated 1-flowered, Leaves linear ellipt. Pet. obovate, Stem angular 2101 Erect leafy, Leaves oblong, Flowers solitary about 7-parted, Cal. leafy longer than cor.

2102 Weak, Leaves lanc. erect, Branches few 1-Howered, Flowers 7-13-parted, Sepals linear shorter than cor.

2103 Erect, Leaves lanc. linear, Pan. many-flowered brachiate, Cal. subulate thrice as short as cor.

2104 Leaves obovate acute at each end, Flowers corymbose, Branches smooth, Stem erect

2105 Leaves lanceolate attenuate at each end smooth, Stipules lateral setaceous, Racemes axillary compound

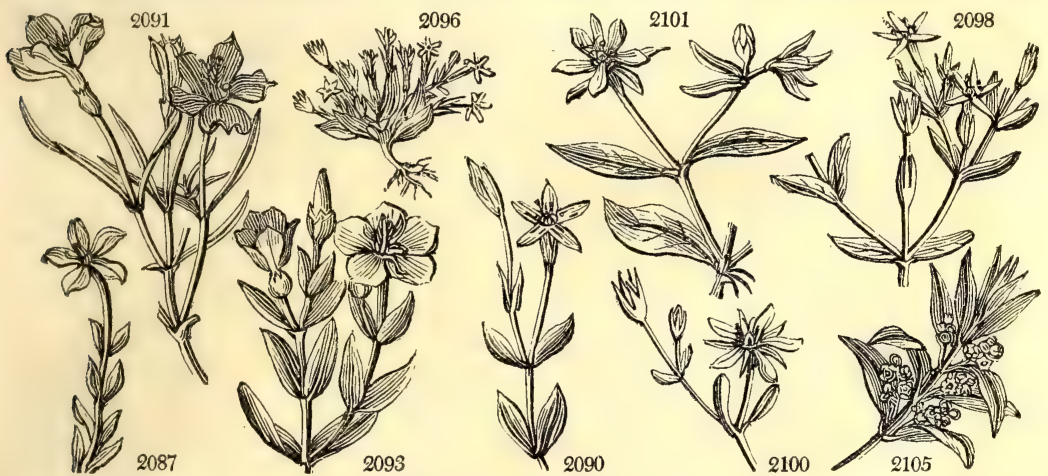

and Miscellaneous Particulars.

as a substitute for hops, two ounces of the leaves being substituted for a pound of hops. The powdered roots are sometimes eaten in Lapland. The only species cultivated is the wild plant of our rivulets.

363. Villarsia. A genus divided from the last, and named after Villars, a French botanist of repute, who wrote the Flora of Dauphiny, in 1786, a work used even at the present day. This is an aquatic genus of easy culture, and increased by seeds or dividing at the root. V. nymphoides is one of the most elegant of British water-plants

364. Chironia. Named after Chiron, one of the fathers of medicine, botany, and surgery. He is mythologically represented to have been the son of Saturn, or of Time and Experience. Many plants, the virtues of which he is believed to have first discovered, have borne his name. The genus, however, to which it is now applied, is probably not one of those. It consists of pretty plants of short duration, generally with pink flowers. The species are not long-lived plants, and therefore require to be frequently raised from cuttings. Peat mould suits them best, and a little loam mixed with it ; and young cuttings planted in the same kind of soil, under handglasses, strike root readily.

365. Eustoma. From हu, well, and sopa, mouth or orifice, in allusion to the colored aperture of the tube of the flower. A pretty little plant rarely seen in gardens. It resembles a Sabbatia.

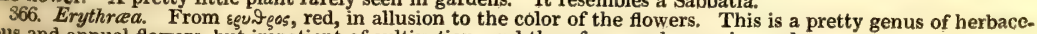
ous and annual flowers, but impatient of cultivation, and therefore rarely seen in gardens.

367. Sabbatia. Named after Liberatus Sabbati an Italian botanist, author of many works on botany. In 1779 he published the first volume of the Hortus Romanus, a fine work, in folio, of which the seventh and last volume appeared in 1784. A pretty N. American genus of plants resembling Chironia.

368. Logania. Named by Mr. Brown, after a Mr. James Logan, said to have been the author of some experi$\mathrm{K} 2$ 
369. PHLOX. $W$. 2106 paniculáta $W$ $\beta a l b a$

2107 unduláta $W$ 2108 acumináta $\boldsymbol{P h}$ 2109 suavéolens $W$. 2110 maculáta $W$. 2111 pyramidális $H . K$ 2112 pilósa $W$ 2113 amo'na $B$. $M$. 2114 Carolína $W$. 2115 triflóra $M i$. 2116 suffruticósa Vent. 2117 glabérrima $W$. 2118 divaricáta $W$. 2119 stolonífera $H$. $K$ 2120 ováta $W$ 2121 subuláta $W$. 2122 setácea $W$. B nivális

2123 cárnea $B . M$

370. POLEMO'NIUM. $W$ 2124 réptans $W$. 2125 cærúleurn $W$ $\beta$ álbum $\gamma$ maculátum
2126 mexicánum Cav. 371. VES'TIA. W.en 2127 lýcioides $W$ en.
LYCHNIDEA. panicled white waved-leaved Lyons's or $\Delta$ or D $\Delta$ or pyramidal $\frac{1}{\Delta} \Delta$ hairy-leaved $\frac{\partial}{\Delta}$ or Fraser's-hairy $\frac{D}{\Delta} \Delta$ or pubescent or shining-leaved $\frac{\nabla}{\Delta} \Delta$ or smooth $\Delta \Delta$ or early-flowering $\frac{\Delta}{\Delta} \Delta$ or creeping creeping
ovate-leaved
$\downarrow$ awl-leaved $\Delta$ or fine-leaved $\frac{D}{\Delta} \Delta$ or snow-white $\quad \frac{\nexists}{\Delta} \Delta$ or flesh-colored $\not \nabla \Delta$ or

\section{. Greek-valerian.} creeping blue-flowered $\$ \Delta$ or white-flowered $\Delta$ or spotted-flowered $\frac{\$}{\Delta} \Delta$ or Mexican Dे $\Delta$ or

Vestia.

Box-thorn-like

Polemoniacea. Sp. 18-24.

au.s Pk N. Amer. 1732. D p.1 Mil.ic.2.t.205.f.2 3 au.s W N. Amer. 1813. D p.1 3 jl.au $\quad \mathbf{R} \quad$ N. Amer. 1759. D p.l 4 my.au Pu N. Amer. 1812. D p.l Bot. mag. 1880 2 jl.au W N. Amer. 1766. D p.l

4 jl.au $\quad \mathrm{R} \quad$ N. Amer. 1740. D p.l Jac. vind.2.t.127 4 jn.au F N. Amer. 1800. D p.1 Bot. cab. 342

1 my.jn Pk N. Amer. 1759. D p.1 Bot. mag. 1307

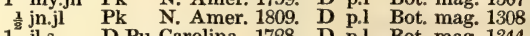

$1^{2}$ jl.s D.Pu Carolina 1728. D p.1 Bot. mag. 1344

1 jl.s $\quad$ Pu Carolina $\quad . .5$ D p.1 Sweet fl.gard. 29

$1 \frac{1}{2}$ jl.s D.Pu N. Amer. 1790. D p.l Bot. reg. 68

3 jn.au $\mathbf{R}$ N. Amer. 1725. D p.1 D. elt.t.166.f.202

1 ap.jn L.B N. Amer. 1746. D p.1 Bot. mag. 163

$\begin{array}{lll}\frac{1}{4} \text { jn.s } & R & \text { N. Amer. 1800. D p.l Bot. mag. } 563\end{array}$

$1 \frac{1}{4}$ my.jl $\quad$ Pu $^{\frac{1}{4}}$ N. Amer. 1759. D p.l Bot. mag. 528

$\frac{1}{2}$ ap.jn F N. Amer. 1786. D p.l Bot. mag. 411

$\frac{1}{2}$ ap.my F N. Amer. 1786. D p.1 Bot. mag. 415

ap.my W N. Amer. 1820. D p.l Bot. cab. 780

au.s Pk N. Amer. 1816. D p.l Bot. mag. 2155 Polemoniacea. Sp. 3-12.

$\frac{1}{2}$ ap.my L.B N. Amer. 1758. D co Mill. ic. 2. t. 209

$2^{2}$ jn B Britain bu. pl. D co Eng. bot. 14

2 jn W $\quad$ W.... $\quad$... D D co

jn St

1 ap.my B Mexico 1817. D co Bot. reg. 460 Polemoniacea. Sp. 1.

3 jn $\quad$ Y Chili 1815. C s.p Bot. reg. 299 Boraginece. Sp. 3-6. 2128 appendiculátum $P h$. appendaged $\frac{\ddagger}{2}$ cu $\quad \frac{1}{2}$ my.jn P.B N. Amer. 1813. D p.l 2129 virgínicum $W$. Virginian $\frac{1}{\downarrow} \Delta$ cul $\frac{1}{2}$ my.jn W N. Amer. 1739 . D m.s Bot. reg. 331 2130 canadénse $W . \quad$ Canadian $\quad \frac{1}{4} \mathrm{cu}{ }^{\frac{1}{2}}$ my.jn W Canada 1759. D m.s Bot. reg. 242

373. PHACE'LIA. Mich. Phacelia. 2131 bipinnatífida Mich. bipinnatifid

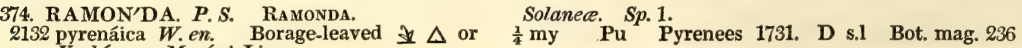
Verbáscum Mycóni Linn.

375. VERBASCUM. $W$. MULLEIN.

2133 thápsus $W$.

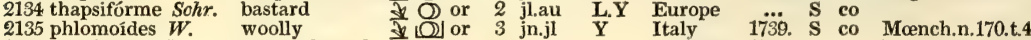
2136 sinuátum $W$. scollop-leaved $\underset{\downarrow}{ }$ () or 2 jl.au $\quad$ Y $\quad$ S. Europe 1570. S co FI. græc. t. 227 2137 bipinnatifidum B.M. cut-leaved $\quad$ Q or 2 jl.au Y Tauria 1813. S p.1 Bot. mag. 1777 2138 austrále Schr. $\quad$ southern 2139 condensátum Schr. close-flowered $\frac{1}{2}$ or 4 jl.au $\mathbf{Y}$ Austria 1820. S co Schr. mon. t.3 2140 níveum Ten. 2 snow-white \& O or 3 jl.au P.Y Naples 1823. S co Ten.neap. t. 22 2141 cuspidátum Schr. pointed 2 or 4 my.jn $Y$ Vienna 1817. S co Schr.mon.t.1.f.1

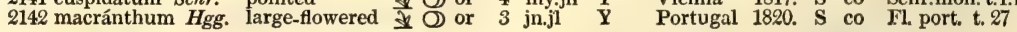

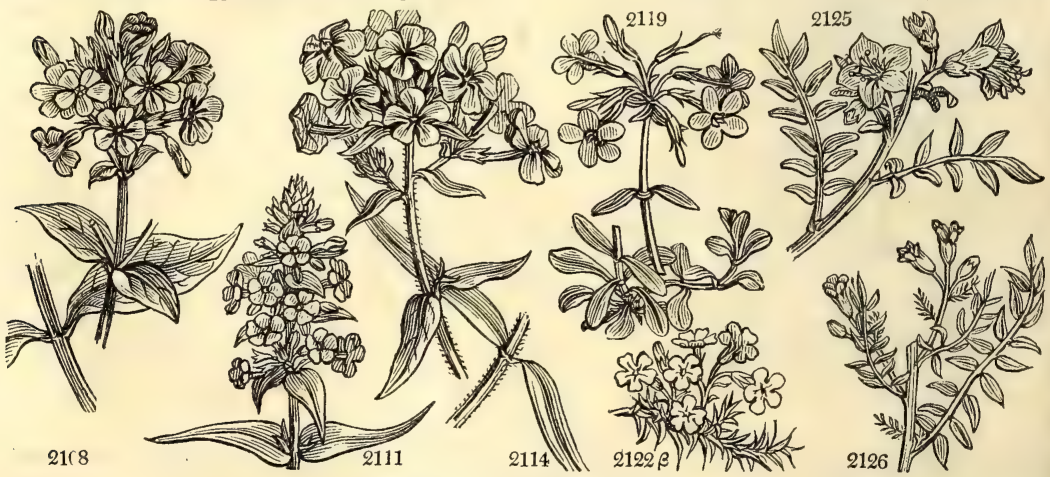

History, Use, Propagation, Culture,

ments upon the generation of plants. Small bushes or herbaceous plants with opposite entire leaves, and terminal or axillary bunches of white flowers. Eleven species, natives of New Holland, are described. Ripened cuttings may be struck in sand under a hand-glass.

369. Phlox. From $\phi \lambda \circ \xi$, flame. The plant so named by the ancients is supposed to have been an Agrostemna. The genus now so called is a native of North America only, and is one of the handsomest in cultivation. It consists of most elegant border flowers, valuable for blossoming late in the season, and for their lively colors of red, white, and purple, while the majority of plants that flower in autumn have yellow, and generally syngenesious blossoms. Most of the species delight in a rich moist soil, or loam and leaf mould or peat The dwarf species are admirably adapted for pots, or a select rock-work : they require some protection in severe winters. 370. Polemonium. From $\pi 0 \lambda s \mu \rho s$, war. Pliny relates, that the plant which he called by this name received its appellation from having been the cause of a war between two kings, who could not agree which of them first

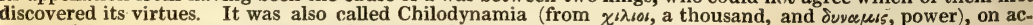
count of its extraordinary merit. The plant which possessed all these good qualities is now forgotten. Its name has descended to a flower which ornaments the garden, but which preserves nothing of the virtue of its progenitor, beyond a slight vulnerary quality. P. cæruleum is a border flower of long standing, and of the

371. Vestia. Named by Willdenow, in his Enumeratio Plantarum, in honor of his friend Dr. Vest of Clagen- 
2106 Leaves lanc. flat rough at edge, Stem smooth, Corymbs panicled, Segments of cor. rounded

2107 Leaves obl. lanc. somewhat wavy rough at edge, Stem smooth, Corymbs panicled, Segm. of cor. blunt 2108 Leaves ovate acum. beneath pubescent decussate, Cor. panic. Segm. of Cor. roinded 2109 Erect, Stem smooth not spotted, Leaves ovate lanc. quite smooth, Raceme panic. Teeth of cal. erect

2110 Erect, Stem rough spotted, Leaves obl. lanc. smooth rough at edge, Pan. obl. close, Teeth of cal. recurved

2111 Leaves cordate ovate acute smooth, Flowers densely pyramidal, Teeth of cal. upright, Stem spotted

2112 Hairy, Stem erect, Leaves linear-lanceolate, Sepals subulate, Tube of cor. curved pubescent

2113 Hairy, Stems assurgent, Leaves ovate lanceolate, Sepals subulate, Tube of cor. smooth straight

2114 Laves lanceolate sessile smooth thick, Stem erect rough, Flowers whorled terminal

2114 Lcaves lanceolate sessile smooth thick, stem eaves lanc. smooth, Branches of corymb 3-flowered, Teeth of cal. linear

2116 Leaves lanc. shining on both sides acute nearly without veins, Stem smooth trifid above shrubby at base

2117 Tufted assurgent smooth, Leaves linear lanceol. smooth, Corymb term. fastigiate, Teeth of cal. mucron.

2118 Dwarf diffuse pubescent, Leaves ovate lanc. chiefly alternate, Branches few-fl. lax, Cal. subul. Pet. cord.

2119 Stoloniferous pubescent, Fertile stems erect simple few-leaved, Leaves oval, Corymb few-flowered

2120 Leaves ovate, Flowers solitary

2121 Dwarf tufted pubescent, Leaves fascicled subulate pungent ciliated, Pedicels few terminal

2122 Leaves ciliated lowest setaceous upper lin. lanc. Branches 3-5-fl. at end, Cal. spreading hairy, Pet. retuse

2123 Stem erect rounded, Leaves lanc. smooth half stem-clasp. Cal. edged, Tuhe of cor. twice as long as limb

2124 Pinnx 7, Flowers terminal nodding

2125 Leaves pinnate, Flowers erect, Cal. longer than tube of corolla

2126 Pinnæ many the terminal 3-lobed, Flowers nodding, Cal. viscid

\section{The only species}

2128 Very hairy, Radical leaves subpinnatifid, cauline lobed angular, Sinus of calyx with reflexed appendages 2129 Leaves pinnate or pinnatifid, Segm. ovate lanceol. cut serrate, Fascicles of flowers clustered

2130 Smoothish, Leaves lobed angular, Fascicles of flowers close together

2131 Erect, Leaves pinnatifid, Segments cut lobed, Racemes generally bifid

2132 A stemless plant with hoary leaves and short scapes of purple flowers. The only species

\section{Leaves decurrent.}

2133 Lvs, cren. toment. upper acute, Raceme spiked dense, Cor. rotate with obl. obt. segm. Anth. nearly equal 2134 Lvs, cren, toment. upper acumin. Raceme spiked dense, Cor. rotate with obov, round segm. 2 of anth obl. 2135 Lvs, cren tom radic, ell. stlkd. Caul. obl. ac. upper brd. ov. cusp. slightly decur. Fasc. remotish, Two an, obl. 2136 Loaves toment. radical and lower cauline sinuated upper crenate slightly decurr. Spikes pan. Fl clustered

2136 Loaves toment. radical and lower cauline sinuated upper crenate slightly decurr. Spikes pan. Fl. clustered
2137 Leaves bipinnatifid
[Fasc. of rac. remote, Two anth. obl.

2137 Leaves bipinnatifid 2138 Leaves crenate tom. Radic. obl. lanc. narr. to stalk, Caul. obl. acute decurr. upper broad ov. cusp. $\frac{1}{2}$ decur.

2139 Leaves tom. radic. ellipt. narr. at base uneq. doubly crenate, Caul. obl, acute simply crenate upper round. ovate cusp. slightly decurr. Racemes dense, Two anthers oblong

2140 Leaves $\frac{1}{3}$ decurrent crenate snow-white, Raceme spiked dense, Anthers equal

2141 Leaves crenulate tomentose the upper cuspidate, Fascicles of raceme remote, Two anthers oblong

2142 Leaves cren. tom. rad. ellipt. obl. narr. at base caul. obl. acute $\frac{1}{2}$ decurr. Fasc. of rac. rem. Two anth. obl.

2127

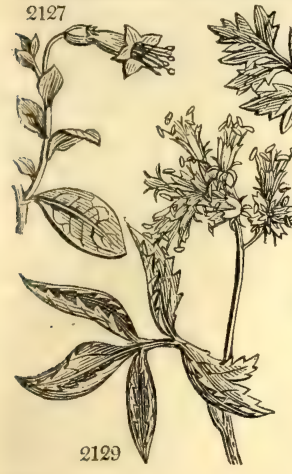

furth. A native of Chili, with pale-green smooth leaves, and pale yellow flowers. It is very nearly related to Lycium.

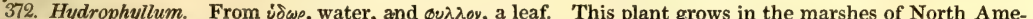
rica, and in the spirng time has a small quantity of water in the cavity of each leaf. The species are two only, both humble plants, with neat foliage, which protects the small white flowers. $\mathbf{H}$. virginicum is used as a salad, under the name of Shawanese salad in North America.

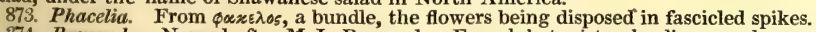

374. Rumonda. Named after M. L. Ramond, a French botanist, who discovered many new plants in France. A very pretty dwarf plant, kept in a frame with other alpine plants. Formerly a species of Verbascum, (V. myconi.)

375. Verbascum. An alteration of barbascum, on account of the beard (barba) with which all the leaves and stems are closely covered. The species are all very fine looking plants, well calculated for shrubberies, among other tall plants. They have been well illustrated by M. Schrader in a learned Monograph. V. thapsus has been so called from its native place, the Isle of Thapsos. V. blattaria is said to have the power of driving away the blatta or cockroach. $V$. pulverulentum is one of the most magnificent of native herbaceous plants, sending up a stem a yard high, covered with many hundreds of gold colored flowers. Correa observes of this golden rod, that in still weather two or three blows with a stick will briffg down all the corollas. The nap of 
2143 ovalifolium $H, K$ oval-leaved

2144 Boerhaávii $W .{ }^{K}$. annual

2145 elongátum W.en. long-stalked

2146 pyramidátum $\boldsymbol{W}$.en. pyramidal

2147 hæmorrhoidále $\boldsymbol{W}$. Madeira

2148 floccósum $P$.S. wool-bearing

2149. Lychnitis $W$. white

2150 pulveruléntum $E$. B. powdered

2151 ferrugíneum $W$. rusty

2152 cupreum $\boldsymbol{B}$. $M$.

2153 nigrum $W$

2154 phneníceum $W$.

2155 virgátum $E$. $B$.

2156 Blattária $W$.

2157 glábrưm W.en.

2158 repándum $W$.en.

2159 pinnatífidum

2160 Osbéckii $W$.

2161 orientále $M . B$.

2102 spectábile $M . B$.

2163 spinósum $L$.

376. DATU'RA. $W$.

2164 férox $W$.

2165 Stramónium $W$

2166 Tátula $W$.

2167 fastuósa $W$

2168 Métel $W$.

$2169 \Re^{\prime}$ vis $\boldsymbol{W}$.

170 smooth-fruited

377. BRUGMAN'SIA. P. S. BRUgmansia

2171 suavéolens $W$.en smooth-stalked

2172 arbórea $W . e n$. downy-stalked

378. LISI AN'THUS. $W$. LisIanthus.

2173 longifólius $W$.

2174 glaucífólius $\dot{J a c}$.

2175 exsértus $W$.

2176 cordifólius $W$.

379. SPIGE'LIA. $W$

2177 Anthélmia $W$.

2178 marilándica $W$

black-rooted

purple-flowered

slender

oth

innatifid

Osbeck's

spiny

THORN-APPLE.

Chinese

chinge

purple

downy

* $\triangle$ or $1 \mathrm{jl}$.s

O or 2 jl.au

₹ 0 or 5 jl.au

3) or 3 jl.au

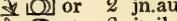

7e or $3 \mathrm{jn.j \textrm {l }}$

s 0 or 3 jn.au

D or 3 jn.au

$\checkmark \Delta$ or $3 \mathrm{my}$.au $\mathrm{Br}$

7 $\triangle$ or 3 my.au $\mathrm{Br}$

₹ $\Delta$ or 2 my.au $\mathbf{Y}$

$\Delta$ or

Tor 4 au

₹ 0 or 2 jl.au

De or 3 jl.au

J $\triangle$ or $1 \mathrm{my}$

(1) or 1 jl.au

d $\Delta$ or $2 \mathrm{jn} . \mathrm{jl}$

o or o jijl

is or

1 my.jn

Solanece. Sp. 7-10.

O or 3 jl.s

$\mathrm{O}$ clt $3 \mathrm{jl.s}$

or 3 jis

0 or 3 jl.s

$\mathrm{O}$ or $2 \mathrm{jn}$.

O or 2 jn.s

or 2 jl.s
O Caucasus 1804. D p.l Bot. mag. 1037

Pu S. Europe 1731. S co Mill. ic. 2. t. 273

C..... 1813. S co

Macasus 1804. S co Sweet fl. gard. 31

Madeira 1777. S co

.

S co Eng. bot. 58

S. Europe bot. 487

Caucape 1683. 162

Caucasus 1798. D p.l Bot. mag. 1226

England ch.so. D p.l Eng. bot. 59

S. Europe 1596. D p.l Bot. mag. 885

Britain gra.pl. S co Eng. bot. 550

Britain gra.pl. S co Eng. bot. 393

...... 1805. S co

...... 1813. S co

Archipel. 1788. S p.l

Spain 1752. S p.1

Tourn. it. 2. t. 83

co Bot. reg 558

1824. S co Alp. exot. t. 36

W China 1731. S s.l Zano.h.212.t.162

W England rub. $S$ s.1 Eng. bot. 1288

B N. Amer. 1629. S s.1 Meerb. ic. 2. t.13

Pu Egypt 1629. S r.m Kno.the.1.t.S.11

W Asia $\quad \begin{array}{llll}\text { W } & \text { A } & \text { r.m } & \text { Bot. mag. } 1440 \\ \text { W } & \text { Africa } & \text { S } & \text { r.m Jac. vind. } 3 . \text { t. } 82\end{array}$

W S. Amer. 1805. S r.m Jac. seh. 3, t. 339

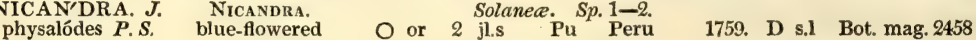
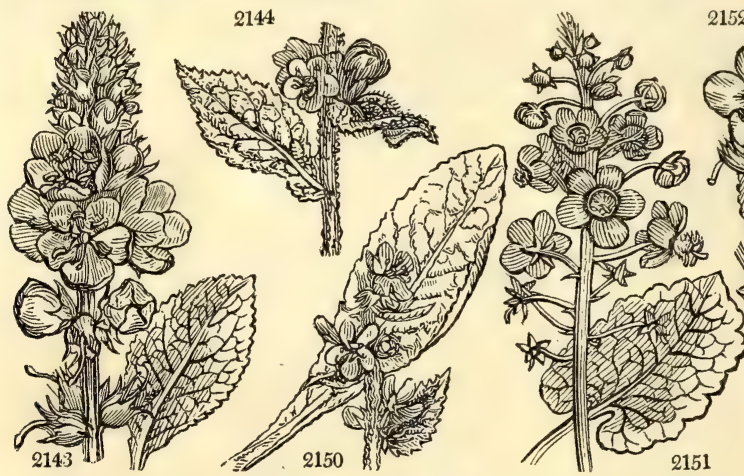

1759. D s.1 Bot. mag. 2458

History, Use, Propagation, Culture,

this species, of V. lychnitis, and of several others, may be used as tinder, and to make wicks for lamps; whence the name Lychnitis applied to one of the species, from $\lambda v$ xyos, a lamp. Several mules have been produced between the species of this genus; and it has been questioned whether those accounted species are not productions of this kind.

376. Datura. An alteration of the Arabic name tâtôrah Forskahl, About Goa and Canara, it is called

Daturo, Rumphius. Stramonium is an abbreviation of the Greek word $\sigma \tau \tau^{2} x$ youcovizov, or mad-apple, on account of the dangerous effects of the fruit of that species. Metel or Methel, is an Arabic name employed by Serapion, ch. 375, and expresses the narcotic effect of the plant. Tatula is altered from Datula, a name given to the Datura by the Turks and Persians. D. stramonium is an instance of a South American plant, naturalized within a comparatively short time, the seeds having been introduced from Constantinople in Gerarde's time, and by him "dispersed through this land" Kalm says, that this plant and a species of Phytolacca are the worst weeds in America. Professor Martyn observes, that " in the earth brought with plants from rarious parts of that extensive country, we are sure to have the thorn-apple come up." At night, the leaves next the flowers rise up and enclose them. The whole plant smells strongly of bean meal. Every part of the plant is poisonous, bringing on delirium, tremors, \&c. but under proper regulations it is a useful medicine in asthma, \&c.

D. fastuosa has a fine polished purple stalk, varied with dots or lines; the leaves are large; the flowers of a beautiful purple outside, and a satiny white within ; some are single, others semidouble. They have an agreeable odor at first, but if long smelt to become less agreeable, and are narcotic. D. ceratocaulon is a fine species; its seed will sometimes remain in the ground several years before it will vegetate.

377. Brugmansia. So named by Persoon, in honor of Professor S. J. Brugmans, author of some botanical works, and especially of a dissertation " De Plantis Inutilibus, et Venenatis," published at Groningen, in 1783.

B. arborea is one of the greatest ornaments of the gardens of Chili. The flowers which come out at the 
Leaves sessile.

2143 Stem erect simple, Leaves oval sessile tooth-crenate smooth above, Flowers spiked 2144 Leaves sublyrate, Flowers sessile

2145 Leaves $\frac{1}{2}$ decurrent tomentose on both sides, Stem branched, Three filaments hairy in the middle

2146 Leaves nearly naked lower oblong attenuated at base upper cord. acum. sess. Racemes panic. Starn. beard.

2147 Leaves ovate oblong at base atten. toment. obsoletely cren. Racemes spiked elongate, Fl. without bractes

2148 Lpaves ovate sessile beneath closely woolly, Stem branched, Filaments bearded

2149 Leaves wedge-shaped oblong naked above, Stem angular panicled

2150 Leaves ovate oblong subserrate powdery on both sides, Stem rounded panicled, Hairs of stamens white

2151 Leaves subvillous rugose cauline subsessile equally crenate, Radical oblong cordate doubly crenate

2152 Stems virgate simple, Leaves cordate ovate rugose crenate woolly beneath, Pedunc. with 1 bract. solitary

2133 Leaves oblong cordate stalked wavy crenate subpubescent

2154 Leaves naked radical uneq. toothed, Caul. lanc. toothed wedge-shaped at base, Stem naked, Rac. elong.

2155 Leaves oblong lanc. toothed sessile radical sublyrate pubescent, Stem branched, Flowers aggreg. sessile

2156 Leaves stem-clasping oblong smooth doubly serrated, Peduncles 1-flowered solitary

2157 Leaves naked lower obl. stalked upper obl. lanc. Stem simple pub. Raceme term. Stalks altern. very short

2158 Leaves naked radical sinuated cauline oblong cordate stem-olasping coarsely toothed, Pedunc. alternate

2159 Leaves tomentose radical bipinnatifid cauline pinnatifid, Flowers clustered sessile

2160 Leaves cut naked, Stem leafy, Calyxes woolly, Pedunc. 2-flowered

2161 Leaves ovate oblong beneath hoary the lower narrowed at base upper subcordate, Racemes lax panicled

2162 Leaves cordate acuminate, Spike lax downy, Two lower stamens dechinate smooth

2163 Stem leafy prickly shrubby

2164 The upper spines very large converging at the top of the pericarp

2165 Leaves ovate smooth angular toothed, Pericarp prickly

2166 Leaves ovate subcordate smooth angular toothed, Stem spotted, Pericarp prickly

2167 Leaves ovate angular, Pericarps tuberculated nodding.

2168 Leaves cordate nearly entire pubescent, Pericarps prickly globose nording

2169 Leaves ovate angular toothed smooth, Stem hollow herbaceous, Pericarps smooth erect

2170 Leaves ovate lanceolate wavy beneath hoary, Stems dichotomous cornute, Pericarps obovate pendulous

2171 Leaves oblong entire smooth, Calyxes 5-toothed

2172 Leaves oblong entire powdery, Stalks and branches pubescent, Cal. spathaceous acuminate

2173 Leaves lanceolate acute pubescent, Stem rounded

2174 Leaves ellipt. lanceolate obtuse smooth, Stem rounded, Peduncles long 1-flowered

2175 Leaves ovate lanc. pedunc. trichotomous, Genitals very long

2176 Leaves cordate

2177 Stem herbaceous the upper leaves 4 together

2178 Stem simple, All the leaves opposite sessile lanceolate oval

2179 Leaves sinuated, Calyxes closed acute-angled

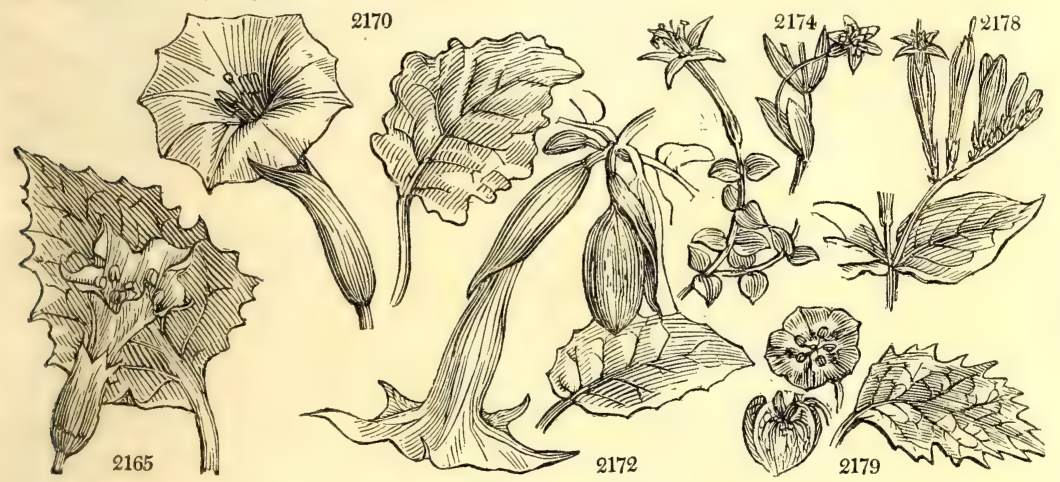

and Miscellaneous Particulars.

divisions of the branches, have a loose tubular calyx nearly four inches long, which, opening like a spathe, a corolla is protruded, with a narrow trumpet-shaped tube, which spreads wide at the brim, where it is divided into five angles, which terminate in very long points: they are white within, pale yellow outside, and one tree will perfume the air of a large garden. It flowers freely in the bark-stove, in a moist heat.

378. Lisianthus. From $\lambda \nu \sigma i s$, dissolution, and $\alpha y .905$, a flower; a name given to the plant on account of the medical virtues possessed by it of dissolving humours. It is a powerful cathartic. The species are very handsome stove plants. Cuttings root readily in sand under a bell-glass.

379. Spigelia. So named by Linnæus, in honor of Adrian Spigelius, born at Brussels in 1578; professor of anatomy and surgery at Padua; author of Isagoge in rem Herbariam; died in 1625.

$\mathrm{S}$. anthelmia is so named from its peculiar efficacy in destroying worms, for which it has been long in use among the negroes in the West Indies. Dr. Browne, after a number of successful experiments, says it operates in so extraordinary a manner, that no other simple can be of equal efficacy in any other disease, as this is in those which proceed from these insects. (Hist. of Jamaica.) The same plant procures sleep almost as certainly, and in an equal degree with opium.

S. marilandica is used as a vermifuge in North America, and according to Dr. Garden, (Letters to Dr. Hope, with very powerful effects. The annual plant may be treated like other tender annuals; but $S$. marilandica is rather difficult to preserve; according to Sweet, " it requires to be grown in a pot, that it may be protected from severe frosts, or too much wet: it will sometimes survive the winters when planted in the open ground in a bed of peat : the best soil for it is an equal mixture of loam and peat, and young cuttings, planted under a hand-glass, root readily." (Bot. Cult. 424.)

380. Nicandra. Nicander was a Greek physlcian, who lived about a century and half before Christ. The genus was formed by Adanson; it consists of the Atropa physaloides of Linnæus. The Indians of Peru make use of the berries of this plant to bring away gravel, and to relieve persons who have a stoppage of urine. 
381. HYOSCY'AMUS. $\boldsymbol{W}$. Henbane. 2180 niger $W$ $\beta$ annuus 2181 álbus $W$. 2182 reticulátus $W$ 2183 Seneciónis $\boldsymbol{W}$. en. 2184 aúreus $W$

2185 canariénsis $\mathrm{Ker}$ 2186 pusillus $W$. 2187 physaloídes $W$. 2188 Scopólia $\boldsymbol{W}$. 2189 agrestis $K i t$ 2190 pállidus $W . \& K$. 2191 múticus $L$

2192 orientális Bieb.

eastern

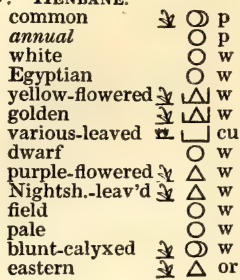

2193 Tabácum $W$.

2193 Tabácum

2194 macrophýlla

2196 unduláta $R . B r$.

2197 rústica $W$.

2198 paniculáta $W$.

2199 glutinósa $W$

2200 plumbáginifólia $W$.

2201 pusílla $W$.

2202 quadriválvis $P h$.

2203 nána Lindl.

2204 Langsdorffii $W . e n$.

2205 cerinthoides

2206 repánda $W$.
Tobacco

\section{Virginian}

large-leaved

shrubby

sweet-scented

L $\Delta$ clt 2 my.s

panicled

panicled

or 3 jl.s

or $4 \mathrm{jl}$.s

curled-leaved $\downarrow \Delta \cup$ or 2 my.jn

$\begin{array}{lll}\text { Primrose-leav'd } \frac{10}{0} \text { or } & 3 & \text { au } \\ \text { four-valved } & \text { or } 2 \text { jl.au }\end{array}$ Rocky-mount

Or 2 jl.au

니 cu $5^{\frac{1}{4}}$ jn

O or 5 au

O or 2 au

Honeywort

Havannah
Solanea. Sp. $13-14$.

n.jl St Britain rub. S s.1 Eng. bot. 591

jl.au Pa.W S. Europe 1818. S s.l Bot. mag. 2394

jl.au R $\begin{aligned} & \text { Egypt 1640. } \\ & \text { S co Com.hort.77.t.22 }\end{aligned}$

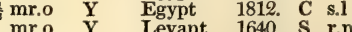

Levant 1640 S rm Bot mag. 87

Canaries 1816 D s.l Bot reg 180

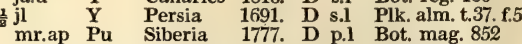

ap.my D.Pu Carolina 1780. D p.1 Bot. mag. 1126

ap.my Y.Vy Hungary 1820. S p.1 Sweet f. gard.27

mr.my Y.Pu Hungary 1815. S p.1

Pu Iberia 1821. D s.1 Bot. mag. 2414.

Solanea. Sp. $14-26$

Pk America 1570. S r.m Blackw. t. 146

Pk America $\ldots$ S r.m

W N. S.W. 1800. D r.m Bot. mag. 673

G America 1570. S co Blackw. t. 437

G Peru 1752. S r.m Flor. per.2. t.129

S Peru 1759. S r.m Bot. rep. 484

W America 1816. D r.m Jacq. fragm. t.84

W Vera Cruz 1733. S r.m Mil. ic.2.t.185.f.2

W N..Amer. 1811. S r.m Bot. mag. 1778

W N. Amer. 1823. S co Bot. reg. 833

G Chili 1819. S co Bot. mag. 2221

W Ha.... 1821. S co Lehm. nic. t. 2

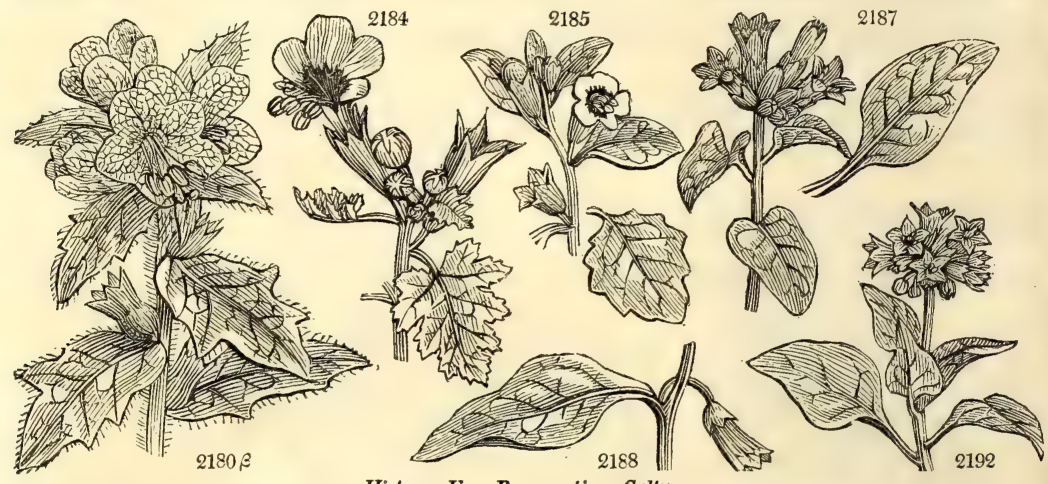

History, Use, Propagation, Culture,

381. Hyoscyamus. From is ن́o, a pig, and zuxeos, a bean; the fruit has been thought to resemble a bean, and, although dangerous to other animals, is said to be eaten by pigs with safety. H. niger is a well-known foetid weed, which follows civilized man, growing on rubbish of old houses, dunghills, \&c. It has a strong peculiar odor, greatly affecting the heads of some persons, and the whole plant is reputed poisonous. Sir J. E. Smith and Professor Martyn say they have often eaten the seeds without suffering inconvenience. Lightfoot, on the contrary, says, a few of them have been known to deprive a man of his reason and limbs. A species of bug (Cimex) and of beetle (Chrysomela) take their specific names from feeding on the plant but no quadruped is known to eat it, unless the goat and sheep, and that very rarely and sparingly. As a medicine, henbane is of immemorial use, and is still continued in the Pharmacopoias. - It is given with or without opium in coughs, epilepsy, convulsions, \&c. Country people sometimes smoke the leaves for the toothach.

382. Nicotiana. So named from John Nicot of Nismes, in Languedoc, ambassador from the king of France to Portugal, who procured the seeds from a Dutchman who had received them from Florida. The first plant was said to have been presented to Catherine de Medicis, whence the French name Herbe a la Reine. The name tobacco, which has superseded all others, is the appellation of a district of Mexico. Petum or Petume Bras., Tabac, Fr., Taback, Ger., and Tabac, Ital. The species grown as tobacco are the N. tabacum and rustica; the former greatly preferred. The popular narcotic which it furnishes is probably in more extensive use than any other, and its only rival is the betel of the east. According to Linnæus, tobacco was known in Europe from 1560. It was brought to England from Tobago in the West Indies, or Tobasco in Mexico, (and hence the name,) by Ralph Lane, in 1586, but only the herb for smoking. Afterwards, according to Hakluyt, seeds were introduced from the same quarter. Sir Walter Raleigh first introduced smoking; in the house in which he lived at Islington are his arms on a shield, with a tobacco plant on the top. Smoking has consequently been common in Europe for upwards of two centuries. It is a powerful narcotic, and also a strong stimulant with respect to the whole system, but especially to the stomach and intestines, to which, in small doses, it proves emetic and purgative. The smoke thrown up the anus acts as a glyster: an infusion of the leaves forms a powerful lotion for obstinate ulcers: the oil applied to a wound is said by Redi to be as fatal as the poison of a viper. The decotion, powder, and smoke of tobacco, are used in gardening to destroy insects, and poison of a viper. The decotion, powder, and smoke of tobacco, are used in gardening to

Tobacco, as used by man, says Du Tour, (Nouveau Cours $d$ 'Agriculture, \&c.) gives pleasure to the savage and the philosopher, to the inhabitant of the burning desert and frozen zone. In short, its use either in powder, to chew, or to smoke, is universal ; and for no other reason than a sort of convulsive motion (sneezing) produced by the first, and a degree of intoxication by the two last modes of usage. A hundred volumes, he adds, have been written against it of which a German has preserved the titles. Among these books is that of James Stuart, king of England, who violently opposed it. The Grand Duke of Moscow forbade its entrance into his territory under pain of the knout for the first offence, and death for the next. 'The emperor of the Turks,
king of Persia, and Pope Urban VIII. issued similar prohibitions, all of which were as ridiculous as those which attended the introduction of coffee or Jesuit's bark. At present, all the sovereigns of Europe, and most of those of other parts of the world derive a considerable part of their revenue from tobacco.

Tobacco is cultivated in Europe as far north as Sweden, and is also grown in China, Japan, and other eastern 
2180 Radic. leaves sinuated pinnatifid upper stem-clasping, Flowers nearly sess. Cor. netted

9181 Leaves stalked the lowest rounded entire the rest cordate ovate sinuate toothed, Fl. axill. sess. or stalked 2182 Cauline leaves stalked cordate sinuate acute, Flowers entire inflated

2183 Leaves stalked 3-lobed cut-toothed, Flowers stalked, Segm. of cor. equal flat

2184 Leaves stalked ovate acute angular toothed, Flowers stalked, Three upper segm. of cor. wavy

2185 Lower leaves cordate ovate angular obtuse, floral ovate entire

2186 Leaves stalked oblong lanc. toothed, Flowers stalked, Calyx teeth mucronate

2186 Leaves stalked oblong lanc. toothed, Flowers stalked, Calyx teeth mucronate

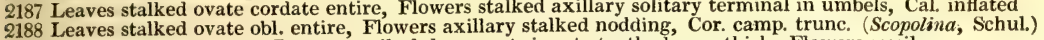

2189 Stem simple pubescent, Leaves sessile $\frac{1}{2}$ decurrent sinuate toothed smoothish, Flowers sessile

2190 Leaves stem-clasping angular, radical angular toothed, Flowers sessile 1-colored

2191 Leaves stalked ovate acute angular, Cal, pointless, Bractes undivided

2192 Leaves deltoid ovate repand, Cal. of fruit tumid, Stamens exserted

2193 Leaves sessile obl. lanc. acumin. the lower decurr. Mouth of cor. inflated, Segm. acuminate

2194 Leaves stem-clasping ovate acute auricled at base, Mouth of cor. inflated, Segm. short acuminate

2195 Stem shrubby simple, Lvs. stalked lanc. obliquely acuminate, Coroll. inflated at mouth, Segm. acumin. 2196 Stem nearly sim. Lvs. somew. stlkd. ov. lanc. wavy, Tube of cor. cyl. much longer than cal. Seg. uneq. round 2197 Stem rounder, Leaves stalked ovate entire, Tube of cor. cylind. longer than cal. Segment rounded obtuse 2198 Stem nearly sim. Lvs. stlkd. ov. subcord. entire, Tube of cor. clav. very sm. much longer than cal. Seg. obt. 2199 Leaves stalked cordate entire, Fl. racemose 1-sided, Cal. 2-lipp. upper lip longest, Cor. ringent, Segm. acute 2200 Leaves sessile lower obovate spatulate obtuse upper $\frac{1}{2}$ stem-clasping wavy, Tube of cor, very long clavate 2201 Stem 2201 Stem dichot. Lvs. sess. radic. obl. oval. Cal. very short, Tube of cor. cyl. thrice as long as cal. Segm. acute 2203 Leaves lanceolate hairy, radical longer than the solitary flowers, Petals obtuse

2204 Lower leaves ovate obtuse stalked upper sessile decurrent, Tube of cor. clavate long, Limb obtuse

2205 Stem branc. at base, Lvs. stlkd. all cord. ent. Tube of cor. clav. pub. much long. than cal. Seg. very sh. acute

2206 Leaves stem-clasping cord, spat. roundish repand, Tube of cor. slender very long, Segm. ovate acute plic.

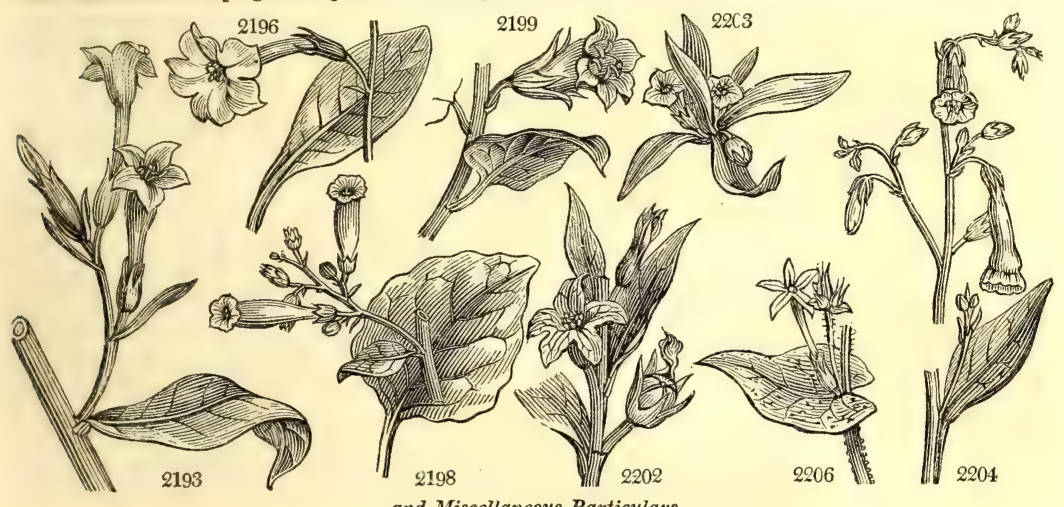

and Miscellaneous Particulars.

and hot countries. The sort preferred is the N. tabacum, which is an elegant plant, grown also in gardens as a border flower. N. rustica, fausse tabac, Fr., Bauern taback, Ger., and Tabacca cimarosa, Span., is also frequently cultivated, especially in Europe, it being considered hardier than the Virginian sort Parkinson says, " whic knew so rightly to cure." Tobacco has been successfully cultivated and cured in this country, but its growth is prohibited to encourage our commerce with America. It is now only grown for curiosity as a border flower, or by gardeners for the destruction of insects. In Germany and other northern countries, most families who have gardens grow enough of $\mathrm{N}$. rustica for their own use; but as they do not know how to cure it, it is not much valued, and is never made into chewing tobacco or snuff.

In the culture of Tobacco in America, the plants are raised on beds early in spring, and when they have acquired four leaves, they are planted in the fields in well prepared earth, about three feet distance every way. Every morning and evening the plants require to be looked over, in order to destroy a worm which sometimes invades the bud. When four or five inches high they are moulded up. As soon as they have eight or nine leaves, and are ready to put forth a stalk, the top is nipped off, in order to make the leaves longer and thicker, by diverting all the energies of the plant to them. After this, the buds which sprout from the joints of the leaves are all plucked, and not a day is suffered to pass without examining the leaves, to destroy a large caterpiliar, which is sometimes very destructive to them. When they are fit for cutting, which is known by the vrittleness of the leaves, they are cut with a knife close to the ground, and, after lying some time, are carried to the drying shed, where the plants are hung up by pairs upon lines, having a space between, that they may not touch one another. In this state they remain to sweat and dry. When perfectly dry, the leaves are stript from the stalks and made into small bundles tied with one of the leaves. These bundles are laid in heaps, and covered with blankets. Care is taken not to over-heat them, for which reason the heaps are laid open to the air from time to time, and spread abroad. This operation is repeated till no more heat is perceived in the heaps, and the tobacco is then stowed in casks for exportation. (Long. Jam. iii. 719.)

In the manufacture of tobacco, the leaves are first cleansed of any earth, dirt, or decayed parts ; next, they are gently moistened with salt and water, or water in which salt along with other ingredients has been dissolved, according to the taste of the fabricator. This liquor is called tobacco sauce. The next operation is to remove the midrib of the leaf; then the leaves are mixed together, in order to render the quality of whatever may be the final application equal: next, they are cut into pieces with a fixed knife, and crisped or curled , the are them into cords, or twist them into rolls by winding them with a kind of mill round a stick. These operations are all performed by the grower, and in this state (rolls) the article is sent from America to other countries, where the tobacconists cut it into chaff-like shreds for the article is sent from America to other countries, where the tobacconists cut it into chaff-like shreds for
smoking, by a machine like a straw-cutter; form it into small cords for chewing; or dry and grind it for snuff. In manufacturing snuff, various matters are added for giving it an agreeable scent, and hence the numerous varieties of snuffs. The three principal sorts are called Rappees, Scotch or Spanish, and Thirds. The first is only granulated, the second is reduced to a very fine powder, and the third is the siftings of the second sort. The best Havannah segars are made from the leaves of N. repanda. The Indians of the Rocky Mountains of N. America prepare their tobacco from N. quadrivalvis and N. nana. 


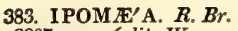
2207 quamóclit $W$. 2208 dissécta $P h$. 2209 carolina $P h$. 2210 tuberósa $W$. 2211 paniculáta $\dot{B}$. Reg. 2212 pentaphýlla Jac. 2213 umbelláta $L$ 2214 tuberculáta $B$. Reg. 2215 péndula $\boldsymbol{R} . \mathrm{Br}$ 2216 Pes-tígridis $W$

2217 platénsis $\mathrm{Ker}$. 2218 chryséides Ker. 2220 setósa Ker. 2221 scábra $\mathrm{Gm}$. 2222 Turpéthum $\mathrm{Br}$. 2223 lutéola W.en. 2224 coccínea $W$. en. 2225 lacunósa $W$. I. insignis B. R. 2227 Bona-nox $W$ 2228 sanguínea $V a h l$. 2229 mutábilis $R$. Reg. 2230 cándicans $\boldsymbol{B} . \boldsymbol{M}$. 2231 Jálapa $P h$. $\beta$ rosea 2232 hepaticifólia $W$. 2234 campanuláta $W$ 2235 violacea $W$. 2236 cárnea $W$ 2237 repánda $W$. 2238 sibirica $\boldsymbol{P}$. $\boldsymbol{S}$. 2239 speciósa $\boldsymbol{P}$. S. 2240 purpúrea $P . S$ $\beta$ incarnáta r vária 2241 discolor Jac. 2242 triloha $W$. 2243 hederifólia $W$ 2244 Nil $P$. $S$.

2245 hederácea $B$. Reg. 2246 cuspidáta $P$. S. 2247 tamnifólia $W$. 2248 grandiflóra B. Rep. 2249 muricáta Jac. 2250 obscúra B. Reg.

2251 sagittifólia $\boldsymbol{K e r}$. 2252 médium $W$. 2253 denticuláta $R . B r$ 2254 glaucifólia $W$. 2255 angustifólia $\dot{J a c}$.

I POMEA. wing-leaved cut-leaved Carolina $\$$ or 10 jn.s panicled $\triangle \mathrm{Jm} 20$ jn.s five-leaved $\$[0$ or 20 au.s umbel-flowered $\$ \square \nabla$ or $20 \mathrm{jn} . \mathrm{jl}$ tubercled $\$ \square$ or 10 au.s pendulous $\$ \mathbb{N}$ or $10 \mathrm{my} .0$ palmated

Plata Mr. Herbert's कु $\Delta$ or 4 jn.s pale-blue $\$$ or 9 jn.s rough $10 \mathrm{~s}$ square-stalked $\$$ or $5 \mathrm{jl.s}$ crimson-scarlet $\bar{O}$ or $10 \mathrm{jn.s}$ starry $\mathrm{O}$ or 10 jl.au splendid \$ $\square$ or 15 jn.s

prickly $\$[0]$ or $10 \mathrm{jl}$.au

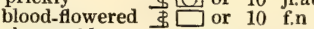
changeable $10 \mathrm{my}$.s hoary \$ $\triangle$ or 15 jn.au Jalap rose-colored, \$ $\mathrm{N} \mathrm{m} 10$ au.s Hepatica-leav'd $\$$ or 10 au.s

Nightshade-lvd. $\$[0]$ or 8 jl.au bell-flowered \$ए丁 or 8 au.s purple-flowered $\$$ or 8 au.s purple-flowered $\begin{aligned} & \text { S } 0 \text { or } 8 \text { au.s } \\ & \text { flesh-colored } 10 \text { au.s }\end{aligned}$ flesh-colored
scolloped Siberian 0 or 8 jl.au broad-leaved $\square$ or 8 jl.au great-purple 0 or 10 jn thesh-colored thesh-colored striped \$ $\bigcirc$ or 10 jn.s $\begin{array}{lll}\text { spotted } & \$ \\ \text { three-lobed } & \text { or } 20 \mathrm{jn} . \mathrm{s} \\ & & \end{array}$ Ivy-leaved \$ $O$ or $10 \mathrm{jl}$ blue five-lobed \$ $O$ or $10 \mathrm{jl}, \mathrm{s}$ sharp-pointed $\bigcirc$ or 10 jn.jl Tamnus-leaved \$ $\mathrm{O}$ or $10 \mathrm{jl}$ great-flowered \$ $\square$ or $8 \mathrm{~s}$ rough-stalked \$잉 or 8 jl.au

Catesby's \& $\triangle$ or 3 jn.s arrow-headed \$0ु or 6 jl.au arrow-headed
denticulate $\begin{array}{llll}\text { glaucous-leaved } \$ \bar{D} \text { or } & 6 & \mathrm{my} . \mathrm{jl}\end{array}$ narrow-leaved $\$[0]$ or 6 jl.au

trifid \$ٔ $\$$ or 10 jl.au

thick-leaved $\quad *$ [O] or $10 \mathrm{jn} . \mathrm{jl}$

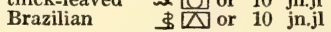

\section{6 tridentata $\boldsymbol{P} . S$.}

2257 marítima $R$. $B r$. 2258 brasiliénsis $I$. 2219 cærúlea Ker. 2226 gossypiifólia $\boldsymbol{W}$.

2233 solanifólia $W$. tuberous-rooted $\bar{t}$ or 10 jl.au bristly 9 au bright-scarlet \$ [0] or 10 jn.s

vulacea. Sp. 52-170.

D.R E. Indies 1629. S r.m Bot. mag. 244

Georgia 1813. C s.p Wil.phy.1.t.2.f.3

Pu Carolina 1732. C r.m Dill, elt. t.84.f.98

Pa.Y W. Indies 1731. C s.p Bot. reg. 768

Pk E. Indies 1799. C s.p Bot, reg. 62

W W. Indies 1739. S s.p Jac. ic. 2 t. 319

S W. Indies 1739. R r.m Plu. am.88. t.102

Pu E. Indies 1815. C l.p Bot. reg. 86

Pk N. S. W. 1808. R 1.p Bot. rep. 613

E. Indies 1732. C s.p Dil.el.t.318.f.411

V S. Amer. 1817. S r.m Bot. reg. 333

Y China 1817. S r.m Bot reg 270

L.B E. Indies 1818. S r.m Bot. reg. 276

Pu Brazil 1817. S r.m Bot. reg. 335

W S. Amer. 1804. S r.m

W Ceylon 1759. S r.m Bot. mag. 2093

Carolina 1759. S r.m Bot. mag. 221

D.R W. Indies 1713. S r.m Bot. rep. 99

W N. Amer. 1640. C r.m Dill.elt.t.87.f.10\%

$\mathrm{Pu} \quad$..... $\quad$... C $\quad$ s.p Bot. reg. 75

W W. Indies 1773. S s.1 Bot. mag. 752

D. R W. Indies 1812. C s.l Bot. reg. 9

Pu S. Amer. 1812. C p.l Bot. reg. 39 "

W N. Amer. 1776, R p.1 Bot. mag. 1603

Li America 1733. C r.m Bot. mag. 1572

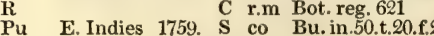

Pk America 1759. C s.p Plum. ic. t.94.f.1

Pu.w E. Indies 1800 , S s.1 Rhd.mal.11.t 56

$\mathrm{Pu}$ S. Amer. 1732. S s.l Plum.ic.t.93.f.1

F S. Amer. 1799. S s.l Jac. am. 26, t. is

S W. Indies 1793. C s.p Par. lond. 81

F Siberia 1779. S co Pa.it.3.p.723.t. K

Pu E. Indies 1778. C p.l Bot. mag. 2446

D.Pu America 1629. S co Bot. mag. 113

F America 1629. S co

St America 1629. S co Bot. mag. 1682

B.w $\quad$....... $\quad$... S S co Bot. mag. 1005

V W. Indies 1752. S s.l

$V$ S. Amer. 1773. S s.1 Pl. ic.82.t.93. f.2

L.B America 1597. S s.p Bot. mag. 188

B N. Amer 1720 S s.p Bot reg. 85

L.Pu S. Amer. 1732. S s.p Fl.per.2.t.119.f a

B Carolina 1732, S co D. elt.t.318,f.410

W E. Indies 1802. S s.l Bot. rep. 188

Pu E. Indies 1777. S co Jac. schœ.3.t.323

E. Indies 1732. S s.p Bot. reg. 239

Pu Carolina 1819. S co Bot. reg. 437

$\mathrm{Pa}$ E. Indies 1778. S co

Y E. Indies 1778. S co Bot. reg. 317

Pk Mexico 1732. R s.p Dil. elt.t.87.f.101

Pk India 1800. S s.1 Jac. ic. rar. t.317

2915
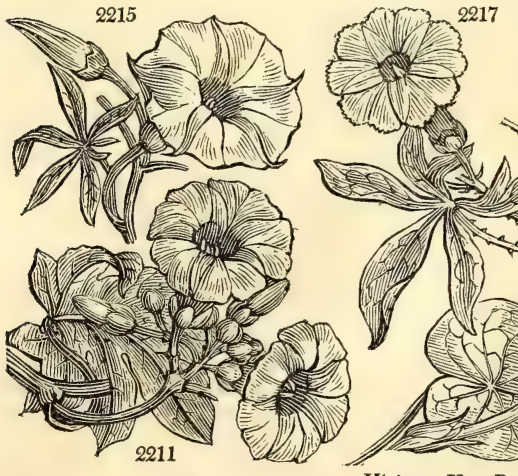

History, Use, Propagation, Culture.

$\mathrm{Pu} \quad$ E. Indies 1770. S s.p Bot. reg 319

Pu S. Amer. 1726. R s.p Plu. am.89. t.104

383. Ipomaa. From 4 เros, a bindweed, or something analogous, and oposos, similar. This genus is nearly allied to Convolvulus and Calystegia. It consists chiefly of twining stove plants, free flowerers, and of the easiest culture. I, tuberosa is a plant of great beauty and fragrance. In Jamaica it is evergreen, thickly covered with leaves and large flowers, and much used to shade arbors. Browne says it may be carried over an arbor of 300 feet in length. Every part of the plant abounds with milk, and is purgative. Long thinks Scammony might be made from its tubers, and Loureiro affirms them to be edible. 
1. Leaves pinnate, digitate, or palmate.

0207 Leaves pinnate pinnæ filiform, Pedunc. a little longer than leaf 1 -flowered

2208 Leaves palmate, Segments narrow pinnatifid toothed, Pedunc. about 2-flowere

2209 Leaves digitate, Leaflets stalked, Pedunc. 1-flowered

Q210 Leaves palmate, Lobes 7 lanceolate acute entire, Pedunc. 3-flowered

2211 Smooth, Leaves palmate, Lobes 7 oblong lanc. entire, Cymes dichotomous, Cal. equal obtuse, Caps. erect

2212 Leaves digitate in $5 \mathrm{~s}$ hairy entire, Seeds smooth

2213 Leaves digitate in 7, Peduncles umbelled very short

2214 Leaves digitate or nearly pedate 7-parted smooth, Stalks warted rough, Pedunc. 1-flowered

2215 Leaves palmate pedate, Lobes ciliate mucronate at end, Pedunc. 1-flowered

2216 Leaves palmate, Flowers aggregate

2217 Branches peduncles and petioles tubercled, Leaves palmate, Lobes 7 narrow oblong with a short point 2. Leaves cordate, angular, or lobed.

2218 Leaves obl. cordate rarely obsoletely 3-lobed, Pedunc. 1-fl. shorter than leaf, Calyx very smooth

2219 Leaves cordate 3-lobed villous, Pedunc. 2-3-fi. Edge of cor, nearly entire, Stigmas 3-lobed

2220 Branches petioles peduncles and calyxes bristly, Leaves naked cordate 3-lobed, Lobes tooth sinuated

2221 Stem twining, Leaves cordate 3-lobed, Pedunc. longer than petiole, Fruit nodding

2222 Leaves cordate angular, Stem membranous square, Peduncles many-flowered

2223 Leaves cordate acuminate angular, Pedunc. first dichotomous afterwards branching

2224 Downy, Lvs, cord. acum. at base angular, Pedunc. 5 -flowered, Cal, warted bearded, Limb. of cor. entire

2225 Smooth, Lvs, cord. below obscurely repand or ang. Pedunc. short 1-fl. Cal, hairy ciliated, Cor. small short

2226 Leaves cordate at the end 5-lobed smooth, Peduncle many-flowered corymbose

2227 Very smooth, Leaves cordate entire or angular, Pedunc. 1-3-fl. Cal. aristate, Cor. undiv. Tube very long 2228 Pedunc. upwards cymose trichotomous longer than the 5-lobed cordate or hastate leaves

2229 Leaves cordate entire or 3-lobed acuminate above pubescent beneath villous, Flowers numerous in cymes 2230 Smooth, Leaves cordate acuminate entire, Peduncles many-flowered without bractex

2231 Stem warted, Leaves cord, ovate rugose villous beneath entire or lobed, Pedunc. 1 many-fl. Seed woolly

2232 Leaves 3-lobed, Flowers aggregate

83. Leaves cordate entire.

2233 Leaves cordate acute entire, Pedunc. 1-flowered solitary as long as leaves

2234 Leaves cordate, Pedunc. many-fl. Outer calyx orbicular, Cor. campanulate lobed

2235 Leaves cordate entire, Flowers close together, Cor. undivided

$2230^{\circ}$ Leaves roundish cordate smooth, Pedunc. many-flowered, Cor. edged

2237 Leaves cordate oblong repand acuminate, Peduncles branched cymose

2238 Leaves cordate acuminate smooth, Peduncles 2 -flowered

2239 Leaves cordate ovate acute above hairy, beneath silky, Pedunc. longer than the stalks in umbels

2240 Leaves cordate undivided, Fruit cernuous, Stalks thick, Leaves cordate entire, Ped. many-f. Cal. hispid

2241 Stem very tall, Leaves orbicular rounded, Flowers spotted with eyes

2942 Leaves 3-lobed cordate, Peduncles 3-flowered

2243 Leaves 3-lobed cordate, Peduncles many-flowered racemose

2244 Leaves cordate 3-lobed, Flowers half 5-cleft, Peduncles shorter than the petioles

$22+5$ Hairy, Leaves cordate 3-lobed, lateral lobes acuminate intermediate acute, Pedunc. 1-f. Cal. hairy

2246 Leaves cordate 3-lobed, Lobes cuspidate, Peduncles 1-f. Sepals linear very hairy at base

2247 Leaves cordate acuminate hairy, Flowers aggregate

2248 Leaves cordate ovate obtuse entire, Pedunc. about 2-fl. Cal. coriaceous, Stem and petioles pubescent

2249 Leaves cordate roundish with a long point smooth, Pedunc. thick 3-fl. and cal. smooth, Stem muricated

2250 Leaves cordate acuminate, Pedunc. filiform 1-fl. and cal, smooth, Stem very hairy

4. Leaves sagittate or hastate.

2251 Very smooth, Leaves oblong sagittate with a very deep sinus, Auricles acuminate, Pedunc. 1-flowered 2252 Leaves linear hastate pointed, Auricles toothed, Flowers solitary, Cal. sagittate

2253 Smooth, Leaves hastate lanceol. or linear acute, Lobes toothed, Pedunc. 1-fl. Sepals oblong lanc, ovate 2254 Leaves sagittate truncate behind, Peduncles 2 -flowered

2255 Leaves linear hastate obtuse mucronate smooth, Auricles nearly entire, Peduncles 1-flowered 5. Leaves oblong, entire, or lobed.

\$256 Leaves oblong 3-pointed dilated at base toothed, Pedunc. 1-fl. thick 4-cornered

$$
\text { 6. Leaves rounded. }
$$

2257 Creeping smooth, Lvs, roundish emarginate or 2-lobed thickish at base beneath with 2 glands, Cal. obt. 2258 Leaves emarginate with 2 glands at base, Peduncles 3-flowered

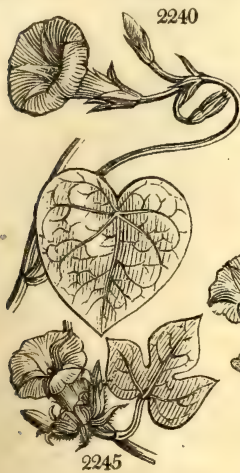

2245

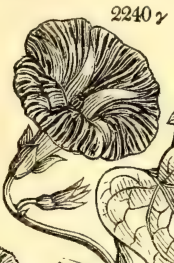

$2240 \mathrm{r} \quad 2248$
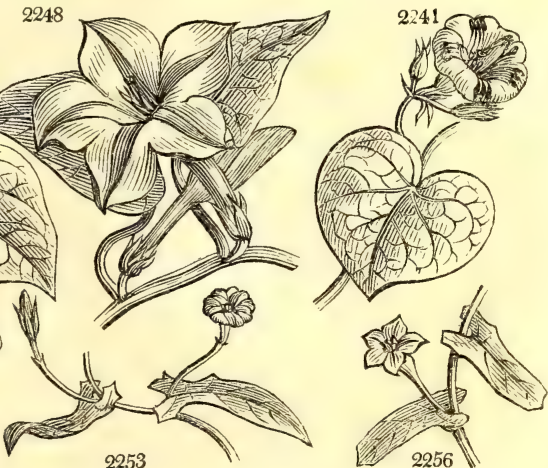

2253

2256

and Miscellaneous Particulars.

I. bona-nox, like most of the species of this genus and Convolvulus, varies much in the leaves, which it produces cordate, lobed, or panduriform.

I. nil is a highly beautiful plant, with the corollas of a clear blue color, whence its name of Anil or Nil (Indigo.)

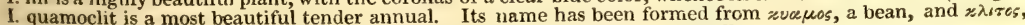
dwarf, because it resembles the kidney-bean in its climbing stem, but is less tall.

I. jalace ing which its root affords.

It is said to have been first brought to Europe in 1610 . Its virtue as a purge resides chiefly in the resin. 
384. CONVOU VULUS, $W$. BIND-WEen.

small $\Delta w 11$ jn.s $F$ Britain cor. fi. R co Eng. bot. 312

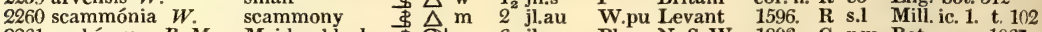
2261 erubéscens $B$. $M$. Maiden-blush $\quad$ \$团 or 6 jl:s $\quad$ Pk $\quad$ N. S. W. 1803. C r.m Bot. mag. 1067

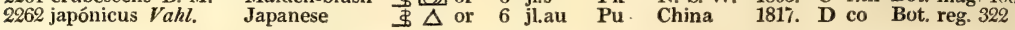

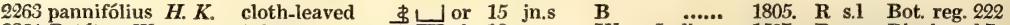
屯.

2205 bícolor $V a h l$. 2266 pandurátus $W$.

2267 althæoides $W$. 2268 bryoniæefólius $B$. 2269 macrocárpus $W$. 2270 gláber $W$.

2271 pentánthus $B . M$. 2272 canariénsis $W$

2273 farinósus $W$. 2274 ciliátus $W$. en. 2275 máximus $W$ 2276 Hermánniæ $W$

2277 siculus $W$ 2278 elongátus $W$. en.

2279 Imperáti Vahl. 2280 réptans $W$ 2281 hirtus $W$. 2289 Dorýcnium $W$.

involucrated \$잉 or $6 \mathrm{jn} . \mathrm{au}$ Virgínian

Althæa-leaved $\omega * \Delta$ or 1 jn.s Althaea-leaved $*$ or 1 jn.s long-fruited $\$$ or 10 il.au smooth $\$ \square$ or 12 my.jn 1597.

W.pu Isl. France1818. W.pu N. Amer. 1739 .

Pk Levant 1597. R s.l Bot. mag. 359 Pu S. Amer. 1752. S co Plum. ic. 91 f Cayenne 1806. C p.l Aub. gui. t. 53

five-flowered \$ $\square$ or 6 jl.s $\quad$ L.B E. Indies 1808. C s.l Bot. mag. 2151 Canary 15 or 20 my.s Pu Canaries 1690. R s.l Bot. mag. 1228 mealy-stalked $\$ \Delta$ or 6 my.jn Pk Madeira 1777. R s.1 Par. lond. 45 hairy $\quad 0$ or 6 jl.s $\quad$ Pk Ceylom great-ceylon

1816. S co

Ceylon 1799. R r.m Rhd. mal.11.t.53 Peru 1799. R r.m Jac. ic. 2. t. 315

small-flowered ** $\bigcirc$ or 1 jn.au L.B S. Europe 1640. S co Bot. reg. 445 long-peduncled $*$ or 1 jl.au W Canaries 1815. S co Bot. reg. 498

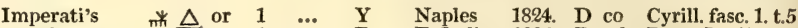

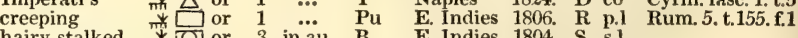
hairy-stalked 4 [O] or 3 jn.au B $\quad$ E. Indies 1804. S s.1
Pk Madeira 1788. R r.m Bot. reg. 133

L.B Majorca 1789. S co Jac. col.4.t.22.f.2

$\mathrm{Pu}$ S. Europe 1714. R s.1 Tri.ob.91.t.91.f.2

W S. Europe 1796. R s.1 Bo. mus.138.t.96

Pk Levant 1640. C p.1 Bot. mag. 459

Pk $\quad$ ….. 1770. C 1.p Bot. mag. 289

S. Europe 1680. R s.1 Jac. aus. 3. t.296

Levant 1806. C s.l

Canaries 1733 C s.l Vent. choix. 24

Canaries 1779. C p.l Jac ic. 1. 34

S. Europe 1629. S co Bot. mag. 27 2282 suffruticósus $H$. $K$. 2284 lineátus $W$. 2285 saxátilis $W$ 2286 Cneórum $W$ 2287 lineáris $W$. 2288 cantábrica $W$. 2290 scopárius $W$. 2291 flóridus $W$ 2292 trícolur $W$.

shrubby Majorca dwarf rock

silvery-leaved narrow-leaved Flax-leaved silky-leaved Broom three-colored $* \mathrm{O}$ or

385. ARGyreiA. Lour. Silver-weed. 2293 cuneáta Ker. 386. NEMO'PHILA. 2294 phacelioídes wedge-leaved

Nevophila. shady
ㄴ. $\square$ or

387. CAlystegia. $\boldsymbol{R}$. $\boldsymbol{B r}$. Benrbind.

2295 sépium $R$. $B r$. $\beta$ incarnáta 2296 sylvéstris $\boldsymbol{W}$. en. 2297 spithamæ'a $\mathbf{P h}$. 2298 Soldanélla $R, B$ r. sea great-hedge red-flowered wood

mall-upright sea

Convolvulacee. Sp.1-4.

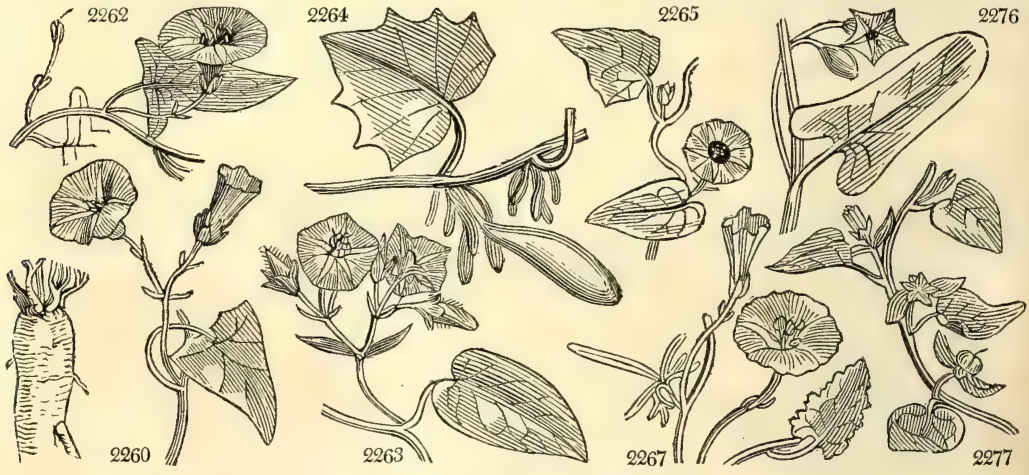

History, Use, Propagation, Culture, Convolvulacea. Sp.3-7.

क $\triangle$ or 6 jn.s W Britain m.hed. R s.l Eng. bot. 313 $\Delta$ or 6 jn.s $R \quad N$. Amer ... $R$ co Bot. mag. 732 $\$ \Delta$ or 18 jn.s W Hungary 1815. R co

W N Amer 1706 R co Hook ex fl 97 sh. $\mathrm{R}$ s.l Eng. bot. 314 
1. Climbing; leaves sagittate or hastate.

2259 Leaves sagittate acute at each end, Peduncles about 1-flowered

2200 Leaves sagittate truncate behind, Peduncles rounded 3-flowered

22061 Leaves cordate sagittate behind sinuate repand, Pedunc. axillary solitary about 2-flowered

2262 Leaves lanceolate hastate acute, Auricles 1-toothed behind, Stem simple, Peduncles 1-flowered

$\$ 2$. Climbing; leaves cordate hastate.

2263 Leaves cordate hastate hirsute, Pedunc. about 3-flowered, Bract. linear remote from calyx 2264 Leaves cordate hastate angular lobed 5-nerved smoothish, Ped. long, Fl, fasc. Sepals lanceol. acuminate 3. Climbing; leaves cordate lobed.

0265 Leaves cordate villous at the base angular lobed, Peduncles 1-flowered, Outer sepals bract-like 2266 Pubescent, Leaves broad cordate entire or lobed fiddle-shaped, Pedunc. long, Flowers fascicled \&4. Climbing; leaves quinate or palmate.

2267 Leaves cordate sinuate silky lobes repand, Pedunc. 2-flowered

2268 Leaves 7-lobed palmate hispid middle lobe sinuated drawn out, Pedunc. axill, solitary very long jointed 2269 Leaves palmate pedate 5-parted, Pedunc. 1-flowered

2270 Very smooth, Leaves digitate quinate, Leaflets stalked acuminate entire, Pedunc. branched divaricating 5. Climbing; leaves cordate or subcordate.

2271 Leaves oblong cordate acuminate subrepand smooth, Pedunc. umbelled 5-flowered, Flowers sessile 2272 Leaves cordate pubescent, Stem perennial villous, Pedunc. many-flowered

2273 Leaves cordate acuminate repand, Pedunc. 3-flowered, Stem mealy

2274 Leaves cordate ovate acuminate ciliated, Heads stalked very hairy with an involucrum

2275 Leaves cordate ovate acuminate entire smooth, Stem and leaf-stalks smooth

2276 Tomentose, Leaves cordate oblong obtuse subrepand, Pedunc. longer than stalk, Limb acute

8. Prostrate; leaves cordate.

2277 Leaves cord. ovate upper acute, Ped. 1-fl. shorter than leaves, Bractes obl. lanc. longer than ciliated cal. 2278 Leaves cordate ovate cusp. Ped. 2-fl. longer than leaves, Bractes lin. subul. shorter than parted peduncle 7. Prostrate; leaves cordate lobed or hastate.

2279 Leaves panduriform or entire emarginate cordate at base, Peduncles 1-flowered, Stem creeping 2280 Leaves hastate lanceolate, Auricles rounded, Stem creeping, Peduncles 1-flowered

2281 Leaves cordate and somewhat hastate villous, Stem and leaf-stalks hairy, Peduncles many-flowered 8. Prostrate; leaves ovate or oblong and linear.

2282 Leaves linear lanceolate, Stem ascending villous, Peduncles axillary 1 -flowered 3 times as long as leaf 2283 Leaves lanceolate obtuse naked lined, Branches declinate, Flowers silky $\frac{1}{2} 5$-cleft

2284 Leaves lanceolate silky lined stalked, Peduncles 2 -fl. Cal. silky leafy

2285 Very hairy, Leaves linear, Flowers capitate, Calyxes acuminate

2286 Leaves lanceolate tomentose, Flowers capitate, Calyxes hairy, Stem nearly erect

2287 Stems erect shrubby, Leaves linear acute silky, Flowers terminal umbelled panicled, Cal. hairy

2288 Leaves linear lanc. acute, Stem branched nearly erect, Cal. hairy, Pedunc. 2-flowered

2289 Leaves neariy linear silky, Stem panicled, Cal. naked obtuse

2290 Leaves linear hairy, Peduncles about 3-flowered, Cal. silky ovate acute, Branches twiggy

2291 Prostrate hoary, Leaves linear lanceolate smooth, Thyrse terminal pyramidal compound

2292 Leaves lanceolate ovate smooth, Stem declinate, Flowers solitary

2293 Leaves wedge-shaped emarginate beneath silky, Peduncles 2-flowered

2294 The only species

2295 Leaves sagittate very acute, behind obtuse or trunc. entire, Bract. ac. longer than cal. twice as short as cor.

2296 Leaves cordate, Lobes angular truncated, Pedunc. rounded 1-fl. Bract. ovate obt, inflated, Sepals obtuse 2297 Leaves cordate pubescent, Stem erect, Peduncles 1-flowered

2298 Leaves reniform, Peduncles 1-flowered, the angles winged

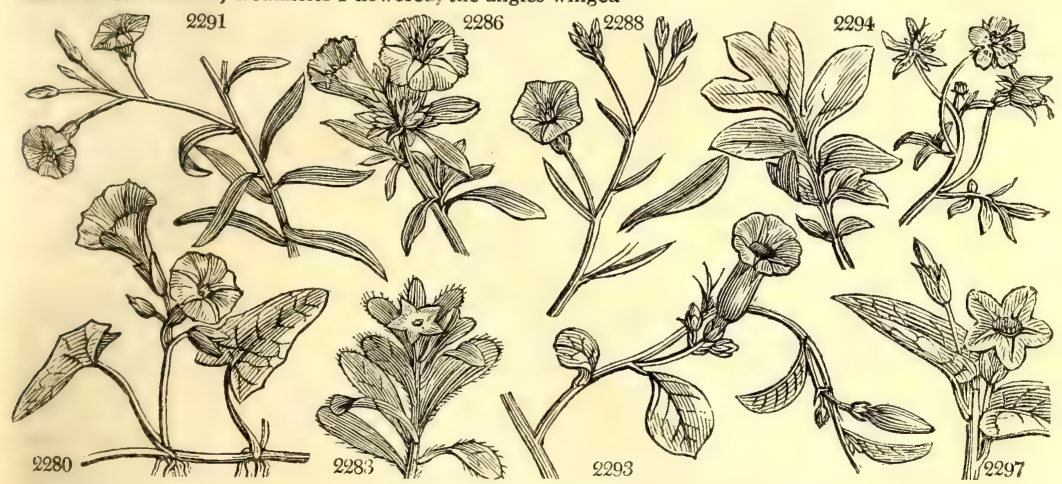

and Miscellaneous Particulars.

pical climates much in the same manner as our potatoe, but with more room for its trailing stalks. Not only the tubers, but the young leaves and tender shoots are boiled and eaten; and as is the case with all plants long in cultivation, there are several varieties.

C. tricolor is a well known border-annual, commonly called C. minor, with reference to another border-

tower, Ipomoa purpurea, which gardeners and seedsmen commonly call C. major

C. reptans, is a common potherb in the East Indies and in China.

385. Argyreia. From aerugov, silver, in allusion to the silvery texture of the leaves of the plant. A beautiful genus nearly related to Convolvulus.

386. Nemophila. From $y \varepsilon \mu 05$, a grove, and $\phi i \lambda \varepsilon \omega$, to love; the species growing in shady woods. A small hardy N. American plant, with bright blue flowers and divided leaves.

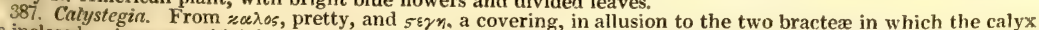
is inclosed. A very artificial genus, distinguished from Convolvulus and Ipomoa, only by the presence of bracteæ, and by its capsule being one-celled. C. sepium, the Convolvulus sepium of Willienow, has inedical properties similar to Scammony, for which Withering thinks it may serve as a sulstitute. Swine, it is said, eat the roots in large quantities, and yet are not purged by them. C. soldanella is an acrid purge. 
388. COB形'A Cav. 2299 scándens Cav. 389. CAN'TUA. $W$. 2300 coronopifólia $\boldsymbol{W}$. 2301 inconspicua $H . K$ 390. HOITZiA. Cav. 2302 coccínea Cav. 2303 cærúlea Cav.

391. RET'ZIA. Th 2304 spicáta $T h$.

392. LUBI'NIA. Comm 2305 atropurpúrea $L k$. 393. EPA'CRIS. R. Br. 2306 purpuráscens $R$.

2307 pulchélla $R . B r$.

2308 grandiflóra $R . B r$. 2309 obtusifólia $R$. $B r$.

2310 exsérta $R$. $B r$

2311 microphyiled 394. STYPHE'LIA. $R$. Br. STYPHELIA. 2312 longifólia $R . B r$ 2313 viridiflóra $R$. Br. 2314 triflóra $R$. $B r$. 2315 tubiflóra $R$. Br long-leaved green-flowered three-flowered crimson

395. LISSAN'THE $R, B r$ LISSANTHE. 2316 daphnoides $R$. Br. Br. Daphne-leave. 396. Astrolo ma. $R$. Br. Astroloma. 2317 humifúsum $\boldsymbol{R}$. Br. Juniper-leaved 397. SPRENGE'LIA. $\boldsymbol{R}$. Br. SPREnGELia. 2318 incarnáta $R . B r$. flesh-colored 398. ANDERSO'NIA, $R, B r$. ANDERSONIA 2319 sprengelioídes $R . B r$. Sprengelia-like $\downarrow$ or 399. LYSINE'MA. $R . B r$. LYSINEMA. 2320 púngens $R, B r$ $\beta$ rúbrum

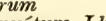
pungent red $r$ 堂 ᄂ 2321 attenuátum $L k$. narrow-flower'd $\square$ or 400. MONO'TOCA. R. Br. MoNotoca. 2322 elliptica $R$. $B r$. elliptic

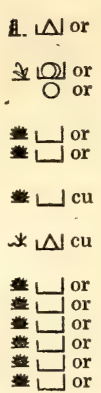

Cobceacea. Sp. 1. Polemoniacece. Sp. 2-16.

au s S Carolina 1726. C 1.p Ex. bot. 1. t. 13 America 1793. S co Ex. bot. 1. t.14 Polemoniacea. $S p .2-5$.

... S Mexico 1824. C r.m Cav.ic. 6. t. 365 ..P Pa.B Mexico 1824, C r.m Cav, ic. 6. t. 366 Convolvulacea. Sp. 1. 4 my.jn Br C. G. H. Primulacea. Sp. 1-3.

...' i Pu C. G. H. 1820. C 1.p Epacridea. $\quad$ Sp 6-18.

3 ja.mr Pu N. S. W. 1803. C s.p Bot. mag. 844 4 ap.jn Pk N. S. W. 1804. C s.p Bot mag 1170 3 ja.jn S N S. W 1803 . C s.p Bot. mage 989 3 ap.jn W N. S. W. 1804. C s.p Ex. bot. 1. t. 40 2 a.p.jn W V.Di, L. 1812. C 1.p ... $\quad \ldots \quad$ N. S. W. 1822. C l.p

Epacridea. $\quad$ Sp.4-8.

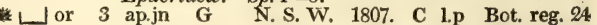

政 or 4 ap.jn G N. S. W. 1791. C s.p Bot. rep. 312 政 6 my.au Pk N. S. W. 1796. C s.p Bot. mag. 1297 6 my.au C N. S. W. 1802. S s.p Smithn.hol.t.14 Epacridece. Sp. 1-6.

3 jn.jl W N. Holl. 1818. C s.p Bot. cab. 466 Epacridea. $S p .1-6$.

2 my.o S N. S. W. 1807. C s.p Bot. mag. 1439 Epacridea. $S p .1-2$

2 ap.jn F N. S. W. 1793. C s.p Bot. mag. 1719 Epacridea. Sp. 1 -6.

2 mr.jl Pk N. Holl. 1803. C s.p Bot. mag. 1645 Epacridea. Sp. 2-5.

2 f.ap W N. S. W. 1804. C I.p Bot. mag. 844 f.ap $\quad \mathrm{R} \quad$ N. S. W. 1804. C 1.p Bot. mag. 1199 f.ap Pk N. S. W. 1812. C 1.p Bot.cab.38 Epacridea. Sp. 2-5.

8 my.au W N. S. W. 1802. C 1.p 6 my.au W V. Di. L. 1804. C s.p L.nov.holl.1.t.61

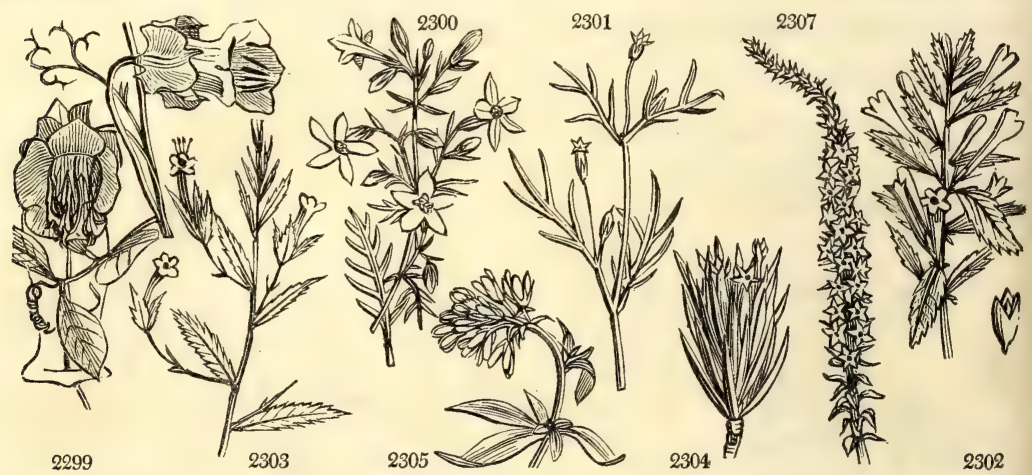

History, Use, Propagation, Culture,

388. Cobaca. In honor of Barnadez Cobo, a Spanish Jesuit, who wrote upon subjects of natural history about the middle of the 17th century. The name arose with Cavanilles. This is the most rapid growing greenhouse climber known, having been found to grow 200 feet in length in one summer in a conservatory. It will thrive almost equally well in the open air during summer, but is destroyed by frost; and its shoots are only of annual, or at most of biennial duration. It strikes in sand in moist heat, but it generally ripens seeds, which, sown early in spring, and forwarded in a stove, will flower in the greenhouse or open air the same season.

389. Cantua. From Cantu, the native name of the genus among the Peruvians. Pretty greenhouse plants, rarely seen in gardens.

390. Hoitzia. Hoitzit is the name of this plant in Mexico. A handsome plant with brilliant scarlet flowers. It is occasionally raised from Mexican seed, but is very rare in collections.

391. Retzia. Named after John Retzius, professor of hotany at Lund, in Sweden. His Observationes Botanicæ is a work of reputation. A small upright shrub with whorled lanceolate leaves, and clustered brown flowers, almost hidden among the leaves.

392. Lubinia. A genus dedicated by Commerson to M. de Saint Lubin, a French officer who travelled in the East Indies. A small plant with ascending stem and fleshy smooth leaves, of little merit.

393. Epacris. Named by Forster from $\varepsilon \pi t$, upon, and axpos, the top of a thing; because in New Zealand the species grow on the top of the mountains. A most ornamental genus, which Sweet observes, thrives " best in a sandy peat soil ; the rougher and more turfy the soil is, the better the plants will thrive: these should always be shifted in fresh pots before they are turned out of doors in spring, as their roots are so very fine, and always be shifted in fresh pots before they are turned out of doors in spring, as their roots are so very fine, and
are generally matted round the pots, so that the hot sun coming against the pots destroys them, and they look brown all through the summer, and are very difficult to recover. Young cuttings planted in pots of sand under bell-glasses in autumn or winter, or early in spring, will strike root readily, but thay will not strike so readily in summer : when rooted, they should be potted singly in small pots, and set in a close frame, and must be hardened to the air by degrees." (Bot. Cult. 186.)

394. Styphelia. A name derived from $\sigma \tau \cup \phi o s$, dense, in allusion to the compact habit of the genus. Erect 
2299 The only species

2300 Lobes of leaves linear entire oblong, Flowers panicled terminal, Cor. tubular twice as long as cal. 2301 Plant smaller than the last, Leaves very narrow, Cor. short blue

2302 Stem half shrubby, Leaves sessile ovate acute pubescent

2803 Stem half shrubby, Leaves subsessile linear toothed spinous

2304 Leaves in fours linear sessile erect, Flowers clustered hidden among the leaves

\$305 Leaves fleshy dark-green glabrous obovate, Stem ascending

2306 Sepals acuminate as long as tube of cor. Leaves cucullate subsess, with a recurved end longer than base 2307 Sepals acum. as long as tube of cor. Lvs. conc. their base longer than spreading point, Spike flow. at base 2308 Cor. cylindrical 4 times as long as cal. Flowers pendulous, Leaves acuminate flat

2309 Flowers nodding, Leaves lanceolate erect imbricated with a callous obtuse end, Stamens included

2310 Leaves lanceolate acute erect above flat beneath convex, Cal. obtuse as long as tube, Stamens exserted

2811 Sepals obtuse as long as tube of cor. Leaves cucullate acute spreading, Spike flowering at end

2312 Leaves long lanceolate attenuated at end, above concave smooth at edge, Branches pubescent 2313 Leaves obovate oblong obtuse mucronate flat smooth above roughish at edge, Flowers spreading 2314 Leaves oblong lanceolate flat glaucous smooth, Branches smooth, Flowers corymbose, Ped. 1-3-flowered 2315 Leaves linear obovate mucronate rough above revolute at edge, Flowers nodding

2316 Leaves ellipt. lanceolate concave with a short callous point, Segm. of cor. smooth

2317 Prostrate much branched, Leaves lanceolate linear convex above ciliated at edge

2318 Anthers connate bearded, Cal. colored, Leaves long acuminate

2319 Leaves spreading with a flat point

2320 Cor. monopetalous, Tube entire as long as cal. Leaves ovate acuminate spreading

2321 Leaves sessile cordate acuminate pungent recurved, Cal. imbric. as long as narrow tube of cor.

2322 Spikes erect subterminal aggregate or axillary solitary, Leaves ellipt. oblong 4 times broader than long 2323 Spikes axillary few-flowered nodding stalked, Leaves oblong acute flat mucronate

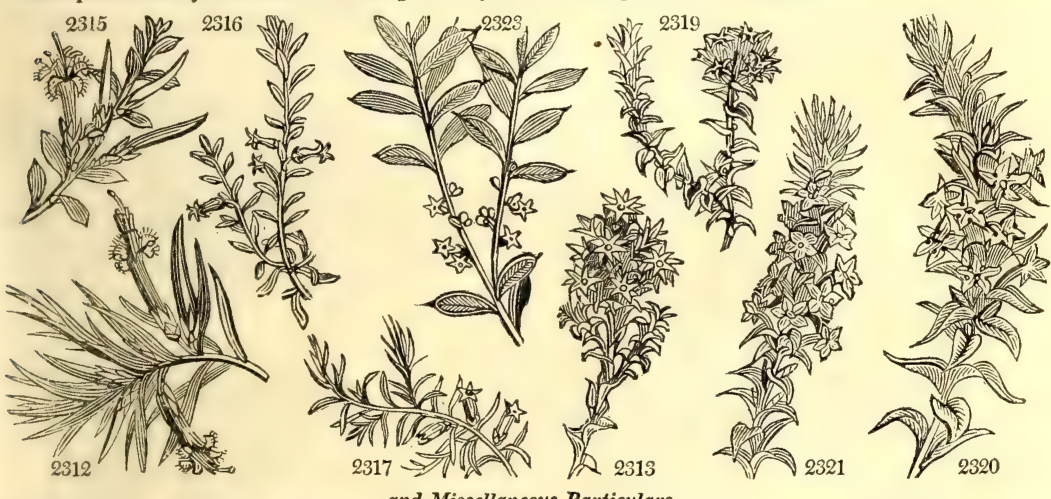

and Miscellanems Particulars.

branched shrubs, natives of New Holland, with scattered mucronate leaves, and axillary, nodding, very showy flowers. Culture as for Andersonia.

395. Lissanthe. A New Holland genus of shrubs with small white flowers, the segments of which are smooth, not bearded as in Leucopogon, to which the genus is next. From this difference its name has been contrived; $\lambda, 6 \sigma 0 s$, smooth, and oy.tos, a flower.

396. Astroloma. From $\alpha$ seav, a star, and $\lambda \tilde{\omega} \mu \alpha, \mathbf{3}$ fringe, in allusion to the stellate disposition of the little bundles of hairs at the bottom of the tube. A genus of neat little bushes, with axillary erect flowers. Culture as for Andersonia.

397. Sprengelia. So called in honor of Curt Sprengel, professor at Halle, in Saxony, a learned man and respectable botanist. His Historia Rei Herbariæ is a monument of industry and information. This is a handsome half-hardy genus, delighting in a shady aspect, sandy peat soil, and dry bottom. They must be watered sparingly when not growing freely. Cuttings root in sand under a bell-glass.

398. Andersonia. Named by Mr. Browne, first, after William Anderson, a navy surgeon, who died in Cook's last voyage ; secondly, after Dr. Anderson, formerly director of the botanical garden, St. Vincents ; and lastly, after William Anderson, the curator of the apothecaries' garden, Chelsea. Aocording to Sweet, this genus "grows freely in a sandy peat soil with the pots well drained; and care should be taken not to over-water it, as they are very liable to get sodden, when they seldom recover. The very young tops put in for cuttings, under a bell-glass in sand, will root readily. When tirst potted off, they should be put singly in small thumbpots, and kept close in a frame for a few days, and hardened to the air by degrees." (Bot. Cult. 133.)

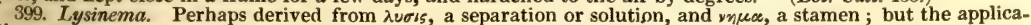
tion of the name is not obvious. Shrubs with the habit of Epacris. They prefer rough turfy soil, and cuttings root readily in sand under a bell-glass.

400. Monotoca. From povos, one, and rozos, birth, because only one ovulum is borne by the ovarium, a remarkable circumstance in the natural order of the genus. The species are little shrubs, with axillary or terminal spikes of white flowers. They require well drained pots, and their cuttings must be taken off when very young, and planted in sand under a bell-glass. 
401. LEUCOPO'GON. $R, B r$. LEUCOPOGON. 2324 lanceolátus $R . B r$. small-flowered 2325 ericoides $R$. Br. Heath-leaved 2326 amplexicaúlis $\dot{R}$. Br. stem-clasping 2327 juniperinus $R . B r$. Juniper-leaved 402. STENANTHE'RA, $\boldsymbol{R} . \boldsymbol{B r}$. STENANTHERA. 2328 pinifólia $\boldsymbol{R} . \mathbf{B r}$. 403. $\mathrm{AZA}^{\prime}$ LEA. $W$. 2329 indica $\boldsymbol{W}$.

$\beta$ purpurea pléna

々 variegáta

álba

$\varepsilon$ aurantiaca

2330 póntica $W$.

$\beta$ glaúca

albiflóra

2331 calendulácea $P h$.

$\beta$ flammea

2332 canéscens $P h$.

2333 nudiflóra $\boldsymbol{W}$.

a coccínea

$\beta$ speciosa

$\gamma$ cuprea

$\varepsilon$ rutilans

ל̌ cárnea

n álba

จ papilionácea

- partíta

* semipléna

$\lambda$ flore pleno

2334 bicolor $P h$.

2335 viscósa $P h$.

$\propto$ odoráta

$\beta$ vittáta

$\gamma$ físsa

2336 nítida $P h$.

2337 glauca $P h$

2338 híspida $P h$.

common-white

narrow-petaled
Epacridece. 12 my.au W

6 ... $\mathrm{Pk}$

3 … W

ap.jn W

Epacridea. Pine-leave

Azalea.

Indian

double-purple

variegated

pure-white

orange

yellow

glaucous

white flowered

orange

flame-colored

downy

naked-flowered

small-scarlet

large-scarlet

orange

copper-colored

deep-red

pale-red

early-white

variegated

five-parted

semi-double

double-flowere

two-colored

viscid

striped-flowered

shining-leaved

dwarf-glaucous $\mathrm{s}$

tall-glaucous ㄴ.vor

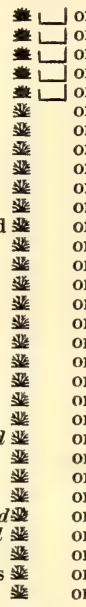

4 mr.my W

4 mr.my O

6 my.jn $Y$

6 my.jn W

4 my.jn $O$

4 my.jn $\mathrm{R}$

3 my.jn $\mathrm{Pk}$

3 my.jn $\mathrm{Pk}$

4 my.jn S

my.jn S

3 my.jn Ful

4 my.jn D.R

3 my.jn L.R

3 my.jn W

4 my.jn St

my.jn W

4 my.jn W

4. my.jn St

jl.au W

3 jl.au

3 jl.au

3 jl.au Pk

4 jl.au Pk

15 jn

Rhodoracee. Sp. 10-14.

N. S. W. 1790. C s.p Bot rep. 287

N. S. W. 1815. C l.p Cav.ic.4.t.347.f.1

N. S. W. 1815. C 1.p Linn. trans.8.t.8

N. S. W. 1804, C 1.p Bot. cab. 447

N. S. W. 1811. C s.p Bot. reg. 218

China ${ }^{1808 .}$ C p.l Bot.mag. 1480

China 1819. C p.l

China 1824. C p.1

China 1819. C p.l Bot. reg. 811

$\begin{array}{llll}\text { China } & \text { 1819. } & \text { C } & \text { p.1 } \\ \text { China } & \text { 1822. } & \text { C } & \text { p.l }\end{array}$

Turkey 1793. L s.p Bot. mag. 433

..... $\quad$... L s.p Bot. mag. 2383

$\ldots \quad$ L s.p

1806. L s.p Bot. mag. 172

N. Amer. 1812. L s.p Bot. reg. 145

N. Amer. 1812. L s.p

N. Amer. 1734. L s.p

N. Amer. 1734. L s.p Bot. mag. 180

N. Amer. 1734. L s.p Bot. cab. 624

N. Amer. 1734. L s.p

N. Amer. 1734. L s.p

N. Amer. 1734. L s.p

N. Amer. 1734. L s.p Bot. reg. 120

N. Amer. 1734. I s.p

N. Amer. 1734. L s.p

N. Amer. 1734. L s.p

N. Amer. 1734. I s.p

N. Amer. 1734. L s:p

N. Amer, 1734. L s.p Trew.ehret. t.48

N. Amer. 1734. L s.p Meerb. ic. 2. t. 9

N. Amer. 1734. L s.p

N. Amer. 1734. C 1.p

N. Amer. 1734. L s.p

N. Amer. 1812. C 1.p

N. Amer. 1734. L s.p Bot. reg. 414

N. Amer. 1734. L s.p Dend. brit. 6

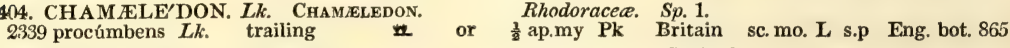
405. BREX'IA. Nor. BREXIA.

2340 madagascariénsis $P$.s. Madagascar

406. OPHIORHI'ZA, $L$. SNAKE-ROoT.

2341 Múngos $\boldsymbol{L}$.

common

$\Phi \square$ or $30 \mathrm{jn}^{\mathrm{G}}$ Mauritius 1812. C s.p Bot. reg. 730 Rubiacea. Sp. 1.

- $\square$ or 3 my.d W E. Indies 1820. C s.p
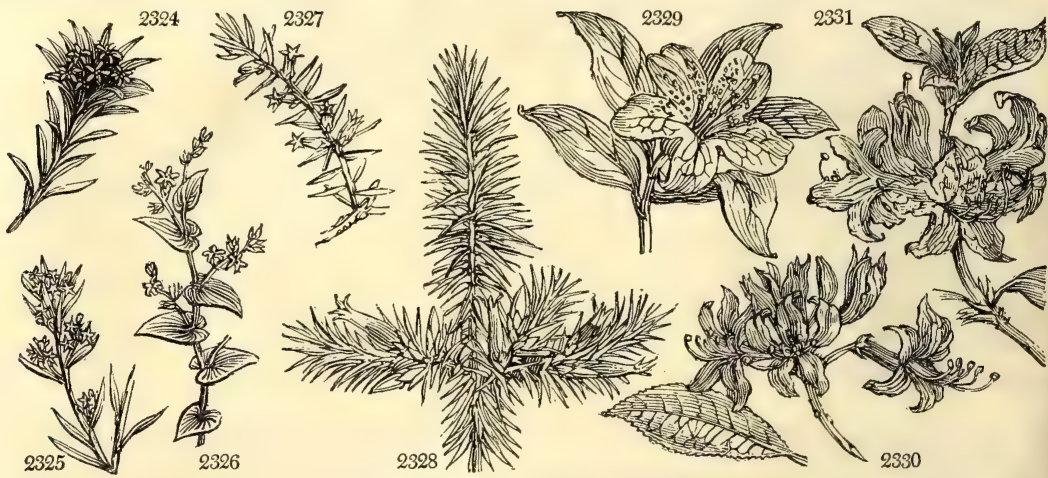

History, Use, Propagation, Culture,

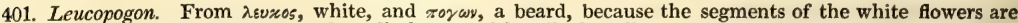
bearded. A very extensive genus of small shrubs, with spiked axillary or terminal flowers. Culture as for Andersonia.

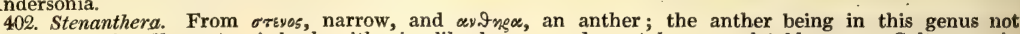
so broad as its filament. A bush with pine-like leaves, and erect large scarlet blossoms. Culture as in Andersonia.

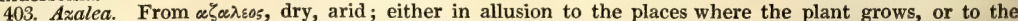
brittle dry nature of its wood. This is a very ornamental genus, from its abundance of flowers of almost all colors, and the fragrant smell of most of the species. A. indica is the most delicate, but flowers well in a moist heat in rough peat well drained. According to Sweet, "s it thrives best in a sandy peat, and the pots to be well drained with small pieces of potsherd: it should be set in an airy part of the greenhouse in winter, and great care must be taken not to over-water it: in summer it should be exposed to the open air, but not in a very sunny situation. Young cuttings taken off close to the plant, and planted in pots of sand, will root readily, if plunged in heat under a bell-glass." (Bot. Cult. 144.) T. Blake keeps his plants "s in peat and leaf-mould, plung in the sudden heat causing the (Hort. Trans. iv. 133.) J. Nairn uses the most fibrous part of peat-earth and sand; he places them in a considerable heat, and always in the shade, and when the plants exhibit blossom buds in March, he then raises the temperature from $50^{\circ}$ to $60^{\circ}$. This species strikes by cuttings of the young wood, taken off close to that which is ripened, planted in pots of sand, and plunged under a bell-glass.

The hardy Azaleas are best grown in compartments or groups by themselves, or with other American or European plants requiring a moist peat soil, and rather shady situation. Where peat is not to be had, the 
2324 Spikes nodding aggregate, Ovaries 2-celled, Drupes oval, Leaves lanceolate flat 3-nerved 2324 Spikes axillary close together 3-4-flowered, Leaves obl. lin. moderately spreading mucronate 2325 Spikes axillary and terminal spreading stalked longer than the leaves, Leaves cordate stem clasping 2326 Spikes axillary and termers subsessile solitary or 2 together, Leaves divaricating lanceolate linear bristly pointed

2328 The only species. Leaves like those of a fir very close together

2329 Flowers nearly solitary, Calyx hairy

2330 Leaves oblong narrowed at the end shining ciliated smooth, Corymb. terminal, Tube of cor. glandular

2331 Nearly naked flowered, Leaves oblong pubescent on both sides, Flowers large not viscid, Cal, teeth obl

2332 Leaves beneath thinly downy nerve not bristly, Flowers rose-colored not viscid, Cal. very minute 2333 Leaves oblong narrowed at the base ciliated smooth, Corymb terminal, Cor, hairy outside, Stam. exsert.

2334 Naked flowered, Leaves oblong slightly pubescent on both sides, Flowers small not viscid, One segment of corolla linear 4 times as long as the others

2335 Branches hispid, Leaves same color on both sides with the nerve hispid, Cal. teeth very short round

2336 Branches smooth, Leaves small oblanceolate mucronate coriaceous with a hispid nerve, Flowers viscid 2337 Branches hispid, Leaves acute smooth on both sides glauc. beneath with a hispid nerve, Fl. very viscid 2338 Branches upright very hispid, Leaves long lanceolate hispid above, Flowers very viscid

2339 The only species

2340 Leaves long narrow entire with a brown edge

2341 The only species

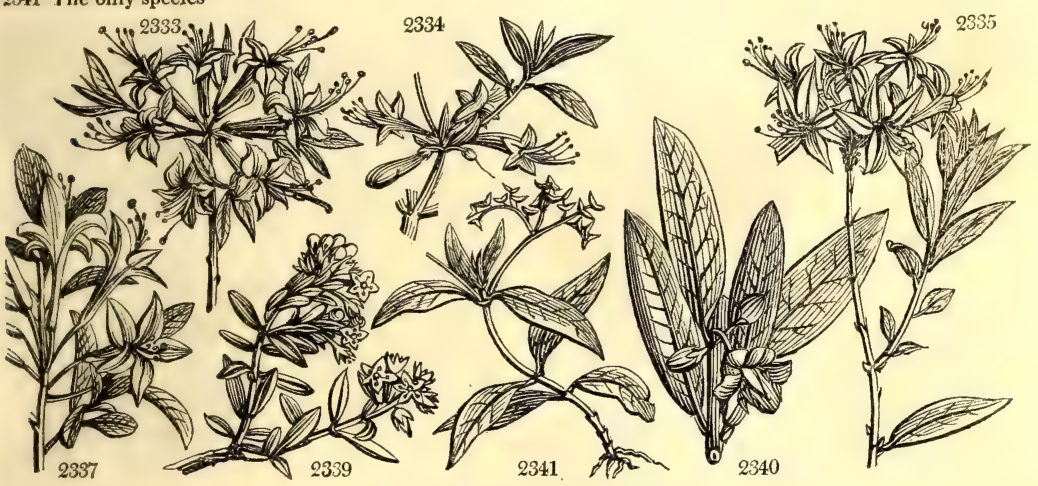

and Miscellaneous Particulars.

nex' best soil is a soft black sandy loam with leaf-mould, or mould from any decayed vegetable matter unmixeà with animal remains, as the mould of decayed thatch, or the sweepings of stack-yards, wood-piles, \&c. Seeds are obtained from many of the sorts, and should be sown in pans or shallow wide pots thinly covered, placed in a shady situation, and kept moderately moist. When fit to transplant, they should be pricked into other pots, and placed under a glass, and shaded till they have struck roots afresh. They may then be hardened by degrees, and, when their roots fill the pots, planted out in beds, or where they are finally to remain. Most of the hardy Azaleas are well adapted for growing in pots, and for forcing early in spring. The deciduous sorts flower better than those which are subevergreens.

By intercrossing with Azalea and Rhododendron, some new and curious varieties or hybrid species have been produced, especially in Colvill's nursery, under the direction of Mr. Sweet : and from some thousands of seedlings which have not yet flowered, many more are expected. (See Encyc. of Gard. part II. b. i. ch. viii. sect. 7. The juice in the bottom of the flower of $\mathbf{A}$. pontica is poisonous, and communicates its bad properties to the unwholesome honey of Pontus. Several fine varieties of the Azalea indica have lately been brought to this country ; but many of the best varieties are still among the desiderata of English cultivators.

404. Chamaledon. From xowas, dwarf, and $\lambda \varepsilon \delta \circ$, a kind of cistus. This has been formed from the well known Azalea procumbens of Linnæus, one of the most interesting of our northern plants.

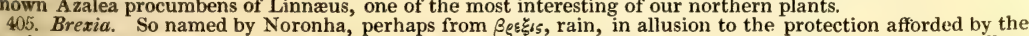
fine large leaves of the genus against rain. Fine stove plants with firm, spiny, or entire leaves, and axillary green flowers. In the garden they are commonly called Theophrastas.

406. Ophiorhiza. From ops, a snake, and $\dot{\rho}_{6} \zeta_{\alpha}$, a root, from the use which is made of the roots in the East Indies for curing the bites of dangerous snakes. Mungos is an Indian name. A pretty stove plant, whose white flowers are well relieved by the dark red back ground of the calyxes and pedicels. 
407. ALLAMAN'DA. $W$. Allamanda. 2342 cathártica $W$ villow_leaved 408. THEOPHRASTA. $\boldsymbol{L}$. Theophrasta 2343 Jussiæ'i Lindl. prickly 409. ClaviJa. Fl. per. ClaviJa. 2344 macrophýlla $F$. per. long-leaved

410. VIN'CA. $W$. 2345 herbácea $\dot{W}$

2346 mínor $W$

$\beta$ argenteo variegáta $\gamma$ aureo variegata

\&lore pleno 2347 májor $W$. $\beta$ variegáta 2348 parviflóra $W$

2349 rósea $W$.

$\beta$ alba

$\gamma$ ocelláta

411. NE'RIUM. $R$. Br. 2350 oleánder $\boldsymbol{W}$.

$\beta$ álbum

$\gamma$ spléndens

¿variegátum

2351 odórum $W$

ß cárneum

r plénum

GHA. R. Br. WIIGH'TIA. 2352 antidysentérica $R . m$. oval-leaved

2353 zeylánica $R$. Br. spear-leaved

2354 tinctória $R$. $B r$. dyer's

413. ECHI'TES. $\boldsymbol{R}, \boldsymbol{B r}$. ECHITES.

2355 biflóra $W$.

2356 suberécta $W$

2357 torósa $W$

2358 umbelláta $W$

2359 diffórmis $\boldsymbol{P h}$.

2360 bispinósa $W$

2361 caryophyllata $R$.

large-flowered

ed-eyed

Apocynea. Sp. 1. Myrsinea. Sp. 1. Myrsinea. $S p .1-4$

站 $\square$ or 3 W Hispanio. 1818. S r.m Lind, coll, 26

$\square$ or $30 \quad$... W W. Amer. 1816. C r.m

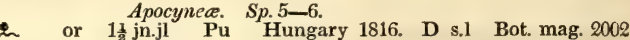

\& or $4 \mathrm{mr}$.s V Britain bu. pl. S co Eng. bot. 917

2 or 4 mr.s $\mathrm{V}$ Britain ... $\mathrm{S}$ co

2 or $4 \mathrm{mr} . \mathrm{s}$ Britain $\quad \ldots . \mathrm{S}$ co

i or $4 \mathrm{mr} . \mathrm{s}$ Britain ... $\mathrm{S}$ co

England groves. S co Eng, bot. 514

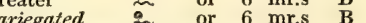

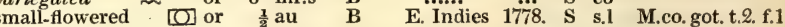

Madagascar $\square$ or 1 mr.o R.w E. Indies 1756. C r.m Bot. mag. 248

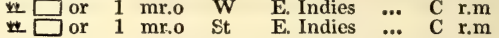

Apocynea. Sp. $2-5$.

common J or 8 jn.o R S. Europe 1596. L r.m Lam. ill. t. 174

: J 8 or jn.o W S. Europe ... I r.m Bot. cab. 700

$\checkmark$ or 7 jn.o $\mathbf{R}$..... 1814. L r.m

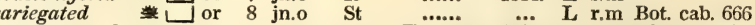

or 6 jn.au Pa.R E. Indies 1683. C r.m Rheed. mal.9.t.2

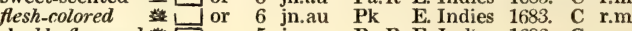

$\square$ or 5 jn.au Pa.R F. Indies 1683. C r.m Bot. reg. 74

Apocynea. $S p .3-5$.

$\$ \square$ or $10 \quad \ldots \quad$ W E. Indies 1778. C r.m Rhed. mal.1.t.47

\$ $\square$ or 10 ... W E. Indies ... C r.m Bur.zeyl.t.12.f.

... W E. Indies 1812, L 1.p

\section{Apocynea. $S p, 10-60$}

or 20 jl W W. Indies 1793. C p.1 Jac.amer.30.t.21 Savanna-flower $\$$ or 10 jn.au Y Jamaica 1759. C p.l Bot. mag. 1064 climbing 10 jn.au $\mathbf{Y}$ Jamaica 1778. C p.I Jac.amer.33.t.27 umbelled $\$$ or $15 \mathrm{jl}$ W Jamaica-1733. C p.l Jac.amer.30.t.22 deformed \$

$\square$ cul 1 jl.n Pk C. G. H. 1795. C p.l

$\square$ or 6 o Pa.Y E. Indies 1812. C p.l Bot. mag. 1919

$\$$ or $8 \quad \ldots \quad$ Pk $\mathrm{E}$. Indies 1823. C p.l

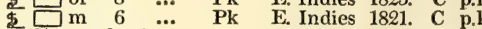

孛 $\square$ or 20 jn.au $\quad \mathbf{Y}$ W. Indies 1821. C p.1 Bot. mag. 2473

Apocynea. Sp. $1-2$

2365 frutéscens $H . K$. shrubby $\quad 10$ jlau Pu E. Indies 1759. C p.1 Bur.zeyl.t.12.f.1

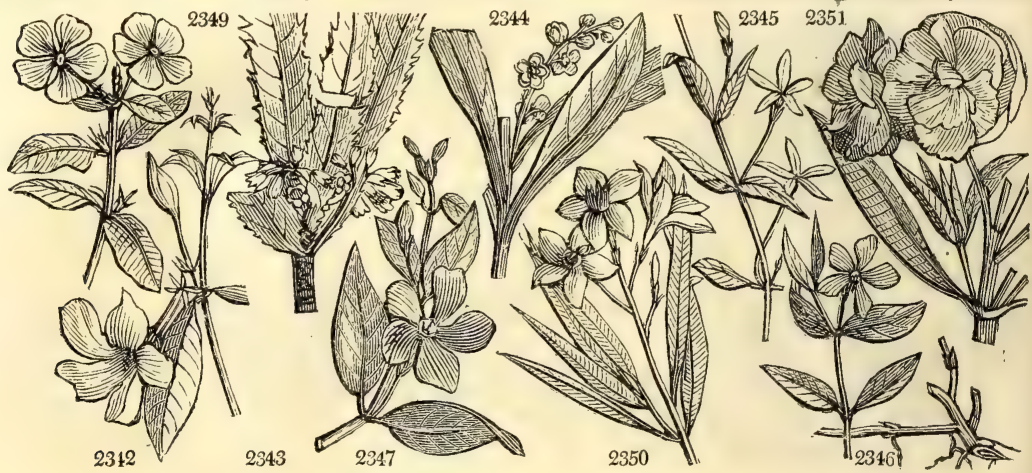

History, Use, Propagation, Culture,

407. Allamanda. In memory of Dr. Frederick Allamand, a professor of natural history in the university of Leyden, who went to Guiana about 1769 , and to Russia about 1776 , and sent descriptions, figures, and specimens of plants to Linnæus. It is a milky shrub, of cathartic qualities; flowers freely, and strikes with ease in a moist heat.

408. Theophrasta. Theophrastus was born at Eresus in Lesbos, 310 years before Christ, and died at the age of 83. Linnæus has justly termed him the prince of botanists. The genus which has been selected to commemorate his name, is a curious prickly-leaved, low plant, native of St. Domingo, where it is called by the negroes wild cocoa. In the collections of this country it is rare, and no means has yet been discovered of propagating it, except by seeds.

409. Clavija. Named in honor of Joseph Clavijo Faxardo, a Spanish naturalist, who translated into his own language the works of Bufion. A fine genus of plants, exceedingly rare both in gardens and herbaria.

410. Vinca. A name, the true origin of which is buried in obscurity. None of the fanciful etymologies which have been formed of it, appear entitled to attention. The Anglo-Saxons called it peruince, the English, periwinkle, the French, pervenche. This is a genus of well-known little shrubs, valued for their early and long continued flowering, and the hardy species as being evergreens which thrive under the shade and drip of trees. V. minor and major, like other plants which run much at the root, very rarely produce seeds. V. rosea is continually in flower, and is easily propagated by cuttings under a hand-glass.

411. Nerium. From yneos, damp, the plant growing upon the borders of rivulets, in the southern parts of Europe. This is a genus of beautiful evergreen shrubs of easy culture and propagation, and free flowerers great part of the year. N. tinctorium affords a blue equal to that of indigo, and it is thought by Dr. Roxburgh might be cultivated for that purpose.

N. oleander is very common in the Levant, and especially in the Isle of Candia, and in Sicily, Magna Græecia, 
2342 The only species. Leaves 4 together subsessile ovate oblong, Flowers in villous fascicles

2343 A small prickly-leaved bush without branches and with terminal clusters

2344 Leaves very long lanceolate retuse toothed spinous

2345 Stems herbaceous prostrate, Leaves oblong lanceolate smooth, Flowers stalked, Cal. ciliated 2346 Stems procumbent, Leaves ellipt. lanc. smooth at edge, Flowers stalked, Teeth of cal. lanceolate

2347 Stems nearly erect, Leaves ovate ciliated, Flowers stalked, Teeth of calyx setaceous elongated

2348 Stem herbaceous erect square, Leaves lanceolate, Flowers twin or solitary stalked 234.9 Stem erect, Flowers twin sessile, Leaves ovate oblong, Stalks 2-toothed at the base

2950 Leaves lin. lanc. 3 together ribbed beneath, Sepals squarrose, Nect. flat 3-toothed

2351 Leaves linear lanc. 3 together, Corona filamentose, Anthers at end feathery

2352 Leaves ovate oblong shortly acuminate smooth, Corymbs terminal, Tube of cor. 6 times as long as calyx 2353 Leaves obl. lanceol. subacuminate smooth, Corymbs terminal, Tube of cor. 4 or 5 times as long as calyx 2354 Leaves ellipt. lanc. and ovate acum. smooth, Branches and corymbs divar. Tube of cor. twice as long as cal.

2355 Stems sarmentose, Leaves oblong, Pedunc. 2-flowered

2356 Pedunc. many-flowered, Cor. cylindrical hairy outside, Leaves ovate mucronate pubescent beneath 2357 Pedunc. racemose, Leaves lanceolate acuminate, Follicles torulose very long

2358 Pedunc. umbelled, Leaves ovate obtuse mucronate

2359 Leaves oval lanceolate acute at base the lowest linear, Flowers in fascicled corymbs

2360 Prickles two extra-foliaceous, Leaves lanceolate smooth, Cor. hypocrateriform

2361 Panicle terminal, Cal. spreading as long as corolla, Leaves ovate mucronate

2362 Stem erect rounded, Leaves oval acuminate smooth, Flowers terminal in threes

2363 Stem erect angular, Leaves ovate lanceolate obsoletely crenate, Corymbs axillary dichotomous

2364 Leaves ovate lanceolate entire strongly marked with crimson veins

2365 Stem erect shrubby, Leaves lanceolate oval, Cor. acute, Throat villous

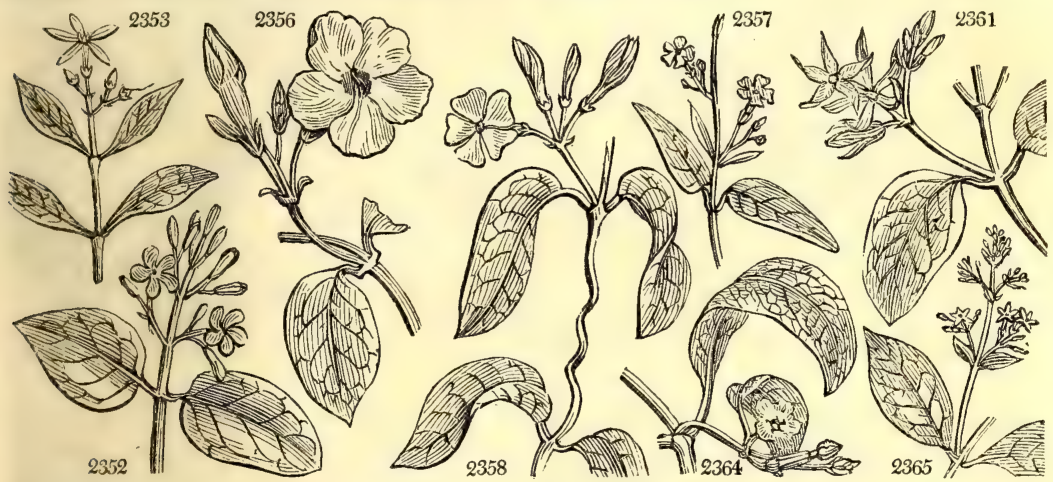

and Miscellaneous Particulars.

\&c. by rivers and torrents : the leaves are acrid and poisonous. Young cuttings planted under a hand-glass, and placed on a little heat, root freely.

N. odorum and its varieties, though treated as a greenhouse plant, requires a stove to make it flower freely.

412. Wrightia. Named after Dr. William Wright, a Scotch physician, who resided some years in the West Indies at the end of the last century, and the author of one or two botanical tracts. W. antidysenterica is reputed to be a specific in the dysentery. The wood is well adapted for the turner, and to make eabinets and other elegant furniture. It is very white, and of a fine grain like ivory, only much lighter. It mixes admirably with ebony.

W. zeylanica is an elegant branched shrub, with whitish yellow flowers and an agreeable odor. Both species may be treated like Nerium.

413. Echites. A name employed by Pliny as the designation of a kind of Clematis; it is derived from $€$ ¿ 15 , a viper, on account of the twisting nature of its shoots. This is a genus of plants somewhat singular in habit, with opposite, veined, shining leaves, and flowers in peduncles void of scent. They all flower freely, and root readily under a hand-glass in sand.

E. biflora supports itself partly by stems, and partly by twining on trees, hence frequently acquiring the air
readily under a hand-glass in sand. of a tree. It grows in salt marshes.

E suberecta climbs : when it grows in savannahs it does not rise above three feet, and sometimes not more than one foot high.

E. sanguinolenta is remarkable for the beauty of its foliage, the veins of which are stained with crimson.

414. Ichnocarpus. An unexplained name, the meaning of which is unknown. Climbing shrubs of Sierra Leone and the East Indies, with long branches covered with smooth entire leaves, and white sweet-scented flowers. Cuttings root freely in sand under a hand-glass. 
415. Plumiéria. $W$. Plumeria. 2366 rúbra $W$

2367 acumináta $H, K$. 2368 álba $W$ 2369 obtúsa $W$ 2370 pudíca Jac 2371 bícolor $F l$. per.

2372 tricolor $F l$ per. red acuminated white blunt-leaved wax-flowered two-colored three-colored

Apocynea. Sp. 7-14.

9 or 15 jlau R Jamaica 1690. C r.m Bot. mag. 279

T.

$\square$ or 15 jl.au W Jamaica 1733. C r.m Jac. am.t.174.f.2

$9 \square$ or 10 jl.au W W. Indies 1733. C r.m Cat. car. 1. t. 99 $\square$ or 5 jl.au Y S. Amer. $\ldots$ C r.m

W.Y S. Amer. 1815. C r.m Bot. reg. 480

Va W. Indies 1815. C r.m Bot, reg, 510

Apocynea. Sp. $1-5$.

f.mr Y China 1818. C r.m Bot, reg. 409

417. CAMER A'RI A. W. Bastard-Manchineel. Apocynea. Sp. 4 -6. Q374 latifólia $W$

2375 Tamaquárina $A u b$. yellow-flowered 2376 dúbia $B$. $M$ doubtful narrow-leaved

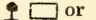

30 au W

Havannah1733. C r.m Bot. rep. 261

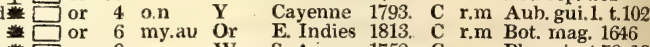

2377 angustifólia $W$

418. TABER'NæMONTA'NA. $W$. TAB

2378 citrifólia $W$. Citron-leaved

2379 laurifólia $\dot{W}$. Laurel-leaved

2380 coronária $\boldsymbol{H} . \boldsymbol{K}$. Rose-bay-like

2381 amygdalifólia Jacq. almond-leaved

419. AMSO'NIA. Mich. Amsonia.

2382 latifólia $P h$.

2383 salicifólia $P h$

2384 angustifólia $P h$.

420. CER'BERA. $W$.

2385 Ahoúai $W$.

2386 Mánghas $W$.

2387 maculáta $\boldsymbol{W}$.

2388 ováta Cav.

2389 Thevétia $W$.

2390 fruticósa Roxb.

421. TEC'TONA. $W$

2391 grándis $W$

broad-leaved

Willow-leaved

Cerbera.

oval-leaved

spear-leaved

waved-leaved

oval-ieaved

linear-leaved

shrubby

Tenk-WOOD.

great

\section{Rnemontana. Apocynece. Sp. 4-34.}

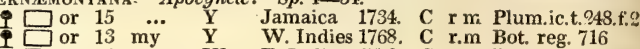

or 4 my.s W E. Indies 1770. C r.m Bot. mag. 186

my.s W S Amer. 1780 C r.m Bot reg. 338

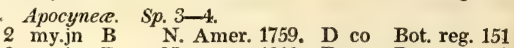

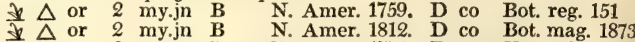

$\$ \Delta$ or 2 my.jn $B \quad$ N. Amer. 1774. D co Vent. choix. 29 Apocynea. Sp. 6-10.

등 or 20 jn.jl $\quad$ Y $\quad$ Brazil 1739. C r.m Bot. mag. 737

$\square$ or 4 jn.jl W Bourbon 1782. C r.m Bot. rep. 130

* $\square$ or 3 ... $\quad$ Y $\quad$ N. Spain $\ldots$ C r.m Cav. ic.3. t. 270

$\$$ or 12 jn.jl Y $\quad$ \$. Amer. 1735. C r.m Bot. mag. 2309

Verbenacea. Sp.1

$\Phi \square \mathrm{tm} 100 \ldots$ W E. Indies 1777. S l.p Roxb. cor. 1. t. 6 Verbenacea. Sp. 1.

2392 heterophýlla W. en. various-leaved [0] or $\mathcal{2}$ my.d B N.Spain 1813. S r.m Bot. reg. 92

423. BUME'LiA. $W$. Bumelia.

2393 lycioídes $P h$.

2394 ténax $W$.

Boxthorn-leav, s. Sapotea. $S p .8-26$.

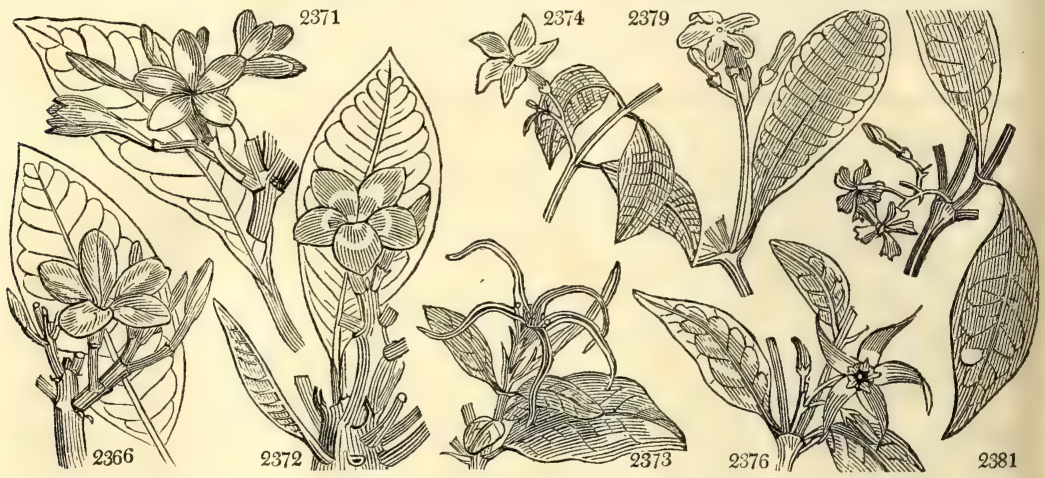

History, Use, Propagation, Culture

415. Plumieria. So named by Tournefort, in honor of Charles Plumier of Marseilles, a Franciscan friar, who travelled into South America. He is distinguished for the accuracy of his observations, and for the fidelity of his drawings, which are the only representations of many of the most curious plants of the West Indies and South America. His drawings of flowers have seldom, even in these days of pictorial excellence, been equalled. He was the author of Plantæ Americanæ, 1693, and other excellent works. This is a fine flowering genus. "It succeeds best in a light loamy soil, and requires but little water. Large cuttings taken off" and laid to dry for a considerable time, may be stuck in the tan in a moderate heat, or planted in pots, and they will root freely; they must not be covered with a glass, or it will rot them. To have the plants flower well, they should be kept very dry when not in a growing state, which will throw them into bloom." (Bot. Cult. 95.)

416. Strophanthus. From $\sigma \tau \rho \varepsilon \varnothing \omega$, to turn or twist, and $\alpha y \vartheta \circ 5$, a fiower; in allusion to the manner in which the segments of the corolla are twisted together before expansion. A most beautiful genus of tropical shrubs, with bright yellow flowers more or less spotted with red. They require the same treatment as Echites.

417. Cameravia. So named by Plumier, from Joachim Camerarius, a physician and botanist of Nuremberg, who was born in 1534, and died in 1598. He published an edition of Matthiolus, in Latin and German, with new figures, and many observations ; but the most celebrated man of the name was Ralph James Camerarius, a German botanist, who published in 1719 , a tract, in which the first principles of the arrangement of plants by their seeds were propounded. This is a fine flowering genus, of easy culture, and cuttings root freely under a hand-glass in a pot of sand.

418. Tabernamontana. So named by Plumier, in memory of James Theodore, surnamed Tabernæmontanus, from Berg-Zabern, the place where he was born. He published "Krauterbuch," and figures of plants in 1589-90; was physician to the Elector Palatine, and died in 1590. This is a genus of easy culture but little 15eauty. All the species root in sand under a hand-glass.

419. Amsonia. So named by Clayton in his Flora Virginiana; referred to Tabernæmontana by Linnæus, now separated again. These are pretty plants, which grow in any soil ; and may be propagated by cuttings under a hand-glass, or dividing at the root.

420. Cerbera. A poetical name formed in allusion to the mythological dog Cerberus, whose bite was poison. ous, as is the juice of this genus. Ahouai and Manghas are vernacular names of the countries where the spe- 
2366 Leaves ovate oblong flat, Leaf-stalks with two glands 2367 Leaves scattered lanceolate acute, Flowers corymbose terminal 2368 Ieaves lanceolate revolute, Peduncles tuberous above 2368 Leaves lanceolate stalked obtuse

2369 Leaves lanceolate stalked obtuse

2371 Leaves oblong acuminate flat at edge, Cor. white and yellow

2372 Leaves oblong acute, margins flat veiny, Cor. tube red, throat yellow, limb white

2373 Branches dichotomous, Leaves mucronate-acuminate, Cor. infundibuliform

2374 Leaves rounded ovate acuminate at the base transversely striated, Flowers terminal corymbose 2374 Leaves rovate oblong netted, Umbel stalked few-flowered, Flowers large yellow sweet (C. lutea.) 2376 Leaves ovate lanceolate wavy, Corona 10-cleft: alternate segm. shorter obtuse 2376 Leaves ovate

2378 Leaves ovate, Flowers lateral in clustered umbels

2379 Leaves ovate, Peduncles few-flowered, Stamens included

2380 Leaves lanceolate ovate, Branches divaricating

2381 Teaves oval lanceolate, Stamens longer than tube of corolla

2382 Stem smoothish, Leaves oval lanceolate the upper acuminate beneath a little hairy 2383 Stem smooth, Leaves linear lanceolate acute at each end quite smooth

2384 Leaves narrow lanceolate close erect pubescent, Stem obviously pubescent

2385 Leaves ovate acute

2386 Leaves lanceolate, Nerves transverse

2387 Leaves lanceolate attenuate at each end veiny spotted, Cymes axillary branched

2:88 Leaves ovate scattered subsessile, Flowers terminal about 5

2389 Leaves linear very long. Flowers subsolitary axillary, Fruit roundish

2390 Dichotomous, Leaves broad lanceolate, Corymbs terminal, Drupes obliquely cup-shaped gaping

2391 Leaves obovate scabrous very large whitish beneath

2392 The only species. A pretty stove annual

2393 Prickly, Leaves lanceolate obtuse acute at base attenuate smooth 2394 Leaves obovate lanceolate beneath silky, Peduncles axillary clustered

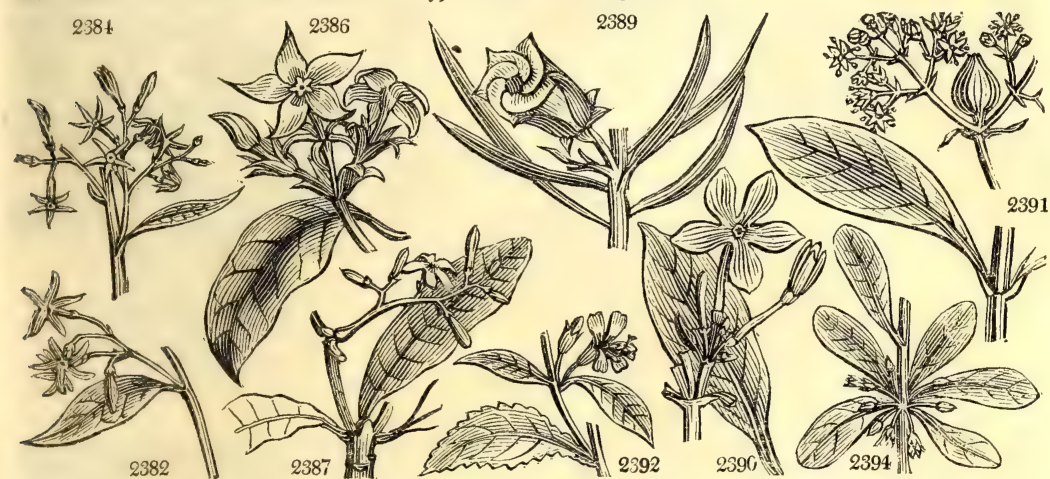

and Miscellaneous Particulars.

cies so called are found. Thevetia is named after Andrew Thevet, a French monk, who travelled in Brazil about 1530. C. A houai has thick succulent leaves about three inches long, and near two broad, of a lucid green, smooth, and very full of a milky juice, as is every part of the shrub. The flowers are in loose bunches at the ends of the branches, and are succeeded by nuts, the kernels of which are a most deadly poison. The wood stinks abominably, and is not used even by the Indians for fuel. They put small stones into the empty nuts, string them, and fasten them about their legs when they dance.

string them, and fasten them about their legs when they dance. the drupe ovate, the size of a goose's egg, inclosing two seeds resembling two large chestnuts, poisonous and emet:c.

C. Thevetia is an elegant shrub or small tree, with acuminate leaves, and large, specious, nodding, yellow, sweet-smelling flowers. The fruit is a green drupe, containing a nut with a single kernel in it. Cuttings of all the species strike very readily in sand under a hand-glass.

421. Tectona. Altered by Linnæus from Tekka, its name in Malabar. This is a timber-tree of immense size and great durability, and is justly called the oak of the east. The trunk is erect, and the bark ash-colored; the leaves are obovate, downy underneath, and on young trees from 12 to 24 inches long, and from 8 to 16 broad. The flowers are in panicles, small, white, and fragrant. The seeds are lens-shaped in t-celled drupes. The tree abounds in the vast forests of Java and Ceylon, Malabar, Coromandel, \&c., and especially in the empires of Birman and Pegu. The wood has, by long experience, been found to be the most useful in Asia. It is easily worked, and at the same time both strong and durable. It is considered superior to all others for shipbuilding. Calcutta and Madras draw all their supplies of wood for ship-building from the teak forests of Ava and Pegu. Some of the finest vessels that have ever arrived in the Thames have been of teak tree, built in Bengal. The tree was introduced to the British possessions by Lord Cornwallis, and is now planted with a view to timber in the mountainous parts of Bengal. In our stoves it thrives in loam and peat, and ripened cuttings root freely in sand under a hand-glass.

422. Caldasia. A pretty stove herbaceutant, with handsome small blue flowers. It was named by Will denow, after the MSS. of Baron Humboldt, in honor of Joseph Caldas, a meritorious Spanish botanist, residing

denow, after the MSS. of Baron Humboldt, in honor of Joseph Caldas, a meritorious Spanish botanist, residing
at Popayan in South America. It may be propagated by cuttings.

423. Bumelia. A name given by the Greeks to our common ash. Swartz applied the name to this West Indian 
2395 salicifólıa $W$. 2396 nígra $W$.

2397 lanuginósa $P h$.

2398 reclináta $P h$.

2399 serráta $P h$.

2400 rotundifólia $S w z$.

424. CHRYSOPHYL/LU

2401 Cainito $W$.

2402 argénteum $W$.

2403 monopyrénum

2404 glábrum Jacq.

425. SIDERO $/ X Y L O N$. $W$. IRON-WOOD. 2405 inérme $W$.

426. JACOUI'NIA. $W$. 2406 armilláris $W$. 24,07 aurantíaca $\boldsymbol{H}$. $\boldsymbol{K}$. 2408 ruscifólia $W$.

427. A'CHRAS. $W$. 2409 mammósa $W$. 2410 Sapóta $W$

2411 Zapotilla

428. COR'DIA. $W$

2412 Mýxa $W$

2413 monoíca $R o x b$

2414 Sebesténa $W$.

2415 Geraschánthus $W$. 2416 macrophýlla $W$. 2417 Collocócca $W$. 2418 nodósa Lam. 2419 elliptica $S w$. 2420 Patagónula $W$

429. VARRONIA. $W$ 2421 lineáta $W$

2422 mirabiloídes $W$.

JACQUINIA. obtuse-leaved orange-flower' prickly

SAPOTA.

Mammee

common Cordia. rough-le Spanish-elm broad-leaved long-leaved hairy. elliptic spear-leaved

VARRONIA. round-spiked jointed
Willow-leaved $9 \square \mathrm{tm} 20 \quad \ldots \quad$ W $\quad$ S. Amer. 1758. C p.l Cat. car. 2. t. 75 black

woolly-leaved

reclinate

serrated

round-leaved

W. STar-APPLE. common narrow-leaved smooth

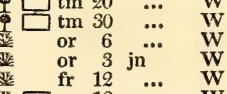

W. Indies 1806. C r.m

Carolina 1806. C r.m

Carolina 1806. C r.m Vent. choix. 22

Missouri 1812. C r.m

Jamaica 1823. C r.m

Sapotce. Sp. 4-14.

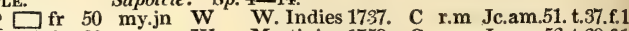
$\square$ fr $200 . .6$ W Martiniq. 1758. C r.m Jc.am.53.t.38.f.1

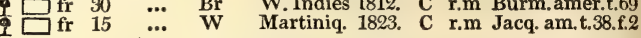
Iron-wood. Sapotea. Sp. 3-8. Naseberry-tree $\frac{1}{\square}$ fr $10 \quad \ldots .$. W $\quad$ S. Amer. 1731. C 1.p Jac.am.57.t.41.b smooth-leaved i $\square$ or $30 \ldots$ W $\mathbf{E}$. Indies 1640, C p.l Rhed.mal.4. t.37 Birch-leaved

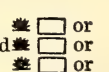

. Indies 1768. C p.1 Jac.amer.53.t.39 4 ap.s O Sandw. 1. 1796. C p.1 Bot. mag. 1639 ... W S. Amer. 1729. C p.l D.elt. t.129. f.149

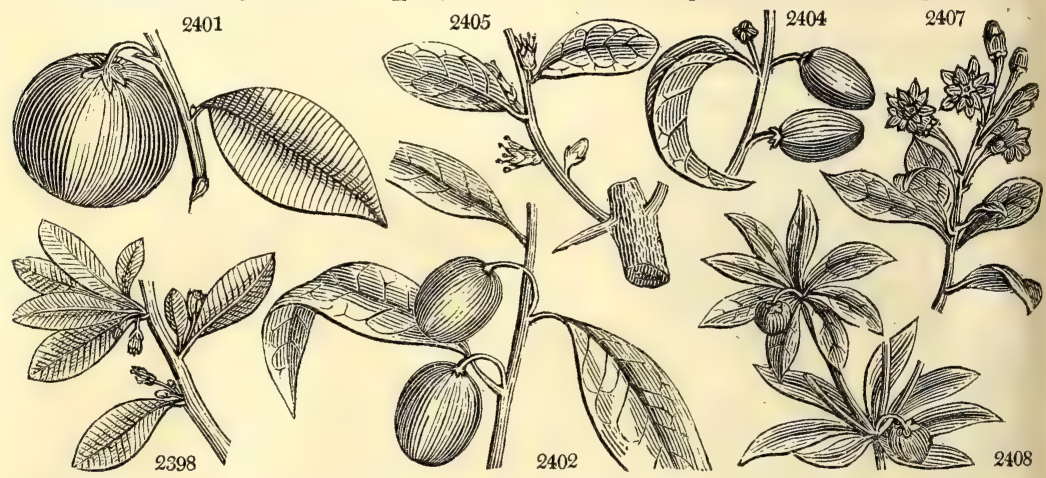

History, Use, Propagation, Culture,

genus. These are plants with good foliage, but no beauty of blossom. Some of the species are robust enough to bear our winters in the open air ; but they are rather tender, and require to be placed in a sheltered situation or against a warm wall, and covered with mats during winter. Cuttings root in sand under a hand-glass. The stove species are low West Indian trees, and known there under the name of Bully tree. They thrive well in loamy soil, or loam and peat, and cuttings will root, but, according to Sweet, " not freely, in sand under a hand-glass," being well ripened before they are taken off

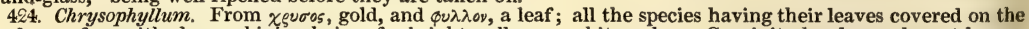
under surface with dense shining hairs of a bright yellow or white color. C. cainito has large elegant leaves, ferruginous underneath; it forms a tree of considerable size, with slender flexible branches. The leaves and fruit, like the Achras, to which the tree is very nearly allied, are full of milk, which the fruit retains even in the most perfect state. This milk is rough and astringent before the fruit ripens ; but when it grows to full perfection, it becomes sweet and gelatinous, with an agreeable clamminess. Being mixed with a small quantity of orange juice, it binds the body extremely. The tree is of general and easy culture in Jamaica, and is here grown chiefly for its foliage. Sweet says, ripener shoots of all the species taken off and planted in sand, will root under a hand-glass with a strong moist heat.

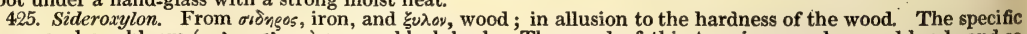
name melanophleum ( $\mu$ s $\lambda \alpha_{5} \phi \lambda_{0}(05)$ means black-bark. The wood of this tree is very close and hard, and so heavy as to sink in water. It grows well in loam and peat; and cuttings somewhat ripened may be struck in sand under a hand-glass.

426. Jacquinia. So named by Linnæus, in honor of James Nic. Jos. de Jacquin, professor of botany at Vienna, born at Leyden, in 1727, author of many splendid works. A noble genus, well devoted to perpetuating the memory of one of the first of botanists. The name of one of the species armillaris, (from armilla, a garland, ) has been applied in consequence of the shoots being used by women in America as garlands. This beautiful genus requires some care in propagation, but is of easy culture in the bark-stove, in loam and peat, and with a moist heat. "Cuttings," Sweet observes, "will strike root with ease in sand, under a hand-glass, in heat."

427. Achras. The Greek name of the wild pear. The root of the word has been thought to have been found in ac, the Celtic for a point, in allusion to the many stout spines with which the tree is covered. The word Sapota, applied to one of the species, is derived from its Mexican name Cochit-zapotl. This is a genus of fruitbearing timber-trees, chiefly natives of the West Indies. A. mammosa, or American marmalade, grows in America to the height of 35 or 40 feet, having a straight trunk covered with an ash-colored bark. The branches form a regular head; the leaves a foot in length, and near three inches broad in the middle. The flowers are 
2395 Leaves lanceolate ovate acuminate, Peduncles clustered axillary and lateral 2396 Leaves terminal oblong lanceolate sinooth wavy at edge, Branches lax

2397 Spiny, Branches spreading pubescent, Leaves oval lanceolate smooth above beneath woolly Q.308 Spiny bushy loosely reclinate, Sterile branches divaricate divided, Leaves small obovate smooth 2399 Unarmed, Leaves evergreen oblong lanceolate acute at each end prickly serrate, Berries large 2400 Leaves rounded edged veiny coriaceous smooth on both sides

2401 Leaves ovate with parallel veins beneath tomentose shining 2402 Ieaves falcate ovate beneath downy shining

2403 Leaves oblong acuminate beneath downy gold color, Fruit ovate 1-seeded

2404 Leaves ovate oblong smooth on both sides, Fruit elliptical smooth

2405 Leaves oblong ovate obtuse, Flowers lateral and axillary

2406 Leaves wedge-shaped, Branches at the ramifications nodose whorled 2407 Leaves obovate lanceolate acuminate pungent

2408 Leaves lanceolate acuminate

2409 Flowers solitary, Leaves cuneiform lanceolate

2410 Flowers solitary, Leaves lanceolate ovate

2411 Brachiate diffuse, Fruit rounded with the mucro of the hilum shorter

2412 Leaves ovate smooth above, Corymbs lateral, Calyxes 10-striated

2413 Leaves roundish ovate toothed veiny scabrous, Corymbs axillary monocious

2414 Leaves ovate subcrenate subrepand rough, Cal. cylindrical shorter than the tube

2415 Leaves lanceolate ovate rough, Panicle terminal, Cal, tomentose 10-striated

2416 Leaves ovate villous a foot and half long

2417 Leaves oblong ovate entire, Flowers corymbose, Cal downy inside

2418 Leaves in $3 \mathrm{~s}$ ovate oblong acuminate, Branches nodose hispid, Cal. bearded

2419 Leaves oblong attenuated at the end entire coriaceous, Racemes comp. diffuse

2420 Leaves oblong lanceolate smooth on each side the upper serrate, Branches pilose

2421 Leaves lanceolate linear acuminate hoary beneath, Pedunc. lateral axillary naked 2422 Leaves ovate on long stalks, Stalk above the base bent inwards and jointed, Cor. hypocrateriform

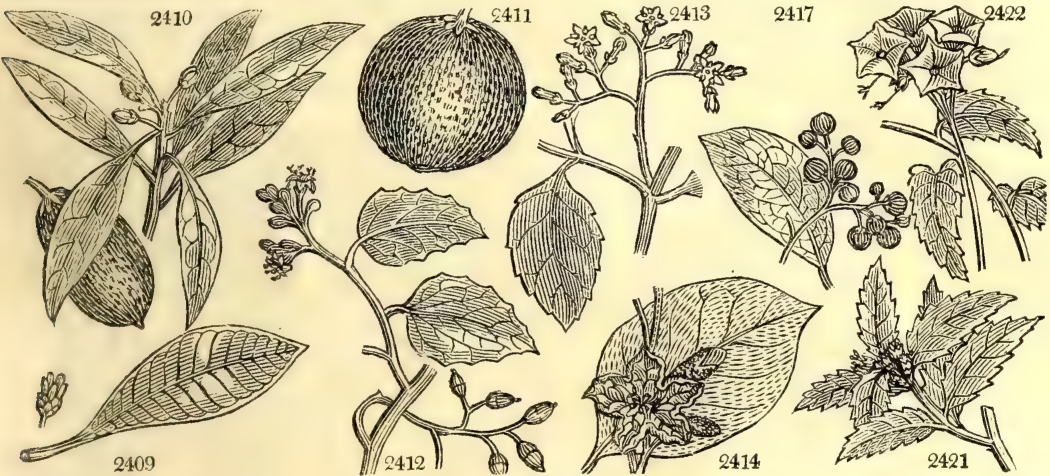

and Miscellancous Particulars

cream-colored, and are succeeded by large oval or top-shaped fruit, covered with a brownish skin, under which is a thick pulp of a russet-color, very luscious, called natural marmalade, from its likeness to marmalade of quinces. It is commonly planted in gardens for the fruit in Jamaica, Barbadoes, Cuba, and most of the West India islands. In this country it has been hitherto grown only as a part of botanic collections, but some attempts have been lately made to cultivate it as a stove fruit, and we have no doubt they will be attended with success. "Cuttings root readily in a pot of sand plunged in heat, under a common hand-glass. The cuttings should be taken off as near the stem of the plant as possible, not being so apt to rot as when cut off in the middle of the shoot. No leaves should be taken off or shortened above the sand." (Sweet.)

A. sapota is a large, tall, straight tree, without knots or branches, for twenty feet or more. The head spreads into many small branches; the bark is dark-grey and full of chops; the fruit is bigger than a quince, round, and covered with a thick grey rind, yellow when ripe. The flesh is as yellow as a carrot, with two stones the size of almonds, of a rich smell and taste. The variety called the Naseberry has fruit as big as a bergamot pear, and similarly shaped. When it is green or first gathered, the juice is white and clammy, and will stick like glue; then the fruit is hard; but when it has been gathered two or three days, it grows soft and juicy, and then the juice is clear as spring-water and very sweet; in the midst of the fruit are two or three black stones or seeds, about the bigness of a pompion seed. It is esteemed an excellent fruit in the West Indies. In our stoves it is propagated like the mammee tree.

428. Cordia. So named wy Plumier after E. Cordus, a German botanist of the 16 th century. Valerius Cordus, his son, was born in 1515, and died in 1544. He left a History of Plants, and was the author of some Observa tions upon Dioscorides. Sebestena, the name of a species, is sebestân in Persian. Myxa is derived from a viscidity, on account of its viscid mucous juice, which is used for glue in the cast. Geraschanthus, from

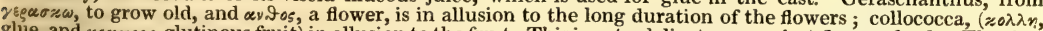
glue, and zor $x$ os; glutinous fruit) in allusion to the fruit. This is not a delicate genus, but flowers freely. The timber of $\mathrm{C}$. myxa is tough and solid, and used in the east for procuring fire by friction. The leaves bruised with C. prepared. C sebestena is very ornamental, on a in the and ageea coals, will perfume Browne, of any I have seen in America. A small piece of the wood put on a pan of lighted coals, will perfume a whole house. From the juice of the leaves, with that of a species of fig, is prepared the fine red color with which they dye their clothes in Otaheite. Poultry in the West Indies feed on the berries of C. collococca, which is there called the clammy cherry, or Turkey berry-tree. All the species grow readily in loam and peat, and cuttings strike in sand, under a glass, in heat.

429. Varronia. Named after Marcus Terentius Varro, a most learned Roman, born 116 years before Christ, I. 4 


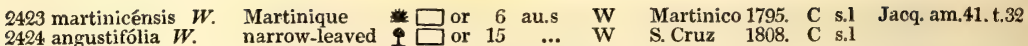
2424 angustifólia $W$. 430. EHRE'TIA. $W$. 2425 tinifólia $W$. 2426 áspera Roxb. 431. BOURRE'RIA. Ga nta 432. ELLI'SIA. $W$. 2429 Nycteléa $W$. Ehretia.

Tinus-leaved $\$$ tm $30 \mathrm{jn.jl}$ W Jamaica 1734. C p.l Trew. ehr.4. t.25 ert. Bourreria. fleshy-fruited dry-fruited

Elisisia. cut-leaved

433. SERSAIJ'SIA. $R$. Br. Sersalisia. 2430 sericea $R$. $B r$. silky-leaved

434. MANGLilla. Juss. ManglidLA. 2431 milleriána Pers. Miller's

435. ARDI'SIA. $W$. 2432 acumináta $W$. 2433 solanácea $R o x b$. 2434 crenuláta $P$. S 2435 lateriflóra $W$. 2436 littorális $B . R$. 2437 élegans And. 2438 coloráta $L k$. 2439 excélsa $W$. 2440 paniculáta Roxb. 2411 pyramidális $R$ th 2441 pyramidális Rth. 2442 lentiginósa $\mathrm{Ker}$. 2444 coriácea $S w z$. 436. ARDUI'NA. $W$. 2445 bispinósa $W$. 437. STRYCH'NOS. $W$. 2446 Nux-vómica $W$. 2447 potatórum $W$. 438. CARIS'SA. $W$. 2448 Carándas $W$ 2449 spinárum $W$ 439. PEDE'RIA. $W$. 2450 foe'tida $W$.

Ardisia. acuminated Nightsh.-like crenulated side-flowering sea-side elegant red-flowered Laurel-leaved panicled pyramidal dusty dotted

coriaceous

Arduina. two-spined

STRYohNos. Poison-nut Clearing-nut

Carissa.

Jasmine-flow. spiny

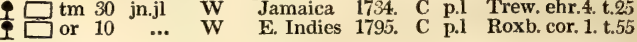
$\square \operatorname{tm} 45$ Cordiacece. Sp. 2 .

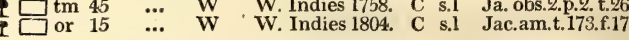
Hydrophyllere. $S p .1-2$.

cu 2 jl.au W Virginia 1755. S co Eh.n.cu.2.t.7.f.1

*ـ or $6 \begin{gathered}\text { Sapotece. Sp. 1-2. } \\ \ldots\end{gathered}$ W. Holl. 1772. C p.l

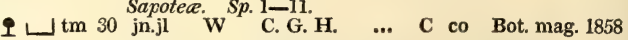

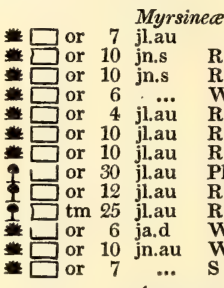

Sp. $13-28$.

Pederia. stinking

Apocynece. Sp.

粪 $\bigsqcup_{\mathrm{cu}} 2 \mathrm{mr.au}$ W C. G. H. 1760. C p.l Bot. cab. 387 Apocynea. Sp. $2-9$.

$9 \square \mathrm{p} \quad 15 \quad \ldots \quad$ G.w E. Indies 1778. S p.l Roxb. cor. 1. t. 4

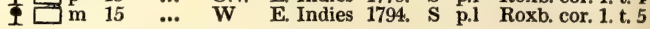
Apocynea. Sp. 2-10.

W W E. Indies 1790. C s.p Bot. cab. 663 Rubiacea. Sp. $1-3$

且 J or 6 f 6 Pu China 1806. C 1.p Icon. Kæmpf. 9

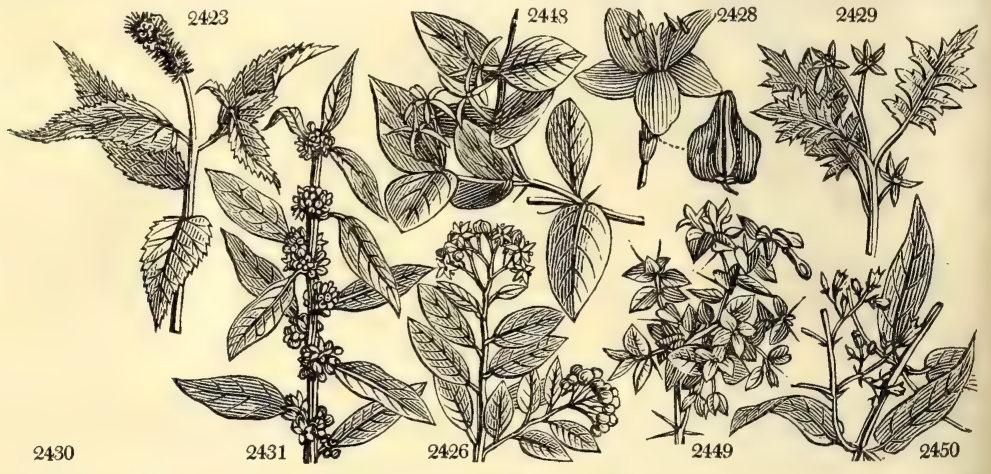

History, Use, Propagation, Culture,

and lived a hundred years. The work he left upon the agriculture of his time is invaluable. In French a species is called Monjoli, (my beauty) on account of its beauty.

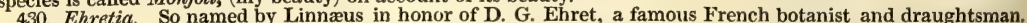
He drawings for Patrick Browne's History of Jamaica; and a large collection of his drawings is now extant in the Banksian collection. Large trees of the Tropics, with handsome foliage and white flowers, which are not often produced in Europe.

431. Bourreria. A genus divided from Ehretia, with which it nearly agrees. It was named after one Bourer, an apothecary at Nuremberg.

432. Ellisia. Joseph Ellis was an English naturalist, fellow of the London Royal Society, and correspondent of Linnæus. He published, besides his Natural History of Corallines, many papers in the Transactions of the Royal Society.

433. Sersalisia. Named after John Baptiste Sersalis, a Neapolitan clergyman, much praised by Fabius Columna. Culture the same as for Sideroxylon

434. Manglilla. This genus is called in Dombry's Manuscript Papers, from which M. de Jussieu obtained his knowledge of it, Manglille de Perou. The original species was a Peruvian shrub, with alternate leaves and bunches of numerous axillary flowers.

435. Ardisia. A name derived from $\nsim \rho \delta 15$, a point, on account of the acute segments of the corolla. An ornamental genus of plants, much valued by collectors for the beauty of their foliage, flowers, and berries. They are of easy culture : cuttings strike root freely in a pot of sand, plunged in a moist heat, under a handglass.

436. Arduina. In honor of Pietro Arduini, curator of the economical garden of Padua. A genus scarcely distinct from Carissa. It is a pretty little plant not unlike the box, easily propagated by cuttings under a bellglass in sand.

437. Strychnos. A name given by the Greeks to the Solanum. The root of the name has been found in the verb reww, to strew, to throw down; the property of the original and modern plants being narcotic. S. nux-vomica is a middling sized tree with a crooked trunk and smooth ash-colored bark: the leaves round, shining, smooth, 
2423 Leaves broad ovate serrate rugose, Spikes terminal, Flowers clustered, Cal. large inflated

9424 Leaves linear toothed obtuse revolute at edge rough above tomentose beneath, Spikes linear oblong

2425 Leaves oblong ovate entire smooth, Flowers panicled

2426 Leaves ovate roughish, Flowers corymbose spiked 1-sided

S427 Leaves ovate entire smooth, Flowers corymbose, Cal. smooth

2428 Leaves ovate very smooth reflexed at edge, Berry juiceless 4-cornered

2129 The only species, resembling a Hydrophyllum

2430 Leaves ovate obtuse downy beneath, Cor. villous outside, Barren filaments lanceolate

2431 Leaves oblong acute at each end, Flowers solitary lateral

2432 Panicles axillary and terminal, Leaves oblong acuminate narrowed at base

2432 Corymbs axillary 3-parted, Leaves oblong narrowed towards each end

2434 Panicles terminal, Leaves lanceolate ovate repand crenate acuminate attenuated at base

2435 Racemes lateral axillary compound, Leaves oblong acuminate entire

2436 Corymbs axillary simple, Leaves entire ovate elliptical coriaceous

2437 Leaves oblong entire coriaceous shining, Pan. terminal, Sepals rounded, Cor. thrice as long as calyx

2438 Leaves oblong entire coriaceous shining, Pan. terminal, Sepals round, Cor. twice as long as calyx

2439 Racemes axillary simple, Leaves obovate at the edge cartiliginous serrated

2440 Leaves wedge-shaped oblong nearly sessile entire smooth reflexed, Panicles decompound

2441 Raceme terminal pyramidal, Pedunc. altern. umbelliferous, Leaves oblong obtuse smooth entire

2442 Leaves lanc. crenate, Corymbs compound, Flowers spotted

2443 Leaves lanceolate coriaceous sinuate narrowed towards the base, Cor, campan. dotted : Lobes obtuse

2444 Flowers panicled, Leaves oblong entire veinless coriaceous

2445 Leaves cordate ovate mucronate subsessile, Spines bifid at end

2446 Unarmed, Leaves ovate stalked, Cymes subterminal

2447 Leaves opp. ovate acute 5 -nerved veiny, Cymes axillary

2448 Leaves ovate mucronate netted veiny, Segm, of cor. lanceolate

2449 Leaves ovate acute veiny, Segments of cor. oblong

2450 Leaves cordate lanceolate, panicles short opp. few-flowered, Bractes very small

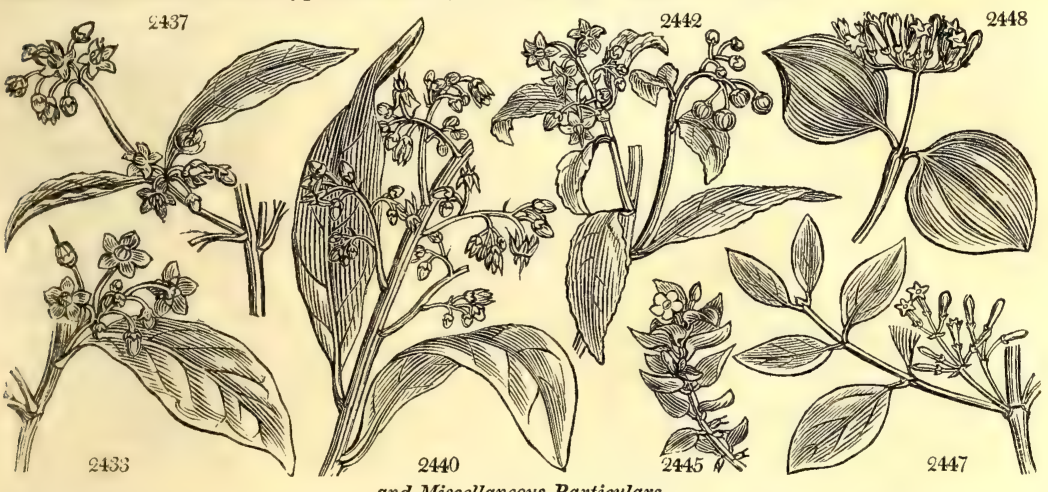

and Miscellaneous Particulars.

entire ; and the berry the size of a pretty large apple. The wood is hard, durable, and very bitter. The seeds, which form the officinal nux-vomica, are employed in the distillation of country spirits, to render them more intoxicating. The pulp of the fruit seems perfectly innocent, being eaten greedily by many sorts of birds. The seed consists chiefly of a gummy matter with a little resin, the latter intensely bitter. It is reckoned amongst the most powerful poisons of the narcotic kind. It proves fatal to dogs in a very short time, and to most other quadruped vermin, and even some birds, as crows and ducks From dissections both of the human subject and of dogs that have been poisoned by it, no injury appears done to the stomach or intestines, which proves that it acts upon the nervous system, and destroys life by the virulence of its narcotic influence.

S. potatorum is a larger tree than the other. The pulp of the fruit when ripe is eaten by the natives: the ripe seeds are dried and sold in every market of the East Indies to clear muddy water. A precious quality in countries where the water is rarely of a good quality. Hence the English name of clearing-nuts. The natives never drink clear well-water, if they can get pond or river water, which is always more or less impure. One of the seeds is rubbed very hard for a minute or two round the inside of the vessel containing the water, which is generally an unglazed earthen one, and the water left to settle; in a very short time the impurities fall to the generally an unglazed earthen one, and the water left to settle; in a very short time the impurities fall to the
bottom, leaving the water clear, and perfectly wholesome. These nuts are constantly carried about by the more provident part of our officers and soldiers in time of war, to enable them to purify their water; they are easier to be had than alum, and are probably less hurtful to the constitution.

438. Carissa. A word of no known meaning. Carandas is a slight alteration of Caraunda, the Bengalese name of the tree. C.Carandas is a small tree, with dichotomous branches, and entire, glossy, ovate leaves, flowers like those of Jasminum grandiflorum, and berries black when ripe, eatable, and of a sweet acid flavor. Currant-jelly is made of them in the East Indies.

C. spinarum is a diøeceous plant with horizontal branches, coriaceous glossy leaves, and terminal peouncles of five or six small flowers. Neither of the species require much water, and the pots should be well drained to prevent their getting sodden. Cuttings strike root freely under a bell-glass in sand plunged in heat.

139. Paderia. From pador, stink, in allusion to the foetid smell of the flowers. A climbing smooth shrub, with opposite stalked entire leaves, and dull purple flowers. 
44.0. GELSE'MIUM. $J$. GeLsemium. $2+51$ sempervírens $\boldsymbol{H}$. $\boldsymbol{K}$. evergreen

441. RAUWOL'FIA. $W$. RaUWolfia. 2452 nitida $W$.

2453 canéscens $W$.

shining

2454 tomentósa $W$. downy

hoary

2455 ternifólia Kunth. three-leaved

442. VALLE'SIA. Fl. per. Vallesia.

2456 glábra $L k$. smooth

443. BCEOBO'TRYS. Vahl. ВєовотRY'

2457 indica Roxb. Indian

444. SOLAN'DRA. $W$. Solandra

2458 grandiflóra $W$. great-flowered

2459 viridiflóra $B$. $M$. green

445. CES'TRUM. $W$. Cestrum

2460 laurifólium $\boldsymbol{W}$. Laurel-leaved

2461 macrophýllum Vent. large-leaved

2462 fotidissimum W.en. stinking

2463 noctúrnum $W$.

2464 Párqui $W$.

2465 auriculátum $W$.

2466 vespertinum $W$.

2467 fastigiátum Jacq.

2468 dí́rnum $W$.

2459 venenátum $W$.

2470 salicifólium Jacq.

2471 tomentósum $W$.

2472 hirsítum Jacq.

night-smelling

Willow-leaved

ear-leaved

cluster-flower'

Honeysuckle

day-smelling

poisonous

sallow-leaved

downy

2473 pendulinum hairy

2474 odontospérmum. Jac tooth-seeded

2475 tinctórium Jacq. dyer's

2476 undulátum $\mathrm{Fl}$. per. wavy

2477 cauliflórum Jacq.

2478 citrifólium Retz.

446. A'TROPA. $W$

2479 Belladónna $W$

2480 frutéscens $W$.

2481 aristáta Poir.

2482 arboréscens $\boldsymbol{L}$

stem-flowering

lemon-leaved

Atropa.

Apocyner. Sp. 1

8. or 6 jni.jl Y N. Amer. 1640. C s.p Cat.car. 1.t.53

Apocynea. Sp. 4-12.

I cu 12 jn.s W S. Amer. 1752. C s.p Bot. cab. 339

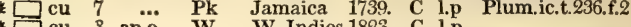

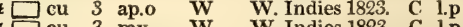

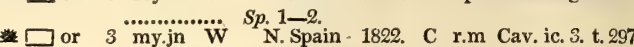
Rhamnea. Sp. 1.

$3 \mathrm{n} \quad$ W E. Indies 1817. C co Bot. mag. 2052 Solanea. Sp. $2-3$.

$9 \square$ or $15 \mathrm{mr}$ Pa.Y Jamaica 1781. C r.m Jac.schœn.1.t.45

my.jl G S. Amer. 1815. C r.m Bot. mag. 1948 Solanea. Sp. 19-50.

$\square$ p 7 my.au W W. Indies 1691. C p.l Smith spic. 2. t.2

7 my.au W W. Indies 1812. C p.1 Vent.choix. 18

10 my.au $\mathbf{Y}$ E. Indies ... C p.l Jac.scho.3. t. 329

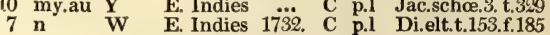

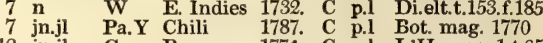

12 jn.jl G Peru 1774. C p.l L'Her. s.n.1.t.35

12 my.jl G W. Indies 1759. C p.l Jac.schœ.3. t. 328

$4 \mathrm{n}$ W W. Indies ... $\quad$ C p.l Bot. mag. 1729

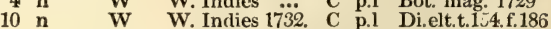

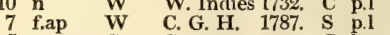

5 ap.jn G.w Caraccas ... C C.p Jac.schœ.3.t.326

6 jn.jl $\quad Y \quad$ S. Amer. 1790. C p.1

8 jn.jl G $\quad . . . . . \quad$ 1818. C p.l Jac.schœ.3.t.324

6 jn.jl G.w Caraccas 1824. C p.l Jac. schœe.3.t.327

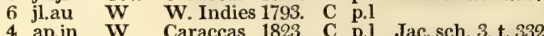

15 ... $Y$ Y Peru 1822. C p.1 Fl. per.2.t.155

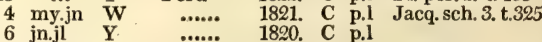

Solanee. Sp. 4-14.

Deadly-Nights. \& $\Delta p \quad 5$ jn.jl $\quad$ V Britain rub. $R$ co Eng. bot. 592

shrubby 在 5 ja.mr Y Spain 1737. C s.l Cav. ic. 2. t. 102

bearded $\quad \begin{array}{llllll} & \end{array}$

447. MANDRAGO'RA. W.en. Mandrake.

2483 officinalis $W . e n$. officinal $\neq \Delta p$ Solanee. Sp. 1.

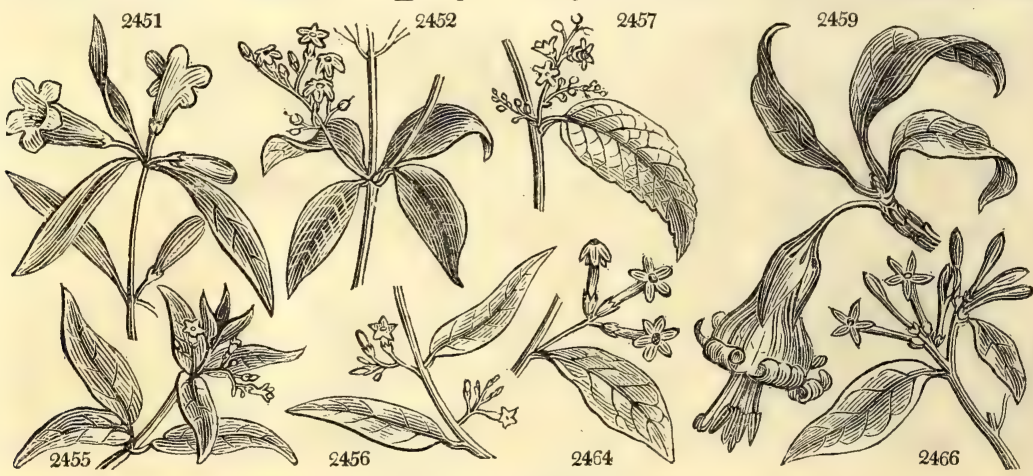

History, Use, Propagation, Culture,

440. Gelsemium. One of the ancient names of the jasmine. A beautiful climbing evergreen shrub, rather too delicate to bear the cold of our winters ; but with a little protection it produces in abundance its charming yellow flowers of delicious fragrance.

441. Rauwolfia. So named by Plumier, in honor of Leonhard Rauwolf, physican at Augsburg, who travelled through Palestine and other countries of the east, in 1753.5. His travels were translated into IEnglish, under the revision of Mr. Ray, and with additions by him. The species abound in a milky juice, which is considered more or less of a deleterious nature. They produce berries about the size and color of those of the privet. Cuttings root in sand under a hand-glass.

442. Vallesia. In honor of Fr. Vallesio, principal physician to Philip II., king of Spain. He wrote upon the plants of holy writ. Small Peruvian shrubs.

443. Boobotrys. From pasos, small, and Borevs, a bunch; the flowers growing in little bunches. An elegant shrub with white flowers, produced freely from the axillæ of the leaves.

444. Solandra. In honor of the celebrated and excellent Daniel Solander, whose botanical merits will never be forgotten in this country. He accompanied Sir Joseph Banks in his voyage with Captain Cook, and the information afforded by his manuscript notes made at that time has not yet been exhausted. The species are very beautiful, and remarkable for the extraordinary size of their flowers. Sweet observes, "if allowed plenty of room and moisture, they grow very rapidly, but produce no flowers. The best way is to plant them in a loamy soil, and allow them to grow fast at first, till they have made a great many shoots; then keep them very dry till their leaves drop off, and they will produce plenty of flowers. Cuttings taken off and stuck in a pot of mould, will root without any further care. The best way to have plants flower young, is to take the cuttings from the flowering shoots." (Bot. Cult. 107.)

445. Cestrum. A name given by the Greeks to the Betony, but having no relation whatever to the plant which bears the name now. Cestreau, Fr. This is a genus of easy cultivation, but of little beauty. The flowers are all white, and in some cases sweet-scented; the fruit of all poisonous.

446. Atropa. A mythological name. Atropos was one of the Fates, and it was her especial duty to cut the thread of human life. The fruit of this genus is well adapted to fulfilling her office. A. belladonna (fine lady) has 
9451 Scandent quite smooth, Leaves lanceolate, Flowers axillary subsolitary

2452 Leaves 3 or 4 together lanceolate acuminate shining, Flowers terminal

2453 Leaves 4 together oblong ovate acuminate pubescent, Flowers terminal and axillary

2454 Leaves 4 together oblong narrowed both ways tomentose, Flowers terminal and axillary

2455 Leaves 3 together oblong acuminate smooth, Flowers between the petioles corymbose

2456 Leaves lanceolate cymbiform incurved at end

2457 Leaves oblong ovate acuminate coarsely serrated

2458 Leaves smoothish stalked, Anthers of the same shape

2459 Flowers stalked, Segm, of flower long acuminate revolute

2460 Filaments toothed or naked, Leaves elliptical coriaceous shining, Flowers fascicled stalked

\$461 Filam, toothed, Leaves ovate oblong acuminate smooth, Flowers fascicled sessile

2462 Filam, naked, Segm. of cor. emarginate, Flowers racemose, Leaves ovate and lanceolate

2463 Filam. toothed, Peduncles racemose as long as leaves

2464 Filam. toothed or naked, Flower-bearing stem panicled, Stipules linear

2465 Filam. naked, Stipules amplexicaule lunate, Leaves ovate, Flowers panicled terminal

2466 Filam. naked shorter than throat of cor. Flowers aggreg. sessile terminal and lateral, Leaves elliptical

2467 Filam. naked, Pedunc. elong. as long as leaves spiked at end, Leaves oblong, Stip. elliptical

2468 Filam, naked, Segm. of cor, rounded reflexed, Leaves lanceolate

469 Leaves lanceolate oblong coriaceous, Flowers sessile

2470 Filam. toothed, Flowers racemose, Leaves linear lanceolate

2471 Flowers clustered sessile terminal, Branches leaves and calyxes downy

2472 Filam. toothletted, Spikes axillary longer than leafstalks, Leaves obl. pub. on both sides, Stip. falcate

2473 Filam. naked the length of the tube of the corolla, Flowers aggreg. sessile terminal, Leaves elliptical

2474 Filam. naked, Leaves lanceolate, Racemes short axillary and terminal, Cor. revolute

2475 Filam. naked, Leaves lanc. ovate, Racemes axillary and terminal, Flowers pedicellate, Cor. acum. reflex

2476 Filam. toothed, Leaves ovate acute wavy, Pedunc. axillary and terminal few flowered

2477 Filam. naked exserted, Flowers stalked clustered, Cor. campanulate, Leaves elliptical

2478 Leaves large ovate acute entire shining naked on both sides coriaceous nerved, Petioles black shining

2479 Stem herbaceous, Leaves ovate entire

2480 Stem shrubby, Peduncles clustered, Leaves cordate ovate obtuse

2481 Stem shrubby, Leaves oblong entire smooth, Branches downy, Sepals aristate

2482 Stem shrubby, Peduncles clustered, Cor. revolute, Leaves oblong

2483 The only species

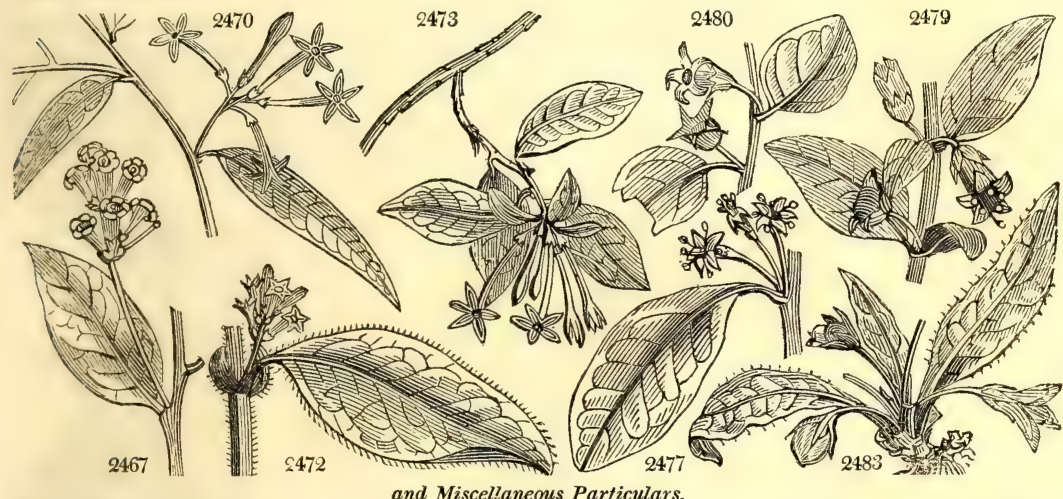

and Miscellaneous Particulars.

its speoific name, according to some, from its being used as a wash among the ladies, to take off pimples or other excrescences from the skin; or, according to others, from its quality of representing phantasms of beautiful wo-
men to the disturbed imagination. The inspissated juice of the berries is used in the form of extract for anointing the eyelids in some opthalmic complaints. Its effect in dilating the pupil is quite remarkable. It has branching stems with the root leaves often a foot long and five inches broad, and the whole plant is more or less tinged with purple. The flowers are void of scent; the berries are larger than cherries, at first green, but when ripe of a beautiful shining black color, full of purple juice, with roundish dotted channelled seeds. The whole plant, and especially the berries, is poisonous. Buchanan relates the destruction of the army of Sweno the Dane, when he invaded Scotland, by the berries of this plant, which were mixed with the drink which the the Dane, when he invaded Scotland, by the berries of this plant, which were mixed with the drink which the
Scots, according to truce, were to supply the Danes with. The Danes became inebriated, and the faithless Scots fell on them in their sleep. Dr. Milne (Indigenous Botany) remarks, that nature has been more parsimonious in her warnings with respect to this plant, than to others of the same natural family. Neither the smell nor the taste is offensive; and if the color of the flowers proves in some degree a repellant, that of the fruit, on the other hand, is in an equal degree, at least, attractive and inviting.

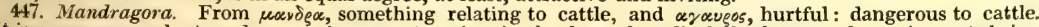
It is a venomous plant, and was an important engine in the days of medical charlatanry, from the roots being supposed to bear a resemblance to the human form. In old herbals the figures display the male mandrake with a lung beard, and the female with a prolix head of hair. Miller says, " mountebanks carry about fictitious images, shaped from roots of bryony and other plants, cut into form or forced to grow through moulds of earthenware, as mandrake roots." Happily such mountebanks have ceased to exist in Britain. On the continent they are still common, and Box tells us (in 1810), that by means of a few cuts with a knife, they add the image of the exterior organs of generation, male or female, to mandrake roots, and then sell them to by mountebanks in sea-port towns of France. For an ingeniously indelicate figure of a mandrake root, see the Flora Graca, the plates for which have been all selected by Sir James Smith. The plant is of easy culture, but is the better for the protection of a frame or shelter of a south wall during winter. 
48. PHY'SALIS. $W$. 2484 somnifera $W$. 2485 flexuósa $W$. 2486 curassávica $W$ 2487 viscósa $W$. 2488 pensylvánica $W$ 2489 Alkekéngi $W$. 2490 peruviána $W$. 2491 pubéscens $W$. 2492 anguláta $W$ 2493 chenopodifólia $W$ 2494 barbadénsis $W$. 2495 mínima $W$. 2496 pruinósa $\dot{W}$. 2497 prostráta $W$ 2498 tuberósa $W$. 2499 parvifióra $W . E$ 2500 dúbia $L k$. 2501 fœetidissima $\mathrm{Lag}$. 449. SA'RACHA. Fl. per 2502 procúmbens $F$. $p$. 2503 umbelláta Jacq. 450. LY'CIUM. $W$ 2504 áfrum $W$. 2505 rigidum $W$. 2506 ruthénicum $W$. 2507 bárbarum $P$. S . 2508 turbinátum $P$. $S$. 2509 europæ'um $\boldsymbol{P} . S$ 2510 lanceolátum $P$ oir. 2511 chinénse Mill. 2512 hórridum $W$. 2512 hórridum $W$. succulent-lvd. 2514 caroliniánum $P h$. 2515 trewiánum Duh.

451. SOLA'NUM. $W$. 2516 peruviánum $L$. 2517 Lycopérsicum $\boldsymbol{W}$. 2518 cerasifórme Dun. 2519 Humbóldti $W$. 2520 pyrifórme Dun.

2521 tuberósum $W$

W. Potatoe $\beta$ Commersoni Poir. Wild-Potatoe 2522 Seaforthiánum And. Seaforth's 2523 betáceum $\boldsymbol{P}$. S. Beet-leaved 2524 muricátum $W$. 2525 laciniátum $W$ 2526 quercifólium $\boldsymbol{W}$. 2527 radicans $W$. stinking

SARACra. procumbent

BOX-THORN. African rigid Russian Willow-leaved top-shaped European spear-leaved Trew's

Nightshade. Peruvian Love-apple Cherry Humboldt's Pear-shaped

Winter Cherry. clustered flexuose w w Curaçao \\ clammy $\pm \Delta w$ Pensylvanian $\frac{\text { v }}{\Delta} \mathrm{w}$ common downy $\mathrm{O}$ w angular-branch w Goose-foot-lvd. \\& $\triangle$ w Barbadoes $\widehat{O}$ w small $\mathrm{w}$ hairy-annual $\bigcirc \mathrm{w}$ trailing tuberous $\leq \Delta \mathrm{w}$ small-flowered glaucous-leaved.w O w $\$ \mathbb{\Delta}$ or 4 jn.jl Pa.Y Peru 1822. D co

Solanea. $S p, 12-28$.

* or 10 jn.jl V C. G. H. 1712. C p.l Bot. reg. 354

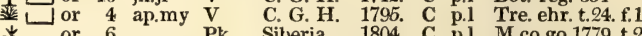
* or 6 ... Pk Piberia 1804. C p.l M.co.go.1779.t.2 or 12 my.au V China 1709. C co Du.ed.n.119.t.31 or 12 my.au Pk S. Europe 1730. C co Mic.gen.t.105.f. 1 or 12 my.au Pk S. Europe ... C co Duh. ed. n.t. 32 or ${ }_{\text {W }}$ C. G. H $17 \ddot{\text { Pu }}$ C co Dend. brit. 8 or 3 jl.au P. C. G. H. 1791. C p.l or 4 jl.s $B$ Carolina 1806. C p.1 L'He.s.n.45.t.23

Duh. ed. n. t. 30 \ $\Delta$ w $2 \underset{\text { my.jn }}{\text { Solanea. Sp. }} \underset{\text { Peru }}{79-360 .}$ 1823. D co Feuill. 3. t. 25 O clt 3 jl.s $\quad$ G $\quad$ S. Amer. 1596. S r.m R.am.5. t.154. f. 1 O clt 3 jl.s $\quad$ G $\quad \ldots . . . \quad$ 1800. S r.m Jac. vind. 1.t.11 O clt 2 jl.s $\quad Y \quad$ S. Amer. 1822. S co W.hort.ber. t.27 $\mathrm{O}$ clt 2 jl.s $Y$...... 1823. S co Dun. sol. t. 26

* $\triangle$ ag 2 jn.au W Peru 1597. R r.m Bau.prod.89.t.89 * $\triangle$ cul 2 my.o W S. Amer. 1822. R co Hort. trans. g or 20 jl.s Pk Barbadoes1804. C 1.p Bot. rep. 504 娄 $\square$ or 4 jn.jl Pk S. Amer. 1803. C 1.p Bot. rep. 511 : $\square$ or 3 jl.au V Peru 1785. C lp Feu per 779 t.15

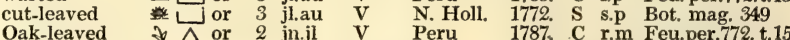

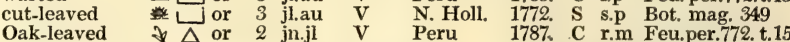

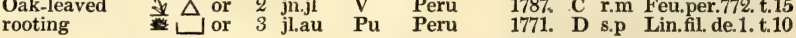

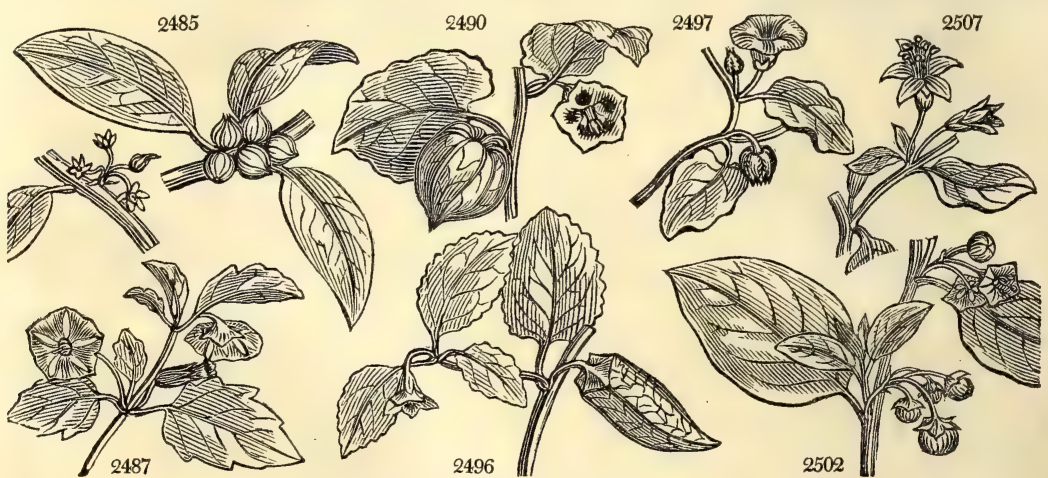

IIistory, Use, Propagation, Culture,

448. Physalis. From Qvots, a bladder. The fruit is enclosed in an inflated calyx. The berries of $\mathbf{P}$. alkekengi are acidulous and slightly bitter; they were esteemed detergent and aperient by the ancients, In Spain, Germany, and Switzerland, they are eaten as a common fruit. Phy. peruviana produces a pleasant fruit for tarts, and is in some countries, and even English gardens, cultivated for that purpose.

449. Srracha. A plant resembling Atropa, or Physalis, to which it is too nearly related. It was named by the authors of the Flora Peruviana after Isidore Saracha, a Spanish botanist.

450. Lycium. So called because the original species was a native of Lycia, a country of Asia Minor. Some of the Cape species of this genus have elegant flowers and merit cultivation, and L barbarum is valuable for covering naked walls, arbors, \&c. It grows four or six feet in a season, flowers freely, and is readily propagated by cuttings at any season of the year. L. europæum is used for hedges in Tuscany, being armed with small cuttings at any season of the year. L. europæum is used for hedges in Tuscany, being armed with small
thorns. Clusius says they eat the small shoots in Spain with oil and vinegar. L. ruthenicum is an ornamental shrub from its very white bark. The greenhouse species root readily in sand under a hand-glass.

451. Solanum. By some ingenious commentators this word has been derived from solari, to comfort. The derivation may be possible, but the application is not evident. This extensive genus, which belongs to the Luridæ of Linnæus's system of natural orders, does not contain many handsome plants ; but it includes, besides the Tomato and egg plant, celebrated in cookery, the potatoe, whose tubers, as a human food, if equalled, are not surpassed by those of any other plant. Some of the species are singular on account of their leaves and 
2484 Stem shrubby rounded, Branches upright, Flowers clustered

2485 Stem shrubby, Branches flexuose, Flowers clustered

2486 Stem shrubby, Leaves ovate tomentose

2487 Leaves in pairs repand obtuse subtomentose, Stem herbaceous panicled above

2488 Leaves ovate subrepand obtuse nearly naked, Flowers in pairs, Stem herbaceous

2489 Leaves in pairs entire acute, Stem herbaceous branching below

2490 Pubescent, Leaves cordate entire

2491 Pubescent, Stem angular, Leaves in pairs cordate nearly entire soft, Teeth of cal. acuminate

2492 Much branched, Branches angular smooth, Leaves ovate toothed

2493 Pubescent, Stem erect $\frac{1}{2}$ shrubby, Leaves subcordate toothed angular, Petioles decurrent

2494 Much branched, Leaves ovate cordate pub. Flowers pendulous, Calyx in fruit ovate acuminate angular

2495 Much branched, stalk of fruit much longer than the villous leaf

2496 Much branched, Leaves villous, Peduncles erect

2497 Much branched, Stem procumbent rounded hairy. Leaves rather fleshy

2498 Pubescent, Leaves ovate angular, Stem herbaceous, Berries viscid, Root tuberous

2499 Hairy, Leaves cordate acute toothed, Pedunc. at length reflexed, Cal, with segm. twice as short as cor.

2500 Leaves oval unequal acute toothed smoothish, Flowers solitary, Calyx powdered, Cor. tomentose

2501 Leaves in pairs toothed repand tomentose-viscid oval, Stem herbaceous panicled above

2502 Leaves in pairs unequal ovate smooth, Flowers in umbels

2503 Stem erect hairy, Umbels axillary stalked cernuous, Flowers plaited

2504. Branches diffuse spiny, Leaves linear fleshy attenuated at base fascicled, Pedunc. longer than cal.

2505 Branches upright spiny, Leaves linear fascicled, Pedunc. shorter than calyx, Stam. as long as tube of cor.

2506 Branches droop. spiny, Lvs. lin. lanc. atten. at base fasc. Ped. longer than cal. Stam, as long as limb of cor.

2507 Branches drooping, Buds spiny, Cal. trifid, Stam. as long as limb of cor.

2508 Branches drooping spiny rounded, Leaves sessile lanceolate acuminate, Cal. trifid, Berry turbinate

2509 Branches lax spiny, Leaves oblong lanc. obtuse obliquely bent, Stam. shorter than limb of cor.

2510 Branches erect flexuose at end recurved rounded much spreading spiny, Leaves subsessile lanc. acute

2511 Stem and branc. droop. striated rarely spiny, Lvs. stalked ov, obt. Cal. 5-toothed, Style longer than stam.

2512 Spiny, Leaves obovate fleshy smooth, Peduncles very short

2513 Spiny, Leaves ovate entire acute glaucous, Flowers panicled

2514 Unarmed, Leaves narrow spatulate oblong, Flowers 4-cleft tetrandrous

2515 Erect spiny, Branc. dif. angular, Lvs. stalked lanc. acute, Cal. 2 or 3-fid, Style scarcely longer than stam.

\section{1. Lycopersicon (Love Apples.) Anthers conical, joined at end. Berry many-celled.}

2516 Villous hoary, Leaves stipulaceous unequally pinnatifid, Segm. obtuse, Pedunc, and pedicel bracteated

2517 Hairy, Leaves unequally pinnatifid, Segments cut glaucous beneath, Berries torulose furrowed smooth

2518 Hairy, Lvs. unequally pinnat. Segm. cut glauc. beneath, Sepals as long as cor. Berries round rather hairy

2519 Hairy, Lvs. unequally pinnat. Segm. cut glauc. beneath, Pedunc. with bract. Sepals twice as long as cor.

2520 Hairy, Lvs. unequally pinnatifid, Segm. cut glaucous beneath, Pedunc. without bract. Berries obconical

\section{\$2. Unarmed. Leaves pinnate, pinnatifid, or entire.}

2521 Root tuberous, Stem herbac. Segm. of lvs. unequal, the altern. ones minute, Pedicels stalked, cor. 5-ang

e Root tuberous, Stem herbaceous, Leaves pinnate sublyrate pilose, Pedic. jointed, Cor. 5-cleft

2522 Leaves pinnate waved, upper simple lanc. Racemes in panicled cymes sometimes longer than petioles

2523 Leaves cordate ovate oblong hairy on each side waved at edge, Racemes pendulous as long as petioles

2524. Stem half shrubby rooting ascending runners muricated, Lvs. obl. lanc. pubescent simple, Racemes ?-fid

2525 Smooth, Leaves pinnatitid segments linear lanceolate terminal elongated, Racemes lateral corymbose

2526 Stem angular wavy rough, Leaves pinnatifid, Racemes cymose

2527 Stem rounded prostrate rooting, Lvs. deeply pinnat. Sinuses obtuse, Racemes cymose as long as petioles
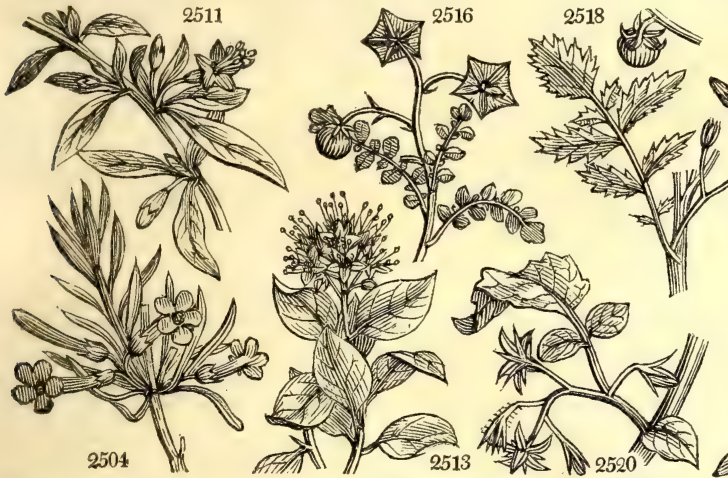

2515

and Miscellaneous Particulars.

spines; and others retain their fruit in our stoves during winter, which may be a recommendation to some to admit them in collections.

S. dulcamara has roots which smell like the potatoe; being chewed, a sensation of bitterness is first felt, and then of sweetness, whence the specific name. The berries excite vomiting and purging, and the twigs and leaves have been used in rheumatic and scorbutic cases with good effect.

S. tuberosum, Pomme de Terre, Fr., Kartoffel, Ger., Pomo de Terra, Ital., Potades, Span., \&c. is supposed to be a native of South America, and to be found in a wild state in elevated places in the tropical regions, and in the more temperate districts of the western coasts of that country. Some tubers, said to be of the wild potatoe, have been received from these parts by the Horticultural Society, and cultivated by them; their produce differs very little, if at all, from that of the common cultivated sort; they are small, roundish, and pink and white colored. (Hort. Trans. 5. 257.) It appears probable that the potatoe was first brought into Europe from the mountainous parts of South America in the neighbourhood of Quito, where they were called papas, to Spain, early in the 16 th century. From Spain, where they were called battatas, they found their way to Italy, and there received the same name as the truffle, taratoufli. From Italy they went toVienna, through the governor of Mons in Hainault, who sent some to Clusius in 1598. To England the potatoe found its way from North A merica, being brought from Virginia by the colonists sent out by Sir Walter Raleigh in 1584, and who' returned in July 1586; and, "probably," says Sir Joseph Banks, "brought with them the potatoe." Gerarde, 
2528 corymbósum $W$. 2529 oligánthum $L k$. 2530 Dulcamára $\boldsymbol{W}$. 2531 macrocárpon $W$ 2532 æthiópicum $\boldsymbol{W}$. corymbed few-flowered Bitter-sweet

large-fruited Ethiopian 2533 Zuccágniánum Dun. scabrous 2534 Pseudo-cápsicum $W$. Winter-cherry 2535 nodiflórum Jacq. thick-jointed 2536 guineénse $W_{\text {en }}$. large-berried 2537 melanocérasum $W$.en.small-berried 2538 suffruticósum $\boldsymbol{W}$.en. fringed-leaved 2539 nigrum $W$. black-berried 2540 miniátum Bern. red-berried 2541 húmile Bern. green-berried 2542 villósum $W$.en. orange-berried

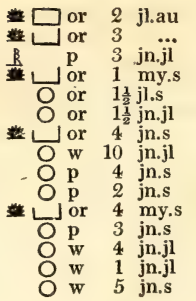

$\mathbf{V}$
$\mathbf{W}$
$\mathbf{V}$
$\mathbf{B}$
$\mathbf{W}$
$\mathbf{W}$
$\mathbf{W}$
$\mathbf{W}$
$\mathbf{G}$
$\mathbf{W}$
$\mathbf{W}$
$\mathbf{W}$
$\mathbf{W}$
$\mathbf{W}$
$\mathbf{W}$

O or 4 jn.s

2543 pátulum $W$. 2544 críspum $\mathrm{Fl}$. per. 2545 bombénse Jacq. 2546 Cervantésii Lag. 2547 verbascifólium $W$ 2548 auriculátum $W$. 2549 diphýllum $\boldsymbol{W}$. 2550 havanénse $\boldsymbol{W}$. 2551 lycioídes $W$ 2552 uniflórum $\mathbf{L}$ ag. 2553 stellátum Jacq.

\begin{tabular}{|c|c|c|c|c|}
\hline spreading & & or & & jn.s \\
\hline Natre & 9 & or & 18 & jn.jl \\
\hline Bomba & 㖪 & or & 12 & jn.jl \\
\hline Cervantes's & 等 & or & 4 & my.jn \\
\hline Mullein-leaved & 耀 & or & 7 & jn.jl \\
\hline ear-leaved & 锌 & or & 4 & \\
\hline two-leaved & 些 & or & 3 & jn.jl \\
\hline Havannah & 娄 & or & 5 & jl.au \\
\hline spiny & & or & 4 & my.jn \\
\hline one-flowered & & or & 3 & my.jn \\
\hline stellat & & or & 6 & jn,jl \\
\hline
\end{tabular}

Peru

1824. C co

Britain hed. C s.l Eng. bot. 565

Peru 1759. C s.p Mill. ic. 2. t. 294

Ethiopia 1597. C 1.p Jac. vind. 1. t.12 1823. S co Dun. sol. t. 11

Madeira 1596. S r.m Sabb. rom. t. 59

I. France 1822. S co Jacq. ic. 2. t. 326 Guinea $\quad . .6$ S s.l Di.elt.t.274.f.354 $\begin{array}{lllll}\text { Virginia } & \ldots & \text { S } & \text { s.1 } & \text { Di.elt.t 275.f. } 356\end{array}$

Birginia 1804 s.

$\begin{array}{llll}\text { Barbary 1804. C } & \text { l.p } \\ \text { Britain rub. S } & \text { s.l }\end{array}$

$\begin{array}{lll}\text { Britain rub. } & \text { S } & \text { s.1 } \\ \text { S. Europe } 1823 \text {. } & \text { S } & \text { co }\end{array}$

S. Europe 1823, S co

Barbadoes ... S s.1 Di.elt.t.274.f.353

India $\quad \ldots . \quad$ S $\quad$ s.l Di.elt.t.275.f.355 Chili 1824. C co Fl, per. 2. t. 158 Mexico 1822. C co Mexico 1818. C co

W. Indies 1749. S p.1 Jac. vind. 1. t.13 Madagasc.1773. S p.1 Scop. insub.3.t.8 W. Indies 1699. C s.1 Jac. ic. 2. t. 322 W. Indies 1793. C co Jac.amer.49.t.35 Peru 1791. C s.p Jac. ic. 1. t. 46

N. Spain 1820. D co

..... 1822. C co Jac. ic. 2. t. 325

1823 C co Cav, ic 3 t 243 W. Indies 1781, C co Jac.amer.50.t. 36 S. Amer, 1714. C s.p Jac. vind, 1. t.14 ....... 1820. C co

Bahama 1732. S p.l Di.elt.t.271.f. 350 C. G. H. 1662. C p.1 Bocc. sic. 8. t. 5 W. Indies ... C co Jacq. ic. 2. t. 329 B. Ayres 1727. C s.l D.e.364.t272f 351 B W. Indies 1752. C l.p Jac.amer.t.40.f.3 $\begin{array}{llllll}\text { Pa.B } & \text { Mexico } & \text { C.. } & \text { C } & \text { s.l } & \text { Bot. mag. } 2173 \\ \text { V } & \text { C. G. H. 1792. } & \text { C } & \text { s.p } & \text { Bot. mag. 1921. }\end{array}$ 2561 bonariénse $W$. Buenos Ayre 2563 lanceolátum Cav. lanceolate 2564 gigantéum $W$. tall

wave-leaved red-spined 2556 igneum $W$. 2557 subarmatum 2558 bahaménse $W$. half-armed Bahama 2559 tomentósum $\boldsymbol{W}$. woolly 2560 lanceæfólium Jacq. lance-leaved

2547

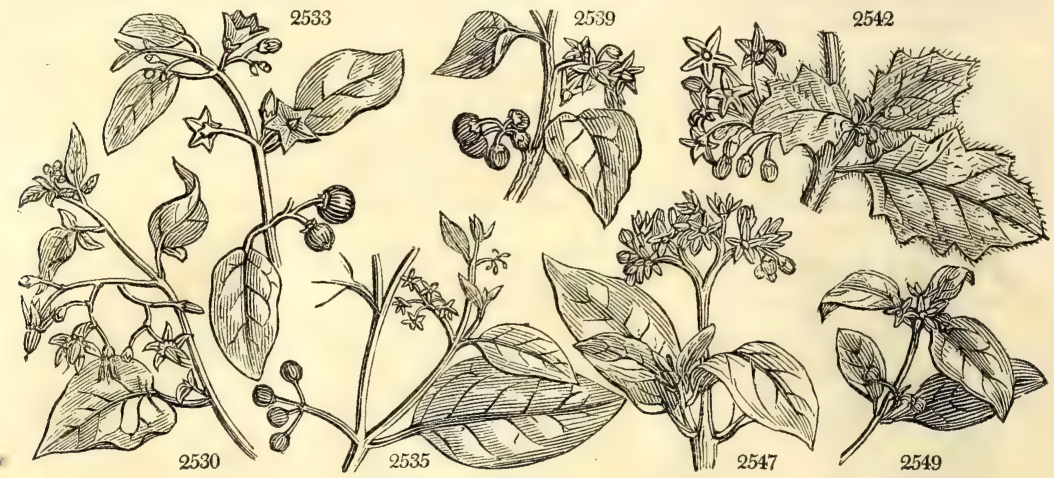

2542

History, Use, Propagation, Culture,

2549

in his Herbal, published in 1597, gives a figure of the potatoe, under the name of Potatoe of Virginia, whence he says he received the roots; and this appellation it appears to have retained, in order to distinguish it from the battatas or sweet potatoe (Convolvulus battatas) till the year 1640, if not longer. "The sweet potatoe," Sir Joseph Banks observes, " was used in England as a delicacy long before the introduction of our potatoes ; it was imported in considerable quantities from Spain and the Canaries, and was supposed to possess the power of restoring decayed vigor. The kissing comfits of Falstaff, and other confections of similar imaginary qualities, with which our ancestors were duped, were principally made of these and of eringo roots." Gough says the potatoe was first planted by Sir Walter Raleigh on his estate of Youghall near Cork, and that they were soon after carried into Lancashire. Gerrarde and Parkinson, however, mention them as delicacies for the confectioner, and not as common food. Even so late as Bradley's time they are spoken of as inferior to skirrets and radishes.

The use of potatoes, however, became more and more known after the middle of the 18 th century, and has greatly increased in all parts of Britain within the last thirty years. It is also very general in Holland, and many parts of France and Germany, and is increasing rapidly in Russia. In Spain, and the East and West Indies they are not much cultivated, owing to the heat of the climate; but in all the temperate parts of North America, Australasia, and South America they are grown by the colonists. In China they are cultivated, but not extensively, owing to the slow progress which every thing new makes in that country. Indeed, no root hitherto discovered is so well adapted for universal use as the tubers of the potatoe; for, having no peculiarity of taste, and consisting chiefly of starch, their farina is nearly the same as that of grain. Hence, with the flower of potatoes, puddings, and such preparations as do not call the gluten of wheat-flower into action, may be made equal to those of millet or rice, and excellent bread with a moderate proportion of good wheat-flour. Potatoe starch, independently of its use in the laundry, and as a hair powder, is considered an equally delicate food as sago or arrow-root. As starch and sugar are so nearly the same, that the former is easily converted into the latter, the potatoe yields a spirit equal to that of malt by distillation, and a wine or beer by the fermentative process.

The varieties of the potatoe are very numerous, differing in earliness, lateness, form, size, color, and quality. The names for these are quite arbitrary or local. In general, every district has its peculiar or favorite varieties. Some of these degenerate, and others improve when removed from one district to another. New varieties 
6. Unarmed. Leaves lobed, sinuate, angular, toothed, or entire.

2528 Leaves ovate lanceolate entire or lobed, Racemes cymose opp. to the leaves, Cor. 5-parted 2529 Leaves lanceolate sinuate tomentose bright-green, Pedunc, few-flowered, Sepals ovate acute 2530 Stem wavy, Leaves ovate cordate upper lanceolate, Corymbs opposite the leaves 2531 Stem smooth, Leaves cuneate at the base sinuate smooth, Peduncles few-flowered short 2532 Leaves ovate repand angular smooth, Peduncles 1-flowered cernuous, Berries torulose 2533 Leaves ovate angular repand smooth unequal at base, Pedunc. 1-flowered cernuous, Berries round 25.34 Leaves oblong lanceolate subrepand, Peduncles 1-flowered outside the leaves

2535 Branches rounded, and leaves smooth ovate entire, Flowers umbelled

2536 Branches smooth angular toothed, Leaves ovate smooth entire, Flowers numerous umbelled 2537 Stem and branches angular toothed, Leaves subovate sinuate angular, Flowers umbelled 2538 Leaves ovate toothed angular ciliated, Umbels extrafoliaceous stalked 2539 Stem angular, Leaves ovate toothed naked, Flowers in umbels

2540 Branches strigose pubescent angular winged, Wings toothed, Leaves ov. rep. smooth, Flowers in umbels 2541 Branches angular toothed pubescent, Leaves ovate repand upper entire, Flowers in umbels 2542 Stem rounded villous, Leaves ovate angular toothed villous hoary, Flowers in umbels

\section{Unarmed. Leaves quite entire.}

2543 Stem shrubby, Branches powdery, Leaves oblong lanceolate powdery on both sides, Racemes spreading 2544 Leaves ovate and subcordate waved curled acuminate, Flowers corymbose

$25+5$ Leaves oval pointed at each end smooth, Racemes cymose

2546 Stem erect, Leaves ovate lanceolate attenuated at each end pubescent, Racemes 2 and 3-chotomous 2547 Leaves ov. obl, acuminate entire downy, Surface discol. Axils leafless, Corymbs terminal dichotomous 2548 Leaves ovate oblong acuminate woolly axillary, Leaflets semicircular, Corymbs di-trichotomous

2549 Lvs. in pairs one obl. narrow. towards each end obt. other smaller obov. ellipt. Cymes stalk. opp. the lvs. 2550 Leaves ovate lanceolate acute shining smooth, Peduncles 1-flowered, Berries oval

2551 Branches spiny, Leaves elliptical, Peduncles filiform 1-flowered

2552 Stalks axillary 1-flowered, Cal. 10-cleft, Leaves mostly in pairs subsessile elliptical

2553 Stem climbing flexuose, Lvs, ovate lanc. smooth acuminate, Pedunc. in pairs, Cal. unequally toothed

\section{$\$$ 5. Prickly. Leaves entire or sinuate-angular.}

2554 Leaves discolored the lower sinuate prickly upper entire unarmed, Pedunc. few-flowered

2555 Stem unarmed, Leaves lanceolate repand undulated acute

2556 Leaves lanceolate acuminate revolute on both sides at the base

2557 Stem prickly, Leaves lanceolate pubescent beneath entire edge revolute at base

2558 Leaves lanceolate repand obtuse reflexed at edge

2559 Stem prickly, Prickles acerose, Leaves cordate unarmed repand wavy, the young ones purple

2560 Leaves lanceolate oblong attenuate at each end roughish beneath prickly, Raceme short unarmed 2561 Stem nearly unarmed, Leaves ovate oblong sinuate repand rough, Corymb extrafoliaceous stalked 2562 Stem nearly unarmed, Leaves lanceolate ellipt. entire above smooth beneath tomentose, Cymes mealy

2563 Stem downy, Leaves lanceolate long entire hoary beneath, Racemes terminal, Sepals subulate

2564 Stem with downy prickles, Leaves lanceolate acute unarmed above smooth beneath hoary

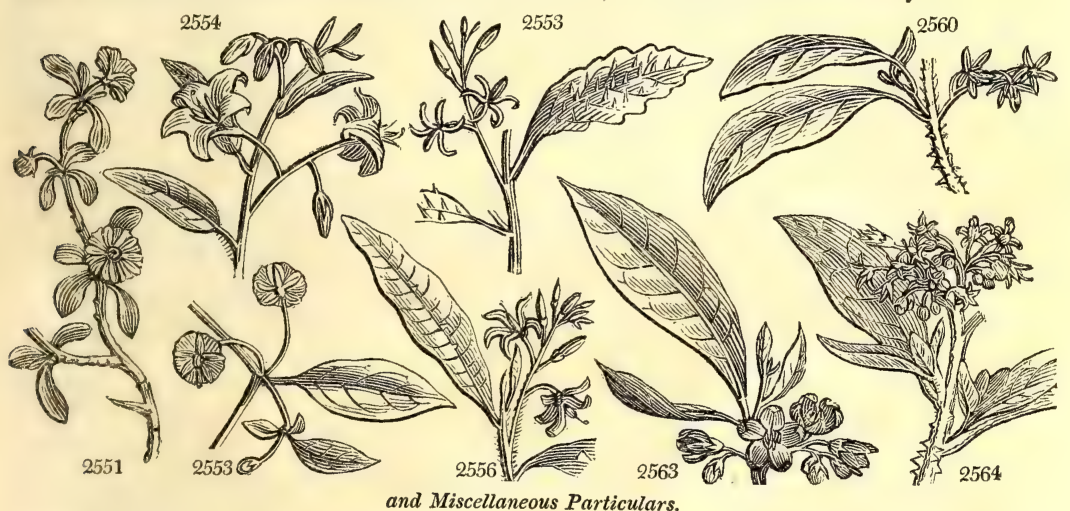

are readily procured by sowing the seeds, which, with care, will produce tubers the third year, and a full crop the fourth. As few of the early sorts produce blossoms, to procure seeds from them deprive the plant of its tubers as they appear, and keep the runners from which they proceed above ground, by not earthing up the plant, and blossoms and seeds will soon be produced. This proceed above ground, by not earthing up the is developed in the Philosophical Transactions for 1806. It appears that the same sap gives existence both to the tuber and blossom, and that whenever a plant of the potatoe affords either seeds or blossoms, a diminution of the crop of tubers, or an increased expenditure of the richness of the soil, must necessarily take place. This led Mr. Knight to attempt the practice adopted by the Dutch florists with their bulbous flowers, viz. to pinch off the flowers to strengthen the bulbs. This, in the potatoe, Mr. Knight thinks may add an ounce in weight to the tubers of each plant, or considerably above a ton per acre. The practice is now general among scientific cultivators even in field culture.

The curl is a well known disease of potatoes, which frequently disappoints the cultivator of a crop, or renders that produced of little value. A great variety of opinions exist as to this disease: without enumerating these, we may state, as the general result of experiments by different persons, that the curl arises in most, or at least in many cases, from using over ripe tubers as seed stock, or from the employment of seed stock which has been injured or improperly kept during the winter; that is, kept exposed to the light and air instead of being covered with earth, or sand, or straw, so as to preserve their juices. The experiments of various farmers and gardeners, as recorded in the Farmer's Magazine and Caledonian Hort. Mem., lead to the above conclusions. on dung or tan of the potatoe, both in the field and garden, is universally known. It may be forced in pots or houng or tan beds; and, for this purpose, using sets from tubers that have been retarded a year in an ice 1822 . The cold place, is found a great advantage. Thus, in planting in December 1823, use tubers of crop 1822. These, from the long period of repose which they have had, will be found highly exciteable by heat, and of much more rapid growth than sets of the preceding crop. As matter of curiosity, boxes containing alternate layers of light earth and potatoes of the last season but one may be placed in any dry covered place, free December in November, and they will produce a brood of young tubers in contact with the old ones on the

Potatoes following, without either leaves, roots, or runners. (Hort. Trans. i. 225.)

temperature best preserved by burying in pits in dry ground, so deep as to be under the influence of surface temperature, or so enveloped with thatch as to produce the same effect. At a certain depth, they will keep 
2565 Melongéna $W$. 2566 insánum $\boldsymbol{P} . S$ 2567 ovígerum Dun. 2568 sodómeum $W$. 2569 indicum $W$. 2571 marginátum $W$. 2572 campechiénse $W$ 2573 aculeatissimum $\mathcal{J} a c$ 2574 mammósum $W$. 2575 stramónif 2577 Milléri $W$. 2578 trilobátum $W$ 2579 carolinénse $W$. 2580 Pyracántha $S m$. 2581 virginiánum $\boldsymbol{W}$ 2582 Jacquíni $\boldsymbol{W}$.

2583 Balbísii Dun. 2584 téctum $P . S$. 2570 coágulans $W$.

Egg-plant Mad-apple oval-egg-plant Indian scollop-leaved white-edged purple-spined most-prickly nipple

broad-leaved Malabar Miller's three-lobed Carolina orange-thorned Virginian Jacquin's

decurrent covered

t. Nycterium.

452. NYCTE'RIUM. Vent. NYcterius
2585 cordifólium Vent. heart-leaved 2586 amazonium ent. heart-le

2587 lobátum Nutt. yellow

2588 fontanesiánum Dun. Desfontaines'

453. CAP'SICUM. $W$. CAPSICUM. 2589 ánnuum $W$.

2590 sphæ'ricum $W$. en. 2591 baccátum $W$. 2592 sinénse $W$. 2593 gróssum $W$. 2594 frutéscens $W$ 2505 bicolor Jucq. 2506 icolor Jacq. 2597 péndulum $W$. en 2597 péndulum $W$. 2598 lóngum Dec. 2600 tetragónum Mill. 2601 angulósum Mill. 2602 conoídes Mill. 2603 pyramidále Mill. 2604 microcárpum Dec. 2605 cerasiflórum $L k$. 2606 micránthum $L k$.

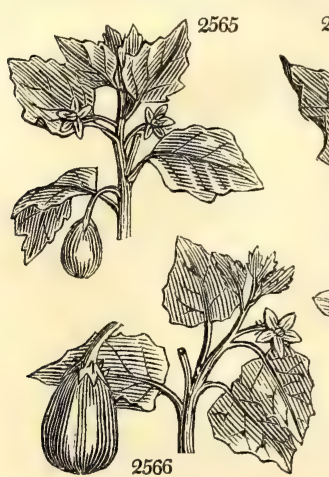

2566 oval-fruited large shrubby black-spined

globular-fruited $1 \mathbf{v} \square$ cul 2 ap.jl 业 $\square$ cul 3 jn.s

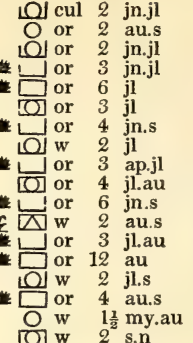

B Africa, \&c.1597. $\begin{array}{lll}\text { C } & \text { l.p } & \text { Pluk.phy.226.f.2 } \\ \text { B } & \text { E Indies 1815. S l.p Plu.alm.t.226.f. }\end{array}$ B Arabia 1597. S co

V Africa 1688. C r.m Her. lugd. t. 575 $\mathrm{Pu}$ India 1732. S p.l Di.elt.t.270.f.349

W Arabia Fe.1802. C s.p Jac. schö.4. t.469

Pu Africa 1775. C s.p Bot mag 1928

V A

Pa $\mathrm{A}$ America 1732. C s.p Di.elt.t.268.1.347

Pa.B W. Indies 1699. S s.p Plu.alm.t.226.f.1

Pu W. Indies 1778. C s.p Jac. ic. 1. t. 44

Pu E. Indies 1795. C 1,p

W C. G. H. 1762. C s.1 Jac. ic. 2, t. 330 V India 1759. C s.p Bu. in.57.t.22.f.2

Pa.B Carolina 1732. S p.1 Jac ic 2 t. 331

$\mathrm{Pu}$ Madagasc.1789. C r.m Ex. bot.2. t. 64

V Virginia 1662. S s.p Di.elt.t.267.f.346 E. Indies 1804, S s.p Jac. ic. 2. t. 332

\section{W S. Amer. 1816. C co Bot. reg. 140}

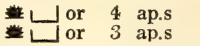

Mexico 1824. C co Cav. ic. 4. t. 309

Solanea. Sp. 4-7.

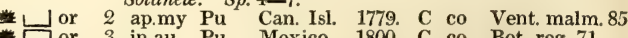

7 or 3 jn.au Pu Mexico 1800. C co Bot. reg. 71

or 2 jl.au Y Louisiana 1813. S co Pursh, am 2, t.7 or 2 jl.s $Y$ Brazil 1813. S co Bot. reg. 177

Solanex. Sp. 18-24.

$\square$ cul 4 jn.s Pu W. Indies 1804. C r.m Bot. mag. 1835

Cherry-pepper $O$ cul 1 jn.s

pendulous cul 2 ap.jl

long-fruited $\mathrm{O}$ cul 1 jn.jl

heart-fruited $\bigcirc$ cul 1 jn.jl

quince-fruited $O$ cul 1 jn.jl

angular-fruited $\bigcirc$ cul 1 jn.jl

conical $\square$ cul 2 ap.jl

pyramidal w cul 2 ap.jl

mall-fruited cul 2 ap.jl cherry-flowered $\square$ cui 2 jn.s mall-flowered cul 3 my.jn W 1807. C r.m

\begin{tabular}{llrll} 
W & India & 1548. & S & r.m \\
W & $\ldots \ldots .$. & 1807. & C & r.m \\
W & $\ldots \ldots .$. & 1731. & C & r.m \\
W & China & 1807. & C & r.m \\
W & India & 1759. & S & r.m \\
Pa.Y & India & 1656. & C & r.m \\
Pu & W. Indies 1804. & C & r.m \\
Pa.Y & W. Indies 1739. & S & r.m \\
W & \multicolumn{1}{c}{..... } & 1804. & C & r.m \\
W & India & 1548. & S & r.m \\
W & India & $\ldots$. & S & r.m \\
W & India & $\ldots$. & S & r.m \\
W & India & $\ldots .$. & S & r.m \\
W & India & 1750. & C & r.m \\
W & Egypt & 1750. & C & r.m \\
W & $\ldots \ldots . .$. & 1820. & C & r.m \\
W & $\ldots . .$. & 1823. & C & r.m \\
W & Brazil & 1824 & C & r.m
\end{tabular}

1548. S r.m Knor. th. 2.t.c. 6 
6. Prickly. Leaves sinuate, angular and lobed.

2565 Stem prickly, Leaves ovate subsinuate downy prickly, Flowers many-parted, Seeds naked 2566 Stem prickly, Leaves ovate tomentose, Pedunc. pendulous thick, Cal. prickly

2567 Stem nearly unarmed, Leaves rvate subrepand tomentose unarmed, Berries ovate oblong, Seeds pulpy 2568 Stem diffuse, Prickles straight dilated at base, Lvs. obl, sinuate pinnatifid, Pedunc. 2-fid, Berries globose 2569 Stem prickly, Leaves oblong tomentose sinuate angular, Segm. sinuate toothed, Sepals reflexed 2570 Leaves ovate oblong sinuate repand downy white beneath, middle nerve beneath with smooth prickles 2571 Leaves subcordate sinuate lobed beneath hoary above white at edges, Berries 3-celled globose 2572 Stem very prickly hairy, Lvs. cord. obl. lob. Lobes tooth. Fertile cal. very prickly, Berries cher.-shaped 2573 Stem very prickly, Lvs. cordate lob. Lobes acute toothed villous and prickly on both sides, Berries round 2574 Stem vil. with scat. prickl. Lvs. subcord. lob. prickly on both sides very vil. Ber. like the teat of an animal 2575 Stem prickly, Lvs. cordate sinuate acutely lob. vil. and prickly on both sides, Pedunc. and cal. unarmed 2576 Stem prickly, Lvs. cord. angular toment. with the racemes and calyxes prickly, Ber. hairy cov. by calyx

2577 Stem prickly, Leaves smoothish lobed obtuse prickly, Peduncles in pairs

2579 Stem prickly, Leaves ovate oblong tomentose sinuate angular acuminate, Racemes simple .ax 2780 Stem prickly, Leaves oblong acute sinuate pinnatifid downy, Prickles straight scarlet

2581 Stem erect prickly, Lvs. pinnat. sinuated prickly on both sides, Segm. sinuated obtuse, Racemes prickly

2589 Stem decumbent diffuse prickly, Leaves sinuate pinnatifid prickly on both sides smooth, Calyxes prickly

8. Prickly. Leaves pinnatifid or bipinnatifid, Berries covered by the enlarged and prickly calyx.

2583 Stem villous prickly, Lvs. pinnatifid, Segm. acute sinuate toothed, Racemes cymose lateral and terminal 2584 Stem shrubby rounded prickly, Leaves bipinnatifid prickly on both sides villous

2585 Leaves cordate entire, Racemes divided, Cal, unarmed

2586 I eaves elliptical sinuate tomentose, Flowers several large terminal

2587 Stem and leaves prickly, Leaves ovate pinnatifid hairy on both sides

2588 Stem woody prickly hairy, Leaves deeply pinnatifid, Anthers small

2589 Fruit oblong pendulous and erect their stalks smooth, Stem herbaceous

2590 Fruit globose pendulous, Stalks smooth, Stem shrubby

2591 Fruit globose ovate erect in pairs, Stalks smooth, Stem shrubby

2592 Fruit ovate pendulous in pairs, Stalks pubescent, Stem shrubby

2593 Fruit oblong ovate subcompressed erect, Stalks smooth, Stem herbaceous

2594 Fruit oblong obtuse, Stalks smooth, Stem erect

2595 Fruit oblong mucronate, Stalks smooth, Stem shrubby

2596 Fruit globose, Stalks smooth, Stem shrubby

2597 Fruit oblong, Stalks pubescent, Stem shrubby

2598 Fruit oblong acuminate incurved, Stalks smooth, Stem herbaceous

2590 Fruit heart-shaped, Stem herbaceous

2600 Fruit very large angular obtuse, Stem herbaceous

2601 Fruit heart-shaped angular, Stem herbaceous

2602 Fruit ovate conical erect, Stem half shrubby

2603 Leaves linear lanceolate, Fruit pyramidal erect yellow, Stem shrubby

2604 Fruit ovate erect, Footstalks and leaves pubescent, Teeth of the calyx 5 subulate spreading

2605 Young stalks ciliated, Berries erect globose

2606 Leaves ovate acuminate, Stalks ciliated, Cal, obtuse

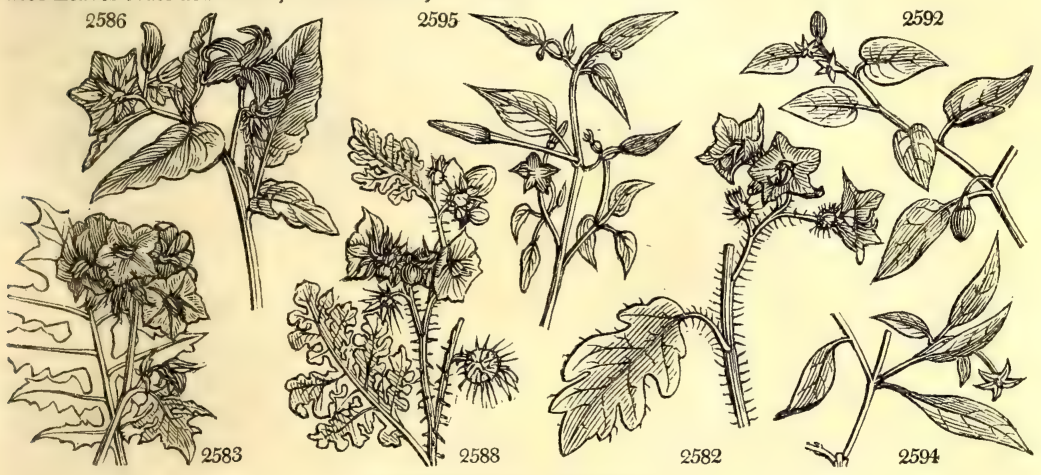

and Miscellaneous Particulars.

ripe, dried in the sun, pounded and mixed with salt: it is then kept stopt in bottles, and is commonly known by the name of Cayenne-pepper. A mixture of sliced cucumbers, shallots or onions cut very small, a little lime juice and Madeira wine, with a few pods of bird pepper, well mashed and mixed with the liquor, seldom fails to provoke the most languid appetite in the West Indies. It is there called Man-dram Gathered fresh from the plant, the pods of all the species are liberally used both in the East and West Indies, to assist digestion and correct flatulencies.

C. frutescens and minimum, the latter by many considered only a variety of the former, low shrubs with an oval red berry more sharp and biting than any of the others, furnish the Cayenne pepper of the shops. The ripe pods are dried in the sun, and then in an oven after bread is baked, in an earthen or stone pot, with The ripe pods are dried in the sun, and then in an oven after bread is baked, in an earthen or stone pot, with
flour between the strata of pods. When quite dry they are cleaned from the flour, and beaten or ground to fine powder. To every ounce of this, a pound of wheat flour is added, and it is made into small cakes with leaven; these are baked, cut into small pieces, baked again that they may be as dry and hard as biscuit, and then are beaten into powder and sifted. It is then fit for use as a pepper, or for being packed up, in a compressed state, and so as to exclude air, for exportation.

C. annuum, Piment, Fr. Spanischer Pfeffer, Ger, Peberone, Ital, is cultivated for its fruit, which is used in a green state for pickling, and ripe for mixing with other ingredients, as Tomatos, \&c. to form sauces. They are also dried and ground, and used like Cayenne pepper. The seed is sown in the end of March or beginning of April on a moderate hot-bed, and covered a quarter of an inch. When the plants are two or three inches in growth, 8ome are transplanted into a new slight hot-bed to forward them for final planting; or in default or such a hot-bed, they are placed in a bed of light rich earth, from twelve to eighteen inches apart, where they are finally to remain in the end of May, and protected during night by mats. They will flower in July, and 
454. IEE'A. $W$. 2607 sambucína $W$. 2608 æquáta $\boldsymbol{W}$ 2609 críspa $L$.

455. SPERMADICTYON. Roxb. SPERM 2611 suavéolens Roxb. sweet-scented DENTELL

457. MACROCNE'MUM, $W$ Macrocnenum

2613 jamaín 2614 strictum Roxb. upright

\section{Rubiacece. Sp. 2-6.}

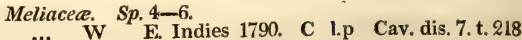
$\begin{array}{cccccc}c u & 10 & \ldots & \text { W } & \text { E. Indies 1790. C } & \text { I.p } \\ \text { cu } & 10 & \ldots & \text { G } & \text { E. Indies 1777. C } & \text { l.p }\end{array}$

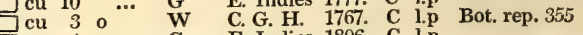
$\mathrm{cu} 4 \mathrm{O}$ Rubiacea. Sp. 1-2.

o W E. Indies 1818. C I.p Bot. reg. 348 Rubiacea. Sp. 1.

W Samaica 1806. C p.l Sw. obs.68.t.3.f 1

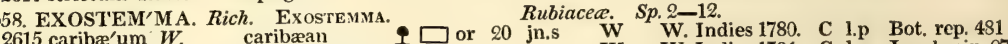
2615 caribæum $W_{\text {. }} \quad \begin{aligned} & \text { caribæan } \\ & \text { many-flowered }\end{aligned}$ 459. BURCHEU'LIA. $R . B r$. BURChELLIA. 2617 bubalína $\boldsymbol{R}$. Br. Cape 460. RONDELE'TIA. $W$. Rondeletia. 2618 americána $W$. 2619 lævigáta $H$. $K$ 2620 hirta $H . K$.

461. COUTARE'A. Aub. Coutarea. 2621 speciósa $A u b$ laurel-leaved

462. POR'Tlan'Dia. $W$. Portlandia 2622 grandiflóra $W$. great-flowered 2622 grandiflora $W$

463. CAMPA'NULA, $\boldsymbol{W}$. BELL-Flower. 2624 cenisia $W$ 2625 microphýlla Kit. 2626 Bellárdi All. 2627 púlla $W$.

2628 Zoysii $W$ 2629 carpática $W$. 2630 rotundifólia $E . B$ 2631 pusilla Hänke. 2632 púmila $B$. $M$. 2633 pubéscens $\boldsymbol{W}$ 2634 grácilis $R$. $B r$ 2635 Scheuchzéri Vill 2636 pátula $W$ 2636 pátula $\boldsymbol{W}$. $W$. 2638 persicifólia $W$. 2639 pyramidális $W$. 2640 obliqua $\boldsymbol{W}$. en. 2641 americána $W$. American hairy Portlandia hexandra W $\beta$ máxima ciliated small-leaved Bellardi's russet blunt-leaved Carpathian round-leaved diminutive dwarf pubescent slender Scheuchzer's spreading spreading

Peach-leaved large-peach-lvd. pyramidal oblique American

Rubiacea. Sp. 1.

3 my.jn S C. G. H. 1818. C r.m Bot. mag. 2339 Rubiacea. Sp. 3-18.

$\square$ or 10 au W W. Indies 1752. C s.p Plu. ic. t. 242. f.1 or 12 jl.au W W. Indies 1790. C s.p Jamaica 1776. C s.p Bot. cab. 350

$\square$ or $12 \begin{aligned} & \text { Rubiacea. Sp. } 1 . \\ & \text {... Pu }\end{aligned}$ Rubiacea. Sp. 2.

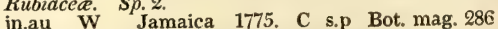

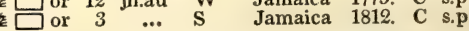

Campanulacea. Sp. 75-240.

$\downarrow \Delta$ or $\frac{1}{4}$ jn.jl $B$ Switzerl. 1775. $R$ co All. ped.1.t.6.f. 2 $\pm \Delta$ or $\frac{1}{2}$ jn.jl $B$ Hungary 1820. R co

\pm or $\frac{1}{8}$ jn.jl $B$ Italy 1813. R co All.ped.1.t.85.f.5 $\frac{1}{\Delta}$ or $\frac{1}{2} \mathrm{jn} . \mathrm{jl} \quad \mathrm{B}$ Austria 1779. R co Bot. cab. 554 $\frac{1}{\Delta} \Delta$ or ${ }^{\frac{1}{2} j n . a u}$ D.B Carniola 1813. D co Jac. ic. 2. t. 334 $\downarrow \Delta$ or $\frac{\pi}{2}^{\frac{1}{2}}$ jn.au B ${ }^{2}$ Carp.Alps 1774. D p.l Bot. mag. 117 $\Delta$ or $\frac{1}{3}$ jn.jl Pa.B Switzerl. 1821. R co Bauh. pr.34.t.34

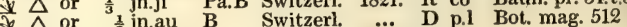
$\downarrow \Delta$ or 1 jn.au B Bohemia 1813. D co 女 \pm or $\frac{3}{4} \mathrm{jn} . \mathrm{au}$ B Europe 1813. D co Bot. cab. 485 D or 1 jl.au $V$ Britain past. $S$ p.l Eng. bot. 42 (2) 3 jl.au Pu Britain hed. b. S r.m Eng. bot. 283 D 1596 . D pl Fl dan 1087 D $\triangle$ or 3 jl.s $\quad$ B $\quad$ Europe 1596. D p.1 Bot. mag. 397 \& $\Delta$ or 4 jl.s $\quad$ Pa.B Carniola 1596. D p.I O) or 3 jn.jl B ...... 1813. D p.1 Jac. sch. 3.t. 336

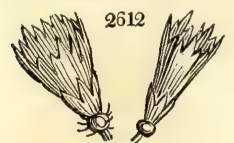

2611

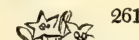

B Pensylv. 1763. C

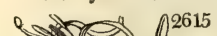

2617

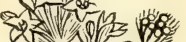

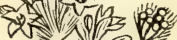

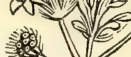

湜
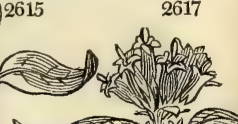
or ${ }_{1}$ jn.au B Britain hea. D p.1 Eng. bot. 866 $\checkmark \Delta$ or $\frac{1}{2}$ jn.au B Switzeri. 180 , D.l Bot.
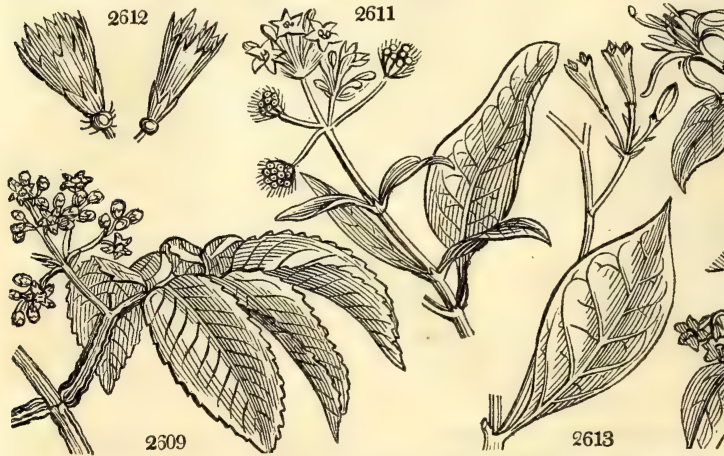

2613
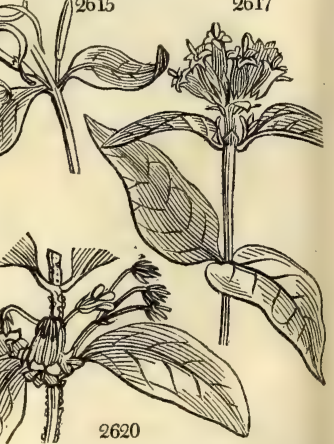

History, Use, Propagation, Culture,

produce plenty of pods from August till the end of September. They may be also raised under hand-glasses, and in very warm situations treated as common annuals. C. cerasiforme is sometimes cultivated for the same purposes as the common capsicum.

454. Leea. Named after the first James Lee, of the Hammersmith Nursery, an excellent cultivator and most worthy man. The plants have little more beauty than a hemlock. Cuttings root easily under, a hand. glass in heat.

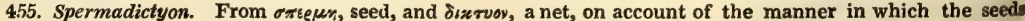
cover the placenta. A pretty stove plant with sweet white flowers.

456. Dentella. A diminution of dens, a tooth; the divisions of the corolla having each three little teeth.

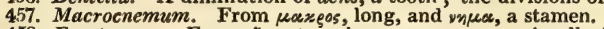

458. Exostemma. From $\varepsilon \xi$, out, and $\sigma \tau \varepsilon \mu \mu \alpha$, a crown, in allusion to the protrusion of the stamens; one of the characters on account of which the genus has been separated from Cinchona.

The genus Cinchona, which was so named after the Countess of Cinchon, who being cured by the use of this plant, first brought it into notice, is very nearly related to this, and is a most impcrtant genus, as furnishing the Peruvian or Jesuit's bark. The bark is taken from various species; but that which produces the best is said to be $C$. officinalis, a native of Peru, and not yet introduced to this country. The Jesuit's bark tree of Jamaica is the Exostemma caribæum, but land there is too valuable for its culture. Our species are not very common in collections, being of slow growth, and not very easily propagated. Sweet 
2607 Stem furrowed angular smooth, Leaves nearly bipinnate 2608 Stem rounded pubescent, Leaves pinnated

2009 Stem angular fringed, Leaves pinnated

2610 Stem angular, Stalks smooth, Leaves broad ovate serrated

2611 Leaves opposite ellipt. Flowers terminal in umbels

2612 Stem creeping much branched smooth, Leaves stalked opposite oval flat entire

2613 Corymbs axillary long naked

2614 Leaves elliptical acute opposite, Flowers whorled sessile

2615 Peduncles axillary and terminal 1-flowered, Leaves ovate lanceolate

2616 Flowers terminal panicled smooth, Caps. terminal smooth, Leaves elliptical acuminate smooth

2617 The only species. A fine plant with tubular red flowers like a honeysuckle

2618 Leaves sessile, Panicle dichotomous

2619 Leaves stalked elliptical acute smooth

2690 Leaves oblong acuminate hairy rigid nerved beneath, Stalks axillary erect

2621 The only species. An hexandrous plant

2622 Flowers pentandrous, Leaves lanceolate elliptical

2623 Flowers pentandrous, Leaves ovate coriaceous

\section{Leaves smooth.}

2624 Stems 1-flowered, Leaves ovate smooth subciliated

2625 Lower leaves obovate wedge-shaped crenate, Upper linear entire, Stem simple 1-flowered

2626 Stem 1-flowered naked, Leaves stalked elliptical lanceolate deeply toothed

2627 Little stems 1-flowered, Radical and cauline leaves ovate subcrenate, Cal. cernuous

2628 Stems about 3-fl. Lvs. entire, the rad. ov, on tong stalks, the cauline obl. ov. sessile obtuse, Fls. nodding 2629 Lvs. all cordate serrate stalked smooth, Branches filiform 1-flow. Cal. reflex. glutinous, Cor. spreading 2630 Smooth, Radical leaves oblong and kidney-shaped serrate : cauline linear entire

2631 Smooth, Leaves all serrate: radical cordate ovate firm shining; cauline linear alternate remote

2632 Radical leaves ovate crenate with flattened stalks, Flowers racemose 1-sided cernuous

2633 Stem hairy decumb. angular, Lvs. stalk. ser. smooth, rad. cordate, lower cauline ovate, Cor. short large 2634 Stem filiform angular striated, Branches about 1-flowered, Leaves lanceolate or linear, Flowers 5-cleft 2635 Pubescent, Lvs. rather hairy : rad. obov. rounded serrated; cauline clustered lin. entire, Sepals setaceous 2636 Leaves upright : radical lanceolate-oval, Panicle spreading

2637 Leaves wavy : radical lanceolate-oval, Panicle contracted

2638 Stem angular, Lvs. stiff obsoletely crenate serrate : rad. obl. obovate; cauline lanc. lin. Flow. large

2639 Lvs. smooth ov. cord, cartilaginous-serrated, the caul. lanc. Stem upright elong. branch. Lower ped. 3-fl. 2640 Lvs, obl. lanc. point. at each end serr. with veins hairy beneath, Stem erect, Rac. term. Seg. of cor. obliq. 2641 Lvs. cord. and lanc. serr. lower stalks ciliated, Fls. axill. sessile, Cor. 5-parted flat, Style longer than cor.

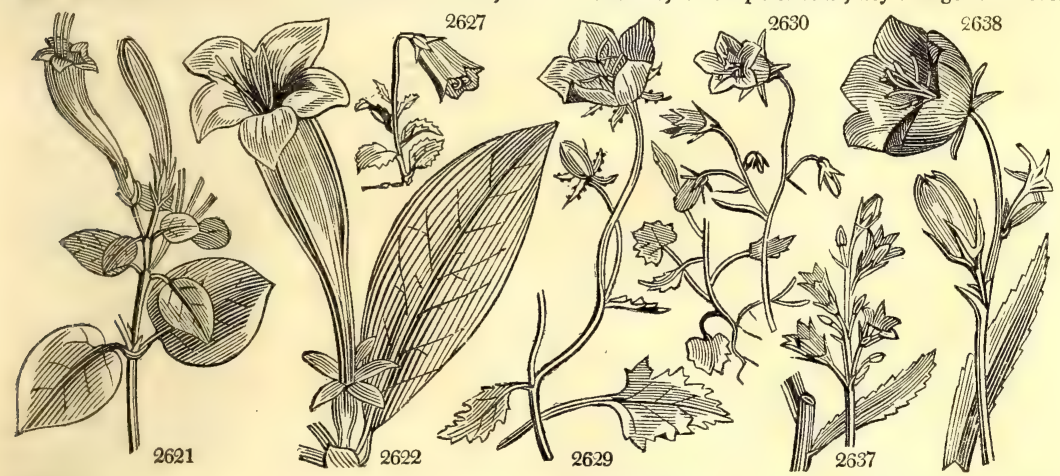

and Miscellaneous Particulars.

advises cuttings to be " taken off when ripe, planted in a pot of sand, plunged in moist heat, and covered with a bell-glass."

459. Burchellia. Named by Mr. Robert Brown, after William Burchell, a traveller in the southern part of Africa, from whom we have two volumes of travels, and the promise of other works hereafter. The species is a beautiful dwarf shrub with scarlet flowers in terminal clusters.

460. Rondeletia. Plumier established this genus in memory of William Rondelet, a scientific physician, whose attention was chiefly occupied by fishes and algæ. He was born in 1507, and died in 1566. Rabelais ridicules him under the name of Rondibilis. He is said to have given a disgusting proof of his fondness for anatomy by dissecting his own son.

461. Coutarea. So named by Aublet from its vernacular name in Guiana, Coutari. A most beautiful plant, requiring the utmost heat of the stove; but very rare in gardens, if it indeed exists in cultivation at all

462. Portlandia. In honor of the Duchess of Portland, once a famous patroness of botany. Splendid plants of the natural order Rubiaceæ. Portlandia grandiflora is common and easily grown. P. coccinea is perhaps not in the country, although stated to have been introduced in 1775 .

463. Campanula. A diminution of campara, a bell; on account of the form of the corolla, which resembles

a little bell. Rapunculus is a diminution of $r$ a bell is 80 called because the corolla in its form resembles a little round and elegant mirror (speculum), whence in 
2642 nítida $W$.

2643 aúrea $W$.

2644 versícolor $H . K$.

2645 lilifólia $W$.

2646 stylósa Lam.

2647 grandiflóra $W$.

2648 rhomboídea $W$.

2649 verticilláta $W$.

2650 marsupiiflóra $F$

2652 excísa Schl.

2653 latifólia $W$. 2654 eriocárpa Bieb.

2655 urticifólia $W$.

2656 Trachélium $W$

2657 Rapunculoídes $W$.

2658 macrostáchya Panz.

2659 sarmática B. Reg.

2660 bononiénsis $W$

2661 ruthénica $W_{\dot{*}}$ en.

2662 glomeráta $W$.

2663 specíosa Horn.

2664 Cervicária $W$

2665 collína $B . M$.

2666 azúrea $B . M$.

2667 lactiflóra Bieb.

2668 aggregáta $W$.en

2669 thyrsoidea $W$.

2670 peregrina $W$.

2671 cérnua $T h$.

2672 capénsis $W$.

2673 barbáta $W$. 2674 punctáta $W$ 2675 Médium $W$.

2676 longifólia La Peyr. 2677 spicáta $W$

2678 alpina $W$.

2679 móllis $W$.

2680 saxátilis $W$.

2681 alliariæfolia $W$

2682 lamiifólia Bieb.

2683 sibírica $W$

2684 divérgens $W$. en

2685 linguláta $W$.en.

2686 caucásica Bieb.

2687 laciniáta $W$.

2688 coronáta $B . R$. Reg.

2689 cichorácea Sibt.

capitáta B. M

2690 lanuginósa $\boldsymbol{W}$. en. smooth-leaved $\forall \Delta$ or

$\Delta$ or $\frac{1}{4} \mathrm{jl}$

various-colored $\downarrow$ or 3 jl.s

Lily-leaved $\Delta$ or a jl.s

onf-styled

great-flowered $\frac{\partial}{\Delta} \Delta$ or

Great-flowered $\frac{\ddagger}{\Delta} \Delta$ or

whorled $\frac{\Delta}{\Delta}$ or

cernuous \& $\Delta$ or

bitten $\$ \Delta$ o

giant

woolly-fruited $\$ \Delta$ or

Nettle-leaved $\vec{x} \Delta$ or

Throatwort 1 or

cheping $\Delta$ or

creeping

Betony-leaved

panicled

Russian

clustered

showy

wave-leaved

Sage-leaved

azure

milk-colored

crowded-flower.

rough-leaved $\forall$ 이잉

nodd-flowered 10 or

Cape

bearded

辛 $\Delta$ or

dotted-flowered $\Delta$ or

Canterb-bells

long-leaved

spiked

alpine

soft

rock

Alliaria-leaved

Nettle-leaved

Siberian

spreading

tongue-leaved

Caucasian

jagged-leaved

crowned

headed

() or 4 jn.s.

$\triangle$ or 4 jn.s

\. or $11 \mathrm{jl}$

$\checkmark \Delta$ or

$\triangle$ or

1늘 my.jn

jn.au

$2 \mathrm{jl}$

${ }_{1}^{2} \frac{1}{2 n}$ n.jl

1 jl.au

4 jl

2 jn.jl

4 jn.au

3 jn.jl

$1 \frac{1}{2} \mathrm{jn} . \mathrm{jl}$

2 jn.au

2 jn.au

2 my.s

2 my.jn

$3 \mathrm{jl}$

1 jl.au

$1 \frac{1}{2} \mathrm{jn.jl}$

2
2 jl.s

2 jn.au

2 jn.au

$\frac{1}{2}$ jn.au

1 jn.au

woolly-leaved $¥$ O) or 2 my.au B

W N. Amer. 1731. D p.l Dod. me. 4. t.111

Y Madeira 1777. S s.p Bot. reg. 57

Greece 1788. D s.l Bot. rep. 396

Pa.B Siberia 1820. R co Gmel. sib. 3. t. 27

B Siberia 1782. D p.1 Bot. mag. 252

Pa.B Switzerl. 1775. D p.1 Bot. cab. 603

L.B Siberia 1783. D s.1 Pal. it. 3. t.G. f.1

Pa.B ….. 1818. R co

W.P Madeira 1777. S s.1

Switzerl. 1820. R co Bot. cab. 561

Pu. Britain s.m.p. S p.l Eng. bot. 302

B Caucasus 1823. R co

Pu Germany 1800 . D co

V Britain woods. D p.l Eng. bot. 12

B England woods. D p.1 Eng. bot. 1369

B Hungary 1814. S co

Pa.B Siberia 1803. D co Bot. reg. 237

B Italy 1773. D co M.h.2.s.5.t.4.f.38

B Caucasus 1815 . D co

Britain ch. pl. D p.1 Eng. bot. 90

U Siberia 1824. R co

L.P Germany 1768. S s.p Bot. cab. 452

Caucasus 1803. D p.1 Bot. mag. 927

L.B Switzerl. 1778. D p.1 Bot. mag. 551

W Siberia 1814. C s.p Bot. reg. 241

Pa.B Bavaria 1817. C s.p Bot. cab. 505

Switzerl. 1785. S s.p Bot. mag. 1290

W C. G. H. 1804. S p.l

C. G. H. 1803. S s.p Bot. mag. 782

L.B Italy 1752. R p.l Bot. mag. 1258

W Siberia 1813. D co Bot. mag. 1723

B Germany 1597. S co Knor. th. 1.t.G.2

D.B Pyrenees 1820. R co La. peyr. pyr. t.6

L.B Switzerl. 1786. S s.p All.p. 1. t. 46. f.2

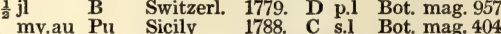

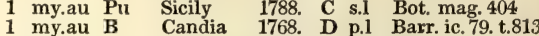

1 jl,s B Caucasus 1803. C p.1 Par. lond. 26.

$\Delta$ or 3 jn.jl Pa.Y Iberia 1823. R co Buxb. cen. 5.t.18

bे or 1 jl.s B Siberia 1783. C s.p Bot. mag. 659

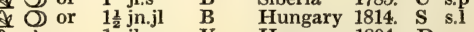

Hungary 1804. D co PL. rar. hun.t.64

Caucasus 1804. D co

Greece 1788. D p.1 Bot. rep. 385

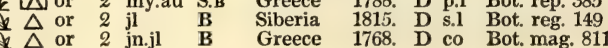

1814. S s.l

2691 Erínus $W$. en. forked $\quad$ or $\frac{1}{2}$ jl.au Pa.B S.Europe 1768. S s.l M.h. s. 5. t.3.f.25 my.jn B England m.s.p. D co Eng. bot. 73
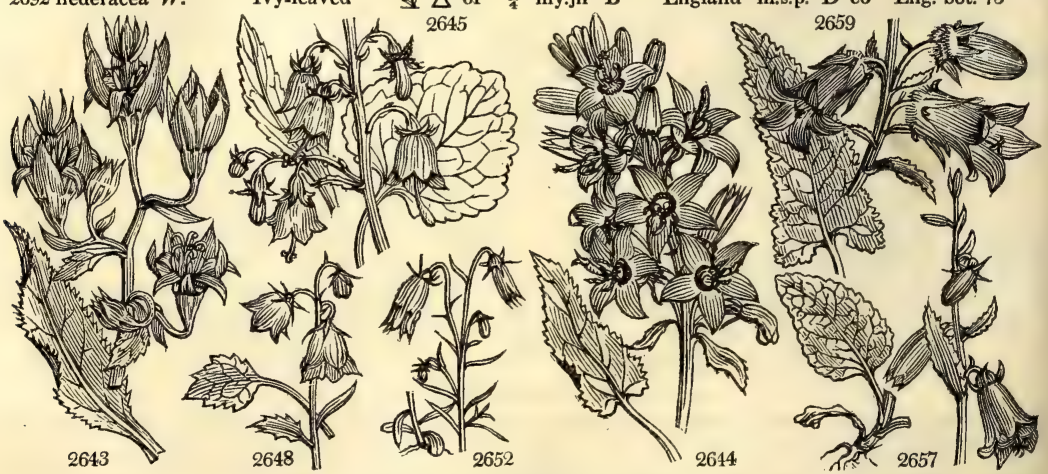

History, Use, Propagation, Culture,

English it is called Venus' looking-glass. Ancient mirrors were always round, on which account the astrological sign of Venus was $Q$, or a figure of the antique mirror and its handle. This is a shewy genus; some of the species are beautiful, and all of them of easy culture in the borders of the flower garden or shrubbery. One or two species are used in dietetics, and probably the roots of the whole might be eaten. Almost all the species have long thick white roots, which abound in an acrid milky juice.

C. rapunculus is much cultivated in France and Italy, and sometimes in Britain, for the roots, which are boiled tender and eaten hot with sauce, or cold with vinegar and pepper. It is sown in Spring on deep light soil in drills, and will be ready for use by the autumn of the same year. C. persicifolia and Rapunculoides may also be cultivated for the same purpose

C. pyramidalis was a very fashionable plant thirty years ago, and is still cultivated, but has given way to Lobelia splendens and fulgens. It is still in demand in Holland as an ornament to halls, staircases, and for being placed before fire-places in the summer season; for which purpose it is planted in large pots, and trained in the fan manner, so as to cover a large surface. In the shade it will continue in flower for two or three 
2642 Leaves oblong crenulate rigid sessile, Flowers erect flat

2643 Caps. 5-celled, Leaves elliptical serrate smooth, Flowers panicled 5-parted, Stems shrubby fleshy

2644 Leaves cordate serrate smooth, Thyrse terminal, Sepals subulate, Corolla rotate spreading

2645 Leaves lanceolate : cauline acutely serrated, Flowers panicled nodding

2046 Leaves stalked subcordate acutely serrated, Flowers small nodding, Style exserted

2647 Leaves ternate oblong finely serrated, Stem 1-flowered, Flower spreading

2648 Leaves rhomboidal serrated, Spike one-sided, Cal. toothed

2649 Leaves about 6 lanceolate toothed, Flowers whorled

2649 Lery long 2650 Stem erect, Lvs. altern. opp. and ternate lin. lanc. entire, Pan. pyram. Flowers cernu. glob. trunc. Style 2651 Stem branched upright twiggy, Lvs. lin. lanc, toothed, Pedunc. filiform long, Cor. funnel-shaped 3-4-cleft 2652 Smooth, Stem.1-fl. Lower lvs. obl. cauline lin. subsetaceous, Cor. cernuous with the bott. of seg. cut out i 2. Leaves rough.

2653 Stem rounded striated smooth, Lvs. ovate lanc. doubly serrated, Pedunc. axillary 1-fl. erect, Cal. smooth 2654 Stem furrowed pubescent, Leaves ovate-lanceolate doubly serrate, Pedunc. axillary solitary, Cal. woolly 2655 Stem angular hispid, Lvs. ov, lanc. coarsely serrated, Pedunc. axillary 1-flowered cernuous, Cal. hispid 2656 Stem angular, Leaves stalked, Cal. ciliated, Peduncles trifid

2657 Leaves cordate-lanceolate, Stem branched, Flowers one-sided scattered nodding, Cal. reflexed

2658 Leaves oblong unequally toothed rough beneath, Stem panicled, Bractes and calyx ciliated

2659 Leaves downy : lower cord. lanc. stalked, Flower nodding, Germens woolly

2660 Leaves ovate lanceolate beneath scabrous sessile, Stem panicled 2660 Leaves ovate lanceolate beneath scabrous sessile, Stem panicled
2661 Stem rounded and lvs, beneath tomentose, Lower lvs. cordate lanc. stalked, upper sessile, Raceme term.
2662 Stem angular simple smooth, Leaves scabrous oblong lanceolate cordate sessile, Head clustered 2663 Stem anguiar simple smooth, Leaves scabrous oblong lanceolate cordate sessile, Head clustered

2664 Hispid, Flowers sessile, Head terminal, Leaves lanceolate linear wavy

2665 Stem simp. few-fl. Lvs, hairy, lower cord. lanc. stalked, upper obl. sessile, Flowers nodding, Cal. hispid 2666 Leaves ovate-oblong sessile serrated, Stem simple angular, Flowers panicled

2667 Leaves lanc. twin serr. and branched stem hispid, Flowers panicled, Calyxes hispid, Seg. dilated serrated 2668 Stem angular smooth, Caul. leaves sessile equally toothed wavy lanceolate, Floral cordate, Cor. tubular 2669 Hispid, Raceme ovate oblong terminal, Stem quite simple, Leaves linear lanceolate

2670 Leaves ovate rugose, Leafstalks with a dilated and serrated edge, Stem simple hispid, Flowers spreading 2671 Leaves oblong waved hairy, Flowers terminal cernuous, Cal, smooth

2672 Leaves lanceolate toothed hispid, Pedunc. very long 1-flowered with strigose capsules

$$
\text { 83. Capsules covered by the reflexed recesses of the calyx. Medium. }
$$

2673 Stem simple erect pubescent, Lvs. lanc. crenate, Racemes simple with nodd, flowers, Cor. bearded inside 2674 Hairy, Radical leaves stalked ovate acute serrate, Flowers cernuous dotted inside villous

2675 Stem undivided erect hispid. Leaves lanceolate ohtusely serrated sessile 3-nerved at base, Flowers erect 2676 Hispid, Caps. 5-celled, Branches pyramidal, Peduncles axillary, Flowers erect solitary

2677 Hispid, Spike lax, Flowers alternate, Leaves linear entire

2678 Stem simple, Pedunc. axillary 1-flowered 2-leaved

2679 Caps. 5-celled covered stalked, Stem prostrate, Leaves very soft nearly round

2680 Caps. 5-keeled covered, Flowers alternate nodding, Leaves obovate crenate

2681 Radical leaves reniform coarsely doubly serrate : cauline ovate toothed sessile

2682 Leaves reniform cordate doubly crenate stalked tomentose beneath, Flowers one-sided reflexed

2683 Stem panicled pubescent, Leaves lanceolate obtuse wavy

2684 Stem simple diverging pubes. Lvs. lanc. obtusely serrated sessile veiny, Pedunc. axill. 3-fl. and terminal 2685 Hispid, Stem simple, Flowers capitate terminal, Leaves lanceolate obtuse crenate

2686 Lvs. obovate wavy rough, Stem creeping, Branches erect few-flow. Segm. of the hispid cal. nearly equal

2687 Cans. stalked, Leaves serrated : radical lyrate; cauline lanceolate nearly wedge shaped

2688 Radical leaves stalked cord, doubly serr. Raceme few-flowered lax

2689 Caps. covered, Leaves oblong wavy hispid; radical sinuated, Flowers clustered sessile terminal

2690 Leaves woolly : radical lyrate; cauline rounded ovate serrate, Flowers cernuous

4. Corolla in some degree unequal, Stigma nearly simple, Capsule opening at the end.

2691 Stem dichotomous, Leaves sessile, the upper opp. 3-toothed

2692 Leaves cordate 5 -lobed stalked smooth, Stem lax
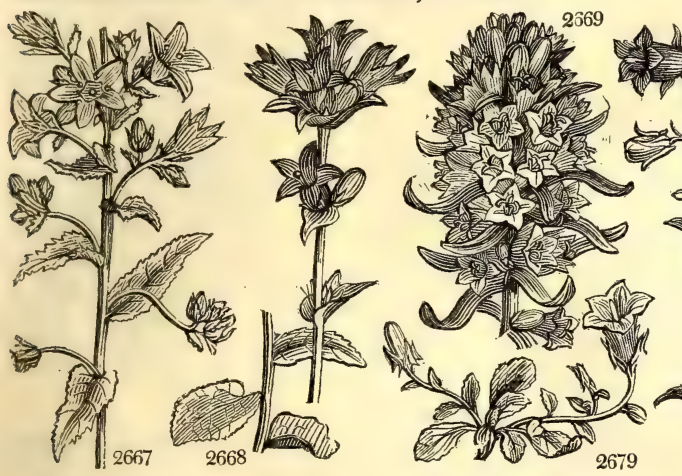

and Miscellaneous Particulars.

2678

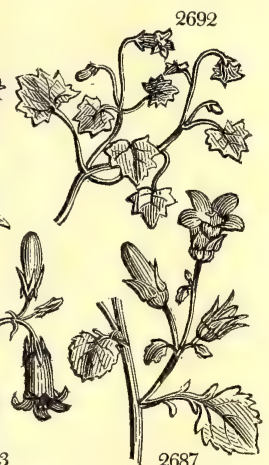

2683

2687

months. The art of producing a very large plant is to begin with pots of a small size, and shift frequently during two years, till at last the plant occupies a pot of a foot or more in diameter. Rich light soil should be used, but no animal manures or recent dung as these are found in diameter. Rich light soil should be flower the second, and seedlings the third year. C. carpatica and grandiflora may be treated in a similar manner.

C. lilifolia has a singular anomaly in the leaves, which before the panicle is produced come out in a kind of rose on the summit of the stem, but are, through its prolongation, afterwards dispersed. The flowers vary much both in size and color, and the roots are eaten in China both raw and boiled.

C. glomerata is a handsome rock or pot plant; it requires a dry lean soil, otherwise, as in most plants, the flowers lose the intensity of their color in that which is very rich.

C. hederacea is a very small plant, with the leaves so much resembling those of Veronica hederifolia, that

Linnaus suspected it to be a hybrid.

C. medium is a very ornamental border flower of the easiest culture, and with varieties, double and single, 
2693 fruticosa $W$. 2694 Prismatocárpus 2695 Spéculum $\boldsymbol{W}$. $\beta$ alba

2696 hýbrida $W$

2697 pentagónia $W$. 2698 perfoliáta $P . S$.

464. LOBE'LIA. $W$. 2699 símplex $W$. 2700 lineáris $\boldsymbol{W}$.

2701 pinifólia $W$

2702 unidentáta $\boldsymbol{H}$. $\boldsymbol{K}$.

2703 Dortmánna $\boldsymbol{W}$.

2704 salicifólia Túpa $\mathbf{H}$. K. gigant . gigantéa $\mathrm{B}$. $\mathrm{M}$

2706 racemósa $\boldsymbol{B} . \boldsymbol{M}$.

2707 bellidifólia $W$

2708 tríquetra $\boldsymbol{W}$.

2709 longiflóra $\boldsymbol{W}$.

2710 secûnda $W$.

2711 goodenioídes $H . K$.

2712 assur'gens $W$.

2713 fúlgens $W$. en.

2714 verbascifólia $\mathrm{Sm}$.

2715 cardinális $W$

2716 spléndens $W$. en.

2717 débilis $W$.

2718 aláta $R$. $B$ r.

2719 siphilitica $\boldsymbol{W}$

2720 surinaménsis $W$. $\beta$ rubra

2721 grácilis $R, B r$ 2722 purpurásce

2723 infláta $W$.

2724 cliffortiána $W$.

2726 úrens $W$.

2727 amœ'na Mich.

2728 minúta $W$

2729 Lauréntia $W$

2730 tenélla Biv.

2731 campanuloides $T h$.

2732 Erinus $W$

2733 erinoides $W$.

2734 bícolor $\boldsymbol{H}$. $K$.

2735 ilicifólia $\boldsymbol{B} . \boldsymbol{M}$.

2736 pubéscens $W$.

2737 lútea $W$.

2738 hirsúta $W$.

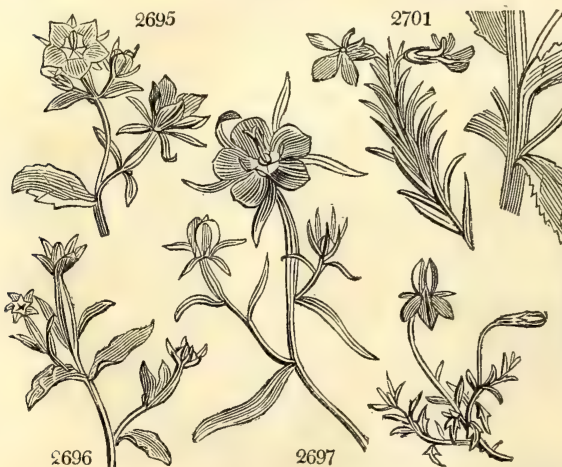

2697 shining wenus'Look,-gl.w ${ }^{*} \bigcirc$ or

white

w 3 or

five-angled * $\mathrm{O}$ or

perfoliate

Lobelia. linear-leaved

Pine-leaved

single-toothed

water

Kalm's

racemose

Daisy-leaved

triangular

ong-flowered

ide-flowering

Goodenia-like

furple

Mullein-leaved $\$ \Delta$ or

or

st $\Delta$ or

feeble

se $\mathrm{N}$ or

winged-stalked $\&$ or

blue-cardinal

shrubby

slender

$\frac{\$}{\Delta} \Delta$ or

ᄂ

or 1 ja,

\& $\triangle$ or 1 jn.a

bladder-podded $\frac{1}{O}$ cul 11 jl.au

purple-flowered $\bigcirc$ or $1 \frac{1}{2}$ jl.au

small-flowered $\mathrm{O}$ cu $\frac{1}{2}$ jl.au

acrid

beautiful-blue $\forall \Delta$ cul $1 \frac{1}{2}$ jn.jl

small $\bar{v} \Delta$ cul 1 in jns

Italian

slender

chinese

ascending

trailing

Holly-leaved

downy-leaved

yellow

of or $\frac{1}{4} \mathrm{jl}$

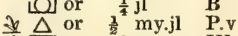

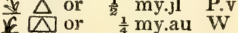

L $N$ or $\frac{1}{2}$ jn.s

L) or ${ }^{\frac{1}{2}} \mathrm{jn} . \mathrm{au} \quad \mathrm{B}$

N or ${ }_{1}^{2}$ my.s $\mathrm{Pk}$

$\checkmark \Delta$ or $\frac{1}{2}^{2}$ jn.au B

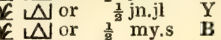

* 5 or

simple-stalked
C. G. H. 1787. S p.l

C. G. H. 1787. S s.1 L'Her. s.an.2.t.3

S. Europe 1596. S s.1 Bot. mag. 102

England cha, fi. S s.1 Eng. bot. 375

Turkey 1686. S s.1 Bot. reg. 56

N. Amer. 1680. S s.1 M.h.2.s.5.t.2.f.23

Sp. 46-170.

C. G. H. 1794. C $1 . p$

C. G. H. 1752. S s.p Bot. rep. 273

C. G. H 1794. R l.p Bot. mag 1484

Britain lakes, R lp Eng bot 140

Chili 1794. R s.p Bot. mag. 1325

arolina 1820. S co Bot. mag. 2238 W. Indies 1818. C co Bot. mag. 2137

C. G. H. 1790. C s.p

C. G. H 1774. C s.p

Jamaica 1752. S s.p Jac. vind. 1, t. 27

C. G. H. 1790 .

N. Amer. 1799. D s.1 Will. hor. ber.30

W. Indies 1787. C s.p Bot. rep. 553

Mexico 1809. C s.p Bot. rep. 659

Nepal 1822. D r.m

Virginia 1629. C s.p Bot. mag. 320

Mexico 1814. C s.p Bot. reg. 60

C. G. H. 1774. S s.p

N. S. W. 1804. S s.p La. no.hol. 1.t.72

.B Virginia 1665. C s.p Bot. reg. 537

W. Indies 1786. C s.p Bot. mag. 225

W. Indies 1820 . C s.p Bot. cab. 749

D. B N. S. W. 1801. S s.p Bot. mag. 741

B N. S. W. 1809. D s.p

Pa.B N. Amer. 1759. S s.p Li,ac.up.1741t 1

Pk N Amer 1733. S s.p Li.ac.up.1741.t.1

B Amer. 1735. S s.p Li.h.cl.426.t.26

England hea. S s.l Eng. bot. 953

N. Amer. 1812. D s.l Ann. mus. 18.t.1

C. G. H. 1772. R s.p Bot. mag. 2077

Italy 1778. S s.p Mich. ge. 18.t.14

Sicily 1821 D co

China 1820. D co Bot. reg. 733

C. G. H. 1752. S s.p Bot. mag. 901

C. G. H. 1759. R s.p Her.lugd. t. 109

C. G. H. 1795. C s.p Bot. mag. 514

C. G. H. 1815. D s.p Bot. mag. 1896

C. G. H. 1780. R s.p Jac. sch.2, t. 178

C. G. H. 1774. S s.p Bot. mag. 1319

C. G. H. 1759. C s.p Bur. afr. t. 40. f.2

Hist

of blue, red, purple, and white flowers. Like other biennials, it may either be sown where it is to remain any time after midsummer, or sown in beds in spring for transplantation.

C. speculum and hybrida are annual border flowers of considerable beauty.

464. Lobelia. In honor of M. Lobel, author of various works, and particularly of that called Icones Plant-

arum; he was born at Lisle in 1538, became physician and botanist to James I., and died in London in 1616. This genus furnishes some of our most splendid herbaceous plants, as L. cardinalis, fulgens, and splendens. The predominant color of the corollas is blue.

L. Dortmanna (from Dortmann, an apothecary, who first sent it to Clusius), is a beautiful aquatic with leaves reflected into an elegant curve at the end, and the flowers in loose spikes.

L. longiflora, which grows by moist places and rivulets in the West Indies, is a very poisonous plant Taken internally it brings on an invincible purging. If the plant be handled, and the hand be unawares applied to the eyes or lips, it brings on an inflammation. In the Spanish West Indies it is called Reventacavallos, because horses are reported to burst with eating it.

L. fulgens, splendens, and cardinalis, are the three grand ornaments of the genus. They are readily mul tiplied by cuttings or slips, or by seeds when they ripen, and grow well in light rich soil. The culture of $\mathrm{L}$. cardinalis is given at length by Justice, who designates it "a flower of most handsome appearance, and which should not be wanting in curious gardens, on account of the rich color of its flowers." The culture of $\mathrm{L}$ 
\$5. Capsules prismatical. Prismatocarpus.

2693 Caps. columnar 5-celled, Stem shrubby, Leaves linear subulate, Peduncles very long, Panicles terminal 2694 Caps. linear 2-celled, Leaves lanceolatt coarsely serrated smooth, Stem decumbent

2695 Stem very much branched diffuse, Leaves oblong crenate, Flowers solitary

2696 Stem branched at base upright, Leaves oblong crenate, Cal. aggregated longer than corolla 2697 Branching diffuse, Lower leaves oblong obtuse, Upper lanceolate, Flower solitary, Cor. longer than calyx 2698 Stem simple, Leaves cordate toothed stem-clasping, Flowers sessile clustered

2699 Leaves linear villous, Stem erect

2700 Leaves linear smooth, Stem erect

2701 Shrubby, Leaves linear erect close together

2702 Leaves linear one toothed on each side

2703 Leaves linear 2-celled, Scape simple naked racemose

2704 Leaves lanceolate, Raceme spiked

2705 Stem erect, Leaves lin. lanc. obtuse alternate entire, Raceme terminal

2706 Stem half shrubby erect, Leaves lanc. ovate serrate toothed, Rac. term. Pedic. as long as flowers

2707 Leaves ovate toothed hairy, Stem simple

2708 Leaves lanceolate pinnatifia toothed, Raceme terminal

2709 Leaves lanceolate toothed, Peduncles very short lateral, Tube of cor. filiform very long

2710 Smooth, Lower leaves oblong toothed, upper lanceolate entire, Peduncles racemose 1-sided

2711 Erect simple slightly pubescent, Lvs. obl. obt. almost entire, the lower spatulate, Spike naked small flow. 2712 Leaves broad lanceolate serrate below toothed decurrent, Racemes compound terminal

2713 Leaves narrow lanceolate toothed revolute at edge and stem pubescent, Raceme terminal

2714 A tall plant with rugose coarse leaves, and a long spike of fine red fiowers

2715 Leaves oblong lanceolate cartilaginous-toothed and erect stem smooth, Raceme terminal 1-sided leafy

2716 Leaves narrow lanceolate toothletted flat at edge and stem quite smooth, Raceme terminal

2717 Leaves lanceolate serrated smooth, Peduncles lateral longer than the leaf

2718 Flowers axillary, Stem winged, Radical leaves ovate lanceolate with glandular reflexed teeth

2719 Lvs. ovate-obl. acute at each end unequally serrated, Flowers axillary solitary, Recesses of calyx reflexed

2720 Lvs. obl. acuminate serrated smooth, Pedunc. axill. 1-fl. Sepals linear lanc. spreading, Anthers bearded

2721 Ieaves ovate cut, Stem divided, Racemes terminal naked, Upper lip of cor. bearded

2722 Smooth, Stem ascending 4-cornered, Leaves ovate-lanceolate cut serrate twice as short as leafsta!k

2723 Stem hairy, Lvs. toothed serrate, the lower ov. obl. the upper ovate, Pedunc. axillary 1-fl. Caps. inflated

2724 Stem erect, Leaves cordate obsoletely toothed stalked, Corymb terminal

2725 Smooth erect, Stem 3-cornered, Leaves ovate round repand, Pedunc. longer than leaves

2726 Stem erect, Lower leaves obovate toothletted, upper lanceolate serrate, Raceme terminal 1-sided

2727 Quite smooth, Lvs. broad lanc. serr. Spike many-flowered 1-sided, Sepals entire, Lower petals ov. acute

2728 Radical leaves ovate, Scapes capillary

2729 Stem prostrate, Leaves lanceolate oval-crenate, Stem branched, Peduncles solitary 1-flowered very long

2730 Radical leaves spatulate repand, Cauline setaceous, Stems simple 1-flowered erect

2731 Leaves somewhat stalked lanceolate oblong toothed, Stems decumbent, Peduncles elongated

2732 Stem spreading, Lvs, toothed, lower ellipt. stalked, upper sess. narrow lanc. Pedunc. longer than leaves 2733 Stems prostrate filiform, Leaves stalked oblong toothed

2734 Stems spreading, Lower leaves oblong toothed pubescent subsessile, Upper lip of cor. reflexed

2735 Leaves ovate lanceolate deepiy toothed, Peduncles axillary 2 or 3 times as long as leaves

2736 Stems angular prostrate and leaves lanceolate toothed hairy, Peduncles axillary 1-flowered

273, Stems procumbent, Leaves lanceolate serrated, Flowers sessile spiked

2738 Shrubby hairy prostrate, Leaves ovate toothed, Flowers lateral with very long stalks 2 or 3-flowered

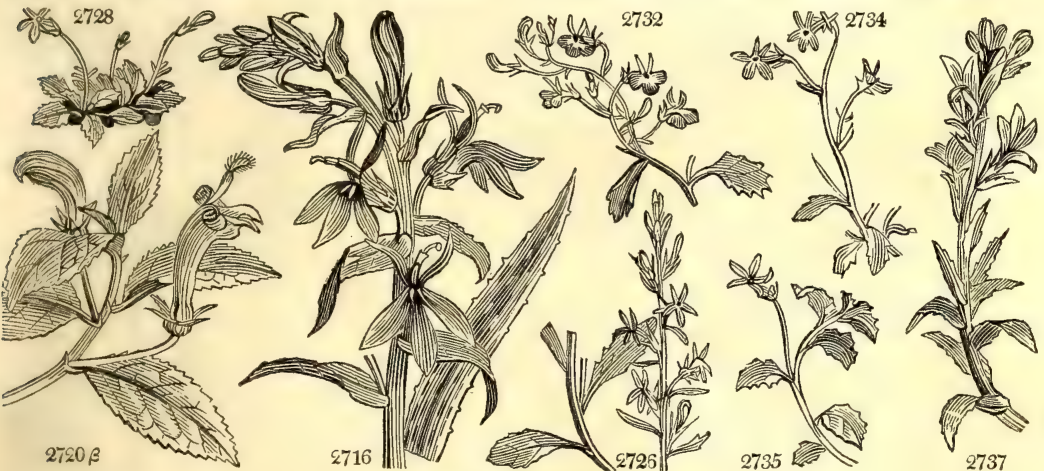

and Miscellaneous Particulars.

fulgens is given by J. B. Van Mons, and W. Hedges, in the Hort. Trans. Both confess that very little art is required. Hedges, to procure strong flower stalks, keeps the plants in pots, shifts very frequently from a smaller to a larger size, places them first in cucumber frames, and when they begin to flower in a stove. The pots in which they are allowed to flower are nine inches in diameter, and, in order to supply abundant moisture, pans are placed under the pots constantly filled with water. The soil used is equal parts of loam and leaf-mould, with a third of the whole of sand. They begin to flower in July, and continue flowering through the autumn. One plant so treated produced a flower-stalk which measured six inches in circumference at the base; the neight of the centre spike of flowers was five feet and a half; the shoots from the bottom and sides of the main stem were in number seventeen, and rising four and a half feet.

L. splendens and cardinalis may either be treated as above, or as a tender border, or as frame plants. Var Mons observes, that $\mathrm{L}$. cardinalis perishes in sandy soil, but becomes strong and multiplies in loam, while, at the same time, it produces the most brilliant colors in the former. The same thing may doubtless be predicted of the other species; it being a well known law of nature as to living beings, that their energies are concentrated in proportion to the obstacles thrown in the way of their expansion.

L. siphilitica has its specific name from its supposed efficacy in the cure of siphilis, among the North
. American Indians. Sir William Johnston purchased the secret from them, but Woodville says, its virtues have not been confirmed by any instances of European practice. 
2739 variifólia B. $M$. 2740 corónopifólia $W$. 2741 crenáta $W$. 2742 spéculum B. $M$. 2743 pedunculáta $B . M$. 2744 decúmbens $B$. $M$. 2745 pyramidális $B$. $M$. 465. PHYTEU'MA. $W$. 2746 pauciflórum $L$. 2747 Scheuchzéri $W$. 2748 scorzonerifóliu

2749 Michélii All.
2750 hemisphæ'ricum $W$. 2751 comósum Wulf. 2752 orbiculáre $W$. 2753 cordátum $B$. M. 2754 betonicifólium Vill. 2755 spicátum $W$

2756 ovátum $W$.

2757 virgátum $W$.

2757 virgátum $W$.
2758 campanuloídeum $H . k$. 2759 canéscens $W$. en. 2760 pinnátum $W$. 2761 stríctum $B: M$. Buck's-horn notched-leaved $\mathrm{N}$ or Looking_glass long-stalked decumbent pyramidal

RAMPION. few-flowered Scheuchzer's Micheli's $\frac{\Delta}{\Delta} \mathrm{pr}$ tufted $\mathrm{O}$ pr round-headed $¥ \Delta \mathrm{pr}$ heart-leaved spiked oval-spiked

twiggy C $\triangle$ pr 1 jn.au $B$ hoary $\frac{72}{\Delta} \mathrm{pr} \quad 2$ jn.au Li winged-leaved $\Delta \mathrm{pr}$

2 jn.jl B various-leaved linear-leaved $\frac{\$ \Delta}{\Delta} \mathrm{pr}$

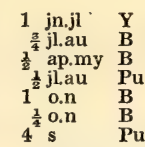

C. G. H. 1812. C s.p Bot. mag. 1692 C. G. H. 1752. S s.p Bot. mag. 644 C. G. H. 1794. C s.p

C. G. H. 1812. S s.p Bot. mag. 1499 C. G. H. 1819. D co Bot. mag. 2251 C. G. H. 1820. D co Bot. mag. 2277 Nepal 1822. D co Bot. mag. 2387 . $5 p$. 16-35.

$\frac{1}{3}$ my.jn B $\quad$ Switzerl. 1823. D p.l Mot.jn B 1797 jl.au B $\quad$ Alps 1819. D p.l

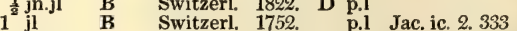
$\begin{array}{llllll}\frac{1}{8} \text { jn.jl } & \text { B } & \text { Switzerl. } & \text { 1752. } & \text { p.l Jac. ic. 2.333 } \\ \text { Austria } & \text { 1752. } & \text { s } & \text { s.1 Jac. au. 5.t.ap.50 }\end{array}$ 1 jn.au V England ch. pa. D p.l Eng. bot. 142 $\frac{1}{2}$ jl.au B Hungary 1804. co Bot. mag. 1466 2 jn.jl Pa.B S. Europe 1818. D p.l jn.au B Europe 1597. D p.1 Bot. mag. 2347 Europe 1814. D p.1

Lebanon 1820. D p.1 Bot. cab. 667 Caucasus 1804. D p.l Bot. mag. 1015 Hungary 1804. D p.l Pl, rar. hu. t. 14 Candia 1640. D p.1 Vent. cels. 52 S. Europe 1819. D p.1 Bot. mag. 2145

466. TRACHE/LIUM. $W$. ThroatworT. 2762 cæráleum $W$. 2763 diffusum $W$.

467. ROEL/LA. $W$. 2764 ciliáta $W$.

2765 squarrósa $W$. 2766 decúrrens $W$

2767 muscósa $W$.

blue

spreading

\section{RoELLa.} ciliated trailing decurrent

Moss-like

468. GOODE'NIA. $R$. Br. Goodenia. 2768 ováta $\boldsymbol{R}$. Br. oval-leaved 2769 grandiflóra $R$. $B r$. large-flowered 469. EU'THALES. $R$. $B r$. Euthales, 2770 trinérvis $R . B r$. three-nerved 470. DAMPIE'RA. $R$. Br. Dampiera. 2771 strícta $\boldsymbol{R} . \boldsymbol{B r}$.

471. SAMO LUS. $W$. 2772 Valerándi $R . B r$ 2773 littorális $R . B r$. upright

\section{Campanulacea. Sp. 2-4.}

(1) or 2 jl.s $\mathrm{B}$ Italy 1640 . S r.m Bot. reg. 72

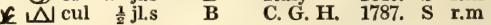

Campanulacea. $S p .4-8$.

* L or 1 jn.s Pu C. G. H. 1774. S s.p Bot. mag. 378

$\begin{array}{llll}2 \mathbb{N} \text { or } & \frac{1}{2} \mathrm{jl} & \text { B } & \text { C. G. H. 1787. S s.p }\end{array}$ $\begin{array}{llll}\text { Q } & \text { or } 1 \text { jl.s } & \text { B } & \text { C. G. H. 1787. S 1.p L'He. se.an.4.t.6 }\end{array}$ மل $\mathrm{cu} \quad \frac{2}{4} \mathrm{jl.s} \quad \mathrm{B}$ C. G. H. 1802. S

Goodenovia. Sp. 2-33.

- L or 2 jn.o Y N.S. W. 1793. S s.p Bot. rep. 68 II $\square$ or 4 jn.au $\quad$ N.S. W. 1803. S s.p Bot. mag. 890 Goodenovice. Sp. 1.

$4 \mathrm{~N}$ or 1 my.s P.Y N. Holl. 1803. C 1.p Bot. mag. 1137

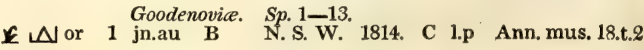
BRooK-WeED. Primulacea? Sp. 2-8.

common $\triangle \mathrm{pr} \quad \frac{3}{4} \mathrm{jn} . \mathrm{au} \mathrm{W}$ Britain mar. D co Eng. bot. 703 sea-side $\quad$ W pr $\quad \frac{1}{2}$ jl.s $\quad$ W $\quad$ S. W. 1806. D s.l Bot. cab. 435

472. VELLE'IA. Sm. Velleia. Goodenovia. Sp. 1-6.

2774 lyráta $R . B r$. lyrate $\quad \triangle \mathrm{V}$ or $\frac{1}{2}$ ap $\quad \mathrm{Y}$ N. Holl. 1819. D s.p Bot. reg. 551

473. SCE'VOLA. R. Br. Scevola. 2775 Lobélia $H . K$. Purslane-lyd. 2776 crassifólia $R . B r$. thick-leaved 2777 microcárpa $R$. Br. small-fruited 2778 suavéolens $R$. Br. sweet-scented

\section{w or 2 Goodenovice. Sp.4-25.}

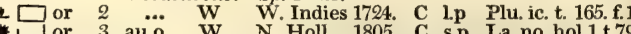
(11) W. W. Holl. 1805. C s.p La.no. hol.1.t.79 W or $1 \frac{1}{2}$ my.s P.V N. S. W. 1790. D s.p Bot, mag. 287

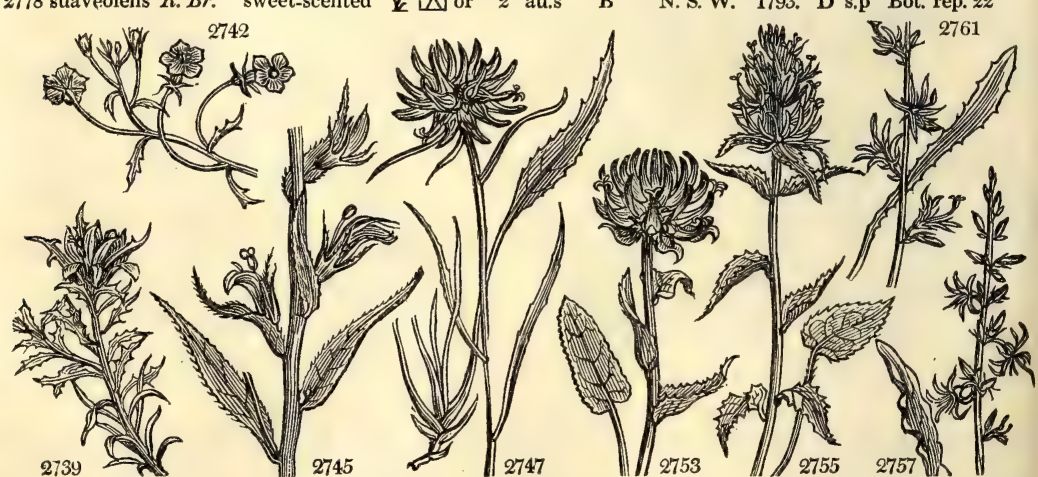

History, Use, Propagation, Culture,

405. Phyteuma. Фurevece, was the name of a plant much used among the ancients for apbrodisiacal purposes. No qualities of such a kind have been ascribed to the modern plant. This is a handsome genus, and with Roella is well adapted for rock-work or pots. The roots of P. spicatum are edible, and used in Switzerland like those of the rampion.

466. Trachelium. From z९a $\chi y_{5}$, rough, which its leaf is in a high degree. A pretty little favorite of the flower border, easily cultivated and preserved.

467. Roella. Named after G. Roelle, professor of anatomy at Amsterdam. He procured this plant for Cliffort. A pretty little leafy bush, with beautiful flowers of blue and white.

468. Goodenia. So named by Sir J. E. Smith, in honor of his friend Dr. Goodenough, Bishop of Carlisle, and a lover of natural history. Herbs or small shrubs, with alternate leaves, and terminal or axillary flowers, which are generally yellow, sometimes blue.

499. Euthales. From $\varepsilon v$, well, and $\lambda \propto \lambda \lambda \omega$, to push or sprout. Very like the last in all external characters. 
2739 Stems erect, Leaves linear entire and toothed, Flowers solitary terminal 2740 Leaves lanceolate toothed, Peduncles very long

2741 Leaves lanceolate crenate smooth, Stem twining

2741 Leaves lanceolate crenate smooth, Stem twining 2742 Stem prostrate, Ped. axillary solitary l-flow. very long, Cor. hypocrateriform

2743 Leaves stalked recurved pinnatifid, Pedunc. elong. lat. solitary 2-flowered

\$74 Leaves obovate toothed shorter than the axillary solitary peduncles

2745 Leaves lanc. serrulate with long points, Racemes leafy panicled, Cal, as long as cor.

2746 Head leafy, Leaves all lanceolate

\section{Flowers in heads.}

9747 Head rather leafy shorter than the linear bractes, Leaves lanceolate toothed

2748 Spike elongated cylindrical, Lower flowers remote, Leaves lanceolate crenated, Upper linear

2749 Head roundish, Bractes oblong lanceolate, Leaves linear rigid nearly entire

2750 Head roundish, Bractes ovate, Leaves linear nearly entire scarcely shorter than stem

2751 Head terminal sessile, Leaves toothed : radical cordate

2752 Head roundish longer than bractes, Radical leaves ovate cordate bluntly serrated, Cauline lin. lanceolate 2753 Bractes cordate acum. shorter than the roundish head. Rad. lvs. obl. cord. crenate, Caul, $\frac{2}{2}$ stem-clasping 2754 Spike oblong, Leaves simply crenate : radical lanceolate cordate; cauline lanceolate

2755 Spike oblong lengthened, Styles downy trifid, Radical leaves cordate doubly toothed

2756 Spike ovate, Styles hairy longer than the flower bifid, Radical leaves cordate doubly toothed

\section{\$ 2. Flowers axillary scattered.}

2757 Branches twiggy, Lvs. lanc. acute at each end uneq. toothed roughish, Flowers deeply divided in pairs 2758 Lvs. ovate acute sessile serrated rough, Stem angular quite simple, Fl, racemose sessile, lower clustered 2759 Leaves sessile, Lower obovate crenate-serrate, Upper lanceolate entire, Flowers racemose

2760 Leaves pinnate, Flowers very large in cymes

2761 Rad. leaves lin. spatulate entire, Flowers $\frac{1}{2}$-whorled in 3-flowered alternate parcels

2762 Branches erect, Leaves ovate serrated flat

2763 Much branched diffuse, Branches divaricating recurved, Leaves subulate

2764 Leaves linear ciliated upright, Flowers sessile

2765 Diffuse, Leaves ovate recurved toothed, Flowers terminal aggregate

2766 Leaves lanceolate ciliated entire decurrent, Flowers solitary terminal

2767 Leaves ovate toothed reflexed smooth, Flowers terminal solitary

2768 Erect smooth, Leaves ovate acute toothed serrated, Axillæ bearded, Sepals subulate filiform

2769 Erect pubescent, Branches angular, Lower leaves lyrate, Upper obovate acute

2770 A small herbaceous plant with large entire radical leaves

2771 Ieaves lanceolate entire or toothed fleshy smooth, Cor. hairy outside

2772 Stems diffuse branching, Racemes axillary and terminal

2773 Stem rounded branched leafy, Radical leaves spatulate : cauline lanceolate

2774 Smooth, Bractes of the dichotomies distinct, Leaves lyrate or toothed-cut at base

2775 Leaves ohovate smooth entire

2776 Spikes terminal and axillary, Leaves fleshy obovate toothed

2777 Leaves alternate obovate toothed smooth, Fruit very small

2778 Leaves entire obovate thick rough, Drupe berried (Goodenia calendulacea.)

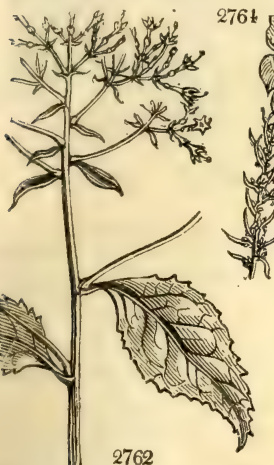

2762

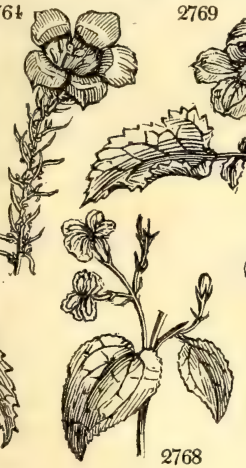

69

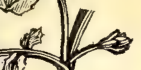

Nivity 2771

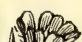

2774

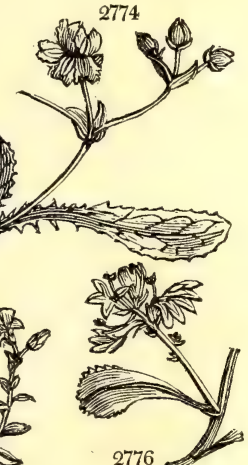

470. Dampiera. Named by Mr. Robert Brown, in honor of Captain William Dampier, a famous voyager, whose knowledge and attention, in matters connected with botany, are attested by the remains of voyager, tions made during his voyages, and now preserved in the Sherardian Herbarium at Oxford.

471. Samolus. Derived from two Celtic words, san, salutary, and mos, pig; a plant which is salutary to pigs. Pliny says, it was considered among the Gauls as a specific in all maladies of swine. The plant was collected with mystic ceremonies. S. Valerandi was named after Dourez Valerand, a botanist of the 16th century, mentioned by Bauhin. Small marsh plants with white flowers.

472. Velleia. Named by Sir James Smith, after Major Velley, a gentleman who paid much attention to marine algæ. The genus resembles Goodenia in appearance.

473. Sccevola. So named from scava, the Latin word to express the left hand, the flower having the Goodenia. of being defective of one half of its corolla. An extensive New Holland genus resembling 
474. CAPRIFO'LIUM. R.S. HONEY-SUCKLE. $\beta$ rúbrum

2780 etrúscum $R$. S

2781 dioícum $R$. $S$.

2782 sempervirens $R$. S.

$$
\beta \text { minus }
$$

2783 grátum R.S.

2784 flávum $B$. M.

2785 pubéscens $H$ Hook

2786 impléxum $R$. $S$.

$\beta$ serotínum

$\gamma$ bélgicum

¿ que cifólium

2788 japónicum $R$. $S$

2789 flexuósum Ker.

475. LONI'CERA. R. $S$. 2790 Xylósteum $W$.

2792 alpígena $W$

2793 cærúlea $W$

2794 nigra $L$.

2795 tatárica $L$. $\beta$ rúbra

2796 ciliáta $P$ sh. $\beta$ alba 476. SYMPHO' 2798 glomeráta $P h$. 2799 racemósa $P h$.

477. DIERVIL'LA. $J$

2801 húmilis $P$. $S$

478. TRIOS'TEUM. $W$.

2802 perfoliátum $W$. 2803 angustifólium $W$

479. COFFE'A. $W$.

2804 arábica $W$.

2805 occidentális $W$. Minorca Woodbin
late-red Dutch

Oak-leaved

Japanese flexuose Fly Pyrenean red-berried blue-berried black Tartarian red ciliated common crimson

DiERVILLA. yellow-flowered

FEVERWORT. perfoliate COFFEE-TREE. Arabian 2779 itálicum $R . S$.

2787 Periclýmenum $R$. S. 2791 pyrenáica $W$.

2797 ibérica Bieb.

2800 punicea Sims.

Caprifoliacea. $S p .11$.

white-Italian \& or 10 my.jn P.Y England woods. C co Eng. bot. 799

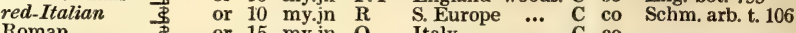
somall-flowered $\frac{\text { \$ }}{\$}$ or 15 my.jn ${ }^{\circ}$

$\begin{array}{lllll}\text { or } 6 & \text { jn.jl } & \text { Pu N. Amer. 1766. } & \text { C co } & \text { cot. reg. } 138\end{array}$ or 15 myau $\mathrm{S}$ N Amer 1656. C s.p Bot mag. 781 smallet rumpet $\frac{5}{5}$ or 15 my $\mathrm{S}$ Carolina 1656. C s.p Bot mag. 1753 evergreen $\quad$ or $20 \mathrm{jn}$.au R $\mathrm{R}$. Amer. 1730. C s.1 H.an.15.n.10.t.8 bright-yellow $\$$ - or 10 my.jn Y Carolina 1810. C s.l Bot. mag. 1318 hairy-yellow $\$$ or 20 my.jn Y Canada 1822. C co Hook. ex. fl. 27

2781

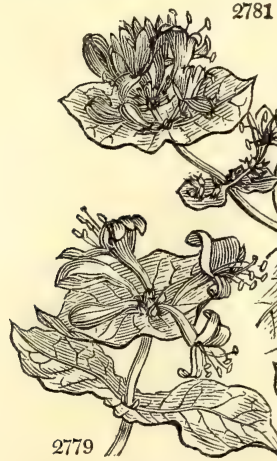

Caprifoliacea. Sp. 8-19.

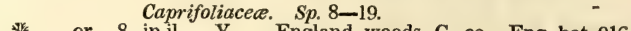

or $8 \mathrm{jn}$.jl $\mathrm{Y}$ England woods. C co Eng. bot. 916

or 4 my W Pyrenees 1739. C co Magn. hort. 209

or $4 \mathrm{mr}$ Pa.Y Switzerl. 1597. C co Schm. arb. 110

or 10 ap.my $\mathrm{Pk}$ Russia 1752. C co Bot. reg. 31

or 10 ap.my $\mathbf{R}$ Russia 1752. C co

or 4 ap.my W.R N. Amer. 1824. C co

or 4 ap.my W.R N. Amer. 1824. C co

or 6 ap.my $\mathrm{O}$ Iberia 1824 C Caprifoliacea. Sp. 3.

or 4 au.s Pk N. Amer. 1730. C s.l Schm. arb. t. 115 or 4 jl.s $\quad$ Pk N. Amer. 1817. C s.1 Bot. mag. 2211 or 4 jl.s $R \quad$ N. Amer. 1815. C s.l Bot. mag. 2469 Caprifoliacea. Sp. 1

or 3 jn.jl Y N.Amer. 1739. C s.1 Bot. mag. 1796 Caprifoliacea. Sp. 2-3.

m 2 jn.jl D. R N. Amer. 1730. D p.1 Schk. ha. 1. t. 41 cu 1 jn.jl $\mathbf{Y}$ Virginia 1699. D p.1 Plu, al, t. 104, f.2

Rubiacea. Sp. 2 -28.
au.n W Yemen 1696. S r.m Bot. mag. 1303

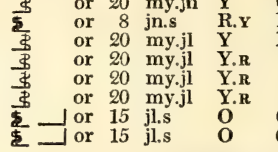

(15.1 Schm. arb.t. 112

\footnotetext{
History, Use, Propagation, Culture,
}

474. Caprifolium. A poetical name, signifying goat-leaf; that is to say, a leaf which climbs like a goat. Chevrefeuille, Fr., Geisblatt or Baumlilie, Ger., and Caprefoglio, Ital. This is a beautiful genus of flowering odoriferous mostly twining shrubs, valuable in the flower garden, shrubbery, and against walls, arbors, or trunks of trees. Like most British twiners, the honeysuckle follows the sun. Like other twiners, it bears pruning well, for, as Professor Martyn observes, "those plants which in a state of nature cannot ascend without the assistance of others, are often liable to lose large branches; they have therefore a proportionate vigor of growth to restore accidental damages." Against a wall, the climbing kinds are very liable to attacks from aphides, and the caterpillar of Phalœna tortrix ; and the sphinges, or hawkmoths, according to Withering, extract the honey from the very bottom of the tubular flowers with their long tongues.

In raising the honeysuckle from seeds, they should be sown the autumn after they are ripe, otherwise they will not come up the first year. Cuttings are sometimes apt to rot, owing to water lodging in their tubular stems above the last joint. To obviate this inconvenience, some make the cuttings of double the usual length, and insert both ends in the ground, leaving the part above ground in the form of a semicircle. Commonly, however, such cuttings root only at one end; or if at both, but very weakly at what was the top end.

475. Lonicera. Named after Adam Lonicer, a German, who was born in 1528, and died in 1586. There was another Lonicer, John, who wrote commentaries upon Dioscorides. A section of what was formerly called Lonicera, comprising the species with a shrubby upright stem, neither climbing nor prostrate plants. All hardy and easily increased by layers or cuttings.

476. Symphoria, is a syncope of symphoricarpos, from $\sigma v v$, together, $\phi \varepsilon \rho \omega$, to bear, and zoe ${ }^{2} \circ$, fruit; a plant which bears its fruit together in clusters. A small genus of low branching shrubs, formerly constituting part of Lonicera.

477. Diervilla. Dierville, a French surgeon, travelled in Acadia, whence he sent this plant to his friend Tournefort, who named it after him. A pretty low shrub, with yellow flowers appearing in the spring.

478. Triosteum. From $\tau$. roots of this genus and of Diervilla are used indiscriminately in N. America for Ipecacuana. (Viola. Ipec.)

479. Coffea. An alteration of the Arabic name qahoueh, which is the name for the liquor of coffee; the grain is called boun. Cahwa, Pers., Cahvey, Turk., and Eleave, Egypt. 
2779 Flowers whorled terminal, Leaves deciduous, the upper perfoliate

9780 Heads term. generally 3 together, Lvs. decid. pubes. opp. upper perfo. smooth, lower with stalks only conn. 2781 Whorls in heads with bracteæ, Lvs. deciduous glaucous beneath, Upper perfoliate, Cor. gibbous at base 2782 Spikes nearly naked terminal, Lvs, oblong evergreen, the upper perfoliate, Tube of cor. ventricose above

2783 Flowers whorled terminal, Leaves evergreen obovate glaucous beneath, Upper perfoliate

2784 Whorls in heads, Cor. ringent, Segm. obl. obt. Lvs. deciduous ovate glaucous beneath, Upper perfoliate 2785 Whorls terminal capitate glandular, Leaves pubescent the upper connate perfoliate

2786 Flowers capitate terminal, Leaves evergreen all distinct

2787 Flowers capitate terminal, Leaves deciduous all distinct

9788 Flowers in pairs terminal sessile, Leaves evergreen all distinct

2789 Flowers sessile with distinct berries, Leaves ovate entire smooth, Stem wavy

2790 Pedunc. 2-flowered longer than flowers, Leaves entire ovate-elliptical pubescent

2791 Pedunc. 2 -flowered, Leaves obovate lanceolate smooth glaucous beneath

2792 Berries united, Leaves oval-lanceolate

2793 Berries globose united, Styles undivided

2794 Leaves elliptical entire

2795 Leaves cordate obtuse

2796 Leaves ovate and cordate ciliated, Cor. with an evident spur

2797 Pedunc. 2-flowered shorter than flowers, Berries twin, Leaves cordate roundish tomentose

2798 Flowers axillary capitate clustered

2799 Raceme terminal, Cor. bearded inside

2800 Leaves cordate ovate, Berries distinct, Pedunc. axillary 2-flowered shorter than leaf

2801 The only species. Racemes terminal, Leaves serrated

2802 Leaves oval acuminate, Leaves abruptly narrowed at base, Axillæ 1-many-flowered 2803 Stem hispid, Leaves oval-lanceolate somewhat connate, Axillæ 1-flowered

2804 Leaves oblong ovate acuminate, Peduncles axillary aggregate, Cor. 5-cleft 2805 Leaves oblong lanceolate acuminate, Panicle few-flowered trifid terminal, Cor. 4-cleft

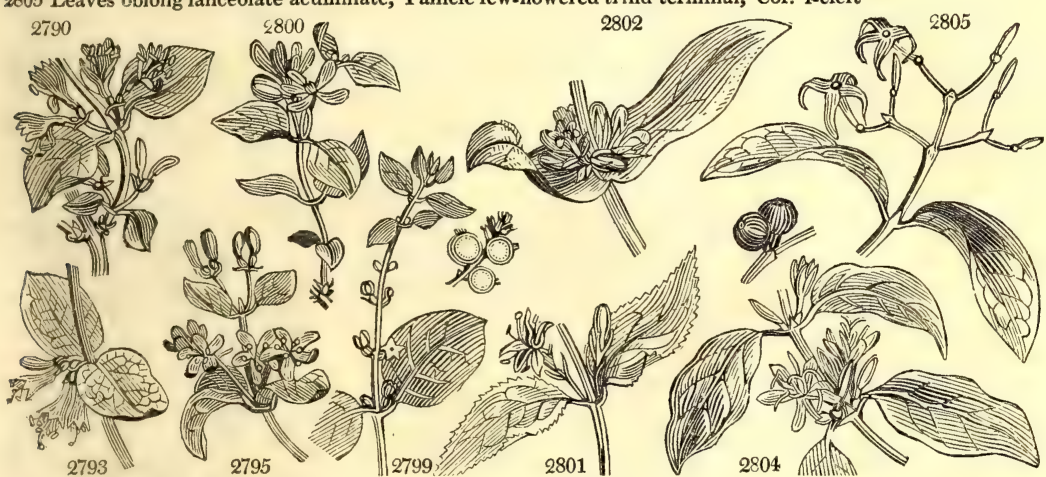

and Miscellaneous Particulars.

C. arabica is an erect, conicaı-shaped, low tree, with a light brown bark, and opposite, oblong, wavy, shining, light green leaves ; flowers in clusters at the base of the leaves, white, of a grateful odor, but of short duration; berries green, red when fully grown, and black when ripe. A decoction of this berry forms the well known beverage which is said to have been drank in Ethiopia from time immemorial. It was introduced into Arabia from Persia about the middle of the 15th century, and proceeded by Mecca, Medina, and Grand Cairo, Damascus, and Aleppo to Constantinople, where two coffee-houses were opened in 1554 . It is thought to nave been introduced to Venice soon after 1615: it was known at Marseilles in 1644, and Thevenot, a French nave been introduced to Venice soon after 1615 : it was known at Marseilles in 1644, and Thevenot, a French
triveller, brought it to Paris in 1657 . Till 1660, it was drank by such only as had been accustomed to it in the Levant. Ahout the end of the 17 th century a coffee-house was opened at Paris, by one Pascal, an Armenian, who, not succeeding, came to London, where coffee had been previously introduced by Daniel Edwards, a Turkey merchant, who brought home with him a Greek servant, Pasqua Roffee, who understood the roasting and making of coffee, and afterwards set up a coffee-shed, which he was enabled in time to turn to a house in the churchyard of St. Michael's, Cornhill, In 1688 Ray affirms that London might rival Grand Cairo in the number of its coffee-houses.

The coffee-tree was first introduced to Europe through the Dutch, who procured some berries at Mocha to be sown at Batavia; which being done in the year 1690 , Governor Witsen presented a plant to the botanic garden of Amsterdam, where it bore fruit and produced many young plants. From these the East Indies and most of the gardens of Europe have been furnished. Coffee was afterwards cultivated by the Dutch in Surinam in 1718, and by the French in Cayenne and the Mauritius soon afterwards. It was next grown in Martinique, and so spread to the neighbouring islands and to Jamaica in 1730, or earlier. The plants are raised from seeds, then transplanted into nursery lines. Plantations are made chiefly on hills and the skirts of mountains, and, if possible, where the soil is moist and shaded. The trees are planted from five to ten feet apart, according to the goodness of the soil and situation. They produce fruit the next year after planting ; and the produce of a good tree is from 11 to $2 \mathrm{lbs}$. of berries. The berries are gathered when they begin to fall, and in this state their pulpy bark begins to shrivel. They are further dried under sheds, and there passed

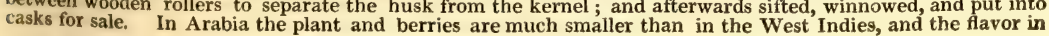


480. CHIOCOC'CA. $W$. SNow-BERRY 2806 racemósa $W$. 481. SERIS'SA. $W$ 2807 foe'tida $W$.

$\beta$ flore-pleno

82. CAN'THIUM, Pers.

2808 chinénse Pers.

2809 dumetórum Rox

483. PSYCHO'TRIA. $W$. 2810 asiática $W$.

2811 citrifólia $W$.

2812 parasítica $W$.

2813 brachiáta $W$.

2814 herbácea $W$.

2815 pubéscens $W$.

2816 undáta Jaco

2817 elliptica $B$. $R$.

484. HA MEL'LIA. $W$.

2818 pátens $W$.

2819 sphærocárpa $\boldsymbol{P} . S$

2820 ventricósa Swz.

2821 chrysántha $S w z$.

485. POSOOUE'RIA. Aut

486. VANGUIE'RA. $W$ Vong-flowered

2823 édulis $W$. eatable

2824 spinósa

prickly

487. GaRdE'NIA. P.S. Gardenia.

2825 radicans $W$

2826 flórida $W$.

$\beta$ flore pleno

2827 Thunbérgia $W$

2828 latifólia $W$.

2829 Rothmánnia $W$.

2830 uliginósa $W$

2831 armáta $S w$.

2832 micrántha $W$

2833 amœ'na $B$. M

2834 hexándra $W$.

2835 campanuláta Roxb. bell-flowered

488. GENI'PA. $P$. $S$.

2837 americána $P . S$.

2838 Merianm $P$. S.

rooting

Cape Jasmine double

starry

broad-leaved

spotted-flower,

marsh

armed

small-flowered

rimson-tipped

GENIP-TREE.

American

hairy

489. OXYAN'THUS. Dec. OXYANThUs

2839 specísus $H . K$
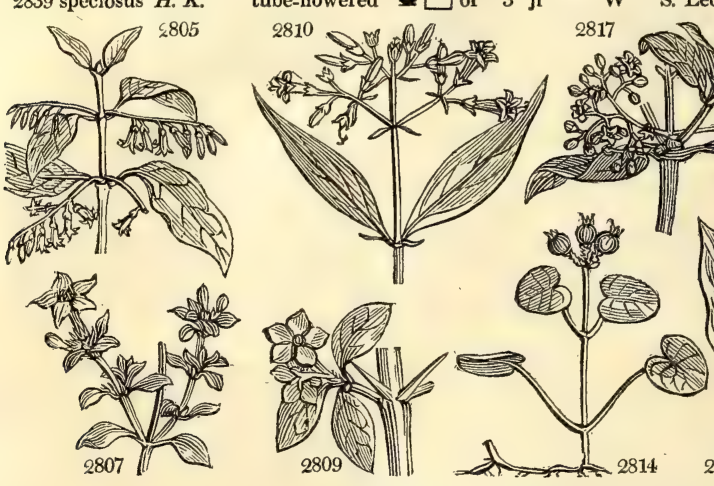

History, Use, Propagation, Culture, Rubiacea. Sp.1.

Rubiacee. Sp.2-4.

Rubiacea. $S p .8-100$.

Rubiacea. Sp. 4-7.

Rubiacea. Sp. $1-3$.

Rubiacea. Sp 9

Rubiacea., $S p .12-41$.

Rubiacea. $S p$. 2-5.

Rubiacee. Sp. 1.

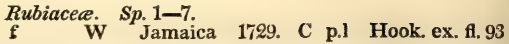

2 my.s W Japan 1787. L r.m Bot. mag. 361 my.s Japan 1787. L r.m

China 1804. C r.m Thun. G.t. 2. f.4

E. Indies 1777. C r.m Roxb. cor. t. 136

$4 \quad \cdots \quad$ W $\quad$ W. Indies 1806. C $1 . p$ Lam. ill. t. 161

... W W W. Indies 1793. C r.m

$7^{\frac{1}{2}}$ my.au W W. Indies 1802 . C l.p

$\frac{1}{4}$ ap.jn W Jamaica 1793. C 1.p Jac. amer. t. 46

$6 \quad$-.. Y.G. Jamaica 1812. C $1 . p$

3 my.jn G Bahamas 1823. C 1 p Jac. sch. 3. t. 260

5 jl.au S Hispaniola1752. C p.l Ex. bot. 1. t. 24

10 jl.au O Mexico 1811. C p.1 Fl. per. 2. t. 221

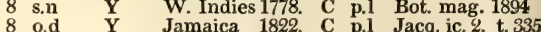

$\square$ fr $15 \quad \ldots \quad$ G Prdia 1809. C p.l Lam. ill. t. 159 jn.jl G Madagas. 1816. C p.l

* $\downarrow$ or $1 \mathrm{mr}$.jn W China 1804. C r.m Bot. reg. 73

5 j1.o P.Y China 1754. C 1.p Bot. reg. 449

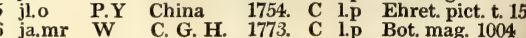

ja.mr W C. G. H. 1773. C l.p Bot. mag. 1004

jl P.Y C. G. H. 1774. L l.p Th.ac.st.1776.t.2

3 jl.s W E. Indies 1802. C l.p Roxb.cor 2 t.135 $10 \quad \ldots$ W W. Indies 1813. C 1.p

.... W China 1806. $\mathrm{C}$ r.m Th. g. n. 8.t.1.f.1 6 jls $\mathrm{W}$ China $\ldots$ C r.m

1823. C r.m Bot. cab. 512

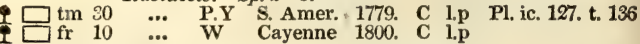

W S. Leone 1789. C p.l Lind. coll. 13

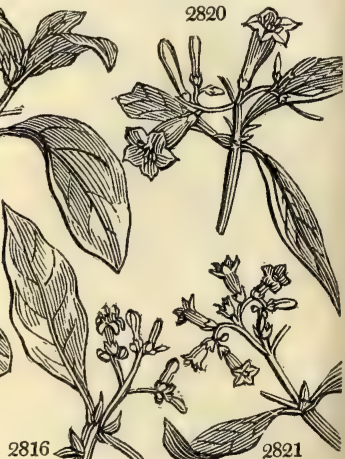

$$
\text { climate }
$$

limates, obtained at the expence of

consequence greater; bulk being, in these richer soils and more himid climates, obtained at the expence of otherwise if kept six weeks it loses its vital powers. Cuttings of ripened wood root in sand under a glass in moist heat : transplanted, and furnished with plenty of water and pot room, they flower and fruit abundantly.

480. Chiococca. Snowberry, ( $\chi^{60 \%}$, snow, and жoжzos, berry). Its berries are of a bright whiteness.

481. Serissa. A name of Commerson's, the meaning of which is not known. The genus is remarkable for the trifid segments of corolla.

482. Canthium. From canti, the Malabar name of the plant. Spiny rigid plants with small opposite leaves. and solitary, sessile, usually fragrant, white flowers.

483. Psychotria. From $\psi \times \eta$, life; in allusion to the powerful medicinal effects of one of the species, $P$.

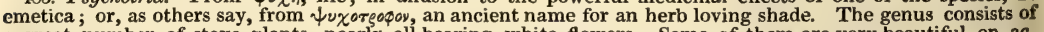
a great number of stove plants, nearly all bearing white flowers. Some of them are very beautiful on account of their foliage: one species, P. parasitica, is parasitical upon trees in the West Indies.

484. Hamellia. In honor of the celebrated Henry Louis Du Hamel Du Monceau, born in 1700, died in 1782, author of numerous works on vegetable physiology. The genus consists of handsome shrubs of the West Indies, with tubular yellow or orange-colored flowers.

485. Posoqueria. The Galibis in French Guiana call this plant aymara-posoqueri. A fine shrub, with white flowers more than a foot long, and an eatable yellow berry as big as a hen's egg. 
2806 Leaves ovate acuminate, Racemes subdivided axillary 1-sided nodding

2807 Leaves opposite ovate lanceolate, Stipules spiny, Flowers axillary sessile

2808 Spiny, Flowers sessile hairy

2809 Spiny, Leaves ovate wedge-shaped obtuse, Sepals leafy, Berries crowned

2810 Stipules emarginate, Leaves lanceolate ovate

2811 Stipules ovate persistent, Leaves elliptical acuminate subcoriaceous, Berries ribbed

2812 Stipules stem-clasping retuse, Leaves ovate acuminate succulent veinless, Cymes stalked as long as leaves 2813 Stipules ovate oblong bifid, Raceme terminal compound, Flowers clustered sessile 2814 Stem herbaceous creeping, Leaves cordate stalked

2815 Stipules 2-toothed, Leaves lanceolate ovate acuminate pubescent, Panicles cymose spreading 2816 Stipules connate entire deciduous, Leaves oblong ribbed wavy acuminate

2817 Leaves ellipt. narrowed each way, Panicles term. erect lax brachiate shorter than the leaves

2818 Racemes terminal colored, Leaves 3 together villous pubescent

2819 Branches rounded, Leaves ternate oblong hairy on both sides, Flowers corymbose

2820 Racemes terminal and axillary, Cor. campanulate ventricose, Leaves ternate

2821 Racemes terminal, Leaves oblong wedge-shaped acuminate smooth, Flowers stalked

2822 Stipules and leaves oblong-acuminate, Corymbs terminal about 6-flowered, Tube of cor. much curved

2823 Stem unarmed, Leaves large ovate stalked

2824 Stem spiny, Leaves small nearly sessile

2825 Leaves lanceolate, Cor. hypocrateriform, Cal. angular, Stem rooting

2826 Leaves elliptical, Cor. hypocrateriform, Sepals subulate lanceolate vertical

2827 Leaves elliptical, Cor. hypocrateriform, Calyx bursting at side, Sepals dilated at end 2828 Leaves obovate roundish, Cor. hypocrateriform, Sepals subulate bluntly keeled

2829 Leaves oblong, Stipules subulate. Sepals subulate rounded, Tube smooth dilated short

2830 Branches scarred with two spines at the end, Leaves oblong ovate obtuse, mouth of cor. villous

2831 Terminal spines of the branches 4, Sepals linear wedgc-shaped, Flowers clustered

2832 Leaves elliptical acute at each end longer than the spines, Flowers sessile smooth

2833 Spines axillary straight shorter than the oval smooth leaf, Flowers terminal solitary

2834 Unarmed, Lvs. ovate pubescent beneath, Fls. usually hexandrous, Cor. hairy on each side, Tube short $2835 \mathrm{~A}$ fine species, of which no detailed character has yet been given

2836 Very like G. florida, from which it chiefly differs in being smaller with narrower leaves

2837 Leaves oblong lanceolate, Peduncles axillary many-flowered, Tube short

2838 All over hairs, Leaves oblong-obovate, Flowers clustered on the summit, Fruit rounded flat

2839 The only species, with very long white flowers
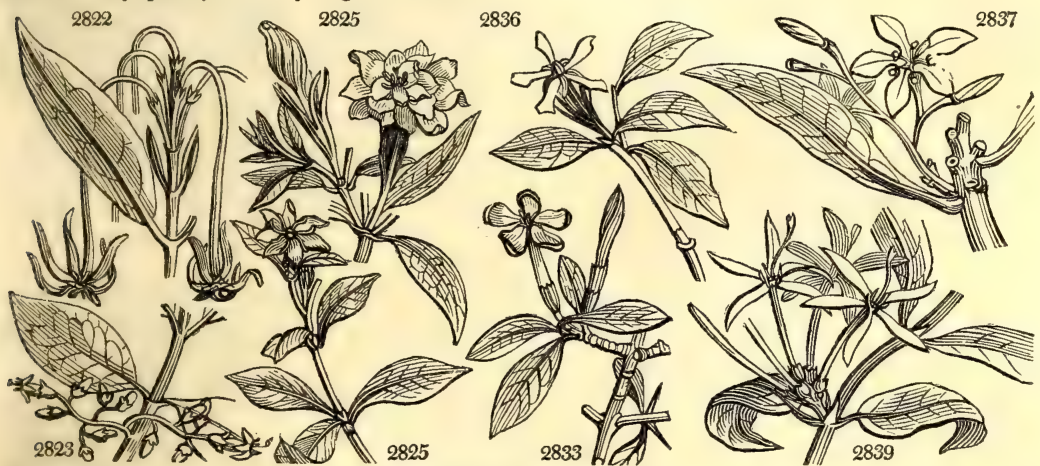

and Miscellaneous Particulars.

496. Vanguiera. An abbreviation of the Madagascar name of one species, Voa-vanguier. A fine looking bush, with broad, green, entire leaves. It is said to bear a fine fruit as big as an orange

487. Gardenia. So named by Ellis, in honor of his friend and correspondent A. Garden, M. D. of Charleston, in Carolina, who sent home many new species of plants. This is a beautiful genus, and most of the species are highly odoriferous, and free flowerers. G. florida, on the first approach, smells like the flower of the orange, but on being more closely smelled to, like Narcissus. According to Thunberg, there are hedges of it in Japan, and the Japanese are very fond of it near their houses, and in the walks of their gardens. The fruit and seeds are used there to dye yellow. G. Rothmannia smells most during night: it bears an ovate, fleshy, angular berry, black when ripe, and about the size of a small pear. Almost all the species are spiny in their wild state; but lose their spines at an advanced age, or under high culture and keeping. In the stove they require a moist heat to make them flower freely, as do the cuttings to make them strike. Acccrding to Sweet, the best way to flower the greenhouse species is to set them in a close frame on a little bottom heat, but not to plunge the pots.

488. Genipa. A name contrived by Plumier from the name, Genepapo, it bears in Guiana and Brazil. G. americana is an exceedingly rare plant in collections. It bears an excellent fruit, in much request in Dutch Guiana, where it is called Marmalade-box.

489. Oxyanthus. From okूus, acute, and cey. 05 , a flower, on account of the acute segments of the corolla. A genus divided froin Gardenia, from which it is readily distinguished by the long tube of the flower. 
490. RAN'DIA. $P$. $S$. 2840 longiflóra $\boldsymbol{P}$. $\dot{L}$ 2841 latifolia $P . S$.

491. MUSS $N^{\prime}$ A $W$ round-leaved 2842 pubéscens $\boldsymbol{H}$. $\boldsymbol{K}$. pubescent 492. PINCKNE'YA. Mi. Pinckneya. 2843 púbens $M i$.

493. ERI'THALIS. $W$. ERIthalis. 2844 fruticósa $W$. 494. WEBE' RA. $W$

2845 corymbósa $W$ 2846 cymósa $W$.

495. PLO'CAMA. $W$. 2847 péndula $W$.

496. MORIN'DA. $W$. 2848 umbelláta $W$. 2849 citrifólia $W$. 2850 Róyoc $W$.

497. CEPH Laurel-leaved 2851 elata $W$. tall 2852 pedunculata $P . L$. long-peduncle 2853 calycína Lindl. US Afz. Guinea-PEACH. 2854 esculéntus $A f z$. common
499. HIRTEL'LA $W$. 2855 americána $\boldsymbol{W}$. American

500. TRIPHA'SIA. Lour. TRIPHASIA. 2856 Aurantiola Lour three-leaved Limónia trifoliáta W

501. VI'TIS, $\boldsymbol{P}$. $S$. 2857 vinífera $W$ 2858 indica $W$ 2859 Labrúsca $W$ $\beta$ búcois álbis 2860 vulpina $W$

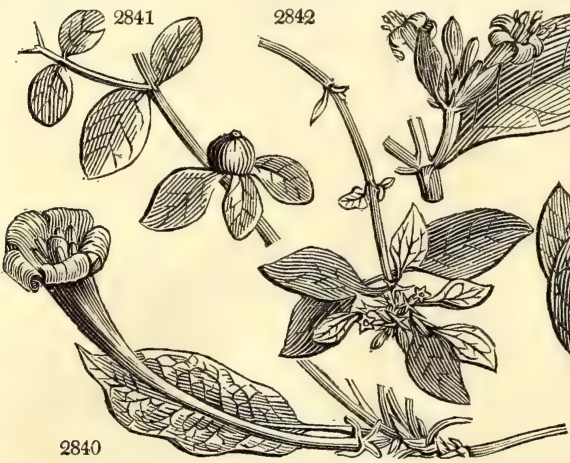

VINE. common Grape Indian dian downy-leaved Bland's Grape Fox-grape

15 ... $\mathrm{Pk}$. 1 .

Rubiacece. Sp. 2-10.

* or 4 au.s W E. Indies 1796. C 1.p. Par. lond. 93

I $\square$ or 12 my.jn W W. Indies 1733. C l.p Br. ja. 143.t.8.f.1 Rubiacea. Sp. 1-18.

* Rubiacea. Sp. 1 .

ㄴ $\mathrm{tm} 20$ jn.jl Georgia 1786. $\mathrm{L}$ p.l Mich. amer.t.13 Rubiacea. Sp. 1-4.

1. $\square$ fr 15 jl.au W Jamaica 1793. C p.l Br. jam.t. 17.f.3 Rubiacece. Sp. 2-4.

$\square$ or 6 ... W W $\quad$ E. Indies 1759. C 1.p Rh. mal. 2.t. 23 20 W E. Indies 1811. C I.p Rubiacece. Sp. 1-3.

L $ـ$ or 2 ... W Canaries 1779. C 1.p Rubiacea. Sp. 3-8.

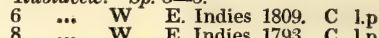

$\square$ or 8 a... W $\quad$ W $\quad$. Indies 1793. C 1.p Rhe. mal. 1.t.59 Rubiacea. Sp. 3-24.

2 f $\cdots \quad$ Pu Jamaica 1793. C 1.p 4. ap my W Brazil 1816, C C lp Par. lond.99 Rubiacea. $S p .1$.

p.1 Hor.trans.5.t.18 Rosacea. Sp. 1-13.

W. Indies 1782. C 1.p Aub. gui. 1.t.98 Aurantiacea. $S p .1$.

2 jn.jl W China 1798. C r.m Bot. rep. 143

Vinifera. Sp. 9-24.

fr 30 jn.jl $\mathbf{G}$ Various $\ldots \quad$ C r.m Jac. ic. 1.t. 50 1692. C s.1 Rhed. mal, 7. t.6 fr $10 \quad \ldots \quad$ G $\quad$ N. Amer. 1656. L s.p Jac. schœn. 426 G N. Amer. 1805. L s.p G N. Amer. 1656. C s.p Jac. schœn.425

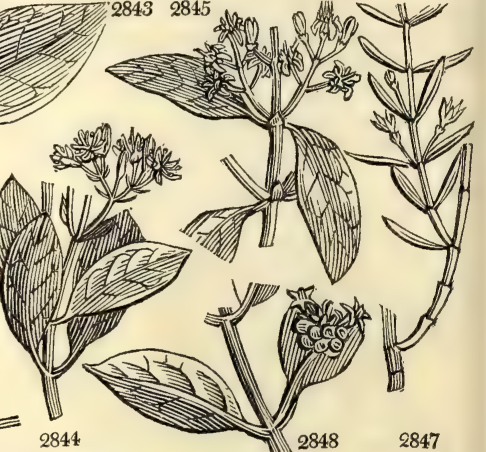

History, Use, Propagation, Culture,

490. Randia. So named in honor of Isaac Rand, F.R.S., who published the first catalogue of the Apothecaries' Garden at Chelsea.

491. Mussanda. A name by which Burmann designates a plant of this genus. $V$. $f$. Zeyl. t. 76. The species are all of singular beauty, and especially distinguished by the large colored segment of the calyx, which is either white or purple, and very remarkable.

492. Pinckneya. So named by Michaux, after some American gentleman of the name of Pinckney, who is now forgotten. The genus is nearly the same as Mussænda. It thrives best, according to Sweet, when turned out against a south wall, and protected by a mat in frosty weather.

493. Erithalis. A name given by Pliny to a plant remarkable for the verdure of its foliage ; $\varepsilon \rho$, a particle signifying augmentation, and $9 \alpha \lambda \lambda \omega$, to be green. It is now applied to a pretty genus of South American plants.

494. Webera. In honor of G. Henry Weber, a German botanist, who published Flora Gottingensis, in 1778, and other works of merit. He is chiefly known for the attention he bestowed upon muscology. Small plants with bunches of white flowers.

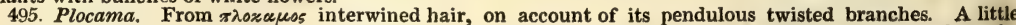
bush with the habit of some kind of Galium. The flowers are very small, and not much longer than the calyx.

496. Morinda. Morus indica, Indian mulberry; so named by Vaillant, from the shape and color of its fruit. The bark of the roots of this genus is used in the $\mathbf{E}$. Indies to dye yellow.

497. Cephaelis. From $\approx \varepsilon \varnothing \propto \lambda \eta$, a head, on account of the flowers being united in heads, remarkable for the large, often colored, involucrum in which they are enveloped. Species are very rare in collections; and require a high temperature.

498. Sarcocephalus. From $\sigma \propto \rho x \circ 5$ flesh, and $x є ф \propto \lambda \eta$, a head, in allusion to the large fleshy fruit of the genus. This is like a pine-apple without its crown, of a dull uniform color, and consisting of a solid fleshy mass containing many minute seeds. The flavor is said to be excellent. A plant now common in gardens mass containing many minute seeds.

near London, but it has not yet fruited. trees of the tropics, usually supporting themselves upon other plants. Flowers, which are generally blue or purple, are rarely seen in this country. Cuttings root in sand under a hand-glass. 
2840 Leaves ovate stalked, Spines curved, Flowers in terminal umbelled cymes

2841 Spines of the branches terminal in pairs, Leaves ovate roundish, Cor. hypocrateriform

2842 Branches and leaves pubescent, Tube of corolla much longer than calyx

2843 A large tree with downy long leaves dividing but little into branches

2844 Leaves obovate, Cymes compound stalked terminal

2845 Leaves oblong acute, Corymb terminal

2846 Leaves ovate acuminate, Cymes many-flowered axillary stalked

2847 A small shrub with the appearance of Galium

2848 Erect, Leaves lanceolate ovate, Flowers clustered

2849 Leaves ovate acuminate smooth on both sides, Flowers solitary

2850 A long trailing plant with ovate entire smooth leaves

2851 Heads globose terminal, Peduncles elongated, Involucre 2-leaved, Leaves smooth

2852 Leaves coriaceous lanceolate smooth, Heads on very long stalks

2853 Heads not in an involucrum so long as the flowers, Leaves lanceolate wavy

\section{The only species}

2855 Racemes simple axillary solitary, Common peduncie villous, Leaves oblong, acuminated

2856 Leaves 3-leaved

2857 Leaves sinuateå naked

2858 Leaves cordate toothed villous beneath, Tendrils bearing the fruit

2859 Leaves cordate angular 3-lobed toothed, beneath downy clear white

2860 Leaves cordate 3-lobed coarsely toothed smooth, Teeth unequal with long-pointed divisions

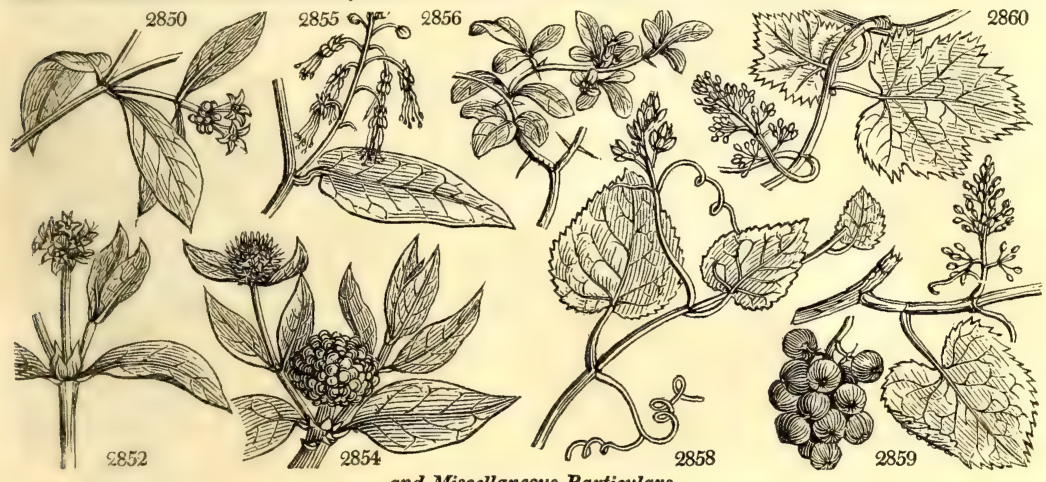

and Miscellaneous Particulars.

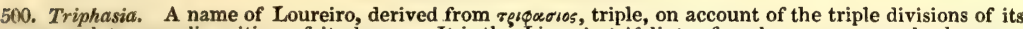
flowers, and ternary disposition of its leaves. It is the Limonia trifoliata of gardens, a common bush, sometimes covered over with the little orange berries, which have an agreeable orange-like taste.

501. Vitis. From the Celtic gwyd, a tree or shrub. The $G$ being suppressed in the pronunciation, according to the usage of Celtic nations, the Latins have made of it vitis; the Spaniards vid ; the French vigne; and the English vine. The term muscat, applied to particular kinds of grape, is not derived from the perfumed or musky flavor of those varieties, but from the berries attracting flies, musca, for which reason the Latins called the kind vitis apiaria.

V. vinifera is universally known for its fruit, and for producing the first liquor in the world; a liquor which, notwithstanding all that 'is said of its dangerous qualities, is yet eagerly drank by all who can procure it, and preferred before all others by those who are unlimited in their means and choice. The grape vine is among fruits what wheat is among the cereal grasses, or the potatoe among the farinaceous roots; and, like them, in every country where it will grow, it is cultivated with pre-eminent care. In Britain, its culture is now confined to the garden as a dessert fruit; though formerly grown in many places for the wine-press. Besides the V. vinifera, the V. labrusca (from busca, the Hebrew for grape) and laciniosa are all cultivated, and both are now so intermingled with the first species by hybrid products, that for all practical purposes they may be considered as only varieties.

The varieties of the grape in countries where it is grown for the wine-press, are almost as numerous as the vineyards ; for as these for the most part differ in soil, aspect, elevation, or otherwise, and as the vine is greatly the child of local circumstances, its habits soon become adapted to those in which it is placed. When it is considered that a vineyard once planted will last two or three centures, it will readily be conceived that the nature of a variety may be totally changed during only a part of that time. The varieties most in esteem for wine making, are small berries, and bunches with an austere taste. The Burgundy, as modified by different soils and situations, may be considered the most general vineyard grape of France, from Champagne or Marne to Marseilles and Bourdeaux. The best wine in Italy and Spain is also made from grapes of this description; but in both countries many of the larger ber of liquor. The sweet vines, as the Malme ( grapes allowed to remain on the plants till over ripe. That wine is the strongest, and has most flavor, in which both the skins and stones are bruised and fermented. The same thing is the case in making cider; but in both processes bruising the stones or kernels is often neglected. 
2861 cordifólia $P h$.

2862 ripária $P h$.

2863 rotundifólia $P h$.

2864 laciniósa $W$.

$2865 \mathrm{cæ}^{\prime}$ sia $\mathrm{Sab}$.

502 A MPELOP'SIS.

2866 . A MPELOPSIS.

2866 cordáta Mich. heart-leaved

2868 quinquefólia Mich. Virgin.-creeper

2869 hirsúta Donn.

503. RHA M'NUS. $W$.

2870 colubrína $L$.

2871 elliptica $H, K$.

2872 erythroxylon $\boldsymbol{P}$

2873 longifólia Desf

2874 cathártica $W$

2875 infectória $W$

2876 lycioídes $W$.

2877 oleoídes $W$.

2878 crenuláta $W$.

2879 saxátilis $W$.

2881 tetragóna $W$

2882 lanceoláta $P h$.

2883 alpína $W$

2884 púmila $\dot{W}$.

2885 Frángula $W$.

2886 latifólia $W$.

2887 glandulósa $W$

2888 prinoides $W$

2889 minstacina $W$

2890 alnifólia $W$.

2891 hýbrida $\boldsymbol{P}$. $S$

2892 Alatérnus $W$. en

2893 Clusii $W$

504. GNOP'LIA. Mich

2894 lineáta $W$.
2895 volubilis $W$

hairy

BUCK-THORN.

Bahama red wd

oval-leaved

Red-wood

long-leaved

purging

yellow-berried

Boxthorn-like

Olive-leaved

Teneriffe

rock

Tea

spear-leaved

Alpine

dwarf

berry-bearing

broad-leaved

Madeira

Winter-ber.-lv.

wiry

Alder-leaved

hybrid

bd.-lvd.-Alater.

narrow-leaved

Enoplia.

lined

twining

$\begin{array}{cccc}\text { or } & 10 & \ldots . . & \mathrm{G} \\ \text { or } & 20 & \text { my.jn } & \mathrm{G} \\ \text { or } & 20 & \ldots . . & \mathrm{G} \\ \text { fr } & 20 & \text { jn.jl } & \mathrm{G} \\ \text { or } & 10 & \ldots . . & \mathrm{G}\end{array}$

Viniferce. Sp. 4-6.

or 20 ap.my P.G N. Amer. 1803. C co

or 15 jl.au P.G N. Amer. 1700. C co Act. bon. 3. t. 24

or 60 jn.jl P.G N. Amer. 1629. C co Corn. can.t. 100

or 60 ap.my P.G N. Amer. 1806. C co Rhamni. Sp. 24-70.

은 20 jn G Bahamas 1762. L co Jac. vind. 3. t. 50 or 5 au $\mathbf{G}$ Jamaica 1758. L co Brow. jam. t. 29 or 6 jl.au Y.G Siberia 1823. L co Pall, ross. t. 63 England hed. L co or $6 \mathrm{jn} . \mathrm{jl} \quad \mathrm{G} \quad \mathrm{S}$. Europe 1683. I co or $\quad G$ Spain 1752. L co or 4 jn.jl $G$ Spain 1752. L co or $8 \mathrm{mr} \quad \mathrm{G}$ Teneriffe 1778. L p.1 or 3 my.jn $\mathbf{G}$ Europe 1752, C co

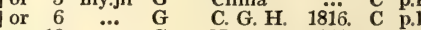
or $12 \quad \ldots . \quad$ G $\quad$ N. Amer. 1812. C p.1 or 1 jl G Carniola 1752. L co or 12 ap.my W Britain woods. S co or $4 \mathrm{jl} \quad \mathrm{G}$ Azores 1778. $\mathrm{L}$ co or 15 jn.jl $\mathrm{G}$ Canaries 1785 C or 15 au.s W $\quad$ C. G. H. 1778. C p.l or 13 W.G Africa 1775. S p. $\begin{array}{lllll}\text { or } & 4 & \text { my } & \text { G } & \text { N. Amer. 1778. L co } \\ \text { or } & 12 & \text { my.jn } & \text { G } & \end{array}$

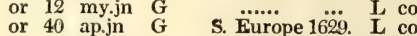
or 30 ap.jn G S. Europe 1629. L co

Eng. bot. 1629

Ard, me. 78, t.14

Cav. ic. 2. t. 182

Jac. aust. 1. t. 53

Hall. his. 1. t. 40

Jac. coll. 2, t. 11 Eng. bot. 250

Dend. brit. 11

'Her.

L'Her. sert. t. 5 Rhamni. Sp. 2.

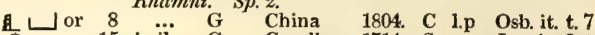
\$ or $15 \mathrm{jn} . \mathrm{jl}$ G Carolina 1714. S s.p Jac. ic. 2.t. 336
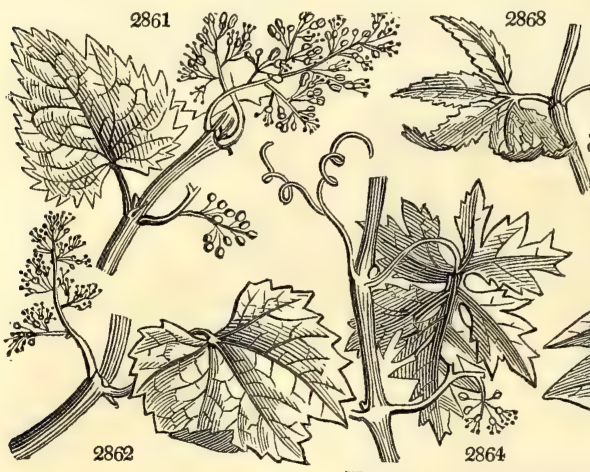

15

10

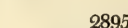

2895
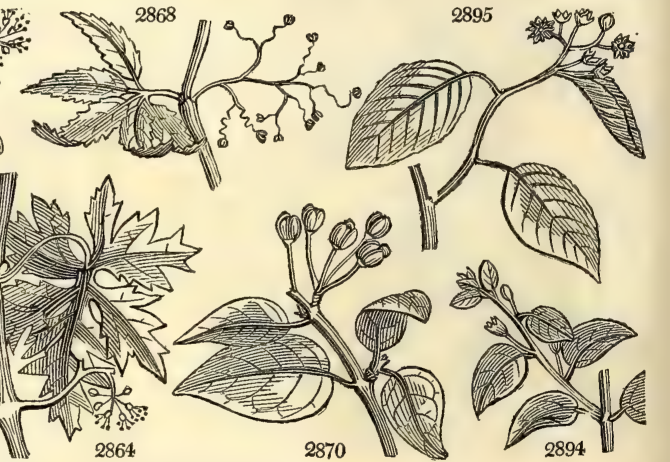

2870

History, Use, Propagation, Culture,

The varieties of dessert grapes on the continent are few : the best they have, as the Muscats and Frontignacs, have been obtained from this country. The Chasselas or frame grape (our Muscadine), is almost the only eating grape known in the Paris fruit market. In Britain, we have not only the best varieties, but we grow the fruit to a larger size and of a higher flavor than is done any where else in the world. This is owing to the perfeotion of our artificial climates, and the great attention paid to soil and subsoil, and other points of culture.

The vine is universally propagated by cuttings, either a foot or more long, with a portion of two year old wood, or short with only one bud, or one bud and half a joint, \&c. Varieties without end are raised from seed; and it is thought that by propagating from the seeds of successive generations some sorts may ultimately be procured better adapted for ripening their fruit in the open air than now known. A seedling vine carefully treated will show blossoms in its fourth or fifth year; say that it produces a fair specimen of its fruit in the sixth year, then a new generation may be obtained so often.

The vine will thrive in any dry soil, or in any soil with a dry subsoil ; but it produces the best flavored fruit among granitic and calcareous fragments, and loamy soil in thin strata, with little manure, and when the vine is old and the berry and bunch small : on the contrary, the most luxuriant crops, large bunches and berries, in a good depth of friable loam, dry below and richly manured with the strongest of animal manures.

There are three methods of pruning the vine in hot-houses; the fruit tree method, in which the plant is spread out in the fan manner, and treated like a common fruit tree; the long or. young wood method, in which all the wood above a year old is cut out down to the stool or stock; and the spurring-in method, in which the fruit is produced from young wood grown annually from the sides of a main shoot or shoots of old wood. The two last methods are the best.

Vitis vulpina, the foxgrape, (so called from the foxy flavor of its berries) is cultivated much in North America, of which country it is a native. Many improved varieties have been raised by the American gardeners, and have been sent to Europe under the name of the Bland, the Isabella, the Oswego Tokay, \&c. \&c.; but they are all tainted with the bad taste peculiar to the species, and can be in no estimation when even an early July grape is to be procured.

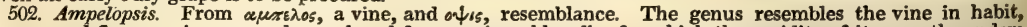
leaves, and flowers; is commonly employed for covering old walls, for which the rapidity of its growth renders it very suitable.

503. Rhamnus. From the Celtic ram, signifying branching. From this word the Greeks have gained gepyos, the Latins ramus, and the French rame, or in old French reim; for which reason the arms of the 
2861 Leaves cordate acuminate nearly equally toothed smooth on both sides, Racemes loosely many-fruited 2862 Leaves unequally cut toothed shortly trifid, Stalk nerves and edge pubescent

2803 Leaves shining on both sides reniform cordate equally toothed, Flowers in many little heads 2864 Leaves quinate, Leaflets many-cleft

2865 Shoots very cæsious, Leaves cordate angular

2866 Leaves cordate acute toothed 3-lobed, Nerves villous beneath, Racemes twin bifid 2867 Leaves bipinnate smooth, Leaflets cut-lobed, Racemes stalked twin bifid

2868 Leaves palmate 3-5-leaved smooth on both sides, Leaflets stalked oblong acuminate

2869 Leaves palmate 3-5-leaved on each side pubescent, Leaflets ovate acuminate coarsely toothed

2870 Flowers monogynous hermaphrodite erect, Caps. 3-coccous, Stalks rusty tomentose

2871 Flowers hermaphrodite trigynous axillary in umbels, Leaves elliptical acute entire villous beneath 2872 Spines terminal, Leaves linear-lanceolate serrate acute

9873 Unarmed, Leaves lanc. acute at each end serrated with hairs at the axillæ, Flowers axillary clustered

2874 Spines terminal, Flowers 4-cleft diœecious, Leaves ovate, Stem erect, Berry 4-seeded

2875 Spines terminal, Flowers 4-cleft diøecious, Stems procumbent

2876 Spines terminal, Leaves linear entire obtuse

2877 Spines terminal, Leaves oblong entire

2878 Branches spiny, Flowers 4-cleft or trifid diœcious, Leaves oblong obtuse evergreen

2879 Spines terminal, Flowers 4-cleft hermaphrodite

2880 Spines terminal, Leaves ovate serrulate, 'Branches divaricating

2881 Leaves ovate entire smooth sessile, Branches square

2882 Unarmed, Leaves lanceolate serrulate acute at each end pubescent beneath

2883 Flowers diceious, Leaves ovate-lanceolate glandular crenulate

2884 Creeping, Flowers hermaphrodite, Leaves stalked ovate crenate

2885 Flowers monogynous hermaphrodite, Leaves entire smooth, Berry 2-seeded

2886 Flowers monogynous hermaphrodite, Cal. villous, Leaves elliptical entire acuminate rounded at base

2887 Flowers hermaphrodite racemose, Leaves ovate bluntly serrated smooth at the base glandular

2888 Flowers polygamous, Style triple, Leaves ovate serrated

2889 Flowers hermaphrodite, Stigma triple, Leaves cordate, Branches with tendrils

2890 Flowers hermaphrodite, Leaves oval acuminate serrated veiny beneath

2891 Flowers hermaphrodite, Leaves oblong acuminate scarcely perennial

2892 Flowers dioecious, Stigma triple, Leaves evergreen elliptical serrated acute at the base obtuse

2893 Flowers diocious, Stigma triple, Leaves evergreen lanceolate acute at each end mucronate toothed

2894 Leaves ovate ribbed veiny repand, Flower-stalks one flowered, Stem erect

2395 Dioecious unarmed, Stem twining, Leaves ovate mucronate repand subcrenate striated

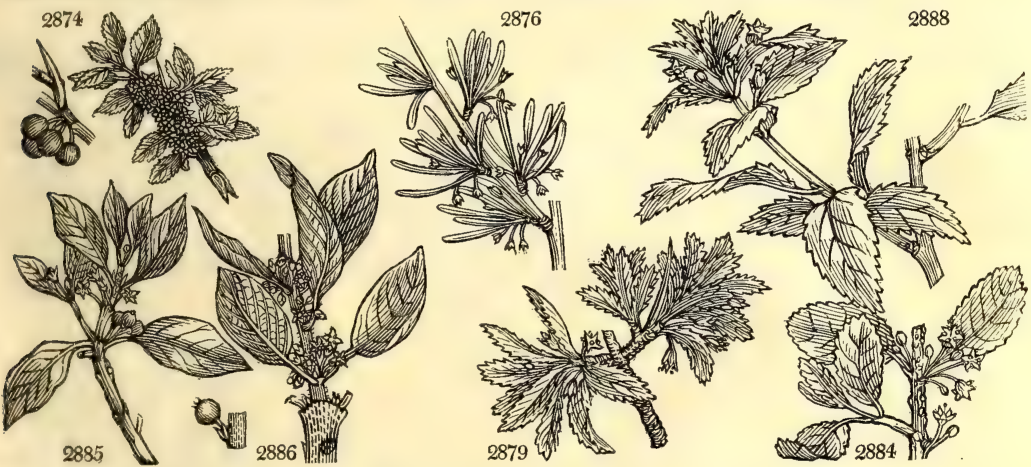

and Miscellaneous Particulars.

town of Rheims are two branches intertwined. R. catharticus was formerly used in medicine, and is stil employed in color-making, and sometimes in dying. The juice of the unripe berries has the color of saffron, and is used for staining maps or paper. They are sold under the name of French berries, as those of $R$. Clusii are, under the name of Avignon berries. The juice of the French berries when ripe, and mixed with alum, is the sap green of the painters ; but if the berries be gathered late in the autumn, the juice is purple. The bark affords a beautiful yellow dye. The inner bark, like that of elder, is said to be a strong cathartic, and to excite vomiting. The berries operate briskly by stool, but occasion thirst and griping. It is said by Woodville that the flesh of birds which feed on them is purgative.

$R$. lycioides furnishes the wood of which the Monguls make their images, on account of its hardness and orange red color.

R. saxatilis greatly resembles R. catharticus. The berries are used to dye the Maroquin or Morocco leather yellow.

R. theezans has leaves like the common tea, which are used as such by the poor of China, and called Tia. (Osbeck.)

R. frangula has dark purple berries, which are purgative, like those of the common buckthorn. Gathered before they are ripe they dye wool green and yellow; when ripe, blue-gray, blue, and green. The bark dyes yellow, and with preparations of iron, black. From a quarter to half an ounce of the inner bark boiled in small beer, is a sharp purge. In dropsies or constipations of the bowels in cattle, it is a very certain purgative. The flowers are particularly grateful to bees. Goats devour the leaves voraciously ; and sheep will eat them. Charcoal prepared from the wood is used by the makers of gunpowder. The berries of this species, and also of the cornus, are said to be brought to market and sold for those of the buckthorn; but they are easily distinguished, the true buckthrn having four seeds, this two, and the cornus one.

$\mathbf{R}$. hybridus is the offspring of $\mathbf{R}$. alpinus and alaternus, first procured by $L$ 'Heritier about 1778 .

$\mathbf{R}$. alaternus is an ornamental evergreen, with mellifluous blossoms, much frequented by bees. It is sometimes confounded with the Phillyrea; but they may be easily distinguished by the position of their leaves, which are alternate in these, but placed opposite by pairs in that. It is a rapid growing shrub, and useful for thickening screens, clothing walls, \&c.

504. CEnoplia. From oivor $\lambda$ v乡, vinous. Its little fruit, full of juice, resembles the berry of a grape. The Rhamnus volubilis and lineatus belong to this genus, and are beautiful little climbing plants, but rather impatient of cold. 
505. PALIU'RUS. Gart. Christ's-THORN. 2896 austrális Gart. 506. ZI'ZYPHUS. $W$. 2897 Lótus $W$ 2898 Napéca $W$ 2899 Jújuba $\boldsymbol{W}$. 2900 vulgáris $W$.

507. CELAS'TRUS. $W$ 2901 lúcida $W$ 2902 bulláta $\dot{W}$ 2903 scándens $W$. 2904 cassinoídes $W$ 2905 tetragóna $\boldsymbol{P}$. S 2006 buxifólia $W$. 2907 pyracántha $W$. 2908 cymósa B.M. 508. SENA'CIA. Lam. 2909 unduláta Lam. 2910 octogóna Lam.

509. EUO'NYMUS. $W$. 2911 japónica $W$. 2912 europæ'a $W$ $\beta$ pumila

2913 verrucósa $\boldsymbol{W}$. 2914 latifólia $W$. 2915 atropurpúrea $W$ 2916 americána $W$. 2917 angustifólia $P h$.

510. CEANO'THUS. W 2918 americána $W$. 2919 intermédia $P h$. 2920 sanguínea $P h$. 2921 microphýlla $P h$. 2922 asiática $\boldsymbol{W}$. 2923 africána $W$ 2924 globulósa $\dot{H}$. $\boldsymbol{K}$. 2925 azúrea Desf.

511. STA'AVIA. $W$. 2926 radiáta $W$. 2927 glutinósa $W$

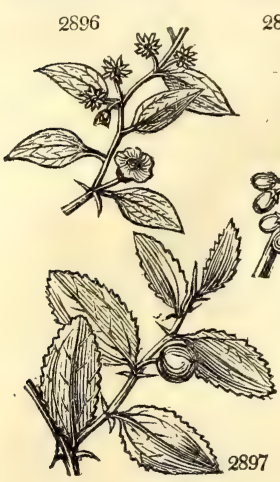

European ZizYPHUS. Lote-tree oblique-leave blunt-leaved common

StafF-TreE. shining Virginian climbing crenated four-sided Box-leaved Pyracantha-lv cymose

Senacia. wave-leaved angular-leave

SPINDLE-TREE

Japan

European dwarf warted broad-leaved purple evergreen narrow-leaved

Ceanothus

New Jerey intermediate red-stalked small-leaved Asiatic African round-headed blue rayed

2898
StTaAVIA.
rayed

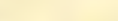

Rhamni. Sp. 1-4.

业 or 4 jn.jl P.G S. Europe 1596. S co Lam. illus, t.210 Rhamni. Sp. 4-38.

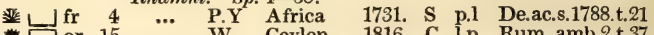

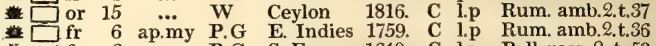

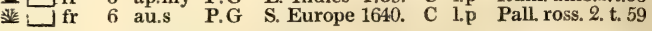
Rhamni. Sp. 8-55

tor 2 ap.s W C. G. H. 1722. C p.l Meerb. ic. 1. t.12 $\underline{B}$ or $20 \mathrm{jl}$ W Virginia 1759. L s.1 Plu. alm t.28.f.5 $B$ or 15 my.jn $W \quad$ N. Amer. 1736. L s.1 Sch.handb.1.t.47 \& $\iota_{\text {or }} 4$ au.s W Canaries 1779. C p.1 L'Her.ser.6.t.10 $\begin{array}{lllllllll}\text { or } & 6 & \ldots & \text { W } & \text { C. G. H. } & 1816 \text {. C } & \text { p.l }\end{array}$

造 or 4 my.jn W C. G. H. 1752. C p.1 Bot. mag. 2114. at or 2 my.jn W C. G. H. 1742, C p.l Bot. mag. 1167 整 1 or 3 jl W C. G. H. 1815. C p.l Bot. mag. 2070 Pittosporea. Sp. 2-4.

$\square$ or $12 \ldots$ W Bourbon 1785. C 1.p L or 6 o.n G Peru 1786. C 1.p Fi. per. 3. t. 229 Rhamni. Sp. 7.

19. Japan 1804. C p.l Kæmpf. ic. t. 8 \$ or 6 my.jn $G$ Austria 1763. L p.l Schm. arb. t. 72 or 10 jn.jl G Austria 1730. L s.l Bot. mag. 2384. or 6 jn.jl Pu N. Amer, 1756. L p.l Schm, arb. t. 73 or 6 jn.j1 Pk N. Amer. 1683. L s.p Schm. arb. t. 75 Rhamni. Sp. 8-20.

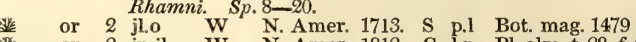
or 2 jn.jl W N. Amer. 1812, C l.p Pl. alm. t. 28. f, 6 or 2 my.jl W Missouri 1812. C 1.p * $\longleftarrow$ or $1 \frac{1}{2}$ jn.jl W N. Amer. 1806. I p.l

1.au Pa.Y Ceylon 1691. C p.l Cav.ic.5.t.440.f.1 or 6 mr.ap W C. G. H. 1712. C p.l Pl, ph.t. 126. f. 1 * 6 ap.my Co N. Holl. 1803. C p.l Lab. no.h.1.t.8

Rhamni? Sp. 2.

n $\_$or 2 my.jn W C. G. H. 1787. C p.l Br. cen. 165.t. 82 L $L_{\text {or }} 3$ ap.my $Y$ C. G. H. 1793. C p.1 Wend. coll. t. 22 
2896 Prickles stipulary twin, one straight one recurved, Leaves ovate crenulate smooth stalked

2897 Prickles twin, one recurved, Leaves ovate oblong obsoletely crenate

2898 Prickles in pairs recurved, Pedunc. corym. Fls. half digynous, Leaves ov. oblique smooth on both sides 9899 Prickles solitary recurved, Leaves rounded ovate obtuse downy beneath, Peduncles aggregate

2900 Prickles in pairs, one recurved, Leaves ovate retuse toothed smooth

2901 Leaves oval acute shining margined smooth, Flowers axillary

2902 Leaves ovate acute, Panicles terminal

2903 Leaves oblong acuminate serrated, Racemes terminal, Stem twining

2904 Leaves ovate acute at each end serrated evergreen, Flowers axillary

2905 Leaves ovate serrated, Branches square

2906 Spines axillary, the larger leafy, Leaves lanceolate obovate serrated obtuse, the younger acute 2907 Spines naked, Branches rounded acute

2908 Spines naked, Branches angular, Leaves obovate serrate toothed, Cymes axillary

2909 Leaves lanceolate stalked wavy at edge, Cymes umbelled terminal, Caps. 2-celled 2-seeded 2910 Leaves elliptical angular nerveless evergreen, Caps. 1-seeded

2911 Flowers 4-cleft, Leaves rounded ovate toothed

2912 Flower-stalks compressed 3-flowered, Flower usually tetrandrous, Leaves oblong-lanceolate smooth

2913 Flower-stalks filiform rounded, Leaves ovate acuminate smooth, Branches warted

2914 Flower-stalks filiform rounded many-fl. Lvs. ovate oblong acuminate, Branches smooth, Petals roundish 2915 Flower-stalks compressed many-flowered, Stigmas square truncated, Lvs. obl. acuminate pubes. beneath 2916 Flower-stalks rounded 3-flowered, Fl. pentan. Lvs. obl. lanc. smooth subsess. acute serr. Branches square 2917 Branches square, Leaves subsessile long linear elliptical subfalcate entire, Fruit warted

2918 Leaves ovate oblong acute subcordate serrate 3-nerved beneath soft with hairs, Corymbs contracted 2919 Leaves oblong acuminate mucronate serrulate 3-nerved, Corymbs loose

2920 Leaves obovate serrated pubescent beneath, Panicles on very short stalks, Branches deep red

2921 Decumbent smooth, Leaves very small in bundles oblong entire, Corymbs of the branches terminal 2922 Leaves ovate acuminate veiny, Cymes axillary

2923 Leaves lanceolate obtuse netted with veins, Panicle terminal

2924 Leaves obovate tomentose beneath, Heads of flowers in panicles

2925 Leaves oblong somewhat cordate serrate tomentose beneath, Racemes compound stalked

2926 Leaves lanceolate 3-cornered spreading, Ray of calyx shorter than the head

2927 Leaves linear lanceolate 3-cornered spreading, Ray of calyx longer than the head

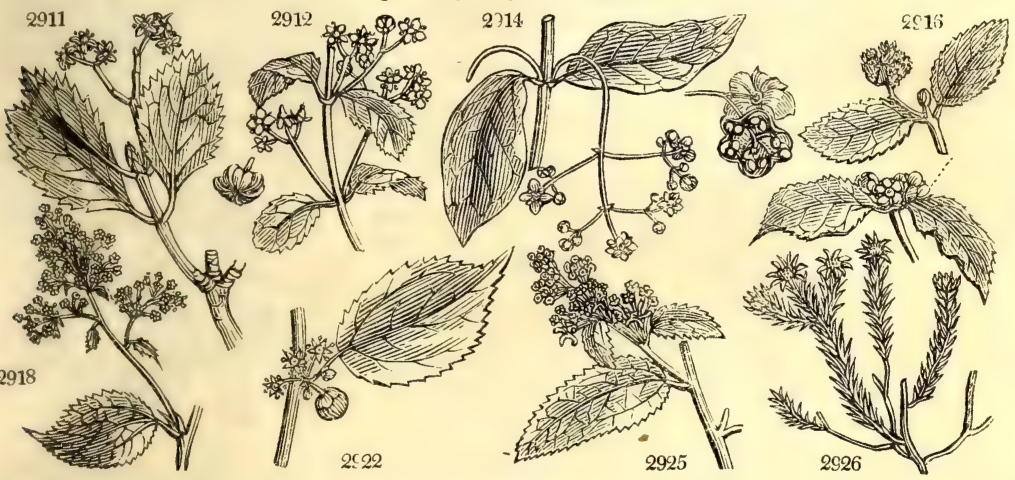

and Miscellaneous Particulars.

Z. jujuba is a middle-sized tree, with ovate leaves, pale yellowish flowers, and red oval fruit, about the size of olives, inclosing a stone of the same shape. They are sweet, and eaten in the East Indies and China.

$Z$. vulgaris is a middle-sized branching tree, bearing a saffron-colored drupe shaped like an olive, but smaller.

The plant grows wild in Calabria, and is cultivated in other parts of Italy, and in Spain. The fruit is eaten green or dried as a sweatmeat. It is common in China, Japan, Syria, \&c. and is said to have been first introduced into Italy from the latter country in the time of Augustus. All the species are readily increased by ripened cuttings planted under a hand-glass.

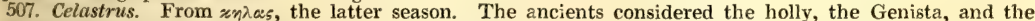
Celastros, the trees which ripened their fruit latest. The Celastros of the ancients is thought to have been a kind of Euonymus, to which this genus is nearly allied. It consists of shrubs or small trees, with alternate leaves, and numerous small flowers. The plants are of easy culture, but of no great beauty.

508. Senacia. A genus divided by M. de Lamarck from Celastrus, and founded upon the Celastrus undulatus of L'Heritier.

509. Euonymus. From $\varepsilon v$, well, and ovouse, a name, well named. The application of the name is, however, obscure to us. Euonymus was also a Heathen divinity; according to Epimenides she was the mother of the Furies by Saturn. Fusain, or Bonnet de Prêtre, Fr., Spindelbaum, Ger., and Fusaggine, Ital. The species form neat little trees of no great beauty or use. E. europæa is called prick-wood, from the use of the wood for.merly as skewers. E. americana best merits culture, and next, E. latifolia. They are easily increased by seed or ripened cuttings.

510. Ceanothus. Keovw wos is a name used by Theophrastus to designate a prickly plant, from «sw, to prick. This is a genus of North American plants, one species of which, $C$. americana, is very common in gardens. The leaves are dried in Carolina and used as tea, and the root to dye wool a Nankeen cinnamon color. The

511. Staavia. Named after Martin Staaf, a correspondent of Linnæus, Little Cape shrubs, with heads of
51tecies are of the easiest culture, but of very little beauty. flowers resembling those of some compound plant. Young cuttings in sand, and covered with a bell, soon strike root. 
512. POMADER'RIS. Lab. Pomaderris. 2928 apétala $\boldsymbol{H} . \boldsymbol{K}$. 2929 elliptica $\boldsymbol{H} . \boldsymbol{K}$. 2931 phylicifólia Lodd. apetalous oval-leaved woolly Phylica-leaved or

515. MANGI'FERA. $W$. Mango-TreE. 2932 indica $W$. Indian
Rhamni. Sp. 4.

7 my.jn Pa.Y N. Holl. 1803. C s.p Lab. no. h. 1.t.87 10 my.jl Pa.Y N. Holl. 1805. C s.p Bot. mag. 1510 ap.jn PaY N Holl 1806. C s.p Bot. mag. 1823 ap.jn Pa.Y N. Holl. 1819. C s.p Bot. cab. 120

Terebintacea. Sp. $1-3$.

20 jn.s R.G E. Indies 1690. S r.m Bot. rep. 425 Celastrince. Sp. 1.

514. SCHRE'BERA. Retz. Schrebera. 2933 álbens Retz. whitish

$6 \quad \ldots \quad G$ Ceylon 1824, C p.1 N. ac. h. 2. t.4.f.1 515. BILLARDIE'RA. Sm. APPle-BerrY. 2934 scándens $W$. 2935 mutábilis $H$. $K$. 2936 longiflóra $L a b$. 2937 fusifórmis $L a b$.

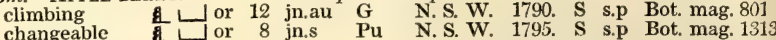
Pittosporea: Sp. 4. blue berried or 20 jn.s G V. Di. I. 1810. S s.p Bot. mag 1507 spindle-fruited f $\square$ or 8 jn.au B V. Di. L. 1823. S s.p Lab. n. h.1.t.90 516. ELEODEN'DRUM. $W$. OLIVE-WOOD. 2938 A'rgam $W$. 2939 orientále $W$ 2940 austrále $H$. $K$ spiny $15 \mathrm{jl}$, or 15 . Sp. 3-6.

2940 australe thick-leaved

I or $15 \mathrm{jl}$ G.Y Morocco 1711. C 1.p Com.hor. 1.t. 83 2941 oppositifólia $W$. 2941 oppositifólia 2943 hirsúta $W$. 2944 pectináta $W$. en. 2945 ericoídes $W$. 2946 cupressina $W$. 2947 tenuifólia $W$. en 2948 succulénta $W$.en. 2949 capitáta $W$.

Diosma.

opposite-leaved linear-leaved hairy-leaved pectinated

Heath-leaved Cypress-leaved slender-leaved succulent-lyd. pale-purple

en. ADENANDRA. one-flowered

2950 uniflóra $W$, en. 2950 uniflora $W . e n$. 2952 frágrans $B, M$. 2953 álba $T h$.

2954 margináta $T / 2$ tor or red white-flowered $\downarrow$ or margined or

519. BARYOS'MA. W. en. BARYosma. 2955 serratifólia $W$. saw-leaved 2956 latifolia $W$. broad-leaved

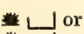

mr.jl
Diosm Diosmea. Sp. $9-36$.

W. S. W. 1796. C s.l Vent. malm. 117

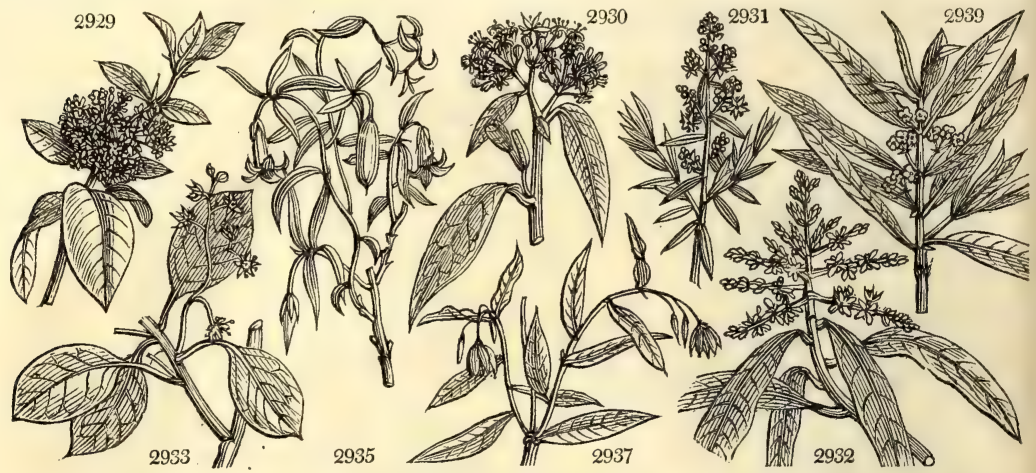

History, Use, Propagation, Culture,

512. Pomaderris. From $\pi \tilde{\omega} \mu \alpha$, a lid, and $\delta \varepsilon p \rho j s$, a skin, on account of the membranous lid with which the cells of the capsule are covered. New Holland shrubs, with the habit of Ceanothus, from which they are distinguishable only by their fruit. Cuttings root freely in sand under a hand-glass.

513. Mangifera. From Manga or Manghos, the vernacular name of the fruit, and fero, to bear. This is a large spreading tree, bearing a fruit in great estimation in the East. 'The wood is brittle, brown, and used only for indifferent works. The leaves are seven or eight inches long, and two or more broad, lanceolate, entire, of a shining green, and sweet resinous smell. The flowers are produced in loose bunches at the ends of the branches. The fruit is a berried drupe, large, flattened like a lens, kidney-shaped; the flesh soft and pulpy, like a damascene plum ; the shell almost kidney-shaped, of a leathery crustaceous substance, and onecelled This fruit, when fully ripe, is yellow and reddish, replete with a fine agrecable juice : some are full of fibres, and the juice runs out of these on cutting, or with a little handling; but those which have few or no fibres are much the finest; they cut like an apple, but are more juicy, and some are as big as a large man's fist. It is esteemed a very wholesome fruit, and, except very fine pine-apples, is preferable to any fruit in India; gentlemen there eat little other fruit in the hot months; but if no wine be drank with it, the Mango is apt to throw out troublesome boils, at least with new comers, which are, however, conducive to health. In Europe we have only the unripe fruit brought over in pickle.

Loureiro remarks, that there are many varieties, differing chiefly in the figure, size, color, and taste of the fruit, as apples and pears do in Europe. Retzius, on the contrary, affirms, that there are certainly several distinct species; the number of stamens in some being double; the racemes in others compound ; the fruit kidney. shaped, globular, fleshy, almost juiceless, \&c.

According to Sweet, " the Mango ripens fruit in this country, when the plants are of a good size. Sandy loam, or a mixture of loam and peat, is most suitable to it, and the pots should be well drained, as the plants are apt to get sodden with too much water. Fresh seeds from the West Indies vegetate freely. The plant may also be increased from cuttings, which root best in sand under a hand-glass." (Bot. Cult. 77 .)

Knight, Hallet, and some other horticulturists are at present cultivating this tree with a view to its fruit. Knight recommends for such trees, training the shoots downwards, and at no great distance from the glass. There are trees in the garden of Earl Powis which must bear very soon.

514. Schrebera. Named after John Chr. Daniel Schreber, a German botanist, chiefly known by an edition of 
2928 Leaves ovate-oblong doubly-serrated tomentose beneath, Flowers apetalous in racemes 2929 Leaves oval tomentose beneath, Heads of flowers in umbels panicled

2930 Cymes panicled terminal, Leaves ovate lanceolate entire coriaceous rusty beneath

2931 Leaves linear, Flowers in axillary clusters as long as leaves

2932 Leaves lanceolate wavy, Panicles terminal many-flowered, Stamen 1

2983 The only species

2934 Peduncles solitary 1-flowered, Leaves somewhat hairy

2935 Leaves lanceolate linear, Peduncles solitary 1-flowered smooth, Fruit smooth

2936 Leaves smooth, Cor. cylindrical, Peduncles solitary 1-fl. Petals very long rolled inwards at edge 2937 Panicles few-flowered, Leaves somewhat hairy, Anthers connivent

2938 Branches spiny, Leaves ovate obtuse

2939 Leaves lanceolate acute with red veins

2910 Leaves elliptical coriaceous toothletted, Petals and stamens four

2941 Leaves 3-cornered obtuse ciliated, Flowers terminal

2942 Leaves linear obtuse smooth spreading, Flowers terminal solitary

2943 Leaves linear carinate mucronate villous, Peduncles 1-flowered terminal corymbose

2944 Leaves 3-cornered acute dotted ciliated

2945 Leaves 3-cornered obtuse smooth, Flowers terminal solitary

2946 Leaves oblong lanceolate carinate appressed rough at edge, Flower terminal nearly solitary

2947 Leaves linear carinate mucronate ciliated upright, Peduncles 1-2 flowered corymbose terminal

2948 Leaves linear carinate acute thickish fringed upright, Flowers terminal subsessile solitary or 4 together

2949 Leaves 3-cornered villous-hispid imbricated, Flowers in spiked heads

2950 Leaves lanceolate smooth, Flowers terminal solitary, Calyxes fringed

2951 Leaves oblong smooth ciliated, Flowers terminal in umbels, Calyxes smooth

2952 Leaves ovate oblong glandular scattered, Peduncle glutinous aggregate terminal twice as long as leaves

2953 Leaves linear carinate mucronate at the edge cartilaginous and rough, Flowers axillary and solitary

2954 Leaves cordate, Lower ovate, Upper lanceolate, Umbels terminal

2955 Leaves linear lanceolate serrulate

2956 Leaves ovate crenate pubescent, Peduncles lateral 1-flowered, Branches downy

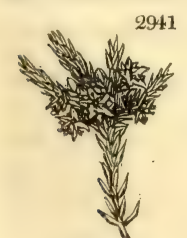

2950

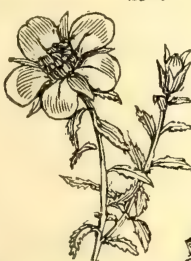

6)
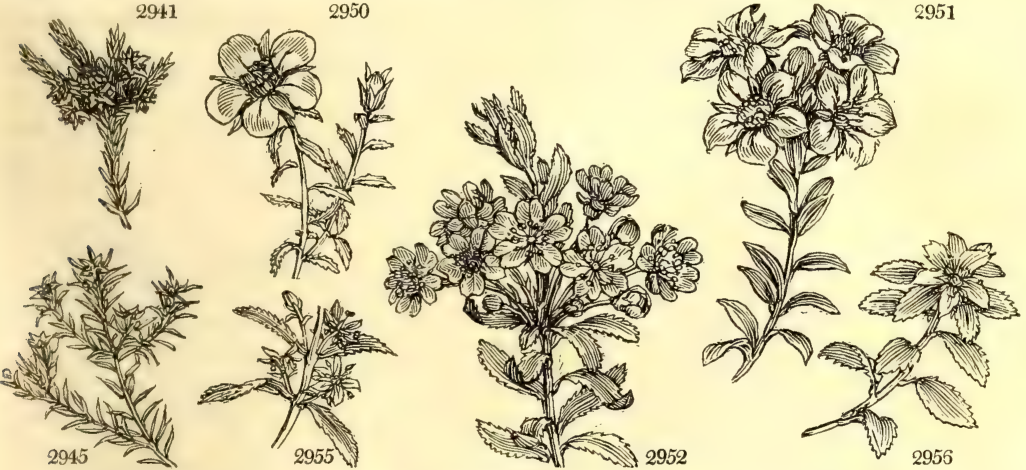

and Miscellaneous Particulars.

Linnæus's Genera Plantarum, which he published in 1789, in which he unadvisedly altered all the names of Aublet, without ever having seen the plants.

515. Billardiera. Named in honor of Jacques Julien Labillardiére, a French botanist, who visited Syria, and afterwards New Holland, in D'Entrecasteaux's expedition. His reputation as a botanist was almost annihilated by the Prodromus Novæ Hollandiæ of Brown. The species of this genus are desirable as climbers for a conservatory, especially B. longiflora, which is a fast grower and an abundant flowerer; and when in fruit, its fine blue berries make a handsome appearance. They thrive well in an equal portion of loam and peat ; and cuttings root readily in sand under a bell-glass : they may also be raised from seeds, which are produced in abundance. (Bot. Cult. 149.)

516. Elcodendrum. From $\varepsilon \lambda \alpha \iota \alpha$, an olive, and $\delta \varepsilon y \delta \rho \diamond$, a tree; a tree resembling an olive. E argam furnishes an oil by expression from the fruit as in the common olive: it is used at table by the Moors, and in various works by Europeans. The tree is rather tender, and requires protection during winter.

E. australe, and the stove species, "grow freely in a mixture of loam and peat; and ripened cuttings will soon root in sand under a hand-glass." (Sweet.)

517. Diosma. From $\delta 105$, divine, and ofur, smell; that is to say, a smell divine among the Hottentots, who rub their greasy bodies with the powdered leaves of all the species, which they call Bucku. To Europeans the smell is unpleasant. This is a genus of handsome shrubs, bearing a general resemblance to heaths, but with larger leaves. The flowers are in corymbs at the ends of the branches. D. ericoides, and other species, are the kinds chierly used by the Hottentots to scent the ointments with which they anoint their skin. Young cuttings root freely in sand under a bell-glass.

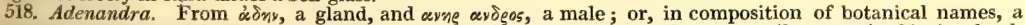
stamen; on account of the appendage of the stamens. This is a very natural genus, easily recognized by its glandular anthers. Sweet "found it succeed best in sandy peat, but some prefer mixing a little sandy loam with it. The young tender tops strike best, made into cuttings, and planted in a pot of sand under a bell-glass : it does not require to be plunged in heat." (Bot. Cult. 127.)

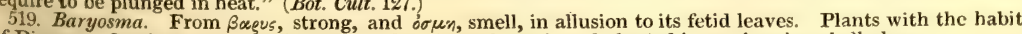
of Diosma. Cuttings root readily, taken off in ripened wood, and planted in sand under a bell-glass.

$$
\text { N S }
$$


520. AGATHOS'MA. W. en. Agathosma. 2957 hispidum $W$. 2958 ciliátum $W$. 2959 villósum $W$

2960 imbricátum $W$.

2961 acuminátum $\boldsymbol{W}$. 2962 cerefólium $V e n$. 2963 pubéscens $W$. en 2964 crenátum $W$. 2965 ovátum $W$. 2966 pulchéllum $W$. 2967 rúbrum $W$. 2968 tetragónum $W$. 521. NAU'CLEA. $W$. 2969 orientális $W$. 522. PITTOS'PORUM. 2970 coriáceum $\boldsymbol{W}$. 2971 viridiflórum $B$. $M$. 2972 Tobíra $\boldsymbol{H} . \boldsymbol{K}$ 2973 undulátum $\boldsymbol{H}$. $\boldsymbol{K}$. 2974 revolútum $H$. $K$. downy-leaved 503. 2976 parviffórum $L, T$. small-flowered $L$ or 2977 ferrugíneum $\dot{B} . \dot{R}$. rusty or

524. THOMA'SIA. Gay. Thomasia. 2978 purpúrea Gay. 2979 solanácea Gay. 2980 quercifólia Gay. 525. SERIN'GIA. Gay. 2981 platyphýlla Gay.

526. BUTTNERIA. $W$. 2982 scábra $\boldsymbol{W}$. 2983 microphýlia $W$.

527. AYE'NIA. $W$. 2984 pusilla $W$ lævigáta $\boldsymbol{P}$. S. crenated blunt-leaved square-branch. NAUCLEA. oriental

V. Pittosporum thick-leaved green-flowered glossy-leaved ty-leaved

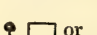

Diosmea. Sp. 12.

ciliated $\begin{array}{lllllll}\text { or } & 1 & \text { jn.au } & \text { V } & \text { C. G. H. } & \text { 1786. C } & \text { p.l }\end{array}$

shaggy $\quad$ or $1 \frac{1}{2}$ jn.au V C. G. H. 1786. C p.l We. co.pl. 1.t. imbricated J or 3 ap.jn Pk C. G. H 1774 C pl We co pl 1. acuminate or 5 ap.jn V C. G. H. 1812. C p.1 We.co.pl.1.t.28 Chervil-scented $L$ or 2 ap.jn W C. G. H. 1790. C p.I Vent. malm.93

0 ... Y E. Indies 1800. L r.m Rhe. mal, 3.t. 33 Pittosporea. Sp. 6-11.

$10 \mathrm{my}$ B Madeira 1787. I. p.l Bot. rep. 151

6 my.jn G $\quad$ C. G. H. 1806. C p.l Bot. mag. 1684

6 mr.au W China 1804. C p.l Bot mag 1396

3 f.jn W.y N.S. W. 1789. C s.p Bot. reg. 16

6 f.ap $Y$ N. S. W. 1795. G s.p Bot. reg. 186

6 f.my Y Guinea 1787. G s.p

Büttneriacea, Sp.

3 ap.jl Br N. Holl. 1810 C 1.p L.t.v. 10.t.19.f? 4 ap.jl $\quad Y \quad$ N. Holl. 1791. C s.p Bot. mag. 1766

\section{Büttneriacece. Sp.3.}

purple 酒 $ـ$ or 3 ap.jl Pu N. Holl. 1803. C s.p Bot. mag. 1755 Solanum-like ${ }^{-}$or 3 ap.jl Pu N. Holl. 1803. C s.p Bot. mag. 1486 oak-leaved 造 $\square_{\text {or }} 3$ ap.jl Br N. Holl. 1803. C s.p Bot. mag. 1485 Büttneriacea. Sp. 1.

Nettle-tree-lvd, J or 12 ap.jl W N. Holl. 1802. C s.p Mem. mu. vol.7 Buttneria. Biittneriacea. Sp. 2-14.

rough-leaved $\square \mathrm{cu} \quad 6 \mathrm{jl} \quad \mathrm{Pu} \quad$ W. Indies $1793 . \quad \mathrm{C}$ p.l Ca.d. 5.t.148.f.1 small-leaved $\square \mathrm{cu} 5$... W.pu S. Amer. 1816. C 1.p Ca.d.5.t.148. f.2 Ayenia. $\quad$ Malvacea. Sp. 2-4.

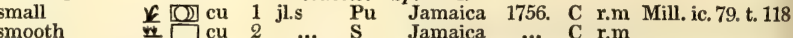
528. CALODEN'DRUM. $W$. CAlodendrum. Rutacea. Sp. 1

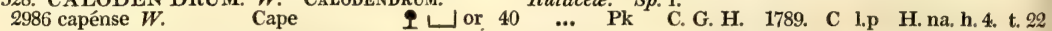
529. TODDA'LIA. Lam. ToDnalia. 2987 asiática Lam. prickly Scopolia aculeata Sm.

530. BURSA'RIA. Cav. Bursaria. 2988 spinósa Cav. thorny

* $\square$ or $6 \begin{gathered}\text { Terebintacea. Sp. } 1-5 . \\ \text {... W }\end{gathered}$

\section{Pittosporea. Sp. 1.}

y or 10 au.d W N. S. W. 1793. C s.p Bot. mag. 1767 531. CEDRE'LA. $W$. BASTARD-CEDAR. 2989 odoráta $W . \quad$ Barbadoes $\$$ tm 50 Cedrelea. Sp. 2. ... Pk W. Indies 1739. C l.p Br.ja.158.t.10.f.1

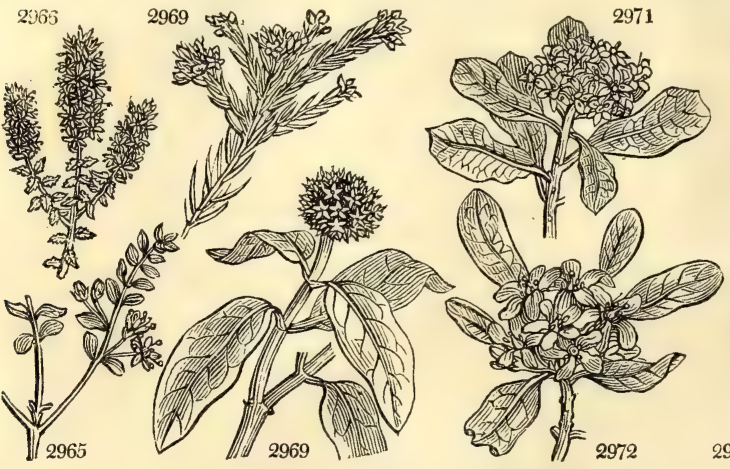

History, Use, Propagation, Culture,

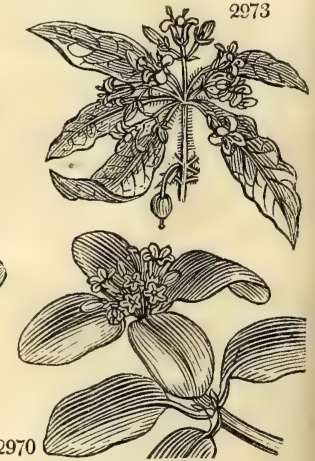

520. Agathosma. From araios, good, and ookn, smell; to be understood as Diosma. This genus resembles that, and requires the same culture. The Hottentots use the leaves of A. pulchella dried and powdered, under the name of $B u c k u$, to mix with the grease with which they anoint themselves. It gives them so rank odor, that Thunberg says, he sometimes could not bear the smell of the men who drove his waggon.

521. Nauclea. A noble genus of Rubiaceous plants, bearing their flowers in round heads. The meaning of the name is nowhere explained. One species, N. Gambir, is said to yield the gamboge gum of the shops.

522. Pittosporum. From $\pi t \tau \tau \eta$, resin, and $\sigma \pi \circ \circ \circ$, a seed. The capsule is resinous. These are handsome shrubs, with good foliage and pretty flowers. P. tobira, a native of Japan, is nearly hardy. Ripened cuttings root freely in sand under a hand-glass, or one species may be grafted on another.

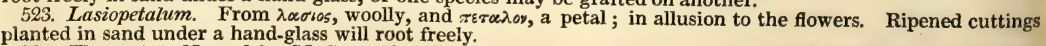

524. Thomasia. Named by M. Gay, after M. Thomas, an industrious collector of Swiss plants. Divided lately from Lasiopetalum.

525. Seringia. Also named by M. Gay; in honor of M. Seringe, an ingenious Swiss botanist, author of Melanges de Botanique, and other useful works. Divided from Lásiopetalum, with which it agrees in habit and appearance.

526. Büttneria. David Sigismond Augustus Büttner, was a professor of botany at Gottingen, who published, 
2957 Leaves 3-cornered blunt villous hispid spreading, Umbels terminal 2958 Leaves lanceolate carinated ciliated, Umbels terminal

2959 Lvs. aggregate linear lanceolate channelled glandular villous imbricated, Heads of branches terminal

2960 Leaves aggregate ovate acuminate imbricated dotted fringed, Heads of branches terminal umbelled

2961 Leaves alternate aggregate subcordate acuminate pubesc. dotted, Flowers in terminal umbelled branches

2962 Leaves imbricate spreading lanceolate ciliated, Heads terminal, Five stamens sterile.

2963 Leaves aggregate oval obtuse glandular ciliated spreading, Heads of branches terminal

2964 Leaves ovate crenate dotted beneath, Flowers axillary solitary

2965 Leaves opposite smooth ovate entire revolute at edge beneath rusty with dots

2966 Leaves ovate glandular-crenate smooth, Flowers axillary in pairs

2967 Leaves 3-cornered mucronate smooth below dotted in two rows, Segments of calyx smooth

2968 Leaves ovate carinate ciliated imbricated 4 ways, Flowers terminal solitary

2969 Leaves oblong acute, Peduncles equal, Stamens the length of corolla

2970 Leaves ohovate obtuse smooth coriaceous, Capsules 2-valved

2971 Leaves obovate blunt shining netted beneath, Panicle globose terminal

2972 Leaves obovate obtuse smooth coriaceous, Capsules 3-valved

2973 Leaves oval lanceolate narrowed at each end and stalks smooth, Peduncles of the branches terminal

2974 Leaves elliptical obtuse pubescent beneath revolute at the edge

2975 Leaves elliptical acuminate smooth, Leafstalks rusty with down

2976 Sepals smooth inside

2977 Sepals hoary on both sides

2978 Leaves linear elliptical entire, Stipules leafy, Petals 5, Stamers

2979 Petals 5, Stamens 10

2980 Leaves 3-lobed beneath hispid downy, Petals $\mathbf{O}$

2981 Leaves ovate lanceolate coarsely toothed

2982 Leaves lanceolate toothed hastate at base, Rachis stem and leafstalks angular prickly

2983 I eaves elliptical entire emarginate, Prickles stipulary, Branches wavy smooth

2984 Leaves cordate smooth

2985 Leaves ovate entire smooth, Ovary stalked, Nectary 10 cleft rayed

2986 Leaves ovate obtuse entire with parallel veins, Flowers terminal panicled

2987 Stem branches and leaves prickly, Leaflets ovate lanceolate subserrated

2988 Stem spiny, Leaves emarginate, Flowers racemose

2989 Cal. and cor. naked

$2990 \mathrm{Cal}$, and cor. fringed

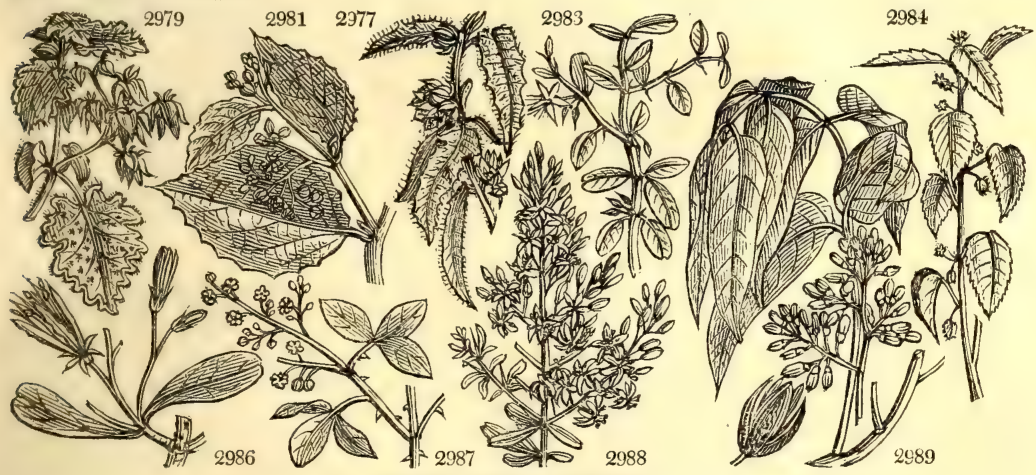

and Miscellaneous Particulars.

in 1750, a catalogue of the plants in the garden of an amateur named Cunon. Ripened cuttings planted in sand under a hand-glass will root freely.

527. Ayenia. In honor of the Duke D'Ayen, of the house of Noailles. He was a great patron of botany. Cuttings root freely in sand in a moist heat.

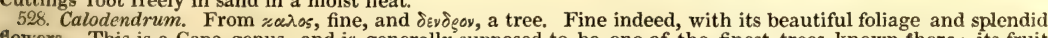
flowers. This is a Cape genus, and is generally supposed to be one of the finest trees known there; its fruit bears great resemblance to a chestnut, but seldom arrives here perfect. It grows freely in an equal mix ture of loam and peat; and ripened cuttings root readily in pots of sand under a hand-glass. (Bot. Cult. 159.)

529. Toddalia. Kaka Toddali is the Malabar name of the shrub. Cuttings root readily in sand under a bell-glass.

530. Bursaria. From bursa, a pouch; the capsules resemble those of Thlaspi Bursa Pastoris so much, that Labillardiere fancied he had found a cruciferous tree when he discovered the plant in New Holland. "This is a pretty plant. It is very desirable for a greenhouse or conservatory, being an abundant flowerer, and very showy when covered all over with its elegant little white flowers; an equal mixture of sandy loam and peat is the best soil for it ; and young cuttings are not difficult to root in sand under a bell-glass." (Bot. Cult. 155.)

531. Cedrela. From cedrus, the cedar-tree. The wood of plants of this genus is one of the kinds of cedar of commerce. All that comes from New Holland in the form of packing cases, is supposed to be the wcod of a spe- 
532. HOVENIA. Th. 2991 dúlcis $T h$. 2992 acerba Lindl.

533. BRU'NIA. $W$. 2993 nodiflóra $W$. 2994 paleácea $W$. 2995 lanuginósa $W$. 2996 verticilláta $W$. 2997 deústa $T h$. 2998 microphýlia $T h$. 2999 láxa Th.

3000 alopecuroídes $T h$. 3001 abrotanoídes $W$. 3002 supérba Donn. 3003 fragarioídes $W$ 3004 ciliáta $\boldsymbol{L}$ 3005 ericoídes $\boldsymbol{W e n d l}$. 3006 phylicoídes $T h$.

\section{BROSSE'A. $L$} 3007 coccínea $L$

535. I'TEA. $L$ 3008 virgínica $W$.

536. CYRIL'LA. $L$. 3009 caroliniána $P h$.

537. CLAYTO'NIA. W 3010 virgínica $\boldsymbol{P h}$. 3011 caroliniána $\boldsymbol{H}$. $\boldsymbol{K}$. 3012 lanceoláta $P h$. 3013 sibírica $W$ 3014 alsinoídes $P h$. 3015 perfoliáta Donn.
Hovenia. sweet sour

Brunia. imbricated chaffy woolly whorled black-tipped small-leaved spiked

Fox-tail superb Strawberry-lik ciliated heathy Phylica-like

Bross.ea. scarlet

ITEA.

Virginian

Cyrilla.

Carolina
Thyme-leaved

Virginian

spatula-leaved spear-leaved Siberian

Chickweed-like small-flowered

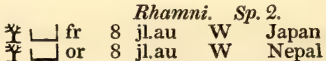

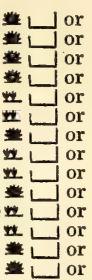

jl.au W C. G. H.

1786. C p.l Bre.cent.22.t.10 jn.au

jn.au

jn.au

jn.au

2 jn.au

$1 \frac{1}{2}$ my.jl

4 my.jl

1 my.jl

my.jl

3 jl.au
1812. C p.1 Bot. mag. 2360
C. G. 1774. C p.l Bot. cab. 572

C. G. H. 1794. C p.l

C. G. H. 1804. C p.

C. G. H. 1804. C p.

C. G. H. 1805. C p.

C. G. H. 1816. C p.

C. G. H. 1787. C p.1 Bot. cab. 355

C. G. H. 1791. C p.l

C. G. H. 1794. C p.

C. G. H. 1805. C p.l
Rhamni. Sp. 14-24.

,. C p.1 Bot. reg. 501

$\begin{array}{lllll}\text { C. G. H. } & 1812 . & \text { C } & \text { p.1 } & \\ \text { C. G. H. } & \text { 1804. } & \text { C } & \text { p.1 } & \text { Wend.coll.2.t.57 }\end{array}$ Ericece. Sp. 1.

* $\square$ or $\quad 4 \quad \ldots \quad$ S $\quad$ S. Amer. $\quad$... $\quad$ C 1.p Plum, ic. 64. f. 2 Ericea. Sp. 1.

or 6 jn.au W N. Amer. 1744. L s.p Bot. mag. 2409 Ericea. $S p .1$.

* $\downarrow$ or 6 jn.au W Carolina 1765. C 1.p Bot. mag. 2456 Portulacea. Sp. 6-11.

7) $\Delta$ pr $\frac{1}{2}$ mr.my St N. Amer. 1748. D s.p Bot. mag. 941

7 $\triangle$ pr $\quad \frac{1}{4}$ mr.my Pk N. Amer. 1789. D s.p Par. Iond. 71

妾 $\Delta$ pr $\frac{1}{2}$ mr.my W N. Amer. 1812. D p.l Pursh.am. 1. t.3

O pr $\quad \frac{1}{4}$ my.au R R Siberia 1768. S p.l Bot. mag. 2243

O cu $\frac{1}{4}$ mr.jn W Nootk. Sd.1794. S p.l Bot. mag. 1309

$\frac{1}{2}$ my.au W N. Amer. 1794. S s.p Bot mag. 1336

Balsaminea. Sp. 4-16

538. IMPA'TIENS. $W$. Balsam. 3016 Balsámina $W$. garden 3017 coccinea $H, K$ 3018 biflóra $P h$. glandular-leav. two-flowered

Touch-me-not

\section{[0] or 3 jl.o $\quad$.}

E. Indies 1596. S r.m Blackw. t. 583 $\mathrm{O}$ or 2 jn.s $\mathbf{R} \quad$ E. Indies 1808. S r.m Bot. mag. 1256 $\mathrm{O}$ or 2 jn.s $\mathrm{O}$ N. Amer, ... $\mathrm{S}$ r.m Sweet fl. g. 43 $\mathrm{O}$ or 2 jn.s $\quad \mathrm{Y}$ England w.s.pl. S s.p Eng. bot. 937
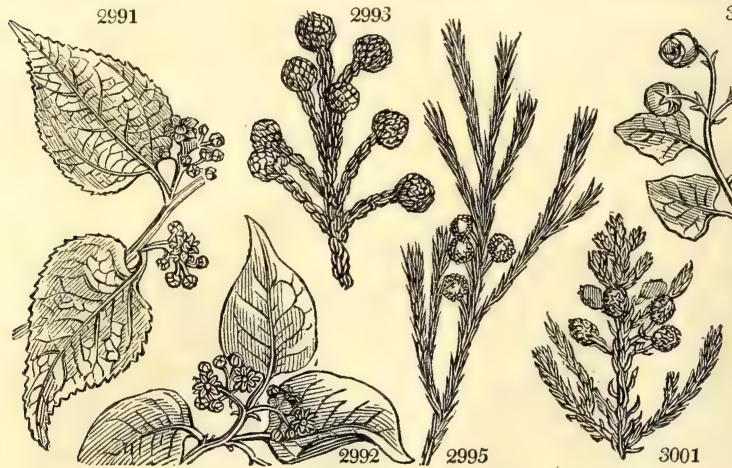
3007

History, Use, Propagation, Culture,

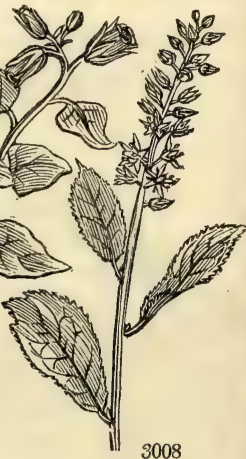

3008

cies of Cedrela. This tree shoots out many side branches towards the top, which are furnished with winged leaves, composed of 16 or 18 pair of leaflets, so that they are sometimes near three feet long. The flowers are on a branching raceme, and the fruit a woody capsule about the size of a pigeon's egg. The bark, leaves, and fruit have, when fresh, a smell like assafœetida, but the timber has a pleasant smell. In the British West India islands the tree has the common name of cedar. The trunk is so large as to be hollowed out into canoes and periaguas, for which purpose it is extremely well adapted; the wood being soft, it may be cut out with great facility, and being light, it will carry a great weight on the water. There are canoes in the West Indies which have been formed out of these trunks forty feet long and six broad: the wood is of a brown color, and has a fragrant odor, whence the title of cedar has been given to it. It is frequently cut into shingles for covering houses, and is found very durable; but as the worms are apt to eat this wood, it is not proper for building ships, though it is often used for that purpose, as also for sheathing of ships. It is often used for wainscoting of rooms, and to make chests, because vermin do not so frequently breed in it, as in many other sorts of wood, this having a very bitter taste, which is communicated to whatever is put into the chests, especially when the wood is fresh; for which reason it is never made into casks, because spirituous liquors will dissolve part of the resin, and thereby acquire a very bitter taste. Cuttings of Cedrela strike root under a hand-glass in sand.

532. Hovenia. Named after David Hoven, a Dutch commissary in Japan, who gave facilities and encouragement to Thunberg while in that country. A small tree, nearly hardy. Its fruit is eaten in China and Japan, and is said to resemble a Bergamot pear in taste.

533. Brunia. So named after Cornelius Brun, a traveller into the Levant and Russia at the end of the last and beginning of the present century. This, Sweet observes, "' is a pretty Cape genus; its species are pretty bushy shrubs, with heath-like leaves, and are handsomest while young. The flowers are not so showy as in many other genera, but some of them are very elegant. A sandy peat soil suits them best, with a moderate supply of water; and young cuttings planted in sand under a bell-glass will strike root freely." (Bot. Cult. 153.)

534. Brossaea. Gui de la Brosse was physician to Louis XIII, and in 1626 procured the establishment at Paris of the Jardin des Plantes, of which he was the first director. A very doubtful plant. It is said to be a shrub like a Cistus, with scarlet fiowers half an inch long.

535. Itea. From irea, the Greek name of the willow. The name Salix having been given to the modern willow, that of Itea has been applied to a plant resembling the willow in leaves and place of growth. This is a handsome plant which thrives well either in peat-soil or sandy loam, and is increased by layers. 
2991 Fruit sweet fleshy, Leaves glabrous a little shining 2992 Fruit austere, Leaves downy quite opaque

2993 Leaves 3-cornered incurved acute, Flowers terminal on the lateral branches 2994 Leaves 3-cornered brown at end, Chaff of the heads exserted colored

2995 Leaves half round erect-spreading withered at end at the base and branches hairy, Heads round latera 2996 Leaves 3-cornered obtuse smooth, Heads terminal, Branches whorled clustered

2997 Leaves 3-cornered black at the end smooth, Heads terminal

2998 Leaves ovate 3-cornered fleshy smooth, Heads terminal, Branches divaricating

2999 Leaves 3-cornered and spiked, Flowers smooth

3000 Leaves 3-cornered acute smooth, Heads lateral globose smooth

\$001 Leaves linear-lanceolate reflexed spreading : their edge fringed at base, Heads terminal corymbose

3002 Leaves half rounded spreading incurved hairy at the end with a withered beard

3003 Leaves 3-cornered appressed ciliated at edge

3004 Leaves ovate acuminate ciliated. A very doubtful species

3005 Leaves short acute 3-cornered at the end spreading fuscous and callous, Heads round at end of branches 3006 Leaves ovate convex imbricated, Heads terminal hairy

S007 A little shrub like a Cistus, with ovate stalked alternate pale-green leaves

3008 Leaves ovate acute serrated, Spikes pubescent

3009 Leaves wedge-lanceolate acute membranous nerved, Spikes slender

3010 Leaves very long linear, Petals entire

3011 Leaves short oval abruptly narrowed into the stalk

3012 Leaves lanceolate, Raceme solitary elongated, Root tuberous

013 Leaves nerved: radical and cauline ovate, Raceme1-sided, Petals bifid

3014. Radicai leaves spatulate ovate : cauline ovate distinct, Root fibrous

3015 Radical leaves spatulate rhomb-shaped: cauline perfoliate

S016 Flower-stalks clustered, Leaves lanceolate : the upper alternate, Spur shorter than flower

3017 Leaves alternate oblong oval serrated, Leafstalks with many glands, Spur incurved as long as flower 3018 Flower-stalks generally 2-flowered, Leaves ovate serrated, Flowers orange-brown spotted inside 3019 Flower-stalks clustered, Leaves ovate, Points of stem tumid

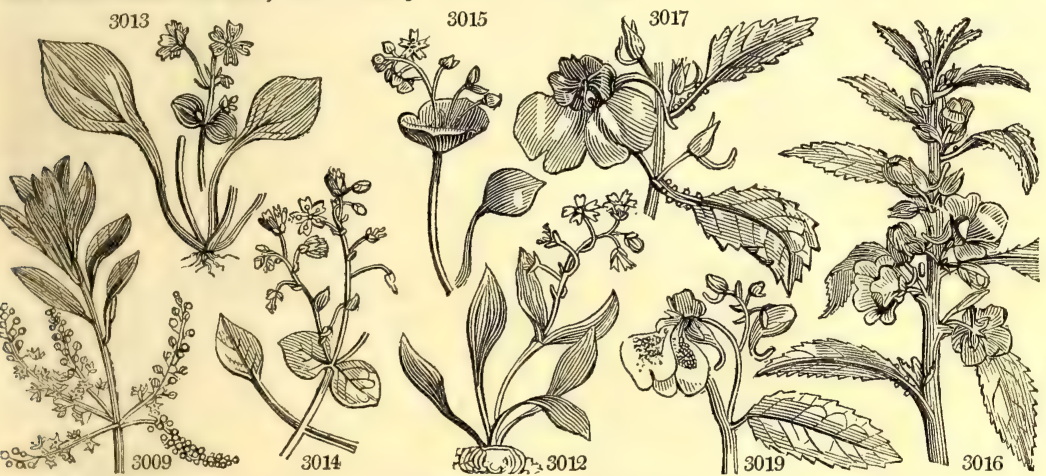

and Miscellaneous Particulars.

536. Cyrilla. In honor of Dominico Cyrilli, professor of medicine at Naples, and a fellow of the Royal Society of London. He published, in 1788, a work upon the rare plants of Naples, which is now one of the scarcest of botanical works. This is a pretty shrub. Young cuttings will root under a bell-glass in sand, but not very freely.

537. Claytonia. In memory of Mr. John Clayton, who collected plants chiefly in Virginia, and sent them to Gronovius, who published them in his Flora Virginica. C. perfoliata is very hardy, and is not easily eradicated where once introduced. It grows on the poorest soil, vegetates early, and the whole of the herbage gathered and boiled makes a very tender spinage.

538. Impatiens. A metaphorical name given to these plants on account of the elastic force with which their capsules burst, and scatter their seeds upon the slightest touch. I. Balsamina is one of the most beautiful of popular annuals, forming a shewy cone of finely variegated carnation-like flowers. The prevailing colors of the petals are red and white, the former extending to every shade of orange, purple, scarlet, lilac, pink, and especially carnation or flesh color. Those are esteemed the most beautiful varieties which have the flowers double, and striped in the manner of a flake or bizarre carnation: but none of the varieties are permanent or can be continued by seeds, and the plant does not root readily by cuttings. The way to procure very large plants is to sow early in the season, as in March, to commence transplanting into 3-inch pots as soon as the plants have two proper leaves, and to shift every week or ten days into pots a size larger every time, till at last they are in pots of the largest or of a very large size, and in the richest light mould. The plants should be kept all the time in a hot-bed or pit, plunged, and with abundance of room and air, and the heat of the melon or pine. Fairweather, by transplanting only three or four times from No. 48, pots to those of eight inches diameter raised, produced balsams "four feet high, and fifteen feet in circumference, with strong thick stems, furnished with side balsams "four feet high, and fifteen feet in circumference, with strong thick stems, furnish
branches from bottom to top, and these covered with large double flowers." (Hort. Trans, iii. 406.)

The juice of the balsam, prepared with alum, is used by the Japanese to dye their nails red. (Thunberg.)

I. Nolitangere, Ne me touchez pas, Fr., Springsame, Ger., and Erba Impatienta, Ital., is the only species found wild in Europe. When the seeds are ripe, upon touching the capsules, they are thrown out with considerable force : hence the names Impatiens and Nolitangere. In the day-time the leaves are expanded, but at night they hang pendent, contrary to what is observed in plants, which from a deficiency of moisture, or a too great per-

spiration from heat, commonly droop their leaves during the day. Only the goat is said to eat this plant.

I. biflora, the American Noli-me-tangere, resembles this plant, but is handsomer. 
539. SAUVAGE'Si A. Jacq. Siuvagesia. 3020 erécta $L$. erect

540. VI'OLA. $W$ 3021 palmáta $W$. 3022 pedata $W$ 3023 pinnáta $W$. 3024 sagittáta $\boldsymbol{W}$. 3025 lanceoláta $W$ 3026 obliqua $W$. 3027 cuculláta $W$

3028 sorória $P h$. $30 \mathcal{2 9}$ papilionácea $P h$. 3030 ambigua $\boldsymbol{W} . \boldsymbol{K}$ 3031 uliginósa $S c h r$. $31) 32$ clandestina $P h$ 3033 blánda $P$ /

30 \& 4 vrimulifôlia $P h$. S035 hirta $W$

3036 collina Bess. 3037 campéstris Bieb. 3038 palústris $\mathrm{Sm}$. 3034 Schmidtiána $S c h$. 3040 odoráta $W$ ๔ purpúrea $\beta$ álba y cerálea ò purpárea pléna \& álba pléna $\zeta$ cartulea pléna n pállida pléna 3041 alpina Jacq.

3042 canina $\boldsymbol{W}$ 3043 sylvéstris $K i t$. 3044 neglécta $\mathrm{Schm}$ 3045 glaúca $B i e b$. 3046 láctea $E$. 3047 moritána $\boldsymbol{W}$ 3)48 Nuttállii $P h$. 3049 débilis Mich. 3050 valdéria $\boldsymbol{W}$. en 3051 cenisia $W$ 3052 canadénsis $W$ 3053 striáta $W$ $305+$ pubéscens $\boldsymbol{W}$ 3055 cóncolor $\boldsymbol{L}$. $\boldsymbol{T}$ 3056 mirábilis $\boldsymbol{W}$ 3057 biflóra $W$. 3058 uniflóra $W$. 3059 arboréscens $\boldsymbol{W}$.

3060 trícolor $\boldsymbol{L}$. 3061 banática $K i t$. 3062 arvénsis Murr. S063 altáica Pall. 3064 rothomagénsis $\boldsymbol{P} . S$. 306.5 sudética $W$. en. 3066 lútea $E$. $B$. 3067 grandiflóra $\boldsymbol{L}$ 3068 Zóysii $W$.

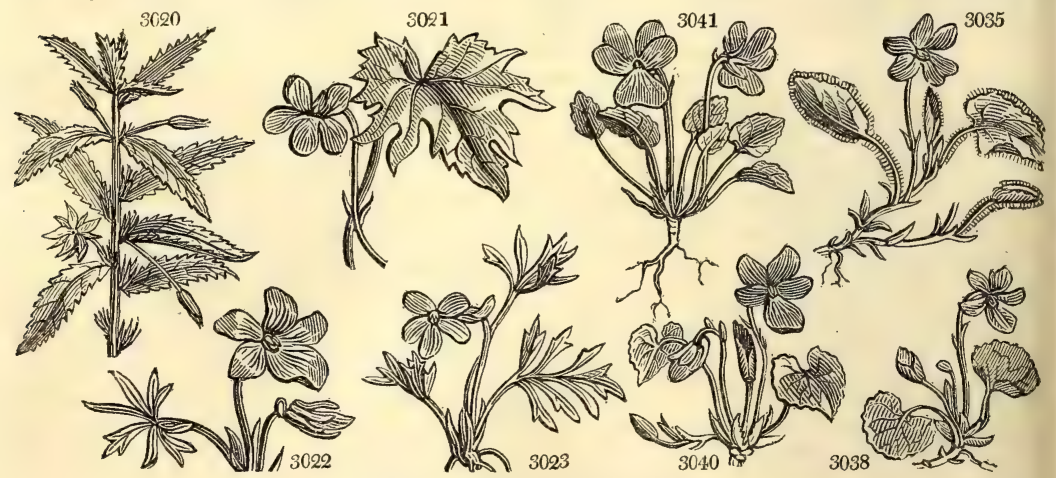

History, Use, Propagation, Culture,

Violet. palmated cut-leav winged-leaved $\frac{\partial}{\Delta} \Delta$ or ved $\Delta$ or spear-leaved $\$ \Delta$ or oblique-flower. $\downarrow$ or hollow-leaved $\vec{\alpha} \Delta$ or white-rooted $\vec{x} \Delta$ or variegated $\vec{x}$ or (a) swamp * $\Delta$ or white-flowered $\vec{x} \Delta$ or Primrose-leav. $\vec{x}$ or hairy

hill

field

marsh

Austrian

sweet pulte-flowered ता $\Delta \mathrm{ft}$

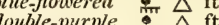
double-white double-blue

Neapolitan Alpine arrow-leaved $\frac{1}{2} \Delta$ or purte-flowered $\Delta \mathrm{it}$

Violacea. $S p .1-6$.

my.jn Pk S. Amer, 1820, S co Jacq.am, t.51. f. 3 Violacea. Sp. 50-120.

$\frac{1}{2}$ my.jn $\mathrm{Pu}$ N. Amer. 1752. D p.I Bot. mag. 535 my.jn B N. Amer. 1759. D p.l Bot. mag. 89 竞 my.jn $V$ S. Europe 1752. D p.i Gm.sib.4.t.49.f.4 1 jn.jl W. W N. Amer. 1775. D p.t

Y.sib.t.t.49.f. 2 myj B N Amer 177\% D P. ap.my P.V Hungary 1823. D co ap.my $\mathrm{Pu}$ Carinthia 1823. D co

$\frac{1}{2}$ my.jl W N A mer 1802 D p.

(1) so. D p.l Eng. bot. 894

Thr.my B Poland 1822. D co

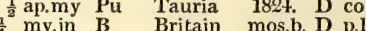

my.jn B Austria 1821. D co

Britain gard. D p.l

$\frac{1}{2} \mathrm{mr} y$ Britain gard. D p.

$\frac{1}{2}$ mr.my B Pu Britain gard. D P.

$\frac{1}{2} \mathrm{mr}$.my W Britain gard. D p.

$\frac{1}{2}$ mr.my B Britain gard $\mathrm{D}$ p.

$\prod_{i \pi} \Delta \mathrm{ft} \quad \frac{1}{2}$ mr.my $_{\frac{1}{2} \text { mr.my Pa.B Britain }}$ Bard. D p.l

ذi $\Delta$ or $\frac{1}{4}$ my.jn D.Pu Austria 1823. D co Jac. aust. t. 242

dog's औ $\Delta$ w $\frac{1}{4}$ ap.jn $B \quad$ Britain hea. D p.l Eng. bot. 620

neglected $\quad \frac{\downarrow}{\Delta} \Delta$ or

glaucous $>\Delta$ or

$\pm \Delta$ or

weak $\frac{ \pm \Delta}{\Delta} \Delta$ or

ringed-leaved $\frac{\$}{2} \Delta$ or

Alpine or

Canadian $\pm \Delta$ or

streaked $\quad \nabla \Delta$ or

downy $\frac{\downarrow}{\mathrm{t}} \Delta$ or

green-flowered $¥ \Delta$ or

broad-leaved $\$ \Delta$ or

two-flowered $\frac{\downarrow}{\Delta}$ or

\& $\Delta \Delta$ or

$\frac{1}{2}$ my.jn B $\quad$ Hungary 1820. D co

$\frac{1}{2}$ my.jn P.B Crimea 1821. D co

1 my Cr England moi.h. D p.l Eng. bot. 445

1 my.jn L.B Al. of Eur.1683. D p.l Bot. mag. 1595

$\frac{1}{2}$ my.jn B Missouri 1812. D co

ap.my W N. Amer. 1820. D cn

$\frac{1}{8}$ my.jn $\mathbf{P}$ Mr. Cenis 1805. D p.l Al. p. 2. t. 24. f.3

jn.jl B Mt. Cenis 1759. D p.l Al. p.2. t. 22. f. 6

$\frac{1}{2}$ my.jn L.B N. Amer. 1783. D p.l

jn.jl St N. Amer. 1772. D p.

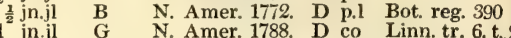

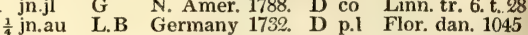

$\frac{2}{4}$ ap.my $\mathbf{Y}$ Al. of Eur.1752. D p.l Bot. mag. 2089

$\frac{1}{3}$ jn.jl $\mathrm{Y}$ Siberia 1774. D co Gm. si.4.t. 48.f.5

ap.my P.B Spain 1779. L r.m Barr. ic. 568

Heart's-ease $\quad \mathrm{O}$ or $\frac{1}{2}$ ap.s $\quad$ Y.Pu Britain co. fi. $\mathrm{S}$ co Eng. bot. 1287

Banatian $\quad$ or $\frac{1}{2}$ ap.s Y.Pu Germany 1820. S co

corn $\quad$ or $\frac{1}{2}$ ap.s Y Britain ... S co

Tartarian $₫ \Delta$ or $\frac{1}{2}$ mr.jn P.Y Siberia 1805. D co Bot. reg. 54

Rouen $\frac{\$}{2} \triangle$ or $\frac{1}{2}$ my.au $B \quad$ France 1783. D co Bot. mag. 1498

L $\wedge$ or $\frac{1}{2}$ my.au Y Germany 1805. D co

my.au Y Britain m.pas. D p.1 Eng. bot. 721

my.au D.B Switzerl.

$\begin{array}{llllll}\frac{1}{8} \text { jl.s } & \text { Y } & \text { Carinthia } & \ldots & \text { D p.1 } & \text { Da. hel. } 566 . t .17 \\ & & \text { Jac. co. 4.t.11.f.1 }\end{array}$

539. Sauvagesia. In honor of Jacques Boissier de Sauvages, a French botanist, who died in $1767 . \quad$ He published a Flora of Montpellier, and other works. A genus of small herbaceous plants, more singular than beautiful.

540 . Viola. The ancients feigned that violets were the first food of the cow Io, one of Jupiter's mistresses.

This is an extensive genus of low herbs, mostly with violet and white flowers, and well adapted for the flowerborder, rock-work, or for growing in pots. V. odorata is a favorite flower, on account of its fragrance and early appearance. It is a native of every part of Europe, in woods, amongst bushes, in hedges, and on warm banks. 
S020 Stem simple, Leaves narrow lanceolate, Stipules very long

$\$ 1$. Stemless, Stipules membranous.

3021 Pubescent, Leaves palmated 5-lobed toothed and undivided

3022 Leaves pedate 7-parted

3023 Leaves many-cleft, Segments lobed

0024 Leaves obl, acute cord. sagittate serr. cut at base, Flowers inverted, Three lower vetals bearded at base 3025 Smooth, Leaves shining lanceolate obsoletely toothed or crenulate, Flowers whitish 3025 Smooth, Leaves shining lanceolate obsoletely toothed or crenulate, Flowers whitish [middle 3027 Smooth, Leaves cordate serrate smooth hooded at base, Petals obliquely turned : lateral bearded 3028 Leaves cordate crenated pubesc. beneath, Lower petal bearded at base, Flower-stalks shorter than leaves 3029 Lvs. triang. cord. ac. cren. somewhat hood. Pet. obov. : 3 low. beard. below mid. conniv. : 2 upper reflexed 3030 Leaves oblong cordate obtuse crenate naked at the base with unequal inflexed hooded lobes 3031 Stemless, Leaves cordate smooth, Peduncles bracted above the middle

3032 Smoothish, Lvs. roundish obt. at base cord, cren. serrate, Runners fowering, Pet. lin. not longer than ca!. 3033 Leaves cordate obtuse acutish flat smooth, Petals not bearded, Flower-stalks as long as leaves 3034 Leaves oblong subcordate, Stalks membranous

3035 Leaves cordate and stalks hispid with hairs, Cal. obtuse

3036 Subhirsute, Runners none, Leaves cordate, Calyxes obtuse, Flowers sweet-scented

3037 Leaves cordate vertilinear at base pubescent, Runners none

3038 Leaves reniform smooth, Root creeping, Calyx obtuse

3039 Leaves cordate acuminate subcrenate smooth, Bractes close under the flower, Lower petal truncate 3040 Crecping runners and stalks smoothish, Cal. obtuse

3041 Nearly stemless, Leaves roundish elliptical crenate stalked, Stipules lin. serrated, Spur as long as calyx

8. Caulescent, Stipules membranous.

3012 Old stem ascending, Leaves oblong cordate obt. dotted, Stipules setaceous toothed, Cal lanceolate acute 3043 Stem square erect, Radical leaves cordate reniform, Flower-stalks longer than the leaves

3044 Stem erect angular, Lvs. cord. toothed crenat. smooth, Stip. tooth. on one side, Bract. above midd. of staik 3045 Stem spread. compressed, Lower lvs. cord. ovate : upper ovate-lanceol. crenul. Stip. tonthed on each side 3046 Stem ascending rounded, Leaves ovate lanceolate, Stipules cut serrated

3047 Stem erect, Leaves cordate oblong, Stipules toothed on one side, Anthers free

3048 Pubescent, Stem simple erect, Leaves ovate obl. acute, Petals lanc. entire, Flower-stalks length of leaves $30+9$ Caulescent weak, Stipules membranous lanceolate slightly torn, Leaves shortly cordate toothed

5050 Stems erect and procumbent, Leaves oblong entire sinuated ciliated hispid, Stipules undiv. Calyxes acute 3051 Stems filiform undiv. procumb. Leaves ovate stalked : their edge at the base ciliated, Stipules undivided 3052 Smoothish, Leaves subcordate acuminate serrated, Flower-stalks length of leaves, Stipules short entire 3053 Leaves cordate acuminate serrated flattish, Stipules lanceolate serrated ciliated

3054 Villous pubescent, Stem erect leafy at top, Leaves broad cordate, Stipules oblong serrated at end

3055 Erect, Leaves broad lanceolate, Stipules linear lanc. entire, Flower-stalks axillary in pairs very short

3056 Stem erect and leaf-stks. 3-corner. Rad. fl. with cor. but sterile : caul. apet. fertile, Lvs. reniform cord. cren. 3057 Stem weak about 2 -flowered, Leaves reniform serrate, Calyxes acute, Stipules entire 3058 Stem 1-flowered, Leaves cordate toothed

3059 Leaves linear lanc. toothed, Stipules linear entire, Spur very obtuse much shorter than calyx

\section{\$3. Stipules pinnatifid, Stigma cup-shaped.}

3060 Stem ang. diffuse, Leaves oblong toothed crenate, Stipules lyrate pinnat. Cor. twice as iong as smooth cal. 3061 Stem. ang. dec. diffuse, Lower lvs. cord. upper ovate obl. toothed cren. Cor. scarcely longer than smooth cal. 3062 Stem angular decumb. diffuse Leaves ovate oblong toothed crenate, Cor scarcely longer than hairy cal 3063 Caulesc. smooth, Leaves thickish ovate and oval cren. Flowers inverted wavy, Petals rounded broad renif. 3064 Stern angular diffuse and leaves oblong serrated hairy, Stipules lyrate pinnatifid, Cor. twice as long as cal. 3065 Stem 3-cornered simple, Lvs. obl. toothed, Stipules palm. many-cleft, Petals crenate, Spur as long as cal. 30156 Stern 3-cornered simple, Leaves ovate oblong crenated ciliated, Stipules palmate cut 3067 Stem 3-cornered simple, Leaves oblong, Stipules pinnatifid

3068 Stem very short erect, Leaves roundish crenate, Stipules entire, Flower-stalks 3-cornered

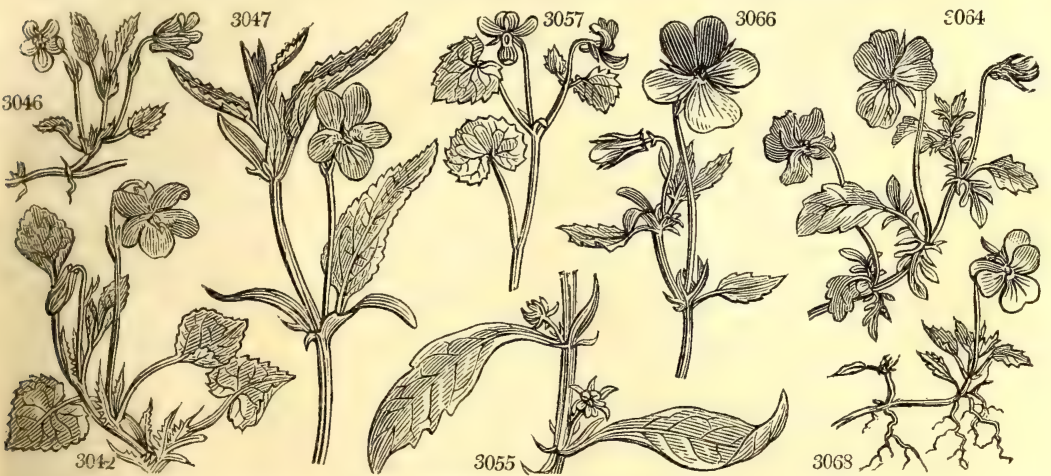

and Miscellaneous Particulars.

Desfontaines says it is frequent about Cassa and Tozzer, in Barbary, in the palm groves; the blue and white growing promiscuously and flowering in winter. Hasselquist found it in Palestine, Thunberg in Japan, and Loureiro in China, near Canton. The double purple and the Neapolitan are the most esteemed varieties: the latter forces well, and where there is a stove or warm pit, may be had from Christmas to April, when others are in flower in the open air.

In medicine, the fowers of violets act as a laxative, and the syrup is used by chemists to detect an acid or an alkali : for this purpose the V. odorata is cultivated to some extent at Stratford upon Avon. (Withering.) 
306 y calcaráta $W$. spurred $\quad$ \& $\Delta$ or $\frac{1}{2}$ mr.jn L.B Switzerl. 1752. D p.1 3070 cornuta $W$. horned $\quad$ \& $\Delta$ or $\frac{1}{2}$ my.jn B Pyrenees 1776. D p.1 Bot. mag. 791

541. IONI'DIUM. Vent. IoNIDIUM. 3071 polygalæfólium $V$. whorl-leaved 3072 Ipecacuanha Vent. New Ipecac 542. PHY'LICA. $W$. 3073 ericoídes $\boldsymbol{W}$. 3074 parviflóra $\dot{W}$. 3075 lanceoláta $W$. 3076 capitáta $W$. en . \$077 pubéscens $W$. 3078 erióphora $W$. 3079 rosmarínifólia $P . S$. Rosemary-lvd. 3080 axilláris $\boldsymbol{P}$. $\boldsymbol{S}$. 3081 plumósa $\dot{W}$. 3082 villósa $W$. 3083 stipuláris $W$. 3084 cordáta $W$. 3085 buxifólia $\dot{W}$ 3086 spicáta $W$. 3087 myrtifólia $\boldsymbol{P} . \boldsymbol{S}$. 3088 callósa $\boldsymbol{W}$. 3089 imbricáta $W$. 3090 cylíndrica $\boldsymbol{W}$. en . 3091 racemósa $W$. 3092 pinifólia $W$ 3093 squarrósa $\boldsymbol{W}$ Phylica. Heath-leaved small-flowered lance-leaved

headed axillary-flower. feathered

villous

heart-leaved

Box-leaved

spiked

Myrtle-leaved callous-leaved imbricated

cylindrical

cluster-flower

Pine-leaved squarrose

\# or 1 ap.au G.y S. Amer. 1797. C l.p Vent. malm. 27

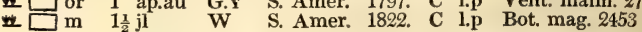

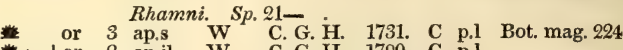

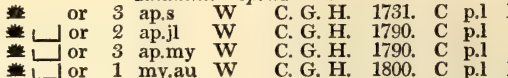

C. G. H. 1800. C p.l Bot. reg. 711 f.ap W C. G. H. 1774. C p.1 Bot. cab. 695 $\begin{array}{lllll}\mathrm{n} & \mathrm{W} & \text { C. G. H. 1774. C } & \text { p.l Pl am.t. 445. f. } 1\end{array}$ $\begin{array}{llllll}3 & \text { W } & \text { C. G. H. 1815. C } & \text { p.l Bot. cab. } 849\end{array}$ 2 my.jn W C. G. H. 1812. C p.l 2 mr.my W C. G. H. 1752. C p.l Bot. cab. 253 $2 \mathrm{my}$ W C. G. H. 1790. C p.l 3 my.s W C. G. H. 1786. C p.l Bur, afr. t. $43 . \mathrm{f} 2$ 2 my.jn P.Y C. G. H. 1789. C p.I Com. rar. 62.t.12 2 my.s W C. G. H. 1759. C p.l Bot. cab. 848

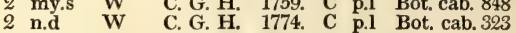
$\begin{array}{llllll}3 & \cdots & \text { D.Y } & \text { C. G. H. } & \text { 1816. C } & \text { p.l }\end{array}$ 1 mr.ap W C. G. H. 1774. C p.1 1 au.n W C. G. H. 1801. C p.I

2 ap.au W C. G. H. ... C C.l Wendl, coll. t.

5 my.s W C. G. H. 1790. C

6 my W C. G. H. 1789. C p.1

2 au.n W C. G. H. 1800. C p.l Bot. cab. 36

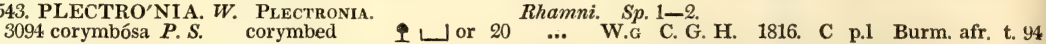

544. CONOCAR'PUS, $W$, ButTON-TREE 3095 eréc $W$. upright 3096 procumbens $W$. procumbent 545. CY'PHIA. W. 3097 volúbilis $W$. 3098 bulbósa $W$. 3099 Phyteuma

\section{Crphia.} twining bulbous

Combretacea. Sp. 2-4.

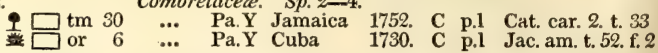

546. LightFoo'Tia. L'Her. LightFootia.

3100 oxycoccoides

lance-leaved

it or

Campanulacea. Sp. 3-8.

$\begin{array}{lllll} & & & & \end{array}$

547. JASI'ONE. $W$. SheeP's Scabious.

3102 montána $\underset{W}{W}$.

mountain perennial

548. LAGOE'CIA. $W$ 3104 cuminoídes $W$.

549. HE'DERA. $W$. 3105 Hélix $W$.

$\beta$ poética

$\gamma$ vegéta

$\delta$ arbórea

$\varepsilon$ chrysocárpa

3106 capitáta Swz.

wild Cumin.

Campanulacea, Sp. 2-5.

Campanulacea. Sp. 2.

jl B.w C. G. H. 1787. C s.l Ex. bot. 2. t. 69 Bur. afr.t. 38. f.1 Bot. reg. 625

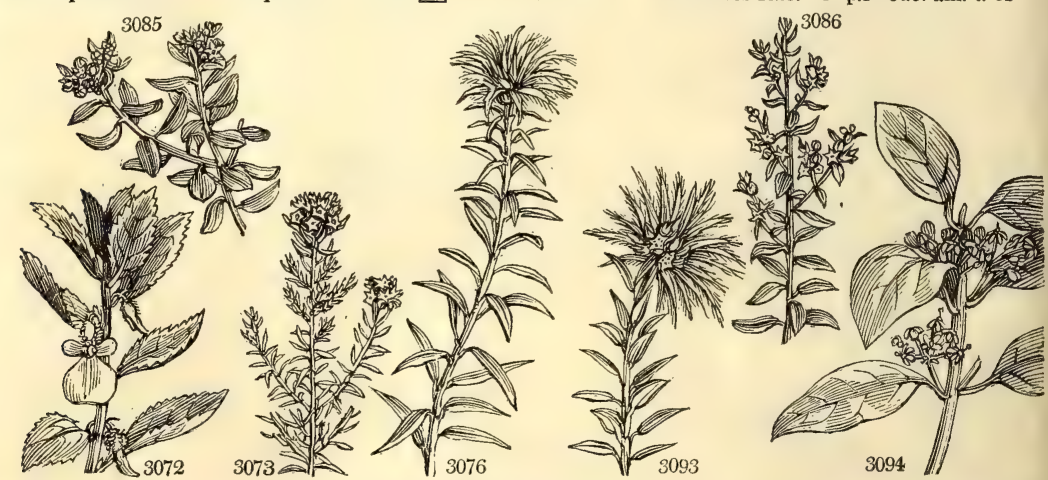

History, Use, Propagation, Culture,

V. hirta and canina bear a consıderable resemblance to V. odorata; but the first may be distinguished by its hairy petioles, and the last by its flowers being inodorous.

$V$. arborescens is readily propagated by young cuttings planted under a hand-glass.

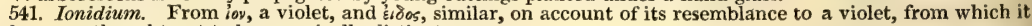
is by some thought not to be generically distinct.

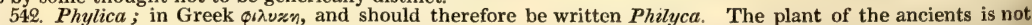
known. Some think it was the Holly. P. ericoides occupies large tracts of ground about Lisbon, in the same manner as heath occupies many lands in England. Young cuttings of all the species root readily in sand under a bell-glass.

543. Plectronia. From $\pi \lambda \varepsilon \approx \tau \rho \circ$, a spur. The tree is furnished with stiff spines like the spurs of a cock.

544. Conocarpus. From zwyos, a cone, and zaeros, a fruit: its fruit resembles the cone of an alder. Tropical trees, with alternate entire leaves and small heads of yellowish flowers.

545. Cyphia. From zuфos, curved, on account of its curved stigma. Small Cape plants resembling Lobelia. 
3069 Stem short, Spur subulate longer than petals, Leaves somewhat ovate, Stipules toothed 3070 Stem ascending 3-cornered, Leaves cordate crenate, Spur subulate longer than calyx, Upper petal acum.

3071 Stem ascending, Leaves opposite sessile and stipules lanceolate, Flowers nodding longer than leaves 3072 Leaves ovate obl. Pedumc. axillary solitary drooping, Lower lip very large emarginate

3073 Leaves linear lanceolate obtuse revolute at edge smooth, Branches umbelled, Heads round downy 3074 Leaves subulate acute rough somewhat hairy, Branches panicled many-flowered

$\$ 075$ Leaves scattered linear lanceolate hoary beneath, Heads terminal hairy

3076 Leaves linear lanceolate villous, Bractes woolly, Heads terminal

3077 Leaves linear lanceolate acute spreading villous hoary beneath, Bractes colored villous very long

3078 Leaves linear hairy tomentose beneath revolute at edge, Heads terminal, Flowers downy

3079 Leaves linear flattish hoary beneath erect, Heads ovate downy

3080 Leaves linear lanceolate revolute at edge hoary beneath, Flowers axillary solitary racemose

3081 Leaves linear subulate very villous, Flowers terminal axillary, Cor. spreading

3082 Leaves linear upper villous, Flowers racemose

308.3 Leaves linear revolute at edge rough hoary beneath, Stipules filiform colored, Bractes bifid naked

3084 Leaves cordate ovate spreading, Stem proliferous

3085 Ieaves ovate scattered opposite and three together beneath netted veiny tomentose

3086 Leaves oblong cordate acuminate beneath hoary, Spikes cylindrical, Flowers length of bractes

3087 Leaves ovate mucronate smooth above and shining beneath hoary, Racemes leafy panicled

3088 Leaves oblong cordate acuminate hairy beneath white, Flowers in heads

3089 Leaves cordate ovate smooth, Flowers racemose

3090 Leaves linear lanc, revolute at edge villous hairy beneath, Flowers cylind. Bractes as long as flowers

3091 Leaves ovate smooth, Flowers simple panicled racemose

3092 Leaves acerose flat on each side very smooth, Flowers panicled racemose

3093 Leaves linear ciliated arcuate spreading, Head terminal

3094 Branches squarè, Leaves opposite stalked lanceolate ovate entire smooth

3095 Erect, Leaves lanceolate

3096 Procumbent, Leaves obovate

3097 Leaves entire and toothed linear, Stem twining

3098 Leaves digitate, Leaflets pinnatifid, Stem erect

3099 Leaves oblong crenated ciliated, Scape erect

3100 Leaves and petals lanceolate

3101 Leaves subulate, Petals linear

3102 Leaves linear lanceolate narrow at the base hispid wavy curled

3105 Leaves linear smoothish flat obtuse

3104 The only species

3105 Leaves ovate 3-5-angular and 3-5-lobed floral ovate acuminate veiny, Umbels erect

3106 Leaves elliptical entire, Racemes compound terminal, Flowers sessile in small heac's

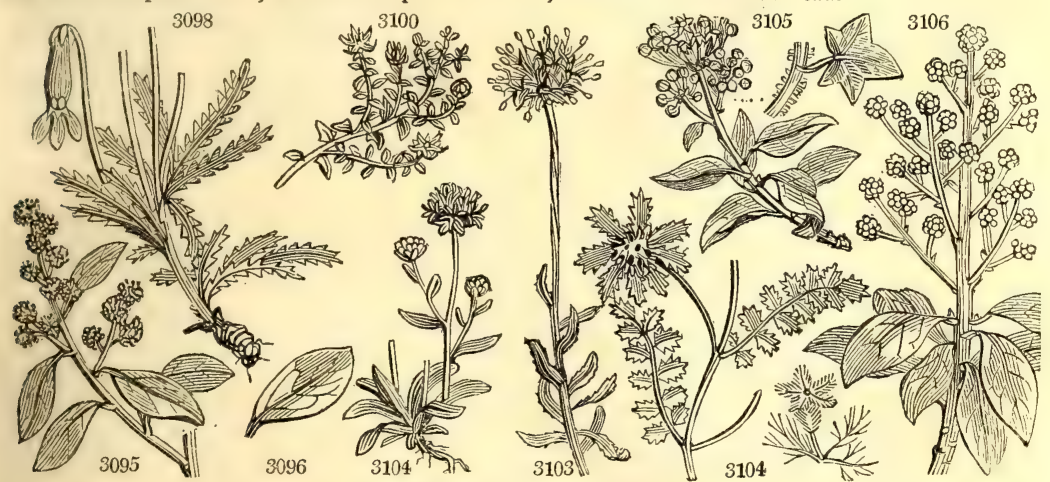

and Miscellaneous Particulars.

546. Lightfootia. Named after the Rev. John Lightfoot, an English clergyman, and author of the first Flora 547. Jasione. genus is very nearly related to Campanula, from which it is by some thought not different.

547. Jasione. A name applied by Pliny to an eatable plant. J. montana so resembles Scabiosa, as to be often mistaken for a plant of that genus. Linnæus gives a curious account of the process of fecundation in this plant, from which may be observed its affinity to Syngenesia, where it was first placed.

548. Lagocia. From $\lambda \alpha_{\gamma} \omega_{5}$, a hare, and oiros, a residence. The little seeds enveloped in the downy involucrum have been likened to young leverets in a hare's form. The seeds should be sown in autumn soon after they are ripe, otherwise, if this is deferred till spring, they commonly remain a year, and sometimes two or three years, before they grow.

549. Hedera. A name for which many etymologies have been offered. The best explanation is, that it has been derived from hedra, cord, in Celtic. Lierre, Fr. H. helix is a valuable ornamental evergreen for covering naked buildings or trees, for training into fanciful shapes, as of human figures, \&c. on skeletons of wirework, or trained up a stake so as to form a standard. Flowering so late in the season, it is much resorted to by 
550. RIBES. $W$. 3107 ríbrum $\dot{W}$ $\beta$ album $\gamma$ sylvestre 3108 petræ'um $W$. 3109 multiflórum Kit. 3110 spicátum $\mathrm{Sm}$. 3111 trífidum Mich. 3112 procúmbens $\boldsymbol{P a l l}$. 3113 rigens Mich.

3114 prostrátum $P h$. 3115 alpinum $W$. 3116 aúreum $P h$. 3117 nigrum $W$.

3118 flóridum $W$.

3119 laxiflórum $P h$.

3120 resinósum $P h$.

3121 hirtéllum $P h$. 3122 grácile $P h$. 3123 triflórum $P$. 3124 orientále Desf. 3125 diacántha $W$. 3126 reclinátum $\dot{W}$ 3127 Grossulária $W$. 3128 Uva-críspa $\boldsymbol{W}$. 3129 oxyacanthoídes $W$. 3130 lacustre $P h$. 3131 Cynósbati $W$.

551. GRONO'VIA. W 3132 scándens $W$.

552. ACHYR A N'THES. 3133 argéntea $W$ 3134 áspera $W$. 3135 porrigens $\boldsymbol{H} . \boldsymbol{K}$. 3136 nívea $W$

3137 fruticósa Lam. 3138 pubéscens Roth.
Currant. red white wild

rock

many-flowered

acid

trifid

trailing

stiff

glandulous

Alpine

golden

black

Pensylvanian

loose-flowered clammy

\section{hairy}

slender

three-flowered

eastern

two-spined

procumbent

rough-Gooseb.

mth.-Gooseb.

Hawthorn-lvd.

prickly-fruited

Gronovia.

climbing

\begin{tabular}{|c|c|c|c|c|}
\hline & & & Grossu & acea \\
\hline S桿 & fr & 4 & ap.my & G \\
\hline 柾 & fr & 4 & ap.my & G \\
\hline 齿 & or & 4 & ap.my & G \\
\hline 薙 & or & 4 & my & $\mathbf{R}$ \\
\hline 些 & or & 5 & ap.my & Gr \\
\hline 整 & or & 4 & ap.my & G \\
\hline 影 & or & 4 & ap.my & $\mathrm{Pu}$ \\
\hline 正 & fr & 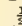 & my.jn & $\mathrm{Pu}$ \\
\hline 柆 & or & 6 & ap.my & G \\
\hline 楼 & or & 1 & ap.my & $\mathrm{Pu}$ \\
\hline 霊 & or & 3 & ap.my & G \\
\hline 默 & or & 8 & ap.my & $\mathbf{Y}$ \\
\hline 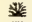 & fr & 5 & ap.my & G \\
\hline$\Delta$ & or & 4 & ap.my & G \\
\hline Ni & or & 4 & ap.my & Y.G \\
\hline 牙 & or & 3 & ap.my & Y.G \\
\hline
\end{tabular}

or 3 ap.my Y.G

or 4 ap.my Y.G

or 4 ap.my G.R

or 4 my.jn G.x

or 4 my in G.

or 2 m.

or 2 ap.my $P$.

fr 4 mr.ap $G$

or 3 ap.my $\mathbf{W}$.

or 4 ap.my Y.G

Sp. 25-49.

Britain riv. ba. C r.m Eng. bot. 1289

$\begin{array}{llll}\text { Britain } & \cdots & \text { C } & \text { r.m }\end{array}$

Britain ... C r.m

England moun. C co Eng. bot. 705

Hungary 1822. C co Bot. mag. 2368

England m. wo. C co Eng. bot. 1290

Quebec 1823. C co

Dahuria 1804. L m.s Pall, ross. 2.t. 65

N. Amer. 1812. C co

N. Amer. 1777. L s.l L'Her, st. 1.t. 2

Britain woods. C co Eng. bot. 704

Missouri 1812. C r.m Bot. reg. 125

Britain m.hed. C r.m Eng. bot. 1291

N. Amer. 1729. C co Dil. el.t.244.f.315

N. Amer 1810 C

N. Amer. 1800. L co Bot. mag. 1583

N. Amer. 1812. L s.1

N. Amer. 1812. L s.l

N. Amer. 1812. L r.1

Syria 1824. C co

Siberia 1781. L r.l

W. ho. be. $1, t .61$

Germany 1683. L co

. 97

N. Amer. 1705. L co D. el.t. 139.f.166

ap.my Y.G N. Amer. 1812. C p.l

Cucurbitacec. Sp. $1-2$.

月. $\square$ cu 6 jn.jl G.Y Jamaica 1731. C p.i Jac. ic. 2. t. 338

Amaranthacea. Sp. 6-28.

upright $\quad \mathrm{cu} 1$ my.o W Sicily 1713, C 1.s Bocc. sic. 16. t.9

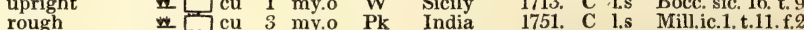
rough ${ }^{\mathrm{cu}} 3$ my.o $\mathrm{Pk}$ India 1751. C 1.s Mill.ic.1.t.11. white white cu 2 my.jl W shrubby

Canaries 1780. C r.m

E. Indies 1820. C r.m

pubescent $\mathrm{cu} 1 \frac{1}{2}$ ap.jl $\mathrm{Pk}$..... 1821. C r.m

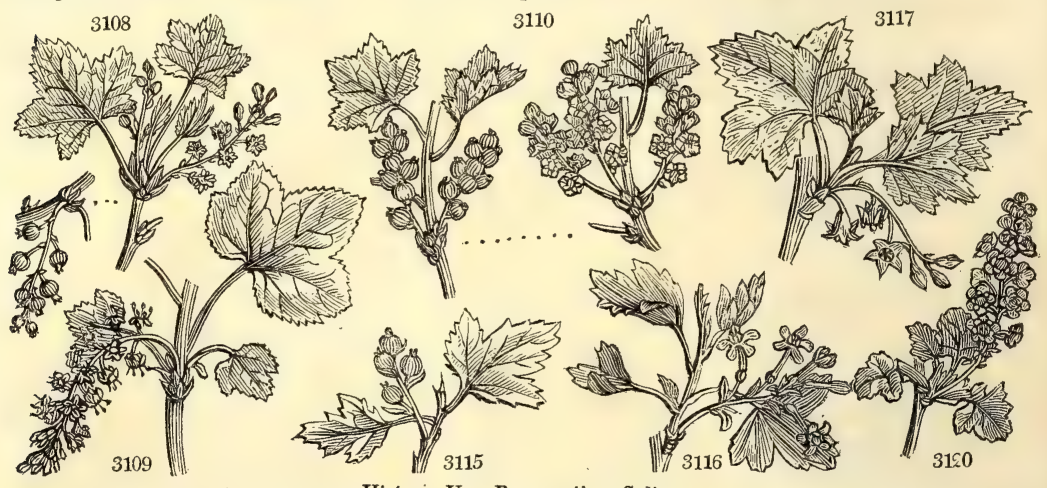

History, Use, Propagation, Culture,

bees and flies, when little other food is to be had. The berries increase during the winter, are full formed in February, and ripen in April ; furnishing food for wild pigeons, blackbirds, thrushes, \&c. in the spring. Blackbirds, and several other birds, build their nests in the stumps of ivy tufts. Sheep are fond of the leaves, especially during severe weather. The ancients held ivy in great esteem, and Bacchus is represented crowned with it to prevent intoxication.

H. Helix vegeta, the giant or Irish ivy, perhaps a distinct species, is a native of the island of Madeira.

550. Ribes. The name of an acid plant mentioned by the Arab physicians, and supposed to be the plant now called Rheum Ribes. R. grossularia is so called because its berries resemble little half-ripe figs, - grossi. This is a genus of well known shrubs; some of them much cultivated for their fruit. $R$. rubrum, the common red currant, is the Groseilles en grappes, or Groseilles d'outre mer, Fr., Gemeine Johannisbeere, Ger., and Uvetta, Ital: The English name currant is evidently from the similitude of the fruit to that of the grape of Zante, which dried forms the corinths or currants of the shops. The fruit has an agreeable sub-acid taste, and is generally relished both at the dessert and in pies and tarts. Equal weights of fruit and pure sugar, put over the fire, yield a liquor which forms a most agreeable jelly, used as a sweetmeat to eat with hare, venison, and Welch mutton, to flavor punch, and as a medicine. It is also much used for making wine, and is grown $\iota 0$ a considerable extent for that purpose in Essex, Kent, and about Pershore in Worcestershire. The principal varieties are the white, and pale or Champagne; but any number of varieties may be procured from sowing the seeds; from which, however, none superior to those in general use have been hitherto originated.

The culture of the red currant is known to every countryman. It grows freely by cuttings of last year's wood, which should be of sufficient length to form a handsome plant, with a clean stem, ten inches high. It grows in any soil, but prospers best in one loamy and rich. The best flavored fruit is produced from plants in an open free situation, but they will grow under the shade of walls or trees, and either as low bushes or trained against walls or espaliers. They bear chiefy from spurs, and therefore, in pruning, most of the young wood is cut to within two or three buds of that where it originated.

R. nigrum, the black currant, is common in moist woods in Russia and Siberia, where a wine is made of the berries alone, or fermented with honey, and with or without spirits. In Siberia they make a drink of the leaves : these tincture common spirits so as to resemble brandy; and a few of them dried and mixed with black tea, answer all the purposes of the green material. Many persons dislike the very peculiar flavor of the berries 


\section{Unarmed. Currants.}

3107 Leaves smooth pendulous, Flowers flattish, Petals obcordate, Leaves obtuse 5-lobed, Stem erect $\beta$ Berries yellow

$\gamma$ Lobes of leaves shortish, Leaf-stalks, Flower-stalks, and Flowers pubescent

[Stem erect

3109 Racemes spiked pendulous, Petals oblong, Bractes shorter than flowers

3110 Spikes erect, Petals oblong, Bractes shorter than flower

311 Leaves moderately lobed smoothish abave pub. beneath, Flowers small, Sepals trifid, Berries red harry

3112 Racemes erect, Flowers flat, Leaves obtusely lobed, Stem procumb. [fruit stiffly upr. Ber. rough red

$\$ 113$ Branc. upr. Leaves smooth above beneath pub. nett. Lob. and teeth acute, Rac. loosely many-f. always in

3114 Stems prost. Lvs. lobed smoothish younger pub. Rac. nearly erect, Petals deltoid, Bract. min. Berr. hispid

3115 Racemes erect, Bractes as long as flowers or longer, Peduncles hairy with glands, Lvs. shining beneath

3116 Very smooth, Lvs. 3-lobed, Lobes spreading with a few teeth, Bract. lin. as long as fi.-stalks, Berries smooth

3117 Lvs. dotted beneath, Racemes hairy loose, Flow. campan. Brac. shorter than fl.-stalks, Ped. simple at base

3118 Leaves dotted on each side, Racemes pendulous, Flowers cylindrical, Bractes longer than germen

3119 Leaves cordate 5-lobed cut-toothed smooth, Stalks slender, Racemes loose erect the length of leaves

3120 Glandular hairy, Rác. erect, Lvs. 5-lobed obtuse cren. roundish, Bractes lingulate longer than fl.-stalk

\section{Prickly. Gooseberries.}

3121 Spine one under the axillæ, Branches hispid, Lvs, small $\frac{1}{2}$-trifid : lobes toothed, Berr, solitary smooth red 3122 Spine under axillary very short, Lvs, on slend. stalks pub. on both sides: lobes acute cut and toothed, Ped. 3123 Prickles solitary, Peduncles 2 or 3-flowered, Berries polished [capillary

3124 Somewhat prickly, Leaves round cut-lobed hairy, Racemes short, Berries rough with hairs

3125 Prickles twin or solitary, Leaves wedge-shaped 3-parted and obsoletely 3-lobed toothed, Fl, racemose erect 3126 Branches somewhat prickly reclinate, Bract. of the peduncle 3-leaved

3127 Leaf-stalks hairy, Peduncles 1.flowered, Bractes 2, Fruit hairy

3128 Peduncles 1-flowered, Bructes connate-tubular, Fruit smooth

3129 Branches prickly all over

3130 Spine sub-axillary compound, Stem hispid all over, Leaves lobed beyond middle, Berries racemose hispid 3131 Prickles sub-axillary, Berries prickly racemose dull brown

\section{Leaves like those of the vine stinging cirrhose}

3133 Leaves roundish ovate acuminate, Calyxes reflexed pressed close to the spike

3134 Leaves obovate acute narrowed at base, Calyxes reflexed pressed close to the spike

3135 Leaves ovate lanceolate opposite, Spikes elliptical corymbose on long stalks, Stem shrubby

5136 Leaves whorled ovate downy, Corymbs compact dichotomous, Flowers with corollas

3137 Stem erect, Ovate leaves and calyxes smooth

3198 Stem erect rounded and elliptical oblong leaves pubescent, Spikes axillary and terminal stalked

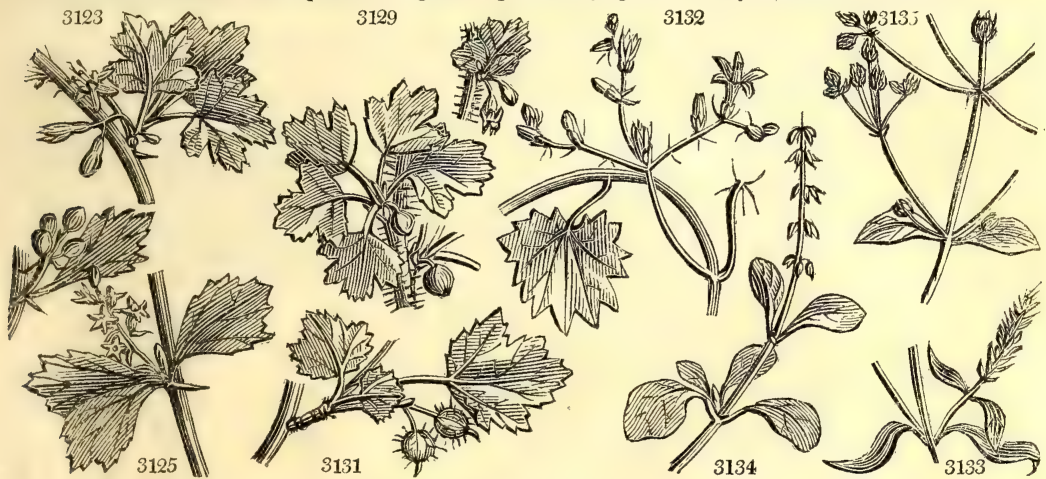

and Miscellaneous Particulars.

of the black currant, which are therefore not much used in the kitchen or dessert, and seldom in wine making. They make a jelly or jam in estimation as a gargle for inflammatory sore throats.

The culture of the black currant is similar to that of the red; but as it is less apt to bear on spurs than on young wood, the shoots are not so much shortened in this as in the other. It is singular that no varieties have been raised of this species, nor will it produce hybrids, as far at least as has been tried with the other cultivated sorts of Ribes.

R. Grossularia and R. uva crispa are the rough and smooth gooseberries; Groseille, Fr., Johannisbeere, Ger., and Uvospina, Ital. ; in universal culture and estimation in Britain, but not much known or esteemed in any other country. The climate of France, Italy, and Spain is too warm; and the summers of many parts of the north of Europe too rapid for their attaining a good size. They are, however, more in vogue now in the latter countries than they have ever been before; but as the quality of the fruit soon degenerates when the plants are not kept in high cultivation, it can never become very popular in countries where the pear, vine, fig, and olive grow freely, and which being planted and once established in the soil, grow and bear for ages with very little care.

The varieties of the gooseberry are very numerous, and yearly increasing in Lancashire and other counties where the fruit is grown for prizes, by raising from the seed. These new varieties, however, are valued more ac cording to the size of the berry, than its flavor, or the prolificacy of the plant; so that few so originated are fit to be added to the list of table or kitchen fruit. Twenty-five pennyweights is considered a great weight for a gooseberry, but some have been raised a few dwts. heavier. (See the Manchester Gooseberry Book, pub. annually.)

The gooseberry is generally propagated by cuttings, and trained as a dwarf bush, or sometimes on espalier rails : one variety, the green-gage, makes very neat half-standards, and bears better in that state than as a bush. They require a loamy soil, an open airy situation, and yearly attention to pruning, and refreshing their roots with manure and stirring the surface.

551. Gronovia. In honor of John Frederick Gronovius, a learned botanist at Leyden. This is a trailing plant like the cucumber, with broad hairy leaves, which sting like the nettle. Treated like the melon, it will produce ripe seeds, but is a plant of neither beauty nor use.

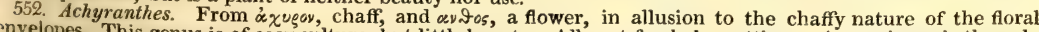
chvelopes. This genus is of easy culture, but little beauty. All root freely by cuttings. A. porrigens is the only
handsome species. 
553. Philoxe/RUS. $R$, $B$ r. Philoxerus.

3139 vermiculátus $R$. $B r$. creeping

3140 brasiliénsis $R . B r$. upright $\quad$ a 554. DESMOCH

3141 lappácea $J$

3142 prostráta $D$. $C$

3143 muricáta $D$. C

3144 alternifólia $D . C$.

3145 pátula $R$. $S$.

Bur $\square$ or

prostrate
prickly
alternate-leav'd

alternate-leav'd or
spreading

555. ILLECE'BRUM. Juss. KNOT-GRASS.

3146 verticillátum $W$ whorled

3147 cymósum Vill. cymose

3148 echinátum Poir. prickly

文 $\Delta \mathrm{w}$

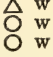

Amaranthacea. Sp.2-6.

$\begin{array}{llllll}\text { jl.o } \quad \text { Pk } & \text { S. Amer. } \quad . . & \text { C } & \text { r.m Her. parad. t. } 15\end{array}$ Amaranthacea. Sp. 5-12.

1 au.o Pu E. Indies 1759. C 1.p Rhd. mal.10.t.59

2 jl.au G.Pu E. Indies 1793. D 1.p Rumph.6. t.11

3 au.n G India 1777. C I.p Rumph.5. t. 83

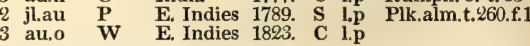

Amaranthacea. Sp. 3-15.

$\frac{1}{4}$ jl W England bog.pl. S p.l Eng. bot. 895

3149 Achyrantha $R$. Br. creeping * $\mathbb{E} \square$ cu $\frac{1}{4}$ jn.au W Buenos A.1732. D 1.p Dill. elt.8. t.7.f.7

3150 polygonoídes $R$. Br. Persicaria-leav $\mathbf{N}$ cu 1 jn.au W America 1731. C r.m Herm. par. 17

3151 séssilis R.Br. $\quad$ sessile-flowered $\mathrm{cu} \frac{1}{2}$ jl.o $\mathrm{Br}$ E. Indies 1778. S r.m Rhd. mal.10.t.11

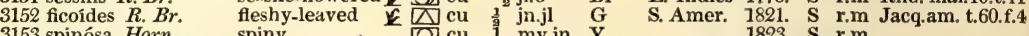

3153 spinósa Horn. spiny $\quad$ O] $\mathrm{cu} 1$ my.jn $\mathrm{Y}$...... 1823. S r.m

557. PARony'Chia. Juss. Paronychia

3154 capitáta Juss. capitate. Amaranthacece. Sp. 4-18.

3156 alsinifólia $J . \quad$ chickweed-lvd. $\mathrm{L}$.

3157 hispánica D.C. Spanish

558. CHENo' LEA. $W$. Chenolea.

3158 diffúsa $W$. silky

559. ANY'CHIA. Mich. ANYCHIA.

3159 dichótoma Mich. forked

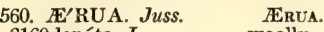

3160 lanáta $J$.

woolly

spear-leaved

561. LESTIBUdE'SIA. $R$. Br. Lestibudes

3162 paniculáta $R$. Br: panicled

3163 trigyna $R . B r$ oval-leaved

3164 virgáta $R . B r$ wave-leaved

562. RHAGO'DIA. $R . B r$. Rhagodia.

3165 hastáta $R$. Br. spear-leaved

3166 Billardiéri $R . B r$. Labillardiere's

563. DEERIN'GiA. $R$. Br. DeEringla.

3167 celosioídes $R$. Br. Berry-bearing

564. TRIAN'THEMA, $L$. Trianthema.

3168 monógyna $L$. monogynous

565. CELO'SiA. R. Br. Cоск's-сомв.

3169 argéntea $W$. silvery-spiked

3170 cristáta $W$

3171 comósa $W$.

3172 coccínea $\dot{W}$

3173 cérnua $B$. Rep.

3174 castrénsis $W$.

3175 Monsónix $W$

common

common

scarlet

scarlet

branched

downy

3176 nodiflóra $W$. knotted

1812. D s.1

1 jn.au W Spain 1683. D

Chenopoder. Sp.1.

步 1 au.s G :C. G. H. 1758. C r.m

$\begin{array}{lll}\frac{1}{2} \text { my.au G } & \text { N. Amer. 1806. S l.p Ort. dec. t.1 }\end{array}$ Amaranthacee. Sp. 2.

(D) $\mathrm{cu} 1$ ap.au W E.Indies 1691. C r.m Mill.ic.1.t.11.f.

cu 2 ap.au W E. Indies 1768. C r.m Bur.ind, t.65. f. 2

4 [ $\mathrm{cu} 3$ jn.s P.Y Jamaica 1733. C r.m Slo.jam.1.t.91.f.1

CD $\mathrm{cu} 1 \frac{1}{3}$ au.o W Senegal 1777. C r.m Jac.vind. 3, t. 15

$\square$ cu 4 au.o G ...... 1815. C r.m Jac. ic. 2, t. 339

Chenopodea. $\quad$ sp. $2-7$.

« L cu 1 jn.jl G N. Holl. 1823. C co

cu 5 jn.jl G N. Holl. 1823. C co Lab.n.holl.1.t.96 Amaranthacea. $S p .1$.

[O] cu 6 au.o W $\quad$ E. Indies 1804. S s.1

Portulacea. Sp. 1-6.

[] $\mathrm{w} 1$ my.jn P.G Jamaica 1820. S co Her.para.2.t.213 Amaranthacee. Sp. 8-22.

[0] or 1 jn.s L.F China 1714. S r.m Mart. dec. 1.t.7

(0) or 2 jn.s D.R Asia 1570. S r.m Lam.ill, t.168.f.1

[Q] or 1 jn.s Pk E. Indies 1802. S r.m

[O] or 5 jn.s Pu China 1597. S r.m

एJ 3 jl.au Pu E. Indies 1809. S r.m Bot. rep. 635

O 2 jl.s Pu E. Indies 1739. S r.m Bar. rar. t. 1195

3 jl.s W E. Indies 1778. S r.m Pl.al.11. t.334.f.4

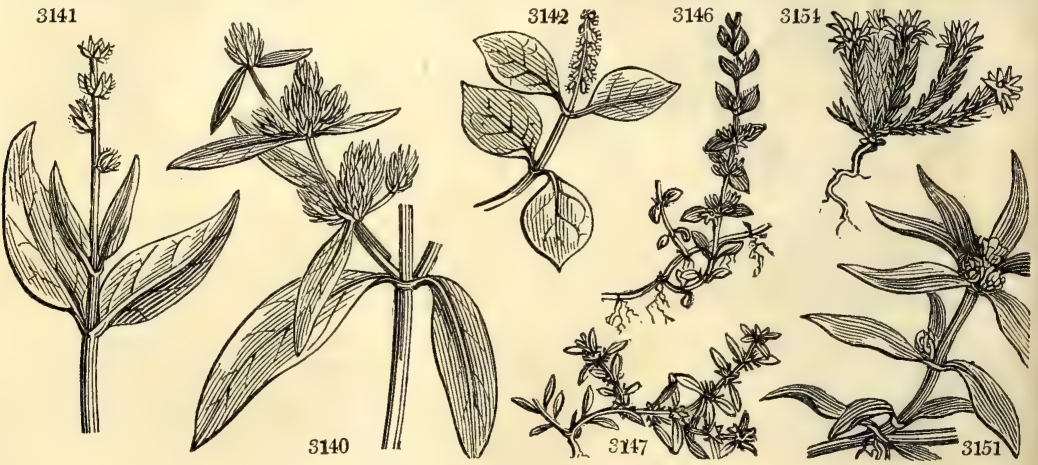

History, Use, Propagation, Culture,

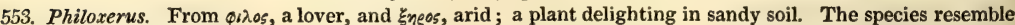
Gomphrena or Achyranthes.

554. Desmochata. From $\delta \varepsilon \sigma \mu \circ$, a bond, and $\chi \alpha s \tau$, a sheath, in allusion to the coherence of the flowers in their heads. It was called Pupalia by Jussieu, from its Malabar appellation. Plants nearly related to Achyranthes, in which they were included by Linnæus.

555. Illecebrum. A name of Pliny, designating a kind of wild purslane. It is now applied to singular little weed-like plants, with white scarious stipules to their leaves.

556. Alternanthera; that is to say, alternate anthers, those organs being by turns fertile and barren.

557. Paronychia. Something which cures whitlows, or maladies of the finger nails, called by the Greeks raроучx

558. Chenolea. From $x \eta y$, a goose, and olea, an olive. The leaves are silvery, like those of the olive; the plant humble like the Goosefoot. This plant is noticed for its silvery leaves: it is propagated by young cuttings planted under a hand-glass.

559. Anychia. A word with the same meaning as Paronychia (in No. 557.), and a genus with similar habits. 
3139 Stems creeping, Leaves rounded fleshy, Heads solitary terminal oblong 3140 Stem erect shrubby, Leaves ovate oblong acuminate, Heads round stalked leafless

3141 Stem $\frac{1}{2}$-shrubby spreading smooth, Leaves opp. ovate acum. roughish, Flowers with long purple bristles 3142 Stems shrubby prostrate, Leaves opposite ovate, Fascicles of flowers remote spreading at length reflexed 3143 Stem shrubby spreading, Leaves alternate ovate naked, Fasc. of flowers remote ovate, Bristles callous 3144 Stem erect, Leaves alternate ovate smooth, Racemes many, Fascicles ovate remote, Bristles callous 3145 Stem shrubby spreading pubescent, Flowers in round prickly spikes

3146 Stems filiform smooth, Leaves roundish, Calyxes 5-cornered bearded

3147 Stem branched erect, Leaves rounded smooth bearded, Flowers cymose, Bractes very short 3148 Stem branched prostrate, Flowers clustered axillary naked, Calyxes ventricose beneath hairy

3149 Heads sessile, Flowers smooth three times as long as utricle, Leaves ovate mucronate unequal 3150 Stems creeping hairy, Leaves broad lanceolate stalked, Heads round naked

3151 Heads subsessile, Calyx ovate acuminate nearly as short again as utricle, Leaves ovate lanceolate 3152 Stems creeping smooth, Leaves broad lanceolate stalked, Heads round pubescent

3153 Leaves ovate lanceolate deflexed, Flowers axillary clustered, Cal. spiny, Stem tomentose dichotomous

3154 Stems rising, Leaves carinate oblong ciliated at base, Flowers terminal mixed among the bractes 3155 Stems sub-erect much branched, Leaves spreading villous, Braetes very large concealing the flowers 3156 Stems diffuse, Leaves ovate, Flowers heaped, Bractes shining

3157 Flowers surrounded by shining bracteæ, Stems procumbent, Leaves smooth

\section{The only species}

3159 Stem dichotomous, Leaves lanceolate: of the stem opposite, of the branches altern. Flowers sol, axillary

3160 Stem herbaceous erect, Flowers lateral woolly, Leaves alternate ovate

3161 Leaves lanceolate downy, Spikes cylindrical numerous terminal

3162 Leaves ovate oblong, Stem rising panicled, Spikes alternate terminal remote

3163 Leaves ovate acuminate flat, Raceme loose, Bractes scarious, Pistil trifid

3164 Shrubby smooth, Cauline leaves spatulate, Stem leaves lanceolate, Flowers heaped spiked

3165 Half shrubby erect, Branches diffuse, Leaves nearly opp. hastate entire smooth

3166 Shrubby erect, Branches unarmed, Leaves entire linear oblong and lanceolate flat beneath powdery

3167 Leaves cordate acuminate, Raceme spiked loose, Flowers trigynous

3163 Stems depressed jointed smooth, Leaves oval obtuse entire red at edge

3169 Leaves linear lanceolate, Stipules falcate, Peduncles angular, Spikes scarious ovate cylindrical 3170 I eaves ovate acuminate, Stipules falcate, Common peduncle striated, Spike oblong compressed 3171 Spikes cylindrical comose, Leaves lanceolate

3172 Leaves ovate upright without auricles, Stem furrowed, Spikes multiple crested

3173 Flowers panicled nodding, Leaves lanceolate, Stem ribbed

3174 Leaves lanceolate ovate lined very much acuminate, Spikes crested, Stipules falcate

3175 Leaves subulate whorled, Stem branched straggling, Spikes compact cylindrical

3176 Leaves wedge-shaped acutish, Spikes globose lateral

3158

3166

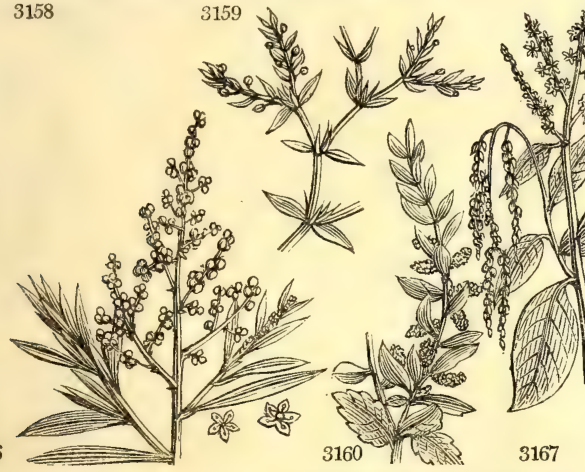

3163

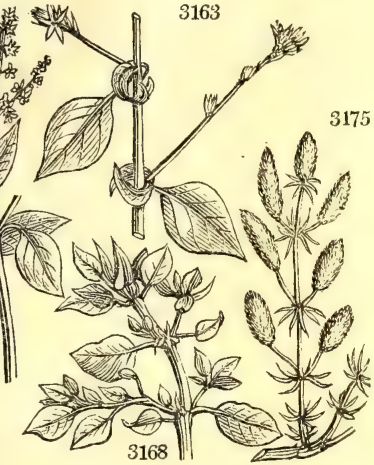

and Miscellaneous Particulars.

560. Frua. From its Arabic name êroùâ. Little weeds like Illecebrum

561. Lestibudesia. Named by M. du Petit Thouars, after Fr. Jos. Lestiboudois, a Flemish botanist, author of a work called Botanographie Belgique, published in 1781. The species are readily increased either by seeds or cuttings.

562. Rhagodia. From paywins, bearing berries. The fruit is a small berry, by which character the genus is chiefly distinguished from Chenopodium.

563. Deeringia. Named by Mr. Brown, in memory of Dr. Charles Deering, author of a Flora of Nottingham, and a skilful botanist of his day. Weak shrubs, with terminal spikes of flowers, and a berried inflated pericarp.

564. Trianthema. Brom rets, three, and ces. 05 , flowers. The flowers are frequently placed in threes in the axillæ of the leaves. Little tropical weeds.

565. Celosia. From $x \eta \lambda \varepsilon 05$, burnt, because the flowers of some species appear as it were singed. C. cristata is a well known tender annual, of which there are many varieties, as in the balsam, and which, like that plant, will attain a large size and singular beauty by repeated shiftings. Thunberg states that the flowers or crests are frequently a foot in length and breadth in Japan. T. A. Knight sent a flower to the Horticultural society 
566. GOMPHRE'NA. $R \cdot B r$. Globe Amaranth. 3177 globósa $W$. 3178 perénnis $W$. 3179 arboréscens $W$. 3180 interrúpta $W$. 567. MOL'LIA. $W$. 3181 diffúsa $\boldsymbol{H}, \boldsymbol{K}$. 3182 aristáta $\boldsymbol{H} . \boldsymbol{K}$. 568. GLA'UX. $W$ 3183 marítima $W$.

569. THE'SIUM $W$ 3184 linophýllum. $W$ 3185 alpínum Hayne. 3186 ebracteátum Hayne. 3187 umbellátum $W$. 3188 amplexicaúle $W$.

570. HELICO'NIA. $W$ 3189 Bíhai $W$.

3190 húmilis $W$

3191 Psittacórum $W$

571. STRELIT'ZIA 3192 augústa $\boldsymbol{H}$. $\boldsymbol{K}$. 3193 reginæ $\boldsymbol{H} . \boldsymbol{K}$. 3194 ováta $H . K$. 3195 farinósa $\boldsymbol{H}$. $\boldsymbol{K}$. 3196 angustifólia $\dot{H}$. $\boldsymbol{K}$ 3197 parvifólia $\boldsymbol{H} . \boldsymbol{K}$. 3198 húmilis $L k$ 3199 júncea $\boldsymbol{L} k$.

annual perennial trailing

Mounia.

forked

bearded

Black Saltwo

sea

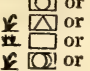

OLr

L

2 $\triangle \mathrm{cu}$

Bastard Toad Flax.

common

Alpine

umbelled

heart-leaved

\) $\triangle \mathrm{cu}$ august

Canna-leaved

ovate-leaved

mealy-stalked

narrow-leaved

small-leaved

dwarf

rush-leaved

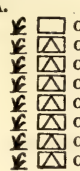

$\$ \Delta \mathrm{cu} \frac{1}{2}$ jn.

₹ $\triangle \mathrm{cu}{ }^{\frac{1}{2} \mathrm{jn} . \mathrm{jl}}$

$\$ \Delta$ cu 1 jn

jn

Musact

Plantain-leav'd $f \mathbb{D}$ or 12 jl,au

Pwarf or 6 jl.au

Musacea.

Amaranthacea. Sp. 4-25.

my.o P.W India 1714, S r.m Rhd.mal.10.t.37

W S. Amer. 1802. C r.m

Amaranthacee. Sp.2-3.

W Canaries 1779. S 1p Will hortber 11

W Canaries 1780. C 1.p

Salicarice. Sp. 1.

Fritain salt m. S $\mathbf{s . 1}$ Eng. bot. 13

talacea. Sp. 5-33.

W England ch.pa. D p.1 Eng. bot. 247

W Germany 1814. D p.l Jac. aust.5. t.416

Germany 1814. D p.l Sch.bo.j.1800.t.7

C. Amer. 1782. D p.l Pl. man.t.342.f.1

C. G. H. 1787. C s.l

Sp. 3-12.

W. Indies 1786. S s.p Sw. ob.96. t.5. f. 2

Caraccas 1798. D s.p Jac.sch.1.t.48,49

W. Indies 1797. S s.p Bot. mag. 502 $\mathrm{Sp} .8$.
8 f.my W C. G. H. 1791. S p.l

8 ap.my $Y$ C. G. H. 1773. S p.1 Red. 1il. 77, 78

C. G. H. 1777. S p.1 Bot.mag.119,120

C. G. H. 1795. S p.l

C. G. H. 1778. S p.l

C. G. H. 1796. S p.1 Bot. reg. 516

$\begin{array}{llll}\text { C. G. H. } & \ldots & \text { S } & \text { p.l } \\ \text { C. G. H. } & \ldots & \text { S } & \text { p.l }\end{array}$

\section{DIGYNIA.}

572. APO'CYNUM. R. Br. DoG'S-BANE. 00 androsmifelium $W$. Tutsan-leaved 3201 cannabinum $W$. Hemp-like 3202 hypericifólium $W$. Hyperic.-lvd. 3203 venétum $W$. Vyperic.-lv
Venetian

$\frac{\downarrow}{\downarrow} \Delta$ or
$\frac{\Delta}{\downarrow} \Delta$ or
$\frac{\Delta}{\downarrow} \Delta$ or

\begin{tabular}{lll} 
& \multicolumn{2}{c}{ Apocynea } \\
2 & jl.s & St \\
3 & jl.s & W \\
2 & jn.jl
\end{tabular}

573. MELODI'NUS. Forst. Melodinus. 3204 scándens $\boldsymbol{W}$. climbing 3205 monógynus $R o x b$. East Indian 574. PERIPLO'CA. $\boldsymbol{R}$. Br. Periploca 3206 græ'ca $W$. 3207 lævigáta $\boldsymbol{W}$.

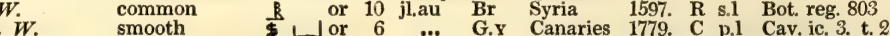

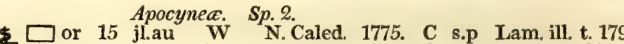
W Amer. 1758. S co Jac. vind, 3. t.66 jl W E. Indies 1820. C r.m Bot. reg. 834 Asclepiadea. Sp. 2-13.

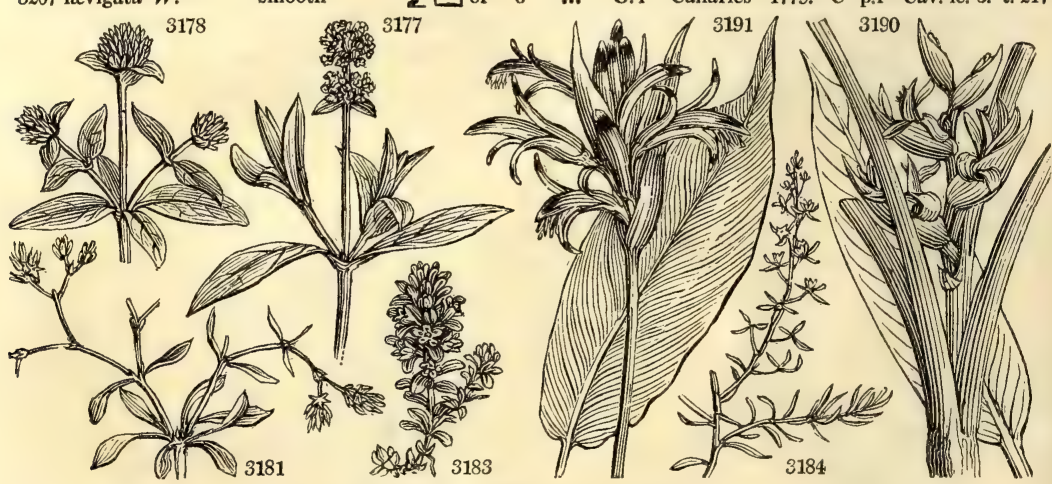

History, Use, Propagation, Culiure,

which measured eighteen inches in width, and seven inches in height from the top of the stalk, thick, full, and of the most intense purplish red. (Hort. Trans. iv. 322.) To produce this, the great object was to retard the protrusion of the flower-stalk. Hence, a rich compost was employed, the plants put first into pots of four inches diameter, and then transplanted to others a foot in diameter; the object being not to compress the roots, as that has a tendency to accelerate the flowering of all vegetables. The plants were placed close to the glass in a heat of from 70 to 100 degrees, all side branches removed, and pigeon-dung water used in watering. Had the of from 70 to 100 degrees, all side branches removed, and pigeon-dung water used in watering.
shiftings from pot to pot, been more frequent, it appears probable the size might have been still greater.

566. Gomphrena. Gromphrena is a name applied by the ancients to a plant bearing red and green leaves on the same stem; probably our Amaranthus tricolor. G. globosa is a popular tender annual, valued for its heads of flowers, which, if gathered before they are too far advanced, will retain their beauty several years. The other species propagate readily by cuttings under a glass.

567. Mollia. So called from its softness. The species are small weeds.

568. Glaux. From r revesoy, a name under which Dioscorides describes a maritime plant with glaucous leaves. This plant is maritime, and has glaucous leaves. A pretty little plant, and well adapted for pots and rock work. It will grow at a considerable distance from the sea in sand kept moist.

569. Thesium. Athenæus says, on the authority of Timachides, that this plant was called $9 \eta \sigma \varepsilon^{2}, 0 y$, because it formed part of the garland presented by Theseus to Ariadne. If this be so, the accent should be placed on the penultimate and not on the antepenultimate syllable. It is, however, very certain that the Thesion of the an cients had no resemblance to that of the moderns, which is a genus of little obscure plants or weeds.

570. Heliconia. A name given to this plant in an ingenious sense, as indicating its affinity with Musa. H. Bihai is a large herbaceous plant, bearing considerable resemblance to Strelitzia. It grows in rich well 
3177 Stem erect hairy, Leaves oblong pubescent, Heads globose solitary 2-leaved, Keels of bracteæ winged 3178 Leaves lanceolate, Heads 2-leaved, Florets distinguished by a peculiar perianthium

3179 Hairy twining
3180 Stem ascending, Leaves oblong silky beneath, Spikes clustered panicled terminal interrupted

3181 Stem branched diffuse, Leaves spatulate whorled about 7, Calyxes with a membranous margin 3182 Stem branched diffuse, Leaves lanceolate silky bearded

3183 The only species

3184 Spike branched, Bractes 3, Leaves linear lanceolate with a very short tube to the calyx 3185 Stems prostrate simple, Raceme terminal leafy 1-sided, Flowers sessile surrounded by bractex $\$ 186$ Stem erect simple, Raceme leafy, Flowers stalked without smaller bracteæ 3187 Leaves obovate mucronate, Flowers racemose

3188 Leaves cordate stem-clasping, Racemes termina

3189 Leaves at the base and end acute, Spadix erect radical, Spathes 2-ranked many-flowered 3190 Leaves narrowed at base at end acumin. Spadix erect flexuose radical, Spathes 2-ranked many-flowered 3191 Leaves very smooth nerved rounded at base, Inflorescence very smooth, Spadix erect without bracter

3192 Scape half as short as leaf-stalks which are hardly twice as long as the 6 feet leaf

3193 Scape scarcely longer than the leaf-stalks which are three times as long as the oval leaf 3194 Scape longer than leaf-stalk and leaves, Leaf-stalk twice as long as the ovate oblong leaf 3195 Scape a little longer than the leaf-stalks which are half as long again as the obl. leaf unequal at the base 3196 Scape as long as leaf-stalk which is 7 times longer than the lanceolate leaf

3197 Scape the length of the leaf-stalk which is 20 times longer than the linear lanceolate leaf 3197 Scape the length of the leaf-stalk which is 20 times longer thate concave leaf 3199 Leaf-stalk very long with no leaf

\section{DIGYNIA.}

3200 Stem upright herbaceous, Leaves ovate smooth on each side, Cymes terminal smooth 3201 Stem upright herbaceous, Leaves oblong tomentose beneath, Cymes lateral longer than the leaves 3902 Stem erect herbaceous, Leaves oblong cordate smooth, Cymes shorter than the leaves 3203 Stem erect herbaceous, Leaves elliptical lanceolate mucronate at the edge rough with little teeth

3204 Leaves oblong ovate thick at edge, Panicle downy 3205 Leaves oval lanceolate acuminate, Panicle smooth

\$206 Flowers terminal hairy inside

3207 Flowers smooth, Segments obtuse, Cymes trichotomous, Leaves oblong lanceolate veiny smooth

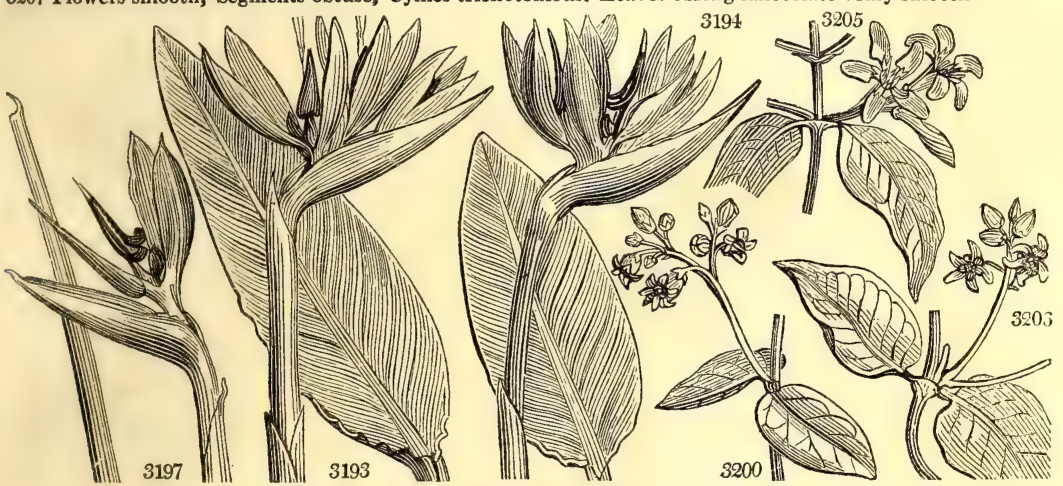

and Miscellaneous Particulars.

shaded gullies in moist woods. The berries are small and succulent, and each contain three hard rugged seeds.

H. Psittacorum bears a great resemblance to Canna : it grows in the wet parts of woods, and on the highest mountains. All the species require a strong heat to make them flower freely.

571. Strelitzia. So named by Sir Joseph Banks, in honor of Charlotte, queen of George III., of the family of Mecklenburgh Strelitz, and said to have patronized botany. This is a splendid genus, generally kept in the stove; but which, Sweet observes, "will thrive, and flower as well in the greenhouse or conservatory. A light sandy loam is the best soil for the species, and they may be increased, but slowly, by suckers. By rubbing the pollen on the stigma, when the plants are in bloom, perfect seeds are readily obtained." (Bot. Cult. 111.)

572. Apocynum. From aro, away, and жvwy, a dog; that is to say, a plant from which dogs must be driven. Pliny says his Apocynum is mortal to them. This is a genus of plants of little beauty, but of easy culture in any soil. The first species is acrid and blisters the skin. From the stalks of A. cannabinum the Indians of North America prepare a substitute for hemp, of which they make twine, bags, fishing-nets and lines, and linen for their own wear.

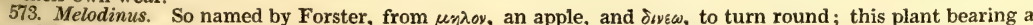
round fruit like an apple, and having a tring oblong-ovate leaves, and nearly allied to Rauwolfia Cuttings root readily in sand under a hand-glass. This, and the succeeding genera, as far as No. 592, are all Asclepiadeous plants, and require nearly similar management

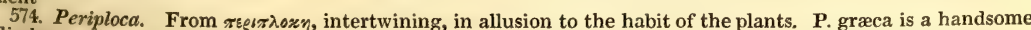
climber, and grows freely in common garden soil, and is propagated by cuttings under a glass, or by layers. 
575. CRYptostégia. $\boldsymbol{R}$. $\boldsymbol{B r}$. Cryptostegia. 3208 grandiflóra $\boldsymbol{R}, \boldsymbol{B r}$. large-flowered 业 [ ] or 576. HEMIDES'MUS. $\boldsymbol{R}$. $B r$. Hemidesmus 3209 indicus $\boldsymbol{H} . \boldsymbol{K}$. Indian 577. SECAMO'NE. $R \cdot B r$. Secamone 3210 ægyptíaca $\boldsymbol{H}$. $\boldsymbol{K}$. Egyptian 3211 emética $R$. Br. narrow-leaved 578. MICROLO'MA. $R$. Br. Microloma. 3212 sagittátum $\boldsymbol{H} \boldsymbol{K}$ arrow-leaved 579. SA RCOSTEMTA $R$. Br. Sarcostev 3213 viminále $\boldsymbol{H} . \boldsymbol{K}$. twisting \& $\square \mathrm{cu}$ 580. D 3214 exténsa $H . K$. smooth-leaved $\$$ 3215 acútum $R . B r$. acute-leaved 3216 monspelíacum $R . B r$. Montpelier 3217 crassifólium $R . B r$. obtuse-leaved 3218 pilósum $R, B r$. 3219 vincetóxicum $R, B r$, officinal lúteum

3220 nigrum $R, B r$ 3221 sibíricum $\boldsymbol{R} . \dot{B}$. 3229 médium $R$. $B$ r.

3223 undátum $B$. Rep. 3224 mucronátum B.Rep. sharp-pointed \$ $\$$ or 3225 viridiflórum $\boldsymbol{B}$. $\boldsymbol{M}$. green-flowered $\$ \square$ or 582. OXYSTEL/MA. $R . B r$. OXYSTELMA. 3226 esculéntum $\boldsymbol{R} . \mathrm{Br}$. esculent 583. GYMNE'MA. $\boldsymbol{R}$. $B r$. GYMnema. 3227 sylvéstre $R . B r$. netted-leaved 584. CALO'TROPIS. $R . B r$. Calotropis. 3228 prócera $\boldsymbol{H} . \boldsymbol{K}$. bell-flowered 3229 gigantéa $\boldsymbol{H} . \boldsymbol{K}$. curled-flowered $\square$ or 585. DISCHI'DIA. $R . B r$. Dischidia. 3930 bengalénsis Coleb. Bengal 586. XYSMALO'BIUM. $R$. $B r$. Xysmalobium. 3231 undulatum $H$ waved-leaved 587. GOMPHOCAR'PUS. $R . B r$. GomphocARPUS. 3232 arboréscens $\boldsymbol{H} . \boldsymbol{K}$. broad-leaved or 3233 crispus $\boldsymbol{H} . \boldsymbol{K}$. curled-leaved or 3234 fruticósus $\boldsymbol{H} . \boldsymbol{K}$. Willow-leaved w or 588. ASCLE'PIAS. $R . B r$. Swallow-wort 3235 syriaca $W$. Virginian $\forall \Delta$ or 32:36 phytolaccoídes $P h$. Phytolacca-like $\frac{\downarrow}{\Delta} \Delta$ or 3237 amœ'na $W . \quad$ oval-leaved $\vec{\nabla} \Delta$ or
Asclepiadere. Sp. 1.

Asclepiadea, Sp. 1-2

... G Ceylon 1796. C 1.p Bur.zeyl.t.83.f.1 Asclepiadea. Sp.2-4.

$\begin{array}{llllll}6 & \text { Wl Egypt 1752. C } & \text { s.l Alp æo t } 134\end{array}$ Asclepiadea. Sp. 1-2.

jl.au G.P C. G.H. 1775, C s.l Jac. sch. 1 t. 38 Asclepiadea. Sp. 1-12.

6 jl W E. Indies 1731. C r.m Alp.æg. t. 190 Asclepiadece. Sp. $1-4$.

3 jl.au W E. Indies 1777. C p.I Jac. ic. 1.t. 54 Asclepiadea. Sp. 11-50.

3 jl W Spain 1596. D co Tre. oh. 44. t. 82 au.s Pk S. Europe 1596. D co Jac. ic. 2. t. 340 $\begin{array}{llll}\ldots & \text { G } & \text { G. H. 1816. C co }\end{array}$ 2 jn.s W C. G. H. 1726. C p.I Bot. reg. 111 my.au W Europe 1596. D s.1 Flor. dan. 849 my.au Y Europe 1596. D s.l 3 jn.au W S. Europe 1596. D s.1 Bot. mag. 2390 3 jl.au G Siberia 1775. D co Mur. gott. 2. t. 7

W. Indies 180 . D co

Trinidad 1804. C l.p Bot rep. 410 Asclepiadece. Sp. 1-2

Y E. Indies 1816, D s.I Rox cor 1 t 11 Asclepiadea. Sp. 1-4.

8 ... Gr Ceylon 1816. C 1.p Wil. ph. 1.t.5.f.3 Asclepiadea. Sp. 2.

6 jl.s W.P Persia 1714. C s.1 Bot. rep. 271 6 jl.s W.p E. Indies 1690. C r.m Bot. reg. 58 Asclepiadece. $S p .1-2$

$\frac{1}{2} \quad \ldots \quad$ W India 1818. C s.l Lin.trans.12.t.15 Asclepiadece. Sp. 1-2.

il Gr C. G. H. 1783, C p.l Comm, rar t 16 Asclepiadece. $S p .3-4$.

$5 \mathrm{~d}$ W C. G. H. 1714. C i.p Jac. sch. 1. t. 50 1 jl $\quad$ Y $\quad$ C. G. H. 1774. C p.l Comm, rar. t. 17 jn.s W C. G. H. 1714. C p.l Bot. mag. 1628 Asclepiadea. Sp. $15-65$.

4 jl.au Pu N. Amer. 1629. D co Blackw. t. 521 3 jl.au Pu N. Amer. 1812. D co

3 jl.au Pu N. Amer. 1732, D p.l Dil. el.t. 27.f .30
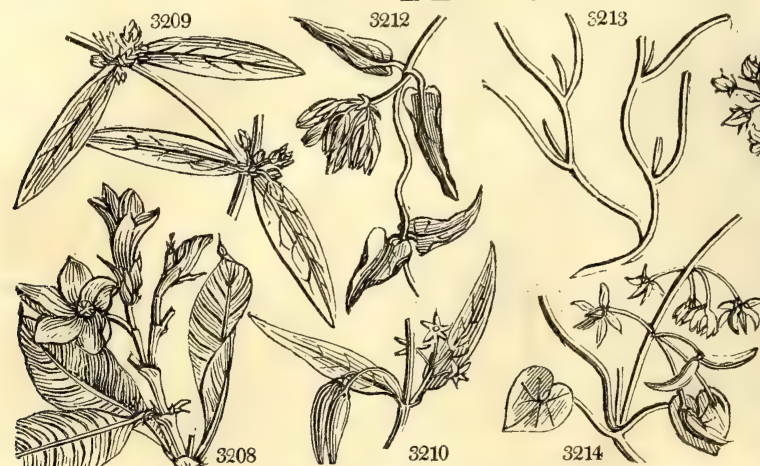
3224 
3208 The only known species

3209 Spikes axillary imbricated, Leaves elliptical obtuse mucronate, Stem smooth

3210 Flowers hairy inside panicled, Leaves lanceolate elliptical

3211 Flowers smooth, Corymbs few-flowered axillary, Leaves linear lanceolate without veins

3212 J.eaves sagittate pubescent, Limb of the corolla acute

3213 Stem twining perennial leafless

3214 Stem twining shrubby, Leaves cordate acute, Flowers hairy at edge

2215 Leaves oblong ovate cordate acute, Segments of cor. oblong obtuse

3216 Leaves reniform contracted at end $\frac{1}{2}$ lanceolate, Segm. of cor. lanceolate obtuse

3217 Leaves cordate ovate obtuse fleshy with a little point smooth, Crown 10-cleft as long as corolla

3218 Leaves ovate acute and calyxes hairy, Crown 10-cleft as long as corolla

3219 Stem erect, Flowers beardless, Partial stalks of umbel twice as long as common stalks, Crown 5-lobed

3220 Stem climbing upwards, Fl. bearded, Partial stalks of simpie umbel scarcely longer than common stalk 3221 Leaves lanceolate linear opposite and three together, Stem decumbent

3222 Stem twining upwards, Corollas beardless, Stalks of umbel divided, Corona 5-lobed

3223 Leaves oblong cordate acuminate wavy, Umbels axillary proliferous

3224 Stem hairy, Leaves heart-shaped mucronate, Umbels axillary proliferous

3225 Leaves cordate ovate acuminate, Umbels simple solitary, Partial flower-stalks longer than common one

3226 Cor. smooth rotate, Racemes axillary, Leaves linear lanceolate veiny

3227 Leaves rounded ovate netted pubescent beneath, Flowers in umbels

3228 Segments of cor. spreading

3229 Segments of cor. reflexed involute

\section{Leaves thick fleshy ovate}

3231 Leaves sessile oblong lanceolate wavy smooth, Umbels lateral, Petals ciliated

3232 Leaves ovate oblong smooth obtuse with a point

3233 Leaves cordate lanceolate wavy hispid

3234 Leaves linear lanceolate smooth

3235 Leaves oval downy beneath, Stem simple, Umbels nodding

3236 Stem erect simple, Leaves broad ovate oblong acute smooth paler beneath, Umbels nodding

3237 Stem simple downy in two rows, Leaves subsessile oblong oval downy beneath

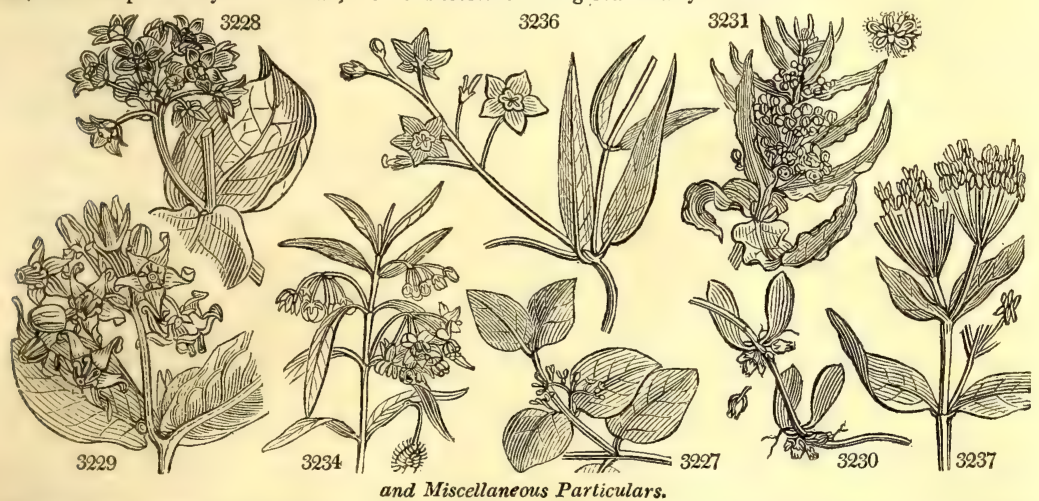

the peculiar structure of the stamens. The milk of Gymnema lactiferum is used instead of the Vaccine ichor, and the leaves are employed in sauces in the room of cream.

584. Calotropis. From $\approx \lambda_{05}$, beautiful, and $\tau \rho \varsigma \pi \omega$, to turn, in allusion to the beauty of the flowers, which continually turn towards the sun. This is a handsome free-flowering genus. Young cuttings root freely in sand under a hand-glass, but not crowded, as, if the leaves are injured, they are very apt to damp and get mouldy.

585. Dischidia. From $\delta \iota_{5}$, twice, and $\sigma^{\prime} \chi^{i} \zeta \omega$, to split; but the application is unexplained. Little trailing

plants with small opposite fleshy leaves.

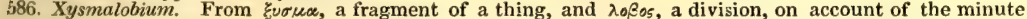
alternate divisions of the corona. The flowers of this genus are very large; those of $\mathbf{X}$. grandiflorum are of the size and color of Fritillaria meleagris.

587. Gomphocarpus. From roupos, a club, and zaৎто5, fruit. A genus resembling Asclepias in habit, but well distinguished by the inflated club-like fruit.

588. Asclepias. The name of many ancient physicians. It is the Greek name of the Æsculapius of the Latins. This is a genus of tall-growing herbaceous plants, which thrive best in peat or any very light soil. They require a good deal of room to show their characters, and are readily propagated by seeds or dividing the roots. A. syriaca is very odoriferous, and in Canada, when in fower, charms the traveller, especially when passing through woods in the evening. The French there eat the tender shoots in spring as we do asparagus. The natives make a sugar of the flowers, gathering them in the morning when they are covered with dew, and collect the cotton from
the pods to fill their beds. On account of the silkiness of this cotton, Parkinson calls the plant Virginian silk. A. nivea has jointed fleshy roots, the juice of which is very effective in bringing away worms. The root 
3238 purpuráscens $W$. 3239 variegáta $W$ 3240 curassávica $W$ $\beta$ alba 3241 nivea $W$ 3242 parviflóra $W$. 3243 incarnáta $W$. 3244 púlchra $W$. en 3245 decúmbens $W$ 3246 verticilláta $W$. 3247 longifólia $P h$. 3248 tuberósa $W$. 3249 Linária $W$. 589. GONO'LOBUS. 3250 hirsútus Mich. 3251 lævis Mich. 3252 suberósus $\boldsymbol{H}$. $\boldsymbol{K}$. 3253 discolor $\boldsymbol{B} . \boldsymbol{M}$. 3254 crispiflórus $H$. $K$ 3255 diademátus $\mathrm{Ker}$. 590. Pergula'ria. $\boldsymbol{R} . \boldsymbol{B r}$. Pergular 3256 odoratíssima $H . K$. large 3257 minor $H . K$. small 3258 sanguinolénta Lind. bloody 591. MARSDE'NIA. $R . B r$. MARSDENIA 3259 erécta $R$. $B r$. upright 3260 suavéolens $\boldsymbol{R}, \boldsymbol{B r}$. $\quad$ sweet-scented 592. HO'YA. $R$. Br. 3261 carnósa $R$. Br. 3262 lanceolátã Hort. 3263 crassifólia Haw. 3264 Pottsii Hort. 3265 trinérvis Hort. 593. CEROPE'GiA. Roxb. Ceropeaia 3266 dichótoma Haw. dichotomous 3267 juncea Roxb.

594. STAPE'LIA. $R . B r$. STAPElia 3269 grandiflóra Mass. great-flowered 3270 spectábilis Haw. grandiflóra B. M 3271 ambigua $W$. 3272 sorória $W$.en. $\$ 273$ pátula $W$. en 3274 refléxa Haw. 3275 lúcida $D$. C 3276 Juvéncùla $W$. en. 3277 Massónii Haw. 3278 Astérias $W$. 3279 stelláris Haw. 3280 hirsíta $W$. $\beta$ at; $a$ Jacq. 3281 hamáta Jacq. 3282 comáta Jacq. B multiflóra D. C. 3283 rúf $W$ 3284 pulvináta $W$. Hoya. fleshy-leaved lanceolate thick-leaved cordate sister reflexed

Masson's

Star-fish starry hairy dark-flowered hooked $\downarrow \Delta$ or 3 jl.au

$\pm \Delta$ or 4 jl.au t $\triangle$ or 3 jn.s bै or 3 jn.s Almond-leaved $\not \Delta$ or $3 \mathrm{jl} . \mathrm{s}$ small-flowered $\downarrow \Delta$ or 3 jl.o decumbent $\frac{\Delta}{\Delta}$ or 2 jl.au te $\Delta$ or 2 jl.au

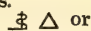
2
2 jl.s

P.G N. Amer. 1732. D p.l Dil. el. t. 28.f. 31 W N. Amer. 1597. D p.l Bot. mag. 1182

S S. Amer. 1692. S r.m Bot. reg. 81

W S. Amer. $\ldots$ S r.m

W N. Amer. 1730. D p.l Bot. mag. 1181

W N. Amer. 1774. C r.m Jacq. ecl. t. 28

Pu N. Amer. 1710. D p.1 Bot. reg. 250

$\mathrm{Pu} \quad \mathrm{N}$. Amer. ... D p.l

O N Amer 1731. D pl

W.G N. Amer. 1759. D p.1 Pl ma. t. 336, f. 3 P.Pu N. Amer. 1816. D p.1

O N. Amer. 1690. D s.1 Bot. reg. 76

Asclepiadea. Sp. 6-

6 jn $P$ N. Amer. 1806. C 1.p Bot. cab. 365

6 jn G N. Amer. 1806. C l.p

G America 1732. C $\quad$ p.1 D. el. t. 229.f.296

G N. Amer. 1809. C p.1 Bot. mag. 1273

W.G S Amer. 1741. C s.p Pl ic t 216 f. 1

G Mexico 1812. C s.p Bot. reg. 252

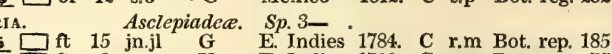

$\square \mathrm{ft} 8$ my.au Y.G E. Indies 1790. C r.m Bot. mag. 755

$\square$ cu 6 jl.au G.Y S. Leone 1822. C r.m Bot. mag. 2532

Asclepiadea. Sp. 2-.

$\square \mathrm{ft} \quad 2$ jl.au W $\quad$ Syria 1597. C s.l Jac. vind. 1.t. 38

\section{Asclepiadea. Sp. 5-}

\$ $\square$ or 10 jl.au Pk Asia 1802. L r.m Bot. mag. 788

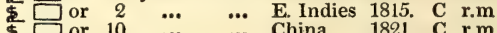

$\$$ or 10 ... China 1821. C r.m

5 or $10 \quad \ldots \quad \ldots$ China 1824. C r.m

* $\rightarrow$ cu 1 Asclepiadea. Sp. 3 Y

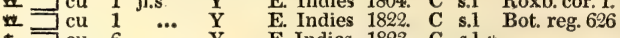

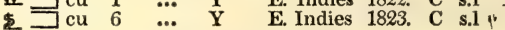

Asclepiadece. Sp. 65- .

$\Longrightarrow$ cu 1 s.d D.Pu C. G. H. 1795. C s.1 Mass. stap. t. 11 2 cu 1 jn.au i. $\mathrm{cu} 1$ jn.au shaggy $\mathrm{cu} \mathrm{1}^{\frac{1}{4}} \mathrm{~s}$ many-flowered

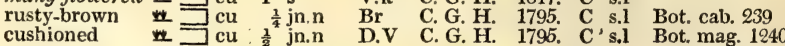

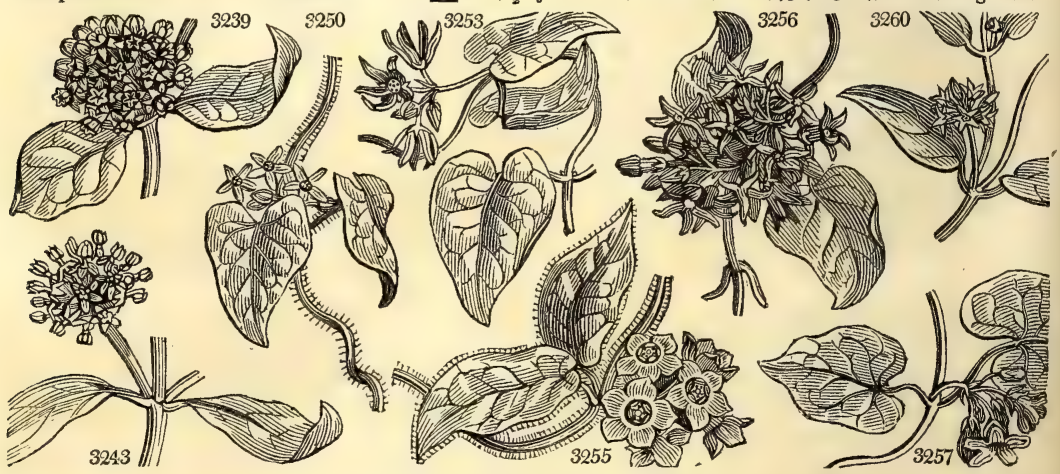

History, Use, Propagation, Culture,

dried and reduced to powder, is frequently used by the negroes as a vomit, and hence its name of wild or bastard Ipecacuanha.

A. vincetoxicum (tame-poison) is so named because it was formerly esteemed an alexipharmick; and it is called swallow-wort from the fancied resemblance of the follicles or seeds to a swallow flying.

589. Gonolobus. The derivation and meaning of this word have not been explained. The genus consists chiefly of climbers of little beauty but easy culture.

590. Pergularia. From Pergula, trellis-work, which the plants are very proper for covering. This is a climbing genus, much valued for the fragrance of its flowers. It grows well in loam and peat, and cuttings root freely in sand under a hand-glass.

591. Marsdenin. So named by Mr. R. Brown, after William Marsden, Esq. the author of the excellent 
3938 Stem simple, Leaves ovate villous beneath, Umbels erect, Nect. resupinate

3239 Leaves ovate rugose naked, Stem simple, Umbels subsessile, Flower-stalks downy

3240 Leaves stalked lanceolate smooth shining, Stem simple, Umbels erect solitary lateral

S241 Leaves ovate-lanceolate smooth, Stem simple, Umbels erect lateral solitary

3242 Leaves lanceolate acuminate smooth narrowed at base, Stem half shrubby erect, Umbels lateral solitary

3243 Leaves lanceolate smooth, Stem divided upwards, Umbels erect in pairs

3244 Leaves lanceolate pubescent beneath, Stem divided upwards, Umbels erect in pairs

3245 Leaves villous, Stem decumbent

3246 Stem exect simple downy in lines, Leaves very narrow linear mostly whorled

3247 Stem decumbent and leaves very long linear pubescent, Appendages of crown without horns

3248 Stem erect hairy with spreading branches at end, Leaves scattered lanceolate hairy

3249 Leaves linear subulate channelled, Umbels stalked nodding : lateral many-flowered

S250 Runners and leafstalks very hairy, Lvs. acum. by degrees perceptibly hairy on both sides, Foll. muricated 3251 Runners smoothish, Leaves conical cordate acute by degrees, Flowers and follicles smooth

3252 Leaves cordate acuminate with the sinus open

3253 Leaves cordate, Corymbs axillary, Common flower-stalk longer than the leafstalks Cor. discolored

3254 Leaves oblong cordate with the sinus closed, Petals crisp at end

3255 Villous, Leaves oblong elliptical lanceolate cordate, Crown at bottom of tube

3256 Leaves cordate acuminate, Cal. shorter than tube of cor.

3257 Leaves cordate obtuse with a point, Cal, as long as tube of cor.

3258 Leaves ovate lanc. very smooth, Cymes shorter than leaves, Sap blood-colored

3259 Stem erect, Leaves cordate ovate acute, Cymes umbellate, Flowers not bearded

3260 Stem somewhat erect, Leaves oval-lanceolate smooth veinless, Tube inflated, Orifice bearded

3261 Leaves ovate, Flowers bearded

3262 Leaves ovate-lanceolate acute small

3263 Leaves obovate obtuse very thick

3264 Leaves cordate

3265 Leaves oblong slightly cordate at base with 3 distinct nerves

3266 Stems upright jointed rounded, Leaves linear acute

3267 Leaves lanceolate sessile, Peduncles 2-flowered, Stem fleshy

3268 Leaves smooth with an edge, Peduncles simple, Calyx very smooth

1. Cor. 5-cleft with no ball. Crown double: the outer with the ligules united at base; inner with the append-

ages united upwards into a beak, downwards expanded into a wing. (TRUE STAPELIA.)
3269 Branches quadrangular clavate: angies with remote incurved teeth, Seg. of cor. lanc. acute fringed at edge 3270 Segments of cor. fringed with white covered at base with very close long red hairs black at end, beyond mid. striped with pale

3271 Branches erect 4-ang. clav. Angles toothed rem. incurv. Cor. large flat with lanc. hisp. seg. fring. at edge 3272. Branches spreading 4.ang. Angles toothed, Teeth remote acute incurved, Cor. whole color. vil. in middle 3973 Cor. flat cil. rugose above in mid. hairy otherwise smooth, Beak sub. ac. Wings obl, obt. 1-tooth. inside 3274 Stam. deltoid with inner process recurved unguiculate, Top of style impressed with the mark of a cross 3275 Branches sq. erect velvety, Teeth erect, Disc. of fls. shining hairy with ovate-acum. revolute ciliated seg. 3276 Fls. flat smooth rugose crosswise, Beaks subul. gibb. Ligules lanc. acum. Bran. fl.-bearing about the mid. 3277 Branches four together large equal sided with flat pubescent angles

3278 Branches several erect square toothed, Teeth short erect, Fl. large, Segm. lanc. ciliated revolute at edge 3279 An obscure species said to be cultivated in the gardens, but of which nothing is known

3280 Flowers flat ciliated hairy all over the disk, Beaks subulate acute with a broad acute wing at the back

3281 Fls. flat cil. rugose above hairy in centre, One or more of teeth hooked, Wings parallel with erect beaks $3282 \mathrm{Fl}$. cil. Disk flat shaggy in mid. Segm. at first deflexed afterwards spreading, Wings obl. trunc. crenulate Differs chiefly in the dark color of the flowers which are clustered and not solitary

$3283 \mathrm{Segm}$. of $\mathrm{fl}$. lanc, acum. Ligules linear lanc. wavy, Branches erect square with erect teeth

3284 Branches reclinate, Segm. of fl. rounded rugose acuminate ciliated : the bottom elevated closely hairy

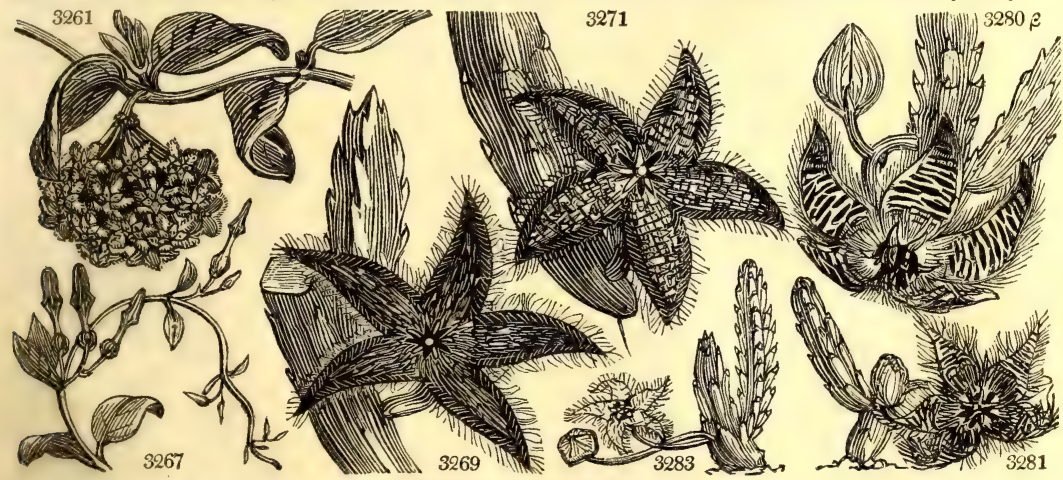

and Miscellaneous Particulars.

History of Sumatra, in which one species, used as Indigo in the island is figured. Little neat shrubs, with axillary bunches of small white sweet-scented flowers.

592. Hoya. Named after Mr. Thomas Hoy, for many years gardener to the Duke of Northumberland. He died about 1821 . H. carnosa is of easy culture, flowers freely, and is propagated by cuttings in a moist heat. Its flowers are very mellifluous, and it has been said that one or two plants, placed when in flower in a vinery of ripe grapes, will entice the wasps from eating the fruit.

593. Ceropegia. From «neos, wax, and $\pi n \gamma^{\prime n}$, a fountain; literally, a fountain of wax, poetically, a candelabre ; on account of the umbels of bright yellow flowers. Curious naked plants with tumid fleshy stems. Same culture as Hoya.

594. Stapelia. So named by Linnæus, in memory of Bodæus à Stapel, a physician of Amsterdam, com. 
3285 fissiróstris Jacq. 3286 concínna $W$. 3287 glanduliffóra $w$ 3288 glandulífera Haw. 3289 acumináta $W$.

3290 hispidula Horn.

3291 apérta $W$.

3292 ramósa $\dot{W}$.

3293 árida $\boldsymbol{W}$.

3294 incarnáta $W$

3295 parviflóra $W$

3296 pilifera $W$

3297 Gordoni Mass.

3298 mammillaris $W$

3299 articuláta $W$.

3300 gemmiflóra Mass. 3301 stýgia Haw.

$\beta$ moschata Haw.

3302 hircósa W. en.

3303 vétula $W$

3304 Simsii Haw.

vetula B. M.

3305 rugósa $\boldsymbol{W}$. en.

3306 paniculáta $W$, en.

3307 divaricáta $W$.

3308 púlchra Haw.

3309 irroráta $W$

3310 verrucósa $\boldsymbol{W}$.

3311 roriflua $W$. en

3312 pulchêlla $\boldsymbol{W}$.

3313 lépida $\boldsymbol{W} . e n$.

3314 ciliáta $W$.

3315 revolúta $W$.

3316 glaúca $W$. en.

3317 pruinósa $\boldsymbol{W}$.

3318 obliqua $W . e n$. 3319 maculósa Jacq.

3319 maculosa Jacq.

3321 variegáta Haw.

3322 Curtisii Haw. variegáta B. M.

3323 planiflóra $W$.en.

3324 margináta $\boldsymbol{W}$. en.

3325 conspurcáta $W$. en

3326 normalis Jacq.

3327 orbiculáris $\boldsymbol{B}$. Rep
3328 bufónia $\boldsymbol{W}$. en.

3329 anguina Haw.

3330 picta $\boldsymbol{H}, \boldsymbol{K}$.

3331 gemináta $W$

3332 decóra $W$. $\begin{array}{lll}\text { split-beaked } & \mathrm{cu} & 2 \frac{1}{2} \\ \text { spruce } & \ldots & \text {... }\end{array}$

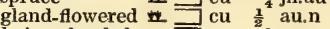

hairy-glanded $=\mathrm{cu} \frac{1}{2} \mathrm{au} . \mathrm{n}$

acuminated $\mathrm{cu}^{\frac{3}{2}} \mathrm{jls}$

hispid $\mathrm{cu}_{\frac{2}{4} \mathrm{jl} . \mathrm{au}}$

open-flowered $\Longrightarrow \mathrm{cu} \quad 2^{4} \mathrm{jl}$.au

branched

业 $\Longrightarrow \mathrm{cu} 1 \frac{1}{2}$ jn.jl

dry cu $\mathrm{cu}^{\frac{1}{4}} \mathrm{au}$

small-flowered $=\mathrm{cu} 1$ ji.

hairy-tubercled $\mathrm{cu} 1$ jn.au

Gordon's

prickly

jointed

gem-flowered $\mathrm{cu}_{\frac{1}{2}}$ o.n

Stygian $\mathrm{cu} \frac{1}{2} \mathrm{jl} . \mathrm{s}$

musky

pur. smooth.-fl, w $\mathrm{cu}^{2} \mathrm{z}$ my.n

Sims's $\frac{c^{\frac{1}{2}}}{2}$ my.n

Y.G C. G. H. 1823. C $\quad$ s.l Jac. stap. c. ic.

Gr C. G. H. 1795. C s.1 Mass. stap. t. 18

Br C. G. H. 1795. C s.l Mass. stap. t. 19

$\begin{array}{lllll}\mathrm{Br} & \text { C. G. H. } & \mathbf{H} & \text { C } & \text { s.1 }\end{array}$

P.St C. G. H. 1795. C s.l

Y.P C. G. H. 1795. C s.1 Mass. stap. t. 37

D.P C. G. H. 1795. C s.1 Mass. stap. t. 32

Y C. G. H. 1795. C s.1 Mass. stap.t. 33

F C. G. H. 1793. C s.1 Mass. stap. t. 34

Y. Gr C. G. H. 1795. C s.1 Mass. stap. t. 35

D.P C. G. H. 1790. C s.l Mass. stap. t. 23

Br C. H. 1796. C s.1 Mass. stap. t. 40

D.P C. G. 1774. C.I Bur.

D.P C. G. H. 1795. C s.1 Mass. stap. t. 15

D.P C. G. H. 1810, C s.l

.. C. G. H. ... C C s.l

Pu C. G. H. … C s.l Jac. stap. c. ic.

D.Pu C. G. H. 1793. C s.1 Mass. stap. t. 16

wrinkled $\quad \square$ cu $\frac{1}{2}$ my.au P.St C. G. H. 1805. C s.l Jac. stap. c. ic.

panicled $\square \mathrm{cu} \frac{1}{2} \mathrm{jn} . \mathrm{s} \quad \mathrm{V}$ C. G. H. 1805. C s.l

straddling $\quad \exists \mathrm{cu} \quad \frac{3}{4}$ jn.n

D.F C. G. H. 1793. C s.l Bot. mag. 1007

beautiful Sulph. $\square$ cu $\quad \frac{1}{2}$ au.s $\quad$ Y.St $\quad$ C. G. H. 1800: C s.l Bot. mag. 786 dewy $\begin{array}{lllll}\frac{1}{2} & \text { jl.s Y.St C. G. H. 1795. C } & \text { s.1 Bot. cab. } 127\end{array}$

wart-flowered $\mathrm{cu}_{\frac{1}{2}}$ au.o Y.St C. G. H. 1795. C s.1 Mass. stap. t. 8

dew-bearing $=\mathrm{cu} \frac{1}{2} \mathrm{jl.s}$ Y.St C. G. H. 1802. C s.l Jac. stap. c. ic.

beautiful $=\mathrm{cu}^{\frac{1}{2}}$ my.n Y.St C. G. H. 1795. C s.1 Mass. stap.t. 36

pretty $\quad \begin{array}{cc}\frac{1}{2} \\ \mathrm{Cu}\end{array}$

ciliated $=\mathrm{cu}_{\frac{1}{2}}$ o.d G.St C. G. H. 1795. C s.1 Mass. stap. t. 1

revolute-flower. $\square$ cu 1 jn.s

glaucous

Pu C. G. H. 1790. C s.l Bot. mag. 724

R.Pu C. G. H. 1799. C s.l Jac. stap. c. ic

D.Br C. G. H. 1795. C s.1 Mass. stap. t. 41

oblique-flower. $\mathrm{w}$ cu 1 jn.s spotted two-furrowed
variegated $\begin{array}{llll}\text { variegated } & \mathrm{cu} & 1 & \mathrm{jn} . \mathrm{s} \\ \text { Curtis's } & \mathrm{cu} & 1 & \mathrm{jn} . \mathrm{s}\end{array}$

plain-flowered $\# \mathrm{cu} \quad \mathrm{i}$ jl.n

red-edged $\square \mathrm{cu} \frac{x^{2}}{2} \mathrm{jn.s}$

white-edged $\Rightarrow \mathrm{cu} \frac{1}{2} \mathrm{jn} . \mathrm{O}$

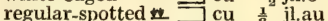

orbicular

toad $\mathrm{cu} 1 \mathrm{jn} . \mathrm{j}$

snake-speckled $\Longrightarrow$ cu $\frac{1}{2} \mathrm{jn} . \mathrm{j}$

Pa.V C. G. H. 1805. C s.l

Br.v C. G. H. 1804. C s.l Bot. mag. 1833

Y.St C G H 1805 C s.

Y.St C. G. H. 1727. C s.l Jac. stap. t. 3

Y.St C. G. H. 1690. C s.l Bot. mag. 26

P.Y C. G. H. 1805, C s.l Bot. cab. 191

Y.St C. G. H. 1805. C s.1

Y.St C. G. H. 1795. C s.l Jac. stap. c. ic.

Y.St C. G. H 1821 C s.l Bot reg 755

Y.St C. G. H. 1799. C s.l Bot. rep. 448

Y.St C. G. H. 1806. C s.1 Bot. mag. 1676

Y.St C. G. H. 1812. C s.1 Bot. cab. 828

Y.St C. G. H. 1799. C s.l Bot. mag. 1169

3333 reclináta $W$

3087

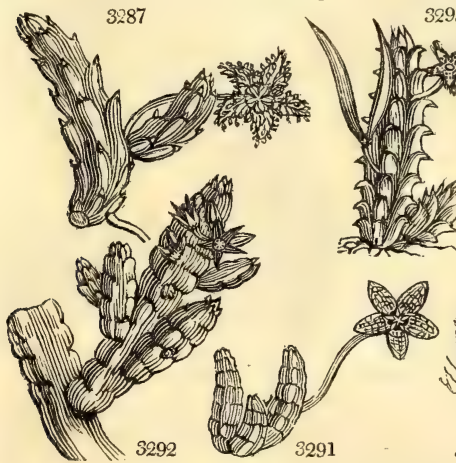

History, Use, Propagation, Culture,

mentator on Theophrastus, 1644. This is a genus of singular plants, without leaves, diminutive, very succulent, and some of them with flowers large in proportion to the plant, curious, and often smelling very disagreeably. They are mostly natives of the deserts of Africa, and have been chiefly discovered by Masson, 
3285 Flowers cuspidate rugose scabrous ciliated, Beaks half split

3286 Branches and branchlets upright square quite smooth, Angles toothed, Teeth erect, Flower flat hispid 3287 Branches many erect square, Angles toothed, Teeth erect acute, Cor. covered with clavate glands 3288 Cor. very villous with white spatulate hairs, Ligules minute rhomboid-oblong entire

3289 Branches several suberect 4-cornered toothed, Flower flat smooth rugose, Segments caudate

3289 Branches several suberect 4-cornered toothed, Flower flat smooth rugose, Segments caudate 3290 Pedunc. aggreg. rad. much longer than cor. Segm. acum. hispid with clavate hairs, Beaks subul. conniving 3291 Branches many divaricating square toothed, Flower flat with ovate obtuse rugose segments

3292 Branches many erect square toothed, Flowers clustered sessile, Segm. lanc. acute folded back

3293 Branches many erect square with spreading acute teeth, Flowers solitary stalked, Segm. setaceous

3294 Branches erect square toothed, Teeth spreading acute, Flowers sessile, Segm. lanc. flat

3295 Branches several square toothed recurved, Flower small, Segm. narrow flat spreading fringed at edge

3296 Branches several rounded furrowed tubercled hairy, Flower solitary sessile

3297 Branches and branchlets rounded tubercled spiny, Flowers solitary large 10-cleft

3298 Cor. smooth, Seg. lanc. Fl. stalks shorter than cor. Branches flowering in mid. 6-sid. with prickly tuber. 3299 Joints of branches obl. round. nett. obscurely warted, Spines sin. Cor. wart. above with triangular segm. 3500 Branches several erect sq. with nearly upright acute teeth, Fl. flat rough 5-cleft with ov. lanc. ciliate seg. 3301 Cor. rugose dark with pink hairs, Branches thick short yellowish green

3302 Cor. ciliated rough above dotted beneath, Ligules erect 3-parted : middle lanceol, longer than sides 3303 Branches many erect square smooth, Cor. flat smooth with lanceolate obtuse segments

3304 Teeth of branches rounded, Fls. closed ventricose with 5-nerved ov. acum. seg. Beaks split open

3305 Ball spurious depressed 5 crenate in the circumference, Beaks and wings rounded obtuse, Tube of cor. $\mathbf{O}$. 3306 Cor. 5-parted flat hairy warted across, Appendages obtuse obscurely toothed, Beaks subulate conniving \$2. Cor. 5-cleft with no ball. Ligules not connate at base spreading. Appendages lengthened into incurved beaks, gibbous, but not winged at back. (GoNosTEMoN. Haw.)

3307 Branches several sq. divaricat. smooth tooth. narr. by deg. Cor. very smooth 5-cleft, Seg. lanc. spreading \$ 3. Cor. 5-cleft with a ball. Ligules connate spreading. Appendages lengthened into incurved beaks, not winged. (Podanthes. Haw.

3308 Much branched weak, Flowers in pairs wrinkled minutely hairy at bottom

3309 Branches many suberect toothed, Teeth spreading acute crossing, Cor. flat rugose, Segm. lanc. acute

3310 Branches many erect with acute crossing teeth, Cor. flat wart. elevated in the middle into a rough table

3311 Cor. 5-cleft camp. smooth dotted even at bottom, Segm. of outer crown ob. emarg. Inner hooked 2-lobed

3312 Branches severai reclinate with acute teeth, Fl. clustered, Segm. triangular acute with a round centre

3313 Rim obsolete, Beaks rounded obtuse, Wings conical subulate acute spreading, Ligules retuse

3314 Stem square with spreading teeth, Flower stalked, Segm. ovate scaly ciliated

84. Cor. 5-cleft reflexed with no ball. Ligules connate at base. Appendages lengthened into long beaks with short wings. (Tromotriche. Haw.)

3315 Branches square erect with sprearing teeth, Cor. smooth, Segments ciliated acute revolute

$3316 \mathrm{Segm}$. of cor. ovate acute fringed revolute, Beaks clavate, Branches square with rounded angles

3317 Branches square toothed, Teeth recurved, Segm. of cor. flat ovate hairy

5. Cor. 5-cleft, with a large ball in the middle. Ligules connate at base. Appendages produced into long beaks, and subulate or filiform wings. (ORBEA. Haw.)

3318 Cor. 5-cleft rugose smooth, Segm. ovate-acumin. bent obliquely, Marginal fringe clavate white and violet 3319 Ball solid, Beaks and wings rounded obtuse, Ligules trifid, Cor. flat beneath fringed at mouth

3320 Cor. 5-cleft, Ligules oblong emarginate, Sepals broad ovate acuminate, Branches thick green not spotted 3321 Ball spurious, Beaks rounded obtuse, Wings subulate obtuse spreading, Ligules bifid acute

3322 Cor, sulphur colored with entire ligules

3323 Ball spurious, Beaks rounded obtuse, Wings subulate obtuse spreading, Ligules bifid, Cor. flat beneath 3324 Ball 5 angular, Ligules 2-toothed obt. Appendages diverging the inner clavate the outer subulate obtuse 3325 Cor. fringed at edge with clavate hairs, Ball tumid, Appendages bifid diverging

3326 Cor. rugose across flat dotted in a regular maner, Inner horns hooked obtuse, Ball round tumid

3327 Branches several erect spreading 4-cornered toothed, Ball closely dotted, Segm. rugose cordate striated 3328 Ball spurious, Beaks round. obt. Wings filiform obt. sprearing, Ligules bifid obt. Cor. flat with no tube 3329 Ball large, Ligules half divided, Speckles of flower wavy tortuous

3330 Branches simple 4-furrowed torulose, Seg. ov. acum. rugose, Ball elevated rugose depressed in middle

$\$ 6$ Cor.5-cleft flat with no ball. Ligules none. Appendages produced into a short beak and a longer incumbent wing. (OBEsia. Haw.)

3331 Cor. 5-cleft strigose, Seg. revolute at edge, Wings hooked incumbent on their beak, Shield 5-lobed fleshy 3332 Joints of stem ob]. rounded, Fls. in pairs, Seg. of cor. lanceolate acuminate rough above revolute at edge \& 7 Cor 5-cleft, with the segments folded back. Ligules none. Appendages or beaks simple, with no wings. 3533 Branches several 4-cornered reclinate with acute spreading teeth, Segm, of flower folded back fringed

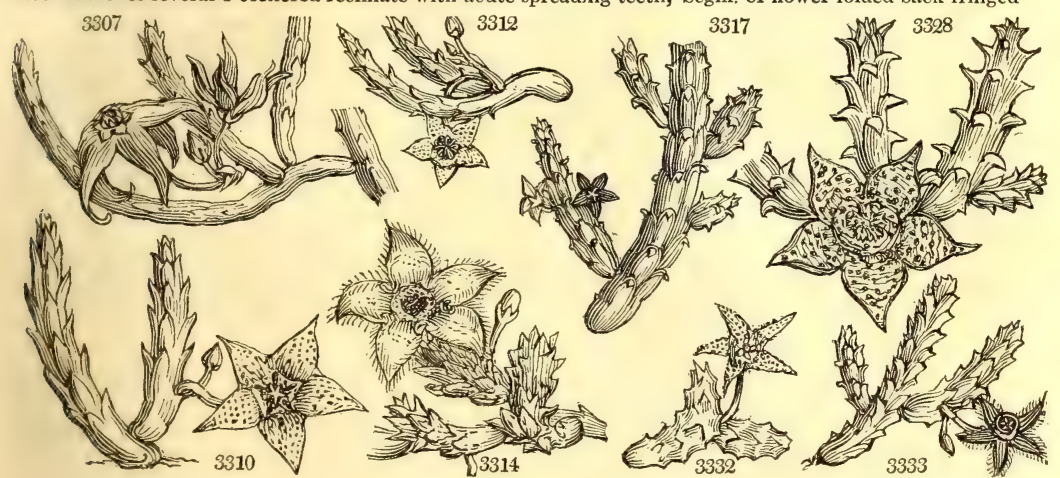

and Miscellaneous Particulars.

a collector for Kew gardens about the end of the last century, and who published a monograph of the genus. 'They have been divided into several genera by Haworth, who has not been followed by other writers. Some or the species, as S. pilifera and articulata, are eaten by the Hottentots and by the Dutch settled at the Cape 
3334 élegans $W$.

3335 cæspitósa $W$. $\beta$ hirtella W. en.

3336 radiáta $\boldsymbol{H} \boldsymbol{K}$

3337 Jacquini

radiata $\mathrm{J} . \mathrm{S}$

3338 defléxa J.S. elegant

tufted

small hairy

Jacquin's

deflexed $\square$ cu 1 jn.au $\mathrm{Y}$
C. G. H. 1795. C s.l Bot. mag. 1184 C. G. H. 1790 . C s.l Mass. stap. t. 29 C. G. H. $\quad \ldots$ C s.l Jac. stap. c. ic. C. G. H. 1795. C s.1 Bot. mag. 619 C. G. H. 1802. C s.l Jac. stap. c. ic.

C. G. H. 1806. C s.l Bot. mag. 1890

3389 pedunculáta $\boldsymbol{W}$. long-peduncled $\square \mathrm{cu} \quad \frac{1}{4}$ jn.n $\quad$ Br.P C. G. H. 1790. C s.1 Bot. mag. 793

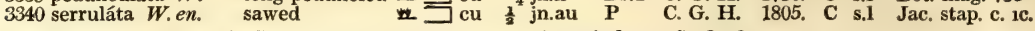
595. PIARAN'Thus, $R, B r$. Piaranthus.

3341 pullus $R$ Br.

many-flowered $\square$ cu $\frac{1}{2}$ au.s D.Pu C. G. H. 1774. C s.l Bot. mag. 1648

3342 punctátus $R . B r$. dotted $7 \mathrm{cu} \frac{\frac{1}{2}}{2}$ jl.n $\quad$ D.Pu C. G. H. 1795. C s.1 Mass. stap. t.24

596. HUER'NIA. R. Br. HuERNiA.

3343 reticuláta $\mathrm{Haw}$. netted

3344 campanuláta Haw. bell-shaped

3345 venústa Haw. handsome

3346 lentiginósa Haw. freckled

3347 guttáta Haw.

3348 húmilis Haw.

3349 tubáta $W$. en.

3350 barbáta Haw.

críspa Haw.

freckled

Asclepiadea. Sp.9-11.

$\mathrm{cu}^{\frac{3}{4}}$ au.n Y.St C. G. H. 1795. C s.l Mass. stap. t.4

tube-flowered $\mathrm{cu}^{\frac{1}{4}}$ au.n Y.St C. G. H. 1795. C s.l Mass. stap. t. 5

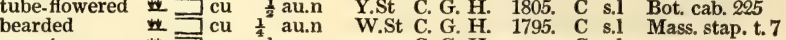

3351 clavigera Haw.

monstrous

clubbed

$\Longrightarrow$ cu $\frac{1}{4}$ au.n

til. $\ddot{n}$

Y... C. G.

C s.l

597. BRACHYSTEL/MA. $\boldsymbol{R}$. Br. BRAChYsTELMA. Asclepiadea. Sp. 1.

3352 tuberósum $\boldsymbol{R} . \mathbf{B r}$. tuberous $\quad \square$ cu $1 \frac{1}{2}$ jn.jl Pu $\quad$ C. G. H. 1821. C s.l Bot. reg. 722

598. CARAllu'ma. $\boldsymbol{R}$. Br. Caralluma.

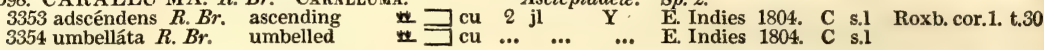

599. SWER'TIA. $W$. FELWORT.

3355 perénnis $W$. marsh

600. GENTIA'NA. $\boldsymbol{W}$. Gentian.

3356 lútea $\boldsymbol{W}$.

3357 purpúrea $W$.

3358 pannónica $\dot{W}$

3359 punctáta $W$.

3360 septémfida Pall.

3361 asclepiadéa $W$.

3362 macrophýlla $\dot{W}$.

3,363 cruciáta $W$

3364 ochroléca Fröl.

3365 incarnáta $\boldsymbol{B}$. $\boldsymbol{M}$.

3366 Saponária $W$.

3366 Saponária $\boldsymbol{W}$.

3368 Pneumonánthe $\boldsymbol{W}$.

3369 caucásea $\boldsymbol{H} . \boldsymbol{K}$.

3370 adscéndens $\boldsymbol{W}$.

3371 triflóra Pall.

3372 álgida Pall.

3373 acaúlis $\boldsymbol{W}$.

3374 vérna $W$.

3375 bavarica $W$

3376 nivális $W$.

3377 viscósa $\boldsymbol{H}$. $\boldsymbol{K}$.

yellow

yellow

Gentianea. Sp. 1-15.

1804. C s.l

当 $\Delta$ or 1 jl.au Pu England al.ma. D m.s Eng. bot. 1441

Gentianea. Sp. 28-I10.

Q $A$ or 3 jn.jl $\quad$ A Al of Eur.1768. D p.1 Mot. 117

round-petalled $\& \Delta$ or 1 jn.jl Pu Al. of Eur. ... D p.l Jac. aus. 2.t. 136

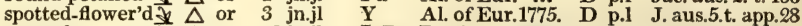

crested $\frac{1}{\Delta}$ or $\frac{3}{4}$ jn.jl L.B Persia 1804. D p.l Bot. mag. 1229

Swallow-wort-l. $\triangle 4$ or 1 jl.au B Austria 1629. I p.l Bot. mag. 1078

long-leaved $\overrightarrow{ \pm} \Delta$ or 1 jl.au D.B Siberia 1796. D p.1 Pall. ross.2.t.96

Cross-wort $\underset{\perp}{ } \Delta$ or 1 jn.jl D.B Austria 1596. D p.l Jac. aus. 4. t. 372

pale-flowered $\downarrow \Delta$ or 2 au.s P.Y N. Amer. 1803. D p.l Bot.mag. 1551

flesh-colored $\Varangle \Delta$ or 20 Pk N. Amer. 1812. D p.l Bot. mag. 1856

barrel-flowered $\frac{1}{\Delta}$ or 2 au.s B N. Amer. 1776 D p.1 Bot mag. 1039

Catesby's $\frac{1}{2} \Delta$ or $1 \frac{1}{4} \mathrm{jn} . \mathrm{jl} \quad \mathrm{B} \quad \mathrm{N}$. Amer. 1803. D p.1 Bot. rep. 418

CalathianViolet $\frac{j}{\Delta} \Delta$ or $\frac{1}{2}$ au.s $\quad$ B $\quad$ England moi.h. D p.l Eng. bot. 20

Caucasian $\frac{7}{2}$ or $\frac{1}{2}$ jl $\quad$ V Caucasus 1804. D p.l Bot. mag. 1038

porcelain-flow. $\downarrow \Delta$ or $\frac{\pi}{4}$ jn.jl B Siberia 1799. D p.l B.mag.705.\&723

three-flowered $\ddagger \Delta$ or $\frac{1}{2} j n . j l \quad B \quad$ Siberia 1807. D p.l Pall.ross.t.93.f.1

narrow-leaved $\Delta$ or $\frac{1}{2}$ jn.jl W Siberia 1808. D p.l Pall. ross. 2. t. 95

dwarf $\triangle$ or ${ }^{\frac{1}{4}}$ mr.my B Wales walls. D p.l Eng. bot. 1594

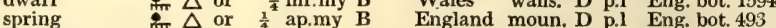

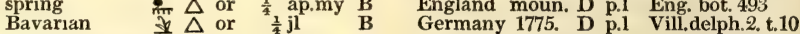
small Alpine. $\$ \mathrm{O}$ or $\frac{1}{4}$ au $\quad$ B $\quad$ Scotland sc.alp. D s.1 Eng. bot. 896

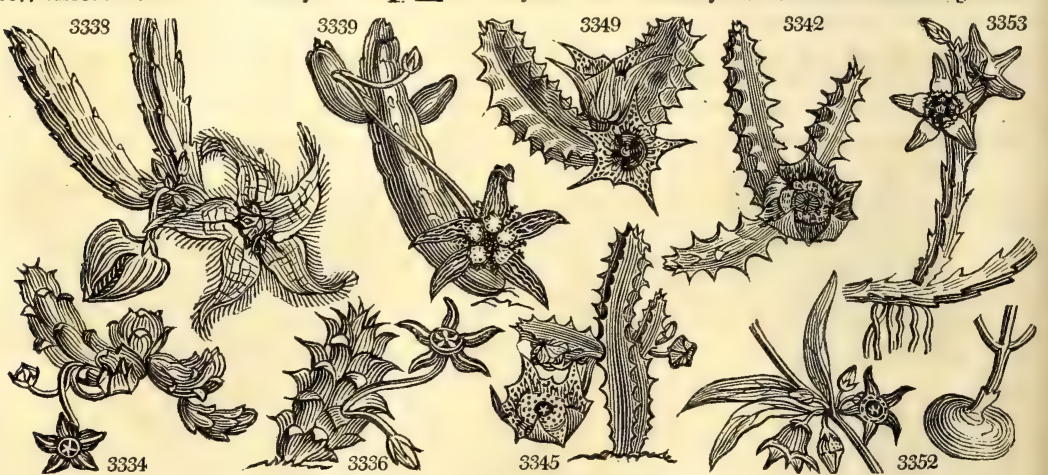

History, Use, Propagation, Culture,

pickled in vinegar; but in general they are without use. According to Sweet, "the best soil for them is a sandy loam, mixed with old lime or brick rubbish; if planted in a richer soil, they will thrive better for a time, and produce larger flowers; but then they are very apt to rot off, particularly if they chance to get a little too much water: a very little water serves them, except when in flower, when it may be given more freely. They are readily increased by cuttings, which should be laid to dry in the stove, till they begin to shrivel; then planted in pots they will root immediately. If planted as soon as taken off, when full of juice, they are likely to rot. (Bot. Cult. 109.)

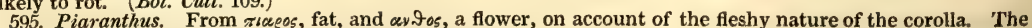
species are only artificially distinguished from Stapelia.

596. Huernia. Named after Justus Huernius, an obscure botanist. The species have the same appearance 
3354 Branches several clustered oblong toothed, Segm. of cor. 3-angular hispid fringed at edge 3335 Branches clustered procumbent 4-cornered with spreading acute teeth, Seg. of cor. folded back fringed

3336 Branches clustered short with conical acute teeth, Segm. of cor. distant folded back naked 3337 Cor. with seg. refl. at edge and fringed with simple hairs, Bottom rounded elevated, Lig. falcate hooked 3338 Cor. rugose ciliat. pubes. in midd. Seg. revolute at edge all bent down, Beaks subul. Wings scarcely any

8. Cor. 5-cleft with no ball. Ligules not connate at base, spreading. Appendages elongated into a bifid rostrum, with globose fungous tips. (CARUNCUlaria. Haw.)

3339 Branches several divar. 4-corn. toothed, Ped. very long, Seg. of cor. lanc. rev. at edge with fringed angles 3340 Branches oblong jointed, Peduncles twin, Cor. revolute at edge with wings and lobes serrated at end

3341 Six-cornered erect with spreading prickles, Flower sessile clustered, Segm. of cor. lanceolate silky above 3342 Joints 4-cornered toothed, Flowers fascicled, Segm. of cor. lanceolate papillose

3343 Branches 5-cornered toothletted, Cor. with 10 angles, Tube bearded inside and elevated into a ball 3344 Cor. campanulate closed at bottom by clavate horizontal hairs, Ligules spreading truncate dark 3345 Branches 4 and 5-cornered, Young branches very much spreading, Cor. 10-cleft, Tube smooth 3346 Cor. 10-toothed, Alternate segments obsolete, Branches 5-cornered spreading with hooked tubercles 3347 Cor. concave at bottom, Stems simple above glaucous, The teeth of the branches horizontal 3348 Branches several 4-5 angular spreading, Cor. rounded 10-cleft, Segm. alternately longer, Flowers solitary 3349 Branches simple very thick 4-5-cornered with very large teeth

3350 Branches several 4-5-cor. clust. nearly erect, Teeth of branches acute spreading, Cor. campanul, 10-cleft 3351 Cor. campanulate dotted inside; not dotted outside, Beaks gibbous, Shield low with 5 emarginate lobes 3352 The only species

3353 Branches distant 4-cornered long slender ascending, Flowers with segments tipped with purple 3354 Branches clustered 4-cornered short thick erect, Flowers in close terminal heads

\section{Cor. 5-cleft, Peduncle 4-cornered, Stem undivided, Radical leaves oval}

3356 Cor. 5-cleft rotate whorled, Whorls cymose, Calyxes spathaceous, Leaves broad ovate 3357 Cor. 5-cleft campanulate dotted in streaks whorled, Cal. membranous spathaceous 3358 Cor. 6-cleft campanulate much dotted whorled, Cal. coriaceous truncate

3359 Cor. 6-cleft campanul. much dotted whorled, Cal. membr. truncated, Lobes shorter than tube of cal. uneq. 3360 Cor. hypocrateriform 5-7-cleft, Intermediate segments torn, Leaves cruciate 3-nerved

3361 Cor. 5-cleft campanulate opp. axillary subsessile, Leaves stem-clasping ovate-lanceolate

3362 Cor. 4-5-cleft sessile whorled, Radical leaves as long as stem which is naked beneath

3363 Cor. 4-cleft naked hypocrateriform whorled subsessile, Stem two edge narrowed at base

3364 Flowers terminal sessile, Cor. 10-cleft ventricose acute, Alt. segm. shorter entire, Leaves lanceolate

3365 Flowers clustered terminal tub-shaped with an unequal lacerated mouth, Leaves oval

3366 Flowers in whorled heads sessile, Cor. 10-cleft ventric. closed, Alt. segm. fringed smaller, Lvs, ovate lanc.

3367 Flowers whorled ventricose 10-cleft, Segm. altern. unequally bifid and torn, Lvs. remote oppos, and ternate 3368 Cor. 5-cleft campanulate acuminate terminal and axillary stalked, Leaves linear obtuse

3369 Cor. 5-cleft hypocrat. beard. Seg. ovate, Cal. trunc. with eq. subul. teeth, Lvs. ov. lanc. as long as branches 3370 Cor. campanulate 5-cleft toothed between the segments, Cal. 3-toothed opening on one side, Lvs. lanceolate 3371 Cor. campanulate 5-cleft clustered sessile, Leaves linear : floral alternate lengthened

3372 Cor. campanulate 5-cleft terminal stalked 3 together, Segm. acute, Leaves lanceolate 3-nerved 3373 Cor. 5-cleft campanulate as long. as the square stalk

3374 Cor. 5-cleft funnel-shaped, I eaves ovate acute : radical spreading larger than the cauline

3375 Cor. 5-cleft funnel-shaped, Leaves ovate obtuse : radical clustered imbricated less than the cauline 3376 Cor. 5-cleft funnel-shaped, Branches alternate 1-flowered, Cauline leaves lanceolate

3377 Cor. 5-cleft monogynous, Panic. trichotomous, Bractes perfoliate, Leaves oblong 3-nerved
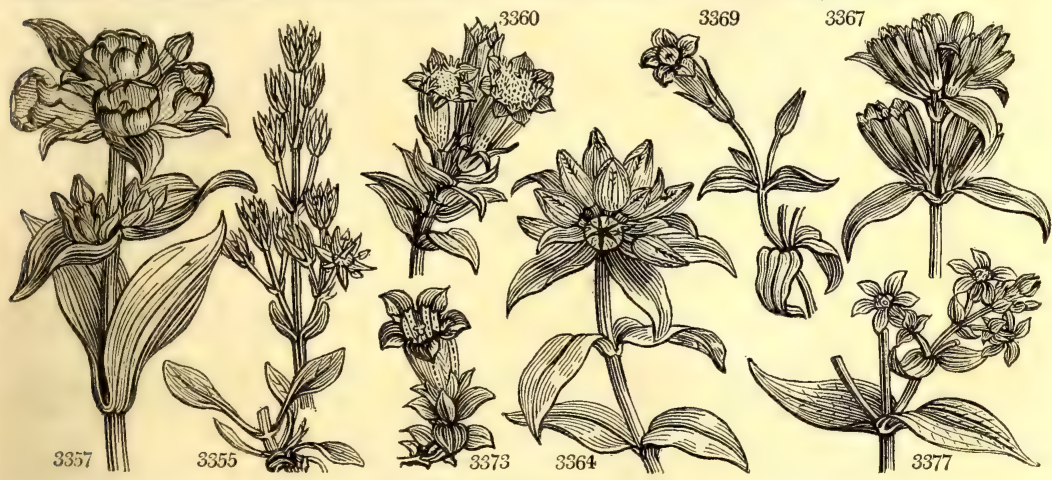

and Miscellaneous Particulars.

as Stapelia, require the same culture, and are natives of the barren blowing sands of the Cape of Good Hope.

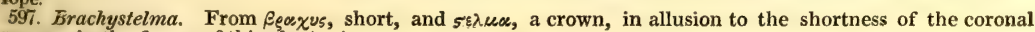
processes in the flower of this plant.

598. Caralluma. The Indian name of this plant, which exactly resembles Stapelia in appearance.

599. Swertia. So named by Linnæus, in honor of Eman. Sweert, a cultivator of bulbs and flowers in Holland, and author of Florilegium, 1612. Pretty herbaceous plants, with blue flowers.

600. Gentiana. From Gentius, King of Illyria, who, according to Pliny, first discovered the tonic virtues of plants of this genus. "This is a very handsome genus of herbaceous plants: most of the species succeed well in a light rich soil, but a few require peat, and some must be grown in pots to be protected by frames in winter. 
3378 intermedia $\boldsymbol{B} . \boldsymbol{M}$. 3379 gélida Bieb. 3380 Amarélla $W$. 3381 campéstris $\dot{W}$. 3382 ciliáta $W$. 3383 crinita $\boldsymbol{P h}$.

601. HYDRO'LEA. $\boldsymbol{W}$. 3384 spinósa $W$.

602. FALKIA. $L$. 3385 répens $W$

603. DICHON'DRA. $W$. 3386 répens $R . B r$. 3387 sericea $\boldsymbol{W}$.

604. VELEZIA. $W$. 3388 rígida $W$.

605. BUMAL'DA. Th. 3389 trifólia $T h$.

606. HEUCHE'RA. $W$. 3390 americána $W$. 3391 pubéscens $P h$. 3392 villósa $P h$. 3393 cauléscens $\boldsymbol{P h}$.

607. CUSSO'NIA. $L$. 3394 thyrsiflóra $L$ 3395 spicáta $L$

608. ANA'BASIS. $W$ 3396 tamariscifólia $W$ 609. SALSO'LA. $W$. 3397 Káli $W$ 3398 rosácea $W$. 3399 Sóda $W$. 3400 satíva $W$. 3401 hirsúta $W$. 3402 laniflóra $W$ 3403 vermiculáta $W$ 3404 muricáta $W$.

610. KO'CHIA. Roth. 3405 hyssópifólia $R$. 3406 dentáta $P h$. 3407 trigyna Link.

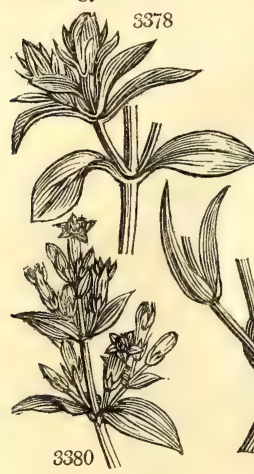

3382 clavate $\$ \Delta$ or 20 $\$ \Delta$ or 1 jn.jl jringed

HYdRoleA. thorny

FALKia. creeping

DICHONDRA. creeping silky rigid

Bumalda. three-leaved

Heuchera. viscid pubescent villous caulescent

Cussonia. thyrse-flower. spike-flowered

Anabasis. Tamarisk-leav.

SALTWORT. prickly rose-colored long fleshy-lvd. cultivated hairy small-leaved Egyptian

KоснIи. Hyssop-leaved tooth-leaved

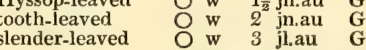

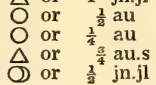

Pu N. Amer. 1820. D p.l Bot. mag. 2303

P.Y Siberia 1807. D p.1

Pu Britain ch. pa. S co Eng. bot. 236

Pu Britain gra.pa. S co Eng. bot. 237

L.B Germany 1759. D p.l Bot. mag. 639

L.B N. Amer. 1804. S p.1 Bot. mag. 2031

* J or 1 jn.jl P.B S. Amer. 1791. C 1.p Bot. reg. 566

Convolvulacea. Sp. 1.

2 $\Delta$ or $\frac{1}{4}$ my.au Pk $\quad$ C. G. H. 1774. C p.l Bot. rep. 257

Convolvulacea. Sp. 2-5.

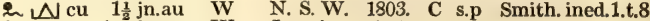
2 $\triangle \mathrm{cu} 1 \frac{1}{2} \mathrm{jn} . \mathrm{au}$ W Jamaica 1793. C s.p

Caryophyllea. Sp. 1.

*. J cu 2 jn.s........... Sp. 1.

1812. S co

Saxifragea. Sp.4-6.

₹ $\triangle$ or $1 \mathrm{my} . \mathrm{jl} \mathrm{Pu}$ N. Amer. 1656. D s.1 Plk. alm.t.58.f.3 $\$ \Delta$ or 1 my.jl Pk.v N. Amer. 1812. D 1.p \ $\Delta$ or $\frac{3}{4}$ my.jl Pk N. Amer. 1812. D l.p ₹ $\Delta$ or 1 my.jl W N. Amer. 1812. D 1.p

Araliacea. Sp. 2

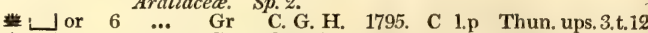

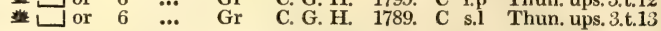

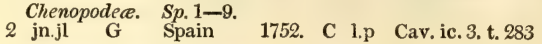

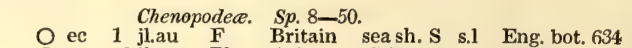

O cu ${ }^{\frac{1}{2}}$ jl.au Pk Asia 1759. S s.1 Schk. ban.1.t.57

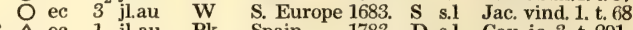
E $\triangle$ ec 1 jl.au Pk Spain 1783. D s.l Cav, ic.3. t. 291 O w 1 jl.au Gr Denmark 1791. D s.1 Fl. dan. 187 O cu 2 jn.au Y Siberia 1797. D s.l Pa.it.2.p.736.t.P. O 11 jl.au Gr Siberia 1759. S s.1 Cav. ic. 3. t. 287 O w 1 jl.au Gr Egypt 1773. S s.1 All.taur.3.t.4.f.2
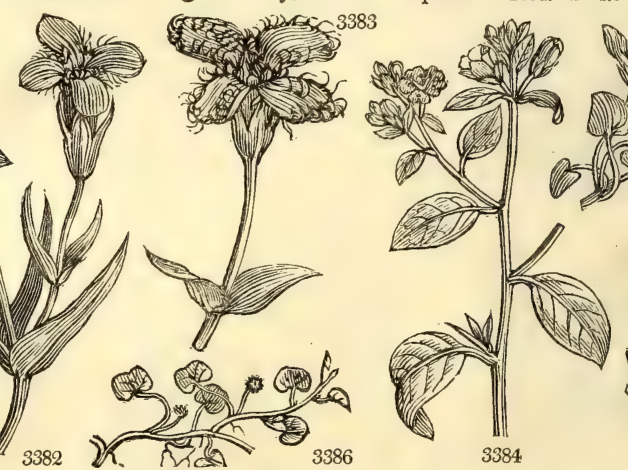

P.it.1.p.491, t.H Chenopodea. Sp. 9-11.

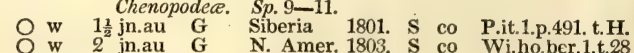
3385

History, Use, Propagation, Culture,

Some of them may be increased by dividing at the root, but most of them seed freely; the seeds should be sown as soon as ripe, they will then quickly vegetate, but if left till spring before they are sown, they will not come up till the second year. (Bot. Cult. 371.)

G. lutea has a thick root of a yellowish brown color, and very bitter taste. In Switzerland and Germany it occupies extensive tracts of ground untouched by any cattle. It was formerly used as hops in brewing, and is at present the principal European bitter used in medicine. The root of $G$. purpurea is as thick as a man's arm and two feet long; it is extremely bitter, and used as a substitute for G. lutea.

$\mathrm{G}$. acaulis and verna are two beautiful edging plants, and answer well in pots.

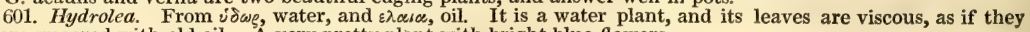
were smeared with old oil. A very pretty plant with bright blue flowers.

602. Falkia. Named after John Falk, a Swede, born in 1725, died in 1774. He was professor of botany in the apothecaries' garden at St. Petersburg, and followed Pallas during a part of his journey in Siberia. Upon his return he committed suicide; perhaps the only instance upon record of suicide among naturalists.

603. Dichondra. From $\delta$ s, double, and xovdeos, grain; on account of the double nature of the capsule. Little inconspicuous trailing plants, seldom seen or desired in collections.

604. Velezia. So named by Linnæus, in memory of Christoval Velezius, examiner, first physician, and demonstrator of botany in the college of apothecaries at Madrid. A small weed, native of the south of France, resembling a dried up Gentiana.

605. Bumalda. Named after Ovide Montálban, better known under the name of Jean Antoine de Bumalda, born at Bologna, published in 1657 a Bibliotheca Botanica, and in 1668 a Dendrologia.

606. Heuchera. In memory of Jean Henry de Heucher, archiater, and professor of medicine at Witteberg, 
3378 Leaves obovate oblong 3-nerved, Flowers terminal clustered, Cor. ventricose not opening 3378 Leaves obovate 5 -cleft terminal and axillary clustered, Intermed. segm. torn, Leaves lanc. 3-nerved 337 Cor. 5 -cleft hypocrateriform bearded, Segm. lanc. acute, Leaves lanc. Branches shorter than joints 3380 Cor. 4-cleft hypocrateriform obtuse, Orifice bearded, Two outer sepals very large

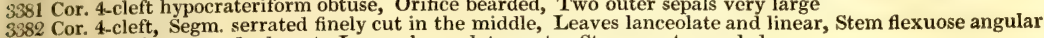
$3 \$ 83$ Cor. 4-cleft, Segm. finely cut, Leaves lanceolate acute, Stem erect rounded

3384 Leaves lanceolate, Flowers terminal corymbose, Capsules a little hairy

3385 A creeping plant with cordate obtuse stalked leaves

3386 Pubescent, Leaves reniform retuse and emarginate

3387 Leaves reniform emarginate pubescent beneath

3388 The only species

3389 A slender branched purple shrub

3390 Viscid, Scape and leaves roughish, Leaves rounded lobed toothed, Pet. lanc. Stam. much exserted 3391 Powdery, Scape and Ivs. below smooth, Lvs. acutely lobed toothed, Pet. spatulate, Stam. scarcely exserted 3392 Very villous, Leaves acutely lobed, Pet. shorter than calyx, Stamens exserted

3393 Shrubby at base, Lvs. smooth above acutely lobed toothed, Cal. short villous, Pet. linear, Stam. exserted

3394 Leaves digittate, Leaflets sessile wedge-shaped truncate 3-toothed, Flowers racemose

3395 Leaves digittate, Leaflets 7-3-parted wedge-shaped acuminated serrated at end, Flowers spiked

3306 Leaves subúlate, Pericarps not juicy

3397 Spreading hairy, Leaves subulate mucronate, Calyxes solitary, Appendages opened out colored 3398 Leaves subulate mucronate, Calyxes opened out

3399 Smooth, Branches ascending, Lvs. half round acute, Cal. in fruit keeled across the middle membranous 3400 Herbaceous, Leaves rounded smooth, Flowers clustered

3401 Erect spreading hairy, Leaves obiong half round obtuse, Flowers twin axillary

3402 Leaves rounded pubescent, Flowers axillary, Anthers colored

3402 Pubescent, Branches panicled, Leaves filiform with an axillary tuft, Floral very short, Cal. solitary

3404 Tomentose, Cal. with 5 angles and 5 awns, Leaves lanceolate flat

3405 Pubescent, Leaves linear flat, Cal, clustered woolly with a hooked dorsal spine

3406 Leaves broad lanceolate toothed, Cal, surrounded by a toothed crown, Seed round emarginate on one side 3407 Erect, Leaves filiform obtuse fleshy, Flowers axillary sessile 3 together, Style trifid

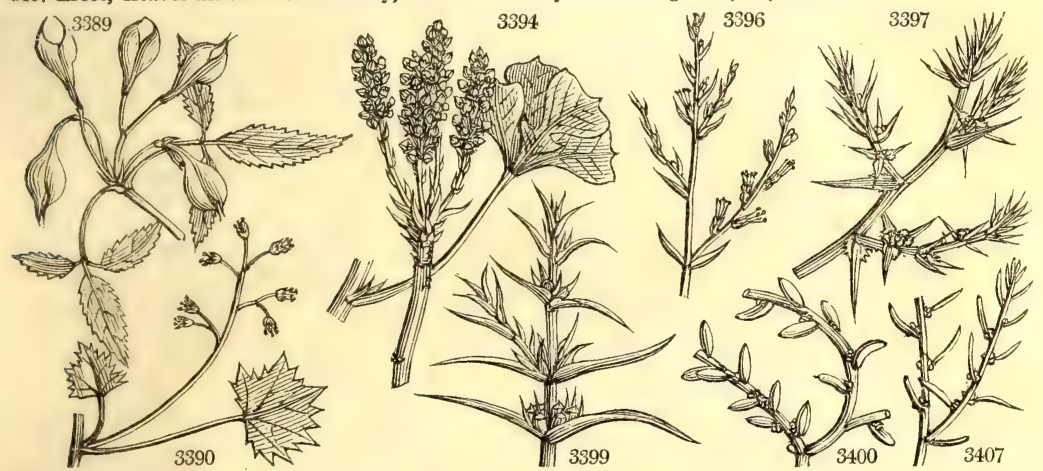

and Miscellaneous Particulars.

author of Hortus Wittebergensis, 1711-13. Very neat North American plants, requiring the culture of alpine piants.

607. Cussonia. In memory of Cusson, a celebrated botanist, who after laboring to complete the order of umbellate plants, had all his labor annihilated by his wife, who in his absence used the paper upon which his plants had been glued for household purposes. It is a genus of easy culture, and readily increased by cuttings planted in sand and placed under a hand-glass.

608. Anabasis. One of the names given by the Greeks to the Equisetum. A small plant, quite similar to some species of Chenopodium.

609. Salsola. From salsus, salt. From these plants, which are chiefly maritime, is obtained the kelp of our 8hores. This is a genus of plants producing the alkaline salts called barilla, soda, potash, and kelp. Most of them are herbaceous and annual, but some have shrubby stems.

S. kali, (Qaly or álqaly, Arabic. Bochart,) is found on the sandy shores of most parts of the world, and is very generally burned for soda for the glass manufacture.

S. soda is cultivated in Languedoc and also in Spain for making barilla; but is reckoned inferior to S. sativa, which grows on the Spanish shores of the Mediterranean, and affords all the best soda consumed in Europe. It is called by us Spanish or Alicant soda. In September, the crop is cut and laid in small heaps to dry. These heaps are then collected and burned, forty or fifty of them in a hole, in the ground.

Soda is in common use in the manufacture of glass and soap; with sulphuric acid, it forms Glauber's salts with marine acid, common salt; with the salt of Homberg, borax; and with cream of tartar, Rochelle salt.

610. Kochia. A genus divided from Salsola by Roth, and named by him after his friend Koch, a German botanist. 

3408 prostráta Schrad. 3411 erióphora $S c h r$. 3412 sericea $S c h r$. 3413 sccpária Schr.

611. CHENOPO'DIUM.

3414 Bónus-Henrícus $W$. Engl. Mercury $\varepsilon$

3415 úrbicum $W$.

3416 Atriplicis $\dot{W}$

3417 rúbrum $W$.

3418 guinéense $W$

3419 murále $W$.

3420 Quinoa $W$

$$
\beta \text { rubrum }
$$

$\beta$ rubrum
3421 rhombifólium $W$.en

34.22 serotinum $L$.

3423 ficifólium $\boldsymbol{H}$. $\boldsymbol{K}$.

3424 álbum $W$.

3425 hýbridum $W$.

3426 Bótrys $\boldsymbol{W}$.

3427 botryoides $\mathrm{Sm}$.

3428 fœ'tidum Schr.

3429 multifidum $W$.

3430 ambrosioídes $W$ ß suffruticósum

$\beta$ suffruticosum

3432 gravéolens $W$.

3433 glaúcum $W$.

3434 crassifólium $\boldsymbol{H}$. Par.

trailing

sand

woolly

wooll

summer Cypres

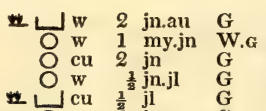

S. Europe 1780. C s.l Jac. aust.3.t.294 Hungary 1822. S s.l

Crimea 1821. S s.1 Pall. ill. t. 35

Spain 1823. S s.l Schrad. hal. t. 3

Engl. Mercury $\mathbb{E}$

uprigh

purple

red

Guinea

nettle-leaved

green Quinoa

red Quinoa

Fig-leaved

white

Maple-leaved

cut-leaved

many-clustered

fetid

Buenos Ayres

Mexican

half shrubby

$\mathrm{O}$ or

American Jw

Oak-leaved

3435 ólidum $\mathrm{Sm}$.

3436 polyspérmum $W$.

3437 caudátum $W$.

3438 laterále $W$.

thick-leaved

\section{stinking}

Allseed

oval-leaved

oblong-leaved

3439 lanceolátum $W . c n$. spear-leaved

3440 aristátum $W$. bearded

3441 sépium Mayer. hedge

3442 acutifólium $E$. $B$. acute-leaved

3443 maritimum $W$. Sea Blite

3444 fruticósum $W$. en. shrubby Salsóla fruticósa E, B.

3445 altíssimum $W . e n$. grass-leaved

3446 sálsum $R . B r$. Saltwort

3447 setígerum $D$. C. bristly

612. BE'TA. $W$.

3448 vulgáris $W$

3449 pátula $W$.

3450 cícla $W$.

3451 trigyna $H . K$.

3452 marítima $W$.

613. BO'SEA. $W$.

3453 Yervamóra $\boldsymbol{W}$

BEET.

common

spreading

white

Hungarian

sea

Golden Rod.

tree $\triangle$ cu 1 my.au G

$\begin{array}{llll} & w & 1 & \text { au } \\ & w & 3 & \text { au.s }\end{array}$

w 2 au.s

o 2 au.s

w 1 au.

cul 3 j

O ${ }^{1}{ }^{1} \mathrm{jl} . \mathrm{s}$

O w 2 jl.s

O w 2 au.s

O $1 \frac{1}{3} \mathrm{jl.s}$

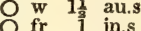

w 1 jn.au

O w 4 jn.au

$\Lambda \mathrm{w} 2$ jn.o

$\mathrm{O}$ fr $1 \frac{1}{2} \mathrm{jn} .0$

J w 3 jl.au

4 jl.au

$1 \frac{1}{2}$ jl.au

O w 2 jl

Oे $\begin{array}{lll}\text { w } & 1 & \text { jl.au }\end{array}$

w 2 jlau

[0] $w$ au.s

O w 2 jl

O $\mathrm{w} \quad 1$ jn.s

O $\begin{array}{lll}\text { w } & 2 & \text { jn.jl } \\ \text { w } & 1 & \text { jl.au }\end{array}$

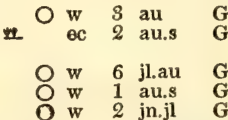

Chenopodec.
C. G. H. 1824. C s.l Schrad. hal t. 2

Greece 1629. S co Schr.hal, t.1. f.1

Sp. 34-72.

Britain rub. D co Eng. bot. 1033

Britain dungh. S co Eng. bot. 717

China 1780. S co Jac. vind. 3.t. 80

Britain dungh. S co Eng. bot. 1721

Guinea 1790. S co Jac.ic.rar.2.t.345

Britain rub. S co Eng, bot. 1722

Peru 1822. S co

Peru 1822. S co Feuill. per. t. 10

N. Amer. 1807. S co

Spain 1821. S co

England dungh. S co Eng. bot. 1724

Britain rub. S co Eng. bot. 1723

Britain rub. S co Eng. bot. 1919

S. Europe 1548, S co Fl. grac t 263

Britain sea sh. S co Eng. bot. 2247

1823. S co

Buenos A.1732. D co Dill.elt. t.66.f.77

Mexico 1640. S co Moris.s.5.t.35.f.8

America 1732. C co Dill.elt.t.66.f.76

Mexico 1823. S co

England rub. S co

...... 1809. S co

Eng. bot. 1454

Britain rub. S co Eng. bot. 1034

Britain rub. S co Eng. bot. 1480

Guinea 1806. S co Jac. ic. 2. t. 344

17..... 1781. S co

Pensylva. 1809. S co

Virginia 1771. S co Gm.sib.3.t.15.f.1

Mritain 1823. S co

Eng. bot. 1481

Britain sal.m. S co Eng. bot. 633

England sea sh. C co Eng. bot. 685

Italy 1775. S co Schr.halop.1. f.3

Astracan 1782. S co Jac.vind, 3. t. 83

S. Europe 1822. S co

Sp. 5-7.

Q cul 4 au $\mathrm{G}$ S Europe 1548. S r.m Schk. han.1.t.56 Lo) $\mathrm{w}$ au G Madeira 1778. C r.m

D cul 6 au G Portugal 1570. S r.m

O) w 3 jl.au G Hungary 1796. S r.m P.rar.hun.1.t.35

cul 1 au G Chenopodea. Sp. 1-2.

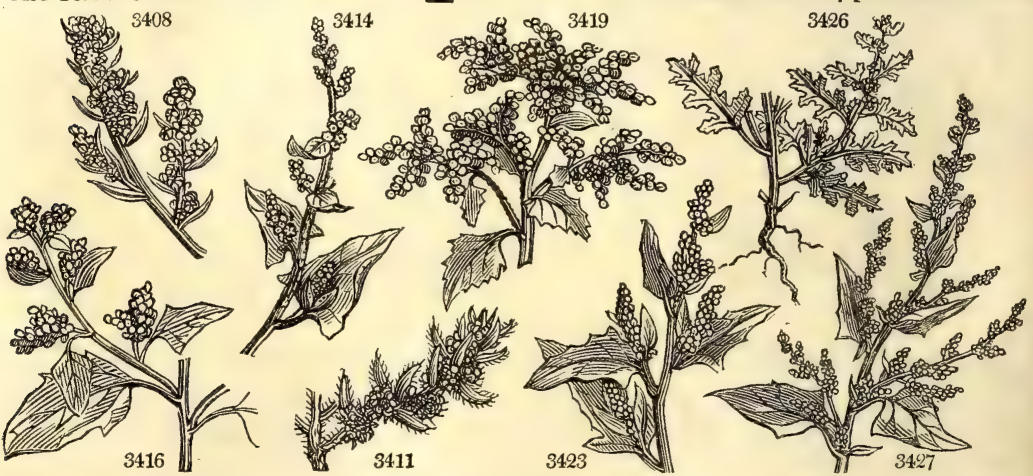

History, Use, Propagation, Culture,

611 Chenopodium. From $x$ y, a goose, and rovs, foot; many species having large angular leaves extremely similar to the webbed feet of a water-fowl This is a genus of succulent herbs, with their leaves for the most part covered with powdery granules; the whole plant of no beauty, but generally edible as a pot-herb.

C. Bonus Henricus is cultivated in some gardens as a perennial spinage, it being hardy and of early growth. The leaves are sometimes applied to wounds, and for cleansing old ulcers.

C. album is the most common of the species, and used to be hoiled and eaten as greens; but C. maritimum is preferred to all the species for this purpose. The foreign species are of the easiest culture, and increased either by seeds or cuttings.

C. maritimum, where it abounds, is burned with Salsola kali and other marine plants, to produce soda.

612. Beta. From bett, red, in Celtic. B. vulgaris, Betterave, or beet-radish, Fr.; Rothe Rübe, Ger. ; and Barba Brettola, Ital., is a well known culinary root, used in salads either raw or boiled; forming a beautiful varnish; very much used as a pickle; preserved as a confiture; made a substitute for coffee; and yielding a 
3408 Hoary, Leaves linear flat, Calyxes about 3 downy with opened obovate appendages

3409 Leaves linear somewhat fleshy pubescent, Flowers axillary about 3 together, Cal. with blunt appendages 3410 Herbaceous very hairy, Leaves linear fleshy, Dorsal spine of cal. straight

S411 All woolly, Leaves linear fleshy spreading, Cal. in fruit stellate with 5 prickles hooked at end

\$112 Branches diffuse, Leayes lanceolate silky, Calyxes not prickly

3413 Pubescent, Leaves linear lanceolate ciliated, Cal. in pairs, Appendages very short acute

\section{Leaves flat angular.}

3414 Leaves triangular hastate entire, Spikes compound clustered leafless axillary and terminal

3415 Leaves triangular toothed, Racemes clustered very upright close to the stem very long and leafless

3416 Leaves rhomboid-ovate and lanceolate : the lower sinuate toothed, Pan. axillary branched, Stem erect

3417 Leaves cordate triangular rather obtuse toothed, Racemes erect compound leafy shorter than the stem

8418 Leaves ovate unequally toothed acute, Racemes branched naked and simple stem erect

3419 Lvs. ov. uneq. tooth. acute shining, Race. corym. naked shorter than the leaf, Stem branched spreading 3420 Lvs. triangular ovate obsoletely toothed the younger powdery, Racemes clustered shorter than leafstalk

3421 Leaves triangular acute repand toothed, Racemes axillary erect nearly leafless, Bractes minute inflexed 3422 Leaves deltoid sinuate toothed rugose smooth uniform, Racemes terminal

3423 Leaves hastate sinuate eroded entire behind, Upper oblong entire, Seeds dotted

3424 Leaves rhomboid ovate eroded entire behind, Upper oblong entire, Seeds smooth

3425 I,eaves ovate-acuminate subcordate angular toothed, Racemes panicled naked terminal and axillary

3426 Leaves oblong sinuated, Racemes naked multifid, Upper bractes entire lanceolate

3427 Leaves ovate acute entire, Stem erect, Racemes cymose elongated nearly leafless

3428 Leaves oblong sinuated, Racemes naked many-cleft, Upper bractes S-lobed at end

3429 Leaves pinnatifid, Segm. linear the lower toothed, Clusters of flowers axillary sessile

3430 Leaves lanceolate remotely toothed, Racemes leafy simple

3431 Leaves ovate lanceolate sparingly toothed, Spikes simple slender long leafless, Flowers trigynous

3432 Leaves oblong sinuate-toothed wedge-shaped at base, Clusters of flowers axillary

3433 Leaves oblong repand glaucous beneath, Spikes clustered simple naked axillary and terminal

3434 Leaves thick rhomboid-angular somewhat sinuated entire behind, Racemes erect compound leafy

3435 Ieaves rhomb-ovate, Flowers clustered 2. Leaves flat entire.

3436 Leaves ovate, Stem decumbent, Cymes dichotomous leafless axillary

3437 Leaves ovate obtuse entire, Panicle terminal naked elongated, Stem simple erect

3438 Cauline leaves lanceolate obtuse, Branch-leaves oblong, Peduncles lateral solitary 1-flowered

3439 Leaves ovate lanceolate acute entire, Racemes axillary compound naked, Stem divaricating

3440 Leaves lanceolate fleshy entire, Corymbs dichotomous aristate axillary

3441 Leaves ovate sinuate, Racemes leafy simple

3442 Leaves wavy half-round, Flowers axillary sessile

3. Leaves rounded.

3443 Stems diffuse, Leaves oblong $\frac{1}{2}$ rounded, Flowers axillary clustered

3444 Erect shrubby, Leaves semicylindrical obtuse blunt

3445 Quite smooth, Branches panicled erect, Leaves filiform acutish, Flowers in threes stalked

3446 Hexbaceous nearly erect, Leaves linear fleshy unarmed, Cal. succulent transparent

3447 Leaves rounded thick smooth terminated by a straight long bristle

3448 Flowers clustered, Lower leaves ovate, Root fleshy

3449 Flowers clustered, All the leaves linear-lanceolate, Branches divaricating

3450 Leaves with very thick ribs, Flowers three together, Root scarcely any

3451 Racemes erect panicled leafless, Flowers trigynous twin and solitary, Lvs. cordate acute unequal at base

3452 Flowers in pairs, Stem diffuse, The branches much interwoven, Root scarcely any

3453 Leaves alternate stalked ovate acute with the veins and nerves purple

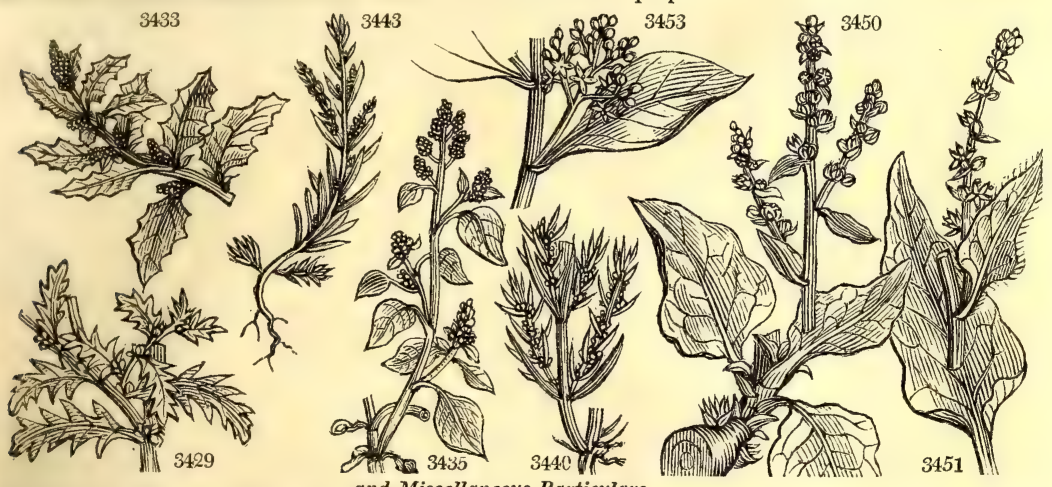

and Miscellaneous Particulars.

sugar equal to that of the cane. There are several varieties; those most esteemed for salads are the small red and Castelnaudary, and for extracting sugar, the green-topped. The seed is sown in March or April, on deep well comminuted soil. When the plants show two or three proper leaves they are thinned out, so as that each plant may occupy or be allowed a square foot of surface. By September or October the roots are fit for use, and may either be taken up as wanted, or taken up and buried in sand in the root-cellar

B. Cicla, (Cicla is said by De Théis, to be a corruption of sicula, under which name it is spoken of by Catullus,) Bette, or Poirée a cardes, Fr. ; Mangold Kraut, Ger, ; and Biettola, Ital, is employed in horticulture as a spinage plant, and for being used as chard or asparagus; and in foreign agriculture for the production of sugar. It is much grown in the south of Germany and Switzerland, where the lamina of the leaves is used as spinage or put in soups, and the midrib is boiled and eaten with melted butter or gravy as chard. The culture is the same as for the red beet; but, as the leaves are larger, the space allowed each plant is proportionally increased.

B. maritima is or may be used as a spinage plant or as greens.

613. Bosea. Ernest Gottlieb Bose, a German, published at Leipsig, in 1775, a work upon the secretions of 
614. HERNIA'RIA. $W$. RUPTURE-WORT. 3454 glábra $W$ 3455 hirsuta $W$ 3456 frutić́sa 3457 polygonoides $\mathrm{Cav}$. 3458 incána Bieb. 3459 alpína Vill.

615. UL'MUS. $L$.

3460 campéstris $L$

3461 suberósa Mönch

3462 fruticósa $W$.

3463 glábra $E$. $B$.

3464 montána $E$. $B$

3465 americána $P h$.

3466 aláta Mich.

3467 álba Kit.

3468 húmilis $\mathrm{Amm}$.

3469 críspa $W$

3470 fúlva $P h$

3471 púmila Pall.

3472 chinénsis $P . S$

616. PLANE'RA. Mich

3473 Richardi Mich.

3474 parvifólia
U. parvifólia Jacq.

617. PHYL'LIS. $W$.

3475 Nóbla $W$.

618. CORI A N'DRUM. $W$ 3476 sativum $W$. common

3477 testiculátum $W$. twin-fruited

619. SCAN'DIX. P.S. 3478 pécten $W$.

3479 austrális $W$.

3480 pinnatífida Vent.

smooth

hairy

ghrubby

Knot-grass

alpine

Elm-Tree. comm. English cork-barked

shrubby

smooth

Wych

white Amer

winged

white Hungar.

low

curled

slippery

dwarf

China

Planera.

Hornbeam-lvd, 非

small-leaved

Canary

Scandix.

Venus's Comb

radiated

cut-leaved
$U$. pendula W Ulm. nemoralis W.
Bastard Hare's Ear.

Ear. ${ }_{3}^{\text {Rubiaceq. }}$ G $S p .1$.

$\underset{\Delta}{\Delta} \underset{\Delta}{\Delta} \underset{w}{w} w$

立 jl.au G

or 8 ap.my $\mathrm{Br}$

tm 60 ap.my $\mathrm{Br}$

tm 40 ap.my $\mathrm{Br}$

tm 40 ap.my $\mathrm{Br}$

tm 30 ap.my $\mathrm{Br}$

tm 30 ap.my $\mathrm{Br}$

or 6 ap.my $\mathrm{Br}$

or 20 ap.my $\mathrm{Br}$

tm 60 ap.my $\mathrm{Br}$

Ulmacea. Sp. 2 or $12 \mathrm{my} \mathrm{Br}$
Amaranthacea. Sp. 6-11.

I Amaranthacea. Sp. 6-11. $\mathrm{G}$. $\mathrm{S}$ co Eng. bot. 206

$\frac{1}{4}$ jl.au G England sa.gr. S co Eng. bot. 1379

${ }^{\frac{1}{2}}$ my.au G Spain 1814. C l.p Lob. ic. 85

my.au G S. Europe 1752. C l.p Cav, ic. 2. t. 131

\section{Ulmacea. Sp. 13}

tm 80 ap.my Br Britain hed. L co Eng. bot. 1886

tm 40 ap.my Br Britain hed. L co Eng. bot. 2161

Europe $\quad \ldots$ G co

hed. I, co Eng. bot. 2248

Britain hed. S co Eng. bot. 1887

Amer. 1752. G co

N. Amer. 1820. G co

Hungary 1824. G co

Siberia $\quad \cdots \quad$ G co

$\begin{array}{llll}\text { N. Amer. } & \ldots & \text { G } & \text { co } \\ \text { N. Amer. } & \ldots & \text { G co Mich. arb. 3. t. } 6\end{array}$

Mich. arb. 3. t. 5

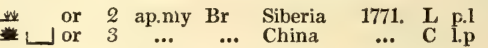

or 12 ap.my Br ${ }^{\text {N. Amer. 1760. G co Pall. ross. 2.t. } 10}$

$1822 \quad$ G

Jacq. schö,t. 262

Umbelliferce. $S p .2-3$.

0 clt 2 jn W England fields. S co Eng. bot. 67

O w 2 jn.jl W $\quad$ S. Europe 1640. S co Pl. al. t. 169. f. 2

620. ANTHRIS'CUS. $P$. S. Rough Chervil

Umbelliferce. Sp. 3-10.

W $\mathrm{w}^{\frac{1}{2} \mathrm{jn} . \mathrm{jl}}$ W Britain co.fi. S co Eng. bot. 1397

my.jn W S. Europe 1713. S co Col. ecph. 1. t. 90

11 my.jn W Persia 1805. S co Vent. cels. 14

Umbellifere. Sp. 2-9.

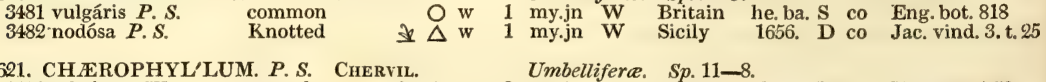

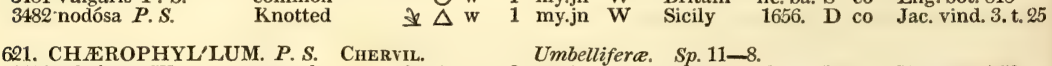
3483 sylvéstre $W$. smooth \& $\Delta$ w 3 my.jn W Britain hed. D co Eng. bot. 752 3484 sátivum $P . S$. garden $\quad \mathrm{O}$ cul $1 \frac{1}{2}$ my.jn W England he. ba. D co. Eng. bot. 1268 Sc. cerefolium W.
3485 procumbens $P h$. procumbent $\quad$ * $\bigcirc$ w 1 jn.jl $\quad$ W Virginia 1699. D co M.s.9.t.11.f.ult.

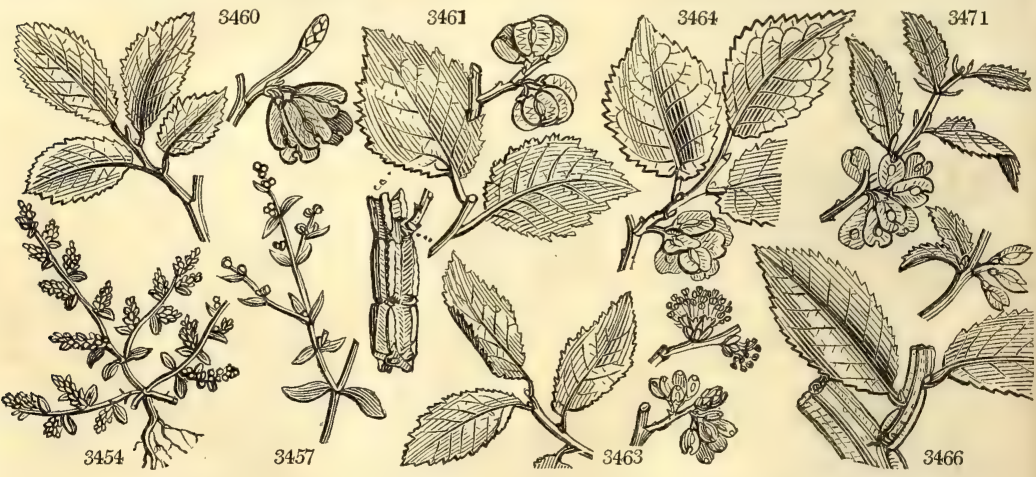

History, Use, Propagation, Culture,

plants. Another Bose (Caspar) was a professor of botany at Leipsig, where he published, in 1728, a dissertation upon the motions of plants. Ripened cuttings root freely in sand under a hand-glass, without heat

614. Herniaria. From hernia, a rupture, for which disorder it was formerly imagined to be a cure, but has long since been rejected even by the herbalists. H. fruticosa is well adapted for growing in pots or for rockwork, and is readily increased by seeds or cuttings; cuttings of the greenhouse species root freely under a hand-glass.

615. Ulmus. From Elm, its name in Anglo-Saxon, Teutonic, Gothic, and nearly all the dialects of Celtic. This is a genus of hardy trees, most of them valued for their timber. The species, like those of the genus Salix, are so nearly related as to be often confounded. Linnæus considered all the European elms as forming only one species. The U. campestris and glabra are those most generally cultivated in Europe. U. campestris grows also in Palestine, and Dr. Walker conjectures that it was originally brought from that country by the Crusaders. It is a tall elegant tree, but produces much less valuable timber than the U. glabra. U. suberosa, often called the Dutch elm, is frequently grafted on the U. giabra, as is also the U. campestris in the Scotch nurseries.

616. Planera. In honor of John James Planer, a German botanist, who published in 1788 an Index Plantarum Agri Erfordiensis, in one volume 8vo. A genus closely related to Ulmus, from which it is perhaps scarcely distinct.

617. Phyllis. From $\phi u \lambda \lambda \sigma v$, a leaf: the plant is remarkable for the beauty of its leaves. Phyllis, who was 
3454 Smooth, Clusters many-flowered

3455 Hairy, Clusters few-flowered

3456 Leaves obovate acute hairy, Flowers clustered 4-cleft hispid, Stem shrubby

3457 Smooth, Stem erect dichotomous, Leaves ovate cuspidate, Flowers terminal and axillary

3458 Half shrubby, Leaves ovate oblong hoary, Calyxes hairy

3459 Clusters few-flowered hairy, Root thick woody

3460 Leaves doubly serrate unequal at base, Flowers subsessile clustered 5-andr. Fruit smooth

3451 Lvs. doubly serr. nearly equal at base, Fl. subsessile clustered 4-andr. Fruit smooth, Bark corky winged

3462 The branches only corky not the stem, Stature little more than that of a man, otherwise like the last

3463 Leaves doubly serrated smooth unequal at base, Flowers nearly sessile 5-cleft, Fruit obovate naked

3464 Leaves doubly serrated unequal at base, Flowers 6-8-andr. stalked, Fruit fringed at edge [at edge

$3466 \mathrm{Br}$. with cork. wing here and there on each side, Lvs. obl, ov. by deg. ac. nrly eq. at base, Fr. hairy closely frin.

3467 Leaves doubly serrated unequal at base acuminated pubescent beneath

3468 Leaves equally serrated equal at base

3459 Leaves irregularly doubly serrated equal at base with a long point rough above beneath soft downy

3470 Lvs. doubly ser. uneq. at base, Axil. of veins bearded beneath, Fl. clust. 5-andr. Fruit pubes. not fringed

3471 Decumbent, Branches smooth, Leaves very small equal at base

3472 Leaves small coriaceous shining shortly serrated ovate oblique at base

3473 Leaves subsessile oblong-cordate subcrenately coarsely toothed emarginate at base, Caps. short

3474 Leaves lanc. equally serrate equal at base shining, Flowers stalked tetrandrous, Fruit smooth

3475 The only species. Leaves lanceolate entire opp. 4 inches long, Corymbs axillary

3476 Fruit globose

3477 Fruit twin

3478 Seeds with a very long beak, Leaflets many-cut

3479 Seeds subulate hispid, Flowers radiant, Cauline leaves smooth

3480 Stem scabrous, Leaves decompound smooth, Umbels fascicled with a single leaf

3481 Seeds ovate hispid, Cor. of one shape, Stem smooth

3482 Seeds cylindrical hispid, Stem hispid, Joints tumid

3483 Stem striated with tumid joints

3484 Seeds shining ovate subulate, Umbels lateral sessile

3485 Stem hairy decumbent, Leaves bipinnatifid, Umbel simple few-flowered

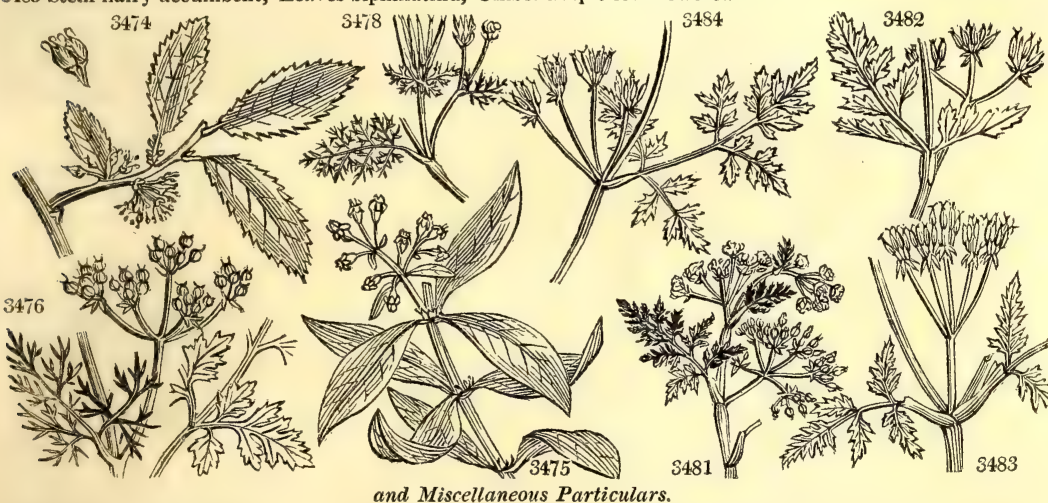

turned to a bare tree by the gods for having hung herself for love of the absent Demophoon, became a tree covered with verdure upon receiving in that form the embraces of her lover returned.

618. Coriandrum. From *og 6 , a bug, in allusion to the smell of the leaves of the plant. C. sativum has been long cultivated, chiefly in Essex, and is considered as naturalized. The leaves are strongly scented; the seeds, which are slightly aromatic, are used to cover the taste of senna, and in spices as currie powder, and seasoning for black puddings : also, covered with sugar, as a sweetmeat; formerly they were steeped in wine or vinegar, and then dried, to render them milder.

619. Scandix. A name given by the Greeks to a plant used as an eatable, which appears to be that now called

Scandix pecten. It is derived from $\sigma * \varepsilon \omega$, to prick, on account of the sharp points of the seeds,

620. Anthriscus. The name of a plant resembling Scandix, described by Pliny. A, vulgaris bears a near resemblance to the common chervil (Chærophyllum sativum), and being gathered as such, and put into soups, by the Dutch soldiers who were in England in 1745, some of them were poisoned by it.

621. Charophyllum. An ancient Greek name of the Chervil, derived from $x \alpha s \rho \omega$, to rejoice, and $\phi \nu \lambda \lambda{ }^{\circ}$, leaf, that is to say a plant whose leaves have an agreeable smell C. sylvestre has poisonous roots; though the leaves are occasionally used as a pot-herb, and are much liked by cows. The stems and leaves áye a beautiful green, and the umbels a yellow : the plant in a wild state is found only on fertile. soils.

C. sativum is cultivated in gardens for the leaves, which are used in soups and salads. To have a succes, sional supply, sow in February and August in shallow drills from six to nine inches apart. 
3486 bulbósum $W$. 3487 témulum $W$. 3488 hirstum 3488 hirsutum $W$. 3489 aromáticum $W$ canadénse $P h$. Síson canadénse W.
W

3491 Claytóni $\boldsymbol{P h}$.

3492 colorátum $W$. -

3493 aúreum $W$.

622. ERYN'GIUM. $W$.

3494 fo'tidum $W$.

3495 aquáticum $W$.

3496 virginiánum $\dot{P} h$.

3497 virgátum $P h$.

3498 plánum $W$.

3499 pusillum $W$.

3500 tricuspidátum $W$.

3501 corniculátum $B$. $M$.

3502 maritimum $W$

3503 campéstre $W$.

3504 galioídes $\boldsymbol{P}$. $\dot{S}$.

3505 amethýstinum $W$

3506 cærúleum $\boldsymbol{P}$. S.

3507 rigidum $P$. $S$.

3508 alpínum $W$.

3509 Bourgáti $W$.

623. SANI'CULA. $W$.

3510 europæ'a $\boldsymbol{W}$.

3511 canadénsis $W$.

3512 marilándica $W$.

624. ECHINO'PHORA. 3513 spinósa $W$.

625. DAU'CUS. $W$. 3515 Caróta $W$.

$\beta$ hortensis
3516 maritimus $\boldsymbol{P} . \boldsymbol{S}$.

3517 mauritánicus $\boldsymbol{W}$.

3518 lácidus $W$.

3519 crinítus Desf.

3501 Gingidium $W$

3522 híspidus $P$. S

626. CAU'CALIS. $W$.

3523 grandiflóra $W$.

3524 daucoídes $W$

3525 latifólia $W$

3526 pámila $W$.

3527 orientális $W$.

3 pulchérrima W. en.

3528 platycárpos $\mathrm{Spr}$.

3529 leptophylla $W$. bulbous-rooted rough 0 w 3 il ${ }^{1 \frac{1}{2} j n . j l}$

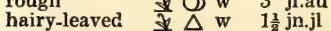
hairy-leaved
aromatic aromatic
three-leaved sweet-rooted yellow golden

ERYNGO. stinking marsh

Virginian oval-leaved flat-leaved dwarf trifid horned sea-holly field Galium-leaved amethystine blue-flowered stiff

Alpine cut-leaved

Sanicle. wood Canadian Maryland

* $\Delta$ cu 2 jl.au dy $\mathrm{cu} \quad 1$ jl.au I $\triangle \mathrm{cu}$

jl.au

Umbelliferc. Sp. $16-55$.

$4 \square$ or 1 av.o W W. Indies 1714. D s.l Her. lugd. t. 237

$\Delta$ or 4 jl.s W N. Amer. 1699. D s.l Bot. reg. 372

$\Delta$ or 2 jl.s G N. Amer. … D s.l Del. eryng. t. 19

$\Delta$ or 1 jn.jl L.B N. Amer. 1810. D s.l Del. eryng. t. 20

$\Delta$ or 3 jl.s L.B Europe 1596. D s.l Jac. aus. 4.t. 391

$\Delta$ or $\frac{3}{4}$ jn.au $G$ Spain 1640. D s.l Del, eryng. t. 16

(D) or $2^{4} \mathrm{~s}$ G Spain 1699. D s.l Del eryng t 9

$\triangle$ or 1 jn.au G Portugal 1803. D s.l Bot. mag. 1427

$\Delta$ ec $1 \frac{1}{2}$ jl.o $\quad$ B Britain sea sh. D s.l Eng. bot. 718

$\Delta$ ec 2 jl.au B Britain pas. D s.l Eng. bot. 57

$\Delta$ or $\frac{1}{2}$ jl.au G Portugal 1810. D s.l

$\Delta$ or 3 jlau

2 jl.au

$\frac{3}{4}$ jl.au

L.B Styria 1648. D s.l

B Caspian 1816. D s.l Mo. s. 7.t. 35. f. 2

$\Delta$ or

$\Delta \Delta$ or

$2^{4}$ jl.au

jn.au Pa B S. France 1731 D s

Umbelliferce. $S p$. 3-2.

$7 \Delta \mathrm{w} \quad 1$ jn.jl W Britain woods. D s.l Eng. bot.98

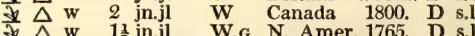

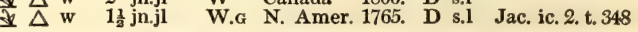

$W$. Sea-Parsnep. prickly

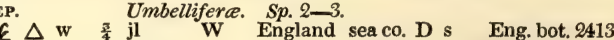

Carrot.

wild

Garden

sea-side

fine-leaved

shining

whorl-leaved

shining-leaved

prickly-seeded

hispid

Bur-Parsley. great-flowered great-flowered broad-leaved dwarf oriental

beautiful

broad-seeded fine-leaved
$\frac{f}{\Delta} \underset{w}{w}$

Umbellifere. Sp. 8-17.

\. $\mathrm{m} 3$ jn.jl W Britain b. of fi. S s.l Eng. bot. 1174

D cul 3

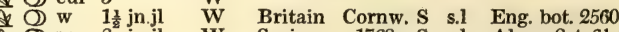

D 3 jn jl W Spain 1768. S s.l Al. pe. 2.t.61.f.

\ 1 w 2 jl.au W S. Europe 1807. S s.l Mo.3. s.9.t.13.f.

$\$ \Delta \mathrm{w} \quad 2 \mathrm{jn} . \mathrm{jl} \quad \mathrm{W}$ Barbary 1804. S s.l Desf. atl. t. 62

O w 2 jn.jl W France 1722. S s.l Mo. s. 9. t.9. f.10

○ w 11 Umbellifera. Sp. 7-27.

O $1 \frac{1}{2}$ jn $R \quad$ England ch. fi. S co Eng. bot. 197

$w_{w}$ jlau $\mathbf{R}$ England ch. fi. S co Eng. bot. 198

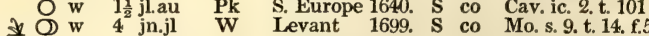

O 2 jn.jl w Caucasus 1816. S co Bux.cen. 3.3

w w j au $\mathbf{S}$. Europe 1800 S co Mo.s.9.t.14.

O $\mathbf{w}^{\frac{1}{2} \text { jl.au }} \mathbf{P k}$ Europe 1739. S co Sch.han. 1.t.61

3498
\$ 0 w $1 \frac{1}{2}$ jn.jl $\quad$ Pk Barbary 1804. S $\begin{aligned} & \text { S.l } \\ & \text { s.l Desf. atl.t. } 63\end{aligned}$

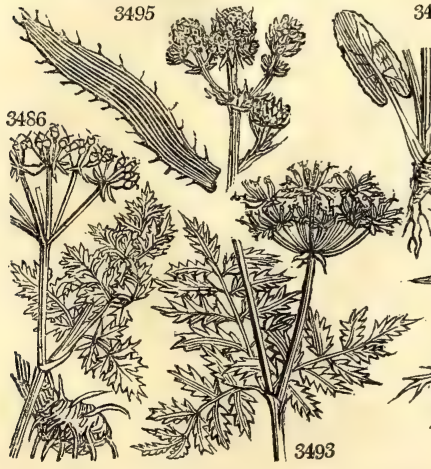

History, Use, Propagation, Culture,

622. Eryngium. From the Greek verb \&evrsiy, to belch. Dioscorides positively declares that the plant is a specific for all complaints arising from flatulence. These are singular plants, somewhat like thistles in general appearance : they are generally of a bluish hue, prickly, and with large involucres, and dry coriaceous leaves. E. maritimum has long been in esteem as an aphrodisiac; the roots were formerly and are now, in some cases, kept in the shops candied, and formed in Shakspeare's time the kissing comfits of Falstaff. The Arabs regard the plant as an excellent restorative, and English grooms often mix the dried plant with the corn they give to stallions in the covering season. The virtue is said to reside chiefly in the roots : the tops, Linnæus says, are eaten like asparagus in Sweden.

623. Sanicula. From sanare, to cure. This a vulnerary, to which marvellous virtues were formerly ascribed. S. europæa used to be considered a powerful vulnerary, but is now wholly rejected in medicine. Sir J. Smith says it partakes of that virose acrimony which is found in most umbelliferous plants growing in a moist fat soil.

624. Echinophora. From $\chi^{\prime \omega v o s, ~ a ~ h e d g e h o g, ~ a n d ~} \phi \xi \rho \omega$, to bear. In allusion to the strong rigid spines of the 
3486 Stem smooth with tumid joints, hairy at base

3487 Stem scabrous, joints tumid

3488 Stem equal, Leaflets cut acute, Fruit with two awns

3489 Stem equal, Leaflets cordate serrate entire, Fruit with two awns

3490 Leaves ternate smooth, Radical leaflets about 3-lobed, Cauline rhomb. ovate cut finely serrate

3491 Stem above smooth, Joints tumid, Leaves biternate pubescent, Styles persistent

3492 Stem equal, Leaves supra-decompound, Involucres colored

3493 Stem equal, Leaflets cut, Seeds furrowed colored awnless

3494 Radical leaves lanceolate serrate, floral many cut, Stem dichotomous

3495 Leaves gladiate serrate spiny, Flowers undivided, Stem simple

3496 Leaves linear-lanceolate ensiform very long, Leaflets reflexed and palere trifid, Heads panicled

3497 Leaves all ovate cordate on very short stalks toothed, Stem virgate colored upwards

3498 Radical leaves oval flat crenate, Heads stalked

3499 Radical leaves oblong cut, Stem dichotomous, Heads sessile

3500 Radical leaves cordate: cauline palmate with the auricles reflexed, Paleæ tricuspidate

3501 Rad. lvs. obl. lanc. toothed spiny, Stem trichotomous, Lvs. of involucre entire larger than the heads sping

3502 Radical leaves roundish plaited spiny, Heads stalked, Paleæ 3-toothed

3503 Radical leaves stem-clasping pinnate lanceolate

3504. Leaves sessile digitate spiny very small, Stem slender and weak dichotomous, Heads sessile

3505 Radical leaves trifid at the base somewhat pinnate

3506 Rad. lvs. cordate obl, obt. cren. lobed, Branches col. Lvs. of the involucrum very long stiff pungent entire

3507 Leaves palmate cut, Bractes stiff pinnatifid pungent, Stem thick

3508 Radical leaves cordate : cauline ternate cut, Involucres spiny pinnated ciliated

3599 Radical and cauline leaves alternate 3-parted twice trifid, Involucres subulate many-leaved spiny

3510 Lower leaves palmate, Lobes trifid cut-serrate, Florets all sessile

3511 Leaves all compound subternate, Leaflets ovate attenuate at base mucronate serrate, Florets all sessile

3512 Leaves all digitate, Leaflets oblong cut-serrate, Male flowers numerous stalked

S513 Leaflets subulate prickly entire

3514 Leaflets cut unarmed

3515 Seeds hispid, Stalks nerved beneath

3516 Fruit hispid with compressed bristles, Leaflets dilated rounded fleshy hairy, Umbels in fruit convex

3517 Seeds hispid, Central floret sterile fleshy, Common receptacle hemisphærical

3518 Leaves shining, Stem hairy, Leafstalks smooth, No sterile central foret

3519 Stem rough simple, Lvs. bipinn. Leaflets rather whorled many-cleft rigid, Bristles of fruit hairy purple 3520 Rays of the involucre flat, Segments recurved

3521 Fruit large very prickly

3522 Stem and lvs. bipin. vil. Leafl. ovate lobed toothed, Involucres very broad, Prickles of fruit dilated at base

3523 Involucres each 5-leaved, One leaflet twice as large as the others

3524 Umbels trifid leafless, Umbellules 3-leaved 3-seeded

3525 Universal umbel trifid, partial 5-seeded, Leaves pinnated serrated

3526 Universal umbel about 5-cleft, partial 3-seeded, Leaves supra-decompound, and decumbent stem villous 3527 Umbels spreading, Partial leaflets supra-decompound cut with linear segments, Fruit woolly $\beta$ Fruit bristly

3528 Universal involucre about 3-leaved, Umbel trifid, Involucels 3-leaved

3529 Common involucre scarcely any, Úmbel bifid, Involucres 5-leaved

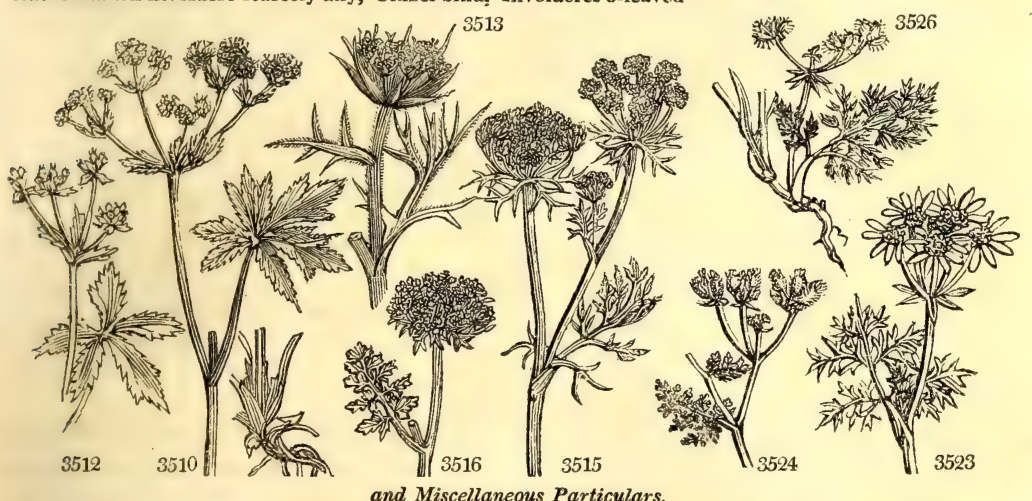

and Miscellaneous Particulars.

involucrum, and indeed of the whole plant. Very much like an Eryngium, once said to have been found in England.

625. Daucus. From $\delta \propto s \omega$, to make hot; on account of its effects in medicine. D. Carota (from Kar, red, in Celtic), is well known for its esculent root. There are several varieties : the largest, and that best adapted for field culture, is called the Altringham, from a village of that name in Cheshire. The early horn and orange are the best garden sorts. The seeds do not retain their vegetative powers more than a year, for which reason
and the cautious cultivator ought to prove them before sowing. The last week of March and first of April is the best season for sowing for a main crop. On farms where a deep sandy loam occurs, few crops of the root kind afford a more valuable return. In Norfolk and Suffolk they are a good deal in use as a field crop, and especially near Lowestoft in the latter county.

626. Caucalis. According to Linnæus, derived from $x \varepsilon w$, to trail along; on account of the low habit of the plants. It is supposed that Pliny's Caucalis was the same as the Caucalis grandiflora of the present
day. 
627. TORILIS. Gartn. 3530 Anthriscus $W$. 3531 infésta $H . K$. arvénsis W.

628 OLIVERIA Vent. 630. MYR'RHIS. P. S. MYRR 3535 odoráta $P . S$. 631. BU'NIUM. $W$

3536 Bulbocástanum $W$. great B. Flexuosum Sm

3537 rigens $S p r$. Conium rigens $\mathrm{W}$. 632. OENAN'THE. $W$ 3538 fistulósa $W$. $353 y$ crocáta $W$. 3540 prolífera $W$. 3541 globulósa $W$. 3542 apiifólia Brot. 3543 peucedanifólia $W$ 3544 pimpinelloídes $W$. 3545 inébrians $W$.

633. CFITH'MUM. $W$. 3546 marítimum $W$. 3547 latifólium $W$.

634. ATHAMAN'TA.

3548 Libanôtis $W$ 3550 sibírica $W$. 3551 condensáta $W$ 3552 incána $W$. 3553 Oreoselínum $W$

3554 sícula $W$ 3555 Matthioli $W$. $\beta$ ánnua W.

635. PIMPINELI 3557 Saxífraga $W$. 35.58 nigra $W$. 3559 mágna $W$. 3560 dissécta $W$ 3563 dichótoma $W$. upright spreading

notted

fine-leaved mountain

broad-leaved

Siberian

close-headed

hoary 3532 nodósa $W$ Thyme-scented 3549 Cervária $W$ 3556 creténsis $W$ 3561 peregrima $W$ 561 peregrina $W$

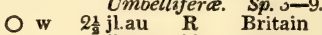

$\mathrm{O}$ w 1 jl.au $\mathbf{Y}$ Britain

O w 1t my.jl W Britain

Umbelliferce. Sp. 1.

○ cu 1 my.jl Pu Bagdad Umbellifere. Sp.1.

jn.jl W W

Umbelliferce. Sp. 1-20.

* $\Delta$ ec $1 \frac{1}{2}$ my.jn $W$ Britain

Umbellifere. $S p$. 2-

* $\Delta \mathrm{w} 2$ my.jn W Britain past. D co Eng. bot. 988

业 $\sqcup$ w 1 jn.jl $\quad$ W $\quad$ C. G. H. 1787. C co

WATER-DROPWORT

common $¥ \Delta \mathrm{p} \quad 2$ Umbellifera. Sp. 8-20.

Hemlock $\quad \frac{\$}{\Delta} \mathbf{p} \quad 2$ jn.au $\mathbf{F}$ Britain dit. D m.s Eng. bot. 363 Britain dit. D m.s Eng. bot. 2313

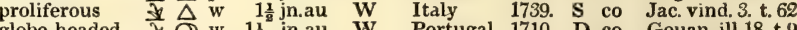
globe-heartion 1710. D co Gouan. ill.18.t.9 Parsley-leaved $\neq \Delta, \quad w \quad 2$ jn.au $W$ Portugal 1806. D co Sabb. rom. t. 8

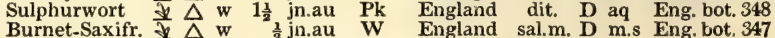
various-leaved $\triangle \mathrm{D} \quad \mathbf{1}^{\frac{1}{2}}$ au.s $\quad$ W C. G. H. 1816. D co

Umbelliferce. $S p .2-4$. SAMPHIRE. $\triangle$ cul 1 jl.s W W Britain s.cliffs. D r.m Eng. bot. 819 wedge-leaved

\section{SPIGNELL. \\ Umbelliferce. Sp.9-14.}

divaricated $\Delta$ w 2 jl.au $\mathbf{W}$ Flixweed-leav. $\mathrm{d} \quad 3 \mathrm{jn} . \mathrm{jl} \quad \mathrm{W}$ Sicily 1686. D co Zano.his.70.t.48 fine-leaved $\Delta \mathrm{w} \quad 2$ jn.jl $\mathrm{W}$ Carniola 1802. D co Jac.ic.rar.1.t.57

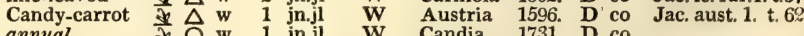

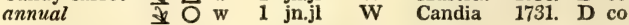

Umbellifera. $S p .7-9$.

(1)

common \& $\Delta \mathrm{cu} 1 \mathrm{jn.au} W$ Britain drypa. D co Eng. bot. 407 black-rooted $\Delta \mathrm{w} \quad 1$ jn.au W Germany 1683. D co great $\Delta \mathrm{w} \quad 2$ jn.au $W$ England woods. D co ... D co Retz. obs. 3. t. 9

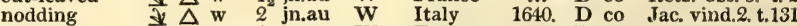
Anise \&े $O$ ec 1 jn.au W Egypt 1551. D co dichotomous $\frac{7}{4} \mathrm{w} \frac{1}{4} \mathrm{jn} . \mathrm{au} \quad \mathrm{W}$ Spain 1798. D co

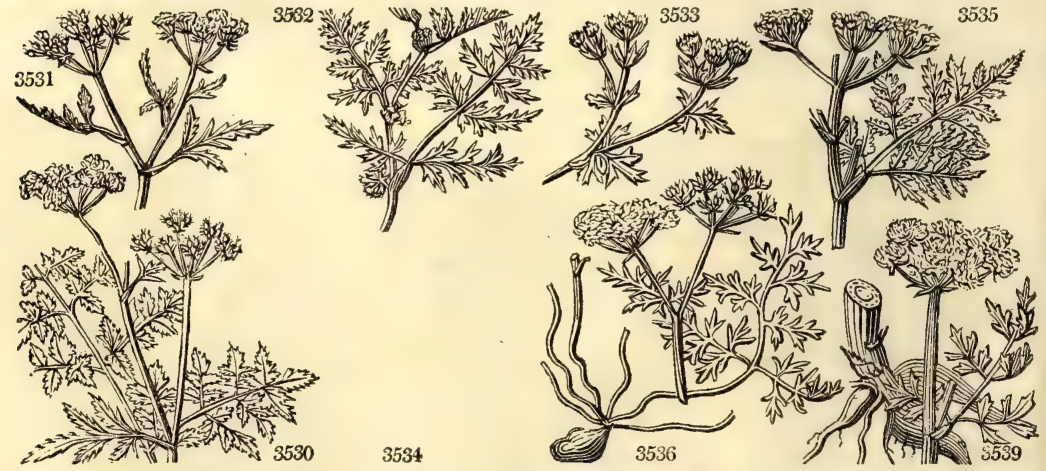

History, Use, Propagation, Culture,

627. Torilis. A name contrived by Adanson and adopted by Gærtner, and other botanists. It probably, like many of Adanson's words, has no meaning.

628. Oliveria. Named in honor of G. A. Olivier, a French botanist, who travelled in the East. He published a splendid work on insects, by which he is better known than by his botanical merits.

629. Ledeburia. So named by Professor Link, after M. Ledebure, the author of a Catalogus Horti Dorpatensis, published in 1819; in which work this plant stands as Tragium tauricum.

630. Myrrhis. This plant has been long in cultivation. Formerly the young leaves were put into salads; and the roots were boiled and eaten cold, or in tarts, and in a variety of sauces, or candied. The seeds are put into soups in Germany, and in the north of England employed in polishing and perfuming oak floors and furniture.

631. Bunium. From Brvios, a hill, because the plant grows in dry and elevated situations. Terre Noix, Fr. Erdnuss, Ger., Castagno di terra, Ital. The roots of B. Bulbocastanum are or used to be dug up and eaten raw by the poorer classes. They are farinaceous, sweet, and supposed to be very nourishing. Swine are very fond of them, and wili soon become fat by feeding on them.

632. Enanthe. From oเy, a vine, and ay0os, a flower. The CEnanthe, says Pliny, smells like the vine in flower, and it is from that that it takes its name. This genus, like most of the aquatic umbelliferæe, is chiefly poisonous. CE. crocata is considered eminently so. The juice of the root or an infusion of the leaves is very efficacious in cutaneous diseases : in large doses it produces a fatal tetanus. The herb is applied in poultices to those ulcers that form in the cleft of the hoof of kine. 
3530 Involucres many-leaved, Seeds ovate, Styles reflexed, Leaves decompound, Outer leaflet lin. lanceolate 3531 Universal involucre scarcely any, Seeds ov. Styles reflexed, Leaves decompound, Stem much branched

3532 Umbels simple subsessile, Leaves supra-decompound

3533 Leaves pinnate, Leaflets sessile 3-5-cleft, Segm. 3-fid ciliated, Flowers fascicled villous

5534 Radical leaves pinnate, Pinnæ ovate serrated cut, The upper 3-pinnatifid with linear 3-forked segments 3535 Villous, Leaves ternate decompound, Leaves ovate lanceolate pinnatifid, Central f. male

3536 Leaves uniform, Involucre many-leaved

3537 Seeds somewhat muricated, Peduncles furrowed, Leaflets channelled obtuse

3538 Stoloniferous, Cauline leaves with filiform fistulous pinnæ

3539 All the leaves many cut obtuse nearly equal

3540 Outside stalks of the umbels longest branched male

3541 Leaves bipinnate, Fruit globose

3542 Leaves bi-tripinnate; the upper pinnate, Leaflets wedge-shaped cut serrate striated

3543 Cauline leaves pinnate; radical bipinnate, Leaflets linear

3544 Radical leaves caudate split : cauline entire very long simple

3545 Lower pinnæ of the leaves ovate; upper linear, Stalks angular

3546 Leaflets lanceolate fleshy

3647 Leaflets wedge-shaped split (Tenoria, Spr.)

3548 Leaves bipinnate tlat, Umbel hemispherical, Seeds hairy

3549 Leaves pinnate decussate cut angular, Seeds naked

3550 Leaves pinnate cut angular

3551 Leaves subpinnate, Leaflets imbricated downwards, Umbel lens-shaped

3552 Pubes. hoary, Lvs. supra-decompound, Leaflets wedge-shaped 4-toothed, Umbel with many rays globose

3553 Leaflets divaricating, Leaves thrice pinnate

3554 Lower leaves shining, First umbels subsessile, Seeds hairy

3555 Leaves capillary, Styles persistent erect, Seeds oblong hairy

3556 Leaflets linear flat hairy, Petals divided, Seeds oblong hairy

$\beta$ Leaves many-parted, Segm. linear rounded acuminated

3557 Stem furrowed smooth, Leaves pinnated smooth : radical roundish finely toothed; cauline linear

3558 Stem furrowed pubescent, Leaves pinnate pubescent : radical cordate cut obtuse toothed; cauline linear 3559 Leaves all alike pinnate, Leaflets lobed, the odd one 3 -lobed

3560 Leaves pinnate, Pinnæ many-parted, Segments falcate acute

3561 Radical leaves pinnate crenate; upper wedge-shaped cut, Umbels nodding

3562 Radical leaves trifid cut

3563 Peduncles opp. the leaves, Flower leaves bifid or trifid, Leaf-stalks winged membranous

3543

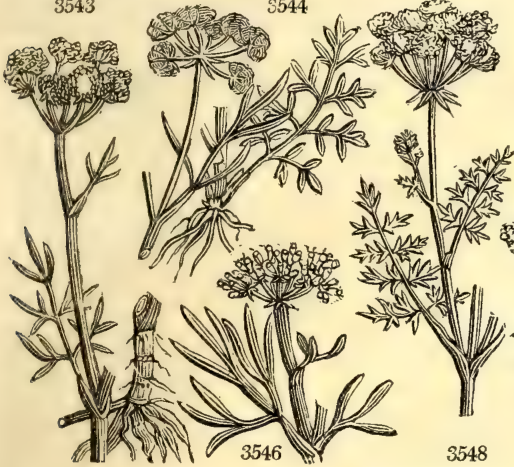

3556 pioner
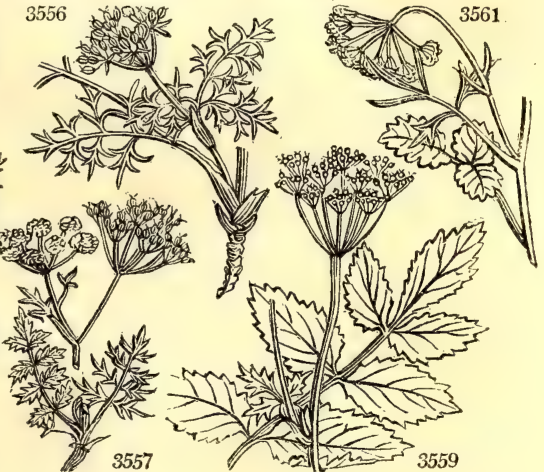

and Miscellaneous Particulars.

633. Crithmum. From zot , barley. Its seed is very similar to a grain of barley. Saint Pierre, Fr., Meerfenchel, Ger, and Finochio marino, Ital. The C. maritimum is found on stone walls, as well as by the sea shore. The inhabitants, where it abounds, not only use it as a pickle, but as an ingredient in salads, and as a pot-herb. In the garden it may be grown on beds of sand and rubbish, or in pots. Braddick, an ingenious horticulturist, cultivated it at Thames Ditton, in a sheltered dry situation screened from the morning sun : he protected it by litter during winter, and in spring sprinkled the soil with a little powdered barilla. "This I do," says he, "to furnish the plant with a supply of soda, since in its native place of growth it possesses the power of decomposing acid." With this treatment it flourished abundantly, producing an ample supply of leaves and shoots, which were cut twice in the season. (Hort. Trans. ii. 232.)

634. Aihumanta. A plant found upon Mount Athamas in Thessaly, as some say ; others, however, believe it to have been named after King Athamas, a king of Thebes, who first brought. it into use.

635. Pimpinella. According to Linnaus, this name has been altered from bipennula, twice pinnate, in allusion to the leaves. P sax that some make several species, as P. minor, major, and dissecta. The root is acrid, and used as a masticatory in tooth-ache, also externally to take away freckles, and in gargles to dissolve viscid mucus.

P. anisum (änysin, Arabic; Golius.) is cultivated in Malta and Spain, whence the seeds are annually imported into England for their use in medicine. They are aromatic and carminative, and yield an oil both by distillation and expression, which is much used in flatulencies, as are the seeds in substance. The oil is also 
636. PHEIIAN'DRIUM $W$. WATER-HEMLOCK. S564 aquáticum $W$. 637. DON'DIA. Spreng. Dondia. 3565 Epipáctis $S p r$. yellow 638. TR ACHYSPER'MUM. $L k$. 3566 cop'ticum Spr. Egyptian 639. AM'MI. $W$ 3567 Visnága $\boldsymbol{W}$ 3568 május $W$. 3569 glaucifólium $W$ 3570 daucifólium $W$ 640. BU'BON. $W$. 3571 macedónicum $W$. 3572 rígidum $W$ $\beta$ gummiferum Sm. 3573 Gal'banum $W$ 3574 levigátum $W$ 3575 gummiferum $W$ 641. CU'MINUM. $W$. 3576 Cýminum $W$. 649. SE'SELI. $W$. 3577 pimpinelloides $W$. 3578 leucospérmum $W$.et $K$ 3579 montánum $\boldsymbol{W}$ 3580 glaúcum $W$. 3581 ammoídes $\dot{W}$ 3582 tortuósum $W$ 3583 divaricátum $\boldsymbol{P} h$. 3584 Hippomárathrum 3585 grácile $\boldsymbol{W}$. en. 3586 elátum $W$.

643. THAP'SIA. $W$. 3587 villósa $\boldsymbol{W}$. 3588 fœ'tida $\dot{W}$. 3589 Asclépium $W$ 3590 gargánica $W$.

644. ACTINOTUS. $L a b$. 3591 Helian'thi Lab.

\section{TRI'NIA. Hoffm.} 3592 Hoffman'ni Bieb. Pimpinella dioica 5593 Hennin'gii Bieb.

646. SI'UM. $W$ 3594 latifólium $W$. 3595 angustifólium $W$. 3596 nodiflórum $W$ 3597 répens $W$. 3598 Sisarum $\boldsymbol{W}$. Bubon. Macedo Macedo stiff-leaved gummy stiff-leaved
Lummy
smovage-leaved gum-bearing a cu Cumin. common

Dow Saxifrage. woolly-headed $\neq \Delta w$ mountain $\neq \Delta w$ crooked $x$ O shining-leaved $\frac{}{2} \Delta$ or shining-leaved $\frac{\partial}{\partial} \Delta$ or various-leaved $\frac{ \pm}{\Delta} \Delta$ w tall

Deadey Carrot \& $\Delta w$ villous stinking oriental Garganian

Actinotus Sun-flower

WATER-PA RSNIP, broad-leaved $\frac{\Delta}{\Delta}$ procumbent procumberit $\Delta$ creeping
Umbellifere. Sp. 1.

3 jn.jl W Britain rivul. C aq Eng. bot. 684

Umbellifera. Sp. 1.

7 $\triangle$ pr $\frac{1}{4}$ mr.ap Y Alps w 2 jn.jl W Egypt

Carrot-like O w 2 jn.au W S. Europe 15y6. S co Gæ. de.fr.1.t.107 preat $\quad$ w 2 jn.il W S. Europe 1551. D co Blackw. t. 447 glaucous-leav'd $₹ \Delta \mathrm{w} \quad 11 \mathrm{jn} . \mathrm{jl}$ W France 1816. D co Carrot-leaved $\frac{7}{\Delta}$ w 2 jl.au P.X Pyrenees 1734. D co Scop. carn. t. 10

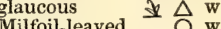
Umbelliferce. Sp. 5-7.

2 jn.au P.Y Greece 1596. S co Blackw, t. 380

3 jn.au Pk Sicily 1710. S co Bocc.mus.2.t.76

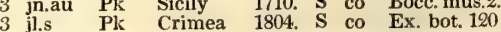

6 jl.au Y.G C. G. H. 1596. S s.l Bot. mag. 2489

4 mr.d Y C. G. H. 1774. S s.1

jl P.Y C. G. H. 1731. S $\mathbf{s . 1}$ Com, hort.2.t.58 Umbelliferie. Sp. 1.

jn.jl W Egypt 1594. S co Cav. ic. 4. t. 360

Umbellifera. Sp. 10-14.

1 jI W S. Europe 1796. D co

$1 \frac{1}{2} \mathrm{jl}$ W Hungary 1805. D co Pl. rar. hung. 80

$1^{2}$ jn.jl W Italy 1658. D co Jac.vind.2.t.129

2 jl.au W France 1759. D co Jac. aust.1.t.144

$\frac{1}{2}$ jn.jl W S. Europe 1759. S co Jac. vind. 1.t.52

1 o W S. Europe 1597. D co

1 jn.jl $\mathrm{Y}$ N. Amer. 1812. D co Bot. mag. 1742

2 j Pu Austria 1656. D co Jac aust. 2 t.143

$1 \frac{1}{2}$ jn.jl $\quad \mathrm{Y}$ Hungary 1805. D co P.ra.hun.2.t.117

W Austria 1710. D co Gouan.ill.16.t.8

Umbelliferce Sp $4-0$.

2 jn.jl Y S. Europe 10. D s.1 Moris.s.9 t.18.f.3 2 jl.au Y Spain 1596. D s.l Moris.s.9.t.18.f.7 jl.au Y Levant … 2 jl.au L.Y Barbary 1683. D s.I Gouan.il.18.t.10 Umbelliferce. Sp. 1 .

Trinia. Umbelliferce. Sp.

Hoffmann's $¥ \Delta \mathrm{w} \quad$ my.jn W England rocks. D co Eng.bot. 1209

Hot.ning's $2 \Delta$

要 $\triangle$ cul $\frac{1}{2}^{\frac{1}{2}} \mathrm{jn}$ W jn.au W Hungary $1803 . \quad$ Pl.rar.hung.t.27

Umbellifere. Sp. 8-28.

3 jl.au W Britain rivul D aq Eng. bot. 204.

1 jl.au W Britain rivul. D aq Eng. bot. 139 Britain rivul. D aq Eng. bot. 639 Britain moi gr. D m.s Eng. bot. 1431 China 1548. D $\mathrm{rm}$ Schk. han.1.t.69

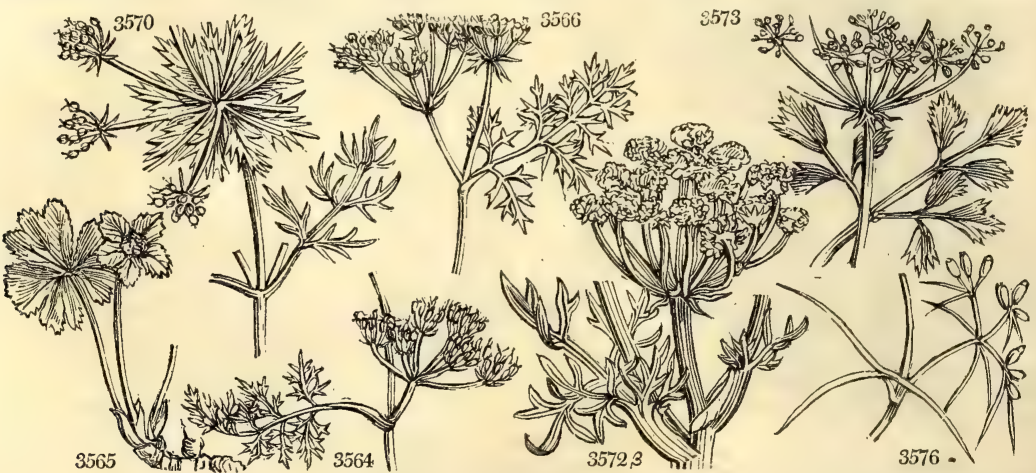

History, Use, Propagation, Culture,

used by vermin-killers to scent poisonous baits, or to neutralize or obliterate other smells. Anise is sometimes sown in gardens for the leaves, to be used as a garnish, or for seasoning, like fennel.

636. Phellandrium A name under which Pliny describes an umbelliferous plant, of similar nature to the one now so called. In running streams the leaves of this plant become divided, like those of Ranunculus aquatilis in the same situation. When the plant grows in an angle, out of the rapid course of the stream, it produces its flowers; but it flowers best on the muddy banks of ditches and ponds. According to Linnæus it renders horses paralytic, the disease being brought on by a Coleopterous insect, the Curculio paraplecticus, which breeds in the stalks, and is cured by pigs' dung The seeds are sometimes used in agues.

637. Dondia. A curious little plant resembling Astrantia. The meaning of its name is unexplained. 638. Trachyspermum. From rea ${ }^{2}$, , rough, and $\sigma \pi \varepsilon \rho \mu n$, seed; on account of the roughness of the seeds.
Nearly related to Ammi, with which it agrees in habit.

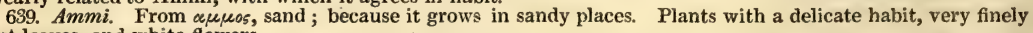
cut leaves, and white flowers.

640. Buban. Bubonion is a name of Pliny's, now applied to this plant; as Pliny's was used in medicine, so is this, and there the resemblance ceases. B. macedonicum is put among clothes to scent them in some parts of the East. From B. Galbanum (derivation obscure) the drug of that name is obtained, though it is not clear that it may not also be got from other species. It is collected from the spontaneous exudation of the 
3564 Ramifications of leaves divaricating

3565 Leaves stalked digitate 3-lobed, Scape angular with only one umbel

3566 Leaves supra-decompound, Leaflets filiform, Umbels opp. the leaves, Leaves of involucre uriequal

3567 Universal umbel united at base

3568 Lower leaves pinnate lanceolate serrate; upper multifid linear

3569 Segments of all the leaves lanceolate

3570 Leaves supra-decompound, Leaflets 3-parted pinnatifid

3571 Leaves rhomb-ovate cut-toothed, Teeth acuminate, Umbels numerous, Seeds hairy 3572 Leaflets linear

3573 Leaflets ovate wedge-shaped acute finely serrate, Umbels few, Seeds smooth, Stem glaucous 3574. Leaflets lanceolate very obtusely and obscurely crenate, Seeds smooth

3575 Leaflets cut acuminate : lower broadest, Seeds smooth

3576 The only species. Lower leaves broad, Upper capillary

3577 Stem declinate, Umbels nodding

3578 Stem erect flexuose, Leaves decompound very fine, Umbels dense very downy

3579 Leaf-stalks branch-bearing membranous oblong entire, Cauline leaves very narrow

3580 Leaf-stalks branch-bearing membranous obl. entire, Leaflets single and two together channelled smooth

3581 Radical leaves with imbricated leaflets

3582 Stem tall rigid, Leaflets linear fascicled

3583 Stem procumbent branched, Leaves bipinnatifid shining, Involucels halved

3584 Involucels connate one-leaved

3585 Stem ascending, Ieaves triternate very fine, Umbel nodding with long rays

3586 Stem elongated with callous points, Leaves bipinnate, Pinnæ linear distant

3587 Leaflets toothed villous united at base

3588 Leaflets many-cut narrowed at base

3589 Leaves digitate, Leaflets bipinnate finely many-cut

3590 Leaves bipinnate, Leaflets pinnatifid, Segm. lanceolate

3591 Downy, Leaves decursively pinnated, Invol. soft long with 10-18 rays

3592 Seeds rough with sharp ribs

3593 Seeds smooth with blunt ribs

3.594 Leaves pinnate, Umbel terminal

3595 Leaves pinnate, Umbels axillary stalked, Common invol. pinnatifid

3596 Leaves pinnate, Umbels axillary sessile

3597 Stem creeping, Leaflets roundish toothed angular

3598 Leaves pinnate : floral ternate
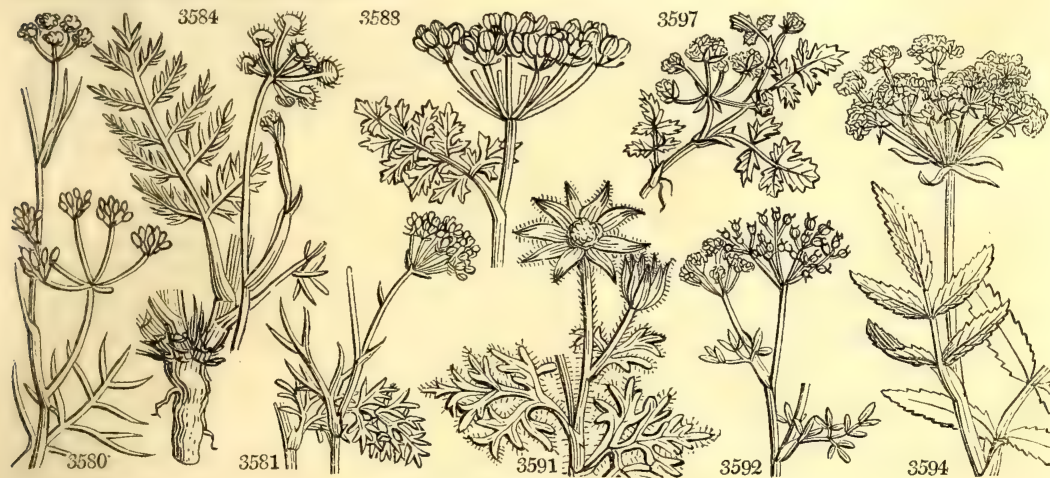

stem, or by an incision in the stalk a little above the root, from which it immediately flows, and soon becomes sufficiently concreted for gathering. Medicinally considered, this gum-resin is said to hold a middle place between Asafotida and Ammoniacum; but it is far less fotid than the former.

641. Cuminum. From the Arabic name of the plant qamoun. (Golius.) This is a dwarf fennel-looking plant, cultivated in the south of Europe and lesser Asia for its seeds, which are hot and aromatic, and used ike those of Anise, Caraway, \&c.

642. Seseli. Golius (p. 167.) says, a plant related to this is called Seycêlyous in Arabic. There is also a Greek $\sigma \varepsilon \sigma \varepsilon \lambda$.

643. Thapsia. The Thapsia, says Dioscorides, derives its name from the isle Thapsus, where it was first dis-

covered. Plants resembling Smyrnium in habit.
644 . Actinotus. From $\propto x \tau i \nu$, a ray, in allusion to the ray-like appearance of the involucrum. Curious New Holland plants with the habit of Astrantia.

645. Trinia. Named by Hoftmann after Dr. Trinius, a celebrated Russian botanist, who has published some works upon grasses. Plants resembling Pimpinella in appearance.

646. Sium. Siw signifies water in Celtic. This is a genus of aquatic plants, S. nodiflorum bears a good deal of resemblance to the water-cress (Nasturtium officinale), and, unless when in flower, is not very easily distinguished from it by the,inexperienced. It is commonly considered poisonous, though, according to Dr. 
3599 rigidum $W$. 3600 Falcária $W$. 3601 sículum $\boldsymbol{W}$. 647. SI'SON. $W$. 3602 Amómum $W$. 3603 ségetum $W$. 3604 inundátum $W$. 3605 verticillátum $W$. 3606 sálsum $W$.

648. CICU'TA. $W$. 3607 virósa $W$. 3608 maculáta $W$.

649. CO'NIUM. $W$. 3609 maculátum $W$ 3610 africánum $W$.

650. SMYR'NIUM. $W$. 3611 perfoliátum $W$. 3612 Olusátrum $W$ 3613 apiifólium $\boldsymbol{W}$. 3614 cordátum $\boldsymbol{P h}$. Thápsia trifoliata W. 3615 aureum $W$. 3616 integérrimum $W$.

651. A'PIUM. $W$. 3617 Petroselinum 3618 gravéolens $W$.

652. ÆGOPO'DIUM. $W$. 3619 Podagrária $W$.

653. ME'UM. Jacq. 3620 Bunius Jacq. 3621 Mutellína P.S. Coriander-lvd.

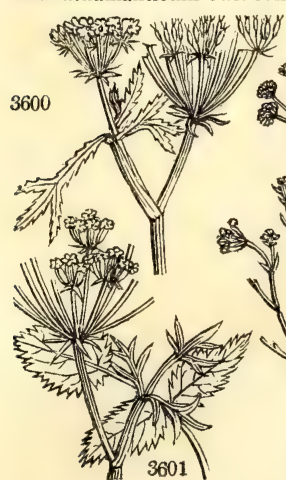

3601

Virginian
decurrent
Sicilian

Sicilian

HoNewort. hedge corn

whorl-leaved fine-leaved

Cowbane. long-leaved spotted

HeMLOCK. common

Rue-leaved

Alexanders. perfoliate

common

Smallage-lvd. heart-leaved

golden

entire-leaved

Parslex.

garden

Gout-weEd.

* $\Delta \mathrm{w} \quad 2$ jl.au $\mathrm{W}$ Virginia 1774. D s.p Moris.s.9.t.7.f. $\not \vec{\Delta} \mathrm{A} \quad 2$ jl.au W Europe 1726. D s.p Jac. aust. 3.t.257 Umbelliferce. Sp. 5-16.

O w 3 jl.au W Britain hed. S m.s Eng. bot. 954

W 2 jl.au w England ch.fi. S m.s Eng. bot. 228

O 1 my.jn W Britain dit. S aq Eng. bot. 227

D $\triangle$ w 1 jl.au W Britain m. me. D m.s Eng. bot. 395

7 $\triangle$ w 1 jl.au P.Y Siberia 1804. D co P.a.p.1779t8.f1.3 Umbelliferce. Sp. $2-5$.

\} \Delta \mathrm { m } \quad 3 \mathrm { jl } \quad \text { W Britain ditch. D m.s Eng. bot. } 4 7 9

₹ $\triangle \mathrm{p} \quad 1 \frac{1}{2}$ jl.au $\quad \mathrm{W} \quad$ N. Amer. 1759. D co Pl. alm. t.76.f. 1 Umbelliferce. Sp. $2-3$.

1 $2 \mathrm{~m} 5$ jn.jl W Britain hed. S co Eng. bot. 1191

O w 3 jn.s - W C. G. H. 1759. ¿ s.l Jac. vin. 2.t. 194

\section{Umbelliferce. $\quad S p .6-7$.}

₹ $\Delta$ cul $3 \mathrm{my} Y$ Italy 1596. D s.l Pl. rar.h.1.t. 23 ₹ 0 cul 4 my.jn G Britain seaco. S s.l Ei g. bot. 230 \$f $\triangle$ cu 1 my.jl P.Y Candia 1731. D s.l 立 $\Delta$ or $1 \frac{1}{2}$ jn.jl D.Pu N. Amer. 1597. D s.I

$\neq \Delta$ cu 1 my.jn $Y \quad$ N. Amer. 1699. D r.m

\section{Umbelliferce. Sp. 2-5.}

* (1) cul 3 jn.jl I.,Y Sardinia 1548. $\mathrm{S}$ r.m

(1) cul 4 jn.au W Britain ditch. S m.s Eng. bot. 1210

\ $\Delta \mathrm{w} 2$ Umbellifere. Sp. 1 . Umbellifere. Sp. 1.
my.jl W Britain sh.pl. D m.s Eng. bot. 940 Umbellifere. Sp. 3-7.

$\searrow$ (D) 1 j $\quad$ W Pyrenees 1778. S co Jac. vin. 2.t. 198 $\downarrow \Delta$ or 1 jl.au Pu Austria 1774. D co All. pe, t. 60.f. 1

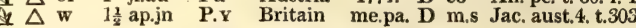

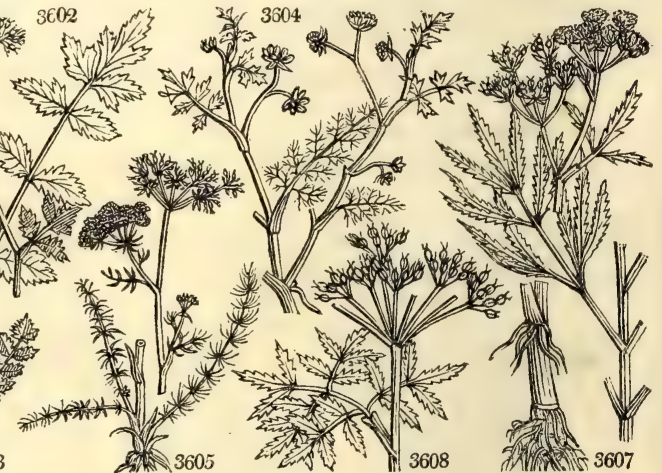

History, Use, Propagation, Culture,

Withering, the juice, in doses of from two to four ounces, either alone or with milk, every morning, is an excellent alterative in cutaneous dizeases.

S. sisarum (from Dgizer, its Arabic name, in which language it signifies carrot), Chervis, Fr., Zuckerwiirtzel, Ger., and Sisaro, Ital, is cultivated for its roots or tubers, which, boiled and eaten with butter, are sweet and agreeable. A crop may either be raised from seed or offsets; if from the former, sow in March or the beginning of April, and when the plants come up, whether in rows or broadcast, thin them, so as nine or ten square inches may be allowed to each plant. With the usual summer culture the roots will have attained their full size in September, and may be taken up as wanted for use. In growing from offsets, allow about the same distance planting about the end of April, and giving the usual culture afterwards.

647. Sison. From the Celtic sizun, which signifies a running stream. Many of the plants grow in such situations. This genus is called Honewort, from its being used formerly to cure a swelling in the cheek called the Hone.

648 Cicuta A word used by Virgil ( $E c l$. 2 and 5.), but of unknown meaning. C. virosa is poisonous to mankind and kine, but not to horses, sheep, or goats; the smell being weak in the spring, cows are apt to be killed by it, but afterwards the odour enables them to avoid it. C. maculata is used in medicine like Conium maculatum

649. Conium. Said by Linnæus to be derived from zoys, powder, dust; but the applieation of the term is not evident. C. maculatum is a well known poisonous plant, lately admitted into the Materia Medica. According to Linnæus, sheep eat the leaves, but horses, cows, and goats refuse them. Ray informs us, that the thrush will feed upon the seeds, even when corn is to be had. Curtis says hemlock is eaten by few or no insects. The dried fistulous stalks of this and several other umbelliferous plants are called by the country people kecksies. As a medicine, hemlock seems to act on the constitution in a great measure like opium.

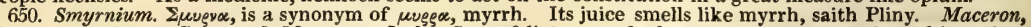
Fr., Smyrnerkraut, Ger., and Macerone, Ital. S. perfoliatum and olusatrum are or may be cultivated as Asparaginous and salad plants, though they are now almost entirely supplanted by the celery, which they somewhat resemble in flavour. The seeds are sown in March in rows two feet apart, and afterwards thinned out to six inches. As the plants advance, they are earthed up like celery, and, like it, are ready for use during to six inches. As the plants advance, they are earthed up like celery, and, like it, are ready for use during
autumn and winter. Olusatrum is from olus, pot-herb, and atrum, black, from the dark colour of its foliage. Our English name, Alexanders, is certainly a mere corruption of Olusatrum.

651. Apium. From apon, water, in Celtic ; from the place where the plant'grows. A. Petroselinum, (rזrea, stone, and selinum - Stone Selinum) Persil, Fr., Petersilie, Ger., and Petroselina, Ital., is a well known seasoning herb, and it is also sown among pasture grasses as likely to counteract the liver rot in sheep. There is a variety called the Hamburgh or large rooted parsley, which is cultivated for its roots, which, as well as the 
3599 Leaves pinnate, Leafiets lanceolate nearly entire

3599 Leaves pinear decurrent connate

3601 Radical leaves ternate; cauline bipinnate

3602 Leaves pinnate, Úmbels erect

3603 Leaves pinnate, Umbels cernuous

3604 Creeping, Umbels bifid

3604 Creeping, Umbels bifid
3605 Leaflets whorled capillary

3606 Rad. lvs. compound, Leaflets whorled fascicled lanc. Stem leafless, Umbellif. branches dichotomous

3607 Umbels opp. to the leaves, Leaf-stalks edged obtuse

3608 Serratures of leaves mucronate, Leaf-stalks membranous two-lobed at end

3609 Seeds unarmed, Stem branched shining spotted

3610 Seeds muricated, Petioles and peduncles smooth

3611 Cauline leaves simple stern-clasping

3612 Cauline leaves ternate stalked serrate

3613 Cauline leaves wedge-shaped obtuse trifid toothed

3614 Radical leaves simple cordate crenate; cauline ternate serrate, Umbels terminal

3615 Leaves pinnate serrate, All the florets fertile

3616 Cauline leaves doubly ternate entire

3617 Cauline leaves linear with minute involucres

3618 Cauline leaves wedge-shaped

\section{Upper leaves ternate, Lower biternate sessile}

3620 Stem diffuse branching, Radical leaves broad; cauline very narrow

3621 Stem simple, Sheaths of leafstalks dilated membranous, Leafiets multifid pinnatifid 3622 All the leaves very finely cut

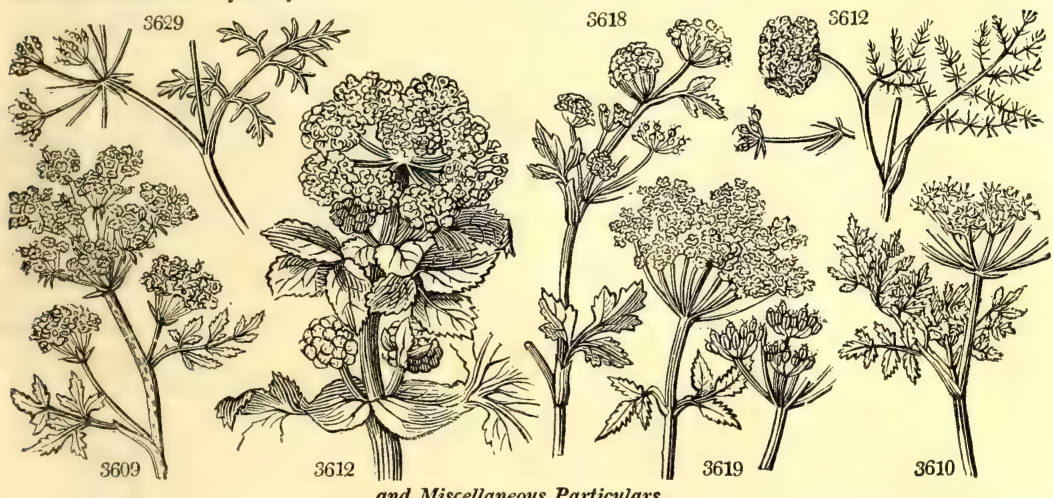

and Miscellaneous Particulars.

roots of the other varieties, communicate an agreeable flavor to soups and stews. The curled thick-leaved variety is that most esteemed for soups and as a garnish : it is sown in drills, and should be thinned out when it is so far advanced as to shew the finer curls of the leaves. It is too commonly left to grow as it came up which makes it but a very inferior article for garnishes. The Hamburgh sort should be thinned so as each plant may occupy ten or twelve square inches of surface.

A. graveolens is one of our most valuable salad plants, and is a remarkable instance of the effect of cultivation, being in its wild state, rank, coarse, and unfit to eat ; and blanched in the garden, sweet, crisp, juicy, and of a most agreeable flavor. The green leaves are used in soups, and in Italy and the Levant, where the plant is grown, but not blanched, this is its principal application. Here both the leaves and seeds are used in soups and stews, and the blanched stalks in that way and also as a salad, either alone or in composition. One variety, the Celeriac, is grown entirely for the root or base of the leaves, which assumes a bulbous form, is solid and white, and used either in soups or as a salad.

In order to produce excellent celery, a deep rich light soil is required, and especially a soil on a dry bottom. The seed in the main crop is commonly sown in the beginning of April on a bed for transplantation; the plants so raised are commonly pricked out into other beds, and placed four or six inches asunder. At eight or twelve inches height the plants so brought forward are transplanted into trenches for blanching. These trenches are small open ditches of from six inches to a foot deep, and they are dug from two and a half to three feet apart from each other, in order to admit of earthing up the plants to the height of two feet or more above the natural surface. The excavated earth is laid in the intervals, and some dung is dug into the bottom of the trenches. Along these the plants are inserted at four or five inches apart, and as they grow, the earth from the sides of the trenches and from the wide intervals between them is applied to the plants in small layers at a time, till at the end of the autumn the ditches have become banks two or three feet high. The celery is now fit to use, and by earlier and later crops this salad is had in perfection from August or September till May following. Celery is grown to great perfection in Lancashire, where blanched stalks have been dug up four feet six inches long, and weighing nine or more pounds, of the best quality. A variety of modes of cultivating the celery are brought together in the Encyclopæedia of Gardening, which well deserve the perusal of those who aim at growing this root in the best manner.

652. Aggopodium. From $\propto$ « $\propto$ \% semble the cloven foot of a goat. The leaves of $\mathrm{E}$. Podagraria smell like those of Angelica, and may be eaten in spring salads.

653. Meum. From $\mu s i o v$, very small, in allusion to the extreme delicacy of the leaves, which are as fine as hairs. 
654. ANE'THUM. $W$. 3623 gravéolens $\boldsymbol{W}$. 3624 ségetum $W$. 3625 Sówa Roxb. 3626 Fœnículum $W$. $\beta$ dulce

655. CA'RUM. $W$. 3627 Cárui $\boldsymbol{W}$. 3628 simplex $W$. 656. CNIDIUM. Cuss. 3629 Monniéri $W$. 3630 Siláus $W$ 3631 alsáticum $W$ 3632 aristátum $W$ 3633 pyrenæ'um $\dot{W}$.

657. BUPLEU'RUM. $W$ 3634 rotundifólium $W$. 3635 stellátum $W$. 3636 petræ'um $W$. 3637 graminifólium $\boldsymbol{W}$. 3638 angulósum $\boldsymbol{W}$. 3639 pyrenáicum $W$ 3640 longifólium $W$. 3641 falcátum $W$. 3642 exaltátum $\dot{B} i e b$. 3643 odontites $W$. 3644 semicompósitum $W$. 3645 ranunculoídes $W$. 3646 tenuissimum $W$. 3647 Gerárdi $W$ 3648 júnceum $\boldsymbol{W}$. 3649 núdum $\boldsymbol{W}$. 3650 fruticósum $W$. 3651 coriáceum $W$. 3652 fruticéscens $W$. 3653 canéscens $P . S$ 3654 spinósum $W$ 3655 diffórme $W$. 658. HYDROCO'TYLE 3656 vulgáris 3657 nitidula Rich. 3658 nepalénsis Hook. 3659 americána $\boldsymbol{P h}$. 3660 umbelláta $P h$. 3661 asiática $W$. 3662 repánda $P h$ 3663 villósa $W$. 659. SPANAN'THE. Jac. SPananthe. 3664 paniculáta 660. ULOSPER'MUM. $L k$. BROAD-SEED. 3665 dichótomum $L k$. dichotomous 661. ETHU'SA. $W$. Fool's-PARSLEY. 3666 Cynápium $W$. 3667 fátua $W$.

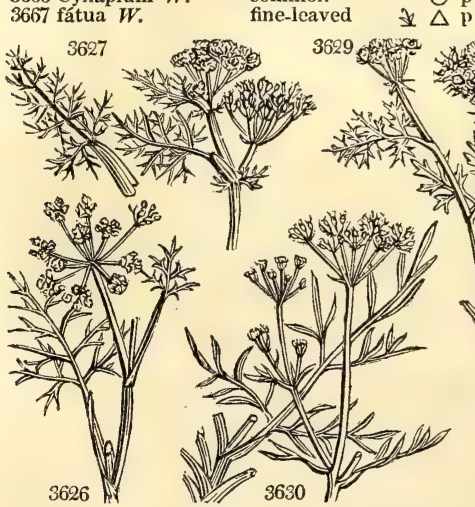

History, Use, Propagation, Culture,
54. Anethum. From $\alpha \theta \omega$, to burn, the plant being very heating. Large quantities of the seeds are yearly

DiLL. Portugal Indian

Fennel

Finochio

Caraway. common simple-stalke annual meadow small-headed bearded

yrenean Thorough-wax starry Grass-leaved angular-leaved $\Delta$ pr long-leaved twisted-stalked $\Delta \mathrm{pr}$ tall $\Delta \mathrm{pr}$ Opr Crowfoot-like $\& \Delta \mathrm{pr}$ slender branching naked-stalked shrubby

thick-leaved

Grass-lvd.-shr. hoary various-leaved

W. PennYwort. marsh Nepal tuberous umbelled 으 $\triangle W$ hick-leaved or $\Delta \mathrm{W}$ Pilewort-leaved $\Delta \backslash$ $\triangle \mathrm{pr}$ $\bigcirc$ pr $\bigcirc$ pr 此 $\triangle$ pr $1 \frac{1}{2}$

Umbellifera. sp. 4-5.

$\begin{array}{llllll}\text { cul } 3 \text { jn.jl } & \mathbf{Y} & \text { Spain 1570. S } & \text { r.m }\end{array}$

\& $\triangle$ cul $\dddot{6}$ jl.au $\mathrm{Y}^{\cdots}$ England ch.pl. S s.l 2 $\Delta$ cul 4 jl.au Y Italy ... $\mathrm{S}$ s.1 Umbelliferce. Sp. 2.

2 my in W Britain me pa, S s.l Eng bot 1503 my.jn W Siberia 1816. S s.1 Unbelliferce. Sp. 5-6.

11 jl.au W S. Europe 1771. S co Jac. vind. 1.t. 62 jn.au Y England mea. D co Eng. bot. 2142

6 jn.au L.Y Austria 1774. D co Jac. aust. 1.t.70

$1 \frac{1}{2} \mathrm{jn} . \mathrm{jl} \quad \mathrm{W}$ Pyrenees 1739. D co 1 jn.jl W Pyrenees 1731. D co Gou. ill. 11. t.5 Umbelliferce. Sp. 22-34.

2 jn.jl Y England co.fi. S co Eng. bot. 99

1 my.jl G Switzerl. 1775. D co Ha.h.n.771.t.18 $1 \frac{1}{2}$ my.jl G Switzerl. 1768. D co Plu.ph.t.50.f. 5 $\frac{1}{8}$ my.jl G Switzerl. 1768. D co Jac. ic. 1.t. 56

$1 \frac{1}{2}$ my.jl G Switzerl. 1759. D co

1 my.jl G Pyrenees 1814. D co Go.ill. t. 4. f. 1.2 my.jl G Switzerl. 1713, D co Cam. hort. t. 38 $\frac{1}{2}$ my.s G Germany 1739. D s.l Jac. aus.2.t. 158 2 jl G Tauria 1807. D s.1

$\frac{3}{4} \mathrm{jn} . \mathrm{au} \quad \mathrm{G} \quad$ Italy 1749 . S co Jac. vind. 3. t. 91 jn.au G Spain 1778. S co Gou. ill. t. 7.f. 1 1 jl.au G Pyrenees 1790. D 1.p Park. theat. f. 7 1.au G England sea sh. S s Eng. bot. 478

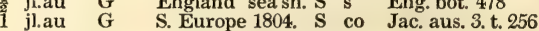
1 jl.au G S. Europe 1722. S co $1 \frac{1}{2}$ o G $\quad$ C. G. H. 1778. C l.p 3 jl.au G S. Europe 1596. C co Dend. brit. 14 $\frac{3}{4} \quad \ldots \quad$ G $\quad$ Gibraltar 1784, C $1 . s$ Jac. ic 2, t. 351

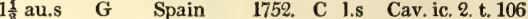
5 au.s G Barbary 1809. C l.s Desf. atl. 1.t. 57 1 au.s G Spain 1752. C 1.s Go. ill.8.t.2.f.3 1 au.s G C. G. H. 1752. C l.s

Umbelliferce. Sp. 8-54.

$\frac{1}{4}$ my.jn R Britain wa.pl. D c.p Eng. bot. 751

my G Java 1820. D co Hook. ex. fl. 29

$\frac{1}{2} \mathrm{jl} G$ Nepal 1820. D co Hook. ex. fl. 30

my.au R N. Amer. 1790. D p Spr. um. t. 2. f. 3

N. A.

1 jn.jl $\quad$ G $\quad$ N. Amer. 1806. D p Spr. um.t. 2. f. 1 au G C. G. H. 1795. D p

Umbellifera. Sp. 1.

2 jl.au W Caracas 1795. D s.1 Jac. ic. 2. t. 350

Umbelliferce. Sp. 1.

$1 \frac{1}{2}$ jn.jl W Barbary 1800. S co Desf. atl. 1. t. 66 Umbelliferce. Sp. 2-3.

$\begin{array}{lllll}2 & \text { jl.s } & \text { W } & \text { Britain co. fi. S co Eng. bot. } 1192\end{array}$

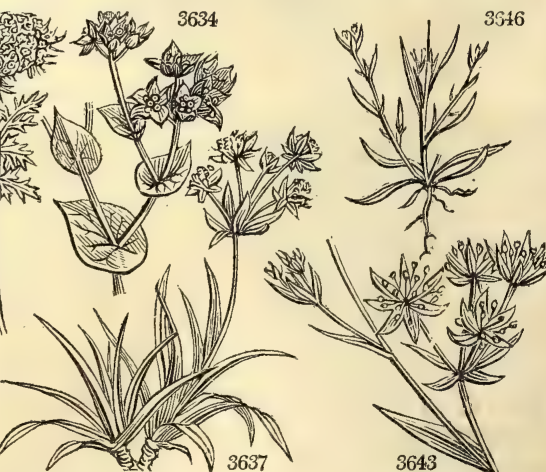
imported into this country from the south of France. They are used in medicine as carminatives, and, as it is said, in the manufacture of the British gin. No one has succeeded in growing the plant for a crop in this country.

655. Carum. A native of Caria, according to Pliny, b. xix. c. 8. Carvi, Fr., Kümmel, Ger., and Carvi, Ital. C. Carvi is cultivated both in agriculture and horticulture : in the former for its seeds, which are used to flavor cakes, to form sugar plums, to flavor spirits, and form a carminative distilled water. In the culinary art the leaves are sometimes used as an ingredient in salads, or as a pot herb, like parsley; and the roots are said to be superior in flavor to those of the parsnip.

656. Cnidium. The ancient name of an herb, supposed to have been an Orach, and certainly having no affi. nity to the plants now called Cnidium.

657. Bupleurum. From $\beta \varepsilon_{5}$, an ox, and $\pi \lambda \varepsilon v \rho \circ$, a rib. How applied is not apparent. These are plants remarkable among the Umbelliferous tribes for having simple leaves. 


\section{Fruit compressed}

\section{Cauline leaves three, Fruit oval}

3625 Leaves supra-decompound, Umbel with $5-15$ rays, Fruit obl, flat with three ribs at base 3626 Fruit ovate

3627 Stem branched, Sheaths of leaves ventricose, Common involucre $\mathbf{O}$.

3628 Stem quite simple, Sheaths of leaves appressed, Common invol. many-leaved

3629 Umbels close, Comm. invol, reflexed, Seeds with 5 membranous ribs

3630 Leaves thrice pinnated, Pinnules distinct with a nerve lanceolate 3-lobed with an odd one

3631 Leaflets pinnatifid, Segm. trifid bluntish

3632 Leafstalks of the hranches somewhat membranous loose entire, Lvs. supra-decom. Leaflets lanc. awned

3633 Leaves doubly pinnate Leaflets cut acute, Involucels bristly longer than the umbel

3634 Common involucres none, Leaves perfoliate

3635 Involucels joined together: the universal three-leaved

3636 Involucels about 5-leaved joined together, universal 5-leaved, Caul. leaves cord. lanc. stem-clasping

3637 Involucels 7-leaved; universal about 3-leaved, Radical leaves linear, Scape one-leaved

3638 Involucels 5-leaved orbicular; universal 3-leaved ovate, Leaves cord. lanc. stem-clasping

3639 Invol. 5-leaved roundish emarginate con.; universal 3-leav. cut at base, Lvs. lanc. cordate stem-clasping 3640 Involucels 5-leaved ovate; universal about 5-leaved, Leaves stem-clasping

3641 Involucels 5-leaved acute; universal about 5-leaved, Leaves lanceolate, Stem flexuose

3642 Stem branched leafy, Lvs. lin.-lanc. chan. nerved, Invol, 4-leaved uneq. very narrow shorter than umbel 3643 Involucels 5-leaved acute, universal 3-leaved, Central florets tallest, Branches divaricating

364t Leaves lanceolate, Umbels terminal and axillary, Seeds rough

3645 Involucels 5-leaved lanceolate longer; universal 3-leaved, Leaves cauline lanceolate

3616 Umbels simple alternate 5-leaved about 3-flowered

3647 Stem erect branching, Lvs. lin. acum. Invol. 5-leaved, Involucels 5-leaved lin. subul. longer than umbel 3648 Stem erect panicled, Leaves linear, Involucr. 3-leaved as long as umbel, Involucels 5-leaved

3649 Stem branched leafless, Radical leaves decompound flat cut, Involucres and involucels lanceolate-oblong 3650 Leaves lanceolate obovate entire sessile

3651 Leaves lanceolate narrowed each way entire sessile

3652 Leaves linear, Involucre common and partial

$36 \tilde{3}^{3}$ Lvs. peren. lanc. mucronate nerved, Flowering branches branched striated, Involucr. subulate appressed 3654 Branches of panicle sessile naked spiny, Leaves linear

3655 Vernal leaves decompound flat cut, Summer leaves filiform angular trifid

3656 Leaves peltate, Umbels 5 -flowered

3657 Leaves orbicular reniform 5-7-lobed, Flowers capitate sessile, Peduncle shorter than petiole 3658 Leaves orbicular reniform 7-lobed crenated, Flowers in numerous heads on short stalks

3659 Root tuberous, Leaves peltate roundish lobed unequally crenate, Clusters subsessile few-flowered

3660 Leaves crenate peltate emarginate at base, Umbels many-flowered and flowers stalked

3661 Leaves cordate reniform equal toothed crenate smooth, Umbels axillary sessile many-flowered

3662 Lvs. rounded cordate repand toothed beneath and stalks hairy, Umbels capitate about 3-fl. Fruit netted 3663 Stem decumbent and erect branches villous, Lvs. ov. cordate cuspidate 3-nerved, Umbels axillary sessile

3604 Stem erect smooth, Leaves triangular acummate crenate bearded at base, Umbels axillary spreading

3665 The only species

3666 Leaves all of one shape

3667 Leaflets verv fine whorled, Stem very leafy, Comm. invol. many-leaved
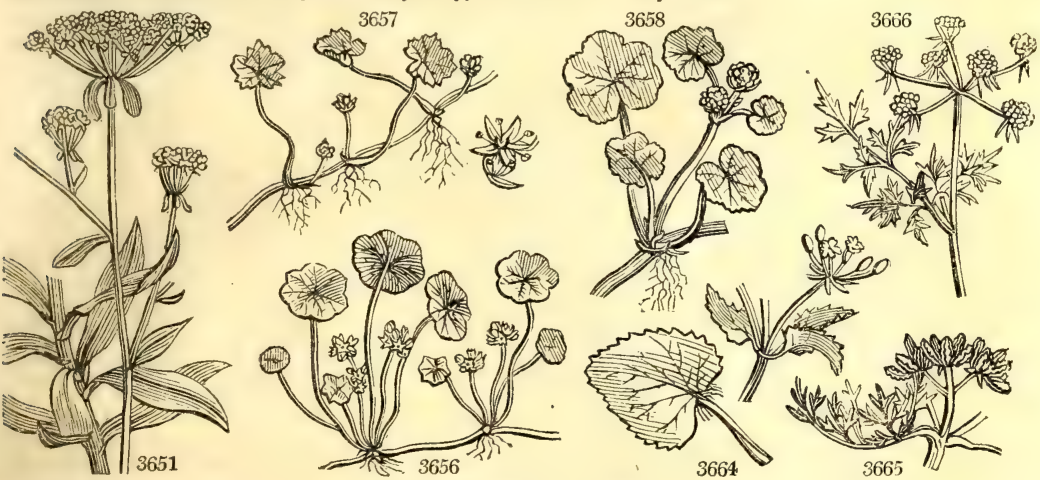

and Miscellaneous Particulars.

658. Hydrocotyle. From idwo, water, and zorvin, vessel; its leaf is round and a little depressed in the centre, so as to hold a drop of water. 'This is a genus of aquatics and marsh plants of no great beauty, their flowers being obscure and of dull colors. H. vulgaris, the Wassernabel of the Germans, has been supposed to communicate the liver rot to sheep. This is a vulgar error, arising from the circumstance of the fluke or flounder insect (Fasciola hepatica) being found in marshes where this plant, and also the Drosera and Pinguicula, abound, as well as in sheep's livers. It is a known fact, however, that sheep never feed on any of these plants.

659. Spananthe. From $\sigma$ rayos, rare, and $\alpha$. 705 , a flower, in allusion to the small number of flowers in the umbel.

660. Ulospermum. From $\tilde{\delta} \nu \lambda \circ$, curled, and $\sigma \pi \varepsilon \xi \mu \alpha$, seed, on account of the membranous curled ribs of the seed. A plant referred to Conium by Desfontaines, and to Cachrys by Sprengel, but very distinct from both.

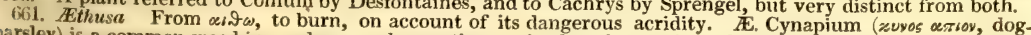
parsley) is a common weed in gardens, and sometimes mistaken for parsley ; from which, however, it is easily 
662. IMPERATO'RIA. $\boldsymbol{W}$. MASTERWort. 3668 Ostrúthium $W$ 663. SELI'NUM. $W$. 3669 palústre $W$. 3670 montánum $W$. en. 3671 austriacum $W$. 3672 Carvifólia $W$. 3673 Chabræ'i $W$ 3674 Seguiéri $W$ 3675 latifólium Bieb. $\$ 676$ decíp.ens $W$.

664. ANGE'LICA. $W$. $36 \pi 7$ Archangélica $W$ 3678 sylvéstris $W$. 3679 Razoúlii $W$. 3680 verticilláris $W$. 3681 atropurpúrea $W$. 3682 lúcida $W$.

665. LIGUS'TICUM. $W$, 3683 Ievísticum $\boldsymbol{W}$. 3684 scóticum $\boldsymbol{W}$. 3685 peloponénse $W$. 3686 austriacum $W$. 3687 cornubien'se $W$ 3688 pyrenáicum $\boldsymbol{W}$. 3689 cándicans $W$. 3690 peregrínum $\boldsymbol{W}$. 3691 baleáricum $W$. 3692 longifólium $\dot{W}$.

666. HASSELQUIS 3693 ægyptiaca $\boldsymbol{W}$. 3694 cordáta $W$.

667. ARTE'DIA. $W$. 3695 squamáta $W$. 668. FE'RULA. $W$. 3696 commúnis $W$ 3697 sibirica $W$. 3608 glaúca $W$. 3699 tingitána $W$. 3700 orientális $\boldsymbol{W}$. 3701 nodiflóra $W$. 3702 pérsica $W$ 669. LASERPI'TIUM. 3703 latifólium $W$. 3704 trílobum $W$. 3705 aquilegifólium $W$. 3706 gallicum $W$ 3707 triquetrum $P$. S. 3708 angustifólium $W$. 3709 pruténicum $W$.

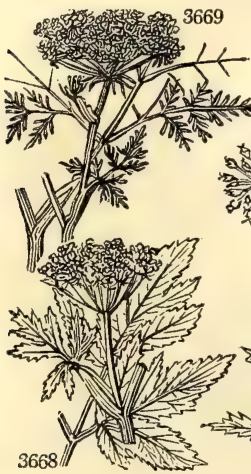
W. LAserwort. broad-leaved \& $\Delta w$ three-lobed s $\Delta w$ Columbine-lvd, $\frac{j}{ \pm} \Delta{ }^{w} w$ French $\searrow \Delta w$ winged $\frac{\partial}{\Delta} w$ narrow-leaved
Prussian common marsh mountain $\quad \frac{\$}{\Delta} \vec{w}$ Caraway-leaved $\frac{ \pm}{\Delta} \mathrm{w}$ Caraway-leaved $\$ \Delta w$ Fennel-leaved $\frac{J}{\mathrm{w}} \mathrm{w}$ Fennel-leaved $\begin{gathered} \pm \\ \text { broad-leaved }\end{gathered}$ broad-leaved
shrubby

Angelica. garden wild तै $\triangle w$ whorled-flower, $\Delta$ dark-purple $\vec{\Delta} \mathrm{w}$ shining $\Varangle 0 \mathrm{w}$ Lovage. common Scotch Hemlock-lvd.

Austrian

Cornish ฟै $\Delta{ }_{w}$ Parsley-leaved $\frac{\downarrow}{\partial} \Delta \mathrm{w}$ Minorca. $\frac{d}{\Delta} \mathrm{cu}$ long-leaved $\$ \Delta \mathrm{w}$
Umbelliferce. Sp.1.

my.jl Pk Scotland m.al.p. D co Eng. bot. 1380 Umbelliferce. Sp. 8-15.

4 jl.au W Britain mar. D c.l Eng. bot. 229

4 jl.au W Switzerl, 1816. D co

2 jlau W Austria 1804 D co Jac aus, 1, t. 71

W A

W Austria 1774. D co Jac. aust. 1. t. 16

1.au W Austria 1791. D co Jac. aust. 1.t. 72

4 jl.au W Italy 1774. D s.I Jac. vind. 1.t.61

2 jl.au W Caucasus 1816. D s.1

jn.jl W Madeira 1785. C s.l Sch. se.h.3.t.1.13

Umbelliferce. Sp. 6-10.

4 jn.au G England wa. pl. is m.s Flor, dan. t. 206 6 jn.au F Britain m. wo. D m.s Eng. bot. 1128 2 jn.au P.Pu Pyrenees 1816. D co Gou. ill. 13.t. 6 6 jl G Italy 1683. D co Jac. vin. 2. t. 130 6 jl.au Pu Canada 1759. D co Cor. can. t. 199

2 jl.au P.Y Canada 1640. S co Jac. vind. 3.t. 24 Umbellifere. Sp. 10-20.

jn.jl P.Y Italy 1596. D co Blackw.t. 275

2 jn.jl W Britain sc. sh. S co Eng. bot. 1207

4 my.jl P.r Switzerl. 1596. D co J. au. 5. t. ap. 13

2 jn.au W Austria 1596. S co Jac. aus.2. t. 151

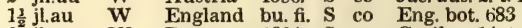

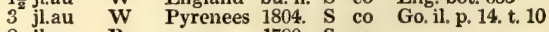

2 jl.au P.y $\quad$...... 1780. S co

2 jn.jl L.Y Portugal 1633. S co Jac. vin. 3.t. 18

j jn.jl Y Minorca 1804. D co

P.Pu Siberia 1804. D co M. s. 9. t. 15. f. 1

Egyptian Hasselquistia. $\quad \begin{aligned} & \text { Umbellifere. } \\ & \text { Sp. 2. }\end{aligned}$

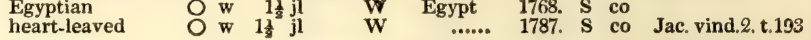
Artedia. Umbelliferce. $S p .1$.

Fennel-leaved $\bigcirc \mathrm{w} \quad 1 \frac{1}{2} \mathrm{jl}$ W Levant 1740. S co Lam. ill. t. 193 Giant-Fennel. Umbellifere. Sp. 7-26.

common $\ \Delta$ or 10 jn.jl Y S. Europe 1597. D s.l Moris.s.9.t.15.f.3

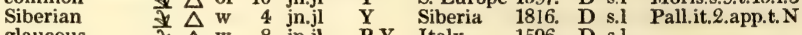

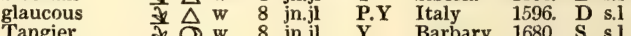

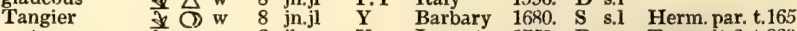
eastern $\quad \ \Delta \mathbf{w} \quad 3$ jl.au $\quad \mathbf{Y} \quad$ Levant 1759. D s.p Tourn.it.3.t.239

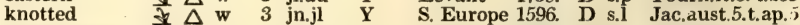

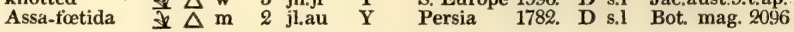

\section{Umbelliferce. Sp. 14-17. 1640 . D co Jac, aust.2, t. 146

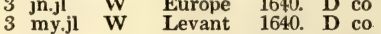

3 my.jl W Levant 1640. D co

3 jn.jl $\quad$ Y $\quad$ S. Europe 1683. D co Plu.phy.t.198.f.6 3 jn.jl P.Y Constant. 1816. D co Vent. cels. t. 97 2 jn.jl Pk $\quad$ S. Europe 1738. D co Moris.s.9.t.19.f.9 Prussian $\Delta$ w 3 jl.au W Germany 1759. D co Jac. aust.2. t.153

\footnotetext{
History, Use, Propagation, Culture,
}

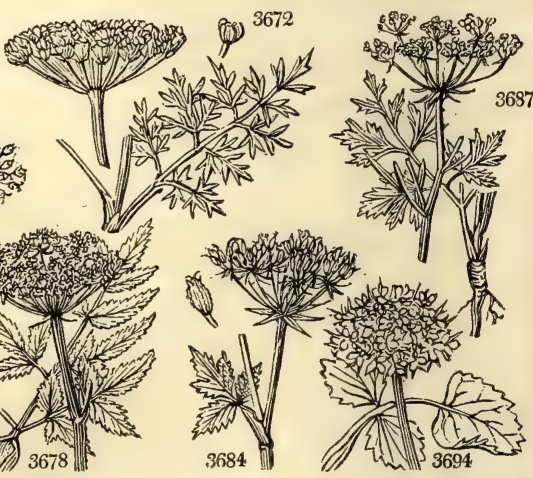

distinguished by being of a darker green, a different shape, flat, and not curled, and of a disagreeable smell. When eaten in mistake for parsley it occasions vomiting, which may be stopped by a very large dose of brandy. It is deleterious to geese.

662. Imperatoria. A metaphorical name given to this plant to express its many virtues. For the same reason the English call it Masterwort. The root, which is very acrid, is sometimes used in toothache, and an infusion of it in wine instead of bark in quartan agues.

663. Selinum. From $\sigma \varepsilon \lambda \eta y \eta$, a name of the monn, in allusion to the crescent-like form of the seeds when cut across. 'The Greeks seem to have used the word selinon, with reference to the same plants as we call umbelliferous.

664. Angelica. So called, in allusion to its agreeable smell and medicinal qualities. A. archangelica (from «ex , superior, an augmentative prefix), is sometimes cultivated in gardens for its leaf-stalks, to be blanched and eaten as celery, or candied with sugar. It is considered stimulant and anti-pestilential.

665. Ligusticum. This plant, says Dioscorides, grows in great abundance in Liguria, near Mount Appennine, from which circumstance it derives its name. $\mathbf{J}$. levisticum and scoticum are sometimes used as potherbs or ingredients in salads, and are accounted emmenagogue. The root is carminative; and an infusion of the leaves is used as a purgative to calves in the Isle of Sky.

666. Hasselquistia. So named by Linnæus, in memory of his pupil, Frederick Hasselquist, M. D., who 


\section{The only species}

3669 Stem striated, Root fusiform divided, Rays of umbel hispid 3670 Leaves 3-parted thrice sinuated. A doubtful species, scarcely distinct from the next 3671 Stem furrowed, Common involucre many-leaved, Leaflets wedge-shaped cut

3672 Stem furrowed with acute angles, Comm invol. O, Leaflets lanceolate cut at the end with a callous point 3673 Stem rounded striated, Comm. invol. O, Sheaths of leaves loose, Leaflets filiform linear 3674 Stem rounded striated, Comm. invol. O, Leaflets trifid linear mucronare

367.5 Stem striated, Lvs. pinnat. subcor. Leaflets ov.-obl. at base cartil. serrace, Upper sheaths enlarged leafless 3676 Stem woody naked beneath, Lower leaves bipinnate, Pinnæ lanceolate entire and cut serrate

$3 \leftarrow 77$ Leaves doubly pinnate ovate lanc. serrated with the odd leaflet lobed 3678 Leaflets equal ovate lanceolate serrated

3679 Leaflets lanceolate serrated decurrent

3680 Leaves very much divaricating, Leaflets ovate serrate, Stem with the peduncles whorled 3681 Outer pair of leaflets united together; terminal leaflet stalked

$\$ 682$ Leaflets equal ovate cut serrate

3683 Leaves multiple, Leaflets cut upwards

3684 Leaves biternate

3685 Leaves many times pinnate, Leaflets pinnately cut

\$686 Leaves bipinnate, Leaffets confluent cut entire

3387 Leaves decompound cut : cauline ternate lanceolate entire, Furrows of seed obsolete

$\$ 688$ Lvs. supra-decompound, Leaflets pinnatifid, Seg. linear mucronate, Comm. invol. scarcely any deciduous 3639 Lvs, supra-decom. Leaflets wedge-shaped cut smooth, Comm. invol. 2leav. leafy, Ribs of seed mem. smooth 3690 Invol. of the 1st umbel scarcely any : of the lateral umbels membranous at base, Rays branched 3691 Leaves pinnate, Lower leaflets acute with a smaller one

3692 Leaves biternate; radical decompound, Leaflets lin. lanc. entire

\section{Leaves pinnate, Leaflets pinnatifid}

3694. Leaves cordate

\section{Seeds sealy}

\section{Leaflets linear very long simple}

3697 Leaflets linear subulate rounced, Comm invol. $o$

3698 Leaves supra-decompound, Leaflets lanc, linear flat

3699 Leaves cut, Segm. 3-toothed unequal shining

3700 Pinnæ of leaves naked at base, Leaflets setaceous

3701 Leaflets with appendages, Umbels nearly sessile

3702 Leaves supra-decompound many cut acute decurrent, First umbel sessile

3703 Leaves obliquely cordate toothed, Teeth mucronate, Wings of seeds crisp 3704 Leaflets 3-lobed cut

5705 Leaves obtuse ovate at base lobed

3706 Leaflets wedge-shaped trifid, Segm. oblong bluntish with a callous point at end

3707 Stem naked 3-cornered, Branches angular, Leaflets obl. toothed crenate, Involucres many-leaved short 3708 leaflets lanceolate obtuse mucronate entire sessile

3709 Leaves lanceolate entire : the outer joined together

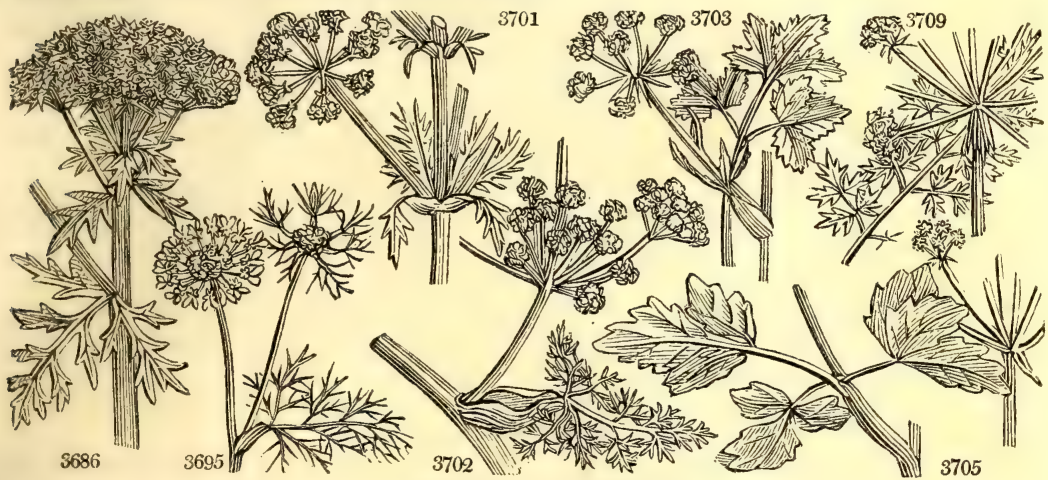

and Miscellaneous Particulars.

travelled into the Holy Land, \&c. and died at Smyrna in 1752. Author of Travels in Palestine. A remarkable genus, supposed with some reason to be a monstrous alteration of a species of Tordylium.

667. Artedia. So named by Linnæus, in honor of Peter Artedi, a Swedish natiralist, one of the first who attempted to divide umbelliferous plants into genera. His method was followed by Linnæus, and was, perhaps, not more defective than many of those which have been proposed in modern days. He died in 1735 .

668 Ferula. From ferire, to strike. The stalks were used as a rod for children, because they made more noise than harm. F. communis is one of the tallest of herbaceous plants. The flower-stalk soon becomes dry after the seeds ripen, and then the Sicilians take out the pith and use it for tinder. It is very abundant in Apulia, where it is eaten by buffaloes. Gerarde says, it grew to the height of fifteen feet in his garden in Holborn. The drug asafoetida is obtained from one or more species of this genus natives of Persia ; and one species, the F. asafoetida, though introduced to our gardens in 1782, is now lost. The drug is the inspissated juice of the root, which being bared of earth and cut across at the top, it oozes out, and when dry, is scraped off as opium is from the capsule of the poppy. The plant grows three feet high, with yellow flowers and hemlockike leaves and habit.

669. Laserpitium. The Latin name of the Silphion of the Greeks. D'Herbelot says, that the natives of Africa called the plant silphi or serpi, whence the Latins formed lac serpitium and Laserpitium. (Bibl. Or. 
3710 silaifólium $W$. 3711 peucedanoídes $W$. 3712 Siler $W$

3713 lúcidum $W$.

3714 feruláceum $W$.

3715 pilósum $W$. en.

3716 hirsutum $W$.

670. PEUCE'DANUM.

3717 officin

3718 arenárium $\dot{P}, S$

3719 itálicum $P . S$.

3720 alpéstre $W$.

3721 sibíricum $W$

3722 aúreum $W$.

671. PASTINA'CA. $W$.

3723 lúcida $W$.

3724 sativa $W$.

3725 Opópanax $W$.

3726 dissecta Vent.

3726 dissecta Vent. cut-leaved
672. HER A'CLEUM. $W$. Cow-ParsneP.

3728 flavéscens $W$. yellowish

3729 angustifólium $W$. narrow-leaved

3730 élegans $W$.

3731 sibíricum $W$.

3732 Panáces $W$.

Fig-leaved

3734 alpínum $W$

3735 pyrenáicum Cusson. Pyrenean

3736 púmilum $W$. dwarf

673. TORDY'LIUM. $W$. HaRTWORT.

\section{7 syriacum $W$. W. HAR'T}

3737 syriacum $W$. Syrian

3738 officinále $W \cdot$ officinal

3740 ápulum $W$.

3741 máximum $W$. great

3742 siffólium $W . \quad$ red-flowered

674. ASTRAN'TIA. $W$. MasterWORT.

3743 máxima $B . M$.

3744 májor $W$.

3745 minor $W$.

3746 carniólica $W$.

Hellebore-lvd
great-black

small

Carniolian

675. ZOSI'MIA. Hoffme. Zosimis.

3747 absinthifolium $P$. S. Wormwood-lvd.

676. RU'MIA. Hoffm.

3748 taúrica Hoffm.

378 taúca Hoffm. Taurian

3749 capénsis $L k$.

Cape

$\begin{array}{ll}2 & \mathrm{jn} . \mathrm{jl} \\ 2 & \mathrm{jn.j1} \\ 3 & \mathrm{my} . \mathrm{jl} \\ \frac{1}{4} \mathrm{jl} & \mathrm{jl} \\ 1 & \mathrm{jn} \\ 1 & \mathrm{jn} . \mathrm{jl} \\ \mathrm{jn} . \mathrm{jl} & \end{array}$

P.Y Italy

$\begin{array}{llllll}\text { P.Y } & \text { Italy } & \text { 1791. } & \text { D co } & \text { Jac. aus. app. t.44 } \\ \text { Pk } & \text { Italy } & \ldots & \text { D co } & \text { Jac. ic. } 2 . \text { t. } 350\end{array}$

1640. D co Jac aust. 2 t. 145

W P S

P.Y Levant 1752. D co

P.Y Alps 1759 .

Umbelliferce. Sp. 6-21.

7. $\Delta \mathrm{m} \quad 6$ my.jl Y $\quad$ England salt m. D c.l Eng. bot. 1767

$\begin{array}{llllll}6 & \text { my.jl } & \text { Y } & \text { England salt m. D c.1 } & \text { Eng. bot. 1767 } \\ 5 & \text { jn.jl } & \text { Y } & \text { Hungary 1816. D c.l } & \text { P.rar.hun.1.t.20 }\end{array}$

8 my.jl Y Italy $\quad \ldots$ D c.l Lob. ic. 781

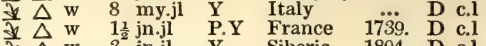

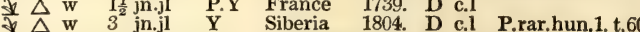

Umbelliferce. Sp. $4-6$.

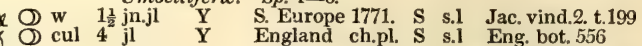

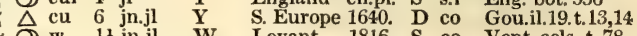
\ل $\mathrm{w} \quad 1 \frac{1}{2} \mathrm{jn} . \mathrm{jl}$ W Levant 1816. S co Vent.cels. t.78 Umbelliferce. Sp. 10-19.

Umbelliferce. Sp. $10-19$.
my.jn W W

$\Delta \mathrm{w} \quad 4 \mathrm{jn.jl} W$ Austria 1789. D co Jac.aust.2.t.173

$\Delta \mathrm{w} \quad 4$ my.jn W Britain $\mathrm{D}$ co Jac. aust.2. t.174

音 $\Delta \mathrm{w} \quad 3 \mathrm{my}$.jn W Austria 1800. D co

\& $\Delta$ w 2 my.jn $\mathrm{G}$ Siberia 1768. D co Gmel, sib.1, t. 50

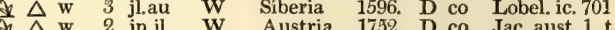

Awitria 1732. D co Jac. aust. 1. t. 61

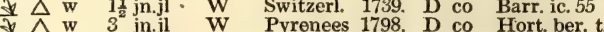

变 $\Delta \mathrm{w} \quad \frac{1}{2} \mathrm{my} . \mathrm{jl} \quad \mathrm{W}$ Dauphiny 1800. D co Vill.delph.2.t.14

Umbellifera. Sp. $6-8$.

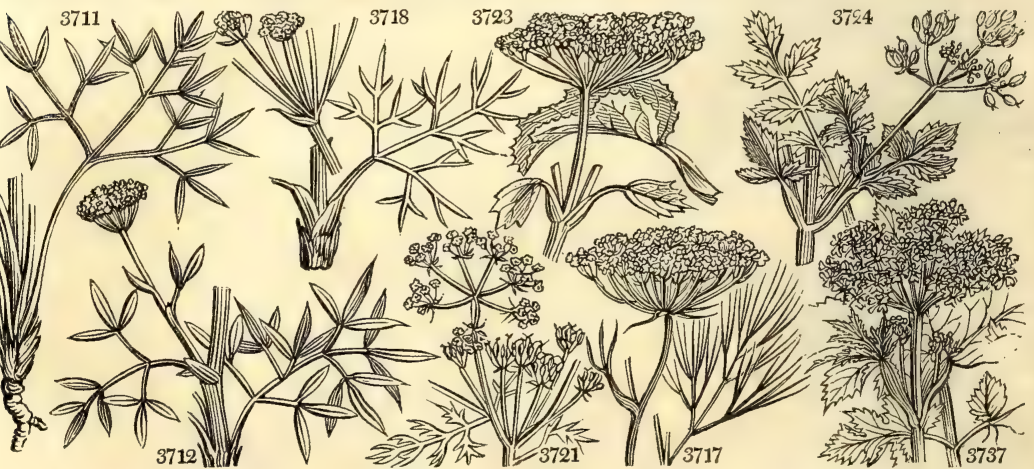

History, Use, Propagation, Culture,

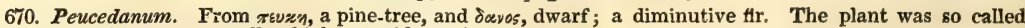
on account of its strong smell, which resembles resin.

671. Pastinaca. One of the names given by the Latins to the Daucus of the Greeks. It is derived from pastus, nourishment. P. sativa is a well known culinary root, and grown also in agriculture for feeding cattle. It was much in use during Catholic times to eat with salted fish. In the north of Ireland a sort of beer is brewed from the roots mixed with hops; a very good wine is also made from them; and by distillation they yield an ardent spirit, similar to that afforded by the potatoe. The parsnep is much cultivated in Jersey and
Guernsey, chiefly for feeding milch cows. The variety preferred is called the Coquaine, the roots of which, Dr. Macculloch informs us (Caled. Hort. Mem. i. 408.), sometimes run four feet deep, and are rarely so small in circumference as six inches. The time of sowing is February and March, in drills to admit of stirring the soil between the rows. They should be thinned so as that each plant may have a surface of twelve or fourteen square inches, and, with the usual routine culture, the crop will be mature in October. They may be taken up and housed like the carrot, or as wanted for use : as they are not easily injured by frost, the latter mode is the best, where they are grown only for the table.

P. opopanax (oros, juice, $\pi \alpha \nu$, all, and $\alpha \varkappa o s$, cure : a cure for all complaints) produces from its stem, when it is cut, a gum resin which is a famous cure in the East for all sorts of maladies.

672. Heracleum. Named after the hero Hercules, who, according to a modern French author, was not only

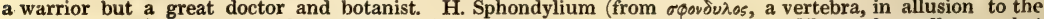
jointed stem), the Heilkraut of the Germans, is common in most parts of Europe. The seeds smell somewhat 
3710 Leaves pinnatifid, Segm. lanceolate, Common involucre scarcely any, Stem smooth 3711 Leaflets linear-lanceolate veiny striated distinct

3712 Leaflets oval-lanceolate entire stalked

3713 Leaves supra-decompound linear-subulate smooth, Comm. invol. pinnated

3714 Leaflets linear

3715 Hairy, Stem rounded simple, Lvs. tern. bipinnate, Leaflets alternate ovate pinnatifid cut wedge-shaped 3716 Leaves supra-decompound hairy, Leaflets many cut, Leaves of many-leaved invol. membranous at edge

3717 Leaves 5 times 3-parted filiform linear

3718 Leaves ternate decompound, Leaflets linear obtuse stiffish, Comm. invol. scarcely any

3719 Leaves 3-parted filiform longer, Umbels deformed

3720 Leaflets linear branched

3721 Leafiets linear acute, First umbeis sessile

\$722 Leaves thrice pinnate, Cauline leaflets linear lanceolate : radical oblong many-cut

3723 Leaves simple cordate lobed shining acutely crenate

3724 Leaves simply pinnate

3725 Leaves pinnate, Leaflets with their front base cut out

3726 Stem rounded rough branched, Leaves bipinnatifid, Peduncles rigid villous

37.27 Leaves pinnate, Leaflets 5 oblong pinnatifid acute toothed, Cor. of one shape

3728 Leaves pinnate, Leaflets 5 oblong pinnatifid acuminate toothed rough at edge, Flowers radiant

3729 Leaves cruciate pinnate, Leaflets linear, Corollas flosculous

3730 Leaflets pinnatifid crosswise toothed

3731 Leaves pinnated, Leaflets 5: the intermediate sessile, Cor. of one form

3732 Leaves pinnated, Leaflets 5 : the intermediate sessile, Flowers radiant

3733 Leaves pinnated rugose on each side scabrous, Flowers somewhat radiant

3734 Leaves simple cordate obsoletely lobed serrated

3735 Leaves simple 3-leaved cordate toothed beneath pubescent

3736 Leaves simple and ternate many cut torn, Segments linear

3737 Involucres longer than the umbels

3738 Partial involucres the length of flowers, Leaflets ovate laciniate

$\$ 739$ Seeds furrowed wrinkled plaited, Universal involucre 1-leaved trifid

3740 Umbellules remote, Leaves pinnated with roundish cut pinnæ

3741 Umbels clustered radiant, Leaflets lanceolate cut serrated

3742 Umbels clustered radiant, Leafiets angular toothed pubescent

3743 Radical lvs. palmate 3-lobed unequally twice serrated; cauline sessile lobed, Involucre longer than umbel

3744 Radical leaves 5-lobed, Lobes trifid acute toothed, Involucres lin. lanceolate entire

3745 Radical leaves digitate, Leafiets about 7 lanceolate acute deeply toothed

3746 Radical leaves 5-lobed, Lobes oblong acutish trifid mucronate-toothed, Involucres entire

\$747 Hoary, Leaves decompound, Leaflets wedge-shaped trifid, Flowers angular, Fruit villous

\$748 Stem dichotomous knotty, Leaves decompound, Involucre short, Female flowers with a long ray 3749 Stems decumbent, Sheaths loose, Seeds smooth

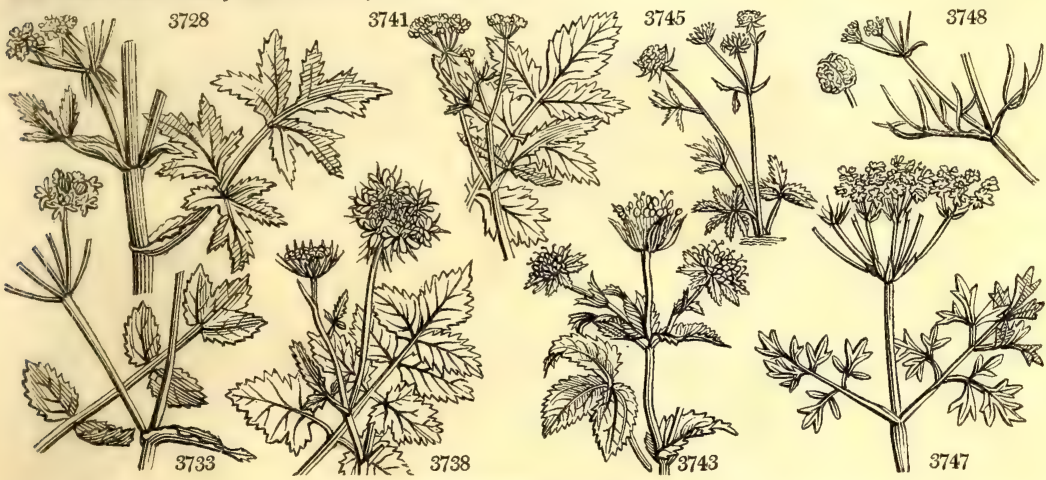

and Miscellaneous Particulars.

like a bug. Gmelin informs us, that the inhabitants of Kamtchatka, about the beginning of July, collect the footstalks of the radical leaves, and after peeling off the rind, which is very acrid, dry them separately in the sun, and then tying them in bundles, lay them up carefully in the shade in bags; in this state they are covered with a yellow saccharine efflorescence, tasting like liquorice; this being shaken off, is eaten as a great delicacy. From the stalks thus prepared and fermented with bilberries the Russians distil an ardent spirit, which, Gmelin says, is more agreeable to the taste than spirits made from corn. A kind of ale is brewed from the leaves and seeds in Poland and Lithuania, and attempts have been made to extract sugar from this plant, but forty pounds of the dried stalks only yielded a quarter of a pound of powdery sugar. The young shoots may be eaten as asparagus. Rabbits and swine are fond of the leaves, but not horses. H. sibiricum is used in the same manner in the north of Siberia and Kamtchatka.

673. Tordylium. Bodæus à Stapel thinks that the derivation of the name is to be found in rogyus, a latre, and $i \lambda \lambda_{a}$, to turn, because the seeds seem as if turned in a lathe. But this seems to be a commentator's guess only.

6? 4. Astrantia. From cegৎov, a star, and $\alpha y \tau l$, similar; so called with reference to the beautiful starlike dispositon of the involucrum of all the species, and of A. minor in particular.

675. Zosima. Named by Hoffmann, in honor of the three famous brothers Zosimades, the celebrated patrons of 80 many fine editions of the Greek classics. A remarkable plant, formerly referred to Heracleum, native of most of the eastern parts of the world.

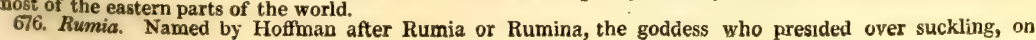


677. CA'CHRYS. $W$. 3750 Libanótis $W$. 3751 Morisóni $W$. 3752 panacifólia $\boldsymbol{W}$. 678. HIPPOMA'K 3753 sículum $L k$
Cachrys.

Umbellifera. Sp. 3-10.

smooth-seeded $\& \Delta w \quad 3$ jl.au $\mathbf{Y}$ Sicily 1570. D co Schk. han.1.t.65 Morison's $\quad \begin{array}{llll}\frac{1}{2} \text { jl.au } & \mathbf{Y} & \text { S. Europe 1710. D co Mor.umb.t.3.f.1 }\end{array}$

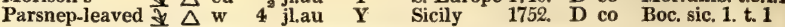
RUM. $L k$. Hippomarathrum. Umbelliferc. Sp. 1.

hairy $¥ \Delta \mathrm{cu} 3 \mathrm{jl} . \mathrm{au} Y \mathrm{Y}$ Sicily $1640 . \mathrm{D}$ co Bocc. sic. t. 18

\section{TRIGYNIA.}

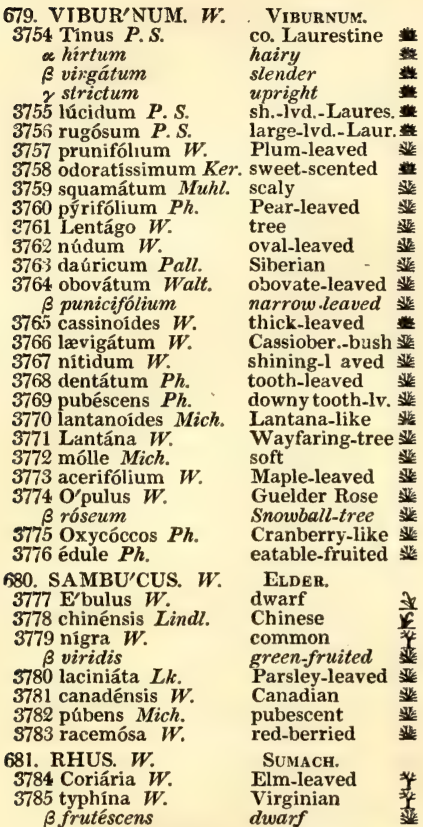

\section{Caprifoliacea. Sp. 23-36}

or 4 mr.d W S. Europe 1596. L co Bot. mag. 38 or 4 mr.d W S. Europe ... L co or $4 \mathrm{mr}, \mathrm{d}$ W $\mathrm{S}$. Europe $\ldots . \quad \mathrm{L}$ co or 4 mrd W S. Europe $\mathbf{L}$ or 4 mr.d W S co Clus. hist, 49 or 8 my.jn W N. Amer. 1731. L p.l Dend. brit. 23 or $f$ W China 1818. L B Bet. 456 or $6 \mathrm{jl}$ W N. Amer. 1822. L p.l Dend. brit. 24 or 6 my.jn W N. Amer... L p.l Dend brit. 22 or 8 jl W N Amer 1761. L pl Dend brit 21 or 8 jl in $\mathrm{Pa} Y \mathrm{Y}$. Amor. 1701. L p.1 Dend. brit. 21 or 8 my.jn Pa.Y N. Amer. 1752. $\mathbf{L}$ p.I Bot. mag. 2281 or 2 jn.jl W Dahuria 1785. I p.l Pall. ross. i. t. 38 or 2 my.jn W N. Amer. 1812. L p.l. or 2 my.jn W N. Amer. 1812. L p.l or 3 jn.jl W N Amer 1761 $\mathrm{L}$. or 10 jlau Pa. N Amer 1724 L p.l Mil ic 1. 83.1 or 2 my in W $\mathrm{N}$ Amer. 1758 $\mathrm{L}$.1 N. Amer. 1758. L p.I or 5 jn.jl W N. Amer. 1736. L. p.l Dend brit. 25 or 3 jn.jl W N. Amer. 1736. L p.l or 5 my.jn W N. Amer. ... L L.l or 10 my.jn W Britain hed. L p.l Eng. bot. 331 or 6 jn.jl W N. Amer. 1812. L p.l or 4 jn.jl W N. Amer. 1736. L co Dend brit. 118 or 10 my.jn $W$ or 14 my.jn $\mathbf{W}$

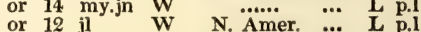

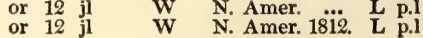
Caprifoliacea. Sp. 7-9. cu 3 jn.jl P.Pk Britain wa.gr. D co Eng. bot. 475 cu 4 s.o W China 1823. D co ec 15 my.jl W Britain hed. C co Eng. bot. 476 or 8 my.jl W or 8 my.jl W $\quad \ldots . . . . . .6$ C co Schm. arb.t.144 or 6 jn.au W N. Amer. 1761; C s.1 Schmid arb. 149 or 6 W N. Amer 1812 C or 12 my.jn Gr. S. Europe 1596. C Terebintacece. Sp. $33-75$.

ec 10 jl G S. Europe 1596. I co Dend. brit 136 N. Amer. 1629. S co Dend, brit. 17,18 cu 6 jl G $\quad$...... ...
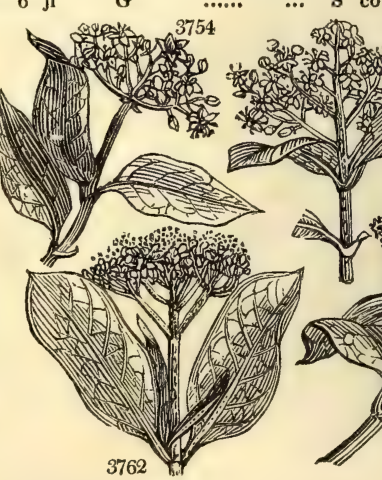

3758
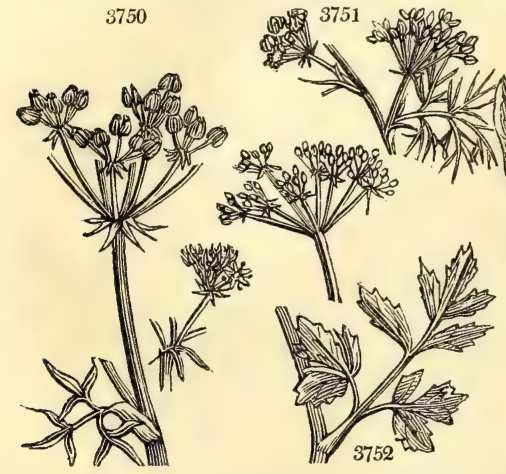

History, Use, Propagation, Culture,

which account all vascular substances, with firm outside but very cellular structure inside, were said to be Ruminosa. The seeds of this genus are of that nature. There was also a Dr. Rumy, professor of agriculture in some Polish university.

677. Cachrys. One of the names given by the Romans to the Rosemary. According to Morison, the name was derived from z«sw, to grow hot, on account of the carminative qualities of the plant. The Cossacks of the Jaik chew the seeds of C. odontalgica for pain in the teeth, and obtain relief by the copious salivation which follows their use. This genus is well known by its corky large smooth seeds.

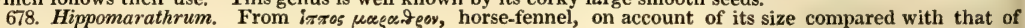
common fennel

679. Viburnum. This name is derived, according to the account of Sebastian Vaillant, from the Latin word viere, to tie, on account of the pliability of the branches of some species. V. tinus ( $\tau$ ivov, small, dwarf, tiny) is one of the most ornamental of evergreen shrubs, with shining leaves and shewy white flowers, which appear during the winter months. V. hucidum and strictum are taller and more tender than the common species, of which they are by many considered as only varieties.

V. lantana (from lento, to tie) grows chiefly on calcareous soils : it has pliant mealy twigs, and the bark affords a bird lime.

V. opulus, (alteration of populus) var roseum, is a most ornamental shrub, producing large white bunches of 
3750 Leaves bipinnate, Pinnre opposite linear rather pungent, Seeds furrowed smooth

\$751 Leaves supra-decompound setaceous many-cut, Seeds even smooth

3752 Leaves pinnate and ternate, Leaflets oblong crenate

$\$ 753$ Leaves bipinnate, Leaflets linear, Stem furrowed

\section{TRIGYNIA.}

3754 Leaves ovate oblong entire, Divisions of the veins and the young branches glandular hairy

$\propto$ Leaves oval oblong beneath and at edge hairy

$\beta$ Leaves lanceolate oblong at the edge and veins beneath hairy

Leaves ovate hairy on both sides stiff

3755 Leaves coriaceous ovate lanceolate shining entire

3756 Leaves broad ovate rugose hairy beneath, Common involucre 7-leaved

3757 Leaves obovate roundish and oval smooth finely serrated with edged stalks

3758 Evergreen smooth, Leaves coriaceous elliptical oblong distantly toothed

3759 Leaves oblong obtusely serrated, Stalks and peduncles with scaly pubescence

3760 Smooth, Leaves ovate nearly acute subserrate, Leaf-stalks smooth, Fruit ovate oblong, Cymes stalked

3761 Leaves broad ovate acuminate finely serrated, Stalks edged crisp

3762 Leaves obl, narr, at base rather blunt entire revolute at edge smooth above shising with netted veins

3763 Leaves ovate serrate dotted with hairs, Cymes dichotomous few-flowered

3764 Smooth, Leaves obovate crenate toothed or entire obtuse, Umbels sessile, Fruit roundish ovate

3765 Smooth, Leaves ovate lanceolate acute at each end crenate revolute at edge, Stalks keeled glandular 3766 Leaves obl. lanc. unequally and finely serrated at base wedge-shaped and entire, Branches compr. square 3767 Leaves linear lanceolate shining above obsoletely serrated or entire, Branches square

3768 Leaves ovate tooth-serrated plaited

3769 Leaves oval acuminate tooth-serrated plaited pubescent

3770 Somewhat decumbent, Lvs. rounded cord. abruptly acumin. toothed with the stalks and nerves powdery 3771 Leaves ovate oblong cordate serrate beneath rugose with veins downy

3772 Leaves roundish cord. furrowed with plaits beneath downy with a very soft pubescence, Cymes radiant 3773 Leaves cord, ovate generally 3-lobed loosely serrat. stalks without glands at base with stipules and downy 3774 Leaves 3-lobed acuminate toothed, Stalks glandular smooth

3775 Leaves 3-lobed acute behind 3-nerved divaricating rarely toothed, Stalks glandular, Cymes radiant

3776 Leaves 3-lobed behind obtuse 3-nerved, Lobes very short tooth-serrated, Serrat. acumin. Cymes radiant

3777 Cymes 3-parted, Stipules leafy, Stem herbaceous, Leaves pubescent beneath

3778 Cymes with many abortive fleshy flowers, Stem herbaceous warted, Leaves quite smooth 3779 Cymes 5-parted, Stem arborescent

3780 Flowers umbelled, Leaves pinnatifid, Stem shrubby

3781 Cymes 5-parted, Leaves about twice pinnated, Stem shrubby

3782 Panicle ovate, Leaflets lanceolate acuminate unequal at base, Leaf-stalk hairy, Stem shrubby

3783 Panicle ovate, Leaflets oblong acuminate nearly equal at base, Stalks smooth, Stem arborescent

3784. Leaflets ovate oblong obtuse mucronate scabr. above villous beneath, The last joints of stalk membranous 3785 Leaflets lanceolate acuminate finelv serrated hairy beneath

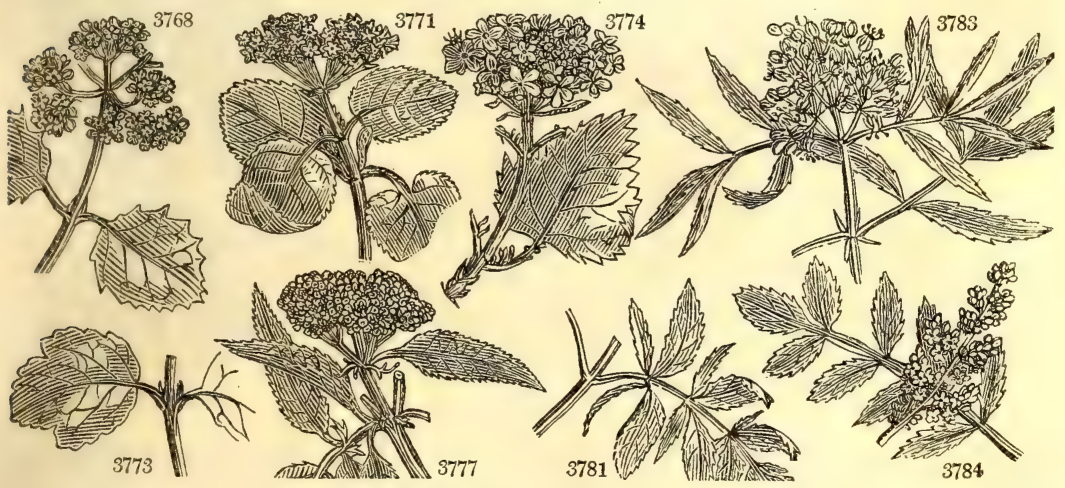

and Miscellaneous Particulars

white flowers, resembling those of Hydrangea, and like them abortive. With lilac, laburnum, and scarlet thorn it forms an elegant group.

680. Sambucus. A musical instrument called by the Latins sambuca, is supposed to have been made of the wood of this tree, on account of its hardness. The tree was always famous for this quality; so that Pliny says it consists of nothing but skin and bones. (b. xvi. c. 39.) S. ebulus is supposed to prevent discases in swine if used as litter: the root is violently cathartic, the leaves drive away mice, and the berries dye blue.

S. nigra with its varieties, and S. racemosa, are very shewy trees in shrubberies when in flower and fruit. S. nigra is narcotic, purgative, and acrid; the flowers in decoction are diaphoretic and expectorant; used to flavor vinegar, and deleterious to turkeys.'The French put layers of them in heaps or casks of apples, to wlich they communicate a most agreeable odor. The berries are poisonous to poultry; but make a powerful wine much in esteem among country people. As the common elder will grow either exposed to the sea breeze or on high mountains, it is recommended as a nurse-plant in forming plantations. To thrive and be productive as a fruit tree however, it requires a deep, rather moist, and rich soil

681. Rhus. Derived from the same root as Rosa, rhudd, in Celtic, signifying red, on account of the color of the fruit. P\&s, in Greek. Sumach, its English name, is an alteration of sim $\delta q$, its name in Arabic. (Forsk.) In some of the species of this genus the flowers are hermaphrodite; in others, as $\mathrm{P}$ elegans, pentaphyllum, and Toxicodendron, the maie and female are on separate plants. In $R$. toxicodendrón, thev 
3786 javánica $W$. 3787 glábra $W$. 3788 élegans $W$ 3789 viridiflóra $P h$ 3790 púmila $P h$

(7) V́rnix $W$.

3792 succedánea $W$.

3793 Bucku-Améla Wal

3794 juglandifólia Wall.

3795 glaúca Desf

3796 oxyacánthaSchousb.

3797 oxyacanthoides

3798 Zizyphína Ten.

3799 semialáta $W$

3800 copallina $W$

3801 Toxicodéndron

$\propto$ radicans $\mathrm{L}$

$\beta$ véra

$\gamma$ microcárpa

3802 aromática $P h$.

$\beta$ suavéolens W.

3803 pendulína Jacq.

3804 dentáta $\boldsymbol{W}$.

3805 cuneifólia $\boldsymbol{W}$.

3806 incisa $\boldsymbol{W}$

3807 tomentósa $W$.

3808 villósa $W$.

3809 pubéscens $W$.

3810 viminális $W$

3811 angustifólia $W$

3812 rosmarinifólia $W$

3813 pentaphýlla Desf.

3814 lævigáta $W$.

3815 lúcida $W$.

$\beta$ mínor

3816 Cótinus $W$

682. CASSI'NE. $W$

3817 capénsis $W$.

3818 Colpoon $W$.

3819 Maurocénia $W$

3820 xylocárpa Vent. $\begin{array}{llll}\text { Java } & \text { cu } 10 & \text { jl.s } \\ \text { smooth } & \text { or } 8 \text { jl.s }\end{array}$

scarlet

green-flowered

dwarf poisonous

Varnish

red Lac

Walnut-leaved wthorn

Parsley-leaved

Service-leaved

Lentiscus-leav.

Poison-Oak

common

true

small_fruited

female sweet

male sweet

pendulous

rough-stalked

wedge-leaved

cut-leaved

woolly-leaved

hairy

pubescent

Willow-leaved

narrow-leaved

Rosemary-leav.

various-leaved

polished-leaved

shining-leaved

small-shin

Cassine.

Cape Phillyrea

Colpoon-tree

Hottentot Cher

bony-seeded

or $8 \mathrm{jl.s}$

or $10 \mathrm{jl}$

or $15 \mathrm{jl}$

p $\quad 1 \quad$ jl

cu $2 \mathrm{jl}$

cu

or $8 \mathrm{my}$

or $6 \mathrm{my}$

$\ldots$

jl...

...

6 . ec 10 jn

or $10 \quad \ldots$

or $6 \quad$...

3

6 au.s

3 jn.jl

3 jn.jl

2 jn.jl

2 jn.jl

my

... G G

...

j1 ${ }^{\cdots}$

...

... W

... G

6 jl.au

6 jl.au

6 jn.jl

Rhamni. Sp. 4-8.

1 jl.au W C. G. H. 1629. C s.l.p Bur. afr. t. 85 jlaus

W C. G. H. 1791. C s.lp Bur, afr, t. 86

W C. G. H. 1690. C s.l.p Di. el. t.121.f.147

Pa.Y Antilles 1816. C s.l.p Vent. Ch. t. 23

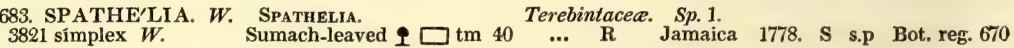

684. STAPHYLF'A. $W$. BLADDER-NUT.

3822 pinnáta $W$.

3823 trifólia $W$

five-leaved or 6 Rhamni. Sp. $2-4$.

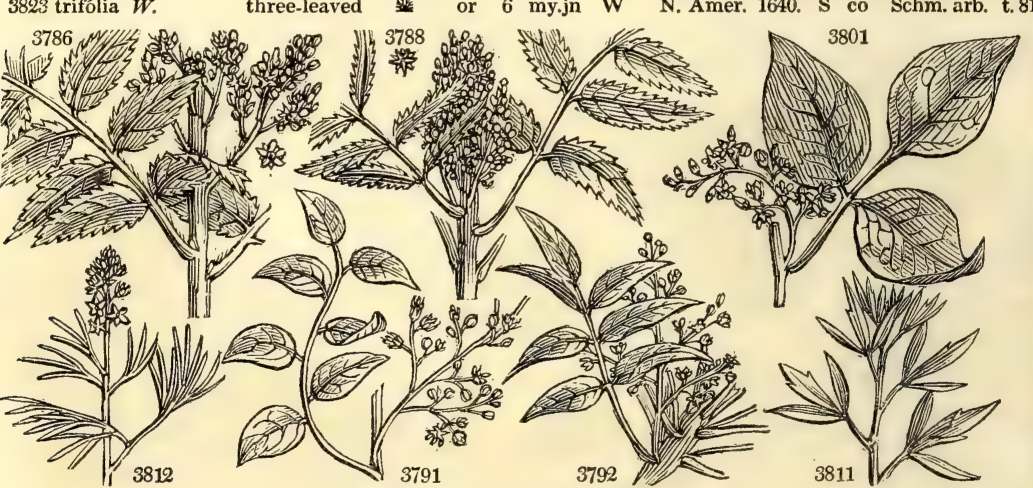

History, Usc, Propagation, C'ulture,

are polygamous males, being mixed with the hermaphrodites. The species from the Cape of Good Hope rarely flower in this country, and are chiefly cultivated for the sake of their foliage, which is neat and not susceptible of injury from bad management.

$\mathbf{R}$. Coriaria is used instead of oak bark for tanning leather, and it is said that that of Turkey is chiefly tanned with this plant. The seeds are in common use at Aleppo at meals to provoke an appetite. Both leaves and seeds are used in medicine as astringent and styptic.

$\mathbf{R}$. javanica in China affords an oil by bruising the berries and boiling them in water: they use it as a varnish, but it does not keep its polish so well as the oil of $\mathbf{R}$. vernix.

R. glabra has berries which dye red, and the branches boiled with the berries afford a black ink-like tincture. This plant is like a weed in some parts of North America, where it overruns land left for a few years in pasture.

R. vernix affords the true Japan varnish, which oozes out of the tree on its being wounded, and grows thick and black when exposed to the air. It is so transparent, that when laid pure and unmixed upon boxes or furniture, every vein of the wood may be clearly seen. With it the Japanese varnish over the posts of their doors and windows, their drawers, chests, boxes, scymitars, fans, tea-cups, soup-dishes, and most articles of household furniture made of wood. The milky juice of the plant stains linen a dark brown. The whole shrub is in a high degree poisonous; and the poison is communicated by touching or smelling any part of it. In forty-eight hours inflammation appears on the skin, in large blotches, principally on the extremities, and on the glandular parts of the body : soon after small pustules rise in the inflamed parts, and fill with watery matter, attended with burning and itching. In two or three days the eruptions suppurate; after which the inflammation subsides, and the ulcers heal in a short time. It operates, however, somewhat differently upon 
3786 Leaflets ovate acuminate serrate beneath downy

3787 Leaflets lanceolate acuminate with close serratures smooth on both sides whitish beneath

3788 Leaflets lanceolate acuminate in the middle distantly serrated smooth in both sides, Flowers dicecious

3789 Smoothish, Leaflets lanceolate oblong serrated downy beneath, Racemes erect green

3790 Dwarf, Branches and leaf-stalks pubescent, Leaflets oval, Fruit very downy

3791 Leaflets entire annual opaque, Leaf-stalk entire equal

3792 Leaflets entire perennial shining, Leaf-stalk entire equal

3793 Leaves very large coarse rugose and downy

3794 Leaves pinnated in 9 pair rugose smooth above

3795 Leaflets obcordate, some of them very glaucous

3796 Stem shrubby unarmed, Leaves ternate hoary cuneate ovate, the middle one longest

3797 Prickly, Leaves ternate smooth, Leaflets narrow wedge-shaped at the end 3-lobed and entire

3798 Spiny, Leaflets wedge-shaped toothed beyond the middle, above shining with prominent nerves

3799 Leaflets unequally serrated, Outer petioles with membranous joints

3800 Leaflets entire, Leaf-stalk membranous jointed

3801 Stem rooting

¿ Leaves large entire or rarely toothed, Creeping

$\beta$ Dwarf, Leaves variously sinuated downy about flowering time, Erect

$\gamma$ Leaflets oblong oval with a long point, Fruit very small

3802 Leaflets sessile ovate rhomb-shaped cut serrate hairy

3803 Leaflets lanceolate entire sessile smooth on each side ciliated, Common stalk pubescent, Branches pend. 3804 Leaflets obovate mucronate toothed smooth, Stem scabrous

$\$ 805$ Leaflets sessile wedge-shaped very smooth 7-toothed, Teeth mucronate

3806 Leaflets sessile wedge-shaped cut pinnatifid beneath downy and veiny

3807 Leaflets stalked rhomb-shaped angular downy beneath

3808 Leaflets obovate entire sessile hairy on both sides

3809 Leaflets obovate mucronate smooth, Branches villous

3810 Leaflets linear lanceolate entire smooth narrowed at base : the intermediate one stalked

3811 Leaflets stalked linear lanceolate entire downy beneath

3812 Leaflets sessile linear revolute rusty beneath

3813 Prickly, Leaves fingered, Leaflets linear lanceolate at the end toothed or entire

3814 Leaflets oblong entire sessile acute on each side smooth, Panicle terminal long

3815 Leaflets obovate sessile very narrow at the base smooth on both sides, Corymbs axillary

3816 Leaves obovate

3817 Leaves stalked ovate retuse crenated, Panicle twice as short as leaf

3818 Leaves stalked ovate subserrate entire at base

3819 Leaves sessile entire obovate coriaceous

3820 Leaves stalked ovate subserrate, Peduncles dichotomous shorter than the leaves, Fruit ovate

3821 Leaves like the mountain ash, Flowers in long erect panicles from among the leaves

3822 Leaves pinnate

3823 Leaves ternate

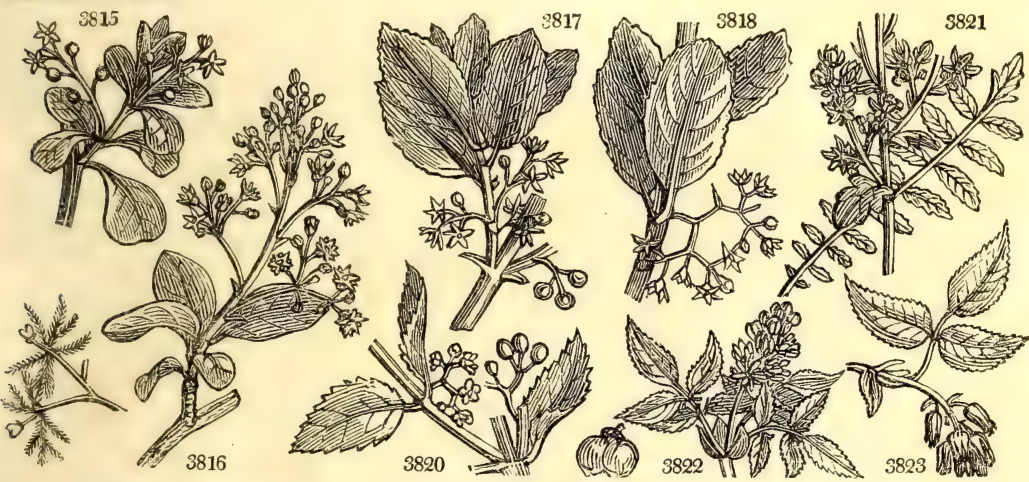

and Miscellaneous Particulars.

lifferent constitutions; and some are incapable of being poisoned with it at all. Persons of irritable habits are most liable to receive it

Rhus aromatica and suaveolens, the male and female of one species, have been made into a distinct genus called Schmaltzia, by Desvaux and Turpinia, and afterwards Lobadium, by the ingenious M. Rafinesque Schmaltz. The expressed oil of the seed of this species, and also of $\mathbf{R}$. succedanea, acquires the consistence of suet and serves for making candles.

$\mathbf{R}$. Toxicodendron is poisonous to some persons, like $\mathbf{R}$. vernix, but in a less degree, Kalm relates, that of two sisters, one could manage the tree without being affected by its venom, whilst the other felt its exhalations as soon as she came within a yard of it, or even, when she stood to windward of it, at a greater distance; that it had not the least effect upon him, though he had made many experiments upon himself, and once the juice squirted into his eye; but that on another person's hand, which he had covered very thick with it, the skin, a few hours after, became as a piece of tanned leather, and peeled off afterwards in scales.

R. pumila is another dangerous species. Lyons, the collector, suffered severely for several weeks, after only collecting the seeds.

R. cotinus is cultivated for tanning leather near Valcimara in the Apennines, where it is called Scotino.

682. Cassine. An American name. These are shrubs with handsome foliage, but generally inconspicuous white or green flowers. C. Maurocenia has its specific name in honor of the Venetian senator F. Mauroceni, who had a fine garden at Padua.

683. Spathelia. The upright habit and want of bra ches make this tree resemble a palm-tree, anciently called $2 \pi c .9 \eta$ A very handsome stove shrub, rarely flowering.

684. Staphylea. From $\sigma \tau \alpha \oint \nu \lambda \eta$, a bunch, in which form its fructification is disposed. Handsume hardy 
685. TA'MARIX. $W$. 3824 gállica $W$. 3825 articuláta $W$ 3826 germánica $\dot{W}$. 686. TURNE'RA. $W$ 3827 ulmifólia $W$

$\beta$ angustifólia $\mathbf{B}$. M. 3828 élegans Otto. 3829 trióniflóra Sims. 3830 Pumiléa $\boldsymbol{W}$. 3831 cistoides $W$. 3832 racemósa $\boldsymbol{W}$. 687. DRY'PIS. $W$ 3833 spinósa $W$. 688. AL/SINE, $W$. 3834 média $W$. 3835 segetális $\boldsymbol{L}$. 3 336 mucronáta $\boldsymbol{L}$ 689. TELE'PHIUM $W$ ORPINE 3837 Imperáti $W$. True 690. CORRIGI'OLA. $W$. Strapwort. 3838 littorális $W$. 3839 telephiifólia Pourr. Orpine-leaved 691. PHARNA'CEUM. $W$. Pharnaceum. 3840 Cerviána $W$. 3841 lineáre $W$ 3842 Mollégo $\boldsymbol{W}$. 3843 incánum $W$ 3844 dichótomum $W$ 3845 áfra $W$ 693. BASE'LLA. $W$. 3846 rúbra $W$. 3847 nigra Lour. 3848 álba $W$. 3849 lúcida $W$ 3850 cordifólia $\boldsymbol{P} . S$
TAMARISK,

French Indian German

Turnera. Elm-leaved

narrow-leaved elegant Nettle-leaved Betony-leaved clustered

DRYPIS prickly

Chick WeEd. common corn forked

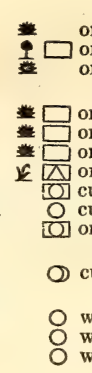
or 12 my. $\mathrm{F}$

Portulacea. Sp. 3-18.

England so co, C s.1 Fng bot. 1318 $\begin{array}{llllll} & \text { Pk } & \text { E. Indies } & \text {... } & \text { C } & \text { 1.p Vah. sym. 2.t.32 }\end{array}$ 2. C M.s Mil. ic. t.262. 1.2 Portulacea. Sp. 6-23.

8 jn.s Y Jamaica 1733, C p.l Hort, cliff, t 10 8 ap.s Pa.Y Jamaica 1733. C s.p Bot. mag. 281 8 ap.s Pa.Y Jamaica 1733. C s.p Bot. mag. 281 3 ... Pa.Y Brazil 1821. C s.p

ja.d Pa.Y Brazil 1812. C s.p Bot. mag. 2106

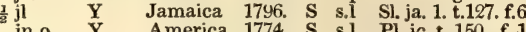
jn.o $\quad \mathbf{Y}$ America 1774, S s.l Pl. i $\%$ t. 150. f. 1 Caryophyllea. Sp. 1.

$\frac{3}{4}$ jn.jl P.Pu Italy

1775. S s.1 Bot. mag. 2216 Caryophyllea. Sp. 3-6.

w 1 jl.s W Britain fields. S co Eng. bot. 537 w 1 jn.jl W S. Europe 1777. S co Portulacea. Sp. $1-2$.

\ $\Delta \mathrm{W} 1 \mathrm{jn} . \mathrm{au}$ W S. Europe 1658. D s.l Lam. ill. t. 213 Portulacece. Sp. 2-3.

O cu $\frac{1}{4}$ jl.au W England so. co. S s Eng. bot. 668 jl.au W Spain 1822. S s Caryophyllea. Sp. 5-22.

umbelled $O \mathrm{cu} 1$ jn W Russia 1771. S co Gm. si.3.t.20.f.2 linear-leaved ${ }^{-} \mathrm{cu} \quad \frac{1}{2}$ my.jn W C. G. H. 1795. C s.1 Bot. rep. 326 Ladies'Berlstr, $\square \mathrm{cu} \frac{1}{4}^{2} \mathrm{jl}$.au W E. Indies 1752. C s.1 Bur. ind t. 5. f.4

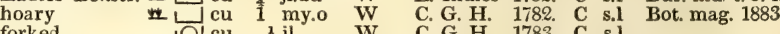

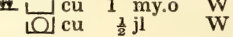

C. G. H. 1783. C 8.1

Sp. 1.

African 3 cu 3 Pu Africa 1732. C r.m Jac. col, 1. t. 29 Malabar-NightshadF. Chenopodece. Sp. 5.

red $*$ [D] cul 8 jl.s Pk E. Indies 1731. S r.m

black $\quad *$ cul 3 jl.s W China 1822. S r.m

whitc w cul 8 jl.n W W Indies 1688 , S r.m Plu. al, t.63, f shining $\quad *$ cul 6 jln W E Indies 1802 S rm

heart-leaved $*$ \& cul 6 jl.n $\quad$ P.Pu E. Indies 1802. S r.m

TETRAGYNIA.

694. Parnas'sia. $W$. Grass of Parnassus. 3851 palustris $W$. 3852 caroliniána $P h$ 3853 asarifólia $P h$.

\section{Farnassus.}

marsh $\$ \Delta$ pr

Asarum-leaved $\frac{\neq}{\ddagger} \Delta$
Hypericinea. $S p .3-5$.

$\frac{x}{2}$ jl.au W Britain bogs. D m.s Eng. bot. 82

1 my.jn W N. Amer. 18(12. D m.s Bot. mag. 1459

N. Amer. 1812. D m.s Vent. mal. t. 39

\section{PENTAGYNIA.}

695 . EVOU VUIUS. 3854 linifólius $L$

Evolvulus. flax-leaved $\begin{array}{ll}3855 \text { emarginátus } L & L \\ 3856 \text { nummularius } L & \text { emarginate } \\ \text { Money-wort }\end{array}$

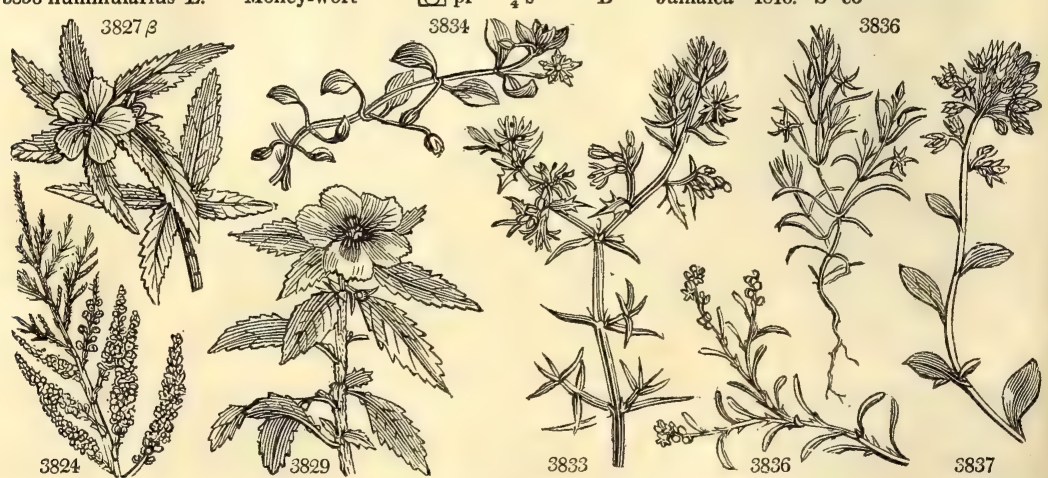

Convolvulacea, $S p, 5-21$.
au.s B Jamaica 1732, S co Br. jam, t.10. f. 2

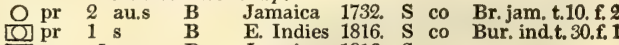
O $\mathrm{pr} \quad \mathrm{s} \mathrm{s} \quad$ Jamaica 1816 , S co

History, Use, Propagation, Culture,

shrubs. S. pinnata has hard smooth nuts, which are strung for beads by the Catholics in some countries, while in others the kernels, though bitter, are eaten by the inhabitants.

685. Tamarix. Tamarisci were people who inhabited the Spanish side of the Pyrenees, where one species grows abundantly on the banks of the Tanaris, now called the Tambra. T. gallica, as it stands the sea breeze, is sometimes used as a hedge plant in such situations.

686. Turnera. So named by Plumier, in memory of William Turner, M. D. Prebendary of York, \&c. author of " A new Herball," London, 1551: died in 1568. All the species are of the easiest culture, but few of them of any beauty. They are chiefly weeds with yellow Cistus-like flowers.

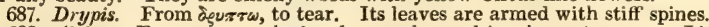

688. Alsine. From $\alpha \lambda \sigma 05$, shady place, where alsine loves to grow. Little weeds of no beauty. Morgeline, Fr.

689. Telephium. Pliny says, Telephus was a king of Mysia, and had his wourds cured by Achilles with this plant. A little inconspicuous weed, with the appearance of a minute Euphorbia.

690. Corrigiola. A diminutive of corrigia, a thong; and applied to the plant we call Polygonum avioulate, 
3824 Bractes shorter than flower-stalks, Spikes lateral panicled, Leaves lanceolate subulate stem-clasping 3825 Flowers sessile, Spikes lateral, Leaves very short sheathing, Branches with turbinate mucronate joints 3826 Spikes terminal solitary, Bractes longer than flower-stalks, Leaves linear lanceolate sessile

3827 Flowers sessile, Leaves oblong acute serrate pubescent with two glands at base

3828 Flowers sessile, Leaves ellipt. cuneate obtusely serrated scabrous with two glands at base 3829 Bractes subulate, Leaves ovate acute at each end with two glands at the base

3830 Flowers sessile, Leaves without glands

3831 Peduncles axillary leafless, Leaves serrated at end

3832 Raceme terminal long, Leaves ovate unequally obtusely serrated

3833 A small glaucous plant with rigid prickly leaves

3834 Petals bipartible, Leaves ovate cordate

3835 Petals entire, Leaves subulate

3836 Petals entire short, Leaves bristly, Calyxes awned

3837 Leaves alternate

3838 Flowers stalked, Calyxes membranous at edge

3839 Stem diffuse procumbent, Leaves oblong ovate, Branches leaflese

3840 Peduncles umbelled lateral as long as linear leaves

3841 Umbels unequal, Leaves linear distant

3842 Peduncles 1-flowered lateral, Flowers as long as leaves, Stem depressed

3843 Common peduncles very long, Leaves linear, Stipules hairy

3844 Peduncles axillary elongate dichotomous, Leaves whorled linear

3845 A fleshy shrub with many small opposite fleshy roundish leaves

3846 Leaves flat, Peàuncles simple

3847 Leaves round ovate, Spikes lateral

3848 Leaves ovate wavy, Peduncles simple longer than the leaf

3849 Leaves cordate, Peduncles clustered branched

3850 Leaves cordate roundish, Peduncles simple shorter than the leaf

\section{TETRAGYNIA.}

3851 Radical leaves cordate acuminate, Nectaries many-parted

3852 Radical leaves nearly orbicular, Nectaries with 3 bristles

3853 Radical leaves reniform, Petals unguiculated, Nectaries 3-parted

\section{PENTAGYNIA.}

3854 Leaves linear lanceolate sessile, Peduncles 1-3-fl. a little longer than the leaves 3855 Leaves reniform repand

3856 Leaves roundish, Stem creeping, Flowers nearly sessile
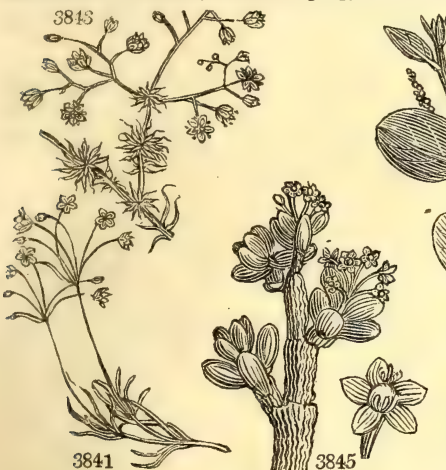

3848

3841

and Miscellaneous Particulars.

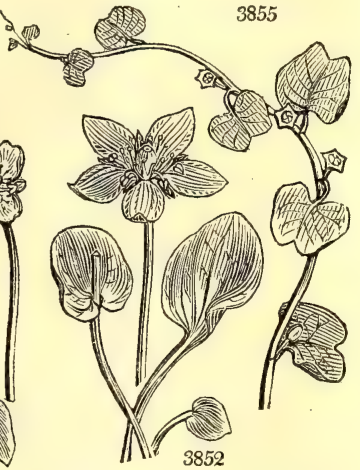

3852

in allusion to the long and slender shoots of that plant. The Corrigiola of modern times is related to the Polvgonum.

691. Pharnaceum. Named after Pharnaces, king of Pontus, who is said by Pliny to have been the first to use the plant. Pretty little herbaceous plants, with fine leaves, and elegant umbels of usually white flowers.

692. Portulaciria; that is to say, a Portulaca-like plant. The leaves of this plant resemble purslane, whence also the English name, as well as the Latin name.

693. Basella. A Malabar name. The species of this genus are used in China as spinage plants: they are alsn raised on a hotbed at Paris in spring, and transplanted into a warm border for the same purpose, and are said to furnish a summer spinage equal to that of the orache.

694. Parnassia. From Mount Parnassus, the abode of grace and beauty, where, on account of the elegance of its form, this plant is feigned to have first sprang up. P. palustris is one of the most elegant of marsh plants, well deserving a place in aquatic collections.

695. Evolvulus. Derived from evolvo, to turn; in the same sense as Convolvulus, which this genus entirely resembles in habit. 
3857 alsinoídes $L$. 3858 latifólius $\mathrm{Ker}$. 696. ARA'LIA. $W$. 3859 spinósa $W$. 3860 híspida $P h$. 3861 racemósa $P h$. 3862 nudicaúlis $P$

697. ACTINOPHYI 3863 digitatum Wall. 698. RO'CHEA. Dec 3864 falcáta $\boldsymbol{P}$. S. 3865 coccínea $P$. $S$. 3866 cymósa Haw. 3867 fláva Haw.

3868 odoratíssima Haw. 3869 jasmínea Sims. 3870 versícolor Burch. 699. CRAS'SULA. $W$ 3871 perfoliáta $I_{\text {. }}$ 3872 ramósa $W$. 3873 tetragóna $W$ 3874 móllis $W$. 3875 acutifólia $P$. S 3876 nudicaúlis $\boldsymbol{W}$

3877 arboréscens $W$. 3878 oblíqua $\boldsymbol{W}$. 3879 láctea $\boldsymbol{W}$.

3880 cultráta $I V$.

3881 ciliáta $\boldsymbol{W}$. 3882 unduláta Haw. 3883 scábra $W$

3884 biconvéxa Haw. 3885 obvalláta $W$

3886 ramuliflóra $L k$ 3887 corymbulósa $L k$.

3888 columnáris $W$. 5889 imbricáta $W$. 3890 canéscens Globuléa canéscens 3801 perflata $P$. 3892 punctáta $W$. 3893 marginális $\boldsymbol{W}$. 3894 pellúcida $W$.

3895 spathuláta $\boldsymbol{W}$. 3896 cordáta $W$.

3897 tomentósa $W$. 3898 linguæfólia $\boldsymbol{H} a w$. 3899 Cotylédonis $W$ 3900 orbiculáris $\boldsymbol{W}$.

3901 retrofléxa $W$. 3902 lineoláta $W$. 3903 centauroídes $\boldsymbol{W}$ 390.4 dichótoma $W$. 3905 glomeráta $\boldsymbol{W}$.
Chickweed Aralia. Angelica-tree hispid berry-bearing \pm or 4 jn.s $W$ naked-stalked $\frac{\Delta}{B}$ or 4 jn.jl W

\section{M. $\boldsymbol{R}$. \& $\boldsymbol{P}$. ACtinophyllum. Araliacea.} finger-leaved

RocheA. sickle-leaved scarlet cymose yellow

sweet-scented jasmine-like

changeable

\section{Crassula.}

perfoliate

branching

squat

acute-leaved

naked-stemmed_us

or J or

... $G$

Crassulacea.

2 jn.s 1 jn.au

$\frac{1}{2} \mathrm{au}$

1. au.s

1 jn.jl Pk

$\frac{3}{4}$ ap.my W

mr.s $\mathbf{R}$

3 jl.au W

w J or 2 jl.au Pk

au

1 au

$\begin{array}{ll}\frac{1}{2} \text { s.n } & \text { W } \\ \frac{1}{4} \text { my.s } & \text { G }\end{array}$

tree

oblique-leaved

white

sharp-leaved.

my.jn $\mathrm{Pk}$

$\begin{array}{ll}\frac{3}{4} \text { s.o } & \text { W } \\ \text { jlau } & \text { W }\end{array}$

ciliated

w w or $\frac{1}{2}$ jl.au

wave-leaved $\frac{1}{2} L$ or $\frac{1}{2}$ au.n

rough-leaved w or $\frac{1}{2}$ jn.jl P.y

Houseleek-lvd, iv or ${ }^{2}$ jl.au W

branch-flower. $L^{2}$ or $1^{\frac{1}{2}}$ jn.jl W

corymbulose or 1 jl au

columnar

imbricated

grey

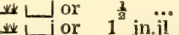

$\checkmark \Delta$ or 1 jl.au

threaded

dotted

margined

pellucid

w or $1 \mathrm{~s}$

w or 1 ap.au W

业L or 2 jl.au P.Y

in.s Pk

notched-leaved - ل J or $\frac{1}{2}$ jl.s W

heart-leaved

downy $\Delta$ ior 1 ap.my $W$

tongue-leaved $\triangle$ or 1 au

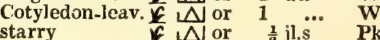

Orange-flower.
channelled

Centaury-flow.

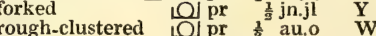

F. Indies 1733. S co Bur. zeyl. t. 6.f.1 Brazil

Virginia 1688. R p.l Dend. brit. 46

N. Amer. 1799. R p.l Bot. mag. 108:5

N. Amer. 1658, D s.p Mor. s. 1 t 2. f.9

N. Amer. 1731. D s.p PI, al, t. 238, f. 5

Sp. $1-6$.

E. Indies 1820, C s.l

Sp. 7.

C. G. H. 1710. C s.l Bot. mag. 495

C. G. H. 1800. C s.l

C. G. H. 1802. C s.l Pl. al, t. 314. f. 2

C. G. H. 1793. C s.l Bot. rep. 26

C. G. H. 1815. C s.l Bot. mag. 2178

C. G. H. 1817. C s.l Bot. reg. 320

Sp. 44-83.

C. G. H. 1725, C s.l Plant. grass. 13

C. G. H. 1774. C s.l

C. G. H. 1711. C s.l

C. G. H. 1774. C s.1

1795. C s.l Plant. grass. t. 2

G. H. 1732. C s.l Plant. grass. 133

C. G. H. 1739. C s.l Bot. mag. 384

C. G. H. 1759. C s.l Plant. grass. 79

C. G. H. 1774. C s.l Bot. mag. 1771

C. G. H. 1732, C s.l Bot. mag 1940

C. G. H. 1732, C s.l Plant. grass. 7

C. G. H. 1797. C s.l Bot. cab. 584

C. G. H. 1730. C s.l Di. el.t.99. f.117

C. G. H. 1800 . C $\mathrm{s.1}$

C. G. H. 1795. C s 1 Plant. grass. 61

C. G. H. 1822. C s.1

C. G. H. 1822. C s.l

C. G. H. 1789. C s.l Burm, afr. t. 9

C. G. H. 1760. C s.1

C. G. H. 1800. C s.1

C. G. H. 1785. C s.l Sc. del. ins. 3. t.6

C. G. H. 1759. C s.l

C. H. 1774. C s.I

C. G. H 1732, C s.l Di.el t.100.f 119

C. G. H. 1774. C s.l Plant. grass. 49

C. G. H. 1774. C s.l Bot. cab. 359

C. G. H. 1790 . C si

C. G. H. 1803. C s.1

C. G. H. 1800, C s.

C. G. H, 1731, C s.1

C. G. H 1788, C s.

C. G. H. 1774, C s.1 Bot. mag. 1765

C. G. H. 1774, S s.l Herm lug t 553

C. G. H. 1774. S s.1 Plant. grass. 67

C. G. H. 1774. S s.l

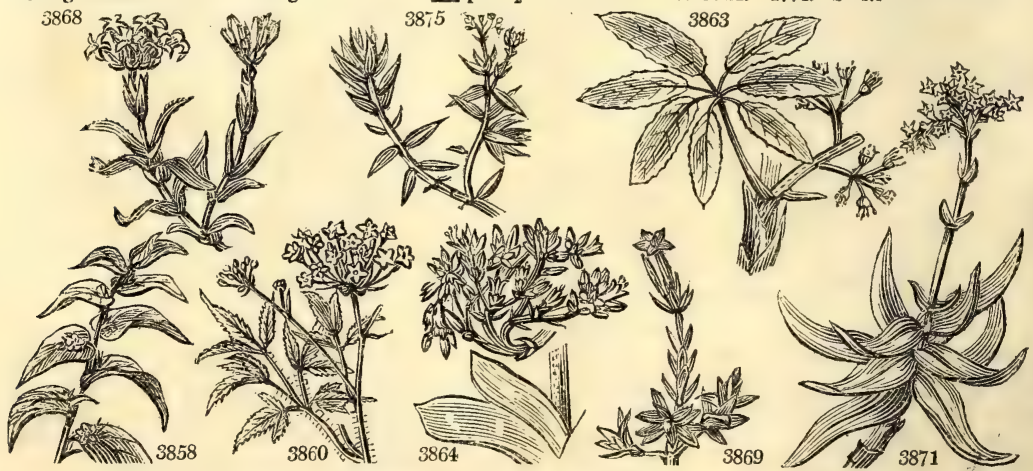

History, Use, Propagation, Culture.

696. Aralia. A name of unknown meaning, under which one species was sent to Fagon from Ouebec, 11 1764, by one Sarrazin, a French physician. A. spinosa is an ornamental low tree for lawns, on accourt of its Angelica-like leaves.

697. Actinophyllum. From $\alpha z \% i y$, a ray, and $\phi \nu \lambda \lambda \omega y$, a leaf; because the leaflets are disposed as it were 11 rays round a centre. Fine Aralia-like plants, with beautiful foliage, but not with any attraction in the appearance of the flowers. 
3857 Procumbent villous, Leaves oval subsessile, Capsules deflexed

3858 Very hairy, Leaves subsessile oblong cordate acuminate, Flowers sessile 3 together

3859 A rborescent, Stem and leaves prickly

3860 Stem suffruticose and leaf-stalks hispid, Leaves decompound

;861 Stem herbaceous smooth, Leaves decompound, Peduncles axillary branched umbelled

3862 Stemless, Leaves decompound, Scapes leafless

3863 Leaflets 5 very smooth shining elliptical entire

3864 Leaves opposite nearly connate oblong with an auricle on one side, falcate

3865 Leaves ovate oblong flat, edge with a cartilagin.fringe, at the base,connate sheathing, Flowers term. sessile 3866 Leaves linear with a cartilaginous fringed edge, Stem shrubby, Cyme terminal

3867 Leaves flat connate perfoliate smooth, Flowers in corymbose panicles

3868 Leaves linear flat fringed with cartilage connate sheathing at base, Flowers terminal sessile

3869 Stem decumbent, Leaves ovate cruciate, Head 2-flowered, Petals connate

3870 Frect, Leaves oblong lanceolate with cartilaginous teeth at base sheathing, Umbels double many-How.

\$1. Shrubby, Leaves subulate.

3871 Leaves lanceolate subulate sessile connate channelled convex beneath

$387^{\circ}$ Leaves subulate above flat connate perfoliate smooth much spreading. Pedunc, long, Flowers cymose

3873 Leaves subulate incurved obscurely 4-cornered spreading, Stem erect shrubby rooting

3874 Leaves $\frac{1}{2}$ cylindrical acute gibbous beneath smooth nearly erect, Cymes terminal compound

3875 Leaves connate rounded subulate spreading, Cymes few-flowered on long stalks, Stem shrubby decumbent 3876 Leaves subulate radical, Stem naked

82. Shrubby, Leaves broad, smooth.

3877 Leaves roundish acute glaucous fleshy dotted, Cyme trichotomous

3878 Leaves opposite ovate oblique entire acute distinct somewhat cartilaginous at edge

3879 Leaves ovate attenuate at base connate entire dotted inside the edge, Cymes panicle-shaped

3880 Leaves opposite obovate cultrate oblique connate entire

$$
\text { 3. Shrubby, Leaves broad, distant, ciliated. }
$$

3881 Leaves opposite oval flattish distinct fringed, Corymbs terminal

3882 Leaves connate ovate expanded cartilaginous crenated; upper ovate elliptical wavy, Stem dichotomous 3883 Leaves opposite spreading connate rough fringed, Stem rough backwards

3884 Leaves linear obtuse sheathing convex on both sides, Flowers cymose, Stem decumbent

3885 Leaves obl. con obtuse falcate with a cartilaginous fringed edge, Pan. long, Pedunc. opposite clustered 3886 Leaves obovate subconnate, Branches axillary few-flowered, Petals lanceolate reflexed

3887 Leaves lanceolate convex beneath, Corymbs small axillary, Petals lanceolate

3888 Leaves round imbrict Shrubby, Leaves broad, very closely imbricated.

3889 Leaves ovate acute smooth imbricated in rows, Flowers axillary sessile

3890 Leaves radical decussately imbricated tringed lanceolate cultrate hoary

5. Shrubby, Leaves broad, very much perfoliate.

3891 Leaves connate perfoliate cordate dotted

3892 Leaves opposite ovate dotted fringed, Lower oblong

3893 Leaves cordate perfoliate acuminate flat spreading dotted within the edge

3894 Stem flaccid creeping, Leaves opposite

$$
\text { \$6. Shrubby, Leaves stalked. }
$$

38.55 Leaves stalked cordate roundish acute crenate, Corymbs panicle-shaped

3896 Leaves stalked cordate obtuse entire, Cymes panicle-shaped

\section{Herbaceous.}

3897 Villous, Leaves connate lanceolate fringed, Stem nearly naked terminal, Spike whorled

3898 Lower leaves distinct opposite tongue-shaped ciliated pubescent, Flowers whorled sessile close, Stem leafy 3899 Leaves connate oblong downy fringed, Stem rather naked, Flowers corymbose close

3900 Leaves oblong obtuse cartilaginous-fringed tufted, Scape panicled, Branches opposite cymose

$$
\text { 8. Annual or biennial. }
$$

3901 Leaves connate oblong remote flat, Stem simple, Cyme compound, Flower stalks bent backwards 3902 Leaves cordate sessile, Peduncles terminal axillary approximate umbellate

5903 Stem dichotomous, Leaves sessile oblong ovate cordate flat, Peduncles axillary 1-flowered

3904 Stem dichotomous, Leaves sessile ovate oblong channelled recurved, Peduncles axillary 1-flowered

3905 Stem dichotomous rough, Leaves lanceolate, End flowers in bundles
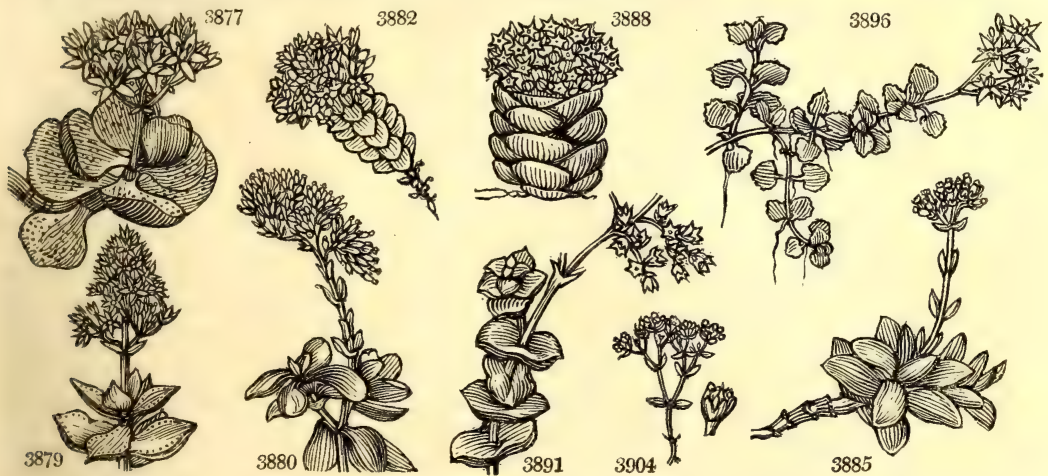

and Miscellaneous Particulars.

698. Rochea. Named after M. de la Roche, author of "Historia Eryngiorum," a work of reputation. This succulent genus thrives well in sandy loam and requires but little water. "Young cuttings taken off and laid to dry a few days, and then potted, or stuck in the tan, will root directly." (Sweet.)

699. Crossula 699. Crassula. From crassus, thick, in allusion to the fleshy nature of the leaves and stems of all the
species. These plants grow best in sandy loam and brick rubbish, with the pots well drained. "Cuttings root 
3906 glábra Haw. 3907 Alnídes $W$. 3908 capitélla $\dot{W}$. 3909 rúbens $W$. 3910 verticilláris $W$. 3911 expánsa $W$. 3912 spársa $W$. 3913 diffísa $\dot{W}$. 3914 moscháta $W$.

700. GISE'KIA. $W$. 391 pharnaceoídes 701. LI'NUM. $W$. 3916 usitatissimum $W^{*}$. 3917 nervósum $\boldsymbol{W} . \& \dot{K}$. 3918 perénne $W$. 3919 trigynum Sm. 3920 hirsútum $W$ B hypéricifólium Sims. 3921 ascyrifólium $H$. $K$. 3922 narbonénse $W$. 3923 refiéxum $W$. 3924 tenuifólium $W$ 3925 angustifólium $\dot{H} . K$. 3926 gállicum $W$. 3927 maritimum $W$. 3928 alpinum $\boldsymbol{W}$. 3929 austríacum $W$. 3930 virginiánum $\boldsymbol{W}$ 3931 rigidum $P h$.

3932 flávum $W$

3933 campanulátum $\boldsymbol{W}$. $\beta$ taúricum W. en. 3934 strictum $W$ 3935 suftruticósum $W$ 3936 arbóreum $W$. 3937 a fricánum $W$. 3938 nodiflórum $W$. 3939 cathárticum $\boldsymbol{W}$. 3940 quadrifólium $\boldsymbol{W}$. 702. DRO'SERA. $W$. 3941 rotundifólia $W$ 3942 longifólia $W$. 3443 ánglica $H . K$. 3944 filifórmis $P h$. 703. COMMERSO NIA.

$\begin{array}{llllll}3945 \text { platyphylla } \boldsymbol{B} . M \text {. } & \text { broad-leaved } \\ 3046 \text { dasyphýlla } \boldsymbol{B} \text {. Rep. hairy-leaved } & 3 \text { jn.jl W Moluccas 1806. C 1.p Bot. mag. } 1813\end{array}$

smooth-cluster.

Aloe-like square-spiked $\frac{1}{1}$ (D) annual red whorl-flowered awl-leaved alternate-lvd. $\mathrm{pr}$ diffuse musky

Gisekia trailing

\section{FLAX} conimon nerved three-styled hairy

Mirllow-flowe Narbonne reflex-leaved $\frac{\Delta}{\Delta}$ slender-leaved $\frac{1}{\Delta} \Delta$

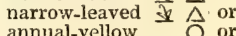
annual-yellow sea

Alpine

Austrian

Virginian stiff-leaved yellow

glaucousupright Spanish tree

African

knotted

purging

four-leaved

Sun-DEW. round-leaved long-leaved great thready-leaved $\Delta$ pr $\begin{array}{ll}\frac{1}{2} \text { jn.o } & \text { W } \\ \frac{1}{2} & \text { jn.au }\end{array}$ $\frac{1}{2}$ my.jn Pk $\frac{1}{4} \mathrm{jl} \quad \mathrm{Pk}$ $\frac{1}{2}$ jn.jl W $\frac{1}{2}$ jn.jl $\quad$ W ${ }_{\frac{1}{2}}^{\frac{1}{2} \text { my.jl }} \quad$ Wk

Portulacere. $\frac{1}{2} \mathrm{jl} . \mathrm{au} \quad \mathrm{W}$

Plant. grass. 55 C. G. H. 1774, S s.l Italy 1759. S $\mathrm{s.l}$ Europe 1788. S s.I C. G. H 1774. S s.1 C. G. H. 1774. S s.i N. S. W. 1794. S s.l Sp. $1-5$.

[ত] cu 1 jn P.Gr E. Indies 1783.

Caryophyllea. Sp. 25-54.

ag 12 jn.jl B Britain co. fi. S co Eng. bot. 1357 $\star \Delta$ or $1 \frac{1}{2}$ jn.jl B Hungary 1822. D co Wal. \& kit.t.105 $\triangle$ or 3 jn.au B England ch. so. D co Indies 1799. Co 1 ja jl.au $\quad$ B $\quad$ Indies 1799. C p.l 1\% Austria 1759. D co 1 1 ju Caucasus 1807. D co

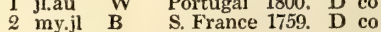
$\begin{array}{llll}2 & \text { my.jl } & \text { B } & \text { S. France 1759. } \\ 1 \text { jl } & \text { B } & \text { S. Europe } 1777 . & \text { D co }\end{array}$ $\begin{array}{llll}1, \mathrm{jl} & \text { B } & \text { S. Europe 1777. } & \text { D co } \\ 1 \frac{1}{2} \mathrm{jn} . \mathrm{jl} & \mathrm{Pk} & \text { Europe 1759. } & \text { D co }\end{array}$ 1 jl Pu England sa.pa. D co 1 jl.au Y France 1777. S co 2 jl.au Y S. Europe 1596. D co $\frac{1}{2}$ jl.au B Austria 1739. D co

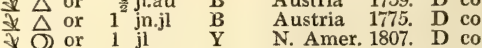

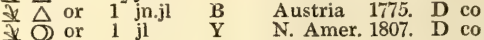

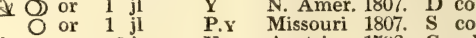
7 or $\frac{3}{4}$ jn.au $Y$ Austria 1793. C p.l

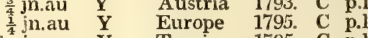

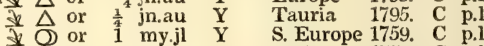

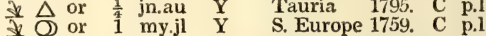
we or 1 au Pk Spain 1759. C p.l Cav. ic. 2, t. 108

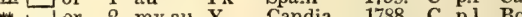
w ${ }^{2}$ or 2 my.au Y Candia 1788. C p.1 Bot. mag. 234 望 $L_{\text {or }} 1$ jn.jl $Y$ C. G. H. 1771. S p.l Bot. mag. 403 ₹ $\triangle \mathrm{w} \quad \frac{1}{2}$ jl.au W Italy 1759. D s.l Moris.s.5.t.6.f.11 O w $\frac{1}{2}$ jn.au W Britain dr.pa. S p.l Eng. bot. 382 th bor $_{2}$ my.jn $Y \quad$ C. G. H. 1787. S p.1 Bot. mag. 431 Droseracea. Sp. 4-32.

$\frac{1}{4}$ jl.au W Britain tur.bo. S p Eng. bot. 857 $\frac{1}{2}$ jl.au W Britain tur.bo. S p Eng. bot. 868 W jl.au W England tur.bo. S p Eng, bot. 869 $\frac{5}{4}$ my.jn $\mathrm{Pu}$ N. Jersey 1811. S p Buttncriacea. Sp. $2-3$.

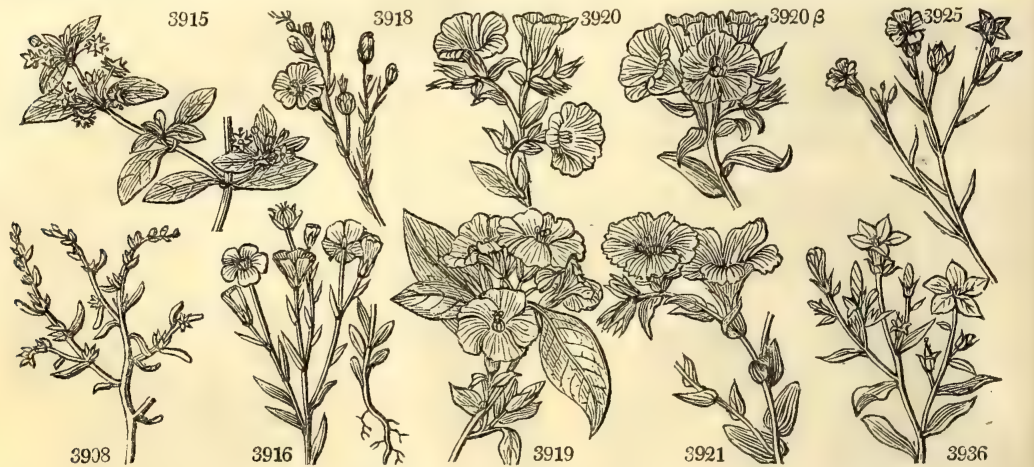

History, Use, Propagation, Culture,

easily if laid to dry a few days after cutting off, before they are planted, to dry up the wound, that they may not rot. They require no covering, but may be placed in any convenient situation." (Sweet.)

700. Gisekia. In honor of $\mathbf{P}$. D. Giseke, a Danish botanist, who lived abcut the end of the last century. A small weed-like piant, with the habit of Chenopodium.

701. Linum. Llin, in Celtic, signifies thread, whence $\lambda$ svov, in Greek, and linum, and its derivations, in Latin. L. usitatissimum, is a well known thread or clothing plant, which has been cultivated from the remotest antiquity for its cortical fibres, or boon, which, when separated from the woody matter or harl, as it is technically called by the growers, forms the lint and tow which is spun into yarn, and wove into linen cloth. The seeds are sown on well comminuted loamy soil, which is in good heart, in April, broadcast: during summer weeds are carefully removed; and when the plant is in full flower, or (if seed is desired) when the seed capsules are ripe, it is pulled up by the roots, the capsules torn off by a comb, and the stalks tied in bundles and carried to a pond or pool of stagnated water. Into this water the bundles are thrown, and kept under the sturface by being loaded with planks, stones, $\& \mathrm{c}$. for ten days or a fortnight, till an appearance of decay or softness is indicated by the bark; they are then taken out and spread on the grass, or on the gravelly banks of a river for a fortnight, where the alternate dews and heats accelerate the progress of decay. It is next taken up, and when quite dry tied into bundles and stacked till wanted by the flax-cleaner. Some cul. tivators do not steep the flax in water, but only spread it on the surface of grass ground, which is called dewretting, and has nearly the same effect as the other; but the more recent practice, not yet however very general, is neither to steep or dew-ret, but to dry, bind, and stack as in saving a crop of corn, and afterwards to separate the capsules and the fibre by machinery. By this process the fibre is obtained of much greater 
3906 Stem dichotomous pubescent, Leaves linear-lanceolate, End flowers in bundles

3907 Ieaves ovate acute distinct ciliated, Stem simple downy, Raceme compound, Branches panicled 3908 I.eaves oblong lanceolate acute connate ciliated, Stem smooth, Raceme elongated, Fl. in bundles sessile 3009 Leaves fusiform depressed, Cyme 4-fid leafy, Flowers sessile, Stamens reflexed

3910 I eaves spreading, Flowers whorled awned

3910 Leaves spreading, Frical subulate channelled above spreading, Peduncles axillary solitary 1-flowered 3911. Leaves half cylindrical subulate channelled above spreading, Peduncles
3912 Leaves alternate somewhat spatulate acute entire, Raceme compound

3913 Leaves oblong narrowed at base remotely crenate, Peduncles opposite the leaves and axillary solitary 3914 Stem procumbent, Leaves connate oblong acute, Peduncles axillary 1-flowered, Flowers tetrandrous

3915 Leaves elliptical lanceolate

3916 Sepals ovate acute 3-nerved, Petals crenate, Leaves lanceolate, Stem nearly solitary 3917 Sepals and leaves lanceolate subulate 3-5 nerved smooth, Stems branched at end $\$ 918$ Sepals obovate obtuse about 5-nerved smooth, Stems numerous ascending

3919 Leaves elliptical acute nearly entire, Styles 3, Cap iules 6-celled

3920 Sepals hairy acuminate sessile alternate, Leaves alternate; of the branches opposite

3921 Sepals hairy acuminate, Flowers spiked, Spikes revolute, Leaves cordate-ovate pubescent 3922 Sepals acuminate, Leaves lanceolate scattered upright rough acuminate, Stem rounded branched at base 3923 Sepals acuminate, Leaves ovate lanceolate acuminate reflexed smooth, Filaments connate 3924. Sepals acuminate, Leaves scattered setaceous rough backwards

3925 Sals elliptical 3-nerved and capsules acuminate, Leaves linear lanceolate 3-nerved, Stems numerous 3926 Sepals subulate acute, Leaves linear lanceolate, Peduncles of panicle about 2-flowered, Flowers sessile 3927 Sepals ovate acute blunt, Leaves lanceolate lower opposite

3928 Sepals rounded obtuse, Leaves linear acutish, Stems declinate 3929 Sepals rounded obtuse, Leaves linear straight acute

3930 Sepals acute alternate, Capsules pointless, Stem panicled, Leaves lanceolate : radical ovate 3931 Sepals ovate acuminate 3-nerved fringed, Leaves very stiff short, Petals oblong very narrow 39.2 Sepals acuminate scabrous, Leaves with two glands at base, smooth at edge, Cor. monopetalous 3933 Base of the leaves dotted with glands on both sides

3934 Sepals subulate, Leaves lanceolate upright mucronate rough at edge 3935 Leaves linear acute rough, Stems half shrubby 3936 Leaves wedge-shaped, Stems arborescent

3937 Leaves linear lanceolate, Flowers terminal stalked

3938 Flower leaves lanceolate, Flowers alternate sessile, Cal. as long as leaves 39:39 Leaves obovate lanceolate entire, Stem dichotomous upwarts, Petals acute 3940 Leaves 4-together

3941 Leaves orbicular radical, Scape racemose erect

3942 Scapes radical ascending, Leaves oval, Stigmas emarginate

3943 Scapes radical erect, Leaves oblong lanceolate, Stigmas clavate

3944 Scapes radical branched, Leaves filiform very long

3945 Leaves cordate ovate acuminate unequally tooth-serrated, rough above downy beneath

3946 Leaves long cordate unequally serrate hairy on both sides

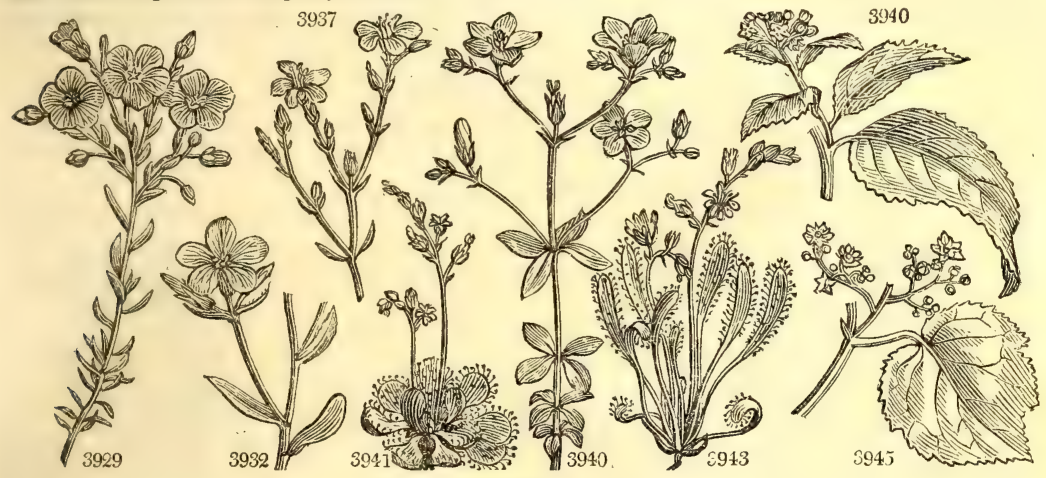

and Miscellaneous Particulars.

strength; there is less loss of seed, less demand for labor at a busy season, and the refuse of the operati'n forms an excellent food for horses or cattle. The machines for breaking and cleaning flax are worked by hand, and the best at present is considered that of Bundy. The process of steeping and spreading flax has the further effect on the fibre of bleaching it : when the machine is used, the bleaching progress is effected by steeping in soft soap. Flax seed yields by expression a valuable oil; in powder it is much used in poultices; and the refuse, after pressing for oil, forms a cake fit to feed.broken-winded horses, to fatten cattle, and for manure.

L. perenne may be used for the same purpose as the other : both species have been proposed by some gardeners to be adopted as border-flowers.

742. Drosera. From deoros, dew, on account of the pellucid dew-like glands on the surface of the leaves, whence also our English name sun-dew. The famous Italian liqueur is called Rossoli, on account of the usage of this plant in its composition. D. rotundifolia is an acrid caustic plant, by some supposed to occasion the rot in sheep : it curdles milk, removes warts and corns, and takes away freckles and sunburn: distilled with wine it produces a very stimulating spirit, and it was formerly inuch used as a tincture spiced and sweetened. The leaf hairs support globules of clear liquor even in the hottest weather, are very irritable, and close upon small insects that touch them, after which the leaf itself bends and holds the dead insect imprisoned.

703. Commersonia. Named by Forster in memory of M. Commerson, the French traveller and botanist, who accompanied Bougainville in his voyage round the world. He stopped at the Isle of France, where he who accompanied Bougainville in his voyage round the world. He stopped at the Isle of France, where he
died in 1774 , after having discovered an immense quantity of new plants. C. dasyphylla is a pretty flowering shrub: both species grow freely from cuttings in sand under a hand-glass. 
704. RUlingia. $\boldsymbol{R}$. Br. Rulingia. 3947 pannósa $R$. $B r$. cloth-leaved

705. ARME'RIA. W. en. THRIFT. (3949 maritima $W$ en common 3950 alpína $W . e n$. flat-stemmed 3951 arenária $P$. S 3952 littorális $W$. . en. 3953 alliácea $u$. sand sand ciliated Garlic-leaved 3954 denticuláta Bertoloni.toothed 3955 plantagínea $\boldsymbol{W}$. en. Plantain-leav' 3956 scorzonéræfólia w.en.large-headed 3957 latifólia $W$. en . broad-leaved 3958 fasciculáta $W$. en. bundled

706. STA'TICE, W.en. SEA-LAVENDER. 3959 graminifólia $W$. Grass-leaved 3960 Limónium $W$. 3961 Gmelini $W$. 3962 scopária $W$. 3963 latifólia $W$ 3964 oleifólia $W$. 3965 auriculæfólia $W$. 3966 emargináta $W$ en. 3967 cordáta $W$ 3968 scábra $W$ 3969 virgáta $\boldsymbol{W}$. en. 3970 reticuláta $W$. en. 3971 cáspia $\boldsymbol{W}$. en. 3972 echioídes $W$. 3973 spathuláta Desf. 3974 speciósa $W$ 3975 conspicua $\dot{B}$. $M$. 3976 tatárica $W$. 3977 flexuósa $W$. 3978 purpuráta Thunb. 3979 minúta $W$. 3980 pectináta $W$. 3981 suffruticósa $W$ 3982 monopétala $W$ 3983 ferulacea $W$. 3984 sinuáta $W$. 3985 aláta $W$. en 3986 mucronáta $W$ 3987 globularifólia Desf, tough-leaved 3988 incána $L$ 989 macrophýlla $L i n k$. large-leaved 3990 agyptíaca Delisle. Egyptian Gmelin's Broom

broad-leaved Olive-leaved Auricula-leaved emarginate blunt-leaved rough-branched twiggy matted Caspian rough-leaved spatula-leaved Plantain-leavedy showy Tartarian zigzag purple

triangular-stlk. narrow-leaved Sicilian-shrubb Fennel-leaved scollop-leaved winged
Buttineriacea. Sp. 1.

2 ${ }^{2}$ or $1 \mathrm{my}$ W N. Holl 1819. C 1.p Bot. mag. 2191

Plumbaginea. Sp.11-20.

\begin{tabular}{|c|c|c|c|c|c|c|}
\hline$\triangle$ or & 吾 jn.au & $\mathbf{R}$ & Europe & & D co & Sch.bot.han.t.87 \\
\hline & & $\mathbf{R}$ & & co & D $\mathrm{s.1}$ & Eng. bot. 226 \\
\hline$\triangle$ or & $\frac{1}{2} \mathrm{my} \cdot \mathrm{au}$ & $\mathrm{Pu}$ & Carinthia & "** & D s.1 & \\
\hline$\Delta$ or & $\frac{3}{2}$ my.au & Pk & France & c. & D & \\
\hline$\triangle$ or & my.au & $\mathbf{P k}$ & S. Europe & & D s.l & \\
\hline$\triangle$ or & 1 my.jn & W & Spa & 1798. & D s.l & Cav. ic. 2. t. 109 \\
\hline$\triangle$ or & $1 \frac{1}{2} \mathrm{my} \cdot \mathrm{jn}$ & $\mathbf{F}$ & Naples & 1816. & D & \\
\hline or & 1 my.jn & $\mathbf{R}$ & S. Europe & 1816 & D & \\
\hline$\triangle$ or & 1 my.jn & & S. Europe & 1816. & D & \\
\hline$\triangle$ or & 2 my.ji & L.R & Algarbia & 1740. & D p.l & Jac. vind, 1. t. 42 \\
\hline or & 1 ap.au & $\mathbf{P u}$ & Portugal & .. & D s.1 & ent. cels, t. 38 \\
\hline
\end{tabular}

Plumbaginea. Sp. 32-70.

$\checkmark \Delta$ or 1 jn.jl $\mathbf{R}$

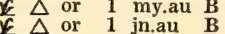
f $\Delta$ or 1 jn.au B f $\triangle$ or 1 jn.au B $\triangle$ or 1 myau $R$ $\Delta$ i or $\Delta$ or $\Delta$ or $\Delta$ or $\Delta$ or f $\triangle$ or 이 or 它 $\Delta$ or $\Delta$ or $\Delta$ or $\triangle$ or $\triangle$ or 4 or \& $ـ$ or $\triangle$ or N $\triangle$ or N or L $\triangle$ or $\triangle \Delta$ or $\checkmark \Delta$ or
1 jl.au R

$\frac{3}{4}$ my.jl B

$\frac{3}{4}$ my.jl B

1 my.jl B

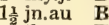

$\frac{1}{2}$ jl.au B

1 jl.au P.B

1 jn.au Pu

1 jl.au W

1 jl.au

$1 \frac{1}{2} \mathrm{jn}$

1 jl.au

6 jn.jl $\mathrm{Pu}$

$\frac{1}{4}$ jn.jl

s.o

$\frac{1}{2}$ my.s

$3^{\frac{1}{2}}$ jl.au

$1 \mathrm{my}$

1 my.s

1 jn.au

P.

1 my.s W

1 jn.au $\mathrm{Pk}$

my.jn W

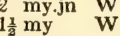

Siberia 1780. D s.1

England mud.s. D s.1 Eng. bot. 102

Siberia 1796. D s.I Gmel, sib.2. t.90

Siberia 1791. D p.l

Italy 1688. D s.l Scop. ins. 1. t. 10

Barbary 1781. D s.l

Gibraltar ... D s.1

S. Europe 1752. D s.l Barr. ic. 805

C. G. H. 1788. S r.m

Spain $\quad$... D s.l

England mud.s. D s.l Eng. bot. 328

Caspian Sea ... $\quad$ S s.1 Gm.sib.2.t.89.f.2

S. Europe 1752. D s.1 Fl, græc. 298

Barbary 1804. D s.1 Bot. mag. 1617

Russia 1776. D p.l Bot. mag. 656

Russia 1804. D s.1 Bot. mag. 1629

Russia 1731. D p.l Sweet fl.g. 37

Siberia 1791. S p.l

C. G. H. 1800, s p.l

Mediterr. 1658. S p.l Plu.al. t. 200. f,3

Canaries 1780. S p.1

Siberia 1779. C rm Gm 0 t.88.

Sicily 1731. C r.m Boc. sic. t. 16,17

Siberia 1796. D s.1 Plu.alm.t.28. f.t

Levant 1629. S r.m Bot. mag. 71

B..... 1806. D s.1

1784. C r.m L'Her.stirp. t.13

1823. D r.m

$\begin{array}{lll}\text { Egypt } & \text { 1823. D } & \text { r.m Bot. mag. } 2363\end{array}$
Siberia 1796. D s.1

\section{POLYGYNIA.}

707. MYOSU'RUS. $\boldsymbol{W}$. MoUsE-TAIL.

Ranunculacea. Sp. 1.

3991 minimus $W$. small $O \mathrm{cu} \quad \frac{1}{4}$ ap.my $Y$ Britain cor. fi. $S$ co Eng. bot. 435

708. CERA TOCE'PHALUS. $\boldsymbol{P}$.S. Ceratocephalus. Ranunculacea. Sp. 1-2.

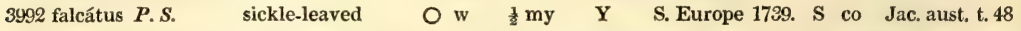

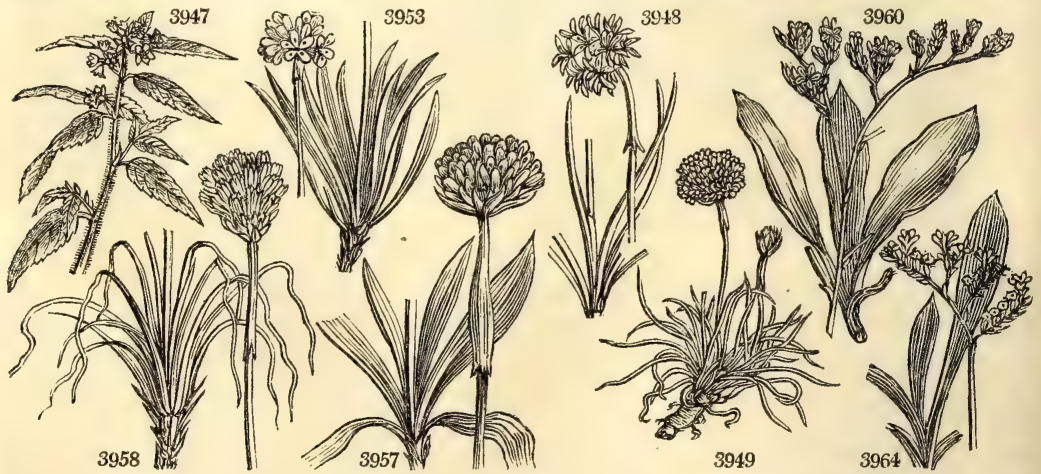

History, Use, Propagation, Culture,

704. Rulingia. Named in honor of J. P. Rüling, author of an Essay on the Natural Orders. A plant related to Commersonia.

705. Armeria. Derivation unexplained. This is a genus of handsome plants, for the most part wel suited for rock-work, or growing in pots. A. vulgaris is considered the most valuable edging plant next to the box.

706. Statice. From $\sigma \tau \alpha \tau i \zeta \omega$, to stop. This plant, says Pliny, stops diarrhœa. This is a very ornamental 
3947 The only species

3948 Scape rounded smooth, Outer leaves of involucrum acute, Leaves linear flat obtuse 3949 Scape rounded pubescent, Leaves of involucr. obtuse, Leaves linear flat obtuse ciliated at base 3950 Scape compressed smooth, Leaves of involucr. ellipt. rounded, Leaves lin. flat acute membr. at edge 3951 Scape long, Bractes 2 or 3 longer than head, Leaves linear stiff smooth

3952 Scape rounded smooth, Outer leaves of involucr. lanceol. acute as long as head, Leaves lin. flat fringed 3953 Scape rushy, Leaves linear lanceolate acute flat narrowed downwards

3954 Quite smooth, Scape simple, Leaves linear flat, the first toothletted, Leaves of involucr. ovate lanc. acum. 3955 Scape rounded roughish, Outer leaves of invol, obl. ov. acute : inner obl. obtuse, Leaves lanc. flat 3-nerved 3956 Scape rounded smooth, Outer leaves of involucr. elliptical mucronate, Leaves lanc. flat acute 3-nerved 3957 Leaves long lanceolate entire smooth 3-nerved acute soft, Leaves of involucr. acute edged

3958 Scape rounded smooth, Leaves of involucr. elliptical obtuse, Leaves linear acute channclled

3959 Branches 3-cornered, Leaves linear channelled

3960 Scape panicled rounded, Leaves wavy at edge oblong smooth obtuse mucronate beneath

3961 Scape panicled pubescent, Leaves elliptical mucronate beneath and nearly smooth

3962 Scape panicled much branched and lvs. ovate oblong obtuse somewhat wavy, beneath mucronate smooth 3963 Scape panicled much branched rough, Leaves pubescent, Hairs in starry bundles

3964 Scape panicled rounded, Lower branches sterile, Leaves oblong spatulate obtuse smooth nearly blunt 3965 Scape simple rounded, Spikes lateral and terminal 1-sided, Leaves spatulate acute

3966 Leaves spatulate emarginate, Scape erect panicled, Upper branches simple, Lower bifid, Flow. 1-sided 3967 Scape panicled, Leaves spatulate retuse

3968 Leaves somewhat radical obovate-oblong obtuse, Branches rough

3969 Lvs. lanc, wedge-shaped acute, Scape erect roughish branched panicled, Fl. 1-sided, Cal. at edge membr. 3970 Lvs. lanc. cuneate obtuse, Scape decumbent branched panicled, Fl. branches long, Bractes mem. at edge 3971 Lvs. spatul. ret. Scape erect branched rough, Sterile branches pectinate, Fl.very close, Brac. transparent 3972 Rough with hoary dots, Scape panicled rounded jointed much branched divaricating, Leaves spatulate 3973 Radical leaves spatulate obtuse glaucous entire on long stalks, Scape rounded, Flowers racemose 1-sided 3074 Scape branched nearly round, Branches 2-edged winged, Fl imbricated, Lvs, obov, cuspidate mucronate 3975 Scape leafy, Branches 3-cor. winged, Fl. aggregate in interrupted spikes, Bractes acum. longer than cal. 3976 Scape dichotomous, Leaves lanceolate mucronate, Flowers alternate distant

3977 Scape dichotomous corymbose, Spike-headed, Fl. imbricated, Lvs. lanc. wedge-shaped mucronate 3-nerved 3978 Stem leafy, Leaves obovate wedge-shaped 3-nerved mucronate

3979 Stem shrubby leafy, Leaves clustered wedge-shaped smooth pointless, Scape few-flowered 3980 Stem and branches panicled 3-cornered, Leaves obovate stalked, Spikes 1-sided

3981 Stem shrubby naked above and branched, Heads sessile, Leaves lanceolate sheathing

3982 Stem shrubby leafy, Flowers solitary, Leaves lanceolate sheathing

3983 Stem shrubby branched, Branches imbricated, Paleæ with a bristle at end

3984. Stem herbaceous two-edged, Radical leaves lyrate; cauline linear

3985 Stem winged, Radical leaves sinuate ; cauline lanceolate, Peduncles cuneate 3-winged

3986 Stem crisp, Leaves elliptical entire, Spikes 1-sided

3987 Scape panicled rounded, Branches clustered, Leaves obovate spatulate mucronate smooth, Cal, acute

3988 Scape panicled, Leaves lanceolate 3-nerved wavy mucronate at end, Branches of panicle 3-cornered

3989 Leaves broad lanceolate glaucous mucronate, Scape winged, Flowers close corymbose

3990 Radical leaves alternately pinnatifid sinuated, Intermediate segments of cor. linear

\section{POLYGYNIA.}

\section{Leaves quite entire}

\section{Horns of the pericarp falcate ascending}

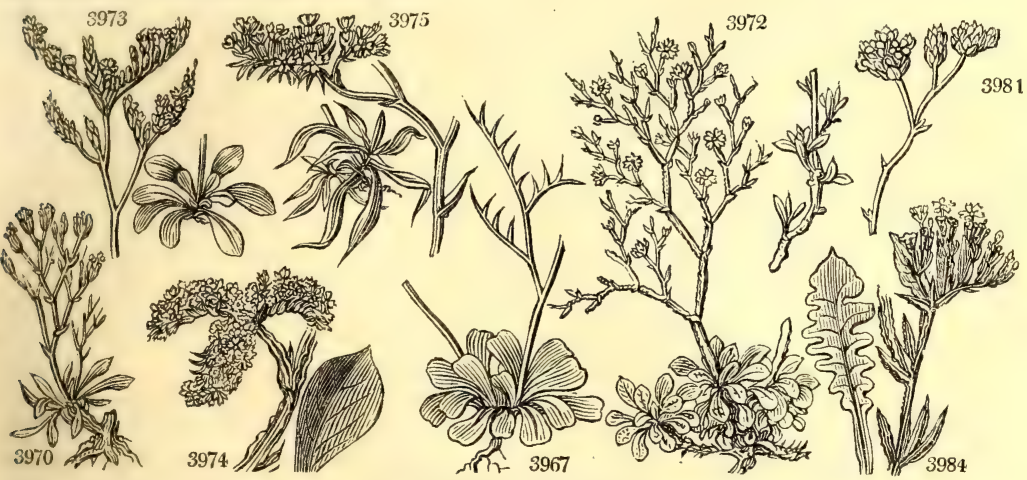

and Miscellaneous Particulars.

genus; the species are not common, and require a little care in cultivation. Statice speciosa and tatarica, are among the prettiest of hardy border flowers. S. limonium is an inhabitant of salt marshes in many parts of England, whence its name, from $\lambda \varepsilon s \mu o v$, a marsh

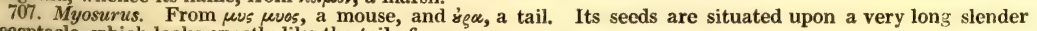
receptacle, which looks exactly like the tail of a mouse.

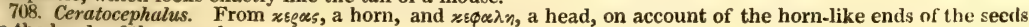
in the heads of the capsules. 
709. XANTHORHI'ZA. $\boldsymbol{W}$. Yellow-ROOT. 3993 apiifólia $\boldsymbol{W}$. Parsley-leaved tw

710. SIBBAI/DIA. $W$. SibBaldia. 3094 procúmbens $P$ S procumbent 3995 parviflóra $P$. S 3996 erécta $W$.
Ranunculacea. Sp. 1.

or 3 f.ap Pu.Gr N. Amer. 1766. Sk s.p Bot. mag. 1736 \& $\triangle \mathrm{cu} \frac{\pi}{8} \mathrm{jn} . \mathrm{au} \underset{\mathrm{Y}}{\mathrm{Y}}$ Britain sc. al. D s 1 Eng. bot. 897 small-flowered $\underset{7}{\Delta} \mathrm{cu} \frac{2}{\frac{1}{3}} \mathrm{jn}$.au $\mathrm{Y}$ Cappadocia... $\mathrm{D}$ s.l

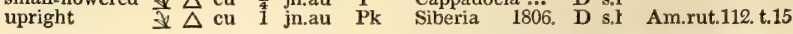

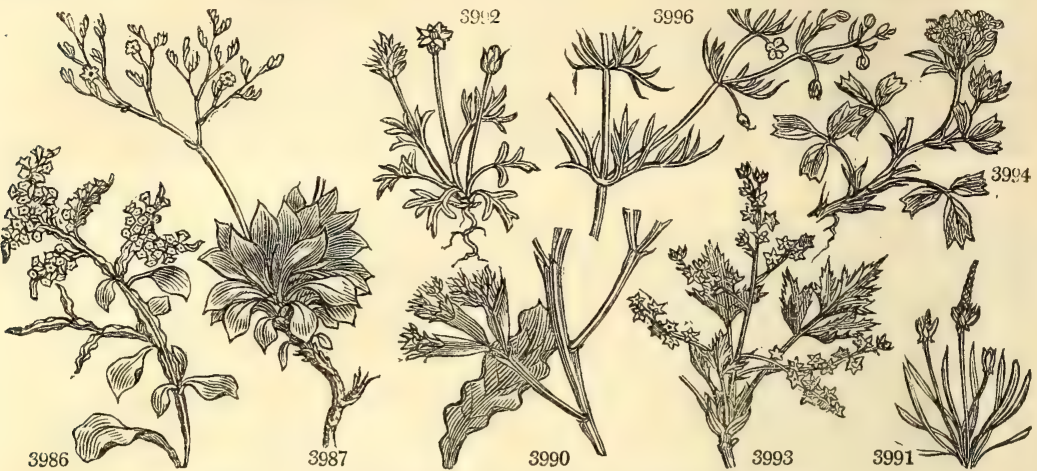

History, Use, Propagation, Culture, and Miscellaneous Particulars.

709. Xanthorhiza. From छूy.Tos, yellow, and $\dot{c} \zeta \alpha$, a root, on account of the deep yellow color of the roots. A small shrub, with much cut leaves, and branches of dull purplish brown small flowers.

710. Sibbaldia. So named by Linnæus, in memory of Sir Robert Sibbald, professor of physic at Edinburgh author of Scotia Illustrata, \&c. 1684. Small alpine plants, with the aspect of Alchemilla.

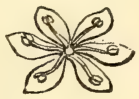

\section{Class Vi. - HeXandria. 6 Stamens.}

This class contains the most beautiful of the herbaceous plants of our gardens. With a few exceptions, it is to a considerable degree a natural assemblage, comprehending a large proportion of those favorites of gardeners, the orders Amaryllideæ, Asphodeleæ, Bromeliaceæ, Liliaceæ, and Melanthaceæ. The class also includes a few grasses and palms, some genera of Berberideæ, all Hypoxideæ, and many Junceæ.

The Amaryllidex, or lilies of the hot-houses, consist of a number of beautiful species, the generic distribution of which is uncertain, and difficult to determine. Much attention has been paid to the subject by Messrs. Ker, Herbert, and others; by the former, perhaps, with the most success; a great deal still remains to be done. The limits of the genera are very obscure, and their extreme characters similar. Among the Bromeliaceæ are found the delicious pine-apple, and the curious Tillandsias, some of which are called air-plants. The asparagus and the officinal squill are included in Asphodeleæ. To the same class are related the lily of the valley, the Solomon's seal, and many other curious little plants. The Phormium tenax, which produces the strong flax of New Zealand; the aloes, curious for their fantastic foliage; the fragrant tuberose ; the plantains, so valuable as an important article of food in all the tropics, are all contained in this class. Hither also, are referred the valuable rice, the curious bamboo, and the rush, some of the species of which are well known for their use in œeconomical purposes, others as the most worthless weeds of our heaths.

Hexandria Trigynia is chiefly made up of the natural order Melanthaceæ, among which the Colchicum and Trillium are found.

\section{Order 1. MONOGYNIA.}

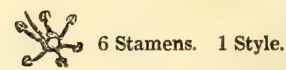

\section{Monocotyledons. Perianth superior, colored.}

\section{A. Perianth with the orifice surmounted by a corona or nectary.}

711. Narcissus. Sepals 6, equal. Cup funnel-shaped, of a single leaf. Stamens inserted within the cup.

712. Pancratium. Flower funnel-shaped, with a long tube. Sepals 6 . Cup 12-cleft, membranous. Stamens inserted on the edge of the cup.

713 Eucrosia. Flower ringent nodding. Crown formed by the dilated bases of the stamens. Stamens declinate, united into a tube, which is split on its upper side.

714. Eurycles. Flower funnel-shaped, regular. Crown fleshy, short. Stamens inserted into the edge of the cup.

715. Chlidanthus. Flower funnel-shaped, irregular. Stamens erect, included, united by their dilated bases; the short filaments 2-toothed. Anthers innate. Ovary 3-celled, many-seeded. Style filiform. Stigma 3-lobed. Capsule cartilaginous, 3-valved. Seeds membranous.

716. Calostemma. Flower funnel-shaped, with a 6-parted limb. Crown tubular, with a 12-toothed mouth, the alternate tceth anther-bearing. Ovary 1-celled, 2-3-seeded. Style filiform. Stigma obtuse. Berry 1-2-seeded.

717. Chrysiphiala. Flower funnel-shaped, with a tube narrowed downwards thickened at the base, with a dilated 6-cleft limb. Crown 6-cleft. Stamens erect, upright. Stigma thickened, obsoletely trifid. 
3993 Roots very yellow, Leaves compound

3994 Leaves ternate, Leaflets smooth above hairy beneath, Flowers corymbose, Petals as long as calyx 3945 Procumbent, Leaves ternate, Leaflets 3-toothed on each side rough with hairs, Flowers clustered 3996 Leaflets linear multifid, Plant erect

\section{B. Perianth with the orifice naked.}

* Stigma undivided.

718. Lophiola. Flower woolly, 6-parted, bearded inside. Anthers erect. Filaments naked. Ovary neariy superior.

719. Argolasia. Flower woolly, longer than the filaments : limb 6-parted, spreading. Pericarp 3-celled.

720. Anigozanthus. Flower tubular, incurved: with a 6-parted irregular limb. Stamens inserted into the mouth, ascending.

* Stigma 3-lobed. Guzmannia has Perianth inferior.

721. Musa. Spathe superior. Cor. of 2 petals: one of which is erect and 5.toothed; the other concave and honey-bearing. Berry oblong, 3-cornered, many-seeded

792. Urania. Cal. O. Cor. 3 petals. Nect. 2-leaved: one of the leaves bifid. Caps. 3-celled, many-seeded. Seeds in two rows with an arillus.

723. Bonapartea. Calyx 2-leaved. Petals 3 convolute. Stamens inserted in the receptacle. Anthers exserted. Style 3-cornered. Caps. 3-celled, 3-valved. Seeds numerous, terminated by a bristle.

724. Agave. Flower erect, tubular, or funnel-shaped. Filaments longer than flower, erect. Capsule triangular, many-seeded.

725. Furcrae. Flower campanulate, 6-parted. Stamens inserted in a gland, thickened downwards, compressed, subulate at end. Capsule 3-valved, 3-celled, many-seeded.

726. Bromeli. Cal. 3-fid. Petals 3. A honey-bearing scale at base of petal. Berry 3-celled.

727. Guzmannia. Cal. 3-parted, not superior, with convolute segments. Petals 3, rolled together into a tube. Anthers united in a cylinder. Caps. 3-celled, 3-valved. Seeds numerous, oblong, naked.

728. Pitcairnia. Cal. 3-leaved, half inferior. Petals 3. Stigmas 3, twisted together. Caps. 3, opening inwards. Seeds winged or terminated at each end in a long bristle

729. Tillandsia. Cal. 3-fid, persistent, convolute. Cor. 3-fid, campanulate. Caps. 1-3-celled. Seeds comose.

730. Pontederia. Flower monosepalous, 6-cleft, 2-lipped. Stamens inserted into the tube of flower at the

top. Caps. 3-celled.

731. Hamanthus. Involucre many-leaved, many-flowered. Flower 6-parted. Berry 3-celled.

732. Galanthus. Sepals 3, concave. Cup formed of 3 small emarginate sepals. Stigma simple.

733. Leucoium. Flower campanulate, 5-parted, with the ends of the sepals thickened. Stigma simple.

734. Strumaria. Sepals 6, spreading. Style thickened below the middle, and cohering occasionally with the filaments. Stigma trifid. Capsule inferior, roundish, 3-celled.

735. Crinum. Flower funnel-form, half six-cleft, with a filiform tube, and a spreading recurved limb. Sepals subulate, channelled. Seeds fleshy.

736. Cyrtanthus. Flower incurved, tubular, clavate, 6-cleft: segments ovate, oblong. Filaments inserted into the tube, conniving at end.

737. Brunsvigia. Flower 6-parted. Capsule turbinate, 3-winged, nearly transparent, many-seeded.

738. Nerine. Sepals 6, spreading, wavy. Stamens declinate, unequal in direction or proportion. Capsule few-seeded. Seeds round like peas.

739. Amaryllis. Flower nodding, irregular, funnel-shaped, ringent. Filaments declinate, unequal in provortion or direction. Seeds flat, numerous.

740. Vallota. Flower vertical, regular. Stamens regularly spreading. Seeds numerous, flat.

741. Griffinia. Flower 6-parted, ringent. Stamens declinate, with the upper one erect, and away from the rest. Seeds few, round, fleshy.

742. Sternbergia. Flower vertical, regular, funnel-shaped, with an erect limb. Stamens slightly declinate. Anthers versatile. Seeds round like peas.

743. Zephyranthes. Flower vertical, nearly regular, funnel-shaped, with an erect limb. Stamens nearly regular. Anthers versatile. Seeds flat.

744. Habranthus. Flower campanulate, nodding Stamens declinate, unequal, inserted into a fleshy rim of the base of the tube. Stigma 3-lobed.

745. Doryanthes. Flower 6-parted. Filaments shorter than flower. Anthers erect.

746. Gethyllis. Flower 6-parted, with a filiform very long tube. Spathe obliquely truncated. Berry clavate. radical, 1-celled.

747. Polyanthes. Flower funnel-shaped, incurved. Filaments inserted into the throat. Ovary at the boitom of tube.

748. Alstrnemeria. Sepals 6, campanulate or 2-lipped, the two lower half-tubular at the base. Stamens declinate or erect. Stigmas 3, linear. Caps. roundish-oval, 3-6-angular, 3-valved, or pulpy within, and nnt opening.

749. Conanthera. Sepals 6, reflexed. Anthers united in an acute cone. Caps. oblong, 3-celled, 3-valved. Seeds few, roundish.

750. Hypoxis. Spathe 2-valved. Flower 6-parted, superior. Caps. long, narrow at the base. Seeds roundish,

751. Curculigo. Sepals 6, flat. Spathe of one valve. Style very short. Stigmas 3, diverging. Caps. 1-celled, 4-seeded, spongy, beaked.

\section{Monocotyledons. Perianth inferior.}

A. Perianth glumaceous, irregular.

752. Bamtrusa. Scales 3, covering the 5-flowered spikelets. Glume 2-valved. Style bifid. Seed 1

753. Calamus. Sepals 6 . Berry dry, 1-seeded, imbricated backwards.

754. Ehrharta. Glume 2-valved, abbreviated, 1-flowered. Paleæ 4, in pairs, the outer compressed acinaciform, transversely wrinked. 
B. Perianth not coloured, regular. Stems herbaceous. Aroideæ and Junceæ.

755. Acorus. Spadix cylindrical, covered with florets. Sepals 6, naked. Style O. Caps. 3-celled.

756. Orontium. Spadix cylindrical, covered with florets. Sepals 6, naked. Style 0 . Follicles 1 -seeded.

757. Tupistra. Cor. 1-petalous, 6-fid, nearly equal. Anthers sessile in middle of sepals. Style 3 cornered, thick. Stigma clypeate, 3-lobed.

758. Tacca. Cal. 6-parted. Cor. 6-petalous, inserted into the calyx, bearing the anthers. Stigma stellate. Berry dry, hexangular, many-seeded.

759. Aspidistra. Cor. 1-petalous, 6-fid, equal. Anthers at bottom of tube. Style stipitate. Stigma clypeate.

760. Juncus. Sepals 6, persistent. Stigmas 3. Caps. 1-celled, 3-valved. Seeds very numerous.

761. Luzula. Sepals 6. Stigmas 3. Caps. 1-celled, 3-valved, 3-seeded. Seeds fixed to a central receptacle.

C. Perianth not colored, regular. Fruit, a drupa. Stems arborescent. Palms.

762. Corypha. Cal. 3-leaved. Cor. of 3-petals. Berry 1-seeded. Seed large, round, bony.

763. Licuala. Cal. 3-parted. Cor. 3-parted. Cup truncated, band-like. Drupe 1-seeded.

764. Thrinax. Cal, 6-toothed. Cor. O. Stigma funnel-form, oblique. Berry 1-seeded.

\section{Perianth partly or wholly colored, regular.}

765. Tradescantia. Cal. 3-leaved. Petals 3. Filaments with jointed hairs. Caps. 3-celled.

766. Dichorizandra. Cal. 3-leaved. Petals 3. Two of the stamens separate from the rest. Caps. 3-celled.

767. Agapanthus. Flower funnel-shaped, regular, six-parted. Stamens declinate.

768. Blandfordia. Flower tubular, withering, with a 6-lobed mouth. Stamens inserted on the tube. Anthers fixed to a base like an extinguisher. Ovary stalked. Stigma simple. Capsule 3-partible. Seeds in two rows, with a loose downy skin.

769. Hemerocallis. Flower campanulate, with a cylindrical tube. Stamens declinàte. Stigma small, simple, villous.

770. Aloe. Flower tubular, with a 6-cleft spreading mouth, and honey at the bottom of the tube. Filaments inserted into the receptacle. Caps. 3-celled, 3-valved, many-seeded. Seeds in two rows, with a membranous edge.

771. Lilium. Sepals 6, campanulate, with a longitudinal honey-line, and generally reflexed. Valves of the capsule connected by a mesh of hairs.

772. Tulipa. Sepals 6, campanulate. Style 0 .

773. Fritillaria. Sepals 6 , campanulate, with a honey-pore above the claws.

774. Dracrena. Flower 6-parted, erect. Filaments thickest in the middle, or simple. Berry 3-celled, 1-seeded.

775. Phylloma. Flower 6-parted, tubular. Sepals imbricated. Stamens hypogynous, included. Style seta. ceous. Stigma simple. Berry coriaceous, many-seeded.

776. Aletris. Flower funnel-shaped, wrinkled. Stamens inserted into base of segments. Capsule 3-celled, with many seeds.

777. Tritoma. Flower 6-toothed. Stamens inserted into the receptacle, exserted, alternately longer. Capsule 3-celled, many-seeded.

778. Veltheimia. Flower tubular, 6-toothed. Stamens inserted in the tube. Caps. membranous, 3-winged, with 1-seeded cells.

779. Sanseviera. Cor. monosepalous, with a filiform tube, and a 6-parted revolute limb. Stamens inserted into the limb. Berry 1-seeded.

780. Tulbaghia. Flower funnel-shaped, with a 6-cleft limb. Crown of the throat 3-leaved; the leaves bifid as large as the segments.

781. Yucca. Flower campanulate, spreading. Style O. Caps. 3-6-ceiled, with a hole at the end.

782. Erythronium. Sepals 6, campanulate. Two little tubercles attached to the base of every other sepal.

783. Gloriosa. Sepals 6, wavy, reflexed. Style oblique, trifid at end.

784. Bulbocodium. Sepals 6 , funnel-shaped, with narrow claws bearing the stamens.

785. Uvularia. Sepals 6, erect. A hollow at the base of the sepals. Filaments very short. Flowers solitary, axillary. Capsule compressed, 3-cornered. Seeds with an arillus.

786. Streptopus. Sepals 6, campanulate. Stigmas very short. Berry globose, polished, papery. Seeds naked.

787. Convallaria. Flower 6-cleft, campanulate. Berry spotted, 3-celled.

788. Smilacina. Flower 6-parted, spreading. Filaments diverging, fixed to the base of the segments. Berry globose, 3-celled. Flowers terminal, panicled, or umbelled.

789. Polygonatum. Flower 6-cleft, cylindrical. Filaments inserted into top of tube. Berry globose, 3-celler, with 2-seeded cells. Flowers axillary.

790. Ophiopogon. Flower half superior, persistent. Anthers sessile. Stigma simple. Berry 1-seeded.

791. Eucomis. Flower 6-parted, persistent, spreading. Filaments united at base into a circle. Capsule

3-celled. Seeds ovate. Scape with a leafy crown.

792. Brodica. Flower campanulate, 6-parted. Filaments inserted into the throat. Ovary stalked. Capsule 3-celled, with many-seeded cells.

793. Peliosanthes. Flower rotate, 6-parted; sepals vaulted at base. Ovary 3-celled, with 2-seeded cells.

794. Aphyllanthes. Spathe glumaceous, imbricated. Flower 6-parted, with a spreading limb. Capsule 3-celled, 3-valved, many-seeded.

795. Sowerbaea. Sepals 6 . Filaments 3, each bearing two anthers, with three sterile filaments between them.

796. Allium. Flower 6-parted, spreading. Spathe many-flowered. Umbel clustered.

797. Albuca. Sepals 6 : the inner conniving; the outer spreading, generally with a grcen stripe at their back. Style 3-cornered. Seeds flat.

798. Xanthorrhcea. Sepals 6, persistent. Filaments flat, naked. Caps. 3-cornered. Seeds two, compressed, edged.

799. Thysanotus, Flower 6-parted, spreading, persistent; with the inner segments fringed. Stamens 6-declinate. Filaments smooth. Ovary with two seeded cells. Seeds 2, one erect, one pendulous.

800. Eriospermum. Sepals 6, campanukate, persistent. Filaments dilated at base. Caps. 3-celled. Seeds enveloped in wool.

801. Gagea. Stamens adhering to base of sepals. Style clavate. Caps. 3-celled, 3-valved, covered by the remains of flower. Seeds small, numerous, round.

802. Ornithogalum. Sepals 6 , erect, persistent, spreading above the middle. Filaments dilated at base, or subulate. Caps. roundish, angular, 3-celled. Seeds roundish, naked. Flowers white or green.

803. Scilla. Sepals 6, spreading, deciduous. Filaments filiform, attached to base of sepals. Flowers blue or pink.

804. Puschkinia. Flower 6-parted. Cup very short, 6-toothed, covering the throat. Stamens within the cup.

805. Massonia. Limb of flower 6-parted. Filaments attached to the neck of the tube. Capsule 3-celled, 3-winged, many-seeded. 
806. Eremurus. Sepals 6, after flowering, rolled together. Stamens naked, rolled together inside the flower, barren, much exserted. Style after fecundation reflexed.

807. Bulbine. Sepals 6, spreading. Filaments smooth. Caps. ovate. Seeds angular. Leaves flat. Flowers generally white or purple.

808. Asphodelus. Flower 6-parted, spreading. Six valves covering the ovary.

809. Anthericum. Sepals 6, spreading. Filaments bearded. Caps. ovate. Seeds angular. Leaves succulent, fistular. Flowers yellow.

810. Arthropodium. Sepals 6, spreading: the three inner wavy at the edge or fringed. Filaments bearded. Capsule nearly round.

811. Chlorophytum. Flower 6-parted, spreading, equal, persistent. Stamens 6. Filaments filiform, smooth. Ovary with many-seeded cells. Style filiform. Stigma 1. Capsule deeply 3-lobed, with compressed veiny lobes ; three-celled, 3-valved. Seeds few, compressed.

812. Casia. Flower 6-parted, spreading, equal, deciduous. Stamens 6. Filaments beardless, narrowe: at each end. Anthers inserted by an emarginate base. Ovary 3-celled, with 2-seeded cells. Style filiform. Capsule lobed, or clavate at end. Seeds ventricose.

813. Narthecium. Sepals 6, spreading, persistent. Filaments filiform, hairy. Caps. prismatical. Seeds with an appendage at each end.

814. Dianella. Sepals 6 , spreading. Filaments thickened at end. Berry 3-celled, many-seeded.

815. Eustrephus. Flower 6-parted, the 3 inner sepals fringed. Capsule berried, 3-celled, 3-valved, manyseeded.

816. Asparagus. Flower 6-parted erect; the 3 lower sepals reflexed at end. Berry 3-celled, many-seeded.

817. Drimia. Flower campanulate, 6-cleft, with revolute segments. Stamens inserted jnto the sepals.

Stigma capitate.

818. Uropetalon. Flower six-cleft, with the alternate segments shortest. Capsule membranous. Seeds black, shining.

819. Hyacinthus. Flower erect, 6-cleft, with equal segments. Stamens inserted in the middle of the flower.

Cells of capsule 2-seeded.

820. Zuccagnia. Sepals cylindrical : the 3 outer longest, lanceolate, setaceous, reflexed. The other characters of Hyacinthus.

821. Muscari. Flowers ovate or cylindrical, very shortly divided. The other characters of Hyacinthus.

822. Lachenatia. Sepals 6, obtuse, the 3 inner the longest. Stamens erect. Capsule 3-winged. Seeds globose.

823. Phormixm. Sepals 6 , the 3 inner the longest. Stamens ascending, exserted. Capsule oblong, 3-cornered. Seeds compressed.

824. Cyanella. Sepals 6 : the 3 lower hanging down. Style and lowest stamen declinate. Capsule roundish, 3-celled.

\section{Dicotyledons.}

825. Leontice. Cal, 6-leaved, deciduous. Petals 6. Six leaves inserted upon the claws of the corolla, spreading at end

826. Caulophyllum. Cal. 6-leaved. Petals 6, opposite the calyx. Cells of anther opening at edge.

827. Diphylleia. Cal. 3leaved, deciduous. Petals 6, opposite the calyx. Anthers opening with a membrane dividing from the base to the tip. Berry 1-celled. Seeds 2-3, roundish.

828. Prinos. Cal. 6-cleft. Cor monopetalous, rotate Berry 6-seeded.

829. Berberis. Cal. 5-leaved. Petals 6, with glands upon their claws. Style O. Stigma umbilicate. Berry 1. celled, 2-4-seeded.

830. Nandina. Cal. many-leaved, imbricated. Petals 6. Berry juiceless, 2-seeded.

831. Cossignia. Cal. 5-parted. Petals 4 or 5. Capsule 3-celled, opening at end with about 3-seeded cells.

Flowers in panicled racemes.

832. Hillia. Cal. double, the lower 6-leaved, the upper superior, 2 or 4-leaved. Cor. 6-cleft, with a very long cyliridrical tude. Anthers sessile, in the throat of the corolla. Seeds comose.

833. Richardia. Cal, 6-parted, persistent, superior. Cor. funnel-form, 6-cleft. Stigmas 3, capitate. Fruit 3-partible. Seeds 5 , truncate.

834. Canarina. Cal. 6-leaved. Cor. 6-c eft, campanulate. Stigmas 6. Capsule inferior, 6-celled, manyseeded.

835. Frankenia. Cal. 5-cleft, funnel-shaved. Petals 5. Stigma 2-3-parted. Caps. 1-celled, 3-valved.

836. Peplis. Cal. campanulate, with a 12-cleft mouth. Petals 6 or O, inserted in the calyx. Caps. 2-celled, many-seeded.

\section{Order 2. DIGYNIA. 6 Stamens. 2 Styies.}

837. Oryxa. Glumes 2, 1-flowered. Paleæ2, nearly equal, adhering to the seed.

858. Atraphaxis. Cal, 2-leaved. Petals 2, sinuated. Stigmas capitate. Seed 1.

\section{Order 3. TRIGYNIA. 3 Styles.}

1. Monocotyledons.

839. Flagellaria. Sepals 5. Berry 3-1-seeded.

840. Scheuchzeria. Sepals 6. Anthers linear Stigmas sessile, lateral. Capsules inflated, distinct, 2.seeded.

841. Triglochin. Sepals 6, the 3 outer in a different row from the inner. Style 0 . Capsule opening by the

842. Lichtensteinia. Sepals 6, withering, persistent, wavy, spreading. Stamens hypogynous, shorter than the sepals. Capsule many-seeded, half 3-valved.

843. Myrsiphyllum. Flower 6-parted, revolute. Styles 3, contiguous, straight. Ovary stalked. Berry 3-celled, with 2 -seeded cells.

844. Tofieldia. Bracteæ 3. Sepals 6. Capsules 3, superior, united at the base, many-seeded.

845. Melanthium. Polygamous. Flower rotate, 6-parted, with 2 glands at the base of each segment. Filaments from the elongated claws of flower. Capsule 3-fid, 3-celled. Seeds membranous.

846. Medeola. Flower 6-parted, revolute. Berry 3-seeded.

847. Xerophyllum. Flower 6-parted. Stigmas 3, oblong, sessile. Caps. 3-celled, with 2-seeded cells.

848. Wurmbea. Flower 6-parted, with an hexangular tube. Filaments inserted in the throat. Styles conniving. Caps. oblong, 3-cornered. Seeds round.

849. Androcymbium. Sepals 6, unguiculate, cucullate. Stamens inserted in the middle of sepals. Ovaries 3. Styles filiform.

850. Trillium. Cal. spreading, 3-leaved. Petals 3. Berry 3-celled.

851. Colchicum. A spatha. Flower 6-parted, with a tube proceeding directly from the root. Anthers incumbent. Caps. S, connected, inflated.

852. Helonias. Sepals 6. Styles 3, distinct. Capsule 3-celled, 3-horned, few-seeded.

853. Nolinea. Flower 6-parted, spreading. Style very short. Capsule 3-cornered, membranous, 3-celled, opening by bipartible dissepiments. Seeds solitary, convex on one side.

851. Aponogeton. An amentum composed of scales. Neither calyx nor corolla Capsules 4, 3-seeded. Stamens varying from 6 to 7 and 12 . 
855. Sabal. Spathes partial. Filaments free, thickened at base. Berry 1-3-seeded. Seed bony. Embry6 lateral. A palm.

Calyx 3-leaved. Petals 3, conniving. Seed 1, 3-cornered.

857. Oxyria. Calyx 2-leaved. Petals 2. Styles 2.

\section{Order 4. POLYGYNIA.}

858. Wendlandia. Sepals 6. Petals 6, succulent. Style reclinate. Caps, 6, 1-celled, many-seeded.

859. Damasonium. Spathe 1-leaved, half-bifid, winged. Flowers superior, 6-parted, with the 3 inner segments petaloid. Stamens 6-12. Ovary with 6-8-parietal prominent placentas. Style short. Stigmas 6-12.

860. Actinocarpus. Flower 6-parted: the 3 outer sepals falling off late, the inner petaloid. Stamens 6. Ovaries 6-8, connate at base, 2-seeded. Capsules connate at base, stellate above.

861. Alisma. Flower 6-parted : the 3 outer sepals falling off late, like a calyx; the 3 inner petaloid. Stamens 6. Ovaries indefinite in number, 1-seeded. Capsules distinct, not opening.

\section{MONOGYNIA.}

711. NARCISSUS. $W$. 3997 poéticus Sal. 3998 recúrvus Haw. 4000 angustifólius $H . K$. 4001 biflórus $W$. 4002 tenúior $\boldsymbol{H}$. $\boldsymbol{K}$ 4003 crenulátus Haw. 4004 Trewiánus $B$. $M$. 4005 floribúndus $\mathbf{S a l}$. 4006 fistulósus Haw. 4007 cerínus $H a w$. 4008 Tazétta $W$. 4009 Macleaii Lindl. 4010 orientális $L$. 4011 papyráceus $B . M$. 4012 itálicus $B . M$. 4013 tereticaúlis $\dot{L} . T$. 4014 compréssus $L . T$. 4015 bifrons $B . M$. 4016 primulinus Haw. 4017 Jonquílla $W$. $\beta$ flore-pléno

4018 grácilis Lindl. 4019 viridiflórus $B$. $M$. 4020 serotínus $W$. 4021 calathínus $L$. 4022 odórus $L$. 4023 nútans $H$. $\boldsymbol{K}$. 4027 cápax Sal.

4 ()28 montánus $B$. Reg. 4029 galánthifólius Haw. 4031 Bulbocódium $W$. $40: 32$ inflátus How. 4033 lobulátus Haw. 4034 tenuifólius $L, T$. 4035 incomparábilis $W$

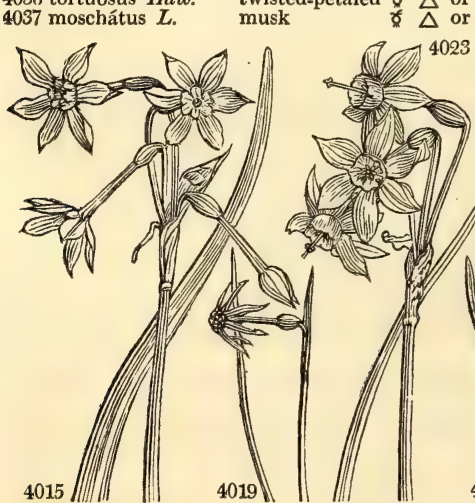

Narcissus

Poet's spreading-flow. two-flow-leaved slender Bazelman-maj. Grand-Monarq. hollow-stalked waxen-cupped Polyanthus Mac Leay's oriental paper Italian round-stalked flat-stalked Jonquil-scent. Cowslip-cupped Jonquil double slender green-flowered late-flowered great Jonquil sweet-scented nodding

funnel-flowered neat

Rush-leaved capacious mountain Snowdrop-leav. whitish inflated lobed slender-leaved

Butter \& Es Butter \& Eggs musk 3999 patelláris Sal. 4024 infundibularis $\mathrm{Sal}$. 4025 pulchéllus $B . M$. 4026 triándrus $B$. $M$. 4030 álbicans Haw. 4036 tortuósus Haw. 4037 moschátus $L$.

Pret's

Bazelman-min. Hoop-petticoat $\triangle$ or 1 my $\triangle$ or 1 my $W$ $\triangle$ or 1 ap.my $W$ $\triangle$ or 1 ap.my $W$ $\triangle$ or 1 my L.Y $\triangle$ or 1 mr.ap $W$ $\triangle$ or $1 \frac{1}{2} \mathrm{mr}$.ap W. $\triangle$ or 2 ap W.Y $\triangle$ or 1 ap W $\triangle$ or 1 mr.ap W $\Delta$ or 1 mr.ap W \& $\triangle$ or 1 mr.ap W $\triangle$ or $1 \frac{1}{2}$ mrap P.Y $\triangle$ or 1 mrap L.Y $\triangle$ or 1 mr.ap $Y$ $\triangle$ or 1 mr.ap $Y$ $\Delta$ or $\frac{3}{4}$ ap.my $Y$ $\triangle$ or 1 ap.my $Y$ $\Delta$ or $1 \frac{1}{2}$ ap.my $\mathbf{Y}$ $\Delta$ or $\frac{1}{2}$ au.o $\mathbf{G}$ $\triangle$ or $\frac{x}{2}$ au.o $\mathbf{P}$. o $\triangle$ or 1 ap.my $\mathbf{Y}$

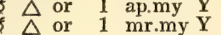
$\triangle$ or $\frac{1}{2}$ mr.my Y $\triangle$ or $\frac{1}{2}$ mr.my Y $\triangle$ or ${ }^{\frac{3}{4}}$ ap.my W $\triangle$ or $\frac{1}{2}$ ap.my P.Y $\Delta$ or 1 ap.my W $\triangle$ or $\frac{3}{4} \mathrm{my} \quad W$ $\Delta$ or ${ }^{\frac{1}{4}}$ mr.ap $Y$ $\Delta$ or $\frac{1}{4}$ mr.ap $Y$ $\triangle$ or ${ }^{\frac{1}{2}}$ ap.my $\mathbf{Y}$ $3^{\frac{1}{2}}$ ap.my $\mathbf{W}$ ap.my $\mathbf{Y}$ $1 \frac{1}{2}$ ap W 1 mr.ap W
Amarylidece. $\triangle$ or 1 mr.ap P.Y $\Delta$ or $\frac{1}{2}$ mr.ap P.Y

Sp. $55-59$.

S. ... O co Park. par. 76 Europe ... O co

England $\quad O$ co Eng. bot. 275

S. Europe 1570, O co Bot. mag. 19?

Britain mea, O co Eng bot. 276

17..... O co Bot. mag. 379

Spain $\quad$... 0 O co

... O r.m Bot. mag. 940

... O r.m

... O $\quad$ O r.m

…... $\cdots$ o $\mathrm{rm}$

Spain 1759. O s.1 Bot. mag. 925

Mediterr. 1815 , O $s .1$

Levant ... $\quad$ O co Bot. mag, 948

S. Eur... ... O co Bot. mag. 947

... O co Bot. mag. 1188

Spain $\quad . .0$ O co

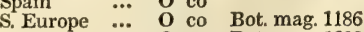

... O co Bot. mag. 1299

Spain 1 $\ldots$ 156... O r.m Bot. mag. 15

Spain 1596. O r.m

... O co Bot. reg. 816

1629. O r.m Bot. mag. 1687

Barbary 1629. O r.m Clu. hist. t. 252

S. Europe 1629. O r.m Bot. mag. 78

S. Europe 1629. O s.l Bot. mag. 934

S. Europe 1789. O s.l Bot. mag. 945

$\begin{array}{llll}\text {....... } \quad \text {... O s.l Park. par. } 92 & \text { O }\end{array}$

$\begin{array}{lllll}\text { Spain } \quad \ldots & \text { O s.l Bot. mag. } 1262\end{array}$

Portugal 1629. O s.l Bot, mag, 48

... O s.1 Red. lil. 177 ?

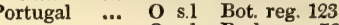

...... ... O s.l Park. par. 73

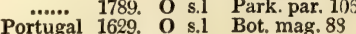

$\begin{array}{llll}\ldots . . . . & \ldots & \text { O } & \text { s. }\end{array}$

00 s.

O s.l

Portugal 16̈9 O co Bot mag. 121

$\begin{array}{llll}\text { Spain } & 1629 . & \text { O co } & \text { Bot. mag. 924 } \\ \text { Spain } & 1759 . & \text { O co } & \text { Bot. mag. } 1300\end{array}$

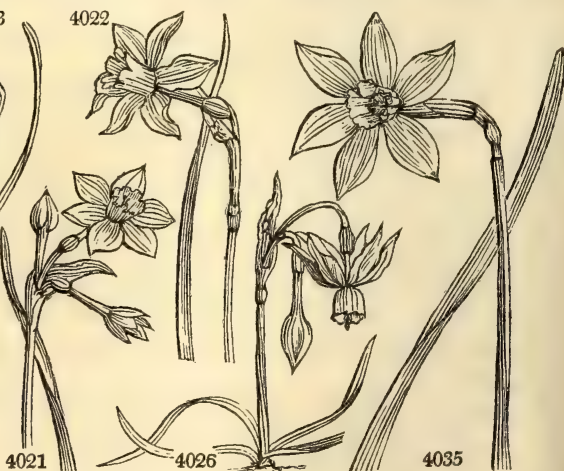

4021 - 4026

711. Narcissus. From yøern, stupor, on account of the dangerous effects produced by the smell, even of the least perfumed kinds, upon the nerves. For this reason Narcissus was consecrated to the Furies, who by means of it were accustomed to stupify those whom they wished to punish. Jonquilla, a name applied to one 


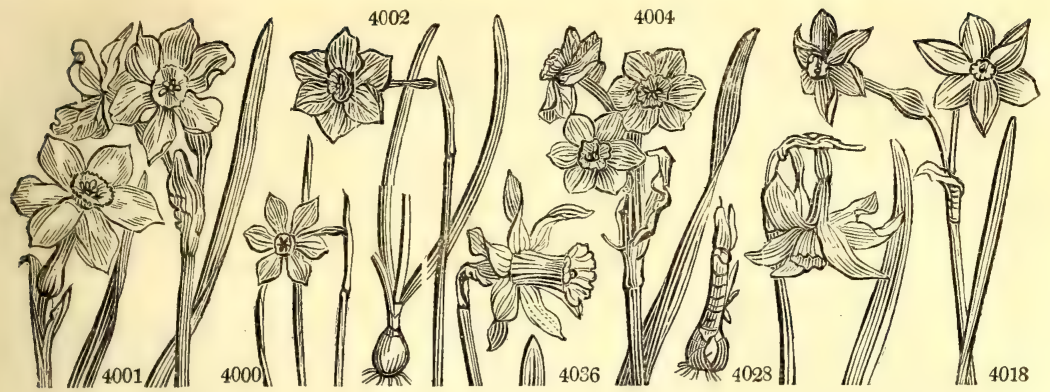

MONOGYNIA.

3997 Segm. refl. imbr. at base, Cup expanded flat, Three anthers shorter than the tube, Leaves erect narrow 3998 Lvs, $\frac{1}{0}$ an inch broad glauc, at end rec. Seg. imbr. Cup plait. with scarlet rim, Stig. as long as inner stamens 3999 Lvs. erect glauc. Seg. imbric. with,deflexed edges, Cup yel. minutely plaited, Stig. as long as inner stamens $4000 \mathrm{Seg}$. horizontal obo. not imbric. Cup saucer-shaped with very red edge, Lower anth. half included in tube 4001 Scape kneed before flowering usually 2-3-flowered, Cup all yellow

4002 Very slender, Spathe 1-2-fl. Seg. white, Cup yellow cup-shaped 3 or 4 times as long as segm.

400.3 About 3-flowered, Seg reflexed white, Cup spreading plaited crenulate yellow

4004 Like N. Tazetta, differing in the 3-lobate cup, and in the edges of the upper leaves not being turned up 4005 Flowers about 16, Seg. round-oval reflexed incurved white, Cup large straight yellow entire 4000 Segm. white almost twice as long as the straight inflated nearly entire yellow cup 4007 2-3-f. Cup very large thick truncate entire waxen twice as short as white segm.

4008 Spathe many-flowered, Cup camp. truncate shorter than petals, Leaves flat

4009 Spathe 1-2-fl. Scape compr. 2-edged, Sepals spread. imbricated a little longer than truncated entire cup 4010 About 10-ft. Seg, white round ov, thrice as long as pale yel spread irreg. cut cup, Scape striat. rounded 4011 Few-flowered, Seg. stellate as long as tube, Cup cupulate crenate, Style within the crown

4012 Many-flowered, Cor. bent back, Segm. stellate, Cup spreading cupulate slightly trifid

4013 About 6-fl. Seg, round-ovate imbr. white, Cup citron spreading entire or lobed, Scape rounded below

4014 Many-f. Pedunc. nearly erect, Seg. imbr. 3 times as long as the erect eroded cup, Lvs. remarkably broad 4015 Scape obtusely compressed smooth, Segm. very yellow ovate imbr. 3-4-times as long as cup

4016 Like the last, but the cup is more entire and the leaves broader

4017 Spathe 1-3-flowered, Seg. reflexed spatulate, Cup much shorter than seg. saucer-shaped spreading crenate

$401812-18$ inches high, Lvs. linear subulate chann. Scape rounded 1-2-fl. Ovary inflated, F1. sulphur-colored 4019 Leafless at flowering, Flowers green with acute segm.

4020 Spathe 1-fiowered, Cup 6-parted very short, Leaves subulate

4021 About 3-flow. Cup obsoletely curled outside obtusely angular not twice as short as seg. Scape $1 \frac{1}{2} \mathrm{ft}$. high 4022 Segm. of starry cor, distinct at base, Cup even distinctly 6-lobed

4023 About 2-fl. Seg. refl. pale yellow, twice as long as cup which is deeper col. trun. cylind. Style exserted 4024 A slight variety of $\mathrm{N}$. incomparabilis

4025 1-7-fl. Leaves erect, Segm. reflexed lanceolate longer than cup which is cyathiform 6-fid repand 4026 All white, Cup twice as short as segm. which are reflexed

4027 A very obscure plant of which no description is anywhere given

4028 Cor. pendulous white with straight half-expanded segm. Cup cyathiform with a crenulate mouth

4029 Segm. twisted stellate, Cup cyathiform much plaited twice as short as segm.

4030 Sulphur-colored or nearly white, Cup turgid entire as long as segm. Style protruded, Leaves obtuse

4031 Flower yellow, Crown turgid truncate entire, Style included, Leaves erect before flowering

4032 Fl. yel. Crown inflated at the end contracted entire, Style exserted, Lvs. always spreading on the ground 4033 Crown undulate lobed at end, Style included

4034 Crown deeply 6-lobed, Style very long, Leaves shining erect before flowering

4035 Segm. sulphur, Crown campanulate yellow at the end spreading 6-lobed, Lobes inbricated

4036 Leaves flat and scape striated, Segm. much twisted shorter than crown, Germ. 6-furrowed

4037 Leaves twisted, Scapes and germens smooth, Segm. twisted the length of crown

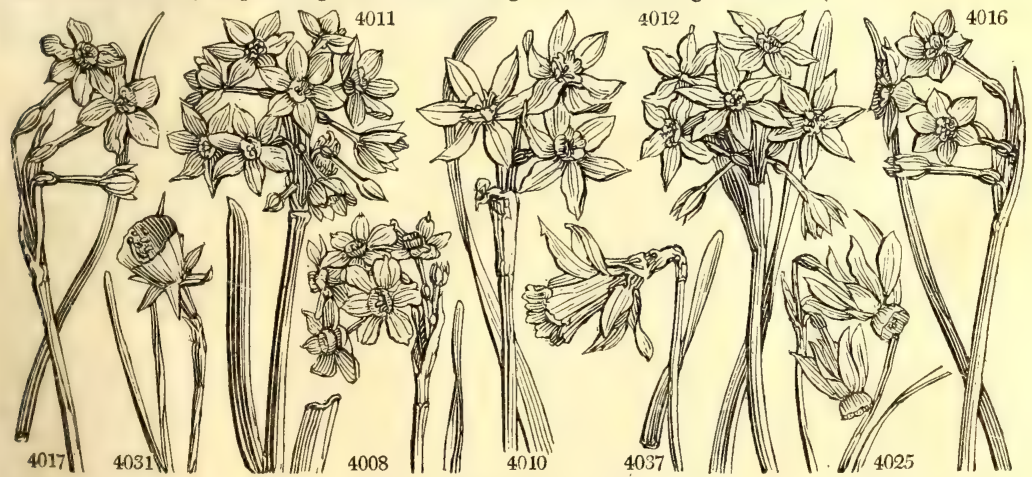

and Miscellaneous Particulars.

of the species, is a diminution of juncus, a rush; as Tazzetta is of tazza, the Italian name for a cup. This is a popular flower of great beauty, some species very fragrant, and all of them of the easiest culture. They also force well, either in pots of earth or on glasses of water. Their forcing may be greatly accelerated by retard- 
4038 serrátus Haw. serrated 4039 spúrius Haw. spurious 4040 Pseudo-Narcissus $L$. Daffodi 4041 tubiflórus Sal. 4042 bícolor $B . M$. two-colored 4043 Sabíni Lindl. 4044 niveus $W . e n$. 4045 obvalláris Sal. 4046 májor $B$. $M$. 4047 propinquus Sal. 4048 nóbilis Haw. 4049 Ajax Sal. 4050 púmilus Sal. 4051 minor $W$. Sabine's snowy Sibthorp's large allied anied oble great small

712. Pancra'tium, $W$. Pancratium. 4052 zeylánicum $W$. $W$ one-flowered 4053 verecúndum $\dot{K} . R$. Narcissus-leav. 4054 marítimum $L$. sea

4055 caroliniánum $K$. R. Carolina 4056 canariénse $K . R$. Canary 4057 illýricum $L$. Illyrian

4058 Amáncaes $K . R$. Narcissus-flow. 4059 calathínum $\boldsymbol{K} . \boldsymbol{R}$. 4060 nútans $K$. $R$. 4061 undulátum $K$. $R$. 4062 littorále $L$ 4063 Dryándri $K . R$. 4064 angústum $K$. $R$. 4065 rotátum $K . R$. 4066 mexicánum $K$. $R$. 4067 guianénse $\mathrm{Ker}$. 4068 pátens Red. 4069 pediále Lodd. 4070 frágrans Red. 4071 biflórum Roxb. 1072 caribæ'um $L$. 4073 amæ'num $W$ 4074 ovátum $K$. $R$ 4075 speciósum $L$. cup-flowered nodding wave-leaved tall

narrow-leaved narrow-leaved large-crowned
Mexican Guiana spreading long-flowered fragrant two-flowered Caribean handsome oval-leaved large

713. EUCRO'SIA. B. Reg. Eucrosia. 4076 bícolor B. Reg. two-colored

714. EU'RYCLES. Salisb. EURYCLES. 4077 amboinénsis Sal. heart-leaved 4078 australásica Cunningham

Pancratium australasicum Ker.

715. Calostemma. $R$. Br. Calostemma

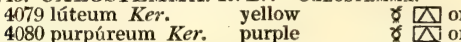
4080 purpúreum $\mathrm{Ker}$. purple

716. CHLIDAN'THUS. Herb. ChLidanthus. 4081 frágrans Lindl. fragrant $\measuredangle \Delta$
717. CHRYSIPHIALA. Ker. ChrYsiphiala. \& $\triangle$ or $\frac{3}{4}$ mr.ap P.Y S. Europe $\ldots . . . \quad$ O co \% $\triangle$ or 1 mr.ap P.Y England woods. O co Eng. bot. 17 $\gamma$ or 1 mrap W Y E خ $\Delta$ or 1 ap.my W.Y Spain 1629. O co Bot. mag. 1187 \% $\Delta$ or 1 ap.my $\mathrm{Y} \quad \ldots . . . \quad \ldots . . \quad$ O co Bot. reg. 762 \% $\triangle$ or $1 \mathrm{my} \quad \mathrm{W}$ S. Europe ... $\quad$ O co \& $\Delta$ or 1 mr.ap $Y$ Spain $\ldots$ o co B. m.1301. f. inf. \% $\Delta$ or 1 mr.ap $\mathrm{Y}$ Spain 1629. O co Bot. mag. 51

\% $\Delta$ or 1 mr.ap $Y$ Spain 1629. o co B.m. 1301. f. su. \% $\mathrm{or} 1$ mrap $\mathrm{Y}$ \% $\Delta$ or 1 mr.ap $\mathrm{Y}$ $\Delta$ or $\frac{1}{2}$ mr.ap $Y$ \% $\Delta$ or $\frac{2}{2}$ mr.ap $Y$

…... $\quad \cdots \quad$ O co

Spain $\quad \ldots .6$ o co Pass. hort. 8 Spain 1629. O s.1 Bot. mag. 6

Amaryllidere. Sp. 24.

\& $\mathrm{W}$ or 1 jn.jl W Ceylon 1752. Sk r.m Bot. reg. 479

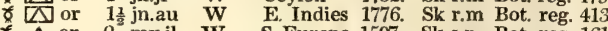
$\Delta$ or 2 my.jl W S. Europe 1597. Sk s.p Bot. reg. 161 $\mathbb{N}$ or 2 jn.jl W Carolina 1759. Sk r.m Cat. car. 3.t.5 $\Delta$ or $1 \frac{1}{2}$ jn.jl W Canaries 1815. Sk r.m Bot. reg. 174 $\Delta$ or $1 \frac{1}{2}$ my.jn W S. Europe 1615. Sk s.p Bot. mag. 718

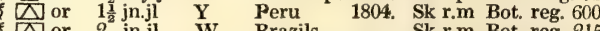

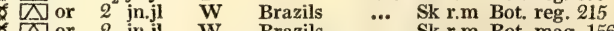

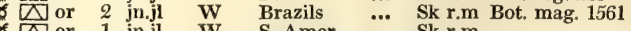
S. Amer. $\ldots$ Sk r.m

$\triangle 1$ or 2 my.au W S. Amer. 1758. Sk r.m Bot. mag. 1879 $\Delta$ or 2 my.au W $\triangle$ or $1 \frac{1}{2}$ my.au W

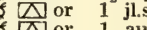
Dor 2 or $\triangle$ or 2 jlau W ॠ or 3 au W \ or 1 my.au W \% or 1 my.au W

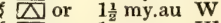
\% $\triangle 1$ or 1 my.au W or $1 \frac{1}{2}$ my au W ... $\quad$ Sk r.m Bot. mag. 825

C....... Sk r.m Bot. reg. 221

Carolina 1803. Sk r.m Bot. mag. 1082

Mexico 1732. Sk r.m Di. el. t.222.f. 289 Guiana 1815. Sk r.m Bot. reg. 265 W. Indies 1822. Sk r.m Bot. cab. 558 Brazil 1820. Sk r.m Bot. cab. 809 W. Indies 1819. Sk r.m Bot. cab. 834 E Indies 1820 Sk $r$ m

W. Indies 1730. Sk r.m Bot. mag. 826 Guiana 1790. Sk r.m Bot. mag. 146 W. Indies $\ldots . \quad$ Sk r.m Bot. reg. 43

W. Indies 1759. Sk r.m Bot. mag. 1453

Amaryllidea. $S p .1$

₹ $\triangle$ or 1 ap.my O Cape Hor. 1816. O lt.l Bot. reg. 207

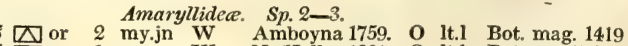
my W. Holl. 1821, O It.1 Bot, reg. 715

Amaryllidere. $S p .2-3$.

n Y N. Holl. 1819 o s.l Bot. reg. 421 n Pu N. Holl. 1819. O s.l Bot. reg. 422 Amaryllidece. Sp. 1.

1 my.jn $\mathbf{Y}$ B. Ayres 1820. O 1t.1 Lindl. coll. 34 Amaryllidea. Sp. 2-5. 4082 fláva Ker.

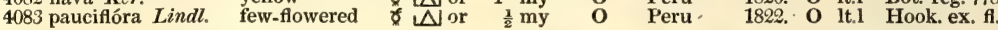

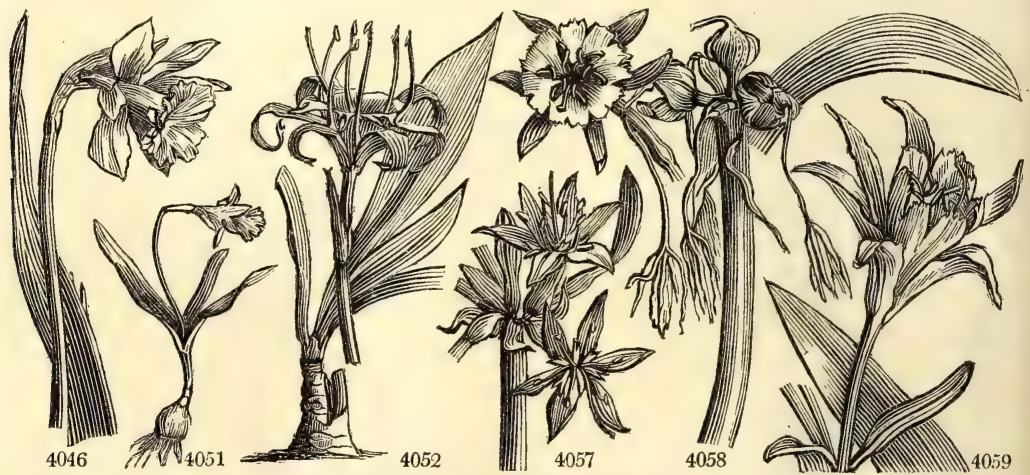

History, Use, Propagation, Culture,

ing the bulbs one season in an ice-house. Many fine bulbs of this genus, are annually imported from Holland, and some from Naples, especially the italicus, which grows wild round that city in great beauty. The genus has been injudiciously separated into several by Haworth, whom however no one has followed.

712. Pancratium. A name given by the Greeks to a kind of Scilla. The word signifies all-force, from

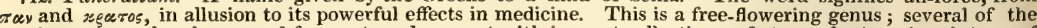
species are very handsome and fragrant, and are met with in most collections of stove plants. A mixture of light loam and rich vegetable mould suit them best, and care must be taken not to give them much water, when they are not in a growing state. They are to be increased by suckers, or from seeds, which often ripen freely. If any plant happen to lose its heart, if it be kept dry, it will throw out abundance of suckers, which is the readiest way of propagating it. (Bot. Cult. 89.) P. maritimum, illyricum, and carolinianum, are nardy ; the other species are stove-plants. P. amancaes has yellow flowers, and is not less beautiful than rare. 
4038 Scape striated compressed, Segm. flat : the outer ovate acuminate not so long as the serrated crown 4039 Scape smooth compressed, Crown very yellow deeply 6-cleft spreading, Segm, $\frac{1}{2}$ erect lanceolate 1040 Scape two-edged straight striated, Segm. sulphur, Crown yellow with serrate crenate orifice $4041 \mathrm{Segm}$. incurved horizontal a little twisted, Crown funnel-shaped ventricose at base very short 4042 Like the last, but the crown is yellow, the segm. of flower yellowish

4043 Spathe 1-fl. Scape 2-edged, Cup columnar plaited shorter than the sepals, Tube about as long as sepals 4044 Scape 2-edge nearly trian. Spat. 1-2-fl. Seg. of cor. lanc. acute, Crown plaited crenate thrice as long as limb $4045 \mathrm{Segm}$, half as long as tube ovate, Crown funnel-form 6-cleft plaited upwards

4046 Leaves twisted very glaucous, Crown campanulate very large very open at orifice

$4047 \mathrm{Segm}$. $\frac{1}{2}$ erect twisted incurved spreading, Crown as long as segm. deeply and irregularly cut

4048 Scape deeply striated, Seg. much spread. twisted ellipt. shorter than crown which has a very open orifice 4049 Scape deeply striated, Mouth of crown 6-cleft expanded deeply and irregularly crenate

4050 Pet. narrow obcuneate not imbricating at base, Crown 6-cleft at mouth spreading minutely rugose 4051 Spathe 1-flowered, Crown curled waved lobed, Scape 6 inches high

4052 One-flowered, Leaves lig. lanc. Segments of limb longer than tube, Stamens incurved conniving 4053 Spathe 2-4-fl. Lvs, lin, acute, Limb of cor, shorter than tube, Altern. div. of crown deeper, Stam. incurved 4054 Many-fl. Lvs, sheath. downw. very glauc. with an obt. point, Cr. much unit. to turb.limb, Anth. bent inw 4055 Many-flowered, Leaves neither glaucous? nor sheathing downwards, Anthers incumbent

4056 Many-fl. Lvs. strap-shap. somew. glauc. obt. Tube twice as short as limb, Fil. not longer than teeth of cr. 4057 Many-fl. Lvs. strap-shap. cces. Scape 2-edged, Pet. lanc. conv. longer than tube, Cr. short with very deep div. 4058 Many-fl. Leaves bright-green, Tube as long as stellate nodding limb, Stamens short abruptly bent inwards 40591 or many-f. Spat. herb. Limb erect turb. a little shorter than blunt. 3-cor. tube, Cro. not much shorter than 4060 Few-flowered, Leaves obt. Spathe dry, Cor, nodding, Anthers longer than filaments

$[\operatorname{limb}$ 4061 Lvs, stalked ellip. shortly pointed, Scape compressed, Petals linear wavy, Racemes of crown 1-toothed

4062 Many-flowered, Leaves many lorate narrowed each way, Tube rounded twice as long as limb

4063 Leaves lanc. lorate, Petals little shorter than tube, 5 times as long as crown

4064 Many-f. Lvs. lorate with long points shin. Petals spread. longer than tube 3 times as short as nar. crown 4065 Two or many-flowered, Leaves linear-lorate obtuse many, Crown turbinate rotate longer than filaments 4066 Two-flowered, Lvs. few linear-lanceolate with long points, Crown rotate turbinate longer than filaments 4067 Many-flowered, Leaves oval-oblong stalked, Spathe 4-valved, Cup narrow 4 times as short as the limb 4068 Lvs. broad-lin. Flowers many sessile with linear straightish segments longer than tube, Crown obconical 4069 Leaves lanceolate dark-green, Flowers a foot long, Stamens short

4070 A slight variety of P. amænum, No. 4073

4071 One or 3-fl. Leaves linear cuneate, Tube as long as lin. petals, Seg. of crown eroded, Fil. length of crown 4072 Many-fl. Lvs, many lin. lanc. Tube twice as short as limb, Cr. twice as short as stam. with 1-tooth. recesses 4073 Lvs, many oval-lanc. 3 or 4 times as broad as stalk, Umbel sessile spreading, Tube shorter than limb 4074. Compactly many-fl. Lvs. oval stri. nar. each way, Tube round. nearly as long as limb, Teeth of crown entire 4075 Lvs. many lanc. elliptical with a point three times as broad as their stalk, Tube twice as short as limb

\section{The only species}

4077 Leaves stalked cordate rounded with concentric distant nerves 4078 Like the last, but is smaller with a 6-parted crown

\section{Flowers yellow}

4080 Flowers purple

\section{A small plant with bright yellow flowers appearing before the leaves}

4082 Leaves linear ligulate, Flowers 6-7-cylindrical, with oblong obtuse segments 4083 Leaves oblong lanceolate stalked, Flowers 2 campanulate funnel-shaped

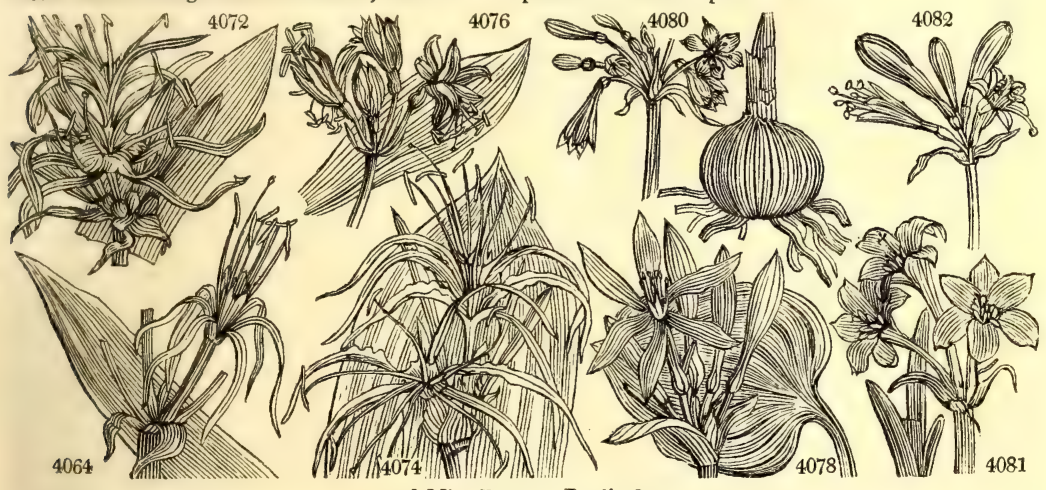

and Miscellaneous Particulars.

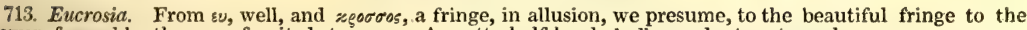
flower, formed by the cup of united stamens. A pretty half-hardy bulbous plant, extremely rare.

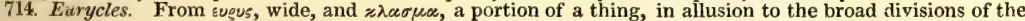
crown. A genus formerly included in Pancratium, from which it is distinguished not only by its fiowers, but by its broad leaves, which are like those of the Hemerocallis.

715. Calostemma. From $\approx u \lambda \odot 5$, beautiful, and $s \varepsilon \mu \mu \alpha$, a crown, in allusion to the beauty of the colored corona of the flower. Very pretty New Holland bulbs, requiring the cultivation of other greenhouse bulbs.

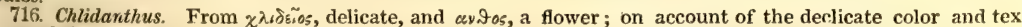
ture of the beautiful yellow flowers. The plant requires a stove, and produces the scape before the leaves.

717. Chrysiphiala. So named by Mr. Ker, in allusion to the golden cup-like flowers; $\chi$ guros, gold, and Q $\alpha \lambda \lambda$, a goblet. Bulbous plants from the same country and with the same habits as the last. 
718. LOPHIOTA $B$. $M$ ' LOPHIOLA. 4084 aúrea $B . M$. golden-flower.

719. ARgOLA'SIA. Juss. Argolasta.

4085 plumósa $W$. woolly

720. ANIGOZAN' 4086 flávida $R$. $B$ r

721. MU'SA. $W$. 4087 paradisiaca $W$ 4088 sapiéntum $W$. 4089 rosácea $W$. 4090 coccínea $W$.

722. URA'NIA. $W$. 409j. speciósa $W$. 723. BUONAPAR 4092 júncea $F l, p$. 724. $\mathrm{AGA}^{\prime} \mathrm{VE}, \boldsymbol{H} . \boldsymbol{K}$. 4093 yuccæfólia Haw. 4094 americána $W$. 4095 Milléri Haw. 4096 flấccida Haw. 4097 lúrida Jacq. 4098 angustifólia Haw. 4099 Karátto Mill. 4100 vivípara $W$. 4101 virgínica $W$ 4102 geminiflóra $\mathrm{Ker}$.

URANia, Agave. Miller's flaccid Vera Crúz narrow-leaved Karatto viviparous Virginian pair-flowered
Hamodoracee. Sp. 1

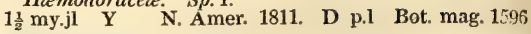

$\begin{array}{lll}\text { Haemodoracea. Sp. } 1 . & \\ 1 \frac{1}{2} \cdots \mathrm{W}^{2} & \text { C. G. H. } & \text { 1787. D s.l.p }\end{array}$

Hamodoracea. Sp. 1-2.

my.s N. Holl. 1803. R s.p Bot. mag. 1151 Musacea. $S p .4-5$. russet-green-fl. Plantain-Tree.

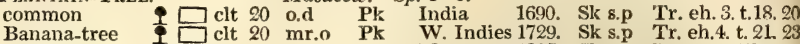
rose-colored $\square$ clt $20 \mathrm{mr} .0$ Pk W. Indies 1729. Sk s.p Tr. eh.4. t. 21.23 or 20 f.my Pu Mauritius 1805. Sk s.p Bot. reg. 706

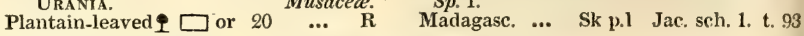
F. $P$. Buonaparten. Bromeliaced. Sp. 1-2. Rush-leaved $\square$ or

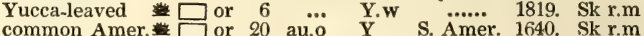
or 6 Bromeliacee. Sp.10. Sk rm Bot. rep. 438

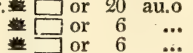

$6 \quad \ddot{0}$ 8 jn.jl

G $\quad$ S. Amer. 1790. . Sk r.m

G V. Amer. 1790. Sk r.m Bot. G Vera Cruz 1731. Sk s.p G S. Ämer. 1760. Sk r.m G S. Amer. 1731. Sk s.p Com. præl, t. 15 P.G N. Amer. 1765. Sk r.m Bot. mag. 1157

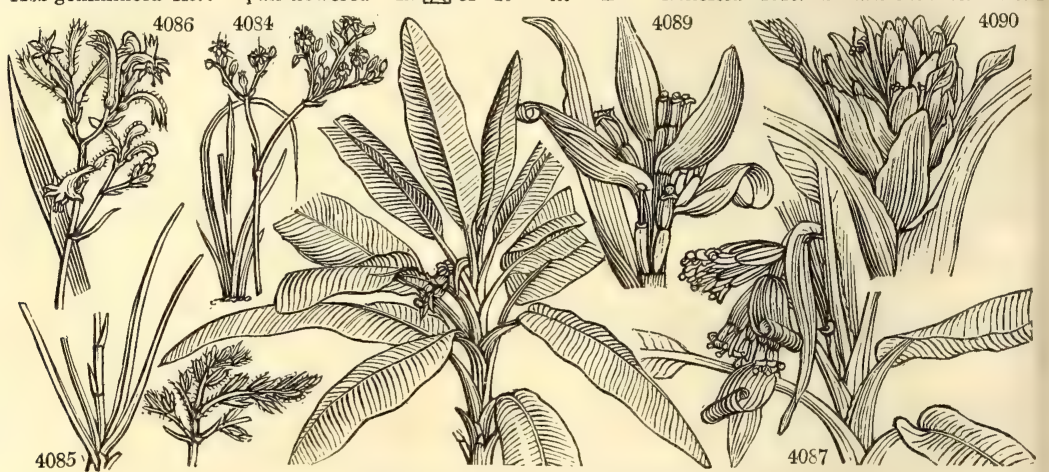

History, Use, Propagation, Culture,

718. Lophiola. From $\lambda .06 a$ a crest, on account of the little crest of the petals. It is a very rare North American plant, and thrives best in pots set in satucers of water.

719. Argolasic. From ceros, white, and $\lambda \propto \sigma$ sos, wool, on account of its calyx, which is white and velvety on the outside. It requires the same culture as the last.

720. Anigozanthus. Named by Labillardiere, from $\alpha v i \sigma \times \omega$, to raise up, and $\alpha \nu 905$, a flower. Its flowers are raised upon very long conspicuous scapes. Curious New Holland plants, with yellow or green flowers.

721. Musa. So named by Plumier, in memory of Antonius Musa, the brother of Euphorbus, and the the freedman of Augustus. Such is the sense in which Linnæus admits the word. But the Arabic name for the plant, mauz, is a much more likely derivation. This splendid genus consists of species which have perennial, roundish, solid, watery bulhs, with biennial, and sometimes longer enduring stems. The stems are straight, erect,varying from five to twenty-five feet in height, simple, thick, round, smooth, fungous, watery, and lamellated. The leaves are oblong, entire, trom three to ten feet in length, and under two feet in width. The flowers are in large terminating racemes, without a calyx or perianthium, generally whitish : the fertile flowers occupying the lower, and the barren the upper, part of the raceme. The former are succeeded by oblong, angular, fleshy berries, sweet, eatable, and containing many black seeds. They are natives of the old world, and for the most part cultivated there: none appear to be natives of America.

M. paradisiaca rises with a soft herbaceous stalk fifteen or twenty feet high, with leaves often more than six feet long, and near two feet broad. When the plant is full grown, the spike of flowers appears from the centre of the leaves; it is near four feet in length, and nods on one side. The fruit which succeeds the fertile flowers on the lower part of the spike is eight or nine inches long, and above an inch in diameter, a little incurved, with three angles; at first green, but when ripe of a pale yellow color. The skin is tough, and within is a soft pulp of a luscious sweet flavor. The spikes of fruit are often, so large as to weigh upwards of forty pounds. Gerarde, and other old authors, name it Adam's apple, from a notion that it was the forbidaen fruit of Eden; whilst others supposed it to be the grapes brought out of the promised land by the spies of Moses. It is certainly one of the most useful fruits in the world, and seems to have migrated with mankind into all the climates in which it may be cultivated. The fruit is so much esteemed by all Europeans who settle in America, that the first thing they do in establishing a plantation is to begin with a Plantain waik; enlarging it as their family increases. Some or other of the trees are bearing most part of the year; and their fruit is often the whole food on which a family subsists. When used instead of bread, it is roasted or boiled when just full grown: it is also eaten boiled with salt-meat or fish, and when ripe it is made into tarts, sliced and fried with butter, or dried and preserved as a sweetmeat. A tcrmented liquor is made from them, and in some places a cloth from the fibres of the trunk; the leaves make excellent mats, or serve for stuffing mattrasses. Long (Jam. 788.) says, this fruit and the banana are among the greatest blessings bestowed by Providence upon the inhabitants of hot climates. Three dozen plantains are sufficient to serve one man for a week instead of bread, and will support him much better.

M. sapientum is by some considered a variety of the plantain, from which it differs in having its stalks marked with dark purple stripes and spots. The fruit is shorter and rounder, with a softer pulp, of a more luscious taste. An excellent marmalade, and a drink like the best Southnam cider, are made from it. There are many varieties both of the plantain and banana.

M. rosacea and coccinea, are very ornamental plants, on account of the color of the flowers, but scarcely to be distinguished from M. paradisiaca. The culture of all the speciea is easy in lofty houses, with abundance 


\section{The only spocies}

4085 Leaves linear carinate smooth, Scape angular corymbose, Flowers woolly

4086 Stem and leaves smooth, Down of branches deciduous, Anthers with a reflexed end

4087 Spadix nodding, Male flowers persistent

4088 Stem spotted, Spadix nodding, Male flowers deciduous

4089 Spadix nodding or erect, Male flowers deciduous, Spathes elliptical obtuse, Fruit oblong

4090 Spadix erect, Flowers capitate, Spathes clustered scarlet very large yellow at end

4091 A plant like a Banana

4092 Leaves multifarious cæspitose recurved very narrow and rigid

4093 Lvs. lorate atten. erect recurved glaucous above chan. with marginal minute dense white serrulations 4094 Stemless, Lvs, toothed spiny, Scape branched, Tube of cor. contracted in middle, Stem longer than cor 4095 Leaves toothed spiny, Scape quite simple

4096 Leaves narrow lanceolate flaccid recurved, Spines marginal minute

4097 A little stemmed, Leaves toothed spiny, Scape branched, Stam. longer than cylind, cor.

4098 With a stem, Leaves narrow lanceolate glaucous tooth-serrated

4099 Leaves erect bright green with an entire brown edge

4100 Stemless, Leaves toothed, Scape branched, Tube of cor. narrowed in middle, Stem as long as cor.

4101 Stemless, Leaves cartilaginous sawed, Scape simple

4102 Leaves thready at edge, Flowers of spike approximating by pairs

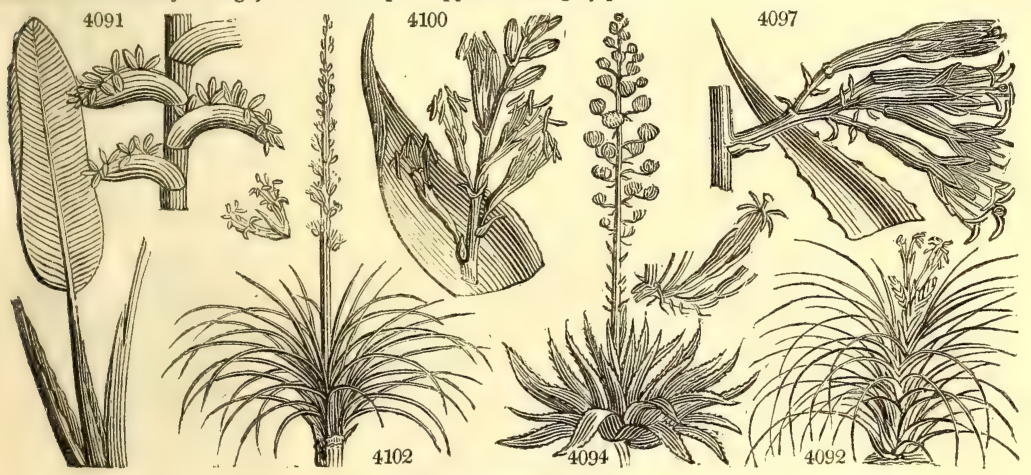

and Miscellaneous Particulars.

of room for the roots, and a rich loamy soil kept rather moist. A plant of the banana was planted in the pit of a stove about 1811. "It was then about six feet high, with a single stem. In each succeeding year it has produced a bunch of fruit; and in 181.9 two bunches; the first ripe in May, the other in August, having about four dozen of fruit on each bunch. The plant is now sixteen feet high, and measures three feet round at the bottom." (Hort. Trans. iv. 138.)

722. Urania. A name of one of the muses, unjustifiably applied to this genus by Schreber, in the room of that of Ravenala, which it bears in Madagascar. To grow this plant luxuriantly, a strong heat and a good supply of water are required. Fresh imported seeds will grow freely.

723. Buonapartea. So named by the authors of the Flora Peruviana, after Napoleon Bonaparte, emperor of the French. Fine plants like Bromelia, with long, narrow, recurved leaves, and spikes of simple blue flowers, which were never yet seen in this country.

724. Ag ve. Altered from arovos, admirable, which this genus may well be said to be, considering its appearance, its size, and the beauty of its flowers. In mythology, Agave is the name of one of the Nereids. A. americana is a popular succulent throughout Europe. It grows wild or is acclimated in Sicily, the A. americana is a popular succulent throughout Europe. It grows wild or is acclimated in Sicily, the
south of Spain, and Italy, and is much used in the latter country, planted in vases as an ornament to piers, parapets, and about houses. About Milan and other towns in Lombardy, where it will not endure the winter, they use imitations of copper so well formed and painted, as to be readily mistaken for the original. In France and Germany it is still very common; and in this country formerly used to be the regular companion of the orange, myrtle, and pomegranate, then our principal greenhouse plants. An idea used to prevail that the American Aloe only flowered once in a hundred years; but, independently of this unnatural application of time to the inflorescence, it has long been known to flower sooner or later, according to the culture bestowed time to the inflorescence, it has long been known to flower sooner or later, according to the culture bestowed
on it. Many have flowered within these few years in this country; and if the plant had the same treatment as the pine-apple, it would probably flower nearly as often. There is a variety with striped foliage, and sometimes the stripes are of different shades of white, yellow, and red, as in the queen pine-apple. There are hedges of the plant in Spain, Portugal, Sicily, Calabria, and the West Indies. According to Long, (Jamaica, iii. 710.) the leaves are useful as a succedaneum for soap. For this purpose, after being cut, they are passed between the rollers of a mill with their point foremost; and the juice being conducted into wide shallow receivers, through a coarse cloth or strainer, it is exposed to a hot sun, until the aqueous part being exhaled, it is reduced to a thick consistence. It may then be made up into balls, with the help of ley ashes. It will lather with salt water as well as fresh. This soap may also be prepared by pounding the leaves in a wooden mortar, and then expressing the juice, which may be brought to a consistence by the sun or by boiling. One gallon of juice thus prepared, will yield about one pound of a soft extract. The juice, in both these ways, must be carefully strained; and the extract must never be combined with tallow or other unctuous materials. The leaves are also used for scowering pewter, and other kitchen utensils, and foors. The inward spongy substance of the decayed stalk is used for tinder. The fibres of the leaves, separated by bruising and steeping in water, and afterwards beating them, make a strong thread for common uses. All the species greatly resemble each other, and it is doubted, whether, in the works of several travellers, different species of Agave Aloe, and even Bromelia, are not confounded in their descriptions of their uses. There is, for example, a variety of the Agave americana, called Karatas by Long, and there is a species of Bromelia of that designation; hedges of Karatas are frequently mentioned without noticing the generic name of the plant. 
725. FURCR E'A. $\boldsymbol{V}$. 4103 gigantéa Vent. t104 tuberósa $H$. K. 4105 cubénsis $W$. 4106 rigida Mill. $\$ 107$ austrális Haw.

726. BROME'LIA. $W$. 4108 Ana 4109 semiserráta $W$. en. $\$ 110$ lúcida $W . e n$. 4111 Pinguin $W$. 4112 sylvéstris $W$ 4113 fastuósa Lindl. 4114 Karátas $W$. 4115 nudicaúlis $W$. pyramidalis $\dot{\mathrm{B}} . \mathbf{M}$. 4116 pállida $\mathrm{Ker}$. 4117 chrysántha Jacq. 4118 linguláta $W$. 4119 bracteáta $W$ 4120 Acánga $L$ 4121 exsúdans Lodd. 4122 hámilis $W$ 4123 melanánthà Ker.

727. GUZMAN'NIA. 4124 trícolor Fl. Per. 728. PITCAIR'NIA. $W$ 4125 broméliæfólia $W$. 4126 angustifólia $W$. 4127 intégrifólia $B . M$. 4128 latifólia $W$ 4129 bracteáta $\dot{H}$. $K$. 4130 sulph area $\boldsymbol{B}$. $R$. 4131 furfurácea $W$. en. 4132 coarctáta $\boldsymbol{R}$. \& $\boldsymbol{P}$ 4133 staminea $B$. $M$. 729. 'TILLAN'DSIA. 4134 utriculáta $W$ 4135 serráta $W$. gigantic tuberous

Cuba

rigid entire-leaved

Pine-apple. common half-sawed-lv broad-leaved wild noble upright-leaved naked-stalked pale golden-flowered $\frac{\Delta}{4}$ or tongue-leaved red-bracted recurved sweating dwarf black-flowered $\triangle$ or

l. Per. Guzmannia three-colored Pitcairnia. scarlet narrow-leaved entire-leaved broad-leaved large bract.-red $\triangle 7$ or yellow-flower'd drooping-leav'd contracted or long-stamened $\triangle \mathbb{E}$ or Tilla ndsia. bladder saw-leaved

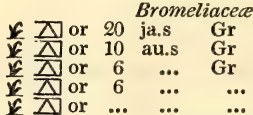

Sp. 5-7.

S. Amer. 1690. Sk r.m Bot. mag. 2250 S. Amer. 1739. Sk r.m

S. Amer. 1739. Sk r.m J. am. t. 260.f. 25 S. Amer. 1768. Sk r.m

Bromeliace Sp. 16-29.

4 ja.d P S. Amer. 1690. Sk r.m Bot. mag. 1554 3 ja.d Gr S. Amer. ... Sk r.m

4 ja.d Pk S. Amer. ... Sk r.m D. el.25.t.21.f.22 3 mr.ap $R \quad$ W. Indies 1690. Sk r.m Jac. am. pic. t. 91 3 jl cr S. Amer. 1820. Sk r.m Bot. mag. 2392 4 au.s Pu S. Amer. 1815. Sk s.p Lindl, coll. 1

$\begin{array}{lllll}2 & \text { au.s } & \text { Pu } & \text { S. Amer. 1815. Sk s.p Lindl. coll. 1. } \\ & \ldots & \text { Pk } & \text { W. Indies 1739. Sk r.m Jac. v. 1.t. 31, } 32\end{array}$ 2 f.mr Cr R. Janiero ... $\quad$ Sk r.m Bot. reg. 203

$1 \frac{1}{2} n \quad$ G. $Y$ S. Amer. 1817. Sk s.p Bot. reg. 344 $2 \quad \ldots \quad Y \quad$ Caraccas 1819. Sk s.p Jacq. sch. 1.t. 55 $1 \frac{1}{2}$ my.jn $Y \quad$ S. Amer. 1759. Sk r.m Plum. ic. t.64,f.1 $2^{2}$ s.o Pk Jamaica 1785. Sk r.m Par. lond. 40 2 ... $\quad$... $\quad$ Brazil 1822. Sk s.p Pis. bras. t. 91 $\begin{array}{llllll}2 & \text { s.o } & \mathbf{Y} & \text { W. Ind. } & \text { 1820. Sk r.m Bot. cab. } 801\end{array}$ $1 \mathrm{mr} \quad$ Pk $\quad$...... 1789. Sk r.m Jac. ic. 1. t. 60 $1 \frac{1}{2} \mathrm{my} \quad$ Bl Trinidad 1824. Sk r.m Bot. reg. 766 Bromeliacea. Sp. 1

1 my G.s S. Amer. 1820. Sk r.m Lindl, coll. 8 Bromeliacea. Sp. 9-14.

2 jn S Jamaica 1781. Sk s.p Bot. mag. 824 2 ja.d S Sant. Cruz 1777. Sk s.p Bot. mag. 1547 2 au $\quad$ R W. Indies 1800. Sk s.p Bot. mag. 1462 2 au.s S W. Indies 1785. Sk s.p Bot. mag. 856 ap.my $\mathbf{R}$ W. Indies 1799 . Sk s.p Red. lil. 73,74

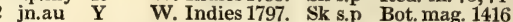
jn.au R S. Amer. 1816. Sk r.m

2 my.jn $\mathbf{Y}$ Chile 1822, Sk rm Feuill, chil. t. 39 ja $\mathrm{S} \quad$ S. Amer. 1823. Sk r.m Bot. mag. 2411 Bromeliacea. Sp. 11-27.

k

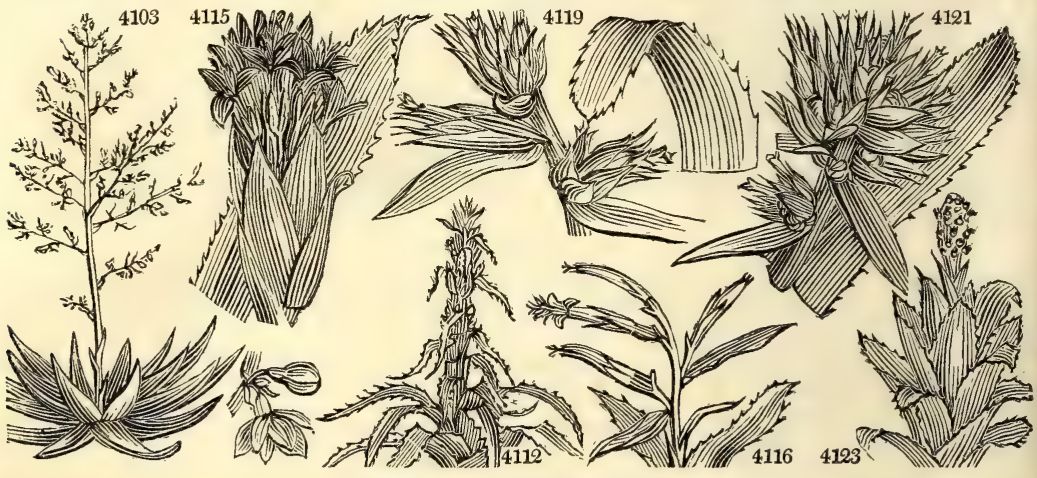

History, Use, Propagation, Culture,

725. Furcraa. Named in honor of M. Fourcroy, the famous French chemist. A noble genus resembling the last.

726. Bromelia. So named by Linnæus, in memory of Olaus Bromel, a Swede, author of Lupulogia, and other works, 1694, \&c. Ananas, Fr., Ger., and Ital; and Nanas among the Peruvians, where it was origin ally found by Europeans. This fruit may, without hesitation, be pronounced the first in the world, though
it has not been known in Europe above two centuries, and has only been cultivated about a century as a fruit plant in Britain. It passed from Brazil to the West, and thence to the East Indies, where it has long been successfully cultivated. About the middle of the seventeenth century it was brought to Holland, by $\mathrm{Mr}$. La Court, a merchant, and cultivated at Driehoek, his seat, near Leyden; and from thence it was imported into this country, and first fruited by Sir Matthew Decker, at Richmond, about 1715, or earlier. La Court began by growing his pines without bottom heat, as dry stove plants; but afterwards had recourse to low pits and tanner's bark. Plans of his pits, and an account of his mode of culture, are published in his work, entitled, Aenmerkingen over Lusthoven, Plantagion, \&c. (See Ency. of Gard. p. 1129, Anno. 1737.) Sir M. Decker, Bradley informs us, adopted pits; and soon after pine stoves, or larger and more commodious pits, were, by the year 1730, in most of the first English gardens, and some also in Scotland, where the pine-apple was first fruited by Justice, at Crichton, near Edinburgh, in 1732. The pine is now cultivated very generally in Britain, in several places in Ireland, and at most of the capital cities on the continent. In one or two of the southern provinces of Spain, it is grown in sheltered situations in the open air.

There are many varieties of the pine in the West Indies, procured by raising from seed : in this country there are upwards of thirty sorts, but the queen, New Providence, and one or two others, are most esteemed. The plants are propagated by suckers, and by that singular production, proceeding from the summit of the fruit, called a crown : from large suckers fruit is sometimes obtained in eighteen months, but, in general, a period of two or three years is required, and for the New Providence sometimes longer. Loamy soil well enriched with rotten dung, and the pots sufficiently drained, with abundance of heat without sudden extremes, will ensure large and well flavored fruit. (See The varions Modes of cultivating the Pine-Apple from its first Introduction to the Improvements of Mr. Knight, \&c. 8vo. 1822.)

Some of the other species of true Bromelia have crowns, and the fruit of most of them is eatable, though small. B. Pinguin has the fruit separately in clusters, and not in a cone or pine, as in the Ananas. It is very common in Jamaica, in most of the Savannahs, and on the rocky hills. It is used there for fencing pas- 
4103 Leaves entire, Scape branched

4103 Leaves entire, Scapes very long spiny at edge

4104 Cor. hexapetalous, Leaves ciliate spiny

4106 Leaves linear lanceolate entire upwards, at the base serrate spiny

4107 An obscure plant described by Haworth only and supposed to be Doryanthes excelsa!?

4108 Leaves fringed with spines mucronate, Spike comose

4109 Leaves at the end toothed spiny, Spike comose

4110 Leaves entire, Spike comose

4111 Leaves ciliated spiny mucronate, Raceme terminal

4112 Leaves ciliated spiny with a very long point, Raceme term. comp Flowers sessile shorter than bractea

4113 Leaves ciliated spiny with a very long point, Raceme rigid compound, Flow. in numerous lateral spikes

4114 Leaves erect, Flowers stemless sessile aggregate

4115 Radical leaves toothed spiny : cauline entire

4116 Panicle lax few-fl. spreading, Peduncles 1-flowered, Upper spathes fertile as long as flower spreading 4117 Leaves serrate spiny, Bractes lanceolate toothed, Raceme compound shorter than leaves

4118 Leaves serrated spiny obtuse, Spikes alternate

4119 Leaves serrate spiny, Bractes ovate lanceolate, Scape elongated, Raceme compound

4120 Panicle diffuse, Leaves ciliate spiny mucronate recurved

4121 Raceme compound, Flowers heaped shorter than the long red entire bracter, Calyx acute

4122 Nearly stemless, Leaves aggregate sessile, Axillæ stoloniferous

4123 Leaves ligulate oblong very blue, Spike oval woolly with small sessile flowers

4124 Scape upright, Spike imbricated, The lower bracteæ green; the upper scarlet

4125 Leaves ciliate spiny, Peduncles and germens quite smooth

4126 Leaves ciliate spiny, Peduncles and germens downy

4127 Leaves narrow glaucous entire, Calyx villous

4128 Leaves entire somewhat spiny at base

4129 Leaves entire a little spiny at base, Bractes as long as peduncle and calyx

4130 Leaves entire white beneath, Raceme imbricated dense

4131 Leaves toothed spiny recurved, above shining smooth, beneath mealy

4132 Spike compound contracted, Leaves ensiform aculeate, Cor. with a black spot at bottom

4133 Leaves linear lanc. entire, Petals revolute, Stamens longer than cor.

4134 Culm panicled

4135 Leaves upwards serrate spiny, Spike comose
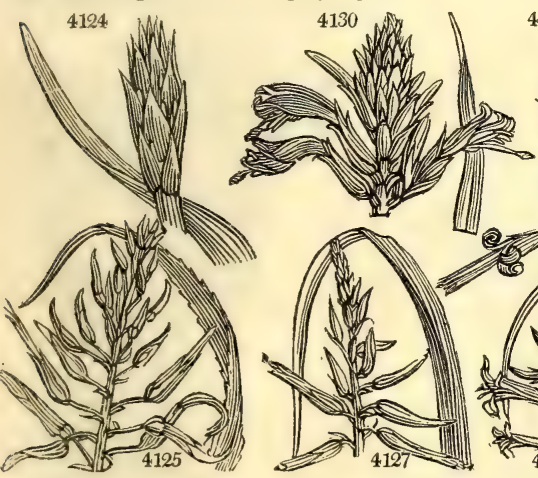

4133

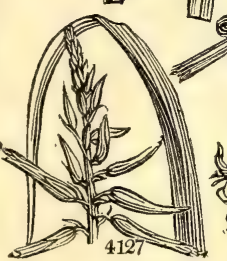

and Miscellaneous Particulars.

135

ture lands, on account of its prickly leaves. These, stripped of their pulp, soaked in water, and beaten with a wooden mallet, yield a strong thread which is twisted into ropes and whips, and manufactured by the Spaniards into a good cloth. The juice of the fruit in water makes a cooling draught in fevers; it is extremely diuretic, destroys worms, and makes a good vinegar.

B. Karatas, so called from its Brazilian name, Karaguata-acanga, generally grows at the root of some shady tree, in hilly and woody places in America and the Caribbee islands. It is an elegant plant, producing numerous radical leaves, which are of a subulate-linear shape, sharp pointed, and edged with spines. 'The flowers are scentless, seated in the bosom or middle part of the plant, rose colored, with the calyx and germ downy. The length of the leaves is six or seven feet. The fruits are oval, two or three hundred in number, and grow sessile in a heap or central group, surrounded by paleaceous expanded leaves or bractes; they contain a succulent whitish or yellowish flesh, under a coriaceous and yellowish bark. When ripe, they are far from unpleasant; but when unripe they set the teeth on edge, and excoriate the mouth. The economy of this plant in the preservation of its fruit to maturity is wonderful : being so protected by the spines of the surrounding leaves, as to be secure from all injuries.

B. humilis propagates itself by runners or shooting processes, which proceed from the axillæ of the lower leaves, and produce a young plant from their extremities.

Bromelia fastuosa is the most beautiful of the genus. It has never flowered more than once in this country, when the figure in Mr. Lindley's Collectanea Botanica was obtained. Bromelia sylvestris resembles this, but is less beautiful.

727. Guzmannia. Named after Anastatio Guzman, an industrious apothecary, and zealous collector of objects of natural history in South America. A beautiful evergreen herbaceous plant, with the foliage of Tillandsia, and a spike of bractex, the uppermost of which are richly colored with rose.

728. Pitcairnia. So named by Mons. L'Heritier, in honor of William Pitcairn, M. D. an eminent physician of London, and a collector of foreign plants, particularly from the Alps. The species are remarkable for their long, narrow, green, prickly leaves, and for their uniform panicles of bright red. Pitcairnia staminea is very handsome. They require the same treatment as Bromelia.

729. Tillandsia. So named by Linnæus, in memory of Elias Tillandsius, professor of physic at Abo, author 

4138 linguláta $W$. 4141 nútans $W$.

4144 xiphioídes $\dot{B}$. Reg. $\begin{aligned} & \text { recurve-leaved } \\ & \text { Air-plant }\end{aligned}$

730. PONTEDE'RIA. $\boldsymbol{W}$. Pontederia.

4145 cordáta $P h$.

4147 dilatáta $H$. $K$.

731. HEMANTHUS. $W$

4150 coarctátus $W$.
4151 rotundifólius $B$. $M$.

4156 pubéscens $W$

$\beta$ albiflós W.

4158 lanceæfólius $W$.

4161 cárneus $K e r$.

732. GALAN'THUS. $W$.
4136 amœ'na Lodd. 4137 usneoídes $W$. 4139 flexuósa $W$. 3 pállida

4140 ánceps Lodd.

4142 stricta $B, M$

4146 angustifólia $P h$.

4148 lanceoláta Lodd.

4149 coccíneus $W$.

4152 puníceus $W$.

4153 multiflórus $W$.

4154 tigrinus $W$.

4155 quadriválvis $W$

4157 maculátus Jacq.

4159 carinátus $W$.

4160 pumílio $W$.

4162 Hyalocárpus Jacq.

4163 nivális $W$.

4164 plicátus Bieb.

charmin

pendulous

flexuose

pale

two-edged

nodding

stiff-leaved

heart-leaved

spreading 美 $[\vec{X}$ or

BLOOD-FLOWER

Bron round-leaved of $\triangle \mathrm{\Delta}$ or wave-leaved \& $\triangle$ or many-flowered $\delta$ or tiger-spotted 7 or four-valved pubescent white-flowered spotted-leaved spear-leaved

keel-leaved

dwarf

flesh-colored

\begin{abstract}
china-fruited
\end{abstract}
SNOWDROP.

common
plaited

SNOW-FLAKE. spring summe 4165 vérnum $W$.

4166 æstivum $W$

4167 pulchéllum $P . L$.

neat narrow-leaved $\Delta$ or compressed or

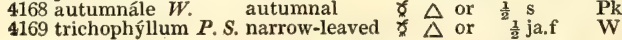

E $\mathrm{E}$ or 2 jn $\quad \mathrm{V} \quad$ W. Indies 1819. Sk s.p Bot. cab. 76

E $\bar{L}$ or 2 jn.ji $\quad \mathrm{Y}$ Jamaica 1776. Sk s.p Jac. amer. t. 62

F $\triangle$ or $1 \quad \ldots \quad$ B $\quad W$. Indies 1790. R s.p Jac. amer. t. 63

W. Indies 1815 , $\mathbf{R}$ s.n Bot. reg. 749

W. Indies 1820, R s.p Bot. cab. 771

Jamaica 1793. R s.p

Brazil 1810. R s.p Bot. mag. 1529

Jamaica 1793. R s.p Sl. ja.1.t. 121.f.1

Buen. Ay. ... R s.p Bot. reg. 105

$\frac{1}{2}$ jl $\quad$ Wu Buen. Ay

Commeline

2 jn.au B

jn.au B

$\begin{array}{lll}2 & \text { my } & \text { B } \\ 2 & \text { au } & \text { B }\end{array}$

N. Amer. 1759. D 1

N. Amer. 1806. D 1

E. Indies 1806. D 1

N. Amer. 1815. D 1

Bot. mag. 1156

Amaryllidea. Sp. 14-16.

1 au.o R C. G. H. 1629. O r.m Bot. mag. 1075

1 f.mr Pk $\quad$ C. G. H. 1795. O r.m Bot. reg. 181

1 jn.o S C. G. H. 1790. O s.l.p Bot. mag. 1618

1 my.s S C. G. H. 1722. O r.m Bot. mag. 1315

1 my.s D.R S. Leone 1783. O r.m Bot. mag. 961

1 f.d F C. G. H. 1790. O r.m Bot. mag. 1705

1 s.o F C. G H 1790 O rm Bot mag. 1523

1 s.o F $\quad$ C. G. H. 1790. O r.m Bot. mag. 152

$\begin{array}{lllll}1 & \text { au } & \text { W } & \text { C. G. H. 1774. O } & \text { r.m Bot. cab. } 702\end{array}$

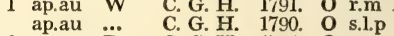

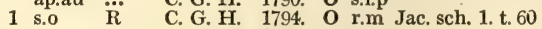

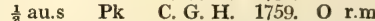

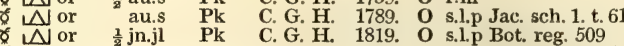

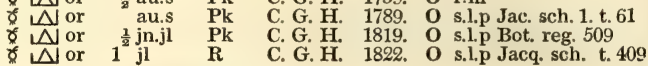

Amuryllidea. Sp. 2.

6 $\Delta$ or ${ }^{\frac{1}{2}}$ ja.mr W Britain mea. O co Eng. bot. 19

* $\triangle$ or $\frac{1}{3}$ ja.ap W Crimea 1818. O co Bot. reg. 545

Amaryllidea. Sp. 5.

ช $\Delta$ or $\frac{3}{4}$ ja.mr W Germany 1596. O s.l Bot. mag. 46

\% $\Delta$ or $1 \frac{1}{3}$ ap.my W England m.me. O s.l Eng. bot. 621

ซ $\triangle$ or $1 \frac{1}{2}$ ap.my W

f $\Delta$ or $\frac{1}{2} \mathrm{~s}$.

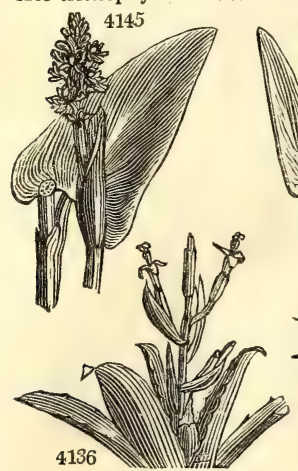

4148

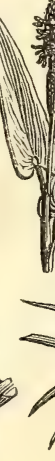

Port.... ... O s.l Par. lond.

Barbary 1812. O s.1 Bot. reg. 544

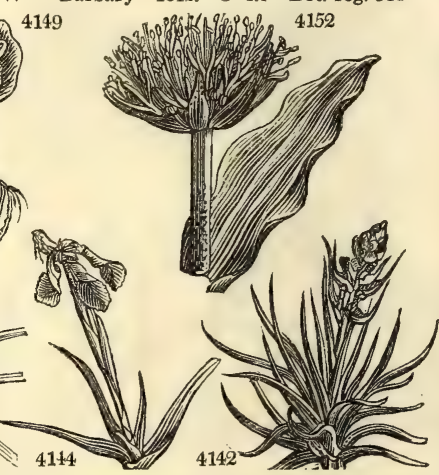

4140 1

History, Use, Propagation, Culture,

of Flora Aboensis, 1673. Several species of this genus are parasitical, and others require the same treatment as Pitcairnia or Bromelia.

T. utriculata is a valuable plant in the woods of the West Indies, as containing a supply of water in dry seasons. The seed being pappose, is carried about by the wind, and sticks readily on the bark of trees: there, especially on decaying ones, it sends out small brown fibres which take hold of the bark, and weave and mat themselves among one another: from this foundation rise several leaves on every side, like those of Aloes or Ananas; they are folded or inclosed one within another, each three feet and a half long, and three inches broad at the base, but ending in a point, having a very hollow or concave inward side, and a round or convex outward one, forming a bason or cistern, containing about a quart of water, which, in the rainy season falls upon the upper parts of the spreading leaves, and being conveyed down them by channels, lodges in the bottom as in a bottle; for the leaves, having swelled out at the base, bend inwards close to the stalk, thus hindering the evaporation of the water by the heat of the sun. From the midst of the leaves rises a round, smooth, straight, green stalk, three or four feet high, having many branches, and when wounded yielding a clear white mucilaginous gum. The flowers come out here and there on the branches. The corolla is of a yellowish-white or herbaceous color; and the calyx is made up of three green viscid leaves with purple edges. Men, birds, and insects supply themselves with water from this plant. Dampier says, he has many times, to his great relief, stuck his knife into the leaves just above the roots, and let out the water into his hat.

T. usneoides deserves, for its appearance and uses, to be shortly described. The stem is no bigger than a thread; the skin whitish, as if covered with hoar-frost, within tough and black like a horse hair. Many of these together stick on the branches of the ebony or other trees superficially by the middle, and send down on each side some of the same stems, very often a yard long, hanging on both sides, curled, or turning and winding one within another, and resembling an old man's beard, whence its curled, or turning and winding one within another, and resembling an old man's beard, whence its
common name in Jamaica. The stems are branched, and the branches, which are two or three inches long, are set with roundish, white, frosted leaves. The flowers come out at the end of the branches. This slender parasitical plant is found among the trees in many parts of Jamaica, but does not grow so commonly there, nor so luxuriantly, as it does in the more northern provinces of the main continent, where it is said to overrun whole forests. It is frequently imported from Jamaica to North America, for the use of the 
4136 Leaves lanceolate channelled slightly prickly, outer acute inner retuse 4137 Filiform branched twisted rough

4138 Leaves lanceolate ligulate entire ventricose at base

4139 Leaves linear subulate entire imbricate, Spike lax

4140 Leaves narrow channelled recurved, Spike imbricated simple oval two-edged

4141 Spikes subdivided nodding, Flowers distinct ovate, Leaves ovate lanceolate membranous

4142 Leaves radical stiff frosted, Flowers imbricated in an ovate spike of whitish bractes

4143 Leaves subulate rough reclinate, Stems 1-flowered, Glumes 2-flowered

4144 Flower tubular trfiid, Segments of the tripetaloid limb reflexed twice as short as tube, Lvs. entire

4145 Leaves cordate, Flowers spiked

4146 Leaves long-triangular narrowed by degrees, at the base truncate cordate, Petals lin. lanc.

4147 Leaves sagittate obtuse, Flowers in crowded umbels

4148 Leaves lanceolate elliptical cordate, Spike oblong

4149 Leaves linguiform flat smooth pressed on the ground 2-ranked, Umbel shorter than the spathe 4150 Leaves linguiform oblong flat smooth callous at end, Umbel contracted shorter than spathe, Limb erect 4151 Leaves rounded fringed with pink hairs, Umbel few-flowered, Leaves of spathe cordate blunt 4152 Leaves oblong elliptical acute retuse wavy, Umbel contracted, Limb and stamens erect

4153 Leaves ellipt. lanceol, acute concave erect, Umbel longer than spatha, Limb spreading, Stam. ascending 4154 Leaves linguiform flat smooth fringed at edge depressed, Umbel contracted, Limb and stamens erect 4155 Leaves lanceolate ciliated villous above smooth beneath, Spathe campanulate 4-valved

4156 Leaves oblong lanceolatc hairy all over, Umbel fastigiate rounded, Limb and stamens erect

4157 Leaves broad much spotted with brown

4158 Lvs. ellipt. atten. at base depressed flat smooth ciliated at edge, Pedunc. longer than spathe and flower 4159 Leaves linear carinated

4160 Leaves linear lanceolate erect smooth, Peduncles length of spathe and flowers, Limb spreading

4161 Leaves 2 round ovate acuminate and scape hairy backwards, Spathe reflexed withered, Stam. included 4162 Leaves oblong obtuse smooth erect not spotted, Umbel rounded, Limb erect

4163 Leaves smooth

4.i64 Leaves plaited

4165 Spathe 1-flowered, Style clavate

4166 Spathe many-flowered, Style clavate

4167 A slight variety of the last

4168 Spathe many-flowered, Style filiform

4169 Vernal, Sepals entire, Style filiform with a blunt stigma

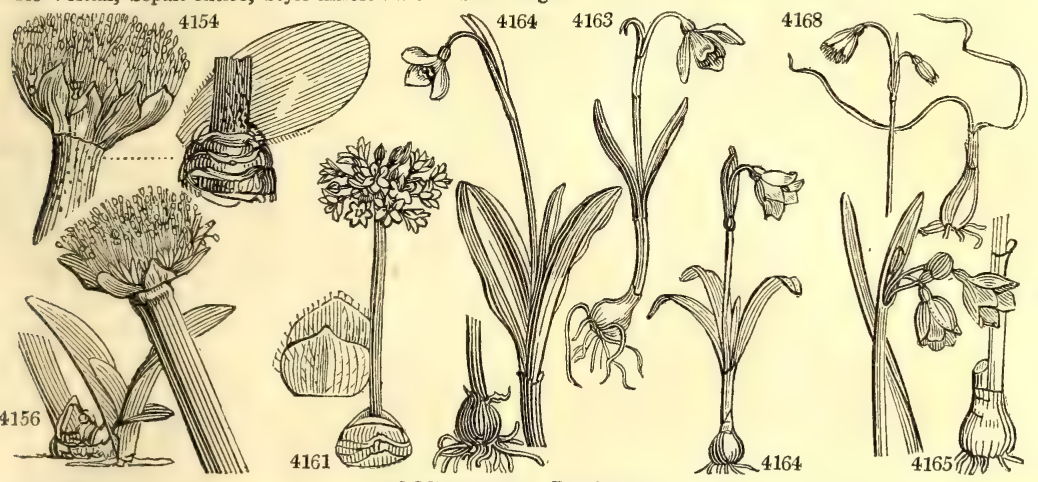

and Miscellaneous Particulars.

sadlers and coachmakers, who commonly stuff their pannels, cushions, \&c. with it. In Louisiana and the neighbouring settlements, this plant being very carefully gathered and stripped of the bark, is made into mattrasses, cushions, pannels, \&c. It is manufactured by tying the stalks in bunches, and sinking them in water, or burying them under ground in a moist place, until the bark rots : they are then taken up, boiled in water, and washed, until the fibres are quite cleared of the pulp. These are not only used instead of horsehair, but are so very like it, that a man cannot distinguish them, without a strict examination, and that even with a glass, unless he observes the branchings of it.

The Bonana bird's nest is always made of the fibres of this plant, and is generally found hanging by a few threads from the tops of the most expanded branches of the most lofty trees, especially those that spread over ponds or rivers.

In cultivating Tillandsia in our stoves, the parasitical species may either be hung up in baskets of moss, or fastened in moss to some plant, or to the stump of a tree set up on purpose : if planted in pots, they require but little water, and a sandy loam, with bits of sticks and small pieces of potsherds mixed with it. (Sweet.) They are, however, extremely difficult to manage under any mode of treatment.

730. Puntederia. So named in memory of Julius Pontedera, professor of botany at Padua, author of Tabulæ Botanicæ, 1718, \&c. This is a genus of aquatic, herbaceous, perennial plants, with fibrous roots sheathing stem-leaves, and blue flowers in spikes or umbels from the cloven sheath of the leaves. A loamy soil in a cistern of water grows them well, and they are not without beauty.

731. Hamanthus. From áuผc, blood, and ay flowers. An ornamental genus, which thrives best in sandy loam and a little peat, and placed in a dry stove or bulb-house near the glass. The species require no water when in a dormant state, as the bulbs then ripen, and afterwards flower freely. (Sweet.)

732. Galanthus. From $\gamma \propto \lambda \alpha$, milk, and $\alpha$ y. It is rather singular, and also to be regretted, that no variations or hybrids have been produced from this early and pretty little flower.

733. Leucojum. From $\lambda$ su\%os, white, and "oy, a violet. A genus resembling the last in habit, but differing in technical characters. The little autumn species is very pretty, but difficult to cultivate. 
734. STRUMA'RIA. Jac, STRUMARIA 734. STRUMA RIA. Jac. STRUMA 4171 rubélla $W$. 4172 angustifólia $W$. 4173 línguæfólia $W$. 4174 filifólia $H . K$. 4175 spirális $H$. $K$. 4176 crispa $B$. $M$. 4177 stelláris Jacq. 4178 gemmáta $B$. $M$.

735. CRI'NUM. $W$. 4179 americánum $W$. 4180 erubéscens $W$. 4181 Commelíni Ker. 4182 defixum Ker.

4183 amœ'num Roxb. 4184 sumatránum $K e$ r. 4185 longifólium Ker. 4186 cruéntum Ker.

4187 asiáticum $W$ C. toxicarium Roxb. 4188 amábile Donn. 4188 amábile Donn.

4189 bracteátum $W$. 4191 pedunculátum $B . R$. 4192 ensifólium $R o x b$. 4.193 lorifólium Roxb. 4194 augústum Roxb.

4105 brachýndrum 196 brachyandrum hert4196 plicatum Hort. plaited 4197 declinátum Herb. sloping 4198 submérsum Herb. lake 4200 confértum Herb. crowded 4201 aquáticum Burch. water 4202 arenárium Herb. sand 4203 mauritiánum Herb. African 4204 scábrum Herb. rough

736. CYRTAN'THUS. $\boldsymbol{H}$. $K$. Cyrtanthus 4205 angustifólius $W$. 4206 collinus $B$. Reg. 4207 spirális B. Reg. 4208 oblíquus $W$. 4209 unifórus Ker 4210 odórus $\mathrm{Ker}$.

4211 pállidus Sims

737. BRUNSVi'gia. Heist. Brunsvigia. 4212 Josephinæ R. L. B minor B. Reg. 4213 multiflóra $H . K$ 4214 margináta $H$. $K$. 4215 Rádula $\boldsymbol{H}$. $K$. 4216 striáta $H$. $K$. 1217 falcáta $B . M$. 4218 toxicária $\mathrm{Ker}$. 3 coranica Ker. 4219 ciliáris Ker.

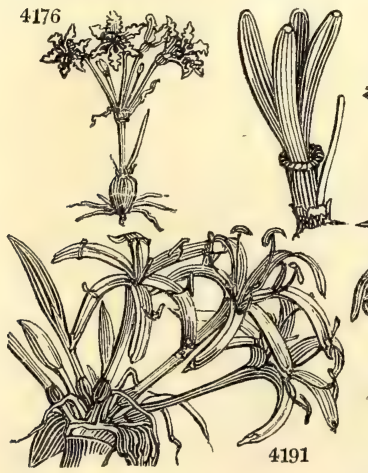

* $\mathrm{N}$ or Amaryllidece. Sp. 9-11.

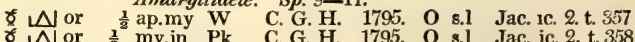
† $\triangle$ or $\frac{1}{2}$ my.jn Pk $\quad$ C. G. H. 1795. O s.1 Jac. ic. 2. t. 358 narrow-leaved $\delta \mathbb{N}$ or $\frac{1}{2}$ ap.my Pk C. G. H. 1795. O s.l Jac. ic. 2. t. 359 tongue-leaved $\gamma$ or \% $\triangle$ or 8 or ${ }^{\frac{1}{2}}$ ap.my $\mathrm{WK}$ $\begin{array}{lllll} & \text { C. G. H. ... } & \text { O s.1 Jac ic. 2. t. } 356\end{array}$ $\frac{1}{2} \mathrm{n} \quad$ W $\quad$ C. G. H. 1774. O s.l Bot. reg. 440 ap.au Pk C. G. H. 1774. O s.l Bot. mag. 1389 $\begin{array}{lllll}\frac{1}{4} \text { ap.au Pk } & \text { C. G. H. } 1790 . & \text { O } & \text { s.1 } & \text { Bot. mag. } 1363\end{array}$ 商 o.n Pk C. G. H. 1794. O s.l Jac. sch. 1. t. 71 au Pa.Y C. G. H. 1812. O s.1 Bot. mag. 1620

Amaryllidea. Sp. 26-88.

2 jl.au W S. Amer. 1752. O r.m Bot. mag. 1034 2 jn.au Pa.w W. Indies 1789. O r.m Bot. mag. 1232 jn.au W S. Amer. 1798. O r.m Jac. sch. 2. t. 202 2 au.s W E. Indies 1810. O r.m Rhe. m. 11. t 38 ... W E. Indies 1810. O r.m Sumatra 1810. O r.m

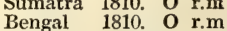

E. Indies 1810. O r.m Bot. reg. 171

China 1732. O r.m Bot. mag. 1073

E. Indies 1810. O r.m Bot. mag. 1605 Mauritius 1810. O r.m Bot. reg. 179 ....... 1810. O r.m

N. S. W. 1790 . O r.m Bot. reg. 52

Pegu 1819. O r.m

Pegu 1819. O r

N.

China 1818. O r.m

Silhet 1818. O r.m Bot. mag. 2231

Rio Janei. 1820. O r.m Bot. mag. 2469

Mauritius 1821. O r.m Bot. mag. 2466

N. Holl. 1822. O r.m Bot. mag. 2522

C. G. H 1820 O r.m Bot. mag. 2352

N. Holl. 1822. O r.m Bot. mag. 2355

Mauritius 1812. O r.m Bot. cab. 650

Azores 1810. O r.m Bot. cab. 529

Amaryllidea. Sp. 7-8.

narrow-leaved $\delta \Delta$ or 1 my.jn $O \quad$ C. G. H. 1774. O r.m Bot. mag. 271

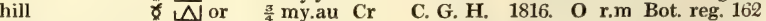
spiral-leaved \& $\mathrm{N}$ or 1 my.au S $\quad$ C. G. H. 1790. O r.m Bot. reg. 167 oblique-leaved $\$ \mathbb{N}$ or 2 my.au G.o C. G. H. 1774. O r.m Bot. mag. 1133 one-flowered $\frac{\gamma}{\mathbb{N} \text { or }} \frac{1}{2}$ my.au W.R C. G. H. 1816. O r.m Bot. reg. 168 sweet $\quad \delta \quad$ or $\frac{3}{4}$ my.jl $\mathbf{C r}$ C. G. H. 1818. O r.m Bot. reg. 503

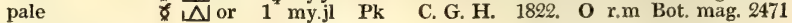

Amaryllidece. Sp. 8.

$\begin{array}{llllll}\text { Josephine's } & \mathbb{N} \text { or } 1 \frac{1}{2} \mathrm{jn} . \mathrm{au} & \mathrm{S} & \text { C. G. H. 1814. O r.m Red. lil.t. } 370.379\end{array}$ smaller of or 1 jn.au S C. G. H. 1814. O r.m Bot.r. 192, 193 many-flowered $\mathbb{S}$ or 1 jn.au $\quad$ R $\quad$ C. G. H. 1752. O r.m Bot. mag. 1619 red-margined $\$ \mathbb{N}$ or 1 s.o $\quad \mathrm{S} \quad$ C. G. H. 1795. O r.m Jac. sch. 1. t. 65 rasp-leaved $\delta \mathbb{N}$ or $\frac{1}{2}$ ap.au $R \quad$ C. G. H. 1790 . O r.m Jac. sch. 1.t. 68 striated $\quad \forall \mathbb{N}$ or $\frac{1}{2}$ s.o $\quad$ Pk C. G. H. 1795. O r.m Jac. sch. 1. t. 70 sickle-leaved $\delta \Delta$ or $\frac{3}{4}$ my.jn $R \quad$ C. G. H. 1774. O r.m Bot. mag. 1443 Poison-bulb $\delta$ N p 1 s.o Pk C. G. H. 1774, O r.m Bot. reg. 567 cor. Poison-bulb 8 \ p 1 s.o Pk $\quad$ C. G. H. 1815. O r.m Bot. reg. 139

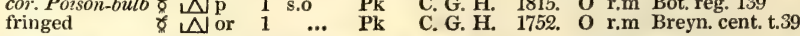


4170 Leaves linear ensiform rounded obtuse flat, Scape compressed, Stamens longer than cor.

4171 Leaves linear obliquely bent, Petals flat

4172 Leaves linear flat, Germen with three glands

4173 Leaves linear ensiform rounded obtuse flat, Scape rounded, Stamens as .ong as cor.

4174 Leaves filiform, Petals acute

4175 Leaves filiform spiral, Petals acute colored outside

4176 Leaf filiform straight, Umb. many-flowered, Petals wavy flat

4177 Sepals spreading alternately bearded beneath the ends

4178 Scape flexuose much longer than the lanceol. ciliated leaves, Pedunc. very long, Petals wavy channelled

4179 Leaves striated, Umbel sessile many-flowered, Tube furrowed about as long as limb

4180 Lvs. lanc. lor. with cartil. teeth, Umb. subs. many-fl. Tube longer than limb, Stam. little long. than style 4181 Ends of sepals hooked inwards, Leaves linear channelled, Scape 4-fi.

4182 Bulb with a very long tap-root, Leaves stiff erect with long points smooth at edige, Umb. sess. many-fl.

4183 Buib spherical, Leaves narrow with a nearly smooth edge, Umb. few-fl. sesis. Sep. lin. lanc. as long as tube 4184 Bulb oval not with a neck, Lvs. broad lin. lanc. straight with a white cartil. toothed edge, Umb. of fl. sess. 4185 Bulb round, Leaves narrowed lax channelled hispid at edge, Umb. sess. many-fl. Seg. shorter than tube 4186 Bulb ovate with a neck, Leaves broad subulate roughish at edge, Spathe herbaceous

4187 Bulb cylind, above ground, Lvs. lanc. smooth at edge longer than scape, Umb. stalk. Sep. long lin. reflexed

4188 Bulb very large with long red neck, Lvs. broad glauc. smth. at edge, Umb. many-t1. Tube shorter than limb 4189 Bulb with long neck, Lvs, obl. lanc. with obt. point smooth wavy at edge, Umb. many-fl. with pale bractes 4190 Bulb cylindrical scarcely with a neck, Leaves lorate with a smooth edge, Umb. on a very long stalk

4191 Bulb cylindrical like a leek, Scape central broad compressed, Umb. many-f. lax stalked

4192 Bulb ovate, Leaves scattered straight of one form

4193 Bulb cylindrical ovate, Leaves lorate very long, Umb. many-fl. stalked

4194 Bulb colum. above ground, Lvs. many lanc. with smooth edge, Scape as long as lvs. Umb. stalk. 20-30-fl. 4195 Bulb columnar, Leaves many bluntly acuminate, Flowers sessile, Segments longer than tube

4196 Like C asiaticum, but with leaves strong plaited backwards about their middle

4197 Bulb oblong, Leaves acute wavy smooth at edge, Flowers many stalked declinate

4198 Bulb oblong ovate red, Leaves rough at edge, Flowers spreading, Sepals lanceolate flat not revolute

4199 Bulb round, Lvs. wavy rough at edge, Sepals obov. flat, Flowers very large with a tinge of pink at back 4200 Bulb ovate, Leaves narrow channelled acute, Flowers upright crowded

4201 Bulb ovate, Leaves very long narrow green twisted, Flowers campanulate, Stamens spreading

4202 Bulb ovate, Leaves a little rough at edge, Umbel 5-flowered shortly stalked, Sepals lanc. flat

4203 Leaves long narrow weak, Scape shorter than leaves, Umbel 5-6-flowered

4204 Leaves long narrow recurved ruugh at edge, Scape 2-edged, Umb. 5-flowered, Sepals broad

4205 Leaves linear channelled, Flowers cernuous, Tube cylindrical

4206 Leaves 3 linear glaucous, Pedunc. somewhat shorter than flower, Stamens included

4207 Many-flowered, Leaves 3 ligulate spiral obtuse glaucous

$\$ 208$ Leaves lanceolate obtuse flat oblique, Cor. pendulous obversely conical

4809 Leaf solitary linear glaucous, Limb as long as throat

4210 Flowers about 4 straightish nodding, Anthers included, Leaves linear not glaucous

4211 Leaves linear lanc. keeled appearing after the flowers, Cor. nodding, Limb as long as tube

4212 Lvs. strap-shaped erect spreading glaucous, Scape twice as long as the rays of the many-flowered umbel

4213 Leaves linguiform lying on the ground smooth

4214 Leaves lingulate pressed on the ground with a cartilaginous edge

4215 Leaves elliptical pressed on the ground rough with little pustules 4216 Leaves elliptical ovate erect edged

4217 Leaves falcate with a muricated discolored cartilaginous edge

4218 Umbel hemispherical close, Leaves many erect oblique glaucous

\section{Leaves strongly fringed with white hairs}

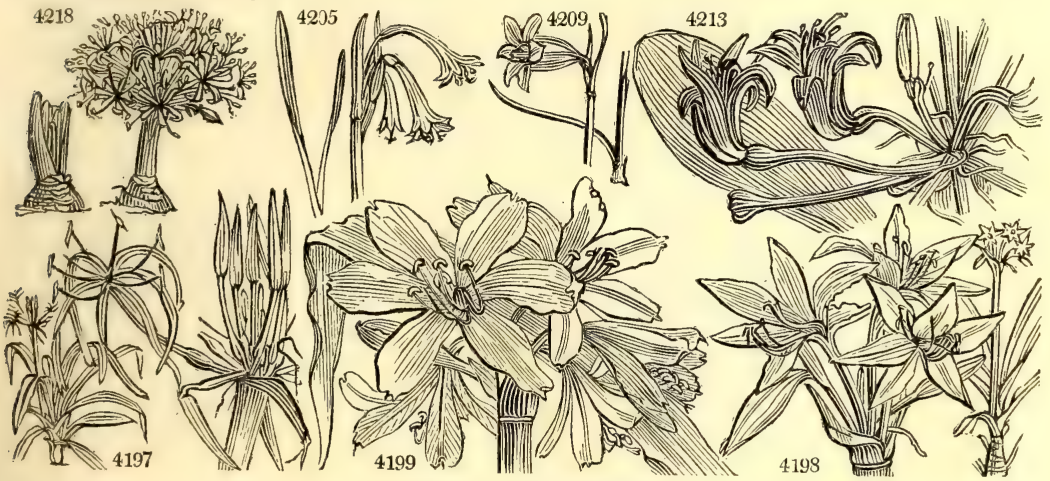

and Miscellaneous Particulars.

736. Cyrthanthus. From *uezos, curved, and av905, a flower. The tube of the flower is long and round. This is an elegant genus, and the species grow well in sandy loam mixed with a little peat. They require plenty of water when in a growing state, but scarcely any when dormant; and they should be fresh potted just before they begin to grow, then they will flower freely. They may be increased by offsets from the bulbs, or from seeds. (Bot. Cult. 176.)

737. Brunsvigia. Named after the noble family of Brunswick. This is a splendid genus; some or the bulbs grow to a great size, and require large pots to have them thrive and flower in perfection. They require plenty of water when in a growing state; but must when dormant be kept so by wholly withholding
water. 
738. NERI'NE. Herb. 4220 curvifólia $W$. 4221 corúsca $B . M$ 4223 venústa $B$. $\boldsymbol{M}$. 4224 flexuósa $W$. 4225 húmilis $W$. 4227 aúrea $W$.

4228 radiáta

4229 rósea Herb.

4230 laticóma Ker.

4231 pulchélla Herb.

739. AMARYL'LIS. $W$ 4232 Pumilio $W$.

4233 pudíca $\mathrm{Ker}$.

4234 formosissima $W$.

4235 aúlica Ker.

4236 psittácina $\mathrm{Ker}$.

4237 calyptráta $\mathrm{Ker}$.

4238 equestris $W$.

$\beta$ májor

4939 regine $W$.

4240 ádvena $B . M$

$\beta$ cerina Lindl.

241 solandræflóra Lindl.

4242 pulverulénta Her acuminata Ker.

4243 cyrtanthoídes Sims. Cyrtanthus-like $\varnothing$ $\backslash$ or

4244 ignea Lindl.

4245 can'dida Lindl.

4246 marinénsis $\mathrm{Ker}$.

4247 reticuláta $W$

4048 austraĺsica $\mathrm{Ker}$

4249 insignis $\mathrm{Ker}$.

4250 moluccána

4.251 crocáta $K . R$.

4252 rútila $K$. $R$.

4253 fúlgida $B$. Reg.

4254 blánda $K$. $R$.

4255 Belladónna $W$.

4256 vittáta $W$.

$\beta$ major Lindl.

4257 coránica $K . R$.

4258 longifólia $W$.

$\beta$ Govenia

4259 revolúta $W$.

4261 ornáta $W$.

4262 gigantéa $K . R$.

4263 latifólia $W$.

4264 tatárica Pall.

740. VALLO'TA. Herb. 4265 purpúrea Herb.

$\beta$ mínor

white

Maranhâo

netted-veined

striped-leaved

New Holland noble

Molucea

saffron-flower.

fiery

striped-tubed

charming

Belladonna Lily o 8 or

pale-flowered of $\triangle$ or

superb

large

sickle-leaved

long-leaved

Gowen's

revolute

Ceylon

Yucca-flowered

gigantic

broad-leaved o 0 or

o $\triangle$ or 4222 sarniénsis $W$ 4226 unduláta $W$.

$\beta$ striatifolia Crinum latifolium Rox

$\beta$ pállida

4260 zeylánica $\dot{W}$

Tartarian or

Amaryllidece. Sp. 12.

1 my.s $\mathbf{P} \quad$ C. G. H. 1777. O r.m Bot. mag. 725

1 s.o $R$ Japan 1659. $\mathrm{r}$ m Bot mag.

1 jn.jl S $\quad$ C. G. H. 1806. O r.m Bot. mag. 1090

1 s.o Pk C. G. H. 1795. O r.m Bot. reg. 172

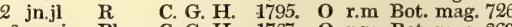

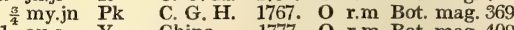

1 au.s $Y$ China 1777. O r.m Bot. mag. 409

$1 \frac{1}{2} \mathrm{jn} . \mathrm{jl} \quad$ Pk China 1758. O r.m Bot. rep. 95

$\begin{array}{llll}\frac{1}{2} \mathrm{jl} & \text { Pk } & \text { C. G. H. 1818. O r.m Bot. mag. 2124 }\end{array}$

C. G. H. 1820. O r.m Bot. mag. 2407

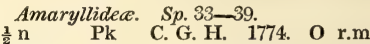

$\begin{array}{lllll}\frac{1}{2} \mathrm{n} & \mathrm{Pk} & \text { C. G. H. } & \text { 1795. O } & \text { O.m Ker's rev.pl.8.f.8 }\end{array}$

${ }^{\frac{3}{4}}$ my.au D.R N. Amer. 1658. O r.m Bot. mag. 47

$1 \frac{1}{2}$ my.au G.s Brazil … 0 r.m Bot. reg. 444

$1 \frac{1}{2}$ my.au G.s Brazil 1816. O r.m Bot. reg. 199

$1 \frac{1}{2}$ my.au G

1 jl.o $\mathrm{S}$

$1 \frac{1}{2}$ jl.o $\mathrm{S}$

2 my.jn $\mathrm{s}$

$\begin{array}{ll}\frac{3}{4} \text { my.jn } & \text { S } \\ \text { my.jn } & \text { P.Y }\end{array}$

$\begin{array}{ll}\frac{3}{4} \text { my.jn } & \text { P.y } \\ 1 \frac{1}{2} \text { ap } & \text { P.y }\end{array}$

$1^{2}$ ap.my $R$

$\frac{3}{\frac{3}{4} \mathrm{jn}} \quad \mathrm{Cr}$

$\begin{array}{lll}1 & \mathrm{n} & \mathrm{S} \\ 1^{\frac{1}{2} \mathrm{~s}} \mathrm{my} . j n & \mathbf{W} \\ \mathrm{R}\end{array}$

1 ap.my $\mathrm{Pu}$

1 ap.my $\mathrm{Pu}$

2 jlau W

3 jlau Pk

2 jl.au Pk

$\frac{3}{4}$ ap.my $\mathbf{S}$

$\frac{3}{3}$ ap.my Ve

$1 \frac{1}{2}$ my.jn $\mathrm{Pk}$

2 jl.s F

$\begin{array}{lll}2 & \text { jl.s } & \mathbf{F} \\ 1 & \text { ap.my } & \text { St }\end{array}$

$8 \mathbb{N}$ or 2 my.jl St

ช $\triangle$ or 2 jl $\quad$ Pk

2 jn.jl Pk

$2 \mathrm{~s}$

3 jl.au

2 jn.jl

2 jl.au

3 jl.s

ji.s

Amaryllidece.

Brazil 1816. O r.m Bot. reg. 164

W. Indies 1710, O r.m Bot, mag. 305

W. Indies 1710. O r.m Bot. reg. 234

America 1725, O r.m Bot reg. 453

Chili 1807. O r.m Bot. reg. 1125. 1

Chili 1821. O r.m Bot. reg. 1125. 2

. Amer. 1820. O r.m Lindl. coll. 11

Chili 1821. O r.m Bot. mag. 2399

Chili 1824. O r.m Bot. reg. 809

Peru 1822. O r.m Bot. reg. 724

Maranhåo 1821. O r.m Bot. reg. 719

Brazil 1777. O r.m Bot. reg. 657

Brazil 1815. O r.m

N. Holl. 1816. O r.m Bot. reg. 426

E. Indies 1819. O r.m Bot. reg. 579

Moluccas 1819. O r.m Bot. mag. 2292

Brazil 1815. O r.m Bot. reg. 38

Brazil 1815, O r.m Bot. reg. 23

Brazil O r.m Bot. reg 226

C. G. H. 1754. O r.m Bot. mag. 1450

W. Indies 1712 O p.l Bot. mag. 733

C. G. H. $\quad \ldots$ O p.1 Red. lil. 470

C. $\ddot{\mathrm{G}}$ H 1769. O r.m Bot. mag. 129

C. G. H. 1816. O r.m

C. G. 1752. r.m Bot. reg. 139

o r.m

Ceylon 1771. O r.m Bot. mag. 1171

W.pu Guinea 1774. O r.m Bot. mag. 1253

S. Leone 1792. O r.m Bot. mag. 923

E. Indies 1806, O r.m Rh. mal. 11, t.39

Siberia 1822. r.m

\% Nor $1 \frac{1}{2}$ my.jn

C. G. H. 1774. O r.m Bot. reg. 552

C. G. H, 1774, O rm Bot. mag 143
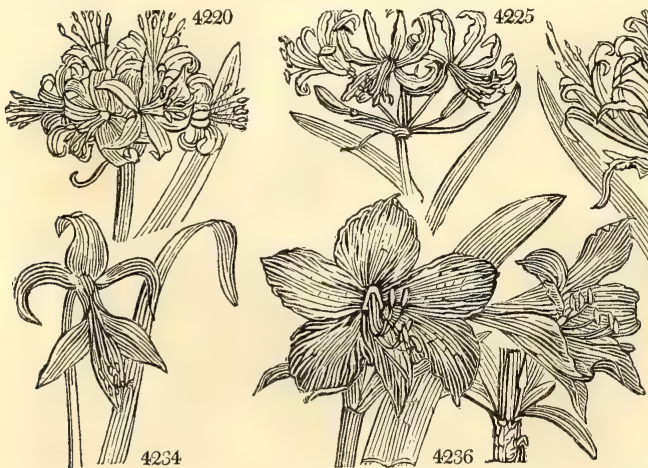

History, Use, Propagation, Culture,

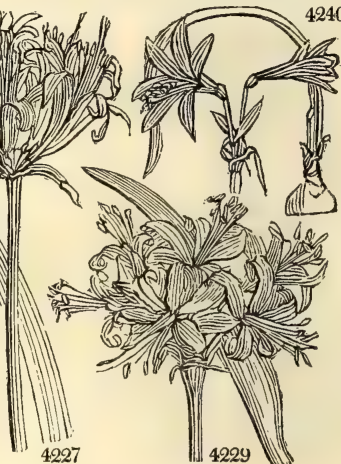

738. Nerine. A fanciful name. Nerine was the daughter of Nereus. The plant has become naturalized in Guernsey, having been part of the cargo of a Cape ship, which was cast away many years ago on the coast of the island. N. sarniensis is a popular autumnal bulb, imported annualiy from the islands of Jersey and Guernsey, where it is grown in the open air in a sandy soil. Here it requires the protection of a frame to perfect the bulbs, so as it may flower the following year. The reason is, that the leaves on which the perfection and future flowering of every bulb depends, are protruded in the beginning of winter, the perfection and future flowing our winters are too long, gloomy, and severe, to admit of these leaves performing their functions properly. Hence two or more winters in a very mild situation in the open air are required to do what in Jersey is done in one winter; or two winters (as W. Williamson experienced) in a cold frame, or one winter only (agreeably to Knight's experience) in a frame with artificial heat. (Hort. Trans. iii. 450. iv. 177, and Caled. Mem. ii. 62.) 
4220 Leaves narrow sub-involute glaucous falcate, Petals lin.-lanc. wavy, Stamens erect sub-exserted 4221 A mere variety of the foregoing, from which it differs in having crimson flowers 4222 Many-fl. Leaves many narrow sub-involute not glaucous upright

4223 Like the last, but the flowers are scarlet and appear at the same time as leaves

4224 Lvs. very narrow obt. min. pustulate, Sepals recurved divaricating: the one bearing the stamens remote 4225 Leaves few ligulate channelled, Sepals turned upwards oblique, Stam. declinate shorter than cor.

4226 Laxly many-fl. Lvs. few lin. Cor. recurved stel. irregular, Sepals curled; the lowest placed under the stam. 4227 Fl. stalked erect, Cor. infundibulif. clavate, Sepals linear lanceolate, Stamens straight, Leaves quite blue 4228 Five sepals, or all rising in a semicircular ray wavy, Stam. deflexed twice as long as cor.

4229 Leaves broad nerved lying on the ground, Sepals equally revolute, Stamens very long

4230 Leaves linear lorate, Scape flat smooth, Peduncles upright hispid 3-cornered twice as long as flower 4231 Leaves glaucous, Cor. deformed pale streaked with red

4232 Flower sessile, Leaf one linear, Sepals longer than tube ovate obl. reflexed acute, Stamens inclined 4233 One-flowered, Cor. regular erect turbinate conniving, One sepal pushed aside by the stamens 4234 Tube fringed, Cor nodding with a very ringent limb, Stam, included in the involute lower segments 4235 Tube crowned by a short entire green membrane

4236 Two-flowered half ringent, Membrane of the tube very short two-colored toothletted, Stamens included $4237 \mathrm{Mem}$. of orifice entire, Limb half ringent nodding with outer seg. incurved at end, the inner recurved 4238 Tube fringed, 2-3-f. Stalks shorter than the erect spatha, Tube horizontal, Limb curved upwards

4239 Tube fringed, 2-4-f. Lvs. few lorate acum. with a keeled rib, Cor. cernu. deeply turbin. Tube short thick 4240 Many-fl. Tube fringed, Leaves 1 or more linear ligulate involute glaucous, Stalks as long as nodding cor.

4241 Flowers about 2 with a very long tube and a nearly regular limb

4242 Leaves long strap-shaped with the scape very coesious, Flowers 4 ringent with taper pointed segments

4243 Cor. funnel-shaped campanulate drooping, Stamens straight exserted, Leaves green lorate obtuse 4244 Umbel 6-fl. Sepals rolled into a cylindrical tube, Flower-stalks the length of flowers, Stigma simple 4245 Flower solitary erect, Sepals conniving, Stamens ascending, Anthers innate, Leaves linear fleshy 4246 Flower nodding ringent, Outer sepals broadest, Throat naked, Tube the'length of the ovary

4247 Leaves several lorate-oblong narrow. towards the base, Flower cernuous cucull. tubular obliquely ringent

4248 Leaves linear very long and weak, Limb nodding 2-lipped, Flower-stalks many times longer than ovary 4249 Lvs. numerous spreading flat with rough edge, Fl. about 10 with nodd. spreading obsoletely 2 -lipped limb

4250 Bulb spherical, Spathe bifid erect obtuse, Flowers sessile, Leaves with a long point wavy downwards 4251 Spathe withered scarcely as long as stalks, Cor. cern. uneq. Tube as long as germen, Upper sepal remote 4252 About 2-fl. Spathe arid refl. Limb turbin. bilabiate: three upper sep. conniv. recurv. lower narr. remote 4253 Leaves obl. lanc. not glaucous, Flowers nodding with an oblique mouth, the upper one much reflexed 4254 Lvs. many obl, obtuse, Pedunc. divaricating as long as $\mathrm{fl}$. Tube short turbin. Limb recurved spreading 4255 With many fl. on stalks, Lvs. ligul. Cor. regular turbin. nodd. Sepals recurv, at end, Tube scarcely any

4256 Cor. cucul. campanulate, Outer sepals separate to the bottom; inner united half way by the interior ribs

4257 Lvs, altern. turn. both ways fal. Scape flat, Cor. regul. Tube twice as short as revol. limb. Stam. erect spread. 4258 Umb. many-fl. shortly stalked, Leaves attenuated glaucous, Tube about twice as long as limb

4259 Many-fl. Leaves acuminate glaucous, Flowers erect recurved stalked cucullate, Limb spreading revolute 4260 Leaves many lorate lanceolate wavy thick in the middle, Limb cernuous as long as tube

4261 Lvs. many lorate atten. channelled rough at edge, Limb obsoletely 2-lipped shorter than tube nodding 4262 Leaves obl. lanceolate narrowed both ways wavy rough at edge, Limb nodding shorter than tube 4263 Spathe many-fl. Flowers stalked tubular at base, Leaves obl. lanceolate

4264 Spathe 2-fl. Cor. campan. deeply 6-parted, Upper seg. very narr.; lower ob. acum.Lvs. lin. longer than scape

4265. The only species, Amaryllis purpurea of Willd

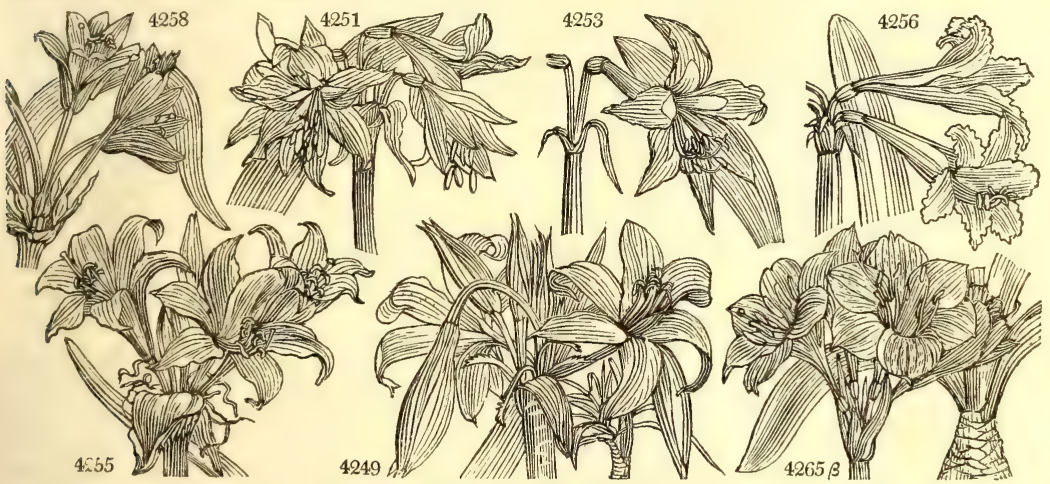

and Miscellaneous Particulars.

739. Amaryllis. Name of a nymph celebrated by the poets, and especially by Virgil Derived from

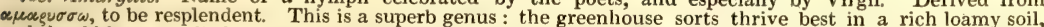
and should have but little water given them after they have done flowering, so that the bulbs may harden, to produce more flowers the following season. Most of them are increased freely by offsets, and ripen plenty of seed. A shell taken from the bulb, with a leaf on it, and planted in a pot of mould, will produce a bulb; as will almost any bulbous-rooted plant. (Bot. Cult. 131.)

The stove Amaryllises grow best in light loam and rich soil, and the strong growing kinas require large pots to flower in perfection; they are increased by offsets and by seeds, which they bear plentifully, if care be taken to shake some pollen on the stigma at the proper period.

740. Vallota. A name of unknown meaning. The only species of this genus is a beautiful Cape plant, with bright purple flowers, of which two varieties are known in gardens 
741. GRIFFI'NIA. Ker. Griffinia. 4266 hyacinthina Ker.

742. STERNBER'GIA. $W$. STERered

4268 colchiciflóra $W . \&$. Colchicum-fl. 4269 clusiana Ker. $\mathrm{K}$. Colchicum 4270 lútea Ker. Ecluse's $\delta \Delta$ or 4971 chloroléca $\mathrm{Ker}$ yellow $\gamma \Delta$ or 43. ZEPHYRAN'THES. Herb. ZEPHYRANTHES. 4272 tubispátha Herb. tube-sheathed $\delta \square$ or 4273 atamas'co Herb. Atamasco-Lily 8 or 4274 rósea $\mathrm{Lindl}$. rosy

744. HABRAN'THUS. Herb. Habranthus 4275 versícolor Herb. changeable $\delta \Delta \mathrm{ft}$ 745. DORYAN'THES. $R$. $B r$. DoRYANTHES, 4277 excélsa $R . B r$. gigantic $\backsim \cup$

746. GETHYL'LIS. $\boldsymbol{H} . \boldsymbol{K}$. Gethyllis. 4278 spirális $W$. 4279 ciliáris $W$ 4280 villosa $W$ lanceoláta $W$ spiral-leaved fringed hairy spear-leaved

747. POLI AN'THES, $L$ Tuberose. 4282 tuberósa $W$ Bflore pléno 4233 grácilis $L k$. common double slender \% $\triangle$ or \% $\triangle$ or \& $\triangle$ or * $N$ or ¿ or

Amaryllidece. Sp. 2.

1 jn.s B S. Amer. 1815. O r.m Bot. reg. 165 Pa.P S. Amer. 1815. O r.m Bot. reg. 511 Amaryllidea. Sp. 4-5,

$\frac{1}{4}$ au.s Y Hungary 1816. O r.m W.\&Kit. 2.t.157 $\frac{1}{2}$ au.s P.Y Constant. … O $\quad$ O r.m Clu. hist. 1. t.163 $\frac{1}{2}$ au.s $\quad$ Y S. Europe 1596. O r.m Bot. mag. 290

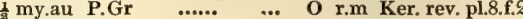
Amaryllidea. Sp. 3.

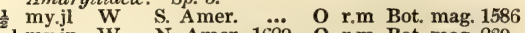
$\frac{1}{2}$ my.jn W N. Amer. 1629 . O r.m Bot. mag. 239 my.jn R Havann. 1823. O r.m Bot. reg. 821 Amaryllidea. Sp. 2.

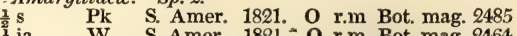
$\frac{1}{2}$ ja W S. Amer. 1821.- O r.m Bot. mag. 2464 Amaryllidece. Sp. 1

20 jl.au Cr N. S. W. 1800. Sk s.p Bot. mag. 1685 Amaryllidec. Sp. 4-10.

$\frac{3}{4}$ jn.jl W C. G. H. 1780 . s.p Bot. mag. 1088

jn.jl W C. G. H. 1788. s.p Jac.schœen.1.t.79

W C. G. H

3 au.s W E. Indies 1629. O r.m Bot. reg. 63

3 au.s P.Y Brazil $10 \%$

Amaryllidece. Sp. 5-14.

1 jn.s St Peru 1753. S r.m Bot. mag. 139

$\frac{3}{4}$ f.mr S Peru 1776. R l.s.p Bot.mag. 125

6 jn.jl G.Cr S. Amer. 1806. R l.s.p Bot. mag. 1613

$1 \frac{1}{2}$ jn W.P.Y Chili 1822. S l.s.p Bot. reg. 731

4285 Ligtu $W . W$ striped-flower'd 4286 salsilla $W$. $\quad$ eatable-rooted 4287 Flos Martini Ker. Flor de St. Mar. $\$$ \ or 4288 pulchel'la Sims. red-flowered $t \square$ or 749. Conanthe'RA. Fl. per. Conanthera. 4289 campanuláta $L i n d l$. bell-fiowered $\measuredangle \sqcup$ or 750. HYPOX'IS. $W$. 4.990 erécta $W$ 4291 sobolifera $W$ 4292 villósa $W$ 4293 decúmbens $W$. 4294 obliqua $W$. 4295 aquática $W$. 4296 álba $W$. 4297 obtása B. Reg. 4298 ováta $W$ 4299 stelláta $W$. $\beta$ élegans P.S. Hypoxis. upright creeping villous villous
obliqué-leaved $\Delta$ or water $\Delta$ or white white iv or smooth-leaved $\triangle \mathrm{N}$ or star-flowered $\triangle \mathrm{N}$ or white star-flow. $\triangle$ or

Amaryllidee.
$\frac{3}{4} \mathrm{mr}$$\underset{\mathrm{Chili}}{\mathrm{B}}{ }^{1-2}$ 1823. R 1.s.p Bot. mag. 2496 Hypoxidea. Sp. 15-19.

$\frac{1}{2}$ jn.jl Y N. Amer. 1752. O p.l Bot. mag. 710

$\frac{1}{2}$ jn.s $\quad$ Y C. G. H. 1774. O p.1 Bot. mag. 711

$\begin{array}{lllll}\frac{3}{4} \text { jn.s } & \text { Y } & \text { C. G. H. 1774. O p.1 Jac. ic. 2. t. } 307\end{array}$

$\frac{1}{2}$ jn.s Y Jamaica 1755. O p.1 Mill. ic.1.t.39.f.2

$\begin{array}{llllll}\frac{1}{3} \text { jn.jl } & Y & \text { C. G. H. } & \text { 1795. O p.l } & \text { Bot. rep. } 195\end{array}$

$\begin{array}{lllll}\text { jn.jl } & \text { Y } & \text { C. G. H. 1787. O p.I }\end{array}$

光 jn W C. G. H. 1806. O p.1 Jac. coll $4 . t .2 . \mathrm{f} 1$

$\begin{array}{llllll}\frac{1}{3} & \text { jn } & \mathbf{Y} & \text { C. G. H. 1816. O p.1 Bot. reg. } 159\end{array}$

$\begin{array}{lllll}\frac{1}{2} \text { f.my } & \text { Y } & \text { C. G. H. 1806. O s.p Bot. mag. } 1010\end{array}$

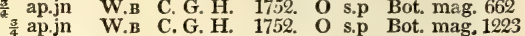

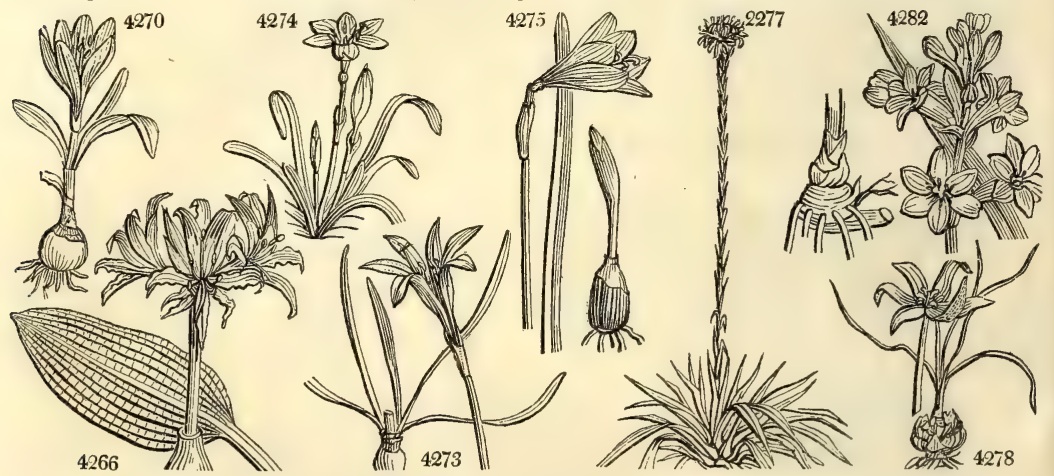

History, Use, Propagation, Culture,

741. Griffinia. Named by Mr. Ker, after William Griffin, Esq. of South Lambeth, an amiable man, and most assiduous and successful collector of bulbous plants. His collection is even now one of the finest in Europe. These species resemble Amaryllis, but have broad-stalked leaves, and blue flowers.

742. Sternbergia. Named after Count Caspar Sternberg, a celebrated botanist and patron of botany. The species consist of the hardy plants formerly referred to Amaryllis; they are all hardy, and, with the exception of $S$ lutea, very rare.

743. Zephyranthes. A fanciful name employed by Mr. Herbert. It seems to mean wind-flower. These are pretty plants, with solitary white or pink flowers. The species are so nearly hardy, as to survive in a warm border all but our severest winters.

744. Habranthus. From $\dot{\alpha} e_{\rho} \circ$, delicate, and $\alpha_{\nu}$. habit, and principally distinguished by their very unequal declinate stamens.

745. Doryanthes. So called by Correa de Serra, from dogv, spear, and cev. straight stem, surmounted by a head of crimson flowers. This is a fine plant from New South Waies. It grows freely in a mixture of sandy loam and peat, but does not flower till it gets large: a conservatory is the most proper place for it, as the flower-stem grows to a great height before the flowers expand. It may be increased by suckers from the roots, but these are sparingly produced. (Bot. Cult. 181.)

746. Gethyllis. From $\gamma \eta$ i $\varepsilon \omega$, to rejoice. The flowers are much valued at the Cape of Good Hope for the delicious perfume of their flowers. The species are very curious : but few have been introduced Their bulbs re quire the usual attention as to not watering them when in a dormant state; they are increased by offsets or sceảs. 
4266 Leaves with a flat stalk, The three lower sepals wavy, Scape with a prominent line along each side 4267 Leaves oval-lanceol. with a stalk two-edged crosswise, Umbel remarkably stalked, Sepals uniform

4268 Leaves linear obliquely twisted shining

4969 Leaves lorate flat very glaucous laxly spiral

4270 Leaves many-keeled, Flower sessile on a two-edged scape, Sepals oval-oblong obtuse

4271 About 2 flowered, Leaf linear, Tube very short, Sepals rounded at end

4272 Leaves few linear, Spathe 1-leaved sheathing erect bifid twice as short as stalk

4273 Leaves many ligulate, Spathe bifid longer than stalk, Sepals acuminate

4274 Leaves lying flat on the ground shorter than the one-flowered scape, Spathe bifid fleshy at end

4275 Leaves linear

4276 Leaves cylindrical

\section{The only species}

4278 Leaves linear spiral smooth, Sepals ovate oblong 4279 Leaves linear spiral ciliated, Sepals ovate oblong

4280 Leaves linear filiform spiral villous, Sepals ovate oblong

4281 Leaves lanceolate flat, Sepals lanceolate

4282 Leaves linear lanceolate, Sepals oblong

4283 Leaves linear, Scape racemose, Sepals linear

4284 Stem erect, Cor. spreading, Three outer sepals wedge-shaped 3-toothed, I,eaves lin. lanc. sessile 4285 Stem erect, Leaves spatulate oblong, Pedunc. longer than involucr. Cor. 2-labiate 4286 Stem twining, Cor. cylindrical in branched umbels

4287 Stem erect, Leaves linear lanceolate, Flower-stalks twisted, Outer sepals obcordate mucronate 4288 Stem weak, Leaves spatulate ciliated, Umbel many-flowered, Peduncles 2-flowered

\section{Flower campanulate spreading}

4290 Hairy, Scape 4-fl. shorter than lin. lanc. leaves, Pedunc. twice as short as leaves 4291 Like the last, but the leaves are shorter more villous and incurved, Petals more obtuse 4292 Villous, Scape 4-fl. shorter than lin. lanc. lvs. Pedunc. shorter than flower, Fruit cylindrical 4293 Pilose, Scape 2-fl. decumbent shorter than lin. lanc. leaves

4294 Scape 3 -fl. pilose as long as leaves, Pedunc. thrice as long as ff. Leaves lanc. smooth obliquely bent 4295 Leaves linear, Scapes umbelliferous or 1-fl. Height depending on depth of water 4296 Scape 1-flowered shorter than filiform rounded smooth leaves

4297 Leaves at the edge and keel hairy, Scape hispid many-flowered racemose, Sepals obtuse 4298 Leaves ovate-lanceolate entire smooth, Scapes 1-flowered

4299 Scape 1-flowered shorter than the lin. lanc. loose keeled smooth ieaves
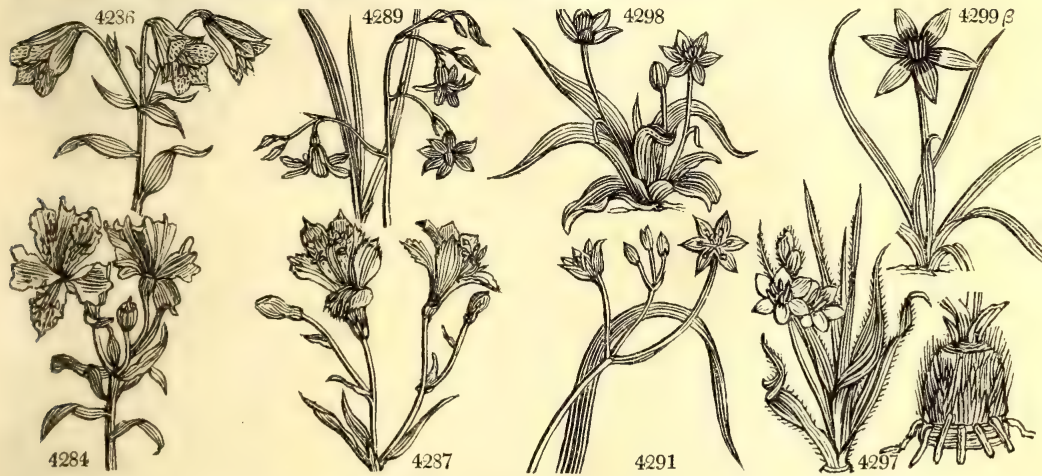

and Miscellaneous Particulars.

747. Polianthes. From rov.vs, many, and ay.9os, a flower; in allusion to the abundance of the blossoms. This is a very popular bulb, on account of its highly odoriferous flowers. It is imported annually from Italy and America, and flowers freely in pots of sandy loam and some rotten dung or leaf mould. R. A. Salisbury is of opinion that we might grow our own bulbs, by planting the offsets in such a situation as would obtain for them a "sufficient degree of heat in summer to bring their 'eaves out to their full magnitude, that of the roots following of course." "The theory," he adds, "which I would recommend any intelligent gardener to adopt in its general management is, to keep the roots growing as vigorously as possible from May to October, but in a state of complete rest and drought for the rest of the year." (Hort. Trans. i. 53.)

748. Alstromeria. So named from Baron Claudius Alstroemer, of Sweden, who in his travels through Europe sent many plants to Linnæus. The species are beautiful, and A. Ligtu is as fragrant as mignionette. A Salsilla is cultivated in Peru and the West Indies for its roots, which are used like the tubers of the potatoe.

A. Ligtu, Sweet observes, " is generally considered difficult to flower; but it will blossom well by letting the pots be dry for a considerable time till the shoots are all dried up; then give it a good watering, and put it in a moist heat, and it will flower abundantly. It may be increased by parting the roots or by seed." (Bot. Cult. 15.) The finest kinds have not yet been introduced to this country.

15.) The finest kinds have not yet been introduced to this country.
749. Conanthera. From zovos, a cone, and cevinec, an anther; their anthers being, which is singular among these plants, united into a cone. A pretty little Peruvian genus, of which two species are now known.

750. Hypoxis. From íro, beneath, and okvs, pointed, in allusion to the sharm points of the inferior sepals. The species are plants with yellow flowers of little beauty, if we except $H$. stellata, which has a dark spot at the claws of its white petals. They increase fast by seeds or offsets. 
$\mathbf{4 3 0 0}$ stellipílis $\mathrm{Ker}$. 4301 veratrifólia $W$. 4302 lineáris B. Rep. 4303 serráta $W$. 4304 júncea $W$.

751. CURCU'LIGO. $H$. 4305 sumatrána Roxb. 4306 plicáta $H$. $K$. 4307 orchioídes $W$ 4.308 brevifólia $H . K$ 4309 latifólia $H . K$. 4310 recurváta $H . K$. 752. BAMBU'SA. $W$ 4311 arundinácea $W$ 4312 verticilláta $W$.

753. CA'LA MUS. $W$. 4313 ruden'tum $W$. 4314 Zalácca $W$.

754. EHRHAR'TA, $W$ 4315 panícea $W$. 755. A'CORUS. $W$. 4316 cálamus $W$. 4317 gramíneus $W$

756. ORON'TIUM. $W$. 4318 aquáticum $W$ 4319 japónicum $W$

757. TUPIS'TRA. B. $M$. 4320 squálida $B . M$.

758. TAC $^{\prime} \mathrm{CA} . W$ 4321 pinnatífida $W$ 4322 integrifólia $B . M$.
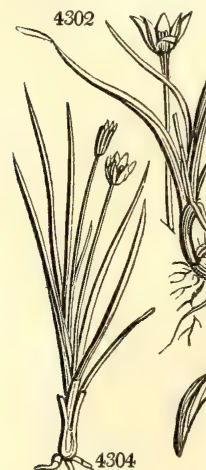

starry-haired plaited-leaved linear-leaved saw-leaved rushy

K. Curculigo Sumatra

plaited-leas narrow-leaved short-leaved broad-leaved recurved-leav'd

Bamboo Cane. whorl-flowered

Calamus. common Java

Ehrharta. Panic-grass

Acorus. sweet-flag grass-leaved

Orontium. aquatic Japan

TUPISTRA. Amboyna

Tacca.

Salep entire-leaved

\begin{tabular}{|c|c|}
\hline$\checkmark \Delta$ or & \\
\hline$\Delta$ or & $\begin{array}{l}1 \\
2 \\
2 n\end{array}$ \\
\hline $\bar{f} \sim$ or & ap.my \\
\hline$\Delta$ or & 1 jn.jl \\
\hline $\bar{N}$ or & $\frac{1}{2} \mathrm{jn} . \mathrm{jl}$ \\
\hline
\end{tabular}

Hypoxidece.

6 or $3 \mathrm{ji} \mathbf{Y}$ $\Delta$ or $1_{\frac{1}{2}} \mathrm{jn} . j 1 \quad \mathrm{Y}$ W or ${ }^{\frac{1}{2}} \mathrm{jn} . \mathrm{jl} \quad \mathrm{Y}$ 牙 or ${ }^{\frac{1}{2}}$ my.jl $\quad Y$ or $1 . . Y$

Graminea.
C. G. H. 1821. O s.p Bot. reg. 663

C. G. H. 1788. O 1.p Jac. ic. 2. t. 367

C. G. H. 1792. O 1.p Bot. rep. 171

C. G. H. 1788, O l.p Bot mag. 709

Carolina 1787. O 1.p Smi, spic.15. t.16 Sp. 6-10.

Sumatra 1818. O 1.p Bot. cab. 443

C. G. H. 1788, O 1.p Bot. reg. 345

E. Indies 1800. O l.p Roxb cor.1. t.1s

E. Indies 1804. O 1.p Bot. mag. 1076

Poolo Pin. 1804. O 1.p Bot. mag. 2034

Bengal 1805. O l.p Bot. reg. 770

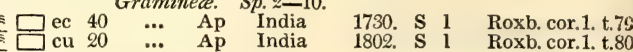
alme. $S p$.

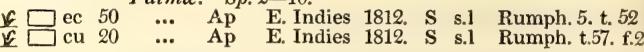
Graminea. Sp. $1-8$

业 $\triangle \mathrm{V}$ cu 2 my.jl Ap C. G. H. 1790. S co Smith ined.1.t.9 Aroideo. $\quad$ Sp. 2-3.

* $\triangle \mathrm{m} 2$ jn.jl Ap Britain pools. D m.s Fng. bot. 356 $\Delta \mathrm{cu} \quad \frac{1}{3} \mathrm{f}$ Ap China 1786. D s.p Smi. spic.15.t.17 Aroidece. $S p .2-4$.

当 $\Delta \mathrm{cu} \quad \frac{1}{2} \mathrm{jn} \quad \mathrm{Ap} \quad \mathrm{N}$. Amer. 1775. D s.p Hook. ex. fl. 19

$\Delta$ ec 2 ja.ap Ap Japan 1783. D s.p Bot. mag. 898 Aroidece. $S p .1$.

$\sum \square$ cu 2 ap id Amboyna 1810. R l.p Bot. reg. 704 Aroidea. Sp. 2.

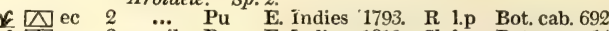

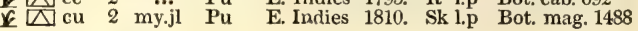
Indies 18

\section{(6)}

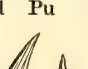


4300 Leaves radical numerous white beneath with stellate hairs, Umbel few-flowered 4301 Scape 1-fl. shorter than the oblong elliptical smooth plaited leaves

4302 Leaves linear smooth channelled, Flower solitary green outside

4303 Scape 1-fl. shorter than the linear ciliate serrate keeled leaves, Flowers out of flower refiexed

4304 Leaves channelled hairy entire, Scapes 1-fl.

4305 Leaves lanceolate on long stalks, Head sessile, Flowers shorter than bractes 4306 Leaves linear subulate, Flowers sessile

4307 Leaves linear subulate, Flowers stalked

4308 Leaves lanceolate, Tube of flower very long

4309 Leaves elliptical, Head sessile, Tube of flower scarcely longer than limb

4810 Leaves elliptical recurved, Head stalked cernuous, Tube of flower very short

4311 Panicle branched divaricating

4312 Spike terminal simple whorled

4313 Prickles of stem reflexed, Spadix divaricating straight

4314 Prickles spreading, Spadix radical

4315 Culm divided, Panicle branched, Flowers erect digynous

4316 Point of scape very long leafy

4317 Point of scape scarcely longer than spadix

4318 Leaves lanceolate-ovate

4319 Leaves ensiform

4320 The only species

4321 Leaves tripartite multifid

4322 Leaves ovate lanceolate entire stalked

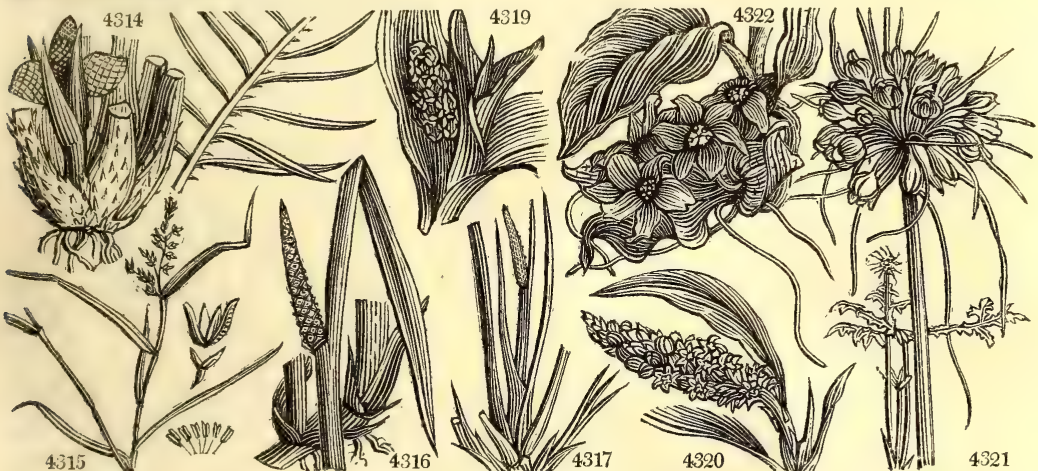

and Miscellaneous Particulars.

there are several species or varieties, all distinguished by a stem which is perennial, unbranched, long, round, solid, jointed, scandent when near trees, but without prickles or tendrils, extremely tough and pliable. The diflerent sorts grow on the banks of rivers in the East, like our reeds, and furnish valuable props for plants, cables, ropes, withs, wicker and wattled work, baskets, hoops for petticoats, walking-sticks, \&c.

C. Zalacca, the Salxck, is cultivated for the fruit, which is about the size of a walnut, and covered with scales like those of a lizard; within the scales are two or three sweet yellow kernels. This tree is supposed to yield the dragon's blood.

754. Elhrharta. So named by Linnæus, in honor of Frederick Ehrhart, a native of Switzerland, a very diligent and acute observer. These are very curious grasses, of which an account has been published in the Transactions of the Linnean Society.

755. Acorus. From $\alpha$, privative, and zogn, the pupil of the eye, maladies in which are supposed to be cured by the virtues of this plant. Acorus Calamus, Linnæus observes, is the only native aromatic plant of northern climates; the root powdered might supply the place of foreign spices. It has a strong aromatic smell, and a warm, pungent, bitterish taste. The flavor is greatly improved by drying. The roots are commonly imported from the Levant; but those of our own growth are full as good. The Turks candy them, and regard them as a preservative against contagion. In many counties of England, in which the plant abounds, it was formerly used to strew the floors of houses instead of rushes; a purpose for which its fragrant leaves made it very suitable.

The aromatic principle is an essential oil, which can be obtained by distillation. The root has been employed in medicine since the time of Hippocrates. By the moderns it is successfully used in intermittent fever even after bark has failed, and is certainly a very useful addition to Cinchona. It is also a useful adjunct to bitters, and stomachic infusions. Thomson says, (Mat. Med. 134.) it is too seldom prescribed. Though the plant is abundant in the fenny districts of England, yet what is used by the druggists is imported from the Levant. No cattle whatever eat the plant.

756. Urontium. The Greek name of a plant now unknown to us as such. It is thought co have been so called from growiug on the edge of the Orontes, a river of Asia Minor $O$. japonicum has broad leaves like those of the lily of the valley, green on the upper side, and covered with very minute hairs, so that they look like a fine velvet. Cattle, hogs, and stags, are very fond of these leaves in the spring, and they come out among the earliest. Kalm states, that the Indians gather the seeds and eat them when dried like peas, boiling them repeatedly in water before they are fit for use; they also boil them in milk or butter, and use them instead of bread. They call the plant Tawkee. It grows in marshes, near moist and low grounds, very plentifully in Virginia, Canada, and other provinces of North America.

757. Tupistra. A diminutive of $\tau$. $\pi \alpha_{5}$, a mallet, on account of the peculiar form of the flower. An obscure plant, supposed to belong to the order Aroideæ. It has long lanceolate broad leaves, and radical spikes of dingy purple flowers. It requires the heat of a bark-bed.

758. Tacca. The Malay name of the plant. T. pinnatifida has a red root, the size of a man's fist, roundish. 
759. ASPIDIS'TRA Ker AsPIDISTRA. 4323 lurida $K e$

760. JUN'CUS. $\boldsymbol{L}$. 4324 acútus $W$

4325 maritimus $P$. $S$. 4326 conglomerátus $W$. 4328 glaucus $W$. 4399 bálticus $W$. 4330 árcticus $L$. 4331 filifórmis $W$ 4332 trifidus $W$. 4333 squarrósus $W$. 4334 grácilis $E$. $B$. 4336 lampocárpus $\boldsymbol{L} . T$. 4337 acutiflórus $\boldsymbol{L}$. $\boldsymbol{T}$. 4339 uliginósus $\boldsymbol{H} . \boldsymbol{K}$. 4310 aristátus Mich. 4342 bulbósus $W$. 4343 bufónius $W$. 4344 triglumis $\dot{W}$. 4345 biglúmis $W$. 4346 castáneus $H$. $K$.

761. LU'ZULA Dec. 4347 pilósa $W$. 4348 Forstéri $E . B$. 4349 máxima $W$. 4350 lútea $W$. 4350 nivea $W$ 4353 campéstris $W$. 4354 congésta $W$. en 4355 spicáta $W$ 4356 flavéscens $\mathcal{L} k$. dingy

RusH.

sort

coast

coast

arctic

least

three-leaved

Goose-corn

slender bearded

half-whorled bulbous-rooted toad

three-flowere black-spiked

Luzula.

hairy

Forster's

wood

yellow

snowy

field 4327 effúsus $W$. 4335 capitátus $W$. 4338 obtusiflórus $\boldsymbol{L}$. $\boldsymbol{T}$. 4341 subverticillátus 4351 álbida $W$
Juncece Sp.

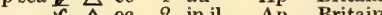

headed $\mathrm{O}$ cu ${ }^{\frac{1}{2}} \mathrm{jl.au}$ blunt-flowered $\Delta$ w $1 \frac{1}{2}$ au two-flowered

cu 1 jl

$\triangle \mathrm{cu} \quad \frac{3}{4} \mathrm{jl} . \mathrm{au}$

1 jl.au

1 jl.au

Iili Juncec. Sp. 10-25.

white-headed 내 $\triangle$ cu 1 my.jn Ap

FAN-PAL:

great sharp-flowered $\Delta$ w 2 jl.au little-bulbous $\Delta$ w 1 jn.jl

1822. Sk co Bot. reg. 628

sea co. S s Eng. bot. 1614 sal.m. S s Eng. bot. 1725 moi.p. S m.s Eng. bot. 835 moi.p. S m.s Eng. bot. 836 England moi.p. S m.s Eng. bot. 665

Europe 1820 . S s

Norway 1822. S m.s Flor.Dan.t.1094

Britain tur.bo. S m.s Eng. bot. 1175

Scotland sc.alp. S m.s Eng. bot. 1482

Britain sa.hea. S m.s Eng. bot. 933

Scotland sc.alp. S m.s Eng. bot. 2174

Europe 1823. S s

Britain moi.p. S m.s Eng. bot. 2143

Britain moi.p. S m.s Eng. bot, 238

Britain mar. S m.s Eng. bot. 2144

England tur.he. S m.s Eng. bot. 801

N. Amer. 1823. S s

Europe 1821. S m.s

Britain ... S m.s Eng bot. 934

Britain w.s.gr. S m.s Eng, bot. 802

Britain bgs.m. S m.s Eng. bot. 899

Scotland bgs.m. S m.s Eng. bot. 898

Scotland sc.alp. S m.s Eng. bot. 900

Britain woods. S m.s Eng. bot. 737

Switzerl. $\quad \ldots$ S m.s

Switzerl. ... S S m.s Leer.her.t.13.f.6

Switzerl. 1770. S m.s Sch.gram.t.7.f.7

Britain bar.pa. S m,s Eng. bot. 672

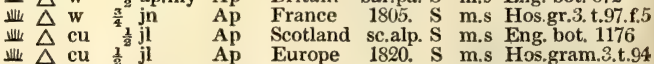

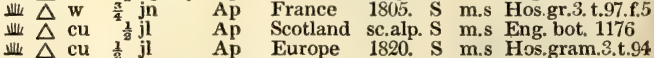

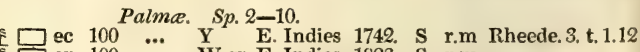

4357 umbraculifera $W$

4358 Taliéra $R o x b$.
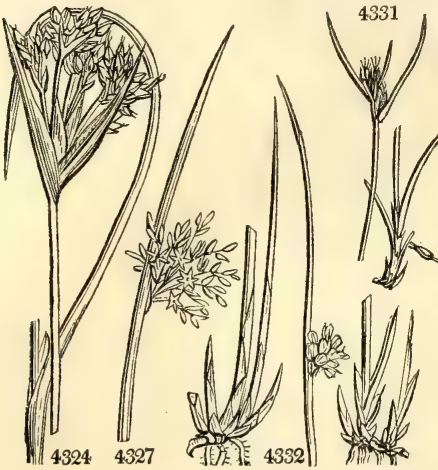

History, Use, Propagation, Culture,

... W.gr E. Indies 1823, S r.m

In its natural state it is one of the most bitter and acrid but loses something of these qualities by culture. The raw root is rasped, and washed frequently in water, when a white meal falls to the bottom like starch: this is again washed twice or thrice, till no more acrimony can be perceived in the water. The meal is then dried in the sun. The first infusions are thrown away carefuliy, being looked upon as noxious and even deadly. In Otaheite and the other Society isles, they make of this meal a tasteful, nourishing, gelatinous cake-like salep. In Banda, where sago bread is not common, they use this as a succedaneum, and it is even preferable to the other. They also apply it as a plaster to deep wounds. The petioles and stalk boiled a long time lose their acrimony, and are rendered fit for food, as well as the roots, in China and Cochin-China.

759. Aspidistra. From $\alpha \sigma \pi i s$, a little round shield, on account of the form of the fiower. A plant with the same habit as Tupistra, but with solitary radical flowers half buried in the earth.

760. Juncus. From the Latin, jungo, to join: the first ropes were made of rushes. The Junceæ and Cyperaceæ form intermediate links between the Gramineæ and the Liliaceæ; some of the latter, as Anthericum, bearing considerable resemblance to the Juncex.

$J$. acutus and maritimus are planted on the sea-embankments of Holland, and also in some parts of our own coasts, and in America. The roots run deep into the sand, and form a matted body which holds it together. In Holland, when the plants are fully grown and in flower, they are cut down down, dried, and bound up like corn. The J, acutus, being very rough, is used for scouring copper and other vessels, and is one of the plants imported into this country for that purpose, under the name of the Dutch rush. The other species, and often both, are plaited into mats, baskets, chair-bottoms, ropes, \&c.

J. conglomeratus and effusus are used when green for making little baskets and children's ornaments ; and the pith of this and other species is used as wicks for watch-lights, and children's toys.

J. glaucus and conglomeratus are bad weeds in wet-bottomed clayey pastures. The best way of removing them is to dig them out, and to prevent their growth, to lay the land dry by surface and under-drainage. These species, and some others, are gathered green by the Dutch gardeners, and used when dry as tyes for fruit-trees. Sir J. E. Smith says, " they both, probably, served for strewing floors in Englanì, as mentioned by Shakspeare and Sir Thomas More, about the time of Edward IV., and later; till more refined manners wrought 


\section{The only species}

4324 Culm rounded mucronate, Panicle terminal, Invol. 2-leaved spiny

4325 Panicle terminal proliferous, Involucre 2-leaved spiny, Caps. obl. acute as long as sepals 4326 Culm upright, Pan. lateral globose, Caps. retuse, Flowers triandrous

4327 Culm upright, Pan. lateral decompound effuse, Caps. clavate truncate at end

4328 Culm glaucous at the end bent inwards and rounded, Pan. lat. erect, Caps. oblong acute

4329 Culm pungent, Panicle effuse

4330 Culm erect, Umbel lateral, Pedunc. many-fl. Flowers sessile

4331 Culm filiform nodding, Panicle lateral

4332 Leaves and flowers ternary terminal

4333 Leaves setaceous, Heads clustered leafless

4334 Leaves linear flat, Stem dichotomous racemose higher than leaves, Flowers solitary

4334 Leaves linear flat, Stem dichotomous racemos in an involucre

4335 Culm filiform, Head terminal sessile solitary in an involucre

4337 Leaves jointed compressed, Culm not jointed, Panic. compound dichotomous, Sepals acute

4338 Leaves and stem jointed round, Panic. divaricating, Sepal obtuse as long as capsule

4339 Leaves bristly somewhat knotty, Heads 3-flowered proliferous, Culm bulbous rooting

4340 Bulbous, Culm leafy crect compressed, Flowers 3-androus and bracteæ bearded

4341 Culm procumbent, Leaves setaceous jointed, Corymb dichotomous divaricating, Head 5-fl. sessile

4342 Ieaves linear channelled, Culm leafy at base, Pan. cymose, Caps. obtuse

4343 Leaves linear channelled, Culm dichotomous racemose, Flowers solitary

4344. Leaves flat, Head 3-flowered terminal erect leafless with bracteæ

4345 Leaves flat, Head 2-flowered terminal one-sided leafy at base

4346 Leaves flat stem-clasping, Head terminal double many-flowered leafy at base, Bractes acute

4347 Leaves pilose, Panic. cymose divaricating, Flowers solitary, Caps. obtuse

4348 Leaves pilose, Panic. cymose erect, Flowers solitary, Caps. pointed

4349 Leves pilose taper-pointed, Panic. cymose decompound, Flowers in bundles

4349 Leaves pilose taper-ponted, Paning

4350 Leaves and sheaths smooth, Corymb comp. sioner than leaves, Sepals mucronate equal, Ront fibrous

4351 Leaves pilose, Corymb decomp. spreading shorter than leaves, Sepals mucronate equal, Ront fibrouts

4353 Leaves pilose, Spikes terminal, Capsules obtuse

4354 Like the last, but the culm is panicled with ovate spikes

4355 Leaves flat, Spike racemose nodding compound at base, Capsules acute

4556 Like Luzula pilosa, but heads are yellower, Leaves broader, Flowers and capsules larger

4357 Fronds pinnate palmate with a thread between the segments, Spadix erect

4358 Seeds roundish dark-colored rugose the size of a nutmeg

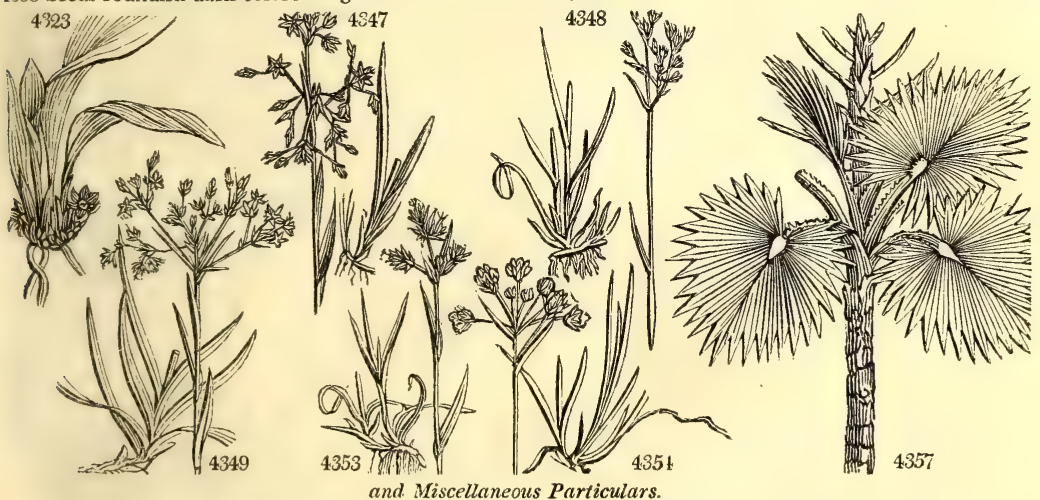

them into mats, and foreign commerce at length introduced carpets. For the former purpose, indeed, as well as for chair-bottoms and hassocks, Scirpus lacustris has superseded their use. (English Flora, p. 162.)

761. Luzula. These plants were called by the ancient botanists Gramen Luzula; whence this name has been contrived by Decandolle to distinguish the rushes with flat leaves, from those which have leaves resembling the stem.

762. Corypha. From zoeuøn, the summit of any thing; a name applied by Linnæus to this noble genus of palms, the topmost leaves of which form immense fans twenty feet long and fifteen wide. In Ceylon this palm is called Tallipot, and, according to Knox (Hist. of Ceylon.), it grows as big and tall as a ship's mast, and very straight. The leaves are of great use, one being so broad and large, that it will cover fifteen or twenty men. Being dried it is very strong and limber; and though it be very broad when open, yet it will fold close like a fan, and then is no bigger than a man's arm. The whole leaf spread is round, but is cut into triangular pieces for use : these they lay upon their heads as they travel, with the narrow end foremost, to make their way for use : these they lay upon their heads as they travel, with the narrow end foremost, to make their way
through thickets. Soldiers all carry them, not only to shade them from the sun, and to keep them dry in case of rain on their march, but to make their tents for them to lie under. These leaves all grow on the top of the tree. It bears no fruit until the last year of its life, and then yellow blossoms, most lovely to behold, but smelling very strongly, come out on the top, and spfead abroad in great branches; these come to a fruit, round and very hard, as big as our largest cherries ; in such abundance, that one tree will yield seed enough for a country; but not good to eat. The flowers smell so strong, that they cut down the trees when they are near country ; but not good to eat. The flowers smell so strong, that they cut down the trees when they are near
houses. The trunk within is a pith only, which they beat in a mortar to flour, and bake cakes of it, which taste much like white bread. The leaves also serve for covering their houses, and for writing on with an iron style. Most of the books which are shown in Europe for the Egyptian papyrus, are made from the leaves of this palm. In Malabar it is called Codda-pana. Rumphius, Loureiro, and Adanson mention several other species of this palm.

The $\mathrm{C}$. taliera is a fine tree of prodigious use in the northern provinces of India for covering houses and for other useful purposes. 
763. LICUA'LA. $W$. 4359 spinósa $W$

764. THRI'NAX. $W$ 4360 parviflóra $W$.

765. TRADESCAN 4361 virgínica $W$ 4362 rósea $P h$ 4363 subáspera $B$. $M$. 4364 crassifólia $W$. 4365 erécta $W$. 4366 díscolor $W$. 4367 malabárica $W$ 4368 fuscáta $L o d d$. 4369 parviflóra Fl. per. 4370 geniculáta $W$. 4371 cristáta $W$. 4372 Zanónia Red.

\section{DICHORIZAN} 4373 thyrsiflóra Vand. 767. AGAPAN'THUS. 4374 umbellátus $W$ $\beta$ variegatus

4375 præ'cox $W$. en

768. BLANDFOR'DIA

grandiflóra $R . B r$. 4378 gramínea $\boldsymbol{H}$. $\boldsymbol{K}$. 4379 fáva $H . K$. 4380 disticha Donn.

4381 fúlva $W$.

4382 Liliast Anthericum Liliast 438z Japónica $B . M$. 4384 cærúlea $H$. $K$.

770. A'LOE. $W$ 4385 atrovirens Dec. 4386 tortuósa Haw. 4387 rigida Dec. 4388 áspera Haw. 4389 viscósa Haw. 4390 álbicans Haw. 4391 cymbifórmis Haw. 4392 reticuláta Haw. 4393 recúrva Haw. 4394 retúsa $W$. 4395 mirábilis Haw. 4396 translúcens $H . K$
Licuala. spiny

Thrinax. small

W. SPIDERWor common rose-flowered Lyon's thick-leaved \& $\Delta$ or upright purple-leaved Grass-leaved rusty small-flowered knotted crested Gentian-leav'd or
Palma. Sp.1-2.

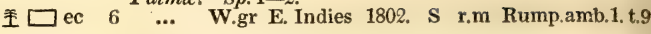
Palma. Sp. 1-3.

生 $\square$ ec $15 \quad$... W.gr Jamaica 1778, S r.m Commelinea. Sp. 12-29.

11 my.o B N. Amer. 1629. D p.1 Bot. mag. 105 1 my.o Pk Carolina 1802. D r.m Bot. cab. 370

my.o Pu N. Amer. 1812. D r.m Bot. mag. 1597 3 jl.o B Mexico 1796. L s.p Bot. mag. 1598 2 jl.au B Mexico 1794. S r.m Bot.mag. 1340 1 ap.s W S. Amer. 1783. Sk s.p Bot. mag. 1192 1 jl.au $\mathrm{Pu}$ E. Indies 1776. Sk r.m Rheed.ma.9.t.6

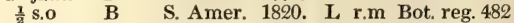

$1^{\frac{1}{2}}$ au.s B Peru 1822. L r.m Fl. per. t. 272

1 jl.au B W. Indies 1783. L s.p Jac. amer. t. 64 1 jl.s B Ceylon 1770. D r.m Bot. mag. 1435 $1 \frac{1}{2}$ jl.d B W. Indies 1759. S r.m Red. lil. 192 A. Vand. Dichorizandra. Commelinee. Sp. 1-4.

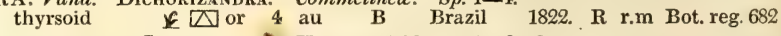
W. African Lily. "Hemerocallidere. Sp. 2-3. large-flowered $\gamma \mathrm{N}$ or 3 ja.au B $\quad$ C. G. H. 1692. R r.m Bot. mag. 500

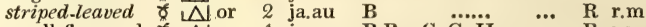

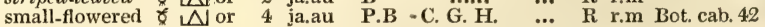
Hemerocallidece. Sp. 2-3. R. Br. BLANDFordia.

2 jl.au Or N. S. W. 1803. S s.l.p Ex.bot.1.t.4 noble $l$ arge-flowered $\frac{\mathbb{N} \text { or }}{\mathcal{N} \text { or }}$

2 jl.au Cr N. S. W. 1812. S s.l.p Lab. no.ho.t.11: Hemerocallidee. Sp. $7-9$

1 jn.jl L.Y Siberia 1759. R s.l Bot. mag. 873 2 jn $\mathrm{Y}$ Siberia 1596. R s.l Bot.mag. 19 2 my.jl Or China 1798. R s.l Sweet fl. gar. 28 + jn.au Ful Levant 1596. R s.1 Bot. mag. 64. $1 \frac{1}{2}$ my.jn W Switzerl. 1629. R s,1 Bot. mag. 318 narrow-leaved $x$ yellow $\triangle$ or fan-like $\Delta$ or copper-colored $\Delta$ or Savoy-Spiderw. $\Delta$ or um $\mathbf{L}$

white-flowered $\Delta$ or 1 au.s $W$ Japan 1790. R p.l Bot.mag. 1433 blue-flowered $\Delta$ or $1 \frac{1}{2}$ my.jl B Japan 1790. R p.l Bot. mag. 894

Aloe.

dark-green

twisted

rigid

rough

clammy

white-edged

boat-lcaved

netted

E $\wedge$ gr rough cushion $\triangle \mathrm{gr}$ wi.

Hemerocallidea. Sp. 99-116.

$1 \mathrm{my} G$ C. G. H. 1823. S s.l

1 my.s G C. G. H. 1794. S s.1 Bot. mag. 1337

C. G. H 1795, C s.

1 jn $\mathrm{G}$ C. G. $\mathrm{H}$ 1795. C s.1

C. G. H. 1795. C s.

C. G. H. 1795. Sk s.l Bot. mag. 1452

${ }_{4}^{3}$ my.au G C. G. H. 1795. Sk s.1 Bot. mag. 802

my.au G C. G. H. 1704. C s.l Bot. mag. 1314

au G C. G. H 1795. C s.1 Bot mag. 135

1 my.jl G C. G. H. 1720. Sk s.l Bot. mag. 455

$\frac{5}{4}$ my.au G C. G. H. 1795. Sk s.l Bot. mag. 1354

$\begin{array}{lllll}\frac{5}{4} \mathrm{my} . \mathrm{au} \mathrm{G} & \text { C. G. H. } & \text { 1795. } & \text { Sk s.l } & \text { Bot. mag. } 1354 \\ \frac{5}{4} \mathrm{my} . \mathrm{au} \mathrm{G} & \text { C. G. H. } & \text { 1795. } & \text { Ls s.l } & \text { Bot. mag. } 1417\end{array}$

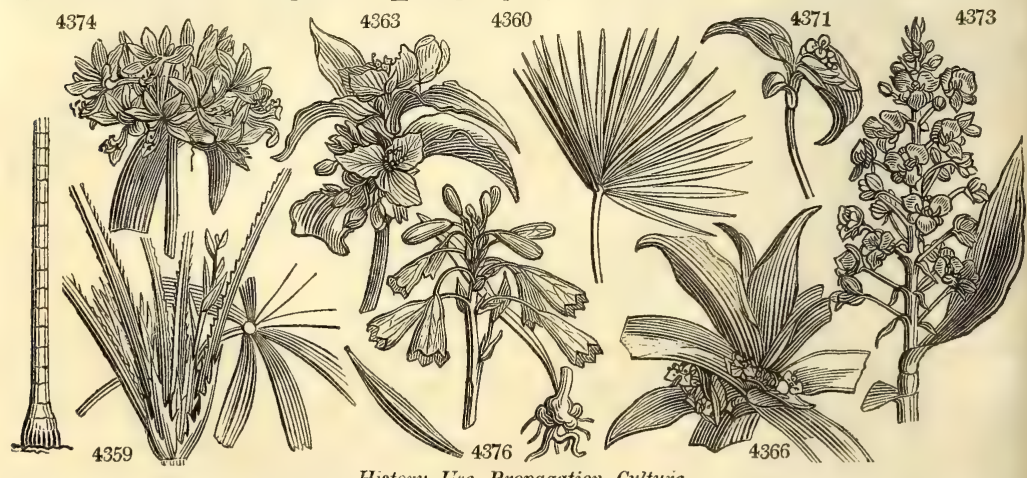

History, Use, Propagation, Culture,

763. Licuala. The Macassar name of this plant in the Moluccas. The fruit of this palm is a fleshy oval drupe, about the size of sweet-bay berries; it continues long green, but finally becomes brown or blackish : the nut is oblong, hard, and striated. In the Isle of Celebes, and in Macassar, they make much use of the narrow leaves for tobacco pipes, and of the middle broad one for wrapping up fruit, \&c. The wood, if the pith and hard rind may be so called, like that of most palms, is of little use.

764. Thrinax. From $\theta$ esvo , a fan. The leaves of this little palm form a sort of fan. Brown (Hist. of Jamaica.) says, that this tree covers whole fields in many parts of Jamaica; that it grows both in the rocky hills and low moist plains near the sea, but seems to thrive best in the former. It shoots by a simple stalk, and rises generally from four or five, to ten or fourteen feet in height. It is always furnished with leaves in form of a fan, sustained by slender compressed foot-stalks, and bears a great abundance of small berries, which serve to feed both the birds and beasts of the wood, when they are in season. The trunk seldom exceeds four or five inches in diameter: it is much used for piles in wharfs, and other brildings made in the sea ; for it stands the water well, and is never touched by the worms. The foot-stalks of the leaves split and pared, serve to make baskets, bow-strings, ropes, \&c. where strength and toughness are required. The leaves are called thatch, and are used as such, especially for out-houses, and stand the weather many years ; but such coverings are apt to harbour rats and other vermin.

765. Tradescantia. So named by Ruppius, in memory of John Tradescant, gardener to Charles I. He introduced the first species to Europe. The museum of the Tradescants is celebrated as one of the earliest ever 
4359 Frond palmate, Segments linear toothed truncate at end, Stem spiny

4360 Fronds flabelliform palmate plaited with stiff lanceolate segments, Stem compressed not prickly

4361 Erect, Leaves lanceolate smooth, Flowers umbelled clustered terminal 4362 Erect, Leaves grassy very long, Peduncles few-flowered ، Cal. smooth

4363 Erect smooth branched, Leaves long recurved ciliated, Pedunc. lat. and term.

4364 Leaves ovate at the edge and under woolly, Flowers umbelled clustered terminal

4365 Erect, Leaves ovate narrow at base smooth, Peduncle terminal naked bifid racemose

4366 Stemless smooth, Bractes equitant compressed, Leaves lanceolate colored beneath

4367 Erect smooth, Peduncles solitary very long

4368 Stemless with rusty hairs, Leaves elliptical acuminate radical

4369 Creeping, Leaves ovate oblong: under the flowers cordate, Pedunc. umbelled axillary

4570 Procumbent hairy

4371 Creeping smooth, Spathes 2-leaved imbricated

4372 Erect, Leaves broad lanceolate, Pedunc. lateral solitary many-flowered, Bractes double

4373 Leaves oval lanceolatẹ whole-colored, Racemes thyrsoid many-flowered

4374 Peduncles length of corolla, Leaves linear

4375 Peduncles twice as long as corolla, Leaves linear

4376 Bractes twice as short as flower-stalks, Leaves very narrow

4377 Bractes as long as flower-stalks : the inner much the shortest

4378 Leaves linear keeled, Three inter. petals wavy, Nerves of the petals undivided

4379 Leaves linear keeled, Petals flat acute, Nerves of the petals undivided

4380 Leaves linear keeled distichous, Sepals wavy acute spreading reflexed, Nerves branched

4381 Leaves linear keeled, Three inner petals obtuse wavy, Nerves of outer petals branched

4.382 Leaves linear flat, Scape simple, Nerves of petals undivided

4383 Leaves cordate acuminate, Cor. funnel-shaped

4384 Leaves ovate acuminate, Limb of cor. campanulate

\section{Flowers small. Cor. bilabiate. (APICRA. $W$ )}

4385 Leaves spreading ovate 3 cornered, Edge and keel with short subulate teeth

4386 Leaves spirally trifarious spreading blackish, on the outside smooth, Stem much twisted

4387 Nearly stemless, Leaves multifarious green not spotted: the upper horizontal rugose

4388 Leaves trifarious orbicular ovate acuminate green beneath very rough, Stem erect

4389 Leaves trifarious ovate acute very green not warted, Stems upright simple

4390 Leaves polished mucronate whitish, Edges and keel cartilaginous

4391 Leaves cymbiform obtuse glaucous very hollow above, Suckers numerous

4392 Leaves equilaterally triquetrous obtuse glaucous netted above concave

4393 Leaves subulate thick erect recurved concave above warted beneath, Edges obscurely pearly

4394 I eaves 6 -farious at the end retuse deltoid pale-green lined above

4395 Leaves ciliate spiny 5-farious deltoid cuspidate at the edge and keel ciliate spiny, Obsoletely netted below 4396 Proliferous, Leaves multifarious lanceolate rounded elegantly ciliated; at end with obl. pellucid spots

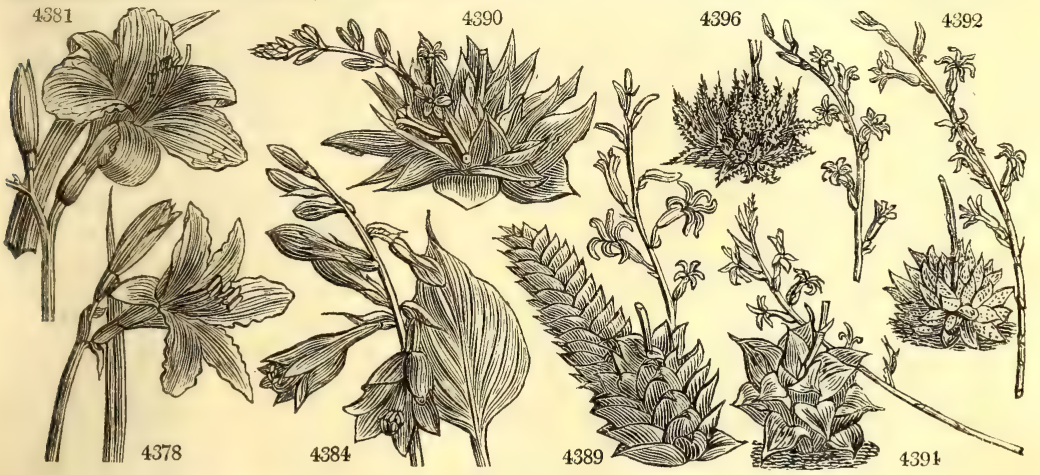

and Miscellaneous Particulars.

formed in this country : it was left to Ashmole, from whom it came to the university of Oxford, bearing his name. All the species are of the easiest culture, but few of them can be called beautiful. $T$, virginica is usually admitted as a border-flower.

766. Dichorizandra. A name contrived by Mikan, from $\delta 65$, two, $\chi$ wets, separately, and ayne, in botanical composition, a stamen; to express the separation of two anthers, upon which the character of the genus depends. Beautiful herbaceous stove plants, with the foliage of Commelina or Tradescantia.

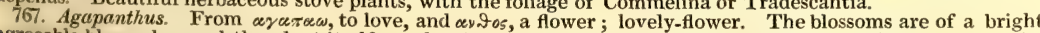
agreeable blue color, and the plant itself much prized. It is nearly hardy, and cultivated without any trouble, in large pots of common earth.

768. BIrandfordia. In compliment to George, Marquis of Blandford, son of the second Duke of Marlborough, a lover of plants, but not of honor. Beautiful New Holland liliaceous plants, very rarely seen in collections Their flowers resemble those of Cyrtanthus.

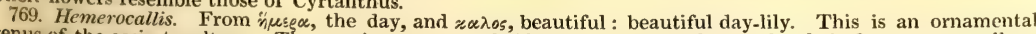
genus of the easiest culture. The species are remarkable among border flowers for their fine orange, yellow, or blue flowers. The Hemerocallis cærulea has been considered a distinct genus by Mr. Salisbury, and called Saussurea.

770. Aloe. A word for which several derivations have been offered. That it has been obtained from the Arabic âlloèh, seems most probable. The genus has been divided by Mr. A. H. Haworth and others into 


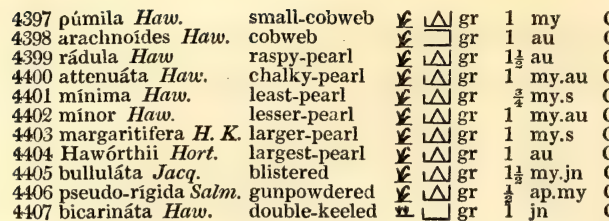

4408 spirális Haw. 4409 spirélla Haw. $\$ 410$ pentagóna Haw. $\beta$ torta

4411 imbricáta Haw. 4412 foliolósa Haw. 4413 semiglabráta Haw. 4414 erécta Haw. 4415 brévis Haw. 4416 fasciáta Haw. 4417 scábra Haw. 4418 papillósa $\mathrm{Salm}$. 4419 pseudo tortuósa Sal. 4420 concínna Haw. 4421 cordifólia Haw. 4422 asperiúscula Haw. 4423 cúrta Haw. 4424 tortélla Haw

great-spiral small-spiral five-sided $\begin{array}{lll}\text { twisted } & \mathrm{gr} & 1 \\ \text { rough-flowered } & \mathrm{gr} & 1 \frac{1}{3} \mathrm{jn} . \mathrm{jl}\end{array}$

Lᄂ $\mathrm{gr} \quad 1$ au.s - 1 gr au

*. $\mathrm{gr} 1 \frac{3}{4} \mathrm{jn} . \mathrm{jl}$ small-leaved t $\mathrm{gr} 1$ jn.au half-smoothed ${ }_{\text {gr }} \quad \ldots$ erect-pearl short-pearl barred-pearl rough papillose

此 $\begin{array}{lll}\text { gr } & \frac{1}{4} & \cdots\end{array}$

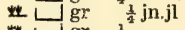
w * $\mathrm{gr}$ twisted-triang. $\mathrm{gr} 1$ jl.au mat

heart-leaved small-thick short-twisted little-twisted

L $\mathrm{gr}^{\frac{1}{2}} \quad \ldots$

些 gr

th gr $^{2}{ }_{\frac{1}{4}} \mathrm{jn}$

thL

$\frac{1}{2}{ }_{\frac{1}{2}} \mathrm{jl}$

4425 nitida Salm. 4426 setáta Haw. 4427 obliqua Haw. 4428 maculáta $\boldsymbol{H}$. $\boldsymbol{K}$ 4429 nígricans Haw. 4430 glăbra Haw. 4431 carináta $W$. 4432 lingua. $W$. 4433 anguláta Haw. 434 acinacifólia Haw. 4435 brevifólia Haw. 4436 intermédia Haw. 4437 verrucósa $W$. 4438 nitens Haw. 4439 subcarináta Salm. shining 岂 gr bristle-edged we broad-marbled narr.-marbled $\square$ gr dark-tongue $f \mathrm{v} g r$ smooth-keeled $\bar{k} \Delta \mathrm{gr}$ rough-keeled $\mathrm{f}$ gr acute-tongue $\checkmark \Delta g r$ retuse-tongue $\triangle \mathrm{gr}$ longsword-lvd. sht.-lvd.-tonguef $\Delta \mathrm{\Delta} g x$ middle-tongue $\triangle \mathrm{vr}$ warted $\triangle \mathrm{Vgr}$ shining $\mathrm{\Delta}$ gr obscure-keeled $\bar{v} \Delta \mathrm{gr}$ turgid-cushion $\Delta \mathrm{gr}$

$\begin{array}{ll}1 & \text { jl } \\ \frac{1}{\frac{2}{2}} \text { jn } \\ 1^{\frac{1}{2}} \text { jn.au } \\ 3 & \text { jl.au } \\ 2 & \text { jn.jl } \\ 3 & \text { jn.jl } \\ 2 & \text { jn.jl } \\ 3 & \text { mr.n } \\ 2 & \text { mr.n } \\ 3 & \text { mr.s } \\ 3 & \text { jl.au } \\ 2 & \text { mr.n } \\ 2 & \text { mr.n } \\ 3 & \text { mr.n } \\ 2 & \text { jn.jl } \\ \frac{1}{2} \mathrm{~s}\end{array}$

C. G. H. 1752. Sk s.1 Bot. mag. 1361

C. G. H. 1727. Ls s.1 Bot. mag. 756

C. G. H. 1805. Sk s.I Jac. schœen. t. 35

C. G. H. 1790 . Sk s.l Bot. mag. 1345

C. G. H. 1725. Sk s.1 Bot. mag. 1360

C. G. H. $\quad \ldots$ Sk s.1 Bot. mag. 815

C. G. H. 1739. Sk s.1 Brad.succ.3.t.21

C. G. H. 1801. Sk s.

C. G. H. $\quad$... Sk s.l

C. G. H. $\quad \ldots$ Sk s.l

C. G. H. 1820, S s.

C. G. H. 1790 , S s.l

C. G. H. 1808, S s.I

C. G. H. 1731. Sk s.l Bot. mag. 1338

C. G. H. 1731. Sk s.1 Bot. mag. 1455

C. G. H. 1795. C s.l Bot. mag. 1352

C. G. H. 1811. Sk s.

C. G. H. 1818. Sk s.1 Pl. grasses, 57

C. G. H. 1810. Sk s.l Bot. mag. 1360

C. G. H. 1818. Sk s.1

C. G. H. 1818. Sk s.

C. G. H. 1820, Sk s.l

C. G. H. 1818 . Sk s.1

C. G. H. 1818. Sk s.

C. G. H 1817. Sk s.1

C. G. H. 1818. Sk s.1

C. G. H. 1816. Sk s.I

C. G. H. 1817. Sk s.I

$\begin{array}{lll}\text { C. G. H. } & \text { Sk s.l Bot. mag. } 2304\end{array}$

C. G. H. 1818. Sk s.l

C. G. H. 1759 . Ls s.1

C. G. H. 1759. C s.1 Bot mag. 765

C. G. H. 1790. Ls s.1 Bot. mag. 838

C. G. H. 1796. Sk s.1

C. G. H. 1731. Ls s.1 Bot. mag. 1331

C. G. $\mathrm{H}$. ... Ls s.l

C. G. H. 1791. Sk s.1

C. G. H. 1819. Sk s.I Bot. mag. 2369

C. G. H. 1809. Sk s.1

C. G. H. 1790 . Sk s.

C. G. H. 1731. Sk s.1 Bot. mag. 837

C. G. H. 1818. Sk s.l

C. G. H. 1818. Sk s.

4441 acumináta Haw. mid.-hedgehog $\mathbb{L} \Delta \mathrm{gr} \quad 3 \mathrm{mr} . \mathrm{my}$ Or 4442 tuberculáta Haw. tuberc.-hedgeh. $\mathbb{N}$ gr 2 mr.my Or 4443 húmilis $W$. dwarf-hedgeh. $\triangle \mathrm{gr} 1 \mathrm{mr} . \mathrm{jn}$ Or 4444 can'dicans Haw. marbled-white $\Delta$ gr 1 jl $R$ 4445 vírens Haw. apple-green, $\triangle \mathrm{gr} 3$ au.s $\mathrm{Y}$

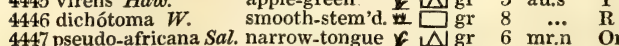
$\begin{array}{lllll}4447 & \text { pseudo-africana Sal. narrow-tongue } \\ 4448 \text { Prin'cipis Haw. the Prince's } & \mathrm{gr} & 6 \mathrm{mr} . \mathrm{n} & \text { Or } \\ 4 & \mathrm{gr} & 5 & \mathrm{mr} . \mathrm{n} & \mathrm{Y}\end{array}$

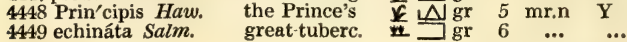

C. G. H. 1795. Sk s.l Bot. mag. 757

C. G. H. 1796. Sk s.l

C. G. H. 1731. Sk s.l Plant. grass. 39

C. G. H. 1796, Sk si

C. G. H. 1790. Sk s.1 Bot. mag. 1355

C. G. 1780 .

C. G. H. 1731. Sk s.l Bot. mag. 1322

C. G. H. 1821. Sk s.1

C. G. H. 1821. Sk s.1

4450 vulgáris $\boldsymbol{H} . \boldsymbol{K}$. yellow-flower'd $\mathbf{w} 12$ my.au Y 4451 purpuráscens Haw. purple 12 jl.o $\mathrm{Pu}$ 4452 soccotrina Haw. soccotrine $\quad$ is 12 f.ap $\mathbf{R}$ 4453 arboréscens $H . K$. tree 12 mr.n $\mathrm{R}$

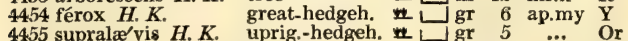

Levant 1596. Sk s.l Plant.grass. 27 C. G. H. 1789. C s.l Bot. mag. 1474 C. G. H. 1731. C s.l Bot mag. 472

C. G. H. 1731. C s.l Bot. mag. 1306

C. G. H. 1759. C s.l Bot. mag. 1975 4455 supralæ'vis $H . K$. uprig.-hedgeh. ${ }_{\text {gr }} 5 \quad \ldots \quad$ Or $\quad$ C. G. H. 1731. S s.l Com.præ.71,t.20

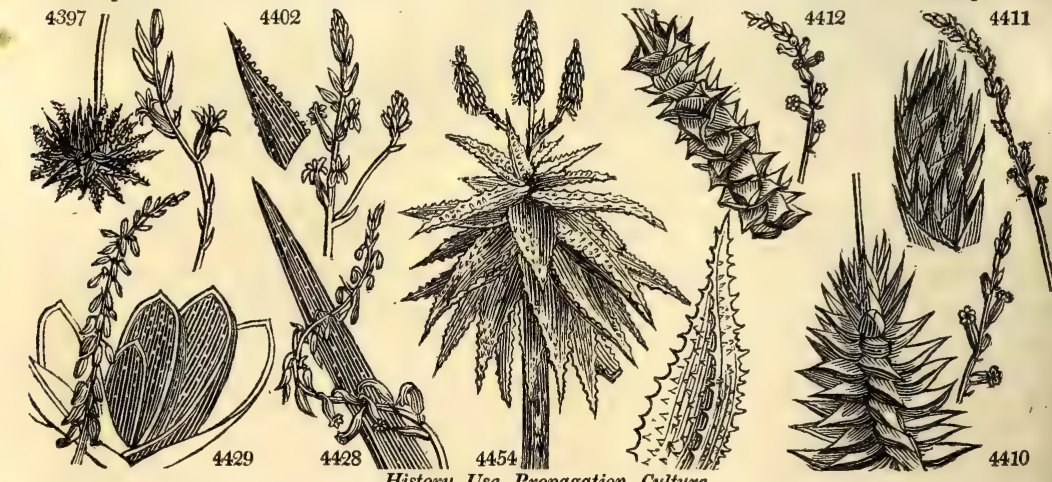

History, Use, Propagation, Culture,

many genera, but their opinion has not been adopted by men of science. The species consist of odd looking succulents ; some of them may be classed as trees, others as shrubs, but the greater number have more the habit and appearance of evergreen herbaceous plants. One or two species are used in medicine or the arts.

A. vulgaris purpurascens, soccotrina, and arborescens, which some consider as not specifically different 
4397 Leaves very green, Spines marginal herbaceous, Tubercles numerous

4398 Leaves exparided lanceolate flat above, with the edges cartilaginous thick ciliated

4399 Leaves erect recurved subulate all over rough, Tubercles very minute numerous and pearly

4400 Leaves erect recurved subulate, Tubercles above large pearly below very minute

4401 Leaves spreading ovate acuminate with very numerous small warts

4402 Leaves long oblong acuminate with middle-sized pearly warts in rows

4403 Dichotomous, Leaves long ovate acuminate with great pearly warts, Capsules wrinkled across

4404 Stemless, Lvs. ovate acum. cuspidate upw. 3-cor. keeled, Edges and keeled cren. with coarse pearly warts

4405 Leaves rigid spirally 5 -farious ovate acuminate sparingly warted with dark-green tubercles

4406 Leaves spirally trifarious recurved at end covered all over with minute dark-green warts

4407 Lvs. multifarious cordate very hard deep-green twice keeled, with dark-green raised warts on under side

2. Flowers small. Cor. regular.

4408 Leaves very spiral 5-farious ovate acum. smooth dark-green with some obscure spots beneath 4409 Leaves very spiral 5-farious lanc. acumin. smooth pale-green with some obscure spots beneath 4410 Leaves 5 -farious and spiral smooth green obsoletely spotted beneath

4411 Erect rounded, Cor. rugose, Leaves multifarious erect polished not spotted

4412 Leaves multifarious very short and close together orbic. ovate horizontal polished bright-green

4413 Stemless dichotomous, Leaves dark-green erect ovate obl. acum. mucronate

4414 Leaves upright straight the old ones incurved ovate-obl. abruptly acuminate with small warts

4415 Soboliferous, Leaves spreading ovate acute with large warts

4416 Leaves erect lanc. acuminate above flat and smooth barred with large warts beneath

4417 Leaves semi-cylindrica! 3-cornered thickened upwards very rough except at base

4418 Leaves attenuated erect with large white warts depressed in the centre

4419 Stem twisted, Leaves trifarious spiral imbricated spreading ovate acute smooth

4420 Leaves nearly trifarious densely imbricated spreading with an obtuse recurved point

4421 Leaves very rigid cordate stem-clasping thick dark-green above keeled and rough, Edge rough

4422 Leaves rigid rounded cordate closely inflexed dark-green edged a little rough above

4423 Leaves spirally trifarious blackish-green equilaterally triangular very rough

4424 Leaves close spirally trifarious blackish quite smooth outside, Stem much branched

$$
\text { 3. Flowers curved. (GAsteria. Haw.) }
$$

4425 Differs from A acinacifolia only in having blunter points to the leaves

4426 Leaves lorate lanceolate with a long bristly point keeled above at the edge fringed with memb. bristles

1427 Leaves spirally multifarious mottled narrow linguiform obtuse with a point

4428 Leaves tongue-shaped smooth pointed, Flowers racemosecernuous curved

4429 Differs from A. lingua only in having broader and shorter leaves

4430 Smooth, Lvs. multifarious acuminate spotted deeply keeled beneath with a cartilaginous edge and keel

4431 Stemless, Leaves acinaciform papillose

4432 Leaves distichous tongue-shaped acute spotted serrated with tubercles at edge

4433 Leaves distichous tongue-shaped retuse with a point obscurely spotted curved to one side

4434 Stemless, Leaves distichous acinaciform with cartilaginous prickly edges

1435 Leaves exactly distichous parabolically tongue-shaped short obtuse with edges smooth upwards

4436 Leaves bifarious ensiform bright-green

4437 Leaves ensiform acute papillose distichous

4438 Leaves spiral multifarious shining deeply keeled at the sides obscurely spotted, Edges cartilaginous

4439 Lvs. bright-green multifarious spreading with white warts obtuse with a point, Edges densely cartilaginous

\$440 Leaves oblong acute entire above towards the end swollen pellucid with darker markings

$$
\text { \$ 4. Flowers large. (AloE.) }
$$

441 Leaves acuminate glaucous above flat smooth sparingly prickly beneath very rough

4442 Leaves acuminate above a little hollow very prickly all over

1443 Stemless, Leaves spiny ascending 3-cornered subulate

4444 Leaves distichous ensate lean smooth beneath white with warts running together

4445 Leaves oblong lanceolate green sparingly spotted, Edges with a few distant green spines

4446 Stem dichotomous, Leaves ensiform serrated, Stamens longer than cor.

4447 Stem shrubby simple, Lvs. revol. recurved narrow ensiform glauc. Warts prickly scatt. over both sides

4448 Leaves very green erect recurved, marginal and dorsal spines at the end red

4449 Leaves oblong lanceolate spiny toothed beneath white with warts, Petals unequal

$$
\text { ** With a stem. }
$$

4450 Leaves spreading ascending spiny at edge, Pedunc. branched, Branches with a double bract

4451 Leaves ensiform glaucous recurved at end, Marginal serratures white

4150. Leaves oblong ensiform somewhat spotted, Edges cernuous white with straight spines

4453 Leaves stem-clasping reflexed spiny at edge

4454 Leaves ovate ensiform glaucous deflexed covered over especially beneath with scattered spines

4455 Leaves oblong ensiform glaucous incurved above smooth beneath covered with scattered prickiy warts

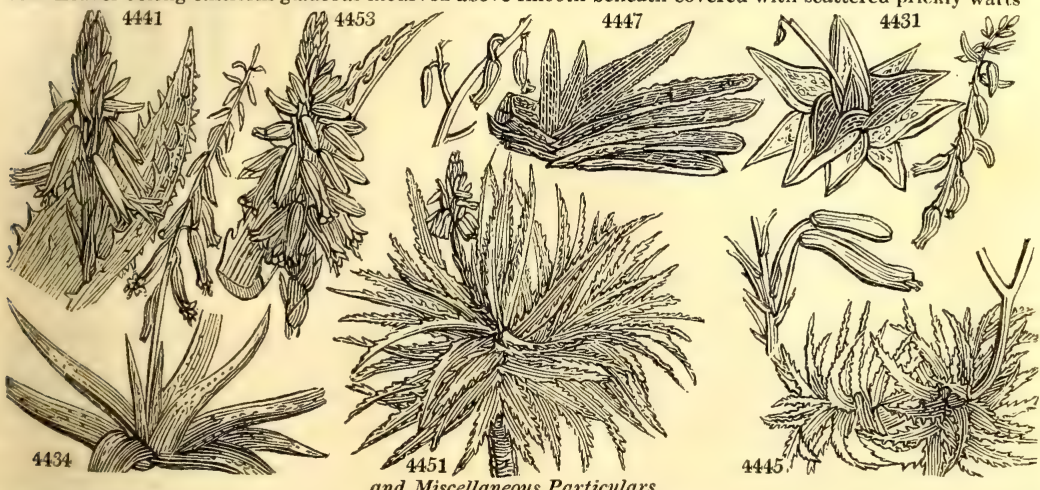

and Miscellaneous Particulars.

are cultivated in Barbadoes and other West India islands, to obtain the hepatic aloes, which are brought to Fngland and used chiefly for horses. The aloes known by the name of Succotrine, is made chiefly from the species of that name, and A. spicata; being originally manufactured in the island of Zocotra or Socotora, in the straits of Babelmandel it retains the name; this drug is lighter colored, and not so coarse as the horse or 
4456 flavispína Haw. 4457 pícta $H$. $K$. 4458 latifólia Haw. 4459 saponária Haw. 4460 serruláta $\boldsymbol{H}$. $K$. 4461 mitræfórmis Dec. 4462 nóbilis Haw. 4463 dístans Haw. 4464 albispina Haw. 4465 distans $H$. $K$. 4466 depréssa $H . K$. 4467 suberécta Haw. 4468 paniculáta Jacq. A. striata Haw.

4469 lineáta $H . K$. 4470 glaúca $H$. $K$. 4471 spicáta $W$. 4472 africána $H$. $K$. $\beta$ angústifolia 4473 plicátilis $W$. 4475 Commelíni Salm. 4476 mácra Haw. 4477 albocincta Haw. 4478 sérra Dec. 4479 chinénsis Hort. 4480 rufocincta Haw. 4481 cæ'sia Salm. 4482 micracan'tha $B$. $M$. small-spin 4483 xanthacántha Salm. yellow-spined

771. LI'LIUM. $W$. LILY. $\begin{array}{ll}4484 \text { cándidum } W . & \text { white } \\ 4485 \text { japónicum } W \text {. } & \text { Japan }\end{array}$ 4486 longiflórum Thunb. long-flowered 4487 caroliniánum $P s h$. Carolina autumnale Lodd.

4488 bulbiferum $W$.

$\beta$ umbellátum

489 daúricum $\mathrm{Ker}$. pensylvánicum B. M.

4490 con'color $H . K$.

4491 Catesba'i $\boldsymbol{W}$.

4492 philadélphicum $W$

$\beta$
andinum Ker.

$\beta$ rúbrum

4494 supérbum $W$

4495 Mártagon $W$

4496 cróceum Bernh.

4497 spectábile Link.

4408 showy

408 chalcedonicum $W$. Scar.-Martagon

4499 pyrenáicum $W$.en.

4500 pompónium $W$. Scar.-Pompone

4501 monadélphum $B . M$. monadelphous

4502 tigrinum $H$.

4503 púmilum $\boldsymbol{R}$. $\boldsymbol{L}$
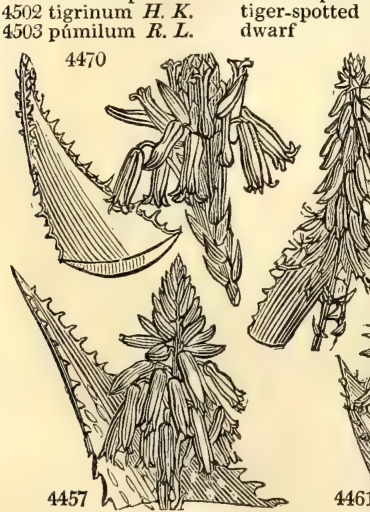

dwarf

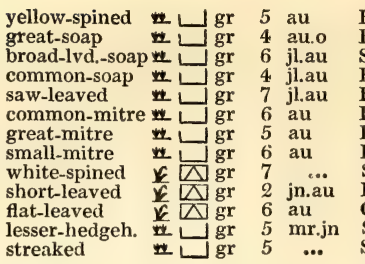

lined $\square \mathrm{gr} \quad 5 \quad \ldots . \quad \mathrm{s}$ wa.s 4 ja.s African ja jn.jl $R$ mr.s Pk jn $\cdots \ddot{0}$ $\mathrm{jn}$ jn jl in $\cdots$ jl

\% $\triangle$ or 3 jin. Sp. 20-24.

\% $\triangle$ or 2 jl.au W China 1596. O r.m Bot.mag. 278 $\Varangle-\Delta$ or 2 my.j: W China 1804. O r.m Bot. mag. 159 \& $\Delta$ or 2 jl.au $\mathrm{O} \quad$ N. Amer. 1819. O r.m Bot. reg. 560

orange $\Varangle \Delta$ or 3 jn.jl $O$ Italy 1596. $O$ p.l Bot. mag. 36 umbel-fl. orange $\not{t} \Delta$ or 3 jn.jl O Italy 1596. O p.1 Bot. mag. 1018 $\begin{array}{lllllllll}\text { f } & \text { or } & 2 & \text { jl } & \mathbf{R} & \text { China } & \text { 1806. } & \text { O p.1 } & \text { Bot. mag. } 165\end{array}$ iladelphian $\triangle$ or 5 jl.au $\triangle$ L.O N. Amer, 1757. O r.l Bot. mag. 519 $\triangle$ or 4 jl.au Sc N. Amer. 1819. O r.l Bot. reg. 594 \% $\triangle$ or 4 jl.au L.O N. Amer. 1629. O p.1 Bot. mag. 800 \% $\triangle$ or 4 jl.au O N. Amer. 1629. O p.1 Bot. mag. 858 \% $\triangle$ or 6 jn.au L.O N. Amer. 1727. O p.l Bot. mag. 936 б $\triangle$ or 3 jl.au Pu Germany 1596. O co Bot. mag. 893

\% $\triangle$ or 3 jl.au Y ...... 1596. O co f or 3 jlau 0 o

\% $\triangle$ or 4 jl.au $R$ Levant 1596. O p.1 Bot. mag. 30 t $\triangle$ or 2 jl.au D.O Pyrenees 1596. O p.1 Red. lil. 145 \& $\Delta$ or 2 my.jn $\mathbf{R}$ Siberia 1629. O r.1 Bot. mag. 971 ‡ $\triangle$ or 2 jn.jl Y Caucasus 1800. O r.l Bot. mag. 1405 \% $\triangle$ or 6 jl.s O China 1804. O r.l Bot. mag. 1237

ซ $\triangle$ or $1 \mathrm{jn}$ Sc Dauria 1816. O r.1 Bot reg. 132

Dauria
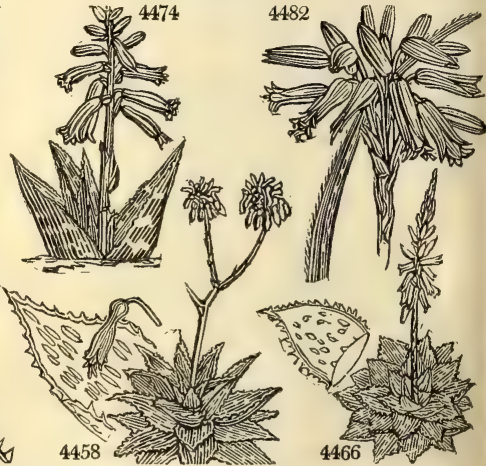

History, Use, Propagation, Culture,

hepatic aloes. A. spicata is cultivated extensively at the Cape of Good Hope, and a considerable part of what is sold as coming from Socotora is from that quarter. All the medicinal aloes are grown on the poorest soil. In preparing the drug, the leaves are cut off close to the stem, then cut in pieces, and the juice expressed; this is allowed to remain at rest for forty-eight hours, during which time a feculent matter is deposited; after which the supernatant liquor is poured off into flat dishes and evaporated in the sun. At the Cape, in the month of July, the leaves are pulled, then cut into pieces, the juice expressed, and inspissated by means of heat.

The month of March is the period for cutting the aloes in the island of Barbadoes. The leaves are cut off close to the stem, and disposed in tubs, in such a manner that the juice runs out. After a sufficient quantity of it is collected, it is exposed to heat in copper boilers; and as it becomes more inspissated by a constunt and regular fire, it is ladled from one boiler to another, and fresh juice added, until that in the last, which is called the teache, acquires the consistence of honey; when it is poured into calabashes, and hardens by age. It is 
4456 Suckers from the root, Lvs. obl. acum. glauc. spread. cover. at side and back with very broad brown spines 4457 Caulescent, Leaves ensiform toothed mottled spreading

1458 Leaves ovate lanc. pale-green with obl. obsolete whitish barred spots, Spines rufous

4459 Leaves obl. lanc. dull green rather glaucous with obl. large transverse spots and rufous spines

4460 Leaves spotted, Edges and keel serrulate at end

4461 Leaves thick spiny at edge below spinulose appressed not dotted, Racemes in umbels

1462 Leaves erect broadly ovate acute, Spines marginal numerous white

4463 Leaves erect spreading remote ovate acute, Spines marg. few large yellow

4464 Leaves ovate acum. green, Edge and keel very spiny, Spines long very white

4465 Leaves cæspitose very short glaucous 3-cornered at end, Angles with numerous white spines

4466 Distinguished from A. serra by the spines not being united at base

4467 Leaves acuminate above flat smooth beneath warted

4468 Leaves glaucous streaked, Edges obsoletely toothletted

\$69 Leaves green lined, Spines red

4470 Leaves very glaucous, Spines red

4471 Leaves lorate ensiform downward spotted with white, Marginal spines middle-sized red

4472 Leaves broad ensiform recurved smooth hard, Spines marginal and dorsal red at end

4473 Leaves tongue-shaped smooth distichous, Flowers racemose pendulous cylindrical

4474. Leaves trifarious painted channelled, Angles cartilaginous

4475 Leaves ovate oblong attenuate spreading glaucous, The edge and keel upwards with white spines

4476 Caudex leafy, Leaves lorate ensiform channelled spreading green serrulate

4477 Glaucous polished, Leaves oblong acuminate with a deep white entire cartilaginous edge

4478 Leaves tufted with the spines of the edge united at base, Scape toothed

4479 Leaves smooth pale-green straight erect-spreading soft

4480 Leaves lorate lanceolate acuminate green, Edge red with many white teeth

4481 Stem shrubby, Leaves long-lanceolate recurved at end glaucous smooth spotted with red spines

4482 Lvs. narrow sword-shaped beneath spotted with white, Spots warty scatt. Edge with minute white spine 4483 Caulescent, Lvs, ovate acum. glaucous spreading at the edge and back spiny, Spines very broad yellow

4484 Leaves lanc. scattered narrowed at base, Cor. camp. smooth inside

4485 Leaves scattered lanc. Cor. cernuous campanulate

4486 Leaves scattered lanceolate, Cor, tubular campan. Stem smooth

4487 Leaves nerveless whorled cuneate-lanceolate, Flowers solitary with revolute spotted sepals

448 Leaves scattered, Cor. campan. upright rough inside

4489 Leaves scattered lanc. : the upper whorled, Stem 1-fiowered winged

4490 Leaves scatt. lanc. obl. Cor. erect revol, camp. within papillose without smooth

4491 Leaves scatt. lin. lanc. Stem 1-flowered, Cor. erect, Pet. with long claws wavy at cdge reflexed at cnd 4492 Leaves whorled, Flowers erect, Cor. campan. Petals clawed

4493 Leaves whorled linear, Flowers reflexed, Cor, revolute campanulate

4494 Lower leaves whorled; upper scatt. Flowers racemose reflexed, Cor. revolute

4495 Leaves whorled ovate lanceolate, Flowers reflexed, Cor. revolute

4496 Leaves ternate or scattered lin. falc. 3-nerved ciliated, Pedunc. pubes. Cor. erect rough inside

4497 Leaves ternate or scattered linear 3-nerved ciliated, Pedunc. tomentose, Flowers erect rough inside

4498 Leaves lin. lanc. scattered, Flowers reflexed, Cor. revolute dotted inside

4499 Leaves scattered linear, Pedunc. long, Flowers reflexed, Cor. revolute papillose inside

4500 Leaves scattered lin. subulate, Flowers reflexed, Cor. revolute toothed and warted inside

4501 Like a Martagon, but the stamens are united in a tube

4502 Leaves scattered sessile 5-nerved, The upper cord. ovate, Cor. revolute papillose inside

4503 Leaves linear subulate scattered smooth, Flowers reflexed, Sepals revolute smooth inside

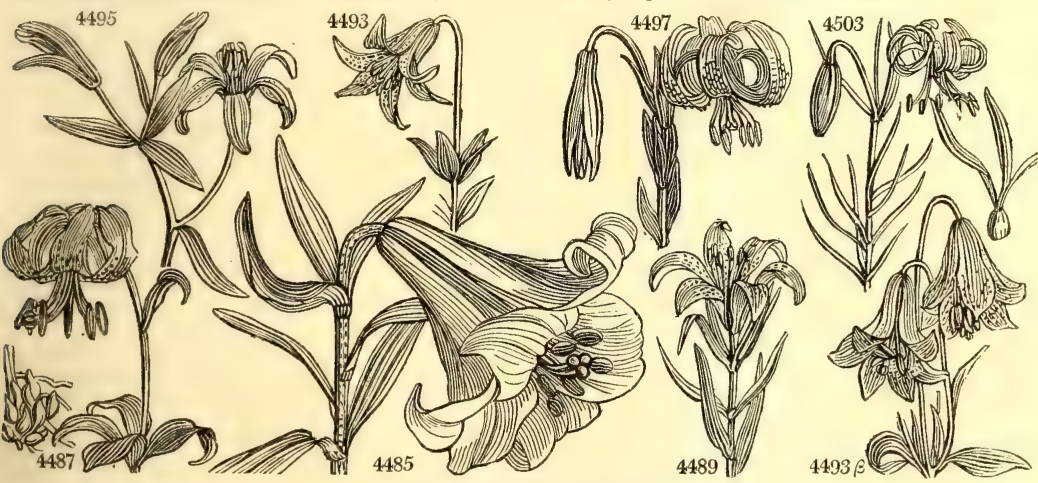

and Miscellaneous Particulars.

brought home in these calabashes, or large gourd-shells, which contain from sixty to seventy pounds weight each. (Thomson's Mat. Med. 141.)

In the West Indies, the Cape, and most countries where the woody prickly species abound naturally, they are planted as hedges, and the fibres of the leaves, after being macerated for juice, manufactured into cordage or coarse cloth

A. picta, latifolia, and saponaria are so named from the spots of the leaves, which are of the color of soft soap.

The curious species of aloes, inhabitants of the greenhouse, require but little water: sandy loam, mixed with a little lime rubbish or gravel, suits them best; and they flower more abundantly by being exposed to the open air in summer. They are increased by suckers; or leaves, stripped off the plants and laid on a pot of mould, or planted shallow in it, will produce young plants. (Bot. Cult. 130.)

771. I. ilium. From the Celtic word $L i$, which signifies whiteness. The lily has always becn considered the 
772. TU'LIPA. $W$. 4504 sylvéstris $W$. 4505 túrcica Roth. 4506 óculus sólis $R . L$ 4507 Gesneriána $W$. 4508 suavéolens $W$. 4509 clusiána $B$. $M$ 4510 celsiána $\boldsymbol{P}$. $S$. 4511 cornúta $R . L$ 4511 cornúta $R$ biflóra $L$.

\section{FRITILLA'RI} 4513 Imperiális $W$ a rúbra ß fláva 4514 pérsica $W$ $\beta$ minima Swert. 4515 obliqua $B . M$. 4516 tulipifólia Bieb. 4517 verticilláta $W$. 4518 pyrenáica $\boldsymbol{H} . \boldsymbol{K}$. 4519 nigra $B$. $M$. 4520 nervósa $W$. en. 4521 lútea Bieb. 4502 latifólia $W$ 4523 Meleágris $W$. 4524 lanceoláta $P$ h Lilium kamchats 774. DRACA'NA. $W$.
4525 Dráco $W$. 4525 Dráco $W$.
4526 ensifólia $W$. wild TuLr.

nar.-waved-lvd. $\delta \Delta$ or 2 ap.my st

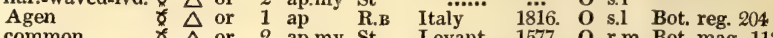

common $\quad \delta \quad \Delta$ or 2 ap.my St Levant 1577. O r.m Bot. mag. 1135

Van Thol $\quad \triangle$ or $\frac{1}{3}$ mr.ap R.Y S. Europe 1603. O r.m Bot. mag. 839

Clusius's $\Varangle \Delta$ or 1 jn W.pu Sicily 1636. O r.m Bot. mag. 1390

Cels's

herned

two-flowered

$\triangle$ or $1 \frac{1}{2}$ jn.jl Y Levant

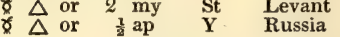

Fritilla RY.

Crown Imper of or

red-flowered $\delta \Delta$ or

yellow-flowered $\varnothing \Delta$ or

Persian

oblique-leaved of or

tulip-leaved $\delta \triangle$ or

tulp-leaved or

cluster-flowered $\stackrel{\Delta}{\circ}$ or

cluster-flowered of $\Delta$ or

nerved-leaved $\delta \vec{\Delta}$ or

yellow-flower.

broad-leaved

chequered

spear-leaved

of

$8 \Delta$ or

\% $\Delta$ or

$\Delta$ or
Liliacec. Sp. 12-19.

4 mr.ap Persia 1596. O co

4 mr.ap $R$ Persia 1596. O co

4 mr.ap Y Persia 1596. O co

ap.my $\mathrm{Br}$ Persia 1596. O co Bot. mag. 1537

Br.p Caucasus ... O co Bot. mag. 857

my Br.p Crimea 1822. O co

1 a $\quad \mathrm{Pu}$ Crimea 1823, O co

1 my Y.Pu Pyrenees 1596. O co Bot. mag. 664

$1 \frac{1}{8} \mathrm{my}$ D.P Caucasus O co

1 ap.my Y Caucasus 1812. O co Bot. mag. 1538

1 ap.my $\mathbf{R}$ Caucasus 1604 o co Bot mag. 853

$1 \mathrm{mr}$ my $\mathrm{Pu}$ Britain moi p. $\mathrm{O}$ co $\mathrm{Bng}$ bot. 629

Kamschat.1759. O co Lin. tr. 10. t. 11
1806. O r.m Bot. reg. 535

ap.my Br Persia 1596. O co Bot. mag. 962

$1 \frac{1}{2}$ my.jn D.P ...... 1605. O co Bot. mag. 952

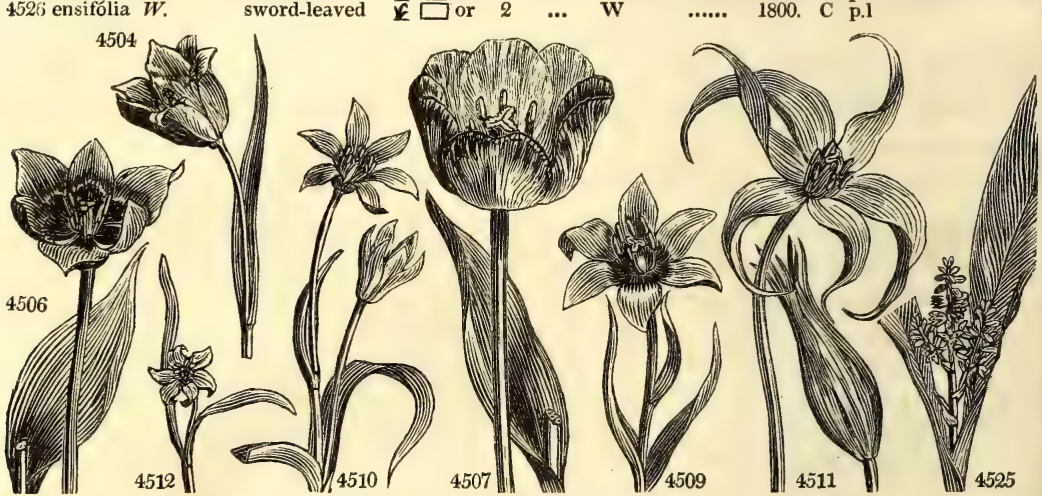

History, Use, Propagation, Culture,

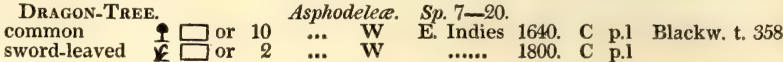

emblem of whiteness. This is a splendid genus, all the species of which are considered border flowers of great beauty. The more common sorts, species, and varieties, will thrive in any soil and situation, even under the shade of trees. The Canadian, Pomponian, and Philadelphian martagons are somewhat tender, and require the protection of ashes or rotten bark in winter. They are generally planted in borders, and need not be taken up oftener than every three or four years in September, and replanted six inches deep in the October following. None of the species can be safely transplanted after they have pushed leaves, without weakening them so as to prevent their flowering for several years. This remark, indeed, will apply to most bulbous rooted plants. Mr. Griffin, of South Lambeth, whose superior skill in the cultivation of bulbous plants is well known (Hort. Trans. iv. 544.), has been in the practice of keeping the lilium japonicum in pots, protected by a greenhouse or garden frame; but he thinks the thrive best in the former. He places the bulb in twenty-four sized pots, not lower than an inch from the surface of the mould, which is composed of about two-thirds peat and one-third loam, the bottom of the pot being covered to the depth of two inches, with broken pieces of tile and the rough siftings of peat. The plants are kept entirely from frost, and are watered very little when in a dormant state, for they are then very impatient of wet in excess. The pots kept in the greenhouse are placed at a distance from the flue to prevent the mould drying quickly. (Hort. Trans. iv. 554.) Mr. S. Brooks grows in a brick-pit, which he can cover with mats or glasses at pleasure; but he says, it " appears to be sufficiently hardy to endure our winters, as I have had a bed of them two years in the open ground without protection." (Hort. Trans. iv. 552.)

772. Tuliza. Linnæus classed this among barbarous names. In Persian it is called thoulybân (De Souza), whence undoubtedly its origin. In old French it is called tulipan. T. Gesneriana (Gesner, a Zurich botanist), may be called the king of florists' flowers, having been a prime object of attention with this class of cultivators for nearly three centuries. It appears to have been brought to Europe from Persia by way of Constantinople in 1559, and in a century afterwards to have become an object of considerable trade in the Netherlands, and a sort of mania among the growers, who bought and sold bulbs at prices amounting to $500 l$. sterling and upwards; in those days an immense sum. The taste for tulips in England was at its greatest height about the end of the seventeenth and the beginning of the eighteenth century. It afterwards declined, and gave way to a taste for rare plants from foreign countries. The tulip, however, is still extensively cultivated in Holland, from which all Europe is supplied with bulbs, and also to a considerable extent in England, both in tradesmen's gardens and in those of the opuient. It is, however, like the auricula, pink, \&c. more the poor man's flower than that of the botanists or country gentleman.

The varieties of the tulip are endless, and their names arbitrary, like those of all florists' flowers. One of the latest London catalogues (Mason's) enumerates six sorts of early blowing tulips ; four perroquets or middle blowers.; twenty-two double sorts; and upwards of 600 single late sorts ; the last being the only sorts valued oy florists as competition flowers. These late sorts are classed by the Dutch as under:

Prime baguets (baguette, Fr., a rod or wand); very tall; fine cups with white bottoms, well broken with fine brown, and all from the same breeder.

Baguets Rigaut's (supposed from Rigaud, some eminent florist's name, or rougeaude, red face) ; not quite so tall, but with strong stems, and very large well-formed cups, with white bottoms, well broken with fine brown, and all from the same breeder. 
4504 Stem 1-fi. smooth, Flower nodding, Petals acute bearded at end, Leaves lanceolate 4504 Stower erect, Petals lanceol acuminate, Leaves lanceolate linear

4506 Coat of bulb woolly inside, Leaves ciliated glaucous, Stem and flower smooth

4507 Stem 1-fl. smooth, Flower erect, Petals obtuse smooth, Leaves ovate lanceolate

4508 Stem 1-fl. pubescent, Flower erect, Petals obtuse smooth, Leaves ovate lanceolate 4509 Flower erect stellate with a dark eye, Leaves linear lanceolate 4510 Leaves lin. lanc. convolute, Petals lanceolate greenish outside

4511 ene-flowered, Flower from fusiform spreading, Sepals very long caudate 4512 Flowers erect flat, Stem 2-leaved 2-3-flowered, Leaves linear subulate

4513 Raceme comose naked below, Leaves entire

4514 Raceme naked, Leaves oblique

4515 Leaves glaucous numerous oblique, Cor. turbinate

4516 Leaves lanc alternate remote, Stem 1-flowered naked upwards, Angles of caps, obtuse

4517 Leaves linear whorled opp. and alternate when old cirrhose, Stem many-flowered, Capsule winged 4518 Lower leaves opp. Inner flowers among the leaves

4519 Leaves scattered flat coriaceous glaucous, Cor. campanulate revolutc at end

4520 Leaves alternate linear nerved flat, Stem 1-flowered

4521 Leaves lin. lanc, alternate; the upper approximated shorter than the terminal solitary flower 1520 Leaves lanc approximated, the upper opp. as long as the terminal solitary flower, Capsule obtuse angled 4522 Leaves alternate linear channelled, Stem one-flowered

4523 Leaves alternate linear channelled, Stem one-flowered

4525 Leaves fleshy spiny at end

4526 Herbaceous caulescent, Leaves ensiform

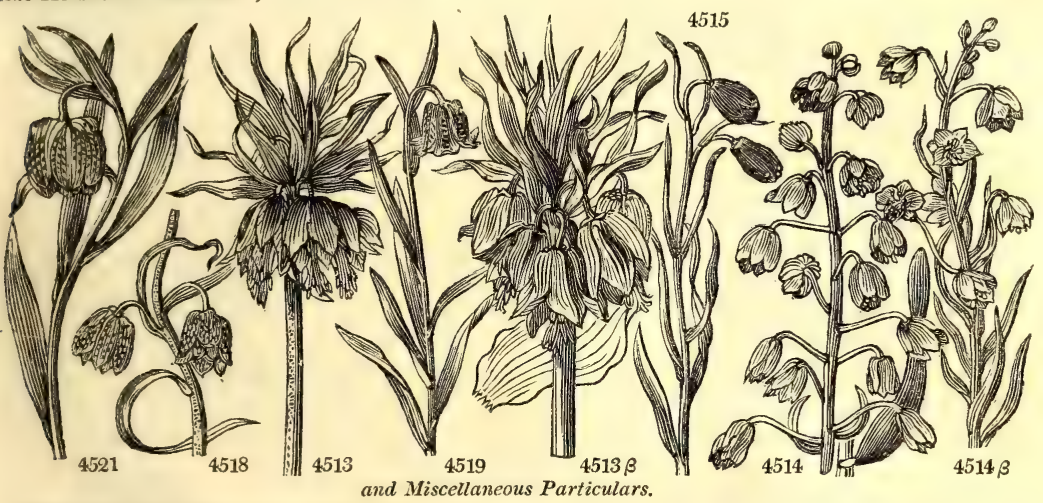

Incomparable Verports; very perfect cups, cherry and rose, and white bottoms, well broken with shining brown.

Byblomens, or mixt flowers, the flamands of the French florists, with bottoms white, or nearly so, from different breeders, and broken with variety of colors.

Bizarres (bizarre, Fr. odd, irregular); ground yellow, from different breeders, and broken with variety of colors.

What are called breeders are procured from seed, and consist of one plain color on a white or yellow bottom These being cultivated on a dry and rather poor soil, become broken or variegated, and produce new varieties. The time that elapses before they break, varies from one to twenty years or more, and sometimes this change never takes place, so that whoever thinks of raising new varieties of tulips from seed, must be possessed of an ample fund of patience and perseverance. The early dwarf tulip, known among florists as the Van Thoil, is a distinct species, T. suaveolens.

In raising tulips from seed the florists pursue a mode in some respects the reverse of that practised with other plants. Instead of saving the seed to be sown from the finest variegated tulips, they prefer unbroken flowers or breeders, selecting such of these as have tall strong stems, with large well-formed cups, clear in the bottom. Plants raised from seed saved from the finer variegated sorts, form poor weak breeders of no value. The seed is sown on fine light soil, thinly covered, and protected and shaded by a frame. At the end of the second year the bulbs are taken up and replanted three inches apart; and again at the end of the fourth year. Some will bloom the fourth year, most the fifth, and ill of them the seventh year Being now furnished with a set of breeders, all that the flolist can do is to take up and replant till they break or shew variegation, which, as already observed, some will do in a year or two, and some not for a long period, or never. Some vary the soil to promote breaking, but in doing this there is often danger of weakening the strength of the flower.

In cultivating choice tulips, an open airy situation, dry at bottom, is made choice of ; there excavations are made commonly in the form of beds four feet broad, of any convenient length, and two and a half or three feet deep. In the bottom a layer of well rotten hot-bed dung is laid and well trod in, and on this two or two and a half feet of rich fresh sandy loam. On this the roots are planted six inches apart, and covered four inches. The best season is the beginning of November. In very severe winters, protection by mats or by a layer of decayed tanner's bark, may be requisite ; but the tulip is very hardy, and almost the only protection it requires is shading and shielding from rain and winds during full bloom. The bulbs should be taken up annually, as soon as the flowers are decayed, and kept in a dry airy situation till wanted for planting. (See Madocks, Hogg, Emerton, \&c)

T. clusiana and $T$. celsiana are both elegant little border bulbs, inferior indeed to their prototypes in splendour of coloring, but more elegant in their simplicity.

773. Fritillaria. Fritillus signifies a dice-box, and is said to have been the origin of this name. This is a genus with flowers shewy and singular in appearance. They require a deep loamy soil, and are readily in creased by offsets or seeds. They will grow in the shade of trees and shrubs, and do not require to be taken up above once in three years.

774. Dracena. From 1 cazcesyo, the female of seceway, a dragon, because the inspissated juice becomes red powder very like the eastern dragon's blood. D. draco has the habit of a palm. The trunk is nearly 
4527 umbraculifera $W$. 4528 cérnua $W$. 4529 férrea $H$. $K$. 4530 frágrans $H$ 4531 ováta $B . M$. umbel-flowered drooping purple

sweet-scented oval-like

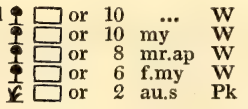

Mauritius 1788. C p.l Bot. cab. 289 Mauritius ... C P p l Jac. sch. 1. t. 96 China 1771. - R p.1 Bot. mag. 2053 Africa 1768. R p.1 Bot. mag. 1081 S. Leone $\quad . . \quad$ R p.l Bot. mag. 1180

775. PHYLlo'MA. B. $\boldsymbol{M}$. Phylloma 4532 aloiflórum $\boldsymbol{B} . \boldsymbol{M}$. aloe-like

$1 \square$ or $10 \begin{aligned} & \text { Asphodelea. } \\ & \text { ap Op }\end{aligned}$ Or $\begin{aligned} & \text { Sp. } \\ & \text { Bourbon 1766. R p.l Bot. mag. } 1585\end{aligned}$

776. ALE'TRIS. $W$. 4533 farinósa $W$.

Aletris. colic-root colic

777. TRITO'MA, $B$. $M$. TRITOMA. 4535 Uvária $H . K$.
4536 média $H . K$. 4537 púmila $H . K$ least

Hemerocallidea. Sp.2-3.

₹ $\Delta$ or $\frac{1}{2}$ jn $\quad W \quad$ N. Amer. 1768. R s.p Bot. mag. 1418 $\$ \Delta$ or $\frac{1}{2}$ jl.au $\quad \mathbf{Y}$ N. Amer. 1811. R s.p Willd. ho. ber. 8

Hemerocallidea. Sp. 3.

778. VELTHE'IMIA $\boldsymbol{H} \boldsymbol{K}$ VeLtheimi 4538 viridifólia $W$. green-leaved 4539 glaú $W$ green-lea
glaucous

4539 glaúca $W$. glaucous

75. SANSEVIE'R 4541 stenophýlla $L . K$. 4542 polyphýila Haw. 4543 guineénsis $W$.

4544 læte-vírens Haw. 4.45 fulvocin'cta Haw. 4546 spicáta Haw. 4547 zeylánica $W$. 4548 lanuginósa $W$. 4549 grandicúspis Haw. 4550 púmila Haw. 4551 cárnea $H$. $K$. sessiliflóra B. M.

780. TULBA'GHIA. $W$. 4552 alliácea $W$ 4553 cepácea $W$

781. YUC'CA. $W$ 4554 gloriósa $W$. 4555 aloifólia $W$. 4556 tenuifólia Haw. 4557 dracónis $W$. 4558 concáva Haw. 4559 obliqua Haw. $\beta$ májor 4560 flac'cida Haw. 4561 serruláta Haw. 4562 recur'va Haw. 4563 supérba Haw. 4564 glaucéscens $\dot{H a}$ 4564 glaucéscens $H a$ Sprdg.-glaucou narrow-leaved upright-glauc. Guinea

light-green

fulvous-edged

spiked

Ceylon woolly dwarf flesh-colored

Hemerocallidea. Sp, 2-4.

( 2 ja.n F.W C. G. H 1781. S Hemerocallidea. Sp. 12-14.

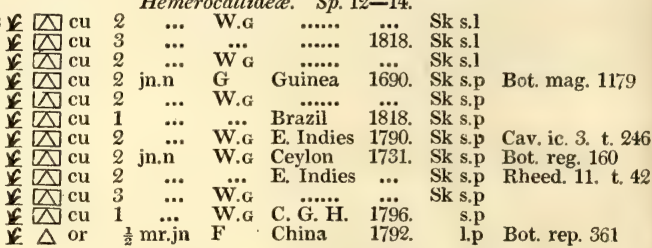

Tulbaghia Narcissus-lvd.

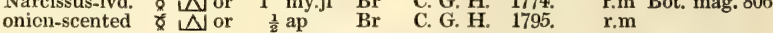
Adam's NeEde. Liliacea. Sp. 12. Aloe-leaved slender-leaved drooping-lvd. hollow-leaved oblique-leaved large flaccid rough-edged recurve-lvd. superb glaucous thready

d

* or 4 jl.au W.gr America 1596. S r.1 Bot. mag. 1260 or 1 au.s W.gr S. Amer. 1696. R r.1 Bot. mag. 1700 * J or 8 au.s W.gr S, Amer. 1732. R r.l Dl. el, t.324.f.417 or $1 \frac{1}{2}$ au W.gr ..... 1816. R r.l \# or 4 ... W.gr $\quad$ W..... 1808 . R r.

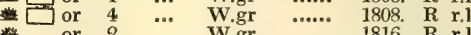

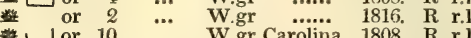
L or 10 ... W.gr Carolina 1808. R r.l or 3 au W.gr Georgia 1794. R r.l Par lond 31 * lor 10 au W.gr ...... ... R r.l Bot. rep. 473 or 2 jl.au W.gr N. Amer. 1819. R r.l Sw. fi. gard 53

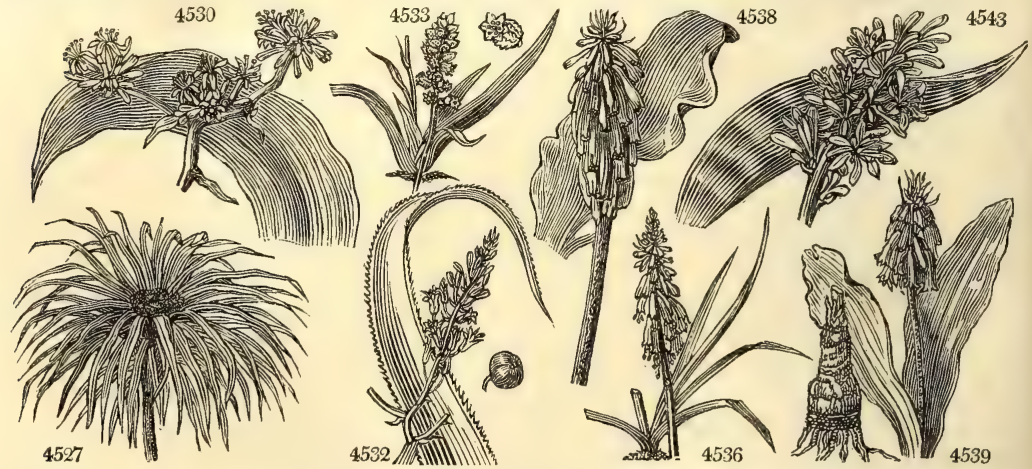

History, Use, Propagation, Culture,

equal in size, which is rarely more than eight or ten inches the whole length; the inner part very pithy, next to this a circle of strong fibres, and the outside soft; the same diameter the whole length; circular marks or rings are left the whole length where the leaves have fallen off. The top sustains a large head of these, coming out singly all round it.

775. Phylloma. From $\phi \nu \lambda \lambda \omega \nu$, a leaf, and $\lambda \omega \mu \alpha$, an edge, in reference to the broad red edge of the leaves. The plant resembles an aloe in foliage and flowers, and requires the same culture.

776. Aletris. From $\alpha \lambda \varepsilon \_\rho$, meal, in allusion to the powdery dust with which the whole plant appears to be covered. Small North American plants, which may be cultivated with a little attention in rich leaf mould.

777. Tritoma. From $\tau \varepsilon \varepsilon s$, three, and $\tau \varepsilon \mu \nu \omega$, to cut, in allusion to the three sharp edges of the ends of the leaves. (v. Ker, in Bot. Mag. fol. 744.) The species of this genus thrive best in peat soil, but will do very well in any other light earth. They are hardy enough to endure our mildest winters in the open air, and only require the protection of a frame in severe frosts. There being also a genus of insects called Tritoma, Professor Link calls this genus Tritomanthe.

778. Veltheimia. Frederick Augustus de Veltheim was a German botanical amateur, of whom nothing more is known. This genus resembles the last, and is of easy culture in any light loamy soil; and readily increased 
4527 Leaves lanceolate narrowed each way, Corymb very short terminal many-flowered 4528 Leaves lanc. obliquely bent, Panicle hanging down divaricating 4529 Leaves lanceolate acute discolored

4530 Leaves lanceolate lax, Flowers very fragrant

4531 Head of flowers sessile in the centre of the ovate leaves

4532 Leaves tooth-spiny, Racemes axillary

4533 Flowers stalked oblong tubular, Cor. in fruit smooth mealy, Leaves broad lanceolate mucronate 4534 Flowers sub-sessile campanulate, Cor. in fruit rugose very rough, Leaves lanc. ensiform acute

4535 Leaves with the keel and edge rough, Cor. clavate cylindrical 4536 Leaves with keel and edge smooth, Cor. clavate cylindrical 4537 Leaves with keel and edge rough, Cor. globose at end

4538 Leaves lanc, plaited wavy obtuse, Teeth of the limb rounded straight 4539 Leaves lanc. glaucous curled at edge mucronate at end, Limb spreading

4540 Leaves about 11 spreading flaccid broadly lanceol, ensiform glaucous obscurely barred 4541 Leaves beneath convex lined channelled not barred

4542 Leaves about 19 sub-erect rigid brittle broad lanceolate ensiform glaucous obscurely barred

4543 Leaves lanc. uniform. Style twice as long as stamens, Bractes thrice as short as tube of cor. Flow. sessile

4544 Leaves about three flaccid lanc. ensiform pale-green with scarcely any bars

4545 Leaves lanc. revolute recurved dull green slightly edged with fulvous

4546 Leaves about eleven nearly erect rigid brittle lanc. ensif. with very obscure bars

4547 Leaves smooth oblong acute flat and lin. lanceolate channelled, Style the length of stamens

4548 Leaves with woolly nerves : lower oblong; rest lin. Pedunc. without bracteæ

4549 Leaves about 12 sub-erect lanc. ensif. much barred with a small bristle at end

4550 Leaves about 20 spreading lanc. ensif. much barred, with 4-6 strong lines beneath

45.51 Leaves distichous lanceolate ensiform keeled, Flowers solitary sessile

\section{Nectary 1-leaved 6-toothed}

4553 Nectary 3-leaved

4554 Leaves quite entire

4555 Leaves crenulate straight

4556 Leaves linear very narrow stiff closely curved back into a semicircle serrulate at edge

4557 Leaves crenate nodding

4558 Leaves erect incurved rough on both sides dull glaucous with strong white marginal threads

4559 Leaves lorate linear lanc. obliquely bent glaucous, Suckers tuberous

4560 Leaves all very flaccid weakly recurved with very strong brownish threads

4561 Leaves in a close head very stiff green rough at edge

4562 Leaves recurved deflexed with a few threads

4563 Leaves a little plaited mucronate, Flowers very close together camp. not opening curved outwards at end 4564 Leaves linear lanc. narrow glaucous with fine white marginal threads

4565 Leaves erect recurved broadly channelled with very strong twisted brown marginal threads
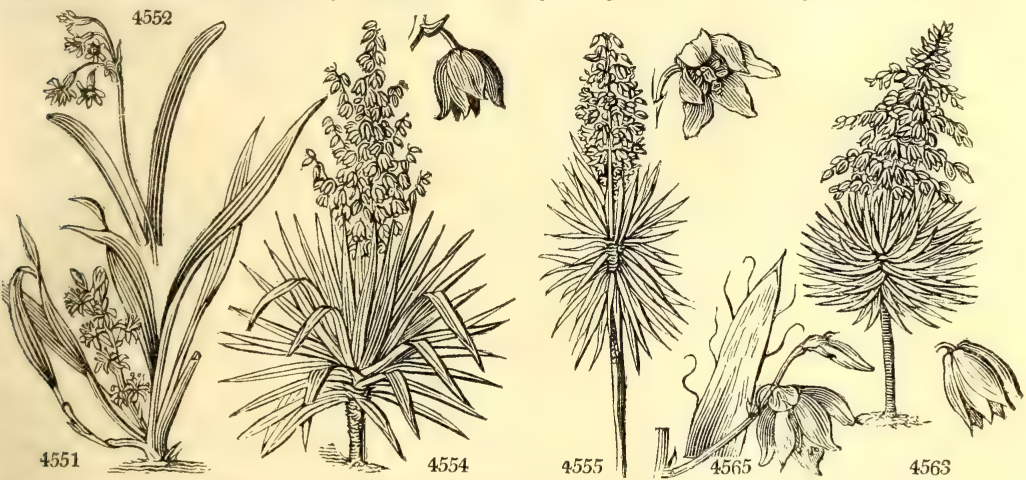

and Miscellaneous Particulars.

by offsets from the bulbs; or by pulling off the leaves close to the bulb, and then planting them in puts of mould, when, like most other bulbous rooted plants, they will produce bulbs at their base. The species are quite hardy, although usually treated as greenhouse plants.

779. Sanseviera. This is a succulent genus, of the easiest culture and propagation in sandy loam with little water. It is probable that nearly all the numerous kinds adopted here from the works of Mr. A. H. Haw orth, are varieties of one common stock, which in the woods of Guinea sports into an infinite number of
forms.

780. Tulbaghia. This was named in honor of — Tulbagh, a Dutch governor of the Cape of Good Hope, who patronized travelling naturalists Very pretty plants, less fragrant than beautiful; they are rarely seen in collections, but may be cultivated in very light sandy peat in a good greenhouse.

781. Yucca. The inhabitants of St. Domingo call this plant Yuca. The species are considered highly desirable from their palm, or oriental pine-apple, or aloe character, and as being evergreens. For this reason they make a striking contrast in not flower freely. They are well adapted for a conservatory, as even the reputed hardy species do not thrive generally in the open air. 
4566 rufo-cin'cta Haw. 4567 stricta Sims.

4568 conspícua Salm.

4569 angustifólia $P h$.

4570 crenuláta Haw.

4571 arcuáta Haw.

782 ERYTHRO'NIU

4572 Dens cánis $W$. $\beta$ albiflórum

4573 americánum $\boldsymbol{H}$. $\boldsymbol{K}$.

783. GLORIO'SA. $W$.

4574 supérba $W$.

4575 símplex $L$.

784. BULBOCO'DIUM.

4576 vêrnum $W$.

785. UVULA'RIA. $W$. 4577 perfoliáta $W$.

4578 táva $P h$

4579 lanceoláta $W$.

4580 grandiflóra $\dot{H}$. $K$.

4581 sessilifólia $W$.

4582 chinénsis $B$. $M$.

4583 amplexifolius $R . \mathcal{L}$. heart-leaved

4584 róseus $P h$. rose-colored

4585 lanuginósus $P h$. woolly

787. CONVALLA'RIA. Desf. LiLy of

4586 majális $W$.

ß rábra

r flóre pléno

common

red-flowered

double

788. SMILACI'Na. Desf. Smilacina.

4587 umbelláta Desf.

4588 boreális Desf.

4589 bifólia Desff

4590 trifólia Desf.

4591 stelláta Desf.

4592 racemósa Desf. oval-leaved

least

least star-flowered, $\frac{\downarrow}{\Delta} \Delta$ or

789. PIY 4593 verticillatum Desf whorl-leaved $\downarrow \Delta$ or 4594 4595 pubéscens $P h$. pubescent 4596 vulgáre Desf. angular

4597 multiflórum Desf. common

4598 latifólium Desf

4599 oppositifóliumLodd. opposite-leaved $\$ \Delta \Delta$ or
W.G $\quad \ldots . . .1$ 1816. Sk r.m

W.g Carolina 1817. Sk r.m Bot. mag. 2222

W.G $\quad \ldots . .$. 1816. Sk r.m

W.G Missouri 1811. Sk x.l Bot. mag. 2222

W.G

W.G 1817. Sk s.

Liliacece. Sp. 2

L mr Pu
Europe 1596. O p.l Bot. mag. 5

$\begin{array}{llllll}\frac{1}{4} & \text { mr } & \text { W } & & \\ \frac{1}{4} & \text { ap.my } & \text { Y } & \text { N. Amer. 1665. O p.1 } & \text { Bot. mag. } 1113\end{array}$ Liliacece. Sp. 2-3.

6 il.au Or E. Indies 1690. O s.p Bot. reg. $7 \%$

2 jl.au B Senegal 1756. O s.p

Melanthacece. Sp. 1

$\frac{1}{4}$ f.mr D.Pu Spain

Melanthacea. Sp. $6-9$.

$\frac{1}{2}$ my.jn Pa.Y N. Amer. 1710. Sk p.1 Ex bot. 1. 49 my.jn $Y$ N. Amer.... Sk p.l Ex. bot. 1. t. 50 1 in.au $Y$ N. Amer. 1710. Sk p.l Corn, can. t. 41 1 my.jn Y N. Amer. 1802. Sk p.1 Ex. bot. 1. t. 51 $\frac{1}{2} \mathrm{jn}$ L.Y N. Amer. 1790. Sk p.l Ex. bot. 1. t. 52 s.n Pk China 1801. Sk p.l Bot. mag. 916

Smilacea. $S p .3$

$\$ \Delta$ or $1 \mathrm{my}$ W Hungary 1752. Sk It.s Red. lil. 259

$\Delta$ or $1 \frac{1}{2}$ jn.jl Pk N. Amer. 1806. Sk lt.s Bot. mag. 1489 THE VALleY. Smilaceq. $S p .1$.

\$ $\Delta$ or $\frac{1}{2}$ my.jn W Britain woods. $R$ s.l Eng. bot. 1035 t $\Delta$ or $\frac{1}{2}$ my.jn $F$ Britain gard. R s.l

my.jn W Britain gard. $R$ s.

Smilacee. $S p, 6$.

$\frac{3}{4}$ my.jn $\quad \mathrm{N}$ Amer. 1778. R s.l Bot. mag. 1155

1 my.jn W N. Amer. 1778. R s.1 Bot. mag. 1403

1 my.jn W N. Eur 1596 R sl Bot mag 510

$\frac{1}{4}$ jn.jl W N. Amer. 1812. R s.1 Gmel. sib. 1.t. 6

$\frac{1}{2}$ my.jn W N. Amer. 1633. R s.1 Bot. mag. 1043

1 my.jn W N. Amer. 1640. R s.1 Bot. mag. 899

Smilacea. $S p .7-8$

1 my.jn W Scotland woods. R s.1 Eng. bot. 128

1 jn W N. Amer. 1812. R s.l

1 my.jn W N. Amer. 1812. R s.I Willd, ber. 45

2 my.jn W.G England moun. R s.l Eng. bot. 280

2 my.jn W Britain woods. R s.1 Eng bot. 279

1 my.jn W Germany 1802. R s.l Jac. aus. 3. t. 232

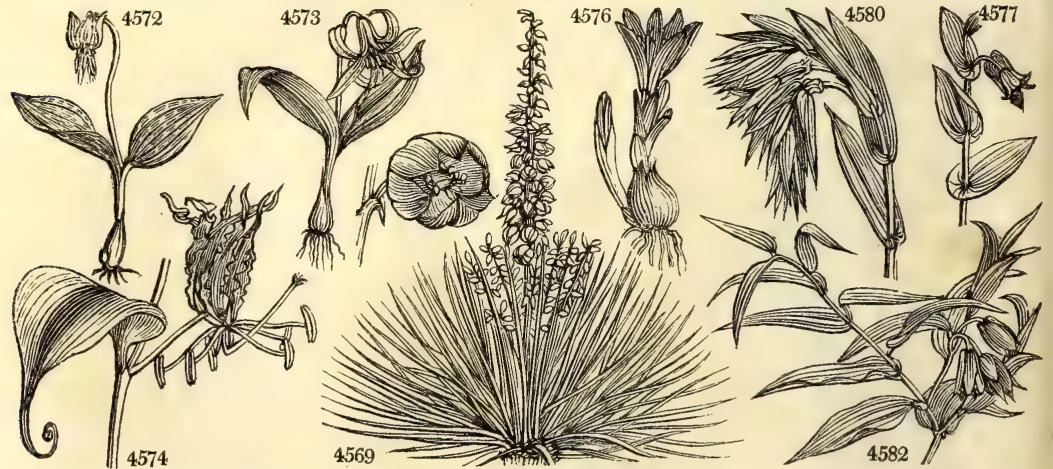

History, Use, Propagntion, Oulture,

782. Erythronium. Frorn sev. bulbs, the favorites of gardeners, from the cottager's border to the nobleman's flower garden. The E. americanum runs very much at the root, and will not flower unless confined and prevented wasting its vigour in long subterraneous surculi.

78:. Gloriosa. So named on account of the glorious colors of its flowers, and the elegance of their form. This is a splendid and curious genus, which requires considerable care in its treatment so as to make it flower freely. The late John Sweet, of Bristol, has given the following directions; "When the stalks and foliage have decayed in the autumn, and ieft the root, like a well-ripened potatoe, in a dormant state, the pot in which it is, must be removed from the bark-bed (to a dry part of the house) at some distance from the fire: all the warmth at this time necessary being merely what is sufficient to keep the earth in the pot free from damp : and to prevent the waterings of the house, or other moisture, falling on the earth in the pot, it should be covered, by inverting upon it another pot of the same size; or if larger, it will hang over its edges, and more effectually exclude the wet. If the roots are small, two or three may be placed together in the same pot, whilst in their dormant state; but if they are thus shifted, the mould must be well shaken down in the pot, in orier to prevent the access of air to them : the old mould in which they grew must also be used; for fresh earth or sand would stimulate them to move too early. About the second week in March, the roots must be replanted, putting one or two, according to their size, into pots measuring six inches over. The best compost for them is fresh loam, mixed with an equal quantity of peat-mould, of good quality; the loam should be good, not over rich with dung, nor too heavy. The roots are to be covered about two inches deep and care must be taken not to break them, unless nature has shown where it is practicable to divide them easily. The pots, when filled, must be plunged into the bark-bed, where the heat should be equal to ninetyfive degrees of Fahrenheit's scale. Water is to be given very sparingly at first; and though, as they grow, 
4566 Leaves erect lin. lanc. flaccid glaucous green quite smooth with a slight red edge 4567 Stemless, Leaves linear very straight, Scape branched at base, Cor. round campanulate 4568 Leaves few loosely headed long lanceolate, their edges rough

4569 Leaves erect rigid narrow ensiform glaucous with a broad white edge and a few threads $\mathbf{4 5 7 0}$ Leaves a little recurved glaucous lin. lanc. at the edge and keel rough, beneath glaucous 4571 Leaves lin. lanceolate recurved almost into a circle deep green 7-8 lines broad roundish at edge

4572 Style filiform

4573 Style clavate 3-cornered

\section{Leaves cirrhiferous}

475.5 Leaves acuminate

4576 A small plant like a Crocus

4577 Leaves perfoliate ovate

4578 Leaves perfoliate elliptic oblong obtuse, Cor. narrowed at base scabrous within, Anthers cuspidate 4579 Leaves perfoliate ovate lanceolate acute

4580 Leaves perfoliate oblong acute, Petals smooth on both sides, Nect. roundish

4581 Leaves sessile

4582 Leaves stalked

4583 Leaves stem-clasping and stem smooth

4584 Smooth shining Leaves stem-clasping serrulate ciliated, Anthers short 2-horned

4585 Downy hoary, Leaves sessile cordate acuminate, Pedicels in pairs on a very short stalk

4586 Scape naked smooth, Leaves ovate

4587 Leaves ovate oblong obtuse ciliated, Scape leafless, Umbel capitate

4588 Leaves radical elliptical, Umbel terminal

4589 Leaves cordate, Flowers tetrandrous

4590 Leaves stem-clasping in threes, Raceme terminal simple

4591 Leaves alternate stem-clasping elliptical acute, Raceme terminal simple

4592 Leaves alternate sessile ovate acuminate, Panicle terminal naked

4593 Leaves whorled

4594 Stem furrowed, Leaves alternate amplexicaul. oblong pubescent at edge, Pedunc. axillary 2-fl.

4595 Stem rounded furrowed, Leaves amplexicaul. ovate downy beneath, Pedunc. axill. about 2 -fl.

4596 Leaves alternate stem-clasping, Pedunc. axillary 1-fl.

4597 Ieaves alternate stem-clasping, Stem round, Pedunc. axillary many-fl.

4598 Leaves alternate stem-clasping acuminate, Stem angular, Pedunc. axillary many-fl.

4599 Stem round, Leaves opposite oblong acuminate shining, Pedunc. umbell. 3-5-flowered
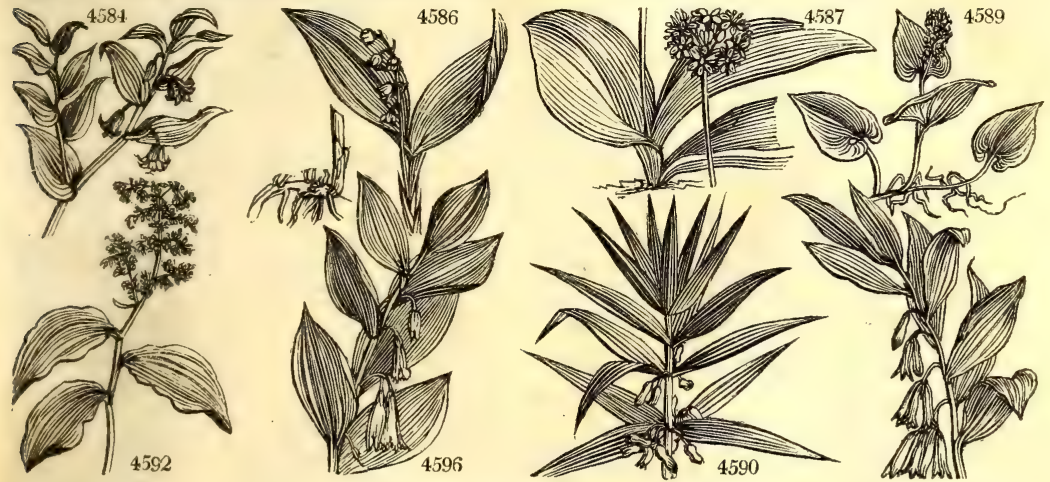

and Miscellaneous Particulars.

they will require a more liberal supply, yet it is necessary at all times to be very moderate in giving it. The heat must be well kept up; and as the roots extend, they must be supported. Under such treatment as I have described, I have known one plant grow ten feet in the course of a season, and to have numerous blossom-stems upon it." It is readily increased by dividing the roots. (Hort. Trans. iii. 2, 3.) The flowers are at first green, they afterwards assume those beautiful markings of yellow for which they are so much esieemed.

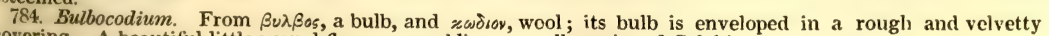
covering. A beautiful little vernal flower resembling a small species of Colchicum.

785. Uvularia. A diminutive of $u v a$, a bunch of grapes. A genus of little beauty and of easy culture,

786. Streptopus. From $s \xi \varepsilon \varphi \omega$, to turn, and $\tau 8 s$, a foct, or, in botanical language, stalk. Its flower-stalks are constantly twisted. A plant like an Uvularia in habit.

787. Convallaria. From convallis, a valley, in allusion to the places where it grows. (Muguct, Fr.) C. majalis is an elegant and delicate scented plant, which has long been a favorite of the florist; though, as it is not a native of hot countries, it is not likely to be the Lily of the Valley of Solomon. Notwithstanding the fragrance of the flowers when green, yet when dried they have a narcotic odour, and if reduced to powder excite sneez. ing. An extract prepared from the flowers or from the roots partakes of the bitterness, as well as of the purgative properties, of aloes. A beautiful and durable green colour may be prepared from the leaves with lime.

The plant is very common in the woods about Woburn in Bedfordshire, and from thence the London markets are supplied with the flowers. It forces freely, and few plants are more eligible for that operation.

788. Smilacina. A diminution of Smilax, another genus of plants, which see in its place. These are very pretty little hardy American flowers, requiring some delicacy in their management.

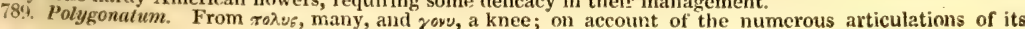


790. OPHIOPO'GON. Ker. SNaKe's BeARD. 4600 japónicus Ker Japan Smilacea, Sp. 2-3.

Japan $\quad \mathrm{N}$ cu $1 \frac{1}{2}$ jn $\quad$ L.Y Japan 791. EUCO'MIS. $W$. Eucomis. 4602 nána $W$. 4603 purpureocaúlis $H . K$. purple-stalked 4604 bifólia $W$. 4605 régia $W$. 4606 unduláta $W$ 4607 punctáta $W$. 4608 striáta $H$. $\dot{K}$.

792. BRODI $\mathbf{E}^{\prime}$ A. $L, T$ T. $T$ Bropisa L. T. large-flowered $\gamma\llcorner\triangle \mathrm{J}$ or $\begin{array}{lll}4610 \text { ixioídes Sims. } & \begin{array}{l}\text { Ixia-like } \\ \text { close-headed }\end{array} 611 \text { congésta } L . T . & \text { o }\end{array}$ 793. PELIOSAN'THES. $\boldsymbol{B}$. $\boldsymbol{R}$. Peliosanthes.

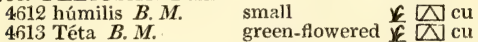
794. APHYLLAN'THES. $W$. LILY PINK. 4614 monspeliénsis $W$. Rush-like \& $\Delta \mathrm{pr}$ 795. SOWERB压A. L. T'. SowerbaA. 4615 júncea $R . B r . \quad$ Rush-leaved

GarLIC.

796. AL'LIUM. $W$. 4616 Ampeloprásum $W$ 4617 Pórrum $W$. 4618 lineáre $W$. 4619 suavéolens $W$. 4621 subhirsútum $W$ 4622 obliquum $W$ 4622 obliquum $W$ 4623 mágicum $W$
4.024 róseum $W$. 4625 defléxum $W$. 4626 strictum Schrad. 4627 neopolitánum $\mathrm{Cy}$. 4628 ciliátum Cyr.

4629 tatáricum $L$. 4630 descéndens $W$. 4631 flávum $W$ 4632 pállens $W$. 4633 paniculátum $\boldsymbol{L}$. 4634 caucásicum Bieb. 4635 rotúndum $L$. 4636 globósum Bieb. 4637 moschátum $L$. 4638 guttátum Fisch. 4639 rupéstre Bieb. 4640 pusillum $W$. en. 4641 sphærocéphalon $W$ 4642 parviflórum $W$. 4643 cárneurn $W$. en.

gt.-round-head $\gamma$ Leek linear-leaved sweet-smellin o $\triangle$ pr long-rooted o $\triangle \mathrm{pr}$ hairy o $\triangle \mathrm{pr}$ oblique-leaved of $\triangle \mathrm{pr}$ oblique-leaved $\delta \Delta$ pr Homer's Moly $\gamma \Delta \mathrm{pr}$ $\begin{array}{lll}\text { Rose-colored } & \gamma & \Delta \mathrm{pr} \\ \text { deflexed } & \delta & \triangle \\ \mathrm{pr}\end{array}$ upright Neapolitan ciliated

Tartarian purple-headed $\delta \Delta$ pr sulphur-colored $\delta$ pale-flowered $\delta \triangle \mathrm{pr}$

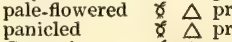
Caucasian round globose musky spotted rock diminutive small-headed small-flowered flesh-colored
$\mathbb{N} \backslash \mathrm{pr}$

$\Delta p r$

\% $\Delta$ pr

\& $\Delta$ pr

\& $\triangle \mathrm{pr}$ Asphodelea. Sp. 7-9.

$\frac{3}{4} \mathrm{my} \quad$ Br C. G. H. 1774. O r.m Bot. mag. 1495 2 mr.ap G.B C. G. H. 1794. O r.m Bot, rep. 369 $\frac{1}{4}$ ap.my L.G C. G. H. 1792. O r.m Bot. mag. 840 采 ap.my L.G C. G. H. 1792. O r.m Bot. mag. 840 mr.ap $G$ C. G. H. 1702. O r.m Di. el. t.92.f.10 2 jl $\quad$ G.B C. G. H. 1783. O r.m Bot. mag. 913 2 jn.d G C. G. H. 1790. O r.m Bot. mag. 1539 Hemerocallidece? Sp.3.

3 jn B Georgia 1806. O p.l Par, lond. t. 98 $\frac{1}{2}$ jl B Chili : 1821. O p.1 Bot. mag. 2382 $\frac{3}{4} \mathrm{my} \quad$ B Georgia 1806. O p.1 Lin.tr.v.10.t. 1 Asparagea. Sp. 2

$\frac{1}{2}$ my.jn G E. Indies 1809. D r.l Bot. mag. 1532 ap G.Pu E. Indies 1807. Sk s.p Bot. mag. 1302 Asphodelea. Sp. 1.

1 jn.jl R France 1791. R s.p Bot. mag. 1132 Asphodelece. Sp. 1.

my.jl Pk N. S. W. 1792. R s.p Bot. mag. 1104

Asphodelea. Sp. 76-107.

jl.au Pu England sun.hi. O co Eng. bot. 1657 ap.my W Switzerl. 1562. S r.m Blackw. t. 421 jn.jl W Siberia 1752. O co Gmel. sib.1.t.13 jn.jl W Austria 1801. O co Jac. ic. 2. t. 364 W Austria 1739. O co Bot. mag. 1229 W S. Europe 1596. O co Bot. mag.

W Siberia 1759. O co Bot.

1 jn.jl G.w Austria 1596. O co Bot. mag. 1148

1 Pa.pu France 1752. O co Bot. mag. 978

$\frac{1}{2}$ jn.jl Pa.pu

jl Pk Naples 1821. O co $\frac{3}{4} \mathrm{my}$ W Naples 1820 . O co

1 jn.jl W Siberia 1787. O co Bot.mag. 1142 jl Pu Switzerl. 1766. O co Bot. mag. 251

jn.jl Y Austria 1759. O co Bot mag. 1330

2 jn.j1 Pa.X S. Europe 1779. O co Bot. mag. 1420

2 jn.j1 Pu S. Europe 1780. O co Bot. mag. 1432

$\varnothing \triangle \mathrm{pr} 1 \mathrm{jn} . \mathrm{jl}$ Pk Caucasus ... O co Bot. mag. 973

خ $\triangle$ pr $1 \frac{1}{2}$ jl $\quad$ Pu $\quad$ S. Europe 1820. O co

of $\triangle$ pr 1 au.s Pu Caucasus 1821. O co Gmel sib 1. t.10 \% $\Delta$ pr au,s W.pu S. Europe 1823. O co Wald.\& K.1.t.68

\% $\triangle \mathrm{pr} 1 \frac{1}{2} \mathrm{jn} \quad \mathrm{Pu}$ Crimea 1824. O co

\% $\triangle \mathrm{pr} \quad \frac{2}{2} \mathrm{jn} \quad \mathrm{Pk}$ Siberia 1821. O co

б $\triangle \mathrm{pr} \quad 1_{1}^{\frac{1}{2} \mathrm{jl}} \quad \mathrm{R} \quad$ Europe 1759. O co

\& $\triangle$ pr 1 jn.jl Pa.pu ..... 1816. O co

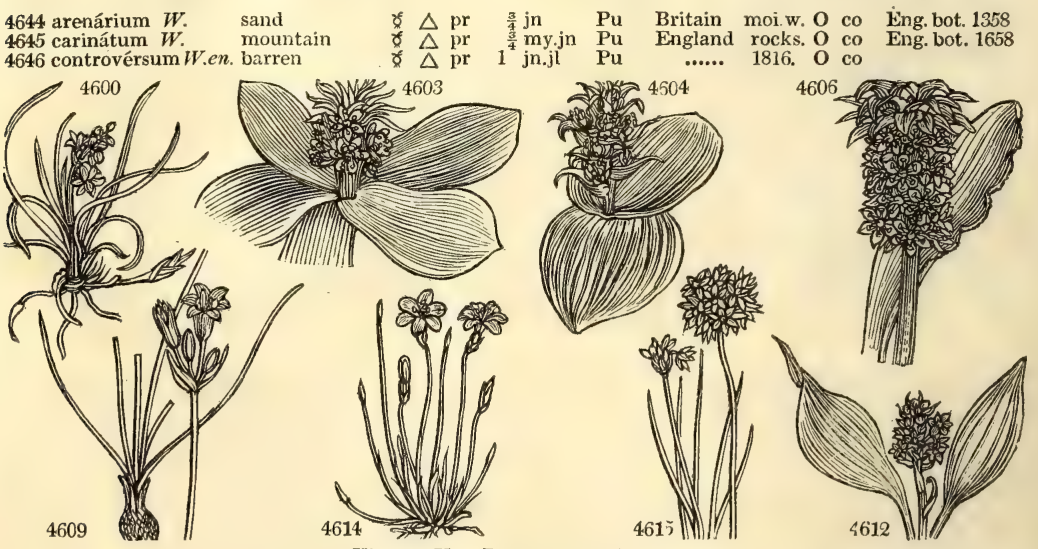

History, Use, Propagation, Culture,

stem. The English name arises from the roots, which in P. vulgare are full or knots, and a transverse section of them shews characters which dreamers have discovered to represent the impress of the famous seal of Solomon.

790. Ophiopogon. From opts, a snake, and $\pi \omega$ roy, a beard : snake's-beard. This plant is best grown in pots, as it requires the protection of a frame during severe frosts.

791. Eucomis. From év, well, and жoun, hair; on account of the fine tuft of leaves, in botanical language called coma, by which the stem is surmounted. Handsome herbaceous plants which are nearly hardy.

792. Brodica. Named by Sir James Smith, after James Brodie, Esq. of Brodie House, a gentleman to whom the botany of Scotland is indebted. Highly curious little plants with blue flowers.

793. Peliosanthes. From $\pi \varepsilon \lambda 605$, livid, and ov. name of the plant in India; and having been adopted by Dr. Roxburgh, ought not to have been neglected in this country. 
4600 Scape naked, Leaves linear thrice as long as scape

4601 Scape naked, Raceme spiked, Flowers aggregate

4602 Scape clavate, Leaves broad lanceolate acute

4603 Scape clavate, Leaves multifarious expanded

4604 Scape clavate, Leaves elliptical acute twin lying on the ground

4605 Scape cylindrical, Leaves tongue-shaped obtuse lying on the ground

4606 Scape cylindrical, Leaves ovate oblong wavy spreading, Crown as long as raceme

4607 Scape cylindrical, Leaves oblong lanceolate channelled spreading, Crown short, Racemes long

4608 Scape cylindrical, Leaves lanceolate spreading striped, Crown short, Raceme long

4609 Flowers large lax, Leaves of corona lanceolate undivided

4610 Leaves of the corona subulate

4611 Flowers clustered, Leaves of corona bifid

4612 Scape shorter than ovate-lanceolate leaves

4613 Scape branched longer than leaves

4614 The only species

4615 The only species

A. Stem leafy. Leaves not fistular.

A. Stem leafy. Leaves not fistular.
Umbel not bulbiferous. Leaves fat.

4616 Umb. globose, Stam. 3 cusp. Sepals with a rough keel

4617 Stam. tricuspidate, Root tunicated

4618 Umb. globose, Stam. tricuspidate twice as long as flower

4619 Umb. capitate, Stam. subulate twice as long as flower

4620 Umb. capitate, Stam lanceolate longer than flower, Leaves elliptical

4621 Umb. fastigiate, Stam. subulate, Leaves linear ciliated

4622 Stam. filiform thrice as long as flower, Leaves oblique

4623 Cauline leaves lanceolate, Umbel dense depressed, Stamens subulate shorter than flower

4624 Umb. fastigiate, Sepals emarginate, Stamens very short simple

4625 Stam. 3-pointed as long as flower, Leaves very narrow, Scape declinate

4626 Very upright, Leaves channelled

4627 Umb. loose few-flowered, Leaves smooth

4628 Very like Allium subhirsutum differing only in the smallness of the flowers, Sepals 3 lines long Umbel not bulbiferous. Leaves not fat.

4629 Stamens simple, Umbel flat, Leaves half-rounded

4630 Outer peduncles shorter than the rest, Stamens 3-pointed

4631 Flowers pendulous, Sepals ovate, Stam. Ionger than flower

4632 Flowers pendulous truncated, Stam. simple as long as flower

4633 Pedunc. capillary effuse, Stam. simple, Spathe very long

4.634 Stam. simple twice as long as flower, Spathe as long as flower-stalks : one valve shorter

4635 Umbel globose, Stam. 3-pointed, Flowers lateral nodding, Leaves half-round

4636 Stamens simple twice as long as flower, Umbel globose, Spathe subulate very long

4 4h37 Umbel fastigiate about 6-flowered, Sepals acute, Stamens simple, Leaves setaceous

4638 Umbel globose very dense, Spathes lanc. as long as flow.-stalks, Stam. 3-pointed longer than fl. Lvs. $\frac{1}{2}$ round

4639 Flower-stalks nearly equal, Sepals ovate conniving as long as simple stamens, Style longer than stamens

4640 Spathe ovate shorter than umbel, Stamens simple shorter than flower

4641 Leaves half-round, Stamens 3-pointed longer than flower

4642 Umbel globose, Stamens simple longer than flower, Spathe subulate

4643 Umbel sub-globose, Stamens 3-pointed shorter than flower

Umbel bulbiferous. Leaves flat.

4644 Sheaths of leaves rounded, Spatheblunt, Stamens 3-pointed

4645 Umbel spreading, Peduncles nodding, Stamens subulate, Spathes with very long points

4646 Flowers all male, Stamens 3-pointed, Spathe with a very long point
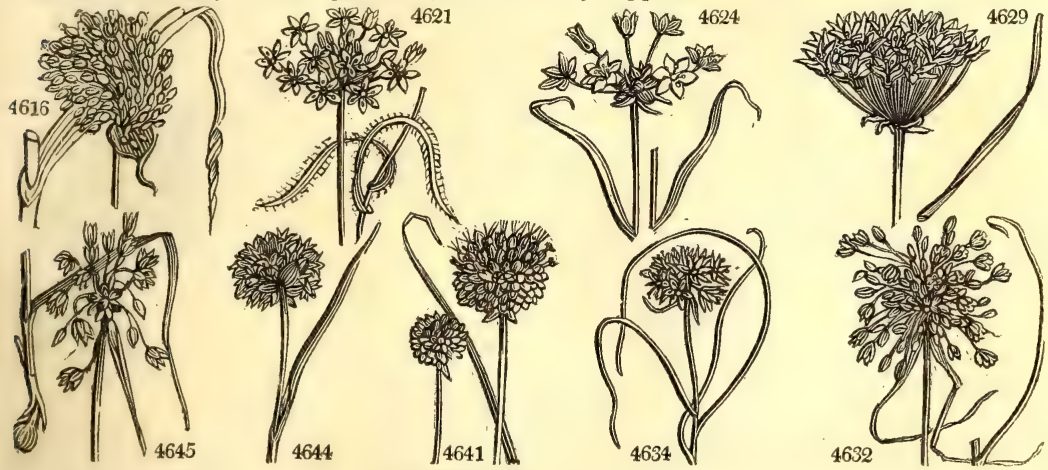

and Miscellaneous Particulars.

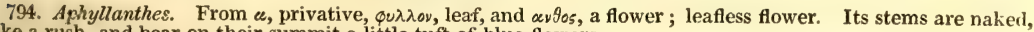
like a rush, and bear on their summit a little tuft of blue flowers.

705. Sowerbaa. So named in honor of the late James Sowerby, an excellent draughtsman and ingenious naturalist. The power he possessed of representing the general features of plants within the compass of a few inches, as in his English Botany, has never been possessed in the same degree by any other individual than the late Sydenham Edwards. His execution as an artist is fully attested by the superb plates of the Flora Londinensis, of his own Fungi, and indeed of almost every botanical work of merit which appeared during his life. His talents and his reputation are inherited by his sons. This plant requires plenty of water, and is easily increased by dividing the roots.

796. Allium. From the Celtic all, which signifies hot or burning. This is a genus of strongly scented bulbous plants, all of them edible, and some of them of the greatest antiouity as potherbs. 
4647 Bulbs compound, Stamens 3-pointed

4648 Leaves crenulate, Sheaths 2-edged, Stamens 3-pointed

4649 Iike Allium carinatum, but the stamens are three-pointed

4650 Stamens subulate twice as long as flower, Spathe longer than umbel

Umbel bulbiferous. Leaves not flat.

4651 Leaves half round, Spathes much longer than umbel, Sepals obtuse, Stamens simple exserted 4652 Stamens 3-pointed

4653 Leaves rough half-round furrowed beneath, Stamens simple

B. Leaves radical, not fistular.

4654 Scape rounded, Umb. many-fl. fastigiate, Leaves linear channelled angular beneath, Stam. subulate 4655 Scape rounded, Leaves lin. lanceol. Umb. fastigiate, Sepals very narrow, Stamens simple 4656 Scape rounded, Leaves lanceolate, Umb. hemispherical, Sepals spreading, Stamens simple

4657 Scape rounded, Lvs. lin. lanc. wavy, Umb. hemispherical, Roots very long, Stam. simple twice as long as fl.

4658 Scape oblique 4 cornered, Leaves linear, Umb. fastigiate, Stamens simple as long as $\mathrm{fl}$.

1659 Scape rounded, Leaves half-round, Spathe acum. longer than umbel, Stam. simple longer than flower 4660 Scape $\frac{1}{3}$ rounded, Leaves lanceolate acuminate flaccid ciliated sheathing, Umbel fastigiate, Sepals obtuse 4661 Scape 2 -edged angular, Umbel clustered, Stamens simple as long as flower, Leaves linear oblique

4662 Scape nearly 2-edged, Umbel capitate, Stamens longer than flower, Leaves linear spiral

4663 Scape 2-edged, Umb. drooping before flowering, afterw. erect, Lvs. lin. flat, Stam. 3-pointed longer than f,

4664 Scape rounded, Leaves subulate, Umbel globose, Stamens 3-pointed

4665 Scape 2-edged, Leaves linear convex and smooth beneath, Umbel roundish, Stamens subulate

4666 Scape rounded very long, Leaves linear channelled, Stamens subulate connate at base

4667 Scape 2-edged, Leaves linear channelled angular beneath, Umbel fastigiate

4668 Scape 3-cornered shorter than the lin. furrowed leaves, Umb. fastigiate, Stamens simple, Sepals obtuse 4669 Scape rounded longer than the linear subulate leaves, Umb. fastig. Stamens simple, Sepals mucronate 4670 Scape rounded, Leaves linear

4671 Scape 3-cornered, Leaves lanceolate stalked, Umbels fastigiate

4672 Scape and leaves 3-cornered, Stamens simple

4673 Scape rounded, Leaves linear flat ciliated, Umb. few-flowered, Sepals obovate concave

4674 Scape nearly cylindrical, Leaves lanceolate sessile, Umbel fastigiate

4675 Scape half-round, Leaves lanceolate oblong flat smooth, Umbel globose, Seeds solitary

4676 Scape 4-cornered, Umb. fastigiate cernuous, Leaves linear flat, Stamens subulate longer than flower

4677 Leaves twisted linear, Umbel loose, Filam. subulate as long as flower

4678 Scape rounded longer than leaves, Umb compact, Stam, subul, as long as flower

4679 Scape rounded at end, Umbel half globose, Leaves linear flat chann. at base, Stam. subul. longer than fl. 4680 Scape rounded, Umb. fastigiate, Leaves half-round compressed, Stam. lanceolate shorter than $\mathrm{f}$.

\$681 Scape rounded, Umb. few-flowered fastigiate, Leaves lin. channelled, Stam. lanceolate shorter than fl.

C. Leaves fistular.

4682 Scape leafy, Umb. fastigiate, Spathes nearly equal, Sepals mucronate

4683 Scape leafy at base

4684 Scape fistular twisted, Umb. bulbiferous proliferous, Stamens 3-pointed

4685 Scape rounded with an angle, Leaves linear obtuse, Umb. rounded, Stamens setaceous twice as long as f.

4686 Seape ventricose beneath longer than the round leaves

4687 Scape as long as the round ventricose leaves

4688 Scape as long as the round subulate leaves

4689 Scape not quite naked round, Leaves half-round, Stamens sıbulate, Sepals lanceolate acute

4690 Scape round, Leaves setaceous subulate ciliated, Sepals ovate lanceolate emarginate at ends 4691 Scape scarcely any, Capsules cernuous, Leaves flat ciliated

\section{Three stamens fertile.}

4692 Inner sepals glandular at end inflexed, Leaves subulate channelled recurved 4693 Inner sepals glandular at end inflexed, Peduncles spreading, Leaves linear lanc. fiat reflexed
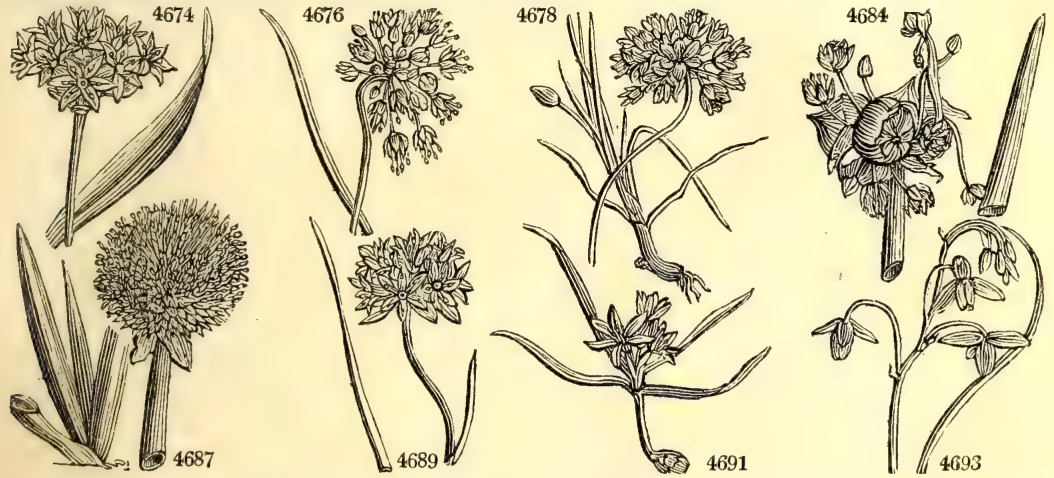

and Miscellaneous Particulars.

A. cepa. (Cep signifies head in Celtic.) Oignon, Fr, Zwiebel, Ger. and Cipolla, Ital, is universally cultivated for the kitchen, and is used as a pot-herb, salad, and pickle. It is commonly raised from seed, which is sown on rich, loamy, and rather moist soil, in March; and being thinned, weeded, and the soil stirred, the bulbs will be fit to take up in September, when they may be kept through the winter like potatoes or apples. It is also grown from small bulbs, which are planted on the surface of the soil in March, and swell to a large size (if not earthed up) in the course of the season. Sometimes onion-seeds are sown in autumn in a very dry situation, and the young plants are taken up and transplanted in spring: or a sowing is made very early in spring on a warm border or on a hot-bed, and the crop transplanted from that.

There is a variety called the underground-onion, which multiplies its bulbs by offsets below the surface.

The species called the tree onion, like several others, produces its bulbs instead of or among the umbel of flowers. It is occasionally cultivated, but chiefly as matter of curiosity.

A. fistulosum is grown chiefly as a scallion, or spring salad onion. It has almost no bulb, but large succulent fistular leaves, strong in flavor. It is sown in autumn, and fit to be used in spring.

797. Albuca. Derived from alöus, white, in allusion to the coior of the flowers of this genus. Not a very happy allusion though, because the flowers are mostly green. The stem of the Asphodel was called albuca by 
4694. minor $W$ 4696 viridiflóra $W$. 4697 coarctáta $W$.

4698 fastigiáta $W$. 4699 caudáta $W$ 4700 setósa $W$ 4701 vittáta $B$. $M$. 4702 physódes $B$. $M$ 4704 aúrea Jacq. 4705 abyssinica Jacq. 4706 frágrans $W$. 4707 viscósa $W$ 4708 spirális $W$. 4695 fláccida $\dot{J} a c$ 4703 exuviáta $\boldsymbol{B} . \boldsymbol{M}$

small $\quad$ \& Nor 1 my.jn $Y$

flaccid $\varnothing \cup$ or 2 my.jn $Y$.W

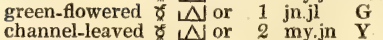

C. G. H. 1768. O s.1 Bot. mag. 720

C. G. H. 1791. O r.m Jac. ic. 2. t. 144 C. G. H. 1794. O r.m Bot. mag. 1656 C. G. H. 1774. O r.m

level-topped $\mathrm{N}$ or $1 \frac{1}{2}$ my.jn $W \quad$ C. G. H. 1774. O r.m Bot. rep. 450 upright-flower. $\delta \mathrm{N}$ or 2 my.jl W C. G. H. 1791. O r.m Jac. ic. 2. t. 442 bristly of $\triangle$ or 1 my.jl G C. G. H. 1795. O r.m Bot. mag. 1481 ribbon $\quad \mathrm{N}$ or $\frac{1}{2}$ jl.au Y.G C. G. H. 1802. O s.p Bot. mag. 1329

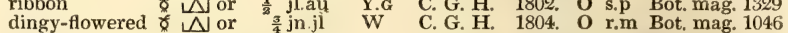

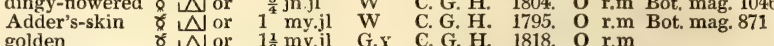
golden Abyssinian o $\mathrm{N}$ or sweet-scented $\delta$ N or 1 jn.jl Y.G C.G.H 1818. O r.m Jac.schœn.1.t.81 clammy-leaved $t$ or 1 my.jn W $\mathrm{C}$. G H 1779.

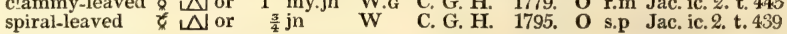

798. XANTHORRHE'A. R. Br. Xanthorrhea. Asphodelea. 4709 hástilis $R . B r$. yellow-gum $\mathbb{N} \mathrm{veu} 4$ ap.my W

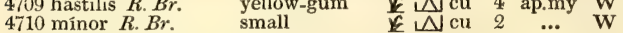
4711 bracteáta $R . B r$. long-bracted $\quad \mathbb{E}$ cu $2 \quad \ldots .6$ 799. THYSANO'TUS, $R . B r$. ThYsanotus. 4712 júnceus $R . B r$. Rush-like $\frac{\mathcal{J}}{\gamma} \backsim \mathrm{Nr}$ pr au.s $\mathrm{Pu}$ 800. ERIOSPER'MUM. $W$. ERIospermery 4714 latifólium $W$ 4715 pubéscens Jacq. 4716 lanceæfólium $W$. 4717 parvifólium $W$ 4718 folioliferum $B$. 801. GA'GEA. Sal. 4719 lútea $\boldsymbol{B} . \boldsymbol{M}$. 4720 sylvática $W_{\text {. en }}$. 4721 spathácea $W$. 4722 minima $P$. S 4723 circináta $L$. 4724 serotína $B . M$. broad-leaved downy spear-leaved

$\gamma$ Asphodelea

au.s $\mathbf{P u}$
Asphodelea Sp. 3-7.

N. S. W. 1803. Sk s.p N. S. W. 1804. Sk s.p N. S. W. 1810. Sk s.p Sp. 2-21.

N. S. W. 1804. O s.p Bot. reg. 656 N. S. W. 1822 . O s.p Bot. reg. 655 Sp. 5-9.

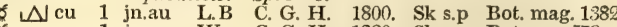
\% cu 1 jn W.G C. G. H 1820. Sk s.p Bot. reg. 578

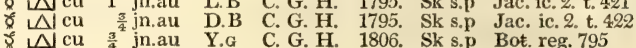
leaflet-bearing $\delta \mathrm{S} \mathrm{cu} \quad \frac{3^{\frac{3}{4}}}{\mathrm{j} n . a u}$ Y.G GAGEA. bundle-flower'd $\delta \Delta$ pr $\frac{1}{4}$ mr.ap $\mathrm{Y}$ wood sheathed starry

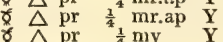
netted mountain

Sp. 6-7.

Britain woods. O s.p Bot. mag. 1200 Europe $\quad \ldots$ O s.p P.i.u.N.a.5.t1.f. Germany 1759. O s.p H.in.us.an.15, t1 Sweden 1759, O s.p

Siberia 1789. O s.p Pall it t D f ? Wales $\quad . . \quad$ O s.p Eng, bot. 793

802. ORNitho'GALUM. $W$. Star of Bethlehem. Asphodelec. Sp. 29-47. 4725 uniflórum $W$. one-flowered $\delta \Delta$ or $\frac{1}{4}$ my.jn Y Siberia 1781. O s.p N.c.p.18.t.6.f.3 4726 ixiódes $H$ 4727 niveum $W$. 4728 umbellátum $W$. 4729 vírens Lindl. 4730 narbonénse $W$. 4731 fimbriátum Bieb. 4732 pyrenấicum $W$ 4733 stachyódes $W$ 4734 lácteum $W$. 4735 revolútum $W$. 4736 elátum $B$. Rep. 4737 latifólium $W$. 4738 scilloides $W$ 4739 prasínum $B$. Reg. 4740 comósum $W$. 4741 pýramidále $W$ Ixia-like snowy common greenish Narbonne fringed close-spiked

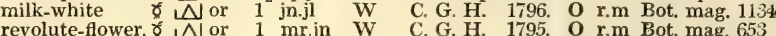

\% $\triangle$ or $\frac{1}{2}$ my.jn W California 1796. O s.p C. G. H. 1774. O r.m Bot. reg. 235 England me.pa. O co Eng. bot. 130 $\checkmark \mathrm{N}$ or 11 ji.jn $\mathrm{G}$ Del. Bay 1823, O co Bot. reg. 814 6 or 13 jl W S. Europe 1810. O co Bot mag. 2510 ช $\triangle$ or $\frac{1}{2}$ f.mr W Crimea 1820. O co Lindl. coll. 28 6. $\Delta$ or $2 \frac{1}{2}$ ap.jl L.Y S. Europe 1771. O co Ren. spec. t. 90 Nor 1 mr.jn W C. G. H. 1795. O r.m Bot. mag. 653 broad-leaved of $\triangle$ or $1 \frac{1}{\mathrm{j} n . j \mathrm{l}} \mathrm{W}$ Egypt 1629. O r.m Bot. mag. 876

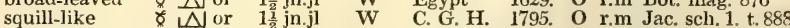

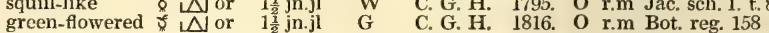
green-flowered
short-spiked

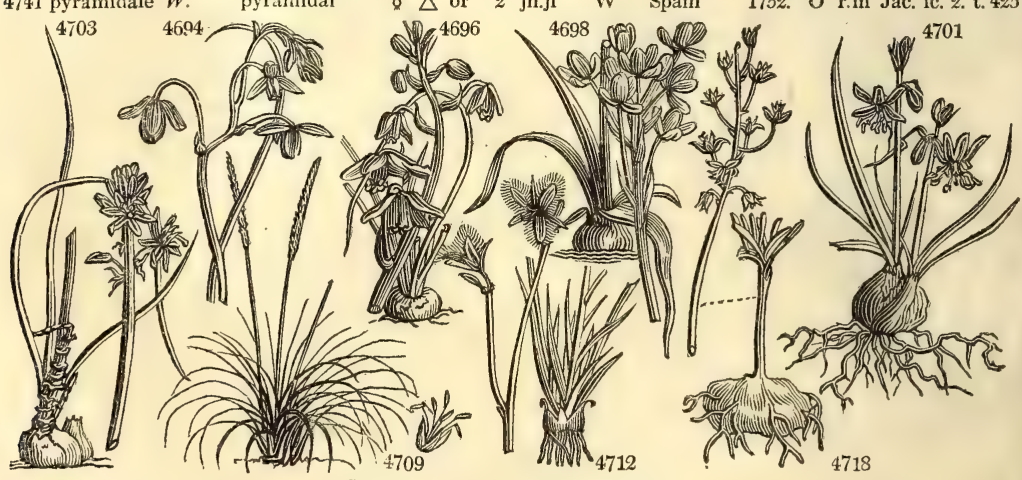

History, Use, Propagation, Culture,

the Latins. A genus of little beauty, but of easy management in sandy loam and decayed vegetable soil, and propagation is effected by suckers from the old bulbs; or by taking off leaves with a scale, and planting them round the edge of a pot of sandy loam.

798. Xanthorrhcea. From kूev

799. Thysanotus. From ivoavos, a fringe, on account of the fringe of the sepals. Elegant little New Holland plants, with bright purple blossoms and slender grassy leaves.

800. Eriospermum. From ęco, wool, and $\sigma \pi \varepsilon e \mu n$, seed, on account of the envelope of the seed. Very curious little Cape plants, with deformed or unusually shapen leaves.

801. Gagea. Named by R. A. Salisbury, Esq., after his friend Sir Thomas Gage, a great amateur of botany. A genus of curious little bulbous plants, none of which excecd the height of more than three or four inches, and principally distinguished from Ornithogalum by the yellow color of their flowers. 
46.4. Inner sepals glandular at end inflexed, Scape erect, Fl. nodding, Lvs. linear subulate channelled smooth 4695 Inner sepals glandular at end inflexed, Peduncles spreading at right angles, Lvs. lanc. lin. obliquely lent 4693 Inner sepals glandular at end inf. Scape erect wavy, Fl. cernuous, Lvs. lin. subul. chann. outside hairy 4697 Inner sepals vaulted at end, Leaves smooth, Peduncles the length of bractes

\section{Six stamens fertile.}

4698 Inner sepals vaulted at end, Leaves lin. flattish, Scape sliorter than leaves, Pedunc. very long spreading 4699 Inner sepals glandular at end inflexed, Leaves lin. lanc. eonvol. upright shorter than scape 4700 Inner sepals glandular at end reflexed, Leaves lin. lanc. flattish, Pedunc. at right angles, Flowers erect 4701 Scape shorter than leaves few-flowered, Flowers nodding, Filam. 2-toothed

4702 Leaves lanceolate, Raceme pyramidal before the leaves, Filam. glandular at base

4.703 Leaves lin, subulate channelled, Scape simple shorter than leaves, Scales of root wrinkled across

4704 Inner sepals glandular at end inflexed, Lvs. lin. lanc. flat, Pedunc. very long erect spreading, F1. upright 4705 Inner sepals vaulted at end, Leaves lin. lanceol. channelled upright, Pedunc. shorter than nodding flow. 4706 Inner sepals vaulted at end, Leaves lin. lanc. channelled, Pedunc. spreading the length of nodding flow. 4707 Inner sepals vaulted at end, Lvs. lin. subul. chann. hairy clammy, Ped. spread. twice as long as nodd. fl. 4708 Inner sepals vaulted at end, Leaves lin. subulate convolute at the end spirally twisted villous

4709 Stem very short, Leaves 2-edged lengthwise, Scape very long higher than the spike

4710 Stemless, Leaves 3 cornered flat in front beyond the middle hollowed, Scape very long higher than spike 4711 Stemless, Leaves 3 cornered below the middle in front little raised abovemiddle concave, Bracts very long

4712 Roots fibrous, Stems branched diffuse rounded striated, Branches somewhat angular, Anthers unequal 4713 Bulbs fascicled, Leaves radical channelled nearly as long as the rounded simple stem

4714 Leaves roundish acuminate cucullate at base 4715 Leaf sub-cordate acute cucullate pubescent

4716 Leaves ovate lanceolate at the edge wavy involute

4717 Leaves elliptical obtuse flat

2718 Leaf proliferous, Leaflets filiform undivided sessile

4719 Radical leaf linear flat, Peduncles simple umbellate, Sepals obtuse smooth, Bulbs clustered

4720 Radical leaf linear lanc. flat, Pedunc. simple somewhat umbellate, Sepals obtuse smooth, Bulb solitary 4721 Leaves linear filiform upright, Pedunc. about 3 with a three-leaved involucrum

4722 Scape angular naked, Pedunc. umbellate branched pubescent, Sepals lanc, acute

4723 Scape naked, Pedunc. 3 umbell. pubescent. Leaves filiform, Three outer sepals longer than the others

4724 Leaves half cylindrical, Cauline dilated at base

4725 Scape 2-leaved, Leaves opp. Pedunc. 1-fl. Outer sepals lanc. retuse : inner ellipt. twice as broad 4726 Scape naked, Flowers umbelled, Filam. all 2-forked bearing the anther in the middle 4727 Raceme few-flowered, Sepals lanceolate, Leaves filiform channelled, Filam. subulate 4728 Corymb few-flowered, Pedunc. longer than bractes, Filam, subulate

4729 Raceme spiked many-fl. Lvs, lin. lanc. weak, Every other stamen with two teeth, Bractes Ionger than fi 4730 Raceme oblong, Filam. lanceolate membranous, Pedunc. and fl. spreading

4731 Corymb few-flowered shorter than lanceolate strongly fringed leaves

4732 Raceme very long, Sepals linear obtuse, Filam. lanceol. equal, Style the length of stamens 4733 Raceme very long, Sepals lanc. oblong, Filam. broad lanceol. alternately shorter

4734 Raceme long, Filam. subulate alternate lanceolate, Bractes membranous ovate twice as long as pedunc 4735 Raceme few-flowered, Sepals linear oblong obliquely bent emarginate, Filam. lanc. subul. Leaves linear 4736 Leaves short oblong erect, Scape very long, Flowers campanulate the length of stamens

4737 Raceme very long, Filam. subulate, Pedunc. much longer than flower, Leaves lanceolate

4738 Raceme very long, Filam. subul. Pedunc. length of fl. Bractes the length of pedunc. Lvs. lin. lanc. loose 4739 Lvs. glaucous twisted upwards, Raceme divaricating on a long scape, Filaments with an ovate base 4740 Raceme very short, Bractes lanc. the length of flowers, Sepals obtuse, Filam. subulate

4741 Raceme conical, Fi. numerous ascending, Sepals oblong flat, Stam. lanc. equal, Style very short

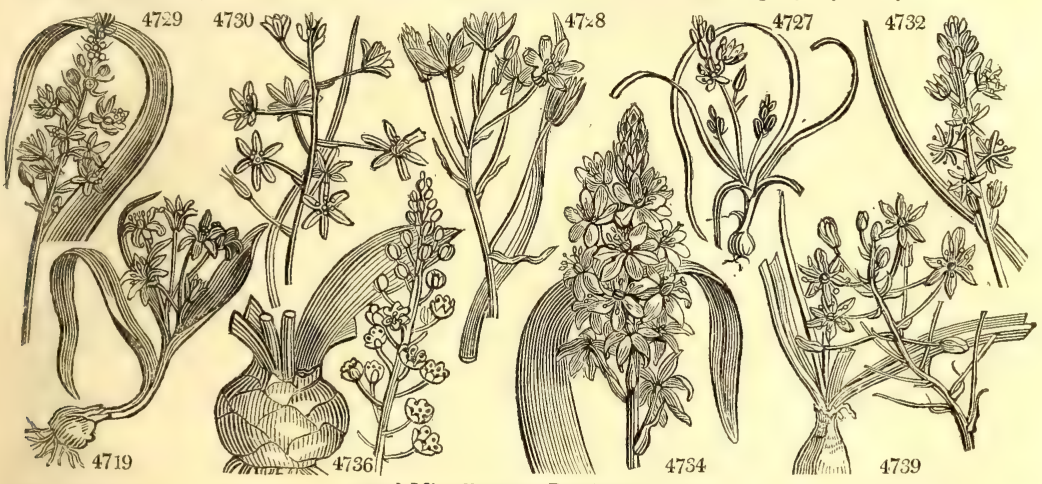

and Miscellaneous Particulars.

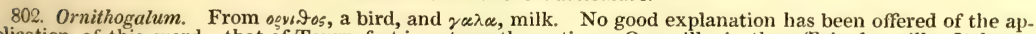
plication of this word; that of Tournefort is not worth quoting. O. squilla is the officinal squill. It has a bulb almost as big as the human head, pear-shaped, and tunicate like the onion. From the middle of the root arise several shining leaves a foot long, and two inches broad at their base, lessening all the way to the top, where they end in pcints. They continue green all the winter, and decay in the spring; then the flowerstalk comes out, rising two feet high, naked about half way, and terminated by a pyramidal thyrse of white flowers.

The squill is one of the few medicines known in the early ages of Greece, which is still held in great estimation. It is very nauseous, intensely bitter and acrimonious, without any perceptible smell. It is poisonous to several animals : if much handled it exulcerates the skin; and in large doses frequently repeated, it not only excites nausea, but strangury, bloody urine, and hamorrhoids, with fatal inflammation and gangrene of the stomach and bowels. Under proper management, however, it is a medicine of great practical utility. In 
4742 odorátum $W$ 4743 barbátum $W$. 4744 juncifólium $W$. 4745 rupéstre $W$. 4746 arábicum $W$. 4747 thyrsoides $W$. 4748 aúreum $W$. 4749 flavíssimum $J a c$ 4750 coarctátum $W$ 4751 caudátum $W$. 4752 unirólium $B$. $M$. 4753 Squílla $B . M$.

803. SCIL'LA. $W$. 4754 itálica $W$. 4755 peruviána $W$. 4755 peruviána $W$ 4757 Lilio-Hyacinthus $W$. 4758 amo'na $W$. 4759 sibírica $H . K$. 4760 præ'cox $W$ 4761 vérna $W$.

4762 unifólia $\boldsymbol{L}$.

4763 hyacinthoides $W$. 4764 autumnális $W$. 4765 bifólia $W$. 4766 umbelláta $W . c n$. 4767 cérnua $L k$. 4768 indica Roxb. 4769 campanuláta $W$. 4770 non scripta $\mathrm{Sm}$. $\beta$ cámea r alba

4771 brevifólia $B . M$ 4772 corymbósa $B$. $M$. 477 esculénta $B . M$. 4774 romána $B . M$. o 1 or great-flowered of 1 or thyrse-flower golden or $N$ or great-ycllow great-ycllow
close-flowered
$\mathbb{N}$ or long-spiked o $\mathbb{N}$ or one-leaved $\Delta$ or officinal Squill $\Delta$ or

SQuitr. Italian corymbose Portugal

\section{Lily-rooted}

nodding

early-flow

one-leaved

one-leaved

autumnal

two-leaved

umbelled

cernuous

Indian

Spanish

Harebell's

flesh-colored

white

short-leaved

Cape

Quamash

Roman

$\begin{array}{ll}\frac{3}{4} \text { jl.au } & \text { W } \\ \frac{1}{2} \text { my.au } & \text { W }\end{array}$

1 mrap W

$1 \frac{1}{j n . j l} W$

$\frac{3}{4} \mathrm{jn} . \mathrm{jl}$

1 jn.j.

$1 \frac{1}{2} \mathrm{jn} . \mathrm{jl}$

3 f.au W.

$\frac{1}{2}$ jn.jl W

$3^{\frac{1}{2}}$ ap.my WV

7 or ${ }^{4}$ myjn

$\triangle$ or $\frac{2}{2}$ au $B$

$\triangle$ or ${ }^{\frac{1}{4}}$ au.s $\quad$ Pk

\& or $\frac{1}{4}$ f.ap $\quad B$

$\Delta$ or $\frac{1}{4}$ ap $\quad B$

$\triangle$ or a

$\Delta$ or $\frac{3}{4} \mathrm{mr} . j n$ B

$\triangle$ or $\frac{a}{4} \mathrm{mr}$.jn $\mathrm{Pk}$

\& or $\frac{3}{4} m r . j n \quad W$

б $\Delta$ or $\frac{1}{2}$ ja $\mathrm{Pk}$

\% $\triangle$ or $^{\frac{1}{4} \text { au.d }} \mathrm{Pk}$

o $\Delta$ ec 1 my.jl P.

\% $\Delta$ or 1 my w Rush-leaved $\delta$ or 1 or my.jl W

\section{Asphodelere. $S p .21-35$.}

1605. O p.l Bot. mag. 663

$\triangle$ or 1 my D.B Spain 1607. O r.m Bot. mag. 749

or $\Delta$ or my L.B Portugal 1777. O p.1 Bot. mag. 1999

t $\Delta$ or I' my.jl B S. Europe 1597. O co Red. lil. 205

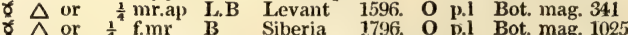

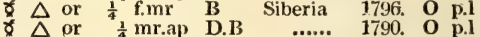

8 or $\frac{1}{4}$ ap.my $B$ Britain rocks. O s.l Eng. bot. 23

$1 \ldots$

804. PUsChKi'Nia. Bieb. Puschininia.

4775 scilloídes $B i e b$. little

805. MASSO'NIA. $W$. 4776 latifólia $W$.

4777 longifólia Jacq.

$\beta$ candida Burchell

4778 muricáta $H$. $K$.

4779 scabra $H$. $K$. pustulata B. M.

4780 echináta $W$.

4781 paucifóra $\dot{H}$. $K$

4782 angustifólia $W$.

4783 unduláta $W$.

4784 ensifólia $B . M$.

Massonia.

\% $\Delta$ or

Asphodelca.
$\frac{1}{2}$ my.jn P.B

Asphodelece.

broad-leaved

long-leaved

white

$\frac{\gamma}{\Delta}$ cu ap.my W

shagreen-leaved $\frac{6}{\Delta} \Delta \mathrm{cu} \quad \frac{\frac{1}{4}}{4}$ ja.ip W

rough-leaved $\delta \Delta \mathrm{cu} \quad \frac{1}{4} \mathrm{my} \quad \mathrm{W}$ few-flowered t $\Delta \mathrm{cu} \frac{1}{4} \mathrm{my}$ W narrow-leaved $\delta \Delta \mathrm{cu}{ }^{\frac{1}{2}} \mathrm{mr}$.ap $\mathrm{W}$ trumpet-flower. $\frac{6}{6} \cup \mathrm{cu}{ }^{2} \frac{1}{2} \mathrm{f} . \mathrm{s} \quad \mathbf{L}$

C. G. H. 1795. O r.m Bot. rep. 260

C. G. H. 1794. O r.m Bot. mag. 972

. 1757.0 rm Bot mag. 1164

Portugal ... 0 O s.l

Madeira 1585. O r.m Bot. mag. 1140

England dr. pa. $O$ p.l Eng. bot. 78

England woods. $O$ p.1 Eng. bot. 24

$\begin{array}{lll}\text { Pyrenees 1822. } & \text { p p.1 } & \text { B.ph.n.41.t.8.f. } 6\end{array}$ Spain 1815. O p.i

E. Indies 1816. O p.l

Spain 1633. O p.1 B.mag. 127.1102

Britain woods. O co Eng. bot. 377

Britain woods. O 3.1 Bot. mag. 1.161

Britain woods. O s.l

C. G. H. 1811. O s.l Bot mag. 1468

C. G. H. 1793. O s.l B.m.1478 in note

N. Amer, 1811. O s.l Bot. mag. 1574

Italy 1596. O s.1 Bot. mag. 934

Sp. 1.

Siberia 1819. O s.I Lindl. coll. 24

Sp. 9-10.

C. G. H. $\quad \ldots \quad$ O s.I Jac, sch. 4. t. 457

C. G. H. $\because 00$ O s.l Bot. reg. 694

1790. $O$ s.l Bot. mag. 559

C. G. H. 1790, O s.l

C. G. H. 1790. O s.l

C. G. H. 1775. O s.I Bot. mag. 73t,

C. G. H. 1791. O s.l

C. G. H. 1790. O s.l Bot. mag. 554

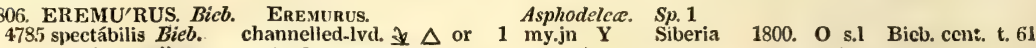
478.5 spectabilis Bieb. channelled-lvd. 18 or 1 my.jn

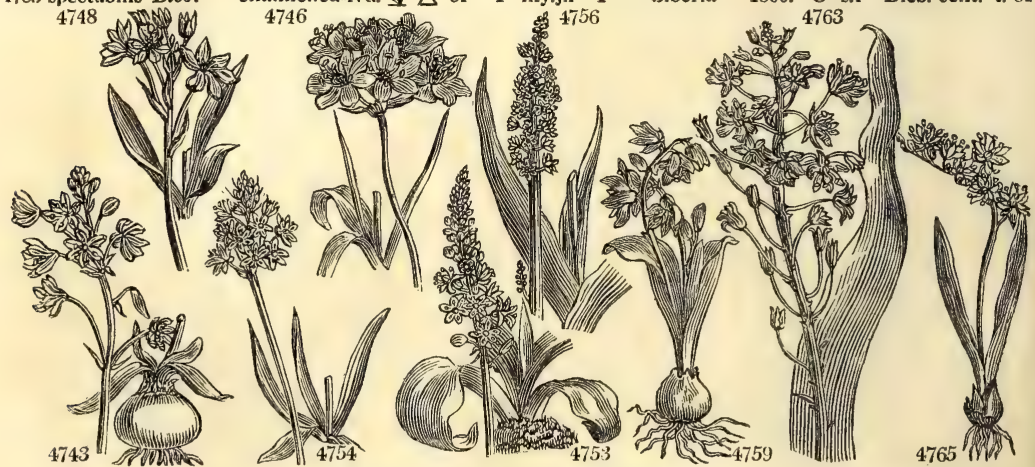

History, Use, Propagation, Culture,

dropsy it has long been esteemed the most certain and effectual diuretic with which we are acquainted, and it is usually employed in asthma.

803. Scilla. From $\sigma \varkappa v \lambda \lambda \omega$, to injure, according to Miller, because its root is a violent poison as well as an article of medicine. In Arabic it is called assyl; has not the name scilla been obtained rather from this root? The genus is so ill defined that botanists are more guided by their blue colour than by any precise mark, in referring plants to this rather than Ornithogalum.

S. peruviana or hyacinth of Peru is erroneously named, being a native of Spain. It is valuable as an evergreen, or rather wintergreen, its fine lucid green leaves appearing before winter and continuing through that season, till it sends up its thick succulent scapes about the end of April. There are two varieties, one with a deep blue, and the other with a white flower. Like other Spanish bulbs it is liable to be destroyed by an extraordinary severe winter.

S. verna is a maritime plant found on the coast of Cornwall, Wales, the Isle of Man, and the Hebrides,

S. non-scripta is the Hyacinthus of that name of Linnæus, the Jacinte des bois, of the French, and Niederlandische or Englische Hyacinthe, of the Germans. The fanciful specific name of non-scriptus was 
4742 Raceme long, Flam. subul. Sepals lanc. at the end callous inflexed, Leaves linear depressed flat 4743 Raceme few-fi. Filam. subulate, Sepals lin. obtuse : 3 outer bearded at end; inn. mucron. Leaves filiform 474 Raceme long many-fl. Filam. subulate, Sepals lanc. acute, Leaves filiform subulate 4745 Leaves filiform fleshy, Scape few-flowered

4746 Corymb many-flowered, Filam. subulate, Cor. broadly campan. Outer sepals obsoletely 3-toothed 4747 Corymbs many-fl. racemose, Filam, alternately forked, Leaves lanceolate

4748 Raceme contracted corymbose, Filam. alternately emarg. Leaves lanc. with cartilaginous teeth

4749 Like the last, but the flowers very yellow, and the bractes very narrow the length of the flower-stalk 4750 Raceme many-fl. contracted, Altern. filam. emarginate, Leaves linear channelled

4751 Raceme very long, Leaves lanc. linear, Flowers spreading, Stam. dilated alternately wedge-shaped 4752 Leaf solitary longer than scape, Flowers few spiked sessile

4753 Flowers without the leaves, Bractes reflexed

4754 Raceme conical oblong

4755 Corymb clustered conical

4756 Raceme oblong conical, Sepals lined

4757 Raceme few-flowered, Peduncles without bracter, Leaves lanceol, lying on the ground

4758 Scape angular, Peduncles alternate shorter than flower, Bractes obtuse very short

4759 Four-leaved, Scapes many half-rounded striated 2-flowered decumbent after flowering

4760 Scape angular, Raceme corymbose, Peduncles twice as long as fl. Bractes obsolete

4761 Raceme few-flowered with bractes, Flowers campanulate, Leaves linear channelled : radical many

4762 Leaf roundish somewhat spiked on one side

4763 Raceme cylindrical many-flowered, Sepals half as long again as the ovaries, Peduncles colored

4764 Leaves filiform linear, Flowers corymbose, Peduncles naked ascending the length of the flower

4765 Flowers racemose, Leaves lanceolate linear about two elevated on a scape

4766 Scape rounded, Corymb few-flowered umbelled, Bractes filiform the length of peduncles

4767 Flowers campanulate 6-parted, Raceme cernuous

$4768 \mathrm{~A}$ species which has not yet been seen in flower, nor described

4769 Raceme many-f obl. conical, Flowers campan. erect, Bractes 2-parted longer than pedunc. Lvs. lanceol.

4770 Flowers campanulate 6-parted revolute at end

4771 Flowers 6-parted, Raceme cernuous, Leaves shorter than scape

4772 Flowers funnel-shaped corymbose erect, Scape shorter than the leaves

4773 Scape longer than keeled linear leaves, Spike racemose, Five sepals ascending; the lower deflexed

4774 Flowers campanulate half six-cleft racemose, Stamens membranous

4775 The only species, like a pale-flowered variety of Scilla sibirica

4776 Leaves roundish smooth

4777 Leaves lanceolate oblong acuminated

4778 Leaves roundish smooth towards the end muricated

4779 Leaves roundish veiny warted rough

4780 Leaves ovate and lanceolate with hairy tubercles, Sepals filiform

4781 Leaves lanceolate and elliptical veinless warted, Warts naked, Sepals ovate

4782 Leaves oblong lanceolate flat smooth

4783 Leaves lanceolate wavy smooth

4784 Leaves lanceolate, Sepals much shorter than the tube, Filam. capillary alternately longer

4785 Scape naked simple, Stamens twice as long as flower, Leaves linear channelled
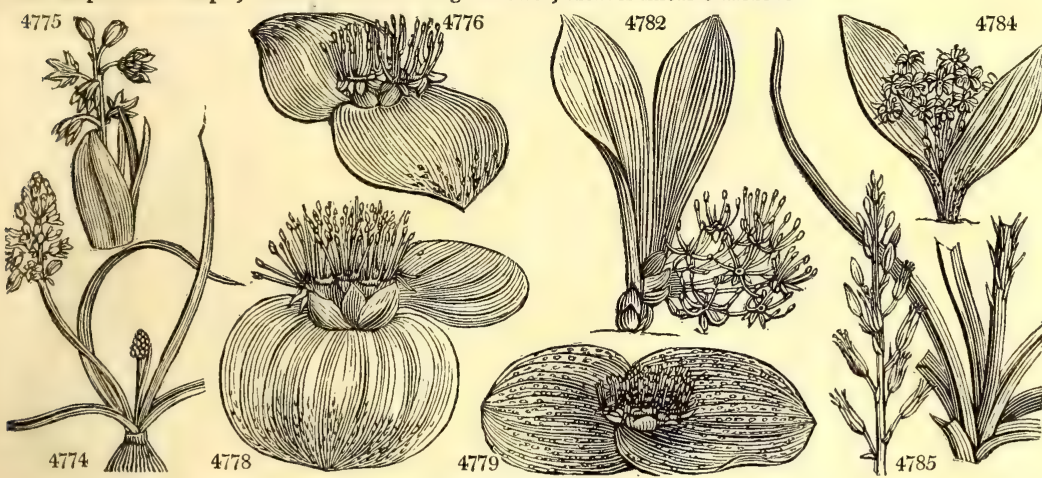

and Miscellaneous Particulars.

applied to this plant by Dodonæus, because it has not the marks of $\mathrm{Ai}, \mathrm{Ai}$, on the petals, as other hyacinths are supposed to have, and therefore is not the Hyacinthus poeticus. This idea has its origin in the Roman mythology, in which Apollo, being much grieved for the death of the youth Hyacinthus, changed his blooa into a flower which bore his name, \&c. It is a native of almost every part of Europe and of Persia.

804. Puschkinia. Named after Count Mussin Pouschkin, a Russian botanist and patron of botany. A very remarkable little plant, resembling a Scilla in appearance, but well defined by the very curious union of its stamens into a cup.

805. Massonia. So named by Thunberg, after Mr. Francis Masson, author of Stapeliæ Novæ; a successful botanical collector at the Cape of Good Hope, Madeira, the West' Indies, and finally North America, into whose wildernesses he went to die. Very singular plants, with broad leaves lying flat on the ground, and com. pact umbels of flowers.

806. Eremurus. From égnuos, desert, and żece, a tail : tail of the desert. Its long spikes of yellow flowers may be easily imagined to merit such an appellation in their native abodes. 
807. BULBI'NE. $W$. en. Bulbine. 4786 frutescens. W. en. 4787 rostráta $W$. en. 4788 alooídes $W$. en. 4789 pugionifórme $L k$. 4790 longiscápa $W$. en. 4791 ánnua $W$.en.

4792 ciliáta $L k$.

808. ASPHO'DELUS. $W$. AsPHODEL.

4793 lúteus $W$ 4794 tauricus $W$. en. 4795 ramósus $W$

4796 álbus $W$.

4797 fistulósus $W$. 4798 clavátus Roxb.

4799 créticus Lam.

4800 intermédius Horn.

4801 nútans $W$. $W$.

4803 serotinum

4803 serotinum

4805 péndulum Horn.

4806 albucoídes Ait.

4807 sulphúreum $W .8 K$.

hrubby beaked Aloe-leaved

dagger-leaved annual

yellow

Taurian

upright

onion-leaved

Candseeded

w. J or

Asphodelece.

L or 2 mr.au $Y$

$\checkmark$ Jor 1 ap.au Y

1 ap.jn $Y$

1 ap.au $Y$

s. my.jn $\mathrm{Y}$

Nor

$\triangle$ or

f $\triangle$ or 3 my.jn $\mathrm{Y}$

$\checkmark \Delta$ or 3 my.jn W

$\Delta$ or 2 my W

$\triangle$ or 2 my $\quad$ w

[0] or 1 jl.au W

L or 2 jn $\quad$ Y

Asphodelece.

nodding $\triangle \mathrm{N}$ or 1 ap.au W

broad-leaved $\Delta$ or 2 ap.au W

late-flowering $₹ \Delta$ or $\frac{1}{2}$ au.s W

branched $\frac{\partial}{\Delta} \Delta$ or $2^{2}$ my.jn W

pendulous $\quad \frac{\Delta}{\Delta} \Delta$ or $1 \frac{1}{2} \mathrm{jl} \quad \mathrm{W}$

Albuca-like $\neq \Delta \triangle$ or

sulphur-colored $\$ \Delta$ or

glaucous $\$ \Delta$ or

1 jl W

$1 \frac{1}{2} \quad \cdots \quad W$

$1^{2} \mathrm{jl} \quad \mathrm{Y}$

$\frac{3}{4} \mathrm{my} \quad \mathrm{W}$

4810 filifóliuni Jacq. thread-leaved $\$$ or

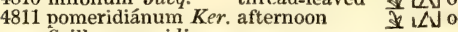
Scilla pomeridiana

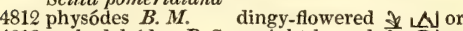

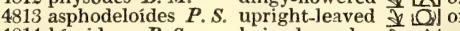

4814 híspidum $P . S . \quad$ hairy-leaved $\$ \Delta$ or

4815 frá

4816 flexifólium $W$.

4817 filifórme $W$.

4818 floribúndum $W$

4819 revolútum $W$.

4820 vespertínum $W$

4821 graminifólium $W$

4822 triflórum $W$.

4823 canaliculátum $W$.

4824 Liliágo $W$.

4825 Lilias'trum $W$.

\& $\Delta$ or

flexuose-leaved $\frac{\downarrow}{\Delta} \Delta$ or

thread-leaved $\frac{s}{\partial} \Delta$ or

thick-spiked

curled-flowered $\overrightarrow{\mathrm{I}} \mathrm{\perp}$ or

aiternoon-flow. $¥ \mathrm{\perp} \cup$ or

waved-leaved $\vec{\perp} \Delta$ or

three-flowered $\frac{1}{\Delta} \triangle$ or

channelled.lvd. $\frac{1}{\Delta}$ or

grass-leaved $\frac{1}{\Delta}$ or

1 ap.my W.

my.jn W

$1 \frac{1}{2}$ my.jn W

810. ARTHROPO'DIUM. $R$. Br. Arthropodium.
4826 paniculátum $R . B r$. panicled Asphodeleze.

4827 cirrátum $R . B r$. New Zealand $\frac{N}{\Delta}$ or 3 my.jn W

811. CHLORO'PHYTUM. Ker. ChLorophytu

4828 inornátum Ker. dwarf $\triangle \mathrm{cu} 1$ jn.au W

4829 elátum $R, B r$. tall

Anthericum elatum H. K.

4830 orchidástrum Lindl. Orchis-like $\quad \star \star \triangle \mathrm{V}$ cu 2 ja.d W

812. C无'SIA. $R$. Br.

Casia.

Asphodelea. Sp. $1-5$

Sp. $7-19$

1812. C s.1 Jac. ic. 2. t. 403

G. H. 1732. O s.1 Bot. mag. 1317

C.

C. G. H. 1759. Sk r.m Bot. mag. 1339

C. G. H 1731. S s.p Bot. mag. 1451

C. G. H. 1823. S s.p

Sp. 8-10.

1596. R co Bot. mag. 773

Tauria 1812 R

S. Europe 1551. R co Bot. mag. 799

S. Europe .... R co Blackw, t. 238

S. Europe 1596. R co Bot. mag. 984

E. Indies 1808. S co

1821. $\mathbf{R}$ co

Canaries 1822. R co

. G. H. 1812. Sk s.l Jac. ic. 2. t. 407 C. G. H. 1812. Sk s.l Jac. ic. 2.t. 408 England moun. Sk s.l Eng. bot. 793

Europe 1570. Sk s.1 Bot. mag. 1055

N. Holl. 1822. Sk s.l

C. G. H. 1788. Sk s.1

Hungary 1823. Sk s.l

T. 1823. Sk s.1

Bot. cab. 330

C. G. H. 1795. O r.m Bot. mag. 1046

C. G. H. 1759. O r.m Jac. vind. t. 181

C. G. H. 1774. O s.p Jac. ic. 2. t. 409

C. G. H. 1795. Sk s.p Bot. reg. 311

C. G. H. 1795. Sk s.p Jac ie. 2, t 412

C. G. H. 1774. Sk s.p

C. G. H. 1774. Sk s.p

C. G. H. 1731. Sk s.l Bot. mag. 1014

C. G. H. 1803. Sk s.1 Bot. mag. 1040

C. G. H 1794. Sk s.l Jac, ic. $2, \mathrm{t}, 411$

C. G. $\mathrm{H}, 1782$ Sk s. J Jac ic 2.

C. G. H. 1774. Sk r.m Bot. mag. 1124

S. Europe 1596. Sk s.1 Bot. mag. 914

S. Europe 1629. Sk co Bot. mag. 318

Sp. $2-6$.

N. S. W. 1800. C s.p Bot. mag. 1421 N. Zeal. 1821. Sk s.p Bot. reg. 709

Sp. 3-5.

S. Leone ... D co Bot. mag. 1071

C. G. H. 17̈51. S l.p Red. Hil. 191

S. Leone 1822. S 1.p Bot. reg. 813

P. S. W. 1816. S I.p

Asphodelea. Sp. 2-3.

813. NARTHE'CIUM. B. M. NARTHECIM.

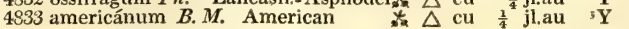

tur.bo D m.s Eng. bot. 535

N. Amer. 1811. D p Bot. mag. 1505

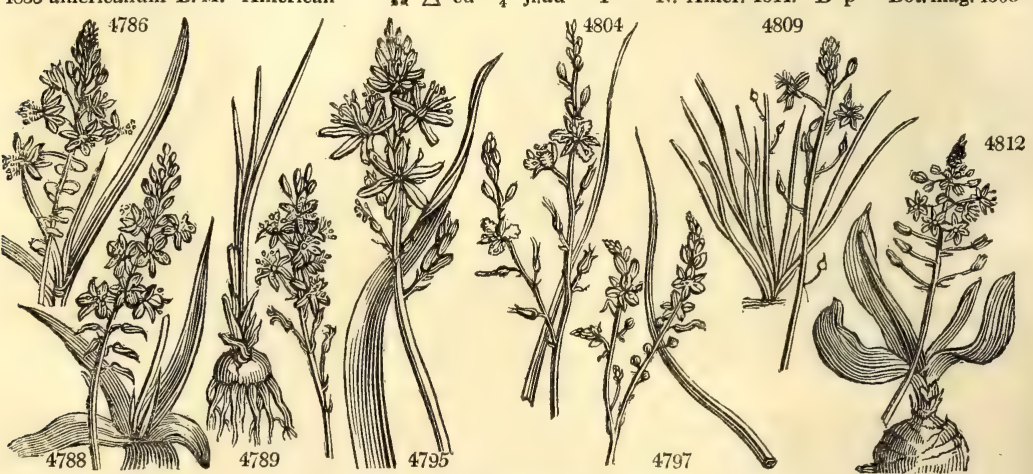

History, Use, Propagation, Culture,

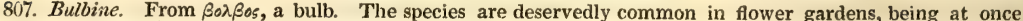
shewy, fragrant, of easy culture, and rapid increase by suckers.

808. Asphodelus. From $\alpha$, privative, and $\sigma \phi \alpha \lambda \lambda \omega$, to supplant: that is to say, a fower which cannot be supplanted or surpassed. Linn. The yellow and white species are old inhabitants of our gardens, of easy culture and rapid increase. Immense tracts of land, in Apulia are covered with the latter species, which affords very good nourishment to the sheep. It was sacred to Proserpine, and used in funeral ceremonies.

809. Antinericum. A name applied by the Greeks to the stem of the asphodel, and not misapplied to this set of plants, which in some sort resemble the asphodel. Plants with fleshy leaves, and spikes of bright yellow flowers; easily cultivated if kept dry. 
4786 Leaves fleshy rounded, Stem shrubby erect branched

4787 Leaves fleshy rounded glaucous, Stem shrubby short rooting

4787 Leaves fleshy rounded glaucous, Stem shrubby short rootin
4788 Leaves fleshy tongue-shaped lanceolate flat on both sides

4789 Leaves fleshy linear acuminate channelled, Scape twice as long as leaves

4790 Leaves fleshy subulate half rounded flexuose glaucous 3 times as short as scape

4-91 Leaves fleshy subulate rounded, Scape racemose

4792 Leaves ensiform fleshy 3 cornered fringed, Scape simple, Raceme very long

4793 Stem leafy, Leaves 3 cornered striated

4794 Stem leafy, Lvs. subul. 3 cornered striated, Bractes membranous lanceol. : the upper longer than flowers 4795 Stem naked branched, Pedunc, altern, longer than bract, Leaves ensiform carinate smooth

4796 Stem naked simple, Pedunc. clustered the length of bractes, Leaves linear keeled smooth

4797 Stem naked, Leaves upright striated subulate fistular

4798 Leaves linear weak, Scape erect branched, Flowers small

4799 Stem leafy naked above branched, Leaves filiform striated toothed ciliated

4800 Stem nearly naked, Leaves upright cylindrical fistular

4801 Leaves fleshy lanceolate flat concave at base reflexed at end, Raceme nodding at end

4802 Leaves fleshy oblong lanceolate acuminate nerved straight 4 times as short as scape

4803 Leaves flattish, Scape 1-flowered

4804 Leaves flat, Scape branched, Flowers flat, Pistils straight

4805 Leaves linear keeled shorter than the branched scape, Flowers clustered in threes pendulous

4806 Leaves linear channelled smooth cartilaginous at edge, Scape simple

4807 Ieaves lanc. linear channelled with an obtuse concave end, Scape and raceme simple, Flowers spreading

4808 Raceme simple long many-flowered, Pedunc. spreading in flower, appressed in fruit

4809 Roots fibrous, Filaments declinate : the outer not bearded

4810 Leaves filiform flexuose reflexed longer than scape, Scape simple filiform, Raceme few-flowered

4811 Leaves fiaccid glaucous with the edge and nerves rough, Stem panicled branched, Filam. not bearded

4812 Leaves oblong, Raceme corymbose, Stamens dilated in middle papillose

4813 Leaves fleshy linear-subulate half-rounded upright

4814. Leaves fleshy compressed hispid

4815 Leaves rounded filiform upright shorter than scape, Scape simple

4816 Leaves linear filiform flexuose reflexed at base ciliated the length of the branched scape

4817 Leaves filiform rounded roughish, Filaments smooth, Sepals lanceolate

4818 Leaves flat smooth linear lanceolate acute, Scape simple, Raceme many-flowered cylindrical compact

4819 Leaves 3-cornered rough, Scape branched, Flowers revolute

4820 Leaves linear ensiform keeled 3-cornered shorter than the branched scape

4821 Leaves linear flat depressed shorter than the branched scape, Alternate sepals wavy

4822 Leaves channelled sword-shaped, Scape simple, Bractes remote 3-flowered

4823 Leaves fleshy hairy sword-shaped 3-cornered channelled on the narrow side, Scape simple

4824. Leaves fiat, Scape simple, Flowers flat, Pistil declinate

4825 Leaves flat, Scape simple, Flowers campanulate, Stamens declinate

4046 Racemes divided, Pedicels clustered, Inner sepals crenulate, Capsules pendulous

4827 Raceme divided, Bractes leafy, The bearded half of filam. with 2 appendages at base, Lvs. lanc. ensiform

4 S28 Stemless, Leaves lanceolate radical little longer than simple scapes

4829 Leaves flat, Scape branched, Peduncles clustered, Flower flat

4830 Lvs. lanceol, acuminate upright spreading, Panicle branched upright many-flowered, Branches smooth

4831 Flowers nodding, Stamens propendent, Filaments striped, Leaves flat, Bulbs clustered

1832 Leaves ensiform, Filaments woolly

4833 Bractes unequal: the lower embracing the stalk; the upper setaceous

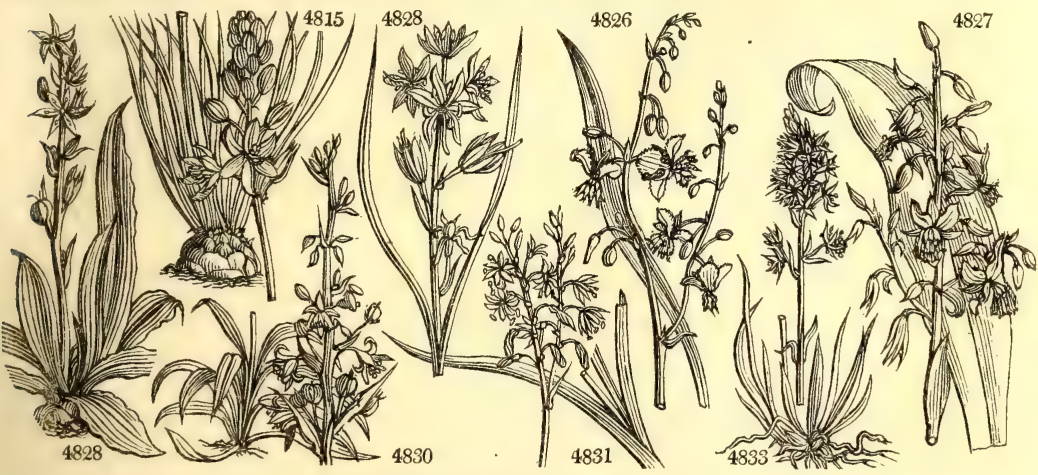

and Miscellaneous Particulars.

810. Arthropodium. From $\alpha \rho$ ` Distinguished by its bearded filaments.

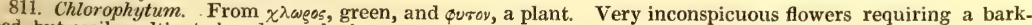
bed, but easily cultivated under such circumstances.

812. Casia. Named after Frederick Cæsius, who lived in 1703.

813. Narthecium. From vag. $7 \xi$, a rod or wand, in allusion to the slender spike of flowers. This genus resembles a small Anthericum, from which genus it has been separated. 
814. DIANEL'LA. Lam. Dianella. 4834 læ'vis $R$. $B r$. 4835 longifólia $R . B r$. 4836 strumósa Ker. 4837 nemórósa Lam. D. ensifolia W.

4838 cærúlea $R$. $R r$. 4839 divaricáta $R$. Br 815. EUS'TREPHUS. 4840 latifólius $R . B r$. 4841 angustifólius $R$. $B r$. narrow-leaved 816. ASPAR'AgUS. $L$. Asparagus. 4842 officinális $L$. $L$. common 4. sylváticus $\boldsymbol{W} . \& \boldsymbol{K}$. wood 4844 verticilláris $B i e b$. 4845 declinátus $W$. 4846 marítimus Bieb. 4847 decúmbens $W$. 4848 scándens $W$. 4849 daharicus Fisch. 4850 falcátus $W$.

4851 racemósus $W$. 4852 Broussonéti Jacq. 4853 retrofráctus $W$. 4854 asiáticus $W$. 4855 æthiópicus $W$. 4856 álbus $W$.

4857 acutifólius $W$. 4858 flexuósus $W$. 4859 aphýllus $W$. 4860 subulátus $W$ 4861 capénsis $W$. 4862 sarmentósus $W$ smooth long-leaved strumous wood

blue whorl-leaved long-leaved maritime decumbent climbing Dahurian sickle-leaved branching Broussonet's Larch-leaved A siatic angular-stalked white needle-leaved flexuous prickly awl-leaved Cape linear-leaved

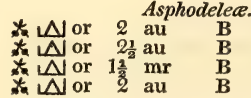

Sp. 6-15

N $\mathrm{Nor}$ a

N. Hk s.p

N. Holl. 1822. Sk s.p Bot. reg. 734

N. Holl. 1822. Sk s.p Bot. reg. 751

E. Indies 1731. Sk s.p Bot. mag. 1404

$\star \mathrm{N}$ or 2 my.au B N. S. W. 1783. R s.p Bot. mag. 505 t $\Delta$ or 3 jl.au B N. S. W. 1805. R s.p Asphodelea. Sp. 2.

$\square$ or 3 jn.jl P.Pu N. S. W. 1800. C s.p Bot. mag. 1245 $\square$ or 3 ji P.Pu N. S. W. 1820. C s.p Asphodelea. Sp. 21-32.

₹ $\Delta$ cul 4 jn.au $G$ England sea co. $S$ r.m Eng.bot. 339 ₹ $\Delta$ cu 2 jn.au $G$ Hungary ... R r.m Pl.rar.hu.3.t.201 \ $\Delta$ cu 2 jn.au W Caucasus 1752. R r.m Buxb.cen.5.t.37 E $\Delta$ cu 5 ... W.G C. G. H. 1759. R s.p 7 $\triangle$ cu 2 jn $\mathbf{G}^{\mathrm{G}}$ Caspian 1823. R

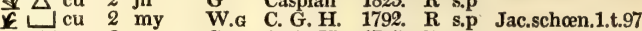

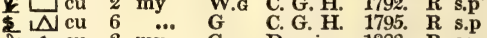
\& $\triangle$ cu 3 my $G$ Dauria 1823. R s.p E cu 3 ... W.g E. Indies 1792. R s.p Bur.zeyl.t.13.f. 2 $\square$ cu 3 ... W.G E. Indies 1808, R s.p

$\square \mathrm{cu} 2$... ... Canaries 1822. R s.p

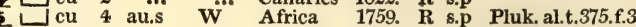

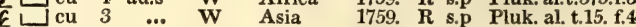
L $\begin{array}{llllllll}\text { cu } & 3 & \ldots & \text { W } & \text { C. G. H. 1816. R s.p }\end{array}$ * cu 2 ... W Spain 1540. R s.p Moris.s.1.t.1.f.3 \# cu 2 ... W.G Spain 1640. R s.p Park. theat. f.3

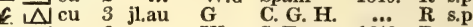
W. S. Europe 1640 . R s.p Moris $1 . t 1$. \begin{tabular}{lllllll}
$\mathrm{cu}$ & 3 & $\ldots$ & $\ldots$ & C. G. H & 1811 & $\mathrm{R}$ \\
\hline
\end{tabular}

+ ا cu 4 ap.my G G ${ }^{\cdots}$ C. G. H. 1691. R s.p Jac.schœ.3.t.266 $\$ \square \mathrm{cu} 6 \mathrm{au}$ W.g Ceylon 1710. R r.m Rhe.mal.10.t.10

Drimia.

tallest

tall

ciliated ciliated
dwarf

\% $\triangle$ or

Asphodelea. Sp. 7-11.

4863 altíssima Jacq.

4864 eláta $B . M$.

4866 pusilla $W$.

4867 lanceæfólia $B . M$ 4868 revolúta $B$. $M$. 4869 média Jacq. \& $\triangle$ or

Copperas-leav'd $\delta$ $\triangle$ or reflex-flowered $\delta \backslash \triangle$ or intermediate 1 or

818. UROPE'TALON, Ker. Uroperalon. 4870 glaúcum Burchell glaucous-leaved $\delta$ $\triangle$ or 4871 crispum Burch. curled-leaved of $\triangle$ or 4872 serótinum Ker. late-flowering of $\Delta$ or 4873 fúlvum Hort. tile-red

\& $\Delta$ or

$1 \frac{1}{2}$ au.s W.G C. G. H. 1791. O s.p Bot. mag. 1074 o.n R.G C. G. H. 1799. O s.p Bot.mag. 822 $1 \frac{1}{2}$ s Pu.w C. G. H. ... O s.p Bot. mag. 1444 1 my.jn $G$ C. G. H. 1793. O s.p Jac. ic. 2. t. 374 $\begin{array}{llll}\frac{1}{4} \text { s.o } & \text { Pu } & \text { C. G. H. 1800. O s.p Bot. mag. } 643\end{array}$ $\begin{array}{lllll}\frac{1}{4} & \text { au } & \text { G } & \text { C. G. H. 1774. O s.p } & \text { Bot. mag. } 1380\end{array}$ Asphodelea. Sp.4.

1 jl.au G C. G. H. 1816. O l.p Bot. reg. 156 * $\cdots$ G... G C. G. H. 1816. O l.p $\frac{3}{4}$ jn.au G.R Spain 1629. O l.p Bot. mag. 859

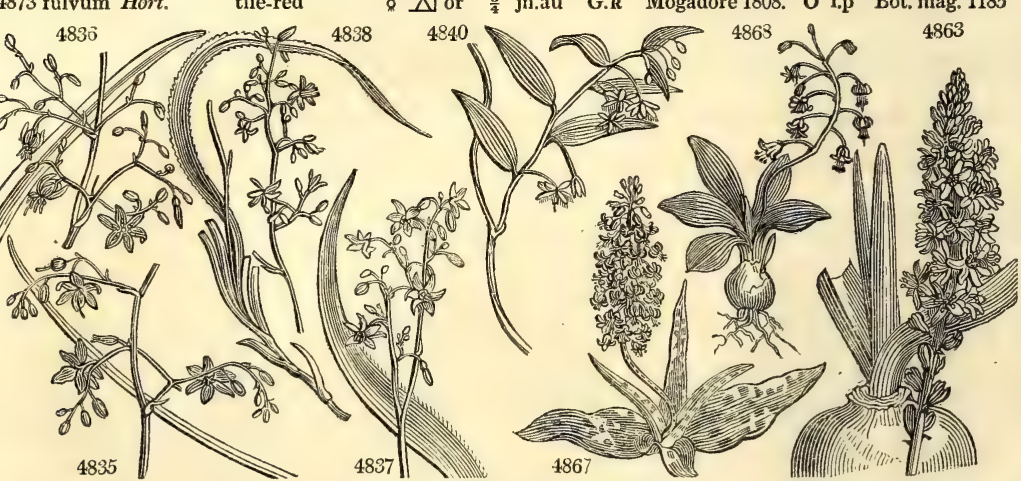

History, Use, Propagation, Cullure,

814. Dianella. A diminution of Diana, the name which the genus originally received from Commerson The species are found in the recesses of forests, where the goddess of hunting may be supposed to inhabit.

815. Eustrephus. From $\varepsilon v$, well, and $s \rho \varepsilon \emptyset \omega$, to turn, in allusion to the twining habit of the species.

816. Asparagus. From $\sigma \pi \propto \rho \alpha \sigma \sigma \omega$, to tear, on account of the strong prickles with which some of the species are armed. Some are dicecious, and others are prickly evergreen climbers. A. officinalis, Asperge, Fr. Spargel, Ger, and Asparago, Ital, is one of the oldest and most delicate of culinary vegetables. It is found on the sea-shores in different parts of Britain and in many parts of Europe, and is abundant in the inland sandy plains in Russia, Turkey, and Greece. Asparagus was in much esteem both among the Greeks and Romans. It is much praised by Cato and Columella, and Pliny mentions a sort which grew near Ravenna, a deep sandy country, three shoots of which would weigh a pound. It is equally admired by the moderns, and assiduously cultivated in private gardens everywhere, and to a great extent round London, Paris, and Vienna. In no part of the world is it grown to such perfection as in the market gardens round London. That of the parish of Mortlake is particularly strong and succulent : the soil is a sandy loam, deeply trenched, and well mariured; the seed is sown in drills and thinned out till the plants stand six inches apart in the row, and the rows are a foot asunder. Round Paris and Vienna more pains are taken in preparing the soil, by forming excavations and filling them with layers of turf, durable manure, as bones, wood-chips, \&c., sand, manure, loam, \&c. ; but though plantations on such beds last longer than on our's, they do not yield better shoots, and it may justly be questioned whether they are equally profitable to the cultivator.

The culinary preparations of asparagus are few, its very delicate flavor rather being deteriorated than improved by powerful tastes. It is best boiled and served alone, to be eaten with butter and salt; or with the points of the shoots cut in small pieces, and served up as green pease. It is esteemed diuretic, and in Paris 
4834 Radical leaves sword-shaped flat shorter than the stem with the keel and edges smooth, Panicle simple 4835 Radical leaves ensiform long smooth at the edge and keel, Panicle upright

4836 Leaves bright-green smooth, Panicle lax decomp. Sepals of pendulous flower reflexed, Filam. strumous 4837 Leaves linear-lanceolate at the edge prickly, Keel smooth

4838 Stem leaves numerous long ensiform rough at the edge and keel, Branches of panicle short 4839 Leaves radical lin.-lanceolate at the keel and edges smooth, Panicle decompound straggling

4840 Leaves ovate or elliptical-lanceolate, Anthers after flowering twisted 4841 Leaves linear or linear-lanceolate, Anthers after flowering straight

4842 Stem herbaceous round erect, Leaves setaceous

4843 Stem herbaceous erect rounded, Leaves setaceous $\frac{1}{2}$-whorled and whorled, Stipules solitary unarmed 4844 Stem half-climbing, Branches straggling, Leaves setaceous curved, Flowers globose

4845 Stem unarmed rounded, Branches declinate, Leaves setaceous

4846 Stem much branched wavy, Leaves setaceous pungent, Flowers campanulate

4847 Stem herbaceous unarmed decumbent much branched, Branches wavy, Leaves setaceous

4848 Herbaceous unarmed twining, Leaves lanceolate falcate

4849 Stem herbaceous erect, Branches straight, Leaves bundled setaceous long, Pedunc. sol. nodding

4850 Prickly solitary recurved, Branches round, Leaves fascicled linear falcate, Pedunc. 1-fl. clustered

4851 Prickles solitary, Branches striated, Leaves bundled linear-subulate falcate, Racemes many-fl, axillary

4852 Branches striated, Leaves linear falcate unequal, Flowers few

4853 Prickles solitary, Branches round reflexed bent back, Leaves setaceous bundled

4854 Prickles solitary, Stem erect, Branches filiform, Leaves bundled setaceous

4855 Prickles solitary reversed, Branches angular, Leaves lanceolate linear

4856 Prickles solitary, Branches angular wavy, Leaves bundled 3-cornered blunt deciduous

4857 Stem unarmed angular shrubby, Leaves needle-like rigid perennial mucronate equal

4858 Herbaceous unarmed, Branches wavy, Leaves lanceolate

4859 Stem unarmed angular shrubby, Leaves subulate striated unequal diverging

4860 Unarmed, Branches bent back, Leaves rounded subulate

4861 Spines 4, Branches clustered rounded, Leaves setaceous

4862 Leaves solitary linear lanceolate, Stem wavy, Prickles recurved

4863 Leaves oval sub-erect plain, Raceme long cylinarical, Bractes hooked back upon themselves

4864 Leaves linear lanc. obliquely bent smooth, Flowers nodding

4865 Leaves linear keeled ciliated

4866 Leaves lanceolate smooth channelled at base, Flowers erect

4867 Leaves wedge-shaped smooth, Scape few-flowered

4868 Leaves lanceolate smooth wavy, Peduncles horizontal

4869 Leaves linear lanceolate half-round

4870 Leaves broad lanceolate erect much shorter than scape, Peduncles very long

4871 An undescribed species, said to be in the gardens about London

4872 Leaves bright green channelled striated, Sepals oval the length of stamens

4873 Leaves glaucous, Raceme lax, Sepals linear much spreading longer than stam.

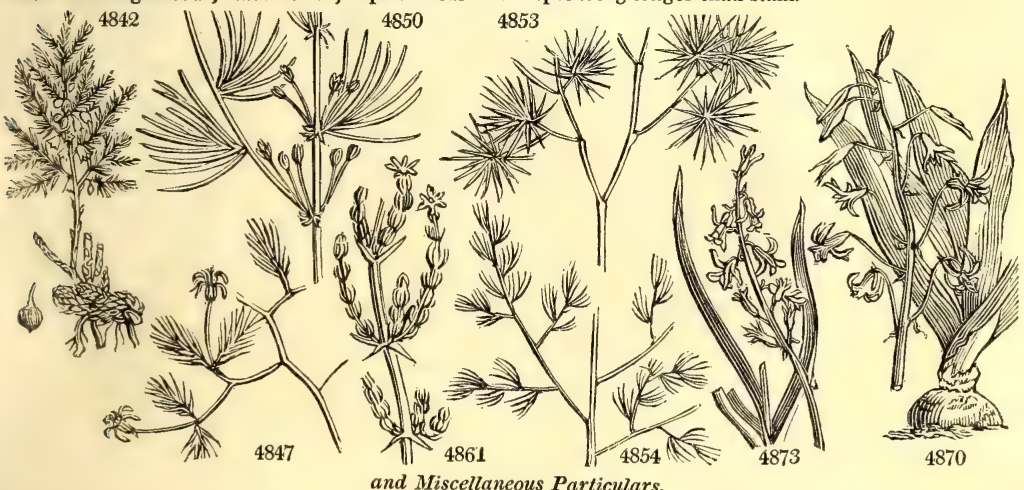

is much resorted to by the sedentary operative classes, as taylors, weavers, \&c. when they are troubled with ymptoms of gravel or stone.

There are some varieties and subvarieties of asparagus, but excepting the red-topped and green-topped, the others are merely local varieties, and can hardly be said to be obtainable by seed.

In the kitchen garden asparagus is generally grown in beds four feet broad, and in rows a foot or eighteen inches apart by nine inches in the row. The plants are either raised from seed where they are to remain, or raised on a seed-bed the preceding year and transplanted. 'The value of the crop depends on the soil being dry, sandy, trenched two and a half or three feet deep, and powerfully manured. During winter the beds are covered with dung or litter to protect them from the frost. In spring this is raked off into the alleys and dug in, while the beds are stirred with a fork, to admit the air, heat, rain, \&c. to stimulate the rising shoots. Asparagus from seed will be fit to cut the third year, in perfection the fifth, and will continue good for ten or twelve years. The season for cutting is from the middle of April to the middle of June.

Asparagus is extensively forced, generally by taking up the roots and placing them on dung or tan beds; but sometimes a more gentle forcing is given by covering the beds with dung in the manner of forcing sea-cale By the former mode earlier crops are obtained, but the roots are lost ; by the latter, the crop is only forwarded a week or two, but the roots remain to produce the following year.

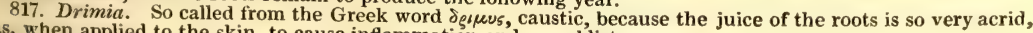
as, when applied to the skin, to cause inflammation and even blisters.

818. Uropetalon. From \& $\varrho \alpha$, a tail, and $\pi \varepsilon \tau \kappa \lambda \sigma y$, a petal, in allusion to the manner in which the divisions of the flower are lengthened out. Curious and rare bulbous plants, very nearly related to Zuccagnia; perhaps
not generically distinct. 
819. HYACIN'THUS. B. $M$. HYACINTH. 4874 amethýstinus $W$. Amethyst-col. \& $\Delta$ or 4875 orientális $W$. garden of $\triangle$ or

820. ZUCCAG'NIA. Thunb. ZuCCAGNIA. 4876 viridis Thunb. green of $\triangle$ or

821. MUSCA'RI. $B$. $M$. GRAPE-HYACINTh 4877 moschátum $B . M$. musk $\beta$ fí́vum B. M. yellow 4878 ciliátum $C y r^{2}$ ciliated 4879 comósum $R$. $\beta$ monstrósum $\quad$ feathered 4880 pállens Fisch. 4881 botryoides $B$.

4882 racemósum $B$. $M$. starch of $\Delta$ or

Asphodelea. Sp. 2-3.

$\frac{3}{4}$ ap.my B S. Europe 1759. O 1.p Red. 1il. 14 $\frac{3}{4}$ mr.ap B Levant 1596. O r.m Bot. mag. 937 Asphodelea. Sp. 1-2. $\frac{3}{4}$ au G C. G. H. 1774. O 1.p Red. lil. 203

Asphodelere. Sp. 6-8.

$\frac{1}{4}$ ap.my B Levant 1596. O s.1 Bot. mag. 734

$\frac{x}{4}$ ap.my G.Y Levant 1596. O s.l Bot. mag. 1565

1 my Br.pu Crimea 1822. O s.l Bot. reg. 394

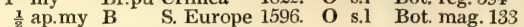

$\frac{x^{2}}{2}$ ap.my $B \quad$ S. Europe 1596. O s.1 Moris.s.4.t.11.f.2

$\frac{1}{2}$ my Pa.B Crimea 1822. O s.l

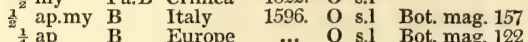

Asphodelea. Sp. 26-29.

2. LACHENA'LIA. $W$. LAchenalia. 4884 orchioídes $W$. 4885 pállida $W$. 4886 hyacinthoides $W$. 4887 angustifólia $W$. 4888 contamináta $W$. 4889 pátula $W$. 4890 frágrans $W$. 4891 unicolor $B . M$. 4892 lúcida $B, M$. 4893 racemósa $B . M$. 4804 pustuláta $W$ 4895 purpúreo-cærúl.b.m. 4896 nervósa $B$. $M$. 4897 violácea $W$. 4898 bifólia $B$. $M$. 4899 rósea $\boldsymbol{B}$. Rep. 4900 unifólia $W$. 4901 sessilifióra $B$. Rep. 4902 isopétala $W$. 4903 trícolor $W$. 4904 lutéola Jacq. 4905 pendula Jacq. 4906 rúbida $W$. 4007 dotted-flower' 4 yos serótina Jacq. sea-green Orchis-like pale-flowered $\quad \mathrm{N}$ pr Hyacinth-flow. of $\sim \mathrm{pr}$ narrow-leaved $\delta\llcorner\mathrm{V} p r$ contaminated $8 \mathrm{\sim} \mathrm{pr}$ spreading-flow. sweet-scented \& $\triangle$ pr self-colored $\delta \mathrm{V} \mathrm{pr}$ glossy-leaved $\delta \triangle \mathrm{pr}$ starch blistered purple-blue nerved-leaved violet cowled-leaved $\delta$ i pr rose-colored $\delta \mathrm{N}$ pr one-leaved $\delta \mathrm{N}$ pr sessile-flowered $\delta, \triangle \mathrm{pr}$ equal-flowered $\delta \Delta \mathrm{v}$ pr three-colored $\delta \mathrm{N}$ pr yellow o $\Delta \mathrm{pr}$ dotted-flower'd $\delta$ $\triangle \mathrm{pr}$ four-colored \& $\triangle \mathrm{pr}$ late
1 mr.ap G.w C. G. H.

1 f.ap G.Y C. G. H. 17. O s.l Jac. ic. 2. t. 39

$\frac{1}{2}$ mr.ap Pa.B C. G. H. 1782. O s.1 Bot. mag. 1269

1 mr.ap W.R C. G. H. 1812, O s.1 Jac. ic. 2 t. 38

1 ap.my W C. G. H 1793. O s.l Bot mag. 735

$1 \mathrm{fmr} \quad \mathrm{Pk} \quad \mathrm{C}$ G. H 1774. O s.l Bot mas. 1401

3 ap.my W.pk C. G. H 1795. O s.1 Jac.

ap.my W.pk C. G. H. 1795. O s.1 Jac. ic. 2. t. 38

1 mr.my W.R C. G. H. 1798. O s.l Bot. reg. 302

$\frac{1}{2}$ my.jn Pk C. G. H. 1806. O s.l Bot. mag. 1373

$\frac{1}{3}$ mr.my Pk C. G. H. 1798. O s.l Bot. mag. 1372

$1 \frac{1}{2} \mathrm{my}$ W.g C. G. H. 1811. O s.l Bot, mag. 1517

1 ja.ap W.G C. G. H 1790 O s.l Bot mag. 817

1 ap.my R.P C. G. H. 1798. O s.1 Bot. mag. 745

$\begin{array}{lllll}\frac{3}{4} \text { jn } & \text { Pk } & \text { C. G. H. 1810. O s.1 } & \text { Bot. mag. } 1497\end{array}$

1 mr.ap L.B C. G. H. 1795. O s.1 Jac. ic. 2. t. 394

$\begin{array}{lll}\frac{1}{2} \text { mr.ap } & \mathrm{Pk} & \text { C. G. H. 1813. O s.l Bot. mag. } 1611\end{array}$

1 ap.my Pk C. G. H. 1800, O s.l Bot, rep. t. 296

1 mrap W. C. G. H 1795 O s.l Bot.mag.766

2.

$\begin{array}{llllll}\frac{1}{2} & \text { my.jn } & \text { R } & \text { C. G. H. 1804. O s.l Bot. rep. } 460\end{array}$

as my.jn W.pu C. G. H. 1804. O s.l Jac. ic. 2. t. 401

$\begin{array}{llll}1 \text { ap.my R.Y } & \text { C. G. H. 1774. O s.1 Jac. ic. rar.1.t.61 }\end{array}$

1 ap.my Y.R $\quad$ C. G. H. 1774. O s.1 Bot. mag. 82

$\begin{array}{llll}3 & \text { mr.my R.Y } & \text { C. G. H. } 1789 \text {. O s.l } & \text { B. mag. } 588.1097\end{array}$

$3^{4}$ S.O $\mathrm{R}$ C. G. H 1803 O s.1 Bot mag. 993

1 mr.ap Sc.Y C. G. H 1774. O s.1 Bot.

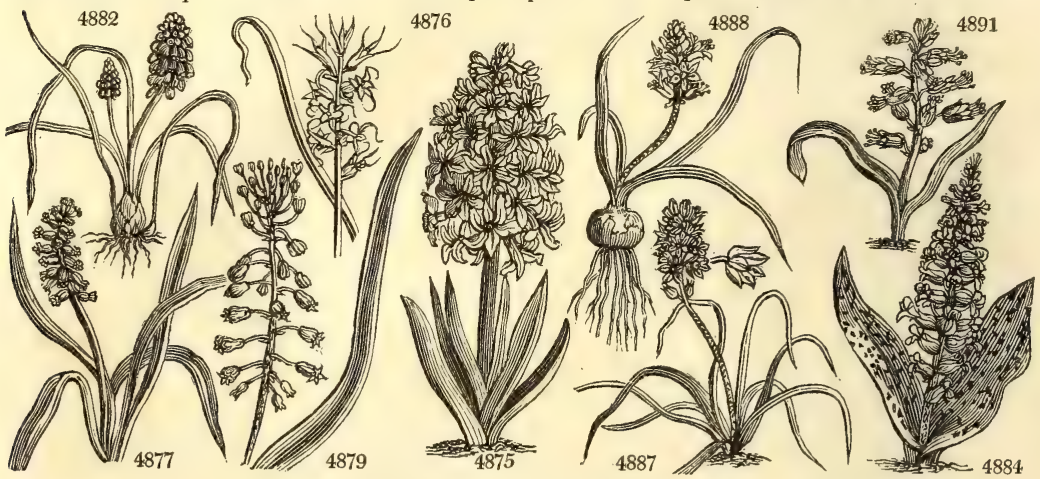

History, Use, Propagation, Culture,

819. Hyacinthus Every one knows the fable of Hyacinthus, who was killed by $\Lambda$ pollo and changed to this fler. Bochart, however, remarking that the ancients applied the name to a red flower, concludes that the Arabic yâgòut, which signifies red, has something to do with the name. A conjecture certainly sufficiently learned, but less plausible.

H. orientalis is the origin of one of our finest florist's flowers, and, like the tulip and narcissus, of a considerable commerce to the Dutch. It is a native of the East, and abundant about Aleppo and Bagdat, where it flowersin February. It seems to have been first cultivated as a flower by the Dutch; but when is unknown. Most probably in the beginning of the sixteenth century, soon after the revival of commerce in the west of Europe, when the merchants of Holland traded to the eastern shores of the Mediterranean and the Archipelago. About the end of the sixteenth century there were seven or eight varieties known in England. In 1620, Swertius, in his Florilegium, figured forty varieties; Miller says the Haarlem florists in his time (say 1720) had above 2000 varieties, and though the passion for this flower has greatly declined, they have still upwards of half that number. In England three or four hundred sorts are annually imported from the Dutch fiorists by the secdsmen.

A fine double hyacinth is characterized by strength and enlargement of all the parts, and by bright distinct colors. The fundamental varieties are double, semidouble, single, red, white, purple, blue, and yellow, in mary different shades and variegations. A variety degenerates in a few years; but some have existed undeteriorated upwards of a century. Varieties are raised from seed, and flower the fourth or fifth year: their names are after the growers or their patrons, favorite friends, public characters, or the celebrated names of history and antiquity.

The seeds of the hyacinth are sown in October, after they have ripened, or in the following March. They remain three years with no other culture than covering with a little earth in autumn, but the fourth seasor they are trarisplanted into beds, where they remain two or three years longer till all the bulbs have flowered.

The soil is essentially a very sandy loam and vegetable mould; and if in forming the beds this soil can be made to the depth of two feet, and at the bottom of the bed a layer of six or nine inches of cow-dung 
4874 Flowers campanulate half 6 -cleft cylindrical at base 4875 Flowers funnel-shaped half 6 -cleft ventricose at base

4876 Leaves linear channelled longer than scape

4877 Flowers cylindrical ovate uniform horizontal subsessile

4878 Flowers camp. cylindrical half 6-cleft, Pedunc. in fruit very long and horizontal 4879 Flowers cylindrical angular on long stalks, the upper sterile on very long stalks

4880 Flowers campan. cylindrical, Limb erect shorter than tube, Leaves lin. lanc. erect 4881 Flowers globose uniform : the lower remote, Leaves linear upright channelled 4882 Flowers ovate uniform clustered : the upper sessile, Leaves lax dependent linear

4883 Flowers campanulate sessile, Inner sepals longer spreading obtuse, Leaves lin. lanc. smooth 4884 Flowers campanulate sessile, Inner sepals longer spreading obtuse, Lvs, obl. lanc. with cartila. cren. edge 4885 Flowers campanulate sessile, Inner sepals longer spreading obt. Scape ang. at end short. than lin. obl. lvs. $4886 \mathrm{Fl}$ campanulate sessile, Inner sepals longer spreading emarg. Lvs. lin. chann. lax twice as long as scape 4887 Fl. campan. sessile, Inner sepals longer spreading obov. obt. Lvs. lin. channelled lax longer than scape $4888 \mathrm{Fl}$. camp. cylind. on short stalks erect, Inner sep. long lanc. obt. erect, Lvs. lin. chann. lax long. than scape 4889 Flowers camp. stalked, Inner sepals longer obovate spreading, Lvs. lanc. channelled shorter than scape $4890 \mathrm{Fl}$. camp. stalked horizontal, Inner sep. longer obt. Stam. longer than fl. Lvs. lanc. twice as short as scape 4891 Leaves two, Scape not longer than leaves, Fl. short horizontal, Stamens long declinate 4892 Leaves two oblong, Raceme compact, Flowers short campanulate nearly as long as stamens 4893 Leaves three lanceolate blistered shorter than scape, Flowers campanulate erect 4894 Flowers camp. on short stalks, Inner sep. long. obtuse, Scape 3 cornered reclinate, Leaves blistered $4895 \mathrm{Fl}$. camp. stalked, Inner sep. long obt. revol. Stam. longer than fl. Scape angular at end, Leaves blistered 4896 Leaves two oval-edged, Flower erect conical shorter than spreading stamens

4897 Fl. camp. flat at base length of stalk, Inner sep. long. obt. Stam. longer than fl. Scape ang. at end, Lvs, obl. 4898 Leaves lanceolate erect unequal : the larger cucullate at base, Scape few-flowered shorter than leaves 4899 Lvs, lin. lanc. two-spreading, Flowers whole-colored with the outer sepals nearly as long as the inner 4900 Flowers cylindrical length of stalks, Inner sepals longer obtuse unequal, Leaf one lin. lanceol.

4901 Lvs. two lin. lanc. spreading, Fl. erect sessile clust. ovate with inner sep. much the narrowest and longest 4902 Flowers cylind. stalked, Sepals linear obtuse equal, Scape angular at end, Leaves lanc. deflexed 4903 Flowers cylind, stalked pendulous, Inner sepals longer emarginate, Leaves lanceolate

4904 Flowers cylind. stalked pendulous, Inner sepals longer emarginate spreading, Leaves obl. spreading 4905 Leaves twin obl. not spotted, Scape erect not spotted, Flowers cylindrical pendulous

4906 Flowers cylind. on short stalks pendulous, Inner sepals longest, Leaves oblong

4907 Leaves twin lin. lanc. spotted, Scape erect, Flowers pendulous with the inner limb of sepals spreading 4908 Flowers camp. stalked, Outer sepals long spreading: inner connate, Leaves long channelled

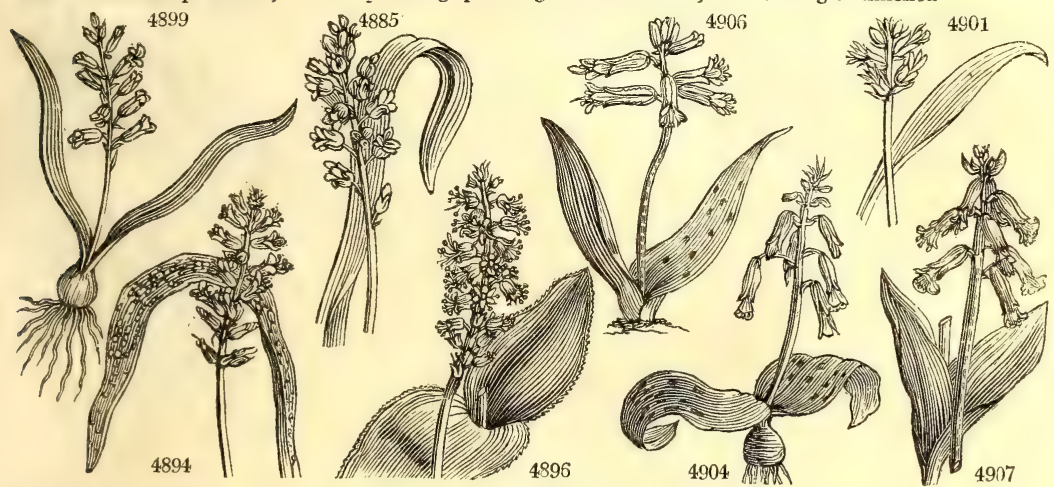

and Miscellanecus Particulars.

deposited, the plants will thrive the better. The season of planting is from the middle of October to the middle of November. The bed should be protected from heavy rains and severe frosts by the usual means and about the beginning of April, when the flowers begin to open, an awning of canvass should be fixed over them, to exclude all extremes of weather, and the more brilliant moments of sunshine. In three weeks or a month after blooming the bulbs should be taken up, unless they are intended to remain for seed. They should be dried in the shade, or under a few inches of dry earth, kept dry, and afterwards cleaned and wrapped up in separate papers, or laid on open airy shelves till wanted for replanting.

The hyacinth forces well, especially some of the blue sorts; it also does better than most bulbs when planted on water.

820. Zuccagnia. This plant was named in honor of Attili Zuccagni, superintendant of the garden at Florence, It is scarcely a different genus trom Uropetalon.

821. Muscari. Something which smells of musk, called $\mu \circ \sigma \chi 05$ in Greek, muscus in Latin, misk in Arabic (Forskahl.) M. comosum; $\beta$ monstrosum, is a most ornamental border flower. The bulb is large, ovate, and solid: the leaves narrow, a foot long, with obtuse points : the flower-stalks rise near a foot and a half high; they are naked at the bottom for about seven or eight inches, above which the panicles of flowers begin, and terminate the stalks. The flowers stand upon peduncles which are more than an inch long, each sustaining three, four, or five flowers, whose petals are cut into slender filaments like hairs; they are of a purplish blue color, and, having neither stamina nor germ, never produce seeds. The other species are very pretty hardy flowers.

M. racemosum was named starch hyacinth by William Curtis, from the smell of the flower.

8.2. Lachenalia. So named in honor of Wernerus de la Chenal, of Switzerland, author of some medical and botanical tracts printed at Basle. The numerous species of this genus were chiefly introduced from the Cape by Masson : they bear a strong general resemblance, and are yet individually different; they may be styled diminutive, but pretty; they grow readily in sand and peat, and may be forced or retarded so as to flower at almost any season. They must be very sparingly watered when not in a growing state. 
823. PHOR'MIUM. $W$. Flax-LILY. 4909 tenax $W$.

824. CYANEL'LA. $W$. 4910 capénsis $W$. 4911 lútea $W$.

825. LEON'TICE. $W$. Iris-leaved

Cyanella. purple-flower. yellow-flowere

LEONTICE. 4912 chrysógonum $W$. oak-leaved 4913 Leontopétalon $W$. Lion's-leaf

826. CAULOPHYLLUM. Mich. CAULOPHYLUM 4914 thalictroídes $P h$. Columbine-lvd. $¥ \Delta \mathrm{cu}$ 827. DIPHYLLE'IA. Mich. Diphylleia. 4915 cymósa Mich. 4916 verticillátus $W$. 4917 ambiguus $P h$. 4918 lævigátus $P h$. 4919 lanceolátus $P h$. 4920 gláber $W$. 4921 lúcidus $W$. 829. BER'BERIS. $W$. 4922 vulgáris $W$. $\beta$ violácea r alba 4923 canadénsis $P h$ 4924 ilicifólia $W$. 4925 crética $W$. 4926 sibírica $W$. 4928 sinénsis Desf. 4929 fasciculáris Dec. 4930 aristáta $D e c$. 4931 heterophýlla Juss. 830. NANDI'NA. $W$. 831. COSSIG'NIA. Juss. 4933 pinnáta Lam. 832. HIU/LIA. $W$. 4934 longiflóra $W$. 4935 tetrándra $W$.

blue-berried
WINTER-BERRY.
deciduous
Carolina
smooth
scarlet-berried
evergreen
shining
BERBERRY.
common
purple-fruited
white-fruited
Canada
Holly-leaved
Cretan
Siberian
emarginate
Chinese
clustered
Nepal
various-leaved

Nandina. garden

Cossignia pinnated

\section{HuLLIA.} long-flowered mountain 828. PRI'NOS. $W$. 4927 emargináta W. en. 4932 doméstica $W$

Asphodelea. Sp. 1.

E $\triangle \mathrm{J}$ ec, 6 au G.w N. Zeal. 1788. R I.s.p Cook. it.v.2. t.96 Asphodelece. Sp. 2-4.

1 jl.au B $\quad$ C. G. H. 1768. O s.p Bot. mag. 568

jl.au $\mathbf{Y}$ C. G. H. 1788. O s.p Bot. mag. 1252

Berberidece. Sp. 2-3.

$1 \mathrm{mr} . j n \mathrm{Y}$ Levant 1740. D s.l.p M. his. 3. t.15.f.7 ap.my $Y$ Levant 1597. D s.l.p M. his, 3. t.15, f.6 Berberidece. Sp. $1-2$

$\frac{3}{4}$ my Y.G N. Amer. 1755. D s.p Mic. Am. 1.t. 21 Berberidece. Sp. 1.

$\Delta$ pr $\frac{3}{4}$ my.jn W N. Amer. 1812. D 1.p Bot. mag. 1666 Rhamnea. Sp. 6-11.

6 jl.au W N. Amer. 1736. L s.p Dend. brit. 30

4 ... W Carolina 1812. L 1t.s Dend. brit. 29

4 jl.au W N. Amer. ... L I It.s Dend. brit. 28

4 jn.jl W Carolina 1811 L it

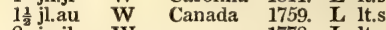

Berberidece. Sp. $10-38$

8 ap.my Y England bu. pl. L co Eng. bot. 49

8 ap.my Y

8 ap.my $\mathbf{Y}$

8 ap.my $\mathbf{Y}$

4 jl.au $Y$

6 ap.my $\mathbf{Y}$

1 jn.jl $Y$

3 ap.my $\mathbf{Y}$

4 ap.my $\mathbf{Y}$

or 10 ap.my $\mathbf{Y}$

or 6 ap.my $\mathbf{Y}$

or 4 ap.my $\mathbf{Y}$

...... $\quad$... L $\mathrm{L}$ co

Canada 1759. L co

T.del Fue. 1791. L r.m

Candia 1759. I co

Siberia 1790. L co

Siberia 1790. G co

China 1815. G co

California 1819. C co Bot mag. 2396

Nepal 1820. C co Hook. ex. fl. 98

Magellan 1805. L co Hook. ex. fl. 14 Berberidea. Sp.1.

* ${ }^{*}$ or 6 jn.jl G.Br China 1804. C p.l Bot. mag. 1109 Sapindacea. Sp. 1.

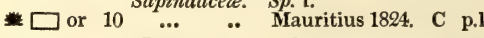
Rubiacece. Sp. 2

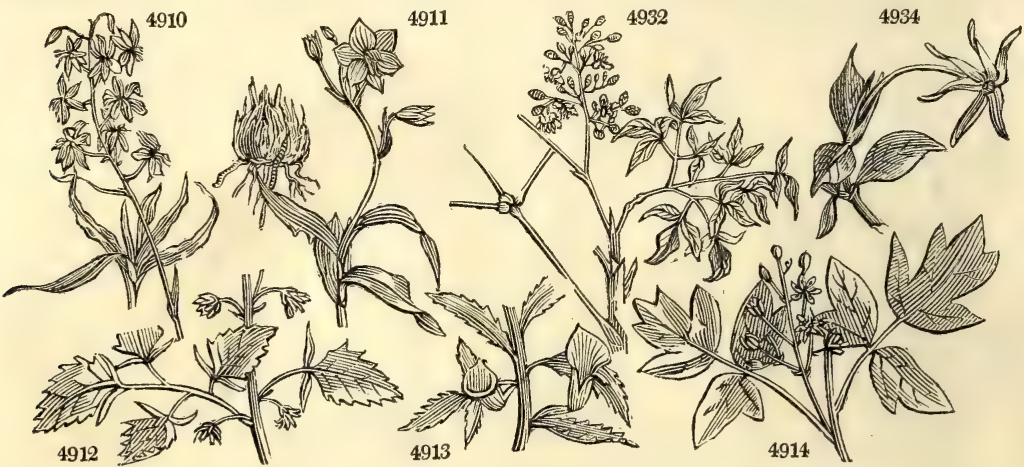

History, Use, Propagation, Culture,

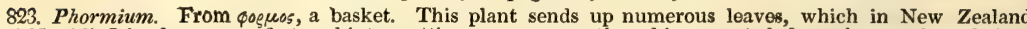
and Norfolk Island are manufactured into matting ; or a coarse thread is separated from them and made into cordage and coarse linen, as is done from different species of Aloe, Agave, and Liliaceæ in the Levant and south of Europe. The plant thrives in any rich light soil, increases readily by offsets, and is said to stand the open air about Cork, where thoughts are entertained of using it as a substitute for flax. The experiments, however, which have been made in New Holland by some spirited individuals respecting its cultivation, have all failed.

824. Cyanella. Derived from zvavos, blue, in allusion to the color of the flowers of some species; all are very pretty and easily cultivated.

825. Leontice. An abridgment oi Leontopetalum, its ancient name; from $\lambda \varepsilon \omega \nu$, a lion, and $\pi \varepsilon \sigma \alpha \lambda \sigma y$, a leaf, because the shape of the leaves was thought to resemble the print of a lion's foot.

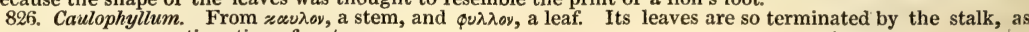
to appear a mere continuation of a stem.

827. Diphylleia. From $\delta \iota s$, two, and $\varphi \nu \lambda \lambda o v$, a leaf. The plant has never more than two leaves.

828. Prinos. This was the Greek name of the evergreen oak; from tesw, to saw, on account of the strongly toothed leaves of that plant. The species are low shrubs of little beauty; but of the easiest culture in any light soil.

829. Berberis. Berberys, according to Golius, (p. 246), is the Arabic name of this plant. B. vulgaris is at once an ornamental shrub, a fruit tree, a hedge plant, a dye, a drug, and a reputed enemy to the corn farmer. When covered with flowers in spring, or with fruit in autumn, it is a fine object. The leaves are of a yellowish or bluish green, and gratefully acid to the taste. The smell of the flowers is offensive when near, but pleasant at a certain distance. The berries are so very acid, that birds seldom touch them. The berberry, however, is cultivated for the sake of these, which are pickled and used for garnishing dishes; and being boiled with sugar, form a most agreeable rob or jelly ; they are used likewise as a sweetmeat, and are put into sugar-plums or comfits. As a medicine the fruit is considered a mild restringent acid, agreeable to the stomach, and of efficacy (like other vegetable acids) in hot bilious disorders, and in a putrid disposition of the humours. The roots boiled in a lye yield a yellow colour: and in Poland they dye leather of a fine yellow 


\section{The only species, resembling an Agave}

4910 Stem leafy panicled, Racemes divaricating, Leaves lanceolate wavy 4911 Scape naked branched, Racemes erect, Leaves linear lanceolate flat

4912 Leaves pinnated, Leaflets whorled lanceolate acute 3-pointed 4913 Radical leaves biternate; cauline ternate, Fruit ovate

4914 Cauline leaf triternate ; floral biternate

4915 Quite smooth, Leaves palmate angular lobed serrated with taper-pointed lobes

4916 Leaves obovate lanceolate acuminate doubly serrated, Veins beneath hairy

4917 Leaves oval pointed at each end mucronate serrulate pubescent beneath, Female flowers solitary 4918 Leaves lanceol. serrated acuminate smooth on each side, Flowers all 6-cleft

4919 Leaves lanceol. very finely and distantly serrated acute at each end quite smooth, Male flow. 3-androus

4920 Leaves lanceol. obt. smooth serrated at end

4921 Leaves elliptical acuminate smooth somewhat serrated at end

4992 Racemes simple pendulous, Leaves obovate ciliate-toothed

4923 Branches dotted, Prickles in 3s, Lvs. simple obovate remotely toothed, Racemes short, Fruit globular 4924 Spines 3-parted, Leaves oval with a few large spiny teeth, Ped. short 4-fl. Pedicels elongate corymbose 4925 Spines 3-5-parted, Leaves oval-oblong entire or serrated, Racemes 3-8-flow. almost shorter than leaves 4926 Spines 3-7-parted, Leaves lanceolate obovate ciliate-toothed, Peduncles 1-flowered shorter than leaf 4927 Spines 3-parted, Leaves lanceolate obovate ciliate serrate, Racemes pendulous, Petals emarginate 4928 Spines 3-parted very few, Leaves obl, obtuse entire or a little toothed, Racemes many-fl. nodding 4929 Lvs. pinnated in 4 or 5 pairs, Leafiets ovate lanceolate spreading toothed, Racemes erect much clustered 4930 Spines simple scarcely two-toothed at base, Lvs, obl. with 4 or 5 spiny teeth, Racemes spreading many-fl. 4931 Spines 3-parted, Lvs. ovate lanceolate smooth some entire some three-toothed, Pedicels solitary one-flow.

4932 Leaves supra-decompound with lanc. entire leaflets

4933 Leaves pinnate lanceolate emarginate

4934 Cor. 6-cleft, Segments lanceolate revolute, Leaves ovate acute

4935 Cor. 4-cleft, Segments ovate, Leaves obovate

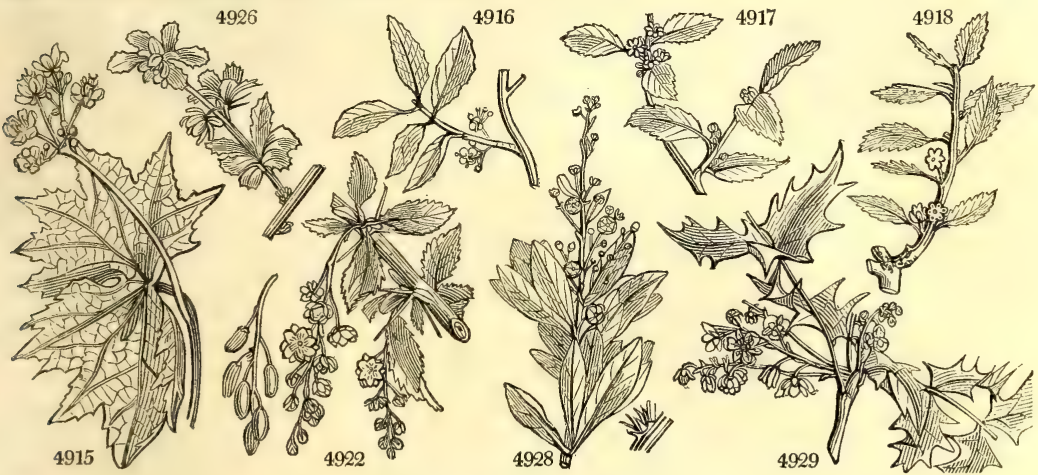

and Miscellaneous Particulars.

with the bark of the root. The inner bark of the stems also will dye linen of a fine yellow, with the assistance of alum. Kine, sheep, and goats are said to eat it; horses and swine to refuse it. This species varies with red, purple, pale yellow, and stoneless fruit.

Insects of various kinds are remarkably fond of the flowers of the barberry; and the Æcidium Berberidis, its particular inhabitant, is supposed to generate the dust which, carried from the bush by winds, and lighting on wheat and other growing corns, gives rise to the Puccinia, a minute fungus, which closes up the pores of the leaves, and appears like rust or mildew. (Sir J. Banks on Blight, \&c.) Many highly respectable authorities in Britain, on the continent, and in America, are in favor of and against this opinion. Willdenow, Withering, and Dwight have stated various remarkable cases on good authority. Sir J. Banks and his draughtsman Bauer proved the fact of the mildew being a fungus.

Linnæus observed, that when bees in search of honey touch the filaments, the anthers approximate to the stigma and explode the pollen. Sir J. Smith ascertained that the same effect is produced by touching the inside of the filaments with a small bit of stick. (Phil. Trans, vol. lxxviii. 1. 158.)

All the other species are much esteemed as ornamental plants. B. aristata is a fine hardy evergreen shrub. B. ilicifolia and emarginata are also hardy, but less ornamental. $\mathbf{B}$. fascicularis is a beautiful ornamental nearly hardy shrub, remarkable for its pinnated leaves.

830. Nandina. Nandin is the name of this shrub in Japan, where it is a garden shrub: the flowers are in panicles, and succeeded by berries of the size of a pea. In the greenhouse it grows freely in loam and peat, and ripened cuttings, with their leaves on, root in sand under a hand-glass.

831. Cossignia. Named by Commerson, after M. de Cossigny, a French naturalist, then living at Pondicherry. Fine plants with handsome pinnated leaves.

832. Hillia. So named by Jacquin, in honor of Sir John Hill, author of many large works on botany and other parts of natural history, as well as general literature Owing to some differences with his contemporaris, and writing against the Royal Society, after being rejected as a fellow, his memory in England hes not met with much respect ; in truth it was but little that it deserved. The species are of easy culture, and cuttings root
readily in sand. 

833. RICHAR'DIA. $L . \underset{\text { Richandia. }}{\text { rough }}$
4936 scábra $L$.

834. CANARI'NA. $W$. Canarina. 4937 Campánula $W$. Canary

835. FRANKE'NIA. $W$. Sea-Heath 4938 læ'vis $W$. 4939 Nóthria $W$. 4940 hirsúta $W$. 4941 pulverulénta $W$.

836. PEP'LIS. $W$. 4942 Pórtula $W$.

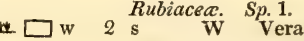

Campanulacee. Sp. 1.

2 $\mathbb{N}$ or 3 ja.mr O Canaries 1696. R r.m Bot. mag. 444

Sea-Heatr.
smooth Frankeniacea. Sp. 4-16. $\begin{array}{lllll}\text { Cape } & \Delta \mathrm{cu} & \frac{1}{4} & \text { jn.au F } & \text { C. G. H. 1816. D s.1 Be.c. 171.t.1.f. }\end{array}$ hairy $\triangle \mathrm{cu}{ }^{\frac{1}{4} \mathrm{jn} . \mathrm{jl}}$ L.B Siberia 1789. D s.1 Fl. græc. 343 powdery $\quad \Delta \mathrm{cu} \frac{1}{4}^{\frac{1}{4}} \mathrm{jl} \quad \mathbf{R} \quad$ England seaco. D s.l Eng. bot. 2222

Water Purslane. Salicaria. Sp. $1-2$.

common $O \mathrm{cu} \frac{1}{4} \mathrm{jl.s} \quad \mathrm{Pu}$ Britain wat.pl. S aq Eng. bot. 121

\section{DIGYNIA.}
837. ORY'ZA. $W$.
4943 sativa $W$.
RICE.
Graminea. Sp. 1.
common 此四ag $2 \mathrm{jl}$ Ap E. Indies 1596. S aq Cat, car. 1. t. 14

838. ATrAPHAX'IS. $W$. Atraphaxis. Polygoner. $S p, 2-3$.

4944 spinósa $W . \quad$ prickly $\quad$ N cu 2 au Ap Levant 1732. C 1.p Dend. brit. 119

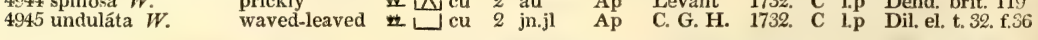

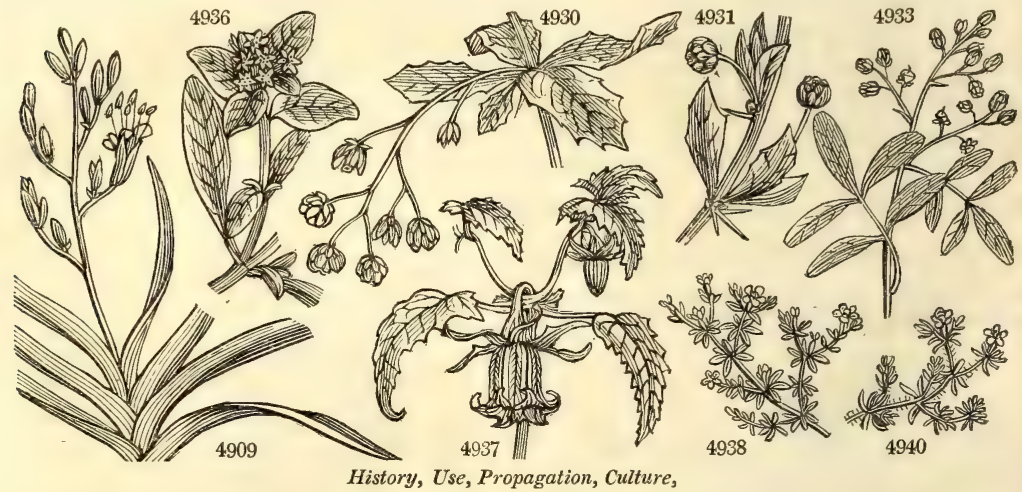

833. Richardia. So named by Houston, after Richard Richardson, an English botanist. Cuttings root in sand under a glass.

834. Canarina. That is to say, a plant native of the Canaries. This plant, Sweet observes, "is very desirable, as it flowers in autumn and winter, when few other plants are in bloom. After flowering, the stem lies down, and the roots continue dormant all the summer, when they need but little water. When they begin to grow they had better be placed in the stove, as they will not flower so abundantly in the greenhouse. A light loamy soil suits them best, or a mixture of loam and peat ; and they are readily increased by dividing the roots, or from cuttıngs planted in the same kind of soil under a hand-glass," Bot. Cult. p. 162.)

835. Frankenia. In honor of John Frankenius, professor of botany at Upsal, who first enumerated the plants of Sweden in Speculum Botanicum, 1638, and Speculum Botanicum Renovatum in 1659.

836. Peplis. One of the Greek names of the Purslane. The plant now so called resembles the Purslane in some points.

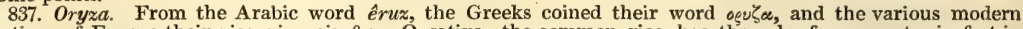
nations of Europe their rice, riz, reis, \&c. O. sativa, the common rice, has the culm from one to six feet in length, annual, erect, simple, round, jointed. Leaves subulate-linear, reflex, embracing, not fleshy. Flowers in a terminating panicle. Calycine leaflets lanceolate. Valves of the corolla equal in length; the inner valve in a terminating panicle. Calycine leaflets lanceolate. Valves of the corolla equal in length;
even, awnless ; the outer twice as wide, four-grooved, hispid, awned. Style single, two-parted.

o. mutica, the dry or mountain rice, cultivated in Ceylon, Java, and of late in Hungary, has the culm three feet high, and more slender. Fruit longish, with awns the longest of all. It is sown on mountains and in dry soils; rots with a long inundation, and perishes with sea water.

The varieties of rice, as of other cultivated grain, are as numerous as the different soils, climates, and other physical circumstances, in which it is cultivated: besides the dry rice, the chief sorts, by some considered species, are the 0 . præcox, or early rice, and the 0 . glutinosa, or clammy rice, both cultivated in irrigated lands.

The native place of rice, like that of the other sorts of grain in common use, is unknown; it is cultivated in great abundance all over India, where the country will admit of being flooded; in the southern provinces of China, in Cochinchina, Cambodia, Siam, Japan, \&c. In Japan it is very white, and of the best quality. It has also been introduced into cultivation in the southern kingdoms of Europe, Italy, Spain, the south of France, and within a few years into Hungary and Westphalia. In Carolina it has long been a staple commodity, Houghton's account of its introduction there is, that Ashby was encouraged to send a hundred pound bagfull of rice to that province, from which, in 1698, sixty tons were imported into England. Dalrymple says, that rice in Carolina is the result of a small bag of paddy, given as a present from Dubois, treasurer of the East India Company, to a Carolina trader. A Dutch vessel also, from Madagascar, brought rice into the same province; and to this is attributed their having two kinds. (Oricntal Repertory, 1. )

In the hilly parts of Java, and in many of the Eastern islands, the mountain rice is planted upon the sides of hills, where no water but rain can come; it is, however, planted in the beginning of the rainy season, and reaped in the beginning of the dry season. The natives call it Paddy Gunung, which signifies mountain rice. It is entirely unknown in the western parts of India, but it is well known in Cochinchina, where it thrives in dry light soils, mostly on the sides of hills, not requiring more moisture than the usual rains and dews supply, neither of which are frequent at the season of its vegetation.

There is a kind of hill rice which is hardy enough to grow on the edge of the Himalayan snows. It is almost to be expected, that this will, at some future time, prove an acquisition of value to the European cultivator.

Rice is extensively cultivated in the East Indies and China, and chiefly on low grounds near large rivers, 
4936 The only species, Leaves lanceolate ovate rough

4937 The only species, _Leaves stalked hastate toothed

4938 Flowers solitary, Petals repand obtuse, Leaves linear ciliated at base 4939 Flowers fascicled, Petals acute, Leaves linear ciliated at base

4940 Flowers fascicled, Petals repand obtuse, Leaves linear oblong hairy at base

4941 Flowers solitary, Petals subrepand, Leaves roundish ovate powdery beneath

4942 Flowers hexandrous axillary solitary, Flowers stalked rounded ovate

DIGYNIA.

4943 The only species

4944 Prickly

\$045 Unarmed, Leaves wavy

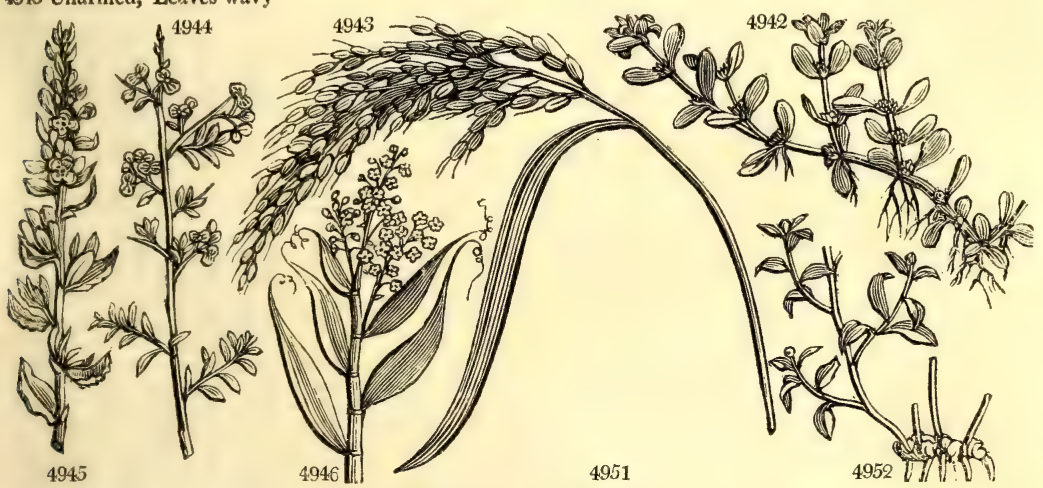

and Miscellaneous Particulars.

which are liable to be annually inundated, and enriched by the deposition of mud. According to Sir George Staunton's account, the Chinese obtain two crops of rice in a year from the same ground, and cultivate it in this way from generation to generation on the same soil, and without any other manure than the mud deposited by the water of the river used in overflowing it. After the waters of the inundation have withdrawn, a few days are allowed for the mud to get partially dry ; then a small spot is enclosed by a bank of clay slightly ploughed and harrowed, and the grain, previously steeped in dung, diluted with animal water, is then sown very thickly on it. A thin sheet of water is immediately brought over it, either by a led stream, or the chainpump. Thus a seed-bed or nursery is prepared, and, in the meantime, the remainder of the tract is preparing for being planted. When the plants are six or seven inches high, they are transplanted in furrows made by the plough, so as to stand about a foot apart every way; water is then brought over them, and kept on till the crop begins to ripen, when it is withheld; so that when harvest arrives the field is quite dry. It is reaped with a sickle, threshed with a flail or the treading of cattle, and the husk taken off by beating it in a stone mortar, or passing it between two flat stones, as in a common meal mill. The first crop being cut in May, a second is immediately prepared for by burning the stubble, and this second crop ripens in October or November. After removal, the stubble is ploughed in, which is the only vegetable manure such lands can be said to receive from removal, the stubble is ploughed in, which is the only vegetable manure such lands can be said to receive from
man. In Japan, Ceylon, and Java, according to Thunberg, Davis, and Raffles, aquatic rice is cultivated nearly in the same manner. Mountain-rice is grown much in the same way as our barley.

In Lombardy and Savoy rice is sown on rich lands, the sower often wading to the knees in water: one crop a year only is obtained ; but four crops are often taken in succession. In America a similar practice obtains.

In Westphalia, and some other parts of the south of Germany, rice has long been cultivated; there it is sown on lands that admit of irrigation; but the water is not admitted till the seed has germinated, and it is withdrawn, as in Italy, when the crop comes into flower. From long culture in a comparatively cold country, the German rice has acquired a remarkable degree of hardiness and adaptation to the climate; a circumstance which has frequently been alluded to as an encouragement to the acclimating of exotics. It is found, Dr. Walker remarks (Essays on Nat. Hist.), that rice seeds direct from India will not ripen in Germany at all, and even that Italian or Spanish seeds are much less early and hardy than those ripened on the spot.

In Hungary rice has not been long cultivated: the mountain sort has chiefly been tried, and that in the manner of our barley or summer-wheat.

In England a crop of rice has been obtained near Windsor, on the banks of the Thames.

In the stove, or in a hot-bed, rice may be grown in pots of rich soil placed in pans of water, and in August they may be set in the greenhouse, or under any glass roof open at the sides, and they will produce perfect grains.

By far the best imported rice is that from Carolina : it is larger and better tasted than that of India, which is small, meagre, and the grains frequently broken. As an article of diet, rice has been extolled as superior almost to any other vegetable : but, whatever it may be in warmer climates, where it is a common, and to many persons almost their only food, it does not appear so well calculated for European constitutions as the potatoe; for we find that the poor constantly reject the use of rice when potatoes are to be had; and whilst these can be obtained, we may venture to predict, that rice will always be considered in this country, rather as a dainty, to be eaten with sweet condiments, spices, fruit, \&c. than as ordinary food. (Willich's Family Cyclopadia.

838. Atraphaxis. A name given by the Greeks to the Atriplex of the Latins ; derived from $\propto$, privative, and reassiv, to nourish; that is to say, a plant yielding no nourishment. Cuttings root freely in sand under a glass; but the plants are of neither beauty nor curiosity. 


\section{TRIGYNIA.}

839. Fla Gella'ria. $\boldsymbol{W}$. Flagellaria. 4946 índica $W$.

\section{SCHEUCHZE'RIA. $\boldsymbol{W}$. SCHEUCHzERIA} 4947 palústris $W$. marsh if $\Delta$

841. TrigLO'CHIN. $W$. Arrow Grass. 4948 palústre $W$ 4949 bulbósum $B$. $M$ 4950 maritimum $W$. Arro

\& $\Delta$ ec jn.jl w ${ }^{S p}$. 1 .

Alismacece. Sp.1.

my.jn Br England sp. bo. S m.s Eng. bot. 1801

Alismacea. Sp. 3-7.

842. LiCHTENSTEI'NIA. $W$. Lichtensteinia. Melanthaceie. Sp. 1 $\begin{array}{lllllllll}4951 \text { lævigáta } W . & \text { smooth } & \text { I } N \text { pr } & 1 & \ldots & \text { B } & \text { C. G. H. } & \text { 1824. } & \text { s.l }\end{array}$

843. MYRSIPHYL'LUM. W.en. MYrsiphylum. Smilacea. Sp. 2.

4952 asparagoídes $W$. en. broad-leaved $\quad$ \$ $\Lambda$ cu 6 mr.o $\quad$ G.w C. G. H. 1702. R s.p Her. lugd. t. 681

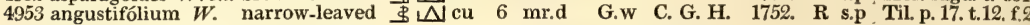

844. TOFIEL'DIA. Hud. ToFIELDIA.

$\begin{array}{ll}4954 \text { alpina Smith } & \text { Scotch } \\ 4955 \text { pubéscens Mich. } & \text { downy }\end{array}$

845. MELANTHIUM. $L$. Melanthium. 4956 púmilum $W$. dwarf 4957 gramineum Cav. grass 4958 júnceum $W$. Rush-leaved 4959 secúndam $W$ 4960 uniflórum $W$ 4961 víride $W$. side-flowering yellow branching

Melanthacece. Sp.2-7.

\& cu $\frac{1}{4}$ jlau G Britain bgs.m. S m.s Eng. bot. 536 $\Delta$ cu $\frac{1}{4}$ ap.my W N. Amer. 1790. S m.s Pl.ma.t.342.f.3 Melanthacea. Sp. 6-12.

my.j W C 1800.0 .

$\triangle$ cu 1 my.jn W Mogador 1823. O s.1 Cav. ic.t. 587.f.1

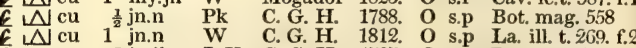
$\begin{array}{lllll} & \mathrm{N} \text { cu } & \frac{3}{4} \mathrm{jn} . j \mathrm{l} & \text { L.Y C. G. H. 1787. O s.p Bot. mag. } 767\end{array}$ $\triangle \mathrm{Cu} \quad \frac{1}{2}$ o.n $\quad \mathrm{G} \quad$ C. G. H. 1788. O s.p Bot. mag. 994 846. MEDE'OLA. W.en. Medeola

Indian Cucum. \& $\Delta \mathrm{cu} \frac{3}{4} \mathrm{jn}$. Y.G Virginia 1759. R s.p Bot. mag. 1316 847. XEROPHYL'LUM. Mich. Xerophylum. Melanthacea. $S p .1$

4963 setifólium $W$. bristle-leaved $\delta$ cu 2 my.jn W N. Amer. 1823. R s.p Bot. mag. 748 848. WURMBE'A. L. WURMBEA. 4964 longiflóra $W$. 4965 spicáta $B$. 4966 capénsis $W$. bell-flowered spiked

\& $\mathrm{Ncu}$ spotted-flower. 849. ANDROCYM'BIUM $W$ ANDROCrMBIUM 4967 eucomóides $W$. dwarf 850. TRILLIUM. $W$. Trillium. 4968 séssile $W$. 4969 petiolátum $P h$. sessile-leaved $* \Delta$ or Plantain-leaved $t \Delta$ or 4970 erythrocárpum Mi. painted-flower. $* \Delta$ or 4971 ovátum $P h$. 4972 púmilum $P h$. 4973 cérnuum $W$. 4974 eréctum $W$. $\beta$ album 4975 péndulum $P h$ 4976 grandiflórum $P h$.

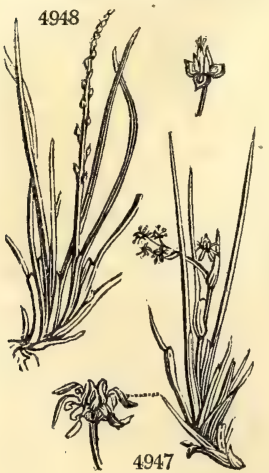
por drooping-flow, $\star \Delta$ or stinking white-flowered * $\Delta$ or 2utentums $\Delta$ or pendulous $* \Delta$ or

\footnotetext{
Melanthacea. Sp.
}

s my.jn W C. G. H 1788, O s.l Bot. mag. 1291 my.jn Pu C. G. H. 1788. O s.1 Bot. mag. 694 $\frac{3}{4}$ my.jn Br.r C. G. H. 1768. O s.p

Melanthacea. Sp. 1

$\begin{array}{llll}\frac{3}{4} \mathrm{mr} . \mathrm{my} \mathrm{G} & \text { C. G. H. 1794. O s.p Bot. mag. } 641\end{array}$ Melanthacece. Sp. 9-10.

$\frac{1}{2}$ ap.my $\mathrm{Br} \quad$ N. Amer. 1759. R s.p Bot. mag. 40 $\frac{1}{2}$ ap.my $\mathrm{Br} \quad \mathrm{N}$. Amer. 1811. K s.p

$\frac{1}{2}$ my.jn W N. Amer. 1811. R s.p

$\frac{1}{2}^{2}$ my.jn P.Pu N. Amer. 1812. R s.p

竞 my.jn $\mathbf{R}$ Carolina 1812. R s.p

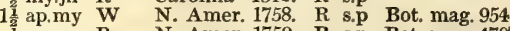

ap.my $\mathrm{Br} \quad \mathrm{N}$. Amer. 1759. R s.p Bot, mag. 470

$J^{2}$ ap.my W N. Amer. ... R s.p Bot. mag. 1027

$\frac{1}{2}$ ap.my W N. Amer. 1805 . R s.p W. ho.b. 1.t. 35

N. Amer. 1799. R s.p Par, lond. 1

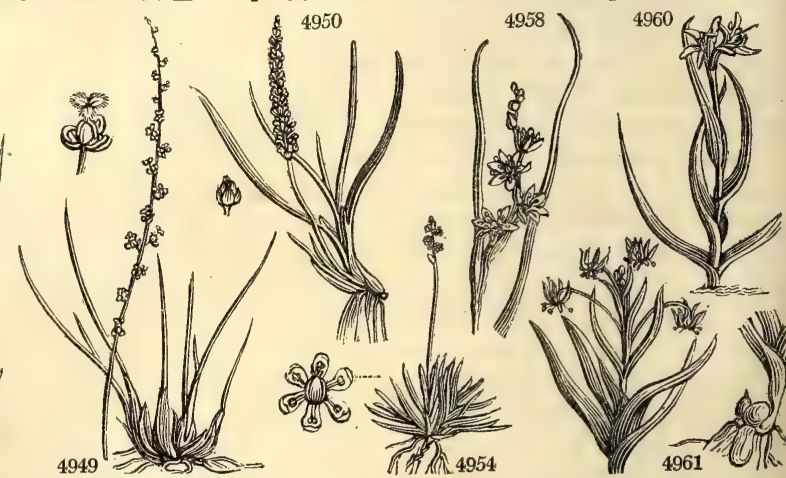

History, Use, Propagation, Culture

839. Flagellaria. From flagellum, a thong, in allusion to the length, toughness, and slenderness of its shoots.

840. Scheuchzeria. So named by Linnæus, in memory of the two brothers, John James Scheuchzer, professor of mathematics at Zurich, author of Itinera Alpina ; and John, professor of physic at Zurich, author of a famous Treatise on Grasses. A curious little marsh plant.

841. Triglochin. From $\tau e \varepsilon s 5$, three, and $\gamma \lambda \omega \times s 5$, a point, in allusion to the three angles of the capsule. Al domestic cattle are fond of the hardy species, which afford an early bite on the sides of Highland mountains, and are greedily eaten where they occur in salt marshes.

842. Lichtensteinia. Named after M. Von Lichtenstein, a Prussian traveller at the Cape of Good Hope

843. Myrsiphyllum. From $\mu \nu \rho \sigma^{\prime} \nu \eta$, a myrtle, and $\phi \nu \lambda \lambda \circ \nu$, a leaf, in allusion to the resemblance between the leaves of the species and those of myrtle.

844. Tofieldia. Named by Hudson, after a Mr. Tofield, a country gentleman living near Doncaster. 


\section{TRIGYNIA.}

4046 A shrub with distichous branches, Leaves cirrhous at end

4947 A rushy aquatic plant

4948 Capsules 3-celled linear

4949 Capsules 3-celled smooth linear narrowed at end

4950 Capsules 6-celled ovate

4951 The only species, Sepals very narrow

4952 Leaves ovate cordate at base oblique

4953 Leaves alternate ovate-lanceolate

4954 Smooth, Flowers clustered in spikes, Sepals obtuse, Capsules oblong 4955 Scape rachis and leaf-stalks downy all over

4956 Leaves lanceolate bearded at base, Stem 3-flowered, Sepals sessile

4957 Stemless, Leaves imbricated grassy, Flowers sessile

4958 Leaves linear subulate, the upper dilated at base, Spike wavy, Sepals with claws

4959 Leaves linear, Spike one-sided, Sepals with claws

4960 Leaves lin. lanc. longer than one-flowered stem, Sepals lanc. with claws

4961 Peduncles one-flowered cernuous

4962 Leaves whorled in the middle of stem, in threes at the summit

4963 Leaves of the stem setaceous

4964 Spike many-flowered longer than leaves, Tube twice as long as limb 4965 Leaves lanceolate channelled upright, Tube shorter than stellate limb

4966 Leaves lanceolate hooded

4967 Leaves oblong lanceolate cucullate

4968 Flower sessile erect, Petals lanceolate erect twice as long as calyx

4969 Flower sessile erect, Petals linear lanceolate erect a little longer than calyx

4970 Stalk of flower nearly erect, Petals oval-lanceolate acute recurved about twice as long as narrow calyx

4971 Stalk of flower erect, Petals oblong acute spreading a little longer than calyx

4972 Stalk of flower erect, Petals scarcely longer than calyx, Leaves oval oblong obtuse sessile

4973 Stalk of flower recurved, Petals lanceolate acuminate flat reflexed the length and breadth of calyx

4974 Stalk of flower inclining, Flower nodding, Petals scarcely longer but much broader than calyx

4975 Flower pendulous, Petals ovate with a short point, Leaves rounded rhomboid acuminate subsessilc 4976 Flower cernuous, Petals spatulate-lanceolate erect at base much longer than calyx

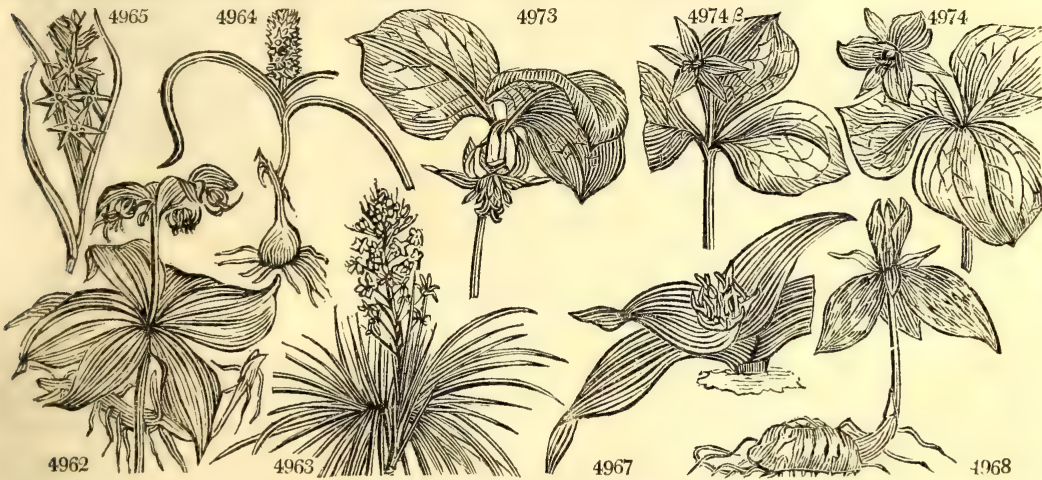

and Miscellaneous Particulars.

845. Melanthium. A name applied by the Greeks to the Nigella of the Latins. What resemblance the modern plant bears to the ancient has not been stated.

846. Medeola. A name in remembrance of Medea, the famous sorceress, given to this plant on account of supposed powerful effects in medicine, but which it is now thought not to possess.

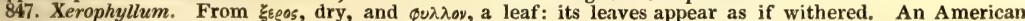
plant with a long spike of white flowers, resembling Helonias.

848. Wurmbea. So called by Thunberg, in gratitude for services rendered him at Batavia by one Wurmb, a Dutch agent there. Jussieu considers this not generically distinct from Melanthium.

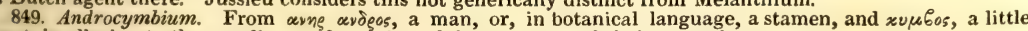
boat, in allusion to the peculiar conformation of the stamens and their appendages.

850. Trillium. From trilix, triple; the calyx has three sepals, the corolla 3 petals, the pistil 3 styles, and the stem 3 leaves. These are curious little plants, somewhat difficult to keep. Sweet says, they do best on a bed of peat, and may be increased, though slowly, by the division of the root or by seeds. 
851. COL'CHICUM. $W$. Meadow-Saffron. 4977 autumnále $W$ $\beta$ album

4978 arenárium $W$. en 4979 byzántinum $\dot{B} . M$. 4980 variegátum $L$ 4981 umbrósum Fisch. 4982 versícolor $\mathrm{Ker}$. 4983 montánum $L$.

852. HELO'NIAS. $L$. 4984 lutea $B . M$. 4985 bulláta $W$. 4986 læ'ta $B . M$ 4987 glabérrima $B$. $M$. 4988 bracteáta $B . M$. 4989 ténax $\boldsymbol{P h}$.

4990 angustifólia Mich. 4991 graminea $B$. $M$.

853. NOLI'NA, Mich. 4992 georgiána $M$.

854. APONOGE'TON. 4993 Pronogeto 4993 monostáchyon $W$.
499-1 distáchyon $W$. 4995 angustifólium $W$.

855. SABAL. $P . S$. 4996 Adansóni B. $M$. 856. RU'MEX. $W$ 4997 Patiéntia $W$. 4998 sanguíneus $\dot{W}$. 4999 crispus $W$. 5000 Británnica $W$. 5001 persicarioídes $W$. 5002 ægyptíacus $W$. 5003 dentátus $W$ 5004 marítimus $W$. 5005 palústris $\mathrm{Sm}$. 5006 divaricátus $W$ 5007 acútus $W$. 5008 obtusifólius $W$. 5009 púlcher $\boldsymbol{W}$. 5010 confértus $W$ 5011 nemorósus $\mathrm{Schr}$. 5012 condylódes Bieb. 5013 brasiliénsis $L k$.

common white-flowered

broad-leaved

Crim

changeable

mountain

Helonias.

spiked-flower.

spear-leaved

channel-leaved

smooth

tough-leaved

narrow-leaved

panicled

Nolina.

Georgian simple-spiked broad-leaved

-

Adanson's

Dock.

Patience

bloody-veined

curled

sharp

broad-leaved

Fiddle

close-headed

wood

whole-colored

Brazilian chequer-flower.

large-bracted

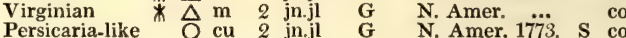

\% $\Delta \mathrm{m}$

$\Delta \mathrm{m}$

$\triangle$ or

$\Delta$ or

$\triangle$ or 1 au

$\triangle$ or $\frac{1}{2}$ au

$\triangle$ or $\frac{1}{4}$ au

Melanthacee.

$\Delta$ or 2 jl.au $\quad Y \quad$ N. Amer. 1759. R s.p Bot. mag. 1062

$\Delta$ or 1 ap.my $\mathbf{P u}$ N. Amer. 1758. R s.p Bot. mag. 747

$\Delta$ or $\frac{1}{3}$ jn W N. Amer. 1770. K s.p Bot. mag. 803

$\triangle$ or 1 my.jn $Y \quad$ N. Amer. 1811. R s.p Bot. mag. 1680

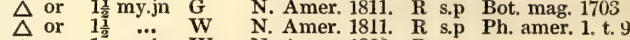

$\triangle$ or $1 \frac{1}{2}$... W

2 my.jn W

N. Amer. 1823. R s.p

Melanthacee. Sp. 1.

$\Delta$ or $2 \frac{1}{2}$ jl.au W Georgia 1812. R s.p Pl.ma.t. 342.f.1 Fluviales. Sp. 3.

过 cu $\frac{1}{2}$ au.o Pk E. Indies 1803. O p.l Bot. rep. 406

$\begin{array}{lllll}\frac{1}{2} & \text { my.jl } & \text { W } & \text { C. G. H. 1788. O p.l Bot. mag. 1293 }\end{array}$

$\begin{array}{llllll}\text { my.jl } & \text { W } & \text { C. G. H. } & 1788 . & \text { O p.I } & \text { Bot. mag. } 1293 \\ \text { ap.s } & \text { C. G. H. 1788. O p.l } & \text { Bot. mag. } 1268\end{array}$ Palma. Sp. 1.

$\triangle 7$ or 6 jn.au $\mathrm{G}$ Florida 1810. S s.l Bot.mag. 1434 Polygonea. $\mathrm{Sp}$. 37-79.

Egyptian O cu 1 jn.jl G E $\mathrm{jl}$.

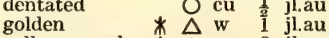

yellow-marsh $* \Delta w$ w 2 jl.au

spreading $\mathrm{O}$ w 2 jl.au

* $\triangle$ dy 2 jn.jl

G Egypt 1732. S co Till.pis. t.37. f. 1

G Britain salt ma. R co Eng. bot. 725

G England mar. $\mathbf{R}$ co Eng. bot. 1932

G Italy 1793. S co Til. pis.t. 37. f 2

G Britain wat.pl. R co Eng. bot. 724

* $\triangle$ w 3 jn.au $G$ Britain rubble. $R$ co Eng. bot. 1999

* $\triangle \mathrm{W} \quad 2$ jn.au $\mathrm{G}$ Britain gra.pa. R co Eng. bot. 1576

$\triangle$ cu 4 jn.jl

* $\Delta$ cu 2 jl

t. $\triangle$ cu $1 \frac{1}{3} \mathrm{my}$

G $\quad$ 17..... R co

G Germany ... $\mathbf{R}$ co

G Caucasus $\cdots$ S co

G Brazil 1822. R co

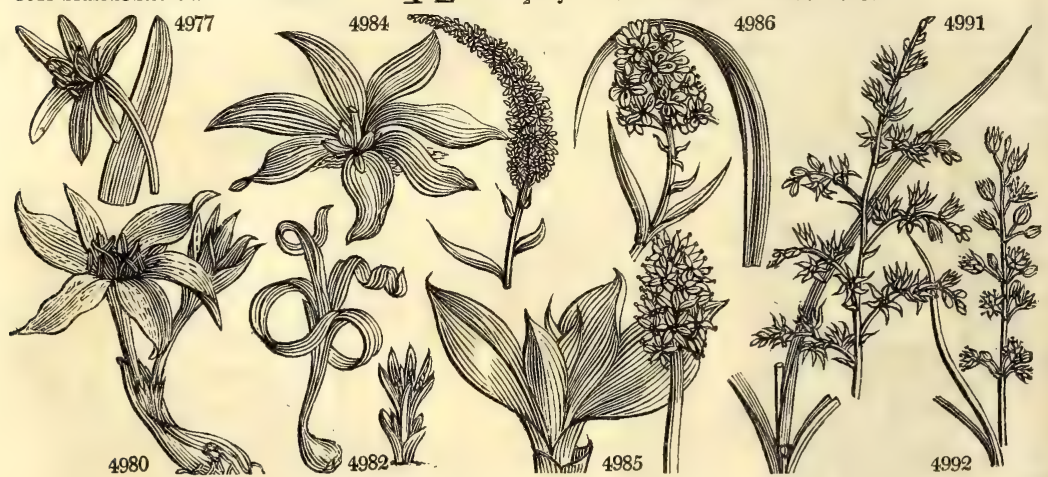

History, Use, Propagation, Culture,

851. Colchicum. From Colchis, saith Dioscorides, where this plant grows in abundance; but it is probable that the term Colchicum was applied to all poisonous plants, among which this certainly held no inconsiderable place. The economy of this plant in regard to its bulbs, flowers, and sceds, is sirgular, and may be classed with other anomalies found in Crocus, \&c. The bulb, which in C. autumnale is about the shape and size of that of a tulip, is formed in the following manner :-

From the permanent, striated, dilated tuber of the old root, sinuated on one side, and clothed with the coat of the preceding root-leaves, a new plant springs, which is tuberous at the base, throws out fibres at bottom like other bulbs, and is received into the bosom of the former tuber, which embraces it half round. This has an outer radical spathe, which is cylindric and tubular, cloven at top on one side, and half under ground. From two to six flowers half emerge from this spathe without leaves. In the mean time the fruits, much later than the flowers, sit on the stem rising out of the spathe. As the plant advances the new tuber increases, the old one, deprived of its nutriment, perishes, and at the same time the former pushes forth from its base the germ of a succeeding plant. There are commonly two lateral germs from the same tuber; one lower, just described, bearing the flower and seed; the other superior, caulescent like the former, but more slender, and scarcely floriferous.

The flowers, which arise with long slender tubes from the root, die off in the end of October, without leaving any external appearance of seeds. These lie buried all the winter within the bulb; in spring they grow up on a fruit-stalk, and are ripe about the time of hay-harvest. May not the very great length of the styles account in some measure for the delay in the ripening of the seeds? As this plant blossoms late in the year, and probably would not have time to ripen its seeds before winter, Providence has contrived its structure such, that it may be performed at a depth within the earth, out of the reach of the usual effects of frost; and as seeds buried at such a depth are known not to vegetate, a no less admirable provision is made to raise them above the surface when they are perfected, and to sow them at a proper scason. 


\section{Leaves flat lanceolate erect}

4978 Leaves linear channelled erect, Styles shorter than flower 4979 Leaves 5 ovate-oblong very broad, Flowers very numerous 4980 Leaves wavy spreading

4981 Two or many-flowered, Sepals linear oblong obtuse, Leaves small oval grassy-green 4082 Leaves 4 glaucous spiral, Flowers small very dwarf, Style one 4983 Leaves appearing with flower linear much spreading

4984 Scape leafy, Leaves oblong lanceolate, Flowers diøecious 4985 Leaves lanceolate ensiform nerved, Bractes linear-lanceolate 4986 Scape leafy, Raceme oblong, Bractes short oblong, Leaves smooth lanceolate linear 4987 Leaves channelled nerved, Segments of flower broad ovate with a transverse nectary at base 4988 Root horizontal, Leaves lanc, erect, Bractes longer than flower, Nectaries distinct 4989 Scape leafy, Raceme showy lax, Bractes membranous, Leaves subulate setaceous very long 4990 Raceme oblong lax, Leaves very long and narrow, Caps. oblong 4991 Leaves grassy, Panicle loose, Segments of flower ovate acute

4992 Leaves very long narrow dry, Flowers racemose

4993 Leaves oval, Spike one cylindrical

4994 Spike bifid, Leaves linear oblong floating, Bractes entire 4995 Spike bifid, Leaves linear lanc. erect, Bractes bipartite

4096 The only species

1. Hermaphrodite. Valves marked with a grain.

4997 Valves cordate entire : one grained, Leaves ovate lanceolate

4998 Valves entire : one grained, Leaves cordate lanceolate

4999 Valves entire all grained, Leaves lanceolate wavy acute

5000 Valves ovate entire veinless all grained, Fruit-stalks pendulous, Leaves lanceolate

5001 Valves toothed all grained, Leaves lanceolate

5002 Valves trifid setaceous : one grained

5003 Valves toothed all grained, Leaves lanceolate

5004 Valves toothed grained, Leaves linear

5005 Valves lanceolate grained toothed at base, Leaves linear lanc. Whorls distant

5006 Valves toothed all grained, Leaves cordate-oblong obtuse pubescent

5007 Valves toothed all grained, Leaves cordate-oblong acuminate

5008 Valves toothed all grained, Leaves cordate oblong obtuse crenate

5009 Valves toothed: one grained, Radical leaves panduriform

5010 Valves rounded cordate repand : one grained, Leaves cordate oblong wavy at edge

5011 Valves oblong obtuse entire : one grained, Leaves lanceolate

5012 Valves entire lanceol. one grained, Leaves cordate lanceolate

5013 Valves entire lanceolate acute grained, Upper leaves linear-lanceolate

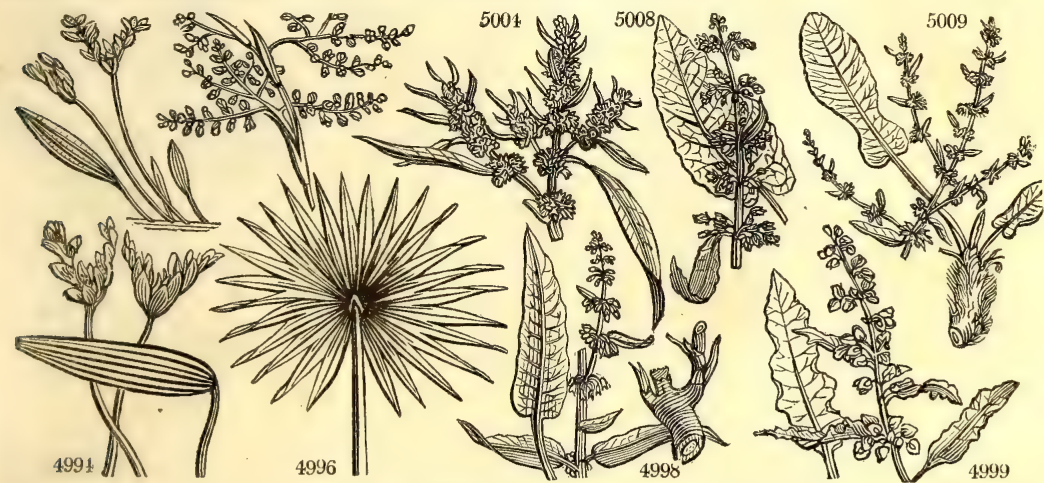

and Miscellaneous Particulars.

There are a few varieties of common Colchicum cultivated by florists; viz. the white, striped-flowered, striped-leaved, broad-leaved, many-flowered, and double-flowered. No cattle are said to eat it; though it is remarkably abundant in the meadows of the Italian Alps, and the leaves must certainly be frequently made into hay.

C. autumnale, as a medicine, has been known since the days of Hippocrates. It possesses diuretic, purgative, and narcotic properties : and on the continent, where it was recommended to notice by Baron Stoerck, it is a favorite remedy in dropsy, particularly hydrothorax, and in humoral asthma. But as it does not differ in its mode of action from squill, and is more uncertain in its operation, it has not been much used in that complaint in this country. In gout and rheumatism, however, its efficacy has been fully ascertained : and in allaying the pain it may be almost said to possess a specific property. It operates on the bowels chiefly, and the nerves, diminishing the action of the arterial system. (Thomson's Mat. Med. 257.)

All the species are ornamental as border-flowers, and may be blown in water-glasses.

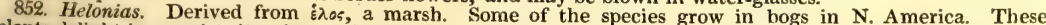
plants delight in a moist situation and peat soil : they increase slowly by dividing at the root or by seeds.

853. Nolina. Named after an American botanist of French extraction, called P. C. Nolin. This plant is best grown in pots, as it requires protection during winter.

854. Aponogeton. A name of the same meaning as Potamogeton (see that genus), of which it is probably an incomplete anagram. These plants are bulbous aquatics, and grow freely in loam and peat plunged in cistern of water. They are very pretty ornaments of the aquarium.

855. Sabal. A name employed by Adanson. It is supposed to have no meaning.

856. Rumex. A name given by the Latins to a root of thorn.

$\mathbf{R}$, patientia (so called from the slowness of its operation as a medicine) and sanguineus, were formerly 
5014 purpúreus $L k$. 5015 stríctus $L k$. 5016 ucránicus Horn.

purple upright Ukraine

* $\Delta \mathrm{w}^{4} \quad \stackrel{\mathrm{j} l}{\mathrm{j} l}$

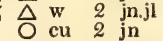

$\underset{\mathbf{G}}{\mathbf{G}}$

* $\triangle \mathrm{w} \quad 5$ jl.au

i- $\begin{array}{rll}\mathrm{cu} & 1 & \mathrm{jn} \\ \mathrm{cu} & 2 & \mathrm{jn} . \mathrm{jl}\end{array}$ O cu 2 jl.au O cu 1 jl.au 5019 Lunaria $W$. 5020 vesicárius $L$ 5021 róseus $W$. 5023 scutátus $W$. 5024 sarcorhizus $L k$. 5025 hastifólius Bieb.

bladder

rose

Tangier

French-sorrel fleshy-rooted spear-leaved

光 $\triangle$ cu $1 \frac{1}{2} \mathrm{jn} . \mathrm{au}$

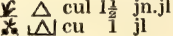

点 $\triangle \mathrm{Cu}$ cu $1 \frac{1}{2}$ au

5026 alpinus $W$.

5027 aculeátus $W$

5028 spinósus $W$.

5029 gigantéus $\boldsymbol{H}$. $K$.

5030 tuberósus $W$

5031 acetósa $W$.

5032 acetosélla $W$.

5033 arifólius $\boldsymbol{W}$.

857. OXY'RIA. Dec.

5034 ácida $R . B r$.

\section{Alpine \\ large-prickly \\ tall}

$\triangle \mathrm{cu} \quad 1 \mathrm{jl}$

O cu 22 jn.jl

4 cu 12 jn.au

tuberous-root.

halberd-leaved $\frac{1}{2} L_{j} \mathrm{cu} \quad 1 \frac{\mathrm{x}}{2}$ ap.d

MOUNTAIN SORREL.

common te $\Delta \mathrm{m} \quad 1 \mathrm{jn} . \mathrm{jl}$

commonel $\Delta$ cul 2 jn.jl
Britain riv.ba. $\mathbf{R}$ co Eng. bot. 2104

Italy 1683. $\mathbf{S}$ co Cav.ic.1.t.41.f.1

Canaries 1698. C s.1 Plu.alm.t.252.f.

Africa 1656. S co Moris.s.5.t.28.f.7

Egypt 1737. S co

Barbary 1680. R co Zanon.hist.9. t.6

France 1596 R

C. G. H 1824, C co

Crimea 1823. R co

France 1597. R 1.p Zorn. ic. 261

Candia 15. R co Bauh prodr.t.55

Candia 1656. S co Fl. græec. 347

Sandw. Is. 1796. $\mathbf{R}$ co

Italy 1752. R co Fl. grac. 348

Britain me.pa. R co Eng. bot. 127

Britain gra.pa. R co Eng. bot. 1674

Africa 1775. C s.1 Jac. vind. 3. t.93

Sp. 1.

Britain alp.pa. R p.1 Eng. bot. 910

\section{POLYGYNIA.}

858. WENDLAN'DIA $W$. WENDLANDIA. 5035 populifólia $\boldsymbol{W}$. Poplar-leaved $\$$

859. DAMASO'NIUM. $W$. Damasonium. 5036 indicum $W$

Indian

辰 or

$6 \underset{\text { jn.jl Wermea. Sp. } 1 .}{\text { Menisperma 1759. C co }}$ Hydrocharidea. Sp. 1-2. 860. ACTINOCAR'PUS. $R$. Br. ACtinocarpUs. Alismacee. $S p .2-4$.
5037 minor $R \cdot B r$.
small
* $\triangle$ or
$\frac{1}{4}$ my.au W N. S. W.

$\frac{1}{8} \mathrm{jn.au}$ W England

861.

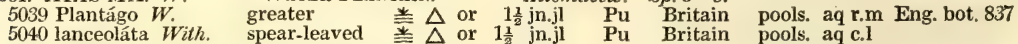

5041 triviális $P h$.

$\begin{array}{ll}5042 \text { nátans } W \text {. } & \text { floating } \\ 5043 \text { ranunculoides } W & \text { lesser }\end{array}$

blunt-leaved

党 $\Delta$ or $1 \frac{1}{2} \mathrm{jn} . \mathrm{jl}$

W N. Amer. 1816. aq c.1

$\Delta$ or $\frac{x}{4}$ jl.au

W Wales al.lak, aq r.m Eng bot 775

Pu Britain tur.bo. aq p Eng. bot. 326

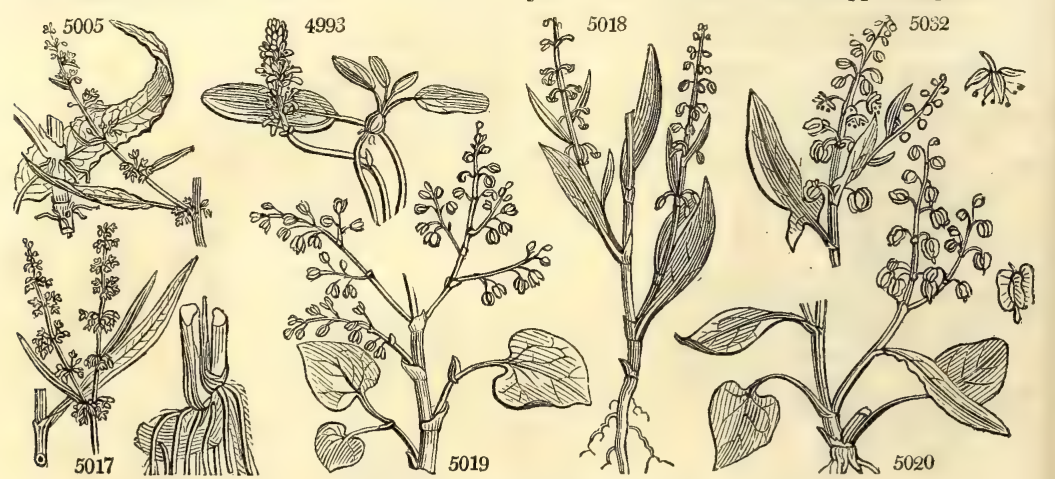

History, Use, Propagation, Culture,

used as spinage plants. The former is still used on the continent, and mashed with a small proportion of $\mathbf{R}$. acetosa or scutata, makes a very good spinage.

$R$. crispus has a fusiform yellow root, which, taken in a recent state, and bruised and made into an ointment or decoction, is said to cure the itch.

$R$. obtusifolius is a domestic weed of the worst description: it is found in every country of Europe, but almost confined to cultivated grounds or rubbish, rick-yards, neglected yardens, and places used as retiring grounds by men or cattle. It is never found on poor or wet-bottomed land. It is refused by cattle; but the leaves were formerly used for wrapping round butter and cream-cheese; and the roots, along with those of $\mathbf{R}$. acutus, by the dyers. In powder, the roots of most docks are said to be one of the best articles for cleaning the teeth. The leaves of all of them are considered laxative rather than otherwise.

$\mathbf{R}$. acetosa has been long cultivated in gardens for its leaves as spinage and salad; but $R$. scutatus is much more delicate. The Laplanders use the leaves of the R. acetosa to turn their milk sour : in Ireland they are eaten with fish and other alkalescent food. The root is powerfully astringent, and considered antiscorbutic : dried and boiled it gives out a beautiful red color. All domestic cattle eat this and most other species of the genus.

R. acetosella, where it abounds naturally, is a certain indication of dry, poor, gravelly, irony soil.

R. alpinus, monk's or bastard rhubarb, was formerly used as true rhubarb, but in larger doses.

The different species of Rumex attract the cultivator's attention as weeds more powerfully than as culinary, medicinal, or dying plants. The sorts vilgarly known as docks produce a large quantity of seeds, and ripen them rapidly and perfectly. Fortunately they are heavy, and are not carried to a great distance from the parent; but almost every one grows, and once a year old they are tedious and expensive to eradicate. The first season they may be destroyed by hoeing; but when the tap-root is established, unless it be wholly eradicated by the weeding, or dock-hook, or spade, the ground cannot be considercd as cleared. Any part of the 
5014 Valves veiny toothed grained, Lower leaves cordate oblong, upper oval, all with colored veins 5015 Valves toothed one grained, Leaves ovate lanceolate repand entire

5016 Like $R$. persicarioides but differing in having auricled leaves and longer teeth to the valves \$2. Hermaphrodite. Valves naked.

5017 Valves entire, Leaves cordate smooth acute

5018 Valves toothed, Flower-stalks flat reflexed thickened

5019 Valves smooth, Stem shrubby, Leaves cordate

5020 Flowers in pairs, All the valves very large membranous reflexed, Leaves undivided

5021 Flowers distinet, Wing of one valve very large membranous veiny, Leaves eroded

5022 Flowers distinct, Valves cordate obtuse entire, Leaves hastate-ovate

5023 Leaves cordate hastate

5024 Stem shrubby, Root tuberous, Leaves roundish running down into the stalk

5025 Valves entire reniform, Leaves hastate, Middle lobe cordate, Stem much branched diffuse 83. Flowers diocious.

5026 Valves entire naked, 'Leaves cordate obtuse rugose

5027 Leaves lanceolate stalked, Fruit reflexed, Valves fringed

5028 Female calyx 1-leaved, Outer valves reflexed hooked

5029 Flowers monœcious, Valves naked, Leaves oblong ovate

5030 Leaves lanceolate sagittate, Lobes spreading

5031 Leaves oblong sagittate

5032 Leaves lanceolate hastate

5033 Leaves stalked hastate serrated acute with simple spreading auricles, Valves naked cntire

5034 Leaves sagittate reniform

\section{POLYGYNIA.}

5035 Leaves alternate stalked cordate ovate with a glandular point

\section{Leaves cordate}

5037 Fruit 8-cleft, Leaves 3-nerved

5038 Leaves cordate oblong, Fruit 6-cleft

5039 Leaves ovate acute, Capsules bluntly 3-cornered

5040 Leaves lanceolate

5041 Leaves oval cordate 9-nerved

5042 Leaves elliptical obtuse, Capsules striated

5043 Leaves linear-lanceolate, Capsules 5-cornered incurved

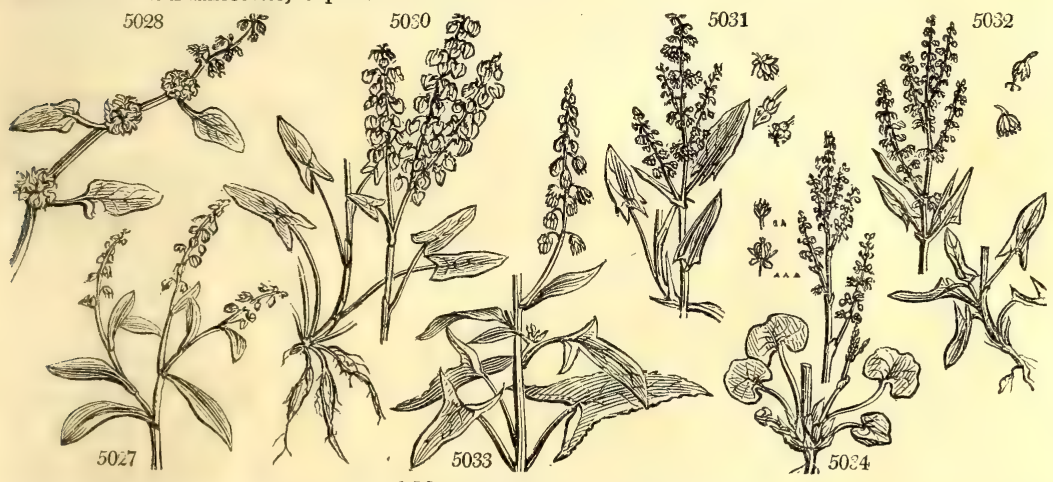

and Miscellaneous Particulars.

root left will generate buds and send them to the surface, and if the plough or spade cut a root into pieces an inch long, each piece will grow, whether near the surface or buried to some depth. The less careful agriculturist often receives dock-seeds with his grass-seeds, brought from the stable-keepers and not properly cleaned : these come up the first year, and establish themselves along with the clover unobserved. The second year they flower, and if the crop is not early cut the seed ripens, and in using the hay is either mixed with the litter of the stable or with the hay-seeds, to be again carried to the field. Such as purchase town-manure cannot avoid receiving dock-seeds; but they may destroy them by fermenting the manure well before using it : others, who desire to get rid and keep clear of this weed, should be most particular in their choice of seeds of every kind, especially of grasis-seeds ; should weed them out as soon as they can be discovered; and, for such as remain till the second year, they may be pulled by hand when in the flower-stalk, and during or after a day's rain. (See Encyc. Agr. art. Peren. Weeds.)

857. Oxyria. From o us $_{5}$, acid, in allusion to the qualities of its leaves. The plant is one of those singular individuals which has the character of two distinct genera, and yet is referable to neither. Wahlenberg made it a Rheum, Linnæus a Rumex, Mr. Brown what it now is. It was formerly used as a salad.

358. Wendlandia. Named in honor of J. C. Wendland, a German botanist. He has published various works upon plants, many of them illustrated with numerous colored figures. This is a climbing plant, referred by Decandolle to Cocculus.

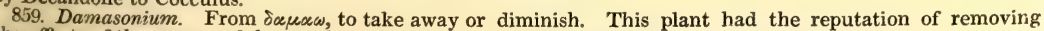
the effects of the venom of the sea-dog. Handsome floating aquatics.

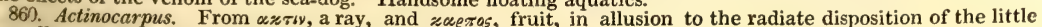
carpella round a common axis. Pretty floating aquatics.

861. Alisma. Derived from alis, water, in Celtic. Alisma Plantago grows in watery places, and is called water-plantain, from the resemblance between its leaf and that of the common plantain. 


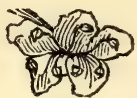

\section{Crass Vil. - heptandria. 7 Stamens.}

A small class, of which the Parinarium, which is a good tropical fruit, and the valuable Horse-chesnut Esculus, are the only remarkable genera. The Astranthus is a curious genus of the natural order of Homalineæ.

\section{Order 1. MONOGYNIA. 7 Stamens. 1 Style.}

862. Trientalis. Cal. 7-leaved. Cor. 7-parted, equal, flat. Berry without juice.

863. Disandra. Cal. about 7-parted. Cor. rotate, 7.parted. Caps. 2-celled, many-seeded.

864. Pisonia. Cal. campanulate, 5-cleft. Cor. O. Berry 1-celled, 1-seeded.

865. Petiveria. Cal. 4-leaved. Cor. O. Style lateral. Stigma pencil-shaped. Seed 1, with four reflexed awns at the end.

866. AEsculus. Cal. 1-leaved, inflated. Cor. 4-5-petaled, unequal, pubescent, inserted in the calyx. Caps. 3-celled. Seeds large, chesnut-like.

867. Jonesia. Cal. 2-leaved. Cor. funnel-shaped, with a closed fleshy tube and 4-cleft limb. Nectary, a ring inserted in the throat of the tube. A Legumen.

\section{MONOGYNIA.}

862. TRIENTA'LIS. $\boldsymbol{W}$. WINTER-GREEN. 5044 europæ'a $W$. 5045 americána $P h$. 863. DISAN'DRA. $W$. 5046 prostráta $\mathrm{IV}$. 864. PISO'NIA. $\boldsymbol{W}$ 5047 aculeáta $W$. 5048 frágrans $L k$. 5049 macrophýlla $\boldsymbol{L} k$. 5050 nigricans $W$. 5051 obováta $L k$. 5052 mexicána $\boldsymbol{W}$ 5053 nítida $W$ 5054 grándis $\dot{R}$. $B r$. 865. PETIVE'RIA. $W$. 5055 alliácea $W$. 5056 octándra $W$ 866. AE'CULUS. $W$. 5057 Hippocástanum $W$. 5058 Pávia $\boldsymbol{W}$ 5059 díscolor $\boldsymbol{P} h$. 5060 fláva $W$. 5061 glábra $\boldsymbol{W}$. en

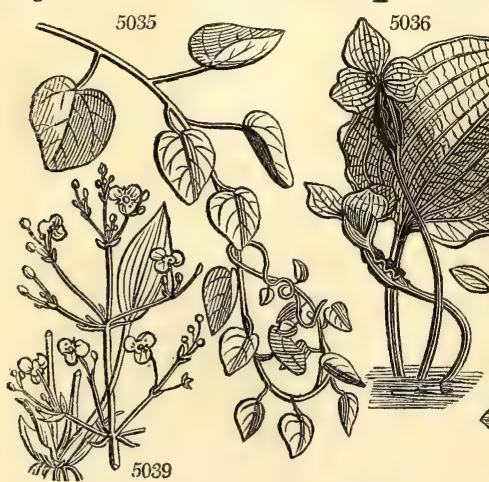
Pisonia. prickly fragrant long-leaved black obovate Mexican shining large

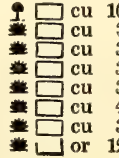

Petiveria. Horse-Chesnut. common

Primulacea. Sp. 2. oval-leaved $\$ \Delta \mathrm{cu} \frac{2}{2}$ my.jn W Britain m. wo. R s.p Eng. bot. 15 spear-leaved $\$ \Delta$ cu $\frac{1}{9}$ jl.au W N. Amer. 1816. R s.p

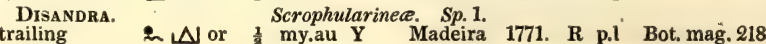

Nyctaginee. Sp. 8. -12 .

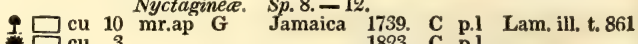
Garlic-scented $\square$ cu 2 jn pu W Jamaica 1759, C p.1 Tr. ehr. 33.t.67 dwarf if $\square$ cu 2 jn.jl W W. Indies 1737. C p.1 Pl. ic. 213.t. 219 tm 40 ap.my W Asia 1629. S co Sch. arb.1. t. 38 dwarf 1 or 20 my.jn Sc N. Amer. 1711. G s.1 $\begin{array}{lllllll}\text { dwarf } & \text { or } 8 \text { my } & \mathbf{R} & \text { Georgia } & 1812 . & \text { G } & \text { s.1 } \\ \text { yellow-flowered } & \text { or } 20 & \text { my.jn } & \mathbf{Y} & \text { N. Amer. 1764. } & \text { G } & \text { s.1 }\end{array}$ $\begin{array}{llllll}\text { yellow-flowered } & \text { or } 20 & \text { my.jn } & \text { Y } & \text { N. Amer. 1764. G s.1 } \\ \text { smooth-leaved } & \text { or } 12 & \text { my.jn } & \text { G.Y } & \text { N. Amer. 1812. G } & \text { co }\end{array}$ 
868. Dracontium. Spathe cymbiform. Spadix covered. Cal. O. Petals 5. A berry,

869. Calla. Spathe ovate. Spadix covered. Cal. O. Cor. O. A berry.

870. Parinarium. Cal. 5-cleft. Petals 5. Stamens 14, of which 7 are barren. Drupe fleshy' cribrose. Nut 2-celled, with 1-seeded cells.

\section{Order 2. DIGYNiA. Q 7 Stamens. 2 Styles.}

871. Limcum. Cal. 5-leaved. Petals 5, equal. Caps. globose, 2-celled.

Order 3. TETRAGYNia. 4 Stamens. 4 Styles.

872. Saururus. Cal. a spike of 1-flowered scales. Cor. O. Ovaries 4. Berries 4, 1-seeded.

873. Astranthus. Cal. O. Cor. hypocrateriform, with a 14-cleft limb. Seed 1, small, superior.

Order 4. HEPTAOYNIA. Oौfo 7 Stamens. 7 Styles.

874. Septas. Cal. 7-parted. Petals 7. Ovaries 7. Caps. 7, many seeded.

\section{MONOGYNIA.}

5044 Leaves lanceolate entire

5045 Leaves narrow lanceolate acuminate oblique

5046 L.eaves reniform crenate, Flower-stalks in pairs

5047 Spines axillary horizontal, Leaves ovate narrowed at each end, Corymbs axillary

5048 Unarmed, Leaves opposite acuminate narrowed into a short stalk very smooth fleshy

$50 \pm 9$ Unarmed, Leaves opposite a little narrowed towards the base entire smooth, Lateral nerves paralle

5050 Unarmed, Leaves ovate acuminate, Flowers cymose erect, Fruit berried

5051 Unarmed, Leaves opposite acute scarcely narrowed at the base entire smooth with parallel nerves

5052 Leaves ovate entire villous, Flowers in umbels

5053 Leaves shining pointed (Lilac de Madagascar.)

5054 Leaves oblong acuminate smooth, Cymes compound, Flowers polygamous, Fruit spiny

5055 Flowers hexandrous

5056 Flowers octandrous

5057 Leaves digitate 7, Petals 5 spreading

5058 Leaves quinate smooth unequally toothed, Petals 4 with connivent claws the length of the calyx 5059 Leaves quinate pointed at each end downy beneath unequally toothed, Petals 4

5060 Leaves quinate beneath at the rib pubescent, Petals 4 with connivent claws longer than the calyx

5061 Leaves quinate quite smooth, Petals 4 spreading with claws the length of the calyx, Fruit spiny

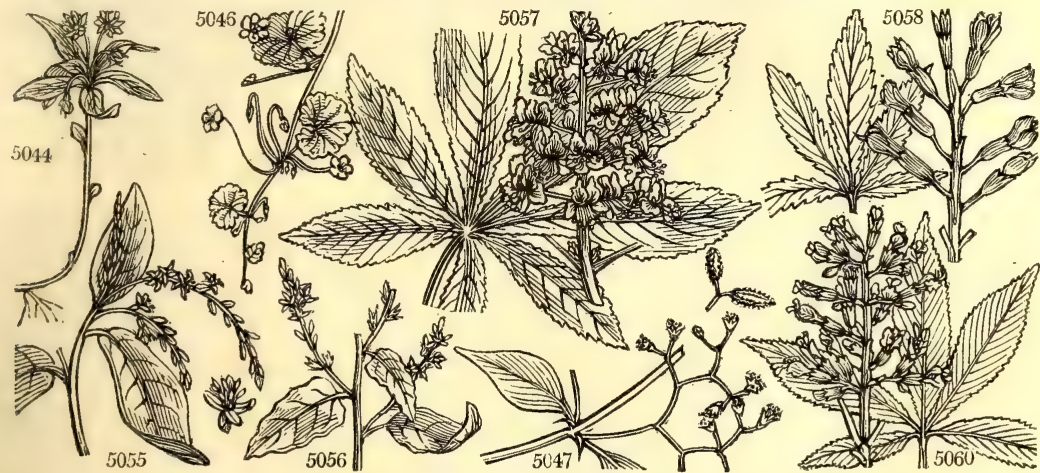

and Miscellaneous Particulars.

several other islands in the West Indies, where it is very troublesome to whoever passes, fastening itself by its strong crooked thorns to the clothes; and the seeds being glutinous and burry, also fasten themselves to whatever touches them: so that the wings of the ground-doves and other birds, are often so loaded with the seeds, as to prevent their flying, by which means they become an easy prey.

865. Petiveria. So named by Plumier, in honor of James Petiver, apothecary of London, and fellow of the Royal Society, author of Museum, 1695; Gazophylacium, 1702, collected into one volume folio, with many plates. P. alliacea, is common in savannahs and woods in the West Indies, where it is a troublesome weed, and tastes the milk of cows that feed on it. It is so acrid, that on chewing a little, it burns the mouth and leaves the tongue black, dry, and rough, as it appears in a malignant fever. It is thought, however, to be coveted by Guinea-hens, and hence its vulgar name of Guinea-hen weed.

866. AEsculus, or Esculus, as Pliny writes it. A name which the Latins gave to a tree which furnished them with an esculent nut: that plant was the Quercus Esculus of Linnæus. Marronier, Fr., Marronicn- 
5062 cárnea Hort. 5063 pállida $W$. en 5064 parviflóra $\boldsymbol{H} . \boldsymbol{K}$. 867. JONE'SIA. $W$. 5065 pinnáta $W$.

868 DRACON'TIUM. $W$ 5066 polyphýllum $W$ 5067 spinósum $W$. 5068 pertúsum $\boldsymbol{W}$. 869. CAL'LA. $W$. 5069 æthiópica $\dot{W}$. 5070 palústris $W$.

5071 aromática $\dot{R} o x b$. 870. PARIN A'RIUM 5072 excélsum Sab.

5073 malsum Sab. Guinea Plum.

JoNesia. winged-leaved prickly perforated

\section{Calla.}

Ethiopian marsh aromatic flesh-colored $\quad$ or 7 jn Pu N. Amer. 1823. G co Dend. brit. 121

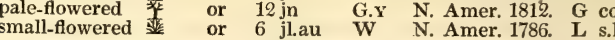

W. Dragon. purple-stalked
$20 \begin{aligned} & \text { Leguminosa. Sp. } 1 . \\ & \text {... }\end{aligned}$ Aroidece. Sp. 3-9.

1. $\mathrm{cu} 2$ mr.jn Ap India 1759. R it.l Bot. reg. 700

E $\triangle 1$ cu 2 ap.my Ap Ceylon 1759. R lt.1

月 $\mathrm{cu} 6$ ap.jn Ap W. Indies 1752. R p.1 J.sch.2, t. 184. 5 Aroidece. Sp. 3-5.

$\checkmark$ Nor 3 ja.my Ap C. G. H. 1731. Sk r.m Bot. mag. 832 $\triangle \mathrm{cu} \quad \frac{1}{2} \mathrm{jl} . \mathrm{au} \quad \mathrm{Ap} \quad \mathrm{N}$. Europe1768. D p Bot. mag. 1831 $\triangle \mathrm{N}$ or $2 \mathrm{jl}$ Ap China 1813. D r.m Bot. mag. 2279 Chrysobalanea. Sp. 2-5.

$9 \square$ fr $60 \quad \ldots \quad$ W S. Leone 1822. C I

\section{DIGYNIA.}

871. LI'MEUM. $W$ 5074 africánum $W$.
Limeum. African

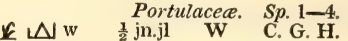 \\ 1774. R s.p}

\section{TETRAGYNIA.}

872. SAURU'RUS. $W$. LIZARD'S-TAIL. 5075 cérnuus $W$.

5076 lúcidu

5077 chinénsis Hort. drooping

shining

Chinese
Aroidece. $S p .3$.

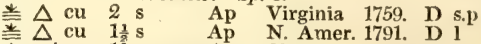

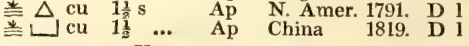

Homalinea. Sp. 1-2.
Jacq. ecl. t. 18

US. L. Astranthus.

\section{HEPTAGYNIA.}

874. SEP'TAS. $W$. 5079 capénsis $W$. 5080 globiflóra $\dot{B}$. $M$

5081 umbélla $H$. S.

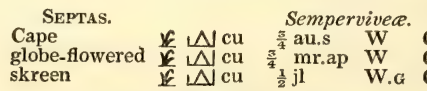

Sp. 3.

C. G. H. 1774. R s.p Bot. rep. 90

globe-flowered 14 cu $\frac{\pi^{4}}{4} \mathrm{mr}$.ap W $\quad$ C. G. H. 1809. R s.p Bot. mag. 1472

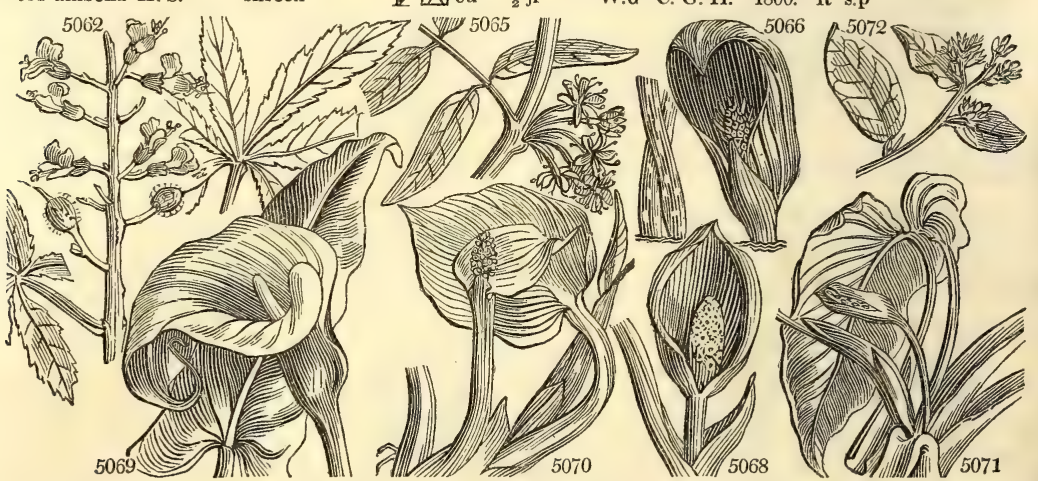

History, Use, Propagation, Culture,

baum, Ger., and Marrone, Ital. Æ. hippocastanum (izros, horse, horse-chesnut; because it was formerly a veterinary medicine) is a magnificent tree, at once grand from its magnitude and massy form, and beautiful when in blossom, from being covered with spikes of delicate white and pink flowers, protruding from among elegant digitate leaves. It is a rapid growing tree, and speedily produces a considerable bulk of timber, which, however, is of little value as such. The plant is best adapted for an ornamental tree in the outskirts of plantations, in avenues, or singly on lawns. It is much prized by the French as an ornamental avenue tree, and when the geometric style of gardening was in vogue in this country was a good deal planted, as at Bushy park, Canons, Castle Howard, \&c. During the rage for the picturesque, it fell into disrepute from its "compact lumpish parabolic form;" but the public are now convinced that there are other beauties besides those peculiarly adapted for representation by painters, and the taste for trees beautiful or interesting from their flowers, foliage, or other details, is now reviving. The nuts or capsules are large and mahogany colored, and have often occasioned regret that they are not edible, like those of the Spanish chesnut. Deer eat them greedily, and may be seen watching about the trees for their fall during windy weather. In Turkey they are ground and mixed with horse provender. According to some, swine and sheep may be fattened on them, and poultry when they are boiled. They are of a saponaceous nature, and broken and steeped in hot water might save soap, where that article is excessively dear. This tree migrated from the northern parts of Asia into England by Constantinople, Vienna, Italy, and France. Parkinson in 1629 places it in his orchard as a fruit tree, and describes the nuts as superior to the ordinary sort.

E. Pavia was so named by Boerhaave, in honor of Peter Paw, a Dutchman, and professor of botany at Leyden, in 1601.

The other species have beautiful flowers, but are not free growing trees. 
5062 Leaves 6-7-nate obov. acuminate 2-serrate, Petals 4 connivent with claws shorter than cal. Anth. smooth 5063 Leaves quinate, Petals spreading with claws shorter than calyx, Stam. twice as long as cor. Fruit spiny 5064 Leaves quinate, Petals 4, Stamens twice as long as corolla

5065 The only species

5066 Leaves supradecompound, pedate, Segments pinnatifid, Scape much shorter than leaf-stalks 5067 Leaves sagittate, Peduncles and petioles prickly

5068 Stem climbing, Leaves cordate ovate bored through

5069 Leaves sagittate cordate, Spathe cucullate, Spadix male upwards

5070 Leaves cordate, Spathe flat, Spadix hermaphrodite all over

5071 Leaves cordate acuminate, Spathe boat-shaped hiding the spadix

5072 Leaves ovate-oblong green above white beneath

5073 Leaves long oblong-lanceolate very white all over

$D I G Y N I A$.

5074 Leaves oblong stalked

TETRAGYNIA.

5075 Leaves cordate stalked

5076 Leaves deeply cordate ovate-lanceolate shining

5077 Leaves cordate ovate acuminate shining nerved

5078 Leaves ovate lanceolate serrated

\section{HEPTAGYNIA.}

5079 Leaves connate crenate roundish, Stem nearly leafless

5080 Floral-leaves 4 spatulate doubly crenate, Umbel compound

5081 Stem-ieaves about two hooded and connate into a skreen, Flowers many minute

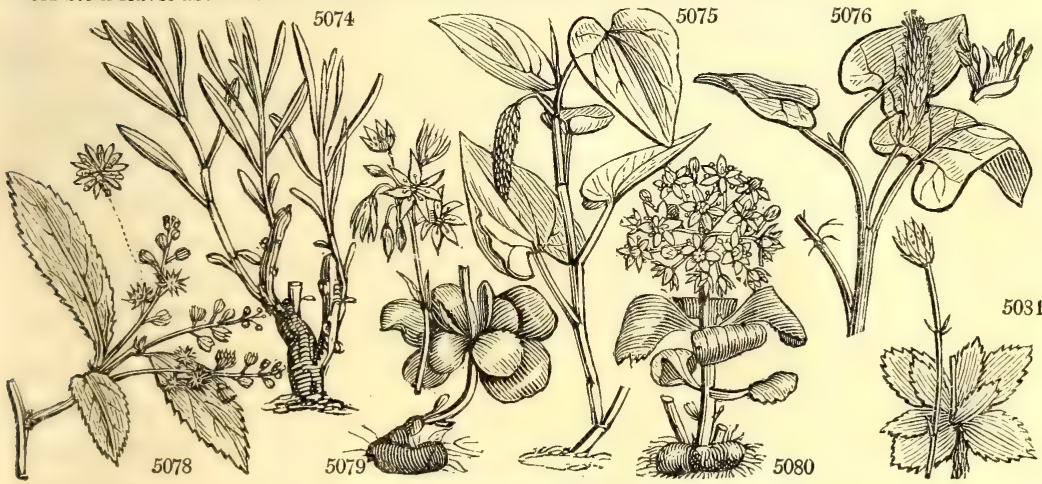

and Miscellaneous Particulars.

867. Jonesia. Named in honor of the famous Sir W. Jones, who to his other accomplishments added the knowledge of botany. The most fragrant tree of India. Large cuttings root well in sand under a handglass.

868. Dracontium. From secswy, a dragon. The stems of some species are mottled like the skin of a snake.

869. Calla. A name of one of Pliny's plants, which probably was applied to something of the same natural order as that now called Calla.

870. Parinarium. The Guiana name of the genus is Parinari. Very fine trees with fine bunches of terminal flowers, which are succeeded by plum-like fruits, that in hot climates are esteemed and served up at table. It has been called Petrocarya by Schreber and other Linnæan botanists, who fancy science to depend upon names.

871. Limenm. An ancient name of a poisonous plant. It is derived from $\lambda$ ouscs, pest, poison. It was used, says Pliny, to poison arrows with. The plant to which modern botany has applied this name is a dangerous poison.

872. Saururus. From $\sigma \propto v \rho \alpha$, a lizard, and $8 \rho \alpha$, a tail ; on account of its long and pyramidal tail, which inay be compared to the tail of a lizard. Aquatic plants with neat foliage, but with no beauty in their flowers.

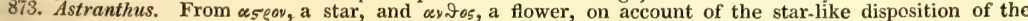
segments of the flower. A small Chinese bush with serrated leaves, and spikes of pale whitish green flowers.

874. Septas. From septem, seven. All the parts of the flower are in seven. Very neat little Cape plants, with umbels of white flowers. 


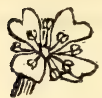

\section{Class Vili. - OCtandRIA. 8 Stamens.}

THIs is a class, which, with reference to the plants which compose it, is of much consequence to the botanist and gardener. To the former it is recommended by the singular Melastomaceous plants which it contains, the curious Michauxia, and the Jeffersonia, remarkable for its capsule, which opens like a snuff-box. To the gardener it possesses irresistible attraction, not only in the delightful Tetrathecas, Boronias, and Correas of New Holland, in the Dimocarpus of China, celebrated for its truly excellent fruit, and in the Fuchsias, Enotheras, Combretums, and Vacciniums, some of which form the pride of our hardy gardens; but also in the magnificent tribe of Heaths, which are certainly the most beautiful of plants, under cultivation. This is abundantly attested by the splendid collections of Lee of Hammersmith, Rollison of Tooting, and last, but not least, of Loddiges of Hackney, where the precision of science is combined with the allurements of form and coloring.

\section{Order 1. MONOGYNIA. 1 Style.}

\section{Ovary superior}

875. Tropaolum. Cal. 1-leaved, 5-cleft, spurred. Petals 5, unequal. Nuts coriaceous, furrowed. Seed 1, roundish.

876. Roxburghia. Cal. 4-leaved. Petals 4. Nectary 4 lanceolate leaves inserted in the middle of the petals. Anthers 2, hanging down from the base of each nectarial leaf. Caps. 1-celled, 2-valved, many seeded. Seeds on a spongy placenta.

877. Grislea. Cal. 4-cleft. Pet. 4, from the recesses of the calyx. Filaments very long, ascending. Capsule globose, 1-celled, many-seeded.

878. Boronia. Cal. 4-cleft, persistent. Petals 4, ovate. Nect. coronate. Filam. ciliated, incurved. Stigma capitate. Caps. 4, 2-valved. Seeds solitary, with an arillus.

879. Tetratheca. Cal. 4-cleft. Petals 4. Anthers 4-celled. Caps. 2-celled, 5-valved: with valves bearing the septa in their middle. Seeds about 2.

880. Correa. Cal. campanulate. Petals 4. Caps, 4-celled, opening with 4 valves. Cells 1-2-seeded.

881. Mimusops. Cal. 4-leaved. Petals 4. Nectary 16-leaved. Drupe pointed.

882. Ornitrophe. Cal, 4-parted. Petals 4, bearded in the middle. Ovary double. Berries 2, 1-seeded.

883. Dimocarpus. Sepals 5 . Petals 5 , reflexed, villous inside. Berries 2, one of which is often abortive, barked, tubercled, 1-celled, 1 -seeded.

884. Melicocca. Cal. 3-parted. Petals 4, reflexed below the calyx. Stigma peltate. Drupe with a bark.

885. Blighıa. Cal. 5-parted. Petals 5. Style very short. Stigmas 3. Seed solitary with a very large arillus.

886. Metaiba. Cal. 5-parted. Petals 5, with two scales at their base. Caps. oblong, 1-celled, 2-seeded.

887. Kolreuteria. Sepals 5. Petals 4, irregular. Nect. 4 bifid scales. Caps. inflated, 3-celled, with 2 -seeded cells.

888. Guarea. Cal. 4-toothed. Petals 4. Nectary cylindrical, bearing the anthers on the orifice. Caps. 4-celled, 4-valved. Seeds solitary.

889. Amyris. Cal. 4-toothed. Petals 4, oblong, spreading. Stigma capitate. Berry drupaceous, by abortion 1-seeded.

890. Ximenia. Cal, 4-cleft. Petals 4, hairy, revolute. Drupe 1-seeded.

891. Backia. Cal. 5-cleft. Petals 5. Caps. 3-4-celled, many-seeded, covered with the calyx. Seeds few.

892. Erica. Sepals 4, persistent. Cor. 4-cleft, persistent. Filaments inserted in the receptacle. Anthers

bifid. Caps. membranous, 4-8-celled.

893. Menziesia. Cal. 1-leaved. Cor. 1-petalous, ovate. Filam. inserted in the receptacle. Caps. 4-celled, with the septa from the inflexed edges of the valves. Seeds many, numerous.

894. Chlora. Sepals 8 or 10 . Cor. 1-petalous, 8-cleft. Caps. 1-celled, 2-valved, many-seeded.

895. Michauxia. Cal. many-cleft. Cor. rotate, 8-10-parted, revolute. Nect. 8-valved, staminiferous. Caps. 8-10-celled, many-seeded.

896. Jeffersonia. Sepals 5, colored, deciduous. Petals 8, incurved spreading. Stamens surrounding the ovary. Caps. obovate, stipitate, 1-celled, opening below the end

897. Dodonca. Sepals 4. Cor. O. Filaments very short. Anth. oblong. Caps. 3-celled, 3-winged. Seeds 2.

898. Lawsonia. Cal, 4-cleft. Petals 4. Stamens in 4 pairs. Caps. 4-celled, many-seeded. Seeds angular.

\section{\$2. Ovary inferior.}

A. Seeds many.

899. Osbeckia. Cal. 4-cleft : its lobes separated by a fringed scale. Cor. of 4 or 5-petals. Anthers rostrate. Caps. 4-5-celled, surrounded by the truncated tube of the calyx. Recept. compressed, half ovate.

900. Rhexia. Cal, urceolate, 4-5-cleft. Petals 4, inserted in the calyx, oblique. Anthers declinate. Caps. setose, 4-celled, inside the calyx. Recept. lunate. Seeds numerous cochleate.

901. Enothera. Cal. tubular, 4-cleft, with deciduous deflexed segments. Petals 4, inserted in calyx.

Stigma 4-cleft. Caps. 4-celled, 4-valved, inferior. Seeds naked, affixed to a 4-cornered central receptacle.

902. Gaura. Cal. 4-cleft, tubular. Petals 4, ascending towards the upper side. Nect. inferior, 1-seeded.

903. Evilobium. Cal, 4-cleft, tubular. Petals 4. Caps. oblong, inferior. Seeds comose.

904. Fuchsia Cal. funnel-shaped, colored, deciduous. Petals, 4, in the throat of calyx, alternate with its segments. Nectary an 8-furrowed gland. Stigma capitate. Berry oblong, obtuse, 4-cornered, 4-celled. 905. Jambolifera. Cal. 4-toothed. Petals 4, funnel-shaped. Filaments flattish. Stigma simple. Fruit a 4-celled drupa.

906. Oxycoccus. Cal. 4-cleft. Cor. 4-parted, with linear revolute segments. Filaments conniving. Anthers tubular, 2-parted. Berry many-seeded.

907. Vaccinium. Cor. urceolate or campanulate, 4-5-cleft, with reflexed segments. Filaments inserted on the ovary. Berry 4-5-celled, many-seeded.

\section{B. Seed one.}

908. Memecylon. Cal. with a striated bottom, and an entire edge. Cor. 1-petalous. Anthers inserted on the side of the end of the filament. Berry crowned with the cylindrical calyx.

909. Lagetta. Cor, caducous, tubular, 4-toothed, with 4 petal-like glands. Drupe hairy, pisiform, 1-seeded. 910. Daphne. Cor. 4-cleft, like a corolla, withering, including the stamens. Drupe 1-seeded.

911. Dirca. Cor, tubular, with an obsolete limb. Stamens longer than tube. Berry 1-seeded. 
912. Gnidia. Cor. funnel-shaped, 4-cleft; with 4-8-petaloid scales at the orifice. Nut somewhat drupaceous.

913. Stellera. Cor. 4-cleft, inflated in middle. Stam. inserted in throat, very short. Nut 1, beaked.

914. Passerina. Cor. 4-cleft, naked. Style filiform, lateral, long. Stamens inserted on the tube. Nut 1, coated.

915. Lachnaea. Flowers in heads. Cor. 4-cleft, with an unequal limb Filaments long, with an unequal insertion. Nut somewhat drupaceous.

916. Combretum. Cal. 4-toothed, campanulate, superior. Petals 4, inserted in the calyx. Stamens very long. Caps. 4-angular, with membranous angles, 1-celled. Seed 1, oblong.

\section{Order 2. DIGYNIA. 2 Styles.}

917. Galenia. Cal. 4-cleft. Cor. O. Capsule roundish, 2-seeded.

918. Aphananthe. Sepals 5. Two stamens opposite 2 sepals, 6 opposite and alternate with three other sepals.

919. Weinmannia. Sepals 4. Petals 4. Caps. 2-celled, 2-beaked.

920. Möhringia. Sepals 4. Petals 4. Caps. 1-celled, 4-valved.

\section{Order 3. TRIGYNIA. 8 Stamens. 3 Styles.}

921. Polygonum. Cal. O. Cor. 5-parted, like a calyx. Seed 1, angular, covered. (Stamens and styles uncertain in number.)

922. Coccoloba. 'Cal. 5-parted, colored, finally becoming berried. Cor. O. Berry formed of the calyx, 1-seeded.

925. Paullinia. Sepals 5. Petals 4. Nect. 4-leaved, unequal. Caps. turbinate, 3-cornered, 3-celled, with 1.seeded cells. Seeds with an arillus.

924. Seriana. Sepals 5. Petals 4. Nect. 4-leaved. Samaræ 3, longitudinally united, globose, connected downwards in a membranous wing.

925. Cardiospermum. Sepals 4. Petals 4. Nect. 4-leaved, unequal. Caps. 3, connate, inflated.

926. sapindus. Sepals 4. Petals 4. Caps. fleshy, connate, ventricose.

\section{Order 4. TETRAGYNIA.}

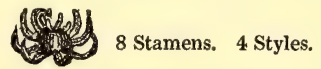

927. Verea. Sepals 4. Cor. hypocrateriform, 4-cleft, with acute segments, and a ventricose tube. Scales 4, at the base of the ovaries, linear. Capsules 4, 1-celled, many-seeded.

928. Bryophyllum. Sepals 4. Petals 4, connate into a cylinder. Seeds many.

929. Paris. Sepals 4. Petals 4, narrower. Anth. attached to the middle of filament. Berry 4-celled.

930. Adoxa. Cal, 2-3-cleft, inferior. Cor. 4-5-cleft, superior. Berry 1-celled, 4-5-seeded, united with the calyx.

931. Elatine. Sepals 4. Petals 4. Caps. 4-celled, 4-valved, depressed, many seeded; the dissepiments opposite the sutures.

932. Haloragis. Sepals 4, superior. Petals 4, caducous. Drupe dry. Nut 4-celled.

933. Forskóhlea. Cal. 4-leaved. Petals 8 spatulate. Seeds 4 enveloped in wool. 
MONOGYNIA.

875. TROP 死'OLUM. $W$. INDIAN CRESS 5082 minus $W$. 3 flore pleno

5083 május $W$.

$\beta$ flore pleno

5084 adúncum $\mathrm{Sm}$. T. peregrinum B.M.

5085 pinnátum $B . R$.

5086 hýbridum $W$

876. ROXBURG'HIA. $W$. ROXBURGHIA

877. GRIS'LEA. $W$ 5088 tomentósa $W$.

878. BORO'NIA. Sm. 5089 ledifólia Gay. 5090 pinnáta $\mathrm{Sm}$. 5091 serruláta $\mathrm{Sm}$.

small

double-flowered great $\$ 0$ cul 6 jn.o jn.o

pinnate-flower. ㄴ $\Delta$ or 2 jn.o $P$

2 0 or 4 jn.au

Tropaeolea. Sp. 5-13. 879. TETRA THE'CA. $W$. Tetratheca.
5092 júncea $\boldsymbol{W}$.

880. CORRÉA. $W$. 5093 álba B. Rep

5094 speciósa B. Rep.

5095 virens $H$

881. MI'MUSOPS. $W$.

5096 Eléngi $W$.

5097 Kaúki $W$

5098 hexan'dra Roxb.

Grislea.

Boronis.

Ledum-leaved

Hawth.-scent.
Rose-scented

Corrata.

white-flowered 閧

red-flowered

green-flowered

Minusops.

pointed-leaved

obtuse-leaved

hexandrous

882. ORNI'TROPHE. $W$. Ornitrophe. 5099 serráta $W$.

5100 cominia $\dot{W}$. saw-leaved
yellow-berried $\$$ or 12

883. DIMOCAR'PUS. $\boldsymbol{W}$. Dimocarpus

5101 Litchí $W$.

Lee-Chee

Longan ? $\mathrm{fr} 15 \mathrm{Sapindacece}$ Sp. 2-6.

6 ap Aroidea. Sp. 1. Pk.G E. Indies 1803. Sk p.1 Bot. mag. 1500 Salicaria. Sp. $1-3$

3 my.jn R E. Indies 1804. C s.p Bot. reg. 30 Rutacea. $S p .3-13$

$11 \mathrm{mr}$ i N. S. W. 1814. I s.p Vent malm. 59 f.my Pu N. S. W. 1794. L s.p Bot. rep. 58

Tremandrece. Sp. 1-5.

1803. C s.p Sm.nov. h. 1,t.2 Rutacea. $S p .3-4$.

3 ap.jl W N. S. W. 1793. C s.p Bot. rep. 18

3 ap.jl R N. S. W. 1806. L s.p Bot. reg. 26

2 my.n G N. S. W. 1800. C s.p Bot.reg. 3 Sapotea, $S p .3-6$

$\square$ or $15 \quad \ldots$ W E. Indies 1796. C p.l Rox.cor. 1. t. 14 ... W $\quad$ W. Indies 1796. C p.l Rum. am. 3. t.8 Sapindacea. Sp. 2-9.

$\cdots$ W Jamaica 1759. C p.1 Sl ja. 2.t. $208 . \mathrm{f}$

884. MELICOC'CA. W. HoNEY-BERRY 5103 bijuga $W$. winged-leaved 885. BLIG'HIA. $\boldsymbol{H}, \boldsymbol{K}$. Akee-Tree.

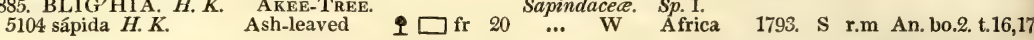

fr 16 Sapindacea. Sp. 1.

1786. I r.m Buchoz. ic. t. 99

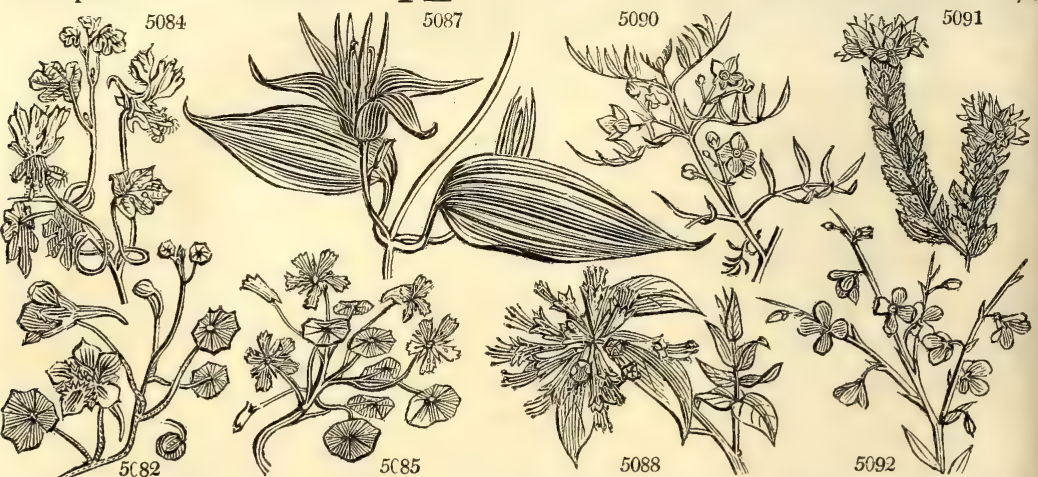

History, Use, Propagation, Culture,

875. Tropaolum. From tropaum, a trophy. The leaf resembles a buckler, and the flower an empty helmet, of which trophies were formed. T. majus is an ornamental annual, and also a culinary plant The flowers are eaten in salads, and are very grateful : they are also used as a garnish. The seeds, which consist of three conjoined berries or nuts, with grooved wrinkled gibbous husks that become fungous when dry, are pickled in salt and vinegar, and used as a substitute for capers, to which some prefer them. In the evening the flowers emit spontaneously at certain intervals visible sparks like those of an electric machine. This was first observed by the daughter of Linnæus.

876. Roxburghia. In honor of William Roxburgh, M. D. born in Scotland, and settled in the East Indies author of a splendid work on the plants of the coast of Coromandel. A singular plant, the natural affinities of which are yet obscure; it grows in loam and peat, and may be increased, though but slowly, by dividing at the root.

877. Grislea. So named after G. Grisley, a Portuguese surgeon, author of Viridarium Lusitanicum, 1661. A free flowering shrub of considerable beauty; it grows in loam and peat, and cuttings root in sand under a hand-glass in heat.

878. Boronia. So named after Francis Borone, an Italian servant of Dr.Sibthorp, who perished from an accident at Athens. Pretty little New Holiand plants, generally with red flowers. These are valuable plants, as flowering nearly all the year. "They thrive best in sandy peat, with the pots well drained with broken potsherds. They may be propagated by layers or ripened cuttings, taken off at a joint and planted in sandy peat, and placed under a bell-glass, will strike root, if properly managed : the glass must be taken off occasionally to dry them, as they are very liable to damp off,"

879. Tetratheca. From $\tau \varepsilon \tau \rho \alpha$, four, and 9 nжn, a cell, in allusion to the four cells of the anthers, for which the plants are remarkable. Cuttings root in sand under a bell-glass.

880. Corrae. So named after Josepn Correa de Serra, a learned Portuguese, who, without publishing much, was one of the most profound theoretical botanists of this age. He died at Lisbon in 1823. "Ripened cuttings 


\section{MONOGYNIA.}

5082 Leaves peltate repand mucronate, Petals acute

5083 Leaves peltate repand, Petals obtuse

5084 Leaves peltate 5-lobed palmate toothed, Petals jagged

5085 Leaves peltate, Lobes obtuse unequal, Flowers pinnate

5086 Leaves peltate 5-lobed, Lobes obtuse repand, Petals cuneate toothed at end

5087 Leaves cordate many-nerved

5088 Leaves minute tomentose beneath, Corymbs axillary spreading

5089 Leaves linear lanceolate entire tomentose beneath

5090 Leaves pinnated with an odd one in 2-4-pairs very smooth, Leaflets linear acute, Pedunc. dichotomous

5091 Leaves simple trapeziform acute serrulate at end smooth

5092 Leaves alternate few lanceolate and branches smooth

5093 Leaves ovate downy beneath, Teeth of calyx small acute distant

5094 Leaves ovate obtuse beneath rusty with down, Flowers erect, Calyx truncate

5095 Leaves ovate-oblong cordate, Flowers pendulous, Calyx with 4 acute teeth

5096 Leaves alternate ovate acuminate

5097 Leaves alternate clustered at the ends of the branches oblong very obtuse

5098 Leaves alternate obovate emarginate, Flowers hexandrous

5099 Leaves ternate rough, Leaflets stalked ovate acuminate serrate, Racemes simple

51.00 Leaves ternate, Leaflets stalked oblong narrowed at each end pubescent beneath, Racemes compound

5101 Leaves pinnated, Leaflets flat acute, Fruit scaly, Flowers apetalous

5102 Leaves pinnated, Leaflets rugose blunt, Fruit hispid, Flowers pentapetalous

5103 The only species

5104 The only species

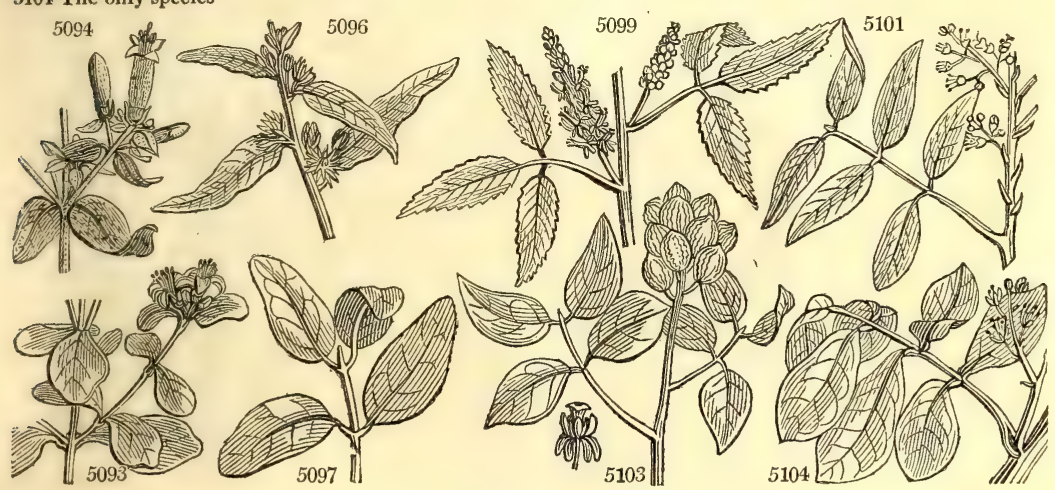

and Miscellaneous Particulars.

will root freely in sand under a bell or hand-glass. The cuttings must not be planted too thick, or they will be liable to damp. C. speciosa has generally been reckoned difficult to strike from cuttings, but it roots as freely as the others if properly managed, and requires the same treatment."

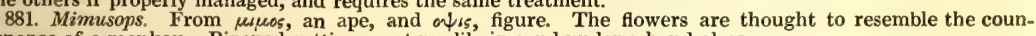
tenance of a monkey. Ripened cuttings root readily in sand under a hand-glass.

882. Ornitrophe. From aeyis, a bird, and reoøn, nourishment. Its fruit is much eaten by small birds. In the Isle de France it is called bois de merle, or thrush-wood. Cuttings root in sand under a hand-glass.

883. Dimocarpus. From $\delta$ i $\delta \mu \circ$, double, and $\varkappa 0 \rho \pi 05$, fruit; its fruit grows in pairs. These are fruit-bearing trees, cultivated in China. The fruit is a berry in bunches of a red color, and rather larger than the grape. The bunches are small; the skin of the berry is tough and leathery; the pulp is colorless, semitransparent, and of a slightly sweet subacid taste. The fruit of $\mathrm{D}$. Litchi is frequently brought to England dried like raisinz; that of $\mathrm{D}$. Longan has been ripened by John Knight, Esq. of Lee Castle, in a lofty stove, erected for the purpose of growing tropical fruits. A bunch was presented to the Horticultural Society, in September 1816, "supposed to be the only one ever produced in Europe, and which persons well acquainted with the long-yen in its native places of growth; pronounced to be quite as good as those grown within or near the tropics." (Hort. Trans. ii. 408.)

884. Melicocca. From $\mu \varepsilon \lambda_{l}$, honey, and $x_{0 \%} x_{05}$, fruit; its fruit, which resembles the yolk of an egg, has a very sweet flavour mixed with a little acid. This tree is cultivated in some parts of South America and in Jamaica for its fruit, which grows to the size of a large plum, and is very mellow. The natives suck it for the sake of the salivation which it produces. In our stoves it thrives well in light loamy soil, and cuttings root in sand under a hand-glass in heat.

885. Blighia. Named in honor of the famous Captain Bligh, who first carried the bread-fruit to the West Indies. This is an esteemed African fruit tree with a reddish or yellow pome, about the size of a goose's egg, 


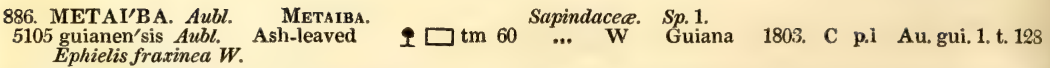

5106 paniculáta $W$. panicled 10 jl.au W W Chin

888. GUA'REA. $W$.

5107 trichilioídes $W$

889. AMY'RIS. $W$.

5108 polygama $W$

5109 sylvática $W$.

890. XIME'NIA. $W$.

5110 americána $W$.

891. BEC'KIA. Sm

5111 frutéscens $S m$.

5112 virgáta $\mathrm{Sm}$.

5113 densifólia $\mathrm{Sm}$.

892. ERI'CA. $W$

5114 Plukenétii $L$

5115 Petivérii $W$.

5116 Bánksia $W$.

5117 penicilliflora $\mathrm{Sal}$. calyculata Wendl.

5118 folliculáris Salisb. melástoma Andr.

5119 verticilláta $A n d r$.

5120 Sebána Donn.

5121 Ewerána $\boldsymbol{H} . \boldsymbol{K}$

5122 socciflóra Salisb.

5123 densifólia $W$.

5124 grandifóra $\dot{L}$.

5125 cephalótes Thunb.

5126 cruénta $H . K$

5127 perspícua $W$.

5128 speciósa $A n d r$.

5129 ignéscens $A n d r$.

5130 discolor $A n d r$.

5131 versícolor $W$

5132 fasciculáris $\dot{H}$. $\boldsymbol{K}$. octophýlla $\mathbf{L}$. coronáta Andr.

5133 spléndens $\boldsymbol{P} . S$.

5134 mammósa $\dot{L}$.

5135 prócera $W$.

5136 gélida Andr.

5137 serratifólia $A n d r$

Guarea.

Ash-leaved

A MYris.

simple-leaved

wood

Ximenia.

American

BeCKIA.

Chinese

twiggy

close-leaved

Heath.

Plukenet's

Petiver's

Banks's

white-pencilled

yellow-pencill.

verticillate

Seba's

Ewer's

green-pencilled

dense-leaved

great-flowered

purple-headed

bloody-flowered

clear-flowered

specious

fiery

different-color

various-colore

cluster-flower.

splendid

nipple

lofty

green verticill.

saw-leaved

Meliacea. $S p .1-5$

1763. R co Bot. reg. 320

$9 \square \mathrm{tm} 15$ my.jn W S. Amer. 1752. L r.m Cav. di. 7. t. 210

- $\square$ or 12 Terebintacea. Sp. 2-28.

W Chili 1790. C p.l Cav. ic. 3.t. 239

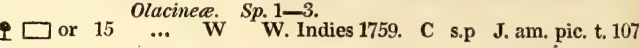
Myrtacea. Sp. 3-7.

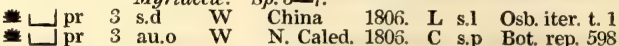

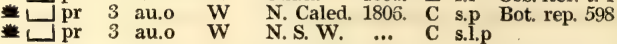

Ericea. Sp. 294-300.

\begin{tabular}{lllllll} 
spl & \multicolumn{1}{l}{ ap.jl } & $\mathbf{R}$ & C. G. H. & 1774. & C s.p & And. hea. vol. 1
\end{tabular} I. C. G. H. 1774. C s.p L. ill. t. 288. f. 3 L or $2^{3}$ ap.jl W C. G. H. 1774. C s.p And hea. vol, 2 * Jor 2 f.jl Y

C. G. H. 1794. C s.p And. hea. vol. 1

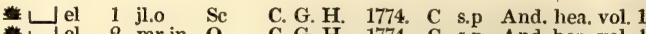
el 2 mr.jn O C. G. H. 1774. C s.p And. hea. vol. 1 spl $2 \frac{1}{2 j l . n}$ Pk.G C. G. H 1793 C s.p And hea vol ? Ju 2 ap.my G C. G. H. 1799. C s.p And. hea. vol, 1 or 2 mr.au C. G. H. 1811. C s.p $\begin{array}{llllll}\text { spl } 3 & \text { my.s } & \text { Y } & \text { C. G. H. 1775. C } & \text { s.p } & \text { Bot. mag. } 189\end{array}$

L or 1 mr.jl Pu C. G. H. 1812. C s.p

2 my.s D.R C. G.H. 1774. C s.p And hea vol

11 mr.jn W.pu C. G. H 1790 C s.p W. 1 . 1 .

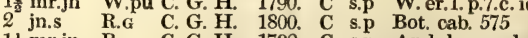

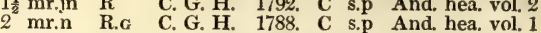

2 my.n O.R C. G. H. 1790. C s.p And. hea. vol. 1

11 f.jn Pu C. G. H. 1787. C s.p And. hea. vol. 1
S C. G. H. 1792. C s.p W. er. 8.p.5.c. ic Pu C. G. H. 1762. C s.p And. hea. vol. 1 W C. G. H. 1791. C s.p

G.w C. G. H. 1790, C s.p Bot. cab, 699

O C. G. H. 1790, C s.p And. hea, vol, 1

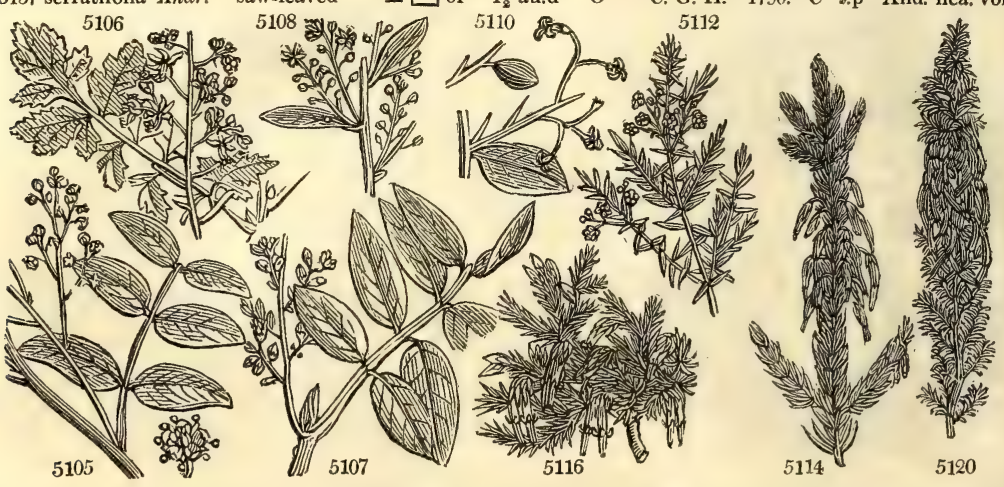

History, Use, Propagation, Culture,

with the arillus of the seed of a grateful subacid flavor. In the West Indies it is esteemed very wholesome and nourishing. Here it grows well in loam and peat, and ripened cuttings with all their leaves on root best in sand under a hand-glass.

886. Metaiba. The vernacular name of the plant in French Guiana. Large cuttings root best under a hand-glass in sand.

887. Kölreuteria. So named by Laxmann, in honor of Joseph Gottlieb Kölreuter, who published De plantis quibusdam Rarioribus, Tubing, 1755, with a dissertation De Insectis Coleopteris. He also made many experiments on the pollen of flowers, hybrid plants, \&c. published in the Petersburgh Transactions.

This shrub should be planted in as sheltered a situation as possible, as it will not flower if too much exposed; and if the wood is not well ripened, the tops of the shoots will be injured by the frost.

888. Guarea. The natives of Cuba call the plant Guara. This tree, though it has an inconspicuous flower yet has fine large leaves. All parts of the plant, especially the bark, smell strong of musk, and may be used instead of that perfume for many purposes. The wood is full of a bitter resinous substance, which renders it unfit for rum-hogsheads, being observed to communicate both its smell and taste to all spirituous liquors: but it is often cut for staves and heading, when there is a scarcity of other timber. The powder of the bark is said to be a good emetic; and is sometimes used among the negrnes for that purpose. Ripened cutting root in sand under a hand-glass.

889. Amyris. Derived from $\mu \nu \rho j e$, myrrh. Its resinous gum has an excellent perfume. Almost every species of this genus produces some valuable gum or resin. A. gileadensis produces the celebrated balm of Gilead. It is a shrub with purplish branches, striated a little, with crowded ternate leaves, and protuberant buds loaded with balsamic resin. 
5105 Leaves alternate abruptly pinnated in 23 or 4 pairs

5106 The only species. Leaves pinnated toothed torn

5107 Stalks of the leaves short tumid inflated

5108 Leaves simple lanceolate entire, Racemes simple axillary numerous 5109 Leaves ternate crenate acute

5110 Peduncles many-flowered, The lower usually changed into spines

5111 Leaves opposite beardless, Teeth of calyx membranous colored 5112 Leaves linear lanceolate, Peduncles axillary umbelled

5113 Leaves imbricated four ways obtuse with a little reflexed point, Teeth of calyx leafy

A. Tubiflore. Corollas long and cylindrical.

5114 Stamens long connivent colored, Leaves in threes, Calyx imbricated, Bractes distant from calyx 5115 Stamens long connivent colored, Leaves in threes, Calyx imbricated, Flowers solitary, Cor. cylindrical 5116 Stamens long connivent colored, Leaves in threes, Calyx imbricated, Segments of cor. reflexed 5117 Stamens long connivent colored, Lvs. in 3s, Cal. imbricated, Fl. 3, Cor. globose scarcely longer than cal.

5118 Stamens long connivent colored, Leaves in threes, Calyx imbricated, Flowers solitary, Cor. conical

5119 Anth. bearded, Style incl. Cor. cylind. contracted above the base, Fl. pend. Leaves 4 whorled 5190 Stamens long connivent colored, Leaves in threes, Cal. imbricated, Flowers 3 , Cor, cylindrical incurved 5121 Anthers bearded, Leaves in threes, Flowers terminal solitary

5122 Stamens exserted colored, Leaves in 3s, Cal. imbricated, Flowers 3, Cor. conical, Leaves recurved 5123 Anth. bearded incl. Style exsert. Cor. tubular clavate pubes. Fl. axill. Leaves 3 imbricated 5124 Anthers beardless exserted, Cor. incurved smooth, Style long, Flowers axillary stalked, Lvs. 6 smooth 5125 Anth. beardless included, Style exserted, Cor. tubular clavate, Cal. pubescent, Fl. capitate, Leaves 6 5126 Ant. beard. includ. Style exsert. Cor. tub. incurv. Cal. simple gland. tooth. Fl. axill. whorl. Lvs. 3 rough 5127 Anthers beardless, Lvs. 3, Flowers solitary or 3 term. Cal. imbric. Cor. villous [at edge 5128 Cor. cylind. Anthers bearded, Lvs. 3, Fl. term. 3, Cal. imbric. Style exserted rounded at end 5129 Anthers beardless, Lvs, 4, Fl, term. Bractes ovate distant from cal. Sepals ovate acumin.

5130 Anthers bearded included, Style exserted, Cor. tubul, clav. Cal, double, Fl. term. 3, Lvs. 3 smooth 5131 Anthers beardless, Leaves 3 smooth, Fl. 3 term. Cal. imbric. Corolla smooth

5132 Anth. bearded, Style incl. Cor, cylind. ventric. Flowers umbelled capitate, Lvs. 8 linear truncate

5133 Anth. beardless exserted, Cor, tub. clavate pubescent, Fl, term. racemose, Leaves 5 or more smooth 5134 Anth. bearded, Style includ. Cor. clav. cylind. Flow, umbell. Lvs, 6 linear refiexed

5135 Anth. beardless included, Style exserted, Cor. ventricose at base, Fl. term. Lvs. 4 pubescent erect 5136 Anth. bearded, Lvs, 4-6, Fl. axill. Cal. imbr. Bract lanc. Sepals broad lanceol.

5137 Anth. beardless, Lvs, 4 ciliated, Fl. term. Two bractes next cal. one distant, Cor. smooth

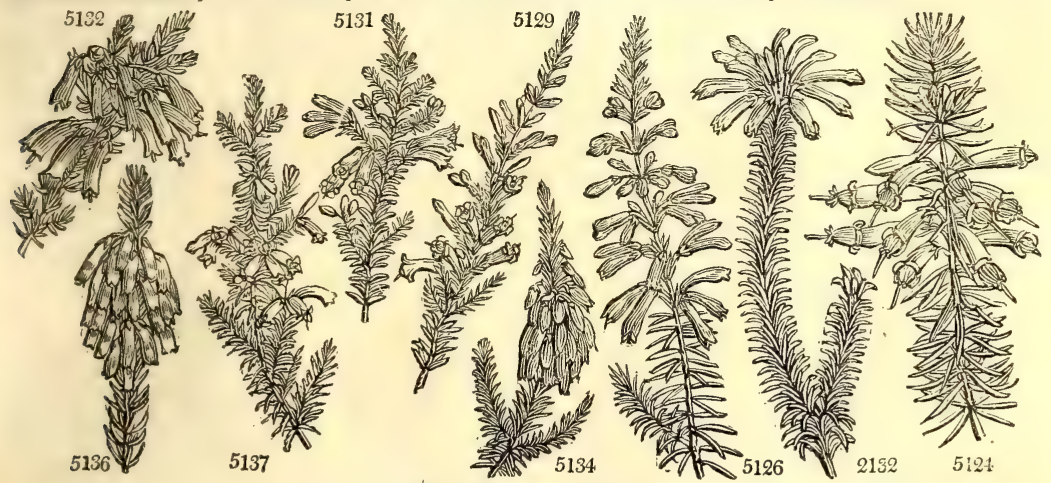

and Miscellaneous Particulars.

A. Opobalsamum produces the balsam of Mecca. It has pinnate leaves, with sessile leaflets. It grows near Bederhunin, a village between Mecca and Medina, in a sandy rocky soil, confined to a small tract about a mile in length, and attains the height of fifteen feet. The balsam is obtained by incision. Neither of these species are yet introduced to Britain : those we possess grow in loam and peat, and cuttings root freely in a pot of sand under a hand-glass.

890. Ximenia. Francis Ximenes was a Spanish naturalist from whom we have, published in 1615 , four works upon the plants and animals useful in medicine in New Spain. The flowers of this tree have an odor like frankincense : the fruit is yellow, shiny, the size of a pigeon's egg, with a thin rind and sweet subacid pulp : it is eaten by negroes and children in the West Indies. Cuttings root in sand under a hand-glass.

891. Backia. From Abraham Bæck, who was physician in ordinary to the king of Sweden, and who communicated plants to Linnæus, by whom the genus was dedicated. These plants are of free growth in sandy loam and peat, and so hardy as to require little more than protection from frost during winter. Young cuttings root in sand under a bell-glass.

892. Erica. From se $\% \omega$, to break, in allusion to the brittle branches of the plant. It was also reputed a specific for breaking the stone in the bladder. La bruyere, Fr., Heide, Ger., Erica, Ital., and Brezo, Span. Ling or common heath abounds in barren wastes in every part of Europe, and especially in the northern countries. Though little regarded in warm climates, the different species of native Erica are made subservient to a great variety of purposes in the bleak and barren highlands of Scotland, and other northern countries. The poorer inhabitants cover their cabins with them instead of thatch, or else twist them into ropes, and bind down the thatch with them in a kind of lattice work. They also make the walls with alternate layers of heath, and a sort of cement made of black earth and straw. The hardy Highlanders frequently 
5138 clavæflóra Salisb. sessiliflóra Andr. 5139 spicáta Thunb.

5140 transpárens $W$

5141 viréscens $L o d d$.

5142 flam'mea $A n d r$.

5143 Patersónia Andr.

5144 glandulósa $W$.

5145 gílva Wendl.

5146 Sparman'ni $W$.

5147 perspícua Wendl.

5148 costáta $A n d r$.

5149 purpúrea $W$.

5150 eláta $A n d r$.

5151 sulphúrea Lodd.

5152 laniflóra Wendl. sordida Andr.

5153 tubiflóra $L$.

5154 simpliciflóra Donn.

5155 Archéria Andr.

5156 spúria $A n d r$.

5157 Hibber'tia Andr.

5158 conspícua $H$. $K$.

5159 curviflóra $L$.

5160 triphylla $L k$

5161 monadélpha $B . M$.

5162 concínna $H$. $K$.

5163 pellúcida Andr.

5164 Linneána $H . K$

5165 hirsúta Lodd.

5166 erubéscens $A n d r$.

5167 Leeána $H$. $K$.

5168 colórans Lodd.

5169 onosmæflóra Sal.

5170 víridis Andr.

5171 sariguínea Lodd.

5172 longifólia Donn.

5173 pinea $W$.

5174 aúrea $A n d r$.

5175 elongáta Lodd.

5176 lanáta Wendl.

5177 Bowieána Lodd.

5178 coccinea $L$.

5179 exúdans Lodd.

5180 Massóni Thunb.

5181 gemmifera Lodd.

5182 bícolor Andr.

5183 exsúrgens $A n d r$.

5184 vestíta Thunb.

$$
\text { a álba }
$$

$\beta$ incarnáta

z purpúrea

\& rósea

coccinea

$\eta$ lútea

5185 rósea $A n d r$.

5186 Nivénia Andr.

5187 áspera $A n d r$.

5188 cylindrica $A n d r$. club-flowered

spiked

ansparent

greenish

flame-flowered

Paterson's

glandul.-haire

dull-yellow

Sparrmann's

glassy

ribbed-flowere

purple-flower.

tall

sulphur

sordid

tube-flowered

single-flowered

Lady Archer's

spurious

Hibbert's

conspicuous

curve-flowere

three-leaved

mona

pellucid

pellucid

hairy

reddish

Lee's

coloring

onosma-flower:

green-flowered

bloody

long-leaved

Pine-tree-leav.

gold-colored

turbinate

woolly

Bowie's

scarlet-flower'

dewy

Masson's

gem-bearing

two-colored

quiver-formed

tremulous

white

flesh-colored

purple

rosy

scarlet

yellow

rose-colored

Niven's

rough

cylindric

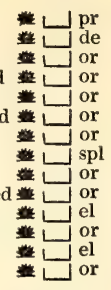

$\frac{1}{2}$ au.o

$2 \frac{1}{2}$ ja.d

$1 \frac{1}{2} \mathrm{my}$

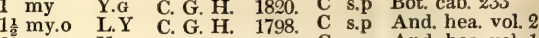

$2 \frac{1}{2} \mathrm{mr} . \mathrm{au} \mathrm{Y}$ C. G. H. 1791. C s.p And. hea. vol. 1

1 my.jn R.o C. G. H. 1801. C s.p

1 my.jn Y C. G. H. 1820. C s.p

1 mr.s D.O C. G. H. 1794. C s.p And. hea. vol. 3

$\begin{array}{llll}1 \frac{1}{2} & \text { my.jn } & \mathrm{Pk} & \text { C. G. H. 1819. C }\end{array}$

$2_{2}$ f.jn Pk C. G. H. 1795. C s.p And, hea. vol, 1

2 ja.d L.Pu C. G. H. 1789. C s.p Bot. cab. 703

3 jl.s $\quad$ O $\quad$ C. G. H. 1790 . C s.p And. hea. vol. 2

2 jn.jl Y $\quad$ C. G. H. 1805. C s.p Bot. mag. 1984

mr.au L.S C. G. H. 1790. C s.p And, hea. vol. 1

ap.jl Pk C. G. H 1775 C s.p And. hea. vol. 1

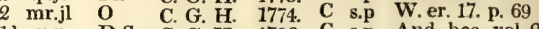

$1 \frac{1}{2}$ au.n D.S C. G. H. 1796. C s.p And. hea. vol. 2

2 ap.au Pu C. G. H. 1796. C s.p And. hea. vol, 1

2 in.s O.Y C. G. H 1800 L s.p And, hea. vol. 3

a my au D C. G. 1774 C s.p And hea vol a

2 jl.o Y C. G. H. 1774. C s.p And. hea. vol, 1

$\begin{array}{lllll}2 \text { jl.n R.y } & \text { C. G. H. 1822. C s.p }\end{array}$

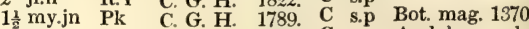

$2 \frac{1}{2}$ s.o $\quad$ F $\quad$ C. G. H. 1773. C s.p And. hea. vol. 2

2 jn.n W C. G. H 1800 C s.p And. hea. vol. 3

11 ja.my W C. G. H. 1790. C s.p And. hea. vol.2

1 inr.ap W.pu C. G. H. 1800. C s.p Bot. cab. 754

$1 \frac{1}{2} \mathrm{mr} . \mathrm{jl} \quad \mathrm{F} \quad$ C. G. H. 1800. C s.p And. hea. vol. 3

$2 \frac{1}{2}$ ja.au O.y $\quad$ C. G. H. 1788. C s.p And. hea. vol. 1

2 ap.jn W.r C. G. H. 1817. C s.p Bot. cab. 224

$1 \frac{1}{2}$ mr.s Y C. G. H. 1789. C s.p And. hea, vol, 1

$2 \frac{1}{2}$ my.s D.G C. G. H 1800 C s.p And. hea. vol.2

$1^{\frac{2}{2}}$ ja.d Cr C. G. H. 1815. C s.p Bot. cab. 86

2 f.jl R $\quad$ C. G. H. 1787. C s.p Ic. hor. kew. 4

2 au.d $R \quad$ C. G. H. 1790 . C s.p

2 jl.s o C. G. H. 1799. C s.p And. hea. vol. 2

$1 \frac{1}{2}$ f.n W C G H 1810 C s.p Bot. cab. 758

f.my O C.G.H. 1775. C s.p W.eric.5.p.5.c.ic

1 au.d W C. G. H. 1822. C s.p Bot. cab. 842

D.R C. G. H. 1783. C s.p And. heaths, v.1

R C. G. H. 1810. C s.p Bot. cab. 287

R.G C. G. H. 1787. L s.p Bot. mag. $350^{\circ}$

S C. G. H 1802 C s.p Bot. cab. 457

G.R C. G. H. 1790. C s.p

D.O C. G. H. 1792. C s.p Bot. cab. 835

W C. G. H. 1789. C s.p

Pk C. G. 1789. C s:p And, heaths, v.1

C. G. H. 1789. C s.p And. heaths, v.2

Pu C. G. H. 1789. C s.p And heaths, v

L.K C. G. H. 1789. C s.p And heth, v.

O C. G. H. 1789. C s.p And. heaths, v.

D.R C. G. H. 1789. C s.p And. heaths, v.1

Y C. G. H. 1789. C s.v And. heaths, v.

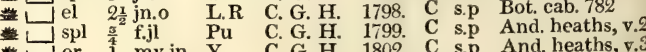

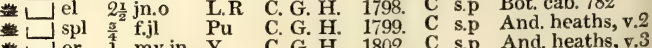
$\begin{array}{llllll}\text { or } & 1 & \text { my.jn } & \text { Y } & \text { C. G. H. } & 1802 . \\ \text { or } & 2 & \text { my.jn } & \text { W } & \text { C. G. H. 1798. C } & \text { s.p And. heaths,c.ic }\end{array}$
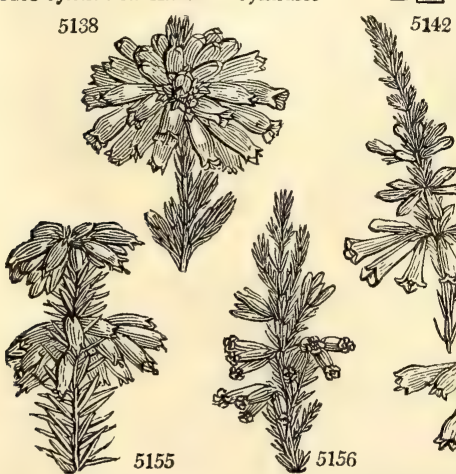

5149

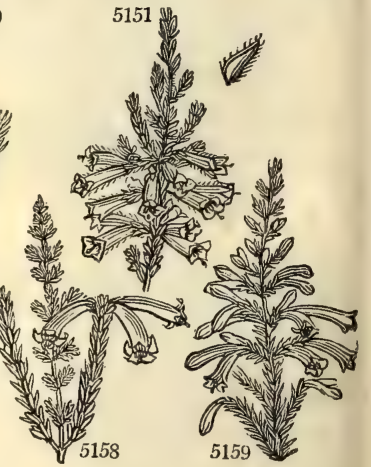

History, Use, Propagation, Culture,

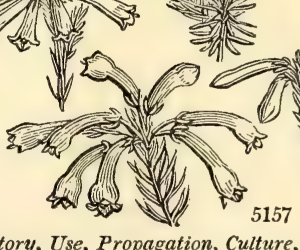

5159 ㄴ.

make their beds with it. In most of the western isles they dye their yarn of a yellow color, by boiling it in water with the green tops and flowers of this plant; and woollen cloth boiled in alum water, and afterwards in a strong decoction of the tops, comes out a fine orange colnr. In some of these islands they tan their leather in a strong iecoction of it. Formerly the young tops are said to have been used alone to brew a kind of ale and Boethius relates that this liquor was much used by the Picts. In some of the isles it is said they still brew ale with one part malt, and two parts of the young tops of heath, sometimes adding hops. In many parts of Great Britain besoms are made of it. The turf, with the heath growing on it, is cut up and dried for the fuel of the cottager, for heating ovens, covering under-ground drains, \&c. Sheep and goats will sometimes eat the tender shoots, but they are not fond of them. Cattle not accustomed to browse on heath give bloody 
5198 Anth. bearded, Lvs. 4-6, FI. axill. Cal, imbr. Sepals orbicular obovate

5139 Anthers bearded, Lvs. 4-6, Flow. axillary, Cal. imbric. Sepals rhomboid with long claws 5140 Anth. beardless, Leaves 4 3-cornered ciliated, Flowers terminal subsolitary

5141 Anthers included bearded, Cal. leafy, Leaves 4 hairy, Flowers terminal, Style exserted

5142 Anthers beardless included, Lvs. 3-4, Flowers terminal few, Cal. imbr. Cor. pubescent

5143 Anthers bearded, Lvs. 4-6, Fl, axillary, Cal. imbric. Sepals subulate from a broad base

5144 Anth. beardless, Lvs, 4 linear glandular hairy, Cor. clavate, Cal, hispid

5145 Anthers bearded, Style incl. Cor. cylind. Sepals membran. Fl. axill. whorl. Lvs, 4 lin. smooth

5146 Anth. beardless, Lvs. 4, Fl. term. 4 closely packed in a 4-cornered head, Sep. lin.-subul Ped. very short

5147 Anthers beardless, Flowers solitary or 3, Cal. imbric. Cor. villous

5148 Anthers beardless, Flowers 3, Cal. imbricated, Cor. smooth, Leaves pubescent

5149 Anth. beardless exserted, Ovary turbinate, Lvs. 4-6, Fl, axillary, Two bractes close to cal, one remote

5150 Anthers beardless exserted, Lvs. 4-6, Flowers axill. Bractes remote, Ovary with 8 furrows smooth

5151 Anthers beardless included, Bractes next calyx, Cor. hairy solitary, Leaves 4 hairy

5152 Anthers exserted gibbous at base, Bractes remote, Cal. leafy, Lvs. 4, Branches hairy, Fl. terminal

5153 Anthers beardless, Lvs. 4, Bractes a little distant from cal. Sepals oblong revolute at edge

5154 Anthers beardless exserted, Lvs 4, Bractes linear distant from cal. Sepals ovate acuminate

5155 Anth. beardless, Lvs. 4-6, Fl. axill. Two bractes next cal. one remote, Ovary cylind. Cor. pubescent viscid

5156 Anthers beardless included, Lvs, 4, Fl. term few, Bractes lin. remote, Sepals ovate acuminate

5157 Anthers beardless, Lvs. 4-6, Fl. axill. Two bractes next cal. one remote, Ovary cylind. Cor. smooth viscid

5158 Anthers beardless included, Lvs. 4, Fl. term. few, Bractes remote, Sepals ovate obtuse

5159 Anth. beardless, Cor. curved clavate smooth, Fl. solitary term. Leaves 4 linear smooth

5160 Anth. beardless included, Cal. leafy imbricated, Leaves 3 smooth spreading, Style exserted

5161 Anth. beardless exserted, Cor. cylind. ovate, Sepal col. obl. obt. Leaves 3 appressed erect, F1. 3 terminal

5162 Anth, beardles: included, Cor. cylindrical narrowed at base, Fl, term. urnbell. Leaves 6 smooth

5163 Anth. beardless, Lvs. 4, Fl. term. 4 closely packed in 4-cornered head, Sepals lin. subul. Ped. length of f.

5164 Anth. beardless, Leaves 4, Fl. term. 4 closely packed in a 4-cornered head, Sepals lanceolate

5155 A handsome species with tufted hairy leaves. It resembles E. linnæana

5106 Anth. beardless, Leaves 4, Fl. term. 4 closely packed in a 4-cornered head, Sepals ovate roundish

5167 Anth beardless, Leaves 4, Fl, axillary, Cor, ribbed, Bractes nearly as long as calyx

5168 Anth beardless included, Leaves 6 ciliated, Flowers terminal, Cor. clavate at first white afterwards red

5169 Anth. beardless, Lvs. 4-6, Fl. axillary, Cor. ribbed cylind, with a spreading limb, Bractes $\frac{1}{2}$ length of cal.

5170 Anth. beardless, Lvs. 4-6, Fl. axill. Cor. ribbed widest in middle with a revol. limb, Bractes length of cal.

5171 Leaves spreading smooth, Flowers clavate incurved smooth

5172 Anth. beardless, Leaves 4-6, Fl. axillary, Cor. not ribbed, Sepals linear

5173 Anth. beardless, Leaves 4-6, Fl. axillary, Cor. not ribbed, Sepals from a broad base linear subulate

5174 Anth. beardless, Leaves 4-6, Fl. axillary, Cor. not ribbed, Sepals ovate acuminate

5175 Leaves upright smooth, Fl. term. 4 turbinate hairy

5176 Anth. includ. beardless, Bractes remote from flower, Leaves very short imbricated

5177 Leaves 3 smooth spreading distant, Fl. axillary pendulous cylindrical smooth

5178 Anth. beardless included, Leaves 4-6, Fl. axill. Two bractes next cal. : one remote, Ovary turbinate

5179 Leaves 4 hairy clammy, Fl. cylindrical terminal curved smooth, Style exserted

5180 Anth. heardless, Leaves 4-6 hairy, Fl. axill. Two bractes next cal. : one remote, Ovary clavate

5181 Leaves short with long hairs, Fl. large axillary pendulous cylindrical with a green mouth

5182 Anth. bearded, Leaves 3 ovate rough, Fl. 3 cernuous smooth, Cal. villous colored

5183 Anth. beardless exserted, Leaves 4-6, Fi. axill. Bractes remote, Ovary with 4 furrows smooth

5184. Antil. beardless included, Lvs, 4-6, Fl. axill. Bractes remote, Limb of cor. revolute, Ovary with 8 furrows

[silky upwards

5185 Anth. beardless included, Leaves 4-6, Fl. axill. Bractes remote, Limb of cor. erect spreading

5186 Anth. beardless exserted, Ieaves 3, Fl. terminal numerous, Bractes remote

5187 Anth. beardless included, Leaves 3 hairy, Fl. capitate, Cal. imbr. Cor. very hairy

5188 Anth. beardless, Leaves 4 triangular smooth, Fl. term. cylindr. smooth

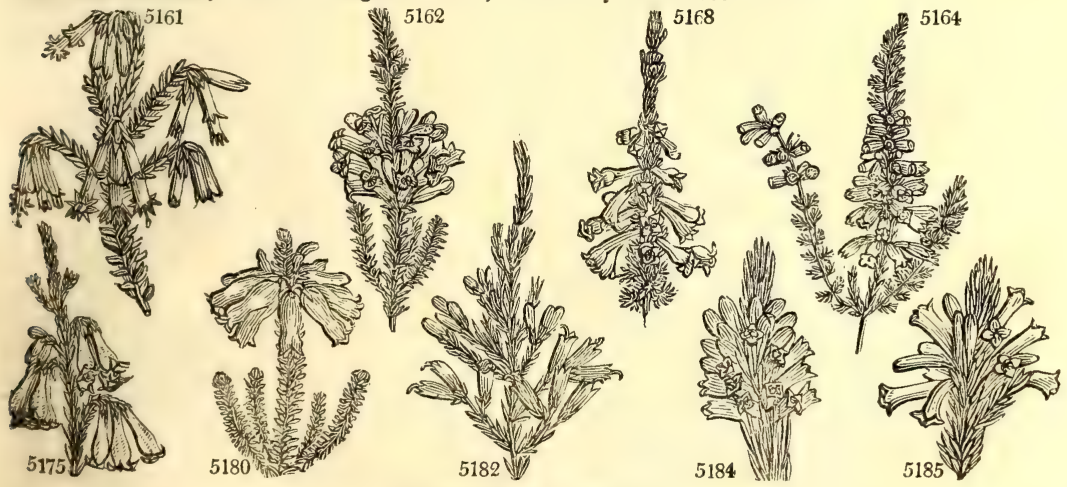

and Miscellaneous Particulars.

milk, but are soon cured by drinking plentifully of water. The branches of heath afford shelter, and the seeds a principal part of their food to many birds, especially those of the grouse kind: and for this purpose the seedvessel is formed and protected in such a manner, that the seeds are preserved a whole year, or even longer. Bees collect largely from the flowers, and honey made from them was anciently supposed to be of a bad quality, but in fact it is only of a darker color. The foliage affords nourishment to the Phalæna quercus or great egger moth. Dodder frequently entwines itself about this plant, and gives it a singular appearance.

Till the latter end of the last century, this genus consisted of three or four humble British shrubs, and the heath of Spain (E. mediterranea), a slow growing tree. But when the Cape of Good Hope fell into the hands of the British, collectors were sent out, and soon brought to light some hundreds of species. It may serve as 
5189 Monsónia Thunb. 5190 Halicácaba $L$. 5191 lanuginósa $A n d r$. 5192 glábra $L k$.

5193 cerinthoídes $L$. 5194 pectinifólia Sal. 5195 prínceps Andr.

5197 infláta $W$.

5198 ferruginea $A n d r$. 5200 túmida $\mathrm{Ker}$.

5201 fistulæflóra $\mathrm{Sal}$. 5202 obbáta Andr.

5203 acumináta $A$ indr.
5196 blánda $A n d r$. 5199 metulæflóra $B . M$.

Lady Monson's bladder-flower. large brown-fl. smooth

Honey-wort-fl. pectinated fine-red charming inflated rusty nine-pin tumid white slender-fl. bottle pointed-leaved

red slender-f $\mathrm{f}$ Porcelain swelled glutinous sundew-like 5205 ventricósa Thunb.] 5206 præ'gnans Andr. 5207 glutinósa $W$. $\beta$ droseroides Lam 5208 tetragóna Thunb. 5209 Irbyána Andr.

5210 jasminiflóra $A n d r$. 5211 ampullácea Curt. 5212 Shannoniána Lodd. 5213 retórta Thunb. 5214 tenuiflóra Andr. 5215 Cliffórdia Lodd. Lady Clifford's

air. Hyacinth-flow.

5217 fastigiáta $L$. Walkéria Andr.

5218 infundibuláris $L k$. 5219 Aitónia Andr.

5220 lútea $L$.

5221 comósa $L$ a rúbra

5222 muscári $W$ 5223 daphnæefóra Sal. 5224 Parmentiéri Lodd. 5225 Bonplándia Lodd. 5226 Humeána Lodd.

5227 denticuláta $L$.

5228 radiáta $A n d r$.

5229 aristáta $A n d r$.

5230 primuloídes indr. $\beta$ múndula Lodd.

5231 moscháta Lodd.

5232 concáva Lodd.

5233 Coventryána Lodd. 5234 erósa Lodd. 5235 juliána Lodd. 5236 tróssula Lodd.

square-flower'd

Jasmine-flower

flask -lower.

Lady Shannon's recurved-leav'd

funnel-shaped Aiton's

yellow 'ed-flowered white-flowered musk

Daphne-flower. Parmentine's Bonpland's Sir A. Hume's toothletted radiated awned Cowslip-flower neat musk-scented concave Lord Coventry's bitten
July
neat neat yacinth-flow. $\amalg$ or

\section{Coris-leaved}

$$
\text { 教 إ }
$$

W

Y
W
W
. G. H. 1780. C s.pl And. heaths,v.2 C. G. H. 1803. C s.p And. heaths, v.3 C. G. H. 1820. C s.p G. H. 1774. C s.p Bot. mag. 220 C. G. H. 1800. C s.p 1800. C s.p Bot. cab. 647 C. G. H. 1800. C s.p And. heaths, v. 3 C. G. H. 1800. C s.p Th.eric.67.t.2 f. 2 C. G. H. 1798 . C s.p And. heaths, v.3 C. G. H. 1798. C s.p Bot. mag. 612 C. G. H. 1812. C s.p Bot. reg. 65 C. G. H. 1800. C s.p And heaths, v.3 C. G. H. 1796. C s.p And. heaths, v.2 C. G. H. 1800. C s.p Bot. cab. 216

C. G. H. 1802. C s.p Bot. mag. 1720 C. G. H. 1787. C s.p Bot. mag. 350 C. G. H 1796. C s.p And.heaths,c.ic C. G. H. 1787, C s.p Ico. hor.Kew.17 $\mathrm{Pu}$ C. G. H. 1787. C s.p Pet. mus. t. 161 L.Y C. G. H. 1789. C s.p And, heaths,v.3 W.G C. G. H. 1800, C s.p And. heaths,v.3 W.pk C. G. H. 1794. C s.p And. heaths, v, 1 .R C. G. H. 1790. C s.p Bot. mag. 303 pu C. G. H. 1806. C s.p Bot. cab. 168 $\begin{array}{llll} & \\ \text { C. G. H. } & 1787 \text {. C } & \text { s.p } & \text { Bot. mag. } 362 \\ \text { C } & \text { s.p And. heaths,v. } 3\end{array}$ C. G. H. 1812. C s.p Bot. cab. 34 C. G. H. 1798. C s.p And. heaths,v.3 C. G. H. 1797. C s.p Bot. cab. 256

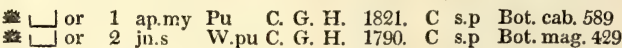

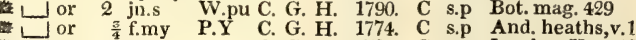
L or $\frac{3}{4}$ ap.au $\quad$ C, G. H. 1787. C s.p Ico.hor.Kew.18 -
- de ap.au Pk $\quad$ C. G. H. 1787. C s.p W.eri.12.p.7.c.ic J el $\frac{3}{4}$ ap.au W C. G. H. 1787. C s.p And. heaths,v.2 $\sqcup$ fr $1 \frac{1}{2} \mathrm{mr} . j \mathrm{l}$ W C. G. H. 1790. C s.p And. heaths,v.1 聮 de $1 \frac{1}{6}$ ap.my Pa.puC. G. H. 1791. C s p Bot. cab. 154 $\square$ de 1 jl.au Pa.pu C. G. H. 1810. C s.p Bot. cab. 197 $\square$ pr 1 mr.s Pa.Y C. G. H. 1812. C s.p Bot. cab. 315

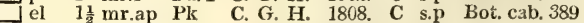
$\square$ or $1 \frac{1}{2}$ ap.my Pu $\quad$ C. G. H. 1821. C s.p $\begin{array}{llll}\text { or } 1 \frac{1}{4} \text { ap.my Pu } & \text { C. G. H. 1821. C } & \text { s.p } \\ \text { or } 1 \text { au.n } & \text { C. G. H. 1798. C } & \text { s.p And. heaths,v.1 }\end{array}$ $\square$ or $1 \frac{1}{2} \mathrm{mr} . \mathrm{au}$ D.P.w C. G. H. 1801. C s.p And. heaths,v.3 L or $\frac{1}{2}$ ap.jl P.w C. G. H. 1802. C s.p Bot. mag. 1548 L pr $\frac{z}{4}$ my.jl R.w C. G. H. ... C $\quad$ C s.p Bot. cab 114 لـ $1 \frac{1}{2}$ my.jl G $\quad$ C. G. H. 1805. C s.p Bot. cab. 614 ل el ${ }^{\frac{3}{4}}$ mr.ap Pa.pu C. G. H. 1808. C s.p Bot. cab. 124 U pr 1 jn.jl Pk C. G. H. 1808. C s.p Bot. cab. 423 敬 de $\frac{3}{4}$ ap.my Pa.pk C G. H. 1817. C s p Bot. cab. 133 Lel ${ }^{3}$ el $j l \quad R \quad$ C. G. H. 1800. C s.p Bot. cab. 799 皿 L. J pr $1 \frac{1}{2}$ ap.my W.pk C. G. H. 1800. C s.p Bot. cab. 668

5237 coriifólia $L$. calycína W.

5238 andromedæfióra An. Andromeda-fl. $L$ J pr $2 \mathrm{mr}$.jn $\quad$ Pk $\quad$ C. G. H. 1803. C s.p Bot. mag. 1250

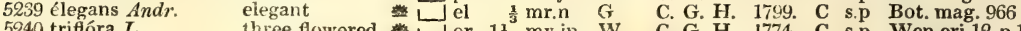
5240 triflóra $L$. three-flowered $\amalg$ or $1 \frac{1}{2} \mathrm{my} . j \mathrm{n}$ W C. G. H. 1774. C s.p Wen.eri.12.p.13

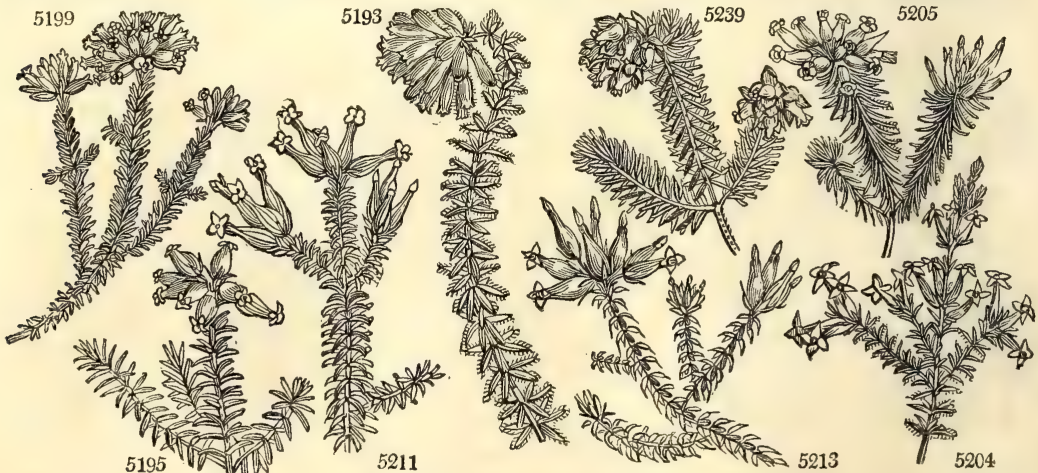

History, Use, Propagation, Culture,

an easily recollected date, to say that all of them were sent home during the reign of George III., and as a tribute to merit, that most of them were gathered by Mr. Francis Masson. Their beauty needs no encomium ; many are pretty, some are graceful or elegant, a few splendid, and there are curious, grotesque, and odoriferous species. Their culture and propagation is one of the most delicate branches of the art of gardening: it may be said to have been invented in England, and in the Hammersmith nursery, and places Britain far before all countries in this art as in so many others.

The only soil in which heaths will grow is earth of peat : if any substitute can be found, it is in leaf-mould 
B. Ventricose. Corolla injlated.

5189 Anthers bearded, Bractes oblong next cal. Cor. twice as long as calyx

5190 Anthers bearded, Bractes ovate next cal. Cor. 4-cleft thrice as long as calyx

5191 Anthers bearded, Bractes ovate next cal. Cor. 4-parted scarcely twice as long as calyx

5192 Anthers bearded included, Cal. leafy, Bractes remote from $f$. Leaves 4 spreading smooth

5193 Anthers beardless, Flowers terminal, Two bractes next fl. : one remote, Cor. viscid-hairy

5194 Cal. rhomboid-spatulate, Cor. woolly inside, Leaves narrow-ovate cuneate pectinate

5195 Anth. beardless, Fl. term. Two bractes next fl. : one remote, Cor. smooth, Sepals lin. lanceolate

5196 Anth. bearded, Two bractes next fl.; one remote, Leaves 6, Beards of anth. very short

5197 Anth. bearded, Bractes remote, Leaves 4 smooth, Beards of anth. very long

5198 Anth. beardless, Fl. term. 8, Bractes remote, Leaves 4, Sepals terminated by 3 or more bristies

5199 Anth. beardless, Fl. term. Two bractes next cal.; one remote, Cor. smooth, Sepals ovate acuminate

5200 Pubescent, Two subul. bractes next cal. Leaves decussate 4, Cor, villous many times longer than calyx

5201 Cal. minutely ciliated, Tube narrow-cylindrical urceolate, Anthers beardless

5202 Anth. beardless, Fl. term. 4, Cal. imbric. Sepals ovate oblong acute, Leaves recurved ciliated

5203 Anth. beardless, Fl. term. many, Cal. imbric. Leaves recurved terminated by a bristle

C. Limbata. Corolla elongated, narrowed upwards, with a fat liml.

5204 Anth. beardless, Leaves ciliated and flowers 4, Sepals subulate, Stigma exserted

5205 Anth. bearded, Bractes remote, Leaves 4 ciliated, Beards of anth. very short

5206 Anth. bearded included, Leaves 4 ciliated, Fl. capitate, Bractes remote

5207 Anth. bearded included, Cor. globose ovate, Leaves opposite and scattered fringed with glands linear

5208 Anth. beardless, Fl, terminal 3, Leaves 3, Bractes remote, Sepals subulate, Cor. 4-cornered

5209 Anth. included beardless, Fl. umbelled, Bractes remote

5210 Anth. beardless, Fl. term. 3, Leaves 3, Bractes remote, Sepals ovate oblong

5211 Anth. beardless, Fl. term. 4, Leaves 4, Bractes remote

5212 Flowers long conical striped, with a flat limb, The whole surface of corolla shining

5213 Anth. beardless, Fl. term 8, Leaves 4, Bractes remote, Sepals terminated by a long bristle

5214 Anth. beardless, Fl. term. 4, Cal. imbricated, Sepals from a broad base, subulate, entire

5215 Anth. beardless, FI. term. Leaves 4 smooth, Cor. slender, Style included

5216 Anth. beardless, Fl. term. 4, Cal. imbricated, Sepals ovate acuminate serrulate

5217 Anth. beardless included, Flowers fascicled, Style included, Leaves 4

5218 Anth. included beardless, Leaves 4 smooth erect, Fl, term. Cal. imbricated leafy

5219 Anth. beardless, Leaves 3, Fl, term. Fl. 3, Bractes remote, Cor. viscid

5220 Anth. bearded, Style included, Flowers terminal, Leaves lin. 2 smooth, Branches deflexed

5221 Anth. beardless included, Style included, Leaves 4, Flowers clustered

5822 Anth. beardless, Cor. somewhat 4-cornered, Sepals lanceolate entire, Fl, term. sessile, Leaves 4 smooth 5223 Cal. ovate cuspidate scarcely serrated, Cor. three lines long, Limb twice as short as tube recurved 5224 Leaves 4 spreading, Fl. 4 terminal

5225 Leaves 4 erect, Fl. simple on little axillary branches, Cor. ovate

5226 Leaves 3 smooth erect imbricated, Fl. 3 terminal, Cor. hypocrateriform, Tube slender

5227 Anth. beardless included, Sepals membranous ciliate toothed, Fl, term. sessile, Leaves 4 smooth

5228 Anth. beardless included, Leaves 4-6, Fl. axill. Bractes remote, Limb of cor. revolute, Ovary smooth

5229 Anth. beardless, Fl. terminal, Cal, imbricated, Fl. 4. Sepals oblong obtuse, Leaves recurved setose

B230 Anth. beardiess, Flowers terminal subsessile 5, Bractes next calyx, Leaves spreading 5

5231 Leaves short erect, imbricated, Flowers terminal solitary, Tube ovate, Limb recurved

5232 Leaves 3 filiform spreading, Fl, 3 term. rotate, Stamens and styles exserted

5233 Leaves dense acerose smooth erect, $\mathrm{Fl}$. axillary, Tube cylindrical

5234 Leaves densely imbricated erect, Flowers large axillary, Petals sawed

5235 Leaves dense spreading, Fl. 4 terminal, Tube ovate longer than limb

5236 Leaves 4 narrow erect smooth, Flowers terminal 4 very numerous, Tube ventricose

D. CALYCINE. Corolla inclosed in the inflated calyx.

5237 Anthers crested, Cor. ovate, Style included, Cal. turbinate, Leaves 3, Flowers umbelled

5238 Anthers crested, Bracteas remote, Leaves 3 much longer than the joints green

5239 Anth. crested, Leaves 3, Cal. imbricated, Style included, Flowers terminal, numerous

5240 Anth. crested, Leaves 3 , Cal. imbricated, Style included, Flowers terminal three

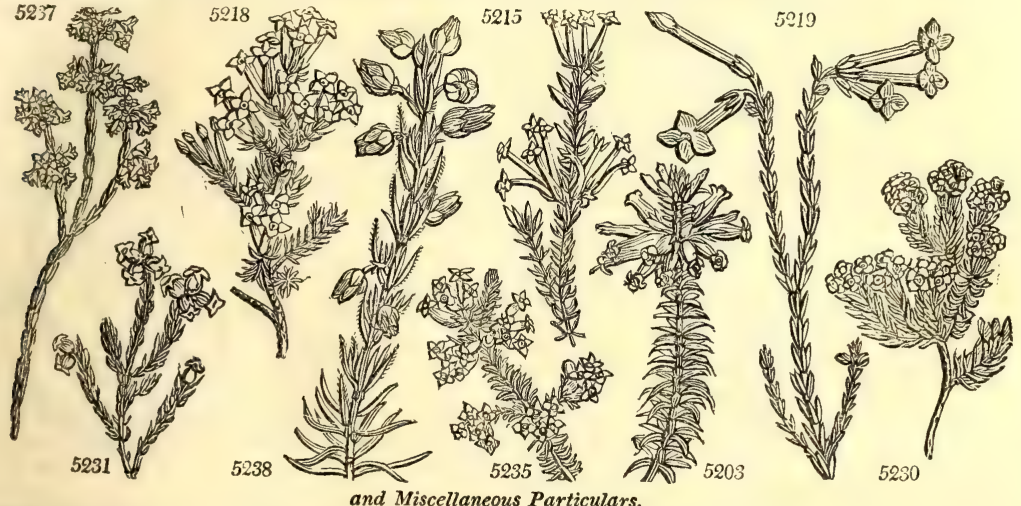

sifted very fine and mixed with fine sand. Earth of peat is obtained by collecting peats from bogs or turf from the surface of peaty wastes and moist places, and laying the peats or turves in a heap to rot aud moulder into earth. This they will require several years to do; but in the meanwhile a portion of mould may be obtained whenever it is wanted, by turning the turves and sifting the fragments. Sometimes this peat is found without any mixture of sand; at other times, where streims have run into the bog or lake while the peat was forming, it is mixed with fine sand that had been held suspended in the water. This last is the best sort of peat for the Erica family; and therefore where peat is not sandy naturally, fine white sand 
5241 flagelláris $L k$. 5242 bracteáta Thunb. 5243 túrgida $L k$. $52 \pm 4$ lachneæfólia $A n d r$. 5245 nigríta $L$ 5246 báccans $L$. 5247 fúgax Salisb. 5248 triúmphans Lodd. 5249 phylicoídes $W$. 5250 incúrva Wendl. 5251 tenuifólia $L$. 5252 Thunbérgia $W$. 5253 taxifólia $\boldsymbol{H}$. $K$ 5254 petioláta Thunb. 5255 imbricáta $L$.

$52: 6$ velleriflóra Salisb. 5257 Bruniádes $\mathcal{L}$. 5258 capitáta $L$ $5<59$ páters And 5260 fimbriáta $A n d r$. 5261 melanthéra Thunb. 5262 Háccida $L$ 5263 sexfária $H . K$ 5264 frágrans $A n d r$. 5265 oppositifólia $A n d r$. 5266 biflóra $L k$. 5267 spumósa $L$. 5268 vulgáris $L$. Calluna vulgaris Sal. $\beta$ álba

$\gamma$ flore pléno 5269 glaúca $\mathrm{Sal}$ 5270 pyrolæflóra Sal. 5271 láxa Andr. 5272 lúcida Andr. 5273 squamúsa $A n d r$. 5274 togáta $B$. $M$ 5275 canaliculáta Andr. 5276 horizontális Andr. 5277 globósa $W$ 5278 gnaphalódes $W$ 5279 rubélla Lodd. wiry

red-bracted turgid

Lachnea-leav' black-tipped Arbutus-flower fugacious

conquering phylica-like incurved

slender-leaved Thunberg's Yew-leaved Rosemary-lea imbricated

woolly-flower Brunia-like downy-headed spreading fringed

dark-anthered flaccid

six-angled fragrant

opposite-leaved two-flowered frothy common

white-flowered double-flowered glaucous

Pyrola-flower', loose-flowered lucid

scaly-cupped large-cupped channelled

horizontal-lvd. globular-flower Gnaphal.-like thrift-flowered

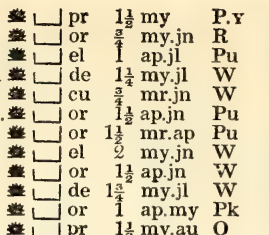

C. G. H. 1820. C s.p C. G. H. 1800. C s.p C. G. H. 1821. C s.p

C. G. H 1793, C s.p And heaths, v.3 C. G. H. 1790. C s.p And heaths, v.1 C. G. H. 1774. C s.p Bot. mag. 358 C. G. H. 1800 , C s.p C. G. H. 1802. C s.p Bot. cab. 257

C. G. H. 1800, C s.p C. G. H. 1821, C s.p

C. G. H. 1794. C s.p Seb.mu.1.t.73.f.6

C. G. H. 1794. C s.p Bot. mag. 1214

${ }_{1}^{1 \frac{1}{2}}$ my.au ${ }_{\text {jl.n }}^{\text {O }}$ C. G. H. 1788. C s.p And. heaths, v.1

这 mr.jl Pa.pu C. G. H. 1774. C s.p And. heaths, v.3 1 my.au Pk C. G. H. 1786. C s.p

C. G. H. 177t. C s.p And. heaths, v. 1

C. G. H. 1790 . C s.p W.er.16 p. 53 c.ic

C. G. H. 1774. C s.p And. heaths, v.1

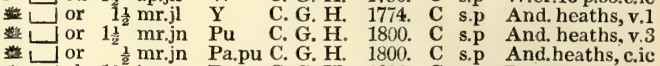
$\checkmark$ el $1 \frac{1}{2}^{\frac{1}{2}}$ jn Pa.pu C. G. H. 1803. C s.p Bot. cab. 867

Ide 1 my W C. G. H. 1822. C s.p

U

L $\mathrm{ft}^{\frac{\mathrm{s}^{2}}{4} \mathrm{mr} . \mathrm{jn} \mathrm{Pu}}$

$\frac{1}{2}$ mr.my W

C. G. H. 1774. C s.p And. heaths, v.2

C. G. H. 1803. C s.p And. heaths, v.2

C. G. H. 1804. C s.p And. heaths, v 3

C. G. H. 1819. C s.p Bot. cab. 683

C. G. H. 1786, C s.p Bot. cab. 566

Britain heaths. C s.p Eng. bot. 1013

2 f.jl W

2 f.jl

2 my.jl

$\mathrm{Pu}$

...... $\quad \ldots \quad$ C $\quad$ s.p

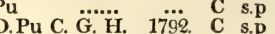

C.p Bot. mag. 580

C. G. H. 1790. C s.p

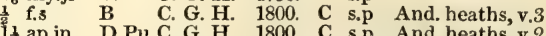

s.p And. heaths, v.2

* ap.jn F C. G. H. 1794. C s.p And. heaths, v.3

$\frac{3}{4}, \mathrm{f} . \mathrm{au}$

$1 \frac{1}{2} \mathrm{jl} . \mathrm{s}$

$\frac{1}{\frac{1}{2}} \mathrm{jl}, \mathrm{s}$

R C. G. H. 1812. C s.p

Pk

C. G. H. 1800. C

C.p And hea vol. 3

1800. C s.p And. hea. vol. 3

C. $\mathrm{G} \mathrm{H}$ 1812. C s.p P.m.68.t.346.f.11

2 jn Pk

, 1814. C s.p Bot. mag. 2165

\section{2 ap.jn $\mathrm{S}$}

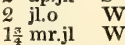
3 my.au G.Pu 5 f.jn W $\begin{array}{lll}5 & \text { f.jn } & \text { W } \\ 5 & \text { f.jn } & \text { W }\end{array}$ $1 \frac{1}{2}$ my.au $\mathbf{O}$ 1 my.au W $1 \frac{1}{6}$ my.au $R$ ${ }_{1 \frac{1}{2}} \mathrm{jl} \quad \mathrm{Pu}$ 1 my.jl Pk

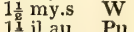
$1 \frac{1}{2} \mathrm{mr} . \mathrm{jl} \mathrm{R}$ $1 \frac{1}{3}$ ap.jn $\mathrm{Pu}$ 1 mr.my W
C. G. H. 1800. C s.p Bot. reg. 115

C. G. H. 1800. C s.p And. hea. vol. 3

C. G. H. 1788, C s.p Bot. mag. 443

$\begin{array}{lllll}\text { Portugal } & \ldots & \text { C } & \text { s.p Li, er. n.9.c.fig.fl }\end{array}$

S. Europe 1658. C s.p

S. Europe 1658. C s.p

C. G. H. 1803. C s.p Bot. mag. 1139

C. G. H. 1800. C s.p And. hea. vol. 2

C. G. H. 1791. C s.p And. hea. c. ic

C. G. H. 1798. C s.p Bot. cab. 557

C. G. H. 1823. C s.p

C. G. H. 1775. C s.p And. hea. vol. 1

C. G. H. 1791. C s.p W.e. 10.p.13.c.ic

C. G. H. 1791. C s.p And hea. vol. 1

C. G. H. 1774. C s.p Bot. mag. 447

C. G. H. 1802. C s.p And. hea. c. ic 5295 incúrva $A n d r$.

Crowberry-lvd incurved

de

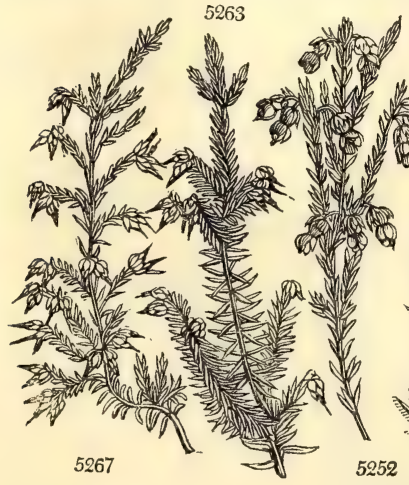

History, Use, Propagation, Culture,

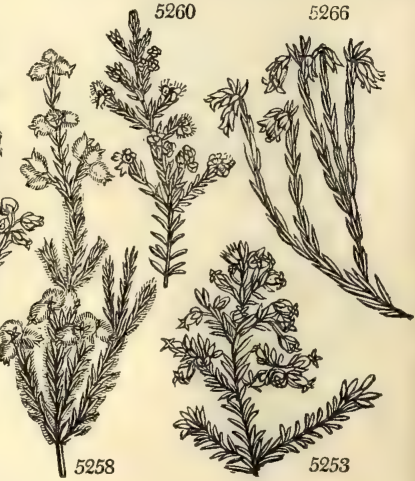

or sand of any color, provided it be free from irony impregnation, should be procured and mixed with it. This sand admits the water to penetrate into the soil and reach the roots of the plant, and also to drain away from the roots so as not to rot them. Pots filled with pure peat-earth are apt to be either hard, dry, and impenetrable to water, or otherwise as wet as a saturated sponge. The free growing kinds (according to Sweet) thrive best in good black peat, and like largish pots to grow in. The dwarf and hard-wooded kinds like a very sandy peat, and smaller pot, well drained with broken potsherds and rough bits of turfy peat; they also require less water than the free growing kinds, as they grow chiefly at the Cape on the tops and sides of mountains, and in the crevices of rocks, \&c. chiefly in very sandy soil, and but little of it. 
5241 Anth. crested, Leaves 3, Cal. imbricated, Sepals carinate, Flowers terminal three, Style included 5242 Anth. beardless, Leaves 3 lanceolate smooth, Fl. umbelled surrounded by colored bractes 5243 Anthers crested, Leaves 3 mucronate smooth with a white edge, Sepals lanceolate, Flowers terminal 5244 Anthers bearded, Leaves 3 oval imbricated, Flowers capitate

5245 Anthers bearded, Leaves 3 smooth, Cor. campanulate, Style included, Flowers 3 sessile 5246 Anthers bearded, Leaves 4, Appendages subulate pectinate longer than the anther

5247 Anthers bearded, Style included, Cor. ovate 4-cornered, Fl, terminal 3, Leaves 3 or 4, Stem pubescent 5248 Leaves long ciliated spreading, Fl, axill. Cor. cylindrical, Cal. with keeled sepals

5249 Anth. bearded included, Style included, Cor. campan. Fl. axill. nodding, Leaves 3 imbricated 6 ways 5250 Anth. beardless exserted, Style exserted, Cor. campan. Fl. terminal capitate, Leaves 4-incurved ciliated 5251 Anth. beardless included, Cor. and calyx scarlet, Leaves opposite

5252 Anth, beardless, Cor. flat, Tube globose, Style exserted, Leaves 3

5253 Anth. beardless included, Cor. ovate, Flowers in umbelled corymbs, Lvs. 3 triangular cartilagin. at edge 5254 Anthers beardless exserted, Style exserted, Cor. campanulate, Flowers 3 terminal, Lvs. 3 lanc. smooth 5255 Anthers beardless exserted, Cor. campanulate, Cal. imbricated, Style exserted, Leaves 3

5256 Anthers much exserted beardless, Cor. campanulate length of the very hairy calyx, Leaves spreading

5257 Anthers much exserted beardless, Cor. campanulate longer than the very hairy calyx, Leaves erect

5258 Anthers beardless included, Cor. globose campan. Cal. woolly, Flowers sessile, Lvs. 3 lin. obtuse villous

5259 Anthers beardless included, Leaves broadish, Fl. terminal, Cal. imbricated

5260 Anthers beardless included, Leaves 3 lines long, Fl. capitate, Cal. ciliated

5261 Anthers beardless of middle length, Cor. campan. longer than cal. Style exserted, Leaves 3

5262 Leaves 4 hairy, Fl. capitate, Sepals and bractes very hairy, Cor. globose, Anthers beardless exserted

5263 Anthers beardless exserted, Style exserted, Cor. campan. Leaves 3 imbricated in 6 rows

5264 Anthers beardless, Leaves linear 3 smooth, Limb of cor. revolute

5265 Anthers beardless, Leaves appressed, Fl. capitate, Cor. limbate

5266 Leaves 2 channelled, Fl. term. on short stalks, Sepals ovate acute, Anth. included crested

5267 Anth. beardless included, Cor. 3, Style exserted, Leaves 3

5268 Anthers bearded, Leaves opposite sagittate

5269 Anth. crested, Leaves 3 erect spreading much longer than joints glaucous, Bractes remote from calyx 5270 Leaves wedge-shaped, Cal. ovate cumeate, Cor. 4-cornered spherical, Anthers bearded

5271 Anth. crested, Leaves 3 ciliated, Cal, imbricated, Style exserted

5272 Anth. crested, Leaves 3 smooth, Cal. imbricated, Style exserted

5273 Anth. crested, Leaves 4

5274 Anth. crested, Leaves opp. appressed, Cal. large cup-shaped, Sepals rounded mucronate

5275 Anth. beardless, Leaves 3, Bractes remote, Cor. campan.

5276 Anth. beardless, Leaves and flowers 4

5277 Anth beardless, Leaves 4 , Flowers 8

5278 Anth. crested, Cor. ovate covered, Style included, Leaves 3, Stigma 4-parted

5279 Anth. beardless, Leaves opposite imbricated appressed, Umbels terminal many-flowered

E. Globose. Corolla small, globose.

5280 Cor, globose, Anth. crested, Two bractes next the calyx, the third remote

5281 Cor. globose, Anth. crested, All bractes close to calyx

5282 Cor. globose, Anth. crested, Bractes remote from cal. Leaves glandular at edge, Sepals ovate

5283 Anthers bearded, Cor. campanulate, Style included, Leaves 3, Flowers scattered

5284 Anth. bearded, Style exserted, Cor. camp. globose, Leaves 3 or 4 roughish, Branches pubescent

5285 Cor. giobose glutinous, Anth. crested, Bractes remote, Leaves roughish

5286 Cor. globose, Leaves quite smooth, Anth. crested

5287 Anth. crested, Leaves 3 ovate smooth, Flowers umbelled ovate, Cal. entire, Branches villous

5288 Anth. crested, Leaves 3 linear smooth, Fl. umbelled globose, Cal. lanceolate short, Branches smooth

5289 Leaves 3 or 4 spreading finely ciliated, Fl. terminal, Bractes remote, Sepals ovate, Anth. included crested

5290 Anth beardless, Leaves 3 triangular smooth, Fl. racemose globose, Branches downy

5291 Anth. crested, Style exserted, Cor. globose campanulate, Fl. terminal umbelled, Leaves 4 smooth erect

5292 Anth. crested, Style included, Cor. ovate, Umb. many-fl. terminal, Leaves 4 or 5, Branches pendulous

5293 Anth. bearded, Cor. globose camp. Cal. appressed ciliated, Fl. term. and axill. 1-sided, Lvs. 4 horizontal

5294 Anth. bearded, Style exserted, Cor. campanulate, Fl. whorled, Leaves 6 linear hairy

5295 Anth. beardless exserted, Cor. campanulate, Fl term. capitate, Leaves 4 incurved ciliated

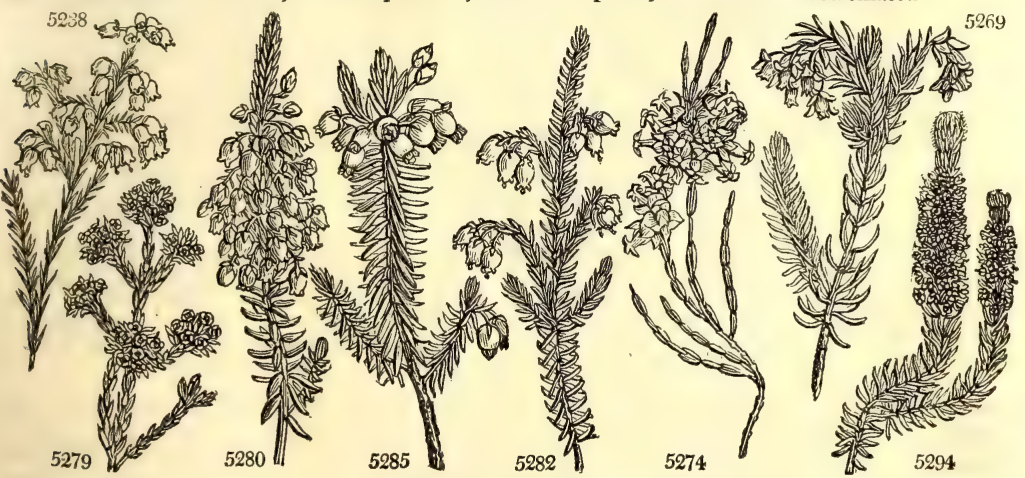

and Miscellaneous Particulars.

The climate for the heaths is not required to be warm during winter; if the frost is excluded, that will be enough. Some species, as the E. persoluta for example, will even bear to have the ground about their roots frozen without injury, provided it is not thawed in the sun or too suddenly, or in a very warm temperature In general the heaths may be kept in the coldest part of the greenhouse, and those not in flower in pits, well covered at night with mats or prepared coverings of reeds or straw. Too much fire-heat in winter will hurt them as much as any thing, as they only require to be kept from frost: most of the kinds might be preserved through the winter in frames: the only difficulty is to keep the damp from them.

Heaths require a great deal of air and light, and therefore should be placed near the glass and near such 
5296 planifólia $\boldsymbol{L}$. 5297 serpyllifólia Lodd. 5298 marifólia Thunb. 5299 hispídula Thunb. 5300 Scholliána Lodd. 5301 Blandfórdia Andr. 5302 sanguinolénta Lodd. 5303 Savilléia Andr. 5304 aggregáta Wendl. $\beta$ alba

5305 congésta Wendl. 5305 paniculáta $I$. $\beta$ alba 5307 suavéolens Lodd. 5308 amo'na Wendl. plumósa Andr. 5309 lævis Andr. 5310 Peziza Lodd. 5311 grácilis Wendl. 5312 nidulária Lodd. 5313 persolúta $L$. 5314 grandinósa Lodd. 5315 pubéscens $L$. 5316 hirtiflóra $H$. $K$. mitraformis W. 5317 cistifólia L $k$. 5318 mucósa $\boldsymbol{L}$. 5319 ramentácea $L$. 5320 mellífera $L k$. 5321 odoráta Andr. 5322 canéscens $A n d r$. eriocéphala A. H. 5323 pura Lodd. 5324 racemósa Thunt. 5325 absinthoídes $L$. 5326 scariósa Thunb. 5327 campanuláta Wend 5328 scopária $L$. 5329 tríceps $L k$. 5330 coarctáta Wendl. 5331 actæa $L k$

5332 conférta Andr.

5333 penicilliflóra Sal. calyculáta Wendi 5334 villósa Andr. 5335 tiaræflóra $A n d r$. 5336 mutábilis $A n d r$. 5337 oblíqua $W$. 5338 fláva $A n d r$. 5339 decóra Andr. 5310 cordáta Andr. 5341 Passerina $W$. 5342 setácea $A n d r$ 5343 tenuíssima $P . S$. 5344 floribúnda Lodd. flat leaved

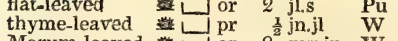
Marum-leaved $\sqcup$ or $2^{\frac{1}{2}}$ my.jn W bristly-stemmed $\amalg$ el 1 jn.au $\mathrm{Pu}$ Scholl's $\amalg$ cu $1 \frac{1}{2}$ my.jn $\mathrm{Pu}$ Ld. Blandford's 㯌 1 or $1 \frac{1}{2} \mathrm{mr} . j n \quad Y$ $\begin{array}{lllll}\text { blood-colored } & \text { pr } & \frac{3}{4} \mathrm{my} . j \mathrm{ll} & \mathrm{Cr} \\ \text { Savile's } & \text { or } & \frac{3}{4} & \mathrm{jn} . \mathrm{jl} & \mathrm{R}\end{array}$ clustered white flowered 教 $\square \mathrm{el}$ close-headed panicled $\square$ de white-flowered sweet-scented feathery $\begin{array}{llll}\text { or } & 1 & \mathrm{mr} . \mathrm{jl} & \mathrm{Pu}\end{array}$ smooth $\downarrow$ de 1 my.jn W mushroom 继 1 de $1 \mathrm{mr} . \mathrm{s}$ gracile or $\frac{3}{4}$ f.jn W nestling garland ${ }_{-1}$ or $1 \frac{1}{2}$ f.my $\mathrm{Pu}$ hailstone pale-downy $\square$ or $1 \frac{1}{2}$ f.d $\mathbf{P u}$ hairy-flowered $1 \frac{1}{2}$ ap.jn $\mathbf{P u}$ cistus-leaved $ـ \mathrm{cu} 1$ my.jn W mucous $\square$ el $1 \frac{1}{2} \mathrm{fau} R$ slender-branch. ${ }^{2}$ el $1 \frac{1}{2}$ jl.d D.R C. G. H. 1787. C s.p And. hea. vol. 1 honey-bearing or 1786 . C s.p And. hea. vol. 1 perfurned de 1 ap.jl W perfurned $\begin{array}{llll}\text { pure } & \mathrm{pr} & \frac{3}{4} \text { au.s } & \mathrm{W} \\ \text { racemed } & \mathrm{el} & 1 \frac{1}{2} \text { ap.my } & \mathrm{Pk}\end{array}$ racemed el $1 \frac{1}{2}$ ap.my $\mathrm{Pk}$ many-flowered $\amalg$ or 1 jn.jl Pu bell-flowered el 1 ap.au Y small-green-fl. $\_$pr 6 ap.my G three-headed $\square$ de 1 my.jn W crowded $\mathrm{cu}_{1}$ my.s $\mathrm{Pu}$ Actæon 近 crowded-flower. $\longleftarrow$ de white-pencilled

$\frac{1}{2}$ f.o W C. G. H. 1800. C s.p And. hea. vol. 2 villous fucu f.jn W C. G. H. 1800. C s.p And. hea. vol. 3 turban-flowered $\square$ pr my.au R C. G. H. 1800. C s.p And. hea. vol. 3 mutable $\quad \begin{array}{lllll}\frac{1}{2} \text { f.o } & \text { Cr } & \text { C. G. H. 1798. C s.p }\end{array}$ oblique-leaved J or 1 au. au $\mathrm{Pu}$ C. G. H. 1789. C s.p And. hea. vol. 1 three-lvd.-yell. 䊦 $\square$ el $1 \frac{1}{2} \mathrm{~s}$ ap. Y $\quad$ C. G. H. 1795. C s.p Bot. cab. 882 graceful el 2 ja.n Pu C. G. H 1790, C s.p And. hea. vol. 3

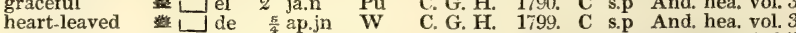
Sparrow-wort $L_{\mathrm{cu}}$ my.n W C. G. H. 1800. C s.p Pet.gaz.t. 3.f.7 bristly-leaved $\amalg$ pr $1 \frac{3}{2}$ f.ap W C. G. H. 1796. C s.p And. hea. vol. 1

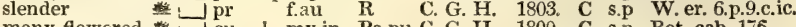

many-flowered ${ }_{2}$ cu 1 my.jn Pa.pu C. G. H. 1800. C s.p Bot. cab. 176

C. G. H. 1795. C s.p W. er. 8.p.7.c.ic.

C. G. H. 1773. C s.p And. hea, vol. 1

C. G. H. 1791. C s.p

C. G. H. 1810. C S.p Bot. cab. 538

C. G. H. 1818. C s.p Bot. cab. 468

C. G. H. 1820. C s.p

C. G. H. 1822 . C s.p

C. G. H. 1774. C s.p

C. G. H. 1795. C $\begin{array}{llll}\text { C } & \text { s.p } & \text { Wot. cab. } 24 \\ \text { C.17. } 73 . c . i c\end{array}$

C. G. H. 1821. C s.p

C. G. H. 1794. C s.p W. er. 8.p.9.c.ic

C. G. H. 1809. C s.p Bot. cab. 764 :

C. G. H. 1774. C s.p Bot. mag. 342

C. G. H. 1790 . C s.p

C. G. H. 1820. C s.p

C. G. H. 1804, C s.p Bot. cab. 633

C G. H. 1807. C s.p Bot. cab. 72

C. G. H. 1795. C s.p W. er.10.p.3.c.ic

C. G. H. 1792, C s.p

H. 1800. C s.p Bot. cab. 477

C. G. H. 1770. C s.p L.e.n. 14.c.fig.t.

C. G. H. 1820 . C s.p

C. G. H. 1801. C s.p

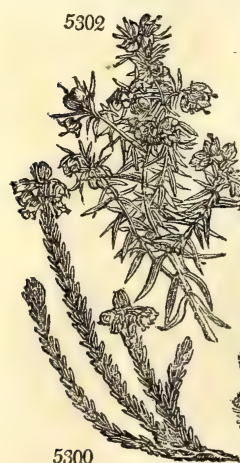

5300

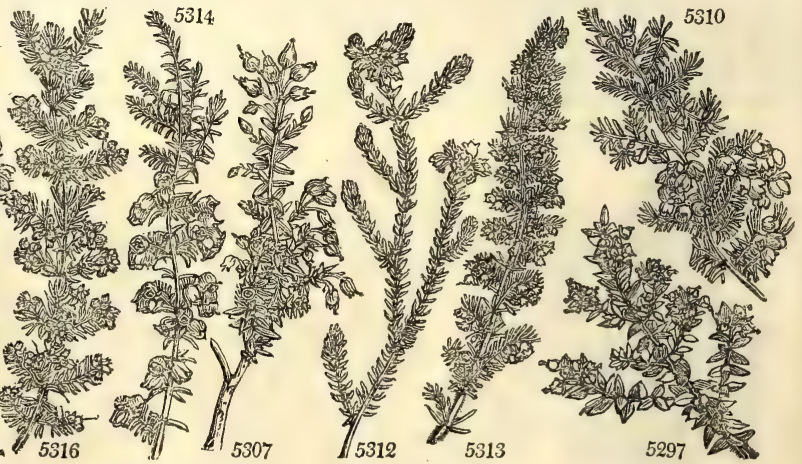

History, Use, Propagation, Culture,

glass as may be opened to admit air every mild day in the year. They require also very regular supplies of water; not much at a time, but so frequently that the earth may never get dry or the plant droop. Many kinds of plants, if they have suffered for want of water, may be recovered by an abundant supply, and placing them under a bell-glass on a little heat; but if once the roots of a heath are thoroughly dried, no art of the gardener will recover the plant. This is the true reason why so many heaths are destroyed when introduced as chamber plants, and also by gardeners who are ignorant of their nature.

Heaths are propagated by cuttings, seeds, and a few by layers. In propagating by cuttings, the tender tops are taken at whatever season of the year they begin to grow, which with most sorts is about the month of June. The strong growing kinds require the cuttings to be rather larger than the others, and some of the stunted growing kinds should be kept in the hot-house a little while when they begin to grow, to draw them to a sufficient length of young wood, or cuttings cannot be procured. Then take the extreme points of the shoots, and with a sharp penknife cut off their lower ends at right angles, placing the cutting on the nail of the thumb, as in cutting the nib of a pan. The cutting will be from three quarters to an inch long: strip off the leaves from the lower end to nearly half the length of the cutting; and, in order that this may be done 
5296 Anth. bearded exserted, Cor. campanulate, Leaves 3 or 4 ovate acute fringed with glands 5297 Leaves 3 ovate, Fl. very minute $3-6$ term. Style long exserted

5298 Anth. bearded, Cor. ovate conical, Style middling, Leaves 3 ovate pubescent white beneath

5299 Anth. beardless included, Cor. roundish, Leaves 3 ovate acute ciliated, Stem hispid

5300 Shoots long, Leaves smooth erect imbricated, Fl. axillary, Cor. globose shorter than stalk nodding

5301 Tube of cor. cup-shaped, Fl. axillary, Cal. imbric. Leaves 4

5302 Leaves 3 spreading acerose, Cor. campanulate rough with short hairs

5303 Bractes remote, Cor. with a short open limb, Anth. included bearded

5304 Flowers capitate, Bractes remote, Cor. hairy, Anth. included bearded

5305 Leaves hairy, Flowers capitate, Anth. included bearded

5306 Bractes remote, Flowers very abundant, Anth. included bearded, Style exserted

5307 Leaves 3 ovate ciliated spreading, Fl. term. 3, Bractes remote, Cor. ovate shorter than its stalk

5308 Anth. bearded, Style included, Cor. camp. Cal. villous, Fl, axill. whorled, Leaves 4 imbric. villous

5309 Anth. included bearded, Fl. capitate, Bractes remote

5310 Leaves 3 narrow spreading, Cor. 4 globose campanulate

[quite smooth

5311 Anth. bearded, Style exserted, Cor. camp. Sepals linear smooth, Fl. terminal umbelled, Leaves 4, Stem

5312 Branches slender upright, Leaves 3 short smooth, Fl. clustered terminal, Cor. globose campanulate

5313 Anth. bearded, Style included, Cor. camp. Sepals ciliated, Leaves 3-4 smooth, Branches pubescent

5314 Leaves 2 spreading very narrow, Leaves 3 terminal, Cor. globose smooth

5315 Anth, bearded, Style included, Cor. ovate pubescent, Leaves 3 hairy, Stem hairy

5316 Anth. bearded, Leaves 4 or more hairy, Fl. terminal, Cor. pubescent

5317 Leaves 4 covered with glandular hairs, Fl. capitate, Bractes none, Cal. hairy, Anth. included bearded 5318 Anth. bearded, Cor. globose mucous, Ped. 3 term. longer than fl. Leaves 4 linear with a cartil. serrul, edge 5319 Anth. crested, Style included, Cor. globose, Fl, umb. Leaves 4 linear 3-cornered smooth

5320 Leaves 4 and branches hairy, Fl, capitate 4 or more, Cal. leafy, Anth. exserted bearded, Style long exserted 5321 Anth. beardless, Bractes remote

5322 Anth. beardless, Leaves linear 3 smooth, Limb of cor. revolute

5323 Leaves 3 short smooth, Fl. solitary term. Cor, ovate smooth, Anth. a little exserted

5324 Anth. beardless, Leaves 4 lanceolate villous, Fl. racemose, Cal, downy

5325 Anth. beardless included, Cor. ovate campanulate, Style exserted, Stigma funnel-form, Leaves 3

5326 Anth. beardloss, Leaves 3 linear smooth, Fl. camp. racemose, Bractes remote

5327 Anth. beardless, Leaves linear 3 smooth, Limb of cor. spreading recurved

5328 Anth. beardless, Leaves linear 3 smonth, Limb of cor. erect

5329 Anth. beardless exserted, Leaves 3 ciliated at base, Fl. term. 3, Sepals scarious

5330 Anth. beardless included, Stigma calypteate, Cor. dilated upwards, Bractes remote

5331 Anth. beardless exserted, Leaves 3 smooth, Fl. term. Style exsert. Stigma peltate

5332 Anth. beardless, Leaves linear 4 smooth, Flowers terminal nearly 12

5333 Anth. beardl. exsert. Cor. urceol. smooth, Fl. term. umb. Leaves 3 pointed ciliated imbricated

5334 Anth. beardless exserted, F1. urceolate villous, Leaves 3 revolute villous

5335 Anth. beardless exserted, Fl. cernuous turban-shaped covered by calyx, Leaves 3

5336 Leaves 3 or 4, Fl, terminal 2, Cor. downy changing from green to crimson

5337 Anth, crested, Cor, ovate viscid, Fl, term. umb. Leaves scattered arcuate truncate

5338 Leaves 3 erect imbricated smooth, Fl. axill. Cor. urceolate, Style exserted

5339 Anth. beardless included, Fl. axillary spiked, Cor, campan. ribbed, Leaves 6 obtuse

5340 Anth. beardless, Leaves 3 ovate villous

5341 Anth. beardless, Leaves 3, Cal. 4-cleft very densely downy

5342 Anth. beardless, Leaves 3 hispid, Sepals hairy upwards, Cor. smooth

5343 Anth. bearded included, Cor. very small obov. obt. smooth, Fl. umb. erect and cernuous, Lvs. 3-4 smouth

5344 Leaves two distant, Fl, numerous very minute globose campanulate, Style exserted

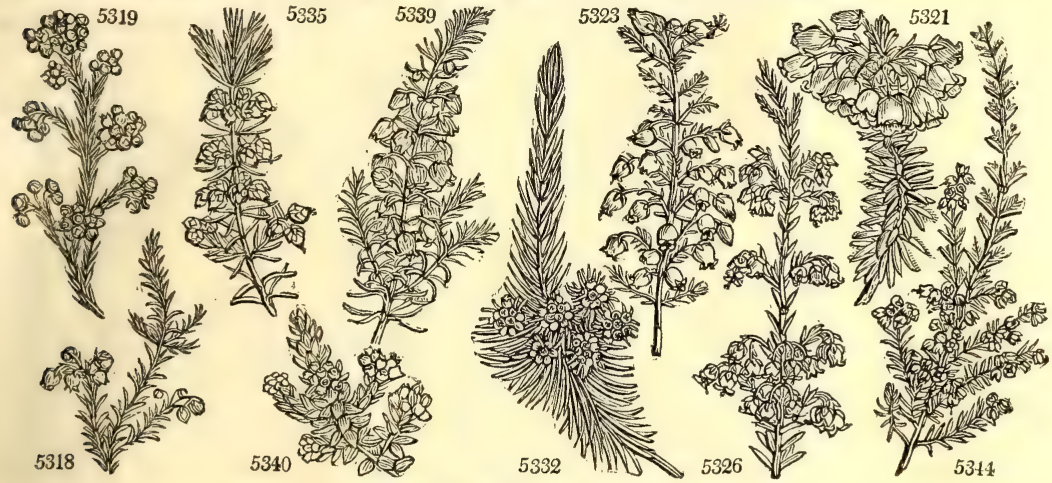

and Miscellaneous Particulars.

without injuring the shoot, use a sharp penknife or a pair of small scissors, for the least bruise or wound spoils the cutting. This done, dibble the cuttings into pots filled with moistened white sand from pits, or with any small sand from pits or rivers, or, in default of that, with powdered sandstone. When they are all planted, water the whole to fix them still better, and when the moisture has subsided, cover them with a small crystal or greenish crystal bell-glass fitted within the rim of the pot, and place them in the shade on a spent hot-bed, keeping them quite close till rooted. The free-striking sorts will have roots in two months, and the others at different periods from three to twelve months, most of them will be ready for transplanting into pots of the smallest size in the following March. Their rooting is easily known by their beginning to shoot, and then the bell should be taken off an hour or two daily.

Many Ericas ripen their seeds in this country, and of other sorts seeds are regularly obtained by the nursery. men from the collectors at the Cape of Good Ho should be sown early in the spring following, in pots filled with equal parts of peat and sand well incorporated ; the seeds should be thinly covered with earth gently pressed down, and bell-glasses placed over them as over the cuttings. The soil must be kept moderately moist by gentle waterings, and in about six or seven weeks 
5345 australis $\boldsymbol{L}$. 5346 cinérea $H$. $K$. ß álba

5347 stricta Donn. 5348 refléxa $L k$. 5349 cérnuad $L$

5350 lanceoláta Pers.

5351 leucanthéra $\mathrm{Andr}$. 5352 tétralix $\boldsymbol{L}$.

$\beta$ álba

5353 cineráscens $W$. en.

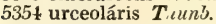

5355 cúbica $L$.

5356 assúrgens $L k$.

5357 nudiflóra $W$.

5358 incána Wendl. \& rubra

5359 reger'minans $\boldsymbol{W}$

5360 scabriuscula $\boldsymbol{L} k$.

5361 bracteoláris Lam

5362 protrúdens $L k$.

5363 flexuósa Andr. divaricáta Wendl

5364 umbelláta $L$

5365 staminea Andr.

5366 latifólia Andr.

5367 cárnea $L$

$\beta$ herbácea Wendl. 5368 mediterránea $L$ 5369 arbúscula Lodd. 5370 vágans $L$ $\beta a l b a$

5371 longipedunculata $L$. 5372 ciliáris $L$.

5373 pilósa Lodd.

5374 álbens $W$.

5375 propéndens $A n d r$. 5376 pyramidális $B$. $\boldsymbol{M}$. 5377 echiiflóra $A n d r$.

5378 filamentósa $\boldsymbol{A} n d r$. 5379 pulchélla Thunb. 5380 viscária $W$

5381 flexicaúlis $\boldsymbol{H}, \boldsymbol{K}$ glandulósa Andr.

5382 tenélla Andr.

5383 alopecuroídes Wen.

5384 furfurósa $\mathrm{Sal}$.

5385 multiflóra $W$.

5386 depréssa $\boldsymbol{W}$. rupéstris Andr.

5387 nana Sal.

5388 palus'tris Andr.

5389 formósa $W$.

$$
\propto \text { álba }
$$

B rúbra

5390 flórida $W$.
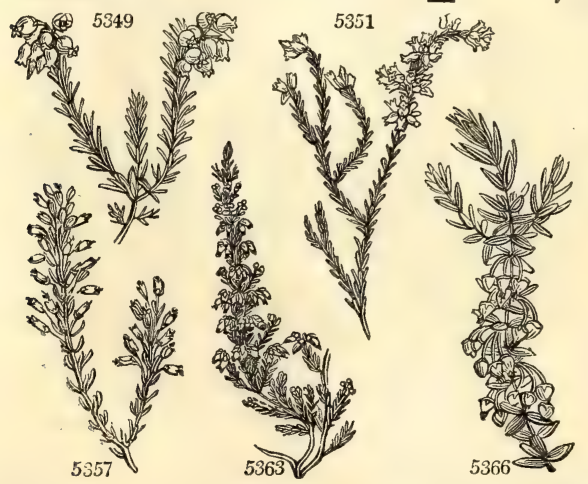

History, Use, Propagation, Culture,

white-flowerin
Spain 1769. C s.p And. hea. vol. 3

Britain hea. L s.p Eng. bot. 1015

Britain hea. L s.p

S. Europe 1765. C s.p And, hea. vol. 2

C. G. H. 1820. C s.p

C. G. H. 1791. C s.p Bot. cab. 822

C. G. H 1791. C s.p W.er.8.p.13.c.ic.

C. G. H. 1803, C s.p

Britain moi.h. C s.p Eng. bot. 1014

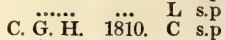

C. G. H. 1778. C s.p Ic. hor.kew. 16

C. G. H. 1790. C s.p And. hea. vol. 1

C. G. H. 1821. C s.p

C. G. H. 1783. C s.p Sm. ined. 3.t. 57

C. G. H. 1810. C s.p

C. G. H. 1810. C s.p

C. G. H. 1791. C s.p

C. G. H. 1805. C s.p Bot. cab. 517

C. G. H. 1800 . C s.p

C. G. H. 1805. C s.p

C. G. H. 1792. C s.p And. hea. vol. 1

umbelled

reflexed-stam

broad-leaved

early-fl.-dwarf

herbaceous

Mediterranean

little tree

Cornish

ng-stalked

ciliated

pilose

pallid

pyramidal

Echium-flower.

ong-peduncled

neat

crook-stalked

Portugal 1782. C s.p And. hea. vol. 2 C. G. H. 1799. C s.p And. hea. vol. 3 $\begin{array}{lllllll}\text { jn.s } & \text { R } & \text { C. G. H. } & \text { 1799. } & \text { C } & \text { s.p } & \text { And. hea. vol. } 3 \\ \text { my.au } & \text { R } & \text { C. G. H. } & \text { 1800. } & \text { C } & \text { s.p } & \text { And. hea. vol. } 2 \\ \text { ja.ap } & \text { Pa.pu Germany } & 1763 . & \text { L } & \text { s.p } & \text { Bot. mag. 11 }\end{array}$

jo. Pk

4 mrmy $\mathrm{Pu}$

1 f.au $R$

1 jl.au

Portugal 1648. C s.p Bot. mag. 471

C. G. H. 1810, C s.p Bot. cab. 843

Cornwall hea. C s.p Eng. bot. 3

C. $\dddot{\mathrm{G}} \ddot{\mathrm{H}} \quad \ldots \quad \mathrm{C}$ s.p

Portugal 1759. C s.p Bot. cab. 103

C. G. H 1800. C s. Bot cab. 606

C. G. H. 1789, C s.p Bot. mag. 440

C. G. H. 1800. C s.p And. hea. vol. 2

C. G. H. 1787. C s.p Bot. mag. 366

C. G. H. 1798. C s.p And. hea. vol. 3

C. G. H. 1800. C s.p Bot. reg. 6

C. G. H. 1792. C s.p Th. er. n. 24. t. 4

C. G. H. 1774. C s.p Ic. hort. kew. 1

C. G. H. 1800. C s.p And. hea. vol. 2

C. G. H. 1791. C s.p And. hea. vol. 2 C. G. H. 1810. C s.p Bot. cab. 874

C. G. H. 1789. C s.p And hea. vol. 1

France 1731. C s.p And. hea. vol. 2

C. G. H. 1789. C s.p And. hea, vol. 2

many-flowered $\square$ or 2 in.n F

C. G. H. 1792. C s.p

C. G. H. 1799. C s.p And. hea. vol, 2

C. G. H. 1795. C s.p Thu.eri, n.82.t.3

C. G. H. 1795, C s.p

C. G. H. 1795. C s.p

C. G. H. 1803. C s.p Thu.eri.n.64.t.6
5355

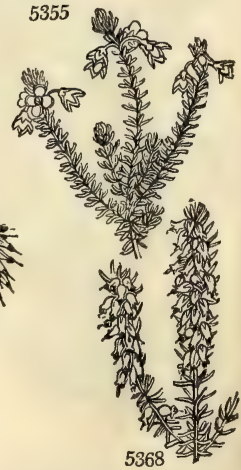

the seeds, if fresh, will begin to come up, when the glasses may be removed by degrees, and the pots kept uear the glass, and shaded from the mid-day sun till autumn, when they may be transplanted into pots of the smallest size.

Seeds which are saved in this country may be sown as soon as gathered, if they ripen before November; but if after that period, it will be better to preserve them till spring, and then treat them like foreign seeds.

Only a few heaths are propagated by layers, such as E. Massoni, retorta, petiolata, and one or two other delicate sorts, which when layed require two years to throw out roots. On the continent most sorts of heaths are propagated by layers, because there they are ignorant of the easiest mode of managing cuttings.

One of the best growers of heaths in Britain is a gardener of the name of Henderson, at Woodhall, in

West Lothian. This judicious cultivator has had an extensive collection of Ericæ for upwards of thirty years under his care, and has given some account of his mode of management in a late volume (vol, iii. p. 323.) 
F. Ovata. Corollas small, not globose.

5345 Anthers crested, Cor. cylindrical, Style exserted, Leaves 3 spreading 5346 Anthers crested, Cor. ovate, Leaves 3, Stigma capitate

5347 Anth. bearded, Style included, Cor. ovate, Fl. term. umbelled, Leaves 4 lin. horizontal

5348 Anth. crested included, Leaves 3 recurved rough at edge, Cal, short, Cor. campanulate viscid

5349 Anth. crested, Leaves 4 ovate ciliated, Fl. capitate, Cal. ciliated

5350 Anth. crested, Leaves 4 lanc. erect smooth, Fl. capitate cernuous

5351 Anth. crested included, F1. capitate, Leaves 3 or 4 lines long

5352 Anth. crested, Cor. ovate, Style included, Leaves 4 ciliated, Fl. capitate

5353 Very like E, cinerea, but the branches and calyx are downy with long hairs, Leaves 5 ciliated

5354 Anth. bearded, Cor, ovate-conical villous, Style included, Sepals lanceolate, Fl. umb. Leaves 3

5355 Anth. beardless included, Cor. camp acute, Style included, Cal. 4 cornered, Leaves 4 spreading

5356 Anth. bearded included, Leaves 4 spreading hairy, Cor. dilated at end, Fl, terminal

5357 Anth. beardless exsert. Style exsert. Leaves 3, Branches downy

5358 Anth. bearded included, Leaves obtuse hairy, Fl. capitate, Bractes remote, Cor. silky

5359 Anth. bearded, Cor, ovate, Style included, Cal. acute, Fl, racemose

5350 Anth, bearded included, Style included, Cor slender, Leaves 4 obtuse glandular, Fl. capitate

5361 Anth. crested included, Cor. prismatical, Leaves 3, Fl. in bundles, Bractes many imbric. involving the fl.

5362 Anth. beardless nearly exserted, Leaves 4 spreading hairy, Fl. terminal umbelled, Sepals ovate

5363 Anthers beardless exserted, Cor. oval twice as long as smooth calyx

5364. Anthers beardless exserted, Cor, campan. Style exserted, Leaves 3 acerose

5365 Anth. exserted, Fl. axill. Leaves linear 3, Filam. very long reflexed

5366 Anth. exserted, Fl. axill. Leaves 3 ovate

5367 Anth. exserted, Fl. axill. Leaves linear 3 or 4, Bractes in middle of flover-stalks, Cor. conical

5368 Anth. exserted, Fl. axill. Leaves 4-5, Bractes above the middle of flower-stalk, Cor. urceolate 5,69 Leaves short spreading, Fl. terminal urceolate, Style a little spreading

5370 Anth. exserted, Fl. axill. Leaves 4-5, Cor. campanulate, Pedunc. the length of cor.

5371 Anth. and style much exserted, Flowers axillary on very long slender hairy stalks

5372 Cor. conical, Ieaves 3 ovate ciliated, Anth. beardless

5373 Plant all over hairy, Cor. ovate, Sepals brown at end, Stamens and style exserted

5374 Cor. conical, Leaves 3 linear smooth, Anth. beardless

5375 Cor, cylindrical, Fl. term. Bractes remote, Anth, beardless, Sepals ovate

5376 Cor. cylind, dilated upwards, Fl. term. Bractes remote, Anth. beardless, Sepals subul. from a broad base

5377 Cor. cylindrical dilated upwards, Fl. axill. Two bractes next cal. Sepals ovate oblong

5378 Cor. cylindrical dilated upwards, Fl. axill. Sepals subulate, Peduncles longer than flower

5379 Cor. cylindrical dilated upwards, F1. axill. Sepals subulate, Peduncles much shorter than flower

5380 Cor. cylindrical dilated upwards, Fl. axill. Sepals linear

5381 Cor. conical, Anth. beardless, Leaves 4, Limb of cor. erect

5382 Anth. beardless, Leaves linear 4 smooth, Fl. terminal 4

5383 Anth، beardless included, Fl. term. Bractes remote, Cor. narrowed upwards

5384 Leaves 3, Anthers beardless exserted, Flowers terminal

5385 Anth. exserted, Fl. axill. Bractes remote, Leaves lin. 5, Cor. camp. Limb reflex. Ped. twice as long as cor.

5386 Cor. cylindrical, Fl. term. Bractes remote, Anth. bearded

5387 Stem spread on the ground, Leaves obtuse, Cor. dewy outside clavate, Anth. bearded

5388 Anth, beardless included, Cor. linear downy, Leaves downy 4

5389 Anth. crested, Leaves 3 ovate entire smooth, Fl, umb. furrowed, Cal. spreading entire

5390 Anth, bearded, Style included, Cor. globose, Cal. villous reflexed, F1. term. umbelled, Leaves 4 hairy

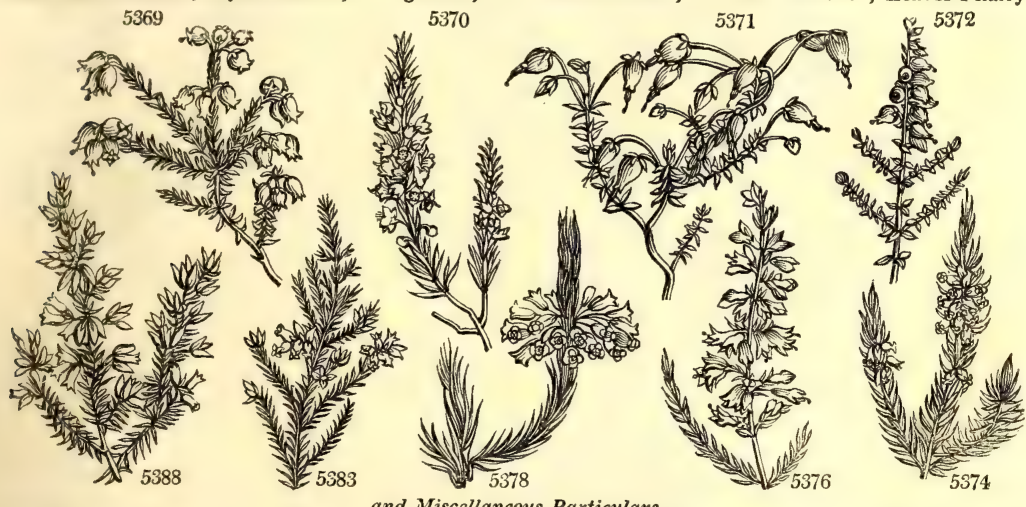

and Miscellaneous Particulars.

of the Caledonian Horticultural Society's Memoirs. He keeps his Ericas, he says, " at all times cool and airy. opening the glasses in winter when there is no frost, and letting the wind blow on them, and using no fire bu in time of frost." " Never," he says, " shift any plant till the pot is quite full of roots. When the plants get large, several of them will continue in good health for three or four years without shifting, and flower well. $I$ have plants of $\mathbf{E}$. retorta here, in pots seven inches in diameter, which are very bushy, being eighteen inche across, and fourteen inches high above the pot. $E$ infundibuliformis, two feet bus , on ( inches in diameter: inches in diameter : these have not been shifted for five years, and are in high health, and covered with strong fine flowers from the mouth of the pot to the top of the plant." (Caled. Mem. iii. 327.)

"A prejudice," Page observes, " having spread that the culture of heaths is difficult, one of the greatest ornaments of the greenhouse has hence of late been neglected; although the method of culture is as easy and nearly as certain as that of the Geranium, but requiring a little more delicacy in the execution." 


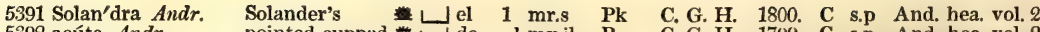
5390 aćta $A$ the 5393 empetroídes Andr. 5394 turrígera Sal. 5395 Bergiána $W$. quadriflóra Andr. 5396 barbáta Andr. bearded pulchélla Andr. articuláris Thunb. 5398 thymifólia Andr. 5399 ténuis $W$. en. 5400 hírta $W$

5401 strigósa $W$.

5402 molleáris Sal. 5403 racemífera $A n d r$. 5404 pilulífera $W$. 5405 catervæé́lia $\mathrm{Sal}$. 5406 tardiflóra Sal. E. mbescens B. M. 5407 parviflóra Sal. 5408 exígua Sal.

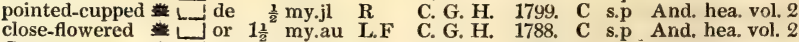
$\begin{array}{llll}\text { Cypress } & \text { or } 1 \frac{1}{2} \text { jn.s } & \text { R } & \text { C. G. H. 1796. C s.p }\end{array}$ Bergius's 整 $\mathrm{cu}^{1} \frac{\lambda_{2}}{2}$ ap.au $\mathrm{Pu}$

C. G. H. 1787. C s.p And, hea. vol. 2 bearded $ـ$ or 1 my.au W C. G. H. 1799. C s.p And. hea. vol. 2 ( 1 jl.s C. G. H. 1787. L s.p W. er.8.p.7.c. ic.

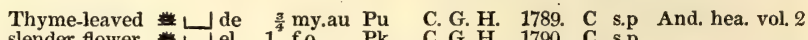
slender-flower. ${ }^{4}$ el 1 f.o $\mathrm{Pk}$ C. G. H. 1790. C s.p hairy-leaved ${ }^{-1}$ or 2 ap.jn R.Pk C. G. H. 1795. C s.p Th. er.n. 56.t.2 dwarf-downy soft-leaved compact-flow. compact-flow.
ball-bearing huddled-leaved or 11 ap.jn R.Pk C. G. H. 1795. C s.p

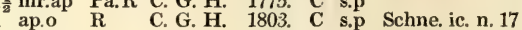
$\frac{3}{4}$ ap.jn $R \quad$ C. G. H. 1803. C s.p And. hea. vol. 3 1 ap.my $R \quad$ C. G. H. 1789. C s.p $\begin{array}{lllll}\frac{3}{4} \text { ap.jn } & \text { R } & \text { C. G. H. } 1790 . & \text { C } & \text { s.p }\end{array}$ lo $1 \frac{1}{2} \mathrm{mr} . \mathrm{s}$ Pu $\quad$ C. G. H. 1790. C s.p Bot. mag. 480 small-fl.-downy 1 J pr $1 \mathrm{mr} . \mathrm{s} \quad$ Pk $\quad$ C. G. H. 1790. C s.p small-downy $\square_{\text {pr }} 1 \mathrm{mr} . \mathrm{s} \quad$ Pk $\quad$ C. G. H. 1790. C s.p

893. MENZIESIA. Sm. 5409 ferrugínea $P h$. 5410 globuláris $\boldsymbol{P h}$. 5411 pilósa $W$.

5412 polifólia $H$. $K$. ß nána

Menziesia ferrugineous globular-flow. pilose

Irish dwarf 5413 cærúlea $\boldsymbol{L} . T$. 894. CHLO'RA. W

Yew-leaved

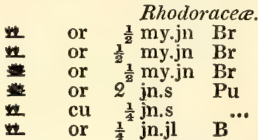

Sp. 5-6.

L s.p Sm. ic. in. 1.t. 56 N. Amer. 1806. L s.p Par. lond. 44

….. 1822. L s.p

reland moun. L s.p Eng. bot. 35

YELLOW-WORT. perfoliate

Gentianea. Sp. 1-2.

895. MICHAUX'IA, $W$. MichaUxia. 5415 campanuloídes $W$. rough-leaved 896. JEFFERSO'NIA. $P h$. JEFFERSONIA. 5416 diphylla $P h$. two-leaved

897. DODON EA. $W$. 5417 viscósa $W$. 5418 bialáta $K t h$. 5419 oblongifólia $\boldsymbol{L} k$. 5420 tríquetra $W$. 5421 angustifólia $W$.

Dodonea. clammy two-winged oblong three-sided narrow un 5 jn.au

IAwsonia. 898. LA WSO'NIA. $W$. 5422 inérmis $W$ 5423 spinósa $W$. 5424 purpúrea $\dot{L} a m$. prickly purple 899. OSBECK'IA. $W$. 5425 zeylánica $W$. 5426 Chinénsis $W$. 5427 stelláta Don.

5428 nepalénsis Hook. Nepal

Osbeckra. Ceylon Chinese starry Nepal

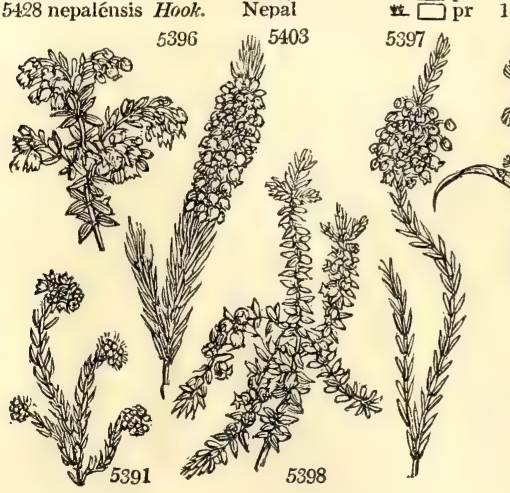

History, Use, Propagation, Culture

Salicarie. Sp.3-6.

sष्य 5420

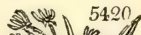

5

Campanulacea. Sp. 1.

4 jn.au L.B Levant 1787. S r.l Bot. mag. 219

Papaveracece. Sp. 1.

$\frac{1}{2} \mathrm{my}$ W N. Amer. 1792. D s.l Bot. mag. 1513

Terebintacea. Sp. 5-17.

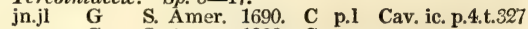
... G S. Amer. 1822. C co 1823. C co

N. S. W. 1790 . C s.p Bot. rep. 230 Jamaica 1758. C s.p

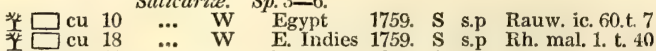

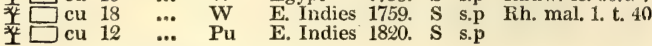

Melastomacea. Sp. $4-7$.

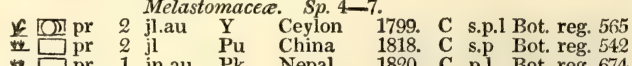

L 1 jn.au Pk Nepal 1820. C p.1 Bot. reg. 674.

1821. C p.l Hook.

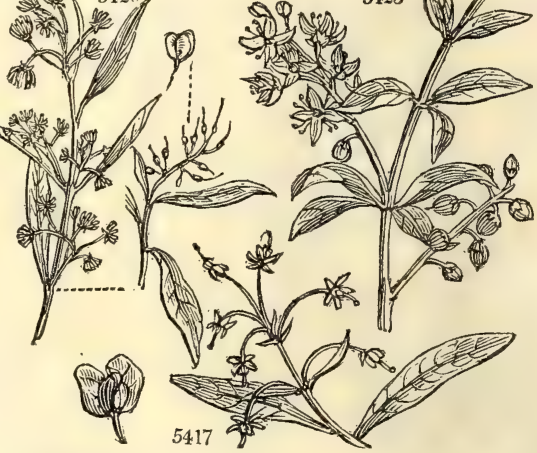

(Prodromus, \&c. art. Erica.) Those who complain of the difficulty of growing the heath, are often, as Loddiges remarks, ignorant people who have never had a heath to grow.

One circumstance in favor of the culture of heaths is, that they are not subject to insects, or at least very rarely so. (Greenhouse Companion, p. 62.)

The number of species is here reduced to those which are certainly different from each other. Of those enumerated in garden catalogues many are mere repetitions of each other.

893. Menziesia. Named in honor of Mr. Archibald Menzies, an assiduous and successful botanist, who accompanied Vancouver, in the capacity of his surgeon, in his voyage round the world. He is still living, and the ornament of the private circle in which he moves. Small heath-like plants, all hardy, and requiring the same cultivation as Erica.

894. Chlora. From $\chi \lambda \omega \cos$, green, in allusion to the color of the dried flower of C. perfoliata. The whole plant dyes yellow.

895. Michauxia. In memory of Andrew Michaux, botanist to the king of France, who travelled into Syria, 
5391 Anth. crested included, Flowers capitate campan. cernuous, Leaves 4 cernuous 5392 Anth. crested included, Fl. 3, Leaves 4 subulate erect mucronate

5393 Anth. bearded, Cor. campan. Fl. whorled, Leaves 6 hairy spiral

5394 Leaves narrow, Cal. recurved horizontal, Cor. globose with segm. imbricated at base

5395 Anth. crested, Leaves 3 lanceolate rough, Fl. 3, Cal. ciliated reflexed

5396 Anth. crested included, Cor. urceolate hairy, Fl. umbelled, Leaves 4 ovate

5397 Anth. bearded included, Cor. globose much less than colored calyx, Leaves 3 with a membranous edge

5398 Anth. 2 horned included, Cor. axill, solitary, Leaves 3 ovate cordate ciliated

5399 Anth. bearded included, Style exserted, Cor. camp. smooth, Fl. term. sol. Leaves 3 lin. Branches hairy

5400 Anth. bearded, Leaves 3 linear hispid, Fl. umbelled, Cal. rough

5401 Anth. bearded, Cor. camp. smooth, Leaves 4 pubescent ciliated

5402 Cal. 4-cleft, Cor. linear smooth urceolate with a recurved limb, Capsule hairy

5403 Anth. bearded included, Flowers racemose, Leaves 6 clustered

5404 Anth. bearded, Leaves 4 ciliated, Fl. umb. Cal. navicular ciliated at end

5405 Anth. bearded perforated, Leaves 4, Stem angular downy, Cor. narrow obovate

5406 Anth. bearded, Leaves 4, Cal. appressed, Cor. linear pubes. with a very short recurved limb, Caps. hairy

5407 Anth. bearded, Leaves 4, Cal. appressed, Cor. linear pubescent, Capsule smooth

[smooth

5408 Anth. bearded, Leaves 4, Cal. appressed, Cor. linear pubes. with an oval tube and very short limb, Caps.

5409 Leaves obov. lanc. beneath, beyond the nerves smooth, Cal. 4-cleft, Fl. urceol. 8-androus

5410 Leaves pubescent beneath, Calyx 4-fid, Cor. with a globose tube

5411 Leaves oval pubescent, Fl, term. aggregate nodding

5412 Leaves beneath densely downy, Cal. 4-parted, Tube of cor. oval

5413 Leaves linear obtuse with cartilaginous teeth, Flowers 5-cleft decandrous

5414 Leaves perfoliate

5415 The only species

5416 The only species

5417 Leaves obovate oblong viscous, Fl. racemose, Fruit with 2 or 3 wings longer than stalk

5418 Leaves lanc. narrowed at both ends viscid, Racemes branched, Fruit always with 2 wings length of stalk

5419 Leaves obl. mucronate entire, Fl. term. sessile

5420 Leaves lanceolate narrowed at each end, Branches 3-cornered, Fruit with narrow wings

5421 Leaves oblong lanceolate with revolute edge, rather clammy, Flowers in short racemes

5422 Unarmed, Leaves subsessile ovate acute at each end

5423 Branches spiny

5424 Leaves subsessile lanceolate with terminal corymbs of flowers

5425 Leaves stalked, Calyx hispid

5426 Leaves sessile, Calyx smooth

5427 Leaves lanc. obl. acumin. 5 nerved and branches hispid, Cal. covered with entangled radiate hairs

5428 Leaves lanceolate sessile, Tube of calyx ciliate scaly

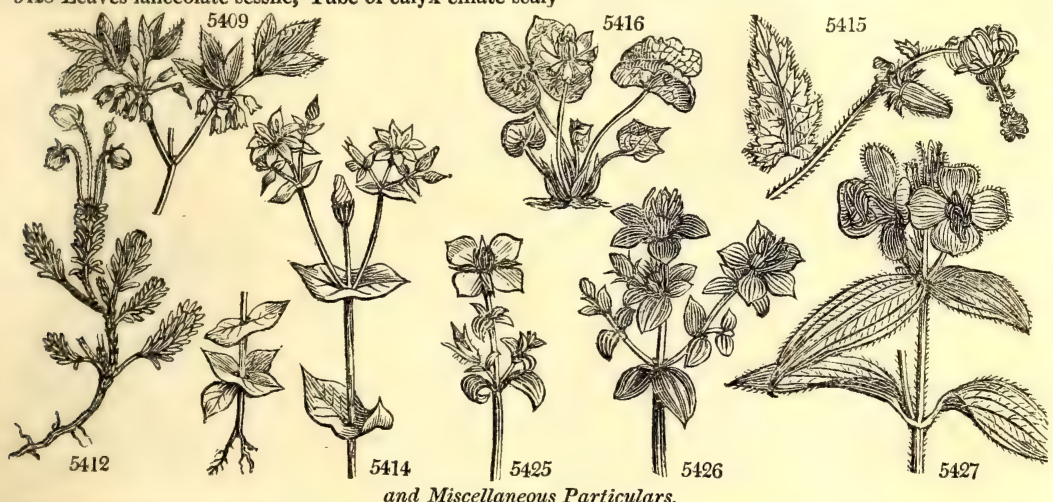

Persia, and North America, and discovered this his genus. It is a handsome biennial, which bears a profusion of shewy flowers bearing some distant resemblance to those of the Passion-flower.

896. Jeffersonia. Named after Mr. Jefferson, the celebrated President of the United States. A very curious plarit, remarkable for the peculiar mode of dehiscence of its capsule.

897. Dodoncea. So named in honor of Rambert Dodoens, professor of medicine, a famous botanist of the sixteenth century, author of Fragum Historia, 1552; and Pemptades, 1583. He was born at Malines, in 1518, and died in 1585. The species are ugly tropical shrubs, of neither use nor beauty.

898. Lawsonia. In memory of Isaac Lawson, M. D. author of A New Voyage to Carolina, London, 1709. $\mathbf{L}$. inermis is the Henna plant, with the leaves of which the Egyptian wornen dye their nails pink. It is of easy culture and propagation.

899. Osbeckia. So named by Linnæus, in honor of Peter Osbeck, a Swedish clergyrnan, member of the academy of Stockholm, and of the society of Upsal: author of a voyage to China and the East Indies, in 1751. Englished by Forster, in 1771. Little plants resembling Melastoma. Young cuttings strike freely under a hand-glass. 
900. RHEX'IA. W

5429 mariána $W$.

5430 vimínea Don.

5431 ciliósa $P h$.

5432 bival'vis $W$.

5433 virgínica $W$.

5434 aquática $W$.

5435 holosericea Humb

5436 glomeráta $W$.

901. ENOTHE'R
5437 biénnis $W$.

5438 grandifióra $W$

5439 parviflóra $W$.

5440 muricáta $W$.

5441 longiflóra $W$.

5442 mollissima $W$.

5143 odoráta $W$.

5444 noctúrna $W$.

5445 villósa $W$.

5445 dentata $L$ indl.

$5+47$ fruticósa $W$.

5448 púmila $W$.

5449 rósea $W$.

5450 purpúrea $W$ E. Romanzovii B
corymbósa B. $M$.

5451 corymbósa $B$. M.
5452 stricta Ledebure

5453 média Link.

5454 lineáris Mich.

5455 sinuáta $W$.

5456 tetráptera $W$.

5457 cæspitosa $B$. $M$.

5458 macrocárpa $B . M$.

5459 glaúca $P h$.

5460 Traséri $P h$.

5461 tenuifólia $F l$. $p$.

5462 acaúlis $C a v$.

5463 tenélla $F l$. per.

5464 speciósa Hook.

5465 virgáta $\mathrm{Fl}$. per.

5466 hirta $L k$.

5467 tríloba Nutt.

5468 albicaúlis $P h$.

902. GAU'RA $W$.

5469 biénnis $W$.

5470 coccínea $P h$.

5471 fruticósa $W$.

5472 mutábilis $W$.

5473 tripétala $\mathrm{Cav}$.

903. EPILO'BIUM. $W$

5474 angustifólium $W$.

5476 latifólium $W$.

5476 latifolium

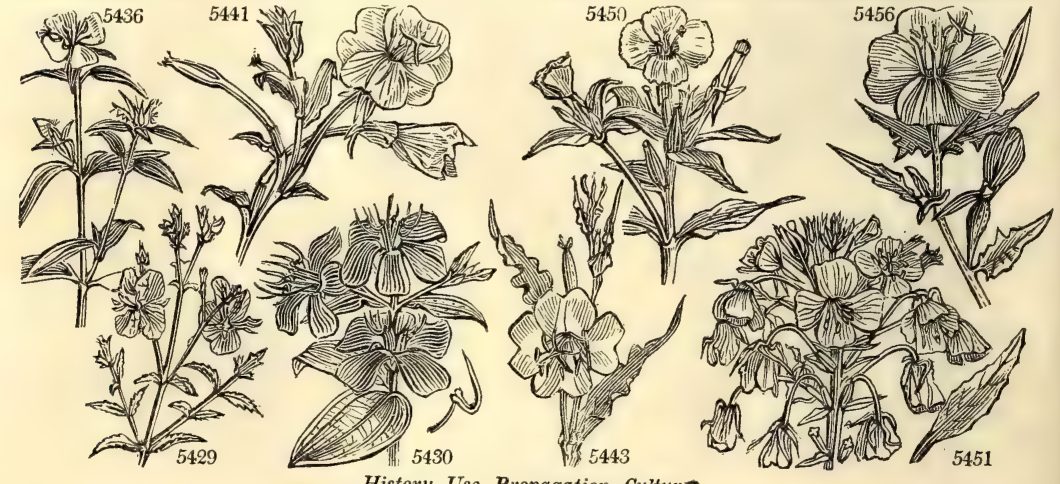

Rhexia.

Maryland

twiggy

ciliated

two-valved

Virginian

marsh

silky

CEnothera.

common

great_flowered

small-flowered

prickly-stalked

long-flowered 10 or

soft wave-leav. ㄱ 0 or

sweet-scented \& $\triangle$ or

night-smelling

villous

shrubby

dwarf

$\downarrow \Delta$ or

$\neq \Delta$ or

ze $\triangle$ or

rosy-flowered \& $\Lambda$ or

purple-flow

corymbose

upright

intermediate

linear

scollop-leaved

white-flowered

turfy

Missouri

glaucous

Fraser's

fine-leaved

stemless

slender

shewy

twiggy

hairy

three-lobed

white-stalked

GAura

biennial

scarlet

shrubby

changeable

three-petalled

WiLlow-HERB.

Rose-bay

$\$ \Delta$ or Orache-leaved $\frac{\downarrow}{\not k} \Delta$ or

$¥ \Delta$ or
Melastomacea. Sp.7-50.

${ }^{3}$ in.au Pu N. Amer. 1759. D s.p Bot cab. 366

$6{ }^{\mathrm{jn} . \mathrm{au}} \mathrm{Pu}$ Brazil 1821. D s.p Bot. reg. 664

1 jn.au Cr Carolina 1812. D p.1 Ph. am. 1.t.10

2 my.jn W Guiana 1893. S p.l

N. Amer. 1759. D p.1 Bot. mag. 968

S. Amer. 1793. C p.1 Aub.gui. 1.t.169

Brazil 1816. C p.l Bot. reg. 323

W. Indies 1818. C p.l Bot. cab. 334

Onagrarize. Sp. $32-41$.
jn. $\mathrm{S}$ Y . Amer. 1629. $\mathrm{s}$ co Flor. dan. 446

4 jn.au Y N. Amer. 1778. S co Bot. mag. 2(168

4 jn.au Y N. Amer. 1757. S co Meerb, ic 1 t 34

3 jl.au Y N. Amer. 1789. S co M. co. got. 6. t.1

3 jl.s $Y$ B. Ayres 1776. S co Bot. mag. 365

2 jn.o $\mathrm{Y} \quad$ B. Ayres 1732. S co Sch.han. 1.t.105

ap.au Y S. Amer. 1790. D co Bot. reg. 147

2 ap.au Y C. G. H. 1790. S co Jac. ic. 3.t. 455

2 jl.au $Y$ C. G. $H$ 1791. S co

$\frac{1}{2}$ jn.au Y Peru 1818. D co Lindl. coll. 10

3 jn.au D.Y N. Amer. 1757. D s.p Bot. mag. 332

$\frac{1}{2}$ my.s D.Y N. Amer. 1757. D p.I Bot. mag. 355

1 my.au Pk Peru 1783. D p.l Bot. mag. 347

N. Amer. 1794. C co Bot. mag. 352

$3 \mathrm{~s}$

11 in.jl

2 jl.au

$1 \frac{1}{2} \mathrm{jn}$

1 ji

1 jn.au

4. jn.jl

2 my.o

$1 \frac{1}{2}$ my.o

$1 \frac{1}{2} \mathrm{jl}, \mathrm{s}$

$\frac{1}{2}$ my.s

$\frac{1}{2}$ ap.au

$1 \mathrm{mr} . \mathrm{s}$

$1 \frac{1}{2} \mathrm{jn}$ my.jl $\mathrm{Pu}$

$\frac{3}{4}$ my.s $Y$

$\frac{1}{3}$ my.au W

Onagraria. $S p .5-7$.

Mexico 1816. D co Bot. mag. 1974

N. Amer. 1822. S D p.1

N. Amer. 1822. D

N. Amer. 1770. S s.1 M. co. got. 5. t. 9

Mexico 1796. S s.1 Bot. mag. 468

N. Amer. 1811. D p.l Bot. mag. 1593

N. Amer. 1811. D s.p Bot. mag. 1592

N. Amer. 1812. D s.p Bot. mag. 1606

N. Amer. 1811. D s.p Bot. mag. 1674

Y.Pu Peru 1824. D co

Chili 1821. D co

N. Amer 1821.

Peru

California 1823. S co

N. Amer. 1822 D co

N. Amer. 18:1. S s.p

au.o R.w N. Amer. 1762, S p.l Bot. mag. 389 竞 au.o S Louisiana 1811. S s.l

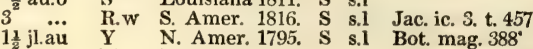

1 au Pk Mexico 1804. S $\begin{array}{llll}\text { S } & \text { s.1 } & \text { Bot. mag. } 388^{\circ} \\ \text { Cav.ic.4. } 396 . f\end{array}$

Onagrarice. Sp. 15-20.

4 jl.au Pu Britain mea. D m.s Eng. bot. 1947

jl.au Pu Al. of Eur.1775. D m.s Bot. mag. 76

R N. Eur. 1779. D co Par. lond. 58

History, Use, Propagation, Culture,

900. Rhexia. A Greek name employed by Pliny to designate a Boragineous plant. It is derived from $\dot{\rho} \varepsilon \sigma \sigma \omega$, to burst; that is to say, good against ruptures. The hardy species thrive best in a bed of peat; or they will grow very well in pots.

901. Enothera. Derived from owvos, wine, and Inow, to hunt. The roots of this plant, $\mathbf{O}$ biennis, eaten after meals, are incentives to wine-drinking, as olives are. This is an ornamental genus of easy culture in light rich soil, and they increase etther by seeds or cuttings. $O$. biennis is called the night primrose, because the flowers usually open hetween six and seven o'clock in the evening. The mode of their expanding is curious. The petals are held together at top by the hooks at the end of the calyx, the segments of which first separate at bottom and discover the corolla, a long time before it acquires sufficient expansive force to unhook the calyx at top; when it has accomplished this, it expands very fast, almost instantaneously, to a certain point, and then makes a stop, taking a little time to spread out quite flat: it may be half an hour from the first bursting of the calyx at bottom to the final expansion of the corolla; which commonly becomes flaccid in the course of the next day, sooner or later according to the heat or coolness of the weather. The 
5429 Lvs. sess. lanc. 3-nerved villous ciliated, Cal, stellate hairy

5430 Leaves ovate lanc. 5-nerved hairy on each side, Panic. term. loosely many-fl.

5431 Leaves finely hispid at edge, Stem quadrangular smooth, Flowers solitary in an involucre

5432 Decandrous, Lvs. sessile smooth ovate obtuse 3-nerved, Caps. 2-valved

5433 Lvs. sessile lanceolate 3-nerved serrate ciliated, Cal. glandular ciliated

5434 Lvs. opp. cordate crenulate hairy, Pan. term. trichotomous, Branches filiform much spreading 5435 Leaves cordate oval silky on each side 7-nerved sessile, Pan. term. Flowers with bractes 10-andr. 5436 Lvs. stalked ovate entire 3-nerved villous, Fl, terminal clustered

5457 Lvs. ovate-lanceolate flat, Stem muricated villous, Stamens shorter than cor. 5438 Lvs, ovate-lanceolate, Stamens declinate, Stem shrubby

5439 Lvs, ovate-lanceolate flat, Stem smooth subvillous, Stamens longer than cor.

5440 Lvs. lanc. flat, Stem purp. muricated, Stamens length of cor.

5411 Lvs. toothletted, Stems simple hairy, Petals distant 2-lobed

5442 Lvs. lanceolate wavy

5443 Lvs. linear lanceolate toothletted wavy pubescent glaucous, Stem hairy

5444 Lvs. lanc. repand toothed pubescent, Stem rounded pubescent

5445 Lvs. lanc. villous, Stem angular hairy

5446 Lvs. sublinear toothletted, Caps, cylindr. very narrow toothed

5447 Lvs. lanceol. somewhat toothed acute, Caps, stalked obl. clavate angular

5448 Lvs. lanc. entire obtuse, Caps. somewhat stalked ellipt. ovate angular

5449 Lvs. ovate narrowed at each end toothed ; lower lyrate, Caps. stalked obovate angular

5450 Lvs. glaucous smooth lanceolate entire, Caps. sessile ovate angular

5451 Stem upright hispid furrowed, Leaves lanc. repand toothletted, Caps. sess. angular cvlindrical 5452 Stem muricated, Lower Ivs. linear very long toothletted ; cauline lanceolate

5453 Stem erect pubescent, Lvs. lanc. lin. soft pubescent, Caps. obl. rounded sessile

5454 Pubescent, Lvs. lin. lanc. acute at each end entire, F1. term. aggregate, Caps. clavate 4-cornered 5455 Lvs. toothed sinuated, Caps. prismatical

5456 Lvs. lanc. pinnatifid at base, Caps. obovate with 4 wings

5457 Lvs. lanc. cut-toothed, Caps. obl. sessile, Tube of cal. very long, Pet. 2-lobed

5458 Stem branched, Lvs. lanc. stalked with distant glandular teeth, Caps. ellipt. 4-winged on short stalks

5459 Leaves broad-oval repand toothed lævigated glaucous, Caps. ovate 4-cornered

5460 Stem simple below, Leaves ovate stalked glandular toothletted, Racemes leafy, Caps. obovate 4-cornered

5461 Lower leaves obiong, upper linear, Caps. cylindrical straight, Petals crenulate

5462 Leaves pinnatifid, with the terminal segment large and toothletted

5463 Leaves linear obovate, Cap3. cylindrical curved

5464 Downy, Leaves oblong lanc. toothed subpinnatifid, Raceme naked, Caps. obovate angular

5465 Leaves lyrate and lanceolate toothed, Caps. stalked clavate

5466 Hairy, Leaves lanc. toothletted, Caps. axillary curved angular acute

5457 Very like CEnothera acaulis, from which it is chiefly distinguished by its yellow flowers

5468 Finely pubescent, Stem and nerves of leaves white, Leaves pinnatifid, Fl, spiked

5469 Leaves lanc. toothed, Pet. obovate ascending spreading, Style and stamens declinate

5470 Leaves lin. lanc, toothletted, Spike close, Petals as long as cal. Stigma entire

5471 Leaves lin. lanc. toothletted, Style and stamens straight

5472 Leaves ovate toothed, Pet. ovate acute cruciate, Style and stamens straight

5473 Leaves lin. lanc. deeply toothed, Pet. 3 ascending, Stamens 6 declinate

5474 Leaves scattered lin. lanc. entire veiny, Fl. unequal

5475 Leaves scattered lin. obsoletely toothletted veinless, Petals unequal entire

5476 Leaves altern. and opposite lanc. ovate nearly entire pubescent veinless, Fl. unequal

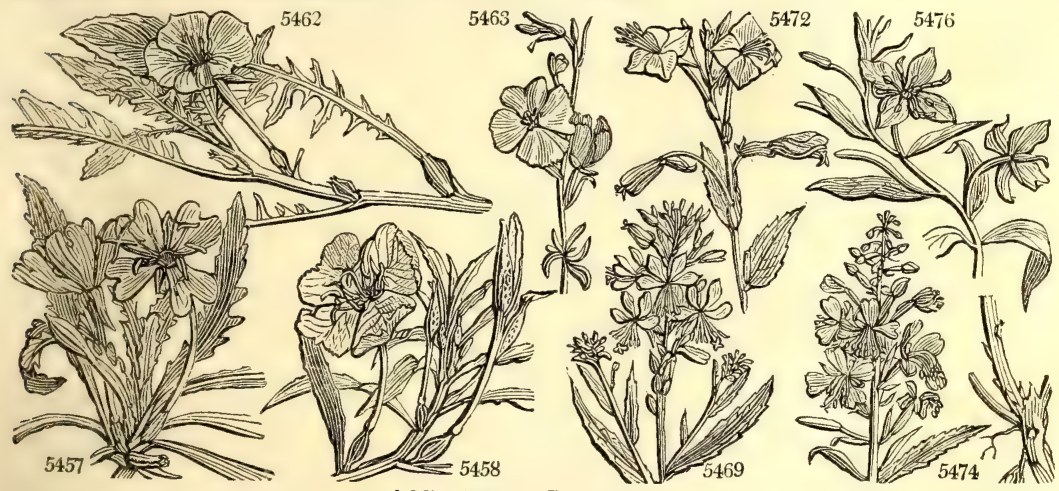

and Miscellaneous Particulars.

uppermost flowers come out first in June; the stalk keeps continually advancing in height, and there is a constant succession of flowers, till late in autumn. The roots are eaten in some countries in the spring.

O. longiflora has flowers uncommonly large and shewy, which continue from July to October.

The dwarf North American herbaceous kinds, are among the most beautiful plants of our borders.

902. Gaura. A very curious genus, so called from ravos, superb. Its flowers are rose colored, in fine terminal spikes. Plants with the habit of OEnothera, and requiring the same management.

903. Epilobium. From $\varepsilon \tau i$, upon, and $\lambda_{0} \mathcal{E}_{05}$, a pod; that is to say, a flower growing upon a pod. E. angustifolium is a native of most parts of Europe, from Lapland to Italy. It is valuable in shrubberies as thriving under the drip of trees, and succeeds every where, even in the smoke of cities, and in parks : it is a good plant to adorn pieces of water, being hardy, of rapid increase, not much relished by cattle, and very shewy when in flower. According to Haller, the young shoots are eatable, although an infusion of the plant stupifies : the pith when dried, is boiled, and becoming sweet, is by a proper process made into ale, and this into vinegar by the Kamtschatdales; it is also added to the cow-parsnip, to enrich the spirit that is prepared 
5477 hirsítum $\boldsymbol{W}$. 5481 róseum $S m$. 5482 alsinifólium $\mathrm{Sm}$. 5483 tetragónum $W$. 5484 colorátum $W$. 5485 alpéstre $\mathbf{S c h m i d t}$. 5486 dahúricum Fisch. 5487 palústre $W$.

5488 alpínum $W$.

904. FUCH'SIA. $W$. 5489 coccínea $W$.

5490 grácilis Lindl. decussáta B. M. 5491 excorticata $W$. 5492 lycioides $W$.
5478 parvifórum $E$. B. 5479 villósum $W$. 5480 montánum $W$

Coalins\&Cream $\Delta$ or small-flowered $\ \triangle \mathrm{pr}$ Cape broad-smth-lv. pale-smooth-lv, $\overrightarrow{ }$ Chickweed-lvd. square-stalked $\frac{\Delta}{\Delta}$ Pink-flowered $\$ \Delta$ or Pink-flowered $\frac{\partial}{\partial} \triangle$ or alpine $\quad \pm 0$ pr Daurian $O \mathrm{p}$ round-stalked $\not \Delta \Delta$ Alpine

Fuchsia. scarlet slender

barked L J or 3 jn.o G.Pu N. Zeal. 1824. C p.l Bot. reg. 857

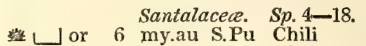
Boxthorn-leav. $\amalg$ or 2 ap.o $\mathrm{S}$ Chili 1796. C p.J Bot. mag. 1024

905. JAMBOLI'FERA. $L$. JАMBOLIFERA. 5493 pedunculáta Dec. peduncled

906. OXYCOC'CUS. $P . S$. Cranberry 5494 palústris $P . S$ common 5495 macrocárpus $P h$. large-fruited 5496 erythrocarpus $P$.S. upright $O$. eréctus Psh.

907. VACCINIUM. $L$. 5497 myrtil'lus $L$. $\beta$ fructu albo 5498 pal'lidum $H$. $K$. 5499 stamíneum $L$. 5500 álbum $L$

5501 cæspitósum Mich.

5502 uliginósum $L$.

5503 diffúsum $H . K$. arbóreum Mich.

5504 ancureum angustifólium H.K. Bluet myrtilloídes Mich.

5505 dumósum B. M. hirtéllum $\mathbf{H}$. K.

5506 fuscátum $H$. $K$. formósum Andr. $\beta$ angustifólium 5507 frond 6 sum $L$. glaucum Mich.

5508 ligusirínum $\boldsymbol{L}$.
WhoRTLE-BERRY, Bilberry 些 white-fruited pale long-stamened white-flowered turfy Bleaberr tree Bluets 電

clustered-flow. Blue Tangles Nㅗ red-twigged
Privet-leaved narrow-leaved as Terebintacea. $S p .1-3$.

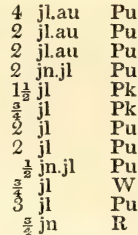

Britain wat.pl. D co Eng. bot. 838 Britain wat.pl. D co Eng. bot. 795 C. G. H. 1799. D co Britain woods. D co Eng. bot. 1177 England mar. D m.s Eng. bot. 693 Britain sc. al. D m.s Eng. bot. 2000 Britain mar. D m.s Eng. bot. 1948 N. Amer. 1805. D 1.p Switzerl. 1820. S l.p Dauria 1822. S co Britain mar. D co Eng. bot. 346 Britain al. riv. D s.1 Eng. bot. 2001

$\square$ cu 4 f.d $\mathrm{G}$ E. Indies 1800 . C 1t.1 Vah. sym.3.t.61 Ericece. Sp.3.

fr $\frac{x}{4}$ my.jn Pk Britain tur. bo. L p Eng. bot. 319 e fr $\frac{3^{\frac{1}{4}}}{4}$ my.jn Pu N. Amer. 1760. L p Dend. brit. 129 fr 2 my.jn Pk N. Amer. 1806. L p Dend, brit. 31
Ericee. $S p .27-30$.

fr $1 \frac{1}{2}$ ap.jn $R$ Britain hea. $\mathbf{L}$ p Eng. bot. 456 or $1 \frac{1}{2}$ ap.jn $\mathrm{G}$ Britain moors, $\mathrm{L}$ p or 2 my.in W N. Amer. 1772 L p or 1 W Hud Bay 1823. I P fr $2^{\frac{1}{4}}$ ap. $\mathrm{my}$ or 20 my.jl Pk Carolina 1765. L p

P1. al. t. 339 , f. 3 Bot. rep. 263

Eng. bot. 581

N. Amer. 1776. L p

N. Amer. 1774. L p Bot. mag. 1106

N. Amer. 1770. I p Bot. rep. 97

N. Amer. ... L p

N. Amer. 1761. L p

Bot. rep. 140 or 2 myjn W N. Amer. 1772. L p

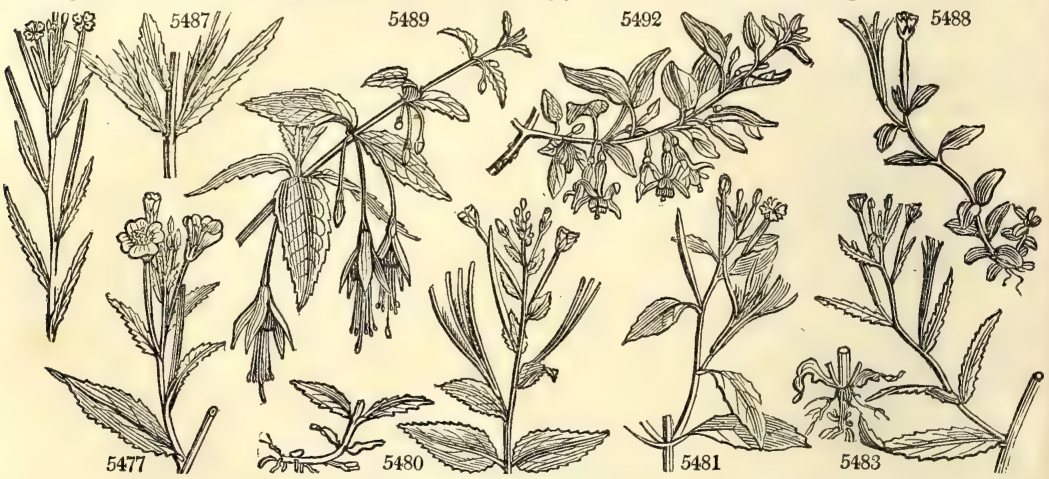

History, Use, Propagation, Culture,

from that plant; as fodder, goats are said to be extremely fond of it, and cows and shecp to eat it; the down of the seeds mixed with cotton or fur has been manufactured into stockings and other articles of clothing.

E. hirsutum is found only in rich moist soil by water. The leaves smell like scalded codlings or gooseberry pye when green, but lose that odor when dry. Cattle are rather fond of the plant both recent and dried.

904. Fuchsia. So named in honor of Leonard Fuchs, a famous German botanist, author of Historia Stirpium, in 1542, with 516 excellent engravings in wood. F. coccinea is one of the most elegant of deciduous greenhouse shrubs; the young wood and nerves of the leaves are tinged with purplish red: the pendent blossoms, like most produced from the axils of the leaves, as the shoots grow, continue during the greater part of the growing season, and are succeeded as they fade by a purple berry. The finest specimen in England of this species is at Salt-Hill.

Many other species have been lately introduced, some of which will probably be very handsome. South America contains some most splendid species, of which we know nothing in this country.

905. Jambolifera. From fero, to bear, and Jambol, the name of a Malabar fruit. Cuttings strike freely in sand under a hand-glass.

906. Oxycoccus. From o६us, acid, and «ox\%os, fruit; on account of its acidity. A genus well distinguished from Vacciniurn, by the narrow revolute segments of corolla. These are pretty little trailing evergreen plants, to which a peat soil and rather a moist situation are absolutely necessary : they are very little changed by culture.

o. palustris bears edible berries which are gathered wild both in England and Scotland, and made into tarts. Lightfoot says, twenty or thirty pounds worth are sold each market day, for five or six weeks together, 
5477 Leaves opp. and altern. subamplexicaul, ovate-lanceolate hairy, Stem much branched hairy 5478 Leaves sessile lanc. pubescent, Stem simple villous, Root fibrous

5479 Leaves altern. lanceolate serrated hairy

5480 Leaves opp. ovate tcothed

5481 Leaves stalked ovate acute toothed, Stem erect branched square, Petals bifid

5482 Leaves on short stalks ovate acute toothed shining, Stem ascending simple, Petals half bifid

5483 Leaves lanceolate toothletted: the lower opposite, Stem square

5484 Stem round pubescent, Leaves lanc. serrul. stalked opp. upper alternate smooth veiny

5485 Leaves opp. and alt. ovate toothletted sess. smooth, Fl. axill. sess. Caps. 4-cornered

5486 Stem erect simple, Leaves toothed pubescent, Ovary with scattered hairs

5487 Leaves sessile lanc. toothletted, Stem rounded, Stigma undivided

5488 Leaves on short stalks opp. lanc. ellipt. obt. entire, Stem ascending few-flowered

5489 Peduncles 1-flowered axillary, Leaves in threes serrated

5490 Branches slightly downy, Leaves opposite stalked smooth, Flowers much longer than leaves

5491 Peduncles axillary 1-flowered, Leaves ovate alternate

5492 Flowers stalked axillary, Sepals reflexed, Leaves ovate-lanceolate about S

5493 Leaves oblong lanceolate smooth, Cymes terminal shorter than the leaves

5494 Leaves oval revolute at edge acute white beneath, Segm. of cor, oval

5495 Leaves oblong flat obtuse, Segm. of cor. lanceolate

5496 Leaves oval acuminate serrulate ciliated, Flower not revolute at first

5497 Peduncles 1-flowered, Leaves serrate ovate deciduous, Stem angular

5498 Leaves ovate acute serrulate smooth, Racemes with bractes, Cor. cylind. camp.

5499 Leaves oval ac. ent, glauc. beneath, Pedic. sol, axill. filif. Cor, open camp. Anth. exserted [exserted

5500 Lvs. oval or obov, acute ent. glauc, ben. Nerves and veins pub. Ped. axill. sol. filif. Cor. open camp. Anth.

5501 Dwarf tufted glabrous, Leaves cuneate rounded deeply sawed membranous, Fl. sol.

5502 Leaves small obov. obt. ent. above smooth, beneath veiny pubescent glaucous, Fl. sol. cor. urceolate

5503 Leaves stalked obovate acute at each end serrate, Racemes nodd. Cor. cylind. camp. Anth. included

5504 Leaves narr. lanceol, membr. ent. Nerves and edge pubescent beneath, Fl. scatt. sol. nearly sessile

5505 Branches and lvs. covered with resin. dots, Lvs. obov. ent. Rac. with bractes, Cor. camp. with round. seg.

5506 Lvs, obl. acute serrul. smooth, Racemes aggreg. term. corym. Cor. cylind. with short erect seg. Style exsert

5507 Leaves obov. blunt ent. glaucous and resinous beneath, Racemes loose, Cor. ovate campanulate

5508 Branches ang. Leaves subsess, erect mucron, lanc. Clusters sessile, Cor, oblong ovate, Fl. stalks none

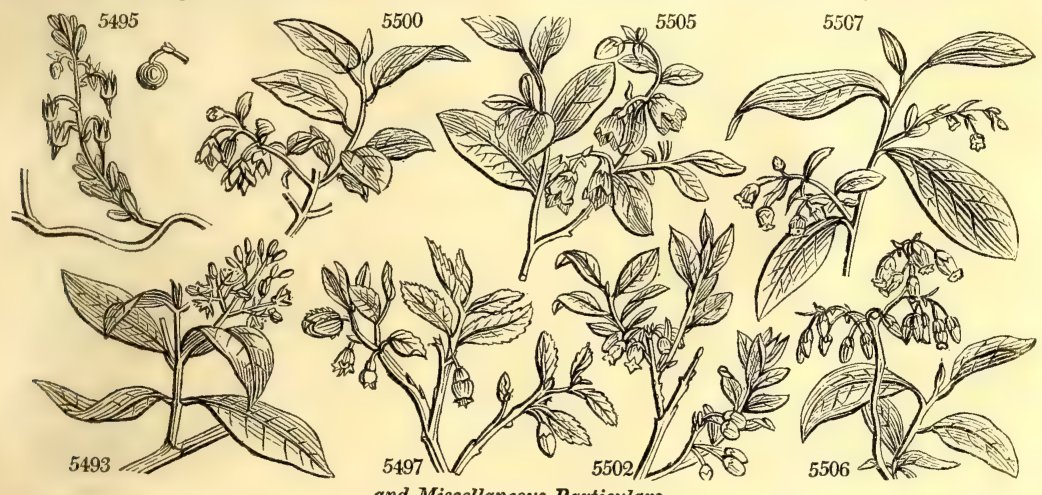

and Miscellaneous Particulars.

in the town of Langtown, on the borders of Cumberland. The plant might no doubt be cultivated with equa! ease as the American species.

O. macrocarpus furnishes the cranberries sent from America : it was first cultivated in this country by Sir J. Banks, on the margin of a pond (Hort. Trans. i. 71.), and subsequently both in moist and dry situations by different cultivators. Peat earth is essential to every mode of culture; but a much less degree of moisture will do than was at first believed. Salisbury found it do very well in pots of bog earth set in the shade; and Milne found " vigorous shoots and abundant crops produced on dry beds of peat earth, even in the warm summer of 1822." The American cranberry he found easier to cultivate than the common sort; but Hallet found both the cranberry and bilberry succeed perfectly under such treatment. (Hort. Trans. iv. 483 , and v. 279. 907. Vaccinium. A name, the derivation of which is not known. Neither are commentators more decided as to what was the Vaccinium of the Latins. The only conclusion to which they have come, is that the

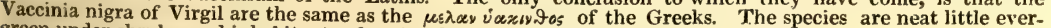
green under shrubs, and inhabitants of moist alpine or subalpine regions in peat earth.

V. Myrtillus is an elegant and also a fruit-bearing plant. The young fresh green leaves, and wax-like red flowers appear in May, and towards autumn the leaves grow darker and more firm, ard the ripe berries are gathered in the north for tarts, and in Devonshire and Poland are eaten with clotted cream. (Eng. Bot.) The berries are very acceptable to children, either eaten by themselves or with milk, or in tarts. The monrgame live upon them in the autumn. The juice stainten by them linen purple Goats browe sheep are not fond of it; and in Arran and the Western Isles are given in diarrhœas and dysenteries with good effect. The High. 

$\begin{array}{cl}5509 \text { resinósum } H . K . & \begin{array}{l}\text { clammy } \\ \text { green-flowered } \\ \beta \text { viridescens }\end{array} \\ \text { red-flowered }\end{array}$ $\gamma$ parviflórum Andr, small-flowered 5510 corymbósum $L$. corymbose disomorphum Mich.

5511 amœ'num $H . K$. broad-leaved 5512 virgátum $\boldsymbol{H} . \mathbf{K}$. twiggy

5513 galezzans Mich. Gale-leaved

5514 tenéllum $\boldsymbol{H} . \boldsymbol{K}$. Pensylvanian pensylvánicum Mich. ramulósum W. húmile W.

5515 padifólium $\mathrm{Sm}$. Madeira arctostáphylos B. M.

5516 meridionále Swz. Jamaica

5517 myrtifólium Mich. Myrtle-leaved

5518 crassifolium Andr. thick-leaved

5519 Vitis Idæa $L$. Cow-Berry

large

largest

5520 hispídulum $W$. Snowberry Gaultheria serpyllifolia Psh.

5521 nitidum Psh. glossy

21 nitidum $P s$

5522 myrsinítes Mich.

$\beta$ lanceolátum

glossy
Mecumbent
Myrsine-leaved

lanceolate obtuse

5523 buxifólium Andr. Box-leaved brachýcerum Mich.

908. MEME'CYLON. $W$. Memecrlon.

5524 capitellátum $\boldsymbol{W}$. Ceylon

909. LAGET'TA. $J$.

5525 linteária $P$. S.

910. DAP'HNE, $W$.

5526 Mezéreum $W$

a rubrum

$\beta$ álbum

5527 Thymelæa $W$

5528 Tarton-raíra $\boldsymbol{W}^{\prime}$

5529 alpina $W$.

5530 Lauréola $W$

5531 póntica $W$

5532 tinifólia $\dot{W}$.

5533 Gnidium $\dot{W}$.

5534 odóra $W$.

5535 Cneórum $W$.

5536 altáica $W$.

5537 oleoídes $\dot{B}$. $M$.

5538 collina $W$.

LAGETTA.

lace-bark

DAPHNE.

Mezereon

red-flowered

white-flowered

smooth-leaved

silvery-leaved

Alpine

Spurge Laure

Pontic

Bonace-bark

Flax-leaved

sweet-scented

trailing

Altaic

Olive-leaved

hairy

$\beta$ neapolitana Hort. Neapolitan $\begin{array}{llll}\text { or } & 4 & \text { my.jn } & \text {... } \\ \text { or } & 3 & \text { my.jn } & \text { Y.G } \\ \text { or } & 3 & \text { my.jn } & \text { Pk } \\ \text { or } & 3 & \text { my.jn } & \text { R.x } \\ \text { or } & 7 & \text { my } & \text { W } \\ & & & \\ \text { or } & 6 & \text { my.jn } & \text { Pk } \\ \text { or } & 3 & \text { ap.my } & \text { Pk } \\ \text { or } & 2 & \text { my.jn } & \text { W } \\ \text { fr } & 1 \frac{1}{6} & \text { my.jn } & \text { Pk }\end{array}$
N. Amer, 1772. L p Canada 1772. L p N. Amer. 1772. L p N. Amer. 1804. L p N. Amer. 1806. I p

N. Amer. 1765. L p N. Amer. 1767. L p N. Amer. 1806. I p

N. Amer, 1772. L p
W. am, t. $30 . f .69$

Bot. mag. 1288

Bot. rep. 125

Bot. rep. 138 Bot, rep. 181
Madeira 1777. L p Bot. mag. 974

* or 2 mr.jn W.g Jamaica 1778. L p

2 J pr 1 my.jl W Carolina 1812. L p

- 1 pr 1 jn.jl Pk Carolina 1787. L p

w. pr $\frac{3}{4}$ ap.jn Pk Britain ...

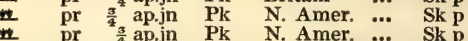

2. $\quad$ pr $\frac{3}{4}$ ap.jn $\quad$ Pk N. Amer. $\ldots$ Sk p

w pr 2 my.jn Pk Carolina 1794. L p

Carolina 1794. L $\mathbf{p}$

Carolina $\quad . . \quad \mathbf{L} \mathbf{p}$

$\begin{array}{lll}\text { Florida } & \ldots & \mathbf{L} \\ \text { p }\end{array}$

Carolina 2 p
Bot. mag, 1152

Eng. bot. 598

Pursh am. t. 13

Bot. rep. 480

Bot. mag. 1550

Bot. mag. 928
55095511 $\square$ or 10 Santalacea. $\quad S p .1-6$.

jl $\quad . . . \quad$ E. Indies 1796. L p.1 Bur. zeyl. t. 30 Thymelce. Sp. 1.

$\square \mathrm{cu} 6$ ja.d W Jamaica 1793. C 1.p Lam. ill. t. 289 Thymelace. Sp. 13-34.

m 4 f.ap Pk England woods. C p.l Eng. bot. 1381

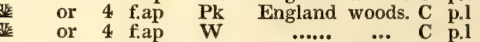

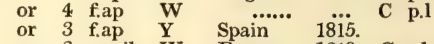

or 3 my.jl $\quad$ W

or 2 my.jl

or 3 ap.my $\mathbf{G}$

or 3

6 ap.my G

2 jn. $\ddot{a u} \quad \ddot{\mathbf{w}}$

3 mr.d Pu

1 ap.s Pk

ap.my W

3 ja.jn Pu

France

1640. G s.1 Fl. grac. 354

1759. S p.l Bot. cab. 66

Britain woods. S s.1 Eng. bot. 119

Pontus 1759. C s.I Bot. mag. 1282

Jamaica 1733. C l.p

Spain 1597. G s.I Bot. cab. 150

China 1771. C r.m Bot. mag. 1587

Austria 1752. L s.p Bot. mag. 313

Siberia 1796. G p.l Bot. mag. 1875

Crete 1815. G p.1 Bot. mag. 1917

$\begin{array}{llll}\text { Crete } & 1815 . & \text { G } & \text { p.1 } \\ \text { Italy } & 1752 \text {. L } & \text { Bot. mag. } 1917 & \text { Bot. mag. } 428\end{array}$

$\begin{array}{llll}\text { Naples } & 1822 \text {. L s.l } & \text { Bot. reg. } 822\end{array}$

ja.jn $\mathrm{Pu}$

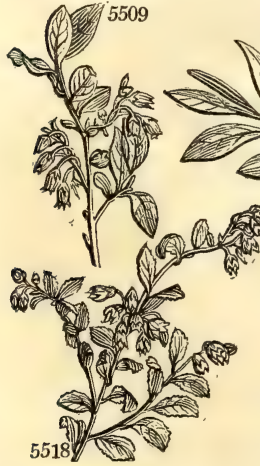
5519 
5509 Lvs. stalked obl. oval blunt entire beneath resin. Racemes lateral one-sided, Cor. ovate conical 5 angular

5510 Fl. branches leafless, Lvs. obl, oval acute at each end ent. young ones downy on both sides, Rac. short scaly

5511 Flowering branches leafless, Lvs. obl. acute at each end smooth, Racem. clust. bract. Cor. cylind. Cal. refl. 5512 Flowering branches oblong leafl. Lvs. lanc. acute at each end serrul, smooth, Rac. sess, corym. obl, bract. Cor. cylind. contracted at mouth

5513 Lvs. sessile cuneate-lanc. serrul. veiny pubes. Clust. sess. Cor. ov. much contracted at mouth, Style exsert. 5514 Branches angular green, Leaves sess. ovate lanc. mucronate, Fasc. clustered term. sessile, Cor. ovate

\section{Flowers racemose, Leaves erenulate ovate smooth}

5516 Leaves ovate obl. acute serrate flat shining, Racemes terminal erect, Cor. prismatical 5517 Creeping very smooth, Leaves stalked oval shining, Clusters axill. sessile few-flowered, Cor. glob. camp. 5519 Dwarf, Leaves obovate emarginate serrulate shining above dotted beneath, Cor. cylind. camp.

\section{Stem creeping hispid, Leaves roundish oval acute bristly at edge}

5521 Erect much branched, Leaves evergeen obl. lanc. acute at each end rigid, Cor. open camp. deeply 5-toothed 5522 Leaves very small sessile oval mucron, beneath hairy dotted, Clusters term. and lat. Cor. obl, ovate

5523 Dwarf, Leaves obovate crenate toothed smooth, Filam. gland. Stigma cap. Cor. short ovate

5524 Ieaves ovate stalked, Umbels capitate axillary sessile

Spikes panicled terminal, Leaves ovate acute

5526 Flowers sessile three on the stem, Leaves lanceolate deciduous

5527 Flowers sessile axillary, Leaves lanceol. Branches simple

5528 Flowers sessile lateral aggregate at the base scaly, Leaves obovate nerved silky

5529 Flowers sessile lateral aggregate, Leaves lanceolate obtuse downy beneath

5530 Racemes axillary 5 -flowered, Leaves lanceolate smooth

5531 Pedunc. lateral 2 -flowered, Leaves lanceol. ovate

5532 Racemes compound erect, Flowers terminal clustered, Leaves oblong

5533 Racemes term. panicled, Leaves linear lanceolate cuspidate

5534 . Head terminal sessile many-flowered, Leaves scattered obl. lanceol. smooth

5535 Flowers fascicled term. sessile, Leaves lanceol. naked mucronate

5536 Flowers term. subsessile, Leaves opp. obl. lanceol. obtuse narrowed at base glabrous

5537 Flowers twin terminal sessile, Leaves elliptic lanceol. smooth

5538 Flowers fascicled terminal, Leaves obovate obtuse above very smooth beneath villous

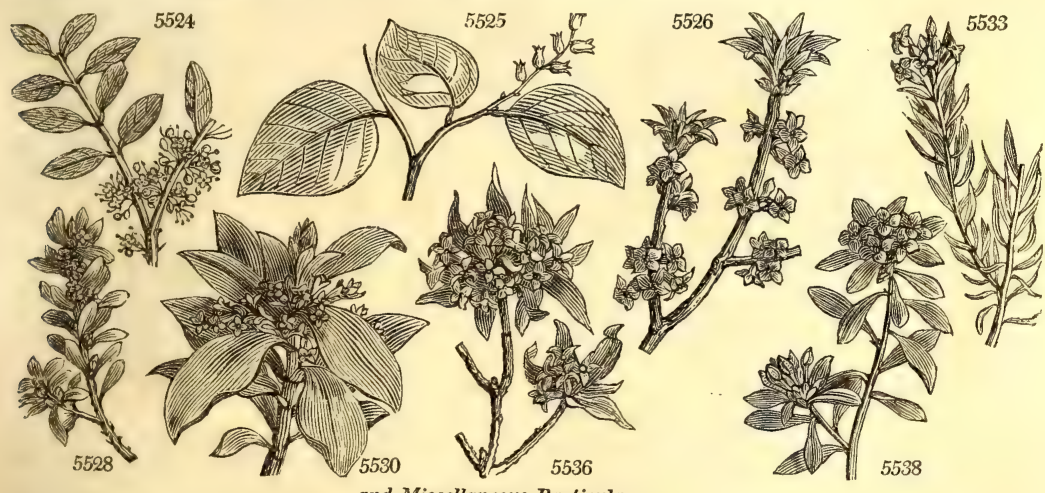

and Miscellaneous Particulars.

908. Memecylon. The Greek name of the fruit of the Arbutus. The shrub now so called has a certain degree of resemblance to the Arbutus. Young cuttings plunged in sand in heat and covered with a hand-
glass will root freely.

909. Lagetta. This plant in Jamaica is called Lagetto. Ripened cuttings will root in sand under a handglass.

910. Daphne. The Greek name of the Laurel. This is a genus of diminutive shrubs, mostly evergreens of great beauty and fragrance in the flower, and with a peculiar velvet texture in the leaf. It is mentioned by Linnæus as a characteristic of the genus, that the terminating buds of the shoots produce leaves, and the lateral ones flowers. This affords a hint to the cultivator to be sparing of his knife.

D. Mezereum (Mâdzaryoùn is the Persian name according to Richardson), Laureole gentille, Fr., Kellerhals, Ger., and Laureola femina, Ital., is an old inhabitant of the shrubbery, and deservedly much admired for its precocity and fragrance. It thrives well in loamy soil, and will grow in the shade and even drip of other trees. It is a native of all parts of Europe from Lapland to Sicily, but was first received from Elbing before it was observed to be a native. The roots of Mezereon acquire a very large size in proportion to the branches, and have more the character of the fusiform or ramose roots of a herbaceous, than of a ligneous vegetable. They are remarkably hot and acrid, and have long and in most countries been a popular topical 
911. DIR'CA. $W$. 5539 palústris $W$. 912. GNI'DIA. $W$. 5540 pinifólia $W$. 5541 imbérbis $H . K$. 5542 simplex $W$ 5543 capitáta $W$ 5544 oppositifólia $\boldsymbol{H} . \boldsymbol{K}$. 5545 sericea $H . K$. 5546 denudáta Lindl. 5547 lævigáta Thunb. 913. STELLE'RA. $W$ 5548 Passerina $W$. 914. PASSERI'NA. $L$. 5549 filiformis $W$. 5550 hirsúta $W$. 5551 tenuiflóra $W$. en 5552 capitáta $W$ 5553 uniffóra $W$ 5554 grandiflóra $W$. 5555 spicáta $W$. 5556 láxa $W$

915. LACHN球A. $W$ 5557 conglomeráta $W$. 5558 eriocéphala $W$. 5559 purpúrea $\boldsymbol{H}$. $\boldsymbol{K}$ 5560 glaúca $\boldsymbol{H} . \boldsymbol{K}$. 5561 buxifólia Lam

916. COMBRE'TUM. 5562 purpúreum $W$. 5563 comósum Hort.
Leather-wood. marsh

GNidia.

Pine-leaved

- $1 \mathrm{p}$ Flax-leaved

purple-twigged

opposite-leaved $\square$

silky

shaven

polished

Stellera.

n. $\amalg p$

2.

Flax-leaved

SPARROW-WORT

filiform

shaggy

slender-flower

slenger

one-flowered

great-flowered

spiked

lax

LACHNAA.

clustered

woolly-headed

purple-flowered

glaucous

green-box-leav,

Combretum. purple comose
Thymelcea. Sp. 1.

mr.ap X Virginia 1750. S s.l Bot. reg. 292 Thymelace. Sp. 8-13.

1 my.jn Pa.Y C. G. H. 1768. C s.p Bot. reg. 19

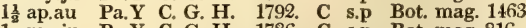

1 my.jn Pa.Y C. G. H. 1786. C s.p Bot. mag. $81 \mathrm{C}$

1 jn.jl Pa.Y C. G. H. 1788. C s.p

1 my.jl Pa.Y C. G. H. 1783. C s.p Bot. reg. 2

$1 \frac{1}{2}$ my.jl Pa.Y C. G. H. 1786. C s.p Bot. rep. 225

my.jl Pa.Y C. G. H. 1820. C s.p Bot. reg. 757

my.jl Pa.Y C. G. H. 1822. C s.p

Thymelace. Sp.1-3.

jl.au W S. Europe 1759. C s.p Jac. ic. 1. t. 68 Thymelaea. Sp. 8-19.

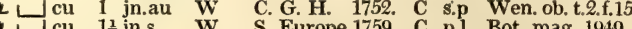
$1 \frac{1}{2}$ jn.s W S. Europe 1759. C p.1 Bot. mag. 1949

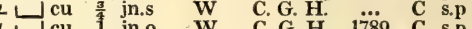

W C. G. H. 1789. C s.p Wen. ob. t.2.f.17

立 ap.my W C. G. H. 1759. C s.p Wen. ob.t.2.f.18

1 my.jn W C. G. H. 1789. C s.p Bot. mag. 292

my.jn W C. G. H. 1787. C p.I Bot. cab. 311

C. G. H. 1804. C p.l Bot. cab. 755

Thymelae. Sp. 5-28.

2 jn.jl W C. G. H. 1773. S r.m

2 jn.jl W C. G. H 1793. C p.l Bot mag. 1295

2 jn.jl Pu $\quad$ C. G. H 1800 . C p.1 Bot mag. 1594

2 my.jl W C. G. H. 1800. C p.1 Bot. mag. 1658

2 my.jl W C. G. H. 1800. C p.l Bot. mag. 1657

Combretacece. Sp. 2-20.

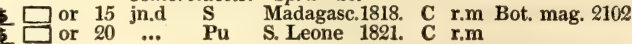

DIGYNIA.

917. GALE'NIA. $W$. Galenia. $\quad \underset{\text { Chenopodece }}{S} p_{0} \mathbf{1}_{\mathbf{H}}^{3}$. 918. APHANAN'THE. $L k$. Aphananthe. Amaranthacea. Sp. 1. 5565 celosiódes $L k$. Cock's-comb $\quad$ J cu $1 \frac{1}{2}$ jl $\quad$ W.g Brazil $\quad 1813$. C p.l

919. WEINMAN'NIA. $L$. Weinmannia. Saxifragea. Sp. 1-12. 5566 pinnáta $L$. pinnate $\square$ or 6 my.jn W Jamaica 1815. C r.m 920. MGEHRIN'GIA. W. MoenRINGIA. Caryophyllea. Sp. 1-3. 5567 muscósa $W$. mossy $1 \Delta$ w $\frac{1}{4}$ jn.jl L.Pu S. Europe 1775 . s.1 Sch. ha. 1.t. 108

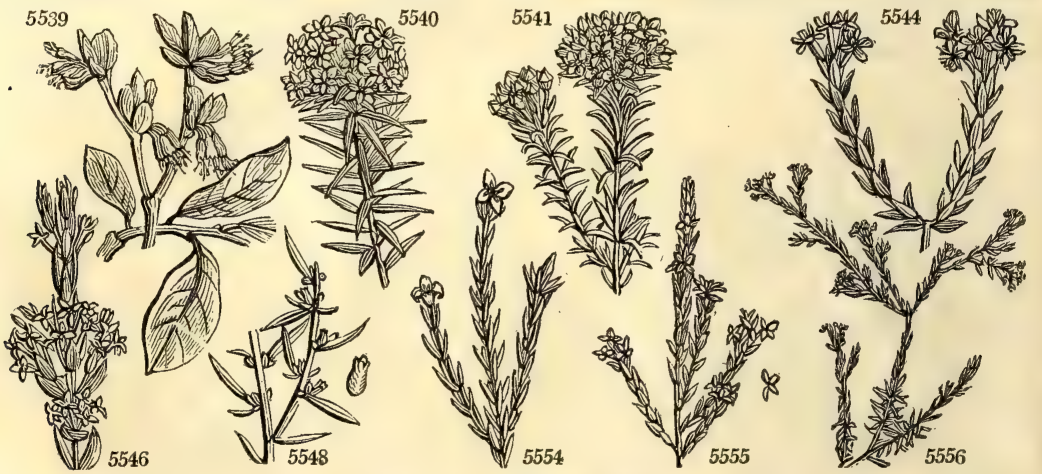

History, Use, Propagation, Culture,

application for the toothach. The whole plant is extremely acrid, especialiy when fresh, and if retained in the mouth excites great heat and inflammation, particularly of the throat and fauces. The berries when swallowed prove a powerful poison, not only to man, but to many quadrupers. Both the bark and the berrie of Mezereon in different forms have been long used externally in cases of obstinate ulcers and ill-conditioned sores. In France the bark is used as an application to the skin, which, under certain management, produces a serous discharge without blistering, and is thus rendered useful in chronic cases of a local nature, answering the purpose of what is called a perpetual blister, while it occasions less pain and inconvenience. In our own country the Mezereon has been principally employed in syphilitic cases. The branches make a good yellow dye.

D. Laurecla is valuable in the shrubbery as thriving under the shade and drip of other trees, and never growing to an unshapely size and figure, and in the nursery as affording stocks for the more rare species. The roots and other parts of the plant possess similar qualities to those of the Mezereon.

911. Dirca. From diere, a fountain. A plant which grows in watery places. Bois de Plomb, Fr. This shrub grows in hilly swamps in North America : it is in all its parts remarkably tough, and the twigs are in con sequence used for rods, and the bark for ropes, baskets, \&c. Layers are generally two years in rooting cuttings do not succeed, and it does not ripen seeds here. Snails, Sweet observes, are particularly fond of this plant.

912. Gnidia. One of the names given by the ancients to the Daphne. These plants "thrive well in a sandy peat soil, with their pots well drained with broken potsherds: care must be taken not to over water them, or to let them flag for want of water, as their roots are very tender and are easily killed; the tenderest kinds are G, oppositifolia, and G. pinifolia. (Bot. Cult. p. 198.) 
5539 The only species. Flowers appearing before the leaves

5540 Leaves scattered 3-cornered, Flowers in umbellate heads, Scales four bearded

5541 Leaves scattered 3-quetrous linear acute: floral lin. lanc. shorter than heads, Scales eight beardless 5542 Leaves all linear acute, Flowers terminal sessile, Scales four and cor. smooth

5543 Leaves scattered lanc. smooth, Flowers capitate surrounded by bractes, Peduncle naked

5544. Leaves opp. lanceolate tomentose, Flowers terminal, Scales 4

5545 Leaves opp. ovate tomentose, Flowers terminal, Scales 8

5546 Leaves ovate oblong imbricated hairy with naked nerves

5547 Leaves opp. ovate smooth, Fl. terminal subcapitate

5548 Leaves linear, Flowers axillary sessile 4-cleft

5549 Leaves lin. convex imbricated in 4 rows, Branches downy

5550 Leaves fleshy smooth outside, Stems downy

5551 Leaves linear smooth, Fl, sessile in terminal filiform silky heads

5552 Leaves linear smooth, Heads stalked downy

5553 Leaves lin. opposite, Flowers term. solitary, Branches smooth

5554 Quite smooth, Leaves oblong acute concave rugose outside, Fl. term. sessile solitary

5555 Leaves ovate villous, Flowers lateral solitary

5556 Leaves ovate scattered, Flowers capitate, Branches lax cernuous

5557 Heads clustered, Leaves loose

5558 Heads solitary woolly, Flowers imbricated in four rows

5559 Leaves opp. imbricated 4 ways, Heads smooth

5560 Leaves scattered elliptical ovate, Heads woolly

5561 Leaves oval sessile very smooth, Fl. capitate woolly

5562 Leaves opposite ovate acute, Racemes one-sided bracteate, Bractes shorter than peduncle, $\mathrm{Fl}$. decandrous 5563 Leaves opp. oblong hairy, Racemes numerous terminal one-sided

\section{DIGYNIA.}

5564. Erect shrubby, Leaves linear fleshy

5565 Flowers loosely spiked very minute, Bractes lanceolate membranous

5566 Leaves pinnate, Leaflets obovate crenate smooth

5567 Leaves linear connate, Sepals flat the length of the stem-joints lanceol. acute

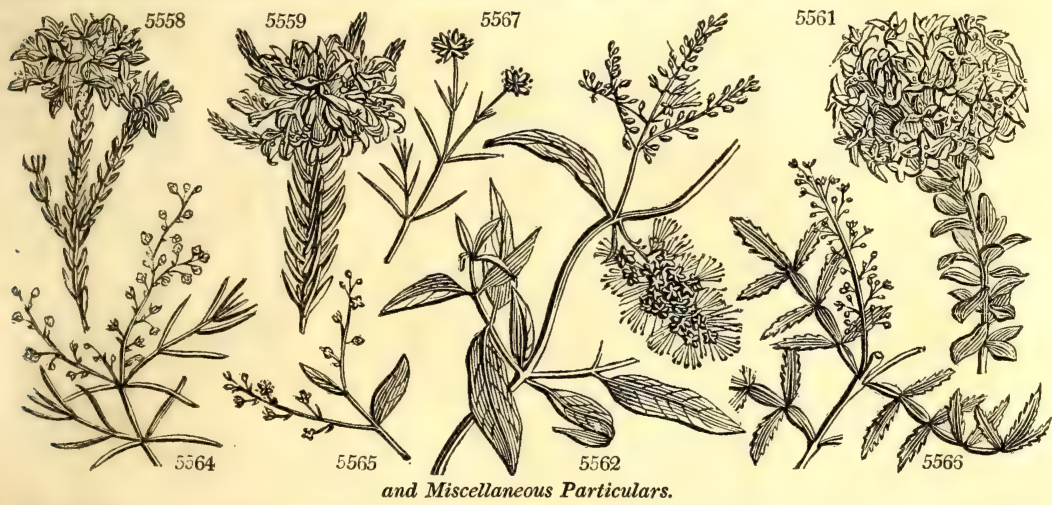

913. Stellera. So named by Gmelin, in memory of Georg. Wilh. Steller, adjunct of the academy at Petersburg, who collected plants in Kamtschatka, and died in Siberia, in 1746. An inconspicuous plant resembling the next genus and requiring the same culture.

914. Passerina. From passer, a sparrow. Its seed has an appendage at the end like the beak of a sparrow. Young cuttings root freely under a bell-glass in sand.

915. Lachnaea. Derived from $\lambda \propto \chi y \eta$, wool, on account of the woolly heads of flowers.

916. Combretum. A name employed by Pliny. The plant of the ancients could have no relation to the plant now called by this name, which is a genus of splendid climbing shrubs, with beautiful branches of flowers which are often crimson or purple, and sometimes white. A number of species are found at Sierra Leone. They are all stove plants.

917. Galenia. So named by Linnæus from the famous physician Claudius Galenus, born at Pergamus, 133 years before the Christian æra. A coarse-looking shrub, with the leaves obscurely papillose or bladdery, and the stem round.

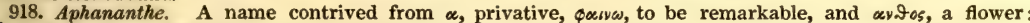
that is to say, a plant which is not remarkable for the beauty of its flowers. A curious little Brazilian weed.

919. Weinmannia. In honor of John William Weinmann, a German botanist, who published in 4 vols. folio, his Phytanthoza Iconographica, about the middle of the last century. Handsome shrubs, with pinnated leaves.

920. Moehringia. So named by Linnæus, from Paul Henry Gerard Moehring, a physician, author of Hortus Proprius, 1736. A little inconspicuous weed-like plant. It suits very well for rock-work, or to be grown in small pots. 


\section{TRIGYNIA.}

921. POLY'GONUM. $W$. Persicaria. 5568 amphíbium $L$. 5569 ocreátum $\boldsymbol{L}$. spear-leaved 5570 virginiánum $\boldsymbol{L}$. Virginian

\section{Polygonea.}

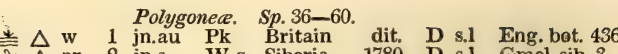
\& $\triangle$ pr 2 jn.s W.G Siberia 1780. D s.l Gmel. sib. 3. t. D s.1 Pa.th. 857. f. 6

\begin{tabular}{|c|c|c|c|c|c|c|c|}
\hline 5571 lapathifólium $H$. & pale-flowered & ש & $\begin{array}{l}1 \text { jn.s } \\
1 \\
\text { jl.s }\end{array}$ & $\begin{array}{l}\mathbf{G} \\
\mathbf{R}\end{array}$ & $\begin{array}{l}\text { England dungh. } \\
\text { Britain wat. pl. }\end{array}$ & $\begin{array}{l}\text { s.1 } \\
\text { s.1 }\end{array}$ & $\begin{array}{l}\text { Eng. bot. } 1382 \\
\text { Eng. bot. } 989\end{array}$ \\
\hline 3 tinctórium Lourei & dyer's & (이 $\mathrm{dy}$ & 2 jl.au & $\mathbf{R}$ & China 1776 . & S.I & \\
\hline$W$ & small & O w & $\frac{1}{2}$ au.s & $\mathbf{P k}$ & England wat.co. & s.1 & 1043 \\
\hline 5 Persicária $L$. & spotted & $\mathbf{w}$ & $2^{2}$ jl.au & $\mathbf{P k}$ & Britain & s.1 & 756 \\
\hline 5576 incánum Schmidt & hoary & w & 2 jl.au & $\mathbf{W}$ & Germany 1804 . & s.1 & et. h. br.t. 3. f. 8 \\
\hline 5577 barbátum $L$. & bearded & cu & $2 \mathrm{jr}$ & $\mathbf{W}$ & China & s.l & \\
\hline
\end{tabular}
5577 barbátum $L$. $\quad$ bearded $\triangle$ cu 2 jn

5578 orientále $\boldsymbol{L} . \quad$ common $\quad \bigcirc$ or 6 jl.o

$\begin{array}{lll}\text { R } & \text { E. Indies 1707. S co. Bot. mag. } 213 \\ \text { W.G } & \text { E. Indies 1781. S co }\end{array}$

\begin{tabular}{|c|c|c|c|c|c|c|c|c|}
\hline 5579 frutéscens $W$. & shrubby & or & 2 jl.au & $\mathbf{P k}$ & Siberia & 1770 . & L s.l & Bot. reg. 254 \\
\hline 5580 aviculáre $\boldsymbol{L}$. & Knot-grass & w & 3 ap.o & G & Britain & rubble. & S! co & Eng. bot. 1252 \\
\hline 5581 arenárium Bieb. & sand & & 1 my.au & $\mathbf{P u}$ & Hungary & 1807. & S co & Pl. rar. hu. t. 67 \\
\hline 582 élegans Tenore. & elegant & & 2 ap.au & W.G & Naples & $182 !$ & D co & \\
\hline 5583 eréctum $\boldsymbol{L}$. & upright & & 1 jl.au & P. R & N. Amer. & 1792. & D s.l & \\
\hline 5584 chinénse $W$. & Chinese & dy & 6 jl.au & W.G & China & 1795. & S $\mathrm{s.l}$ & Bur. in. t. 30. f. 3 \\
\hline 5585 sagittátum $W$. & arrow-leaved & cu & 6 jl.au & W.G & N. Amer. & 1759. & S s.l & Lin. hor. cl. t.12 \\
\hline ólium $W$. & Arum-leaved & $\mathrm{cu}$ & 6 my.o & W.G & N. Amer. & 1816. & S s.l & Pl, am. t. 398 . f.3 \\
\hline 5587 Convólvulus $L$. & common-clim & w & 3 my.s & W.G & Britain & corn.fi. & S s.l & Eng. bot. 941 \\
\hline 5588 dumetórum $\boldsymbol{L}$. & bush & un & 12 my.s & W & S. Europe & e 1803. & S co & Flor. dan. t. 756 \\
\hline 5589 scándens $L$. & American-clim & 1. $\Phi \Delta$ un & $12 \mathrm{jl} . \mathrm{s}$ & Pk & N. Amer. & 1749. & D co & Pl, al, t. 177. f. 7 \\
\hline littorále $L k$. & sea-shore & $\Phi \bar{\Delta}$ un & $1 \mathrm{jn}$ & W.G & S. Europe & e & S co & \\
\hline Bellar'di All. & Bellardi's & un & 1 jn.jl & W.G & S. Europe & & S co & \\
\hline acetósum & sour & un & $\frac{1}{2} \mathrm{~d}$ & W.G & Crimea & 1020. & co & \\
\hline
\end{tabular}
5592 acetósum Bieb.

5593 crispulum $B . M$. 5594 Bistórta $L$. 5595 vivíparum $\boldsymbol{L}$. 5596 divaricátum $L$ 5597 undulátum $L$. 5598 acidulum $W$. en. 5599 salígnum $W$. en. 5600 tatáricum $L$ 5601 emarginátum $R$ 5602 Fagopýrum $L$ 5603 alpinum $\mathbb{I l l}$. 922. COCCOLO

\section{upright \\ it $\triangle$ pr $1 \frac{1}{9} \mathrm{jl}$.au}

Snake's-weed Alpine-Bistort divaricating wave-leaved narrow-leaved Willow-like

Tartarian

notch-seeded Buck-Wheat alpine f $\Delta \mathrm{m} 1 \frac{1}{2} \mathrm{my} . \mathrm{s}$ $\frac{1}{\mathrm{~L}} \mathrm{\Delta}$ pr $\frac{1}{2} \mathrm{my.s}$ $\ddagger \Delta$ un 2 jl.au 5 $\triangle$ un 2 jn.jl J un un 2 my.au cu 2 jl.au O ag 2 jl.au $\downarrow \triangle$ un 1 my.au 도 $\triangle$ un 3 jn.jl
W.G Crimea 1820. S co

\section{W.pk Siberia 1800. C s.l Bot. mag. 1065} Pk Britain me. pa. 1$)$ co Eng. bot. 509

W.G Britain al, pas. D s.l Eng, bot. 669

W.G Siberia 1759. D co Gm. si. 3.t.11.f.1

W.G Siberia 1816. D s.l

W.G Siberia 1816. D s.l

W.pk Siberia $175^{\prime}$. S s.1 Gm. si.3.t.13.f.1

Pk China 1796, S s.l
W.G Siberia 1789. D s.1 Gmel. sib. 3.t.10

Polygonea, Sp. 8-20.

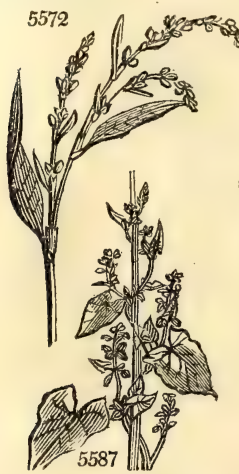

round-leaved I $\square$ fr $60 \quad \ldots \quad$ W.G W. Indies 1690 . C r.m Jac. amer. t. 73

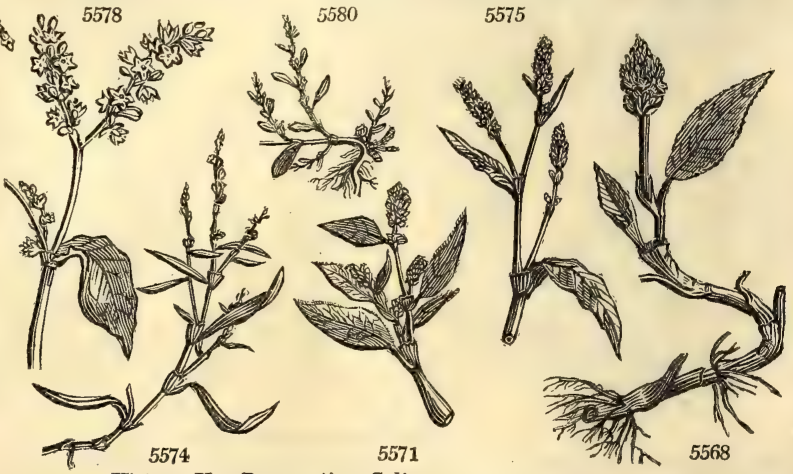

History, Use, Propagation, Culture

921. Polygonum. From tohus, many, and yoyv, knee, many joints. These are nearly all common weeds of tomper $P$ Bistorta being one of the strongest vegetable astringents, might well be applied to the purpose of tanning leather, if it could be procured in sufficient quantity. The young shoots were formerly eaten in herb-puddings in the north of England, where the plant is known by the name of Easter Giant, and about Manchester they are substituted for greens under the name of Patience Dock. (Curtis, Withering.) The root was formerly considered to be alexipharmic and sudorific.

P. viviparum is so named on account of the flowers frequently changing into vegetable bulbs. The roots have the same qualities as those of P. Bistorta, and are eaten in Sweden and Lapland, Siberia and Tartary.

P. amphibium is one of the most difficult weeds to eradicate from recovered alluvial lands, and has no equal in this respect unless Equisetum. The roots, which in the water are properly stems, are found to a great depth in such soils; and though by fallowing or otherwise stirring the surface, the ieaves may be prevented from showing themselves for several years; yet if the field be allowed to lie a year in grass, the surface will be found abounding with Polygonum. Many tracts in Scotland which have been recovered from rivers and estuaries for an unknown series of years still abound with this plant, and as under such circumstances it never advances so far as to flower and seed, the individuals must be the same which formerly were suspended in the water. As an aquatic, it has a gay, showy appearance, when in flower.

P. Hydropiper is a powerful diuretic, and will dye woollen cloth of a yellow color.

$\mathbf{P}$. tinctorium, and also chinense and aviculare, are cultivated in China for dying cloth of a beautiful blue or green. 


\section{TRIGYNIA.}

\section{Flowers pentandrous.}

5568 Half digyn. Spike ovate, Stipules lacerate, Leaves oblong or lanceolate 5569 Flowers trigynous, Leaves lanceolate

5570 Flowers half digynous, Cor. 4-cleft unequal, Leaves ovate

\section{\$2. Flowers hexandrous.}

5571 Flowers digynous, Stipules unarmed, Pedunc. rough, Seeds depressed on each side 5572 Flowers half digynous, Leaves lanc. wavy not spotted, Spikes filiform nodding

5573 Flowers trigynous, Spikes twiggy, Stipules smooth truncate ciliated, Leaves ovate acute smooth 5574 Flowers nearly monogynous, Leaves lin. lanceol. flat, Spikes filiform erect, Stem rooting at base 5575 Flowers half digynous, Spikes ovate-oblong erect, Pedunc. smooth, Stipules ciliated 5576 Flowers digynous, Spikes oblong, Leaves obl, lanceolate pubescent beneath 5577 Flowers trigynous, Spikes twiggy, Stipules truncate ciliated, Leaves oblong acute smoothish

\section{Flowers heptandrous.}

5578 Flowers digynous, Leaves ovate, Stem erect, Stipules hairy hypocrateriform

\section{\$4. Flowers octandrous.}

5579 Leaves lanceolate narrowed each way, Stipule lanceol. shorter than the joint. - Tragiopyrum. Bicb. 5580 Flowers axill. Leaves ellipt. lanceol. rough at edge, Nerves of stipules remote

5581 Flowers trigynous, Spikes term. leafless, Leaves lanc. lin. Stems angular declinate herbaceous

5582 Flowers large axillary, Spike compact, Stem stout sheathed

5583 Flowers trigynous axillary, Leaves oval, Stem erect herbaceous

5584 Flowers trigynous, Peduncles rough, Leaves ovate stalked, Bractes cordate sessile

5585 Leaves sagittate, Stem prickly

5586 Leaves hastate, Stem prickly

5587 Leaves cordate sagittate, Stem angular, Segm. of cal. obtusely keeled

5588 Leaves cordate, Stem smooth, Leaves keeled winged

5589 Leaves cordate, Raceme simple axillary, Stem smooth

5590 Stem procumbent, Leaves oblong acute veiny fleshy, Stipules ciliated much shorter than the joints 5591 Flowers axill, trigynous, Leaves ellipt. lanceol. Sheaths ciliated

5592 Flowers trigynous axillary, Leaves lanceolate fleshy veinless, Stipules 2-parted

$$
\text { * Stem not twining. }
$$

5593 Leaves stalked obovate mucronulate smooth with a crisp revolute edge

5594 Stem simple one-spiked, Leaves ovate wavy running down the stalk

5595 Stem simple one-spiked, Leaves revolute lanceolate at edge

5596 Flowers trigynous racemose, Leaves lanceolate smooth, Stem divaricating spreading smooth

5597 Flowers trigynous panicled, Leaves lanceolate wavy rough above pubescent beneath

5598 Flowers trigynous racemose-panicled, Leaves linear lanceolate smooth

5599 Flowers trigynous racemose-panicled, Leaves linear lanceolate smooth acuminate ciliated at edge 5600 Leaves cordate sagittate, Stem unarmed, Seeds toothed

5601 Leaves cordate sagittate, Stem unarmed, Seeds truncate at end emarginate winged

5602 Leaves cordate sagittate, Stem unarmed, Angles of seeds equal

5603 Flowers trigynous racemose-panicled, Leaves ovate lanc. smooth ciliated at edge

5604 Leaves cordate roundish shining

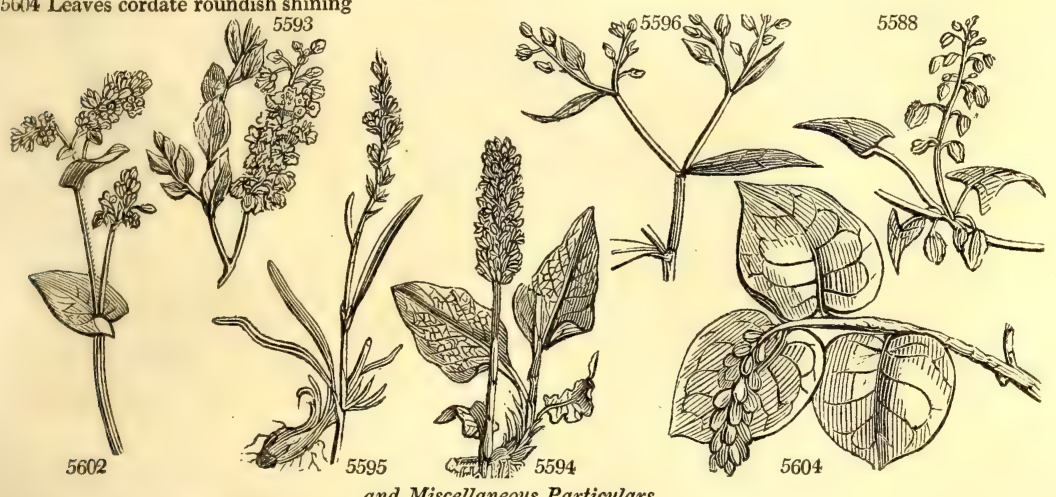

and Miscellaneous Particulars.

P. orientale is a well known annual, showy, and fit for shrubberies. The seeds were first sent to Europe by Tournefort, who saw it growing in the garden of the monks of the three churches near Mount Ararat. Thiey cultivate this plant there, not only for the beauty of the flowers, but for its medicinal qualities, which are the same with those attributed to our common species. (Mill. Fig.) The seeds are farinaceous.

P, aviculare is so named from the gratefulness of its seeds to small birds; the English name, knot-grass, from the knottiness of the stem, and because it is eaten by cattle; many such plants having obtained the name of grass, though they bear no similitude to real grasses. Hogs eat it with great avidity, and hence it is known in many countries by the name of hogweed. All other domestic quadrupeds are said to eat it. The seers are useful for every purpose in which those of buckwheat are employed, but they are much smaller.

P. Fagcpyrum, (Fagus, beech, and zugos, corn, its grain is like the mast of beech,) properly beechwheat, Bled noir or Sarrazin, Fr. Buckwheat is considered a native of Asia and not of Europe, though sometimes found in a seemingly wild state. It will not, however, bear the frosts of our springs or the severity of winter. In China and other countries of the East, it is cultivated as a bread corn. The flower is also used in cookery and bread-making in various parts of Europe, to make cakes and crumpets in England, and as rice or gruel in Germany and Poland. The seed is said to be excellent for horses and poultry, the flowers for bees, and the plant green for soiling cows, cattle, sheep or swine. As an agricultural plant it is valuable, as standing only a short time on the ground; but it produces little straw for manure.

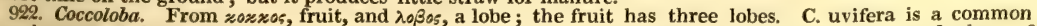
tree in most of the sugar colonies, generally near the sea. It is remarkable for its large leaves, and when of 
5605 latifólia Lam. 5606 pubéscens $W$. 5607 excoriáta $W$ 5608 punctáta $W$ 5609 barbadénsis $W$. 5610 diversifólia $J a c q$ 5611 laurifólia Jacq. 923. PAULLI'NI 5613 curassávica $W$. 5613 curassávica $W$. 5614 barbadénsis $W$. 5616 caribæ'a Jac. 5617 meliæfólia Juss. 924. SERIA'NA. $W$. 5618 sinuáta $W$. 5619 caracásana $W$. 925. CARDIOSPER'M 5620 Halicácabum $W$ 5621 Coríndum $W$. 5622 pubéscens Lag. 926. SAPIN'DUS. $\boldsymbol{W}$. 5623 Saponária $W$. 5624 marginátus $\dot{W}$.en. 5624 marginátus 5626 longifólius $\mathrm{Vahl}$. 5627 emarginátus Vaht. 5628 rubiginósus $R o x b$. broad-leaved downy oval-leaved spear-leaved Barbadoes

various-leave laurel-leaved

Paullinia. winged-leaved shining-leaved Barbadoes Supple-Jack Caribæan

Beadtree-lvd.

Seriana. sinuate-leaved $\square$ or 15 tooth-leaved $\square$ or 15

$W$. Heart-seed.

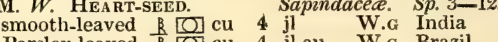
Parsley-leaved downy

SoAP-BERrY. cornmon edged Ash-leaved long-leaved emarginated rusty

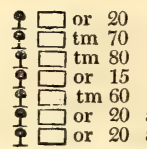

$\square$ or 15 i. or 18 or 16 or 20 or 10

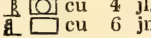

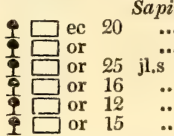
Sapindacea. Sp. 6-39.

Sapindacea. Sp. 2-21. jn S. N. Spain S N. Spain 1823. S co

... W.G S. Amer, 1812. C r.m La. il. t. 316. f. W.G W. Indies 1690. C r.m Pl.phy. 22. f. 8 ... W.G W. Indies 1733, C r.m PI. ic. t. 146. f. 1 ... W. W W. Indies 1733, C r.m Jac. am. 114.t. 77 W. W. Barbadoes1790, C r.m Jac. obs. 1. t. 8 W.G St. Dom, 1818. C r.m Hook. ex. fl. 102 W.G Caraccas 1822. C r.m Jac. sch. 3.t. 267

.. W.G W. Indies 1752. C r.m Jac.ob 3.t.62.f.12 W.G S. Amer, 1739. C r.m Jac. ob. 3.t.61.f.8 W. W. Indies 1786, C s.p Jac. ob. 3.t.62.f.9 ... W.G W. Indies 1739. R s.p Jac.ob.3.t.61.f.10 ... W.G W. Indies ... C $\quad$ S.p Jac. ob.3. t.62.f.7 W.g Brazil 1819. C s.p Hook، ex. fl. 110

.. W.G S. Amer. ... C co Jac. ob.3.t.61. f.2 1594 S co Bot. mag. 1049

... W.G W. Indies 1697. S p.l Com. hort. t. 94 W.g Carolina ... S $\mathrm{S}$ p.l W.G Carolina ㄲ.. S p.1 Com, hort. t. 94 W.G E. Indies 1820. S co W.G E. Indies 1822, S r.m ... W.G E. Indies 1821. S p.1

\section{TETRAGYNIA.}

927. VE'REA. $W$. 5629 laciniáta $P . S$ 5630 crenáta $W$ 5631 acutiflóra Haw.

Verea. cut-leaved

Vere's

Sempervivea. $S p .3-8$.

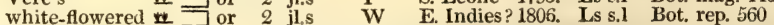

928. BRYOPHYL $/$ LUM. Sal. BRYOPHYLLUM 5632 calycínum $\mathrm{Sal}$. 929. PA'RIS. $W$. 5633 quadrifólia $W$ 930. ADOX'A, $W$ 5634 Moschatéllina $W$ 931. ELA'TINE. $W$. 5635 Hydropiper $W$ cupped Sempervivece. $S p .1$.

cu 2 ap.jl G.Pu E. Indies 1800. Ls s.l Par. lond. 3 PARIS. Herb

Moschatel.

Asphodelee? Sp. 1-2. fl $\Delta \mathrm{cu} \frac{\mathrm{s}}{2} \mathrm{my} . \mathrm{jn} \mathrm{G}$ Britain woods. $D$ p.I Eng. bot. 7 Saxifragea. Sp. 1

tuberous $\triangle \mathrm{cu} \frac{2}{4}$ mr.my G.w Britain woods. D s.p Eng. bot. 453 WATER-WORT.

small $\mathrm{O}$ cu $\frac{1}{6}$ au $\mathrm{G}$ England mar.la. S s.l Eng. bot. 955
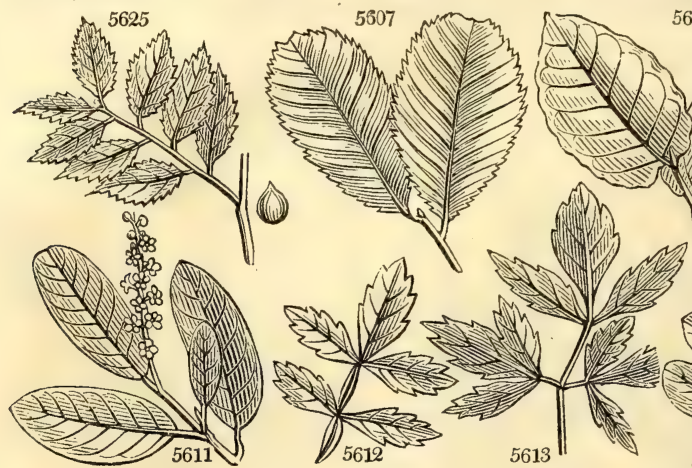
5609

History, Use, Propagation, Culture,

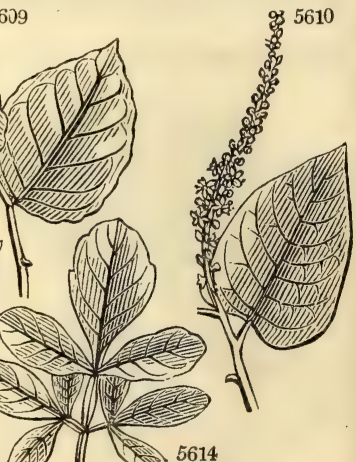

$$
\text { / }
$$

a considerable size, its wood is valued for cabinet work. The berries are of the size of grapes, reddish brown or purplish without, with a thin pulp, rather astringent, and a large stone within. All the species grow freely in light loamy soil; and ripened cuttings, taken off at the joint, and placed under a hand-glass, in a pot of sand, will root freely: one cutting under a glass is sufficient, as the leaves must not be shortened. (Bot. Cult 41.)

923. Paullinia. So named by Linnæus, from Simon Paulli, professor of botany at Copenhagen ; author of Botanicum Quadripartitum, 1640, and Flora Danica, 1648. P. polyphylla affords a well known walking-stick. In the woods of Jamaica it rises with a slender, woody, tough, flexile stalk, and ascends among the bushes to a considerable height. When the wood is ripe it is cut down, barked, and used as riding or walking sticks.

All the species succeed well in a light loamy soil; and large sized cuttings root in sand under a handglass.

924. Seriana. Named by Schumacher, after one Paul Serjeant. Cuttıngs root in sand under a hand-glass.

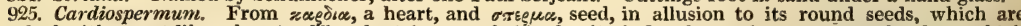
marked with a spot like a heart. The plant is remarkable for its inflated membranous capsule, from which it is sometimes called balloon vine.

920. Sapindus. A syncope of sapo-indicus, Indian soap. Its fruit is covered with a pulp, which is used in America for washing linen. S. Saponaria bears a berry as large as a cherry, inclosing a nut of a shining black when ripe. These nuts were formerly brought to England for buttons to waistcoats; some were tipped with silver, and others with different metals; they were very durable, as they do not wear, and seldom broke. The skin or pulp which surrounds the nut is saponaceous, and is used in America to wash linen; but it is very apt to burn and destroy it, if often used, being of a very acrid nature.

The whole plant, especially the seed-vessel, being pounded and steeped in ponds, rivulets, or creeks, is ob. 
5605 Leaves entire very broad contracted at base

5606 Leaves orbicular pubescent

5606 Leaves orbicular pubescent

5608 Leaves ianceolate ovate

5609 Leaves cordate ovate wavy

5610 Leaves of the branchlets ovate, of the branches ovate cordate

5611 Leaves oblong obtuse at each end coriaceous flat

5612 Caps. pyriform, Leaves in 2 pairs with an odd one, Leaflets ovate lanceolate sessile crenate 5613 Valves of caps. half obcordate, Leaves 2 ternate, Leaflets oval crenate, Footstalk edged 5614 Valves of caps. half ovate villous, Leaves 2 ternate, Leaflets oval entire and serrated coriaceous 5615 Valves of caps, obovate, Leaves supradecompound, Leaflets ovate cuneate erenate at end 5616 Leaves biternate, Leaflets oval toothletted at end, Branches prickly

5617 Caps. pyriform 3-winged at end, Leaves in 3 pairs with an odd one, Leaflets subsessile pubescent beneath

5618 Leaves ternate, Leaflets ovate lanceol. toothed sinuated, Wings of fruit dilated behind

5619 Leaves biternate, Leaflets oblong remotely toothed quite smooth, Wings of fruit rounded behind

5620 Stem stalks and leaves smooth, Leaves biternately cut, Segm. stalked cut-toothed 5621 Leaves beneath downy biternately cut, Segments stalked cut obtuse

5622 All over pubescent, Capsules obtuse

5623 Rachis of leaves winged, Leaflets entire lanceol, of 3-4 pairs : the terminal with long points 5623 Rachis of leaves winged unarmed, Leaflets lanceolate of 6 pairs

5625 Rachis not winged, Leaflets ovate oblong smooth of 3 pairs

5626 Rachis not winged, Leaflets lanceolate smooth of 5 pairs : one terminal

5627 Rachis not winged, Leaflets oblong emarginate villous beneath

5628 Rachis not winged, Leaflets oblong lanceolate acute villous beneath of $3-5$ pairs

\section{TETR AGYNIA.}

5629 Leaves 3-parted toothed: the floral linear entire

5630 Leaves obovate doubly crenate

5631 Leaves broad lanceolate opposite crenate thick, Segm. of cor. acute

5632 Leaves oval crenate, Flowers long pendulous cylindrical

5633 All the parts of the plant green and in fours

5634 The only species

5635 Leaves opposite, Flowers alternate stalked tetrapetalous

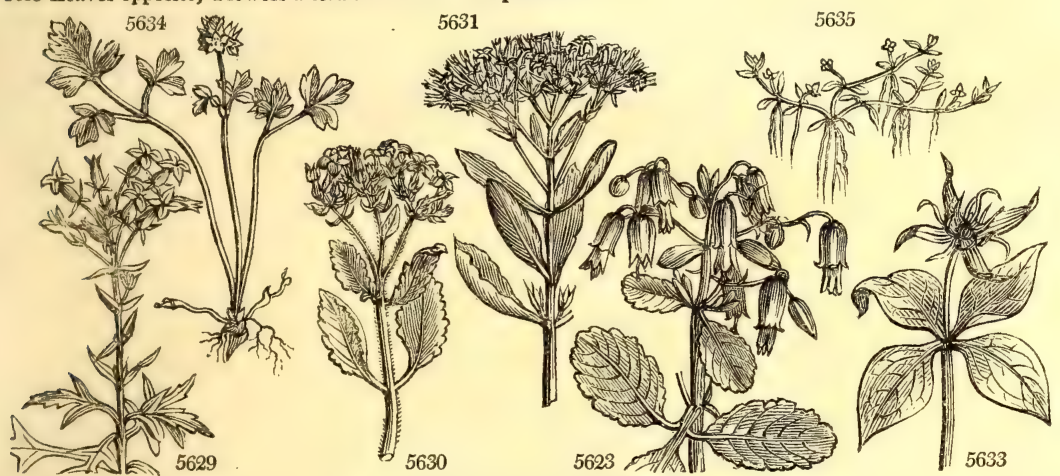

and Miscellaneous Particulars.

served to intoxicate and kill the fish. Loureiro celebrates the berries, slightly bruised and steeped in water, as a very excellent soap; and remarks that it is only required to use them with prudence, all abstergents being in some degree corrosive.

927. Verea. So named after the late James Vere, Esq., a gentleman of fortune, who patronized gardening, and had once a fine collection of living plants. The species thrive best in sandy loam, and should be plunged in the bark pit to make thern flower. The leaves placed on a pot of mould, or on the tan, will shoot out young

plants from the notches of the margin. (Bot. Cult. 33.)
928 . Bryophyllum. From $\beta$ evw, to grow, and $\phi \nu \lambda \lambda$, a leaf. If the leaves are laid upon damp earth their notches push forth roots, whence proceed young plants. This plant requires very little water, and the pot to be well drained : it flowers best plunged in a tan heat; rich loamy soil suits it best.

929. Paris. According to some authors, this word is derived from par, equal; in allusion to the regularity of the parts of the plant. Few plants are more readily distinguished than this, by the proportion and regularity of all the parts.

The regular number is four, or some aliquot part or multiple of that number. There are, however, some-

times only three leaves, and they are even said to vary from one to seven. The calyx also has sometimes three leaves. The leaves and berries are said to partake of the properties of opium; and the juice of the latter to be useful in inflammations of the eyes. Linnæus says, the root will vomit as well as ipecacuanha, given in a double quantity. It is a suspicious plant, which has nevertheless been used in medicine in a great variety of ways.

960 . Adoxa. From $\propto$, privative, and $\delta 0 \xi \kappa$, glory - inglorious. This plant is minute, and by no means beautiful, and grows in obscure places.

931. Elatine. From $\varepsilon \lambda \leftrightarrow \tau \eta$, a fir, in Greek. Its fine leaves have been compared to those of a fir-tree. 
932. HALO'RAGIS. $W$. Haloragis.

5636 Cercódia $W$.

933. FORSKOH'LEA.

5637 tenacíssima $W$.

5638 cándida $W$.

whorl-flowered th 1 cu 2 ap.s G. Halorage. Sp. $1-5$.

5638 cándida $W$. $W$.

ForsKoHLEA.

ap.s G.R New Zeal.1772. C s.p Jac. ic. 1. t. 69 clammy clammy

Urticea. Sp. 3-5.

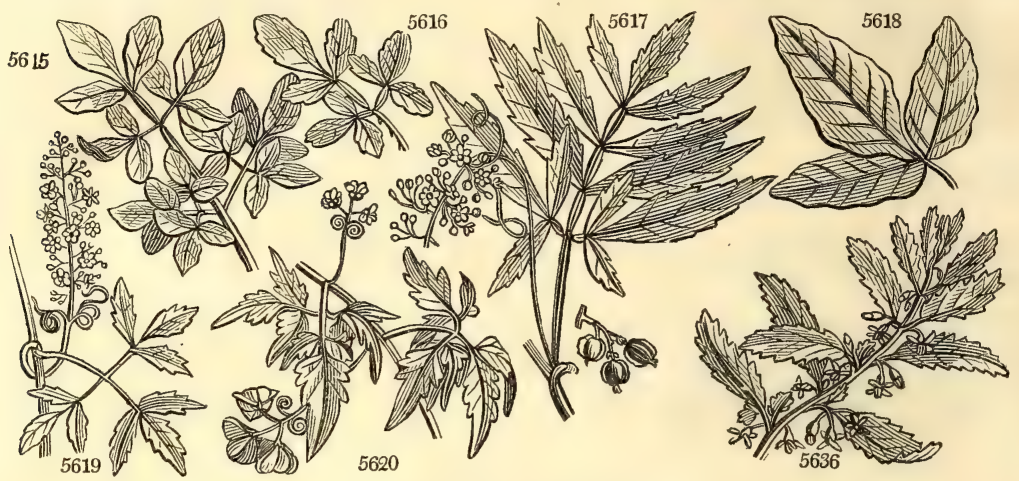

History, Use, Propagation, Culture,

932. Haloragis. From $\alpha \lambda_{5}, \alpha \lambda \circ 5$, the sea, and $\varsigma_{\xi}$, the berry of a bunch of grapes. This plant grows on the sea shore, and its fruit is globular like a berry.

933. Forsköhlea. In memory of Peter Forsköhl, a Swede, born in 1732; he was professor at Copenhagen; 


\section{Leaves serrate, Flowers whorled}

5637 Pilose hispid, Leaves elliptical unarmed, Sepals oblong lanceolate acute 5638 Rough, Leaves elliptical wavy unarmed, Sepals ovate obtuse

5639 Strigose, Leaves ląnceolate with spiny teeth, Sepals lanceolate subulate
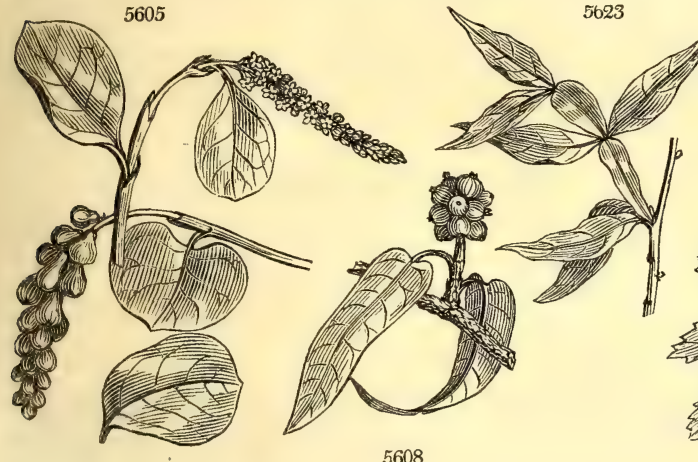

5608

and Miscellaneous Particulars.

travelled at the expence of the king of Denmark into Egypt and Arabia, and died in the latter country of the plague in 1763. Inelegant plants, with the aspect of a nettle. 


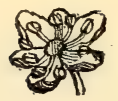

\section{Class IX. - EnNeandria. 9 Stamens.}

ONE of the smallest of the Linnean classes ; containing, however, three important genera ; the Laurel, famous for the valuable spices it produces, and for the beautiful foliage of its insipid species; the Cashew nut, well known at the tables of the great or luxurious; and the Rhubarb, one of the most valuable of medicines.

The class itself is extremely unnatural, and the assemblage of genera most incongruous.

\section{Order 1. MONOGYNIA. 98989 Stamens. 1 Style.}

934. Laurus. Cal. 4-6-parted. Nect. 3 glands, with 2 bristles surrounding the ovary. Anthers opening transversely. Valves hinged to the upper side.

\section{MONOGYNIA.}

934. LAU'RUS. $W$ 5640 Cinnamómum $W$. Cinnamon 5641 Cássia $W$ 5642 Malabátrum P.S. 5643 cámphora $W$. 5644 chloróxylon $W$ 5645 aggregáta Sims. 5646 nóbilis $W$

$$
\beta \text { unduláta }
$$
5647 Culilában $I$.
Bastard-Cinn

tall

Camphire-tree Cogwood-tree glaucous Sweet-Bay wave-leaved willow-leaved Culilaban

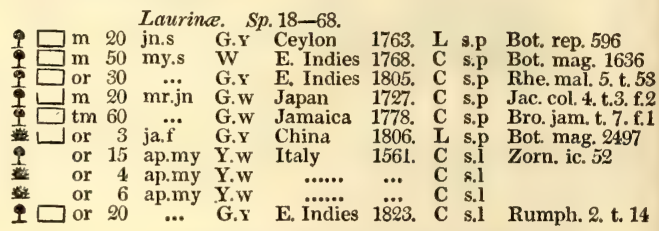

E. Indies 1823

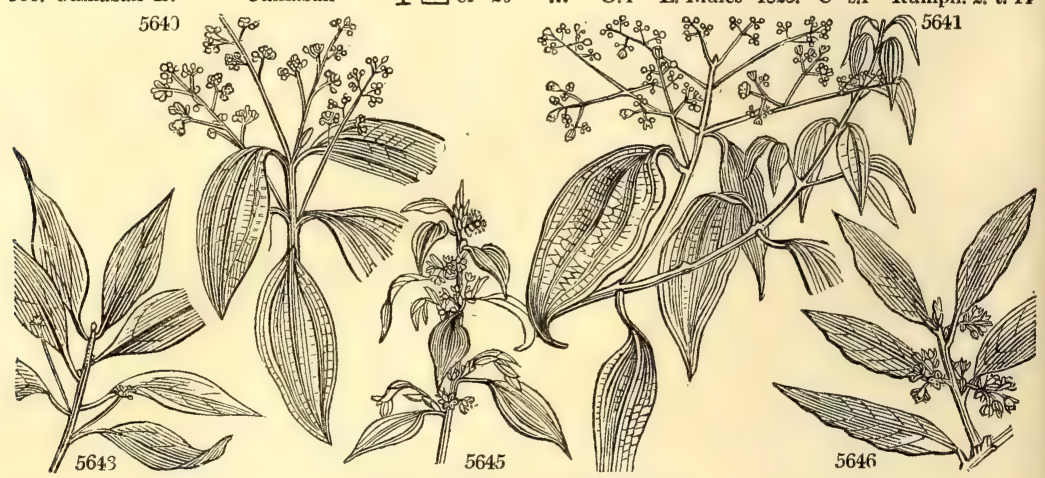

History, Use, Propagation, Culture,

934. Laurus. From the Celtic blaur (the $b$ is dropped in pronunciation, laur), green. The laurel is perpe tually green. This genus contains several important spice or drug-bearing trees, besides the poetical laurel and a fruit tree.

I. Cinnamomum ( $q u$. China Amomum) has a smooth ash-colored bark, a short erect trunk, and wide spreading branches, which form an elegant head. The leaves are of a bright green above, pale beneath, and white veined; the flowers are in panicles, have no shew, and are inodorous, or perhaps somewhat foetid; the fruit is the size of a middling olive, soft, insipid, and of a deep blue; it encloses a nut, the kernel of which germinates soon after it falls, and therefore cannot easily be transported to a distance. The timber is white, and not very solid; the root is thick and branching, and exudes abundance of camphor. The inner bark forms the cinnamon of commerce. There are many varieties, and probably some of them species, especially in the island of Ceylon, but only four are said to be barked. Besides Ceylon, the tree grows plentifully in Malabar, Cochin China, Sumatra, and the Eastern islands. It has been cultivated in the Brazils, the Mauritius, India, Jamaica, and other places. The soil in which it thrives best is nearly pure quartz sand. That of the cinnamon garden near Colombo in Ceylon, was found by Dr. Davy to consist of 98.5 of silicious sand, and of $1 \cdot 0$ only of vegetable matter in 100 parts. "The garden is nearly on a level with the lake of Colombo; its situation is sheltered; the climate is remarkably damp; showers are frequent, and the temperature is high and uncommonly equable." (Davy's Ceylon, p. 39.)

The trees that grow in the valleys, in a white sandy soil, are fit to be barked when four or five years old, but those in a wet soil or in shady places, require to be seven or eight years of age. The bark is good for nothing if the tree be older than eighteen years. The tree was formerly propagated by a species of pigeon that ate the fruit and voided the seed; but since Falck, one of the Dutch governors, about the middle of the eighteenth century, raised it from berries sown in his garden, it has been regularly cultivated.

The barking commences early in May, and continues until late in October. Branches of three years old are selected, and topped off with a pruning knife or bill hook. To remove the bark a longitudinal incision is made through it on both sides of the shoot, so that it can be gradually loosened and taken off entire, forming hollow cylinders. The bark in this state, tied up in bundles, is allowed to remain for twenty-four hours, by which a fermentation is produced that facilitates the separation of the epidermis, which, with the green pulpy matter under it, is carefully scraped off. The bark now soon dries, contracts, and assumes the quilled form, after which the smaller pieces are put within the larger. The cinnamon, when dry, is tied up in bundles of 30 lbs. weight, and carried to the Government store-house, where the quality is determined by inspection of the bundles. It was formerly chewed for this purpose; and the surgeons who used to be thus employed, had their 
935. Anacardium. Cal. 5.parted. Petals 5, reflexed. Anthers 9, and one filament barren. Nut reniform, upon a fleshy receptacle.

936. Cassytha. Cal. 6-parted. Nect. 3 truncate glands surrounding the ovary. Inner filaments glanduliferous. Drupe 1-seeded.

987. Eriogonum. Cal. campanulate, 6-cleft. Nut 1, 3-cornered, covered by the calyx.

Order 2. TRIGYNIA. 9 Stamens. 3 Styles.

938. Rheum. Cor. 6-cleft, persistent. Nut 1, 3-cornered.

Order.3. HEXAGYNIA. 9 Stamens. 6 Styles.

939. Butomus. Sepals 6. Caps, 6, many-seeded.

\section{MONOGYNIA.}

5640 Leaves 3-nerved ovate-oblong, Nerves vanishing towards the end 5641 Leaves triple-nerved lanceolate

5642 Leaves opp. very long acute at each end triple-nerved veiny across

5643 Leaves triple-nerved lanceolate ovate

5644 Leaves 3-nerved ovate coriaceous, Nerves reaching the end

5645 Leaves ovate acuminate 3-nerved glaucous beneath, Flowers axillary numerous

5646 Leaves lanceolate veiny perennial, Flowers 4-fid dioicous

5647 Leaves triple-nerved opposite

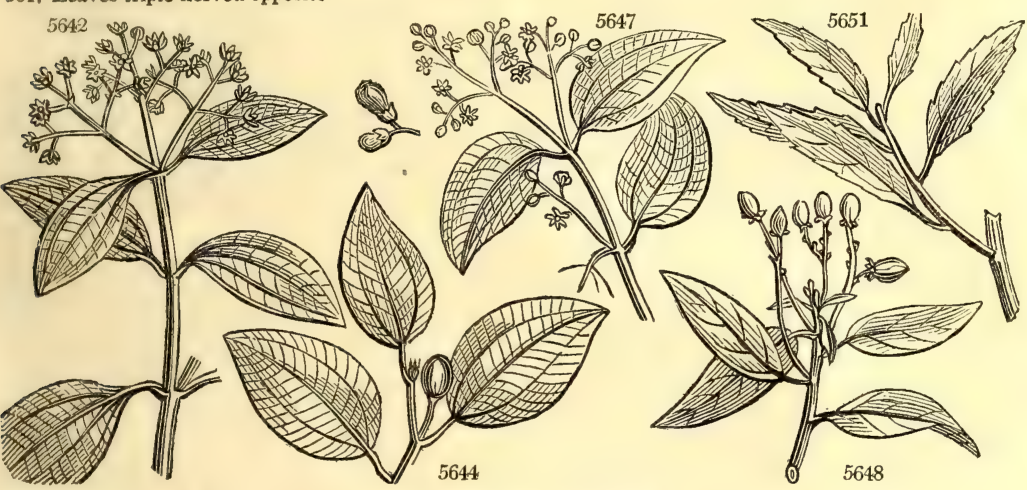

and Miscellaneous Particulars.

mouths so excoriated, as to be unable to continue the process longer than two days together: but tasting is now seldom had recourse to.

Cinnamon bark is astringent, cordial, and tonic. But the principal use of cinnamon is to cover the nauseous state of other remedies. (Thomson's London Dispensatory, 354.)

An oil is procured from the leaves and roots of cinnamon; the former is called the oil of cloves, and the latter the oil of camphor: both are powerfully stimulant, and used in cramps of the stomach, flatulent colic, hiccough, toothach, and nervous langour.

According to Sweet L. Cinnamomum is the hardest plant of the genus to cultivate in our stoves. " 1 have scarcely," he says, " ever seen it do well any where but at Messrs. Loddiges," who generally keep their stoves warmer than other gardeners usually do ; and the cinnamon likes a warm atmosphere, and very littie water in winter. It grows best in a mixture of sandy loam and peat, the pots being well drained with small potsherds. Fipened cuttings soon take root in a pot of sand, plunged under a hand-glass, in a good moist heat. (Bot. Cult. 74.)

The plant has regularly flowered and ripened seeds in the hothouse of the Bishop of Winchester for several years past.

L. Cassia is also decorticated like the cinnamon, but it is considered of inferior value, on account of containing a greater proportion of mucilage. What are called Cassia buds, are not obtained from this tree, but are the hexangular fleshy receptacles of the seed of the $\mathbf{L}$. Cinnamomum. Cassia bark and buds are used in the same manner as cinnamon bark : the tree also affords an oil of similar use. In our stoves, the cassia grows more readily than the cinnamon; the same kind of soil suits it; and cuttings root freely treated in the same manner. (Bot. Cult. 74.)

L. Camphora, an alteration of the Arabic name, kâfoìr, is nearly allied to the cinnamon tree. The roots, wood, and leaves of this tree have a very strong odor of camphor; and from the roots and smaller branches it is obtained by distillation. They are cut into chips, which are suspended in a net within a kind of still or iron pot, the bottom of which is covered with water, and an earthen head fitted to it; heat is then applied, and the steam of the boiling water, penetrating the contents of the net, elevates the camphor into the capital, where it concretes on straws, with which this part of the apparatus is lined Camphor is stimulant, narcotic, and diaphoretic, but its stimulant powers are very transitory, and followed by sedative effects. In moderate doses it operates as a cordial, increasing the heat of the body, and exhilarating, besides softening, and rendering fuller the pulse, and promoting diaphoresis; in large doses it allays irritation and spasm, abates pain, and induces sleep. But in immoderate doses camphor produces vomiting, vertigo, delirium, convulsions, and other 
5648 indica $W$ 5649 fœ'tens $W$. 5650 canariénsis $W$.en. 5651 Pérsea $W$ 5652 Borbónia $W$. 5653 carolinénsis $P$. S 5654 geniculáta $P h$. 5655 Dióspyrus $P h$. 5655 Dióspyrus $P$.

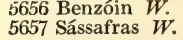
935. ANACAR'DIUM 5658 occidentále $W$. 936. CASSY'THA. 5659 filifórmis $I V$

937. 5660 . $\begin{array}{ll}5660 \text { tomentósum } P h . & \text { woolly } \\ 5661 \text { sericeum } P h . & \text { silky }\end{array}$ Red-Bay flexuose twiggy common

Cassitha.

Eriocior
Royal-bay $\quad J$ tm 20 mr.o G.x Madeira 1665. C l.p Pl. alm.t.304 f.1 Madeira, or Til. $\$$ tm 20 mr.o G.Y Madeira 1760. C 1.p

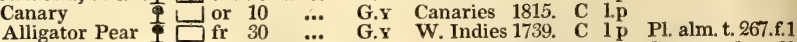
brd.-lvd.-Carol. 9 J or 15 ap.my Y.G N. Amer. 1739. C 1.p Cat. car. 1. t. 63 or 6 ap.my $Y$ or 6 ap.my G.Y N. Amer. 1810. L 1.p Bot. mag. 1470 N. Amer. 1683. S p.s.1 Com. hort.1.t.97 Cashew
Terebintacece. Terebintacer. Sp. 1.?

\& $\square$ cu 3 Laurince. $S p .1-2$.

1699. C r.m Cat. car. 3. t. 9 $E[$ cu 3 ap.au W E. Indies 1796. C s.p P1. al. t. 172. f. 2 Polygonere. Sp. 2-3.

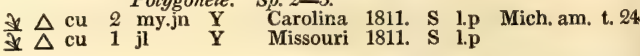

\section{TRIGYNIA.}

938. RHE'UM. $W$. 5662 Rhapónticum 5663 undulátum $W$
RHUBARB. common Bucks
Polygonea. Sp. 7-10.

* $\triangle$ cul 4 my.jn W.g Asia 1573. R co Sabb.hort.1.t.34 * $\Delta$ cul 4 my.jn W.g China 1734. R co Amæn. ac. 3.t. 4 5654
5655

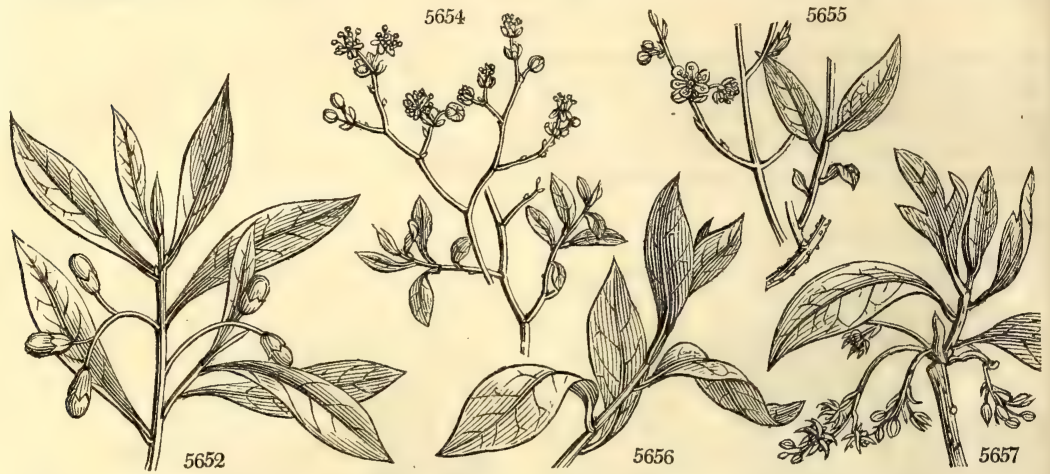

History, Use, Propagation, Culture,

deleterious effects. The greater part of the camphor brought to Europe is obtained in Sumatra from the Dryobalanops Camphora. This tree is cut and split, and the camphor which is found concreted in the heart of it is picked out and washed in a ley of soap. Zea describes a variety of camphor which is procured in South America from a tree, the botanical characters of which are not yet known, but which is termed caratta by the natives. The camphor exudes from the bark in the form of tears. (Thomson's London Dispensatory, 356.)

L. Chloroxylon has its specific from the color of the wood, $\chi \lambda$ woov, green, and $\xi u \lambda .0 y$, wood; it is esteemed one of the best timber trees in Jamaica, and used on all occasions where strength and durability are required: being both hard and tough, it answers better than any other wood for the cogs of sugar mills.

L. nobilis, the Laurier, Fr., Lorbecrbaum, Ger., Alloro, Ital., Laurel, Span., the Laurus of the Romans, and Daphne of the Greeks, was designated nobilis, by Linnæus, because it was consecrated to priests, sacrifices, and heroes in the ages of antiquity, and has been celebrated accordingly. To the poet and sculptor it still affords emblems for victorious heroes; and it is also used in cookery and medicine. In the south of Italy it grows to a sufficient height to be considered a tree; but is so prolific in suckers and low shoots as always to have the character of a shrub. It forms a dense and yet broken and picturesque mass of a very fine deep green, inclining to olive, and is abundantly covered with berries, which are dark purple or black, when ripe Oil is obtained from the latter by boiling water. Both the leaves and the berries have a sweet fragrant odour, and an aromatic, astringent taste; and the oil, which is of a yellowish green color, has a stronger but similar odor and taste. Water distilled from the leaves shews traces of prussic acid; and it is probably on this component that their medicinal and poisonous property depend. Leaves, berries, and oil are narcotic and carminative. (Thomson's London Dispensatory, 360.)

$\mathbf{L}$ indica. grows in the Canary Isles and Virginia. The wood is of a yellow color, not heavy, good for building, but better still for furniture : it is called Vigniatico in the island of Madeira, and is probably what is imported into England under the name of Madeira mahogany. It is hardly to be distinguished from mahogany, except that it is somewhat less brown. (Hawksw. Voy. ii. p. 5.)

L. Persea (Persea is a name under which Theophrastus describes an Egyptian tree not now known, has a trunk as large as our common apple tree; the bark is smooth, and of an ash color; the branches are very succulent and soft, beset with pretty large oblong smooth leaves, like those of laurel, of a deep green color. The flowers are, for the most part, produced towards the extremities of the branches. The fruit is the size of one of our biggest pears. The pulp of the fruit is covered with a tough skinny coat, and contains a large rugged seed, which is wrapped up in one or two thin membranous covers. This fruit is held in great esteem in the West Indies: the pulp is of a pretty firm consistence, and has a delicate rich flavor; it gains upon the palate of most persons, and becomes soon agreeable even to those who cannot like it at first; but it is so rich and mild, that most people make use of some spice or pungent substance to give it a poignancy; and, for this purpose, some make use of wine, some of sugar, some of lime. juice, but most of pepper and salt. This fruit seems equally agreeable to the horse, the cow, the dog, and the cat, as well as to all sorts of birds; when plentiful, it makes a great part of the delicacies of the negroes. (Browne.)

L. Borbonea was regarded by Plumier as a genus distinct from Laurus, and he applied what is now its specific name, in memory of Gaston Bourbon, son of Henry IV. and uncle of Louis XIV. It is a very common tree in swamps in Carolina, and affords a fine grained wood excellent for cabinets ; some of the best resembles watered satin.

L. Sassafras (Sassafras is an alteration of the Spanish word Salsafras, which signifies Saxifrage, the virtues of which are attributed by the Spanish Americans to this plant, ) has the flowers often imperfect as to the male and fomale organs, which, before observation was so accurate and scientific as at present, led to the conclusion 
5648 Leaves veiny lanceolate perennial flat, Branches scarred, Flowers racemose

5640 veiny elliptical acute perennial, Axils of veins villous beneath, Racemes panicled

5649 Leaves veiny elliptical acute perennial, Axils of veins villous beneath, Racemes veiny oblong acute at each end perennial shining, Pedunc. axill. 3-4-flowered

5651 Leaves ovate coriaceous transversely veiny perennial, Flowers corymbose

5652 Leaves lanceolate perennial, Calyx of fruit berried

5653 Leaves oval lanc, perenn. glaucous beneath, Berries globose

5653 Leaves divaricating flexuose, Leaves oval obtuse smooth at the base beneath bearded, Anth. 4-celled 5654 Branches divariclowering, Ieaves decid. oblong beneath veiny downy, Flowers clustered, Buds villous 5656 Leaves nerveless ovate acute at each end entire annual

5657 Leaves entire and 3-lobed

\section{The only species}

5659 Branches filiform lax

5660 Leaves sessile cauline $3-4$ cuneate obovate smooth above 5661 Leaves radical stalked lanc. oblong villous above

\section{TRIGYNIA.}

5602 Leaves obtuse smooth, Veins beneath hairy, Leafst. furrowed above rounded at edge 5663 Leaves villous wavy, Leafst. flat above with an acute edge
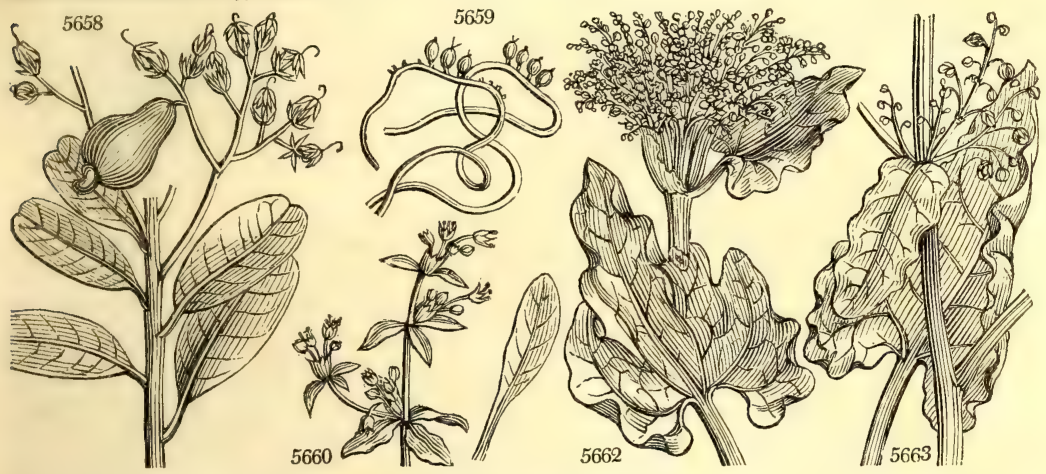

and Miscellaneous Partuculars.

that one plant bore only males and the other only hermaphrodites; it is now found the alleged males are only imperfect hermaphrodites. The wood, root, and bark have a fragrant odor, and a sweetish aromatic taste: their sensible qualities and virtues depend on an essential oil, which can be obtained separate by distilling the chips or the bark with water: it is a stimulating diaphoretic and diuretic, and has been employed in cases of scurvy, chronic rheumatism, gout, and in cutaneous affections ; but its effects are very uncertain ; and even the diaphoresis which it is supposed to occasion may rather be ascribed to the guaiac, and other more powerful medicines, with which it is generally combined. (Thomson's London Dispensatory, 361 .)

The species are well divided into several genera, such as Laurus, Tetranthera, Cinnamomum, and others : but as this division has not been applied to the old species of Laurus generally, it has not been practicable to adopt it here.

935. Anacardium. From ays, in composition, like, and zos $\delta$ se, heart, in allusion to the form of the nut. This is an elegant tree, bearing panicled corymbs of sweet-smelling flowers, succeeded by an edible fruit of the porne kind, of a yellow or red color. This fruit or apple has an agreeable sub-acid flavor, with some degree of astringency. The juice expressed and fermented yields a pleasant wine; and distilled, a spirit is drawn from it, far exceeding arrack or rum, making an admirable punch, and powerfully promoting urine. The dried and broken kernels are occasionally imported for mixing with old Madeira wine, the flavor of which they improve prodigiously. Some planters in the West Indies roast the ripe fruit, or slice one or two into a bowl of punch, to give it a pleasant flavor. The astringency of the juice has recommended it as a very signal remedy in dropsical habits.

The nut protrudes from one end of the apple. (Long.) It is of the size and shape of a hare's kidney, but is much larger at the end next the fruit than at the other. The outer shell is of an ash color, and very smooth, under this is another which covers the kernel; between these there is a thick inflammable oil, which is very caustic; this will raise blisters on the skin, and has often been very troublesome to those who have incautiously put the nuts into their mouths to break the shell. This oil has been used with great success in eating off ring-worms, cancerous ulcers, and corns ; but it ought to be applied with caution. The kernel when fresh, has a most delicious taste, and abounds with a sweet milky juice. It is an ingredient in puddings, \&c. When older it is generally roasted; and in this state is not so proper for costive habits. Ground with cacao, it makes an excellent chocolate. When kept too long it becomes shrivelled, and loses its flavor and best qualities. The thick oil of the shell tinges linen of a rusty iron-color, which can hardly be got out ; and if any wood be smeared with the oil, it prevents the wood from decaying.

From the body of the tree is procured, by tapping or incision, a milky juice, which will stain linen of "a deep black, that cannot be washed out again.

This tree also annually transudes from five to ten or twelve pounds weight of a fine semi-transparent gum, similar to gum arabic, and not inferior to it in virtue or quality, except that it has a slight astringency, which, perhaps, renders it in some respects more valuable. (Long's Jam. iii. 725, \&c.)

As a stove-plant it grows in light loam or rich mould, and ripe cuttings with their leaves, planted in a pot of sand, and plunged under a hand-glass, will strike root.

936. Cassytha. The Greek name of the Cuscuta, which this plant much resembles in habit and characters of analogy. Its affinity, however, is very curious; from a minute analysis of its constituent parts it has been decided by the most learned botanists to be referable to Laurinæ.

937. Eviogonum. From seroy, wool, and rove, a knee. The stem of this plant is very woolly at the joints. The species thrive best in pots, and are principally to be increased by seeds.

938. Rheum. This name was ingeniously supposed by Linnæus to have been derived from $\rho \xi \omega$, to flow, because the root causes a discharge of bile. It, nevertheless, was formed from Rha, the ancient name of the Volga. 
5664 palmátum $W$. 5665 compáctum $\dot{W}$. 5666 tatáricum $W$ 5667 Ríbes $W$ 5668 hýbridum $W$. officinal

thick-leaved

Tartarian

warted-leaved

bastard
* $\triangle \mathrm{m} \quad 5$ ap.my W. G Bucharia 1763. $\mathbf{R}$ co Lin. fasc. 7. t. 4 * $\Delta$ m 3 my.jn W.g Tartary 1758. R co Mill. ic.2.t. 218 * $\Delta$ m 3 my.jn W.g Tartary 1793. R * $\Delta$ cul 2 my.jn W.g Levant 1724. R co An. mus. 2. t. 49 * $\triangle$ cul 5 my.jn W.G Asia 1778. R co Mur. co.got.t. 1

\section{HEXAGYNIA.}

939. $\mathrm{BU}^{\prime}$ TOMUS. $W$. 5669 umbellátus $W$.

\section{Flowering-Rush}

Butomea. $S p .1-2$.
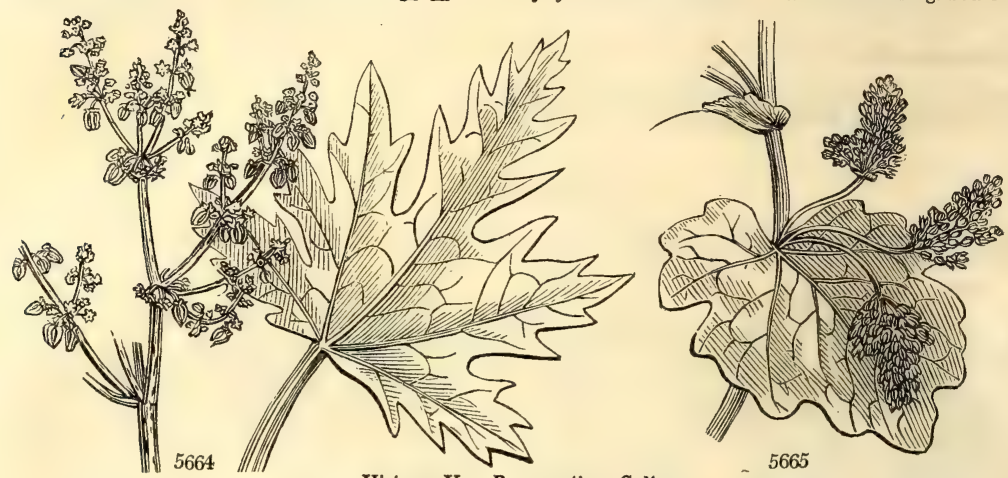

History, Use, Propagation, Culture,

5665

Ammianus Marcellinus, lib xii., says, " the $k$ ha is a river, on the border of which grows a root, which bear its name, and is much renowned in medicine." The construction of the specific names confirms this ; Rha ponticum, Rha barbarum, whence the name $R$ hubarb was obtained.

R. Rhaponticum was thought to be the true rhubarb of druggists, till Dr. Hope of Edinburgh described the R. palmatum, some seeds of which he had received from Russia, as of the genuine species. It is not, however, finally settled, whether these species or the R. compactum yield the foreign roots, nor does it appear of much consequence, as these three species agree so nearly in their medical properties, that any of them may be used with equal certainty of success. All the rhubarb of commerce, known under the names Turkey or Russian, and East Indian or Chinese, grows on the declivities of the chain of mountains in Tartary which stretches from the Chinese town Sini to the lake Kokonor near Thibet. The soil is light and sandy; and the Bucharians assert that the best grows in the shade on the southern side of the mountains. Rhubarb, however, is also cultivated in China, in the province of Chen-See, where it is called Hai-houng. In Tartary, the roots are taken up twice a-year, in spring and in autumn, and after being cleansed and decorticated, and the smaller branches cut off, the body of the root is divided transversely into pieces of a moderate size, which are placed on tables, and turned three or four times a-day, during five or six days. A hole is then bored through each piece, by which it is hung up to dry, exposed to the air and wind, but sheltered from the sun. In about two months, the roots have lost seven parts in eight of their weight, and are fit for the market. In China, the roots are not dug up till winter; and the cultivators, after cleaning, scraping off the bark, and cutting them, dry the slices by frequently turning them on stone slabs heated by a fire underneath; after which, the drying is completed by hanging them up in the air exposed to the greatest heat of the sun. (Thomson's London Dispensatory, 471.)

Rhubarb has been cultivated in different parts of Britain with a view to drying the root for medical purposes with the most perfect success; but such is the prejudice in favor of the foreign article, that sufficient de- 
5664 Leaves palm. acute roughish, Leafst. above obscurely furrowed rounded at edge 5665 Leaves somewhat lobed very obtuse shining finely toothletted smooth 5666 Leaves cordate ovate entire flat smooth, Leafst. half-round angular, Panicle furrowed

5667 Leaves very obtuse somewhat warted, Veins beneath spinulose, Leafst. flat above rounded at edge

5668 Leaves smooth above somewhat lobed acute, Recess of base contracted

\section{HEXAGYNIA.}

5669 Flowers in handsome terminal umbels

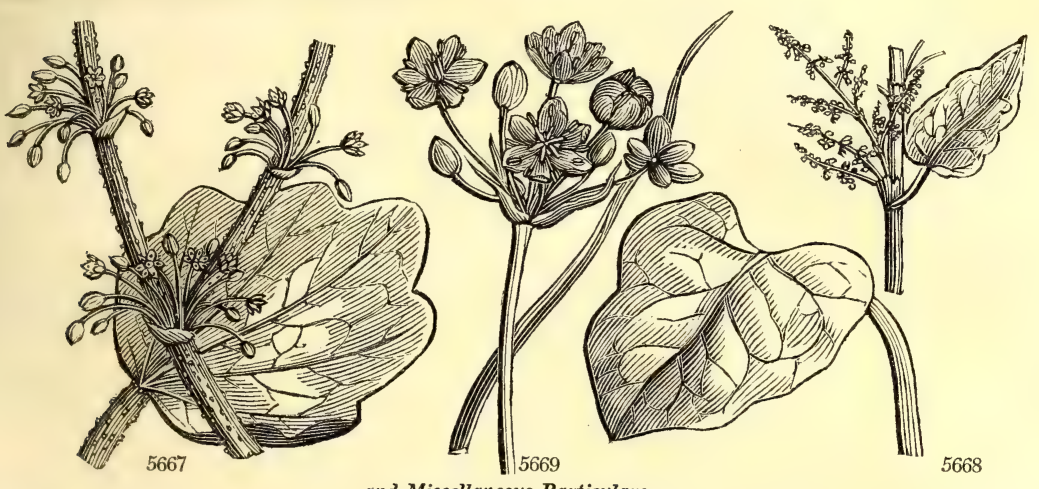

and Miscellaneous Particulars.

mand was not produced to encourage the cultivator. The only point in which British culture was rather deficient was in the drying, but that a little experience would soon have overcome.

R. Rhaponticum and hybridum, indeed any of the species, are or may be cultivated for the petioles of the leaves in a green state, to be used in tarts and pies, as a substitute or along with gooseberries. All that is required is a dry soil well enriched and trenched two, or better, three feet deep. The plants the year after planting may have half their leaves slipped off for the cook, as soon as they arrive at full growth. Keeping the plants from flowering will obviously strengthen the leaves.

Tart rhubarb may be forced either by taking up the roots and planting them in pots, or by covering them with dung where they grow in the open garden, as is done with sea-kale. It may also be blanched, as is done with that vegetable. (See Encyc. of Gard. art. Rheum.)

$\mathrm{R}$. Ribes is so called from a rob made from its stalks, and called Rybès of Serapias.

It is thought that all the supposed species are reducible to Rhaponticum, undulatum, palmatum, and ribes. It is certainly very difficult to distinguish the others.

939. Butomus. From $\beta \varangle s$, an ox, and $\tau i \mu \nu \omega$, to cut; the sharp leaves of the plant cut and cause to bleed the mouths of cattle feeding upon it.

This is the only plant of the class Enneandria that grows wild in Britain. It is an elegant aquatic. "The water-Gladiole, or grassie-Rush," says Gerarde, "is of all others the fairest and most pleasant to behold, and serveth very well for the decking and trimming up of houses, because of the beautie and braverie thereof."

The corolla varies in different shades of red, or purple mixed with white, and is sometimes entirely white. The stem at bottom and the peduncles at top are often tinged with red. The number three is evidently predominant in the fructification; the corolla being doubly tripetalous, the stamens thrice three, the pistils six, the capsules six, in a hexagon form, the involucre three-leaved, 


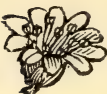

\section{Crass X. - DeCandria. 10 Stamens.}

THis is the last of the Linnean classes in which the stamens are distinct, and bear any determined relation to the other parts of the flower. It is composed of portions of a considerable number of natural orders, of which the most important is Leguminosæ, with which the class usually is made to commence. These are of two kinds: those which are papilionaceous, and those which have a regular expanded flower. The former are remarkable in their kind for bearing distinct stamens combined with a papilionaceous corolla; the greater part are natives of New Holland or the Cape of Good Hope, a very few of the Northern Hemisphere and all of them ornamental plants. Of those with regular flowers the most beautiful genus is the Bauhinia, which, in the latitudes of the tropics, constitutes the most formidable obstacle to the passage of human beings through the woods, which are interlaced in every direction by the climbing or leaning stems of these and other plants commonly called Lianes; the most extensive genus is Cassia, the species of which are little esteemed as objects of ornament, but of material importance in medicine; the famous Senna of the shops being the produce of at least three species. The Hæmatoxylon and Swietenia, the one producing Logwood, the other Mahogany, are included in this class, as are the important Quassia drug, and the beautiful tribes of Kalmias, Rhododendrons, and Andromedas.

The second and succeeding orders are chiefly occupied by the most important of the genera of the natural order of Caryophylleæ, the whole of which have lately been remodelled and arranged, under the direction of Decandolle, by M. Seringe, an ingenious Swiss botanist. Of this order the most extensive genus is Silene, and the most beautiful Dianthus, out of which the fine carnations, pinks, and piccotees of the florist have been obtained

Order 1. MONOGYNIA.

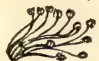

10 Stamens. 1 Style.

\section{Leguminosa. Flowers papilionaceous.}

940. Edwardsiu. Cal. 5-toothed. Pod 4-winged, many-seeded.

941. Sophora. Cal. 5-toothed. Pod necklace-shaped, not winged, many-seeded.

942. Ormosia. Cal. 5-cleft, 2-lipped. Stigmas 2, approximate, obtuse : one on one side. Pod compressed, woody, 1-3-seeded.

943. Anagyris. Cal. 5-toothed, 2-lipped. Keel of 2 petals, which are larger than the wings, which are longer than the standard. Pod compressed, many-seeded.

941. Thermopsis. Cal. oblong $\frac{1}{2}-5$-cleft, 2 -lipped, convex behind. Petals of equal length. Standard re

flexed at edges. Keel obtuse. Stamens persistent. Pod compressed, linear, many-seeded.

945. Virgilia. Cal, 5-cleft. Petals of equal length; standard not reflexed at edges. Stigma beardless. Pod compressed, oblong, many-seeded.

946. Cyclopia. Cal. 5-cleft, unequal, pushed inwards at base. Standard with longitudinal wrinkles: wings with a transverse plait. Stamens deciduous. Stigma bearded on one side. Pod compressed, many-seeded.

947. Baptisia. Cal. half 4-5-cleft, 2-lipped. Petals of equal length. Standard reflexedat edges. Stamens deciduous. Pod ventricose, stalked, many-seeded.

948. Podalyria. Cal. 5-cleft, unequal, pushed inwards at base. Standard larger than the rest. Stamens persistent, connate at base. Pod ventricose, many-seeded.

949. Chorozemia. Cal, half-5-cleft, 2 lipped. Keel ventricose, shorter than wings. Style short, hooked. Stigma oblique, obtuse. Pod ventricose, many-seeded.

950. Podolobium. Cal. 5-cleft, 2-lipped. Keel compressed, the length of the wings, which are equal to the expanded standard. Ovary many-seeded in a single row. Style ascending. Stigma simple. Pod stalked, linear, oblong, moderately ventricose, smooth inside.

951. Oxylobium. Cal. deeply 5-cleft, rather 2-lipped. Keel compressed, the length of the wings, which are equal to the open standard. Style ascending. Stigma simple. Pod many-seeded, ventricose, ovate, acute.

952. Callistachys. Cal. 2-lipped. Standard erect, keel and wings drooping. Style incurved. Stigma simple.

Pod stalked, woody before ripening, many-celled.

953. Brachysema. Cal. 5-cleft, but little unequal, with a ventricose tube. Standard shorter than the compressed keel, which is as long as the wings. Ovary with a stalk, surrounded at base by a little sheath Style filiform, long. Pod many-seeded, ventricose.

954. Gompholobium. Cal. 5-parted, nearly equal. Standard unfurled. Stigma simple. Pod many-seeded, nearly spherical, very obtuse, smooth.

955. Burtonia. Cal. deeply 5-cleft. Cor. deciduous. Petals nearly equal. Ovary 2-seeded. Style subulate, dilated at base. Stigma blunt, beardless. Pod roundish, moderately inflated. No appendage to the seed.

956. Jacksonia. Cal. 5-parted, nearly equal. Corolla and stamens deciduous. Ovary 2-seeded. Style subulate, filiform. Stigma simple. Pod moderately inflated, ovate or oblong, with valves downy inside. No appendage to the seed.

957. Viminaria. Cal, 5-toothed, angular. Style capillary, a little longer than the 2-seeded ovary. Stigma simple. Pod valveless, ovate. No appendage to the seed.

958. Spharolobium. Cal. 5-fid, 2-lipped. Style on one side at the end, with a membranous appendage, on the other beardless. Stigma terminal. Pod spherical.

959. Aotus. Cal. 5-cleft, 2-lipped. Stamens deciduous. Ovary 2-seeded. Style filiform. Pod 2-valved. No appendage to the seed.

960. Dillwynia. Cal, 5-cleft, 2-lipped, narrow at base. Petals and stamens deciduous, inserted into the middle of tube of calyx. Standard twice as broad as long, spreading, 2-lobed. Ovary 2-seeded. Style hooked. Stigma capitate. Pod inflated. Seeds with an appendage.

961. Eutaxia. Cal. 2-lipped. Standard a little broader than long. Ovary 2-seeded. Style hooked. Stigma capitate. Pod moderately ventricose. Seed with an appendage. Leaves opposite.

962. Sclerothamnus. Cal. 5-cleft, 2-lipped, with 2 bractes at base. Keel as long as wings. Ovary 2-seeded, stalked. Style ascending filiform. Stigma simple. Pod ventricose.

: 963. Gastrolobium. Cal. 5-cleft, 2-lipped, without bractes. Petals of equal length. Ovary 2-seeded, stalked. Style subulate, ascending. Stigma simple. Pod ventricose. Seeds with an appendage.

964. Euchilus. Cal. deeply 5-cleft, 2-lipped, the upper lip very large, with 2 bractes at base. Keel as long as wings. Ovary 2-seeded, stalked. Style subulate, ascending. Stigma simple. Pod compressed. Appendage of the seed with the hind lobes entire.

of the seed with the hind lobes entire.
965 . Pultenae. Cal. 5-cleft with even-sized lips, 2-bracted. Ovary sessile, 2-seeded. Style subulate, ascending. Stigma simple. Appendage of the seed with the hind lobes cut.

966. Daviesia. Cal. angular without bractes. Keel shorter than standard. Ovary stalked, 2-seeded. Style straight. Stigma simple. Pod compressed, angular, opening with elasticity. Appendage of seed entire behind.

967. Mirbelia. Cal. 5-cleft, 2-lipped. Pod 2-celled, with each suture bent inwards. 
968. Cercis. Cal. 5-toothed. Pod compressed with the seed-bearing suture winged. Seeds obovate, with a straight embryo.

969. Schotia. Cal. 5-cleft. Petals 5, inserted on the calyx, and approaching the papilionaceous form. Pod stalked.

\section{Leguminosa. Flowers nearly regular.}

970. Bauhinia. Cal. 5-cleft, deciduous. Petals spreading, oblong, clawed; the upper one more distant; all inserted in the calyx.

971. Afzelia. Cal. tubular, with a 4-cleft deciduous limb. Petals 4, with claws: the upper very large. The upper filaments sterile. Pod many-celled. Seed with an arillus at base.

972. Hymencas. Cal. 5-parted. Petals 5, nearly equal. Pod filled with a powdery fæcula.

973. Cynometra. Cal, 4-leaved : the opposite leaves largest. Pod 1-seeded, fleshy.

974. Cassia. Cal. 5-leaved. Petals 5. The three upper anthers sterile : three lower beaked.

975. Cathartocarpus. Cal. 5-parted, deciduous. Cor. regular, of 5 petals. The lower filaments bowed. Pod long, round, woody, many-celled. Cells filled with pulp.

976. Parkinsonia. Cal. 5-cleft. Petals 5, ovate, the lowest reniform. Style O. Pod necklace-shaped.

977. Poinciana. Cal. 5-parted. Petals 5, clawed; the upper dissimilar. Stamens very long, all fertile. Pod plano-compressed.

978. Cosalpinia. Cal. 5-parted, with the lowest segment largest and vaulted. Petals 5. Stamens woolly at base, all fertile. Pod unarmed. Seeds compressed.

979. Guilandina. Cal, 5-cleft, the lowest segment largest. Petals inserted in the neck of the calyx, nearly equal. Pod prickly. Seeds stony.

980. Hyperanthera. Cal. 5-parted. Petals inserted in calyx, unequal. Pod 3-valved, torulose. Seeds winged.

981. Hoffmannseggia. Cal. 5-parted, persistent. Petals 5, clawed, spreading: the upper broader, glandular at base. Filaments glandular. Stigma clavate. Pod linear, compressed, many-seeded.

982. Adenanthera. Cal. 5-toothed. Petals 5. Anthers with a globose gland at their extremity. Pod membranous. Seeds lentiform.

983. Cadia. Cal. 5-cleft. Petals 5, equal, obcordate. Pod many-seeded.

984. Prosopis. Cal. hemispherical, 4-toothed. Pod many-seeded.

985. Hamatoxylon. Cal. 5-parted. Petals 5. Caps. lanceolate, 1-celled, 2-valved; valves navicular.

986. Copaifera. Cal. O. Petals 4. Pod 1-seeded.

\section{Ovary superior. Stamens united in a tube. Flowers complete.}

987. Trichilia. Cal. 4 5-toothed. Petals $4-5$, ovate or oblong. Stamens sometimes nearly distinct. Caps. 3-celled, 3-valved, with one or two seeded cells. Seeds with a berried arillus.

988. Melia. Cal. 5-toothed. Petals 5. Drupe with a five-celled nut.

989. Quivisia. Cal, urceolate, 4-5-toothed. Petals 4-5, short, silky outside Stamens with a short tube. Stigma capitate. Caps, coriaceous, 4-5-celled, opening at the end into 4-5-valves.

990. Swietenia. Cal. 5-cleft. Petals 5. Caps. 5-celled, woody, opening at base. Seeds imbricated, winged. 991. Ekebergia. Cal. 4-parted. Petals 4. Nect. a ring surrounding the ovary. Berry 5-seeded.

992. Heynea. Cal. 5-toothed. Petals 5. Style 1. Ovary 2-celled. Caps. 2-valved, 1-celled, 1-seeded. Seed with an arillus not winged.

\section{Ovary superior. Stamens separate. Flowers complete.}

993. Guaiacum. Cal. 5-parted, unequal. Petals 5, equal. Caps. angular, 2-5-celled.

994. Zygophyllum. Cal. 5-leaved. Petals 5. Nect. 10-leaved, covering the ovary and bearing the stamens. Caps, 5-celled.

995. Fagonia. Cal. 5-leaved. Petals 5, cordate. Caps. 5-celled, 10-valved; with 1-seeded cells.

996. Tribulus. Cal. 5-parted. Petals 5, spreading. Style O. Caps. 5, gibbous, spiny, many-seeded.

997. Dictamnus. Cal. 5-leaved, deciduous. Petals 5, clawed, unequal. Filam. declinate, with glandular dots. Caps, 5, united.

998. Ruta. Cal. 5-parted. Petals concave. Recept. surrounded by 10 honey-spots. Caps. lobed.
999. Crowea. Cal. 5-parted. Petals 5, sessile. Stamens flat, subulate, connected by entangled hairs. Anthers united lengthwise to the filaments on their inner side. Style from the base of the ovary. Caps. 5 , united. Seeds with an arillus.

1000. Codon. Cal. 10-parted. Cor. campanulate, 10-cleft. Caps. many-seeded.

1001. Gomphio. Petals 5. Filaments scarcely any. Anthers long, pyramidal, erect, opening at end by a donble pore.

1002. Quassia. Cal. 5-leaved. Petals 5. Nect. 5-leaved. Drupes 5, distant, 2-valved, 1-seeded, inserted on a flestiy receptacle.

1003. Limonia. Parts of the flower 4 or 5 . Stamens free, twice as numerous as petals, or sometimes as many only. Fruit berried, pulpy, 4-5-celled, with 1-celled seeds.

1004. Glycosmis. Parts of the flower 5 . Stamens with flat subulate filaments, and elliptical anthers. Style short, cylindrical. Ovary 5-celled. Fruit fleshy, 1-2-celled, 1-2-seeded. Coat of the seed membranous.

1005. Murraya. Parts of the flower 5. Cor. campanulate. Stamens with linear subulate stamens, and roundish anthers. Fruit fleshy, berried, 1-2-celled, 1-2-seeded. Coat of the seed thick, woolly.

1006. Cookia. Parts of the flower 5. Petals navicular, villous. Stamens with linear distinct filaments, and roundish anthers. Fruit berried, globose, 1-5-celled, with one-seeded cells.

1007. Gertnera. Cal, 5-parted. Petals 5 torn. Filaments slightly cohering at base: one longer than the rest. Samara 1-seeded, with four unequal wings.

1008. Monotropa. Cal. like a corolla, gibbous at the base. Capsule 5-celled, many-seeded,

1009. Dionaea. Cal, 5 -leaved. Petals 5 . Capsule 1-celled, gibbous, many-seeded.

1010. Garuga. Cal. campanulate, 5 -cleft, bearing the stamens. Petals equal. Stigma 5-lobed. Drupe with 2-5 1-seeded nuts.

1011. Kalmia. Cal. 5-parted. Cor. hypocrateriform, with a limb having 5 horns beneath. Caps. 5-celled.

1012. Ledum. Cal. 5-cleft. Cor: flat, 5-parted. Caps. 5-celled, bursting at base.

1013. Rhodora. Cal. 5-toothed. Petals 3. Stamens declinate, Caps. 5-celled.

1014. Rhododendron. Cal. 5-parted. Cor. somewhat funnel-shaped. Stamens declinate. Caps. 5-celled.

1015. Epigan. Outer calyx 3-leaved, inner 5-parted. Cor. salver-shaped. Caps. 5-celled.

1016. Andromeda. Cal. 5-parted. Cor. ovate, with a 5-cleft orifice. Caps. 5-celled : valves contrary to the dissépiment.

1017. Enkianthus. Cal. small, persistent. Cor. campanulate, with a 5-cleft limb. Nectaries 5, at base of corolla. Anthers 2-horned. Capsule 1.

1018. Gualtheria. Outer calyx 2-leaved : inner 5-cleft, ovate. Nect. with 10 points. Caps. 5-celled, clothed with an inner berried calyx.

1019. Arbutus. Cal, 5-parted. Cor. ovate, with a 5-cleft orifice; pellucid at base. Berry 5-celled.

1020. Clethra. Cal, 5-parted. Petals 5. Stigma 3-fid. Caps. 3-celled, 3-valved.

1021. Mylocaryum. Cal. 5-toothed. Petals 5. Stigma capitate, 3-cornered, sessile. Caps. 3 or 4-winger, 3-celled.

1022. Pyrola. Cal. 5-parted. Petals 5. Capsule 5-celled, opening at the angles.

1023. Chimaphila. Cal. 5-parted. Petals 5. Stigma sessile, thick, orbicular, sunk in the ovary. Anthers beaked, opening by a 2 -valved cleft. Caps. 5 -celled, opening at the angles. 
1024. Inocarpus. Cal, bifid. Cor. funnel-shaped. Stamens in a double row. Drupe 1-seeded. 1025. Styrax. Cal. inferior. Cor. fuñnel-shaped. Drupe 2-seeded.

\section{Ovary inferior. Flowers complete.}

1026. Jussica. Cal. 4-5-parted. Petals 4-5. Caps. 4-5-celled, oblong, opening at the angles. Seeds numerous, minute.

1027. Getonia. Cal. 5-leaved, persistent. Filaments alternately broader, 5 in the orifice of the calyx. Seed coated, oblong, crowned by the calyx.

1028. Quisqualis. Petals 5, inserted on a filiform calyx.

1029. Melastoma. Cal 5-cleft, campanulate. Petals 5, inserted in calyx. Berry 5-celled, surrounded by ca.r.x.

1030. Petaloma. Petals 5, between the segments of the calyx. Berry 1-celled.

1031. Acisanthera. Cal. ventricose, 5-cleft. Petals 5. Anthers sagittate, versatile. Caps, crowned, 2-celled, many-seeded.

\section{Flowers incomplete, or apetalons.}

1032. Dais. Involucre 4-leaved. Cor. 4-5-cleft. Berry 1-seeded.

1033. Bucida. Cal. 5-toothed, superior. Berry 1-seeded.

1034. Samyda. Cal. 5-parted, colored. Nect. campanulate, stamen-bearing. Caps. berried inside, 4-valved, 1 ce.led. Seeds nidulant.

\section{Order 2. DiGYNiA. 10 Stamens. 2 Styles.}

1035. Royena. Cal. urceolate. Cor. 1-petalous, with a revolute limb. Caps. 1-celled, 4-valved.

1036. Trianthema. Cal. mucronate under the end. Cor. O. Stam. 5-10. Ovary blunt. Caps. cut round.

1037. Scleranthus. Cal. 1-leaved. Cor. O. Seeds 2, included in calyx.

1037. Scleranthus. Canonia. Petals 5. Sepals 5. Capsule 2-celled, acute.

1039. Hydrangea. Cal. superior, 5-toothed. Petals 5. Caps. 2-celled, 2-beaked, opening by a hole between the beaks.

1040. Chrysosplenium. Cal. 4-5-cleft, colored. Cor. O. Caps. 2-beaked, 1-celled, many-seeded

1041. Saxifraga. Cal. 5-parted. Petals 5. Caps. 2-beaked, 1-celled, many-seeded.

1042. Tiarella. Cal. 5-parted. Petals 5, inserted in the calyx, entire. Caps. 1-celled, 2-valved: one valve largest.

1043. Mitella. Cal. 5-cleft. Petals 5, inserted in calyx, pinnatifid. Caps. 1-celled. 2-valved; with equal valves.

1044. Gypsophila. Cal. 1-leaved, campanulate, angular. Petals 5, ovate, sessile. Caps. globose, 1-celled.

1045. Saponaria. Cal. 1-leaved, naked. Petals 5, clawed. Caps. 1-celled, oblong.

1046. Dianthus. Cal, cylindrical, 1-leaved, with scales at the base. Petals 5, clawed. Capsule cylindrical, 1-celled.

\section{MONOGYNIA.}

940. EDWARD'SIA. Sal. EDwardsia. 5670 grandiflóra Sal. large-flowered 5671 chrysophýlla Sal. golden-leaved 5672 microphýlla Sal. small-leaved

941. SOPHO'RA. H. $\boldsymbol{K}$. SoPHORA. $\begin{array}{ll}5673 \text { tomentósa } W . & \text { downy } \\ 5674 \text { japónica } W . & \text { Japanese } \\ 5675 \text { alopecuroídes } W . & \text { Fox-tail } \\ 5676 \text { flavéscens } W . & \text { Siberian }\end{array}$ 942. ORMO'SIA. Jacks. ORMOSIA. Leguminosa. Sp.3. J or 12 my.jn Y. 1 . N. Zeal. 1772, C s.p Bot. mag. 167

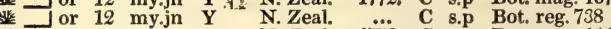
J or 6 my.jn $Y$ N. Zeal. 177̈2. C s.p Bot. mag. 1442

* $\square$ or 12 Leguminose. Sp. 4- • 1690 . C p.1 Trew. ehret. t.59

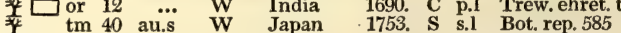
I $\Delta$ or 4 jl.au B . Levant 1731. D r.l Pall. astr. t. 87 Il $\Delta$ or 2 my.jl $\mathrm{Y}$ Siberia 1785. D r.l Leguminose. Sp.1-4. 5677 dasycárpa Jacks, smooth-leaved $9 \square$ or 10 jn.jl B W. Indies 1793. C lt.l Lin.tran.10.t.26

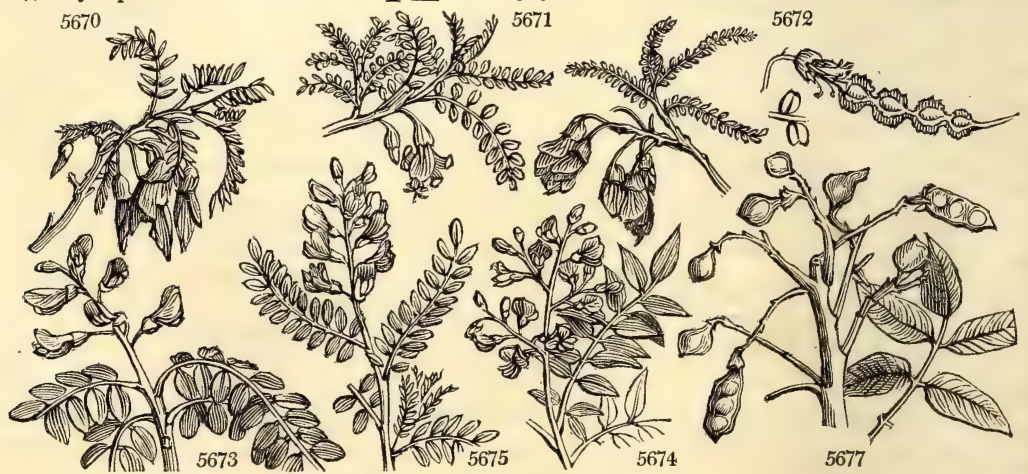

History, Use, Propagation, Culture

940. Edwardsia. Named after the late Mr. Sydenham Edwards, a celebrated botanical draughtsman. The reputation of the Botanical Magazine has arisen almost wholly from the skill he displayed in the management of the figures of that work. These plants are hardy enough to survive through our winters out of doors, when they are not very severe : but are best protected under a frame, or planted in a conservatory: they generally ripen seeds, by which, or by young cuttings planted under a bell-glass in sand, they may be readily encreased. (Bot. Cult. 183.) 
Order 3. TRIGYNIA.

10 Stamens. 3 Styles.

1047. Cucubalus. Cal. 1-leaved, inflated. Petals 5, clawed. Berry superior, 1-celled, many-seeded.

1048. Silene. Cal. 1-leaved, ventricose. Petals 5, clawed. Caps. $\frac{1}{2}-3$-celled, opening at end, many-seeded.

1049. Stellaria. Cal. 5-leaved, spreading. Petals 5, 2-parted. Caps. 1-celled, many-seeded.

1050. Arenaria. Cal. 5-leaved, spreading. Petals 5, entire. Caps. 1-celled, many-seeded.

1051. Cherleria. Cal. 5-leaved. Nectaries 5, bifid, petal-like. Every other anther sterile. Caps. 3-valved, 3-celled, 3-seeded.

1052. Brunnichia. Cal, ventricose, 5-cleft. Cor. O. Caps. 3-cornered, 1-celled, 1-seeded.

1053. Garidella. Cal. 5-leaved, petaloid. Nect. 5, two-lipped, bifid. Caps. 3, united, many-seeded.

1054. Malpighia. Sepals 5, with two honey pores at base. Petals 5, roundish, clawed. Filaments cohering at base. Drupe 1-celled, with 3 one-celled nuts.

1055. Banisterin. Cal. 5-parted, with two honey pores outside at the base. Petals roundish, clawed. Filaments cohering at base. Samaræ 3, 1-seeded, with a single wing at end.

1056. Hiræa. Cal, without glands. Petals 5, with claws. Samaræ 3, surrounded by two opposite wings.

Order 4. PENTAgYNia.

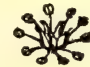

10 Stamens. 5 Styles.

1057. Cnestis. Petals 5. Capsules 5, one-seeded.

1058. Averrhoa. Sepals 5. Petals 5, spreading upwards. Stamens inserted in a nectariferous ring: every other one shorter. Apple 5-cornered, 5-celled.

1059. Spondias. Cal. 5-toothed. Petals 5. Drupe with a 5-celled nut.

1060. Cotyledon. Cal. 5-cleft. Cor. 1-petalous. Five honey scales at the base of ovary. Caps. 5.

1061. Sedum. Cal. 5-cleft. Petals 5. Five honey scales at base of ovary. Caps. 5.

1062. Penthorum. Cal. 5-cleft. Petals O. to 5. Caps. 5-pointed, 5-celled.

1063. Grielum. Cal. 5-cleft. Petals 5. Filaments persistent. Pericarps 5, one-seeded.

1064. Biophyton. Sepals 5. Petals 5. Stamens all distinct; the five outer shortest. Styles 5, emarginate at end. Capsule ovate, round, somewhat 5-cornered.

1065. Oxalis. Sepals 5, distinct or united at base. Petals 5. Stamens united at hase, the five outer shortest.

Styles 5, pencil-shaped, or capitate at end. Capsule oblong or cylindrical.

1066. Agrostemma. Cal, 1-leaved, coriaceous. Pet. 5-clawed. Limb obtuse, undivided. Caps. 1-celled.

1067. Lychnis. Cal. 1-leaved, oblong, smooth. Petals 5-clawed, with a nearly 2-fid limb. Caps. 5-celled.

1068. Cerastium. Sepals 5. Petals bifid. Capsule 1-celled, opening at end.

1069. Larbrae. Cal. 5-cleft, urceolate at base. Petals 5, biparted, perigynous. Styles 5. Ovary 1-celled, many-seeded. Capsule 6-valved at end.

1070. Spergula. Sepals 5. Petals 5, entire. Capsule ovate, 1-celled, 5-valved.

\section{Order 5. DECAGYNIA. 24: 10 Stamens.}

1071. Phytolacca. Sepals 5. Berry superior, 10-celled, 10-seeded.

\section{MONOGYNIA.}

5670 Leaflets 13-19 lanceolate oblong

5671 Leaflets 8.10 lines long obovate, Pubescence yellowish brown 5672 Leaflets $25-41$ obovate

5673 A tree, Leaflets roundish or oval very obtuse at each end as well as the calyx downy 5674 A tree, Leaflets oblong ovate acute and pods smooth

5675 Herbaceous, Leaflets oblong when full-grown silky above

5676 Herbaceous, Leaflets ovate-oblong smoothish

5677 Leaflets 9-11 acuminate smooth on each side, Pods downy

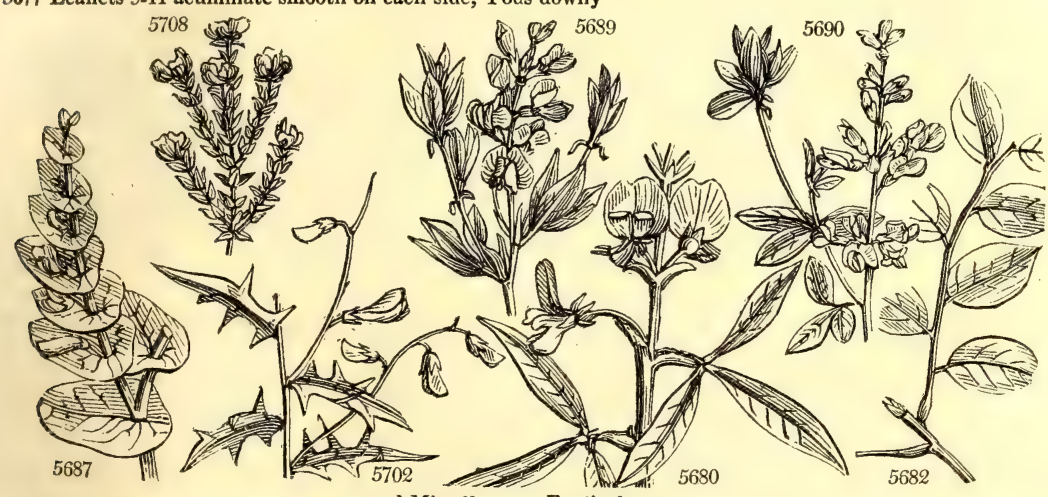

and Miscellaneous Particulars.

941. Sophora. An alteration of the Arabic name Sophera. This genus has been much altered from what it formerly was. It now consists chiefly of fine trees, some of which are hardy.

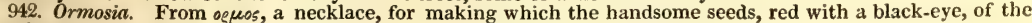
species are well adapted. The kind cultivated in England is exceedingly rare. 
943. ANAGY'RIS. $W$. 5678 fo'tida $W$ 5679 latifólia $\boldsymbol{W}$.en. 5680 índica Wall. Baptisia nepalénsis Hook.

944. THERMOP'SIS. $R$. $B r$. THERMOPSIS. Podalýria lupinoides W.

945. VIRGI'LIA. Lam. Virgilia.

5682 lútea $P h$.

5683 aúrea $H$. $K$.

5684 intrusa $\boldsymbol{H} . \boldsymbol{K}$.

5685 capénsis $\boldsymbol{H} . \boldsymbol{K}$.

yellow-flower'd * $\Delta$ or 15 jn.jl $\mathrm{Y}$ N. Amer.

vetch-leaved

5686 genistoides $\boldsymbol{H}, \boldsymbol{K}$. Br. Cxclopia.

947. BAPTI'SIA. $R$. $B r$. Baptisin.

5687 perfoliáta $\boldsymbol{H}$. $\boldsymbol{K}$. perfoliate

5688 villósa $P h$.

5689 austrális $\boldsymbol{H} . \boldsymbol{K}$.

5690 álba $\boldsymbol{H} . \boldsymbol{K}$

5691 tinctória $\boldsymbol{H} . \boldsymbol{K}$.

villous

blue-flowered

$\frac{1}{x}$ or

white-flowered $\frac{\Delta}{\Delta}$ or

948. PODALY'RIA. $R . B r$. Podalyra

5692 myrtillifólia $\boldsymbol{W}$. Myrtle-leaved

5693 serícea $\boldsymbol{H}$. $\boldsymbol{K}$.

5694 cuneifólia $V$

5695 biflóra $W$.

5696 calyptráta $\boldsymbol{H}$. $K$.

5697 styracifólia $\boldsymbol{B} . \boldsymbol{M}$.

5698 buxifólia $W$.

5699 oleafólia $\boldsymbol{P} . \boldsymbol{L}$.

5700 hirsúta $\boldsymbol{H} . \boldsymbol{K}$

5701 cordáta $\boldsymbol{H} . \boldsymbol{K}$.

silky

wedge-leaved

two-flowered

one-flowered

Storax-leaved

Box-leaved

Olive-leaved

hairy

heart-leaved

949. CHOROZE'MIA. Lab. Choroze

5702 ilicifólia $\boldsymbol{H}$. $\boldsymbol{K}$. Holly-leaved

5708 nána $H$. $K$.

5704 rhómbea $\boldsymbol{H} . \boldsymbol{K}$. dwarf

few-flowered

950. PODOLO'BIUM. $H . K$. Podolobium

5705 trilobátum $H . K$. common

951. OXYLO'BIUM. $H . K$. OXYLobium.

$\begin{array}{ll}5706 \text { arboréscens } H . K . & \text { tall } \\ 5707 \text { ellipticum } H . K . & \text { oval-leaved }\end{array}$

5707 ellipticum $H . K$. oval-leaved or

5708 cordifólium $H . K$. heart-leaved or

952. CALLISTA'CHYS, Vent. Callistachys.

5709 lanceoláta $V$. spear-leaved

5710 ováta $B . M$

oval-leaved

953. BRACHYSE'MA. $H$. $\boldsymbol{K}$. BRACHYSEMA.

Leguminose. Sp. 3.

ap.my Y Spain 1570. C p.1 Bot. cab. 740

Nepal

1821. S p.l Hook ex. fl. 131

Leguminosa. $S p .1-3$.

jn.jl $\mathrm{Y}$ N. Amer. 1812. C p.l Mich. arb.c. ic. $\begin{array}{llll}\text { j1 } & \mathbf{Y} & \text { Abyssinia 1777. C } & \text { p.l L'H.st. no.1.t.75 }\end{array}$ my.au Y.w C. G. H. 1790. C p.l

Leguminose. Sp. 1-2.

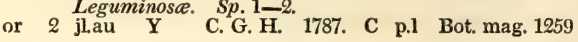

Leguminose. Sp. $5-7$.

3 au Y Carolina 1732. D c D.elt.t.102.f.122

2 jn.jl Y N. Amer. 1811. D c

4. jn.jl B N. Amer. 1758. D c

2 jn.jl W N. Amer. 1724. D c

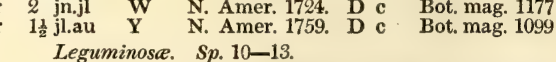

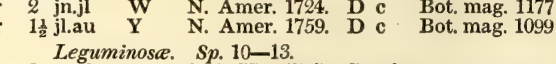

6 ap.jl Pu C. G. H. 1795. C p.l

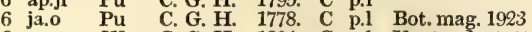

6 my.au W C. G. H. 1804. C p.1 Vent.cels. t. 99

6 f.jn Pu C. G. H. 1789. C p.l Bot. mag. 753

6 ap.jl $\mathrm{Pu}$

6 my.jl $\mathbf{P k}$

2 my.jl B

my $\mathrm{Pu}$ C. G $\mathrm{H}$. 1804 .

2 jl.au $\quad$ B C. G. H. 1774. C p.I

2 my.jl B C. G. H 1794. C p.I

Leguminose. Sp. 3.

3 mr.o Y N. Holl. 1803. S s.p Lab. voy. 1. t. 21

$\frac{3}{4} \mathrm{mr} .0 \quad \mathbf{Y} \quad$ N. Holl. 1803. S s.p Bot. mag. 103?

$2^{4}$ ap.jn $\mathbf{Y} \quad$ N. Holl. 1803. S s.p

Leguminose. Sp. 1-2

ap.jl Y N. S. W. 1791. S s.p Bot. mag. 1477

Leguminosa. $\$$ p. 3-5.

6 ap.jn Y V. Di. L. 1805. S s.p Bot. reg. 392

my.s Y V. Vi.L. 1805. S s.p Lab.n.ho.1.t.135

ap.s $\quad$ N. S. W. 1807. S s.p Bot. rep. 492

Leguminose. Sp. 2-3.

3 jn.au Y N. Holl. 1815. S s.p Bot. reg. 216

jn.au Y N. Holl. 1815. S s.p Bot. mag. 1925

Leguminosa. Sp. 2.

5711 latifólium H.K. broad-leaved 2 \& jor 3 ap.jl $\mathbf{C r}$ N. Holl. 1803. C s.p Bot. reg. 118 5712 undulátum Ker. wavy-leaved in cu 3 mr.ap G N. S. W. 1820. C s.p Bot. reg. 642

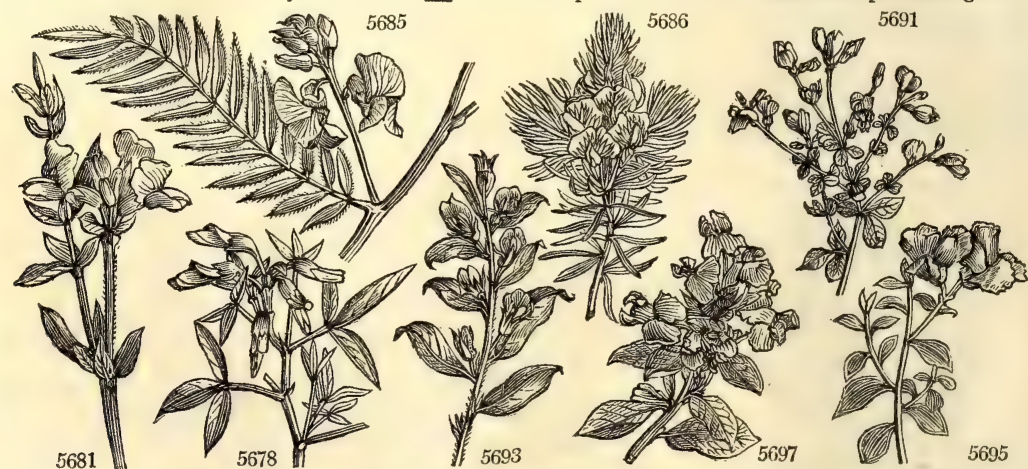

History, Use, Propagation, Culture,

943. Anagyris. From $\propto$ vee, like, and ruৎos, a circle. Its pod is curved inwards at its extremity. Small trees native of the South of Europe and North of Africa, and one doubtful species of Nepal. Young cuttings root in sand under a hand-glass.

944. Thermopsis. So named from the resemblance of the flower to that of a Lupine. This genus is cultivated with difficulty. it grows best in a light loamy soil, and may be increased by seed; dividing the root is liable to injure the plant, so that it is increased with difficulty by that means. (Bot. Cult. 427.)

945. Virgilia. A genus dedicated by Lamarck to the poet Virgil, whose Georgics contain many things interesting to botanists.

946. Cyclopia. Named by Ventenat, from $x v x \lambda_{05}$, a circle, and $\pi 85$, a foot, in allusion to the replicate circle which is found about the base of the pods.

947. Baptisia. So named from $\beta \alpha \pi \tau \omega$, to dye, in allusion to the economical properties of some species. Herbaceous plants of easy cultivation, and as border flowers ornamental.

948. Podalyria. Podalyrus was a son of Æsculapius. Small Cape shrubs, with simple silky leaves and purple blossoms. The species may be grown in leaf mould and peat, or peat loam, and rooted by cuttings in sand, or raised from seeds.

949. Chorozemia. M. Labillardiére originally discovered this plant upon the south-west coast of New 
5678 Leaves lanceolate acute

5679 Leaves elliptical obtuse

5680 Leaves lanceolate shining silky beneath

5681 Leaflets oblong-lanceolate, Stipules lanceolate twice as long as stalk, Pedicels whorled

5682 Leaves pinnate, Leaflets with a short point smooth, Racemes long pendulous

5683 Stamens persistent, Ovaries downy, Leaflets oval obtuse pointless

5684 Stamens persistent, Ovaries smooth, Base of calyx pushed inwards, Leaflets oval obt. with a little point 5685 Stam. decid. woolly at base, Ovaries downy, Keel acuminate, Leaflets lanceolate

5686 Leaflets subulate and sepals pointless, Bractes oblong ovate shorter than peduncle, Branchlets smooth

5687 Leaves perfoliate entire roundish

5688 Stem and leaves very hairy, Leaflets oval obtuse, Raceme terminal spiked

5689 Leaves ternate stalked, Leaflets cuneate lanceolate, Stipules longer than stalk lanceolate

5690 Leaves ternate stalked, Leaf. ellipt. obl. Stipules deciduous subulate shorter than stalk, Ovaries smooth 5691 Leaves ternate stalked, Leafl, roundish obovate, Stipules setaceous obsolete

5692 Leaves oblong obovate on both sides with the calyxes silky, Pedunc. one-fl, as long as leaves

5693 Leaves oblong obovate on both sides with the calyxes silky, several times longer than the 1-flow. fl-stalk 5694 Leaves cuneiform emarginate silky, Pedunc. shorter than leaf

5695 Leaves oval silky on both sides shorter than 2 -fl. peduncle, Cal. downy rough

5696 Lvs. oval and obov. pubes. beneath netted : when full-grown not silky, Cal. vill. with a scarious refl. limb

5697 Leaves ovate reticulate, Branches hairy angular striated, Peduncles as long as leaves

5698 Leaves simple ovate downy, Fl. axillary, Peduncles longer than leaf

5699 Leaves elliptical-lanceolate, Peduncles 1-fl. shorter than leaves, Calyx deeply split

5700 Leaves villous stalked: upper ovate; lower roundish, Cal. villous with segments as long as wings

5701 Leaves cordate roundish subsessile very villous, Segments of villous calyx shorter than wings

5702 Leaves pinnatifid-toothed spiny oblong-lanceolate : with an entire point longer than the teeth 5703 Leaves sinuate-toothed spiny oblong obtuse, Bractes below the end of stalk

5704 Leaves entire flat mucronate: lower rhomboid orbicular; the upper elliptical lanceolate

5705 Lvs. opp. spiny toothed 3-lobed with a transverse base, Lateral lobes much shorter than term. toothed one

5706 Leaves lin. lanc. Bractes adhering to top of the footstalk, Corymb. clust. Pods scarcely longer than cal 5707 Leaves oval. obl. Bractes deciduous below the end of footstalk, Corymb. clust. Pods twice as long as cal. 5708 Leaves ovate cordate hairy, Umb, terminal sessile

5709 Leaves lanceolate acute

5710 Leaves ternate obovate mucronate silky beneath

5711 Leaves ovate flat, Standard oblong obovate

5712 Leaves elliptical wavy mucronate, Standard oblong cordate

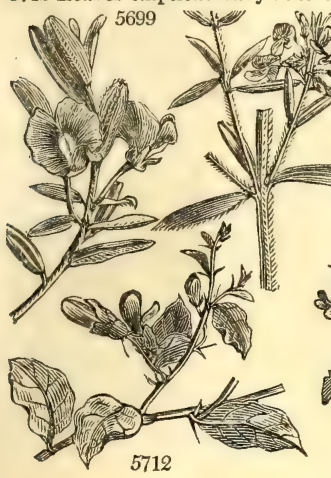

5712

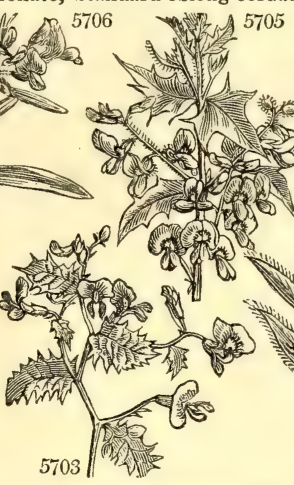

and Miscellaneous Particulars.

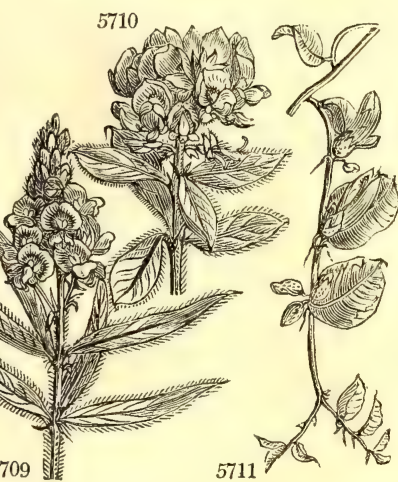

5709
5711

Holland, at the foot of the mountains, in a loamy soil, near a spot where, after having been tantalized with finding many salt springs, his party had just met with an ample supply of fresh water. This welcome refresh ment, of which he speaks feelingly in his book, seems to have suggested a name for this plant, which he had

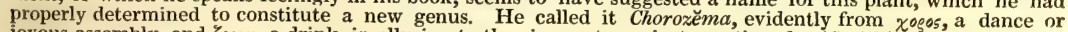
joyous assembly, and $\zeta_{\varepsilon \mu \alpha}$, a drink, in allusion to the circumstance just mentioned. (Smith.)

This genus ripens abundance of seeds, from which it may be readily increased, and also by young cuttings in sand under a bell-glass.

950. Podolobium. This and the succeeding names ending in lobium, refer in that part of their derivation to their pod; this genus is called from $\pi \varepsilon_{5} \pi 0 \delta 05$, a foot, the pod being on a stalk. The species may be treated as Chorozemia.

951. Oxylobium. From oร้us, pointed, the pods being pointed. See Podolobium.

952. Callistachys. From $x \alpha \lambda$, beautiful, and $5 \propto x v_{5}$, a spike, in reference to the fine spikes of yellow flowers. These are handsome conservatory shrubs, which grow rapidly and flower freely. They may be raised from seeds or cuttings in sand under a bell-glass.

953. Brachysema. From $\beta \rho \alpha \chi v s$, short, and $\sigma \eta \mu \alpha$, a standard, The standard of the flower of the genus is very short. This is a handsome climber, increased by layers, cuttings in sand, or by seeds. 
954. GOMPHOLO'BIUM. $\boldsymbol{H}, \boldsymbol{K}$ GOMPHOLOBIU latifolium $\boldsymbol{H}, \boldsymbol{K}$. G. fimbriàtum Sm

5714 grandifiórum $\mathrm{Sm}$. large-flowered 5715 marginátum $\boldsymbol{H} . \boldsymbol{K}$. small-flowered 5716 polymórphum $H$. $K$ 5717 mínus $\mathrm{Sm}$. 5718 tomentósum $\boldsymbol{H}$ hairy-stalked 5719 venústum $H$ hairy-stalked venustum $H$. $K$ purple-flowered de 955. BURTO'NIA. $\boldsymbol{H} . \boldsymbol{K}$. Burtonia. 5720 scábra $\boldsymbol{H}$. $\boldsymbol{K}$. 956. J ACKSO'NIA. $H . K$. JACKSONIA 5721 scopária $\boldsymbol{H} . \boldsymbol{K}$ 5722 spinósa $\boldsymbol{H} . \boldsymbol{K}$

957. VIMINA'RIA. $H . K$ RusH-BRoo 5723 denudata H.K. leafless $\quad$ \& J cu 958. SPH EROLO'BIUM. $\boldsymbol{H}$. $\boldsymbol{K}$. SPHEROLOBIUM. 5725 vimineum $\boldsymbol{H} . \boldsymbol{K}$. yellow-flowered 5726 médium $\boldsymbol{H} . \boldsymbol{K}$. ${ }^{\text {red-flowered }} \downarrow$ or 959. AO'TUS $H$. $K$ 5727 villósa $\boldsymbol{H} . \boldsymbol{K}$.

960. DILLWY'NIA. $H$. Aotus. villous

H. Dillwyina. 5729 ericifólia $\boldsymbol{H} . \boldsymbol{K}$. $\quad$ Heath-leaved 5730 glabérrima $\boldsymbol{H}$ 5731 parvifólia $B . M$. 5732 cineráscens $\boldsymbol{R} . \boldsymbol{B r}$ 5733 juniperína Lodd. 961. EUTA'XIA. $H . K$. Eutaxia. 5734 myrtifólia $\boldsymbol{H} . \boldsymbol{K}$. Myrtle-leaved 962. SCLEROTH 5735 mist 963. GastrolóbiUM. $\boldsymbol{H} . \boldsymbol{K}$. Gastrolobium. 5736 bilobum $\boldsymbol{H} . K$. two-lobed or 964. EUCHI'LUS. $\boldsymbol{H} . \boldsymbol{K}$. Euchilus. 5737 obcordátus $H$. $K$. heart-leaved 965. PUlten 死'A. $H . K$. PultenaA. 5738 daphnoídes $\boldsymbol{H} . K$. Daphne-leaved 5739 obcordáta $\boldsymbol{H}$. $\boldsymbol{K}$ heart-leaved 5740 scábra $\boldsymbol{H}$. $K$. 5741 rcabra $\boldsymbol{H}$. $K$. 5741 retúsa $\boldsymbol{H} . \boldsymbol{K}$. 5742 stricta $B . M$. 5744 paleácea $S m$. 5745 stipulâris $\boldsymbol{H}$. $K$ 5746 vestita $H$. $K$. 5747 villósa $H$. $K$. chaffy scaly awned villous
Leguminosa. $S p, 7-10$.

2 mr.s $Y$ N. S. W. 1803. C s.p Ex. bot. 58

2 mr.s Y

2 mr.s $\mathbf{Y}$

N. Holl 1803, C s.p

mr.au $Y$

3 ap.jl $\mathbf{Y}$

$\begin{array}{lll}3 & \text { ap.jl } & \mathbf{Y} \\ \text { ap.jl } & \mathbf{P u}\end{array}$

Leguminos

my.jl Y N. Holl.

Leguminosa. $S p .2-4$.

jn.au Y N. S. W. 1803. C s.p Bot. cab. 427.

ap.s $\quad Y \quad$ N. Holl. 1803, C s.p Lab.n.ho.1.t.136

Leguminose. Sp. 2.

3 jn.s Y N. Holl. 1789. C s.p Bot. mag. 1190

jn.s Y N. Holl. 1824. C s.p

Lesuminosa. Sp. 2-4.

2 my.au Y N. Holl. 1802. S s.p Bot. mag. 969

3 jn.au $\mathbf{R} \quad$ N. Holl. 1803. S $\mathbf{S}$ s.p

Leguminosa. Sp. 1-3.

2 ap.jn $\mathbf{Y}$ N. Holl. 1790, S s.p Bot. mag. 949 Leguminose. Sp. 6-10.

2 ap.jl Y N. S. W. 1794. C s.l.p Ex. bot. t. 26

2 mr.jl Y N. S. W. 1794. C s.l.p Ex bot. 25

N. S. W 1800 C s.lp Bot. mag. 944

mrjl Y N. S. W 1800. C s.lp Bot. mag. 1597

$2 \mathrm{mrjl} \mathbf{Y}$

2 mr.jl Y N. S. W. 1819. C s.l.p Bot. mag. 2247 Leguminose. Sp.1-2.

$1 \frac{1}{2}$ mr.jn Y N. Holl. 1803. C s.l.p Bot. mag. 1274

Leguminose. Sp. 1.

1 my.jn Y N. Holl. 1803, C s.l.p

Leguminose. Sp. 1-3.

2 mr.my Y N. Holl. 1803. C s.l.p Bot. reg. 411 Leguminosa. Sp. 1.

N. Holl 1803. C s.l.p Bot. cab, 60 Leguminosa. Sp. 13-19.

jn.ji Y N. S. W. 1792 C s.lp Bot. mag. 1394 my.jl $Y$ V. Di. L. 1808. C s.l.p Bot. mag. 574 1/ my.jl Y N. S. W. 1803. C s.l.p

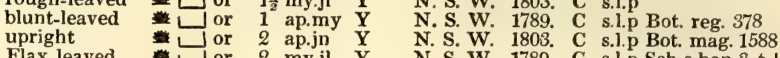

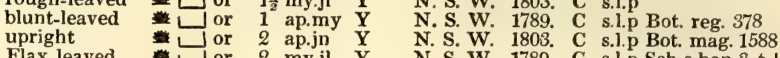
Flax-leaved ${ }^{-}$or 2 my.jl $Y$

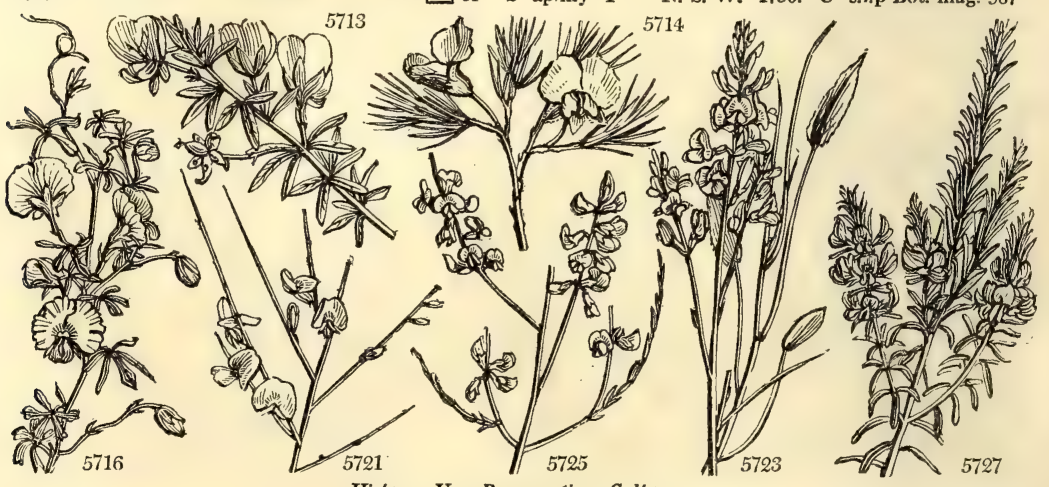

History, Use, Propagation, Culture.

954. Gompholobium. The name of this genus alludes to the tumid shape of the legume, which swells from a narrow base upwards; according to the primary signification of rouфos, a word thence used to signify a club or wedge, or any thing formed upon a similar principle. Delicate plants, difficult to preserve, requiring a large proportion of sand in the peat, and moderate watering. Young cuttings root under a bell-glass in sand.

955. Burtonia. A genus defined in the Hortus Kewensis, without an explanation of the origin of the name. This plant, Sweet observes, requires more than ordinary treatment to keep it in good health. an equal mixture of very sandy loam and peat is the best soil for it, and the pots to be well drained with small potsherds, that the water may pass off freely, as nothing is more injurious to it than too much water. Young cuttings are not difficult to root, planted in sand under a bell-glass; it may also be raised from seeds, which are sometimes produced. (Bot. Cult. 156.)

956. Jacksonia. Named after Mr. Jackson, formerly librarian to Aylmer Bourke Lambert, and an excellent practical botanist, of whom too little is known. Young cuttings will root in sand under a bell-glass, or ripened ones under a hand-glass.

957. Viminaria. From vimen, a twig. The appearance of the species which have no leaves is that of a bundle of naked twigs. 
5713 Leaves term. Leaf. lin. or obl. lin. an inch and more long, Stem erect, Keel fringed, Cal. in fruit reflexed

5714 Leaves ternate linear mucronate straight, Branches angular smooth

5715 Leaves ternate, Leafl. obovate edged flat, Stipules as long as leafstalk, Cor. length of calyx

5716 Lvs. tern. and quinate, Leafl. linear recurved at edge, somewhat dilated at end, Stem procum. or twining 5717 Leaves ternate linear smooth mucronate, Branches round hairy, Keel hairy

5718 Leaves pinn. Leafl. subulate linear mucronate rough above, Cal. hairy shorter than pod, Keel silky ciliate 5719 Leaves pinn. of many pairs, Leafl. subulate veiny revolute at edge and calyxes smooth, Cor. purple

5720 Leaves ternate, Cal. smooth, Style beyond the middle beardless

5721 Arborescent unarmed, Branches angular, Racemes terminal

5722 Shrubby, Branches spiny 2-3-chotomous spreading angular, Bractes very short

5723 Segments of calyx straight ovate

5724 Flowers racemose, Segments of calyx lanceolate reflexed

5725 Tube of cal. a little shorter than lips, Style included bowed from the base, Cor. yellow 5726 Tube of cal. twice as short as the lips, Cor. red

5727 Cal, silky with appressed hairs, Pods stalked, Seeds dotted rugose, Leaves rough above

5728 Flowers axillary ternate, Leaves subulate mucronate

5729 Corymbs terminal sessile, Leaves subul. rough with dots divaricate twisted, Branches pubescent

5/30 Corymbs terminal stalked, Leaves filiform erect smooth, Mucro weak recurved

5731 Leaves short spreading decussate, Fl. capitate, Pedunc. with two bractes, Stigma capitate

5732 Corymbs terminal sessile, Leaves filiform erect, with a weak short point, Branches silky

5733 Leaves acerose horizontal, Branches weak, Heads 3-9-flowered

5734 Leaves lanceolate or lanceolate-obovate, Peduncles axillary twin, Appendages of wings very short

\section{The only species}

5736 Lvs, beneath somew. silky retuse, Lobes round. longer than little point, Stalk of pod as long as tube of cal.

5737 The only species

5738 Heads terminal, Leaves obovate oblong flat quite smooth 3 times as long as broad, Point pungent

5739 Heads term. Leaves cuneate obcord. retuse flat smooth scarcely twice as long as broad, Point pungent

5740 Heads term. few-fl. Leaves cuneate truncate bristly pointed recurved at edge rough above villous beneath

5741 Heads term. Leaves linear retuse blunt flat smooth, Bractes a little longer than cal.

5742 Heads term. Leaves obovate mucronate smooth, Stem upright, Calyx and jods hairy

5743 Bractes shorter than 6-8-fl. head, Lvs. lin. with a little point and recurv. edge, Stip. shorter than footstalk

5744 Leaves linear mucronate revolute recurved at end, Stipules solitary 2-nerved with membr. torn sheaths

5745 Heads many-fl. Bractes about as long as cal. Leaves flat linear acute, Stipules bitid flat imbricated

$5746 \mathrm{Fl}$. axill. Leaves linear lanceolate mucronate smooth, Stip. imbric. ciliated, Cal. and bractes bearded

5747 Racemes leafy, Leaves linear oblong, above concave, beneath cal, and branchlets pilose

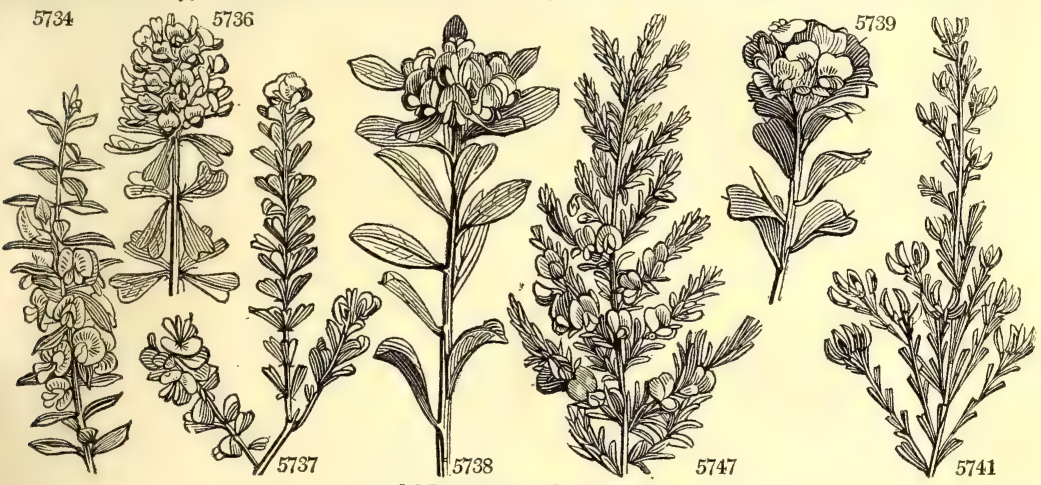

and Miscellaneous Particulars.

958. Spherolobium. From $\sigma \phi \alpha i \rho c$, a sphere; the pods being nearly spherical. See Jacksonia.

959. Aotus. From $\alpha$, privative, and $\omega \tau \alpha$, ears, in allusion to the want of the appendages to the calyx in this genus. In Pultenæa, to which it is most nearly allied, they are very distinct.

960. Dillwynia. Named by Sir James Edward Smith, after Mr. Lewis Weston Dillwyn, whose labors upon Confervæ and other parts of British botany are well known. These plants being liable to suffer from wet, the pots must be well drained with sherds and refuse peat siftings. Young cuttings root freely in sand under a bell-glass.

961. Eutaxia. From $\varepsilon v \tau \propto \xi \iota$, modesty, in allusion to the humble, modest appearance of the plant. Mr. Sweet directs to top the plants frequently when young, otherwise they are apt to run up naked and unsightly.

962. Sclerothamnus. From $\sigma x \lambda \eta{ }^{\circ}$, hard, and $\tau \alpha \mu y \circ$, a shrub. The species are rigid plants with stiff hard leaves.

963. Gastrolobium. From r $\alpha_{5}$, the belly; or, in botanical composition, something inflated. The pods of the genus are much swollen.

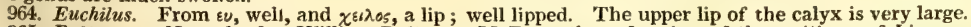

965. Pultenaa. Named after William Pulteney, M. D., author of a view of the writings of Linnæus, and 
5748 fléxilis $\boldsymbol{H} . \boldsymbol{K}$. 5749 tenuifólia $\boldsymbol{R}$. $\boldsymbol{B r}$. 5750 bíloba $R$. $B r$

966. DAVIE'SIA. $L . T$. 5751 aciculáris $\mathrm{Sm}$. 5752 ulicína $\mathrm{Sm}$. 5753 corymbósa $\mathrm{Sm}$. 5754 mimosoídes $\boldsymbol{H} . \boldsymbol{K}$ D. glauca Lodd 5755 latifólia $H . K$. 5756 aláta $\mathrm{Sm}$. 967. MIRBE'LIA. L. T 5757 reticuláta $L . T$ 5758 dilatáta $\boldsymbol{H} . \boldsymbol{K}$. 968. CER'CIS. $W$. 5759 Siliquástrum $W$. 5760 canadénsis $W$. 969. SCHO'TIA. $W$ 5761 speciósa $\boldsymbol{H}$. $\boldsymbol{K}$. 5762 tamarin'difólia 5763 stipuláta $\boldsymbol{H} . \boldsymbol{K}$

970. BAUHI'NIA. $W$. $576+$ scándens $W$. 5765 racemósa $W$ 5766 aculeáta $W$. 5767 divaricáta $W$. 5768 aurita $W$ 5769 porrécta $W$ 5769 porrécta $W$. 5770 parviflóra $\mathscr{W}$ 5771 variegáta $W$ 5773 purpúrea $W$. 5774. tomentósa $W$ 5775 acumináta $\boldsymbol{W}$. 5775 acuminata $W$.
5776 forficáta $L i n k$. 971. AFZE'LIA. Sm. 5777 africána $\mathrm{Sm}$. 972. HYMEN E'A. $W^{\prime}$ 5778 Coúrbaril $W$. 5779 verrucósa $W$
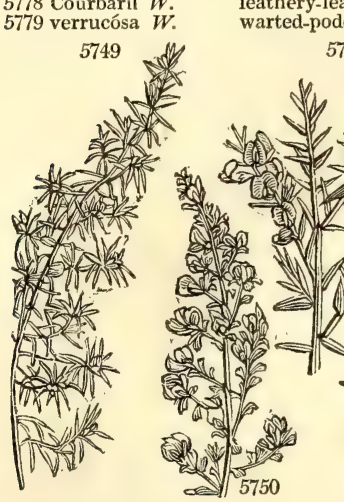
two-lobed winged reticulated European

American long-eared variegated white purple tomentose african shining-leaved

Daviesia. needle-leaved Furze-leave glaucous-leav'd green-leaved

broad-leaved lobed-leaved Judas-Tree.

Schotia. small-leaved Tamarind-leav large-stipuled

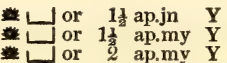

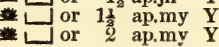

N. S. W. 1801. C s.l.p

N. S. W. 1817. C s.l.p Bot. mag. 2086 N. S. W. 1817. C s.l.p Bot. mag. 2091 Leguminosa. Sp. 6-10.

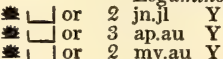
N. S. W. 1804. C s.l.p N. S. W. 1792. C s.l.p Bot. cab. 44 N. S. W. 1804. C s.lp

N. S. W. 1809. C s.l.p Bot. rep. 526

J or 3 my.au Y N. S. W. 1805. C s.1.p Bot. mag. 1757 造 $\bigsqcup_{\text {or }} 3$ my.au Y $\quad$ N. S. W. 1818. C s.l.p Bot. reg.728 Leguminosa. Sp. 2-4.

* J or 3 my au B N. S. W. 1792. C s.1.p Bot. mag. 1211 * ${ }^{*}$ or 3 my.au B N. Holl. 1803. C s.l.p Leguminose. $S p .2$.

* or 20 my.jn Pu S. Europe 1596. L co Bot. mag. 1138 花 or 18 my.jn Gr N. Amer. 1730. L co

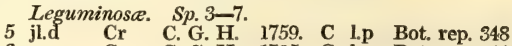

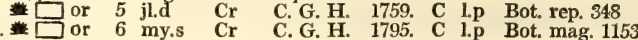

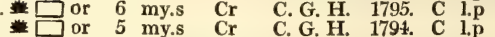
Leguminosce. Sp. 13-30. small-lvd. clim. \$ $\square$ or $30 \quad \ldots \quad$ W.x E. Indies 1799. C 1.p Rhe. mal. 8. t.29 great-leaved \$ $\square$ spl $20 \ldots \ldots$... $\quad$ E. Indies 1790. C lt.l Vah. sym. 3. t.62 prickly-stlkd. $\$$ or 6 jn.au W W. Indies 1737. C 1t.l Plu. ic. t. 44. f. 1 smooth-leaved small-flowered acute-leaved pincer-leaved AfZelia.

\section{$\$$ or 6 jn.au \\ $\$$}

$\$$ pr $15 \mathrm{jl}$

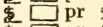

$\begin{array}{llll}\$ & \text { pr } & 20 & \end{array} . .$.

W W. Indies 1742. C lt.l Hort. cliff t 1

W Jamaica 1756. C lt H Hort. cliff. t. 1

St W. Indies 1737. C I.1 Mil. ic. 1. 61

St W. Indies 1737.

E. Indies 1808. C It.

E. Indies 1690 . C lt.1 Rh. mal. 1. t. 32 E. Indies 1777. C It.

E. Indies 1778. C It.1 Rh. mal, 1, t. 33 $\$$ or 10 my.jn W ... W E Indies 1808, C lt 1 Rh. mal. ... W Brazil 1823. C lt.l Leguminosce. Sp. 1

Locust-Tree.

or $20 \quad \ldots \quad$ Y.P W. Indies 1688. C p.l La. ill.t.330. f. 1 Leguminosa. Sp. 2 ... Madagas. 1808. C p.l La.ill.t. 330. f. 2 ed
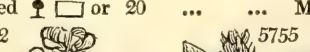

20
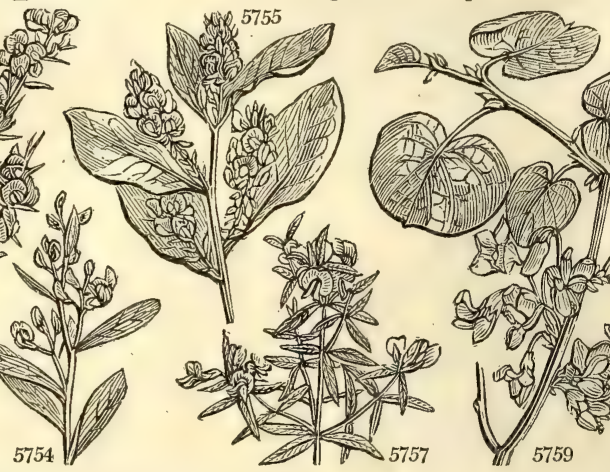

\section{$=$}
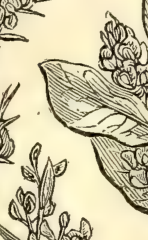

t.

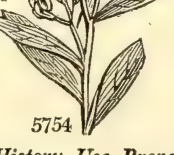

History, Use, Propagation, Culture,

of various other works of merit. These are small New Holland bushes, with numerous yellow flowers, frequently brown on the outside.

966. Daviesia. Named after the Rev. Hugh Davies, a Welsh botanist. Plants like furze. The species root best when the cuttings are somewhat ripened and planted in pots of sand, and covered with a hand-glass without bottom heat.

967. Mirbelia. In honor of Mr. Mirbel, a distinguished French physiological botanist, whose elucidations of the reticulated structure of vegetables make it proper to oonsecrate to his merits plants remarkable for their reticulation.

968. Cercis. Kegæis is a name of Theophrastus, supposed to have appertained to the tree now so called. Gainier or Arbre de Judée, Fr., Arbold Amor, Span. Handsome low trees, with singular leaves and fine shewy flowers. These having an agreeable poignancy, and being abundant on the branches, are frequently eaten in salads on the continent, and those of the $\mathrm{C}$. canadensis are pickled by the French families in Canada. The wood of both species is finely veined with black and green, and takes a good polish; and the young branches of the Canadian species are said to dye wool of a fine nankeen color. They may be propagated either by layers or seeds : the latter make the best plants. Gerarde, in compliance with the popular notions of his time, says, "this is the tree whereon Judas did hang himselfe; and not upon the elder tree, as it is said."

969. Schotia. So named by Jacquin, in memory of Richard van der Schott, a Dutchman, gardener at Schoenbrunn, and his companion in his travels. This beautiful genus has lately been increased by Burchell, the Africar traveller. " They require," Sweet observes, " rather more warmth than a common greenhouse, to keep them in good health through the winter. The coldest part of the stove will suit them better; but they should not be plunged in the tan, as they want no bottom heat. A mixture of loam and peat is the best soil for them; and cuttings planted in sand, and plunged in mould (not in tan), under a hand-glass, will strike root." (Bot. Cult. 105.)

970. Bauhinia. So named by Plumier, in honor of the two famous botanists, John and Caspar Bauhin. The species consist of trees or shrubs, most of them climbing. The leaves are simple, but two-lobed or two- 
5748 Very smooth, Fl, axill. Leaves oblong linear mucronate flat

5749 Heads terminal 2 -flowered, Fruit lateral, Leaves subulate linear hairy above concave

5750 Heads terminal few-fl. Leaves wedge-shaped at the end dilated 2-lobed above rough beneath silky

5751 Leaves linear revolute pungent straight rough, Flowers axillary solitary

5752 Branches spiny smooth spreading, Leaves lanceolate or linear, Pedunc. axill. 1-fl. Bractes 8 imbricated 5753 Leaves linear oblong flat pointless, Pedunc. axill. twin corymbose many-fl. Calyx regular

5754 Branches unarmed, Lvs. long-lanc. with a very short weak point, Corymbs axill. Upper lip of calyx retuse

5755 Branches unarmed, Leaves ellipt. or oval veiny attenuated at base, Racemes axillary many-f.

5756 Stem leafless winged, Umbels lateral, Calyx and bractes fringed

5757 Leaves lanceolate linear veiny, Ovaries 2-seeded

5758 Leaves wedge-shaped at the end dilated-trifid

5759 Leaves orbicular cordate

5760 Leaves cordate acuminate

5761 Leaves 7-10 pairs oval-lanceolate mucronate, Stipules subulate

5762 Leaves 8-10 pairs oval obtuse mucronate or not, at the base in front a little swollen

5763 Leaves 5 pairs oval acute mucronate, Stipules half-ovate falcate mucronate

5764 Stem tendril-bearing, Lobes of leaves attenuated

5765 Stem tendril-bearing, Fl, triandr. on outside with stam. at base hairy, Lvs. downy beneath, Lobes rounded 5766 Stem prickly

5767 Leaves smooth, Lobes divaricate acute 2-nerved, Petals lanceolate

5768 Leaves at the base nearly transverse, Lobes lanceolate porrect 3-nerved, Petals lanceolate

5769 Leaves cordate, Lobes porrect acute 3-nerved, Petals lanceolate

7770 Leaves cordate, Lobes porrect acute s-nerved, Proth

5771 Cal. 1-leaved bursting, Petals sessile ovate, Lobes of leaves ovate obtuse

5772 Leaves cordate downy beneath, Lobes ovate obtuse, Cal. narrowed upwards lengthened

5773 Flowers triandrous, Lobes of leaves oval obtuse

5774 Leaves cordace, Lobes half orbicular downy

5775 Leaves ovate, Lobes acuminate half-ovate spreading

5776 Stem prickly, Leaves cordate with porrect 4-nerved lobes

5777 Leaves alternate abruptly pinnated, Pod woody, Seeds black with a scarlet arillus

5778 Leaflets coriaceous veinless unequal at base, Flowers of panicle stalked

5779 Leaves veiny unequal at base, Panicle wavy spreading, Pedunc. many-fl. Pods warted

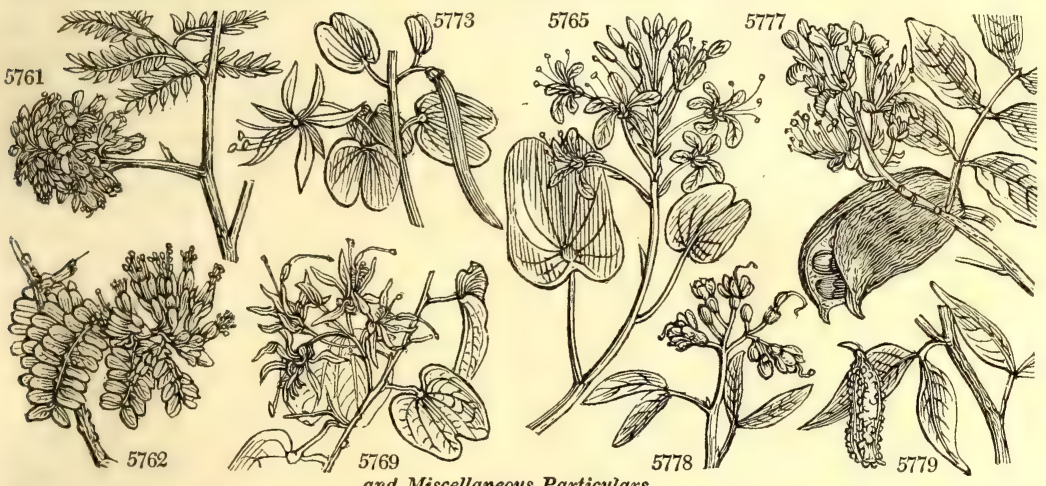

and Miscellaneous Particulars.

parted, which circumstance gave occasion, it is said, to Plumier to name this genus from the two brothers. They merit a place in the stove, where they are easily cultivated in light loamy soil, and cuttings taken off when the plants are in a growing state, not over ripened, nor yet quite succulent, with their leaves on, will do well in sand under bell-glasses in moist heat. The species rarely flower in this country. In their native woods they are great ornaments of the trees, among which they climb in every direction. The stem of Bauhinia scandens, which had twined around a smaller plant, is said to have been the origin of Æsculapius's snaken rod, which he brought from India.

971. Afzelia. Named by Sir J. E. Smith, after Dr. Adam Afzelius, an amiable and excellent Swedish botanist, resident for many years, in the service of the African Company, at the colony of Sierra Leone, and now living at Upsal.

972. Hymencea. A poetical application of this plant, the leaves of which grow in pairs, to Hymen, the god of marriage. Courbaril is a vernacular American name. This tree is abundant in the West Indies, where it grows to a large size, with a spreading head. It has stiff sub-perfoliate leaves obliquely placed, and terminal spikes of flowers, which are succeeded by thick, fieshy, brown pods, shaped like those of the garden bean; they are six inches long, and two inches and a half broad, of a purplish brown color, and a ligneous consistence, with a large suture on both edges; they contain three or four roundish compressed seeds, divided by transverse partitions, and inclosed in a whitish substance of fine filaments, as sweet as honey. The Indians eat this substance with great avidity, though it is apt to purge when fresh gathered, but it loses this quality as it grows old.

grows old. in large lumps, is called gum Anime, and makes the finest varnish that is known, superior even to the Chinese lacca: for this latter use it is dissolved in the highest rectified spirits of wine. It burns readily, and with a clear flame, emitting a grateful and fragrant smell, for which reason it is sometimes ordered by way of fumigation in the ohambers of persons laboring with asthmas or suffocative catarrhs. Its vapours not only strengthen the head, but all parts of the body affected with cold. Some apply it outwardly, dissolved in oil or spirits of wine, to strengthen the nerves. An oil may be distilled from it, useful in palsies, in cramps, and 
973. CYNOMETRA. $\boldsymbol{W}$. CYNometra. 5780 cauliflóra $W$.

974. CAS'SIA. $W$. 5781 diphýlla $W$. $5782 \mathrm{Ab}^{\prime}$ sus $W$. 5783 viminea $\dot{W}$. 5784 bacilláris $\dot{W}$. 5785 Tágera $W$. 5786 Tora $W$.

5787 bicapsuláris $W$. 5788 sennoídes $W$. 5789 acumináta $W$ 5790 mollissima $W$. en. 5791 corymbósa $W$. 5792 emargináta $W$. 5793 obtusifólia $\boldsymbol{H}$. $\boldsymbol{K}$. 5794 péndula $W . e n$. 5795 lævigáta $W$. en. 5796 sericea $W$. 5797 dispar $\boldsymbol{W}$. en. 5798 occidentális $W$. 5799 pátula $W$ 5800 prostráta $W$. en. 5801 arboréscens $W$ 5802 itálica Lam. 5803 Sénna $\boldsymbol{H} . \boldsymbol{K}$. 5804 orientális $P$. $S$. 5805 ruscifólia $W$. 5806 purpúrea $R o x b$ 5807 ægyptíaca $W$. en. 5808 biflora $W$

5809 chinénsis $W$ 5810 hirsúta $\boldsymbol{H} . \dot{K}$ 5811 coromandeliána $W$.en 5812 lanceoláta $P$. S 5813 bracteáta $W$. 5814 tomentósa $\dot{W}$. 5815 glandulósa $W$. 5816 grándis $W$. 5817 planisiliqua $P . S$. 5818 robinioides $W$. en. 5819 stipulácea $W$. 5820 cuspidáta $W$. en. 5821 marilándica $W$. 5822 aláta $W V$.

5823 ligustrina $\boldsymbol{W}$ 5824 multiglandulósa $W$. 5825 frondósa $W$. 5826 Sóphera $W$ 5827 reticuláta $W$. en. 5828 auriculáta $\boldsymbol{W}$. 5829 Chamæcrista $W$. 5830 hirta $W$. en. 5831 margináta $W$. en. 5832 mimosoídes $W$ 5833 microphýlla $W$ 5834 nictitans $W$. 5835 capénsis $T h$. 5836 procúmbens $W$.

stem-tlowerin.
Cassia two-leaved four-leaved twiggy rod long-podded oval-leaved six-leaved Senna-leaved pointed soft-leaved corymbose notch-leaved blunt-leaved pendulous smooth silky-leaved unequal occidental shining prostrate

tree

Italian Senna false Senna true Senna Ruscus-leaved purple

Egyptian two-flowered Chinese woolly . Coromandel lanceolate bracteate tomentose glandular fine

flat-podded Robinia-like large-stipuled cuspidate Maryland broad-leaved Privet-leaved glandular smooth-shrub. round-podded Matapasto eared dwarf long-haired white-edged Mimosa-leave small-leaved Virginian Cape procumbent

Leguminose. Sp. 1-2.

... Y.P E. Indies 1804, C s.l.p Lam. ill. t. 331

Leguminosa. Sp. 56-149.

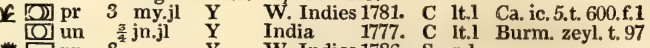
$\square \mathrm{pr} \quad 3^{\frac{3}{4}} \ldots \mathrm{Y}$ \% or $3 \ldots$ Y $1 \frac{1}{2} \mathrm{jl}$ W. Indies 1786. S p.1 E. Indies 1782. C co E. Indies 1803, C p.l E. Indies 1693. C r.m Dill. elt. 63. f, 73 W. Indies 1739 C p.l Plu ic $t 76 . f$ E. Indies 1808. S s.p Jac. ic. 1. t. 70 Surinam 1820. S s.p S. Amer. 1816. S p.1 B. Ayres 1796. C s.p Bot. mag. 633 Jamaica 1759. C p.1 Sl.hi.2.t.180.f.1.4 Jamaica 1732. C p.l Dil. el. t. 62. f. 72

S. Amer. 1820. C p.l

Jamaica 17̈̈1. C s.p S. Amer. 1824. C s.p W. Indies 1759. C p.l Bot. reg. 83 W. Indies 1778. C lt.1 S. Amer. 1819. C co E. Indies 1800 . C p.l Rh. ma. 6. t. 9,10 S. Europe ... S co Mo, h. 2, t 24, 2 Egypt - 1640. S lt.1 Levant $\quad \ldots$ S lt.1 Tabern. ic. 507 Madeira 18̈6. C lt.1 Jac. ic. 1, t. 71 E. Indies 1821. C co Bot. reg. 856 Egypt 1822. C co W. Indies 1766. C p.l Bot. mag. 810 China 1807. S p.1 Jac. ic. 1. t. 73 America 1778, C s.p E. Indies 1822. C co W. Indies 1822 . C co W. Indies 1822, C co W. Indies 1822. C co W. Indies 1822 . C co W. Indies 1822, C co Brey. cent. t. 14 W. Indies 1822. C co Plum. spec. t. 7 S. Amer. 1823. C co

Chili 1786. C 1t.1 Feu. per. 3, t. 49 S. Amer. 1820. C co

N. Amer. 1723. C s.p Di. el. t.260.f 339 W. Indies 1731. C p.1 Jac. ob.2. t.45.f Baham.Is.1726. C p.1 Bot. reg. 109 Teneriffe 1779. C s.p Jac. ic. 1. t. 72 W. Indies 1769. C lt.1 Jac. ic. 1. t. 74

E. Indies 1658. C lt.l Rh. ma. 2. t. 52

S. Amer. 1821. C co

E. Indies 1777. C lt.1 Pl. alm. t. 314.f

America 1699. S r.m Bot. mag. 107

S. Amer. 1820. C co

Surinam 1823. C co

Ceylon 1806. S lt

Santa Cr. 1810. S lt.

N. Amer, 1800 . S lt.1 Pl alm. t. $314 . f^{5}$

C. G. H. 1816. S lt.l Bot. cab. 511?

C. G. H. 1816. S lt.l Bot. cab. 511 ?
N. Amer. 1806. S lt.l Com, pet. t. 11

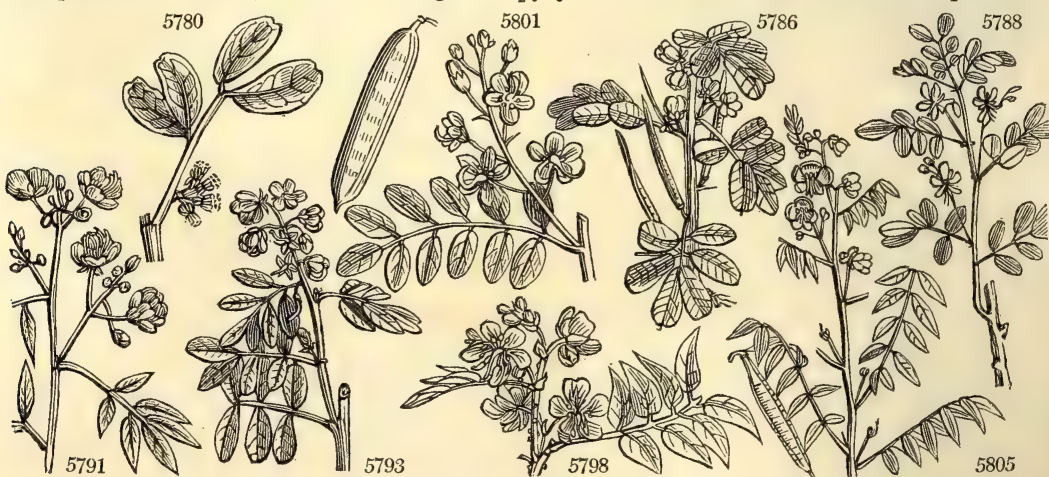

History, Use, Propagation, Culture,

contractions of the sinews. The solution in spirits has been thought not inferior to Guaiacum in venereal cases. A decoction of the leaves expels flatulency, and gives ease in colicky pains, by gently opening the bowels ; and the inward bark is an excellent vermifuge in substance or decoction.

The tree is excellent timber; but it must be very old before it is cut, otherwise the heart will be but small. It is in great request for wheel-work in the sugar-mills, particularly for cogs to the wheels, being extremely hard and tough: it is so heavy, that a foot cube weighs about a hundred pounds, and it will take a fine polish. It is much inhabited by wild honey bees. (Browne.)

Besides this locust-tree, there is the American tree of that name, Robinia Pseud-acacia, and the locust-tree of scripture, Ceratonia siliqua. 
5780 Flowers growing upon the trunk

5781 Leaves 1 pair and calyxes smooth, Stipules cordate-lanceolate

5782 Leaves 2 pairs obovate, Two subulate glands between the lower pai

5783 Leaves 2 pairs ovate oblong acuminate, An obl. gland between the lower pair, Spines obsolete 3-toothed

5784 Leaves 2 pairs ovate oblique, An obtuse gland between the lowest, Racemes axill. stalked

5785 Leaves 3 pairs : with a gland on the footstalk, Stipules ciliate cordate acuminate

5786 Leaves 3 pairs obovate : outer largest, A subulate gland between the lower pair

5787 Leaves 3 pairs obovate smooth : the inner roundest with a globose gland between

5788 Leaves 3 pairs, Leaflets obtuse elliptical, A gland between the lower leaves

5789 Leaves 3 pairs, Leaflets ovate acuminate, A sessile gland between the leaflets

5790 Leaves 3 pairs ovate acuminate with soft down on each side

5791 Leaves 3 pairs lanceolate subfalcate smooth, A gland between the lowest, Corymbs stalked, Pods cylind. 5792 Leaves about 4 pairs ovate, Flowers racemose irregular, Stem arborescent

5793 Leaves 3 pairs obovate obtuse beneath very villous outer largest, A gland between lowest, Pods recurved 5794 Leaves 3 or 4 pairs obovate the outer largest, A gland between the lower pairs, Pods pendulous rounded 5795 Leaves 4 pairs ovate hairy with a subulate gland between the leaflets, Peduncles 4-flowered 5796 Leaves 4 pairs obovate pubescent ciliated, A stalked gland between all, Pedunc. 4-fl. Pod jointed 5797 Leaves 4 or 5 pairs oblong obtuse : the outer the largest with a gland between every pair 5798 Leaves 5 pairs ovate lanceolate rough at edge : outer largest, A gland at foot of leafstalk 5799 Leaves 5 pairs oblong acute smooth, A gland at base of footstalk, Branches smooth

5800 Leaves 5 pairs elliptical smooth with an obl. gland between the lower, Stip. subul. falcate, Rac. axillary 5801 Leaves 5 pairs elliptical smooth, An oblong gland between the lower, Racemes axillary 5802 Leaves 5 pairs cordate obtuse, Stalks without glands

5803 Leaves 6 pairs obovate smooth, Stalks without glands, Spikes racemose, Pods leafy compressed falc $\lambda$ te 5804 Leaves 5 pairs lanceolate equal, Gland above the base of the leafstalks

5805 Leaves 6 pairs ovate lanceolate smooth with a gland at the base of the stalk, Pod compressed edged

5806 Leaves 8-9 pairs ovate lanceol. hairy with a gland at base of stalk, Racemes many-fl. shorter than leaves 5807 Leaves 6 pairs lanceolate acute the outer largest, A gland on leafstalk, Peduncles 2 flowered

5808 Leaves 6 pairs obl. smooth : lower smaller with a subulate gland between the lowest, Stalks 2 -flowered 5809 Leaves 6 pairs ovate acute smooth, with a gland at the base of the stalk, Pod cylindrical hooked 5810 Leaves 5-6 pairs ovate acuminate woolly : the outer largest

5811 Leaves 6 or 8 pairs lanceolate acute smooth, with a gland on the leafstalk, Pod round smooth 5812 Leaves 2 pairs obovate veiny, Stipules lanceolate appressed, Leaflets nearly equal

5813 Leaves 10 pairs oblong obtuse without glands, Racemes long, Bractes ovate tumid imbricated 5814 Leaves 6-8 pairs linear obliquely rounded at base above hairy, Panic. axillary, Pod villous

5815 Leaves in many pairs with many glands, Stipules subulate

5816 Leaves 2 pairs velvety without glands

5817 Leaves 5 pairs ovate lanceolate smooth with a gland at the base of the leafstalk

5818 Leaves 6-9 pairs lanceolate acuminate smooth, $\mathbf{A}$ gland on the leafstalk

5819 Leaves 8 pairs ovate-lanceolate, A gland between the lower, Stipules ovate very large

5820 Leaves 10 pairs ovate-lanceolate obtuse mucronate smooth, Stalk without gland

5821 Leaves 8 pairs ovate-oblong equal, Gland at the base of the leafstalk

5822 Leaves 8 pairs oval-oblong: the outer smaller, Leafstalks without glands, Stipules spreading

5822 Leaves 7 pairs lanceolate : the outer smallest, A gland at base of leafstalk

5824 Leaves 6 pairs oval-obl. obt. hairy : the outer largest, A subulate gland between each pair, Pods linear

5825 Leaves 9 pairs oval-obl. smooth obt. A cylindrical gland between the lowest, Footst. with no gland at base 5826 Leaves 10 pairs lanceolate with an oblong gland at the base

5827 Leaves 10 pairs, Leaflets oblong rounded at each end beneath hoary, No gland on stalk, Pod compressed 5828 Leaves 12 pairs obtuse mucronate, Glands many subulate, Stipules reniform bearded

5829 Leaves many pairs, Gland of the footstalk stalked, Stipules ensiform

5830 Branches hairy, Stipules lanceolate linear with elevated lines, Leaflets cuspidate

5831 Leaves 15 pairs, Leaflets with a cartilaginous white edge and a subulate gland between every pair

5832 Leaves many pairs linear with an obsolete gland at the base of the leafstalk, Stipules setaceous

5833 Leaves many pairs linear mucronate with a gland between the lowest, Pedunc. solitary 1-fl.

5834 Leaves many pairs, Flowers pentandrous, Stem erect

5835 Leaves many pairs linear, Stem flexuose erect villous. The plant in Bot. Cab. is something else?

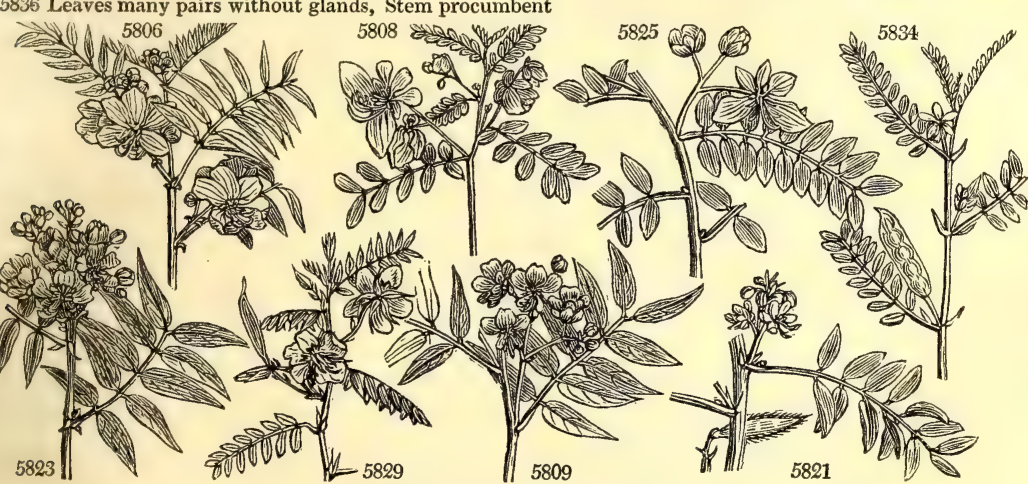

and Miscellaneous Pariiculars.

973. Cynometre. A name contrived to indicate the peculiar form of the pods of this genus, which grow from the old stems and branches of the tree. Large cuttings root best planted in sand, and plunged in heat under a hand-glass.

974. Cassia. According to Olaus Celsus, this name is to be traced to the Hebrew, Ketzioth, rendered by $\mathrm{K} \alpha \sigma a y$ in the Septuagint, and Latinized by Cassia. Cuttings of the species, which do not seed freely, root in pots of sand, in moist heat, and covered by a hand-glass.

Of the trivial names of different species of Cassia, that of Absis is the name under which it is described by Professor Alpinus, and is supposed to have arisen from a river of Palestine of that name. Tagera is a Malabar name, Sophera, an Egyptian name, and Senna, the Arabic name of the plant - Soenna. 
975. CATHARTOCAR'PUS. $\boldsymbol{P}$. S. CAthartocarpus. Leguminosa. Sp. 2 -5.

5837 Fis'tula $P . S$. purging $\quad$ m 3 jn.jl Y E. Indies 1731. C 1.p Rh. mal. 1.t. 22 5838 javánicus P.S. Java $\quad$ m $4 \quad \ldots \quad$ Pk $\quad$ E. Indies 1779. C 1.p Co. hort. 1.t.111 976. Parkinso'nia. $W$. Parkinsonia

5839 aculeáta $\boldsymbol{W}$. prickly Leguminosa. Sp. 1.

977. POINCIA'NA. H. $K$. Poinclana. 5840 pulchérrima $H . K$. Flower-fence 5841 eláta $H$. smooth

\section{$\begin{array}{cccc} & \\ & & \text { Leguminosa. Sp. } 2 .\end{array}$}

\section{C FSAIPI'NIA, $\boldsymbol{H}, \boldsymbol{K}$, BRASILETTO} 5842 bijuga $W$. 5844 Sap'pan $W$. 5845 Crísta $S w$. 5846 mimosoídes $W$. 5847 Núga $H . K$. 5848 cassioídes $W$. en 5849 mucronáta $W$.en. 5850 punctáta $W . e n$. broad-leaved smooth narrow-leaved oval-leaved Mimosa-leaved acute-leaved Senna-like mucronate dotted

$\square$ or 10 jn.s R.Y.G E. Indies 1691. S r.m Bot. mag. 995

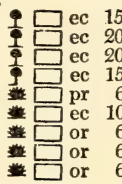

\section{Leguminosce. Sp. 9-18.}

.. Y Jamaica 1770. S p.l Sl.h.2.t. 181.f.2,3 ... Or Jamaica 1739. S p.l ... Y E. Indies 1773, S p.I Roxb.cor.1.t.16 ... W.y Jamaica ... S p.l Plu. gen. t. 68 $\ldots \quad Y \quad$ E. Indies 1806. S p.1 Rh. mal. 6. t.8 $\ldots \quad$ Y E. Indies 1801. S p.1 Rum. am. 5. t.50 S. Amer 1821 S p.1 $\begin{array}{llllll}\ldots & \ldots & \text { Brazil } & 1823 . & \text { S } & \text { p.1 } \\ \ldots & \ldots & \text { Brazil } & \text { 1820. } & \text { S } & \text { p.1 }\end{array}$

979. GUILANDI'NA. $\boldsymbol{H} . \boldsymbol{K}$. Nicker-Tree 5851 Bónduc $\boldsymbol{H} . \boldsymbol{K}$.

980. HYPERANTHE'RA. W. Horse-Radish-Tree. Leguminosa, Sp. 1-2

5852 Moringa $W . \quad$ smooth $\quad 9 \square$ or $10 \quad \ldots \quad \ldots$. E. Indies $1759 . \quad$ c p.1 Jac. ic. 3. t. 461 981. HOFFMA NSEg'GiA. Cav. Hoffmanseggia. Leguminosa. Sp. 1-2.

5853 falcária Cav. sickle-leaved $\square \mathrm{cu} \quad 2$ jl.au $\quad \ldots$ Chili

982. ADENAN'THE'RA. $W$. Adenanthera. Leguminosie. Sp. $2-5$.

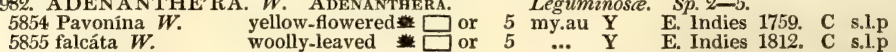
983. $\mathrm{CA}^{\prime}$ DIA. $W$ 5856 purpúrea $W$. 984. PRO'SOPIS. Rox. 5857 spicígera $L$ woolly-leaved $\square$ or 5 ... $\quad$ Y $\quad$ E. Indies 1812. C s.l.p Ru. amb. 3.t.11 Cadia. Leguminosa. Sp. 1.

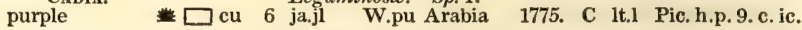
Prosopis. Leguminose. Sp. 1.

985. HEMATOX'YLON. $W$. LoGWOOD.

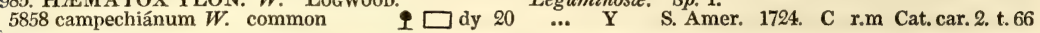
986. COPAI'FERA. $W$. BALSAM OF CAPEVI. Leguminosa. Sp. 1.

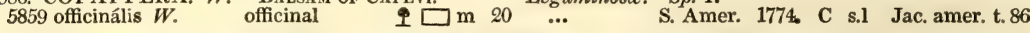

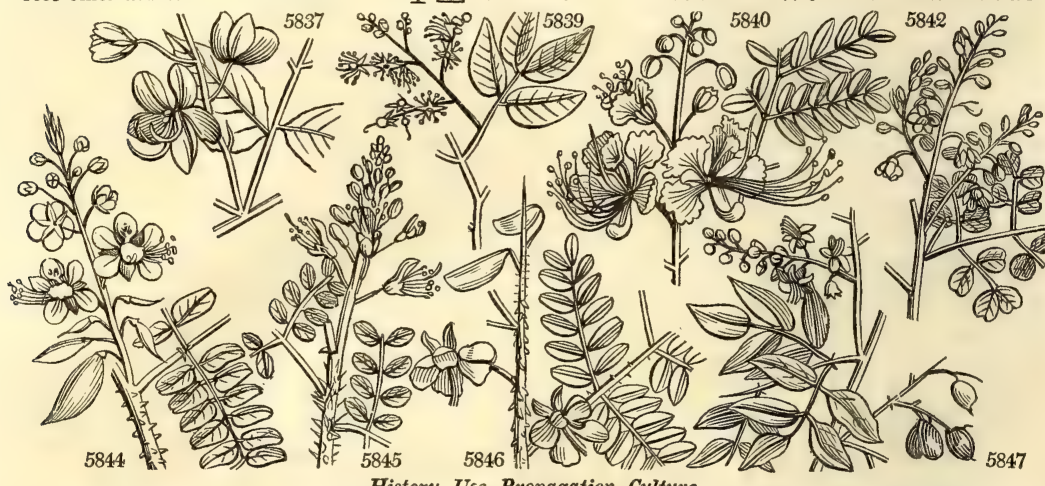

History, Use, Propagation, Culture,

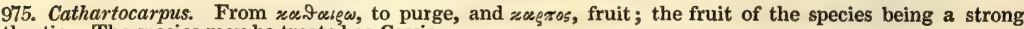
cathartic. The species may be treated as Cassia.

976. Parkinsonia. So named by Plumier, in memory of John Parkinson, apothecary, of London, author of Paradisus Terestris, 1629, and Theatrum Botanicum, 1640. It is a handsome low tree, not unlike the Laburnum, and planted in the West Indies near houses, as the latter is in this country.

977. Poinciana. So named by Tournefort, in memory of De Poinci, governor of the Antilles, placed by Linnæus among the promoters of botany.

P. pulcherrima is a low spiny tree, with an odor, when the leaves are bruised, like savin. It is a native of both Indies, and in Barbadoes is planted in hedges, whence the name of flower-fence, or Spanish carnations, which it is there called. In our stoves they require a strong heat to make them flower well. They are readily increased either by cuttings or seeds.

978. Casalpinia. So named by Plumier, in honor of Andreas Casalpinus, chief physician to Pope Clement VIII., and the father of systematic arrangement in plants, in his now very scarce work, entitled, De Plantis, libri sedecim, Flor. 1583. He died at Rome in 1602. The wood of all the genus may be used in dying. In our stoves the plants are thorny, and, therefore, not being much liked, are seldom suffered to grow large enough to flower freely.

C. sappan is a prickly tree, with the heart of the wood red, heavy, and very hard : it dyes a beautiful red, which, however, is said not to stand. It is very durable in sea-water, and exported abundantly by the Chinese for trenails in ship-building, and as a dye.

C. crista and brasiliensis afford the Brazil wood used in dying, and extensively imported to England from the West Indies. The timber of the last species is elastic, tough, and durable, and takes a fine polish ; is of a beautiful orange-color, full of resin, and yields a fine fuli tincture by infusion. The best Brazil wood is said to be produced by Cæsalpinia echinata. Cuttings, Sweet observes, will not root freely, but will sometimes succeed if taken off in a growing state, but not too young, and plunged in a pot of sand, under a hand-glass, in moist heat. (Bot. Cult. 32 .

979. Guilandina. Named after Melchior Guilandin, a Prussian traveller in Africa, and demonstrator of Botany at Padua. He died in 1590. The species are all fine trees, with large compound leaves.

980. Hyperanthera. From $\dot{x} \pi \xi$, upon, and $\alpha$ y $\vartheta \eta \rho \alpha$, an anther. The five barren stamens of this 
5857 I eaves 5 pairs

5838 Leaves 12 pairs

5859 The only species

5840 Prickly, Calyxes unequal smooth 5841 Unarmed, Calyxes equal downy

5842 Prickly, Leaves doubly in 2 pairs, Leaflets obcordate and calyxes smooth, Stam. as long as corolla 5843 Unarmed, Leaflets ovate-oblong, Rachis pubescent, Cal. downy, Stamens shorter than corolla

5844 Prickly, Leafl. obl. oval uneq. sided obt. and cal. smooth, Stamens longer than cor. Upper petal very small

5845 Prickly, Leaflets oval, Racemes simple, Petals ovate shorter than the smooth calyx

5816 Prickly, Leaflets oblong obtuse, Stamens shorter than cor. Pods woolly

5847 First petiole prickly beneath, Leaflets acute and cal. smooth, Pods 1-2-seeded

5848 Stipules spiny, Leaflets oblong retuse, Leafstalks hairy

5849 Prickly, Leaflets oblong obtuse mucronate smooth

5850 Unarmed, Leaflets unevenly bipinnate, Leaflets elliptical obtuse mucronate dotted

5851 The only species

5852 Flowers half decandrous, Leaves about bipinnate, Lower leaflets ternate, Pods 3-cornered

5853 Stem decumbent, Leaves bipinnate ovate glaucous

5854 Leaves decompound smooth on each side

5855 Leaves decompound downy beneath

5856 The only species

5857 The only species. Branches spiny, Leaves alternate conjugate

5858 The only species. Leaves abruptly pinnated, Leaflets obcordate

5859 The only species

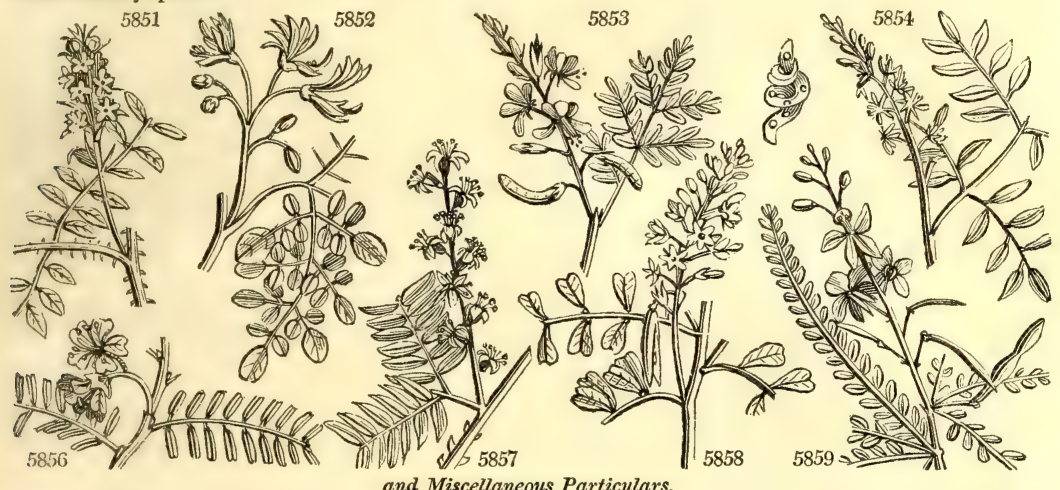

and Miscellaneous Particulars.

genus are surmounted by the five fertile ones. (Vahl.) Cuttings root best under a hand-glass in sand.

981. Hoffmanseggia. Naned by Cavanilles, after John Charles Hoffmansegg, whom he calls a distinguished naturalist. It may be with some propriety be employed to commemorate the merits of the present distinguished Count Hoffinansegg. Cuttings, somewhat ripened, root under a hand-glass in sand.

982. Adenanthera. From $\propto \delta \eta v$, a gland, and $\alpha$ In have each anther tipped with a gland. Large cuttings, with the leaves not shortened, root best in a pot of sand plunged in heat under a hand-glass. (Bot. Cult. 13.)

983. Cadia. Contrived by Forskahl, from the Arabic name of the plant, - qadhy.

984. Prosopis. One of the names under which Dioscorides described the Arctium Lappa. The present plant has no sort of resemblance to that of the ancients. It is a leguminous plant, and the pods are eaten as a condiment in India.

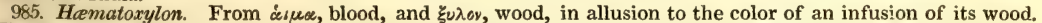
The logwood of commerce. This is a crooked stemmed low tree, with pinnate leaves, originally from the Bay of Campeachy; the inner bark and wood red, the latter dark and very hard. It makes an excellent fence, the smaller shoots are cut for hoops, and the stems for exportation for dying. The gum is a gentle subastringent. In our stoves it grows well in loam and leaf-mould, kept rather moist, and cuttings root in sand under a handglass in heat.

986. Copaifera. This tree is so called from bearing the drug Copaiba, which is the name given to the tree itself by the people of Brazil. Beaume de Copahu, Fr., Kopaiva Balsam, Ger., Balsamo del Coppaiba, Ital. This is a lofty elegant tree, with a handsome branching head, the extreme branches flexuose at the axils, the bark ash-colored, and the leaves pinnate. It grows abundantly in the woods of Tolu, near Carthagena, and of Quito, in Brazil. The copaiba balsam of the shops is procured by wounding or boring these trees to the pith, near the base of the trunk, when it flows abundantly, in the form of a clear colorless liquid, which is thickened, and acquires a yellowish color by age. The operation is performed two or three times in the same year; and from the older trees the best balsam is obtained.

Copaiba balsam is stimulant, diuretic, and gently purgative. It has been recommended in pulmonary com. plaints, and it certainly affords considerable relief in hæmorrhoidal affections. (Thompson's London Dispensatory, 265.) It may be increased by ripened cuttings in sand under cover. 
987. TRICHÍLIA. $W$. TRICHLIA. 5860 glábra $W$. 5861 odoráta $\dot{B}, \boldsymbol{R}$, 988. ME'LIA. $\boldsymbol{W}$. 5862 Azedarách $W$. 5863 sempervirens $W$. 5864 Azadiráchta $\boldsymbol{W}$. 989. OUIVI'SIA. Cav. 5865 heterophylla Cav. 990. SWIETE'NIA. $W$. 5866 Mahágoni $\boldsymbol{W}$. 5867 febrifuga $W$.

991. EKEBER'GIA, $W$ 5868 capénsis $W$.

992. HEY'NEA. Rox. 5869 trijuga $R o x b$.

993. GUA I'ACUM. $W$. 5870 officinále $W$

994. ZYGOPHYL'LUM 5871 . 5872 Fabágo $W$. 5873 fo'tidum $W$. insuave B. $\dot{M}$. 5874 maculátum $W$. 5875 álbum $\boldsymbol{W}$.

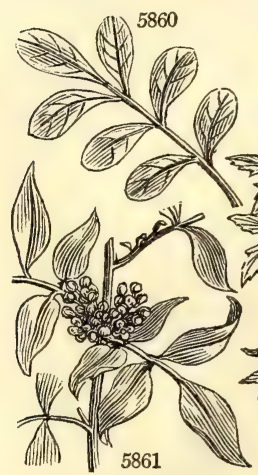

smootl sweet-scented

BEAD-TREE. common evergreen Ash-leaved

Quivisia. various-leaved $\square \mathrm{cu}$

Mahogan Y-Tree. common Febrifuge

Ekebergia. Cape

HEYNEA. Walnut-like

Meliacea. Sp. 2-18.

韭 $\square$ or 10 jn.jl W W. Indies 1794. C l.p J.amer.t.175.f.38 $\square$ or 10 jn.jl W W. Indies 1801. C 1.p Bot. rep. 637 Meliacez. Sp. 3-7.

* J or 40 jn.au B Syria 1656. S s.1 Bot. mag. 1066

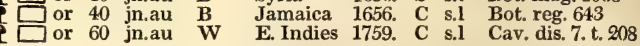
Meliacea. Sp. 1-4.

... W Is. France 1822. C p.l Cav. diss. t. 213 Meliacea. Sp. 2-3.

$\begin{array}{lllll}\ldots & \text { W } & \text { Indies } 1734 . & \text { C } & \text { p.l Cav, dis. 7. t. } 209\end{array}$ R E. Indies 1796. C p.I Rox, cor. 1 t. 17 Meliacece. Sp. 1.

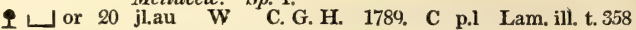
Meliacea. Sp. 1.

LIGNUM-VITE-TREe. Rutacea. Sp. 1-4

officinal $\square \mathrm{m} 40 \mathrm{jl}$.s B $\quad$ W. Indies 1694. C 1.p Lam. ill, t. 342

W. Bean-Caper

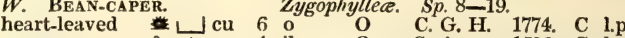

common $¥ \triangle$ cu 4 jl.s O.w Syria 1596. C l.p Lam.ill.t.345.f.1

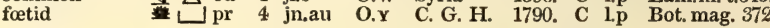

spotted-flower. $\begin{array}{llllllll}\mathrm{pr} & 4 & \text { o.n } & \mathrm{Y} & \text { C. G. H. } & \text { 1782. } & \text { C } & \text { 1.p }\end{array}$

W Canaries 1779. C 1.p Linn. dec. 1. t. 6

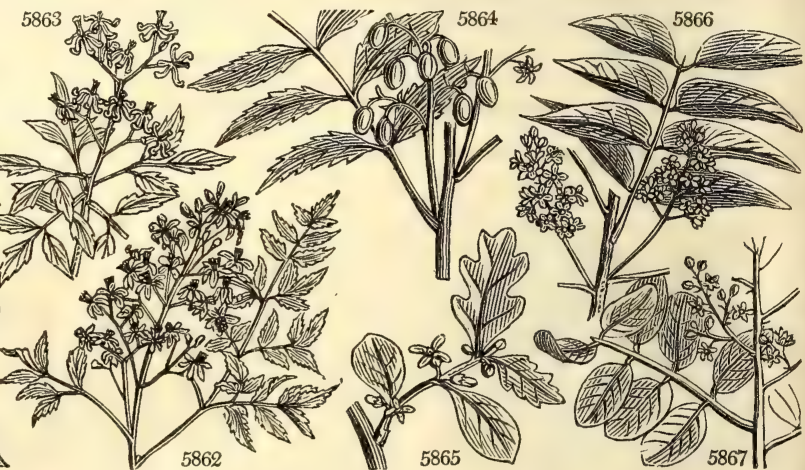

History, Use, Propagation, Culture,

987. Trichilia. From $\tau_{\rho} \iota \chi \alpha$, ternary, nearly all the parts of the plant, the leaves, the stigmas, the cells of capsule, the seeds, being produced by threes. T. glabra is a tall branching tree, with an unpleasant foetid smell. The species are rarely seen in collections, and seldom, when cultivated, flower.

988. Melia. M $\varepsilon \lambda_{i} \propto$ was the Greek name of the manna ash, from $\mu \varepsilon \lambda_{b}$, honey. This tree has been thought to resemble the ash in its foliage.

M. azedarach (azadaracht, Arab.) grows to a large tree in the south of Spain and Italy, producing long loose bunches of blue flowers, succeeded by pale yellow berries, about the size of a cherry. These berries consist of a pulp, which is poisonous in a high degree, and mixed with grease, will kill dogs, enclosing a nut which is bored and strung as beads by the Catholics.

M. sempervirens is considered by some as only a variety of the Azedarach.

989. Quivisia. The tree is called Boss de Quivi in the Isle of France

990. Swietenia. So named by Jacquin, in honor of the illustrious Gerard L. B. Von Swieten, archiater to Maria Teresa, Empress of Germany, who at his persuasion founded the botanic garden at Vienna.

S. mahagoni. The mahogany tree is a lofty branching tree, with a wide handsome head, the flower of Melia, and the fruit of Cedrela, about the size of a turkey's egg. It grows in the warmest parts of America, as in Cuba, Jamaica, Hispaniola, \&c. The trees on the Bahama islands are not so large, but are more curiously veined, and are known in Europe as Madeira wood. They generally grow on the solid rock, where there seems to be no earth for their nourishment. Mahogany, like other timber, varies in durability, firmness of grain, and St. Domingo and the Bahama islands.

$\mathrm{S}$. febrifuga is a lofty tree, in general apearance like the Mahogany. The wood is of a dull red color, remarkably hard and heavy; it is reckoned by the natives the most durable wood they know, and on that account is used for all the wood-work in their temples; it is also very serviceable for various other purposes. The bark is internally of a light red color : a decoction of it dyes brown of various shades, according as the cloth has been prepared. Its taste is a bitter and astringent united, and very strong, particularly the bitter; at the same time not any way nauseo'ds or otherwise disagreeable. In India it is used for the cure of intermit the diseases in which the cinchona bark proves serviceable. (Thompson's London Dispensatory, 533.)

991. Ekebergia. Charles Gustavus Ekeberg was a Danish naturalist, who travelled in Asia from 1770 to 1771. Cuttings to succeed must have their leaves entire, and be planted in sand and covered.

992. Heynea. Named after Dr. Benjamin Heyne, a learned German botanist and physician, who travelled many years in India, where he formed a large collection of dried plants.

993. Guaiacum. From guaiac, the name given to the tree by the natives of Guiana. Gijuac, Fr., Gujakgummi, Ger., Gujaco, Ital. This tree rises forty feet high, and is four or five feet in circumference, with many divided knotted branches, greyish bark, and abruptly pinnate leaves. It has blue flowers, which are succeeded by compressed berries of a roundish form. The tree takes many years to arrive at its full growth. The roots run far into the ground perpendicularly, contrary to the usual growth of timber trees in the West Indies, which generally shoot the largest prongs of their roots in a horizontal direction, and are commonly observed to run very near the surface. The bark is thick and smooth, the wood of a dark olive color, and cross grained, the strata running obliquely into one another, in form of an $\mathbf{X}$. It is a valuable timber where 
5860 Leaves pinnated smooth, Outer leaflets largest 5861 Leaflets lanceolate undulate, Flowers with 4 petals

5862 Leaves bipinnate, Leaflets smooth somewhat quinate 5863 Leaves bipinnate, Leaves cut rugose shining about 9, Petiole rounded at base 5864 Leaves pinnate

5865 Leaves alternate oval and obovate entire sinuate-toothed or pinnatifid, Pedicels twin axillary 1-flowered 5566 Leaves pinnate in four pairs, Leaflets ovate-lanceolate equal at base, Panicles axillary 5867 Leaves pinnate in four pairs, Leaflets elliptical roundish emarginate unequal at base, Panicle terminal 5868 The only species, Leaves pinnated with an odd one, Panicles axillary

5869 Leaves pinnated with an odd one in 3 pairs, Pan. axill. on long stalks

5870 Leaflets of 2 or 3 pairs obtuse, Capsules 2-celled

5871 Leaves simple opposite sessile roundish

5872 Leaves conjugate stalked, Leaflets obovate, Peduncles erect, Calyx smooth

5873 Leaves conjugate stalked, Leaflets obovate, Flower nodding, Calyx pubescent

5874 Leaves conjugate stalked, Leaflets linear-lanceolate

5875 Leaves conjugate stalked, Leaflets clavate fleshy with a cobweb surface

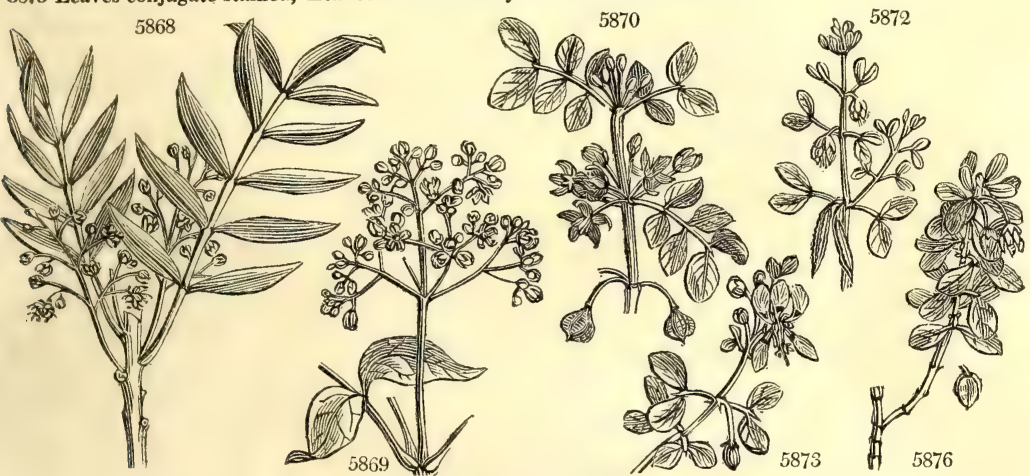

and Miscellaneous Particulars.

strength and duration is required, and woight no object. It takes a fine polish, turns well, and is much used for ship blocks. It is one of the most valuable trees of the West Indies; since the timber, the bark, fruit, leaves, and blossom, are all applicable to some useful purpose. The wood yields by incision the peculiar substance called Guaiacum, erroneously termed a gum, of great importance in medicine.

All the parts of this tree possess medicinal qualities; but the wood and the peculiar substance afforded by it are the only parts used: the virtues of the wood depend altogether on the peculiar matter it contains. This is spontaneously exuded from the tree, and is called native gum: it concretes in tears, which are semipellucid, and very pure; but the greater part of it is obtained by making incisions into the trunk, or, as it is termed, jagging the tree. This operation is performed in May; and the juice which flows copiously, is contermed, jagging the tree. This operation is performed in May; and the juice which flows copiously, is con-
creted by the sun. It is also obtained by sawing the wood into billets, and boring a hole longitudinally through them; so that, when one end of a billet is laid on a fire, the guaiac melting runs through the hole from the opposite end, and is collected in a calabash. Boiling the chips or raspings in salt and water also separates the guaiac, which, as it rises to the surface, may be collected by skimming.

Both the wood and the guaiac are stimulant, diaphoretic, diuretic, and purgative. The wood was introduced into Europe by the Spaniards as a remedy for lues venerea in 1508, and gained much celebrity from curing Van Hutten; but it had long before been used for the same purpose by the natives of St. Domingo. It obtained so much reputation, that the exhibition of mercury was discontinued for a considerable length of time, and even in the eighteenth century its specific powers over this disease were maintained by Boerhaave but frequent disappointments and more correct observations have shown that it possesses no powers of eradicating the venereal virus; and that it is useful only after a successful mercurial course, for repairing the strength and vigor of the system, "and where a thickened state of the ligament, or of the periosteum, remains,
or where there are foul indolent ulcers ;" (Pearson's Observations, \&c. p. 10.) or in suspending the progress of some of the secondary symptoms for a short time, as ulcers of the tonsils, eruptions, and nodes. The decoction of the wood has been found more useful in cutaneous diseases, scrofulous affections of the membranes and ligaments, and in ozæna. The guaiac itself is an efficacious remedy in chronic rheumatism and arthritic affections, as well as those diseases for which the decoction of the wood is usually given; and in every respect it may be regarded as the active ingredient of the wood. Its sensible effects are a grateful sense of warmth in the stomach, dryness of the mouth and thirst, with a copious flow of sweat, if the body be kept externally warm, or if the guaiac be united with opium and antimonials: but when the body is freely exposed, instead of producing diaphoresis, it augments considerably the secretion of urine. (Thomson's London Dispensatory, 318.)

Lignum vitæ in the stove grows freely in loam and peat. "Cuttings," Sweet observes, " are generally supposed to be difficult to root; but I find ripened cuttings, taken off at a joint, root readily, planted thin in a pot of sand, and plunged under a hand-glass in heat. When the cuttings are rooted, which will be easily perceived by their growing at the top, they should be potted off; when great care must be taken not to break off the young roots in taking the sand from them, as they are very small and easily broken. Pot them off in very small pots, and keep them under a close glass or a few days, till they have struck fresh root, when they must be exposed to the air by degrees." (Bot. Cult. 63.)

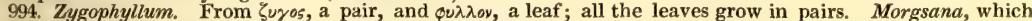
is the name of one species, is the Syrian name of the plant. These are plants of little ornament, generally with fleshy leaves, and flowers of a yellow or whitish yellow color. 
5876 Morgsána $W$. 5877 sessilifólium $W$ 5878 coccíneum $L$. 995. FAGO'NIA. $W$. 5879 crética $\boldsymbol{W}$. 5880 arábica $W$. 996. TRI'BULUS. $W$ 5881 máximus $W$. 5882 terréstris $W$. 5883 cistoídes $W$.

997. DICTAM'NUS. 7 5884 Fraxinélla Link. 5885 álbus $L$

998. RU'TA. $W$. 5886 gravéolens $W$. 5887 montána $W$ 5888 chalepénsis $P$. S 5889 angustifólia $\dot{P}$. $S$ 5890 pinnáta $W$ 5891 pubéscens $W$.en 5892 linifólia $W$. 5893 patavína $\boldsymbol{L}$. 5894 macrophýlla Sol. 5895 albiflóra Hook. 999. CRO'WEA. Sm. 5896 saligna $\mathrm{Sm}$. I000. CO'DON. $W$. 5897 Royéni $W$.

1001. GOM'PHIA. $W$. 5898 nitida $W$. 5899 obtusifólia Dec.

1002. OUAS'SIA. $W$. 5900 amára $W$ 5901 Simarúba $W$.

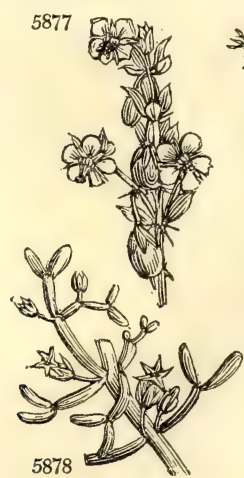

995. Fagonia so

995. Fagonia So named by Tournefo

four-leaved sessile-leaved scarlet

Fagonia.

Cretan

Arabian

Caltrops. great small Cistus-like

Fraxinella. red white

Rue. common mountain ciric. narrow-leaved winged-lea Flax-leaved Paduan

large-leaved

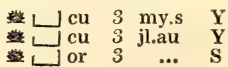

C. G. H. 1732, C 1.p Di.elt.t.116.f.141 Zygophyllea. Sp. 2-10

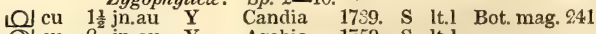

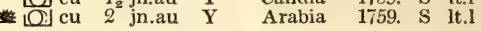
Zygophyllece. Sp. 3-7.

[0] pr $1 \frac{1}{2}$ jn.jl $Y$ Jamaica 1728. S s.l Jac. ic. $3 . t .462$

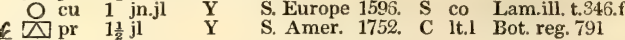
Rutracea. Sp. 2.

خ $\triangle$ or 3 my.jl $\mathbf{P u}$ Germany 1596. R p.l Jac. aust.5. t.428 \} \triangle \text { or } 3 \text { my.jl W Germany 1596; R p.l } Rutacece. Sp. 10-24.

jn.s G.Y S. Europe 1562. C co Lam. ill. 345, t. 1 $\triangle$ un 2 au.s G.Y S. Europe 1596. C co Jac. ic. 1. t. 70 L un 2 jn.s G.y Africa 1722. C r.m

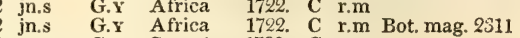
mr.au G.y Canaries 1780. C r.m $\triangle$ un 11 my.au G.Y Spain 1816. C co A un $1 \frac{1}{2}$ jn.s G.Y Spain 1752. C r.m Bot. rep. 565

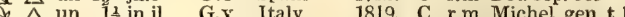
J un 3 jl G.Y Africa 1820. C r.m Bot.mag. 20!8

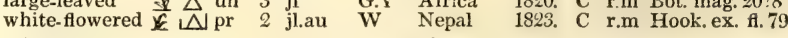
Crowea.

Willow-leaved ${ }^{\prime}$ or 3 jl.d Pu N. S. W. 1790. C s.l.p Bot. mag.989 Codon. $\quad$ (................. Sp. 1 $\begin{array}{llll}\text { prickly } & \text { C. G. H. 1801. } \mathrm{c} \text { it.l Bot. rep. } 325\end{array}$ ButTON-FLOWER.

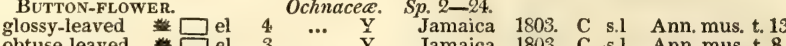
obtuse-leaved $\square$ el 3 ... $\quad$ Y $\quad$ Jamaica 1803. C s.l Ann.mus t. 8 Quassia. Simarubacea. Sp. 2-4.

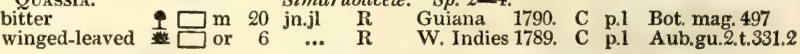

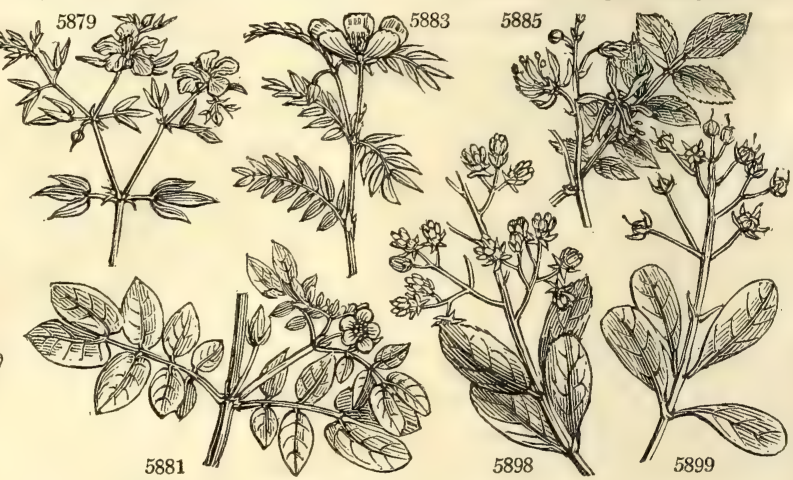

History, Use, Propagation, Culture,

patron of botany. Small prickly plants of no beauty.

996. Tribulus. Small prickly plants of no beauty. du Chevalier, Fr. The term Caltrops is taken from the form of the fruit, which resembles the La Croix that were formerly cast in the way to obstruct an enemy's cavalry. It is composed of five nuts, united into a subglobular whorl armed with prickles.

$\mathrm{T}$. terrestris is a native of most of the hot and temperate parts of the world : it is common about Kingston in Jamaica, where it is called Turkey blossom, and planted in gardens for the sake of its flowers, which have an agreeable smell. The fowls are observed to feed much on them, which is thought both to fatten them and heighten their flavor. In the south of Europe, it is a common weed in arable land, and is troublesome to cattie by the prickly fruit running into their feet. All the species are pretty, though seldom cultivated.

997. Dictamnus. An ancient name of what is now supposed to be the Origanum Dictamnus. Fraxinella, Fr., in allusion to the remarkable similarity which exists between the leaves of the plant and Fraxinus, the ash. The whole plant, especially when gently rubbed, emits an odor like that of lemon-peel, but when bruised it has something of a balsamic scent. This fine scent is strongest in the pedicels of the flowers, which are covered with glands of a rusty red color, exuding a viscid juice or resin, which exhales in vapor, and in a dark place may be seen to take fire. The root is used in medicine, and, it is said, with much success, as an opiate and drastic.

998. Ruta. This name is nearly the same in all languages. Purn, in Greek; Ruta, in Latin; ruz, in Runic; rude, ruta, or rutu, in Anglo-Saxon; rutiza, in Sclavonic; in French and English, rue, \&c. The root of the word is beyond the ingenuity of etymologists. $R$. graveolens was formerly in much repute as a medicinal plant, and also as emblematical of repentance and grace. In Shakspeare and other old authors, it is called herb of grace, as rosemary is called herb of remembrance. The leaves have a powerful unpleasant odor, and a hot, bitter, nauseous taste. In the recent state they will inflame and blister the skin; but much of this is dissipated in drying. Medicinally, rue is stimulant and antispasmodic, and is supposed to possess emmenagogue powers. It was in high estimation as early as the time of Hippocrates, who frequently ordered it in female complaints. In modern practice, it is chiefly used in hysteria and flatulent colic. (Thomsun's it in female complaints. In

999. Crowea. So named by the president of the Linnean Society, after his friend James Crowe of Norwich, an excellent British botanist, whose collection of willows we believe still exists. This plant continues in flower the greater part of the year. An equal mixture of sandy loam and peat is the best soil for it, and care must be taken not to over water it, or it will look yellow and unhealthy. It likes an airy situation, 
5876 Leaves conjugate stalked, Leaflets obovate, Stem shrubby

5877 Leaves conjugate sessile, Leaflets lanceolate oval rough at edge, Stem shrubby

5878 Leaves with double leaflets stalked, Leaflets cylindrical fleshy smooth, Petals acuminate

5879 Spiny, Leaflets lanceolate flat smooth

5880 Spiny, Leaflets linear convex

5881 Leaflets in 4 pairs : the outer larger, Pericarps 10-seeded blunt

5882 Leaflets in 6 pairs nearly equal, Seeds with four horns

5883 Leaflets in 8 pairs nearly equal

5884 Leafstalk obscurely edged

5885 Leafstalk scarcely edged at all

5886 Leaves supradecompound, Leaflets oblong terminal obovate, Petals entire 5887 Leaves supradecompound, Leaflets all linear, Petals entire

5888 Leaves supradecompound oblong, Terminal leaflet obovate, Petals toothed

5889 Leaves supradecompound, Lobes oblong cuneate nearly equal, Bractes very small ovate, Petals ciliate

5890 Leaves pinnate, Leaves lanceolate attenuate at base serrate crenate, Petals entire

5891 Leaves mostly ternate lanceolate pubescent : lateral very short, Cal, and ovaries villous

5892 Leaves simple lanceolate smooth, Filaments ciliated, Stem simple herbaceous

5893 Leaves in middle ternate linear narrowed at the base entire, Calyxes villous

5894 Leaves pinnatifid, Segments oblong somewhat stalked: the terminal very large, Petals ciliated

5895 Leaves bipinnate with obovate retuse leaflets, Flowers 4-petalous 8-androus

5896 The only species

5897 The only species

5898 Leaves ovate-lanceolate acuminate serrated at end, Cal. as long as cor. Berries ovate

5899 Leaves lanceolate entire very obtuse at end, Branches of panicle short angular

5900 Flowers hermaphrodite, Leaves pinnate with an odd one, Leaflets opposite sessile, Stalk jointed winged 5901 Flowers monocious, Leaves abruptly pinnated, Leaflets alternate stalked, Stalk naked

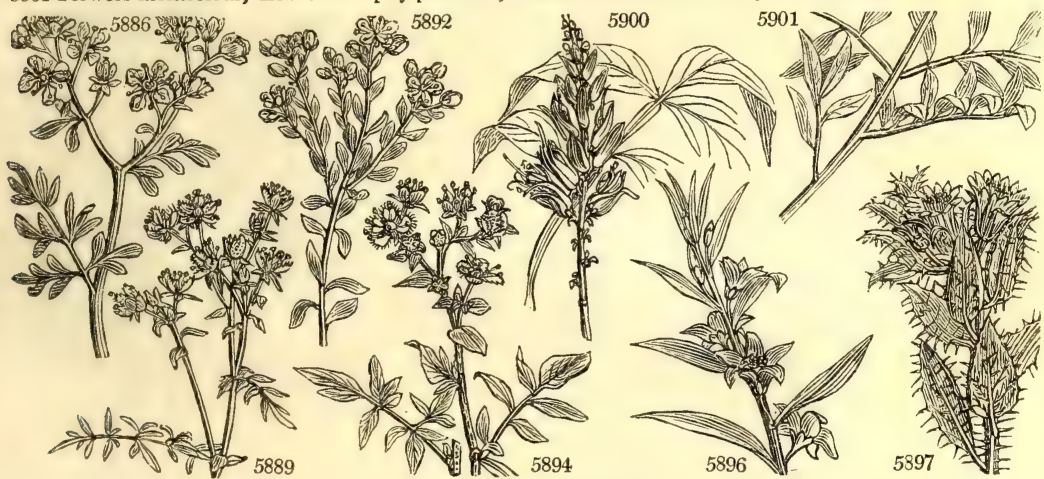

and Miscellaneous Particulars.

and not to be crowded amongst other plants. Cuttings strike root freely in sand, under a bell-glass. (Bot. Cult. 173.)

1000. Codon. From $\approx \omega \delta \omega y$, a bell. The corolla of this plant is globular, and formed like a bell in its upper part. A scarce Cape shrub, of which Thunberg speaks in terms of great delight upon finding a solitary individual growing by the side of a precipice in its native country.

1001. Gomphia. From ropøos, a club; but the application is not obvious. These are most beautiful tropical bushes, with long spikes of brilliant yellow flowers, and neat serrated shining entire leaves.

1002. Quassia. So named by Linnæus, in memory of Quassi, a negro slave of Surinam, who found and discovered to Rolander, a Swede, the wood of $Q$. excelsa, which he had employed with success as a secret remedy in the malignant endemic fevers of Surinam.

Q. amara is a lofty tree with strong branches, white light wood, their bark and leaves not unlike those of the common ash. The flowers are in terminal racemes, of a bright red. The root, wood, bark, and indeed all the parts of this tree are intensely bitter. Linnæus says that the wood of the root is a noble remedy, but that the wood of the small branches, which has since been substituted for it, is good for nothing. The wood of both is now thought to be less intensely bitter than the bark, which is at present regarded as the most powerful medicine. Quassia has no sensible odor; its taste is that of a pure bitter, more intense and durable than that of almost any other known substance: it imparts its virtues more completely to watery than spirituous menstrua, and its infusions are not blackened by the addition of martial vitriol. It is said that considerable quantities of this drug are used by the brewers instead of hops.

o. Simaruba, or mountain damson, as it is called in Jamaica, is a tall tree with alternate branches, and a smooth grey bark, maculated with yellow spots. The leaves are pinnate; the flowers are male and female on the same axillary panicles, yellowish white; the fruit consists of five smooth, ovate, black, one-celled berries, on a common receptacle, and open spontaneously when ripe.

The officinal part of this tree is the bark of the root; it is inodorous, and has a bitter, but not disagrceable taste. The pieces are of a very fibrous texture, rough, scaly, warty, and of a full yellow color in the inside when fresh. Alcohol and water take up all its active matters by simple maceration, at a temperature of sixty degrees of Fahrenheit better than at a boiling heat; it is tonic, and has been employed with advantage in intermittent fever, obstinate diarrhœea, dysentery, and dyspeptic affections. (Thomson's London Dispensatory, 62$.

The different species of quassia flower freely in the stove; are of easy culture in loam and peat, and are increased by ripened cuttings taken off at a joint, and not deprived of their leaves, and planted in a pot of sand under a hand-glass.

A 32 
1003. LIMO'NIA. $\boldsymbol{W}$. 5902 monophýlla $W$. 5903 crenuláta $\boldsymbol{H}$. $\boldsymbol{K}$.

1004. GLYCOS'MIS. Cor 5904 citrifólia Lindl. Limónia parviflór 5905 pentaphýlla Corr. five-leaved 5906 arbórea Corr. tree

1005. MURRA'YA $W$. 5907 exótica $W$. 5908 paniculáta $W$ Wall.

1006. COOK'IA. $W$. 5909 punctáta $W$

1007. GÆRTNE'RA. $W$. GFRTNERA. 5910 racemósa $W$. clustered

1008. MONO'TROPA. $W$ 5911 uniflóra Mich. 5912 Hypópithys $\boldsymbol{W}$.

1009. DION拜A. $W$. 5913 Muscípula $\boldsymbol{W}$.

1010. GARU'GA. Rox 5914 pinnáta $H$. $K$.

1011. KAL/MIA. $W$. 5915 latifólia $W$. 5916 angustifólia $W$. $\beta$ rubra

5917 glaúca $W$. 17 glaúca $\boldsymbol{W}$. glaucous $\beta$ rosmarinif 5918 hirsúta $W$
LrMONIA. simple-leaved crenulate

Grycosurs

Murraya. Ash-leaved panicled Garuga.

Kalmia.

Calico-bush

Sheep-Laurel

red-fiowered

Aurantiacea. Sp. 2-11.

$\square$ or $4 \quad \ldots \quad$ W $\quad$ E. Indies 1777. C r.m Rox. cor. 1. t. 83 ... W E. Indies 1808. C r.m Rox. cor. 1.t.86 Aurantiacex. Sp. 3.

… $\square \mathrm{fr} 6$ ja.d W ${ }^{2}$ China $\quad$... $\quad$ C r.m Bot. mag. 2416

9 $\square$ or 20 jn.jl W E. Indies 1790. C r.m Rox. cor. 1. t. 84 9 $\square$ or 20 my.au W E. Indies 1796. C r.m Rox, cor. 1.t. 85 Aurantiacea. Sp. 2.

都 L $\mathrm{ft} 8$ au.s W E. Indies 1771. C 1t.l Bot. reg. 434

8 W E. Indies 1823. C r.m Hook, ex. fl. 134

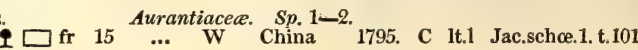
Malpighiacece. Sp. 1-3.

9 $\square$ or 15 mr.ap W E. Indies 1796. C p.1 Bot. rep. 600

\section{. Yellow Bird's-Nest. Monotropece. Sp. 2-4.}

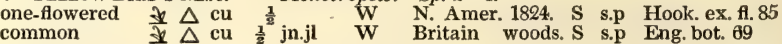

DronaA. Droseracece. Sp. 1.

Venus's Flytrap $\mathbb{N} \mathrm{d}$ cu $\frac{2}{2}$ jl.au W W Carolina 1768. L s.p Bot. mag. 785 winged-leaved $\$$ or 20

E. Indies 1808. S p.1 Rox.cor.3. t. 208

Rosemary-leav.

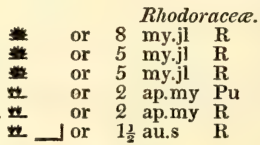

Sp. $4-5$. .
N. Amer. 1734. L s.p Bot. mag. 175 N. Amer. 1736. L s.p Bot. mag. 331 N. Amer N. Amer. 1767. L s.p Bot. mag. 177 N. Amer. 1812, L s.p

N. Amer. 1786. L s.p Bot. mag. 138

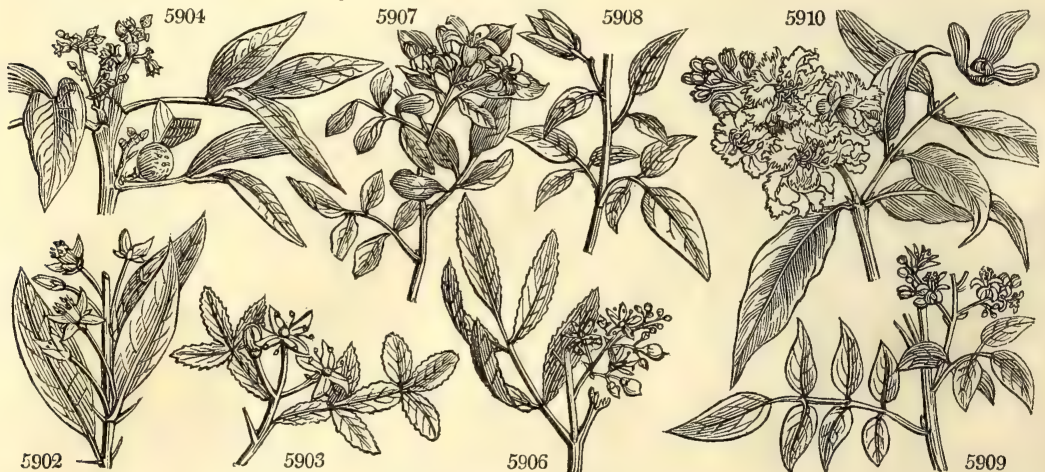

History, Use, Propagation, Culture,

1003. Limonia. The general denomination of the citron in Arabia is lymorn, whence limon and lemon, to which fruits this genus is nearly related. L monophylla is a small thorny tree, with a berry the size of a small nutmeg, very like a lime, and called by the Hindoos wild lime. Ripened cuttings of the species root in sand, under a hand-glass plunged in a moist heat.

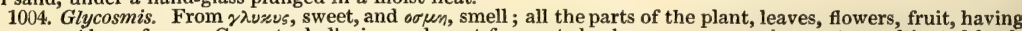
an agreeable perfume. G. pentaphylla is an elegant fragrant shrub, very common in most uncultivated lands in Coromandel, but chiefly under large trees, where birds have dropped the seeds. It flowers all the year there. The whole plant, when drying in the shade, diffuses a pleasant permanent scent; the flowers are ex quisitely fragrant; birds eat the berries greedily.

G. arborea has also very fragrant flowers.

G. citrifolia is a beautiful stove plant, not, indeed, remarkable for the shewiness of its flowers, but most valuable on account of its fruit, which is about the size of a hazel nut, very juicy and sweet, and produced in profusion in our stoves.

1005. Murraya. So named by Koenig, in honor of John Andrew Murray, knight of the Swedish order of Vasa, professor of medicine and botany at Gottingen, and an editor of Iinnæus's Systema Vegetabilium. The species are trees of the smallest size, with dotted pinnated leaves and tragrant white flowers, quite like those of an orange.

1006. Cookia. Named by Sonnerat in honor of our celebrated Captain Cook. The fruit is much esteemed in China, where it arrives at the size of a pigeon's egg, growing in bunches, and it is called Wampee. It grows well in light loam, and ripened cuttings with their leaves on root in sand in a moist heat.

1007. Gertnera. In memory of Joseph Gærtner, M. D. F. R. S. Acad. Imp. Petrop. Memb., author of a most excellent work on the fruits and seeds of plants, Stutg. 1788. It is a large climbing woody shrub, cultivated all over the coast of Coromandel, on account of the beauty and fragrance of its flowers. In the stove it requires a good deal of room to flower freely. It is easily increased in sand under a hand-glass. The genus is now referred to the natural order of Malpighiaceæ, among which it is remarkable for its white flower:s.

1008. Monotropa. From $\mu$ ovos, one, and $\tau \rho \varepsilon \pi \omega$, to turn : its flowers are all turned one way. It is parasitical and without leaves, of a pale uniform hue, having a simple scaly stem; allied in habit to Orobanche, to some of the Orchis tribe in its peculiarity of scent, which is like that of primrose, or beans in blossom. The root is fibrous, much branched, and somewhat creeping, growing among dead leaves or in half decaying vegetable mould. Sir J. E. Smith says, he could never find it truly parasitical. In Sweden, Linnæus informs us, it is given dry to sheep affected with a cough.

Its natural affinity, which is certainly to the heath, Pyrola, and similar plants, is very singular and unexpected. 
5902 Leaves simple, Spines solitary

5908 Leaves pinnate, Leaflets oblong lanceolate crenulate, Spines solitary

5904 Leaves simple and 3-leaved, Leaflets ovate-oblong acuminate, Peduncles axillary shorter than stalk

5905 Leaves pinnate in 2 pairs, Leaflets elliptical entire

5906 Leaves pinnate in 2 pairs, Leaflets oblong obsoletely serrate

5907 Leaflets ovate, Peduncles many-fl. corymbose

5908 Leaflets ovate-acuminate, Pedunc. axill. and solitary

5909 Leaves ovate-lanceolate acuminate nearly equal at base

5910 Leaves pinnated, Leaflets ovate-lanceolate

5911 Large cernuous, Scales close together

5912 Flowers smooth lateral octandrous

5913 The only species

5914 The only species

5915 Leaves ovate-elliptical ternate and scattered, Corymbs terminal

5916 Leaves oblong, Corymbs axillary, Bractes linear-lanceolate, Pedunc. and calyx downy with glands

5917 Leaves opposite oblong polished beneath glaucous revolute at edge, Branches 2-edged

$\beta$ Leaves linear more revolute green beneath

5918 Leaves alternate and opposite ovate-lanceolate and branches hairy, Pedunc. axill. 1-flowered

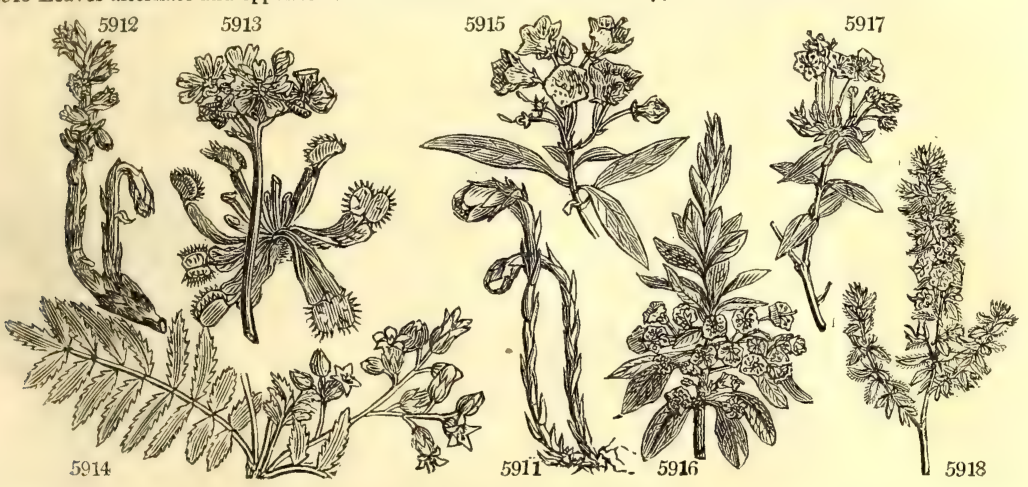

and Miscellaneous Particulars.

1009. Dioncea. One of the names of Venus. It is a singular plant in respect of its leaves, which are of an anomalous form, and have a singular motion by which they catch insects, whence the specific name, muscipula, a fly-trap. The root is scaly, almost like a bulb, and not prolific in fibres. The leaves have the petiole winged as in the orange; the extreme part, or proper leaf, is the part that operates as a trap. Linnæus affirms, that when the entrapped insect ceases to struggle and is quiet, the leaf opens and permits it to escape. This does not agree with Ellis's account, for he affirms that the lobes never open again, so long as the animal continues there. He thinks it probable, that a sweet liquor discharged by the red glands tempts the insect to its destruction. He adds, that if a straw or a pin be introduced between the lobes, they will grasp it as fas as if it were an insect. The flowers grow in a corymb resembling an umbel. It is rather difficult to preserve. Sweet finds it "thrive best when planted in a pot of Sphagnum with a little mould at the bottom of the pot, and placed in a pan of water." Shepherd, of the Liverpool botanic garden, finds that leaves of Dionæa so placed will root and form new plants. In all cases it is necessary that an abundance of fresh cool air should he supplied to the plants.

1010. Garuga. Garugo is the Telinga name of the plant, which is rare in our stoves, although not of recent introduction.

1011. Kalmia. So named by Linnæus in honor of Peter Kalm, professor at Abo in Sweden, author of Travels in America. The species are beautiful peat earth shrubs, deserving a place in every American ground. K. latifolia is a native of Carolina and other parts of North America, of Pennsylvania, New York, \&c. but only in particular places; on rocks, hanging over rivulets, and on the sides of barren hills on the most sterile soil. The noxious qualities of this elegant shrub lessen that esteem which its beauty claims; for though deer feed on its green leaves with impunity, yet when cattle and sheep, by severe winters deprived of better feed, eat the leaves, many die annually. It blossoms in May, and continues in flower a great part of the summer. (Catesby.) The flesh of the Amerizan partridge is said to be poisonous in the winter from its feeding upon the buds of this plant. But Wilson denies this statement. The Indians use a decoction of the leaves
upentis for purposes of self-destruction. A few drops of the tincture poured upon the body of a large and vigorous rattle-snake, killed the reptile in a short time. An ointment made of the powdered leaves has been used with much success in tænia capitis, and some other cutaneous affections. (See Bigelow's Medical Botany.)

The wood, being very hard, is very useful in smaller works. The Indians are said to make small dishes, spoons, and other domestic utensils out of the roots : these are large, of a soft texture, and easily wrought when green; but when dry become hard and smooth. (Curtis.)

$\mathrm{K}$. angustifolia is also reputed poisonous to sheep and cattle. 
1012. LE'DUM. $W$. 5919 palústre $W$. 3 decúmbens

5920 latifólium $\boldsymbol{W}$.

5921 buxifólium $\boldsymbol{W}$ Ammyrsine buxifolia $\mathrm{Ph}$

1013. RHO'DORA. $W$. RHoDora 5922 canadénsis $W$. Canadian

1014. RHODODEN'DRON. $W$. RHOD 5923 ferrugineum $W$. 5924 hirsútum $W$. 5925 daúricum $W$. $\beta$ atrovírens 5926 camtcháticum $W$ 5927 chamæcístus $W$ 5098 caucasicum $W$. 5929 chrysánthum $W$ 5930 punctátum $\boldsymbol{W}$. $\beta$ májor 5931 máximum $W$. \& álbum $\mathrm{Ph}$.

r purpúreum $\mathrm{Ph}$. 5932 catawbiénse $P h$. 5933 pónticum $\boldsymbol{W}$. $\beta$ obtusum

\% myrtifólium 5934 arbóreum $\mathrm{Sm}$. 5935 azaloídes Hort. 5936 hýbridum $B$. Reg. 1015. EPIG压A. $W$. 5937 répens $\boldsymbol{W}$.

1016. ANDRO'MEDA. 5938 hypnoides $W$. 5939 mariána $W$

$$
\text { c ovális }
$$$$
\text { covalis }
$$

5940 ferrugínea $P h$.

5941 rígida $P h$. 5942 jamaicénsis $\boldsymbol{W}$ 5943 speciósa $P h$. ce nítida $\beta$ pulverulénta

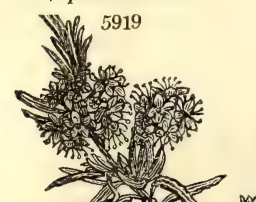
rusty-leaved Daurian dark-leaved Kamtchatka Thyme-leaved Caucasian yellow dotted-leaved dotted-leaved large dotted-lvd. large
white tree Catawba common obtuse myrtle-leaved tree Thompson's hy Herbert's hybr. EPIGEA. creeping $W$. Andromeda. Moss-like Maryland oval-leaved oblong-leaved rusty-leaved rigid rigid large-flowered smooth-leaved mealy-leaved

$\begin{array}{lll}\text { EA. } & & \text { Rhodoracece. } \\ \text { or } & \text { ap.my W } \\ \text { or } 3 \text { ap.my W } & \text { ormy } \\ \text { or } & \frac{1}{2} \text { ap.my W }\end{array}$

Sp. 3.

Europe 1762. Lis.p Bot. cab. 560 Huds. Bay 1762. L s.p N. Amer. 1763. I s.p Bot. cab. 584 N. Amer. 1736. L s.p Bot. reg. 531

\section{Rhodoracee. $S p .1$}

Nor 3 ap.my Pu N. Amer. 1767. L p.l Bot. mag. 474 RENDRon. Rhodoracea. Sp. 15-23.

n or $1 \frac{1}{2} \mathrm{my} . \mathrm{jl} \mathrm{S}$ Switzerl. 1752. L s.p Bot. cab. 65

or $1 \frac{1}{2}$ my.jl $\mathrm{S}$ Switzerl. 1656. L s.p Bot. mag. 1853

业 or 3 mr.d Pu Siberia 1780. L s.p Bot. mag. 636 or 3 f.ap Pu Siberia $\ldots$ L s.p Bot. reg. 194 or 2 ... Pu Kamtsch. 1802. L s.p Pall. ross.1. t. 33 or $\frac{1}{2}$ my.jn Pa.pu Austria 1786. C s.p Bot. mag. 488 or 1 au Pu Caucasus 1803. I s.p Bot. mag. 1145 or $1 \mathrm{jn.jl} \quad \mathbf{Y}$ Siberia 1796. L s.p Par lond 80 or $\frac{1}{2}$ jn.jl $Y$ Pk 1786 . N. Amer. 1786. L s.p Bot. rep. 36 $\begin{array}{lrllllll}\text { or } 6 & \text { jn.au } & \text { Pk } & \text { N. Amer. 1786. } & \text { L s.p } & \text { Bot. reg. } 37 \\ \text { spl } 20 & \text { jn.au } & \text { Pk } & \text { N. Amer. 1736. } & \text { L } & \text { s.p } & \text { Bot. mag. } 951\end{array}$ or 20 jn.au W N. Amer. 1811. L s.p spl 25 jn.au Pu N. Amer. $\quad$ L s.p or 4. jn.au Pu N. Amer. 1809. L s.p Bot. mag. 16/1 spl 12 my.in Pu Gibraltar 1763. L s.p Bot mag. 650 spl 12 my.jn Pu Gibraltar 1763. I s.p Dend. brit. 162

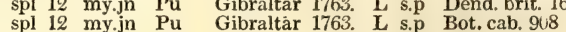
spl $20 \quad \ldots) \quad P$.$u \quad Nepal 1820. L s.p Ex. bot. t. 6$ ... L L s.p Bot. rep. 379 spl 3 jn.au Pk $\quad . . . . \quad$... L L s.p Bot. reg. 195

Rhodoracea. Sp. 1.

pr $\frac{1}{2}$ jl.au W N. Amer. 1736. L s.p Bot. reg. 201

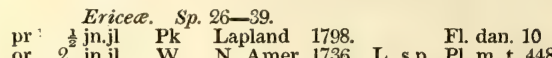
or $2^{\frac{1}{2}}$ jn.jl W N. Amer. 1736. L s.p Pl. m. t. 448. f. o or 2 jn.jl W N. Amer. 1736. L s.p Bot. mag. 1579 or $2 \mathrm{jn} . \mathrm{jl}$ W N. Amer. 1736. I s.p or 3 jn.jl W N. Amer. 1784 L s.p Vent malm so or 20 ap.my W N. Amer. 1774. L s.p or $6 \quad \ldots \quad$ W Jamaica 1793. L s.p or 3 jn.s W Carolina 1800. L s.p or 3 jn.s W Carolina 1800. L s.p Bot. mag. 970 or 3 jn.s W Carolina 1800. L s.p Bot. mag. 6i.

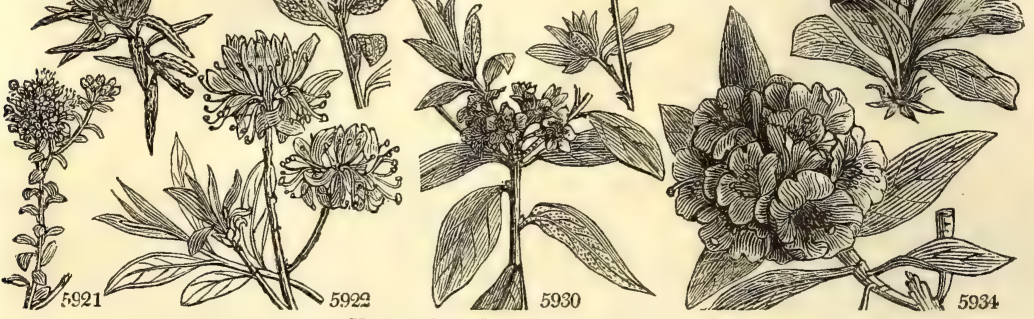

History, Use, Propagation, Culture,

1012 Ledum. Andoy was the name applied by the ancients to the plant producing the substance called Ladanum, and now known by the name of Cistus Ledum. In foliage the Ledum of modern botanists agrees with the plant of the ancients. Pretty American plants, very commonly cultivated for the beauty of their flowers.

1013. Rhodora. A name of the same meaning as Rhododendron. It is well known in shrubberies as remarkable for its purple flowers appearing on the naked shoots before the leaves come out.

1014. Rhododendron. From o $^{\circ}$. of roses. Some of the species form beautiful and even splendid ornaments to the shrubbery or American ground; and all of them are interesting and deserving of culture.

R. ferrugineum and hirsutum abound on the high mountains of Switzerland, Austria, Savoy, Piedmont, Dauphiné, and terminate ligneous vegetation as we ascend, and furnish the shepherds with their only fuel The grouse are said to eat them; and the white hares sometimes gnaw the bark in hard weather; but animas do not seem to feed on them, except from want of other food; and they are suspected of being in a small degree poisonous. The galls of some small insect are frequent on them.

$\boldsymbol{R}$. dauricum is almost peculiar to the subalpine tracts of eastern Asia; it appears first at the mouth of the river Jenisea, and beyond that, especially from the river Uda, in the pine woods, it begins to be common ; but about Baikal it is most abundant, and extends through the deserts of the Mongols to China and Tibet: at the Lena it becomes more rare, and beyond that it is much lower, with a more slender flower and narrower leaves. (Pallas.)

R. Camtschaticum is an elegant evergreen under shrub; it grows abundantly in the peninsula of Kamtchatka and Behring's island in muddy places on the mountains.

$R$. caucasicum is a native of the higher rocks of Caucasus, near the perpetual ice, in the highest range of shrubby vegetation, with Myrtillus and Vitis idæa.

$R$. chrysanthum is a beautiful evergreen, resembling $R$. dauricum, and like it is a native of the aipine regions of Siberia, where it is a noted remedy for rheumatism. It is cultivated in this country with the 
5919 Leaves linear revolute at edge beneath downy

5920 Leaves oblong revolute at edge beneath downy, Flowers about pentandrous 5921 Leaves ovate oblong flat smooth

\section{The only species}

5923 Leaves smooth leprous beneath, Corolla funnel-shaped

5924 Leaves elliptical acute ciliated dotted beneath, Corolla funnel-shaped

5925 Leaves smooth dotted naked, Corolla rotate

5926 Leaves ciliate nerved, Corollas rotate, Calyxes leafy

5927 Leaves elliptical acute glandular ciliated naked, Cor. rotate, Petals obtuse

5927 Leaves elliptical acute gland uinn beneath, Umb terminal, Cor rotate, Petals roundish

5928 Leaves scabrous rusty with down beneath, Umboth, Umbels terminal, Cor. rotate, Pet. obovate irregular 5930 Leaves oblong smooth beneath dotted with resin, Umbels terminal, Cor. funnel-formed

5931 Leaves oblong glabrous discolored beneath, Umb. terminal, Cor. rotate, Petals roundish

$\beta$ Leaves cuneate-lanceolate flat

$\beta$ Leaves cuneate-lanceolate flat Learger oblong-elliptical flattish

$593^{2}$ Leaves larger oblong-elliptical flattish

5933 Leaves oblong smooth : of the same color on both sides, Corymbs terminal, Cor. campan. rotate

5934. Leaves lanceolate acute silvery beneath, Flowers clustered campanulate, Calyxes woolly 5935 Leaves thin rugose lanceolate smooth subdeciduous

5936 Leaves oval coriaceous glaucous beneath

5937 Leaves cordate ovate entire, Cor. cylindrical

5938 Leaves imbricated subulate smooth, Pedunc. solitary terminal, Cor. globose-campanulate 5939 Pedunc. aggregate on the branches, Cor. ovate cylindrical, Leaves oblong-ovate entire deciduous

5940 Pedunc. aggregate axillary, Cur. globose, Leaves ellipt. entire beneath mealy scaly

5941 Arborescent, Ivs. coriaceous cuneate-lanc. acute entire with downy scales beneath, Fl.-stalks scurfy rusty 5942 Pedunc. aggregate, Cor. ovate transparent, Lvs. altern. broad lanc. obtuse entire cinereous beneath 5943 Pedunc. aggregate, Cor. globose campanulate, Leaves oval subserrate shining

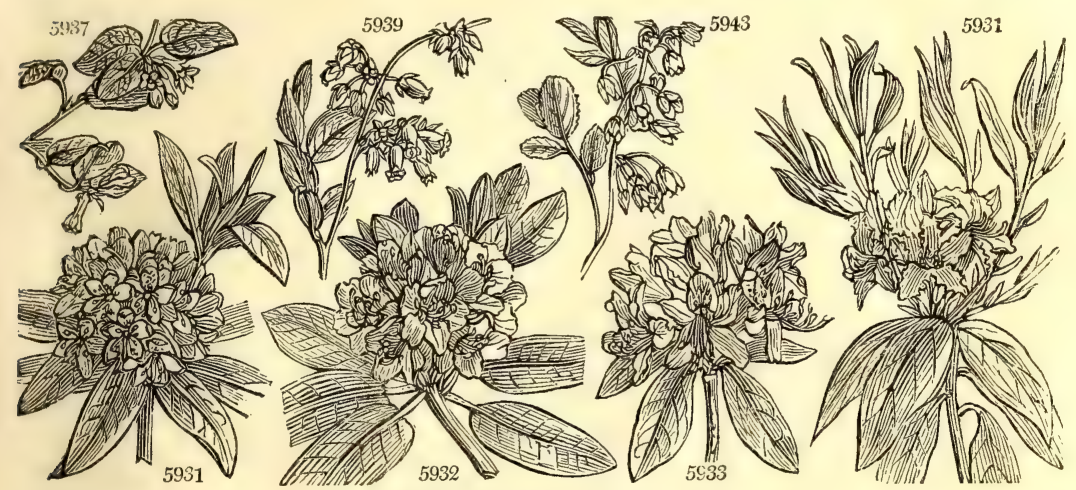

and Miscellaneous Particulars.

greatest difficulty. The leaves have an austere, astringent, bitterish taste, and are stimulant, narcotic, and diaphoretic. When taken, they first increase the arterial action and the heat of the body, producing diaphoresis; and these effects, according to Dr. Home's observations, are followed by a proportional diminution of excitement, the pulse in one case having been reduced thirty-eight beats. It has not been much used in this country. (Thomson's London Dispensatory, 477.)

R. maximum grows on rocks and in barren soils, where it continues flowering great part of the year, and is very ornamental.

R. ponticum grows in wet places in beech and alder coppices, on rocky mountains, but not on high alps.

Rhododendrons are commonly propagated by layers, but some sorts produce seeds, and seeds of others are obtained from America. The seeds "should be sown early in spring, in flat pans or pots of peat soil, and very thinly covered : they may then be set in a close frame, or at the front of a hothouse, till they come up, watering them slightly when dry ; as soon as they are high enough to be laid hold of, they must be pricked out in other pots, which should be placed in a shady situation; they may stand in a frame a few days till they have taken fresh root, but they must not remain long, or it will spoil them. The small kinds may be propagated taken fresh root, but they must not remain long, or it will spoil them. The small kinds may be propagat
freely by cuttings, taken off in the young wood, and planted in sand, under a bell-glass." (Bot. Cult. 815.)

1015. Epigaa. From $\varepsilon \pi t$, upon, and $\gamma \eta$, the earth. The stem grows flat upon the ground, and throws out roots all the length of its branches. A very pretty little American plant with delicate white flowers.

1016. Andromeda. Named in allusion to the virgin Andromeda, who, like this plant, was confined in a marsh, and surrounded by monsters of the waters. For an ingenious explanation of this application, see Linnæus's Flora Lapponica. The species are neat little plants, and some of them considerable shrubs and trees. They all require peat earth, and a moist situation; for those of them which do not grow naturally in bogs are mostly inhabitants of alpine regions, where the air is always more moist than on plains.

A. hypnoides has the appearance of a moss, spreads over great tracts of ground in the Lapland alps, and adorns them with its beautiful red flowers. The Andromeda is generally increased by layers, but may be also raised from seeds. "These must be very thinly covered, as they are small, and would rot if covered deep : 


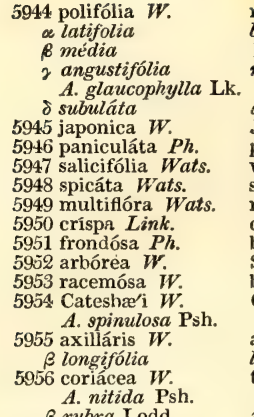

B rubra Lodd.

5957 acumináta $W$.

A. lucida Jacq.

A. populifólia Lam

A. reticuláta Walt.

A. laurina Mich.

5958 floribúnda $P h$.

5959 calyculáta $P h$.

ce ventricósa

$\beta$ latifólia

r nana
5960 angustifólia $P h$.

$\begin{array}{lllll}\text { marsh } & \text { or } & 1 & \text { my.s } & \text { Pk } \\ \text { broad-leaved } & \text { or } & 1 & \text { my.s } & \text { Pk }\end{array}$

Wild Rosemary

narrow-leaved in $_{2}$ or 1 my.s $\mathrm{Pk}$

awl-leaved or 1 my.s Pk

Japan

panicled

spiked

many-flowered

curled

bristly-flowere

Sorrel-tree

branching

Catesby's

axil-flowering

long-leaved

thick-leaved

red-flowered

acute-leaved

Pipe or stem-w.

many-flowered

globe-flowered

broad-leaved

dwarf

narrow-leaved

1017. ENKI A N'THUS. $B$. $\boldsymbol{M}$. ENkIANThUS.

5961 quinqueflóra $B . M$. Canton

1018. GAULTHE'RIA. $W$. Gaultheria.

5962 procúmbens $W$.

1019. AR'BUTUS. $W$. 5963 Unédo $W$

$\beta$ rubra

$\gamma$ plena

¿integrifólia

5964 canariénsis Lam.

5965 Andráchne $W$

5966 alpina $W$.

5967 Uva-ur'si $W$.

trailing iी

Strawberry-Tree.

common

red-flowered

double-flowered

entire-leaved

long-leaved

oriental

black-berried

Bear-berry

5968 phillyré f́ólia P.S. Phyllyrea-leav.

5969 Andrachnoides Link. hybrid A. hybrida B. R.

5970 serratifólia Nois. serrate
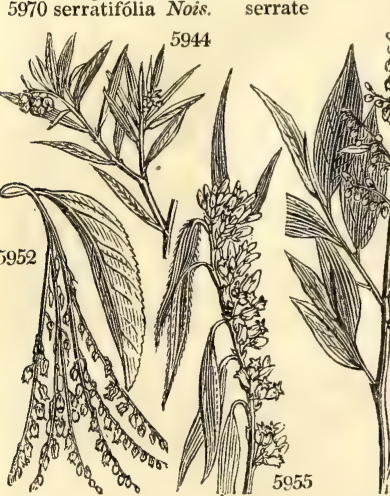

or 3 my.jn W

or $1 \frac{1}{2} \mathrm{f}$.ap

or $1 \frac{1}{2}$ f.ap

cul $\frac{1}{2}$ f.ap

or $3^{\frac{1}{2}}$ fap
W
N $\ddot{\text { Amer... }} \quad \cdots \quad$ L s.p

Britain tur.bo. L s.p Eng. bot. 713

N. Amer. ... L s.p P. ro, 2.t. $70 . f .13$

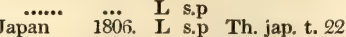

N. Amer. 1748. L s.p Dend. brit. 37

N. Amer. ... I s.p Dend. brit. 38

$\begin{array}{lllll}\text { N. Amer. } & \text {... } & \text { L } & \text { s.p } & \text { Dend. brit. } 38 \\ \text { N. Amer. } & \text {... } & \text { L } & \text { s.p Dend. brit. } 36\end{array}$

$\begin{array}{llll}\text { N. Amer. } & \text {... } & \text { L s.p } & \text { Dend. brit. } 36 \\ \text { N. Amer. } & \ldots & \text { L } & \text { s.p } \\ \text { Dend. brit. } 128\end{array}$

N. Amer. 1824. L s.p

N. Amer. 1806. L s.p

N. Amer. 1752. S s.p Bot. mag. 905

N. Amer. 1736. S s.p

N. Amer, 1793. Sk s.p Bot. mag. 1955

N. Amer. 1765. Sk s.p

N. Amer. ... Sk s.p Bot. mag. 2557

N. Amer. 1765. L s.p Bot. mag. 1095

N. Amer.

Bot. cab. 672

N. Amer. 1765. L s.p Ex. bot. 2. t. 89

N. Amer. 1812. L s.p Bot. mag. 1566 N. Amer. 1748 . L s.p P. ro. 2, t. $72, \mathbf{f} .1$ Russia 1748. I s.p Bot. mag. 1286 Newfoun. 1748. L s.p Bot. cab. 530 N. Amer, $17 \ddot{4} 4 . \quad$ L L s.p

Ericce. Sp. 1?

Ericece. Sp. 1-3.

Ericere. Sp. 8-15.

or $10 \mathrm{s.d}$ W Ireland ir. ro. S co Eng. bot. 2377

or 10 s.d Pk $\quad$ Pk.... $\quad$... $\quad$ L co

or $5 \mathrm{s.d}$ W.G ...... ... L L

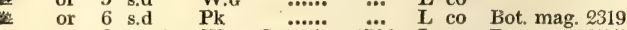

J or 8 my.jn W.G Canaries 1796. L co Bot. mag. 1577

- or 6 mr.ap W.G Levant 1724. G p.1 Bot. reg. 113

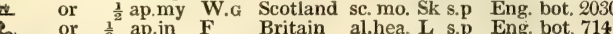

n L J or $\frac{1}{2} \ldots$.... Peru 1812, C s.p

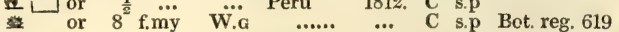

L or 6 f.mr W.G $\quad$...... ... L s.p Bot. cab. 580

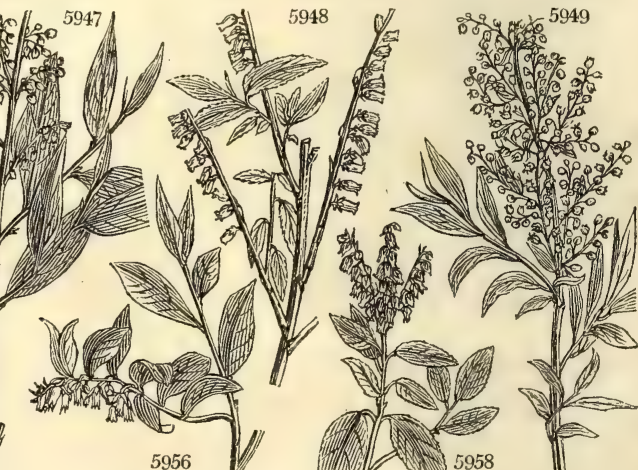

History, Use, Propagation, Culture,

when about an inch high they should be planted out thinly in other pots, where they will grow strong, and, when large enough, may be planted in the open ground. Spring is the best time to plant them out, as the frost and worms are apt to throw them out of the ground in winter, if planted out in autumn. (Bot. Cult. 278.)

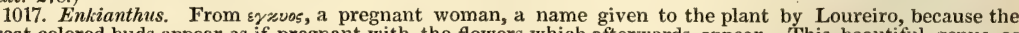
great colored buds appear as if pregnant with the flowers which afterwards appear. This beautiful genus, as Sweet observes, has generally been considered difficult to propagate : the difficulty is now removed, as ripened cuttings root readily planted in pots of sand, and placed under a hand-glass, without bottom heat. The best soil for it is an equal mixture of sandy loam and peat, and care must be taken not to overwater it when not in a growing state : when it gets pretty large it is one of the most ornamental plants for the greenhouse or conservatory. (Bot. Cult. 186.) There are several species confounded under the common name Enkianthus quinqueflora.

1018. Gaultheria. Named after one Gaulthier, a French physician at Quebec. A small evergreen plant, cultivated in the American border for the sake of its ornamental bright scarlet berries. The species may be increased by dividing at the root, by suckers, layers, or from seeds.

1019. Arbutus. An ancient name of this plant, said to be traceable to the Celtic ar boise, austere bush, in allusion to the roughness of the fruit. In like manner Unedo is said by Pliny to have been so called from wnum edo, I eat one, because, being found disagreeable, no one could eat a second. L'Arbousier, Fr., Landbcere, 
5914 Pedunc. aggregate, Cor. ovate, Leaves alternate lanceolate revolute

$\propto$ Leaves oblong

$\beta$ Leaves lanceolate

$\gamma$ Leaves linear-lanceolate

$\delta$ Leaves subulate

5945 Racemes 1-sided panicled terminal, Leaves lanceolate obovate acute serrulate at end

5946 Racemes terminal panicled, Cor. roundish, Leaves ovate entire

5947 Raceme compound, Leaves lanceolate subserrulate hairy shining

5948 Spikes terminal 1-sided, Leaves membranous smooth oval-lanceolate serrulate acute

5949 Raceme compound terminal crowded, Leaves narrow lanceolate rough at edge pilose beneath

5950 Leaves lanceolate wavy beneath rusty scaly, Cor. campan. finally of 5 petals, Anthers awned

5951 Hispid with pubescence, Leaves obov, lanc, acute serrul. Cor, globose hispid, Anthers awned

5952 Panicles terminal, Cor. pubescent, Leaves elliptical acuminate toothletted

5953 Racemes term. simple bracted, Cor. cylindrical, Leaves obl.-lanceolate serrated

5954 Racemes terminal and axillary 1-sided, Cor. ventricose tubular, Leaves oblong lanc. finely serrated

5955 Racemes axillary simple, Cor. oblong, Leaves ovate acute serrulate

5956 Racemes axillary simple, Leaves ovate entire shining, Branchlets 3-cornered

5957 Racemes axillary simple, Leaves ovate lanceolate acuminate serrate

5958 Quite smooth, Leaves obl. ovate acute finely serrulate, Racemes axillary and terminal clustered

5959 Peduncles solitary axillary 1-sided Bractes 2, Leaves oval scaly dotted obsoletely serrated

a Cor. ventricose, Leaves obl. lanceolate

$\beta$ Cor, obl. cylindrical, Leaves oblong oval obtuse

V Very dwarf

5960 Pedunc. solitary axillary, Bractes 2, Leaves narrow oblong lanceolate, Corolla oblong oval

5961 The only species

5962 Leaves oblong obovate mucronate toothed crowded, Stem procumbent

5963 Stem arborescent, Leaves oblong lanceolate, Panicles smooth nodding, Berries many-seeded

5964 Leaves oblong-lanceolate serrated, Panicles vertical hispid glutinous

5965 Stem arborescent, Leaves ovate entire or serrated, Pan. pubescent erect, Berries many-seeded

5966 Stems procumbent, Leaves rugose serrated

5967 Stems procumbent, Leaves entire

5968 Stem much branched, Leaves lanceolate acuminate acutely serrate, Flowers axillary

5969 Bark deciduous, Ovary smooth. The same as next?

5970 Leaves lanceolate serrated very thin a little wavy

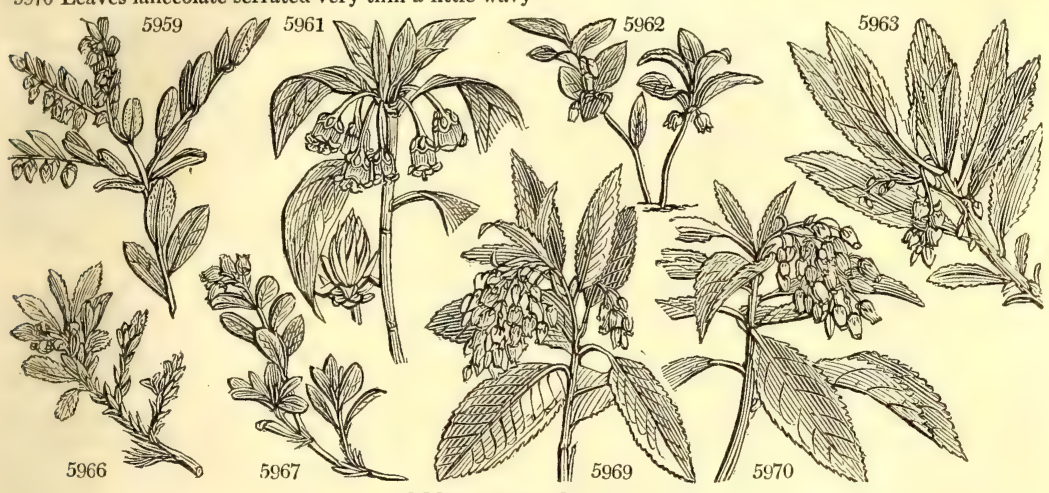

and Miscellaneous Particulars.

Ger., and Arbuto, Ital. This genus includes one of the most elegant of hardy shrubs, the A. unedo. This evergreen is peculiarly beautiful in October and November, covered at once with blossoms and ripe fruits. It is a native of the south of Europe, and is found also near Killarney in Ireland, where it has probably been brought from Spain or Italy at an early period by the priests. It grows there on limestone rocks, in greater luxuriance than it is often to be met with in the woods of Italy : in both countries the fruit is eaten; and in Spain both a sugar and spirit is extracted from it.

A. uva ursi, La Busserole, Fr., Barrenbeere, Ger., and Uva d'orzo, Ital., is abundant in many parts of the continent, especially the alpine regions. It dyes an ash color ; tans leather; the berries are food for grouse and other game, and the leaves are used in medicine. The fresh leaves are inodorous, and have a slightly bitter astringent taste, leaving a sweet sensation in the mouth. When properly dried and powdered, they acquire an odour similar to that of hyson tea; but the taste remains the same, the degree of bitterness only being increased. (Thomson's London Dispensatory, 163.)

It is used sometimes in calculous complaints and ulcerations of the urinary organs.

The dwarf species of this genus and those of Rhododendron and Andromeda, are very fit plants for rock work. A. alpina thrives best in peat kept moist and shaded. All the species may be increased by seeds, or by budding and inarching on each other: the dwarf kinds root readily by layers.

The Uva ursi has been brought into notice in modern times as an efficient remedy in nephritic and even in calculous cases. European practitioners have doubted its powers, but it has found many supporters of respec- 
1020. CLE'THRA. W. 5971 alnifólia $P h$.

5972 tomentósa $P h$.

5973 scábra $P h$.

5974 paniculáta $W$

5975 acumináta $P h$

5976 arbórea $W$.

e minor

1021. MYLOCA'RYU 5977 ligustrinum $P h$.

1022, PY'ROLA. $W$ :

5978 rotundifólia $W$

5979 média $E$. $B$.

5980 minor $W$.

5981 secúnda $W$.

5982 rósea $E . B$.

5983 uniflóra $W$.

1023. CHIMA'PHILA.

5984 maculáta $P h$

5985 corymbósa $P h$. $P$ ýrola umbelláta $\mathrm{B}$. $\mathrm{M}$

5986 édulis $W$.

102.5. STY'RAX. $W$

5987 officinále $W$

5988 grandifolium $W$

5989 pulveruléntum

5990 lævigátum $W$. S. glabrum Cav.

1026. JUSSI $\mathbb{E}^{\prime} \mathbf{A} 、 \boldsymbol{W}$ 5991 grandiflóra $W$ 5992 suffruticósa $W$ 5993 octoválvis $P$. S 5994 erécta $W$

5995 scábra $W . e n$

1027. GETO'NIA. Roxb. tall
Ericea. $S p .6-8$.

Alder-leaved 传 or 4 au.o W N. Amer. 1731. L s.p Lam. ill, t. 369

$\begin{array}{llllll}\text { woolly-leaved } & \text { or } & 4 & \text { au.o } & \text { W } & \text { N. Amer. 1731. L s.p Dend. brit. } 39\end{array}$ rough-leaved panicled

acute-leaved

tree

dwarf

4 au.o

au.o

W Georgia 1806 .

W N. Amer. 1770 . L s.p

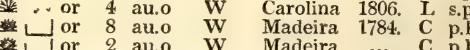

a or 2 au.o W Madeira ...

Privet. BuckWheat-Tree. Ericece. Sp. 1

Privet-like _or 8 my.jn W Georgia ... L p.l Bot. mag. 1625 Winter-Green. $\quad$ Ericece. Sp. 6-10.

round-leaved $\forall \mathrm{cu}{ }^{\frac{1}{3}} \mathrm{jn} . \mathrm{jl} \quad \mathrm{W}$ Britain woods. C s.p Eng. bot. 213 intermediate $\Delta$ cu $\frac{1}{3}$ jn.jl W England woods. C s.p Eng bot. 1945 lesser $\Delta$ cu ${ }^{\frac{1}{3}} \mathrm{jn} . \mathrm{jl} \quad \mathrm{R}$ Britain moi.w. C s.p Eng. bot. 158 serrated $\Delta$ cu $\frac{1}{3}$ jn.jl W Britain moi. w. C s.p Eng. bot. 517 rose-colored $\Delta$ cu ${ }^{\frac{1}{3} \text { jl.au }}$ Pk England woods. C s.p Eng. bot. 2543 single-flowered $\Delta \mathrm{cu} \quad \frac{1}{6}$ jn.jl W Britain al, wo. C s.p Eng. bot. $1+6$

Chimaphila. Ericea. Sp. 2.

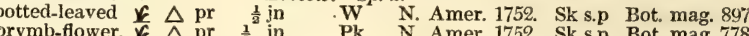

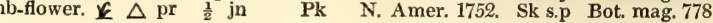

Otaheite-Chestnut. Sapotece. $S p .1$.

Storax. officinal powdery smooth

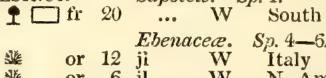

$\begin{array}{llll}\text { 画 } & \text { or } & 12 & \mathrm{ji} \\ \text { or } & 6 & \mathrm{jl} \\ \text { or } & 4 & \mathrm{jl}\end{array}$
6 W N. Amer, 1765. I, s.l Bot. rep. 631 or 4 jn.jl W N. Amer. 1794. L s.l Dend. brit. 41

\section{Jussixa.} great-ffowered $\Delta$ or spear-leaved upright

GeTONIA.

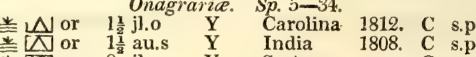

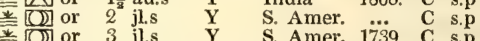
D or 4 jl.s $\quad$ Y $\quad$ S. Amer. 1739. C s.p Pl. ic. t. 175. f. 2

S. Amer. 1816. C s.p Combretacece. Sp. 1-2.

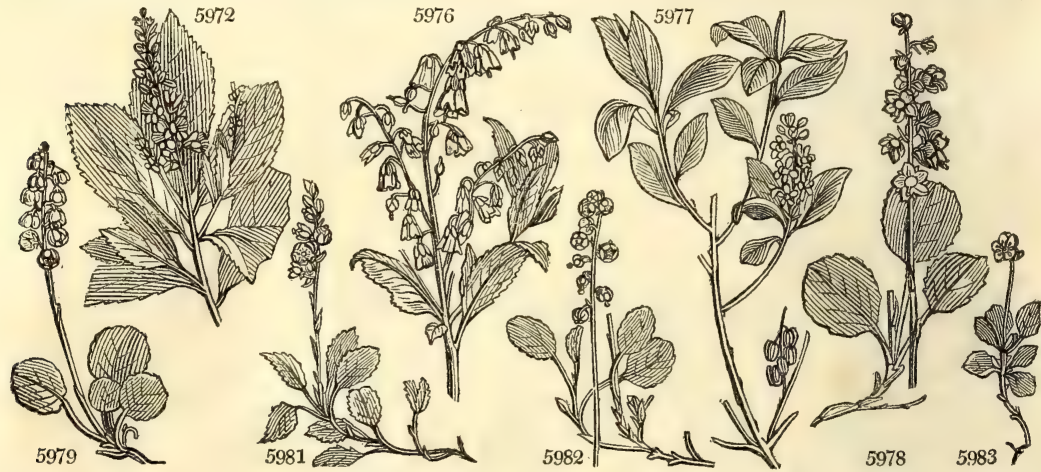

History, Use, Propagation, Culture,

tability in North America. The late professor Barton found the plant of much service in his own case of nephritic paroxysms alternating with gout in the feet. It has also been recommended as a remedy in pulmonary complaints. (See Bigelow's Med, Botany.)

1020. Clethra. King eas was the name given by the Greeks to the Alder, to which, in its leaves, this bears some resemblance. Pretty upright North American plants, with white flowers. One species is a native of Madeira.

1021. Mylocaryum. From $\mu \nu \lambda \eta$, a mill, and zoeva, a kernel or stone; the four wings of the nut may be easily likened to the four sails of a small mill. A North American plant, with the habit of Andromeda, or rather of Clethra.

1022. Pyrola. A diminution of Pyrus, to which, in the leaves, this is thought to be similar. A genus of elegant little plants, mostly evergreens. They grow naturally in the shade, and in rocky or very poor soils; in the garden on sand or gravel shaded; and they are increased by seeds or young cuttings, planted under a handglass. All the species are powerfully astringent and tonic, and one or more of the American sorts is said to constitute the chief ingredient in the scorbutic draughts of Whitlaw.

P. uniflora, Sir J. E. Smith says is one of the most curious and elegant of British flowers.

1023. Chimaphila. From xsine, winter, and $\varnothing i \lambda \varepsilon \omega$, to love; a sort of translation of the English name winter-green. The species may be treated as Pyrola, which they much resemble.

1024. Inocarpus. From is tyos, fibre, and zog ros, fruit. The envelope of the nut is composed of tough interwoven fibres. It is a lofty tree, with alternate subcordate leaves, and flowers in racemes succeeded by by nuts called Rattr in Otaheite. The kernel of these, which is kidney-shaped, and about an inch in diameter, is eaten roasted by the inhabitants of the Society and Friendly Isles, the New Hebrides, New Guinea, the Molucca isles, \&c. It is sweetish, but less plensant than the chesnut, harder and less farinaceous. The bark is astringent, and is used in the dysentery. In New Guinea they smear the heads of their arrows with the expressed resinous juice. (Forst. Escul.)

1025. Styrax. A name altered by the Latins from the Arabic assthirak. Pliny says, that the Arabs in his time used the resin to flavor the perfumes of which they are so fond. S. officinale is a low tree with slender branches, ovate leaves, flowers in racemes from the sides of the branches, succeeded by ovate globular juiceless drupes, containing one or two angular nuts. From this tree storax is obtained in Asiatic Turkey. It issues from incisions made in the bark ; and as it was formerly the custom to collect and export it in reeds, it was named Styrax calamita It has a fragrant od sur, and a pleasant subacidulous, slightly pungent, and 
5971 Leaves obovate serrate beneath pubescent, Raceme simple bracted

5972 Leaves cuneate obovate acute upwards finely serrated beneath white with down

5973 Leaves broad cuneate obovate acute coarsely serrated rough on each side

5974 Leaves lanceolate obovate serrated smooth, Panicle narrow bracted

5975 Leaves oval acuminate smooth on each side glaucous beneath, Racemes white with down

5976 Leaves oblong acuminate serrated smooth, Racemes panicled, Peduncles hairy

5977 Leaves cuneate lanceolate acute, Racemes spiked terminal

5978 Stamens ascending, Style declinate, Raceme many-flowered

5979 Stamens straight, Style declinate long, Peduncle twisted, Raceme many-flowered

5980 Stamens and styles straight, Flowers racemose spreading

5981 Raceme 1-sided

5982 Stamens and styles straight, Flowers racemose closed, Petals rounded obtuse, Peduncle straight,

5983 Peduncle 1-flowered

5984 Peduncles 2-flowered

5985 Peduncles umbelled

5986 The only species

5987 Leaves ovate beneath villous, Racemes simple shorter than the leaf

5988 Leaves obovate villous beneath, Lower peduncles axillary solitary 1-flowered

5989 Leaves subsessile oval or obovate beneath powdery, Fl. axill. and term. in threes on short stalks

5 y90 Leaves oblong smooth on each side, Peduncles axillary 1-flowered solitary or twin

5991 Root creeping, Stems erect with peduncles and calyxes villous, Lower leaves spatulate upper lanceol.te 5992 Erect villous, Flowers tetrapetalous octandrous stalked

5993 Erect, Flowers tetrapetalous octandrous stalked, Caps. many-valved, Leaves lanceolate

5994 Erect smooth, Flowers tetrapetalous octandrous sessile

5995 Flowers tetrapetalous octandrous, Stem erect angul. hairy, Leaves oblong hairy

5996 Leaves opposite ovate, Flowers panicled, Bractes lanceolate

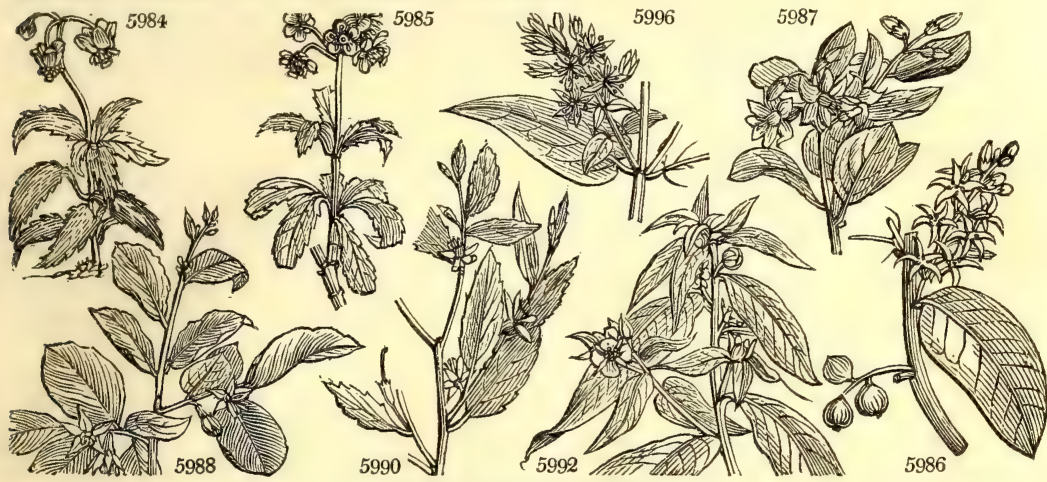

and Miscellaneous Particulars.

aromatic taste; is stimulant, and in some degree expectorant. It was formerly much prescribed in asthma, catarrh, phthisis, and menstrual obstructions; but it is now scarcely ever employed, except as an adjunct on account of its fragrance.

Benzoin is obtained from the S. Benzoin, by wounding the bark near the origin of the lower branches. The

tree is never wounded under six years of age; and cannot sustain these annual incisions above twelve years. (Thomson's London Dispensatory, 525.)

As shrubs this genus affords some plants that may be considered pretty and desirable, on account of their small size and free flowering. They grow best in sandy loam, are commonly propagated by layers, and may dlso be increased by seeds, which they occasionally ripen.

1026. Jussicea. An obscure and most uninteresting genus of plants, selected, not very happily, to commemorate the family of the Jussieus, which has for more than a century and a half been at the head of botanical science. Antoine de Jussieu, born in 1686, and died in 1758, was professor of botany at the Jardin du Roi, and member of the academy of sciences. He published various papers upon exotic plants, and a discourse upon the progress of botany. He also edited the works of Barrelier. Bernard de Jussieu, his brother, born in 1698, died in 1777, was professor at the same garden, and member of the same academy. He also was author of various papers upon plants, a second edition of Tournefort's History of the Plants growing near Paris, and an arrangement of the plants growing in the garden of 'Trianon, which was published by his nephew. Joseph de Jussieu, a third brother, born in 1704 , and died 1779 . He was sent to South America by Louis XV., and remained there for six and thirty years. He made many discoveries, and brought home many new plants. Lastly, Antoine Laurent de Jussieu, their nephew, born in 1748, and still living, as demonstrator of botany at the Jardin du Roi, member of the Institute and of every learned body in Europe. He brought, in his Genera Plantarum, published in 1789, to a degree of extraordinary perfection, that system, the outlines of which had been traced by the hand of Tournefort, and partially filled up by his uncle Bernard. That system has now superseded, among men of science, all others, and if as yet inapplicable to merely popular purposes, can never be dispensed with in all philosophical investigations.

1027. Getonia. A Malabar plant, the meaning of whose name has not been explained. Cuttings root freely in sand, under a hand-glass, and plunged in heat. 
1028. QUisQUA'Lis. $\boldsymbol{W}$. QUisqualis. 5997 indica $W$. Indian

5998 pubéscens Burm. pubescent 5999 áspera $W$. 6000 velutína $W$. 6001 trinérvia $W$. 6002 octándra $W$ $60(0) 3$ tetrándra $W$ 6004 hirta $W$. 6005 Acinodéndron $W$. 6006 cymósa $W$. 6007 rúbra $W$ 6008 purpúrea $W$ 6009 gróssa $W$. 6010 malabáthrica $W$ fol1 corymbósa $H$. $K$. 6012 ecostáta $H . K$. 6013 Tamonéa Aubl. Fothergillia Hort. 6014 álbicans $S w z$ 6015 lævigáta $W$. 6016 díscolor $W$. 6017 nepalénsis Lodd. 6018 heteromálla Don 6019 granulósa Lam.

6020 sanulión 6021 sanguínea Sims. bloody

1030. Petalo MA. $W$. Petaloma. 6022 myrtilloídes Swz. Bilberry-like 1031. ACISANTHE'RA. J. Acisanther 6023 quadráta $\boldsymbol{P}$. S. $\quad$ four-sided 1032. DA'IS. $W$. 6024 cotinifólia $W$. 1033. BUCI'DA. $W$ 6025 Búceras $W$. 1034. SAMY'DA. $W$. 6026 nítida $W$. 6027 pubéscens $W$. 6028 serruláta $W$ 6029 rósea $\boldsymbol{H}$. $\boldsymbol{K}$.

velvetty-leaved three-nerved octandrous hairy

oval-leaved red

purple

large-leaved bristly ribless

Fothergill's

white-leaved smooth two-colored

Nepal

Commerson's

Olive-Bark-Tree.

Jamaica glossy pubescent

Elm-leaved rose-colored

\section{过 or} Dars.
Cotinus-leaved
or 10
jn.jl

Combretacea. Sp, 1-4.

20 my au O.R E Indies 1815, C l.p Bot. mag. 2033 ㅇ.. O.R E. Indies 1815. C 1.p Bur. ind, t. 35.f.2 Melastomacere. Sp. 23-196.

6 au.n P E. Indies 1815, C 1.p Bur, zeyl. t. 72 $\begin{array}{lllll}8 & \text { jl.o } & \mathrm{Pu} & \mathrm{W} \text {. Indies 1815. C } & \text { 1.p }\end{array}$ 8 jl Pu Jamaica 1793. C s.p $\begin{array}{lllllll}3 & \ldots & \text { W } & \text { Ceylon } & 1815 . & \text { C } & \text { l.p } \\ 2 & \ldots & \ldots & \text { Jamaica } & 1815 . & \text { C } & \text { 1.p }\end{array}$

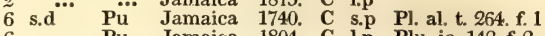

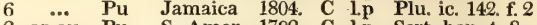
2 ap.au Pu S. Amer. 1792. C 1.p Sert. han. t. 8 6 my.jn Pu Guiana 1793. C s.p Au. gui. 1.t. 161 8 ... Pu Guiana 1804. C 1.p Au. gui. 1.t. 154 2 .... $\quad \ldots \quad$ S. Amer. $\because \ddot{3}$ C $\quad$ l.p mr. Pu E. Indies 1793. C s.p Bot. mag. 529 my.jn $\mathbf{P u}$ S. Leone 1792. C S.p Bot. mag. 904

S. Amer. 1815. C s.p Au. gui. 1.t. 175

... Pu Jamaica 1815. C s.p

... W.G S. Amer. 1815. C s.p Bot. reg. 663

... Pu W. Indies 1793. C s.p Plu. ic. t. 42, f. 1

au Pu Nepal 1820. C p.l Bot. cab. 707

Pu Brazil 1819. C p.l Bot. reg. 644

$\begin{array}{lllll}\mathrm{Pu} & \text { Brazil 1819. } & \text { C } & \text { p.1 } & \text { Bot, reg. } 671 \\ \mathrm{Pu} & \text { Mauritius 1817. } & \text { C } & \text { p.1 } & \text { Bot. mag. } 2235\end{array}$

Pk China 1818. C p.1 Bot. mag. 2241 Melastomacere. Sp. 1-2

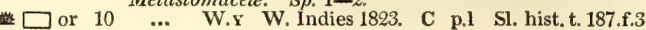
Salicarice. Sp. 1.

... Jamaica 1804. C p.l Br. jam. t. 22. f.1 jn.jl W.G C. G. H.

9 $\square$ ec 25 au.s Y.w Jamaica 1793. C I.p Lam, ill. t. 356 Samydea. Sp. 4-12.

« $\square$ un 7 ... W.G W. Indies 1793, C l.p Br. jam. t. 23, f. a $\square$ un 4 my.au ... W. Indies 1793. C ip Jac. amer. 132 $\square \mathrm{pr} \quad 3 \mathrm{jl} \quad \mathrm{W} \quad$ W. Indies 1723. C s.p Ja. co. 2. t.17.f.1 $\square$ pr 4 jn.jl $\quad$ Pk W. Indies 1793. C s.p Bot. mag. 550

\section{DIGYNIA.}

1035. ROYE'NA. $W$. 6030 lúcida $W$ 6031 villósa $W$ 6032 pállens $W$ 6033 glábra $W$. 6034 pubéscens $W$. en 6035 hirsúta $W$, en. 6036 angustifólia $W$ 0036 angustifoi: 6037 ambígua Vent. 6038 polyándra $W$.

Royena. shining-leaved heart-leaved

pale

pubescent

hairy-leaved

Willow-leaved

obovate-leaved oval-leaved

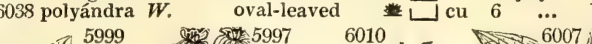

Ebenacea. $S p .9-15$.

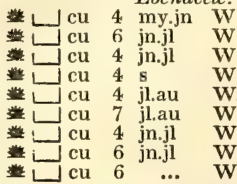

C. G. H. 1690, C p.l La. ill. t. 370.f. 1

C. G. H. 1774. C p.I

C. G. H. 1789. C p.l

W C. G. H. 1731. C 1.p Com. hor. 1.t.65

C. G. H. 1752. C p.l La.ill. t. 370. f. 2

C. G. H. 1789 C

C. G. H. 1815. C p.1 Vent. mal. t. 17 C. G. H. 1774. C p.l 6020

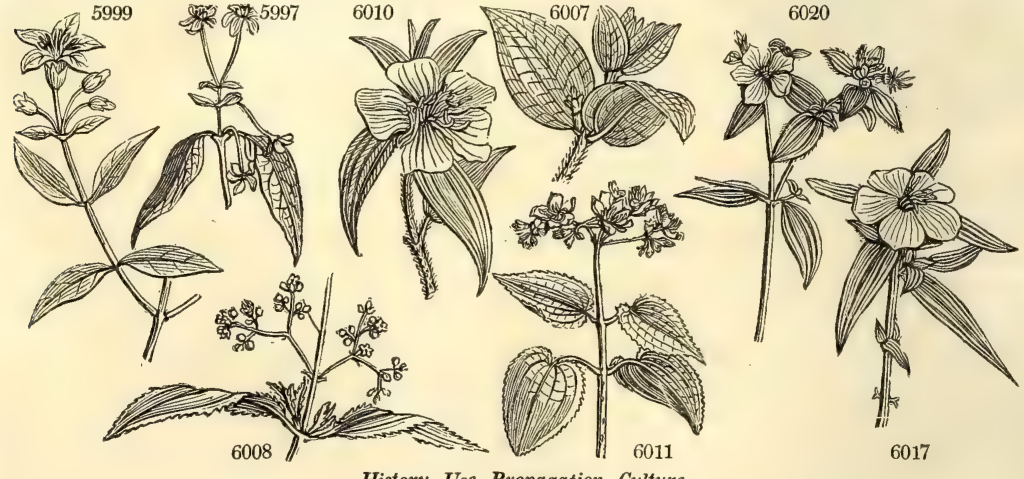

History, Use, Propagation, Culture,

1028. Quisqualis. A Latin word, expressive of uncertainty. It was given by Rumphius to a tree of Amboyna, because it was subject to variation. It is a fine climbing genus of easy culture. The best soil for the species is a mixture of loam and peat; and cuttings root freely in sand, under a hand-glass. (Bot. Cult. 100 .)

1029. Melastoma. From $\mu \varepsilon \lambda \alpha s$, black, and $s \circ \mu \alpha$, mouth. Many of the species produce black berries similar to gooseberries, and which stain the mouth black. This is a very numerous genus of shrubs and low trees; the species display great unity of character, and may be considered ornamental. They require but little water in winter, and are easily increased in sand, plunged in a moist heat.

1030. Petaloma. From $\pi \varepsilon \tau \alpha \lambda \omega y$, a petal, and $\lambda \omega \mu \alpha$, an edge. Flowers of which the petals are inserted on the edge of the calyx. A small plant with the leaves, but not flowers, of Melastoma.

1031. Acisanthera. From axis, a point, the anthers being pointed. Plants with the habit of Melastoma. 
5997 Leaves ovate

5998 Leaves subcordate pubescent

5999 Leaves ovate-lanc. entire 3-nerved rough, Fl. terminal subcorymbose

6000 Leaves 3.nerved entire sessile ovate acute villous silky, Racemes brachiate, Stems square

6001 Leaves 3-nerved without a marginal one entire smooth on each side thin, Racemes term. Fls. sessiie

6002 Leaves entire 3-nerved ovate-lanc. smooth, Margin and nerves hispid beneath, Fl. terminal

6003 Leaves entire 3-nerved oblong emarginate at base, Raceme erect term. Fl. tetrandrous

6004 Leaves toothletted 5-nerved ovate-lanceolate, Stem hispid

6005 Leaves ovate acuminate toothletted 5-nerved, Cymes axillary

6006 Leaves cordate acumin. 5-nerved serrulate pubescent, Cymes terminal, Sepals roundish, Stamens 5 sterile

6007 Leaves cordate subcrenate beneath rusty with down, Flowers axillary and lateral solitary sessile

6008 Leaves ovate lanceolate acuminate 5-nerved pilose somewhat toothletted, Branches bifid, Panic. term.

6009 Leaves entire 5-nerved subcordate scabrous, Cor. little hairy outside

6010 Leaves entire 5-nerved lanceolate ovate rough

6011 Leaves 7-nerved ovate subcordate acuminate ciliated with teeth, Corymb terminal, Flowers 1-sided

6012 Leaves 3-nerved without ribs ovate-lanceol. acuminate toothletted, Corymbs term. trichotomous powdery 6013 Leaves 5-nerved obl. lanceol. acute entire hoary beneath, Pedunc. umbelled, Bractes double

6014 Leaves 5-nerved entire ovate acute smooth above beneath hoarv, Flowers clustered sessile 6015 Leaves entire 5-nerved ovate-oblong smoothish acuminate smooth at edge

6016 Leaves 5-nerved nearly entire oblong acuminate smooth beneath yellowish, Racemes cymose

6017 Leaves lanceolate ciliated 3-nerved obtuse at base, Stems square, Flowers terminal solitary

6018 Leaves cordate oval entire stalked beneath woolly, Petals obcordate, Petals bowed at base

6019 Branches winged, Leaves oval-lancecl. with a long point, Petals obovate pointed, Filam. woollv above

6020 Leaves oblong elliptical 3-nerved ciliated, Calyx setose at end

6021 Stamens 12, Leaves ovate-lanceolate 5-nerved, Stems and globose ovaries very hispid

6022 Peduncles solitary 1-flowered

6023 Leaves 3-nerved ovate crenate opposite

6024 Leaves obovate obtuse, Flowers 5-cleft decandrous

6025 Spikes elongated, Leaves wedge-shaped smooth

6026 Flowers octandrous, Leaves cordate smooth

6027 Flowers dodecandrous, Leaves ovate downy beneath

6028 Flowers 12-androus, Leaves ovate oblong serrulate

6029 Flowers 12-androus clustered, Leaves oblong obtuse serrated pubescent on each side

\section{DIGYNIA.}

6030 Leaves ovate roughish

6031 Leaves cordate oblong downy beneath

6032 Leaves oblong obovate obtuse smooth

6033 Leaves lanceolate smooth

6034 Leaves obovate lanceolate pubescent

6035 Leaves oblong lanceolate very villous

6036 Leaves lanceolate acute hairy beneath

6037 Leaves obovate villous coriaceous, Fl. stalked polyandrous polygynous

6038 Leaves elliptical, Flowers polyandrous polygynous

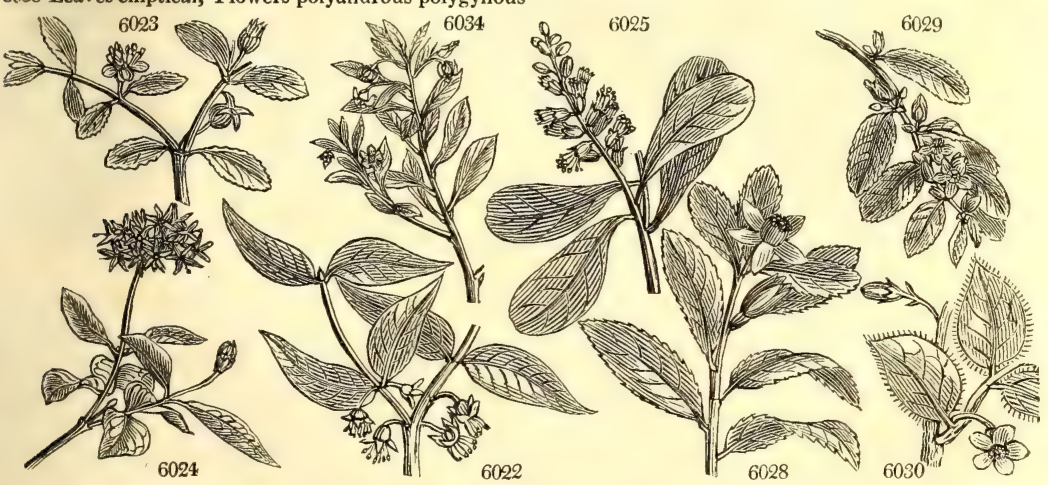

and Miscellaneous Particulars.

1032. Dais. A name of unknown application. The plant resembles in its leaves the Rhus cotinus, whence its specific name. It may be increased by cuttings of the roots placed in a warm situation

1038. Bucida. From $\beta y_{5}$, an ox. The form of the fruit when ripe resembles the horn of such an animal. This tree grows in Jamaica in low swampy lands near the coast; it is remarkable for its slender crooked branches, and the tufted disposition of the leaves: it grows to a considerable size, is reckened an excellent timber tree, and the bark is greatly esteemed by the tanners.

Well ripened cuttings root in sand, plunged in heat, and covered.

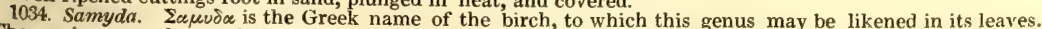

The species are rather tardy in growth, but not difficult to root in sand under a hand-olass.

1035es are rather tardy in growth, but not difficult to root in sand under a hand-glass.

1035. Royena. So named by Linnæus, in honor of Adrian Van Royen, who with his son David wera successively professors of botany at Leyden. It consists of shrubs of little beauty, which are increased by ripened cuttings in sand under a hand_glass. They are chiefly natives of the Cape of Good Hope. 
1036. TRIAN'THEMA. $W$. TriantheMA. 6039 monógyna 6040 decándra $W$ Purslane-leav. $*[0] \mathrm{w}$ trailing

1037. SCLERAN'THUS. $W$. KNAWEL

6041 ánnuus $W$. annual

6042 perénnis $\dot{W}$. perennial

1038. CUNO NIA. $\boldsymbol{W}$.

6043 capénsis $W$.

Cunonia.

Cape I L

1039. HYDRAN'GEA. $W$. HYDRANGEA.

6044 arborés. GEA.

6045 cordáta $P h$.

6046 nivea $P h$. radiata W.

6047 quercifólia $W$

6048 horténsis $W$.
Portulacea. Sp. 2-12.

2 jl.au G Jamaica 1710. S co Plant. grass, 109 $1 \frac{1}{2}$ jl.au G India 1762. S co Bur, in t. 31 f.3

Portulacee. $S p .2-3$.

w $\frac{1}{8}$ jl.au G Britain sa.fi. S co Eng. bot. 351

$\triangle$ w $\frac{1}{2}$ au.s G Britain sa.hea. D co Eng. bot. 352

Cunoniacea. Sp. 1-2?

W. HYdRANGEA. Saxifragea? Sp. 5.

heart-leaved $\quad$ or 6 jl.au W.G Virginia 1736. L p.l Bot. mag. 437 white-leaved or 8 jl.au W.G Carolina 1806. L p.l Dend. brit. 42

Oak-leaved 震 or 4 jn.s W.G Florida 1803. C p.l Bot. mag. 975

1040. CHRYSOSPLE'NiUM. $W$. Golden Saxifrage. Saxifragea. Sp. 2.

6049 alternifólium $W$. alternate-leav. $\Delta$ cu $\frac{2}{4}$ ap.my Y Britain w.sh.p. D m.1 Eng. bot. 54

f050 oppositifólium $W$. opposite-leaved $\Delta$ cu $\frac{1}{4}$ ap.my $\mathbf{Y}$ Britain w.sh.p. D m.1 Eng. bot. 490

1041. SAXI'FRAGA. W. Saxifrage 6051 liguláta Wall

6052 crassifólia $W$

6053 cordifólia $M$. $n$.

6054 Cotylédon $W$.

6055 récta $P . S$.

6056 Aizóon 'P

6057 intácta $W$. en.

6058 mutáta $W$. en

6059 pensylvánica $W$

6060 hieracifólia $W$

6061 erósa $P h$.

6062 punctáta $W$.

6063 umbrósa $W$

6064 hirsúta $W$.

6065 Géum $W$

6066 cuneifólia $W$

SaXifracie.
ligulate

thick-leaved $\triangle$ or 1 mr.my P Siberia 1765. D s.1 Bot. 1 .

eaved

$\checkmark \Delta$ or 1 mr.my $\mathrm{P}$ Siberia 1779. D s.l

$\triangle$ or $\tilde{z}$ my.jl W.G Al. of Eur.1596. D s.l Fl dan. 241

large-margined $F$ or 1 my ji W. A s.l Pl. ph.t.221. f. 1

small-margined ff $\triangle$ or 1 my.jl W.G Tyrol ... D s.1 Hort. ber. 2. t.75

Saffron-colored $\triangle$ or ${ }^{\frac{1}{2} \mathrm{jn} . \mathrm{jl}}$ L.Y Switzerl. 1779. $\mathrm{D}$ s.1 Bot. mag. 351

Pensylvanian $\Delta$ or 2 my.jn G.Y N. Amer. 1732. D s 1 Di. el.t.253.f.328

Hawkweed-lvd. $\Delta$ or 2 my.jn W.G Hungary 1789. D s.l Pl. rar. h. 1.t.18

jagged-leaved $\Delta$ or 1 my.jn Y.G N. Amer. 1812. D s.l

dotted-flowered $\Delta$ or 1 my.jn W Siberia 1699 D s.l Mo.h. 3.t. 17

London-pride $\triangle$ or 1 ap.jn $F$ Britain mount, $D$ s.l Eng, bot. 663

hirsute $\quad \Delta$ or 1 my.jn $\mathbf{F}$ Ireland ir.mou. D s.l Eng. bot. 2322

$\begin{array}{lllllll}\text { hirsute } & \text { or } & 1 & \text { my.jn } & \text { F } & \text { Ireland ir.mou. D s.l } & \text { Eng. bot. 2322 } \\ \text { kidney-leaved } & \Delta \text { or } & 1 & \text { jn.jl } & \text { W } & \text { Ireland ir.mou. D s.l } & \text { Eng. bot. 1561 }\end{array}$

wedge-leaved

(Stock-leaved

6068 sarmentosa $W$

Chinese

6059 cuscutifórmis Lodd. Dodder-like

6070 virginiénsis $P h$.

6071 congésta Sweet

Virginian

Ireland ir.mou. D s.l Eng. bot. 1561
Switzerl. 1768 . D s.l

F $\triangle$ or $\frac{a^{\frac{3}{4}} \mathrm{jn}}{\mathrm{f} n} \mathrm{~W}$. Amer. 1812. D s.1

\& $\triangle$ or 2 jn.jl W.R China 1771. D s.l Bot. maz. $\varsigma 2$

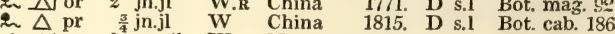
nivális $\mathbf{P h}$.

close-flowered $\frac{1}{\Delta}$ or or ${ }^{\frac{1}{2}}$ my.jl W $\quad$ W. N Amer. 1790. D s.1

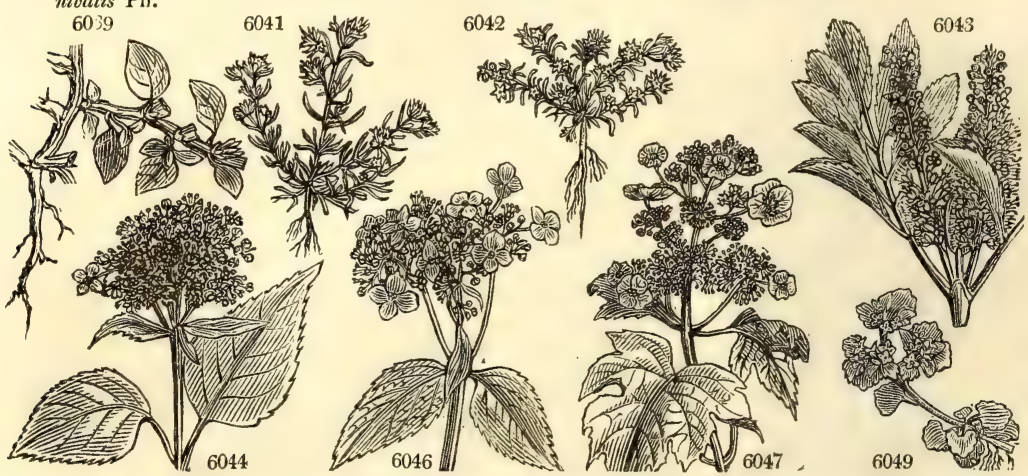

History, Use, Propagation, Culture,

1036. Trianthema. From ress, three, and ay. Tos, flower; the flowers growing by threes in the axillac of the leaves The species are weeds in their natuve countries, and of little interest here

1037. Scleranthus. From $\sigma * \lambda$ n appear very much indurated. S. annuus is common throughout Europe and Siberia on a sandy soil. It flowers about the middle of summer, and sows its seeds very abundantly in autumn, which produce a crop of young plants that generally survive the winter, or, if destroyed, are replaced by another crop arising from those seeds that happen not to vegetate till spring. (Eng. Bot.) The Swedes and Germans receive the vapour arising from a decoction of it into their mouths, to cure the tooth-ache. (Withering.)

S. perennis in several parts of Europe has its roots attacked by the insect Coccus Polonicus, Lin. which yields a fine crimson dye, and is said likewise to live on S. annuus and some Potentillæ. Sir J. Smith has " never been able to find this insect on these plants in England." (F'ora Brit. ii. 283.)

These two species are occasionally found in abundance upon barren heathy wastes.

1038. Cunonia. In memory of John Christian Cuno, of Amsterdam, who described his own garden in Dutch verse in 1750. This is a handsome tree, with fine shining green foliage, contrasted by numerous dense elongated branches of small milk-white flowers, and twigs of a red color: having the habit of a tropical rather than of a Cape plant. Its colonial name is Rood Elze (red alder), although the tree has not in any point of view the least resemblance to the alder of Europe.

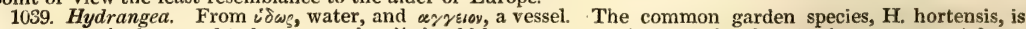
quite a marsh plant, and to be managed well should have a very copious supply of water in summer. A large plant wili consume ten or twelve gallons daily, in warm weather.

H. quercifolia is an elegant plant when in leaf; but as it is barely within the limits of ligneous plants, it dies down to the ground on the approach of frost. $H$. hortensis is much valued on account of the great profusion of its very elegant flowers, which are monstrous in the same manner as the viburnum opulus. It has never 
6039 Flowers pentandrous monogynous

6040 Flowers about decandrous digynous

6041 Calyx of fruit spreading

6042 Calyx of fruit closed

\section{The only certain species}

6044 Cymes naked, Leaves oblong ovate acuminate toothed smooth 6045 Cymes radiate, Leaves cordate toothed

6046 Leaves ovate acuminate toothed beneath white with down, Serratures mucronate

6047 Cymes radiate, Leaves oblong sinuate-lobed toothed

6048 Cymes radiate, Leaves elliptical narrowed at each end toothed smooth

6049 Leaves alternate

6050 Leaves opposite roundish hairy, Stems decumbent

6051 Leaves orbiculate or oval stalked pimpled ciliate cordate at base, Petals round, Sepals mucronate

6052 Leaves oval retuse obsoletely serrated stalked, Stem naked, Panicle bearded

6053 Leaves cordate orbicular serrated stalked, Panicle headed

6054 Leaves radical ligulate with cartilaginous teeth, Stem panicled leafy, Cal. hairy with glancls

6055 Radical leaves rosed straight glaucous supine crenate, Panicle simple

6056 Leaves radical lingulate with cartilag. teeth, Stem simple racemose leafy, Cal. smooth

6057 Radical leaves aggreg. lanc. obov. with cartilaginous teeth, Stem leafy clammy, Calyxes glandular

6058 Leaves rad. lingulate with a cartilaginous repand edge, Stem racemose leafy, Cal. with gland. hairs

6059 Leaves obl. lanc. hairy toothletted, Stem naked, Peduncles alternate in corymbose heads

6060 Leaves obl. lanc. smooth repand toothed, Stem naked, Peduncles 1-flowered aggregate

6061 Smoothish, Leaves oblong-lanc. acute eroded, Stem naked, Panicle oblong

6062 Leaves roundish toothed with long stalks, Stem naked

6063 Leaves obovate retuse with cartilaginous crenæ, Stem naked panicled

6064 Leaves cordate oval retuse with cartilaginous crenæ, Stem naked panicled

6065 Leaves reniform toothed, Stem naked panicled

6066 Leaves cuneiform very obtuse repand, Stem naked panicled

6067 Very hairy, Lvs. elongate spatulate acutely toothed, Stems divaricate dichotomous, Panic. capillary lax 6068 Leaves roundish toothed hairy, Runners creeping, Two petals long

6069 Leaves rhomboid toothed variegated hairy, Runners very weak, Petals nearly equal

6070 Leaves cuneate obovate somewhat toothed shorter than stalk, Stem panicled

6071 Leaves roundish cuneate crenate in front, Stem naked simple, Flowers clustered racemose

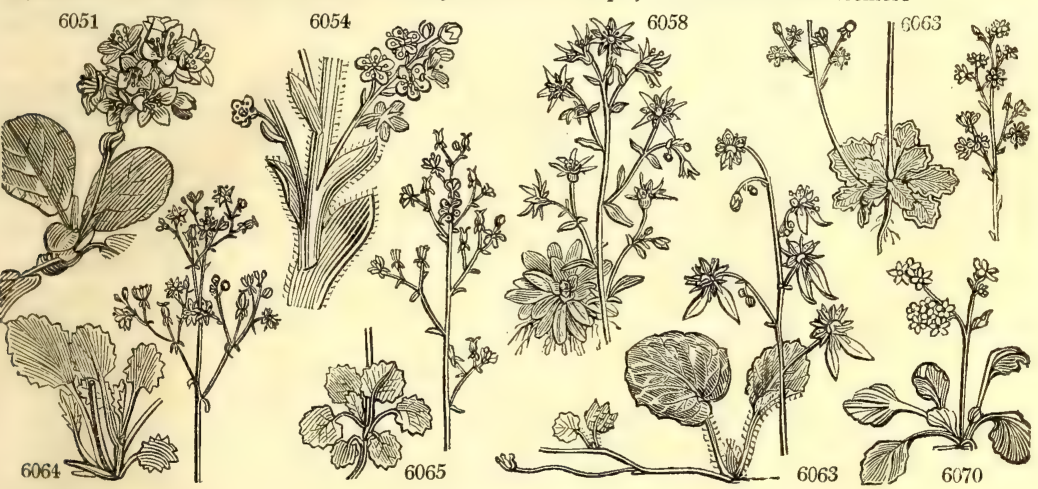

and Miscellaneous Particulars.

been found in a wild state, but is extensively cultivated in the gardens of China and Japan, from whence it was introduced to Kew by Sir Joseph Banks. The flowers are almost always barren; they are naturally of a rose color, but under certain circumstances of culture they become blue. The yellow loam of Hampstead Heath and some other places, and some sorts of peat earth are found to produce this effect; but the cause is not yet ascertained. Dr. Daalen, of Antwerp, finds that turf-ashes, and, still more effectually, those of the Norway spruce, the wood generally used as fuel by him, applied to the roots of Hydrangea, produced the blue color of the petals. (Neil's Hort. Journ. 122.) According to Busch, of Petersburgh, "the hydrangea will be turned blue by watering the young plant, the summer before, with alum water. Our grey colored earth, under the black moor-earth, has the same effect, being combined with aluminous salt." (Hort. Trans. vol, iv, 568 .) Sweet recommends a bed of peat, and says, the longer it remains there the bluer will be the
Howers.

The hydrangea, to flower freely, must not be allowed more than three or four strong shoots from the same root; it must have abundance of pot room, and plenty of water when in flower. It is a good plan to shift the plants twice or oftener during the early part of the season. If plunged and turned out of the pot into an open border in the end of May, they will flower vigorously, and will even stand the winter around and south of London, and flower yearly, and if we!l protected in winter very freely and strongly. The flowers are produced from the extremities of the shoots of the current year.

1040. Chrysosplenium. From $x \rho^{\nu} \sigma \circ s$, gold, and $\sigma \pi \lambda \eta y$, the spleen; a figurative name applied to this plant, with reference to its medicinal qualities. It is said to be a powerful cathartic. In the Vosges the plants are used copiously as a salad, under the name of Cresson de Roche.

1041. Saxifraga. Saxum-frango, to break the stone; a name contrived in reference to supposed medicinal qualities which are now forgotten.

An elegant genus of alpine plants, which have long been favorites in gardens. Many of the species are 
6072 nivalis $W$.

6073 stelláris $\boldsymbol{W}$.

6074 bryoídes $W$

6075 cæ'sia $W$.

6076 androsácea $W$.

6077 oppositifólia $\dot{W}$.

6078 áspera $W$

6079 Hírculus. $W$.

6080 Aizoídes Haw.

6081 autumnális Haw.

6082 rotundifólia $W$.

6083 granuláta $W$.

$$
\text { } \beta \text { pléna }
$$

6084 cérnua $W$.

6085 rivuláris $W$.

6087 pentadáctyla $L a p$

6088 geranioídes $W$.

6089 pedatífida $L . T$.

6090 ceratophýlla $H$. $K$.

6091 ajugifólia $W$.

6092 platypétala $\dot{L}$. $T$.

6093 sibírica $\boldsymbol{W}$.

6094 tridactýlites $W$

6095 petræ'a $W$.

6096 adscéndens $W$

6097 Sternber'gii $W$. en.

6098 hírta $E$. $B$

6099 palmáta $E . B$.

6100 elongélla $L$. $T$.

6101 hypnoides $W$.

6102 moscháta $W$

6103 pygma'a Haw. moscháta E. B.

6104 cæspitósa $W$.

6105 gronlándica $H . K$

6106 muscoídes $W$.

1042. TI AREL'LA. $W$.

6107 cordifólia $P h$.

6108 Menziésii $P h$.

6109 biternáta Vent.

1043. MITEL'LA. $W$.

6110 diphýlla $W$.

6111 cordifólia $P h$.

6112 núda $W$.
clustered-Alp.

thrd.-moss-like $\Delta$ or $\frac{1}{4}$ or ${ }^{\frac{1}{4}} \mathrm{jn} . \mathrm{jl}$

gray

Androsace-lvd.

opposite-leaved

rough

yellow-marsh

smaller-mount.

larger-mount.

round-leaved

grain-rooted

double-flowered

drooping

Alpine-brook

Ivy-leaved

five-fingered

Crane's-bill-lvd.

pedatifid

shining-calyxed

Bugle-leaved

Siberian

Rue-leaved

rock

ascending

large-flowered

hairy

palmate

Jong-stalked

mossy

musky

pigmy

tufted

Greenland

Moss-like

Trarella heart-leaved

leafy-stem

biternate

Mitella

two-leaved

heart-leaved $\vec{\Delta} \Delta \mathrm{pr}$

1 my

1 ap.j

$\frac{1}{\frac{1}{4}} \mathrm{jl}$ jn.jl

$\frac{1}{8} \mathrm{jl}$

r $\triangle$ or or $\frac{1}{4}$ my.jn W

$\triangle$ or $\frac{x}{4}$ my.jn W

$\frac{1}{8}$ mr.ap $\mathrm{Pu}$

$\frac{1}{4}$ au W

$\frac{1}{\frac{1}{2}}$ au jl.au Y

$\frac{1}{2} \mathrm{jl} . \mathrm{au}$

$1 \mathrm{my} . j \mathrm{n}$

$\frac{1}{3}$ my.jn W

$\frac{1}{2}$ ap.my W

$3^{\frac{1}{2}}$ my.jn W

my.jn W

$1^{2}$ jn.jl W

1 jn W

1 my.jn W

$\frac{1}{4}^{\frac{1}{4}}$ ap.my $W$

$\frac{1}{2} \mathrm{my}$ W

1 my W

1 jn $\frac{\text { jn }}{4}$ my.jn W

1 ap.my W

$\begin{array}{lllll}\frac{1}{4} \text { ap.jn } & \text { W } & \text { Britain al. roc. D s.1 } & \text { Eng. bot. 454 } \\ x_{\text {my.jn }} & \text { L.Y } & \text { Pyrenees ... } & \text { D s.1 } & \text { Lapey. fl. t. } 37,38\end{array}$

$\frac{1}{4}$ my.jn W.r Scotland sc. alp. D s.1 Eng. bot. 2314

F $\Delta$ or $\frac{1}{4}$ my.jn $\quad$ Cr $\quad$ Wales w. alp. D s.l Eng. bot. 794

f $\triangle$ or $\frac{1}{2} \mathrm{jl}$ W Pyrenees 1732. D s.l Lapey. f. t. 19

my.jn W.Y Pyrenees ... D s.l Lapey. fl. t. 34

Saxifragea. Sp. 3-10.

$\frac{1}{4}$ ap.my W N. Amer. 1731. D s.p Bot. mag. 1589

1 ap.my W N. Amer, 1812. D s.p

Carolina 1812. D s.p Vent. malm. 54

Saxifragea. Sp. S-10.

$\frac{1}{4}$ ap.my W N. Amer. 1731. D p.l Bot. reg. 166

$\frac{1}{8}$ ap.my W N. Amer. 1812. D p.1 La.ill. t. 373. f. 3

1. jn.au W N. Amer. 1758. D p.l La. ill, t. 373, f. 2

1044. GYPSO PHILA. $W$. GYPSOPHILA.

1044. GYPSO Ptruthium $L$. fleshy-leaved $\& \Delta$ or

6114 fastigiáta $L$.

6115 arenária $W . \& K$.

6116 viscósa Murr.

6117 altíssima $L$

6118 perfoliáta $L$.

6119 acutifólia Fisch.

612) paniculáta $\mathcal{L}$.

6121 glaúca Bieb.

6122 élegans Bieb.

Caryophyllea. $S p .16-36$

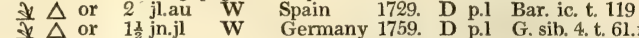

J or 1ijl.au W Hungary 1801. D p.l Pl rar h t. 4i

O or 1 $1 \frac{1}{2} \mathrm{jn} . j \mathrm{l}$ W Levant 1773, s p.l Mur, co, o. 3

upright $\triangle$ or $1 \frac{1}{2}$ jl.au St Siberia 1759. D p.l Gm sib.4.60

perfoliate $\quad \Delta$ or 2 jl.au F Spain 1732. D p.l Dill. elt. t. 276

acute-leaved $\$ \Delta$ or 3 jl.au W.G Siberia 1820. D co

panicled $\$ \triangle$ or 4 jn.jl

glaucous

$\pm \Delta$ or $1 \frac{1}{2} \mathrm{jl}$.s

W Siberia 1759. D p.1

W Caucasus 1822. D co

Jac. au. 5. t. ap.1

legant

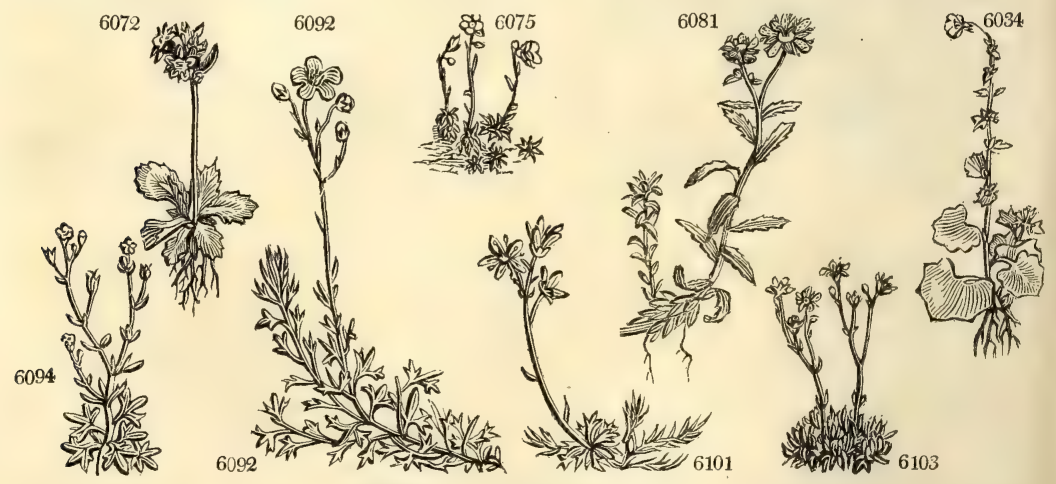

6075

V.pk Crimea 1823. S co Sch. mon.t. 21

History, Use, Propagation, Culture,

quite easy to cultivate, and although naturally mountaineers, not incapable of breathing the more impure air of towns and vallies. The greater part known are delicate and difficult to rear: they are regardless of cold, but suffer from mild and humid weather during the winter months. Most of the species are perennial, with either fibrous or granular roots, and a few are annual. Of the latter one species, S. tridactylites, is common upon very old walls in England, flowering in the beginning of the spring. The parts of fructification are extremely variable in this genus, and have given rise to the construction of many supposed genera, the extremely variable in this genus, and have given rise to the construction of many supposed genera, the
constituents of which have the recommendation of agreeing with one another pretty well in habit. The limits, however, of these genera are too obscure, and the gradations by which they are united so obvious, that they have not yet been adopted by men of science generally. Without interfering with that question, the old mode of considering Saxifrage has been here adhered to, as being the most popular and the best under- 
6072 Leaves obovate crenate subsessile, Stem naked, Flowers headed

6073 Leaves serrate, Stem naked branched, Petals acuminate

6074 Leaves lanc. mucronate with a cartilaginous ciliated edge, Stem naked few-fi. Cal. obtuse

6075 Leaves linear perforated dotted aggregate recurved, Stem many-fl.

6076 Leaves lanc. obtuse hairy, Stem naked 2-flowered

6077 Leaves ovate opposite imbricated : the upper ciliated

6078 Cauline leaves lanc. alternate ciliated, Stems procumbent

6079 Cauline leaves lanc, alternate naked unarmed, Stem erect

6080 Cauline leaves lin. subul. scattered naked unarmed, Stem decumbent

6081 Cauline leaves linear alternate ciliated : radical aggregate

6082 Cauline leaves reniform toothed stalked, Stem panicled

6083 Caulineleaves reniform lobed, Stem branched, Root granular

6084. Cauline leaves palmate stalked, Stem very simple 1-ft. bulbiferous

6085 Cauline leaves palmate : the upper floral ovate, Stem simple about 2-flowered

6086 Cauline leaves ovate lobed, Stem filiform weak

6087 Leaves cuneiform 3-parted with trifid linear segments, Stem simple ascending, Petals lanceolate

6088 Radical leaves reniform 5-lobed many-cleft, Cauline linear, Stem nearly naked branched

6089 Rad. lvs. reniform pedatifid 7-lobed, Caul. palmate and lin. Stem nearly naked branched, Pet. lin. obov 6090 Smooth, Radical leaves 3-lobed, Lobes many-cut ; lateral segments falcate, Stem panicled, Cal. colored 6091 Radic. leaves palm. 5-parted, Cauline linear undivided, Stems ascending many-fl.

6092 Leaves hairy trifid or 5 -fid bearded, Runners procumbent, Stem leafy, Petals obovate rounded

6093 Leaves reniform palm. hairy, Stem and flower-stalks filiform

6094 Caul. leaves wedge-shaped tritid alternate, Stem erect branched

6095 Leaves wedge-shaped, Radic. entire and 3-toothed, Cauline 5-toothed; upper trifid, Pedunc. about 3-f 6096 Leaves palmate 3-parted, Segments subtrifid, Stem branched ascending

6097 Leaves cuneiform palmate 5-fid ciliated longer than the linear petiole, Runners very short tufted

6098 Leaves hairy 3 or 5-parted, Lobes elliptical acute, Runners ascending, Petals obovate 3-nerved

6099 Leaves hairy palmate 5-cleft and trifid, Stem leafy panicled, Petals roundish

6100 Leaves ciliated cuneate trifid nearly 5-cleft, Pedunc. solitary elongate 1-fl.

6101 Cauline leaves lin.entire and trifid, Runners procumbent, Stem erect nearly naked

6102 Radic. leaves aggregate entire and trifid acute linear, Stem viscid nearly racemose, Petals length of cal

6103 Radic. leaves aggregate membranous lin. lanceolate entire or trifid, Stem nearly naked about 2 -f.

6104 Radic. leaves aggr. linear obtuse trifid cut, Stem erect many-fl. Petals twice as long as cal. 6105 Leaves imbric. cuneate-palmate ciliated, Petals round, Styles spreading, Stigmas flat woolly

6106 Radical leaves aggregate entire and trifid oblong obtuse, Stem filiform about 2-fl, Pet. as long as calyx

6107 Leaves cordate acutely lobed toothed, Scape racemose

6108 Leaves ovate cordate acute shortly lobed toothed, Raceme filiform spiked 6109 Leaves biternate

6110 Leaves cordate about 3-iobed toothed, Scape 2-leaved

6111 Leaves orbiculate reniform doubly crenate lucid, Scape setaceous lucid

6112 Ieaves reniform repand ciliated, Scape naked

\section{Calyxes not scaly.}

6113 Flowers clustered, Stems simple roughish, Leaves linear fleshy

6114 Flowers corymbose, Stem ascending, Leaves lanc. lin. obsoletely 3-cornered obt. 1-sided, Stam. exserted 6115 Flowers corymbose, Petals rarely subemarginate, Leaves linear fleshy smooth flat

6116 Flowers corymbose, Branches divaricating, Leaves ovate lanc. smooth at the base cordate amplexicaul 6117 Branches spreading, Flowers panicled small, Pan. much branched, Fl.-stalks viscid

6118 Flowers panicled, Panic. much branched polished, Leaves ovate lanc. half stem-clasping

6119 Fl. trichotomous panicled, Pedunc. villous viscid, Petals emarginate twice as long as calyx

6120 Fl panicled very minute dicecious, Peduncles smooth filiform divaricating, Leaves lin. lanc. rough

6121 Fl panicled, Panic. divaricating, Branches few-flowered pubescent viscid, Leaves lin. lanc. obtuse

6122 Fl. dichotomous, Panic. smooth, Pet. emarg. twice as long as cal. Leaves lanceolate fleshy

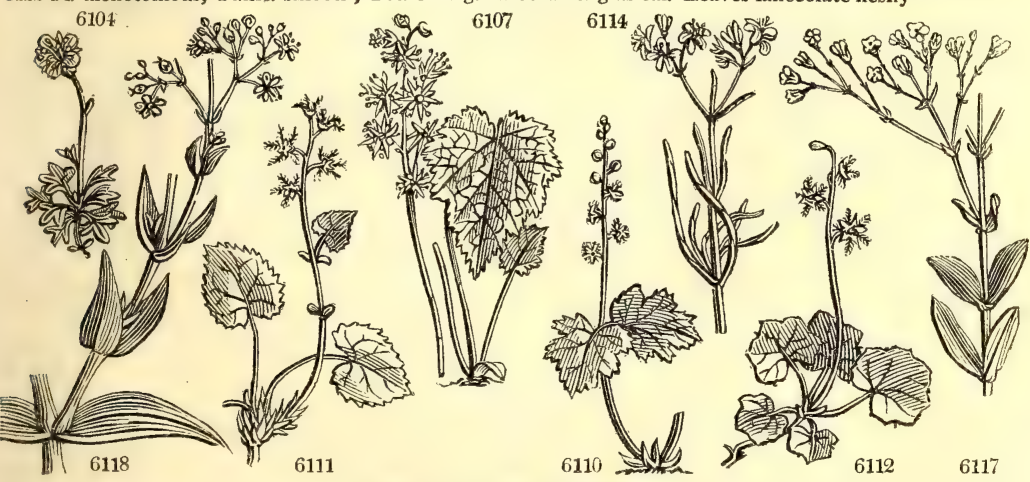

and Miscellaneous Particulars.

stood. The species are subject to great variation in appearance, and to much diversity of opinion among those who profess to be best acquainted with them. A middle course has here been taken, by which the doubtful kinds have been omitted, and those which are recognized, if not defined, satisfactorily, are alone admitted.

1042. Tiarella. From tiara, a particular kind of head-dress, a mitre, in allusion to the form of its capsule. Pretty little North American herbaceous plants, related to saxifrage, and easily cultivated in pots of light andy peat and loam

1043. Mitella. A diminutive of mitra, a mitre; so named for the same reason as the last genus, which it altogether resembles in habit and constitution.

1044. Gypsophila. From qu廿os, chalk, and $\varphi i \lambda \varepsilon \omega$, to love; most of the species delight in chalky districts. 
6123 Stevéni Fisch.

6124 répens $L$.

6125 dúbia $W$.

6126 prostráta $L$

6127 murális $L$.

6128 Saxifraga $L$

$\beta$ rigida Dec.

1045. SAPONA'RIA. $W$. SoAPWORT.

129 officinális $W$

$$
\text { \& plena }
$$

6130 vaccária $W$

6131 pórrigens $\dot{W}$.

6132 ocymoides $\dot{W}$.

6133 orientális $W$.

6134 lútea $W$.
Steven's

creepin

doubtful

trailing

wall

small

\section{common}

double-flowe

perfoliate

hairy

Basil-leaved

small-annual

yellow
\& $\Delta$ or 2 jlau $W$ Iberia 1822. D co

t $\Delta$ or $\frac{1}{2}$ jl.s $\quad$ St Siberia 1774. D p.l Bot. mag. 1448

$\neq \Delta$ or 1 my.s W $\ldots$..... 1815. D p.l

$¥ \Delta$ or $1 \mathrm{jl}$.s W Siberia 1759. D p.l Bot. mag. 1281

\& $\triangle$ or $x$ jn.o F Germany 1739. D s.l La.ill, t. 375. f. 1

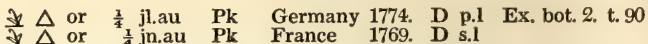

Caryophyllece. $S p, 6-17$.

₹ $\triangle$ or 2 jl.o Pk England hed. D co Eng. bot. 1060

$\triangle$ or 2 jlo

$\mathrm{O}$ or 2 jl au Pk Germany $10.0 \mathrm{~S}$....

O or 1 jl.au Pk Levant 1680. S s.l J. vind. 2. t. 109

$\forall \Delta$ or $\frac{1}{4}$ my.jl $R$ France 1768. R s.p Bot. mag. 154

$\downarrow \Delta$ or 1 jn.au Pk Levant 1732. R s.p Di.el.t.167.f.204

$\pm \Delta$ or $\frac{1}{2}$ jn.au $Y$ Switzerl. 1804. R s.p Smith spic. t. 5

1046. DIANTHUS. $W$.

6136 diminutus $L$. $\quad$ small-flowered

Caryophyllea. Sp. 60-113.

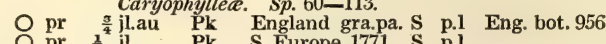

6137 arméria $L$. $\quad$ Deptford $\quad$ or 1 jl.s $\quad \mathbf{R} \quad$ England gra.pa. $\mathbf{S}$ p.1 Eng. bot. 317

6138 pseud-armeria Bieb. false Deptford $\triangle$ or 1 jl.au $\quad$ Pu Crimea 1820. C p.1 Bot. mag. 2288

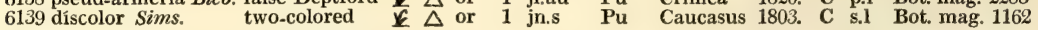

6140 barbátus $L$

6141 latifólius $W$

6142 japónicus Thunb.

6143 cephalótes Ser. headed

Sweet-William broad-leaved

$\Delta$ or $1 \frac{1}{4} \mathrm{jn} . \mathrm{jl}$

Japanese

6144 capitátus Dec. capitate

6145 polymórphus Bieb. variable

$\beta$ diutinus $\mathrm{Lk}$

6146 ferrugi'neus $L$. rusty -

6147 Carthusianórum $L$. Carthusian

6148 atrorúbens $A l l$. dark-red

6149 atróreus

dark-red

6150 fruticósus $i$. fleshy-leaved

6151 suffruticósus $W$. shrubby

6152 caroliniánus Walt. Carolina

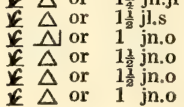

Pk Germany 1573. C r.m Bot. mag. 207

Pk $\quad$...... $\ldots$ C s.l Sw. fl. gard, 2

Pk China $1804 . \quad$ C p.l Thunb. jap. t. 23

Pk $\quad \cdots . .$. 1823. C p.l

$\mathrm{Pu}$ Caucasus 1822. C p.l

Crimea 1822. C p.l

\begin{tabular}{|c|c|c|}
\hline (7) & or & \\
\hline 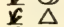 & or & \\
\hline $\mathbb{E}$ & or & \\
\hline 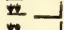 & or & \\
\hline 2. & or & \\
\hline & $\begin{array}{l}\text { or } \\
\text { or }\end{array}$ & $1 \frac{1}{2}$ \\
\hline
\end{tabular}

Br Italy 1756. S p.1 Mi.ic.1.t.81.f.1

R Germany 1573. C s.1 Loes, pruss. t.7

Cr Italy 1802. C s.l Jac. ic. 3. t. 467

Pk Greece 1820. C s.l Bot. cab. 459

Pk Greece 1815. C r.m Tourn. it. 1.t.9

Pk Siberia 1804. C p.1

N. Amer. 1811. C r.m

6153 ásper $W$.

6154 collinus $W . \& K$.

6155 campéstris Bieb.

6156 nítidus $W . \& K$.

6157 diffúsus Sibth.

6158 hir'tus Vill.

6159 guttátus Bieb.

6160 versicolor Fisch.

6161 praténsis Bieb.

6162 chinénsis $L$.
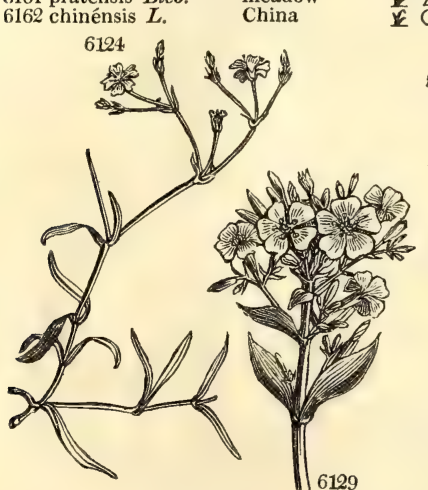

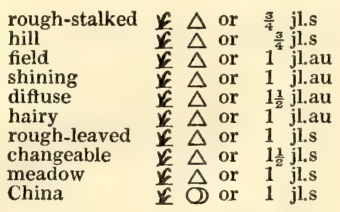

20r
Pk Switzerl. 1822. C s.l

W Hungary 1800. C s.1 Par, lond. 62

W.r Tauria 1815. C s.1 Bot. mag. 1876

R Carpath. 1822. C s.1

R Cyprus 1820. C s.1

R France 1821. C s.l

R Caucasus 1816. C s.l

R.y Russia 1823. C s.l

W.y Crimea 1820 C s.l

R China 1713. S r.m Bot. mag. 25 6134

6135

History, Use, Propagation, Culture,

Some of the species are fine border plants, but the greater part are of little beauty, and only grown in botanic gardens.

1045. Saponaria. In allusion to its mucilaginous sap, which is said to be fit for supplying the place of soap, sapo. S. officinalis plena is considered a border flower, but is inconvenient unless kept in pots, from its spreading very much by the roots, which are underground creepers, like those of couch. The leaves form a lather with soap, and take out spots of grease in the same manner. The whole plant is bitter, and was formerly used to cure the itch and the venereal disease.

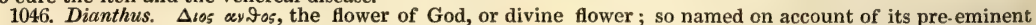
beauty. Most of the species of this genus are highly valued, not only for the beauty of their flowers, but also as being evergreens; their foliage during winter being as abundant and vivid as in summer. The fragrance of some of the species is peculiarly grateful, and no plant in this respect surpasses the carnation. D. barbatus is an old inhabitant of the flower garden, and was much esteemed in Gerarde's time " for its beauty to deck up the bosoms of the beautiful, and garlands and crowns for pleasure." The varieties are numerous, but as the plant has never been treated by florists as a leading flower, they have not been named or improved. A hybrid variety called the Mule, or Fairchild's Sweet-William, is supposed to have been produced from seeds of the 
6123 Fl. panic. Stem diffuse, Leaves lin. lanc. grassy carinate cæsious

6124 Stems panic. few-fl. Stam. shorter than emarginate petals, Leaves linear smooth

6125 Petals obovate emarginate campan. Stamens shorter than corolla, Leaves linear somewhat fleshy 6126 Stems panicled, Styles longer than emarginate petals, Leaves lin. lanc. smooth

6127 Stem dichotomous panicled much branched, Fl. axill. solitary, Leaves lin. flat as long as fl.-stalks

2. Calyxes supported by 2-4 scarious scales. 6128 Stems numerous erect stiff, Fl. panicled terminal, Leaves linear rigid

\section{Flowers fascicled panicled, Cal, rounded villous yellowish, Leaves ovate lanc, acute or not}

6130 FI. panicled, Cal. pyramid. 5-ang. smooth, Bractes membranous acute, Leaves oyate lanc. sessile 6131 Stem erect, Branches divaric. with clammiy hairs, Fl. on long stalks axill. Leaves lanc. linear

6132 Stems erect branched, Fl. panic. and corymbose, Cal, slender glandular purple, Lvs, ovate lanc. 1-nerved 6133 Stem dichotomous, Branches divaricating, Fl. axill. Cal. hispid round, Leaves linear spatulate

6134 Tufted, Stems 2-leaved, Flowers headed with an involucre, Cal. woolly

\section{$\$ 1$. Flowers capitate or corymbose, scssile or stalked.}

$$
\text { * Bractes ovate, blunt. }
$$

6135 Scales of calyx ovate pointless longer than tube, Leaves serrulate

6136 Like the last, but the flowers nearly solitary

\section{** Bractes lanceolate, acute, Calyxes villous.}

6137 Flowers loosely bundled, Scales lanc. subul. as long as tube, Leaves subulate, Calyxes hairy

6138 Flowers densely bundled, Scales ovate subul. as long as tube, Pet. beard. Lvs. subul. pub. rough upright 6139 Fls. aggreg. Scales long. than cal. striat. rough, Jvs. lin. short. than joints rough, Stem simple rough upw.

$$
\text { *** Bractes ovate or lanceolate, Calyxes smooth. }
$$

6140 Flowers aggregate fascicled, Scales ovate subulate as long as tube, Leaves lanceolate

6141 Flowers aggregate racemose corymbose, Scales ovate lanceolate finally longer than calyx, Lvs, obl. lanc

6142 Flawers aggregate fascicled, Scales acute ciliated twice as short as tube, Leaves ovate short

6143 Fls. subsess. capitate, Scales imbric. mucron. at end spreading a little short. than tube, Lvs. long narrow 6144 Glaucous, Fls. sess. capitate, Scales broad ovate with a long awn longer than head, Upper lvs. dilat. at base 6145 Dark green, Flowers sessile capitate, Scales ovate very short pointless, Leaves narrow rough $\beta$ Flowers panicled fastigiate and solitary stalked

$6146 \mathrm{FL}$ aggregate, Involucres and scales scarious rufous oblong awned a little shorter than cal.

$6147 \mathrm{Fl}$ aggregate sessile and stalked, Scales ovate awned shorter than tube, Leaves linear 3-nerved 6148 Like the last, but flowers aggregate headed sessile 3-8

6149 Flowers aggregate, Claws of petals very long, Scales mucronulate closely imbricated, Leaves subul. fleshy 6150 Flowers aggregate, Claws of pet. as long as cal. Scales mucr. closely imbric. very short, Leaves lanc. obt. 6151 Flowers aggregate, Scales ovate subulate thrice as short as tube, Leaves lin. lanc. narrowed at each end 6152 Flowers aggregate on long stalks, Scales twice as short as tube

\section{\$2. Flowers panicled or solitary. \\ * Petals toothed.}

6153 Flowers fascicled, Scales ovate lanceolate shorter than tube, Petals acutely toothed, Lvs. lin. lanc. rough 6154 Like the last, but the flowers more numerous, and the leaves linear lanc.

6155 Stem panicled somewhat hairy, Fl. sol. Scales ovate acute twice as short as cal. Leaves subul.

6156 Flowers fascicled twin, Scales awned as long as calyx, Petals crenate, Stem decumbent, Lvs. anc. obt.

6157 Flowers somewhat corymbose, Scales furrowed mucron. twice as short as tube, Stems diffuse smoothish

6158 Flowers nearly sol. Scales 6 ovate mucron. much shorter than cal. Pet. crenate, Lvs. subul. rough at edge 6159 Stem panicled smooth, Flowers solitary, Scales ovate awned as long as tube, Leaves subulate nerved

6160 Stem many-fl. smooth, Scales cuspid. spreading shorter than tube, Pet. downy at orifice, Lvs. lin. roughish 6161 Stem panicled, Fl. sol. Scales acuminate appressed, Petals acutely toothed, Leaves subul. lanc.

5162 Stem branched, Fl. sol. Scales linear leafy, Petals toothed, Leaves lin. lanc.

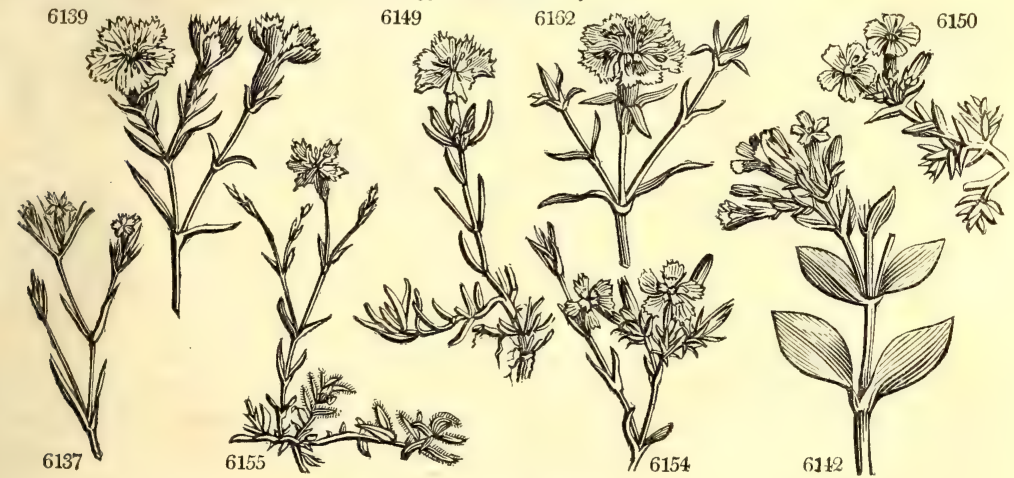

and Miscellancous Particulars.

carnation impregnated by a Sweet-William. D. caryophyllus is considered the source whence have sprung the numerous varieties of the carnation, and some think those also of the pink. The pink, however, is more probably derived from some of the smaller growing species, as plumarius, deltoides, armeria, carthusianorum, \&c.

The carnation is rarely found wild in England, but it may be gathered on the south side of the Swiss Alps. It seems to have been unknown to the ancients, at least in its cultivated state, not being mentioned by Pliny, or sung by any of the Roman poets. It has, however, been cultivated from time immemorial in Europe, and is in the highest favor for its beauty. and rich spicy odour. It is the principal forist's fower of Gerne, and Italy, from which countries the British florists procure their best carnation seed, and also some esteemed varieties.

The varieties of carnation amounted to nearly 400 named sorts in the beginning of the eighteenth century,
. and the number has not since diminished. They are arranged in three classes; flakes, bizarres, and picotees. Flakes have two colors only, and their stripes large, going quite through the leaves; bizarres, Fr. (odd, irregular) are variegated in irregular spots and stripes, and with no less than three colours; picotees, Fr. (piquettée, pricked or spotted) have a white ground, spotted or pounced with scarlet, red, purple, or other colors. Of 
6163 montánus Bieb. 6164 caryophýllus $L$. $\beta$ flore pléno fruticósus

o imbricátus

6165 virgineus Sims. D. sylvestris Jacq. 6166 monadélphus Vent. D. procúmbens Pers.

6167 sylváticus Hoppe

6169 leptopétalus $W$.

6170 púngens $L$.

6170 púngens $\boldsymbol{L}$.

6172 glaúcus $L$.

6173 crenátus Thunb.

6174 rígidus Bieb.

6175 clavátus $S p r$.

6176 suavis $W$.

6177 cæsius $\mathrm{Sm}$.

6178 alpinus $\mathcal{L}$

6179 Hornemánni Ser

6180 Sternbérgii Sibth.

6181 petræus $W . \& K$.

6182 gállicus Pers.

6183 álbens $H . K$.

6184 plumárius $L$.

6185 horténsis $W$.

6186 caucásicus Sims.

6187 frágrans Bieb.

6188 punctátus $S p r$.

6189 serotínus $W . \& K$.

6190 arenárius $L$.

6191 fimbriátus Bieb.

D. orientalis Sims.

6192 plumósus $S p r$.

6193 monspessulánus feathered

6194 supérbus $L$.

Carnation

wheat-ear

virgin

wood

pungent

maiden

rigid

clavate

sweet

mountain

alpine

rock two-colored

tree-Carnation

procumbent

narrow-petalled

glaucous-leaved

long-cupped

Hornemann'

Sternberg's

French
Cape
feathered
garden
Caucasian
fragrant
dotted
late-flowering
sand
fringed
feathered
Moutpelier
superb

$\frac{k}{4} \Delta$ or
$\frac{1}{4}$ or
or
$\Delta$ or
$\Delta$ or

$\frac{3}{4}$ jn.s

$\mathbf{R}$

2 jn.au Cr

3 jn.au Cr

$\triangle$ or $1 \frac{1}{2}$ jn.au F

\& $\Delta$ or 1 jn.jl

₹ $\Delta$ or $1 \frac{1}{2} \mathrm{jn} . \mathrm{s}$

$\Delta$ or 1 jn.jl

$\Delta$ or $1 \frac{1}{2} \mathrm{jl}$

$\Delta$ or 1 au.

$\triangle$ or

$\triangle$ or $\frac{1}{4}$ jn.o

N or 1 au

$\triangle$ or $\frac{3}{4} \mathrm{jn} .0$

$\Delta$ or 1 jn.o

$\Delta$ or ${ }_{\frac{1}{4}} \mathrm{jn}$.jl

$\Delta$ or $\frac{1}{4} \mathrm{jn} . \mathrm{jl}$

$\triangle \Delta$ or 1 jn.jl

\& $\Delta$ or $1 \frac{1}{2}$ jn.jl

if $\triangle$ or $\frac{1}{2} \mathrm{jl}$.au

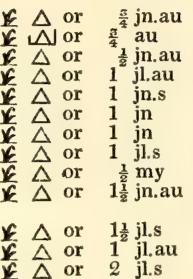

Caucasus 1803. C s.l

England walls, C r.m Eng. bot. 214

England $\quad . . \quad$ C r.m Bot. mag. 39

England ... C C r.m

England ... C C r.m Bot. mag. 1662

S. Europe 1732. C s.1 Bot. mag. 1740

Pk Levant ... $\quad$ C $s .1$ Vent. cels. t. 39

R Ratisbon 1815. S p.l

Y Levant 1804. C s.1 Par. lond. 57

Caucasus 1814. C s.l Bot. mag. 1739

Pk Spain 1781. C s.I

Britain gra.pa. C s.1 Eng. bot. 61

Britain ... C s.1 Di.el.t.298.f.348

C. G. H. 1817. C s.l Bot. reg. 255

Casp. Sea 1802. C s.l

...... $\quad \ldots . \quad$ C $s$.

Pa.pk

F Britain rocks. C s.l Eng. bot. 62

R Austria 1759. C s.l Bot. mag. 1205

R Italy $\quad \ldots$. C s.l

R $\quad \ldots . . . \quad \ldots \quad$ C s.

Pk Hungary 1804. C s.1 Bot. mag. 1204

Pu S. France $\ldots$ C $\quad$ s.l

W C. G. H. 1787. C p.l

W.pu Europe 1629. C s.l

St Hungary 1805. C r.m

$\mathrm{Pu}$ Caucasus 1803. C $\mathrm{s.1}$ Bot. mag. 795

Pu Austria 1804. C r.m Bot. mag. 2067

PaLi ….. 1804. C r.m Bot. cab. 896

$\begin{array}{llll}\text { Pu Hungary 1804. C s.l Pl. rar. h. 2.t.172 } & \end{array}$

Pu Europe $\ldots$. C s.l

Li Iberia 1815. C s.l Bot. mag. 1069

W.Ii M. Bald. … C $\quad$ s.l

R Montpel. 1764. C p.l

W Europe 1596. C $\begin{aligned} & \text { s.1 } \\ & \text { Bot. mag. } 1148\end{aligned}$

\section{TRIGYNIA.}

1047. CUCU'BALUS. $L$. Campion.

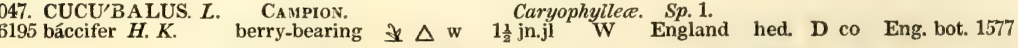

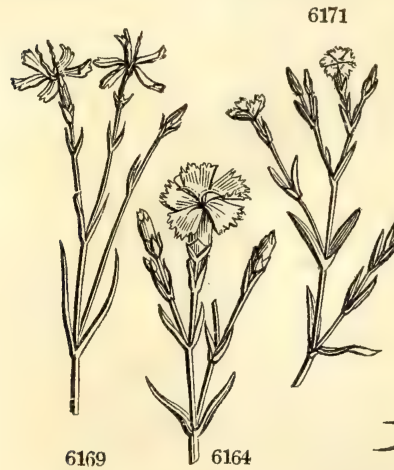

6165

6177

6178

History, Use, Propagation, Culture,

each class there are numerous varieties, arranged under the farther subdivisions of scarlet flake, pink flake, purple flake, yellow flake, \&c.; scarlet bizarre, crimson bizarre, \&c.; and purple picotee, yellow picotee, \&c.

Picotees are rather smaller flowers than carnations, and are distinguished by the serrated margins of their petals ; the colors are principally yellow and white spotted, and the plants are considered hardier than the other sorts. Whatever colors the flower may be possessed of, they should be perfectly distinct, and disposed in long regular stripes, broadest at the edge of the lamina, and gradually becoming narrower as they approach the unguis, or base of the petal, there terminating in a fine point. Each petal should have a due proportion of white, $i . e$. one half, or nearly so, which should be perfectly clear and free from spots. Bizarres, or such as contain two colors upon a white ground, are esteemed rather preferable to flakes, which have but one, especially when their colors are remarkably rich, and very regularly distributed. Scarlet, purple, and pink are the three colors most predominant in the carnation; the two first are seldom to be met with in the same flower, but the two last are very frequently.

New varieties are procured from seeds, and thousands of seedlings are annually blown by florists and amateurs, sometimes without one being found worth keeping. Established or approved varieties are continued by layering and cuttings, or, as they are commonly called, pipings. The soil in which the carnation thrives best is a rich loam rather sandy than otherwise; the climate should be free from extremes of every kind, for which reason they are commonly grown in pots, and protected by a frame during winter, and covered by an awning while in bloom. Carnations grow exceedingly well in beds of properly prepared soil, over which frames are placed in winter, and an awning of canvass or bunting when the plants are in blossom. Those who are curious in blowing their carnations have a great many nice and curious operations to perform when they come into flower. Such petals as are plain, or run from the proper colors of the variety, are extracted by a particular instrument; the remaining petals are next. arranged so as to form a convex imbricated surface; the calyx being slit down or tied up as may be necessary to aid this end. Then the flowerstalks are neatly tied to sticks, and the flower supported in a pendant attitude by means of properly formed brass wires. 
6163 Stem branch. upw. closely dichotom. Fl. sol. Bract. with a spread leafy point, Lvs. lin. subul, 3-nerv. hairy 6164 Stem branched, Fi. sol. Scales very short ovate, Petals very broad beardless, Lvs. lin. sub. channelled glauc.

6165 Stem branched or simple, F1. sol. Scales very short 4 ovate, Pet. broad beardless toothed

6166 Stem dichotomous panicled many-f. glaucous, Fl. sol. Scales 4 pungent spreading shorter than tube

6167 Fl. sol. subcorymb. Scales ov. lanc. short. than tube, Lvs. lin. lanc. obsol. 3-nerv. smooth, Pet. twice toothed $6168 \mathrm{Fl}$. sol. Scales ovate acute very short, Petals emarginate or nearly entire

6169 Stem branched, Fl. sol. Scales ovate acute very short awned, Pet. lanc. narrow, Leaves subul. roughish,

6170 Stem few-f. Fl. sol. Scales very short mucron. spreading, Tube gibbous, Pet. entire, Lvs. cæspitose subul.

6171 Stem decumb. branched, Fl. sol. Scales ovate lanc. acute twin, Upper leaves narr. acute : lower oblong obt.

6172 Like the last, but flowers white, Leaves and stem glaucous

6173 Stem branched, Fl. sol. Scales 6 lanc. appressed, Pet. smooth cuneate obovate, Lvs. lin. acum. channelled 6174 Stems tufted few-fl. Fl. sol. Scales ovate acute short, Leaves subul. spreading downy rough 6175 Stem 1-f. Scales 2 ovate acute short spreading, Cal. contracted in middle, Lvs. lin. chann. roughish at edge 6176 Stem 1-fl. Scales 4 acute short, Petals bearded doubly serrated, Leaves lin. spreading

6177 Stems tufted about 1-ft. Scales roundish short, Pet. crenate downy, Leaves bluntish rough at edge

6178 Stem 1-f. Outer scales as long as tube : inner much shorter, Pet. crenate, Leaves obl. obtuse

6179 Pedunc. bitid term. Scales lanc. cusp. erect short. than tube, Pet. cut, Lvs. lin. nerved serrul. rough at edge 6180 Stems about 2-f. Scales 4 ovate acute twice as short as tube, Petals serrate downy, Leaves linear 6181 Stem about 1-f. Scales ohovate mucronate, Pet. beardless many-cut, Leaves subul, entire smooth nerved

$$
\text { ** Petals fringed. }
$$

6182 Stems ascending about 1-fl. Scales short ovate, Pet. toothed many-cut, Leaves lin. ciliated 6183 F1. sol. Scales 4 lanc. short, Petals emarginate at the end fringed toothed

6184 Glaucous, Stems 2-3-fl. Teeth blunt, Bractes ovate very short pointed, Leaves lin. rough at edge 6185 Like the last, but the petals bearded at their orifice

6186 Stem pan. few-fl. Fl, sol. Scales ovate acum. Petals equally cut crenate, Leaves glaucous rough at edge b187 Stems 1-f. Scales ovate lanceolate acuminate shorter than tube, Pet. beardless, Lvs. subul. rough at edge 6188 Stem branched few-fl. Scales 4 blunt short, Petals beardless dotted, Leaves glaucous linear flaccid 6180 Stems 1-fl. Scales ovate obtuse four times as short as calyxes, Pet. naked, Leaves subul. glauc. ciliated 6190 Stems 1-fl. Scales ovate obtuse, Leaves linear

6191 Stem half-shrubby branched at base 2-fl. Scales 6 lanc. shorter than cal. Leaves subul, rough

6192 Fl. scattered solitary, Scales lanc. lin. spreading a little shorter than tube, Leaves lin. nerved flaccid 6193 Stem panicled few-fl. Fl. sol. Scales subul. straight twice as short as tube, Petals digitate, Lvs. lin. serrul 6194 Stem panic. many-fl. FL. fastigiate, Scales short ov. mucron. Pet, beyond the middle pinn. many-cut hairy

[at orifice

\section{TRIGYNIA.}

6195 Branches divaricating, Leaves ovate, Cal, campanulate, Pet. distant

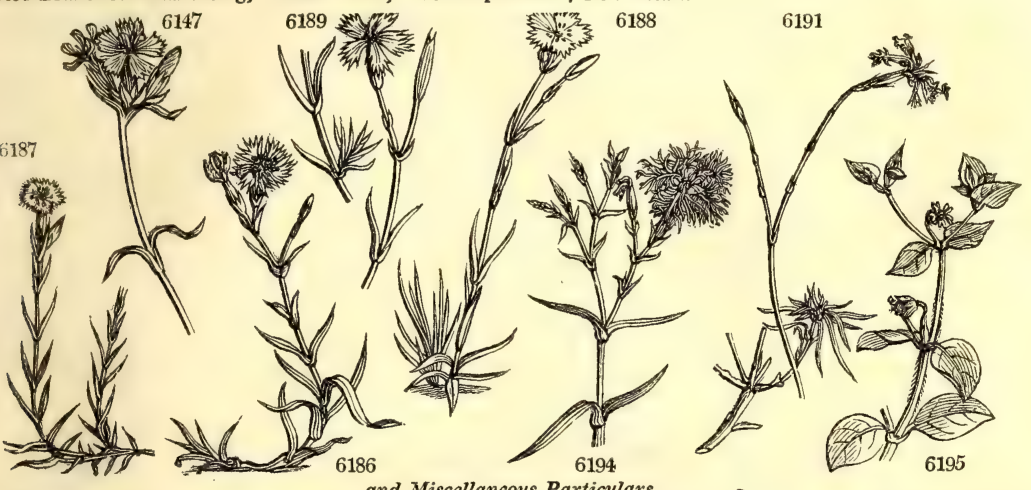

and Miscellaneous Particulars.

Behind the petals a circle of card paper is sometimes fixed to keep them in position, and the pot in which the plant grows is placed on a particular description of saucer, by which it is surrounded by water, in order to prevent the approach of ground insects, and especially of the earwig. These and a number of other operations will be found described at length in Maddock's Florist's Directory, and in the Encyclopædia of Gardening. (Sec. 6406.)

The pink, as a florist's flower, is of much less antiquity than the carnation : it is scarcely mentioned by Gerarde, and Parkinson has given very few varieties. It was chiefly grown as a border flower till within the last fifty years, since which it has been greatly improved and many fine varieties originated. Being one of the hardiest and least expensive of fine flowers, it is much cultivated by operative mechanics and manufacturers round large towns, and no where to such an extent as about Paisley, by the muslin weavers there.

The varieties of pink most cultivated are chiefly those called pheasant's eyes, which seem to have sprung from D. plumarius. Cob pinks are a large sort seemingly intermediate between pinks and picotee carnations; red early pinks are smaller plants than cobs, but larger than pheasant's eyes, and seem to have sprung from cobs and D. armerius or deltoides. The Paisley growers reckon above three hundred varieties of the pheasant's eyes. To garden pinks in general Wildenow gives the appellation of $\mathrm{D}$. hortensis.

The propagation and culture of the pink is the same as that of the carnation, excepting that it is less frequently kept in pots or frames, but planted in beds of fresh loamy soil, and the small side shoots reduced in the autumn in order to throw more strength into those intended to produce flowers the following season. Some cover their pink bed with an awning. Not more than eight or ten flowers are ever allowed to expand on one plant, and these, if they shew a tendency to bursting at the calyx, are to be tied as in carnation culture.

1047. Cucubalus. A name signifying a bar subject; an evil weed. According to Miller, the berries of this plant are no less deadly than those of Nightshade. 
1048. SILE'NE. $L$. 6196 acaulis $L$ 6197 pumílio Sturm

6198 fimbriáta Sims. 5199 lácera Sims. 6200 stelláta $\boldsymbol{H} . \boldsymbol{K}$

6201 infláta $\mathrm{Sm}$. 6202 marítima $W$ 6203 fabária $\boldsymbol{H} . \boldsymbol{K}$ 6204 Béhen $\boldsymbol{L}$ 5205 indica Roxb. 6206 viscaginoıdes Horn Nepal 6207 procúmbens Murr. procumbent 6208 rubélla $L$. 6209 apétala $W$ 6210 spergulifólia Bieb. 6211 Gypsóphila Desf. 6212 carnósa Mönch.

6213 Otites Pers. 6214 volgénsis Otth. 6215 parviflóra Pers. 6216 effusa Otth. 6217 sibírica Pers. 6218 multiflóra Pers. 6219 tatárica Pers. 6220 gigantéa $L$. 6221 viscósa Pers.

6222 cónica $L$. 6223 conoídea $L$ 6224 unduláta $\boldsymbol{H} . \boldsymbol{K}$.

6225 ánglica $L$

6226 lusitánica $L$. 6227 tridentáta Desf. 6228 gállica $L$. 6229 ocymoides Desf. 6230 disticha $\boldsymbol{W}$. 6231 cerastoídes $\boldsymbol{L}$. 6232 quinquevúlnera $\boldsymbol{L}$. 6233 noctúrna $L$. 6234 refléxa $L$

6235 micropétala $\mathrm{Dec}$. 6236 micrántha $L k$.

6237 canéscens Ten. 6238 dichótoma $E h r$. 6239 nyctántha $W$. 6240 bellidifólia Jacq. 6241 vespertína Retz. 6242 crassifólia $L$ 6243 grácilis Dec. 6244 jeniseénsis $W$ 6245 ciliáta Pourr. 6246 péndula $L$.
Catchfly. dwarf

fringed-flower. torn inflated

sea

thick-leaved bladder small-red petalless spurrey-like little

\section{Spanish}

Volga small-flowered effuse

Siberian

many-flowered

Hyssop-leaved

gigantic

clammy

corn

conoid

wave-leaved stemless four-leaved
Caryophyllece. Sp. 107-217.

£ $\triangle$ pr $\quad$ jn.au Pk Britain sc.alp. D p.l Eng. bot. 1081 $\$ 2$ pr $\frac{1}{8}$ jn.au Pu Germany 1823. D co Stur. d. f. 1.t. 11

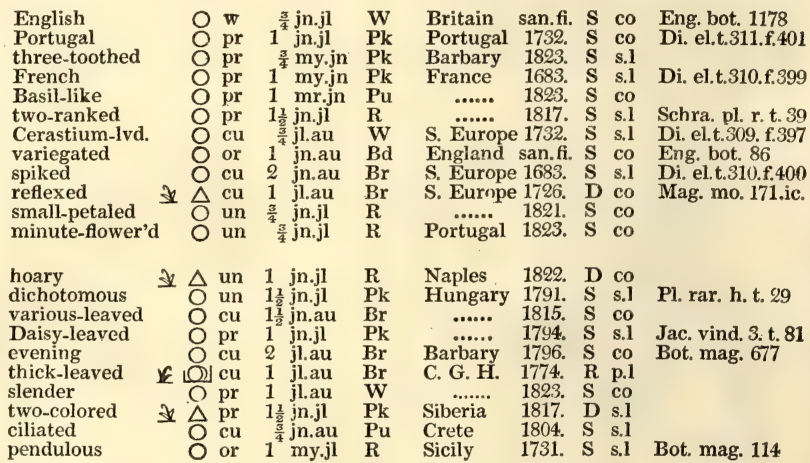

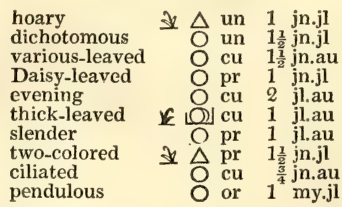

624i quadridentáta Dec. four-toothed $\neq \Delta \mathrm{pr} \quad \frac{3}{4}$ my.jl W Alps $\quad$ 1822. D co 6248 pusilla $W . \& K . \quad$ dwarf $\quad$ \& $\triangle$ un ${ }_{\frac{1}{2}}$ jn.jl. Pk Hungary j804. D s.1 Pl. rar.h. $3 . t .212$ 6249 alpéstris Jucq. Austrian $\quad \frac{1}{\Delta}$ un $\frac{x^{2}}{2}$ my.jl $R$ Austria 1774. D s.1 Jac. aus. 1.t.96 6250 rupéstris $L$. rock

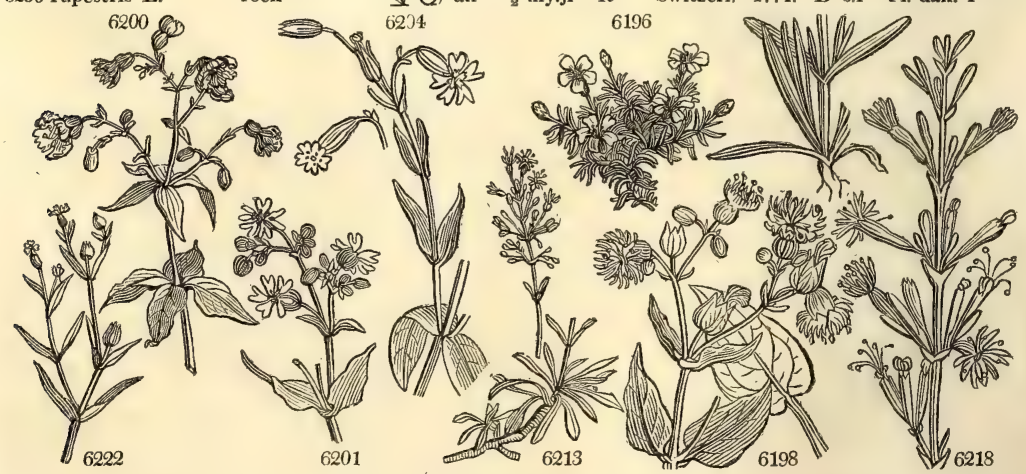

History, Use, Propagation, Culture,

1048 Silene. A poetical name, after the God Silenus, who is represented as always drunk and covered with slaver, as the species of this genus usually are with a viseid secretion. This is a large family of small plants, neither remarkable for use, beauty, or as bad weeds. S. inflata, the Cucubalus Behen $L$., may be used as a sub stitute for asparagus or green pease, the young shoots having the flavor of both. They ought to be gathered 
1. Tufted, Stems scarcely any, Calyx sowewhat inflated, Peduncles 1-flowered. 6196 Smooth, Stems dense, Leaves lin. lanc. Flowers dicecious, Calyx campanulate 6197 Stems less dense, Leaves lin. spatulate pubescent, Cal. inflated hairy

82. Caulescent, Flowers solitary or panicled, Calyx bladdery inflated.

6198 Pubescent, Leaves large ovate-lanc. Fl. in large panicles, Cal. much inflated, Petals fringed 6199 Hispid, Leaves ovate-lanc. on long stalks wavy, Cal. much inflated, Pet. lacerated crowned 6200 Stems erect branched pubescent, Leaves 4 whorled lanc. with long points smooth, Fl. pan. Cal. bladdery 6201 Stems branched, Fl, pan. Cal. bladdery ovate, Pet. bifid naked, Styles very long 6202 Like the last, but hairy with ovate lanc. leaves

6203 Like the last, but creeping with smaller nearly spatulate leaves

6204 Smooth branch. Lvs. lanc. : the lower stalk. Fl. pan. Cal. ovate veiny, Pet. with 2 very short lobes crowned 6205 Pubescent, Stems very tall branch. Lvs. large lanc. F1. pan. Cal. ov. netted, Pet. with a claw hairy at base 6206 Smooth, Stem erect simple rather leafy, Lvs. lin. scarcely ciliat. Fl. in pan. spikes, Claws of pet. not ciliated 6207 Smooth with very leafy branched procumbent stems, Leaves lanc. Fl, axill opp. and terminal, Petals bifid 6208 Nearly smooth, Stems little branched, Leaves obovate serrulate-ciliated, Fl. pan. Pet. obcordate crowned 6209 Hoary, Stem erect branched, Leaves lanc. : the upper linear, Fl. few term. Petals $\mathbf{O}$

6210 Stems procumb. diffuse 2-3-chotomous branched, Lvs. small lin. Petals half-bifid with an obcord, crown 6211 Nearly smooth, Stems wavy branched leafy, Leaves lin. lanceolate, Petals 2 -lobed

6212 Smooth, Stem erect, Leaves acute glaucous, Fl. solitary, Pet. lanceolate with a 2-lobed crown :

$$
\text { \$. Caulescent, Flowers spiked in whorts. }
$$

[Fl. small diocious 6213 Leaves erect, with a few branches, which are scarcely pubesc. or leafy, Lower lvs. numerous spatul. fleshy, 6214 Stem pubesc. branched, Lower leaves large lanc. spatulate: upper lin. long, Fl. panicled with linear petals 6215 Hoary, Stems assurgent nearly simple, Leaves spatulate lanc. Cal. spherical 10-striped

6216 Stems erect nearly simple, Lvs. lin. : lower obt. Fl. very numerous and small, Cal, obov. clavate 10-striped 6217 Half-shrubby smooth, Stems much branch. Lvs. lin. lanc. shortly ciliat. numerous, Cal. infl. clav. 10-striped 6218 Stem simple, Lvs. lin: lanc. : lower broader stalk. Cal. clavate cylindr. 10-strip. Pet. 2-part. Stam. very long 6219 Smooth, Stems erect simple very leafy, Lvs. lanc. small, Spike dense, Cal. clavate netted, Stam. very long 6220 Velvety, Radical leaves cochleate smooth, Cal. tubular 10-striped, Pet. 2-fid, Stamens very long 6221 Pubescent very viscid, Stem simple thick leafy, Leaves large lin. lanc. wavy, Fl. large nodding

$$
\text { 4. Caulescent, Calyx conoid, at the bottom retracted, with very long teeth. }
$$

6222 Pubescent, Leaves linear soft, Cal. short conical

6223 Sterns pubescent, Leaves lanc. lin. nearly smooth, Cal. long conical

6224 Pubescent, Leaves lanceolate wavy: the lower stalked, Fl. large in loose dichotomous panicles

$$
\text { \$5. Caulescent, Flowers spiked, axillary, not opposite, Calyx with } 10 \text { stripes. }
$$

6225 Hairy, Stems branched, Leaves lanc. acute, Cal. ventricose with very long teeth, Petals small crowned 6226 Very hairy, Stems much branched, Lower leaves obovate spat. : upper lanc, obtuse, Petals undivided 6227 Stems branched, Leaves lin. lanc. Spike 1-sided, Cal. cylindrical with 10 ribs, Teeth long, Pet. 3.toothed 6228 Hairy, Stems branched, Lower lvs. spatulate: upper lanc. obtuse, Cal.-teeth short, Pet. obov. crowned 6229 Hairy, Stems branched, Leaves spatulate, Spike 1-sided few-fl. Cal. very hairy, Pet. obovate crowned 6230 Hairy, Stem much branched, Leaves lanc. cusp. Spikes twin dense, Pet. small bifid

o231 Stems simple vill. Leaves pub. : lower spatul. ; upper lanc. Spike 2-ranked few-fl. Pet. obcv. retuse crowned 6232 Pubesc. Stems branch. Lvs, lanc. : lower obt. Spike 1-sid. Cal. vill. with short teeth, Pet. roundish crowned 6233 Stem branch hairy below, Lvs. pubesc. with a long fringe at base, Cal. cyl. nearly smooth ribbed and netted 6234 Like the last, but flowers few distant, Petals smaller

6235 Hairy, Stem branched leafy, Leaves lin. lanc. Flowers terminal, Cal. cylindr. Pet. bifid

6236 Hairy, Fl. sessile 1-sided, Cal. cylindr. appressed, Petals small deeply emarginate

\section{** Calyx clavate.}

6237 Hoary, Stems prostrate branched, Lvs. obovate spatulate ciliated at base, Fl. 1-sided erect, Pet. bifid 6238 Stems branch. pubesc. Lvs. scabrous cil. at base : lower spatul.; upper lanc. F1. sess. nodding, Pet. 2-parted 5239 Pubescent, Lvs. somewhat fieshy : lower spatulate; upper lanceolate, Cal. long clavate, Petals 2-fid 6240 Hairy, Stem erect slender branched, Lvs. lanc. Spikes twin 2-sided, Cal, cylindr. clavate, Pet bifid 6241 Pubesc. Stems branch. Lvs. spatul. obt. Spikes twin 1-sided, Cal. bladdery, Pet. 2-parted with ov. lobes 6242 Velvety, Stem procum. branch. leafy, Lvs. ov. spatul. fleshy, Bract. very small, Pet. with long claws emarg. 6243 Smth. Stem erect slend. branch. Lvs. lin. scarcely ciliat. : low. ov. Fl. on long stks. Pet. 2-part. with lin. lobes 6244 Smooth, Stems usually simple, Lvs. somewhat fleshy lin. lanc. Cal. ov. ventric. Pet. bifid with 4-lob. append. 6245 Pubesc. Stems numerous prostrate very leafy at base, Lvs. lin. setaceous ciliated, Recesses of calyx deflexed 6246 Pubescent branched supine, Leaves ovate lanc. Fl. axillary pendulous, Petals bifid crowned

\$ 6. Caulescent, Stems upright, Peduncles filiform, Calyx campanulate or cylindrical.

6247 Tufted, Stems erect slender branched, Lvs. small linear very narrow, Fl. small, Petals short 4-toothed 6248 Like the last, but the radical leaves broader, Peduncles long upright

$6 £ 49$ Root branched, Stems simple leafv, Lvs. lanc. lin. obt. Fl. large panicled, Petals broad 4-cleft, Seed ciliated 6250 Smooth, Stems erect branched, Leaves ovate lanc. Fl. panicled very small, Petals obcordate
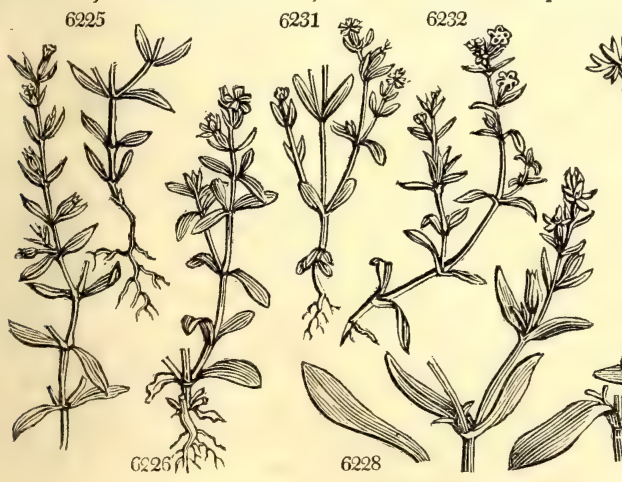

and Miscellaneous Particulars.

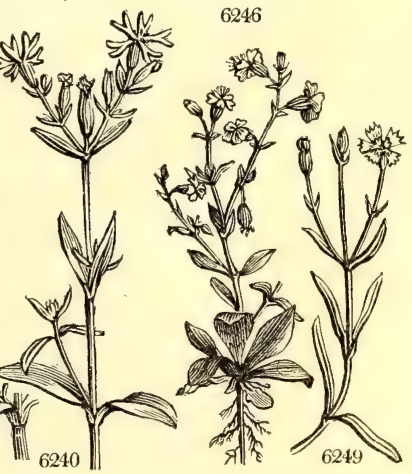

when about two inches long, and the more they are blanched the better. Bryant (Flora Dietetica) says, its culture would well reward the gardener's trouble. S. viscosa is a popular border flower, especially the double variety.

$\mathrm{S}$. quinquevulnera was formerly in culture as a border flower, but is now scldom used for that purpose : 
6251 inapérta $L$ 6252 clandestina 6253 antirrhína $\boldsymbol{L}$. 6254 geminiflóra $W$. 6255 flavéscens $W . \& K$. 6256 linifólia $W$ 6257 crética $L$ 6258 sedoídes Jacq. 6259 saxífraga $L$ 6260 petræ'a $W . \&$ 6261 campánula Pers. unopen-flower hidden-flower. Snap-dragon twin-flowered yellowish Flax-leaved Cretan Sedum-like Saxifrage rock Bell-flowered un 2 jn.jl

O un 1 jn.j.

O u 1 jn.jl

$\pm \triangle$ pr 1 jn.j

$O \mathrm{pr} 1$ jl.au

O pr $\frac{3}{4}$ my.au G.w

$\bigcirc$ pr $\frac{x^{4}}{4} \mathrm{jl}$

ฟ $\triangle$ cu $\frac{1}{4}$ jn.au

ذ) $\triangle$ pr
6262 longipétala Vent.

6263 nútans $L$.

6264 saxátilis Sims.

6265 livida $W$.

6266 ténuis $W$.

6267 viridiflóra $L$.

6268 chlorántha $W$. pr 1 jn.au G.w Barbary 1822. S co

long-petaled

Nottingham

stone

livid

slender

$\$ \Delta$ pr $\frac{3}{4} \mathrm{jl}$

(2) cu 2 jn.j

pale-flowered $\frac{7}{3} \triangle \mathrm{cu} 1 \frac{1}{\mathrm{j}} \mathrm{jn}$.au
Br Madeira 1732, S s.I Di. el.t.315.f.407

R C. G. H. 1801. S co Jac. col.s.t.3.f.

N Amer. 1732. S p.l Di. el. t.313.f.403 Pu N.... 1816. S co Hungary 1804. D p.l Pl. rar. h. 2.t. 175 Candia 1817. S $\mathrm{s.1}$ W Candia 1732. S 5.1 D.e.t.314.f.404, D s.1 Bot, cab. 454 G.w Piediy 1822. D co

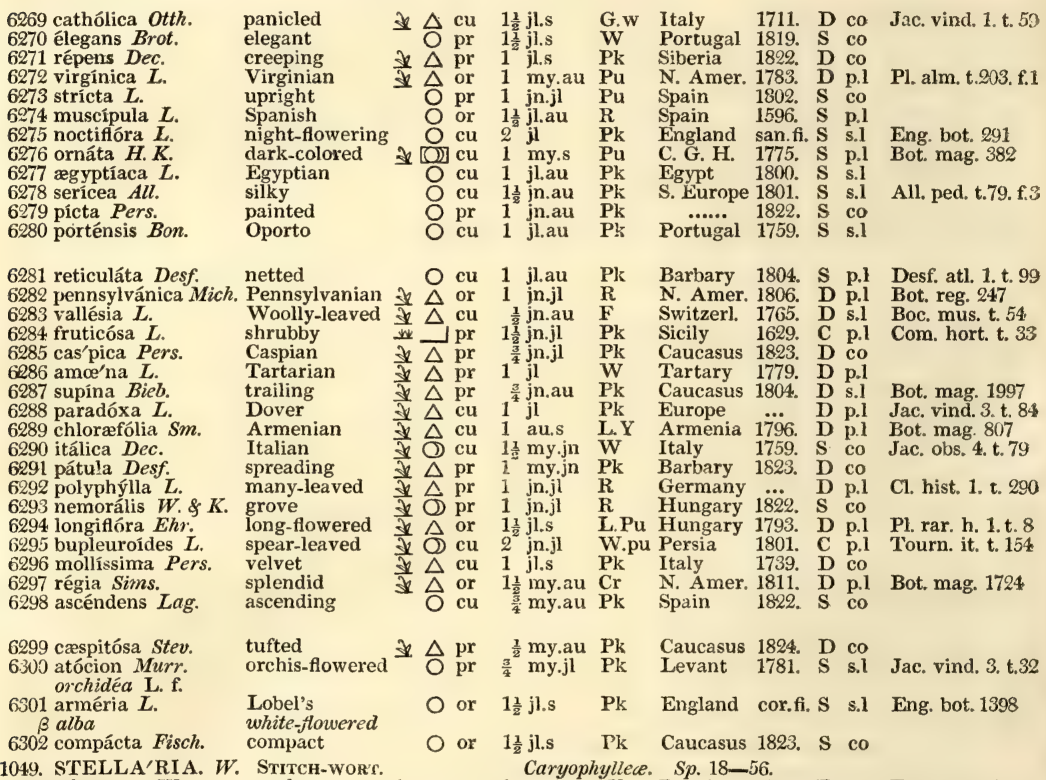

1049. STELLA'RIA. $W$. Stitch-wor'.
6303 némorum $W$. wood $\begin{gathered}\text { Caryophyllece. } \\ \text { Sp. } 18-56 .\end{gathered}$ Britain moi.wo. D co Eng. bot. 92

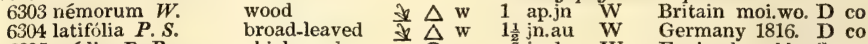
6305 média $\boldsymbol{E} . \boldsymbol{B}$. chickweed $\$ \mathrm{O}$ w $\frac{2}{4}$ ja.d. W England rubb. $\mathrm{S}$ co Eng. bot. 537 Alsine média W.
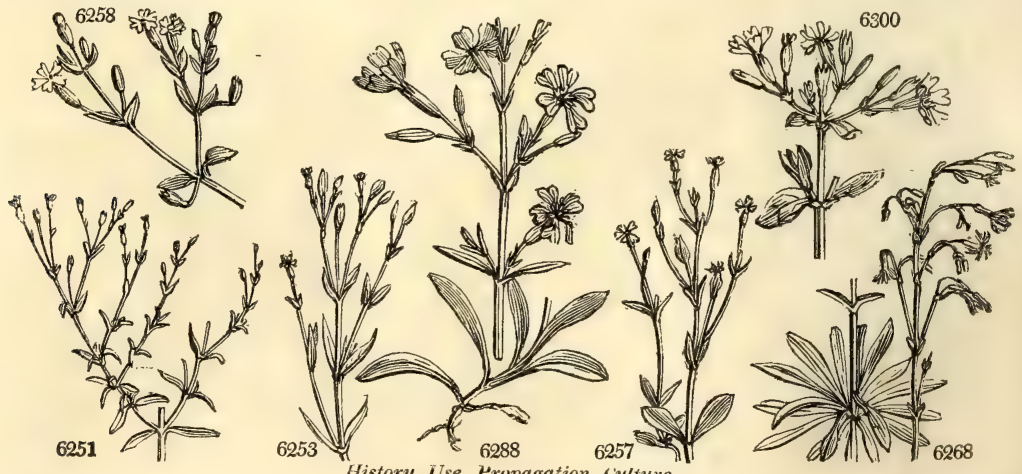

History, Use, Propagation, Culture,

being very low and prolific in flowers, it is well adapted for sowing in pots. S. Armeria is one of the annual

1049. Stellaria. The parts of the flower are stellate. The species are grassy-looking plants of the easiest 
6251 Smooth, Stems erect branched, Lvs. lanc. acute : lower obt. Petals not opening obcordate, Stam. usually 5 6252 Pubesc. Stem erect much branched slender, Lower lvs, obl. obt. : upper lanc. narrow, Pet. short erect bifid 6253 Nearly smooth, Stem erect branched somewhat leafy, Leaves lanc. acute ciliated, Fl. small panicled 6254 Pubescent, Stems branched, Lower leaves ellipt. spatulate: upper lanc. Fl. term. twin, Petals bifid 6255 Pubescent, Stems erect branch. straight, Low. lvs. lanc. spat. : up. linear, F1. loosely panicled, Pet. 2-lobed 6256 Stems branched, Leaves lin. spatulate, Fl. term. Cal. cylindr. clavate, Petals 2-fid

6257 Smooth, Stems erect branched, Low. lvs. ov. stalked obt. : up. lin. acute, Fl. loosely panic. Cal ov. clavate 6258 Viscid pubesc. Stems erect much branch. Lvs. fleshy : low. spatul.; up. ov. Fl. small, Pet. obcord. crowned 6259 Tufted, Stems assurgent, Lvs. lin. acute, Peduncles very long, Cal. long clavate, Petals 2-parted crowned 6260 Tufted shortly bristly, Stems assurgent, Leaves lin. with bristly teeth, Fl. small, Petals 2-fid crowned 6261 Smth. Stems erect or assurg. somew. branch. leafy at base, Lvs. lanc. lin. acute : low. spat. Pet. 2-part. naked

$$
\text { 87. Caulescent, Flowers panicled, rarely solitary, Pedicels opposite short, Calyx tubular. }
$$
* Flowers nodding, Calyxes cylindrical.

6262 Smooth viscid, Stems erect, Lvs. somewhat fleshy lin.-lanc. fringed with fine bristles, Pet. very long 2 -part 6263 Pubesc. Stems leafy at base, Radical lvs. spatul. : upper lanc. lin. Pet. 2-parted reflexed with a long crown 6264 Like the last, but smooth, less branched, and less leafy, Leaves linear, Petals often green

6265 Like the last, but stems flexuose broken down, Petals white above beneath livid green

6266 Smooth, Leaves lin. lanc. ciliated at base, Fl. pan. erect, Cal. ventricose cylindr. Petals 2-parted 6267 Hairy soft, Stem branch. leafy, Lvs. large ov. acum. Fl. in large nodding panicles, Pet. with very long claws 6268 Smooth, Stems erect simple scarcely leafy, Petals 2 parted with filiform lobes

crowned

** Flowers erect, Calyxes clavate.

6269 Velvety glutinous upwards, Stem erect branched leafy, Fl. small loosely panicled, Stamens very long 6270 Stem short about 2 -flowered pubescent, Radic. leaves lanc. lin. acute, Cauline very short, Pet. bifid 6271 Scarcely pubesc. Root long creeping, Stem erect almost simple, Lvs. lin. grassy acute, Fl. few erect panic 6272 Viscid pubesc. Stem procumb, assurgent branch. Fl. large panic. Cal. large clavate, Pet. broad bifid crowned 6273 Scarcely pubesc. Stem upright branched, Lvs, lin. lanc. Fl, panicled erect, Cal netted, Pet. small emarginate 6274 Smoothish viscid, Stem erect, Alternate branches long, Cal. large clavate netted, Petals bifid

6275 Visc. pubes. Stems erect branch. Lvs. large, Fl. large panic. : every other stripe of cal.veiny, Teeth very long 6276 Pubes. Stems erect branch. Lvs, lanc. obt. Fl. panic. : every other stripe of cal.veiny, Pet. with broad toothl 6277 Subtomentose, Stems branch. Lvs, obov, stalked, Fl. term. erect, Pet, obcord. 2-toothed at base [lobe 6278 Silky, Stems branched, Lvs, with a long fringe at base, Fl. large term. Pet. 2-parted crowned 6279 Stems much branch scarcely pubesc. Lower lvs, obov, spatul. Lvs, lin. acute, Cal clavate striped with red 6280 Tufted smooth subviscid, Stems branched at base, Lvs. lin. Fl, panic. Cal, netted, Pet. bifid with lanc. lobes

$$
\text { *** Flowers erect, Calyxes long clavate. }
$$

[at base

6281 Smooth visc. Stems branch. Lvs. lanc. lin. Cal very long. clav nett. Pet. obcord, with a tooth on each side 6282 Viscid pubescent, Stems procumbent, Leaves lin. long, Cal. long tubular, Petals slightly emarg, crenate 6283 Tufted viscid pubesc. Root woody, Stems low assurgent little branched, Cal. long netted, Petals bifid 6284 Suffruticose, Stems suberect smooth branched at base, Cal. long cylindr. viscid-villous, Petals 2-lobed 6285 Scabrous, Stems bran. Fl. term. in the dichotomies, Cal. long cylin. Pet. 2-part. tooth. on each side at base 6286 Pubescent, Root woody, Stems diffuse branched, Leaves soft numerous below, Petals half bifid 6287 Tufted viscid pubescent, Stems woody supine branched, Lvs. lin. acute, Petals with narrow diverging lobes 6288 Stems erect pub. Lvs. roughish scarcely ciliat. Fl. large pan. Pet. with broad obov. lohes \& 2-part. append. 6289 Very smooth glaucous, Stems branched, Leaves roundish acuminate, Fl. large, Cal. not striped

6290 Pilose pubesc. Stems much branch. Lower lvs. ovate-spatul : up. lin. Fl. in large panic. Pet. 2-lob. naked 6291 Pubesc.visc. Stems erect branch. Branch. spread. Low. lvs. ov. spatul. Cal. long narrow, Pet $\frac{1}{6}$ bifid crowned 6292 Pubescent, Stems assurgent much branched leafy, Leaves linear acute, Cal. clavate, Petals bifid 6293 Stem simple pubescent, Leaves pubescent : lower large rounded stal ked, Petals 2-parted crowned 6294 Smooth, Stem twiggy, Leaves lin. lanc. radical very long, Cal, very long, Petals 2 -parted crowned 6295 Smooth clammy, Stem assurgent branch. Lvs. lin. lanc. acute : lower very long, Upper bractes with a broad 6296 Silky, Stems erect hranch. Lvs. wavy, Calyxes long clavate, Pet. 2-part. crowned rmembranous margin 6297 Viscid pubescent, Lvs. lanceol. Cal. long tubular, Petals lanceolate crowned, Stamens very long 6298 Villous viscid, Lvs. lin. lanceol. obt. ciliated, Peduncle 1-fl. spreading in seed, Cal, circularly reflexed at base

$$
\text { 8. Caulescent, Flowers corymbose, Cal. clavate, 10-striped. }
$$

6299 Tufted roughish, Root thick woody branch. Stems simple slender very leafy at base, Lvs small lin acute 6300 Viscid, Stem much branch. pubesc. Lvs. round subciliated: the lower on long stalks, Fl. loosely corymb.

6301 Very smooth glaucous viscid, Leaves ovate-lanc. Fl, in panicled corymbs, Petals obcordate crowned

6302 Smooth, Stems erect branched, Upper leaves lanceolate: lower linear lanc. Umbel dense, Petals obovate

6303 Lower leaves cordate stalked : upper lanc. sessile, Petals twice as long as calyx

6304 Stems diffuse dichotomous rooting at base, Lower lvs. ovate stalked cord. : upper sess. Pet. shorter than cal.

6305 Stems procumbent with a lateral 1-sided hairy line, Leaves lanc. very tender, Fruit deflexed
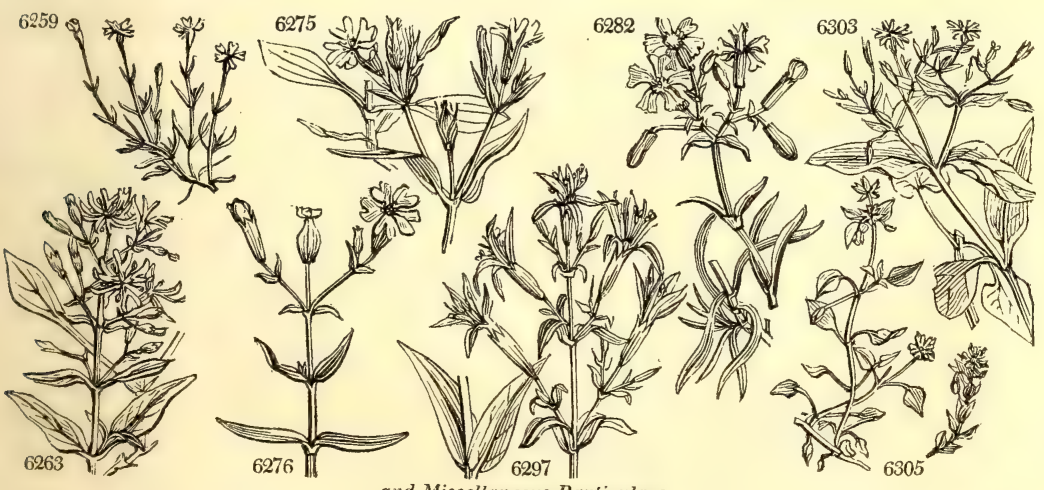

and Miscellaneous Particulars.

culture. S. media is a well known weed, never found but on rich friable soils in a state of culture: the sccis and flower buds are a favorite food of finches and other small birds. 
6306 dichótoma $W$ 6307 bulbosa $W$ 6308 vis'cida Bieb. 6309 Holóstea $W$ 6310 Laxmánni Fisch. 6311 graminea $W$. 6312 glaúca $H$. $K$. 6313 crassifólia $E h r$ 6314 uliginósa $\boldsymbol{H}$. $\boldsymbol{K}$. 6315 cerastoídes $W$ 6316 Arenária $W$. 6317 scapigera $W$. 6318 dahúrica $W$ 6319 murális Link. 6320 longipes Hook.

forked

bulbous

clammy

greater

Laxmann's

lesser

glaucous mar

thick-leaved

bog

Alpine

sand

naked-stalked

daurian

wall

long-stalked

1050. ARENA'RIA. $W$. SandWort.

6321 segetális Lam. Alsine segetális W. 6322 purpúrea Pers. 6323 rúbra $L$. 6324 marina Roth.

6325 média $L$.

6326 canadénsis Pers.

\begin{abstract}
corn
\end{abstract}
purple

red

marine

downy

Canada

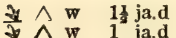

$\pm \Delta{ }^{w} \quad 1$ ja.d

$\neq \Delta \mathrm{w} \quad 1$ ap.jn

1 my.au W

1 my.au W

$\frac{x}{2}$ jn.jl

$\frac{1}{2}$ jn.jl

1 jn.jl

$\frac{s^{\frac{1}{2}}}{4} \mathrm{jn} . \mathrm{jl}$
$7 \Delta \mathrm{w} \quad 1$ ap.jn

s my W

W Britain clt. gr. S co

1823. S co Jacq.icon.t. 468 Hungary 1820. S co Wal. \& Kit.t. 29 Britain woods. D co Eng. bot. 511 Siberia 1823. S co Britain hed. b. D co Eng. bot. 803 Britain moi.m. D p.l Eng. bot. 825 Germany ... Britain rivul. S co Eng. bot. 1074 Scotland sc. alp. D co Eng. bot. 911 Spain 1799. S co Scotland sc.rivu, D co Dahuria 1818. S co Candia 1824. S co N. Amer. 1820. S p.l

Eng. bot. 1269

O w $\frac{5}{4} \mathrm{jn.0}$ W France 1805. S co

Vail. par. t.3. f. 3

O cu $\mathrm{cu}^{\frac{1}{4} \mathrm{jl}} \quad \mathrm{Pu} \quad$ Spain 1823. S s.l

O cu $\frac{1}{3}$ jn.au Pu Britain san.fi. S s.l Eng. bot. 852

$\$ \Delta$ cu $\frac{1}{8}$ jn.jl Pu Britain seaco. D s.l Eng. bot. 958

O W $\frac{1}{4} \mathrm{jl}$ W France 1795. S co

N. Amer. 1812. S p.l

6327 graminifólia $\mathrm{Schr}$. 6328 longifólia Bieb. 6329 rigida $B i e b$. 6330 pinifólia Bieb. 6331 subuláta Ser.

grass-leaved long-leaved stiff

pine-leaved subulate

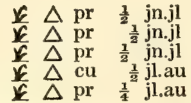

W

Juniper-leaved $f \Delta$ pr $\frac{1}{4}$ jn.jl W

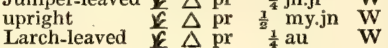
6333 strícta Mich. 6334 laricifólia $L$. rostráta W. \& K. 6335 striáta Vill 6336 Austríaca Jacq. 6337 triflóra $L$ 6338 grandiflóra $\boldsymbol{L}$. 6339 vérna $L$. 6340 Gerárdi $W$. 6341 saxátilis $L$ 6342 péndula $W$ \& \& $K$. 6343 tenuifolia $L$ 6344 mediterránea $I k$ 6345 recírva $A l l$. 6346 setácea Thuill. 6347 fasciculáta Gouan. 6348 filifólia Forst 6349 mucronáta Dec. Alsine mucronáta $\mathbf{W}$

6350 polygonoídes Jacq knotgrass-like 6351 verticilláta $W$.

6552 tetráquetra $L . \quad$ square $\quad \forall \Delta$ pr $\frac{1}{2}$ au 6353 lanceoláta All. lanceolate $\frac{\partial}{\Delta} \mathrm{cu} \quad \frac{1}{4}$ au 6354 cherlerioides $V i l l$. cherleria-leaved $\frac{\partial}{\Delta} \Delta$ pr $\frac{1}{4}$ jl.au 6355 montána $L$. 6356 serpyllifólia $L$. 6357 pubéscens Dec. 6358 brevicaulis Stern. 6359 scábra Poir 6360 ciliáta $L$ 6361 multicaúlis $J a c q$ 6362 trinérvis $L$.

striated

Austrian

three-flowered

great-flowered

vernal

rock

pendulous

fine-leaved

recurved

setaceous

level-topped

thread-leaved

$\frac{\mathrm{c}}{\mathrm{s}} \mathrm{pr}$

$\triangle \Delta$ pr

$\Delta \mathrm{pr}$

$\Delta \Delta$

$\Delta \Delta$ pr

$\triangle \mathrm{pr}$

pr

$\triangle$ pr $\frac{1}{4}$ jn.jl

1. $\mathrm{w}$

* $\triangle \mathrm{cu}$

ذष $\mathrm{pr}$

$\triangle \Delta \mathrm{cu} \quad \frac{1}{4} \mathrm{jl} . \mathrm{au}$

mountain

thyme-leaved

pubescent

hort-stalked

rough

$\Delta$ pr $\frac{1}{4} \mathrm{jn} . \mathrm{jl}$

Plantain leaved $\triangleq \Delta$ pr ${ }^{\frac{1}{2}}$ jl.au W

Siberia 1815. D co Sch. gott. t. 5

Siberia 1823. D co Gmel si. t.63. f.

Siberia 1823. D co

Caucasus 1823. D s.p

Caucasus 1822. D s.p

Armenia 1800. D s.p Sm. ined. 1. t. 35 N. Amer. 1812. D s.p

Britain ... D s.p Jac. aus. 3, t. 272

Switzerl. 1683. D s.p All. pe. 2.t.26.f.4 Austria 1793. D s.p Jac. aus. 3.t. 270 S. Europe 1816. D s.p C. ic. 3. t. 249. f. Switzerl. 1783. D s.p All. ped. 10. f. 1 Britain mount. D s.p Eng. bot. 512 France 1822. D s.p

Germany 1732. D s.p Gm. si.4.t.63.f.2 Hungary 1816. D co Pl.rar. h. 2.t. 87 England san.fi. S co Eng. bot. 219

Mediterr. 1823. S co

Alps 1822, D co Jac. col. t. 16

France ... S S co

Scotland sc. mo. S s.p Eng. bot. 1744

Arabia $\quad .$. D s.p Vah, sym.1.t.12

S. Europe 1777. S co Hall. hist. 1. t.17

Switzerl. 1822. S co Al. ped, t. 64. f. 4 Armenia 1823. C s.p

Pyrenees 1731. D s.p All.p. 2,t.89, f. Switzerl. 1823. D s.l Al ped t 26 f. 5 France ... D s.p

France 1000 . D s.p Bot. mag. 1118

Britain walls. S co Eng. bot. 923

Alp.... $\quad \ldots . .3 \%$ S co

1809 (18)

Ireland ir.mou. S s.p Eng, bot, 1745

Europe 1794. D s.p J. co. 1. t. 17. f.1 Britain woods. S s.p Eng. bot. 1483

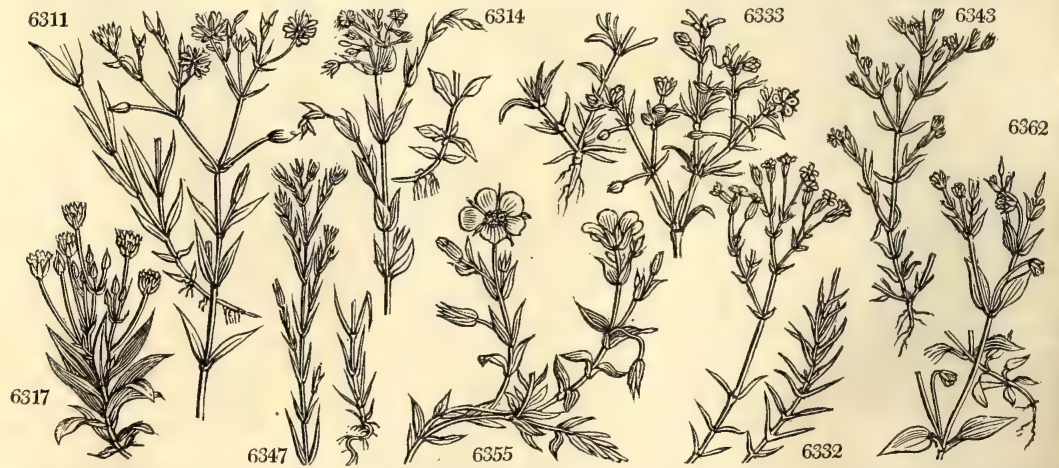

History, Use, Propagation, Culture,

1050. Arenaria. From arena, sand, in which most of the species are found. They are of most difficult discrimination, and are chiefly diminutive weeds found almost exclusively on sandy soils. The flowers vary 
6306 Hairy, Lvs. cord. ovate stem-clasping, Stem dichotomous, Fl. solitary, Sepals lanc. ac. longer than petals 6307 Leaves ovate lanceol. nearly veinless, Pedunc. 1-f. Sepals lanc acute twice as short as petals

6308 Villous viscid, Leaves lin. lanc. Stems dichotomous diffuse, Petals and capsule longer than calyx

6309 Lvs. lanc. acum. serrulate roughish : the upper broader and shorter, Pedunc. filiform very long, Pet. 2-fid 6310 Stem erect few-fl. Lvs. linear acute entire smoothish, Pedunc. filiform very long, Petals 2-parted 6311 Leaves linear smooth at edge, Stems diffuse, Fl. panicled divaricating, Petals the length of calyx 6312 Glaucous, Leaves lin. lanc. smooth at edge, Floral scarious, Petals twice as long as cal. Stem erect weak 6313 Leaves ovate-lanceol. entire smooth thick, Sepals ovate-lanceol. much shorter than petals

6314 Leaves ovate-obl. Pet. deeply divided shorter than calyx, Caps. ovate oblong longer than calyx

6315 Leaves obl. pubescent, Pedunc. 1-fl. twin, Pet. larger than cal. Caps. obl. nearly twice as long as sepals 6316 Leaves spatulate, Stem erect bifid viscid, Branches alternate, Petals emarginate

6317 Leaves linear lanc. obtuse very dense, Pedunc. 1-fl. and umbelled, Pet. scarcely longer than calyx 6318 Leaves lanc. entire sessile acute, Base and stem pubescent, Fl. axill. solitary

6319 Glandular pubescent, Stem procumbent, Leaves ovate fleshy, Petals scarcely longer than calyx cut 6320 Very smooth, Leaves linear-lanc. Pedunc. terminal dichotomous bracted, Pet. broad obovate 2-parted

8 1. Caps. 3-valved, Leaves linear, with scarious stipules at base.

6321 Smooth, Stem erect, Leaves subulate 1-sided, Petals shorter than calyx

6322 Hispid, Stem erect, Branches divaricating, Lvs. setaceous twice as short as joints, Pet. obt. shorter than 6323 Stems prostrate hairy, Leaves filiform shorter than the joint, Sepals lanceolate obtuse scarious at edge

6324 Like the last, but nearly smooth

6325 Stems prostrate, Leaves half cylindrical fleshy as long as joints, Seeds with a membranous wing

6326 Pilose subhispid, Leaves filiform longer than joint, Stamens 5, Seeds obcord. compressed, Caps. globose

$$
\text { 82. Leaves grassy, linear, lanceolate or rounded, without stipules, Caps. 3-valved. }
$$

$$
\text { * Leaves grassy. }
$$

6327 Stems erect simple, Lvs, subul, filiform rough, Panic, trichotomous pubescent lax, Calyxes very obtuse 6328 Ieaves subulate-filiform serrulate, Stems erect simple, Panicle trichotomous smooth compact

6329 Leaves lin. setaceous ciliated rough, Stems erect rigid simple, Sepals acute scarcely longer than corolla 6330 Stems ascending few-fl. pubescent, Lvs. setaceous rigid, Cauline straight, Sepals obtuse striated villous 6331 Leaves setaceous rigid mucronate striated, Stems panicled few-fl. Sepals lanc. much shorter than corolla * Leaves subulate or linear.

6332 Lvs. subulate rigid spiny : lower fascicled; upper distant, Stems erect firm, Pet. obov. twice as long as cal. 6333 Erect smooth many-stemmed, Leaves subulate linear erect, Pan. few-fl. Petals conspicuously striated 6334 Leaves subulate tooth-ciliated, Stems ascending 3-6-f. roughish, Cal. cylindrical, Sepals 3-nerved hairy

6335 Like the last, but stems rigid few-fl. Leaves long straight, Pedunc. and calyx viscid hairy

5336 Lvs, lin. subul. 3-nerved, Stem panicled, Pedunc, terminal very long twin downy, Pet. obt. emarginate

6337 Like the last, but stems 2 -4-fl. Leaves narrow recurved

6338 Lvs, subulate broadish flat 3-nerved ciliated, Radical clustered, Stems 1-fl. Pedunc. very long pubescent 6339 Tufted many-stemmed, Leaves subulate obtuse nerved, Stems panicled elongated

6340 Erect branched, Leaves linear subulate 3-nerved, Pedunc. twin terminal 1-flowered

6341 Leaves subulate, Stems panicled, Sepals ovate

6342 Stems filiform rooting very long diffuse, Flowering branches erect few-fl. Lvs. lin. flat acute fascicled

6343 Leaves subulate setaceous, Stem branched dichotomous, Sepals subulate striated much longer than petals 6344 Stem much branched, Leaves lin. recurved, Sepals with a long point and membranous edge

6345 Radical lvs. clustered recurved subul. 1-sided, Stems tufted simple 3-fl. Sepals and peduncles hairy gland. 6346 Stem much branched, Fl. panicled fastigiate, Leaves setaceous fascicled 1-sided ciliated at base 6347 Leaves subulate fascicled setaceous, Stems erect straight simple, Sepals acuminate with 2 lines 6348 Leaves setaceous fascicled with 2 stripes, Stems suftruticose dichotomous, Pedunc term. 1-2 -flowered 6349 Lvs. setaceous not ciliated at base, Stems tufted prostrate at base, Pedunc. longer than leaf, Sepals awned

6350 Procumbent, Leaves linear obt. Peduncles 2 or 3 1-flowered with 2 bractes at base, Sepals without nerves 6351 Leaves subulate rigid spiny and flowers whorled, Pedunc. 4-fl. capitate

*** Leaves lanceolate, oval or rounded.

6352 Leaves ovate carinate recurved edged imbricated 4 ways, Stems straight downy, Sepals rigid acute keeled 6353 Tufted villous, Branches ascending, Leaves lanceolate narrow acute rigid nerved 6354 Like the last, but smaller, with creeping and tufted stems, and imbricated leaves

6355 Pubescent, Leaves lanc. linear, Barren stems very long procumbent, Pedunc. terminal long 1-flowered 6356 Leaves ovate acute sessile regular ciliated and smooth, Sepals lanceolate 3-nerved acute green opaque 6357 Pubescent, Lvs. ovate acute stalked, Stems spreading branched elongated, Sepals acute shorter than cor. 6358 Leaves oblong acute 3-nerved ciliated imbricated, Stem prostrate, Sepals lanceolate acuminate striped 6359 Leaves lanc. acute spreading hard rough, Stem simple short, Sepals ovate acuminate striped 6360 Leaves ovate and obovate blistered rugose more or less nerved and ciliated, Stems procumbent 6361 Like the last, but leaves pulpy thick and sepals scarcely nerved

6362 Stem slender branched, Lvs. ovate acute stalked ciliated nerved, Pedunc. long bent down after flowering

6307

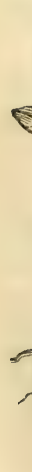

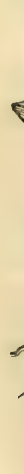
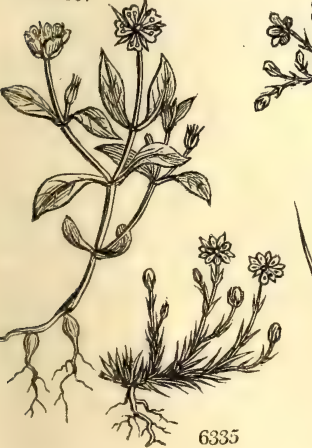

6335

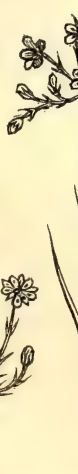

6328

considerably in the and Miscellaneous Particula,s. number. 
6363 baleárica $L . \quad$ Majórca $\$ \Delta \mathrm{pr} \quad \frac{3}{4} \mathrm{mr} . \mathrm{au}$ W Majorca 1787. D s.p L. h. stír. 1.t. 15 6364 peploídes $L$. Sea-chickweed $\frac{\partial}{7} \Delta$ pr $\frac{2}{4}$ my.jl W Britain sea sh. D s.p Eng. bot. 189 6365 procúmbens Vaht. procumbent $\mathcal{K}_{\mathrm{W}} \mathrm{pr}{ }^{\frac{1}{4} \mathrm{jl} \text {.au }} \mathrm{R}$ Egypt 1801. D s.p Vahl. sy. 2. t. 33 1051. Cherléria. $W$. Cherleria. 6365 sedoídes $W$. dwari 1052. BRUNNI'CHIA. $W$. BRUNNichia. 6367 cirrhósa $W$ Carolina \& L or 6 Polygonea. Sp. 1.

1053. GARIDEL/LA. $W$. Garidella.
6368 Nigellástrum $W$.
Nigella-leaved 1054. MALPI'GHi A. $W$. Barbadoes Cherry. 6369 glábra $W$. 6370 punicifólia $W$. 6371 polystáchia $H$. $K$. 6372 média $H . K$. 6373 glandulifera Jacq. 6374 glandulósa $W$. 6375 nítida $W$ 6376 fucáta B. Reg. M. macrophylla Desf. 6377 urens $W$. 6379 canéscens $W$ 6379 canescens $W$ crassifólia $W$ 6380 crassifólia $\mathbf{W}$. 6382 lúcida $W$. 6383 coriácea $W$. 6384 volúbilis Sims. 6385 aquifólium $W$. 6386 coccifera $W$. smooth-leaved Pomegran.-lvd. many-spiked intermediate quadriglandular biglandular glossy-leaved painted

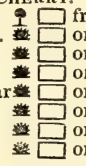
Malpighiacee. Sp. $18-70$.

$6 \mathrm{mr}$.jl $\mathbf{R}$ W. Indies 1757 . C p.l Bot. mag. 813 $\begin{array}{ccccccl}16 & \mathbf{m r} . j \mathrm{l} & \mathbf{R} & \text { W. Indies 1757. } & \mathbf{C} & \text { p.1 } & \text { Bot. mag. 813 } \\ 12 & \cdots & \mathbf{P k} & \text { W. Indies 1630. } & \mathbf{C} & \text { p.1 } & \text { Plum.ic.t.166.f.2 }\end{array}$ 10 mr.my Y W. Indies 1806. C p.l Bot. rep. 604 10 mr.my $\mathbf{Y} \quad$ W. Indies 1790. C p.1 10 mr.my Y W. Indies 1806. C p.I Jac. ic. 3. t. 469

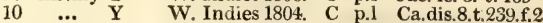
..... 1814. C p.l Bot. reg. 189

stinging $\square$ fr 3 jl.o Pk $\quad$ S. Amer. 1737. C p.1 Bot. reg. 96 narrow-leaved or 7 jl.au Pk W. Indies 1737. C p.l Bot. cab. 321 downy-leaved 9 or $20 \ldots \ldots$... $\quad$ W. Indies 1742. C p.l downy-leaved
thick-leaved yellow-spiked $9 \square$ or 20 au $\quad$ Y S. Amer. 1823. C p.l Aub.gu. 1.t. 183 wedge-leaved $\square$ or 6 my.au Pk W. Indies 1759. C p.l Bot. mag. 2462 leathery-leaved $\underline{\varphi}$ or 30 my.au Pk Jamaica 1814. C p.l Slo.h.2.t.163.f.1 twining \$ 5 or 10 au.s $\mathbf{Y}$ W. Indies 1793. C p.l Bot. mag. 809 Holly-leaved $\square$ or 7 au.s Pk S. Amer. 1759. C p.l C. di. 8.t.236. f.2 Kermes'Oak-lv. $\square$ or $22 \quad \ldots \quad$ Pk $\quad$ W. Indies 1733. C p.l Bot, reg, 568

1055. BANISTERIA. $W$. BANISTERIA. 6387 ciliáta $W$.

6388 purpúrea $W$. 6389 chrysophylla $W$. 6390 laurifólia $W$. 6391 nítida $W$. 6392 sericea $P$. $S$. 6893 fúlgens $W$. 6394 heterophýlla $W$. 6395 brachiáta $W$.

1056. HIRE'A. $W$. 6396 reclináta $W$. 1057. CNES'TIS. Lam. 6397 glábra Iam. ciliated purple

Star-apple-lvd. Bay-leaved glossy $\begin{array}{llllllll}\text { silky } & \text { or } & 10 & \ldots & \text { Y } & \text { Brazil 1810. } & \text { C } & \text { s.l Cav. dis. 9. t. 258 } \\ \text { shining-fruited } & \text { or } & 6 & \ldots & \text { Y } & \text { W. Indies 1759. } & \text { C } & \text { r.m }\end{array}$

Malpighiacee. Sp. 9-60. various-leaved 10 cross-branched $\square$ or 10 HirdeA.
reclined CNestrs.
smooth or $10 \begin{array}{ccccc}\text { Connaracec. } & \text { Sp. } 1-9 . \\ \text {... } & \text { W.G Mauritius 1823, C s.1 Lam. il.t. 387. } 1\end{array}$ ㄴ.4 or 10 Malpighiacea. Sp. 1-19.

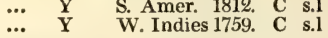

1 $\square$ or 10 … Y Y Brazil 1796. C s.l Cav. dis. 9.t. 254

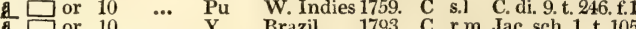
Brazil 1793. C r.m Jac. sch. 1.t. 105 ... Y Jamaica 1733 C s.

S. Amer 1809. C s.J Cav. diss, t. 244 $\begin{array}{lll}\cdots & \text { S. Amer. 1809. C s.J Cav. diss. t. } 244 \\ & & \end{array}$ Cav. dis. t. 253

PENTAGYNIA.

1058. AVERrho'A. W. Averrhoa.

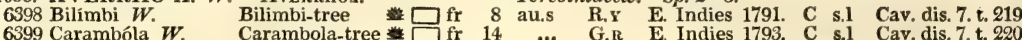

Terebintacece. Sp. $2-3$.

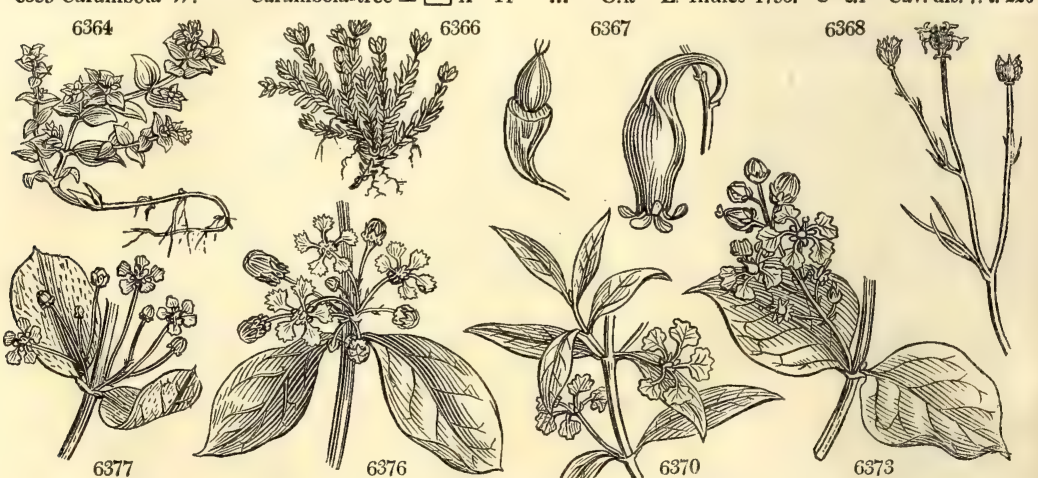

History, Use, Propagation, Culture,

1051. Cherleria. John Henry Cherler was an assistant of John Bauhin in preparing his Historia Plantarum. A little obscure weed.

1052. Brunnichia. A catalogue of the books upon natural history was published by one Mr. F. Brunnich, a Danish raturalist, in 1793.

1053. Garidella. So named by Tournefort, in honor of Pierre Garidel, M. D., physician at Aix in Provence, author of Histoire des Plantes qui naissent en Provence, 1719, with many figures. A plant of little curiosity or beauty. Small inconspicuous plants of the easiest management

1054. Malpighia. So named by Plumier in honor of Marcello Malpighi, professor of medicine at Bologna, author of Anatome Plantarum, 1765 and 1769; a celebrated work, the best of its time on the structure of vegetables. The species are handsome evergreen trees and shrubs, some of them fruit-bearing and others climbers. M. glabra is grown for its fruit in the West Indies, and the fruit of M. urens is also eaten under the name of Barbadoes cherry, but that of both species is much inferior to European cherries. All the species have the under sides of their leaves covered with prickly bristles which when handled run into the fingers. Ripened cuttings root freely in sand under cover.

1055. Banisteria. So named by Dr. Houstoun, in memory of the Rev. John Banister, a curious botanist, who lost his life in search after plants in Virginia. The species are chiefly evergreen climbers and twiners; some of them, as B. fulgens and chrysophylla, have fine shewy fnliage as well as beautiful flowers. 
6363 Tufted creeping, Leaves ovate shining fleshy ciliated, Pedunc. long 1-fl. Flowers cernumus 6364 Leaves ovate acute fleshy approximated, Fl. solitary on short stalks, Sepals obl. acute as long as col. 6365 All over pubescent, Leaves lin. lanceol. Stems prostrate much branched, Seeds very minute

(366 Leaves spreading

\section{Leaves cordate sagittate}

6368 Petals sessile spreading, Stamens 10-12

6369 Leaves ovate entire smooth, Peduncles umbelled 6370 Leaves ovate entire smooth, Peduncles 1-flowered

6371 Leaves entire oblong acute smooth shining with 2 glands beneath at the base

6372 Leaves entire oblong lanceolate acute smooth with 2 glands at a distance from the base

6373 Leaves ovate nearly entire with hairs on both sides, Fl.-stalks with a truncate gland at top

6374 Leaves ovate elliptical acuminate entire smooth with 2 glands at base

6375 Leaves oblong acuminate entire smooth, Racemes axillary, Fl. monogynous

6376 Leaves elliptical shining hairy beneath, Fl, axillary corymbose

6377 Leaves obl. ovate with decumbent stiff bristles, Peduncles 1-fl. aggregate

6378 Leaves lin. lanceol. with decumbent bristles on each side, Peduncles umbelled

6379 Leaves obl. obtuse pubescent, Racemes axillary compound

6380 Leaves ovate entire obtuse downy beneath, Racemes terminal

6381 Leaves ovate downy beneath acute, Flowers yellow spiked

6382 Leaves obovate wedge-shaped entire veinless shining, Raceme terminal

6383 Leaves ovate acute entire smooth on each side, Racemes terminal spiked

6384 Leaves oval acuminate shining, Racemes corymbose terminal

6385 Leaves lanceol. toothed-spiny hispid beneath

6386 Leaves subovate tonthe-t-spiny

6387 Leaves orbicular cordate ciliate toothletted smooth, Petioles with 2 glands

6388 Leaves roundish ovate obtuse smooth, Racemes axillary and terminal, Seeds erect

6389 Leaves ovate oblong acutish towards the end obsoletely ciliated beneath shining gold-colored

6390 Leaves ovate-oblong rigid, Racemes terminal

6391 Leaves ovate oblong entire beneath shining, Panicle terminal leafy

6392 Branches 2-edged, Leaves ovate downy beneath, Petioles with 2 glands

6393 Leaves subovate downy beneath, Racemes brachiate, Peduncles umbelled

6394 Leaves downy beneath orbicular cordate, Branches divaricating roundish, Petioles with 2 glands

6395 Leaves subovate, Branches brachiate, Seeds narrower inwards

6396 Leaves simple obovate obtuse pubescent above smooth beneath

6397 Leaves pinnated, Leaflets ovate stalked smooth on each side, Racemes fascicled

\section{PENTAGYNIA.}

6398 Leaves pinnated, Leaflets ovate-lanceolate, Fruit oblong with obtuse angles 6399 Leaflets ovate unequal acuminate, Fruit obl, acute-angled

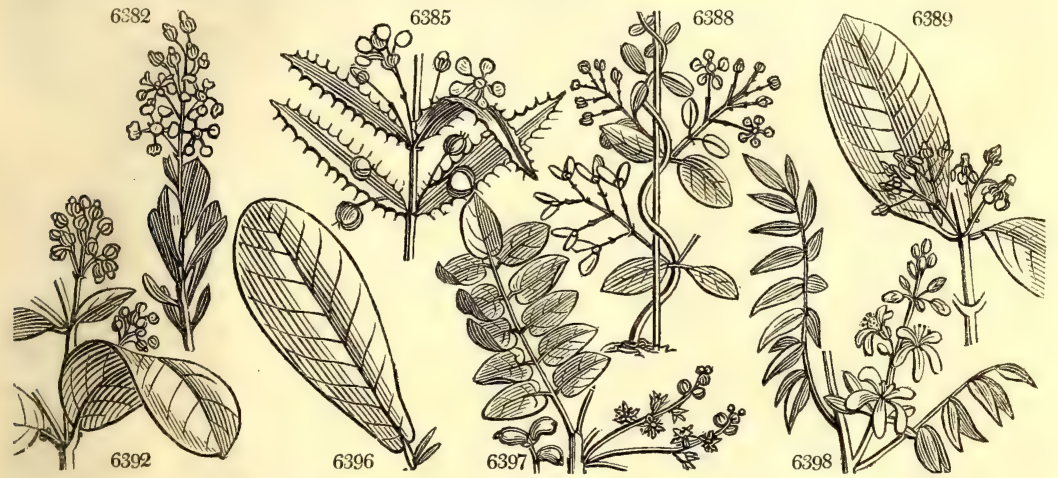

and Miscellaneous Particulars.

All of them root freely in ripened wood in sand under a hand-glass. In most respects they resemble the last genus.

1056. Hiraa. Named after John Nicholas de la Hire, a French physician, who died in 1727. Plants with the appearance of Banisteria.

1057. Cnestis. From *yn $\omega_{\omega}$, to scratch. The capsules, covered with hairs, excite a troublesome itching. Fine evergreen stove shrubs.

1058. Averrhoa. So named in honor of Ebn Elvelid Ebn Rushad, commonly called Averrhoes, of Corduba in Spain, a famous commentator on Aristotle and Avicenna. He also published Calliget, or the plants used in food, \&c. He died at the beginning of the thirteenth century. The specific names are vernacular appellations. The species are evergreen trees, singular for the fruit growing frequently on the trunk itself, below the leaves: the flowers grow in racemes; the fruit is a five-celled pome. A. Bilimbi is a beautiful tree with a green fleshy oblong fruit the thickness of the finger, filled with a grateful acid juice; the substance and seeds not unlike those of cucurnber. They make a syrup of the juice, and a conserve of the flowers, which are esteemed excellent in fevers and bilious disorders. bears a fruit the size of a hen's egg, with a pulpy employed also in dying, and have a peculiar sensitive quality, of which an account is given by Dr. Bruce in the Philosophical Transactions, 
1059. SPON'DIAs. $W$.

6400 Mómbin $W$.

6401 Myrobálanus $W$ 6402 dúlcis $W$

1060. COTYLE'DON. $W$. 6403 orbiculáta Haw. 6404 ováta Haw. 6405 papilláris $L$. 6406 oblónga Haw. 6407 curviflóra 6408 ramosíssima Mill. 6409 fasciculáris $W$. 6410 coccínea $W$. 6411 decussata Sims. 6412 hemisphæ'rica $W$. 6413 spúria $W$.

6414 cæspitósa Haw. linguafórmis $\mathbf{H}, \mathbf{K}$. 6415 serráta $W$

6416 hispánica $W$ 6417 Malacophýllum $W$. 6418 umbilicus $W$.

в Mucizóni Brot.

6419 lútea $W$.

1061. SE'DUM. $W$. 6420 verticillátum $W$. S. triphyllum Haw. 6490 maximum Haw. 6423 Teléphium Haw.

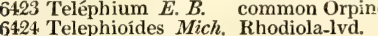
6425 Anacámpseros $W$ 6426 divaricátum $W$. 6427 Aizóon $W$. 6428 spúrium $W$. cn. 6429 oppositifólium $B . M$. opposite-leaved 6430 hýbridum $\boldsymbol{W}$. Germander-lvd. 6431 populifólium $W$. Poplar-leaved 6432 ternátum $P h$. Purslane-leaved 6433 stellátum $W$. 6454 spathulátum $W$. en. spathulate 6435 серæа $W$. 6436 spinosum $W$ en panicled Crássula spinósa $\mathrm{W}$ 6437 dasyphýllum $W$. 6438 refléxum $E$. $B$. 6439 glá́cum $E$. $B$. 6440 collínum $W_{\text {. }} e n$. $64+1$ viréscens $\boldsymbol{W}$. en. 6442 septanguláre Haw. 6144 rupéstre $W$. spiny

Hog Plum. flat-stemmed yellow

NAVEL-WORT. round-leaved ovate-leaved conical

long-leaved curve-flowered many-branched scarlet cross-leaved thick-leaved arrow-leaved notch-leaved Spanish Penny-wort yellow

STONE-Crop. whorl-leaved

great-purple evergreen spreading yellow

thick-leaved reflex-leaved glaucous hill greenish-flower. seven-rowed green rock

6445 Forsteriánum $H . K$. Forster's 6446 crerúleum $V a h l$. pale-blue 6477 sempervivoides Bieb. Semperviv lik $\frac{f}{\Delta}$ or

Terebintacea. $S p .3-7$

... Y.G W. Indies 1817 C s.p Slo, his. 2.t. 219

Y G W. Indies 1739 C s.p Mer sur t. 13

... Y G Society Is. 1793. C s.p Lam. ill. t. 384

Sempervivece. $S p .17-20$.

* cu 2 jl.au R C. G. H. 1789. C s.

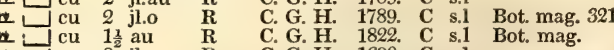

cu 2 jl.s

- $1 \frac{1}{20}$

R C. G. H. 1822, C s.I Bot. mag.

C. G. H. 1690, C s.I

Or C. G. H. 1818. C s.I Bot. mag. 2044

$\ldots$ C. G. H. 1768. C s.1

R C. G. H. 1759. C s.1 Burm, afr t 18

Sc C. G. H. 1816. C s.1 Bot. cab. 832

Sc C. G. H. 1819. C s.l Bot. mag. 2518

... C. G. H. 1731. C s.l Plant. grass. 87

Y.. C. G. H. 1731. C s.l Com rar, t. 23

California 1796. C s.1

Y Siberia 1732. C s.1 Di, el. t. 95. f.112

Y Spain 1796. C s.l Plant. grass. 122

P.x Davuria 1815. C s.1 P.it.3.ap.t.G. f.I

Y Britain sha.roc. C s.1 Eng. bot. 325

Y Portugal 1823. S s.1

England moi.ro. C s.l Eng. bot. 1522

Sempervivece. $\quad$ sp. $41-60$.

\& $\Delta$ or $1 \mathrm{jl}$.s $\quad$ Pk $\quad$ S. Europe ... $D$ s.1 Am. ac.2.t.4.f.14

\& $\Delta$ or 2 jl.s $\quad$ W $\quad$ Spain 1794. D s.l

C $\triangle$ or 2 jl.s W Europe 1794. D s.l

$\triangle$ or 2 jl.s $\quad \mathrm{Pu}$ Britain bor.fi. D s.l Eng. bot. 1319

$\triangle$ or $1 \mathrm{jl}$.s Pu N. Amer. 1810. D s.l

$\checkmark$ or $\frac{1}{2}$ jl.au Pu France 1596. D s.l

E jor $\frac{1}{2}^{2}$ jn.jl Pk Madeira 1777. R s.l

$\Delta$ or 1 jl.s $\quad$ Y Siberia 1757. D s.1

$\frac{1}{2}$ jl.s Pk Caucasus 1816. D s.1 Bot. mag. 2370

$\frac{1}{2}$ jl.s W Caucasus ... D s.l Bot. mag. 1807

$\frac{1}{2}$ my.jl Pu Siberia 1766. D s.1 Mur. c. go.6. t. 5

1 jl.au W Siberia 1780. D s.1 Bot. mag. 21

1 jlau W N. Amer. 1789. D s.l Bot. reg. 142

$\frac{x^{2}}{2}$ jn.jl W $\quad$ S. Europe 1640. S s.1 Cam. ho.7. ic. 2

W Hungary 1815. S s.1 Pl. ra.h.2. t.104

W France 1640. S s.

Siberia 1790 . D s.1 Gm, sib. t. 67. f.2

\& or 1 jl.au

$\Delta$ pr $\frac{1}{4}$ jn.jl

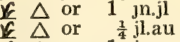

$\Delta$ or 1 jn.au

or 1 jn au

$1 \mathrm{jnj}$

$\frac{2}{2}{ }^{\frac{1}{2}} \mathrm{jn} . \mathrm{jl}$

$\frac{1}{2}$ jn.jl

$\frac{x}{4}$ jl.au

1 $\frac{1}{4}$ jl.au

\section{4}
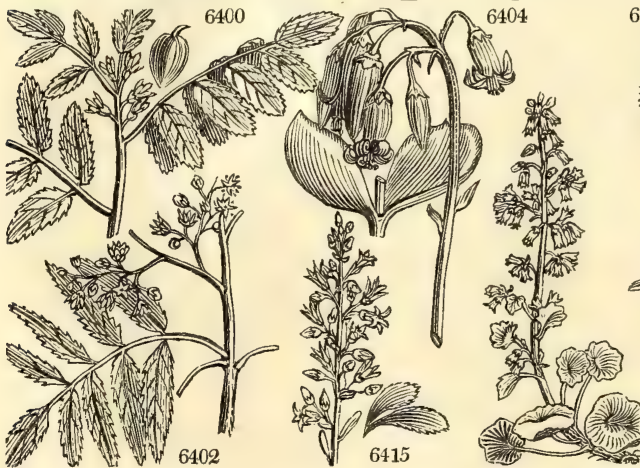

W England walls. D s.

Y

Britain walls. D s.1

1815. D s.1 Eng. bot. 2477

..... 1815. D s.

$1795.0 \mathrm{~s}$

Portugal 1774, D s.

Y England rocks. D s.1 Eng. bot. 170

W. roc. D s.1 Eng. bot. 1802

P.B Africa 1822. D s.1 Bot. reg. 520

Iberia 1823. D s.l Bot. mag. 2474
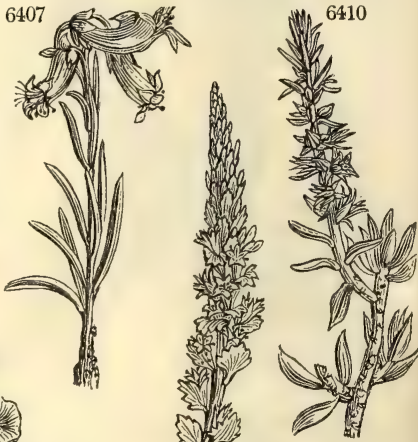

History, Use, Propagation, Culture,

Both species form handsome plants in our stoves; they grow freely, and ripened cuttings root readily in sand under a hand plass.

1059. Spondias, One of the Greek names of the plum. The plants of this genus bear fruit like plums; which are also called hog plums in the West Indies. These are deciduous fruit-bearing trees, natives or cultivated in both Indies. S. Mombin (the South American name) flowers from the sides of the branches, and is known by its oblong or ovate fruit like a plum, having a luscious thin pulp covering a large fibrous stone 'The skin is yellow, purple, or variegated; the pulp is yellow and thin, having a singular but not unpleasant taste, and a sweet smell. The seed scarcely ever ripens, but it is so easily increased by cuttings, that if a branch laden with young fruit be set in the ground, it will grow, and the fruit will soon come to maturity. In St. Domingo they make hedges of the boughs, which flower and bear fruit in a few months. It is also cultivated for the sake of the frtilt, though it is not in much esteem in Jamaica.

The flowers of S. Myrobalanus (the Myrobalanus of Dioscorides was an Egyptian or Arabian tree, which 
6400 Common petiole compressed

6401 Common petiole round, Leaves shining acuminate

6402 Common petiole round with 6 pairs of leaflets which are serrated and ribbed

6403 Leaves orbicular spatulate powdery obtuse with a point, Fl. panicled, Stem erect branched

6404 Leaves ovate spatulate obtuse powdery with a point edged with red, Fl. panicled, Stem erect branched 6405 Leaves opp. rounded ovate, Flowers corymbose

6406 Leaves obl. spatulate obtuse smooth with a point, Fl. panicled, Stem erect branched

6407 Leaves semicylindrical scattered, Fl. panicled nodding, Tube curved

6408 Leaves ovate spatulate obtuse with a point powdery, Fl. panicled, Stem much branched divaricating

6409 Leaves wedge-shaped fascicled, Stem thickened, Branches fleshy conical

6410 Leaves obovate acute fleshy, Spike leafy terminal

6411 Leaves crossing rounded mucronate glaucous, Fl. panicled pendulous

6412 Leaves half orbicular scurfy dotted flat above, Fl. few small sessile

6413 Leaves spatulate obtuse naked with a point

6414 Leaves glaucous narrow tongue-shaped at the end obcuneate mucronate, F1. cymose, Stem leafy

6415 Leaves oval crenate, Stem spiked

6416 Leaves oblong nearly round, Flowers fascicled

6417 Leaves lanceolate acute fleshy, Spike cylindrical terminal leafless

6418 Leaves peltate crenate, Stem nearly simple, Fl. pendulous, Bractes entire

6419 Leaves peltate crenate, Stem nearly simple, Flowers erect, Bractes toothed

\section{Leaves whorled 4}

6421 Leaves amplexicaul. cordate ovate obtuse unequally and deeply serrated

6422 Leaves amplexicaul. cordate oblong obtusely serrated whitish

6423 Leaves flattish serrated, Corymb leafy, Stem erect

6424 Leaves flat ovate acute at each end toothed, Flowers in corymbose fascicles

6425 Leaves wedge-shaped narrowed at the base subsessile, Stems decumbent, Fl. corymbose

6426 Leaves wedge-shaped rhomboid emarginate stalked, Stems branched, Pan. term. divaricating

6427 Leaves lanceolate serrated flat, Stem erect, Cyme sessile terminal

6428 Leaves roundish obovate flat crenated at end with a cartilaginous muricated edge

6429 Leaves flat opposite spatulate toothed

6430 Leaves wedge-shaped concave somewhat toothed aggregate, Branches creeping, Cyme terminal

6431 Leaves tiat cordate toothed stalked, Corymbs terminal

6432 Leaves whorled obovate entire smooth, Cyme in three divisions

6433 Leaves flattish angular, Fl. lateral subsessile solitary

6434 Stems branched, Leaves entire : lower spatulate, Stigmas acute

$6+35$ Leaves flat lanceolate, Stem branched, Flowers panicled, Petals acute awned

6436 Radical leaves obovate with a long mucronate point, Stem simple, Spike term. long

6437 Leaves opposite ovate obtuse fleshy, Stem weak, Fl. scattered

6438 Leaves subulate scattered separate at base: the lower recurved

6439 Leaves giaucous subulate scattered separate at base, Fl. cymose, Cal. lanceolate

6440 Lvs, rounded subulate acute: those of the barren branches glaucous spreading, Branches of cyme recurver 6441 Lvs. rounded subulate acute : those of the barren branches glaucous spreading, Branches of cyme compact 6442 Leaves subulate in 7 rows glaucous very close distinct at base

6443 Leaves subulate scattered separate at base, Fl. in cymes, Petals half as long as lanceolate calyx 6444 Leaves subulate scattered separate at base glaucous, Fl. in cymes, Petals twice as long as calyx 6445 Leaves subulate spreading in many rows close, Cal. short obtuse

6446 Leaves oblong alternate obtuse separate at base, Cyme bifid smooth

6447 Leaves flat spatulate ovate acute entire pubescent, Corymb hemispherical
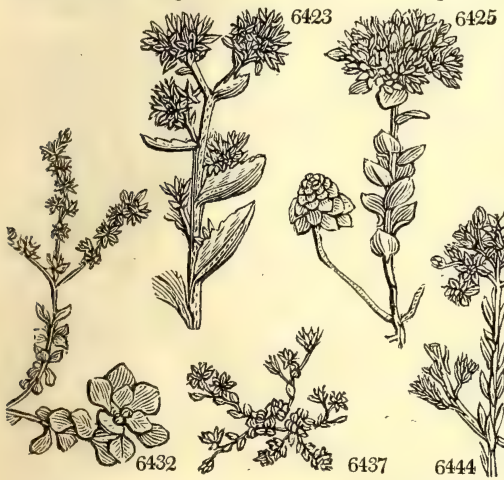

$$
6429
$$

6431

[erect 
6448 altissimum $\boldsymbol{P} . S$ tall Sempervivum sediforme W. 6449 quadrífidum $W$. four-cleft 6450 hispánicum $W$. Spanish 6451 álbum $W$. white

6452 ácre $W$.

6453 sexanguláre $W$

6454 ánglicum $W$. English

6455 ánnuum $W$.

6456 villósum $\dot{W}$. hairy

6457 monregalénse $P . S$. clammy

6458 atrátum $W$. dark-annual

naked-branch.

1062. PENTHO'RUM. $W$. PENTHORUM 6460 sedoídes $W$.

American

E $\triangle$ or

jl.au

P.x

$\frac{1}{\Delta}$ or ${ }^{\frac{1}{2}}$ jl $j n, j l$

\& $\triangle$ pr $\frac{1}{4}$ jn.jl

$\leqslant \Delta$ pr $\frac{x}{4}$ jn

$\frac{\mathrm{F}}{\mathrm{E}} \Delta \mathrm{pr} \quad{ }^{\frac{1}{2}} \mathrm{jn} . \mathrm{jl}$

O pr ${ }^{4} \mathrm{au}$

v $\triangle$ pr $\frac{1}{2}^{\frac{1}{8}}$ jn.jl

$\Delta$ pr $\frac{1}{2} j n . j l$

- L pr ${ }^{\frac{3}{4}} \mathrm{jl} . \mathrm{au}$

Y N. Asia 1800. D s.l Pa. it.3.a.t.P.t.1 P.X Spain 1732. D s.l Jac. au. 5. t. a.47 W England rocks. D s.l Eng. bot. 1578 Y Britain walls. D s.1 Eng. bot. 839 Y England walls. D s.1 Eng. bot. 1946 W Britain rocks. D s.1 Eng. bot. 171 W N. Europe 1739. S s.1 Pk Britain m.al.p. D s.1 Eng. bot. 394 W S. Europe 1816. D s.1 Bot. cab. 464 Pu Italy 1795. S s.1 Jac. aus, 1.t. 8 Sempervivea. Sp. 1.

$\Delta$ cu 1 jlau G.x Virginia 1768. D s.l Lam. ill. t. 390 Rosacea. Sp. 1.

1063. GRIE'LUM. $W$. GRIELUM. 6461 tenuifólium $W$. slender-leaved $Y$ Oxalis sensitiva $\mathbf{L}$.
Ox nsitive

$\triangle$ un

\section{Oralidece. $S p .1-2$.}

$\begin{array}{cc}\text { Oxalidea. } \\ \frac{1}{2} \mathrm{jl} . \mathrm{s} & \mathrm{Y} p .1-2 .\end{array}$

1823. S s.l Jac. ox. t. 78, f. 4

1065. OX'ALIS. $W$. 6463 Plumiéri Jacq.

Oxalis.

Plumier's

perennia

annual

free-flowering

upright

procumbent

red-flowered

ros

lateral

long-styled

tube-Howered

side-flowerin

hairy-stalked $\triangle \triangle$ or

many-flowered $\delta \Delta$ or

branching-red $\delta \Delta \mathrm{L}$ or

rose-colored of $\triangle \mathrm{N}$ pr

Oxalidea. Sp. $72-154$

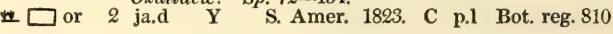

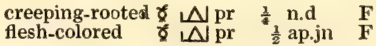

N. S. W. $\quad$.. $\quad$ O s.p

America 1798. S s.p Dill. elt. t. 221

America 1798. S s.p

N. Amer. 1658. O s.p Jac. ox. t. 4

Britain sh. roc. O s.p Eng. bot. 1726

N.S. W. $\quad \ldots$ S s.p

C. G. H. 1793. O s.p Jac, ox, t.78, f.1

Chili 1823. O s.p Bot. mag. 2115

C. G. H. 1824, O s.p Jac. sch, t. 2(14

6473 tubiflóra Jacq.

6475 hirta $L$.

6477 rubélla

6478 rosácea Jacq.

6479 reptátrix Jacq. 6480 incarnáta $L$.

6481 serícea $L$

6482 violácea $L$

6483 caprina $L$.

5484 cérnua Thunb.

6485 compréssa Jacq.

6486 dentáta Jacq.

6487 lívida Jacq.

6488 lobáta Sims. silky

o $N$ or ap.my $Y$

violet-colored $\frac{\delta}{8} \Delta$ or $\frac{x}{4} \mathrm{my}$.jn $\mathrm{L}$.

Goat's-foot

drooping

compressed

toothed

livid

t $\triangle$ or $: \frac{3}{4} \mathrm{mr} . \mathrm{jn}$

f $\triangle$ or $\frac{1}{4}$ f.my Y

$\forall$ or

$\frac{1}{4}$ ja.d Y

$\frac{1}{4}$ n.d F
\& $\triangle$ or $\quad \frac{2}{4}$ o.n $\quad$ F

C. G. H. 1793. O s.p Jac. ox. t. 9

C. G. H. 1790. O s.p Jac. ox. t. 10

C. G. H. 1790. O s.p Jac. ox, t. 12

C. G. H. 1787. O s.p Jac. ox. t. 13

C. G. H. 1789. O s.p Jac. ox. t. 15

$\begin{array}{llll}\text { C. G. H. } & \text { 1791. } & \text { O s.p } & \text { Bot. mag. } 1031 \\ \text { C. G. H. 1793. O s.p } & \text { Bot. mag. } 1698\end{array}$

C. G. H. 1795. O s.p Jac. ox. t. 20

C. G. H. 1739. O s.p Jac. ox. t. 71

C. G. H. 1794. O s.p Jac. ox. t. 77, f. 1

N. Amer. 1772. O s.p Jac. ox. t.80. f. 2

C. G. H. 1757. O s.p Jac. ox. t. $76 . \mathrm{f} .1$

C. G. H. 1757. O s.p Jac. ox. t. 6

C. G. H. 1794. O s.p Jac. ox. t. 78. f.3

C. G. H. 1793. O s.p Jac. ox. t. 7

C. G. H. 1793. O s.p Jac. ox t. 8

C. G. H. 1823. O s.p Bot. mag. 2386

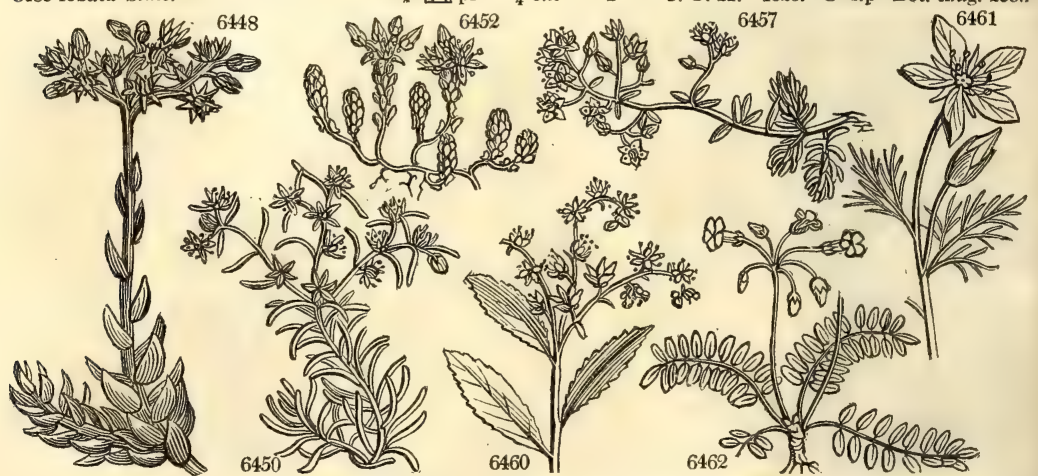

History, Use, Propagation, Culture,

They seem destined by nature to clothe rocks and dry arid places, after a certain portion of vegetable soil has been generated by lichens and mosses.

Orpine is the French name of two or three species. S. album is said to have the same virtues as used to be attributed to the houseleek, Sempervivum tectorum: it is pickled by some in the manner of samphire. $\mathrm{S}$. acre is considered antiscorbutic ; its juice applied to the skin blisters it, taken inwardly it vomits, and applied externally to gangrenes promotes suppuration

1062. Penthorum. From $\pi \varepsilon v \tau \propto$, five, in allusion to the five-marked angles of the capsules. Succulent North American plants of no beauty whatever.

1063. Grielum. A small uninteresting Cape plant, with yellow flowers and hoary leaves like scuthernwood. Derived from rgrïos, old, in allusion to its hoary aspect.

1064. Biophytum. Bis фvroy, plant of life, in allusion to the lively irritable nature of the foliage. This genus, the Oxalis sensitiva of Jacquin, has been lately divided by $\mathbf{M}$. De Candolle from Oxalis, chiefly on 
6448 Petals 8, Leaves scattered : the lower rounded; upper depressed

6449 Leaves scattered rounded obtuse, Stem simple, Fl. in umbels with 4 petals 6450 Leaves linear rounded depressed scattered, Cyme open, Petals 4 6451 Leaves oblong obtuse roundish sessile spreading, Cyme branched 6452 Leaves subovate adnate-sessile gibbous nearly erect alternate, Cyme trifid

6453 Leaves subovate adnate-sessile gibbous nearly erect imbricated six ways

6454 Leaves subovate adnate-sessile gibbous alternate, Cyme branched bifid

6455 Stem erect solitary annual, Leaves ovate sessile gibbous alternate, Cyme recurved

6456 Leaves oblong flattish above and peduncles axillary about 1 -fl. pubescent, Petals ovate obtuse

6457 Leaves whorled linear, Stem procumbent panicled, Peduncles villous viscid

6458 Stem erect, Flowers corymbose fastigiate

6459 Leaves scattered oblong-cylindrical obtuse, Stems shrubby much branched, Cymes terminal

6460 The only species

6461 Peduncles simple 1-fl. Leaves tripartite multifid linear downy

6462 Peduncles many-fl, at end

81. Peduncles many-flowered, Stems suffinticose, Cells of ovary usually 1 seeded.

6463 Stem erect leafy, Umbel 4-fl. the length of leaves, Leaflets entire ovate obtuse

8. Caulescent, Leaves palmate 3-foliate, Leaflets all sessile, obcordate.

6464 Pedunc. 2-3-fl. somewhat longer than leaf-st. Lvs. 2-lobed obcord. ciliated, Styles a little longer than inner 6465 Stem hairy, Umb. 5-6-fl. longer than leaves, Lvs, obcordate, Styles longer than both stamens [stamens

$\beta$ Stem decumbent, Peduncles 2 or 3 -flowered

6466 Stem erect, Umbels 2-6-fl. about as long as leaves, Leafl. obcord. Styles the length of inner stamens 6467 Stem rooting, Peduncles shorter than leafst. Leafl. obcordate, Styles the length of inner stamens 6468 Smoothish, Pedunc. 2-fl. longer than leafst. Leaf. 2-lobed, Styles the length of inner stamens

6469 Stem rooting, Pedunc. 2-fl. the length of leafst. Leaflets obcordate, Styles middling

6470 Stem erect, Pedunc. axill. four times as long as leaf at the end corymbose racemose, Leafl. obcordate

6471 Stem naked at base, Pedunc. lateral umbell. at end, Leafl. cun. emarg. Styles shorter than outer stamens

8. Caulescent, Leaves sessile, 3-leaved, villous, not glandular, Pedunc, axillary, 1-flowered.

6472 Stem branch. Ped. much long. than lvs. Bractes next cal. Leafl. lin. emarg. Styles long. than inner stam. 6473 Ped. 4 times as long as lvs. Bractes appressed to cal. Leafl. lin. cun. obt. Styles shorter than outer stamens 6474 Stem declined, Branches 1-sided, Leafl. lin.-cuneiform, Peduncles scarcely longer than leaves

6475 Leafl, lin. cun, ret. Ped. much long. than lvs. Bractes remote from cal. Stam. with neither teeth nor glands 6476 Stem much branched, Leaf. lin. cuneate obt. Pedunc. much shorter than lvs. Bractes remote from cal. 6477 Leaf. lin. cuneate, Pedunc. much longer than leaves, Bractes remote from cal. Styles intermediate 6478 Leafl. obl. cuneiform, Pedunc. much longer than leaves, Bractes remote from cal. Styles intermediate

4. Caulescent, sparingly leafy, Leaves stalked, 3-5-leaved, Pedunc. axill. 1-flowered. 647 a Stem short, Leaves on long stalks, Leafl. 3 ovate-rounded, Styles very short

6480 Stem branched, Leaves stalked in fascicled whorls with 3 obcordate leaflets, Styles very long

\$5. Stemless, Pedunc. 1-2 or many-flowered, Leaves radical, many-leaved, usually 3-leaved

6481 Leaf. 3 obcordate silky, Umbel longer than leaves, Fl. nodding, Styles intermediate

6482 Leafl. 3 obcordate smooth, Umb. 3-9. fl. Styles very short, Fl. nodding

6483 Leafl. 3 obcordate 2-lobed smooth, Umb. 2-4-fl. Flowers erect, Styles very short

6484 Leaf. 3 obcordate 2 -lobed smooth subciliated, Umb. many-fl. Fl. drooping, Styles very short

6485 Petiole flattish, Leaf. 3 obcordate pubescent, Umb. 2-fl. Sepals entire, Styles very long

6486 Leaf. 3 obcordate smooth subciliate, Umb. 2-5-fl. Sepals 3-toothed at end, Styles very long

6487 Leafl. 3 obcordate 2 parted beneath violet, Umbel 2-fl. Styles middling

6488 Smooth, Pedunc. 1-fl. longer than leaf, Leaflets obcordate, Root tuherous
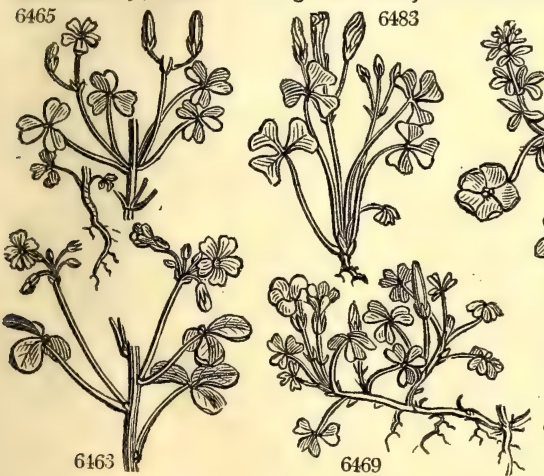

6477

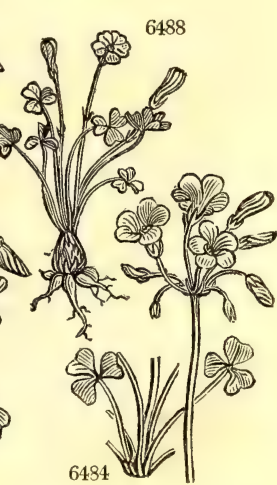

and Miscellaneous Particulars.

account of its irritable pinnated foliage, and its stamens being distinct, and five of them only being perfect. It is a very pretty annual, and if well managed so as to acquire, as in China, a stem six or nine inches high, is quite a remarkable object. Cultivated in common earth, and propagated by seeds, which it produces in abundance.

1065. Oxalis. The Oxalis of the ancients, which was named from o६vs, sharp, or sour, was a very different plant from this, which is thought to have been the Oxys of Pliny. The name employed by Linnæus has, however, been adopted by his followers, although Clusius, Ray, Plumier, Tournefort, Haller, and others, called the genus Oxys.

This is a tribe of pretty little plants, of which most of the species flower freely, but all of them are without their leaves half the year. The root is commonly bulbous; in some species only thick and fleshy; in a few branched: the bulbs consist of fleshy scales, sometimes closely imbricate, sometimes loose and diverging. In

a few the subterraneous stipe and the terminating fibre of the bulb produce little dog-toothed bulbs, in such 
6489 monophýlla $L$. 6490 rostráta Jacq.

6491 crispa Jacq. 6492 leporína Jacq. 6493 asinina Jacq. 6494 lanceæfólia $J a c q$ 6495 fabæfólia Jacq.

6496 laburnifólia Jacq. 6497 sanguínea Jacq. 6498 trícolor Jacq. 6499 ciliáris Jacq. 6500 arcuáta Jacq. 6501 fláccida Jacq. 6502 ambigua $J a c q$ 6503 unduláta Jacq. 6504 fuscáta Jacq. 6505 sulphúrea Jacq. 6506 speciósa $W$. 6507 variábilis $J a c q$

grandiflóra Jacq. 2 Simsii D. C,

6509 convéxula Jac 6510 margináta Jacq. 6510 margináta Jacq. 6511 pulchélla Jacq. 6512 obtása Jaç

6514 acetosélla $L$ 6515 americána Dec. 6516 tenélla Jacq. 6517 nátans $L$. 6518 filicaúlis Jacq. 6519 bifida Thunb. 6520 cuneifólia Jacq. 6521 lineáris Jacq. 6522 reclináta $J a c q$.

6523 glábra Thunb. 6524 versicolor $L$. 6525 elongáta Jacq. 6526 tenuifólia $J a c q$. 6527 polyphýlla Jacq. 6528 filifolia Jacq. 6529 pentaphýlla Sims.

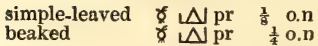

curled

hare's-eared ass's-eared

spear-leaved

Bean-leaved
Y

W C. G. H. 1793. O s.p Jac. ox. t. 23

W C. G.H. 1795. O s.p Jac. ox. t. 25

Y C. G. H. 1792. O s.p Jac. ox. t. 24

C. G. H. 1795. O s.p Jac. ox, t. 26

C. G. H. 1794. O s.p Jac. ox. t. 27

Laburnum-lvd. $\delta$ V pr $\quad \frac{1}{4}$ s.o bloody-leaved $\quad \mathcal{N}$ pr $\quad \frac{2}{4}$ o.d three-colored $8 \times \mathrm{N}$ pr $\quad{ }^{4} \frac{1}{4}$ o.d ciliate-leaved bowed flaccid ambiguous wave-leaved brown-spotted sulphur-color. specious variable great-flowered Sims's

purple

convex-leaved green-edged beautiful blunt-leaved woolly-leaved common

American

slender

floating

hilobed-leaved cloven-leaved wedge-shaped linear-shaped reclining

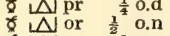
$\Delta$ or $\frac{1}{2}$ o.n $8 \mathrm{Npr} \quad \frac{1}{4}$ o.n

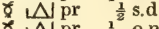
$\checkmark \mathrm{pr} \quad \frac{1}{2}$ o.n t $\sim$ pr $\frac{1}{2}$ my.jn $\checkmark$ pr $\frac{2}{4}$ o.n P.Y \& $\Delta \mathrm{pr}$ $\sqrt{\mathrm{N}}$ or $\frac{1}{4} \mathrm{ood}$ t $\triangle$ or $\frac{1}{4}$ o.d

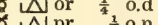
$\gamma \sim \mathbb{N}$ or $\frac{1}{2} \mathrm{n} . \mathrm{ja}$ ช $\triangle \mathrm{pr} \quad \frac{1}{4} \mathrm{s.d}$ ᄂ el $\frac{1}{4}$ o.n \& $N$ or ${ }^{\frac{1}{4}}$ o.n $\triangle$ cul $\frac{1}{4}$ ap.my $\mathrm{F}$ ช $\Delta$ pr $\frac{1}{4}$ ap.my W ¿ ${ }^{\circ}$ or $\frac{1}{8}$ ap.my Li * $\triangle$ or $\frac{1}{6}$ s.d W \% $\Delta$ or 사 or $\frac{1}{2}$ ap.my W $\checkmark \sqrt{ }$ or ${ }^{\frac{1}{2}}$ s.n $\quad$ s.n

C. G. H. 1793. O s.p Jac. ox. t. 28 C. G. H. 1795. O s.p Jac. ox, t. 29 W.R C. G. H. 1794. O s.p Jac ox, t. 47 $\mathrm{Pu}$ C. G. H. 1793. O s.p Jac. ox. t. 30 C. G. H. 1795. O s.p Jac. ox. t. 31 W.R C. G. H. 1812. O s.p Jac. ox. t. 51 W C. G. H. 1790. O s.p Jac. ox. t. 43 W C. G. H. 1795. O s.p Jac ox. t 4 C. G. H. 1795 O s.p Jac ox t. 45 C. G. H 1795. O sp Jac. ox. t. 63 C. G. H. 1795. O s.p Jac. ox. t. 63 W.R C. G. H. 1795. O s.p Jac. ox. t. 60 H. 1795. O s.p Jac. ox. t. 59 W C. G. H. 1790. O s.p Jac. ox, t. 54 C. G. H. 1790. O s.p Bot. mag. 168 C. G. H. 1812. O s.p Jac. ox. t. 56 s.p. 5 C. G. H. 1812. O co Jac. ox, t. 68 C. G. H. 1795. O co Jac. ox. t. 69 C. G. H. 1812. O s.p Jac. ox. t. 79. f.1 C. G. H. 1791. O s.p Jac. ox. t. 77. f.2 Britain grov. O co Eng. bot. 762 N. Amer. ... O co

C. G. H. 1793. O s.p Jac. ox. t. 19

C. G. H. 1795, O s.p Jac. ox. t. 76 . f. 2

C. G. H. 1815. O s.p Jac. sch. 2. t.205

C. G. H. 1791 O s.p Jac. ox. t. 79. f.4

C. G. H. 1793. O s.p Jac. ox. t.41

C. G. H. 1795. O s.p Jac. ox. t. 32

C. G. H. 1795. O s.p Jac. ox. t. 3

smooth

6 $\mathrm{N}$ or $\frac{1}{8}$ my.jn $\mathrm{Pu}$

C. G. H. 1795. O s.p Jac. ox. t. 76. f. 3

striped-flower. $\mathrm{N}$ or $\frac{1}{4}$ ja.mr $\mathrm{Cr} \quad$ C. G. H. 1774. O s. $\rho$ Bot. mag. 155 elongated $\mathrm{N}$ or $\frac{1}{2}$ s.o W C. G. H. 1791. O s.p Jac. ox. t. 37 fine-leaved $\mathbb{N}$ or ${ }^{\frac{1}{2}}$ o.n $\quad$ W.R $\quad$ C. G. H. 1790. O s.p Jac. ox. t. 38 many-leaved to $\mathbb{N}$ or $\frac{2}{2}$ ja.s Pa.pu C. G. H. 1791. O s.p Jac. ox. t. 39 thread-leaved $\mathbb{N}$ or ${ }^{\frac{1}{4}} \mathrm{ja.s} \quad \mathrm{Pk}$ C. G. H. 1822. O s.p Jac. sch.t. 273

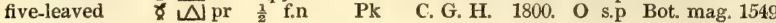

6530 lupinifólia $J a c q$. 6531 flava $L$

6532 pectináta $\mathrm{Jacq}$.

6533 flabellifólia Jacq. 6534 tomentósa $L$

\section{Lupine-leaved $\quad \Delta \mathrm{dpr} \quad \frac{1}{4}$ o.n $\quad \mathrm{Y}$ nectinated pectinated $\triangle \mathrm{Npr}$ $\begin{array}{ll}\frac{1}{2} \text { S.n } & \text { Y } \\ \frac{1}{2} \text { S.n } & \text { Y.R }\end{array}$} fan-leaved
downy-leaved $\frac{1}{2}$ S.n $\frac{\text { Y.R }}{4}$ ap.my

C. G. H. 1791. U s.p Jac. ox. t. 72 C. G. H. 1775. O s.p Bot, reg. 117 C. G. H 1790. O s.p Jac ox t 75 C. G. H. 1789. O s.p Jac. ox. t. 74

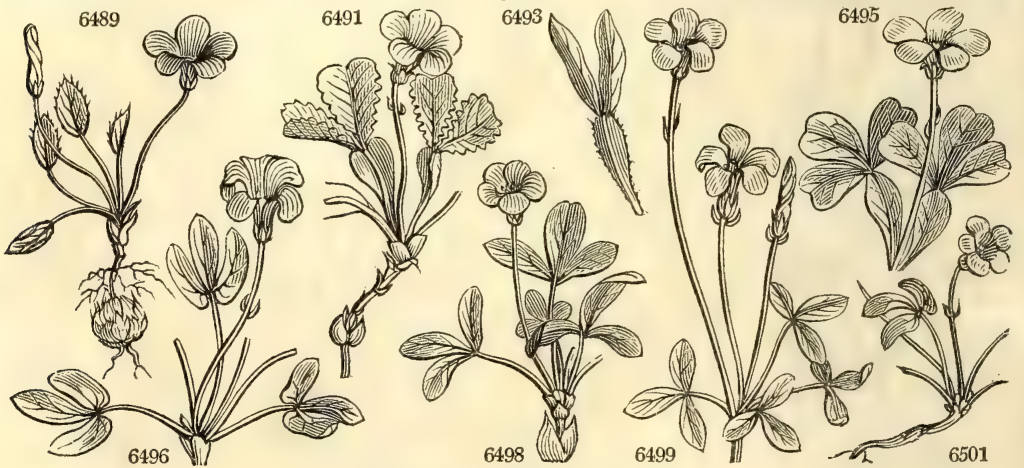

History, Use, Propagation, Culture,

abundance as to fill the whole pot to the very bottom, as in purpurea, cernua, reptatrix. Sometimes the bulb strikes very deep, as in tomentosa ; the original bulb near the surface striking a radical fibre downright from its base, which puts out from its side a new bulb, producing the next year's plant, whiist the former perishes. Sometimes fusiform, thick and long fibres spring in a monstrous form from the bulbs, as in glandulosa and some others, Some of the species have a proper stem (Caulis), when it bears all the leaves and peduncles alternately, and not in a terminating umbel: this is either branched or quite simple, and that for the most part inconstantly. Others have a stipe; the leaves and flowers being aggregate together at the end of the stalk; this bears none or very few leaves along it, seldom many. In some species the stipe is always subterraneous, as in breviscapa, purpurea, \&c. ; in others it is always above ground, as in gracilis, versicolor, tenuifolia. Stipes are commonly quite simple; some, however, are branched, the branches terminating in umbels, as in incarnata and polyphylla. Hence the division of the species into caulescent and stipitate. The leaves are not, perhaps, truly sessile in any of the species; they are subsessile in a few, but in most are petioled. They are simple in three species, binate in four, digitate in six, in the rest ternate: almost all of them have an acid 
\$6. Stemless, Leaves simple.

6489 Leaves ellipt. obtuse, Scape 1-fl. Filam. smooth, Styles middling covered with glandular hairs 6490 Leaves obovate retuse, Scape 1-fl. Styles very short, Filaments glandular

\section{\$7. Stemless, Leaves 2 or 3-leaved, Stalks winged}

6491 Leafi. 2 roundish obovate emarginate wavy at edge, Styles very long and filaments glandular 6492 Leafl. 2 ellipt. emarg. with a cartilaginous toothletted edge, Filam. glandular

6493 Leaf. 2 lanceolate with a cartilagincus toothletted edge, Filam. glandular

6494 Leaf. 2-3 with a cartilaginous scabrous edge, Filam. smooth

6495 Leafl. 3 obovate emarg. mucronate, Styles and filaments glandular

\section{\$ 8. Stemless, Leaves stalked, 3-leaved, Stalks not winged.}

6196 Pubescent, Lateral leafiets obliquely oblong: middle lanceolate, Scapes higher than petioles 6497 Pubescent, Leafl. obl. obt. : middle cuneate at base, Scapes length of petiole

6498 Pubescent, Leaf. obl. obt. : middle subcuneate, Scapes longer than petiole

6499 Pubesc. Leafl. obl. obt. subemarg. Pedunc. longer than petiole with 2 bractes immediately below the cal.

6500 Pubescent, Leafl. obl. emarg. Pedunc. length of petiole with 2 bractes immediately below the cal.

6501 Pubescent, Leafl. obl. retuse : middle cuneate, Peduncles twice as long as leaves with 2 bractes in middle

6502 Subhirsute, Leafl. obov, obl. obt. Pedunc. equal to petiole with 2 bractes in their middle, Styles glandular 6503 Subhirsute, Leafl. obov. obl. obt. Ped. longer than petioles with 2 bractes below their middle, Styles hairy 6504 Pubesc. Leafl. obt. lateral ovate : midd. cuneate, Pedunc. twice as long as petiole with 2 bractes in midd. 6505 Pubesc. Leafl. roundish, Pedunc. as long as pet. with 2 bractes at base, Calyx with clavate hairs at edges 6506 Pub. Leafl, roundish, Ped, as long as pet. with 2 bractes below mid. Cal, with simple and glan. hairs mixed 6507 Pub. Leafl. round, mid, cun, at base, Ped, as long as lvs. or long. with 2 bractes below mid. Styles very short

$\beta$ Flowers large, Leaves red beneath

$\gamma$ Flowers large, Leaves green on both sides

6508 Pubesc. Leafl. roundish, Scapes longer than leaf with 2 bractes below the middle 6509 Smooth, Leaf. roundish dotted, Stipules dilated acuminate, Bractes alternate

6510 Pub. Leafl. obcor. roundish, Scapes nearly twice as short as pet. with 2 bractes in mid. Styles intermediate 6511 Pub. Leafl. obcor. roundish, Scapes thrice as short as petiole with 2 bractes in midd. Styles very long 6512 Densely pubesc. Leafl. obcordate, Scape longer than leaves with 2 bractes above middle, Cal. obtuse 6513 Woolly, Leafl. obcordate, $\mathrm{Ca}_{1}$, acute

6514 Root toothed creeping, Leafl. obcord. downy, Scape longer than leaves, Petals oval obtuse

6515 I oot toothed creeping, Leafl. obcord. downy, Scape longer than leaves, Pet. obl. unequally emarginate 6516 Smoothish, Leaflets obcordate, Scape longer than the leaves, Styles very short

6517 Leaflets obcordate smooth, Pedunc. the length of leaves, Styles very short

6518 Leaf. obcord. 2-lobed, smooth, Pedunc. longer than leaf, Styles intermediate

6519 Leafl. obcord. 2-lobed smooth, Pedunc. longer than leaf, Styles very long

6520 Leafl. cuneate emarg. hairy, Pedunc. the length of petiole, Styles very short, Filam. glandular

6521 Leaf. lin. emarg. downy, Pedunc. shorter than petiole with 2 bractes at summit, Styles very long 6522 Leaflets linear subcuneate emarginate, Pedunc. as.long as petiole, Style intermediate

9. Leaves 3 or 5-leaved, glandular at end. 6523 Leaflets 3 linear cuneiform emarginate ciliated with many glands beneath 6524 Leaflets 3 linear emarginate with 2 glands beneath, Styles and filaments glandular 6525 Leaflets 3 linear emarginate with 2 calli at end, Styles very short

6526 Leaflets 3 linear emarginate with many glands beneath, Styles very short, Inner filaments glandular 6527 Leaflets 3 linear emarginate with 2 glands beneath, Styles intermediate and filaments glandular 6528 Leaflets 3 linear entire at end and glandular, Styles very long and inner filaments glandular 6529 Leaflets 5 linear at the end nearly entire with 2 callous glands, Styles intermediate

\section{Leaves palmate or peltate, many-leaved, not glandular at end.} 6530 Leaflets 7 lanceolate acutish smooth spotted at base, Petioles compressed, Styles very short 6531 Leaflets 6-7 smooth linear channelled acute, Styles very short, Filam. glandular

6532 Leaflets 7 smooth lin. lanc. obtuse, Cal, appressed, Styles very long and filaments glandular 6533 Leaflets 7-9 smooth lin. emarg. Cal, reflexed at end, Styles intermediate

6534 Leaflets 9-19 all over downy lanceolate cuneate emarginate

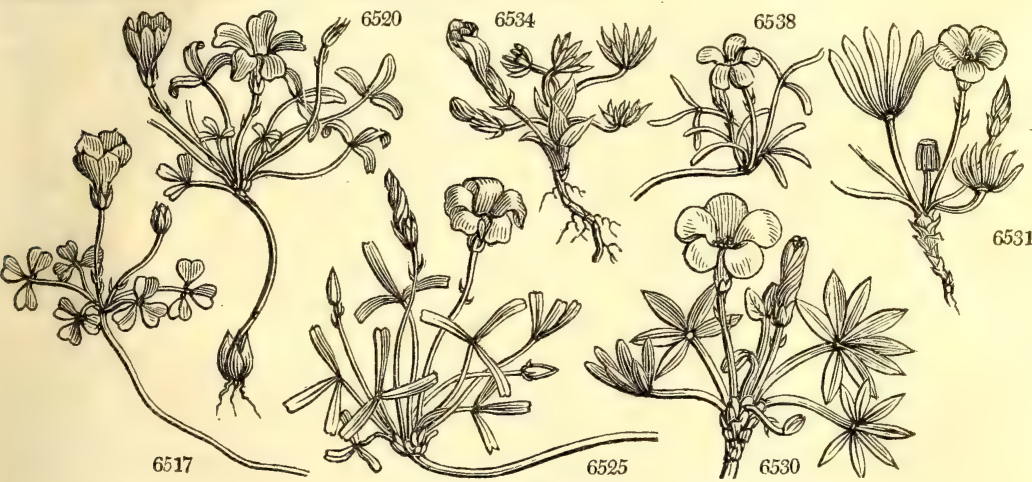

and Miscellaneous Particulars.

taste; whence their names of Oxalis or Oxys, wood Sorrel, \&c. The partial stem bearing the flower is a peduncle in the caulescent, a scape in the stipitate species.

Many of the species ripen seeds, from which, or from offsets, they are readily propagated, and grown in light sandy soil : care being taken to give the pots little or no water when the plants are in a dormant state. An excellent work has been written on the genus by Jacquin, in which ninety-six species are described. All that were known in Europe at that time, were cultivated in the Imperial gardens of Schönbrunn with great success, under the immediate inspection of Jacquin, by whom the following directions are given for their management. They are best kept in pots which will hold a good many roots. The earth should be so light and sandy as never to become hard, but always to be soft enough not to resist the point of the finger when pressed upon it ; when the flowering time is passed, the pots should be placed aside, where they require neither care nor water ; but when the flowering time is passed, the pots should be placed aside, where they require neither care nor water; but
are well protected from mice. In the beginning of August they should be placed in the open air and moderately watered. About the end of that month, or a little later, the leaves should appear. About the middle of September, earlier or later, according to the weather, they should be placed in a very sunny, airy greenhouse, 
1066. A GROSTEM'MA. $\boldsymbol{W}$. ROSE-CAMPION. 6535 Githago $W$. $\beta$ niceen'sis W. 6536 coronária $W$. B alba r plena

6537 Flos-jóvis 6538 Caeli-rósa

1067. $\mathrm{LYCH}^{\prime}$ NIS. $W$. 6539 chalcedónica $W$ $\beta$ alba r plena 6540 Floscúculi $W$. 6541 coronáta $W$. 6542 fúlgens $F i s c h$. 6543 viscária $W$

$$
\text { e pléna }
$$

6544 alpina $W$

6545 læ'ta $W$.

6546 diúrna With. sylvéstris W. en.

6547 vespertina With. dionca W. en.

1068. CERAS'TIUM. $W$ 6548 perfoliátum $W$. 6549 vulgátum $W$. 6550 viscósum $W$ 6551 diffúsum $P$. 6552 brachypétalum $P$.S. 6553 semidecándrum $W$. 6554 tetrándrum $H . K$ 6555 arvénse $W$ 6556 dichótomum $W$. 6557 alpínum $W$ 6558 ovátum W.en. 6559 strictum $W$

B suffruticosum W. 6560 máximum $W$.

6561 dahúricum Fisch. amplexicáule B. $\mathrm{M}$ 6562 dioícum $W$. 6563 latifólium $W$. 6564 tomentósum $W$. 6565 mánticum $W$. Corn-cockle Italian O common \& $\Delta$ or ed $\triangle$ double-flowered $\bar{c}$ umbelled $1 \frac{1}{2} \mathrm{jn}$ smooth-leaved $\widehat{\mathrm{O}}$ or $1 \frac{1}{2} \mathrm{jl}$

Caryophyllee. Sp. 4.

$$
\text { Lrchisis. }
$$
scarlet white-flowered $\frac{\downarrow}{\nu} \Delta$ or double-flowered $\$ \Delta \Delta$ Ragged-Robin $\frac{\nabla}{\Delta}$ Chinese splendid viscid double Alpine - 0 or red-flowered $¥ \Delta$ or white-flowered $\$ \Delta$ or

Mouse-ear Chickweed perfoliate common narrow-leaved $\& \Delta w$ spreading mall-flowered $\leqslant$ w east etrandrous field forked Alpine oval-leaved upright suffruticose greatest glaucous Spanish broad-leaved white long-peduncled

1069. LARBRE'A. St. Hil. LARBrea. 6566 aquática St. Hil. water

jn.jl Pu Britain Caryophyllece, Sp. 9-12.

$\frac{1}{2}$ ap.s W

$\frac{1}{2}$ ap.my W

$\frac{1}{4}$ mr.ap W

$\frac{2}{2}$ my.jn W

$\frac{1}{2}$ my.au W

$\frac{3}{4}$ in.jl W

$\frac{1}{2}$ jn.j1

a jn.jl

1 my.jl

2 jn.jl

$1 \frac{1}{2}$ my.s

$\varepsilon \triangle W$

$$
\begin{aligned}
& \text { v } \Delta w^{\frac{3}{3}} \text { jn.jl } \\
& \text { 紊 jn.jl } \\
& \frac{1}{2} \text { jn.jl }
\end{aligned}
$$

\section{Caryophyllea. Sp. 1.} P 1794. S co

1596. S co Bot. mag. 24 ...... ... S co

R $\quad \cdots . . . \cdots$ C r.m

R Germany 1726. S co Bot. mag. 398 Levant 1713. D s.l Bot. mag. 295

2 jn.jl R Russia 1596. D p.l Bot. mag. 257

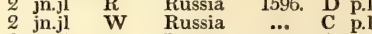

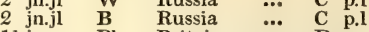

$1 \frac{1}{2}$ jn.s $\quad$ Pk $\quad$ Britain m. me. D co Eng. bot. 573

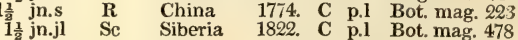

Britain rocks, D co Eng bot 788

Scotland sc.roc. D p.1 Eng. bot. 2254 Portugal 1778, C s. Britain $\quad$... $\quad$ D co Eng. bot. 1579

Britain wa.\&fi. D co Eng. bot. 1580

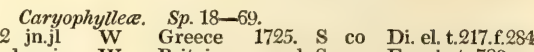
光ap.jn W Britain san.pl, S co Eng. bot. 789

$\frac{x^{2}}{2}$ ap.s W Britain pas. D co Eng. bot. 790

1816. D co

Britain walls, S co Eng. bot. 1630

Scotland san.sh. S co Eng. bot. 166

Britain cor. fi. D co Eng. bot. 93

Spain 1725. S co

Britain w. alp. D co Eng. bot. 472

Carinthia 1816. D co

Austria 1793. D co Sc. car. t. 19. f. 1

S. Europe 1796. D co

Siberia 1792. S co Gm, si 4. t.62.f.

Siberia 1815. D co Bot. mag. 1789

Spain 1766. D co

Britain w.alp. D co Eng. bot.473

S. Europe 1648. D co

Hungary 1801. S co Pl, rar. h. t. 96

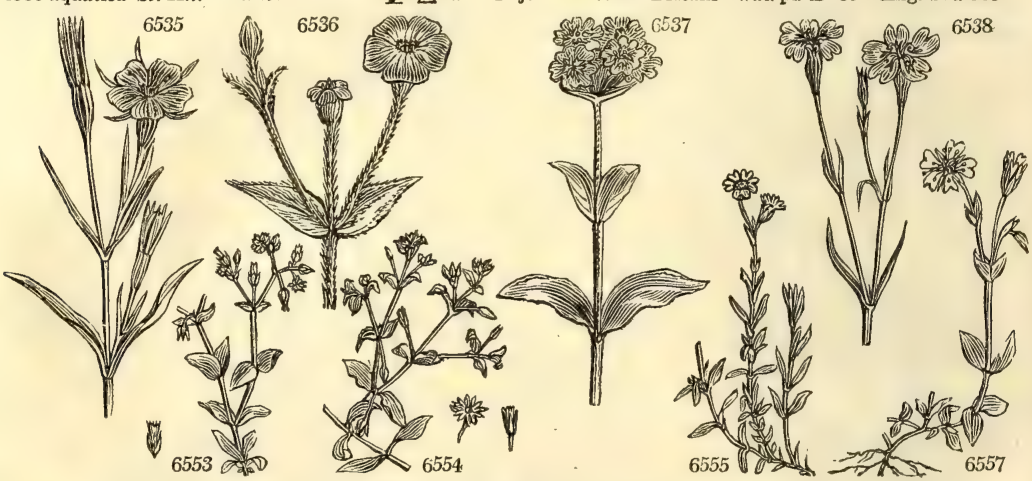

History, Use, Propagation, Culture,

when they will flower well. Oxalis monophylla and rostrata will not, however, blossom unless placed in a very hot stove.

O. Acetosella, la petite oseille or surelle, Fr., is used as a salad plant, and is more delicate than the Rumex salads : its acid approaches nearly to that of the juice of lemons, or the acid of tartar, with which it also corresponds in its medical effects, being esteemed refrigerant, antiscorbutic, and diuretic. An infusion of the leaves, or a whey made by boiling the plant in milk, given in ardent fevers, is said to allay inordinate heat, and to quench thirst.

The expressed juice depurated, properly evaporated, and set in a cool place, affords a crystalline acid salt in considerable quantity, which may be used whenever vegetable acids are wanted. It is employed to take iron moulds and ink stains out of linen, and is sold under the name of essential salt of lemons. (Withering.) This salt when genuine, which it seldom is, consists of the vegetable alkali and a peculiar acid, which, according to Bergman, seems more allied to the acid of sugar than that of tartar. What is sold for it in this country, appears sometimes to consist of $\mathbf{C}$. Tart., with the addition of a small quantity of vitriolic acid. For taking out spots in linen, the stained part is dipped in water, sprinkled with a little of the salt powdered, then rubbed on a pewter plate, after which the spot is washed out with warm water. (Curtis, from Newm. Chem. by Lewis.) Twenty pounds of leaves fresh yield six pounds of juice, from which two ounces, two drachms, and one scruple of salt have been obtained. (Lewis.)

1066. Agrostemma. Ares $s \varepsilon \mu \mu \alpha$, crown of the field. The beauty of the flowers of the common cockle weed well entitles it to such a distinction. The foreign species are very pretty annuals. A. Githago (git or gith was the name of certain black and aromatic grains, supposed to have been of Nigella sativa, which were employed by the Romans in cookery. The seeds of the plant Githago are externally similar) is an ornamental weed, and along with corn poppy and blue bottle makes a fine appearance in the fields of the slovenly husbandman, where the soil is dry and gravelly. 
6.535 Hairy, Stem dichotomous, Flowers on long stalks, Leaves linear 3 A slight variety, with longer divisions to the calyx

6536 Downy, Stem dichotomous, Peduncles long 1-fl. Cal. campanulate ribbed

6537 Downy, Flowers in umbellate heads, Cal. cylindr, clavate ribbed

6538 Smooth, Stem dichotomous panicled erect, Flowers terminal solitary

6539 Smoothish, Flowers fascicled, Cal. cylindr. clavate ribbed, Petals 2-lobed

6540 Stems ascending smoothish, Fl. dichotomous fascicled, Cal. camp.10-ribbed, Pet. torn with an appendage 6541 Smooth, Flowers terminal and axillary 1-3, Cal. rounded clavate ribbed, Petals torn 6542 Hairy, F1. 2-3 fastigiate, Cal, rounded clavate woolly, Petals 4-cleft

6543 Stem viscid about the joints, Limb of petals nearly entire, Leaves linear spatulate

6544 Smooth, Stems tufted upright, Fl, in dense capitate umbels, Cal, camp. Petals bifid 6545 Fl. solitary, Cal. with ten keels, Petals bifid, linear-lanc. subciliated

6546 Fl. dichotomous panicled diøcious, Petals $\frac{x}{2}$-bifid, Lobes narrow diverg. Caps. round

6547 Fl, dichotomous panicled dicecious, Petals $\frac{1}{2}$-bifid, Lobes broad avoreximating, Caps. conical

6548 Smooth glaucous, Stem erect branched or simple, Leaves lanceolate connate obtuse

6549 Hairy pale green viscid, Leaves ovate, Petals length of calyx, Fl. longer than fl.-stalk

6550 Hairy viscid diffuse, Leaves lanceolate oblong

6551 Stem much branched villous, Leaves ovate-lanc. hispid, Flowers numerous in dichotomous panicles

6552 Leaves ovate, Flowers panicled, Cal villous longer than petals, Caps. scarcely longer than sepals

6553 Hairy viscid, Flowers pentandrous, Petals emarginate

6554 Hairy subviscid, Flower 4-fid 4-androus, Pet. bifid shorter than calyx

6555 Leaves linear lanceolate obtuse ciliated at base, Pet. twice as long as calyx

6556 Glutinous hairy, Fl. solitary in the dichotomies, Sepals lanc. acute the length of petals, Leaves lanc

6557 Leaves ellipt. naked or hairy, Pan. dichotomous few-fl. with bractes, Caps. oblong recurved

6558 Stems prostrate, Leaves ovate acute subciliated smooth, Flowers terminal subcorymbose

6559 Leaves sublinear acuminate smooth, Peduncles glandular, Pet. twice as large as calyx

$\beta$ Leaves very narrow and smooth

6560 Downy, Leaves lanc.-lin. acute, Flowers very large in dichotomous umbels, Pet. crenate and 2-lobed

6561 Leaves cordate ovate, Stem clasping, Peduncles in fruit very long deflexed

6562 Hairy viscid, Leaves lanceolate, Fl. dicecious, Petals thrice as long as calyx

6563 Leaves elliptical scabrous, Pedunc. terminal simple subsolitary, Capsule ovate

6564 Leaves oblong spatulate hoary, Sepals hoary scarious at edge, Caps. cylindr. longer than calyx

6565 Very smooth, Leaves lanc. linear, Pedunc. very long, Caps. acute shorter than corolla

6566 This is the Cerastium aquaticum of English botany

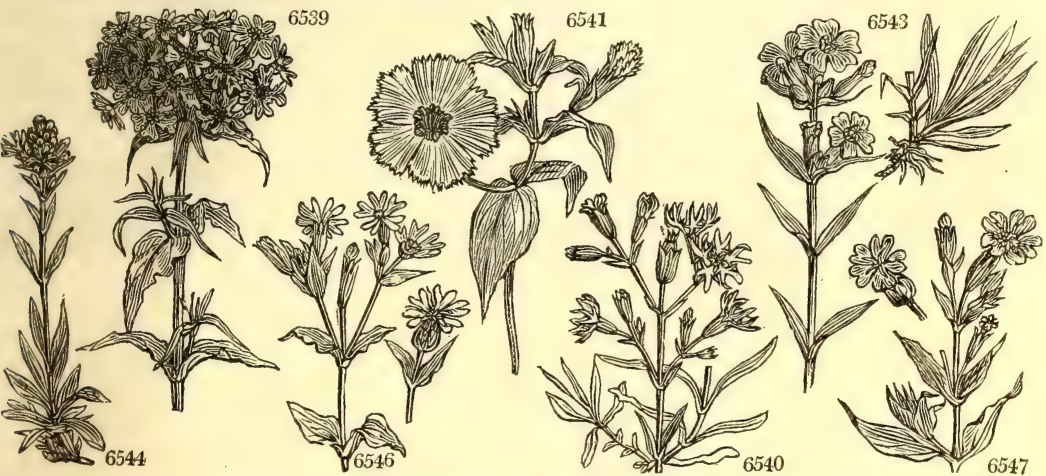

and Miscellaneous Particulars.

A. coronaria and flos-jovis are shewy border flowers, the first generally increased by seeds, and the other oy cuttings or division of the plant.

1067. Lychnis. From $\lambda v x$ yos, a lamp, in allusion to the cottony leaves of some species, which have been used as wicks to lamps. I. chalcedonica, Croix de Malthe, Fr, and Portug. Croce de Cavaliere, Ital., and C. de Jerusalem, Span,, is an old and much esteemed border flower, the double varieties of which require some care in cultivation, to prevent their returning to the single state, and to propagate them by cuttings. $\mathrm{L}$. fulgens and coronata are also very handsome species. "They do best in a light rich loamy soil, but they must be often taken up and divided, or they dwindle away; the best time of doing this is early in spring. L. coronata thrives and flowers abundantly if planted out in the open ground in spring; but it requires to be taken up in autumn and potted, or the severe frosts in winter will kill it, or injure it very much. All may be raised by cuttings planted under hand-glasses, or by seeds, which often ripen in abundance. (Bot. Cult. 389.) L. viscaria and floscuculi are more hardy, and grow in common garden soil, and increase abundantly by flowers in their double varieties.

1068. Cerastium. Derived from zşas, a horn, in allusion to the cornute form of the capsule of many species. Most of the annual species, and some of the others, are weeds; a few may be grown in pots or on rock-work, for both of which they seem well adapted. They are very prolific in seeds, and contribute materially to the support of small birds.

1069. Larbrea. A genus founded by Aug. St. Hilaire, in the second volume of Mémoires du Muséum, upor the Cerastium aquaticum of Linnæus. He named it after the Abbé de Larbre, who at the age of 80 , published a Flora of Auvergne. 
1070. SPER'GULA. $W$. SPURREY. 6567 arvénsis $W$. rough-seeded 6568 pent́́ndra. 6568 pentándra $\boldsymbol{W}$ 6569 nodósa $\boldsymbol{W}$. 6570 saginoídes $W$. 6571 subuláta $W$. smooth-seeded knotted smooth-awl-sh $\triangle w$
Caryophyllece. Sp. 5-14.

1.au W Britain san. fi. S co Eng. bot. 1535 ${ }^{1}$ jn.jl W Fngland san fi. S co Eng. bot. 1536 $\frac{1}{2}^{2}$ jl.au W Britain san.he. D co Eng. bot. 694

$\frac{1}{2}$ jn.au W Scotland sc.alp. D co Eng. bot. 2105 $x^{2}$ jn.jl W Britain san.he. D co Eng. bot. 1082

\section{DECAGYNIA}

1071. PHYTOLAC'CA, $W$. Phytolacca 6572 octándra $W$. 6573 abyssínica $\dot{W}$ 6574 dodecándra $W$. en 6575 decándra $W$. 6576 icosándra $W$ 6577 dioíca $W$. Virginian Poke

Chenopodea. Sp. 6

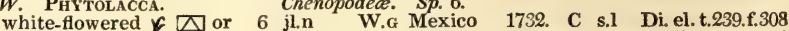
white-flowered $\triangle$ or 6 my.jn W.G Africa 1775, R s.1 Hoff. c. goet. t.2 or 6 my

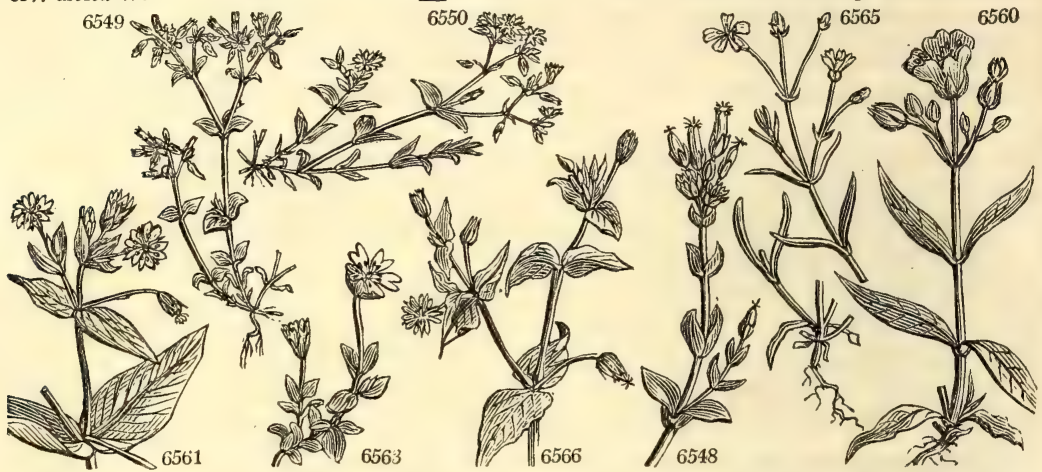

History, Use, Propagation, Culture,

1070. Spergula. From spargere, to scatter, because it scatters its seeds abroad, to the great profit of the farmer in Holland, who obtains from it meadows affording the most delicious butter. $\mathbf{S}$, arvensis is a common weed in sandy soils, in Scotland called yarr, and in Norfolk pickpurse. In the Netherlands and in Germany it is sown on corn stubbles, to supply a bite for sheep during winter. It may be sown and reaped in eight weeks, either in autumn or spring. It is said to enrich the milk of cows, so as to make it afford excellent butter; and the mutton fed on it is preferable to that fed on turnips. Hens eat spurry greedily, and it is supposed to make them lay a great number of eggs, whether in hay, or cut green, or pasture. Von Thaer observes, it is the most nourishing, in proportion of its bulk, of all forage, and gives the best flavored milk and butter. It has been recommended to be cultivated in England; but it is not likely that such a plant can ever pay the expense of seed and labour in this country, even on the poorest soil ; or at all events, as Professor Martyn observes, we have many better plants for such soils.

1071. Phytolacca. From фvтoy, a plant, and lacca, lac; that is to say, a plant whose fruit gives out a fine red color like lac. The English-American name Poke, applied to one species, is a corruption of Pocan, the name by which it was formerly known in Virginia.

P. decandra has large ramose roots, shoots half an inch in diameter, and five or six feet high ; the leaves five inches long, and two and a half inches broad, smooth and of a deep green It grows vigorously in a good deep soil, and furnishes ample supplies of young shoots, which in America and the West Indies are boiled and eaten as spinage. (Correa de Serra, in Hort. Trans. iv. 446.) 
6567 Leaves whorled, Pedunc. in fruit reflexed, Seeds reniform angular rough 6568 Leaves whorled, Flowers pentandrous, Seeds depressed winged smooth 6569 Leaves opposite subulate smooth : upper fascicled, Cal, not nerved

6570 Leaves opposite subulate blunt naked, Pedunc. solitary very long smooth 6571 Leaves opposite subulate awned ciliated, Pedunc. very long solitary hairy

\section{DECAGYNIA.}

6572 Flowers octandrous octogynous 6573 Flowers decandrous pentagynous 6 . Leaves ovate obl. with a recurved point 6575 Flowers decandrous decagynous 6576 Flowers icosandrous decagynous 6577 Flowers diøecious
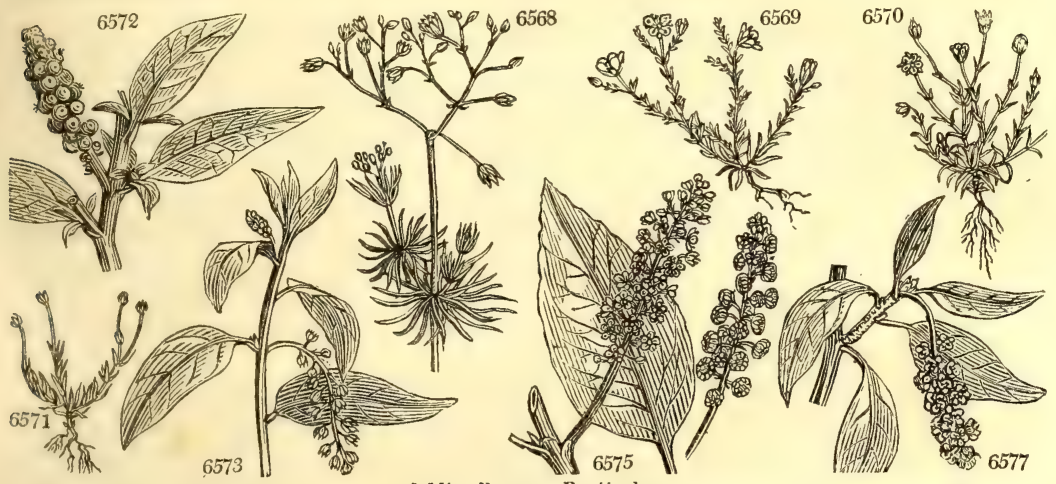

and Miscellaneous Particulars.

An ounce of the dried root, infused in a pint of wine, and given to the quantity of two spoonfuls, operates kindly as an emetic, and is preferable to most others, as it hardiy alters the taste of the wine. In its medicinal properties, the Phytolacca approaches nearer to Ipecacuanha than to any other vegetable; but it is slower in its effects, and it remains longer in action, although it may be checked by an opiate. Sometimes its operation produces vertigo and stupor. The powder of the leaves possesses the same virtues as the root, but in a weaker degree. It is one of the plants which have had a temporary reputation for the cure of cancer, and some sensible men have been converts to its efficacy. The fermented berries give out a liquor which yields alcohol by distillation. From half a bushel of the berries, six pints of spirits were obtained, sufficiently strong to take fire and burn with readiness. Two ounces of this given to a dog occasioned nausea and drowsiness, with slight spasmodic motions, but no vomiting. Poultry are fond of the berries, but if eaten in large quantities, they give the flesh a disagreeable flavor. The juice stains paper and linen of a beautiful purple color, but it will not last long; if a method could be found of fixing the dye, it might be very useful. The vignerons in Portugal for many years used the juice of the berries of the elder-bush to give a deep color to the Port wines, to which it was thought to communicate a disagreeable taste when mixed in too great a quantity. Complaint of this practice having been made to government, orders were given that the stems of that plant should be cut down and destroyed before they produced berries : but they forgot to include the Phytolacca in the proscription, so that the berries of that plant supply the same purpose in a much worse manner. 


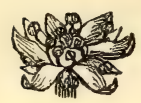

\section{Class XI. - Dodecandria. 12 Stamens.}

This is a small incongruous class, containing no extensive genus of importance except Euphorbia. Some botanists have been of opinion that it ought to be cancelled, but it is probable that Linnæus understood the application of his own principles as well as some of his more pretending followers, and it is certain that if the Iinnean plan can be made to act suecessfully, its artificial arrangement must be rigorously observed. Euphorbia and Reseda, which are usually referred hither, should more properly be referred, the former to Monœeia, and the latter to Polygamia.

\section{Order 1. MONOGYNIA.}

12 Stamens. 1 Style.

1072. Asarum. Cal. 3-4-cleft, superior. Cor. O. Capsule coriaceous, crowned.

1073: Bocconia. Cal. 2-leaved. Cor. O. Style bifid. Caps. 2-valved, 1-seeded.

1074. Bassia. Sepals 4. Cor. 8-cleft, with an inflated tube. Stamens 16. Drupe 5-seeded

1075. Blakea. Sepats 6, inferior, with a superior entire calyx. Petals 6. Caps. 6-celled, many seeded.

1076. Bejaria. Cal. 7-cleft. Petals 7. Stamens 14. Berry 7-celled, many-seeded.

1077. Agathophyllum. Petals 6. Calyx truncate. Drupe 1-seeded.

1078. Rhizophora. Cal. 4-parted. Cor. 4-parted. Stigmas 2. Seed 1 very long, fleshy at base.

1079. Garcinia. Sepals 4, inferior. Petals 4. Berry 8-seeded, crowned by the peltate stigma

1080. Grangeria. Cal. 5-cleft. Petals 5. Stamens 15. Drupe 3-cornered. Nut 3-cornered, bony, 1-seeded.

1081. Halesia. Cal. 4-toothed, superior. Cor. 4-cleft. Nut quadrangular, 2-seeded.

1082. Decumaria. Sepals 8-12, superior. Petals 8-12. Caps. 8-celled, many-seeded.

1083. Eurya. Cal. 5-leaved, with 2 bractes at base. Petals 5. Caps. 5-celled, many-seeded.

1084. Aristotelia. Sepals 5. Petals 5. Style trifid. Berry 3-celled. Seeds twin.

1085. Canella. Cal. 3-lobed. Petals 5. Anthers 16, united to an urceolate nectary. Berry 1-celled, 2-4-seeded.

1086. Cratceva. Petals 4. Cal. 4-cleft. Berry 1-celled, many-seeded.

1087. Triumfetta. Petals 5. Sepals 5. Capsule hispid, opening in four.

1088. Peganum. Petals 5. Sepals 5, or O. Capsules 5-celled, 3-valved, many-seeded.

1089. Hudsonia. Petals 5. Sepals 3, tubular. Stamens 15. Capsules 1-celled, 3-valved, 3-seeded.

1090. Nitraria. Petals 5, vaulted at end. Cal. 5-cleft. Stamens 15. Drupe 1-seeded.

1091. Portulaca. Petals 5. Cal. 2-fid. Capsule 1-celled, cut across.

1092. Talinum. Petals 5. Sepals 2. Capsule 3-6-valved, many-seeded. Leaves without stipules. Seeds not winged.

1093. Anacampseros. Like Talinum, but having stipules and winged seeds.

1094. Lythrum. Cal. 12-toothed, tubular, unequal at base. Petals 6, inserted in calyx. Caps. 2-celled, many-seeded.

1095. Nescea. Like Lythrum, but calyx campanulate.

1096. Heimia. Cal, 12-toothed. Petals 6. Capsule 4-celled.

\section{MONOGYNIA.}

1072. A'SARUM. $W$ 6578 arifólium Mich. 6579 curopæ'um $W$. 6580 canadénse $W$. 6581 virgínicum $W$. 1073. BOCCO'NIA. $W$ 6582 frutéscens $W$. 6583 cordáta $W$.
Asarabacca. arum-leaved common Canadian sweet-scented

BocConia.

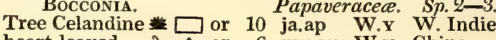
heart-leaved $\$ \Delta$ or 6 my.au W.y China

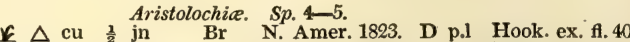

$\Delta \mathrm{m}{ }_{3}^{2} \mathrm{my} \quad \mathrm{P} \quad$ Fngland woods. $\mathrm{D}$ p.l Eng. bot. 1083

$\begin{array}{lllll}\Delta \text { cu } & 3^{\frac{3}{4}} \text { ap.jl } & \text { Br } & \text { Canada 1713. D p.l Bot. cab. } 889\end{array}$

$\frac{3}{4}$ ap.my $\mathrm{Br} \quad$ Virginia 1759. D p.1 Sweet fl. gard.18

Papaveracea. Sp. 2-3. 1739 s r.m Bot, cab. 83

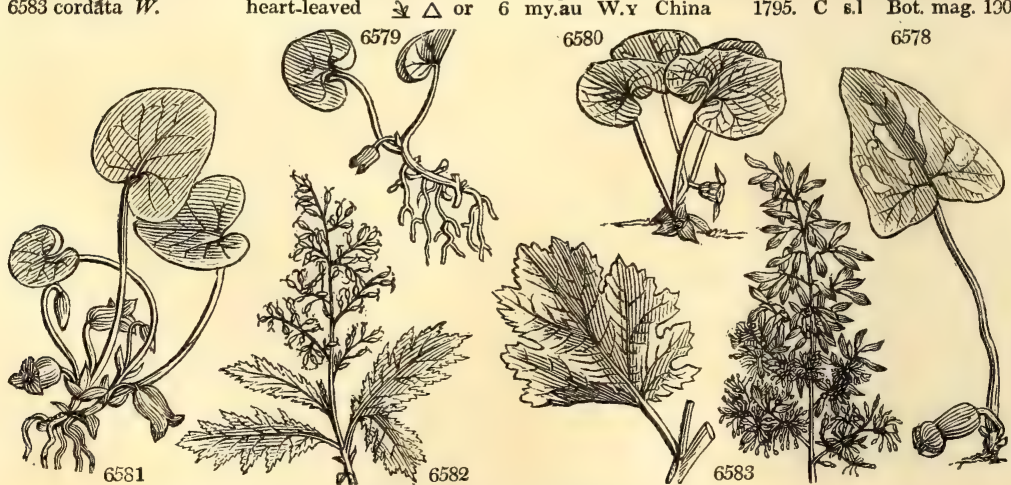

History, Use, Propagation, Culture,

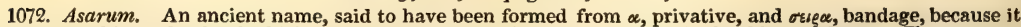
was not used in garlands of which the ancients were so fond; in that case it should be Asârum. The common name, Asarabacca, is Latin, $q u$ : the berry of Asarum? Little inconspicuous herbaceous plants. The leaves of A. europæum are emetic, cathartic, and diuretic; and, perhaps, as Dr. Cullen has remarked, they form the most useful species of errhine stimulants. A proper dose snuffed up the nose for a few successive evenings at 
1097. Cuphea. Cal. 6-12-toothed, occasionally gibbous at base. Pet. 6, inserted in calyx, or O. Caps. 1-celled, onening on side longitudinally along with the calyx.

1098. Kleinhovia. Sepals 5. Petals 5. Nect. campanulate, 5-toothed, staminiferous, united to the column of ovary. Ovary stalked. Caps, with 5 -angles and 5-cells inflated, cells 1-seeded.

\section{Order 2. DIGYNIA. 2 Styles.}

1099. Callicoma. Flowers in round heads. Calyx 4-5-leaved. Corolla 0.

1100. Heliocarpus. Sepals 4. Petals 4. Styles simple. Caps. 2-celled, compressed, radiating on each side longitudinally.

1101. Agrimonia. Cal, 5-toothed, surrounded by another. Petals 5. Grains 2, in the bottom of the calyx.

\section{Order 3. TRIGYNIA. 12 Stamens. 3 Styles.}

1102. Reseda. Involucre many-leaved spreading. Hermaphrodite flower central, apetalous, surrounded by several fringed petaloid barren flowers.

1103. Euphorbia. Involucre 1-leaved, ventricose, regular. Flowers naked, aggregate. Female Horet surrounded by many monandrous male florets.

1104. Pedilanthus. Like Euphorbia, but involucre calceiform.

1105. Visnea. Cal. 5-leaved, inferior. Petals 5. Stigmas 3. Nut 2-3-celled, half inferior.

\section{Order 4. TETRAgrniA. 12 Stamens. 4 Styles.}

1106. Calligonum. Cal, 5-parted. Corolla O. Filaments about 16, united at base. Ovary superior, 4-cornered, Styles 4. Nut with a many winged crust, 1-celled.

Order 5. PENTAGYNIA.

12 Stamens. 5 Styles.

1107. Glinus. Sepals 5. Cor. O. Nectary with bifid bristles. Caps. 5-angular, 5.celled, 5-valved, manyseeded.

1108. Blackwellia. Cal. $\frac{1}{8}$-superior, persistent, at the base turbinate, many-parted; with villous ciliated segments. Petals 15. Capsule 1-celled, many-seeded.

1109. Gastonia. Cal. entire. Petals 5-6. Stam. 10-12 : two opposite each petal. Styles 10-12, very small, united at base. Capsules 10-12-celled.

\section{Order 6. DODECAGYNIA.}

1110. Sempervivum. Cal. 12-parted. Petals 12. Caps. 12, many-seeded.

\section{MONOGYNIA.}

6578 Leaves subhastate cordate, Calyx tubular shortly trifid 6579 Leaves reniform obtuse twin

6580 Leaves reniform mucronate

6581 Leaves cordate obtuse smooth stalked

6582 Leaves oblong sinuated

6583 Leaves cordate somewhat lobed

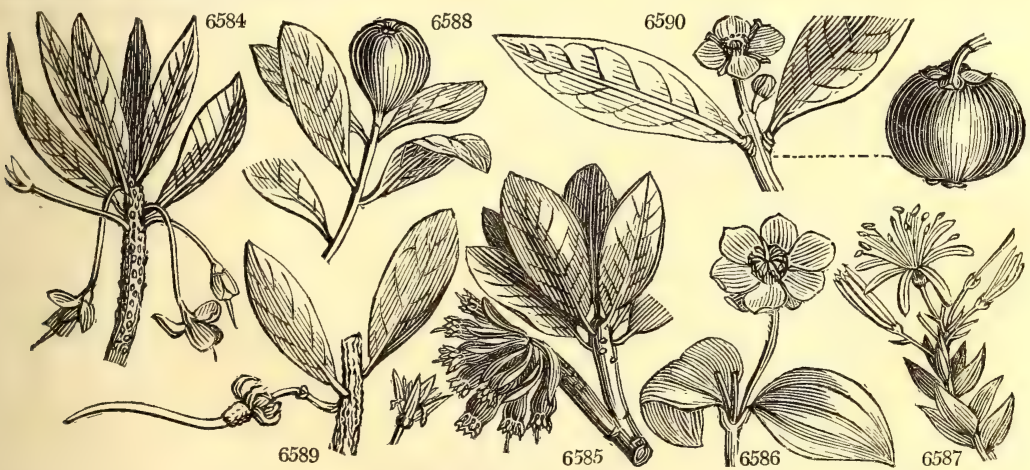

and Miscellaneous Particulars.

bed time occasions a copious discharge from the nostrils, which continues to flow for several days. (London Dispensatory, 185.) The herb was formerly employed to correct the effects of excessive drinking, whence in French it is still called cabaret.

1073. Bocconia. In memory of Paolo Boccone, M. D., a Sicilian, and Cistercian monk under the name of Sylvius; author of Icones et Descriptiones rariorum Plantarum Siciliæ, Melitæ, Galliæ, et Italiæ; pub- 
1074. BAS'SIA. $W$. 6584 longifólia $W$. 6585 latifólia $W$. 6586 trinérvia $W$.

1076. BEJA'RIA. P 6587 racemósa $P h$.
1075. BLA'KEA. $W$.
BASsia, broad-leaved

BLAKEA.

three-ribbed

Bejaria.

sweet-scented long-leaved

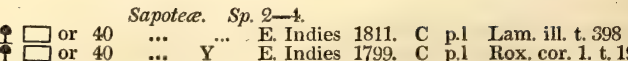
Melastomea. $\quad$ Sp. $1-4$

$9 \square$ or $14 \mathrm{jn.j1}$ W Jamaica 1789 . L s.p Bot.mag. 451

Rhodoracea. Sp. 1-3.

* $ـ$ or 4 jn.jl Pu Florida 1810. C l.p Vent. cels. t. 52

1077. A G ATHOPHYL/LUM. $W$. Madagascar-NuTMEG.
6588 aromáticum $W$.
aromatic 1078. RHIZO'PHORA. $W$. MANGRove. Rhizophorea. Sp. 1-9.

6589 Man'gle $W . \quad$ common $\& \square \mathrm{cu} 10 \ldots \ldots$ E. Indies 1820. C p.l Jacq. am. t. 89

1079. GARCíNiA. $W$. Mangosteen. Guttiferce. Sp.1-8.

6590 Mangostána $W$. common $\perp \square$ fr $20 \ldots$ Pu Java $\quad$ 1789. C r.m Bot. cab.845

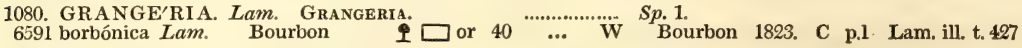

1081. HALE'SIA. $W$. SNowdrop-Tree. 6592 tetráptera $W . \quad$ four-winged 严 6593 diptera $W$

1082. DECUMA'RIA. $W$. DECUMARIA. 6594 bárbara $P h$. 6595 sarmentósa $P h$. larger

1083. EU'RYA. Thunb. EURYA. 6596 chinénsis Abel. Chinese

1084. ARistotélia. $W$. Aristotelia 6597 Mácqui $W$. shining-leaved

Ebenacea. Sp. 2-4.

my W Carolina 1756. C p.l Bot. mag. 910

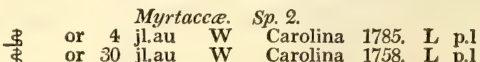

or 30 jlau W Carolina 1758. L p.l Act.par. 1. t. 13 Ternströmeacea. Sp. 1-4

2 f.d W China 1823. C p.l Abel.China,c.fig Rhamnea? Sp. 1. or 4 ap.my W.G Chili

1733. C 1.p Dend. brit. 44 Guttiferce. Sp. 1.

1085. CANelíl, $W$. Canella. 6598 álba $W$.

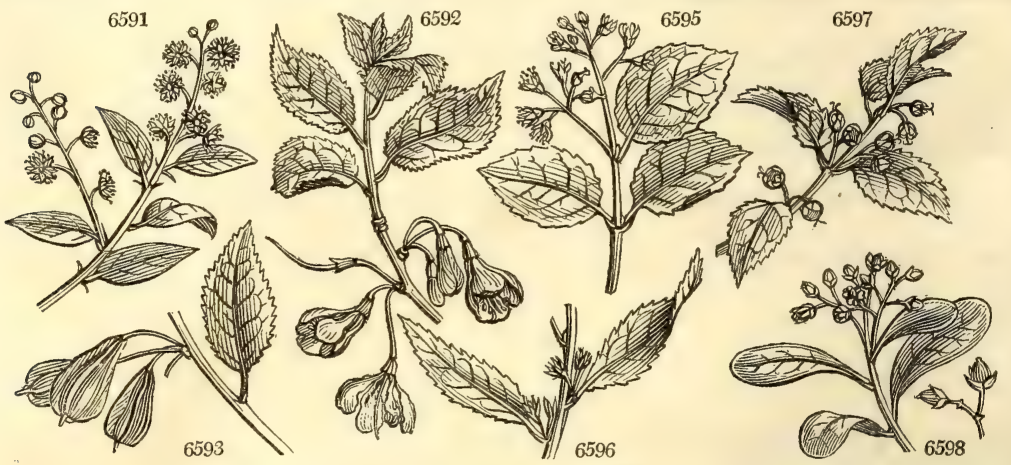

History, Use, Propagation, Culture,

lished by Morrison at Oxford, 1764, quarto, and other works. B. frutescens is very ormamental in its foliage. The Indian kings, Hernandez tells us, planted it in their gardens, which must have been for its beauty, as it is neither culinary nor medicinal, though the juice is acrid, and used in the West Indies to take off warts.

1074. Bassia. So named by Koenig, in honor of Ferdinando Bassi, curator of the botanic garden at Bologna. Tall trees, natives of the hottest parts of the East Indies, with tufted alternate leaves growing only at the end of the shoots. Ripened cuttings root freely in sand.

1075. Blakea. So named by Dr. Patrick Browne, after Mr. Martin Blake of Antigua, a great promoter of useful knowledge, and a patron of the doctor's Natural History of Jamaica. This is one of the most beautiful plants of the West Indies. It supports itself for a time by the help of some neighboring shrub or tree, but it grows gradually more robust, and at length acquires a pretty moderate stem, which divides into a thousand weakly declining branches, well supplied with beautiful rosy blossoms on all sides. It cannot display itself to so great advantage in our stoves; but it flowers freely, and thrives well in loam and peat, well supplied with water. Ripe cuttings root in sand in moist heat and covered.

1076. Bejaria. So named by Mutis, in honor of Bejar, a Spanish botanist. The original species are natives of New Grenada. That in gardens, which is a native of the southern states of North America, is a beautiful shrub from three to four feet high, with pink flowers of an agreeable scent. It is found upon the banks of swamps and ponds, and requires the protection of a frame or greenhouse.

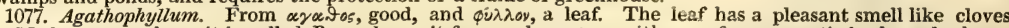
In Madagascar, where it is called Ravendsara, it forms a large tree with a rufous aromatic bark, and a heavy insipid wood. The leaves are alternate and coriaceous. The dried fruit is very aromatic.

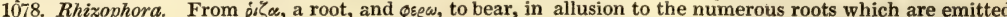
by the seeds, which vegetate among the branches of the tree while yet adhering to their footstalk. This is the common Marigrove, which covers immense tracts of coast within the tropics, rooting and vegetating even as far as low water mark.

1079. Garcinia. So named in honor of Laurent Garcin, M. D., F. R. S., who travelled into the East Indies. Mangostans is the Malayan name. This tree bears a fruit, which in the East Indies ranks with that of the pine-apple. It rises with a taper stem, sending out many branches, not unlike a fir-tree, with oval leaves, seven or eight inches long. The flower is like that of a single rose; the fruit round, the size of a middling orange; the shell is like that of the pomegranate, the inside of a rose color, divided by thin partitions, as in oranges, in which the seeds are lodged, surrounded by a soft juicy pulp, of a delicious flavor, partaking of the strawberry and the grape, and is esteemed one of the richest fruits in the world. It is a native of the Molucca islands, whence it has been transplanted to Java and Malacca. The head of the tree is in the form of a parabola, so fine and regular, and the leaves so beautiful, that it is looked upon in Batavia as the tree most proper for adorning a garden, and affording an agreeable shade. It was introduced to England in 1789. According to Dr. Garcin, (Phil. Trans.) " it is esteemed the most delicious of the East Indian fruits, and a 
6584 Leaves lanceolate, Peduncles 1-flowered very long horizontal axillary 6585 Leaves elliptical acute, Peduncles 1-flowered nodding terminal

6586 Calyxes two, Leaves with three nerves finely striated across beneath

6587 Leaves ovate-lanceolate smooth, Flowers terminal in panicled racemes

6588 Leaves stalked alternate obovate obtuse coriaceous entire smooth

6589 Leaves acute, Fruit subulate-clavate

6590 Leaves ovate, Peduncles 1-flowered

6591 Leaves alternate stalked ovate entire smooth veiny

6592 Leaves ovate acuminate, Veins hairy beneath, Wings of the fruit equal

6593 Lvs. obl. ovate obtusely pointed green on both'sides very soft beneath, Wings of fruit alternately larger

6594 Leaves all ovate, Stem climbing

6595 Lower leaves rounded: upper ovate-lanceolate, Stem sarmentose

6596 Branches at end pubescent, Leaves cuneate oval, Flowers axillary

6597 Leaves opposite evergreen ovate shining serrated

6598 Leaves oblong obtuse shining, Racemes terminal

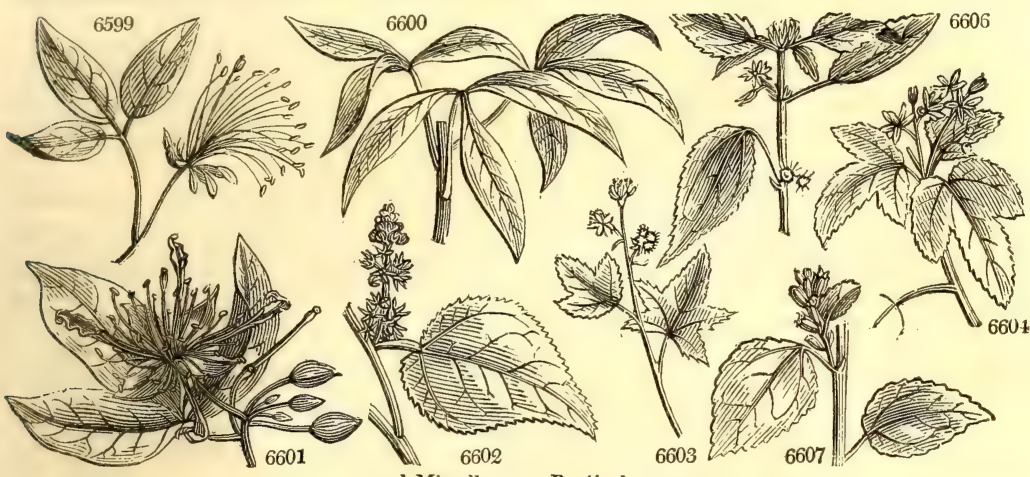

and Miscellaneous Particulars.

great deal of it may be eaten without any inconvenience; it is the only fruit which sick people are allowed to eat without scruple. It is given with safety in almost every disorder; and we are told that Dr. Solander, in the last stage of a putrid fever in Batavia, found himself insensibly recovering by sucking this delicious and refreshing fruit. The pulp has a most happy mixture of the tart and sweet, and is no less salutary than pleasant. It is propagated by ripe cuttings in sand in moist heat. But the plant rarely survives long after its pleasant. It

1080. Grangeria. Named after N. Granger, a traveller in Egypt, Persia, \&c. who died at Bassora in 1733. His voyage into Egypt was published in 1745. This is a tree the size of an oak, with alternate ovate entire leaves. The flowers are small, in small terminal and axillary racemes.

1081. Halesia. So named by Ellis, in honor of the learned and venerable Stephen Hales, D. D., F. R. S., author of Vegetable Staticks, 1727. The species are very ornamental shrubs, valuable for blossoming early in the season. The flowers hang in small bunches all along the branches, each bud producing from four to eight or nine; they appear before the leaves, are of a pure snowy whiteness, and last for two or three weeks; they are succeeded by pretty large winged juiceless drupes, hanging likewise in bunches. The leaves of $H$. diptera are six times the size of those of $H$. tetraptera, and the fruit has two large wings and two minute ones. They are propagated by cuttings of the roots.

1082. Decumaria. Derived from decem, ten, all the parts of fructification answering to the number 10. It is commonly propagated by layers, but will grow by cuttings in sand under a hand-glass.

1083. Eurya. A name of Thunberg's, supposed to have been formed from svevs, broad; its application no one has been able to discover. The Eurya chinensis is a little evergreen bush, bearing many whitish flowers on the under side of the branches and hidden by the leaves. It is easily propagated by cuttings.

1084. Aristotelia. After the celebrated ancient philosopher and naturalist Aristotle. Macqui is the name of this shrub in Chili. It grows freely in a sheltered situation; but its flowers are of little beauty. They are succeeded by small berries of a purple or black color, slightly acid and eatable: the inhabitants of Chili make a wine from them, which they give in fevers, and for curing the plague. It is increased by layers or ripened cuttings.

1085. Canella. A name given by Murray, on account of the resemblance between its wood and the aromatic flavor of Canella, Cinnamon. This tree rises very straight, from ten to fifty feet in height. The branches are erect, not spreading, and only at the top of the tree; furnished with petiolated leaves of a dark green color, thick, and shining like those of the laurel, and emitting a similar odor. The flowers, which exhale a powerful aromatic perfume, are small, seldom open, and in bunches. The inner bark of the branches is freed from the cuticle, and dried in the shade. This bark is stimulant, and slightly tonic. It is a useful adjunct to bitters in some cases of dyspepsia and atonic gout; but it is employed chiefiy on account of its flavor, and to correct the griping quality of the resinous cathartics. It is said to prove useful in scurvy (London Dispensatory, 207.) 
1086. CRATE'VA, $W$. Garlick-Pear. 6599 gynándra $W$ 6600 Tápia $W$ 6601 frágrans $H, K$ 1087. TRIUMFET'TA. $W$ 6602 Láppula $W$. 6603 Bartrámia $W$. 6604 semitríloba $W$ 6605 grandiflóra $W$ 6606 an'nua $W$. 6607 rhomboídea Jacq. 6608 macrophýlla $V a h t$. 6609 trichocláda Link. 6610 oblongáta Wall.

1088. PE'GANUM. $W$. 6611 Hármala $W$. 6612 daúricum $W$ sweet-scented

prickly-seeded Currant-leav'd mallow-leaved large-flowered annual rhomboidal large-leaved hairy-branched oblong

\section{Peganum.} Syrian-Rue mooth \& $\square$ or 19

$\downarrow \Delta$ cu 1 jl.au $\underset{\text { W }}{\text { Sp. }}$ Spain

1089. HUDSO'NIA. $\boldsymbol{W}$. $\begin{gathered}\text { Hudsonra. } \\ \text { Heath-leaved }\end{gathered}$
Hericoídes $\boldsymbol{W}$.

1090. NITRA'RIA. $W$. Nitraria. 6614 Schobéri $W$. thick-leaved

1091. Portula'CA. $\boldsymbol{W}$. Purslane. 6615 satíva $H . S$. garden 6616 olerácea $H . S$. 6617 parvifólia $H . S$. 6618 pilósa $W$ 6619 quadrífida $W$ 6620 Meridiána $\boldsymbol{W}$. 6621 foliósa $L i n d l$. 6622 mucronáta Link Guinea 6623 teretifólium $P$ sh. round-leaved 6624 ciliátum $R . \& P$. ciliated 6625 trianguláre $W$. 6627 pátens $W$ 6628 refléxum $H$. $S$.

Tiliacee. Sp. 9-29.

Rutacee. Sp.

Cistinea. $S p .1$

\section{thin-leaved}

PrickiUMFETTA. 6626 crassifólium $W$.

Capparidea. Sp. 3-12

‥ W.pu Jamaica 1789. C $\quad$ r.m Plu.alm.t.147.f.6 jn.jl W S. Leone 1795. C r.m Bot. mag. 596

jl.au Y.G Jamaica 1739. C 1p Plum.ic. t. 255 jn.jl Y.G E. Indies 1759. C 1.p Ru. am.6.t.25.f.2

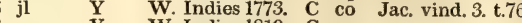
$\ldots \quad \mathbf{Y} \quad \mathbf{W}$. Indies 1810. C co au.s $\quad$ E. Indies 1760. C co Bot. mag. 2296 au.s Y Peru 1818, C co Lind. coll. 29 1820 . $\mathrm{co}$ au.s $\mathbf{Y}$ Nepal 1823. S co au.s $\mathbf{Y}$ Nepal 1823. S co 2. $ـ \mathrm{pr} \quad \frac{3}{4}$ my.jl $\underset{\mathrm{Y}}{\mathrm{N}}$. Amer. 1805. L s.p Bot. cab. 192

Ficoidee. Sp. $1-3$.

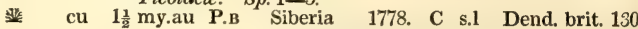
Portulacea. Sp. 8-12.

1582. S r.m Plant. grass. 123 ou $\mathrm{cu}^{\frac{1}{3}}$ au $\mathrm{Y}$ Jamaica 1799. S s.l hairy $\quad \mathrm{cu} \frac{1}{2}$ jn $\mathrm{Pk}$ W. Indies 1690. S s.l $O$ pr ${ }^{\frac{1}{4}}$ my.jn $\quad \mathbf{Y} \quad$ E. Indies 1791. S $\mathrm{S}$ s.I

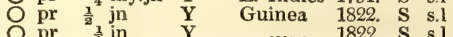
, col.2.t.17.f. s.l Bot. reg. 793

Portulacea. Sp. 6-18. f $\triangle$ pr 1 au Pu Chili 1823. S s.p Hook. ex. fl. 82

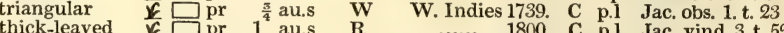
spreading-flow.

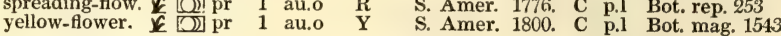

1093. ANACAMP'SEROS. $\boldsymbol{L}$. Anacampseros. $\quad$ Portulacece. $\mathrm{Sp}$. $5-7$.

6629 rotundifólia $B . M$. round-leaved w w eu $\frac{3}{4}$ jl.s $\quad$ Pk $\quad$ C. G. H. 1732 . C s.l Bot. cab. 591 Talinum Anacampseros W.

6630 arachnoídes $B$. $M$. cobweb 6631 rúbens Haw. red-leaved 6632 filamentósa $B, M$. thready 6633 lanceoláta Haw. spear-leaved

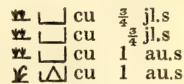

Pk C. G. H. 1790. C s.l Bot. mag. 1368 R C. G. H. 1796. C s.l Pk C. G. H. 1795. C s.l Bot. mag. 1367

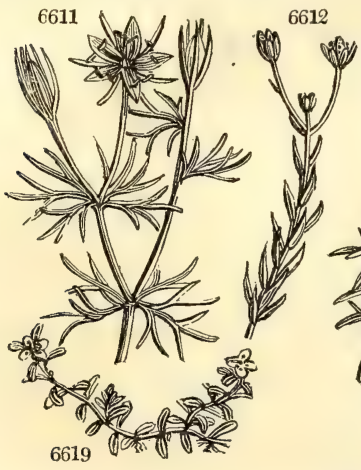

C. G. H. 1796. C s.l

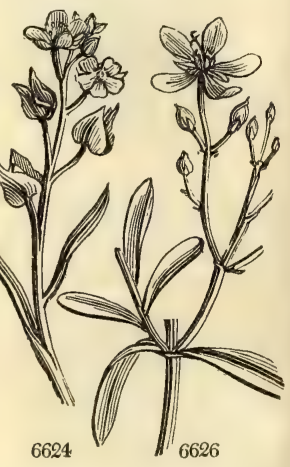

History, Use, Propagation, Culture,

1086. Cratava. In honor of Cratievus, a Greek botanist and contemporary of Hippocrates. C. Tapia, an American name, produces a fruit about the size of an orange, with a mealy pulp and a strong smell of garlic, which is communicated to the animals that feed on it. All the species prefer a rich loamy soil, and may be increased by cuttings in sand under a hand-glass.

1087. Triumfetta. So named by Plumier, in memory of Giov. Battista Triumfetti, prefect of the botanic garden at Rome, author of Hortus Romanus, 1681, and other works. T. semitriloba has a tough strong bark which serves for ropes and other conveniences of that kind in the inland parts of the West Indies. The whole plant is mucilaginous and emollient. Cuttings root in sand under a hand-glass. All the species are

uninteresting weed-like shrubs of tropical countries.
1088. Peganum. Iny avoy was the Greek name of the rue, which the modern plant resembles. Harmala is the Arabic name ( $h$ harmel) of the species so called. The species are of easy culture and propagation in any light soil.

1089. Hudsonia. So named by Linnæus, in honor of William Hudson, apothecary of London, F. R. S. and author of Flora Anglica, 1762 and 1778, octavo. It is a heath-like plant which grows in peat soil, and young cuttings are rooted in sand under a bell-glass. It is extremely rare in gardens,

1090. Nitraria. So named by Schreber, who first found it in Siberia near the nitre works, with other saline vegetables. This is a curious thorny shrub, peculiar to the salt deserts of Siberia. Pallas informs us, that the berries, though saltish and insipid, are eaten in the Caspian desert, but in that arid soil they are almost the only luxury. Camels feed on the twigs. Linnæus had the shrub twenty ycars before it flowered in Sweden; 
6599 Unarmed, Leaves entire, Flowers gynandrous

6600 Leaflets ovate acuminate, Petals ovate roundish obtuse with globose ovaries

6601 Stem twining, Cor. regular, Petals very long wavy, Peduncles capitate-racemose

6602 Leaves emarginate at base, Flowers without calyx

0603 Leaves entire at base undivided

6604 Leaves half three lobed, Flowers complete

6005 Leaves subcordate ovate entire serrated rather hairy : the floral ones lanceolate, Branches hairy 6006 Leaves ovate undivided rarely lobed

6607 Leaves rhomboid: the upper lanceolate ovate, Flowers complete

6608 Leaves ovate cordate entire unequally serrated acuminate downy glandular at base, Fl. complete

6609 Leaves ovate cordate 7-nerved acuminate serrate hairy, Flowers clustered

6610 Leaves oblong serrate 5-nerved softly hairy, Fl, terminal clustered

6611 Leaves multifid, Stem herbaceous

6612 Leaves oblong acute, Stem herbaceous

6613 Leaves subulate acerose hairy, Calyx erect pubescent

6614 Leaves entire obtuse

6615 Leaves wedge-shaped fleshy, Fl. sessile, Stem and branches nearly erect

6616 Leaves wedge-shaped fleshy, Fl. sessile, Branches prostrate

6617 Much branched prostrate, Leaves wedge-shaped minute fleshy, Fl. on long stalks and sessile

6618 Leaves subulate alternate hairy at the axillæ, Flowers sessile terminal

6619 Bractes 4, Flowers 4-fid, Joints of the stem hairy

6620 Leaves elliptical fleshy flat, Joints hairy, Flowers sessile terminal

6621 Leaves subulate, Cal. hairy, Involucre many-leaved, Flowers about 3, Petals retuse

6622 Axils hairy, Leaves obversely oblong, Involucre 8-leaved

6623 Leaves cylindrical fleshy, Corymbs terminal stalked

6624 Leaves linear oblong ciliated, Flowers solitary

6625 Leaves flat chann. wedge-shaped emarg. mucronate, Raceme simple with a 3-cornered peduncle 6026 Leaves flat obovate mucronate, Corymb long, Peduncle 3-cornered

6627 Leaves ovate flat, Panicle terminal, Peduncle dichotomous

6628 Leaves lanc. ovate sessile opposite, Panicle branched

6629 Leaves ovate difform smooth green, Peduncles round long panicled

6630 Leaves ovate acuminate difform green shining cobwebbed, Raceme simple, Peduncles round long 6631 Leaves ovate acuminate difform shining cobwebbed dark-red, Rac. simple, Pedunc. very long 6632 Leaves imbricated expanded dark-green cobwebbed rugose above, Threads axillary longer than leaves 6633 Leaves lanceolate fleshy convex beneath, Scape leafy short 1-flowered

6621
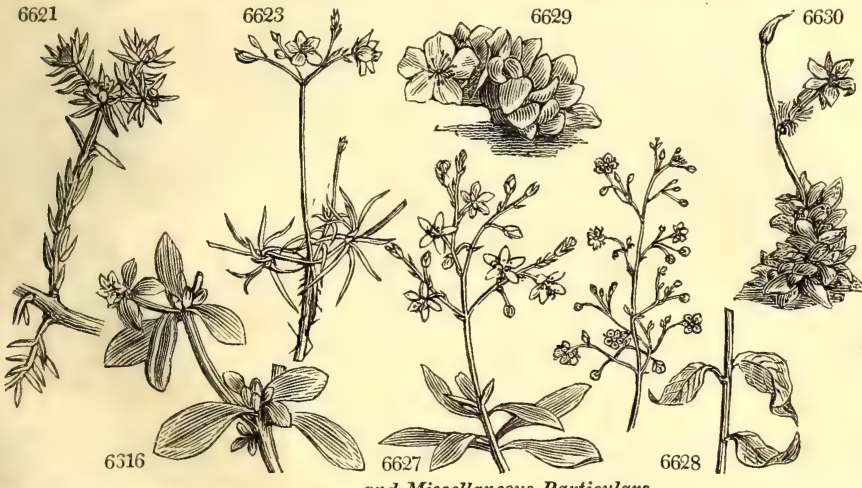

6630

and Miscellaneous Particulars.

and during ten years having in vain tried to make it flower in the garden at Upsal, he at length succeeded by watering the plant with salt water; it flowered, however, at Gottingen without this assistance. Murray expresses a surprise that it has not been used in its native soil for making soda : but perhaps it does not grow in sufficient quantity, or there may be an ample harvest in that salt region of plants that answer the same purpose.

In this country it thrives in sandy loam with a little salt put round it, and is increased by layers, or cuttings in sand under a hand-glass.

1091. Portulaca. An ancient name of unknown origin. The species are succulents of the easiest culture. $P$. sativa and oleracea were formerly cultivated as potherbs, salads, for garnishings and pickling, though now little used for any of these purposes.

1092. Talinum. One of those names invented by Adanson, which probably were the mere creations of that botanist's erratic brain. This is a succulent genus allied in habits to Portulaca, and of the easiest culture.

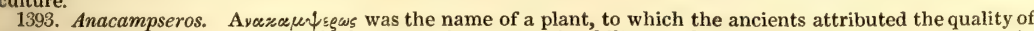
restoring the passion of love, for which purpose it was used in philtres and incantations: from $\propto \nu \alpha \approx \alpha \mu \pi \tau \omega$, to return, and şws, love. The species are succulents, and grow freely in a sandy loam mixed with a little lime rubbish, and require but little water. Cuttings root readily, but should be laid to dry a few days before being planted. Leaves taken off close to the plants, and laid to dry a few days, and then planted, will root, and shoot out young plants at their base. 
1094. I.YTH'RUM. $W$. 6634 Salicária $W$. 6635 virgátum $W$ 6636 alátum $P h$. 6637 lineáre $W$. 6638 hyssopifólium $W$. 1095. NES E'A. Kunth. 6639 triflóra Kunth. Lythrum triflorum $\mathbf{W}$ 6640 verticilláta Kunth.

1096. HEI'MIA. Link. 6641 salicifólia Link.

1097. CU'PHEA. Jacq. 6642 viscosíssima $W$. 664'3 procúmbens $\mathrm{Cav}$. 6644 lanceoláta $H . K$. 6645 decándra $H . K$ 6646 circroides Sims. 6647 multifóra Lodd. 6648 Melvílla Lindl. 1098. KLEINHO'FIA. 6649 Hóspita $W$.
LYTHRUM.

\section{common}

fine-bran

De $\triangle$ white-flowered $2 \Delta$ or

Hyssop-leaved $\rightarrow$ or

three-flowered $\$ \Delta$ or W. rlflowered \& $\triangle$ or Heimia. willow-leaved clammy procumbent procumbent

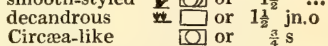
many-flowered $1 \frac{1}{4} \mathrm{sr}$ scarlet \& green $W$. Kleinhofia. heart-leaved
Salicaria. $\quad S p .5-10$.

jl,au Pu Britain riv, ba. D co Eng, bot. 1061 3 jn.s Pu Austria 1776. D co Bot. mag. 1003 3 my.n Pu N. Amer. 1812. D s.t Bot. mag. 1812 $1 \frac{1}{2}$ jl.au W N. Amer 1812. D s.l

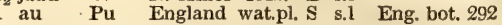
Salicarice. Sp. $2-3$.

2 au B America 1802. D p.l 2 jl.s $\quad$ Pu N. Amer. 1759. D p.l

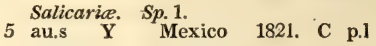
Salicaria. $S p .7-19$.

jl.au Pu America 1776. C s.1 Sw. fl. gard. 60 jl.s Pa.pu Mexico 1816. S s.l Bot. reg. 182 $\begin{array}{lllll}\frac{1}{2} & \text { Pu Mexico 1796. C } & \text { s.l }\end{array}$

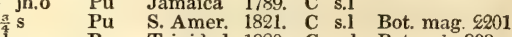

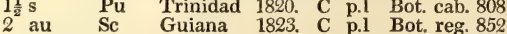
Malvacea, Sp. 1

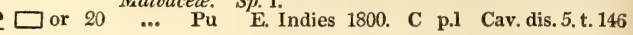

\section{DIGYNIA.}

1099. CALLi'COMA. B. R. Callicoma. 6650 serrátifólia $B . R$. saw-leaved 1100. HELIOCAR'PUS. $W$. HeLIOCARPUS 6651 americánus $W$. American 1101. Agrimo'NiA. $W$. Agrimony. 6652 Eupatória $W$. 6653 odoráta $W$. 6654 répens $W$ 6655 parviflóra $W$ 6656 striáta $P h$. common sweet-scenter creeping $\frac{\downarrow}{\downarrow} \Delta$ or 2 jl.s white-flowered $\Delta$

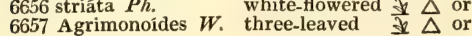

Cunoniacea. Sp. 1.

my.au Y N. S. W. 1793. C s.p Bot. rep. 566

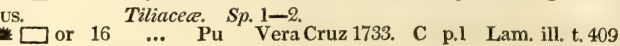
Rosacea. Sp. 6-9.

3 jn.jl $\underset{Y}{\text { B }}$ Britain bor. fi. D co Eng. bot. 1335 $4 \mathrm{jl} \quad \mathrm{Y}$ Italy 1640 . D co jl.s $\quad \mathbf{Y}$ Levant 1737. D co f $\quad$ Y N. Amer. 1766. D co

11 jn.au $\mathrm{Y}$ Italy

Col. ecp. 1. t.144

\section{TRIGYNIA.}

1102. RE'SEDA. $W$. 6658 Iutéola $W$. 6659 crispáta Link.
RESEDA. Dyer's-weed curled
Resedacea. Sp. 19-23.

ag 2 jn.jl Ap Britain wa.gr. S s.l Eng. bot. 320

$O$ un 2 jn.jl Ap Portugal 1823. S co

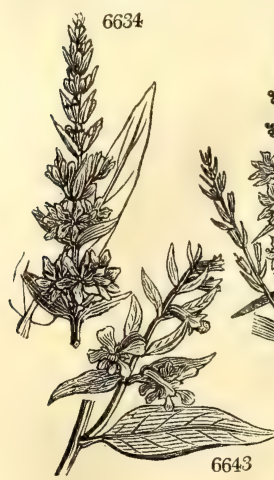

6635

\section{sis 6636}

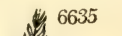


6634 Leaves opp, cordate lanceolate, Flowers spiked 12-androus

6635 Leaves opp. lanc. Panicle virgate, Flowers 12-androus 3 together

6636 Leaves opp. ovate obl. acute cordate at base closely sessile, Branches 4-winged, F1. axil. sol. 6-androus 6637 Leaves opposite linear, Flowers opp. hexandrous

6638 Leaves alternate linear, Flowers hexandrous

6639 Smooth, Leaves opp. subsessile lanceolate entire, Pedunc. axill, opposite, Head 3-flowered 6640 Leaves opp. somewhat downy stalked, Flowers whorled linear

6641 Leaves linear-lanceolate acute, Flowers axillary

6642 Fl. axill. solitary, Leaves ovate-lanceolate scabrous above, Stem erect hispid, Style hairy 6643 Branches decumbent viscous, Leaves ovate lanceolate hispid on short stalks

6644 Fl, axill. sol. Lvs. lanc. hairy, Stem erect hairy, Style smooth, The 2 long filam. having a tuft of wool longer

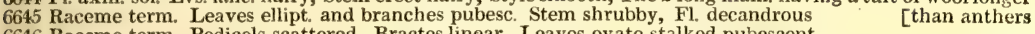
6646 Raceme term. Pedicels scattered, Bractes linear, Leaves ovate stalked pubescent

6647 Leaves small lanceolate, Flowers small solitary terminal, Bush compact

6648 Leaves lanceolate scabrous narrowed at each end, Racemes term. Cal. long bowed, Petals $\mathbf{O}$

6649 A smooth tree, with broad cordate acuminate entire leaves

\section{$D I G Y N I A$.}

6650 The only species

6661 The only species

6652 Fruit hispid, Cauline leaves pinn. with obl. ovate leaflets, Spikes elevated, Pet. twice as long as calyx 6653 Fruit hispid, Leaves pinnate with obl. leaflets the lower veiny short, Pet, twice as long as calyx

6654 Fruit hispid, Cauline leaves pinnate with obl. leaflets, Spikes subsessile, Petals 3 times as long as calyx 6655 Fruit hispid, Cauline leaves pinnate with many lanceol. leaflets, Petals half as long again as calyx 6656 Spikes virgate, Fruit reflexed turbinate furrowed crowned with hairs

5657 Fruit smooth, Cauline leaves ternate, Stamens usually 8

\section{TRIGYNIA.}

6658 I eaves lanc, entire with a tooth on each side at base, Cal. 4-fid

6659 Leaves lanceolate wavy entire with two glands at base

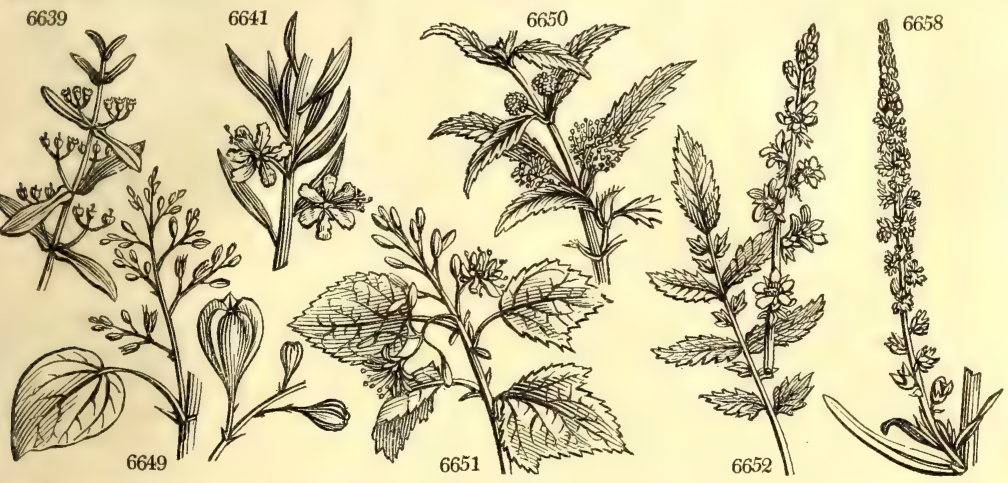

and Miscellaneous Particulars.

gathered smell like apricots. When the plant is coming into flower it will dye wool a full nankeen color, and gathered in September a darker yellow. It has been used for dressing leather. Sheep and goats eat it, but kine, horses, and swine refuse it.

1102. Reseda. From resedo, to calm, to appease. The Latins thought it useful as a topical application in external bruises, R. Luteola, a diminutive of lutea, yellow, is used by dyers, especially in France. (Chaptal's Chimie appliqué à l'Agriculture, \&c.) It affords a most beautiful yellow dye for cotton, woollen, mohair, silk and linen. Blue cloths are dipped in a decoction of it, in order to become green. The yellow color of the paint called Dutch Pink, is obtained from this plant. The entire plant, when it is about flowering, is pulled up and employed both fresh and dried. Mr. Swayne observes, that it is one of the first plants which grow on the rubbish thrown out of coal pits. It flowers in June and July. The root and bottom leaves are formed from the fallen seeds before winter; and thus it happens in this, as in many other cases, that the wild plant is biennial, whilst the cultivated plant, growing from seeds sown in the spring, is annual. It is an observation of Linnæus's, that the nodding spike of flowers follows the course of the sun, even when the sky is covered; pointing towards the east in a morning, to the south at noon, westward in the afternoon, and to the north at night.

R. odorata is a well known and universal favorite. The flowers are highly odoriferous, and there are very few to whom this odor is offensive. The plant is in great demand in London for rooms and placing in balconies, and forms for these purposes an extensive articie of culture among the florists and market gar deners. The plants are in many cases sown and transplanted into pots, three or four plants to a pot four inches in diameter. To obtain plants for blowing from December to February, a sowing should be made in July in the open ground, and the plants potted in September. The crop for March, April, and May, should be sown not later than the twenty-fifth of August, the plants from this sowing will not suffer by exposure to rain, whilst they are young; they must, however, be protected from early frosts, like the winter crop; they are to 
6660 canéscens $W$. 6661 glaúca $W$. 6662 dipétala $W$. 6663 scoṕría Brouss. 6664 sesamoídes $I V$. 6665 viréscens Horn. 6666 fruticulósa $W$. 6667 álba $W$ 6668 pruinósa Delisle. 6669 undáta $W$. 6670 bipinnáta $W$. 6671 saxátilis Pourr. 6672 ramosis'sima $W$. 6673 lútea $W$.

6674 Phyteúma $W$. 6675 mediterránea $W$ 6676 odoráta $W$

$\beta$ frutéscens hoary glaucous Flax-leaved Broom-like spear-leaved green green fo 0 un 3 my.o frosted waveleaved $\frac{\$}{\Delta} \Delta$ un 1 in.au bipinnate-leav. un 2 jn.au rock $\quad \frac{v}{\partial} \Delta$ un $1 \frac{1}{2}$ jn.au branching $\quad \forall$ un 2 jn.au trifid $\$ 2$ un $1 \frac{1}{2}$ jn.s Mediterranean $\bigcirc$ un $1 \frac{1}{2}$ jn.s

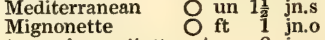
tree-mignonette $L_{1}$ or 2 jn.o

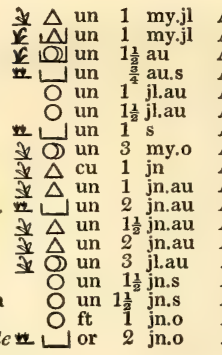

Spain

1597. D s.1 Cl. his. 1. t. 295 S. Europe 1700. D s.1 Pl. alm. t.107. f.2 C. G. H. 1774. C s.l Teneriffe 1815. C s.l

France 1787. S s.l All.p. 2.t. 88, f.3 Spain 1820 S co Spain 1820. S co Jain 34 S. Europe 1596. C s.1 Lob. ic. 222 Egypt 1824. C s.I Spain 1739. D s.l Bar. rar. t. 587 Spain - 1816. C s.l Spain 1816. D s.I Spain 1816. D s.1

Britain ch. so. C s.1 Eng bot. 321

S. Europe 1752. S s.1 Jac aust. 2 t 139 Palestine 1791. S s.1 Lind, coll. 22 Egypt 1752. S r.m Bot. mag. 29 Egypt 1752. S r.m Bot. reg. 227

1103. EUPHOR'BIA. $W$

SPURGE. twin-spined upright-triang.

spreading-trian marbled Canary seven-angled nine-angled warty-angled naked naked many-angled many-angled Porcupine variable-stem 6681 canariénsis 6682 heptagóna W: 6684 mammilláris $W$ 6685 cereifórmis $W$ 6686 officinárum $W$ 6687 polygona Haw. 6689 Hystrix $W$. 6690 várians Haw. 6691 grandifólia Haw.

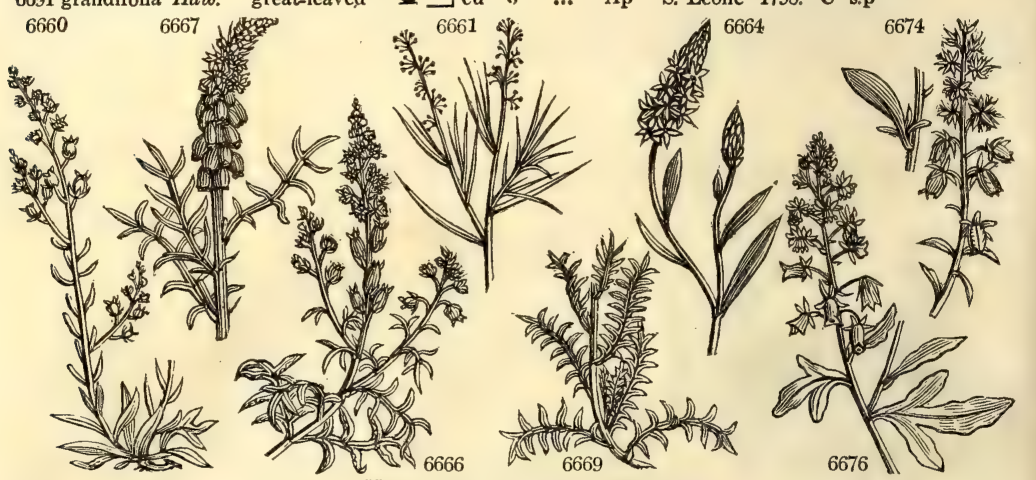

Euphorbiacea. Sp. 135-160.

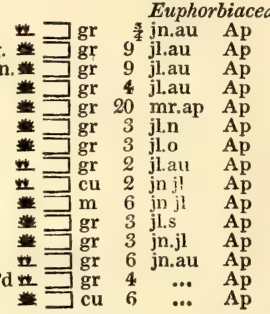

C. G. H. 1794. C s.l Plant. grass. 151 E. Indies 1768. C s.l E. Indies 1688. C s.p Rh. mal. 2.t 42 E. Indies 1804. C s.p Canaries 1697. C s.p Plant. grass. 140 C. G. H. 1731. C s.p Brad, suc. 2. 13 C. G. H. 1790. C s.p

C. G. H. 1759. C s.p Com. præl. t. 9 C. G. H. 1731. C s.p Bur. afr. t. 9. f. 3 Afríca 1597. C s.p Plant. grass. 77 C. G. H. 1790, C s.p

India 1690. C s.p Plant. grass, 46 C. G. H. 1695. S s.p Jac. sch. 2.t. 207 E. Indies 1800. C s.p

be thinned in November, leaving not more than eight or ten plants in each pot; and at the same time, the pots being sunk about three or four inches in some old tan or coal ashes, should be covered with a frame, which it is best to place fronting the west : for then the lights may. be left open in the evening, to catch the sun whenever it sets clear. The third, or spring crop, should be sown in pots, not later than the twenty-fifth of February; these must be placed in a frame, on a gentle heat, and as the heat declines the pots must be let down three or four inches into the dung-bed, which will keep the roots moist, and prevent their leaves turning brown, from the heat of the sun, in April and May. The plants thus obtained, will be in perfection by the end of May, and be ready to succeed those raised by the autumnal sowing. (Rishon in Hort. Trans. ii. 372.)

$\mathbf{R}$. odorata frutescens, if left to itself, hardly appears a distinct variety, but trained against a wall or to a stick it, and also the common mignonette, may be made to assume a frutescent character. According to Sabine, the tree mignonette is to be propagated from seeds sown in spring; it may also be increased by cuttings, which will readily strike. The young plants should be put singly into small pots, and brought forward by heat, that of a gentle hot-bed being preferable, but they will grow well without artificial heat As they advance, they must be tied to a stick; taking care to prevent the growth of the smaller side shoots, by pinching them off, but allowing the leaves of the main stem to remain on for a time to support and strengthen it. When they have attained the height of about ten inches or more, according to the fancy of the cultivator, the shoots must be suffered to extend themselves from the top, but must be occasionally stopped at the ends, to force them to form a bushy head, which by the autumn will be eight or nine inches in diameter, and covered with bloom. Whilst the plants are attaining their proper size, they should be shifted progressively into larger pots, and may ultimately be left in those of about six inches in diameter at top. (Hort. Trans. iii. 181.)

Mr. Lindley's theory of the nature of the inflorescence of this genus being remarkable, and only explained in his Collectanea Botanica, which is in few hands, it is here transcribed entire. "The usual idea of the flower of Reseda has been, that it is furnished with a calyx of a variable number of divisions, with as many petals, producing from their surface certain anomalous appendages, and with an ovary and stamens inserted on a great fleshy body, called nectary by Linnæan botanists, squama by others, and raised to the rank of a distinct organ by M. Mirbel, under the name of Gynophore To us, however, it has always appeared, that this could by no means be the real structure of the plant, and that by a slight alteration of terms it not only might be much more satisfactorily explained, but its real affinity ascertained with some degree of probability. For even allowing for a moment an analogy between the nectary of this plant and the discus of others, particu. larly of some Tiliaceæ, there is still a great difficulty remaining to be overcome in the anomalous structure of the supposed petals, of which we can imagine no probable explanation. We are therefore of opinion, that a much more natural mode of understanding Reseda is to consider it as having compound flowers; taking the calyx of authors for an involucrum, their petals for neutral florets, and their nectary for the calyx of a fertile 
6660 Leaves lanceolate wavy hairy

6661 Leaves linear toothed at base, Styles 4

6662 Ieaves linear entire, Styles 4, Barren florets 2

6663 Leaves linear entire, Fl. trigynous, Fruit clavate, Stem twiggy

6664 Leaves lanceolate entire, Fruit stellate

6665 Nearly related to $R$. luteola, but the leaves are not toothed at base

6666 Leaves pinnate recurved at end, Styles 4, Involucre 5-parted spreading, Stem half shrubby

6667 Leaves pinnate, Styles 4, Involucres 6-parted

6668 Branches above and younger leaves covered with large distinct blisters

6669 Leaves pinnate wavy, Styles 3 or 4

6670 Leaves bipinnatifid very rough, Flowers spiked

6671 Leaves all trifid: segments of the upper leaves linear flat; of the lower lanceol. wavy, Stem quite smple

6672 Leaves linear simple or trifid, Stem erect branched, Fruit obovate

6673 Leaves all trifid : the lower pinnate

6674 Leaves entire and 3-lobed, Involucres 6-parted very large

6675 Leaves entire and 3-lobed, Involucres shorter than florets

6676 Leaves entire and 3-lobed, Involucres as long as florets

$$
\begin{aligned}
& \text { 1. Stem thick, fleshy, naked, or with a few leaves, Flowers dispersed. } \\
& \text { * Prickly. }
\end{aligned}
$$

6677 Fleshy prickly compressed channelled inflexed at end, Prickles twin diverging

6678 Naked erect prickly triangular jointed, Branches erect somewhat channelled

6679 Prickly nearly naked triangular jointed, Branches spreading

6680 Naked prickly jointed with 3-cornered expanded branches obsoletely marbled with white

6681 Prickly naked nearly quadrangular, Prickles twin hooked, Fl. subsessile

6682 Prickly naked with 7 angles, Prickles solitary subulate flower-bearing

6683 Prickly naked erect with 9 angles, Prickles solitary flower-bear. ascending fuscous, Branches pendulous

6684 Prickly half naked, Angles warted with spines between, The young warts leafy

6685 Prickly naked with many angles, Prickles solitary subulate

6686 Prickly naked with many angles, Prickles twin

6687 Prickly naked with numerous simple erect 10-13-angled stems, Prickles dark

6688 Prickly half naked, Prickles twin, Angles obliquely warted leafy upwards, Leaves oblong

6689 Stem round half naked leafy upwards, Leaves lanc. linear, Peduncle 1-fl. at length spiny

6690 Prickles twin, Stem rounded or angular, Angles obliquely warted, Leaves nearly oblong

6691 Prickles twin horizontal, Stem rounded simple, Leaves oblong spatulate very large
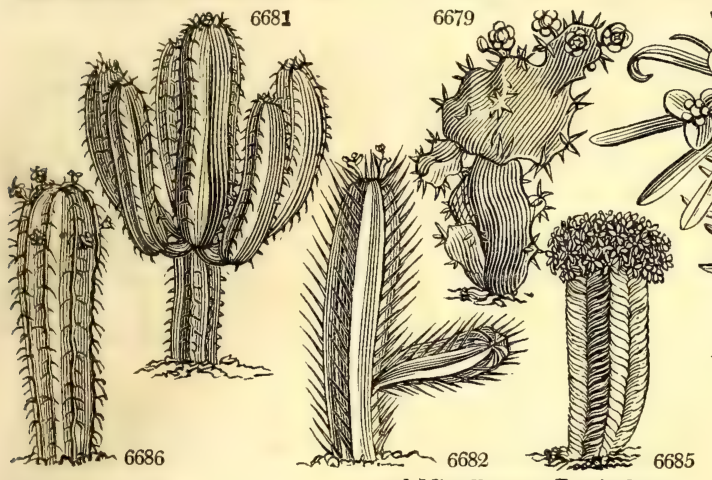

and Miscellaneous Particulars.

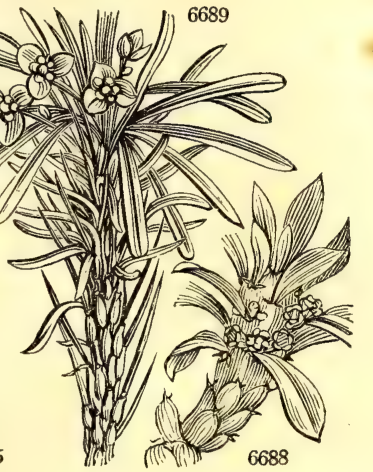

floret in the middle. In support of this opinion, we may observe, firstly, that there is a difference in the time of expansion of the neutral florets, and of the stamens of the fertile one; the former being quite open, in very many capituli, before one anther of the latter has burst in a single flower. Secondly, that there is an evident analogy between the appendages of the neutral florets, and the stamens of the perfect florets inasmuch as in Reseda odorata those of the upper sterile florets are of nearly the same number as the real stamens; because in Reseda alba, and some others, in which a union of filaments takes place in the perfect floret, there is a corresponding but more complete union of the sterile appendages; and because occasionally, in Reseda odorata, stamens are changed into bodies altogether similar to the sterile appendages, and in Reseda Phyteuma the same appearance is always assumed by the perfect stamens after the anthers have performed their functions. Thirdly, that there is an equal analogy between the calyx of the neutral florets, and that of the perfect floret; because both have a peculiar glandular margin; the same form; both produce their stamens from their surface; and because the upper edge of the calyx in sterile florets has the same reiation to the axis of each particular head, as that of the perfect floret has to the axis of the whole inflorescence. In Reseda Phyteuma, which has the margin of its neutral florets rolled back, the same thing occurs in the perfect floret. Fourthly, that there is no instance of the same analogy existing between the discus and petals of other plants. We may also observe, that in Reseda Phyteuma, there is a campanulate tube to the calyx, into the upper edge of which the stamens are inserted.

"To determine the affinity of Reseda to other orders, will not be so easy as to explain its structure. One cannot avoid remarking the resemblance between its calyx and the squama of Amentaceæ and Ulmacex. Ficoidex, Grossulaceæ and Cacti, on account of placentation and structure of seed, may be supposed to have a certain relation to it: as may Chenopodeæ with regard to inflorescence, absence of petals, and habit. But we are disposed to believe its real place in the system is in the neighbourhood of Euphorbiacex, where we have placed it in Flora Scotica. They agree with it in having the same sort of aggregation of flowers, similar habit, no corolla and ternary division of ovarium. The insertion of their ovula is the same, as is also the direction of the radicle. They differ, however, firstly, in the presence of albumen; which yet is not
then is of entirely absorbed in Keseda till the seed is perfectly ripe, and which exists even after that time in the seed of $\mathbf{R}$. alba, where it is fleshy as in Euphorbiaceæ. Secondly, in their solitary seeds ; in which respect Resedaceæ may be supposed to bear the same relation to Euphorbiaceæ as Campanulaceæ do to Compositæ ; or as some sections of Rubiacex to the others. In R. suffruticulosa the ovules appeared to be reduced to a single row, and the same is said to obtain in Ochradenus. Thirdly, in elastic dehiscence of capsule; hut as this is not universal in Euphorbiaceæ, it is not, strictly speaking, an objection of importance." (Lindley's Coll. Bot.)

1103. Euphorbia. Euphorbus was physician to Juba, king of Mauritania, and first used this plant in medicine. This is a genus of grotesque and curious plants, few of them of either beauty or use, and most of 
6692 cucumerina $W$. Cucumber-like 6603 man' 6694 lanifera Haw. 6695 geminispína Haw. double-spined

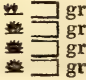

$3^{\frac{1}{3}} \quad \cdots \quad A p$

C. G. $\mathbf{H}$.

6696 melofórmis $W$.

Melon-like

粪

6697 Caput-medúse 6698 tesselláta Haw. gr. Med. Head 6699 fructuspina Haw. small Med. Hd 670 procumbens scaly 6702 cláva $W$.

6703 buvieurifolia $W$. 6704 maurit́nnica $W$ 6705 mauritánica 6706 Ornithópus Jacq. 6707 apýlla 6708 balsamifera $W$. 5709 Tirucálli $W$

cone-shaped

Barbary hooked Bird's-foot leafless

Indian-Tree

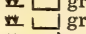

w L

w 12 s. 1 .

n $\mathrm{gr} 1 \mathrm{mr}$

whr 1x jn.jl

t $1 \frac{1}{2}$ jn.au

L $L_{1}{ }_{1}$

-

$1 \frac{1}{2} \mathrm{jn} . \mathrm{au}$

gr

6710 atropurpárea $W$.en. dark-purple 6711 piscatćria $W$. 6712 bracteáta Jacq. 6713 péndula Haw. 6714 dendroides $W$ 6715 cyathóphora $\dot{W}$. 6716 repánỏa Haw. 617 biglandulósa Haw 6718 nudiflóra Jac. б, 19 cotinifólia $W$ 6720 petioláris Sims. 6721 inellífera $W$ 6722 linarifólia $W$ 6723 variegáta $B$. $M$. 6724 prunifólia $J a c q$.

dark-purp

2. 니 $\mathrm{cu}$ $\begin{array}{ll}1 & \cdots\end{array}$ bracteated pendulous tree-like colored waved

w $\begin{array}{llll} & & & \\ 3 & \cdots & \text { Ap }\end{array}$ 步 $\square \mathrm{cu} \quad 1 \frac{1}{2} \quad \ldots .$. — $\Rightarrow \mathrm{cu} \quad \mathrm{l} \quad \ldots . \mathrm{Ap}$ * $-\mathrm{cu} \quad 1 \frac{1}{2} \quad \ldots \quad$ Ap

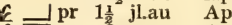
[2] $\mathrm{cu} 2 \mathrm{au}$ $3 \mathrm{~s}$ \% $6 u$ naked-flowered Cotinus-leaved $\square$ or 10 jl,au A long-stalked $\square \mathrm{cu} 3$ my.jn Ap honey-bearing $\longleftarrow$ pr 6 ap.my Ap Toad-flax-lvd. $\square$ cu 3 ... Ap pie-bald $\mathrm{O}$ cu s Ap Plum-leaved $\&$ Qا cu 2 jn.jl Ap

6725 ocymoídea $W$. 6726 dentáta Mich. 6727 hypericifólia $W$ Basil-leaved toothed

Hypericum-Iv.

6728 Humbóldtii $W$.en. 6729 prostráta $W$. 6730 rósea $\boldsymbol{W}$ 6731 maculáta $W$ 6732 picta $W$. 6733 pilulifera $W$ 6734 hyssopifólia $W$. 6735 thymifólia $W$. 6736 chamesýce $W$ 6737 Péplis $W$. 6738 polygonifólia $W$ 6739 Ipecacuánhæ $W$. 6740 canaliculáta Pers.
Humboldt's

trailing red

spotted painted globular

Hyssop-leaved thyme-leaved scollop-leaved purple

purple

Ipecacuanha

channelled

\begin{tabular}{|c|c|c|}
\hline & & n. \\
\hline & w & jn.jl \\
\hline & w & $1 \frac{1}{2} \mathrm{jn} . \mathrm{s}$ \\
\hline & w & 1 jl.o \\
\hline & w & $\frac{1}{2} \mathrm{jl} . \mathrm{o}$ \\
\hline & w & u \\
\hline & W & $1 \frac{1}{2} \mathrm{jl}$ \\
\hline & $\begin{array}{l}\mathrm{w} \\
\mathrm{w}\end{array}$ & $\frac{1}{3}$ jn.aul \\
\hline & w & 1 au.s \\
\hline & w & jl.au \\
\hline & w & jl,au \\
\hline & w & I jl.au \\
\hline & w & $\frac{x}{4}$ jn.jl \\
\hline & & \\
\hline
\end{tabular}

Ap
Ap

Mexico

Mexico
C s.p Vail, it. t. 5

18Q3. C s.p

1823. C s.p

C. G. H. 1774. C s.p Bot. rep. 617

Africa 1731. C s.p Com. præl.t. 7

$\ddot{G} \ddot{H}$ 1788. C s.p

C. G. H. 1731. C s.p Plant. grass. 150

C. G. H. 1768. C s.p Bur.afr.t.10. f.1

C. G. H. 1727. C s.p Plant. grass. 14

C. G. H. 1774. C s.p Jac. ic. 1. t. 85

C. G. H. 1791. C s.p Jac. sch.1.t. 106

Africa 1732. C s.p Di.el.t.289.f.373

C. G. H. 1795. C s.p Bur. afr.t.6. f. 3

C. G. H. 1816. C s.p Jac, frag, t. 120

Teneriffe 1815. C s.p

Canaries 1779. C

$\begin{array}{llll}\text { India } & 1690 . & \text { C } & \text { s.p }\end{array}$ Rh. mal/2.t. 44

Teneriffe 1815. C s.p

Canaries 1777. C

1809. C s.p Jac. sck. 2, t. 276

Italy... 1808. C s.p

Italy 1768. C s.p

S. Amer. 1806. C s.p Bot. reg. 765

E. Indies 1808. C s.p

Bourbon 1808. C s.p

S. Amer, 1690 C s.p Hook ex, fi, 59

W. Indies 1800. C s.p Bot. mag. 883

Madeira 1784. C s.l Bot. mag. 1805

1794. C s.1 Jac. ic. $1 . t .86$

S.1 Bot. mag. 1747

..... 1799. S s.l Jac. sch. 3. t. 277

S. Amer. 1733. S s.l

N. Amer. 1806. S s.1

America 1727. S s.1 Hook, ex, ff. 36

S. Amer. 1809. C s.1

W. Indies 1758. S s.1

E. Indies 1808. S s.1

S. Amer. 1660. S s.1 Jac, vin. 2. t.186

S. Amer. 1789. S s.l Jac. ic. 3. t. 477

E. Indies 1800. C s.l Jac. ic. 3. t. 478

W. Indies 1787. C s.l

India 1699. S s.I Pl. alm.t.'113. f.2

S. Europe 1752. S s.1 Mo.h. 10. t.2.f.19

England sea.sh. S s.l Eng. bot. 2002

N. Amer. 1704. S s.l Jac. co.s. t.13.f.3

N. Amer. 1812. D s.l Bot. mag. 1494

Carthagin.1819. S co Bot. cab. 727

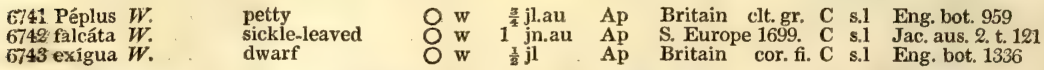

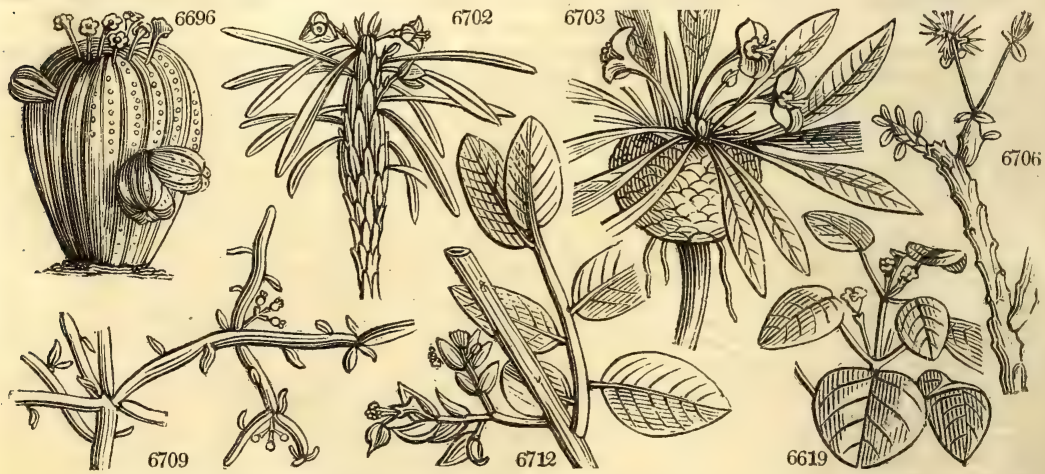

History, Use, Propagation, Culture,

the annuals poisonous weeds. One species ( $\mathbf{E}$ edulis), not yet introduced, is said to be used as a pot-herb in Cochin China; one ( $\mathbf{E}$, punicea) is a very splendid plant, and the $\mathbf{E}$. officinarum, and one or two other species gathered along with it, are used in medicine. They are all milky, mostly herbaceous, several however shrubby, upright for the most part, very few of them creeping; some are leafless, but most of them are leafy. Stems angular or tubercled, or more frequently cylindric or columnar; unarmed, or in the angular sorts resernbling the upright Cactuses, and armed with prickles, which are either solitary or in pairs, placed in a single row on the top of the ridges. Such as have leaves have them simple, most frequently alternate and naked; in some sorts, however, they are opposite, and are then commonly attended with stipuies, and in a few they are placed by threes in whorls. Peduncles in the leafless sorts naked, bearing from one to three flowers; in the leafy ones axillary, but more frequently from two to five or more in a terminating umbel; each some- 
6692 Prickly elliptical obtuse furrowed, Prickles subsolitary, Peduncles 3-flowered 6693 Warts very large green downy at end, Spines about 4 strong black at end 6694 Simple rounded obovate with warts woolly at end

6696 Unarmed globose with many angles

** Unarmed

6697 Unarmed imbricated, Warts with one leaf, Flowers somewhat stalked, Divisions palmate

6698 Stem closely tessellated with warts upwards thickly branched

6699 Unarmed imbricated with warts bearing a linear leaf

6700 Unarmed with round procumbent branches, Warts 4-cornered

6701 Unarmed imbricated, Warts with a roundish leaflet, Fl. term. solitary sessile with palmate segments

6702 Unarmed imbricated, Warts with a lanceolate leaflet, Fl. stalked with entire segments

6703 Unarmed imbricated capitate, Warts rhomboid with lanceolate stalked leaves, Segm. of flower entire

6704 Unarmed half naked shrubby filiform flaccid, Leaves alternate

6705 Warts large imbricated hooked at end : the upper having an oval leaflet at length withering

6706 Unarmed warted, Warts with a deciduous leaf, Pedunc. solitary or 3 terminal 1-flowered

6707 Unarmed naked leafless branched, Branches square, Fl. solitary terminal

6708 Unarmed shrubby upright, Head terminal, Leaves lanceolate smooth glaucous

6709 Unarmed half naked shrubby filiform erect, Branches spreading regularly clustered

\$2. Stem uniform, shrubby, upright, Flowers scattered or aggregate, not in umbels.

6710 Unarmed, Leaves lanceolate clustered entire, Umbel terminal sessile, Invol. connate colored

6711 Unarmed shrubby upright, Umbel 5-fid term. Invol. oblong, Leaves lanc. smooth

6712 Unarmed shrubby, Leaves oblong alternate distichous, Bractes persistent

6713 Unarmed shrubby naked, Branches rounded effuse dependent jointed

6714 Umbel multifid dichotomous, Invol, subcordate : the first 3-leaved

6715 Unarmed, Leaves panduriform ovate, Fl, term. suberect, Invol, colored

6716 Villous, Leaves with long stalks alternate broadly ovate repand-toothed, Stem erect striated

6717 Leaves opp. minute stalked obovate entire, Two glands on the stem at the base of petioles

6718 Unarmed shrubby, Leaves ovate entire, Cyme axillary naked

6719 Leaves opp. subcordate stalked emarginate entire, Stem shrubby

6720 Stalks whorled longer than the orbicular leaf, Fl. solitary, Stem unarmed naked

6721 Leaves scattered lanceolate acute smooth, Pedunc. dichotomous, Caps, muricate

6722 Unarmed shrubby, Leaves scattered lanc. mucron. Fl. solitary term. with a 3-leaved invol. Caps. muricate

6723 Leaves oval entire wavy edged with white, Caps. smooth, Stem hairy

6724 Dichotomous, Leaves ovate serrate acute villous, Fl. solitary, Upper dichotomies cymose

5. Dichotomous, herbaceous, Flowers solitary or aggregate, not umbelled.

6725 Unarmed branched, Leaves subcordate entire shorter than their stalk, Fl. solitary

6726 Dwarf hairy, Leaves opp. oval toothed, Flowers clustered at the end of branches

6727 Dichotomous, Leaves serrate oval-obl. smooth, Corymbs terminal, Branches divaricate

6728 Dichotomous, Leaves ovate obl. acute at each end smooth stalked entire, Capsules smooth

6729 Dichotomous, Leaves oval obsol. serrated, Pedunc. axill. 3-flowered, Stems diffuse smooth

6730 Dichotomous diffuse, Lvs. obov. oblique somewhat cord. at base toothletted at end, Pedunc. 1-fl. axillary

6731 Dichotomous, Leaves serrate oblong hairy, Fl. axill. solitary, Branches spreading

6732 Dichotomous, Leaves ovate hairy stalked entire, Pedunc, axill. 1-fi. Caps. smooth

6733 Dichotomous, Leaves serrate oval oblong, Pedunc. 2-headed axillary, Stem erect

6734 Dichotomous, Leaves subcrenate linear, Fl. fascicled term. Stem erect

6735 Dichotomous, Leaves serrate oval-obl. Heads axill, clustered subsessile, Stems procumbent

6736 Dichotomous, Leaves crenulate roundish smooth, Fl. solitary axill. Stems procumbent

6737 Dichotomous, Leaves entire half cordate, Fl. solitary axillary, Stems procumbent

6738 Leaves opp. entire lanceolate obtuse, Fl. solitary axillary, Stems procumbent

6739 Dichotomous, Leaves entire lanceolate, Peduncles axillary 1-f. as long as leaves, Stem erect

6740 Branches alternate dichotomous channelled filiform, Leaves ovate stalked pubescent

\section{Flowers umbelled with an involucre.}

$$
\text { * Umbel trifid. }
$$

6741 Dichotomous, Invol. ovate, Leaves entire obovate stalked

6742 Dichotomous, Invol. subcordate mucronate, Leaves lanceol. obtuse

6743 Dichotomous, Invol. lanceolate, Leaves linear

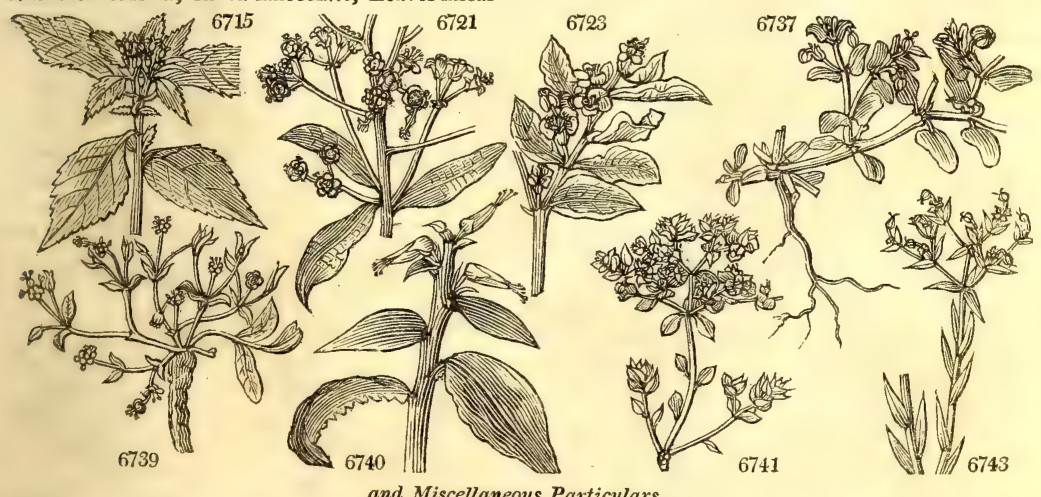

and Miscellaneous Particulars.

times in a many-flowered head, but more often dichotomous, trichotomous, or even tetrachotomous, with single flowers between the divisions at the base and in the forkings; having bractes in number the same with the peduncles, forming a sort of involucre. The juice of every species of Spurge is so acrid that it corrodes and ulcerates the body wherever it is applied; so that it is seldom used internally. Externally it is dropper on warts or corns to remove them, and in the hollow of a decayed tooth, to remove the pain by destroying the nerve, or it is rubbed behind the ears to give relief in the tooth-ache by blistering.

E. officiuarum, and also antiquorum and canariensis, furnish the Euphorbium of the Materia Medica. In the lower regions of Mount Atlas, the inhabitants collect the concreted gum resin, which they call furbiunc in September. It is obtained by making slight incisions in the branches of the plant with a knife, from which a milk-like juice exudes, and forms into tears of an oblong or roundish form. The quantity yielded is so 
6744 minima Haw. 6745 micrántha $W$. 6746 tuberósa $W$. 6747 acumináta Bieb.

least

small-flowered $\bigcirc \mathrm{w} \quad \frac{1}{3}$ jl.s

$\begin{array}{lll}\text { tuberous } & \\ \text { pointed } & \mathrm{Cu}_{\mathrm{W}}^{\frac{3}{4}} \mathrm{o.d} & \mathrm{o.d}\end{array}$

Ap $\quad \ldots . . . \quad 1800$. C s.1

Ap Ethiopia 1800, C s.l Bur. afr. 9.t.4 Albania 1820. S co Boc. sic.t. 13. f.1

Caper

6748 Lathyris $W$

6749 valentina Pers.

6750 diffúsa $W$.

$6751 A^{\prime}$ pios $W$.

6752 læ'ta $W$

6753 genistoídes $W^{\prime}$

6754 spinósa $W$

6755 nummulariæfólia $W$.

6756 epithymoídes $W$.

0757 dúlcis $W$

6758 carniólica $W$.

6759 Pithyúsa $W$.

6760 portlándica $W$.

6761 Parálias $W$.

$\varsigma$ suffruticósa

6762 rígida Haw.

6763 júncea $W$.

6764 aléppica $W$.

6765 segetális $W$.

6766 biumbelláta Pers.

Spanish

diffuse

Pear-rooted

Mezereon-lvd.

Genista-like

prickly

broad-leaved

sweet

Carniolian

Juniper-lvd.

Portland

sea

shrubby-sea

rigid

rushy

corn

(2) w 3 my.o

O $1 \frac{1}{2}$ jl.au

O w $\frac{1}{2}$ jl.au

$\left\{\Delta w 1^{\frac{1}{2}} \mathrm{jn.jl}\right.$

- J cu 1 jl.au

it cu 2 mys

政 cu $1^{\frac{1}{2}}$ my.jn Ap

$\triangle$ cu 1 my.jn Ap

f $\triangle$ cu 1 au

re $\mathrm{cu} 1 \mathrm{jn} . \mathrm{jl}$

\& $\triangle$ pr $\frac{1}{3}$ my.s

$\triangle \mathrm{pr} \quad 1^{\frac{2}{3} \mathrm{jl} . \mathrm{s}}$

I cu 1 jl.s

* cu 2 jl.au

\& $\triangle \mathrm{Jcu} 1$ jl.au

$\Delta \mathrm{V}$ cu 1 jl.au

double-umbell $\&$ $\mathrm{w}$ cu $1^{\frac{1}{3}} \mathrm{jl}$.au

6767 angustifólia Haw. narrow-leaved $\Delta$.

6769 provinciális $W$. linear-leaved $\mathrm{O}$ w $1 \frac{1}{2}$ au.n

6770 juncoídes Haw.

6771 helioscópia $W$.

6772 serráta $W$.

6773 crética Haw.

6774 punicea $W$.

6775 verrucósa $W$.

6776 corolláta $W$.

6777 spathulæfólia Haw. 6778 corallioides $W$

Rush-like

Wart-wort

[0] $\mathrm{w}$ il

narr. notch-lvd. $\stackrel{\mathrm{O}}{\mathrm{Cu}} \mathbf{1}^{\frac{3}{4} \mathrm{jl} \text { jlau }}$

Cretan hoary $\Delta$ un $3 \ldots$

scarlet-flowered

warted f $\Delta$ un $\frac{3}{4 n}$

great-flowered $\triangle$ un $1 \frac{1}{2} \mathrm{jl.s}$

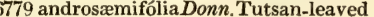

6780 pilósa $\boldsymbol{W}$

6781 orientális $W$.

6782 platyphýllos $W$.

$\beta$ stricta E. B.

6783 literáta $W$

6784 E'sula $W$.

6785 sylvática $W$.

6786 Erythrina Link $_{\text {. }}$

6787 glareósa Bieb.

6788 bialáta Link.

6789 uralénsis Fisch.

6790 micrántha Bieb.

6791 crispáta Horn.

6793 fragífera

hairy

oriental

annual-warty

upright-warty

blotch-leaved

leafy-branched $x$

$\leftarrow \Delta$ un 2 jl.s

$\triangle$ un 11 my Ap

A un 1 jul A

万ิ 1 jl.au

Of w 12 jl.au

O w ${ }^{1}$ w jl.au

wood

fieshy

swo-winged

Ural

small-flowered

crisp

F $\triangle \mathrm{cu} \frac{1}{2} \mathrm{my} . \mathrm{jl}$

un 2 jl.s

vicu j jl.s

$\Delta \mathrm{O}^{\mathrm{w}} \mathbf{1}_{3} \mathrm{jl} . \mathrm{s}$

$\Delta$ w $^{\frac{3}{4}} 3^{\frac{3}{4} \mathrm{jl.s}}$

$\mathrm{O}$ un $\frac{1}{2} \mathrm{my}$

$\triangle$ un $3^{\frac{1}{2}} \mathrm{my}$

c $\triangle$ un $\frac{1}{2} \mathrm{my}$

berry-bearing $\Delta$ un $2^{\frac{1}{2}}$ my

\section{Ap}

Ap $\quad$ England d.st.pl. S co Eng. bot. 2255

$\begin{array}{llll}\text { Austria } & 1798 . & \text { S } & \text { s.l } \\ \text { Candia } & 1596 . & \text { D } & \text { s.l }\end{array}$

C. $\ddot{\mathrm{G}} \ddot{\mathrm{H}}$ 1758. $\quad$ C s.l

Levant 1710. C s.1

Levant 1710. C

Austria 1805. D co

S. Europe 1759. D co

Carniola 1795. D co

S. Europe 1741. C s.1

Britain sea.s.

England sea.sh. C s.l

...... $\quad \ldots$ C $\quad$ s.l

Madeira 1779. D s.I

Crete 1779. D s.I Jac. sch. 1.t. 107

S. Europe 1739. D s.I Alp. exot. t. 64

1789. D s.1 Jac. aus. 5. t.450

...... 1780. D s.1

S. Europe 1800. S s.l

$1800^{\circ}$ S s.1

Britain cor.f. S s.l Eng. bot. 883

S. Europe 1710. D s.1 Jac. ic. 3. t. 483

Levant 1768. C r.m

Jamaica 1778. C s.l Bot. reg. 190

France 1800. C s.1 Mor, s. 10.t.3.f.3

N. Amer. 1803. D s.l Bot. cab. 390

...... 1800. C s.l

S. Europe 1752. D s.I

Hungary 1804. D s.1

Siberia 1758. D s.l

Levant 1739. D s.l

England cor.fi. S co

Britai.. 1790. S co Jac. ic. 3. t. 482

Britain woods. S co Eng. bot. 1399

S. Europe 1768. D co

C. G. H. 1823. D co

Tauria 1820 D

...... 1823. S co

Ural 1821. D co

Tauria 1822. S co Bux.cen.2.t.25

Caucasus 1821. D co

Italy 1890 .

Germany 1801. C co Jac. aust. t. 436

England woods. D co Eng. bot. 840

Hungary 1807. D co Pl. rar. h. t. 162

S. Europe 1570 D

S. Europe 1570. D s.l

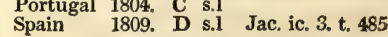

England $\quad . . \quad$ S co Eng. bot. 333 6797 myrsinítes $W$.

6798 imbricáta $\boldsymbol{P}$.
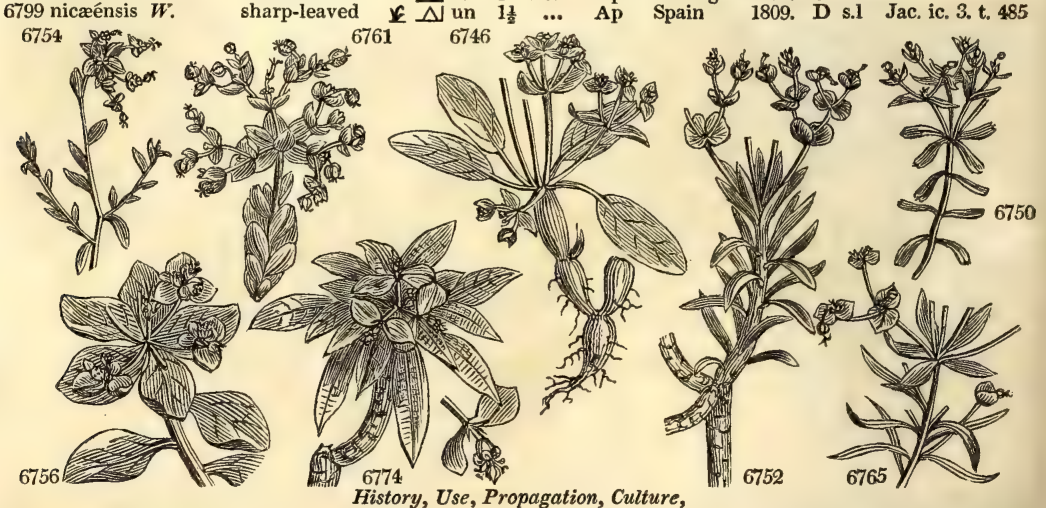

616746 .

considerable, that the plants are cut once only in four years; the supply then obtained being sufficient for that space of time for all Europe. The recent juice is so corrosive as to erode the skin wherever it touches; and the people who gather the gum are obliged to tie a cloth over their mouth and nostrils, to protect them from the acrid dust of the withered branches, which induces the most violent sneezing. It is inodorous; and, when first chewed, has little taste, but it soon gives a very acrid burning impression to the tongue, palate, and throat, which is very permanent, and almost insupportable. Euphorbium possesses powerful cathartic, emetic, errhine, and rabefacient properties. It has been given as a hydragogue in dropsies; but, owing to the violence of its effects, its internal use is now exploded: neither as an errhine can it be used alone, for it occasions so 
6744 Dichotomous, Umbel trifid, Invol. broad obovate, Leaves entire obovate spatulate on long stalks 6745 Dichotomous, Leaves lanceolate obovate serrate, Invol. cordate, Caps. warted 6746 Invol. 4-leaved, Stem naked, Leaves oblong emarginate

6747 Umbel subtrifid, Leaves mucronate, Cauline spatulate lanc. Invol, ovate, Caps. smooth

\section{** Umbel 4 or 5-fid.}

6748 Umbel 4-fid dichotomous, Leaves opposite entire

6749 Umbel 4-fid trifid, Invol. ovate acute, Leaves lanc. : lower spatulate

6750 Umbel 4-fid dichotomous, Invol. obtuse, Leaves altern. lin. cuneate emarginate mucron. Stem diffuse 6751 Umbel 4-fid bifid, Invol, reniform: the first obcordate

6752 Umbel 4 or 5-fid twice dichotomous, First invol. oblong : upper rhomboid-roundish, Leaves lin. lanceol. 6753 Umbel 5-cleft bifid, Invol. ovate, Leaves linear erect

6754 Umbel 5-cleft simple, Invol. ovate : first 3-leaved, Leaves oblong entire

6755 Umbel 5-cleft bifid, Upper leaves rounded obovate serrulate mucronate : lower lanc. reflexed

6756 Umbel 5-cleft bifid, Invol. ovate toothletted, Leaves entire lanc. oblong villous beneath

6757 Umbel 5-cleft bifid, Invol. subovate toothletted, I.eaves lanc. obtuse, Caps. warted hairy

6758 Umbel 5-cleft bifid, Rays nodding, Invol. ovate entire, Leaves lanc. acute, Caps. warted smooth

6759 Umbel 5-cleft bifid, Invol. ovate mucronate, Leaves lanc. : the lower involute imbricated downwards

6760 Umbel 5-cleft dichotomous, Invol. subcordate concave, Leaves lin. lanc. acute smooth spreading

6761 Umbel 5-cleft bifid, Invol. cordate reniform, Leaves imbricated upwards

6762 Branches filiform, Leaves numerous linear oblong retuse, Rib mucronate, Fl. solitary terminai 6763 Umbel 5-cleft dichotomous, Leaves and invol. linear lanceolate acute

6764 Umbel 5-cleft dichotomous, Invol. ovate lanceolate mucronate, Lower leaves setaceous

6765 Umbel 5-cleft dichotomous, Invol. cordate acute, Leaves lin. lanceolate : the upper broadest

6766 Umbel multifid double, Invol. subcordate, Leaves linear

6767 Umbel multifid clustered, Invol. subcordate, Leaves numerous close very narrow

6768 Umbel multifid dichotomous, Invol. half orbicular cordate, Sterile branches many, Lvs. lin. lanc. obtuse 6769 Umbel 5-cleft bifid, Invol. cordate mucronate, Leaves oblong

6770 Umbel 5-cleft bifid, Invol. half orbic. cordate submucronate, Leaves linear imbricated backwards

6771 Umbel 5-cleft bifid dichotomous, Invol. obovate, Leaves cuneiform serrate smooth, Caps. smooth

6772 Umbel 5-cleft trifid dichotomous, Inv_l. 2-leaved reniform, Leaves amplexicaul. cordate serrate

6773 Umbel multifid bifid, Invol, orbicular, Leaves linear lanc. villous

6774 Umbel 5-cleft trifid, Invol. oval acuminate colored, Caps. smooth, Leaves glaucous beneath

6775 Umbel 5-cleft trifid, Invol. ovate, Leaves lanc. serrulate villous, Caps. warted

6776 Umbel 5-cleft trifid dichotomous, Invol. and leaves oblong obtuse, Divisions of invol. white

6777 Umbel 4-fid bifid, Invol. obovate, Leaves spatulate lanc. entire reflexed, Stem half shrubby branched

6778 Umbel 5-cleft trifid dichotomous, Invol, ovate, Leaves lanceolate, Caps. woolly

6779 Naked smooth, Umbel 5-cleft bifid, Leaves sessile lanceolate veiny on each side

6780 Umbel 5-cleft trifid bifid, Invol. ovate entire, Leaves lanc. hairy subserrulate at end

6781 Umbel 5-cleft 4-fid dichotomous, Invol. roundish acute, Leaves lanceolate

6782 Umbel 5-cleft 3-fid dichotomous, Invol. with a hairy keel, Leaves serrate lanceolate, Caps. warted

6783 Umbel 5-cleft 3-fid dichotomous, Invol. lanceolate, Leaves lanc. toothed pubescent, Caps. smooth warted 6784 Umbel multifid bifid, Invol. subcordate 2-horned, Barren branches with 1-shaped leaves

$6 / 85$ Umbel 5 -fid bifid, Invol. perfoliate cordate acute, Leaves lanc. entire

6786 Leaves lanc. obtuse, Umbel 5-fid dichotomous, Invol, ovate obtuse 2-horned

6787 Umbel 5 -fid bifid, Leaves spatulate lanc. mucronate coriaceous serrulate, Invol. ovate, Caps. smooth

6788 Leaves obversely obl. Invol. oblong and ovate serrulate at end, Umbel 5-fid dichotom. Caps. keeled twice 6789 Leaves linear with long points entire smooth, Umbel 5-fid bifid, Invol. lanceolate, Leaves 2-horned 6790 Umbel trifid dichotomous, Leaves serrate somewhat hairy : lower spatulate; upper and invol. spatulate 6791 Upper branches hairy, Leaves smooth lanceolate, Caps. warted, Invol. cordate

6792 Umbel sub-5-fid bifid, Caul. leaves and invol. cordate lanceolate obtuse toothletted, Invol. reniform 6793 Leaves lanceolate, Umbel 5-fid, Invol. oval obtuse, Caps. ramentaceous hairy

\section{***Umbel 6-many-fid.}

6794 Umbel multifid dichotomous, Invol. roundish entire, Branches none

6795 Umbel multifid dichotomous, Invol. subcordate, Branches sterile, Leaves setaceous, Cauline lanceolate 6796 Umbel multifid bifid, Invol. subtriangular, Leaves sessile erect, Caps. rough

6797 Umbel 8-fid bifid, Invol. subovate, Leaves spatulate spreading fleshy mucronate rough at edge

6798 Umbel dichotomous bifid, Invol. roundish mucronate, Leaves obovate imbricate serrulate

6799 Umbel 5-fid bifid, Invol. cordate roundish entire, Leaves lanceolate mucronate coriaceous

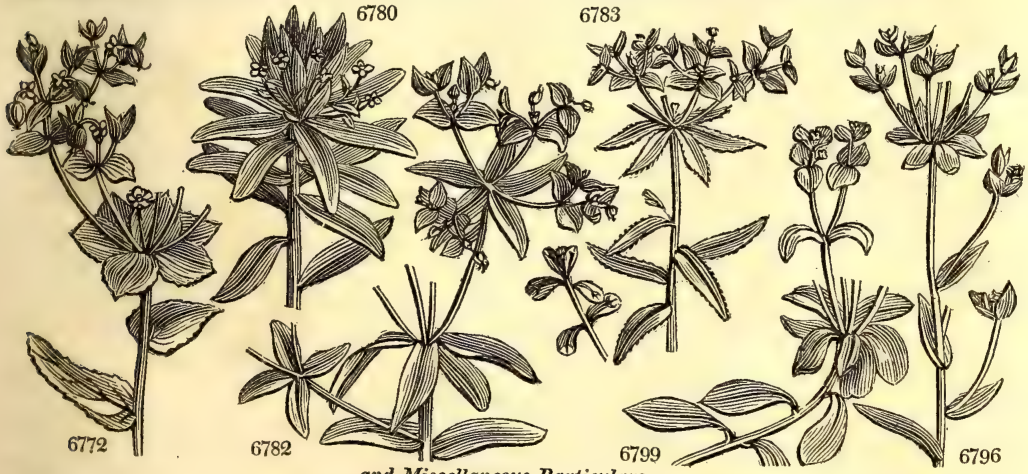

and Miscellaneous Particulars.

much inflammation as to produce hæmorrhage from the nostrils, and swells the integuments of the head. When properly diluted, however, with starch or any other inert powder, and cautiously used, it is an effectual and excellent errhine in lethargy, deafness, palsy, amaurosis, and similar cases. (London Dispersatory, 298.)

E, Lathyris has seeds about the size and color of caper buds, and in Paris is sometimes substituted for that pickle. Eaten in any quantity they must prove highly deleterious.

E. helioscopia has a peculiarly acrid milky juice, which is often applied by country people to eat off warts ;

but should be used with caution where the parts are tender. According to Linnæus, sheep eat it, and are

purged by it, and their flesh acquires a bad taste; but this is not the case with cows. 
6800 palústris $W$ 6801 emarginata $W$ 6802 hibérnica $W$. 6802 hibernica $W$ 6804 amygdaloides $W$. 6805 charácias $W$. 6806 glaucéscens $W$. 6807 agrária Bieb. 6808 pállida $W$. 6809 prócera Bieb. 6810 ceratocar'pa Ten. 6811 salicifólia Hort.

marsh freckled Irish willow-leaved

wimond-leav. upright-red glaucous

field

pale

pale

horn-fruited

horn-fruited

1104. PEDILAN'THUS. Neck. Slipper Plant.

6812 tithymaloídes Kunth. Myrtle-leaved

6813 carinatus Donn. keeled

1105. VIS'NEA. $W$. VISNEA.

6814 Mocanéra $W$

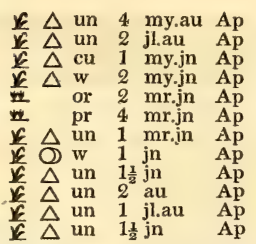

Sweden 1570. D s.1 Fl, dan. 866

Italy 1758. D co

Britain fields. D co

England England mo. pl, C co Eng. bot. 442

Crime... 1823. D co

Crimea 1821. S co

Hungary 1822. D co

Crimea 1819. D co Gmel sib t 94

Naples 1823. D co Ten. neap. t. 63

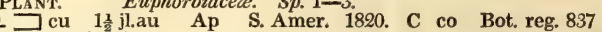

$\square \mathrm{cu} \mathrm{1 \frac {1 } { 2 }}$ jl.au Ap ..... 1817. C co Bot. mag. 2514 L or 5 Ebenacee. Sp. 1

\section{TETRAGYNIA.}

1106. CAlli'gonum. $W$. Calligonum. 6815 Pallásia $W$. Caspian

Polygonea. Sp. $1-5$.

or 4 au G.w Casp. Sea 1780. C 1.p Pall.ros.2.t.77,78

\section{PENTAGYNIA.}

1107. GII'NUS. $W$. GLINUS. 6816 lotoídes $\dot{W}$. hairy

Ficoidea. Sp. $1-3$.

O un $1 \frac{1}{2} \mathrm{jl} Y$ S. Homalinee. Sp. 1-6.

6817 integrifolia $\mathrm{Lam}$. entire-leaved $\square$ or $6 \quad \ldots \quad$ W Madagasc.1823. C s.p Lam.ill, t.412.f.2 1109. GASTO'NIA. Juss. Gastonia. 6818 paimata Wall. palmate 
6800 Umbel multifid 3-fid bifid, Invol, ovate, Leaves lanceolate, Branches barren

6801 Umbel multifid bifid, Invol. broadly cord. Leaves obl. emarg. smooth, Stem branched, Capsules warted 6802 Umbel 6-fid dichotomous, Invol. oval, Leaves entire, Branches none, Capsules warted 6803 Umbel multifid dichotomous, Invol, reniform cordate, Leaves lanceolate villous 6804 Umbel multifid dichotomous, Invol. perfoliate orbiculate, Leaves obtuse 6805 Umbel multifid bifid, Invol. perfoliate emarginate, Leaves lanceolate entire 6806 Leaves linear lanceolate entire close together, Capsules smooth

6807 Umbel multifid bifid, Cauline leaves and involucres cordate oblong rough at edge subserrulate 6808 Urnbel multifid trifid, Invol, roundish, Leaves lanc. attenuated, Stem simple, Caps. smooth 6809 Umb. 5-fid 3-fid dichotomous, Leaves lanceolate hairy serrulate at end, Capsules smooth 6810 Leaves lanceolate entire smooth, Caps. warted smooth, otherwise like E. palustris 6811 Leaves entire lanceolate villous, Umb. multifid, Inv. reniform cordate

@12 Leaves ovate acuminate

6813 Leaves ovate acuminate keeled beneath

6814 The only species

\section{TETRAGYNIA.}

6815 Fruit winged, Wings membranous crisp toothed

\section{PENTAGYNIA.}

6816 Stem hairy, Leaves obovate

6817 Leaves ovate obtuse usually entire, Fl. terminal panicled

6818 Leaves palmate, Stem aculeate

\section{DODECAGYNIA.}

6819 Stem arborescent smooth branched, Leaves cuneiform smoothish ciliated, Ciliæ spreading smooth

6820 Stem shrubby, Leaves orbicular-spatulate villous, Nectaries nearly square truncate

6821 Stem shrubby, Leaves cuneiform viscid ciliated, Ciliæ cartilaginous appressed

6822 Stem shrubby, Leaves orbicular-spatul. glutinous at edge with globose glands and cuneiform trunc. nects. 6823 Leaves obovate acute smooth with a cartilaginous edge, Cymes clustered

6824 Stem with dense spreading bristles, Leaves curved with longitudinal green spots beneath 6825 Leaves closely packed together in a broad flat disk

6826 Suckers spreading lateral, Leaves ovate mucronate warted, Branches of cyme bifia 6827 Leaves obovate gibbous beneath villous, Nects. 2-lobed

6828 Leaves spatulate cuneiform obtuse villous, Nects. palmate

6829 Stem pubescent, Leaves spatulate scattered

6830 Leaves ciliated, Suckers spreading, Nects. cuneiform with a swelling

6831 Margins of leaves serrate toothed, Offsets spreading

6832 Leaves entire oblong ovate smooth stalked, Cymes spreading, Pedunc. and calyx hairy

6833 Leaves stem and petals hairy at end

6834 Leaves ciliated, Offsets short round nearly sessile, Petals 6 fringed
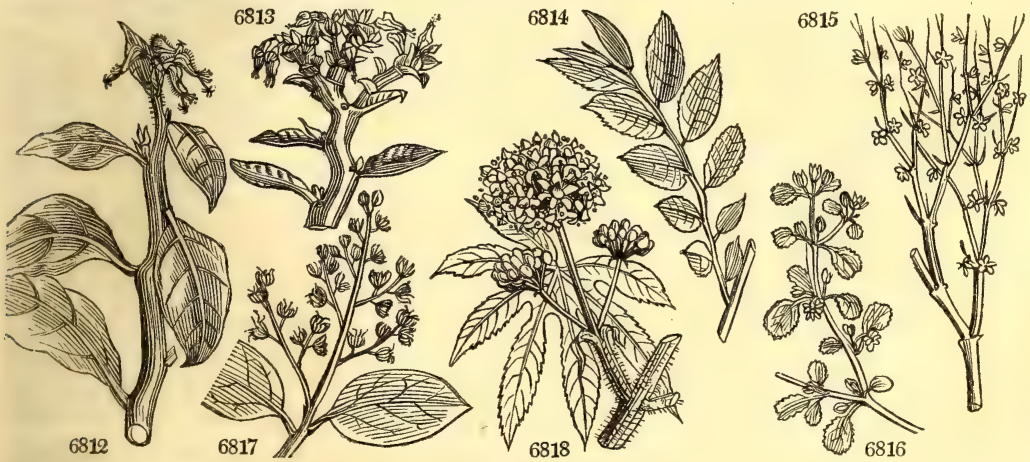

and Miscellaneous Particulars.

1106. Calligonum. From ж⿻і㇒, beautiful, and yove, a knee or joint. This plant produces, instead of leaves, curious greenish excrescences disposed in joints, which give it a remarkable appearance.

1107. Glinus. A name employed by Theophrastus to designate a kind of maple. This plant is, however, more like a purslane.

1108. Biackwellia. Named after Elizabeth Blackwell, who published an Herbai in 1735, containing figures of between two and three hundred plants, drawn and ergraved by herself. Curious stove plants with pretty foliage, but inconspicuous spikes of whitish green flowers.

1109. Gastonia. Named by Commerson after Gaston de Bourbon, son of Henry IV. In the Isle de Bourbon it is called Bois d'éponge.

1110. Sempervivum. From semper vivere, to live for ever, in allusion to the tenacity of life common to plants of the genus. This is $\mathrm{z}$ succulent genus, some species of which are ornamental or singular, and others 


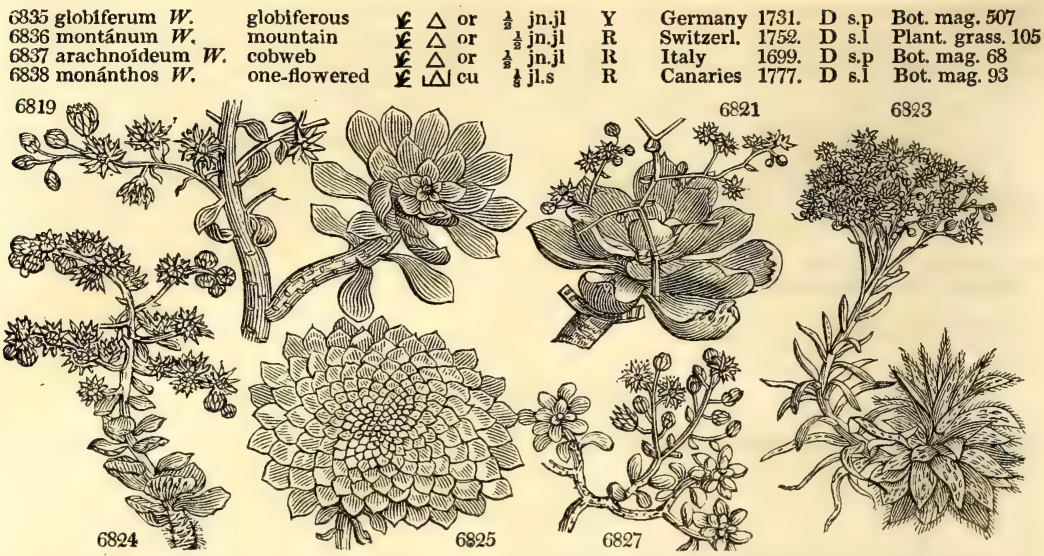

History, Use, Propagation, Culture,

curious. S. tectorum, common on the roofs of buildings, is used by country people as an application to burns, inflammations, and ulcers, alone, in a bruised state, or mixed with cream. Linnæus informs us, that house-

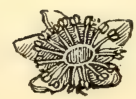

Crass XII. - ICOSANDRIA. Stamens many, perigynous, or inserted into the Calyx.

To gardeners this is one of the most interesting of the Linnean classes, containing a greater proportion than any other of objects which come within their observation and management. It also consists of genera for the most part naturally allied; and comprises not only the most remarkable portion of Ficoideæ, all Cacti, and the chief of the Myrtacex, but almost every genus of the beautiful and hardy tribes of Rosacem. Its characters are well defined, and depend upon the insertion of a number of distinct stamens, exceeding twenty, into the inner surface of the calyx ; modifications of which organ are here found to be of more than ordinary importance in characterising the genera.

The genera are extremely natural, and have been all studied with unusual attention. Some difference of opinion exists among botanists as to the limits which ought to be assigned to them, and great diversity of nomenclature has thence arisen. "But," as has been observed by a modern author, " in a class so strictly natural as this is, greater difficulty is always to be expected in finding characters for genera, than in those of which our knowledge is more imperfect, and whose series of individuals may therefore be considered less complete." In the apple and pear tribe, Pomacea, where the greatest difficulty is thought to exist, we adopt plete." In the apple and pear tribe, Pomaceæ, where the greatest difficulty is thought to exist, we adopt
Mr. Lindley's arrangement, as published in the Transactions of the Linnean Society, which we find admitted by all botanists of authority.

But if it is difficult to ascertain the definite limits of the genera of Icosandria, it is yet more perplexing to arrive at a satisfactory conclusion respecting the species of which the genera are constituted. Having all been, as long as gardens have existed, the objects of cultivation, it has happened that many individuals have, under the action of domestication, wandered so far from their original types, as to have acquired new characters for themselves, of so peculiar a kind as to have rendered it impossible at the present day to refer them with certainty to the source from which they originally sprung. To remedy this confusion, which has been thus increasing for ages, some persons have thought it necessary to distinguish the species by such artificial characters as they are now found to possess, without reference to any changes the genera may have undergone; but it has been found that no facilities of discrimination have been gained by multiplying distinctions in consideration of differences which are neither permanent or remarkable, nor connected with natural habit, but purely artificial. To others it has appeared proper to endeavour to reduce the aberrant forms which now exist to those from which, upon mature consideration, they may be presumed to have been derived, and to simplify the arrangement and discrimination of the species by confining them within their primitive limits. As we think the latter to be the most simple principles of arrangement, and as they are certainly the most philosophical, we shall here follow those authors who have adopted them

It is usual in this class to distinguish the orders with two and three styles from that with five: but the different species vary so much in the same genus in this respect, that we have only separated the genera into those with one style, Monogynia ; with two, three, or five styles, Di-Pentagynia ; and with many styles, Polygynia.

\section{Order 1. MONOGYNIA.}

\$1. Ovary inferior.

1111. Cactus. Cal. imbricated. Petals numerous, in many rows : the inner the largest. Stigma many-cleft. Berry many-seeded.

1112. Rhipsalis. Cal. 3-4-parted, very short. Teeth acuminate, membranous, very fine. Berry 1-celled, pellucid. Seeds 12 , in the centre

1113. Bartonia. Cal. 5-cleft. Petals many. Caps. cylindrical, 1-celled at the end with $3-5$ lid-like valves. Placentas 3-5, parietal, bearing seeds in a double row. 
6835 Leaves ciliated, Offsets globose

6836 Leaves entire, Offsets spreading

6837 Leaves with entangled hairs, Offsets round

6838 Leaves rounded clavate clustered, Pedunc. naked 1-f. Nects. obcordate

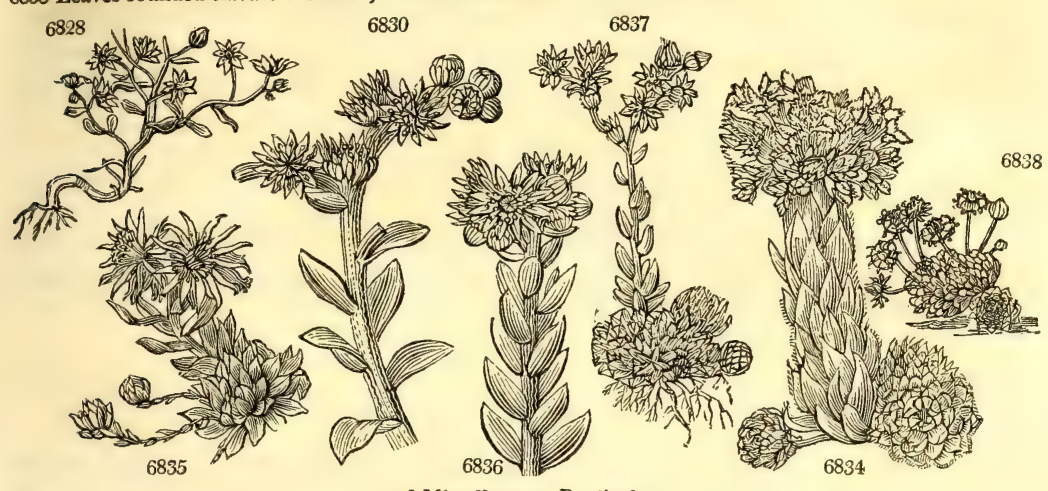

and Miscellaneous Particulars.

leek is a preservative to the coverings of houses in Smoland. It may easily be made to cover the whole roof of a building, whether of tiles, thatch, or wood, by sticking the offsets on with a little earth or cow dung.

1114. Philadelphus. Cal. 4-5-parted. Petals 4-5. Style 4-cleft. Caps. half-superior, 4-5-celled, many-seeded. Seeds with an arillus.

1115. Leptospermum. Cal. persistent at base, 5-cleft, half-superior. Petals 5, clawed, round, longer than stamens. Stigma capitate. Caps. depressed, 4-5-celled. Seeds angular, slender.

1116. Falricia. Cal. 5-cleft, half-superior. Petals 5, sessile. Stigma capitate. Capsule many-celled. Seeds winged.

1117. Metrosideros. Cal. 5-cleft, half-superior. Petals 5. Stamens very long, separate. Stigma simple.

Caps. 3-4-celled.

1118. Psidium. Cal. 5-cleft. Petals 5. Berry soft, pulpy, many-seeded. Cotyledons leafy, very small.

Radicle very large, arcuate. Testa bony.

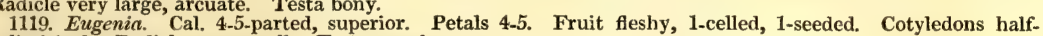
cylindrical. Radicle very small. Testa membranous.

1120. Caryophyllus. Cal. funnel-form. Fruit dry, 1 or 2-celled. Otherwise like Eugenia.

1121. Myrtus. Cal. 5-cleft. Petals 5. Berry 2 or 3-celled, many-seeded. Radicle and cotyledons distinct.

1122. Calyptranthus. Cal. truncate, before flowering covered with an hemispherical deciduous lid. Cor. $O$.

Berry 1-celled, 4-seeded.

1123. Pimenta. Cal. 5-fid. Petals 5. Ovary 2-celled. Ovules solitary, appense. Style straight. Stigma somewhat capitate

1124. Olynthia. Cal, 5-cleft. Petals 5. Stigma hooked. Berry 1-celled. Seeds angular. Embryo conferruminate.

1125. Stravadium. Cal. 4-cleft. Petals 4. Fruit 4-cornered, 1-seeded. Flowers in terminal racemes.

Leaves alternate.

1126. Eucalyptus. Cal. truncate, covered with an entire deciduous lid. Cor. O. Capsule 4-celled, opening at end, many-seeded.

1127. Punica. Cal. 5-cleft. Petals 5. Berry many-celled, many-seeded. Seeds berried, Placentas parietal.

\section{\$2. Ovary superior.}

1128. Amygdalus. Cal. 5-cleft. Petals 5. Drupe with a nut perforated on its surface.

1129. Prunus. Cal. 5-cleft. Petals 5. Drupe with a hard smooth nut.

1130. Chrysobalanus. Cal. 5-cleft. Petals 5. Style lateral. Drupe with a 5-furrowed, 5-valved nut.

Order 2. DI-PENTAGYNIA.

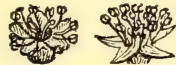

Many perigynous Stamens. 2 to 5 Styles.

1. Ovary inferior

1131. Mespilus. Cal. 5-parted, with leafy divisions. Disk arge, honey-bearing. Styles smooth. Apple turbinate, open, 5-celled, with a bony putamen.

1132. Crategus. Cal, 5-toothed. Petals spreading, orbicular. Ovary 2-5-celled. Styles smooth. Apple fleshy, oblong, closed by the teeth of the cal., or by the thickened disk. Putamen bony.

1133. Pyrus. Cal. 5-toothed. Petals roundish. Apple closed, 5-celled, with a cartilaginous putamen. Cells 2-seeded. Testa cartilaginous.

1134. Cydonia. Cal. 5-parted, with leafy divisions. Apple closed, many-seeded. Testa mucilaginous.

1135. Photinia. Cal. 5-toothed. Petals reflexed. Ovary half-superior, villous, 2-celled. Styles 2, smooth.

Pericarp 2-celled, included in the fleshy calyx. Testa cartilaginous.

1136. Raphiolepis. Cal. with a funnel-shaped deciduous limb. Filaments filiform. Ovary 2-celled. Apple closed by the thickened discus, with a papery putamen. Seeds gibbous.

1137. Eriobotrya. Cal. woolly, bluntly 5-toothed. Petals bearded. Stamens erect, the length of teeth. Styles 5, filiform, included, hairy. Apple closed, 3-5-celled. Chalaza none. Radicle inciuded between the bases of cotyledons.

1138. Amelanchier. Cal. 5-toothed. Petals lanceolate. Ovary 10-celled. Ovules solitary. Apple 3-5-celled, with a cartilaginous putamen. 
1139. Cotoneaster. Flowers polygamous. Cal: turbinate, bluntly 5-toothed. Petals short, erect. Stamens length of teeth. Styles smooth, shorter than stamens. Achenopses parietal, included in calyx.

\section{\$2. Ovary superior.}

1140. Waldsteinia. Cal. 10-cleft; the alternate segments smaller.- Petals 5. Styles clavate, deciduous. Grains 2, obovate.

1141. Spircea. Cal, spreading, 5-cleft. Petals 5. Caps. 1-celled, 2-valved, opening inwards, 1-3-seeded

1142. Gillenia. Cal. infundibuliform, 5-toothed. Petals 5. Stamens very short. Capsule 5-celled.

1143. Sesuvium. Cal. 5-parted, colored. Petals O. Caps, ovate, 3-celled, cut round, many-seeded.

1144. Aizoon. Cal, 5-parted. Pet. O. Caps, 5-celled, 5-valved.

\section{Order 3. POLYGYNIA. Stamens many, perigynous, Styles many.}

1145. Tetragonia. Cal. 3-5-parted. Petals O. Drupe inferior, with a 3-8-celled nut.

1146. Mesembryanthemum. Cal. 5-cleft. Petals many, linear. Capsule turbinate, fleshy, inferior, manyseeded.

1147. Hymenogyne. Styles about 12, united in a delicate tube. Caps. 1-celled, many-seeded. Otherwise like Mesembryanthemum.

\section{MONOGYNIA.}

1111. CAC'TUS. $W$. 6839 mammilláris $\dot{L}$ 6840 coronátus $W$. 6841 depréssus Dec. 6842 stelláris $W$ 6843 viviparus $\dot{P}_{u r} \cdot \boldsymbol{s}$. 6844 gibbósus Haw. 6844 gibbósus Haw. gibbous 6846 lánifer Haw. 6846 lánifer Haw. 6847 geminispínus Haw. two-spin 6847 geminispinus Haw. two-spined 6849 recúrvus $M$ ill. 6850 nóbilis 68.51 senílis Haw.

Cactus. garland depressed hoary viviparous recurved crook-spined old broad-spined 6853 macracánthus Haw. long-spined
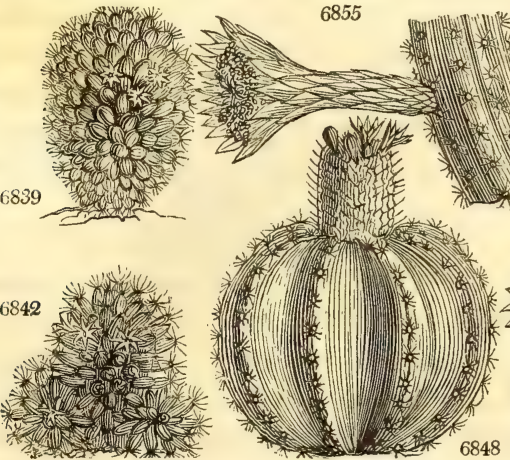

6855

$\mathrm{w}=\mathrm{gr}$
$\mathrm{gr}$
$\mathrm{w}=\mathrm{cu}$
$\mathrm{w}=\mathrm{cu}$

1 Cacti. Sp. $68-90$. $5 \quad \ldots \quad \ldots \quad$ S. Amer. 1820. C $\quad$ S.p $\begin{array}{lllllll}\frac{1}{2} & \cdots & \ldots & \text { S. Amer. 1789. C } & \text { S.p }\end{array}$ my.jn Pk S. Amer. 1815. C s.p

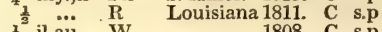

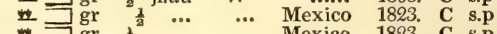

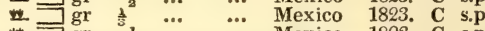

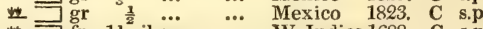

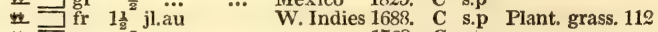
—

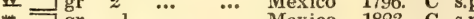

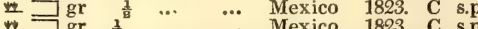

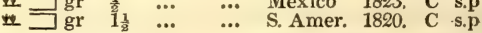

Bot. cab. 79

Bot. reg. $13^{7}$

History, Use, Propagation, Culture,

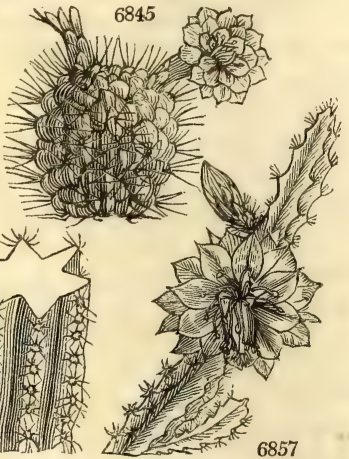

6857

1111. Cactus. A name under which Theophrastus describes a spiny plant, an article of food, which grew in Sicily. This genus consists of succulent plants, permanent in duration, singular and various in structure; generally without leaves, and having the stem or branches jointed; for the most part armed with spines in bundles, with which in many species, bristles are intermixed. These bundles of spines are placed on the top of the tubercles in the smaller melon thistle, which is tubercled all over, and produces its flowers between the of the tubercles in the smaller melon thistle, which is tubercled all over, and produces its flowers between the
tubercles. In the great melon thistle the spines are ranged in a singie row on the ridge of the ribs. These tubercles. In the great melon thistle the spines are ranged in a single row on the ridge of the ribs. These
are of an ovate or globular form. The torch thistle, on the contrary, are slender, rise up high, are jointed and branched; many of them are almost cylindrical, with from five to ten shallow ribs; some, however, are square or three cornered. The structure of the creeping Cereuses is the same with these, except that the stens are weak and cannot support themselves; they therefore seek support from trees, and throw out roots from the stem, like ivy. In the Indian figs the branches are jointed, and flatted like the sole of a shoe; the bundles of spines or bristles are scattered over the surface, and the flowers are produced from the edge of the extreme spines or bristles are scattered over the surface, and the flowers are produced from the edge of the extreme
branches. In the Phyllanthus the branches are thinner, they are indented along the edge, and the flowers come out singly from the indentures. This seldom has any spines. Pereskia has a round stalk with leafy branches; the leaves alternate, flat, and thick; the prickles are large and stiff, and come out in bundles on the stalk and branches, chiefly at the axils; the flowers are produced several together from the axils also. In this and the Indian figs the flowers are pitcher-shaped; in the other species they are subcylindrical and longer ; in Phyllanthus very long. The fruit in some of the sorts is small, like currants; but in most it is larger, and shaped like a fig, whence their name of Indian fig.

C. melocactus, the great melon thistle or Turk's cap, appears like a large fleshy green melon, with deep ribs, set all over with strong sharp thorns. When it is cut through the middle, the inside is found to be a soft, green, fleshy substance, very full of moisture. The flowers and fruit are produced in circles round the upper part of the cap. Some of those which have been brought to England, have been more than a yard in circumference, and two feet and half high including the cap. But in the West Indies there are plants near twice as large. Linnæus observes, that this plant resembles a hedge-hog in its form and spines; and on the top has a discoid, convex, villous body, from which the flowers. proceed. 
1148. Rosa. Cal. urceolate, 5-cleft, fleshy, contracted at orifice. Petals 5. Grains bony, hairy, included in the fleshy tube of calyx.

1149. Rubus. Cal. 5-cleft. Petals 5. Berry composed of many cohering fleshy grains. Receptacle nearly dry.

150. Dalibarda. Cal, 5-cleft. Petals 5. Berry dry. Styles 5, long, deciduous.

1151. Fragaria. Cal, 10-cleft. Pet. 5. Grains inserted upon a fleshy deciduous receptacle.

1152. Comarum. Cal. 10-cleft. Petals 5, less than calyx. Receptacle ovate, spongy, persistont.

1153. Potentilla. Cal. 10-cleft. Petals 5. Grains rugose, roundish, naked, fixed to a small àry receptacle.

1154. Tormentilla. Like Potentilla, but cal. 8-cleft. Petals 4.

1155. Geum. Cal. 10-cleft. Sepals unequal. Petals 5. Grains generally with a jointed awn.

1156. Kerria. Cal. 5.cleft. Pet. 5, orbicular. Ovaries 5-8, smooth, globose. Ovules solitary. Styles filiform. Capsules globose.

1157. Calycanthus. Stamens unequal, deciduous; the 12 outer fertile. Grains many.

1158. Chimonanthus. Stamens equal, persistent; the 5 outer fertile, in maturity closing the orifice of the calyx by their united bases.

1159. Dryas. Cal. simple, 8-cleft. Petals 8 . Grains with a hairy tail.

1160. Coluria. Like Sieversia, but the style jointed with the top of ovarium and deciduous, and the achenia glandular, included in the long turbinate tube of the calyx.

1161. Sieversia. Cal. 10-cleft. Petals 5. Stamens indefinite. Ovaries indefinite, with an ascending ovule Styles terminal, continuous. Achenia awned with the persistent style. Embryo erect.

\section{MONOGYNIA.}

6839 Roundish covered with ovate bearded tubercles

6840 Simple clavate, Tubercles ovate with woolly spines at end, Wool shorter than spines

6841 Roundish depressed with ten angles

6842 Proliferous, Warts small cylindrical, Spines fine whitish the lowest like hairs

6843 Roundish multiplex, Warts cylindrical bearded above furrowed proliferous

6844 Roundish deeply 16-angled, Angles with a remarkable swelling below each parcel of spines

6845 Warts large very green downy at end, Spines about 4 strong expanded

6846 Simple rounded obovate, Warts woolly at end with more than 20 spines

6847 Columnar, Warts small very numerous with little spines between, 2 in each parcel much longer than rest

6848 Roundish with about 14 angles

6849 Roundish with 15 angles, Spines broad recurved numerous

6850 Oblong with many angles, Angles and spines middle-sized straight

6851 Oblong with about 20 angles, Rays of spines capillary long

6852 Depressed spheroidal with about 21 angles, Rays of spines variable the lowest very broad flat deflexed

6853 Rounded bright green with 14 angles, Ribs straight with long thick white spines

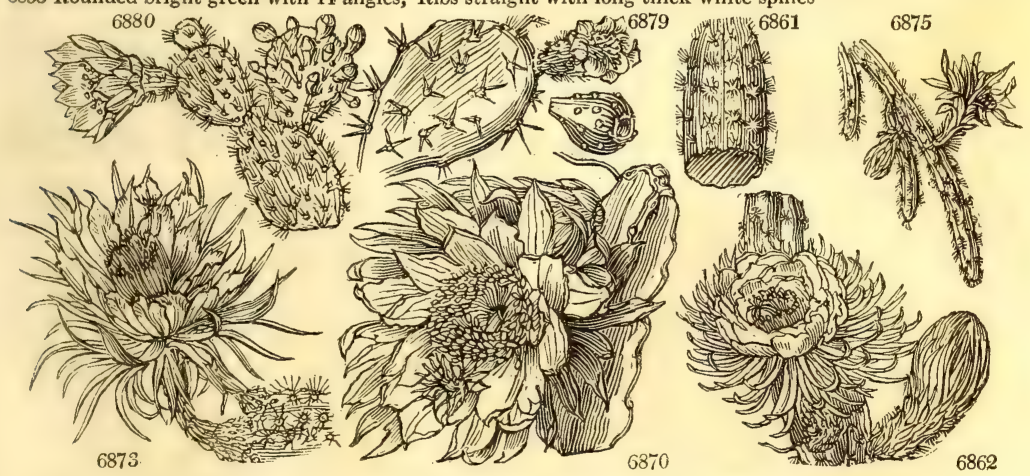

and Miscellaneous Particulars.

C. melocactus, mammillaris, and proliferus, by many thought to be but one species, grow upon the steep sides of rocks in the hottest parts of America, where they seem to be thrust out of the apertures, having little or no earth to support them : their roots shooting down into the fissures of the rocks to a considerable depth, so that it is troublesome to get the plants up. As they delight in such rocky places, they seldom live long when transplanted into a better soil. In times of great drought the cattle repair to the barren rocks where these plants grow, rip them up with their horns, tear off the outside skin, and greedily devour all the fleshy moist part. The fruit is frequently eaten by the inhabitants of the West Indies. It is about three quarters of an inch in length, of a taper form, drawing to a point at the bottom, but blunt at the top: the taste is an agreeable acid.

C. repandus has a fruit about the size and shape of a Bergamot pear, having many soft spines on the skin ; the outside is a pale yellow, the inside very white, full of pulp, having a great number of small black seers lodged in it. It frequently flowers in July, and in warm seasons will perfect its fruit, which has very little flavor in this country, but is frequently served up at table in the West India islands.

The fruit of lanuginosus and peruvianus are also occasionally eaten where they are natives.

C. grandiflorus and flagelliformis have flowers remarkable for their beauty and sweetness. C. grandiflorus, when arrived to a sufficient strength, will produce many exceeding large, beautiful, sweet scented flowers, like most of this kind, of very short duration, scarcely continuing six hours full blown: nor do the flowers ever open again when once closed. They begin to open between seven and eight of the clock in the evening, are fully blown by eleven, and by three or four in the morning they fade, and hang down quite decayed; but during their short continuance, there is scarcely any flower of greater beauty, or that makes a more magnificent appearance ; for the calyx of the flower, when open, is near a foot diameter; the inside of which, being of a splendid yellow color, appears like the rays of a bright star; the outside is of a dark brown. the petals being of a pure white add to the lustre; the vast number of recurved stamens surrounding the style in the centre of a pure white add to the lustre; the vast number of recurved stamens surrounding the style in the centre of
the flower make a fine appcarance: add to all this the fine scent of the flower, which perfumes the air to a the flower make a fine appcarance : add to all this the fine scent of the flower, which perfumes the air to a
considerable distance. There is scarce any plant which deserves a place in the hothouse so much as this, especially as it may be trained against the wall, where it will not take up any room. The usual season of its 
6854 hexagónus $L$. $\quad$ four-angled 6855 peruviánus $W$. Peruvian 6856 tetragónus $L$. six-angled 6857 speciosíssimus Desf. beautiful 6858 pentagónus $L$. five-angled 6859 Royéni $L$. nine-angled 6860 albispinus Salm - whitespined 6861 lanupin sus 6862 repándus $L$. 6863 obtúsus Haw. 6864 imbricátus Haw. 6865 níger Salm.

6866 cylindricus $L$. 6867 serpentínus $W$. 6868 multanguláris $W$. 6869 heptagonus $W$ 6870 trianguláris $L$ 6871 triqueter $W$. 6872 trigónus Haw. 6873 grandiflórus $L$. 6874 réptans $W$.

6875 flagellifórmis $L$ 6876 quadranguláris $H a w$ 6877 elátior $W$. 6878 Túna $L$.

6879 nígricans Haw. 6880 polyanthus Haw. 6881 brasiliénsis $W$. 6882 húmilis Haw. 6883 Dillénii Ker. 6884 opúntia $L$. 6885 strictus Haw. 6886 decumánus $W$. Opúntia máxima 6887 tuberculátus $W$. 6888 cochinillifer $L$. 6889 monacánthus $W$. 6890 elongátus $W$. 6891 triacánthos $W$.

6892 lanceolátus Haw. 6893 tomentósus Link. 6894 subinérmis Link. 6895 spinosíssimus $L$. 6896 férox $W$. 6897 curassávicus $L$. 6898 frágilis Nutt. 6899 foliósus $W$. 6900 pusillus Haw. 6901 phyllánthus $L$.

Spleenwort C. alátus W.

wavy-angled

blunt

imbricated

black

cylindric

serpentine

many-angled

seven-angled

great-triangul. Dillenius's Indian Fig great-oblong Haw.

\section{warted}

single-spined

long

three-spined

spear-shaped

downy

few-spined

Pin-pillow

brittle

glaucous

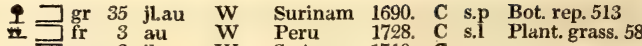

青 $\mathrm{fr} \quad 3 \mathrm{au}$

it

- $\mathrm{gr} 3 \mathrm{jl}$

2. $7 \mathrm{fr} 2 \mathrm{jr}$

\# or 2 …

we fr 1 jl

w $\mathrm{fr}_{\mathrm{cu}}^{20} \mathrm{au}$

least-triangular

night-flowering

trailing $=\mathrm{cu} 2$...

creeping

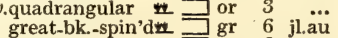
yellow-spined lesser-bk.-spin. many-flowered $\Longrightarrow \mathrm{cu} \quad 3$ jl.au thin-branched wi humble

\# $\mathrm{cu}$ o

-

Wr 3 jl.au

Cochineal Fi

-

10 ...

- $\mathrm{clt} 5 \mathrm{jl. \textrm {s }}$

w cul $22 \ldots$

些 $\mathrm{gr}$

gr 20

- $7{ }_{2} \mathrm{jl}$

cluster-spined

gr $20 \mathrm{jl}$

v $\mathrm{gr} \quad 3$ jo.

青 $\mathrm{gr} 6 \mathrm{jn} . \mathrm{jl}$

w

$2 \quad \cdots$ $\frac{1}{2}$ jn $\mathrm{gr}^{\frac{1}{2}} \mathrm{j}_{\mathrm{jn}}$
W S. Amer. 1710. C s.p

Cr S. Amer. 1816. C s.p Bot. reg. 486

W S. Amer. 1769. C s.1

S. Amer. 1728. C s.l

S. Amer 1820 C s.l

w w Indies 1690 c sp

Herm. par. t.115

W. Indies 1728. C s.p Bot. reg. 336

... $\quad$...... 1820. C s.p

$\ldots$..... 1820. C s.p

... Peru 1799. C C.1

... Peru $\quad \ldots$ C $s .1$

... S. Amer. 1815. C s.1

W W. Indies 1728. C s.1

W W. Indies 1690. C s.p Bot. mag. 1884

W. S. Amer. 1794. C s.p

W. Amer. 1809. C s.p Plu.am, t.200. f.2

W.y Jamaica 1700. C s.p Bot. rep. 508

…... 1813. C s.l

Peru 1690. C s.l

... S. Amer. 1809. C s.l Plu. mag. 17

Y... S. Amer 1731 C s.1 Plam. t.199.f.1

Pa.Y S. Amer. 1731. C s.1 Plant. grass. 138

Pk S. Amer. 1795. C s.l Bot. mag. 1557

Y S. Amer. 1811. C s.l Plant.grass. c.ic

Y Brazil 1816. C s.l

… $\quad \ldots . . .1795$. C s.1

Y S. Europe 1596. C s.1 Bot. mag. 2393

... $\quad$ s...... 1796. C s.1 Plant.grass. c.ic

... S Amer. 1816. C s.1

… S. Amer... 1817. C s.l

Y S. Amer, 1796 C

... $\quad$...... 1820 C s.l

... Jamaica 1732. C s.p

.. Curassao 1690. C s.p Knor.the.2. t.s.2

Y... N. Amer, 1814. C s.p

Y S. Amer. 1817. C s.p

Pk S. Amer. 1710. C s.p Plant. grass. 145

Pk Jamaica 1817. C s.p Bot. mag. 2092
(... $\quad$...... 1819. C S.1

... S. Amer. 1817. C s.p

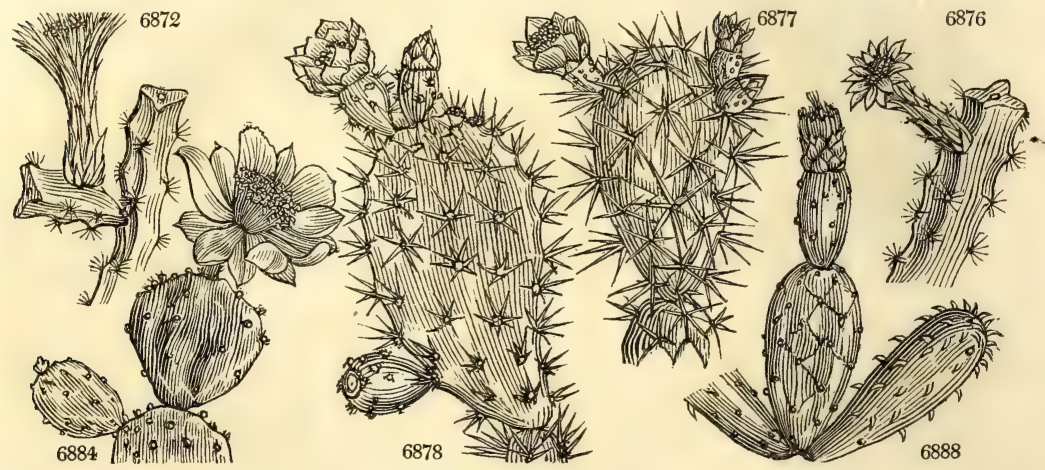

History, Use, Propagation, Culture,

flowering is in July, and when the plants are large, many flowers will open the same night, and there will be a succession of them for several nights together. Sometimes six eight, or ten flowers open at the same time on one plant, making a most magnificent appearance by candle-light : but none of them are succeeded here by any appearance of fruit,

C. flagelliformis produces a greater number of flowers than the foregoing sort: they come out in May, and sometimes earlier, when the season is warm. The petals are of a fire pink color both within and without; they are not so numerous, and the tube of the flower is longer than that of the other. These flowers keep oper three or four days, provided the weather, or the place where the plants stand, be not too warm : and during their continuance they make a fine appearance. This sort has very slender trailing branches, which require a support : they are not jointed, nor do they extend so far as those of the other sort. Fruit sometimes succeeds the flowers, but seldom ripens.

C. triangularis, the strawberry pear, Poirer de Chardon, Fr., bears the best flavored fruit of any of the sorts; it is slightly acid, and at the same time sweet, pleasant, and cooling; in Martinique and other West India islands it is much esteemed.

C. opuntia, native of the country of the Opuntiani, whose chief town was Opus, in the vicinity of Phocis, though like the others a native of America, is now found growing wild on the sides of the roads between Rome and Naples and other parts of Italy, and even in the Valais. Gerarde says, it was brought from Virginia into England, and Collinson had it from Newfoundland. It was fruited in Scotland in a stove by 
6854 Erect with deep furrows long with 6 distant angles

6855 Erect with deep furrows long with about 8 obtuse angles

6856 Erect with deep furrows long with 4 compressed angles

6857 Erect with deep furrows long slightly quadrangular with toothed angles

6858 Erect with deep furrows long jointed with about 5 angles

6859 Erect slender with shallow furrows jointed with 9 angles, Joints ovate, Spines as long as wool

6860 Erect slender with shallow furrows jointed with 9 angles not glaucous, Spines white; a variety of the last 6861 Erect slender with shallow furrows long with 9 obsolete angles, Spines shorter than wool

6862 Erect slender with shallow furrows long with 8 compressed wavy angles, Spines longer than wool

6863 Erect slender with shallow furrows, Branches jointed few bluntly triangular

6864 Erect slender with shallow furrows, Scarcely ang. Surface covered with variously imbric. lobed divisions

6865 Erect slender with shallow furrows black with numerous brown spines longer than the wool

6866 Erect slender with shallow furrows weak cylindrical, Surface covered with netted crossing furrows

6867 Erect rounded below long elegant with about 9 angles, Spines snow-white weak, Wool very short

6868 Erect with 18 close obtuse angles with bristly yellowish spines longer than the wool

6869 Erect with deep furrows oblong with 7 angles

6870 Creeping triangular rooting

6871 Decumbent rooting 3-cornered, Spines fascicled divaricating seven two or three lines long

6872 Creeping rooting 3-cornered with scarcely channelled angles, Spines 5-7 in stellate fascicles

6873 Creeping rooting with about 5 angles

6874. Creeping 5-cornered with subulate spines longer than the wool

6875 Creeping rooting hispid with 10 angles

6876 Creeping with 3 or 4 angles which are scarcely channelled, Spines $5-7$ in stellate parcels

6877 Erect, Joints broadly ovate-oblong, Spines subulate very long blackish

6878 Erect, Joints broadly ovate-oblong, Spines subulate long yellow

6879 Erect, Joints oblong und lanceolate, Spines of various shapes brownish black

6880 Joints oblong and ovate, Spines of various shapes yellow, Fl. numerous solitary

6881 Stem rounded, Branches ovate compressed flat, Spines solitary or 3 together subulate strong

6882 Joints cuneate obovate decumbent, Spines variously shaped yellow

6883 Erect, Joints obovate roundish glaucous, Stigma 6-lobed

6884 Creeping prostrate, Joints ovate, Spines even numerous hair-shaped

6885 Erect, Joints ovate elliptical, Spines even numerous short

6886 Joints ovate oblong very thick, Spines unequal

6887 Jointed proliferous, Joints oval, Warts with a cluster of spines the length of the wool

6888 Joints ovate oblong unarmed

6889 Erect, Joints lanceolate-oblong, Clusters of spines fuscous weak with one strong white spine

6890 Erect, Joints oblong or oval, Spines numerous variable brown; one very long straw-colored

6891 Jointed proliferous, Joints ovate oblong with strong white spines longer than wool

0892 Nearly erect, Joints lanceolate with even short spines, Leaves 3 lines long

6893 Branches oblong with short soft hairs, Spines small

6894 Branches oblong scarcely spiny

6895 Joints very long slender compressed, Spines very long slender clustered white

6896 Joints oblong with numerous stiff spines of which one is very long and white at base

6897 Joints brittle cylindrical ventricose compressed much divaricating

6898 Joints brittle cumpressed short, Spines numerous variable white erect

6899 Jointed proliferous, Joints lanceolate-glaucous, Spines bristly longer than wool

6900 Joints brittle linear-lanceolate divaricating, Spines unequal

6901 Proliferous smooth branched ensiform compressed serrated with a central woody rib

6902 Branches ensiform compressed obovate with spreading teeth, Spines few setaceous longer than wool

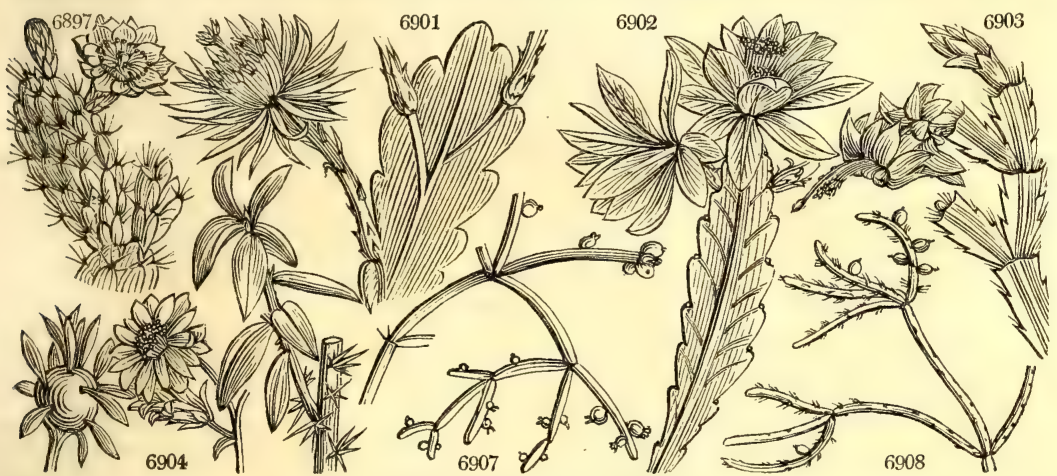

and Miscellaneous Particulars.

Justice, in 1750, and recently by Braddick, near London, in the open air. This active horticulturist, having eaten with pleasure of the prickly pear in Virginia, was desirous of cultivating it here. He recollected that the plant in its wild state delighted in a dry soil, amongst rocks, near the skirts of the sunny sides of the forests; and having heard that it would stand the open air in this country, he planted it in the compost described below, placed in a sheltered situation open to the sun. "The first plant that I turned out has lived in the open ground of this country for six or seven years, during which period it has endured one exceeding hard winter, and several trying springs; and in all, except the two first years, it has never failed to ripen its fruit and seeds, so that it may be now considered decidedly acclimated. The compost used by me for growing the Cactus Opuntia, is the following: one half is carbonate of lime, for which lime-rubbish from old buildings will answer; the remaining half consists of equal portions of London clay and peat-earth, having the acid neutralised by barilla : these are intimately blended and sifted. One square yard of this compost I conceive to be sufficient for one plant, which must be placed in the middle of a small artificial hillock, raised eighteen inches above the surface of the ground, which ground should be rendered perfectly dry, if not naturally so, by under-draining. Neither the leaves, flowers, nor fruit should ever be suffered to touch the ground, but they should as constantly as they are produced be kept from the earth by placing stones, pebbles, flints, or bricks under them, in imitation of artificial rock-work." (Hort. Trans. ii. 238.)

C. Ficus indica is very common in Jamaica, and on it feed the wild sort of cochineal insect. The fruit is large and of a deep purple color, and when eaten dyes the urine of a bloody color. 
6903 truncátus Link. $\quad$ truncate $\quad$ gr 1 jn $\quad$ Pk Brazil 1818. C s.p Bot. reg. 696 6904 Peres'kia $L$. Barbad.Gooseb. $\square$ gr 5 o.n W W. Indies 1696. C s.p Dil.el.t.227.t.294 $\begin{array}{lllllllll}6905 \text { grandifólius Haw. large-leaved } & & \text { gr } & 3 & \ldots . & \ldots & \text { Brazil 1818. } & \text { C } & \text { s.p } \\ 6906 \text { longispinus Haw. long-spined } & \text { gr } & 2 & \ldots & \ldots & \text { S. Amer. } & 1808 . & \text { C } & \text { s.p }\end{array}$

1112. RHIP'SALIS. Gert. Rhipsalis. 1112. RHIP'SALIS. Gert. Rhipsalis.
6907 Cassútha $G$.
Cáctus péndulus W. 6908 parasíticus Haw. parasitic $\quad$ 2 $\square \mathrm{cu} \quad 1 \ldots \ldots . \quad$ Y $\quad$ S. Amer. 1800. C s.p Plant. grass. 59

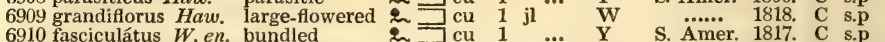
6910 fasciculatus W. en. bundled $\quad 2 \quad \mathrm{cu} \quad 1 \ldots \ldots$ Y $\quad$ S. Amer. 1817. C s.p E Indies 1817. C s.p Bot. mag. 2461 1113. BARTONIA. $\mathrm{Ph}$. Bartonia. Loasece. Sp. 2.

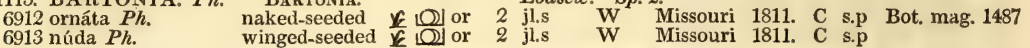

1114. PHILADEL'PHUS. $W$. SYringa.

6914 coronarius ß nánus

6915 inodórus $W$. common dwarf scentless 6916 inodorus $W . \quad P h$ larárus $P h . \quad$ large-flowered 1115. LEPTOSPER'MUM. $W$. LEPTOSPERMUM 6918 scopárium $W$. New Zeal. Tea 6919 flavéscens $W$ 6919 . 6921 lanigerum $H$. $K$. 6922 pubescens $W$ yellowish fine-branched pubescent 6923 grandifólium $L . T$. large-leaved 6924 parvifólium $W$. small-leaved 6925 stellátum $\mathrm{Cav}$. short-leaved 6926 arachnoideum short-leaved cobweb 6927 flexuósum Link. 6928 juniperinum $W$. 6928 juniperinum $W$. Juniper-leaved 6930 porophy'llum Cav. dotted 6931 triloculáre $V_{\text {. }} \quad$ trilocular

1116. FABRI'CIA. $W$. FABRicia. 6933 myrtifólia $W$. opposite-leaved 6934 lavigáta $W$. smooth-leaved

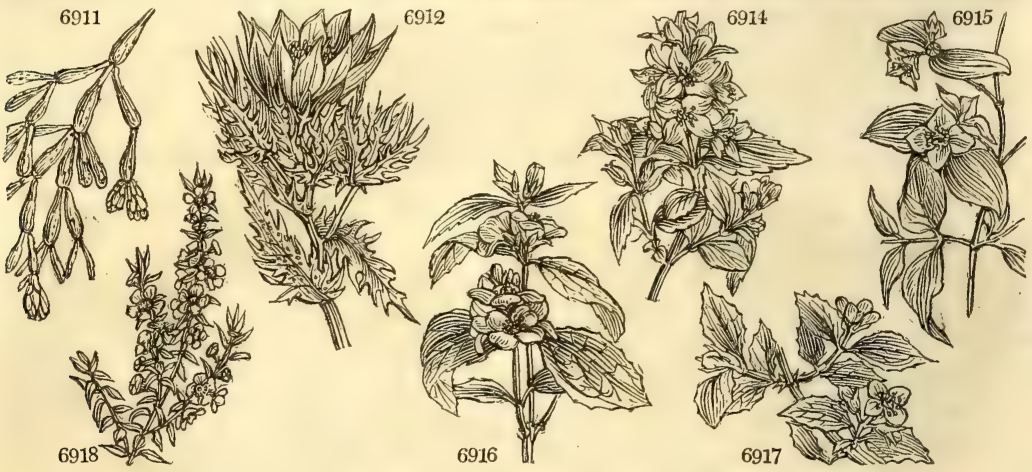
Myrtacea. $S p .4-6$. or 8 my.jn W S. Europe 1596. L co Bot. mag. 391 or 2 jn.jl W Carolina 1738. L co Bot. mag. 1478 or 6 jn.jl W Carolina 1811. L co Bot. reg. 570 N. Amer, 1820, L co Dend. brit. 47 Myrti. Sp. 16-20.

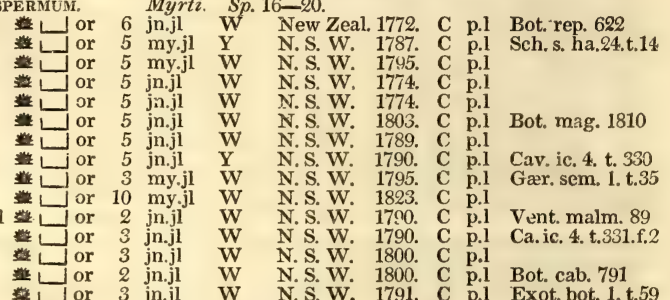
jn.jl W

History, Use, Propagation, Culture,

C. tuna (tyn the Arabic name for fig) is used as a hedge plant in Spain, South America, and the West Indies. When the island of St. Christopher was to be divided between the English and the French, three rows of the tuma were planted by common consent between the boundaries. (Sloane.) Sir J. E. Smith informs us, that the stamens of the flower are very irritable; and that if a feather be drawn through them, in two or three seconds they begin to lie down gently on one side, and in a short time become recumbent at the bottom of the flower.

C. cochinillifer is the species on which the cochineal insect chiefly feeds. The insect feeds on other succu. Ient plants besides those of the Cactus genus, but this species is cultivated because least annoying by its prickles. It produces an edible fruit larger than that of $\mathrm{C}$ opuntia. On the top of the fruit there grows a red flower : this when the fruit is ripe, falls down on the top of it, and covers it so that no rain or dew can wet the inside. A day or two after, the flower being scorched up by the heat of the sun, the fruit opens wide, and the inside appears fuil of small red insects. The Indians, when they perceive the fruit open, spread a large linen cloth, and then with sticks shake the plant, to disturb the insect, so that they take wing to be gone, but keep hovering over the plant, till by the heat they fall down dead on the cloth, where the Indians let them remain two or three days till they are dry. The cochineal plants are called by the Spaniards Toona. They are pianted in the country about Guatimala, Chiape, and Guaxaca, in the kingdom of Mexico.

The difference, in point of goodness, observable in the cochineal, is entirely owing to the plant it feeds upon. The prickly pear (C. tuna) so abundant in Jamaica, is covered with the insects, but not having their proper food, they are in general diminutive, and have very little red tincture in their bodies. The delicate red colored juice of the fruit is the natural food of the insect. The exuviæ and animal salts of the insect are, from the minuteness of its parts, inseparable from the essential principles of the dye, and must diminish the brilliancy of the color: and this has put some persons upon inspissating the juice of the fruit itself. The ripe fruit is said to check fluxes by its mild restringency; it is also a powerful diuretic, and sometimes imparts a tinge to the urine.

C. pereskia, so cailed from the generic name of Plumicr, who made this species a distinct genus, in memory of N. F. Peiresk of Aix, whose name, as Tournefort says, is his only monument, has fruit about the size of a walnut, having tufts of small leaves on it, and within a whitish mucilaginous pulp.

In our stoves, according to Sweet, "sandy loam, or loam mixed with a little brick rubbish, is the best soil for all the Cacti : the pots should be as small as the plants will allow, and well drained with potsherds. Tley 
6903 Branched, Joints short oblong truncated

6904 reaves elliptical fleshy, Spines about $\frac{1}{2}$ an inch long, Buds little woolly

6904 Leaves numerous variable strong, Leaves lanc. oblong with a strong rib beneath

6905 Spines numerous variable strong, Leal fleshy, Spines $\frac{1}{2}$ an inch long, Buds very woolly

6907 Branches pendulous whorled round smooth naked green

6908 Branches pendulous whorled round green the younger covered with bundles of white harrs 6909 Branches round as thick as a quill, Spines scarcely any

6910 Pendulous, Branches rounded fascicled, Hairs bundled in six line

6911 Jointed erect, Branches round and angular, Young spines in minute inconspicuous parcels

6912 Ovary leafy, Seeds naked

6913 Ovary naked, Seeds winged

\section{Leaves somewhat toothed ovate oblong}

6915 Leaves quite entire

6916 Leaves ovate acuminate toothletted, Axlls of veins hairy, Stigmas 4 linear

6917 Leaves hairy oblong-ovate acute sharply and angularly toothed

6918 Leaves ovate mucronate obsoletely 3-nerved, Cal. smooth with colored membranous teeth 6919 Leaves lin.-lanc. obtuse nerveless, Cal. smooth with membranous naked teeth

6920 Ieaves lanc. lin. acute 3-nerved, Cal. silky villous, with membr. colored naked teeth

6921 Leaves oblong or oval mucr, pubescent on each side obsoletely 3-nerved, Branches villous, Cal. very vili.

6922 Leaves lanc. oblong hairy oblique reflexed at end

6923 Leaves oval lanceolate, Young shoots colored, Flowers large, Teeth of ealyx colored

6924 Leaves obovate nerveless, Branches and calyxes hairy with membranous colored teeth

6925 Leaves ovate lanceolate short three nerved, Fl. sol."sessile, Cal. entire persistent

6926 I eaves subulate pungent, Branches hairy, Calyxes and teeth villous

6927 Branches flexuose, Flowers sessile fascicled, Cal hairy

6928 Leaves lin.-lanc. pungent, Branches silky, Cal. smooth with membranous colored naked teeth

6929 Leaves lin.-lanc. pungent, Branches hairy, Cal. smooth with membranous col. pubescent teeth

6930 Leaves oblanc. densely dotted, Fl. sol. terminal, Sepals deciduous

6031 Leaves acicular rigid fascicled, Flowers solitary, Teeth of calyx colored

6932 Leavos linear recurved at end, Cal. smoothish, Teeth leafy lanc. naked, Stamens louger than cor.

5933 Leaves ianceolate obcvate opp. Teeth of caiyx round

6034 Leaves obovate altexn. glaucous, Teeth of calyx triangular

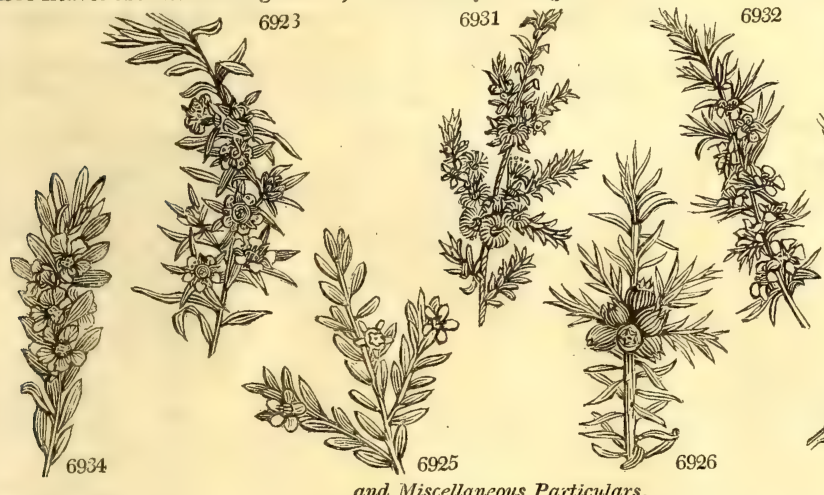

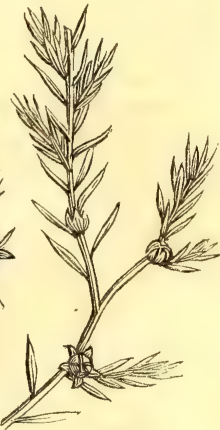

6929

and Miscellaneous Particulars.

require very little water. The best way to flower them is to expose them to the air ali the summer, which rakes them get plump and throws them. into flower-bud. Most of the species are fine flowers. Cutting, after they are taken off, should be left to dry a few weeks till they are shrivelled, then potted, and they will root immediately. (Bot. Cult. 31.)

1112. Rhipsalis. From pin, a willow branch, in allusion to the flexible decumbent branches of the genus. Curious, branched, jointed, leafless, prostrate plants. Culture as in Cactus.

1113. Bartonia. Named by Pursh, in honor of Dr, B, S. Barton of Philadelphia, an American botanist. Beautiful plants, with alternate pinnatifid rough glaucous leaves, and large white flowers, which open during the night, and spread a most agreeable odor. Very rare, if they yet exist, in collections.

1114. Philadelphus. A name used by Athenæus for a tree which is now unknown. Bauhin appiied it to this genus. The species are free flowerers, well adapted for the shrubbery. The native country of P. coronarius is not known ; it is generally referred to the south of Europe, but it has only been found twice in Italy, and then in situations where it might have been planted. The flowers have the appearance and odor of those of the orange, but the odor in near contact is much more powerful. Seeds are seldom produced in this country. The leaves taste like fresh cucumbers. P. grandifiorus is a very shewy plant. All the species grow freely in common soil, and are increased by layers.

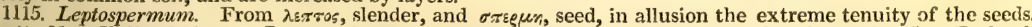
Pretty New Holland plants. L. scoparium grows commonly in dry places near the shores in New Zealand, and the underwood in Adventure Bay, Van Dieman's Land, chiefly consists of this shrub. The leaves were used by Captain Cook's ships' crews as tea, whence they named it the tea plant. The leaves have a very agreeable bitter flavor, with a pleasant smell, when fresh; but lose something of both, when dry. If thi irfusion was made strong, it proved emetic to some, in the same manner as green tea. It was also used with spruce leaves, in equal quantity, to correct their astringency in brewing beer from them; and they rendered the beer exceedingly palatable.

Young cuttings of all the species will root readily in sand, under a bell_class: the species may also be raised from seeds; but plants from cuttings are best, as they flower young, and the seediings do not fcwer till they attain a considerable size. (Bot. Cult. 214.)

1116. Fabricia. Dedicated by Gartner to John Christian Fabricius, the famous Eritomologist. The species 
1117. ME'TROSIDE'ROS. $\boldsymbol{W}$. Metrosideros. 6935 híspida $\mathrm{Sm}$. 6936 floribúnda $\mathrm{Sm}$. 6937 costáta Sm. 6938 glomulífera $\boldsymbol{W}$. 6939 angustifólia $W$ 6940 margináta $P . S$. 6941 lineáris $W$. 6942 pinifólia $W$. en. 6943 viminális $W$ 6944 salígna $W$. 6945 lanceoláta $W$. 6946 speciósa $B . M$. 6947 véra Lindl. 6948 semperfórens Lod 6949 linearifólia Link. 6950 rugulósa $W$.

1118. PSI'DIUM. $W$. 6951 pyriferum $W$. 6952 pomiferum $W$ 6953 aromáticum $W$. 6954 cordátum $B$. $M$. 6955 montánum $W$. 6956 polycárpum $A n d$. 6957 Cattleiánum Lind 1119. EUGE'NIA. $W$ 6958 malaccénsis $W$. 6959 Jámbos $W$. 6960 baruénsis $W$. 6961 myrtifólia Ker. M. austrális B. M 6962 axilláris $W$. 6963 frágrans $W$. 6964 Mini $W$. 6965 elliptica $W$. 6966 ligustrina $W$. 6967 uniflóra $W$. 6968 zeylánica $W$ 6969 latifólia $W$ rough many-flowered ribbed

cluster-flowered narrow_leaved margined linear-leaved Pine-leaved long-leaved willow-leaved spear-leaved splendid true Iron-wood ever-blowing linear-leaved Guava. white red aromatic cordate clustered purple

EugenIA.

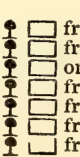

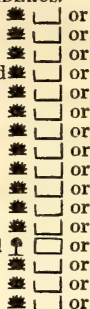

Myrtacea. Sp. 16-20.

6 my.au Y N.S. W. 1789. C s.l Exot. bot. 1.t.49 6 jl.au W N.S. W. 1788. C s.l $\begin{array}{lllllll}6 & \ldots & \text { Y } & \text { N. S. W. 1816. } & \text { C } & \text { s.l } & \text { Gæ. se. 1.t.34.f.2 }\end{array}$ 15 my.jn Y.G N. S. W. 1805. C s.1 $\begin{array}{llllll}6 & \text {... } & \text { Y.G } & \text { C. G. H. 1787. } & \text { C } & \text { s.1 }\end{array}$

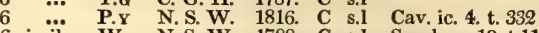
6 jn.jl W N.S. W. 1788. C s.l Ser. han.19.t.11 6 jn jl G N.S. W. ... C s.l Wen, col. 1.t.16 10 mr.jn $R \quad$ N.S. W. 1800. C s.l Gæ. se. 1.t.34.f.

6 my.jn R N.S. W. 1788. C s.l Bot. mag. 1821 my.jn $\mathbf{R}$ 10 mr.jn $\mathbf{C r}$ mr.jn $\mathbf{G}$ $6 \mathrm{mr} . j \mathrm{n} \mathrm{Cr}$ $6 \mathrm{mr} . \mathrm{jn} \mathrm{Pl}$

Myrtacea.

N. S. W. 1788. C s.l Bot. mag. 260

N. S. W. 1803. C. s.I Bot. mag. 1761

E. Indies 1819. C. s.1 Lindl. coll. 18

N. S. W. 1818. C p.l Bot. cab. 523

N. S. W. 1820, C p.

S. W. 1821. C p.I

Sp. 7-10.

W. Indies 1656. C r.m Rum. am. 1, t.47 W. Indies 1692. C r.m Rhe. mal. 3.t. 35 W. Indies 1779. C r.m Aub. gui. 1.t.191 W. Indies 1811, C r.m Bot. mag. 1779 W. Indies 1779 , C $\quad$ r.m

Trinidad 1810. C r.m Bot. reg. 653

S. Amer. 1818, C r.m Lindl. coll. 16

Malay Apple-tr. $9 \square$ fr 25 my.au S E. Indies 1768. C s.p Bot. rep. 458 narrow-leaved $\square$ fr 25 f.jl G.y E. Indies 1768. L s.p Bot. mag. 1696 many-flowered $\square$ or $20 \ldots$ W $\quad$ S. Amer. $\ldots \quad$ L s.p Jac. ic. 3. t. 486 myrtle-leaved $\square$ or 8 ap.jl W N. Holl. 1818. L s.p Bot. reg. 627

axillary $\quad$ or $10 \mathrm{~s} \quad$ W Jamaica 1793. C s.p sweet-scented 10 ap.my W small-fruited $\square$ or 10 ... W Guiana 1803. C s.p Au. gui. 1.t. 197 round-fruited $\quad$ or $8 \mathrm{my.s}$ W N.S. W. 1790. C s.p Bot. mag. 1872 privet-leaved $\square$ or 8 au W Hispaniol.1798. C s.p one-flowered $\square$ or 7 ja.mr W Brazil 1759. C s.p Bot. mag. 473 Ceylon $\quad \square$ or $10 \mathrm{jn} . \mathrm{jl}$ W Ceylon 1798. C s.p Bot. rep. 619 broad-leaved $\square$ or $10 \ldots$ W Guiana 1793. C s.p Aub. gui. 1.t.199 1120. CARYOPHYLILUS. $P$. S. Clove-Tree. Myrtacea, Sp. 1

6970 aromáticus $P . S$. aromatic $\quad \square$ cul $20 \quad \ldots \quad$ W Moluccas 1797. C 1.p Ru. amb. 2.t.1.2 1121. MYR'TUS. 6971 commúnis $W$ a romána $\beta$ tarentina MYrtLe. common L L or 6 jlau W Myrtacere. Sp. 10-35.

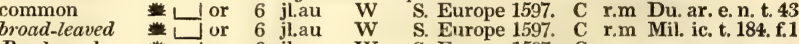
Box-leaved ${ }^{2}$ or 6 jl.au W S. Europe 1597. C r.m

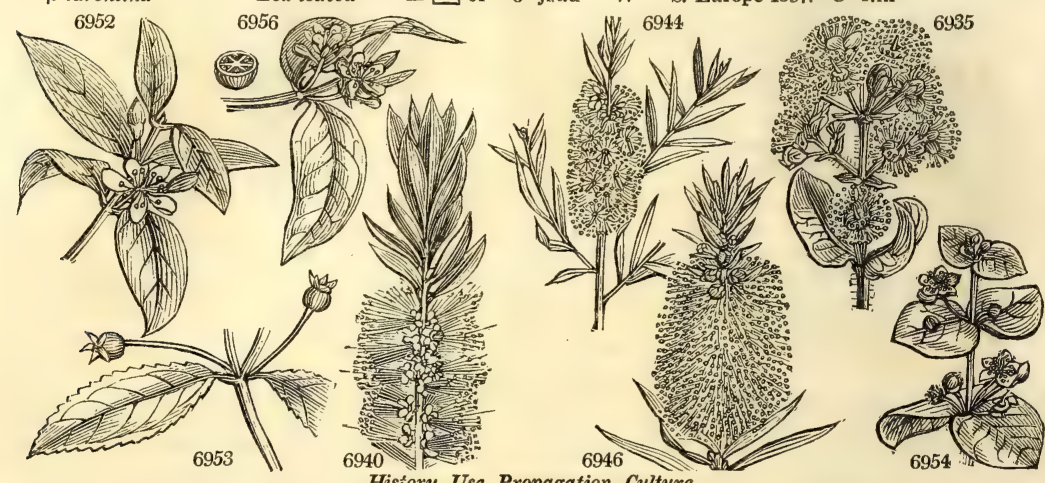

Hisiory, Use, Propagation, Culture,

requiring to grow to a good size before they produce flowers are well adapted for a conservatory : the culture and propagation as in Leptospermum.

1117. Metrosideros. From $\mu n \tau \rho \alpha$, the heart of a tree, and $\sigma i \delta$ nov, iron, in allusion to the hardness of the wood. One species (M. vera) is called iron wood. The Chinese make their rudders and anchors of it; and among the Japanese it is so scarce and valuable that it is only allowed to be manufactured in the service of their king. The bark is used as a remedy for fluor albus and diarrhœe, being mixed with Pinang, and a small quantity of cloves and nutmegs. This is a genus distinguished at sight by the peculiar character of the shrubs of Australasia, with both sides of the leaf alike. M. hispida, lanceolata, and speciosa, are beautiful plants, but not free flowerers. They are rather difficult to strike. Sweet recommends " ripened wood planted under a bell-glass in sand."

1118. Psidium. One of the Greek names of the Pomegranate. In English it is called Guava, a corruption of the American name Guayaba. Most of the species are cultivated in the tropics for their fruit, which also ripens freely in this country, though it is of little merit. $\mathbf{P}$. pyriferum bears fruit the size of a hen's egg, yellowish, with a peculiar smell. The rind is brittle and fleshy; pulp rather firm, full of bony seeds, flesh colored, sweet, aromatic, and pleasant. In the West Indies it is eaten with avidity, not only by the natives, but by Europeans: with those who are not accustomed to it, the Guava is apt to occasion a slight flux; but Jacquin affirms, that when he has been thirsty on a journey he has eaten of it to satiety without suffering any harm. It is eaten raw in the dessert, but the seeds are scarcely separable. It is also preserved with sugar. $\mathbf{P}$. pomiferum has fruit like a pomegranate, which is seldom eaten, though eatable, and being astringent is counted strengthening for the stomach. P. Cattleianum is reckoned one of the best of the Guavas; the fruit is of a flne deep claret color, and the pulp in consistence and flavor bears a considerable resemblance to the strawberry.

All the species are of easy culture in light and rather rich loam, and are increased readily by seeds, layers, or cuttings in sand under a hand-glass. 
6935 Leaves opposite cordate at base stem-clasping, Branches calyxes and peduncles hispid 6936 Leaves opposite stalked ovate lanceolate, Panicle brachiate, Pedic. umbelled

6937 Leaves opposite stalked lin.-lanc. acuminate oblique, Panicle brachiate decompound

6938 Leaves opposite ovate netted veiny beneath pubescent, Heads lateral stalked and bractes downy

6939 Leaves opposite lin.-lanc. naked, Pedunc. axillary umbelled, Bractes lanc. smooth

6040 Leaves alternate lanceolate 3-nerved, Fl, racemose clustered terminal smooth

6941 Leaves scattered linear channelled acute rigid, Fl. lateral clustered sessile

6942 Leaves alternate lin. filiform rigid mucronate channelled rough, Fl. clustered sessile

6943 Leaves alternate linear-lanceolate, Fl. clustered lateral pubescent

6944 Leaves alternate lanceolate narrowed at each end mucronate, Fl. lateral clustered sessile smooth

6945 Leaves alternate lanceolate mucronate, Fl. lateral clustered sessile pubescent

6946 Leaves scattered lanceolate veiny glandular mucronate, Caps. downy at end

6947 Leaves ovate-lanceolate acuminate quite smooth, Cymes stalked many-flowered

6948 Very like M. lanceolata, but the blossoms appear more copiously

6949 Leaves alternate lin.-lanceolate with a long acute point

6950 Leaves lin.-lanceolate with a long point dotted rough

6951 Leaves elliptical pubescent beneath, Peduncles 1-fiowered

6952 Leaves oblong lanceolate pubescent beneath, Peduncles 3-flowered

6953 Leaves oblong acuminate smooth, Peduncles 1-flowered

6954 Leaves sessile cordate rounded smooth on each side, Pedunc. 1-fl. clustered

6955 Leaves oblong acuminate crenulate shining, Peduncles many-fl.

6956 Leaves ovate oblong acute sub-crenate, pubescent above rugose beneath, Branches reclinate

6957 Leaves obovate smooth coriaceous, Fruit purple

6958 Leaves entire oblong, Peduncles 4-fl. lateral

6959 Leaves entire lanceolate, Pedunc. 4-fl. terminal

6960 Leaves entire ovate-lanceolate, Ped many-fl. axillary shorter than petiole

6961 Leaves elliptical, Pedunc. trichotomous lateral and terminal, Stamens much longer than petals

6962 Leaves entire oblong acuminate obtuse flat, Pedunc. axill. many-f. the length of petioles

6963 Leaves entire roundish ovate obtuse, Pedunc. axill. many-fl. trichotomous the length of leaves $696+$ Leaves entire oblong-lanceolate acuminate, Pedunc. axillary many-f. racemose shorter than leaf 6965 Leaves entire elliptical acuminate, Pedunc, panic. axill, and terminal, Fruit globose

6966 Leaves entire lanceolate narrowed at base obtuse veinless, Pedunc. 1-fl. solitary terminal

6967 Leaves entire ovate-lanceolate, Pedunc. 1-flowered solitary lateral

6968 Leaves entire oblong acuminate coriaceous not dotted, Pedunc. 1-fl. filiform

6969 Leaves entire ovate oblong acuminate netted with veins, Pedunc. 1-f. about 3 in fruit nodding

\section{The only species}

6971 Flowers solitary, Involucre 2-leaved

$\infty$ Leaves ovate longer than the peduncles

$\beta$ Leaves ovate with round berries

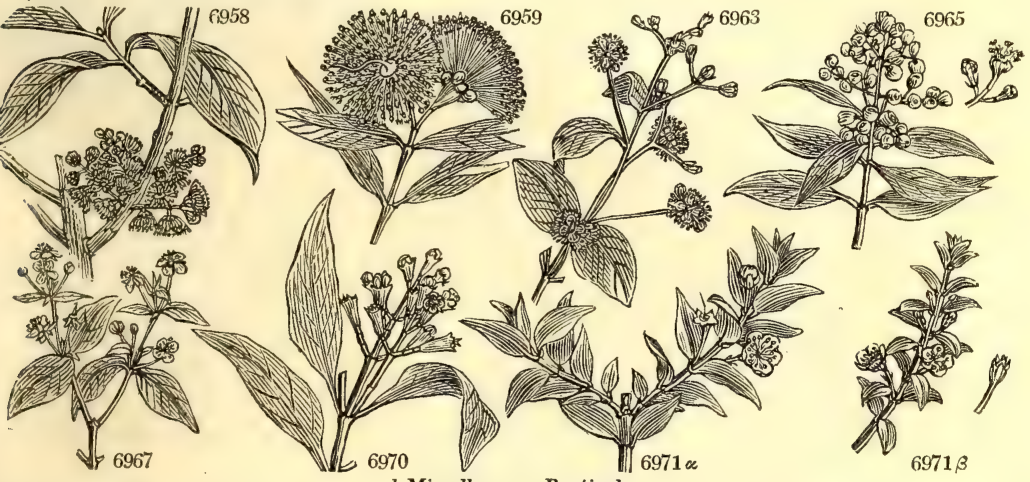

and Miscellaneous Particulars.

1119. Eugenia. In honor of Prince Eugene of Savoy, who was a protector and encourager of botany, and possessed a botanic garden. Some of the species bear edible fruits: that of $\mathbf{E}$. malaccensis is ovate, an inch and a half in diameter, flesh smelling like the rose, agreeable to the taste, and wholesome. It is generally cultivated between the tropics. E. Jambos bears smaller fruit, edible, but not so much esteemed; it is nevertheless excellent, resembling in appearance and flavor a Brussels apricot, and produced in great abundance in the stove. All the species grow freely in two-thirds loam and one-third peat, and flower abundantly when the plants are of a good size. Ripened cuttings strike root freely in sand under a hand-glass.

1120. Caryophyllus. The Arabs, who have been acquainted from all antiquity with the clove, called it qarunfel, which the Greeks altered into Caryophyllon. Giroflier, Fr. The fruit is thought to bear some resemblance to a nail, and hence is called clove, clou, Fr., Chiode, Ital., Clavo, Span., Naghel, Ger. and Dutch. The whole tree is aromatic, and the fruit or clove is considered as one of the hottest and most acrid substances of the aromatic class, and as such is often used, not only internally, but externally, as a stimulant; as in paralytic cases for example, in which the oil of cloves has been administered to advantage: it is also made use of in the tooth ache, in which it often succeeds in suddenly abating and subduing the pain. $A$ tincture of cloves in rectified spirit is kept in the shops, as well as the essential oil, which latter is perhaps seldom free from sophistication. For culinary purposes, the uses of cloves are innumerable. The Dutch, who had for a long time the monopoly of the spice trade, prevented while they could the tree from being removed from the Moluccas and other islands, where it grows naturally; but the French now cultivate it in Cayenne and St. Domingo. There are a few specimens in the British gardens. 1t grows freely in loam and
Came peat, and ripened cuttings are not difficult to root in sand, in moist heat under a hand-glass.

1121. Myrtus. From kupov, perfume. Mugros of the Greeks. Le Mirte, Fr., Myrte, Ger., Myrtus, Dutcl, Mirto, Ital. and Span., Myrta, Portug., Myrter, Dan. and Myrten, Swed. The common myrtle is a well known popular shrub, which has been in English gardens for an unknown length of time; evidently from

$$
\text { E e }
$$




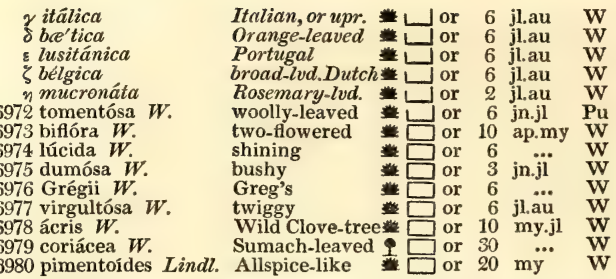

S. Europe 1597. C r.m

S. Europe 1597. C r.m Blackwell, t. 114 S. Europe 1597. C r.m Clus. hist. 1. t. 1 S. Europe 1597. C r.m

S. Europe 1597. C rm

China 1776. C s.p Bot. mag. 250

Jamaica 1759. L s.p Br. jam, t. 25. f.3

Surinam 1793. L s.p

W. Indies 1793. L s.p

Dominica 1776. L s.p Gæ. se. 1.t.33 f.3 Jamaica 1787. L s.p Plu. ic. t.208. f. 1 Jamaica 1759. L s.p Pl. alm. t. 155.f.3 Hispaniol.1759. L s.p Pl. ic. t. 208. f. 2 W. Indies ... L s.p Bot. cab. 178

1122. Calyptran'THES. $W$. Calyptranthes. Myrtacea. Sp.4-6.

6981 Zuzýgium $W$. oval-leaved $\square \mathrm{tm} 20 \mathrm{my}$.jl W $\quad$ W. Indies 1778. L s.p Br. jam. t. 7. f.2

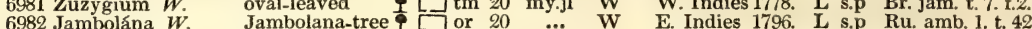

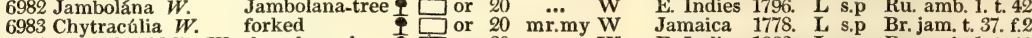
6984 caryophyllifolia $W$. clove-leaved $\$ \square$ or $20 \ldots$ W $\quad$ E. Indies 1822. L s.p Ru, amb. 1.t.41

1123. PIMEN'TA. Lindl. Pimenta. Myrtacea. Sp. 1

6985 vulgáris Lindl. Allspice-Tree $\perp \square$ cul 30 my.jl W W. Ẃ Wies 1723. L s.p Bot. mag. 1236 Myrtus Pimenta $\mathbf{L}$.

1124. OLYN'THIA. Lindl. OLYNTHIA. Myrtacea. Sp. 1.

6986 disticha Lindl. ${ }^{2}$ globe-berried $9 \square$ or 2 ap.jl W Jamaica 1793. L s.p Bot. mag. 867 Mýrtus disticha $\mathrm{W}$.

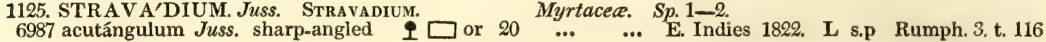

1126. EUCALYP'TUS. $W$. Eucalyptus. 6988 robústa $\mathrm{Sm}$. 6989 rostráta Cav. 6990 piluláris $\mathrm{Sm}$. 6991 tereticórnis $\mathrm{Sm}$. 6992 resinifera Sm. 6993 marcináta Sm. 6994 capitellat 6994 capitelláta $S m$ 6995 salígna $\mathrm{Sm}$. 6996 botryoídes Sm. 6997 botryoídes $S m$. 6998 hæmastóma $S m$. 6999 piperita $S m$. 7000 obliqua $W$ 7001 corymbósa $W$.

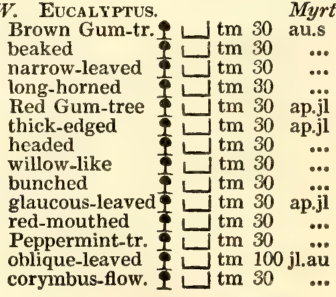
Cp. $30-40$.
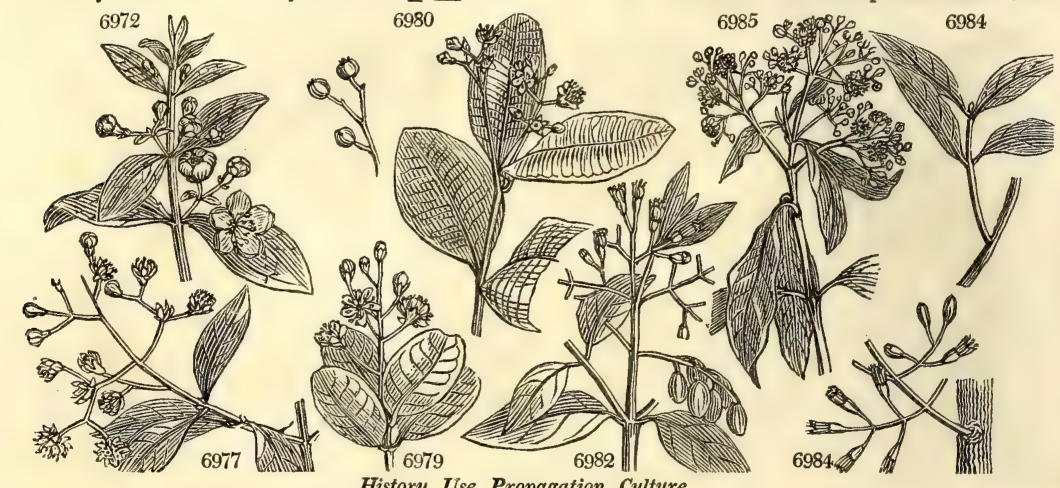

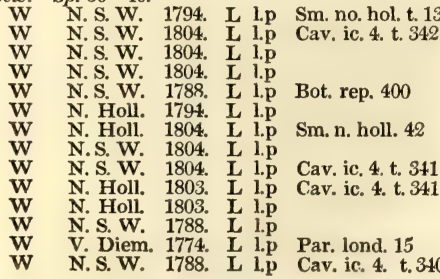

History, Use, Propagation, Culture,

what Gerarde and Evelyn say, before the invention of greenhouses, and probably in that case preserved by covering or housing in rooms. It was a great favorite among the ancients, for its elegance, and its evergreen sweet leaves. It was sacred to Venus, either on this account, or perhaps because it flourishes most in the neighbourhood of the sea. Myrtle-wreaths adorned the brows of bloodless victors, and were the symbol of authority for magistrates at Athens. Both branches and berries were put into wine, and the latter were used in the cookery of the ancients. The myrtle was also one of their medicinal plants. All parts of it are astringent, but it is discarded from modern practice.

M. coriacea, sometimes called wild cinnamon, is a most elegant tree, with a handsome ash-colored straight trunk, and pyramidal head. It grows slowly, and flowers late twice a year In old trees, the bark becomes white, and hangs down in shreds which have an aromatic quality. The timber is red, very hard, and used in mill-work. The berries, which are the size of peas, and of an agreeable aromatic smell and taste, are used in culinary purposes.

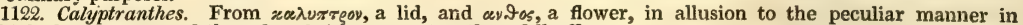
which the segments of the calyx, being grown together, fall off.

Zuzygium, is so called from ov\}uros, coupled, in allusion to the manner in which the branches and leaves are united by pairs. C. Jambolana, frequently called the Java plum, bears a black esculent ierry. Cuttings of this genus, Sweet observes, "do not strike freely ; ripened ones strike best in sand under a bell-glass ; but the plants root best from layers." (Bot. Cult. 34 .)

1123. Pimenta. A genus readily distinguishable from Myrtus by the structure of its ovarium. It is a handsome tree, common in the hilly parts of the north side of Jamaica. The flowers are without shew, and are succeeded by spherical purple berries crowned with a persistent calyx : they are called Jamaica pepper or all-spice, from their taste being thought to resemble a composition of all other spices. The berries are gathered before being ripe, and are carefully dried on mats or terraced floors in the shade. In ten or twelve 
Leaves ovate-lanceolate acute

$\delta$ Leaves ovate-lanceolate close together

Leaves lanceolate ovate acute

Leaves lanceolate acuminate

Leaves lin.-lanceolate acuminate. Very small

697 " Peduncles 1-flowered, Leaves 3-nerved downy beneath

6973 Peduncles 2-flowered, Leaves lanceolate

6974 Peduncles about 3-fl. Leaves subsessile lanceolate attenuated

6975 Racemes axillary very short, Leaves stalked broad lanceolate acuminate

6976 Peduncles axillary many-fl. Leaves ellipt. acute entire pubescent beneath

6977 Racemes lateral and terminal, Leaves broad lanceolate attenuated

6978 Peduncles axillary terminal and corymb. trichotomous, Leaves ellipt. convex coriaceous veiny dotted

6979 Peduncles 3-chotomous terminal, Leaves roundish elliptical convex coriaceous veinless dotted

6980 Leaves elliptical flat with close parallel transverse veins, Cymes stalked few-flowered shorter than leaves

6981 Pedunc. axillary 3-chotomous spreading, Leaves ovate obtuse, Branches dichotomous 6982 Panic. subterminal, Leaves ovate emarginate

6983 Peduncles terminal panicled trichotomous downy, Leaves ovate attenuated at end

6984 Panicles lateral, Leaves elliptical ovate entire

6985 Flowers trichotomous panicled, Leaves oblong lanceolate acuminate

6986 Leaves distichous deflexed ovate-lanceolate

6987 Leaves crenate, Raceme very long, Drupe ovate

6988 Lid conical contracted in middle broader than calyx, Leaves ovate

6989 Lid rostrate, Umbels lateral, Leaves ovate-lanceolate attenuate oblique

6990 Leaves linear lanceolate, Lid conical contracted in middle, Umb. lateral

6991 Lid conical rounded very smooth membranous, Umb. lateral solitary

$6992 \mathrm{Lid}$ conical rounded coriaceous twice as long as calyx, Umb. lateral solitary

6993 Leaves ovate thickened at edge, Umbels lateral

6994 Leaves ovate-lanceolate, Heads lateral solitary, Fruit globose

6995 Leaves lin.-lanceolate, Heads lateral solitary, Fruit turbinate

6996 Lid hemispherical obtuse, Heads lateral solitary, Fruit turbinate

6997 Heads lateral solitary, Pedunc cuneate compressed, Fruit turbinate

6998 Umb lateral and terminal, Pedunc. compressed, Branches angular

6999 Pedunc. compressed, Branches angular, Umbels lateral panicled or solitary

7000 Pedunc. and branches round, Umb. lateral solitary

7001 Umb. corymbose panicled terminal, Calyx round, Lid hemispherical mucronulate
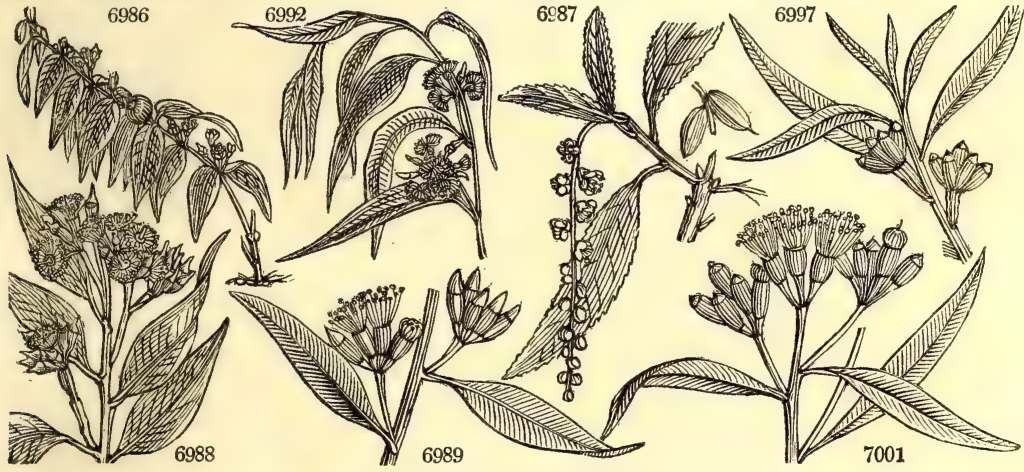

and Miscellaneous Particulars.

days they become wrinkled, dry, and of a dark brown color, and are then packed in bags or casks for sale. Some kiln-dry them by which the same object is sooner effected. The berries have an agreeable aromatic subastringent taste, resembling that of a mixture of cinnamon, cloves, and nutmegs, with the warm pungent taste of the cloves; qualities which reside chiefly in the cortical part of the dried berry, and are better taste of the cloves; qualities which reside chiefy in the cortical part of the dried berry, and are better
extracted by a watery infusion, than by spirit or distillation. They are much used in the kitchen, and also by the druggists to cover the disagreeable taste of other remedies, or to give them warmth. An oil is obtained by distillation which is said to be nearly equal to that of oil of cloves, and sometimes substituted for it.

1124. Olynthia. So named from o $\lambda$ y. 905 , a little fig or berry. A genus separated from Myrtus on account of the singular manner in which all the parts of the seed are consolidated. A small stove plant common in collections.

1125. Stravadium. The Malabar name of this plant is Tsjera samstravadi, from which Stravadium has been contrived. A fine tree with racemose flowers, and large, four-cornered, oblong fruit. A delicate stove plant rarely seen.

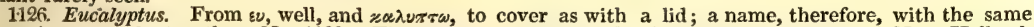
meaning as Calyptranthes, No. 1122. This genus consists of the loftiest timber trees of New Holland. Botanists knowing them principally from dried specimers, their respective heights cannot be stated correctly. They are all of the tallest habit, and soon grow beyond the limits of our stoves. In Van Dieman's Island a manufactory has been established for the preparation of extract of tannin from the bark of various species of Eucalyptus. A considerable quantity of the substance has been imported into England recently, and it is said to have been found by the tanners to be twice as powerful in its operation as oak-bark.

E. resinifera produces a gum resin something like the Kino of druggists (obtained from a species of Pterocarpus), and for all medical purposes full as efficacious.

All the species, Sweet observes, "are fine plants for a large conservatory, as they grow very fast, and are L e 2 
7002 paniculáta $L . T$. 7003 cornúta $L a b$.

7004 reticuláta Link. 7005 longifólia Link. 7006 média Link. 7007 mucronáta Link. 7008 triántha Link. 7009 persicifólia Lodd. 7010 pulverulénta $\mathrm{Link}$. 7011 elougáta Link.

7012 myrtifólia Link.

7013 microphýlla Link. 7014 stenophýlla Link. 7015 hypericifólia Dum

7016 hirsúta Link. hairy

1127. PU'NICA. $W$.

7018 nána $W$.

7019 Granátum $W$

$\beta$ álba

r pléna horned

long-leaved

intermediate

mucronate

Pree-flowere

powdery

long

myrtle-leaved

mall-leaved

w-leaved hairy

Pomegranate. dwarf

common

white-flowered

double-flowered

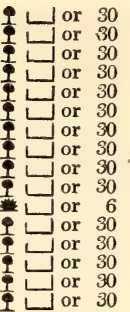

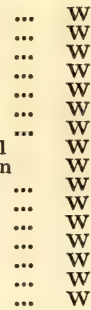

N. S. W. 1804. L s.p

N. Holl. 1803. L s.p Lab. voy. 1, t. 20

N. Holl. 1823. I co

N. Holl. 1823. L co

N. Holl. 1823. L co

N. Holl. 1823. L co

N. Holl. 1823. L co

N. Holl. 1817. I co

Bot. cab. 501

N. Holl 1823.

N. Holl 1823. L co

N. Holl. 1823. L co

N. Holl. 1823, L co

N. Holl. 1823. L co

N. Holl. 1823. L co

N. Holl. 1823. L co

\section{Sp. 2.}

J or 5 jl.s

fr 18 jn.s

or $10 \mathrm{jn} . \mathrm{s}$

W. Indies 1723. C r.m Bot. mag. 634

S China 154. C r.m Bot. mag. 1839

S. Europe $\cdots$ C $\quad$ r.m Tr. ehr. t. 71.f. 2

Bot. mag. 2087

1128. AMYG'DALUS. $W$. ALMond

7020 Pérsica $W$.

$\beta$ Nectarina

2 pléna

7021 commúnis $W$

$\beta$ amára

7022 nána $W$.

7023 incána $W$.

7024 orientális $W$.

7025 púmila $W$. Prúnus sinénsis $\mathrm{P} . \mathrm{S}$.

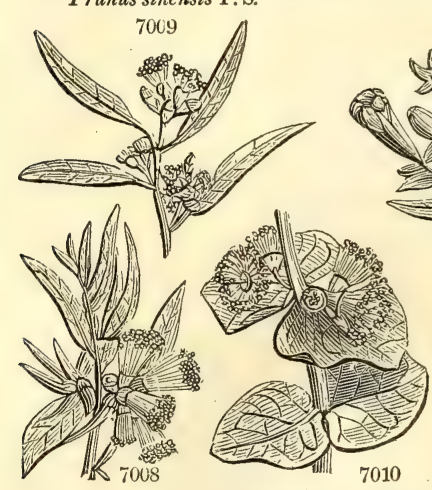

$\begin{array}{lllll}\text { common Peach } & \text { fr } & 15 & \text { ap.my } & \mathbf{R} \\ \text { Nectarine } & \text { fr } & 15 & \text { ap.my } & \mathbf{R} \\ \text { double-flowered } & \text { or } & 15 & \text { ap.my } & R \\ \text { Sweet-almond } & \text { fr } & 15 & \text { mr.ap } & R \\ \text { Bitter-almond } & \text { fr } & 15 & \text { mr.ap } & R \\ \text { common-dwarf } & \text { or } & 2 & \text { mr.ap } & \mathbf{R} \\ \text { woolly } & \text { or } & \text { mr.ap } & R \\ \text { silvery-leaved } & \text { or } 10 & \text { mr.ap } & R \\ \text { double-dwarf } & \text { or } & \text { my.jn } & \mathbf{R}\end{array}$

Sp. 6.

Persia 1562. B h.l

Persia 1562. B h.l

Persia $\quad$... B h.l

Barbary 1548. S h.1

Barbary 1548, S h.l Blackw.t. 195

Russia 1683. B s.l Bot. mag. 161

Caucasus $\ldots$ B s.l Pall. ross. 1.t. 7

Levant 1756. B s 1

China 1683. L s.l Bot. mag. 2176

7018

\section{$7019 \beta$}

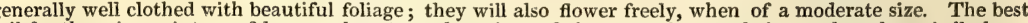
soil for them is a mixture of loam and peat; and cuttings of them may be struck in sand under a bell-glass; but they are not so free to root, as most of this natural order are. (Bot. Cult. 189.)

1127. Punica. This fruit was called by the ancients Malum Punicum, Carthaginian apple; because, as Pliny tells us, the tree was first known to grow in the vicinity of Carthage. Hence has the term Punica. been constructed. P. nana has very small fruit and flowers, and is used in the West Indies as a hedge-plant, as P. Granatum (from granum, grain, on account of the numerous grains of its fruit) is in the south of France and in Italy. The latter, in its wild state, is a thorny bush not unlike our hawthorn: the flowers have a fine appearance, and the fruit is very ornamental. It will produce fruit, trained against a south wall, in many parts of England; and under a glass-case, or against a flued wall, it is probable, the fruit might be as highly flavored as that imported from Genoa and Leghorn. The flowers come out at the ends of the branches, singly, or three and four together : and, therefore, in pruning, care must be had to bring into action only the strongest buds. For this purpose, all the weak shoots should be cut out, and the stronger ones shortened, so as to produce bearing-shoots over the whole tree. The best soil is a rich strong loam.

The double-flowering varieties are to be treated in the same manner, and are highly ornamental.

1128. Amygdalus. The Greek name of the almond. The species are fruit-trees, or ornamental trees and shrubs, both much esteemed for the gay color and early appearance of their flowers. A. Persica, the peach and nectarine, bears the most exquisitely delicious of European fruits; it is more gratifying to the palate by its mass of juicy pulp than the grape, and more delicate than the melon. Some, however, prefer the grape and melon to the peach and nectarine; but the most delicate of taste consider the latter as surpassed only ly the pine-apple. The varieties of peach and nectarine are numerous, and by raising from seed might easily be rendered innumerable. The best varieties have been raised in France, at Montreuil, a village of peach growers for the Paris market. Some good varieties have been raised in England by Mr. Knight, and other members of the Horticultural Society. The peach, to attain its proper flavor, must be protected by glass during the spring and earlier summer months, and exposed to the direct influence of the weather during the ripening process. Ripened under glass, unless very liberal supplies of air are given, the flavor will be very inferior. Mr. Knight considers that the direct rays of the sun (without the intervention of glass) are of great advantage to the proper ripening, and essential to the coloring of the peach.

Linnaus divides the A. Persica into two varieties; that with downy fruit, or the peach, and that with smooth fruit, or the nectarine. There are various instances on record (Hort. Trans. vol. i. p. 103.) of both fruits growing on the same tree, even on the same branch ; and one case has occurred of a single fruit partaking of the nature of both. The French consider them as one fruit, arranging them in four divisions; the péches, or free-stone peaches, the flesh of whose fruit separates readily from the skin and the stone; the péches lisses, or free-stone nectarines, or free-stone smooth peaches; the pavies, or cling-stone peaches, whose flesh is firm, and adheres 
7002 Lid hemispherical obtuse, Cal. angular, Umb. panicled terminal

7003 Lid very long and cornute, Heads lateral solitary, Style persistent 3-4-fid at base, Leaves lin. lanceolate 7003 Lid very long and cornute, Heads lateral solitary, Style persistent 3-4-fid at base, Leaves

7005 Leaves lanceol. unequal at base, on one side rounded with an incurved point, Branches axillary many-fl. 7006 Leaves lanceolate with a long point at the base subovate oblique with parallel nerves beneath

7007 Leaves lanceol. with a short point wavy with parallel nerves beneath and a marginal nerve on both sides 7008 Leaves obl. unequal at base attenuated somewhat falcate with axillary 3-fl. peduncles and sessile flowers

7009 Leaves lanceolate stalked, Pedunc. short axillary 6-12-flowered

7010 Leaves amplexicaul. with a short point glaucous beneath

7011 Leaves lanc. attenuated with a filiform point netted with veins beneath

7012 Leaves acute reticulated, the nerves united at the margin

7013 Leaves talcate at end, those on the branchlets small clustered

7014. Leaves linear narrowed at base obtuse veiny with nerves united on this side the edge

7015 Leaves 6 lines long and 1 $\frac{1}{\mathrm{a}}$ broad with the lateral parallel nerves united on this side the edge

7016 Leaves stalked cordate obtuse with nerves downy beneath, Branches and peduncles strigose

7017 Leaves amplexicaul. lanceolate with a long point glaucous beneath

7018 Leaves linear, Stem shrubby

7019 Leaves lanceolate, Stem arborescent

7020 Leaves with all the serratures acute, Flowers sessile solitary

\section{Lower serratures of the leaves glandular, Flowers sessile in pairs}

7022 Leaves ovate attenuate at base simply and finely serrate

7023 Leaves oblong lanceolate serrate downy beneath

7024 Leaves lanceolate entire silvery perennial shorter than footstalk

7025 Leaves lanceolate doubly serrated

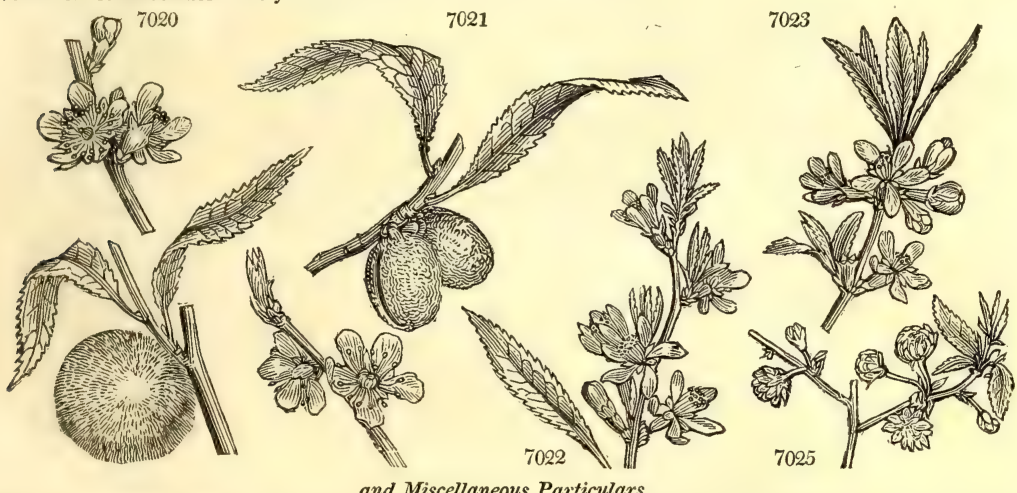

and Miscellaneous Particulars.

both to the skin and stone; and the brugnons, or nectarines, or cling-stone smooth peaches. Knight. (Hort. Trans. iii. 1.

The double-blossomed peach is one of the most ornamental of spring-flowering trees; its blossoms appear about three weeks later than those of the common peach.

A. communis and amara, and especialiy the former, are employed as ornamental trees in front of shrubberies, and in suburban gardens. In the south of France, Italy, Spain, and different parts of the Levant, they are cultivated for their fruit. In France they have above a dozen species or varieties, besides a hybrid called the almond peach. (See Duhamel.) The common and bitter almond are only to be distinguished by the taste of the kernels of their fruit. The Jordan almonds, which come from Malaga, are the best sweet almonds brought to England; the bitter come chiefly from Magadore. The bitter cuticle of almonds is taken off by immersion in boiling water. The almond eaten as food is not very digestible, and requires to be well masticated.

Robertson (Hort. Trans. iii. S82.) and various botanists consider the peach and almond as one species.

Four distinguished and ingenious attempts have been made to class the varieties of peaches and nectarines by the leaf and flower as well as the fruit : the first is by Poiteau, in the Bon Jardinier; the next by Count Lelieur, in his Pomone Française; the third by Robertson, nurseryman, of Kilkenny, whose arrangement is founded on the glands of the leaves; and the fourth, and nnost important, by Mr. George Lindley, in the fifth volume of the Horticultural Society's Transactions. The latter writer has, in a peculiarly distinct manner, arranged no fewer than $\mathbf{1 5 5}$ sorts of peaches and nectarines in well defined divisions or sections.

The bitter almond contains less fixed oil, than the sweet almond, and a portion of prussic acid or hydrocyanic acid, upon which its narcotic power is supposed to depend. This variety is said to operate as a poison on dogs and some other animals, but not generally on the human species. The distilled water exerts an action not less deleterious than that of laurel water on the human frame. It produces vertigo, head-ache, tinnitis aurium, dizziness of sight, and vomiting, when taken to the extent of thirty drops only and a drachm of it has killed a stout dog. When a large doze is taken, death almost instantly follows. In order to counteract its poisonous effects recourse is had to diffusibles, as brandy and ammonia ; or three or four spoonfuls of oil of turpentine may be given at intervals of half an hour. The fixed oil, which both varieties of the almond yield by expression in large quantity, is insipid and inodorous when heat has not been employed.

Sweet almonds are used more as food than as medicine, but they afford little nourishment. Heartburn is said to be relieved by eating six or eight of them decorticated. When triturated with water, milky mixtures or emulsions are formed; and they are also used in pharmacy for assisting, by trituration, the combination of substances, such as camphor and the resins with water. Bitter almonds are scarcely ever used medicinally, (London Dispensatory, 151.)

A. hana and pumila are very ornamental shrubs, both in their double and single varieties. 
1129. PRU'NUS. $W$. 7026 Pádus $W$. B rúbra W. 7027 virginiána $P h$ 7028 serótina $W$. 7029 occidentális $W$. 7030 lusitánica $W$. 7031 caroliniána $\boldsymbol{W}$. 7032 Laurocérasus $W$. 7033 Maháleb $W$. 7034 púmila $W$. 7036 chamæcérasus $W$. 7037 Cérasus $W$. 7938 Pseúdo-cerasus Lind 7039 semperflóren 7040 ávium $W$

7041 pensylvánica $W$. 7042 nígra $W$.

$70+3$ japónica $P$. S.

7044 brigantiáca Vill.

7045 doméstica $W$. 7046 insitítia $W$. 7047 cerasifera $W$. 7048 depréssa $P h$. 7049 Chícasa $P h$. 7050 maritima $P h$. 7051 Susquehánna $P h$. 7052 spinósa $W$. 7053 prostráta $W$. 7054 boreális Mich. 7055 pygmæa $W$. 7056 armeníaca $\dot{L}$. 056 armeniaca $\boldsymbol{L}$.

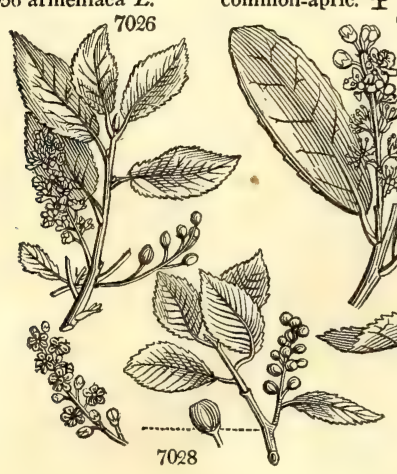

PlưM \& Cherry. Bird-cherry Cornish-Bird Virginian American-Bird West Indian Portugal Laurel Evergreen Bird common Laurel perfumed dwarf

Black choke-ch. bastard-cherry common-cherry Chinese-cherry Toussaint-cher. Corone-cherry Pensylvanian black

Japan Briançon Apr. common-Plum Bullace-tree Myrobalan Sand-cherry Chicasaw-Plum sea

glaucous-leaved Sioe-tree

Birch-leaved

Choke-cherry

pigmy common-apric. 壮
Rosacece. Sp. 33-47.

or 30 ap.my W Rritain woods. L co Eng. bot. 1383 or 30 ap.my W Britain ... L co Will. ar.t.4.f.2 or 30 my.jn W Virginia 1724. $\mathbf{L}$ co Will ar, $5 . \mathrm{f} .9$ or 30 my.jn W N. Amer. 1629. $\mathrm{L}$ co Dend. brit. 48 or 20 ja $\mathrm{W}$ Jamaica 1784 or 20 Ja.d W Jamaica 1784. L co or $30 \mathrm{my} \quad \mathbf{W}$ Portugal 16.18. S co or 12 ap.my W Levant 1629. C co or 20 ap.my $\mathbf{W}$ or 20 ap.my $W$ or 2 my W or 4 my or 8 my W fr 20 ap.my W fr 6 ap.my $\mathbf{P k}$ fr 20 ap.my $\mathrm{W}$ or 50 ap.my W or 30 my or 30 my W or 20 ap.my W $\begin{array}{ll}\text { or } 2 & \text { mr.my. Pk } \\ \text { fr } 20 \text { ap.my W }\end{array}$ fr 20 ap $\mathrm{W}$ fr 20 ap W or 8 ap my W or 4 my or 4 my or 6 ap.my W $\begin{array}{llll}\text { or } & 4 & \mathrm{my} & \mathrm{W} \\ \text { or } & 6 & \mathrm{my} & \mathrm{W}\end{array}$ or 15 mr.ap W or 1 ap.my $P$ or $4 \mathrm{my}$ W fr 15 f.mr W

Mill. ic. t.196. f, 1

Duh. ar. 1.t. 133 Austria 1714. G co Jac. aust, 3, t.227 N. Amer. 1756. L s.l Mill, ic. t. 89, f. 2 N. Amer 1805. Austria 1597. L s.1 England woods. G s.1 Eng. bot. 706 China 1821. G co Bot. reg. 800

...... ... G co Dend. brit. 131

... S co Blackw. t. 425

N A mer 1773. Gill. ar.t. 3. f.

Japan 1810. G co Bot. reg. 27

Dauphiny 1823. G co

England hed. G r.m Eng. bot. 1783

Britain hed. S co Eng. bot. 841

N. Amer. 1629. L r.m

N. Amer. 1805. L s.1

N. Amer. 1806. L s.l N. Amer. 1800. L s.l N. Amer. 1800. L s.p

Britain hed. S co Eng. bot. 842

Crete 1802. L s.l Bot. reg. 136

N. Amer. 1822, L co

N. Amer. 1822. $\mathrm{Co}$ Levant 1548. L b

Lam. ill. t. 431 7033 7037

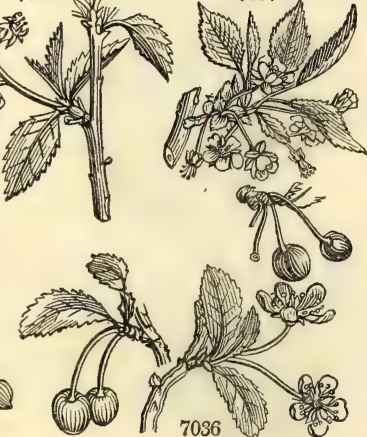

History, Use, Propagation, Culture

1129. Prunus. The origin of this name is wholly unknown. The Greeks called it $\pi$ gourn, and the Latins prunus. From this genus have been obtained the principal characters of that section of the natural order Rosaceæ, which is called Amygdaleæ or Prunaceæ, and which is curiously and chemically known by the presence of Prussic acid all in the species, and in all their parts.

P. Padus (a name of Theophrastus), the bird-cherry, is an ornamental tree, by its purple bark, leafy bunches of white flowers, and berries successively green, red, and black. It is common in the native woods of Scotland and Sweden, and in both countries the berries are infused in spirits in order to give them an agreeable flavor. The fruit is nauseous to the taste, though greedily eaten by birds. The bark is used by the Finlanders to cure venereal complaints, and also with success by regular practitioners in Stockholm for the same purpose. (Stockholm Acts.) The tree is very leafy, and dislikes a wet soil; but bears lopping as copsewood. The wood is beautifully veined, and used for cabinet work in France, as is that of P. virginiana in America.

$\mathbf{P}$. rubra greatly resembles $\mathbf{P}$. Padus. $\mathbf{P}$. caroliniana is an imperfect evergreen.

P. Lauro-cerasus is one of our most popular evergreens. It was first brought from Constantinople to Holland in 1576; the first we read of in England was one at Highgate, in the garden of Mr. James Cole, a merchant of London, who, as Parkinson informs us, used to cover it in winter with a blanket. In less than half a century afterwards (1688), Ray informs us, the laurel was common in English gardens. It is now as universal in shrubberies as the rose. The kernel-like flavor of the fresh leaves has led to their use in flavoring custards and other culinary preparations; but as these leaves are poisonous, they ought to be used with caution. To brute animals the effect of the distilled water of laurel leaves is almost instant death ; and two women in Dublin, and Sir T. Boughton in England, have been poisoned by it.

P. lusitanica is a most beautiful evergreen shrub, nearly as universal as the lauro-cerasus. It was brought to England from Portugal, but does not appear to be a native of that country; probably of Madeira or some other islands possessed by the Portuguese in the sixteenth or seventeenth centuries.

P. Mahaleb (Mahhaleb the Arabic name) flowers profusely, and disperses an odor resembling that of Clematis for a considerable distance around. Its fruit is round, shining black, and so hard that it has been bored for beads by the catholics. The wood is perfumed and used by the French in cabinet-work, especially in the village of St. Lucie, near Commercy, whence, among the French, the plant has obtained the name of Bois de St. Lucie.

P. Cerasus, the cultivated cherry, is by some considered a distinct species, and by others only a variety of $\mathbf{P}$. avium, the gean or wild black cherry. Lucullus is said to have first introduced the cultivated cherry to Italy, in 73 A. C. from a town in Pontus in Asia, called Cerasus, whence its specific name, and it was introduced to Britain 120 years afterwards. Many suppose that the cherries introduced by the Romans into Britain were lost, and that they were re-introduced in the time of Henry VIII. by Richard Haines, the fruiterer to that monarch. But though we have no proof that cherries were in England at the time of the Norman conquest, or for some centuries after it; yet Warton has proved, by a quotation from Lidgate, a poet who wrote about 
7026 Flowers racemose, Racemes pendulous, Lvs. decid. doubly serrat. somewhat rugose, Petioles with 2 glands $\beta$ Serratures of leaves less, Racemes more erect

7027 Flowers racemose, Racemes erect, Leaves deciduous doubly toothed smooth, Stalks with 4 glands

7028 Flowers in loose racemes, Lvs. decid. simply serrated : lower serratures glandular, Rib beard, towards base 7029 Flowers in lateral racemes, Leaves without glands oblong acuminate entire smooth on each side

7030 Flowers racemose, Racemes lateral, Leaves evergreen without glands oblong acuminate entire

7031 Flowers racemose, Leaves evergreen ovate-lanceolate serrated without glands

7032 Flowers racemose, Leaves evergreen with two glands at back

7033 Flowers corymbose terminal, Leaves ovate

7034 Umbels sessile aggregate few-flowered, Cal. acute, Branches virgate round, Leaves narrow lanceolate

7035 Umbels sessile aggregate few-fl. Sepals lanc. Stipules setaceous compound, Lvs, obl, oval suddenly pointed

7036 Umbels sessile, Leaves obovate obtuse smooth with glandular serrature

7037 Umbels somewhat stalked, Leaves ovate-lanceolate smooth folded together

7038 Leaves obovate acuminate flat serrated, Racemes pubescent

7039 Flowers racemose, Calyxes serrated, Leaves ovate serrated glandular at base

7040 Umbel sessile, Leaves ovate-lanceolate pubescent beneath folded together

7041 Umbel subsessile aggregate many-fl. at length panicled, Leaves obl. lanceolate serrated smooth

7042 Umbel sessile solitary few-fl. Leaves deciduous ovate acuminate finely serrated, Petioles with 2 glands

7043 Peduncles solitary, Leaves ovate acuminate smooth, Branches unarmed

7044 FI. lateral clustered, Leaves doubly serrated roundish acute

7045 Peduncles subsolitary, Leaves lanceolate ovate convolute, Branches not spiny

7046 Peduncles twin, Leaves ovate villous beneath convolute, Branches spiny

7047 Peduncles solitary, Leaves elliptical smooth, Fruit pendulous, Branches nearly unarmed

7048 Umbel sessile clustered few-fl. Cal. obtuse, Branches angular prostrate, Lvs. cun. lanc. glaucous beneath

7049 Buds clustered 2 -fl. Ped. very short, Cal. smooth, Leaves oblong acum. serrulate, Branches spiny

7050 Pedunc. subsolitary, Leaves ovate-oblong acuminate doubly serrated

7051 Peduncles solitary, Leaves obovate obl. beneath glaucous serrated entire at base

7052 Peduncles solitary, Leaves ellipt. lanceolate pubescent beneath, Branches spiny

7053 Peduncles twin, Leaves ovate cut serrate without glands beneath white, Stem prostrate

7054 Flowers corymbose, Ped, elongated, Leaves oval oblong eroded membranous smooth

7055 Umbels sessile aggregate few-fl. Leaves ovate ellipt. acute smooth on each side with 2 glands at base

7056 Flowers sessile, Leaves subcordate

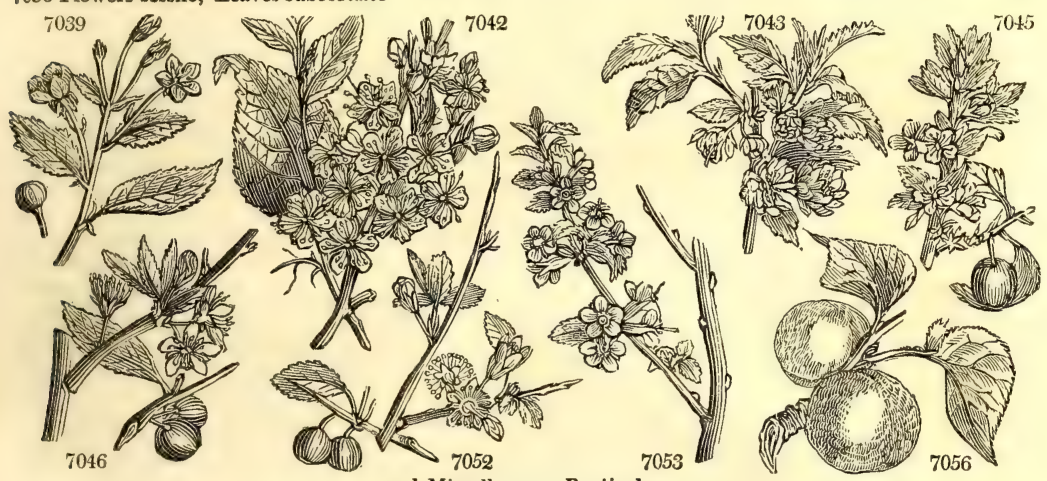

and Miscellaneous Particulars.

or before 1415, that the hawkers in London were wont to expose cherries for sale in the same manner as is now done early in the season. The tree is now very generally cultivated both as a wall and standard fruit, and has been forced for upwards of two centuries.

The Romans had eight varieties of cherry: in the British gardens are upwards of forty sorts. The French divide their cherries into griottes, or tender-fleshed; bigarreaux, or hard-fleshed; and guignes, or small fruits. The fruit of many varieties is somewhat heart-shaped, hence the very general cognomen ; why some sorts are called dukes is not as obvious. The Morello cherry is very distinct from the other varieties, bearing almost exclusively on the preceding year's wood, and the pulp of the fruit having the consistence and flavor of the
Morel, whence the name. Cherries are grafted or budded on seedlings from cherry-stones, or better from seedlings of the wild cherry. For dwarfing, they are worked on the bird cherry or perfumed cherry: the latter is preferred in Holland.

Cherry trees are very ornamental in shrubberies and woods, and valuable as encouraging the different species of thrush. The gum of cherry trees is eatable, and equal to that of gum arabic; the wood is hard and tough, and used by the turner and cabinet maker.

Prunus Pseudo-Cerasus, the Chinese cherry, is of recent introduction, and most valuable on account of its bearing an excellent fruit, and producing it abundantly in a forcing-house.

P. avium, the gean, guigne, Fr., attains a large size, and its timber is of considerable value : the black corone cherry is supposed to be an improved variety of it, as are the different geans.

P. domestica is generally considered the original of the plum tree, Prune, Fr., Pflaumen, Ger., and Prugno, Ital. Many, however, conjecture that P insititia, spinosa, and domestica, are the same species. There are severai sorts of plums found wild in Britain, independently of the sloe, such as the bullace, damson, are severai sorts of plums found wild in Britain, independently of the sloe, such as the bullace, damson,
muscle, and winesour. The plum is said to love a lofty exposure, and to be favorable to the growth of grass under it. The bark dyes yellow, the wood is used in turnery, and the dried fruit or prune is formed into electuaries and gentle purgatives. Prunes were originally brought from Damascus, whence their name of damask, but are now chiefly imported from France

There are a great many varieties of the plum in France, and in British gardens nearly a hundred sorts. By far the best dessert plum is the oreengage, Reine Claude, Fr. Regina Claudio, It It is well known throughout Europe, and perfectly distinct from every other variety. The damson is the best baking plum, and the winesour the best for sweetmeats. Plums are generally grafted or budded on muscle or damson stocks.

Prunus Armeniaca, Abricot, Fr., Abricosenbaum, Ger., Albicocco, Ital, Albarcoque, Portug. is a fruit tree next in esteem to the peach. From its trivial name, it is generally supposed to have originated in Armenia, but Regnier and Sickler assign it a parallel between the Niger and the Atlas; and Pallas states it to be a native of the whole of the Caus Thunberg describes it as a very large, spreading, branchy tree in Japan Grossier says, that it covers the barren mountains to the west of Pekin, that the Chinese have a great many varietics of the tree doubleli e 4 
$\begin{array}{lllllllll}7057 \text { sibirica } W & \text { Siberian-apric. } & \text { fr } & 6 & \text { ap } & \text { Pk } & \text { Siberia } & \text { 1788. } & \text { L r.m Pall. ross. 1. t. } 8 \\ 7058 \text { dasycárpa } & \text { Ehr. }\end{array}$ 1130. CHRYSOBA'LANUS. $W$. Cocoa Plum. Rosacea. Sp. $2-4$.

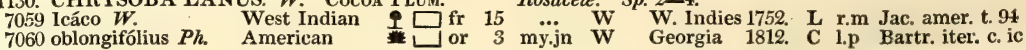

\section{DI-PENTAGYNIA.}

1131. MES'PILUS. Lindl. Medlar.

7061 germánica $W$. common-eatabl. * 7062 grandiflóra $H . K$. large-flowered

1132. CRATEgUS. $L$. HawthorN.

7063 coccínea $W$.

7064 cordáta $W$.

7065 pyrifólia $W$. C. edulis Hort.

7066 ellíptica $W$. 7067 glandulósa $W$. 7068 fláva $W$.

7069 parvifólia $W$ 7070 punctáta $W$. 7071 Crus-gálli $\dot{W}$.

\& pyracánthifólia $\gamma$ salicifólia

7072 Pyracántha Lindl.

7073 spathuláta $P h$.

7074 apiifólia $P h$.

7075 Oxyacántha $\boldsymbol{E}$. B. $\beta$ rósea

y major

S precox

\& pléna

ร aúrea

7076 eriocárpa Lindl.

7077 monógyna Pall.

7078 Azarólus $W$.

7079 tanacetifólia $B$. $R$.

7080 odoratíssima $\boldsymbol{B} . \boldsymbol{R}$.

7081 pentagyna $W . \& K$.

7082 torminális $L$.

1133. PY'RUS. Sm.

7085 melanocárpa $P h$.

Scarlet-fr. Haw. Maple-leaved Pear-leaved

oval-leaved * hollow-leaved yell. Pear-berr. Gooseberry-ivd. spotted-fruited Cockspur-thorn Pyracantha-lv. Willow-leaved

Evergr.-thorn spatula-leaved Parsley-leaved common-Haw. red-flowered great-fruited Glastonbury double-flowered yellow-berried woolly-fruited one-styled Azarole

Tansy-lv. Azar. sweet-sc. Azar,

five-styled

Wild-service

black

Pyrus. red-berried

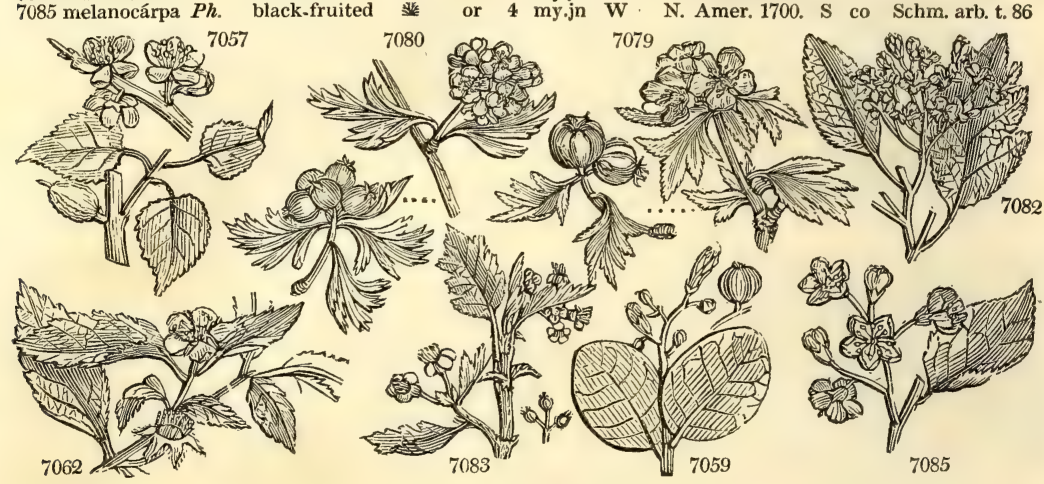

fr 12 my.jl W Wracea. England hed. G h.l Eng. bot. 1523

or 12 my.jn W $\quad$...... 1800. $\mathcal{L}$ co Ex. bot. 1.t. 18 Rosacea. Sp. 21-32.

or 20 ap.my W N Amer. 1683. B co Dend. brit. 62 or $20 \mathrm{my}$ W N. Amer. 1738. B co Dend. brit. 63 or $15 \mathrm{jn} \quad \mathrm{W} \quad \mathrm{N}$. Amer. 1765. B co Dend. brit. 61

or $20 \mathrm{my}$ W N. Amer. 1765. B co or 20 my.jn W N. Amer. 1750. B co Dend. brit. 58 or 20 my W N. Amer. 1724. B co Dend, brit. 59 or 15 my.jn $\mathbf{W} \mathbf{N}$. Amer. 1704. B co Dend brit 65 or $1.5 \mathrm{my}$ W N. Amer. 1746. B co Dend. brit. 57 or 20 my.jn W N. Amer. 1691. B co Dend, brit. 56 or 20 my.jn W N. Amer. ... B co or 20 my.jn W N. Amer. ... B co or $10 \mathrm{my} \mathrm{W} \mathrm{S}$. Europe 1629, $\mathrm{S} \mathbf{s}$ or 15 my.jn W N. Amer. 1806. B co or 15 my.jn W N. Amer. 1806. B co or 15 my.jn W W W Amer. or 15 my.jn W Britain hed. $\underset{B}{\mathrm{~S}}$ co

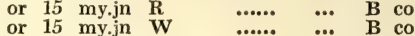
or 15 my.jn W or 15 my.jn W $\quad$...... ... $\quad$ B co or 15 my.jn W $\quad \ldots . . . . \quad \ldots . . \quad B$ co or 15 my.jn W Britain woods. B co or 15 my.jn W Siberia ... B co or 15 my.jn $W$ or 15 my.jn W or 15 my.jn W or 15 my.jn W or 15 my.jn W tm 50 ap.my W or 20 ap.my W

\section{Rosacer. Sp. 24-30.}

Siberia $\quad . . \quad$ B co Pall. ross. 1. t. 18

S. Europe 1640. B co Bot. rep. 579

Greece 1789. B co Bot. rep. 591

Crimea … B co Bot rep, 590

Hungary 1820 B co

England woods. S co Eng. bot. 298

Hungary 1819. G co Dend. brit. 64 or 4 my.jn W N. Amer. 1700. G co Mill. ic. 100 or 4 my.jn W. N. Amer. 1700. S co Schm. arb. t. 86

History, Use, Propagation, Culture,

blossomed, which they plant on little mounts for ornament, and dwarfs in pots for their apartments. It appears from Turner's Herbal, that the apricot was cultivated here in 1562; and in Hackluyt's Remembrancer, 1582 , it is affirmed, that the apricot was procured out of Italy by Wolfe, a French priest, gardener to Henry VIII. The fruit seems to have been known in Italy in the time of Dioscorides, under the name of Precocia, probably, as Regnier supposes, from the Arabic, Berkoch; whence the Tuscan, Bacoche or Albicocco, and the English Apricock ; or, as Professor Martyn observes, a tree when first introduced, might have been called a precox, or early fruit; and gardeners, taking the article $a$ for the first syllable of the word, might easily have corrupted it to apricocks. The orthography seems to have been finally changed to apricot about the end of the last century.

There are fifteen or twenty excellent varieties of apricot, besides the peach apricot, a large fruit supposed to be a hybrid between a peach and an apricot. The trees are generally budded on plum stocks, and always trained against walls. A pricots do not force freely.

1130. Chrysobalanus. From xevoos, gold, and Ganayos, an acorn; in allusion to the size, color, and form of its fruit. C. Icaco (the West Indian name) bears flowers and fruit not unlike the plum, which is sold in the markets of the West Indies, and eaten both raw and preserved. Both species grow well in a sandy loam. Large cuttings root best, taken off at a joint, and planted thinly in a pot of sand, without having their leaves injured, and a hand-glass placed over them. (Bot. Cult. 39.)

1131. Mespilus. In Greek $\mu \varepsilon \sigma \pi t \lambda \eta$, from $\mu \varepsilon \sigma \circ s$, half, and $\pi i \lambda \circ s$, bullet; the fruit resembling half a bullet or round ball. In French it is called nefle, from the Celtic naff, which also signifies truncate. M. Germanica, bears a turbinated berry, which is eaten raw in a state of incipient decay. It is little cultivated, but one or two trees are generally introduced in shrubberies or in complete orchards: There are one or two varieties besides the wild sort; what is called the Dutch medlar is reckoned the best. It is grafted on seedlings of the 
7057 Flowers sessile, Leaves ovate acuminate simply serrate, Petioles without glands 7058 Flowers sessile, Leaves ovate acuminate doubly serrate, Petioles with glands

7059 Leaves orbicular alternate, Flowers in loose racemes

7060 Leaves wedge-shaped hoary beneath, Stamens smooth, Flowers in large panicles

\section{DI-PENTAGYNIA.}

7061 Unarmed, Leaves lanceolate downy beneath, Flowers sessile solitary

7062 Leaves cuneate oblong woolly beneath, Petals roundish or oval, Stamens smooth, Fruit obl. ovate

7063 Spiny, Leaves cordate ovate cut angular smooth, Petioles and cal. glandular, Styles 5 7064 Spiny, Leaves cordate ovate cut angular smooth, Pet. and cal. without glands, Styles 5 7065 Spiny or not, Lvs. ovate ellipt. cut serrate somewhat plaited and hairy, Cal. villous, Sep. lin.-lanc. Styles 3

7066 Spiny, Leaves ellipt. unequally serr. smooth, Pet. and cal. glandular, Berries round with 5 seeds 7067 Spiny, Lvs. ov. wedge-shaped ang. smooth shining, Pet. stip. and cal. glandular, Berries oval with 5 seeds 7068 Sp ny, Lvs, obov, cuneiform angul. smooth shining, Pet. stip. and cal. glandular, Berries turbin. 4-seeded 7069 Spiny, Leaves cuneiform ovate cut serrate, Sepals lanc. cut the length of pet. Styles 5

7070 Spiny or not, Leaves obovate cuneiform smooth serrated, Cal. villous, Sepals subulate entire 7071 Spiny, Leaves obovate cuneirorm subsessile shining coriaceous, Sepals lanc. serrate, Styles 2

7072 Spiny, Leaves lanc. ovate crenate, Cal. of fruit obtuse

7073 Spiny, Leaves fascicled small very much narrowed downwards subspatulate trifid, Cal. downy 7074. Spiny, Leaves deltoid cut-lobed, Tube of calyx oblong with serrated sepals

7075 Leaves obtuse subtrifid serrated smooth, Pedunc. and cal. nearly smooth, Sepals lanc. acute

7076 Leaves obtuse 3-lobed serrated smooth, Pedunc. and calyx covered with wool

7077 Spiny, Leaves 5-cleft cut wedge-shaped, Lower lobes divaricating, Stipules half cordate

7078 Leaves obtuse subtrifid toothed pubescent, Sepals ovate

7079 Leaves pinnatifid hairy on both sides, Segments serrate, Flowers with bractes

7080 Leaves pinnatifid downy on both sides, Segments trifid

7081 Leaves ovate trifid serrated : at the axillæ of the veins beneath hairy, Pedunc. and cal. pubesc. Styles 5 7082 Leaves cordate ovate cut-lobed serrated, Lower lobes divaricating, Flowers corymbose

7083 Leaves lobed sinuate serrated : at the base truncate cuneate beneath villous, Calyxes villous, Styles 5

7084 Unarmed, Lvs. obovate obl. acute crenate toothed downy beneath, Rachis glandular above, Cal. downy 7085 Unarmed, Leaves obovate obl. acuminate serrated smooth beneath, Rachis glandular above, Cal. smooth

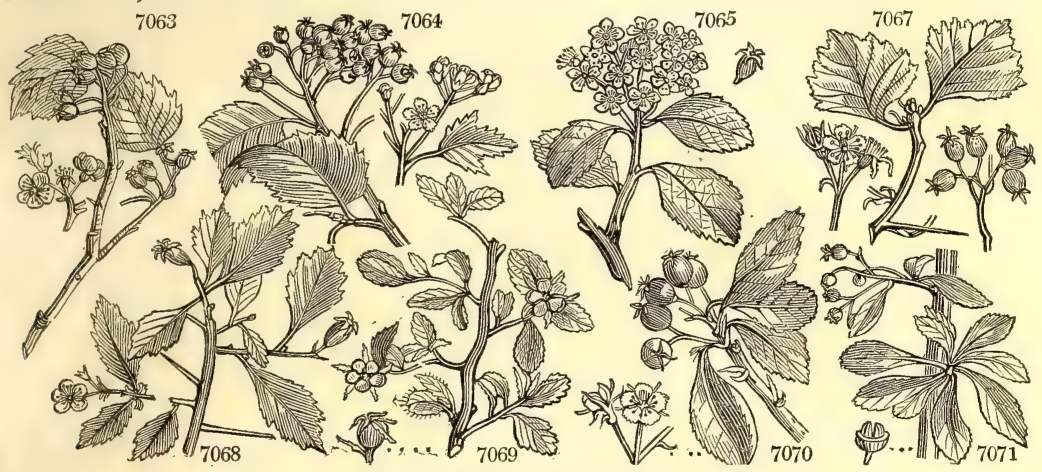

and Miscellaneous Particulars.

wild medlar, or on any other species of the same genus : often on the common thorn. The other species bears fruit similar to M. germanica, but more dry.

1132. Cratceus. From z९cros, force, on account of the extreme hardness of the wood of the original Cratægus, which appears to be what is now called Pyrus aria, the beam-tree. This is a very ornamental genus of small hardy trees, valuable for the neatness of their foliage, the earliness of their flowers in spring, and the rich colors of their berries in autumn.

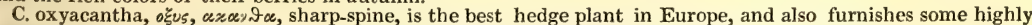
ornamental varieties, especially the double-blossomed and scarlet-blossomed.

The fruit of C. odoratissima is very agreeable. That of the Azarole (âl z'arour Arabic, according to Castel and John de Souza) is much esteemed in the South of Europe. In this country it rarely arrives at perfection.

1133. Pyrus. From the Celtic peren, the Anglo-Saxons made pere, the English, pear, the French, poire, ard the Latins, pyrus, or for the fruit, pyrum. From the Celtic word api, which also signified a fruit resembling an apple, the Greeks obtained $\propto \pi \omega \omega_{0}$, the English, apple, the Germans, apfel. To this day the French distinguish a tribe of small fruited apples by the name $a p i$.

P. malus, Pomme, Fr., Apfel, Ger, and Pomo, Ital., is the most popular of British fruits. None can be brought to so high a degree of perfection with so little trouble; and of no other are there so many excellent varieties in general cultivation, calculated for almost every soil, situation, and climate, which our island afford. Very good apples are grown in the Highlands and Orkneys, and even in the Shetland isles, (Caled Hort. Mem. vol. ii.) as well as in Devonshire and Cornwall; some sorts are ripe in the beginning of July, and others, which ripen later, will keep till June. Unlike other fruits, those which ripen latest are the best.

The tree attains a great age, is in general very prolific, and the timber is valuable for the turner, millwright 
7086 commúnis $W$. 7087 Pollvéria $W$. 7088 salicifólia $W$ 7089 nivális $W$. 7090 Málus $W$. 7091 spectábilis $W$ 7092 prunifólia $W$ 7093 baccáta $\boldsymbol{W}$. 7094 coronária $W$. 7095 angustifólia $W$. 7096 A'ria $W$.

7097 intermédia $W$.

7098 hýbrida Mönch 7099 pinnatífida $\boldsymbol{E}$. $\boldsymbol{B}$. 7100 doméstica $E$. B. 7101 aucupária $E . B$. 7102 americána $P h$.

7103 microcárpa $P h$.

7104 Chamæ Méspilus $I$ 7105 sinaica Thouin. -106 édulis $W$ 107 dioíca $W$.

1134. CYDO'NIA. Juss.

7108 vulgáris $W$.en.

7109 japónica $P . S$.

\& alba
7110 chinénsis Thouin.

common-Pear woolly-leaved Willow-leaved white-leaved Apple-trec

Chinese-apple Siberian-crab small-fruited sweet-sc. crab narrow-leaved white Beam-tr. Swedish Bm-tr. hybrid

True Service Mountain Ash 产 purple-berried small-fruited

Bastard Quince Mt. Sinai Meril. eatable dicecious QUINCE. common Japan white

1135 PHOTI'NIA Lindl ProTivis

7111 serruláta Lindl. smooth-leaved Cratagus glábra $\mathrm{B}$.

7112 arbutifolia Lindl. Mesp. bengalensis Hort.

Arbutus-lvd. doubtful

获

RAPHIOLE'PIS. Lind

7114 indica Lindl.

7115 rúbra

7116 phrostémon Lindl. long-stamened

7117 salicifólia Lindl. willow-leaved

1137. ERIOBOTRYA Lindl. Loquat. 7118 japónica Lindl. common
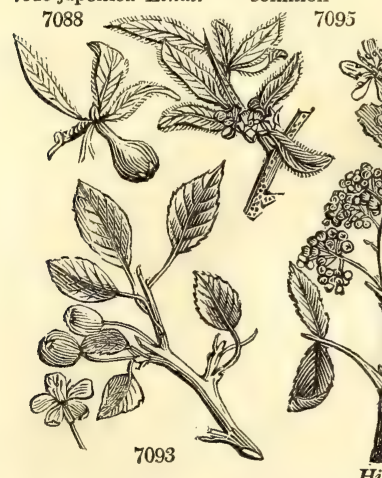

善

or 20 ap $\quad W \quad$ England woods. G co Eng. bot. 1784 or 20 my.jn W Russia 1780. G co Bot. reg. 514 or $6 \mathrm{my}$ W Austria ... $\quad$ L p.1 Jac. aus. 2. t. 107 fr 20 ap.my W Britain woods. G r.m Eng. bot. 179 fr 20 my Pk China 1780. G co Bot. mag. 267 fr 20 ap.my $\mathrm{Pk}$ Siberia 1758. G co Mill. ic. 2. t. 269 or 15 ap.my $\mathrm{Pk}$ Siberia 1784. G co Dend. brit. 51 or $20 \mathrm{my} \quad \mathrm{Pk}$ Virinia. 1724. G co Bot. mag 2009 or $20 \mathrm{my} \mathrm{Pk} N$ Amer 1750 G co Dend brit 132 tm 40 my.jn W Britain moi.w. G co Eng. bot. 1858 tm tm 40 ap.my W tm 40 my.jn W fr 30 my.jn w or 30 my.jn W or 15 my.jn W or 10 my.jn $\mathbf{W}$ or 8 my.jn W fr 20 my.jn W fr 10 ap.my W Rosacea. $S p .3-4$. Sweden 1789. G co …...... S co Mönch weis. t. 9 England rocks. S co Eng. bot. 2331

England moi.w. S co Eng. bot. 350 Britain moi.w. S co Eng. bot. 337 Canada 1782. L co Dend. brit. 54 N. Amer. ... L co Pyrenees 1683. L co Schm, arb. t. 87 Levant 1820. G co Dend. brit. 49

France 1816. G co Dend. brit. $5 \AA$

or 40 Austria 1573. L h.l Jac. aus. 4. t. 342 or 4 ja.d $\mathrm{S}$ Japan 1815. L r.1 Bot. mag. 622

fr 15 my.jn Pk China $18 . .18$ L Rosacere. $S p .3-5$.

I_f or 10 ap.jl W China 1804. C p.l Bot. mag. 2105

i_f or 10 jl.au W California 1796. G p.1 Bot. reg. 491

I $\downarrow$ J or 10 ... W W Nepal 1821. L p.1 Linn.tr. 13.t. 10 
7086 Leaves ovate serrated, Pedunc, corymbose

7087 Leaves serrated downy beneath, Flowers corymbose

7088 Leaves lin. lanc. hoary white with down beneath, Fl. axillary solitary subsessile

7089 Leaves ovate stalked entire silky beneath, Flowers corymbose

7090 Umbel sessile, Leaves ovate oblong acuminate serrated smooth, Claws shorter than cal. Styles smooth

7091 Umbel sessile, Leaves oval oblong serrated smooth, Claws longer than cal. Styles woolly at base

7092 Umbel sessile, Pedunc pubescent, Styles woolly at base, Leaves ovate acuminate

7093 Leaves equally serrulate, Pedunc. clustered, Apples like berries, Cal, deciduous

7094 Leaves cordate cut-serrate angular smooth, Pedunc. corymbose

7095 Leaves lanc. oblong shining tooth-serrated narrowed at base entire, Pedunc. corymbose

7096 Leaves roundish ovate cut serrate hoary beneath, Flowers corymbose

7097 Leaves ovate lanceolate cut-lobed toothed beneath snow-white, Flowers corymbose

7098 Leaves pubescent beneath pinnated with the last pinna very large pinnatitid and simple

7099 Leaves half pinnated downy beneath

7100 Leaves pinnated villous beneath

7101 Leaves pinnated smooth on both sides

7102 Leaves pinnated, Leaflets acute almost equally serrated and common petiole smooth

7103 Lvs. pinnated, Leaflets acuminate unequally cut serrated and common petiole smooth, Serratures bristly 7104 Leaves oval acutely serrated smooth, Fl. in corymbose heads

7105 Leaves ovate oblong entire somewhat downy, Peduncle simple downy corymbose

[mucronate

7105 Leaves ovate oblong entire somewhat downy, Peduncle simple downy corymbose

7107 Leaves oval serrated, Fl. solitary dicecious, Pet. linear the length of calyx

7108 Leaves downy deciduous

7109 Leaves smooth shining evergreen

7110 Leaves smooth deciduous

\section{Leaves oblong acute serrulate, Pedicels longer than calyx}

7112 Leaves oblong lanc. distantly toothed, Pedicels shorter than caly $x$

7113 Leaves lanceolate distantly serrated, Panicle hairy

7114 Raceme imbricated with persistent foliaceous bractes, Petals roundish

7115 than calyx

7116 Leaves long lanceolate, Stamens spreading longer than the calyx

7117 Leaves linear lanceolate, Sepals subulate much longer than stamens, Panicle contracted

7118 Leaves lanceolate serrated

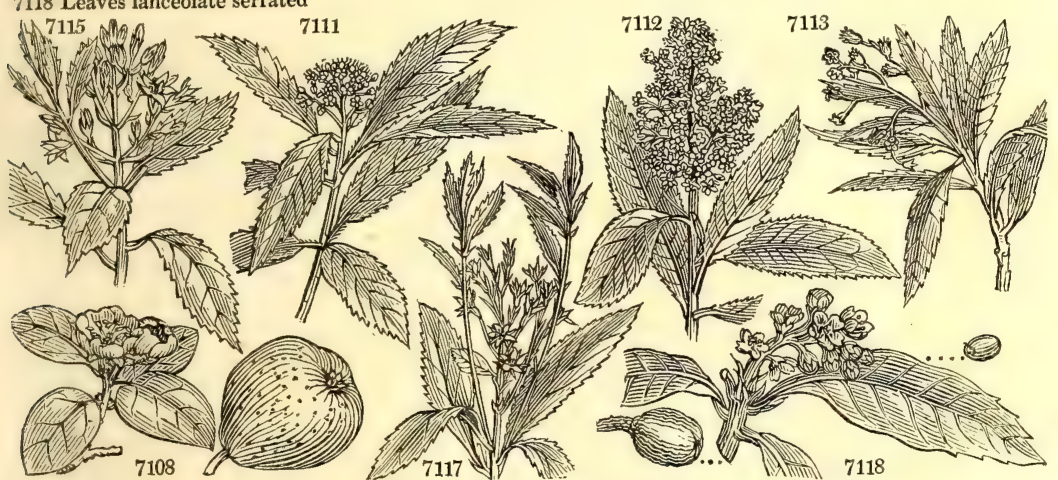

and Miscellaneous Particulars.

underneath, and they are generally profusely covered with blossoms and fruit. Of $\mathbf{P}$. domestica there are two varieties, the pear and apple-shaped, cultivated in some parts of France and near Genoa for their fruits. Those like the medlar and quince are not eaten till in a state of incipient decay. There are but few of the true service in English gardens, but the $\mathbf{P}$. hybrida and pinnatifida are common, and their fruit, which resembles that of the mountain ash, is sometimes made use of.

P. aucuparia and Americana are handsome trees for shrubberies, the former very popular in suburban gardens.

1134. Cydonia. So called from being native of the ancient town Cydon in the Island of Crete; or perhaps it may be a corruption of malus-cotonea, by which the Latins designate the fruit. C. vulgaris is a deformed low tree, sometimes cultivated for its fruit, which is a pome with a persisting calyx like the medlar. It is used as a marmalade for flavoring apple-tarts. It prefers moist loam, and is raised by layers. It is most in use, however, as a stock for the pear. C. japonica is a beautiful low bush, remarkable for the brilliancy of its blossoms, which vary from the richest scarlet to the most delicate blush color. It is hardy, and well adapted for single plants, upon grass, or for forming ornamental hedges in flower gardens.

1135. Photinia. So named, we believe, from $\omega_{5} \phi \omega \tau, s$, light, in allusion to the lucid surface of the leaves of the species. P. serrulata and arbutifolia are elegant shrubs, and nearly hardy. The latter succeeds perfectly against a south wall.

1136. Rayhiolepis. From eaфis, a needle, and $\lambda \epsilon \pi / s$, a scale, in allusion to the numerous, subulate, persistent bractex, which are mixed among the racemes of flowers. Pretty Chinese small shrubs, formerly known under the collective name of Cratægus indica.

1137. Eriobotrya. From eosov, wool, and Gorevs, a bunch of grapes, in allusion to the woolliness of its raceme This genus is excellently characterized by the structure of its seed, of which the radicula is retracted within the cotyledons, not exserted as in all the other genera of Pomacee. E. Japonica produces an agreeable fruit the cotyledons, not exserted as in all the other genera of Pomacea. E. Japonica produces an agreeable fruit
about the size of a gooseberry, of a fine yellow color, and, according to Sir Joseph Banks, as good as the mango. To ripen it with flavor, it requires the temperature of the stove, and comes into use in March. It may be grafted on any species of the genus, or on the hawthorn. 


\section{AMELAN'CHIER. Lindl. Amelanchier.
7119 vulgáris Lindl.}

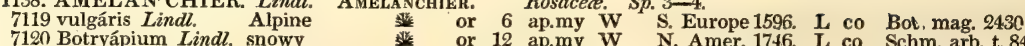

7121 ovális Lindl.

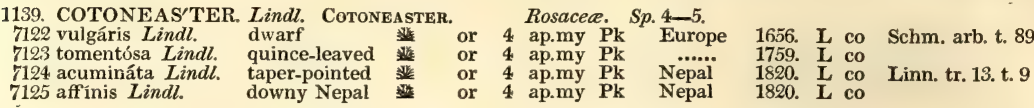

7125 affinis Lindl. $\quad$ downy Nepal 道 or 4 ap.my $\mathbf{P k}$ Nepal 1820. $\mathbf{L}$ co

1140. WALDSTE'INIA. $W$. WaLdsTeinia

Wosacea. $S p .1$.

1141. SPIRÁ'A. $W$.
7127 lavigáta $W$.

7127 lrvigáta $W$.

7128 salicifólia W.en.

ค alba

SPIREA. Rosacea. Sp. 23-34.

smooth-leaved 3 or 4 ap.jn $R$ Siberia 1774. L p.l Sch. arb. 1. t.49

willow-leaved or 5 jn.au Pk Britain moi.h. L co Eng. bot. 1468

white-flowered $\quad$ or 5 jn.au W N. Amer. ... L co Mil. ic. t.257.f.2

7129 carpinifólia $W$. en. Hornbeam-lvd,

7130 tomentósa $W$. tomentose

7131 alpina $W$. Alpine

7132 hypericifólia $W$. Italian May

7133 chamædrifólia $W$.

7134 ulmifólia $W$.

7135 betulifólia Pall.

7136 crenáta $W$

Germander-lvd.

Elm-leaved

Birch-leaved

Hawthorn-ivd.

7137 oblongifólia W.en. oblong-leaved

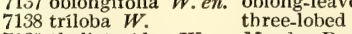

7139 thalictroides $W$.

7140 obováta $W$. en

7141 opulifólia $\dot{W}$.

7142 sorbifólia $W$

$\beta$ alpína

7143 bélla Sims.

7144 corymbósa Lodd.

7145 cratægifólia Link.

7146 Arúncus $W$

7147 Filipéndula $W$ $\beta$ pléna

7148 Ulmária $W$.

$\beta$ pléna

Meadow Rue-1v.

obovate-leaved

Gueld, Rose-lv.

pinnated

large-flowered

pretty

corymbose

Hawthorn-lvd.

Goat's-beard

Dropwort

t or 2 jn.

double-flowered $\Delta$ or $1 \frac{1}{2} \mathrm{jn} .0$

Meadow-sweet $\Delta$ or 2 jn.o

7149 lobáta $W$

double-flowered
palmated

$\begin{array}{lllll}2 & \text { jn.o } & \text { W } & \text { Britain } & \text { m.me. D co } \\ 2 & \text { jn.o } & \text { W } & \text { Britain } & \text { m.me. bot. } 960\end{array}$

2 jl.au R

N. Amer. ... I co Dend. brit. 66

N. Amer. 1736 . Sk p.l Sch arb. 1. t. 51

Siberia 1806. Sk p.1 Pall ros, 1, t. 20

N. Amer. 1640. L co Sch. arb. 1. t. 26

Siberia 1789. L p.1 Pall. ros. 1.t. 15

Carniola 1790. L p.l Jac. vin, 2. t. 140

N. Amer. 1812. L p.I Dend. brit. 67

Siberia 1739 , L p.l Sch arb 1 t 55

Hungary 1816. I p.l Pl. rar.h. 3.t.235

Siberia 1801. L p.l Dend. brit. 68

Siberia 1790. Sk p.1 Pall, ros. 1. t. 18

Hungary 1816. Sk p.l

N. Amer. 1690. L co Sch. arb. 1.t. 52

Siberia 1759. Sk co Sch. arb, 1. t, 58

Siberia 1817. Sk co Pall, ros, 1.t. 25

Nepal 1820. L co Bot. mag 2426

N. Amer. ?1819. L co Bot cab 671

1823. L co

Siberia 1633. D p.1 Pall. ros. 1, t. 26

Britain m. pas. D co Eng. bot. 284

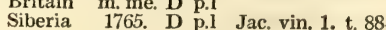

1142. GILLE'NIA. Mönch. Gillenia.

7150 trifoliáta Mönch. three-leaved

7151 stipulácea $W$. large-stipuled

Rosacee. $S p .2$.

1143. SESU'VIUM. $W$. Sesuvium.

7152 Portulacástrum $W$. Purslane-lvd

7153 séssile $P . S$.

7154 revolutifólium $W$.en, revolute-leaved $\frac{\Delta}{4}$

7154 revolutifólium W.en. revolute-leaved
7155 longifólium $W$. en. long-leaved
7156 répens $W$. en.

1144. AIZO'ON. $W$.

7157 canariénse $W$.

7158 glinoídes $W$.

7159 hispánicum $W$.

Arzoon.

Purslane-lvd.

hairy

Spanish

7160 lanceolátum $W . \quad$ spear-leaved

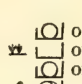

잉 or

2 jn.au R.w N. Amer. 1713. D p.l Bot. mag. 489

Ficoidece. Sp. 5-7.

jn.jl R.w W. Indies $1692, \mathrm{C}$ r.m La ill t. 434. f.1

3 jn.jl R.w W. Indies ... C r.m Plant, grass,

$1 \frac{1}{2}$ jl.au R.W S. Amer. $\ldots$... D 1.p Bot. mag. 1701

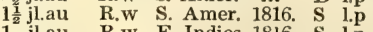

jl.au R.w E. Indies 1816. S l.p R. am.5.t.72.f.1

Ficoidece. $S p .4-16$.

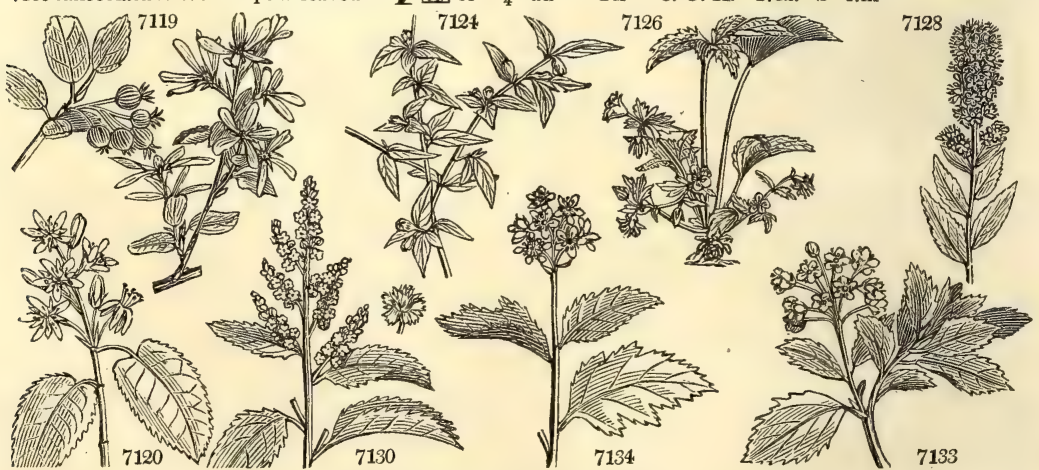

History, Use, Propagation, Culture,

1138. Amelanchier. According to Clusius, Amelancier is the old Savoy name of the plant. It has been adopted by Mr. Lindley as the title of a small group of plants nearly related to Pyrus, but curiously distinguished by the 10-cells of the ovary.

1139. Cotoneaster. Named in allusion to the cottony nature of the fruit and young branches of the most common species. Small inconspicuous bushes, with solitary pink flowers almost hidden among the leaves.

1140. Waldsteinia. Named by Willdenow, in honor of Franz de Waldstein, a distinguished German botanist. Plants with the aspect of Potentilla or rather Geum.

1141. Spircea. $\Sigma_{\pi \in \mathrm{r} \rho} \alpha$, signifies a cord. Spireon is Pliny's name for a plant the blossoms of which are used in garlands. That plant is thought to have been the Viburnum Lantana. This genus aftords some orna- 
7119 Leaves roundish elliptical acute pubescent beneath, Sepals smooth, Germen villous

7119 Leaves roundish elliptical acute pubescent beneath, Sepals smooth, Germen vill

7121 Leaves roundish elliptical acute smooth, Petals obovate, Sepals and germen pubescent

7122 Leaves ovate rounded at base, Cal. and pedunc. naked

7123 Leaves elliptical obtuse at each end, $\mathrm{Cal}$. and pedunc. woolly

7124 Leaves ovate acuminate a little hairy on each side, Cal. and pedunc. naked

7125 Leaves ovate attenuate at base, Cal, and pedunc. woolly

\section{Leaves radical stalked 5-lobed}

\section{Leaves lanceolate entire sessile, Racemes compound}

7128 Leaves oblong serrated smooth, Racemes decompound

7129 Leaves ovate elliptical acute at each end smooth coarsely serrated, Racemes spreading panicled 7150 Leaves lanceolate unequally serrate downy beneath, Flowers doubly racemose

7131 Leaves linear-lanceolate toothletted smooth, Corymbs lateral

7132 Leaves obovate entire, Umbels sessile

7133 Leaves obovate cut-toothed at end, Corymbs stalked

7134. Leaves ovate lanceolate doubly toothed, Corymbs stalked

7135 Leaves broad ovate cut-serrate smooth, Corymbs terminal compound leafy

7136 Leaves obovate acute toothed at end 3-nerved, Corymbs close stalked

7137 Leaves oblong lanceolate serrated at end and entire, Corymbs stalked

7138 Leaves roundish bluntly lobed toothed, Umbels stalked

7139 Leaves obovate obtuse 3-lobed, Umbels lateral sessile

7140 Leaves obovate obtuse at the end bluntly and unequally 3-nerved, Corymbs axillary sessile

7141 Leaves ovate 3-lobed serrated, Corymbs stalked

7142 Leaves pinnated, Leaflets even serrated, Flowers panicled

7143 Leaves ovate acute smooth serrated stalked glaucous beneath, Cymes pubescent

714t Leaves oblong bluntly and irregularly serrated, Flowers in dense corymbs

7145 Leaves obovate obtuse forwards doubly serrated smooth, Corymbs terminal compound, Flowers capitate

7146 Leaves supra-decompound, Spikes panicled, Flowers diøeciou

7147 Leaves pinnated, Leaflets even serrated, Flowers corymbose

7148 Leaves pinnated downy beneath, The end lobe larger and 3-lobed; the side ones undivided

7149 Leaves pinnated smooth, The end lobe 7-lobed; the lateral 3-lobed, Corymbs proliferous

7150 Stipules linear entire, Calyx tubular campanulate

7151 Stipules leafy ovate cut-toothed, Calyx campanulate

7152 Leaves spatulate oblong, Joints of stem tumid, Fl, stalked 7153 Flowers sessile, Leaves linear oblong flat

7154 Leaves linear lanc, revolute at edge, FI, terminal sessile

7155 Leaves lin. spatulate, Joints of stem equal, Fl, stalked

7156 Leaves lanc. spatulate, Joints of stem creeping filiform, Fl, stalked

7157 Leaves cuneiform ovate, Flowers sessile

7158 Leaves roundish cuneiform pilose, FI. sessile, Cal. hairy

7159 Leaves lanceolate, Flowers sessile apetalous

7160 Leaves lanceolate, Flowers panicled
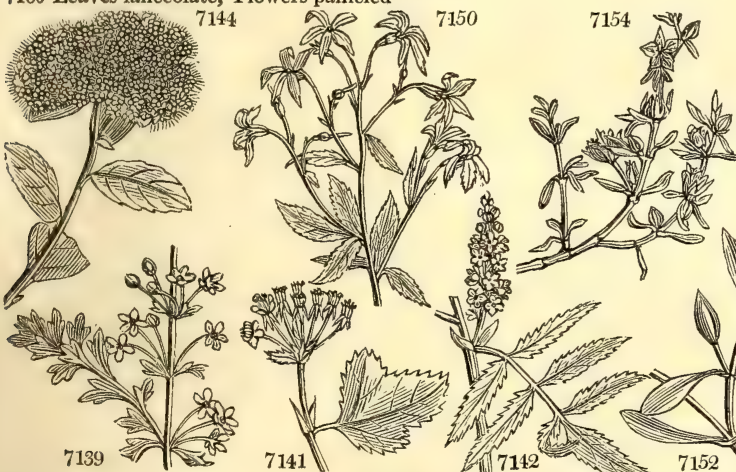
1145. TETRAgo'NiA. $W$. Tetragonia.

7161 expánsa $W$.

7162 crystállina $W$.

7165 Tetrápteris Haw. 7166 spicáta $W$.

7167 herbácea $W$.

7168 echináta $W$.

7169 lineáris Haw.

7170 obováta Haw.
7163 fruticósa $W$.

7164 decúmbens $W$.
N. Zeal. spinage cul 6 aus Diamond 2 jn shrubby winged-seeded ${ }_{\text {spiked un }} 2$ jl.s herbaceous Hedge-hog linear obovate 包 un $\frac{4}{4}$ my.au G iv un ${ }_{1 \frac{1}{2}} \mathrm{~s}$... trailing

Ficoidece. Sp. 10-16.

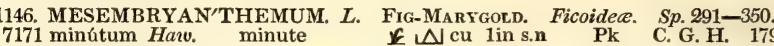

7172 minum Havo minute

7173 perpusíllum Haw. very small

7174 obcordéllum Haw. obcordate

7175 obconéllum Haw. conical

7176 ficifórme Salm. fig-like

7177 truncatéllum Haw. truncated

7178 fibulifórme Haw. cloth-button

$71-9$ uvæfórme Haw. berry-like

7180 nucifórme Haw. Nut-shaped

7181 testiculáre Ait.

Nut-shaped

eight-leaved

obtuse-cloven

7184 físsum Haw. cleft-leaved

7183 obtúsum Haw.

7186 magnipúnctum Sal. large-dotted

$$
\beta \text { unciale }
$$

smal

allied

hoary

aloe-like

dog-chap

wolf's-chap

fox-chap

bastard

white

tiger-chap

cat-chap

7193 álbidum $L$.

7194 tigrínum Haw.

7195 felinum Haw.

7196 mustellinum Haw. weasel-chap

197 murinum Haw.

7198 dolahriforme Haw. ha

7199 scapígerum Haw. hatchet-leaved

7200 carínans Haw.

7201 denticulátum Haw, toothed

\& glaúcum glaucous

$\gamma$ candidissimum fair

7202 robústum Haw. robust

7203 compáctum $\boldsymbol{H} . \boldsymbol{K}$. compact

7204 quadrífidum Haw. quadrifid

7205 bífidum Haw.

bifid

f $\triangle \mathrm{cu}$ lin s.n

N cu lin s.d

$\triangle \mathrm{cu} \frac{1}{6} \mathrm{f} . \mathrm{O}$

$\triangle \mathrm{cu}$ cu

$\Delta \mathrm{cu}$ lin f.o

fin $\mathrm{f}$.

\ $\mathrm{cu}$ lin ...

$\triangle \mathrm{cu}$ lin ...

$\Delta \mathrm{cu}$ lin.

$\mathbb{C u}{ }^{\frac{1}{8}} \frac{n}{n}$

$\triangle \mathrm{cu}^{\frac{1}{4} \mathrm{mr} \text {.ap } \mathrm{Pk}}$

cu

r

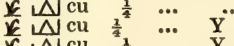

造 ${ }^{\frac{1}{8}}$...

$\triangle \mathrm{cu} \quad \frac{1}{8} \quad .$.

L $\triangle \mathrm{cu} \quad \frac{3}{4}$

iv $\mathrm{gr}{ }^{\frac{1}{4}}$ au.o

th

政 $\frac{1}{4}$

w $\triangle \mathrm{gr}$

N $\mathrm{gr}$

gr

$\checkmark \mathrm{gr}$

$\triangle \mathrm{gr}$

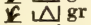

$\frac{1}{8} \mathrm{~s}$

i.

$\frac{1}{2}$ au.s

Nor

or

$\Delta$ or

N $\mathrm{N}$ or

w.

*

L $\Delta$ or

7206 bibracteátum Haw. double-bracted $L$ ros

7208 tuberculátum Mill. warted

7209 ramulósum Haw. small heron-be, w or

7210 pisifórme Haw. Pea-shaped $\mathbb{\Delta}$ or

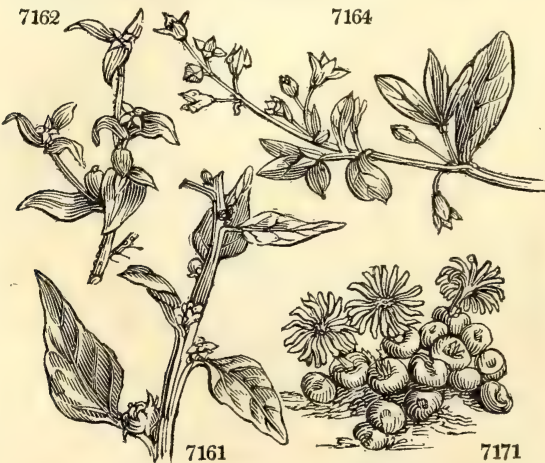

7171

$\frac{1}{4}$ ap

$\frac{1}{4}$ ap

$\frac{1}{4}$ ap

$\frac{1}{2} \mathrm{n}$

$\frac{1}{4} \mathrm{n}$

$\frac{x^{3}}{3}$ ap.n

$\frac{1}{4}$ ap

$\frac{1}{4}$ ap

$\frac{x}{3} \mathrm{mr} . \mathrm{n} \quad \mathrm{Y}$

7174

Pk C. G. H. 1795. C s.l Bot. mag. 1376

PaY C. G. H. 1816. C s.

c.

C. G. H. 1786. C s.l

$\mathrm{Pa}$ Y C G. H 1795. C s.l

C. G. H. 1795. C s.l

C. G H 1820 C sl Bur. dic. t.10, f.2

W. C. G. H. 1790. C s.l

C. G. H. 1774. C s.l Bot. mag. 1573

C. G. H. 1819. C s.1

C. G. H. 1792 , C s.1

C. G. H. $1776, \mathrm{C}$ s.

C. G. H. 1775, C s.l

C. G. H. 1822. C s.I

C. G. H. 1822. C s.l

C. G. H. 1822. C s.I

C. G. H. 1795. C s.l

C. G. H. 1819. C s.1

C. G, H 1717. C s.1 Plant. grass. 95

C. G. H. $\quad$ C s.1

C. G. H. 1795. C s.

C. G. H. $\ldots$ C s.l

C. G. H. 1714. C s.l Bot. mag. 1824

C. G. H. 1790. C s.l Bot. reg. 260

C. G. H. 1730. C s.l Plant. grass. 152

C. G. H. 1820. C s.1

C. G. H. 1790. C s.l

C. G. H. 1705. C s.1 Plant. grass. 6

C. G. H. 1823. C s.

C. G. H. 1818. C s.

C. G. H. 1793. C s.1

C. G. H. $\quad \cdots \quad$ C s.

C. G. 1795 C s.

C. G. H. 1795. C s.

C. G. H. 1780 . C $\quad$ s.

C. G. H. 1795. C $\quad$ s.1

C. G. H. 1803, C s.

C. G. H. 1732. C s.1 Di, el, t.186,î.,229

C. G. H. 1732. C s.1

C. G. H. 1791. C s.

C. G. H. 1796. C s.I

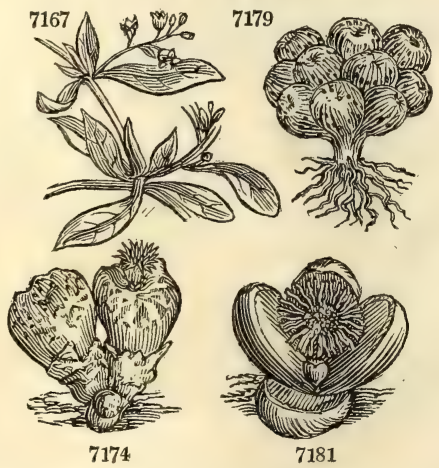

7181

1145. Tetragonia. From rereas, quaternary, and ravise, an angle, in allusion to the four angles of the bony pericarpium. The species are succulent trailers of no beauty, but possibly all fit to be used, like Chenopodium, as a spinage. T. expansa has been so used by Captain Cook when visiting New Zealand, and lately introduced for the same purpose in British gardens; as a summer spinage, it is as valuable as the orache, or perhaps more so. Every gardener knows the plague that attends the frequent sowing of common spinage through the the warm season of the year; without that trouble it is impossible to have it good, and with the utmost care it cannot always be obtained exactly as it ought to be, (particularly when the weather is hot and dry, from the rapidity with which the young plants run to seed. The New Zealand spinage, if watered, grows freely, and produces leaves of the greatest succulency in the hottest weather. Anderson, one of its earliest cultivators, had only nine plants, from which, he says, "I have heen enabled to send in a gathering for the kitchen every other day since the middle of June, so that I consider a bed with about twenty plants quite sufficient to give a daily supply, if required, for a large table." 
7161 Herbaceous, Leaves ovate rhomboid, Fruit with 4 horns

7162 Frosted, Leaves ovate sessile, Fruit not horned

7163 Shrubby, Leaves linear, Fruit winged

7164 Shrubby frosted, Leaves obovate, Fruit winged

7165 Procumbent, Leaves sessile lanceolate decumbent, Wings of fruit 8 alternately smaller

7166 Smooth herbaceous erect, Lower leaves ovate: upper lanceolate smooth, Fl, racemose

7167 Smooth herbaceous, Leaves ovate stalked, Fruit winged

7168 Herbaceous, Leaves rhomboid ovate, Fruit ubinate

7169 Leaves alternate linear revolute at edge with a dorsal line above

7170 Leaves alternate frosted obovate with winged decumbent stalks

\section{Stem none or very short, Root perennial, Leaves large.}

7171 Whitish polished unarmed, Flower with a long tube

7172 Smooth rather glaucous with branched confluent spots, Ovary exserted

7173 Smooth green with great confluent branched spots, Ovary included

7174 Glaucous, Spots branched confluent, Ovary included

7175 Green, Spots confiuent wart-like, Ovary included

7176 Pyriform glaucous retuse at end, Spots generally distinct green and obsolete

7177 Very depressed and rather glaucous, Spots nearly distinct, Ovary exserted

7178 Somewhat hoary and pubescent much depressed

7179 Nearly globose pale green berry-shaped with little dark scarcely confluent spots

7180 Glaucous smooth, Ends of the leaves unequally distinct flat above

7181 Leaves about 4 broadly ovate or parabolical half rounded expanded

7182 Leaves 6.8 oblong-ovate half round erect

7183 Green, Leaves unequally half rounded acinaciform obtuse

7184 Whitish, Leaves equally half rounded very blunt

7185 Stemless, Leaves rounded very smooth

7186 Leaves perfect about 4 clavate 3-cornered very thick glaucous with many large dots

7187 Leaves hoary at the base half rounded and thin upwards gibbous and keeled

7188 Stemless, Leaves entire half round green marbled at the end keeled 3-cornered

7189 Stemless, Lvs. glaucous towards the end and the bractes incurved and toothed, Pedunc. length of leaves

7190 Leaves glaucous, Marginal fringes numerous very deep

7191 Nearly steml. Lvs, glauc, towards end entire or with large teeth, Bractes entire, Pedun, longer than leaves

7192 Stemless smooth whitish, Lvs. half round entire at end keeled 3-cornered little thickened with a reclirved

7193 Stemless very smooth white, Leaves thick subulate 3-cornered obtuse with a point [point

7194 Green stemless, Leaves cordate ovate expanded marbled with white and with a deep fringe

7195 Stemless glaucous, Leaves deeply tooth-fringed obsoletely dotted with a cartilaginous keel at end

7196 Stemless green with clear spots, Leaves 3-cornered towards the end with a shortly toothed fringe

7197 Nearly stemless glaucous, Leaves with 3 rows of toothed fringe and small dots

7198 Leaves exactly hatchet-shaped, The old stem nearly six inches high and erect

7199 Leaves keeled 3-cornered green, Scape strong panicled 2-edged

7200 Leaves erect incurved keeled upwards long glaucous rugose with large dots

7201 Leaves very glaucous triquetrous compressed at the end with a dilated keel which is often toothletted

7202 Leaves obt, dotted with gibbous pustules at the base in the inside, Stem strong short decumbent branch 7203 Stemless, Leaves connate dotted half round at the end triquet. reflexed acute, F1. sessile, Cal. cylin. 6:fid 7204 Nearly stemless, Leaves hoary glaucous obtuse towards the end with a few spots, Cal. 4-fid

7205 Nearly stemless, Leaves glaucous very blunt with many dots, Cal. 2-4-fid

7206 Nearly stemless branched, Leaves subul. elong. dott. very glauc. Bractes 4 crossing shorter than scape

7207 Stemless, Leaves subulate elongated acute glauc. much dott. Bractes 2 longer than scape

7208 Like the last, but leaves half cylindr. connate warted outside

7209 Leaves obl. at the base inside with elevated pustules, Old stem three inches long decumbent

7210 Leaves papulose iced, the first pisiform, the next half round, Stem much branched corky

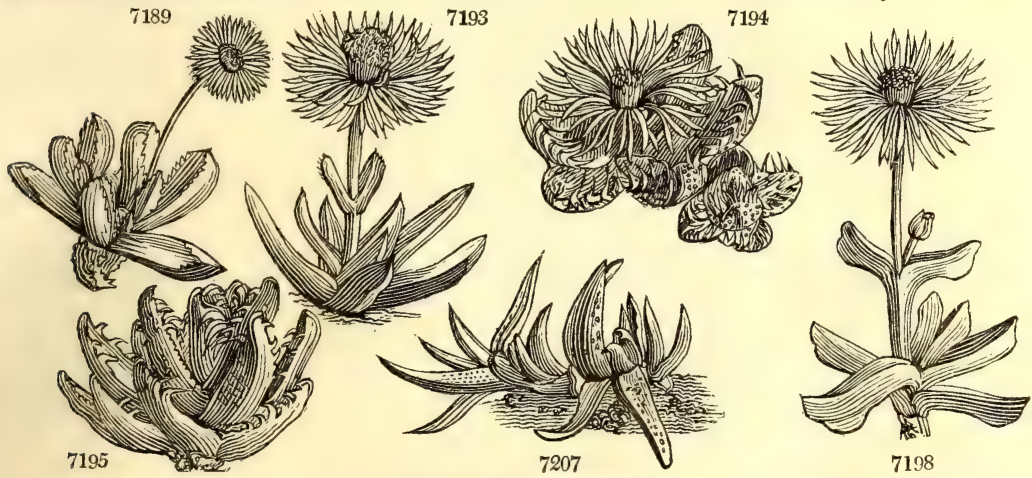

and Miscellaneous Particulars.

The seed should be sown in the latter end of March in a pot, which must be placed in a melon-frame; the seedling piants, while small, should be set out singly in small pots, and kept under the shelter of a cold frame, until about the twentieth of May, when the mildness of the season will probably allow of their being planted out, without risk of being killed by frost. The plants must be put out three feet apart in very rich soil. In five or six weeks from the planting, their branches will have grown sufficiently to allow the gathering of the leaves for use. In dry seasons, the plants will probably require a good supply of water. They put forth their branches vigorously as soon as they have taken to the ground, and extend before the end of the season three feet on each side.

1146. Mesembryanthemum. From $\mu \varepsilon \sigma n \mu \beta_{\rho} \iota$, the mid-day : on account of the flowers usually expanding at that time : the termination anthemum, which signifies flowering, is, to say the least of it, superfluous. The species of this extensive genus are singular, yet beautiful, and some even splendid plants. Their leaves are of odd shapes, and the habits of most of the sorts slovenly and insignificant, though some are grotesque; but the 
7211 monilifórme Haw. bracelet 7212 scalprátum Haw. great-tongue 7213 frágrans Salm. 7214 prepin'gue Haw. 7215 médium Haw. 7216 cultrátum Haw. 7217 lúcidum Mill. 7218 adscéndens Haw. 7219 pustulátum Haw. 7220 lóngum Haw. a depréssum B. M. $\beta$ declive Haw. $\gamma$ angus'tius Haw. Spurpuras'cens Haw. $\varepsilon$ uncátum Haw. है attol'lens Haw.

7021 linguætórme Haw. $\beta$ rufescens Haw. r reddish-green rubcruciatum Haw. subcruciate prostratum Haw. prostrate 17022 láturgens Haw. B breve Haw. 7223 depréssum Haw. B lividum Haw.

$722+$ cruciátum Haw. 7225 taurinum Haw. 7226 Sálmii Haw. B semicruciatum Sal halmian $\gamma$ angustifo $\gamma$ ang s brevifólum Haw or 7228 heterophýllum Haw. various-leaved $\triangle \Delta$ or 7229 ang $\beta$ pállidum Haw. pale

heterophýllum Jack. variable 7230 diffórme Haw. deformed 7231 bidentátum Haw. two-toothed $\beta$ május Haw. large

7232 semicylindricum $H a$. semi-cylindric 7233 gibbósum Haw. gibbous 7234 luteovíride Haw. yellow-green 7235 perviride $H$ aw. 7230 perviride Haw. 7236 pubéscens Haw. 7238 obsubulátum Haw. reverse-quilled 7239 cylindricum Haw. cylindrical 7240 teretifólium Haw. round-quilled 7241 teretiúsculum Haw. turgid

7242 bellidiflórum $I$ ß subulátum Mill. $\gamma$ viride Haw 7243 acútum Haw.

7244 punctátum Haw. 7245 diminútum Haw. diminutive
$\beta$ cauliculátum Haw. small-stemmed
$\mathbb{N}$
N Nor or ${ }^{\frac{1}{8}}$ mr.ap $\underset{Y}{\mathrm{~W}}$ \& $\mathrm{N}$ or vor \& $\mathrm{N}$ or L $\Delta$ or v $\Delta$ or L. $N$ or f $\triangle$ or N $\Delta$ or 사 or i $N$ or i $\Delta$ or $\checkmark \Delta$ or f $\Delta \mathrm{v}$ or E $\triangle$ or \& $N$ or N $N$ or v $\triangle$ or f $\Delta$ or f $\triangle$ or E $\Delta$ or $\checkmark \triangle$ or ne w L * ᄂ or a f or L $\longleftarrow$ or $\checkmark \Delta$ or $\checkmark \Delta$ or is 些 L w $4 \Delta$ or t 남 E $\triangle$ or * $\triangle$ or E $\triangle$ or 남 $\checkmark \Delta$ or $\checkmark \triangle$ or Daisy-flowered $\triangle$ or great-green $\triangle$ or Pea-green $\mathbb{N}$ or great-awl-leav. $\triangle \mathrm{N}$ or spotted awl-lvd. $\sim$ or $\frac{\Delta}{\Delta}$ or

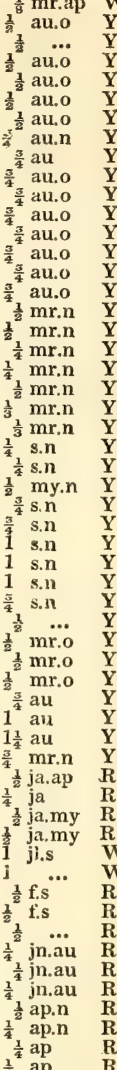

C. G. H. 1791. C s.1 C. G. H. 1714. C s.l Di. el. t.183.f.224 C. G. H. C. G. 1792 C s. C. G. H. C. G. H. $10 \ddot{2} 20$. C s.l C. G. H. 1732. C s. C. G. H. 1805. C s.l C. G. H. 1818. C s.l

C. G. H. 1725. C s.l Plant. grass. 71

C. G. H. $\quad \ldots \quad$ C s.l

C. G. H. $\quad \ldots$ C s.l

C. G. H. $\quad \ldots \quad$ C $s$.

C. G. H. 1819. C s.J

C. G. H. 1819. C s.l

C. G. H. 1819. C $\mathbf{\text { C.I }}$

C. G. H. 1732. C s.I

C. G. H. 1732. C s.l

C. G. H. 1820 . C s.l

$\begin{array}{llll}\text { C. G. H. } & & \text { C } & \text { s.l } \\ \text { C. G. H. } & 1819, & \text { C } & \text { s.l }\end{array}$

C. G. H 1620 C s.

C. G. H. 1802. C s.I

C. G. H. 1819. C s.l

C. G. H. 1792. C s.1

C. G. H. 1795. C s.I

C. G. H. 1818. C s.

C. G. H. 1818, C s.1

C. G. H. 1823, C s.l

C. G. H. 1819. C $\mathrm{s.1}$

$\begin{array}{llll}\text { C. G. H. } & 1819, & \text { C } & \text { s, } \\ \text { C. G. H. } & 1795 . & \text { C } & \text { s.l }\end{array}$

C. G. H. 1790 . C s.

C. G. H. 1790. C s,

C. G. H. 1790. C s.l Bot. rep. 540

C. G. H. 1732, C s.l Di. el, t.194.f.242

C G. H. 1818, C s.l

C. G. H. 1818. C s.l

C. G. H. 1732. C s.1 Di, el.t.194.f.241

C. G. H. 1780. C s.l

C. G. H. 1795 . C s.

C. G. H, 1792. C s.l

C. G. H. 1792. C s.1

C. G. H. 1717. C s.I Plant. grass. 5

C. G. H. 1796, C s.

C. G. H. 1792, C s.I

C. G. H. 1794. C s.

C. G. H. 1794. C s.l

C. G. H 1717 C s. Di el 189. 239

C. G. H. 1717. C s.l

C. G. H. 1717. C s.1

C. G. H. 1793. C s.I

C. G. H. 1793, C s.

C. G. H. 1789. C s.

C. G. H. 1789. C s.l
7246 lóreum Dill. 7247 diversifólium $L$. $\beta$ glaúcius Haw. $\gamma$ brevifólium Haw. Slate-virens Haw. $\varepsilon$ atro-virens Haw. 7248 decipiens Haw. 7249 dúbium Haw.

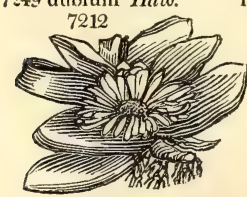

leathery-stlkd. $\sim \wedge$ or short horned-lv. $\triangle$ or $1 \mathrm{mr}$. glaucous short-leaved $\triangle$ or 1 au bright-green $\triangle \mathrm{N}$ or 1 au dark-green $\triangle$ or 1 au middle 1 or 1 at

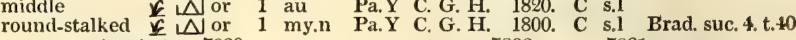

PaY C G H 1732 C s.l Di, el t 200 f 255 Pa.Y C. G. H. 1819. C s.I Di. el. t.198.f.252 Pa.Y C. G. H. 1726. C s.l $\mathrm{Pa}$.Y C. G. H. $\mathrm{H}$ C $\mathrm{C}$ s. Pa.Y C. G. H. $\quad \ldots$ C s.l Pa.Y C. G. H. $\quad$... $\quad$ C s.l Pa.Y C. G. H. 1820 . C $\begin{array}{lll}1800 . & \text { S.1 } \\ 72221\end{array}$

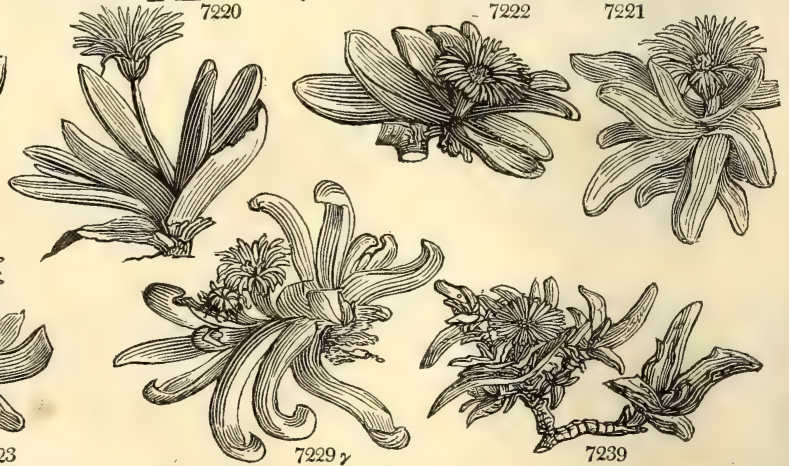

History, Use, Propagation, Culture,

fowers make ample amends by their profusion, the brilliancy of their colors, and the length of time the species continue in flower. Few are annual, fewer biennial, many are perennial, but most are shrubly, 
7211 First leaves connate spheroidal, next half round subulate very long recurved green 7212 Leaves sloping graver-shaped very broad thickest on one edge at the base inside pimpled, Fl sessile 7213 Nearly steml. Lvs. tongue-shaped thick; one convex blunt at end, the other with a long kecl, Fl. stlkd. frag. 7214 Leaves obliquely tongue-shaped pale green very soft, the younger ciliated pubesc. hooked inwards at end 7215 Nearly stemless, Lvs. tongue-shaped sloping 4-inches long, 1-broad cultrate, Pedunc. an inch long 7216 Nearly stemless, Lvs. distichous tongue-shaped at the edge and end cultrate. Fl. stalked 7217 Leaves long very green and polished, Pedunc. longer than calyx, Caps. small depressed 7218 Leaves broad tongue-shaped ascending obtuse green longer than veduncles

7219 Leaves tongue-shaped ascending 5-6-in. long, 3-11-lines broad, with large pimples at the base inside 7220 Leaves long tongue-shaped shining thinner, Flowers subsessile, Caps. large depressed

7221 Leaves unequally tongue-shaped thick green partially keeled, Caps. little elevated subsessile

7222 Leaves tongue-shaped obtuse thick often sloping and a little hollowed, Caps. large conical subsessile 7223 Prostrate, Lvs. narr. tongue-shaped obt. recurved depressed variously bent inwards at end, Caps. depressed 7224 Leaves lin. tongue-shaped half cylindr. very soft cruciate, Old stem three inches long 7225 Leaves bifarious obliquely crossed half round obt. very thick yellowish green incurv. Old stem 6 in. high 7226 Stemless, Lvs. $\frac{1}{2}$ cylin. subul, variously obliquely hooked blunt with broad smooth spots at base, Caps. flat [half included

7227 Lvs. crossing suberect or spreading half round subulate acute soft often pustulate at base, Ovary exserted 7228 Stemless, Leaves green deformed the upper longest 7229 Leaves linear linguiform half cylindrical very long

7230 Lvs, obliquely cruciate long variously obliquely deformed with one or more obscure teeth, Old stem 3-6-in. $7231 \mathrm{Lvs} . \frac{1}{2}$ cylin. thick soft with two large opp. fleshy teeth beyond the midd. at the end variously and obliquely [deformed 7232 Lvs, very narr 7233 Nearly stemless, Leaves yellowish green spreading ovate half cylindrical rarely keeled at end 7234 Stem weak two or three inches long, Lvs. obl. $\frac{1}{2}$-cylindr. upwards 3-cornered yellowish green 7235 Stem weak two or three inches long, Leaves half-cylindr. 3-cornered or subovate very green 7236 Leaves downy hoary or silky smooth

7237 Leaves subulate glaucous at the base above flat, Styles 8

7238 Leaves obsubulate thick obtuse green

7239 Leaves 3-cornered cylindr. subglaucous dotted 3 inches long. The old stem 3 inches closely branched

7240 Lvs. 4 in. long green roundish or cylindr. : the younger polished $\frac{1}{2}$ round very green the old stems 6 in. 7241 Leaves 3-cornered rounded very thick green dotted two inches long

7242 Leaves 3-cornered blunt with three rows of teeth at end, The old stem branched half shrubby

7242 Leaves half round subulate incurved with clear spots, Spots obsolete not wrinkled

7244 Leaves half round subulate incurved with clear spots, Spots large numerous with a white head

7245 Leaves half round subulate incurved with clear spots, Spots nearly middle sized with a little white point

\section{Cluster-leaved. Stem about a foot high decumbent perennial, Leaves in capitate clusters, Flowers} polygamous, Calyx 5-leaved.

7246 Lvs. capit. closely clustered $\frac{1}{8}$ cylindr. 3-cornered elong. recurv. somewhat glaucous, Stems roundish white 7247 Lvs, capitate closely clustered long 3-cornered half cylindr. glaucous or green, Stems angular red

7248 Lvs. somewhat clustered long $\frac{2}{2}$-cylindr 3-cornered minutely wrinkled, Stems prostrate with distant joints 7249 Leaves clust. longish broad erect half cylindr. 3-cornered shining, Joints close, Styles 12

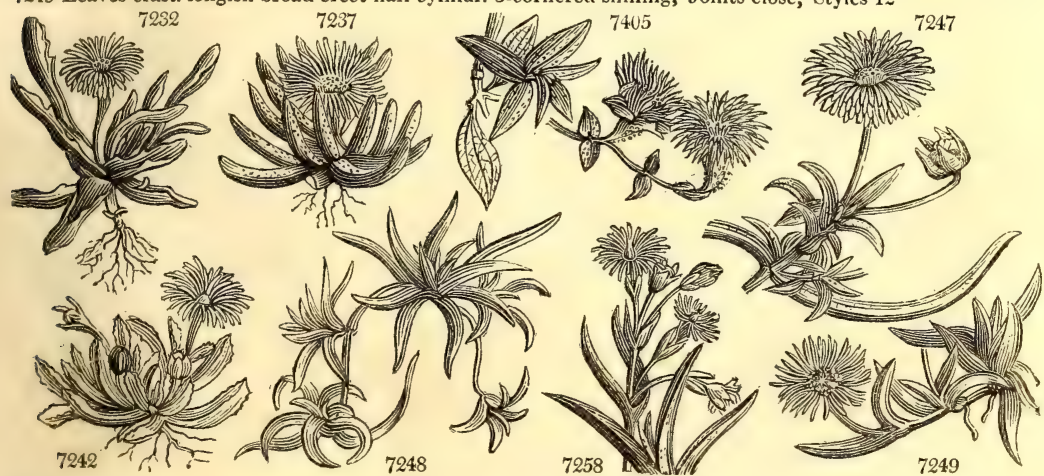

and Miscellaneous Particulars.

especially towards the base. Leaves mostly opposite, seldom alternate, thick, or succulent, of varicus forms. Flowers solitary, axillary, or extra-axillary, but more frequently terminating, The fruit is some- 
7250 corniculátum Haw. long-horned $\beta$ isophýllum Dec. equal-leaved 7251 procámbens Haw. procumbent 7252 tricolorum Haw. three-colored 7253 pugionifórme $L$. B cárneum Haw. $\gamma$ purpureum Haw. ¿ biénne Haw.

7254 capitátum Haw. 7255 brevicaúle Haw. 7256 corúscans Haw. 7257 elongátum Haw. $\beta$ minus Haw. $\gamma$ fusifórmc Haw.
1 $\triangle$ Jor 1 mr.my Pa.Y C. G. H. 1732. C s.l I $\mathrm{N}$ or 1 mr.my Pa.Y C. G. H. 1732. C $\checkmark \mathrm{N}$ or 1 mr.my Pa.Y C. G. H. 1820. C s.l N or 1 o Y.R C. G. H. 1794. C s.l long dagger-lvd. ${ }^{2}$ or 1 jl.s $\quad$ Pa.Y C. G. H. 1714. S s.l

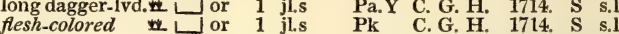
$\begin{array}{llllll}\text { purple } & \text { or } 1 & \mathrm{jl} . \mathrm{s} & \mathrm{Pu} & \mathrm{C} \text {. G. H. 1714. S s. }\end{array}$ biennial 1 or 1 jl.s Pa.Y C. G. H. 1714. S s.1 short dagger-lv. $L_{\text {or }} 1$ jl.s $\quad$ Pa.Y C. G. H. 1717. S $\quad$ s.l dwarf dagg. lvd.n L. or or $^{\frac{1}{4}}$ jl.s Pa.Y C. G. H. 1820. S s. glittering-dagg. $L_{\text {or }} 1$ jl.s Pa.Y C. G. H. 1812. S S.

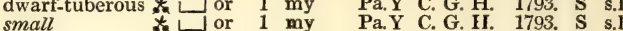
$\begin{array}{lllll}\text { small } & \text { or } & 1 & \text { my } \\ \text { fusiform } & \text { or } & 1 & \text { my }\end{array}$
Plant. grass. 108

Bot. mag. 2144

Dill. elth. f. 269

Bot. reg. 494

Bot. reg. 493

\begin{tabular}{|c|c|c|c|c|}
\hline 258 geminátum Jacq. & small & & or & \\
\hline simile Haw. & short-jointed & & or & \\
\hline 260 láxum $W$. & long-jointed & & or & \\
\hline nentósum Haw. & sarmentose & & or & \\
\hline caúle Haw. & stiff-stemmed & & or & my.jn \\
\hline lii Salm. & large-rough & & or & 1 my.jn \\
\hline tósum Haw. & threa & & or & ar.ap \\
\hline um Haw. & saw-leaved & & or & \\
\hline Haw & & & or & \\
\hline aúle Haw. & ked & & or & \\
\hline$s$ Haw. & & & or & \\
\hline ns Haw. & tat & & or & \\
\hline frme $L$. & eav. & & or & \\
\hline Haw. & & & or & U.s \\
\hline Haw. & po & & or & \\
\hline octum Haw. & lered & & or & \\
\hline éssum Haw. & co & & or & \\
\hline Haw. & & & or & \\
\hline tum Haw. & isy-floy & & or & \\
\hline & $\mathrm{Hc}$ & & or & $\mathbf{u}$ \\
\hline liátum Haw. & Les & & or & \\
\hline éscens Haw. & glat & & or & \\
\hline & Ro & & or & \\
\hline Haw. & vi & & or & $\mathbf{n}$ \\
\hline aterále $H a w$. & sided & & or & \\
\hline Haw. & ht-green & & or & $\frac{1}{2}$ jn \\
\hline$H . K$. & & & or & $\frac{1}{4} \mathrm{jl} . \mathrm{au}$ \\
\hline e Haw. & & & or & jl.au \\
\hline $\operatorname{lium} L$. & thick-le & & or & \\
\hline a Haw. & club-lea & & or & $\frac{2^{2}}{4} \mathrm{jn} . \mathrm{jl}$ \\
\hline & The & & & 1.au \\
\hline
\end{tabular}

$\begin{array}{llll}\text { C. G. H. 1819. C } & \text { s.l Jacq. frag. } 5 \mathrm{C}\end{array}$ C. G. H. 1819. C s.l C. G. H. 1820. C s. N. Holl. 1805. C s.l C. G. H. 1819. S s.l C. G. H. 1810. S s.l Jac. frag t. $51 . f 2$ C. G, H. 1732. C s.1 Di.el. t.212, f.273 C. G. H. 1795. C s.1 C. G. H. $\quad \ldots$ C s. C. G. H. 1802. C s. C. G. H. 1818. C s. C. G. H. 1818. C s.I $\begin{array}{llll}\text { C. G. H. 1714. C s.l } & \text { Bot. rep. } 80\end{array}$ C. G. $\mathrm{H}$. $\quad \ldots$ C C s.l C. G. H. 1802, C s.l C. G. H. 1811. C s. C. G. $\mathrm{H} . \quad \ldots \quad$ C s. C. G. H. $\quad \ldots$ C s.

C. G. H. 1768. C s.1 Plant. grass. 41 C. G. H. 1690. C s.l Di. el, t.212.f. 272 C. G. H. 1811 C s.1 Plant, grass. 89 N. Holl. 1804. C s.l V. Di. L. 1820. S s. N. Holl. 1804. C s.l N. Holl. 1791. C s.l C. G. H. 1821. C s. C. G. H. 1774, C s.l N. Zeal. 1773. C s. Di. el. 201.057 N. Holl. 1803. C s. C. G. H. 1810. S s.l

7282 forficátum $x$. 7283 geminátum Haw. scissar-leaved twin-shooted 7284 marginátum Haw. white-edged 7285 rostêllum Haw. little-beak

w

Pk C. G. H. 1758. C s.l Jac. vind, 1. t. 26 7286 perfoliátum Mill. great-perfoliate 1 or $1^{\frac{1}{2}}$ jn.au $\beta$ monacánthum Bradl.one-spined ${ }^{2}$ or 1 jn.au Pa.pu C. G. H. $\quad \ldots$ C. C

C. G. H. 1792. C s. W C. G. H. 1793. C s.l W.pk C. G. H. 1820. S s.1 Pa.pu C. G. H. 1714. C s.l 7287 uncinéllum Haw. small-hooked $\sqcup$ or 1 jn.au 7288 uncinátum Haw. lesser-perfoliate 7289 semidentátum Haw. slender-hooked w

jn.au Pa.pu C. G. H. 1819. C s.l 7290 víride Haw. green-perfoliatew 7292 cúrturn Haw. short-sheathed 3 május Haw. politum Haw. $\gamma$ politum Haw. large polished

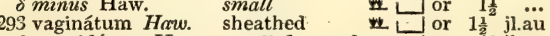

t.
Pa.pu C. G. H Pa.pu C. G. H 170. C s. Plant. grass. 54 w or $1 \frac{1}{2} \quad \cdots$ \& parvifórum Haw. small-flowered $\frac{1}{1}$ or $1 \frac{1}{2}$ jl.au W Pa.pu C. G. H. 1792. C s.l C. G. $\mathrm{H} . \quad \ldots \quad$ C C. G. $\mathrm{H} . \quad \ldots \quad$ C $\mathrm{s}$. C. G. H. C. G. H. 1802 .

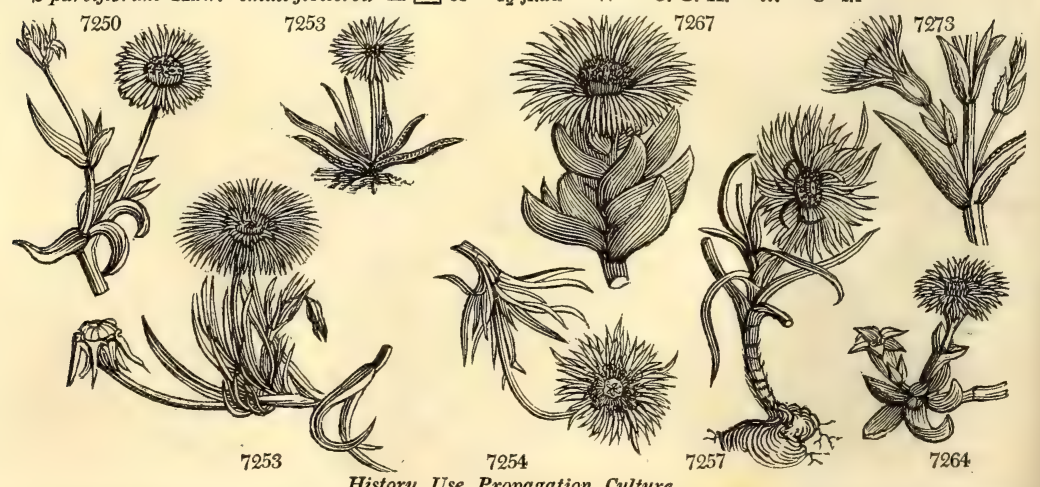

History, Use, Propagation, Culture,

times shaped like a fig. Linnæus arranged the species from the color of the flower; Haworth chiefly from the leaves. 
7250 Leaves clust. 3-cornered $\frac{1}{2}$ cylindr. very long glaucous incurved, Stems scarcely angular, Joints distant

7251 Leaves in pairs corniculate incurved $\frac{1}{2}$ cylindr. 3-cornered glaucous, Stems flexuose procumbent 7252 Leaves exactly cylindr. three inches long acute green, Styles 20

7253 Leaves glaucous about a foot long 3-cornered, Angles dilated with a broad furrow, Stem simple

7254 Leaves somewhat glaucous 6-7 inches long 3-cornered, Old stem simple

7255 Leaves green 3-4 inches long 3-cornered, Old stem two inches high simple erect

7256 Leaves dagger-shaped long glittering, Stem shrubby perennial

7257 Leaves glauc. about a span long bluntly 3-cornered channelled or half round, Root large tuberous fleshy

3. Trailers. Stems prostrate or creeping, angular, Calyx 5-leaved, Flowers polygynous, Leaves connate at base acutely 3-cornered.

7258 Branches long slender spreading, Lvs. equilateral 3-corn. green hooked a little outwards at end, F1. 3 or 2 7259 Lvs, equilateral 3-corn, glauc. much dotted straight at end lon, than joints, Edges not serr. Stems firm proc. 7260 Lvs. conn. comp. 3-corn. very green warted often short. than joints, Edges finely tooth. Branches very slen.

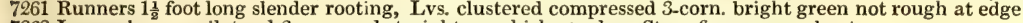
7262 Leaves long equilateral 3-cornered straight roughish at edge, Stem firm procumbent

7263 Leaves compressed 3-cornered large recurved serrulate very rough, Old stems firm decumbent [decum. 7264 Lvs. bright green clust. thick comp. 3-corn. acinacif. dott. lon. than joints with rough edges, Stems short 7265 Lvs. comp. 3-corn. acinacif. glauc. not serrated and scarcely cartilaginous at edge generally lon. than joints

7266 Lvs. comp. 3-corn. greenish rugose the edges with cartilaginous serratures generally shorter than joints

7267 Leaves acinaciform, Edges curled wavy rough

7268 Leaves acinaciform polished glaucous with entire cartilaginous edges 7269 Leaves acinaciform with the edges and keel rough and red

7270 Leaves compressed 3-cornered acinaciform and equilateral, Every edge roughish

7271 Old leaves equilateral 3-cornered green incurved three inches long blistered inside at base, Keel serrulate 7272 Leaves about two inches sharply 3-cornered, the old ones comp. with their keel upwards serrulate burnt 7273 Young lvs, incurved equilateral 3-cornered soft glauc. with a cartilaginous smoothish white edge, Styles 7 7274. Leaves acinaciform or compressed 3-cornered glauc. with a pink smooth cartilag. edge, Stems prostrate 7275 Leaves not equilateral 3-cornered greenish, Stems prostrate, Pedunc. terminal solitary winged, Styles 8 7276 Leaves equilateral 3-cornered greenish, Edges smooth cartilaginous, Stems weak prostrate

7277 Lvs. comp. 3-corn. acinacif, smooth dotted green, in the inside at the base blistered, Keel roughish at edge 7278 Livs. comp. 3-corn. acinacif, smooth dotted green, in the inside at the base blistered, Keel roughish at 7279 Leaves glaucous dotted 3-cornered incurved smooth

7280 Leaves 3-cornered not dotted smooth very green half cylindrical at base

7281 Leaves clustered expanded obsoletely 3-cornered clavate obtuse green with a little point

\section{\$4. Perfoliate. Leaves connate sheathing generally three-cornered upwards, usually hooked at end, Calyx 5-leaved.}

7282 Leaves 3-cornered compressed green prickly at end, Stem 2-edged decumbent

7283 Leaves erect white smooth 3-cornered thick sheathing beyond their middle with a cartilaginous edge 7284 Leaves 3-cornered subacinaciform white at edge, Keel dilated

7285 Leaves beaked connate half round subulate recurved dotted green, Stems prostrate branched knotty

7286 Leaves white thick hard dotted usually with about three spines beneath, Branches few

7287 Leaves whitish thick dotted recurved at end usually with one spine beneath, Branches many 7288 Leaves greenish with two spines beneath at the end

7289 Branches simple slender upright hard, Lvs. 3-cornered dotted white with 1-4 teeth at the back upwards 7290 Leaves quite entire very green smooth thick hooked backwards at the end

7291 Leaves acute-angled 3-cornered acum. incurved recurved green rough at edge

7292 Erect, Lvs. usually close recurved smooth green with the angles roughish above, sheath often sharp

[rough upwards

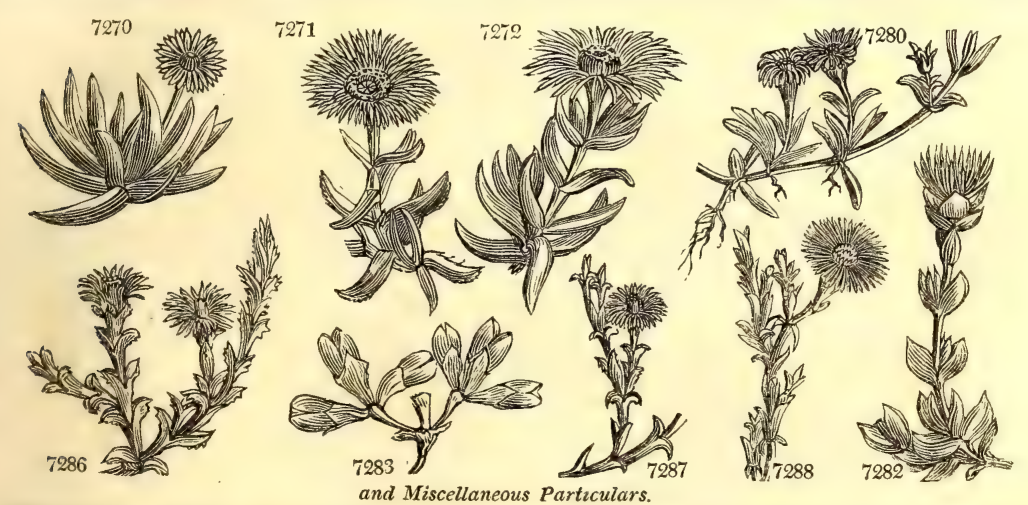

Most of the species are so hardy, that on dry rock-work, in a sheltered part of the garden, they will endure ordinary winters. Every thing, however, depends on kecping them dry. Among the hardy sorts may be reckoned 
7294 parviflórum Haw. 7295 rigidum 7296 tenéllum Haw. 7297 imbricátum $\boldsymbol{H}$. $\boldsymbol{K}$. $\beta$ médium Haw. viride Haw.

7298 multiflórum Haw. e minus Haw. r rubrum Haw. ¿ pátens W. $\varepsilon$ nitens Haw.

7299 umbellátum Haw. $\beta$ anómalum W. 7300 tumidulum Haw. $\beta$ minus Haw. 7301 foliósum Haw. 7302 lineolátum Haw. $\beta l a^{\prime} v e$ Thunb. r nitens Haw.

7303 serrátum $L$ 7304 gladiátum Jacq. 7305 heteropétalum Haw. 7306 glaucínum Haw. $\beta$ crássum Haw. 7307 mutábile Haw. 7308 inclaúdens Haw. 7309 cauléscens Mill. 7310 deltoídeum Haw. 7311 muricátum Haw. $\beta$ minus Haw. mall-flowered 2 or 3 au rigid $1 \frac{1}{3}$ au least-perfoliate $\bigsqcup^{2}$ or $1 \frac{1}{2}$ au imbricated or $3 \mathrm{jl}$ intermediate $\quad$ or $3 \mathrm{jl}$ green 3 or $3 \mathrm{jl}$ many-flowered or 3 jl.s small or 3 jls red-flowered 3 or 3 il shining $\mathrm{w}$ or 3 ... umbel-flowered or 3 jn.s anomalous or 3 ins tumid small leafy lined smooth shining

- $3 \mathrm{mr}$ wer $3 \mathrm{mr}$ we or 3 s v or $\frac{2}{2} \mathrm{jl} . \mathrm{s}$ L or $\frac{1}{2}$ jl.s

saw-keeled L purple-serrate various-petaled or 2 my.au Pk

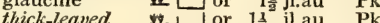
changeable 2 or $1 \frac{1}{2}$ jl.s $\quad$ Pk open-flowered $1 \frac{1}{2} \mathrm{jn} . \mathrm{s}$ $\begin{array}{llll}\text { open-flowered or } 1 \frac{1}{2} \text { jn.s } & \mathbf{P k} \\ \text { smooth delta-lv. }\end{array}$ smooth delta-lv. $\omega_{-}$or $1 \frac{1}{2} \mathrm{my} . \mathrm{jl}$ great delta-lvd. less $1 \frac{1}{2}$ my 7310 microphýllum Haw, small-leaved 7313 mucronátum Haw. mucronated 7314 pygmæ'um Haw. pigmy 7315 pulchéllum Haw. neat \& revolutum Haw. revolute w. or ${ }^{2}$ or 然 or ${ }^{\frac{1}{4}}$ my 2. or L or $\frac{1}{4}$ ap 4. $\square$ or ${ }^{\frac{1}{4}}$ ap

7316 máximum Haw. 7317 lunátum $W$. 7318 falcátum $L$ 7319 decúmbens Haw. 1320 incurvum Haw. $\beta$ dilátans Haw. pállidius Haw. $\delta$ densifólium Haw. є róseum W. 7321 confértum Haw. 7322 falcifórme Haw. 7323 glomerátum $\boldsymbol{L}$. 7324 infléxum Haw. 7324 infléxum Ha 7326 versícolor $H a w$. 7327 retrofléxum Haw. 7328 imbricans Haw. 7329 defléxum $\boldsymbol{H}$. $\boldsymbol{K}$. 7330 leptáleon Haw. 7331 polyánthon Haw. 7332 fléxile Haw.

7333 polyphýllum Haw. 7334 violáceum $D e c$ 7335 emarginátum $L$. 7336 dilatátum Haw. 7337 virgátum Haw. 7338 bracteátum Haw. 7339 ánceps Haw. $\beta$ pállidum Haw.

4 Lor $1 \frac{1}{2}$ mr.au Pk

pallid spreading $3 \mathrm{jl.s}$

W C. G. H. 1800. C s.l

W C. G. H. 1793. C s.

W C. G. H. 1792. C s.1

W C. G. H. 1792. C s.l

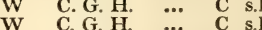

W C G H $170 \%$ C

W C. G. H.

$\begin{array}{llll}\text { C. } \mathrm{G} . \mathrm{H} . & \ldots & \mathrm{C} & \mathrm{s} .1 \\ \text { C. } \mathrm{G} . \mathrm{H} . & \cdots & \mathrm{C} & \mathrm{s} .1\end{array}$

$\begin{array}{llll}\text { C. G. } H . ~ & \text { H. } & \text { C } & \text { s. } \\ \text { C. G. H. } & 1820, & \text { C } & \text { s. }\end{array}$

C. G. H. $\quad$.. C C.

W C. G. H. 1727. C $\quad$ s.l

Pk C. G. H. $\quad$ Cö C $\quad$ s.l

C. G. H. 1802. C s.

C. G. H. 1820. C s.

C. G. H. 1802. C s.

C. G. H. 1819. C s.l

C. G. H. 1819. C $\quad$ s.l

C. G. H. 1707. C s.I Dil.el.t.192.f.238

C. G. H. 1792. C s.

C. G. H. 1794. C s.l

C. G. H. C

C. G. H. $\quad \ldots \quad$ C s.l

C. G. H. 1702 . C s.1 Plant. grass, 60

C. G. H. 1805. C s.1 Bot. rep. 388

C. G. H. 1731. C s.1 D.e.t.195.f.243-4

C. G. H. 1731. C s.l Plant.grass.53

$\begin{array}{llll}\text { C. G. H. 1731. C s.1 } & \text { D.e.t.195.f.245-7 }\end{array}$

C. G. H. C. C s.l

C. G. H. 17005, C

C. G. H. 1794, C s.l

C. G. H. 1805. C s.l

C. G. H. 1793. C s

C. G. H. ... C S.I

$\begin{array}{lllll}\text { C. G. H. } & \text { 1787. C } & \text { s.l } & \text { Bot. reg. } 358\end{array}$

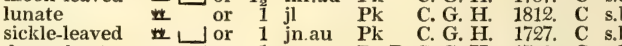

decumbent 1 or 1 my.o Pa.R C. G. H. 1759. C s.l

incurved $1 \frac{1}{2}$ jn $\quad$ or $\quad$ C. G. H. 1802. C s.l

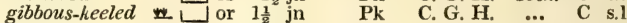

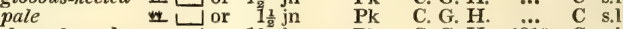

dense-leaved $L_{\text {or }} 1 \frac{1}{2} \mathrm{jn} \quad \mathrm{Pk}$ C. G. H. 18019. C s.l

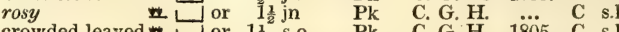

crowded-leaved $L^{-}$or $1 \frac{1}{2}$ s.o $\quad$ Pk $\quad$ C. G. H. 1805. C s.I

sickle-shaped 2 or $1 \frac{1}{2} \mathrm{jl}$,au Pk C. G. H. 1805. C s.

$\begin{array}{llllll}\text { clustered } & \text { or } 1 \frac{1}{2} & \text { jn.au } & \text { Pk } & \text { C. G. H. 1732. C s.l }\end{array}$

inflexed w or 1 jn.au Pk C. G. H. 1819. C s.l

scabrous or $1 \frac{1}{2}$ jl 1 Pk C. G. H. 1731. C s.

changeable-fl. $\square$ or 1 my.au Pk C. G. H. 1795. C s.l

white-barked $L^{-}$or $1 \frac{1}{2}$ my.o Fk C. G. H. 1794. C s.l

imbricating ${ }^{-}$or 2 my.o Pk C. G. H. 1818. C s.

deflexed $L_{\text {L }} 1$ jl.o or Pk C. G. H. 1774. C s.

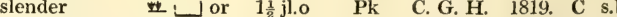

copious-flower, or 1 au Pk C. G. H. 1803. C s.I

flexile J or $1 \frac{1}{2}$ au Pk C. G. H. 1820 C s.1

many-leaved $L$ or 2 jn.o Pk C. G. H. 1819. C s.l

violet or 2 jn.o Pu C. G. H. 1820. C s.l

notch-flowered or 2 jn.au Pk C. G. H. 1732. C

twiggy

bracted we Y C G H 1774. C s.

two tod or $1 \frac{1}{2}$ jl.o
L 1 or $1 x^{2} \mathrm{~s}$.

$\begin{array}{lllll}\text { Pk } & \text { C. G. H. } & \text { 1811. } & \text { C } & \text { s.1 } \\ \text { P.Pk } & \text { C. G. H. } & \text { 1819. C } & \text { s.1 }\end{array}$

Dill. elt. f. 274

Dill, elt. f. 251

Bot. cab. 25

310
D.e. t. 213. f. $275-6$

Dil.el.t.197.f.250

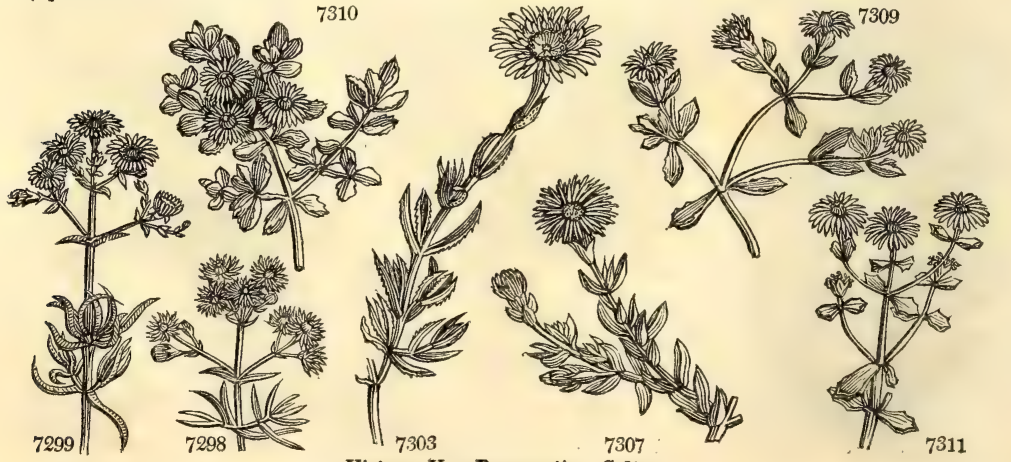

History, Use, Propagation, Culture,

M. hispidum, striatum, barbatum, crassifolium, glaucum, uncinatum, corniculatum, \&c. Hardy, and yet shewy sorts, are M. inclaudens, aurantium, perfcliatum, deltoides, barbatum, \&c. These will grow and 
7294 Leaves half an inch long smooth suberect, Keel not serrulate, Stem three feet high and branches erect 7295 Lvs. about three lines long horiz, and sheaths smootb, Keel rough at end, Branches very stiff and spread. 7296 Lvs. 3 lines long and more spreading thin and sheaths rough at edge, Branches filiform decumbent 7297 Lvs. somewhat compressed 3-cornered glauc. about one inch long, Branches many erect, Cal, turbinate

7298 Leaves somewhat compressed 3-cornered glaucous and the branchlets spreading

7299 Leaves distant roundish somewhat glaucous roughish with dots, Sheaths tumid at end 7300 Leaves remote greenish smooth about an inch and half long recurved at end, Sheaths tumid at end

7301 Leaves somewhat glaucous smooth clustered obtuse an inch long with a recurved point 7302 Leaves connate incurve-recurved blunt, Keel roughish at end with a sheathing line at base

\section{Delta-leaved. Leaves more or less deltoid or hatchet formed. Flowers pink.} 7303 Leaves subulate 3-cornered dotted with the keel serrated backward 7304 Leaves glaucous compressed 3-cornered gladiate, Keel cartilaginous torn, Petals much longer than calyx 7305 Lvs. clust. not dotted glauc. shortly falcate gladiate, Angles cartilag. Petals much shorter than calyx 7306 Lvs. clust. compressed 3-cornered shortly acinaciform glauc. entire dotted with a cartilaginous edge

7307 Leaves distinct clust. equilaterally 3-corn. shortly acinaciform green dotted with a cartilaginous edge 7308 Lvs. subdelt. smooth very green with a gibb. entire keel, Pet. not closing : the inner imbricate very short 7309 Leaves clustered glaucous long 3-cornered deltoid, The sides not toothed, Keel entire

7310 Leaves clust. very glauc. 3-corn, deltoid toothed in three rows, Keel of the bractes and sepals entire 7311 Leaves clust. deltoid with the bractes and sepals 3-cornered glaucous toothletted in three rows

7312 Leaves 3-corn. acuminate awned green blistered inside at the base, Branches much clustered 7313 Leaves obl, ovate acute glaucous 3-corn. with a little white point at end

7314 Leaves connate at base oblong ovate half round not pointed, the winter leaves joined almost to the end 7315 Leaves acute equilaterally 3-corn. cymbiform grey obsoletely dotted with a downy fringe and recurv, foint

\section{\$. Triquetrous. Leaves more or less 3-cornered distinct. Cal. 5-leaved. Styles 5.}

7316 Leaves large clustered much compressed 3-corn. incurved very glaucous, Stem woody erect bushy 7317 Leaves small much clust. somewhat connate compressed 3-corn. closely incurved, Branches clustered 7318 Leaves minute distinctly compressed 3-cornered falcate, Branches numerous filiform

7319 Leaves much compressed 3-corn. very glauc. attenuate at each end incurved, Branches much clustered 7320 Leaves compressed 3-corn. very glaucous attenuate at each end acinaciform, Stem erect

7321 Leaves 3-corn. clust. robust incurved very glaucous, Stem erect much branched 7322 Leaves much clustered thick acinaciform falcate with large spots glaucous

7323 Lvs. bluntly 3-corn. comp. glauc. incurv. atten. at each end, Pedunc. and branches erect filiform comp. 7324 Lvs. clustered falcate inflexed from 3-cornered half round compressed subglaucous smooth

7325 Leaves subtriquetrous green shining warted very rough, Sepals ovate acuminate, Petals crenate at end 7326 Leaves subtriquetrous glaucescent warted very rough, Sepals ovate-acuminate, Petals two toothed at end 7327 Leaves subtriquetrous very glaucous rough, Sepals and petals distant reflexed, Stamens clust. Bark white 7328 Erect woody, Leaves lin. obsoletely 3-corn. smoothish glauc. white imbricated at the ends of old branches 7329 Leaves subtriquetrous glauc. roughish attenuated downwards, Stems clust. deflexed, Pet. very numerous 7330 Leaves subtriquetrous glauc. attenuated upwards smooth, Keel roughish, Branches distant filiform 7331 Leaves small glauc. 3-corn. rough, Branches bushy clust. The young bark brown, Flowers panicled 7332 Leaves small often longer than the joints but inwards by pairs glauc. 3-corn. obtuse smooth

7333 Leaves much clust. strong incurved-recurved clavate compressed dotted glaucous, Branches bushy

7334 Leaves compressed bluntly 3-corn. roughish with dots glaucous, Sepals like spines spreading

7335 Leaves subglaucous subtriquetrous rough, Calyxes spiny, Petals deeply emarginate

7336 Leaves distinct remote subrecurved triquetrous much comp. dotted glauc. Keel gibbous above middle

7337 Leaves distinct distant triquetrous compressed acute subglaucous dotted, Branches twiggy

7338 Leaves green, Bractes 4 broadly ovate keeled embracing the calyx, Pet. white at base, Branches fuscous 7339 Branches decumbent 2-edged brown, Leaves acinacif. 3-corn, with sides membranous downwards, Dots

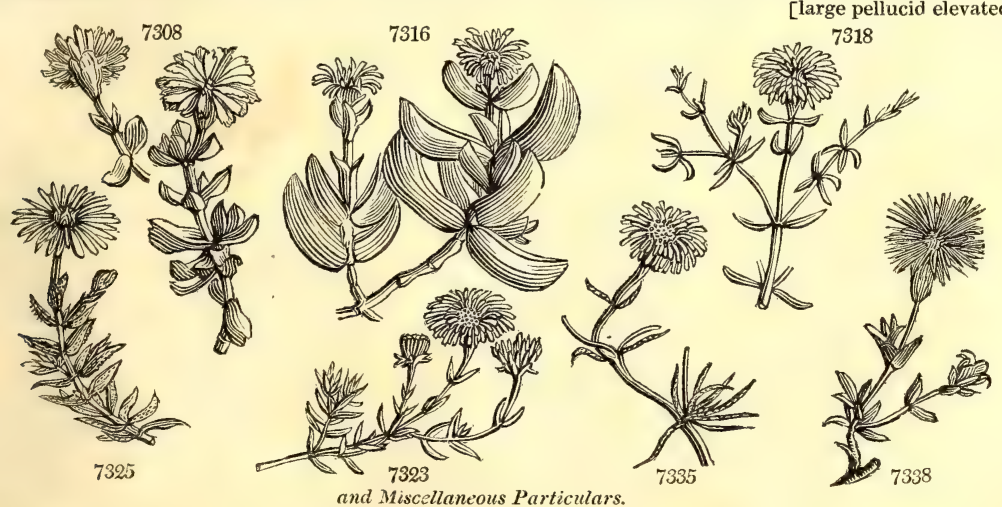

flower vigorously if planted in a bed in the open air and protected during winter, or if planted in a common pit, and matted over duxing frost. 
$73+0$ grácile Haw. stellátum Haw.

$73+1$ radiátum Haw.

$73+2$ compréssum Haw. 7313 jútilum $73+4$ ásperum Haw. $\beta$ caruléscens Haw. 7345 formósum Haw. 734 spectábile Haw. $73+7$ conspicuum Haw. $73+8$ blándum Haw. $73+9$ curviflórum Haw. 7350 aúreum $L$.

7351 cymbifólium Haw. 7353 glaúcum $L$

7354 strictum Haw.

7355 cymbifórme Haw. 7356 granifórme Haw. 7357 mólle $H$. $K$

\section{starry}

4. Jor $1 \frac{1}{2}$ au.n

rayed rough

blue

white-eyed showy

dark-showy bland

curve-flowered golden-flower'd

\begin{tabular}{|c|c|c|}
\hline NL & & $1 \frac{1}{2}$ au.n \\
\hline *L & or 1 & $\frac{1}{2} \frac{1}{2}$ jl.s \\
\hline & or & \\
\hline & or 1 & ... \\
\hline & $\begin{array}{l}\text { or } \\
\text { or }\end{array}$ & $i^{2}$ aus \\
\hline & or & 1 my.au \\
\hline & or & \\
\hline & or & $1 \frac{1}{2} \mathrm{jn}$ \\
\hline & or & \\
\hline & or & mr.o \\
\hline$\frac{1}{4}$ & or & 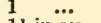 \\
\hline$\frac{w}{w} L$ & or & $1 \frac{1}{2}$ jn.au \\
\hline & or 1 & $1 \frac{1}{2} \quad$ jn.jl \\
\hline$\frac{1}{21}$ & or & $1 \frac{1}{2}$ \\
\hline & or & $\frac{\frac{2}{3}}{3}$ S.0 \\
\hline & & \\
\hline
\end{tabular}

C. G. H. 1794. C s.l ort-leaved glaucous-leav'd erect boat-shaped grain-leaved soft-leaved

C. G. H. 1732, C s.l D.R C. G. H. 1792. C s.I ... C. G. H. 1818. C s.l C.. C. G. H. 1820. C s.I C. G. H 1787 C si C. G. H. 1822. C s I C. G. H. 1793. C s.l C. G. H. 1795, C s.l C. G. H. 1793, C s. C. G. H. 1774. C s.l 7352 aurántium Haw.

compressed spreading Pk C. G. H. 1811. C s.l s.1 Bot. mag. 396 C. G. H. 1810. C s.l Bot. reg. 582 C. G. H. 1818. C s.l C. G. H. 1750. C s.l Bot. mag. 262 C. G. H. 1696. C s.l Plant. grass. 146 C. G. H. 1727. C s.I Brad.suc. 2.t.20

C. G. H. 1696. C s.1 Bot. mag. 59 scarlet-floweredwe $ـ$ or $1 \frac{1}{2}$ my.s S two-colored $1 \frac{1}{2}$ or 1 or $1 \frac{1}{2}$ Or spreading 1 or 1 my.s or small unequal-cuppediw or $1^{\frac{1}{2}}$ my.s Or slender-leaved $\mathbf{z}$ or 1 jn.s S

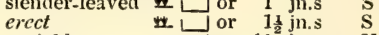
variable w or $1 \frac{1}{2} \mathrm{jn}$.au thorn-leaved ${ }^{2}$ or 1 s.o hooked 4 or 1 s.o crooked-leaved or 10 bent-leaved in or $1 \frac{1}{2} \mathrm{O} \quad \mathrm{Pk}$

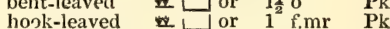
thread-stalked \begin{tabular}{lll} 
or & 1 & f.mr \\
\hline
\end{tabular} thorny $\square$ or $1 \frac{1^{2}}{2}$ jn.s Pk upright-shrub. $\amalg$ or $1 \frac{1}{2}$ my.jn Pk coral $\sqcup$ or 1 my.jn Pk long-calyxed $\underbrace{\circ}$ or 1 my.jn Pk Haworth's $\square$ or 1 ja.jn $\mathrm{Br}$ white-wooded $\longleftarrow$ or spot-leaved ${ }^{2}$ or $1 \frac{1}{2} \mathrm{~m}$ my.jn Y Decandolle's $\sqcup$ or $1 \frac{1}{2}$ my.jn Y purple and saff, or 1 aus $\mathrm{Pu}$

737 l

7374 verruculatum

$\beta$ Candóllii Pl. gr.

púrpuro-cróceum Haw.

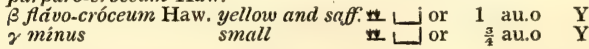

C. G. H. 1732, C s.I Di. el, t.202.f.258

C. G. H. $\quad \ldots$ C $\mathrm{s}, \mathrm{l}$

C. G. $\mathrm{H} . \quad \ldots \quad$ C $\quad$ s.l

C. G. H. 1716, C s.1 Brad, suc. 1. f.7

C. G. H. 1700. C s.l Plant. grass. 82

C. G. H. $\quad \ldots$ C s.I

C. G. H. 1796. C s.I

C. G. H. 1793. C s.l

C. G. H. $\quad$ C. C $\quad$ s.I

C. G. 1820 . C s.l

C. G. H. 1795. C s.I

C. G. H. 1800, C s.I

C. G. H. 1714, C s.l Di. el. t.208.r.2n

C. G. H. 1723. C s.l D.el.t.209.f.2\%7,8

C. G. H. 1820, C s.I

C. G. H. 1822. C s.l

C. G. H. 1793. C s.l

C. G. H. 1774. C s.1

C. G. H. 1731. C s.l

C. G H. $\begin{array}{llll}\text { C } & \text { s.l Plant. grass. } 36\end{array}$

C. G. H. 1816. C s.l

C. G. H. $\quad \ldots$ C s.l

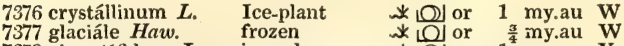

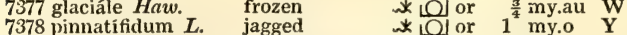

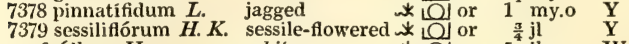
g ́́lbum Haw. $\mathrm{K}$. 7380 hurnifúsum $\boldsymbol{H} \boldsymbol{K}$. 7381 Aitóni Jacq. white ${ }^{*}$ Q jl.au W W narrow-lvd. icy $\frac{1}{2}$ or ${ }^{\frac{1}{2}}$ jiton's jn.o

7382 lanceolátum Haw. spear-leaved 이 or ${ }^{\frac{3}{4}}$ my.au W róseum Haw 7383 cordifólium $\dot{L}$. 7384 pomeridiánum $L$. $\beta$ glábrum pink

heart-leaved great yellow-fl. ل्ف or

$\frac{3}{4}$ my.au Pk Lل or $1^{\frac{1}{2}}$ my.s.au $\mathrm{Pk}$ 7385 Candol'lii Haw. Decandolle's 7386 pilósum Haw. hairy-yellow 7387 calenduláceum Haw. Pot-marigold 7388 Helianthoides H.K. Sun-flower 7388 Helianthoídes $\boldsymbol{H} . \boldsymbol{K}$. Sun-flower
7389 limpidum $\boldsymbol{H} . \boldsymbol{K} . \quad$ transparent 이 or 1 jl.au Y 잉 or $\frac{1}{2}$ au $\quad \mathbf{Y}$ 일 $\frac{15}{4}$ jn.au $Y$ 이 or or $\frac{3}{4}$ au.o $\mathbf{Y}$

Greece 1727. S s.l Plant. grass. 128 Greece $\quad \ldots$ S $\quad$ s.l C. G. H. 1774. S s.l Bot. mag. 67 C. G. H. 1774. S s.l C. G. H. $\quad \ldots \quad$ S $\quad$ s.l

C. G. H. 1774. C s.l

C. G. H. 1774. S s.l Jac. vind, 3.t.7 C. G. H. 1795. S s.l C. G. H 1813, S s.I

C. G. H. 177t. C s.l Plant. grass. 102 C. G. H. 1774. S s.l Bot. mag. 540 C. G. H. $\quad \ldots$ S s.l C. G. H. 1815. S s.l C. G. H. 1800, S s.l C. G. H. 1819 S s.

C. G. H. 1774, S s.l Plant. grass. 135 C. G. H. 1774. S s.l Jac. ic. 3. t. 488

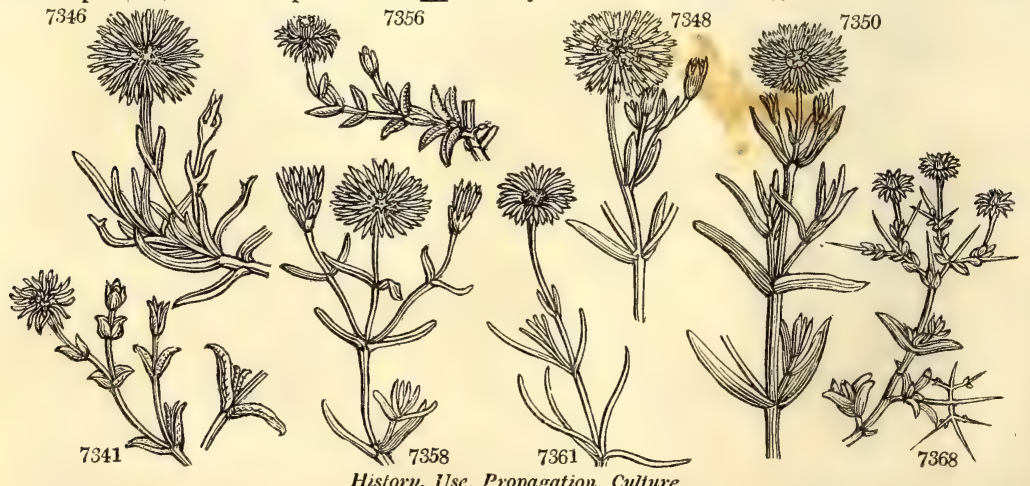

M. nodiflorum grows wild in Italy and Egypt, and in the latter country is burnt for potash, which it produces in excellent quality. 
7340 Leaves glauc. slender roughish, Bractes ovate acute almost surrounding the calyx, Branches very slender 7341 Leaves glaucous, Bractes broad ovate, Branchlets clustered, Stem hoary

7342 Leaves glauc. equilateral 3-corn. very rough, Bractes ovate acute embracing the peduncles upwards 7343 Leaves 6-12 lines long half erect glauc. with little pellucid rough dots

7344 Leaves compressed 3-corn. longish bluish-green with rough pellucid dots, Keel usually onetoothed

7345 Low, Leaves green sparkling in the sun and branches very dense, Flower-stems decumbent

7346 Lowish, Lvs. glauc. 3-corner. and branches very close, Fl.-stems ascending or erect, Styles obovate twice 7347 Leaves green sparkling in the sun and branches close, Flower-stems erect as short as stamen

7348 Lvs, close compressed 3-cornered very green, Ped. longer than bract, Flowers spreading flat in the sun

7349 Leaves compressed 3-cornered glaucous, Branches stout, Pedunc. clavate, Corolla incurved

7350 Leaves cylindrical 3-cornered, Petals orange, Styles dark purple

7351 Leaves cymbiform pale-green with large dots, Branches few 2-edged hoary

7352 Lvs. very glauc. 3-corn. compressed, Sepals obl. ovate, Pet. deep orange imbricated, Styles purple outside 7353 Lvs. acutely 3-corn. much compressed glauc. roughish, Sepals ovate cordate, Pet. sulphur, Styles yellow 7354 Leaves 3-cornered obtuse expanded glaucous with large spots, Stem much branched woody stiff erect

7355 Leaves 3-cornered spreading cymbiform glaucous, Stems branched, Branches filiform nearly erect close 7356 Lvs, distinct 3-corn. ovate granular 3 lines long, Flowers yellow opening in the evening, Stems expanded 7357 Leaves spreading turgid 3-cornered hoary bluntly dotted at edge, Branches clustered 2-edged decumbent \$. Slender, Leaves distinct, dotted, rounded, without warts, Flowers opening in the morning, red, orange, or 7. Slender, Leaves distinct, dotted, roun.

7358 Lvs. rounded 3-corn. somewhat compressed obt. glauc. Pedunc. smooth at base, Sepals obt. nearly equal 7359 Leaves 3-cornered acute green, Pedunc. and cal. unequal rough, Petals yellow inside

7360 Leaves about 3-cornered very green, Pedunc. in fruit clavate, Sepals very unequal, Branches loose 7361 Leaves half round subcompressed subulate green smooth longer than joints, Stems erect or procumbent

7362 Lvs. 3-corn. compressed glauc. rough, Sepals unequal, Petals changing from yellow to pink, Stems effuse 7363 Branches and lvs. cylindrical subul. spiniform erect recurved at end, Pedunc. and keels of bractes rough

7364 Lvs. distant expanded at base incurv. half round subul. Branch. firm suberect roughish angul. compressed 7365 Lvs. 3-cornered subulate incurved below hooked at end, Branches filiform compressed wavy decumbent 7366 Leaves clustered half cylindrical acuminate much recurved at end, Branches erect very close

7367 Tufted, Leaves clustered half cylindrical acuminate with filiform very weak creeping stems

7368 Leaves rounded 3-cornered dotted distinct, Spines branched

7369 Leaves long rounded 3-cornered subulate incurved glaucous edged at base

7370 Leaves rounded incurved smooth thickest in middle glaucous, Stem straight branched

7371 Flowers terminal 3, Two sepals deeply divided

7372 Leaves subulate rounded 3-cornered acute somewhat incurved very glaucous, Bark chestnut-colored

7373 Leaves clustered cylindrical obtuse arcuate glaucous smooth

7374 Leaves connate at base very close and glaucous 3-cornered cylindrical soapy, Flowers afternoon

7375 Leaves clustered 3-cornered half cylindrical mealy obtuse shorter than joint soapy, Sepals very unequal

8. Warted, Leaves and branches almost always more or less warted, Root biennial or annual. 7376 Leaves large ovate acute wavy frosted with three nerves beneath, Root biennial

7377 Leaves large altern, ovate much wavy, as are the stems and cal., bespangled with ice drops, Root annual 7378 Leaves oblong pinnatifid pimpled, Petals minute yellow

7379 Leaves flat spatulate and stems pimpled, Branches divaricating, Fl. sessile

7380 Leaves amplexicaul. spatulate keeled, Pimples conical rough, Petals very minute

7381 Leaves opp. and altern. ovate spatulate wavy pimpled, Branches and calyxes angular, Fl. afternoon

7382 Leaves altern. lanceolate bluntish pimpled, Calyxes stalked crystalline

7383 Leaves stalked cordate ovate, Stems procumbent spreading, Cal. 4-cleft 2-horned

7384 Leaves broad lanceolate flattish smooth ciliated distinct, Stem peduncle and ovaries hairy

7385 Leaves opp. lanc. acute subciliate, Pedunc. solitary subterminal very long hairy, Sepals lanceolate 7386 Lvs. lin.-lanc. ciliated, Stems branched effuse, Pedunc. bractes and cal, shorter than flower woolly villous 7387 Leaves lin.-lanc. scarcely spatulate and calyx ciliated, Sepals linear thick or turgid, Pedunc. scabrous 7388 Leaves spatulate flat smooth, Pedunc. very long, Cal. flat at base angular

7389 Leaves opp. spatulate blunt rough, Pimples oblong, Sepals oblong blunt contracted in middle

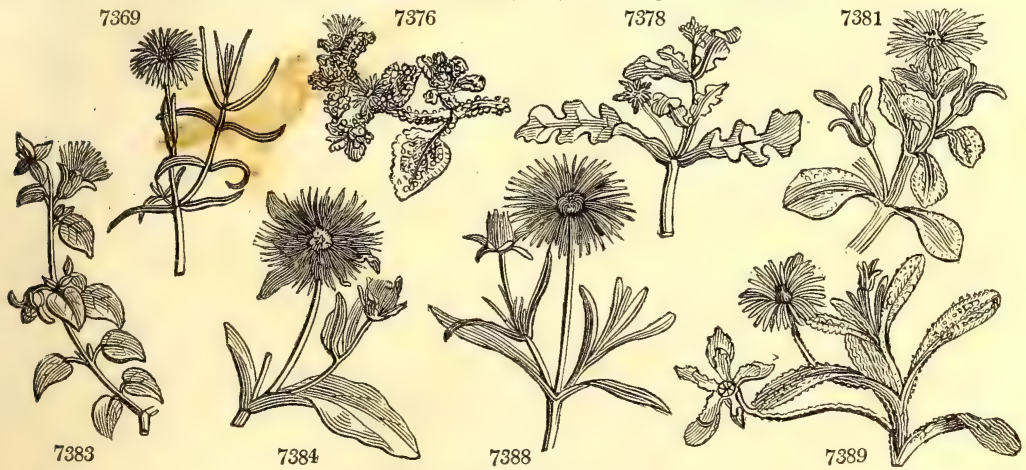

and Miscellaneous Particulars.

M. crystallinum is a popular hothouse annual, which does well in the open air in the summer season.

M. umbellatum forms one of the handsomest shrubs of the genus, standing without support with a stout

F f 4 
7390 trícolor Haw. $\beta$ róseum Haw. $\gamma$ lineáre Thunb.

7391 villósum $L$ 7392 cadúcum $\boldsymbol{H}$. $\boldsymbol{K}$ 7393 apétalum $\boldsymbol{H}$. $\boldsymbol{K}$. 7394 nodiflórum $L$.

7395 ciliátum $\boldsymbol{H}$. $\boldsymbol{K}$. 7396 geniculifor rum 7397 Tripólium $L$. 7398 expánsum $\boldsymbol{L}$. 7399 várians Haw. 7400 tortuósum $L$. 7402 lorátum Haw.

7403 relaxátum $W$.

7404 relaxatum

7405 anatómicum Haw. $\beta$ frágile Haw.

\section{6 réctum Haw.}

7407 crassuloídes Haw.

7408 incómptum Haw.

7409 spléndens $L$.

7411 acuminátum Haw.

7412 sulcátum Haw.

7413 fastigiátum Haw. $\beta$ refléxum Haw.

7414 umbelliflórum $W$.

7415 palléscens Haw.

7416 micránthon Haw. parviflórum Jacq.

7417 júnceum Haw. $\quad \begin{aligned} & \text { Rush-leaved } \\ & 7418 \text { granulicaúle Haw. granulated }\end{aligned}$

7419 ténue Haw.

three-colored

pink

linear

villous

deciduous

dwarf-spread.

knot-flowered

ciliated

joint-flowering 잉 or

Aster-leaved or

Houseleek-lvd.

twisted-leaved

pale-flowered t or

lorate

livid strap-leav.

thick-leaved

s or

brittle

straight

Crassula-like

shining

zigzag

acuminate

level-topped

reflexed

umbellate

pallid

granulated

420 longispinulum Haw. long-spined

7421 spinuliferum Haw. spinulescent

7422 gróssum Haw. gouty

gouty

7423 salmóneum Haw. salmon-colored

7424 canaliculátum Haw. channel-leaved w

7425 viridiflórum $H . K$. green-flowered

7426 tenuiflórum Jacq. slender-flower.

7427 nítidum Haw.

7428 brachiátum $H . K$. three-forked

7429 subincánum Haw.

7430 testáceum Haw.

7431 tuberósum $L$

7432 noctiflórum $L$.

$\beta$ stramineum Haw.

7433 fúlvum Haw.

7434 defoliátum Haw.

7435 horizontále Haw.

7436 speciósum Haw.

7437 mícans $L$

74.38 maculátum Haw.

7439 flávum Haw.

7440 obliquum Haw.

7441 parvifólium Haw.

hoary

w or

in or

wer

tuberous-rootedw night-flowering $\frac{\text { in }}{L} \mathrm{~L}$ or

traw-colored

clubbed

wer

specious 1 d. 些

glittering

spotted-stalked is

small-yellow

oblique

small-leaved

short-leaved

7442 brevifólium $H . K$. . short-lea

7444 pulveruléntum Haw. dusty-leaved

7445 híspidum $L$. : hispid

$\beta$ platypétalum Haw. broad-petalled

$\begin{array}{ll}7446 \text { hirtéllum Haw. } & \text { dwarf-bristly } \\ 7447 \text { cándens Haw. } & \text { glowing-icy }\end{array}$

¡448 floribúndum Haw. pale-bristly

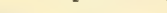

7401

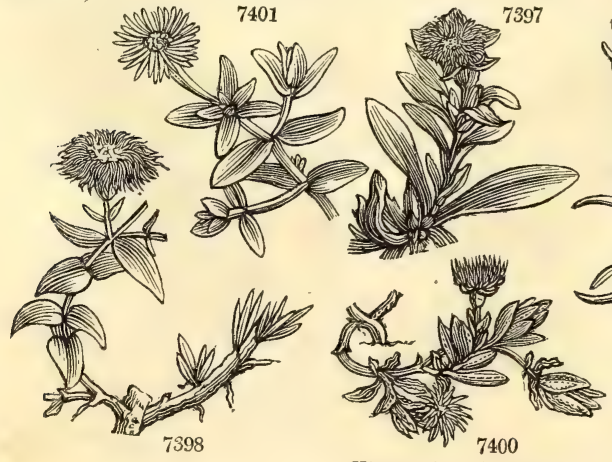

History, Use, Propagation, Culture,
R C. G. H. 1795. S s.l

Pk C. G. H. 1795. S s.l

W C. G. H. 1819. S s.l

$\begin{array}{lllll}\text { Ap } & \text { C. G. H. 1759. C } & \text { s. }\end{array}$

Pk C. G. H. 1774. S s.l

Ap C. G. H. 1774. S s.l Jac. vind. 3. t. 6

Egypt 1739. S s.1 Plant. grass. 88

C. G. H. 1774, C s.

W C G H 1727 C s.

Plant. grass. 17

$\mathrm{PaY} \mathrm{C}, \mathrm{G}$. 1705 C

PaY C. G. 1705. C s.1

Pa.Y C. G. 1706. C s.1 Pet.gaz.t.78.f.10

Pa.Y C. G. H. 1705. C s.1 Di. el. t.181.f.222

W C. G. H 1810. C s.1

Pk C. G. H. 1815. C s.

Pa.Y C. G. H. 1815. C s.1

W C. G. H. 1803. C s.l

$\begin{array}{lllll}\text { W } & \text { C. G. H. } & \text { 1803. } & \text { C } & \text { s.l } \\ \text { W } & \text { C. G. H. } & \text { 1803. } & \text { C } & \text { s.l }\end{array}$

W C. G. H. 1819. C s.l

Pk C. G. H. 1819. C s.

W C. G. H. 1819. C s.I

W C. G. H. 1716. C s.

C. G. H. 1795. C s.1

C. G. H. 1820. C s.l

C. G. H. 1819, C s.l

C. G. H. 1794. C s.I

C. G. H. 1792. C s.l

C. G. H. 1820. C $\quad$ s.l

C. G. H. 1820. C s.

C. G. H. 1804, C s.l

Pk C. G. H. 1800. C s,

... C. G. H. 1820. C s.l

C. G. H. 1819. C s.

Pa.Y C. G. H. 1820. C s.

Pa.Y C. G. H. 1794. C s.l

Pa.Y C. G. H. 1774. C s.l

Pa.Y C. G. H. 1819. C s.l

$\begin{array}{llll}\text { Pk C. G. H. 1794. C } & \text { s.l }\end{array}$

Gr C. G. H. 1774. C s.

Pk C. G. H. 1820. C s.

Y C. G. H. 1790. C s.l

Y C. G. H. 1774. C $\quad$ s.l

Or C. G. H. 1820 . C $\quad$ s.

$\begin{array}{lllll}\text { Or } & \text { C. G. H. } & \text { 1820. } & \text { C } & \text { s. } \\ \text { Or } & \text { C. G. H } & 1714 & \text { C } & \text { s. }\end{array}$

Or C. G. H. 1714, C s.l Dill. elth. f. 264

W.pk C. G. H. 1714. C s.l Bot. cab. 495

$\begin{array}{llll}\text { Str } & \text { C. G. H. 1732. C } & \text { s. }\end{array}$

Str C. G. H. 1820. C s.l

W.pk C. G. H. 1820, C

Str C G H 1795 C

Str C. G. H. 1795. C s.

$\begin{array}{lllll}\text { S C. C. H. 1704. C } & \text { s.1 }\end{array}$

S C. G. H. 1792. C

Pk C. G. H. 1820. C s.

$\mathrm{Pu}$ C. G. H. 1819. C s.

$\mathrm{Pu}$ C. G. H. 1820. C s.l

C. G. H. 1777. C s.l

C. G. H. 1795. C s.1

$\begin{array}{llll}\text { C. G. H. } & 1795 . & \text { C } & \text { s.l } \\ \text { C. G. H. } & 1792 . & \text { C } & \text { s.I }\end{array}$

$\begin{array}{llll}\text { C. G. H. } & 1792 . & \text { C } & \text { s.l } \\ \text { C. G. H. } & 1704 . & \text { C } & \text { s.1 }\end{array}$

C. G. H. 1820 . C $\quad$ s.I

C. G. H. 1792. C s.1

C. G. H. 1820. C s.

Plant. grass. 47

Plant. grass. 35

Bot. mag. 326

Bot. mag. 448

Bot. reg. t. 863

Dill. elth, f, 278

Di. el. t.214.f. 280

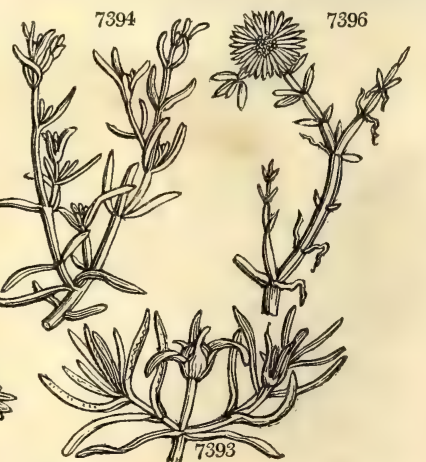

stem, two or three feet high, with terminating white flowers, which open, when the sun shines, from seven or eight in the morning to two or three in the afternoon, and smell like those of the hawthorn. The fruit of M. edule is eaten by the Hottentots and Dutch inhabitants of the Cape, and is called Hottentots' figs. 
7390 Leaves linear inflexed channelled blunt rough, Pedunc. and calyx jewelled with crystals

7391 Leaves pubescent connate not dotted, Stem hairy

[of leaves 7392 I aves filiform half round distinct, Pimples ovate, Fl. lateral sessile: the terminal surrounded by a pair 7393 Leaves amplexicaul. distinct linear flat above pimpled longer than joints, Fl. stalked

7394 . Leaves alternate roundish obtuse ciliated at base

7395 Leaves opp. connate half round, Stipules membranous reflexed torn fringe-like 7396 Leaves half round papulose distinct, Fl, sessile axill. Cal. 4-cleft

7397 Leaves alternate lanceolate flat not dotted, Stems lax simple, Cal. 5-cornered

7398 Leaves flattish lanceolate not dotted spreading distinct opp. and altern. remote

7399 Leaves lanc, acuminate keeled fleshy bluntly 3-cornered channelled, Pedunc, very thick

7400 Leaves flattish oblong ovate papulose clustered connate, Cal. 3-leaved 2-horned

7401 Leaves amplexicaul. glaucous distinct obl. lanc. inflexed concave, Sepals ovate obl. longer than cor.

$7+02$ Leaves lorate long channelled inflexed blunt very glaucous convex beneath, Sepa!s obtuse as long as cor. 7403 Lvs. lorate obl. blunt glauc. livid channelled dotted papulose keeled, Stems branched rounded decumbent 7404 Leaves lorate acuminate green smooth, Stem very short and thick

7405 Leaves lanc. elliptical crystalline when dead having only the nerves remaining, Stems procumbent

7406 Leaves connate ovate papulose, Branches erect clustered

7407 Leaves lanc. lin. somewhat channelled convex beneath, Fl. solitary terminal

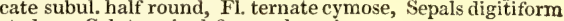
cs half round not dotted recurved distinct close, Cal. terminal finger-shaped

410 Lvs. close flexuose recurved very green half round, Sepals finger-shaped, Stems flexuose shining slender 7411 Leaves acuminate green, Sepals 2 much elongated

7412 Leaves close linear subulate half round pale green deeply channelled, Sepals acute

7413 Leaves close flexuose reflex subulate half round glaucous, Sepals equal 3 membranes on each side

7414 Leaves distinct roundish pimpled, Stem erect, Branchlets 1-flowered

7415 Leaves opposite amplexicaul. distichous oblong-lanceolate acute bluntly keeled, Pimples minute

7416 Leaves lanc. linear keeled not dotted distinct, Flowers stalked, Two sepals very long

7417 Lvs. subulate half round acute remote, Fl. term. dichotomous, Sepals very unequal, Branches sometimes 7418 Branches round granular closely dotted

7419 Leaves very siender 1-sided effuse, Leaves erect linear very fine

7420 Branches procumbent knotted at the base, Spines of the leaves very long

7421 Leaves close half round chamnelled, Stem and branches erect thick

7422 Leaves lin. round obtuse narrowed at each end, Old stem strumose at base, Branches effuse

7423 Branches filiform weak long prostrate, Old roots strumose above, Leaves lin. furrowed longer than joints

7424 Leaves lin. half round with shining pimples, Stems procumbent filiform

7425 Leaves half round pimpled hairy, Cal, hairy, Stem thick, Branches diffuse knotty

7426 Leaves half round blunt channelled spreading iced, Branches diffuse weak cinereous

7427 Beautifully pimpled all over, Leaves half round, Branches knotty slender, Fl. small dichotomous

7428 Stems and leaves cylindrical pimpled, Branches dichotomous

7499 Leaves expanded compressed 3-cornered somewhat hoary soft recurved at end mucronate

7430 Leaves half round somewhat triquetrous glaucous, Fl. 3-chotomous testaceous, Stem erect shrubby

7431 Leaves subtriquetrous compressed minutely pimpled recurved at end, Old root tuberous large

7432 Leaves remote obsoletely cylindrical glaucous, Fl. 2 ternate cymose, Bark white

7433 Leaves remote subcylindrical glaucous exactly half erect, Fl. ternate, Bark cinereous

7434 Leaves half round, Pedunc. terminal aggregate clavate cymose

7435 Leaves remote half cylindrical glaucous exactly horizontal, Fl. ternate

74.36 Leaves half cylindrical subul. subacute incurved sparkling, Sepals and petals obtuse, Cor. funnel-shaped

7437 Leaves half cylindrical obtuse subrecurved much sparkling, Sepals and petals subacute

7438 Leaves expanded remote blunt compressed subcylindrical, Stems very rough spotted

7439 Leaves half round narrowed at each end sparkling incurved erect variously bent, Branchès filiform

7440 Leaves distant cylindrical blunt small shining pimpled : one of each pair deflexed, Branches hard suberect

7441 Leaves graniform expanded bluntly 3-cornered papulose shining, Branches hard rough erect

7442 Leaves cylindrical blunt spreading short, Branches numerous diffuse filiform

7443 Leaves expanded very short or globose cylindrical, Branches numerous filiform divaricating decumbent

7444 Leaves cylindrical 3-cornered obtuse with white dots, Calyx 6-cleft

7445 Leaves cylindr. very blunt and cal. smooth obconical green pimpled sparkling, Stamens longer than styles

7446 Leaves close cylindrical blunt with crystalline pimples, Cal. turbinate hairy, Stamens length of styles 7447 Leaves cylindrical incurved crystalline hoary blunt sparkling, Branches long weak procumbent

7448 Lvs. subcylindr. incurv. pimpl. obt. Cal. hemispheric. pimpl. hairy cluster. Branch. numerous spreading

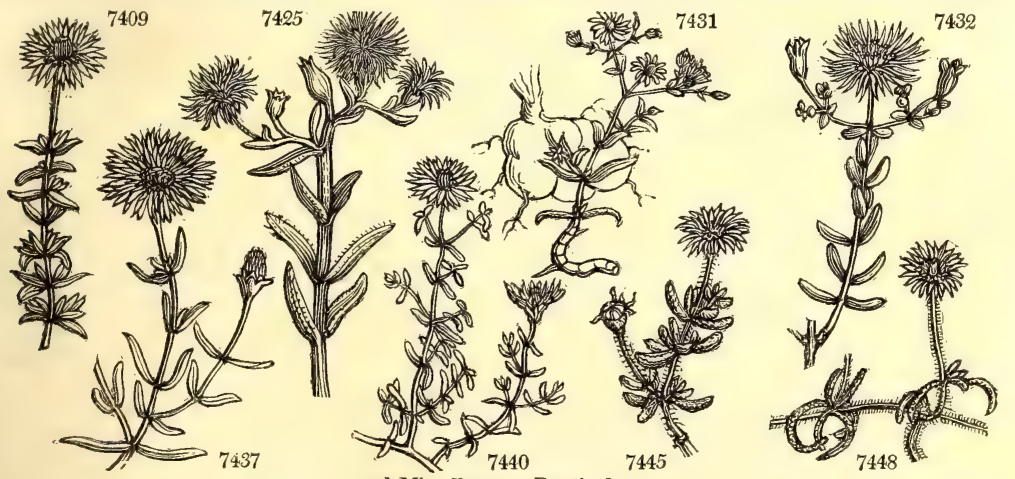

Mr. Haworth's arrangement of the genus, which is the only intelligible one, is here followed.

Respecting the general culture of the genus, Sweet observes, "the dwarf kinds require but little water, and to be grown in small pots in a very sandy or gravelly soil. The species should be kept quite dry when in a dormant state; 
7419 torquátum Haw. 7450 calycínum Haw. 7451 striátum Haw. \& pállens

7452 attenuátum Haw. 7453 hispifólium Haw. $\beta$ róseum Haw.

7454 echinátum $H$. $K$ 7455 strumósum Haw. 7456 barbátum $L$. 7457 stelligerum Haw. 7458 stellátum Dec. M. hirsútum Haw 7459 dénsum Haw. 7460 bulbósum Hazs. 7461 intonsum Haw. 1147. HYMENO'GYN 7462 glábra Haw. Mesemb. glabrum H. K.

\section{$\begin{array}{lllllllll}\text { twisted } & 2 \\ \text { long-cupped } & 2 & \text { or } & \frac{3}{4} \text { my.o } & \text { Pk } & \text { C. G. H. } & 1820 . & \text { C } & \text { s.l } \\ \frac{3}{4} \text { jl.au } & \text { W } & \text { C. G. H. } & 1819 . & \text { C } & \text { s.l }\end{array}$

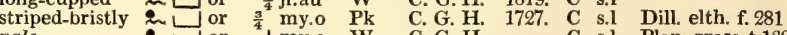 pale 2 5 or $\frac{1}{2}$ my.o W slender 2 L or $\frac{1}{2}$ my.o W bristle-stemmed $L$ or ${ }^{\frac{x}{2}}$ my.o W $\quad$ C. G. H. 18.21 . C s.l rosy 2 or 1 my.o Pk C. G. H 1818. C s.l hedge-hog 2 ${ }^{\frac{1}{2} j l .0}$ Y C G. H 1774. C s. tubr. hedge-hog*t $\_$or $\frac{2}{2}$ au Pa.Y C. G. H. 1820. C s.1

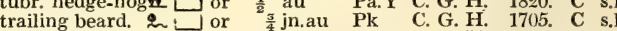 C. G. H 1716. C.1 Bot. mag. 70 \\ dwarf bearded $\underbrace{}_{\text {J }}$ or $\frac{1}{4}$ my.au Pk C. G. H. 1732. C s.1 Bot. mag. 1220

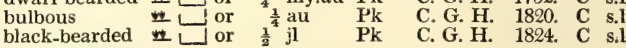 \\ aw. HYMENOGYNE.}

$\begin{array}{llll}\text { Ficoidec. Sp. } 1 . & \\ \frac{3}{4} \text { jl.o } & \text { Pa.Y C. G. H. 1787. S } & \text { s.l } & \text { Bot. rep. } 57\end{array}$
POLYGYNIA.

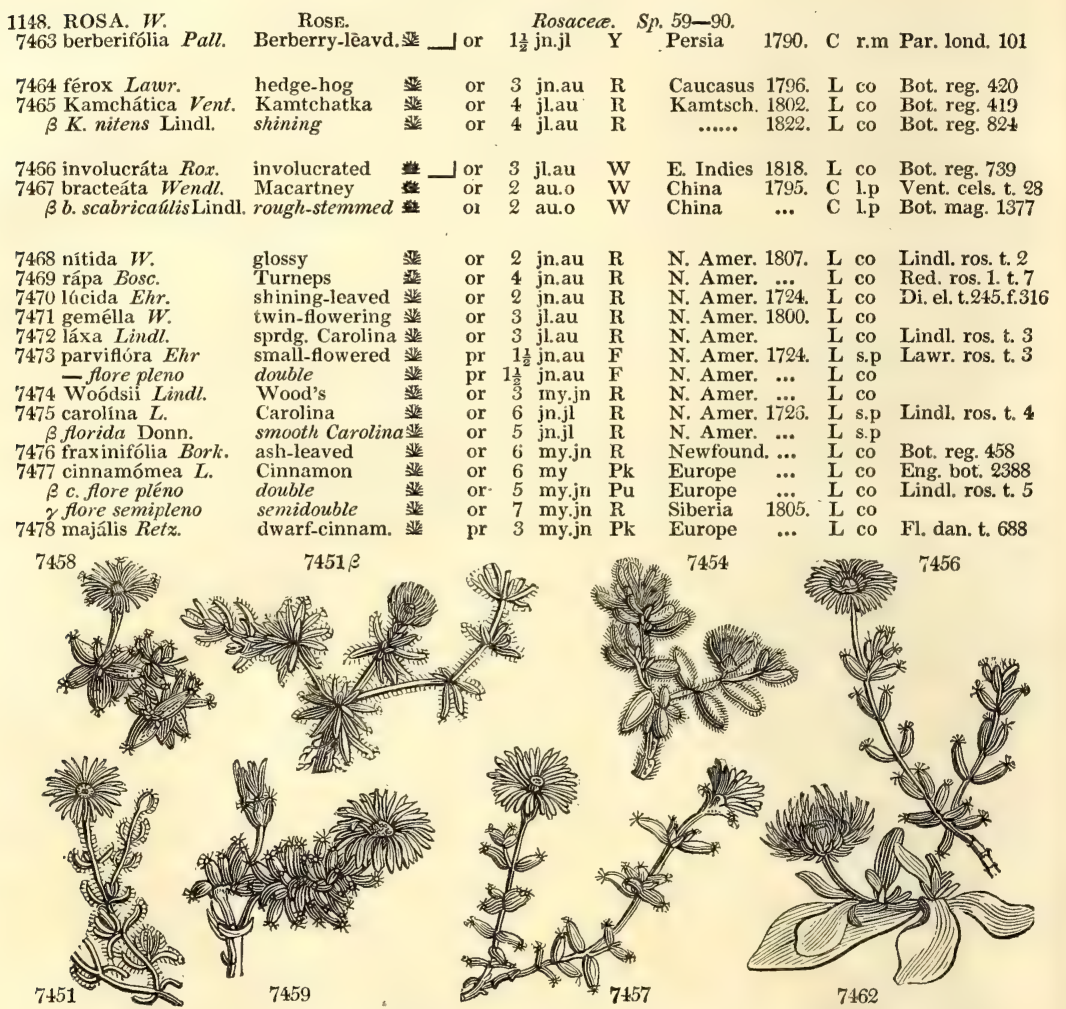

History, Use, Propagation, Culture,

but when growing freely, and at the flowering season, they require a moderate supply of water. The stronger and more woody kinds may be planted in a richer soil ; but the poorer the soil is, the dwarfer they will grow, and the more abundantly they will flower; they also require more water than the dwarf kinds, particularly at the flowering season, but need very little in winter. A good dry frame is sufficient to preserve them through the winter, with the covering of mats in frosty weather. Cuttings of any of them strike root readily, planted in pots of earth, and kept dry till they begin to wither; when they may have a little water, and they will root very soon. (Bot. Cult. 224.)

1147. Hymenogyne. From úuny, a membrane, and zus, a woman, or, in botanical language, a style, in allusion to the cohesion of the styles into a membranous tube. An artificial division of Mesembryanthemum.

1148. Rosa. From rhos, signifying red in Armorican, whence podov, Greek, and rosa, Latin. The rose has been a favorite flower from time immemorial among the civilized nations of Europe and Asia. The shrub varies in size in different species, from one foot to six or eight, and the colors are red, white, yellow, purple, striped; simple, or in almost numberless shades and mixtures; the flowers are single, semi-double, and double. The odour is universally grateful. It is cultivated in every garden, from that of the most humble cottager upwards ; some species, as R. centifolia, damascena, \&c. are also cultivated by commercial gardeners on a large scale for distilling rose water, and for making attar, or essential oil of roses. Six pounds of rose leaves will impregnate by distillation a gallon of water strongly with their odor; but a hundred pounds affords scarcely half an ounce of attar. The rose is also used in medicine. Botanists are not agreed as to the number of 
7449 Lvs. subcylindr. incurved pimpled obt. hoary, Cal. hemispheric. pimpled numerous, Stamens longer than 7450 Leaves cylindrical fine, Two sepals leafy much longer than the others

7451 Erect, Leaves subulate half cylindrical, Cal. woolly, Stamens the length of styles

[styles

7452 Slender, Lvs. half cylindr. blunt or half round, Cal. hairy at base, Pedunc. long and branches decumbent. 7453 Branches, leaves, peduncles, and calyxes hispid

7454 Leaves obl. ovate subtriquetrous gibbous, Sepals very unequal filiform ragged hispid the length of petals 7455 Leaves close depressed cylindrical hispid all over, Old root tuberous

7456 Procumbent, Leaves remote suboblong exactly half erect with 5 rays at end, Cal. 5-cleft very irregular 7457 Erect decumbent, Leaves remote nearly oblong horizontal flat above with 6 rays at end, Cal. 5-cleft equal 7458 Lvs. tufted hoary thick half round pimpl. rough with many rays at end ciliated at base, Cal. 6-8-fid hairy

7459 Densely tufted, Leaves half round papulose rough with many rays at end, Cal. 6-cleft very hairy

7460 Branches villous, Leaves horizontal, Root tuberous

7461 Branches erect decumbent hairy, Leaves with about 10 rays at end, Calyx with a black beard

7462 Leaves on long stalks spatulate lanceolate green

\section{POLYGYNIA.}

\section{Leaves simple}

Div. I. Simplicifolia. Lindl, ros. mon. p. 1.

7464 Arms very close unequal of the same form

7465 The prickles below the stipules falcate larger than the rest, Leaves opaque $\beta$ Leatlets shining

7466 Div. III. Bracteate. Lindl. p. 7.

7467 Teaflets lanceolate elliptical down contiguous pectinate 7467 Leaflets oblong obtuse very smooth, Bractes closely appressed pectinate $\beta$ Branches covered with setæ

Div. IV. Cinnamomere. Lindl. p. 13

7468 Dwarf, Arms very close and slender, Leaflets shining narrow lanceolate flat

7469 Tall diffuse, Branchlets unarmed, Leaflets oblong wavy shining, Fruit hemispherical

7470 Compact, Prickles of the branches stipulary, Leafl, obl. imbricated fiat shining, Fruit depressed globose 7471 Fruit depressed glob, and pedunc. smooth, Fl, twin, Leafl. obl, acute, Petioles and veins pubesc. beneath 7472 Diffuse, Branches twiggy nearly unarmed, ieafl. oblong wavy opaque glaucous

7473 Dwarf, Stipules linear, Prickles acicular, Leaflets lanceolate smoothish finely serrated, Cal. viscid

7474 Erect, Prickles stipulary straight, Leaflets oblong glaucous blunt smooth

7475 Stipules convolute, Leaflets lanceolate, Sepals spreading

$\beta$ Leaflets not downy

7476 Tall unarmed, Branches upright glaucous, Leafl. opaque wavy not downy

7477 Tall cinereous, Branches upright, Prickles stipulary straight, Stipules wavy, Leafl oblong rug , Prickles stipulary straight, Stipules wavy, Leafl. oblong rugose downy

[beneath

7478 Dwarf cæsious, Branches straight coloured, Prick. scatt. nearly equal, Stip. lin. Leafl. obl, flat glaucous

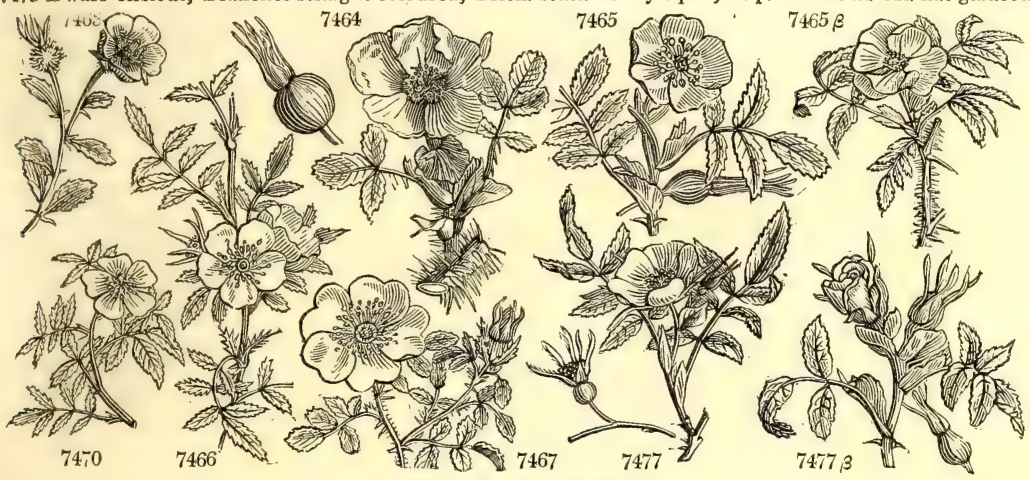

and Miscellaneous Particulars.

original species of this genus : some regard all the European species as originated from one source ; others, and especially the moderns, divide them into species, subspecies, and varieties. The most scientific work which has appeared in England on roses is the Rosarum Monographia of Mr. Lindley, 1819, in which above a which has appeared in England on roses is the Rosarum Monographia of Mr. Lindley, 1819, in which above a ninety plates of A Collection of Roses from Nature, 1810. In France, Guillemeau has published Histoire Naturelle de la Rose, 1800; and Redouté and Thory are engaged in a splendid work, in folio, entitled Les Roses, containing plates of all the known species and varieties of this flower. Thory has published a separate tract on their culture, entitled Prodrome de la Monographie du Genre Rosier, \&c. 1820; Pronville, a Nomenclature Raisonnée, in 1818; and Vibert, Observations, \&c. in 1820. A copious and intelligent account of the Scotch roses has been given by Mr. Sabine (Hort. Trans. iv, 231.), and some hundreds of new varieties have flowered from seedling plants in the Hammersmith nursery, and will soon be found in the sale catalogues.

Species and varieties. The lists of the London and Paris nurserymen contain upwards of 500 names: that of Calvert and Co., Englishmen, who have established a nursery at Bonne Nouvelle near Rouen, enumerates near 900 sorts. The greater part of these have been raised, within the last thirty years, from seed on the continent, where it ripens better than in this country. A number of varieties have also been raised in Britain, especially of the R. spinosissima, or Scotch rose, of which above 300 varieties are procurable in the Glasgow nursery. New varieties are raised in France and Italy annually; Villaresi, royal gardener at Monza, has raised upwards of fifty varieties of Rosa indica; not one of which has, as far as we know, reached this 
7479 macrophýlla Lindl. long-leaved

$\begin{array}{cl}7480 \text { alpína } L . & \text { Alpine } \\ \beta \text { pyrenáica Gouan. } & \begin{array}{l}\text { Pyrencean } \\ \text { r pendulína L. }\end{array} \\ 7481 \text { rubélla } S m . & \begin{array}{l}\text { perdulous } \\ \text { reddish }\end{array}\end{array}$

481 rubélla $\mathrm{Sm}$. reddish

7483 aciculáris Lindl. acicular

$\beta$ a. pauciflóra Lindl, few-flowered

7484 sulphúrea $H . K$. double-yellow

7485 lutéscens $P_{s h}$. $\quad$ hispid-stemmed 초

híspida B. M

7486 spinosíssima L. Scotch

Blush, Anderson's Double

Lady's

Blush, Double Pink

Blush, Double Provins

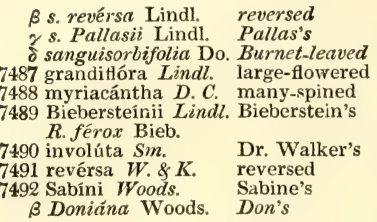

7493 damascéna Mill. Damask
7482 strícta Lindl. uprig. Carolina

Blush, Double Lady's

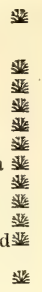

or $6 \quad \ldots \quad$... Nepal

1822. C co Lindl. ros. t. 6

or 3 jn.jl Pk Switzerl. 1683. L r.m Bot. reg. 424'

or 3 jn.jl Pk Pyrenees ... L co Gouan. ill. t. 19

or 5 my.jn Pu Switzerl. 1726. L co Iaur. ros.t. 91

or 2 jn.jl Pk England sea sh. L co Eng. bot. 2521

or 2 jn.jl Pk

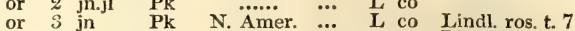

or 6 my.jn Pk S.beria 1805. $\mathrm{L}$ co Lindl, ros. t. 8

or 6 my.jn Pk Stberia 1805. L co

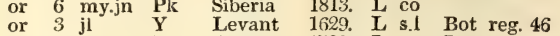

or 3 my.jn Pa.Y Siberia? 1780. L co Lindl. ros. t. 9

$\begin{array}{llll}\text { or } & 2 \text { jn.jl W.n Britain sa.hea. L p.l Eng. bot. } 187\end{array}$

Garden Varieties.

Blush, Double Rose

Agathe, Rouge

Argentea

Auguste, Belle

Aurora

Bifera Carnea

Bifera de Naples

Bifera Grandiflor

Belgique carnée

Belgique violette

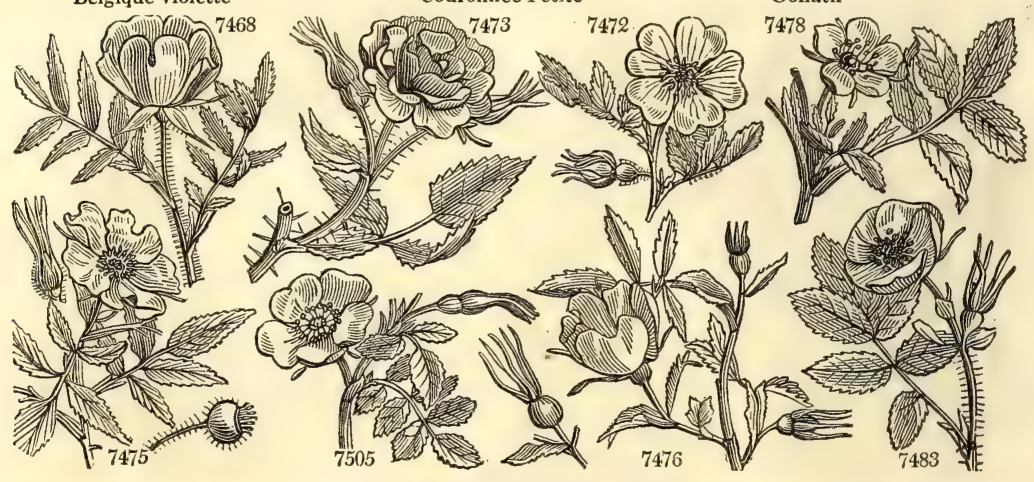

Blush, Dutch Double

Blush, Princess Double

Crimson, Double

Marbled, Double Crimson

\begin{tabular}{|c|c|c|c|c|c|c|c|}
\hline 辈 & or & 1 my.jn & W & Siberia & 1814. & L co & Bot. reg. 43 \\
\hline 事 & or & 2 my.jn & W & Siberia & $\ldots$ & L co & Pall. ross. t. 75 \\
\hline N & or & 3 my.jn & W & & & L co & \\
\hline S: & or & 4 my.jn & W & Siberia & 1818. & L co & Bot. reg \\
\hline 至 & or & 1 my.jn & W & S. France & 1820. & L co & Lindl. ros. t. 10 \\
\hline N1 & or & 2 my.jn & W & Caucasus & 1892 & L co & \\
\hline
\end{tabular}

\$ or 2 jn.jl W. R Hebrides moun. I co Eng. bot. 2068

or 5 jn.jl W.R Hungary 1816. L co W. \& K. h.t.264

or 8 myin W. Britain woods.

or 4 my.jn Pk Britain hed. $\mathbf{L}$ co

난.

Garden Varieties.
Belgic, Blush

Blush, Early

Blush, Imperial

Blush Monthly

Blush, Watson's

Brunswick

Cluster, Pale

Couronnée, Belle
Marbled, Double Dark Marbled, Double Light Purple, Double Red, Double Dark

Couronnect

7479
Damas Argente

Damas Pourpré

Damask, Blush

Damask, Red

Damask, White

Egyptian

Emperor

Felicité
Purple, Small Double Light

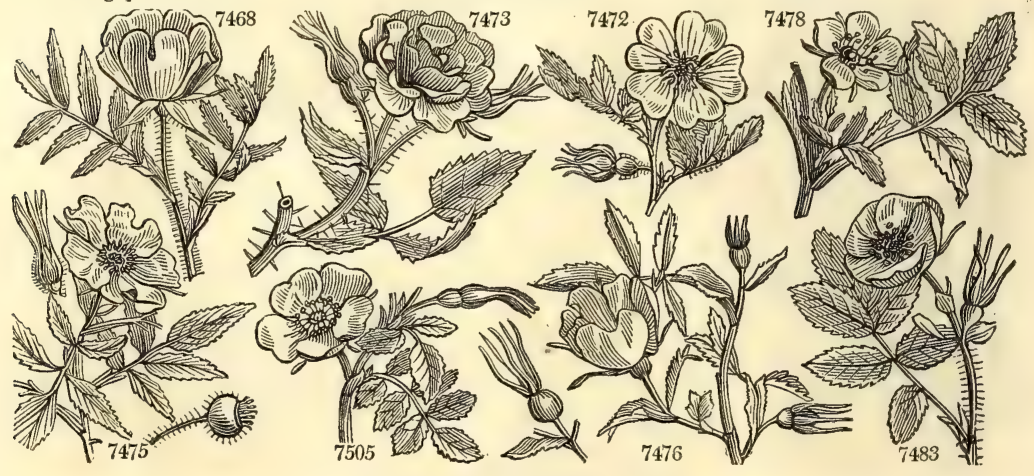

History, Use, Propagation, Culture,

country. Some of them are quite black, others shaped like a ranunculus, and many of them highly odoriferous. The most remarkable only are here arranged under the species to which they are referable.

A modern invention, of Dutch origin, in the culture of roses, is that of forming standards, by budding on stocks of any of the hardy woody growing sorts, as the dog rose, $R$. canina, or the tree rose, R. villosa. They are budded at different distances from the ground, according to taste and the purposes in view, and form, after a few years, handsome round heads, which flower freely, and preserve the variety a longer time than in plants raised from cuttings or layers. They are particularly valuable for shrubberies and lawns, where the culture at the root required by dwarf roses could not be given, and if omitted would occasion the degeneracy of the variety.

New varieties of the rose are obtained from seed; but the usual mode of propagation is by layers. All will grow by cuttings, and some, as the sempervirens, freely; but that mode is seldom resorted to. For preserving delicate varieties, the best mode seems decidedly that of budding on hardier sorts.

No species of rose, wild or cultivated, thrives well in or very near large towns, on account of the smoke and confined air. The yellow and Austrian roses ( $R$. lutea and $\mathbf{R}$. bicolor) are difficult to flower in any situation, but seldom or never blow in the suburbs of London: even the monthly rose does not thrive so well there as at some miles distance in the country. Roses are generally planted in the front of shrubberies, and in borders; they are also planted by themselves in rose gardens or rosaries, in groups on lawn, either with common edgings, or with edgings of wire, in imitation of basket-work. These last are called baskets of roses; the ground enclosed in the basket-margin is made convex, so as to present a greater surface to the eye, and increase the illusion; the shoots of the stronger sorts are layered or kept down by pegs till they strike roots 
7479 Lvs. very long, Petioles with a few glands and lanc. leafl. downy ben. Sep. very narr. longer than pointed

Div. V. Pimpinellifolia. Lindl. p. 36.

[petals

7480 Unarmed, Fruit long pendulous, Peduncle hispid

$\beta$ Tube of calyx and peduncle hispid

$\gamma$ Leaflets several and stem colored

7481 Arms close equal, Fruit long pendulous

$\beta$ Fruit dark colored shorter than usual

7482 Much branched, Branchle ${ }^{t}$ s unarmed, Fruit long pendulous

7483 Tall, Branches acicular unequal, Leafl. glauc. rugose convex, Fruit obampullaceous cernuous

$\beta$ Foliage bright pale green

7484 Stipules linear dilated at end divaricating, Leafl. glauc. flattish, Tube hemispherical [simply serrate 7485 Arms of branches very close uneq. reflex. slender, those of the branches very small nearly equal, Leaf. flat

7486 Arms unequal, Leaflets flat naked simply serrated

Garden Varieties.

Red, Double Light

Red, True Double

Two-colored, Large Double

Two-colored, Small Double
White, Large Double

White, Large Semi-double

White, Small Double

White, Whitley's Double
Yellow, Globe Double

Yellow, Large Double

Yellow, Pale Double

Yellow, Small Double

$\beta$ Dwarf, Arms very slender : the lower deflexed, Fruit ovate

$\checkmark$ Taller, Arms nearly equal close

$\delta$ Tall, Leaflets $9-11$ oblong, Fruit depressed globose

7487 Setæe of the branches none, Prickles nearly equal distarit, Leaflets flat not downy simply serrate

7488 Arms unequal : the larger dagger-shaped, Leaflets glandular not downy round

7489 Arms unequal : the larger falcate strong, Branches and orbicular leaflets glandular

7490 Arms very unequal and close, Leaflets doubly serrate pubescent, Petals convolute, Fruit aculeate

7491 Arms setaceous nearly equal reflexed, Leaflets doubly serrate pubescent, Fruit hispid

7492 Setæ few, Prickles unequal distant, Leaflets doubly serrated downy, Sepals compressed

$\beta$ Setæ scarcely any, Prickles nearly straight

Div. VI. Centifolie. Lindl. p. 60.

7493 Arms unequal : the larger falcate, Sepals reflexed, Fruit long

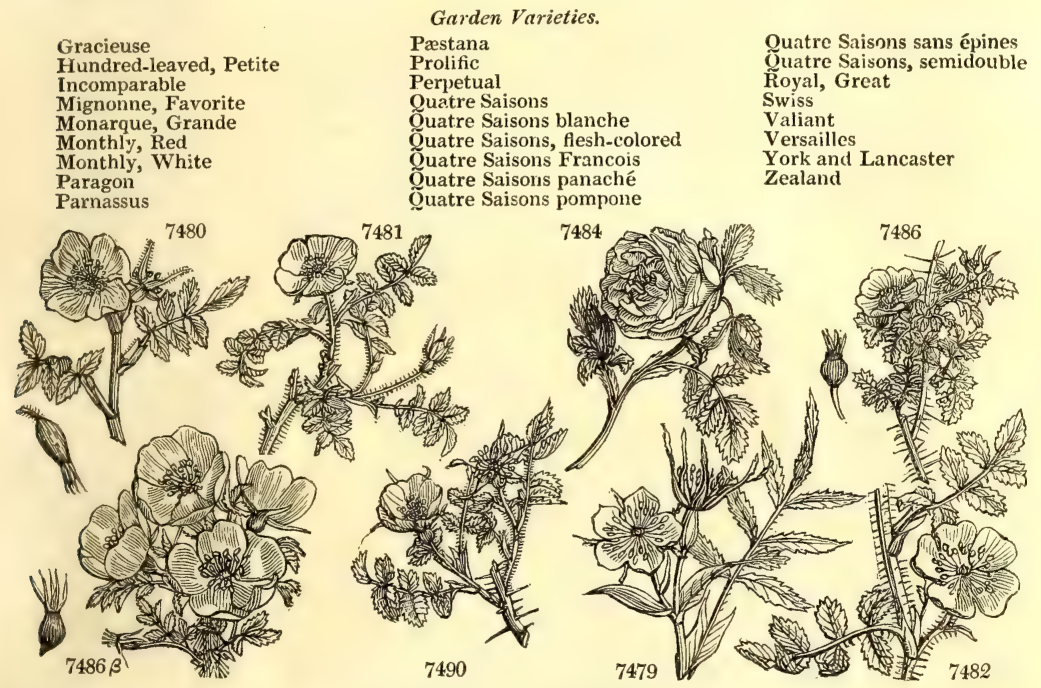

and Miscellaneous Particulars

into the ground, so that the points of the shoots furnished with buds appear only above the soil, which is sometimes covered with moss or smail shells. Under this treatment, the whole surface of the basket becomes, in two or three years, covered with rose-buds and leaves of one or of various sorts. Where one of the larger free-growing sorts is employed, as the moss, or any of the Provence varieties, one plant may be trained so as to cover a surface of many square yards. Where different sorts are introduced in the same basket, they should be as much as possible assimilated in size of leaves and flowers and habits of growth, and as different as possible in the colors of their flowers. By mixing small-flowered with large showy sorts, the beauty of the former is lost without adding to the effect of the latter.

In rosaries, commonly, but one plant of a sort is introduced, and the varieties which most resemble each other are placed together, by which their distinctions are better seen. Particular compartments are often devoted to one species, as the Scotch, Chinese, yellow, burnet-leaved, \&c. which has an excellent effect ; sometimes a piece of rock-work in the centre is covered with the creeping roses, and on other occasions these are trained to trellis-work, which forms a fence or hedge of roses round the whole. In this hedge, standard roses are sometimes introduced at regular distances; a grove of standards is also frequently formed in tiie centre of the rosary, and sometimes they are introduced here and there in the beds.

Standard roses, however, have certainly the best effect in flower borders, or when completely detached on a lawn: their sameness of form, and that form being compact and lumpish, prevents them froin grouping well, either among themselves or with other objects. Their beauty consists in their singularity as rose plants, and in their flowers; and, therefore, to display these beauties to the best advantage, they require to be sec:s singly, or in succession. This is the case where they occur as single objects or a lawn, or in the centre, and here and 
7494 Centifólia $\boldsymbol{L}$. Provins

Aunay, Belle d'

Aurora

Belgic, Red

Blandford or Kingston

Blush Royal

Bourbon

Bright Crumpled

Cabbage, Blush

Cabbage, Single

Carmine

Carmine, Superb

Centfeuilles anemone

в muscósa Mill. Moss

Moss, Blush

y Pompónia D. C. Pompone

Dwarf Bagshot

De Meaux

$\delta$ c. bipinnáta Red. 7495 gállica $L$.

Admirable

Aigle noir

Albanian

Amaranth

Antwerp

Atlas

Belle Aurore

Burning Coal

Beauté Aimable

Beauté Rouge

Beauté Supréme

Bijou

Bishop

Black Frizzled

Blue

Bouquet rouge royale

Brunette

Brussels

Buonaparte

Cardinal

Carmine

Carmine Brillante

Carmine, Proliferous

Carnation

Catalonian

bipinnate sile

S. Europe 1596.

L r.m Red. ros 1. t. 1

Garden Varieties.

Centfeuilles de Bruxelles

Centfeuilles de Hesse

Centfeuilles gaufrée

Chamois

Cluster

Constance

Cramois, Grand

Cumberland

Dragon

Duchesse d'Angoulême

Duchesse de Berri

Elysian

\$ $\quad$ or 3 jn.jl $\quad \mathbf{P k}$

Garden Varieties.

Moss, Common

啮 $\quad$ or 2 jn.jl Pk

Garden Varieties.

Mossy de Meaux

Mignonne Charmante

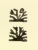

Emperor

Juno

Louis XVIII.

Malta

Mère Gryone

Mottled Purple

Neapolitan

OEillet

Pencilled

Petite Hollande

Persian

... I r.m Red. ros. 1. $t .8$

Moss, Dark

... L r.m Red. ros. 1. t. 21

Pompone

Pompone, Proliferous

S. Europe $13 . . . \quad$ L co Red. ros. 2.t.

$\begin{array}{lll}\text { Champion } & \text { Fiery } & \text { Italian } \\ \text { Chancellor } & \text { Flanders } & \text { Josephine } \\ \text { Changeable } & \text { Flemish } & \text { Junon } \\ \text { Cherry } & \text { Formidable } & \text { King } \\ \text { Clementine } & \text { Fringed } & \text { La Dauphine } \\ \text { Coquette } & \text { Garnet } & \text { L'Ombre agreable } \\ \text { Couleur de feu } & \text { Gay } & \text { L'Ombre superbc } \\ \text { Cramoisie, Grand } & \text { Giant } & \text { Leyden } \\ \text { Cramoisie, Belle } & \text { Gloria Mundi } & \text { Lisbon } \\ \text { Crimson, Dutch } & \text { Granaat Appel } & \text { Lively } \\ \text { Crimson, Purple } & \text { Grand Monarque } & \text { Lurid } \\ \text { Crimson, Royal } & \text { Grand Sultan } & \text { Maiden } \\ \text { Crown } & \text { Henry IV. } & \text { Majorca } \\ \text { Cupid } & \text { Herminie, Belle } & \text { Malabar } \\ \text { Damask, Black } & \text { Hervy } & \text { Maita } \\ \text { Delicious } & \text { Hollande, Noir de } & \text { Manteau Royal } \\ \text { Dingy } & \text { Hundred-leav., Blush } & \text { Marbled } \\ \text { Duc de Guiche } & \text { Hundred-leav.,Dutch } & \text { Marbled, Dark } \\ \text { Duchesse d'Orleans } & \text { Hundred-leaved, Sin- } & \text { Marbled, Double } \\ \text { Dwarf Proliferous } & \text { gleton's } & \text { Marbled, Grand } \\ \text { Enchanter } & \text { Imperatrice } & \text { Margaret } \\ \text { Enfant de France } & \text { Incomparable } & \text { Matchless } \\ \text { Eucharis } & \text { Infernal } & \text { Mauve } \\ \text { Fanny Bias } & \text { Invincible } & \text { Mignonne }\end{array}$

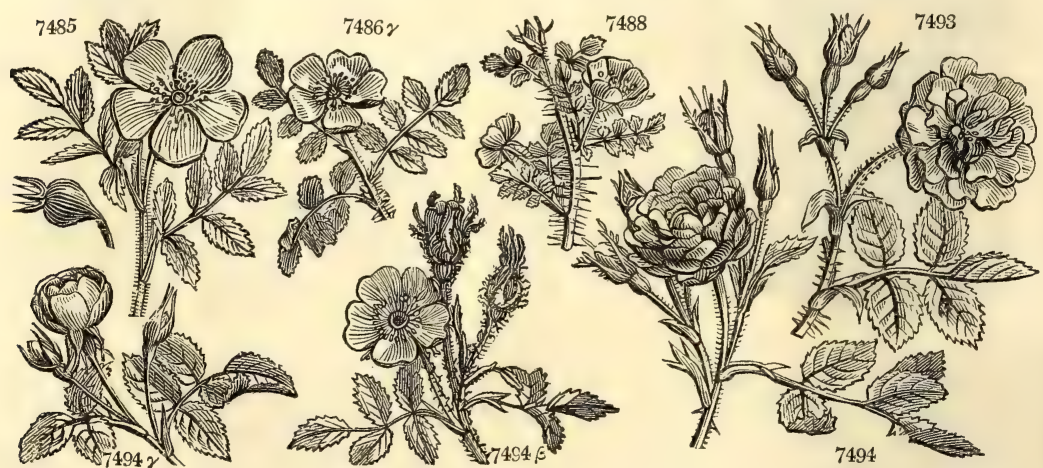

History, Use, Propagation, Culture,

749

there among groups of flowers; or in lines or avenues, along flower walks. In the gardens of the Grand Trianon, they are planted profusely in large masses, like plantations of trees and shrubs, and there much of their individual beauty is lost, and no good general effect produced.

Most species of the rose, in their wild state, grow in sandy and rather poor soil, except such as are natives of woods, where the soil is richer, and comparatively moist. But all the cultivated roses, and especially the double-flowering kinds, require a rich loamy soil, inclining to clay rather than sand; and they require also, like most double flowers, plenty of moisture when in a growing state.

To produce strong flowers, roses require some attention to pruning; old wood should be yearly cut out, and the young shoots thinned and shortened according to their strength, and whether number or magnitude of flowers be wanted. Those sorts which throw up numerous suckers should be taken up every three or four years, reduced, and replanted; and most sorts, excepting the standards, will be improved by the practice, provided attention be paid to remove a part of the old soil, and replace it by new. The points of the shoots 
7494 Arms unequal : the larger falcate, Leaflets glandular-ciliate, Fl. cernuous, Cal. viscid, Fruit oblong

\section{Pompon, Gros}

Pourprée Aimable

Pourprée Favorite

Pourprée Violette

Prolific

Provins, Blush

Provins, Cabbage

Provins, Childings

Provins, Common

Provins, Damask

Provins, Dutch
Garden Varieties.

Provins, Early

Provins, Grand

Provins, Imperial

Provins, Invincible

Provins, Royal

Provins, Scarlet

Provins, Semidouble

Provins, Shailers

Provins, Single

Provins, White
Rouge Superbe

Sans pétales

Souchet

Spongs

Striped Nosegay

Surpassarite

Syren

Trianon, Belle de

Versailles

Vilmorin

\section{B Calyxes and peduncles mossy}

Moss, Prolific

$\gamma$ Smaller in every part

\section{Provins, Dwarf}

Provins, Small

$\delta$ Leaves bipinnate

7495 Arms nearly equal of the same shape weak, Leaflets rigid ellipt. Fl. erect, Sep. ovate, Fruit nearly round

Mignonne, Blush

Mignonne, Dark

Mignonne, Favorite

Mignonne, Red

Mignonne, Semidou-$$
\text { ble }
$$

Mignonne, Striped

Mirabelle

Mogul

Montauban

Morocco

Mottled, Rlack

Natalie

Negrette

Negro

Ninon de l'Enclos

Nonpareil

Nonsuch

Normandy

Officinal

Officinal, Blush

Officinal, Carmine

Orleans

Ornement de Parade
Moss, Single

Garden Varieties.

Garden Varieties.

Rheims, De
Moss, White
Moss, Striped
St. Francis
Garden Varieties.

\begin{tabular}{lll} 
Panachée, Petite & Pourpre Velours & Sable \\
Paradise & Prince & Sanspareil \\
Paragon & Princess & Sceptre \\
Pavot & Prince William V. & Shell \\
Perruque & Prolific & Spanish \\
Phonix & Pronville & Stadtholder \\
Plicate & Proserpine & Stepney \\
Pluto & Provins Pulmonaire & St. John's \\
Prstana & Purple, Blue & Striped Nosegay \\
Pomona & Purple, Bright & Superb Red \\
Pompadour & Purple, Favorite & Sultana \\
Pomponne Bizard & Purple, Grand & Trafalgar \\
Poniatowsky & Purple, Light & Triumphant \\
Poppy & Purple, Royal & Tuscany \\
Porcelaine & Pyramid & Two-Colored \\
Portland & Queen & Velvet, Double \\
Pourprée, Belle & Ranunculus & Velvet, Semidouble \\
Pourpre Bouquet & Ranunculus, Early & Velvet, Single \\
Pourpre Charmante & Red and Violet & Velvet, Striped \\
Pourpre de Tyr & Royal Red & Venetian \\
Pourprée, Grande & Roi de France & Victory \\
Belle & Rosa Mundi & Violet, Dark \\
Pourprée, Point & Rose de Parade & Violette, Belle \\
Pourpres, Roi des & Royal Virgin & Violette and Rouge \\
\hline
\end{tabular}

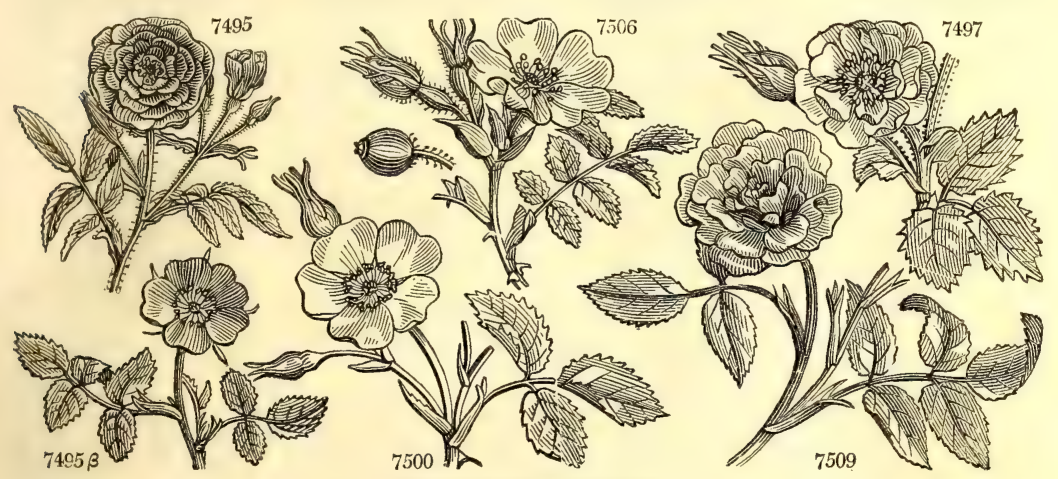

and Miscellaneous Particulars.

of the more delicate sorts of roses, are very apt to die when pruning is performed in winter or spring; to avoid the consequences of this evil, many give a second pruning in June, or do not prune the tender sorts at all till the beginning of that month. A very good time for performing the operation, is immediately after the bloom is over; cutting out old exhausted wood, shortening shoots which have flowered to a good bud accompanied with a healthy leaf, but leaving such shoots as are still in a growing state untouched till October. Where very large roses are wanted, all the buds but that on the extreme point of each shoot should be pinched off as soon as they make their appearance, and the plant liberally supplied with water. To lessen evaporation, and keep up a constant moisture at the roots of their roses, the Paris gardeners generally mulch them with half-rotten up a constant moisture at the roots of

The earliest flowering rose is the monthly, which, in mild seasons, and planted against a wall, will sometimes flower in the beginning of April ; the roses next in succession are the cinnamon, which fiowers in May; the damask in the end of May or beginning of June; the blush, York and Lancaster, Provins, and Dutch 
B pumila $\mathbf{L}$ wild officinal 严 or $\frac{3}{4}$ jn.jl $\mathbf{R}$ Austria 1810. L co Jac. aus. t. 198 7496 parvifólia $E h r$ Burgundy or $1^{\frac{4}{j n} \mathrm{jl}} \mathrm{Pu}$ Europe L r.m Bot. reg. 452

7498 villósa $L$

7499 tomentósa $S m$

$\beta$ móllis Sm.

r t. resinósa Lindl.

7500 álba $L$

\begin{tabular}{|c|c|c|c|c|c|c|c|}
\hline Frankfort & 電 & or & 5 jn.au & Pk & 1629. & L r.m & Miss L. ros. t. 63 \\
\hline Apple-bearing & 齿 & or & 8 jn.jl & $\mathbf{R}$ & Britain highl.v. & L r.m & Eng. bot. 583 \\
\hline downy-lvd. dog & 载 & or & 6 jn.jl & $\mathrm{Pk}$ & England & L co & Eng. bot. 990 \\
\hline soft & 亚 & or & $6 \mathrm{jn} . \mathrm{jl}$ & $\mathbf{R}$ & Britain & L co & Eng. bot. 2459 \\
\hline turpentine & 幽 & or & jn.jl & R & Ireland & L co & \\
\hline single white & 䶕 & or & $4 \mathrm{jn} . \mathrm{jl}$ & W & Crimea & L r.m & Miss $I$ ros \\
\hline
\end{tabular}

Garden Varieties.

Agate

Belle Aurore

Blanche à cœur vert

Blanche de Belgique

7501 hibérnica $\mathrm{Sm}$.

7502 lútea Mill. - punícea Mill. 7503 rubiginósa $L$.

American, Single

Blush

$\beta$ micrántha Sma. r umbelláta Leers.

S sépium Thuill.

є inodóra Agdh.

R. Borreri Woods.

7504 pruinósa Lindl.

7505 glutinósa $\mathrm{Sm}$.

7506 caucásea Lindl.

7507 canína $L$

$\delta$ collina Jacq.

$\varepsilon$ dumetorum $\mathrm{T}$

7508 rubrifólia Vill.

$\beta$ Redutéa Thory.

7509 indica $L$
Blush, Double White Eliza

Bouquet Blanc

Celestial

Due d'Yorck
Henriette, Belle

Joanne d'Arc

Grand Cuisse de Maiden's Blúsh, Clus-

Nymphe ter

Irish or 2 jn.n Pk Ireland ir.thi, Sk co Eng. bot. 2196

single-yellow or 3 jn Y Germany 1596. L r.m Bot. mag. 363

Austrian or 3 jn Y.o Germany 1596. L r.m Bot. mag. 1077

Sweet Briar $\quad$ or 5 my.jn Pk Britain ch. ba. S co Eng. bot. 991

Garden Varieties.

Clementine

Double

Maiden

Semidouble Mannings

small-flowered or 6 my.jl Pk Britain thick. L co Eng. bot. 2490

Semid.Sw.Briar业 or 4 my.jn Pk Germany L r.m Miss L ros, t. 65

dwarf or 3 my.jn Pk Britain thick. L co

scentless or 6 my.jn Pk Britain hed. L co

frosted or 3 my.jn Pk Siberia 1818. L co

Cretan or 2 my.jn Pk Candia 1821. L co Red, ros. 1. t.125

Caucasian $\quad \mathrm{B} \quad$ or $20 \mathrm{jn.jl} \quad \mathrm{R} \quad$ Caucasus 1798. $\mathrm{L}$ co Lindl. ros. t. 11

dog, or Hip $\quad$ or 8 jn.jl Pk Britain hed. L co Eng. bot.992

hill

bushy

red-stained

Redouté's

or 8 jn.ji

or 8 jn.j

or 8 jn.jl

or 6 jn.jl

or 20 ja.d

$\mathrm{Pk}$ Britain hed. $\mathbf{L}$ co

Britain hed. L co

England hed. L co Eng. bot. 2579

Europe 1814. L co Bot. reg. 430

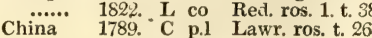

Garden Varieties, referable either to Rosa indica or $R$. semperflorens.

$\begin{array}{llll}\text { Alba } & \text { Bengale à fl. panaché } & \text { Carnescens } & \text { Cucullata } \\ \text { Animating } & \text { Bengale Blanche } & \text { Centifólia } & \text { Elegant } \\ \text { Atro-nigra } & \text { Bichonia } & \text { Chiffonnée } & \text { Florida } \\ \text { Bengale à Bouquet } & \text { Boursault } & \text { Cérise éclatante } & \text { Gigantea }\end{array}$

B odoratissima Sweet. Sweet Chinese _ or 3 f.au Pa.pk China 1810. C p.I Bot. reg. 804

r pumila Red. dwarf $\quad$ or 1 my.au Pk China ... C p.l Red. ros. 1.t. 48

7510 curt, ever-blowing 10 ja.d $\mathbf{C r}$ China

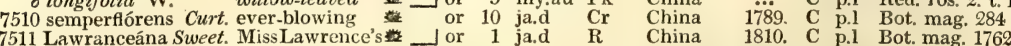

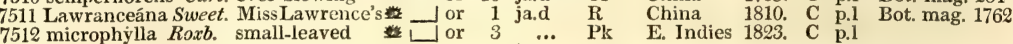

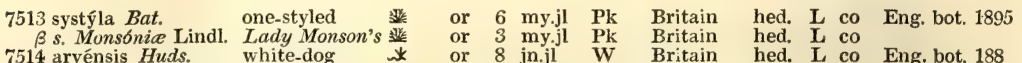

7514 arvénsis Huds. white-dog \& or 8 jn jl W Britain hed. $\mathbf{L}$

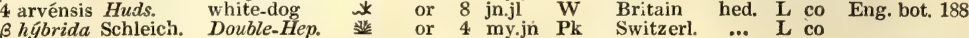

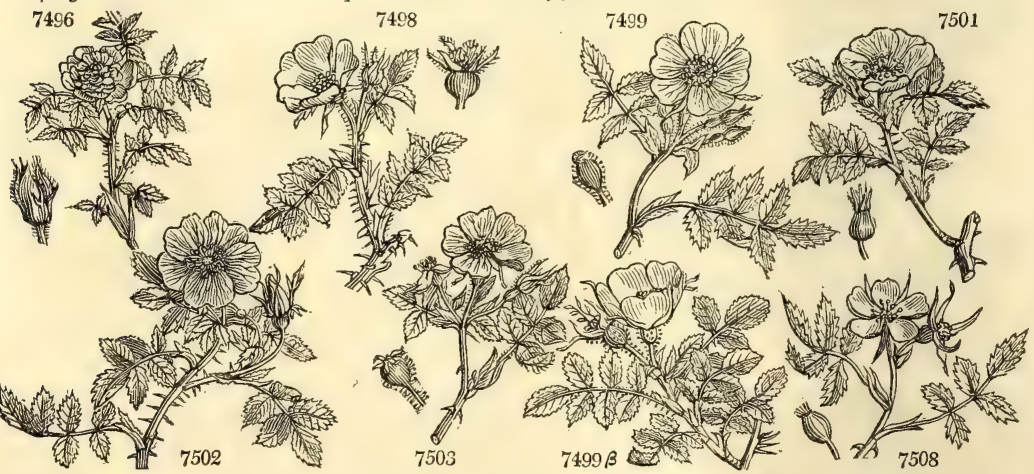

History, Use, Propagation, Culture,

hundred-leaved, in June, July, and August. The Virginia and musk roses are the latest European sorts they flower in September, and in shaded situations will sometimes continue in bloom till the middle of October; but the earliest rose (the monthly) is also the latest, and generally continues flowering till interrupted by frost. The earliest sorts may be materially forwarded by being planted against a south wall and if portable sashes are placed before them, and the wall is either flued and heated by fires, or a lining of dung placed behind, the plants may be brought to flower in February or March. The monthly rose being protected by glass in autumn, or aided by artificial heat, may be continued in bloom till Christmas. A very 
$\beta$ Flowers single, Roots creeping

7496 Dwarf, Arms nearly equal, Leaflets rigid ovate acute finely serrate, Sepals ovate

Div. VII. VILlosæ. Lindl. p. 72.

7497 Tube of calyx turibinate

7498 Leaflets ellipt. obtuse, Fruit very large with close stiff prickles, Sepals viscid hispid

7499 Leaflets ovate nearly acute, Fruit hispid or naked

$\beta$ Root-shoots upright, Sepals nearly simple

$\gamma$ Dwarf cæsious, Leaflets narrow, Flowers very red

7500 Leaflets oblong glaucous naked above simply serrate, Sepals reflexed, Fruit unarmed

\begin{tabular}{lll} 
& \multicolumn{2}{c}{ Garden Varieties. } \\
Maiden's Blush, Great & Nova cælestis & Rosea \\
Maiden's Blush, Small & Nova plena & Simonvis
\end{tabular}

$\begin{array}{lll}\text { Moraga la Favorite } & \text { Petite cuisse de Nym- } & \text { Spineless Virgin } \\ \text { phe } & \text { Thornless, Double }\end{array}$

White, Semidouble

7501 Prickles unequal : the smaller setiform, Leaflets ovate acute naked simply serrate

Div. VIII. Rubiginose. Lindl. p. 84.

7502 Prickles straight, Leaflets flat concave, Cal. nearly naked entire

7503 Prickles hooked, Leaflets rugose opaque, Cal. and peduncles hispid

\begin{tabular}{|c|c|c|c|}
\hline \multicolumn{4}{|c|}{ Garden Varieties. } \\
\hline Monstrous & Petite Hessoise & Scarlet & White, Semidouble \\
\hline Mossy & Royal & Tree, Double & Zabeth \\
\hline
\end{tabular}

$\beta$ Prickles nearly equal or none, Sepals deciduous

$\gamma$ Branches of the inflorescence very prickly, Fruit long

$\delta$ Branches weak flexuose, Leaflets acute at each end, Sepals very long and narrow

$\varepsilon$ Prickles much hooked rearly equal, Leaflets less glandular than usual, Sepals deciduous

7504 Branches glandular, Leaves frosted on each side: the upper somewhat whorled

7505 Branches hairy, Leaflets hoary roundish viscid

7506 Leaflets soft ovate, Ovaries 50-60

Div. IX. CanINE. Lindl. p. 97.

7507 Leaflets rigid ovate, Ovaries $20-30$

$\beta$ Leaflets more or less hairy beneath, Sepals and peduncles hispid

$\gamma$ Leaflets hairy on both sides, Sepals and peduncles smooth

7508 Prickles small distant, Leaflets ovate and branches glauc. opaque discolored, Ovaries 20-30

$\beta$ Dwarf with setæ upon the branches

7509 Leaflets ellipt. acuminate smooth crenate serrate glaucous beneath, Ovaries 40-50

$\begin{array}{lccc} & \text { Garden Varieties, referable either to Rosa indica or } R \text {. semperflorens. } \\ \text { Lie de Vin } & \text { Monstrosa } & \text { Purpurea } & \text { Thisbe } \\ \text { Lucida } & \text { Moonshine } & \text { Sanguinea } & \text { Terneaux } \\ \text { Major } & \text { Nigra } & \text { Sans épines } & \text { Veloutée } \\ \text { Minor } & \text { Noisette } & \text { Subalba } & \end{array}$

B Fruit ovate, Flowers very fragrant

$\checkmark$ A little bush, smaller in every respect

$\delta$ Leaves lanceolate, Branches nearly unarmed

7510 Leaflets ovate-lanceolate crenate serrate, Ovaries 15, Petals entire

7511 Dwarf, Leaflets ovate acute finely serrated, Petals acuminate, Ovaries 7-8

7512 Leaflets finely serrate shining, Cal. muricated with very dense prickles, Sep. short broad acute apiculate

$$
\text { Div. X. SrSTYLe. Lindl. p. } 111 .
$$

7513 Root-shoots assurgent, Prickles very strong hooked

$\beta$ Stem lower, when in flower erect many-Howered, Branches with a few setæ

7514 Root-shoots flagelliform, Prickles unequal falcate, Leaflets glaucous beneath

$\gamma$ Root-shoots thicker and shorter, when in fl. erect many-f. Branches with a few scat. setæ, Styles distirict

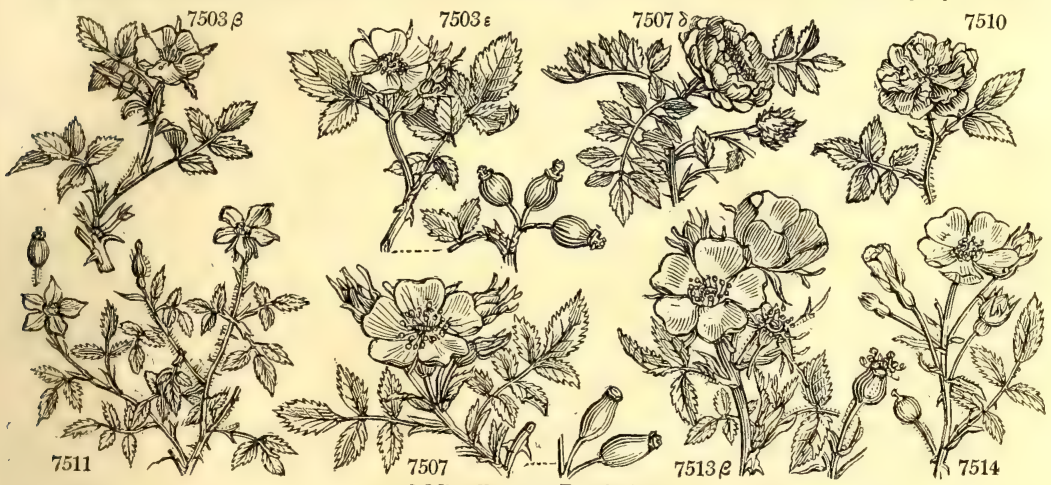

and Miscellaneous Particulars.

common mode of obtaining late roses, and one of the greatest antiquity, is by cutting all the flower shoots off when the buds begin to appear, or by rubbing off all the rudiments of shoots, of every kind, early in spring; a second crop is in consequence produced, which will not be in a state to bloom before the autumn.

The best roses for forcing are the common and moss Provence; the Indian sorts force well, or rather, in stoves, continue in bloom all the year; but the commoner varieties of these not being fragrant, they are in less repute than the European roses. Rose plants should be a year in pots previously to the autumn when it is intended to force them; they should be planted in pots of six or eight inches diameter, in rich loam, and 
7515 sempervírens $\boldsymbol{L}$. ß subdecídua

7516 multiflóra Thunb. 7517 Brunonii Lindl.

7518 moscháta Mill. B-fl. pleno

$\gamma$ m. nepalénsis

o arbórea Pers.

m. nivea Lindl. evratina Bosc.

7519 rubifólia $R$. Br.

Muscade-rouge

7520 sínica Ait.

7521 Bank'siæ $R, B r$.

$\beta$ - flore lúteo

1149. RU'BUS. $W$.

7522 rosæfolius $\mathrm{Sm}$. $\beta$ coronárius

7523 pinnátus $W$

7524 Idæ'us $W$.

7525 occidentális $W$ 7526 pauciflórus Wall.

7527 cuneifolius $P h$.

7528 canadénsis $W$.

7529 híspidus $W$.

$7580 \mathrm{cæ}^{\prime}$ sius $W$.

7531 corylifolius $E . B$.

7532 fruticósus $W$.

$\beta$ ălbus

$\gamma$ plénus

7533 argutus Link.

7534 sánctus Schreb.

535 paniculátus Schlect. holy

7536 sanguinoléntus Link.blood-red

7537 jamaicénsis Suz.

7537 jamaicensis Swa.

7538 ulmifolius Schott. elm-leaved

7540 Schlechtendáhlii $W e$. Schlechtendahl'

7541 rugósus Smith. rugose

7542 plicátus Weihe. plicate

7543 rhamnifólius Weihe. Buckthorn-lvd.

7544 nítidus Weihe. shining

7545 tomentósus $W$. en. woolly-leaved

7546 glandulósus $\dot{W}$. en. glandular ß R. leucostáchys Smith.

7547 hirtus $W$. en. hairy

7548 laciniátus $W$. en. jag-leaved

7549 triviális $P h$.

7550 villósus $W$.

7551 strigósus $P h$

7552 flagelláris $W$. en.

7553 inerrnis $W$. en.

7554 odorátus $W$.

7555 suberéctus $E, B$.

$\begin{array}{lrl}\text { or } & 20 & \text { jn.au } \\ \text { or } & 20 & \text { jn.au } \\ \text { or } & 12 & \text { jn.jl } \\ \text { or } & 12 & \ldots \\ \text { or } & 12 & \text { jl... } \\ \text { or } & 12 & \text { jl.o } \\ \text { or } & 12 & \text { jl.o } \\ \text { or } & 30 & \\ \text { or } & 4 & \text { jl... } \\ \text { or } & 4 & \text { jl.au } \\ \text { or } & 6 & \text { au.s } \\ \text { or } & 4 & \text { au.s }\end{array}$

W

W

Pk
W
W

$\mathbf{W}$
$\mathbf{W}$

$\ddot{\mathbf{W}}$

Fk

$\mathbf{F}$

$\begin{array}{lrr}\text { or } & 5 & \text { my.jl } \\ \text { or } & 20 & \text { jn.jl }\end{array}$

or .......
S. Europe 1629. I co

C...... 1818. L co

1822. C co Lindl. ros t. 14

Barbary 1596. L r.m M.Lawr.ros.t.53

1822. L co Bot. reg. 829

Persia 1824. L co

...... 1822. L co

N..... 1822. L co

N. Amer. 1800 . L p.l Lindl, ros. t. 15

\section{W China 1759. L p.l Lindl. ros. t. 16 W China 1807. C p.l Bot. reg. t. 397 \\ China 1824. C p.l}

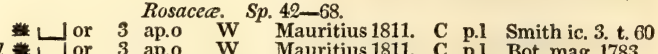
or 3 ap.o W Mauritius 1811. C p.l Bot. mag. 1783 or 5 jn.jl Pk Madeira 1789. C $\mathbf{\text { p.l }}$

fr 5 my.jn W Britain m.wo. Sk r.m Eng. bot. 2442

fr 5 my.jn W N. Amer. 1696. Sk co Dil.el.t.247.f.319

fr 10 my.au $R$ Nepal 1822. C co Bot. reg. 854

or $3 \mathrm{jn}$.jl W N. Amer. 1811. Sk co

or 3 jn.jl W N. Amer. 1811. Sk co

or 3 au W Canada 1768. Sk co

fr 2 jn.jl

or $10 \mathrm{jl}$

or 10 in.s

or 10 jis

or $10 \mathrm{jn}$.

or 6 jn.s

or 3 jn.jl

or 8 jn.jl

or $10 \mathrm{jn.jl}$

or 4 ...

2 4 or 6 ...

or $10 \mathrm{jn.s}$

or $10 \mathrm{jn} . \mathrm{s}$ or $10 \mathrm{jn} . \mathrm{jl}$ or 6 in or 10 jn.s or 3 jn. or 10 . or 10 jn.s

or 10 jn.s or $12 \mathrm{jn} . \mathrm{s}$ or $7 \mathrm{jn} . \mathrm{jl}$ or 3 jl.au or $3 \mathrm{jn.jl}$ or 6 jn.jl $\begin{array}{lrl}\text { or } & 6 & \mathrm{jn} . \mathrm{jl} \\ \text { or } & 12 & \mathrm{jn} . \mathrm{jl}\end{array}$

$\begin{array}{lllll}\text { smooth } & * & \text { or } & 12 & \text { jn.j } \\ \text { flowering } & * & \text { or } & 7 & \text { jn.j } \\ \text { upright } & * & \text { or } & 4 & \mathrm{jn} . \mathrm{s}\end{array}$

$\begin{array}{llll}\text { flowering } & \text { or } 7 & \text { jn.j } \\ \text { upright } & \text { or } 4 & \text { or } 4 \mathrm{jn}, \mathrm{s}\end{array}$

Britain bor.fi. Sk co Eng. bot. 826

Britain hed. Sk co Eng bot 827

Britain hed. L co Eng. bot. 715

Britain ... I co

... L co

N. Amer. 18̈23. L co

Palestine 1823. $\mathbf{L}$ co

I..... 1821. L co

I. France 1824. C co

Jamaica 1822. C co

Spain 1823. L co

Germany 1823. L co

Europe 1823. I co

S. Amer. 1824. L co

Britain hed. L co

Britain hed. I co

Britain thick, L co

Germany ... L co

Germany $18 i 6$. L co

Hungary 1816. I co Pl.rar.hu.2.t.141

17.. L co Dend, brit, 69

9k co

N. Amer. 1777. Sk co

N. Amer.

N. Amer. 1789. Sk co

N. Amer. 1805. Sk co

N. Amer. 1700. Sk co Bot. mag. 323

W Britain woods. Sk co Eng bot. 2579
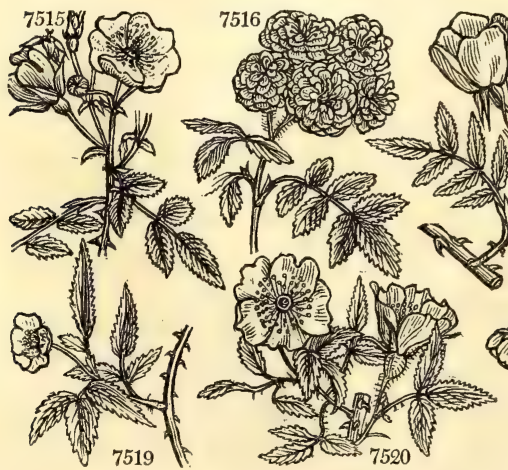

7517

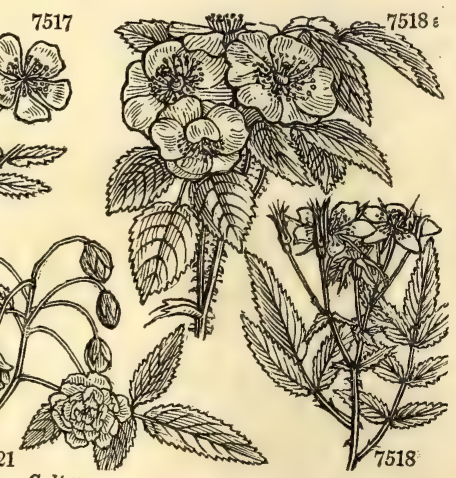

/, 7521

7518

plunged in an open airy situation; their flower buds pinched off as they appear; and the plants put early into a state of rest, by excluding the sun and rain, but not a free circulation of air.

All the species of roses are very liable to the attacks of insects, especially of the aphides; some, and especially the briar and Scotch rose, are attacked by the Cynips rosæ, which, by puncturing the bark, occasions the production of rose-galls, and of those mossy tufts often seen on wild roses, which were known formerly under the name of Bedeguar, and used in medicine. Under cover tobacco smoke will prove an effectual remedy for the aphides; but the larvæ of many others, and especially of tipula and the tenthredinidæe, which occasion the wrapping up and shrivelling of the leaves, can only be removed by washing with limewater or hand picking.

1149. Rubus. From the Celtic rub, which signifies red. Many of the species are only biennial woody plants, producing suckers or stolones from the roots, which ripen and drop their leaves one year, and resume their 
7515 Root-shoots climbing, Prickles nearly equal falcate, Leaves evergreen $\beta$ Leaves nearly deciduous

7516 Branchlets peduncles and calyx downy, Leaflets soft lanceolate rugose, Stipules pectinate

7517 Branchlets lanceolate, Leaflets and calyxes downy glandular, Stipules entire

. $\beta$ Flowers double

$\gamma$ Leaflets ovate lanceolate, Petals acute, Pedicels and calyxes glandular

Stem arborescent

6 Stem branched, Leaflets ovate-obl. acuminate rugose, Petals large obcordate

$\zeta$ Stem erect, Flowers double pink

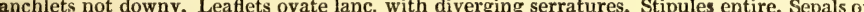

$\beta$ Leaflets smooth on each side

Div. XI. Banksians.

7520 Stipules setaceous deciduous, Petioles and rib prickly, Fruit muricate

7521 branches and fruit unarmed

* Shrubby.

7522 Leaves quinate pinnate and ternate green on each side, Stem and petioles prickly, Fl. solitary

7523 Leaves quinate pinnate and ternate rugose smooth on each side, Stem petioles and pedunc. prickly, Raceme 7524 Leaves quinate pinnate and ternate white beneath, Leafl. rhomboid lined 7525 Leaves three white beneath, Stem prickly, Petioles round

7526 Lvs. pinnate, Stem round, Leaf. 5-7 obl. plicate serr. white beneath, Pan. cymose, Pet. shorter than calyx 7527 Branches pet. and ped. downy, Leafl. 3-5 cuneate obovate unequally toothed upwards, Racemes term. pan. 7528 Smoothish, Leafl. 10-5-3 lanceolate naked on each side finely serrated, Stem unarmed, Bractes lanceolate 7529 Leaves 3 naked, Stems and petioles very hispid, Bristles stiff

7530 Leaves ternate nearly naked: the lateral 2-lobed, Stem prickly round

7531 Stem erect roundish, Prickles many close, Leafl. 5 pubesc. beneath, the lateral sessile, Cal. of fi. refiexed 7532 Stem angular furrowed, Leaf. 5 obtuse shining and even above, hoary beneath, Pan. decomp. hoary

7533 Stem with small straight prickles, Leafl. 3 and 5 obl. acum. doubly and finely serr. pubes. beneath, Fl. pan. 7534 Stems square hoary, Leafl. 3 obov, round. unequally and finely cut-tooth. hoary beneath, Pan. small hoary 7535 Stem aculeate, Leafl. 3-5 unequal ovate acumin. serr. with fine white down beneath, Fl. panicled 7536 Stem densely prickly and strigose, Leaf. 5 lanc. acum. serrul. smooth, Pedunc. axill. few-flowered 7537 Lvs. 3-5 cut-serr. downy beneath, Stem petioles and leaves pubesc. with recurved prickles, Pan. diffuse 7538 Stem decum. very prick. Leafl. 3 subcord. ov. doub. acute. cren. smooth prick. beneath, Branches very red 7539 Differs from R. corylifolius in having the upper shoots and peduncles covered with short hairs

7540 Differs from the last in having the leaves covered all over beneath with soft hairs

7541 Unarmed, Branches lvs. beneath and calyxes downy with brown hairs, Lvs. 3-lobed, Fl. sol. on short stalks

7542 Stem suberect angular prickly smooth, Leafl, 5 cordate ovate cusp. pubes. beneath, Pan. simpie

7543 Stem angul. furrowed, Leaf. 5 orbicular cusp. hoary beneath, Pan. comp. divaricating, Cal. prickly at base 7544 Stem suberect angular smooth, Leafl. 5 ovate shining pubes. beneath, Panicle prickly

7545 Leaves 3 obovate downy and soft on each side, Fl. panicled

7546 Leaves tern. Leafl. roundish ovate acum. mucronate serr. Stem pet. ped. and cal. prickly and glankular

7547 Lvs. 5-3 hairy, Leafl. ov. acum. unequally ser:. Stem decum. and pet. prickly and gland. Ped. unarm. gland. 7548 Lvs. 3-5-nate, Leafl. pinn. Stem pet. and ped. with recurver prickles

7549 Procumbent, Stipules subulate, Lvs. 3-5 digitate, Leafl. ovate obl. smoothish serrate, Pedicels solitary 7550 Leaves 5 ellipt. acumin. finely serrate villous on each side, Stem and petioles prickly

7551 Unarmed hispid, Leafl. 3 or pinnate quinate ovate blunt at base white beneath : the odd one cordate

7552 Lvs. 3-nate smooth unequally serr.: interm. ov.-cuneate at base; lat. rhomb. Stem round proc. and pet. prick.

7553 Lvs. ternate, Leafl. ovate acute urequally serrate downy beneath, Stem pet. and ped. unarmed

7554 Leaves simple palmate, Stem unarmed many-leaved many-flowered

7555 Leaves pinnate about 7 hairy beneath: the upper ternate, Stem ascending with small straight prickles

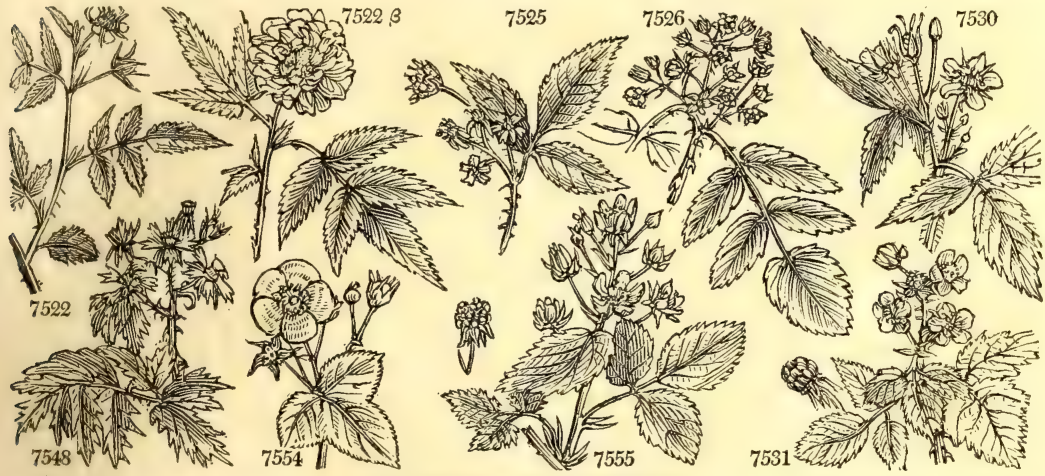

and Miscellaneous Particulars.

foliage, produce blossom shoots, flower, and fruit, and die the next. The common raspberry and bramble are examples.

$\mathbf{R}$. idæus is a native fruit, greatly improved by cultivation; it has a grateful subacid taste, and like the strawberry, is one of the few fruits that does not undergo the acetous fermentation in the stomach. There are red and yellow varieties, and one very excellent sort that bears twice a-year, in July and September. The raspberry requires a soft rich moist soil, and if a plant stands singly or a single row is planted by itself, the situation should be gently shaded. Where a plantation is made of several rows together it may be placed in the ation should be gently shaded. open garden, as the plants will shade one another to a sufficient degree. Frequent renewal is necessary to prevent the stools getting large and matted when they send up only weak suckers. No more suckers should be
left at the stools than are intended to bear the following year, unless young plants are wanted; and if very 
7556 moluccánus $\boldsymbol{W}$. 7557 refléxus $\mathrm{Ker}$.

7559

7559 saxátilis $W$ 7560 triflórus Richardson 7561 pistillátus $P h$ 7562 árcticus $\boldsymbol{E}$. $\boldsymbol{B}$. 7563 chamæemórus $W$.

Molucca reflexed small-leaved

$2 \square$ or 3 jl.au stone

1150. DALIBAR'DA. Mich. Dalibarda.

7564 violæoídes $M i$. Violet-leaved \& $\Delta \mathrm{cu}$ 7565 fragarioídes $M i$. Strawberry-lvd. $\$ \mathbf{v} \mathrm{cu}$

1151. FrAGA'RIA. $W$. Strawberry.

7566 vésca $W$.

7568 collína $W$

7569 elátior $W$.

7570 canadénsis Mich.

7571 virginiána $P h$.

7572 grandiflóra $\boldsymbol{W}$.

7573 chiloénsis $W$.

7574 indica $\boldsymbol{H} . \boldsymbol{K}$.

1152. CO'MARUM. $W$

1152. CO'MARUM. $W$. Coma RuM.
7575 palústre $W$.

wood
one-leaved

Green Pine

Hautboy

Canada

scarlet

Pine

yellow-flower'd $\Delta$ or

Comarum. Fragária sterilis E. B.

1153. POTENTILIA. $\boldsymbol{W}$. Cinquefoll.

7577 fruticósa $W$. shrubby

7578 floribúnda $\dot{P} h$. cluster-flower

7579 Anserína $W$. Wild Tansey

7580 atrosanguínea Lodd. crimson

7581 nepalénsis Hook.

7582 Salesóvii W.en.

7583 spléndens Wall.

7584 híspida W.en.

7585 sericea $W$.

7586 multífida $W$.

7587 fragarioídes $W$.

7588 ruthénica $W$.

7589 rupéstris $W$.

7590 bifúrca $W$.

7591 pimpinelloídes $W$.

7592 pensylvánica $W$.

7593 supina $W$

7594 récta $W$.

7595 argéntea $W$.

7596 intermédia $W$.

rerimson

Nepal
white-shrubby

fine

hispid

silky

cut-leaved

\& $\triangle$ fr 1 my.jn $W$

$\Delta$ fr $\frac{3}{4}$ ap.n W

$\triangle$ fr $1 \frac{1}{2}$ ap.my W

$\triangle$ fr $1 \frac{1}{2}$ ap.my W

$\triangle \mathrm{fr} 1$ ap.my $\mathrm{W}$

1 ap.my W

R E. Indies 1810. Sk 1.p

Ru.am.5.t.47.f.

$\begin{array}{lll}\text { China } & \text { 1818. L co Bot. reg. } 461 \\ & \text { Bot. reg. } 496\end{array}$

my.o Y

Rosacea. Sp. 2.

$\begin{array}{llll}\text { jn.jl Pu Britain sp. bo. D p Eng. bot. } 172 & \text { Pu }\end{array}$

Britain banks. D 1.p Eng. bot. 1785

Rosacere. Sp. 40-74.

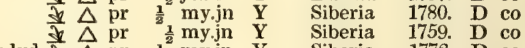

政 $\Delta$ pr.jn $Y$

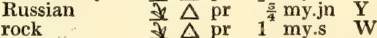

Burnet-leaved $\frac{\text { है }}{\Delta} \mathrm{pr}$

Pensylvanian $\frac{\Delta}{\Delta} \mathrm{p}$

trailing $\frac{d}{\Delta} \mathrm{pr}$

trailing $\quad$ to $\Delta$ pr

upright $\quad \frac{\downarrow}{\partial} \mathrm{pr}$

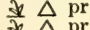

various-leaved $\frac{ \pm}{\Delta} \Delta$

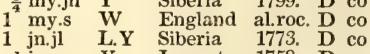

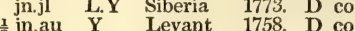

1 jn.au Y

$\frac{1}{4}$ jl.au Y

1 jn.jl Y

1 jn.au $Y$

N. Amer. 1725.

Siberia 1696, D co

S. Europe 1648. D co

Britain gra.pa. D co

Switzerl. 1786. D co

Hungary 1806. D co

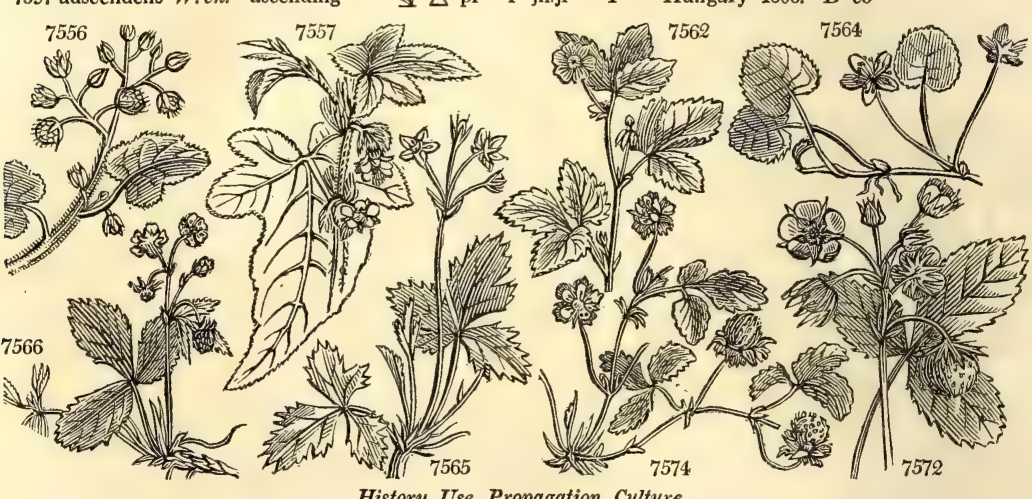

History, Use, Propagation, Culture,

large fruit is the object, no suckers should be left at all: on the contrary, when the strongest suckers are wanted, the fruit-bearing shoots should be cut down.

R. occidentalis is a showy plant for large shrubberies. The fruit of $R$. cæsius is blue, edible, and it continues till frost. R. corylifolius and fruticosus are both common in our hedges; the shoots of the latter are much tougher than those of the former, and are preferred by thatchers for binding their roofs, and by straw-hive and mat makers. The berries, eaten at the moment they are ripe, are cooling and grateful ; a little before, they are coarse and astringent; and a little after, disagreeably flavored or putrid. They are sometimes made into pies; but great care is requisite in gathering the fruit, for one berry of the last sort will spoil a whole pie. The double-flow ering variety is considered very ornamental.

The fruit of $R$. arcticus and chamæmorus is eaten in the north of Scotland and Sweten. In the iatter country, Dr. Clarke informs us, it is much prized in soups, sauces, and for making vinegar; and Dr. Clarke was cured of a bilious fever by eating great quantities. The plant is rather difficult to preserve in gardens, but by raising successive generations from the seed it might perhaps be subjected to the same culture as the cranberry. The fruit of $R$. pauciflorus, the Nepal raspberry, is very agreeable.

1150. Dalibarda. Denis Dalibard was a French botanist, who published, in 1749, a catalogue of the plants in the neighbourhood of Paris. Small plants, resembling the little species of Rubus. 
7556 Leaves simple cordate somewhat lobed downy beneath, Stem prickly decumbent

7557 Branches round villous, Lvs. cordate obl. 5-lobed : the middle lobe elongated, Stip. and bractes pectinate 7558 Leaves 3.5 downy beneath, Stem peduncles and petioles with recurved prickles

\section{** Herbaceous.}

7559 Leaves tern, naked, Runners creeping herbaceous, Panic, few-flowered

7560 Leaves tern. naked, Leafl. rhomboid acute cut serrate : the odd one stalked, Flowers about 3

7561 Stem unarmed 1-flowered, Leaves term. smooth finely serrate, Pet. obl. entire, Styles approximating

7562 Leaves ternate, Stem unarmed 1-flowered

7563 Leaves simple lobed, Stem unarmed 1-flowered

7564 Leaves simple cordate crenate, Peduncles 1-flowered

7565 Leaves ternate, Leafl, cuneate serrate-cut, Tube of cal. obconical

7566 Cal. of fruit reflexed, Pubescence of petioles spreading, of the peduncles appressed

7567 Leaves simple

7568 Cal. of fruit erect, Pubescence of pedunc. erect, of petioles much spreading, Leaves downy on each side $7569 \mathrm{Cal}$. of fruit reflexed, Pubescence of pedunc. and petioles much spreading

7570 Large, Leaves broad oval, Pedic. long recurved pendulous, Recept. much excavated globose villous 7571 Cal. of fruit spreading, Pubescence of petioles erect, of peduncles appressed, Leaves smoothish above 7572 Cal. of fruit erect, Pubescence of peduncles and petioles erect, Lvs. smoothish above

7573 Cal. of fruit erect, Pubescence of peduncles and petioles much spreading, Lvs, villous on each side

7574 Outer sepals larger than the rest obovate 3-toothed

7575 Leaves pinn. Petals smaller than calyx

7576 Leaves tern. Petals larger than calyx

7577 Leaves pinnate, Leafl. lin. obl. flat, Petioles long, Branches 1-2-fi.

7578 Leaves pinnate, Leafl. lin. obl. revolute at edge, Petioles short, Corymbs terminal

7579 Leaves interruptedly pinnate silky, Leaflets finely serrate, Stem creeping, Pedunc. 1-fl.

7580 Leaves ternate stalked, Leafl, obovate cut serrate white with down beneath, Sepals ellipt. Pet. obcordate 7581 Rad. lvs. quinate cauline tern. Leafl. cuneate obl, serrate, Stipules large adnate entire

7582 Leaves pinnate white with down beneath, Leafl. serrate, Stem shrubby

7583 All over silky, Lvs. interruptedly pinn. Fl. dichoto. corymb. Sepals ov. acute, Stem erect nearly simple 7584 Lvs. interruptedly pinn. with spread. hairs, Leafl. lanc. cut toothed, Stip. cut, Pet. obcord. larger than cal 7585 Lvs, bipinnatifid in many pairs downy on each side : segments parallel approximating, Stem decumbent 7586 Lvs. bipinnatifid in four pairs smooth above downy beneath: segments distant, Stem decumbent

7587 Leaves pinnate : the outer largest, Runners creeping

$758 \mathrm{~S}$ Rad. leaves subpinn. cauline tern. Leaf. lans. unequally coarsely serrate hairy on each side

7589 Leaves pinnate alternate, Leaf. 5 ovate crenate, Stem erect

7590 Leaves pinnate nearly equal, Leafl. oblong subbifid : the outer confluent

7591 Leaves pinnate, Leaf. roundish toothed equal, Stem erect

7592 Leaves pinnate upper ternate, Leafl deeply toothed, Stem erect pubescent

7593 Leaves pinnate, Leaf. oblong deeply toothed, Stem decumbent dichotomous, Pedun. axill. solitary

7594. Leafl. 7-5 lanceolate coarsely toothed, Petals obcordate larger than calyx, Stem erect

7595 Leaf. 5 cuneiform cut downy beneath, Stem erect

7596 Radic. leaves 5-nate, Cauline ternate, Stem nearly erect much branched

7597 Lvs. 5-nate with adpressed hairs : of the branches ternate, Leafl. obl cuneate deeply toothed, Stem ascend.

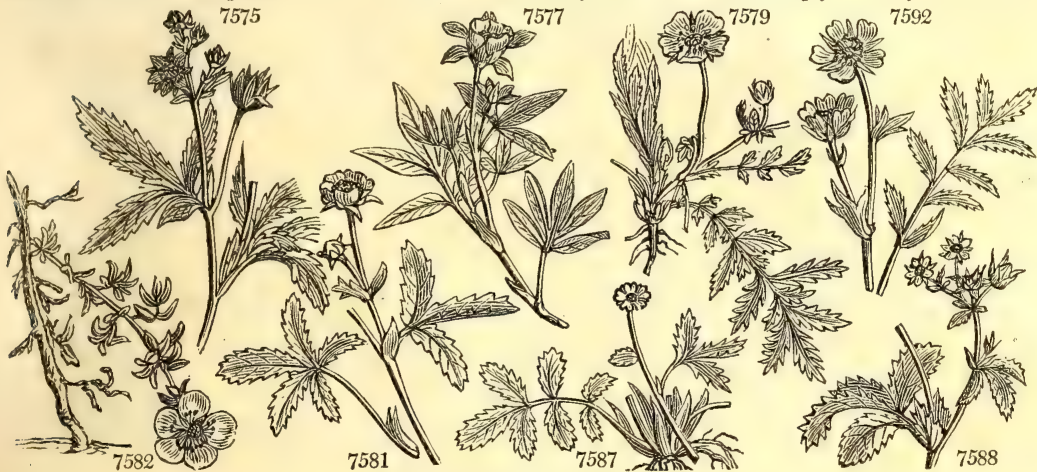

and Miscellaneous Particulars.

1151. Fragaria. From fragrans, in allusion to the perfumed fruit. Fraisier, Fr, Erdbeere, Ger., and Tragolo, Ital. This is a genus of fruit-bearing herbaceous plants, of which there are few in the vegetable kingdom, and none to equal the strawberry in wholesomeness and excellence. This fruit is universally grateful, alone, or with sugar, cream or wine; and has the property, so valuable for acid stomachs, of not undergoing the acetous fermentation. Besides the species or subspecies enumerated, there are upwards of sixty mongrel varieties or different names, some of which, recently produced from seed, are of great excellence. The strawberry is not only a valuable and easily cultivated out-door fruit, but forces well, and with a little trouble in choosing a succession of sorts, they may be had at the dessert every month in the year, though during the three winter months they are without flavor.

In cultivating the strawberry an open situation and rich loamy soil, rather strong, is required for most varieties; and from their large mass of foliage and flowers, they must, till the fruit is set, have copious supplies of water. The row culture is most convenient, and frequent renewal insures vigorous plants and large fruit.

1152. Comarum. A name given by the Greeks to the Arbutus. The Comarum of the moderns produces a fruit not unlike that of the Arbutus.

1153. Potentilla. In allusion to its supposed potential virtues in medicine. These, however, appear to con. 
7598 hírta $W$. 7599 stipuláris $W$. 7600 opáca $W$. 7601 vérna $W$. 7602 aúrea $W$ 7604 álba $W$. 7605 cauléscens $W$. 7606 Clusiána $W$. 7607 lupinoídes $\dot{W}$ 7608 nitida $\boldsymbol{W}$.

7609 réptans $W$. 7610 sarmentósa $W$. en. 7611 diffusa $\boldsymbol{W}$. en. 7612 monspeliénsis $W$ 7613 nivea $W$. 7614 norvégica $W$. 7615 tridentáta $W$. 7610 grandiflóra $W$. 7603 astracánica $W$ stipular small-rough spring golden golden Astracan white Alpine
Clusius's close-flowered shining common sarmentose Montpelier snowy Norwegian trifid-leaved great-flowered $\frac{\neq}{\Delta} \Delta$ cu various-leaved

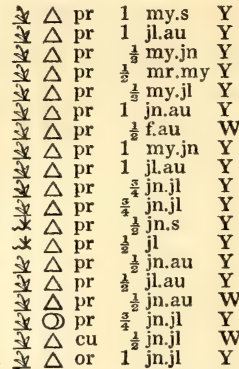

S. Europe 1725. D co Siberia 1797. D co Gm. si.3.t.37.f.2 S. Europe 1680. D co Jac. ic. 1.t. 91 Britain hghl.p. D co Eng. bot. 37 Scotland sc.alp. D co Eng. bot. 561 Siberia 1787. D co Jac. ic. 1.t. 92 Wales w. alp. D co Eng. bot. 1384 Austria 1759. D co Jac. aus, 3. t.220 Austria 1806. D co Bot. mag. 1327 Al. of Eur.1739. D co Bot. cab. 654 Austria 1798. D co Jac. au.5.t.ap.25 Britain me. pa. D co Eng. bot. 862 N. Amer. 1804. D co France 1817. D co 1680 . France 1680. D co M. h. s. 2.t.20f. Siberia 1816. D co Bot. cab. 460
N. Europe1764. D co Fl. dan. 171 Scotland sc. alp. S co Eng. bot. 2389 Siberia 1640. D co Bot. mag. 75

1154. TORMENTIL'LA. $L$. SEPTFoIL.
7617 réptans $W$. 7618 erécta $W$. officinális E. B.

1155. GE'UM. $W$. 7619 stríctum $P h$. 7620 agrimonoídes $\boldsymbol{P h}$. 7621 album $P h$. common \& $\Delta w$ 1 my.o $\mathbf{Y}$ Eritain bar.pa. D co Eng. bot. 863

Rosacece. Sp. 10-20.

AVENS.

upright $\frac{D}{\partial} \Delta$ or

1 my.jn St N. Amer. 1778. D p.l Jac. ic. 1. t. 93

$1 \frac{1}{2}$ jn.jl W N. Amer. 1811. D p.l

1 jl.au W N. Amer. 1730. D p.1 Jac. vin. 2.t.175

1 l.au W N Amer.

N. Amer. $\ldots$ D p.

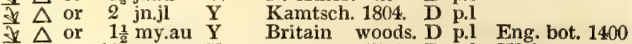
7623 macrophyllum $W$. en. large-leaved 7624 urbánum $W$. common 7625 intermédium $W$. en. wood 7626 rivále $W$

7627 hýbridum Jac. hybrid

7628 pyrenáicum $W$. Pyrenean

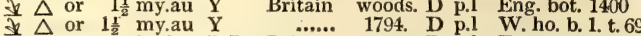
$\frac{\downarrow}{\Delta}$ or $1 \frac{1}{2}$ my.j $_{1}$ R.Br Britain m.mea. D p.l Eng. bot. 106 I $\triangle$ or 1 jn.jl R.Br Europe ... D p.l Jac. ic. 1.t. 94 ₹ $\triangle$ or $1 \frac{1}{\mathrm{j}} \mathrm{jn}, \mathrm{jl} \quad \mathrm{Y}$ Pyrenees 1804. D p.l Lam. ill, t. 443

1156. KER'RIA. Dec.

7629 japónica $D e c$ Corchorus japonicus I

Kerria. Rosacece. $S p .1$. Japa

\$ or 3 ja.d Y Sp. Japan

1804. C co Bot. mag, 1296

Calycanthece. Sp. 3-5.

1157. CALYCAN'THUS. L. ALLSPICE 7630 flóridus $W$. Carolina Nate 7631 fértilis $W$. glaucous-lvd. 凿 7632 lævigátus $W$. en. smooth-leaved
1726. L 1.p Bot. mag, 503 ft 3 my.jl $\mathrm{Br}$ N Ama $\ldots$ L l.p Bot. reg. 404

1158. CHIMONAN'THUS. Lindl. Chmonantrus. Calycanthece. Sp. 1.

7633 frágrans Lindl. Japan $\quad$ 型 $\quad$ ft 6 f.d $\quad$ Y.R Japan 1766. L 1.p Bot. mag. 466

Calycánthus pracox W.
$\beta$ grandiflórus Lindl. large-flowered $\quad$ ft $\quad 8$ f.d $\quad$ Y.R $\quad$ China $\quad \ldots \quad$ L co Bot. reg. 451

1159. DRY'AS. $W$. DRYas, Rosacce. Sp. 1-3.

7634 octopétala $\dot{W}$. mountain $\searrow \Delta$ cu $\frac{3}{4}$ jn.au $W$ Britain al. roc. D s.p Eng. bot. 451

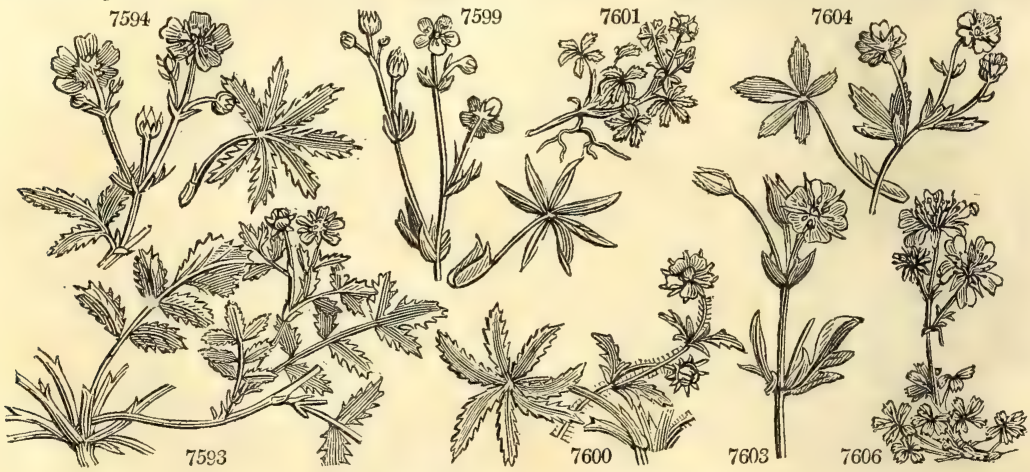

History, Use, Propagation, Culture,

sist of nothing beyond a slight vulnerary quality. P. fruticosa and floribunda are shewy shrubs. P. anserina is remarkable for the silvery whiteness of its foliage, which is eaten by geese, as the roots were once by the country people in some places. All the species are pretty, and deserving cultivation.

1154. Tormentilla. From tormina, the dysentery, which this plant was formerly employed for curing. $T$. erecta was once a plant of some importance in œconomy and medicine. The roots are still used in most of the Western Isles of Scotland and in the Orkneys for tanning leather, for which they are superior even to oak-bark. They are first boiled in water, and the leather is then steeped in the cold liquor. In the islands of Tirey and Col, the inhabitants have destroyed so much ground by digging them up, that they have been prohibited the use of them. They are also used for dying of a red color. And Mr. Young informs us, that many swine are reared with them on the mountains of Killarney.

In the London Materia Medica it is employed in intermittents, and as a local application in the form of gargle and lotion, in ulcerations of the tongue and mouth, against spongy gums, and as an application to foetid ill conditioned sores; but it is seldom used. (London Dispensatory, 538.)

1155. Geum. From $\gamma \in \nu \omega$, to taste well. The roots of G. urbanum have a mildly astringent aromatic taste, somewhat like that of cloves, whence this plant has the name of Caryophyllata. They should be gathered in dry warm situations, for in shady moist places they have little virtue. Gathered in the spring, and put fresh into ale, they give it a pleasant flavor, and prevent its turning sour. Infused in wine, it is esteemed a good 
7598 Leaf. $5-7$ cuneiform cut pilose, Stem erect hairy

7599 Leafl. 7 sessile seated upon a dilated stipule

7600 Rad. Ivs. 5-7 lin. cuneiform toothed, Petals retuse the length of calyx, Stems filiform decumbent hairy

7601 Leaves 5-nate obovate toothed pubescent, Pet. obcord. larger than calyx, Stems declinate

7602 Rad. lvs. 5-nate, Leaff. cuneif. ciliate 5-toothed at end, Caul. Z-nate subsess. Pet. obcord. larger than calyx

$7603 \mathrm{Rad}$. lvs. 5-nate oblong toothed : upper 3-parted, Cor. larger than calyx, Stem ascending

7604 Leaves 5-nate with connivent serratures at end, Stems filiform procumbent, Recept. hairy

7605 Leaves 5-nate with connivent serratures at end, Stems many-fl. decumbent, Recept. hairy, Pet. obovate

7606 Leaves 5-nate with connivent serratures at end, Stems many-fl. decumbent, Recept. hairy, Pet. roundish

7607 Leaves 5-nate silky on each side, Leaf, obovate bluntly toothed at end, Pet. length of cal. Recept. woolly

7608 Leaves subtern. downy with 3 connivent teeth, Stems 1-fl. Recept. woolly

7609 Leaves 5-nate, Stem creeping, Pedunc. 1-flowered

7610 Leaves 5-nate obovate coarsely serr. Stip. cut bifid, Pedunc. 1-fl. axill. Stem producing runners

7611 Rad. lvs. subpinnate: cauline ternate, Leafl. lanc. unequally and coarsely serrated with spreading hairs on

7612 Leaves ternate, Stem branched erect, Peduncles with a knee at base

[each side

7613 Leaves ternate cut downy beneath, Stem ascending

7614 Leaves ternate, Stem dichotomous, Pedunc. axillary

7615 Leaves ternate cuneiform 3-fid at end

7616 Leaves ternate toothed hairy on both sides, Stem decumbent longer than leaves

7617 Stem creeping, Leaves stalked

7618 Stem nearly erect, Leaves sessile

7619 Fl. erect, Awns hooked naked, Caul. lvs. pinn. Leafl. and stipules split, Petals longer than calyx

$7620 \mathrm{Fl}$. erect, Lvs. pinn. Leafl. nearly equal irregularly cut toothed, Stip. ovate nearly entire, Pet. oval length of

7621 Fl. erect, Rad. lvs. pinn. : cauline tern. upper simple, Lower stip. cut, Pet. length of calyx

7622 Fl, erect, Awns hooked naked, Caul. lvs. tern. : upper lanc. Petals shorter than calyx

7623 Fl. erect, Awns hooked naked hairy at end, Rad. lvs. lyrate pinnate : terminal pinnate cordate

7624 Fl. erect, Awns hooked naked, Caul. lvs, tern. : radical lyrate pinnate

7625 Fl. nodd. Pet. length of cal. Awns hooked naked, Grains hairy, Rad. lvs. lyrate pinn. : cauline ternate

$7626 \mathrm{Fl}$. nodd. Pet. length of cal. Awns feathery twisted in the middle

$7627 \mathrm{Fl}$. nodd. Cal, leafy longer than the polypetalous corolla

7628 Fl. nodd. Pet. longer than cal. Awns hairy twisted at base, Rad, lvs. lyrate pinnate : cauline simple trifid

7629 The only species

7630 Leaves oblong downy beneath

7631 Leaves lanceolate smooth on each side glaucous beneath

7632 Sepals lanc. Lvs. obl. acute by degrees somewhat rugose smooth and green on each side, Branches very

[straight and erect

7633 The only species. Fl. small very fragrant pale yellow appearing in the winter

7634 Leaves toothed

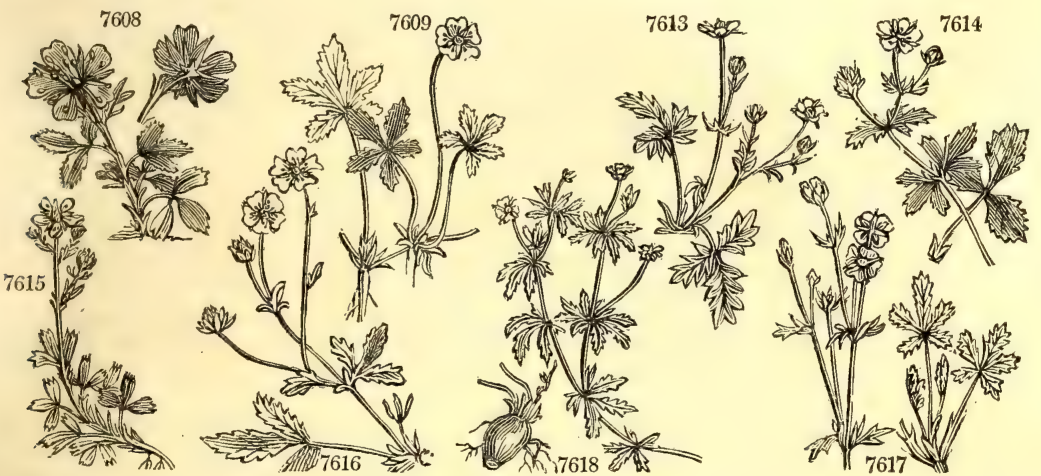

and Miscellaneous Partıculars.

stomachic; but in water, Haller affirms it to have been attended with bad effects, when given in malignant fevers, producing delirium. Chewed in the mouth, the roots take off from a disagreeable breath.

1156. Kerria. So named after Mr. William Ker, a botanical collector, who was sent some years since to China, whence he sent many curious plants. The plant named after him is the common Corchorus japonica of the gardens.

1157. Calycanthus. From $\approx \alpha \lambda v \xi$, and $\alpha \nu$ จ os, a flower; the calyx being colored and similar to petals, which are not present in the genus. Small North American shrubs, with chocolate-colored blossoms. The flowers of $\mathrm{C}$. floridus have an agreeable scent like those of allspice, and is so called in Carolina.

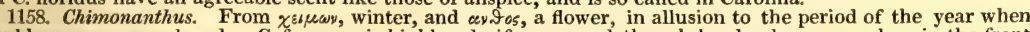
its blossoms are produced. C. fragrans is highly odoriferous, and though hardy, deserves a place in the front border of a conservatory, on account of the odor it disperses early in spring.

1159. Dryas. A name poetically applied to this little plant, from the resemblance of its leaves to those of the oak, which was sacred to the Dryads. This is a delicate evergreen plant, and with its snow-white blossoms is a great ornament to alpine heights. The stalk and branches are woody and perennial, lying flat upon the ground, and spreading wide about the root in tufts.

It requires some care to preserve it in gardens, and grows better in a shaded bed of peat than in pots. 
1160. COLU'RIA. R. Br. Coluria. 7635 potentilloídes $R$. Br. Siberian 1161. SIEVER'SIA. Willd. Sieversia. 7636 montána $R$. Br. mountain 7637 réptans $R . B r$. creeping

\} \Delta \text { pr } { } _ { \frac { 1 } { 2 } } ^ { \text { Rosacea. } } \text { in } S p . 1 - 3 .

1780. D p.l Jac. vin. 3, t. 68 v $\Delta \mathrm{pr}$ Rosacece. $S p .2-4$.

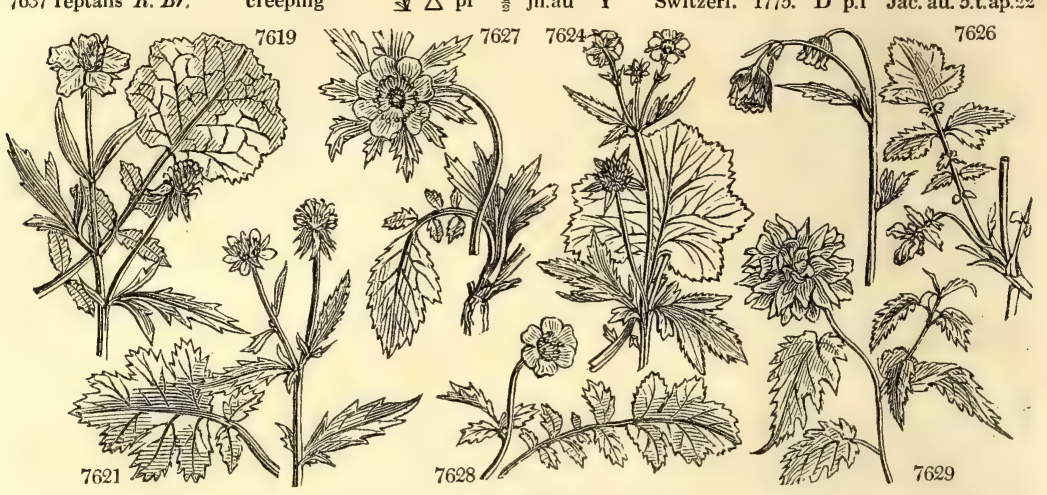

History, Use, Propagation, Culture,

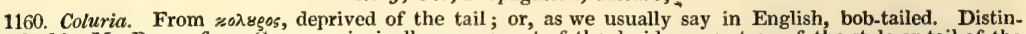
guished by Mr. Brown from Geum, principally on account of the deciduous nature of the style or tail of the grains.

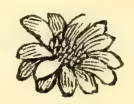

Class XIII. - POLYANDRIA. Stamens many, hypogynous, or inserted under the Ovary.

THIs class agrees with the last in having hermaphrodite flowers, with an indefinite number of stamens, which neither cohere in any part of their length, nor are distributed in distinct parcels ; but it is distinguished by the stamens being inserted distinctly from the floral envelopes, immediately under the ovary, into what has been called the receptacle by Linnæus and his followers ; torus, by Mr. Salisbury ; and thalamus, by some other botanists. The class consists of the greater part of several extensive natural orders, such as Ranunculaceæ, Magnoliaceæ, Cistineæ, \&c. ; and, like the last, is replete with subjects of interest to gardeners and florists. The various kinds of Clematis form the most valuable portion of the hardy climbing plants of the verandah. The various kinds of Clematis form the most valuable portion of the hardy climbing plants of the verandah. Preonia, well known for the richness of its coloring, and the robustness of its constitution, is the ornament of every cottage; and the noble varieties of Magnolia, the pride of the North American forest, are the finest exotics of the shrubbery. Nymphæa and Nelumbium are beautiful genera of aquatic plants. Annona, or the custard apple, is one of the most important of the fruit trees of tropical countries; and the celebrated water vine of Sierra Leone is a species of Tetracera. Nor must Sarracenia, with its curious pitcher-like leaves ; Papaver, from which opium is extracted; Cimicifuga, whence is obtained the antidote to the dangerous bite of Papaver, from which opium is extracted; Cimicifuga, whence is obtained the antidote to the dangerous bite of
the rattle-snake; Bixa, or the arnotta tree, from the fruit of which the coloring matter for the red cheese of England is procured; nor Hepatica, with its modest beauties, be omitted.

The commencement of M. Decandolle's laborious Systema Vegetabilium has included nearly every thing contained in the class, and is followed in the discrimination of the species, as being the best authority which can be taken.

\section{Order 1. MONOGYNIA. Style 1.}

1162. Capparis. Cal. 4.leaved, coriaceous, deciduous. Petals 4. Stamens long. Stigma capitate. Berry with a rind, 1-celled, stalked, subglobose, or like a pod.

1163. Marcgraavia. Cal. 6-leaved, imbricated. Corolla monopetalous, calyptriformis. Berry many-celled, many-seeded. Style 0 .

1164. Actea. Cal. 4-leaved, deciduous. Petals 4. Berry 1-celled. Seeds half orbicular.

1165. Actea. Canguinaria. Cal. 2-leaved. Betals 8. Pod ovate, 1-celled.

1165. Sanguinaria. Cal. 2-leaved. Betals 8. Pod ovate, 1-celled.

1166. Podophyllum. Cal. 3-leaved. Petals 9. Berry 1-celled, crowned with the stigma.

1168. Romeria. Petals 4. Caps. long, 2-3-4-valved; the valves opening from the vertex to the base. Seeds reniform, scurfy, without a glandular crest.

1169. Glaucium. Cal. 2-leaved. Petals 4. Pod 2-celled, linear, 2-3-valved. Seeds several, dotted.

1170. Papaver. Cal. 2-leaved. Petals 4. Capsule 1-celled, opening by pores under the persistent stigma.

1171. Meconopsis. Petals 4. Style short. Stigmas 4-6, radiating, convex, distinct. Capsule opening with 4-6 valves.

1172. Argemone. Cal. S.leaved. Petals 6. Capsule half valved.

1173. Sarracenia. Cal. double, 3-5-leaved. Petals 5. Caps. 5-celled. Style with a clypeate stigma.

1174. Nymphaea. Sepals at the base of the discus. Petals and stamens connected with the whole po the discus, which covers the carpella.

1175. Limnocharis. Sepals 3. Petals 3, very delicate, withering. Plant monocotyledonous. 
7635 Stem about 2-flowered, Awns straight naked, Cal, of fruit erect, Lvs. pinnate toothed

7636 Leaves pinnate : the outer leaflet very large round, lower smaller by degrees

7637 Leaves pinnate cut, Runners creeping
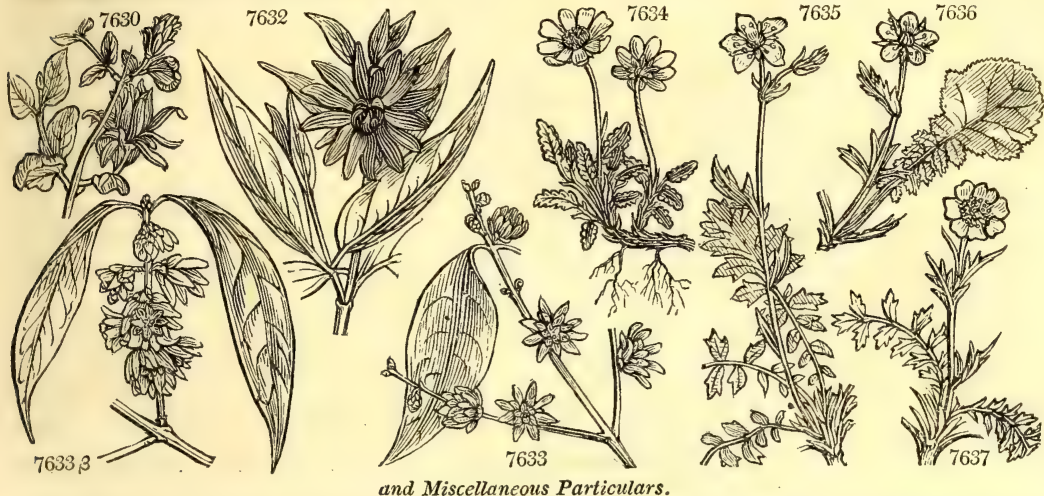

and Miscellaneous Particulars.

1161. Sieversia. Named by Willdenow, after M. Sievers, a well known Russian botanical collector. Plants resembling Geum in habit.

1176. Nuphar. Sepals, petals, and stamens inserted at the base of the discus.

1177. Euryale. Sepals, petals, and stamens united with the discus, which covers the carpella.

1178. Bixa. Cal. 5:toothed. Petals 10. Capsule hispid, 2-valved.

1179. Prockia. Cal. 3-leaved, besides two extra leaves at base. Cor. O. Berry 5-angled, many-seeded.

1180. Sloanea. Cal. 1-leaved, 5-9-fid. Cor. O. Anthers united to filaments beneath the end. Caps. echinate, 3-6-celled, 3-6-valved. Seeds 2, with a berried arillus.

1181. Apeiba. Cal, 5-leaved. Petals 5. Caps. echinate, many-celled.

1182. Sparmannia. Cal. 4-leaved. Petals 4. Filaments cohering at base, torulose. Capsule echinate, 5-angled, 5-celled. Cells 2-seeded.

1183. Entelea. Sepals 4-5. Petals 4. Stamens indefinite, uniform. Anthers roundish, incumbent. Stigma denticulate. Caps, roundish, echinate, 6-celled, half 6-valved, many-seeded.

1184. Muntingia. Cal. 5-parted. Petals 5. Berry 5-celled, 1-5-many-seeded.

1185. Grewia. Cal. 5-leaved, coriaceous, colored inside. Petals 5. Scales 5. Ovary usually stalked. Drupe 4-lobed, 4-celled. Nut 1-2-seeded.

1186. Tilia. Cal. 5-parted. Petals 5. Capsule coriaceous, globose, 5-celled, 4-valved, opening at base, I-seeded.

1187. Corchorus. Cal. 5-leaved, deciduous. Petals 5. Style scarcely any. Stigma 1-3. Capsule pod-shaped, 2-celled, 2-5-valved, many-seeded.

1188. Grias. Cal. 4-cleft. Petals 4. Stigma sessile, cruciate. Drupe with an 8-furrowed nut

1189. Calophyllum. Cal. 4-leaved, colored. Petals 4. Drupe globose.

1190. Mammea. Cal. 2-leaved. Petals 4. Berry very large, 4-seeded.

1191. Ochna. Cal. 5-leaved. Petals 5. Berries 1-seeded, with a large roundish receptacle.

1192. Elaocarpus. Cal. 5-leaved. Petals 5, torn. Anthers 2-valved at end. Drupe with a curly nut.

1193. Alangium. Cal. 6-10-toothed, superior. Petals 6-10, linear. Berry coated, 1-3-seeded.

1194. Mentzelia. Cal. 5-leaved. Petals 5. Capsule inferior, cylindrical, many-seeded.

1195. Lagerstromia. Cal. 6-cleft, campanulate. Petals 6. Stamens many, of which the six outer are thickest. Caps. 4-6-celled, many-seeded.

1196. Egle. Cal. 1-leaved, 5-lobed. Petals 5, spreading. Style short, thick. Berry coated, turbinate, globose, finally woody, with $12-16$ cells.

1197. Cistus. Cal. 5-leaved, with two small leaflets. Petals 5. Caps. 5-celled; the valves bearing the dissepiments in the middle.

1198. Helianthemum. Divisions of the calyx often unequal: the two outer the smallest. Caps. 1-celled, 3-valved, with the dissepiment in the middle of the valves.

\section{Order 2. DI-TRIGYNIA. Styles 2-3.}

1199. Bauera. Cal. 7-9-leaved, persistent. Petals 7-9, deciduous. Caps, inflated, 2-celled, many-seeded.

1200. Fothergilla. Cal, truncate, entire. Cor. O. Filaments very long, clavate. Ovary bifid. Caps. 2-celled, 2-horned. Seeds solitary, bony.

1201. Curatella. Cal. 5-leaved. Petals 4. Styles 2. Caps. 2-parted. Cells 2-seeded.

1202. Paonic. Cal. 5-leaved. Petals 5. Style O. Caps. many-seeded, like a pod.

1203. Hibbertia. Stamens distinct, filiform, equal. Anthers oval, oblong. Ovaries 1-15. Styles filiform, inflexed. Carpella membranous, generally 1-2-seeded.

1204. Delphinium. Cal. O. Petals 5. Nectary bifid, cornute behind. Siliques 3-1.

1205. Aconitum. Cal. O. Petals 5; the upper vaulted. Nectaries 2, hooded, stalked, recurved. Siliques 3-5.

1200. Trachytella. Carpella 1-2, berried, many-seeded; otherwise Tetracera.

Order 3. PENTAGYNIA.

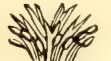
Stamens mariy, hypogynous. Styles 5 .

1207. Cimicifuga. Cal, 4-leaved. Cor. with four urceolate nectaries. Caps. 4. Seeds scaly.

1208. Aquilegia. Cal. O. Petals 5. Nectaries 5, horned between the petals. Caps. 5, distinct. 
1209. Nigella. Cal. O. Petals 5. Nectaries 5, trifid between the corolla.

i210. Reaumuria. Cal. 5-leaved. Petals reflexed, 5. Caps. 5-celled, 5-valved, many-seeded. Seeds woolly. 1211. Colbertia. Ten stamens much longer than the others. Carpella 5, united? Stigma capitate. Seeds several in each cell, reniform, inclosed in a pellucid pulp.

1212. Tetracera. Flowers often diœcious or polygamous. Carpella 3-5, capsular, surrounded by the imbricated sepals. Seeds 1-2, shining, ovate, with an arillus.

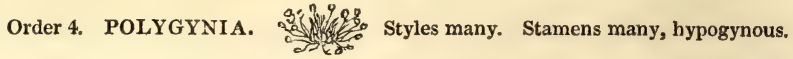

1213. Nelumbium. Cal. 4-5-leaved. Petals many. Fruit turbinate, in a truncate discus, with several -seeded hollows. Nuts ovate, crowned with the persistent style.

1214. Dillenia. Cal. 5-leaved. Petals 5. Capsules many-seeded, connate, replete with pulp.

1215. Mlicium. Cal. 6-leaved. Petals 27 . Caps. many, placed in a circle, 2-valved, 1-seeded.

1216. Liriodendron. Cal. 3-leaved. Petals 6. Samaræ imbricated in a cone. Caps. 1-2-seeded, not opening, : ttenuated.

1217. Magnolia. Cal. 5-leaved. Petals 6-9. Caps. 2-valved, 1-seeded, imbricated in a cone. Seeds pendulous.

1218. Michelia. Cal. 3-leaved. Petals 15. Berries many, 4-seeded.

1219. Uvaria. Cal. 3-leaved. Petals 6. Berries numerous, pendulous, 4-seeded.

1220. Annona. Sepals 3, united at base, concave, cordate, acute. Petals 6, thick; the interior thicker or none. Anthers subsessile, with a dilated angular end. Berry pulpy, many-celled towards the outside.

1221. Artabotrys. Cal. 3-parted. Petals 6 . Stamens hypogynous. Ovaries distinct, 2-seeded. Berries 2-seeded. Seeds collateral erect, without arillus.

1222. Guatteria. Sepals 3, united at base, ovate, subcordate, acute. Petals 6, ovate or obovate. Berries dry, coriaceous, ovate or subglobose, stalked, 1-seeded.

1223. Asimina. Cal. 3-parted. Petals 6, spreading, ovate-oblong; the inner smallest. Anthers subsessile. Berries usually 3 , sessile. Seeds several.

\section{MONOGYNIA.}

1162. CAP'PARIS. $W$. Caper-Tree. Capparidec.

7638 spinósa 7639 jamaicénsis $W$ 7640 frondósa $W$. 7641 ováta $W$. 7642 salig'na $P$. S. 7643 lineáris $W$. $\begin{array}{ll}7643 \text { lineáris } W . & \text { linear-leaved } \\ 7644 \text { Bréynia } W . & \text { Oleaster-leav' }\end{array}$ 7645 cynophallophora $W$. Bay-leaved 7 ist 6 odoratíssima $W$. sweet-scented 7647 ferrugínea $W$. ferrugineous common $\begin{array}{llccc}\text { common } & \text { cul } 3 & \text { my.au } & \mathbf{W} \\ \text { Jamaica } & \text { or } & 4 & \ldots & \text { W }\end{array}$ large-leaved $\begin{array}{llll}\text { or } & 7 & \cdots & \text { G }\end{array}$ acute-leaved w or 3 my.au W Willow-leaved w or 8 W

$\cdots \quad$ W

$\ldots \quad$ W

Sp. 10-116

1163. MARCGRAA'VIA. $W$. MarcGraAvia.

... $\mathrm{W}$

S. Europe 1596. C s.1 Bot. mag. 291

Jamaica 1793. C r.m Jac.am. e.p.t.101 Carthag. 1800. C s.l Jac. amer. t. 103 S. Europe $\quad \ldots \quad$ C $\quad$ s.l Boc. sic. t. 42 . f. 3 Sant.Cruz 1807. C r.m

W. Indies 1793, C r.m Jac amer, t. 102 W. Indies 1752, L I.p Jac. amer. t. 103 W. Indies 1752. C r.m Jac. amer. t. 98 Capparidea. Sp. 1-2.

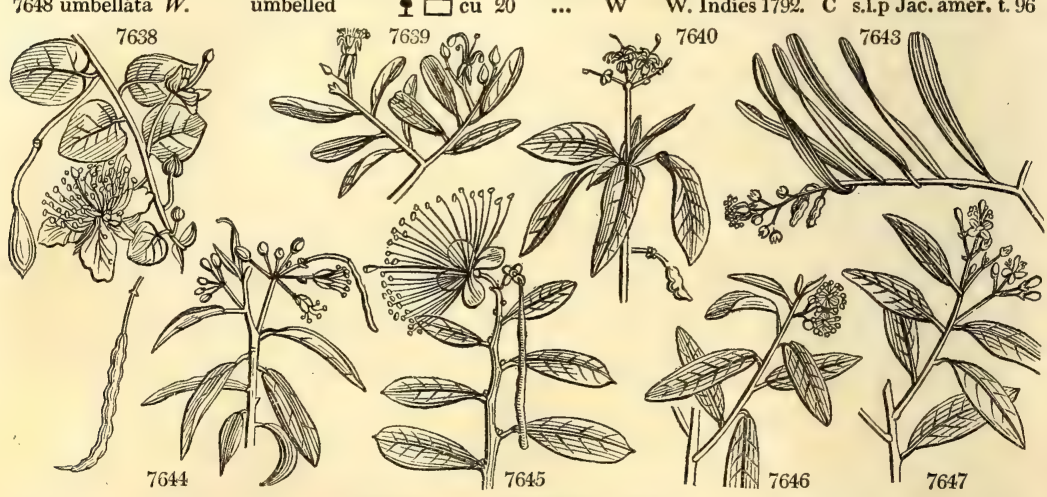

History, Use, Propagation, Culture,

1162. Capparis. From its Arabic name Kabar, from which the Greeks made zorzapis. Caprier, Fr., Capriolo, Ital. and Kapernstrauch, Ger. This is a genus of low shrubs, some of which produce berries and others pods. C. spinosa has the habit of the common bramble; it grows in similar situations in the south of Europe, and especially on rocks and ruins. The chief supply of caper buds is from Sicily ; but the plant is cultivated in the neighbourhood of Toulon in orchards, in the intervals between fig and olive trees, and in the neighbourhood of Paris, where it is trained on low walls, and the shoots during winter laid down and covered with soil to protect them from the frost. In this country it is generally treated as a stove plant; though it has stood the winter in the open air in some situations, and by raising from the seed for several generations might probably be naturalized. A plant stood near a century against the wall of the garden of Camden House, Kensington; it produced many flowers annually, though the young shoots were frequently killed to the stump during winter.

As a pickle, the flower buds of the caper are in great esteem throughout Europe. In Italy, the unripe fruit is prepared in the same way as the flower buds ; both are highly acrid and burning to the taste. In the isles of the Mediterranean, and near Toulon, the flower buds of the caper are gathered just before they begin to expand, which forms a daily occupation during six months, when the plants are in a flowering state. As the buds are gathered they are thrown into a cask among as much salt and vinegar as is sufficient to cover 
1224. Xylopia. Cal. 3-5.lobed. Petals 6; the exterior largest. Stamens usually inserted in a globose receptacle. Berries 2-15, on short stalks, compressed, frequently dry and opening. Seeds shining.

1225. Hepatica. Invol. 3-leaved, 1-flowered, resembling a calyx, entire. Sepals petaloid, 6-9, arranged in 2 or 3 rows. Ovaries many. Grains without an awn.

1226. Anemone. Invol. 3-leaved, distant from the flower, cut. Sepals 5-15, petaloid. Petals O.

1227. Clematis. Invol. O, or like a calyx under the flower. Sepals 4-8, colored. Petals $O$, or shorter than the sepals. Grains terminating in a feathery awn.

1228. Naravelia. Petals 6-12, longer than calyx. Grains seated on a thick hollow stalk.

1229. Thalictrum. Invol. O. Petals O. Grains dry, not awned, sometimes stalked, sometimes with a longitudinal furrow.

1230. Adonis. Sepals 5, appressed. Petals 5-15, with a naked claw. Grains many, 1-seeded, spiked, ovate, pointed with the persistent hardened style.

1231. Knowltonia. Sepals 5. Petals 5-15, with a naked claw. Ovaries upon a globose receptacle. Grains 1-seeded, berried, with a deciduous style.

1232. Ficaria. Sepals 3, deciduous. Petals 9, with a honey-pore at base. Grains obtuse.

1233. Ranunculus. Sepals 5, not deciduous. Petals 5, rarely 10, with a honey-scale at base. Grains pointed.

1234. Trollius. Sepals colored, 5-10-15, deciduous, petaloid. Capsules many, subcylindrical, many-seeded.

1235. Isopyrum. Sepals 5, deciduous. Petals 5, equal, tubular, 2-lipped. Ovaries 2-20. Capsules compressed, membranous, many-seeded. Seeds minute, dotted.

1236. Eranthis. Involucre under the flower, cut into many divisions. Sepals 5-8, colored, oblong, deciduous.

Petals 6-8, tubular. Capsules stalked. Seeds globose.

1237. Helleborus. Sepals 5, persistent, roundish, obtuse, large, usually green. Petals 8-10, tubular, nectariferous. Stigmas orbicular. Capsules coriaceous.

1238. Coptis. Sepals 5-6, colored, petaloid, deciduous. Petals small, cucullate. Stamens 20-25. Caps.6-10, on long stalks, membranous, 4-6-seeded.

1239. Caltha. Sepals 5, colored, round. Petals O. Stamens many. Capsule spreading, 1-celled, manyseeded.

1240. Hydropeltis. Sepals 3-4. Petals 3-4. Ovaries 6-18. Seeds in a pendulous ovate globose capsule.

1241. Hydrastis. Sepals 3, ovate. Petals $O$. Cariopsides berried, many in a head, terminated by the style, 1-celled, 1-2-seeded.

\section{MONOGYNIA.}

7638 Pedunc, 1-fl. solitary, Stipules spiny, Leaves roundish obtuse smooth, Caps, oval 7639 Pedunc. many-fl. Leaves obl. obt, emarginate downy beneath, Cor, campanulate 7639 Pedunc. many-ff. Leaves obl. obt. emarginate

7641 Pedunc. 1-fl. solitary, Stipules spiny, Leaves roundish ovate acute smooth, Capsules oval

7642 Leaves linear lanceolate dilated downwards obtuse at each end smooth, Fruit round torulose

7643 Pedunc. racemose, Leaves linear

7644 Pedunc. racemose, Leaves perennial oblong, Cal. and pedunc. downy, Fl. octandrous

7645 Pedunc. many-fl. terminal, Leaves elliptical blunt smooth, Glands axillary, Fruit cylindrical torulose

7646 Pedunc. many-fl. Leaves obl. lanceolate acute dotted with scales beneath

7647 Pedunc. umbelled, Leaves persistent lanceolate downy beneath, Flowers octandrous

7648 Leaves ovate-oblong acuminate veiny

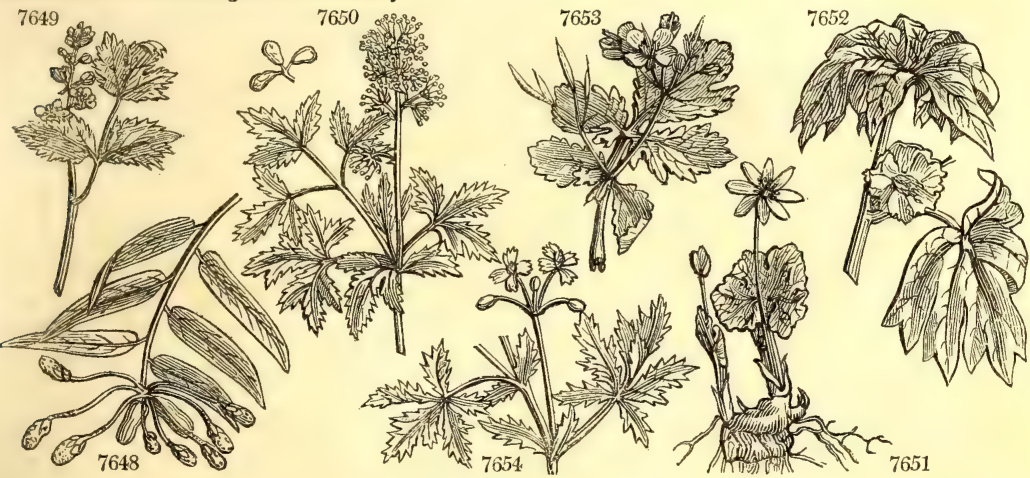

and Miscellaneous Particulars.

them, and as the supply of capers is increased more vinegar is added. When the caper season closes, the casks are emptied, and the buds sorted according to their size and color, the smallest and greenest being reckoned the best, and put into small casks of fresh vinegar for commerce. They will in this state keep fit for use for five or six years. It is said to be a common practice to put filings of copper in the first pickle to save vinegar, and give the buds a green color. The best capers are called nonpareilles, and the second best capucines. ( $N$. Cours complet d'Agr. ; art. Caprier.)

Most of the species are very shewy when in flower: C. cynophallophora has large petals, and stamens upwards of four inches long. Ripe cuttings of all the species grow readily in sand.

1163. Marcgraavia. In memory of George Marcgraaf, of Leibstadt, author of a voyage to Brazil in 1648 . A sub-parasitical creeping shrub : at first it is radicant like some ferms, but as it advances, the stem becomes shrubby, adhering still by its fibres to the trunk of some tree, to the top of which it frequently runs, at length dividing into several subdivided loose pendulous branches, commonly terminated by flowering umbels. It is frequent in the cool wooded mountains of Jamaica, and, according to Browne, appears in such various forms, that it has been mistaken for different plants in the different stages of its growth. It grows freely in British stoves, and cuttings root in sand under a glass. The genus is remarkable for the transformation of part of the uracteæ into fistular bodies, resembling the pitchers of some other plants. 
1164. ACT故A. Ph.

7649 spicáta $W$. en.

7650 americána $P h$.

$$
\text { « álba }
$$

$$
\text { } \beta \text { rúbra }
$$

ACTEA.

Bane-berry

American

white-berried

red-berried

1165. SANGUINA'RIA. $W$. Puccoov

7651 canadénsis $W$. Bloodwort

1166. PODOPHYLLUM. $W$. DuCk's-FOo

7652 peltátum $W$. May-Apple $¥$

1167. Chelido'niUm. $W$. Celandine.

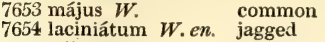

1168. RÖME'RIA. Med. Romeria

7655 hýbrida Dec. hybrid Chelidonium hybridum $\mathbf{L}$.

1169. GLAU'CIUM. J. Horn-Poppy.

7656 lúteum $H . K$. yellow

7657 fúlvum $H . K . \quad$ orange

7658 phœníceum $\boldsymbol{H} . \boldsymbol{K}$. red

1170. PAPA'VER. $W$. POPPY.

7659 hýbridum $W$.

7660 Argemóne $\boldsymbol{W}$.

7661 alpinum $W$.

7662 nudicaúle $W$.

$\beta$ luteum

\section{rough}

Alpine yellow-flowered

7655
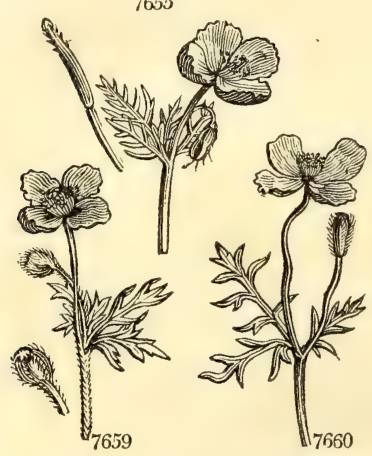

Ranunculacee. Sp: 2.

ฟ $\Delta$ or 3 ap.jn W Britain m. wo. $R$ s.1 Eng. bot. 918

$\Delta$ or 3 ap.jn W N. Amer. $\quad . . \quad$ R p.l Corn.canad. t.77

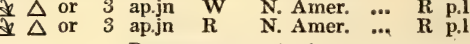

Papaveracea. $S p .1$.

$\frac{1}{2}$ mr.ap W N. Amer. 1680. R s.p Bot. mag. 162 Podophyllacee. $S p .1-2$.

$\frac{1}{2}$ my W N. Amer. 1664. D s.p Bot. mag. 1819 Papaveracea. Sp. 2-5.

表 $\Delta \mathrm{w} 2$ ap.o $\mathbf{Y}$ Britain sha.ba. D co Eng. bot. 1581 1) $\Delta$ or 2 ap.o $\quad$ Y $\quad$ S. Europe ... $\quad$ D co Mill.ic.1.t.92.f.2 Papaveracee. Sp. $1-3$.

$\mathrm{O}$ or 2 my.jn Pu Britain hed. S co Eng. bot. t. 201

\section{Papaveracea. $S p .3-5$.}

Or 2 jn.o $\mathbf{Y}$ Britain san.sh. $\mathbf{S}$ co Eng. bot. 8

O) or 2 au.s Or S. Europe 1802. S co Sweet fl. gard.35

$\mathrm{O}$ or $2 \mathrm{jn.jl} \quad \mathrm{R} \quad$ England san. fi. S co Eng. bot. 1433

Papaveracea. $S p .11-26$.

$O$ or $1 \frac{1}{2}$ jn.jl $S$ England chal.fi. S co Eng. bot. 43

O or $1 \frac{1}{2} \mathrm{jn}$.jl $\mathrm{S} \quad$ Britain corn fi. $\mathrm{R}$ co Eng. bot. 643

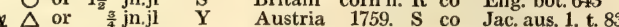

O) or $1 \frac{1}{2}$ jn.au Or Siberia 1730. S s.1 Bot.mag. 2344

O) or $1 \frac{1}{2}$ jn.au $\mathbf{Y}$ Siberia 1730. S s.l Bot. mag. 1633

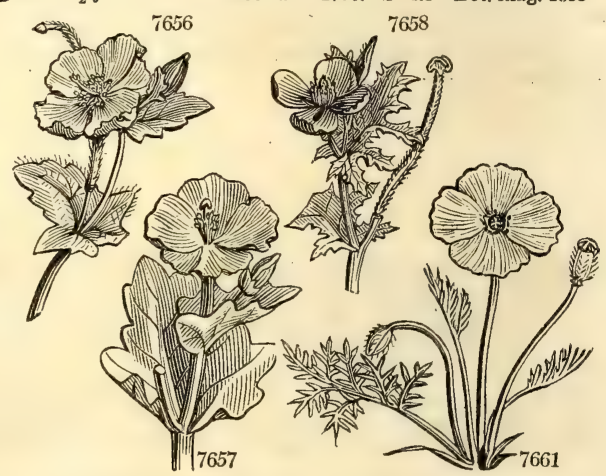

History, Use, Propagation, Culture,

1164. Actaa. Arrn was the Greek name of the elder, which this plant resembles in foliage and fruit. Weed-like plants seldom seen in gardens. The berries of $\mathbf{A}$. spicata are poisonous, and with alum yield a black dye. The tubers of A. racemosa are called snake root, and much used in North America by selfpractitioners, and as an antidote against poison and the bite of the rattle snake.

1165. Sanguinaria. From sanguis, blood. All parts of the plant on being wounded discharge a bloodcolored fluid. This is a singular and very delicate looking plant. It has a tuberous fleshy root with red fibres and a reddish juice : from each bud of the root there springs only a single fig-like glaucous leaf, with a one-flowered scape ; the flower has no smell, and is very fugacious. It abounds in the woods of Canada, and in the back settlements, where the Indians stain themselves with its red juice.

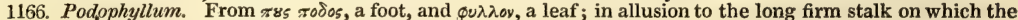
leaves are placed. Low neat herbaceous plants, with white flowers hidden by the overshadowing broad leaves. 1167. Chelidonium. From $\chi \varepsilon \lambda \delta \delta \omega \nu$, the swallow, because it was thought to flower with the arrival of that bird, and to perish with its departure. The English word celandine appears to be a corruption of chelidonium. The juice of C. majus is of an orange color and very acrimonious. It cures tetters and ringworms. Diluted with milk it consumes white opake spots on the eyes. It destroys warts, and cures the itch. There is no doubt but a medicine of such activity will one day be converted to more important purposes. (Withering.) The root, according to Loureiro, is extremely bitter, and greatly esteemed among the natives of Cochin-China, for a variety of uses in medicine.

1168 Römeria. Named after J. J. Römer, professor of botany at Landshut, and the collaborator of Schultz in an edition of the Species Plantarum of Willdenow. He died in 1820. A genus intermediate between Chelidonium, Glaucium, and Papaver.

1169. Glaucium. All the parts of the species appear covered with a glaucous bloom. Handsome sea-coast plants. G. luteum has large and numerous flowers, which, although of short duration, succeed one another in great abundance during most part of the summer, make a fine contrast with the sea-green dew-bespangled leaves, and are a great ornament to our sandy shores. The whole plant abounds in a yellow juice, is foetid, and

of a poisonous quality, and said to occasion madness.
1170 . Papaver. Said by De Theis to have been so called from the Celtic papa, which signifies pap, or the soft food given to children, in which the seeds were formerly boiled to make the infants sleep. Opium is derived from ow 0 , juice; it is supposed to have been the Nepenthes of Homer. Rhoeas, the name of one of the species, is from $\rho \in \omega$, to flow or fall, in allusion to the quickly perishable nature of the flowers. The poppy produces a great quantity of seeds, for which reason Cybele, the mother of the gods, is represented crowned with poppy-heads as a symbol of fecundity.

The species of this genus are all shewy, with large, brilliant, but fugacious flowers. They are all easy of culture in almost any soil; and one species affords that singular medicine opium. P. Rhoeas is one of the commonest weeds among corn on gravelly soils; but in its double and semidouble variegated varieties, it is also one of the handsomest of garden annuals. The capsules, as in P. somniferum, contain a milky juice of a narcotic quality : an extract from them has been successfully employed as a sedative; and some foreign practitioners are said to prefer this extract to opium.

P. somniferum, although it is found growing wild in the southern parts of Europe, and even in England, yet there is every reason for thinking that its seed must have been carried to these parts from Asia. It was very early cultivated in Greece, perhaps at first solely for the sake of its seed, which was used as food. It is extensively cultivated in most of the states of Europe in the present age, not only on account of the opium, 
7649 Berries roundish, Petals length of stamens, Raceme ovate, Leaves 2.3 ternate

7650 Berries ovate-oblong, Petals shorter than stamens, Raceme ovate, Leaves bi-triternate

\section{The only species}

7652 Stem erect 2-leaved 1-flowered, Fruit ovate

7653 Peduncles umbelled, Leaves pinnated with roundish toothed lobed segments, Petals elliptical entire 7654 Peduncles umbelled, Leaves pinnated with finely cut segments, Petals serrated or cat

7655 Pods 3-4-valved erect with rigid bristles at end

7656 Stem smooth, Cauline leaves repand, Pod warted roughish

7657 Stem smooth, Cauline leaves roundish sinuated, Pods rough, Flowers subsessile

7658 Stem hairy, Cauline leaves pinnatifid cut, Pod bristly

7659 Caps. subglobose torose hispid, Stem leafy many-flowered

7660 Caps. clavate hispid, Stem leafy many-flowered

7661 Caps. hispid, Scape 1-fl. naked hispid, Leaves bipinnate

7662 Caps. hispid, Scape 1-f. naked hispid, Leaves simple pinnate sinuated

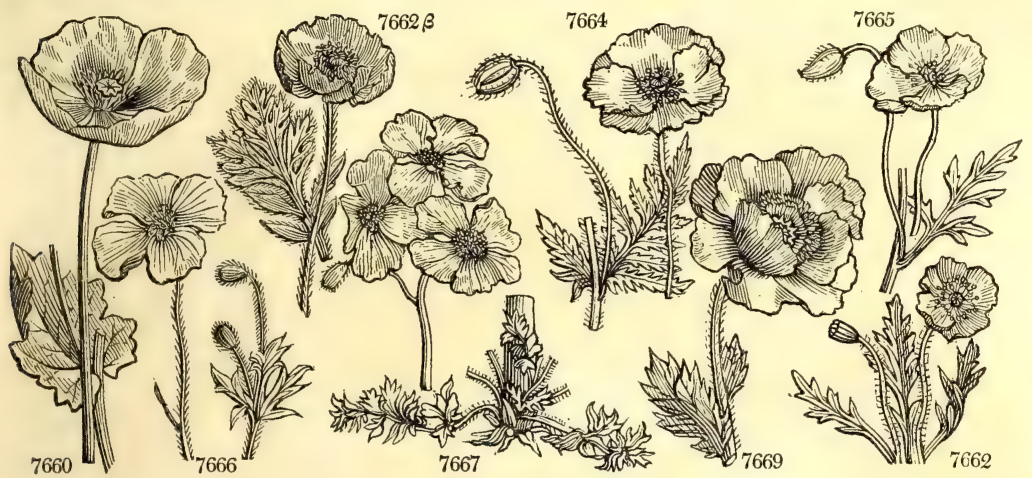

and Miscellaneous Particulars.

for which it is reared in Turkey, Persia, and India, but also on account of the capsules, and of the bland oil obtained from the seeds. All the parts of the poppy contain a white, opaque, narcotic juice ; but it abounds more in the capsules: hence these are the only officinal parts of the plant, and for them chiefly is the plant cultivated in this country. They are gathered as they ripen; and as this happens at different times, there are annually three or four gatherings. They are brought to market in bags, each containing about 3000 capsules, and sold to the druggists. The London market is chiefly supplied from Mitcham in Surrey.

The milky juice of the poppy, in its more perfect state, which is the case in warm climates only, is extracted by incisions made in the capsules, and inspissated; and in this state forms the opium of commerce. The mode of obtaining it appears to have been nearly the same in the time of Dioscorides as is at this day adopted. The plants, during their growth, are carefully watered and manured, the watering being more profuse as the period of flowering approaches, and until the capsules are half grown, when it is discontinued, and the collection of the opium commences. At sunset, longitudinal incisions are made upon each half-ripe capsule, passing from below upwards, and not penetrating to the internal cavity. The night dews favor the exudation of the juice, which is collected in the morning by women and children, who scrape it from off the wounds with a small iron scoop, and deposit the whole in an earthen pot, where it is worked by wooden spatules in the sunshine, until it attains a considerable degree of thickness. It is then formed by the hand into cakes, which are laid in earthen basins to be further exsiccated, when it is covered over with poppy or tobacco leaves. Such is the mode followed in India, and according to Kampfer's account, nearly the same is practised in Persia; and when the juice is drawn in a similar manner in this country and inspissated, it has all the characters of pure opium.

Opium is brought to this country in chests from Turkey and India. The Turkey opium is in flat pieces, covered with leaves. East Indian opium is in round masses, covered with the petals of the poppy in successive layers, to the thickness nearly of one-fourth of an inch. Mr. Kerr relates, that at Bahar, it is frequently adulterated with cow-dung, the extract of the poppy procured by boiling, and various other substances. In Malava it is mixed with oil of sesamum, which is often one half of the mass; ashes and the dried leaves of the plant are also used. It is also adulterated with the aquecus extract of the capsules, the extracts of Chelidonium glaucum, Lactuca virosa, and Glycyrrhiza glabra, and sometimes with gum arabic, tragacanth, aloes, and many other articles.

Poppy heads or capsules possess anodyne properties; they are chiefy employed, boiled in water, as fomentations to inflamed and ulcerated surfaces; and a syrup, prepared with the inspissated decoction, is used as an anodyne for children, and to allay the tickling cough in chronic catarrh and phthisis.

Opium operates as a powerful and very diffusible stimulus, but its primary operation is followed by narcotic and sedative effects in a degree much greater than could be expected from the previous excitement it induces. It acts directly on the nervous system, and when taken into the stomach destroys irritability, and allays pain in the most distant parts of the body, independent of the circulation, and without inducing any change on the composition of the blood. As the principle, therefore, on which opium acts is the same over all the body, the topical application of it is capable of producing similar effects, only in a diminished degree, to those resulting from it when it is taken into the stomach.

In moderate doses, opium increases the fulness, the force, and the frequency of the pulse, augments the heat of the body, quickens respiration, and invigorates both the corporeal and mental functions, exhilarating heat of the body, quickens respiration, and invigorates both the corporeal and mental functions, exhilarating
even to intoxication; but by degrees these effects are succeeded by langour, lassitude, and sleep; and in many instances headach, sickness, thirst, tremors, and other symptoms of debility such as follow the excessive use 
7663 armeniacum Lam. Armenian 7664 Rhœ'as $W$. common-corn 7665 dúbium $W$.

7666 caucásicum $M . B$. Caucasian

7667 floribúndum Desf. many-flowered 3

7668 somníferum $W$. garden

7669 orientále $W$. oriental

7670 bracteátum Lindl. bracted

1171. MECONOP'SIS. Vig. Meconopsis.

1172. ARGEMO'NE. $W$. Argemone.

7672 mexicána $W$. Mexican

f albiflóra Sims. white-flowered

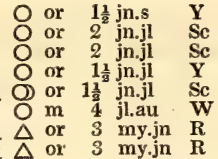

Armenia 1815. S s.p

Britain corn fi, S co Eng. bot. 645

Britain san. fi. S co Eng. bot. 644

Caucasus 1813. S co Bot. mag. 1675

Levant 1815. S co Bot. reg. 134

England corn fi. $\mathbf{R}$ co Eng. bot. 2145

Levant 1714. $R$ co Bot. mag. 57

Siberia 1818. $\mathbf{R}$ co Lindl, coll. 23

Papaveracea. Sp. 1-4.

1173. SARRACE'NIA. $W$. Side-SADdLE-FLower.

7673 fláva $W$.
7674 varioláris $P h$.
adúnca Ex. bot. t. 53

7675 rúbra $W$.

卷 $\Delta \mathrm{cu}$

7676 purpúrea $W . \quad$ purple $\quad$ 兰 $\Delta$ cu 1 jn.jl Pu N. Amer. $1640 . \quad$ R m.s Bot. mag. 849

1174. NYMPH压'A. $W$. WATER-LiLY.

7677 álba $W$

7678 odoráta $W$.

$\beta$ minor

7679 nítida $B . M$.

7680 pygmæ'a $\boldsymbol{H} . \boldsymbol{K}$.

7681 Lotus $W$.

7682 pubéscens $W$

7683 rúbra $B$. $M$

$\beta$ rósea $\mathbf{B}$. $\mathbf{M}$.

white
sweet-scented $\Delta$ or

sweet-scented small. sweet-sc, $\Delta$ or
sw cup-flowered $\triangle$ or pigmy $\triangle$ or Egyptian Lotus Indian Iotus red-flowered rose-colored

\section{Nympharace. Sp. 10-20.}

in.jl W Britain riv.,\&c. R m,s Eng. bot. 160

jl W N. Amer. 1786. R m.s Bot. mag. 819

jl W N. Amer. 1812. R m.s Bot. mag. 1652

jl.au W Siberia 1809. R m.s Bot. mag. 1359

my.s W China 1805. R m.s Bot. mag. 1525

jn.s Pk Egypt 1802 R m.s Bot mag. 797

my au $\mathbf{P k}$ E Indies 1803. $\mathrm{R}$ m Bot. mag. 797

jl.au Pk E. Haies 1803. R m.s Bot. rep. 391

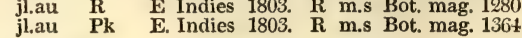

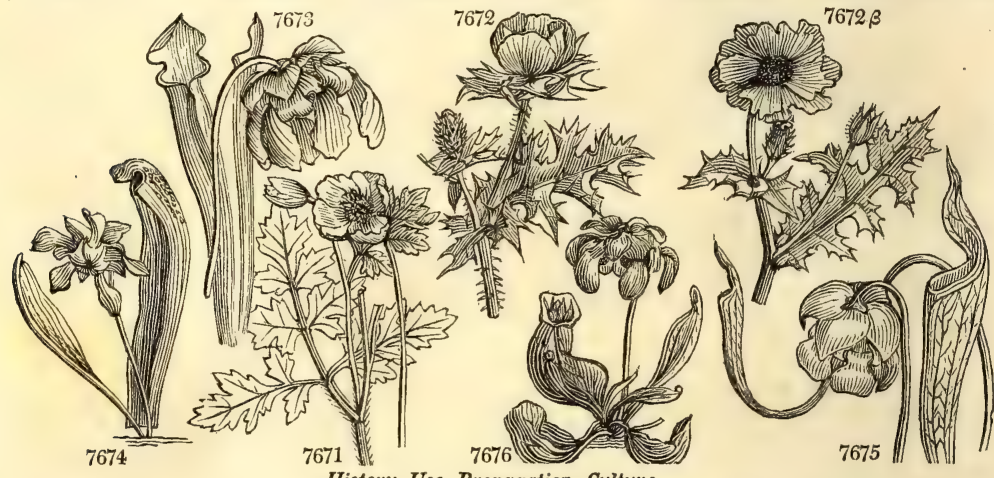

History, Use, Propagation, Culture,

of ardent spirits, supervene. In very large doses the primary excitement is scarcely apparent, but the pulse seems to be at once diminished, drowsiness and stupor immediately come on, and are followed by delirium, sighing, deep and stertorous breathing, cold sweats, convulsions, apoplexy, and death. The appearances on dissection are those which indicate the previous existence of violent inflammation of the stomach and bowels; but notwithstanding the symptoms of apoplexy which an overdose, when it proves fatal, occasions, no particular appearance of an inflammatory state or fulness of the vessels of the brain are perceived.

The Turks call opium afioni; and in the teriakihana, or opium shops of Constantinople, they take it in graduated doses from ten grains to one hundred grains in a day. It is mixed with rich syrup and the inspissated juices of fruit, to render it more palatable and less intoxicating; and is taken with a spoon, or made up into small lozenges stamped with the words, Mash Allah, literally, "The work of God." The Tartar couriers, who travel great distances, and with astonishing rapidity, take nothing else to support them during their journeys. (Dallaway's Constantinople, quarto, 78.) There is, however, some reason for supposing that the Mash Allah, or Maslach of the Turks, contains other narcotics, as those of hemp and of lolium, as well as opium.

The use of opium for the purpose of exhilarating the spirits has long been known in Torkey, Syria, and China; and of late years it has been unfortunately adopted by many, particularly females, in this country. Russell says, that in Syria, when combined with spices and aromatics, he has known it taken to the amount of three drachms in twenty-four hours. Its habitual use cannot be too much reprobated. It impairs the digestive organs, consequently the vigour of the whole body, and destroys also gradually the mental energies. The effects of opium on those addicted to its use, says Russell, are at first obstinate costiveness, succeeded by diarrhoea and flatulence, with the loss of appetite and a sottish appearance. The memories of those who take it soon fail, they become prematurely old, and then sink into the grave, objects of scorn and pity. Mustapha Shatoor, an opium eater in Smyrna, took daily three drachms of crude opium. The visible effects at the time, were the sparkling of his eyes, and great exhilaration of spirits. He found the desire of increasing his dose growing upon him. He seemed twenty years older than he really was; his complexion was very sallow, his legs small, his gums eaten away, and the teeth laid bare to the sockets. He could not rise without first swallowing half a drachm of opium. (Phil. Trans. xix. 289.)

When opium has been taken in an overdose, the first thing to be done for counteracting its bad effect, is the exhibition of a powerful emetic; and for this purpose sulphate of zinc, or sulphate of copper dissolved in water, should be immediately swallowed, and the vomiting kept up for a considerable time, and urged by irritation of the fauces. Large draughts of vinegar and water, or other acidulated fluids, should afterwards be frequer.tly taken; and the powers of the habit supported by brandy, coffee, and cordials. The sufferer should be kept awake, and, if possible, in continued gentle motion. Currie recommends the affusion of warm water at 106 degrees or 108 degrees for removing the drowsiness. (London Dispensatory, 426.$)$

Medical men have of late sought to discover the sedative principle of opium, and have found it in the extractive, from which a crystallized salt called morphia is obtained. Some foreign physicians, and Mr. 
7663 Caps. ellipt. obl. and calyxes smooth, Stem much branch. smoothish, Lvs. pinnated, Lobes lin. terminated 7664 Caps. smooth globose, Stem hairy many-f. Leaves pinnatifid cut

[by a bristle 7664 Caps. smooth globose, Stem hairy many-fi. Leaves pinnatifid cut

7665 Caps. oblong smooth, Stem many-fl. with appressed bristles, Leaves pinnatifid cut 766 Caps. ov.-obl. smooth, Stem much branched and pedunc. covered with decid. setæ, Lvs. glauc. pinnatifid 7667 Caps. smooth obl. Sepals hairy, Stem many-fl. hispid, Leaves pilose : the lower pinnate 7668 Calyxes and caps. smooth, Leaves stem-clasping cut

7669 Caps. smooth, Stems 1-fl. rough, Leaves scabrous pinnate serrate

7670 Caps. smooth, Stems 1-fl. rough, Leaves scabrous pinnate serrate, Flowers subtended by leafy bractes

7671 Caps. smooth obl. Stem many-fl. smooth, Leaves pinnate cut

7672 Caps. 6-valved, Leaves spiny

7673 Leaves erect tubular, Valve with a contracted neck, at the end flat erect

7674 Leaves long, their tube dotted at back, Appendage short vaulted incurved

7675 Lvs. short colored upwards with netted veins, Tube of leaf ending in a recurv. vaulted mucron. appendix 7676 Leaves cucullate ventricose spreading arcuate

7677 Leaves cordate entire, Lobes imbricated round, Calyx 4-leaved

7678 Leaves cordate entire emarginate, Lobes divaricating, Point obtuse, Calyx 4-leaved

7679 Leaves cordate entire, Lateral nerves beneath level, Petioles smooth, Pet. acute, Rays of stigma 12-20 7680 Leaves cordate entire, Lateral nerves beneath level, Petioles smooth, Pet. acute, Rays of stigma 8

7681 Leaves cordate toothed very smooth, Lobes approximating, Calyx 4-leaved

7682 Leaves reniform toothed downy beneath, Lobes round, Calyx 4-leaved

7683 Leaves peltate finely toothed, beneath downy without spots
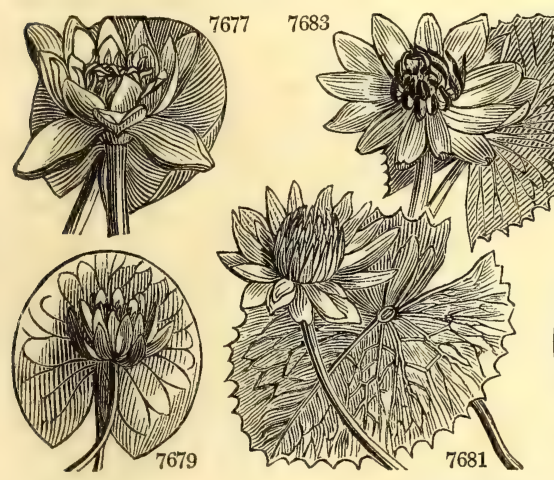

and Miscellaneous Particulars.

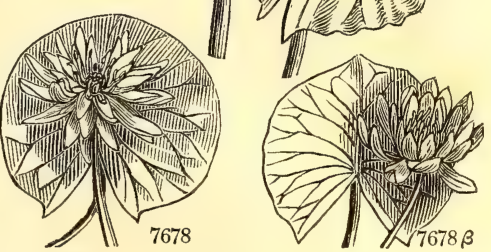

Thomson, the author of The London Dispensatory, have found that a quarter of a grain of the acetate of morphia produces the most beneficial effects that can be expected from an anodyne, allaying pain, and procuring sleep without in any degree affecting the central functions. (London Dispensatory, 420.)

A variety of P. somniferum, known as the black poppy, from the color of its seeds, is cultivated for these to some extent; they are called maw seed, and generally stained of a light blue color.

P. Rhoeas (ceillette, Fr.) and also somniferum are cultivated in Flanders and Germany for their seeds, which are bruised for an oil used in cookery as a substitute for that of olives. In Poland and some parts of Russia, the seeds are used as a seasoning to soups, gruels, and porridge.

Professor Martyn, in his edition of Miller's Dictionary, has collected a body of facts, which clearly prove that opium may be produced to any extent in Britain, and of equal quality to that procured from abroad; the value of labor in this country, however, does not admit of such a thing. We have seen samples of opium made in the south of England quite equal to that of foreign growth, but we understood that the labor of collecting it was greater than could be afforded for its market price.

$P$. cambricum is admired for its yellow petals, and orientale and bracteatum are very splendid plants.

1171. Meconopsis. From $\mu n x \omega v$, a poppy, and ơ $\$$, resemblance. A genus of herbaceous shade-loving plants, just intermediate between Papaver and Argemone. The flowers are yellow.

1172. Argemone. From argema, the name by which the cataract of the eye was known, and which was thought to be cured by this plant. A. mexicana is a troublesome weed in the West Indies, with a fig-like fruit, armed with prickles, and thence, by the Spaniards, called Figo del inferno. The whole plant abounds with a milky glutinous juice, which turns in the air to a fine bright yeliow, and when reduced to consistence is not distinguishable from gamboge. In very small doses it $\mathrm{s}$ probably of equal efficacy, given in dropsies, jaundice, and cutaneous eruptions. It is esteemed very detersive, and generally used in diseases of the eyes : but the infusion is looked upon as a sudorific and resolutive, which may be used with success on many occasions. The seeds are said to be a much stronger narcotic than opium.

1173. Sarracenia. So named by Tournefort in honor of Dr. Sarrazin, a French physician of rank residing in Quebec, who sent this genus to him from Canada: it is called side-saddle flower from the resemblance of the stigma to a woman's pillion. These plants are remarkable for the singular form of the leaves, which are tubular and hold water, and some species have lids or covers, which it is alleged shrink and close over the mouth of the tribe in dry weather, so as to prevent the exhalation of the water. In great drought birds and and other animals resort to them. They grow in bogs in Carolina and Virginia, and in British gardens thrive very well in pots with turfy peat at the bottom, and the upper part filled with sphagnum, or water-moss, in which the plants must be set, and then placed in pans of water; they succeed best in frames in a shady situation. (Bot. Cult. 417.)

1174. Nymphaa. The Nymph, or Naiad of the streams. The species are beautiful aquatics, especially N. alba, which has a large flower filled with petals, so as almost to appear double: it raises itself out of the water and expands about seven o'clock in the morning, and closes again, reposing upon the surface, about 
7684 versícolor $\boldsymbol{H} . \boldsymbol{K}$. 7684 versícolor $\boldsymbol{H}$. 7685 cærúlea $\boldsymbol{H}$. $\boldsymbol{K}$.

1175. LIMNOCHA'RIS. 7687 Plumiéri Rich.

\section{changeable $\$$ or blue} star-flowered

Rich. Limnocharis.

1176. NU'PHAR. $H . K$.
7688 lútea $H . K$.

7689 Kalmiána $\boldsymbol{H} . \boldsymbol{K}$.

7690 mínima $\boldsymbol{E}$. $\boldsymbol{B}$.

NupHa

巻区 or

\section{Nuphar.}

common-yellow光 $\Delta$ or

Canadian $\Delta$ or

least yellow $\Delta$ or

three-colored $\Delta$ or

1177. EURY'ALE, $H . K$. Euryale.

7692 férox $H . K . \quad$ prickly

㐘 $\square$ or

ArnotTa.

1178. BI'XA. $W$.

7693 Orellána $W$

1179. PROCK'IA. $L$.

7694 Crúcis $L$.

heart-leaved

Prockia.

ovate

1. $\mathrm{m}$

au Pk E. Indies 1807. $\mathbf{R}$ m.s Bot. mag. 1189

jns $B$ C. G. H 1792, R m.s Bot. mag. 552

jn.s B E. Indies 1803. R m.s Bot. rep. 330

Hydrocharidea. Sp. 1-2.

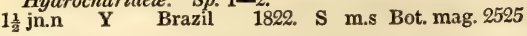

Nymphacacee. Sp. 4-6.

jn.jl Y Brit. pools,\&c. R m.s Eng. bot. 159

jl.au Y Canada 1807. R m.s Bot. mag. 1243

jl.au $\quad \mathbf{Y} \quad$ Scotland al.lak. R m.s Eng. bot. 2292

jl.au $\quad$ Y $\quad$ N. Amer. 1772. $R$ m.s Bot. mag. 684

Nymphareec. Sp. 1.

jl.s $R$ India 1809. $R$ m.s Bot. mag. 1447

Bixinea. $S p .1-2$.

my.au Pk W. Indies 1696. S s.p Bot. mag. 1456 Bixinea. $S p .1-7$.

1180. SLO'A NEA. $W$. Sloanea.

7695 dentáta $W$.

1181. APEI'BA. $W$.

7696 Tibóurbou $W$

7697 Petoúmo $W$.

7698 áspera $W$.

$7699 \mathrm{l}^{\prime}$ vis $W$.

$\square$ cu 3 jl.au $\quad$ Y W. Indies 1822. C s.p Vah.symb.3.t.64 Tiliacec. $S p .1-8$.

A PeIBa. Tiliacer. Sp. $4-7$

hairy or 7 ... Y Y S. Amer. 1756. C p.l Aub.gui.1.t.213

hoary $\quad$ \& $\square$ tm $40 \quad \ldots$. Y $\quad$ S. Amer. 1817. C p.1 Aub.gui.1. t.215 prickly-capsui'd $\square$ tm $30 \quad \ldots . \quad$ Y Cayenne 1792. C p.l Aub.gui.1.t.216 smooth-leaved $\Phi \square$ or $10 \quad \ldots$ G Cayenne 1817. C p.l Aub.gui.1.t.214 1182. SPARRMAN'NIA. W. SParrmannia. 10 Tiliacere. Sp. 1.

7700 africána $W . \quad$ African 1 or $10 \mathrm{mr} . j \mathrm{l}$ W C. G. H. 1790. C p.l Bot. mag. 516

1183. ENTELE'A. $\boldsymbol{R}$. Br. ENTElea.

7701 arboréscens $R . B r$. arborescent

1184. MUNTIN'Gia. $\boldsymbol{W}$. Muntingia. Tiliacea, $S p .1$.

I J or 20 my W ${ }^{2}$ N.Zeal. 1820. C p.1 Bot. mag. 2480 Tiliacee, $S p .1$.

7702 Calabúra $W$. Jamaica

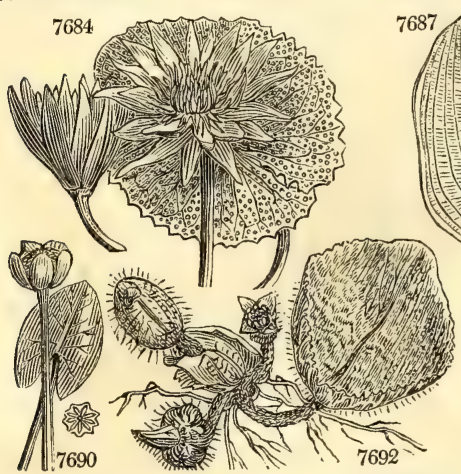

History, Use, Propagation, Culture,

four in the afternoon. The roots have an astringent bitter taste; they are used in Ireland, in the Highlands of Scotland, in the island of Jura, \&c. to dye a dark brown or chesnut color. Swine are said to eat it, goats not to be fond of it, kine and horses to refuse it. The flowers, the herb, and the root were formerly used in medicine, but are all now obsolete.

N. lotus resembles our common white species very much in the form of the flower and leaves, but the latter are toothed about the edge. It is native of the hot parts of the East Indies, Africa, and America. It is very common in ponds, lakes, and rivers in Jamaica; and grows in vast quantities in the plains of Lower Egypt near Cairo, during the time they are under water. It flowers there about the middle of September, and ripens towards the end of October. The Arabians call it Nuphar. The ancient Egyptians made a bread of the seed of the Lotus dried and ground.

All the species grow well in large pots of water with a few inches of rich soil at the bottom : they are propagated by dividing the root, and some sorts which produce bulbs are increased by offsets from these. Mr. Kent, of Clapton, who cultivated exotic aquatics to great perfection, found that the bulbous rooted Nymphæas, if checked in their growth for want of water, from cold, or excessive heat, were apt to form bulbs at the roots and cease growing for the season. Hence the necessity of a regular and powerful moist heat to make them flower freely.

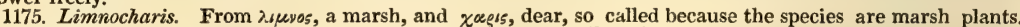
They have beautiful umbels of yellow flowers, and are very easily cultivated in a stove. They are increased by seeds.

1176. Nuphar. The Arabic name is nauffar, according to Forskahl. The species are shewy plants closely resembling Nymphra. N lutea is a native of most parts of Europe, and also of America. Linnaus states, that swine are fond both of the leaves and root; that goats are not fond of it; and that kine, sheep, and horse refuse it: also that crickets are driven out of houses by the smoke in burning it, and that both they and cock-roaches are destroyed by the roots rubbed or bruised with milk. Ray observes, that the flowers smell like brandy.

1177. Euryale. From svevaios, broad, in allusion to the enormous broad floating leaves of the plant. A noble aquatic, easily cultivated in a good stove.

1178. Bixa. The American name of the tree. The drug called Terra Orellana, or Orleana, Roucon or Arnotto, is prepared from the red pulp which covers the seeds of this plant. By maceration in hot water, the seeds are separated from the pulp, the latter is then made into balls or cakes, which when dry are fit for use. Arnotto of a good quality is of the color of fire, bright within, soft to the touch, and dissolves entirely in water. It is reputed to be cooling and cordial, and is much used by the Spaniards in their chocolate and soups, both to heighten the flavor and to give them an agreeable color. It is esteemed good in bloody fluxes 
7684 Leaves peltate at the edge and within the fissure sinuate toothed blistered smooth on each side [end 7685 Leaves peltate nearly entire not dotted smooth on each side 2-lobed at base, Anthers with appendages at 7686 Leaves cordate entire, Lobes divaricating acute, Calyx acute 4-leaved longer than the acute petals

7687 Leaves oblong very blunt at each end, Flowers in umbels

7688 Ieaves cordate entire, Lobes approximating, Cal. 5-leaved longer than petals 7689 Sepals 5, Stigma cut with 8-10 rays, Leaves cordate a littie out of the water, Petioles roundish 7890 Sepals 5, Stigma lobed with 10 rays, Lvs. obl. cord. dott. sub-pubesc. Petioles at base $\frac{1}{2}$ round, at end nearly 7691 Leaves cordate entire half erect, Lobes divaricating, Cal. 6-leaved longer than petals 「3-cornered

7692 Petioles and calyxes covered over with stiff prickles, Leaves sometimes 3 feet acress

7693 Leaves smooth on each side

7694 Leaves cordate ovate toothed, Peduncles terminal racemose

7695 Leaves ovate, Stipules cordate triangular serrated

7696 Leaves cordate lanceol. serrate hirsute beneath, Capsules iristly

7697 Leaves obl. subcordate serrulate hoary beneath, Caps. bristly

7698 Leaves obl. subcordate entire pubescent beneath, Caps. muricated

7699 Leaves obl. obovate acuminate entire smooth, Petals obtuse, Caps. scabrous

\section{The only species}

\section{The only species}

7702 Leaves serrated oblong oblique

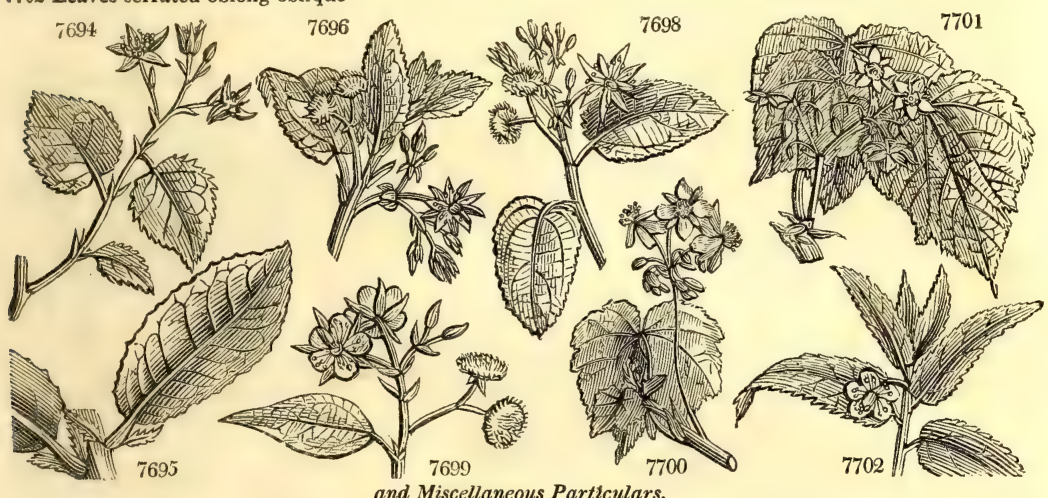

and Miscellaneous Particulars.

and disorders of the kidnies. Mixed with lemon-juice and a gum, it makes the crimson paint with which the Indians adorn their persons. It was formeriy used by dyers to form the color called aurora; but at present it is not held in much estimation as a dye, though it still maintains its ground with painters. Arnotto is well known to be the drug which is used for dying cheese in Gloucestershire, under the name of cheesecoloring. It is used in Holland for coloring their butter. The bark makes good ropes for the common plantation uses in the West Indies; and pieces of the wood are used by the Indians to procure tire by friction.

1179. Prockia. A name of unknown meaning. American or Isle of France plants with alternate entire or toothed leaves, and yellow flowers, which are occasionally unisexual.

1180. Sloanea. Named by Plumier, in memory of the famous Sir Hans Sloane, Bart., physician to the king, and president to the Royal Society; author of the Natural History of Jamaica, and founder of Chelsea garden and hospital. The leaves are like those of the chesnut; the flowers very large, and the fruit as big as a tennis ball, armed.all over with strong spines, and divided regularly into four cells, each containing one small chesnut. It grows freely in our stoves, and ripened cuttings root in sand under a hand-glass.

1181. Apeiba. The vernacular name of the plant in Guiana. Tibourbou and Petoumo are vernacular names among the Caribs. The species grow freely in light loamy soil. Cuttings must be well ripened, and the glass they are put under should have a little air given it occasionally, or they will damp off. The best way of flowering it, is to cut a ring round the bark of a large branch, which stagnates it and throws it into flower. (Bot. Cult. 20.)

1182. Sparmannia. In memory of Anders or Andrew Sparrman, a Swede, fellow of the Academy of Sciences at Stockholm, who travelled into China, the Cape of Good Hope, and the islands of the South Sea. His travels were published in London, 1785, quarto, and there are many descriptions by him in the Philosophical and other transactions. It is a beautiful shrub with snowy white petals, and singular nectaries. It grows freely in loam and peat, and cuttings root in sand under a hand-glass.

1183. Entelea. From $\varepsilon y \tau \varepsilon, \hat{n} s$, perfect. So named by Mr. Brown, because all its filaments are fertile; by which character, among others, it is distinguished from Sparmannia. A fine New Zealand plant, discovered originally by the botanists with Sir Joseph Banks in Cook's second voyage.

1184. Muntingia. Named by Plumier, after Abraham Munting, professor of botany at Groeningen, died in 1682. Calabura is an American name. The flowers resemble those of the bramble, and the fruit cherries. It grows in Jamaica on calcareous subalpine hills, flowering in spring; and in St. Domingo in the wet parts of woods, flowering in August and September. In our stoves it grows freely in light loam. and cuttings root in sand under a hand-glass. 
1185. GRE'WIA. $W$. 7703 hirsita $W$ 7704 Mallacúcca $W$ 7705 Microcos $H . K$ 7706 occidentális $W$. 7707 orientális $\boldsymbol{W}$. 7708 pilósa $P$. S. 7709 asiática $W$

7710 tiliætólia $\dot{W}$ 1186. TI'LIA. $W$. 7711 rúbra Dec. 7712 intermédia Hayne. 7713 parvifólia $\mathrm{Ehr}$.

7714 platyphýlla Scop.

7715 americána $W$. $T$. glábra Vent. 7716 pubéscens $W$. \& leptophýlla Vent. 7717 álba $W . \& K$. T. argentea Dec

7718 heterophýlla Vent 1187. COR'CHORUS. 7719 olitórius $W$. 7720 triloculáris $W$. 7722 acutángulus $W$. 7723 capsuláris $W$ 7724 hirsútus $W$. 7725 siliquósus $W$ 1188. GRI'AS. $W$. 7726 caulifóra $W$.

Grewra. soft-leaved rough-fruited panicled Elm-leaved oriental pilose Asiatic Line-TreE. common

intermediate small-leaved broad-leaved

broad-leaved

pubescent

pubescent

white

various-leaved

Corchorus.

bristly-leaved

three-celled

Hornbeam-lvd.

acute-angled $\mathrm{w}$

heart-leaved

woolly-capsul'd

Germander-lv,

AnCHOVY-Pear. stem-flowering $9 \square \mathrm{fr}$
Tiliacea. Sp. 8-65.

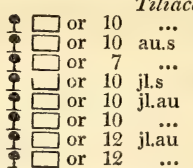

$\mathrm{Pu}$ E. Inảies 1816. C p.l

Pa.pu E. Indies 1792. C c.p

G E. Indies 1779. C c.p Rhee mal.1.t.56

$\mathrm{Pu}$ C. G. H. 1690. C p.l Bot. mag. 422

$\mathrm{Pu}$ E. Indies 1767. C p.I Rhee.mal.5.t.46

… E. Indies 1804. C p.l

E. Indies 1792. C p.l Sonn. it. 2.t. 138 Tiliacea. $S p .8-10$.

tm 50 jn.au Y.G Britain woods. L co tm 50 jn.au Y.G Britain woods. $\mathrm{L}$ tm 50 au.s Y.G Britain

woods.

Y.G Britain woods. 1705

\section{* tm 30 jn.jl Y.G N. Amer. 1752. I co Dend. brit. 134}

* tm 20 jl.au Y.G N. Amer. 1726. L co Dend. brit. 135 tm 20 jl.au Y.G N. Amer. 1726. L co tm 30 jn.au Y.G Hungary 176̈. L co Dend. brit. 71 Tiliacee. Sp. 7-25.

\begin{tabular}{|c|c|c|c|c|c|c|}
\hline jn.at & $\mathbf{Y}$ & India & 1640. & $\mathbf{S}$ & co & Camer.hort.t.12 \\
\hline jl. & $\mathbf{Y}$ & Arabia & 1790. & $\mathbf{S}$ & co & $\mathrm{Ja}$ \\
\hline jn.jl & $\overline{\mathbf{Y}}$ & S. Amer. & 1731. & $\mathbf{S}$ & co & $\mathrm{Ja}$ \\
\hline & $\mathbf{Y}$ & E. In & 1816. & C & co & \\
\hline n.j & $\mathbf{Y}$ & E. Indies & 1725. & C & 1.p & $\mathbf{R}$ \\
\hline & $\mathbf{Y}$ & S. $\mathrm{Am}$ & 1752. & $\mathbf{S}$ & p. 1 & \\
\hline & & Indies & s 17 & C & 1.p & Jac. vind. 3. t. \\
\hline
\end{tabular}
Guttiferis affinis. Sp. 1.

Jamaica 1768. C l.m S1.hi.2.t.217.f.1,2

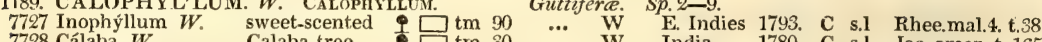

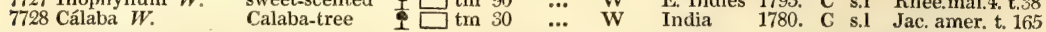

1190. MA MME'A. $W$. Mammee-Tree. 7729 americána $W . \quad$ American. Guttiferce. Sp. 1-3.

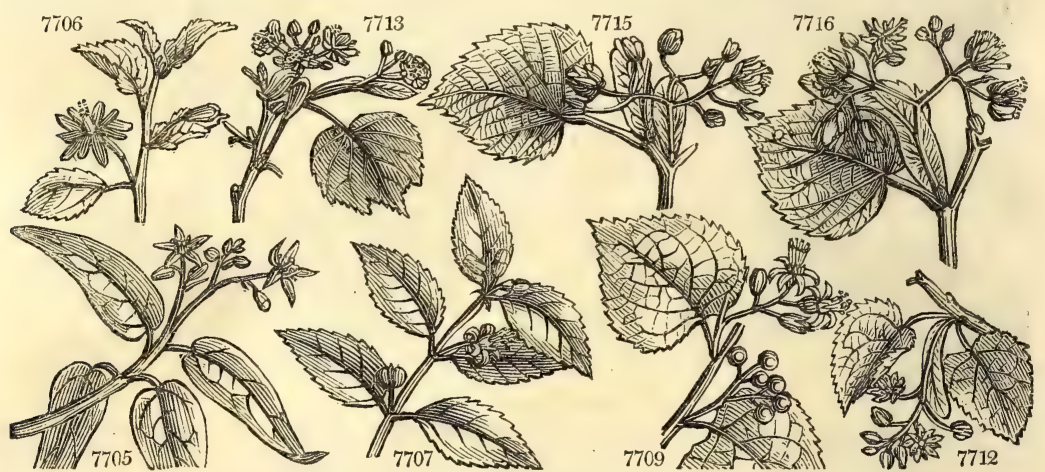

History, Use, Propagation, Culture,

1185. Grewix. So named by Linnæus, in honor of Nehemiah Grew, M. D., F. R. S., famous for his work on the Anatomy of Vegetables. The species are shrubs with elm-looking leaves, generally deciduous, and of no great beauty. Cuttings root in sand under a hand-glass in heat. Some of the kinds produce a sort of berry which is esteemed by the natives of the country where they grow.

1186. Tilia. A name the meaning of which is unexplained. Tilleul, Fr., Linden, Ger., and Tiglio, Ital The species are graceful trees with highly odoriferous flowers, all the soft parts abounding in mucilage.

$\mathrm{T}$. intermedia is wild in Sweden, and will in some degree bear the smoke of London. It is a favorite avenue tree in Holland and Germany, and at Evelyn's suggestions (Sylva) was a good deal employed in this way in England. He describes some enormous lime trees in Switzerland, Germany, and Hungary, and speaks of its esteem in these countries, and by the Romans. "It is a shameful negligence," he says, "that we are no better provided of nurseries, for a tree so choice and universally acceptable :" for in his time they sent into Holland and Flanders, to our excessive cost, whilst our own woods spontaneously produce them, and though of somewhat a smaller leaf, yet altogether as good, apt to be civilized, and made more florid.

Lime-tree wood is turned into light bowls and dishes, and into boxes for the apothecaries. With the twigs they make baskets and cradles. Formerly the bark was used for writing tablets. Shoemakers make dressers of the plank to cut leather on. The truncheons make a far better coal for gunpowder than that of alder itself, and also scriblets for painters' first draughts. The wood is soft, light, and smooth, close grained, and not subject to the worm. The most elegant use to which it is applied is for carving. Many of Gibbon's beautiful works in lime-tree are dispersed about the kingdom in our churches and palaces; as in the choir of St. Paul's, the Duke of Devonshire's at Chatsworth. Trinity College Library at Cambridge, \&c. Evelyn first recommended him to King Charles II. The sap inspissated affords a quantity of sugar. Boutcher remarks, that the timber is stronger and lighter than any sort of willow; and makes a proper lining for rooms, and when painted will last long.

In Lincolnshire, in the forest of Dean, and in various parts of the borders of South Wales they make ropes of the bark. This, by maceration, separates into thin rough layers, and is used for making the mats used by gardeners, and called in the north of Europe bast. They form a considerable part of the exports from Russia. This quality in the bark, and a great degree of viscidity in the whole tree, evince its acknowledged affinity to the mallow tribe. 
7703 Leaves lanc. ovate soft, Cal. very hairy, Pedunc. 3-flowered

7704 Leaves cordate ovate oblong crenated scabrous, Pedic. axillary 3-flowered, Fruit of 4 pieces

7705 Leaves ovate obl. acum. smooth nearly entire, Fl. terminal panicled

7706 Leaves roundish ovate blunt toothed smooth, Peduncles solitary 1-flowered

7707 Leaves ovate crenate rough on each side, Peduncles axillary 3-flowered

7708 Leaves ovate crenate rough thickish, Pedunc. 2-6-fl. axill. and term. Fruit pilose

7709 Leaves cordate roundish hoary beneath, Peduncles axillary about 4, longer than petiole

7710 Leaves cordate roundish smooth on each side, Peduncles shorter than petiole

\section{* Petals naked.}

7711 Lvs. cord. uneq. at base, Petioles and suckers hairy, Axill, of veins beneath beard. Fruit globose smooth 7712 Lvs, cord. acum. ser. smth. twice as long as stalks, Axill. of veins beard. ben. Fr. membr. obl. deform. 2 -seed. 7713 Lvs. cord. round. acum. finely serr. smth. scarcely longer than stks. Ax. of veins ben. beard. Fr. round very 7714 Lvs. cord, round, acum. finely serr. a little downy ben. Fr. turb. woody with prominent ribs [thin \& brittle * Petals with a scale at base.

7715 Lvs. deeply cord. abruptly acum. finely serrated coriaceous smooth, Pet. trunc. at end cren. Fruit ov. ribbed

7716 Lvs. trunc. at base subcord. oblique dent. serr. pubescent beneath, Pet. emarginate, Fruit globose smooth $\beta$ Leaves thin deeply and rarely cut

7717 Lvs. cord. subacum. unequal at base serrated snow-white beneath smooth above, Fruit round with 5 ribs

7718 Lvs. ov. downy beneath, at base either cordate or obliquely or equally truncate, Fruit round with 5 ribs

7719 Caps, obl, ventricose, Lowest serratures of leaves setaceous

7720 Caps. 3-celled 3-valved 3-cornered, Angles bifid scabrous, Leaves obl. Lowest serratures setaceous

7721 Caps. obl. 3-celled 3-valved 6-furrowed 6-pointed, Leaves cordate, Lowest serratures setaceous

7722 Caps. prismatical cuneate acutangular 3-toothed, Lvs. ovate with about 1 seta at the base, Petioles hispid

7723 Caps, roundish depressed rugose, Lowest serratures of leaves setaceous

7724 Caps. roundish woolly, Leaves ovate obtuse downy equally serrated

7725 Caps. linear compressed 2-valved, Leaves lanceolate equally serrate

7726 Leaves 3 feet long obovate, Flowers growing out of the stem and old branches

7727 Leaves oval

7728 Leaves ovate obtuse

7729 Leaves very blunt striated, Peduncles short, Berries 4-seeded

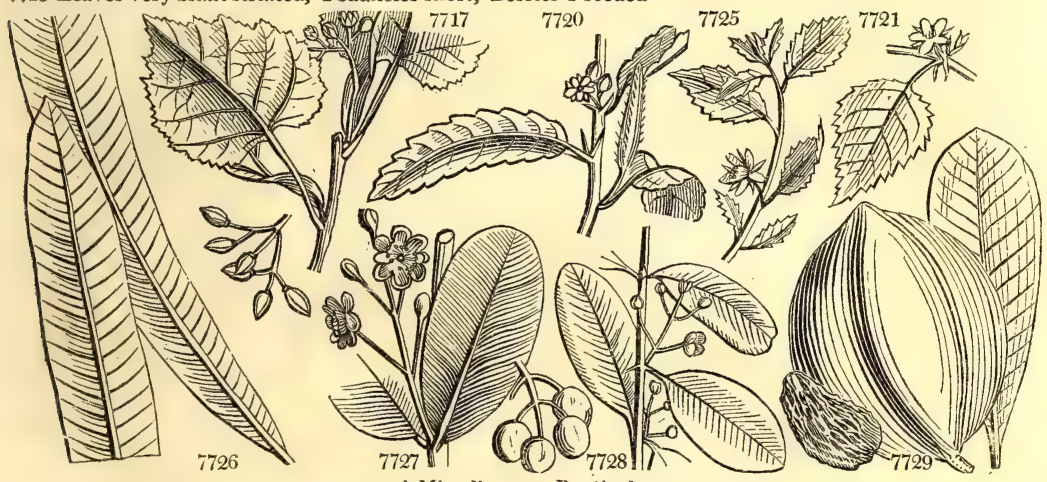

and Miscellaneous Particulars.

The honey made from the flowers of the lime tree is reckoned the finest in the world. Near Kowno in Lithuania, there are large forests chiefly of this tree, and probably a distinct variety or species. The honey produced in these forests sells at more than double the price of any other, and is used exclusively in medicine and for mixing with liqueurs. (Encyc. of Agric.; Poland and Hungary.)

1187. Corchorus. Kosxo९os, the Greek name of a culinary vegetable, supposed to be the same as that now known as C. olitorius. C. olitorius is sown in great plenty about Aleppo as a pot herb, the Jews boiling the leaves to eat with their meat, whence in French it is called Mauve-de-Juif. The other species are weeds.

1188. Grias. From reow, to eat. The fruit is eaten in the West Indies under the name of the Anchovy pear. The uprightness of the growth and the largeness of the leaves give this tree a very elegant appearance. The fruit is about the size of an aliigator's egg, and much like it in shape, only a little more acute at one end, and of a brown russet color. It is frequent in many parts of Jamaica, and grows generally in low moist bottoms or shallow water, where the fruit is pickled and eaten in the same manner with the East Indian mango, which it exactly resembles in taste. It grows in a loamy soil, and large cuttings, Sweet observes, succeed best in the same soil under a hand-glass in heat.

1189. Calophyllum. From $\approx \alpha \lambda .5$, beautiful, and $\phi \nu \lambda \lambda$ v , a leaf, on account of its large beautifully veined leaves. C. Inophyllum ( $s$ ivcs, nibre, because the middle nerve of the leaf seems to ramify into a multitude of fibres) is a very large tree, with leaves like a water lilly, snow-white fragrant flowers, and fruit like a walnut. The trunk when wounded exudes a viscid yellowish juice, frequently hardening to a gum. It is common in Malabar, in sandy soils, and bears fruit twice a year, in March and September, frequently to the age of three hundred years. An oil is expressed from the nuts to burn in lamps, to assuage pains, and to make ointments. The bark and gum is also used for medical purposes. In Java, \&c. they plant this tree about their houses, for the elegance of the shade and the sweetness of the flowers.

C. Calaba (the name among the Caribs) branches from the ground upwards, and is therefore well adapted for tree hedges. It has a green fruit not unlike our cornelian cherry, which is eaten by the natives, and an oil is expressed from it for lamps. Both species grow freely in a light loamy soil, and ripe cuttings are readily struck in sand under a glass and plunged in heat. (Sweet.)

1190. Mammea. An alteration of its American name, Mamey. The name having some resemblance to the I atin word mamma, a teat, Linnæus attributed the derivation to that word, on account of the large fleshy pointed nature of its fruit. Abricot-sauvage, Fr. A handsome tree with a spreading elegant head, like those H h 2 
1191. OCH'NA. $W$

7730 obtusáta Dec.

Squarrose

7731 atropurpúrea Dec. purple-flower'd : $\square$ or

1192. ELFOCAR'PUS. $W$. Elaocarpus

7732 serrátus $\boldsymbol{W}$.

7733 cyáneus $\boldsymbol{B}$. $M$ E. reticuláta Smith.

1193. ALAN'GIUM. J. Alangtum. 7734 decapétalum $W$. Sage-leaved

1194. MENTZE'LIA. $W$. Mentzelia. 7735 áspera $W$. rough 7736 oligospérma Nutt. few-seeded $\Delta \triangle$ or

1195. LAGERSTRO'MiA. $W$. Lagerstroemí. 7737 indica $W$.

7738 Kegínæ $\dot{W}$. Indian or

1196. 纴'GLE, Correa.

7739 Mármelos $\boldsymbol{H} . \boldsymbol{K}$.

1197. CIS'TUS. $J$.

7740 ladaníferus $W$ в planifólius

7741 monspeliénsis $W$.

7742 láxus $W$.en.

7743 hirsútus $W$. en.

7744 villósus $W$.

7745 populifólius $W$.

7746 Corboriénsis $\boldsymbol{P}$. $S$.

7747 undulátus Dun.

7748 vaginátus $W$.

7749 crispus $W$.

7750 salvifólius $\boldsymbol{W}$.

7751 laurifólius $W$

7752 heterophýllus $P$. $S$.

7753 incánus $W$.

7754 purpáreus $P$. $S$.

7755 créticus $W$.

7756 álbidus $W$.

7757 Lédon $W$.

Bengal-Quince.

Rock-Rose. Gum-Cistus

Flat-leav.-Gum

Flat-leav.-G

waved-leaved

hairy

villous

Poplar-leaved

small Poplar-lv

wavy

oblong-leaved

curled-leaved

Sage-leaved

Laurel-leaved

hoary

purple

Cretan

white-leaved

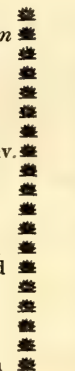

Ochnacea. Sp. 2-11

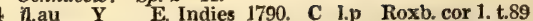
... Pu C. G. H. 1816. C 1.p Plu. al. 263. f.1,2 Elcocarpec. Sp. 2-10.

... W. E. Indies 1774. C p.l Burm. zeyl t.40

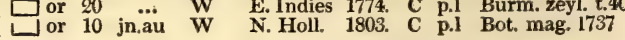

Myrtacea. $\quad S p, 1-2$.

Pa.pu E. Indies 1779. C p.1 Rhee.mal.4, t.17 Loasece. $S p .2-3$.

my.jn $\mathbf{Y}$ America 1733. S co Plum. 1c.

$\begin{array}{lllll}\text { Salicarie. } S p .2-7 & \\ \text { au.0 Pu } & \text { E. Indies 1759. C s.l Bot. mag. } 405\end{array}$ $\begin{array}{lllll}\text { or } 12 & \ldots & \mathbf{R} & \text { E. Indies 1792. } & \text { C p.1 Roxb.cor.1.t.65 }\end{array}$

$\underset{\text { thorny }}{\text { Bengl-Quince. }} \square$ fr $6 \begin{aligned} & \text { Aurantiacece. } \\ & \text { E } p \text {. Indies }\end{aligned}$ 7730

Cistinea. Sp. 18-28.

or 4 jn.jl $\underset{W}{\mathrm{~W}}$ Spain 1629. C s.p Bot. mag. 112

or 4 jin.jl W Spain $\quad$ W $\quad$ C s.p

or 2 jn.jl W $\quad$ S. Europe 1656. S s.p Jacq. coll. 2. t. 8

or 2 jn.jl W $\quad$ Spain 1656. S s.p

or 2 jn.jl W Portugal 1656. S s.p

or 3 jn.jl $\mathbf{P u}$ S. Europe 1640. C p.1 Duha.arb.1.t.64

or 3 my.jn W Spain 1656. C s.p Cav. ic. 3.t.215

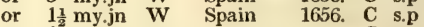

or 2 my jin $\mathrm{Pu}$ Spain

or 2 my.jn Pu

or 2 jn.jl Pu Portugal 1656. S s.p Cav. ic. 2. t. 17

or 2 jn.jl W $\quad$ S. Europe 1548. S s.p Jac. col.2. t. 8

or $4 \mathrm{jn} . \mathrm{jl}$ W Spain 1731. C s.p Clus, 1. p. 78. f. 1

or 2 jn.jl $\mathrm{Pu}$ Algiers ... $\mathrm{S}$ s.p Desf. atl. 1.t.104

or 2 jn.au Pu S. Europe 1596. $\quad$ S s.p Bot. mag. 43

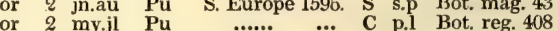

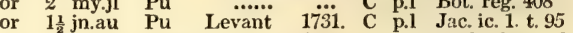

or 2 jn.jl Pa.pu Spain 1640. S s.p Park. theat. f. 1

or 1 jl.au W France 1730. C s.p Duha.arb.1.t.66

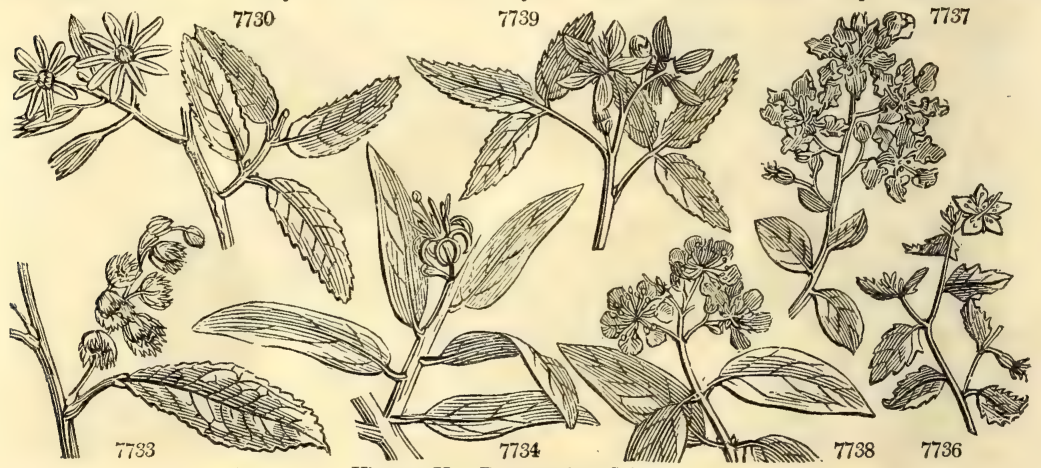

History, Use, Propagation, Culture,

of Magnolia grandiffora, and odoriferous white flowers on peduncles. The fruit is roundish, with a leathery rind, inclosing one thinner, containing a firm bright yellow pulp, having a pleasant singular taste, and a sweet aromatic smell; but the skin and seeds are very bitter and resinous. It is eaten raw alone, or cut in slices with wine or sugar, or preserved in sugar. In Martinico they distil the flowers with spirit, and make a liquor which they call Eau creole.

Some horticulturists are now attempting its culture in our stoves as a fruit tree. It grows freely in sandy loam, and ripened cuttings, with the leaves not shortened, root in sand under a hand-glass in heat. (Sweet.)

1191. Ochna. The Greek name of the wild pear tree, to which the genus so distinguished by Linnaus has no kind of resemblance. The species are pretty free-flowering plants, with shining serrated leaves, and long racemes of beautiful yellow flowers. They grow freely in loam and peat, and cuttings root readily in sand under a hand-glass.

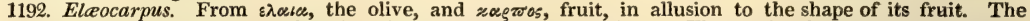
stones cleaned from the pulp, and set in gold, are formed into necklaces. The species thrive in loam and peat, and cuttings root in sand under a hand-glass.

1193. Alangium. So denominated by Lamarck, from a slight alteration of one of its Malabar names, Alangi. It grows in light sandy soil, and cuttings root in sand under a hand-glass in moist heat. (Sweet.)

1194. Mentzelia. Named after Christian Mentzel, a Prussian, physician to the Elector of Brandenburg; he died in 1701. Curious plants related to Loasa.

1195. Lagerstroemia. So named by Linnæus from Magnus Lagerstroem, of Gottenburgh, director of the Swedish East India Company, who procured many curiosities from China, and gave them to the public. $\mathbf{L}$ reginæ is a very handsome shrub: the flowers are in panicles, a span long, pale rose-colored in the morning, growing deeper through the day, and becoming purple in the evening. According to Sweet, this species is rather difficult to preserve through the winter; it requires a good heat, and but little water in winter; if it happens to have too much wet, it is a great chance if it survives : in summer it grows very fast, and requires plenty of room and water. Cuttings of both kinds root readily in sand, under a hand-glass. (Bot. Cult. 73.)

1196. Fgle. A $\gamma \lambda_{n}$ was one of the Hesperides. Correa de Serra named the genus Agle from the fruit having some resemblance to the orange. Sweet observes, that this plant likes a rich loamy soil. The wood 
7730 Stigma capitate, Petals 8-10, Leaves obovate very blunt serrated

7331 Flowers solitary, Leaves ovate acutely toothed, Sepals ovate

7752 Leaves lanceolate ellipt. serrated, Racemes axillary

7733 Leaves obl. lanc. serrated netted, Racemes axillary ciustered, Drupes blue

7734 Petals 10, Branches spiny

7735 Stem branched, Peduncles axillary, Petals crenate obtuse

7736 Stem branched, Peduncles axillary solitary, Petals acuminate, Fruit reflexed

7737 Petals crisp, Panicle terminal, Leaves roundish ovate acute smooth

7738 Petals wavy, Panicle terminal, Leaves oblong smooth

7739 Middle leaflet stalked, Fruit with 12 cells

7740 Leaves subsessile connate at base lin. lanc. smooth above downy beneath, Caps, 10-ce

7741 Leaves lin. lanc. sessile 3-nerved villous on each side, Pedunc. cymose 1-sided

7742 Leaves on short stalks ovate lanceolate acum. wavy at edge : the upper hairy, Cymes hirsute

$77+3$ Lvs. sessile obl. obt. hirsute, Pedunc. short 1-fl. or cymose, Caps. small in a large hairy pyramidal calyx

7744 Leaves roundish ovate rugose tomentose hairy stalked, Pedunc. 1-fl. 1-3 together, Calyx villous

7745 Leaves stalked cordate acuminate smooth, Fl. cymose, Pedunc. with long bractes

7746 fringed at edge rugose and a little glutinous on each side

7747 Leaves sessile linear oblong acute wavy at edge 3-nerved at base, Sepals villous with long points

7748 Lvs. lanc. acute 3-nerv. hairy reticul. beneath stalked, Stalks sheathing the stem with their connate bases

7749 Leaves sessile linear lanceolate waved crisp 3-nerved rugose pubescent, Fl. sessile umbelled

7750 Leaves stalked ovate blunt rugose downy beneath, Pedunc. long hoary 1-flowered

7751 Leaves stalked ovate lanc. 3-nerved smooth above downy beneath, Petioles dilated and united at base

7759 Lvs. ovate lanc. on short stalks sheathing at base revolute at edge, Pedunc. hirsute leafy 1-flowered

7752 LVs. ovate lanc. on short stalks sheathing at base revolute : the upper narrower, Pedunc. 1-flowered

7753 Leaves spatulate toment. rugose 3-nerved sessile subconnate: the upper narrower, Pedunc. 1-filowe
7754 Leaves obl. lanc. acuminate at each end rugose, Stalks short hairy sheathing, Pedunc. short 1-2:3

7755 Leaves spatulate ovate downy hairy narrowed into a short stalk wavy at edge, Pedunc. short 1-flowered 7756 Leaves sessile obl. ellipt. hoary downy about 3-nerved, Fl. 3-8 in terminal umbels, Outer sepals largest

7757 Lvs, conn. obl. lanc. nerv, above smooth and shin. beneath silky, Fl. in corymb. cymes, Ped, and cal.vill.

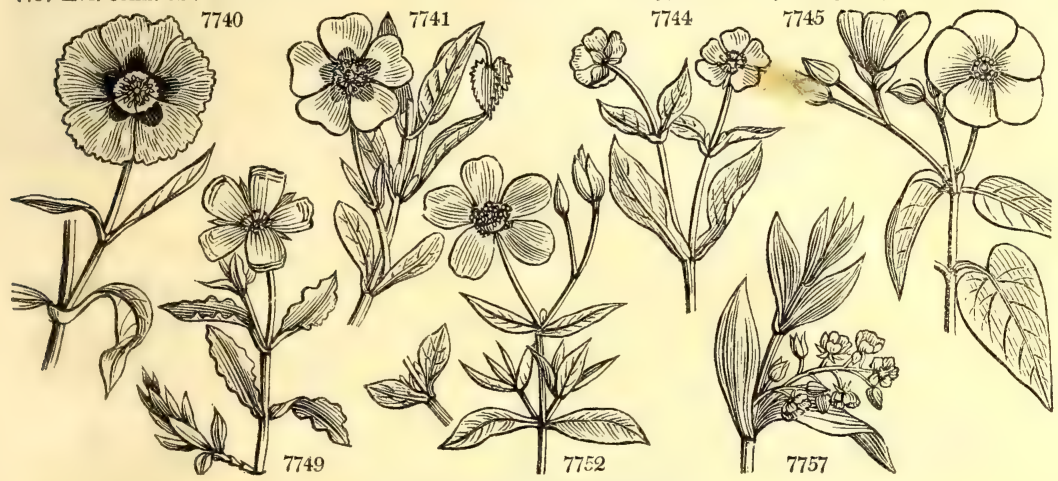

and Miscellaneous Particulars.

requires to be ripened before the cuttings are taken off; then to be planted in a pot of sand without shortening the leaves, and to be plunged under a hand-glass in heat.

1197. Cistus. K. $\sigma \tau 05$, in Greek; derived from $\approx 5 \eta$, a box, or capsule. The capsules of the genus are remarkable. All these words have been formed from the Anglo Saxon, cyst, which signifies a hollow vessel.

The species are for the most part shewy and free-flowering plants; the colors brilliant, and the petals very fugacious. In gardens they are rather difficult to keep in a neat shape, getting naked below, and often.dying wholly or in part during severe winters. They succeed best in glass cases, which can be entirely removed in summer, or in a dry soil under a warm wall.

C. villosus has a strong woody stem, the flowers are produced at the ends of the branches, four or five together, almost in form of an umbel, but it rarely happens that more than one is open at the same time The petals are large, purple, and spread open like a rose; they are but of short duration, generally falling off the same day they expand; but there is a succession of fresh flowers every day for a considerable time in May and June; generally again in September and October, if the autumn be favorable, and even in the wirter if the plants be protected from frosts.

C. ledon and ladaniferus produce the gum ladanum, but not in such quantities as C. creticus. The resin, which is secreted from the leaves and other parts of the shrub, is scraped off by means of a kind or rake, to which numerous leathern thongs are appended instead of teeth. This instrument being drawn backwards and forwards over the plant from time to time, collects the resin. The chief use of this gum in modern practice is in fumigations, its fragrant smell having made it a constant ingredient in such preparations. C. ladaniferus is the most popular species for warm situations in ornamental scenery.

"Most of the species," Sweet observes, "will survive through the winter in the open air, if the weather be not too severe; but it is safest to keep some of all the kinds in pots, that they may be sheltered from severe frosts; and they can be turned out in the borders in spring, when they will thrive and flower well. They will succeed in any common soil, or a mixture of loam and peat will suit them very well. They mas be increased by layers; or young cuttings, as soon as ripened, taken off at a joint, and planted under a handglass, will root readily : they may be also raised from seeds, which are produced in abundance." (Bot. Calt. 168.) 
1198. HELIAN'THEMUM $J$ SUN-RoSE 7758 Libanótis $W$ Rosemary lvd 7759 umbellátum $P . S$ umbel-flower'd 7760 scabrósum $P$. $\dot{S}$. 7761 algarvense Dun. 7762 formósum Dun. 7763 atriplicifólium $P$. S. 7765 canadénse $P . S$. 7766 Tuberária $P . S$. 7767 guttátum $P$. $S$. 7768 ledifólium $P . S$ 7769 ægyptíacum $P$. S 7770 salicifólium $P$. $S$. 7771 punctátum $P$. S 7772 canariénse $P$. $S$. 7773 Fumána $P$. $S$ 7774 læ'vipes $P$. $S$. 7775 Barreliéri Tenore 7776 glutinósum $P . S$ 7777 origanifólium $P$. $S$ 7778 œlandicum $P$. $S$. 7779 itálicum $P$. S. 7780 cánum $W$. en. 7781 marifólium $P$. $S$. 7782 squamátum $P$. 7783 glaúcum $P . S$

7784 tomentósum Smith. 7785 serpyllifólium $P . S$. 7786 vulgáre $P . S$. $B$ flore pleno 7787 nummulárium $P$. S. Soneywort-ly i P.S. dotted-leaved 2 7789 sampsucifólium Cav. bristly-stalked 2 7790 elongátum P.S. long-peduncled wi $\begin{array}{ll}7791 \text { serrátum } P . S . & \text { saw-petalled } \\ 7792 \text { hírtum } P . S . & \text { bristly-calyxed }\end{array}$ bristly-calyxed

7793 pulveruléntum P.S. powdered 7794 atireum $P . S$. golden 2 7796 lavandulæfólium P.S.Lavender-leav, 7797 angustifólium $P$. S. narrow-leaved 2. 7798 mutábile $P . S . \quad$ changeable 7799 polifólium $P$. S. white-mount 2 7800 appennínum P.S. Apennine 7801 pilúsum $P . S . \quad$ hairy 7802 grandiflórum $P . S$. large-flowered \& $\begin{array}{ll}7803 \text { róseum } P . S . & \text { Rose-colored } 2 \\ 7804 \text { cróceum } \dot{P} . S . & \text { Saffron-colored } 2\end{array}$ 7805 sulplúreum $W$. en. Sulphur-color'd

\section{Cistinea. Sp. 48-124}

1 jn $\quad \mathrm{Y}$ Spain 1752. C p.l Barr. ic. 294

2 jn.au W S. Europe 1731. C p.I

jn.jl Y Italy 1775. C p.

3 jl.au $\quad Y \quad$ Portugal 1800. C p.l Bot. mag. 627

Portugal 1780. C p.l Bot mag. 264

Spain 1656. C p.l Barr ic 290

Spain 1656. C p.l Cav. ic. 2. t. 138

N. Amer. 1799. S s.1

S. Europe 1752. S s.p Cav. ic. 1. t. 67 England san.pa. D s.1 Eng. bot. 544

England san.pa. S s.l Eng. bot. 2414

Egypt 1764. S s.l Jac. obs. 3. t 68

S. Europe 1759. S s.p Cav. ic. 2. t. 144

S. France 1816. S s.l

Canaries 1790. C p.l Jac. ic. 1. t. 97

France 1752. S s.p Jac. aust.3. t.252

France 1690. S s.p Bot. mag. 1782

Italy 1820. S s.p Bot. mag. 2371

S. Europe 1790. C p.1 Cav.ic.2.t.145.f.2

Spain 1795. C s.p Cav, ic. 3. t. 262

Germany 1816. S s.p Jac. aust. t. 399

Italy 1799. C s.p Barr. rar. t. 366

S. Europe 1772. C p.I Al.ped.2. t.45.f.3

Britain al.roc. C s.p Eng. bot. 396

Spain 1815. C s.l Cav.ic. 2. t. 139

Spain 1815. C s.1 Cav. ic. 2, t, 261

Scotland sc.alp. C s.l Eng. bot. 2208

Austria 1731. C p.l

Britain gra.ban. C s.l Eng. bot. 1321

C... C s.l

Spain 17\%̈2. C s.1 Cav. ic. 2. t. 142

England ch.hil. C s.l Eng. bot. 2207

France $\quad .$. C p.l Bot. mag. 1803

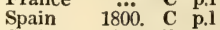

Spain 1804. D s.p Cav.ic.2.t.175.f.1

Spain 1759. C s.1 Barrel, rar. t.488

France $\quad \cdots \quad$ C s.l

Montpelier ... $\quad$ C s.l

Spain 1658. C s.l Barrel ic 444

Levant 1739 . C s.l Jac. ic. 1. $t .96$

..... 1800. C s.l Jac. hort. 3. t. 5

France 1795. C s.l Jac. ic. 1. t. 99

England downs. C s.p Eng. bot. 1322

Italy 1731. C s.p Tabern. ic 1062

S. Europe 1731, C s.1 Al.pe.2.t.45.f.1,2

Italy 1800. C s.p Scop. carn. t. 25

$\begin{array}{lllllll}\frac{1}{2} \mathrm{jn} . \mathrm{au} & \mathbf{P k} & \text { S. Europe } & \ldots & \text { C } & \text { s.p } & \text { Jac. hort. 3. t.65 } \\ { }^{\frac{3}{4}} \mathrm{jn} . \mathrm{au} & \mathrm{Y} & \text { Spain } & \ldots . & \text { C } & \text { s.l } & \text { Desf. atl. 2.t.110 }\end{array}$

$\begin{array}{lllllll}\frac{1}{2} \mathrm{jn} . \mathrm{au} & \mathbf{P k} & \text { S. Europe } & \ldots & \text { C } & \text { s.p } & \text { Jac. hort. 3. t.65 } \\ { }^{\frac{3}{4}} \mathrm{jn} . \mathrm{au} & \mathrm{Y} & \text { Spain } & \ldots . & \text { C } & \text { s.l } & \text { Desf. atl. 2.t.110 }\end{array}$

\section{$D I G Y N I A$.}

1199. BAUE'RA. $H$. $K$. Bauera.

Cunoniacea. Sp. 1.

7806 rubiæfólia $H . K$. Madder-leaved to jo $1 \frac{1}{2}$ jl.d $\quad$ Pk $\quad$ N. S. W. 1793. C s.p Bot. mag. 715

1200. FOthergiL/LA. $W$. Fothergilla. 7807 alnifólia $W \quad$ obtuse-leaved

7808 májor $B$.

7809 Gardéni Jac.

7810 serotína $B . M$.

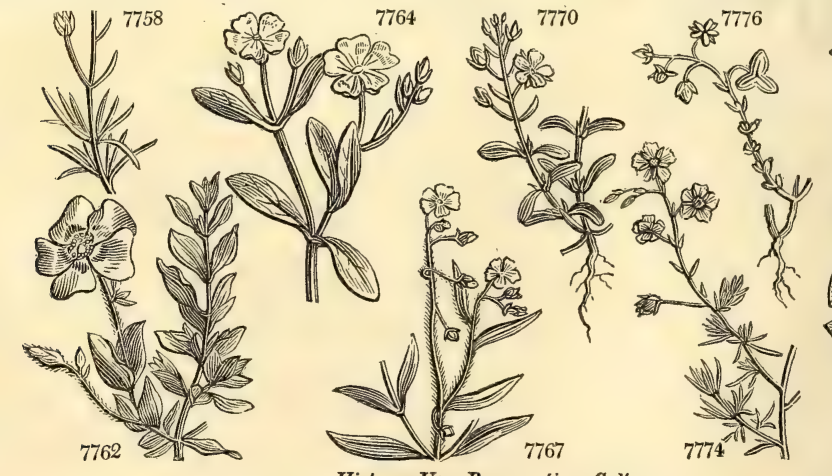
arge-leaved acute-leaved green-leaved

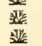

Humamelidee. Sp. 4.

or 4 ap.jn W N. Amer. 1765. L s.p Bot. mag. 1341 or 4 my.jn W N. Amer. 1765. L s.p Bot. mag. 1342 or 4 my.jn W N. Amer. 1765. L s.p Jac. ic. 1. t. 100 or 4 au W N. Amer. 1765. L s.p

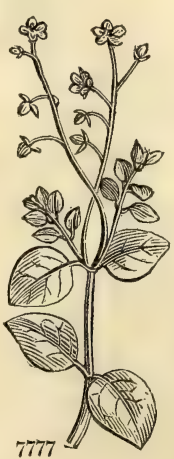

History, Use, Propagation, Culture,

1198. Helicnthemum. From $\eta^{i} \lambda$ เ the blossoms. This is a shewy free-flowering genus of little trailing plants, mostly ligneous, and well adapted for rock-work. A number of them answer best kept in pots, and sheltered by frames during winter; but some are quite hardy, and none are more ornamental than the $\mathbf{H}$. vulgare, and its varieties with orange, yellow, straw-colored, red, and double flowers. It is one of the handsomest plants in cultivation for rockwork. All the species are of easy culture in light soil, and cuttings root freely under a hand-glass.

1199. Bauera. Named after Francis and Ferdinand Bauer, German botanical draughtsmen of the highest 
7758 Stem nearly smooth, Lvs. sess. lin. revol. at edge brownish green above hoary beneath, Fl. sol. Sep. shining 7759 Young shoots visc. with downy hairs, Lvs. sess. lin. obl. viscid downy beneath, Fl, in term. umb. Sep. villous 7760 Branches hairy rough hoary, Lvs. sess. atten. at base green above ash-colored beneath, Ped. shorter than 7761 Leaves sessile hoary ovate-lanc. Pedunc. panic. hairy, Sepals 3 acute hairy

7762 Branches villous, Leaves obov, lanc. hoary, Pedunc. and cal. villous, Sepals 3

[leaves, Cal. hairy

7763 Branches white with scales, Leaves broad ovate blunt wavy at base silvery on each side, Cal. hairy

7764 Branches white with scales upwards, Lvs. stalked ovate-obl. Pedunc. long brached panicl. Sepals 5 scaly 7765 Branches hairy, Lvs. obl. lanc. acute hairy pale beneath, Pedunc. hairy 1-fl. Capsule shorter than calyx 7766 Stems nearly simple, Radical leaves stalked ov. obl. 3-nerved hairy, Ped. panic. few, Cal, smooth shining 7767 Stem hairy, Leaves sess, obl. lin. 3-nerved villous, Racemes lax without bractes, Ped. filiform naked 7768 Stem nearly smooth, Lvs. obl. ellipt. toothl. Fl. opp. with stipules, Ped. erect smooth shorter than calyx 7769 Lvs. on short stalks lin. obl, narr. rev. at edge, Stip. lin. subulate, Pedunc. filif. pubescent, Calyx inflated 7770 Branches hairy, Leaves obov. obl. acute toothletted, Stip. lin. obl. Pedunc. and cal. hairy

7771 Leaves obl. 3-5-nerved rough with short stellate hairs, Racemes long pubescent cinereous few-flowered 7772 Branches hoary, Leaves stalked opp. and alternate blunt glauc. Stipules subulate, Raceme term. erect 7773 Stem tortuose, Leaves altern. lin. rough at edge subinvolute, Pedunc. sol. 1-fl. Caps naked 7774 Leaves setaceous glaucous nearly smooth, Stip. filiform long, Pedunc. racemose, Calyx hairy 7775 Branches villous, Leaves lin. obl. pubesc. Stip. lin. subul. mucron. erect, Pedunc. racemose glutinous 7776 Branches villous glutinous, Leaves lin. vill. glut. ash-colored, Stipules long lax, Pedunc. and cal. villous 7777 Leaves stalked ovate hairy on each side, Racemes short term. Pet. scarcely larger than calyx 7778 Leaves lanc. ellipt. blunt green on each side, Racemes simple few-fl. Cal. subglobose ovate 7779 Branches simple long, Leaves pilose hispid: lower ovate; upper lanc. Racemes simple hairy hoary 7780 Leaves oblong hairy green above hoary beneath, Racemes simple, Pedic. and cal. hoary

7781 Leaves without stipules stalked ovate cordate, Racemes simple solitary few-flowered terminal 7782 Branches silvery with scales, Leaves stalked obl. blunt silvery with small stipules, Cal. scaly 7783 Branches ascend. hoary, Leaves downy glaucous : the lower round; upper ellipt. Stip. and bractes green 7784. Leaves lanc. ovate hoary beneath green above, Calyx furrowed with elevated hairy nerves

7785 Leaves obl. ellipt. hoary beneath deep green shining above, Calyx hoary : its nerves with a few hairs 7786 Leaves scarcely revol, at edge hoary beneath, green and hairy above : lower round; upper obl. Rac. lax

7787 Lower leaves round : upper obl. lin. hairy green beneath, Racemes and calyxes hairy 7788 Leaves obov, obl. somewhat hairy, Racemes few-fl. term. Pet. narrow lanceolate 7789 Leaves ovate-obl. keeled sessile, Peduncles long branched panicled, Stipules O

7790 Stipules O, Leaves lanc. hoary hairy beneath, Pedunc. long 2-leaved and racemose, Caiyxes hairy

7791 Leaves opp. lanc. 3-nerved hairy viscid, Radical obovate, Racemes without bractes, Petals serrated 7792 Leaves obovate obl. revolute at edge downy hairy hoary beneath, Calxes very hirsute white

7793 Leaves obl. linear glaucous above hoary beneath, Cal. hoary minutely pubescent, Branches hoary

7794 Leaves lin. obl. revolute at edge hoary on each side, Calyxes very hirsute white

7795 Leaves lin. very short pubescent opp. Stip. mucronate erect, Pedunc. villous few-flowered

7796 Leaves oblong lin. revolute at edge the younger hoary on each side, Calyxes glaucous, Sepals ciliated

7797 Leaves short stalked lin. oblong hispid above, Racemes lax, Calyx with deciduous hairs

7798 Leaves flat ovate obl. acute smooth above beneath finely downy, Cal. striated smoothish

7799 Leaves obl. ovate obt. flat beneath hoary above smooth green, Cal. striated smooth shining

7800 Leaves stalked obl. lin. downy beneath glaucous above, Cal. shortly hairy striated glaucous obtuse

7801 Leaves linear hoary on each side setose at end, Stipules subulate, Cal. hairy nerved striated

7802 Upper leaves flat obl. hairy, Stipules ciliated longer than stalk, Fl. large, Calyxes hairy

7803 Leaves ovate lanc. a little downy on each side, Stipules linear, Ped. and cal. pilose hirsute

7804 Leaves downy hoary beneath glaucous above revolute at edge, Calyxes yellowish glaucous

7805 Leaves narrow lanc. flat with stellate pubescence on each side, Raceme terminal few-flowered

\section{DIGYNIA.}

\section{The only species}

7807 Leaves cuneate obovate upwards crenate toothed

7808 Leaves ovate-oblong cordate at base, upwards crenate toothed

7809 Leaves ovate acute nearly entire

7810 Leaves oblong acute crenate-toothed upwards, green beneath

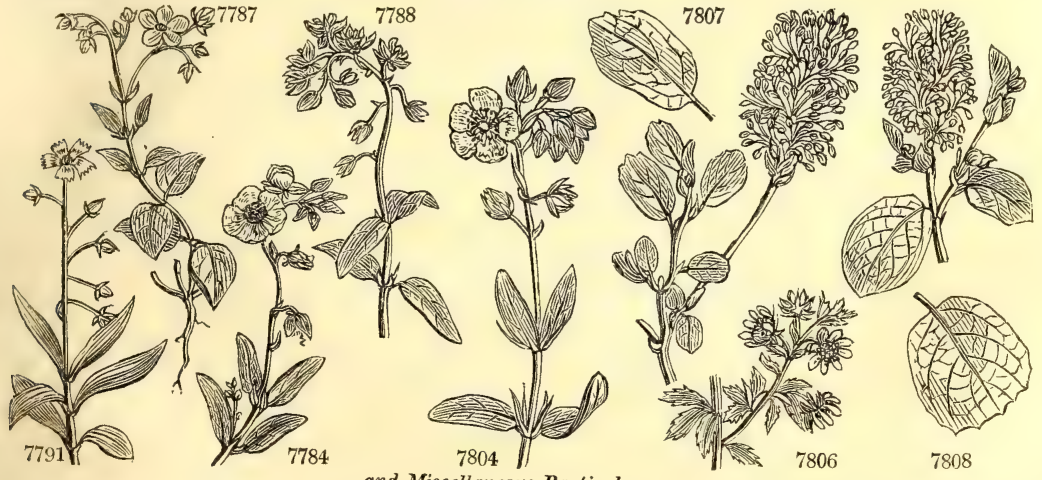

and Miscellaneous Particulars.

cclebrity. Nothing comparable to their works has ever appeared from any other hand. The species is a hardy free-flowering plant, of easy culture in sandy loam and peat, and cuttings root in the same soil under alass.

1200. Fothergilla. In memory of John Fothergill, M. D., an eminent physician and patron of botany, who cultivated a variety of the most curious plants in his garden near London. The species are dwarf deciduous shrubs, of easy culture in light soil or peat, and generally increased by layers. 
1201. CUratel'la. $W$. Curatella.

7811 americána $W$. 1202. PEO'NIA. $W$.

7812 Moután $H$. $K$.

e papaverácea

$\beta$ Banksia

$\gamma$ rósea

7813 albifióra Pall.

$\beta$ tatárica

r sibirica

Srubéscens

E uniftóra

$\zeta$ Whitleji

ท Humei

7814 daúrica $H . K$

7815 corálling $W$.

7816 officinális $W$

$\beta$ rósea

r blánda

Srubra

\& carnéscens

śalbicans

n lobáta Dec.

7817 peregrina $\boldsymbol{H}$. $\boldsymbol{K}$. $\beta$ compácta

y Grevillii

7818 crética Lindl.

7819 paradóxa And

i fimbriáta

7820 ińllis $A n d$.

7821 arietína $A n d$.

7822 decóra And.

a Pallásii

$\beta$ elśtior

7823 húmilis $W$

7824 anómala $W$ laciniata 7825 hýbrida $W$.

7826 tenuifólia $W$.
Americar

PaEONY.

Chinese tree

Poppy-flowered common

Rose-colored

eatable-rooted

Tartarian

Siberian

blush-colored

single-flowered

double-white

double-crimson

Rose-scented

Daurian

entire-leav

Rose-colored

blush

double-red

flesh-colored

whitish

lobed

Turkish

compact

Greville's

early pink

paradoxical

double-fringed

soft

Anderson's

comely

Pallas's

tall

dwarf 2. t. 85 .

mule jagged-leaved
Dilleniacea. Sp. 1-2.

$\begin{array}{lllll}\text {... W } & \text { S. Amer. } \quad \ldots & \text { L s.p Aub. gui.1. t.232 }\end{array}$ Ranunculacee. Sp. 15-17.

3. ap.jn Pu China 1789. C p.l

ap.jn W China 1789. C p.l Bot. cab. 547

3 ap.jn $\mathbf{P u}$ China

ap.jn Pk China

my.jn w Siberia

2 my.jn W Siberia

2 my.jn Pk Siberia

2 my.jn W

2 my.jn W

2 my.jn $R$

2 my.jn $R$

3 my.jn $\mathrm{Pu}$

4 my.jn $R$

3 my.jn $\mathbf{R}$

3 my.jn R

3 my.jn $\mathbf{P k}$

3 my.jn w

3 my.jn W

3 my.jn R

my.jn D.Pu ......

2 my.ju $\mathbf{P u}$

2 my.jn $\mathrm{Pu}$

2 my.jn $\mathrm{Pk}$

2 my.jn $\mathrm{Pu}$

3 my.jn Pu

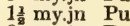

2 my.jn $\mathrm{Pu}$

2 my.jn Pu

2 my.jn $\mathbf{P u}$

2 my.jn $\mathrm{Pu}$

$\begin{array}{lll}2 & \mathrm{my} & \mathrm{Pu} \\ 2 & \mathrm{my} . j n & \mathrm{Pk}\end{array}$

China

China

Siberia

Englan

Switzerl.

.......

(1)

Levant

…....

Candia

Levant

…...

.......

(......

Spain

Siberia

* $\Delta$ or

* $\Delta$ or

* $\Delta$ or 2 my.jn $R$

Siberia

Siberia
1789. C p.1 Bot. mag. 1154

178.. $\begin{array}{lll}\text { C } & \text { p.1 } & \text { s.1 } \\ & & \end{array}$

... $\mathrm{R}$ s.1

... $\quad R$ s.1

1784. R s.1 Bot. reg. 42

... R s.l

1784 R s.

Bot. mag. 1768

R s.1 Hort. trans. c. ic

1790. R s.l Bot. mag. 1441

ï R s.l Eng. bot. 1513

... $\mathrm{R}$ s.l

... $\mathbf{R}$ s.

... R s.

… R s.l

1629. $\mathrm{R}$ si

... R s.

... $\quad \mathbf{R}$ s.l

... $\quad \mathbf{R}$ s.l

... R s.l

... $\quad$ R $\quad$ s.l Sweet fl. gard.19

... $\mathrm{R}$

$\ldots \quad \mathbf{R}$

... R s.

… R s.l

1633. R s.l Bot. mag. 1422

1788. R s.l Bot. mag. 1754

1788. R s.l Pall. ross. 2. t.86

1765. R s.1 Bot. mag. 926

\section{TRIGYNIA.}

1203. HibBer'TiA. $H$. $K$. Hibbertia. 7827 volúbilis $B$. Rep. twining

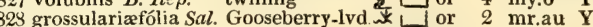
7829 dentáta $R . B r$. toothed
1204. DELPHI'NIUM. $W$. LARKSPUR. 7830 chinénse Fisch. 7831 ambíguum $W$. 7832 consólida $W$. 7833 cuneátum Stev. 7834 Ajácis $W$. 7835 aconiti $W$. 7836 peregrinum $W$. D. junceum Dec 7837 grandiflórum $W$ r flore-pléno

7812 Nill Chinese doubtíul field $\quad O$ or 4 jn.jl wedge-shaped $\$$ or $4 \mathrm{jn} . \mathrm{jl}$ Rocket $\$$ or 2 jn.jl Aconite-like \& $($ ) or 1 jn.jl broad-lvd.-ann. $\mathrm{O}$ or $1 \mathrm{jn} . \mathrm{j}$

... $\mathbf{Y}$

Sp. 3-19.

N. S. W. 1790. C s.p Bot. rep, 126 N. Holl. 1803. C s.p Bot. mag. 1218 N. Holl. 1816. C s.p Bot, reg. 282

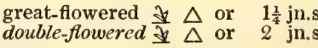

$\begin{array}{lllll}\text { Ranunculacea. } S p .26-53 . & & \\ \text { s.0 } \quad \text { Pu } & \text { Tartary 1819. S } & \text { p.l Bot. cab. } 71\end{array}$

B Barbary 1759. S p.l

B England san.fi. S r.m Eng. bot. 1839

Pk Switzerl 1816. D co

Pu Levant 1801. S p.l Vahl. sym.1.t.13

B Italy 1629. S p.I Al.ped.2.t.25.f.3

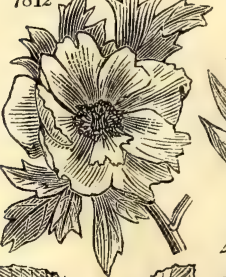

$7812 \beta$ m

D.B Siberia 1741. D p.l Bot. mag. 1686

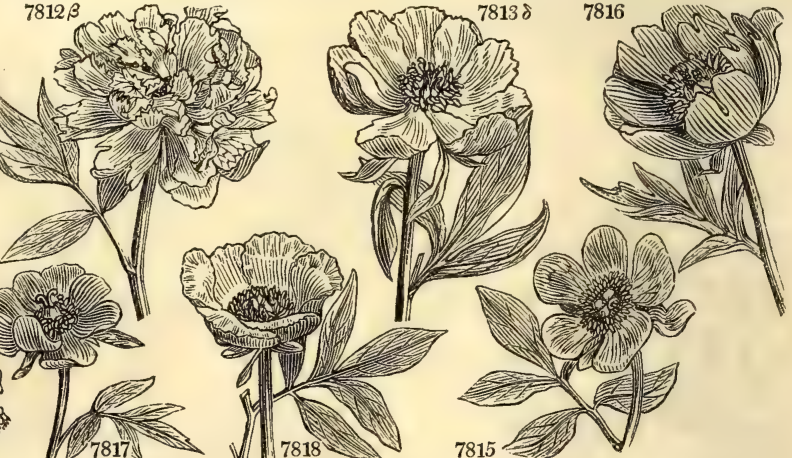

History, Use, Propagation, Culture,

1201. Curatella. From curatus, worked; a name given by Aublet to the genus, because the leaves, which have a rough surface, are used in Guyana for polishing bows, sabres, and other weapons. A small tree with rough leaves, which grows well in sandy loam; cuttings root in sand under a glass.

1202. Paxia. The physician Pæon was the first to use this in medicine. The Greek legend adds, that he used it to cure Pluto of a wound inflicted by Hercules. The species are magnificent flowering plants, especially $\mathbf{P}$. officinalis and moutan, with their numerous varieties. $\mathbf{P}$. moutan and its different varieties are hardy enough to bear our winters in the open air; but they do not flower in such perfection as when planted out in a conservatoiy, or in a pit where they may be protected from the severe frost under glass : they wil thrive well in any rich light soil; and ripened cuttings, slipped off, and planted in the ground, in a shady place, without cover, will root freely. (Bot. Cult. 234.)

$\mathbf{P}$. edulis has a more slender stem than the common Pæony. The Daurians and Mongols boil the root in 


\section{Leaves ovate subrepand toothletted rough}

7812 Segments of leaves ovate obl, glaucous beneath

7813 Capsules smooth recurved, Segm. of leaves smooth shining 3-parted with ovate lanceolate lobes

7814 Capsules downy erect, Segm. of leaves glaucous beneath smooth somewhat lobed with blunt obovate lobe 7815 Capsules downy, Segm, of leaves ovate entire smooth

7816 Capsules downy nearly straight, Segments of leaves unequally cut smooth, Lobes ovate-lanceolate

7817 Caps, downy erect, Segm. of leaves 3-parted cut and entire ovate-lanc. flat hairy beneath

7818 Leaves somewhat shining blistered coriaceous glaucous and downy beneath, Ovaries woolly spreading 7819 Caps. downy straight, Segm. of leaves many-parted blunt somewhat wavy glaucous beneath hairy

7820 Caps, downy straight, Segm. of leaves oval-lanc. flat lobed imbricated beneath cæsious hairy 7821 Caps. downy arcuate spreading, Segm. of lvs. 3-lobed and pinnatifid decurrent ovate-obl, flat hairy beneath 7822 Caps. pubescent spreading, Segm. of leaves 3-parted oblong blunt hairy beneath

7823 Caps. somewhat pilose nearly erect, Segm. of leaves 3-5-parted villous beneath, Lobes obl. entire 7824 Caps. 5 smooth depressed blunt, Segm. of leaves smooth pinnated, Lobes lanc. acuminate

7825 Caps. pubescent, Segments of leaves smooth many-parted, Lobes linear 7826 Caps. downy spreading, Segm. of leaves smooth many parted, Lobes linear

\section{TRIGYNIA.}

7827 Leaves obovate lanc. nearly entire mucronate pubescent beneath, Flowers sessile, Stem twining 7828 Leaves roundish crenate toothed, Fl. stalked opp. to the leaves, Stems procumbent

7829 Leaves obl. acum. smooth with awned serratures, Fl, stalked trigynous

7830 Like D. grandiflorum, from which it differs in having a more rigid stem, and a later time for flowering 7831 Stem erect velvety, Lvs. 3-5-part. Lobes pinnatifid, Racemes lax, Spur straight pubesc. shorter than cal. 7832 Stem suberect smth. with spread. branches, Fls, few loosely racem. Ped. long, than bractes, Caps, smooth 7833 Petioles not dilated at base, Lvs. cun. at base 5-7-lob. Lobes cut acute, Raceme lax branch. Calyxes smooth 7834 Stem erect smoothish nearly simple, Branches much covered with fls. Ped. length of bractes, Caps. pubesc. 7835 Stem erect branch. subpub. Lvs. pedate multifid, Ped. very long, Spur incurv, at end horiz. divid. upwards 7836 Stem erect much branch. Lvs. smooth rigid: low. multifid, Branc. and bractes lin. ent. Rac. lax. Pet. stalk.

7837 Leaves palmate many-parted, Lobes linear distant, Pedicels longer than bract, Pet. shorter than calyx

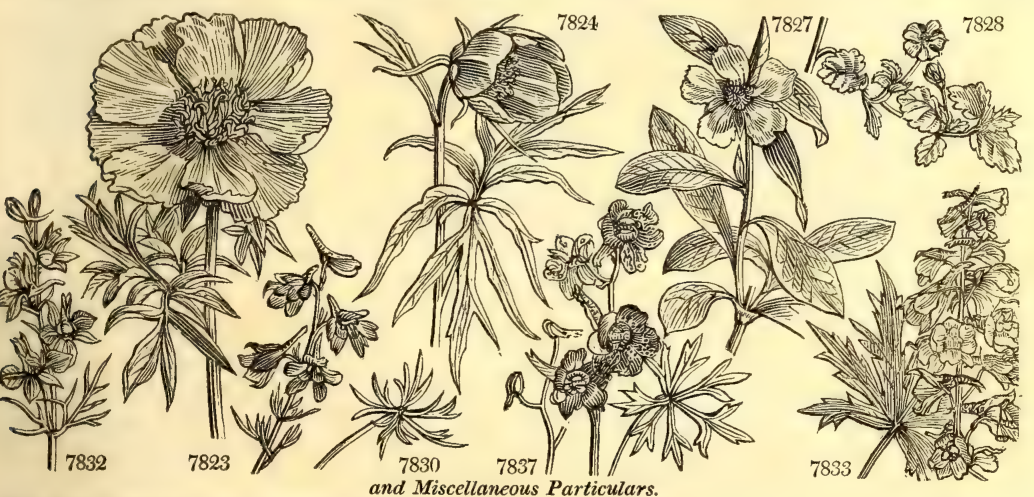

their broth, and grind the seeds and put them into their tea. $\mathbf{P}$. officinalis was by old authors said to be of two sorts, male and female, the flowers of the former being smaller and lighter colored than those of the latter. These distinctions, however, were not indicative of sexual difference, the prony being hermaphrodite, but merely of stronger and weaker growing varieties, according to the practice of the age. Now they are laid aside, the varieties reduced to seven or eight, of which a full account is given in the Horticultural Transactions (vol. ii. 273.). Of these, the double red, the most common, when introduced at Antwerp about the end of the sixteenth century, sold for twelve crowns a root. A useful account of the species and varieties has been published by Messrs. Anderson and Sabine, in the transactions of the Linnean Society.

1203. Hibbertia. Named after George Hibbert, Esq. who was once a distinguished English collector of plants. Twining or trailing plants of New Holland, with bright yellow flowers.

1204. Delphinium. From $\delta \in \lambda \varphi \iota$, , a dolphin, on account of the resemblance between the nectary of the 
7838 cheilánthum Fisch. Doroninsk 7839 intermédium $W$. palmated Bee 7840 elátum $W$. montanum Dec 7841 revolútum Desf. 7842 hýbridum $W$. hirsútum P.S.

7843 mesoleucum Link. white-eyed 7844 exaltátum $W$.

7845 azúreum $P h$.

7846 dictyocárpum Dec.

7847 tricórne $P h$.

7848 urceolátum $W$.

7850 ochroleúcum Stev.

7851 laxiflórum Dec.

7852 puníceum $W$.

7853 staphiságria $W$. en.

7854 píctum W.en.

7855 Requiénii Dec.

1205. ACONI'TUM. $W$.

1205. ACONI'TUM. W. WoLF's-BANE.

7857 ochroleúcum $W$. pale-white

7858 lycóctonum $\boldsymbol{W}$.

7859 japónicum $W$.

7860 variegátum $i V$

7861 An'thora $W$.

7862 pyrenáicum $W$.

7863 versicolor Stev.

7864 septentrionále $W$.

7865 álbum $W$.

$7866 \mathrm{cam}^{\prime}$ marum $W$. rostratum Bernh.

7867 tortuósum $W$.en.

twistin

7869 speciósum Otto

7870 barbátum $P$. S

7871 biflórum Fisch.

7872 Napéllus $W$.

7873 taúricum $W$.

7874 volúbile $W$.

7875 uncinátum $\boldsymbol{W}$. many-colored $\downarrow \Delta$ or 2 $\frac{\nu}{\perp} \Delta$ or $\quad 8$ or 6 ji $\$ \Delta$ or 6 jn.s $\$ \Delta$ or 3 jn.s

\& $\Delta$ or 3 jn.jl $\$ \Delta$ or 3 jl.au $\$ \Delta$ or 6 jl.au netted-capsuled $\$ \Delta$ or 4 jn.j or $\Delta$ or $\frac{3}{4}$ jlau wavy pale-yellow $\downarrow \Delta$ or 2 jl.au or 3 jn Stavesacre anicled great-yellow Japan variegated wholesome Pyrenean northern white rostrate

mountain

hairy

two-flowered Monk's-hood Taurian twining American

$2 \Delta$ or 3 jns

$\downarrow \Delta$ or 6 jl.au

¿ $\triangle$ or 3 jl.au

$\pm \Delta$ or 3 jl.au

\& $\triangle$ or 2 jn.jl

is $\triangle$ or $\frac{1}{2} \mathrm{jn} . \mathrm{jl}$

$\triangle 4$ or 4 in.jl

$\downarrow \Delta$ or 6 jl.au
D.B Siberia

1819. D p.l Bot. reg. 473

Silesia 1710. D p.l Mill. ic. t. 119

$\begin{array}{llll}\text { P.B } & \text { Siberia } & \text { 179.. } & \text { D p.1 } \\ \text { B } & \text { D } & \text { p.1 }\end{array}$

B. $x \quad \cdots \ldots$ 1822. D p.l

L.B Carolina 1805. D p.I

B B Siberia 1817. D p.l

$\begin{array}{llll}\text { B } & \text { Siberia 1817. } & \text { D } & \text { p.l } \\ \text { N } & \text { N. Amer. } 1806 . & \text { D p.1 }\end{array}$

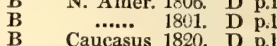

W Iberia 1823, D p.

B Siberia 1823. D p.I

R Siberia $17 \ddot{8}$. D p.1

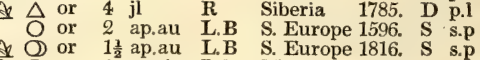

\e () or 4 my.jn L.B Majorea 1824. S co Ranunculacea. Sp. 20-22

$\neq \Delta$ or 3 jn.s Pa.B France 1815, D co Bot. cab. 810

$\not \Delta$ or 3 jn.s L.Y Caucasus 1794. D co Bot. mag.

$\downarrow \mathrm{v}$ or 3 jl.au $\quad \mathbf{Y}$ Al. of Eur.1596. D co Jac. aust.4. t.380

$\downarrow \Delta$ or 6 jn.s B Japan 1790. D co

it $\triangle$ or 5 jn.au P.W S. Europe 1597. D co

or $1 \frac{1}{2} \mathrm{jn} . \mathrm{au}$ P.Y Pyrenees 1506. D co Jac aust 4.389

Il $\triangle$ or 4 jn.jl $Y$ Pyrenees 1739. D co

$\downarrow \Delta$ or 3 jn.s B.Y Siberia 1820. D co

$\downarrow \Delta$ or 4 jl.au B . N. Europe 1800. D co

$\downarrow \Delta$ or 4 jl.au W Levant 1752. D co

\& $\triangle$ pr 4 my.jl

Pu Switzerl.1752. D co

Bot. cab. 794

Bot. mag. 2196

Bot. cab. 203

P.B …. 1812. D co

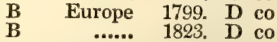

P.Y Siberia 1807. D co

P.B Siberia 1817. D

B Europe 1596.

Tauria 1750. D

Siberia 1799 D co

N. Amer. 1768. D co
Barr. ic. t. 610

Jac. ic. 3. t. 492

Bot. mag. 1119

\section{PENTAGYNIA.}

1206. TRACHYTEL'LA. Dec. Trachytella.
7876 Actæ'a Dec.

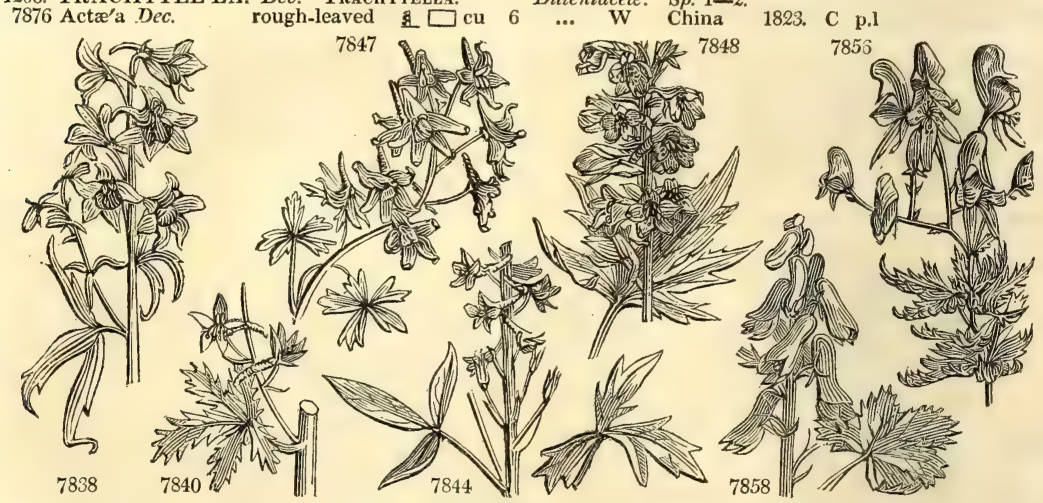

History, Use, Propagation, Culture,

plant and the imaginary figures of the dolphin. The species are shewy annuals or perennials, valuable as border flowers. The leaves are generally much divided, and the flowers in terminal spikes, blue, purple, or red; never yellow or any shade of that color.

D. consolida, (from consolidare, to unite; it being formerly reputed as a most powerful vulnerary, Pied d'Allotette, Fr., Rittersporn, Ger., is a shewy annual, with blue, pink, purple, and white flowers, and semidouble and double. D. Ajacis, so called because some traces may be perceived in the flower of what may be likened to the letters AIA, is by some considered as only a variety of this species: both are universally grown as border annuals. D. elatum is well adapted for shrubberies. All the species are of the easiest culture. The species are extremely difficult to distinguish from each other, and are probably in many cases mere varieties.

1205. Aconitum. So called from growing about Acona, a town of Bithynia. The species are robust freeflowering plants of some beauty and consequence. The stems rise from two to six feet in height, upright, strong, furnished with many digitate or palmate leaves, and terminated by panicles or loose spikes of blue or yellow flowers.

A. Napellus, from napus, a turnip, its grumous roots resembling little turnips, is a well known poisonous plant. Linnæus says, that it is fatal to kine and goats' especially when they come fresh to it, and are not acquainted with the plant; but that it does no injury to horses, who eat it only when dry. He also relates (from the Stockholm Acts) that an ignorant surgeon prescribed the leaves, and on the patient refusing to take them, he took them himself and died. The ancients, who were acquainted with chemical poisons, regarded the Aconite as the most violent of all poisons. Some persons, only by taking in the effluvia of the herb in ful flower by the nostrils, have been scized with swooning fits, and have lost their sight for two or three days. 
7838 Stem erect branch. Lvs. 5-part. Lobes obl. acumin. Pet. shorter than cal. Caps. netted with color pubescent 7839 Petioles not dilat. at base, Lvs. cord. 5-7-fid : up. 3-lobed, Lobes cut serr. Ped. bract. cal. and ovaries smooth 7840 Petioles not dilated at base, Leaves downy 5-lobed, Lobes cuneate at base trifid cut, Spur inflexed

7841 Petioles not dilated at base, Lvs. orbicular cord. 5-fid, Lobes cut acute deflexed, Bractes 3, Ovaries smooth 7842 Petioles sheathing at base, Lvs. many-part. with lin. lobes, Raceme close, Spur straight longer than flower

7843 Lvs. somewhat dilated at base, Segm. cuneiform serr. cut in front, Stem upwards and peduncles pubescent 7844 Petioles not dilated at base, Lvs. fat trifid beyond the middle, Lobes cuneiform trifid at the end acuminate 784.5 Pet. scar. dilat. at base, Lvs. 3-5-part. multif. with lin. lobes, Rac. straight, Pet. beard. at end : low. very vill. 7846 Pet. scar. dilat. at base, Lvs. 3-7-lob. Lobes obl. ac. cut pinnatifid : up. 3-part. Caps. nett. at keel and edge cil. 7847 Pet. smth. but scar, sheath. at base, Lvs. 5-par. Lobes 3.5-fid lin. Pet. sh. than cal. Caps. refl. from their base 7848 Petioles not dilated at base, Leaves concave beyond the middle trifid, Lobes cuneiform cut acuminate at end 7849 Petio. not dilat. at base, Lvs. 5 -lob. with cut lobes, Stem flexu. and petioles hairy, Bractes lin. Caps. smooth 7850 Petioles sheathing at base, Lvs. many-par. with lin. subul. segm. F1. pubesc. Spur acute longer than flowers 7851 Pet. not dilat. at base, Lvs, 3-7-lob. with obl. ac. cut pinnat. lobes, Rac. lax branch. Bractes and ovaries pub. 7852 Petioles sheathing at base, Lvs. many-parted in lin. lobes, Rac. long, Spur straight blunt longer than pedicel 7853 Spur very short, Bracteoles inserted at base of pedicel, Petioles hairy, Pedicels twice as long as flower 7854 Spur scarcely shorter than cal. Bracteoles inserted at base of pedicel, Petioles pubesc. Pedic. scarcely longer 7855 Spur nearly as long as calyx, Bractes inserted in the middle of pedicel, Petioles hairy [than flower

7856 Pan. divaricating, Branches tortuose, Helmet conical half circular, Spur short thick spiral [at end 7857 Fl. spiked or panic. numerous, Lvs, deeply 3-5-lobed with cuneate trifid lobes, Spur slender straight curv. 7858 Helmet conical cylindric. Spur slender spirally twisted, Lip divaricating, Lvs. palm. 3-5-lob. beyond middle 7859 Veiny smooth, Pan. smoothish with ascend. branches, Bag of hoods very large ventric. Spur thick subinvol. 7860 Pan, divaricating very smooth, Branches tortuose, Spur thick somewhat spiral, Lobes of leaves rhomboid 7861 Fls. panic. Sep. and pet. persist. Bag of hoods scarcely any, Spur thick spiral, Lvs. multif. with lin. ac. segm. 7862 All over densely pubesc. Lvs, very large palmate 3-5-lobed beyond middle pubesc. Helmet conical cylindr

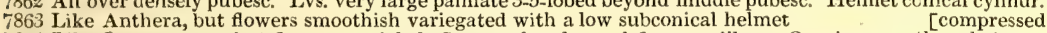
7864 Like Lycoctonum, but flowers panicled, Stem peduncles and flowers villous, Ovaries smooth or hairy 7865 Ovaries 4-5, Helmet conical with a long claw, Rac. lax simple, Lvs. 3-5-parted with trifid toothed lobes 7866 Pan. lax, Helmet conical elongated abruptly mucronate in front, Spur thick spiral, Ovaries 3-5

7867 Pan. lax, Branches 1-4-fl. Spur thick long abruptly kneed, Bags of hoods inflated, Ovaries 3-5 smooth 7868 Ovaries 3 smooth, Raceme lax corymbose, Ped. smooth, Helmet very convex subconical

7869 Pan. lax, Helmet exactly conical, Spur very thick blunt very short, Bag of the hoods very large

7870 Fl. panic. Helmet conical, Spur thick blunt very short. Lvs. deeply lobed with narrow diverging segments 7871 Stem very short, Low. lvs. few on long stalks 5-part. with palm. segm. Hoods hook. blunt, Ovaries 3 villous 7872 Ovaries 3 smooth, Raceme cylindric. long, Leaves divided down to petiole with linear acute furrowed lobes 7873 Ovaries 3 smooth, Rac. cylindr. long very compact, Pedicels smooth shorter than bractes, Lvs, subpedate 7874 Stem twining with spreading hairs, Petioles ciliated, Leaves 3-5-parted with pinnatifid lobes, Ovaries 5-7 7875 Pan. lax, Branches diverging, -Helmet exactly conical, Leaves 3-lobed with entire lobes, Ovaries villous

\section{PENTAGYNIA.}

7876 Leaves very rough toothed
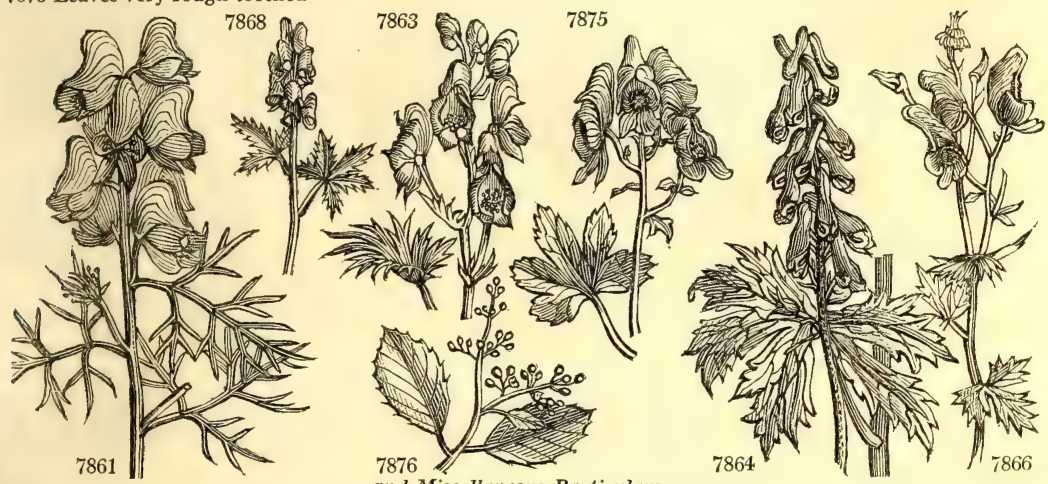

and Miscellaneous Particulars.

But the root is unquestionably the most powerful part of the plant. Matthiolus relates, that a criminal was put to death by taking one dram of it. Dodonæus gives us an instance, recent in his time, of five persons at Antwerp, who ate the root by mistake, and all died Dr. Turner also mentions, that some Frenchmen at the same place, eating the shoots of this plant for those of masterwort, all died in the course of two days, except two players, who quickly evacuated all that they had taken by vomit. We have an account, in the Philosophical Transactions, of a man who was poisoned, in the year 1732, by eating some of this plant in a salad, instead of celery. Dr. Willis also, in his work De Anima Brutorum, gives an instance of a man who died in a few hours, by eating the tender leaves of this plant also in a salad. He was seized with all the symptoms of mania. The Aconite, thus invested with terrors, has, however, been so far subdued, as to become a powerful remedy in some of the most troublesome disorders incident to the human frame. Baron Stoerck led the way by administering it in violent pains of the side and joints, in glandulous scirrhi, tumours, ulcerous tubercles of the breast, \&c. to the quantity of from ten to thirty grains in a dose, of an extract, the method of making which he describes.

Willdenow and the Dublin College consider that the plant used by Stoerck was the A. neomontanum, in which opinion Mr. Thomson agrees in his London Dispensatory.

All the species are poisonous in a high degree. The limits of the species are extremely obscure, and in a very unsettled state; Decandolle in his Systema, increased the number at that time known, but in his Prodromus many of the species of the Systema are considered mere varieties. Dr. Reichenbach has, however, multiplied the species prodigiously, but with little reason.

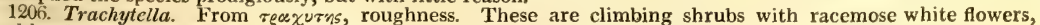
and hard rough leaves, which are used in China for polishing metals and hard wood. 
1207. CIMICI'FUGA. Pl. Bugwort. 7877 Serpentária $P h$.

7878 foetida $W$

7880 palmáta $P h$.

1208. A QUILE'GIA. $W$. Columbine.

7881 viscósa $W$.

7882 vulgáris $W$.

3 flore pleno

7883 glandulósa Fisch.

7884 viridiflóra Pall.

7885 bícolor $P$. $S$. hýbrida $\dot{\mathrm{B}}$. $\mathbf{M}$.

7886 alpina $W$.

7887 canadénsis $W$.

7888 atropurpsirea $W$. en dark-purple

\section{common}

comble flowered $\frac{\vec{v}}{2} \Delta$ or

glandular $\frac{1}{2}$ or

$\frac{\text { J } \Delta}{\Delta}$ or two-colored $\$ \Delta$ or

1209. NIGEL LA. $W$.

7889 damascéna $W$.

7890 coarctáta

7891 sativa $\boldsymbol{W}$.

7892 arvénsis $W$.

7893 hispánica $W$.

7894 orientális $W$.

1210. REAUMU'RIA. $\boldsymbol{W}$. REAUMURIA

7895 hypericoides $W_{0} \quad$ Hypericum-like linifolia $\mathbf{P}$. L.

1211. COLBER'tia. Salisb. Colbertia. 7896 coromandeliánaSal. Coromandel

1212. TETRA'CERA. $L$. Tetracera. 7897 potatória Afz. Water Vine

FENNEL-FLOWER common

small

field

Spanish

rellow

Ranunculacee. Sp. 4-6.

3 jn.jl W.r N. Amer. 1732. D l.p Dill.elt.t.67.f.78

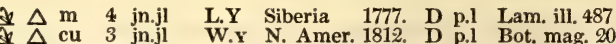

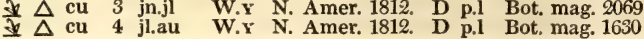

Ranunculacea. Sp. 8-13.

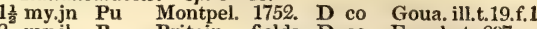
my.jl B Britain fields. D co Eng. bot. 297

my.jl B $\quad \ldots . . . . \quad$ D co

1822. D co

my.jl G.Y Siberia 1780. D co Jacq. ic. 1.t. 102

2 my.jl Pu Siberia $\quad . . . \quad$ D co Bot. mag. 1221

$\downarrow \Delta$ or 1 my.jn B.g Switzerl. 1731. D co Bot. cab. 657

J $\Delta$ or 1 ap.my R.o N. Amer. 1640. D s.p Bot. mag. 246

¿e $\Delta$ or 1 my.jn $\mathrm{Pu}$ Siberia $\ldots$ D s.p

Ranunculacee. Sp. 6-11.

Or 2 jn.s L.B S. Europe 1570. S co Bot. mag. \&2

O or $\frac{3}{4}$ jn.s W.G S. Europe 1793. S co

O or $1 \frac{1}{2}$ jn.s L.B Egypt 1548. S s.1 Zorn. ic. 119

w $1 \frac{1}{2}$ jn.s W.G Germany 1683. S s.i Sch. han.2.t.146

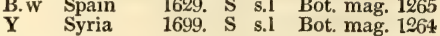

Ficoidea. Sp. 1.

Dilleniacea. Sp. 1.

1800. L s.p Bot. reg. 845

$\square$ or 15 mr.ap Y Coroman. 1803. L p.l Roxb. cor. t. 20

Dilleniacea. Sp. 1-23.

\section{POLYGYNIA.}

1213. NELUM'BiUM. J. Sacred-Bean. $\begin{array}{cl}7898 \text { speciósum } W . & \text { Indian } \\ \beta \text { cas'picum Fisch. } & \text { Caspian } \\ 7899 \text { láteum } W . & \text { yellow-flowered } \square \text { or }\end{array}$

Nymphacea. Sp. 2.

jn.au Pk India 1787. R m.s Bot. mag. 903

... Pk Casp. Sea 1822. R m.s

... Y Carolina 1810. R m.s

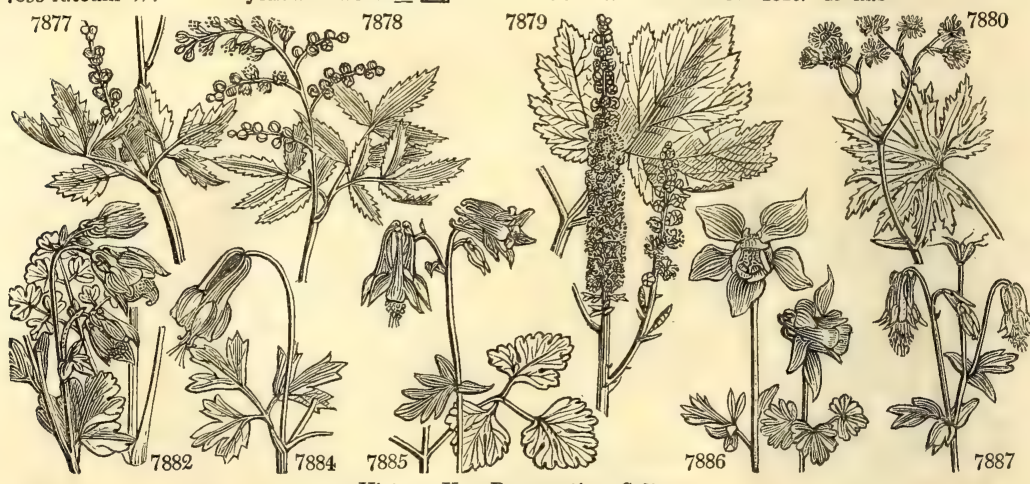

History, Use, Propagation, Culture,

1207. Cimicifuga. From cimex, a bug, and fugo, to drive away, indicating certain virtues a species is supposed to possess. The C. serpentaria is used with success by the native practitioners in North America for curing the dangerous bite of the rattlesnake. Tall, leafy, herbaceous plants, with the appearance of Actæa.

1208. Aquilegia. From aquila, an eagle; the inverted spurs of the flower have been likened to the talons of a bird of prey. The species are smooth-leaved, handsome-flowered plants. A. vulgaris is an old inhabitant of the flower border: the whole plant has been recommended to be used medicinally, but it belongs to a suspicious natural order, and Linnæus affirms, that children have lost their lives by it. A. alpina is the handsomest species.

1209. Nigella. From niger, black, because of the color of the seeds, which are the part of the plant known in cookery. The species are curious or neat little plants, with fine cut leaves like fennel. N. damascena and sativa are sown as hardy annual flowers; and on the continent, the leaves and seeds of the latter species and $\mathrm{N}$. arvensis, are used in cookery instead of more expensive aromatics. They are also said to be extensively used in the adulteration of pepper.

1210. Recumuria. So named by Hasselquist, in honor of René A. F. de Reaumur, author of several entomological works; Histoire des Insectes, \&c. He died in 1757. A small cæsious plant, bearing an abundance of bright lilac flowers.

1211. Colbertia. Named by Mr. Salisbury after the famous Colbert, a patron of the Paris garden, who destroyed with his own hands the vines which had been planted therein in lieu of more curious objects. A fine plant, with leaves like those of Dillenia speciosa.

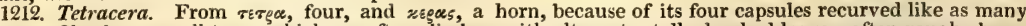
horns. Shrubs or small trees, which are often climbers with alternate stalked naked leaves, often rough above. The flowers are panicled or racemose. The leaves are remarkable as an exemplification of that mode of nervation which M. Decandolle calls feather-nerving.

1213. Nelumbium. This is called in Ceylon Nelumbo. Sir James Smith proposed to call the genus by the more classical namie of Cyamus, but it has been remarked, that it remains to be proved that the holy $* u x \mu \nu$, was this plant. N. speciosum is a native both of the East and West Indies, China, Cochin-China, and Japan, 
7877 Monogynous, Racemes very long, Caps. dry dehiscent, Leaves biternate with serrate or cut segments

7878 Ovaries 4 subsessile very vill. Racemes panicled, Lvs. ternate or biternate, Segm. ovate-lanc. cut toothed 7879 Ovaries 2.3 smooth sessile, Racemes panicled, Leaves biternate, Segments cordate at base

7880 Ovaries $12-15$ in a roundish head, Racemes dichotomous panicled, Leaves palmate

7881 Spurs incurved, Caps, vill. Stem few or 1-f. Lvs, covered with viscid down, Styles not longer than stamens 7882 Spurs incurved, Caps. villous, Stem leafy many-fl. Leaves nearly smooth, Styles not longer than stamens

7883 Spurs incurved twice as short as petals, Upper part of the plant and capsules covered with glandular hairs 7884 Spurs straight longer than limb, Stam, as long as petals, Styles long, Petals oval obl. shorter than petals 7885 Spurs straight longer than very blunt limb, Styles scarcely longer than stamens and petals, Sepals acute the length of petals

7886 Spurs straight somewhat incurved at end twice as short as limb of petals, Stem 2-3-f. leafy, Lvs. finely cut 7887 Spurs straight, Styles and stamens exserted, Sepals acute a little longer than petals, Segm, of leaves 3-parted 7888 Spurs straight as long as limb, Styles and stamens as long as sepals, Sepals the length of petal

7889 Anthers blunt, Caps. 5 smooth 2-cell. united as far as end into an ovate globose one, Fls. in a leafy involucre 7890 Anthers blunt, Flowers in an involucre, Sepals erect conniving

7891 Anthers blunt, Caps. muricate, Stem erect hairy, Flowers naked

7892 Anthers pointed, Styles 5-7 revolute, Capsules and stem smooth, Branches diverging

7893 Anthers pointed, Styles 8-10 erect, Caps. smooth 1-nerved at back, Stem erect smooth, Branches erect 7894 Caps. 5-10 smooth erect, Styles straight

7895 A low shrub, with narrow glaucous leaves

7896 Leaves smooth 10-nerved 1-11 foot long 6 inches broad

7897 Lvs, oval-obl. blunt or nearly acute smooth roughish above somewhat toothed at end, Pedunc. panicled

[pubescent

\section{POLYGYNIA.}

7898 Petals many, Anthers lengthened beyond the cells into a clavate appendage $\beta$ Inner petals scarcely smaller than the outer, blunt

7899 Petals many, Anthers lengthened beyond the cells into a linear appendage
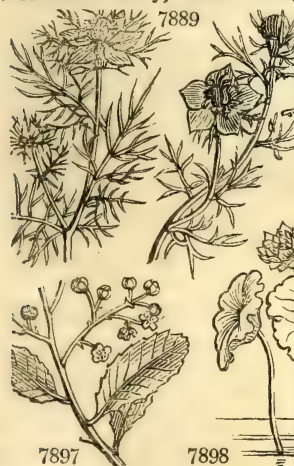
7893

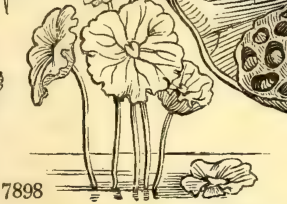

and Miscellaneous Particulars.

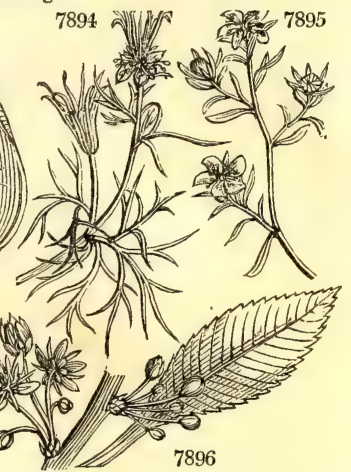

Persia, and some parts of the Russian empire. Thunberg informs us, that it is considered as a sacred plant in Japan, and pleasing to their deities, and that the images of their idols were often drawn sitting on its large leaves. The long stalks are there eaten among other potherbs. Loureiro relates, that it abounds in muddy marshes in India and China, and is cultivated in large handsome pots in the gardens and houses of the mandarins; that there is a variety with the flower of a pure white, and another with a very beautiful luxuriant flower, having about one hundred large petals, white or rose-colored. Both root and seeds are esculent, sapid and wholesome. In China it is called Lien-wha, and the seeds and slices of the hairy root, with the kernels of apricots and walnuts, and alternate layers of ice, were frequently presented to the British ambassador and his suite at breakfasts given by some of the principal mandarins. The Chinese have always held this plant in such high value, that at length they regarded it as sacred. That character, however, has not limited it to merely ornamental purposes; for the roots are not only served up in summer with ice, but they are also Jaid up in salt and vinegar for the winter. The seeds are somewhat of the size and form of an acorn, and of a taste more delicate than that of almonds. The ponds are generally covered with it, and exhibit a very beautiful appearance, when it is in flower; and the flowers are no less fragrant than handsome.

Sir George Staunton remarks, that the leaf, besides its common uses, has, from its structure, growing entirely round the stalk, the advantage of defending the flower and fruit arising from its centre from contact with the water, which might injure them. He also remarks, that the stem never fails to ascend in the water from whatever depth, unless in case of a sudden inundation, until it attains the surface, when its leaf expands, rests, and swims upon it, and sometimes rises above it. This plant bears the rigorous cold of the Pekin winter, though it is reared with difficulty in European stoves. It often grows spontaneously in China, and is propagated in the open air with ease both by the seed and root. The Chinese distinguish many varieties of it.

From the root of the Nelumbo, Sir George Staunton says, the Egyptians are supposed to have prepared their Colocasia, but the plant is now no longer found in that country; from which circumstance some naturalists infer, that it never was indigenous there, but cultivated by the inhabitants with extreme care, The ancient Romans made repeated efforts to raise it among them, from seeds brought out of Egypt; and the 
Dilleniacea. Sp. $1-9$.

1215. ILLI'CIUM. $W$. Anisend-Tree. $\quad$ Magnoliacea. Sp. 2-3.

7901 floridánum $W_{i} \quad$ red-flowered $\_$or 8 ap.jn $\mathbf{R} \quad$ Florida 1766. L s.p Bot. mag. 439

Florida 1790, L p.1 Vent. cels. 22

1216. LIRIODEN'DRON. $W$. TULIP-TREE.

7903 tulipífera $W$.

e obtusiloba

1217. MAGNO'LIA. $W$

7904 grandiflóra $W$

a clliptica

$\beta$ obováta

$\gamma$ lanceoláta

7905 glaúca $P h$

7906 longifólia $P h$.

7907 conspicua $H$. $K$. M. Yulan Dec.

7908 obováta $W$

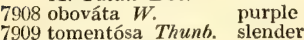

M. gracilis Thunb.

M. Kobus Dec

7910 púmila $W$.

7911 fuscáta $H$. $K$.

$\beta$ annónafólia P. L

7912 cordáta $P h$.

7913 acumináta $W$.

7914 tripétala $W$.

M. umbrella Lam.

7915 macrophýlla $\mathrm{Ph}$.

7916 auriculáta $W_{\text {. }}$

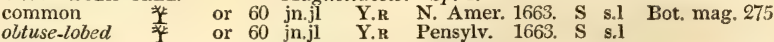

Magnoliacea. Sp. 1.

Magnolia.

Laurel-leaved

ferruginous

broad-leaved

g-leaved

decidu. swamp

evergr. swamp

Yulan

Pensylv. 1663, S s.l

Magnoliacea. Sp. 14-17.

spl 20 jn.o W Carolina 1734. L 1.p

spl 20 jn.o W Carolina 1734. L l.p Bot. rep. 518

spl 20 jn.o W Carolina 1734. L 1.p

spl 20 jn.o W Carolina 1734. L l.p Mich. arb. t. 1

or 20 jn.s W N. Amer. 1688, S p.1 Bot. mag. 2164

or 20 jn.s W N. Amer... S p.1

I or 30 f.ap W China 1789. G p.l Bot. mag. 1621

pyramidal or 20 ap.my W

China 1790. L p.l Bot. mag. 390

dwarf $\quad$ or 4 ja.d W China 1786. C p.l Bot. mag. 977

brown-stalked $\amalg$ or 3 ap.my Br China 1789. L p.1 Bot. mag. 1008

small-flowered $* ـ$ or 3 ap.my Br China 1804. L p.l Par.lond. 5

heart-leaved $*_{k}$ or 40 jn.jl Y.w N. Amer. 1801. L s.1 Bot. cab. 47t

bluish-flowered or $60 \mathrm{my}$.jl Y.G N. Amer. 1736. L s.l Bot. cab. 418

umbrella or 30 my.jn W N. Amer. 1752. L s.l Mich. arb. t. 5

long-leaved $\quad$ or $30 \mathrm{jn}$.jl W N. Amer. 1800 . S p.l Bot. mag. 2189 Orolina 1786. L p.1 Bot. mag. 1206

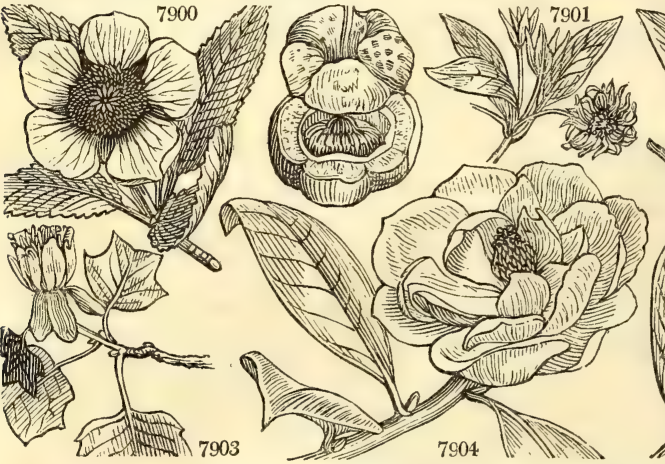

Carolina 1811. G p.1 Bot. reg. 407

History, Use, Propagation, Culture,

modern attempts to cultivate it in Europe, though with the assistance of artificial heat, seldom have succeeded.

Dr. Patrick Browne is of opinion that the ancients confounded two plants under the name of Lotus or Egyptian bean, and that under these titles they described the upper parts of the Nymphæa Nelumbo, and the roots of the lesser Colocasia, now commonly called coccos in Jamaica, Arum Colocasia. (Jam. 243. 332.)

In our stoves the Nelumbium should be grown in a tub or large pot, in a rich loamy soil, and requires a strong heat to flower in perfection. The pot or tub should be kept full of water all the time the plants are growing, but may be allowed to get dry when the flowering season is over. The plants may be increased by dividing at the root, but it is obtained more readily from seeds, which vegetate freely. (Bot. Cult. 83.)

Kent of Clapton says, that the seeds will keep forty years, vegetate freely, and flower the first year. (Hort. Trans. iii. 36.)

1414. Dillenia. So named by Linnæus, in honor of John James Dillenius, the famous professor of botany at Oxford, author of Historia Muscorum, Hortus Elthamensis, \&c. The species are beautiful trees, with large leathery leaves, and axillary or terminating flowers often also large. They thrive best in a light loamy soil. Ripened cuttings, not deprived of their leaves, strike root freely, in a pot of sand plunged under a hand-glass in heat. Good seeds sometimes arrive from India, when the sooner they are sown the better; placed in a moderate hot-bed frame, they will succeed well. (Bot. Cult. 50.)

1215. Illicium. From illicio, to attract, on account of its agreeable perfune. I. floridanum has very fragrant leaves, and capsules having a strong smell of anise when rubbed. This species, and more especially anisatum is powerfully carminative and stomachic. In China it is in frequent use for seasoning dishes, especially such as are sweet. In Japan they place bundles and garlands of the aniseed-tree in their temples before their idols, and on the tombs of their friends. They also use the powdered bark as incense to their idols. A branch put into the decoction of Tetraodon hispidum is supposed to increase the virulence of that poison. The bark, finely powdered, is used by the public watchmen to make a chronometer or instrument for measuring the hours, by slowly sparkling at certain intervals in a box, in order to direct when the public bells are to sound.

Ripened cuttings will root in sand, but the plant is most readily increased by layers.

1216. Liriodendron. From $\lambda$ eıciov, a lily, and $\delta \varepsilon y \delta \rho o y$, a tree. The flowers, which may be likened to a lily or tulip, grow upon one of the loftiest trees of the forest. A smooth tree, not less admired for its fiddle-shaped leaves, than its tulip-like flowers, which are produced at the end of the branches; they are composed of six petals, three without and three within, which form a sort of bell-shaped flower, whence the inhabitants of

North America gave it the title of tulip. These petals are marked with green, yellow, and red spots, making a fine appearance when the trees are well charged with flowers. When the flowers drop the germ swells, and forms a kind of cone, but it does not ripen in England.

The timber is used in America for canoes, but is unfit for boards or planks, as it contracts and expands more than the wood of any other tree.

The tulip tree is now very common in Europe; in the south of France and Italy, it is frequent in public avenues, and flowers when twenty or thirty feet high, and of six or seven years growth. In Britain it requires a 
7900 Leaves elliptic oblong simply serrated, Peduncles 1-flowered

7901 Petals 27-30 purple : outer oblong; inner lanceolate 7902 Petals 9-12 yellowish ovate roundish

7903 Leaves truncate at end with two broad opposite stipules

7904 Leaves evergreen oval-obl. coriaceous shining above ferrugineous beneath, Flowers erect with $9-12$ petals

7905 Leaves elliptical blunt glaucous beneath, Flowers with $9-12$ contracted petals which are ovate concave 7906 Like the last, but leaves evergreen elliptical acute at each end

7907 Lvs. deciduous obovate abruptly acuminate the younger pubescent, Flowers naked erect with 6-9 petals

7908 Lvs. deciduous obov. acute netted nearly smooth, Fls. erect, Sepals 3, Petals 6 obovate, Styles very short 7909 Lvs. decid. obov. point. at each end, younger downy ben., old ones smooth, Fls. erect, Sep. 3, Pet. 6 , Styles

[very short

7910 Leaves evergreen smooth netted ellipt. acuminate at each end subglaucous, Flowers cernuous

7911 Leaves evergreen elliptic obl. : the old smooth; younger and branches fuscous downy, Flowers erect

7912 Lvs, deciduous heart-shaped subovate acute, above smooth, beneath somewhat tomentose, Pet. 6-9. obl. 7913 Leaves deciduous oval acuminate pubescent beneath, Petals 6-9

7914 Leaves deciduous lanc. much spreading, younger downy beneath, Petals 9-12, the outer hanging down

7915 Lvs. deciduous very large obl. obov. subcuneate cordate at base, beneath whitish glaucous, Pet. 6-9 ovate 7916 Lvs. decid. smooth spatulate obov. subcord. at base, Auricles blunt close, Sep. 3 much spread. Pet. 9 oblong 7917 Lvs, decid. smth spatul. obov, subcord. at base, of same color on both sides, Auric. spread. Pet. 9 lanc. acum.

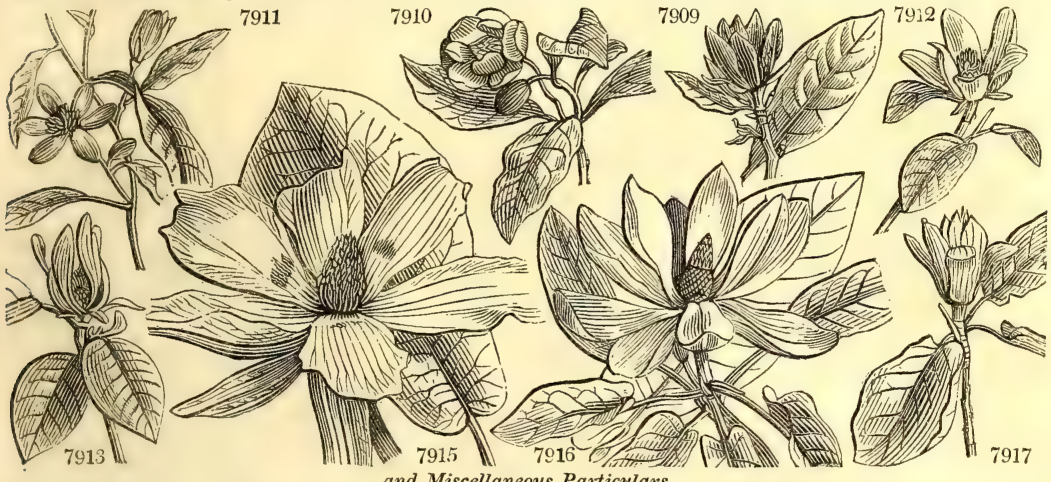

and Miscellaneous Particulars.

greater age, though ringing might probably be successfully applied to throwing this and other ornamental trees into a flowering state. There are many fine old trees round London, in the parishes of Fulham, Walham-green, Kew, \&c., and a very fine one even so far north as Pitcaithly wells in Fifeshire.

1217. Magnolia. In honor of Pierre Magnol, professor of medicine, and prefect of the botanic garden at Montpelier; author of Botanicum Monspeliense, 1676, and other works. The species are chiefly large trees with large leaves, and axillary flowers, also very large and highly odorous.

M. grandiflora is the noblest species; the leaves, which are persistent, are nine or ten inches long, and not unlike those of a common laurel. The flowers are produced at the ends of the branches: they are very large, and composed of eight or ten petals, narrow at their base, but broad, rounded, and a little waved at their extremities; they spread open very wide, are of a pure white color, and have an agrecable scent.

The variety g. elliptica or Exmouth (having been raised from the seed of an old tree in Sir. John Collington's garden of that place) flowers earliest and most freely : it is also the hardiest.

M. glauca is deciduous. In America it is known by the names of white laurel, swamp sassafras, and beaver tree. It has the last name, because the root is eaten as a great dainty by beavers; and this animal is caught by means of it. Kalm says, these trees may be discovered by the scent of the blossoms at the distance of three quarters of a mile, if the wind be favorable. It is beyond description pleasant to travel in the woods at the flowering season, especially in the evening. They retain their flowers for three weeks, and even longer. The berries also look very handsome when they are ripe, being of a rich red color, and hanging in bunches on slender threads. They cure coughs and other pectoral diseases by putting these berries into brandy, and giving a draught of the liquor every morning. The wood is made use of for joiriers' planes. Dillenius remarks, that the flowers never open in a morning, that the calyx falls off at the second opening of the flower, but that the petals dry on, and that the scent resembles that of the lily of the valley, with a mixture of aromatic.

M. conspicua is much valued as a free flowerer, and on account of the early appearance of its white odoriferous blossoms. Yulan is the vernacular name in Japan.

M. acuminata bears a fruit about three inches long, like a small cucumber, and is thence called cucumber tree in America.

M. tripetala has leaves twelve or fifteen inches long and five or six inches wide, narrowing to a point at each extremity, and placed at the ends of the branches in a circular manner like an umbrella, whence its name. The flowers are composed of ten, eleven, or twelve large oblong white petals; the wood is soft and spongy, and the leaves drop off earlier than in the other deciduous sorts.

The different species, Sweet observes, are generally increased by layers or seeds : when the layers are first taken off they should be potted in a mixture of loam and peat, and placed in a close frame till they have taken fresh root None of the leaves should be taken off or shortened, nor any shoots be cut off; or their tops shortened, as they will not succeed so well; for the more branches and leaves are on them, the sooner they will strike fresh root. Most cultivators cut off many of the leaves and shoots of layers, when they are first taken off, thinking the roots will not have so much to nourish, which is the very reason 
1218. MICHE'LIA. $W$. Michelia. Magnoliacea. Sp. 1-7.

7918 Champáca $W . \quad$ sweet-scented $\perp \square \mathrm{tm} 20 \ldots \quad \mathrm{Y}$ E. Indies 1779. C s.1 Rhe. mal. 1.t.19 1219. UVA'RIA. $W$. UvarIA.

7919 Zeylánica $W$.

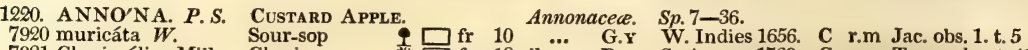

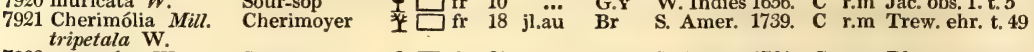

7922 squamósa $\dot{W}$.

7923 paludósa $W$.

7924 reticuláta $W$.

7925 palústris $W$

7926 glábra $W$.

$\begin{array}{llllll}\text { Sweet-sop } \quad 9 \square \text { fr } 20 & \ldots & \text { W.G } & \text { S. Amer. 1731. } & \text { C } & \text { r.m Rhe. mal. 3. t.29 }\end{array}$

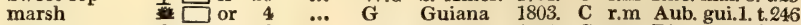

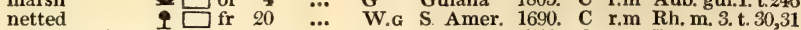

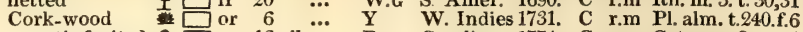
smooth-fruited $\perp \square$ or 16 jl.au Br Carolina 1774. C r.m Cat. car. 2. t. 64

1221. ARTABO'TRYS. $R$. Br. Artabotrys. Annonacere. Sp. 1.

7927 odoratis'sima R.Br. sweet-scented $=\square$ or 6 jn.jl G G. China 1758. S r.m Bot. reg. 423 $U$. hexapetala W.

1222. GUATTE'RIA. R.\&P. Guateria.

7928 rúfa Dun.
7929 virgáta Dun.
Uvaria lanceolata Swz.

1223. ASIMINA. $A d$.

7930 tríloba $P h$

7931 parviflóra $P h$

7932 pygmæ'a $P h$.

Asimina.

trifid-fruited

small-flowered

dwarf

XYLopia.

rough-fruited smooth-fruited

7933 muricáta $W$.

7934 glábra $W$.

. Annonacea. Sp.2-22.

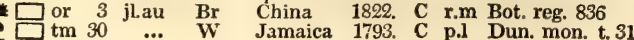

Annonacea. Sp. $3-5$.

糔 or 3 au Pa.pu N. Amer, 1736. S p.l Cat. car. 2. t. 83

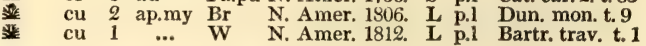

1225. HEPA'TICA. W. en. HePatica. 7935 tríloba $W$.

a corúlea common

$\beta$ carúleo-pléna

$\gamma$ rúbra

$\delta$ rubro-pléna

\& álba

blue

double-blue

double

red double-red

red-anth. white

snowy-white

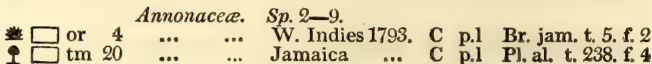

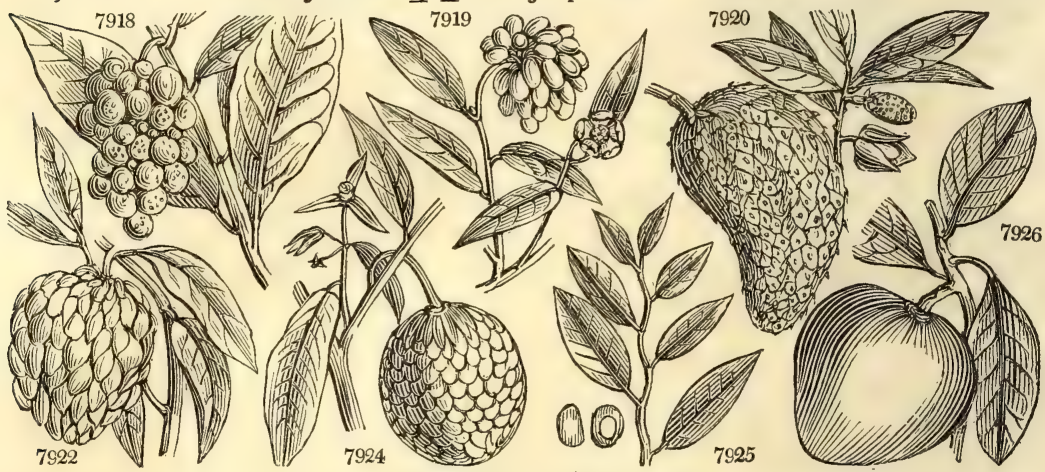

History, Use, Propagation, Culture,

they often lose great part of their crop; layers of any kind of shrub whatever, when first taken off, should not have a single leaf taken off till they have made fresh root: supposing their tops flag ever so much, as long as there is life it will draw up the sap, and help the plant to root afresh. The Chinese kinds are often inarched or budded on M. obovata, which takes readily. (Bot. Cult. 306 .)

1218. Michelia. Named by Linnæus, in honor of Pietro Antonio Micheli, of Florence, author of Nova Plantarum Genera, Flor. 1729, fol. A lofty tree, with fragrant flowers, and fruit edible, but not agreeeable. In our stoves it grows well in light loam, and cuttings root in sand under a glass and plunged in heat.

1219. Uvaria. The fruit grows in bunches like a small bunch of grapes, whence it has been called Uvaria from Uva. The berries are considered a specific for gonorrhoea, and are used under the name of cubebs. These are trees or shrubs with erect or trailing stems, and 1-4-flowered axillary peduncles.

1220. Anona. This is called by the Malays manoa, and at Banda, menona, which it is presumed that the Europeans have corrupted into Anona. As the word signifies in Latin food, it has been adopted by Linnæus in this sense, because of the habitual use made of the fruit by the Americans. The species are for the most part fruit trees, with soft pulpy subacid berries, sometimes as large as an orange, but generally more like a plum.

A. muricata is common in every savannah of Jamaica, flowering in the spring. The large succulent fruit is agreeable to new-comers and over-heated habits; but it is so common, and so much in use among the negroes, that it is now hardly ever used among the better sort of people. The smell and taste of the fruit, flowers, and whole plant, resemble very much those of black currants.

A. tripetala is a large tree with large bright green leaves. The fruit is oblong, scaly on the outside, and of a dark purple color when ripe; the flesh is soft and sweet, and has many brown seeds intermixed with it which are very smooth and shining. It is esteemed by the Peruvians as one of their most delicate sorts.

A. palustris grows wild in soft marshy places in Jamaica, and bears a fine sweet-scented fruit, of no disagreeable flavour; but it is said to be a strong narcotic, and is not eaten on that account. It is called alligator apple. The wood of this tree is so very soft, even after it is dried, that it is frequently used by the country people instead of corks, to stop up their jugs and calabashes; whence it has now universally obtained the name of cork-wood in Jamaica. (Browne.)

To bear fruit in our stoves, these trees require a rich loamy soil, rather moist, and to be trained on a wall or trellis close under the glass. Ringing would also be useful. They are propagated by ripened cuttings, of a good size, with their leaves on, planted in sand, and plunged in heat. 
7918 Leaves lanceolate smooth

7919 Leaves lanc. acuminate, Pedunc. lateral solitary 1-flowered

7920 Leaves ovate lanceolate smooth somewhat shining, Pedunc. solitary 1-flowered

7921 Leaves ovate lanceolate not dotted very finely silky beneath, Outer petal downy outside

7922 Leaves lanceolate smooth with pellucid dots, Outer petals smooth

7923 Leaves obl. acute somewhat downy above, silky and rufous beneath, Flowers on short stalks

7924 Leaves obl. lanc. acute smooth somewhat dotted, Outer petals obl. somewhat closed

7925 Leaves ovate obl. coriaceous very smooth, Fl. solitary stalked

7926 Leaves ovate lanc. smooth, Pedunc. opposite the leaves 2-flowered

7927 Leaves obl. lanc. acuminate smooth shining

7928 Leaves oval acuminate cordate covered beneath, as on the branches, with brown down

7929 Leaves ovate acuminate very smooth nearly_sessile, Pedunc, axillary 1-flowered

7930 Leaves obl. cuneate acuminate, Branches quite smooth

7931 Leaves cuneate obovate mucronate beneath, as on the branches, rufous with down

7932 Leaves obl. linear long-cuneate, Branches quite smooth

7933 Leaves lanc. acuminate strigose beneath bearded at end

7934 Leaves obl, ovate smooth, Pedunc. 1-fl. solitary

7935 Leaves cordate 3-lobed, iobes entire

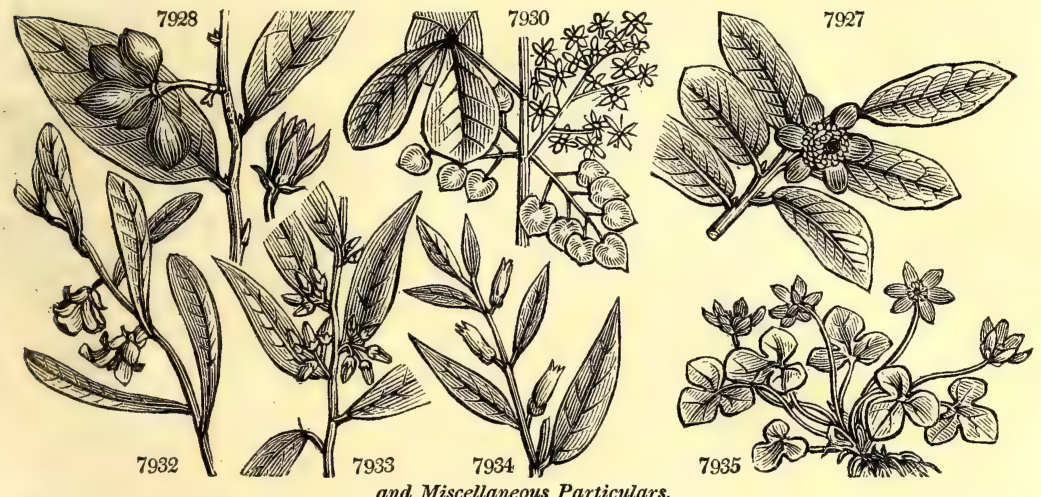

1221. Artabotrys. This name was suggested by the curious grapple or tendril belonging to the peduncle, by which the growing fruit is conveniently suspended on the nearest support. A beautiful Chinese plant, cultivated as an ornamental covering to walls, as well as on account of the fragrance of the blossom, which diffuses an odor like that proceeding from the finer kinds of ripe fruit. The genus is intermediate, between Kadsura and Guatteria.

1222. Guatteria. Named by the authors of the Flora Peruviana, after John Baptist Guatteri, an Italian professor of botany at Parma. G. virgata is one of the best timber trees in Jamaica for strength and elasticity; it is imported under the name of lance-wood, and much used by coachmakers for shafts to light carriages.

1223. Asimina. A name coined by Adanson, without any meaning. Shrubs with deciduous, oblong, often cuneate leaves, and axillary flowers, which often ap ear before the leaves. The species are natives of shady woods in the more southern provinces of North America.

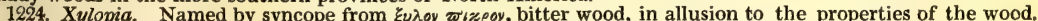
Fruit-bearing trees, but not in much esteem as such. $\mathrm{X}$. glabra is the most useful species. The wood, bark, and berries have an agreeable bitter taste, not unlike that of the orange seed. The wild pigeons feed much upon the latter, and owe that delicate bitterish flavor, so peculiar to them in the season, wholly to this part of their food. Fresh gathered from the tree, they are agreeable to the palate and grateful to the stomach. The bark is also richly impregnated with this juice as well as the wood, and both yield a very agreeable bitter in the mouth while fresh ; but that delicacy diminishes greatly after they are dried. The wood is easily wrought, and esteemed a good timber where it is not much exposed to the weather. The bitter quality of wrought, and esteemed a good timber where it is not much exposed to the weather. The bitter quality of
this tree is communicated with great facility. A handful of the shavings immersed in water and instantly taken out again, will render it of a very bitter taste. Sugar sent over in hogsheads made of this wood was so bitter that no person would purchase it. Bedsteads and presses made of it, are proof against cockroaches and other insects. Carpenters who work the wood, perceive a bitter taste in their mouths and throats. A decoction of it is said to be of service in cholics, and to create appetite.

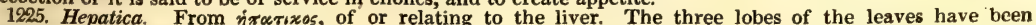
compared to the three lobes of the liver. A great favorite of the flower border, both as being evergreen in its foliage, and for its abundant blossoms and great variety of colors and shades. 
1226. ANEMO'NE. $W$. en. Anemone 7936 coronária $\boldsymbol{W}$. $\beta$ pléna

7937 horténsis $W$ A. stellata Dec.

7938 palmáta $W$.

7939 sibírica $\boldsymbol{W}$.

7940 álba Juss.

7941 baldénsis $W$.

7942 sylvéstris $W$

7943 pavonina Dec

7944 virginiána $W$.

7945 uralénsis $\mathrm{Dec}$

7946 pensylvánica $P h$.

7947 dichótoma $P h$

7948 trifólia $W$

7949 nemorósa $W$.

7950 apennina $\boldsymbol{W}$.

7951 ranunculoídes $W$.

7952 narcissiflóra $W$.

7953 thalictroides $W$.

7954 alpina $W$. en.

7955 praténsis $W$. en

7956 obsoléta Sims.

7957 Pulsatílla $L$.

7958 Halléri $W$. en.

7959 vernális $\boldsymbol{W}$. en.

7960 cérnua $W$.

7961 pátens $W$, en.

7962 capénsis Dec. Atragene capensis $\mathrm{L}$.

Poppy flowered $\stackrel{\Delta}{*}$ or

star \& $\Delta$ or

palmated

Siberian

white

Strawberry-like $₫ \Delta$ or

Snow-drop $\frac{\nabla}{t} \Delta$ or

Peacock-eye $\Delta$ or

Virginian $¥ \Delta$ or

Ural $\frac{j}{2} \Delta$ or

Pensylvanian $\$ \Delta$ or

forked $\frac{\vec{x}}{\Delta}$ or

three-leaved $\frac{\not}{*} \Delta$ or

blue mountain $\Delta$ or

yellow wood $x \Delta$ or

Narcissus-flow. $\searrow \Delta$ or

Meadow-rue-lv. $\Delta$ or

Alpine $\forall$ or

meadow $\nabla \Delta \Delta$ or

pale-flowered $\Delta$ or

com. Pasque fl. $\downarrow \Delta \Delta$ or

spring P. fl. $\quad \vec{\Delta}$ or

drooping $P$. ff. $\frac{}{2} \Delta$ or

spreading $\mathbf{P}$. fl. $\$ \Delta \Delta$ or Cape

1227. CLE'MATIS. $L$. VIRGIN's Bower.

7963 austríaca $H$. $K$.

7964 sibírica $H . K$ Siberian

7965 verticilláris $D e c$. A. Americana $\mathrm{H} \mathrm{K}$

7966 glaúca $W$

7967 hedysarifólia $\mathrm{Dec}$

7968 chinensis Retz.

7969 cirrhósa $W$.

7970 flórida $W$.

ß flore pléno

7971 Viticélla $W$ ३ pléna

7972 Viórna $\boldsymbol{W}$

7973 reticuláta $P h$.

7974 cylindrica $H . K$

7975 crispa $\boldsymbol{B}$. $\boldsymbol{M}$.

7976 baleárica Rich. calycina $\mathbf{W}$.

7977 orientális $W$.

7978 virginiána $\dot{W}$

7979 dioíca $W$.

7980 aristáta $B$. Reg.

American

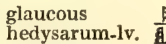

$\frac{\mathrm{R}}{\mathrm{B}}$

Chinese

evergreen

large-flowered

double-flowered

purple

double-purple

leathery-flower.

netted

long-flowered

curled-flowered

Minorca

oriental

Virginian

Jamaica

awned-anther.

7981 brachiáta B. Reg.

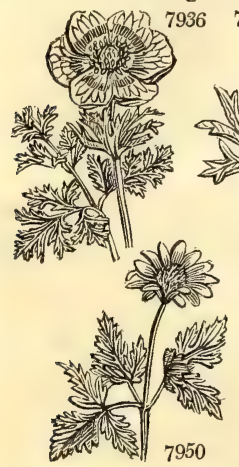

$* \Delta$ or

I $\triangle \Delta$ or

Ranunculacere. Sp. 27-40.

$\frac{1}{2}$ ap.my St Levant 1596. R 1.p Bot. mag. 841

$\frac{3}{4}$ ap.my St $\quad \ldots . . . \quad \ldots$ R r.1

$\frac{3}{4}$ ap.my St Italy 1597. R s.p Bot. mag. 123

$\frac{1}{2}$ my.jn $\mathbf{Y} \quad$ Portugal 1597. R s.p Bot. reg. 200

$\frac{1}{4}$ in W Siberia 1804. R s.p

1 ${ }^{\frac{1}{2} \mathrm{jn}}$ W Siberia 1820. R s.p Bot. mag. 2167

$\frac{1}{2}$ my W Switzerl. 1792. R s.p Jac. ic. 1.t. 103

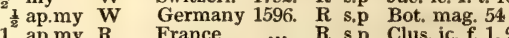

1 ap.my $R$ France ${ }_{10} \quad R$ s.p Clus. ic. f. 1, 2

$\frac{1}{2}$ my.jn W N. Amer. 1722. R s.p Herm. par. t. 18

$\frac{1}{2}$ my B Siberia 1824. R s.p

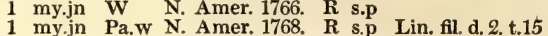

$\frac{1}{2}$ ap.my W France 1597. R s.p Mor. s.4.t.25.f.1

mr.my W Britain woods. $R$ s.p Eng. bot. 355

$\frac{1}{2}$ mr.ap B England woods. R s.p Eng. bot. 1062

$\frac{1}{2}$ mr.ap Y England woods. R s.p Eng. bot. 1484

1 my W Siberia 1773. R s.p Bot. mag. 1120

$\frac{1}{\varepsilon}$ ap.my W N. Amer. 1768. R s.p Bot. mag. 866

W Austria 1658. R s.p Jac. aus. 1. t. 85

${ }_{\frac{1}{8}}$ my D.Pu Germany 1731. R s.p Fl. dan.t. 611

a my Pu Germany ... $\quad$ R s.p Bot. mag. 1863

$\begin{array}{llll}\text { ap.my } & \text { England ch. pa. R s.p Eng. bot. } 51 \\ & \text { Switzerl } & \text { 1816. } & \text { R s.p }\end{array}$

$\begin{array}{llll}\frac{1}{2} & \text { ap } & \text { Pa.w Switzerl. 1752. R s.p Fl. dan. t. } 29\end{array}$

$\frac{1}{2}$ my.jn R.w Japan 1806. R s.p

$1^{2}$ jn.jl Li.Y Siberia 1752. R s.p Bot. mag. 1994

$\begin{array}{lll}\text { mr.ap Pu } & \text { C. G. H. 1795. S p.1 Bot. mag. } 716\end{array}$

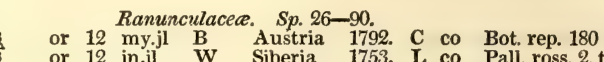

or 12 jn.jl W Siberia 1753. L co Pall, ross. 2.t.76

or 12 ap Pa.Y Siberia ... L co Dend brit 73

or 12 o ... W. W. E. Indies 1819. L co Bot. reg. 599

or 12 W.. W China 1820. I co Retz. obs. t. 2

or 12 mr.ap W.G Spain 1596. C co Bot. mag. 1070

17.1 Bot. mag. 834

or 20 jn $\quad$ Pu Spain $10 .$. L s.1

or 12 in $\quad$ Pu Amer. $17 \ddot{0}$. L co

N. Amer. 1730. S co Di. el, t.118.f.14

or 8 jn.s $\quad \mathrm{Pu}$ N. Amer. 1812. L s.p Dend. brit. 72

or $8 \mathrm{jl} . \mathrm{s}$ B N. Amer. 1802. L p.l Bot. mag. 1160

Pa.pu N. Amer. 1726. L p.l Bot. mag. 1892

Y.w Minorca 1783. C co Bot. mag. 959

L d or

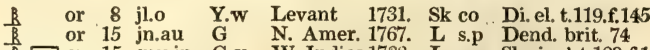

B $\square$ or 15 my.jn G.Y W. Indies 1733. L s.p Slo.ja. 1.t.128.f.1

$B \cup$ or 15 my.au G.Y

N. Holl. 1812, L s.p Bot reg. 238

$\begin{array}{lcccc}\text { C. G. H. } & \text {... } & \text { L s.p } & \text { Bot. reg. } 97\end{array}$

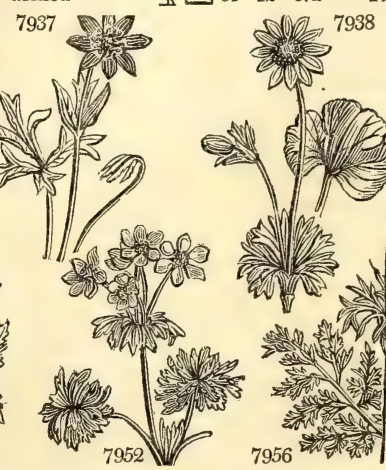

History, Use, Propagation, Culture,

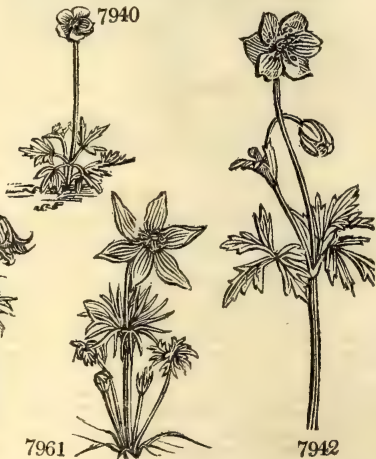

1226. Anemone. From aysus, wind, because the greater part of the species grow in elevated places much exposed to the wind. The species are shewy flowering plants, and A. coronaria and hortensis are well known florists' fiowers, valued for their hardy nature, and also because they will flower at almost any season, accord. ing to the time the roots are kept out of the ground, and the season when they are replanted. The prevailing colors are red, white, and blue, and semidouble flowers are in nearly as much repute as double ones. Many new varieties have been raised from seed; but they are not named by the florists, as in the case of tulips and and pinks. The roots of anemones are solid flattened masses like those of ginger, and like them are multiplied by division. A root which has remained in the soil two or three years, if it has room to extend, attains a great breadth, but is still only one root; and hence the mode of sale is by weight, and the roots are divided when planted.

The soil preferred by the anemone is a fresh loam, rather heavy or light. The usual time of planting is the end of October, covering the roots three inches; but to have an early bloom they may be planted in the beginning of September, and to have a bloom every month in the year, plant every month. The finer sorts 
7936 Leaves ternate with multifid segments and linear mucronate lobes, Sep. 6 oval close

7937 Leaves 3-parted with cuneate cut-toothed lobes, Invol. sessile obl. entire or cut, Sepals 10-12 oblong

7938 Leaves cordate roundish bluntly 3-5-lobed toothed, Invol. sessile trifid, Sepals 10-12 oblong

7939 Leaves ternate with cut-toothed ciliated segments, Invol. on short stalks 3 cut, Sepals 6 round

7940 Leaves ternate or quinate, Segments cut-toothed at the end, Invol. stalked similar, Sepals 5 obovate

7941 Lvs. biternate with a branch. stalk, Segm. many-part. with lin. lobes, Inv. shortly stalk. multifid, Sep. obl.

7942 Leaves ternate or quinate, Segm. cut-toothed at end, Invol, stalked similar, Sepals 6 elliptical

7943 Leaves 3-parted with cuneate cut-toothed lobes, Invol. sessile oblong entire or a little cut, Sep. very acute

7944 Leaves ternate with trifid acuminate cut-toothed segments, Invol. stalked similar, Sepals 5 elliptical

7945 Invol. leaves on short stalks thrice cut with linear cut-toothed segments, Sepals 5 -6 oval-oblong

7946 Leaves 3-parted with cut-toothed acuminate lobes, Invol. sessile similar, Sepals 5 elliptical, Fruit hairy

7947 Leaves 3-parted with cut-toothed oblong lobes, Invol, sessile similar, Sepals 5 elliptical, Fruit smooth

7948 Leaves all stalked ternate with ovate lanc. acute-toothed segments, Sepals 5 elliptical obtuse

7949 Leaves ternate with trifid cut-toothed lanc. acute segments, Invol. stalked similar, Sepals 6 elliptical

7950 Leaves 3-ternate with a branched stalk, Sepals 12-14 oblong obtuse, Leaves of invol. stalked

7951 Radical lvs. 3-5 cut with subtrifid cut-toothed segments, Invol. stalk. 3-parted toothed, Sep. 5-6 elliptical

7952 Radical leaves villous palmate 3-5-parted with cut-toothed lobes, Lobes lin. acute, Fl. umbelled

7953 Flowers umbelled, Floral leaves stalked biternate forming a sort of involucre

7954 Leaves biternate with a branched petiole, Segm. pinnated cut serrate, Sepals 6 spreading

7955 Leaves pinnated with multifid segments, Lobes linear, Flowers pendulous, Sepals 6 erect reflexed at end

7956 Like the last, but the flower larger and paler, and the lobes of the pinnæ broader and awned

7957 Leaves pinnated with multifid segments, Lobes linear, Flower somewhat nodding, Sepals 6 spreading

7958 Leaves pinnated very villous with 3-parted segments, Lobes lanc. lin. acum. Fl. erect, Sep. 6 oval lanceol

7959 Leaves pinnated with cuneate lanceolate trifid smoothish segments, Fl. erect, Invol. very villous

7960 Leaves pinnated villous beneath, Segm. pinnatifid, Lobes cut oblong, Fl. subcernuous, Sep. 6 spreading

7961 Leaves pinnate coming after the flowers, Segm. 3-parted, Lobes toothed cut at end, Fl. erect spreading

7962 Leaves biternate rigid smooth, Segm. cuneiform toothed at end

7963 Pedunc. 1-f. longer than leaf, Lvs. biternate, Segm. ovate-lanc. acum. serrate, Pet. subspatulate obtuse 7964 Pedunc. 1-fl. the length of leaf, Leaves biternate with obl. lanc. acumin. segments, Pet. emarginate at end 7965 Pedunc. 1-fl. Leaves whorled in fours ternate, Segm. stalked cordate lanc. entire, Petals acute

7966 Leaves pinnate, Segm. glaucous smooth cuneiform lobed, Lobes entire blunt, Pedunc. trifid

7967 Fl. panicled, Leaves ternate, Segm. ovate lanc. acumin. nearly entire smooth 5-nerved at base

7968 Leaves pinnated, Segm. ovate lanc. entire, Pedunc. few-fl. longer than leaf, Ovaries about 4, Tails almost

7969 Pedunc. 1-fl. with an involucrum, Leaves ovate subcordate toothed fascicled

[naked

7970 Pedunc. 1-fl. longer than leaf, Leaves tern. decompound, Segm. ovate acute entire, Sepals much pointed

7971 Pedunc. 1-fl. longer than leaf, Leaves entire or ternate decomp. Lobes or segm. entire, Sepals obovate

7972 Pedunc. 1-fl. Sep. connivent thick reflexed at end acuminate, Lvs. smooth with ent. or 3-lob. ov. acute segm. 7973 Pedunc. 1-f. Sep. connivent, Lvs. coriaceous netted nerved smooth with stalked 3-lobed or entire segments 7974 Pedunc. 1-fi. Sep. acumin. wavy at edge thin, Lvs. smooth thin decompound with stalked ov. or obl. segm. 7975 Pedunc. 1-fl. shorter than leaf, Leaves entire 3-lobed very acute, Sepals conniving at base spreading at end 7976 Pedunc. 1-fl. with an involucre under the leaf, Leaves ternate with stalked ternate cut-toothed segments

7977 Leaves pinnate with glaucous smooth wedge-shaped 3-lobed segments, Lobes toothed acuminate 7978 Fl. panicled diœcious, Leaves ternate, Segm. cordate acute coarsely toothed and lobed

7979 Fl. panicled diœcious, Lvs, tern. Segm. smooth ovate cordate acuminate 3-nerved ent. Pedicels pubescent 7980 Fl. panic. diœe. Sep. 4. Lvs. tern. Segm. ovate subcord. acute coarsely toothed 3-nerv. Anth. awned at end 7981 Ped. 31 -fl, or 3 -fid or panic. long. than lvs. Lvs, tern. or pinn. Segm. ovate coarsely toothed, Fl,-buds gloioose

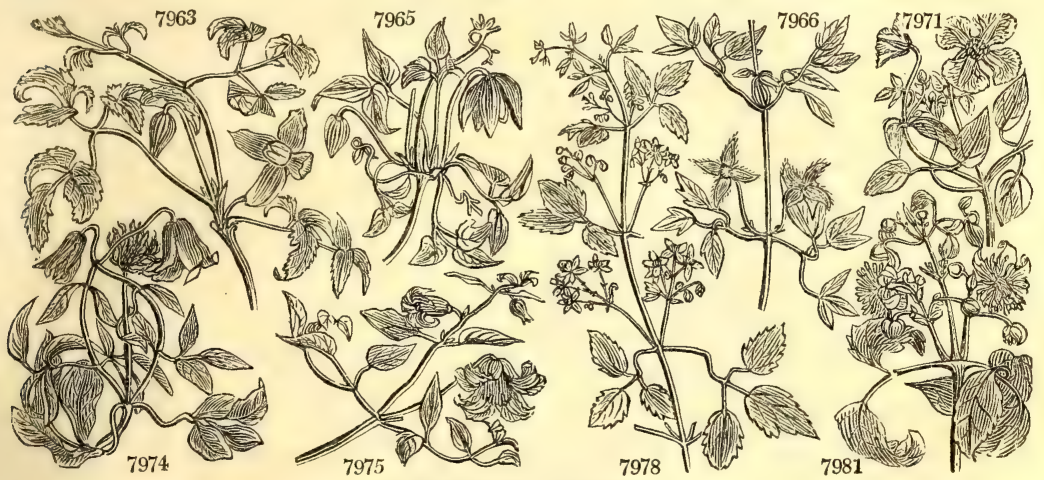

and Miscellaneous Particulars.

require protection from violent storms and excessive iight and heat; but many varieties do exceeding well in borders. A very severe winter will destroy the roots if the surface is not mulched; but the anemone is considerably hardier than the ranunculus. Anemone pulsatilla is common in borders. The roots are mostly tuberous, and when taken up should not be long kept out of ground. Like most tuberous plants, they thrive best in a sandy loam.

1227. Clematis. From $\approx \lambda \eta \mu \propto$, a tendril; the climbing habit of this genus is well known. The species are mostly climbing shrubs of rapid growth, free-flowerers, very ornamental, and some are highly odoriferous. C. florida, viticella, and flammula are admired species. The plants formerly called Atragene, but now properly united to Clematis, are shewy climbers, especially C. austriaca, which grows and flowers freely. Any common garden soil will suit them, and they are readily increased by layers; or young cuttings, planted under a common hand-glass, will root freely. Seeds are often ripened in abundance, by which any quantity may be raised; they are best sown in pans, or wide-mouthed pots, and placed in a shady situation, where they will 
7982 Massóniana Dec. 7983 Vitálba $W$

7984 Flámmula $W$.

a rotundifólia

C. frágrans Tenore.

$\beta$ vulgaris

$\gamma$ maritima $\mathbf{W}$.

7985 erécta $W$.

7986 angustifólia $W$.

7987 ochroleúca $W$

7988 integrifólia $\boldsymbol{W}$.

$\beta$ angustifólia

1228. NARA VE'I

7989 zeylánica $W$.

7989 zeylánica $W$. Ceylon 1 . THALIC'TRUM. $W$. MEADow-RU

7990 alpinum $W$.

7991 fo'tidum $W$.

7992 tuberósum $W$ $\boldsymbol{T}$. corynellum Dec.

799 diofcunellu

7995 elátum $W$.

7996 május $W$.

7997 médium $W$

7998 minus $W$

7999 coricínnum $W$. en.

8000 rugósum $W$

8001 sibiricum $\boldsymbol{W}$

8002 squarrósum $W$.

8003 pubéscens $P h$.

8004 purpuráscens $\boldsymbol{W}$.

8005 augustifólium $W$

8006 lúcidum $W$

8007 flávum $W$.

8008 nígricans $W$.

8009 glaúcum Desf. speciosum W. en $\begin{array}{llll}\text { Masson's } & k \text { or } 12 \\ \text { Traveller's Joy } & \frac{k}{R}, \text { or } & 20 & \text { jl.s }\end{array}$ sweet-scented $\bar{B}$ or 20 jl.o round-leaved $\vec{k}$ or $20 \mathrm{jl} . \mathrm{o}$

broad-leaved $\mathrm{B}$ or 20 jl.o narrow-leaved $\bar{k} \Delta$ or 20 jn.s upright $\$ \Delta$ or $3 \mathrm{jn}$.au narrow-leaved $\$ \Delta$ or 4 my.s silky $\quad \frac{1}{\Delta} \Delta$ or 2 jn.jl entire-leaved $D$ or 2 in.au narr.-cntire-lv. $\$ \Delta$ or 2 jn.au

$\mathbf{W}$
$\mathbf{W}$
$\mathbf{W}$
$\mathbf{W}$
$\mathbf{W}$
$\mathbf{W}$
$\mathbf{W}$
$\mathbf{L} . \mathbf{Y}$
$\mathbf{B}$
$\mathbf{B}$

C. G. $\mathbf{H}$. L s.p

co Eng. bot. 612

France 1596. S co Kn. th. 2, t. c. 9

France 1596. L co

France $\quad \ldots \quad$ L co

S. Europe $\quad . . \quad$ D p.l

Austria 1597. D p.I Jac. aus. 3.t. 291

Austria 1787. D p.1 Dend, brit. 112

N. Amer. 1767. D p.l Bot. cab. 661

Hungary 1596. D p.l Bot. mag. 65

Hungary ... D p.l

Ranunculacea. Sp. 1.

Ranunculacea. Sp. 26-52.

Alpine $\quad$ \& $\triangle$ or $\frac{1}{2}$ my.jl W Britain bgs.m. D co Eng. bot. 262

foetid J $\Delta$ or $\frac{3^{\frac{1}{4}}}{4} \mathrm{my} . \mathrm{jl} W \mathrm{~W}$ France 1640. D co Pl.ra.h.2.t.174

tuberous-rooted $\bar{t}$ or 2 jn $W$ Spain 1713. D co M. ic. 2.t.265.f.2

Canadian $\$ \Delta$ or 3 my.jl W N. Amer. 1640. D co Corn. can. t. 187

dicecious $\neq \Delta$ or 1 jn.jl L.Y N. Amer. 1759. D co

tall $\$ \Delta$ or 2 jn.au L.X Hungary 1794. D co

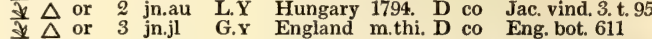

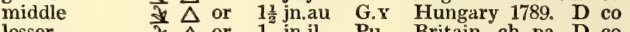

lesser

G.X Hungary 1789. D co

W.

W N. Amer. 1774, D co

L.Y Siberia 1775. D co

L.Y Siberia 1806. D co

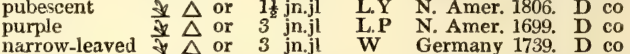

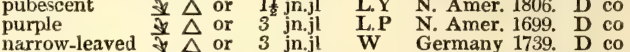

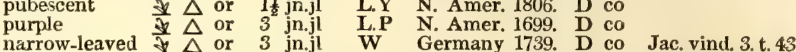
shining $\$ \Delta$ or 4 my.jl Li.Y Spain 1739. D co common $\Delta$ or 4 my.jl $O$ Britain m.me. D co black $\quad \frac{7}{\mathrm{~V}} \Delta$ or 2 my.jl $\underset{\mathbf{P}}{\mathbf{Y}}$ Austria 1798. D co glaucous-leav'd $\frac{7}{ \pm} \Delta$ or $5 \mathrm{jn}, \mathrm{jl}$

Spain

Pl.

Eng. bot. 367

Jac. aus. 5 . t. 421

Mo. his.t. 20 . f.1

8010 ranunculinum $W$.en.

8011 simplex $W$

8012 aquilegifólium $W$.

$\beta$ átro-purpureum

8013 galioídes $\boldsymbol{W}$. en.

8014 contortum $W$.

8015 petaloídeum $W$.

1230. ADO'NIS. $L$

8016 æstivális $W$.

8017 autumnális $W$.

8018 flámmea $W$.

8019 vernális $W$.

8020 fláva $V$ ill

8021 pyrenáica $D e c$.

1231. KNOWLTO

NIA. $\boldsymbol{H} . \boldsymbol{K}$. KNowlto

8023 vesicatoria $H$ thick-leaved

1232. FiCA'RiA. Pers. Pilewort.

8024 ranunculóides $M$ \%on vernal

$\beta$ pléna

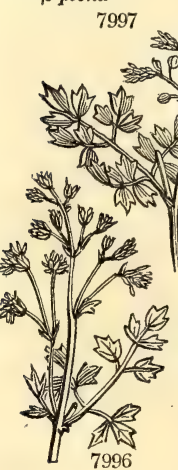

7996

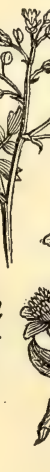
vernal simple-stalked $\$ \Delta$ or dark-pirp Coric $\Delta$ or sweet-scented $\$ \Delta$ or ook-seeded

1 jn.jl Pa.Y N. Amer. 1806. D co

1 my.jn L.Y Sweden 1778. D co Fl, dan. 244

3 my.jl L.Pu Austria 1731. D co Bot. mag. 2025

3 my.jl D.Pu Austria 1731. D co Bot. mag. 118

1 my.jl $Y$ Alsace 1816. D co Mo.his.t.20.f.8

jn.jl W $\quad$ W

Ranunculacea. Sp, 6-14.

O pr 1t jn.jl Sc S. Europe 1629. S co Kn.th. 2.t.A.12

Pheasant's-eye $O$ pr 1 my.o $\mathrm{Cr}$ Britain cor.f. S co Eng. bot. 308

flame-colored $O$ pr 1 jn.jl $Y$ Austria 1800. S co Jac. aus. 4. t. 355

perennial $\$ \Delta$ or $1 \mathrm{mr}$.ap $\mathbf{Y}$ Europe 1629. D s.p Bot. mag. 134

yellow $\$$ O

1 jn.jl Y S. Europe $\quad$ Y... S co

Pyrenees 1817. D co

Ranunculacea. Sp. $2-5$.

Al cu 11 mr.my Y.G C. G. H 1780. S p.l Bot cab. 850

$\begin{array}{llll}\text { K } \Delta \text { cu } 1 \frac{1}{2} \text { f.ap } & \text { Y.G } & \text { C. G. H. 1691. S p.1 Bot. mag. } 775\end{array}$ Ranunculacee. Sp. 1-2.

$* \Delta \mathrm{w} \frac{1}{2}$ mr.my Y Britain he. ba. D 1.p Eng. bot. 584

Britain he. ba. D 1.p

7987
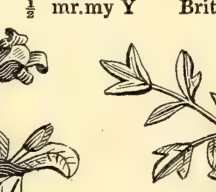

7991

Eng. bot. 611

Eng. bot. 11

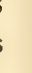


7982 Leaves pinnate with smooth subglaucous ovate cut-toothed 3-lobed segments

7983 Lvs. pinn. Segm, ovate-lanc. cut-toothed acuminate truncate cordate at base, Pedunc. shorter than leaf

7984 Leaves pinnate, Segments smooth entire or 3-lobed round oval oblong or linear rather acute $\propto$ Segments nearly round

$\beta$ Segments oval or oblong lanceolate

$\gamma$ Segments linear

7985 Leaves pinnate with stalked ovate-lanc. entire segments

7986 Pedunc. 1-fl. Sepals 6-8 blunt, Leaves pinnate, Segm. lanc. lin. acute or 3-Jobed, Stems erect

7987 Pedunc. 1-fi. Fl. suberect, Leaves entire ovate; young ones silky

7988 Pedunc. 1-fl. Fl, nodding, Leaves entire ovate lanc. smooth

7989 The only species

7990 Stem simple almost naked, Raceme simple terminal, Fl. nodding, Segm. smooth

7991 Stem simple naked at base: leafy in middle; panicled at end, Lvs. pubescent viscid, Segm. blunt toothed 7992 Fl. loosely corymbose or subsolitary, Invol. none, Bract subsessile

7993 Fl. dicecious, Filam. clavate at end, Pericarp obl. sessile striated, Segm. of leaves bluntly 3-lobed

7994 Fl. diccious, Fil, filiform, Segm. of leaves roundish cordate bluntly lobed smooth

7995 Stem round without bloom, Fl. panicled erect, Segm. of leaves smooth ovate or subcordate subtrifid

7996 Stem round without bloom, Fl. loosely panic. Segm. of leaves smooth glauc. ben. Peric. obliq. round. at base 7997 Stem round without bloom, Fl. loosely panicled, Segm. of lvs. obl cuneiform sharply trifid: upper entire 7998 St. round cover. with a glauc. bloom, Fl. loose. pan. cern. Segm. of lvs, roundish tooth. at end, glauc. beneath 7999 Stem round upright, Fl. cernu. in a very large spreading panic. Segm. of lvs. smooth cuneif trifid acute 8000 St. erect round striat. green, Pan. erect. comp. Fl. clust. Segm. of lvs. ov. subcord, coarsely cren. shin. above 8001 Stem roundish, Fl. panic. cernuous, Segm. of lvs. smooth ov. cuneate trifid, Lobes acute entire or finely cut 8002 Stem round, Fl. panicled cernuous, Petioles stem-clasping winged

8003 Stem simple covered with scattered leaves panicled at end, Stem downy viscid

8004 Fl. dicecious or monœe. Filam. filif. colored, Segm. of lvs. roundish coarsely tooth. smooth glauc. beneath 8005 Stem upright round somewhat furrowed, Root fibrous, Panic. multiple erect, Segm. of lvs. lin. lanc. entire 8006 St. branch. round somew, furrow. Root fibr. Pan. multiple erect, Segm. of lvs. lin. lanc. ent. cuneate at base 8007 Stem branch. erect somewhat furrowed, Root fibr. Pan. multiple erect, Segm. of lvs. cuneiform trifid acute 8008 St. branch. erect somew. furrow. Root fibr. Pan. multiple erect, Segm. of rad. Ivs. cuneif. trif. Caul. obl. lin. 8009 Stem erect round striat. glauc. Pan. multip. erect close, Seg. of lvs. subcord. ov. bluntly trifid glauc. beneath

8010 Leaves simple 5-lobed serrated

8011 Stem erect simple angular, Root creeping, Panic. erect racemose few-flowered, Segm. of leaves linear 8012 Stipules ovate, two at the base of the ramifications of the petiole, Panic. corymb. Fruit 3-cornered

8013 Stem round upright somewhat furrowed, Root creeping, Panic. erect, Segm. of lvs. lin. very narrow entire 8014 Stipules O, Fl. loosely corymbose racemose, Fruit 3-cornered pendulous

8015 Stem round nearly naked, Fl. corymb. Filam. dilated at end, Segm. of lvs. smooth ovate entire or 3-lobed

8016 Cal. hispid at base, Pet. flat obl. blunt, Fruit netted in a long lax spike

8017 Cal. smooth, Pet. conc. conniving scarcely longer than cal. Fruit netted in an ovate head

8018 Cal. hispid at base, Pet. flat acute longer than cal. Flower large, Fruit in a cylindrical head

8019 Lower leaves abortive, Upper sessile, Fruit velvety, Pet. 10-12 oblong somewhat toothed

8020 Cal. smooth distinct at base, Pet. flat obl. twice as long as cal. Fruit smooth in an oblong head

8021 Rad. leaves on long stalks, Stalks trifid, Fruit smooth, Pet. 8-10 obl. cuneate entire

8022 Umb. supradecompound much spreading

8023 Umb. simple few-flowered

8024 Root grumous, Stem leafy, Leaves cordate

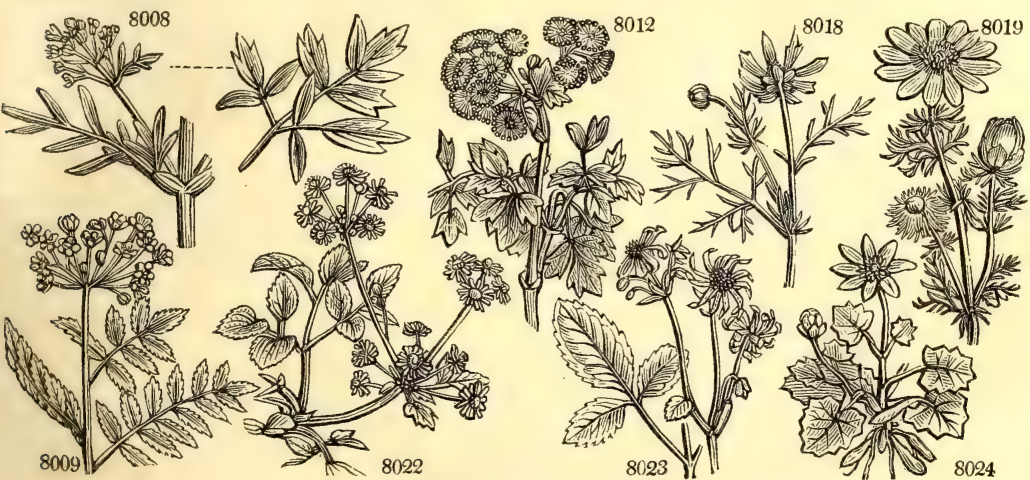

and Miscellaneous Particulars.

1231. Knowltonia. Named after Thomas Knowlton, once the curator of the botanic garden at Eltham. The species grow freely in loam and peat, and are increased by dividing at the root, and by seeds.

1232. Ficaria. So named because the grumous roots bear tubercles like little figs. A common wood plant, remarkable for its shining leaves and bright yellow flowers. The young leaves are sometimes used as greens in Sweden, and the roots were formerly applied in poultices to piles in England, probably from their resemblance to that disease. These roots or tubercles lie near the surface, and are sometimes laid bare by the rains, and in this state have induced the ignorant, under the influence of superstition, to fancy that it rained wheat. The plant is injurious in moist grass lands, but is effectually destroyed by a dressing of coal or wood ashes.

I i 3 
1233. RANUN'CULUS. $W$. Crow-Foot. 8025 Flámmula $W$. 8026 réptans $\boldsymbol{W}$. 8027 Lingua $W$. 8028 nodiflórus $W$. 8029 gramíneus $\boldsymbol{W}$. 8030 parnassif́lius $W$. 8031 amplexicaúlis $W$ 8032 bullátus $W$. 8033 Thóra $W$. 8034 monspeliácusGouan 8035 lácerus Dec. 8036 ophioglossifólius Dec 8037 salsuginósus Pall. 8039 créticus $W$. 8040 cassúbicus $W$. 8041 aurícomus $W$. $80+2$ arbortivus $W$. 8043 scelerátus $W$. 8044 aconitifólius $W$. - flore pléno $\beta$ platanifólius $\mathbf{W}$ 8045 pedátus $W$. en. 8046 illýricus $W$.
$R$. sericeus $\mathrm{W}$ 8047 asiáticus $W$. 8048 chærophyllus $L$. 8049 rutæfólius $W$. 8050 glaciális $W$. 8051 nivális $W$. 8052 montánus $W$ 8053 alpéstris $W$. 8054 pensylvánicus $W$. 8055 bulbósus $W$. 8056 hirsútus $\boldsymbol{H} . \mathbf{K}$. 8057 marylándicus $P h$. 8058 répens $W$. B flore pléno 8059 polyánthemos $W$. 8060 ácris $W$.

$\beta$ flore pléno

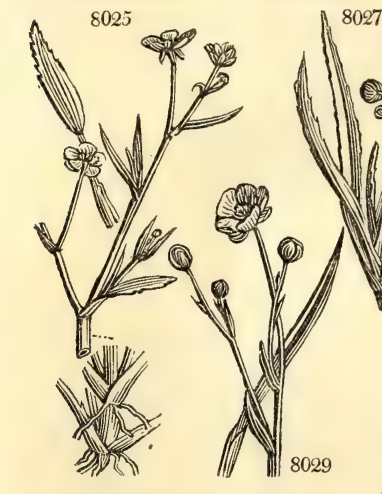

8029 lesser-Spearw. salt $\mathrm{s}$-tongue-1,

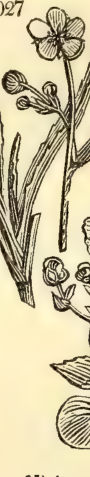
least-Spearw. $\frac{\Delta}{8} \Delta$ great-Spearw. $₫ \Delta$ knot-flowered grassy $\downarrow \Delta$ or Parnassia-lvd. Dे $\Delta$ or Plantain-leav'd $\frac{\text { z }}{\Delta}$ or Portugal $\quad \Delta$ or kidney-leaved $\$ \Delta$ or Montpelier $\neq \Delta$ or torn fumitory-leav'd $\Delta$ Cretan $\Delta$ or Caltha-leaved $\Delta$ or wood $\vec{x} \mathrm{w}$ three-fowered $\mathbb{v} \Delta$ Celery-leaved $O \mathrm{p}$ Aconite-leaved $\$ \Delta$ or doublefiowered $\Delta \Delta$ or Plane-tree-lvd. $\$ \Delta$ or pedate $\Delta$ or illyrian $\Delta$ or common-gard. * $\Delta$ or villous Rue-leaved 考 $\Delta$ cu two-fiowered $\frac{\partial}{\partial t} \Delta$ snowy $\frac{\Delta}{\Delta} \mathrm{pr}$ mountain $\overrightarrow{ } \Delta \mathrm{pr}$ alpine 妾 $\Delta \mathrm{pr}$ Pensylvanian 20 bulbous $\Delta w$ pale hairy $\mathrm{O}$ Maryland te $\triangle$ un creeping ${ }^{*} \Delta \mathrm{w}$ double-flowered $\Delta$ or many-flowered $\frac{\downarrow}{\Delta} \mathrm{un}_{\mathrm{w}}$ double-flowered $\frac{\$ 2}{\Delta} \Delta$ or
Ranunculacea. Sp. 49-160.

1 jn.s Y Britain wa. pl. D co Eng. bot. 387 $\frac{3}{4} \mathrm{jn} . \mathrm{s} \quad \mathrm{Y} \quad$ Britain wa. pl. D co Fl, dan. 108. jn.au $Y$ Britain mud.d. D co Eng. bot. 100 $\frac{2}{3}$ my.jl $\quad \mathbf{Y}$ Sicily 1714. S co Bot. mag. 2171 ap.jn $\mathbf{Y}$ Wales al me. D co Eng. bot. 2306 $\frac{3}{4}$ jn.jl St $\quad$ S. Europe 1769. D co Bot. mag. 386 1 ap.my W Pyrenees 1633. D co Bot. mag. 266 1 my.jn $Y$ S. Europe 1640. D co M. his.t.31. f. 50 $\frac{3}{4}$ my.jn $Y$ Austria 1710. D co Jac aus, 5, t.442 1 ap.my Y S. France

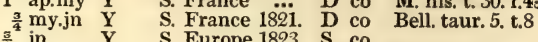
jn $\quad$ Y S. Europe 1823. S co ap.my $\mathbf{Y}$ 1 my.jn $Y$ 1 ap.my $Y$ 2 jn.jl $Y$ $1 \frac{1}{2}$ ap.my $Y$ my.au Y 2 my.jn $Y$ 1 my.jn W 1 my.jn W 2 jn.jl W $\begin{array}{lll} & \text { my.jn } & Y \\ 1 \frac{1}{3} & \text { my.jn } & Y\end{array}$

Siberia 1822. D co

Candia 1658. D co Mo. his.t. 31.f.48 Siberia 1794. D co Bot. mag. 2267 Britain woods. D co Eng. bot. 624 N. Amer. 1713. D co Britain wa.pl. S co Eng. bot. 681 Al. of Eur. 1596. D co Al.of Eur. 1596. D co Bot. mag. 204 Germany 1769. D co Fl. dan.111 Hungary 1806. D co Bot. mag. 2229 S. Europe 1596. D co Jac. aus. 3. t. 222

$\frac{3}{4}$ my.jn $\mathrm{Va}$ 1 my.jn $Y$ $\frac{1}{2}$ my.jl Y jn.au Y $\frac{1}{2}^{\frac{1}{2}}$ jn.au Y Y $\frac{1}{4} \mathrm{jn} . \mathrm{au} \quad \mathrm{W}$ 1 jn.jl Y $\frac{1}{2}$ my.jn $Y$ $\begin{array}{lll}1 & \text { jn.o } & \text { Y } \\ \text { my.jl } & \mathrm{Pa} . \mathrm{Y}\end{array}$ $\frac{1}{2}$ my.au $Y$ my.au Y $\frac{1}{2}$ my.jn $Y$ $x^{2}$ jn $Y$ $\frac{1}{2} \underset{j n . j 1}{\text { jn.jl }}$
Levant 1596. D r.m Mill. ic. 2. t. 216 Portugal ... D r.m Mo. h.t. 30. f. 44 Austria 1759. D r.m Jac. col. 1. t.6,7 Lapland 1775. D s.l Fl, dan. 19 Lapland 1775. D s.1 Fl. lap. t. 3. f. 2 Lapland 1775. D s.1 Jac. aus. t. 325,6 Scotland al.riv. S co Eng. bot. 2390 N. Amer. 1785. D p.1 Jac. ic. 1. t. 105 Britain me.pa. S co Eng. bot. 515 England rubble. D co Eng. bot. 1504 Britain me.pa. D co Eng. bot. 516 N. Europe $130 \%$ D D co Lob. ic. 666 Britain me. pa. D co Eng. bot. 652 Britain ... D co Bot. mag. 215 N. Amer. 1811. D co
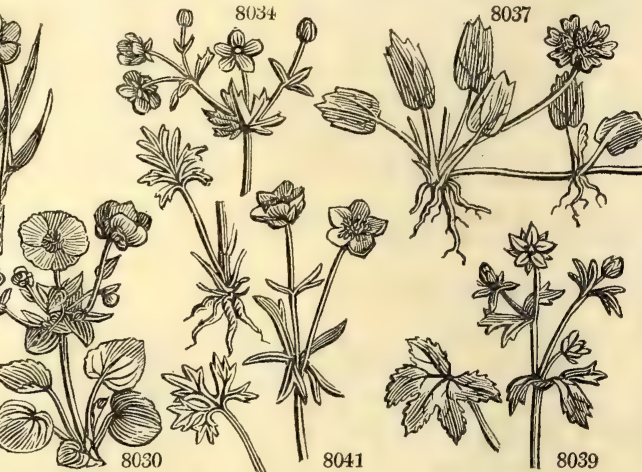

History, Use, Propagation, Culture,

1233. Ranunculus. Said to be so called from rana, a frog, because the species inhabit humid places frequented by that reptile. Renoncule, Fr, Ranunkel, Ger., and Ranuncole, Ital. Some of the species are weeds, one or two border flowers, and R. asiaticus is one of our most esteemed florists' flowers. Some of the species are tuberous and others bulbous rooted, but the most part are tuberous. $R$. sceleratus is one of the most virulent of our native plants. Bruised and applied to the skin it soon raises a blister, and makes a sore by no means easy to heal. Strolling beggars have been said to use it for that purpose, in order to excite compassion. When chewed, it inflames the tongue; and when taken into the stomach, it produces violent effects. It is suspected to have proved poisonous to sheep.

$R$. aconitifolius is a handsome plant, with branching stems, deep green leaves, and pure white flowers; the double variety is an old and much admired border flower.

Of $R$. asiaticus the varieties raised from seed are endless. Maddock, in the end of the last century, had nearly eight hundred, all with proper names, and ranged as purple, gray, crimson, red, rosy, orange, yellow, white, olive, coffee, striped, spotted, \&c. No plant is more prolific in new varieties from seeds ; no two plants, as Maddock observes, producing flowers alike, or the same as the original. Established sorts are propagated by offsets, which generally flower the first year: rare sorts may be multiplied by dividing the crown of the tuber with a sharp penknife into as many parts as there are buds : these will not flower till the second year, but will diminish the risk of losing a very rare variety.

The ranunculus prefers a fresh loamy soil, rather than otherwise inclined to clay : it should be well manured; and it is customary, in forming the beds, to place a stratum of well rotted cow-dung six or nine inches below the surface, which both retains moisture and supplies nourishment. The roots may either be planted in November or earlier, in which case, to prevent their being destroyed by the frost, they should be mulched, or they need not be planted till March. The former mode gives much the strongest bloom, as the roots, when kept in air all the winter, are apt to be over dried, and kept in sand they sometimes get mouldy : and in this and similar cases, the progress of vegetation from the planting to the blossoming period, is more rapic than is natural to the species. Ranunculus roots will retain their vegetative properties two and sometimes three years; a thing not common among bulbs and tubers, unless preserved dormant in an ice cold room.

$R$, bulbosus has a solid white bulb about the size of that of the common Crocus. The flowers are some- 
8025 Leaves smooth lin. lanc.: lower stalked, Stem declinate solid rooting at base, Fruit smooth 8026 leaves lin. entire smooth, Stem creeping and rooting at every joint

8027 Leaves lanc. subserrate sessile half stem-clasping, Stem erect smooth

8028 Rad. leaves stalked oval-obl. Fl. sess. opposite the leaves, Fruit granular scarcely crowned with the stylc 8029 Leaves lanc. or lin. entire, Stem erect very smooth, Scales of the petals tubular

$8030 \mathrm{Rad}$. leaves stalked subcordate ovate-roundish : cauline sessile ovate-lanc. Pedunc. hirsute

8031 Leaves oval-lanceolate acuminate stem-clasping, Scape and peduncles smooth

8032 All the leaves radical-stalked ovate toothed, Scapes naked 1-flowered

8033 Leaves smooth reniform crenate, Floral cut, Stem 2:3-f..smooth

8034 Lvs. woolly 3-lobed with trifid toothed cuneate lobes : upper 3-parted with entire lin. lobes, Cal, reflexed

8035 Leaves cuneiform irregularly cut at the end, Stem smooth branched many-fi. Cal. appressed

8036 Lower leaves stalked cordate blunt: upper obl, sessile, Stem erect hollow, Fruit granular

8037 Rad. lvs. stalked oval or subcord. 3-5-tooth. at end, Runners from neck of plant, Scapes naked 1-fl. erect 8038 Lvs. very smooth many-parted, Lobes obl. Scapes many 1-fl. with appressed hairs, Cal. spreading smooth 8039 Covered with soft hairs, Rad. lvs. stalk. cord. orbic. somewhat cut-tooth. Stem branched, Cal, appressed 8040 Lvs, smooth : radic. stalked reniform crenate; caul. in linear lobes, Cal. pubescent shorter than petals

8041 Leaves smooth : radic. stalked cordate generally 3-parted or lobed, Calyx pubescent shorter than petals 8042 Lvs. smooth : radic. stalk. cordate-roundish crenate some 3-parted or cut, Cal. smooth longer than petals 8043 Lvs, smooth : radic. stalk. 3-part. Lobes 3-lob. bluntly cut, Cal, smooth, Fruit very small in an obl. spike 8044 Lvs. palm. 3-7-parted cut-toothed : upper sessile with lin. lanc. lobes, Stem branch. many-fl. Cal. appressed

$\beta$ Radic. leaves 5-7-lobed with acuminate lobes, Bractes lin. entire 8045 Leaves smooth : radic. stalked 3-parted or pedate; upper linear, Stem erect few-fl. Calyx appressed $\$ 046$ Lvs. silky: first ent. lin. lanc.; rest 3-part. with entire or 3-part. lobes, Stem many-f. Cal, somewhat reflexed

8047 Leaves tern. or bitern. Segm. toothed or cut trifid, Stem erect simple or branched, Fruit in a cylindr. spike $8048 \mathrm{Rad}$. Ivs, stalked villous 3 cut : first ovate toothed or 3-lobed, Stem erect 1-2-fl. Cal. spreading subreflexed 8049 Leaves pinnate with 3-lobed cut multifid lobes, Stem about 1-fl. Cal. smooth, Pet. 8-10

8050 Radical leaves stalked palmate 3-parted with trifid blunt thick lobes, Calyx very hirsute

8051 Leaves smooth : radical stalked 5-fid with entire ovate lobes, Calyx very hirsute twice as short as petals 8052 Rad. lvs, smooth 3-parted round with trifid blunt segments : cauline sess. linear-lobed, Cal. nearly smooth 8053 Leaves round 3-lobed, Lobes blunt crenate at end, Stem about 1-fl. Cal. smooth, Pet. obcord. or 3-lobed 8054 Stem and petioles cover. with stiff hairs, Lvs. 3-fid with stalk. acutely 3-lob. segm. Cal. reflex. Style smooth 8055 Rad lvs, stalked 3-cut with trifid cut segm, of which the middle one is stalked, Stem erect, Cal. reflexed 8056 Lvs. 3-lob. with blunt cut lobes, of which the mid, is stalk. Cal refl. Grains with a single row of minute warts 8057 Stem and petioles with soft hairs at base, Lvs, smooth. trif. with 3-lob. ac. cut segm. Cal. smooth spreading 8058 Lvs. pinnate 3-fid with cuneate 3-lobed cut segm. Runners creeping, Cal, erect, Grains with an acute point

8059 Lvs. 3-5-lob. with lin. divisions, Stem erect and petioles with spreading hairs, Pedunc. furrowed, Cal. hairy 8060 Lvs. pubesc. or smooth, Lobes cut-tooth. acute : upper lin. Stem many-fl, pubesc. Cal, vill. Grains mucron.
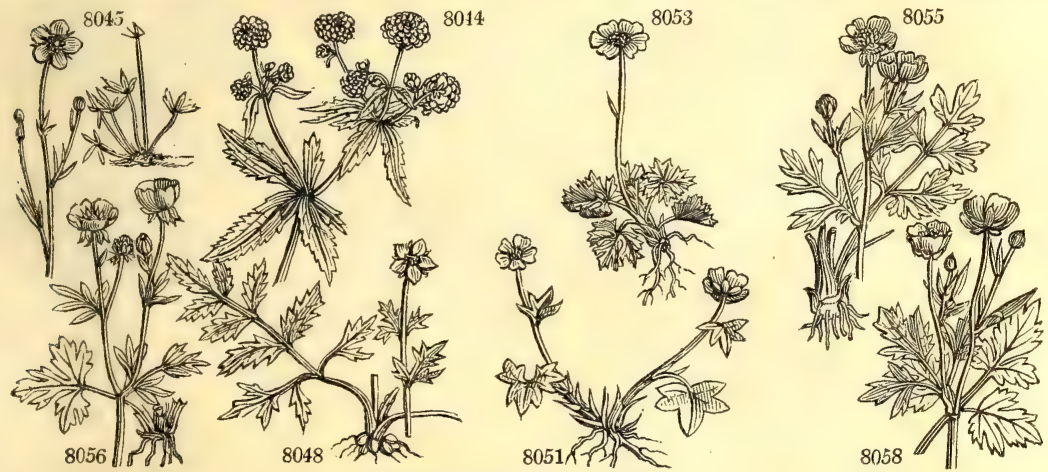

and Miscellaneous Particulars.

times double, but not so frequently as $\mathbf{R}$. acris. It is distinguished from the repens, with which it has been confounded by some authors, by its roots, by its never throwing out runners, and by its reflexed calyx; this last character arises from its particular structure, the lower half being thin and almost transparent, and therefore rot having a sufficient degree of solidity to support itself upright. It is the second flower which, next to the Dandelion, covers the meadows with dazzling yellow. Like most of the Crow-foots, it possesses the property of inflaming and blistering the skin; particularly the root, which is said to raise blisters with less pain and more safety than Spanish flies; hence these roots have been applied for that purpose, particularly to the joints in cases of the gout. According to Hoffman, beggars make use of them to blister their skins, with a view of exciting compassion. The juice of the herb is said to be more acrid than that of $R$. sceleratus, and if applied to the nostrils, it provokes sneezing. The roots, on being kept, lose their stimulating quality, and are even eatable when boiled. Hogs are fond of them, and frequently dig them up. The herb is too acrid to be eaten unmixed by cattle ; accordingly the flowering-stalks are left to perfect the seed in pastures : some of it, however, is consumed, and it is not improbable that this and other pungent plants, mixed with the grasses, may act as a powerful stimulus to some animals, as salt does to others. It abounds in dry pastures, and flowers in May. Besides the name of round-rooted or bulbous Crowfoot, it is called by the common people butter-flower, butter-cups, king-cups, gold-cups ; and it is the cuckoo-buds of yellow hue, of Shakspeare. The repens, hirsutus, and acris, however, are all confounded with this under one name by the vulgar.

R. repens is an obnoxious plant in every description of gardening and agriculture. From the great variety of soil and situation in which it is found, it assumes many varieties ; by a river's side, or in marshes, it will grow three or four feet high, with a stem nearly as large as the human thumb; in barren gravelly fields it is entirely procumbent, with a stem not larger than a small wheat-straw ; but in all states it retains the character of the creeping stem, and it does not lose it in cultivation. Its principal time of flowering is in June, but it may be found in blossom during most of the ensuing summer months in meadows and pastures, under hedges, in shady waste places, church-yards, and gardens. The qualities of this and bulbosus are similar : both blister the skin, and are very acrid in taste. Ijike the acris and bulbosus, it is sometimes found double, but more rarely.

R. acris is supposed to possess the blistering property in a considerable degree, whence Linnæus gave it the 
8061 lanuginósus $W$ 8062 par'vúlus $W$.

8063 hederáceus $W$.

8064 aquátilis $W$.

8065 tripartitus $D e c$.

8066 pan'tothrix Dec. $\beta$ fluviátilis W.

8067 arvénsis $W$.

8068 ox yspérmus $W$.

8069 hyperbóreus $L$

8070 Gouáni $W$.

8071 nemorósus Dec.

8072 muricátus $W$.

8073 parviflórus $W$.

1234. TROL'LIUS. $W$.

8074 americánus Muht. lâxus $\mathrm{Ph}$.

8075 europæ'us $W$

8076 asiáticus $W$.

$\beta$ intermédius

$\gamma$ hýbridus

1235. ISOPY'RUM $W$.

8077 fumarioídes $W$.

8078 thalictroídes $\boldsymbol{W}$.

1236. ER A N'THIS. Sal.

8079 hyemális Sal.

1237. HELLE'BORUS.

8080 níger $W$.

8081 viridis $W$

8082 purpuráscens $P$ er

8083 odórus $W$. en.

8084 dumetórum $W$. en.

8085 fo'tidus $W$.

8086 lividus $W$

1238. COP'TIS. Sal.

8087 trifólia $P h$.

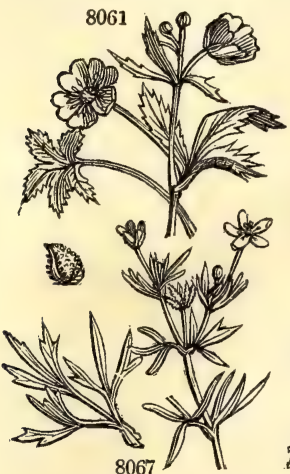

8067

corn woolly-leaved little-upright

Ivy-leaved

various-leaved

three-parted

rigid-leaved

long-lvd.-water

sharp-grained

northern

Gouan's

wood

prickly-seeded

mall-flowered

Globe-Flower

American

European

Asiatic

intermediate

hybrid

IsOPYRUM.

Fumitory-lvd. $\triangle \mathrm{pr}$
meadow-rue-lv. $₫ \mathrm{pr}$

Winter-Aconite. common $\&$ or

$\pm \Delta$ or

$\Delta$ or $\frac{\Delta}{\Delta}$ or \& $\triangle$ or

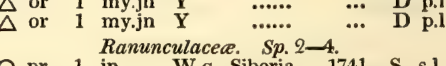

jn W.G Siberia 1741. S s.1 Am. rut. 74. t. 19 $\frac{3}{4}$ mr.ap W.G Italy 1759. D s.l Jac. aust. 2.t.105 Ranunculacea. Sp. 1-2.

$\frac{1}{4}$ ja.mr Y ... Italy 1596. O co Bot. mag. 3

Ranunculacea. Sp. 7-9.

Christmas Rosef $\Delta$ or 1 ja.mr Pk Austria 1596. D r.m Bot. mag. 8 green

purplish

sweet-scented

ushy

three-leaved

Coptis.

three-leaved

2 mr.ap G Britain woods. D co Eng. bot. 200

f $\triangle$ or 11 mr.ap Pu.G Hungary 1817. D s.1 Pl. ra.h.2.t. 101

G or $1 \frac{1}{2} \mathrm{mr}$.ap $\mathrm{G}$ Hungary 1817. D s.l

$\Delta$ or $1 \frac{1}{2}$ mr.ap G Hungary 1817. D.s.l

or $1 \frac{1}{2}$ f.ap G England cha.pa. D co Fing. bot. 613

$\$ \Delta$ or 1 ja.my Pu Corsica 1710. D p.l Bot. mag. 72

Ranunculacee. Sp. 1-2.

$\pm \Delta \mathrm{pr} \quad \frac{1}{8}$ ap.my $\mathrm{Br} \quad$ N. Amer. 1782. D p.l Bot. cab. 173 8063

8064

8066
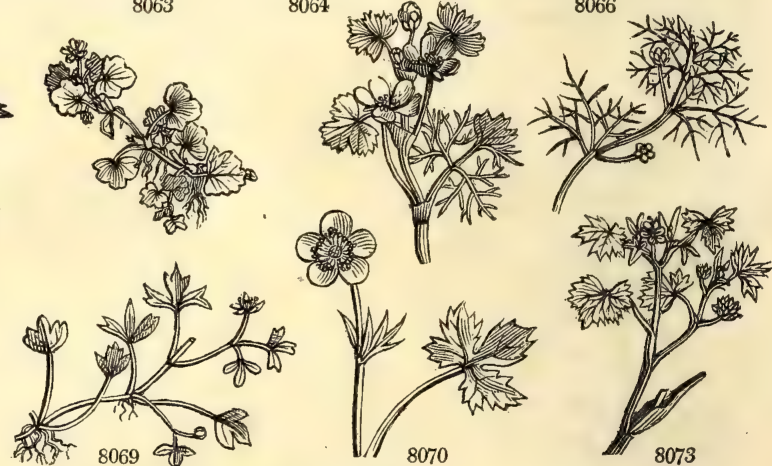

History, Use, Propagation, Culture,

name of acris. Curtis says, that even pulling up the plant, and carrying it to some little distance, has produced a considerable inflammation in the palm of the hand: that cattle, in general, will not eat it ; yet that sometimes, when they are turned hungry into a new field of grass, or have but a small spot to range in, they will feed on it, and hence their mouths have become sore and blistered. According to Linnæus, sheep and goats eat it ; but kine, horses, and swine refuse it. When made into hay it loses its acrid quality, but then it seems to be too stalky and hard to afford much nourishment : if it be of any use it must be to correct, by its warmth, the insipidity of the grasses. In many pastures the flowering stems are left standing in vast abundance to disseminate their seeds : before they do that, they might easily be cut down with the scythe, or pulled up by women and children after a shower, which would more effectually destroy the plants ; they should be gathered into heaps and burnt. It flowers in June and July, and is confounded vulgarly with the repens and bulbosus, under the name of butter-flower or butter-cups, under a notion that the yellow color of butter is owing to these plants. It is the richness and exuberance of the pasture that communicates this color, and not these flowers, which the cattle seldom or ever touch. It is frequent in gardens with a double flower, among other herbaceous perennials, under the name of yellow bachelor's buttons.

R. aquatilis produces flowers which are sornetimes very large, and make a handsome show in ponds and ditches: the curious variety in the floating and immersed leaves, occasioned by the depth and velocity of the stream, adds to the beauty of this common aquatic plant. Dr. Pulteney (Linn. Trans. vol. 5. p. 19.) contradicts the assertions of its deleterious qualities, and proves that it is not merely innoxious, but nutritive to cattle, and capable of being converted to useful purposes in agricultural economy. In the neighbourhood of Ringwood, on the borders of the Avon, some of the cottagers support their cows, and even horses, almost wholly by this plant. A man collects a quantity every morning, and brings it in a boat to the edge of the water, from which the cows eat it with great avidity, insomuch that they stint them, and allow only about twenty-five or thirty pounds to each cow daily. One man kept five cows and one horse so much on this plant with the little which the heath afforded, that they had not consumed more than half a ton of hay throughout the whole year, none being used except when the river is frozen over. Hogs also are fed with this plant, and improve so well on it, that it is not necessary to give them any other sustenance till they are put up to fatten. This property of water-crowfoot is the more remarkable, as all the species have been deemed acrimonious, and some of them are, without doubt, highly so. It is probable this species is rendered inert as a poison by growing in the water; although it must be confessed, that in other instances moisture heightens the deleterious property of vegetables, especially in the umbelliferous tribe. 
8061 Leaves trifid silky, Lobes broad toothed cut, Stem and petiole with reflexed hairs, Grains hooked 8062 A small variety of $R$. hirsutus, with a dwarf 1 -flowered stem

8063 Lvs. reniform 3-5-lobed with broad entire blunt lobes, Pet. scarcely longer than cal. Petals 5-12 [bristles 8064 The submersed lvs, capill. multifid : emersed 3-part. with cuneif. lobes tooth. at end, Grains hispid with stiff 8065 The submersed lvs. capillary multifid : emersed 3-part. with cuneif. lobes toothed at end, Grains smooth 8066 All the leaves capillary multifid, Pet. obovate larger than calyx, Grains smooth

8067 Leaves smooth : radical 3-parted ; cauline multifid with lin. lobes, Grains with long prickles on each side 8068 Lvs. vill. : radic. stalk. ov. 3-part. cut ; floral 3-part. Stem erect dichotom. with spread. hairs, Grains muric. 8069 Lvs. smooth stalk. bifid, Lobes oval obl. divaricat. : the mid. entire, Sheaths auricled at hase, Stem filiform 8070 Radical leaves round with 5 cut lobes : cauline sessile palmate, Stem pubescent, Cal. subvillous

8071 Rad. lvs. trifid beyond midd. with cuneif. trifid lobes, Stem with spread. hairs, Grains hooked with style 8072 Lvs. smooth stalk. roundish 3-lob. coarsely tooth. Pedunc. opp. lvs. Cal, spreading, Grains muricate cornute 8073 Lvs. vill, round 3-lob. coarsely tooth. Stems soft decumb. Cal. reflexed as long as pet. Grains tuberculate

8074 Sepals 5-10 spreading, Pet. 10-15 shorter than stamens

8075 Sepals 15 globose, Pet. 5-10 the length of stamens 8076 Sepals 10 spreading, Pet. 10 longer than stamens

8077 Caps. 10-20, Sepals acute, Root slender nearly simple perpendicular 8078 Caps. 1-3, Sepals blunt, Root creeping grumous

\section{Sepals 6-8-oblong}

8080 Radical leaves pedate smooth, Scape leafless with 1-2-fl. and bractes

8081 Radical leaves pedate smooth: cauline subsessile palmate, Sepals roundish ovate green

8082 Radical leaves palmate downy beneath, Segm. cuneate at base 3-5-lobed at end, Sepals roundish colored 8083 Radical leaves palmate downy beneath, Segm. obl. undivided serrate at end, Sepals ovate obl. acute green 8084 Radical leaves very smooth pedate: cauline subsessile palmate, Sepals roundish green 8085 Stem many-fl. leafy, Leaves pedate very smooth with obl. linear segments 8086 Stem many-fl. leafy, Leaves 3 cut smooth glaucous beneath, Segments ovate-lanceolate

8087 Leaves trifid with obovate toothed blunt 3-lobed segments, Scape 1-flowered

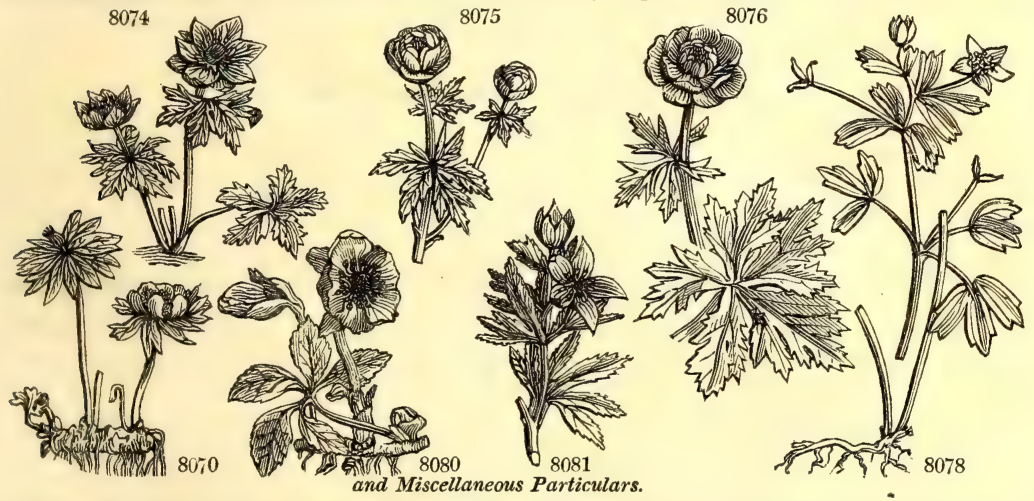

This remark of Dr. Pulteney's is the more important, as in the Swedish experiments the R. aquatilis is recorded as the only one rejected by all the species of domestic cattle; of the common sorts, there is no doubt but that R. Flammula, bulhosus, acris, sceleratus, and arvensis are acrimonious. Before the introduction of Cantharides they were used as vesicatories, and are said to act with less pain than flies, without any effect on the urinary passages; but their action is related to be uncertain, and they are accused of frequently leaving ill-conditioned ulcers.

The acrimony, even of the most virulent, is wholly dissipated in drying; so that in form of hay they appear to be harmless. It is also expelled in decoction; accordingly, the shepherds of Morlachia boil the $R$, sceleratus and eat it; and both $\mathrm{R}$. auricomus and repens are said to be wholly inoffensive, and are ranked by some authors among oleraceous plants.

The Ranunculi give out their acrimony wholly in distillation. The distilled water of $R$. sceleratus is intensely acrimonious; and when cold deposits crystals, which are scarcely soluble in any menstruum, and are of an inflammable nature.

1234. Trollius. A name given to this plant by Conrad Gesner. It is derived from trol or trolen, an old German word, signifying something round, in allusion to the form of the flowers. The species are showy flowers for the general border, and of the easiest possible culture.

1235. Isopyrum. A name given by the Greeks to a plant resembling Nigella, the seeds of which had the same taste. These are small herbaceous plants related to Nigella, but with the habit of Thalictrum.

1236. Eranthis. From ęa, the earth, and ay. the earth. A pretty little tuberous rooted plant, valuable for the early period at which it flowers.

1237. Helleborus. From $\varepsilon \lambda_{\varepsilon} \downarrow$, to cause death, and $\zeta_{\circ \rho} \propto$, food. The dangerous qualities of Hellebore are well known. Leathery leaved plants, most of which are evergreen, and flower in winter and early in spring. $\mathbf{H}$. niger and foetidus have long been in use in popular medicine, especially the latter, as a vermifuge and cathartic. They are both admitted in the London Materia Medica, but being violent poisons, require caution in their application. H. fœtidus, from its deep green and finely divided leaves, forms a most ornamental evergreen bush for the shrubbery.

1238. Coptis. From $x 0 \pi \tau \omega$, to cut, in reference to the numerous divisions of the leaves. Small plants, with the habit of Trientalis. 
1239. CAL'THA. $W$. 8088 rádicans $L . T$. 8089 palústris $W$. B flore pléno

1240. HYDROPEL'T 8090 purpúrea $H . K$

1241. HYDRAS'TIS. 8091 canadénsis $W$.

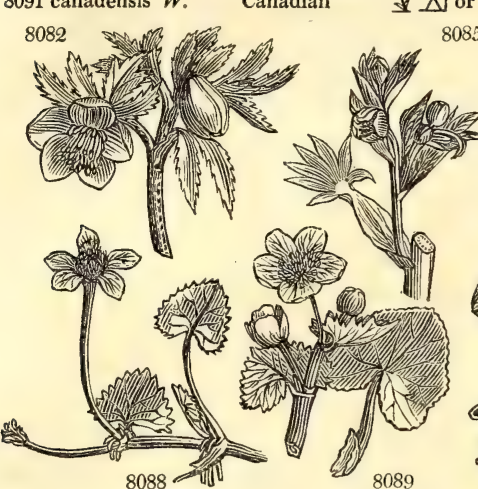

MarSh-MarYGold. creeping $\triangle$ or double-flower'd $\Delta$ or common or
Ranunculacea. Sp. 2-7.

L 2 ap.my Y Scotland sc. ma. D m.s Linn tr. 8. t. 17 1 ap.my Y Britain mar. D m.s Eng. bot. 506 1 ap.my Y $\quad$ Y..... $\quad$... $\quad$ D m.s

Hydropeltidea. $S p .1$

jl.au R N. Amer. 1798. D m.s Bot. mag. 1147

Ranunculacee. Sp. 1.

$\frac{1}{2}$ my.jn G Canada 1759. D m.l Mil. ic. 2. t. 285

History, Use, Propagation, Culture,

1239. Caltha. A syncope of $\% \propto \lambda \alpha .905$, a goblet, in allusion to the form of the corolla, which may be likened to a golden cup. The flower-buds of $\mathrm{C}$. palustris, gathered before they expand, are said to be a good substitute for capers. The juice of the petals boiled with alum dyes paper yellow. The whole plant is acrid, and not eaten by cows, unless in case of extreme hunger.

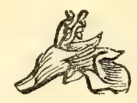

Class XIV. - Didynamia. 4 Stamens, of which two are shorter than the others.

THrs class, which, as its name applies, depends upon the presence of four stamens in the corolla, two of them being longer than the others, is, with the exception of Syngenesia and Gynandria, the most natural and best defined of all Linnæus's great groups, or, as he named them, classes. It is divided into two orders, called Gymnospermia and Angiospermia.

Gymnospermia contains all the genera with what are popularly but erroneously called by the Linnæan school of botany, naked seeds. It answers to the natural order of Labiatæ of Jussieu's method, with the exception of some genera which are excluded on account of having only two stamens, and are found in Diandria. Nearly all the class consists of herbaceous plants, those which are called shrubs being for the most part herbaceous plants, whose stems, from the mildness of the climate in which they grow, become perennial, The most re. markable plants are the rosemary, hyssop, balm, thyme, mint, and marjoram, for the kitchen or laboratory; and the various species of Teucrium, Lavandula, Phlomis, and Dracocephalum, for the flower garden.

In Angiospermia are included the genera with numerous, or rarely a few, seeds, enclosed in a simple pericarpium. These would be combined in a manner not altogether unnatural, if some of the genera were excluded. For instance, the beautiful Linnæa, the emblem of the most highly gifted naturalist the world has ever produced, belongs to Caprifoliacex, and stands alone in point of natural affinity; the same may be said of Melianthus. The greater part of Scrophularineæ, ail Melampyraceæ and Orobancheæ, and nearly the whole of Verbenaceæ and Gesnerieæ are found here. A considerable portion of Acanthaceæ also occupy a station in this order. Among these are many genera of much beauty, but few of interest as useful plants. Among the ornamental families every one will recognize the Bignonia, with its elegant orange or yellow trumpet flowers, and frequentiy twining stem; the Jacaranda, with its fern-like umbrageous foliage and magnificent diadem of blue; the Acanthus, consecrated to sculpture; the noble Clerodendrum, the pride of the Japanese; and the modest Eyebrights (Euphrasia) of our English meadows. In one part of the class we have the Vervain, surrounded by its mystic moonlight charms; in another, the Antirrhinum tribe, remarkable for the grotesque resemblance of its blossoms to the snouts of animals; and close behind it, imperial Pedicularis, proudly rearing her heraldic honours among the snows and deserts of the frozen north. These are succeeded by a long line of forms, principally European, and of various degrees of beauty. Among the useful plants, Digitalis, used in medicine, and Sesamum as oil seed, are all which can be particularized.

Order 1. GYMNOSPERMIA. Pericarpium divided into four lobes resembling naked seeds.

1242. Ajuga. Upper lip of cor. very minute, 2-toothed. Stamens longer than upper lip.
1243. Anisomeles. Calyx tubular, 10-striated, 5-cleft. Upper lip of corolla small, entire ; lower trifid, with the middle segment 2-lobed. Stamens exserted, ascending. Anthers of the short stamens 2-celled, with close cells; of the longer halved or dissimilar. Seeds smooth.

1244. Teucrium. Upper lip of cor. none, 2-parted beyond the base. Stamens exserted.

1245. Westringia. Cal. campanulate, 5-toothed. Corolla subrotate, with the upper segment bifid, Two of the anthers barren.

1246. Satureja. Cal. tubular, striated. Segments of corolla nearly equal. Stamens distant. 
8088 Stem creeping, Leaves triangular cordate serrate crenate

8089 Stem erect, Leaves cordate roundish crenate with round auricles

8090 An aquatic floating plant, covered all over with viscid slime, Roots fibrous

8091 The only species. A small plant with simple stems and a few 3-5-parted leaves

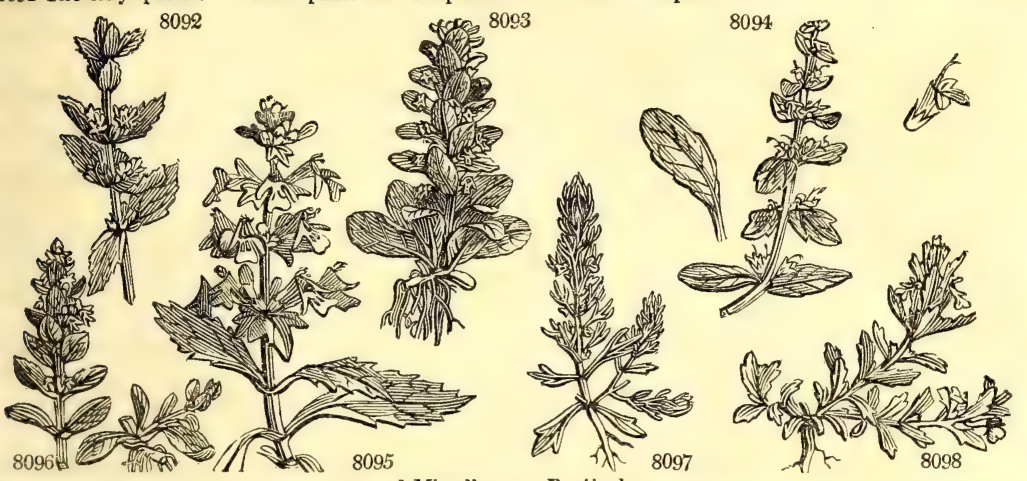

and Miscellaneous Particulars.

1240. Hydropeltis. From $v \delta \omega \rho$, water, and $\pi \varepsilon \lambda \tau \eta$, a buckler; that is to say, a water-piant, with a leaf like a round shield. A curious little floater, with the aspect of Hydrocharis.

1241. Hydrastis. From viwe, water, in reference to the humid places wherein it grows. The root of this plant is yellow, bitter, pungent, and tonical.

1247. Thymbra. Cal, subcylindrical, 2-lipped, with a villous furrowed line on each side. Segm. of cor. flat. Style half bifid.

1248. Hyssopus. Lower lip of cor. 3-parted, with the intermediate segm. subcrenate. Stamens straight, distant.

1249. Nepeta. Cal. dry, striated. Cor. with a longish tube; the middle segments of lower lip crenate. Orifice reflexed at edge. Stamens approximating.

1250. Elsholtzia. Cal. tubular, 5-toothed. Upper lip of corolla 4-toothed; lower longer, undivided, somewhat crenulate. Stamens distant.

1251. Lavandula. Cal. ovate, somewhat toothed, supported by a bractea. Corolla resupinate. Stamens within the tube.

1252. Sideritis. Cal. 5-fid. Cor. ringent or subregular : the upper lip bifid, lower 3-parted. Stamens within the tube. The short stigma wrapping over the other.

1253. Bystropogon. Cal. with 5 subulate teeth, closed at the orifice with hairs. Upper lip of cor. bifid; lower trifid. Stamens distant.

1254. Mentha. Cor. nearly equal, 4-fid, with the broadest segment emarginate. Stamens erect, distant.

1255. Perilla. Cal. with the upper segment very short. Stamens distant. Styles 2, united.

1256. Hyptis. Cal, 5-toothed, increasing in size. Corolla ringent: the upper lip bifid; the lower 3-parted, with the intermediate segment shaped like a little bag. Stamens inserted in the swollen part of the tube, and declinate.

1257. Horminum. Cal. 2-lipped, awned, smooth in the orifice; when past flower, having its upper teeth crossing each other. Upper lip of corolla 2-lobed; lower 3-lobed, with nearly equal segments. Leaves radical. Scape nearly naked.

1258. Glechoma. Cal. 5-fid. Each pair of anthers forming by their union the figure of a cross.

1259. Lamium. Upper lip of corolla entire, vaulted; lower 2-lobed; the orifice toothed at the edge on both sides.

1260. Galeopsis. Upper lip of corolla somewhat crenate, vaulted; lower 2-toothed above.

1261. Galeobdolon. Cal. 5-fid, unequal, awned. Upper lip of corolla vaulted, entire; lower trifid, with acute segments. Anthers smooth.

1262. Betonica. Calyx awned. Upper lip of cor. ascending, flattish. Tube cylindrical.

1263. Stachys. Upper lip of cor. vaulted; lower reflexed at edges, intermediate larger and emarginate. Stamens after flowering reflexed towards the sides.

1264. Zietenia. Cal. 5-parted, with subulate very long equal segments. Segments of lower lip of cor. reflexed; intermediate folded together and emarginate. Stamens after flowering reflexed towards the sides. Grain one.

1265. Ballota. Cal. hypocrateriform, 5-toothed, 10-lined. Upper lip of cor. crenate concave. Grains ovate 3-cornered.

1266. Marrubium. Cal. hypocrateriform, rigid, 10 lined. Upper lip of cor. bifid, linear, straight.

1267. Leonurus. Cal, 5-angled, 5-toothed. Upper lip of cor. villous, flat, entire; lower 3-parted, with the middle segment undivided. Anthers covered, with shining spots.

1268. Phlomis. Calyx 5-angled, 5-toothed. Helmet compressed, keeled, emarginate. Seeds bearded at end.

1269. Leucas. Cal. tubular, 10-striated, 8-10-toothed, with an oritice, either equal or oblique. Corolla ririgent.

Helmet concave, entire, bearded: lower lip 3-fid, with the middle segment largest. Anthers twin, beardless, with divaricating lobes. Stigma 2-lipped, with the upper segment very short.

1270. Leonotis. Differs from the last in having an elongated helmet, and the lower lip small and withering :

the middle segment scarcely larger than the others.

1271. Moluccella. Cal. campanulate, enlarged, wider than corolla, spiny.

1272. Clinopodium. Invol, of many bristles beneath the whorl. Corolla 2-lipped. Upper lip of corolla flat, obcordate, straight. 

1273. Pycnanthemum. Involucre of many bractes beneath the little heads. Cal, tubular, striated. Upper
lip of corolla nearly entire; lower trifid. Stamens nearly equal.

1274. Origanum. Cone 4-cornered, spiked, collecting the calyxes. Upper lip of corolla erect, flat; lower 3-parted, with nearly equal segments.

1275. Thymus. Orifice of bilabiate calyx closed with hairs. Upper limb of corolla flat, emarginate.

1276. Acynos. Cal. 2-lipped, furrowed, hispid, gibbous at base, villous at orifice. Cor. ringent, inflated at

orifice, with the upper lip erect, emarginate; the lower 3-parted, spreading : intermediate segm. concave. All the stamens fertile.

1277. Calamintha. Cal. after flowering closed by hairs. Orifice of cor. inflated. Upper lip emarginate;

lower 3-parted, with the intermediate segment entire, subemarginate or crenulate.

1278. Melissa. Cal. dry, flattish above, with the upper lip somewhat fastigiate. Upper lip of cor. somewhat vaulted, 2-fid : lower less, with middle lobe cordate

1279. Dracocephalum. Cor. inflated at orifice, with the upper lip concave.

1280. Melittis. Cal. smooth, campanulate, blunt, oblique at orifice. Upper lip of cor. flat; lower crenate. Anthers cruciate.

1281. Ocymum. Cal. with the upper lip orbicular; lower 4-fid. Corolla resupinate, with one lip 4-cleft, the other undivided. Exterior filaments having a process at their base.

1282. Plectranthus. Upper lip of cal. largest. Corolla resupinate, ringent, with the tube gibbous upwards, or spurred.

1283. Trichostema. Upper lip of cor. falcate, Stamens very long.

1284. Prostanthera. Calyx 2-lipped, in fruit closed. Tube striated, lips undivided, biunt. Corolla ringent, with a half bifid helmet: middle segment of lower lip large, 2-lobed. Anthers spurred beneath.

1285. Scutellaria. Cal. entire, after flowering closed with a lid. Tube of the corolla elongated.

1286. Prunella. Upper lip of calyx dilated. Filaments forked, upon one point bearing their anthers. Stigma bifid.

1287. Cleonia. Filaments forked, upon one point bearing their anthers. Stigma bifid.

1288. Prasium. Cal. campanulate, 2-lipped. Upper lip of cor. vaulted; lower trifid, with the middle segm. largest cordate. Grains berried.

1289. Phryma. Cal. 2-lipped, 5-toothed. Grain only one.

Order 2. ANGIOSPERMIA.

I. Ovary inferior, or nearly inferior.

1290. Gesneria. Cal. 5-fid. Corolla incurved and recurved. Capsule 2-celled.

1291. Gloxinia. Cal. 5-leaved. Cor. campanulate, with an oblique limb. Filaments with the rudiment of a fifth inserted upon the receptacle.

1292. Linną. Cal. double: of the fruit 2-leaved; of the flower 5-parted. Cor. campanulate. Berry dry, 3.celled.

II. Ovary superior, polypetalous.

1293. Melianthus. Cal, 5-leaved, with the lower leaflet gibbous. Petals 4, with the nectary below the lowest. Capsule 4-celled.

III. Ovary superior, monopetalous.

A. Filaments 5 , the upper only rudimentary.

1294. Bignonia. Cal. 5-fid, cup-shaped. Cor. campanulate, 5-fid, ventricose beneath. Pod 2-celled. Seeds with membranous wings.

1295. Jacaranda. Cal. 5-toothed. Cor. tubular at base, with a dilated throat, and a 5-lobed unequal limb. Fifth filament sterile, long, villous at end. Stigma with two lips. Capsule large, round, woody, with the edge dividing into two valves.

1296. Sesamum. Cal. 5-parted. Cor. campanulate 5-fid, with the lower lobe largest. Stigma lanceolate Capsule 2-celled, the cells divided in two by the inflexed edges of the valves.

1297. Pentstemon. Cal. 5-leaved. Cor. 2 lipped, ventricose. Fifth filament longer than the rest, and bearded at its upper end. Capsule compressed, 2-celled, 2-valved. Seeds numerous, subglobose.

1298. Chelone. Cal, 5-parted, with two bractes. Cor. ringent, ventricose. Fifth filament shorter than the others. Caps. 2-celled, 2-valved. Seeds numerous, with a membranous edge.

1299. Tourretia. Cal. 2-lipped. Corolla ringent : the upper lip galeate, large ; lower 2-toothed, very small. 1299. Tourretia. Cal, 2-lipped. Corolla ringent : the upper lip galeate, large; lower 2-toothed, very small.
Nectary annular, 4-lobed. Stigma truncate. Capsule 4-celled. Dissepiments with $\$$ wings. Seeds cordate.

1300. Martynia. Cal. 5-fid. Cor. ringent. Capsule woody, coated, with a hooked beak, 4-celled, 2-valved.

\section{B. Filaments 4. Capsule many-seeded, opening with elasticity. Seeds large, flat.}

* Calyx bifid.

1301. Acanthus. Cal. 4-parted : the two lateral inner segments short ; the two outer long, with 3 bractes, of which the middle one is toothed, spiny. Cor. labiate, having the orifice closed with hairs. Lower lip very large, 3-lobed. Anthers villous. Stigma bifid. Caps. ovate, with 1-2-seeded cells.

** Calyx 4-fid.

1302. Barleria. Cal, 4-parted. Stamens 2, much smaller than the others. Capsule with 4 angles, 2-celled, 2-valved, elastic, without claws. Seeds 2.

*** Calyx 5-fid.

1303. Phaylopsis. Calyx unequal, with a large dorsal segment. Cells of the ovary 2-seeded, with the scgments of the dissepiment spontaneously dividing in two. Otherwise like Blechum.

1304. Ruellia. Cal. 5-parted, generally with two bractes. Corolla campanulate, with a 5-lobed limb. Stamens in pairs. Capsule narrowed to each end. Teeth opening elastically. Seeds not many.

1305. Blechum. Cal. 5-parted, equal. Cor. funnel-shaped. Capsule about 2-celled, 2-valved : the segments of the crosswise dissepiment finally becoming loose. Seeds many, with hooks.

1306. Aphelandra. Cal. 5-parted, unequal. Cal. 2-lipped. Anthers 1-celled. Capsule 2-celled, 2-valved, with a dissepiment crosswise. Seeds with hooks.

1307. Crossandra. Cal. 5-parted, unequal. Cor. 1-lipped. Stamens included. Anthers 1-celled. Capsule 2-celled. 2-valved, with a dissepiment crosswise. Seeds with hooks.

\section{**** Calyx multifid.}

1308. Thunbergia. Cal. double : outer 2-leaved; inner about 12-toothed. Cor. campanulate. Capsule beaked, 2-celled.

\section{Filaments 4. Capsule, drupa, or berry few seeded. Seeds erect.} * Calyx bifid.

1309. Hebenstreitia. Cal. spathaceous, opening lengthwise beneath. Cor. tubular, unequal, with one upper i-fid lip. Stamens projecting from the lower cleft of the corolla. Caps, 2 -seeded. 
** Calyx 4-fid.

1310. Hosta. Cal. obsoletely 2-lipped, 4-toothed. Corolla ringent, with the middle segment of the lower lip large, emarginate. Drupe with a 4-celled, 4-seeded nut.

1311. Gmelina. Cal. about 4-toothed. Cor. 4-fid, campanulate. Two of the anthers 2-parted, 2-simple.

Drupe baccate. Putamen bony, 4-celled. Cells 1-seeded, the lower sterile.

1312. Lantana. Flowers capitate. Cal. obsoletely 4-toothed. Limb of corolla 4-fid, with an open orifice. Stigma hooked backwards. Drupes heaped, with a 2-celled smooth nut

1313. Aloysia. Calyx deeply 4-cleft. Corolla tubular, 4-lobed. Stigma emarginate. Stamens 4, perfect.

Seeds two.

1314. Lippia. Flowers capitate. Cal. 4-toothed, roundish, erect, compressed, membranous. Corolla 4-fid,

funnel-shaped. Drupe dry, 1-seeded, thin, covered by the calyx. Nuts two, 1-seeded.

1315. Melampyrum. Capsule 2-cclled. Seeds 2, gibbous, polished.

\section{*** Calyx 5-fid}

1316. Selago. Cal. 5-fid. Tube of corolla filiform. Limb nearly equal. Capsule simple or 2-lobed, each lobe with a seed.

1317. Vitex. Cal. 5-toothed. Limb of cor. 5-6-fid. Drupe 1-seeded, with a 4-celled nut.

1318. Cornutia. Cal. 5-toothed. Stamens longer than corolla. Style very long. Berry 1-seeded

1319. Zapania. Flowers capitate. Cal. 5-toothed. Cor. 6-fid. Stigma peltate, capitate, oblique. Fruit covered, bladdery, enclosing two seeds.

1320. Priva. Cal. inflated, 5-toothed. Cor, a little longer than the tube of calyx, contracted at orifice.

Drupe covered by the calyx. Nuts two, 2-celled, 2-seeded. Stamens 2-4.

1321. Spielmannia. Cal. 5-fid. Limb of cor. 5-fid, the orifice closed by hairs. Stigma hooked. Drupe with a 2-celled warted nut.

1328. Verbena. Cal. 5-fid. Cor. funnel-shaped, with an incurved tube, and an unequal 5-fid limb. Stamens

4, fertile. Fruit bladdery, covered, withering. Seeds 4.

1323. Avicennia. Cal. 5-parted. Cor. 2-lipped: the upper lip square. Caps. coriaceous, rhomboid, 1-seeded. Seed germinating within the capsule.

1324. Caldasia. Cal. tubular, 5-toothed. Cor. hyposrateriform, nearly equal. Filaments inserted in top of tube. Caps. 3-celled, 3-seeded, 3-valved. Seeds elliptical.

1325. Clerodendrum. Cal. 5-fid, campanulate. Corolla with a filiform tube and a 5-parted equal limb. Stamens very long, projecting from between the segments of corolla. Drupe 4-seeded, with a 1-celled nut.

1326. Volkameria. Cal. 5-fid. Cor. with 1-sided segments. Drupe 2-seeded. Nuts 2-celled, with 3-seeded cells.

1327. Holmskioldia. Cal, colored, very large, campanulate, spreading, with a nearly entire limb a little shorter than the ringent corolla.

1328. Petraea. Cal. 5-parted, very large, colored. Corolla rotate. Caps. 2-celled, 2-seeded in the bottom of the calyx. Seeds solitary.

1329. Citharexylum. Cal. 5-toothed, campanulate. Corolla funnel-shaped, rotate. Segments villous, above equal. Drupe 2-seeded. Nuts 2-celled.

1330. Duranta. Cal. 5-fid, superior. Drupe 4-seeded, covered by the calyx. Nut 4-2-celled, 2-seeded

1331. Pedalium. Cal. 5-parted. Cor. tubular, ringent, with a 5-cleft limb. Filaments hairy at base. Anthers in pairs, forming a cross. Nut corky, with spiny angles. Seeds 2 , with an arillus.

1332. Myoporum. Cal. 5-parted. Corolla campanulate, with a spreading nearly equal 5-parted limb. Drupe 1-2-seeded, with 2-celled nuts.

1333. Stenochilus. Cal. 5-parted. Cor. ringent: the upper lip erect, half 4-cleft : lower undivided, narrow, deflexed. Stamens didynamous, exserted. Ovary 4-celled, with 1-seeded cells. Stigma blunt, undivided. Drupe berried, 4-celled, Seeds solitary.

1334. Bontia. Cal. 5-parted. Cor. 2-lipped, with an oblong tube: the lower lip 3-parted, revolute. Drupe ovate, 1-seeded, oblique at end.

\section{Filaments 4. Capsule or berry many-seeded. Seeds small, attached to a central receptacle.}

\section{* Calyx bifid.}

1335. Orobanche. Cal, of 2-lobed lateral leaflets. Corolla ringent. Capsule 1-celled, 2-valved, many-seeded. Gland at the base of the ovary.

1336. Crescentia. Cal, 2-parted, equal. Corolla gibbous. Berry stalked, 1-celled, many-seeded. Seeds immersed in pulp.

1337. Castilleija. Cal. spathaceous ; the upper lip bifid, lower none. Cor. 2-lipped : the lower lip very short, trifid, with 2 glands between the segments. Caps. 2-celled.

\section{** Calyx trifid.}

1338. Halleria. Cal, 3 or 5-leaved. Cor. 4-fid, somewhat inflated. Berry 2-celled, many-seeded.

*** Calyx 4 -fid.

1339. Lathrea. Cal. 4-fid. A depressed gland at the base of the suture of the ovary. Capsule 1-celled.

1340. Rhinanthus. Cal. 4-fid, ventricose. Cor. ringent, with the upper lip generally compressed. Capsule 2-celled, blunt, compressed.

1341. Bartsia. Cal. 4-lobed, emarginate, colored. Cor. smaller than the calyx : the upper lip longest. Capsule 2-celled. Seeds angular.

1342. Euphrasia. Cal. cylindrical, 4-fid. Corolla 2-lipped : the upper lip bifid; the lower 3-lobed, with bifid

lobes. Lower anthers with spiny lobes.

\section{**** Calyx 5-fid.}

1343. Antirrhinum. Cal. 5-leaved. Cor. not spurred, gibbous at base : the upper lip bifid, reflexed; lower trifid, closed by the prominent palate. Caps. oblique at base, without valves, opening at the end by three pores.

1344. Linaria. Cal. 5-parted, with the two lower segments remote. Cor. spurred, ringent : the orifice closed by the prominent palate. Caps, ovate 2-valved, opening at the end into 3-5-segments.

1345. Anarrhinum. Cal. 5-leaved. Cor. prominent at base, honey bearing: lower lip flat, without a prominent palate. Caps 2-celled, many-valved.

1346. Nemesia. Cal. 5-parted. Cor. spurred, with a prominent palate. Caps. compressed, truncate, opening lengthwise in the middle, 2celled, 2-valved. Secds numerous, linear.

1347. Maurandya. Cal. 5-parted. Cor. campanulate, unequal. Filaments callous at base. Caps. 2, united, half 5-valved at end.

1348. Gerardia. Cal. 5-fid. Cor. 2-lipped, the lower lip 3-parted, with emarginate lobes : the middle 2-parted. Capsule 3-celled, splitting.

1349. Pedicularis. Cal. 5-fid. Cor. ringent. Capsule 2-celled, mucronate, oblique. Seeds truncated. Leaves multifid.

1350. Erinus. Cal. 5-leaved. Cor. with a 5-fid, equal limb. Lobes emarginate : the upper lip very short, reflexed. Caps: 2-celled.

1351. Mimulus. Cal, prismatical, 5-toothed. Cor. ringent, with the upper lip folded back at the sides.

Stigma thick. Capsule 2-celled, many-seeded 
1352. Hornemannia. Cal. tubular, 5-toothed, plaited. Cor. with the upper lip emarginate : lower 3-lobed. Seeds minute, scurfy.

1353. Mazus. Cal. large, campanulate, spreading. Cor. ringent, with a pimpled throat. Anthers connected. Stigma spatulate. Caps. 2-celled, many-seeded.

1354. Isoplexis. Like Digitalis, but corolla campanulate, with the upper segment as long as the lip, and incumbent upon it before expansion.

1355. Digitalis. Cal. 5-parted. Corolla campanulate, ventricose, 5-fid. Capsule ovate 2-celled.

1356. Scrophularia. Cal, 5-fid. Cor, subglobose, resupinate. Caps. 2-celled.

1357. Vandellia. Cal. 4-fid. Cor, ringent. Two outer filaments from the disk of the lip of cor. Anthers united in pairs. Caps. 1-celled, many-seeded.

1358. Sibthorpia. Cal. 5-parted. Cor. 5-parted, equal. Stamens in remote pairs. Caps. orbicular, compressed, 2-celled, with a transverse dissepiment.

1359. Limosella. Cal. 5-fid. Cor. 5-fid, equal. Stamens approximating in pairs. Caps. 1-celled, 2-valved, many-seeded.

1360. Browallia. Cal. 5-toothed. Cor. closed by the prominent orifice. Two of the anthers larger than the others. Caps. 1-celled.

1361. Stemodia. Cal. 5-parted. Cor. 2lipped. Stamens 4: each filament bifid, and bearing two anthers. Capsule 2-celled.

1362. Trevirana. Cal. 5-leaved. Cor. declinate funnel-shaped. Limb flat, 5-parted, nearly equal. Caps. half 2-celled.

1363. Columnea. Cal. 5-parted, spreading. Corolla ringent: the upper lip 3-parted, with the intermediate segment arched, above the base gibbous. Capsule berried, 1-2-celled.

1364. Russelia. Cal. 5-leaved. Cor. 2-lipped, with a hairy throat : upper lip broader, emarginate, lower trifid, with linear segments. Stigma globose Caps. 1-celled, 2-valved, many seeded.

1365. Dodartia. Cal. campanulate, angular, 5-toothed. Lower lip of cor. broad, 3-fid. Stigma bifid. Caps. globose, 2-celled, covered by the calyx.

\section{GYMNOSPERMIA.}

1242. A'JUGA. $W$.

8092 orientális $\boldsymbol{W}$. 8093 pyramidális $W$. 8094 alpina $W$. 8095 genevénsis $W$. 8096 réptans $W$.

$$
\beta \text { álba }
$$

y rúbra

8097 Chamæ'pitys $W$

8098 I'va $W$

8099 furcáta $\mathrm{Link}$.

1243. ANISOME'LES. $R . B r$. ANisomele

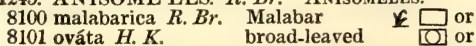

1244. TEU'CRIUM. $W$. Germander.

8102 campanulátum $W$.

8103 orientále $W$.

8104 Bótrys $W$.

8105 nissoliánum $W$.

8106 trifidum $W$.

8107 frúticans $W$

8108 latifólium $B$. $M$.

8109 Márum $W$

8110 multifórum $W$.

8111 régium $W$

small-flowered $\searrow \Delta$ or

great-flowered $\$ \vec{\Delta}$ or

cut-leaved

Spanish
trifid-leaved narrow-leav tr broad-leav, treeve $L$ or Cat-thyme or many-flowered $\downarrow \Delta$ or

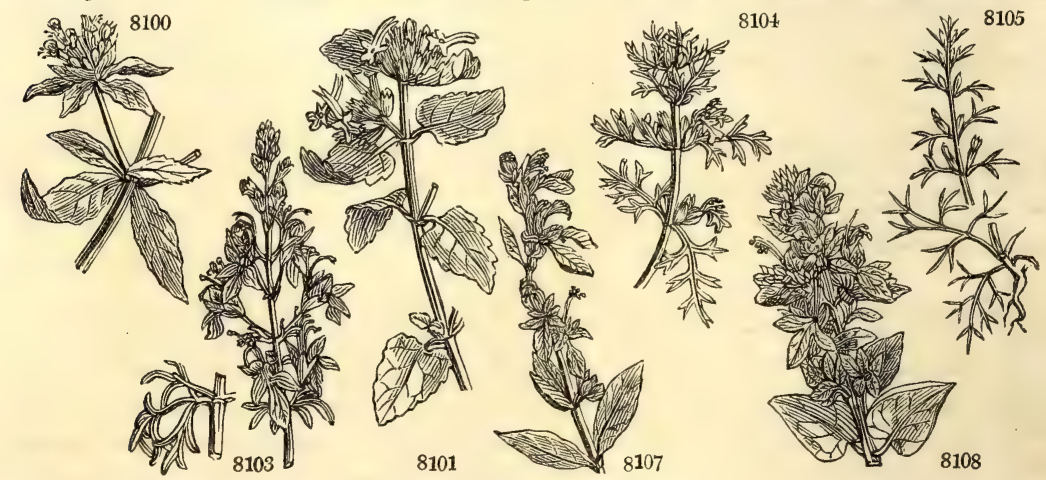

Labiatce. $S p .8-17$.

my.jn B Levant 1732. D s.p Dill.elt.t.53.f.61 \$ $\Delta$ or $1 \frac{1}{2}$ or $\frac{1}{4}$ my.jn Pu Britain sc.mo. D s.p Eng. bot. 1270 $\downarrow \Delta$ or $\frac{1}{2}$ my.jl $B$ England moun. D co Eng. bot. 477

\& $\triangle$ or $\frac{1}{2}$ my.jn $\mathbf{F}$ Switzerl. 1656. D co Bull. herb. t. 361

$\triangle$ or $\frac{x}{2}$ my.jn $B$ Britain moi.w. D s.p Eng. bot. 489

Britain moi.w. D s.p

Britain moi.w. D s.p

England san.fi. S s.i Eng. bot. 77

S. Europe 1759 . S s.1 Fl, graca, 525

Nepal 1844. D co

$\frac{1}{2}$ jl.au $\quad$ R

$\frac{1}{2} \mathrm{jl} . \mathrm{au}-\mathrm{B}$

Labiatce. $S p, 2-5$

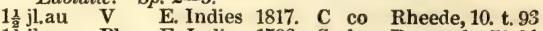
$1 \frac{1}{2}$ jl.au Pk E. Indies 1783. S 1.p Bur.zeyl.t.71.f.1 Labiate. Sp. 44-87.

1 jl.au W Levant 1728. D co

1 jl.au B Levant 1752. D co Bot. mag. 1279

$\frac{3}{4}$ jl.s R S. Europe 1633. S co Ger.ema. 525.f.2

$1^{4}$ jn.jl Pu Spain 1752. D co Mor.his.t.22.f.19

$1 \frac{1}{2}$ jn.au Pu C. G. H. 1791. C r.m

3 jn.s V Spain 1640. C r.m Dil.el.t.284.f.366

3 jn.s V Spain 1640. C r.m Bot. mag. 245

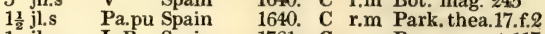

1 jl.s L.R Spain 1731. C co Bocc. mus.t.117

1699. C r.m Plu,alm, t.65, f.1

History, Use, Propagation, Culture,

1242. Ajuga. Said to be an alteration of abigo, to expel or drive away. The Latins attributed emmenagogue qualities to a plant called ajuga, which is believed to be our Teucrium chamapitys. Handsome flowering plants. A. reptans is vulgarly reputed vulnerary, cooling, and gently astringent. It is commonly called bugle, which appears to be a corruption of bugula, a contracted diminutive of buglossum, which the plant resembles in medical qualities.

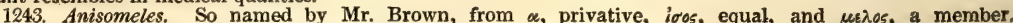
Tropical downy herbaceous plants. Their leaves are crenated, flowers grow in whorls supported by minute bractea; the calyxes are glandular, and the corolla of all the species purple.

1244. Teucrium. Teucer, the Trojan prince, is said by Pliny to have been the first to employ this plant 
1366. Linulernia. Cal. 5-parted. Cor. ringent: upper lip very short. Two lower stamens with a terminal tooth and lateral anther. Capsule 1-celled.

137. Herpestis. Cal, 5-parted, unequal : 2 inner sepals smaller, covered by the others. Cor. tubular, somewhat 2 -lipped. Stamens included. Lobes of anthers spreading. Stigma emarginate.

what 2- Capraria. Cal. 5-parted. Cor. campanulate, 5-fid, acute. Caps. 2-valved, 2-celled, many-seeded.

1369. Buchnera. Cal. absolutely 5-toothed. Limb of corolla 5-fid, equal, with cordate lobes. Capsule 2.celled.

1370. Manulea. Cal. 5-parted. Cor. funnel-shaped. Limb 5-parted, with subulate segments; the four upper large, connected. Caps. 2-celled, many-seeded.

1371. Angelonia. Cal. 5-parted, nearly equal. Cor. irregular, spreading, 2-lipped, with a short tube, and arched orifice : upper lip 2-parted ; lower much larger, 3-parted, with the middle segment slipper-shaped at base. 1372. Schizanthus. Cor. irregular: the upper lip 5-fid; lower 3-parted. Two filaments sterile. Capsule 2-celled.

1373. Besleria. Cal, 5-parted. Cor. tubular, gibbous on each side, with a 5-lobed unequal limb. Berry roundish, 1-celled, many-seeded. Seeds nidulant.

1374. Teedia. Cal. 5-parted. Cor. hypocrateriform, 5-fid, blunt. Style short, persistent. Berry 2-celled, many-seeded.

1375. Brunsfelsia. Cal. 5-toothed, small. Tube of cor. very long, with a flat 5.lobed limb. Capsule berried, 1-celled, many-seeded, with a very large receptacle.

1376. Celsia. Cal. 5-parted. Cor. rotate. Filaments bearded. Capsule 2-celled.

1377. Alonsoa. Cal. 5-parted. Cor. subrotate, resupinate, 5-fid, with the upper segment largest. Stamens declinate. Filaments smooth. Anthers approximating, similar. Capsule 2-celled.

1378. Anthocercis. Cal. 5-fid. Cor. campanulate, regular. Rudiment of a 5th filament. Stigma capitate. Caps. 2-celled, 2-valved, many-seeded The inflexed edges of valves inserted in the placenta.

***** Calyx multifid.

1379. Cymbaria. Cal, 10-toothed. Upper lip of cor. bifid, lower trifid. Capsule cordate, 2-celled.

\section{GYMNOSPERMIA.}

8092 Leaves ovate, Cor. pubescent resupinate

8093 Four-cornered pyramidal villous, Radical leaves very large

8094 Stem simple, Cauline leaves as long as radical leaves

8095 Radical leaves smaller than cauline leaves

8096 Stolones creeping

8097 Leaves trifid, Fl. axillary solitary shorter than leaf, Stem diffuse

8098 Leaves linear toothed forwards, Flowers axillary solitary

\$0y9 Leaves stalked subcordate ovate acuminate acutely crenate hairy, Thyrses axillary stalked

8100 Bractes filiform, Leaves lanceolate entire downwards

8101 Leaves ovate subcordate crenate, Whorls many-f. Bractes linear, Calyx hairy, Glands inconspicuous

8102 Leaves multifid, Flowers lateral solitary

3103 Leaves multifid linear, Raceme compound, Pedicels short

8104 Leaves multifid, Whorls halved

8105 Leaves trifid or 5-fid filiform, Flower stalked solitary opposite, Stem decumbent

8106 Leaves lanceolate trifid, Pedunc. axillary 3-flowered

8107 Leaves lanceolate entire white beneath, Flowers solitary

8108 Leaves entire rhomboid acute villous downy beneath, Flowers solitary

8109 Leaves quite entire ovate acute stalked downy beneath, Flowers racemose one-sided

8110 Leaves oval toothed forwards, floral entire stalked, Whorls racemose, Stem much branched

8111 Leaves ovate toothed forwards, floral entire sessile, Whorls racemose, Stems branched

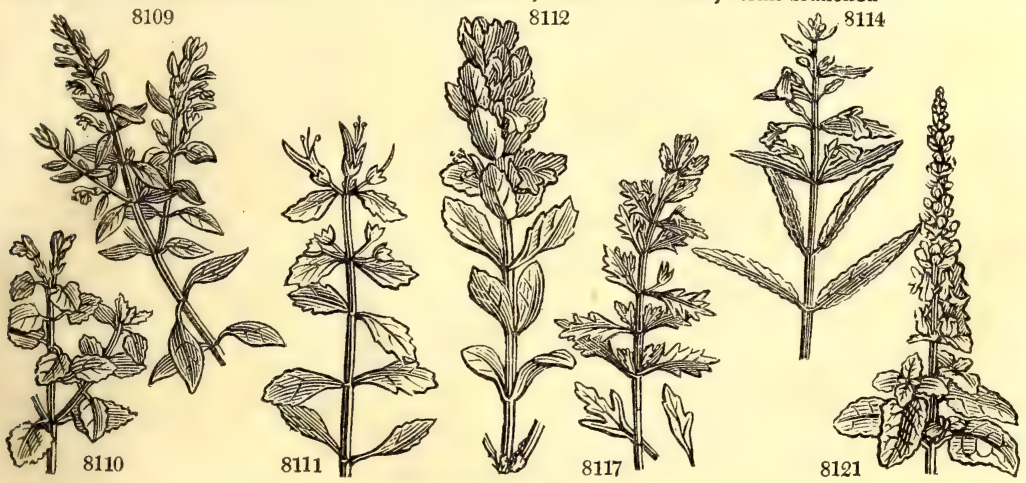

and Miscellaneous Particulars.

medicinally. Under-shrubs or herbs of little beauty ; but several of them aromatic. The leaves and younger branches of T. marum (Mar, Arabic, signifying bitter), when recent, on being rubbed between the fingers, emit a volatile aromatic smell, which readily excites sneezing, but to the taste they are bitterish, accompanied with a sensation of heat and acrimony. Cats are very fond of this plant, and where there are few will T. scerom.

T. scorodonia ( $\sigma x$ xogoioy, garlic, the smell of which this plant possesses) in Jersey is used as a substitute for hops, and the beer is said sooner to become clear than when hops are made use of. Withering found on trial
that it gave too much color to the liquor.

T. scordium, also from $\sigma$ xogodov, garlic, was once in high esteem for destroying worms and for fomentations. 
8112 Laxmanni $W$ 8113 sibiricum $W$ 8114 asiáticum $W$. 8115 lusitánicum Lam. 8116 Arduini $L$. 8117 cubénse $W$. 8118 canadénse $W$. 8119 virgínicum $\dot{W}$ 8120 inflátum $W$. 8121 hyrcánicum $W$. 8122 Abutiloídes $W$. 8123 Scorodónia $W$ 8124 betónicum $W$ 8125 resupinátum $W$ 8126 massiliénse $W$. 8127 Scórdium $W$. 8128 Chamæ'drys $W$. 8129 heterophýllum $W$ 8130 lúcidum $W$.

8131 flávum $W$.

8132 montánum $W$ 8133 supinum $W$. 8134 thymifólium $P . S$. 8135 pyrenáicum $W$. 8136 aúreum $W$. 8137 Pólium $W$

8138 flavéscens $P . S$.

Laxmann's Siberian Asiatic

Portuguese

Arduini's

Cuba

nettle-leaved

Virginian

thick-spiked

Betony-leaved

Wood Sage

hoary

resupinate

sweet-scented

water

wall

various-leaved

shining

yellow-flower.

dwarf mount.

procumbent

thyme-leaved

Pyrenean

golden Poly

Poly

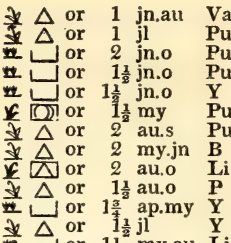

Siberia

1800. C co Pl. rar. hu.1.t.69 Siberia 1804. C co

1777. C r.m Jac. vind. 3.t. 41

Portugal 1822. C co

$\begin{array}{llll}\text { Candia } & 1823 . & \text { C } & \text { co } \\ \text { Cuba } & \text { 1733. } & \text { co } & \text { Jac. obs. 2. t. } 30\end{array}$

Cuba 1733 . C co

N. Amer. 1768. D co N. Amer. 1768. D co Schk. hand. 160 Jamaica 1778. D co

Persia 1763. D co Bot. mag. 2013

Madeira 1777. C r.m Jac.schæ.3.t. 358

Britain woods. C co Eng. bot. 1543

Madeira 1775, C r.m Bot, mag. 1114

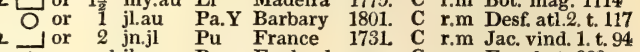

* or $\frac{1}{4}$ jl.au Pu England mar. C r.m Eng. bot. 828

\ $\triangle$ or $\frac{3}{4}$ my.au Pu England old w. C co Eng. bot. 680

Madeira 1759. C r.m

S. Europe 1730. C r.m Magn. hort. 52

S. Europe 1640. C r.m Park.the.109.f.1 S. Europe 1710. C co

Austria 1752. C co Jac. aust.5. t.417 Spain 1816. C co

w Pyrenees 1731. D co

S. Europe 1731. D co Cav, ic. 2.t. 117

S. Europe 1562, C r.m Barr, rar, t. 1074

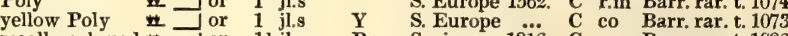
8139 gnaphalódes P.S. woolly-calyxed $-1 \frac{1}{4}$ or 8140 Pseudohyssópus $W$. Hyssop-leaved $\frac{2}{2}-$ or $1 \frac{1}{2} \mathrm{jn}$ 8141 capitátum $W$. round-headed 8142 pycnophýllum $\boldsymbol{P}$. S . close-leaved 8143 púmilum $W$. small

8144 spinósum $W$. thorny

8145 subspinósum $W$. en. Minorca

tor $\frac{3}{4} \mathrm{jl}$.au

$\pm \triangle$ or $\frac{1}{2}$ jl.au Pu

Italy 1804. C co Col, ecphr.1.t.67

Spain 1731. C co Cav, ic. 2.t.119

Spain 1816. C co Barr, rar 1096

Spain 1816. C co Barr.rar, t. 1099

Spain 1640. S co Cav. ic. 1.t.31

1245. WESTRIN'GIA. Sm. Westringia

8146 rosmarinifórmis $S m$. Rosemary-lvd. 8147 Dampiéri $\boldsymbol{B}$. $\boldsymbol{P}$. Dampier's

Minorca 1816. C co

Labiatce. Sp. 2-8.

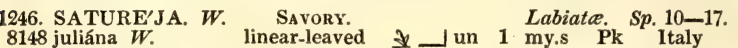

8149 Teneriffæ $W .6 n$.

8150 Thýmbra $W$.

8151 græ'ca $W$.

8152 montána $W$

8153 tenuifólia Tenore.

8154 rupéstris $W$

8155 horténsis $W$

8156 capitáta $W$.

Teneriffe

$\frac{y}{y}$ un 1

whorl-flowered $\frac{1}{\mathrm{n}} \mathrm{un} \mathbf{1}$ or $\mathbf{P u}$ Teneriffe

Grecian $\ \_$or ${ }^{\frac{3}{4} j n . j l}$ Pu.w Greece 1759. D co Alp. exot. t. 264 winter

fine-leaved

rock

summer \$t $\Delta$ or 1 jn.jl

cul $1 \frac{1}{2} \mathrm{jn} . \mathrm{au}$

Pennyroyal_tr.

8157 viminea $W$.

8158 spicáta $W$.

8159 verticilláta $W$

1248. HYSSO'PUS. $W$.

8160 officinális $W$.

8161 orientális W.en.

8162 Lophánthus $W$.

8163 nepetoides $W$.

pike-flowered

cul 1 jn.o

$\mathrm{Pu} S$. Europe 1560. D co

Pu S. Europe 1822. D co

Pu Carniola 1798. S co Jac, ic. 3. t. 494

Pk 1652. C r.m Lam.il.it.504.f. 2

Levant 1596. C r.m Barr. ic. t. 897

whorl

Hrssop.

Labiatce. $S p .5-7$

common or 2 jn.s $\quad$ B $\quad$ S. Europe 1548. C co Jac. aust.3. t.254 oriental or 2 jn.s $\quad$ B $\quad$ Caucasus $\ldots$ C col

\$ $\Delta$ or 2 au.s $Y$ Siberia 1752. C p.l Jac.vind.2.t.182

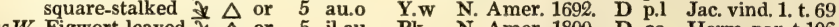
8164 scrophularifólius $W$. Figwort-leaved $\$ \vec{y}$ or 5 jl.au $\quad$ Pk $\quad$ N. Amer. 1800. D co Herm. par.t.106

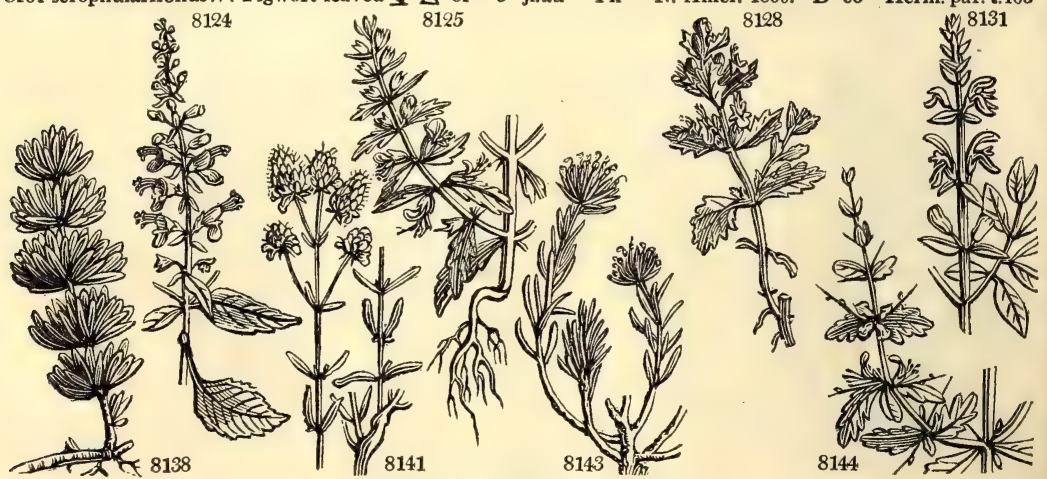

History, Use, Propagation, Culture,

Sheep and goats are said to eat this plant: horses, cows, and swine to refuse it. If cows, compelled by hunger, eat it, their milk gets a garlic flavor.

T. chamædrys, is said to have cured Charles V. of the gout, by a vinous decoction taken for sixty successive days. It is commonly called Germander, which seems to be a corruption of the word Chamædrys, for the French call it germandrée, an evident alteration of gamandré, under which name it first appeared in the very rare Herbier de Mayence, printed in 1485.

1245. Westringia. Named by Sir J. E. Smith, in honor of Dr. John Peter Westring, physician to the king of Sweden, and author of several learned papers on the Lichen tribe. A genus of New Holland plants, chiefly from the colder parts of that country, and having the appearance of our Rosemary. 
8112 Leaves ovate-oblong villous nearly entire, Flowers axillary solitary sessile

8113 Leaves ovate serrate smooth, Pedunc. sol. 3-flowered : intermediate sessile, Bractes linear lanceclite

8114 Leaves lanceolate repand-serrate rectangular at base, Fl. racemose one-sided, Calyx 2-lipped

8115 Leaves lanceolate crenate rugose, Flower racemose onc-sided, Calyx 2-lipped

8116 Leaves ovate serrate, Raceme spiked round sessile terminal

8117 Leaves cuncate serrate cut smooth narrowed into the stalk, Flower solitary stalked

8118 Leaves ovate-lanceolate serrate hoary beneath, Stem erect round terminal, Whorls 6-leaved

8119 Leaves ovate unequally serrate, Racemes terminal, Bractes shorter than flower-stalk

8120 Leaves oblong acuminate unequally serrate pubescent, Spikes sessile terminal, Cal. inflated villous

8121 Leaves cordate oblong obtuse, Stem brachiate dichotomous, Spikes very long terminal sessile spiral

8122 Leaves cordate toothed acuminate, Racemes lateral nodding

8123 Leaves cordate subpubescent toothed stalked, Racemes axillary one-sided, Stem erect herbaceous

8124 Leaves lanceolate crenate tomentose hoary beneath, Racemes terminal, Flower stem brachiate

8125 Leaves cuneiform lanc. serrated villous, Racemes axillary and terminal, Cor. resupinate

8126 Leaves ovate rugose cut crenate hoary, Stems erect, Racemes straight one-sided

8127 Leaves oblong sessile toothed nearly naked, Fl. axillary stalked in pairs, Stem diffuse pubescent

8128 Leaves cuneiform ovate cut crenate stalked, Fl. ternary, Stems procumbent somewhat hairy

8129 Leaves elliptical crenate, Fl. lateral solitary, Lip of cor. woolly outside, Leavee various in form

8130 Leaves ovate cut serrate smooth, Whorls halved, Stems erect smooth

8131 Leaves ovate crenate : floral entire, Whorls halved racemose, Stem bearded in two rows

8132 Corymbs terminal, Cal. with acute unarmed teeth, Leaves lanceolate entire downy beneath

8133 Corymbs terminal, Cal, with acute mucronate teeth, Lvs. linear entire revolute at edge downy beneath

8134 Heads terminal few-flowered, Leaves stalked ovate blunt downy beneath, Stein procumbent

8135 Corymbs terminal, Leaves cuneiform orbicular crenate hairy

8136 Corymbs terminal hairy, Leaves ovate serrate and stems densely woolly at the ends yellow and shining 8137 Heads roundish stalked, Leaves lanceolate blunt crenate revolute at edge downy, Stem decumbent 8138 Heads roundish, and leaves, which are linear lanceolate crenate forwards, tomentose yellow at end $8139 \mathrm{Fl}$. solitary clustered, Leaves linear revolute crenate, Calyxes woolly

8140 Heads roundish lax, Leaves lanceolate crenate forwards downy hoary, Stem woolly corymbose

8141 Heads stalked, Leaves lanceolate crenate tomentose, Stem erect

8142 Heads roundish, Leaves linear revolute crenate forwards close and stem densely woolly

8143 Heads terminal sessile, Leaves linear revol. at edge packed in four close rows, Stem procumbent downy $814+$ Spiny, Upper lip of calyx ovate, Corolla resupinate, Peduncles twin

8145 Leaves entire ovate acute stalked revolute at edge pubescent downy beneath, Fl, racemose

8145 I.eaves beneath and calyxes silvery, Teeth half as long again as tube

8147 Leaves beneath and calyxes ash-colored opaque, Teeth half as short as tube

8148 Whorls fastigiate, Leaves linear lanceolate rough

8149 Lvs. acute revolute at edge pubescent, Pedunc. axillary many-f. Bractes much shorter than calyx 8150 Whorls roundish hispid, Leaves obovate oblong acuminate veinless dotted hispid

8151 Pedunc. axillary 3-6-flowered, Bractes shorter than calyx, Leaves ovate hispid veiny beneath

8152 Pedunc. axillary cymose one-sided, Sepals acuminate mucronate, Leaves lin. lanc. entire mucronate

8153 Stem erect branched with spreading hairs, Upper leaves hairy acute, Ped. 1-flowered axillary

8154 Ped. axill. cymose one-sided, Sepals blunt unarmed, Lvs. roundish ovate atten. at base toothed bluntish 8155 Pedunc. axillary cymose, Leaves lanceolate entire, Stem brachiate

8156 Flowers spiked, Leaves keeled dotted ciliated

8157 Fl. axillary 3 subsessile, Bractes linear, Leaves oblong entire attenuate at base smooth hispid beneath

8158 Flowers spiked, Bractes heaped linear ciliate

8159 Flowers whorled, Leaves linear lanceolate entire

8160 Fl. whorled racemose 1-sided, Middle lobe of cor. 2-lobed entire, Leaves lanceolate, Teeth of calyx erect 8161 F1. whorled racemose 1-sided, Midd. lobe of cor. 2-lobed entire, Lvs. lin. lanc. Teeth of cal. spreading uneq. 8162 Pedunc. axillary cymose, Cor. resupinate, Middle lobe crenate, Leaves oblong cordate toothed [tooth. 8163 Spikes whorled cylind. Midd. lobe of cor. crenate, Style shorter than cor. Lvs, subcord. ov. acum, sharply 8164 Spikes whorl. cylind. Midd, lobe of cor. crenate, Style longer than cor. Lvs, cord.-ov, acum. bluntly tooth.

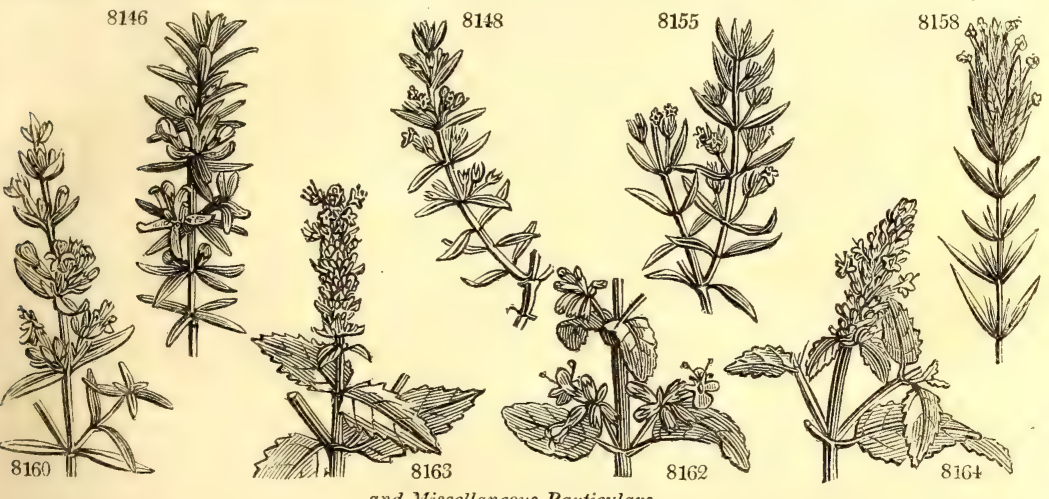

and Miscellancous Particulars.

1246. Satureja. 'The Arabs call all labiate plants by the collective name of ss'atar, according to Bochart. Forskahl says, they call the wild Thyme ss'atar. S. montana and hortensis have been cultivated as culinary aromatics froin time immemorial, and much more formerly than now, when almost all European species are superseded by those of the East Indies.

1247. Thymbra. A name of uncertain origin. The ancients gave it to a plant analogous to Thyme. Possibly it may have been so called after the name of a place. Thymbraea, a town in Lydia, was the spot where the famous battle was fought between Cyrus and Crosus, in which the fate of the latter was decided.

1248. Hyssopus. Latinized from the Hebrew name $c$ ob. The Arabic name azzof, is evidently the same. $\mathrm{K} \mathrm{k}$ 
1249. NE'PETA. $\boldsymbol{W}$.

8165 catária $W$.

8166 angustifólia $W$

8167 crispa $W$.

8168 pannónica $W$.

8169 cærúlea $W$.

8170 violácea $W$.

8171 longiflóra Vent.

8172 Mussini Biel.

8173 incána $W$.

8174 ucránica $W$.

8175 Nepetélla $\boldsymbol{W}$.

8176 gravéolens

8177 núda $W$.

8179 coloráta $W$. en.

8180 melissæfólia $W$. en.

8181 itálica $W$.

8182 marrubioídes $W$.en.

8183 reticuláta

8184 lamiifólia $W$. en.

8185 teucriifólia $W$. en.

8186 tuberósa $W$.

8187 lanáta $W$.

8188 multífida $W$.

8189 botryoídes $W$

1250. ELSHOLT'ZIA. I

8191 cristáta $W$.

1251. LAVAN'DULA. $W$. Lavender. 8192 spíca $W$.

$\beta$ alba

r latifolia W. en.

8193 Stæ'chas $W$.

8194 víridis $W$

8195 dentáta $W$.

8196 pinnáta $W$.

8197 multífida $W$.

8198 abrotanoídes $W$.

8199 carnósa $W$.

1252. SIDER'ITIS. $W$.

8200 canariénsis $W$.

8201 cándicans $W$.

8202 montána $W$.

8203 élegans $W$. en.

8204 romána $W$.

8205 syríaca $W$.

8206 taúrica $W$. en.

8207 perfoliáta $W$.

8208 incána $W$

8209 ilicifólia $W$. en.

8210 spinósa $\boldsymbol{W}$.en.

8211 hyssopifólia $W$. en.

8212 scordioides $W$.

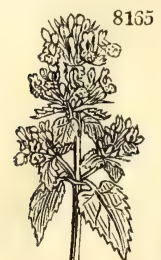

common

white-fiowered

broad-leaved

French

Madeira

tooth-leaved

pinnated

cut-leaved

Southernw.-lv.

thick-leaved

Ironwort.

Canary

Mullein-leaved

mountain

dark-flowered

Roman

Syrian

Taurian

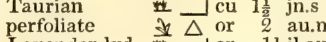

Lavender-lvd. $\square$ or $1 \frac{1}{2}$ jl.au

Holly-leaved $\downarrow \Delta \Delta$ or $1 \frac{1}{2}$ jn.s Hyiny scollop-leaved $\underset{x}{ } \Delta$ or 1 au.n

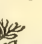

Lab̃iatce, Sp. 25-40.

\} \Delta \text { cu } 2 \text { jl.s } \quad \text { W } \quad \text { Britain ro.sid. D co Eng. bot. } 1 3 7

\& $\triangle 1798$. D co

cu 4 au. $R$ Hungary 1683. D co

4 cu 11 my.jn B

Spain 1723. D co

Persia 18,2. D co

$\begin{array}{lll}\text { Persia } & 18(12 . & \text { D co } \\ \text { Siberia } & 1804 . & \text { D co }\end{array}$

$\begin{array}{lll}\text { Siberia } & 1804 . & \text { D co } \\ \text { Levant } & 1723 \text {. D p.I }\end{array}$

Ukraine 1789. D co

S. Europe 1758. D co

S. Europe 1804. D co

S. Europe 1710. D co

Algiers 1817. D co

Caucasus 1806. D co

W Candia 1752. D p.1

Y.w Italy 1640. D p.1

$\mathrm{Pu}$ Morocco 1801... D co

Pu Armenia 1806. D co

$\mathrm{Pu}$ Pu Armenia 1805. D co

$V$ Spain 1683. D co

S. Europe 1774. D co

Siberia 1796. D co

Siberia 1779. S co

Siberia 1779. S co

ac. aust.2.t.129

Boc. mus, t. 36

Vent. cels. 56

All.ped.2.t. f.1

Jac. aus, 1 , t. 24

Desf. atl. t. 123

Jac.vind.2. t.112

Desf. atl. 2. t.124

Barr. ic. t. 602

Jac. obs. 3. t. 75

Gmel. sib.3. t. 55

Cav. ic. 1. t. 49

$$
\text { Labiate. Sp. } 2-5 \text {. }
$$

Lam.ill, t.502.f.2 Labiate. Sp. 8-12.

S. Europe 1568. C s.l Sch.han.2.t.157

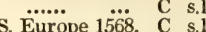

S. Europe 1562. C s.l Barrel, ic. t. 301

Madeira 1777. C p.l Hof.et L.lu. 1.t.4

Spain 1597. C p.l Bot. mag. 401

Madeira 1777. C p.l Bot. mag. 400

Canaries 1597. S p.l Lob. ic. 432

Canaries 1699. C co Comm. rar. t. 27

E. Indies 1788, C co Lin.am.ac.10.t.3

\section{Labiatce. Sp. 17-43.}

L or 3 my.au Y Canaries 1697. C r.m Jac. vind. 3. t. 30 cu 3 ap.jl Y.Br Madeira 1714, C r.m Com.hort.2. t.99 $O$ or 1 $1 \frac{2}{2}$ jl.au Y.Br Austria 1752. S co Jac. aust.5.t.434 $\mathrm{O}$ or $1 \frac{1}{2} \mathrm{jl} \quad \mathrm{Y}$...... 1787. S co Mur.co.got.1.t.4

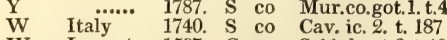
W. $Y$ Levant 1597. C r.m Sabb.hort.3.t.40 Pa.Y Tauria 1822. C co

Y Levant 1731. C co

Y Spain 1752. C co Cav. ic. 2. t. 186

Y Levant ...

Spain $\quad \ldots$ C co

L.Y Pyrenees 1597. C co Sch.han.2.t.158 France 1597. C co Barr. ic. t. 343

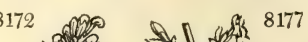

177
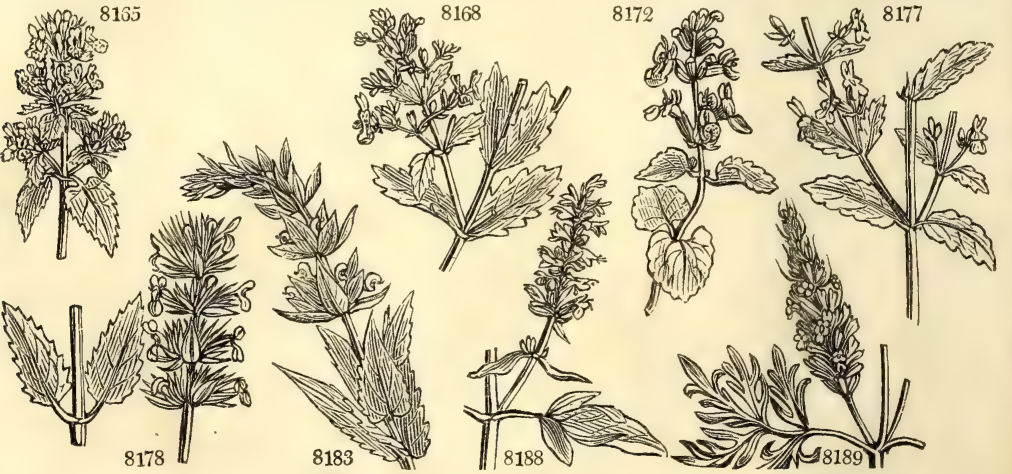

8183

History, Use, Propagation, Culture,

Vide John de Souza, p. 106. The plant to which this name was given is involved in uncertainty. It appears to have been one of the smallest plants, whence some have inferred that " the Hyssop which groweth out of the wall" is a kind of moss. H. officinalis, a neat little evergeen tuft, and most ornamental and fragrant when in flower, was once in considerable repute as a popular medicine, but is now almost out of use.

1249. Nepeta. Said by Linnæus to be derived from Nepet, a town of Tuscany, mentioned by Pliny. N. cataria is called catmint, because cats are very fond of it, especially when it is withered, when they will roll chew it with great pleasure. Ray observes, that plants which he themselves on transplanted from the fields into his garden were always destroyed by the cats, unless he protected them with from seed. Miller has confirmed this by his own experience; having frequently set a plant from another part of the garden within two feet of others which came up from seeds, when the former was torm in pieces and destroyed by the cats, whilst the latter remained unhurt. The true reason of this diin pieces an when the peculiar scent of the plant is excited by being handled or bruised in gathering or transplanting. Hence the Eaglish rulgar saying, 
8165 Flowers spiked, Whorls somewhat stalked, Leaves stalked cordate tooth-serrated 8166 Corymbs stalked spiked, Leaves lanceolate rugose tomentose bluntly serrated 81 . 5 Spike whorled interrupted, Leaves cordate toothed rugose waved crisp stalked hoary 8168 Cymes stalked many-flowered, Leaves lanceolate oblong cordate naked, Lateral lobes of cor. reflexed 8169 Cymes stalked many-fl. hairy, Lvs. oblong cordate villous subsessile, Lateral lobes of cor. reflexed 8170 Cymes stalked many-fl. pilose, Leaves cordate stalked naked subsessile, Lateral lobes of cor. spreading 8171 Cymes remote stalked 1-sided few-fl. Lvs. cordate blunt crenate glandular beneath : floral all sessile

8172 Cymes stalk. 1-sid : lower rem. Lvs. cord. blunt cren. rug. downy without glands : floral generally stalked 8173 Cymes stalked many-flowered, Leaves stalked oblong subcordate crenate downy 8174 Flowers panicled, Leaves lanceolate serrate sessile naked

8175 Cymes stalked, Leaves cordate oblong lanceolate deeply serrate downy

8176 Leaves cordate oblong serrated, Bractes linear, Whorls 8-12-flowered incurved nearly 1 -sided

$\$ 177$ Racemes whorled naked, Leaves cordate oblong sessile naked

8178 Flowers sessile in whorled spikes, Bractes lan. longer than calyx pubesc. Leaves stalked villous beneath 8179 Cymes stalked racemose, Leaves obl. cordate serrate beneath hoary and rugose with veins

8180 Leaves cordate oblong crenate stalked, Stem smooth angular, Flowers whorled capitate clustered $8181 \mathrm{Fl}$. sessile in whorled spikes, Bractes lin. the length of calyx, Leaves stalked

8182 Fl. sessile in whorled spikes, Whorls distant capitate, Bractes lanc. length of cal. Leaves stalked entire 8183 I.eaves sessile lanceolate in approximated whorls, Bractes ovate with netted veins [at end 8184 Cymes stalked many-fl. Tube of cor. filiform curved, Leaves ovate cordate blunt stalked serr. pubescent 8185 Cymes stalked few-fl. racemose, Leaves ovate cordate blunt stalked toothed pubescent

8186 Spikes term. Bractes obl. acum. nerved with colored lines, Lvs. cord. pubesc. Lateral lobes of cor. reflexed 8187 Spikes term, Bractes ov. nerved rugose subscariose, Lvs. obl. cord. villous, Lateral lobes of cor. spreading 8188 Flowers spiked, Leaves pinnatifid entire

8189 Flowers spiked, Lateral lobes of cor. spreading, Leaves pinnatifid with lin. nearly equal segments

8190 Stems prostrate, Leaves ovate subserrate, Spikes terminal, Calyx scarious at end 8191 Spikes solitary unilateral erect, Bractes veiny

8192 Leaves sessile lin. lanc, revolute at edge, Spike interrupted naked

8193 Leaves sessile lin. downy revolute at edge, Spike contracted comose subsessile, Bractes 3-Iobed 8194 Leaves sessile lin. rugose villous revolute at edge, Spike comose, Bractes undivided 8195 Leaves sessile linear pectinate-pinnate, Spike contracted comose

8196 Lvs. stalked pinnate, Leaflets cuneate, Spike imbricated

8197 Lvs. stalked hoary, Leaf. pinnatifid crosswise, Spike simple 4-corn. spiral, Bractes ovate nerved villous 8198 Lvs, stalked pinnate nearly smooth, Leafl. pinnatifid crosswise, Spike branched interrupted 4-cornered 8199 Lvs. stalked ovate cordate serrate fleshy, Spike 4-cornered, Calyxes recurved

8200 Shrubby villous, Lvs. cordate oblong acute stalked, Spikes whorled before flowering nodding 8201 Shrubby downy, Lvs. ovate lanc. cordate narrowed at end white beneath, Whorls about 8-H. remote 8202 Herbaceous without bractes, Cal. larger than cor. spiny, Upper lip trifid 8203 Herbaceous without bractes villous, Stem diffuse, Segm. of calyx nearly equal spiny 8204. Herbaceous decumbent without bractes, Leaves spatulate toothed at end, Cal. spiny, Upper lip ovate 8205 Half-shrubby woolly, Leaves lanc. nearly entire, Fl. in whorled spikes, Bractes cordate acute downy 8206 Half-shrubby downy, Lvs, lanc. cren, Fl. in whorled spikes, Bractes cord. acum, reticulated with nerves 8207 Herbac. pilose-hispid, Upper lvs. lanc. amplexicaul. toothletted, Bractes cord. acum netted hairy at edge 8208 Half-shrubby downy, Lvs. linear lanceolate nearly entire, Flowers and bractes toothed

8209 Hirsute, Lvs. lanc. spiny toothed, Bractes round. cord. shorter than cal. with spiny teeth, Whorls distant 8210 Hirsute, Lvs. lanc. spiny toothed, Bractes cord. acum. longer than cal. with spiny teeth, Whorls close 8211 Lvs. lanc. smooth entire, Bractes cord. toothed-spiny, Calyxes equal

8212 Leaves lanc. toothed smooth above, downy beneath, Bractes ovate toothed spiny, Calyxes equal

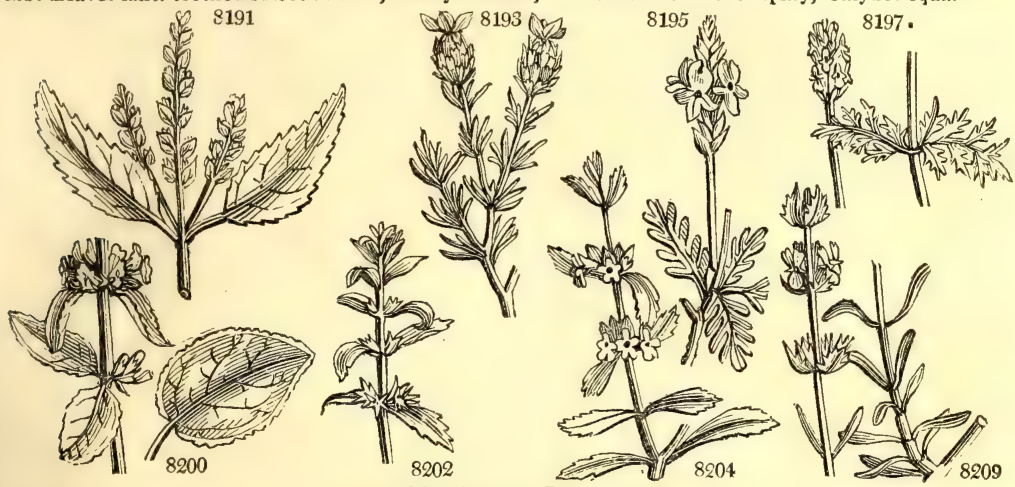

and Miscellaneous Particulars.

"If you set it

The cats will eat it

If you sow it

The cats will not know it."

1250 Elsholtzia. Named by Willdenow, in memory of a Prussian botanist, John Sigismund Ejsholtz, who lived in the middle of the seventeenth century. Inconspicuous hardy herbaceous plants of little merit.

1251. Lavandula. From lavare, to wash. The use of the distillod water of this plant is well known. The flowers of $\mathrm{L}$. spica have an agreeable fragrant odour, and warm bitterish taste. Alcohol extracts their virtues completely, and elevates in distillation all their odorous parts ; water acts less completely. The oil, however, on which their virtues depend, is obtained separate in distillation with water; in the proportion, according to Lewis, of one ounce of oil from sixty ounces of the flowers. Lavender is stimulant and tonic. The oil extracted by alcohol enters into several compositions. The dried leaves in powder were used formerly as a sternutatory; but they are now neglected. The flowers are cut in dry weather, when they begin to blow. (London Dispensatory, 862.)

1252. Sideritis. From oioneos, iron. A name given by the Greeks to a plant by which were cured all 
8213 hirsúta $\boldsymbol{W}$. 8214 crispáta $W$. en 8215 crética $L$.

8216 fœ'tida $W$

1253. BYSTROPO'GON. 8217 plumósus $W$. 8218 origanifôlius $W$. 8219 canariénsis $W$ 8220 punctátus $W$.

1254. MEN'THA. $W$. 8221 Auriculária $W$. 8222 lævigáta $\boldsymbol{W}$. en. 8223 rotundifólia $W$ $\beta$ variegáta 8224 gratíssima $W$. 8225 pubéscens $W$. en 8226 pyramidális Tenore. 8227 víridis $W$. 8228 incána $W$. en. 8229 piperíta $W$. 8230 glabráta $W$ 8231 críspa $W$. 8232 crispáta $W . e n$. 8233 unduláta $\boldsymbol{W}$. $e n$. 8234 odoráta Smith. $M$. citráta W. 8235 balsamea $W$. en. 8236 niliaca $W$ 8237 nemorósa $\boldsymbol{W}$. en 8238 sylvéstris $W$. 8239 macrostáchya $T e n$ w $M$. rotundifolia W. en.

8240 lavandulácea $W$.en. Lavender-lyd 8241 ríbra $H \cdot K$ 8242 acutifólia $H . K$ 8243 boreális Mich. 8244 hirsúta $H$. K. 8245 capénsis $W$. 8246 austriáca $W$. en. 8247 sativa $W$. 8248 hirta $W . c n$ 8249 grácilis $H . K$ 8250 arvénsis $H$. $K$. $\beta$ préc $\operatorname{cox}$ S. M. 8251 gentílis $H$. $K$. 8252 canadénsis $W$. 8253 dentáta $W$. en. 8254 Pulégium $W$. 8255 cervina $W$. hoary perper smoth hairy

curled-leaved $\frac{\downarrow}{\downarrow} \Delta$ or $1 \frac{1}{2}$ jn.j Candian $\mathrm{cu} 1 \frac{1}{3} \mathrm{jn} . \mathrm{s}$ stinking
Y S. Europe 1731. C co Y Gibraltar 1816. C co W Candia 1823. C co

Cav. ic. 4. t. 502 Labiatce. Sp. 4-7.

woolly-flower'd f or $1 \frac{1}{\mathrm{~g}}$ jn.jl Pa.pu Canaries 1779. C p.l L'her. sert. n. 4 entire-leaved $L_{L}$ or $1 \frac{1}{2}$ jl.au Pa.pu Canaries 1815. C p.l L'her. sert. n.5 Canary or 11 jn.au Papu Canaries 1714, C p.l Com hort 2.t.65 cluster-flower'd 1 or $1 \frac{1}{3}$ jl.s Pa.pu Madeira 1775. C p.l L'her, sert. $\mathbf{n} .7$ Mrst. Labiate. Sp. 35-43.

Indian $\square$ or 1 jl.au Pu E. Indies 1796. D co Rum.amb.6.t.16 polished $\quad \triangle$ or $1 \frac{1}{2} \mathrm{jl} \quad \mathrm{Pu}$ round-leaved $\frac{ \pm}{2}$ ongland moi pl. $\mathrm{D}$ co round-leaved $\Delta$ or 2 au.s $R$ R England moi.pl. $\mathrm{D}$ co

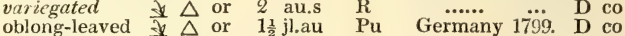

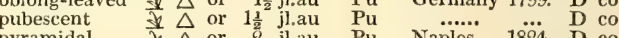
pyramidal $\$ \triangle$ or $\stackrel{2}{j}$ jlau Pu Naples 1824. D co spear $\quad \Delta$ cul 2 au $\begin{array}{llllll}\text { crumpled } & \downarrow \Delta \text { or } 1 \frac{1}{2} \text { jl.au } & \mathrm{Pu} & \ldots . . . & 1807 . & \text { D co } \\ \text { wave-leaved } & \downarrow \Delta \text { or } 1 \frac{1}{2} \text { jl.au } & \mathrm{Pu} & \ldots . . . & 1816 . & \mathrm{D} \text { co }\end{array}$ $\Delta$ cul 2 au

$\mathrm{Pu}$ Britain mar. D co

Pu $\quad$....... 1790. D co

England wat.pl. D co Egypt 180\%. D co Siberia 1640. D co

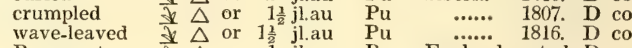

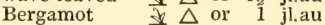

England wat.pl. D co Eng. bot. 1025

Balsam-scented $\$ \Delta$ or $1 \frac{1}{2}$ jl.au Pu Italy 1804. D co

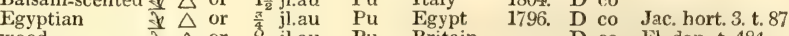
wood $\$ \mathrm{t} \triangle$ or 2 jl.au Pu Britain ... D co Fl. dan.t.484 wild $\triangle$ or 2 jl.au If $\triangle$ or 2 jl.au Lavender-lvd. $₫ \Delta$ or 1 jl.au sharp-leaved $\$ \Delta$ or $1 \frac{1}{2}$ northern $\quad \frac{\downarrow}{\Delta} \Delta$ pr $\frac{3}{4} \mathrm{~s}$ hairy-water $\frac{ \pm}{2} \triangle$ or $1 \frac{1}{2} \mathrm{jl} . \mathrm{s}$ Cape jo $\longleftarrow$ or 1 jlau Austrian $\quad$ \& $\triangle$ or 1 jl.au tall-red \ $\triangle$ or 2 au.s shaggy $\frac{\nabla}{2} \triangle$ or $1_{3}$ au.s narrow-leaved $\not \Delta$ or 1 au corn $\quad \downarrow \Delta$ or $\frac{3}{4} \mathrm{jl}$.s early-flowering $D$ or bushy-red Canadian $\quad \frac{\Delta}{\Delta}$ or toothed $\quad \downarrow \Delta$ or \& $\curvearrowright$ or 1 jl.au Pennyroyal $\$ \Delta \mathrm{m} \quad \frac{1}{4} \mathrm{au}$.s

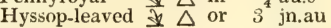

Li Britain wat.pl. D co Eng. bot. 686

Spain 1823. D co Britain wat.pl. D co Eng. bot. 1413 Britain wat.pl. D co Eng. bot. 2415 N. Amer. 1824. D co Britain wat.pl. D co Eng. bot. 447 C. G. H. 1816. D co Germany 1809. D England ... D co Eng. bot. 448

Britain wat.pl. D co Eng. bot. 449 Britain corn fi. D co Eng. bot. 2119 Britain ... D co Sole's Mints, cic Britain pools. D co Eng. bot. 2118 N. Amer. 1801. D co Germany 1816. D co

Britain wetco. D co Eng. bot. 1026 France 1648. D co Mor.his.3. t.7.f.7 8219

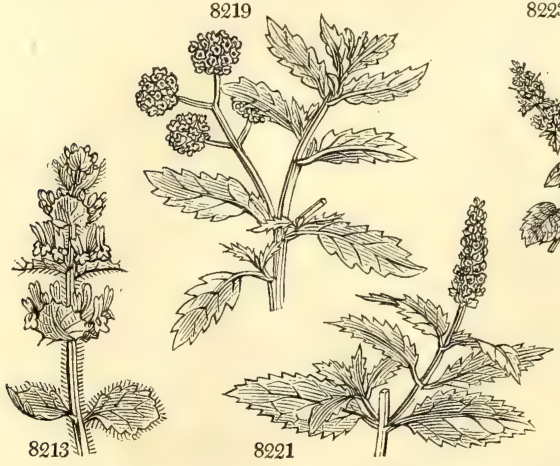

8223 8229

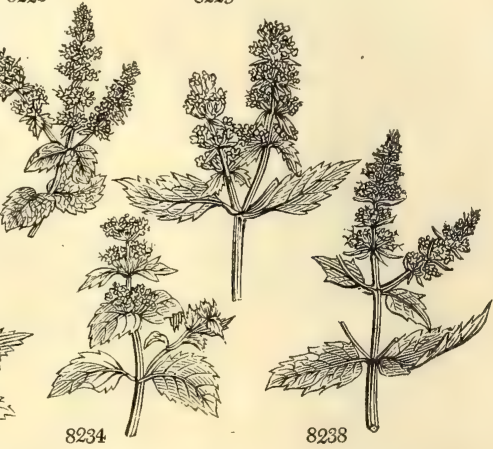

History, Use, Propagation, Culture,

wounds by sword. The plants of the moderns do not possess any such properties. Their flowers, however, have frequently a ferruginous color.

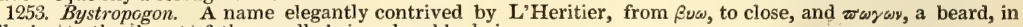
allusion to the throat of the corolla being closed by hairs.

1254. Mentha. M $\omega_{\nu} \tau_{\alpha}$ or $\mu \iota \theta \theta_{n}$, in old Greek. The poets feign that Mintha was a daughter of Cocytus, transformed into the plant which bears her name; an allegorical description of the terrible effects ascribed to their plant by the ancients. M. viridis not being so hot to the taste as peppermint, and having a more agreeable flavor than most of the others, is generally preferred for culinary and some medicinal purposes. The leaves or tops are used in spring salads, and eaten dried as sauce with lamb and in soups.

The medical preparations of spearmint are more pleasant than those of peppermint, but perhaps less efficacious. This herb, as do the other sorts, contains much essential oil, but of an odor less agreeable than that of lavender or marjoram : it is therefore less employed as a cephalic ; but it acts very powerfully on parts to which it is immediately applied, and therefore considerably on the stomach. It acts especially as an antispasmodic, and therefore relieves pains and cholic arising from spasm. It will also stop vomiting dependent on the same cause; but if it arise from an inflammatory irritation in the stomach itself, or in other parts of the body, it aggravates the disease. The infusion of mint in warm water agrees better with the stomach than the distilled water. The officinal preparations are an essential oil, a conserve, a simple water, and a spirit. The conserve is very grateful, and the distilled waters both simple and spirituous, are generally thought pleasant. 
8213 Leaves lanc. toothed blunt pilose, Bractes toothed spiny, Stems hirsute decumbent 8214. Hirsute, Lvs. obl. cuneate toothed wavy downy beneath, Bractes round with spiny teeth, Whorls distant 8215 Shrubby downy, Lvs. cord. obl, crenate stalked downy on each side, Upper lip of cor. ovate entire 8216 Like hyssopifolia, but leaves smooth on each side somewhat toothed lanceolate blunt

8217 Panicle dichotomous, Cal. feathery, Leaves ovate subserrate downy beneath 8218 Panicle dichotomous, Cal. feathery, Leaves ovate entire very white beneath 8219 Panicle dichotomous, Flowers capitate, Leaves ovate crenate most villous beneath 8220 Panicle dichotomous, Flowers capitate, Leaves ovate toothed smooth dotted

8221 Spikes oblong, Leaves oblong serrated hairy sessile, Stamens longer than cor 8222 Spikes cylindr. interrupted, Leaves ovate-obl. subsessile remotely serrate and calyxes smooth 8223 Hoary, Spikes oblong interrupted, Leaves roundish rugose crenate sessile

8224 Spikes obl. Leaves sessile oval finely and equally serrate acum. hoary beneath, Stamens as long as cor. 8225 Spikes obl. Lvs. ovate stalked serr. hoary beneath, Calyxes and peduncles hirsute, Stem much branched 8226 Leaves stalked subcordate slightly pubescent, Spikes middle sized [somewhat hairy 8227 Spikes cylindr. interrupted, Lvs. lanc. subsess. cun. at base finely serrated smth. on each side, Teeth of cal. 8228 Spks. obl. Lvs. obl. comp. blunt. serrat. ses. hoary and downy on each side, Cal. and ped. vill. Stem much br. 8229 Spikes obl. blunt interrupted at base, Lvs. ov. obl. acute serrat. stalked smooth, Cal. quite smooth at base 8230 Flowers racemose whorled, Leaves stalked ovate lanc. serrated smooth

8231 Spikes capitate, Leaves cordate cut-toothed wavy sessile, Stamens length of corolla

[hirsute 8232 Spikes cylindr, interrupt. Lvs. ov.obl. subsess. cuspid. ser, waved complicate hoary on each side, Cal. and ped. 8233 Spikes cylindr. Lvs. ovate obl. subsess. cuspidate serr. wavy complicate hoary on each side 8234 Flowers in heads, Lvs. ellipt. blunt serrated smooth stalked, Stamens shorter than corolla

\$235 Spikes cylindr. interrupted, Lvs, ovate lanc. stalked finely serr. entire at base, Ped. hirsute, Cal [at base 8236 Spikes obl interrupt, at base, Lvs, obl lanc, subses. remotely and finely serrat, entire at base hoary beneath 8237 Spikes cylindr contracted, Leaves obl subcor subses, equally serrated hoary beneath, Cal. and ped. hirsute 8338 Spks. cylindr. interrupt. at base, Lvs. ov. obl. subsess. finely and unequally serr. hoary, Cal. and ped. hirsute 8239 Spikes cylindr. interrupted, Lvs. ovate-ellipt. rounded at end serrated subsessile hoary beneath

8210 Spks. cylindr. interrupt. at base, Lvs, lin. lanc. nearly entire complicate sess, hoary on each side, Ped. and 8241 Flowers whorled, Lvs. ovate stalked serrated entire at base smooth, Teeth of calyx hairy

8242 Fls, whorl. Lvs. ov.-lanc. narrowed at each end, Cal. tubular obl. hairy, Hairs of pedicels spreading, of stems 8243 Low pubesc. Fl, whorled, Lvs, stalked with resinous dots acute at each end, Stamens exserted [deflexed 8244 Flowers capitate or whorled, Lvs. stalked ovate, Calyx hairy on each side, Pedicels hispid backwards 8245 Whorls spiked oblong, Leaves lanceolate entire downy

8246 Fl. whorled, Lvs. ovate stalked serrate hairy, Cal. hairy, Ped, smooth, Stem erect

8247 Flowers whorled, Lvs. ovate acutish serrated, Stamens longer than forolla

8248 Spikes cylindr, interrupted at base, Lvs, ovate stalked serrate beneath hairy, Cal, and peduncle hirsute 8249 Flowers whorled, Lvs. lanc. subsess. Stem much branched erect, Cal. at base and pedicels very smooth 8250 Flowers whorled, Lvs. ovate stalked serrate hairy, Cal, and peduncles hirsute, Stem much branched

8251 Flowers whorled, Lvs, ovate, Stem much branched spreading, Calyxes and pedicels smooth at base 8252 Flowers whorled, Lvs. lanc. serrate stalked hairy, Stam. as long as corolla

8253 Flowers whorled, Lvs, ov. subsess, cuspidate serr. wavy nearly smooth, Pedunc, and calyx smooth at base 8254 Flowers whorled, Lvs. ovate, Stem prostrate, Pedicels and cal downy on each side, Teeth ciliated

8255 Flowers whorled, Lvs. lanc. nearly entire sessile smooth, Bractes palmate

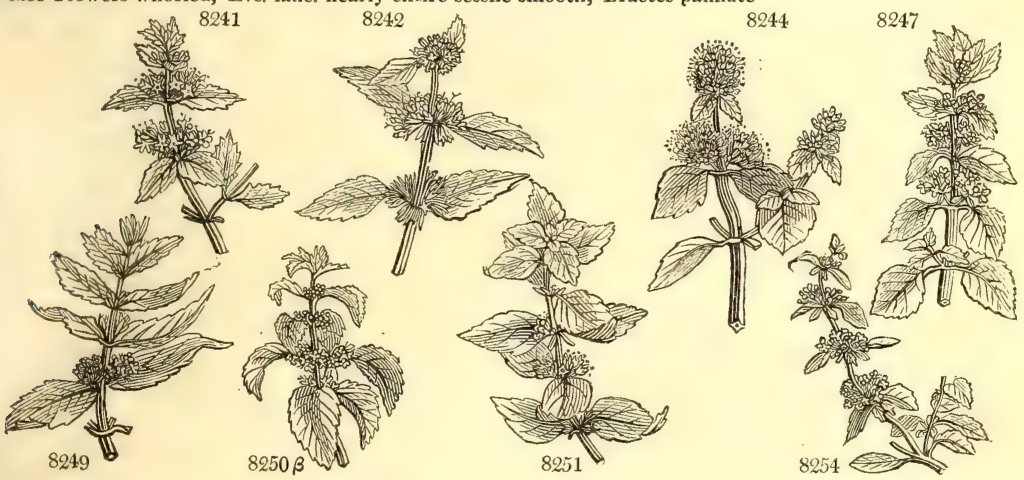

and Miscellaneous Particulars.

Lewis observes, that mint is said to prevent the coagulation of milk; and hence it has been recommended to be used with milk diets, and even in cataplasms and fomentations for resolving coagulated milk in the breasts : upon experiment, the curd of milk, digested in a strong infusion of mint, could not be perceived to be any otherwise affected than by common water; but milk, in which mint leaves were set to macerate, did not coagulate near so soon as an equal quantity of the same milk kept by itself. Dry mint digested in rectified spirits of wine, gives out a tincture which appears by day-light of a fine dark green, but by candle-light of a bright red color. The fact is, that a small quantity of this tincture is green, either by day-light or candlelight, but a large quantity seems impervious to common day-light; however, when held between the eye and a candle, or between the eye and the sun, it appears red; so that if put into a flat bottle it appears green, but when viewed edgewise red.

For medicinal use spearmint is generally cut just as the flowers appear; but for obtaining the essential oil, the flowering plant is preferred. It should be cut in very dry weather. (London Dispensatory, 384.)

M. piperita has a more penetrating smell than any of the other species, and a much stronger taste, pungent and glowing like pepper, sinking as it where into the tongue, and followed by a sensation of coldness. Its stomachic, anti-spasmodic and carminative qualities render it useful in flatulent colics, hysterical affections, retchings, and other dyspeptic symptoms, acting as a cordial, and often producing immediate relief. The officinal preparations are an essential oil, a simple water, and a spirit. The essence of peppsrmint is an elegant medicine, and seems to be the rectified oil dissolved in spirits of wine.

"The cultivators of the plant observe, that to keep up its quality, the roots must be transplanted every three. 
1255. PERIL'LA $W$ 8256 ocymoídes $W$.

1256. HYP'TIS. Poit. 8257 capitáta $\boldsymbol{H}$. $\boldsymbol{K}$ 8258 radiáta Poit. 8259 ebracteáta $\boldsymbol{H}$. $\boldsymbol{K}$. 8260 pectináta Poit. 8262 stachyódes Link. 8253 recurváta Poit. 8264 brévipes Poit.

1257. HORMI'NUM. Ort. Hormintm. 8265 cauléscens Ort. spiked

1258. GLE'CHOMA. $W$. Ground IvY. 8267 hirsúta $P$. S common

A rchangeI

1259. LA'MIUM. $W$ 8268 Orvála $W$.

8269 lævigátum $W$ 8270 rugósum $\boldsymbol{W}$. 8271 gargánicum $W$ 8272 maculătum $W$ 8273 álbum $W$. 8274 moschátum $H . K$. 8275 mólle $W$.

8276 purpúreum $W$ $\beta$ incisum $\mathbf{H} . \mathbf{K}$. 8278 multífidum $W$. smooth rough woolly woolty white musk-scented Pellitory-leav'd ? purple cut-leaved Henbit multifid-leaved 8261 pérsica $\boldsymbol{P}$. $S$ 8266 hederácea $W$. 8277 amplexicáule $W$.

Labiate. $S p .1$. O cu $\frac{1}{2} \mathrm{jl}$.au W India

1770. S s.l Bot. mag. 2395

Labiate. Sp. 8-27.

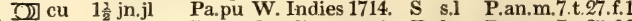
$\triangle 1$ cu 1 jn.jl Pa.pu Carolina 1690. D l.p P.an.m.7.t.27.f.2

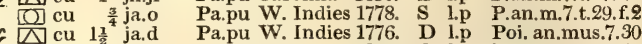
\#. $\mathrm{fu} 1 \frac{1}{\mathrm{j}} \mathrm{jl} \quad$ Pa.pu Persia 1800. C l.p Lin.trans.6.t.12 [0] $\mathrm{cu} 1 \frac{1}{2} \mathrm{jl} \quad \mathrm{W} \quad \ldots . . .1824$. S co

$\checkmark \mathbb{1}$ cu 1 jl Pa.pu Cayenne 1820. D co

jn.au Li S. Amer. 1822. S co

Labiate. $S p .1-3$.

₹ $\triangle \mathrm{pr} 1$ jl.au Pa.R Mexico 1800. C s.p W.h.ber.t. 21

Labiate. Sp. 2.

2 $\triangle$ w 1 mr.my B Britain hed.b. D co Eng. bot. 853

if $\triangle \mathrm{cu} 2 \mathrm{mr}$ my $\mathrm{Pk}$ Hungary ... $\mathrm{D}$ co Pl.rar.hun.t.119 Labiate. Sp. 11-19.

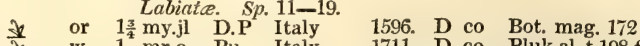

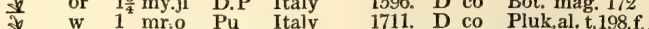
$\frac{\mathrm{d}}{\mathrm{N}} \mathrm{W}$ mr:o Pu Italy 1711. D co Pluk,al.t.198.f. R Italy 2 jl.au Pu Italy 1729. D co Exot. bot. 1. t.48 1 jn.jl Pu Italy 1683. D co Col.ecph.1.t.185 2 ap.s W Britain was.gr. S co Eng. bot. 768 $1 \quad \ldots \quad \ldots$ Levant 1739. D co 1 ap.my $\ddot{\mathrm{W}}$ 1683. S co 1 my au $\mathrm{Pu}$ Britain was.gr $\mathrm{S}$ co Eo Eng. bot. 769 1 myjl Pk Britain san.fi. S co Eng. bot 1938

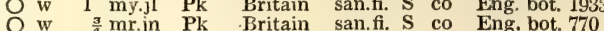
O w $\frac{3}{4} \mathrm{mr} . j n$ Pk Britain san.fi. S co Levant 1752. S co

$\underset{\frac{3}{4} \text { jl.s }}{\text { Labiatce. } S p .4 \text { Pk }}$ Britain chal.fi. S co Eng. bot. 884

1260. GA LEOP'SIS. $W$. Hemp-Netrtle. 8279 Ládanum $W$. red 8280 villósa $\boldsymbol{E} . \boldsymbol{B}$.

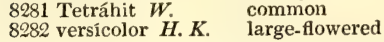
downy large-flowered

O $1^{\frac{3}{4} \text { jl.s }}$ Y Y Britain san.fi. S co Eng bot. 2353 O $\mathrm{w} 1 \frac{1}{2} \mathrm{jl} . \mathrm{au}$ W Britain corn fi. S co Eng. bot. 207 W 1 jl.au $\mathrm{Y}$ Britain san. fi. S co Eng, bot. 667

1261. Galeob'Dolon. $E . B$. Dead-Nettle. Labiate. Sp. 1-2.

8283 lúteum $E . B$. yellow $\quad \ \Delta$ or 1 my.jn Y ${ }^{\text {B }}$ Britain m.sh.pl. D co Eng. bot. 787

1262. BETON'ICA. $W$. BETONY. 8284 officinális $W$. wood 8285 stricta $W$. Danish 8286 incána $W$ 8087 incientális 8288 alopecúrus $W$ 8289 hirsúta $\boldsymbol{W}$. 8290 grandiflóra $W$ hoary oriental fox-tail hairy $\quad \Delta \Delta$ Labiate. Sp. 7-12.

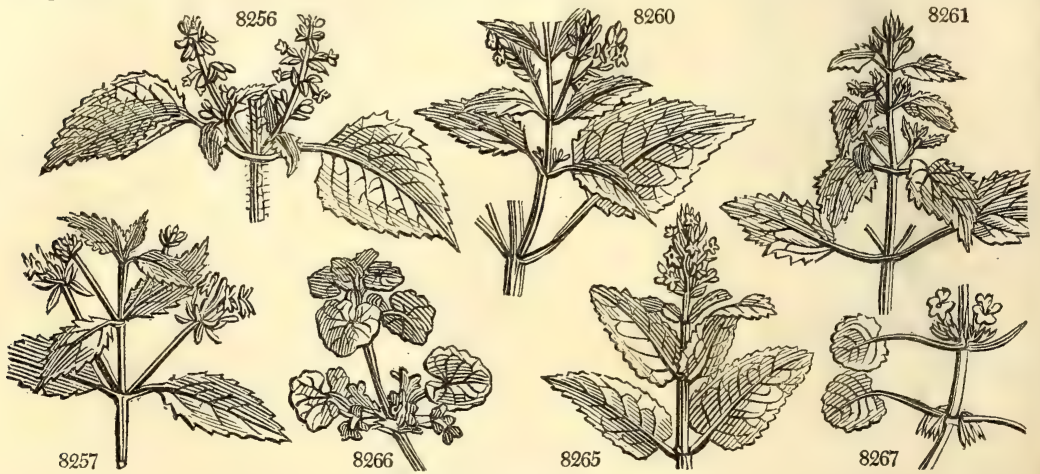

History, Use, Propagation, Culture,

years, otherwise it degenerates into the flavor of spearmint." (Linnean Transactions, v. 176.) If the plant be cut in wet weather it changes to black, and is little worth. (London Dispensatory, 385.)

M. pulegium (from pulex, a louse, which animal it was thought to drive away) smells like spearmint, but less fragrant; the taste aromatic and pungent, with a slight flavor of camphor. These qualities reside in a very volatile essential oil, which rises in distillation with water. It was formerly regarded as emmenagogue, expectorant, and diaphoretic, and was in repute for promoting the uterine evacuation, and relieving hysteria, hooping-cough, asthma; but it is now justly considered of no value, and seldom used in regular practice. (London Dispensatory, 386.)

1255. Perilla. A name the meaning of which has not been explained. An annual plant with a strong balmy fragrance.

1256. Hyptis. From izrios, reversed, because the corolla seems inverted, both as to its form and as to the insertion of stamens. Plants with densely whorled flowers, all natives of the western parts of the world, within, or nearly so, the limits of the tropics.

1257. Horminum. From sepaw, to excite, in allusion to its stimulant qualities. The Horminum of the ancients was reputed aphrodisiac.

1258. Glechoma. Гдихwy was a sort of Thyme among the Greeks. Small trailing herbs. The leaves of G. hederacea are often deformed with red hairy tumours, which are the galls of the Cynips Glechomæ. Before 
8257 Heads stalked in an involucre, Invol. lanc. the length of fiowers, Leaves ovate toothed 8258 Heads stalked in an involucre, Invol. lanc. longer than flowers, Leaves oblong toothed narrowed at base 8259 Heads opp. few-fl. without bractes, Pedunc. shorter than joints, Leaves cord, doubly serrate ; upper oval 8260 Flowers in spiked 1-sided panicles on a two-parted peduncle, Leaves ovate

8261 Flowers in stalked capitate cymes, Leaves of invol. 2 longer than calyx in fruit, Leaves oblong

8262 Leaves ovate subcordate attenuate acutely crenate pubesc. spiked whorled terminal, Cal. 5-toothed

8263 Flowers capitate, Invol, filiform hispid shorter than calyx of fruit, Lower leaves cordate

8264 Heads on a short peduncle, Leaves of invol, oblong lanc. Cal. pubescent not closed with hairs

8265 Stem leafy, Leaves ovate oblong crenat Bractes cordate, acuminate, Cal, pungent

8266 Smooth, Segment of calyx ovate acute

8267 Hirsute, Segment of calyx lanceolate cuspidate

8268 Leaves cord. unequally finely serr. Orifice of cor. inflated, Lower lip 3-toothed on each side, Cal. colored 8269 Leaves cord. rugose, Stem smooth, Cal. smooth the length of tube of corolla

8270 Leaves cord. acute rugose and stems hairy, Whorls many-flowered, Tooth of orifice solitary setaceous

8271 Leaves cord, concave somewhat hoary, Orifice of cor. inflated. Tube straight with two teeth on each side 8272 Leaves cord. acuminate, Whorls 10 -flowered

8273 Leaves cord. acuminate serrate stalked, Whorls 20-flowered

8274 Smooth, Leaves cordate crenate : floral subsessile, Teeth of calyx as long as cor.

8275 Leaves stalked somewhat toothed : lower cordate; upper ovate

8276 Leaves stalked cordate blunt toothed; upper close together, Stem naked below

$\beta$ Leaves cut-toothed

8277 Floral leaves sessile amplexicaul cut ; radical lobed

8278 Leaves many-parted

8279 Joints of stem equal, All the whorls remote, Leaves lanceolate

8280 Joints of stem equal, Leaves ovate lanceolate serrate villous, Helmet crenate cut

8281 Joints of stem thickened upwards, Upper whorls contiguous, Cal, pungent, Cor. little longer than calyx 8282 Stem hispid, Joints thickened upwards, Cor. thrice as long as calyx, Helmet ventricose

8283 All the leaves ovate, Involucre 4-leaved

8284 Spike interrupted, Helmet entire, Middle segm. of lower lip emarg. Cal. smoothish 8285 Spike oblong, Helmet entire, Middle segm. of lower lip crenate wavy, Cal. hairy, Bractes ciliater 8286 Spike interrupted, Helmet bifid, Middle segm. of lower lip crenate, Tube downy incurved

8287 Spike entire, Middle segm. of lower lip entire

$\$ 288$ Spike leafy at base, Helmet bifid

8289 Spike leafy at base, Helmet entire

8290 Spike leafy interrupted, Calyx villous at edge, Teeth subulate, Helmet obcordate

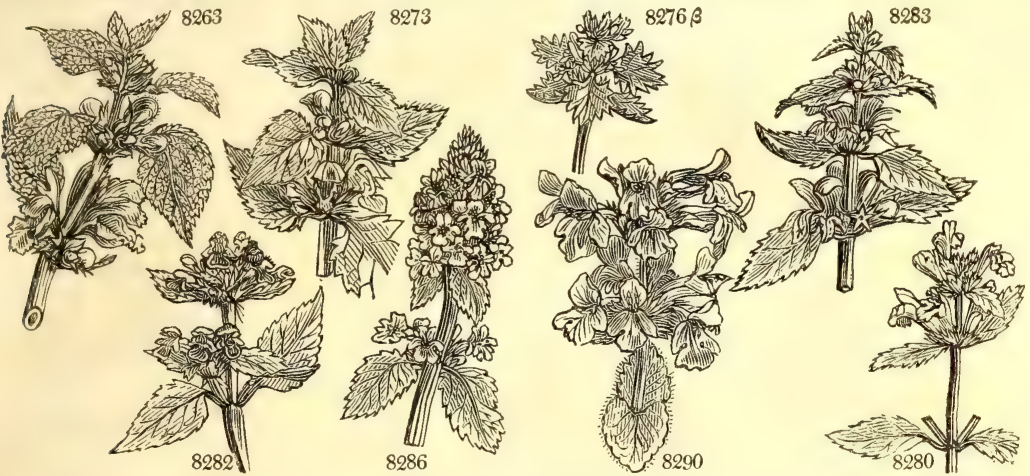

and Miscellaneous Particulars.

the use of hops, the leaves were put in ale, and being bitter, aromatic, and having a peculiar and very strong smell, were much used in popular medicine. It is now, however, seldom used.

1259. Lamium. Lamia was a celebrated marine monster; the flowers of this genus have a considerable resemblance to the grotesque figure of some beast. $\mathbf{L}$. orvala is the only species admitted into the garden. The others are mostly ugly weeds. L. album, Ortie blanche, Fr., Taube Nessel, Ger., and Ortica morta or bianca, Ital., has a disagreeable smell when bruised, and though no cattle whatever will touch it, yet Linnæus says, the leaves are eaten in Sweden as a pot herb in spring.

1260. Galeopsis. From roi $\eta$, a weasel, and $0 \% 15$, appearance. The flower has a grotesque figure, and may be likened to the form of a weasel, or, indeed, of any thing else.

1261. Galeobdolon. A word with the same meaning as Galeopsis, which see.

1262. Betonica. In Celtic botany is called Bentonic; wherefore it appears, that Pliny gave too much way to conjecture, when he wrote that Betonica or Vetonica was so called from the Vetones, a people who dwelt at the foot of the Pyrenees. B. officinalis was formerly much used in medicine, but it is discarded from modern practice. When fresh it intoxicates. The leaves when dry excite sneezing. Sheep eat it, but goats modern practice. When fresh it intoxicates. The leaves when dry excite sneezing. Sheep eat it, but goats
refuse it. The roots are bitter and very nauseous; in a small dose they vomit and purge violently. This plant dyes wool of a very fine dark yellow color. 
1263. STA'CHYS. $W$. 8291 sylvática $W$. 8292 sibírica Link. 8893 mollíssima $\boldsymbol{W}$. en 8294 cor'sica Pers. 8295 palústris $W$. 8296 coccínea $W$ 8297 nepetifólia Desf. 8298 decúmbens Pers. 8299 germánica $W$. 8300 intermédia $\boldsymbol{H} . \boldsymbol{K}$. 8301 lanáta $W$

$\$ 302$ Heráclea $L$

8303 ambígua Smith 8304 tenuifólia $\mathrm{Bieb}$. 8305 salviæfólia Ten. 8306 alpína $W$.

8307 circináta $W$.

8308 Balbísii Link.

8309 ibérica Bieb.

8310 fenículum Psh.

8311 arenária $V a h l$.

8312 crética $W$.

8313 glutinósa $W$.

8314 spinósa $W$.

8315 orientális $W$.

8316 marítima $W$.

8317 oblíqua Pers.

8318 betonicæfólia

8319 æthiópica

8320 hírta $W$.

8322 scordifólia $W$. en.

8323 récta $W$. en

8324 ánnua $W$

8325 arvénsis $W$

8326 latif́́lia $W$

8327 phlomoídes $W$. en.

1264. ZIE'TE'NIA Pers.

8328 lavandulifolia Pers. Zaven

1265. BALlo' TA. $W$. Stinking Horehound,

832.9 nigra $W$. black

8330 álba $W$. white

8331 lanáta $W$. woolly

Panzéria multifida Mœench.

8332 dísticha $W$. distichous $\Delta W$

1266. MARRU'BIUM. $W$. HOREHOUND.

8333 Alýssum $W$.

8334 astracánicum $W$.

8335 peregrínum ${ }^{2}$.

plaited-leaved

stracan or $11^{\frac{1}{2}}$ jl.au Papu Levant

Sicilian $\quad$ ov $\triangle$ or $3 \mathrm{jl} . \mathrm{s}$

Cretan $\quad$ o $\Delta$ or 1 jl.s

8337 candidíssimum $W$. woolly-white $\Delta$ or 3 jl.s

8338 supinum $W$. procumbent

8339 a fricánum $W$

8340 vulgáre $W$.

8341 affine Horn.

8342 hirsútum $W$.

8343 cinéreum W.en.

8344 críspum $W$

F or $1^{\frac{1}{2}}$ au.o

common-white $\Delta \mathrm{m} 2$ jn.s

kindred $\Delta$ or $1 \frac{1}{2}$ jn.s

hirsute $\Delta$ or $1 \frac{1}{2}$ jn.jl

cinereous $\quad \vec{x} \Delta$ or $1 \frac{1}{2} \mathrm{jn} . \mathrm{jl}$

curl-leaved

8345 catariæfólium Lam. Catmint-leaved $\mathbf{x} \Delta$ or $1 \frac{1}{2}$ jl.au

8345 hispánicum $W$. Spanish d $\Delta$ or 1 jlau

8347 Pseu.-Dictámnus $W$.shrubby-white $\frac{\$}{2}$ or $1 \frac{1}{2}$ jl.au 8348 acetabulósum $W$. saucer-leaved $\underline{E}$ or 1 jn.au
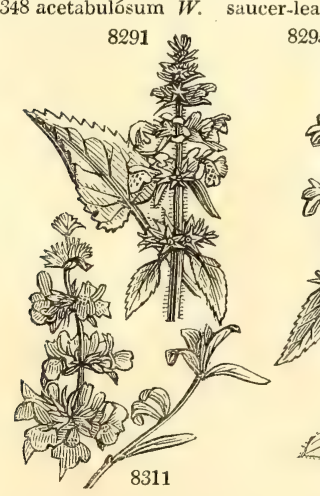

Labiate. Sp. 37-55.

Pa.pu Corfu 1806. D co

$\mathrm{Pu}$ Corsica 1823. D co

$\mathrm{Pu}$ Britain moi.m. D co

S S B B. bot. 1675

Pu ...... 1805. D co

1816.00

England chal.fi. D co

Carolina 1762. D co

Siberia 1782. D p.l

Italy 1822. D co

Britain al.mo. D co

S. Europe 1824. D co

Pu S. Europo 1824. D co

p.1 Lap pyr. 1, t. 8

$\mathrm{Pu}$ Barbary 1777. D p.l L'He. s.nov.t.26

Pu Italy 1823. D co

Iberia 1822. D co

N. Amer, 1824. D co

Levant 1804. D p.l Bot. mag. 1959

Candia 1640. D co Wal.ho.108 t.19

Candia 1729. C co M.h.s.11.t.4.f.17

Candia 1640. D co M.h s.11.t.10.f.9

Levant 1768. D s.l

S. Europe 1714. D co Jac. vind. 1. t. 70

Hungary 1816. D co Pl.rar.hun.t.134

Rochelle 1812. D co

Pu C. G. H. 1770. C p.l Jac. obs. 4. t. 77

$\mathrm{Pu}$ Spain 1725. D co All.ped.1.t.2.

Pa.Y C. G. H. 1774. C p.l Jac. ic. 3. t. 493

V N.Amer.? 1816. D co

S. Europe 1683. D co Jac. aust.4. t. 359

W.Y.P S. Europe 1713. S co Jac. aust.4. t.360

$\mathrm{Pu}$ Britain corn fi. C co Eng. bot. 1154

$\mathrm{Pu} \quad$...... 1775. D co Sp. 1.

Labiatce. Sp. 1. Labiate. Sp. 4-7.

jl.s $\quad$ W Britain hed. D co

Britain $\ldots$. D co

1752. I) co Gmel sib. 3. c.54

1823. $\mathrm{S}$ co

597. C s.1 Ger.herb.379. f. 1

1816. D co Jac ic 1 t 109

1640. D co Jac. aust.2. t.160

$\begin{array}{llll}\text { W } & \text { Sicily } & 1640 . & \text { D co } \\ \text { W } & \text { Levant } & 1596 . & \text { D co }\end{array}$

W Levant 1732. D s.p Dil.el.t.274.f.214

$\mathrm{Pu}$ S. Europe 1714. D co Bocc.mus.2. t.96

$\mathrm{Pu}$ C. G. H. 1710, D p.l Com hort 2 t 90

W Britain rubble. D co Eng. bot. 410

$\mathrm{Pu}$ Siberia? 1822. D co

Pa.pu …. … D co

Pa.pu Spain 1823. D co

Pa.pu S. Europe 1714. C co Herm, par, t.200

Pu Levant 1819. D co

$\mathrm{Pu}$ Spain 1714. C co Herm par. t.201

Pu Candia 1596. C p.1 Lam.ill. t.508.f.2 
8291 Whorls 6-flowered, Leaves cordate stalked

8292 Leaves ovate obl. acum. serrated hairy above with soft down beneath, Segm. of cal. linear mucronate 8293 Whorls spiked 6-fl. Tube of cal. shorter than spread. teeth, Helm. of cor. emarg. Lvs.ov. serr. with soft down 8294 Small, Stems much branched diffuse, Leaves cordate crenate, Cal. campanulate spiny 8295 Whorls about 6-flowered, Leaves linear lanceolate $\frac{1}{2}$ stem-clasping sessile 8296 Whorls 6-flowered, Leaves ovate cordate crenate, Petioles dilated

8297 Leaves cordate cren. pubescent, Whorls 4-6-flowered, Stem erect smooth simple 8998 Whorls many-fl. approximated, Bractes filiform, Leaves cordate toothed, Stem decumbent villous 8299 Hoary, Whorls many-fl. Leaves ovate, Serratures imbricated, Stem woolly

8300 Whorls many-fl. Calyxes subpungent, Leaves oblong subcordate crenate, Stem woolly 8301 Whorls many-fl. Leaves woolly oblong, Stems procumbent at base and rooting 8302 Whorls 10-ff. Calyxes unarmed, Leaves cordate: floral ovate entire sessile, Stem hairy 8303 Whorls 6-f. Leaves oblong cordate stalked, Stem hollow

8304 Whorls 2-fl. Leaves linear naked; lower pinnatifid-toothed

8305 Like S. germanica, but downy not woolly, Leaves narrower, Calyxes long spiny

8306 Whorls many-fl- Leaves cordate thin, Serratures cartilaginous at end, Lips of cor. flat 8307 Whorls spiked 6-flowered, Bractes cordate, Leaves cordate stalked blunt crenate toothed 8308 Leaves ovate crenate pubescent : upper entire, Whorls 6-fl. Cal. hairy with filiform segments 8309 Whorls spiked, Lvs, oblong attenuated at base serrated hairy: lower blunt, Cal. mucronate spiny 8.310 Erect pubescent, Leaves cord. ov. toothed : above smooth ; beneath white with down, Whorls about 6-fl 8311 Whorls a little spiked hairy 6-fl. Cal. spiny, Leaves oblong serrate blunt, Helmet bifid 8312 Hairy, Whorls 30 -flowered, Calyx pungent, Stem hairy

8313 Smooth much branched, Branches spiny, Pedunc. axillary solitary 1-fl. with two bractes 8314 Hoary, Branches brachiate terminated by a spine, Flowers axillary in threes

8315 Leaves downy ovate lanceolate: floral shorter than the whorl

8316 Whorls 6-flowered, Radical leaves oval crenate: upper ovate entire, Cor. twice as long as calyx

8317 Leaves obliquely cordate rugose crenate blunt hairy, Bractes entire shorter than calyx

8318 Leaves cordate ellipt. the lower on long stalks, Stems and spinulose calyxes covered with wool 8319 Whorls 2-flowered, Leaves cordate deeply serrated rugose, Tube of cor. curved

8320 Whorls 6-flowered, Stems prostrate, Upper lip of cor. bifid spreading reflexed, Lvs. broad cord. crenate 8321 Hoary, Whorls 6-fl. Leaves linear lanceolate narrowed at base downy rugose serrated, Calyxes pointless 8322 Whorls 6-f. Calyxes rather pungent, Lvs. cumeate lanceolate blunt serrate at end sessile, Stem decum. 8,323 Whorls subspiked, Leaves cordate ellipt. crenate rough, Stems ascending 8324. Whorls 6-f. Leaves ovate lanc. rugose 3-nerved stalked, Stem erect 8325 Small, Whorls 6-fl. Leaves blunt nearly naked, Corolla the length of calyx, Stem weak 8326 Whorls many-fl, spiked, Upper lip bifid, with acute divisions, Leaves broad cordate rugose bairy 8327 Whorls 8-flowered, Leaves lanceolate cordate crenate rugose, Stem very hairy

\section{Whorls 6-flowered very hairy, Leaves lanceolate entire lined}

8329 Leaves cordate undivided serrated, Cal. acuminate 8330 Leaves cordate undivided serrated, Cal. subtruncate 8331 Leaves palmate toothed, Stem woolly

\section{Leaves whorled halved 2-parted half-spiked}

8333 Lcaves cuneiform 5-toothed plaited, Whorls without involucrum 8334 Leaves elliptical obtuse crenate downy rugose, Calyxes and bractes lanceolate

8335 Leaves oblong hoary rugose toothed; the teeth towards the end largest, Cal. with small subuiate teeth 8336 Leaves lanceolate hoary rugose toothed at end, Cal. with setaceous teeth, Stem branched divaricating 8337 Leaves ovate hoary bluntly toothed rugose, Cal. with subulate teeth, Stem branched at base 8338 Leaves roundish subcordate crenate rugose, Cal. with straight villous setaceous teeth 8339 Leaves cordate roundish emarginate crenate, Calyx 10-toothed spiny

8340 Leaves roundish ovate toothed rugose, Teeth of calyx 10 setaceous hooked

8341 Leaves cordate crenate downy green above, Teeth of calyx mucronate recurved

3342 Leaves cordate ovate crenate, Teeth of cal, 10 spreading lanceolate, Bractes subulate

8343 Leaves roundish cordate unequally crenate, Limb of calyx spreading, Teeth nvate mucronate

8344 Leaves cordate roundish, crenate somewhat toothed, Teeth of calyx 10 unarmed

8345 Leaves ovate greenish deeply crenate, Teeth of calyx subulate smooth spreading

8346 I eaves cordate ovate crenate, Limb of calyx spreading, Teeth ovate mucronate, Bractes oblong 8347 Hoary, Limb of calyx flat villous, Leaves cordate concave, Stem shrubby

8318 Limb of calyx longer than tube membranous, Larger angles rounded

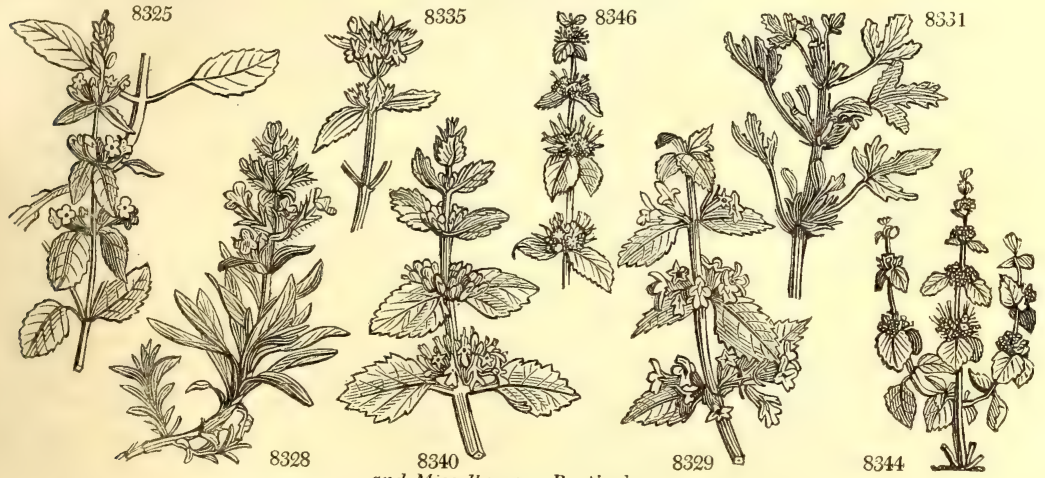

1265. Balicta. So named on account of its offensive odor, from $E_{\alpha \lambda \lambda} \lambda$, to reject.

1266. Marrubium. According to Linnæus is derived from an ancient town of Italy called Maria-urbs, situated on the borders of the Fucine lake. M. vulgare dried, has an aromatic odor, which, however, is soon lost by keeping, and a bitter taste. Both water and alcohol extract its virtues. It is tonic, diuretic, and laxative; was formerly much used in pulmonary affections, and is still a popular remedy for asthma and obsti- 
1267. LEONU'RUS. $R . B r$. MOTH́ERwort.

8349 críspus $V$.

8350 cardiaca

8351 tataricus $W$

8352 sibíricus $W$.

common

Tartarian

Siberian

8353 marrubiástrum $W$. small-flowered

8354 supínus $W$.

procumbent

1268. PHLO'MIS. $\boldsymbol{R} . \boldsymbol{B r}$. PhLomis

8355 fruticósa $W$. en.

8356 lanáta $W$. en.

8357 purpúrea $I V$.

8358 itálica $W$.

8359 Nissólii $W$.

8360 Lychnitis $W$.

8361 Sámia $W$.

$836^{\circ} 2$ Herba-vénti $W$.

8363 alpina $W$.

8364 tuberósa $W$

8365 laciniáta $W$.

8366 púngens $W$

8367 lunarifólia $\mathrm{Sm}$.

8368 ferrugínea Tenore

1269. LEU'CAS. $R . B r$

8369 zeylánica $R$. $B r$.

8870 Ceylon

8371 urticifólia $R$. Br. Nettle-leaved

8373 áspera Link. rough-leaved

1970. LEONO'TIS. $R . B r$. LION's-TAIL

8374 nepetifólia $H . K . \quad$ Catmint-leaved

8375 Leonúrus $H . K$. narrow-leaved

8376 Leonitis $H . K$. dwarf-shrubby

8377 intermédia Lindl. intermediate

1271. MOLUCCEL'LA. $W$. MolucCA-BALM

8378 spinósa $W$.

8379 læ'vis $W$.

8380 tuberósa $W$

prickly

smooth

tuberous-root.

1272. CLINOPO'DIUM. $\boldsymbol{W}$. WILD-Basil

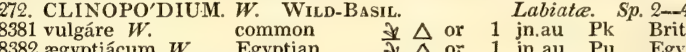

1273. PYCNAN'THemuM. Ph. Pycnanthemum. Labiate. Sp. 4-9.

8383 incánum $P h$. 3 jl.o W

8385 linifólium $P$. Flax-leaved d $1 \frac{1}{2}$ jl.au W N. Amer. 1752. D co Mich.ame.2.t.33

8386 lanceolátum $P h$. spear-leaved \& $\triangle$ or 1 jl.au W N. Amer. 1812. D co

1274. ORI'GANUM. $W$. MarjoraM. Labiate. Sp. 14-24.

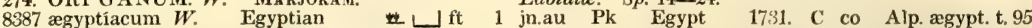
888 Dictámnus

8389 sipýleum $W$.

8390 Tournefórti $W$.

8391 créticum $I V$.

Dittany ofCrete

Mount Sipylus 1551 . C

Tount Sipylus $\mathrm{L}$ or 1 jn.s Pk Levant 1699. C r.m Herm. lug. t.463

Tournefort's or 1 au.s Pk Amorgos 1788. C co Bot. rep. 537

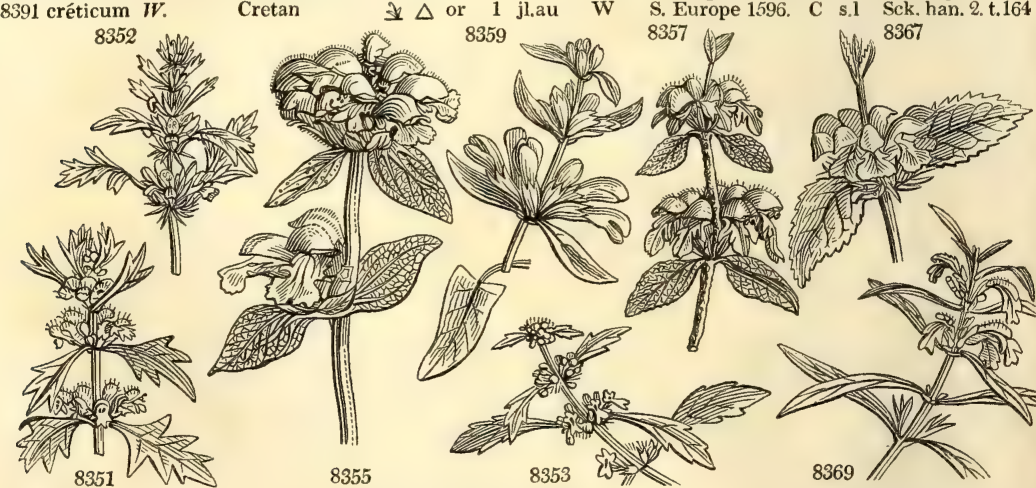

History, Use, Propagation, Culture,

nate coughs. It loosens the belly when taken in large doses, and was consequently recommended in jaundice, nasteria; but its powers are not found by modern practitioners equal to cachexies, (Iondcn Dispensatory, 379.)

the account ancients gam

1267. Leonurus. From $\lambda \epsilon \omega \nu$, a lion, and $8 \rho \alpha$, tail. The spikes of fowers have been compared to the tuft which grows on the end of the lion's tail. L. Cardiaca was formerly used in medicine, but is

erbaceous plants with cut leaves and whorrs of fow the Mullein, and so called from $\phi \lambda \circ \xi$, fire, because the 1268. Phlomis. $\mathbf{\Phi} \lambda$ opos was the Greek name lamps. At this day, $\mathbf{P}$. Lychnitis is so called, because the drier thick cottony line shewy small shrubs or herleaves, which are cottony and russet colored, are used usually of a brownish yellow color

baceous plants, with corolla covered with down, and usually of a brownish yellow color.

1269. Leucas. A name used by Burmann, neglected by Linnæus and others, and restored by Mr. Brown; thick covering of wool.

1270 Leonotis From $\lambda \varepsilon w 4$, a lion, and wrn, an ear. A fanciful name applicd to the fine scarlet-flowering 
8349 Leaves cordate 3-lobed or 5-lobed cut toothed wavy, Cor. larger than pungent calyx

8350 Leaves cuneiform ovate 3-lobed toothed, Cor. larger than pungent calyx, Middle lobe of lower lip acute 8351 Leaves 3-parted cut, Calyxes villous

8352 Leaves 3-parted multifid linear somewhat blunt

8353 Lvs. obl, toothed, Cor. scarcely longer than somewhat pungent calyx, Middle lobe of lower lip roundish

8354 Leaves about 5-lobed, Lobes blunt toothed at end, Cal. sessile spiny

8355 Leaves oblong blunt rugose and branches downy; floral ovate-lanceolate, Bractes ovate acuminate 8356 Leaves elliptical blunt woolly rugose, Branches woolly, Bractes obovate twice as short as calyx 8357 Bractes lanceolate acute pungent, Cal. 5-cornered acuminate, Leaves densely woolly beneath 8358 Bractes lanceolate blunt unarmed, Cal. truncated pointless, Leaves woolly on each side

8359 Lvs. downy on each side : rad. cord. sagitt. ; cauline obl. Whorls without bractes, Cal, with obl. acute teeth 8360 Leaves lanceolate downy : floral ovate, Bractes setaceous woolly length of bluntly toothed calyx

8361 Stem hairy, Lvs. cordate crenate downy beneath, Bractes 3-parted subulate mucronate as long as calyx 8362 Lvs. ovate obl. serrate hairy beneath, Teeth of calyx lanc. subulate erect, Bractes subul. and stem hairy 8363 Radical leaves cordate pubescent ; floral lanceolate, Bractes linear subulate villous, Stem pubescent 8364 Radical leaves cordate rough ; floral oblong lanceolate, Bractes subulate hispid, Stem smooth 8365 Leaves alternately pinnate, Leaflets laciniate, Calyx woolly

8366 Leaves stalked obl. lanc. serr. at end, rough above downy beneath, Teeth of calyx subulate spreading 8367 Leaves cordate crenate downy beneath, Bractes ovate-lanceolate mucronate

8368 Like P. fruticosa, but the lower leaves are cordate stalked, Upper ovate

8369 Leaves lanceolate serrate, Heads terminal, Calyxes with 8 teeth

8270 Leaves obl. toothed pubes. beneath, Whorls many-fl. globose, Cal. incurv. 8-toothed, upper tooth longest 8371 Leaves ovate serrated hoary, Invol. subulate, Cal. obliquely truncate membranous 9-toothed 8372 Invol. linear, Cal. 1-lipped oblique, Leaves ovate hairy

8373 Lvs. lanc. smooth serrated at end, Stem 4-cornered rough, Whorls many-fl. Lip of cor. undivided

8374. Leaves cordate acute serrated somewhat downy, Calyx 7-toothed awned; upper tooth largest 8375 Leaves lanceolate serrate, Calyxes 10-cornered 10-toothed unarmed

8376 Leaves small ovate blunt somewhat downy crenate, Cal. 7-toothed awned

S377 Leaves stalked ovate cordate acuminate cut-toothed, Cal. velvety 10-toothed

$8378 \mathrm{Cal}$ 2.lipp. upper lip lanc. mucron. longest, lower round. 7-tooth. Teeth spiny, Lvs. stalk. ov. deeply tooth. 8379 Cal. campanulate 5-toothed, Teeth equal pointless, Leaves stalked roundish ovate toothed

$8380 \mathrm{Cal}$. funnel-shaped 5-toothed : teeth equal mucronate, Leaves sessile wedge-shaped oblong toothed

8381 Heads whorled, Bractes setaceous hispid, Leaves hairy above remotely toothed, Stem simple 8382 Heads terminal, Bractes setaceous hispid, Leaves smooth above nearly entire

8393 Leaves oblong-ovate acute subserrate hoary, Heads compound, Bractes setaceous, Stamens exserted 8384 Leaves lanceolate ovate subserrate on short stalks somewhat hoary, Heads sessile, Bractes awned 8385 Stem much branched rather rough, Leaves linear 3-nerved entire, Heads terminal fascicled

8386 Stem much branched roughish, Lv. lin. lanceolate veiny entire, Heads terminal fascicled corymbose

8387 Leaves concave downy, Spikes naked

8388 Lower leaves downy, Spikes nodding

8389 Leaves all smooth, Spikes nodding

8390 Spikes 4-cornered, Bractes roundish very large

8391 Spikes aggregate long prismatical upright, Bractes membranous twice as long as calyx

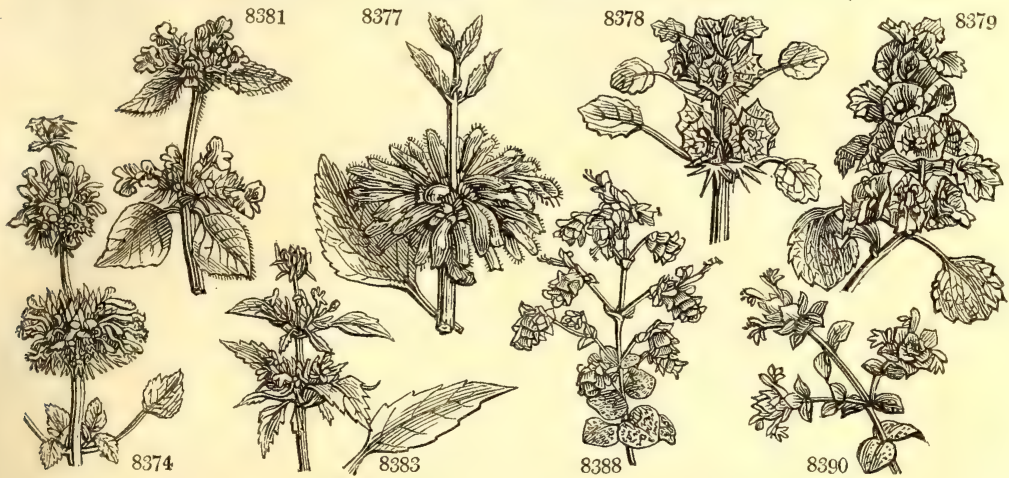

and Miscellaneous Particulars.

plants, known at the Cape by the name of lion's tail. They require a good greenhouse and plenty of air to secure their appearing in perfection. In places badly ventilated their leaves acquire a yellow color, and are apt to fall off:

1271. Moluccella. Brought from the Moluccas. Plants remarkable for the enlarged calyx in which the flower is seated.

1272. Clinopodium. From $\approx \lambda \iota v \eta$, bed, and $\pi \varepsilon_{s}$, a foot. The tufted close whorls of flowers have been compared to the caster of a bed's foot.

1273. Pycnanthemum. From zuzyos, dense, and av. Tos, a flower. The blossoms are in a close head. A North American genus of plants, some of which, as $\mathbf{P}$. verticillatum and incanum, are occasionally seen in gardens

1274. Origanum. From opos, a mountain, and royos, joy. These plants, with their pretty spikes of bracteated flowers and agreeable perfume, may indeed be called the joy of the places where they grow naturally. $O$ vulgare is an aromatic and ornamental plant, growing wild in thickets and hedges, chiefly in a calcareous soil. The dried leaves used instead of tea, are said to be exceeding grateful; they are also used in fomentations: the essential oil is so acrid, that it may be considered as a caustic, and is much used with that intention by 


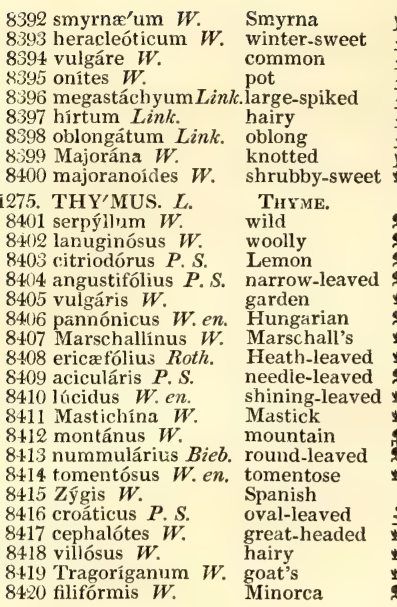

1276. A'CYNOS. Pers. Acynos.

8421 vulgáris Pers. Basil-leaved

Thy̆mus A'cinos W.

8422 villósus Pers. villous

8124 patavinus Pers. Marjoram-lvd.

8425 gravéolens Bieb.

strong-scented

$\checkmark \mathbb{N}$ or $1 \frac{1}{2} \mathrm{jn} . \mathrm{jl}$

$¥ \Delta$ cul 1 jn.n

\$ $\triangle$ cul 2 jn.o

$\star \Delta$ cul 1 jl.n

类 $\triangle$ un $1 \frac{1}{2} \mathrm{jln}$

ฟ $\triangle$ un $1 \frac{1}{2} \mathrm{jl} \cdot n$

\& 2 cul 1 jn.jl
W Smyrna 1722. C r.m

W. Europe 1640. D s.1 Lob. ic. 4.92

Pk Britain ch.wo. D s.l Eng. bot. 1143

Pk Sicily 1759. D co Bocc. mus. t. 38

$\mathrm{Pk}$ S. Europe 1823. D co

Pk Levant 1823. D co

Pk Portugal 1573. S $\begin{aligned} & \text { S } \\ & \text { r.m Moris.s.11.t.3.f.1 }\end{aligned}$

Sp. 20-32.

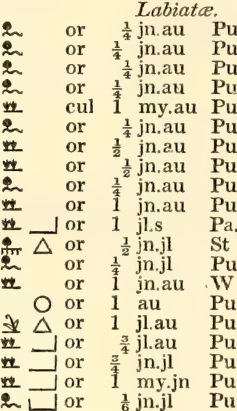

Britain heaths.

C s.p Eng. bot. 1514

….. $\quad \cdots \quad$ C $\quad$ co

$\ldots . . . . . \quad$ C co

S. Europe 1548. C r.m

Hungary 1817. C co

Crimea 1817. C co

Spain 1806. C co

Hungary 1806. C co

Pl.rar.hu.2.t.147

Spain 1596. C co Blackw. t. 134

Hungary 1800. D s.p Pl. rar.hu.1. t.71

Crimea 1822. C co

Spain 1816. C co

Spain 1771. C r.m Barrel. ic. 777

Hungary 1802, D co Pl.rar.hu.2.t.156

Portugal 1759. C co Hof.etL lus.1.1.3

Portugal 1759. C co Hof.etLin.1.t.14

Candia 1640. C co Alp. exot. t.78

$\mathrm{Pu}$ Minorca 1770. C co

\section{$\mathrm{O}$ or Labiate. Sp. $5-7$.}

O or jn.au R Germany 1817. S co

E OJ or $\frac{1}{2}$ jn.s $R$ Austria 1731. S s.1 Jac. aust.1. t. 97

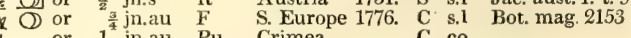

1277. CALAMIN'THA. Ph. Calamint.
8426 grandiflóra Pers. great_flowered $\$$ or 1 Labiata. Sp. 7-9.
jn.s Pu Italy 8427 caroliniána Sweet. Carolina $\$ \Delta$ or 1 jn.jl $\quad F \quad$ Carolina 1804. D co Bot. mag. 997

Thymus grandiflorus B. M.

8428 vulgáris Sweet. common De $\Delta$ or 2 jl.au V England bor.fi. D s.1 Eng. bot. 1676 8429 Népeta Ph. lesser 20 or $1 \frac{1}{2}$ ji.o B England ch.hil. D co Eng. bot. 1414 8430 marifólia Pers. Marum-leaved $\frac{\$ 2}{\Delta} \Delta$ or $1 \frac{1}{2} \frac{j}{j n}$.jl Pu Spain 1788. D co Cav. ic. 6. t. 576 8431 crética Pers. Cretan 1 or $\frac{1}{2}$ jn.jl Pu S. Europe 1596. D r.m Barr. ic. 1166 8432 fruticósa Pers.

1278. MELIS'SA. $W$. 8433 cordifólia Pers. $8+34$ officinális $W$.

shrubby

业

Pu Spain 1752. C r.m

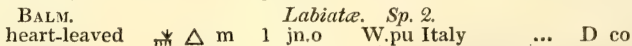

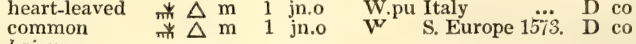

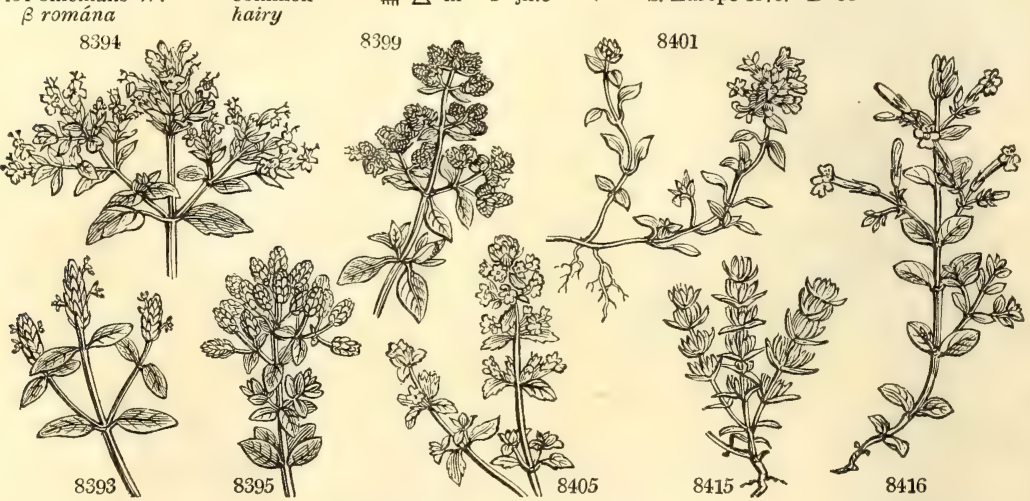

History, Use, Propagation, Culture,

farriers: a little cotton moistened with it, and put into the hollow of an aching tooth, frequently relieves the pain. The country people use the tops to dye woollen cloth purple. It also dyes linen of a reddish brown color. For this purpose the linen is first macerated in alum water and dried; it is then soaked for two days in a decoction of the bark of the crab-tree; it is then wrung out of this, boiled in a ley of ashes, and then suffered to boil in the decoction. According to the Swedish experiments, goats and sheep eat it, horses are not fond of it, and kine refuse it.

$O$. onites and marjorana are culinary aromatics; the latter being principally in use under the name of knotted marjoram, from the flower coming in whorls at the joints. O. vulgare and marjorana are both retained in the Materia Medica as tonics and stomachics, though scarcely ever used. In quack medicine, the leaves dried and powdered form an ingredient in cephalic snuff. Marjorana is so called from marjamic (máryamych), its A rabic name, according to Forskahl, p. 59

1275. Thymus. From avus, courage, on account of its balsamic smell, which revives the spirits of animals. T. serpyllum, from sor same sensible qualities as garden thyme, but the flavor is milder, and rather more grateful. Its essential oil warmth and pungency of the other. It is a common notion that the flesh of sheep that feed upon aromatic plants, particularly wild thyme, is superior in flavor to other mutton. The truth is, that sheep do not crop 
8392 Leaves ovate acute serrated, Spikes clustered in umbels

8393 Spikes on long stalks aggregate, Bractes the length of calyx

8394 Spikes roundish panicled clustered, Bractes longer than calyx ovate colored

8395 Spikes oblong aggregate hairy, Leaves cordate downy

8396 Leaves stalked ovate pubesc. Spikes clustered prismatical, Bractes imbricate ovate smooth ciliated at edge 8397 Leaves stalked ovate acute subserrate hairy, Spikes prismatical, Bractes dense ovate acute

8398 Leaves subsessile ovate acute subserrate hairy, Spikes oblong bluntish

8399 Spikes roundish thin compact stalked, Leaves stalked ellipt. blunt smoothish

8400 Spikes roundish several clustered stalked, Leaves stalked ellipt. blunt downy

8401 Flowers capitate, Stems decumbent, Leaves flat blunt ciliated at base

8402 Flowers capitate, Stems creeping hairy, Leaves blunt villous

8403 Leaves ovate smooth with the smell of common balm

8404 Flowers capitate, Stems procumbent, Leaves cuneate linear ciliated at base

8405 Erect, Leaves revolute ovate, Flowers in whorled spikes

8406 Leaves oblong more ciliated than in T. serpyllum, Cor. with a more obscure spot in the orifice

8407 Stem shrubby, Flowers in whorled spikes, Lvs. linear lanc. bluntish flat about 3-nerved ciliated at base

8408 Erect, Leaves revolute linear-lanc. hairy, Head few-flowered axillary stalked

8409 Flowers capitate, Stems creeping. Leaves linear nerved and furrowed beneath, Bractes ovate

8410 Fl. whorled somew. spiked, Ped. 1-fl. Stem shrubby erect, Lvs. ellipt. entire acute smooth shining above

8411 Flowers in whorled spikes, Cal. woolly with very long setaceous segments

8412 Flowers in whorled spikes, Spikes oblique, Ped, l-f. Lvs. ov. obtuse very entire and calyxes nearly naked

8413 Flowers in whorled heads, Stems filiform, Leaves roundish flat hairy nerved ciliate at base

8414 Flowers in whorled spikes, Cal. woolly with setaceous teeth, Lvs. ellipt. entire downy on each side

8415 Flowers in whorled spikes, Stem erect, Lvs. linear very blunt nerveless revolute at edge ciliated at base 8416 Pedun, about 3-fl. axillary, Lvs. ovate blunt nerved entire sess. Cor. twice as long as calyx, Stem villous 9417 Heads laxly imbricated, Bractes broad ovate colored not dotted, Leaves linear entire

8418 Heads imbricated large, Bractes toothed, Leaves setaceous hairy

8419 Flowers whorled, Stem half-shrubby erect, Leaves hispid acuminate

8420 Flowers axillary subsolitary stalked, Leaves cordate acute entire, Stems filiform

8421 Stem erect branched at base, Leaves ovate acute serrated forwards, Whorls 6-flowered

8422 Hirsute villous larger than the last, Stem much branched, Leaves ovate 8423 Whorls 6 - $f$. Leaves nearly blunt roundish concave subserrated

8424. Nearly smooth, Whorls 6-10-A. Leaves ovate subserrate, Stem ascending

8425 Fls. whorled, Pedunc. 1-flow. Stem branched spreading, Leaves roundish acute subserrate at end hairy

8426 Pedun. axill. 3-4-fl. Bractes lanc. sessile, Leaves ovate acute finely serrated

8427 Leaves rhomboid oval obsoletely toothed upwards, Whorls somewhat stalked about 10-fi. shorter than leaf

8428 Stem weak, Pedun. axill. many-fl. dichotomous, Lvs. ovate blunt serrated hairy dotted 8429 Pedunc. axill. many-fl. in dichotomous corymbs, Lvs. ovate blunt subserrate smoothish

8430 Leaves ovate somewhat toothed glaucous, Pedunc. axill. dichotomous, Segm. of calyx equal

84,31 Racemes terminal, Peduncles solitary very short

8432 Branches thin twiggy, Leaves downy beneath

8433 Villous, Leaves cordate crenate-toothed, Branches axillary elongated flowering 8434 Whorls halved subsessile, Bractes oblong stalked, Leaves ovate acute serrated

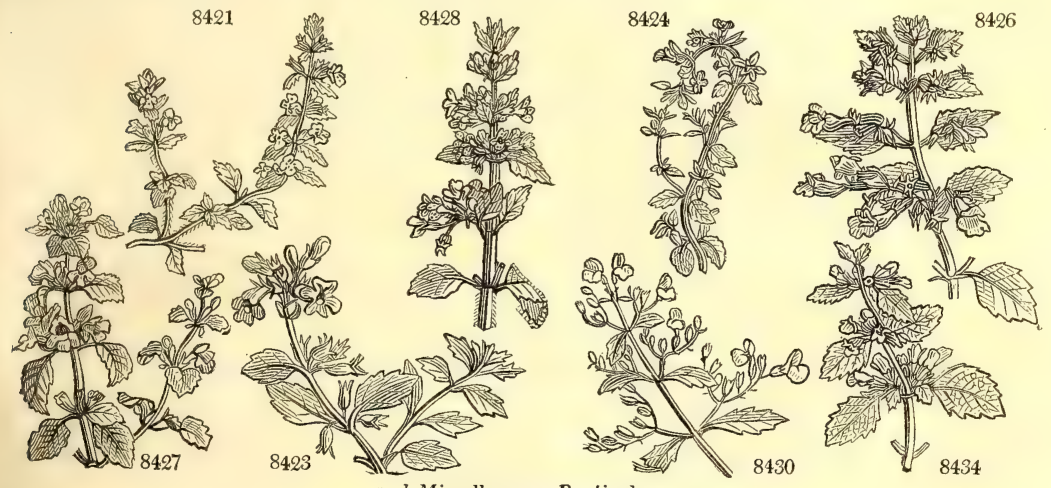

and Miscellaneous Particulars.

these aromatic plants, unless now and then by accident, or when they are first turned on hungry to downs, heaths, or commons; but the soil and situations favorable to aromatic plants produce a short sweet pasturage best adapted to feeding sheep, whom nature designed for mountains, and not for turnip grounds and rich meadows. The attachment of bees to this and other aromatic plants is well known.

Few plants are subject to more varieties than wild thyme. In its most natural state, on dry exposed downs, it is small and procumbent ; but when it grows among furze or other plants, it runs up with a slender stalk to a foot or more in height. It differs also very much in the smoothness or hairiness of its leaves. The flowers are sometimes larger than ordinary, and of a paler purple color, or even white.

T. vulgaris has the aromatic qualities common to lavender, sage, rosemary, and other Verticillatæ. It yields a species of camphor in distillation with water. In Spain they infuse it in the pickle with which they preserve their olives. Before the oriental spices were common, it was much used in cookery.

1276. Acynos. The Greek name of a balsamic plant, which probably was related to Thymus. This genus was included in Thymus by Linnæus.

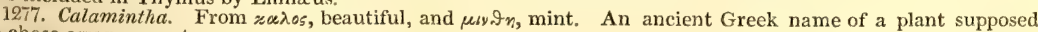
to chase away serpents.

1278. Melissa. This is the Greek name of the bee, from $\cos \lambda$. honey, which is sought by bees in these flowers with avidity, as indeed it is in all the plants of the order. The recent plant has the agreeable odor of 
1279. DRACOCE'PHALUM. $W$. DRagon's-Head. Labiate. Sp. 19-25.

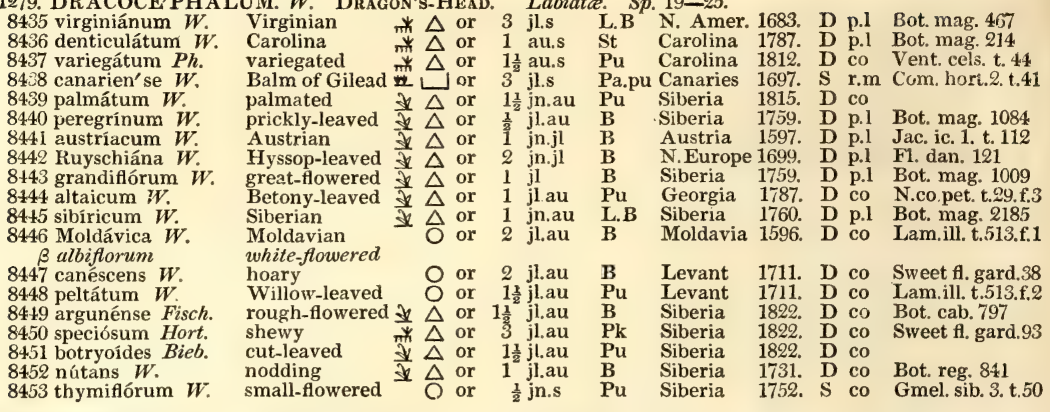

8453 thymiflórum $W$. small-flowered $\triangle \mathrm{O}$ or

1280. MELIT'TIS. $W$.

Bastard-Balm.

8154. Melissophýllum $W$. common

Labiate. $S p .2-4$. 8455 grandiflóra $H . K$. great-flowered

1281. O'CYMUM. $W$.

8456 thyrsifforum $W$.

8457 suáve $W$.en.

8458 viride $W$.en.

8459 monachórum $W$.

8460 gratíssimum $W$.

8461 grandiflórum $W$.

8462 Basílicum $W$.

8463 minimum $W$.

8464 sánctum $W$.

8465 pilósum W. $\mathrm{en}$.

8466 americánum $W$.

8467 tenuiflórum $W$.

8468 polystáchyon $W$.

8469 menthoídes

8470 micránthum $W$, en 8471 mólle $W$.

BASIL.

thyrse-flowered 1 un $1 \frac{1}{2}$ jl.au W W. Indies 1806. C s.l Jac. vind. 3.t. 72

$$
\text { Labiate. Sp. } 20-50 \text {. }
$$
sweet-scented $\square$ un 3 jl.s green un 3 jl.s monk's 0 un 1 jl.au shrubby $\square$ un 2 jl.au great-flowered un 2 s.o common-sweet $O$ cul 1 jl.au bush purple-stalked 0 un 1 jl.s ciliated 1 un 1 jl.s American un 1 jl.au slender-spiked $\square$ un 1 jlau many-spiked 0 un 1 jl.au Mint-leaved un 1 jlau 8472 capitellátum $W$. small-headed $O$ ec $1 \frac{1}{2} \mathrm{jl}$.au 8473 febrífugum Lindl. fever-plant $\square \mathrm{m} \quad 3$ jn.o 8474 cánum Sims. hoary 0 un 1 jl 8475 polycládum Link. many-branched O $1 \frac{1}{6}$ jn.o

\begin{tabular}{|c|c|c|c|c|}
\hline & E. Indies & 1806. C & s.1 & Jac. vind. 3. t. 72 \\
\hline W.G & 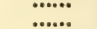 & 1816. C & $\begin{array}{l}5.1 \\
\text { s.1 }\end{array}$ & \\
\hline & E. Indies & 1796. S & $\begin{array}{l}5.1 \\
5.1\end{array}$ & \\
\hline W & E. Indies & 1752. C & s.l & Jac. ic. 3. t. 4.95 \\
\hline & Abyssinia & 1802. C & s.1 & L'He. s.nov. t.43 \\
\hline W & India & 1548. S & r.m & Blackw. t. 104 \\
\hline W & E. Indies & 1573. S & r.m & Sch. han. 2. t.166 \\
\hline $\mathrm{Pu}$ & E. Indies & 1758. $\mathrm{S}$ & s.l & Rhe.mal.10. t.92 \\
\hline & & 316. S & & \\
\hline W & India & 1789. S & s.1 & Jac. vind. 3. t. 86 \\
\hline a.p & E. Indies & 1703. S & s.l & Ru. \\
\hline & E. Indies & & s.1 & Mur.co.got.3.t. 3 \\
\hline W & E. Indies & 1783. & s.l & \\
\hline Pa.pu & & 1816. S & S & \\
\hline & E. Indies & & S s.l & \\
\hline & hin & & s.1 & \\
\hline W & one & & C co & Bot. reg. 753 \\
\hline & & & co & Bot. mag. 2452 \\
\hline & & & co & \\
\hline
\end{tabular}
Lumnitzera ocymoides Jacq.

1282. Plectran'thus. $W$. Plectranthus

8176 fruticósus $W$.

篮 $\downarrow$ or 3 jn.s B C. G. H. 1774. C r.m L'Her.st.85. t.41 8477 Forskohlæ $W$. Forskohl's $\square$ or 3 o.n $\quad$ B $\quad$ Abysinia 1806. C l.p Bot. mag. 2036 8478 parviflórus $W$. en. small;flowered w

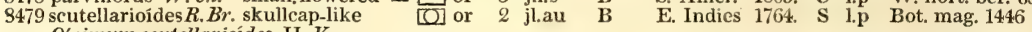
$O^{\prime}$ cimum scutellarioídes $\mathrm{H}$. K.

8480 punctátus $W$.

dotted (OS or 2 ja.my B Africa 1775. S r.m L'Her.st.87.t.41 comose $\mathrm{O}$ pr 2 au $\mathrm{B}$ Nepal 1821. S co Bot. mag. 2318

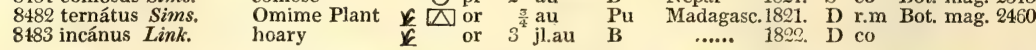
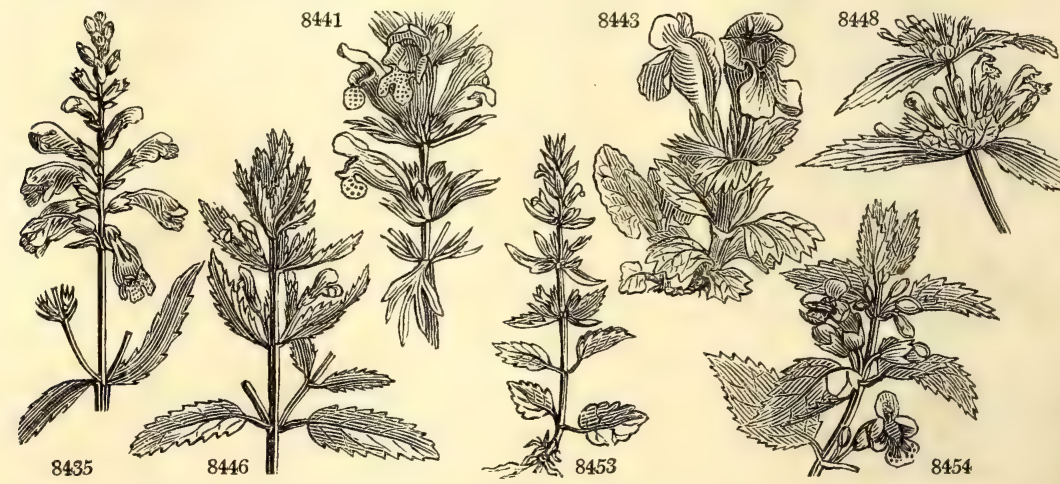

History, Use, Propagation, Culture,

lemons, which is lost in drying, and an austere, slightly aromatic taste. In distillation with water, it yields a small portion of a yellow essential oil, on which its odor depends. It is stomachic and diuretic, and was formerly prized as a corroborant in hypochondriacal and nervous affections; but it is now used only in the form of tea, as a grateful diluent in fevers. For medicinal use the herb should be cut before it fowers, as it is then more odorous. (London Dispensatory, 383.)

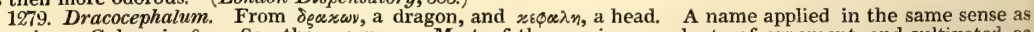
Lamium, Galeopsis, \&c. See those genera. Most of the species are plants of ornament, and cultivated as such in the gardens of the curious. D. canariense smells of citron, especially when rubbed between the fingers. Sown on a hot-bed early in spring, it may be planted out in the borders like other tender annuals. $\mathrm{D}$. austriacum is a handsome plant for a flower border. 
8435 Smooth, Flowers spiked close, Leaves linear lanceolate serrated

$8+36$ Flowers spiked remote, Leaves obovate lanceolate toothletted upwards

8437 Spikes short 4-cornered, Corolla variegated, Leaves oblong toothletted upwards

8438 Flowers spiked, Leaves ternate obolng

8439 Fl. somewhat spiked, Lvs. roundish cuneiform sinuate-toothed, Upper lip of cal. undivided mucronate 8440 Fl. somewhat spiked, Leaves lanceolate remotely mucronate toothed, Bractes lin. lanc. toothed spiny 8441 Fls. spiked, Lvs. sessile linear mucronate, Cauline 3-5-parted at base, Stem branched somewhat villous 8442 Flowers spiked, Leaves and bractes lanceolate undivided pointless, Stem nearly simple smooth

8443 Fls. whorled, Lvs. obl. blunt toothed stalked, Bractes lanc. entire, Upper lip of cal. ellipt. blunt undivided 8444 Fls.whorled, Rad. lvs. cord.ov.; cauline sessile roundish wedge-shaped acutely toothed, Teeth of cal. equal 8445 Flowers whorled, Whorls stalked bifid one-sided, Leaves lanc. cordate acum. serrated smooth

8446 Flowers whorled, Bractes lanceolate deeply toothed dotted beneath, Lower serratures subciliated

8147 Flowers whorled, Bractes oblong ciliated, Cal. striated pubescent, Tube of cor. longer than calyx 8448 Flowers whorled, Bractes orbicular serrate ciliate

8449 Stem erect, Leaves linear lanceolate blunt entire at edge rough, Two upper teeth of calyx largest 8450 Leaves broad-lanceolate finely serrated entire at base, Lower teeth of calyx longest 8451 Flowers in spiked heads, Leaves roundish pinnatifid crenate downy on each side

8452 Flowers whorled, Bractes oblong ovate entire, Cor. twice as long as calyx nodding

8453 Flowers whorled, Bractes oblong entire, Cor. scarcely larger than calyx

\section{Leaves opposite ovate toothed, Calyx 3-lobed hairy}

8455 Cal. 4-lobed smooth, Cor. yellowish white, Segment of lower lip violet in the middle

8456 Flowers in panicled fascicles, Stem much branched

8457 Racemes panicled, Leaves ovate oblong cuneate at base acutely serrated hoary beneath

8458 Racemes panicled, Leaves ovate cuneate at base bluntly serrated, Veins hairy above rough beneath 8459 Stamens toothless, every other one bearded at base

8460 Stem $\frac{1}{2}$ shrubby, Leaves lanceolate ovate subtomentose, Racemes rounded

8161 Stem shrubby, Leaves ovate serrate, Stamens very long

8462 Leaves ovate smooth, Calyxes ciliated

8463 Leaves ovate entire

8464 Leaves somewhat oblong blunt serrated wavy, Stem hairy, Bractes cordate

8465 Leaves ovate oblong, Foot-stalks, bractes and calyxes ciliated

8466 Leaves sublanceolate acuminate subserrate, Racemes rounded, Stem nearly herbaceous

8467 Leaves ovate-oblong serrated, Bractes cordate reflexed concave, Spikes filiform

8468 Cor, 4-fid, Racemes leafless nodding at end

8469 Leaves linear lanceolate serrate

[than calyx

8470 Lvs. broad ovate acum, at each end serr. Bractes shorter than cal. winged at edge, Cor. scarcely longer

8471 Leaves ovate cordate acute serrated rugose, Recesses closed, Bractes roundish wedge-shaped

8472 I.eaves ovate, Flowers aggregate, Footstalks lateral

8473 Downy, Lvs. ovate lanceolate crenate stalked, Whorls terminal racemose, Corolla the length of caly $\mathrm{x}$

8474 Leaves oblong elliptical serrated hoary on long stalks, Stamens twice as long as corolla

8475 Like Ocymum polystachyon, but not having a musky scent as that has

8476 Nectary spurred, Racemes compound. Pedunc. 3-parted, Stem shrubby polished

8477 Nectary gibbous, Racemes leafless, Stem nearly equal

8478 Nectary gibbous, Racemes compound, Pedunc. 1-flowered whorled, Stem half shrubby nearly smooth 8479 Cor. falcate, Flower-stalks branched

8480 Nectary gibbous, Flowers spiked, Stem herbaceous hairy rufous dotted

8481 Flowers whorled sessile, Lower lip of calyx 4-parted, Bractes cordate acuminate

8482 Stem 6-angled, Leaves ternate stalked ovate crenate rugose, Roots tuberous

8483 Leaves stalked cordate crenate hairy, Bractes nearly equal to flower ovate

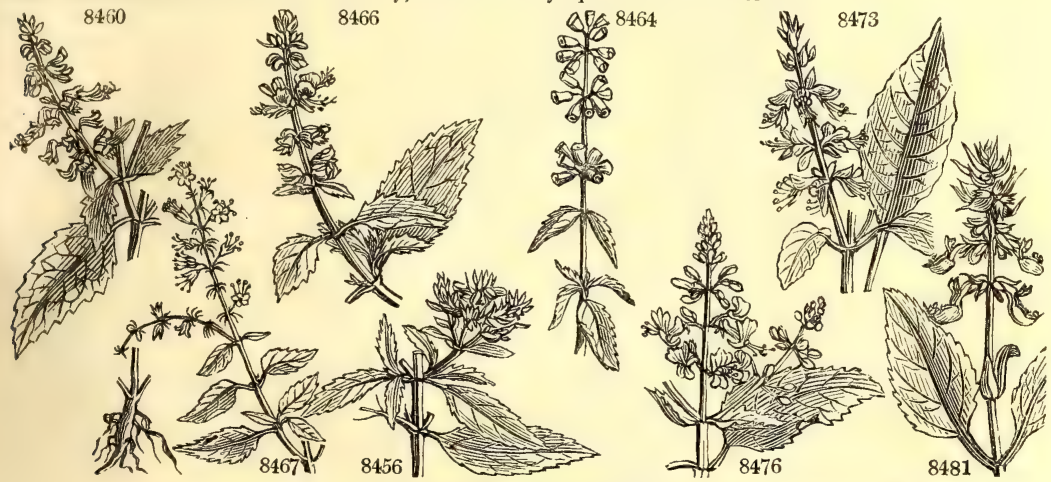

and Miscellaneous Particulars.

1280. Melittis, A name with the same meaning as Melissa.

1281. Ocymum. Said by Mathiolus to be derivea from 't $\omega$, to smell, on account of the powerful scent of the

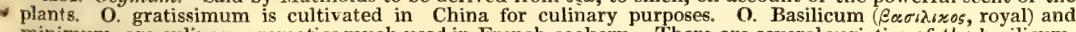
minimum, are culinary aromatics much used in French cookery. There are several varieties of the basilicum, which with some other species were formerly used in medicine, but are now neglected.

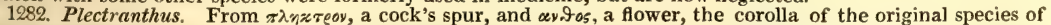
the genus being terminated by a spur-like appendage. Half-shrubby plants with purple flowers, all natives of hot climates. 
1283. TRICHOSTE'MA. $\boldsymbol{W}$. Trichostema. 8484 dichótoma $W$. 8485 brachiáta $W$

1284. Prost anthérA. $R, B$. Prostanthera. 8486 lasiánthos $R, B r$. villous-flower'd br or 1285. SCUTELLA'RIA. $W$. SKULL-CAP.

8487 orientális $W$. yellow-flowered 8488 grandiflúra $P, S$. 8489 álbida $W$ 8490 alpina $W$. 8491 lupulína $W$. 8492 lateriflóra $W$ 8493 pilósa $P h$. 8494 galericuláta $W$. 8495 minor $W$. 8496 hastifólia Pers. 8497 caroliniána $P h$. 8498 integrifólia $P h$. 8499 serráta $P h$ 8500 havanénsis $W$. 8501 peregrina $W$. 8502 colúmnæ $W$ 8503 altíssima $W$. 8504 crética $W$. 8505 par'vula Mich 8506 rubicúnda $W$. en 8507 pállida Bieb.

1286. PRUNEL'LA. $W$ 8508 vulgáris $W$. $\beta$ álba

8509 ováta Pers. 8510 pensylvánica $W$. 8511 hyssopifólia $W$. 8512 grandiflóra $W$. 8513 laciniáta $P . S$. 8514 intermédia $P$. $S$. 8515 incísa Link.

1287. CLEO'NIA. $W$. 8516 lusitánica $W$. 1288. PRA'SIUM. $W$. 8517 május $W$. 8518 minus $W$ 1289. PHRY'MA. $W$ 8519 leptostáchya $W$. Puires pubesce

lesser

Self-Heal. common $\$ \Delta \mathrm{m}$ white-flowered $\$ \mathrm{~s} \mathrm{cu}$ oval-leaved $O$ un Pensylvanian $\searrow \Delta$ un Hyssop-leaved $\downarrow \Delta$ un great-fiowered $\downarrow \Delta \Delta$ ur yellow-flowered $\mathrm{O}$ un various-leaved \& $\triangle$ un cut

Cleonia.

Prasium. grall Sicilian - cu

Phryma.
Labiatce. Sp. 2-4.

1 jn.jl B N. Amer: 1759. S s.1

N. Amer. 1732. C s.p Di.el, t.285.f.369 Labiatce. Sp. 1-13.

2 jn.jl Pu.w N. S. W. 1808. C s.p Bot. reg. 143 Labiatce. Sp. 21-30.

1 jl.s Y Levant 1729. D p.1 Bot. mag. 2120

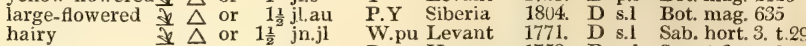
hairy $\$ \triangle$ or $1 \frac{1}{2}$ jn.jl Alpine $\quad \frac{7}{4} \triangle$ or $\frac{3}{4}$ jn.o Tartarian $\$ \Delta$ or 1 jn.s Virginian $\quad \mathrm{J} \Delta$ or 1 jn.s \& $\triangle$ or 1 jl.au

B.w Hungary 1752. D p.l Sweet fl, gard.90 Y.w Tartary 1739. D p.l Schmidel.ic.t.73

B.W N. Amer, 1752, D p.l jl.au B N. Amer. 1805. D p.1 $\begin{array}{lll}\text { jn.s } & \text { B } & \text { Britain } \text { Amer. 1805. D p. D co }\end{array}$ $\frac{x^{2}}{2}$ jn.jl Pu Germany 1798. D co

$\frac{1}{2}$ jn.jl B Carolina 1811. D co Lam.1l. t.515.f.3 2 jn.s B N. Amer. 1731. D p.l Pluk.al, t.441.f.6 4 jn.s B N. Amer. 1800. D s.1 Bot. rep. 494 2 my.jn B Havannah1793. D s.1 Jac. obs. 2. t. 29 2 jn.o V Italy 1683. D co Pl.rar.hu.2.t.125 $1 \frac{1}{2} \mathrm{jn}$.au B Italy 1806. D co Sweet fl.gard.52 1 jl.au D.P Levant 1731. D p.1 Bot. mag. 2548 1 jn.jl Pu Crete 1729. C

$\frac{2}{4}$ jn.jl B N. Amer. 1822. S p

$2^{\frac{1}{4}}$ jl.au $\quad$ Pk $\quad$...... 1823.

Crimea

Labiate. Sp, 8-10. Pk Britain me.pa. D co $\begin{array}{llll} & \text { Wl.au } & \text { W } & \text { Britain me.pa. D co } \\ \frac{1}{2} \text { jl.au } & \mathrm{Pu} & \text { America }\end{array}$

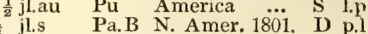
$\begin{array}{lllll}\text { jl.s } & \text { Pa.B N. Amer. 1801. D p.l } & \text { W. hort. ber. t.9 } \\ 1 & \text { jl.s } & \text { L.B } & \text { France 1731. D p.l } & \text { Mor. s.11. t.5. f.7 }\end{array}$ L.B Austria 1596. D p.1 Bot. mag. 337 Y Austria 1713. S p.l Lam.ill, t.516.f.2 Pk Portugal 1790. D s.l

jn.jl L.B Portugal 1710. S co Mill. ic. 1. t. 70 Labiatce. Sp. 2.

great Spanish jn.au Pu Spain 1699. C rm Fl. græca, 584

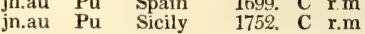

Labiatce. Sp. 1.

slender-spiked $\$ 2 \Delta$ cu $1 \frac{1}{2}$ au.s W.pu N. Amer. 1802. D l.p Pl.amal.t.380.f.5

1290. GESNE'RIA. $W$ 8520 acaúlis $W$. 8521 tomentósa $W$ 8522 aggregáta Ker. 8523 bulbósa $\mathrm{Ker}$. 8524 prasináta $K$ er. 8505 tubifló

1291. GLOXI'NIA, W 8526 maculáta $W$. 8527 speciósa $B$. Reg.

$\quad$ GesneriA.
stemless
woolly
aggregate
bulbous
green
tube-flowered

\section{ANGIOSPERMIA.}

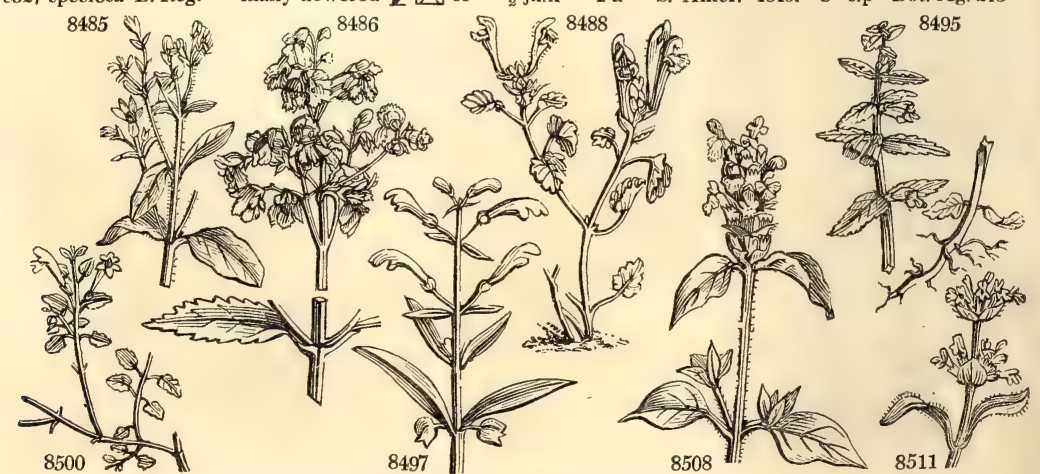

History, L'se, Propagation, Culture,

1283. Trichostema. From $\theta \theta_{\varsigma} \xi \tau^{s} \chi \circ$, hair, and $\sigma \tau \eta \mu \alpha$, a stamen, because its long slender stamens resemble hairs.

1284. Prostanthera. Named in allusion to the spurs of the anthers, the word being derived from

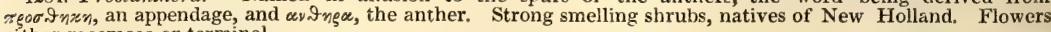
either racemose or terminal.

1285. Scutellaria. From scutilla, a small vessel, on account of the figure of the calyx, which is not unlike a cup with its handle. The calyx inverted, presents the figure of a helmet with visor raised.

1286. Prunella. A barbarous name softened down by Linnæus from the Brunella of some authors, and so called from the German die Bräune, a disorder in the jaws and throat, which this plant is said to cure. Herbaceous plants common by way-sides all over Europe. 
8484 Stamens very long exserted, Leaves linear

8485 Stamens short included

8486 Leaves lanceolate tooth-serrated smooth, Racemes panicled, Corolla hairy

8487 Leaves cut downy beneath, Spikes rounded 4-cornered

8488 Leaves cordate cut crenate pubescent on each side shorter than footstalk, Spikes silort 4-cornered

8489 Leaves subcordate serrate rugose opaque, Spikes 1-sided, Bractes ovate

8490 Leaves cordate cut serrate crenated, Spikes imbricated rounded 4-cornered, Bractes twice as short as fl.

8491 Leaves cordate cut serrate acute smooth, Spikes imbricated rounded 4-cornered, Bractes length of flower

8492 Much branched, Leaves smooth with a scabrous keel, Racemes lateral leafy

8493 Hairy, Leaves ovate rhomboid crenate, Flowers subracemose

8494 Leaves cordate lanceolate crenate, Flowers axillary

8495 Leaves cordate ovate nearly entire, Flowers axillary

8496 Leaves quite entire, lower hastate, upper sagittate, Flowers axillary

8497 Branched very smooth, Leaves stalked linear lanceolate acute entire, Racemes loose leafy, Cal. blunt

8498 Simple densely pubes. Lvs. subsess. obl. or linear blunt entire attenuated at base, Racemes loosish leafy

8499 Branched tall pubescent, Leaves ovate acuminate serrate on short stalks, Racemes usually panicled

8500 Leaves cordate ovate crenate, Flowers solitary axillary, Each lip of cor. trifid

8501 Leaves cordate serrate, Spikes elongated 1-sided, Bractes stalked ovate longer than calyx

8502 Leaves oblong cordate serrate pubes. Spikes elongated 1-sided, Bractes stalked ovate shorter than calyx

8503 Leaves cordate oblong acuminate serrate, Spikes nearly naked

8504 Villous, Leaves cordate blunt and bluntly serrated, Spikes imbricated, Bractes setaceous

8505 Subvillous, Leaves ovate entire all alike, Flowers axillary

8506 Related to S. albida from which it differs in being much less hairy, and in its more slender flower

8507 Lvs. cord. cren. serrate bluntish villous, Spikes long 1-sided hispid, Bractes stalked ovate longer than cal,

8508 Lvs, stalked obl, ovate somew. toothed, Upper lip of cor. trun. with 3 awns, Stem ascending, Spike round

8509 Leaves broad ovate toothed, Stem much branched, Spikes ovate

8510 Lvs. stalked ovate lanc. toothed at base, Lips of cal, equa! : upper truncate with 3 awns, Stem ascending 8511 Leaves sessile lanceolate entire rough, Stem erect

8512 Leaves stalked oblong ovate toothed at base, Upper lip of cor. trifid, Stem ascending

8513 Small, Stem nearly simple villous, Leaves pinnatifid low er oblong, Cor. pale yellow

8514 Leaves entire and sinuated toothed rugose hairy, Upper lip of cor. truncate slightly 3-toothed

8515 Upper leaves linear-lanceolate : lower sinuate toothed somewhat hairy

\section{Bractes laciniate}

8517 Leaves ovate oblong serrated

8518 Leaves ovate with a double crenature on each side

8519 Leaves stalked ovate serrated, Spikes terminal long

\section{ANGIOSPERMIA.}

8520 Leaves lanceolate ovate serrated somewhat stalked terminal, Pedunc. inf. shorter than leaves 8521 Leaves ovate lanceolate crenate hairy, Peduncles lateral very long bearing corymbs

8522 All vill. Branches rounded, Lvs, opp. obl. ovate cren. Ped. 2-4 axill. 1-fl. aggregate, Cor. clavate cylind.

8523 All pubes. Lvs. opp. ovate ellipt, cord. at base serr. cren. Panicle numer. opp. spread. dist. Ped. corymbose 8524 All pubes. Lvs. oval lanc. velvety above, Panicle leafy, Fl, with a campan. inflated orifice, Limb oblique 8525 Leaves opposite ovate crenulate tomentose, Flowers axillary 2-3 together downy

8526 Leaves oblong cordate crenate rugose, Stem spotted

8527 Leaves hoary ellipt. or oblong crenate, Pedunc. erect longer than flower, Sepals angular acuminate

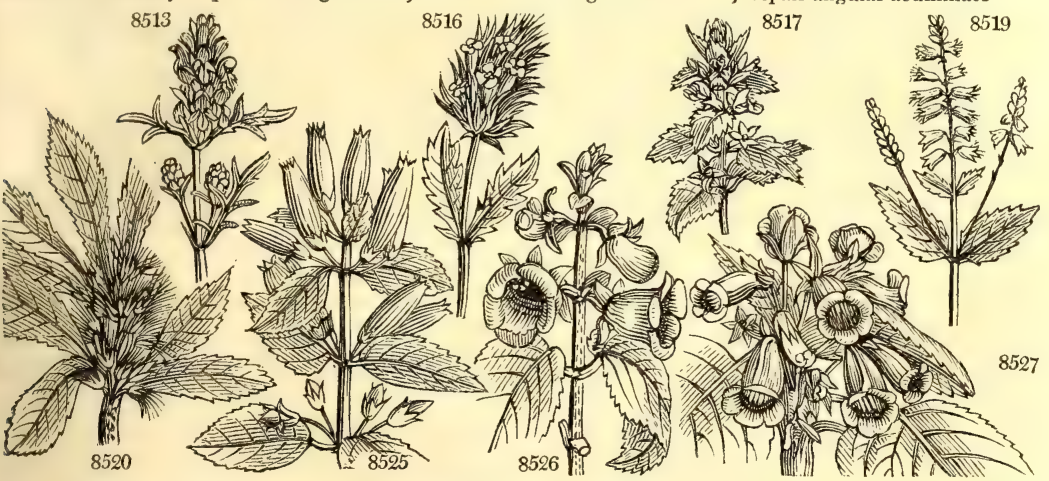

and Miscellaneous Particulars.

1287. Cleonia. An ancient Greek name employed by Theophrastus, lib. 7. cap. 4.: the Cleonæum of Pliny. This is an annual plant six or eight inches high, and nearly related to Prunella, from which some eminent French botanists do not distinguish it.

1288. Prasium. The Greek name of the horehound, which this plant resembles in some respects.

1289. Phryma. A Linnean name, the meaning of which is unknown

1290. Gesneria. In honor of Conrad Gesner, of Zurich, the famous botanist and natural historian, called the German Pliny. Very fine herbaceous or half-shrubby plants, some of which are remarkable for the brilliance of their colors.

1291. Gloxinia. In memory of Ben. Petr. Gloxin, of Colmar, author of Observationes Botanicæ, Argent, 
1292. LINN形A. $W$. 8528 boreális $W$.

1293. MELIAN'THUS. 8530 minor $W$.

1294. BIGNO'NIA. $W$.

8531 únguis $W$.

8532 æquinoctialis $W$.

$\beta$ Chamberlayni

8533 alliácea $W$

8534 laurifólia $W$.

8535 paniculáta $W$.

8536 crucígera $W$.

8537 uncáta $B . M$.

8538 capreoláta $W$.

8539 pubéscens $W$

8540 rigéscens Jacq.

8541 lactiflóra Vaht.

8542 meonántha Link.

8543 grandifólia Jacq.

8544 venústa $B$. Reg.

8545 echináta $W$.

8546 triphýlla $W$

8547 pentaphýlla $W$.

8548 Leucóxylon $W$.

8549 rádicans $W$.

$$
\text { « májor }
$$

$$
\beta \text { mínor }
$$

8550 grandiflóra $W$.

8551 stans $W$

8552 chelonoídes $W$.

8553 spathácea $W$. Spathodea longi

8554 austrális $H$. $K$.

8555 índica $W$.

8556 prócera $W$.

8557 lineáris Cav.

8558 caroliniána $R$. Br. Carolina
8559 ovalifólia $R$. Br.

1296. SE'SA MUM. $W$

8560 orientále $W$

8561 indicum $W$

1297. PENTSTE'MON.

8562 campanuláta $W$.

8563 lævigáta $W$.

8564 hirsúta $W$.

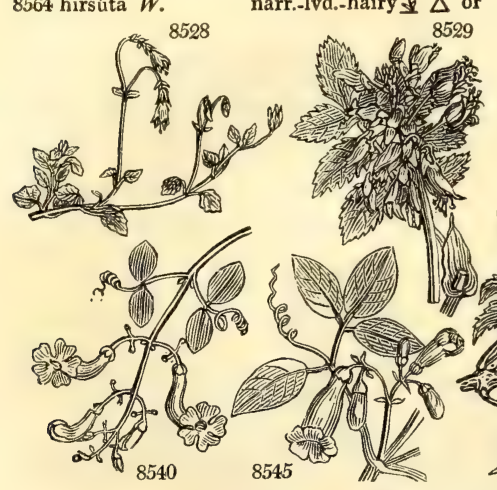

History, Use, Propagation, Culture,
Oily-Grain. oriental Indian
Caprifoliacea. $S p .1$.

LINNEA.

HONEY-FLOWER small 慗 J or $10 \mathrm{my}$ or ${ }^{2} \mathrm{au}$

mp 2 . or $20 \mathrm{jn.j}$ or 20 jn.j. or $20 \mathrm{jn}$.jl comely or bristly-fruited 1 or $20 \ldots$ white-wooded great Ash-lvd. (arge-fish branching salver-shaped

New S. Wales Indian . Pentstemon. clt $1 \frac{1}{2} \mathrm{jl}$ 甲

dry st.c. D 1.p Eng. bot. 433

C. G.H. 1688. Sk s.l Bot. reg. 45

C. G. H. 1696. Sk s.l Bot. mag. 301

\section{Bignoniacea. Sp. $27-75$.}

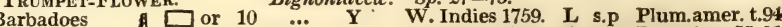

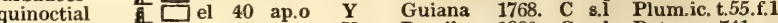
Chamberlayne's 5 el 40 ap.o Y Brazil 1820. C s.l Bot. reg. 741 Garlick-scent. $\mathrm{cu} 10$...

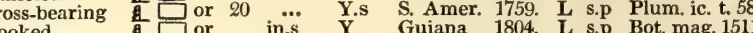

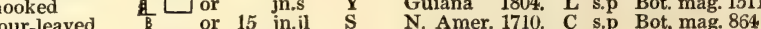
lowny $\square$ or 15 jn.jl Y Campeachy1759. C s.p

Campeachy1759. C s.p

Caraccas 1823. C s.p Jac.schon.t. 210 SantaCruz1823. C s.p Vah. symb. t. 66 Pk N. Holl. ? $\ldots$ C s.p

Y Caraccas 1816. C p.l Bot. reg. 418

Or S. Amer. 1816. C l.p Bot. reg. 249

Pk Guiana 1804. C 1.p Aub. gui.2. t.264

S. Amer. 1733. R l,p

Jamaica 1733. C l.p Marcg.bra.t.118 P̈ W. Indies 1759. C $\quad$ l.p Bot. rep. 43

Or N. Amer. 1640. R s.p

Or N. Amer. 1640. R s.p Bot. mag. 485

S N. Amer. 1640. C s.p Cates. car.1. t.65

Or China 1800 C rm Bot mag 1398

Y America 1730 S l.p Plum. ic. t. 54

R E. Indies 1808. R 1.p Rhee.mal.6. t.26

E. Indies 1794. C 1.p Rox. cor.2. t.144

\section{N. S. W. 1793. C s.p Bot. mag. 865}

India 1775. C 1.p

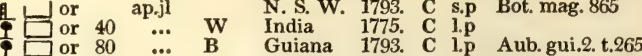
... Pk Mexico 1825. C p.1 Cav. ic. 3. t. 269 Bignoniacea. $S p .2-4$.

J or 10 jl.au B Bahamas 1724. C p.l Cates. car.1.t.42 $\square$ or 10 ap.my B Brazils 1818. C p.1 Bot. reg. 631 Pedaline. Sp. 2-4.

W E. Indies 1731. is co Rhee mal.9. t.54 Scrophularinece. Sp. 9-11.

bell-flowered -1 or $1 \frac{1}{3} \mathrm{mr} .0 \quad$ L.Pu Mexico 1794. D p.1 Bot. mag. 1878 smooth $\Delta$ or 2 au.s L.Pu N. Amer. 1776. D p.1 Bot. mag. 1425 1 au.s L.Pu N. Amer. 1758. D p.1 M.h.s.11.t.21.f.3 $1532 \beta$

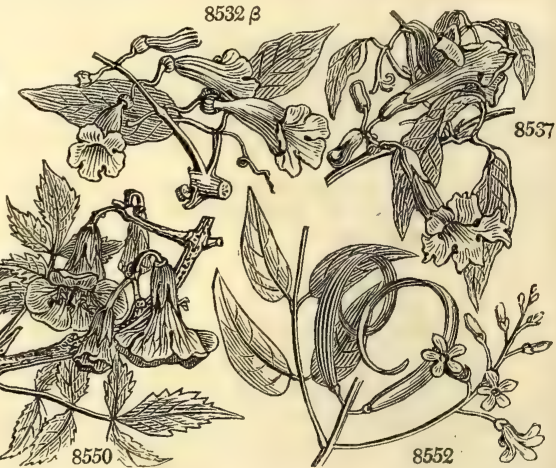

1785, quarto. Handsome low herbaceous plants, with fine shewy flowers. The Gloxinia speciosa is a favorite in every hothouse, on account of the beauty of its rich purple blossoms.

1292. Linnæa. So named by Gronovius, in honor of the celebrated Carl von Linné, the reformer of natural history, and the father of the modern physical sciences. His works are not less numerous than important ; it is to be wished that such another man, with equal talent, industry, and judgment, could be found at the present day, to rescue the science of natural history from the confusion to which it is fast approaching.

1293. Melianthus. From $\mu \varepsilon \lambda s$, honey, and $\alpha$. . 0 s, flower. A shrub, native of the Cape of Good Hope, the blossoms of which are a great attraction to bees. Both the known species are common in collections, but seldom flower.

1294. Bignonia. In memory of Abbé Bignon, librarian to Louis XIV., born 1662, died in 1743. He was the friend and patron of most of the learned men of his time, and especially of Tournefort, by whom this truly noble genus was named. The species are trees or shrubs, inhabitants of hot climates : the leaves are opposite, pinnate, ternate, or conjugate : the flowers in panicles, large, and handsome, of various colors, red, blue, yellow, or white, and eminently beautiful. The stove sorts grow freely in loam and peat, and young cuttings root in sand under a hand-glass. The hardy species grow in any soil, but will not flower well unless the situation be warm. They are increased by cuttings of the roots, by layers, or by young cuttings on gentle heat under a hand-glass or frame. B. radicans is a well known and much admired species, capable of living in the open air in this country against a wall.

1295. Jacaranda. The name of the tree in Brazil. Two kinds remarkable for the goodness of their wood, are described by Piso. Those in the gardens are lofty stove plants with fern-like, elegant leaves, and panicles of beautiful blue flowers. They grow with facility, but flower seldom. 
8528 The only species

8529 Stipules solitary adhering to stalk, Leaves smooth 8530 Stipules twin distinct, Leaves hoary beneath

8531 Leaves conjugate cirrhose, Leaflets ovate acuminate, Peduncles axillary 1-flowered: 8532 Leaves conjugate cirrhose, Leaflets ovate-lanceolate, Pedunc. 2-flowered, Pods linear

8533 Leaves conjugate, Leaflets elliptical entire coriaceous, Pedunc. 5-fiowered axillary, Calyx entire 8534 Lvs. conjugate obl. smooth, Racemes term. Branches dichotomous, Corollas very soft and downy outsid̄e 8535 Leaves conjugate cordate ovate, Flowers racemose, Calyx with a double limb

8536 Leaves conjugate cirrhose : lower ternate, Leaflets ovate cord. acuminate, Racem. axill. Stem muricated 8537 Leaves conjugate quite smooth. Tendrils longer than petiole trifid at end hooked

8538 Leaves conjugate cirrhose, Leaflets cordate lanceolate, Lower leaves simple

8539 Leaves conjugate cirrhose, Leaflets cordate ovate downy beneath

8540 Leaves conjugate cirrhose, Leaflets elliptical blunt, Flowers racemose, Pedunc. 3-fi. Calyxes toothed

8541 Leaves conjugate cordate ovate smooth, Lower racemes leafy, Limb of calyx leafy entire

8542 Leaflets 9-lanceolate subserrate dotted beneath, Corollas ventricose bearded in the orifice

8543 Lvs. conjugate cirrhose, Leafl. obl. acute at each end, Corymb trifid term. Ped. petioles and branches rough

8544 Climbing, Lvs. smooth upper conjugate cirrhose obl, ovate acumin. Peduncles corymbose many-flowered

8545 Lower leaves ternate, upper conjugate, Petioles dichotomous cirrhose, Fruit echinate

8546 Leaves ternate smooth, Leaflets ovate acuminate, Stem shrubby erect

8547 Leaves digitate, Leaflets entire obovate

8548 Leaves digitate, Leaflets lanceolate acuminate entire smooth, Flowers terminal solitary

8549 Lvs, pinnate, Leaflets ovate acuminate toothed, Corymb terminal, Tube of cor. thrice as long as calyx

8550 Leaves pinnate, Leaflets ovate acuminate toothed, Panicle terminal, Tube of cor. the length of calyx 8551 Leaves pinnate, Leaflets oblong lanceolate serrate, Raceme simple terminal, Stem erect

8552 Leaves pinnate with an odd one, Leaflets ovate entire pubescent, Corollas bearded half pentandrous

8553 Leaves pinnate with an odd one, Leaflets ovate hirsute, Cal. 1-leaved spathaceous, Cor. hypocrateriform

8554 Leaves pinnate of four pair, Leaflets elliptical generally entire, Racemes compound

8.555 Leaves bipinnate, Leafl. roundish ovate cordate acuminate, Fl. pentandrous, Calyx tubular, Cor. 5-fid 8556 Leaves bipinnate, Leaflets oblong obtuse, Panicle terminal, Peduncles with bractes, Pods oblong blunt 8557 Leaves simple linear acuminate, Flowers terminal subumbellate, Stem erect

8558 Leaves bipinnate, Leaflets lanceolate acute, Panicle terminal, Peduncle naked, Pods long emarginate 8559 Leaves bipinnate obiong villous oval oblong mucronate, Panicle large lax branched, Corollas silky

8560 Leaves ovate oblong entire

8501 I eaves ovate lanceolate : lower 3-lobed; upper undivided, Stem erect

8562 Stem smooth, Sterile filament bearded upwards, Leaves lanceolate acuminate all finely serrate 8563 Leaves polished ovate-oblong amplexicaul finely toothletted, lower entire, Flowers panicled 8564 Leaves serrulate lanceolate oblong sessile downy obscurely toothed narrow, Flowers panicled

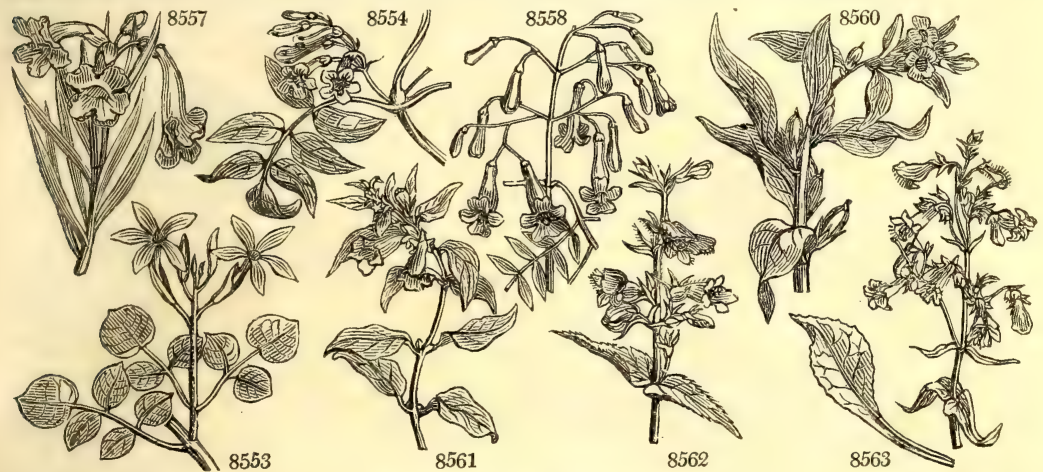

and Miscellaneous Partıculars.

1296. Sesamum. From the Arabic word semsem. Forskahl, p. 68. These plants were introduced into Jamaica by the Jews, and are now cultivated in most parts of the island. They are called vanglo or oil-plant. The seeds are frequently used in broths by many of the Europeans, but the Jews make them chiefly into cakes Many of the oriental nations look upon the seed as a hearty wholesome food, and express an oil from them, not unlike, or inferior to, the oil of almonds. It has been also manufactured for salad oil in this country, but without much success.

S. orientale is frequently cultivated in the Levant, and also in Africa, as a pulse: the seeds have been introduced in Carolina by the African negroes. An oil is extracted from the seeds which will keep many years, and not acquire any rancid smell or taste, but in two years become quite mild, so that when the warm taste of the seed, which is in the oil when first drawn, is worn off, it is used as salad oil, and for all the purposes of sweet oil.

The seeds are also used by the negroes for food: they parch them over the fire, then mix them with water, and stew other ingredients with them. A pudding is made with them, in the same manner as with millet or rice.

In Japan, China and Cochin-China, where they have no butter, they use the oil for frying fish, and in dressing other dishes; as a varnish ; and medicinally as a resolvent and emollient. Nine pounds of the seed yield upwards of two pounds of neat oil.

1297. Pentstemon. From $\pi \varepsilon y \tau \varepsilon$, five, and $s$ nuov, a stamen, because of the four perfect and one imperfect stamen of the genus. Beautiful herbaceous plants, deserving a place in every garden. 
8565 pubéscens $W$. 8566 erianthéra $P h$. 8567 angustifólia $P h$. 8568 glăbra $P h$.

8569 Bradbúrii $P h$

8570 al'bidum Nutt.

1298. CHELO'NE $W$. 8571 glábra $W$. 8572 oblíqua $W$. 8573 Lyóni $P h$. 8574 barbáta $W$

1299. TOURRET 8575 lappácea $W$.

1300. MARTY'N 8576 diándra $W$. 8577 Craniolária $W$ 8578 proboscídea $W$. 8579 longiflóra $W$.

1301. ACAN'THUS. $W$. 8580 móllis $W$. 8581 níger Mill. 8582 spinósus $\boldsymbol{P}$. $\boldsymbol{S}$. 8583 spinosíssimus 8584 ilicifólius $W$.

1302. BARLE'RIA. $W$. 8585 longifólia $W$. 8586 Prionitis $W$. 8587 buxifólia $W$. 8588 purpúrea Lodd. 8589 álba Hort. 8590 cristáta $W$. 8591 mitis $B$. Ree. 8592 longiflóra $W$.

1303. PHAYLOP'SIS. Juss. PHAYLOPSIS. 8593 longifólia Sims.

1304. RUEU/LIA. $J$. 8594 ováta $W$.

8595 strépens $W$.

8596 ocymoídes $\mathrm{Cav}$.

8597 pátula $W$.

8598 láctea $W$.

8599 clandestína $W$. 8600 paniculáta $W$. 8601 tuberósa $L$. 8602 bifóra $W$. 8603 formósa $H$. $K$.

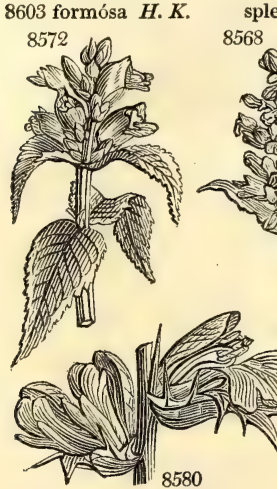

8580

Chelone. Lyon's

scarlet

ered

horn-capsuled
long-flowered Holly-leaved

Barleria. long-leaved thorny

purple

white

crested broad-lv.-hairy $\downarrow \Delta$ or $\frac{1}{7} \Delta$ or $1 \frac{1}{8}$ au.s narrow-leaved $\frac{\partial}{\Delta}$ or $\frac{1}{2}$ au.s Nuttal's $\frac{\partial}{\Delta} \Delta$ or $1 \frac{1}{2} \mathrm{jl}$.s large-flowered $\frac{1}{\Delta} \Delta$ or 2 jls whitish $\$ \Delta$ or $\frac{3}{4} \mathrm{jl}$.s

white-flowered red-flowered $\frac{\nabla}{\nabla} \Delta$ or

$\$ \triangle \triangle$ or

$\downarrow \Delta$ or scarlet-flowered $\mathrm{B} O \mathrm{cl}$

Scroph

Scrophularinea, Sp. 1.

Pedalina, Sp. 4-6.

[0] or

[D] or $1 \frac{1}{2}$ jl.au W S. Amer. 1733. S s.1 Jac. amer.t. 110

O or ${ }^{\frac{3}{4}}$ jn.au L.B America 1738. S r.m Bot. mag. 1056

BEAR'S-BREECH.

H. prickly-leaved $\triangle$ white-spined $\frac{1}{\Delta}$ or

in or

Box-leaved

iv $\square$ or

long-flowered

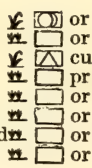

Acanthacere. Sp. 5-14.

3 jl.s P.w Portugal 1759. D co

3 jl.s P.w S. Europe 1629 . D co

Acanthacea. Sp. 8-18.

\section{Acanthacee. Sp. $1-6$.}

long-leaved it $\square \mathrm{pr} 2$ ap.o W S. Leone 1822. C co Bot.mag.2433

Ruellia. Acanthacea. Sp. 18-70.

oval-leaved $\mathbb{L} \mathrm{pr} 2$ jl.au D.B Mexico 1800. D l.p Cav. ic.3. t. 254 whorl-flowered $\mathbb{N}$ pr 2 jl.au Pa.B N. Amer. 1726. D 1.p Sch.han.2.t.177 Basil-like 业 $\square$ pr 11 jl.au B Mexico 1815. C 1.p Cav ic. 5. t. 456 spreading $\square$ pr $1 \frac{1}{2}$ jl.au Pa.V E. Indies 1774. C lp Jac ic $1 \mathrm{t} 119$

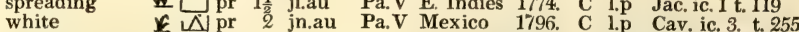
white $\frac{\mathbb{N}}{\mathrm{pr}} 2$ jn.au Pa.V Mexico 1796. C 1.p Cav. ic. 3. t. 255 three-flowered $\overline{\mathrm{pr}} 2$ jl.au B Barbadoes1728. C 1.p Dil.el.t.248.f.320 panicled tuberous-rooted $\triangle \mathrm{pr} \quad 2$ jl.au B Jamaica 1752. C 1.p Slo.jam.1.t.95.f.1 two-flowered $\triangle \mathrm{N}$ pr 1 jl Pa.B Carolina 1765. C l.p splendid $\square$ pr 2 jn.s S Brazil 1808. C s.p Bot. mag. 1400 8568000073

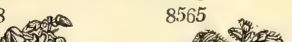
Sp. 4-6.
N. Amer. 1730. D p.l Trew.ehret. t.83
N. Amer. 1752. D p.l Bot. reg. 175
4 jl.s Pu N. Amer. 1812. D p.1 Bot. mag. 186
6 jn.au R.G Peru 1788. S s.l Sal.stir. 5.t.3
11 jl.au R New Spain1731. S s.l Bot. rep. 575
3 jl.s $\quad$ P.w Italy 1548. D co Lam. ill. t. 550
3 jl.s P.w Italy 1629. D co Bot. mag. 1808
... E. Indies 1759. D co Rhee.mal.2, t.48
2 jl.s W E. Indies 1781. S 1.p Pluk.al, t.133.f.4
3 jl.au Or E. Indies 1759. C p.l Rhee.mal.9. t.41
2 jn.jl W E. Indies 1768. D l.p Rhee.mal 2 t.47
2 s $\quad \mathrm{Pu}$ E Indies 1814 D lp Bot.
3 jn.jl W N. Holl. 1815. C co Bot. cab. 360
2 jn.s $\quad$ B $\quad$ E. Indies 1796. C p.l Bot. mag. 1615
3 jn.s $\quad \mathbf{Y} \quad$ E. Indies 1816. C p.l Bot. reg. 191
D p.l 1811.


8565 Stem pubescent, Sterile filament bearded from the end to the middle

8566 Leaves oblong acute subhirsute, Flowers racemose, Leaves of calyx linear very hairy

8567 Stem smooth long linear entire, Flowers in racemose panicles, Leaves of calyx smooth.

8568 Stem and lvs. smooth, Lvs. subamplex. ovate obl. ent. Barren filam. naked clav. Sepals roundish acuminate

8569 Very smooth, Lvs. subamplexicau!. ov. obl. ent. upper roundish, Barren filam. with a short beard at end

8570 Leaves ovate lanc. subserrulate smooth, Fl. fascicled axillary and terminal, Cor, equal 5-cleft spreading

8571 Leaves stalked lanceolate serrate : upper opposite

8572 Leaves lanceolate oblique stalked opposite finely serrated at edge

8573 Smooth much branched, Leaves stalked cordate ovate serrated, Spikes terminal dense

8574 Leaves opposite connate lanceolate entire, Lower lip of corolla bearded

8575 The only species. Leaves pinnated cut cirrhose

8576 Stem branched, Leaves opposite cordate toothed, Flowers diandrous

8577 Stem branched, Leaves opposite 5-lobed toothed

8578 Stem branched, Leaves alternate cordate entire

8579 Stem simple, Leaves roundish repand, Tube of cor. at base gibbous flattened

8580 Leaves sinuated unarmed

8581 Leaves sinuated unarmed glabrous shining green

8582 Leaves pinnated spiny

8583 Leaves laciniate pinnatifid blistered spiny, Spines white

8584 Leaves repand spiny-toothed, Stem shrubby prickly

8585 Spines of whorls 6 , Leaves ensiform very long rough

8586 Spines axillary pedate in fours, Leaves quite entire lancenlate ovate

8587 Spines axillary opposite solitary, Leaves roundish entire

8588 Unarmed, Leaves lanceolate, Flowers axillary solitary sessile

8589 Leaves ovate lanceolate rough, Flowers capitate terminal, Bracteæ ciliate

8590 Leaves oblong entire, Two lateral leaves of calyx ciliated wider than the rest; two linear acute

8591 Unarmed, Leaves lanceolate hairy entire, Fl. aggregate terminal tubular, Bractes very narrow setose

8592 Unarmed, Leaves ovate silky, Bractes cordate scarious, Corollas very long

8593 Leaves lanceolate on long stalks, Flowers in terminal and axillary heads, Cor. small

8594 Leaves sessile oblong entire acute at each end villous, Fl. 3-subsessile, Stem ascending

8595 Leaves stalked ovate entire, Peduncles 3-flowered very short, Stem erect

8596 Subvillous, Stem dwarf branched erect, Leaves ovate concave entire

8597 Leaves stalked ovate very blunt entire pubescent, Flowers 3 subsessile, Stem erect divaricating

8598 Lvs. stalked obl. ovate ciliated somewhat toothed, Pedunc, very short about 3-fi. Stem very villous erect

8599 Leaves stalked oblong blunt attenuated at base somewhat toothed, Pedunc. 3-fi. shorter than leaf

8600 Leaves entire, Peduncles dichotomous lateral, Calyxes sessile, with the upper segment largest

8601 Leaves cuneate ovate crenated, Peduncles 3-parted, Stem simple

8602 Flowers twin sessile

8603 Leaves stalked entire ovate downy, Pedunc. axillary alternate few-flow. very long

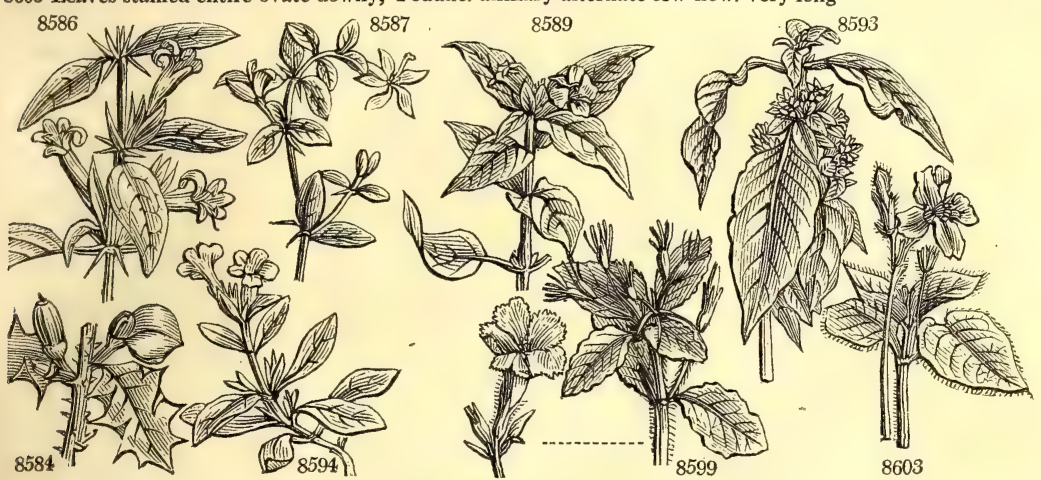

and Miscellaneous Particulars.

herb, supposed to be this plant. Pliny mentions an Acanthus which covered part of his lawn, which some conjecture to be a moss, a thing very improbable in a climate and situation where the musci are seldom seen even in winter.

The leaf of Acanthus mollis is supposed to have furnished the ancients with the elegant Acanthus leaf of their architecture.

1302. Barleria. In honor of the Rev. James Barrelier, a Dominican, and M. D. of Paris, who travelled from France into Spain and Italy, and died aged sixty-eight, 1673; author of Icones, 1714, Paris, folio, a useful work, containing, even at the present day, figures of many things which are to be found nowhere else. The species flower freely and are of easy culture: loam and peat, with a little rotten dung mixed with it, is the best soil for them. Cuttings root freely; they strike best from the young wood, under a hand-glass, in the same kind of soil as the plants grow in. (Bot. Cult. 21.)

1303. Phaylopsis. Named by Willdenow, from фeunos, vile or contemptible, and owis, aspect. Tropical weeds.

130t. Ruellia. In honor of John Ruelle, a native of Soissons, the physician of Francis I. He published a work De Natura Plantarum, in 1536, and Commentaries upon Dioscorides, in 1516. The species are pretty plants, free flowers, and of the easiest culture and propagation. 
8604 fúlgida $H . K$. 8605 ciliáta $W$. en 8606 ríngens $W$. 8607 pubéscens Pers. 8608 foétida $W$. 8609 macrophylla 8610 unduláta Vahl. 8611 tetragóna Link. 1305. BLE'CHUM. 8612 Brównei $\boldsymbol{H} . \boldsymbol{K}$. 806. APHEL AN'DRA. $R . B r$. Bristáta $H . K$
dense-spiked 1307. CROSSAN'DRA. P. L. Crossandra. 8614 undulæfólia $P . S$. wave-leaved wi 1308. THUNBER'GiA. $W$. Thunbergia. 8616 grandiflóra $R$ : large-flowered $\$$ 1309. Hebenstréitia. $W$. Hebenstreitia. 8617 albiflóra $L k$. white-flowered ㄴ. $\square$ pr 8618 chamædryfólia Link .saw-leaved toothed 8619 dentáta $W . \quad \begin{aligned} & \text { toothed } \\ & \text { entire-leaved integrifólia } W \text { pr }\end{aligned}$ aúrea B. Rep. 8621 ciliáta $W$ 8622 spicáta Thunb. 8623 erinoídes $T h$ 8624 cordáta $W$. 1310. HOS'TA. Jac 8625 cærúlea Jac 1311. GMELI'NA. $W$. 8626 asiática $W$ 8627 parviflóra Rox. 1312. LANTA'NA. $W$. 8628 mixta $W$. 8629 trifólia $W$ 8633 ánnua $W$. 8631 strícta $W$. 8632 Rádula $W$ 8633 Cámmara $W$. 8634 involucráta $W$. 8635 récta $W$ 8636 odoráta $W$ 8637 melissifólia $W$ 8638 scábrida $W$. 8639 nívea $V$ ent. 8640 aculeáta $W$. 8641 fucáta $K e r$. 8642 salvifólia $W$ 8643 braziliénsis Link. 8644 álba Mill.

bright-flowered ciliated pr gaping-flower'd 运 pr Di pr Lantana. white

$\square$ or
2 jl.au $\quad$ Sc $\quad$ W. Indies 1804. C $\quad$ 1.p Bot. rep. 527 jl Pu E. Indies 1806. C l.p $\begin{array}{lllll}\text { jl.au } & \mathrm{Pu} & \mathrm{E} . \text { Indies 1807. C } & \text { l.p }\end{array}$ jo S. Amer 1823. C

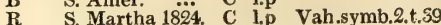
... E. Indies 1824. C 1.p Brazil 1824. C 1.p Acanthacea. Sp.1-15.

jn $\quad$ W. In

Indies 1780. C 1.p Slo.ja.1.t.109.f.1 jn.s S W. In

Acanthacea. Sp.1.

$1 \frac{1}{2}$ ja.jn Or.s E. Indies 1800. C. p.l Bot. reg. 69 Acanthacee. Sp. 2-7.

4 mys W E Indies 1796. S p.l Bot. mag. 1881 6 my.s B E. Indies 1820. C p.1 Bot. mag. 2366 Verbenacea. Sp. 8-12.

1 my.s W C. G. H. 1822. C p.l 2 my.s W C. G. H. 1822. C p.l

1 my.s W C. G. H. 1739. S p.l Bot. mag. 483

1 my.jn W C. G. H. 1792. C p.l Bot. rep. 252

ciliated $\square$ pr 1 my.jl W $\quad$ C. G. H. 1815. C p. spiked $\Delta$ pr 1 my.jl W C. G. H. 1815. C p. Erinus-leaved w $\mathrm{pr} 1 \mathrm{my.n}$ W $\quad$ C. G. H. 1816. C p.1 heart-leaved 1 pr i.au W C. G. H. 1774, C p.l Hosta. Verbenacece. Sp. 1.

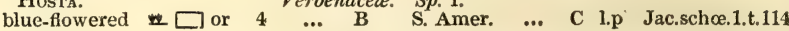
GMelina. Verbenacece. Sp. 2.

oval-leaved $\$ \square$ or 10 ... Y Y E. Indies 1792. C 1.p Lam. ill. t. 542 obovate-leaved $\frac{1}{9} \square$ or $10 \quad \ldots .0$ O $\quad$ E. Indies 1817. C l.p Roxb. cor. t. 32

Nettle-leaved $\square$ or 5 au.0 R.Y W. Indies 1732. C p.l Bot. cab. 68 $\begin{array}{lllllll}\text { Nettle-leaved } & \square \text { or } & 5 & \text { au.o } & \text { R.Y } & \text { W. Indies 1732. C p.1 } & \text { Bot. cab. } 68 \\ \text { three-leaved } & \text { or } & \text { jn.s } & \text { Pu } & \text { W. Indies 1733. C p.l } & \text { Bot. mag. 1449 }\end{array}$ annual OJ or 5 jl.au F S. Amer. 1733. C p.l Bot. mag. 1022 narrow-leaved $\square$ or $3 \ldots$ Pa.pu Jamaica 1733. C p.1 Slo.ja.2.t.195.f.4 Rasp-leaved $\square$ or 3 ... Pu $\quad$ W. Indies 1803. C p.l various-colored $\square$ or 6 ap.s R.o W. Indies 1691 . C p.l Dill.elt.t.56.f.65 round-leaved or 3 my.jl Pk W. Indies 1690 C p.l Plualm. upright upright re or 2 jn.au Pu Jamaica 1758. C p.I Jac.scho.3.t.360 sweet-scented $L$ or 2 my.n W W. Indies 1758. C p.1 Plum.ic.t.71. f. Balm-leaved $\square$ or 2 jl.s Y W. Indies 1732, C p.1 Dill.elt.t.57.f.66 rough $\square$ or 2 s

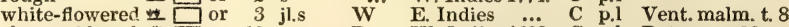
changeable-col. $\square$ or 10 ap.n $R \quad$ W. Indies 1692. C p.l Bot. mag. 96 painted $\square$ or 2 ap.n Pk S. Amer. 1822. C p.1 Bot. reg 798 sage-leaved $\quad$ or 3 ap.n R C. G. H. 1823. C p.1 Jac.schö.3.t.285

Bage-leaved
Brazilian

1313. AIOY'SIA Fl.Per. Alovsia.

Verbenacece. Sp. 1-2.

8645 citriodora Fl Per. Lemon-scented ${ }_{1} L_{\text {J }}$ or 3 my.s Pa.pu Chili $1784 . \quad$ C 1 Bot. mag. 367 Verbéna triphýlla B. M.

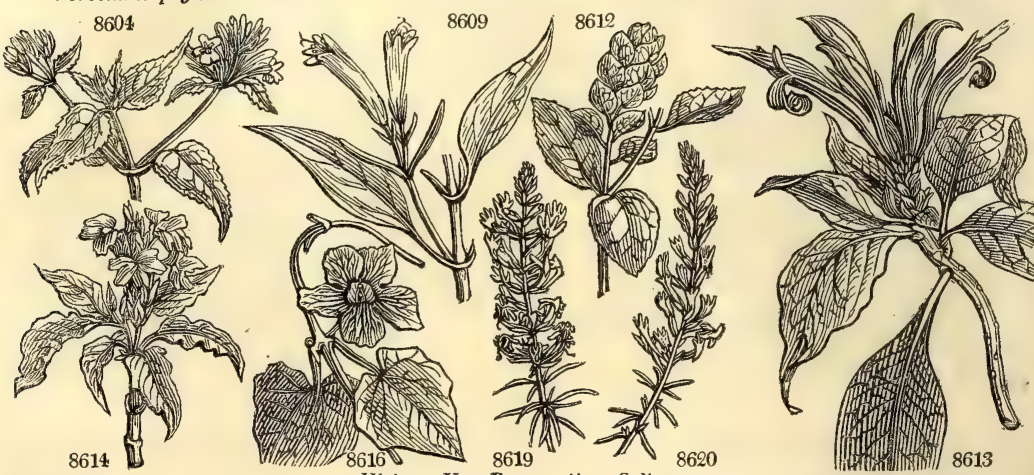

History, Use, Propagation, Culture,

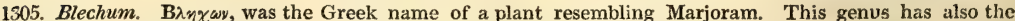
flowers in a dense bracteated spike. It has been separated from Justicia by Jussieu.

1306. Aphelandra. From $\propto \phi \varepsilon \lambda \eta s$, simple, and $\propto y \eta \rho$, a male, on account of the single cell of the anthers.

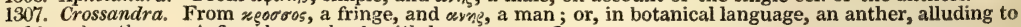
the fringed anthers. A fine shewy shrub with large orange flowers.

1308. Thunbergia. In honor of Charles Peter Thunberg, M. D., knight of the order of Vasa, professor of botany in the university of Upsal, member of several learned societies; author of Travels into Europe, Africa and Asia; Flor. Japonica, \&c. Handsome climbing flowers with a fragrant odor.

1309. Hebenstreitia. John Ernest Hebenstreit, was a professor of botany in the university of Leipsig, and published, in 1728, a dissertation upon plants. Small Cape undershrubs, occasionally cultivated for the sake of their neat foliage and simple modest flowers. They require an airy greenhouse, and are easily propagated from cuttings.

1310. Hosta. After Dr. Nicholas Thomas Host, the author of the superb Gramina Austriaca, in four volumes, folio, and other important works. Smith thinks the genus the same as Linnæus's Cornutia pyramidata. 
8604 Leaves stalked ovate acuminate wavy crenate, Fascicles axillary on long stalks

8605 Leaves ovate somewhat toothletted ciliated at edge on long stalks, Flowers solitary axillary sessue

8606 Leaves oblong entire, Flowers solitary sessile, Stem procumbent

8607 Leaves entire ovate subpubescent, Flowers solitary axillary, Stem erect

8608 Leaves ovate lanceolate entire stalked smooth, Fl. solitary axillary sessile, Branches warted

8609 Leaves ovate lanceolate acuminate entire, Peduncles long 2 -flowered

8610 Leaves stalked oblong wavy, Heads axillary sessile, Stem erect

8611 Stem erect hairy, Leaves stalked ovate acuminate repand toothed hairy, Spike whorled

861\% Leaves ovate elliptical somewhat toothed, Spikes 4-cornered, Bractes ovate down"

8613 The only species

\section{The only species}

8615 Leaves cordate acuminate somewhat angular at base, Stem climbing 8616 Leaves angular cordate, Inner calyx none, Anthers bearded spurred

8617 Leaves linear toothed, Bractes oval linear hairy

8618 Leaves sessile oblong lanceolate blunt serrated hairy at base, Brantes ciliated

8619 Leaves linear toothed, Spikes smooth

8620 Leaves linear quite entire

8621 Leaves linear toothed, Calyxes 3-valved ciliated

8622 Leaves linear toothed at end, Bractes ovate villous, Stem herbaceous

8623 Leaves lanceolate oblong serrated pilose, Bractes entire ciliated hispid

8624 Leaves cordate somewhat fleshy sessile

8925 Corymbs axillary trichotomous

8626 Spines opposite, Leaves ovate entire

8627 Leaves obovate subtrifid and simple, Prickles nearly straight, those of the stem alternate

8628 Leaves opp. ovate acute hairy, Stem prickly downwards, Heads round, Bractes lanceolate

8629 Leaves 3 or 4-ellipt. rugose above villous beneath, Stem unarmed, Spikes oblong imbricated

8630 Leaves opposite, Stem unarmed, Spikes oblong

8631 Leaves opp. oblong lanc. acute, Stem unarmed, Heads roundish, Bractes ovate-lanceolate and squarrose 8632 Lvs. opp. ov. acute serr. rugose rough hairy ben. Stem nearly unarm. rough, Heads obl. Bractes ovate acute 8633 Leaves opposite, Stem unarmed branched, Flowers in leafless capitate umbels

8654 Leaves opp. or in 3s rhomboid ovate blunt rugose downy, Stem unarmed, Heads squarrose, Bractes ovate 8635 Leaves opposite oval rugose, Stem unarmed, Heads squarrose, Bractes oblong, Pedunc. longer than lea 8636 Lvs. opp. or in 3 s ellipt. rugose, Stem unarmed, Heads squarrose with lanc. bractes, Ped. shorter than leaf 8637 Leaves opp. ovate obl. villnus soft, Stem prickly, Spikes hemispherical, Bractes half as short as tube

8638 Lvs. opp. ovate ellipt. rough, Stem prickly, Spikes hemispherical, Bractes half as short as tube lanc. acute 8639 Leaves ovate lanceolate acuminate crenulate, Stem prickly, Head hemisphericai, Bractes linear

8640 Leaves ovate subcordate softish beneath, Stem prickly, Bractes of heads linear cuneiform

8641 Lvs. ovate rugose crenate blunt downy running down the foot-stalk, Head depressed shorter than leaf 8642 Leaves opposite ovate rough above hoary beneath, Heads conical, Bractes squarrose ovate acute nerved 8643 Leaves narrowed from an ovate base sessile serrate pubescent, Bractes lanceolate concave

8644 Leaves ovate narrowed into the stalk acuminate acutely crenate pubescent, Outer bractes cordate

8645 Leaves linear lanceolate ternate, Stem shrubby

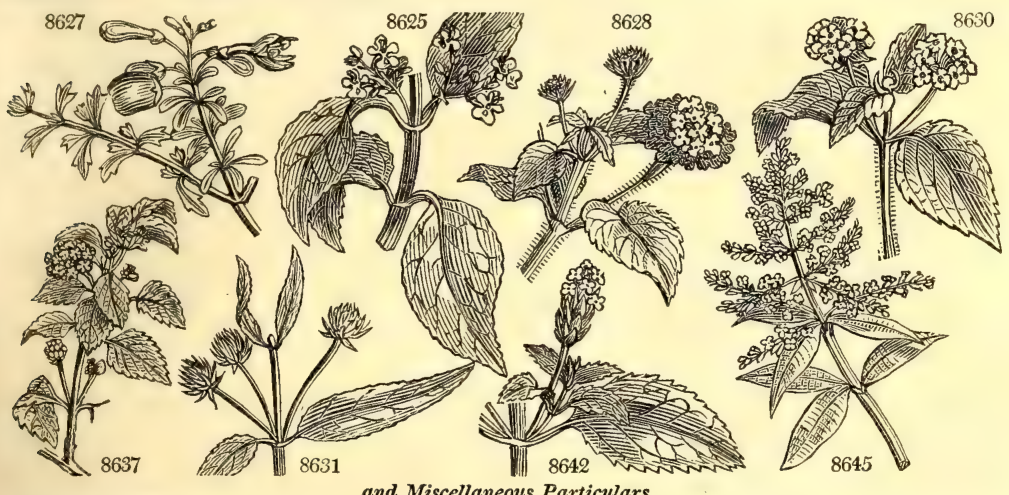

A small shrub rising to the height of four feet. Leaves opposite, ovate, acuminate, somewhat toothed, smooth. Flowers blue, in axillary corymbs, which are shorter than the leaves; they are dotted all over with minute white glandular spots.

1311. Gmelina. In honor of John George Gmelin, a German naturalist, professor of medicine and botany at Tubingen, who travelled in Siberia and Kamtchatka, by order of the Empress Anne of Russia. His Flora Sibirica, in four quarto volumes, is a book of continual reference. These are fine arborescent Indian plants with beautiful flowers, which are seldom produced in this country. They require the utmost heat of the stove.

1312. Lantana. One of the ancient names of the Viburnum, which this resembles a little in foliage The species are rapid growers and free-flowerers, and readily increased by cuttings. They form small bushes with pink, yellow, orange, or changeable heads of flowers, and a peculiar aromatic odor.

1313. Aloysia. Named by Don Antonio Palau, professor of botany at Madrid, and author of an excellent translation of the Linnæus's Species Plantarum into Spanish, after her majesty Maria Louisa, queen of Spair, and mother of the reigning king, Ferdinand. 
1314. LIP'PIA. $L$. 8646 purpúrea Jacq.

1315. MELAMPY'RUM. $\boldsymbol{W}$. Cow-Whea' 8647 cristátum $W$. 8648 arvénse $W$. 8649 praténse $W$ 8650 sylváticum $W$ 1316. SELA'GO. $W$. 8651 spinea Link. 8652 diffúsa $T h$. 8653 fulvo-maculáta 8654 polygaloídes $L$ 8655 spicáta Lin 8656 spúria $W$ 8657 fasciculáta $W$ 8658 lúcida Vent. 8659 ramulósa Link. 8660 teretifólia Link. 8661 ováta $W$

8662 canéscens $W$ 8663 corymbósa $\dot{W}$,

1317. VI'TEX. $W$.

8664 ováta $W$.

8665 altísima $W$ 8666 A'gnus-Cástus $W$. $\beta$ latifólia

8667 incísa $W$

8668 Leucóxylon $\boldsymbol{W}$ 8669 Negúndo $W$. 8670 bícolor $W$. en 8671 trifólia $W$.

1318. CORNU'TIA. $W$. 8672 pyramidáta $W$.

1319. ZAPA'NIA. J. 8673 stæchadifólia $P . S$. 8674 nodiflóra $P h$.

1320. PRI'VA. $P . S$. 8675 mexicána $\boldsymbol{P} . S$. Verbéna mexicána 8676 leptostáchya $P . S$. Tortula aspera W.

1321. SPIELMAN'NIA. 8677 africána $W$.

1322. VERBE'NA. L

8678 bonariénsis $W$.

8679 hastáta $W$

8680 paniculáta $\boldsymbol{P} . S$.

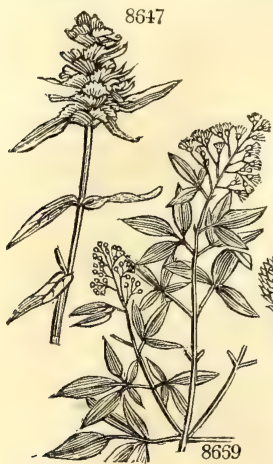

\section{crested}

purple

common

wood

Selago. spiny

spreading

,spotted

Milkwo

limear-leaved

cluster-flower'd

shining-leaved

branchy

round-leaved

oval-headed

canescent

fine-leaved

Chaste-Tree.

oval-leaved

tall

common

broad-leaved

cut-leaved

white-wooded

quadrangular

two-colored

three-leaved

Cornutia.

pyramidal

ZaPANIA.

val-spiked

knot-flowered

Priva.

Mexican

W. spiked tike

W. SPIEL

$\square$ or 3 Verbenacea. Sp. 1-5.

jn.jl R Mexico 1823. C p.l Jacq. ecl, t. $8 \tilde{5}$

Scrophularinea. $S p .4-7$.

O 3 jl.au Y England corn fi. S co Eng. bot. 41

O w 3 jn.jl Y England corn fi. S co Eng. bot. 53

O W 3 jl.au Y Britain woods. S co Eng. bot. 113

3 jl.au Y Britain m. wo. S co Eng. bot. 804

Verbenacee. Sp. $13-40$.

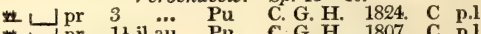

L $\begin{array}{lllllll}\text { pr } & 1 \frac{1}{2} \text { jl.au } & \text { Pu C. G. H. 1807. C } & \text { p.1 }\end{array}$

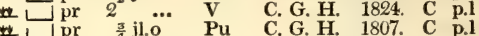

$\begin{array}{lllll}\frac{3}{4} \text { jl.o Pu } & \text { C. G. H. } 1824, & \text { C } & \text { p.1 }\end{array}$

(O) $\mathrm{pr} 1$ jl.o $\mathrm{V}$ C. G. H. 1779. S p.l Bur. afr. $t .42$ f.3

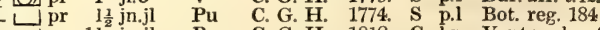

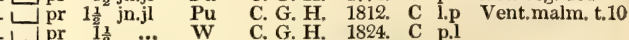

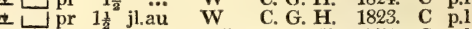

— $\downarrow$ pr 1 jn.jl D.Pu C. G. H. 1774. C p.l Bot. mag. 186

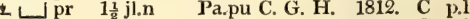

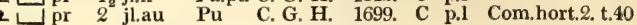

Verbenacee. Sp. 8-15.

$\square$ or 4 jl.au Pu China 1796. C 1.p

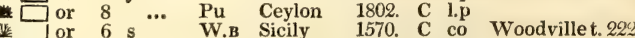

W. W. 6 or 6 s Sicily 1570. C co

- or 4 jl.s Pu China 1758 C p.l Bot. mag. 364

$\Longrightarrow$ or 4 ... Pu Ceylon 1793. C 1.p

... Pu E. Indies 1812. C I.p Rump.am.4.t.19

... $\quad \mathrm{Pu} \quad$ E. Indies 1810. C $1 . \mathrm{p}$

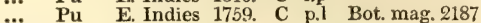

Verbenacee. Sp. 1-2.

- $\square \mathrm{cu} \quad 4 \quad \ldots \quad$ B $\quad$ W. Indies 1733. C 1.p Lam. ill. t. 541

Verbenacea. Sp. 2-10.

$\triangle$ un 1 au.s $\mathbf{P u}$ W. Indies 1732. C 1.p Brow.jam.t.3.f.1 $\begin{array}{llll}\text { jlau } & \text { Pu America 1664. C } & \text { 1.p } & \text { Fl. græc. } 553\end{array}$

Verbenacea. Sp, $2-6$.

$\triangle$ pr 2 au.s V Mexico 1726. C 1.p Dil.el.t.302.f.389

$\triangle \mathrm{E}$ pr 2 jl.au $\quad \mathrm{V} \quad$ E. Indies 1799. C l.p Rox. cor.2. t.146

Verbenacea. Sp. 1.

Vervain. Verbenacea. Sp. 14-36.

cluster-flower'd $¥$ () un 6 jl.o $\quad$ B $\quad$ B. Ayres 1732. R co Dil.el.t.300.f.387 halberd-leaved $J$ un 5 jn.au V Canada 1710, D co Her.parad.t.242 panicled $1 \mathrm{z} \Delta$ un 3 jl.au B N. Amer. 1800. D co

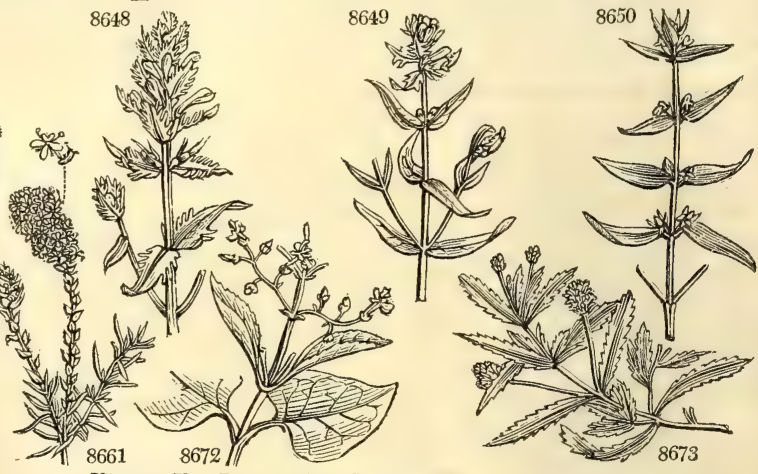

History, Use, Propagation, Culture,

A deciduous under shrub with a most agreeable odor of citrons, and of the easiest culture in any soil. In Jersey and Guernsey, it stands the winter in warm situations.

1314. Lippia. Named in honor of Augustine Lippi, a French physician, born in Paris of an Italian family. He accompanied the ill-fated embassy of Lenoir Duroule to the king of Abyssinia, in the beginning of the eighteenth century, and was assassinated along with the ambassador at Sennaar. His merits entitled him to a more interesting genus than this, which consists of obscure weedy shrubs of South America.

1315. Melampyrum. From $\mu \varepsilon \lambda_{5}$, black, and wveos, wheat. Its grain resembles a grain of wheat, and gives a singularly black color to bread in which it is ground. Smooth narrow-leaved weeds, not uncommon in corn fields and copses. M. pratense is considered nutritive, and was formerly cultivated by the Dutch and Flemish in the manner of Spurrey.

1316. Selago. This has nothing beyond its name in common with the Selago of the ancients; nor is it possible to imagine what induced Linnæus to apply it to the present plants, which are pretty half-shrubby Cape plants, with beautiful corymbs or spikes of flowers. Hardy greenhouse plants, propagated with facility by cuttings.

1317. Vitex. An ancient name applied to some plant of the osier tribe. V.Agnus Castus is an autumn shrub, with whorled spikes of blue and white flowers from seven to fifteen inches long. The dried leaves have a powerfully aromatic odor. The seeds, from the time of Dioscorides and Pliny, have been highly celebrated for securing chastity; hence the absurd officinal name of the shrub, Agnus castus; $\alpha$ ros, in Greek, being the game with castus in Latin: and hence the Athenian matrons, in the sacred rites of Ceres, used to strew their 
8646 Leaves oblong acute serrate rough above pubescent beneath, Heads globose, Bractes obl. lowest longest

8647 Spikes quadrangular, Bractes cordate compact toothletted imbricated

8648 Spikes conical lax, Bractes toothed setaceous colored, Teeth of calyx rough, Corolla closed

8649 Flowers axillary 1-sided, Corollas closed, Leaves lanceolate; floral hastate

8650 Flowers axillary 1-sided, Corollas gaping, All the leaves lanceolate

8651 Leaves linear acute entire reflexed rigid fleshy smooth, Spikes terminal

8652 Leaves linear smooth, Spikes terminal, Branches diffuse

8653 Leaves linear serrate toothed subciliated fleshy, Spikes corymbose

8654 Spikes terminal, Bractes and calyxes keeled rough, Leaves linear smooth reflexed at edge

8655 Leaves sessile linear lanceolate acute entire smooth, Spikes terminal solitary

8656 Spikes corymbose, Leaves linear toothletted

8657 Corymb multiplex, Leaves obovate smooth serrated

8658 Leaves obovate entire shining, Spikes rounded terminal, Stem shrubby

8659 Stem diffuse pubescent upwards, Lvs. lanceolate blunt finely serrate smooth, Spikes terminal subsolitary 8660 Lvs. rounded with a furrow on each side acutish somewhat toothed smooth fleshy, Spikes term. aggregate 8661 Spikes cone-like ovate terminal, Leaves scattered linear, Stem shrubby

8662 Spikes terminal, Leaves filiform fascicled smooth

8663 Leaves filiform fascicled smooth, Panicle compound

\section{Leaves simple ovate}

8665 Leaves ternate entire, Panicle whorled, Berry 3-seeded

8666 Leaves digitate 7 or 5 lanceolate nearly entire, Spikes whorled panicled

8667 Leaves digitate 5, Leaflets cut-pinnatifid, Spikes somewhat whorled

8668 Leaves digitate 5, Leaflets stalked oblong entire, Panicle dichotomous, Berry 1-seeded

8669 Leaves quinate and ternate serrate, Flowers in panicled racemes

8670 Lvs. ternate and quinate, Leafl. lanc. acum. ent. beneath white with down, Branches of pan. dichotom

8671 Leaves ternate and quinate, Leaflets ovate acute entire hoary beneath, Panicle with a straight rachis

$8 \subseteq 72$ Panicle terminal naked elongated

8673 Spikes ovate, Leaves lanceolate serrated plaited, Stem fruticose

8674 Spikes roundish conical, Leaves cuneiform toothed, Stem creeping

8675 Spikes lax, Cal. of fruit reflexed roundish didymous hispid

8676 Spikes filiform very long, Cal. of fruit reflexed hispid, Tube of corolla spiral

\section{The only species}

8678 Spikes fascicled, Leaves oblong lanceolate stem-clasping, Stem very tall trichotomous at end 8679 Spikes long acuminate, Leaves hastate

8680 Spikes filiform panicled, Leaves lanceolate coarsely serrated

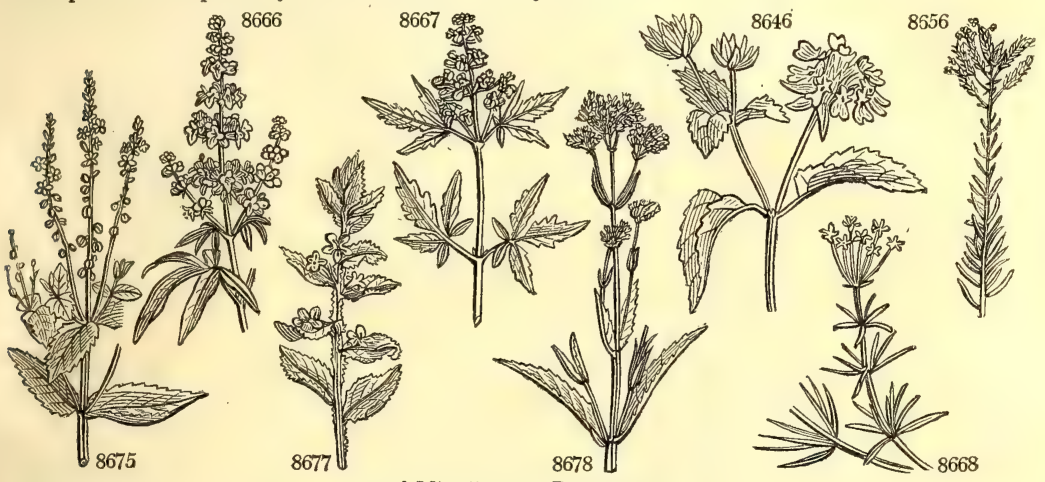

and Miscellaneous Particulars.

couches with the leaves. Hence also it has had the affected name of Piper eunuchorum and monachorum. The seeds of the chaste-tree are, however, so far from being thought antiaphrodisiac, that writers of later times have ascribed to them an opposite quality; their aromatic pungency seems to favor this opinion, and Bergius states them to be carminative and emmenagogue. (Woodville.)

The fruit of $\mathbf{V}$. trifolia is reputed in the eastern countries to be warm, discutient, nervine, cephalic, and emmenagogue; and to be of service in paralysis, weakness, and pains of the limbs. It is in great use among the Indian practitionezi, both internally and externally. The plant has a bitter taste, and a strong somewhat aromatic smell.

1318. Cornutia. So named after Jacques Cornut, a French physician, who travelled into Canada, and published an account of the plants of that country in 1635. Cornutia pyramidata is a shrub with square branches, elliptical ovate entire hoary leaves, and naked pyramidal terminal branches of flowers.

1319. Zapania. Named by Scopoli, after Paul Anthony Zappa, an Italian botanist.

1320. Priva. A genus of small Verbena-like herbaceous plants, with little blue flowers. The derivation of the name is unknown.

1321. Spielmannia. In honor of James Reinhold Spielmann, professor of medicine and botany at Strasburg, author of Prodromus Floræ Argentoratensis; Pharmacopœia Generalis, \&c. A shrub of easy culture in any light soil, and cuttings root freely under a glass.

1322. Verbena. Said by De Theis, to be derived from ferfaen, its name in Celtic. A genus of weedy plants, 
8681 angustifólia $\boldsymbol{H} . \boldsymbol{K}$. 8682 caroliniána $W$. 8683 urticifólia $W$. 8684 strícta $P h$. 8685 Aublétia $W$. 8686 bracteósa $\boldsymbol{P h}$. 8687 Lambérti $B . M$ 8688 spúria $P h$. 8689 officinális $W$. 8690 supina $W$.

8691 prostráta $H . K$.

1323. AVICEN'NIA. $L$ 8692 tomentósa $L$.

1324. CALDA'SIA. $\boldsymbol{W}$. Caldasia. 8693 heterophýlla $W$. blue 1325. Cleroden'DRUM. $B . P$. Clerod 694 frágrans $H, K$ $\beta$ flore pleno 8695 viscósum $\boldsymbol{H} . \boldsymbol{K}$

8696 infortunátum $P$. S. long-flowered 8697 fortunátum $W$. spear-leaved 8698 squamátum $\boldsymbol{H}$. $\boldsymbol{K}$. scarlet 8699 paniculátum $W$. panicled 8700 trichótomum $W$. three-forked 8701 tomentósum $R \cdot B r$. downy

8702 ligustrinum $\boldsymbol{H} . \boldsymbol{K}$. Privet-leaved

8703 heterophýllum $H . K$. various-leaved 8704 inérme $H . K$. smooth

8705 Siphonánthus $H$. $K$. whorl-leaved 8706 macrophýllum $B$. M. large-leaved

8707 phlomoides $L$. Phlomis-like 8708 costátum $R, B r$ ribbed

1326. VOLKAME'RIA. $\boldsymbol{H}, \boldsymbol{K}$. VOLKAME 8709 aculeáta $\boldsymbol{H} K$ 8710 buxifólia $W$. en. box-leaved 8711 japónica $T$. 1327. HOLMSKIOLDIA. $H$. $K$. Holmsiolda. 8712 sanguínea $W$ 1328. PETRE'A. $W$ 8713 volúbilis $W$ scarlet

Petrea. climbing
$\Delta \Delta$ un 3 jn.au \& $\Delta$ un 3 jn.s \. un 3 jl.au ()) or 1 jn au Dr 3 il aur 4 or 41 I 0 un 2 jl.au \& $\triangle$ un 2 jn.s * un $x^{\frac{1}{2}}$ jn.jl
B N. Amer. 1802. D co

N. Amer. 1732. D co N. Amer. 1683. C co Rob. ic. 26

N. Amer. 1802. D co Bot. mag. 1976 N. Amer, 1774. S r.m Bot. mag. 308 N. Amer. 1812. D co S. Amer. ... D co Bot. mag. 2200 N. Amer. 173̈. C p.l Britain 1731 . Spain 1640. S co Park.the.675. f.2 N. Amer. 1794. D co
Myoporinea. $S p .1-3$.

$\checkmark$ pr 2 my.d B New Spain1813. S co Bot. reg. 92

\section{ODENDRUM. Verbenacea. Sp. 15-27.}

- $\square$ or 6 au.d W China 1790. R s.p Vent. malm.70 * $\square$ or 6 au.d W China 1790. R s.p Bot. mag. 1834 * or 6 ... E. Indies $\quad$ C.

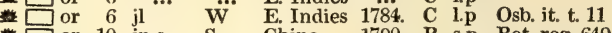
整 or 10 jn.s $\quad \mathrm{S}$ China 1790. R s.p Bot. reg. 649 al or 6 jl.o W Java 1809. C s.p Bot. reg. 406 * $\sqcup$ or 6 ... $\ddot{\text { W }}$ Japan 1800. C 1.p * W a 4 au.n 8 jl $\cdots$ E. Indies 1796. C p.l Bur. ind.t.43.f. W.B E. Indies 1815. C p.l Bot. mag. 2536 au.s W E. Indies 1820. C p.l Bur. ind. t.45.f.l Verbenacea. Sp. $3-5$.

4 au.o W W. Indies 1739. C p.l Bro.jam. t.20.f. 2 4 au W $\quad \ldots . .$. 1820. C p.l

1820. C p.l

Verbenacee. Sp. 1.

... $\mathrm{S}$ India

1796. C p.l Bot. reg. 692 Verbenacece. Sp 1

1399. CITHAREX'YLUM. $W$. FIDDLE-Wood. 8714 cinéreum $W$. ash-colored 8715 caudátum $W$, oval-leaved 8716 villósum $\boldsymbol{W}$. hairy-leaved 8717 pentándrum Vent. pentandrous 8718 quadranguláre $W$. square-stalked 1330. DURAN'TA. $W$. Duranta

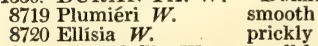

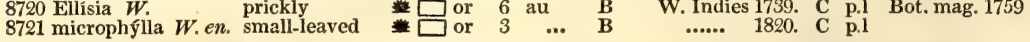

A. $\square$ or 20 jl.au Pu VeraCruz 1733. C r.m Bot. mag. 628 Verbenacea. Sp. $5-9$.

W. Indies 1739 C p.l Jac amer t 118 W

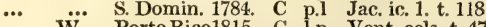
W Porto Rico1815. C 1.p Vent. cels. t. 47 ... W Jamaica 1759. C p.1 Jac. vind.1. t. 22

Verbenacea. Sp. 3-4.

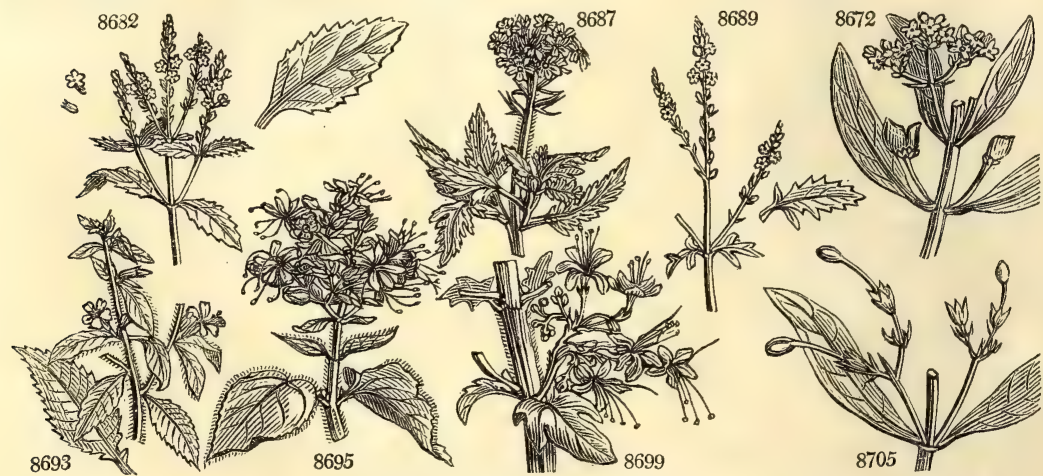

History, Use, Propagation, Culture

with the exception of Verbena Aubletia and Lamberti. V. officinalis was held sacred among the ancients, and used in making leagues by ambassadors, sacrificial rites, incantations, \&c.; and by the moderns as an amulet, and for medical purposes : it is now, however, entirely out of use.

1323. Avicennia. Named after Abu Vali Ibn Tsin, commonly called Avicennes, a Persian physician, born in 980, died in 1036. His Rules of Medicine were formerly the text-book of physicians, and have occupied the learning and time of many commentators.

1324. Caldasia. Named by Willdenow in compliment to Don Josef Caldas, an eminent botanist, native of Popayan, in New Grenada.

1325. Clerodendrum. From $\approx \lambda$ nе० , accident, and $\delta \varepsilon \nu \delta \rho \circ$, a tree, in allusion to the various effects in medicine by its various species. Clerodendrum fortunatum is useful, C. calamitosum and infortunatum, dangerous. The species grow freely in light rich soil, composed of half loam, one-fourth of rotten dung, and one-fourth peat. They require a large pot to flower freely, and cuttings root readily under a hand-glass : the younger the shoots the better. The handsomest species are C. paniculatum and C. squamatum. (Bot. Cult. 41.)

C. inerme is hardy enough to live in the open air against a wall, but it must have the protection of a mat in winter.

1326 Volkameria. Named after John Christopher Volkamer, a German botanist, who died in $1720 . \quad$ John 
8681 Spikes filiform, Leaves linear lanceolate subserrate

8682 Spikes filiform, Leaves lanceolate serrate bluntish subsessile

8683 Spikes filiform panicled, Leaves ovate serrate acute stalked

8684 Hoary, Spikes cylindrical upright, Leaves ovate serrate subsessile, Stem erect round

8685 Spikes solitary stalked, Leaves trifid cut

8686 Decumbent hirsute, Leaves cut, Flowers spiked, Bractes linear very long squarrose

8687 Spikes lax solitary, Stem hispid decumbent rooting, Leaves oblong cut-toothed entire at end

8688 Spikes filiform, Leaves multifid cut, Stems numerous

8689 Spikes filiform panicled, Leaves multifid cut, Stem subsolitary

8690 Spikes filiform solitary, Leaves bipinnatifid

8691 Hirsute, Spikes filiform solitary, Leaves serrate cut, Calyxes twice as long as fruit

8692 Leaves oblong blunt downy beneath

8693 The only species

8694 Leaves subcordate tooth-serrate pubesc. with 2 glands at base, Corymb terminal hemispherical compact

8695 Somewhat downy, Leaves cordate toothed, Cal. large 5-cornered viscid, Segm. of cor, on one side 8696 Leaves subcordate entire, Cor. thrice as long as tube of calyx, Limb bilabiate

8697 Leaves lanceolate quite entire

8698 Leaves cordate obscurely angular, Panicles of branches dichotomous smooth

8699 Leaves 5-lobed toothletted smooth, Panicle brachiate, Axillæ woolly

8700 Leaves lobed and undivided broad ovate entire, Panicle trichotomous

8701 Leaves elliptical acute entire and calyxes downy, The calyx in fruit thickened colored, Corymbs clustered 8702 Leaves oblong lanceolate entire, Petioles peduncles and calyx hairy

8703 Leaves lanc. or lin. lanc. entire quite smooth, Corymbs axill. and term. Cal. 5-toothed and pedunc. smooth

8704 Leaves ovate entire shining, Petioles peduncles and calyxes smooth

8705 Leaves whorled long lanceolate entire smooth, Corymbs axillary few-flowered, Corollas very long

8706 Leaves broad-ovate acuminate serrate subsessile downy beneath, Cal. 5-toothed, Cor. labiate

8707 Leaves ovate entire toothed and angular, Peduncles axillary about 2-flowered

8708 Leaves ovate blunt downy beneath ribbed rugose, Corymb trichotomous

8709 Leaves oblong acute entire, Spines from the rudiments of petioles

8710 Leaves obovate entire retuse shining, Peduncles axillary about 1-flowered

8711 Unarmed, Leaves cordate ovate acute toothed, Racemes 1-sided

8712 Leaves stalked cordate crenate smooth

8713 Leaves ovate, Flowers thirsoid

8/14 Branches round, Leaves oblong acuminate entire, Racemes pendulous, Calyxes toothed

8715 Branches round, Leaves elliptical emarginate blunt entire, Racemes erect, Calyxes somewhat toothed

8716 Branches square, Leaves obovate pubescent beneath somewhat toothed at end, Racemes nodding

8717 Branches bluntly 4-cornered, Leaves ovate obl. toothed upwards pubesc. beneath Fl. bracteate pendulous 8718 Branches square, Leaves ovate acuminate entire, Racemes nodding

8719 Calyxes in fruit twisted, Leaves obovate oblong

8720 Calyxes in fruit erect, Leaves oblong lanceolate acuminate

8721 Spiny, Leaves 9 lines long 3 lines broad subserrate attenuated at each end, Teeth of cal. short subciliated

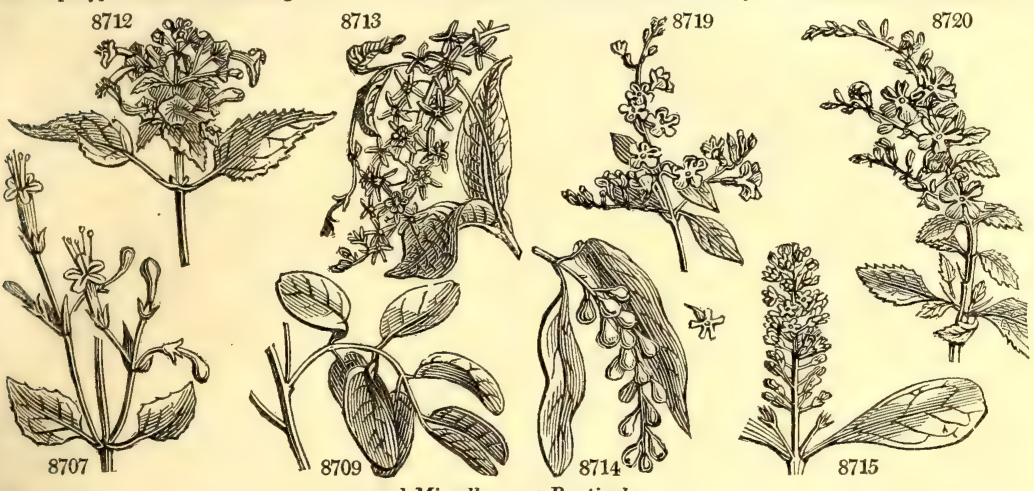

and Miscellaneous Particulars.

George Volkamer, his brother, born 1616, died in 1693, wrote many academical dissertations, and a Flora" of Nuremberg, which was not published till after his death. The species are ornamental plants with the habit of the last genus.

1327. Holmskioldia. A Theodore Holmskiold, a Dane, published some obscure works upon Cryptogamous plants. A handsome herbaceous stove plant, remarkable for the large calyxes of a bright red color.

1328. Petrea. So called by Houstoun, in honor of Robert James Lord Petre, born in 1710, died in 1742. The famous Peter Collinson, in a letter to Linnæus, speaks of his death as the greatest loss that botany or gardening ever felt in this island. A climbing plant with blue flowers.

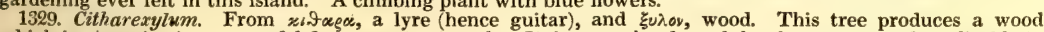
which in America is very useful for carpenters' work. It is very hard, and has been supposed applicable to making musical instruments, a mistake which arose thus; $\mathbf{C}$. melanocardium is called by the French fidéle from its faithfulness or durability in building; the English have corrupted the name to fiddle-wood, as if it were used for making musical instruments, which is a mistake. (Miller.)

Cuttings root in sand under a hand-glass.

1330. Durante. After Castor Durantes, physician to Fope Sixtus V., author of Herbarium, 1584, rlied in

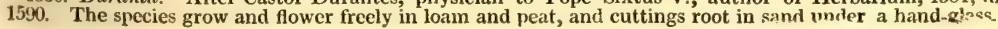


1331. PEda'lium. $W$. Pedalium. 8722 Múrex $W$.

1332. MYOPO'RUM. Forst. MYOPORUM 8723 ellipticum $R . B r$. smooth-leaved 8724 acuminátum $R \cdot B r$, acuminate 8725 parvifólium $R$. Br. small-leaved 8726 tuberculátum $R$. Br. tubercled 8727 viscósum $R . B r$ viscid 8728 débile $R . B r$. 8730 oppositifólium $\dot{R}$. Br.opposite-leav'd 1333. STENOCHI'I US. $\boldsymbol{R}$. Br. STENochIL 8731 gláber $R, B$ 8732 maculátus $K e$ smooth-leaved spotted

1334. BON'TIA, $R, B r$. Bontia. 8733 daphnoides $W$. Barbadoes

1335. OROBAN'CHE. $W$. BROOM-RAPE 8734 májor $W$. 8735 elátior $\dot{W}$. 8736 minor $W$. 8736 mínor $W$. 8737 rúbra $E . B$. $B$. 8739 ramósa $W$.

1336. CRESCEN'TIA. $W$. Calabash-Tree 8740 Cujéte $W$. oval-fruited 8741 cucurbitina $W . \quad$ round-fruited $\square \mathrm{cu} 10$

1337. CAStille'JA. Sin. Castilleja. 8742 sessilifióra $P h$.

1338. HALlE'Ria. $W$. Halleria 8743 lúcida $W$. shining-leaved

1339. LATHRE'A. $\boldsymbol{W}$. ToOTHWORT. 8744 squamária $W$. scaly

1340. RHINAN'THUS. $W$. Yellow-RattLe. 8745 crísta-gálli $W$. Cock's-comb 8746 alectorolóphus Poll. wattled 8747 Trixágo $L$ inflated

1341. BART'SIA. $W$. BARTSIA. 8748 coccínea $W$. scarlet 8749 pállida $W$. 8750 viscósa $W$ 8751 Odontítes $\boldsymbol{H}, \boldsymbol{K}$. yellow 8752 alpina $W$. Alpine

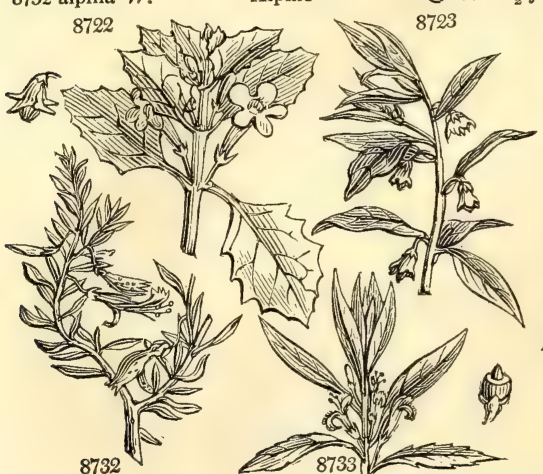

History, Use, Propagation, Culture,

Pedalina. Sp. 1.

W.pu E. Indies 1778. C l.p Lam. ill. t. 538

Myoporince. Sp. 8 .

2 ja.mr W N. S. W. 1789. C 1.p Bot. rep. 283

.

ja.d N. Holl. 1803. C l.p Bot.mag. 1693 N. Holl. 1803. C l.p N. Holl. 1803. C 1.p N. S. W. 1793. C 1.p Bot. mag. 1830

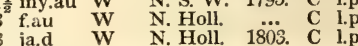

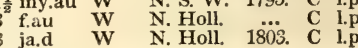
Myoporince. Sp. $2-3$.

2 ja.d $R$ N. Holl. 1803. C s.p Bot. mag. 1942 ap.my S N. Holl 1820, C s.p Bot. reg. 647 Myoporina. $S p .1$

6 jn Y.Pu W. Indies 1690. C p.1 Dill,elt, t.49.f.57 Orobanchea. Sp. $6-20$.

F $\triangle \mathrm{w}^{1 \frac{1}{2} \mathrm{jn} . \mathrm{jl}} \quad \mathrm{Br} \quad$ Britain unc.pl. S s.l Eng. bot. 421 Y. Britain clov.fi. S s.l Eng. bot. 568 Pu Britain irroc. S s. Fng but 1786 E $\triangle c^{\frac{1}{3}}$ au $\quad \mathrm{j}$ Britain ir. $\begin{array}{lll} & \text { cu } 1^{\frac{1}{3}} \text { au.s } \text { Br.pu Britain hemp fi. S s.1 Eng. bot. } 184\end{array}$

Solanea. Sp. 2.

... W J Jamaica 1690. C r.m Jac. amer. t. 11 W W. Indies 1733. C r.m Plum, ic. t. 109

Scrophularinea. Sp. $1-10$

jl.au Pa.Y Louisiana 1811. D 1.p

Scrophularinea. Sp. $1-2$.

Orobanchea. $S p . \mathrm{i}-3$.

ay Gr Britain ary wo. D co Eng. bot. 50

Scrophularinea. Sp. 3-10.

1 jn.au $Y$ Britain mea.pa. S co Eng. bot. 65 pr $1 \frac{1}{2} \mathrm{jn} . \mathrm{au} \quad \mathrm{Y}$ Europe 1820. S co

O pr 1 jn.au $\mathbf{Y}$ Europe ... $\quad$ S co Mor.h.3.t.24.f.8 Scrophlularinece. $S p .5-10$

Scrophularinea. Sp. $5-10$, D s.p Pluk al t. $109 . \mathrm{f} .5$ $\frac{1}{2}$ jn.s L.P Siberia 1782. D s.p Gmel. sib.3. t.42 $\frac{1}{2}$ jl.au Y Britain mar. S m.s Eng. bot. 1045 $\frac{3}{4}$ jl.s Pk Britain mea.pa. S co Eng. bot. 1415 1 jl.au Pu Britain alp.riv. S m.s Eng. bot. 361

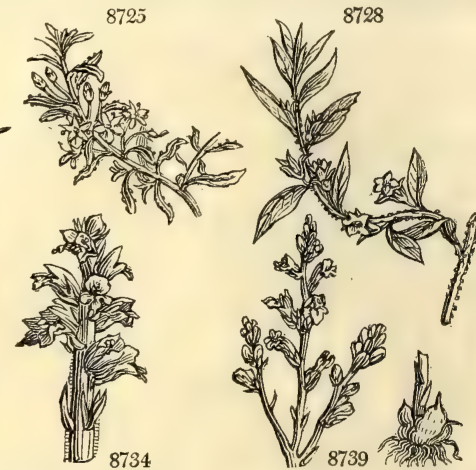

1331. Pedalium. Ty nut-like fruit with four sharp points or horns.

1332. Myoporum. From $\mu \nu \omega$, to shut up, and rogos, a pore; the spots which cover the leaves being, as it were, pores closed with some semi-transparent substance.

1333. Stenochilus. From $5^{\varepsilon v o s, ~ n a r r o w, ~ a n d ~} \chi \varepsilon \iota \lambda \circ 5$, a lip; the narrow lip distinguishing this genus from some of its kindred. Very pretty New Holland small shrubs, with fine red flowers.

1334. Bontia. James Bont or Bontius was a Dutch physician, born at Batavia, published in 1658, a natural history of the East Indies, in the manner of Piso. A South American plant, with the appearance of a Daphne. The leaves are alternate, fleshy, and crenated, and the flowers axillary.

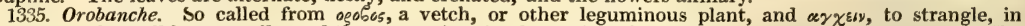
allusion to the well known effect of these parasites in destroying the plants upon which they grow. The species are fleshy herbs of a russet color, fastering themselves to the roots of other plants, and chiefly to Leguminosæ. The root is tuberous, imbricate with scales, and sends out fibres into the soil; the stem is without leaves, scaly, and generally simple: the flowers are in terminating spikes. The whole plant is acrid and astringent, and rejected by all animals, excepting the minuter tribes of Cimices and Thripses.

O. major adheres to the root of broom, furze, and clover, and is particularly destructive to the latter, especially in Flanders, where in some places it deters the farmer altogether from the culture of clover. It has a large. thick, fleshy, oval, scaly root, sometimes bulbous, and sending out fibres which are very brittle. The bulb adheres to the woody roots of furze or broom, and the fleshy root of clover, and the fibres clasp round them.

O. elatior is commonly found adhering to the roots of Centaurea scabiosa and Trifolium pratense. It does 
8722 Leaves truncate, Flowers with a strong smell of musk

8733 Leaves elliptical bluntish mucronate and branches smooth, Sepals lanc. very acute, Orifice of cor. villous 8724 Leaves broadish lanc, acumin. very acute and branches smooth, Sepals ovate lanc. Limb of cor, bearded 8725 Lvs. lin. bluntish sometimes toothed at end with the branches glandular, Peduncles occasionally 2-parted 8726 Leaves lanceolate acute serrated and branches warted with glands

8727 Leaves elliptical acute serrated reflexed and branches viscid with glands

8728 Leaves lanc. toothed at end entire at base, Drupes compressed shorter than calyx, Stem prostrate

8729 Leaves lanceolate at base with recurved teeth, Stems diffuse glandular, Peduncles solitary

8730 Leaves serrate cordate sessile

8731 Leaves lanceolate or elliptical entire sometimes toothed at end, Branches downy, Stem diffuse 8732 Stem silky, Leaves spatulate lanceolate much shorter than flower, Stamens a little protruded

8733 Leaves alternate, Peduncles 1-flowered

8734 Stem simple, Cor. 4-fid inflat. Stam. naked downw. Stigma 2-lobed, Lobes distant, Style pubesc. upwards 8735 Stem simple, Cor. 4-fid, Stamens hairy downwards, Stigma obcordate, Style smooth upwards 8736 Stem simple, Cor. 4-fid, Stamens hairy downwards, Stigma retuse, Style smooth upwards 8737 Stem simple, Corolla tubular, Segm. of lip blunt equal, Stamens fringed on one side at base 8738 Stem nearly simple, Cor. 5-fid, Bráctes 3, Calyx tubular half 4-cleft

8739 Stem branched, Cor. 5-fid, Bractes 3, Calyx short deeply 4-cleft

8740 Leaves cuneate lanceolate close together

8741 Leaves ovate subcoriaceous separate, Fruit ovate acuminate

8742 Leaves at end palmate-cut, Flowers sessile

8743 Leaves ovate acuminate serrate, Corollas 2-lipped, Calyx 3-leaved, Stamens exserted

8744 Stem quite simple, Corollas pendulous with the lower lip trifid

8745 Upper lip of corolla emarginate 2-toothed, Middle segment of lower lip very short

8746 Upper lip of corolla compressed shorter, Calyxes villous

8747 Lower lip of cor. longer than upper, Middle segm. blunt longer than lateral, Cal. vill. Lvs. deeply toothed

8748 Leaves alternate linear 2-toothed on each side

8749 Leaves alternate lanceolate entire, Floral oval toothed

8750 Upper leaves alternate serrated, Flowers distant lateral

8751 Leaves linear lanceolate serrated, Segm. of lower lip of corolla blunt

8752 Leaves opposite cordate bluntly serrated

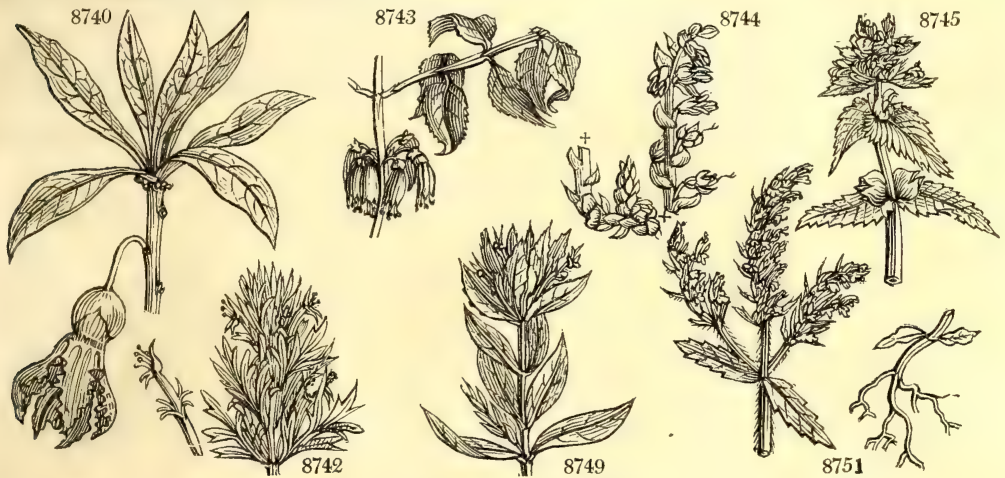

and Miscellaneous Particulars.

not appear among clover till the second year. On the borders of corn-fields it is found on Centaurea scabiosa and nigra, Scabiosa arvensis, \&c.

O. minor also adheres to common red clover and to Hypochæris radicata. O. ramosa is found on Galeopsis tetrahit. Any of the species may be removed to the garden and planted by the whin or broom.

1336. Crescentia. In memory of Pietro Crescenti, of Bologna, author of various agricultural works in the thirteenth century. The fruits after the inside has been scooped out, are dried by the natives of the countries where they grow, and serve for containing water or other fluids.

1337. Castilleja. Named after one Castillejo, a Spanish botanist and friend of Mutis. Some of the species of this genus which have not yet been introduced, are very beautiful plants, and would amply repay a collector

1338. Halleria. After the famous Albert Haller, author of Stirpes Helveticæ, and other considerable works on botany and medicine. A pretty stove plant, with long branches of red flowers. Surely so eminent an investigator of alpine vegetation as Haller was, should have had an alpine genus consecrated to him.

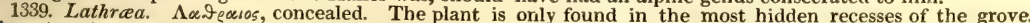
A curious humble parasite without leaves, in the room of which it is covered with abundance of white fleshy scales.

1340. Rhinanthus. From $\rho \omega$, a nose, and $\alpha y \vartheta_{\circ 5}$, a flower; because of its ringent corolla compressed, at the upper lip so as to resemble the snout of some animal.

1341. Bartsia. Named by Linnæus, in honor of his beloved friend John Batsch, M. D., of whom he gives an interesting and melancholy account in his Flora Suecica. Curious herbaceous plants of very difficult cultivation. 
1342. EUPHRA'SIA. $\boldsymbol{W}$. EYE-BRIGHT. 8753 officinális $W . \quad$ common 8754 lútea $W$. yellow 8755 latifólia $L . \quad$ broad-leaved 1343. ANTIRRHI'NUM. $J$. SNap-Dragon 8756 május $W$.

$\beta$ coccíneum $\gamma$ bicolor

\% bicolor
flore pléno 8757 siculum $W$. 8758 oróntium $W$ 8759 Asarina $W$. 8760 mólle $L$.

1344. LINA'RIA. $J$. 8761 Cymbalária $H$. $K$. 8762 pilósa $H . K$. 8763 Elátine $\boldsymbol{H} . \boldsymbol{K}$. 8764 spúria $H$. $K$. 8765 cirrhósa $H . K$. 8766 ægyptíaca $H$. $K$. 8767 triphýlla $H . K$. 8768 latifólia $H . K$. 8769 triornithóphora 8770 bipartíta $P$. S. 8771 purpúrea $\dot{H} . \boldsymbol{K}$. 8772 versícolor $H . K$. 8773 répens $H$. $K$. 8774 Spártea $H . K$. 8775 bipunctáta $H$. $K$. 8776 Hæláva $W$. 8777 trístis $H . K$ 8778 supína $H . K$ 8779 simplex $P$. $S$. 8780 arvénsis $P . S$. 8781 Pelisseriána $H . K$ 8782 viscósa $H . K$ 8783 multicaúlis $H . K$ 8784 reticuláta $H$. $K$. 8785 glaúca $\boldsymbol{H}$. $\boldsymbol{K}$ 8786 alpina $\boldsymbol{H} . \boldsymbol{K}$. 8787 villósa $H$. $K$. 8788 nriganifólia $H . K$ 8789 minor $\boldsymbol{H} . \boldsymbol{K}$. '8790 dalmática $\boldsymbol{H}$. $\boldsymbol{K}$. 8791 hírta $H . K$ 8792 macroúra Bieb. 8793 genistifólia $\boldsymbol{H}$. $\boldsymbol{K}$. 8794 júncea $H$. $K$. 8795 vulgáris $H . K$ c Pelória 8796 canadénsis $P . S$ 8797 chalepénsis $H . K$. 1345. ANARRHI'NUN 8798 bellidifólium $W$. 1346. NEME'SIA. Vent. 8799 chamædrifólia $V$. 8800 fo'tens $\boldsymbol{V}$. 8801 bicórne $\boldsymbol{P} . \boldsymbol{S}$. 8801 bicór

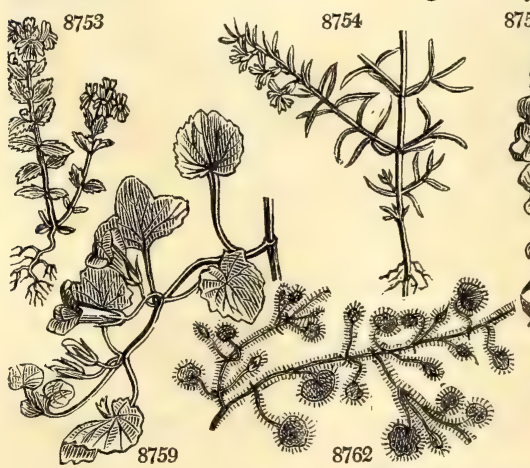
scarlet-flower'd two-colored double-flowered $\Delta$ or Sicilian lesser heart-leaved soft-leaved

Oे or TouD-Fux Ivy-leaved hairy-leaved sharp-pointed round-leaved tendrilled Egyptian three-leaved broad-leaved

\section{two-parted}

purple

various-colored creeping-rooted branching

two-spotted hairy-calyxed brown trailing upright corn 2 or

2 $\Delta$ or $2 \Delta$ or * $\mathrm{O}$ or * O or * Oु or Or $1 \frac{1}{2}^{\frac{1}{4}} \mathrm{jl}$ O $1 \mathrm{jn.s}$

or $1 \mathrm{jn} . \mathrm{jl}$ * $N$ or ${ }^{\frac{1}{4}} \mathrm{jn} . \mathrm{s}$ $\frac{\Delta}{4}$ or ${ }^{\frac{1}{2}} \mathrm{jn} . \mathrm{s}$ Ô or $1^{\frac{1}{4}} \mathrm{jl}$ jl.s $\triangle$ or or $1^{\frac{1}{4}}$ jl.o or $1 \mathrm{jl}$ * $\Delta$ or 1 jl.au $1^{\frac{1}{2}} \mathrm{jl}$ jl.au or 1 jl.au Or 1 jl.a or 1 ji clammy $\quad O$ or $11 \mathrm{jl}$ net-flowered $₫ \wedge$ or $1 \frac{1}{2} \mathrm{my}$.jl glaucous-leav'd $O$ or 1 jn.au Alpine $* \Delta$ or 1 jl.n villous $¥ \Delta \mathrm{J}$ or $1 \mathrm{jl}, \mathrm{au}$ Marjoram-lvd. $\$ \mathrm{~N}$ or 1 jn.s least erect $\mathrm{O}$ w $\frac{1}{2} \mathrm{jn} . \mathrm{n}$ Dalmatian w cu $1 \frac{2^{2}}{3} \mathrm{jn}$.jl shaggy-leaved $\vec{O}$ or 1 jn.s long-horned $¥ \Delta$ or $1 \mathrm{jn} . \mathrm{s}$

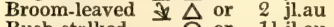
Rush-stalked $O$ or $1 \frac{1}{2}$ jl.au yellow $\Delta \mathrm{w} \quad 1 \mathrm{jn}$.s

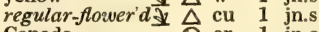
Canada white-flowered $\mathrm{O}$ or Desf. Anarruinum. Daisy-leaved $¥$ (1) pr Nemesia. Chamædrys-lv. $\Delta$ or foetid 1 jn.jl
$1^{4}$ jn.o

1 jn.au

Sp. 3-12.

jl.s W Britain past. S co Eng. bot. 1416 jl.s Pu S. Europe ... S co crophularinea. $S p .5-9$.

jnau SK England old w. S co

S.w England old w. S co

F England old w. C co

$\begin{array}{lll}\text { F } & \text { England } & \text { old w. C } \\ \text { W } & \text { Sicily } & \text { 1804. D }\end{array}$

F Britain san.fi. S s.1 Eng. bot. 1155

W Italy 1699. S r.m Bot. mag. 902

Spain 1752. C $\mathrm{s.1}$

Scrophularinece. Sp. 37-75.

my.n V England old w. D s.l Eng bot. 502 $\mathrm{Pu}$ Pyrenees 1800. D s.l Jac. obs. 2, t. 49 Y England corn fi. S co Eng. bot. 692 Y E. B England corn fi. S co Eng. bot. 691 Y.Pu Egypt 1771. S co Y.Pu Sicily 1596. S s.l Bot. mag. 324 Y N. Amer. 1800, S co Desf. ati.2. t.134 Pu Portugal 1710. C s.p Bot. mag. 525

Pu Barbary 1815. D l.p Sweet fl.gard.30 $\mathrm{Pu}$ S. Europe 1648. S co Bot. mag. 99 P.Y France 1777. D s.l Jac. ic. 1. t. 116 G England ch.hil, $\mathrm{S}$ co Eng. bot. 1253 Y Spain 1772. S s.1 Bot. mag. 200

Y Spain 1749. S co

$\mathrm{Pu}$ Egypt 1803. D co

Br Spain 1727. S s.l Bot. mag. 74

Y Spain 1728. S s.

P.B S. Europe 1816. S s.l Jac. ic. 3. t. 499

P.B S. Europe .... S co

S. Europe 1640. S s.l Barrel. ic. 1162

Br Spain 1786. S s.l Bot. mag. 368

W Levant 1728, S s.l Boc. sic. t. 19. f $\mathrm{Pu}$ Algiers 1788. D l.p Smith ic. pict. 2 Pu.x S. Europe 1800. S co Buxb.cen.4. t. 37 B Austria 1570. C s.l Bot. mag. 205

1786. D 1.p Barrel. ic. 597

B S. Europe 1785. D 1.p Barrel. ic. 598 England san.fi. S s.1 Eng. bot. 2014

Y Levant 1731. S s.1 Buxb.cen.1. t.24 Pu Spain 1759. S co Jac. ic. 1.t.117 Crimea 1822. D co

Y Austria 1704. D co Bot. mag. 2183 Y.Br Spain 1780. S co

Y Britain hed. D co Eng. bot. 658

Y Britain … D co Eng. bot. 260 V N. Amer. 1812. S co Vent. cels. 49 Scrophularinee, $S p .1-6$.

$1 \frac{1}{2}$ jn.au B France 1629. S s.1 Bauh.prod.t.106 Scrophularinea. Sp. 3-5.

$\begin{array}{llll}\text { ap.s } & \text { Pu } & \text { C. G. H. 1787. D co } & \\ \text { Dent.malm. t.41 }\end{array}$ 2 jl.au Pu C. G. H. 1774. S s.l Bur.afr.t.75. f.3

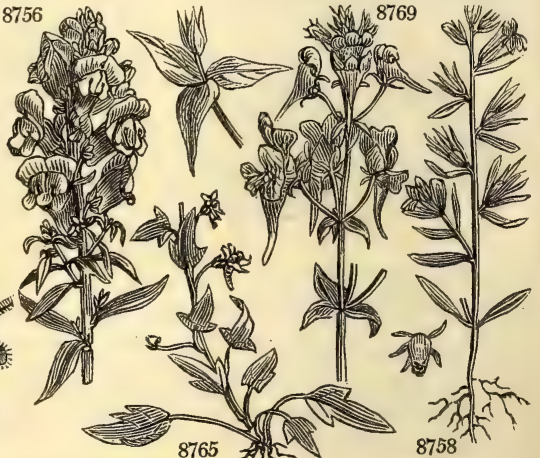

History, Use, Propagation, Culture

1342. Euphrasia. An abridgment of Euphrosine, the name of a woman, expressing joy or pleasure. This has been so called from the joyful effects of $E$. officinalis in disorders of the eyes, but it is now thought to be injurious rather than otherwise. Lightfoot states, that the Scotch Highlanders make an infusion of it in milk, and anoint the patient's eyes with a feather dipped in it.

1343. Antirrhinum. From $\alpha y \tau$, similar, and $e s$, , a nose, because the flowers of most of the species bear a perfect resemblance to the snout of some animal. A. majus and its varieties are popular border flowers of the easiest culture in any dry soil ; the other species are also pretty little plants.

1344. Linaria. The plant out of flower is very similar to Linum, Flax. The species are for the most part pretty annual plants; and some of them, as L. Cymbalaria, well adapted for growing in pots or for rock-work. 
8753 Leaves ovate bluntly toothed, Segm. of lower lip of corolla emarginate

8754 Leaves linear serrated : upper entire, Lateral segments of lower lip of corolla toothletted

8755 Leaves ovate toothed palmate, Flowers spiked, Cor. tubular, Segm. of lower lip blunt

8756 Leaves lanceolate opposite, Flowers racemose, Sepals glandular hairy ovate blunt

8757 I.eaves linear lanceolate ternate, Flowers racemose, Sepals glandular hairy lanceolate acute

8758 I eaves lanceolate : upper alternate, Flowers subsessile, Calyxes longer than corolla

8759 I eaves opposite cordate unequally crenate somewhat lobed hairy, Stems procumbent

8760 Leaves opposite ovate downy, Stems procumbent

8761 Leaves cordate 5-lobed alternate smooth, Stems procumbent

8762 Small, Leaves reniform repand very hairy alternate, Stems procumbent

8763 Leaves hastate alternate, Stems procumbent

$87 \curvearrowleft 4$ Leaves hairy alternate roundish ovate, lower obsoletely toothed: upper subsessile entire, Stem procumb.

8765 I eaves hastate alternate, Stems spreading, Petioles occasionally producing tendrils

8766 Leaves hastate alternate, Stem erect much branched, Peduncles stiff

8767 Leaves ternate ovate blunt 3-nerved rough at edge, Spike terminal, Flowers stalked

8768 Leaves ternate ovate lanceolate 3-nerved, Spike terminal, Flowers sessile

8769 Lvs. whorled lanc. 3-nerved, Stems decumbent, Raceme terminal few-flowered, Cor. very large stalked

8770 Leaves linear lanceolate : lower opposite; upper alternate, Racemes lax, Helmet erect 2-parted

8771 Leaves 4 linear lanceolate, Flower-stem erect spiked

8772 Leaves linear lanceolate : lower ternate, Stem erect spiked

8773 Root creeping, Leaves linear close : lower 4, Calyx as long as capsule

8774 Leaves subulate channelled fleshy : lower 3 , Stem panicled and corolla quite smooth

8775 Leaves linear smooth : lower 4, Stem erect panicled, Flowers in capitate spikes

8776 Leaves linear lanceolate : lower about 4 smooth, Flowers capitate, Calyxes hairy, Stem nearly simple

8777 Leaves linear scattered : lower opposite, Spur subulate, Flowers subsessile

8778 Leaves about 4 linear, Stem diffuse, Flowers racemose, Spur straight

8779 Leaves nearly linear: lower in fours, Calyxes pilose viscid, Fl. racemose, Spur straight, Stem erect

8780 Leaves nearly linear : lower in fours, Calyxes pilose viscid, Fl, racemose, Spur recurved, Stem erect

8781 Cauline leaves linear alternate : radical ovate lanceolate 3-5, Flowers corymbose

8782 Cauline leaves linear alternate : radical lanceolate 4, Cal. villous close to stem

8783 Leaves 5 linear fleshy, Flowers capitate

8784 Leaves linear channelled scattered upon the rootshoots in 5s, Calyx hairy, Pedunc. shorter than bractes

8785 Leaves 4 subulate fleshy, Stems erect, Flowers spiked

8786 Leaves 4 linear lanceolate glaucous, Stem diffuse, Flowers racemose, Spur straight

8787 Leaves all opposite villous, Stem simple, Flowers opposite lateral

8788 Leaves obovate opposite : floral alternate, Stem ascending pubescent, Spur straight

8789 Leaves mostly alternate lanceolate blunt, Stem much branched diffuse

8790 Leaves somewhat stem-clasping lanceolate scattered, Bractes longer than calyx, Stem $\frac{1}{2}$ shrubby

8791 Leaves lanceolate hairy alternate, Flowers spiked: upper sepal very large

8792 Leaves alternate linear-subulate somewhat fleshy, Stem erect simple, Spike term. stalked

8793 Leaves lanceolate acuminate, Panicle twiggy flexuose

8794 Leaves linear alternate, Stem panicled twiggy, Flowers racemose

8795 Leaves lanceolate linear close, Stem erect, Spikes terminal sessile, Flowers imbricated

8796 Leaves alternate linear remote smoote smooth, Flowers racemose, Stem simple, Runners procumbent 8797 Leaves linear lanceolate alternate, Flowers racemose, Cal. longer than cor. Stem erect

8798 Very smooth, Radical leaves obovate lanceolate blunt serrate: cauline divided entire

8799 Leaves ovate serrated stalked, Peduncles axillary 1-flowered

8800 Leaves 4 linear lanceolate acute about 3-nerved smooth, Flowers racemose terminal with bractes

8801 Leaves oblong serrated, Stem erect herbaceous, Capsules 2-horned spreading

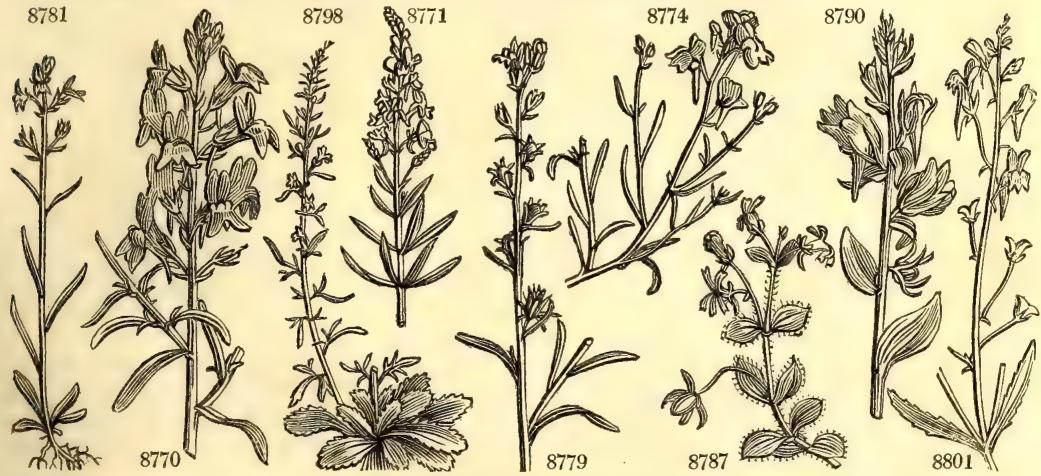

and Miscellaneous Particulars.

L. triphylla is a popular border annual. L. triornithophora is remarkable for the form of its flowers, which resemble three little birds seated in the spur.

$\mathrm{L}$. vulgaris is a very shewy plant, but also a bad weed in sandy pastures.

1345. Anarrhinum. Named by Desfontaines, from $\alpha$, privative, and $\rho i v$, nose, in contradistinction to Antirrhinum, because the plants of this genus have not the snout-like flowers of the latter. Plants resembling Linaria in habit.

1346. Nemesia. A name used by Dioscorides to designate a kind of Antirrhinum, to which genus this is nearly related. 
1347. MAURAN'DYA. $W$. MaUrandya. 8802 semperflórens $W$. red-flowered 8803 antirrhiniflóra W.en.blue-flowered

1348. GERAR'DIA. $\boldsymbol{W}$. Gerardia. 8804 delphinifólia $\boldsymbol{W}$, Larkspur-leav'd 8805 purpúrea $P h$. 8306 tenuifólia $P h$. 8807 fláva $P h$ purple slender-leaved yellow
8808 quercifólia $P h$. Oak-leaved

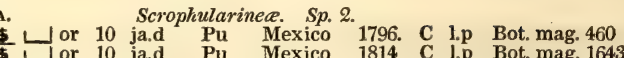

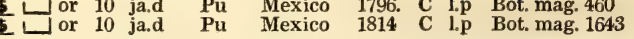

Scrophularinea. Sp. 5-16.

\begin{tabular}{|c|c|c|c|c|c|c|}
\hline & 2.11 & Pk & ndies 180 & C & 1.p & 90 \\
\hline & au & $\mathbf{P}$ & r. 17 & $\mathbf{S}$ & 8.1 & Bot. mag. 2048 \\
\hline & & $P$ & & $\mathbf{S}$ & s.l & Pl \\
\hline & & & . & C & l.p & $P$ \\
\hline & $\mathrm{au}$ & $\mathbf{Y}$ & 18 & SV & 1.p & Pursh.amer \\
\hline
\end{tabular}

Scrophularinea. Sp. 16-40.

349. PEDICULA'RIS, $W$. LousewORT 8809 palústris $W$. 8810 sylvática $W$ 8811 euphrasioídes $W$. 8812 myriophýlla $W$. 8813 resupináta $W$. \begin{tabular}{llllll} 
marsh & \multicolumn{1}{c}{$\mathrm{pr}$} & 2 & $\mathrm{jn} . \mathrm{jl}$ & $\mathrm{Pu}$ \\
$\mathrm{pr}$ & 1 & $\mathrm{my} . \mathrm{jl}$ & $\mathrm{Pk}$
\end{tabular}

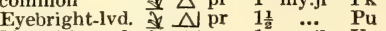
Milfoil-leaved resupinate

8814 Scéptrum Carolinum $W$. sceptred 8815 recutíta $W$. 8816 foliósa $W$. 8817 canadénsis $W$ 8818 incarnáta $W$ 8819 uncináta $W$. 8820 verticillata $W$ 8821 flámmea $W$. 8822 tuberósa $W$. 8823 compácta $W$ 8824 comósa $W$.

jagged-leaved leafy Canadian $\quad \searrow \Delta \mathrm{pr}$ flesh-colored $\mathrm{O}$ pr hooked-flower. $\downarrow \downarrow \Delta \mathrm{pr}$ whorled $\quad \frac{1}{\Delta} \mathrm{pr}$ upright upright close-headed spiked

$\pm \mathrm{N}$ pr
$\pm \Delta$ pr $\nabla \Lambda \mathrm{pr}$ ₹ $\Delta \mathrm{pr}$

Erinus.

1350. ERI'NUS. $W$.

8825 alpinus $P$. $S$. 8826 hispánicus $P$. $S$. 8827 frágrans $W$

smooth-leaved $\neq \Delta$ or hairy-leaved $\$ \Delta$ or fragrant or 8828 Lychnidea Thunb. pale EL or

1351. MI'MULUS. $W$. MonkeY-Flower. 8829 ringens $W$. 8830 glutinósus $W$. 8831 parviflórus Lindl. 8832 alátus $\boldsymbol{W}$. gaping Orange-flower. mall-flowered oval-leaved yellow-flowered $\triangle \Delta$

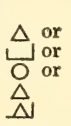

Scrophularinea. $S p .5-12$.

1.au L.P N. Amer. 1759. C p.l Bot. mag. 283

$\frac{1}{2}$ ja.d Or California 1794. C r.m Bot. mag. 354

Y.d Chili 1824. S co Bot. reg. 874

2 jn.s $Y$ America 1812. D p.1 Bot. mag. 1501
1352. HORNEMAN'NIA. W.en. HornemanNIA 8834 bícolor $W$. en.
1353. MA'ZUS. Lour. MazUs.

8835 rugósus $\boldsymbol{H} . \boldsymbol{K}$. China
Scrophularinea. Sp. 1.

$\frac{1}{2}$ my.s Y.Pu China 1780. S s.l Sweet fl.gard.36 Scrophularinea. Sp. 2.

* J or 4 jn.jl Br.o Canaries 1698. S p.l Lind.dig. 27 w. J or 4 jl.au Br.o Madeira 1777. S p.l Lind. dig. 28

1354. ISOPLEX'IS. Lindl. IsopLEXIS. 8836 canariénsis Lind. Canary D. canariensis $\mathbf{L}$.

8837 scéptrum Lind. Madeira D. sceptrum $\mathbf{L}$

Scrophularinee. Sp. $1-2$

jn.s B E. Indies 1816. S s.l

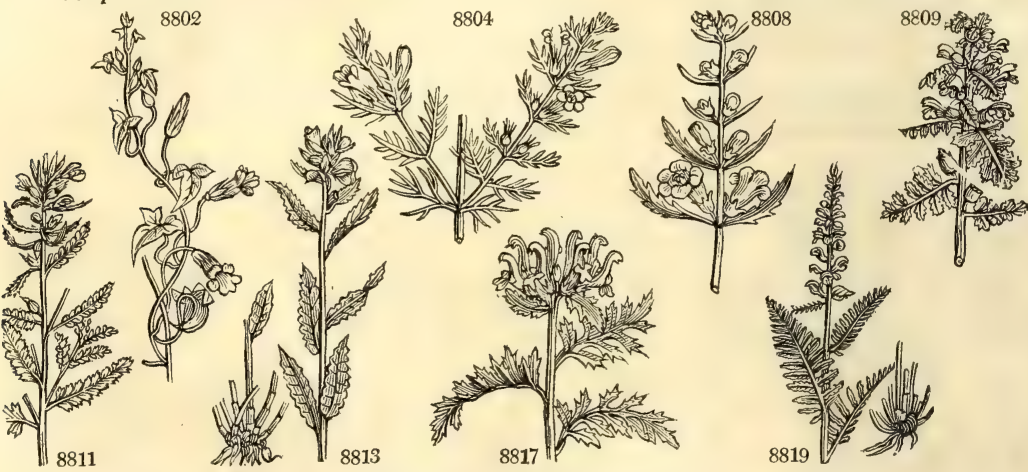

History, Use, Propagation, Culture,

1347. Maurandya. Named in honor of the lady of Dr. Maurandy, the botanical professor at Carthagena. An elegarit greenhouse plant, native of Mexico, and flowering for months together in the summer.

1348. Gerardia. In honor of John Gerarde, our old English botanist, author of the Herbal, 1597, folio, and a great cultivator of exotic plants, of which he published a catalogue in 1596. These are handsome North American herbaceous plants, of such very difficult culture, that few persons have seen them in gardens. They deserve any pains which may be necessary to their successful cultivation.

1349. Pedicularis; of which the English word lousewort is a translation and explanation. The term lousewort is applied from a supposition that sheep which feed much on the plant become lousy; probably because the plants grow in very bad pastures, which may occasion the sheep to be in bad condition and to breed vermin. The species have their leaves very much cut, and that in a very regular manner. Their flowers are red, white, or yellow, and the mixture or shades of these three colors sometimes give the corolla the colour of fire. They grow in general at a considerable elevation; namely, more than a thousand toises above the level of the sea.

P. sceptrum Carolinum was so named by Rudbeck, in honor of Charles XII. It abounds in the north of Sweden and Lapland, where it was greatly admixed by the traveller Dr. Clarke, who sent seeds of it to the Cambridge botanic garden, but they never came to any thing. The flowers grow in long whorled spikes, and 
8802 Orifice of corolla pervious

8803 Orifice of corolla closed

8804 Leaves linear pinnatifid, Stem somewhat branching

8805 Stem oppositely much branched, Leaves linear, Flowers axillary opposite subsessile

8806 Branches panicled, Leaves linear, Peduncles axillary opposite longer than flower

8807 Pubescent, Stems nearly simple, Leaves subsessile lanceolate entire or toothed: lower pinnatifid cut

8808 Smooth, Stem panicled, Leaves stalked pinnatifid, Flowers axillary opposite stalked

8809 Stem branched, Lvs. pinnat. Pinnæ pinnatif. cut, Cal. inflated ovate 2-parted crest. Helmet blunt truncate 8810 Low tufted, Stem branch. at base, Lvs. pinnat. Pinnæ acute. cut, Cal. obl. infl. smooth uneq. 5-cleft crested 8811 Stem branched, Leaves pinnatifid toothed, Cal. tubular 2-parted truncate, Helmet Q-toothed

8812 Stem somewhat branched, Leaves pinnated, Pinnæ in 4 s acutely pinnatifid, Helmet acute 2 -toothed

8813 Stem nearly simple, Leaves lanc. toothed crenate, Cal. 2-fid truncate, Helmet acute

8814 Stem simple, Leaves pinnatifid, Pinnæ repand crenulate, Cal. 5-fid crested, Cor. closed

8815 Stem simple, Lvs. deeply pinnatifid, Pinnæ lanc. pinnatifid toothed, Spike compact leafy

8816 Stem simple, Cauline leaves deeply pinnatifid, Pinnæ lanc. acuminate pinnatifid toothed, Spike leafy

8817 Stem simple, Spike somewhat leafy, Helmet setaceous 2-toothed, Cal. truncate downwards

8818 Stem simple, Leaves deeply pinnatifid, Pinnæ unequally toothed linear-lanc. Calyxes villous 5 -cleft

8819 Stem simple, Cauline lvs. deeply pinnatifid, Pinnæ lin. lanc. doubly toothed, Cal. round smooth 5 -toothed 8820 Stem simple, Cauline leaves pinnatifid in fours, Pinnæ oblong blunt toothed, Spike capitate, Cal. hairy 8821 Stem simple, Lvs. pinnated, Pinnæ imbricated ovate blunt doubly toothed, Cal. 5-toothed, Helmet blunt 8822 Stem simple, Lvs. pinnated, Pinnæ deeply pinnatifid tooth. Cal. 5-fid somew. crested, Helmet uncinate 8823 Stem simple, Lvs. pinn. Pinnæ lanc. pinnatifid confluent at end, Spike capitate naked [acum. emargi. 8824 Stem simple, Lvs. pinnate, Pinnæ pinnatifid somewhat toothed, Spike leafy, Helmet two-toothed

8825 I.eaves caspitose spatulate deeply serrated smoothish, Peduncles terminal subcorymbose

8826 Smaller branched villous, Leaves bluntly serrated, Flowers racemose

8827 Leaves lanceolate oblong toothed, Segm. of limb entire

8828 Leaves lanceolate smooth serrated at end, Stem herbaceous, Segm. of limb bifid

8829 Leaves lanceolate acuminate smooth sessile, Pedunc. longer than flower 8830 Leaves oblong bluntish clammy sessile, Peduncles shorter than flower

8831 Procumb. Stem round rooting hairy, Lvs. cord. ovate toothed 5-nerved, Pedunc. shorter than petioles

8832 Leaves ovate stalked, Stem square winged

8833 Leaves roundish ovate nerved; lower stalked, Stem creeping

8834 Leaves obovate entire at base, Calyxes spreading and peduncles smooth

8835 Raceme lax longer than the few-leaved stem, Calyxes pubescent in fruit increased in size

8836 Segments of cor. acute

8837 Segments of corolla blunt, Raceme comose

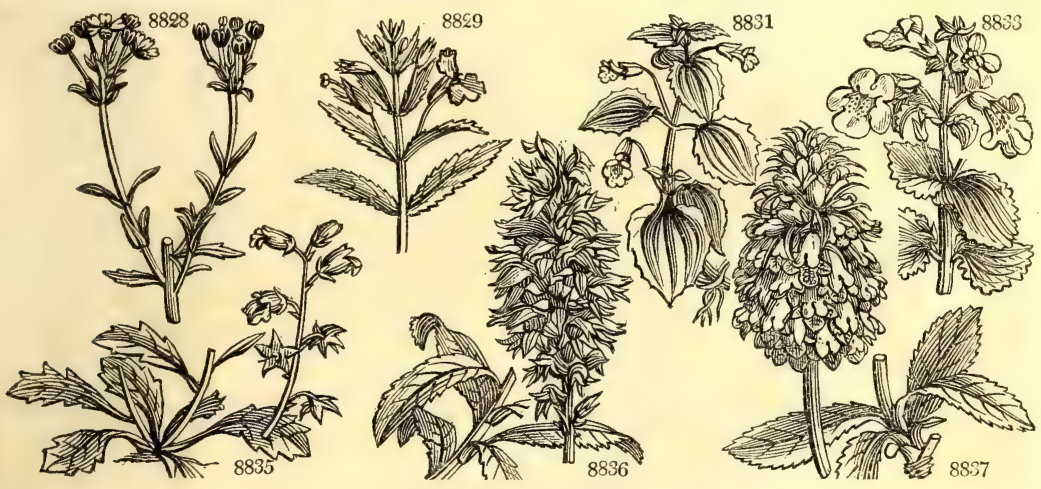

and Miscellaneous Particulars.

each represents a lion couchant. All the species are extremely difficult to keep in gardens. According to Sweet, they succeed best in peat soil and moist situations; the more tender species must be grown in pots in the same kind of soil, and should be protected under frames in severe weather: the best way of increasing them is by seed. (Bot. Cult. 404.)

1350. Erinus. A name under which Dioscorides describes an aquatic plant with a white flower, black

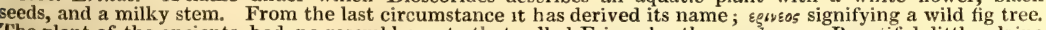
The plant of the ancients had no resemblance to that called Erinus by the moderns. Beautiful little alpine herbaceous plants, well adapted to rock-work in warm damp situations.

1351. Mimulus. From $\mu \mu \omega$, an ape. The flower seeds in front resemble the face of a grinning monkey. The species are showy plants of the easiest culture in almost any soil or situation.

1352. Hornemannia. Named after Professor Hornemann, of Copenhagen, an eminent botanist, and the present editor of the Flora Danica. Little, inconspicuous, but curious annual plants.

1352. Mazus. From $\mu a \zeta o 5$, a teat, on account of the little protuberances which close the mouth of the corolla. East Indian herbaceous plants, not unlike some kinds of Antirrhinum.

1354, Isoplexis. From $6 \sigma_{05}$, equal, and $\pi \lambda_{E} \xi_{65}$, segment, in allusion to the equal-sized divisions of the corolla. 
1355. DIGITA'LIS. $W$. FoX-GLove. 8838 purpúrea $L$. $\beta$ alba

8839 minor $L$.

8840 Thápsi $L$.

8841 ambigua Murr.

8842 ochroleúca Jacq.

8843 fúlva Lindl.

$884 \pm$ lævigáta $W, \& K$.

8845 ferrugínea $L$.

8846 aúrea Lindl.

8847 leucophæ'a Sibth.

8848 lanáta $E h r$.

8849 orientális $\dot{L}$ am.

8850 parvifióra Jacq.

8851 rigida Lindl.

8852 purpuráscens Roth

8853 tubitlóra Lindl.

8854 lútea $L$.

8855 lutes'cens Lindl. 8856 obscúra $L$.

1356. SCROPHULA'RI

8857 marilándica $W$.

8858 nodósa $\boldsymbol{W}$.

8859 aquática $W$.

8860 appendiculáta $W . e n$.

8861 auriculáta $W$.

8862 Scorodónia $W$.

8863 glabráta $W$.

8864 betonicifólia $W$.

8865 biserráta $W$. en.

8866 Scopólii Hoppe.

8867 glandulósa $W$. en.

8868 orientális $W$.

8869 adscéndens $W$. en.

8870 frutéscens $W$.

8871 altáica $W$.

8872 vernális $W$.

8873 argúta $W$.

8874 trifoliáta $W$.

8875 sambucifólia $\boldsymbol{W}$.

8876 laciniáta $W$. en.

8877 lyráta $W$. en.

8878 tanacetifólia $W$. en.

8879 mellifera $W$.

8880 canína $W$.

8881 lúcida $W$.

8882 variegáta $M . B$.

8883 multifida $W$ en

8884 chrysánthemifólia

8885 peregrina $W$.

1357. VANDEL'LIA. $L$. purple

white

dwarf

Mullein

ambiguous

great-yellow

fulvous

shining-leaved

Iron-colored

golden

broad-lipped

woolly

eastern

small-flowered

rigid

purple

small-yellow

small-yellow

Willow-leaved $\frac{\partial}{} \triangle$ or

W. Fiawort.

Maryland

water

ear-leaved

Balm-leaved

spear-leaved

Betony-leaved

doubly-sawed

Scopoli's

Hemp-leaved

ascending

shrubby

in un

white-flowered $\searrow \Delta$ un

yellow

three-leaved \& 0 un

Elder-leaved $\frac{\Delta}{\Delta} \Delta$ un

jag-leaved $\$ \Delta$ un

lyrate-leaved $\frac{\nabla}{\Delta} \Delta$ un

Tansy-leaved

Barbary

ذै $\triangle$ un

If $\triangle$ un

shining-leaved $\frac{j}{\partial} \Delta$ un

variegated un

multifid-leaved $\bar{\nabla} \Delta$ un

n.Chrysant.-lv. $\forall \vec{v}$ un

Nettle-leaved $\frac{1}{2}$ un

8886 diffusa $\boldsymbol{L}$

Scrophularinea. Sp. 19-21.

jn.s Pu Britain hed.b. S co

my Pu Spain 1789. D s.

jl.au L.Y Switzerl. 1596. D co

jl.au L.Y Europe 1... D co

4 jl.au

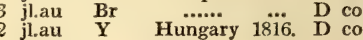

4 jl.au Br Italy 1597. D co

$\begin{array}{llll}\mathrm{Br} & \text { Italy } & 1597 . & \mathrm{D} \\ \mathrm{Br} & \text { Greece } & \text { 1816. } & \mathrm{D} \\ & & \mathrm{CO}\end{array}$

W. Br Greece 1788. D co

W.Br Hungary 1789. D co

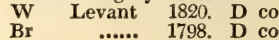

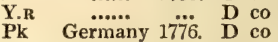

D co Lindl. dig. 20

L.Y France 1629. D co Lindl. dig. 23

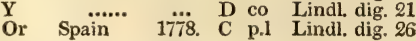

Scrophularinea. Sp. 29-35.

my.jl G.Br N. Amer. 1759. D 1.p

my.jl Bd Britain woods. D co Eng. bot. 1544.

my.jl Bd Britain wat.pl. D co Eng. bot. 854

jl D.Pu Morocco 1805. D co Jac. sch. 3.t. 286

jl.au $\quad$ Br Spain 1772. D co Lob. ic. 533

ap.my $\mathrm{Pu}$ Canaries 1779. S l.p Jac. schme.t209

jn. au Pu Spain 1752. D co Barr, ic. 274

jn.au Br $\quad$....... 1816. D co

jn.au Br Austria 1823. D co

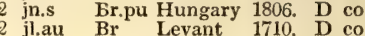

... Br $\mathrm{Br} \quad$...... 1816. $\mathrm{D}$ co

jn.au D.Pu Portugal 1768. D co Herm. lug. t. 547

my.jn Pa,Y Siberia 1786. C co Mur.co.got.4.t. 2

2 mr.my Y Britain m.sh.pl. S co Eng. bot. 567

$\frac{1}{2}$ my.jn $R$ Canaries 1778. S co

my.s R.Y Africa 1731. C co Pluk.al. t.313.f.6

jl.s R.G Spain 1640. D co

Br.pu Hungary 1806. D co

jl.au Br.pu Portugal 1816. D co

jl.au Br.pu Barbary 1786. D co

jn.au Br.pu S. Europe 1683. D co

jn.au Br.pu Levant 1596. D co

jn.au Br.pu Casp. sho. 1816. D co

jn.au Br.pu

jn.au Br.pu Tauria 1816. D co

Scrophularinea. Sp. 1-2.

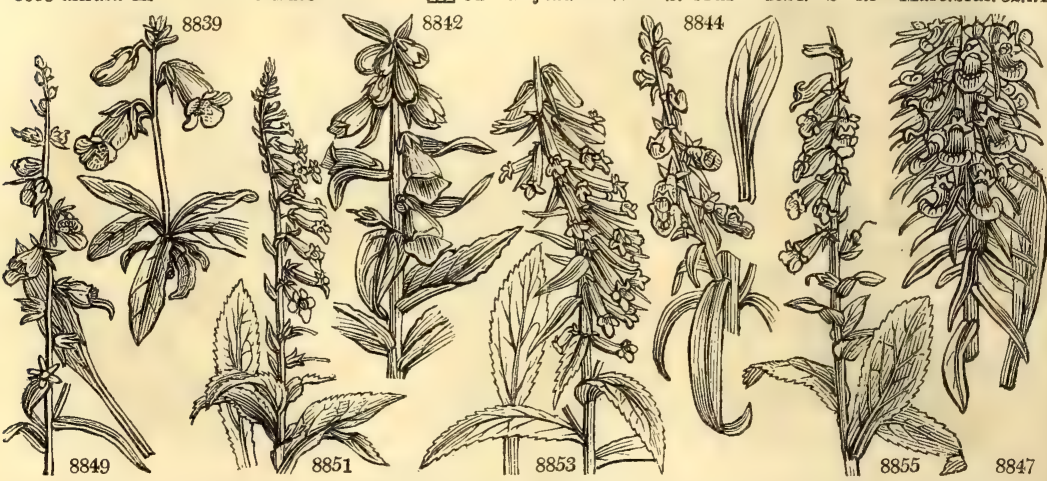

History, Use, Propagation, Culture,

1355. Digitalis. Named by Fuchs, from digitabulum, a thimble, in allusion to the form of the flowers. The species are for the most part shewy border flowers of easy culture. D. purpurea, found both with purple and white flowers, is one of the most ornamental of native plants in rocky copses, neglected hedges, and by road sides. Its large tall spike attracts not only the botanist and florist, but is even conspicunus enough to be introduced in the painter's landscape of such scenery. It is a violent poison; but also a valuable plant in medicine. The leaves are the parts of the plant used. They should be gathered when the plant is in flower, and those only which are fresh selected. The leafstalks and midrib should be rejected, the plant is in flowe remaining part and tho only which are rinhe, or on a tin-pan be dried either in the sunshine, or on a tin-pan or pewter dish before the fire, or the plant be hung up, each leaf separate, in a warm kitchen. Practitioners ought annually to obtain a supply of the recent leaves in the month of July, and dry them themselves; as in the herb-shops they are often so ill dried as to appear black, in which state they are useless. The powder should be kept in closely stopped opaque phials:

Digitalis is directly sedative and diuretic. It weakens the force of all the vital functions; and by a proper exhibition of it, the frequency of the pulse may be diminished any number of pulsations, and regulated at the pleasure of the practitioner; whilst at the same time it admits, to a certain extent, of the employment of such medicines as increase the firmness of the arterial action, and give tone to the habit. When given to the 
8838 Lvs, obl, rugose crenate, Sepals ovate obl. Segm. of cor. transverse acutc, Pedunc. straight as long calyx

8839 Lvs. obl, rugose crenate wavy decurrent, Sepals ovate, Segm. of cor. ovate rounded [as calyx
8840 Lvs, radical flat on the ground, Racemes few-fl. Segm. of cor. ov, round, smooth, Pedun, three times as long 8840 Lvs. radical flat on the ground, Racemes few-fl. Segm. of cor. ov. round. smooth, Pedun. three times as long 8841 Lvs. ov. lanc. tooth. sess. nerved, Lower bractes as long as f. Cor. downy netted, Segm. ov. transverse blunt 8842 Lvs. ov. lanc. acum. toothed and stem villous, Bractes twice as long as lower flowers, Cor. villous net ted 8843 Lvs. lanc. ciliated, Bractes twice as short as flowers, Cor. downy netted, Segm. ov, acute, Lip bearded, 8844 Very smooth branched, Lvs. lin. lanc. Flowers scattered not downy

8845 Raceme dense pyramidal, Sepals edged, Lip of corolla ovate entire bearded

8846 Raceme many-flowered, Sepals edged, Corolla bowed, Lip ovate 3-toothed

8847 Raceme dense cylindrical many-fl. Lip of cor. clawed lunate, Bractes linear longer than fiower

8848 Leaves oblong, Rachis woolly, Lip of cor. ovate

8849 Very smooth, Leaves linear, Flowers scattered, Lips of cor. oblong

8850 Lvs, obl. lanc. wavy deflexed ciliated entire, Raceme dense cylindrical, Segm. and sepals of cor. rounded 8851 Glandul. hairy, Lvs. obl. lanc. rugose wavy tooth. Raceme 1-sided many-fl. Cor. pubesc. Segm. ov. glandul. 8852 Lvs. linear lanc. serrated smooth, Raceme 1-sided, Cor. smooth, Segments rounded

$8853 \mathrm{Segm}$. of cor. ovate obtuse, Flowers of distinct sexes

8854 Lvs. lanc. toothed smooth, Raceme 1-sided, Cor smow 8855 Lvs. cordate oblong flat crenate not downy, Raceme 1-sided, Cor. smooth, Segm, very blunt

8856 Half shrubby, Leaves linear lanc. entire smooth, Corollas ventricose

8857 Leaves cordate serrate acute rounded at base, Stem with blunt angles

8858 Leaves cordate 3 -nerved, Stem with blunt angles

8859 Leaves cordate stalked decurrent blunt, Stem with membranous angles, Racemes terminal

8860 Lvs. ovate cord. smooth cut serrate with appendages at base, Petioles dilated, Racemes term. compound

8861 Lvs. obl. cord. hairy beneath doubly toothed with an appendage at base, Petioles equal, Racemes terminal

8862 Leaves cordate doubly serrate pubescent, Panicles terminal trichotomous with leaves between

8863 Lvs. obl. lanc. cord. doubly serrated smooth, Panicles racemose terminal 3-chotomous, Stem $\frac{1}{2}$ shrubby

8864 Leaves cordate obl. toothed : teeth entire those at base deepest

8855 Leaves obl. lanc. deeply cordate finely and douhly serrated smooth, Pan. racem. term. Ped. 3-chotomous

8866 Lower lvs. tern. cord. cren. toothed; upper entire, Fl. racemose panicled, Bractes ovate lanc. entire at end

8867 Leaves cordate 3-nerved pubesc. on each side, Petioles ciliated, Pedunc. and bractes with glandular hairs

8868 Leaves lanceolate serrated stalked : cauline in $3 \mathrm{~s}$; and the branches opposite

$8869 \mathrm{Lvs}$. lanc. narrowed at each end deeply unequally and doubly toothed smooth, Racemes terminal

8870 Lvs, somew. fleshy : upper sessile toothed smooth recurved at end, Pan. racem. Pedunc. bifid many-flow.

8871 Lvs. cord. doubly toothed: lower teeth bent backwards, Raceme terminal compound, Ped. 2-3-fl. altern.

8872 Leaves cordate pubescent doubly serrated, Panic. axillary dichotomous, Bractes ovate serrate

8873 Leaves cordate smooth doubly serrated, Panic. axillary dichotomous, Capsules acuminate

8874 Leaves smooth: lower ternate pinnate blunt; upper simple, Pedunc. about.3-f. axillary

8875 Leaves interruptedly pinnate cordate unequal, Raceme terminal, Pedunc. axillary twin dichotomous

8876 Lvs. obl. cord. lobed at edge naked as long as pet. Rac. term. comp. Branch. and ped. with glandular hairs

8877 Lvs. interruptedly pinnate oblong subcordate unequal at base, Panicle terminal, Peduncs. dichotomous

8878 Leaves pinnated, Leaflets oblong cut toothed, Panicle terminal, Peduncles dichotomous

8879 Leaves smooth: lower interruptedly pinnate; upper ternate, Leaflets oblong, Flowers axillary

8880 Leaves pinnated, Raceme terminal naked, Peduncles bifid, Calyxes scarious

8881 Lower leaves bipinnate somewhat fleshy very smooth, Racemes bipartite

8882 Stems woody at base, Leaves bipinnatifid pubescent, Racemes long, Pedicels short villous

8883 Leaves bipinnate, Pinnæ acutely cut toothed, Panicle terminal, Peduncle dichotomous

8884 Lvs. smooth : rad. bipinnat. caul. pinnate, Panicle leafy, Ped. dichotomons, Lat. seg. of lower lip emargin. 8885 Leaves cordate lined shining, Pedunc. axillary 2-flowered, Stem hexangular

8886 Leaves roundish subsessile

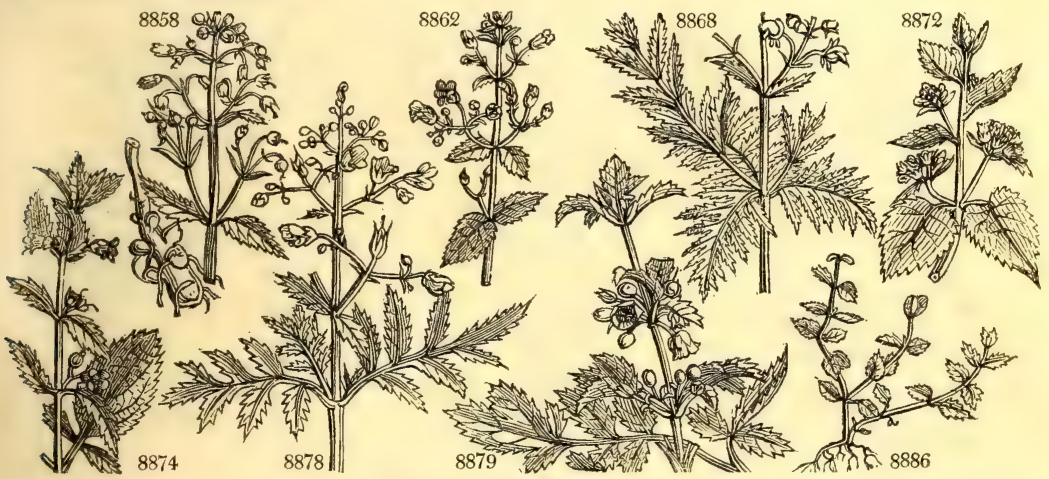

and Miscellaneous Particulars.

full extent of which the system can admit, the pulse intermits, and vertigo, indistinct vision, and nausea, with vomiting or purging, occur; and if, after these indications, the quantity be still increased, or if any considerable portion of the recent herb be inconsiderately swallowed, it produces delirium, hiccough, cold sweats, convulsions, syncope, and death. (London Dispensatory, 287.)

1356. Scrophularia. So named from the roots having a resemblance to scrophulous tumours, which they were, by the peculiar mode of induction of the dark ages, therefore supposed to cure. S. nodosa has the name of figwort from its knobbed roots : it has a rank smell like elder, and a bitter taste; swine that have the scab are cured by washing them with a decoction of the leaves. Wasps resort greatly to the flowers. Goats eat the plant; but cows, horses, sheep and swine refuse it

The same observations apply to $\mathbf{S}$. aquatica, which in French is called Herbe du Siege, because at the celebrated siege of Rochelle by Cardinal Richelieu in 1628, the garrison was reduced to the necessity of supporting life upon the roots of the plant.

1357. Vandellia. Louis Vandelli, a Portuguese, was professor of botany in the garden of Coimbra. He published in 1788, an essay on the plants of Portugal and Brazil, a work which is little known, on account of its extreme rarity. 
1358. SIBTHOR'PIA. $W$. Siвthorpia

1359. LIMOSELLA. $W$. MUDWORT.

8888 aquática $W$. water

1360. BROWAL'Lia. $W$. Browallia. 8889 demíssa $W$. 8890 eláta $W$. upright

1361. STEmódia. $W$. Stemodia. 8891 parviflóra H. $K$.
8892 verticilláris Link.

1362. Trevira'NA. W. $c n$. Trevirana 8893 coccínea W. en. scarlet
Cyrilla pulchel'la B. M.

1363. Colum'NeA. $W$. Columnea. 8894 scándens $H . K$. climbing 8895 hirsúta $W$. hairy 8896 trifoliáta $\dot{\text { Link. }}$ three-leaved

1364. RUSSE'Lia. $W$. Russelia. 8897 multiflóra $B . M$. many-flowered 1365. DODAR'TIA. $W$. Dodartia. 8898 orientális $W . \quad$ oriental

1366. LINDER'NIA. $R$. Br. Lindernia. 8899 Pyxidária $W$. European

1367. HERPES'TIS. $R$. Br. HeRPESTIS. 8900 Monnie'ria $R$. $B r$. Thyme-leaved 8901 cuneifólia $P h$. wedge-leaved 8902 stricta Schrad. upright

1368. CAPRA'RI A. P.S. Capraria.

.8903 biflóra $W$.

8904 cuneáta $H$. $K$. 8905 lanceoláta $W$. 8906 unduláta $W$. 8907 húmilis $W$. shrubby Goatw, wedge-leaved wave-leaved dwarf

1369. BUChNe'RA. B. $P$. Buchnera. 8908 americána $W$. American

1370. MANU'LEa. W. en. Manulea. 8909 fœ'tida Thunb. stinking 8910 villósa Thunb. villous Buchnéra capénsis W.

8911 Buchnéra capénsis W. 8912 viscósa $W$. en. 8913 rúbra Thunb. red 8914 tomentósa Thunb. woolly 8915 Cheiránthus Thunb. Wall-flower 8916 argéntea Thunb. silvery 8917 rhynchan'tha Link. tail-flowered 8917 rhynchan'tha Link. tail-flo
8918 violácea Link.
Scrophularinere. $S p .1-2$.

Scrophularinea. Sp. 1-5.

* $\mathrm{pr} \quad \frac{2}{4}$ jl.s $\mathrm{F}$ Britain mud.pl, S s.l Eng. bot. 357 Scrophularinea. $S p .2$.

* 이 or $\frac{3}{4}$ jn.s B $\quad$ S. Amer. 1735. S s.l Bot. mag. 1136 فل or $1 \frac{1}{5}$ jn.s B Peru 1768. S s.l Bot. mag. 34 Scrophularinea. Sp. 2-8.

[0] $\mathrm{cu} \frac{1}{2}$ jl.au W S. Amer. 1759. S p.l

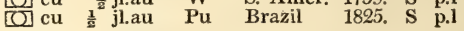
Scrophularine.e. Sp. 1

$\checkmark \square$ spl $1 \frac{1}{2}$ au.o Sc Jamaica 1778. C 1.p Bot. mag. 374 Scrophularinea. Sp. 3-8.

月 $\square$ or 6 au.s Sc W. Indies 1759. C s.p Bot. reg. 805

且 or 4 au.n Pa.pu Jamaica 1780. C s.p Bro.jam.t. 30. f.3 au.n B Scrophularinea. $S p .1-4$

4 jn.au $R$ S. Amer. 1812. C s.p Bot. mag. 1528 Scrophularinea. Sp. $1-2$

¥ $\Delta$ un $1 \frac{1}{2}$ jl.au Pu Levant 3752. C s.p Lam. ill. t. 530 Scrophularinea. $S p .1-3$.

O un 1 jn.au B $\quad$ S. Europe 1789. S s.I Lam. ill. t. 522 Scrophularinea. $S p .3-7$.

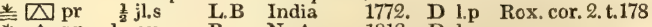

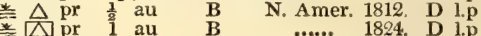

\section{Scrophulariner. Sp. 5-9.}

w un 2 jl.au W S. Amer. 1752. C. 1.p Lam. ill.t.534.f.2 — un 2 ... $\quad$ W $\quad$ S. Amer. 1759. C p.1

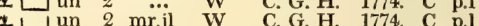
Tru 1 . G. H. 1774. C p.l Bot. mag. 1556 W E. Indies 1781, C p.I

Scrophularinea. Sp. 1-13.

15 $\Delta \mathrm{cu} 1 \frac{1}{2} \mathrm{jn} . \mathrm{au} \quad \mathrm{B} \quad \mathrm{N}$. Amer. 1733. D l.p

Scrophularinea. $s p$. 10—40.

$101 \mathrm{pr} 11$ jn.s W C. G. H. 1794. S s.p Bot, rep. 80

ل्व $\mathrm{pr} 1$ jn.jl W $\quad$ C. G. H. 1783. S s.p Bur. afr. t. 50.f.2

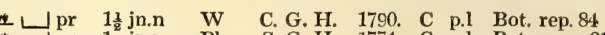

w pr 1 jn.n Pk $\quad$ C. G. H. 1774. C p.1 Bot. mag. 217

\# ${ }^{2}$ el $1 \frac{1}{2}$ ap.s R $\quad$ C. G. H. 1790. C p.l

m el 1 my.n Y C. G. H. 1774. C s.p Bot. mag. 322

4 D) el 1 jn.au Or C. G. H. 1795. S s.p Com. hort. 2.t.42

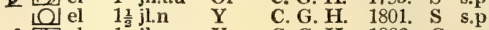

G \begin{tabular}{llllll}
\hline & el jl.n & Y & C. G. H. 1823, C & s.p
\end{tabular}

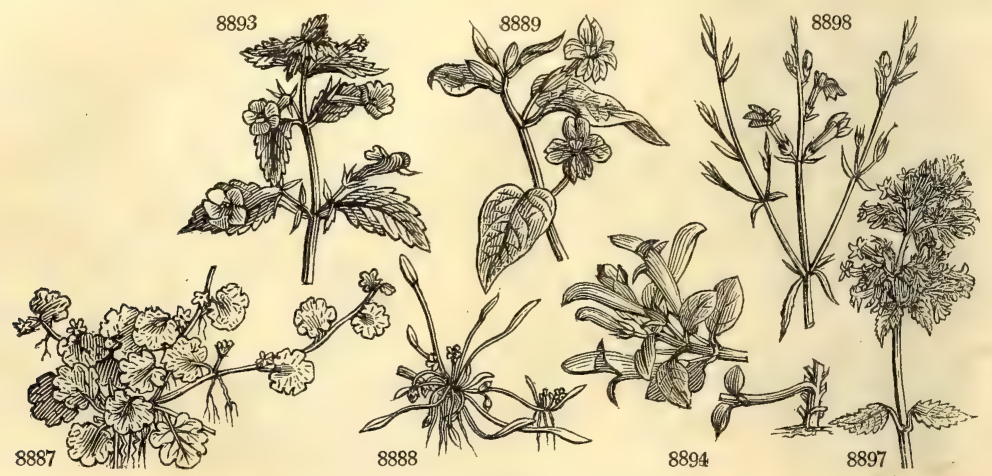

History, Use, Propagation, Culture,

1358. Sibthorpia. In honor of Humphry Sibthorp, M. D., professor of botany at Oxford, who travelled into Greece, for the purpose of collecting materials for a classical Flora Græca, in which he succeeded even beyond his own hopes. After his death the publication of his materials was confided to Sir James Edward Smith, under whose care the work has reached to five hundred figures in folio, of the most magnificent kind; five hundred more have yet to be published. A little trailing plant.

1359. Limosella. From limus, mud. The plant grows by the edge of puddles and in muddy places.

1360. Browallia. Named by Linnæus, in honor of John Browallius, bishop of Aboa, who defended the sexual system against Siegesbeck, in a book entitled Examen epicriseos, \&c., Aboa, 1739, octavo. Handsome plants with blue flowers, often cultivated as tender annuals.

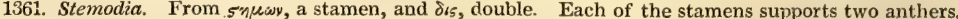

1362. Trevirana. Named after Dr. Treviranus, a German botanist. This beautiful plant, which is commonly called Cyrilla pulchella, is one of the prettiest of the old inhabitants of the stove.

1363. Columrea. In honor of Fabius Columna, or Fabio Colonna, of the noble family of Colonna in Italy, born in 1567. He published his Phytobazanos in 1592, and his Ecphrasis in 1606, both works of high reputation in their day. One species, C. scandens, is common in hothouses, where it is cultivated for the neatness of its foliage and the beauty of its scarlet blossoms. 
8887 Leaves reniform subpeltate crenate

8888 Leaves lanceolate spatulate, Scapes shorter than leaf

8889 Peduncles 1-flowered

8890 Peduncles 1 many-flowered

8891 Leaves opposite and ternate stalked

8892 Leaves opposite and ternate stem-clasping

8893 Leaves ternate ovate hairy

8894 Leaves ovate acute entire subvillous, Sepals entire and corollas pubescent, Upper lip undivided 8895 Leaves ovate acuminate serrate hairy above, Sepals toothletted and corollas hairy 8896 Leaves 3 subsessile oblong acutely crenate pubescent, Cor. hairy, Galea dilated reflexed

8897 Leaves ovate acuminate stalked, Raceme terminal whorled, Peduncles cymose

8898 Leaves linear smooth entire, Stem nearly naked

8899 Leaves obiong ovate entire 3-nerved sessile, Pedunc. axillary 1 flowered, Stem procumbent

8900 Leaves oblong entire, Peduncles longer than leaf, Stem declinate

8901 Very smooth, Leaves cuneate oblong upwards obsoletely crenate, Pedunc. nearly as long as leaf 8902 Stem erect, Leaves lanceolate acute doubly serrated smooth, Flowers whorled

8903 Leaves ovate serrated alternate, Flowers twin

8904 Hairy, Leaves alternate rhomboid cuneiform cut serrate, Flowers twin, Sepals linear 8905 Leaves opposite linear entire, Racemes compound terminal

8906 Leaves opposite ovate-oblong entire wavy : upper subcordate whorled, Racemes spiked

8907 Pubescent, Leaves opposite and ternate ovate serrate stalked, Pedunc. axillary shorter than petiole

8908 Leaves toothed lanceolate 3-nerved

8009 Leaves opposite ovate jagged, Flowers somewhat umbelled terminal 8910 Leaves linear toothed villous, Cal. hairy, Branches subfastigiate

8911 Upper leaves opposite sessile tooth-sinuated, Flowers solitary on long stalks 8912 Leaves opp. lin. lanc. acute at each end toothletted, Raceme terminal, Stamens exserted 8913 Leaves lanc, toothed villous, Racemes of flowers remote

8914 Leaves obovate crenate downy, Stem decumbent

8915 Leaves obl. serrated hairy, Stem nearly leafless, Flowers alternate remote

8916 Leaves ovate toothed silky beneath dotted with silver, Flowers axillary stalked

8917 Leaves wedge-shaped serrated pubescent, Segm. of cor. with very long points

8918 Leaves opp. stalked oblong blunt tooth-serrated when old smooth, Segm. of cor. rounded

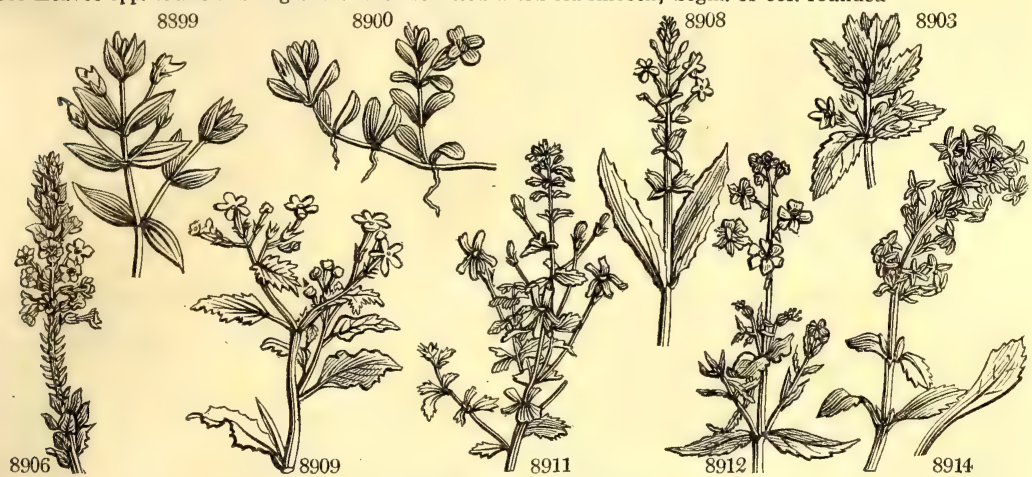

and Miscellaneous Particulars.

1364. Russclia. In honor of Alexander Russel, M. D. F. R. S., born in Scotland; died 1768; author of the natural history of Aleppo, London, 1756. His brother Patrick, published a second edition in 1794, and a work on serpents in 1796 , folio.

1365. Dodartia, by Tournefort, after M. Dodart, member of the academy of sciences at Paris; and an eminent physician. An ugly, leafless, almost flowerless plant, of much rarity and little beauty.

1366. Lindernia. Named after Francis Lindern, an obscure Swiss botanist. Pyxidaria is so called from xukos, the box, which it resembles in foliage.

1367. Herpestis. From غंелnsns, any thing which creeps. An exotic genus of herbs, with opposite leaves and axillary flowers, each of whose stalks bears a pair of bracteæ. Herpestis Monnieria is a beautiful aquatic.

1368. Capraria. So named from capra, a goat, the leaves being much liked by that animal.

1369. Buchnera. Named after John Godfrey Buchner, a German botanist, who published in 1743, his Observations upon the Plants of Saxony. Small Cape shrubs of little interest or beauty. Their leaves are generally small, and their flowers white.

1370. Manulea. Derived from manus, the hand. The five divisions of the flower, in some species, from their form and relative position, resemble an open hand. Handsome Cape shrubs of humble growth. They are rare in collections, but deserving of being very generally cultivated. 


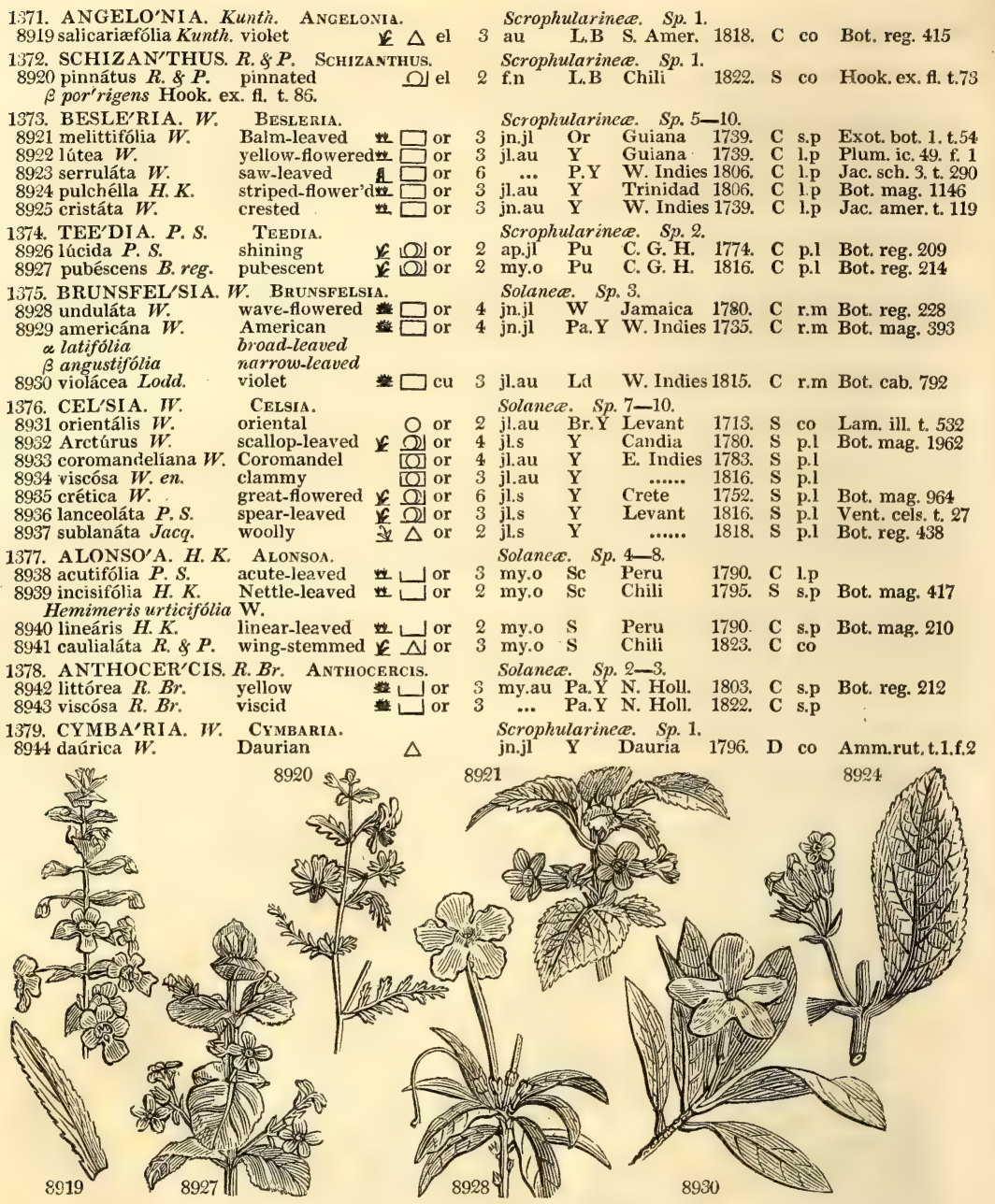

History, Use, Propagation, Culture,

1371. Angelonia. Angelon is the name of the plant among the Spanish colonists of Caraccas, where it grows. A very beautiful stove herbaceous plant, with large light-blue flowers.

1372. Schizanthus. From $\sigma \times \iota^{2} \omega$, to cut, and $\alpha_{\nu} 905$, a flower, in allusion to the numerous divisions of the beautiful purple and yellow flowers. Tender annual plants, with finely cut pale green leaves, and termina panicles of elegant flowers.

1373. Besleria. After Basil Besler, an apothecary at Nuremberg, joint editor with Jungermann, of a sumptuous work entitled Hortus Eystettensis, 1613. The garden belonged to Bishop Conrad, of Eichstedt, and the plates were engraved at his expense.

1374. Teedia. So named by Persoon, but the meaning is unknown. Pretty herbaceous plants, with bright purple flowers and dark berries.

1375. Brunsfelsia. In memory of Otho Brunsfels, of Mentz, a Carthusian monk, and afterwards a physician, author of Figures of Plants in 1530. He died in 1534. The species are handsome tropical shrubs, with neat foliage and shewy white or purple flowers. Cuttings with a little ripened wood strike root freely in heat. 
8919 The only species

8920 The only species

8921 Peduncles branched, Leaves ovate

8922 Peduncles simple clustered, Leaves ovate-lanceolate serrated

8923 Peduncles simple solitary, Calyxes serrated, Cor. smooth with a serrulated limb

8924 Leaves obl. ovate rugose crenate decurrent down the petiole, Cal. serrulate colored

8925 Peruncles simple solitary, Calyxes colored serrated, Cor. hairy with an entire limb, Leaves ovate

8926 Leaves opp. obl. finely serrulate smooth

8927 Leaves downy

8928 Leaves ovate-lanceolate narrowed at each end, Tube of cor. curved, Limb wavy

8929 Leaves obovate acuminate longer than petiole, Tube of cor. straight, Limb entire

\section{Leaves and leafstalks deeply stained with purple}

8931 Cauline leaves bipinnate

8932 Rad. leaves lyrate : upper oblong, Pedicels longer than bractes, Sepals linear entire

8933 Radical leaves lyrate : upper ovate, Bractes longer than pedicels, Sepals linear oblong entire

8934 Radical leaves lyrate : floral cordate half stem-clasping, Peduncles as long as flower

8935 Radical leaves lyrate : upper oblong, Flowers subsessile the length of bractes, Cal. ovate serrated 8936 Somewhat downy, Leaves lanceolate, Flowers axillary solitary

8637 All over wool, Leaves oval oblong blunt crenate, Stamens bearded with capitate hairs

8938 Leaves ovate lanceolate deeply serrated

8939 Leaves ovate acute cut serrated

8940 Leaves ternate remotely toothletted

8941 Leaves ovate acute serrated, Stem winged at angles

8942 Leaves obovate smooth, Segments of cor. length of tube

8943 Leaves obovate dotted with glands downy

8944 Flowers large yellow spotted
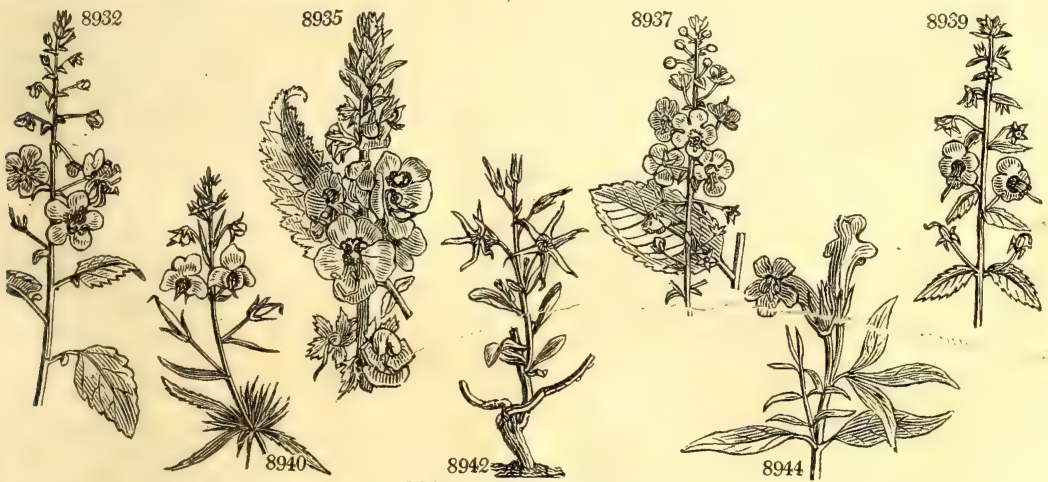

1376. Celsia. In honor of Olaus Celsius, D. D., surnamed the northern Pliny, professor of the oriental lancr: ge the university of Upsal. His Hierobotanicon, or History of the Plants of Scripture, appeared in 1745. There was also another Swedish botanist called Magnus Nicolaus Celsus, who died in 1679 . Besides these moderns, the name is rendered familiar to classical scholars by the reolletion of the famous Cornelius Celsus, who wrote upon agriculture and medicine, and whose purity of style procured him the name of the Cicero of medicine.

1377. Alonsoa. Named by the authors of the Flora Peruviana, after Zanoni Alonso, at the time of the publication of that work, Spanish secretary for the kingdom of Santa Fé, and a great patron of objects connected with natural history. Sir James Smith considers the genus the same as Hemimeris.

1378. Anthocercis. From cy. 05 , a flower, and $x$ seis, a ray, the narrow divisions of the corolla spreading in a radiant manner, like the spokes of a wheel

1379. Cymbaria. From $\approx \nu \mu, \beta \eta$, a boat, in allusion to the shape of the fruit. A small pubescent hoary plant, native of mountainous rocky places in Siberia. 


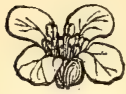

Class XV. - TETRA DYNAMIA. Stamens 6, of which four are longer than the rest.

Turs class consists, with the exception of Cleome, entirely of the natural order Cruciferæ, and has lately been the subject of the most acute and successful investigation of many botanists of celebrity. Our countryman, Mr. Brown, led the way to the improvements which have been made in the genera, in the second edition of the Hortus Kewensis, in which, discarding the uncertain and unnatural characters derived from variations in the floral envelopes, he took a new course, and by indicating with great precision the curious modifications of the seeds and seed-vessels, led the way to an entirely new arrangement of the class. The principles thus developed have been adopted by M. Decandolle, whose learned treatise upon Cruciferæ is here followed without variation.

The difference between the genera with a long pod (Siliquosa), and those with a short one (Siliculosa), has given rise to two orders in the Linnean system. But these are not only ambiguous, but interfere so much with a distribution of the genera according to their natural affinities, that they have been rejected here, and the divisions of M. Decandolle, depending upon variation in the relative position of the various parts of the seed, have been substituted.

The plants of this class have always been celebrated for their antiscorbutic qualities. These seem to reside in an acrid, oily, volatile principle, not yet determined by chemists, and varying in the degree of abundance in which it is found in different species. It is particularly abundant in the seeds of mustard and garden rocket, in the roots of the horse radish, and in the foliage of the Lepidium latifolium, which, administered inwardly, act powerfully upon the gastric organs, or, applied externally, inflame the skin and operate nearly as severely as blisters. A slighter degree of acrimony is found in the foliage of the scurvy grass, the roots of the garden radish, \&c. ; and these, theretore, operate more gently, and perhaps more s.afely, when eaten, scarcely at all
when applied outwardly. Whatever the degree of acrimony may be in these plants, they all appear, when eaten, to produce some specific action upon the digestive organs, and thence upon scorbutic humours; for which reason, the horse radish, water-cress, radishes, and even cabbages are eminently antiscorbutic. They are also admitted by physicians as diuretic, sialagogue, and diaphoretic. It is only when the acrid principle is diffused over a considerable quantity of fleshy and watery substance, that cruciferous plants become eatable, as in the leaves and stems of cabbages and sea-kail, and in the roots of radishes and turnips. Even in these plants, the proportion of acrid principle is much diminished by exclusion from light. Plants of this class are also remarkable for containing a larger quantity of azote than most vegetables; for which reason ammonia is generally evolved in their fermentation or putrefaction: to which circumstance it is possible that the two remarkable phœenomena are to be attributed, viz. ; that cruciferous plants contain a greater portion of nutritive matter than most herbaceous plants; and that they require either a very rich soil manured with animal substances, or at least a situation near the habitations of men. The embryos of all these plants are filled with oil, and the seeds of Camelina sativa, Brassica campestris, some species of Rocket, \&c. are cultivated in many parts of Europe for the sake of their expressed oil, which is used either for culinary purposes or for lamps.

Cruciferous plants are chiefly natives of temperate climates, those which are found within the tropics being in all cases mountain plants, and are nearly all cultivable in the open air; they are mostly found in open sandy plains; some on the tops of the highest mountains at the utmost limits of vegetation. Nine hundred species are now described, of which not more than twenty-two are to be found in the works of Hippocrates, Theophrastus, Dioscorides, or Pliny.

A. Cotyledons four, spirally twisted. Petals 4, cruciate.

1380. Schizopetalon. Petals pinnatifid.

\section{B. Cotyledons two. Petuls 4, cruciate.}

1. Cotyledons flat, accumbent. Radicle lateral. Seeds compressed. (O=) Pleurorhizex, Dec.

* Silique openzng; with a linear dissepiment more or less wide than sceds. Seeds oval, compressed often margined - Catyledons jiat, irccumbent, parallel with the dissepiment. ARABIDEA, Dec.

1389 Cheiranthus. Silique round or compressed. Stigmas 2-lobed or capitate." Calyx bisaccate at base.

1383. Nasturtium. Silique roundish, shortened or declinate. Stigma nearly 2-lobed. Calya equal at base, spreading.

1384. Leptocarpaa. Silique roundish, very slender. Stigmas sessile, 2-lobed. Calyx sprvading, equal.

1385. Notoceras. Silique 4-cornered, 2-edged, the valves elongated at end into a horn or mucro.

1386. Barbarea. Silique 4-cornered, 2-edged, the valves not elongated at end. Calyx equal at base.

1387. Braya. Silique oblong, subcylindrical, with flattish valves and a sessile stigma. Seeds few, ovate.

Calyx equal at base.

1388. Parrya. Silique linear with veiny valves. Seeds in two rows, with a loose wrinkled skin. Stigmas approximating Filaments not toothed.

1389. Turritis. Silique linear with flat valves. Seeds in two rows in each cell

1390. Arabis. Silique linear with flat valves, 1-nerved in the middle. Seeds in one row in each cell.

1391. Macropodium. Silique pedicellate, linear, with flat valves, 1-nerved in middle

1392. Cardamine. Silique linear with flat nerveless valves, often opening with elasticity. Funicles of the

hilum slender.

1393. Pteroneuron. Silique lanceolate with flat nerveless valves, often opening with elasticity : placentas with winged nerves. Funicles dilated.

1394. Dentaria. Silique lanceolate with flat nerveless valves, often opening with elasticity: placentas not winged. Funicles dilated.

** Silicle opening lengthwise, with a broad oval membranous dissepiment, and flat or concave valves. Seed's compressed, frequently margined. Cotyledons flat, accumbent, parallel with the dissepiment.' ALYSSINEA, Dec.

1395. Lunaria. Silicle pedicellate, elliptical or lanceolate with flat valves. Funicles long, adhering to the dissepiment. Calyx somewhat bisaccate. Petals nearly entire. Stamens not toothed.

1396 Ricotia. Silicle sessile, oblong, when ripe losing its dissepiment and becoming 1-celled: valves flat. Calyx with two prominences at base. Petals emarginate. Stamens not toothed.

1397. Farsetia. Silicle sessile, oval or orbicular, with flat valves, Seeds winged. Calyx bisaccate at base. Petals entire.

1398. Berteroa. Silicle sessile, elliptical or obovate, with flat or concave valves. Calyx equal at base. Petals 2-parted. The small stamens touthed

1399. Aubrietia. Silicle oblong with convex valves. Seeds not edged. Calyx bisaccate at base. Petals entire. Smaller stamens toothed.

1400. Vesicaria. Silicle globose inflated with hemispherical valves. Seeds more than 8 . Petals entire. 
1401. Alyssum. Silicle orbicular or elliptical, with valves flat or convex in centre. Seeds 2-4 in cach cell. Calyx equal at base. Petals entire. Some the stamens toothed.

1402. Clypeola. Silicle orbicular, 1-celled, 1-seeded, with flat valves. Calyx equal. Petals entire. Stamens toothed.

1403. Peltaria. Silicle orbicular, 1-celled, 1-4-seeded, with flat valves. Seeds two in each cell: funicles adhering to the dissepiment.

1404. Petrocallis. Silicle sessile, oval, with flattish valves. Seeds two in each cell : funicles adhering to the dissepiment.

1405. Draba. Silicle sessile, oval or oblong, with flat or convex valves. Seeds many, not edged. Calyx equal. Petals entire. All the stamens without teeth.

1406. Erophila. Silicle oval or oblong, with flat valves. Seeds many, not edged. Calyx equal. Petals -parted. Stamens without teeth.

1407. Cochlearia. Silicle sessile, ovate-globose or oblong, with ventricose valves. Seeds many, not edged, Petals entire. Stamens without teeth.

*** Silicle opening, with a very narrow dissepiment, and keeled navicular valves. Seeds oval, sometimes margined. Cotyledons flat, accumbent, contrary to the dissepiment. THLASPIDEA, Dec.

+ Cells of silicle 2-mary-seeded.

1408. Thlaspi. Silicle emarginate at end, with navicular valves, winged at back. Cells two, marysceded.

1409. Capsella. Silicle triangular, cuneate at base, with navicular valves, not winged. Cells many-seeded.

1410. Hutchinsia. Silicle elliptical, with navicular valves, not winged. Cells 2-seeded, rarely manyseeded.

1411. Teesdalia. Silicle oval, emarginate at end, with navicular valves and 2-seeded cells. Stamens having a seale inside at their base.

++ Cells of silicle 1-seeded.

1412. Theris. Two outer petals largest. Silicle compressed, truncate, emarginate

1413. Biscutella. Silicle flat, biscutate, with the cells laterally united to the axis. Style long, persistent. Embryo inverted.

**** Silicle not opening, with concave indistinct valves, and sometimes with scarcely any trace of a dissepiment. Seeds oval, very few. Cotyledons flat, accumbent, parallel with dissepiment. EuclidiEx, Dec.

1414. Euclidium. Silicle drupaceous, ovate, with manifest sutures, Style subulate Cells 1-seeded.

1415. Ochthodium. Silicle coriaceous, subglobose. Stigma sessile. Dissepiment thick. Cells 1-seeded.

***** Silicle opening lengthwise, with concave valves, bearing internally transverse horizontal dissepiments separating the seeds. Seeds not margined. Cotyledons flat, accumbent, parallel with the dissepiment. Anastatice

1416. Anastatica. Silicle ventricose, with valves bearing an appendage outside at the end.

****** Silique or silicle separating across into 1-2-celled, 1-2-seeded joints. Seeds not edged. Cotyledons flat, accumbent, parallel with the dissepiment when there is any. CakiLINEA, Dec.

1417. Cakilc. Silicle 2-jointed, compressed: the upper joint ensiform. Seeds solitary in the cells : upper erect ; lower pendulous.

1418. Rapistrum. Silicle 2-jointed: the upper joint ovate, rugose. Seeds solitary in the cells : upper erect, lower pendulous.

1419. Chorispora. Silique roundish, with many equal joints. Seeds all pendulous.

2. Cotyledons flat, incumbent. Radicle dorsal. Seeds ovate, not margined. (O\|) Notorhizex, Dec

* Silicle 2-celled, opening lengthwise, with concave or keeled valves. Seeds ovate or oblong, not margined. Cotyledons flat, incumbent, contrary to the dissepiment. SisYmbried, Dec.

1420. Malcomia. Silique roundish. Stigma simple much pointed.

1421. Hesperis. Silique roundish, or about 4-cornered. Stigmas 2, erect, conniving. Calyx bisaccate at base.

1422. Sisymbrium. Silique roundish, sessile upon the torus. Stigmas 2, somewhat distinct or connate in a

head. Calyx equal at base.

1423. Alliuria. Silique roundish, a-cornered, with prominent nerves. Calyx lax.

1424. Erisymum. Silique 4-cornered. Calyx closed.

** Silicle with concave valves, and with a dissepiment ellipíical in its greatest diameter. Seeds ovate. Cotyledons flat, incumbent, contrary to dissepiment. CAMELINEX, Dec.

1425. Camelina. Silicle obovate or subglobose, with ventricose valves and many-seeded cells. Style filifo:":n.

1426. Neslia. Silicle subglobose, with concave valves, 1-celled, 1-seeded, indehiscent.

*** Silicle with a very narrow dissepiment, and with keeled or very convex valves. Seeds solitary or few in the cells, ovate, not margined. Cotylcdons flat, incumbent, parallel with the dissepiment. LEPIDINEA, Dec.

1427. Coronopus. Silicle twin. Valves ventricose or subcarinate, scarcely dehiscent, 1-seeded.

1428. Lepidium. Silicle ovate or subcordate, with carinate or rarely ventricose valves, opening with 1-seeded cells.

1429. Athionema. Silicle oval, generally emarginate, with navicular valves, and 1-2-seeded cells. Larger stamens either united or toothed.

**** Silicle with indistinct or indchiscent keeled valves, 1-celled, 1-seeded, with an obliterated dissepiment. Sceds ovate, oblong. Cotyledons flat, incumbent, apparently in the same direction as the dissepiment should be. ISATIDEA, Dec.

1430. Isatis. Silicle elliptical, flat, 1-celled, 1-seeded, with carinate navicular valves, which are scarcely dehiscent.

1431. Myagrum Silicle compressed, almost cuneate, with two empty hollows at end, and at base 1-celled, 1-seeded.

3. Cotyledons incumbent, folded together, or plaited lengthwise through their middle, and enwrapping the radicula. Style gent'ially cnlarged, with a cell and seed at its base. Seeds generally globose, never margined. $(\mathrm{O}>>)$ ORTHOPLOCEA, DeC.

* Siliquc with valves opening lengthwise, and a linear dissepiment. Cotyledons folded together. Brassice Dec.

1432. Brassica. Silique roundish. Style small, short, obtuse. Seeds in one row. Calyx closed.

1433. Sinapis. Silique roundish, with nerved valves. Style small, short, acute. Seeds in one row. Calyx spreading.

1434. Moricandia. Silique 4-cornered, sowewhat 2-edged. Seeds in two rows. Calyx bisaccate at base.

1455. Diplotaxis. Silique compressed, linear. Seeds in two rows. Calyx equal at base.

1436. Eruca. Silique roundish. Style large, cnsiform or conical. Seeds in one row. Calyx cqual at basc. 
** Silicle with concave valves, opening lengthwise, with an elliptical dissepiment. Cotyledons folded together. VELLEE, Dec.

1437. Vella. Larger stamens connate. Style ovate, flat, at the end of a tongue-shaped silicle.

1438. Carrichtera. Stamens all free. Style ovate, flat, foliaceous.

1439. Succowia. Stamens all free. Style slender, conical. Valves of the silicle echinate

*** Silicle indehiscent, ovate or globose, 1-celled, 1-seeded, with indistinct valves. Seeds globose. Cotyledons folded together. ZILLEe, Dec.

1440. Zilla. Silicle 2-celled. Cells 1-seeded.

1441. Calepina. Silicle 1-celled, 1-seed. Seed pendulous. Outer petals rather the largest.

**** Silicle or silique dividing across into one or few-seeded joints or cells. Seeds globose. Cotyledons folded together. RAPHANEE, Dec.

1442. Crambe. Silicle with two joints, of which the lower is abortive, the upper globose 1-seeded.

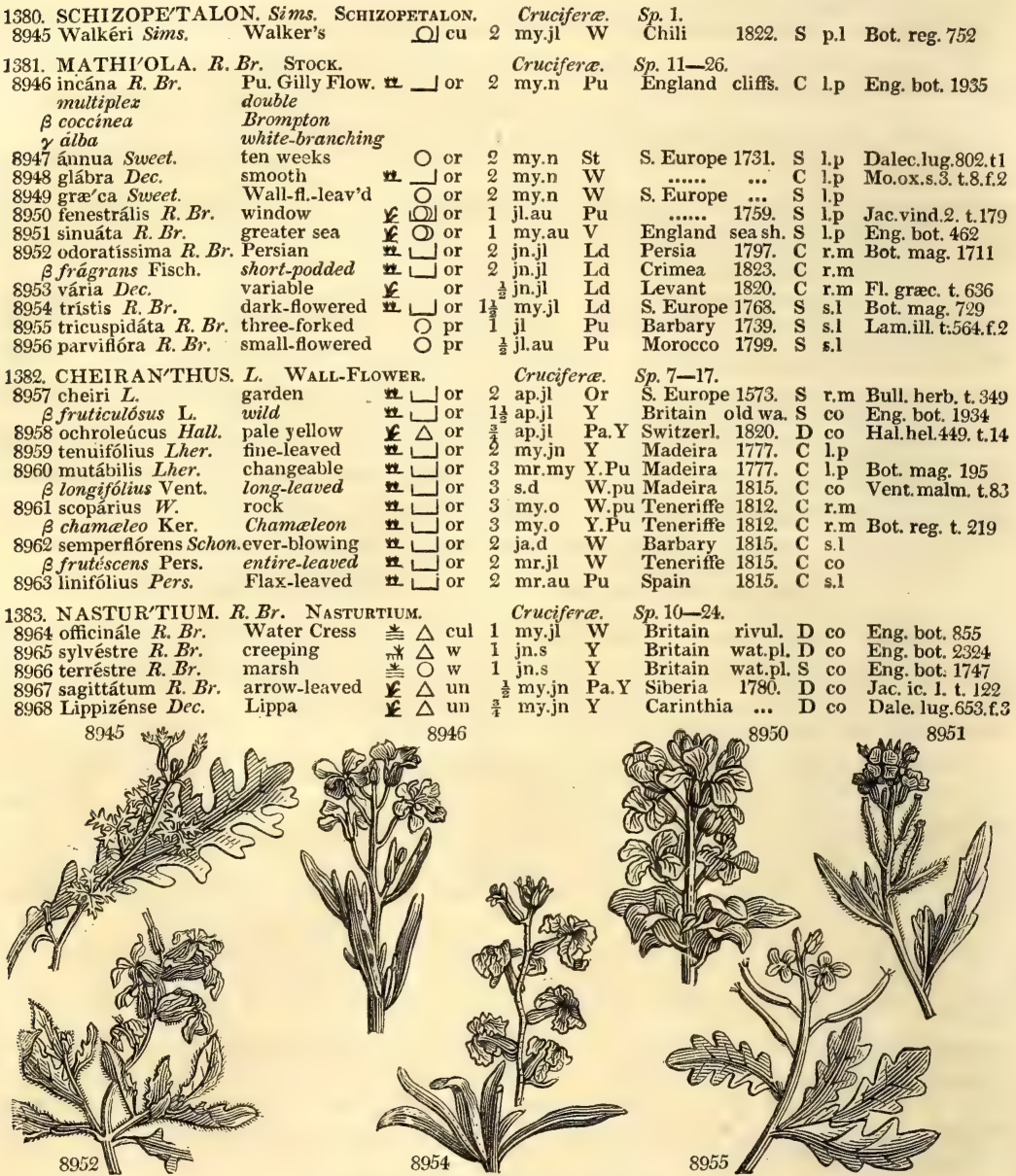

History, Use, Propagation, Culture,

1380. Schizopetalon. A curious genus of Chilian plants, with pinnatifid petals, whence the name has been formed, from $\sigma^{\circ} \chi \zeta \omega$, to divide. A plant of difficult cultivation. It is raised from seeds, which it produces sparingly, and only in a well-aired cool greenhouse.

1381. Mathiola. Named after Peter Andrew Matthioli, an Italian physician, born in 1500, died in 1577. He was first physician to Ferdinand of Austria, and author of a laborious commentary upon Dioscorides. Herbs, or rarely shrubs, nearly all covered with a white stellate soft down. M. incana, annua, græca, and fenestralis are popular border flowers, especially the first; the leaves of all the species, and also of Cheiranthus, and many other plants of this class, may be used as potherbs or salads.

1382. Cheiranthus. So called from the Arabic kheyry, the name of a plant with red sweet-scented flowers. Herbs, or occasionally shrubs, with entire or toothed leaves, and flowers of various colors. C. Cheiri is a 
1443. Raphanus. Silique transversely many-celled or dividing into several joints.

4. Cotyledons incumbent, linear, spirally or rather circinately twisted. (O\|I) SpIrolobex, Dec.

1444. Bunias. Silicle nucamentaceous, indehiscent, 2-4-celled. Cotyledons twisted spirally.

1445. Erucaria. Silique lomentaceous, 2-jointed ; the lower joint having two cells, the upper being ensiform. Cotyledons replicate, somewhat spiral.

5. Cotyledons incumbent, linear, with two legs, or a double plait, that is to say, plaited twice crosswise. Secds depressed. (O.|IIII) DiplecoloBe

1446. Heliophila. Silique elongate or rarely oblong or oval. Dissepiment linear or oval. Valves flat, or in the long siliques somewhat convex. Calyx equal at base.

1447. Subularia. Silicle oval. Dissepiment elliptical. Valves convex. Cells many-seeded. Stigma sessile.

C. Cotyledons 2. Petals 4, not cruciate. Thalamus large, hemispherical or elongated. Stamens 4-6-00.

1448. Cleome. A honey gland at each division of the calyx, except the lowest. Calyx 4-leaved. Petals ascending.

8945 Stem weak cœsious, Petals pinnatifid quickly perishable

8946 Stem shrubby at base erect branched, Leaves lanceolate entire hoary, Pods subeylind, without glands

8947 Stem herbaceous erect branched, Leaves lanceolate blunt hoary, Pods subcylindrical without glands 8948 Stem half shrubby erect branched, Leaves lanceolate smooth, Pods somewhat compressed without glands 8949 Stem herbaceous erect branched, Leaves lanceolate smooth, Pods somewhat compressed without glands 8950 Stem $\frac{1}{2}$ shrubby erect simple, Leaves close obovate downy, Pods downy without glands broadest at base 8951 Stem somewhat erect herbaceous branch. Lvs. obl. downy; lower sinuated, Pods comp. velvety and gland. 8952 Stem erect branched, Leaves downy or pubescent toothed or pinnatifid, Pods compressed downy

$\beta$ Pods twice as short as $\alpha$

8953 Stem erect nearly simple naked, Leaves linear blunt hoary entire, Flowers subsessile, Pods compressed 8954 Stem $\frac{1}{2}$ shrubby at base branched erect, Leaves downy linear entire or toothed, Fl. subsess. Pods roundish 8955 Stem suberect branched, Leaves sinuate pinnatifid, Pods with three acute nearly equal points

8956 Stem suberect branched, Leaves downy lanceolate repand toothed, Fl. sessile, Middle point of pod longest

8957 Leaves lanc. entire, Hairs 2-parted appressed or none, Pods linear, Stigmas with recurved lobes

8958 Lvs. obl. lanc. somew. toothed, Hairs 2-parted or none, Stem decum. branch. Pet obov. Pods erect pointed 8959 Leaves linear entire somewhat silky, Stem half shrubby

8960 Leaves linear-lanceolate acuminate finely serrated downy with 2-parted hairs, Stem shrubby branched

8961 Leaves linear-lanceolate acuminate entire downy with appressed 2-parted hairs, Stem shrubby branched 8962 Leaves lin. lanc. entire roughish, Stem shrubby branched, Pods compressed, Pedic. half as short as calyx 8963 Leaves linear entire rough clustered, Stem shrubby branched, Pods roundish 3 times as long as calyx

8964 Leaves pinnatifid, Segments ovate subcordate repand

8965 Leaves pinnatifid, Segments lanceolate serrate or cut

8966 Leaves pinnated-lobed, lobes confluent toothed smooth, Root fusiform, Petals as long as calyx

$\$ 967$ Downy, Rad. lvs. toothed backwards, cauline sagittate oblong blunt, Stems erect branched from the base 8968 Radical leaves stalked obovate toothed or lyrate : upper pinnatifid, Lobes linear entire

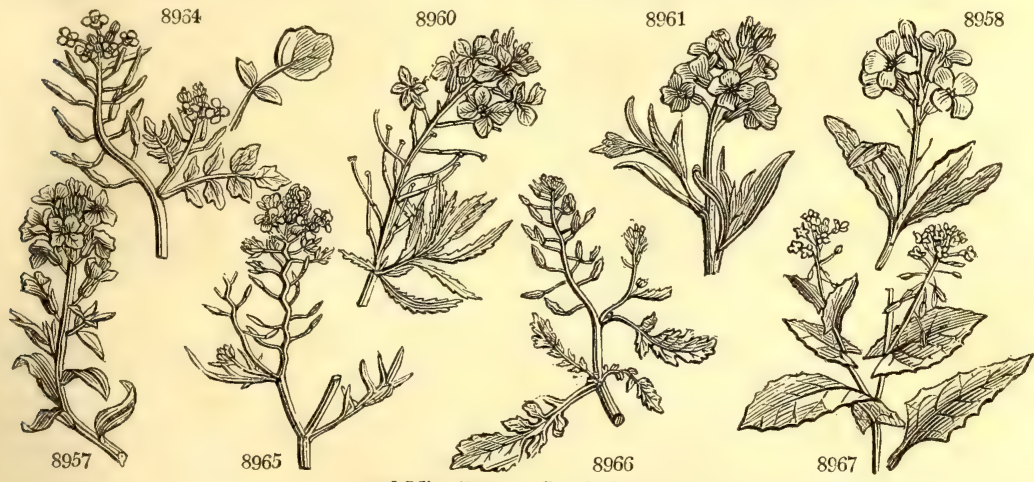

and Miscellaneous Particulars.

popular flower of long standing, admired for its various colors and agreeable odor. Being an acrid and hardy evergreen, it is sometimes sown in pastures, along with parsley, thyme, \&c. as a preventative of the rot in sheep.

1383. Nasturtium, is said to have been so called from the effect its acrimony produces upon the muscles of the nose; nasus tortus signifying a convulsed nose. Pliny. N. officinale is a well known popular salad, gathered wild in most parts where it is found, and since 1808, cultivated to a considerable extent in the neighbourhood of London. A running stream of clear water is essential to its cultivation; in the bed of this stream the plants are inserted in rows in the direction of the current, and all that is necessary is to take up and replant occasionaily, and to keep up the plants free of mud or any accumulation of extraneous matters, and to see that other plants, especially the Sium nodiflorum, a poisonous plant resembling the water-cress, do 
8969 pyrenáicum $\boldsymbol{R}$. $\boldsymbol{B r}$. Pyrenean 8970 amphíbium $\boldsymbol{R} . \mathrm{Br}$. amphibious 8971 benghalénse Dec. Bengal 8972 microspérmum Dec. Chinese 8973 indicum Dec. doubtful

1384. LEPTOCARPAA. Dec. LEPTOCARPA

8974 Loesélii Dec.
Turritis Loesilii R. Br.

1385. NOTO'CERAS. $R$. Br. Notoceras.

8975 canariénse $R$. Br. Canary

8976 hispánicum Dec. Spanish

1386. BA RBARE'A. $R \cdot B r$. Winter Cress

8977 vulgáris $R$. $B r$. common

8978 pra'cox $R$. Br.

8979 ibérica

Barburealvd

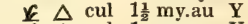
f cul 1 ap.o Y Barburea-lvd. $\triangle$ un 1 my.au Y

8980 plantaginea Dec.
Sisymb. barbaree L.

1387. BRAY'A. Stern. BRAYA.

8981 ajpina Stern. alpine

1388. PAR'RYA. $R . B r$. PARrya.

8982 árctica $R . B r$. northern

1389. TURRI'TIS, $R . B r$. Tower MUSTaRd.

8983 glábra $L$.

1390. AR' ABIS. $L$

8984 vérna $R$. Br.

8985 alpina $L$

8986 álbida Sted. A. caucásica W.

8987 toxophýlla Bieb.

8988 auriculáta Lam.

8989 saxátilis $A l l$.

8990 crispáta $W$.

8991 sagittáta Dec.

8992 hirsúta Scop.

8993 Alliónii Dec.

Turritis stricta W.

8994 murális Bert.

8995 strícta Huds.

8996 ciliáta $R$. Br.

8997 incána Roth.

8998 'Thaliána $L$

8999 serpyllifólia Vill.

9000 pubéscens Desf.

9001 præ'cox $W . \& \dot{K}$

9002 hispida $L$

9003 lyráta $\boldsymbol{L}$.

9004 arenósa Scop.

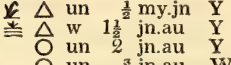

un $\frac{a}{4} \mathrm{jn} . \mathrm{au}$ W

un $\frac{2}{2}$ jn.au Ap

Crucifera.

long-podded $O$ w $1 \frac{1}{2}$ my.jn W

vernal CRESS,

O w 1 my.jn $\mathrm{Pu}$

upright $\Delta$ w 2 my.jn W

lyrate
Pyrerees 1775. D co Act. helv. 4. t.15

Britain riv.ba. D co Eng. bot. 1840

E. Indies .... $\mathrm{S}$ co

China 1820. S co

China a.. S co

Germany 1683. S co Jac. aust..4. t.324

Crucifera. Sp. 2-4.

Canaries 1779. S co Jacq. ecl. t. 111

Spain

Sp. 4-6.

Britain rub. D co Eng. bot. 443

England brooks. D co Eng. bot. 1129

Iberia 1816. C l.p

Levant 1799. D co

$\begin{array}{lll}\text { Cruciferce. Sp.1. } & \text { Pu } \\ \text { jn } & \text { Carinthia 1823. S p.1 }\end{array}$

Cruciferce. Sp. 1

$\frac{\pi}{5} \quad$... Pu MelvilleI. 1820. S p.l Parry's append.

Crucifere. Sp, 1-3.

Crucifera. $\quad S p .32-65$.

Alpine $\triangle \mathrm{pr} \quad \frac{3}{4} \mathrm{mr} . \mathrm{my}$ W.x Switzerl. 1596. $\mathrm{D}$ p.l Bar. ic. 476

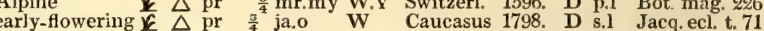

bow-leaved \& () pr 1 jl.au W Volga 1823. S co

hispid-stalked 0 un $\frac{x^{4}}{1}$ my.jn $W$

pubescent 1 un $1 \frac{1}{2}$ ap.my W
(1) un $3^{\frac{3}{4}} \mathrm{my}$

(1) un $\frac{3}{4}$ my W

sagittate $\quad \Delta$ un 1 my.jl W

hairy $\Delta w \quad 1$ my.jl W

wall $\Delta$ un $\frac{1}{3}$ my.jn W

Bristol $\Delta \mathrm{pr} \frac{1}{2} \mathrm{my} \quad \mathrm{Cr}$

ciliated 1 pr $\frac{1}{2}$ jn.jl W

thyme-leaved $\&$ O un $\frac{x}{2}$ jn.jl W

early

short-podded

$\frac{y}{4} \Delta$ un $1 \frac{2}{2}$ ap.my $\frac{\text { W jn.jl W }}{4}$

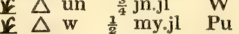

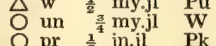

S. Europe $\quad \cdots \quad$ S co

Carniola 1816. D co

Britain rocks. D s.l

Italy 1804. D co

Italy 1824. D co

England rocks. D s.1 Eng. bot. 614

Ireland ir.sh. S s.1 Eng. bot. 1746

Switzerl. 1816. S s.l

Britain walls. S s.1 Eng. bot. 901

S. France 1823. S co Vildauph.3.t.37

Barbary 1825. S co Desf. atl. t. 163

Hungary 1820. D

Britain al.roc. D s.l

N. Amer. ... S co

\begin{abstract}
8977
\end{abstract}
S. France ... S co
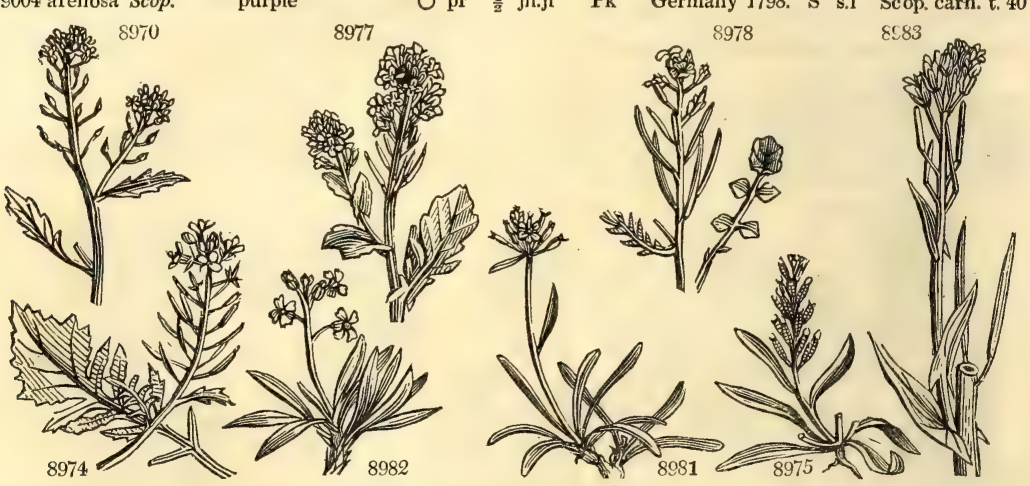

Hestory, Use, Propagation, Culture,

not find their way into the plantation. Near Rickmansworth, in Hertfordshire, there is a fine stream of water on a chalky bottom, in which one cultivator grows five acres, and sends a supply to London every day in the year, Sundays excepted. There are also large plantations at Uxbridge, Gravesend, and other places.

Some market-gardeners, who can command a small stream of water, grow the water-cress in beds sunk about a foot in a retentive soil, with a very gentle slope from one end to the other. Along the bottom of this bed, which may be of any convenient length and breadth, chalk or gravel is deposited, and the plants are inserted about six inches distance every way. Then, according to the slope and length of the bed, dams are made six inches high across it, at intervals; so that when these dams are full, the water may rise not less than three inches on all the plarits included in each. The water, being turned on, will circulate from dam to dam; and the plants, if not allowed to run to flower, will afford abundance of young tops in all but the winter months. A stream of water no larger than what will fill a pipe of an inch bore, will, if not absorbed by the soil, suffice to irrigate in this way an eighth of an acre. As some of the plants are apt to rot off in winter,
the plantation should be laid dry two or three times a year, and all weeds and decayed parts removed, and vacancies filled up. Cress grown in this way, however, is far inferior to that grown in a living stream flowing over gravel or chalk.

The water-cress has lately been cultivated in the neighbourhood of Paris, and also near Edinburgh

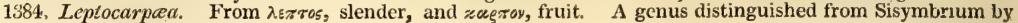
its accumbent cotyledons. 
8969 Radical leaves stalked obovate or lyrate, Cauline amplexicaul pinnatifid, Lobes linear entire 8970 Leaves obl. lanc. pinnatifid or serrated, Root fibrous, Petals larger than calyx, Silicules ellipsoid 8971 Leaves obovate cuneate toothed at end, Pods roundish subturgid, Bractes a little shorter than pods 8972 Lvs. smooth : rad.stalked pinnatif,; caul. stem-clasping cut serr. Pods roundish, Pedic. bracteate very short 8973 Lvs. ovate lanc. toothed backwards acuminate at each end smooth, Pods roundish 4 times as long as stalk

8974 The only species. Leaves stalked pinnatifid sublyrate with cut toothed acuminate lobes

8975 Pods 2-horned, Petals equal, Leaves entire, Hairs strigose fixed by their middle 2-parted appr. scattered 8976 Pods 2 -horned, Petals unequal, Leaves ent. Hairs strigose fixed by their middle 2-parted very numerous

8977 Lower leaves lyrate : terminal lobe roundish; upper obovate toothed

8978 Lower leaves lyrate: terminal lobe ovate; upper pinnatifid with linear oblong entire lobes

8979 Radical and lower leaves pinnatifid-lyrate : lateral lobes ovate; terminal cordate entire

8980 Lower leaves toothed lyrate : lateral lobes dentiform; terminal very large subcordate, upper ovate

8981 Leaves linear narrowed at base smooth acute

8982 Pods lin.-oblong, Anthers oval, Leaves entire, Peduncles smooth

8983 Rad, leaves toothed hairy : cauline stem-clasping entire smooth, Pods erect 6 times as long as stalk

8984 Cauline lvs, cord. stem-clasping rough with 3-parted down, Pedicels shorter than cal. Stigma somew. emarg. 8985 Leaves many-toothed villous with branched hair lanc. acute : rad. somew. stalked; caul. cord. stem-clasp. 8986 Leaves few-toothed hoary with branched hairs : rad. obov. oblong; cauline cordate sagitt. stem-clasping

8987 Lvs. pubesc. with minute stellate down : rad. obl. stalked sinuate toothed; cauline sagittate lanceol. entire 8988 Lvs. somew, toothed rough with branch. hair : lower oval narr. into a stalk ; cauline bluntly cord,-auricled 8989 Lvs, somew, toothed rough with branch. hair : lower oval narr. into a stalk; cauline acutely cord.-auricled 8990 Lvs. acutely toothed lanc. stem-clasping wavy rough with branching hairs : rad. narrowed into the stalk 8991 Lvs. somew. toothed rough : rad. ovate or obl. narrowed into the stalk; cauline lanceol. sagittate cordate 8992 Lvs. toothed rough with generally branched hairs : radical obov. obl. narr. into the stalk; caul. ovate lanc. 8993 Lvs, smooth : radical ovate-oblong somewhat toothed narrowed at base; cauline sessile ovate serrated

8994 Leaves hairy with branched pubescence : radical spatulate bluntly toothed; cauline ovate acutely toothed 8995 Leaves rough with scattered bifid down : radical obov. toothed ; cauline obl. nearly entire, Raceme erect 8996 Leaves somewhat toothed smooth ciliated : radical subsessile oval oblong; cauline oblong, Raceme erect 8997 All the lvs, sessile somew, toothed hoary with branched hairs: radical obov, obl.; cauline obl. Rac. erect 8998 Leaves hairy somewhat toothed : radical stalked ovate oblong, Stem branched, Pods ascending

8999 Leaves nearly entire rough with branched hairs : radical and caul. oval narrowed at base, Raceme lax 9000 Lvs. pubesc. coarsely toothed : rad. spatulate lanc. narrowed into the stalk; caul. lanc. Pods pubescent 9001 Leaves oblong acute sessile entire smooth, Stems strigose, Runners creeping, Pods spreading 9002 Leaves nearly smooth: radical cut; cauline oblong linear entire, Stem generally branched

9003 Rad. leaves lyrate pinnatifid smooth or ciliated : cauline linear, Stem hispid at base somewhat branched $9004 \mathrm{Lvs}$. vill. with forked down : rad. lyrate pinnat. ; caul, cut toothed, Stem branched hisp. with simple hairs

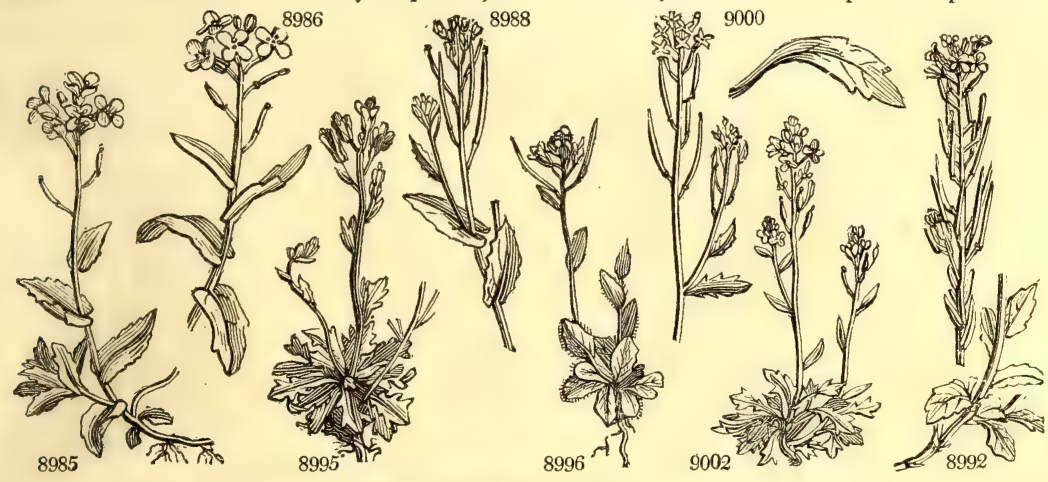

and Miscellaneous Particulars.

1385. Notoceras. From y mediate between Erysimum and Capsella. The species are small annuals, with very minute flowers, which are sometimes apetalous.

1386. Barbarea. A name used by Dodoens, because the plant had been called the herb of St. Barbara by some preceding botanists. B. vulgaris is sometimes cultivated as a spring salad, but is much less delicate than the common cress, and has nothing in flavor to recommend it. B. præcox, the American or Bellessie cress of gardeners, is preferred to the other, and cultivated in a number of gardens.

1387. Braya. A curious little plant, with the habit of Arabis cærulea. Leaves are linear, racemes terminal,

flowers purple. The genus is not completely known; but it appears to be intermediate between Siliquosæ and Siliculosæ ; related to Draba on one hand, and Arabis on the other. It is a native of the Carinthian alps, where it was found by Dr. Hoppe, who named it after Count Bray, a German nobleman.

1388. Parrya. Named by Mr. R. Brown, after Captain Edward Parry, the commander of the British expeditions to discover the north-west passage round America. It was found upon Melville island, and once was raised from seeds brought home by some of the officers, but it never flowered, and is now lost.

1389. Turritis. From turris, a tower; the leaves and seeds giving the stem a pyramidal form. This genus is principally distinguished from Arabis by its seeds being in two rows, and by its habit.

1390. Arabis. Native of Arabia, according to De Theis; but this is a forced explanation, and scarcely the true root of the word. Distinguished from all the neighbouring genera by its linear compressed siliques, and flat valves. 
9005 Halléri $L$ 9006 cebennénsis Dec. 9007 Turríta $L$ 9008 péndula $\boldsymbol{L}$. 9009 lævigáta Dec. 9010 canadénsis $\boldsymbol{L}$. 9011 nútans $W$. 9012 bellidifólia $\mathrm{Jacq}$ 9013 cærúlea Wulf. 9014 collína Ten. 9015 lúcida $L$.

Haller's $\begin{array}{lllllll}\text { Haller's } & \text { O) un } 1 & \text { jn.j1 } & \text { W } & \text { Switzerl. } \ldots & \text { S } & \text { co } \\ \text { Montpellier } & \text { O un } 1 \frac{1}{2} \text { jn.jl } & \text { Paspu S. France } 1820 \text {. S } & \text { co }\end{array}$

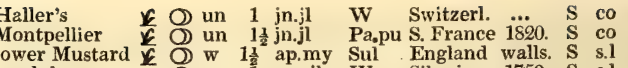
W $1 \frac{1}{2}$ ap.my Sul England walls. S s.l pendulous $O$ un 1 my.jl W Siberia 1759. S s.l polished $\Delta$ un $1 \frac{1}{2}$ my.jn W N. Amer. 1821. D co sickle-podded $\Delta$ un 2 my.jl W N. Amer. 1768. D s.l nodding $\Delta \mathrm{pr} \frac{1}{2} \mathrm{mr}$.ap $\mathrm{W}$ Switzerl. 1658. D co

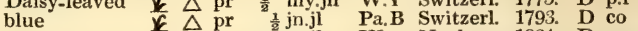
blue $\quad \Delta$ pr $\frac{1}{2}$ jn.jl Pa.B Switzerl. 1793. D co

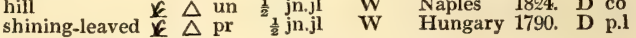
1391. MACROPO'DIUM. $\boldsymbol{R}$. Br. MACROPODIUM. 1392. CARDA'MINE. $L$. LADY'S Sмock. 9017 asarifólia $L$. Kidney-leaved 9018 bellidifólia Crantz. Daisy-leaved 9019 resedifólia $L$ 9020 a fricána $L$ 9021 trifólia $L$.

9022 chilénsis Dec. 9023 granulósa All. 9024 amára $L$. 9025 prórepens Fisch. 9026 praténsis $L$. $\beta$ plena 9027 pennsylvánica $L$. 9029 parviflóra $L$. 9030 impátiens $L$ 9031 latifólia Vahl. 9032 chelidónia $L$.

\section{Crucifere. Sp. 1.} Cruciferce. Sp. 16-55: African
three-leaved $\Delta$ un three-leaved $\Delta$ pr $1 \frac{1}{2} \mathrm{mr}$.ap Chili
granular bitter $\Delta \mathrm{pr} \frac{1}{4}$ ap.my $W$ creeping $\Delta$ un ap.my $\quad$ W double-flowered $\mathrm{pr}$ ap.my $\mathrm{Pu}$ Pennsylvanian $\Delta$ un 1 my.jn W hairy $\frac{\Delta}{4}$ un 1 ja.d W smairy impatient $O$ un 1 ap.jn W broad-leaved 2 or $1 \frac{1}{3}$ jn.au $\mathrm{Pu}$ Chile 1825. D co Italy 1820. D co Siberia 1821. D co

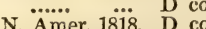
9016 nivále $R . B r$. Siberian \& $\triangle \mathrm{pr}$ 9028 hirsúta $L$

1 jn.s W Siberia 1796. D co Pall. it.2. ap. t.U

$\frac{1}{4} \mathrm{jn} . \mathrm{jl}$ W Italy 1710. D p.l Bot. mag. 1375 $\frac{1}{4}$ ap.jn W Scotland sc.al. D s.l Eng. bot. 2355 $\frac{1}{2} \mathrm{jl}$ W Germany 1658. S co Al.ped.1. t.57.f. 2 1 my.jn W C. G. H. 1691. D co Her, parad. 202 1 $\frac{1}{2}$ mr.ap W Switzerl. 1629. D p.1 Bot. mag. 452

Britain wat.pl. D p.l Eng. bot. 100 Britain me.pa. D m.s Eng. bot. 776

Britain mo.s.p. S m.s Eng. bot. 492 France ... S co Gmel. sib. t. 64 Britain al... roc. S co Eng. bot. 80 Spain 1710. S co Her. parad. 203 Celandine-lvd, $\triangle 1$ or 1 jn.au Pu Italy 1739, D co Pl.rar.hu.2.t.140

1393. Pteroneu'ron. Dec. Pteroneuron.

9033 græ'cum Dec. Cardámine gráca $\mathrm{L}$.

1394. DENTA'RIA. L. DENTARIA. 9034 enneaphýlla $L$. 9034 enneaphyla $L$. 9035 diphýlla Mich. 9036 máxima Nutt. 9037 trifólia $\boldsymbol{W}$ \& $\mathrm{K}$. 9038 pentaphýlla Scop. 9039 pinnáta Lam. 9040 bulbifera $L$.

1395. LUNA'RIA. $L$,

9041 rediviva $L$.

9042 biénnis $D e c$ ánnua $\mathbf{L}$

1396. RICO'TIA. L

9043 ægyptiaca $L$.

two-leaved

large

three-leaved

five-leaved

seven-leaved bulbiferous

O un

Cruciferc. Sp. 1-2.

jn.jl Pa S. Europe 1710. S co Boc. sic. t. 44. f. 2

Crucifera. Sp. 7-16.

1656 D s.p Jac. aust.4. t.316 * el $\triangle \frac{3}{4}$ my.jn W.pu N. Amer. D s.p Bot. mag. t.1465 * $\triangle$ el 2 my.jn Pa.pu N. Amer. 1823. D s.p

* $\triangle$ el 1 my.jn W Hungary 1824. D s.p Wal.\&Kit. t.139 * $\triangle$ el $1 \frac{1}{2}$ my.jn Pa.pu Switzerl. 1656. D s.p Garid, prov. t.29 * el 1 my.jn Papu Switzerl 1683 D s.p Garid prov t 28 $\triangle$ el $1 \frac{1}{2}$ ap.my Pu England sha.pl. D s.p Eng. bot. 309

Crucifera. Sp. 2.

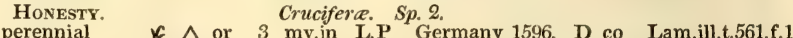

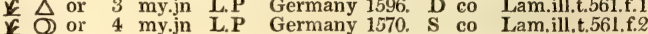
Ricotia. Egyptian

1397. FARSE'TIA. Turr. FARSETIA. 9044 cheiranthoides $R$.Br.stock

9045 suffruticósa Dec. half-shrubby 9046 lunarioídes $R . B r$. oriental

9047 clypeáta $R, B r$. buckler-podded

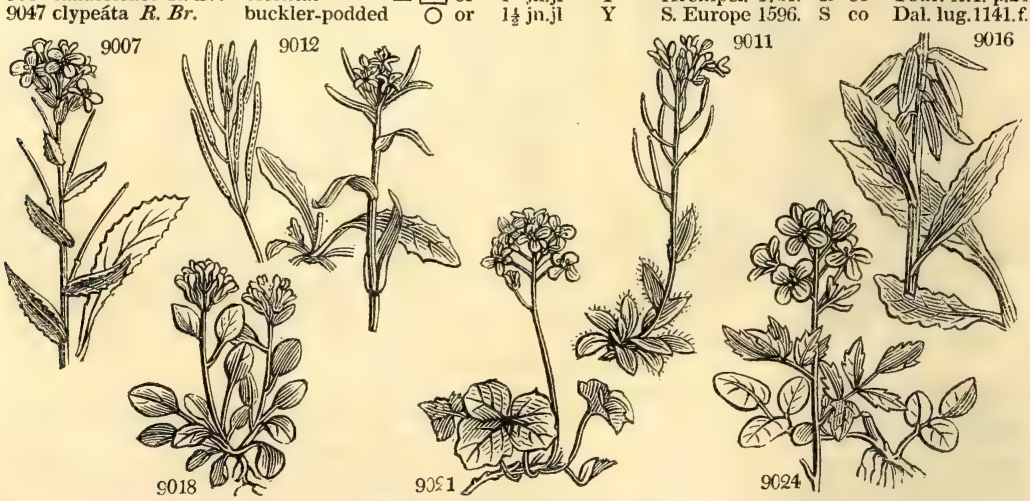

History, Use, Propagation, Culture,

1391. Macropodium. So named because the pod is elevated above the receptacle upon a stalk; raxe gos, long, and $\pi \varepsilon_{\xi}$, a foot or stalk. A genus differing from Arabis chiefly in its stalked pod, and its calyx being a little thickened at the base. A little, smooth, erect, simple herb, with ovate, lanceolate, acuminate leaves, and white fowers.

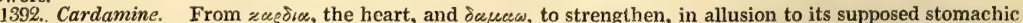
qualities. The leaves of $\mathrm{C}$. pratensis were formerly used in salads. C. impatiens is so named from the sudden bursting of the seed pods, being ripe and pressed between the fingers. C pratensis frequently has double flowers. C. hirsuta and, it is said, other species, produce young plants from the leaves. All that is necessary is to lay the leaf on a moist grassy surface, or on moss kept moist. The plant propagates itself extensively in this way in moist soils.

1393. Pteroncuron. From $\pi \tau \varepsilon e a v$, a wing, and ysveav, a nerve, in allusion to the winged nerves of the pods, by which it is distinguished from Dentaria and Cardamine. 
9005 Lower lvs. stalked lyrate : terminal lobe ovate; upper lanceolate cut, Stem branched weak softly villous 9006 Leaves all stalked ovate acumin. coarsely toothed velvety with very fine down, Pedic. and pods spreading 9007 Lvs. stem-clasping acum. somewhat toothed pubescent, Pedicels length of calyx, Pods 1-sided decurved 9008 Leaves stem-clasping toothed oblong dilated and cordate at base, Stem furrowed hispid, Pods pendulous 3009 Cauline leaves linear sessile smooth : lower somewhat toothed; radical obovate, Pods erect

9010 Cauline leaves sessile oblong lanceolate acuminate somewhat toothed, Pods pendulous falcate [stalk 9011 Lvs. roughish nearly ent. : rad. obov.; caul. ov. or obl. Rac. nodding, Pods erect 2 times as long as their 9012 Lvs. smooth nearly entire : rad. obovate ; cauline ovate, Raceme erect, Pods 4 times as long as their stalk 9013 Leaves smooth nearly entire : rad. oblong obovate; cauline few oblong, Raceme nodding, Pods. erect 9014 Lvs. hoary with stellated down obl. sinuate toothed: rad. stalked; caul. sess. Pods 8 times as long as their 9015 Leaves stem-clasping shining

[stalk

9016 Leaves ovate lanceolate acuminate subserrate, Raceme terminal long

9017 Lvs, smooth stalked cordate roundish subsinuate toothed, Stem erect, Pods erect twice as long as stalk 9018 Leaves smooth thickish : radical stalked ovate entire; cauline few entire or 3-lobed, Pods erect

9019 Leaves smooth membranous stalked : radical undivided; lower cauline 3-fid, upper 5-lobed, Pods erect 9020 Leaves smooth 3-fid, Segments stalked ovate acuminate toothed, Pods spreading

9021 Lvs. smoothish 3-fid, Segm. sess. rhomb. roundish tooth. Scape naked, Lower branches root-like creeping 9022 Leaves above downy trifid, Segments somewhat stalked ovate lanceolate crenate, Stem ascending 9023 Radical leaves stalked ovate subcordate: cauline pinnatifid with oblong entire lobes, Root granular 9024 Leaves pinnatifid, Segments of radical roundish; of cauline toothed angular, Stem rooting at base 9025 Lvs. pinnutifid, Segm. ovate nearly entire: term. round. 3-lobed, Runners creeping, Stem ascend. pubesc. 9026 Lvs. pinnatifid, Segm. of rad. roundish : of cauline linear or lanc. entire, Style very short, Stigma capitate

9027 Leaves pinnatifid or lyrate, Lobes oval angular toothed blunt, Stem erect, Petals oblong linear 9028 Leaves pinnatifid, Segm. of radical roundish mucronate stalked, of the upper oblong subsess. Petals obl. 9029 Leaves pinnatifid, Lobes sessile obl. linear entire the lowest distant from the stem, Petals oblong linear 9030 Leaves pinnatifld, Segm. oval oblong somewhat toothed, lowest close to the stem acute stipule-like 9031 Leaves pinnatifid smooth, Segm. 3.7 roundish toothed angular, Pods erect a little longer than stalk 9033 Leaves pinnatifid nearly smooth, Segm. stalked ovate toothed lower pinnatifid, Segm. 3-4

9033 Segm. of leaves somewhat stalked roundish tooth-lobed nearly equal

9034 Leaves 3 whorled stalked trifid, Segm. oval lanceolate acuminate serrated, Stamens length of petals 9035 Leaves 1-2 alternately shortly stalked 3-fid, Segm. ovate lanceolate coarsely and unequally serrate lohed 9036 Leaves many alternate stalked trifid, Segm. broad oval cut toothed, Axillæ without glands

9937 Leaves many alternate stalked trifid, Segm. ovate-lanceolate remotely toothed, Axillæ with glands

90,38 Caul. lvs. many alternate stalked palmate 5-lobed, Segm. oblong lanceolate acuminate coarsely serrated 9039 Cauline leaves alternate stalked pinnatifid, Segm. oblong acuminate serrate toothed 9040 Cauline leaves alternate pinnatifid: upper undivided mostly bearing bulbs in the axillæ

9041 Pods lanceolate narrowed at each end 9042 Pods elliptical blunt at each end

9043 Leaves sub.bipinnatifid, Lobes oblong sinuate angular

9044 Stem shrubby erect, Leaves linear with close hairs

9045 Stem half-shrubby at base erect, Leaves lanceolate downy

9046 Stems half-shrubby ascending, Leaves oblong obovate stalked and pods hoary with down

9047 Stems herbaceous erect, Leaves oblong repand, Pods velvety with short down, Stigma capitato

9026

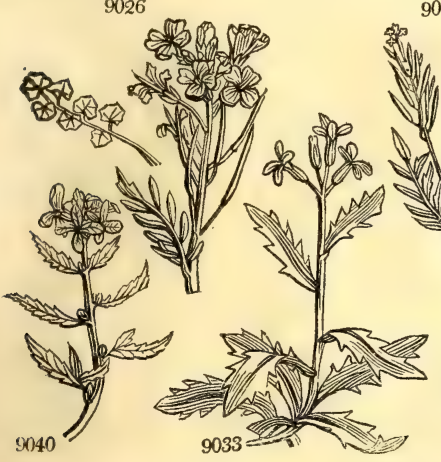

9041
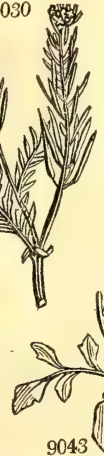

0043
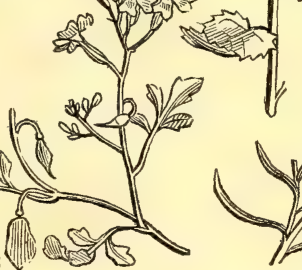

a.

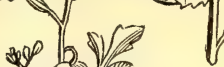

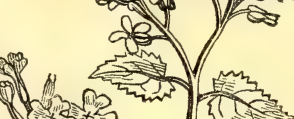

thas

V

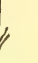

1394. Dentaria. From dens, a tooth; its roots are furnished with projecting angles, which resemble the molar teeth of quadrupeds. Plants with broad palmate or pinnate leaves, and shewy white, yellowish, or purple flowers. The dried root of $\mathrm{D}$. diphylla is used instead of mustard by the Americans, under the name of pepper root.

epper root.

1395. Lunaria. Derived from luna, the moon, in allusion to the broad round silvery silicles. Large hairy plants, with alternate or opposite cordate leaves, and large lilac flowers.

1396. Ricotia. A word, the meaning of which is no where explained. It was probably formed after some obscure botanist. Small weak branched annual plants, with variously lobed foliage, and pale lilac flowers.

1397. Farsetia. In memory of Philip Farseti, a noble Venetian, celebrated for his botanical erudition. A small genus, with hoary entire leaves, and yellow or dirty-white flowers. 
1398. BERTERO' A Dec BERTEROA. 9048 incána Dec.
Farsétia incána $\mathrm{R} . \mathrm{Br}$. 9049 mutábilis Dec. changeable Farsétia mutábilis R. Br.

9050 obliqua Dec. oblique

1399. AUbrie'tia. Adans. Aubrietia.

9051 deltoídea Dec. purple Farsetia deltoidea $\mathrm{R}$. Br.

1400. VESICA'RIA. Lam. Vesicaria. 9052 utriculáta Lam. $\quad \begin{aligned} & \text { smooth } \\ & 9053 \text { sinuáta Poir. }\end{aligned}$ 9054 crética Poir.

1401. ALYS'SUM. $I$. 9055 saxátile $L$ 9056 Gemonénse $L$. 9057 argénteum $W$. 9058 Bertolónii Desc. 9059 murále $W \cdot \& K$. 9060 tortuósum $W . \& K$. twisted 9061 alpéstre $L$. alpine 9062 montánurn $L$. mountain 9063 rostrátum Stev. beaked 9064 micropétalum Fisch. small-petaled 9065 campéstre $L$. field 9066 calycínum $L$. calycine 9067 minimum $W$. small 9068 edéntulum $\dot{W}$. \& $\boldsymbol{K}$. toothless 9069 maritimum Lam. sweet 9070 rupéstre Tenore. rock 9071 halímifólium $W$. purslane-leav'd 9072 spinósum $L$. thorny

1402. ClyPe'Ola. $W$. Treacle Mustard. $90 \% 3$ Ion Thlaspi $L$. annual

1403. Pelta'ria. $L$. Peltaria.

9074 alliácea $L . \quad$ Garlic-scented $\downarrow \Delta \mathrm{pr}$

1404. PETROCAL'LIS. $\boldsymbol{R}$. $\boldsymbol{B} r$. Petrocallis. 9075 pyrenáica $R$. $B r$. Pyrenean o 1405. DRA'BA. $L$. 9076 aizoídes $\dot{L}$. 9077 ciliáris $L$. 9078 aizóon Wahl. 9079 alpina $L$. 9080 hirta $L$. 9081 rupéstris $\boldsymbol{R} . \boldsymbol{B}$ r. 9082 stelláta Jacq. 9083 incána $L$. 9084 confúsa $E h r$. 9085 nemorális $E h r$ 9086 murális $L$ 1406. ERO'PHILA. Dec ERophut. 9087 vulgáris $\mathrm{Dec}$. Draba verna $\mathbf{L}$

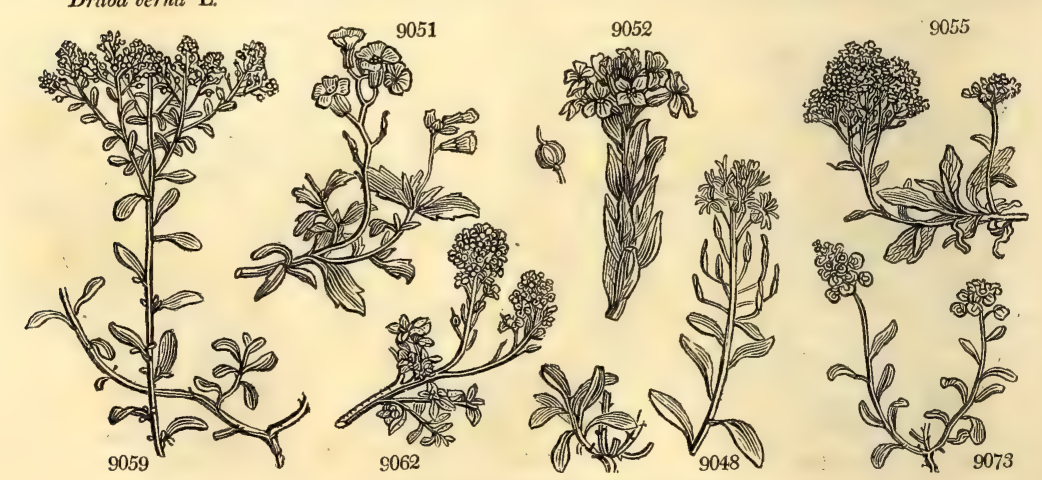

History, Use, Propagation, Culture,

Whitlow Grass. sea-green ciliate-leaved $\Delta p$ evergreen $\Delta$ pr hairy rock stellate $\triangle$ twisted-podded $\mathrm{O}$ pr confused if pr wood $O$ p Cruciferce. $S p .3-5$. $1 \frac{x}{2}$ jl.au W.pk Levant 1640. S s.l Dal.lug.1181.f.2 1802. D co Vent. cels. 85 1823. C co FloraGraca,623 jl W Sicily Crucifera. Sp. 1-2. $\frac{1}{4} \mathrm{mr} . \mathrm{my} \mathrm{Pu}$ Levant Crucifere. $S p .3-10$. ap.jn L.Y Levant 1739. D s.1 Bot. mag. 130 1 ap.jn $\mathbf{L} . \mathrm{Y}$ Spain 1596. C s.1 Clu.his.2.134.f.1 1739. D s.l Alp. exot. t. 118 Cruciferce. Sp. $18-52$.

ap.my $\mathbf{Y}$ Candia 1710. C s.l Bot. mag. 159 1 ap.my $\mathbf{Y} \quad$ Europe $\quad . .6 \quad$ C co Jac. ic. 3. t. 503 1 ap.my $Y$ Switzerl. .... $D$ co All. ped. t.54. f.3 1 ap.my $\mathrm{Y}$

1 ap.my $Y$ Hungary 1820. D co Wal \& Kit.1.6 Hungary 1804. D s.l Wal. \& Kit. t.91 S. Europe 1825, D co All, ped, t. 18, f. 2 Germany 1713. D s.1 Bot. mag. 419 Crimea 1823, S co St.ac.p.3.t.15. f.1 Siberia 1823. S co

$\frac{\frac{3}{4}}{4}$ my.jl $Y$

1 my.jl

jl.au L.Y France 1768. S s.p Barr.ic.t.912.f.2

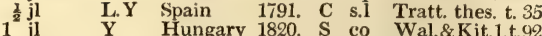

jn.s W England sea co. C s.1 Eng. bot. 1729

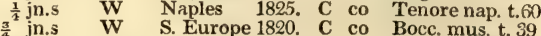

$\frac{1}{3}$ jn.au W S. Europe 1683. C co Bocc. mus. t. 39

Crucifera. $S p .1-3$.

$\frac{1}{4}$ my.jl $\mathbf{Y}$ S. Europe 1710. S co Cav. ic.1.t.34.f.2

Crucifera. Sp. 1-3.

my.jl W Austria 1601. D s.l Jac. aust.2. t.123

Crucifere. Sp. 1.

my.jn Pk Pyrenees 1759. D s.1 Bot. mag.713

Crucifera. $S p .11-60$.

$\frac{1}{4}$ f.ap Y Wales rocks. D s.1 Eng. bot. 1271

$\frac{1}{4}$ f.ap W, Switzerl. 1731. D s.1 Bot. mag. 170

$\frac{1}{4}$ my Y Carinthia 1823. D co

ap.my Y Lapland 1820. D co Wah.lap.t.11.f.4

$\frac{3}{4}$ my.jl W N.Europe 1823. D co Wah.lap.t.11.f.3

$\frac{1}{4}$ my.jl W Scotland al.roc. D s.1 Eng. bot. 1338

$\frac{1}{2}$ my.jl W Pyrenees 1820. D co

$\frac{3}{4}$ my.jn W Britain al.roc. S s.1 Eng. bot. 388

$\frac{3}{4}$ my.jn W N. Europe ... S co Flora Dan. t.130

my.jn Y Europe 1759. S s.l Ho sys 4 t 60 f 1

England moun. S s.l Eng. bot. 912

Crucifere. $s p .1-5$.

$\frac{1}{4}$ mr.ap W Britain walls. S s.l Eng. bot. 586

1398. Berteroa. Named after Charles Joseph Bertero, a pupil of Balbis, and a friend of M. Decandolle, who speaks in high terms of his merits. A genus distinguished from its allies by its bifid petals and peculiar habit. 1399. Aubrietia. Named by Adanson, after Aubriet, the famous French botanical draughtsman. A genus very distinct in habit, and sufficiently different from Berteroa in its' entire petals, and from Alyssum in its bisaccate calyx and oblong fruit.

1400). Vesicaria. From vesica, a blister or bladder. The silicles of this genus are inflated like small bladders. This is a genus which combines species with bisaccate and an equal calyx, with entire and toothed stamens, with edged or not edged seeds, and with a deciduous or persistent calyx. It will, therefore, require division hereafter.

1401. Alyssum. From $\propto$, privative, and $\lambda v \sigma \sigma \alpha$, rage; the Alyssum passed among the ancients for a plant which possessed the properties of allaying anger. The $\alpha \lambda \nu \sigma \sigma o \nu$ of Dioscorides is referred by Sprengel to A. alpestre. The species are shewy plants, of easy culture. A. saxatile is very ornamental early in the seasoir. 
9048 Silicles pubescent somewhat ventricose

9049. Silicles compressed flat elliptical smooth

9050 Silicles flat elliptical downy

9051 Pedicels longer than calyx

9052 Calyx bisaccate, Leaves oblong entire smooth; lower ciliate subspatulate

9053 Calyx equal somewhat spreading and leaves velvety oblong entire or sinuate toothed, Stem herbaceous 9054 Calyx deciduous, Leaves oblong entire or repand wavy hoary with down

9055 Stems $\frac{1}{2}$ shrubby at base subcorymbose, Leaves lanc, entire downy, Pods obov, orb. 2-seeded, Seeds edged 9056 Stems $\frac{1}{2}$ shrubby at base panic. Leaves lanc. nearly entire velvety, Pods roundish 2-4-seeded, Seeds edged 9057 Stems $\frac{1}{2}$ shrubby at base hoary with stellate down, Lvs. obl. spatul. silvery beneath, Pods ovate roundish 9058 Stems $\frac{1}{2}$ shrubby at base hoary with stellate down, Leaves obl. obov. silvery beneath, Pods elliptical 9059 Stems $\frac{1}{2}$ shrubby at base hoary with stellate down, Leaves obl. nearly acute whitish beneath, Pods ovate 9060 Stems $\frac{1}{2}$ shrubby at base twisted diffuse hoary, Leaves hoary sublanceolate, Racemes corymbose 9061 Stems $\frac{1}{2}$ shrubby at base diffuse hoary, Leaves obovate hoary, Racemes simple, Pods ovate oblong 9062 Stems diffuse pubescent, Leaves hoary : lower obovate ; upper oblong, Racemes simple

9063 Stem erect, Flowering branches panic. Lvs. lanceol. downy, Pods roundish elliptic. little longer than style 9064 Stem erect, Leaves lanceolate, Pods hirsute in long racemes twice as long as styde

9065 Stems diffuse, Leaves lanceolate or somewhat linear hairy, Pods roundish rough 6 times as long as style 9066 Stems diffuse, Leaves linear lanceolate hoary, Cal. persistent, Pods four times as long as style 9067 Stems diffuse, Leaves linear lanceolate hoary, Pods roundish emarginate smooth

9068 Stem erect, Leaves velvety oblong sinuated : upper linear, Cal, spreading, Petals bifid

9069 Stems half shrubby at base procumbent, Leaves lin. lanceol. acute somewhat hoary, Pods oval smooth 9070 Stems half shrubby at base somewhat erect, Rad. lvs. obl.-lanc. acute silvery : caul. few lin. Pods woolly 9071 Stems $\frac{1}{2}$ shrubby ascend. Lvs. obl. obt. narrowed at base scaly, Pods roundish smonth twice as long as style 9072 Stem shrubby, Branches and old peduncles spiny, Leaves obl. linear silvery, Pods round smooth

9073 Stems diffuse or ascending

9074 Cauline leaves sagittate stem-clasping, Pods flat smooth

9075 Leaves sessile 3-5-fid at end cuneate at base

9076 Scapes naked smooth, Leaves rigid linear lanceolate keeled ciliated, Stamens as long as petals 9077 Scapes naked smooth, Leaves long linear keeled ciliated, Stamens scarcely as long as calyx

9078 Scapes naked smooth, Leaves linear keeled rigid ciliated, Style as broad as hairy pod but twice as short 9079 Scapes naked downy, Leaves lanceolate flat hairy, Hairs branched, Pods oblong, Style very short 9080 Scapess downy with 2 toothletted leaves, Rad. leaves obl. nearly entire downy, Pods smooth 9081 Scapes naked or 1-leaved downy, Leaves lanc. hairy nearly entire, Pods lanceol, pubescent 9082 Scapes 1-leaved pubescent, Leaves ovate obl. with a short starry down, Pedicels downy, Pods oblong 9083 Stem leafy branched velvety with starry down, Leaves ovate toothed, Pod obl. smooth somewhat twisted 9084 Stem leafy branched velvety with starry down, Leaves obl. somewhat toothed, Pods obl. pubescent 9085 Stem branched leafy downy, Leaves ovate toothed downy, Pods ellipt. obl. many-seeded (32-36) velvety 9086 Stem branched leafy downy, Lvs. ovate toothed subcord. stem-clasping somewhat hairy, Pods smooth few9087 Pods elliptical shorter than stalk, Scapes 5-15-flowered

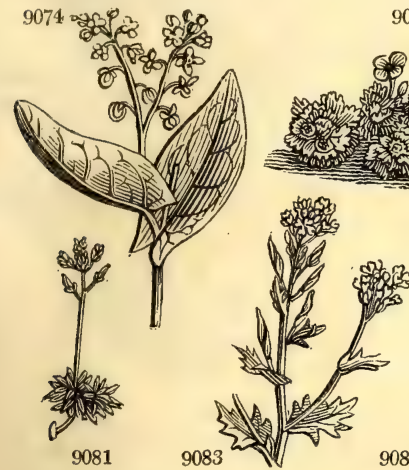

9075

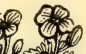

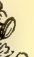
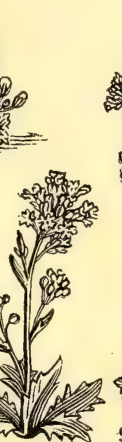

9086

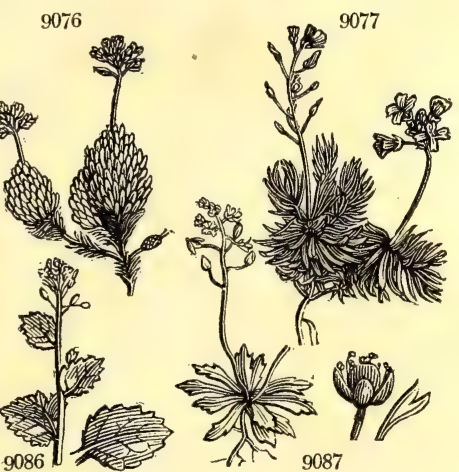

and Miscellaneous Particulars.

1402. Clypeola. From clypeus, a buckler, in allusion to the form of its silicle. A little annual plant, hoary, with stellate pubescence.

1403. Peltaria. A name with the same meaning and application as the last; $\pi \varepsilon \lambda \tau \eta$ signifies in Greek a small buckler.

1404. Petrocallis. From $\pi \varepsilon \tau \rho \circ y$, a rock, and $\nsim \propto \lambda \circ 5$, beautiful, in allusion to the rocky places where it grows, and which it enlivens with its elegant tufts of rose-colored flowers.

1405. Draba. From $\delta$ ec $\beta \eta$, acrid, biting, according to Linnæus. Little annual or perennial plants, found, for the most part, in the cold mountainous countries of Europe ; a few are also found in America. Some of the species have siliques, others silicles.

1406. Erophila. A genus divided from Draba, on account of its bifid petals; and deriving its name from $\eta \xi$, the spring, and $\phi i \lambda \varepsilon \omega$, to love, in allusion to the time of the year when it appears. 

1407. COCHLEA'RIA. $L$. Scurvy Grass.
9088 saxátilis $R$. $B r$ rock 9088 saxátilis $\boldsymbol{R}$. $\boldsymbol{B r}$. rock 9090 macrocárpa $\boldsymbol{W} . \& \boldsymbol{K}$. 9091 glastifólia $L$. 9092 ánglica $\boldsymbol{L}$. 9093 officinális $L$. 9094 grönlándica $L$. 9095 dánica $L$. 9096 acaúlis Desf.

1408. THLASPI. $L$. 9097 latifólium Bieb. 9098 ceratocárpon $L$. 9099 arvénse $L$.

9100 alliáceum $L$. 9101 perfoliátum $L$. 9102 montánum $L$ 9103 alpéstre $L$. Horse-radish large-capsuled $\star$ English common Greenland Danish stemless

ShePherd's PURs broad-leaved of broad-leaved
Siberian Penny-Cress Garlic-scented $\mathrm{O}$ w perfoliate $\neq \Delta, \mathrm{w}$ mountain $\frac{ \pm}{2} \mathrm{O}$

I $\triangle W$

1409. CAPSEL'LA. Mönch. Shepherd's Purse. 9104 búrsa pastóris Mön. common

1410. HUTCHINSIA. $R, B r$. Hutchinsia. 9105 rotundifólia $\boldsymbol{R} . \boldsymbol{B}$ r. round-leaved 9106 stylósa Dec. 9107 alpína $R$. Br. 9108 petræ'a $R$. $B$ r. ป⿻ 2 pr

1411. TEeSDA'LIA. $R \cdot B r$. Teesdalia 9109 nudicaúlis $R . B r$. naked-stalked 9110 reguláris $\mathrm{Sm}$.

1412. IBE'RIS. $L$ 9111 semperflórens $L$. 9112 gibraltárica $L$. 9113 saxátilis $L$. 9114 pubéscens $W$. 9115 sempervirens $L$. 9116 amára $L$ 9117 intermédia Dec. 9118 pinnáta $L$. 9119 odoráta $L$. 9120 umbelláta $L$. 9121 linifólia $L$. 9122 ciliáta All. 9123 taúrica Dec. 9124 violácea $R$. $B r$. 9125 nána All

9126 Tenoreána Dec. regular

Candy-Tuft. broad-leaved Gibraltar rock pubescent pubescent or bitter $O$ or intermediate wing-leaved sweet-scented purple Flax-leaved \& \& 0 or Taurian $\frac{N \text { or }}{O}$ or blunt-lvd.-purp. $\mathrm{O}$ or dwarf $O$ or Tenore's $\triangle$ or

Cruciferce. $S p .9-30$.

$\frac{1}{2}$ jn.jl W Austria 1775. D 8.1 Jac. aust.2.t.128 3 my W England wat.pl. D s.l Eng. bot. 2223

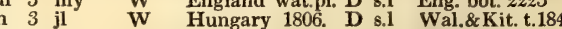
$1 \frac{1}{2}$ my.jl W Germany 1648 S co Mo.his 2 to f $\frac{1}{2} \mathrm{my}$ W Britain sea sh. S co Eng. bot. 552 Britain sea sh. Britain sea sh. S co Eng. bot. 55 Scotland sc. al. D co Eng. bot. 2403 Britain sea sh. S co Eng. bot. 696 Portugal 1824. D co Jacq. ecl, t. 132 Sp. 7-17.

ja.ap

Crucifere.

1 mr.ap W Crimea 1822. D co

$1 \frac{1}{2} \mathrm{jl} \quad W \quad$ Siberia 1779. S co

$\frac{1}{2}$ jn.jl W Britain corn fi. S co Scop. ins. 1. t. 4

$\frac{1}{3}$ my.jl W S. Europe 1714. S co Jac. ic 1659

$\frac{1}{2}$ ap.jl W England sto.pa. D s.l Eng bot. 2354

$\frac{1}{2}$ jl W Austria s... S s.l Jac aust 3.023

$\frac{1}{\frac{1}{2}}$ may.jl W England m.pas. D s.1 Eng. bot. 81 Crucifere. $S p .1$.

$1 \frac{1}{2}$.n W Britain roadsi. S co Eng. bot. 1485 Cruciferce. Sp. 4-11.

$\frac{1}{4}$ my.jl W.pu Switzerl. 1759. D co All.ped.1.t.55.f. 2 in my.jl W $\quad$ S. Europe 1824. D co

$\frac{1}{4}$ ap.jn W Germany 1775. D co Jac. aust.2. 137 mr.my W England rocks. S co Eng. bot. 111 Cruciferce. $\$ p .2$.

or $\frac{1}{2}$ my.jl W Britain gra.pa. S co Eng. bot.327 O pr $\frac{1}{4}$ f.my W S. Europe 1824. S co

Cruciferce.
$1 \frac{1}{9}$ ja.d . 16-24. 1679 . C r.m Zanon.hist.t.165 1 my.jn W.pk Spain 1732. C co Bot. mag. 124 $\frac{z}{4}$ ap.jn W S. Europe 1739. C co Garid.prov.t.101 $\frac{x_{2}}{2}$ ap.jn $\mathrm{Pa} . \mathrm{V} \quad \ldots . . . . \quad \ldots \quad$ C co 3 ap.jn W Candia 17̈̈̈. C co 1 jn.jl W England chal.fi. S co 1 jn.jl W France 1823. S co 1 jn.au W $\quad$ S. Europe 1596. S co 1 jl.au W Geneva 1806. S co 1 jn.jl Pu S. Europe 1596. S co

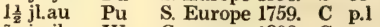
$\frac{3}{4}$ jn.jl Wu Caucasus 1802. C co $\frac{3}{4}$ in:jl W Caucasus 1823. S co jn.jl Pu ...... 1782. S co $\frac{1}{4}$ jn.jl Pu Dauphiny 1822. S co jn.jl Pa.pu Naples 1823, D co

$\begin{array}{cccc}\text { 1413. BISCUTEL'LA. } L \text {. Buckler Mustard. } & \text { Crucifera. Sp. 14-25. } \\ 9127 \text { auriculata } L . & \text { ear-podded } & \text { O un } 1 \frac{1}{2} \text { jn.jl Pa.Y S. Europe 1683. S co }\end{array}$ 9128 erigerifólia Dec. Erigeron-leav'd O un $1 \frac{1}{2}$ jn.jl $\quad$ Pa.Y S. Europe ... $\mathrm{S}$ 9129 híspida Dec. $\quad$ hispid $\quad \bigcirc$ un $1 \frac{1}{2} \mathrm{jn} . \mathrm{jl} \quad \mathrm{Y}^{\mathrm{S}} \mathrm{S}$. Europe 1824. $\mathrm{S}$ co 9130 lyráta $L$ lyre-leaved $\quad O$ un $1 \frac{1}{2}$ jn.jl $\mathbf{Y}$ Spain 1799 . S co 9131 raphanifólia Poir. radish-leaved $O$ un $1 \frac{1}{2} \mathrm{jn} . \mathrm{jl} \quad \mathrm{Y} \quad$ Sicily $1822 . \mathrm{S}$ co

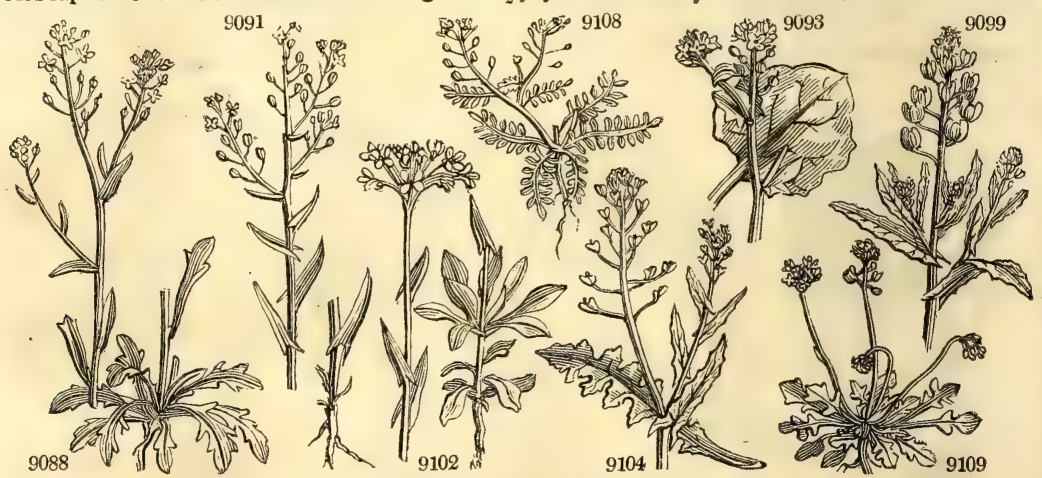

History, Use, Propagation, Culture,

1407. Cochlearia. From cochlear, a spoon. The leaves are hollowed and concave like the bowl of a spoon. The annual species were formerly used as spring salads and antiscorbutics, but are now generally neglected.

C armoracia, the horse radish, is cultivated as a condiment to roast beef. It is called upon the continent Cran, Cran de Bretagne, Raifort Reeredyck, \&c. \&c. Two excellent modes of cultivating it have lately been described in the Horticultural Transactions, by Knight, a nurseryman, and Judd, a gardener. Both agree in trenching the soil to a considerable depth, and putting the manure at the bottom of the trench; but Knight plants the sets on the surface, and calculates on the root that strikes down to the dung for produce. Judd, on the other hand, makes holes quite to the bottom of his trenched soil, and in each drops a set, filling up the hole with wood ashes, rotten tan, or sand, calculating for produce on the shoot made from the set at the bottom of the hole, up through the sand or ashes to the surface. Judd's mode is the most ingenious, and appears the best, but either will do extremely well. A moist soil increases the bitter and alkaline flavor of this and all the Cruciferæ.

Common scurvy-grass has powerful medical properties, as antiscorbutic and sialagogue, and stimulating the digestive organs. For ample details respecting its qualities, consult Wier Cochl. Descr. lib. 1., Basilea, 1567. Moellenoroch Cochl. Cur., Lipsiæ, 1674. Murr, App. Med. 2, p. 420, \&c. 
9088 Pods lentiform smooth, Rad. leaves obl. toothed hairy ; cauline linear oblong

9089 Pods ellipsoid, Rad. leaves obl. crenate; cauline long lanceolate toothed or cut, Root large fleshy 9090 Pods ellipsoid, Rad. lvs. obl. crenate; cauline lanc. toothed, Teeth cartilaginous, Root fleshy, Sepals erect 9091 Pods roundish, Cauline leaves cordate sagittate stem-clasping acuminate entire

9092 Pods ovate roundish with netted veins twice as short as stalk, Rad. leaves stalked ovate entire ; caul. obl 9093 Pods ovate globose twice as short as stalk, Rad. leaves stalked cordate; cauline ovate toothed angular 9094 Pods ovate the length of stalk, Rad. leaves stalked reniform entire ; cauline scarcely any 9095 Silicles ellipsoid the length of pedicel, Leaves all stalked subdeltoid

9095 Silicles roundish emarginate, Pedicels and petioles radical long, Leaves ovate rounded entire

9097 Radical leaves on long stalks cordate repand-toothed; cauline ovate cordate on short stalks 9098 Rad. lvs. somewhat stalked obovate-obl. ; cauline oblong at the base hastate stem-clasp. with acute auricles 9099 Leaves oblong toothed, Stems erect, Silicles obovate orbicular shorter than pedicel

9100 Lvs. obl. tooth. blunt : lower stalked; upper sagit. stem-clasp. with acute auricles, Silicles subov. ventricose 9101 Lvs. somew. tooth. : rad. stalk. ; caul. cord. stem-clasp. Stem branch. Pet. length of cal. Silicles obcordate 9102 Lvs.somew. fleshy ent.: rad. obov, stalk.; caul. obl. sagitt. stem-clasp. Pet. larg. than cal. Silic. obc. 4-seeded 9103 Lvs. nearly entire : rad. ovate stalked; caul. obl. stem-clasp. Pet. as long as cal. Silic. obcord. 8-12-seeded

9104 Radical leaves pinnatifid, Silicles obcordate

[twice as short as silicle 9105 Lvs, somew fleshy entire : lower stalk, obov, caul, ovate obl somewhat stem-clasp. Stam. petals and style 9106 Lvs, somew, fieshy : lower stalk obov, obl. entire; caul obl. Stamens petals and style about length of silicle 9107 Lvs. pinnated smooth, Pet. twice as long as decid. cal. Silicles acute at each end, Style very short exserted 9108 Lvs. pinnated, smooth, Pet. scarcely longer than calyx, Silicles blunt at each end 4-seeded, Stigmas sessile

\section{Petals unequal : outer largest} 9110 Petals equal

9111 Shrubby, Lvs. cuneate or spatul, blunt ent. smooth, Flowers corymbose, Silicles truncate subemarg, at end 9112 Shrubby, Leaves cuneiform obtuse somewhat toothed at end a little ciliated, Flowers corymbose 9113 Shrubby, Leaves linear entire somewhat fleshy rather acute smooth or ciliated, Flowers corymbose 9114 Shrubby, Leaves ciliated blunt linear spatulate; lower somewhat toothed at end, Flowers corymbose 9115 Shrubby, Lvs. obl. blunt narrowed at base smooth, Fls. in long racemes, Silic. emarg. with a narrow recess 9116 Herbaceous, Lvs. lanc. acute somew. toothed, Fls. corym. becoming racem. Silic. obcord. narrowly emarg. 9117 Herbaceous, Lvs. lanc. blunt smooth entire or the rad, somew. toothed, Fls. finally racem. Silic. ovate trun. 9118 Herbaceous smooth, Leaves pinnatifid, Racemes corymbose but little elongated after flowering [style 9119 Herb. smooth, Lv. lin. tooth. ciliat. at base dilat. at end, Silic round. Lobes of end acute spread. short. than 9120 Herbaceous smooth, Leaves lanc. acuminate : lower serrate; upper entire, Silicles umb. acutely 2 -lobed 9121 Herbaceous smooth, Leaves linear entire : radical somewhat toothed, Silicles corymbose 2-toothed 9122 Herb. smoothish, Lvs. lin. entire ciliated at base, Silic. corymb. emargin. with blunt lobes as long as styles 9123 Herb. smoothish, Leaves ciliat. somew. fleshy : lower spatul. 2-tooth. at end; upp. lin. Silic. corymb. emarg. 9124 Herb. smoothish, Lvs. stalked spat. blunt toothed and ent. ciliat. Corymb somew. umbel. Cal. hairy at back 9125 Herbaceous smooth, Lvs, round. spatul. ent. rather fleshy, Silic. corymu. cmarg. with a broad blunt recess 9126 Half-shrubby at base pub. Lvs. rather fleshy cren. : lower ob. narr. at base; u! obl. lin. Sil. somew. corymb. [emarginate

$9127 \mathrm{Cal}$ bluntly 2-spurred, Silicles smooth rough with elevated dots in centre, Lobes of end meeting over style $9128 \mathrm{Cal}$. bluntly 2 -spurred, Silicles smooth even, Lobes at the end somewhat meeting over the style

9129 Cal. acutely 2 -spur. Silic. smooth with elevat. rough points on disk, not overhang. style at end, Stem hispid 9130 Silicles hispid on each disk, Radical leaves lyrate

9131 Silicles smooth even, Radical leaves lyrate

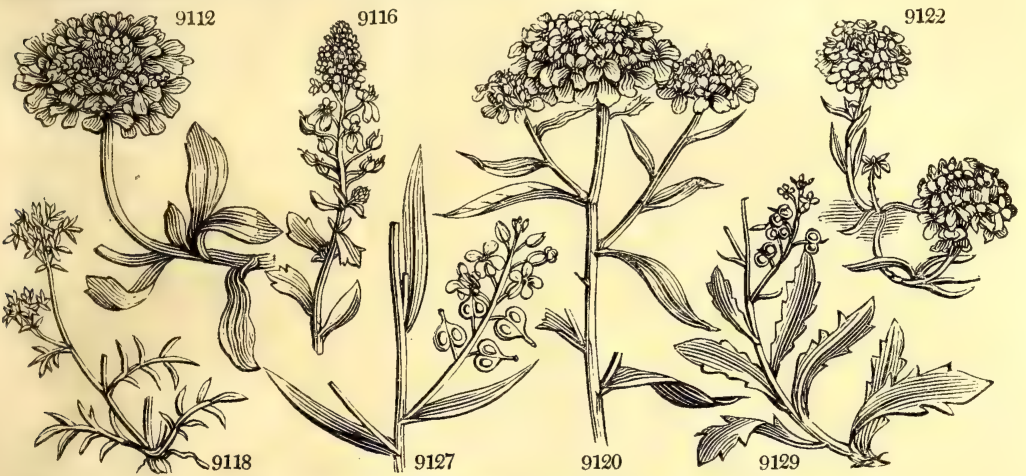

and Miscellaneous Particulars.

1408. Thlaspi. From $9 \lambda \alpha \omega$, to compress. The Thlaspi, says Pliny, bears seeds like the lentil, and compressed, whence its name. T. arvense, when rubbed, has the smell of garlic.

1409. Capsella. A diminutive of capsula. This, which is the common shepherd's-purse, has been separated from Thlaspi on account of its valves not being winged at back.

1410. Hutchinsia. Named after Miss Hutchins, to whom Sir James Smith was indebted for many communications of submarine alge during the progress of his English Botany.

1411. Teesdalia. Named after Mr. Robert Teesdale, author of a Catalogue of the Plants growing about Castle Howard, in the North Riding of Yorkshire, published in the Transactions of the Linnean Society. Small annual smooth herbs, with revolute leaves, and simple scapes of small white flowers.

1412. Iberis. From the country called Iberia, now Spain. Most of the species grow in such countries. They are generally pretty plants, and some of them are commonly cultivated in gardens as hardy annuals, under the name of Candy-tuft ; a name which was originally applied to the I. umbellata only, which was first discovered in Candia, and called Thlaspi Candiæ by Lobel and Dodonæus.

1413. Biscutella. From bis scutella, a double shield, in allusion to the form of its seed-vessel when bursting. Small annual or perennial hispid plants, with small bright yellow flowers. The species are nearly related to each other, and difficult to distinguish. 
9132 maritima Tenore, sea-coast 9133 ciliáta Dec. ciliated

9134 Colum'næ Tenore. Columna'

9135 A'pula $L$. Tenore. Columna's

un $1 \frac{1}{2}$ jn.jl

O un 1 jn.jl

$\bigcirc$ un 1 jn.jl

$\bigcirc$ un 1 jn.jl

9136 lævigáta $L$ smooth-podded $\$ \Delta$ un 1 jn.jl Hungarian un 1 jn buck's-horn-lv. $\vec{y}$ un 1 jn doubtful un $\frac{3}{4} \mathrm{jn} . \mathrm{jl}$

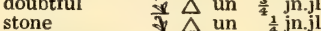
stone
downy-leaved $\frac{\partial}{\Delta}$ un $\frac{1}{2}$ un ${ }^{\frac{1}{4}}$ jn.jl

9139 saxátilis Dec.

9140 sempervirens $L$.

$\mathbf{Y}$
$\mathbf{Y}$
$\mathbf{Y}$
$\mathbf{Y}$
$\mathbf{Y}$
$\mathbf{Y}$
$\mathbf{Y}$
$\mathbf{Y}$
$\mathbf{Y}$
$\mathbf{Y}$

Naples 1824. S co Ten. nap. $t .61$ S. France 1890 S co Dec ic gall t 39 S. Italy 1823. S co Colecp t.284.f I Italy 1710. S co Lam.ill. t.560.f.1 Italy 1777. D co Jac. aust.4. t.339 Hungary 1816. D co Pl.rar.hu.3.t.228 Italy 1790. D co Dec, diss $t$. 18 S. Italy 1820. D co Dec.diss.t.11.f 1 S. Europe 1821. D co Spain 1784. C s.l Barr. ic. t. 841

Cruciferce. Sp. 1-2.

1414. EUCLI'DIUM. R. Br. EUClidium.

9141 syriacum $R . B r$. Syrian

1415. OCHTHO'DIUM. Dec. ОснтноDium.

9142 ægyptíacum Dec. Egyptian Bunias agyptiaca $\mathbf{L}$

1416. ANASTA'TICA, $L$. ROSE OF JERICHO.

1416. A NASTA'TICA. L. Rose

$\frac{3}{4}$ jl.au W Levant

1778. S co Jac. aus. 1. t. 6

Crucifera. $S p .1$.

$\begin{array}{lll}3 & \text { au } & \text { 1787. S co Jac.vind.2, t.145 }\end{array}$

Crucifere. Sp. 1.

1417. CAKI'LE, Tourn. CAKILE.

$\triangle$ cu $\frac{1}{2}$ jn.au W Levant 1597. D co Jac. vind. 1.t.58

9144 marítima Scop. Sea Rocket

Crucifera. Sp. 1-3.

1418. RAPIS'TRUM. Desv. RAPISTRUM. 9145 perénne Dec. perennial f Cakile perennis Lher.

9146 rugósum All. wrinkled Cakile rugosa Lher.

9147 orientále Dec. oriental

Myagrum orientale $\mathbf{L}$.

1419. CHORISPO'RA. Dec. Chorispora. 9148 tenélla Dec. purple

y arcuáta bowed

Raphanus arcuatus W.

9149 sibirica $L$. Siberian

1420. MALCO'MiA. $\boldsymbol{R} . \boldsymbol{B r}$. Malcomia. 9150 africána $\boldsymbol{R} . \boldsymbol{B}$ r. African

9151 taráxacifólia Dec. Dandelion-lvd.

9152 láxa $\mathrm{Dec}$

9153 Chía Dec. dwarf branching

9154 marítima $R . B r$

9155 arenária Dec.

9156 parviflóra $\mathrm{Dec}$.

9158 littórea $R$. $B r$.

1421. HES'PERIS. $L$.

9159 trístis $L$.

9160 laciniáta $A l l$.

lax

dwarf annual

sand

small-flowered

lyrate

small sea

$\frac{3}{4}$ jn.s Pu Britain

Cruciferce. Sp. 3-5.

$\Delta$ un $1 \frac{1}{2} \mathrm{jl} Y$ Germany 1789. D s.l Jac. aust.5.t.414

on $1 \frac{1}{2}$ jn.jl Y

$\begin{array}{llll}\text { S. Europe 1739. S s.l All. ped. 1. t. } 78 & \end{array}$

in 1 jl $\quad Y$ Levant 1795. S co Flo.Græca,t.612

Cruciferc: Sp. 2-4.

un $\frac{1}{2}$ jn.jl Pu Siberia 1780. S co Pall. it. 3.t.L. f.3

O un $\frac{1}{2}$ jn.jl Pu Siberia

O un $\frac{1}{2}$ jn.jl $\mathbf{Y}$ Altai 1823. S co

Crucifera. Sp. 9-15.

$\bigcirc$ or $\frac{3}{4}$ jn.jl Pu Africa 1747. S s.l Bocc.sic.t.42.f.1

() or $\frac{3}{4}$ jn $\quad$ Pu Siberia 1795. S 1.p

or 2 jn Pu Siberia 1820. S co

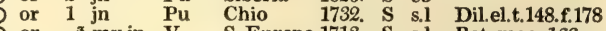

O or $\frac{3}{4}$ my.jn V S. Europe 1713. S s.l Bot. mag. 166

or $\frac{3}{4}$ jn.jl V Algiers 1804. S s.1 Desf.atl.2.t.162

O or $\frac{1}{2}$ jn.jl $\quad$ V $\quad$ S. Europe 1823. S co Dec. ic. gall. t.35

Or $\frac{\pi^{3}}{3}$ jn.jl Pu Cyprus 1820. S co Flor.Græc.t.635

jn.n W.y S. Europe 1683. S s.l Lob. ic. t.331.f.1

Crucifera. $S p .6-20$.

night-smelling $Q$ or 1 ap.jn D.Pu Austria 1629. S s.l Bot. mag. 730

F or 11 my in Pu S. France

9161 runcináta $W . \& K$. runcinate $\quad$ O or $1 \frac{1}{2}$ jn.jl W.pu Hungary 1804. S s.1 PI. rar.h.2.t.200

r bitumino Savi clammy

9162 matronális $L$. common

9163 aprica Poir.

scentless

OD or $1 \frac{1}{2}$ jn.jl W.pu $\ldots . . .$. 1816. S s.1

exposed $\Delta$ or Arabis grandiflóra $\mathbf{L}$

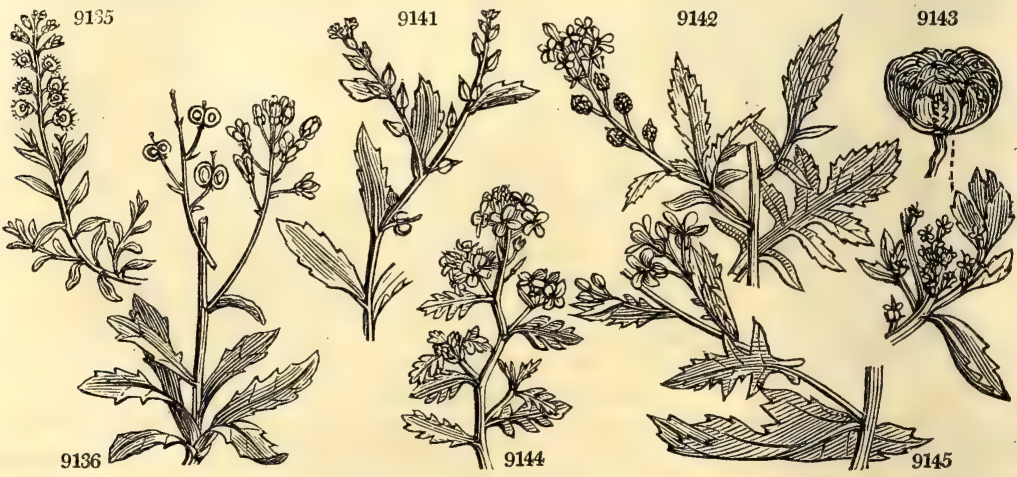

History, Use, Propagation, Culture,

1414. Euclidium. From $\varepsilon v$, well, and $x \lambda \varepsilon \downarrow \delta \circ \omega$, to shut up, because of the firmly closed seed vessel.

1415. Ochthodium. So called from ox

1416. Anastatica. Derived from $\alpha$ $\alpha \sigma \tau \alpha \sigma 5$, resurrection. This plant has been so called because it has the curious property of recovering its original form, however dry it may be, upon immersion in water. The com. mon people believe that if you put this in water at the time when a woman first experiences the pains of childbirth, it will expand at the precise moment when the infant is brought into the world. Commonly called Rose of Jericho. It grows in the arid wastes of Arabia and Palestine, where it is called kaf maryam, that is to say, Mary's hand.

1417. Cakile. An Arabic word employed by Serapio. Smooth fleshy annual plants, with pinnatifid leaves, and white or purple flowers. They all grow upon the sandy coasts of the northern hemisphere. C. maritima is said by Anguillara to be a powerful cathartic. 
0132 Silicles even ciliated at edge, Radical leaves lyrate

9133 Silicles even ciliated at edge, Stem erect elongated leafy, Leaves sessile oblong remotely toothed [at base 9134 Sil. rough on edge and disk with a very fine down, Rad. lvs. obov. cun. acute tooth. Stem somew. nak. hisp. 9135 Silicles rough on the edge and disk with a very fine down, Leaves lanc. serrate, Stem leafy branched hairy 9136 Silicles smooth even, Rad. leaves rough with hair oblong narrowed into stalk : cauline linear few entire

9137 Silicles smooth even, Leaves rough with hairs, generally radical pinnatifid with $2-3$ rem. lobes on each side 9138 Sil. smth. even, Lvs, rough with hairs : rad. sin.-tooth. nar, at base; caul. very few cord. at base $\frac{1}{2}$ stem-clasp. 9139 silicles smooth rough with elevated dots on the disk, Leaves hairy generally radical oblong

9140 Silicles smooth rough with elevated dots on disk, Lvs. mostly radical erect linear lanc. hoary nearly entire

9141 Silicles scabrous with a persistent subulate style, Cauline leaves stalked lanceolate

9142 The only species

9143 The only species

\section{Upper joint of the silicle ensiform}

9145 Silicles smooth : upper joint ovate longer than style, Leaves pinnatifid, Lobes toothed cut acute

9146 Silicles downy : upper joint round rugose shorter than style, Leaves blunt toothed; radical sublyrate

9147 Silicles furrowed smooth, Leaves oblong toothed sinuated

9148 Silique and leaves smooth : upper lanceolate toothed; lower pinnatifid

9149 Siliques and leaves nearly smooth, Leaves all sinuate pinnatifid

9150 Stem branched diff. Lvs. lanc. somew. toothed, Down 2-4-parted, Pedi. shorter than persist. cal. Siliq. rough 9151 Stem erect simple, Lvs, obl. cut tooth. Down 3-parted, Pedi. shorter than decid. cal. Siliq. smth. about 4-cor. 9152 Stem branched somew. hairy at base, Lvs. ov. acute toothed angul. and siliq. smooth, Pedi. shorter than cal. 9153 Stem erect branch. Lvs, obov. ent. Down 2-parted app. Pedi. length of cal. Siliq. round. pub. Style very short 9154 Stem erect branched, Lvs. ellipt. blunt ent. narr. at base, Down appr. 2-4-parted, Pedicels shorter than cal. 9155 Stem erect branched, Lvs. lanc. acute : lower toothed sess. Down stel. Pedi. very short, Pods torulose subul. 9156 Stem erect branched, Lvs. obl. blunt nearly ent. Down tom. stel. Pedicels finally as long as cal. Pods pubesc. 9157 Stem erect branched, Lower lvs. lyrate stalked blunt, Down app. 2-part. Pedicels length of cal. Pods pubesc. 9158 Stem compound erect, Leaves lanceolate linear nearly entire hoary, Pedicels length of cal. Pods hoary

9159 Pedicels very long spreading stiff as broad as silique which is thickened at each edge, Petals obl. oblique 9160 Pedicels shorter than cal. Petals obovate oblong, Leaves obovate cut-toothed, Stem hispid

9161 Pedic. longer than cal. Petals obov. somew. pointed, Lvs. downy : lower lyrate runcinate; upper lanc. acum.

9162 Pedicels length of cal. Petals obov. Siliq. erect torose smooth not thickened at edge, Lvs. ovate lanc. toothed

9163 Pedicels glandular hairy length of cal. Petals obovate, Leaves oblong blunt and stem simple ciliate hispid 9164 Pedic. scarcely so long as cal. Petals obovate, Leaves somewhat radical somewhat fleshy lanc. Scape simple

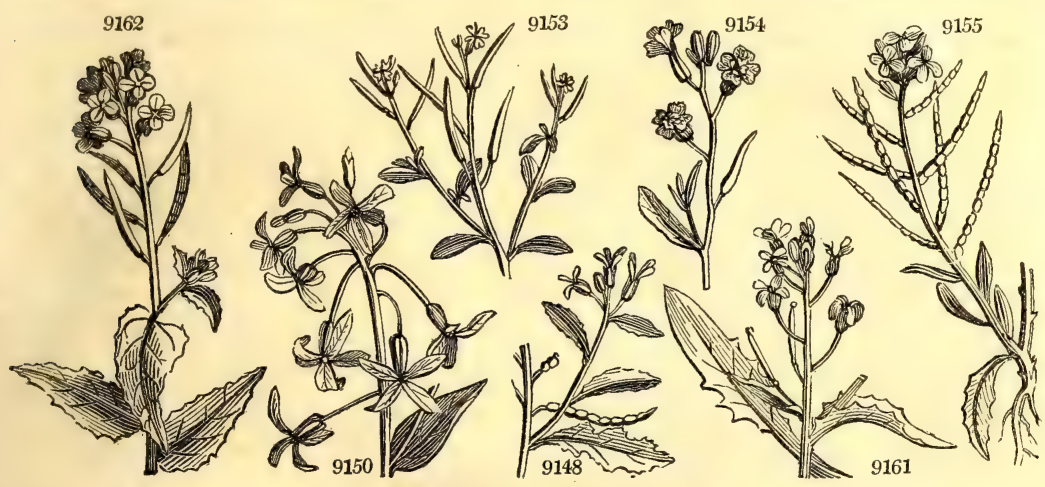

and Miscellaneous Particulars.

1418. Rapistrum; that is to say, resembling Rapa. A genus very near Cakile, from which it differs in having yellow flowers, and leaves not fleshy, and more or less hairy.

1419. Chorispora. From $x$ wess, separately, and $\sigma \pi \circ \rho$, seed; each seed being enclosed separately in the pod. This differs from Raphanus in having flat decumbent cotyledons, not folded incumbent ones. Little annual plants.

1420. Malcomia. Named after Mr. William Malcolm, an eminent nurseryman in the neighbourhood of London, and a person of some botanical acquirements. M. maritima is a common annual, which, sown at different times, or left to sow itself, will be in flower nearly all the year.

1421. Hesperis. From E $\sigma \pi \varepsilon \rho \varepsilon_{5}$ the evening. The flower is more fragrant towards evening than at other periods of the day. H. matronalis, in its double varieties, is rather difficult to keep, and requires to be yearly renewed by cuttings. It prefers a strong loamy soil ; and it has been remarked, that it neither thrives in the renewed by cuttings. It prefers a
neighbourhood of London or Paris. 
1422. SISYM'BRIUM. $L$. SISYMBRIUM. 9165 officinále Scop. Hedge-Mustard 9166 strictissimum $L$. spear-leaved 9167 júnceum Bieb.

9168 hispánicum Jac 9170 sinapoídes $R$. Br. Pyrenean 9171 austriacum Jacq. Austrian $\beta$ Eckartsbergénse W. 9172 I'rio $L$ 9173 Colum'næ Jacq. $\beta$ altíssimum $\mathbf{L}$ $\gamma$ orientále $\mathrm{L}$

9171 pannónicum Jacq. 9175 ásperum $L$

9176 Sophia $L$

9177 millefólium $\boldsymbol{H} . \boldsymbol{K}$. 9178 tanacetifólium $\boldsymbol{L}$ 9179 supinum $L$. 9180 polycerátium $\boldsymbol{L}$. 9181 rigidum $B i c b$. 9182 bursifólium $L$

9183 parious-leaved 9183 pinnatifidum Dec. pinnatifid
9184 integrifólium $L$. 1493. ALLIA'RIA. Adans. HEDGe GarLIC. 9185 officinális Andrz. Erysimum Alliaria I

9186 brachycárpa Bieb. short-fruited $\Delta$ un 1 jl.au W Iberia 1824. D co 1424. ERY'SIMUM. $L$. Henge-MUSTARD. 9187 sessiliflórum $\boldsymbol{R}$. $\boldsymbol{B r}$. sessile-Howered 9188 angustifólium $E h r$. narrow-leaved 9189 cuspidátum Dec. cuspidate 9190 odorátum $R . B r$. fragrant 9191 virgátum Roth. twiggy

9192 ibéricum Dec. Armenian Cheir armeriacus Sims. 9194 repándum $L$. small-flowered 9195 helvéticum Dec. Swiss 9196 diffusum $E . h r$. Alpine 9197 lanceolátum $\dot{R}$. Br. spear-leaved 9198 dúbium Dec. doubtful 9199 ásperum Dec. rough 9200 alpinum Baumg. Alpine Brassica alpina $\mathbf{L}$.

9201 orientále R. Br. Hare's Ear austriacum Baumg.

1425. CA MELI'NA. Crantz Gold of Pleasure Crucifera. $S p, 3-6$.

9202 sativa Crantz. cultivated $\quad$ O ec 1 my.jl Y . Britain corn fi. S s.l Eng. bot. 1254 9203 dentáta Pers. $\quad$ tooth-leaved $O$ un 1 my.jl Y Europe 1806. S s.1 Bauh. his. 2.893 9204 austriaca $R . B r$. Austrian $\bigcirc$ un 1 jn.jl Y Austria 1795. S s.1 Jac. aust.2.t.111 1426. NES'LIA. Desv. Neslia. 9205 paniculáta Desv. panicled Myagrum paniculatum $\mathbf{L}$.

1427. CORO'NOPUS. Sinith. War' Cress. 9206 dídyma $\mathrm{Sm}$ 9207 Ruel'ii All

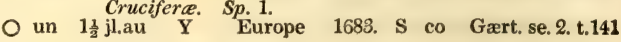

๔ un 11 my.jn $Y$

$\Delta$ un $1 \frac{1}{2}$ my.jl Y

F un 1 my.jl $P$.

F un $11^{2}$ my.jn $Y$

$\triangle$ un $1 \frac{1}{2}$ my.jn W

Britain was.gr. S co Eng. bot. 735

1658. D co Jac. aust.2. t.194

Spain 1820 . S co Jacicra.1.124.

Switzerl. 1823. S co Mor. s.3. t.5. f.10

Pyrenees 1791. S co Jac. vind. 3. t. 97

Austria 1799. S co Jac. aust.3, t.262

England walls. S co Eng. bot. 1631

Italy 1796. S co Jac. aust.4. t. 323

1759. S co Walth.hort.t.22

Y Hungary 1787.

S. France 1778. S co Bauh his.858, f

Britain was.gr. S co Eng. bot. 963

Canaries 1779. C co Jac. ic. 1. t. 127

S. Europe 1778. S

S. Europe 1778. S co Isn.act. par. t.18

Co Jac. vind. 1. t.79

S. Europe 1732, S co Dil el.t.148, 177

S. Europe 1820. D co All, ped. t.57.f.3 15-41.

Siberia 1794. D co L'He.stir.1, t.44 Hungary 1800. S co Pl.rar.hung, t.98 Hungary 1822. S co Bux. cen.t.33.f.1 Austria 1795. D co Armenia 1803. C l.p Bot. mag. 835

Britain fields. S co Eng. bot. 942 Spain 1772. S co Jac. aust. 1, t. 22 Switzerl. 1793. S s.p Jac. vind. 3. t. 9 S. Europe 1731. D co Jac. aust. 1. t. 75 S. Europe 1597. S co Jac. aust. 1. t. 74 N “..... 1823. S co Germany 1793. D s.1 Vil.dauph.3.t.36

England cliffs, S co Eng. bot. 1804

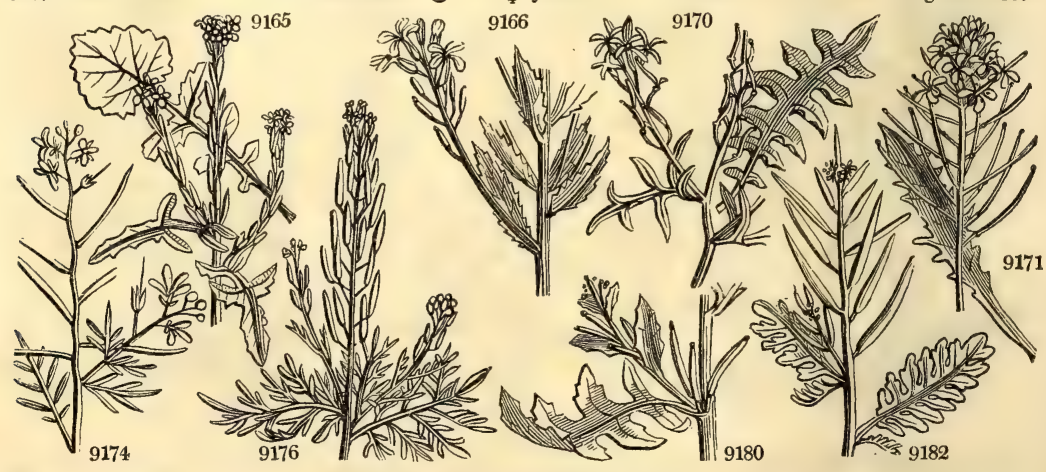

History, Use, Propagation, Culture,

1422. Sisymbrium. $\Sigma_{\varsigma \sigma \nu \mu \beta_{\rho} \odot y}$ was the name given by the Greeks to some aquatic plant not now recognized. It appears to have had an agreeable smell. Ovid advises that Venus should be propitiated with garlands of myrtle, of roses, and of Sisymbrium. S. officinale is a celebrated medicinal plant, and esteemed diuretic detersive, and expectorant, and prescribed in asthma and hoarseness, whence the French call it Herbe aux chantres.

1423. Alliaria. From allium, garlic, in allusion to the smell of the leaves of this plant, for the sake of which it was formerly used in salads.

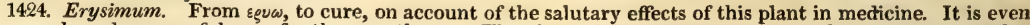
now reckoned a powerful cure for the sore throat. The plant of the ancients appears to have been our garden cress; for Pliny says the Gauls called his Erysimum velar, and the garden cress is to this day called vilhar in 
9165 Leaves runcinate hairy, Stem hairy, Siliques subulate appressed to the rachis 9166 Leaves lanceolate stalked toothed pubescent

9167 Leaves smooth glaucous : lower stalked runcinate pinnatifid; upper linear lanceolate entire

9168 Leaves lanc. toothed sessile smooth, Stem branched divaricating, Siliques erect roundish smooth [base 9169 Leaves pinnated, Lobes oval oblong blunt sinuate-toothed with rounded recesses, Stem hispid backward at 9170 Stem and lvs. smth. : rad. runcin. ; caul. pinnatifid, Lobes and recesses acute, Cal. much spread. Pods rough 9171 Stem pods and lvs. smooth : rad. runcin.; cauline cut or pinnatifid, Lobes and recesses acute, Cal. spreading

9172 Stem and leaves smooth runcinate pinnate, Lobes toothed terminal elongated, Cal. and pods spreading erect 9173 Stem villous somew. hoary, Leaves runcinate pubes. Lobes toothed or ent. acute, Pods nearly erect, Cal. lax

9174 Lowerleaves runcin. hispid with toothed lobes : upper pinnated smooth with lin. ent. lobes, Pods spreading 9175 Lvs. smth. pinnat. with obl. blunt somew. tooth. lobes, Pedic. very sh. Pods muric. rough point. with sh. style 9176 Leaves bipinnate with oblong linear cut lobes, Pedicels 4 times as long as calyx, Petals smaller than calyx 9177 Leaves about 3 -pinnate hoary with very small blunt lobes, Stem $\frac{1}{2}$ shrubby, Petals larger than calyx 9178 Lvs. pinnated, Segm. lanc. cut serrated : outer confluent, Petals larger than calyx, Pods shorter than stalk 9179 Pedic. axillary very short solitary, Pods erect downy, Leaves sinuate pinnatifid, Stem downy backwards

9180 Pedic. about 3 axill. very short, Pods erect smooth, Lvs. sinuate runcin. Lobes acute toothed lowest laryest 9181 Pedic. very short axill. or naked, Pods and stems erect hispid, Leaves smoothish obl. acutely runcin.-pectin. 9182 Leaves lyrate pinnatifid smooth, Stem erect leafy, Pedicels thick shorter than calyx

9183 Rad. leaves lyrate : cauline pinnat. Lobes linear ent. term. largest, Pedic. slender almost shorter than alyx 9184 Leaves linear entire, Branches and pedicels glandular and harry, Pods glandular

9185 Leaves cordate, Pods prismatical much longer than pedicel

9186 Leaves ovate roundish, Pods lanceolate the length of their stalk

9187 Pods length of style: when young covered by the persistent calyx, Fl. sessile, Leaves inear entire 9188 Pods much longer than style when young having a persistent calyx, Fl. subsessile, Leaves linear entire 9189 Pods thrice as long as style 2-edged naked, Fl. on short stalks, Leaves oblong lanceolate sinuate toothed 9190 Leaves lanc. toothed pubescent with a 3-parted down, Stem branched, Pods lax, Stigma 2-lobed [of pod 9191 Lvs. obl. lanc. somew.tooth.pub with 3-part. down, Stem straight round,Length of style great. than breadth 9192 Lower leaves runcinate toothed : upper lanc. undivided, Fl. branches and pods comp. 4-cor. erect spreading

9193 Lvs. lanc. somew. toothlet. roughish green, Pods erect spread. twice as long as stalk, Stigma small subsessile 9194 Leaves linear lanc. repand-toothed, subpubes. Pods spreading torulose scarcely thicker than short pedicel 9195 Lvs. lin. entire and stem cinereous with appressed 2-parted hair, Pods somew. erect, Stigma stalked emarg. 9196 Lvs.lin.ent.or somew.tooth.somew. hoary with 2-part. hair, Claws long. than cal. Pods erect, Stig. near sess. 9197 Lower lvs. lanc. toothed : upper somewhat linear entire, Petals roundish obovate, Claws longer than calyx 9198 Leaves lanceolate toothed narrowed at base, Petals obovate oblong, Pods spreading, Style scarcely any 9199 Leaves lin. obl. : lower toothed runcin. and stem pubesc. rough, Pods spreading, Style very short and thick 9200 Leaves membranous smoothed : cauline cordate sagittate stem-clasping oblong; radical stalked ovate

9201 Rad. Ivs. obov. : cauline cordate stem-clasping, all blunt smooth glauc. Sides of square stalk without nerves

9202 Pods cuneate pyriform with 4 ribs and a longish style, Leaves lanceolate nearly entire 9203 Pods roundish pyriform with 4 ribs and a longish style, Leaves repand toothed

9204 Pods globose, Leaves oblong serrate toothed bluntly stem-clasping at base, Stem smooth

9205 The only species

9206 Leaves pinnatifid, Lobes oblong toothed or cut, Pods compressed twin netted 9207 Lvs. pinnatifid, Lobes ent. toothed or pinnatifid, Pods somew. acute compressed with crested ruguse valves

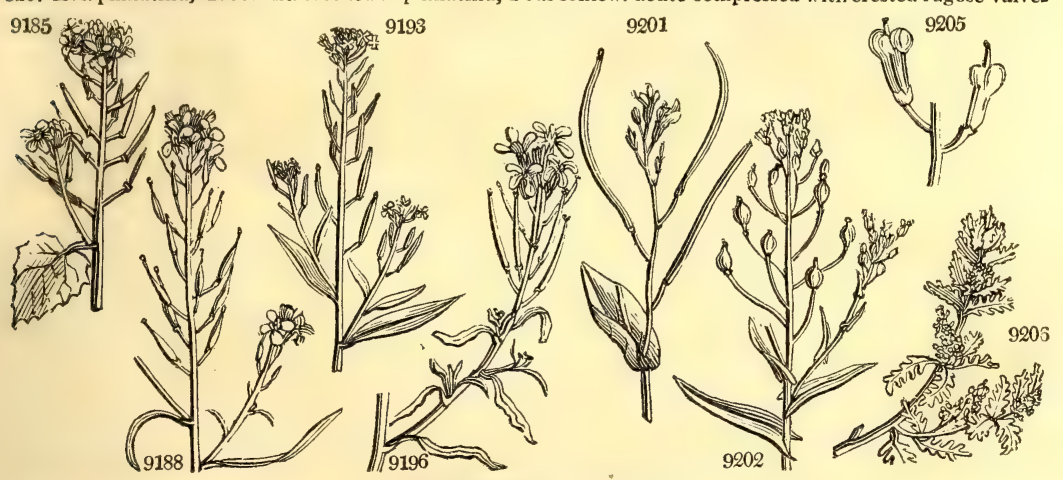

and Miscellaneous Particulars.

the Basque tongue, and in other dialects of France beler or veler. From the seeds of E. perfoliatum, a plant not known in this country, oil for lamps is expressed in Japan.

1425. Camelina; that is to say, chama-linum, dwarf flax. C. sativa is cultivated in many parts of Europe for the seeds, from which oil is obtained. For the method of its culture see Parmentier, in Roz. Cour's d'Agric., v. xi. p. 291. Bosc. Dict. d'Agr. 3. p. 45. Galliz. Bot. Agr. 3. p. 170.

1496. Neslia. A name first employed by M. Desvaux, but not explained by him. $\mathrm{A}$ genus allied to Camelina but well distinguished by its one-seeded indehiscent silicles.

1407, but well distinguished by its one-seeded indehiscent siles.

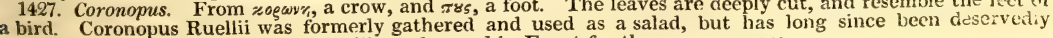
a bird. Coronopus Ruellii was formerly gathered and used as a salad, but has
neglected. C. niloticus is said, by Delile, to be used in Egypt for the same purpose. 
1428. LEPI'DIUM, $L$. PEPPERWort. $\begin{array}{ll}9208 \text { Drába } L . & \text { Whitlow } \\ 9209 \text { chalepénse } L . & \text { Aleppo }\end{array}$

9210 glastifólium Desf. woad-leaved 9211 coronopifólium Fisch. Buckshorn-lv. 9212 sativum

9218 campéstre $R, B$. common Cress 9214 hírtum Smith. 9215 spinósum $L$. 9216 virgínicum $L$. 9217 subulátum $\boldsymbol{L}$. 9218 ruderále $L$. 9219 vesicárium $L$. 9220 perfoliátum $\boldsymbol{I}$. 9221 Cardámines $I$. 9222 divaricátum $\boldsymbol{H} . \boldsymbol{K}$. 9223 bonariénse $L$ 9224 piscídium Forst. 9225 oleráceum Forst. 9226 lyrátum $L$ 9227 latifólium $L$. hoary field hairy prickly Virginian awl-leaved narrow-leaved bladdery various-leaved Spanish Cress close-spiked Buenos A yres Fish-poison eatable lyrate broad-leaved 9228 crassifólium $W . \& K$. thick-leaved 9229 graminifólium Cav. bushy 9230 I'beris $\boldsymbol{L}$. diandrous

1429. ETHIONE'MA. R.Br. AETHONEMA 9231 saxátile $R . B r$. rock 9232 Buxbaúmii Dec. Buxbaum's 9233 monospérmum $R$. Br.one-seeded

1430. ISA'TIS. $L$.
9234 arména $L$. Wonl

9235 lusitánica Brot. Portugal 9236 alpína All. 9237 præcox Kit. 9238 littorális Stev. 9239 tinctória $\boldsymbol{L}$ 9240 campéstris Stev. 9241 canescens $D$. $C$. B ibérica Stev. 9242 aléppica $S c o p$. 1431. MYA'GRUM. $L$. 9243 perfoliátum $\boldsymbol{L}$. 1432. BRAS'SICA. $L$ 9244 olerácea $L$ early. sea side common dyer's field

hoary

Iberian oriental Mragrum perfoliate Cabbage. common

Crucifera. Sp. 23-56. $\triangle$ un 1 my.jn W un 1 my.jl W $\mathrm{O}$ un $1 \frac{1}{2} \mathrm{my}$.j $\Delta$ un $\frac{3}{4}$ my.jl cul $1 x$ jpil W un $\frac{3}{4}$ jn.jl $\$$ O) $w \stackrel{4}{1}$ jn.jl un 1 s un 1 jn.jl n. Jun $\frac{3}{4} \mathrm{jl}$.au un 1 jn.jl un 13 apau un $\frac{3}{4} \mathrm{jl}$ W (2) Un $1 \frac{1}{1}$ jn.jl W O un $2 \frac{1}{2}$ my.jn W O ec 1 s W cul 3 s un $2 \frac{1}{\mathrm{j}} \mathrm{jn} . \mathrm{jl}$ $\triangle$ un 2 jn.jl $\triangle$ un $\frac{3}{4}$ my.jn W c $\Delta$ un 2 au.s W

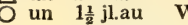

W

Europe 1596. D co Aleppo 1798. S co Barbary 1823. S co Siberia 1824. D co 1548. S co Britain fields. S co Britain fields. S co Levant 1787. S co America 1713. S co Spain 1739. S p.l Britain seaco. S co Crimea 1820. S co Austria 1640. S co Jac.aust. 4. t.346 Spain 1789. C co Arduin.sp.1.t.18 S. Am. 1774. C p.I . Amer. 1732. S co Dil.el.t.286.f.370 Society Isl.1779. S co N. Zeal. 1824. S co Levant S co Britain sea co. D co Hungary 1820. D co 1683. D co Cav. et kit. 1.t. 4 1793. $s$ co 151 . f. 2 Crucifera. Sp. 3-9.

O cu $\frac{1}{3}$ jn.jl F S. Europe 1759. S co Jac.aust.3.t.236 O cu $\frac{1}{2}$ jn.jl Pa.pu Levant 1823. S co Bu.cen.1.t.5.f. 1 \pm O cu $\frac{1}{2}$ jl.au Pa.pu Spain 1778. S co

Crucifere. $\quad S p .9-17$.

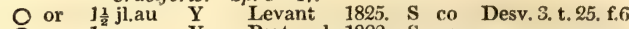
Or 1 my Y Portugal 1822. S co $\star \Delta$ or $\frac{1}{2}$ jn.jl Y $\quad$ Italy 1800. D s.l D or $1 \frac{1}{2}$ my.jn $\mathrm{Y}$ Hungary 1822. S co England corn fi. S s.l Persia 1824. D co

S. Europe 1822 S co Iberia 1823. S co Levant 1739. S s.1 Scop.ins. 2.t. 16 $1 \frac{1}{2}$ my.jn $Y$ to or 1 myjn or 1 jn.jl $\mathbf{Y}$ Crucifere. $S p .1$

O pr $\frac{1}{2}$ jn.jl Pa.Y France 1648. S co Sch, han. 2.t.178 Crucifere. Sp. 12-34.

(1) cu 2 ap.jn $Y$ England cliffs. S r.m Eng. bot. 637

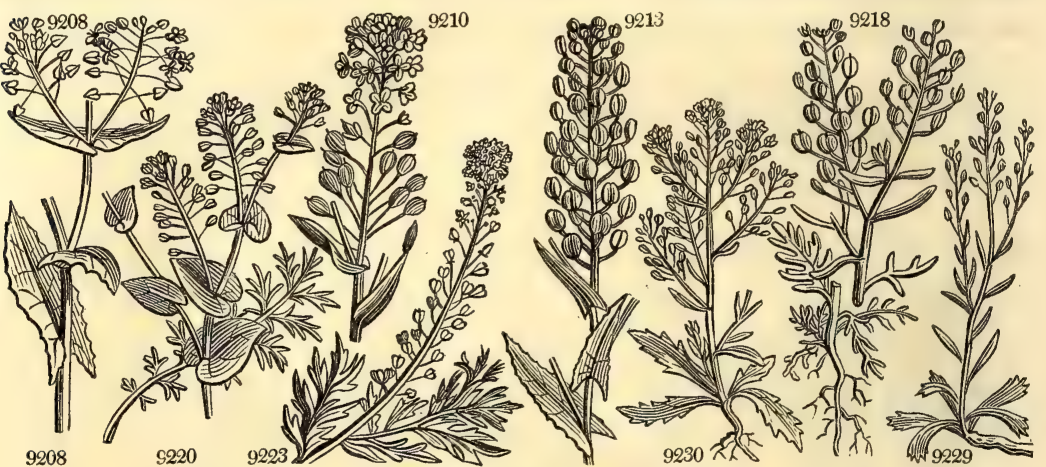

History, Use, Propagation, Culture,

1408. Lepidium. From $\lambda s \tau i s$, a scale. The form of the silicles is that of little scales, $\mathrm{L}$, piscidium is used by the natives of the Society Islands for the purpose of catching fish by inebriating them it was used by the English voyagers as a salad, but it was very pungent. $\mathrm{L}$. oleraceum is a powerful antiscorbutic, and is found of great service to the crews of ships visiting New Zealand; it resembles lettuce in taste, and acts as a mocierate aperient. I. sativum, the common garden cress, is a salad-plant known to every one, and which even the cook can cultivate on moistened cloth or wool in a moist heat. Watering with water, impregnated with muriatic acid gas, or electrifying, will facilitate the germination and developement of the seeds.

1429. Athionema. So named by Mr. R. Brown, apparently in allusion to some tawny or sunburnt tinge in the stamens. From ai $9 \omega$, to scorch, and ynu\%, a stamen. Smith.

1430. Isatis. From $6 \sigma \propto \zeta \omega$, to render equal. The plant was believed to destroy, by its simple application, all roughness and inequalities of the skin. It was formerly called glastum, from the Celtic glas, blue, whence Glastonbury derived its name. The ancient Britons colored themselves with the blue preparation obtained from this plant, whence they received their appellation, Britho being the Celtic word for to paint. The Picts were so named by the Romans for the same reason. On account of the brightness of its manufactured colors the Celts called it gwed (guesde, French, at this day), whence the Anglo-Saxons obtained their name of wata or wad, and the English the word woad. I tinctoria is in occasional cultivation for its leaves, from which a dye, as a substitute for indigo, is obtained. The seeds are sown on well prepared land in good heart; fresh broken old pasture land is preferred; and the great object is to have large leaves ; for which purpose, as M:ller observes, the culture given by the best gardeners to spinage should be imitated, that of sowing on a very rich well pulverised soil, thinning the plants so as they may not touch each other, kecping them perfectly clear of weeds, and frequently stirring the soil between the plants. The culture applied to the turnip in Northumberland would succeed we!l with woad. The seeds are sown in July, and the plants, when they come up, weeded and thinned; next July, or earlier, the first crop of leaves may be gathered, and two or three others will be ob- 
9208 Pods cordate somewhat turgid entire at the end exceeded by the style, Leaves stem-clasping laric. toothed 9209 Pods elliptical twice as long as stalk, Style filiform, Leaves with acute stem-clasping lanceolate auricles 9210 Pods ellipt. smooth shorter than stalk, Style filif. Leaves with blunt stem-clasping obl. bluntly toothed auric. 9211 Pods ellipt. ent. somew. downy pointed with style, Cal, somew. persistent, Rad. lvs. pinnat. : caul. lin. ent. 9212 Pods orbicular winged, Leaves variously divided and cut, Branches not spiny

9213 Pods ovate winged emarginate scaly, Cauline leaves sagittate toothed

9214 Pods ovate winged emarginate hairy, Cauline leaves sagittate villous nearly entire

9215 Pods oblong winged emarginate about 2-horned smooth, Radical leaves pinnatifid with cut lobes

9216 Pods orbic. emarg. shorter than stalk, Flowers with 2-4-stamens, Caul. lvs. lin. lanceol. cut-serrate smooth 9217 Pods ovate somewhat emarginate, Leaves subulate entire, Stem $\frac{1}{2}$ shrubby

9218 Pods ovate emarg. spreading shorter than stalk, Leaves smooth : radical pinnatifid, Fls. diandrous apetal 9219 Pods elliptical slightly emarginate, Leaves pinnatifid, Lobes linear, Joints of stem inflated

9220 Pods ellipt. slightly emarg. Lower lvs. stalked pinnatifid with multifid lobes : upper cord. amplexicaul entire 9221 Pods oval somewhat emarginate, Leaves pinnatifid with oval entire lobes : terminal large roundish 9222 Pods oval somew. emarg. approximat. Lower leaves pinnati. with spread. acute lobes, Stem much branched 9223 Pods orbicular emarginate, Flowers diandrous, Leaves all pinnately multifid minutely ciliated

9224 Pods oblong obovate emarginate, Stigma exserted, Leaves oval-oblong toothed outwardly or entire

9225 Pods ovate acutish, Leaves smooth ellipt.-oblong deeply serrated : upper entire somewhat serrated at end 9226 Pods ovate pointed with stigma, Lower lvs. stalked lyrate pinnatifid, Lobes cut toothed: term. very large 9227 Pods ovate pointed with the stigma, Leaves ovate lanceolate undivided subserrate, lowest on long stalks 9228 Pods ovate pointed with stigma, Leaves smooth somew. feshy entire, Rad. stalked ovate : caul. sess. sagitt. 9229 Pods elliptical pointed with stigma, Stems $\frac{1}{2}$ shrubby, Radical lvs. obov. obl, toothed : cauline linear entire 9230 Pods ovate pointed with stigma, Rad. leaves cut or pinnatifid : cauline linear entire, Stem much branched

9231 Silicles 2-celled many-seeded obcordate, Valves winged at back and entire, Racemes in fruit lax 9232 Silicles 2-celled 2-seeded round emarg. at base and end, Racemes very close, Valves winged at back and ent. 9233 Silicles 1-celled 1-seeded not opening emarginate at end, Leaves oval or obovate

9234. Silicles round cordate at base with a wide margin pointed with the style

9235 Silicles obov. with a broad edge cuneate at base very blunt and emarginate at end, Stem and leaves smooth 9236 Silicles oval-oblong blunt at each end with a leafy winged margin 3 times as long as broad 9237 Silicles elliptical blunt at each end with a coriaceous winged edge three times as long as broad 9238 Silicles obl. cuneate very blunt truncate emarginate narrowed at base, three times as long as broad 9239 Silicles cuneate accuminate at base somewhat spatulate at end very blunt three times as long as broad 9240 Silicles oblong narrowed at base bluntish at end four times as long as broad 9241 Silicles elongate-cuneate downy four times as long as broad and twice as long as the stalk which is obconical 9242 Silicles lin. blunt vill, with reversed down eight times as long as broad and three times as long as their stalk

\section{The only species}

9244 Lvs. covered with glaucous pollen somew. fleshy repand or lobed even in their youngest state quite smooth

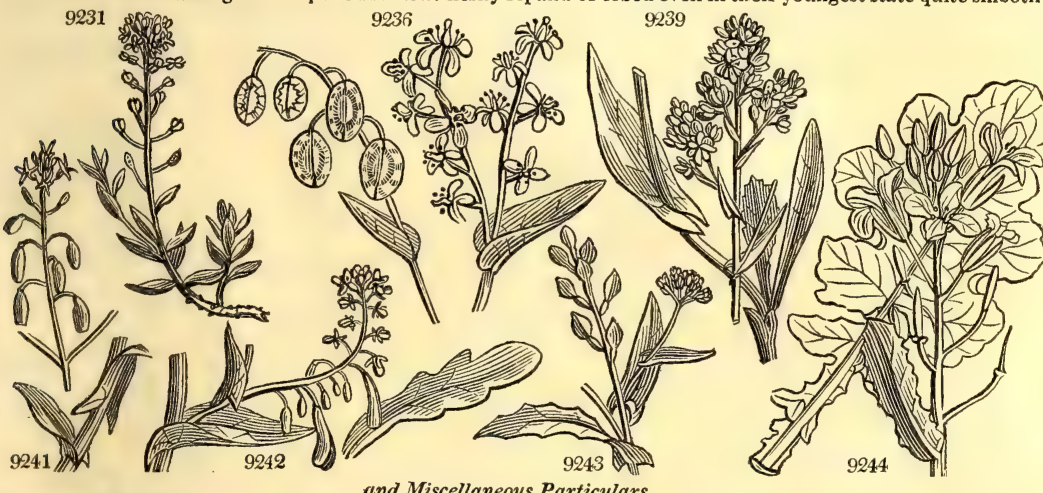

and Miscellaneous Particulars.

tained during the season. The end of the second year the plants may be ploughed down, as the third year they will run to seed, and yield but small leaves. The leaves are pressed, and the juice treated as in making indigo (see Indigofera); but such is the cheapness of the latter article, that no British farmer can afford to raise any sort of substitute

1431. Myagrum. An ancient plant, so named from its properties of catching flies, which the modern plant

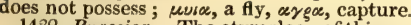

1432. Brassica. The etymology of this word has been explained with great learning and ingenuity by Vossius, Ray, Dalechamp, and others. It comes, however, from the Celtic bresic, which signifies a cabbage. This genus affords the well known pot herbs and roots, and also the oil plant rape, extensively cultivated in agricuiture. There is scarcely an instance in the vegetable kingdom of a plant that produces varieties so different in appearance and qualities as the B. oleracea ; comparing the original plant as it is found on our shores, with wavy sea-green leaves, no appearance of a head, and flowering like wild mustard or charlock, with the red cabbage or cauliflower, the difference is astonishing. A new arrangement of the cultivated species of Brassica has been made by Professor Decandolle (Hort. Trans. vol. 1., and in his Reg. Veg.), whose varieties, or races of

The colza of the Dutch he makes a distinct species (B. campestris), and also the turnip (B. rapa); the rape (B. napus), and the summer rape of the Germans (B. procox)

In Hungary, in the territory of Alba, the B. elongata is cultivated for its oil, for which purpose it is said to be better adapted than any other species.

The culture of all the Brassica tribe is so universally known that it would be a waste of space in a work of this sort to enlarge on it. They all prefer a loamy soil, well enriched with manure and manures of the strongest kind, as nightsoil, offals from the shambles, blood, \&c. are not found too powerful for common cabbage or cauliflower. The turnip prefers a lighter soil than the cabbage tribe, but it must be well manured, and if the 
Garden Varieties.

$\beta$ acephala Dec. Cavalier Cabbage

Thousand-headed Cabbage

Chou möellier

9245 campéstris $L$.

$\beta$ rutabága Dec.

9246 Rápa $\mathcal{L}$.

9247 Nápus $L$.

9248 præ'cox $W . \& K$

9249 chinénsis $L$.

9250 repánda Dec.

9251 Richérii Vill.

9252 monénsis Huds.

9253 erucástrum $L$.

9254 elongáta $E h r$.

9255 cheiranthiflora Dec

Ráphanus cheir.W.

1433. SINA'PIS. $\boldsymbol{L}$.

9256 nigra $\boldsymbol{L}$.

e turgida Pers.

9257 levigáta $L$

9258 integrifólia $W$.

9259 júncea $\boldsymbol{L}$

9260 chinénsis $L$.

9261 brassicáta $L$.

9262 pubéscens $\boldsymbol{L}$.

9263 arvénsis $L$

9264 orientális $L$

9265 Káber Dec.

9266 Alliónii Jaca.

9267 incána $I$

9268 heterophylla $\mathbf{L a g}$

9269 álba $L$.

9270 híspida $W$.

9271 dissécta $L a g$

9272 foliósa $W$.

9273 frutéscens $H . K$.

Borecole

Chou de Milan

Chou Palmier, \&c. \&c

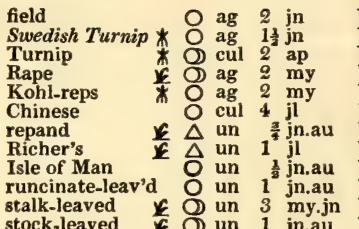

1434. MORIC A N'DIA. Dec. Moricandia.
9274 arvénsis Dec.

9274 arvénsis Dec.

Mustand.

common

turgid

smooth

entire-leaved

fine-leaved

Chinese

cabbage-leaved

downy

Charlock

oriental

Persian

hoary-jointed

various-leaved

white

hispid

cut

leaf

cab S bullata Dec.
Savoy Cabbage
Brussels Sprouts, \&c.
\&c.
costata Dec.
Chou a grosses côtes
tronchuda

England fields. S 6.1 Eng. bot. 2234

Sweden $\quad .$. S co

England corn fi. S r.m Eng. bot. 2176

Britain dit. ba. S co Eng. bot. 2146

Europe 1812. S co

China 1770. S s.l

S. Europe ... D co Vil. dauph. 3.39

S. Europe $\ldots$ D co Vil.dauph.3.t.36

Britain sea sh. S s.l Eng. bot. 962

S. Europe 1790. S s.1 Bull.herb.331

Hungary 1801. S s.I Pl. rar.hu.1.t.28

Spain 1806. S co W.hort,ber, t.19

Sp. 18-51.

O ag 4 my.jn $Y$ Britain corn fi. S r.m Eng. bot. 969

ag 4 my.jn

Q) un 2 jn.jl $Y$

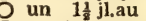

un $1 \frac{1}{2} \mathrm{jn} . \mathrm{jl}$

8 cul $1 \frac{1}{3}$ jl

c un $1 \frac{1}{2}$ jn.jl

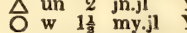

O un $1 \frac{1}{2}, j n . j 1$

un 1 in

un 2 in

c O) un 3 jt

O) un $1 \frac{1}{3}$ my.jn $Y$

$O$ ag 3 jn.jl Y

un 2 jl

un 1 mrap $\mathbf{Y}$

on 1 ap.my $Y$

Britain corn fi, $\mathbf{S}$ r.m

Spain 1769. S co wilhor bert.14

E. Indies 1804. S co Wil.hor.ber.t.14
China

$\begin{array}{llll}\text { China } & 1710 . & \text { S co Jac. vind.2.t.171 } \\ \text { China } & \text { 1782. S co Ard. spec. 1.t.10 }\end{array}$

China 1801. S co

Sicily 1789. D r.m Ardui.spec.1.t.9

Britain corn fi. S s.l Eng. bot. 1748

Levant 1778. S s.1 Sch.han. 1.t.186

Persia 1778. S co

$17 \ddot{89}$ S co Jac, vind 2 t.168

S. Europe 1771. S co Jac. vind.2.t.169

Spain 1822. S co

Britain corn fi. S r.m Eng. bot. 1677

Morocco 1804. S r.m Scho. Maroc. t.4

Spain $\quad$ S co

Levant 1820 . S co

Madeira 1777. C

1435. DIPLOT AX'IS. Dec. Diplotaxis.

9275 pendúla $\mathrm{Dec}$. pendulous

9276 hispida Dec. hispid 9277 erucoídes Dec.
Sinápis erucoides $\mathbf{L}$. dwarf

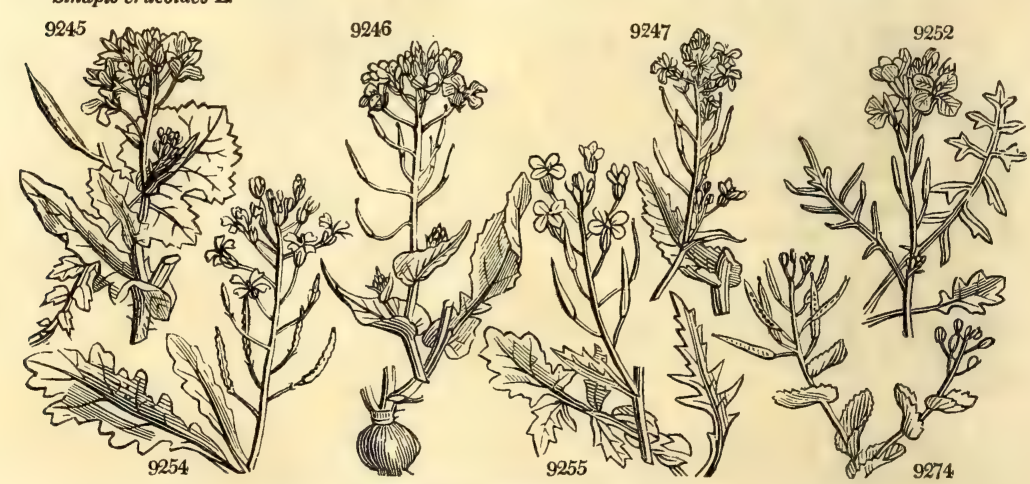

Crucifera. $S p .1-3$.

Sp. $1-3$.
S. Europe 1739.

co Boc.sic.t.25.f.3,

Crucifere. Sp. 9-13.

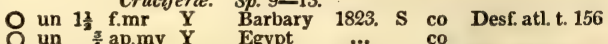

r.m Jac. vind. 2.t.170

History, Use, Propagation, Culture,

manure be well fermented, so much the better for the garden turnip; in the fields, where it is buried in rows or drills, more littery dung will succeed.

The field culture of the turnip is become an important part of the agriculture of light soils ; the best mode is by drills, as in Berwickshire and Northumberland, where are produced crops of treble the weight of those grown in the broad-cast manner in Norfolk. In the latter county a crop weighs from five to fifteen tons per acre in Northumberland from twenty-five to thirty tons; and in Ayrshire as many as sixty tons have been raised on the statute acre (Encyc of Agric.)

The cabbage has been tried as a field plant; but, though it has been said by Sinclair (Hortus Gram. Wob.) to produce more nutritive matter than either turnips or field beet, professional farmers have not found it to answer.

Of all the Brassica tribe it may be observed, that they attain to much the greatest perfection in temperate climates, such as those of Britain and Holland. Without constant and liberal supplies of water, they are small in size, and rigid or stringy in texture. In France and in Italy, and warm climates, it is only the cauliflower and broccoli that attain a large size , and that, in Italy at least, is during the coldest months of the year, and aided by liberal waterings. But in Tarragona the caulifiower is said to reach the enormous weight of 40 ibs.

1433. Sinapis. In Greek oivori, said to be derived from nap, the Celtic designation of all plants resembling the turnip or cabbage. Our English word mustard, and the French moutarde, are modernizations of mustum ardens, hot must; the sweet must of new wine being one of the ingredients of the French mustard for the table. The seeds of all the species are hot, acrid, and will afford an oil by expression, and a powder or meal by drying and grinding, which might serve as the condiment mustard. S. nigra is more particulariy adapted for the latter purpose, though it is often mixed with the seeds of $\mathrm{S}$. alba and arvensis, and often with those of the 
Garden Varietics.

- capilata Dec.

Battersea Cabbage

Early York Cabbage

Early Dwarf Cabbage
Sugar-loaf Cabbage

Penton Cabbage

Red Cabbage, \&c. \&c.
2 caito-

Calo-rapa Dec.

Kohl Rabi

Chou-rave crêpue, \&c. \&c. notrytis Dec.

Cauliflower

Brocolı, \&c. \&c.

9245 Lvs. fleshy with glaucous bloom: the lower when young somew. hispid or ciliat. lyrate toothed; the others

9246 Rad. leaves lyrate without glauc. bloom rough; cauline cut : upper entire [cordate amplexicaul acum. 9247 Lvs. smooth cœsious : radical lyrate; cauline pinnatifid and cren. cord.; upper lanc. stem-clasping 9248 Lvs. smooth cosious : radic. and lower cauline lyrate ; upper cord. lanc. stem-clasping cren. Pods erect 9249 Lvs, oval nearly entire: floral amplexicaul lanc. Cal. longer than the claw of the petals

9250 Radic. leaves fleshy smooth repand toothed, Scapes naked, Style slender distinct from silique 9251 Leaves smooth: lower stalked obl. somewhat toothed; upper linear ianc. few 9252 Leaves smooth somewhat fleshy glauc. pinnated with linear distant somewhat toothed lobes 9253 Leaves runcinate somewhat smonth, Lobes unequal bluntly sinuated, Stem hispid at base 925+ Leaves stalked : lower sinuate pinnatifid hispid; upper smooth toothed, Stem smooth 9255 Rad. leaves stalked lyrate pinnatifid somewhat hispid : cauline few with entire acute lobes

9256 Pods smooth about 4-cornered pressed to the peduncles, Lower lvs. lyrate : upper lanc. entire

$\beta$ Pods turgid veiny diverging with a conical striated beak 9257 Smooth, Lvs. stalked lyrate pinnatifid with acute lobes, Petiole not auricled at base 9278 Smooth, Lvs. ovate lanc. undivided acutely toothed, Pods erect torose with a subulate style 9259 Smooth, Lower leaves ovate lanc. coarsely serrated: upper lanc. entire, Branches fascicled 9260 At the base and nerves hairy, Lvs. blunt cut pinnatifid, Lobes toothed, Pods erect pointed with the style 9261 Smooth, Caul. lvs, cord. amplexicaul obl. entire : lower lyrate pinnatifid toothed, Pods spreading with a 9262 Lvs, pubesc villous lyrate pinnatifid, Terminal lobe large ovate, Pod hairy [conical beak 926. Pods smooth with many angles torulose three times as long as their slender two-edged beak, Stem and lvs. 9264 Pods hairy backwards about 4-cornered torulose shorter than the slender beak [hairy 9265 Pods smooth round with smooth valves twice as long as the conical beak

9266 Pods smooth ovate-oblong, Valves smooth scarcely longer than conical beak

9257 Pods smooth appressed to the raceme somew, torose, Stem branch. rough at base, Lvs. Jyrate rough

9268 Pods downy appressed to raceme somew. torose, Stem bran. rough at base, Lvs. lyrate pinn. hispid on nerves 9269 Pods hispid spreading a little narrower than the ensiform beak, I.vs. Jyrate and stem nearly smooth

9270 Pods hispid spreading a little narrower than the ensiform beak, Lvs. lyrate rough, Stem hispid backwards 9271 Pods suberect torulose shorter than the ensiform beak, Lvs. pinnat. Lobes narr. cut-toothed or pinnatifid 9272 Beak compressed very rough longer than the hispid pod, Lvs. lyrate repand angular smooth

92/3 Calyx bisaccate, Lvs. coriaceous : lower oblong lanc. narrowed at base somewhat toothed

9274 Pods about 4.cornered, Cauline leaves cordate amplexicaul entire

9275 Pods pendulous stalked, Cauline leaves oblong hispid coarsely cut-toothed

9276 Pods pendulous sessile, Leaves obovate coarsely toothed hispid

9277 Pods sessile nearly erect, Style ensiform, Leaves sessile runcinate lyrate toothed
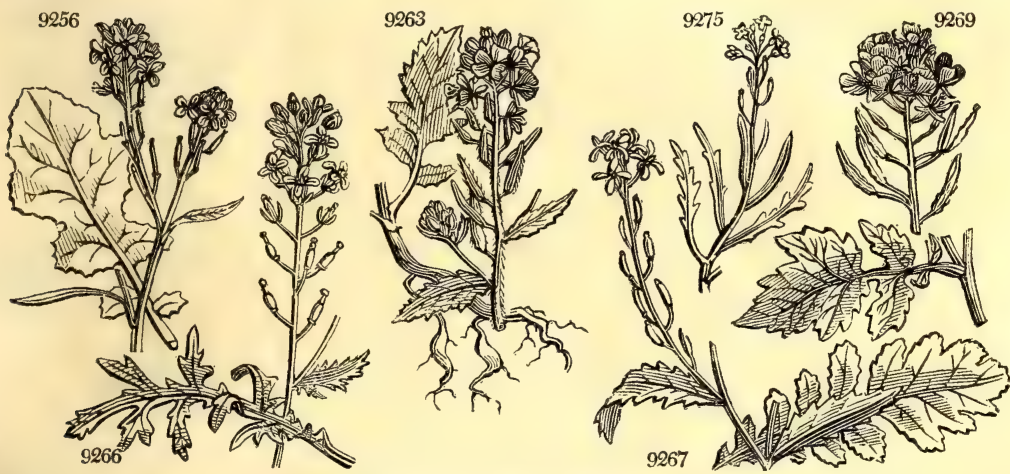

and Miscellaneous Particulars.

Brassica and Raphanus genera. Both S. alba and nigra are grown as small salads to be eaten with cress; they are sown as thick as the seeds will lie, in pots or boxes, or in the area of forcing-houses, in the winter season, and forced, or in leds in the open air, and cut as soon as the seed leaf is fully expanded. For flower of mustard, or for the seed for oil or medical purposes, both white and black sorts are sown in the fields in rick well puiverized soil, in March or April, and kept free of weeds. The crop ripens in July and A ugust, and is either threshed immediately or stacked like other grain. It is like other oleiferous seeds, exhausting for the soil, and such seeds as drop and are buried, will retain their vegetative qualities for an unknown length of time; so that where mustard has once been grown, it will come up occasionally for a century or more afterwards.

If the seeds, Dr. Cullen observes, be taken fresh from the plant and ground, the powder has little pungency, but is very bitter; by steeping in vinegar, however, the essential oil is cooled, and the powder becomes extremely pungent. In moistening mustard-powder for the table, it may be remarked, that it makes the best appearance when rich milk is used; but the mixture in this case does not kecp good for more than two days. The seeds of both the black and white mustard are often used in an entire state medicinally. Half or a quarter of a wine glass of mustard seecis, swallowed fasting, about five in the morning, is the most powerful tonic and strengthener of the digestive organs which is known.

1434. Moricandia. Named by Decandolle, after his friend Stephen Moricand, author of the Flora Veneta, and an excellent Italian botanist. M. hesperidiflora is a favourite food of the camel, notwithstanding its intense acridity.

1435. Diplolaxis. From $\delta \leqslant \pi \lambda_{0 s}$, double, and $\tau \omega \xi$ is, arrangement, on account of the double rows of sects in each cell. 


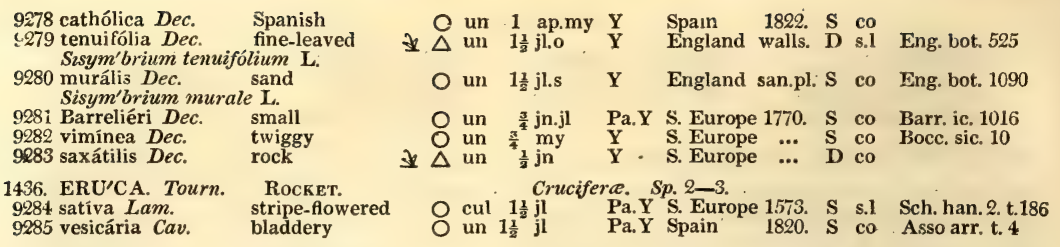

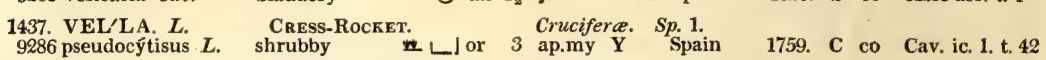

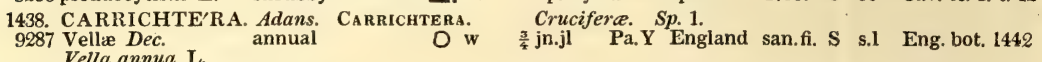
Vella annua $\mathbf{L}$.

1439. SUCCO'W1A. Mönch. Succowia.

9288 baleárica $R$. Br: Minorca

1440. ZIL'LA Forsk. ZuLA. pr $\frac{3}{4}$ jn.jl Y Minorea 1781. S s.I Jac. vind.2.t.144

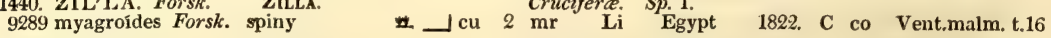

1441. CALEPI'N A. Adans. Calepina.
9290 Corvini Desv.
rugose

1442. CR A MBE, $W$. SEa KaIl. Crucifera. Sp. 10 -13.

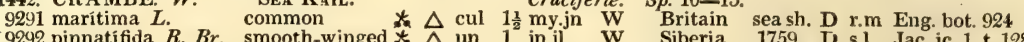

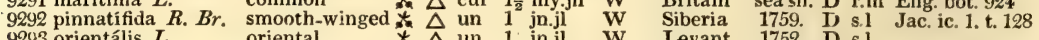

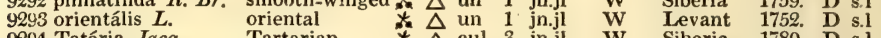

9294 Tatária Jacq. $\quad$ Tartarian $\quad \Delta$ cul 3 jn.jl $\quad$ W Siberia 1789. D s.1 Jac. ic. 1.t. 129

9295 áspera Bieb. $\quad \begin{array}{lllll}\text { rough } & \Delta \text { un } 1 \text { my } & \text { W Tauria 1820. D co }\end{array}$

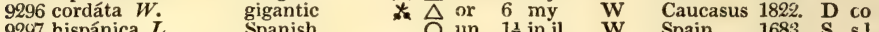

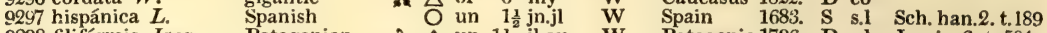

9298 filifórmis Jacq. Patagonian $\$ \Delta$ un $1 \frac{1}{2}$ jl.au W Patagonia 1796. D s.1 Jac. ic.3.t.504

9299 fruticósa $L$. Madeira $\quad$ L un 2 my.n W Madeira 1777. C s.1

9300 strigósa Lher. Canary un $1 \frac{1}{2}$ my.jn W Canaries 1779. C s.1 Jac. ic. 1.t. 120

1443. RA'PHANUS. $L$. Radish. Crucifera. Sp. 5-9.

9301 sativus $L$ common * cu 3 my.jn W pu China

a radicula Dec. long $\quad$ Turnip $\quad$ cu 3 my.jn W.pu China

ß oblon'gus. Dec.

y oleifera Dec.

$\delta$ niger Dec.

9302 caudátus $\boldsymbol{L}$.

9303 Raphanistrum $\boldsymbol{L}$, wild $\bigcirc \mathrm{w} \mathbf{1} \frac{1}{2}$ jn.jl Y Britain

9304 Landra Morett.

9305 maritimus $\mathrm{Sm}$.

yellow-flowered

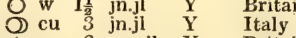

1548. S r.m Lam.ill. t. 566

1548. S r.m

1548. S r.m

1548. S r.m

1548. S r.m

1815. S co Linn, dec. 3. t. 10

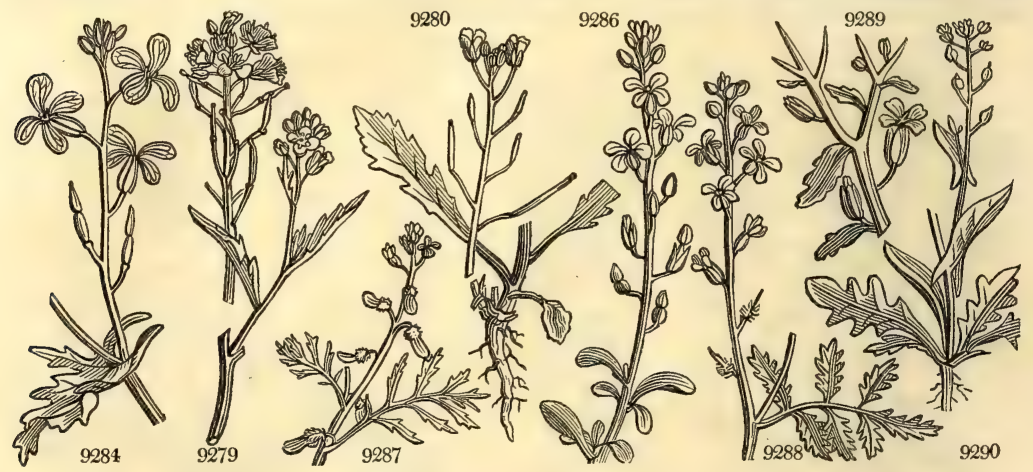

History, Use, Propagation, Culture,

1436. Enuca. The meaning of this word is involved in obscurity. According to Isidore, of Seville, a learned Spaniard, who died in 636, and left a book of etymologies, cruca is an alteration of urica, derived from uro, to burn. From eruca, the Italians formed ruchetta, the French roquetta, and the English rocket. E. sativa is very pungent in the foliage, and is used as a salad in the South of Europe for its aphrodisiacal powers :

"Excitat ad venerem tardos Eruca maritos."

1437. Vella. Latinized from valer, the Gallic name of the cress. A pretty low shrub, with beautiful yellow fowers appearing in the early spring. It is hardy enough to live through the winter in a dry warm south border.

1438. Carrichtera. An unexplained name, first used by Adanson. A small annual plant, with pinnated leaves, and long erect racemes opposite to the leaves. Flowers small, pale yellow.

1439. Succowia. In honor of Professor Suckow, a learned botanist of Heidelberg. An annual, with the habit of the last, from which it differs in its subulate style and solitary seeds.

1440. Zilla. The Egyptian name of the plant, which is a large glabrous herb, with round white branches and oblong toothed leaves, which are boiled and eaten by the Arabs like those of cabbage.

1441. Calepina. A name used by Adanson, the meaning of which is unknown. This plant has been transferred by one author or another to almost every genus of Siliculosæ, but appears to be really akin to Crambe only, from which it differs in its sessile and purely unilocular silicle, in its stamens having no teeth, and in the outer petals being larger than the others.

1442. Crambe. One of the names applied by the Greeks to the cabbage, and especially to the marine cabbage. C. maritima grows on sandy shores in the west of England, and there the common people have from time immemorial been in the practice of watching when the shoots and leafstalks begin to push up the sand 
9278 Pods sess, nearly erect, Style roundish 1-2-seed. Lvs. pinnatif. with cut lobes and lin. sinuate toothed segm. 9279 Pods somewhat stalked erect, Style filif. short without seeds, Upper lvs. entire lower pinnatifid compound 9280 Pods sess. erect, Style short somew. filif. Rad. Ivs. toothed or lyrate smooth, Stems nearly naked ascending 9281 Pods sess, erect, Style short somew. filif. Rad. lvs. runcinate toothed hispid, Stems naked erect 9282 Pods sess. erect, Style short somew. filif. Rad. lvs. lyrate very blunt smooth, Stems naked decumbent 9283 Pods sess. erect narrowed at base, Style short conical, Rad. Ivs. pinnatifid thickish with entire lobes

9284 Lvs. lyrate pinnated with toothed acute lobes, Stem hirsute, Pedicels shorter than deciduous calyx 9285 Lvs. pinnatifid, Lobes acute nearly entire, Stem hirsute, Calyx persistent somewhat bladdery

\section{The only species '}

9287 The only species

9288 The only species

9289 The only species

9290 The only-species

9291 Long filaments forked, Pod blunt, Leaves roundish sinuated wavy toothed glauc. and stem quite smooth 9292 Long filaments forked, Pod blunt, Leaves pinnatifid with obl. acute toothed lobes, Stem smooth

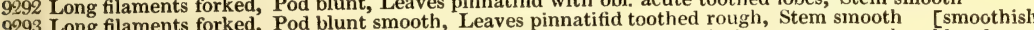
9293 Long filaments forked, Pod 9294 Long filam. forked, Pod blunt, Rad. lvs. decompon pinnated with obl. lin. toothed lobes and stem rough

9295 Long filam. forked, Pod blunt rugose, Lvs. pinnated with obl. lin. toothed lower cord.; upper ov. and stem nearly smooth 9296 Long filam. forked, Pod nearly blunt, Lvs. stalked toothed : lower cord.; upper ov.

9297 Long filam. toothed, Pod blunt, Lvs. lyrate rough, Terminate hairy, Terminal lobe ovate

0299 Long filam toothed on one side, Pod mucronate, Lvs. lyrate pinnatifid toothed hoary

9300 Filam. not toothed, Pod mucronate, Lvs. ov. toothed unequal and somew. auricled at base and stem hispid

9301 Pods round torose acuminate scarcely longer than stalk

9302 Pods depressed acuminate decumbent longer than the whole plant

9302 Pods depressed acuminated

9304 Pods 1-celled jointed substriated 2-6-seeded longer than the subulate style, Lvs. interruptedly lyrate

9305 Pods 1-celled jointed striated 2-6-seeded, Style conical shorter than the last joint, Lvs. interrupted. lyrate

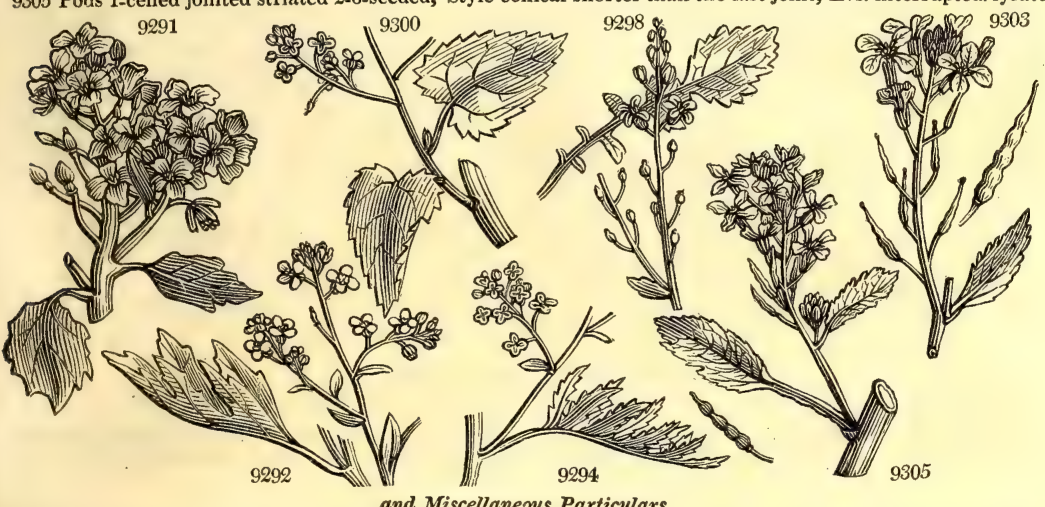

and gravel, in March and April ; when they cut them off under ground, as is done in gathering asparagus, and boil them as greens. About the middle of the last century the plant was first introduced into gardens, grown on deep sandy soil, and blanched either by sand, ashes, litter, or by covering with flower pots, earthen pots made on purpose, or any opaque cover. It is now almost as universal in good gardens as asparagus, and like it is forced either by taking up the roots and planting them on a hotbed, or in the border of a forcing house, or by covering or surrounding them with litter in the open garden. Before covering a bed with warm litter, each plant or stool of plants is covered with an earthenware blanching pot, or a wicker case, to keep off the dung from the young shoots, and to ensure their being blanched. No plant is so easily forced; and, unlike asparagus, it yields produce the first spring after raising from seed.

C. tataria is called by the Hungarians Tatar-Kenyer or Tartarian bread, and its root, stripped of the bark and sliced, is eaten with oil, vinegar, and salt. The boiled root is sweet, and eaten by children. The young shoots are boiled like those of sea kail, and have an excellent taste, but are stringy, which they would not be if well cultivated, which the plant appears to deserve.

1443. Raphanus. From $\rho \alpha$, quickly, and $\varphi \propto$ жорех, to appear, on account of the rapidity of its germination and arriving at perfection. $R$. sativus is a well known salad root, requiring a deep sandy soil to attain a large size. There are several varieties both of the spindle-shaped and globular rooted kinds, and a very distinct sort known as the black or Spanish radish. In the Horticultural Transactions, sixteen varieties are mentioned besides subvarieties, arranged as spring, summer, turnip, autumn, and winter radishes. They are all of easy culture, and the spring, summer, and turnip sorts force well on hot-beds, or on dung-beds covered with mats.

R. caudatus, or tree radish, is remarkable for the length of its pod, which is greater than the whole height of the plant. The young leaves of $\mathbf{R}$. Landra are eaten by the inhabitants of Insubria as salad. 


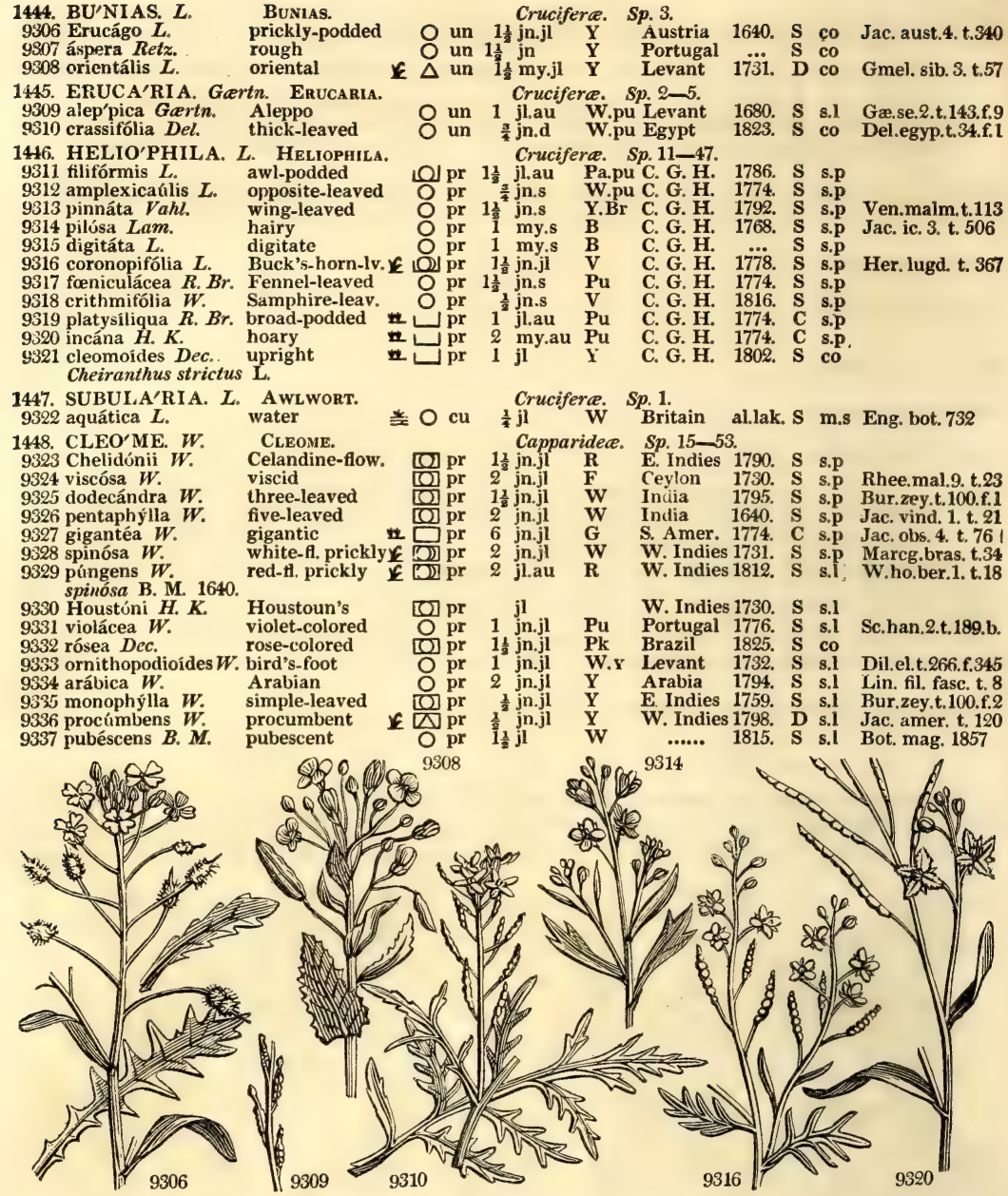

1444. BUNIAS. $L$

9308 orientális $\boldsymbol{L}$.

rickly-podded

145. ERUCA'RIA Gertn ERUCARIA

9310 crassifólia Del. thick-leaved

1446. HELIO'PHILA.

9312 amplexicanlis $\boldsymbol{L}$. opposite-leaved

9315 digitáta $L$

(ia

hair

n 1 pr 2 my.au

C. G. H. 1774. C s.p

C. G. H. 1774. C s.p

1447. SUBUI AwLwORT

9322 aquática $\boldsymbol{L}$. water

Crucifera. Sp. 1

1448. CLEO'ME. $W$

9323 Chelidónii $\boldsymbol{W}$

9324 viscósa $W$

ecándra $W$

27 pentaphylia

9328 spinósa $W$.

9329 púngens $W_{\dot{\mathbf{M}}} \mathbf{1 6 4 0}$

9330 Houstúni $\boldsymbol{H} . \boldsymbol{K}$.

9331 violácea $W$.

9334 arábica $W$

Arabian

simple-leaved

pubescent

$\frac{1}{2}$ jn.jl

jn.j 1

ridece. Sp. $15-53$

O pr $1 \frac{1}{3}$ jn ji $\mathbf{R} \quad$ E. Indies 1790. S s.p

India 1640. S s.p Jac. vind. 1. t. 21

W. Indies 1731. S s.p. Marce.bras.t.34

W. Indies 1730 . S s.I

s.t Sc.han.2.t.189.b.

Y Arabia 1794, S s.l Lin fil fasc. t. 8

W 1815, S s.l Bot.... 1857

History, Use, Propagation, Culture,

1444. Bunias. From byyos, a hill, because the plants grow upon exposed open situations. Linn.

1445. Erucaria. See Eruca, No. 1437. Plants with the habit of Cakile.

145. Erucaria. See Eruca, No. 1437. Plants with he hes a plant loving heat. All the species dry hot plains at the Cape of Good Hope. These are mostly beautiful annual or perennial plants. 
9306 Pods 4-cornered : angles crested, Radical leaves runcinate 9307 Pods 4-cornered: angles crested, Leaves all lanceolate 9308 Pods ovate 2-celled not crested somewhat warted

9309 Pod style-bearing, Lvs. pinnated, Lobes linear : of the lower pinnatifid ; of the upper entire 9310 Stigma sessile, Beak longer than pod, Lvs. pinnated thick, Lobes linear

9311 Smooth, Pods rounded narrowed at each end, Leaves linear subulate

9312 Smooth, Pods moniliform, Lower lvs. opp. : upper altern. cord. stem-clasping obl. entire

9313 Smooth, Pods moniliform pendulous, Lvs. pinnated in 3-5-pairs, Lobes linear entire

9314 Hispid, Pods linear, Lvs. hairy either linear entire or trifid at end and cuneate at base

9315 Hispid, Pods linear, Lvs. oval entire or here and there coarsely cut-toothed

9316 Smooth, Pods linear, Leaves pinnated, Lobes and rachis linear entire

9317 Downy, Pods linear spreading, Lvs. pinnated or bipinnated : lobes filiform

9318 Velvety, Pods linear nodding, Lvs. pinnated somewhat fleshy : lobes subfiliform furrowed above 9319 Smooth, Pods linear erect or pendulous, Lvs. fleshy half round

9320 Pods linear compressed velvety, Style thick conical smooth, Leaves oblong

9321 Pods compressed stalked, Leaves linear lanceolate

9322 The only species

9323 Polyandrous hairy, Lvs. 5-7 cuneiform rough, Racemes term. Pods filiform 9324. Flowers dodecandrous, Leaves quinate and ternate

9325 Flowers dodecandrous, Leaves ternate

9326 Flowers gynandrous, Leaves quinate, Stem unarmed

9327 Flowers hexandrous, Leaves 7, Stem unarmed

9328 Flowers hexandrous, Leaves 7-5, Stem spiny

9329 Flowers hexandrous, Leaves quinate viscid, Stem spiny

9330 Prickly hexandrous, Leaves quinate and ternate : floral simple, Stigma dilated

9331 Flowers hexandrous, Leaves ternate and solitary, Leaflets lanc lin. entire

9332 Unarmed, Lvs. 5 : lower and foral 3; upper sessile ovate, Pod smooth as long as its stalk

9333 Flowers hexandrous, Leaves ternate, Leaflets oval-lanceolate

9334 Flowers hexandrous, Leaves ternate lanceolate blunt, Pods fusiform viscid

9335 Flowers hexandrous, Leaves simple ovate-lanceolate stalked

9336 Flowers hexandrous, Leaves simple lanceolate stalked, Stems procumbent

9337 Unarmed pubescent, Leaves 5-7 : floral simple cordate, Pod the length of the stalk

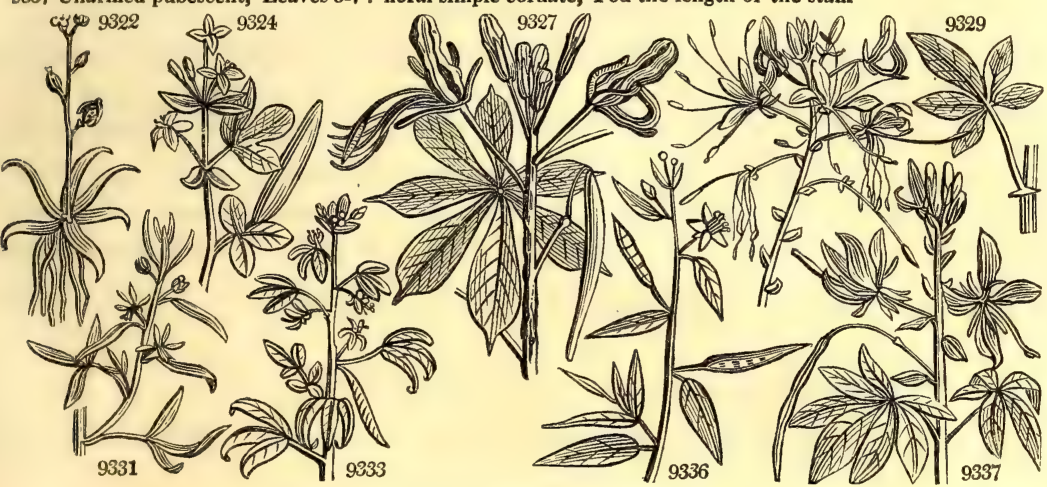

and Miscellaneous Particulars.

1447. Subularia. From subula, an awl, on account of the form of the leaves. A curious little aquatic, not of common occurrence.

1448. Cleome. A name employed by Octavius Horatius, a Latin physician, who lived in the fourth century, to designate a plant resembling Sinapis, and growing in humid places. It appears to have had no relation to
the modern plant. 


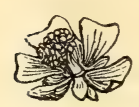

\section{Class XVI. - MONADELPHIA.}

THIs class is distinctly characterized by the filaments being united together throughout the whole or a part of their length; and for the most part consists of plants belonging to the natural orders of Malvaceæ and Geraniaceæ. Of the former, the major part are of little moment, consisting, in a great measure, of weeds or worthless shrubs of various parts of the world. Among them, however, are some plants both of interest and ornament, especially the beautiful Astrapæa, and the various species of Bombax and Hibiscus. The Gossypium, so important as producing the material of cotton, and the Adansonia or Baobab tree of Africa, remarkable for its immense size and use as an article of food, are found in this class. The Geranium, Camellia and Passion fiower are also genera of much beauty ; the latter yielding the well known West Indian fruit called the Granadilla. The common Tamarind, with which this class commences, would more properly be placed in the next, and the succeeding genera of Patersonia, Tigridia, Ferraria, and Galaxia, are in every respect, except the union of their filaments, referable to the third class.

\section{Order 1. TRIANDRIA. Stamens 3.}

1449. Tamarindus. Petals 3, ascending. Three filaments longer than the others and fertile. Legumen 1-3-celled, pulpy inside.

1450. Patersonia. Cor. tubular. Limb 6-parted, with 3 small segments. Caps. 3-celled, inferior.

145.l. Ferraria. Spatha 2-leaved. Cal. O. Petals 6, wavy, curled. Filaments united at base. Style 1. Caps. 3-celled, inferior.

1452. Tigridia. Spatha 2-leaved. Cal. O. Petals 6, the 3 outer large. Filaments united into a very long tube.

1453. Galaxia. Spatha 1-leaved. Cal. O. Corolla monopetalous, 6-cleft, with a long tube. Style 1. Capsule 3-celled, inferior.

Order 2. PENTANDRIA. Stamens 5.

1454. Waltheria. Cal. 5-fid, with a lateral deciduous 3-leaved involucre. Petals 5. Style 1. Stigma pencilled. Caps. 1-celled, 2-valved, 1-seeded.

1455. Hermannia. Cal. nearly naked, campanulate, 5-fid. Pet. 5. Stamens 5. Filaments united at base, lanceolate, frequently winged. Styles 5 , cohering in one. Caps. 5-celled, 5 -valved, many-seeded.

1456. Melochia. Cal. 5-fid, naked, or with 1-3 bracteæ. Petals 5, spreading. Stam. 5, monadelphous at base. Styles 5. Caps. 5-celled. Seeds 1-2 in each cell.

1457. Melhania. Cal. 5-parted, persistent, with a 3-leaved involucre on one side. Pet. 5. Stam. 10, alternately sterile : the fertile ones bearing from 1-2 anthers each.

1458. Ochroma. Cal. double, outer 3-leaved. Petals 5. Anthers anfractuose. Capsule 5-celled, manyseeded. Seeds involved in wool.

1459. Passiflora. Cal. 5-parted, colored. Petals 5 or $\mathbf{O}$, inserted in the calyx. Crown of many filiform rays. Fruit stalked, fleshy.

1460. Erodium. Cal. 5-leaved. Petals 5. Scales 5, alternate, with filaments and honey glands at the base of the stamens. Cocci 5, 1-seeded, awned, at the base of a rostrate receptacle.

\section{Order 3. HEPTANDRIA.}

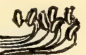

Stamens 7.

1461. Pelargonium. Cal, 5-parted, the upper segment ending in a nectariferous tube running down the peduncle. Cor. 5-petalous, irregular.

Order 4. OCTANDRIA.

Stamens 8

1462. Aitonia. Cal. 4-parted. Cor. 4 petals. Style 1. Berry dry, quadrangular, 1-celled, many-seeded.

Order 5. DECANDRIA.

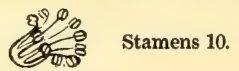

1463. Geranium. Cal. 5-leaved. Petals 5, regular. Glands 5, honey-bearing, united to the base of the longer filaments. Cocci 5, 1-seeded, awned, at the base of a beaked receptacle.

\section{Order 6. DODECANDRIA.}

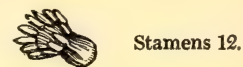

1464. Brownea. Cal, tubular, bifid. Cor. double : outer 5-fid; inner of 5 petals. Legumen 1-celled.

1465. Monsonia. Sepals 5. Pet. 5. Stamens 15, united; their cup 5-fid. Style 5-fid. Cocci 5, 1 -seeded awned, at the base of a beaked receptacle.

1466. Helicteres. Cal. tubular, obliquely 5 -fid. Petals 5. Germen on a long stalk. Style about 5-fid. Caps. 5 , 1-celled, many-seeded, spirally twisted.

1467. Dombeya. Cal. double, outer 3-leaved, deciduous. Petals 5. Stamens 20 , of which 5 are sterile.

Style 5-fid. Caps. 5, united, 1-celled, 1-many-seeded.

1468. Pentapetes. Cal. double, outer 3-leaved, deciduous. Petals 5. Stamens 20, of which 5 are barren. Style obsoletely 5-toothed. Caps. 5-celled, many-seeded, with contrary dissepiments.

1469. Astrapaa. Flowers umbellate, with an involucre. Involucre many-leaved, unequal. Cal. simple, 5-leaved, with 1 bract. Petals 5, convolute-closed. Stamens 25, united into a tube bearing the corolla : 5-sterile.

1470. Pterospermum. Cal. simple, 5-parted. Petals 5. Stamens 20, of which 5 are sterile. Style cylindrical, Stigma thickish, Caps, woody, 5-celled. Seeds winged. 
Order 7. POLYANDRIA. Stamens indefinite in number.

14/1. Malope. Cal. double, outer 3-leaved. Capsules heaped without order, 1-seeded.

1472. Malva. Cal. double, outer 3-leaved. Capsules many, 1-seeded.

1473. Kitaibelia. Cal. double, outer 7-9-fid. Caps. clustered in a 5-lobed head, 1-seeded.

1474. Althaea. Cal. double, outer 6-9-fid. Capsules many, 1-seeded.

1475. Lavatera. Cal, double, outer 3-fid. Capsules many, 1-seeded.

1476. Malachra. Common calyx 3-leaved, many-flowered, large. Caps. 5 , 1-seeded.

1477. Urena. Cal. double, outer 5-fid. Capsule 5-celled, 5-partible, with close 1-seeded cells.

1478. Pavonia. Cal. double, outer many-leaved. Stigmas 10. Capsules 5, 2 -valved, 1-seeded.

1479. Achania. Cal. double, outer many-leaved. Cor. convolute, closed. Stigmas 10. Berry 5 celled,

5-seeded.

1480. Hibiscus. Cal. double, outer many-leaved. Stigmas 5. Capsule 5-celled, many-seeded.

1481. Gossypium. Cal. double, outer 3-fid. Caps. 5-celled. Seeds enwrapped in wool.

1482. Redoutea. Cal. 5-parted, surrounded by a 10-12-leaved involucre. Stigmas 3. Capsules 3-celled, 3-valved, many-seeded, with three placentas alternate with the valves, and bearing on each side woolly seeds.

1483. Palavia. Cal. naked, 5-fid, Capsules many, 1-seeded, united in a head without order.

1484. Cristaria. Cal. naked, 5 -fid. Fruit orbicular, depressed, covered with a skin, and consisting of several carpella, 2-winged in the centre, and many-seeded.

1485. Anoda. Cal. naked, 5-fid. Lobes acuminate, much spreading in fruit. Caps. hemispherical beneath, depressed and stellate above, many-celled, with 1-celled, 1-seeded divisions.

1486. Periptera. Cal. naked, 5 -fid. Petals erect, spirally twisted in the tube, at length distinct. Capsule stcllate, many-celled, with 1-seeded cells.

1487. Sida. Cal, simple, angular. Style many-parted. Capsules several, 1 or 3-seeded.

1488. Laguncea. Cal. simpie, 5-fid. Style 5-fid. Capsule 5-celled, with contrary dissepiments.

1489. Ruizia. Cal. double, outer 3-leaved. Styles 10. Caps. 10,1-celled, 2-seeded, closely cohering.

1490. Carolinea. Cal. simple, subtruncate. Filaments branched. Style very long. Stigmas 6. Caps. woody, 1-celled, manv-seeded.

1491. Adansonia. Cal, simple, deciduous. Style very long. Stigmas many. Caps, woody, 10-celled, manyseeded, with a farinaceous pulp.

1492. Bombax. Cal, 5-fid. Stamens 5, or many. Caps. woody, 5-celled, 5-valved. Seeds woolly. Receptacle 5-cornered.

1493. Myrodia. Cal, naked, tubular, 4-5-toothed, bursting laterally. Petals oblong, linear. Stamens with a long column. Anthers 10-15. Capsule drupaceous, 2-3-celled, with 1-seeded cells.

1494. Gordonia. Cal. simple. Style 5-cornered, with a 5-fid stigma. Caps. 5-celled. Seeds twin, with a leafy wing.

1495. Stuartia. Cal. simple, rotate. Petals 5. Styles 5, united or distinct. Caps. 5-celled, 5-valved. Seeds solitary or twin.

1496. Camellia. Cal, imbricated, many-leaved, the inner leaflets largest.

1497. Barringtonia. Cal. 2-leaved, superior. Petals 4. Drupe dry, large, quadrangular, with a 4-celled ut.

1498. Gustavia. Cal. 4-6-fid. Petals 4-6. Berry dry, 4-5-celled.

1499. Careya. Cal. superior, 4-fid. Petals 4. Berry many-seeded. Seeds nestling in pulp. 
TRIANDRIA.

1449. 'TAMARIN'DUS. $W$. TAMARIND TREE.

9338 indica $W$.

1450. PAterso'nia. $R$. Br. Patersonia

1451. FERrA'RIA. Ker. Ferraria.

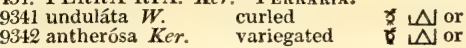

1452. TIGRI'DIA. $J$. TIGER Flower.

9343 Pavónia P.S.

ß leóna Hort.

1453. GALAX'IA. $W$ 9344 ováta $W$.

$\beta$ grandiflora B. R.

mucronutáris Sal.

$\gamma$ mucronularis

9345 graminea $W$.
Trger whole-colored $\Varangle \Delta$ or

Galıxia. oval-leaved great-flowered mucronated various-colored narrow-leaved
Leguminosa. Sp. 1.

Iridea. $S p .2-7$. N. W. 1803. R s.p Bot. mag. 1041 $\triangle$ J or $1 \frac{1}{2}$ my.jl Pu N. S. W. 1814. C s.p Bot.reg. 51

Iridea. $S p, 2-4$.

mr.ap G.Br C. G. H. 1755. O s.p Bot. mag. 144 mr.jl G.Br C. G. H. 1800. O s.p Bot. mag. 751

Iridea. Sp. $1-2$

my.s O.R Mexico 1796. O s.p Bot. mag. 53

my.s O.R Mexico 1823. O s.p

Iridea. $S p .2-3$.

my.s D.Y C. G. H. 1799 s.p Bot. rep. 94

mys D. C G. H 1799.

my

my.s

C. G. H. 1799

jl.au L.Y C. G. H. 1795 . s.p Bot. rep. 94

s.p J.ic. t.291.f.in.si

s.p Jac. f. inf, dextr.

s.p Bot. mag. 1292

\section{PENTANDRIA.}

1454. WALTHE'RIA. W. Waltheria. 9346 americána $W$ 9347 indica $W$.

9348 elliptica $W$ 9349 læ'vis Schrank.

Indian woolly smooth
Byttneriacec. $\quad S p .4-12$.

E D) un 2 my.o $Y$ S. Amer. 1691. C I.p Jac. ic. 1. t. 130 Un 9 jn.au $\mathbf{Y}$ E Indies 1799. $\mathrm{Y}$. $\square$ un 3 ... $\quad$ Y $\quad$ E. Indies 1812 C s.p Ca.dis,6.t.171.f. w $\square$ un 3 jI $\cdots$ Y Guadalou.1823. C s.p Schrank mon.55 9350 althæifólia $W$. 9351 plicáta $W$. 9352 glandulósa $\operatorname{Link}$. 9353 cándicans $W$. 9354 disticha $W$ 9354 disticha $W$. 9355 salvifólia $W$
9356 mícans $W$.

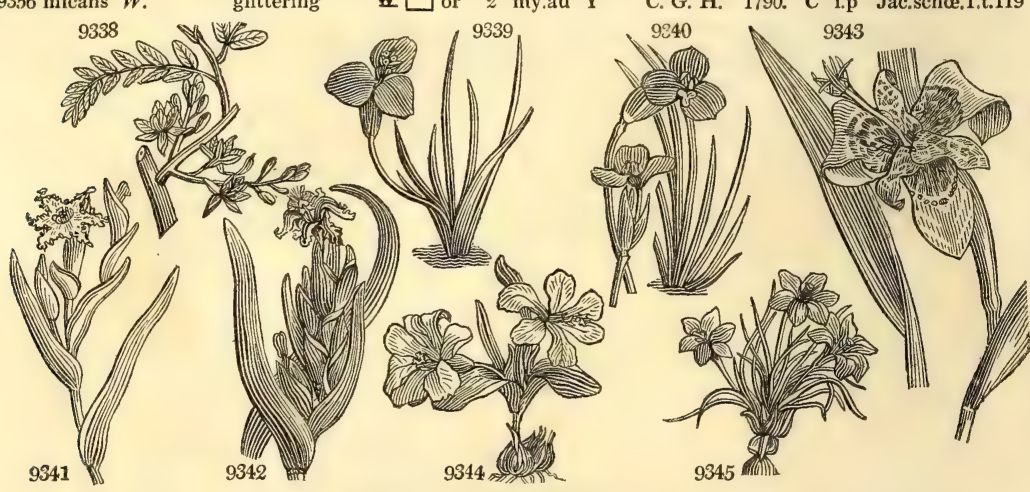

History, Use, Propagation, Culture,

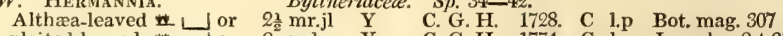
plaited-leaved ${ }^{2}$ or 2 .d Y C. G. H. 1774. C 1.p Jac.schœ.2.t.213 glandular white round-leaved or 2 my.au Y C. G. H 1789. C l.p Jac.scho.1.t.118 Sage-leaved or 2 ap.jn Y C. G. H 1795. C I.p Ca.dis.6.t.180.f.2 $\begin{array}{lllll}\text { glittering } & \text { or } 2 \text { my.au } & \text { Y } & \text { C. G. H. 1790. C 1.p Jac.schœ.1.t.119 }\end{array}$

1449. Tamarindus. Latinized from the Arabic name Tamer-hindy, or Indian date. This tree is a native of the East and West Indies, of Arabia, and Egypt. It is a large beautiful spreading tree The leaves are , sixth of an inch hroad, of a bright green color, downy, oblong, entire, and obtuse : the flowers are in loose bunches of five or six, which come out from the sides of the branches: the calyx is of a straw yellow color, and deciduous: the petals also yellowish, and beautifully variegated with red veins; ovate, concave, acute, indented, and plaited at the edge; and the filaments purplish, bearing incumbent brownish anthers : the pods are thick, compressed, and of a dull brown color when ripe: those from the West Indies from two to five inches long, with two, three, or four seeds : those from the East Indies are twice as long, and contain five, six, or seven seeds : the seeds in both are flat, angular, shining, and lodged in a dark pulpy matter.

In the West Indies, the pods are gathered in June, July, and August, when fully ripe; and the fruit betng freed from the shelly fragments, is placed in layers in a cask, and boiling syrup poured over it, till the cask is filled; the syrup pervades every part quite down to the bottom; and when cool the cask is headed for sale. (Long's Jamaica, iii. 729.) The East India tamarinds are darker colored and drier, and are said to be preserved without sugar. Tamarinds are inodorous, and have an agreeable acid sweetish taste. The acid taste chiefly depends on the citric acid, the quantity of that being greater than of the other. The pulp is refrigerant, and gently laxative. The simple infusion of the pulp in warm water, or a whey made by boiling it in milk, forms a very grateful refrigerant beverage, which is advantageously used in febrile diseases. The dose of the simple fruit required to act upon the bowels is so large, that it is seldom given alone as a purgative, but is generally combined with cassia or manna, the action of which it augments, or with such of the neutral purgative salts as are not decomposed by it; which is the case with those that have potass for their base, and are therefore incompatible in mixtures with this fruit. (Thompson's London Dispensatory, 534.)

The plants thrive in loam and peat, and root under a glass in sand. They form handsome objects, but in our stoves are seldom allowed sufficient room to flower. Miller says, he had several plants twenty years old, and upwards, of fifteen feet high, which never had shewed blossoms. 
TRIANDRIA.

9338 The only species

9339 Stigma deflexed, Scape and spathes silky, Leaves ensiform straight striated

9340 Stigma deflexed, Scape and spathes smooth shining, Keel of leaves woolly at base

9341 Stem branched. Leaves equitant ensiform equal wavy ; inner twice as narr w as the outer 9342 Stem simple, Leaves equitant ensiform; lower narrow

9343 Stem simple wavy, Leaves ensiform nerved, Petals flat; inner small panduriform

9344 Almost stemless, Leares oblong, Spathe 1-valved 1-flowered

9345 Almost stemless, Leaves linear filiform dilated at base, Spathe 1-valved 1-flowered

\section{PENTANDRIA.}

9346 Leaves oval plicate acutely and unequally toothed downy, Heads stalked

9347 Leaves oval plicate bluntly toothed downy, Heads sessile

9348 Leaves lanceolate oblong blunt plicate toothed downy, Heads sessile

9349 Leaves ovate mucronate serrate and stem quite smooth, Heads stalked, Calyxes ciliated

9350 Leaves ovate downy plicate crenate, Lower stipules ovate ; upper broad lanceolate, Cal. angular 9351 Lvs. downy hairy ovate subcord. rugose denticulate, Stipules ovate acute, Cal. in fl. cylind. finally inflated 9352 Leaves oval unequally crenate subpubescent, Stipules ovate acute often cut, Stem glandular pubescent 9353 Leaves whitish downy round ovate crenate, Stipules lanceolate subulate, Cal. campanulate spreading $935 \pm$ Leaves hispid-villous roundish-ovate blunt toothed, Stipules subovate acuminate, Cal. angular

9355 Leaves downy hispid rugose oblong blunt entire subsessile, Stipules long lanceolate subulate, Fls. naked 9356 Lvs. downy hispid somew. rugose obl, very blunt a little toothed at end with short stalks, Stip. lanc.subul.
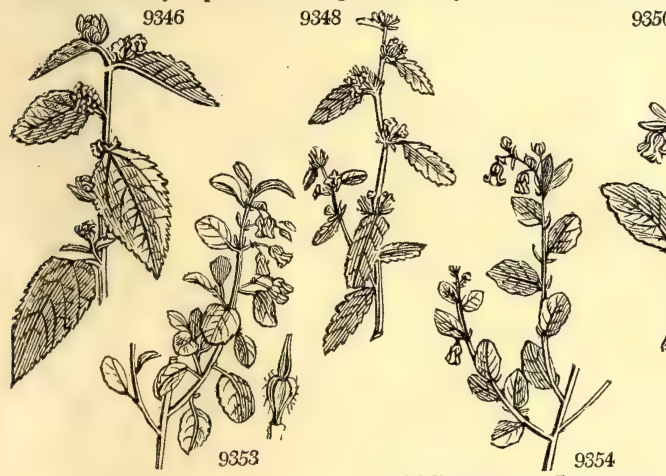

and Miscellaneous Particulars.

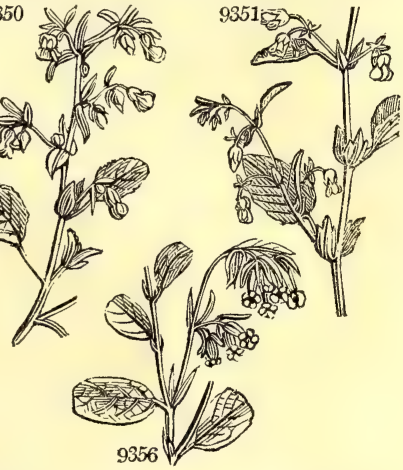

1450. Patersonia. Named after Colonel William Paterson, a gentleman whose remarks on the Cape of Good Hope, New Holland, and Norfolk Island, have been of much service to botany. Handsome plants, which grow readily in loam and peat, and are increased like other herbaceous vegetables.

1451. Ferraria. Named after Jean Baptiste Ferrari, an Italian botanist, author of a work on the culture of flowers, published in 1633, \&c. According to Sweet, " a mixture of sandy loam and peat is the best soil for the species, and they should be kept without water, after they have done growing, till they begin to grow again, when they may be planted in fresh pots and regularly watered: they are increased by offsets from the bulbs, or by seeds." (Bot. Cult. 192.)

1452. Tigridia. In allusion to the spotted flowers, which are marked something like the skin of a tiger. Splendid plants, and tolerably hardy. They do best when planted in the soil and protected by a frame or hand-glass; but will also thrive in sheltered borders, provided they are protected from the winter's frost. They ripen seeds, from which, or from offsets, they may be readily increased.

1463. Galaxia. Thunberg, the author of the name, has not explained its meaning. Like other plants of the bulbous kind, these should be kept dry after flowering and seeding. At the return of the growing season, they should be fresh potted, and kept in a cool part of the greenhouse till they are well rooted, when they may be put into a warmer situation and regularly watered. They seed freely.

1454. Waltheria. In memory of Augustin Frider. Walther, professor of medicine at Leipsic; author of Hortus Proprius, 1735. The species grow in any light rich soil, and are readily propagated. They are of no importance.

1455. Hermannia. In memory of Paul Hermann, who practised physic in Ceylon, and at the Cape of Good Hope, and was afterwards professor of botany at Leyden. He was born in 1640, at Halle, in Saxony, and died in 1695. The species are low shrubs, for the most part, with wrinkled leaves and yellow flowers, which they produce in abundance. They grow freely in any light rich soil, and are readily increased in the same soil. 
9357 frágrans Link. 9358 involucráta $W$. 9359 scordifólia $W$. $9360 \mathrm{~mol}^{\prime} \mathrm{lis} W$.

9361 denudáta $W$ 9362 disermæfólia $W$. 9363 alnifólia $W$. 9364 cuneifólia $W$. 9365 holosericea $W$. 9366 decúmbens $W$.en. 9367 hirsíta $W$. 9368 scábra $W$. 9369 multiflóra $W$. 9370 flámmea $W$. 9371 anguláris $W$. 9372 hyssopifólia $W$. 9373 trifurcáta $W$. 9374 odoráta $W$. 9375 lavandulifólia $W$. 9376 filifólia $W$ 9377 trifoliáta $W$. 9378 procúmbens $W$. 9379 grossularifólia $W$. 9380 pulverulénta $\boldsymbol{B} . \boldsymbol{R}$. 9381 incísa $W$

9382 coronopifólia Link. 9383 tenuifólia $B . M$. 9383 tenuifólia $B . M$. slender-leaved 9385 tomentósa $W$. 9386 caracásana $J a c q$. 9387 corchorifólia W.

fragrant

involucred

w or 2 Germander-lv. ${ }^{2}$ or 2 ap.n $\mathbf{Y}$ smooth

simple-flower'd

Alder-leaved wedge-leaved velvet-leaved decumbent

hairy-branched rough-leaved many-flowered flame-flowered angular Hyssop-leaved three-forked sweet-scented Lavender-leav. thread-leaved three-leaved procumbent gooseberry-lvd. powdered cut-leaved
.

L

mr.ap Y

f.my $Y$

$\begin{array}{lll}2 & \text { au.s } & Y \\ 2 & \text { my.jn } & Y\end{array}$

1 my.jn $Y$

2 my.jn $\mathbf{Y}$

3 mr.ap Y

3 mr.my Y

3 jad or

3 ap.my $\mathbf{Y}$

7 ap.jn Str

3 ap.jl B

3 f.o $\mathrm{Y}$

$1 \frac{1}{2}$ my.s $\quad Y$

$1 \frac{1}{2}$ my.au $Y$

my.au $Y$

$1 \frac{1}{2}$ my.jn $Y$

2 ap.my Y

2 my.au Y

2 jn.ji $\mathrm{Y}$

2 jn.jl Y
C. G. H 1822 C

C. G. H. 1791. C 1.p Ca.dis.6.t.177.f.1 C. G. H. 1794. C 1.p Jac.schœ.1.t.120 C. G. H. 1814. C 1,p

C. G. H 1774 C lp Jac.schœ.1. 122 C. G. H. 1795. C 1.p Jac.schœ.1.t.121 C. G. H 1728, C l.p Bot. mag. 299

C. G. H. 1791. C 1.p Jac.schoe.1.t.124 C. G. H. 1792. C 1.p Jac.schœ.3.t.292 C. G. H. 1821. C 1.p

C. G. H. 1790. C 1.p Schr. s. han.1.t.4 C. G. H 1789. C lp Jac sche 1 t 127 C. G. H. 1791. C 1.p Jac.schœ.1.t.128 C. G. H. 1794. C 1.p Bot. mag 1349

C. G. H. 1791. C 1.p Jac.schœ.1.t.126 C. G. H. 1725. C l.p Ca.dis.6.t.181.f.3 C. G. H. 1789. C l.p Jac.schø.1.t.125

C. G. H. 1780. C 1.p

C. G. H. 1732. C 1.p Bot. mag. 304

C. G. H. 1816. C 1.p Jac.schœ.1.t.123

C. G. H. 1752. C 1.p Ca.dis.6.t.182.f.1

C. G. H. 1792. C 1.p Ca.dis.6.t.177.f.2

C. G. H. 1731. C 1.p

C. G. H. 1800. C 1.p Bot. rep. 164

C. G. H. 1806. C 1.p

C. G. H. 1823. C 1.p

$\begin{array}{lllll}\text { C. G. H. } & \text {... } & \text { C } & \text { l.p } & \text { Bot. mag. } 1348\end{array}$

Corchorus-lvd

9388 Eryor.ha

9388 Erythroxylon $H . K$. red-wood

Melanóxylon $H . K$. black-wood

1458. OCHRO'MA. $W$. Ochrova.

9390 tomentósa $\boldsymbol{W}$. en. woolly-leaved 9391 Lagópus W.en., downy-leaved

1459. PASSIFlo'RA. $W$. Passion Flower 9392 serratifólia $W$ 9393 cúprea $W$.

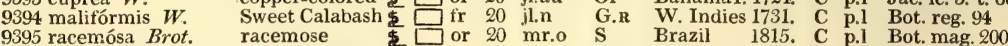

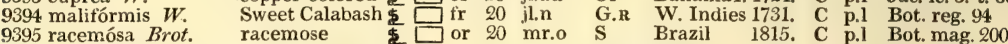
notched-leaved $\$$

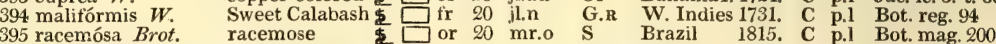

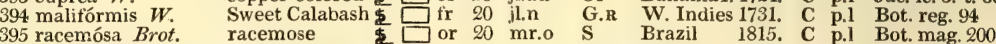

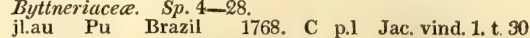
2 my.jn $\mathrm{Pu}$ W. Indies 1768. C p.1 Ca.dis.6.t.172,f.2 my.jn Y Caraccas 1820. C p.l Jacq. ic. 507 Byttneriacece. $S p .2-6$.

甲 $\square$ or 20 my.au W St. Helena 1772. C s.l Bot. mag. 1000

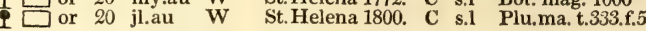

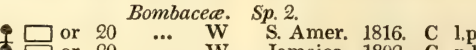
... W Jamaica 1802. C p.1 Cav. dis. 5. t.153 Passiflorea. Sp. 44-95.

or 20 my.o G.Pk W. Indies 1731. C p.1 Bot. mag. 651 9396 quadrangularis $W$. square-stalked $\$$ fr 20 au.s $\quad$ G.B.R Jamaica 1768, S r.m Bot. reg. 14
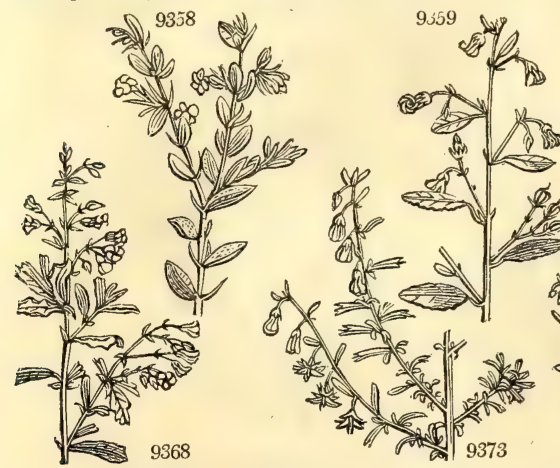

History, Use, Propagation, Culture,

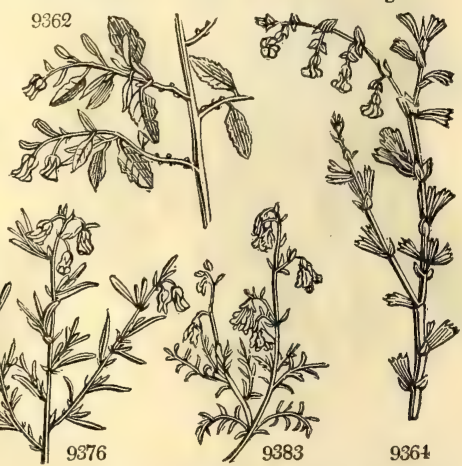

1456. Melochia. According to Forskahl, it is an alteration of the Arabic name melochieh, or melokhieh. Light rich soil suits all the species, and they strike readily in moist heat.

1457. Melhania. A plant which grows upon Mount Melham, in Arabia. Pretty plants, which grow in sandy loam, and root in sand under cover. Sweet observes, that "they are very apt to become covered with insects"

14.58. Ochroma. From wxeos, yellow, the flowers being of that color, according to Schreber. $O$. Lagopus is a very large tree, with divaricating branches, and leaves more than a foot long. The wood is white, tender, and so light, that it is used instead of corks to nets. The capsules contain a very soft fine rufous down, in which the seeds are involved, and which down is said to be used in the manufacture of English beavers. (Desportes Plantes de S. Domingue, iii. 16.)

1459. Passiflora. This genus has been so named, on account of its being supposed to represent, in the appendages of its flower, the passion of Jesus Christ. A beautiful genus of climbers, partly herbaceous, but chiefly suffrutescent or woody ; and all of them exotics and very ornamental. Some species are orloriferous ; others bear edible fruits, fleshy juicy berries of considerable size, though not rich in flavor. Of late, a number of hybrid sorts have been raised, some of which, as P. cæruleo-racemosa, are considered more beautiful than almost any of the natural species.

P. maliformis, the sweet calabash of the West Indies, produces large flowers, red, white, and blue, but of short duration. They are succeeded by fruit, roundish, the size of a large apple, yellow when ripe, having a thicker rind than any of the other sorts; inclosing a sweetısh pulp, in which are lodged many oblong black seeds, of a brownish color, a little rough to the touch. It grows naturally in the West Indies, where the inhabitants call it Granadilla. The fruit is served up there in desserts. It has borne fruit in the garden of the Bishop of Durham in Oxfordshire, and at Vere's, Kensington Gore. (Hort. Trans, iii. 101.)

P. quadrangularis, the Granadilla vine of the French, has leaves five or six inches long, and luxuriant four- 
9357 Leaves stalked oval blunt wavy crenate and stem hairy, Stipules lanceolate

9358 Leaves downy hispid oblong acutish entire subsessile, Stipules lanceolate subulate, Flowers aggregate

9859 Leaves downy beneath oblong blunt crenate stalked, Stipules subulate, Pedic. 1-2-f. Calyxes spreading

9360 Leaves soft with down whitish obl. blunt toothed cuneate at base entire, Pedunc. 2-fl. Cal, campan. velvety 9361 Leaves smooth lanceolate serrate at end acute, Stipules ovate acuminate, Pedic. 2-4-flowered

9362 Leaves white with down lanceolate serrate bluntish wavy at edge, Stipules subul. Pedunc. 1-fl. very short

9363 Leaves smooth broadly obovate cuneiform very blunt crenate emarginate plicate, Stip. lanc. subulate

9364 Leaves pubescent obovate cuneiform truncate emarginate toothed, Stipules ovate acute

9365 Leaves soft whire with down oblong cuneiform rounded at end toothed, Stipules lanceolate

9366 Leaves pubescent downy oblong unequally toothed rounded at each end, Stipules ovate somew. toothed 9367 Leaves beneath white with down oblong obov. cuneiform unequally toothed at end, Stip. $\frac{1}{2}$ cord. acum. 9368 Leaves rough above downy beneath cuneif. obl. unq. toothed entire at base, Stip. half cordate acuminate 9369 Leaves smoothish cuneiform oblong truncate toothed at end, Stipules oblong acute, Racemes few-flow. 9370 Leaves smooth cuneiform lanceolate truncate toothed at end, Calyxes reflexed

9371 Leaves smooth above hairy beneath cuneiform lanceolate truncate toothed at end

9372 Leaves pubescent cuneiform lanceolate blunt toothed at end, Calyx inflated downy

9373 Leaves velvety cuneiform linear blunt entire or 3-toothed at end, Cal. campanulate

9374 Leaves velvety cuneiform lanceolate blunt : upper entire; lower 3-5-toothed at end, Stipules lin. subul. 9375 Leaves velvety lanceolate blunt entire, Stipules linear subulate, Calyxes angular

9376 Leaves smooth rough at edge linear 3-cornered entire, Stipules large lanceolate

9377 Leaves white with down sess. cuneate obcord. somew. crenate at end, Stip. ob!. blunt resembling lat. Ivs.

9378 Leaves smoothish oblong toothed pinnatifid: lower ovate; upper elongate, Stem procumbent

9379 Leaves rough with scattered down linear-cuneiform coarsely toothed, Stipules linear entire

9380 Leaves roughish white bipinnatifid, Pedunc. 2 -flowered very long

9381 Leaves pinnatifid with linear lanceolate entire segments, Petals cut-toothed

9382 Leaves linear pinnatifid fleshy smoothish, Stem pubescent

9383 Leaves pinnatifid with linear entire acute lobes

9384 Leaves ovate lanc. toothed smooth, Pedunc. 5-6-fl. longer than petiole, Branches downy in decurrent lines 9385 Lvs. uneq. sided ovate obl. acutely crenate plaited hoary on each side, Umbels 3.8-fl. longer than petiole 9386 Leaves cordate crenate downy beneath, Fl. capitate subsessile axillary and opposite the leaves

9387 Leaves ovate somewhat lobed serrated smooth, Flowers subterminal capitate sessile

9388 Leaves ovate cordate subpeltate acuminate crenulate beneath downy and reticulated 9389 Leaves cordate entire downy on each side

9390 Leaves cordate somewhat 3-lobed repand subtomentose

9391 Leaves cordate 5-angled somewhat lobed toothletted pubescent beneath

9392 Leaves ovate veiny subserrulate, Petioles with 2 glands, Invol. 3.leaved

9393 Leaves elliptical entire blunt 3-nerved, Petioles without glands, Invol. O

9394 Leaves oblong ovate cordate 3-nerved veiny entire, Petioles with 2 glands, Invol. 3-leaved larger than fl. 9395 Leaves 3 -lobed peltate, Petioles with 4 glands, Flowers terminal racemose

9396 Leaves obl. ovate subcord. entire veiny, Petioles with 6 glands, Stipules roundish ovate, Invol. 3.-leaved

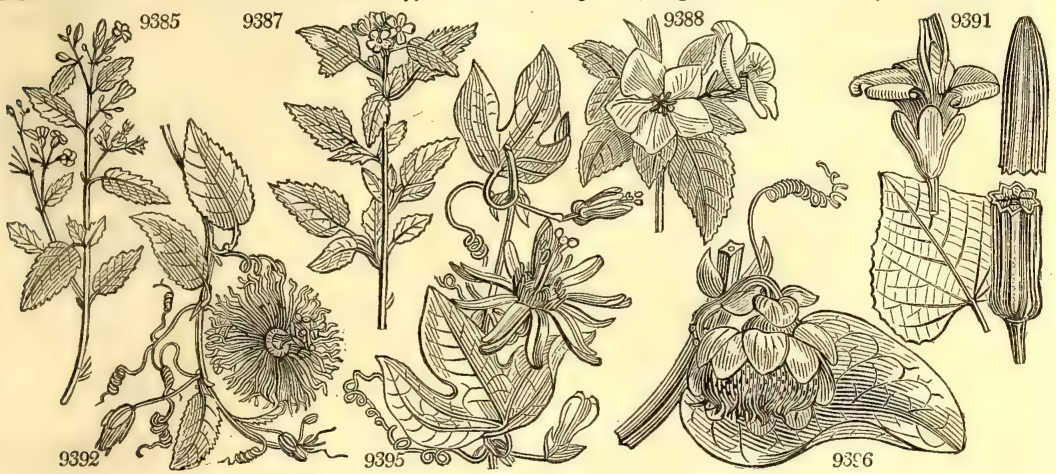

and Miscellaneous Particulars.

cornered ligneous stems. The flowers are red within, and white outside; they are odoriferous, and generally the plant is covered with fruits and flowers at the same time, which makes a fine appearance. The fruit, Sabine describes (Ho, t. Trans. iii. 100.) as very large, of an oblong shape, about six inches in diameter, from the stalk to the eye, and fifteen inches in circumference. It is externally of a greenish-yellow when ripe, soft and leathery to the touch, and quite smooth; the rind is very thick, and contains a succulent pulp of a purple color (which is the edible part), mixed with the seeds in a sort of sack, from which it is readily separated. Wine and sugar are commonly added to it when used. The flavor is sweet and slightly acid, and it is very grateful to the taste, and cooling in a hot climate. It has been successfully cultivated for its fruit in a few places, as at Lord Harewood's, Farnley Hall, \&c. (Hort. Trans, iv. 60.)

P. laurifolia, the water lemon, Pomme de Liane, Fr., has a suffrutescent stem, with divaricating filiform branches, oval smooth leaves, arid very long tendrils. Flowers red and violet, sweet-scented; the fruit about the size of a hen's egg, but rather more elongated, and tapering equally at both ends; when ripe, it is yellow and dotted over with white spots; it contains a whitish watery pulp, which, in the West Indies, is usually sucked through a small hole made in the rind; the rind is tough, soft, and thin; the juice has a peculiar aromatic flavor, is delicately acid, and allays thirst agreeably. It is grown in our stoves, but has not yet been cultivated for its fruit

P. normalis has berries about the size of small grapes. The root has been extolled as a counterpoison and diuretic.

P. Murucuja produces fruit of an oblong oval form, about the size of a large olive, and flesh-colored when ripe. Both the syrup and decoction of the plant are much used in the leeward parts of Jamaica, where it is frequent; and they are said to answer effectually all the purposes for which syrup of poppies and liquicl laudanum are generally administered. The flowers are most in use : they are commonly infused in, or pounded and 
9397 aláta $W$.

9398 laurifólia $W$.

9399 multiflóra $W$

9400 Murucája $W$.

9401 perfoliáta $W$.

9402 rábra $W$.

9403 normális $W$.

9404 lunáta $W$.

9405 Vespertílio $W$.

9406 rotundifólia $W$

9407 punctáta $W$.

9408 lútea $W$.

9409 angustifólia $W$.

9410 al'bida Ker.

9411 pállida $W$.

9412 minima $\dot{W}$.

9413 grácilis Link.

9414 suberósa $W$.

9415 peltáta $W$.

9417 glaúca $W$

stipuláta Aublet.

9418 picturáta Ker.

9419 holoserícea $W$.

9420 hirsúta $W$.

9421 tuberósa $W$.

9422 palmáta Link.

9423 fœ'tida $W$.

9424 rubricaúlis Jacq.

9425 ciliáta $W$

9426 Herbertiána $\mathrm{Ker}$.

9427 adiantifólia B. Reg.

9428 pedunculáris $C$.
9429 edulis $B . M$.
9430 incarnáta $W$.

9431 cærúlea $W$

$\beta$ carúleo-racemósa

$\gamma$ angustifólia

¿ chinénsis

9432 filamentósa $W$.

9433 serráta $W$.

9434 pedáta $W$.

9435 heterophýlla $W$.
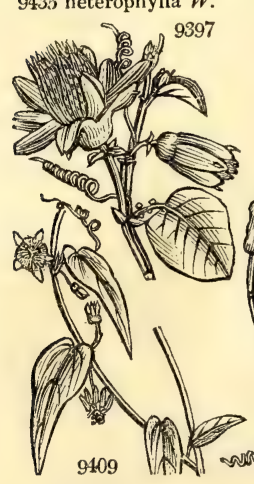

G.B.R W. Indies 1772. C p.1 Bot. mag. 66 G.Pu W.Indies 1690. C p.l Bot. reg. 13

... VeraCruz 1731. C p.l Plum,amer. t.90

S W. Indies 1739. C p.l Bot. reg. 574

Pu W. Indies 1806. C p.1 Bot. reg. 78

R W. Indies 1731. C p.l Bot. reg. 96

VeraCruz 1771. C p.1

Jamaica 1733. C p.1 Bot. mag. 2354

W. Indies 1732. C p.l Bot. reg. 597

W. Indies 1779. C p.I Cav, dis.10. t.290

W.y Peru 1784. C p.1 Bot. cab. 101

Y.W America 1714. R p.l Bot. reg. 79

W W. Indies 1773. C 1.p Bot. reg. 188

W Brazil 1816. C 1.p Bot. reg. 677

Y.a St. Domin. ... C C l.p Bot. reg. 660

W Curassao 1690. C 1.p Bot. reg. 144

W 1823. O co Bot, reg 870

W W. Indies 1759. C p.1 Exot. bot.1. t. 28

G W. Indies 1778. C 1.p Bot. reg. 507

W W. Indies ... C C.p Plum.amer. t.84

W Cayenne 1779. C l.p Bot. reg. 88

\section{Pu Brazils 1820. C 1.p Bot. reg. 673}

W.pu VeraCruz 1733. C p.1 Bot. reg. 59

W W. Indies 1778. C 1.p Bot. cab. 138

G W. Indies 1810. C 1.p Bot. reg. 432

W Brazil 1818. C l.p

W.G W. Indies 1731. S p.1 Bot. reg. 321

$\mathbf{R} \quad$ S. Amer. 1821. S co

Pk Jamaica 1783. C p.l Bot. mag. 288

G N. Holl. 1821. C p.1 Bot reg 737

Or Norfolk I 1790 C pot reg. 737

... Peru 1815. C 1.p Cav. ic. 5. t. 426

W W. Indies ... C C l.p Bot. mag. 1989

Pk America 1629. c r.m Miss Lawr. pass.

W.B Brazil 1699. C s.p Bot. mag. 28

$\mathrm{Pu} \quad$...... 1820. C co Hort. trans.

W.B $\quad \ldots . . .6 \quad \ldots .6$ C co

W.B China $\quad \ldots .$. C co

W.B America 1817.

Chinese or 30 jn.

thready \$

saw-leaved
curl-flowered

various-leaved $\$$ or $15 \quad$...

W.G Martiniq. 1800. C 1.p Plum. amer.t. 79

W.G W. Indies 1781. C p.l Plum. amer.t.81

... W St.Domin.1817. C p.1 Plum. ic. 139. f.1

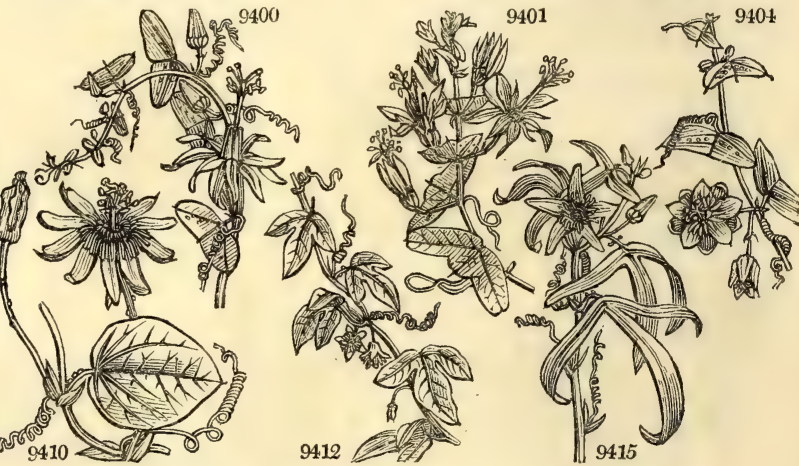

History, Use, Propagation, Culture,

mixed immediately with wine or spirits; and the composition is generally thought a very effectual and easy narcotic.

P. incarnata, the May apple, has a perennial root, herbaceous shoots, and sweet-scented flowers, variegated with purple. The fruit is about the size of an apple, orange-colored, with a sweetish yellow pulp, but it requires the heat of the stove to bring it forward.

P. cærulea is the tallest and most ligneous of the species. The stem will grow almost as large as a man's arm and the shoots will often grow the length of fifteen feet in one summer. The leaves are the most elegant of the genus. The flowers are blue outside, and purple and white within: they have a faint scent, and continue but for one day. The fruit is egg-shaped, of the size and color of the Mogul plum, the yellow skin of which encloses a sweetish disagreeable pulp and black seeds.

Besides the species thus enumerated, some varieties have been procured by cross impregnation, which are very remarkable for their beauty, and for having acquired the hardihood of their parent. The most valuable of these artificial productions, is the $\mathrm{P}$. cæruleo-racemosa raised by Mr. Milne, of Fulham, from seed of $\mathbf{P}$ racemosa impregnated by $\mathbf{P}$. crerulea, and figured in the Transactions of the Horticultural Society, vol. 3. tab. 3., and the P. alato-cærulea, obtained by Mr. J. H. Masters of Canterbury, between P. alata of the West Indies, and P. cærulea.

All the species grow and flower freely in a mixture of loam, and light rich earth or peat, with plenty of room. Most of them fruit in the stove, but the $P$. cærulea seldom fruits in the greenhouse. They are all easily increased either by seeds or very young cuttings, in a close moist heat.

As fruit-bearing plants the Passifloras are thus treated :- "Having procured plants with good roots, plant such as are intended to fruit in a border in the stove, and train them to a trellis near the glass; they will in general produce fruit the second year. The seedlings of the $\mathrm{P}$. incarnata, will produce fruit the first year. All the species will fruit even in large pots ; but Sabine says, the " best method is to plant them in an angle of the bark-bed, which has been parted off, either by boards or brick-work, as low as the pit goes. At the bottom of 
9397 Leaves obl. ovate subcord, ent. veiny, Petioles with 4 glands, Stip. lanc. falcate subserrate, Invol. 3-leaved 9398 Leaves oblong entire veiny, Petioles with 2 glands, Invol. 3-leaved toothed at end

9399 Leaves obl, ent. acute 3-nerved veiny, Petioles with 2 glands, Ped. aggregate axill. FI. apetalous, Invol. O. 9400 Leaves 2-lobed bluntly emarginate, Petioles without glands, Corona campanulate truncate entire

9401 Lvs, cord. 2-lobed blunt mucron. ; up. somew. stem-clasp. Petiol. without glands, Pet. twice as long as cal 9402 Leaves cordate 2-lobed acute mucronate pubescent beneath, Petioles without glands, Fruit obovate

9403 Lvs. 2-lobed emarginate at base, Lobes linear blunt divaricating; the intermediate obsolete mucronate

9404 Lvs. cord. 2-lobed blunt smooth, Petioles without glands, Pedunc. axillary twin, Threads of corona clav. 9405 Leaves cuneiform acuminate divaricating with 2 glands at base, Petioles without glands, Invol, $\mathrm{O}$.

9406 Lvs. round. shortly and bluntly 3-lobed dott. downy ben. Petiol. without glands, Pet. twice as short as cal 9407 Lvs. round. subcord. blunt obsoletely 3-lobed smooth dott. Petioles without glands, Pet. twice as short as cal. 9408 Lvs cord. 3-lobed blunt smooth, Petioles without glands, Pedunc. axill. twin, Pet. twice as narrow as cal. 9409 Lower leaves 3-lobed acuminate; upper undivided lanceolate, Petioles with 2 glands, Flowers apetalous 9409 Lower leaves 3 -lobed acuminate; upper undivided lanceolate, Petioles with 2 glands, Flowers apetalous 9411 Leaves ovate entire 3-nerved veiny, Petioles with 2 glands, Flowers apetalous, Involucrum $\mathbf{O}$.

9412 Lvs. 3-lobed smooth, Lobes lanc.; middle one longest, Petioles with 2 glands, Fl. apetal. Stem corky at base 9413 Leaves subcordate 3-lobed, Lobes rounded with 2 glands, Pedunc. axillary solitary, Flower apetalous

9414 Lvs. 3-lobed smooth, Lobes oblong; lat. very short, Petioles with 2 glands, Fl. apetal. Stem corky at base 9415 Lvs. peltate deeply 3-lobed smooth, Lobes lin. lanc. divaricating, Petioles with 2 glands, Flow. apetalous 9416 Leaves peltate half 3-lobed smooth, Lobes ovate blunt, Petioles with 2 glands, Fl. apetalous

9417 Leaves peltate cordate 3-lobed, Lobes equal oblong blunt, Petioles with 4 glands, Petals length of calyx

9418 Leaves discolored peltate

9419 Leaves 3-lobed downy with a reflexed tooth on each side at the base

9420 Leaves 3-lobed vill, ; lower smooth above, Lobes obl, entire; intermediate longest, Petioles with 2 glands 9421 Leaves 2-lobed glandular beneath, Lobes oblong erect, Peruncles twin

9422 Leaves palmate about 5-parted subserrulate, Involucre 3-leaved entire, Rays a little shorter than corolla 9423 Leaves 3-lobed cordate hairy, Involucres multifid capillary

9424 Leaves and stems all fringed with red hairs

9425 Leaves 3-lobed cordate smooth ciliated serrated, Involucres multifid capillary

9426 Downy, Leaves cordate 3-lobed, Peduncles twice as short as petiole, Corona much shorter than corolla 9427 Lvs, rounded trun. at base slightly 3-5-lobed, Lobes blunt, Petioles without glands, Pet, shorter than cal. 9428 Stem square, Leaves 3-lobed: lobes nearly equal serrated, Pedunc. long 1-flowered 9429 Leaves 3-Iobed serrated smooth, Invol. glandular serrulate caducous, Ovary naked

9430 Lvs. 3-lobed serr. Lobes obl. acute, Petioles with 2 glands, Inv. 3-leaved, Threads of corona longer than cor. 9431 Lvs. palmate 5-parted entire, Petioles gland. Invol. 3-leaved entire, Threads of corona shorter than corolla

9432 Leaves palmate 5-parted serr. Petioles gland. Invol. 3-leaved serrate, Threads of corona longer than cor. 9433 Leaves palmate 7-parted serrated, Petioles glandular, Invol. 3-fid entire

9434 Leaves 7-pedate serrated, Petioles glandular, Invol. 3-leaved serrated

9435 Upper leaves quinate pedate obovate somewhat cut ; lower ternate linear-lanceolate or simple

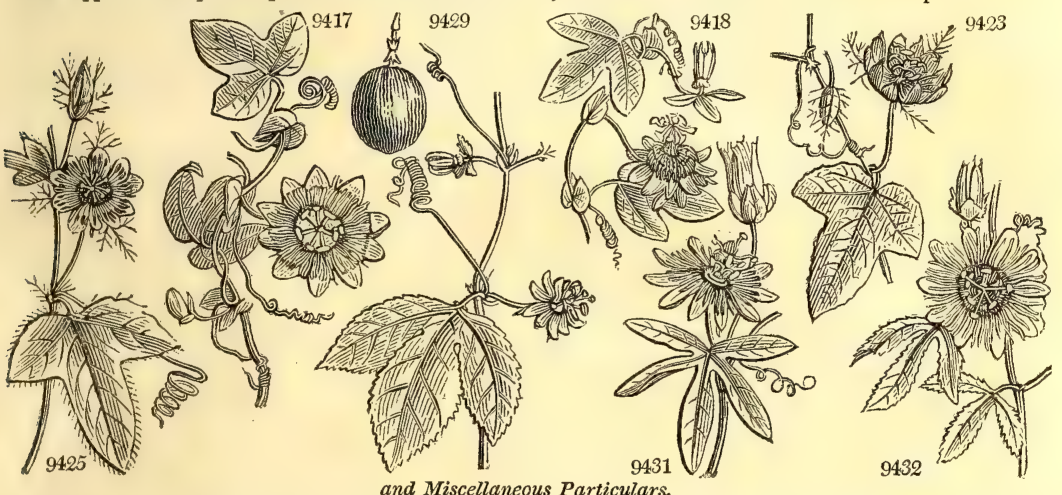

the cavity formed by this division, should be laid some brick-rubbish, over which may be thrown a little dead tan, and the whole be then filled with equal parts of very old tan, and a compost of leaf-mould and rotten dung. Herein the roots will strike freely, and will even spread through the partition into the pit, growing into the fresh tan. Such roots may be trimmed and reduced whenever the tan is changed; but should the plant have been some time in its station, it will be as well to leave part of the old tan in the bottom of the pit, in which the protruded roots may remain undisturbed. They do not require the full heat of the pine stove, for they flourish best in a temperature of from sixty-five to seventy degrees; but they do not bring their fruit to perfection if kept in a common greenhouse or conservatory, though they will grow and flower in it. The shoots, as they advance, must be trained near to and under the inclined glass of the stove: the, flowers will appear in May, and the blooming will continue until September, the fruit setting the whole time; but if it does not set well, it will be advisable to impregnate the stigmas by applying the pollen with a feather. As they grow, the very strong shoots should be cut out from their origin, for these do not bear fruit so abundantly as those which are less vigorous; but the fruiting branches must not be shortened on any account. The temperature must be kept up equally during the time of flowering and fruiting. The crop will begin to come in in August, and will continue until January; but the earlier produce is the best. When the crop is all off; which will be early in January, the heat must be reduced to about fifty degrees, so as to check or stop the growth; this being effected, the shoots must be well cut in. As little old wood as possible, besides the main stem, which rises from the pit to the glass, and a few pieces (about two or three feet of each) of the old. branches should be retained; for all that is to be trained under the glass to bear in each year, ought to be the growth of the same season. It is found that the shoots break better, and in greater quantity, from the older wood than from that of two years' standing. In this dormant and reduced state it is to be lept during January and February, after which the necessary heat may be applied to cause it to resume its functions for the ensuing season." (Hort. Trans. iii. and iv.) 


\begin{tabular}{|c|c|c|c|c|c|c|c|c|c|}
\hline 460. ERO'DIUM. & HeI & & & & & & & & \\
\hline 9436 petræum $W$. & rock & $₫ \Delta \mathrm{pr}$ & $\frac{2}{4} \mathrm{jn} . \mathrm{jl}$ & $\mathrm{Pu}$ & S. Eur & 1640. & $\mathrm{D}$ & co & 21.f.1 \\
\hline 9437 glandulósum $W$. & glandular & $\Delta \mathrm{pr}$ & $\frac{1}{2}$ jn.jl & $\mathrm{Pu}$ & Spain & 1798. & C & l.p & 1.t. 1 \\
\hline $\lim _{x} W$ & A. & $\triangle \mathrm{pr}$ &.$a u$ & $\mathrm{R}$ & Italy & 1814. & D & co & \\
\hline lium $W$. & leaved & $\Delta$ or & mrau & S & rus & 1788. & $\mathbf{R}$ & r.m & Sv \\
\hline n $W$. & lac & $\Delta$ or & & K & Cr & 1794. & $\mathbf{R}$ & r.m & f. 3 \\
\hline$W_{i}$ & long - & un & 4 & $\mathbf{P}$ & S. Europe & 1. & $\mathbf{S}$ & co & 18 \\
\hline $\mathbf{m} \boldsymbol{W}_{\dot{\mathbf{W}}}$ & Hem & 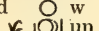 & $\frac{3 \pi}{4}$ & $\mathbf{P}$ & $\mathrm{Br}$ & & $\mathbf{S}$ & co & \\
\hline$u m \mathbf{W}$. & $\begin{array}{l}\text { Numi } \\
\text { Rom }\end{array}$ & & & $P$ & $\mathbf{N}$ & & C & 1 & f. 3 \\
\hline $\begin{array}{l}\text { um } W . \\
\text { fólium } \mathrm{Sw}\end{array}$ & $\begin{array}{l}\text { Roman } \\
\text { Caucalis-leave }\end{array}$ & pr & jn & $\begin{array}{l}\mathrm{Pu} \\
\mathrm{Pu}\end{array}$ & $\begin{array}{l}\mathbf{R} \\
\mathbf{F}\end{array}$ & $\begin{array}{l}1724 . \\
1816 .\end{array}$ & $\begin{array}{l}\text { s } \\
\text { S }\end{array}$ & $\begin{array}{l}\text { co } \\
\text { co }\end{array}$ & \\
\hline um $W$ & musky & pr & my.jl & $\mathrm{Pu}$ & and & m.pas. & $\mathbf{S}$ & s.1 & \\
\hline & leaved & un & $\frac{x}{2}$ jn & $\mathbf{R}$ & $\mathrm{C}$ & 1596. & $\mathbf{S}$ & s.1 & f. 2 \\
\hline$W$. & Chial & un & 1 jn.jl & $\mathrm{R}$ & nt & 4. & 5 & co & f. 1 \\
\hline ódes $W$. & thre & pr & $\frac{3}{4} \mathrm{ja} . \mathrm{d}$ & $\mathbf{P}$ & ary & 9. & $\mathbf{S}$ & r.m & Sweet ger. 23 \\
\hline Tenore. & Go & or & ja. & Pa. & es & 1. & $D$ & co & \\
\hline $\operatorname{les} W$ & $\begin{array}{l}\text { ma } \\
\text { fles }\end{array}$ & or & $\mathrm{n}$ & $\mathrm{F}$ & arope & 1596. & S & co & l.f.2 \\
\hline lum $W$. & & un & $\mathrm{ul}$ & Fl & Egypt & 1732 & & $\begin{array}{l}\text { r.m } \\
\text { co }\end{array}$ & 150 \\
\hline & & 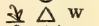 &. $\mathrm{s}$ & Fl & England & & D & co & \\
\hline & dwarf & & 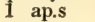 & $\mathbf{Y}$ & M & & & s.l & \\
\hline & & & $\frac{1}{4}$ ap.s & & tope & & & co & \\
\hline & & & j].s & & & & & co & \\
\hline
\end{tabular}

HEPTANDRIA.

1161. PELARGO'NIUM. $W$. STORK's BILL. 9456 longifólium Jacq long-leaved 9457 longiflórum Jacq long flowered $\%$ pr 9458 ovalifólium Sweet oval-leaved $\Delta \mathrm{pr}$ 9459 reticulátum Sweet netted 9460 ciliátum L'Her. 9461 punctátum $W$. 9462 radicátum $V$ ent. 9463 spatulátum $A n d r$. $\beta$ affine Andr. 9464 radiátum Pers. 9465 virgíneum Pers. 9466 undulátum Ait. 9467 lineáre Pers. 9468 niveum Sweet cilated $\Delta \mathrm{pr}$ fleshy fringer $\Delta$ pr -lv. $\Delta \mathrm{p}$ spatula-leaved t $\Delta \mathrm{pr}$ fring.-spatul. $. l v, \pm \mathrm{N}$ pr ray-leaved $\triangle \mathrm{Npr}$ wave-flowered $x$ linear-petalled snow-white $\triangle \mathrm{pr}$ virgin $\triangle \mathrm{Npr}$
Geraniacece. m my.jn $\mathrm{Pk}$ my.jn $Y$ $\frac{1}{2}$ my.jn W my.jn $\mathrm{Pk}$ $\frac{1}{2}$ ap.jn $\mathrm{F}$ ap.my $Y$ i jn.jl $Y$ ap.my Y $\frac{1}{2}$ ap.my $\mathbf{Y}$ $\frac{1}{2}$ jn.au $\mathbf{Y}$ $\frac{1}{2} m y . j l \quad Y$ $\frac{1}{2} m_{y . j l} \quad Y$ $3^{\frac{1}{2}} j$ jn.jl
Sp. 186-uncertain.

C. G. H. 1812. R r.m Jac. ic. 3. t. 518

C. G. H. 1812. R r.m Jac. ic. 3 . t. 521

C. G. H. 1820 . R r.m Sweet ger. t. 106

C. G. H. 1820 . R r.m Sweet ger. t. 91

C. G. H. 1795. R r.m L'Her, ger. t.7

C. G. H. 1794. R r.m Bot. rep. 60

C. G. H. 1802. R r.m Bot. mag. 1718

C. G. H. 1795. R r.m Bot. rep. 152

C. G. H. 1795, R r.m Bot. rep. 282

C. G. H. 1801. R r.m Bot. rep. 222

C. G. H. 1795. R r.m Bot. rep. 317

C. G. H. 1795. R r.m Bot. rep. 292

C. G. H. 1800 , R r.m Bot. rep. 193

..... 1821. R r.m Sweet ger. 182

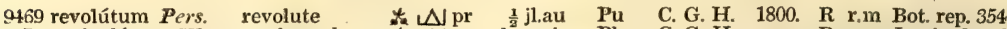

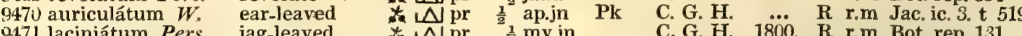
9471 laciniátum Pers. jag-leaved o $\mathrm{pr}$ pr my.jn 9472 oxalidif́́lium Pers. Wood-sorrel-lv. $4 \mathrm{~N} \mathrm{pr}{ }^{\frac{1}{2}}{ }^{\frac{1}{2}}$ my.au $\mathrm{X}$ 9473 nervifólium Jacq. nerved-leaved $\leftarrow \sim \mathrm{pr} \quad{ }^{\frac{1}{2}}$ my.au Va 9474 triphýllum Jacq. three-leaved $\mathrm{N}$ pr $\frac{\pi^{2}}{2}$ ap.my $\mathbf{F}$

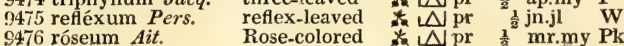

C. G. H. 1801. R r.m Bot. rep. 300

C. G. H. 1812. R r.m Jac. ic. 3. t. 517

C. G. H. 1812. R r.m Jac. ic. 3. t. 515

C. G. H. 1800 . R r.m Bot. rep. 224

$\Delta \mathrm{pr} \quad \frac{1}{2}$ mr.my Pk C. G. H. 1792. R r.m Bot. rep. 17

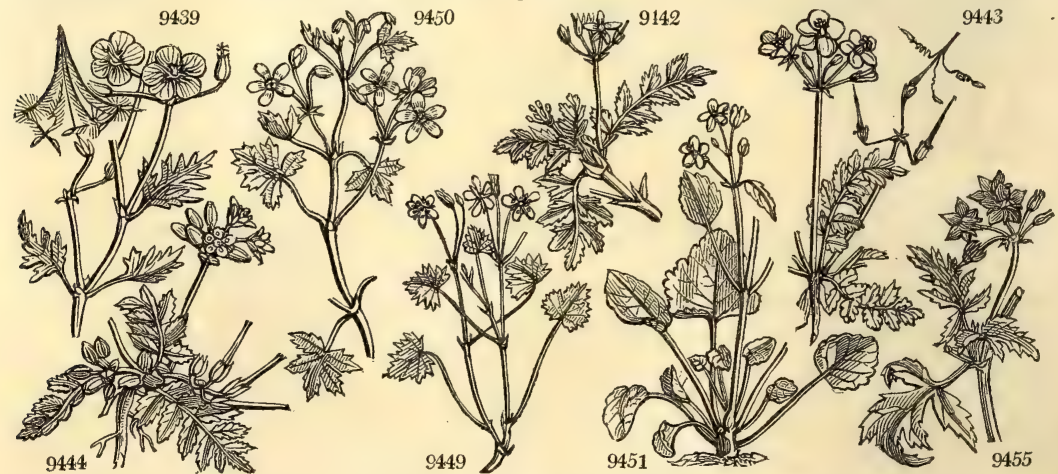

History, Use, Propagation, Culture,

1460. Erodium. From sewilos, a heron, because the fruit resembles the head and breast of that bird. The species are hardy plants, of common treatment, and no great beauty.

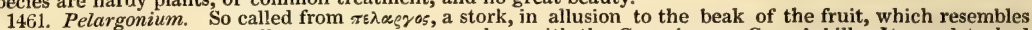
the bill of that bird; as well as to preserve an analogy with the Geranium or Crane's-bill. It was detached by the late learned botanist Mons. L'Heritier, along with Erodium, from the Linnean genus Geranium; and distinguished by its seven fertile stamens, irregular flower, tubular nectary, and spiral-leaver awns, or beaks to the capsule.

" This vast and favorite genus, for which we are almost entirely indebted to the Cape of Good Hope, consists of a numer well marked species. But that number is greatly augmented in almost every book, by the admission of spurious hybrid species or varieties, which continually start up from seed, wherever many of the primary ones are cultivated, and are for a whilc propagated by cuttings, and even by seed. Sooner or later, 
9436 Stemless, Peduncles many-f. Lvs. smoothish pinnat. Segm. pinnatifid, Petals retuse twice as long as calyx 9437 Stemless, Peduncles many-fl. Lvs. downy gland. pinnat. Segm. pinnatif. Petals acute twice as long as calyx 9438 Stem smooth. branch. Ped. many-f. Lvs. smooth. bipinnatif. Lobes lin. Pet. blunt long. than long-point.cal. 9439 Stem branched diffuse downy, Lvs. thick pinnatif. cut, Lobes linear, Pedunc. many-fl. Bractes ovate scariose 9440 Stem prostrate, Leaves bipinnate with linear acute lobes, Stipules and bractes ovate scariose, Ped. many-fl. 9441 Stem ascend. and lvs. somew. villous pinnated, Seg blunt pinnatif. tooth. Ped. many-fl. Pet. length of calyx

9442 Stem prostrate or diffuse hairy, Leaves pinnated, Segm. sess. pinnatifid cut, Pedunc. many-f. Pet. unequal

$\beta$ Caulescent diffuse, Segments pinnated with linear lobes

9413 Nearly stemless, Leaves pinnate with ovate pinnatifid segments, Petals equal larger than calyx

$\beta$ Plant of larger size

9444 Stem procumbent, Leaves pinnated with stalked ovate unequally serrated segm. Pedunc. downy glandular 9445 Stem erect nearly smooth, Leaves 3-cut, Segments cut-toothed, Pedunc many-fl. Calyx striated rierved 9446 Stem erect somewhat diffuse, Leaves smooth subcordate; upper 5-parted with cut toothed lobes

9447 Stem erect branch. shrubby at base, Lvs. 3-lobed or 5-parted very blunt, Stipules and bractes scariose ovate 9448 Stem erect soft, Pedunc. many-fl. Leaves cordate blunt bluntly toothed undivided or 3-lobed 9449 Stem branched hairy, Leaves cordate undivided or 3-lobed blunt toothed, Petals length of calyx 9450 Stem $\frac{1}{2}$ shrubby and leaves nearly smooth; lower cord. undivided toothed, Lobes cuneate 3 -toothed at end 9451 Stem erect and leaves smooth oblong lobed crenate fleshy, Awns feathery from middle to end 9452 Caulescent diffuse smooth, Leaves cordate ovate cut-crenate pubescent, Awns beardless

9453 Stemless, Leaves cordate crenate blunt smoothish, Pedunc. 1-f. Petals larger than calyx

9454 Caulescent diffuse smoothish, Leaves cordate roundish 3-lobed unequally crenate, Awns bearded 9455 Stems diffuse, Leaves opposite 3-cut : segm, lateral cut-toothed divaricating, Peduncles many-flowered

\section{HEPTANDRIA.}

11. HoAREA. Sweet. Petals 5, rarely 2 or $4 \mathrm{obl}$. lin., 2 upper parallel, with long claws abruptly reflexed in the middle. Stamens in a long tube, length of lower petals, bearing 5 or rarely 2.4 anthers, the others sterile, straight or incurved at end, the 3 lower shorter than the fertile ones. Stemless herbs, with tuberous turnip-like roots, and radical stalked leaves.

* Leaves oblong, entire or lobed. Lobes entire or scarcely toothed.

9456 Stemless, Leaves lanceolate entire acute smooth; older pinnatifid linear, Umb. comp. Fl. tetrandrous 9457 Stemless, Leaves lanceolate entire acute smooth, Umb. comp. 4-fl. Fl. tetrandrous, Petals linear 9458 Leaves oval or oval-oblong blunt flat or involute at edge entire hairy, Petals linear wavy twisted 9459 Stemless, Leaves ellipt. lanc. or obl. ent. hairy revol, at edge, Fl. pentandr. Pet. lin. spatul. wavy reflexed 9460 Stemless, Leaves ovate acute entire subciliated, Umb. compound, Fl. pentandrous, Petals linear spatulat 9461 Stenless, Leaves ovate toothed smooth, Umb. compound, F1, diandrous, Pet. linear ; 3 lower shortest 9462 Stemless, Leaves oval obl. entire acute at each end smooth ciliated, Umb. simple, Flowers pentandrous 9463 Stemless, Lvs. obl. subspatul. blunt smooth, Umb. comp. Fl. pentandrous, Petals lin. blunt subrevolute

9464 Stemless, Leaves elliptical spatulate entire smooth, Umb. compound, Fl, pentandrous, Petals cuneiform 9465 Stemless, Lrs, ellipt ovate 9466 Stemless, Leaves lin. lanc. entire ciliated, Umb. simple, Flowers pentandrous, Petals wavy nearly equal 9467 Stemiess, Leaves linear lanceolate repand, Umbel nearly simple, Flowers pentandrous, Petals linear 9468 Stemless, Lvs. smooth : lower ovate ent.; upper pinnatif. Petals reflexed; lower ones much the smallest

** Leaves sagittate, cordate, 3-lobed, or with an appendage at base.

9469 Stemless, Leaves cordate blunt nerved entire, generally with two ears at base, Leaves of invol. revolute 9470 Stemless, Lvs. obl. lanc. acum. at each end hairy ciliat. at edge, generally ent. somet. with 2 obl. lin.append. 9471 Stemless, Leaves entire and cut-lobed at end, Scape flexuose, Umbel compound

9472 Stemless, Leaves ciliated 3-cut: segm. ovate blunt, Umbel compound

9473 Stemless, Leaves smooth 3-cut: segm, blunt lobed nerved glauc. beneath, Scapes hispid, Umbel compound 9474 Stemless, Leaves smooth 3-cut: segm. blunt crenated, Scapes and petioles downy

9475 Stemless, Leaves smooth 3-cut: segm. lobed cut recurved, Two upper filaments and stigmas reflexed 9476 Stemless, Leaves cut-lobed downy, Umb. simple close, Three lower petals much the smallest

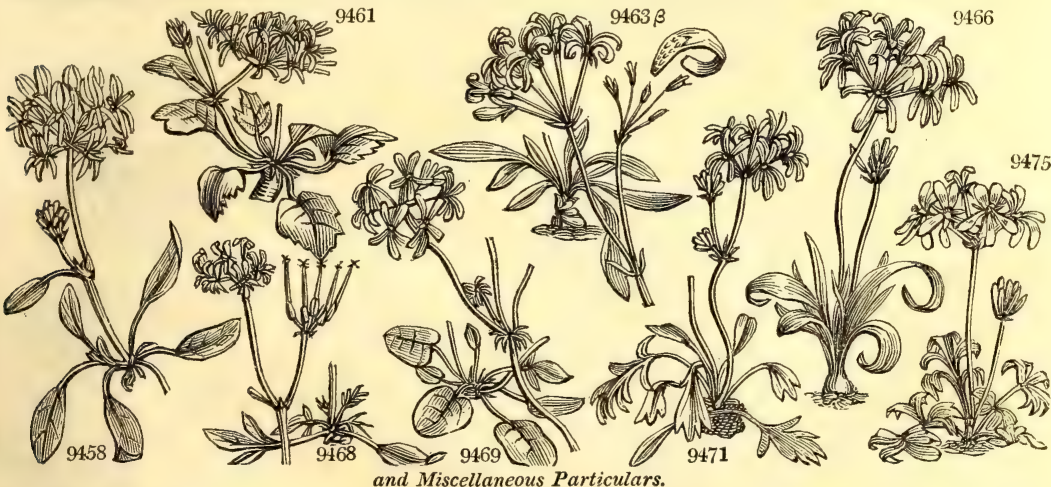

however, they for the most part vanish, even before the eyes of those who witnessed their origin." (Smith.)

The greater part of the species being of the easiest cultivation, and many bearing the confined air of a sitting room better than most plants, it has happened that they have become objects of universal cultivation and attention; of which, indeed, they are in many cases deserving, for their neatness and beauty alone There is, however, an uniformity in their form, coloring, and foliage, for which the liveliest colors will scarcely compensate. The ponular taste for the Pelargonium tribe, or for Geraniums, as they are commonly called, has been much aided by several splendid publications both in this country and abroad; and especially by the Gera. niaceæ of Mr. Sweet, in which it is proposed to figure not only all the species formed by the hand of nature but the multitudes of hybrid creations produced by the assistance of modern ingenuity. It is very doubtfu whether any permament advantage is derived from the obtaining such of these productions as are truly 


\begin{tabular}{|c|c|c|c|c|c|c|c|c|c|}
\hline um Jacq. & & $r$ & & Pk & C. G. H. & 1788. & $\mathbf{R}$ & $\mathbf{r} \mathbf{m}$ & 239 \\
\hline Dec. & ng & 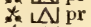 & $\frac{1}{2} a$ & $\mathbf{Y}$ & C. G. H. & & $\boldsymbol{R}$ & $\mathrm{r} \cdot \mathrm{m}$ & 1877 \\
\hline flórum & fin & & & $\mathrm{Y} Y$ & & & $R$ & $\mathrm{r} . \mathrm{m}$ & \\
\hline Jacq & be & & & $\mathbf{P}$ & I. & & $R$ & r.m & 23 \\
\hline 1 Pers. & clox & 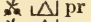 & & $\mathbf{P}$ & & & $R$ & r.m & 378 \\
\hline weet & se & pr & $\frac{1}{2}$ & & C. G. & & R & r.m & \\
\hline n $I$ & $\mathrm{Bi}$ & t. & & W.pu & C. $\mathbf{G}$ & 1800. & $\mathbf{R}$ & r.m & 8 \\
\hline$S w$ & $v$ & $\mathrm{pr}$ & $n r . j 1$ & W & C. $\mathrm{C}$ & & R & r.m & 123 \\
\hline & & & ny & & & & & r.m & \\
\hline Pers. & hair & $* \sim \sim p r$ & $\frac{1}{2}$ & $\mathbf{P k}$ & & & $a$ & r.m & 59 \\
\hline me $P e r$ & win & $\mathrm{jpr}$ & $y$ & $\mathrm{D}$ & C. G & 18 & $\mathbf{R}$ & r.m & 269 \\
\hline is Pers. & pl & $\mathrm{pr}$ &.$j n$ & $\mathrm{Pu}$ & C. & & r & r.m & $\sqrt{3}$ \\
\hline & V & & & Pk & & & 3 & r.m & \\
\hline 18 & b & 索 $\Delta \backslash \mathrm{pr}$ & $y . j n$ & D. Br & C. G. & & $R$ & r.m & r. 73 \\
\hline it. & & $\triangle \mathrm{pr}$ & & D. Br & C. G & & $R$ & r.m & 99 \\
\hline & & & & & & & & r.m & \\
\hline
\end{tabular}

9493 viciæfólium L'Her. wing-leaved th $\backsim$ pr 9494 astragalifólium Pers. Astragalus-lvd. $\triangle \mathrm{N} \mathrm{pr}$ 9495coronillæfóliumPers. Coronilla-lvd. $\mathrm{N}$ pr 9496 heracleifóliumLodd.Cow-parsnip-lv. $₫$ pr

9497 incrassátum B. M. fleshy-leaved 9498 cárneum Jacq. $\quad$ flesh-colored

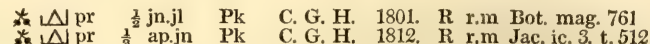

9499 lateritium $W$. brick-colored $\quad$ or $1 \frac{1}{2}$ jn.au $R \quad$ C. G. H. 1800. C r.m

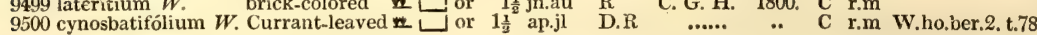

9501 columbínum $W$ : Dove's-foot $\quad \Delta \mathrm{pr} \quad \frac{1}{2}$ jn.o $\quad$ Pu $\quad$ C. G. H. 1795. R r.m Jac.schœ.2.t.133 9502 procumbens Pers, procumbent $\quad \mathrm{N}$ pr $x^{\frac{1}{2}}$ ap.my Pu C. G. H. 1801. S r.m Bot. rep. 234

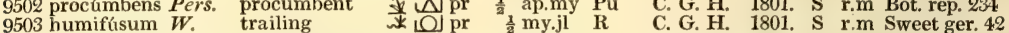

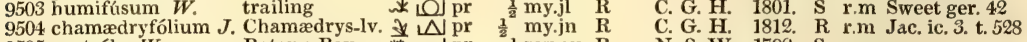
9505 austrále $W$. Botany Bay $\quad$ B pr ${ }^{\frac{1}{2}}$ my.au R $\quad$ N. S. W. 1792. S r.m

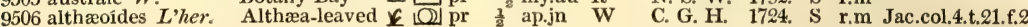

9507 láxum Sweet loose-panicled pr 1 ap.jn W.pk C. G. H. 1821. S p.l Sweet ger. 196 9508 ceratophýllum $L$ 'her.horn-leaved $\square$ or 1 my.jn W.pu Africa 1786. C r.m Bot. mag. 315 9509 dasycaúlon Sims. thick-stemmed $\square$ or 1 jl.d W.pu C. G. H. 1795. C r.m 9510 crithmifólium Sm. Samphire-leav. ${ }^{-}$or 1 my.jn W.pu C. G. H. 1790. C r.m Smith. ic.pict.13 9511 alter'nans Wendl. Parsley-leaved $\downarrow$ or 1 my.au W.pu C. G. H. 1791. C r.m Wendl.her.2.t.9 9512 carnósum Ait. fleshy-stalked f or 1 jn.au W.pu C. G. H. 1724. C rm Sweet ger.98

9514 cotylédonis L'Her. Hollyhock-lvd. $L_{\text {pr }} \quad \frac{3}{4}$ my.jl W St.Helena1765. S r.m Sweet ger. 126

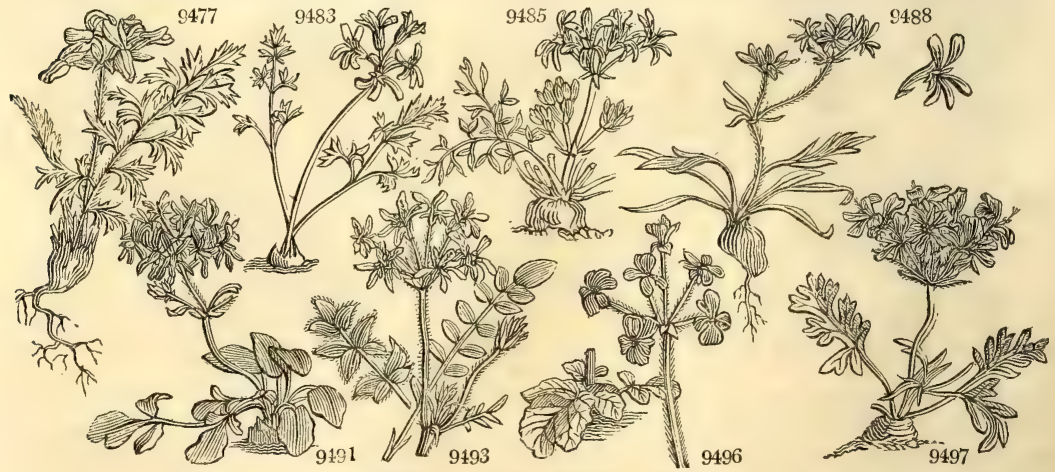

History, Use, Propagation, Culture,

hybrid; but it is quite certain, that to admit them into works of science, is replete with the greatest inconvenience, and can lead to no useful end. In the arrangement here adopted, all those kinds which are manifestly or avowedly artificial productions, are therefore placed at the end of the legitimate species in alphabetical order, an order much more commensurate with their importance, than an arrangement upon scientific principles. 
*** Leaves pinnatifid. Segments cut or multifid.

9977 Stemless, Leaves hairy bipinnated, Lobes linear somewhat blunt, Upper petals reflexed: lower connivent 9478 Nearly stemless, Lvs, bipinnated hairy, Lobes pinnati. cut multifid linear somewhat toothed, Fl. nodding 9479 Stemless, Lvs. hairy pinnated : segm. pinnatifid or trifid, Lobes linear acute

9480 Stemless, Lvs. pinnated : segm. trifid, Lobes linear acum. bearded at end, Pet. lin. blunt

9481 Stemless, Lvs. pinnated : segm. trifid cut at end naked, Pet. blunt all with an oblong spot

9482 Stemless, Lvs. pinnated pubesc : segm. cuneate 3-5-toothed at end, Teeth setose at end, Umb. compound 9483 Stemless, Lvs. pinnated smooth : segm. cut-lobed acute, Urnb. simple, Petals emarginate

9484 Subcaulescent, Leaves pinnated or 3-cut : segm. obl. lanc. smooth entire ciliated at edge acum. at end

9485 Stemless, Lvs, pinnated : segments bipartite, Umbel compound

9486 Stemless, Lvs. pinnated hairy : segm. cut multifid, Umbel simple 4-6-fl. Petals linear

9487 Stemless, Lvs. pinnated : segm. lanc. linear, Umbel compound

9488 Stemless, Lvs. lanc. linear entire and pinnatifid, Umb. compound

9489 Stemless, Lvs. hairy ciliated obovate or lanc. entire or pinnatifid, Stipules adhering to petiole

9490 Nearly stemless, Lvs. hairy pinnated : segm. oval-obl. blunt subpinnatifid or toothed, Petals lin. blunt

9491 Stemless, Lvs, hispid entire or 3 cut, Umbel compound, Flowers dicecious [at end

9492 Stemless, Lvs. downy: some obl, and entire; others pinnated, Upper sepal erect, Barren filam. incurved

8. Dimacria. Lindl. Petals 5. unequal, two upper connivent spreading at end. Stamens shorter than sepals, 5 fertile, two lowermost twice as long as the rest, upper very short; 5 sterile, very small, nearly equal. Stemless herbs, with a tuberous turnip-like root; leaves stalked pinnatifid.

* Leaves pinnated, with an odd segment. Segments entire.

9493 Stemless, Lvs. pinnated villous : segm. ovate in 2 or 4 pairs, Petals nearly entire flat

9494 Stemless, Lvs. pinnated hairy : segm. elliptical in many pairs, Petals wavy twisted at base

9495 Stemless, Lvs. pinnated smooth : segm. of 1 or 2 pairs obovate or oblong

9496 Stemless, Lvs. pinnated smooth: segm. of 2 or 3 pair obovate : the terminal ones confluent

* Leaves pinnate, with an odd one. Segments lobed or multifid.

9497 Nearly stemless, Leaves smooth pinnated: segments lobed blunt, Upper petals obcordate

9498 Stemless, Lvs. smooth bipinnated, Lobes trifid linear blunt, Scape simple

6 3. Crnosiata. Dec. Petals oval, nearly equal, almost twice as long as calyx. Stamens 10 erect, the 5 alternate ones bearing the anthers. Stems shrubby, erect.

94.99 Stem shrubby at base, Lvs, cordate 5-lobed hairy zoned, Lobes acutely toothed at end

9500 Stem shrubby branched, Lvs, cordate 3-lobed toothed hairy : middle lobe 3-lobed, Pedunc. 2-floweerd

14. Peristera. Dec. Petals nearly equal, as long as calyx, or a little larger. Stamens 10, 5 longer, nearly equal, or one only occasionally abortive, 5 alternate, very short, sterile, tooth like. Herbs with stems, and with the appearance of Erodium or Geranium.

9501 Stems many diffuse, Lvs. cordate roundish many-parted, Lobes trifid, Lobelets linear blunt 9502 Caulescent procumbent, Lvs. cord. somewhat lobed crenate-toothed, Pedunc. 2-flowered 9503 Stems many procumbent, Lvs. cord. usually 3-parted or 5-lobed toothed, Pedunc. 3-5-flowered 9504 Much branched procumbent, Leaves ellipt. blunt hoary toothed, Pedunc. 2-flowered, Anthers 5 9505 Diffuse procumbent, Lvs. cordate somewhat lobed villous beneath, Peduncles many-flowered 9506 Diffuse procumbent, Lvs. cordate ovate villous 3-lobed toothed: upper sinuated, Umbel many-flowered

6. OTIdA. Lindl. Petals oblong-linear, nearly equal, about twice as long as calyx, the two upper auricled at the base on the upper side. Stamens 10, erect, 5 fertile, 2 upper spatulate or subulate, 3 lower shorter. Stems shrubby, fleshy. Leaves alternate pinnated, fleshy. Flowers whitish.

9507 Stem shrubby fleshy, Umb. many-flowered loosely panicled, Lvs. pinnated smooth, Petals somew. toothed 9508 Stem shrubby fleshy branched, Lvs. fleshy pinnated : lobes lin. round channelled entire or 3-toothed at end 9509 Stem shrubby fleshy warted, Lvs. fleshy pinnated : segm. cut pinnatifid subtrifid at end [at base 9510 Stem shrubby fleshy, Lvs. fleshy bipinnated: lobes dilated and cut at end, Pedunc. panicl. Upper pet. crisp 9511 Stem shrubby fleshy, Branches hairy, Lvs. pinnat.: segm. stalked subalternate wedge-shaped toothed at end 9512 Stem fleshy thick suffruticose at base, Lvs. smooth thick sinuate-pinnat.: segm. obl. blunt cut toothed at end

86. Polyactium. Dec. Sepals nearly equal, revolute. Petals 5 , nearly equal, obovate. Stamens 10,5 fertile: the four lower long, subulate; upper broad, spatulate, reflexed at end; the fertile ones shorter, incurved at end. Petals with a very large dark bi own spot which is scarcely edged with yellow.

951 Subcaulesc. Lower lvs. pinnat. hairy: segm. pinnati.; lobes obl. blunt cut-toothed; upper smoothish bipinn.

8. Isoperalum. Sweet. Upper sepal ending in a honey pore and not in a tube. Petals 5 , equal. Stamens 10 united in a very short cup, 5-6 fertile, spreading incurved at end; sterile unequal, subulate incurved. Shrub with a fleshy stem.

9514 Stem thick fleshy branched naked, Lvs. cord. subpeltate rugose pubesc. netted with downy veins beneath

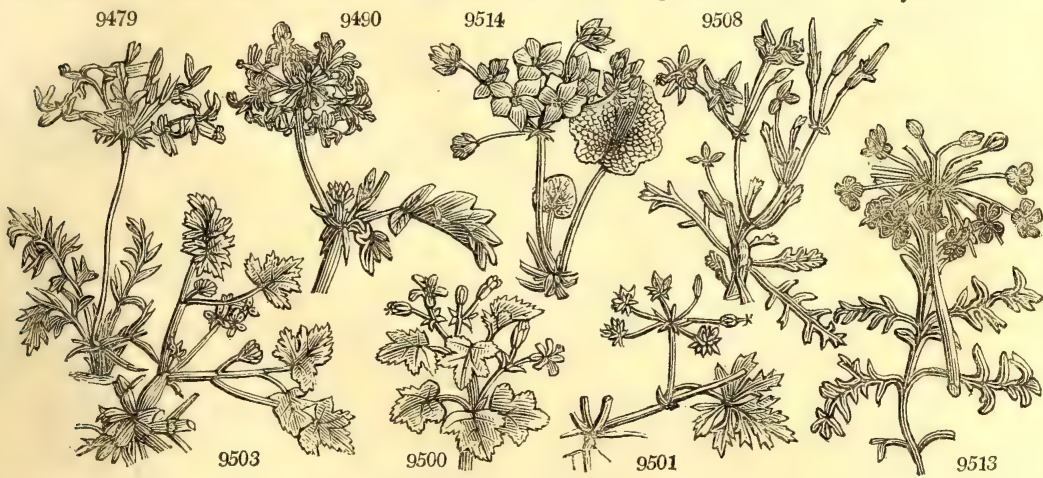

and Miscellaneous Particulars.

The bulbous or fleshy stemmed species are generally very rare in collections, and are far more interesting than the common or vulgar kinds. They are distinguished by so peculiar a habit and constitution, that there can be little doubt of the propriety of separating them into one or more distinct genera, as has been done already by the authors quoted above; especially as the characters upon which they are founded, are generally more certain than those by which Erodium and Geranium are defined. Here, however, they are placed as 


\begin{tabular}{|c|c|c|c|c|c|c|c|c|c|}
\hline 9515 blattárium Jacq. & downy-leaved & Jor & 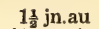 & V & C. G. H. & 1790. & $\mathbf{S}$ & r.m & Sweet ger. 88 \\
\hline 9516 eriostémon Jacq. & velvet-leaved & or & $1 \frac{1}{8} \mathrm{mr} \cdot \mathrm{jn}$ & $\mathbf{W}$ & C. G. $\mathbf{H}$. & 1794. & C & r.m & Jac. scho.2. t.132 \\
\hline olosericeum Swec & silky & or & $1 \frac{1}{2} \mathrm{mr} . \mathrm{jn}$ & D. $\mathrm{Pu}$ & C. G. H. & 1820. & C & r.m & Sweet ger. t. 75 \\
\hline 9518 Enothéræ Jacq. & CEnothera-lik & $\leqslant \Delta 0$ & $1 \mathrm{mr}$.jn & Pk & C. G. H. & 1812. & $\mathbf{S}$ & r. $\mathrm{m}$ & Jac. ic. 3. t. 525 \\
\hline$c q$ & shorn & or & $1 \frac{1}{2}$ jn.o & P.v & C. G. H. & 1791. & $\mathbf{S}$ & r.m & Bot. rep. 338 \\
\hline cánum Pers. & hoary & or & $1 \frac{1}{2}$ jn.o & $\mathbf{P k}$ & C. G. H. & 1820. & $\mathbf{S}$ & r.m & Sweet ger. 114 \\
\hline inatus & carinate & or & jn.o & W.p & H. & 1820. & $\mathbf{S}$ & $\mathbf{r . m}$ & Sweet ger. 21 \\
\hline
\end{tabular}

9522 trícolor B. M. three-colored $\quad \amalg$ pr $1 \frac{1}{2}$ ja.d $\quad$ W.pu C. G. H. 1791. C r.m Bot. mag. 240

9523 canariénse $W$. Canary $\quad$ J pr $1 \frac{1}{2}$ jl.s $\quad$ W.R Canaries 1802. C r.m W.hort.ber. t.17 9524 myrrhifólium Ait. Myrrh-leaved $\frac{1}{2}$ pr $1 \frac{1}{2}$ my.au W.R C. G. H. 1696. R r.m Jac. ic. 3 . t. 531

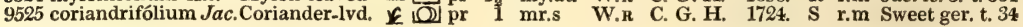
9526 lácerum Jacq. torn-leaved $\quad \mathbb{E} \Delta$ or $\quad 1 \frac{1}{2}$ jn.au $\quad$ Pk $\quad$ C. G. H. 1731. S r.m Jacq. ic. 3. t. 532

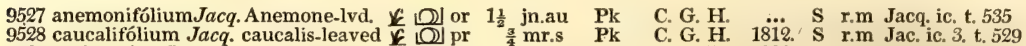
9528 caucalifólium Jacq. caucalis-leaved
9529 multicaúle Jacq.
many-stalked

9530 asarifólium Sweet Asarum-leaved t. $\mathrm{N}$ el $\quad \frac{1}{2} \mathrm{~d} \quad$ D.Pu C. G. H. 1821. D 1.p Sweet ger. 206 9531 dipétalum L'Her. two-petalled $\aleph^{-} \mathrm{N}$ el $\frac{1}{2}$ ap.my Pa.pu C. G. H. 1795. D 1.p L'her. ger. t. 43

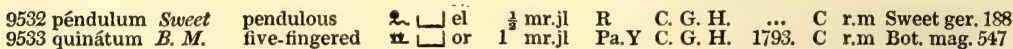

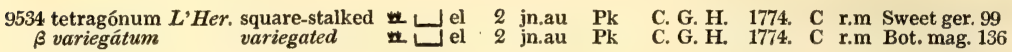

\begin{tabular}{|c|c|c|c|c|c|c|c|c|c|}
\hline 9535 acetósum Ait. & Sorrel-leaved & L1 or & 3 my.s & Pk & C. G. H. & 1710. & C & r.m & Bot. mag. 103 \\
\hline 9536 scándens Ehr. & climbing & \pm L & 3 jn.au & $\mathbf{P k}$ & C. G. H. & 1800. & C & r.m & \\
\hline 9537 púmilum $W$. & dwarf & en & $1 \frac{1}{2} \mathrm{jn} . \mathrm{jl}$ & Pk & C. G. H. & 1800. & C & r.m & \\
\hline 9538 stenopétalum $\mathrm{Ehr}$. & narrow-petalled & den & $1 \frac{1}{2}$ jn.jl & $\mathrm{S}$ & C. G. $\mathbf{H}$. & 1800. & C & r.m & \\
\hline 9530 hýbridum Ait. & bastard & ㄹ. & 2 my.s & $\mathbf{S}$ & C. G. H. & 1732. & C & r.m & Sweet ger. 63 \\
\hline 9540 zonále $W$. & com. horse shoe & or & 2 ap.d & $\mathbf{S}$ & C. G. H. & 1710. & C & r.m & Cav.dis.4.t.98.f. 2 \\
\hline$\beta$ marginátum & whit & or & 2 ap.d & $\mathbf{S}$ & & & C & r.m & \\
\hline 9541 Fothergillii Sweet & Fothergill's & n & 2 ap.d & $\mathrm{S}$ & C. G. 1 & & C & r.m & Sweet ger. 226 \\
\hline 9542 in'quinans Ait. & scarlet-flowered & An & 2 my.s & $\mathbf{S}$ & C. G. H. & 1714. & $\mathbf{C}$ & r.m & Ca.dis.4.t.106.f. 2 \\
\hline 9543 heterógamum L'Her & $r$.six-stamened & 业 & 2 my.s & Pk & ...... & 1786. & C & $\mathrm{r}, \mathrm{m}$ & L'her. ger. t. 18 \\
\hline 9544 mónstrum Ait. & cluster-le & 肯 & 2 jl.au & $\mathbf{R}$ & & 1784. & C & r.m & Sweet ger. 13 \\
\hline
\end{tabular}

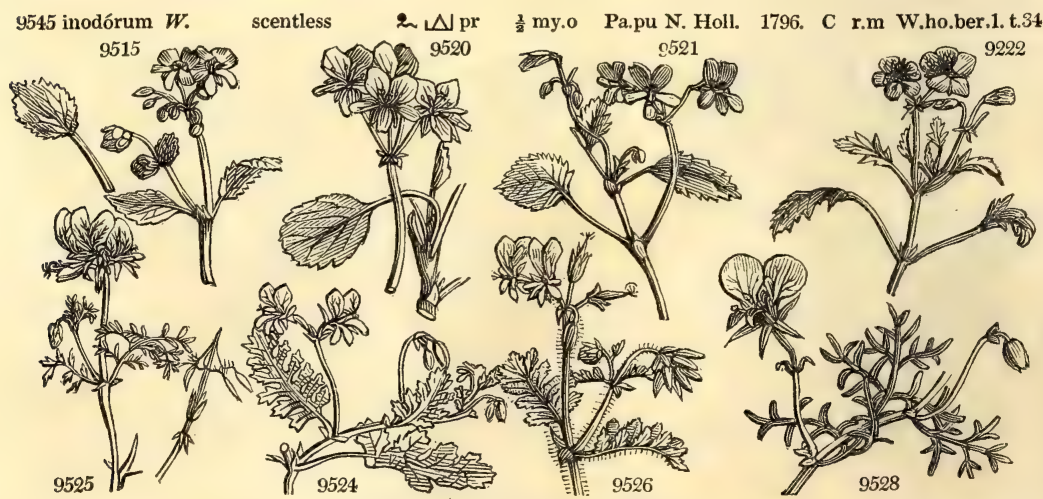

History, Use, Propagation, Culture,

sectional names, so as to present a double arrangement, in which the purposes of combination and analysis are both combined.

As the cultivation of Pelargonium generally is of the easiest kind, so is that of the bulbous rooted species of the most difficult nature. They require plenty of air and light, not to be over-watered, and a great deal of 
8. Camprla. Lindl. Petals 5, uncqual, two upper larger, with an auricled claw. Stamens 10, hairy or pubescent, 5 fertile, erect, 5 alternate sterile, of which the two upper are longer and hooked back. Herbs at the base a little shrubby, branched. Leaves stalked, ovate or oblong, toothed or cut.

* Petals with an appendage to the claw: 5 stamens fertile, erect; 5 sterile, of which the two uppermost are hooked backwards. True CampYla.

9515 Stem suffruticose erect, Lvs. ovate round blunt hoary silky toothed, Upper petals roundish : lower oblong 9516 Stem suffruticose erect, Lvs. ellipt. roundish blunt crenate silky, Upper pet. obovate sharply emarginate 9517 Stem suffruticose erect, Lvs. roundish ovate blunt doubly toothed silky, Upper petals round dark purple 9518 Stem herbaceous ascending, Lvs. obl. lanc. blunt toothed hoary, Pedunc. 1-3-fl. Upper petals obovate 9519 Stem suffruticose ascending, Lvs. lin. lanc. cut-toothed at end hoary beneath, Upper petals obov. oblong 9520 Stem suffruticose, Lvs, ovate plaited serrated downy, 3 upper petals very broad ovate

9521 Stem suffruticose ascending, Lvs. ovate unequally toothed or cut, Stipules carinate, Upper pet. oval wavy ** Upper petals warted above the claw. Tube of stamens very short, 5 fertile recurved, spreading, 5 sterile straight. Phymatanthus. Lindl.

9522 Stem suffruticose erect, Lvs, lanc. villous cut-toothed trifid, Upper petals blistered at base

5 9. Myrrhidum. Dec. Petals 4, or rarely 5, the two upper very large, obovate, cuneate, usually marked with branching lines, the two or three lower much smaller, oblong-linear. Stamens 10, with their tube and filaments straight, generally with 5 anthers, and 5 alternately barren, rarely 7 fertile. Biennial or perennial heris rarely shrubby. Stems round. Leaves pinnate or ternate, often multifid.

$$
\text { * Anthers 5. Petals } 4 \text {. }
$$

9523 Stem suffruticose, Lvs. 3-parted, Lobes toothed at end blunt : lower obovate; middle ovate often trifid 9524 Stem herbaceous strigose ascending, Lvs. hispid on each side rigid pinnated, Lobes cut-toothed 9525 Stem herbaceous biennial somewhat downy, Lvs. bipinnate smooth, Lobes linear subpinnatifid

$$
\text { ** Anthers } 5 \text {. Petals } 5 .
$$

9526 Stem herbaceous hairy suberect, Lvs. bipinnatifid, Segm. lanc. blunt toothed at end

$$
\text { *** Anthers 7. Petals } 4 \text {. }
$$

9527 Stem herbaceous biennial hairy erect, Lvs. pinnated hairy beneath smooth above, Lobes toothed 9528 Stem herbaceous hairy, Lvs. bipinnate, Lobes linear smoothish, Pedunc. 1-f

9529 Stem herbaceous procumbent smooth, Lvs. subbipinnatifid toothed, Pedunc. many-fl. capitate

\$10. SeYmouria. Sweet. Petals 2, distinct at base, abruptly reflexed in the middle. Stamens 5 , nearly equal, in a long straight tube, all fertile.

9530 Lvs, roundish cordate bluntish entire ciliated shining on the upper side

9431 Leaves ovate entire acute smooth, Umb. simple, Flowers peritandrous

11. JEnkinsonia. Sweet. Petals 5, the two upper much larger than the rest, emarginate at end, striated with colored lines, the 3 lower much smaller. Stamens 10, ascending, spreading at end, hairy at base, 7 fertile, of which the three upper are shorter, the three sterile shortened, subulate, of equal length. Stems shrubby. Flowers large.

9532 Lvs. bipinnatifid hairy, Stem procumb. hairy, Flowers heptandrous, Petals 4

9533 Stem shrubby flexuose, Lvs. pubescent palmate 5-fid, Lobes cuneate 3-toothed at end

8 12. Chorisma, Lindl. Petals 4, rarely 5, the two upper with long claws largest, two lower much smaller. Stamens declinate, in a very long tube, jointed in middle, connate, 7 fertile, of which the two lower are loose; the 3 sterile shortened, subulate of equal length.

9534 Branches 4-cornered fleshy, Leaves cordate bluntly lobed somewhat toothed

\$13. Pelargonium. Lindl. Petals 5, unequal, the two upper approximating. Stamens 10, unequal, 7 fertile, 3 sterile, subulate.

* Petals whole colored, the two upper shorter and narrower. Stamens short, erect, the two lowest very short with ricarly sessile anthers. Stem shrubby, fleshy. Ciconium, Sweet.

9535 Leaves very smooth obovate crenate somewhat fleshy, Pedunc. few-fl. Petals linear

9536 Leaves roundish obsoletely lobed crenate smooth zoned, Petals linear breadth of sepals

9537 Leaves roundish obseletely lobed crenate: younger somewhat zoned, Pedunc. 4-fl. Petals linear

9538 Leaves roundish obsoletely lobed crenate downy zoned, Petals linear narrower than sepals

9539 Leaves roundish obsoletely lobed crenate smooth not spotted, Petals linear cuneiform

9540 Leaves cordate-orbicular obsoletely lobed toothed zoned upwards, Pedunc. many-fl. Petals cuneate

9541 Leaves reniform 5-lobed crenate zoned, Stipules cordate obl. acute ciliated, Umbels many-fl. crowded 9542 Leaves round reniform scarcely divided crenate viscid, Petals obovate cuneate

9543 Leaves cordate orbicular cut-lobed toothed pubescent on each side, Petals obl. cuneate

9514 Leaves roundish reniform obsoletely lobed somewhat zoned complicate crisp downy on each side ** Petals nearly equal in size.

A. Stems herbaceous. Leaves cordate, palmate, lobed. Petals small.

9545 Stem diffuse, Lvs. cord. ov. obsoletely lobed bluntly toothed ciliated, Pet. equal to the cal. and one another

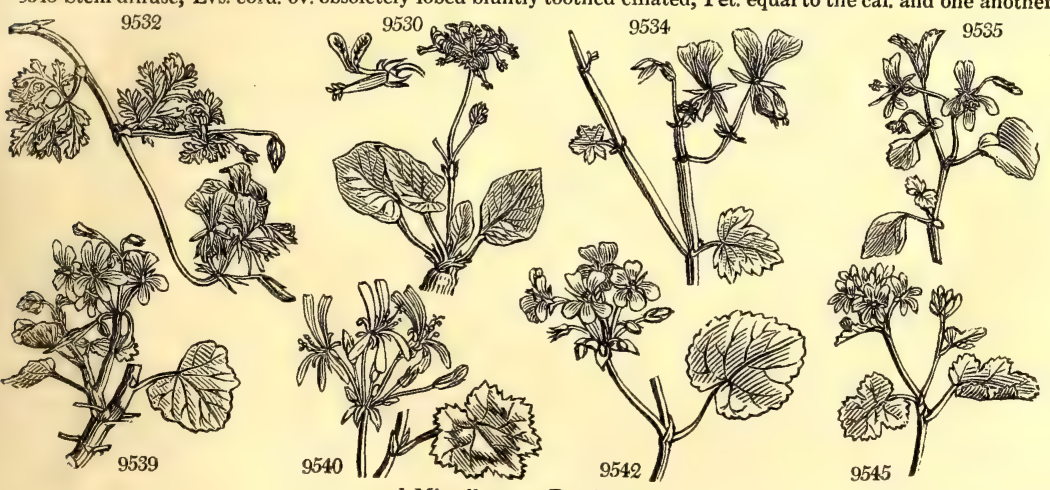

and Miscellaneous Particulars.

attention at all periods. If well managed, they flower beautifully, and are incomparably superior in all points to the commoner races. They are no where in this country managed with so much success as by Sweet, who seems to hold the reins of nature in his hands in a more steady manner than any cultivator of the age. 
9546 glomerátum Jacq. heaped $P$. austrále Sweet, not of Willd.

\section{7 odoratissimum Ait. sweet-scented}

9548 frágrans $W$.
9549 grossularioídes Ait. Gooseberry-lvd.
9550 ánceps Ait.

flat-stalked

9551 tabuláre $L$ ' $H e r$, rough-stalked

9552 alcheinilloides Ait. $\triangle \mathrm{N}$ pr

9553 senecioides $L^{\prime}$ Her. small white-f.

9555 incisum $W$.

9556 tenuifólium $L$ 'Her. fine-leaved

9557 tripartítum sweet trifid-leaved

9558 spinósum $\boldsymbol{W}$. thorny

9559 gibbósum $W$ gouty

carrot-leaved

9560 flávum Ait.

9561 filipéndulifólium $S w$. Dropwort-lvd.

9562 pedicellátum Sweet long-stalked

9563 tris'te Ait. night-smelling

9564 schizopétalum Sweet cut-petalled

9565 lobátum $W$. Cow Parsnep-I

9567 sanguineum Wendl. bloody

\%568 fúlgidum Ait. Cèlan

fiery

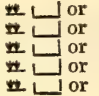

i. $u$ or

- لـ ft

$* \Delta \mathrm{ft}$

$\checkmark \mathrm{N}$ cu

I $\mathrm{cu}$

* $\Delta \mathrm{ft}$

此 el

$\frac{1}{2} \mathrm{my} . \mathrm{o}$

2 my.o $\mathrm{Pk}$

2 my.o Va

2 ap.au $\mathrm{Pk}$

$\frac{1}{2}$ my.jl $\mathrm{Pk}$

$\begin{array}{lllllll}\frac{1}{2} \text { my.au } & \text { Pa.Y } & \text { C. G. H. } & 1775 . & \text { S } & \text { r.m L'Her. ger. t. } 9 \\ \text { My.o } & \text { Pk } & \text { C. G. H. } & 1693 . & \text { C } & \text { r.m Cav.dis.4.t.98.f.1 } \\ \frac{3}{4} \text { jn.jl } & \text { W } & \text { C. G. H. } & \text { 1775. } & \text { S } & \text { r.m L'Her. ger. t.11 }\end{array}$

N. Holl.

... C r.m Sweet ger. 68

C. G. H. 1724. S r.m Ca.dis.4.t.103.f.1

C r.m Sweet ger. 172

C. G H $1731 \mathrm{~S}, \mathrm{~m}$ Cadis $4119 \mathrm{fo}$

C. G. H. 1788. S r.m Jac.col.4.t.22.f.3

3 my.jl R $\quad$ C. G. H. 1791. S r.m Jac.schœ.2.t.136

3 my.au W.R C. G. H. 1791. C r.m Bot. rep. 67

3 my.jl Pu C. G. H. 1768. s r.m L'Her, ger. t. 12

3 ap.au Pa.Y C. G. H. 1794. C r.m Sweet ger. 115

my.jn Pk C. G. H. 1795. C r.m Pater, it. t. p. 67

$1 \frac{1}{2}$ my.jl G

C. G. H. 1712 .

$\frac{1}{2}$ jl.s

$\frac{x}{2}$ my.o

1 my.o

1 my.o

1 in

$\frac{1}{2}$ jl.au
E. $\Delta$ or 1 jl.au

些 Lل or $1 \frac{1}{2}$ mr.jn

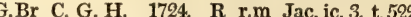
G. Br C. G. H. 1812. R r.m Bot. mag. 1641 G.Br C. G. H. 1822. R r.m Sweet ger. 250 G.Br C. G. H. 1632. R r.m Ca.dis.4.t.107.f.1 Y.Br C. G. H. 1821. R r.m Sweet ger. 232 Y.Br C. G. H 1710, R r.m Sweet ger. 51 Y.Br C. G. H. $\quad \ldots \quad$ R r.m Sweet ger, 230

S C. G. H. $\quad \ldots$ S $\quad$ r.m Sweet ger. 76

C. G. H. 1723. C r.m Ca.dis.4.t.116.f

..... 1812. C r.m Sweet ger. 2.55

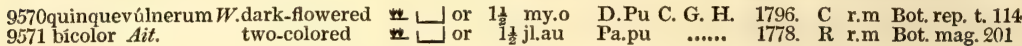

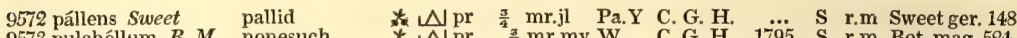
9573 pulchéllum $B . M$. nonesuch $\quad$ 娄 $\triangle$ pr $\quad \frac{3}{4}$ mr.my W $\quad$ C. G. H. $1795 . \quad$ S r.m Bot.mag. 524 9574 píctum Pers. painted $\mathrm{N}$ pr ${ }^{2}$ ap.my W.R C. G. H. 1800. R r.m Bot.rep. 160

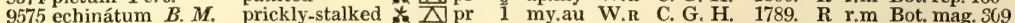
9576 crassicaúle $L$ 'Her. thick-stalked $\star \bar{\Lambda}$ pr $\frac{3}{4}$ jl.au Pa.Y S. Africa 1786. S r.m Sweet ger. 192 9577 primulinum Sweet primrose-flow.

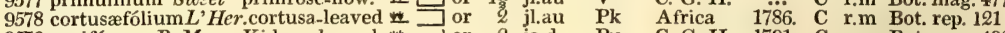
9579 renifórme B. M. Kidney-leaved in or a ja.d Pu C. G. H. 1791. C r.m Bot.mag. 493

9580 láteripes L'Her. Ivy-leaved $\quad$ or 2 jn.au Pa.pu C. G. H. 1787. C r.m L'Her.ger.t.24 9581 peltátum Ait.

peltated

\begin{tabular}{llll}
\hline \\
L
\end{tabular} or 2 jn.au Pu C. G. H. 170I. C r.m Bot.mag. 20

9582 ovále $L$ 'Her. 9583 élegans $W$.

oval-leaved

w or $1 \frac{1}{2}$ my.jl Pu

C. G. H. 1774, S r.m L'Her. ger.t. 28

elegant

C. G. H. 1795. C r.m Bot. rep, $\approx 8$

9584 glaúcum L'Her. glaucous-leav'd J or 3 jn.au W.vy C. G. H. 1775 . C r.m Sweet ger.235 9585 diversifólium Wendl. different-leav'd ti 9586 cuspidátum $W$ 9587 corium $W$ 9587 sorórium $W$. sister

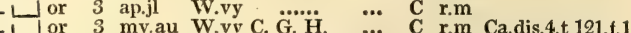
9590 variegátum $W$.

9591 pátulum Jacq. $\quad$ spreading $\quad$ J or 3 ap.jl Pk.vy C. G. H. 1812. C r.m Jac. ic.3. t. 541 9592 saniculæfólium $\boldsymbol{W}$. Sanicle-leaved $L_{\text {L }}$ el 3 jn.au Pu.vy C. G. H. 1806. C r.m Jac. ic. t. 539 9593 fuscátum Jacq. dark-marked Hel 3 ap.jl Pu.vy C. G. H. 1812 C r.m Jac. ic.3. t. 540

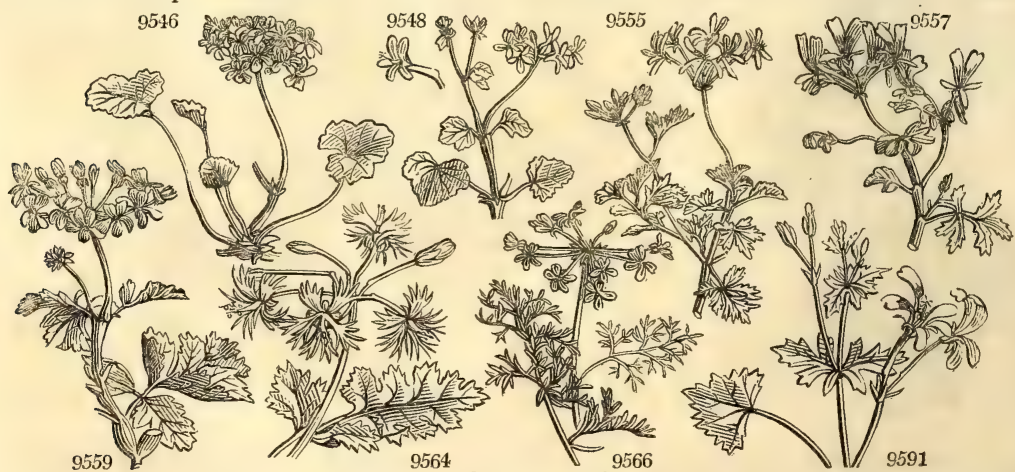

History, Usc, Propagation, Culture,

The most common free-growing kinds will thrive well in any rich light soil, or a mixture of loam and decayed leaves will suit them very well : the dwarfer woody kinds, as P. tricolor, elegans, Blattarium, ovale, 
9546 Stem diffuse, Lvs. cord. somewhat lobed bluntly crenate villous beneath, Pet. larger than calyx

9547 Stem fleshy very short, Branches herbaceous iong diffuse, Lvs. roundish cordate very soft 9548 Branches spreading soft with down, Lvs, rourdish cordate about 3-lobed bluntly toothed very soft 9549 Stems square very smooth, Lvs. cordate roundish cut toothed, Pedunc. about 2-f

9550 Stems 3-cornered 2-edged smooth, Lvs. cordate roundish obsoletely lobed toothed, Umb. many-fi. 9551 Stem hispid, Lvs. reniform 3-5-lobed blunt toothed at end smoothish, Pedunc. long 2-4-fl. 9552 Stem villous, Lvs. cordate 5-lobed palmate villous, Pedunc. few-fl. Stigma sessile 0553 Stem erect, L.vs. bipinnatifid laciniate smooth, Involucres and calyxes blunt

B. Stem half shrubby. Leaves pinnate. Lobes multifid. 9554 Leaves cinereous velvety palmately 3-cut, I.obes linear trifid, Calyxes somewhat hispid 9555 Leaves 3-cut dark-green, Lobes distant 3-parted laciniated, Petals linear flaccid 9556 Stem fleshy naked erect, Leaves hairy bipinnate decompound, Lobes linear subulate 9557 Leaves 3-parted fleshy cut-toothed glaucous, Segments subsessile cuneiform, Honey spur very long 9558 Leaves cuneiform trifid toothed, Petioles and stipules persistent spiny, Umb. comp. few-fl.

$\$$ C. Stem half-shrubby, fleshy. Leaves trifid or pinnate, fleshy, Petals yellowish brown. 9559 Stem with tumid articulations, Leaves pinnate of 1 or 2 pairs with an odd one blunt cuneate cut-toothed

$\$$ D. Nearly stemless. Root fascicled, tuberous. Leaves decompound, laciniated. Petals yellowish brown. 9560 Leaves decompound laciniate hairy, Segm. linear, Umb. many-fl.

9561 Leaves hairy pinnate, Segm. bipinnate; divisions ovate toothed somewhat acute

9562 Leaves smooth ciliated fleshy 5-7-lobed toothed reflexed at end, Umb. many-flow. Fls. on very long stalks 9563 Leaves hairy pinnate, Segm. bipinnatifid; divisions linear acute

9564 Leaves ternate oblong blunt wavy hairy on each side and revolute at end, Petals 2-parted multifid 9565 Leaves cordate downy beneath bluntly 3-5-lobed sinuate-toothed, Scape divided

9566 Leaves decompound smooth, Leaflets cut, Segments channelled linear, Calyx reflexed

8 E. Stem short, or somewhat fleshy. Leaves divided, cut or toothed. Petals scarlet or crimson. 9567 Leaves hairy pinnated, Segments laciniate pinnatifid decurrent, Lobes linear lanceolate 9568 Leaves 3-parted, Segm, sessile cuneate cut toothed, Middle lobe larger pinnatifid

9569 Leaves cord. 3-lobed, Segm. toothed: lateral bifid; middle 3-lobed, Stipules cord. acum. somew. toothed

$\$$ F. Stem half shrubby. Leaves lobed, hainy. Petals with a broad purple spot in the middle. 9570 Leaves hispid 3-parted, Segrn. multifid, Lobes linear-lanceolate serrated

9571 Leaves cordate 3-fid wavy hairy blunt toothed : lateral segments 3-lobed; upper 5-lobed

\&. Stem fleshy, half shrubby. Leaves oblong, or oftener cordate, somewhat cut. Stipules lanceolate, spreading, acute. Roots tuberous, fascicled.

9572 Leaves 3-parted hairy, Lateral segments smaller lobed toothed; term. long cut-toothed, Pet, spreading 9573 Leaves oblong lobed pinnatifid, Petioles united at base, Umb. many-flowered

9574 Leaves cord. obl. subruncinate toothed downy, Scape branched, Umb. many-fl. Involucre leafy

9575 Leaves ovate cordate somewhat lobed crenate villous beneath, Stipules persistent spiny

9576 Leaves reniform obacuminate toothed silky on each side, Bractes 4 times shorter than pedicel

9577 Leaves reniform obacuminate toothed silky on each side, Bractes twice as short as pedicels

95,8 Leaves cordate cut-lobed wavy bluntly toothed downy, Honey-tube 4 times as long as calyx

9579 Leaves reniform crenate-toothed downy beneath, Stipules persistent dilated at base

$\$$ H. Stem shrubby, fleshy. Leaves peltate, or cordate 5-lobed, fleshy. Honey-tube as long as stalk. Stipules broad ovate.

9580 Branches fleshy round, Leaves cordate 5-lobed somewhat toothed fleshy smooth, Umb. many-fl. 9581 Branches fleshy angular, Leaves peltate 5-lobed entire fleshy, Umb. few-fl.

*** Two upper petals broader, shorter, very blunt.

9582 Stem weak prostrate, Branches petioles and peduncles softly hairy, Leaves oval acute toothed hoary 9583 Leaves elliptical roundish finely serrate blunt rigid smooth, Petals all obovate

**** Two upper petals longer and broader. Stems shrubby.

A. Leaves smooth, or nearly smooth, more or less glaucous.

1. Petals white, the upper generally lined with red, or spotted.

9584 Very smooth and glaucous, Leaves lanceolate entire acuminate, Peduncles 1-2-f.

7585 Smooth glaucous, Leaves lanceolate entire or 3-parted; lower toothed, Pedunc. about 1-fl. panicled

9586 Very smooth somewhat glaucous, Leaves ovate acute glaucous somewhat cut remotely serrate

9587 Very smooth, Leaves deeply 3-parted, Segm. acinaciform cut serrate, Peduncles 3-flowered

9588 Very smooth glaucous, Leaves 3-parted, Segm. trifid cuneate; divisions linear lanc. Pedunc. about 2-fl.

9689 Smooth glauc. Lvs. 5-lobed palmati. cord. at base, Lobes toothed tow, the end, Pet, 3 times as long as cal.

9590 Smooth glaucous, Leaves 3-5-lobed palmate-parted, Segments trifid toothed, Stipules ovate cordate acute

2. Petals rosy or violet, upper generally striped with purple.

9591 Smooth glaucous, Leaves long-stalked cordate reniform 3-5-fid toothed, Petals lanceolate-cuneate 9592 Smooth glaucous, Leaves on long stalks cordate roundish 5 -fid toothed zoned above

9593 Smooth glaucous, Leaves cord. 5 -lobed toothed glaucous beneath : younger zoned above; upper 5 -parted

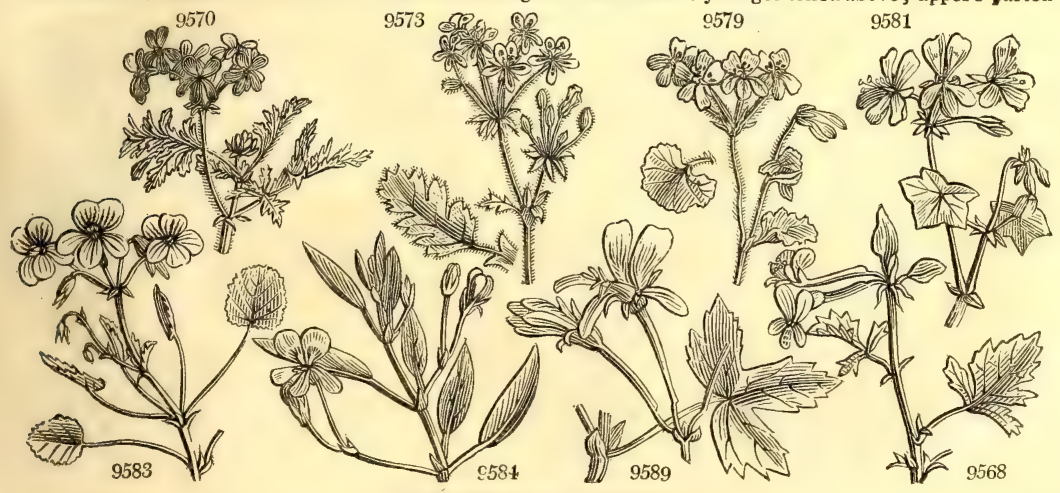

and Miscellaneous Particulars.

\&c. thrive best in an equal mixture of sandy loam and peat, and require their pots to be well drained: the succulent kinds like a light sandy loam, and require scarcely any water when not in vigorous growth: the 


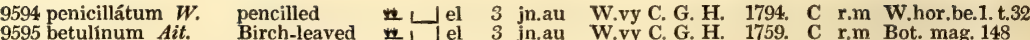

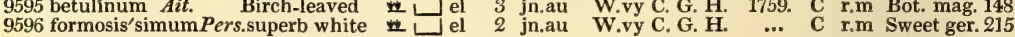

9597 tomentósum Jacq. Pennyroyal $\quad$ J or 3 jn.jl $\quad$ W $\quad$ C. G. H. 1790. S r.m Bot. mag. 518 9598 ribifólium Jacq. currant-leaved 1 or 3 my.jn W C. G. H. 1798. C r.m Jac. ic.3.t.538

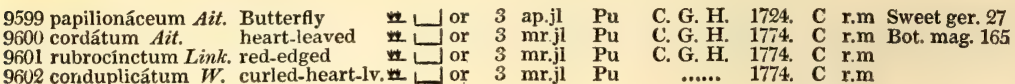

9602 conduplicátum $W$. curled-heart-lv, w or $3 \mathrm{mr} . \mathrm{jl}$ Pu

\begin{tabular}{|c|c|c|c|c|c|c|c|c|c|c|c|}
\hline 9603 cucullátum Ait. & hooded-leaved & L L & or & 3 & mr.jl & $\mathrm{Pu}$ & C. G. H. & 1690. & C & $\mathrm{r} . \mathrm{m}$ & Ca.dis.4.t.106.f.: \\
\hline 9604 speciósum $W$. & specious & \pm & or & 3 & ap.jl & $\mathrm{Pu}$ & C. G. H. & 1794. & $\mathbf{C}$ & r.m & \\
\hline 9605 cochleátum $W$. & concave-leaved & +2 & or & 3 & mr.jl & $\mathrm{Pu}$ & & & C & r.m & \\
\hline 9606 acerifólium $L^{\prime} \mathrm{Her}$. & Maple-leaved & \pm 2 & or & 3 & ap.my & $\mathrm{Pu}$ & C. G. H. & 1784. & $\mathrm{C}$ & r.m & L'Her. ger. t. 21 \\
\hline 607 angulósum Ait. & Marsh mallow-lv & & or & 3 & jl.s & $\mathrm{Pu}$ & C. G. H. & 1724. & C & r.m & Ca.dis.4. \\
\hline 9608 Barringtónii $W$. & Barrington's & in & or & 3 & mr.jl & $\mathbf{P u}$ & C. G. H. & $\ldots$ & C & r.m & \\
\hline 9609 Watsónii Link. & Watson's & in. & or & 3 & mr.jl & $\mathbf{P u}$ & & 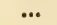 & $\mathbf{C}$ & r.m & Sweet ger. 130 \\
\hline ulterinum $L^{\prime} H$ & lv. & & & 3 & ap.jn & $\mathbf{P u}$ & C. G. H. & 1785. & C & r.m & Sw \\
\hline ilobum Jacq. & three-lol & n & or & 3 & apjl & $\mathbf{P u}$ & C. G. H. & 1800. & C & r.m & t. 136 \\
\hline folium Ait. & Vine-leaved & wi & or & 3 & ap.au & $\mathrm{Pu}$ & C. G. H. & 1724. & C & r.m & Ca.dis. 4 \\
\hline 13 capitátum Ait. & Ros & ע. & or & 3 & ap.au & $\mathrm{Pu}$ & C. G. H. & 1690. & $\mathbf{S}$ & r.m & And. ger. c. ic \\
\hline 014 rúbens $W$. & red-flowered & z & or & 3 & my.jl & $\mathrm{Pu}$ & & ... & $\mathbf{C}$ & r.m & \\
\hline ólium Ait. & & \#. & & & ap.au & Pu & & & C & r.m & Swee \\
\hline jidátum $L$ 'her & r.thre & ne & or & 3 & my.au & W. & C. G. H. & 1780. & C & $\mathrm{r}, \mathrm{m}$ & L'Her. ger. t. 3 \\
\hline 9617 scábrum Ait. & rough wedge-lv & & or & & ap.au & & C. G. H. & 1775. & C & r.m & Jac. ic. 3 . t. 542 \\
\hline 3 hermannifóliu & c. Her & & or & 3 & ap.jn & Pk.vy & C. G. H. & ... & $\mathbf{S}$ & r.m & $3+545$ \\
\hline Ait. & curl-le & Net & or & 3 & jl.n & $\mathrm{Pu}$ & C. G. $\mathbf{H}$. & 1774. & C & r.m & t. 32,33 \\
\hline látum Ait. & d-leavd & & or & 3 & my.au & Vi.vy & C. G. H. & 1779. & C & $\mathrm{r}, \mathrm{m}$ & L'Her.ger. t. 35 \\
\hline 9621 pustulósum Sweet & pimpled & 2. L & or & 3 & my.au & W & C. G. H. & 1820. & $C$ & r.m & Sweet ger. t. 11 \\
\hline $\mathrm{m} W$ & pale-flowered & 2. & or & & ap.au & Pk & & *io & C & r.m & \\
\hline ternátum Jac & nate & & or & & ap.au & & & 320. & C & r.m & weet ger, 165 \\
\hline
\end{tabular}

\begin{tabular}{|c|c|c|c|c|c|c|c|c|c|}
\hline$i t$. & & or & $3 \mathrm{mr} . \mathrm{au}$ & $\mathbf{P u}$ & & 774. & C & r.m & Her. ger. t. 14 \\
\hline Ait. & $\mathrm{O}$ & or & $3 \mathrm{mr}$ & & & & C & $\mathbf{r} . \mathbf{m}$ & $\mathbf{L}$ \\
\hline um Ait. & & 0 & $3 \mathrm{my}$. & Pk.vy & C. G. & & C & r.m & \\
\hline$W$ & & or & $3 \mathrm{~m}$ & $\mathbf{P u}$ & C. & & C & r.m & $\mathrm{C}$ \\
\hline iit. & eaved & II & 3 & $\mathbf{P}$ & & & C & r.m & \\
\hline acq. & & 业 & 3 & I & & & C & r.m & \\
\hline$W$ & & th & jl & $\mathbf{P}$ & C. $\mathbf{G}$ & & C & r.m & 10 \\
\hline rו & & or & jn. & $\mathbf{P k}$ & & & & $\mathrm{r} \cdot \mathrm{m}$ & \\
\hline delpni & & or & 3 ap.jl & Pk & & & C & r.m & \\
\hline
\end{tabular}

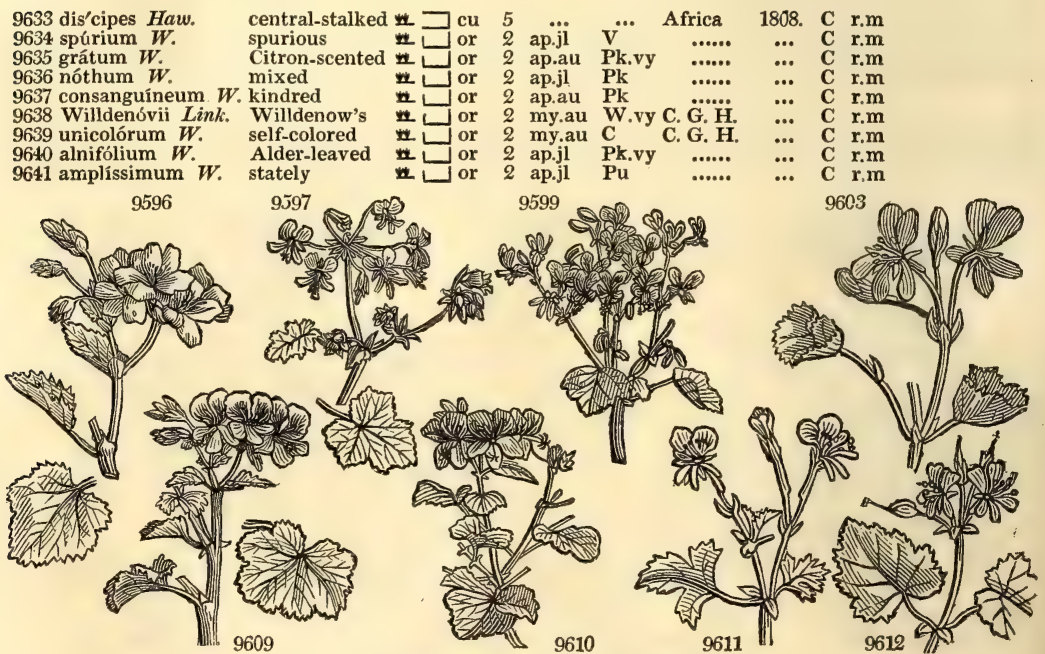

History, Use, Propagation, Culture,

tuberous rooted kinds thrive best in very sandy loam and peat, and require no water after they have flowered, till they begin to grow afresh. Cuttings of the shrubby kinds strike root freely under hand-glasses in the same 
6 B. Flowers white, or scarcely rose-colored; two upper petals deep-red, lined. Lecves ovate, cordate, or reniform toothed, undivided.

9594 Lvs, ovate cut serr, the younger scabrous backwards; adult nearly smooth, Stipules ovate acuminatc 9595 Leaves ovate unequally serrate smoothish, Stipules ovate-lanceolate, Peduncles 2-4-flowered

9596 Umb. many-fl. Leaves ovate acute concave rigid somew. lobed uneq. tooth. truncate at base many-nerved

\& C. Petals white, narrow. Leaves cordate, soft with down. Stipules spreading much. 9597 Stem shrubby fleshy, Branches peduncles and leaves hirsute, Leaves cordate hastate 5-lobed very soft 9598 Stem shrubby fleshy, Branches and pedunc. subhis;id, Lvs. cord. hastate 5-lobed rough, Umb. many-fl

\$. Leaves cordate, flat, toothed. Lower petals linear ; upper purple, lined.

9599 Branches leaves and pedunc. hairy, Leaves cordate roundish angular toothed, Umbels panicled many-f. 9600 Lvs. cord. acute toothed flat hoary beneath and downy, Branches and ped. pilose, Lower pet. subulate-lin. 9601 Leaves cordate acutely crenulate quite smooth, Stipules linear reflexed, Umbels many-flowered

9602 Leaves roundish ovate truncate subcordate at base cut-toothed wavy beneath hoary pubescent

$\$$ E. Leaves cordate, or cuneate, toothed, undivided, or lobed. Lobes blunt, not divided down to the middle Flowers purple. Lower petals oblong or obovate.

1. Leaves undivided, cucullate.

9603 Leaves reniform cucullate toothed pubescent, Branches and peduncles softly hispid, Lower petals oblong 9604 Leaves roundish truncate reniform with acute cartilaginous teeth many-nerved subpubescent

9605 Leaves roundish ovate subcord. concave somewhat angular serr. pubesc. Honey-tube the length of calyx 9606 Leaves cun. at base entire at end palmately 5 -lobed toothed many-nerved rather villous, Stip. cordate ovate 9607 Leaves truncate at base subcucul. roundish bluntiy 5 -lobed toothed pubesc. Stipules cord. ovate acuminate 9608 Leaves reniform blunt cucullate toothletted hairy on each side, Umbels many-flowered

9609 Leaves cord, roundish somewhat lobed tooth-crenate wavy at edge, Stipules cord. acute somew. toothed

\section{Leaves lobed, flattish.}

9610 Leaves cordate bluntly 3-lobed wavy villous soft, Pedunc. about 2-flowered

9611 Leaves truncate at base subcuneate 3-fid flat hairy, Lobes divaricating serrated at end, Lower petals lin. 9612 Leaves cordate 3-lobed roughish blunt toothed, Stipules broad cordate, Stem erect

9613 Leaves cordate lobed wavy softly villous toothed, Stipules broad cordate, Stems diffuse

9614 IVs. subcord. acute slightly 5-lobed serrated, Umb. 5-fl. subcapitate, Ped. scarcely longer than involucrum

3. Leaves lob̆ed. Lobes acutely cut at end.

9615 Lvs, deeply 3-lobed, Lobes round. blunt unequally toothlett. Veins ben. and cal. roughish, Stipules cord. 9616 Leaves cuneate at base trifid, Lobes acute : middle longer subserrate with a midrib muricated beneath 9617 Leaves cuneate at base trifid rough, Lobes lanc. loosely serrated, Pedun. 1-4-flowered

9618 Leaves cuneiform distichous rough plaited truncate at end cut-toothed, Peduncles 2-flowered short

9619 Leaves distichous roundish fleshy subcuneate at base trifid wavy plaited rough toothed, Pedun. about $2-\mathrm{fl}$

9620 Leaves truncate cord. 3-lobed toothed hoary, Stipules scarcely any, Peduncles 3-4-flowered

9621 Lower lvs. deeply 3-lobed beneath pustular, Lateral lobes spreading unequally and acutely toothed

9622 Leaves deeply 3-lobed, Lobes spreading unequally and acutely toothed at end beneath and at edge rough

9623 Leaves 3-parted cucullate rough, Lobes cuneiform cut-serrate at end : the middle one trifid

F. Leaves divided beyond the middle. Lobes toothed, cut, or pinnatifid. Flowers purplish or pale. 9624 Leaves cord. pinnatifid with rounded recesses, Lobes blunt crenate, Branches and petioles hispid 9625 Leaves palmately 7 -lobed, Lobes oblong blunt toothed revolute at edge, Umb. many-fl. capitate 9626 Leaves cord. hastate 5-angled toothed viscid smoothish, Umb. 2-4-fl. Honey tube a little longer than calyx 9627 Leaves palmatifid downy hispid, Lobes acuminate cut toothed, Umb. panicled many-f.

9628 Leaves palmated rough, Lobes narrow pinnatifid revolute at edge, Segm. linear, Umb. few-f.

9629 Leaves palmated roughish cuneate at base, Lobes lanc. remotely toothed, Umb. few- $f$.

9630 Leaves somewhat palmated rough, Lobes 5-7-oblong blunt crisply toothletted at edge, Umb. 5-fl. in heads 9631 Leaves palmated viscid smooth, Lobes linear pinnatifid repand toothed flattish, Umb. few-fl.

9632 Leaves rough palmate 5-lobed, Lobes oblong serrated : middle 3-lobed, Umbels few-fl. compound

$\ddagger$ Uncertain species.

9633 Stem fleshy branched arboreous, Lvs. cord. peltate pubesc. variably glauc. Petioles villous without stipules 963+ Leaves reniform distichous slightly 3-lobed blunt unequally toothed wavy

9635 Leaves slightly trifid unequally and acutely toothed wavy hairy, Peduncles 2-4-fl

9636 Leaves roundish ovate blunt subtrifid folded together wavy toothed hairy beneath, Sepals erect

9637 Leaves slightly 3-lobed flat blunt, Lobes divaricating unequally and finely toothed, Pedunc. 3-fl.

9638 Leaves roundish cuneate slightly 3-lobed wavy toothletted, Branches petioles and peduncles villous

9639 Leaves roundish cuneate slightly 3-lobed wavy toothletted, Honey tube twice as short as reflexed calyx

9640 Leaves ellipt. blunt : floral obsoletely subtrifid unequally toothed somew, cuneate and entire at the base

9641 Leaves flat very smooth half round 7-lobed serrated slightly cordate at base, Pedunc. 2-5-flowered

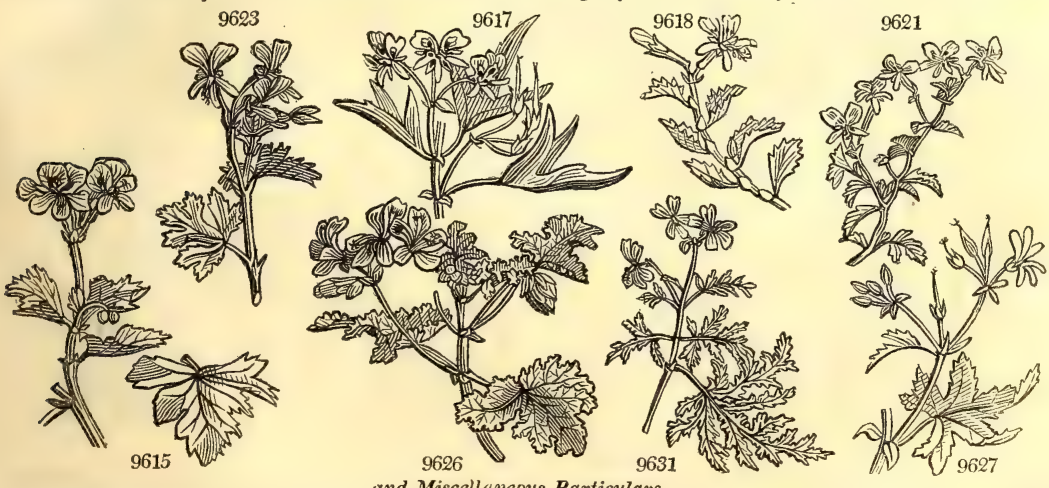

and Miscellaneous Particulars.

kind of soil, or in pots, without being covered by glass, and placed in a shady situation. Many of the kinds may also be increased by pieces of their roots, or from seeds. The tuberous-rooted kinds may be propagated 
1 Aceroídes Sweet ger. 242 2 acutilóbum Do. 184 3 áfluers Do. 194

4 ácidum Do. 261

5 Allénii Do. 229

6 amœ'num Do. 121

$7 æ^{\prime}$ mulum Do. 180

8 anthriscifúlium Do. 233

9 árdens Do. 45

10 ardéscens Do. 231

11 armátum Do. 214

12 asperifólium Do. 169

13 atrofíscum Do. 82

14 atropurpúreum Do. 152

15 atrosanguíneum Do. 15

16 aurantiacum Do. 198

17 Baileyánum Do. 87

18 Bakeriánum Do. 240

20 Barnardianum Do. 191

20 Beadoniæe Do. 191 Do 138

22 bel'lulum Do. 60

23 bipartitum Do. 142

24. Blandfordiánum Do. 101

25 blándum $D o .4$

26 Boýleæ Do 50

27 Brightiánum Do. 227

28 Broughtóniæ Do. 181

29 Brównii Do. 146

30 Breesiánum Do. 64
Garden Varieties.

31 calocéphalon Sweet ger. 201

32 calycínum Do. 81

33 Campyliæflórum Do. 251

34 cándidum Do 128

35 cardiifólium Do. 15

36 cerínum Do. 176

37 chærophýllum Do. 257

38 chrysanthemifólium Do. 124

39 coarctátum Do. 70

40 Colvilliánum Do. 260

41 Colvíllii Do. 86

42 Comptóniæ Do. 122

43 cómptum Do. 255

44 concávum Do. 237

45 concînnum Do. 108

46 cóncolor Do. 140

47 corúscans Do. 173

48 Cosmiánum Do. 189

49 crenátum And. ger.

50 crenulátum Sweet ger. 162

51 cruéntum Do. 170

52 Daveyánum $D o .32$

53 Dennisiánum Do. 20

54 dentátum And. ger.

55 depéndens Sweet ger. 195

56 diffor'me Do. 105

57 Dimacriæfórum Do. 220

58 disséctum Do.247

59 Dobreeánum Do. 253

60 dumósum Do. 19
61 elátum Sweet ger. 96

62 eléctum Do. 238

63 élegans (Hoarea) Do. 132

64 élegans (Dimacria) Do. 202

65 élegans (Campylia) Do. 222

66 eréctum Do. 187

67 eriophýllum Do. 141

68 exímium Do. 26

69 Fair'liæ Do. 178

70 flexuósum Do. 180

71 floccósum Do. 129

72 flóridum $\mathrm{Do} .41$

73 formósum Do. 120

74 fuscátum Do. 210

75 glauciifólium Do. 179

76 grandidentátum Do. 217

77 Grenvilliánum And. ger

78 Hammersléiæ Sweet ger. 225

79 Hoareæflórum Do. 133

80 Hoareánum Do. 80

81 Husseyánum Do 92

82 imbricátum Do. 65

83 incanéscens Do. 203

84 incúrvum Do. 249

85 inscríptum Do. 193

86 intertéxtum Do. 185

87 involucrátum máximum $D 0.33$

88 Jenkinsóni Do. 154

89 jonquillínum Do. 241

90 Kin'gii Do. 248

1462. AITO'NIA. $W$. Aitonia. 9642 capénsis $W . \quad$ Cape

OCTANDRIA.

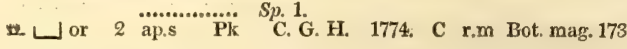

\section{DECANDRIA.}

1463. GERA'NIUM. $W$. Crane's-BuL

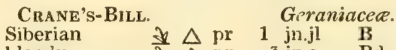

9613 sibiricum NIU 9643 sanguineum $W$. 9645 incanum $W$.

9646 canéscens $W$.

9647 argénteum $W$.

9648 várium $W$.

9648 várium $W$ anemonefólium $W$.

9650 macrorhizum $W$.

9651 tuberósum $W$

9652 ibéricum $W$.

9653 nodósum $W$.

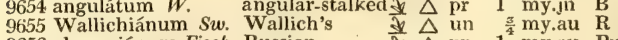

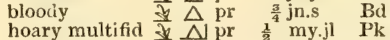

silky-leaved $\frac{\Delta}{d} \Delta \mathrm{pr} \frac{1}{\frac{1}{2}}$ my.jn $\mathrm{Pk}$

silvery-leaved 20

grey $\$ \mathrm{pr}$

3 my.au $\mathrm{R}$

$1 \frac{1}{2}$ my.jn $\mathrm{Pu}$

1 my.au $\mathrm{Pk}$ tuberous-root. $\frac{7}{2}$ Iberian $\Delta \mathrm{el}$

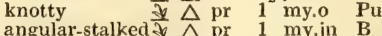

$1 \frac{1}{2}$ jn.s B 9656 vlassoviánum Fisch. Russian d $\Delta$ pr 1 my.au $\mathrm{Pu}$ 9657 striátum $W$. 9658 refléxum $W$. 9659 phæ'um $W$. 9660 físcum $W$.

9661 lividum $W$

9662 eriostémon Fisch. 9663 sylváticum $W$. 9664 praténse $W$. 9665 lon'gipes Dec.

$\stackrel{\Delta}{\mathrm{pr}} \quad 1$ my.au $\mathrm{Pu}$

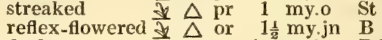
dusky $\Delta$ or $1 \frac{1}{2}$ ap.jn $B d$ brown is $\triangle 1$ or $1 \frac{1}{2} \mathrm{jl} \quad \mathrm{Br}$ wrinkled-leav'd $\frac{1}{2} \Delta$ or $1 \frac{2}{2} \mathrm{jn} . \mathrm{jl} \quad \mathbf{P u}$ woolly-stamen. \& $\triangle$ pr $1 \frac{1}{2} j n . j 1 \quad B$

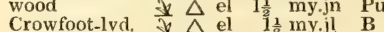

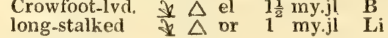

Sp. $45-66$. C.

C. G. H. 1787. S r.m L'Aer. ger.t. 38

S. Europe 1699, D s.l Sweet ger. 59

$\begin{array}{llll}\text { Pyrenees } & . . & \text { D s.l L'Her, ger. t. } 37\end{array}$

Madeira 1788. S r.m Sweet ger. 244

Italy 1576. D s.l Bot. mag. 2420

Italy 1596. R r.m Sweet ger. 155

Levant 1802. D s.l Sweet ger. 84

England moun. D s.1 Eng. bot. 1091

..... 1789. D s.l Bot. mag. 203

Nepal 1819. D s.l Sweet ger. 90

Crimea 1821. D s.1 Sweet ger. 998

Italy 1629. D s.l Bot. mag. 55

Italy 1758. D s.1 Cav.dis.4.t.81.f.1

England m.thi. D s.l Eng. bot. 322

S. Lurope 1759. D co

Switzerl. 1775. D s.l L'Her.ger. t. 39

Siberia 1822. D co Sweet ger. 197

Britain m thi. D s.l Eng bot. 121

Britain me.pa. D s.1 Eng. bot. 404

...... 1823. D co

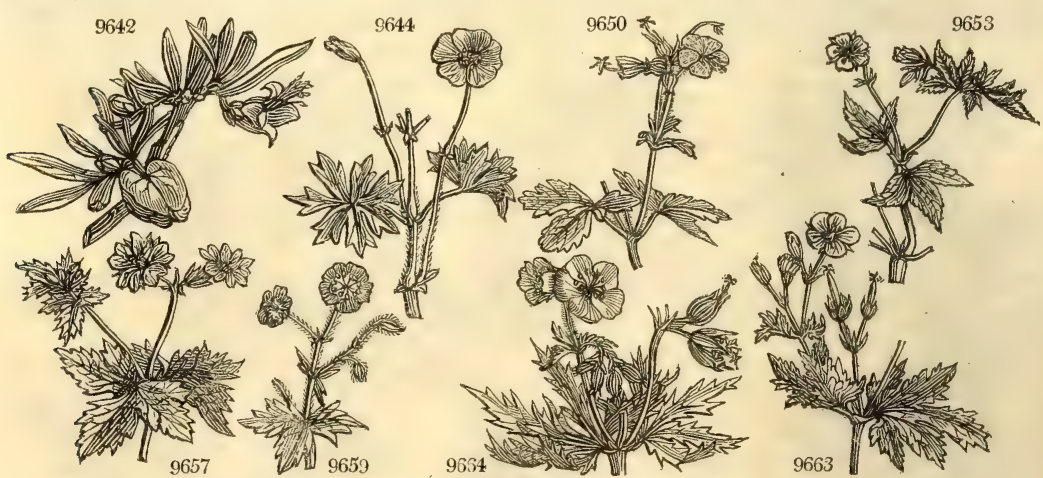

History, Use, Propagation, Culture,

by the little tubercles of the roots, or by seeds. For the general treatment of each species, see Sweet's Geraniacex, (Bot, Cult. 237)

1462. Aitonia. In honor of the late Mr. William Aiton, the King's gardener at Kew. " A pretty genus," Sweet observes, "which thrives well in an equal mixture of sandy loam and peat : young cuttings will root in 
91 Lambérti Sweet ger. 104 92 lanceolátum And. ger. 93 latilóbum Sweet ger. 236 94 laxiflórum Do. 216 95 lépidum Do. 156 96 lineátum Do. 116 97 Lousadiánum Do 44 98 lúteum Bot. rep. 328 99 macránthon Sweet ger. 83 100 Mattocksiánum Do.234 101 melíssinum Do. 5 102 mixtum Do. 71 103 modéstum Do. 204 04 Mostýnæ Do. 10 105 multinérve Do. 17 106 Murrayánum Do. 164 107 mutábile Do. 213 108 nánum Do. 102 109 nervósum Do. 47 110 Newshamiánum Do. 144 111 notátum Do. 208

112 nummularifólium Bot. rep. 123 113 oblátum Sweet ger. 35

114 obscúrum Do. 89

115 obtusifólium Do. 25 116 optábile Do. 62 117 opulifólium Do. 53 118 ornátum Do. 39 119 Pálkii Do.224

120 pannifúlium Do. 9

Garden Varielies.

121 párticeps Sweet ger. 49 122 pátens Do. 125

123 paucidentátum Do. 186

124 pavoninum $D o, 40$

125 pectinifolium Do. 66 126 phœníceum Do. 207 127 pinguifólium $D o .52$ 128 planifólium Do. 219 129 platypétalon $D o .116$ 130 Pottéri Do. 147

131 Principíssa Do. 139

132 pubéscens And. ger. 133 pulchérrimum Sweet ger. 134 134 púlchrum Do. 107 135 pulveruléntum Do. 218 136 pyrethrifólium Do. 153

137 ramulósum Do. 177

138 recurvátum Do. 223 139 reticulátum Do. 143 140 rigéscens $D o .112$

141 ríngens Do. 256

142 Robinsóni Do. 150 143 rotundilóbum Do. 252

144 rubéscens Do. 30

145 rugósum And. ger 146 sæpeflórens Sweet ger. 58 147 Saundérsii Do. 205 148 Scarboróviæ Do. 117 149 scintíllans Do. 28 150 Scóttii Do. 264
151 scutátum Swect ger. 95 152 seléctum Do. 190 153 selenifólium Do. 159 154 serratifólium Do. 221 155 Seymoúriæ Do. 37 156 Smithii Do. 110 157 solúbile Do. 24 158 spectábile Do. 136

159 sphondyliifớlium Do. 246

160 Stapeltóni Do.212

161 striátum Do. 1

162 sulphúreum Do. 163 163 Thyn'nex Do. 74 164 Tibbitsiánum Do. 158 165 torrefáctum $D o .243$ 166 tyriánthinum Do. 183 167 Vandésiæ Do. 7

168 várium Do. 166

169 venifiórum Do. 258 170 venósum Do. 209 171 venústum $D o .167$ 172 verbascifórum Do. 157 173 verbenæfólium $D O .149$ 174 versícolor $D o .78$ 175 vespertínum Do. 239 176 villósum Do, 100 177 viscosíssimum Do. 118 178 Wellsiánum Do. 175 179 Yoúngii Do. 131

\section{OCTANDRIA.}

9642 The only species

\section{DECANDRIA.}

9643 Stem erect diffuse branched, Peduncles longer than petiole, Leaves 5-parted, Loices oblong cut-toothed 9644 Stem erect diffuse branched, Ped. longer than petiole, Leaves opp. 5-parted, Lobes trifid, Lobelets linea: 9645 Stem diffuse, Leaves hoary beneath 7-part. Lobes multifid linear, Pedunc. elongated, Calyxes silky villous 9646 Stem diffuse, Leaves hoary beneath 5-parted, Lobes obl. cut-toothed, Ped, very long and cal. gland. hairy 9647 Stem very short, Radical leaves on long stalks silky on each side 5-7-parted, Lobes 3-fid, Lobelets linear 9648 Stem very short, Rad. leaves stalked glaucous pubescent 5-parted, Lobes cuneiform trifid, Pedunc. radical 9649 Stem shrubby, Leaves smooth palmate 5-cut, Segments bipinnatifid, Peduncles opposite erect hairy

9650 Stem suffruticose at base dichot. at end, Lvs. smooth 5-parted, Lobes toothed at end, Cal. globose inflat. 9651 Root subglobose, Stem naked from base to the branches, Leaves 5-parted, Lobes lin. pinnately cut serrate 9652 Stem villous dichotomous, Leaves 5-7-parted, Lobes pinnately cut, Calyxes ciliate villous

9653 Stem 4-cornered, Lower leaves 5-lobed; upper 3-lobed, Lobes oblong acuminate serrate, Pet. emarginate 9654 Stem angular, Rad. leaves 7-lobed; cauline 5-lobed, Lobes oblong acuminate toothed, Petals einarginate 9655 Stem erect somewhat angular, Leaves opposite 5-lobed, Lobes cuneate ovate lobed-toothed, Stip. connate 9656 Stem round, Leaves 5-lobed, Lobes oval acuminate cut-toothed, Stipules connate bifid

9657 Stem round, Lower leaves 5-lobed; upper 3-lobed, Lobes ovate acute cut toothed, Stipules distinct 9658 Stem round, Leaves altern. 5-7-lobed cut-toothed; upper sessile, Petals reflexed toothed at end 9659 Stem round, Leaves 5-lobed cut-toothed; upper sessile, Petals spreading entire, Filaments hairy at base 9660 Like the last, but with dark fuscous petals

9661 Like Phæum, but the petals are rose-colored and emarginate

9662 Stem round simple, Lvs. 5-lobed, Lobes ovate coarsely toothed : lower on long stalks altern.; upp. sess. opp. 9663 Stem round erect smooth, Lvs, about 7-lobed, Lobes obl. cut serr. Ped. corymbose, Pet. somew, emarginate 9664 Stem round erect downy, Lvs. about 7.lobed, Lobes linear obl. cut serrate, Ped, somew, corymb. Pet. entire 9665 Stem round erect smooth, Leaves palmate subpeltate 5-7-lobed, Lobes oblong coarsely cut, Ped. very long

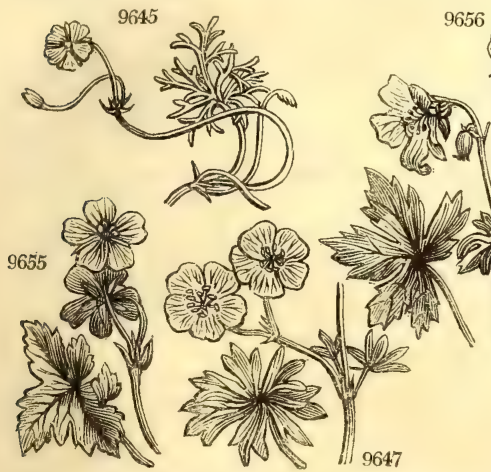

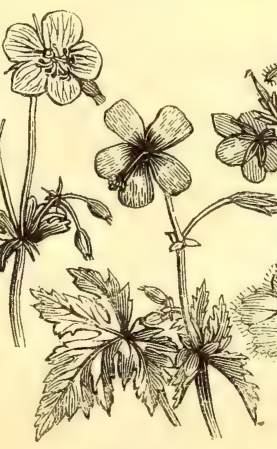

9649

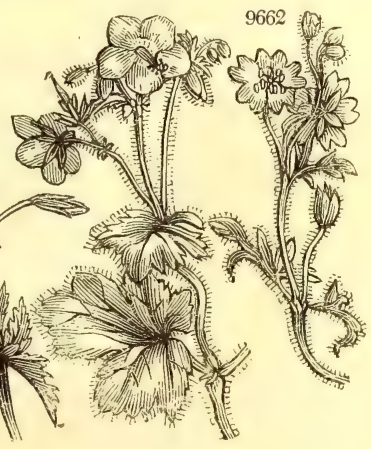

9651

and Misccllaneous Particulars.

sand, under a bell-glass, plunged in heat. The cuttings must not be put in very close together, and the glass must be wiped frequently, as they are apt to damp off." (Bot. Cult. 129.)

1463. Geranium. Teposioy of the ancient Greeks, so called from yegovos, a crane, the capsule and its beak resembling the head of that bird. These are chiefly European plants, in many cases being mere weeds, of no P p 2 
9666 maculátum $W$. 9667 collinum $W$. 9668 palústre $W$ 9669 aconitifólium $W$ 9670 dahúricum $D e c$. 9671 pilósum Forst. 9672 parviflórum $W$.en. 9673 nepalénse Sweet 9674 pyrenáicum $W$. 9675 umbrósum $\boldsymbol{P} . \boldsymbol{S}$. 9676 mujle $W$. 9677 pusillum $W$. 9678 rotundifólium $\boldsymbol{W}$. 9679 columbínum $W$. 9680 disséctum $W$ 9681 saroliniánum $P h$ 9682 bohémicum $W$ 9683 divaricátum $W$ 9684 lúcidum $W$.

$\begin{array}{ll}9684 \text { lúcidum } W . & \text { shining } \\ 9685 \text { Robertiánum } W \text {. } & \text { Herb-Robert }\end{array}$ 9686 purpúreum $W$. purple 9687 Lancastriénse With. Lancashre

1464. BROW'NEA. $W$. BRowNEA.

9688 coccínea $W$. scarlet spotted

hill

marsh

Aconite-leaved

small-flowered

Nepal

mountain

naked-stalked

Dove's-foot

round-leaved

long-stalked

jagged-leaved

spreading

Bohemian

Baddin

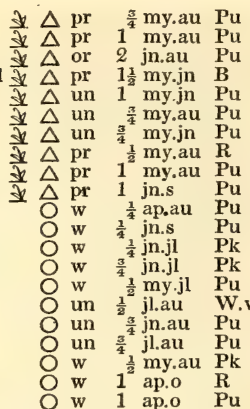

(1) 1 ap.o Pu

N. Amer. 1732. D s.1 Cav.dis.4.t.86.f.2 Siberia 1815. D co

Germany 1732. D s.1 Sweet ger. 3

Switzerl. 1775. D s.1 L'Her. ger. t. 40

Dahuria 1820. D co

N. Zeal. 1821. D co Sweet ger. 119

V. Di. L. 1816. D co

Nepal 1818. D co Sweet ger. 12

Britain me.pa. D s.l Eng. bot. 405

Hungary 1804. D co Pl, rar. h.2.t.144

Britain was.gr. S co Eng. bot. 778

England was.gr. S co Eng. bot. 385

England graba. S co Eng. bot. 157

Britain cha.ba. S co Eng. bot. 259

Britain was.gr. S co Eng. bot. 753

N. Amer. 1725, S co Cav.dis.4.t.84.f.1

Bohemia 1683, S co Cav.dis.4.t.81.f.2

Hungary 1799. S co Pl. rar. h.2. t.123

Britain ston.pl. S co Eng. bot. 75

Britain ston.pl. S co Eng. bot. 1486

Britain ... S s co Vill.delph.3.t.40

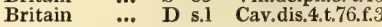

\section{Leguminose. Sp. 1-3.}

๑ $\square$ spl $18 \mathrm{jl}, \mathrm{au}$ Sc W. Indies 1793. C r.1 Jac. amer. t. 121

\section{DODECANDRIA.}

1465. MONSO'NIA. W. Monsonia. 9689 speciósa $W$. large-flowered 9690 pilósa $W$. 9691 lobáta $W$ 9692 ováta $W$. 9693 spinósa $W$. hairy broad-leaved oval-leaved thorny

Geraniacea. Sp. 5-8.

1466. HELIC'TERES. $W$. SCREW-TREE 9694 baruénsis $W$. small-fruited 9694 baruensis $W$. 9695 jamaicénsis $W$ 9696 Isóra $W$ great-fruited East Indian 9697 verbascifolia Cels. Mullein-leaved 9698 ferrugináta Link. rusty

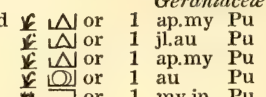

C. G. H. 1774. R r.m Sweet ger. 77 C. G. H. 1778. R r.m Sweet ger. 199 C. G. H. 1774. R r.m Bot. mag. 385

C. G. H. 1774. R r.m L'Her. ger. t. 40

C. G. H. 1790. R r.m L'Her. ger. t. 42

\section{Bombacea. Sp, 5-17.}

$\square$ or 12 s.o Pu W. Indies 1739. C p.1 Jac. amer.t. 149 \begin{tabular}{lrllll} 
or & 8 & jn.jl & $\mathrm{Pu}$ Jamaica 1739. & C & p. \\
\hline
\end{tabular} $\square$ or 12 jn.jl Pu E. Indies 1733. C p.1 Bot. mag. 2061

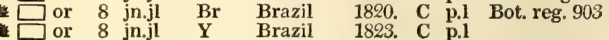

1467. DOMBE'YA. $J$, DOMBEYA 9699 tiliæfólia Cav. linden-leaved 9699 tiliaflia Cav. ferruginous

1468. Pent a Pe'tes. $W$. Pentapetes. 9701 phœnicea $W$. Scarlet-flower'd $\mathbb{E} \nabla$ or 2 jyttneriacea. Sp. 2

Byttneriacea, Sp. 2-10

$\square$ or 15 … W Bourbon 1820. C s.1 Cav.dis.3.t.39.f.2 scarlet-flower'd $\mathbb{E} \square$ or 2 jl.au S India 1690. C s.p Mill. ic. t. 201 9702 ováta $P . S . \quad$ oval-leaved $\square$ or 2 jn.s S N. Spain 1805. C s.p Cav. ic. t. 433

1469. ASTRAPE'A. Lindl. AstrapeA. Byttneriacea. Sp. $1-3$.

9703 Wallichii Lindl. Wallich's $\quad \square$ spl 20 jl.au Pk Madagasc.1820. C s.p Bot.mag.2503 1470. PTErosper'Mum. $W$. Pterospermum. Byttneriacea. Sp. 3-4.

9704 suberifólium $W$. various-leaved $9 \square$ or 10 s.o W E. Indies 1783. C p.1 Bot. mag. 1526 9705 acerifólium $W$. Maple-leaved $\$$ or 10 jl.s $\quad$ W E. Indies 1790. C p.1 Bot. mag. 620 9706 semisagittátum Rox.half-sagittate $\$$ or $10 \ldots \ldots$ W E. Indies 1820 . C p.1

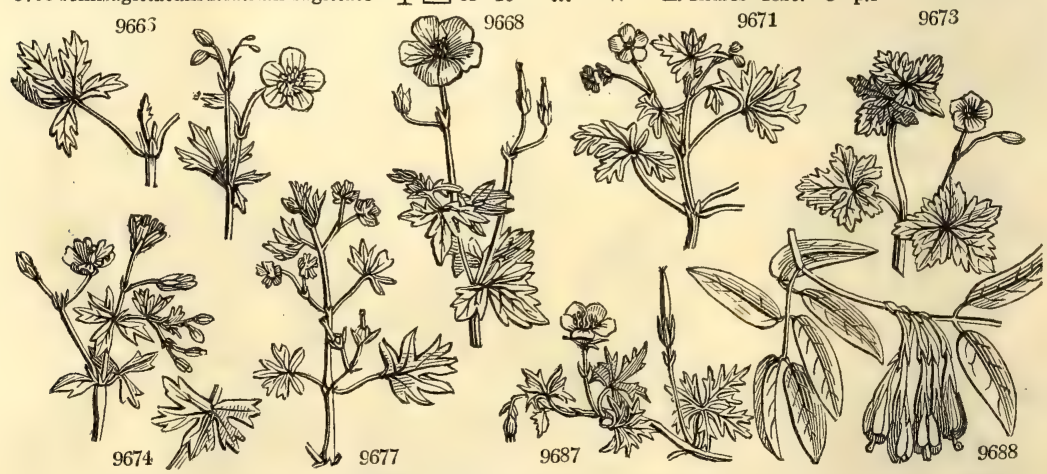

History, Use, Propagation, Culture,

interest, and in others, being extremely shewy border-flowers. The G. Lancastriense is the most elegant, and G. sanguineum the most ornamental of our British kinds. G, anemonifolium, a Cape species, is singularly beautiful, on account of its fine caulescent stem, loaded with large fern-like glossy leaves of the most delicate green, and its fine red rich blossoms broader than half a crown.

1464. Brownea. Named after Dr. Patrick Browne, an English physician, who published a Natural History of Jamaica, in 1756, illustrated with figures from the pencil of Ehret. A splendid genus, as yet rare in British gardens. Loamy soil best suits rooted plants; and ripened cuttings root in sand in close moist heat.

1465. Monsonia. In memory of Lady Ann Monson, a lady of eminent botanical acquirements, who resided for many years in the Fast Indies, and is said to have assisted in compiling Lee's Introduction to Botany. The species are curious and beautiful plants : they grow well in turfy loam and rotten leaves, and are increased by cuttings of the shoots or roots. 
9666 Stem somew, angul erect dichotomous pubesc. backw. Lvs, 3-5-part cut-tootheck : radic on very long stalks 9667 Stem angular diffuse pubesc. backw. Lvs. palmate 5-part.: lobes 3-lobed cut serrate, Ped. and cal. vill. viscid 9668 Stem decumbent villous with spreading hairs, Leaves 5-7-lobed : lobes cut-toothed, Ped. very long hairy 9669 Stem ascending smoothish, Leaves peltate 7-parted : lobes cut, Peduncles and calyx villous

9670 Stem naked at base erect smooth, Caul. lvs. opposite 3-5-part. : lobes cut acute, Ped. 3 times as long as leaf 9671 Stems decumbent branched, Petioles and peduncles hispid, Leaves 3-5-parted : lobes linear blunt trifid 9672 Stems decumbent, Petioles pedunc. and calyx smoothish, Caul. lvs. opp. 3-5-parted : lobes trifid toothed 9673 Stem prostrate compressed, Lvs. opp. 5-lobed : lobes oblong unequally toothed, Ped. elong. and cal. hairy 9674 Stem erect branched, Leaves reniform 7-lobed: segm. oblong obtuse trifid; lobes 3-toothed 9675 Stem more flaccid and nearly naked, Grains nearly smooth. Otherwise like the last

9676 Leaves ren. : rad. 9-lobed; caul. 7-lobed: lobes 3-fid, Pet. bifid length of pointless cal. Fruit smooth rugose 9677 Leaves subreniform 7-lobed: lobes 3-fid, Petals emarg. length of pointless cal. Fruit downy not rugose 9678 Radic. lvs. reniform 7-lobed ; caul. roundish trunc. at base 5-lobed: lobes trifid, Pet. length of awned cal. 9679 Leaves 5-parted : lobes multifid linear, Petals emarginate length of awned calyx, Fruit smooth

9680 Leaves 5-parted: lobes trifid linear, Petals emarginate length of awned calyx, Fruit hairy

9681 Lvs. 5-lob. beyond middle : lobes cut 3-5-fid, Ped. clustered at end, Petals emargin. length of awned calyx 9682 Lvs. 5-lobed : lobes cuneate ovate cut-tooth. Hair of stem spread. hispid, Pet emarg. length of awned calyx 9683 Lvs. 5-lob. : upp. 3-lob. : lobes obl. coarsely and irreg. tooth. Hair of stem spread. hisp. Pet. shorter than cal. 9684 Very smooth, Leaves rounded 5-lobed, Calyx pyramidal angular transversely wrinked, Fruit muricate 9685 Leaves 3-5-parted : lobes trifid pinnatifid, Petals entire twice as long as the angular awned calyx

9686 Like the last, but the petals only a little longer than calyx

9687 Stem prostrate nodose, Leaves opposite deeply 5-lobed

9688 Stamens length of cor. Pedunc. aggregate, Branches smooth

\section{DODECANDRIA.}

9689 Leaves palmate 5-parted, Segm. finely bipinnatifid, Petioles and calyxes smooth

9690 Leaves palmate 5-parted, Segm. 3-parted pinnatifid; beneath calyxes and petioles hairy

9691 Leaves cordate 5-7-fid : lobes blunt serrated; beneath petioles and calyxes somewhat hairy

9692 Leaves ovate oblong subcordate crenate wavy, Stipules rigid, Pedunc. 1-fl. with 2 bractes

9693 Leaves ovate mucronate entire, some subsessile, some on long stalks

9694 Decandrous, Leaves cordate finely serrate downy beneath, Peduncles 2-flowered, Calyxes sub-bilabiate 9695 Decandrous, Leaves cordate crenate velvety with down on each side, Flowers subterminal few corymbose 9696 Decandrous, Leaves cordate ovate tooth-serrate acuminate rough, Flowers axillary

9697 Leaves cordate acuminate serrate downy green, Peduncles axillary few-flowered, Fruit-stalk very long 9698 Leaves cordate lanceolate crenulate downy beneath rusty, Fl. terminal subracemose

9699 Young leaves downy, adult smoothish cordate 7-nerved crenate, Corymb bifid 9700 Leaves downy beneath smooth above ovate oblong 7-nerved subcordate-peltate toothed

9701 Leaves hastate lanceolate serrate

9702 Leaves ovate serrated

9703 Leaves roundish cordate acuminate very large, Stipules large persistent ovate wavy

9704 Leaves oblong acuminate coarsely somewhat toothed at end, Pedicels scarcely longer than petiole 9705 Leaves cordate blunt toothed

9706 Leaves oblong acuminate entire cordate at base sagittate on one side

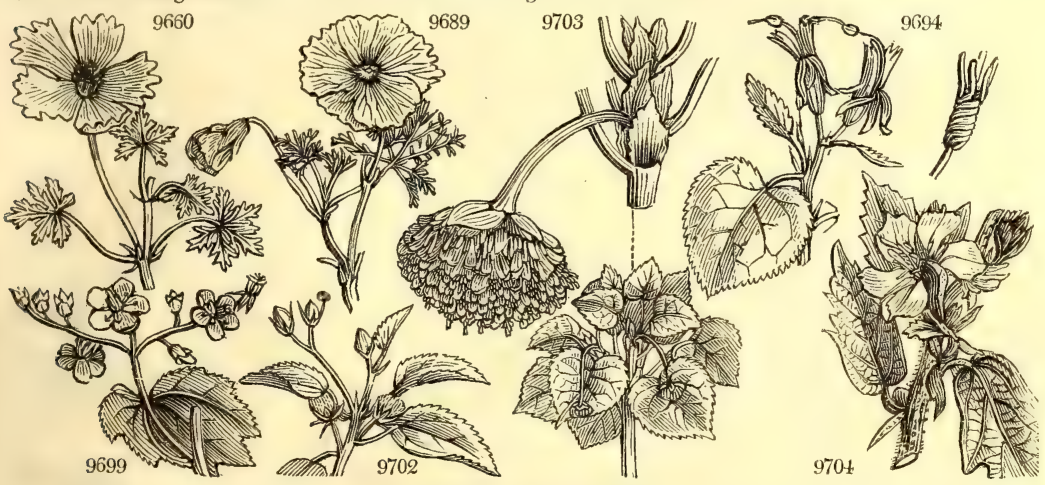

and Miscellaneous Particulars.

1466. Helicteres. Derived from $\dot{\varepsilon} \lambda \cdot \xi$, a screw, in allusion to the manner in which the fruit is twisted. Freeflowering plants of easy culture, and increased in sand closely covered. They have little or no merit.

1467. Dombeya. Named after Joseph Dombey, a famous French botanist, who travelled in Peru with Ruiz and Pavon, in 1777. Ripened cuttings root in sand in moist heat.

1468. Pentapetes. One of the names given by the Greeks to the Cinquefoil ; but having no reference to the present genus, except that the calyx and capsules are in five. The species are of easy culture in any rich light soil, and are readily increased by cuttings in sand.

1469. Astrapae. So called from $\alpha 5 \varrho \alpha \pi n$, lightning, in allusion to the splendid colors of the flowers. A noble genus, remarkable for the large heads of flowers, and the great dilated stipules at the base of the leaves.

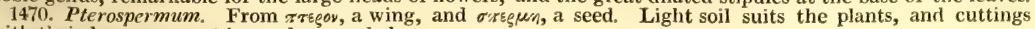
with their leaves on root in sand covered close. 


\section{POLYANDRIA.}

1471 MA'LOPE $W$ 9707 malacoídes $W$. 9708 trífida $W$.

1472. MAL'VA. $W$. 9709 tricuspidáta $H . M$. 9710 americána $W$ 9711 scábra $W$. 9712 scopária $W$. 9713 borbónica $W$. en . 9714 polystáchya $W$. 9715 spicáta $W$.

9716 tomentós 9717 Walthewny down 9718 trachelifolia Link. pointed 9719 gangética $L$ 9720 domingénsis $S p r$ 9722 eprosa W. en. 9723 hispánica $W$. 9724 stipulácea $W$ 9725 ægyp'tia $W$ 9726 trifida $W$. 9727 Tournefortiána $W$. 9728 Alcéa $W$ 9729 moscháta $\boldsymbol{L}$. $\beta$ unduláta Sims. 9730 althæoides Cav. 9731 mauritiána $\boldsymbol{W}$. 9732 sylvéstris $W$. 9733 rotundifólia $W$ e pusílla Sm. 9734 braziliénsis Dec 9735 microcárpa Desf 9736 parviflóra $W$. 9737 verticilláta $\boldsymbol{W}$. 9738 críspa $W$. 9739 amo'na Sims. 9740 virgáta $W$. 9741 capénsis $W$

9742 balsámica $W$

9743 tridactýlites $W$ 9744 divaricáta $H . \dot{K}$. 9745 retúsa $W$. 9746 calycína $W$. 9747 frágrans $W$ 9748 stricta $W$. 9749 bryonifólia $W$. 9750 grossulárifolia $W$. 9751 aspérrima $W$.en, 9752 láctea $W$.

9753 miniáta $W$ 9754 operculáta $W$. 9755 peruviána $\cdot \boldsymbol{W}$ 9756 liménsis $W$. 9757 capitáta $W$ 9758 umbelláta $\mathrm{Cav}$. 9759 abutiloídes $W$. 9760 élegans $W$ 9761 angustifólia $W$ 9762 caroliniána $W$ 9763 prostráta $W$.

MALOPE Barbary trifid

Mallow. Jamaica American Birch-leaved Bourbon many-spiked pointed

Domingo

leprous

Candian

Spanish

long-stipuled Egyptian large-flowered Tournefort's

Vervain

musk

wavy

Althæa-like

Ivy-leaved

common

round-leaved

dwarf

Brazil

small-fruited small-flowered curled

pleasant

twiggy

Cape

balsamic

reflex-flowered straddling

blunt-leaved

large-calyxed

fragrant

upright

Bryony-leaved

Gooseberry-lv. roughest panicled white painted lid-capsuled Peruvian

blue-flowered various-leaved umbelled Bahama elegant

narrow-leaved creeping creeping procumbent
(2) un 1 Malvacea. Sp. 2-4.

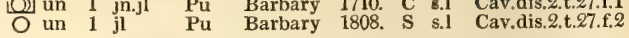
Malvacea. Sp. $56-82$.

4 이 $\mathrm{pr} 1$ jl.au $\mathrm{Y}$ W. Indies 1726. $\mathrm{C}$ co Cav.dis.2.t.22.f.2 O pr 1 jn.jl

$\square \mathrm{pr} \quad 4$ jn.jl

1. $\square$ pr 6 au.s

2. $\square$ pr 4 jl.au

pr 6 jl.au

a pr 3 s.o

c $\overline{\mathrm{N}}$ pr $1 \frac{1}{2} \ldots$ O un $1 \frac{1}{2} \mathrm{jl.au}$ $\bigcirc$ un 1 jl.au

\& $\triangle$ pr 2 jl.au

$\triangle$ un 2 my.jl

on 1 my.j

un $1 \mathrm{jl}$

un 1 jn.au

un 1 jn.jl

un $1 \frac{1}{2} \mathrm{jn} . \mathrm{jl}$

un 1 jl.au

$\triangle \Delta$ pr 2 jl.au

\} \triangle \mathrm { pr } _ { 2 } \quad 2 \text { jl.au }

$\triangle$ un 2 jl.au

$\bigcirc$ or 6 jn.jl

st $\Delta \mathrm{m} \quad 4$ my.

w $1 \frac{1}{2}$ jn.s

w $\frac{3}{4}$ jn.s

un 3 jn.s

un $2^{\frac{4}{j n} \mathrm{jn}}$

$\triangle$ un 2 jn.jl un 2 jn.jl O or 5 jn.au W

L or 3 ap.my $\mathbf{P u}$

L 6 or 6 my.jl $\mathbf{P u}$

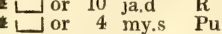

L

* or 3 jin.s W.v

W. Indies 1756. S co

Peru 1798. C co Ca.dis.5.t.138.f.1

Peru 1782. C co Jac. ic. 1. t. 139

Mauritius 1816. C co

Peru - 1798. C co Ca.dis.5.t.138.f.3

Jamaica 1726. C co Cav dis.2.t.20.f.4

E. Indies 1820. C co Pluk. t. 356. f. 1

Java 1824.

Java 1824. D co

E. Indies 1823. S co Plu.alm.t.74. f.6

St. Domin.1824. S co

Cuba 1815. C co

Candia 1825. S co Ca.dis.5.t.138.f.2

Spain 1710. S co Desf. atl, 2.t.170

Spain 1815. S co Cav.dis.2.t.15.f.2

Egypt 1739. S co Cav.dis.2.t.17.f.1

Spain 1815. is co Ca.dis.5.t.137.f.2

Spain 1759. S co Cav.dis.2.t.17.f.3

Germany 1597. D co Bot. mag. 2297

Britain bor.fi. D co Eng, bot. 754

Spain $\quad$ … D co Bot. mag. 2298

Spain 1822. S co Cav. diss.2.t.135

S. Europe 1768. S co Sweet fl. gard.8

Britain was.pl. D co Eng. bot.671

Britain ro.sid. S co Eng. bot. 1092

Britain ro.sid. S co Eng. bot. 241

R.Janeiro 1824. S co

Egypt 1823. D co

Barbary 1779. C co Cav.dis.2.t.26.f.1

China 1683. S co Cav.dis,2.t.25.f.3

Syria 1573. S co Cav.dis.2.t.23.f.1

C. G. H. $1796 . \quad$ Bot. mag. 1998

C. G. H. 1727. C co Cav.dis.2.t.18.f.2

C. G. H. 1713. C p.l Bot. reg. 295

C. G. H. 1800. C co Jac. ic. 1. t. 140

C. G. H. 1791. C p.l Bot.rep. 135

C. G. H. 1792. C co Bot. reg. 182

C. G. H. 1803. C p.1 Cav.dis.2.t.21.f.1

C. G. H. 1812. S co Bot. reg. 297

C. G. H. 1759. C co Bot reg 296

L.d or 3 my.jl Sc

* or 3 my.au W.

C. G. H 1805, C co Jac.schœ.3.t.294

C. G. H. 1731. C co W.hor. ber.1.t.4

C. G. H. 1732, C p.l Bot. reg. 561

C. G. H. 1796. C co Jac.schœen.2.t.39

S. Amer. 1798. C p.l Cav. ic. 3. t. 278

Peru 1795. C co Cav,dis.2.t.35.f.1

Peru 1759. S co Jac.vind.2.t.156

Peru 1768. S co Jac.vind.2.t.141

Peru 1798. S co Ca.dis.5.t.137.f 1

S. Amer. 1814. C co Bot. cab. 222

BahamaI.1725. C co Bot. mag. 2544

C. G. H. 1791, C co Jac. col.4.t.6. f.1

Mexico 1780, C p.l Cav. ic. 1. t. 68

Carolina 1723. C co Cav.dis.2.t.15.f.1

Brazil 1806. S co Bot. mag. 2515

S. Amer. 1815. D co

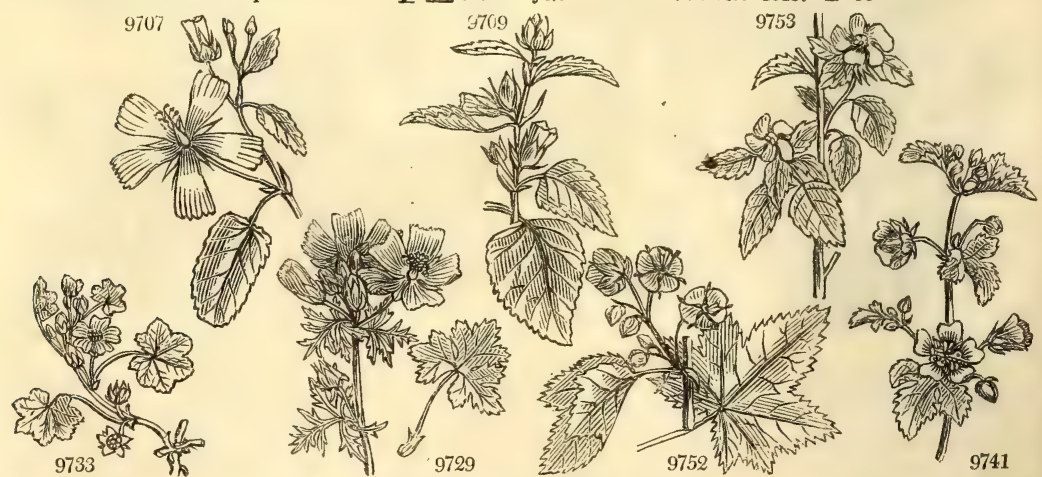

History, Use, Propagation, Culture,

1471. Malope. A name given by the Greeks to the Tree Mallow.

1472. Malva. Altered by the Latins from the Greek word, $\mu \alpha \lambda \propto \chi n$, soft, in allusion to the soft mucilaginous qualities of the species. Some of the species are shew plants, and M. capensis is valued in small greenhouses as flowering all the year. M. sylvestris, Mauve, Fr., has still a place in the Materia Medica, on account of its 


\section{POLYANDRIA.}

9707 Leaves ovate crenate, Stipules oblong-linear

9708 Leaves 3-nerved trifid toothed smooth: lobes acuminate

9709 Leaves oblong or ovate acute serrate, Flowers axillary clustered

9710 Leaves ovate acute crenate serrate hairy, Fl. axillary subsolitary

9711 Leaves ovate-lanceolate doubly toothed obsoletely 3-lobed beneath rough, Peduncles axillary 2-flowered 9712 Leaves ovate crenate-serrate beneath velvety, Fl. axillary clustered

9713 Leaves ovate acute coarsely toothed pubescent; upper cuneate at base, Fl. axillary and terminal spiked 9714 Leaves ovate acuminate serrate rough, Fl. axillary and terminal spiked

9715 Leaves ovate or subcordate rough above downy beneath, Flowers in ovate spikes

9716 Leaves cordate crenate blunt and branches downy, Flowers lateral heaped

9717 Leaves subcordate acute toothed downy beneath, Fl. sessile, Lobes of calyx ovate

9718 Leaves cordate acuminate serrated rough; lower lobed, Pedunc. axillary, Flowers in heads 9719 Leaves cordate blunt smooth, Flowers sessile heaped

9720 Dwarfs, Leaves ovate toothed : adult smoothish; younger hairy, Fl. axillary solitary on short stalks

9721 Leaves reniform broadly crenate and branches leprous, Stems prostrate

9722 Leaves cordate roundish 5-angled crenate villous, Pedicels longer than petiole

9723 Leaves half orbicular crenate; upper rhomboid, Stem erect hairy

9724 Lower leaves 3-lobed entire; upper multifid, Segm. trifid toothed at end

9725 Leaves 3-parted, Segm. trifid ciliated toothed at end, Cor. less than calyx

9726 Leaves 3-parted, Segm, trifid linear blunt, Cor. 3 times as large as calyx

9727 Leaves many-parted: lobes trifid linear, Stem decumbent, Hairs stellated

9728 Lower leaves angular; upper 5-parted cut, Stems and calyxes velvety

9729 Lower leaves reniform cut ; cauline many-parted, Segments linear, Stems and calyxes hairy

9730 Leaves palmated: lobes lanceolate toothed, Hairs simple, Pedicels longer than leaf 9731 Stem erect, Leaves 5-lobed blunt, Pedicels and petioles smoothish or downy on the upper side 9732 Stem erect, Leaves 5-7-lobed acute, Pedicels and petioles hairy

9733 Stem prostrate, Leaves cord, orbic. bluntly 5-lobed, Pedicels in fruit drooping and petioles downy

9734 Stem diffuse, Lvs. cord. orbicular 7-lobed soft: lobes acute, Fls. aggreg. stalked, Leaves of involucre bristly 9735 Stem erect, Leaves cordate roundish about 5-lobed crenate smooth, Fl. axillary sessile clustered 9736 Stem spreading, Leaves roundish bluntly angular crenate smoothish, Fl. axillary sessile clustered 9737 Stem erect, Leaves cordate roundish bluntly angular, Fls, axill. clustered sess. Cal, rough somew. infiated 9738 Stem erect, Leaves angular toothed crisp smooth, Flowers axillary sessile

9739 Pedicels 1-flowered aggregate shorter than leaf, Invol, ovate acuminate, Leaves 5-lobed hairy rugose

9740 Pedicels 1-flowered solitary or twin longer than petiole, Invol. linear, Leaves cut crenate smooth rigid 9741 Pedicels 1-ff. solitary or twin longer than petiole, Inv. ov. Ianc. Lvs. 5-lobed or 3-lobed cren. toothed glutin. 9742 Pedicels 1-fl. solitary longer than petiole, Invol. obl. linear, Lvs, sub-three-lobed acute unequally toothed 9743. Pedicels 1-flowered solitary length of leaves, Leaves subsessile cuneiform trifid entire

9744 Pedicels solitary longer than petiole, Leaves lobate plaited toothed roughish, Branches divaricating 9745 Pedicels solitary longer than petiole, Invol. lanceolate, Leaves oblong very blunt 3-lobed toothed

9746 Pedicels solitary 1-f. twice as long as petiole, Invol. ovate acute very large, Leaves cordate crenate hairy 9747 Pedicels solitary 1-fl. length of petiole, Invol. lanc. Leaves cordate 5-lobed toothed, Branches glutinous 9748 Pedicels solitary 1-fl. length of petiole, Invol. nearly linear, Leaves ovate about 3-lobed toothed hairy 9749 Pedicels solitary 1 or 2 -fl. shorter than petiole, Leaves cordate about 5-lobed blunt rough with stellat. hair 9750 Pedicels solitary 1-3-fl. length of petiole, Invol, obl. linear, Leaves sinuate lobed serrate rugose hairy 9751 Pedicels 1-2-fl. solitary longer than petiole, Invol. linear, Leaves 5-lobed blunt rugose very rough

9752 Leaves angular acute cordate villous, Petals obcordate shorter than calyx, Pedunc. panicled

9753 Leaves ovate 3-lobed toothed downy, Pedunc. axillary racemose few-flowered

9754 Leaves angular 5-lobed; middle lobe largest, Pedunc. axillary racemose, Flowers 1-sided 9755 Leaves palmate, Spikes axillary 1-sided, Fruit toothletted

9756 Leaves 7-lobed rugose, Spikes axillary 1-sided, Fruit smooth

9757 Leaves 5-lobed: lobes pinnatifid sinuate toothed, Pedunc, corymbose capitate, Fruit with two beaks

9758 Leaves subpeltate 5-lobed blunt, Pedunc. axillary umbelled, Invol. obovate stipitate deciduous

9759 Leaves 5 angular downy, Pedunc. axillary bifid few-flowered, Invol. oblong small

9760 Leaves 3-parted hoary, Segm. toothed at end; middle trifid, Pedunc. axillary 1-flowered

9761 Leaves lanceolate toothed downy, Pedunc. axillary 2 few-f. Invol. setaceous deciduous

9762 Leaves palmate 5-lobed cut toothed, Pedicels solitary longer than petiole, Fruit villous

9763 Leaves palmate 5-lobed cut toothed, Pedicels solitary longer than petiole, Fruit smooth, Petals entire

9764 Leaves ovate cut toothed lobed, Pedicels longer than petiole, Fruit villous, Petals entire

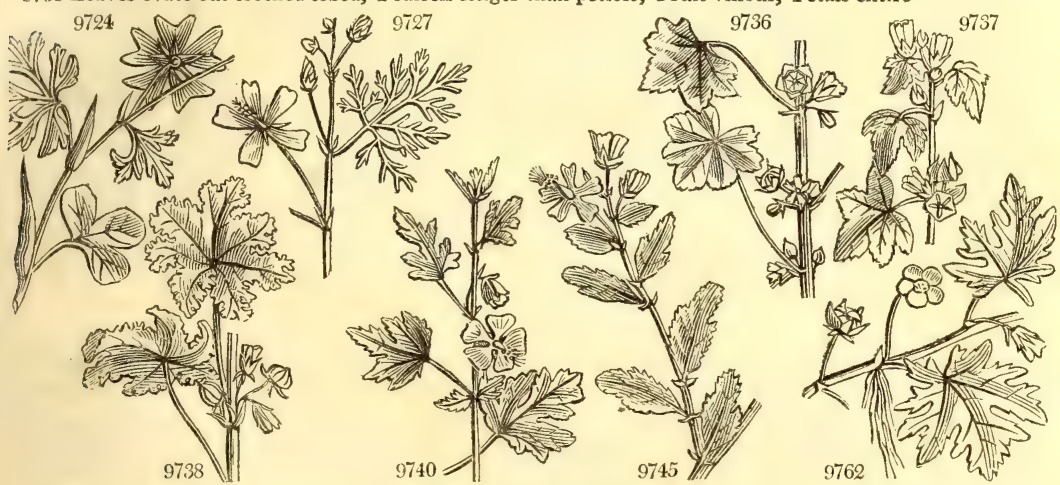

and Miscellaneous Particulars.

demulcent properties; but it is greatly inferior to Althæa, and therefore little used. Malva was an excellent vegetable among the Romans, but what species is uncertain. A tree of the mallow kind is said, by Prosper Alpinus, to afford food to the Egyptians; and the Chinese use some sort of mallow as food.

All the species are of the easiest culture and propagation. 
1473. KITAIBE'Li A, $\boldsymbol{W}$. Kitaibelia. 9765 vitifólia $W$. Vine-leaved

1474. ALTH列A. $W$. 9766 officinális $W$. 9767 narbonen'sis $W$. 9768 cannabina $W$. 9769 hirsúta $W$. 9770 Ludwígii $W$. 9771 acaúlis $W$. 9772 rósea $W$. 9773 pállida $W$. 9774 caribæ'a $B . M$ 9775 flexuósa $B . M$ 9776 ficifólia $W$.

1475. LAVATE'RA 9777 arbórea $W$ 9778 micans $W$. 9779 O'lbia $W$ 9780 unguiculáta $P . S$. 9781 híspida $P$. S. 9782 tríloba $W$. 9783 lusitánica $W$ 9784 plebéia Sims. 9785 marítima $W$. 9786 thuringiaca $W$ 9787 crética $W$. 9788 punctáta $W$. 9789 triméstris $W$. 1476. MALA'CHRA, $W$ MALACHRA 9790 capitáta $W$. 9791 alceæfólia $W$ 9792 radiáta $W$. 1477. URE'NA. $W$. 9793 lobáta $W$ 9794 americána $W$. 9795 sinuáta $W$. 9796 multífida $W$. 1478. PAVO'NIA. $W$ 9797 præmórsa $W$ 9798 spínifex $W$. 9799 odoráta $W$ 9800 coccínea $W$. 9801 columélla $W$. 9802 úrens $W$. y803 zeylánica $W$. 1479. $\mathrm{ACHA}^{\prime}$ NIA. $W$. 9804 Malvavíscus $W$. 3805 móllis $W$. 9806 pilósa $W$.

1480. HIBIS'CUS. $W$. 9807 Moscheútos $P h$. 9808 palústris $P h$. 9809 Pattersónii $H . K$. Marsh Mallow.

Lavatera. Tree Mallow glittering downy-leaved clawed hispid three-lobed Portugal vulgar sea-side

ALACHRA.

Pavonia.

bitten-leaved prickly-seeded fragrant scarlet angular-leaved stinging

Ceylon

Achania. scarlet woolly hairy

Hibiscus swamp marsh

Malvacece. Sp. $\mathbf{3}$.

\$ $\Delta$ or 5 jl.s W Hungary 1801. D p.l Bot. mag. 821

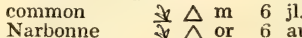
Malvacece. Sp. 11-20.

Hemp-leaved $\mathrm{St} \Delta$ or 6 jn.jl Pu S. Europe 1597. D co Cav.dis.2.t.30.f. Ludwig's O or 6 jn.jl stemless $\quad 0$ or $1 \frac{1}{2} \mathrm{jn} . \mathrm{jl}$ Hollyhock $\$ 2$ or 8 ji.s pale-flowered के or 6 jl.au West Indian [D] or 3 mr.ap Pk

Seringapatam AntwerpHollyh

Levant 1597. D co Malvacea. Sp. 13-26.

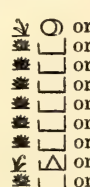
6 jl.o

3 jin.o

6 jl.s

$6 \mathrm{jn.jl}$

3 jn.jl

au.s

$2 \mathrm{~s}$ or 2 ap.jn

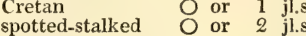
common annual $\mathrm{O}$ or $2 \mathrm{jl.s}$ S. Europe 1683. S co Cav.dis.2.t.29.f. Aleppo 1680. S co Cav.dis.2.t.27.f. China 1573. S co Cav.dis.2.t.28.f.1 Hungary 1805. S co

W. Indies 1816. S co Bot. mag. 1916 . Indies 1803.

Malvacea. Hollyhock-lvd, 10] un 1 au.s Y rayed 2 un 1 jl.au W

Malvacea.

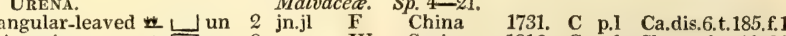
American $\square$ un 2 ... W $\quad$ Surinam 1816. C p.l Sloane 1.t.11.f. cut-leaved 5 un 3 jl.au F E. Indies 1759. C p.1 Ca.dis.6.t.185.f.2 multitid $\square$ un 2 ja.o Pu E. Indies 1817. C p.l Ca.dis.6.t.184.f.2

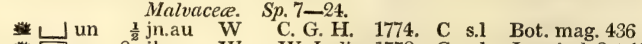

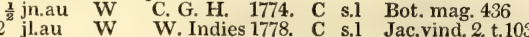
jl.au W W. Indies 1778. C $\quad$ s.1 Jac.vind. 2. t.103 … $\quad$ Sc St. Domin.1816. C $\quad$ s.l Cav.dis.3.t.47.f jl W.pu Bourbon 1807. C s.l Cav.dis.3.t.48.f.3 ... W Mauritius 1801 C $\quad$ s.l Jac. ic. 3. t. 522 jl.s W E. Indies 1790. S s.l Cav.dis.3.t.48.f. Malvacea. Sp. 3-15.

$\square$ or 12 ja.d S Jamaica 1714. C p.l Bot. mag. 2305

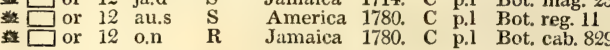

Malvacee. Sp. $46-125$.

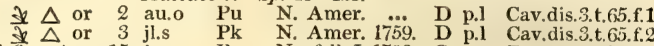
Norfolk Island $\frac{\$}{1} \mathrm{U}$ or $15 \mathrm{jn}$.au Pu Norfolk I. 1792. C s.p Bot. rep. 286

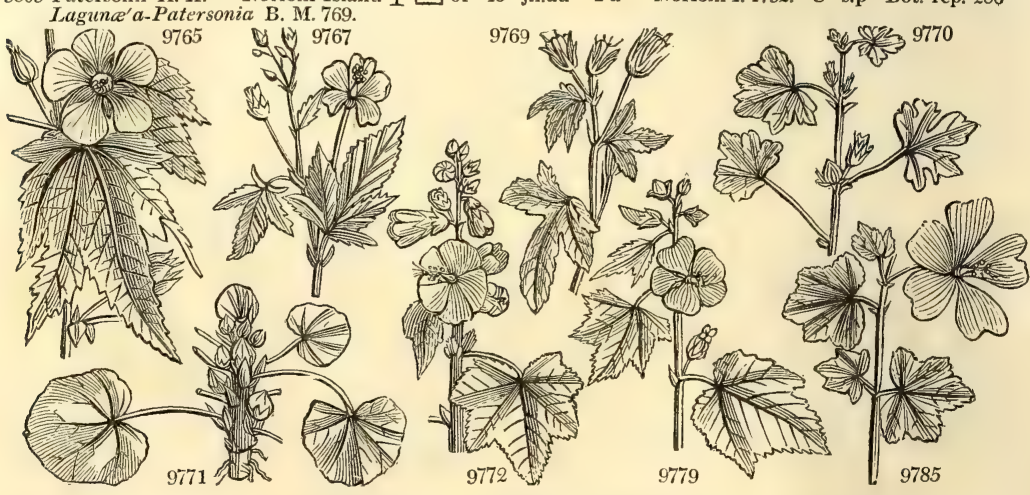

History, Use, Propagation, Culture,

1473. Kitaibelia. Named after Dr. Paul Kitaibel, professor of botany at Pest, in Hungary, and author, in conjunction with Count Waldstein, of a noble work upon the plants of that country, A tall mallow-like plant with vine-like leaves, and white flowers.

1474. Althar. From a $\lambda_{-} \omega$, to cure. The salutary effects of the mucilaginous root, are well known in medicine. Guimauve, Fr. A. officinalis has long been in repute as a demulcent. Its roots are sometimes used as an emollient suppurative cataplasm; and a decoction of the leaves forms a useful fomentation in external abrasions, and in cutaneous eruptions, accompanied with a sharp ichorous discharge

A. rosea is the parent of nearly twenty splendid varieties of border flowers, which seed readily, and the offspring generally resembles the parent variety. All the species are of the easiest culture in common garden soil.

1475. Lavatera. In memory of two Lavaters, physicians of Zurich neither the physiognomist, but two friends of Tournefort. The species resemble those of Malva, in general appearance and culture : much the handsomest is $\mathbf{L}$. arborea, which is a magnificent plant in shrubberies, or in the back of wide borders. 
9765 Leaves 5-lobed acute toothed

9766 Leaves soft on each side cordate or ovate toothed undivided or 3-lobed, Pedunc. axillary many-fl. 9767 Leaves pubescent : lower 5-7-parted; upper trifid, Peduncles many-fl. longer than leaf 9768 Leaves downy hoary beneath : lower palmate; upper 3-parted: lobes narrow coarsely toothed 9769 Leaves cordate rough with hairs smooth above : lower blunt; upper 5-lobed, Stem hispid 9770 Leaves smooth cordate roundish lobed toothed, Pedicels axillary clustered 1-flowered 9771 Leaves roundish cordate 5-angled crenate, Pedicels 1-fl. much shorter than petiole $977 \overline{2}$ Stem upright hairy, Leaves cordate 5-7-angled crenate rugose, Flowers axillary sessile 9773 Stem erect hispid, Leaves roundish cordate, Invol. as long as calyx

9774 Stem upright smoothish, Leaves rounded lobed crenulate serrate, Flowers solitary subsessile

9775 Stem subflexuose hispid, Leaves cordate about 7-lobed blunt on long stalks, Flowers axillary solitary

9776 Stem erect hairy, Leaves palmate 7-lobed beyond the middle : lobes oblong blunt irregularly toothed

9777 Leaves 7-angıed downy plicate, Pedicels axillary 1-fl. clustered much shorter than petiole 9778 Leaves 7-angled acute crenate plaited downy, Racemes terminal

9779 Leaves soft hoary 5-lobed; upper 3-lobed : middle lobe elongated; upper oblong undivided

9780 Leaves downy on each side acutely 5-lobed; upper 3-lobed, Flowers solitary on short stalks

9781 Stem hispid, Leaves hoary 5-lobed; upper 3-lobed or undivided, Flowers subsessile

9782 Stem and leaves downy subcordate sub-three-lobed round crenate, Pedicels aggregate, Calyxes acuminato

9783 Leaves 7-angular downy plaited, Racemes terminal

9784 Stem rough, Leaves 5-lobed downy beneath, Pedunc. axillary aggregate, Petals emarginate 9785 Stem and leaves downy roundish bluntly angular crenate, Pedicels axillary solitary

9786 Leaves somewhat downy : lower angular ; upper 3-lobed : middle lobe longer than the rest

9787 Stem herbaceous hispid, Leaves 5-lobed acute, Pedicels axillary 1-flowered aggregate

9788 Stem rough, Leaves somewhat downy : lower round cordate; upper 3-lobed, Pedicels solitary 1-fl.

9789 Stem herbaceous, Leaves smoothish roundish cordate; upper angular, Pedicels solitary

9790 Leaves cordate roundish bluntly angular toothletted, Invol. stalked 3-leaved 7-flowered, Stem rough 9791 Leaves cordate palmate 5-lobed, Heads stalked 5-leaved 10-flowered, Stem with scattered hairs

9792 Leaves palmate-lobed, Heads stalked 5-leaved many-flowered, Invol. acuminate, Calyxes and stems hairy

9793 Leaves roundish very bluntly 3-lobed velvety on each side 7-nerved 1-glanded, Cal. oblong lanceolate 9794 Lower leaves 3-lobed; upper lanceolate panduriform beneath hoary netted with one gland

9795 Leaves trifid downy pale beneath with 3 glands : lobes angular toothletted blunt

9796 Leaves broad ovate cut lobed with narrow recesses : lobes acute coarsely and unequally toothed

9797 Leaves broadly obovate truncate crenate at end, Pedic. axillary 1-fl. longer than leaf 9798 Leaves ovate acuminate subcordate doubly toothed, Pedicels axillary 1-f.

9799 Leaves ovate subcordate 3-pointed somewhat toothed and branches covered with viscid hairs 9800 Leaves cordate 3-lobed serrate, Pedicels axillary 1-fl. ascending, Involucre 3-leaved

9801 Leaves 5-angular: lobes toothed acuminate, Pedic. axillary 1-f. much shorter than petiole

9802 Leaves 7-angular acuminate toothed hairy, Fl. axillary subsessile clustered

9803 Lower leaves roundish cord. crenate others 3-5-lob. Pedicels axillary 1-fl. Inv. 10-leaved setaceous ciliated

9804 Leaves cordate 3-5-lobed acuminate roughish, Leaflets of invol, erect

9805 Leaves cordate about 3-lobed acuminate soft downy, Leafl. of invol. somewhat spreading 9806 Leaves cordate crenate blunt or acuminate, Branches and petioles hairy

9807 Leaves ovate acuminate serrate downy beneath, Invol. and cal. downy

9808 Leaves ovate toothed somewhat 3-lobed hoary with down beneath

9809 Leaves lanceolate oblong entire white with scales beneath

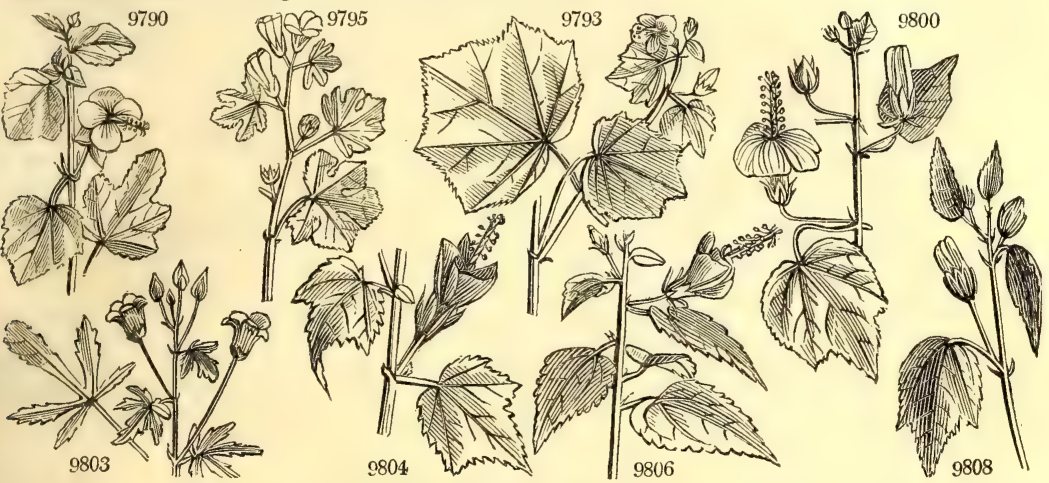

and Miscellaneous Particulars.

1476. Malachra. A name under which Pliny speaks of a tree from the north of Persia, producing a certain gum. It had no reference to the plant called Malachra by the moderns. Sow in light rich soil, and trans plant as with other stove annuals.

1477. Urena, the vernacular narne in Malabar. The species are of easy culture, seed freely, or may be propagated by cuttings in sand under a hand-glass.

1478. Pavonia. In honor of Don José Pavon, the companion of Dombey, in his voyage to Peru, and one of the authors of Flora Peruviana. The species are free-growers, and seed readily: they are also increased by cuttings in sand under a hand-glass.

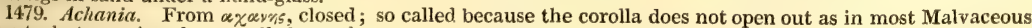
plants, but remains always rolled together.

1480. Hibiscus. One of the Greek names of the mallow. The species are for the most part shewy plants, and not difficult of culture. All of them abound in mucilage, like many of the same natural family, and the 
9810 incánus $P h$. 9811 militáris $P h$. 9812 popúlneus $W$ 9813 tiliáceus $W$. 9814 elátus $S w$. 9815 Lámpas $W$

hoary smooth

Poplar-leaved Lime-tree-lvd. tall three-pointed

.816 Rosa MalabáricaKer. Malabar 9817 membranáceus $W$. leafy-calyxed 9818 lunarifólius $\boldsymbol{W}$. 9819 Rósa-sinénsis $W$ $\beta$ rubro-plénus

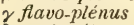
$\delta$ variegátus piénus $\varepsilon$ luteus

9820 phœeníccus $W$ 9821 micránthus $H$. $K$ 9822 xthiópicus $W$ 9823 mutálilis $W$. ß flore pléno 9824 syríacus $W$

๔ purpúreus

$\beta$ ruber

$\gamma$ álbus

¿variegátus

¿albo-plénus \& purpúreo-plénus 9825 acerifólius $P . I$ 9826 diversifólius $W$ 9827 ficúlneus $W$. 9828 Sabdariffa $W$ 9829 speciósus $\boldsymbol{W}$. 9830 prúriens $\boldsymbol{B} . \dot{R}$ 9831 heterophýllus $H . K$ 9832 cannabinus $W$. 9833 suratténsis $W$. 9834 radiátus $W$. 9835 Mánihot $W$ 9836 scáber $P h$. 9837 furcátus $W$. en. 9838 digitátus Cav. 9839 Abelmóschus $W$ 9840 pedunculátus $W$. $98+1$ esculéntus $W$. 9942 strigósus Lindl. 9813 clypeátus $W$. 984t únidens Lindl. y845 tubulósus $W$. 9846 vitifólius $W$. 9847 virgímicus $W$ 9848 pentacárpos $W$. 9849 vesicárius $W$. 9850 Triónum $W$. 9851 híspidus Mill.

eafy-calyxed

Chinese double red double buff double striped double yellow purple-flowered small-flowered dwarf wedge-lv. changeable double-flowered Althra frutex purple-flowered red-flowered
white-flowered striped-fiowered striped-fiowered double white
double purple Maple-leaved different-leaved Fig-leaved

Indian superb various-leaved Hemp-leaved prickly-stalked rayed palmated scabrous
forked-calyxed $\frac{\Delta}{[O}$ or digitate

Musk Okro ver long-peduncled

strigose 遙 L shield-capsuled 6 jol or one-toothed tubular if [0] or Virginian or 2 jl.o angular fruited of $\triangle 4$ ji.s Afvican $\mathrm{O}$ or $1 \frac{1}{2}$ jl.au Bladder Ketmia $\stackrel{O}{O}$ or 2 jn.s hispid $\mathrm{O}$ or $1 \frac{1}{2} \mathrm{jn} . \mathrm{s}$ 9852 Richardsóni Lindl, rough-leaved 9 or 3 jn.s
Y Carolina 1806. D s.p W.hort.ber. t.24 Pu Louisiana 1804. D s.p Bot. mag. 2385 E. Indies 1770. C p.1 Rheemal.1.t.29 Pu E. Indies 1739. C p.l Bot. reg. 232 Pu Jamaica 1790. C p.1 Pk E. Indies 1806. C p.1 Cav,dis.3.t.56.f.2 Sc E. Indies 1818. C p.l Bot. reg. 337

Pk 1..... 1816. C s.l Cav.dis.3.t.57.f.?

\section{$\mathrm{Pu} \quad$ E. Indies $\ldots . . \quad \mathrm{C}$ s.I}

D.R E. Indies 1731. C p.l Bot. mag. 158

D.R E. Indies $\ldots$ C p.l Bot. cab. 519

$\begin{array}{lllll}Y & \text { E. Indies } & \ldots & \text { C } & \text { p.l }\end{array}$

St E. Indies $\ldots . \quad$ C p.1 Bot. cab. 963

Y E. Indies 1823. C p.1 Bot. cab 93\%

Pu E. Indies 1796. C p.l Bot. reg. 230

$\mathrm{Pu}$ E. Indies 1794. C p.1 Cav.dis.3.t.66.f.1

$\mathrm{Pu}$ C. G. H. 1774. C p.1 Cav.dis.3.t.61.f.1

W E. Indies 1690. C p.I Bot. rep. 228

W E. Indies $\ldots$ C

Pu Syria 1596. L co Bot. mag. 83

$\mathrm{Pu} \quad$...... $\quad \ldots \quad \mathrm{L}$ co

$\mathrm{R} \quad \ldots \ldots . . . . \quad \mathrm{L}$ co

W $\quad \ldots \ldots, \quad \ldots \quad$ L co

St $\quad \ldots \ldots . . . . . \quad$ L co

W..... ... L $\mathrm{L}$ co

\section{Pu china....}

Pk China 1798. C s.l Par.lond, c. ic.

Y E. Indies 1798. C s.l Bot. reg. 381

W Ceylon 1732, C p.l Cav.dis.3.t.52.f.2

Y E. Indies 1596. C p.1 Ca.dis.6.t.198.f.1

S Carolina 1778. C s.1 Bot. mag. 360

Y E. Indies 1804. C s.l Bot. rep. 498

W.R N. S. W. 1803. C s.p Bot. reg. 29

Y E. Indies 1759. C s.I Rox. cor. 2.t.190

E. Indies 1731. S s.l Bot. mag. 1356

E Indies 1790. S sl Bot. mag. 1911

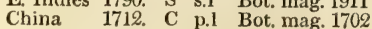

Carolina 1810. D s.1

E. Indies 1816. C $\mathbf{\text { s.1 }}$

W.R Brazil 1816. S co Bot. reg. 608

Y India 1640. C r.m Rheemal.2.t.38

R C. G. H. 1812, C s.l Bot reg 231

Y W. Indies 1692, S r.m Cav.dis.3.t.61.f.2

Pk Peru 1820. C s.l Bot. reg. 860

Y Jamaica 1759. C p.l Cav.dis.3.t.58.f

Y Brazil 1822. C co Bot. reg. 878

Y E. Indies 1796. C s.l Cav.dis.3.t.68.f.2

Y E. Indies 1690, C p.l Rhee.mal.6.t.46

$Y$ Virginia 1798 D s I Jac ic 1.149

L R Venice 1750 S s. Jac. $1 . t 143$

Y. Br

Y.Br Italy 1596. S co Bot. mag. 209

Y.Br C. G. H. ... S So Bot. reg. 806

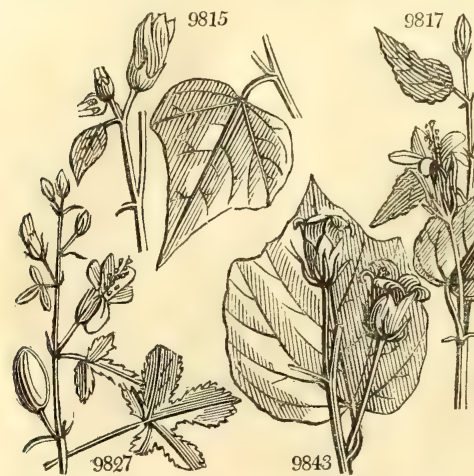

N. Holl.

820. S co Bot. reg. 875

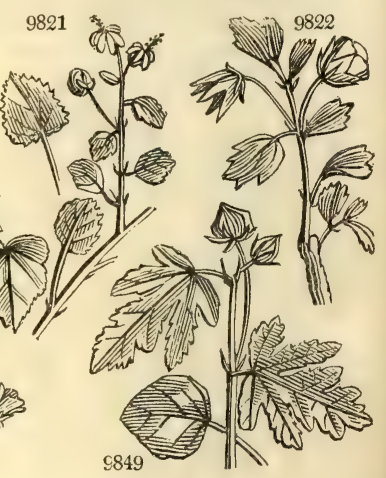

History, Use, Propagation, Culture,

bark of the ligneous sorts may be manufactured into mats or cordage. Of $\mathbf{H}$. tiliaceus, in the island of Otaheite, they make matting of the bark, as fine as our coarse cloth; also ropes and lines, from the size of an inch to that of a small packthread; and fishing nets. (Hawks. Voy. ii. 217.) Forster informs us, they also suck this bark for food, when the bread-fruit fails them : and in New Caledonia, the inhabitants frequently subsist on it, though it is an insipid food, affording very little nourishment.

H. Rosa-sinensis is extremely common in the gardens of China, and the East Indies; but its native country is unknown. Loureiro, however, affirms, that it is spontaneous as well as cultivated both in China and Cochin-China; and that it is so common in the latter, that they have entire hedges of it to their gardens. It has been long known from its appearance on Chinese screens and paper hangings. The variety with double flowers is most frequently cultivated, both in the East and in European hothouses: the plant is, indeed, rarely scen with single flowers. (Smith, spicil.)

H. syriacus is one of our most beautirul hardy shrubs, the more valuable as it is a free-flowerer, will grow in common garden soil, and propagates freely by seeds, layers, and even by cuttings.

H. Sabdariffa (the Turkish name) in the West Indies is called Red Sorrel. The calyxes and capsules, freed 
9810 Leaves ovate acuminate bluntly serrate hoary on each side, Pedicels axillary 1-fl.

9811 Leaves 3-lobed hastate acuminate serrate smooth on each side, Pedicels jointed in the middle 9812 Leaves roundish cordate acuminate (Thespesia Dec.)

9813 Leaves roundish cordate acuminate crenate hoary beneath, Invol. 10-toothed

9814 Leaves roundish cordate entire hoary beneath, Pedunc, very short 1-flowered

9815 Leaves cordate 3-pointed smooth dotted beneath, Pedicels solitary 1-fl. longer than petiole

9816 Leaves cordate acutely serrate, Branches somewhat hairy

9817 Leaves cordate ovate-lanceolate acuminate toothed, Pedicels twice as long as petiole

9818 Leaves roundish cordate acuminate finely toothed hairy beneath, Pedicels thick villous

9819 Leaves ovate acuminate smooth entire at base coarsely toothed at end, Pedicels length of leaf

9820 Leaves ovate acuminate serrate ; lower subcordate 3-pointed, Pedicels jointed at end

9821 Leaves ovate or roundish undivided serrated rough, Pedic. longer than leaf, Cor. reflexed 9822 Leaves cuneiform about 5-toothed hairy, Pedicels longer than leaf, Invol. 8-10-leaved hispid 9823 Leaves cordate angular 5-lobed acuminate toothed downy, Pedicels nearly as long as leat

9824 Leaves cuneiform ovate 3-lobed toothed, Pedic. scarcely longer than petiole, Invol. 6-7-leaved 9825 Leaves cordate 5-lobed hairy: lobes acuminate subrepand, Inv. 6-7-leaved setaceous [undivided
9826 Stem and pctiol. prickly, Pedic. short unarmed very hairy, Lvs. 3-5-lobed blunt toothed; upper obl. lanc. 9825 Leaves cordate 5-lobed hairy : lobes acuminate subrepand, Inv. 6-7-leaved setaceous [undivided
9826 Stem and pctiol. prickly, Pedic. short unarmed very hairy, Lvs. 3-5-lobed blunt toothed; upper obl. lanc. 9827 Stem prickly, Leaves palmate 5-lobed; upper 3-lobed : lobes blunt unequally toothed narrowed at base 9828 Leaves toothed : lower ovate undivided; upper 3-lobed cuneate at base, Flowers subsess. Invol. 12-toothed 9829 Leaves palmate 5-parted: lobes lanceolate acuminate subserrate at end, Pedicels jointed under the end 9830 Stem hairy, Leaves on long stalks ovate about 3-lobed serrate membranous smoothish, Pedic. very short 9831 Stem prickly, Leaves linear lanceolate acuminate usually lobed prickly-serrate, Inv. 10-leaved

9832 Stem prickly, Leaves palmate 5-parted with 1 gland beneath, Fl. subsess. Cal, covered with glandul. hair 9833 Stem rough with recurved prickles, Stipules $\frac{1}{2}$-cord. Leaves palmate 5-lobed, Pedicels length of petiole 9834 Stem rough with recurved prickles, Stipules lanc. Leaves 5-7-parted with lanc. acuminate serrated lobes 9835 Leaves smoothish palmate : lobes 5-7-acuminate coarsely toothed, Inv. hispid 4-6-leaved, Fls. declinate 9836 Stem rough, Leaves rough roundish truncate at base; upper palmate-lobed : lobes dilat. crenate upwards 9837 Stem petioles and calyx muricate, Leaves ovate at base trifid; lower 5-fid : lobes acuminate serrate 9838 Leaves palmated: lobes lanceolate serrate, Petioles muricate, Fl. subsessile solitary, Inv. 7-fid 9839 Leaves subpeltate cordate 7-angular acuminate serrate, Stem hispid, Pedicels longer than petiole 9840 Leaves 3-5-lobed blunt crenate hairy, Pedic. twice as long as leaf, Inv. many-leaved, Cor. campanulate 9841 Leaves cord. 5-lobed blunt toothed, Petioles longer than f. Inv. 10-leaved decidu. Cal. bursting lengthwise 9842 Stem strigose, Leaves 3-lobed angular cordate toothed downy, Peduncle longer than petiole

$98+3$ Leaves cord. angular sparingly toothed nearly smooth, Branches velvety, Caps. turbinate truncate hispid 9844. Stem prickly, Leaves smoothish coarsely toothed without glands, Leaves of the invol, with a tooth inside 9845 Leaves cordate unequally toothed beneath hoary : lower about 5-lobed; upper acum. Pedic. 1-fl. very short 9846 Stem somew. prickly, Leaves smoothish toothed 5-angular acuminate, Fls. cernuous, Caps. 5-winged hairy 9847 Leaves acuminate unequally toothed subvillous : lower undivided cordate; upper ovate-cordate 3-lobed 9848 Leaves cordate oblong toothed bluntish angular slightly 3-lobed smooth, Pedicels longer than petiole 9849 Lvs, toothed : lower undivided ; upper 5 -fid : lobes oblong nearly equal blunt, Cal. inflat. membran. nerved $9850 \mathrm{Lvs}$, toothed : lower undivided; upper 3-parted: lobes lanc. middle one very long, Cal. infl. membr. nerved 9851 Leaves toothed: lower leaves 3-lobed; upper 5-parted blunt, Stem hispid

9852 Leaves hairy 5-lobed : lobes linear oblong coarsely toothed, Cal. very villous longer than involucrum

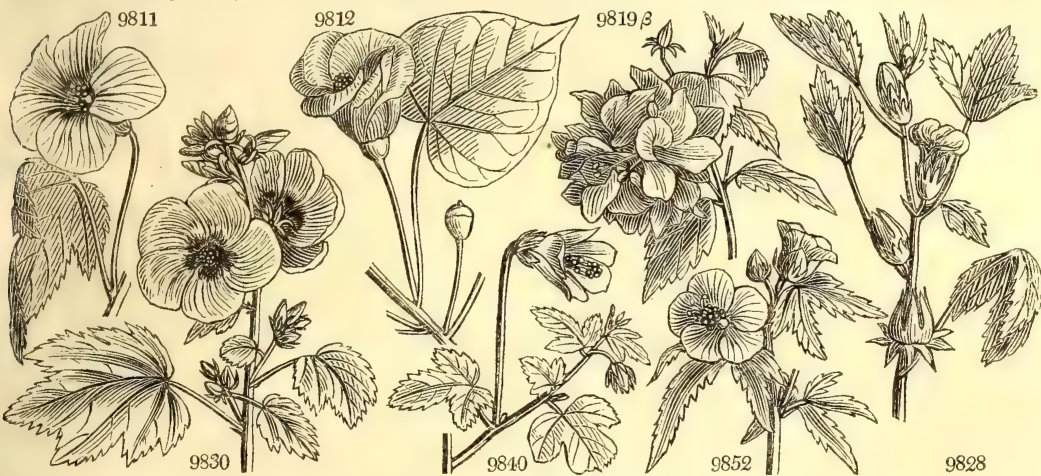

and Miscellaneous Particulars.

from the seeds, make very agreeable tarts ; and a decoction of them, sweetened and fermented, is commonly called sorrel cool drink. 1t is a small diluting liquor, much used in our sugar colonies, and reckoned very refreshing in those sultry climates. (Browne's Jam.) The bark of this species, and also of $\mathbf{H}$ cannabinus, is full of strong fibres, which the inhabitants of the Malabar coast prepare and make into cordage; and it seems as if it might be wrought into tine strong thread of any size.

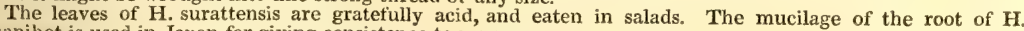
manihot is used in Japan for giving consistence to paper.

H. Abclmoschus, from the Arabic Ab-el-Mosch, grain or seed of musk, has large seeds of a very musk odor, and are frequently used as a substitute for animal musk in scenting powders and pomatums. In Arabia and Egypt they are ground and mixed with coffee, to render it more agreeable to the head and stomach.

H. esculentus, the Okro of the West Indies, is cultivated there, and in some parts of France, for the pods, which are gathered green and used in soups, or pickled like capers. They are full of a nutritive mucilage, and buttered and spiced make a very rich dish. 
1481. GOSSY'PIUM. $W$. Cotton. 9853 herbáceum $W$. common 9854 arbóreum $W$. 9855 vitifólium $W$. 9856 hirsátum $W$. 9857 religiósum $W$ 9858 religiosum $W$ barbadénse $W$.

Vine-leaved

hairy

spotted-barked

Barbadoes

1482. REDOUTE'A. Vent. Redoutea. 9859 heterophýlla Vent. various-leaved

1483. Pala'via. $W$. Palavia. 9860 malvifólia $W$. Mallow-leaved

1484. CRista'ria. Cav. Cristaria. 9861 coccínea $P h$.

1485. ANO'DA. Cav.

9862 hastáta $W$.

9863 cristáta $W$

9864 Dilleniána $W$

1486. PERIP'TER 9865 punícea $\mathrm{Dec}$

1487. SI'DA $W$.

9866 linifólia Cav 9867 angustifólia $W$

9868 spinósa $W$.

9869 alba $W$

9870 bracteoláta $D e c$ 9871 carpinifólia $W$. 9872 erósa Link. 9873 ciliáris $W$ 9874 alnifólia $W$.

9875 compréssa $D e c$ 9876 canariénsis $W$. 9877 rhombifólia $W$. 9878 recísa Linte. 9879 micans Cav.

scarlet

halberd-leaved

crested

Dillenius's

$c$. Periptera

SidA.

flax-leaved

narrow-leaved

prickly

bitten

ciliated

Alder-leaved

glittering

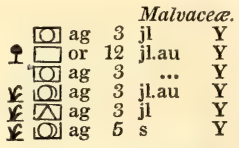

Malvacea.

G or 3 jn $\mathbf{Y}$

Malvacea. $S p$. 1-2

$\bigcirc$ un $1 \frac{1}{2}$ jn.au Pu Peru

1794. C co Cav.dis.1.t.11.f. 4

Malvacece. Sp. 1-4.

\$2 $\triangle \mathrm{pr} \quad \frac{1}{2}$ jl.s $\quad \mathrm{S}$ Missou

이 un $1 \frac{1}{2}$ jn.jl B Mexico

1720. S s.p Cav.dis.1.t.10.f.3

Malvacere. Sp. 1.

white-flowered un 2 jn.jl

bracteolate $\longleftarrow$ un $2 \mathrm{jn.jl}$

Hornbean-lvd.

(1) un 2 ji.s

Q] un $2^{\frac{1}{2}} \mathrm{jn.s}$

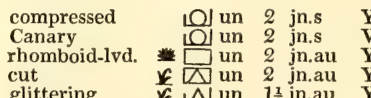

$\mathbb{N}$ un $1 \frac{1}{2} \mathrm{jn} . \mathrm{au}$

\section{Malvacea. Sp. 69-195.}

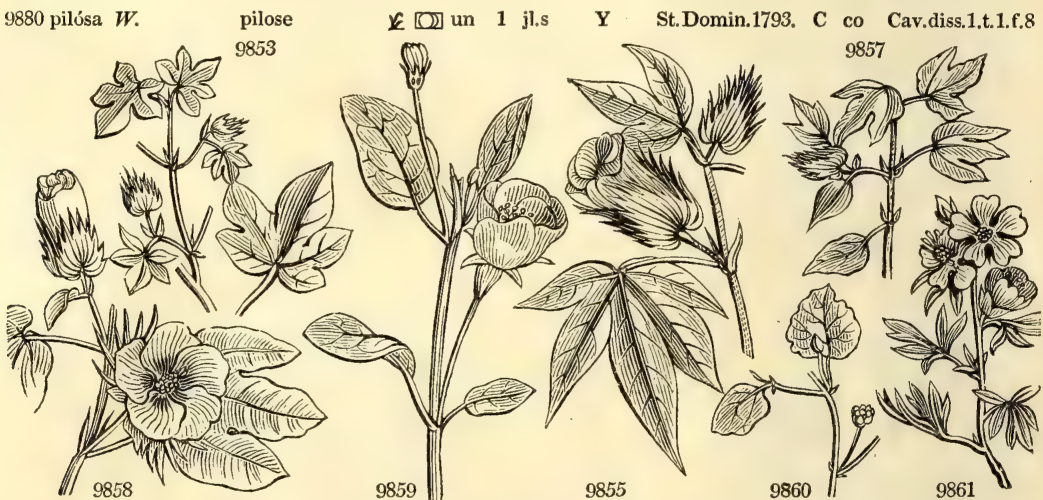

History, Use, Propagation, Culture,

1481. Gossypium. Pliny says, that in Upper Egypt, on the borders of Arabia, grew a shrub called gossypion or xylon. Its fruit enclosed a sort of soft white wool, of which the garments of the Egyptian priests were manufactured. Golius remarks, that goz, which expresses in Arabia, a silky substance, may be the root of the word. An important genus, as furnishing the down used in the cotton manufacture. This down is found lining the capsules which contain the seeds. There are several species cultivated for this purpose in different parts of the world. G. herbaceum is the only species cultivated in Europe, especially in the Levant, and in Malta, Sicily, and Naples: it is also grown in many parts of Asiá.

G. hirsutum is occasionally grown in the West Indies; but G. barbadense is the prevailing species there. In the East Indies and China, G. herbaceum and arboreum are cultivated, and some other species, especially that which produces the nankeen-colored down, not yet introduced to Europe. An oil is obtained from the seeds of all the species, while those of the G. herbaceum are eaten in the Levant, and esteemed wholesome and nutritive.

In the Levant, the herbaceous cotton is sown in well prepared land in March, in lines at three feet distance, and the patches of seeds two feet apart in the lines. The plants are thirned out to two or three in a place, and the earth is stirred by a one-horse plough, or by manual labor with hoes, and irrigated once or twice a week by directing the water along the furrows between the rows. The flowering season is generally over about the middle of September, and then the ends of the shoots are pinched off to determine the sap to the capsules. The capsules are collected by hand as they ripen, a tedious process, which lasts till the end of Nevember. The cotton and the seeds are then separated by manual labor, and the former packed in bales or bags for sale. The seeds are bruised for oil or eaten, and a portion kept for sowing.

The Barbadoes cotton plant is sown in the West Indies in rows, about five feet asunder, at the end of September, or the beginning of October; at first but slightly covered, but after it is grown up, the root is well moulded. The soil should not be stiff nor shallow, as this plant has a tap-root. The ground is hoed frequently, and kept very clean about the young plants, until they rise to a moderate height. It grows from four to six feet high, and produces two crops annually; the first in eight months from the time of sowing the seed the second, within four months after the first; and the produce of each plant is reckoned about one pound weight. The branches are pruned or trimmed after the first gathering; and if the growth is over luxuriant, 
9843 Leaves 5-lobed 1-glandular beneath : lobes round mucronate, Invol. serrate, Stem smooth 9854 Leaves 5-lobed palmate : lobes lanceolate blunt mucronate with 1 gland beneath, Invol, nearly entire 9855 Lower leaves 5-lobed palmate; upper 3-lobed with 1 gland beneath, Inv, tern. Cal, with 3 glands at base 9856 Upper leaves undivided cordate; lower 3-5-lobed with 1 gland beneath, Branches and petioles hirsute 9857 Upper leaves 3-lobed; lower 5-lobed with 1 gland beneath, Branches and petioles spotted with black 9858 Upper leaves 3 -lobed; lower 5-lobed with 3 glands beneath, Stem smoothish

9859 Leaves ciliated elliptical entire rarely trifid

9860 Smoothish prostrate, Peduncles nearly as long as petiole

9861 Leaves very casious, Stem very short

9862 Lower leaves cordate acuminate 5-angled somewhat toothed blunt; upper hastate acuminate 9863 Leaves all crenate : lower roundish cordate blunt 5-angled; upper round hastate acuminate 9864 Lower leaves triangular hastate crenate; upper ovate lanc. nearly entire, Ped. sol. axill. length of leaves

9865 Lower leaves cord. about 5-lobed hastate : upper hastate, Petals erect spatulate somewhat toothed at end

1. Capsules 5-12, 1-seeded, not bladdery.

* Flower-stalks not longer than the leafstalk. Leaves oblong or ovate 9866 Leaves linear entire much longer than the diameter of the flower, Racemes terminal

9867 Leaves linear-lanceolate toothed, A spiny tubercle at the base of the leaves, Pedic. axill. subsolitary 9868 Leaves ovate-lanceolate toothed, A spiny tubercle at the base of the leaves, Pedic. axillary solitary 9869 Leaves oblong ovate subcordate blunt tooth, Pedicels as long as petiole

9870 Leaves ovate-lanceolate acuminate toothed smooth, Branches round downy, Rac. very short bracteolate 9871 Leaves ovate-oblong doubly serrate, Pedunc. axillary very short about 4-flowered, Branches fiattened 9872 Leaves rhomboid narrowed at base serrate-toothed forwards beneath downy, Pedicels shorter than petiole 9873 Lvs. ellipt. subov. blunt toothed at end, Pedic. axill. solitary very short, Stipules ciliated longer than flow. 9874 Lower lvs. roundish ov.; upp. obl. toothed cun. and nearly ent. at base, Pedic. axill. many shorter than pet.

** Flower stalks elongated, distinctly jointed. Leaves oblong or ovate

9875 Lvs, ovate lanc, acumin, toothed hoary beneath, Branches compr. dotted, Pedic, thrice as long as petiole 9876 Leaves lanceolate toothed smooth, Pedic. axillary 1-fl. length of leaf

9876 Leaves oblong-lanceolate toothed cuneate at base hoary beneath, Pedic. axillary 1fl. shorter than leaf 9878 Leaves somewhat rhomboid retuse crenate towards the end hoary beneath, Pedic. longer than petiole 9879 Leaves ovate blunt serrated downy shining, Pedic. axillary solitary much longer than petiole

*** Flower-stalks elongated. Leaves cordate at base, toothed, not lobed. 9880 Leaves ovate cordate blunt toothed, Pedicels solitary 1-flowered longer than petiole

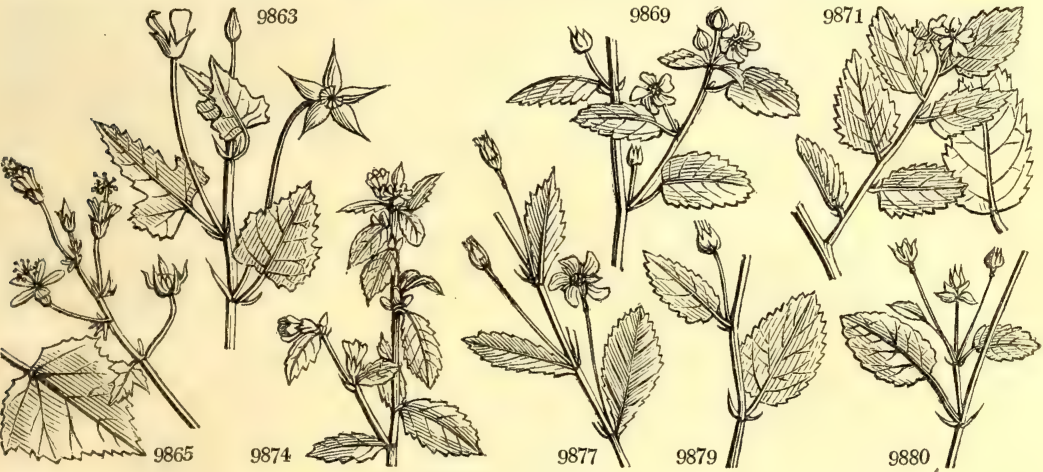

and Miscellaneous Particulars.

this should be done sooner. When great part of the pods are expanded, the wool is picked, and afterwards cleared from the seeds by a machine called a gin, composed of two or three smooth wooden rollers of about one inch diameter, ranged horizontally, close and parallel to each other, in a frame; at each extremity they are toothed or channelled longitudinally, corresponding one with the other; and the central roller being moved with a treaddle or foot-lath, resembling that of a knife-grinder, makes the other two revolve in contrary directions. The cotton is laid in small quantities at a time upon these rollers, whilst they are in motion, and readily passing between them, drops into a sack placed underneath to receive it, leaving the seeds, which are too large to pass with it, behind. The cotton thus separated from the seeds, is afterwards hand-picked and cleansed thoroughly from any little particles of the pods or other substances which may be adhering to it. It is then stowed in large bags, where it is well trod down, that it may be close and compact; and the better to answer this purpose, some water is every now and then sprinkled upon the outside of the bag; the marketable weight of which is usually three hundred pounds. An acre may be expected to produce from two hundred and forty pounds to that quantity; or two hundred and seventy pounds on an average. (Long's Jam. vol. iii. p. 686. \&c. and Browne.

1482. Redoutea. Named after P. J. Redouté, a celebrated French botanical draughtsman, still living. His drawings are inferior to those of the Bauers as accurate representations of nature; but they are generally tastefully arranged and please the eye, notwithstanding a coldness of coloring which often injures their effect.

1483. Palavia. In honor of Don Antonio Palau y Verdera, second professor of botany at Madrid, and author of an excellent translation of the Species Plantarum of Linnæus in Spanish.

1484. Cristaria. From crista, a crest, in allusion to the crested form of the capsules. A pretty plant, not very easily preserved. It answers better in a peat border than a pot, and is increased by division or seed.

1485. Anoda. Named by Cavanilles, from $\alpha$, privative, and nodus, an articulation; because the peduncles do not possess the joints which are found in Sida, from which the plants of this genus have been extracted.

1486. Periptera. So named from the resemblance of the flowers in form to a shuttlecock, $\pi \varepsilon \rho \tau \tau \varepsilon \rho \alpha$.

1487. Sida. A name of Theophrastus, said by some to have been applied to a Malvaceous plant; but 
9881 hamilis $W$. 9882 supína $L$ 'Her 9883 argúta $W$. 9884 cordifólia $W$ 9885 althæ'ifólia $S w z$ 9886 úrens $W$ 9887 dumósa Swz. 9888 paniculáta $\mathscr{W}$.

9889 tríloba $W$ 9890 jatrophoides $W$. 9891 ricinoides $L$ ' $H$ er 9892 Napæ'a Cav. 9893 dioíca Cav.

9894 occidentális $W$. 9895 fo'tida $W$.

9896 brévipes $D e c$

9897 períplocifólia $\boldsymbol{W}$ $\beta$ zeylánica $\gamma$ caribá $a$ 9898 hernandioides $W$. 9899 nudiflóra $W$. 9900 polyántha Link. 9901 auríta $W$ all. 9902 tríquetra $W$. 9903 incána Lin! 9904 umbelláta $W$

9905 refléxa $W$ 0906 crispa $W$ 9907 arbórea $W$ 9908 mauritiána $W$ 9909 grandifólia $W$ 9910 tiliæfólia Fisch. 9911 americána $W$. 9912 Abútilon $W$ 9913 asiática $W$ 9914 Sonneratiána $W$. 9915 populifólia $W$. 9916 mollíssima $W$. y917 orbiculáta Dec 9918 índica $\boldsymbol{W}$. 9919 vesicária $W$ 9920 álbida $\boldsymbol{I}$. 9921 acerifólia $L a g$ dwarf

procumbent un un $\frac{1}{2}$ jl.au smth. sharp-lvd. 化 un heart-leaved Althæa-leaved 避 un 3 jis.s stinging un 11 jl.s panicled 粪 $\square$ un 2 un $1 \frac{1}{2}$ jl.s

three-lobed 娄 J un $3 \mathrm{jl.s}$ Physic-nut-like [O] un 4 au Ricinus-like [0] un 4 au smooth rough 考 $\triangle$ un 4 au.s

downy

[] un $1 \frac{1}{2} \mathrm{jl}$.au J] un $1 \frac{1}{2}$ jl.au short-stalked
Y E. Indies 1800. \& co Cav.dis.5.t 134f.2 Jamaica 1821. S co Ca.dis.6.t.196.f.2 W. Indies 1732 , C co C. G. H. 1732. S co Dil.el.t.171,f.209 Jamaica 1820 C co Sloane 1.t.136.f. Jamaica 1781. C co Cav.diss.1.t.2.f.7 Jamaica 1818. C co Jamaica 1795. C co Cav.dis.1.t.12.f.5

C. G. H. 1794. C co Jac.schœ.2.t. 149 S. Amer. 1787. S co L'Her.stir.1.5 S. Amer. 1787. S co L'Her.stir.1.t.56
Peru Virginia 1748. D co Bot. mag. 2193

Virginia 1759. D co Ca.dis.5.t.132.f.2

America 1732. S co Dill. elt.7.t.6.f 6 Peru 1795. S co L'Her.stir.1.t.53 St. Martha 1822. S co
Periploca-lvd. $[0]$ un 2 jl.au Ceylon 5 un 2 jl.au Caribbee 10 un 2 jl.au Hernandia-lvd, 整 $\square$ un 6 naked-flowered 對 $\square$ un 3 my.jn many-flowered $\square$ un 3 my.jn eared un 3 my.jn triangular hoary umbelled 並 un 3 my.jn एun 3 jl.au [0] un $1 \frac{1}{2} \mathrm{jl} . \mathrm{s}$

reflex-flowered $\square$ un 3 jl.au curled [Q] un 1 jl.au great-flowered $\square$ un 6 jl.au Mauritius largc-leaved \& $\square$ un 20 n.d lime-leaved $1 \mathrm{O}$ un 2 jl.au woolly TO un $1 \frac{1}{2} \mathrm{jl}$.au broad-leaved $1 \frac{1}{2}$ in.au small-flowered [O] un $1 \frac{1}{2}$ jl.au small-flowered
Sonnerat's Sonnerat's
Poplar-leaved un 2 jn.jl soft-leaved if (O) un 2 jn.jl orbicular un 3 jn jl rough-capsuled [0] un $1 \frac{1}{2} \mathrm{jl}$,au bladdery un 3 jlau

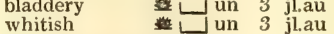

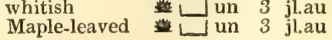

India 1691. S co Dill, elt. 4.t.3. f. 2 Ceylon $\quad .$. S co Pluk. t. 74, f. 7 W. Indies ... S $\mathbf{S}$ co Sloane t. 139. f. 3 Hispanio. 1798. C co L'Her.stir.1.t.58 Peru 1731. C co L'Her.stir.1.t.59 1821. C co

W. Indies 1775, C co Jac. vind. 2.t.118 Wandw. Is. 1818. C co Jamaica 1788. S co Jac. vind. 1, t. 16

Peru 1799. C co L'Her.stir.1.t.64 Carolina 1726. S co Ca.dis.5.t.135.f.2 Peru 1772. C co L'Her.stir.1.t.63 Mauritius 1789. S co Jac. ic. 1. t. 137 1816... C co Bot. reg. 360

1821. S co

Jamaica 1730. S co

India 1596. S co Houtt. syst. t. 61 E. Indies 1768, S co Cav.diss.1.t.f. 2 C. G. H. 1806. C co Cav.diss.1.t.6.f.4 E. Indies 1796. S co Cav.diss.1.t.7.f.9 Peru 1789. C co Cav.dis.2.t.14.f.1 China 1820. C co

India 1731 S co Cav dis 1t 7.10

Mexico 1822. C co Cav,dis.2.t.14.f.3 W. Canaries 1822. C Co B N. Spain 1822. C co

\begin{tabular}{|c|c|c|c|}
\hline 9922 Milléri $\mathrm{Dec}$. & Miller's & un & $1 \frac{1}{2} \mathrm{jl}, \mathrm{au}$ \\
\hline 3 viminea Fisch. & twiggy & 运 & 2 jn \\
\hline semicrenáta Link. & half crenate & un & jis \\
\hline $\mathbf{r}$ & pointed & un & 3 \\
\hline ólia Link. & Spiræa-leaved & 整 & au.s \\
\hline nsis Cav. & Brazilian & (2) un & 2 ils \\
\hline
\end{tabular}

$\begin{array}{lllll}\text { Y } & \ldots \ldots . . & 1749 . & \text { S } & \text { co } \\ \text { Or } & \text { Brazil } & 1821 . & \text { C } & \text { co } \\ \text { Y } & \text { Manilla } & 1823 . & \text { C } & \text { co } \\ \text { Y } & \text { Brazil } & 1820 . & \text { C } & \text { co } \\ \text { Y } & \ldots \ldots . . & 1824 . & \text { C } & \text { co } \\ \text { Y } & \text { Brazil } & 1818 & \text { C } & \text { co }\end{array}$

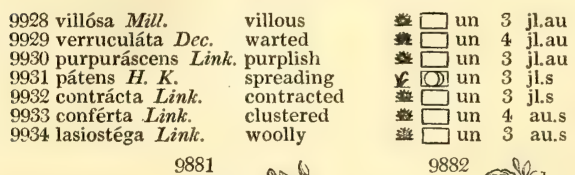

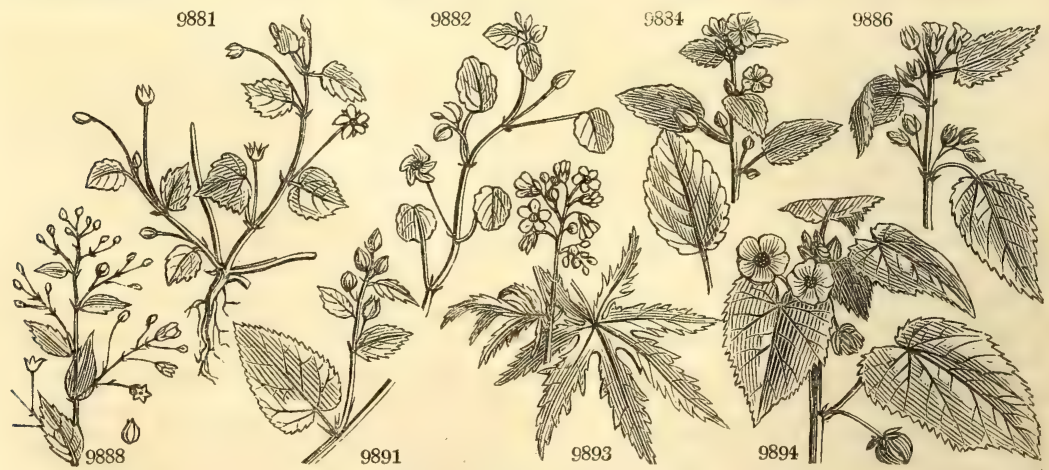

History, Use, Propagation, Culture,

Adanson is of opinion, that our Nymphra was the Sida of Theophrastus. The species are free-flowerers of no 
9881 Leaves roundish cordate hairy above serrated, Pedicels subsolitary longer than petiole

9882 Leaves roundish cordate bluntish crenate softly velvety, Pedic. solitary 1-f. longer than petiole 9883 Leaves cordate serrate attenuated at end downy on the edge of the petiole and the nerves beneath

9884 Leaves ovate cordate toothed somew. angular bluntish downy, Pedic. sol. 1-f. a little shorter than petiole 9885 Leaves cord, somewhat angular blunt serrate cren. downy on each side, Pedic. shorter than petiole 1-5-fi 9886 Leaves ovate cordate acuminate toothed, Pedunc. 3-4-flowered very short

9887 Leaves cordate ovate acuminate serrate smooth on each side, Peduncles many-ff.

9888 Leaves ovate cordate toothed acuminate downy, Pedunc. loosely panicled capillary

$$
\text { **** Leaves palmate, divided into 3-5-7-9 lobes. }
$$

9889 Leaves cordate toothed 3-lobed; middle lobe acute long, Pedicels solitary nearly equal to the leaf 9890 Leaves subpeltate 7-lobed: lobes lanceolate acuminate pinnatifid toothed, Peduncles many-fl. 9891 Leaves subpeltate 5-lobed: lobes ovate acute toothed undivided, Peduncles about 1-flowered 9892 Leaves palmate 5-lobed smooth : lobes oblong acuminate toothed, Peduncles many-f.

9893 Leaves palmate 7-lobed rough : lobes lanceolate cut-toothed, Pedunc. many-f, bracteate corymbose

\section{Capsules 15-40, 1-secded, bladdery.}

9894 Leaves oblong cordate toothed somewhat lobed, Pedicels solitary shorter than petiole

9895 Lvs, cord ovate acute toothed downy on each side, Petioles and pedicels hairy, Stip. setaceous spreading 9896 Lvs. cord. roundish acumin, tooth. velvety, Petioles and branches with spreading hairs, Pedic. very short

$$
\text { 3. Capsules 5-10, many-seeded, often bladdery. }
$$

9897 Leaves cord. lanc. acuminate entire downy beneath, Pedicels divided slender longer than petiole

$\beta$ Leaves narrow rough above

$\gamma$ Leaves more cordate smooth and a little rugose above

9898 Leaves subpeltate cordate ovate acuminate entire downy, Pedic. 1-fl. shorter than petiole

9899 Leaves roundish cordate acuminate entire downy beneath, Panicle terminal racemose

9900 Leaves cordate shortly acuminate subcrenate slightly downy and grecn on each side, Panicle leafless

9901 Lws. deeply cord. with a narr. base acumin. serrul, hairy above hoary beneath, Stips. broad-eared acumin.

9902 Leaves cordate acuminate serrulate velvety on each side, Pedicels solitary 1-flowered

9903 Leaves hoary cordate acuminate acutely crenate, Pedicels 1-f. longer than petiole

9904 Leaves roundish cordate toothed angular acuminate, Pedicels 4-fl. umbelled axillary

* Capsules 9 or more.

9905 Leaves roundish cordate acuminate crenate downy, Pedicels sol. longer than petiole 9906 Leaves cordate acuminate crenate velvety; upper sessile, Pedicels sol. longer than petiole

9907 Leaves round cordate acuminate crenate downy, Pedicels longer than petiole

9908 Leaves roundish cordate acuminate toothed downy beneath, Pedicels longer than petiole

9609 Leaves roundish cordate unequally toothed soft, Pedunc. 2-3-fl. shorter than petiole, Capsules acuminate

9910 Leaves roundish cordate with a broad sinus acuminate toothed soft, Pedicels shorter than petiole

9911 Leaves cordate oblong undivided downy, Pedicels shorter than leaf

9912 Leaves roundish cordate acuminate toothed downy, Peduncles shorter than petiole

9913 Leaves cordate ovate oblong toothed velvety on each side, Pedicels longer than petiole

9914 Leaves roundish cordate acuminate loothed downy, Peduncles longer than leaves

9915 Leaves roundish cordate acuminate unequally repand toothed downy, Peduncles longer than petiole

9916 Leaves roundish cordate acuminate toothed velvety, Peduncles 2 -flowered shorter than petiole

9917 Leaves ovate orbicular reniform toothed hoary beneath, Pedicels longer than petiole

9918 Leaves cordate somewhat lobed soft, Stipules reflexed, Pedicels erect 3 times as long as petiole

9919 Leaves ovate cordate toothed tricuspidate, Pedicels twice as long as petiole

9920 Leaves roundish cordate acuminate toothed hoary on each side, Pedicels length of petiole

9921 Leaves cordate subpeltate 3-5-lobed unequally toothed villous, Pedicels 1.flowered longer than petiole

$$
\text { 4. Uncertain species. }
$$

* Leaves linear, oblong, ovate, or lanceolate.

9922 Leaves linear lanceolate toothed villous beneath, Pedicels axillary 1- $\mathrm{A}$

9923 Leaves lanceolate very long entire hairy, Racemes terminal very short

9924 Leaves broad lanceolate obtuse crenate entire at base 3-nerved; younger downy beneath

9925 Middle leaves oblong blunt acutely crenate in front; upper lanceolate acute serrated in front

9926 Leaves oblong lanceolate serrated entire at base smooth, Pedunc. axillary solitary longer than petiole

9927 Leaves ovate acuminate 5-nerved scarcely toothletted; beneath and branches downy, Stipules filiform

$$
\text { ** Leaves cordate, undivided. }
$$

9928 Leaves subcordate sessile serrate subvillous, Flowers axillary clustered

9929 Stem warted, Leaves cordate lanceolate acuminate acutely crenate downy

9930 Leaves cordate acuminate crenate toothletted, and stems green and downy, Pedic. axillary 1-ft.

y931 Leaves cordate acuminate cut serrate, Peduncles solitary longer than petiole

9932 Leaves cordate acuminate repand rarely crenate hoary, Panicle contracted bracteate

9933 Leaves cordate acute crenate rugose and stems yellow -with down, Flowers subsessile aggregate

n9:34 I eaves cordate acuminate hoary beneath, Pedicels axillary 1-flowered longer than petiole

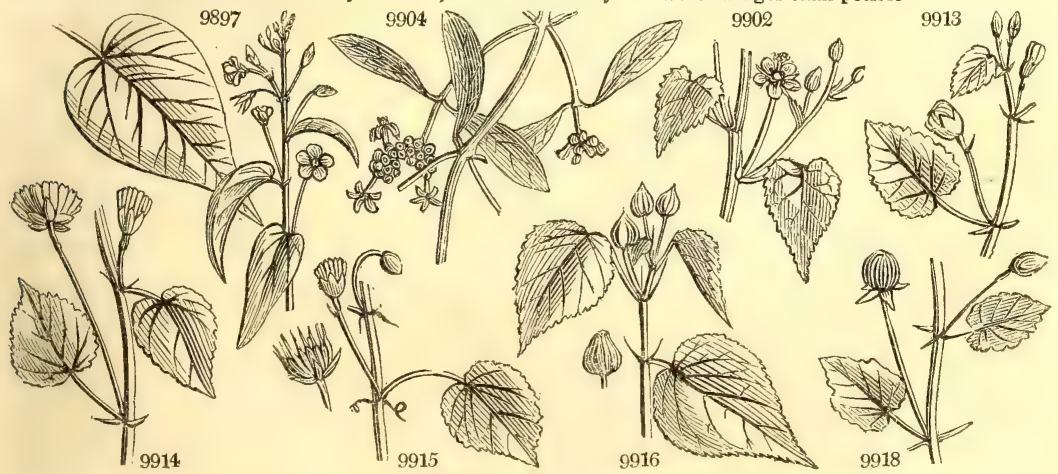

and Miscellaneous Particulars.

great beauty. They are increased by seeds, which they produce freely, or by cuttings in sand under a

hand-glass. 
1488. LAGUNE'A, $W$ 9935 lobáta $W$

1489. RUI'ZIA $W$

3936 variábilis $W$.

1490. CAROLI'NEA. $W$. CARolinea. 9937 álba Lodd. 9938 princeps $W$. 9939 mínor $\boldsymbol{H} . \dot{K}$ 9940 insígnis $\boldsymbol{W}$.

1491. ADANSO'NIA, $W$ great-flowered 9941 digitáta $W$.

1492. BOM'BAX, $W$. 9942 eriánthos $C a v$. 9943 pentándrum $W$. 9944 Ceíba $W$

9945 heptaphýllum $W$ 1493. MYRO'DIA. $W$ 9946 turbinata $W$.

1494. GORDO'NIA. $W$. 9947 Lasiánthus $W$. Lacathéa flórida pubescent Lacathéa flórida P. L. 56.

1495. STUAR'TIA. $W$. Stuartia. 9949 Malachodéndron $W$. Common 9950 pentágyna $W$. curled Malachodéndion ovátum Cav.

1496. CAMEL'LIA. Ker. CAmeru. 1496. CAMEL LIA. Ker. Bohéa Bohea Tea
B951 99.52 víridis Bohea Tea
Green Tea

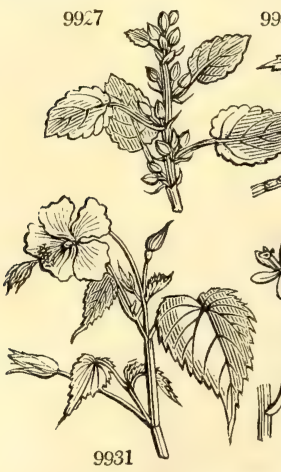
9936
Malvacea. Sp. 1-4.

jl.au W Bourbon 1787. S co Ca.dis.5.t.136.f.1 Byttneriacea. $\quad S p .1-3$.

my W Bourbon 1792. C p.l Jac.schœ. 3.t.295

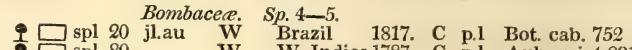
spl 20 … W $\quad$ W $\quad$ W. Indies 1787. C p.l Aub. gui. t.291.2 spl 20 jl.au W Guiana 1798. C p.l Bot. mag. 1412

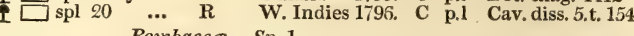
Bombacee. Sp. 1.

$\begin{array}{lllllllll}\text { Sour Gourd } & \text { ec } 60 & \text {... } & \text { W } & \text { Senegal 1724. } & \text { C } & \text { p.l } & \text { Cav. diss. 5.t.157 }\end{array}$ Woolly-fl. Bombacea. Sp. 4-7.

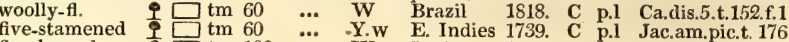
five-leaved $\square \mathrm{tm} 100 \ldots$ W India $\quad \ldots$ W 176 \$ 50 tm 50 W America 1699. C p.1 Plu.alm.t.188.f.4

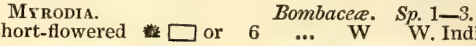

$\square$ or $6 \quad \ldots \quad$ W $\quad$ W. Indies 1793 . C p.l

Ternstromiacea. Sp. 2-4.

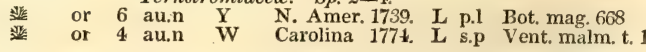

Ternstromiacece, $S p .2$.

* or 10 my.au W N. Amer. 1742. L 1.p Bot. rep. 397 I or 9 jl.au W N. Amer. 1785. L 1.p Exot.bot.2. t.110

Camelliea, $S p .6-8$.

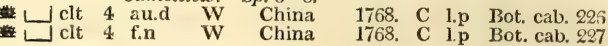

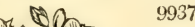

9937 
9935 Leaves cordate 3-lobed: lobes oval oblong acuminate toothed with a very narrow base

9936 Leaves of the flowering branches palmatifid; of the sterile palmate

9937 Leaves digitate, Filaments numerous forked united at base into a tube 9938 Leaflets 5-8 ovate-lanceolate acuminate

9939 Leaflets 7 elliptical-oblong acute at each end, Calyx truncate, Petals erect 9940 Leaflets 5-7 obovate oblong, Calyx sinuated, Petals erect spreading at end

9941 A tree with a very thick trunk with a diameter of 25 feet

9942 Anthers rectilinear, Leaflets 7, Corolla large woolly outside, Trunk prickly 9943 Anthers anfractuose, Leaflets entire, Trunk generally prickly

$99+4$ Stem prickly, Ieaves palmate, Leaflets 5 , Fruit turbinate concave at end 9945 Stem prickly, Leaves palmate, Leaflets 7 entire acuminate, Fruit oblong blunt

9916 Leaves ovate-oblong, Calyxes turbinate, Column of stamens shorter than petals

9917 Pedicels axillary half as short as leaves, Leaves oblong coriaceous smooth serrated

9948 Fls. subsessile, Leaves obov. lanc. downy beneath subserrate membranous, Petals and sepals silky outside

9949 Flowers large white, Filaments purple, Anthers blue

9950 Leaves ovate acute, Flowers solitary subsessile

9951 Leaves elliptical oblong subrugose twice as broad as long

9952 Leaves lanceolate flat three times as broad as long

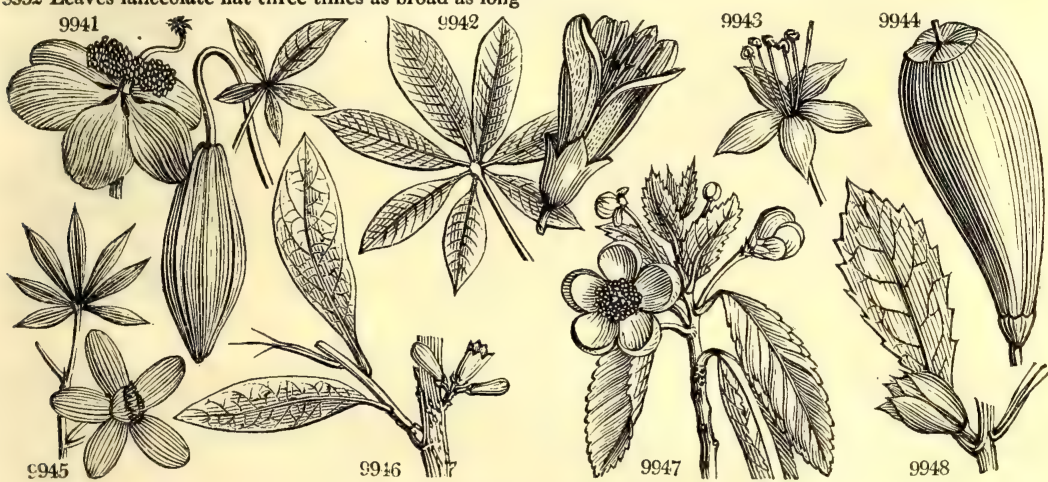

and Miscellaneous Particulars.

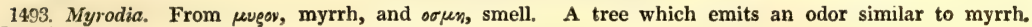
(linn.)

1494. Gordonia. In memory of James Gordon, an eminent nurseryman at Mile-End, near London, a correspondent of Linnæus and other eminent botanists, and the introducer and successful cultivator of many new plants. G. Lasianthus (woolly flower, from $\lambda \propto \sigma 0 s$ and $\alpha$. 905 ), the loblolly-bay, is said to grow naturally in water or very moist situations. Miller, on that account, was unsuccessful in keeping the plant. Gordon and Lee, who, as Ellis relates, (Corres. with Linneus) were better cultivators than Miller, were probably more successful. Sweet says, the species are hardy enough, to bear our winters in the open air; but the young shoots often get injured, and the summer is not long enough to flower them in perfection; it is therefore better to treat them as greenhouse plants. Peat soil suits them best, and a little loam mixed with it: they are readily propagated by layers, or ripened cuttings may be struck in sand under a hand-glass. (Bot) Cult. 199.)

1495. Stuartia. So named by Linnæus, in honor of the Marquis of Bute, in memory of whom there also exists another genus named Butea, by Roxburgh. The species are handsome shrubs, grow in peat soil, and are most readily increased by layers.

1496. Camellia. In honor of George Joseph Kamel, (or Camellus) a Jesuit. His Syllabus Stirpium in Insula Luzone Philippinarum, forms the appendix to the third volume of Ray's History. This is a remarkable genus, as at once furnishing the domestic drug tea, in universal use, and flowering trees and shrubs as universally admired. The seeds of all the species are crushed for oil, which is used like that of hemp or poppy in cookery.

C. Bohea and viridis are the species which chiefly furnish the tea; but C. Sasanqua is also used, and sometimes the leaves of the other species are taken, though that practice is rather to be considered in the light of adulteration. The tea districts of China extend from the twenty-seventh to the thirty-first degree of north latitude. According to the missionaries, it thrives in the more northern provinces ; and from Kæmpfer, it appears to be cultivated in Japan as far north as latitute 45". It seems, according to Dr. Abel's observation, to succeed best on the sides of mountains, where there can be but little accumulation of vegetable mould. The soils from which he collected the best specimens consisted chiefly of sandstone, schistus, or granite. The plants are raised from seeds sown where they are to remain. Three or more are dropped into a hole four or five inches deep; these come up without further trouble, and require little culture, except that of removing weeds, till the plants are three years old. The more careful stir the soil, and some manure it; but the latter practice is seldom adopted. The third year the leaves are gathered, at three successive gatherings, in February, April and June, and so on till the bushes become stinted or tardy in their growth, which generally happens in from six to ten years. They are then cut in to encourage the production of fresh roots.

The gathering of the leaves is performed with care and selection. The leaves are plucked off one hy one : at the tirst gathering only the unexpanded and tender are taken; at the second those that are full grown; and at the third the coarsest. The first forms what is called in Europe imperial tea; but as to the other 
9953 Sasánqua $W$. $\beta$ pléna 9954 japónica $W$
Lady Banks's double common

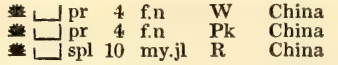

1811. I p.l Bot. reg. 12 1818. I p.l Bot. reg. 547 1739. C $\mathrm{c} .1$

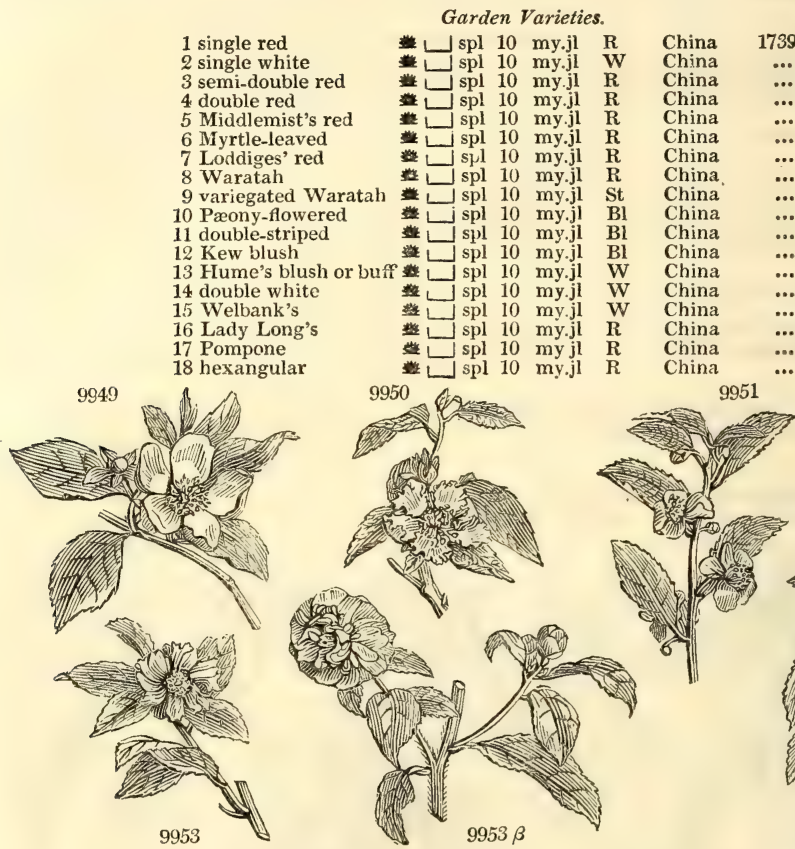

1739. C p.l Bot. mag. 42

... 1 p.l Bot. cab. 633

I p.1 Bot rep. 559

I p.l Bot rep. 199

$\ldots$ I p.1

.. I p.l Bot. mag. 1670

... I p.l

... I p.l Bot. cab. 537

I $\quad$ I p.l Bot. reg. 887

... I p.1

I p.1 Bot rep 91

I p.l Bot. reg. 22

.. I p.1 Bot. reg. 112

... I p.l Bot. rep. 25

... I p.I Bot. reg. 708

.. I p.l Bot, reg. 633

I p.l Bot. cab. 596

$\because \quad$ I p.l $9951 \quad 9952$

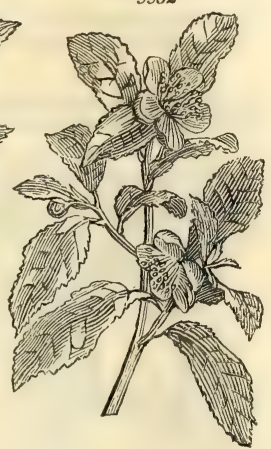

History, Use, Propagation, Culture,

names by which tea is known, the Chinese know nothing; and the compounds and names are supposed to be made and given by the merchants at Canton, who, from the great number of varieties brought to them, have an ample opportunity of doing so. Formerly it was thought that green tea was gathered exclusively from C. viridis; but that is now doubtful : though it is certain there is what is called the green tea district, and the black tea district; and the varieties grown in the one district differ from those grown in the other. Dr. Abel was told by competent persons, that either of the two plants will afford the black or green tea of the shops, but that the broad thin-leaved plant (C. viridis) is preferred for making the green tea.

The tea leaves being gathered, are cured in houses which contain from five to ten or twenty small furnaces, about three feet high, each having at the top a large flat iron pan. There is also a long low table covered with mats, on which the leaves are laid, and rolled by workmen, who sit round it : the iron pan being heated to a certain degree by a little fire made in the furnace underneath, a few pounds of the fresh-gathered leaves are put upon the pan; the fresh and juicy leaves crack when they touch the pan, and it is the business of the operator to shift them as quick as possible with his bare hands, till they become too hot to be easily endured. At this instant he takes off the leaves with a kind of shovel resembling a fan, and pours them on the mats At this instant he takes off the leaves with a kind of shovel resembling a fan, and pours them on the mats
before the rollers, who, taking small quantities at a time, roll them in the palm of their hands in one direction, while others are fanning them, that they may cool the more speedily, and retain their curl the longer. This process is repeated two or three times, or oftener, before the tea is put into the stores, in order that all the moisture of the leaves may be thoroughly dissipated, and their curl more completely preserved. On every repetition the pan is less heated, and the operation performed more closely and cautiously. The tea is then separated into the different kinds, and deposited in the store for domestic use or exportation.

The different sorts of black and green arise not merely from soil, situation, or the age of the leaf; but after winnowing the tea, the leaves are taken up in succession as they fall; those nearest the machine being the heaviest, are the gunpowder tea; the light dust the worst, being chiefly used by the lower classes. That which is brought down to Canton then urdergoes a second roasting, winnowing, packing, \&c., and many hundred women are employed for these purposes.

As more select sorts of tea, the blossoms of the $\mathrm{C}$. sasanqua appear to be collected; the buds also appear to be gathered in some cases. By far the strongest tea which Dr. Abel tasted in China, was that called yutien, used on occasions of ceremony. It scarcely colored the water, and on examination was found to consist of buds and half expanded leaves of the plant.

As substitutes for tea used by the Chinese, may be mentioned a species of moss common to the mountains of Shan-tung, an infusion of ferns of different sorts, and Dr. Abel thinks the leaves of the common camellia and oil camellia may be added. Du Halde observes, that all the plants called tea by the Chinese, are not to be considered as the true tea plant; and Kæmpfer asserts, that in Japan a species of Camellia, as well as the Olea fragrans, is used to give it a high flavor.

The oil-bearing Camellia, C. oleifera, is cultivated for its seeds, from which an oil is expressed, in very general use in the domestic economy of China. It grows best in a red sandy soil, attaining the height of six or eight feet, and producing a profusion of white blossoms and seeds. These seeds, as well as those of any of the other species, are reduced to a coarse powder, which is stewed or boiled in bags; and then pressed, when the oil is yielded. (Dr. Abel's Nar. 176.)

The culture of the tea Camellias in our greenhouses is very simple. The plants are very hardy, and may be preserved in a pit without fire-heat; they grow in loamy soil, or loam and peat well drained, and increase freely by layers, or cuttings of the young wood taken off when it begins to ripen, planted in sand, and covered with a hand-glass in a cool frame or pit.

C. japonica, in the groves and gardens of Japan, is a lofty tree, much admired for its fine form, rich clothing of shining deep green foliage, and elegant red or white flowers, single or double. It is equally admired in 
9953 Leaves ovate-oblong bluntly serrated, Flowers terminal subsolitary, Petals obcordate

9954 Leaves ovate acuminate acutely serrate, Flowers terminal subsolitary

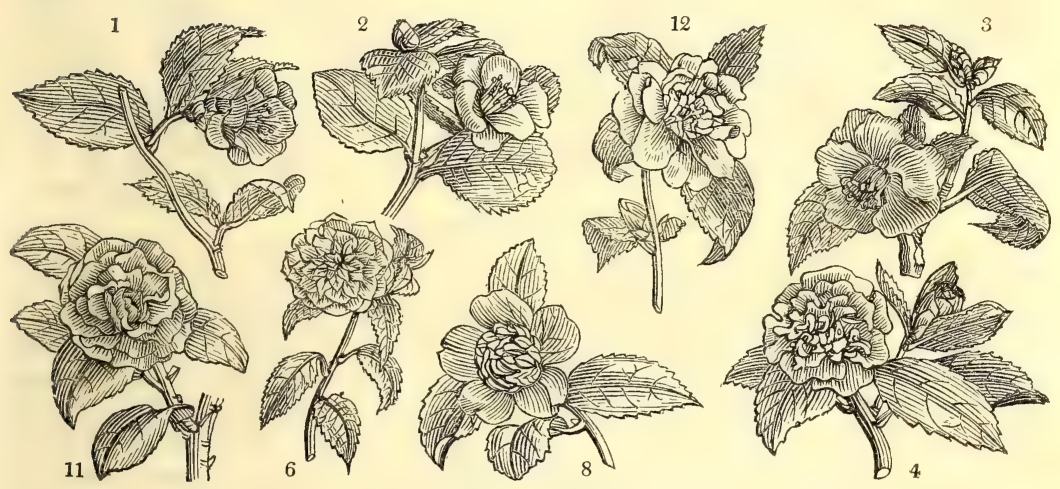

and Miscellaneous Particulars

China as in Japan, and much cultivated in both countries. It is of frequent occurrence in Chinese paintings, with Hibiscus and Chrysanthemum, two of their great favorites. There are several varieties of $C$, japonica in China, most of which have been imported here, and their number considerably increased, and daily increasing, from seedlings raised in this country. The double white, double striped, and double Waratah, (from the central petals resembling those of the Waratah plant of New Holland, Telopea speciosissima, ) are considered the grandest and most marked varieties, and are also free-growers and flowerers; the pæony-flowered and fringed white, are also standard beauties; but all are much admired.

The single red Camellia is propagated by cuttings, layers, and seeds, for stocks; and on these the other sorts are generally inarched, and sometimes budded or grafted. The cuttings are formed of ripened or ripening shoots, taken off in August, cut smoothly across at a joint or bud, two or three of the lower leaves only taken off, and the cuttings then planted and made firm with a small dibber, in pans of sand or loam, or, by some cultivators, sand and peat, or sand alone. The pans are kept in a pit or cold frame, without being covered with glass, but shaded during powerful sunshine; and in the following spring such as are struck will begin to push, when they are to be placed in a gentle heat. In September or October following, the rooted plants will be fit to pot off; and in the second or third spring they may be used as stocks. Such is the practice in the London nurseries. Henderson, of Woodhall, near Edinburgh, puts in Camellia cuttings at any time of the year, excepting when they are making young wood. He puts fifty cuttings in a pot of sand eight inches in diameter, sets them in a cool place in the back of a vinery or peach-house for a month or six weeks, and then plunges them to the brim in a hot-bed where is a little bottom heat. A speedy mode of obtaining stocks is by pianting stools in a pit devoted to that purpose, and laying them in autumn; the following autumn most of the layers will have produced roots, when they may be taken off and potted, and used as stocks in the succeeding spring. Inarching or grafting is performed early in spring, when the plants begin to grow; the chief care requisite is so to place and fix the pot containing the stock, as that it may not be disturbed during the connection of the scion with the parent plant. The graft being clayed over, is then covered with moss to prevent its cracking. When independent grafting is resorted to, the mode called side grafting is often used ; but the operation of tongueing is generally omitted, as weakening the stock and unnecessary, with a view to prevent the scion from being blown off. A few seeds are sometimes obtained from the single red and semi-double Camellias, and from the single Waratah ; these require two years to come up, but make the best stocks of any.

Before they are grafted they are often allowed to come into flower, in case some new variety should be produced; but the best cultivators, as Messrs. Loddiges, Sweet, and Mackay, regularly cross-impregnate the blossoms in Knight's manner, by cutting out the stamens before the anthers are mature, and when the stigma is in a proper state, dusting it with the pollen of the species or variety intended as the male parent.

C. Sasanqua seeds most readily, and is mostly employed as the fermale parent for raising new varieties. The plants, if well treated, flower in four or five years, and if nothing new is produced they still make excellent stocks.

Some cultivators grow the Camellias chiefly in peat. Messrs. Loddiges, who have the most numerous collection of this genus, formerly used loam, with a little sand and peat; and they are grown in a similar soil in Hammersmith nursery. Of late, Messrs. Loddiges find ligh̀t loam alone to answer as well or better. In the Comte de Vandes garden at Bayswater, rotten dung is mixed with loam and peat. Sweet recommends sandy loam and peat. Henderson of Woodhall is one of the most successful growers of the Camellia in Scotland: his compost is as follows : take one part of light-brown mould, one part of river-sand, one part of peat-earth, one half part rotten leaves; nix them all well together, and when the Camellias require shifting, put some broken coal-char in the bottom of the pots, and some dry moss or hypnum over it. (Caled. Mem. iii. 316.)

Camellias have the best effect, and are grown to most advantage in a house entirely devoted to them. Such 
9955 oleífera Abel. 9956 axilláris

1497. B ARRINGT

9957 speciósa $W$.

1498. GUSTA'VIA $W$ 9958 augústa $W$.

1499. CA'REYA. Roxb 9959 herbácea Roxb. oil-seed axillary

栔 L pr 3 $W$. Barringtonia. Laurel-leaved $\perp \square$ spl 20

3 f. $m$ r $\quad$ W Myrtacea. Iyrtacece. Myrtacea. august CAREYa.

9 $\square$ spl 30 ... W Guian CAREYa. Myrtacea. Sp. 1-2.

China 1890. C r.m E. Indies 1818. C r.m Sp. 1.
. I 音 jl.au R

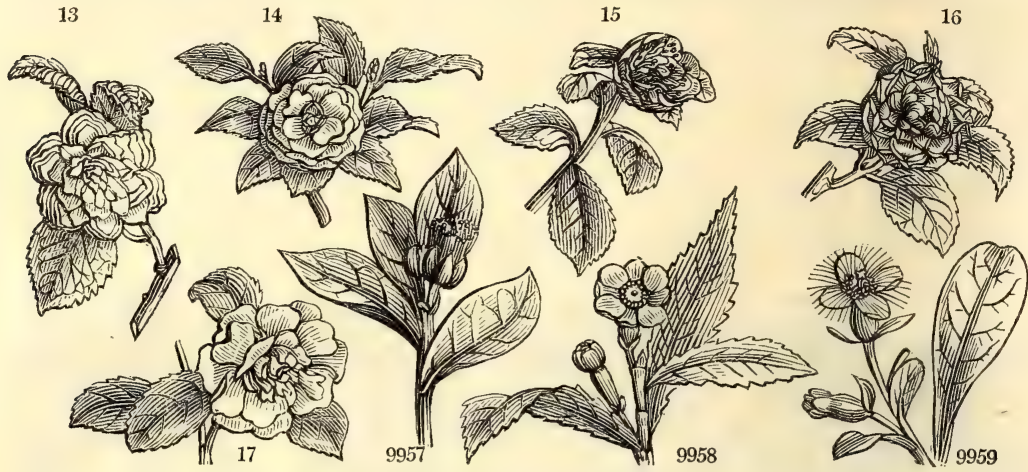

History, Use, Propagation, Culture,

a house should be rather lofty, as the plants never look so well as when six or eight feet high, trained in a conic form, and clothed with branches from the root upwards. The plants should be raised near to the glass by means of a stage, which should be so contrived, that, as they advance in height, it may be lowered in proportion: only the very best crown or patent glass should be used; because it is found from experience, that the least inequality of surface or thickness of material, so operates on the sun's rays, as to concentrate them, and burn or produce blotches on the leaves of the plants. Every cultivator must have observed that leathery shining leaves, like those of the orange, myrtle, \&c. are more or less subject to this solar injury; but the leaves of the Camellia are particularly so. Some nurserymen recommend a roof which will not admit much light; others the use of green glass; of an opaque roof, with glass in front only; or of a house facing the north. Our opinion is, that a light house facing the south, or, better still, glass on all sides, is essential to the perfect growth of the plants; and that all solar accidents may be avoided, or at least rendered of no consequence, by using the best glass, and placing the plants as near it as possible.

To grow the Camellia to a high degree of perfection, considerable care is requisite. The roots are very apt to get matted in the pot, and, by the space they occupy, so to compress the ball of mould, as after a time to render it impervious to water. Hence frequent attention should be had, to see that the water poured on the pots moistens all the earth, and does not escape by the sides of the pot, moistening only the web of fibres. When the plants are in flower and in a growing state, they require to be liberally watered, and also a degree of heat somewhat greater than is usually given to greenhouse plants. If this heat is not given in November and December, the plants will not expand their blossoms freely; and if both water and heat are not regularly applied after the blossoming season, vigorous shoots and flower-buds will not be produced. To form handsome plants, they should be trained with single stems to rods, and pruned so as to make them throw out side branches from every part of the stem : to encourage these, the plants should not be set close together on the stage. In summer they may either be set out of doors on a stratum of scoriæ, or on a pavement, in a sheltered but open situation; or the glass roof may be taken off. The hardier sorts, as the double red, blush, pæonyflowered, \&c. answer very well when planted in the bed or border of a conservatory, provided the roof or entire superstructure can be removed in summer to admit the full influence of the weather. When this entire superstructure can be removed in summer to admit the full influence of the weather. When this
cannot be done, the Camellia and most other plants are better in portable utensils, which admit both of examining their roots, and placing them in the open air, or in a greater degree of heat at pleasure. The single and double red Camellia will endure the open air when trained against a south wall, and protected by mats in winter; and there can be no doubt that in time these and other species will be more perfectly inured to our climate.

Henderson of Woodhall gives the following account of his mode of treating the Camellia. " The best time for a regular shifting of the Camellias is the month of February or beginning of March. After shifting all those that require it, put them into the peach-house or vinery, when there is a little heat; if there be no peach-house, vinery, nor pinery, set them in the warmest part of the greenhouse. They will soon begin to make young wood. From the time they begin to make their young shoots, till they have finished their growth, give them plenty of water They may be kept in the vinery or peach-house till they have formed their flower-buds at the extremity and sides of the young growths, when a few of them may be removed to a colder place, say behind the stage of the greenhouse; for the Camellias are fond of being shaded during 
9955 Leaves thin ovate finely serrate pale-green, Branches slender twiggy

9956 Leaves obovate oblong serrulate; upper entire, Flowers solitary subsessile subaxillary

9957 Leaves oblong blunt large fleshy stalked shining tinged with red

9958 Sepals 4 roundish petaloid, Petals 4, Leaves oblong acuminate toothed

9959 Flowers stalked, Outer stamens longest sterile
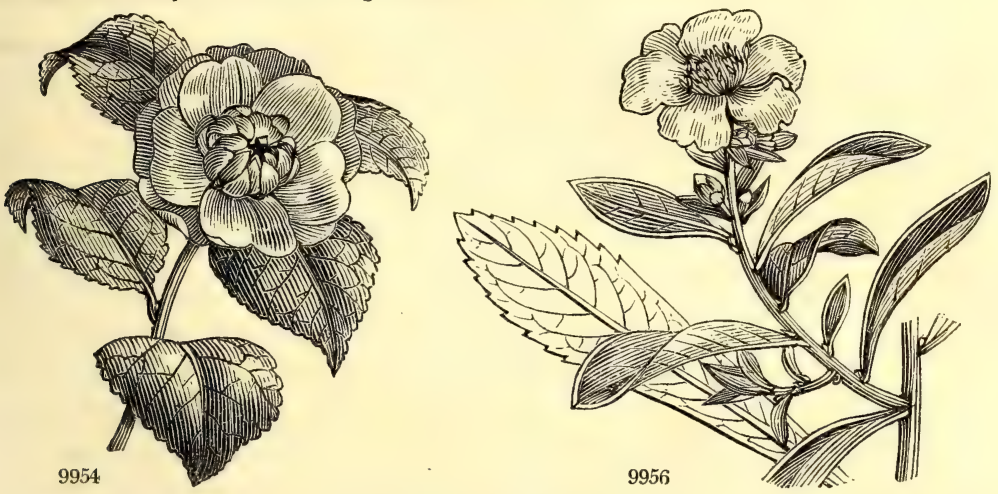

and Miscellaneous Particulars.

strong sunshine. In three or four weeks after, a few more of the Camellias may be brought from the vinery or peach-house, and put into a cooler situation. This may be repeated three or four times, which will make as many different successions of flowering. Those that are wanted to come into flower early, may remain in the warm house till they are beginning to flower, when they should be taken to a cold place, say the coldest place of the greenhouse; then give them plenty of light only, and they will open their flowers well, and stand long. A Camellia cannot stand heat when in flower, indeed they seldom open their flowers fine when in heat, and, at all events, the flowers soon fall off: Those that are kept all the summer in the vinery, will come into flower by the first or middle of October, and a pretty large plant, having perhaps fifty or a hundred flower-buds, will continue in flower till the month of January. Those plants that are removed early from the vinery, will now be in flower, to succeed those that were in flower in October, and have now done flowering. These last should be immediately taken into the heat. They will make their young wood early, and they may remain in heat till they come into flower, which will perhaps be a month earlier next year. By attending to shifting the Camellia plants from the warm-house to the cold, a regular succession of flowers may thus be had from the first of October to the middle of July. I have even had them all the summer, but the flowers are best in the winter. Those produced in summer are far from being so fine, and do not stand half the time of those that come into flower in November, December, January, February, March and April. Camellias delight to be kept damp all the summer months, and a little shaded from the strong sun. Give them plenty of water while they are making their young shoots; they may also get a gentle sprinkling over the leaves once every week during the summer season, except when they are in flower. Camellias will stand a great deal of cold without being much injured, but they will not form many flower-buds without some artificial heat." (Caled. Mem, iii, 316.)

1497. Barringtonia. In memory of the Hon. Daines Barrington, F. R. S., an active Fellow of the Society of Antiquaries, and author of several papers in their Transactions. A lofty tree, the handsomest in the equinoctial flora. It has thick shady bunches of long wedge-shaped coriaceous leaves, and large handsome purple and white flowers, which open at night, and fall at sunrise. They are succeeded by a reddish brown drupe, the seed of which mixed with the bait, inebriates fish in the same manner as Cocculus indicus. It grows on the sea shore and at the mouths of rivers, and is cultivated in the governor's garden at St. Helena. It is very rare in our stoves, though not difficult to manage. Sweet says, "a mixture of two-thirds loam and one-third peat, is a good soil for it. Cuttings taken off at a joint, when the wood is ripe, and put in a pot of sand under a hand-glass in moist heat, will strike root readily: none of the leaves should be taken off or shortened." (Bot. Cult. 21.)

1498. Gustavia. In memory of Gustavus IIF, king of Sweden, who presented a great collection of Indian plants to the elder Linnæus. A tree remarkable for its large white flowers, larger than those of the waterlily, but with a large naked bald receptacle between the corolla and the style. The flowers smell sweet, but the wood is extremely fetid. In Surinam it is used for hoops. In the stove it grows in sand and loam, and roots in sand under a hand-glass.

1499. Careya. Named after Dr. William Carey, the editor of Roxburgh's Flora Indica, and an English physician and botanist residing at Serampore. Beautiful Indian plants, with long red stamens. 


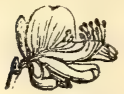

\section{Class XVII. - DIADELPHIA. Stamens united in two separate parcels.}

This class essentially. requires, as its name implies, that the stamens should be united in two separate parcels. These may either be equal, each bearing more anthers than one, as in Smithia, Aschynomene, Fumaria, and others; or unequal, one parcel being reduced to a single stamen, and the other bearing several anthers, as in the greater number of genera included in the class. But besides the plants whose stamens are thus disposed, it has been the practice to admit other genera having papilionaceous flowers, but with their stamens united in one parcel only, such as Platylobium, Bossiæa, Arachis, and others. The propriety of this measure is extremely questionable. It has been before remarked in this work, that the value of an artificial arrangement of objects depends wholly upon the precision with which they are referred to those heads or divisions with the character of which they agree. If this does not obtain, an artificial system ceases to be useful, and its only merit, that of racilitating the discovery of the name of a given object, cannot be said to exist. This principle is particularly applicable to the genera just mentioned. Their artificial character refers them to Monadelphia, but they are retained in Diadelphia, to which their artificial character does not refer them, because, as is alleged, of the are retained in Diadelphia, to which their artificial character does not refer them, because, as is alleged, of the
natural relation which they bear to other genera in Diadelphia. If this reasoning, which is only applicable to an arrangement of plants according to their natural affinities, and which has no allowable reference to an artificial system, were to be admitted, it would follow that Tamarindus, actually included in Monadelphia by the most eminent Linnean botanists, and all the papilionaceous genera stationed in Decandria, should be referred hither also. With such objections attaching to the contrivance of this class, it is not easy to understand in what way it "does honor to the comprehensive powers of Linnæus's mind," as has been somewhere remarked by one of his most distinguished panegyrists.

The structure of the corolla of plants of this class is, for the most part, with the exception of Fumaria and its allies, what has been popularly termed papilionaceous; that is to say, it consists of five petals of different forms and direction, of which the upper, called the vexillum or standard, is larger than the rest, upon which it is incumbent; the two lateral, called the alce or wings, are oblong, distinct, and parallel with the ovarium; and the two lower, called the carina or keel, are enclosed within the alæ, are also parallel with the ovarium, and cohere by their lower edges, so as together to form, as it were, one boat-shaped petal. To this common form of corolla there are, however, some exceptions, as in Amorpha, where the alæ and carina are absent, and in Erythrina, where the alæ are in some cases almost obliterated. In Trifolium the petals all cohere by their claws into an undivided tube.

With regard to the importance of Diadelphous plants as applicable to the purposes of mankind, they may be said to hold the very highest rank. All the numerous varieties of pulse, whether eaten by men or cattle, peas, beans, haricots, caravances, lentils, and others, are all produced by Diadelphous plants. The best of our artificial grasses, such as clover, nonesuch, cow-grass, lucerne, saintfoin, serradilla, \&c. \&c. belong to various Dia delphous genera. A large proportion of the class also consists of useful and ornamental trees and herbs, which will be noticed in their respective places.

\section{Order 1. PENTANDRIA. Stamens 5.}

1500. Monnieria. Cal. 5-parted, with the upper segment long. Cor. ringent. Stamens 2: upper with two anthers; lower with three. Caps. 5, 1-seeded.

1501. Petalostemum. Petals 4 , between the stamens, all united into a slit tube. Vexillum none, but in its place a fifth petal. Legume surrounded by calyx, 1-seeded.

\section{Order 2. HEXANDRIA.}

1502. Corydalis. Pet. 4, 1-spurred at base. Pod 2-valved, compressed, many-seeded.

1503. Cysticapnos. Petals 4, one gibbous at base. Capsule bladdery, many-seeded; the placentas connected by a membranous net work.

1504. Diclytra. Petals 4, two outer equally spurred or gibbous at base. Pod 2-valved, many-seeded.

1505. Adlumia. Petals 4, united in a fungous monopetalous corolla, persistent, and with two protuberances at base. Pod 2-valved, many-seeded.

1506. Sarcocapnos. 'Petals 4, 1-spurred at base. Caps. 2-valved, not opening, 2-seeded. Valves 3-nerved, flattish.

1507. Fumaria. One petal gibbous or spurred at base. Cariopsis indehiscent, 1-seeded, not pointed with a style.

\section{Order 3. OCTANDRIA.}

1508. Polygala. Cal, of 5 leaves, two of them wing-shaped and colored. Caps, compressed, obcordate

1509. Muraltia. Sepals 5, glumaceous, nearly equal. Petals 3, united, the middle bifid with blunt lobes. Ovary with 4 horns or tubercles, 2-valved, 2-celled.

1510. Mundia. Sepals 5, glumaceous, persistent, the two inner wing-shaped. Petals 3, scarcely united at base; the middle one cucullate, beardless. Stamens 7-8, somewhat villous, monadelphous at base, with a tube divided in front.

1511. Securidaca. Sepals 5, the two inner petaloid. Petals 5, united at base : three united into a 3-lobed keel; two oblong. Stamens 8 , diadelphous.

\section{Order 4. DECANDRIA.}

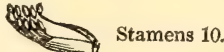

1512. Nissolia. Cal. 5-toothed. Legume 1-seeded, ending in a ligulate wing.

1513. Dalbergia. Cal. obsoletely 5-toothed. Legume leafy, flat, not opening. Seeds solitary or twin.

1514. Pongamia. Cal, colored, cyathiform, obliquely truncate, 5-toothed. Petals clawed, Vexillum spreading. Alæ and carina conniving. Legume substipitate, compressed, flat, rostrate, valveless, 1-2-seeded. Anthers ciliate, glandular at end.

1515. Pterocarpus. Cal. 5-toothed. Legume falcate, foliaceous, varicose, indehiscent, encompassed by a wing. Seeds a few, solitary.

1516. Ecastaphyllum. Cal. campanulate, sub-bilabiate: upper segment emarginate; lower trifid. Filaments equally diadelphous. Legume roundish, valveless, 1-seeded. 
1517. Geoffroya. Cal. 5-fid. Drupe ovate. Kernel compressed.

1518. Dipterix. Segm. of cal. 2, wing-shaped. Legume 1-celled, 1-seeded, coriaceous, 2-valved

1519. Parivoa. Cal, 3-4-fid. Vexillum ample. Alæe and carina O. Legume compressed, 1-seeded

1520. Amerimnum. Cal. sub-bilabiate. Legume compressed, leafy, 2-valved, dehiscent. Some seeds, solitary.

1521. Erythrina. Cal. bilabiate, $\frac{1}{\top}$. Vexillum very long, lanceolate. Legume torulose.

1522 Butea. Cal. sub-bilabiate. Vexillum very long, lanceolate. Legume compressed, membranous, one.

seeded at end.

1523. Viborgia. Cal. 5-toothed, with rounded recesses. Legume turgid, sulcate, wingea.

1524. Piscidia. Stigma acute. Legume with four wings.

1525. Platylobium. Cal. bracteate, 2-lipped, upper lip round, large, bifid. Stam. all united. Legume

stalked, compressed, winged at back, many-seeded.

1526. Borbonia. Stigma emarginate. Calyx acuminate, spiny. Legume mucronate.

1527. Rafnia. Cal. ringent : upper lip bifid; lower spreading trifid; the middle tooth narrowest. Legume

lanceolate, compressed.

1528. Aspalathus. Cal. 5-fid, upper segment largest. Legume ovate, blunt, about 2-seeded.

1529. Sarcophyllum. Cal. campanulate, 5-parted, regular. Legume acinaciform, acute.

1530. Crotalaria. Legume turgid, inflated, stalked. Filaments united with a dorsal fissure.

1531. Bossiaa. Cal. 2-lipped, upper lip largest, half bifid, obtuse. Stam. all united. Legume plano-compressed, stalked, many-seeded, thickened at each edge. Seeds strophiolate.

1532. Scottia. Cal. imbricated with bractes, 5-toothed, with nearly equal teeth. Vexillum complicate, shorter than alæ, which are as long as carina. Stam. all united. Legume stalked, compressed, thickened at each edge. Seeds 3-4, strophiolate.

1533. Templetonia. Cal. ebracteate, with 5 nearly eyual teeth. Carina oblong. Stamens all united, with uniform anthers. Legume pedicellate, plano.compressed, many-seeded. Seeds strophiolate.

1534. Goodia. Cal. with 2 nearly equal lips, upper half bifid, acute. Vexillum unfurled, large. Stamens all

united. Legume stalked, compressed, about 2-seeded. Seeds strophiolate.

1535. Loddigesia. Vexillum much shorter than alæ or carina.

1536. Hovea. Cal. bilabiate, the upper lip half bifid, retuse. Stamens all united. Carina blunt. Legume sessile, roundish, ventricose, 2 -seeded. Seeds strophiolate.

1537. Spartium. Stigma longitudinal, villous above. Filaments adhering to ovary. Cal. lengthened at the

1538. Genista. Cal. 2-lipped: upper one with 2; lower one with 3 teeth. Vexillum bent backwards from

the rest of the flower.

1539. Lebeckia. Cal. 5-parted, with acute segments and rounded recesses. Legume cylindrical, manyseeded.

1540. Ulex. Cal. of 2 leaves, with a small scale at the base on each side. Legume turgid, scarcely longer

than the calyx.

154l. Ononis. Cal. 5-cleft, its divisions linear. Vexillum striated. Legume turgid, sessile. Filaments in one undivided set.

1542. Anthyllis. Cal, inflated, 5-toothed, inclosing the small roundish 1-3-seeded legume.

1543. Arachis. Cal. 2-lipped. Cor. resupinate. Filaments united. Legume gibbous, torulose, veiny, coriaceous.

1544. Lupinus. Cal. 2-lipped. Anthers, 5 oblong, 5 round. Legume coriaceous, torulose, compressed.

1545. Amorpha. Cal. campanulate, 5-fid. Vexillum ovate, concave. Alæ O. Carina O. Legume 2-seeded,

falcate.

1546. Abrus. Cal. obsoletely 4-lobed, the upper broader. Filaments 9, united at base, opening at back.

Stigma blunt. Seed spherical.

1547. Phaseolus. Carina with the stamens and style twisted spirally.

1548. Teramnus. Carina very small, inclosed in the calyx. Five alternate stamens fertile. Stigma sessile,

capitate.

1.249. Carpopogon. Vexillum not callous. Flowers capitate. Pods short, broad, 1-seeded.

1550. Dolichos. Vexillum with two calli at base, parallel, oblong, compressing the wings beneath.

1551. Stizolobium. Cal. campanulate, 2-lipped : upper lip entire, erect; lower trifid, with the middle seg-

ment longest. Vexillum ascending. Alæ dolabriform, lunate at base, the length of carina. Anthers 2 -formed,

hairy. Legume torose, 1-celled, with partitions. Seeds round, with a crested hilum.

1552. Glycine. Cal. 2-lipped. Carina pushing back the vexillum with its end.

1553. Kennedia. Cal. 2-lipped : upper emarginate; lower trifid, equal. Vexillum reflexed, recurved. Alæ

pressed to the carina. Carina remote. Stigma blunt. Legume oblong.

1554. Cylista. Cal. 4-fid, larger than cor.: upper segment bifid at end, or emarginate; lower very large.

Cor. persistent. Legume about 2-seeded.

1555. Galactia. Cal. 4-toothed, with 2 bractes. Petals all oblong; the vexillum broadest and incumbent upon the others. Stigma obtuse. Legume round. Seeds roundish.

1556. Clitoria. Cor, resupinate, with a large spreading vexillum overshadowing the wings.

1557. Orobus. Style linear, cylindrical, downy above. Cal. obtuse at the base, its upper segments deeper and

shorter.

1558. Lathyrus. Style plane, downy above, broader upwards. Cal. with its two upper segments shortest.

1559. Ochrus. Cal. with the two upper segments conniving. Vexillum with two teeth at the sides. Style

flat, villous above. Legume having a membranous wing upon the seed-bearing suture.

1560. Pisum. Style triangular, keeled above, downy. Two upper segments of calyx shorter than the rest.

1561. Vicia. Style bearded beneath the stigma.

1562. Evum. Stigma capitate, hairy all over on the outside.

1563. Ervilia. Like Vicia, but the ovary is plaited in folds.

1564. Cicer. Cal, 5-parted, length of cor; four upper segments incumbent on the vexillum. Legume turgid, 2-seeded.

1565. Liparia. Cal. 5-fid, with the lower segment long. Alæ 2-lobed below. Three teeth of the larger

stamen shorter than the rest. Legume ovate.

1566. Cytisus. Cal, 2-labiate, 2-3. Legume attenuated at base

1567. Mullera. Cal. 4-toothed. Loment moniliform, with fleshy 1-seeded globules cohering by a thread.

1568. Robinia. Cal. 4-fid; upper segment 2-parted. Legume gibbous, long. Leaves unequally pinnate.

1569. Caragana. Cal. subcampanulate. Stigma smooth, truncate. Legume cylindrical. Leaves abruptly pinnated.

1570. Swainsonia. Cal. 5-toothed. Vexillum unfurled, larger than the blunt carina. Stigma terminal.

Style bearded lengthwise in front, not bearded at back. Legume turgid, not bladdery.

1571. Sutherlandia. Cal. 5-toothed. Vexillum without callosities, folded back at edge, shorter than oblong

carina. Stigma terminal. Style with a longitudinal beard behind, a transverse one before. Legume inflated, scariose.

1572. Lessertia. Cal, half 5-fid. Vexillum unfurled. Carina blunt. Stigma capitate. Style bearded transversely at end in front, beardless behind. Legume scariose without valves (compressed or inflated).

1573. Colutea. Cal. 5-toothed. Vexillum with two callosities, unfurled, larger than the blunt carina. Stigma lateral under the hooked end of the siyle, which is longitudinally bearded behind. Legume inflated, scarious.

1574. Glycyrrhiza. Cal. bilabiate, 3-1. Legume ovate, compressed.

1575. Liquoritia. Cal. tubular, equal, 5-parted. Vexillum erect, reflexed at sides. Alæ spreading. Carina bifid. Legume oblong, smooth, 3-4-seeded.
Lequal. 
1576. Coronilla. Cal. 2-lipped, 2-3, Upper teeth connate. Vexillum scarcely longer than alæ. Loment round, jointed, straight.

1577. Hippocrepis. Loment compressed, with many notches on one edge, curved.

1578. Ornithopus. Legume jointed, curved, cylindrical.

1579. Scorpiurus. Loment intercepted by divisions, revolute, round.

1580. Smithia. Stamens divided into two equal bundles. Legume jointed, plaited, included in the bifid calyx. 1581. Sesbania. Cal. 5-toothed. Legume long (round or linear), 2-valved, many-celled, with transverse partitions.

1582. Aschynomene. Stamens divided into two equal bund]. . Legume jointed, straight, exserted. Cal.

2-parted, with toothed lips. 1583. Stylosanthes. Cal, tubular, very long, bearing the corolla. Ovarium below the corolla. Loment one or two-jointed, hooked.

1584. Hallia. Cal. 5-parted, regular. Legume 1-seeded, 2-valved.

1585. Lespedeza. Cal. 5-parted, nearly equal. Carina transversely blunt. Legume lenticular, unarmed, 1-seeded.

1586. Flemingia. Cal, 5-fid, Vexillum striated. I.egume sessile, oval, turgid, 2-valved, 2-seeded. Seeds

spherical.
1587nia. Cal. campanulate, 2-lipped. Cor. inferior. Vexillum cordate, revolute. Anthers alternately oblong and round. Legume jointed, hispid.

1588. Hedysarum. Cal. 5-fid. Carina transversely blunt. Loment with 1-seeded compressed joints.

1589. Indigofera. Cal. spreading. Carina with a spreading subulate spur on each side.

1590. Tephrosia. Cal. with subuate nearly equal teeth. Stamens monadelphous. Legume compressed, subcoriaceous.

\section{PENTANDRIA.}

1500. MonNie/Ria. $W$. Monnieria. 9959 trifólia $W$.

1501. Petalostémum. Mi. Petalostemum. 9960 cándidum $P h$. 9961 cárneum $P h$. 9962 violáceum $P h$. 9963 corymbósum $P h$. corymbose
Dálea Kuhnistéra W.

white PETaLos \& $\triangle$ pr flesh-colored purple
Rutacea. $S p .1$.

1 jl.au W W N. Amer. 1811. D 1.p Mi. am. 2.t.37.f.1 1 1 jl.au Pk N. Amer. 1811. D 1.p

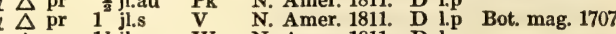

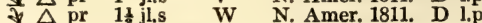

\section{HEXANDRIA.}

1502. CORY'DALIS. Vent. CorYdalis.

9964 nóbilis $P . S$.

9965 tuberósa Dec

9966 fabácea W. en.

9967 sólida Smith

9968 sempervirens $\boldsymbol{P} . \boldsymbol{S}$.

S. glaucous

9970 lictea $P$.

9971 uralénsis Fisch.

9972 capnoídes $P$. $S$.

9973 claviculáta $W$.

1503. CYSTICAP'NO

9974 africána $W . e n$. Fumária vesicária $\mathbf{H}$. $\mathrm{K}$

1504. DICLY'TRA. Dec. DiclYTRA.

9975 Cucullária Dec naked-stalked

9976 formósa Dec.

9977 exímia

9978 canadénsis $\mathrm{Dec}$

\section{blush}

choice

Canadian

1505. ADLU'MIA. Raf. AdLumia

9979 cirrhósa $R a f$

spongy-flow

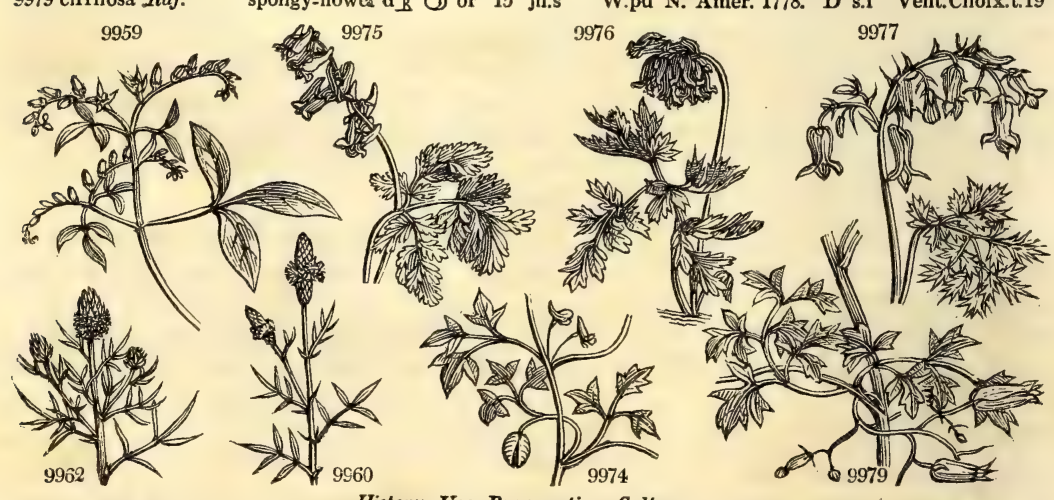

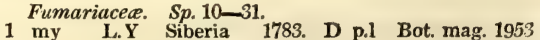

$\begin{array}{llllll}* \Delta & \text { or } & \text { my } & \text { L.Y Siberia 1783. D p.l Bot. mag. } 1953 \\ \text { t } \Delta \text { or } & \frac{1}{2} \text { f ap } & \text { Pu.W Europe 1596. D co Bot. m. 232.2340 }\end{array}$

\ $\Delta$ or $\frac{3}{4}$ f.ap Pu Germany 1815. D co Fl dan. 1394

t $\Delta$ or $\frac{1}{2}$ f.my Pk Britain groves. D co Eng. bot. 1471

O or $2^{2}$ jl.au Y.Pu N. Amer. 1683. D co Bot. mag. 179

$\$$ () or 1 my.jl Y N. Amer. 1812. D co Bot. reg. 66

$\exists \Delta$ or $1 \frac{1}{2}$ ap.o $Y$ England old w. D co Eng. bot. 588

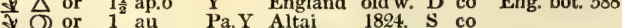

2 my.o R.y S. Europe 1596. S co Plu.alm.t.90. f.2

6 jn.jl W.x Britain thick. S co Eng. bot. 103

$\underset{B}{\mathrm{~B}}$ or 4 jn.jl $\underset{\mathrm{Y}}{\text { Fumariacea. }}$ C. G. 1. H. 1696. S s.1 Boer.lug.1.t. 200

Fumariacece. Sp. 4-8.
4 $\frac{1}{\Delta} \Delta$ or $\mathbf{1}^{\frac{3}{4} \mathrm{jn} \text { jn } \mathrm{jl}} \quad \mathbf{F} \quad$ N. Amer. 1796. D p.l Bot. mag. 1335 $\frac{1}{\partial t} \Delta$ or $1 \frac{1}{2}$ jn.jl $\quad$ F $\quad$ N. Amer. 1812. D p.1 Bot. reg. 51 It $\Delta$ or $\frac{3}{4}$ jn.jl Pk N. Amer. 1819. D co Fumariacce. Sp.1.

History, Use, Propagation, Culture,

1500. Monnieria. In memory of Monsieur Le Monnier, professor of botany in the garden of plants at Paris. He published, in 1745, "Observations sur les Plantes dangereuses des Pyrénées et du Roussillon."

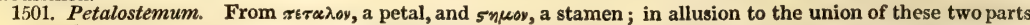
into a tube.

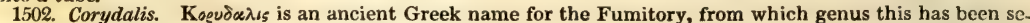
parated. Pretty little plants, well adapted for rock-work or growing on pots. They are easily cultivated and increased. 
1591. Galega. Cal. with subulate nearly equal teeth. Legume with oblique streaks between the seeds.

1592. Phaca. Cal, 5-toothed, two upper teeth most distant. Legume half 2-celled, inflated.

1593. Oxytropis. Carina ending in a mucro. Legume 2-celled or half-2-celled, with the upper suture turned inwards.

1594. Astragalus. Legume 2-celled, more or less gibbous, with the lower suture turned inwards. Carina blunt.

1595. Biserrula. Legume 2-celled, flat, with a contrary dissepiment serrated on each edge.

1596. Dalea. Alæ and carina adhering to the column of stamens. Stamens 5-10, united, without a separate filament. Legume 1-seeded.

1597. Psoralea. Cal. the length of pod. Stamens diadelphous. Legume 1-seeded, subrostrate, valveless.

1598. Melilotus. Cal. tubular, 5-toothed. Carina simple, shorter than alæ and vexillum. Legume longer than calyx, rugose.

1599. Lupinaster. Cal. campanulate, 5-toothed, with setaceous teeth. Stigma uncinate. Legume not knotted, round, many-seeded.

1600. Trifolium. Legume (in general) shorter than the cal., 1 or many-seeded, indehiscent, deciduous.

Flowers more or less capitate.

1601. Lotus. Legume cylindrical, straight. Alæ of the cor. cohering by their upper edge. Filaments dilated upwards.

1602. Tetragonolobus. The characters of Lotus, but the pod square with 4 wings.

1603. Trigonella. Vexillum and alæ nearly equal, spreading, in the form of a tripetalous corolla.

1604. Dorycnium. Cal. 5-toothed, 2-lipped. Filaments subulate. Stigma capitate. Legume turgid, 1 or 2-seeded.

1605. Medicago. Legume falcate or spirally twisted, compressed, membranaceous.

1606. Hymenocarpus. Like Medicago, but the legumes reniform, winged at edge.

\section{PENTANDRIA}

\section{Stem dichotomous, Leaves ternate, Spike bifid}

9960 Spike cylindrical stalked, Bractes longer than flower, Leaves in 3 pairs lanceolate 9961 Spike cylındrical stalked, Bractes subulate length of calyx, Leaflets lanceolate 9962 Spike cylindrical stalked, Bractes nearly as long as calyx, Leaves in 2 pairs linear 9963 Heads with a scaly involucre, Calyxes plumose, Leaflets linear pointless

\section{HEXANDRIA.}

9964 Stem erect simple without scales, Leaves bipinnate, Lobes cuneate cut at end, Bractes acute 9965 Stem simple without scales, Lvs. 2 biternate, Segm. cuneate multifid, Bractes ovate entire, Roots hollow 9966 Stem subsimple erect with scales below the lowest leaf, Leaves 3-4-stalked biternate, Segments obl. blunt 9967 Stem subsimple erect with scales below the lowest leaf, Lvs. 3-4-stalk. bitern. cut, Segm. cuneate or oblong 9968 Stem erect branched, Leaves glaucous decompound, Segm. stalked cuneate trifid, Pods linear

9969 Stem branched diffuse, Leaves glaucous bipinnate, Lobes obl. linear, Bractes lanceol. linear acuminate 9970 Pods roundish shorter than peduncle, Stems angular, Bractes minute, Spur very short and round 9971 Stem erect somewhat branched scarcely longer than radical lvs. Lvs. on long stalks 3-cut, Raceme few-fl. 9972 Stem branched diffuse, Lvs. bipinnate, Segm. obov. cuneate trifid, Pods lin. scarcely longer than pedicel 9973 Stem branched climbing, Leaves bipinnate, Petioles cirrhose, Segm. oval entire

9974 The only species

3975 Spurs 2 straight acute, Scape naked, Raceme simple

9976 Spurs 2 incurved blunt, Scape naked, Raceme compound, Stigma with 2 angles 9977 Spurs 2 incurved blunt, Scape naked, Raceme compound, Stigma with 4 angles 9978 Spurs 2 short blunt, Scape naked simple few-f. Leaves multifid

9979 The only species. - Fumaria fungosa, Hort.

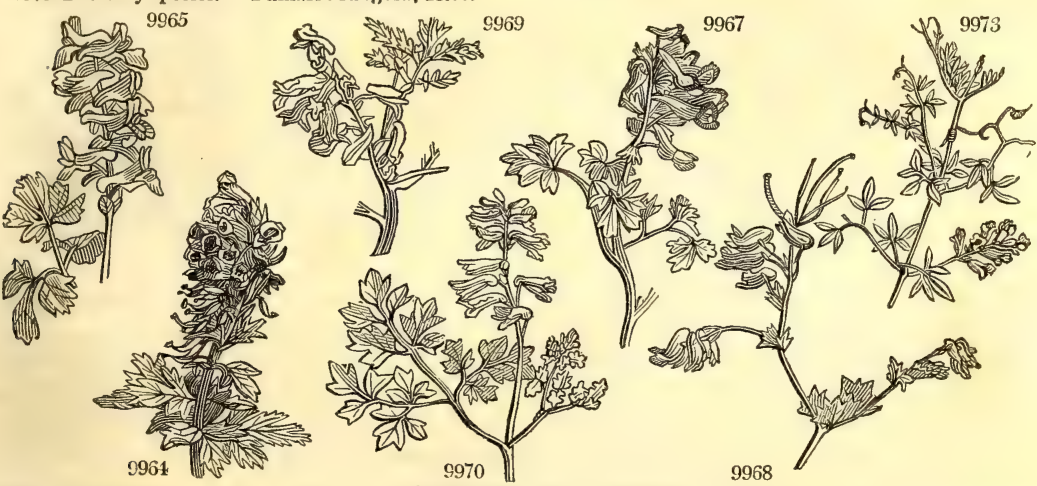

and Miscellaneous Particulars.

1503. Cysticapnos. From xusıs, a bladder, and x«zyos, fumitory. A genus divided from Fumaria on account of its bladdery fruit.

1504. Diclytra. So named by Borckhausen, a German botanist, on account of the two spurs or pouches of the flower. Handsome herbaceous plants, frequently cultivated among choice collections of rare flowers. Their roots are impatient of cold and wet, and should therefore be planted in a warm dry border well exposed to the southern sun.

1505. Adlumia. A name unexplained by its author, M. Rafinesque Schmalz. A tall climbing annual plant of litlle beauty in its flowers, but covering a large space in the course of a summer. 
1506. SARCOCAPNOS. Dec. SARcocapNos. 9980 enneaphýlla Dec. nine-leaved \& $\triangle$ 1507. FUMA'RIA. $P$. $S$. Fumitory. 9981 officinális $P . S$. common 9982 capreoláta $P$. $S$. 9983 parviflóra $P$.S. 9984 spicáta $\boldsymbol{P} . S$ B. $\mathrm{O}$ w 4 my.s F Britain corn fi. S co Eng. bot. 943 small-flowered $\mathrm{O}$ w 2 au.s Pk England corn fi. S co Eng. bot. 590 narrow-leaved $\quad \mathrm{O}$ w 8 jl.au $\quad \mathrm{F}$ S. Europe 1714. S co M.his.3.t.12.f.11

\section{OCTANDRIA.}

1508. POLY'GALA. $W$. MrekworT 9985 incarnáta $W$ 9986 amára $W$. 9987 vulgáris $W$. 0991 speciósa $B$. $M$ 9992 teretifólia $W$ 9993 purpúrea $\boldsymbol{H} . \boldsymbol{K}$. 9994 virgáta $T h$. 9995 myrtifólia $W$. 9996 oppositifólia $W$ 9997 cordifólia $\boldsymbol{W}$. 0998 tomentósa $W$ 9999 Chamæbúxus $W$ 10000 latifólia Ker. 10001 liguláris Ker. 10002 filifórmis $W$. 10003 micrántha $W$ 10004 paniculáta $W$. 10005 Sénega $W$. 10006 lútea $W$

10007 viridéscens $W$. 10008 húmilis Lodd. 10009 sanguínea $W$. 10010 verticilláta $W$. 10011 cruciáta $W$

MrLKWORT. bitter common naked-stalked spear-leaved

showy

columnar-lvd purple twiggy Myrtle-leaved heart-leaved woolly-leaved Box-leaved broad-leaved strap-leaved filiform panicled purple-spiked whorl-leaved four-leaved 9988 májor $\boldsymbol{W}$.

9989 paucifólia $W$. 9990 bracteoláta $W$ large Austrian opposite-leave small-flowered root 28 or golden $\widehat{O}$ or greenish-flower. O or dwarf

1509. MURAL'Tia. Neek. Muraltia. 10012 Heistéria $W$. 10013 alopecuroídes $W$. 10014 stipulácea $W$. 10015 mixta $W$. 1510. MUN'DIA. Kunth. Mundia. 10016 spinósa $W$. spiny

1511. SECURIDA'CA. $W$. Securidac 10017 volúbilis $W$. climbing

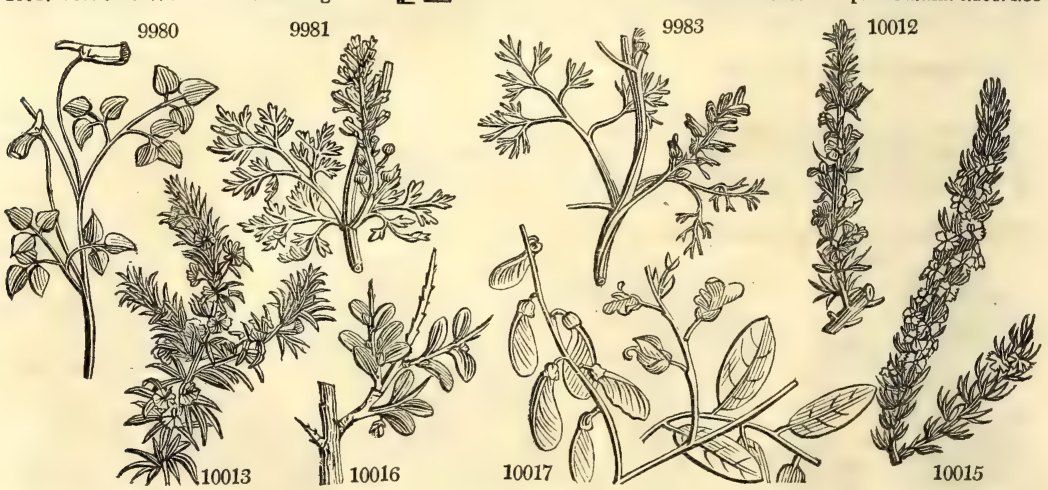

Polygalea. Sp. 27-163.

O or 1 jn.ji Pk N. Amer. 1812, S co Pluk.t. 438, f. 5 D $\Delta$ or $\frac{1}{2}$ jn $\quad$ B Europe 1775. D l.p Bot. mag. 2437 $\downarrow \Delta$ or 1 jl.au $R$ jl.au $\mathrm{R}$ $6{ }^{4}$ my.o Pu

6 my.o Pu

3 my.au Pu

1 my.jn Pu

3 my.jn Pu

3 my.au Pu

2 my.au $R$

3 mr.au $\mathrm{Pu}$

2 mr.au Pu

$\frac{1}{2}$ my.jn $\mathrm{Y}$

$1 \frac{2}{2}$ my.jn $\mathrm{Pu}$

$1 \frac{1}{2}$ my.au $\mathrm{Pu}$

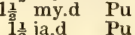

$\frac{3}{4}$ jl.au Pa.p

$\frac{3}{4} \mathrm{jl}$

$\frac{3}{4}$ jn.jl

i jl.au

$1^{\frac{1}{2}} \mathrm{my}$

$\frac{1}{2} \mathrm{jl.au}$

\section{Y}

Britain drypa. D s.1 Eng. bot. 76

Austria 1739. D s.1 Jac. aust.5. t.41c

N. Amer. 1812. D s.1

C. G. H. 1713. S s.p Bot. mag. 345

C. G. H. 1814. C s.p Bot. reg. 150

C. G. H. 1791. S s.p Bot. rep. 379

N. Amer. 1791. C s.p

C. G. H. 1812. C s.p

C. G. H. 1707. S p.i Bot. reg. 669

C. G. H. 1790. C s.p Bot. mag, 492

C. G. H. 1791. C s.p Bot. mag. 2438

C. G. H. 1812. C s.p

Austria 1658. Sk s.1 Bot. mag. 316

C. G. H. 1820. C s.l Bot. reg. 645

C. G. H. 1820. C s.p Bot. reg. 637

C. G. H. 1812. C s.p

C. G. H. 1800. S s.p Bot. rep. 324

N. Amer. 1739. S co Plu. mag. 10.51

Amer. 1815. S co

Pk C. G. H. 1817. C s.p Bot. cab. 490

Pu N. Amer. 1739. S co Pluk. t. 438.f.5

T. Amer. 1739. S co Pluk. t. 438. f. 4

Polygalea. Sp. 4-37.

6 ja.d Pu C. G. H. 1787. C s.p Bot. mag. 340

3 my.au Pu C. G. H. 1800. S s.p Bot. mag. 1006

3 ap.s R C. G. H. 1801. C s.p Bot. mag. 1715

3 ja.d Pu C. G. H. 1791. C s.p Bot. mag. 1714

Polygalea. Sp. 1

3 ja my Pu C. G. H. 1780. C s.p

Polygalea. Sp. $1-8$

History, Use, Propagation, Culture,

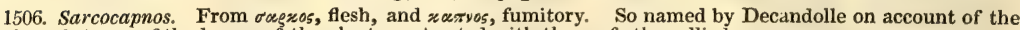
fleshy substance of the leaves of the plants contrasted with those of other allied genera.

1507. Fumaria. From fumus, smoke; in allusion to the disagreeable smell of the plant. The French, with the same meaning, call it Fumeterre, whence our English word Fumitory. The species are handsome weeds. F officinalis was formerly considered a valuable antiscorbutic, and much used in obstructions of the viscera.

1508. Polygala. From $\pi \circ \lambda \nu$, much, and $\gamma \alpha \lambda \alpha$, milk. Dioscorides says, that the plant was believed to excite the lacteal secretions in women. The species are handsome free-flowering plants. The greenhouse kinds are highly ornamental, and some of them continue in bloom all the winter: P. stipulacea all the year. They grow freely in sandy loam, or loam and peat; and are readily increased by cuttings of the young wood, in sand, under a bell-glass.

P. vulgaris was thought to possess something of the properties of P. Senega. Sir J. E. Smith found that an infusion of the herb taken in a morning, fasting, about a quarter of a pint daily, promoted expectoration, and was good in a catarrhous cough. He tried it at Montpelier by the advice of Professor Gouan with success, and has since known it useful. Foreign writers celebrate it as a grateful and nutritious food for cattle. According to the Swedish experiments, kine, sheep, and goats eat it, but swine refuse it.

P. Senega has a woody, branched, contorted root, about half an inch thick, and covered with ash-colored 
9980 Leaves with a branched stalk triternate, Segments ovate angular

9981 Pods round retuse, Pedicels of fruit erect twice as long as bractes, Racemes lax 9982 Pods globose, Pedicels of fruit recurved longer than bract, Racemes oblong 9983 Pods globose with a little point, Pedicels of fruit erect longer than bract

9984 Pods compressed oval smooth, Raceme spiked, Pedicels much shorter than bract

\section{OCTANDRIA.}

9985 Flowers crested spiked, Stem herbaceous branched erect, Leaves alternate subulate

$9986 \mathrm{Fl}$. crested racem. Wings of cal. 3-nerved blunt longer than cor. Stems erect, Lvs, blunt : radic, obovate 9987 Fl. crested racem. Wings of cal. 3-nerved blunt length of cor. Stems procumb. Leaves linear-lanc. acute 9988 Fl. crest. racem. Wings of cal. many-nerv. blunt mucron, short. than cor. Stems erect, Lvs. lin. lanc. acute $9989 \mathrm{Fl}$. crested term. in threes, Stems quite simple erect naked beneath, Leaves ovate

9990 Fl. crested, Raceme term. Wings of cal. cuspidate many-nerv. Stem erect shrubby, Lvs. lin. lanc. smooth $9991 \mathrm{Fl}$ crest. Appendage double, Racemes without bractes subterm many-fl. Lvs, altern. obl, cuneate smooth 9992 Fl. crest. Raceme term. few-fl. Wings of cal. ovate acute many-nerved, Stem shrubby, Lvs. linear subulate 9993 Fl, crested somewhat umbelled, Leaves ovate fieshy

9994 Fl. crested racemose, Bractes 3.lcaved, Leaves obovate oblon

9995 F1. crested, Racemes few-fl. term. Keel falcate, Stem shrubby, Leaves obl. bluntish smooth 9996 Fi. crested, Stem shrubby, Leaves opposite ovate acute

9997 Fl. crested, Raceine terminal, Stem shrubby, Branches downy, Leaves cordate mucronate opposite 9998 Fl. crested whorled, Leaves cordate downy beneath

$9999 \mathrm{Fl}$. beardless, Pedunc. terminal and axill, about 2-fl. Stem shrubby, Leaves obl, lanceolate acute

10000 Fl. crested, Branches downy, Leaves decussating coriaceous glaucous ovate downy beneath

10001 Fl. crest. Branches vill. Lvs. scattered lingulate smonth, Outer lobe of the petals of vexillum very short $10002 \mathrm{Fl}$. beardless lateral, Leaves solitary 3-cornered mucronate

10003 Fl. beardless axillary sessile, Leaves linear mucronate

10004 Fl. crested, Racemes axillary on long stalks, Stems erect branched upwards, Leaves linear acute

10005 Fl. beardless, Spike terminal filiform, Stem erect herbaceous quite simple, Leaves oblong lanceolate

$10006 \mathrm{Fl}$. beardless, Raceme cylindr. capitate terminal, Stem simple, Leaves obl. lanc. acute

$10007 \mathrm{Fl}$. beardless globose capitate terminal, Stem erect simple, Leaves linear bluntish

10008 Leaves ovate-lanceolate imbricated, Stem branched decumbent

10009 Flowers beardless, Pedunc. squarrose, Stem branched erect

10010 Flowers beardless distant, Leaves linear whorled, Stem branched

10011 Flowers beardless in headed spikes, Leaves in fours linear-lanceolate, Stem somewhat branched erect

10012 Fl. beardless lateral, Stem arborescent, Leaves 3-cornered mucronate spiny

10013 Fl. beardless, Peduncles solitary axillary, Leaves fascicled ovate mucronate ciliated at edge

$10014 \mathrm{Fl}$, beardless lateral, Leaves in threes linear acute

$10015 \mathrm{Fl}$. beardless sessile, Leaves round mucronate very close

10016 Leaves obovate or oval, Branches short spiny

10017 Branches a little downy, Leaves oval-obl. acute, Racemes lateral

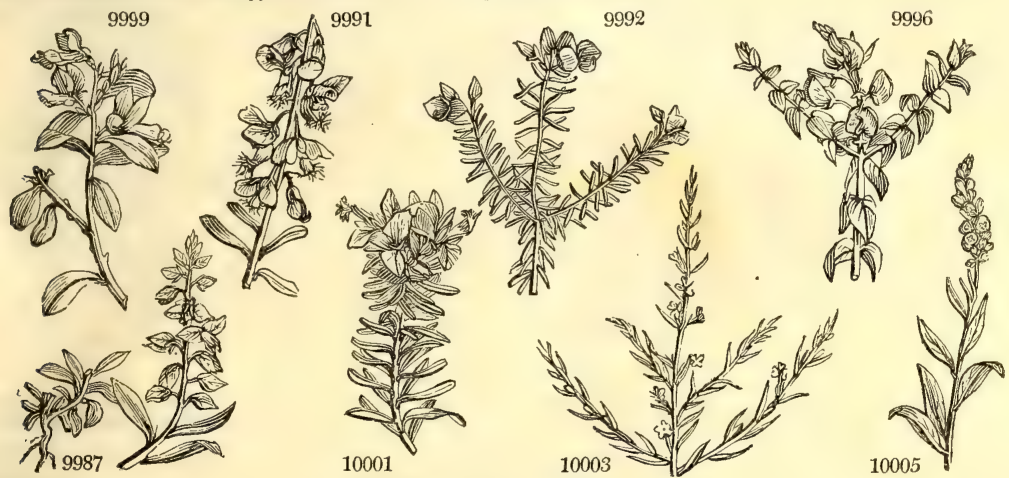

and Miscellaneous Particulars.

bark. It is inodorous; the taste is at first sweetish and nauseous, but after being chewed for less than a minute, becomes pungent and hot, producing a very peculiar tingling sensation in the fauces. Medically, it is considered stimulating, expectorant, and diuretic, and in large doses emetic and cathartic: it increases absorp. ion, and consequently augments the natural excretions, particularly that of urine, and frequently occi it was the it was the antidote employed by the Senegare Indians against the bite of the rattle-snake, and reasoning from the effects of the poison, and of the remedy in removing these, was induced to try it in pneumonic affections, and found it useful. On account of its stimulant properties, however, it can be employed in these complaints only after the resolution of the inflammation by bleeding and evacuations. It proves more directly useful in humoral asthma, chronic catarrh, and some kinds of dropsy. (Thomson's London Dispensatory, p. 450.)

1509. Muraltia. Named after John Von Muralt, a Swiss botanist, who lived in the commencement of the eighteenth century. Handsome bushes, of easy cultivation in a greenhouse, or even in a good pit.

1510. Mundia. So named, in allusion, we presume, to the neatness (munditia) of its appearance. No explanation of the word is given by its author. Pretty little Cape bushes, easily cultivated in a good pit.

1511. Securidaca. From securis, a hatchet, in allusion to the form of the end of the pod. It grows freely in light loam, or loam and peat; and cuttings root in sand covered with a glass. 


\section{DECANDRIA.}

1512. NISSO'LIA. $W$. Nissolia. 10018 fruticósa $W$. 10019 retúsa $W_{\text {. en }}$. 10020 glabráta Link. blunt

1513. DALBER'G1A. $W$. Dalbergia 10021 latifólia $W$. 10022 rubiginósa $W$. 10023 paniculáta $W$. broad-leaved climbing

1514. PONGa'mia, Vent. Pongania. 10024 glábra $P . S$.

1515. P'Terocar'PUS. $W$. Pterocarpus 10025 Marsúpium $W$. emarginate-lvd. 10026 lunátus $W$. 10027 santalinus $W$. Red SaundersWood 9 ec 60 1516. ECASTAPHYL'LUM. Rich. Ecastaphyllum. 10028 Brow'nei Rich. oval-leaved $\$ \square$ or 10

1517. GeOFFro'Ya. $\boldsymbol{W}$. Bastard Cabbage-Tree. 10029 inérmis $W$. smooth $9 \square$ or 8

1518. DIP'TERIX. $W$. TONquin Bean. 10030 odoráta $W$. $\quad$ sweet-scented $\subsetneq \square$ ec 60 1519. Parivo' A. Aubl. Parivoa. 10031 grandiflóra Aubl. large-flowered $\perp \square$ or 30 1520. A Merim'NUM. $W$. Amerimnum. 10032 Brównei $W$. 1 . 10034 E'benus $W$. Browne's broad-leaved Jamaica Ebony 1521. ERYTHRI'NA. $W$. Coral Tr 10035 herbácea $\boldsymbol{W}$. 10036 cárnea $W$. $\quad$ flesh-colored 10038 índica $W$. 10039 fúsca $W$. 10040 cáffra $W$. 10041 picta $W$. 10042 speciósa $H . K$. smooth Indian brown-fowere brown Cape prickly-leaved large-flowered
Leguminosa. $S p .3-6$. \$ $\square$ or $15 \mathrm{jl.n} \mathrm{Y}$ S. Amer. 1766. S p.l Jac. vind.2.t.167 $\begin{array}{lllllllll}\text { or } & 6 & \cdots & \ldots & \text { S. Amer. 1819. } & \text { C } & \text { s.l }\end{array}$

Leguminosa. Sp. 4-9.

... W E. Indies 1811. C s.1 Rox. cor.2. t.113 ... W $\quad$ W. Indies 1811. C s.1 Rox. cor.2. t.115

Leguminosa. $\mathrm{Sp}$. 1-3.

... W E. Indies 1699. C s.l Vent.malm. t.28 Leguminosa. Sp. 3-9.

... W E. Indies 1811 C s.l Rox. cor.2. t.116 ... W S. Amer. 1792 C s.t Lam.ill. t.602,f.5

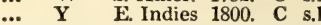

Leguminosa. Sp. $1-4$

... W W. Indies 1733. C r.m Br. jam. t. 32. f.1

Leguminose. Sp. 1-5.

... Jamaica 1778. C p.l Ph.tran.1777.t.10

Leguminosa. Sp. 1-2.

... Pu Guiana 1793. C 1.p "Aub. gui.2. t.296

Leguminosa. Sp. 1

... Pu Guiana 1821. C r.m Aub. gui, t. 303

Leguminosa. Sp. 3-5.

$\square$ or $10 \quad \cdots \quad$ W W. Indies 1793. C r.m Ja.am. t.180. f.58 $\begin{array}{llllll}\text { jl.au } & \mathbf{Y} & \text { S. Amer. 1814. } & \text { C } & \text { l.p } & \text { Ja.am. t.177. f.50 } \\ \text { W. Indies 1713. } & \text { C } & \text { r.m } & \text { Br. jam. t. 31. f.2 }\end{array}$

Leguminosa. Sp. 10-21.

jn.s $\mathrm{S}$ Carolina 1724. C l.p Bot. mag. 877

my Pk Vera Cruz 1733. S r.m Trew. ehret. t. 8 my.jn S W. Indies 1690 S r.m Com hor 1 t.108 F. Indies 1814. S rm Rheedmal.6.t. ... S F Indies 1800 C lp Bumamb 2 t .... S C G H 1816 C lp Rot. $\begin{array}{llllll}\ldots . & \text { S } & \text { C. G. H. 1816. } & \text { C } & \text { l.p } & \text { Bot. reg. 736 } \\ \ldots & \text { S } & \text { E. Indies } & 1696 . & \text { S } & \text { r.m Rum.amb.2. t.77 }\end{array}$ W. Indies 1805. S r.m Bot. rep. 443

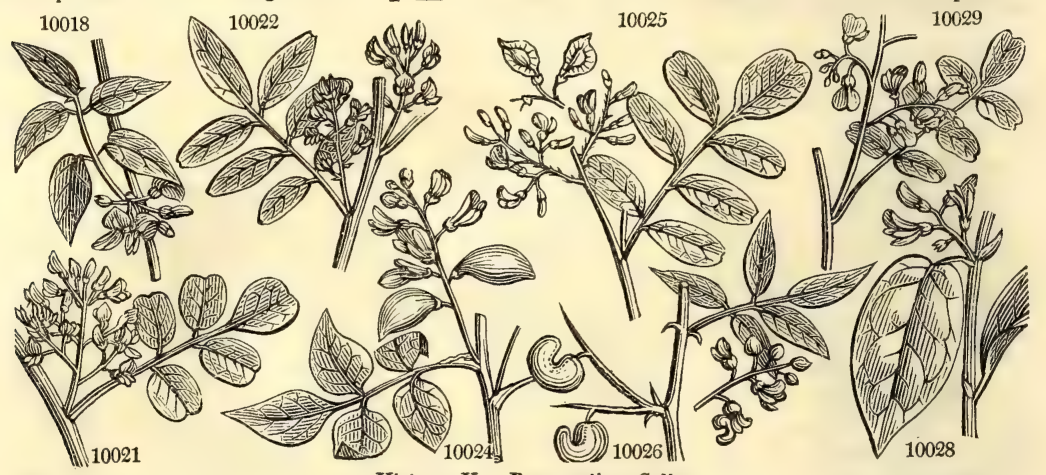

History, Use, Propagation, Culture,

1512. Nissolia. In honor of William Nissole, an industrious French botanist. He was a member of the academy of Montpellier, and author of some papers in its Transactions. He was born in 1647, and died in 1735 . Cuttings root in sand, but not very readily.

1513. Dalbergia. Nicholas Dalberg was surgeon in ordinary to the king of Sweden, and published in 1755 a work upon the Metamorphoses of Plants. Another Dalberg, a punil of Linnæus, travelled in Dutch Guiana, whence he communicated specimens to his preceptor. Ripened cuttings root in sand.

1514. Pongamia. An alteration of the vernacular name of the plant in India.

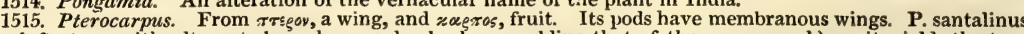
is a lofty tree, with alternate branches, and a bark resembling that of the common alder; it yields the true officinal red saunders wood, first detected by Kœnig in India. It is brought home in billets, which are very heavy, and sink in water. Red saunders wood has an aromatic odor, and is nearly insipid, It is extremely hard, of a fine grain, takes a high polish, and a bright garnet red color, which deepens on exposure to the air. It yields its coloring matter, which appears to be of a resinous nature, to ether and alcohol, but not to water. (Thomson's London Dispersatory, 458.)

The sap yields one sort of Sanguis draconis. Many of the red Indian woods trasude a blood red juice through the clefts of the bark, which hardens into a red resin, not differing from Sanguis draconis, which, therefore, is collected from several trees, and from this among others. (Linn. Suppl.) This drug, however, is chiefly obtained from the P. Draco, and the fruit of Calamus Rotang.

In our stoves these plants thrive in light loamy soil ; and cuttings, with their leaves untouched, will root in sand under a common hand-glass.

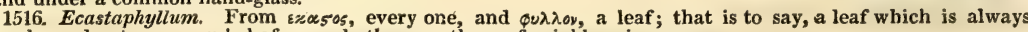
simple, and not compounded of several others, as those of neighbouring genera.

1517. Geoffroya. In honor of Etienne Francois Geoffroi, Memb. Acad. Par., Professor of botany at the Jardin du Roi, and a foreign member of the Royal Society of London. He was the author of several medical botanical works, especially of a Materia Medica. He was born in 1672, and died in 1731 . A tree, branchy at top, with a smooth grey bark and pinnate leaves; and, what is remarkable in papilionaceous plants, a drupe for a fruit. 


\section{DECANDRIA.}

10018 Stem shrubby twining, Leaves pinnated, Leaflets ovate acute smoothish 10019 Leaves pinnated, Leaflets ovate-oblong emarginate

10020 Leaves ternate and quinate, Leaflets oval acuminate smooth, Fl. racemose

10021 Leaves pinnated, Leaflets roundish emarginate, Fruit lanceolate

10022 Leaves pinnated, Leaflets obl. obtuse, Branches and petioles downy

10023 Leaves pinnated, Leaflets ellipt. ernarginate smooth, Panicle terminal, Fruit lanceolate

$1002+$ Leaves pinnated, Leaflets ovate acuminate smooth, Fruit ovate acute veinless

10025 Leaves pinnated, Leaflets elliptical emarginate, Stipules none, Panicle termin.

10026 Leaves pinnated, Spines stipulary, Fruit lunate

10027 Leaves ternate roundish blunt quite smooth, Petals crenate wavy

10028 Leaves simple cordate-ovate downy beneath

10029 Unarmed, Leaflets ovate-lanceolate

10030 Leaves alternate, Raceme terminal

10031 Leaves pinnated, Flowers smooth

10032 Unarmed, Leaves simple stalked alternate subcordate ovate, Racemes compound axillary and lateral 10033 Leaves pinnated, Leaflets ovate acuminate, Stem arboreous

10034 Spiny, Leaves subsessile aggregate obovate oblong, Peduncles 2-flowered

10035 Leaves ternate rhomboid smooth, Stem herbaceous unarmed, Calyxes fruncate 10036 Leaves ternate smooth, Stem arboreous prickly, Calyxes campanulate truncate 10037 Leaves ternate unarmed, Stem arboreous prickly, Calyxes truncate 5-toothed

10038 Leaves ternate unarmed, Stem arboreous prickly, Calyxes spathaceous

10039 Leaves ternate unarmed lanceolate, Stem arboreous prickly, Calyxes bifid

10040 Leaves ternate unarmed, Leaflets blurit, Stem arboreous prickly

10041 Leaves ternate prickly, Stem arboreous prickly

10042 Leaves ternate prickly beneath, Petioles unarmed, Stem prickly

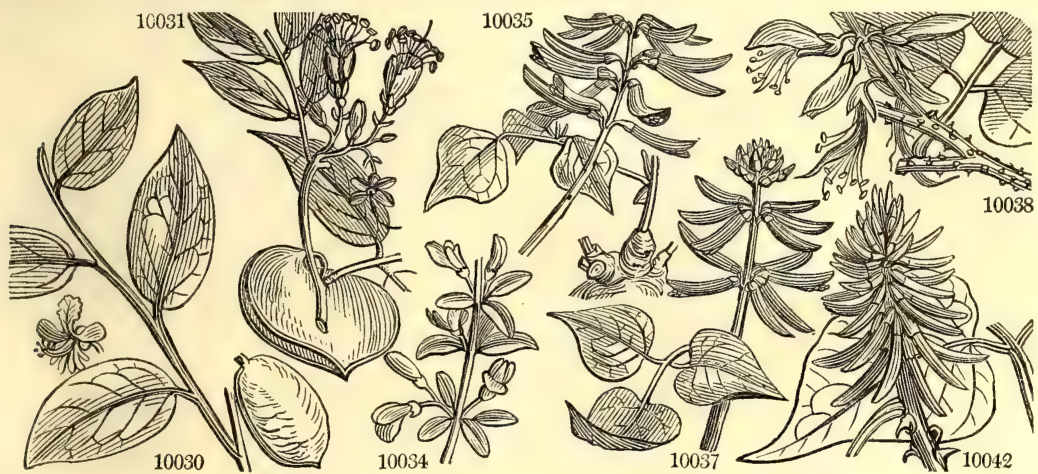

and Miscellaneous Particulars.

This drupe is large, subovate, and incloses a woody nut. The bark, which has a mucilaginous sweetish taste and a disagreeable smell, was first noticed as a vermifuge by Peter Duguid; but Dr. Wright, who resided a long time at Jamaica, has communicated the fullest information concerning this tree. According to him, the bark is powerfully medicinal; and its anthelmintic effects have been established at Jamaica by long experience.

1518. Dipterix. From $\delta 15$, double, and $\pi \tau \varepsilon \rho v \xi$, a wing, in allusion to the two appendages of the calyx. A tree much branched at top, with large alternate pinnate leaves, and racemes of fowers succeeded by almond-like fruits. The kernels of these are very fragrant, and are put by the Creoles into chests of clothes, in order to drive away insects, and communicate a grateful odor. They are in their own country called Tonga, and are the sweet-scented seed sold in shops under the corrupted name of Tonquin bean, for perfuming snuff and other substances. Ripened cuttings root in sand in moist heat.

1519. Parivoa. The name of the tree in Guiana. A very handsome tree.

1520. Amerimnum. One of the names given to the Houseleek by the Greeks. It is derived from $\alpha$, priva tive, and $\mu$ s to this genus, which has nothing in common either with the Houseleek or its ancient name. A. Ebenus is common in the West Indies, and the wood is sent to Europe under the name of American Ebony. Though not the true ebony, yet being of a fine greenish-brown color, and polishing well, it is much coveted by the in strument makers, and is of a very hard durable nature. The flowers of Amerimnum latifolium are yellow, and smell like new hay. In our stoves the species may be treated like Pterocarpus.

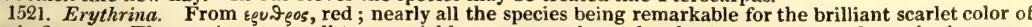
their flowers. The species are small trees, prickly or unarmed, or else shrubs, sometimes almost herbaceous ; leaves, as in Dolichos, ternate, stipulaceous, the petiolules jointed and awned, or glandular, very seldom simple flowers in fascicles from the axils, or in spikes at the end of the stem and branches, often scarlet. (Jussieu.)

In our stoves they thrive well in a light loamy soil. "The best way to flower them," Sweet observes, " is to place them on a dry shelf in winter, when they have no leaves, and give them scarcely any water; when they show flower-buds, they may be plunged in a moist heat, which will make the flowers finer than they 
10043 Crísta-galli $W$. 10044 ovális Wall.

1522. BU'TEA. $W$

10045 frondósa $W$

10046 supérba $W$.

1523. VIBOR'G

10047 sericea $W$

1524. PISCI'DIA. $W$.

10048 Erythrina $W$.

1525. PLATYLO'BI

10050 parmosum $H . K$. large-flowered

10051 trianguláre $H . K$. Small-flowered

1526. BORBO'NIA. $W$. Borbonia.

10053 trinérvia $W$

10054 lanceoláta $W$

10055 perfoliáta $W$.

10056 unduláta $W$

10056 undulata

10058 crenáta $W$ lævigáta $\dot{B}$.

10060 ruscifólia $\dot{B}$. $M$.

1527. RAF'NIA. $T h$.

10061 triflóra $W$

1528. ASPA'LATHUS, $\boldsymbol{W}$. AsPalatius.

10063 álbens $W$.

10064 pedunculáta $H . K$.

10066 asparagoídes $W$.

10067 carnósa $I V$.

10068 crassifólia $B, R e$.

10069 ciliáris $W$

10070 uniflóra $W$.

10071 subuláta $W$.

10072 globósa B. Rep.

10073 araneósa $W$.

10075 argéntea $W$.

10076 cándicans $\boldsymbol{H} . \boldsymbol{K}$.

10077 callósa $W$.

10078 mucronáta $W$

10079 affinis Thunb.

Butea.

Heath-leaved

three-nerved

many-nerved

perfoliate

wave-leaved

heart-leaved

notch-leaved

polished

RAFNIA.

Heath-leaved

Asparagus-lvd.

fleshy-leaved

bristle-pointed

ciliated

single-flowered

awl-leaved

globular

cobweb

cobwe

Indian

white

oval-spiked

thorny-branch.

kindred
10052 .

10057 cordáta $W$

10062 Chen

10065 ericifólia $W$

Cock's-Comb

Leguminose

branch. $\square$ spl 30 Leguminosa. Sp. 2.

-branch.

Leguminose. Sp. 1-4.

silky Jor 3 jl.au $\quad$ C. G. H. 1780. C 1.p

$\square \operatorname{tm} 25 \begin{aligned} & \text { Leguminosa. Sp. } 1-5 . \\ & \text {... }\end{aligned}$

Leguminosa. Sp. 3-5.

L or 4 jn.au Or N. S. W. 1790. S s.p Bot. mag. 469

4 my.3 Or N.S. W. 1792. S s.p Bot. mag. 1520

4. jn.s Or V. Di.L. 1805. S s.p Bot. mag. 1508

Leguminose. Sp. 9-11.

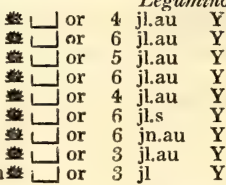

C. G. H. 1812, C l.p

C. G. H. 1759. S p.I Plu.alm.t.297.f.

C. G. H. 1752. C p.l Jac.schœ.2.t.217

C. G. H. 1812. C p.1

C. G. H. 1812. C p.I

C. G. H. 1759. S p.l Jac.schœ.2.t.218

C. G. H. 1774. S p.l Bot. mag. 274

C. G. H. 1799. S p.I Bot. cab. 247

C. G. H. 1790. S p.l Bot. mag. 2128

Leguminosa. Sp. 1-4.

three-flowered $\mathbf{E}$ (O) or 3 jn.jl Pu C. G. H. 1786. S s.l Bot. mag. 482

Goosefoot Leguminosa. Sp. 18-75.

silky

small-leaved $\quad \begin{array}{lll}\mathrm{pr} & 6 & \mathrm{jl} . \mathrm{au}\end{array}$

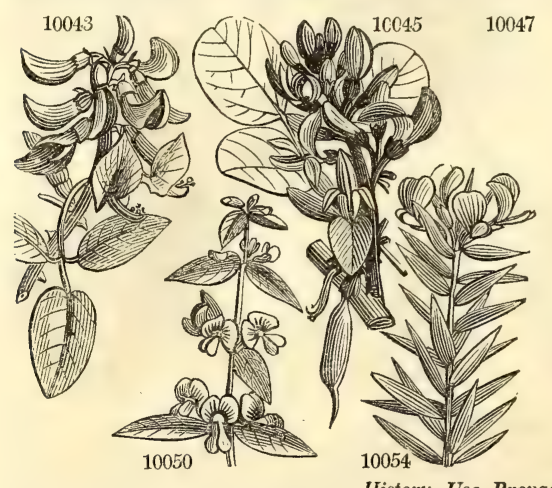

History, Use, Propagation, Culture,

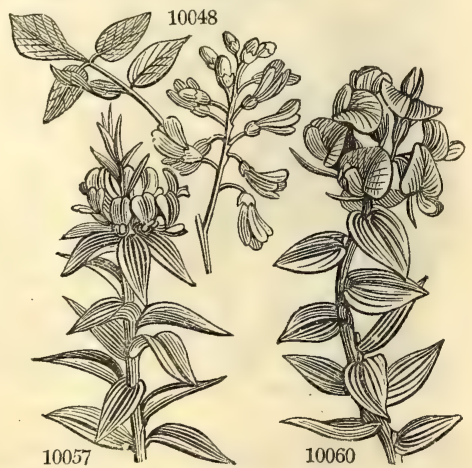

C. G. H. 1774. C p.1

C. G. H. 1775. S p.l Bot. mag. 344

C. G. H. 1789. C p.l Pl.man.t.413.f.6

C. G. H. 1812. C p.l

C. G. H. 1795. C p.l Bot. mag. 1289

C. G. H. 1800. S p.l Bot. rep. 353

C. G. H. 1799. C p.1 Bot. mag. 2233

C. G. H. 1812. C p.l Pl.man. t.414.f.'

C. G. H. 1789. C p.l

C. G. H. 1802. S p.1 Bot. rep. 510

C. G. H. 179.5. S p.l Bot. mag. 829

E. Indies 1759 S p.l Rhee.mal.. t.37

C. G. H 1759. C p.I

C. G. H. 1774. C 1.p

C. G. H. 1812. C 1.p Bot. mag. 2329

C. G. H. 1796. C 1.p

C. G. H, 1822, C 1

1005

10060

would be, if the plants stay out till they are in bloom. Cuttings taken off at a joint, and planted in sand, without being deprived of any of their leaves, strike root readily under a hand-glass in moist heat." (Bot. Cult. 54.)

1522. Butea. Named in honor of the late Earl of Bute, a munificent patron of botanical science. This splendid genus, though of free growth and easy propagation, is yet rare in British collections. From B. frondosa is obtained the Gum lac of commerce. Infusions of the flowers dye cotton cloth, previously impregnated with a solution of alum, or of alum and tartar, of a beautiful yellow color. The plant grows in loam and peat, and "s cuttings should be taken off' at a joint, and planted in a pot of sand, without being deprived of any of their leaves: one pot is enough under a hand-glass, as the leaves take up much room, and, if too confined, are apt to damp off. They should be plunged in a moist heat." (Bot. Cult. S0.)

1523. Viborgia; usually written Wiborgia, received its name after M. Eric Viborg, a learned and acute Danish botanist, author of several botanical treatises in his own language in the end of the eighteenth century. The species, like those of the four preceding genera, may be treated as Scottia.

1524. Piscidia. From piscis, a fish; the inhabitants of America use the bark as a fish poison. This tree has spreading branches and pinnate leaves, and is very common in Jamaica, where it is reckoned one of the best timber-trees in the island. The wood is very hard and resinous, and lasts almost equally in or out of water. It is of a light-brown color, coarse, cross-grained, and heavy. (Browne.) It makes excellent piles for wharfs. The stakes soon form a good live fence. The bark of the trunk is very astringent; a decoction of it stops the immoderate discharge of ulcers, especially when it is combined with the mangrove bark; it cures the mange in dogs, and would probably answer well for tanning leather. (Long, 824.) The bark of the root is used for the same purposes and with the same effects as the leaves and branches of Surinam poison; it is pounded and mixed with the water in some deep and convenient part of a river or creek, when ce it may spread itself; 
10043 Leeves ternate, Petioles prickly glandular, Stem arboreous unarmed

10044 Leaves ternate oblong oval blunt

10045 Branches downy, Leaflets roundish emarginate

10046 Branches smooth, Leaflets obovate roundish blunt

10047 Leaflets and twiggy branches pubescent

10048 Leaves unequally pinnate, Leaflets ovate

10049 Leaves cordate ovate, Ovary hairy

10050 Leaves lanceolate ovate, Ovary smooth

10051 Leaves deltoid or hastate with spiny angies

10052 Leaves sublinear acute villous beneath, Heads terminal

10053 Leaves lanceolate 3-nerved entire

10054 Leaves lanceolate many-nerved entire

10055 Leaves amplexicaul. entire netted

10056 Leaves amplexicaul. wavy with a reiexed mucro

10057 Leaves cordate many-nerved entire

10058 Leaves cordate many-nerved toothletted

10059 Leaves ovate cordate acuminate pungent, Stem hirsute

10060 Leaves rigid pointed pungent oblong dense

10061 Leaves ovate smooth, Branches angular, Peduncles 3 lateral 1-flowered

10062 Leaves fascic.ed 3-angular mucronate stiff hairy, Heads hairy

10063 Leaves fascicled filiform silvery blunt, Racemes leafy, Flowers not hairy

10003. Leaves fascicled subulate smooth, Pedunc. filiform twice as long as leaf

10065 Leaves fascicled filiform blunt hairy, Flowers somewhat racemose

10066 Leaves fascicled 3-cornered mucronate hairy, Flowers lateral

10067 Leaves fascicled fleshy round smooth, Fl. lateral and terminal, Flowers smooth

10068 Leaves fascicled fleshy round smooth setaceous at end, Fl. capitate terminal

10069 Leaves fascicled scabrous somewhat hairy, Heads terminal

10070 Leaves fascicled filiform mucronate smooth, Flowers lateral

10071 Leaves fascicled 3-cornered mucronate smooth

10072 Leaves linear downy imbricated, Heads terminal crowded

10073 Leaves fascicled filiform lax hairy, Heads hairy

10074. Leaves quinate sessile, Peduncles 1-flowered

10075 Leaves ternate and fascicled ovate silky, Heads downy, Stem dichotomous

$100 \%$ Leaves ternate and fascicled filiform silky, Fl. somewhat lateral, Vexillum naked

10077 Leaves three 3-cornered smooth, Spikes ovate

10078 Leaves ternate, Leaflets blunt, Branches spiny

10079 Leaves fascicled fleshy round smooth, Flowers lateral without bractes, Branches twiggy

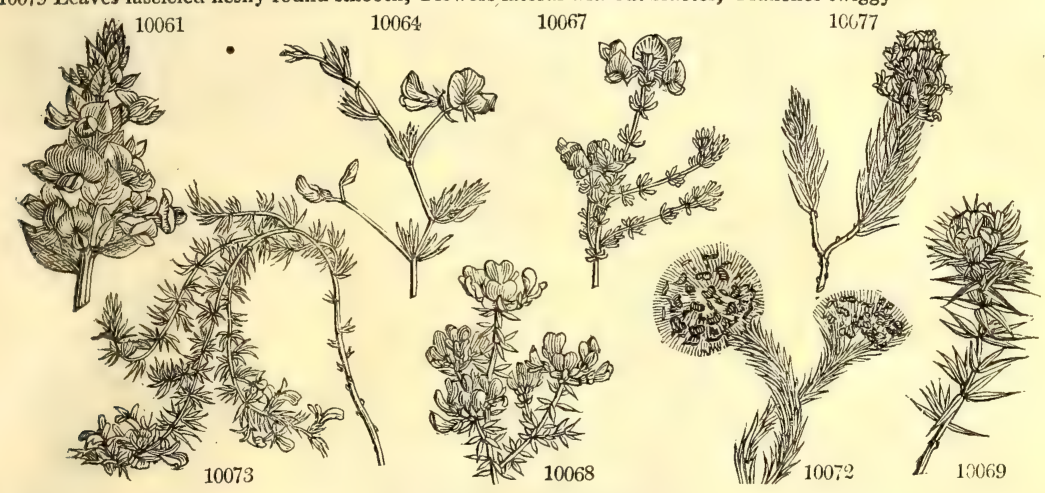

and Miscellaneous Particulars.

in a few minutes the fish that lie hid under the rocks or banks rise to the surface, where they float as if they were dead; most of the large ones recover after a time, but the smaller fry are destroyed. The eel is not intoxicated with common doses, though it is affected very sensibly ; for the moment the particles spread where it lies, it moves off with great agility. Jacquin observes that this quality of intoxicating fish is found in many other American plants.

It is a very free grower in our stoves, but is seldom allowed to grow large enough to flower. Cuttings root in sand under a hand-glass.

1525. Platylobium. From $\pi \lambda \alpha \tau u s$, broad, and $\lambda . \rho_{0}$, a pod, in allusion to the form of the pod. Handsome free-flowering plants, which grow in sandy loam and peat; and are increased by cuttings in sand under a hand-glass, or by seeds.

1526. Borbonia. In memory of Gaston Bourbon, Duke of Orleans, son of Henry IV. of France, a great lover and patron of botany. See Gastonia. Shrubs of easy culture and propagation.

1527. Rafnia. Named, according to Sir James Smith, after Mr. C. G. Rafn of Copenhagen, author of a Flora of Denmark and Holstein, published in 1796 and 1800, in two octavo volumes. A genus of Cape plants, separated from the Linnean Crotalaria and Liparia.

1528. Aspalathus. A native of the island Aspalathus on the coast of Lycia. It was a common practice with the ancients to fix the names of places upon certain plants, as Cytisus, Lycium, and others. It is not certain what plant the ancients intended by their Aspalathus. Shrubs and under-shrubs, with fasciculate linear leaves, and yellow flowers, all of which grow freely in a mixture of sandy loam and peat; and young cuttings, planted in sand under bell-glasses will strike root freely, if the glasses are wiped occasionally, otherwise they are liable to damp off. Some species ripen seeds freely, by which young plants are readily produced. (Bot. Cult. 140.) 
1529. SARCOPHYL'LUM. Th. SARCOPHYluM. 10080 carnósum Th. jointed-leaved 1 cu

1530. Crotala'ria. $\boldsymbol{W}$. Crotalaria. 10081 sagittális $W$. 10082 prostráta $W_{\dot{B}}$ en. 10083 floribúnda $\boldsymbol{B}$. C. 10084 rubiginósa $W$. 10085 platycárpa Link. 10086 anthylloídes $\boldsymbol{H} . \boldsymbol{K}$. 10088 paulina Schranck 10090 benghalénsis P.S 10091 júncea $W$.

10() 91 júncea $W$.

10092 diffúsa Link. 1009 fenestráta $\boldsymbol{B} . \boldsymbol{M}$. 10095 serícea $W$.

10096 retúsa $W$.

10097 verrucósa $\mathrm{W}$

10008 mícans Link. 10099 curtáta Link. 10100 púlchra $\boldsymbol{H} . \boldsymbol{K}$. 10101 semperflórens $P$. S. 10102 hírta W. en.

10103 biflóra $W$. 10104 micrántha Link. 10105 vitellína $K e r$. 10106 pulchérrima $B$. 10107 paniculáta $W$. 10108 lotifólia $W$. 10109 laburnifólia $W$ 10110 cordifólia $W$. 10111 purpúrea $H . K$. 10112 pulchélla $\boldsymbol{H} . K$ 10113 Saltiána B. Rep. 10114 axilláris $W$

10115 orixénsis W.en. 10116 incanéscens $\boldsymbol{W}$. 10117 incána $W$.

10118 pállida $W$

10119 angustifólia $W$ 10120 quinquefólia $W$.

1531. BOSSI瓜'A. Sm. prostrate prony-flowered flat-podded large-fl.-cupped square-stalked St. Pauls small-flowered Bengal striated-stalked diffuse Nepal window-calyxer silky

wedge-leaved blue-flowered glittering short-keeled short-podded ever-blowing hairy

two-flowered small-flowered Yolk of egg panicled Lotus-leaved Laburnum-lvd. heart-leaved dark-purple large-flowered Salt's axil-flowered strigose spreading hoary

pale-flowered narrow-leaved five-leaved

Bossirea. 10121 Scolopéndrium $H$. K. Plank-plant $1012 z$ rúfa $H . K$

10123 heterophylla $V$. 10124 linophýlla $H$. $K$. 10125 prostráta $H . K$ 10126 cinérea H.K. ${ }_{10127 \text { microphýla } H . K \text {. }} \begin{aligned} & \text { downy sharp-lv. } \\ & \text { small-leaved }\end{aligned}$

153. SCOT'TI A. R. Br. ScotTIA. 10128 dentáta $R, B r$. ${ }^{2}$ tooth-leaved red-flowered various-leaved narrow-leaved procumbent prowny sharp-lv. 2 or [प] un (2) un $\frac{1}{2} \mathrm{j}$

Leguminose. Sp. 1.

my.au Y C. G. H. 1812. C s.l Bot. mag. 2502

Leguminosa. $S p .40-87$.

jn.jl Y America 1731. S co Plu.aım.t.169.f.6 $\begin{array}{lll}\mathbf{Y} & \text { E. Indies 1804. S co }\end{array}$ jl.au Y C. G. H. 1810. C co Or E. Indies 1807. S co Y N. Amer. 1823. S co Y E. Indies 1789. C s.I E. Indies 1806. S s.l Brazil 1823. S co E. Indies 1817. S co E. Indies 1806. S s.1 Plu.alm.t.169.f 5 E. Indies 1700 . $S$ p.l Bot. rep. 422

...... $\quad \ldots$ s co

Nepal 1823. S co

E. Indies 181.5. S p.l Bot. mag. 1933 Y E. Indies 1807. S p.l Y.Pu E. Indies 1731. S p.l Bot. reg. 253 B E. Indies 1731. C r.m Bot. rep. 308 Pa.Y ...... 1820. C co $\mathrm{Y} \quad \ldots . . . \mathrm{S}$ co E. Indies 1800. S s.1 Bot. rep. 601 E. Indies 1816. S p.1 Vent. cels. t. 17 E. Indies 1816, S p.l E. Indies 1790. S p.l Bur. ind t.48. f.2 Ceylon 1823. S co Brazil 1819. C co Mysore 1814. C co Bot. mag. 2027 E. Indies 1807. C 1.p Y.G Jamaica 1732. S co Dil.el.t.102,f.121 Y E. Indies 1739. S co Rhee.mal.9. t.27 D.Pu C. G. H 1790. C p. $\begin{array}{llll}\text { C. G. H. } 1790 . & \text { C p.1 } & \text { Bot. reg. } 128\end{array}$ Y $\begin{array}{llll}\text { C. G. H. 1800. C } & \text { C.I } & \text { Bot. mag. } 1699\end{array}$ Y Abyssinia 1810. C p.l Bot. rep. 648 Y Guinea 1781. S p.l Y E. Indies 1816. S p.l Y C. G. H. 1774. S s.p Jac. vind. 3. t. 64 G.Y W. Indies 1714. S s.p Bot. reg. 377 Pa.Y Africa 1775. S s.p Pa.Y C. G. H. 1815. S s.p Jac.schœ.2. t.219 Y E. Indies 1792, C s.p Rhee, mal.9. t.28

Legur dinosa. Sp. 8-12.
my.jl $\mathrm{Y}$ 6 jn.s R N. Holl. 1803. C s.l.p

3 my.d Y N. S. W. 1792. C s.l.p Bot. mag. 114

3 jl.s Or N. Holl. 1803. C s.l.p Bot. mag. 2491

$\frac{1}{2}$ jl.s $\quad \mathrm{Y} \quad$ N. S. W. 1803. C s.l.p Bot. mag. 1493

3 my.jl Y $\quad$ V. Di. Isl. 1803. C s.l.p Bot. reg. 306

N.

Legun.tinosa. Sp. 1.

Leguinsinosa. Sp. 2. 10130 glaúca $B$.

wedge-leaved $\longleftarrow$ o glaucous

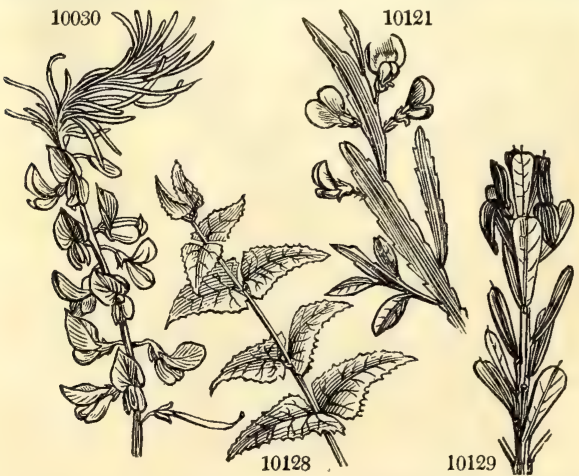

History, Use, Propagation, Culture,
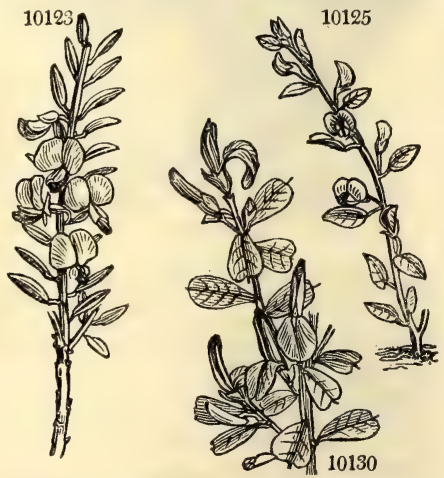

1529. Sarcophyllum. From $\sigma \alpha \rho \xi$, flesh, and $\varphi \nu \lambda \lambda$, v , a leaf. The leaves are thick and fleshy. A somewhat succulent plant, easily injured by over-watering; but otherwise not difficult to preserve or increase.

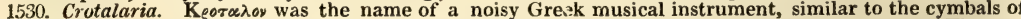
the present day. The pods of this genus are inflated, and rattle, when shaken, in a similar manner. The species are all of easy culture, mostly free-flowerers; but they are shabby plants under cuitivation, and possess no good quality which can render them ohjects of interest or beauty.

1531. Bossiaa. Named by Ventenat, after M. Boissieu-Lamartiniére, who accompanied the unfortunate La Pérouse in his voyage round the world. This beautiful genus, according to Sweet, " thrives best in an equal mixture of sandy loam and peat; if not very sandy, some sand must be added to it to have the plants in health. The pots must be well drained with broken potsherds, as nothing injures them more than too much 


\section{The only species}

10081 Leaves simple obl. lanceolate, Stipules lanceolate acuminate decurrent, Racemes opposite the leaves 10082 Leaves simple lanc ellipt. blunt downy beneath, Racemes opposite the leaves 10083 Leaves very small ternate glaucous, Racemes few-flowered, Vexillum reflexed

10084 Leaves simple lanc. villous, Upper stipules lanc. decurrent, Racemes opposite the leaves, Cal. villous 10085 Branches winged upwards, Lower leaves obl. : upper lanc, acute hairy, Racemes lateral 10086 Leaves simple lin. lanc, acute villous beneath, Flowers and pods inclosed in hairy calyx 10087 Leaves simple long-lanc. Pods downy, Raceme terminal, Stem square

10088 Leaves obl. lanceolate silky beneath, Fl. racemose, Bractes linear much shorter than pedicel 10089 Leaves simple lanc. Upper stipules decurrent with 2 short teeth, Racemes opposite the leaves 10090 Leaves lanceolate subsessile. Lower lip of cal. 3-parted beyond the middle, Stem virgate simple 10091 Leaves simple lanc. subsessile, Pods smooth, Raceme terminal, Stem furrowed

10092 Leaves lanceolate blunt hairy, Fl. terminal, Calyx hairy as long as corolla

10093 Leaves lanceolate, Raceme terminal, Cal. very villous as long as corolla

10094 Leaves simple ov. lanceolate silky ciliated, Standard large erect pointed

10095 Leaves simple lanc. beneath, Pods silky, Raceme terminal, Stem furrowed

10096 Leaves simple obl. cuneiform retuse, Raceme terminal

10097 Leaves simple ovate retuse, Stipules lunate declinate, Raceme term. Branches square

10098 Leaflets 3 oval acute, Hairs shining scattered, Racemes opposite the leaves

10099 Leaflets 3 oval blunt with scattered hairs, Raceme terminal long, Keel shorter than vexillum

10100 Leaves simple obovate oblong silky on each side, Pod 4-seeded length of calyx

10101 Stems round striated, Leaves oval emarginate mucronate, Stipules lunate amplexicaul

10102 Leaves simple lin.-lanceolate blunt hairy, Pedunc. terminal subsolitary, Stem branched diffuse

10103 Leaves simple obl. blunt hairy, Stems prostrate herbaceous, Pedunc. 2-3-fl. axillary

10104 Leaflets 3 oblong blunt mucronate with scattered hairs beneath, Raceme terminal, Calyxes silky

10105 Leaves ternate, Leaflets oval-lanc. acute twice as long as villous petiole, Pods pendulous

10106 Leaves obovate cuneate silky, Racemes term. Bractes and calyx colored

10107 Leaves obl. blunt silky villous, Stipules linear subulate reflexed, Panic. terminal bracteate

10108 Leaves ternate, Leaflets cuneiform emarginate silky beneath, Peduncles axillary solitary 1-flowered

10109 Leaves ternate ovate acuminate smooth, Stipules none, Raceme terminal, Pods stalked pendulous

10110 Leaves ternate obcordate mucronate, Flowers corymbose, Stem shrubby

10111 Leaves ternate, Leaflets obovate retuse, Racemes terminal

10112 Leaves ternate, Leaflets linear lanceolate acute half as long again as petiole downy beneath

10113 Leaves ternate on long stalks, Leaflets oval downy, Racemes axillary lax, Standard blunt

10114 Leaves ternate obl. lanceolate acute silky beneath, Stipules lanceolate subulate, Pedunc. axill. 1-flowered

10115 Leaves ternate obovate strigose beneath, Stipules lanceol. and bractes ovate reflexed, Racemes terminal 10116 Leaves ternate obovate, Stipules leaf-like stalked, Racemes terminal, Pods stalked

10117 Leaves ternate oval villous beneath, Racemes spiked, Keel downy at edge, Pods sessile hairy

10118 Leaves ternate lanceolate smooth, Racemes terminal spiked

10119 Leaves ternate lanc. hoary silky shorter than petiole, Raceme terminal

10129 Leaves quinate

10121 Branches flat linear leafless, Denticulations flower-bearing, Keel naked, Calyx smooth 10122 Branches flat linear leafless, Denticulations flower-bearing, Keel fringed, Calyx smooth 10123 Branches leafy compressed, Leaves obovate and linear flat, Pod many-celled with spongy septa 10124 Branches leafy compressed, Leaves linear with recurved edges, Pod 1-celled

10125 Branches leafy filiform, Leaves oval smooth, Stipules shorter than petiole, Pod 1-celled

10126 Branches leafy round, Stem erect much branched, Leaves ovate-lanc. rough above

10127 Branches leafy spiny round, Leaves obcordate cuneiform

\section{The only species}

10129 Leaves green retuse

10130 Leaves glaucous blunt

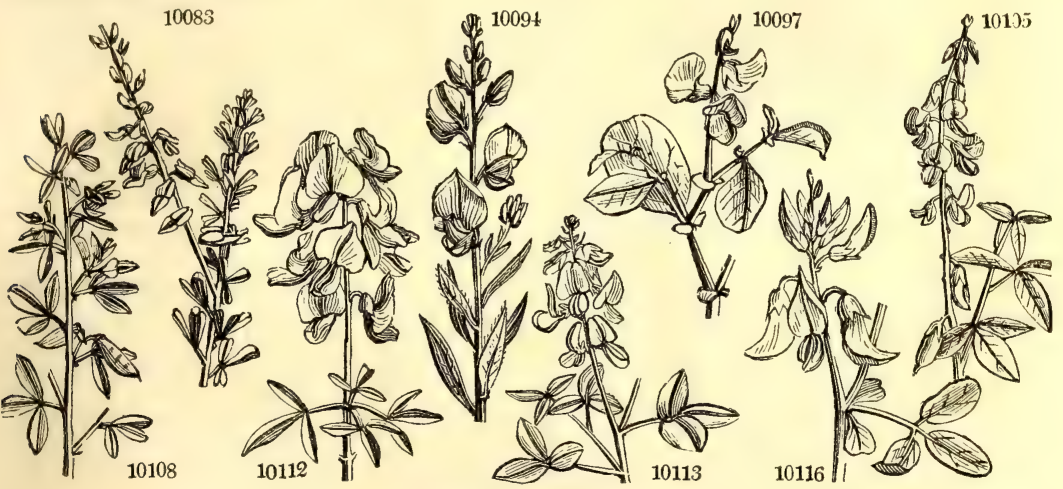

and Miscellaneous Particulars.

water. Cuttings, not too ripe, will strike root if planted in sand under a bell-glass, not too close together, as they are apt to damp; when rooted, they must be potted off in little pots and kept in a close frame, and hardened to the air by degrees." (Bot. Cult. 151.)

1532. Scottia. Named in memory of Robert Scott, M. D., formerly professor of botany at Dublin. A shrub found by Mr. Brown upon the south-west coast of New Holland. Young cuttings root in sand under a bellglass.

1533. Templetonia. Named after John Templeton, Esq., of Orange Grove, near Belfast, a gentleman to whom the editor of the English Botany was under frequent obligations for Irish plants during the progress of that work. 
1534. GOOD'IA, R. Br. GoodiA. 10131 lotifólia $H . K$ smooth 10132 pubéscens $H . K$. downy

1535. LODDIGE'SIA. B. $M$. Lodpigesia 10133 oxálidifólia $B$. M. Oxalis-leaved we

1536. HO'VEA. H. $K$. Hovea. 10134 lineáris H.K. linear-leaved 10135 longifólia $\boldsymbol{H} . \boldsymbol{K}$. long-leaved 10136 lanceoláta $\boldsymbol{B} . \boldsymbol{M}$. $\quad$ spear-leaved 10137 ellip'tica

10138 Cel'si Bonpl. • Cels's

1537. SPAR'TIUM. $W$. BRoom. SPROOM $\beta$ flore-pleno double-flowered Spanish 10140 monospérmum $W$. white single-seed. 恶

10142 prócerum $W . e n$. tall

.

10144 virgátum $W$. long-twigged

10145 púcan $W$.

10146 umbellátum $W$

10147 Scórpius $W$.

10148 seríceum Vent.

10149 multiflórum $W$

10150 angulátum $W$.

10151 pátens $W$.

10152 pilocárpum Link.

10153 cinéreum $W$.

10154 nubigenum $W$.

10155 linifólium $W$.

10156 scopárium $W$

10157 radiatum $W$.

10158 férox $W$.

10159 spmósum $W$.

1538. GENIS'TA. $W$

10160 canariénsis $W$.

10161 cándicans $W$

10162 viscósa $W$.

10163 triquetra $W$.

10164 sagittális $W$.

10165 trianguláris $W$.

10166 tinctória $W$

10167 sibírica $W$.

10168 ováta $W$.

10169 scariósa Viviani

purging

umbelled

Scorpion

silky

white Portugal

small-flowered

woolly-podded

hairy-fruited

cinereous

luster-fiower

common

common

starry

prickly

Genista.

Canary

hoary

clammy

triangular

jointed

three-sided

Green-weed

Siberian

oval-leaved

scariose
* $\downarrow$ or 3 Leguminosa. Sp. 2

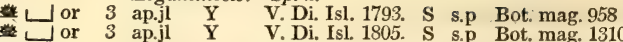
Leguminosa. $S p$

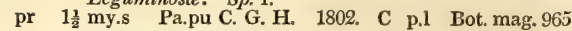
Leguminosa. Sp. 5.

* or $3 \mathrm{mr} . \mathrm{jl}$ Pu N. S. W. 1796. S s.p Bot. reg. 463

* $\sqcup$ or 3 jn.s Pu N. S. W. 1805. S s.p Bot. reg. 614

$\downarrow$ or $3 \mathrm{mr} . \mathrm{jl} \quad \mathrm{Pu}$ N. Holl. 1805. S s.p Bot. mag. 1624

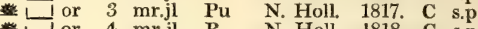

N. Holl. 1818. C s.p Bot. reg. 280

Leguminosa. Sp. 21-37.

业 ec 6 jl.s $\mathrm{Y}$ S. Europe 1548. S co Bot. mag. 85

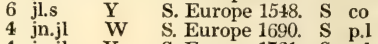

. Europe 1690. S p.l Bot. mag. 683

f $\quad$ S. Europe 1731. S p.l Reneal.spec. t.33

4. jn.jl $Y$ Portugal 1816. C s.1

4. ap.jl Y $\quad$ Teneriffe $\quad \ldots$. C $\quad$ s.l

5 mr.jn $\quad \mathrm{Y}$ Madeira 1777. $\mathrm{C}$ p.1 Jac. ic. 1. t. 147

4 jn.jl Pa.Y S. France 1768. s p.l Bull. herb.t.115

3 ap.jn Y Barbary 1799. C p.1 Desf. atl. 2. t. 180

4 mr.ap Y S. Europe 1570. S p.l Dend. brit. 78

3 my.au Y Mogadore 1812. C p.1 Vent.choix. t.17

6 my W Portugal 1752 S co Duhamax.

3 my in Y Portugal 1752.

3 my.jn Y Levant 1739. C p.1 Vent. cels. 87

4 jn.jl $\quad \mathrm{Y}$ Portugal 1752. S p.l Cav. ic. 2. t. 176

4 jn.jl Y $\quad$ S $\ldots$..... 1823. S p.l

4 jn.jl Y $\quad$ S. Europe … $\quad$ S co Dend, brit. 76

Spain 1739 C p.l

ja.jn $Y$ Spain 1739. C p.l Bot. mag. 442

Y Britain dry hil. $S$ co Eng. bot. 1339

Italy 1758. S s.p Bot.mag. 2260

Barbary 1800. C p.l Bot. reg. 368

S. Europe 1596. C p.1 Lob. ic. 2. p. 95

\section{Leguminose Sp. $21-42$}

U $\mathrm{ft}^{2}$ my.s $\mathrm{Y}$ Canaries 1656. S s.l Bot. reg. 217

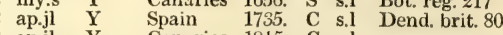

2 ap.jl $\quad \mathbf{Y} \quad$ Canaries 1815 . C $\quad$ s.l

3 my.jn $Y$ Corsica 1770. C s.p Bot. mag. 314

$\frac{1}{2}$ my.jn Y Germany 1570. L co Jac. aust 3 t 209

$2^{\frac{1}{2}}$ my.jn Y Hungary 1815, C co Pl.rar.hu. 2.153

3 in.au $Y$ Britain dry pa. $S$ co Eng. bot. 44

2 jn.au Y Siberia 1785. L co Jac.vind.2. t.190

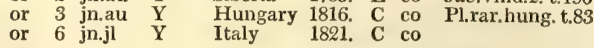
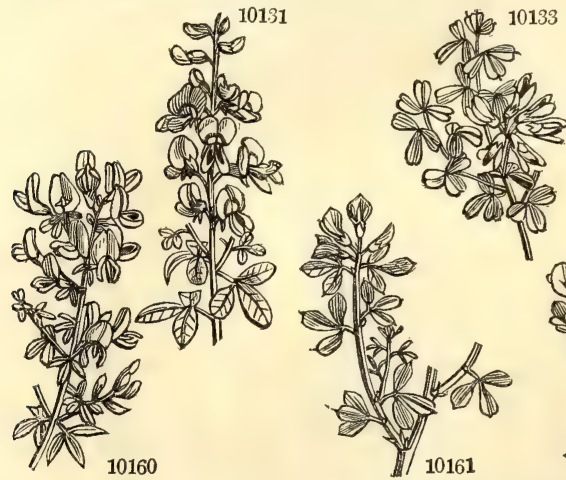

10134

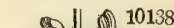

History, Use, Propagation, Culture,

1534. Goodia. In memory of Peter Good, an industrious gardener employed by the Kew garden in collecting seeds in New Holland, where he died.

1535. Loddigesia. Named in compliment to Mr. Conrad Loddiges, a successful cultivator of plants, an assiduous collector, and a most worthy man, whose virtues are inherited by his sons.

1536. Hovea. In honor of Mr. Antony Pantaleon Hove, a Polish botanist, who travelled in the Crimea and Persia, whence many plants were sent to Kew garden. He is still alive, and naturalized in England. Pretty plants, easily cultivated in sandy loam and peat, and rooted in sand under a hand-glass.

1337. Spartium. From $\sigma \pi \alpha \rho \tau o y$, cordage ; the earliest ropes were made of this and similar tough plants. The species are shrubs thick-set with verdant flexible rush-like twigs, which are very ornamental in winter, and generally profusely covered with shewy white or yellow odoriferous and mellifluous blossoms in summer. $\mathbf{S}$. junceum is grown as a green food for sheep in the south of France, and there and in Spain it affords a thread from its fibres, which is sometimes wove into cloth, but more generally twisted into cordage. Bees are very fond of the flowers, as they are of those of most of the species.

$\mathrm{S}$. monospermum, is a very handsome shrub, remarkable for its numerous snow-white flowers. Osbeck remarks, that it grows like willow-bushes along the shore of Spain, as far as the flying sands reach, where scarcely any other plant exists except the Ononis repens, or creeping Restharrow. The use of this shrub is very great in stopping the sand. The leaves and young branches are delicious food for goats. It converts the most barren spot into a fine odoriferous garden by its flowers, which continue a long time. It conver thelter hogs and goats against the scorehing heat of the sun. The twigs are used for tying bundles; servil kinds of herbs that are brought to market are fastened together with them. Forskahl found it in Arabia ; and Desfontaines in Barbary, on the sahdy coast. The Spaniards call it Retamas, from the Arabic name Retam. 
10131 Leaflets obovate and calyxes smooth, Pod varicose

10132 Leaflets obovate cuneate and calyxes downy, Pod smooth

10133 The only species

10134 Leaves linear hairy beneath, Pods smooth

10135 Leaves long linear; beneath veiny, Pods downy

10136 Branches twiggy, Leaves lanc. mucronate downy beneath, Fl, axill twin

10137 Leaves elliptic oblong

10138 Leaves lanc. somewhat rhomboid blunt at end mucronate, Peduncles axillary many-flowered

10139 Branches opposite round flowering at end, Leaves lanceolate

10140 Branches round striated, Racemes lateral few-fl. Flowers subaggregate, Leaves lanceolate silky 10141 Branches round striated, Racemes lateral many-f. Flowers remote, Leaves lanc. sessile a little hairy 10142 Branches round striated, Fl. solitary axillary, Pods villous, Leaves lanceolate hairy

10143 Branches round striated very close, Fl. terminal racemose, Vexillum smooth, Leaves lanc. silky 10144 Branches round striated, Fl. axill. solitary subracemose, Standard and keel downy, Lvs. obl. lanc. silky 10145 Branches round striated, Fl. axillary solitary, Leaves lanc. silky st bsessile

10146 Branches round striated, Fl. term. capitate, Leaves lin. lanc. silky

10147 Branches round striated spreading spiny, Pedunc. axill, many-fl. Leaves obl. acute silky 10148 Leaves lanc. silky beneath, Corolla silky, Branches erect round

10149 Leaves ternate and simple silky, Twigs straight striated flowering on all sides

10150 Leaves solitary and ternate linear lanceolate hoary, Branches hexangular flowering at the ends 10151 Leaves ternate stalked obovate, Branches round striated, Lateral flowers twin nodding 10152 Branches angular, I.eaves simple lanceolate silky beneath, Fl. racemose, Pods hairy

10153 Branches round with ten furrows, Flowers axillary solitary downy

10154 Leaves ternate lanc. hairy stalked, Fl. lateral fascicled, Pods smooth, Branches round striated

10155 Leaves ternate sessile linear silky beneath, Raceme terminal, Branches round furrowed

10156 Leaves ternate and solitary oblong, Fl. axillary, Pods hairy at edge, Branches angular

10157 I.eaves ternate linear, Petioles dilated persistent, Racemes capitate term. Branches angul. opp. clustered

10158 Leaves ternate and simple oblong mucronate, Raceme terminal, Branches striated round spiny

10159 Leaves ternate obovate, Peduncles axillary, Cal. and pods smooth, Branches angular spiny

10160 Leaves tern. obl. downy beneath with spreading hairs, Pedunc. many-fl. terminal, Branches angular 10161 Leaves ternate obovate downy with closely pressed hairs, Pedunc. many-fl. terminal, Branches angular 10162 Leaves ternate obl, smooth, Racemes terminal, Cal. and pods glandular viscid, Branches rounú striated 10163 Leaves ternate: upper simple, Branches triquetrous procumbent

10164 Branches 2-edged membranous jointed, Leaves ovate lanceolate

10165 Leaves lanceolate mucronate smooth, Branches 3-cornered ascending, Pods smooth

10166 Leaves lanceolate smooth, Branches round striated erect, Pods smooth

10167 Leaves lanceolate smooth, Branches equal round erect

10168 Leaves oblong ovate and pods hairy, Branches round striated

10169 Quite smooth, Leaves not ciliated, Cor. 5 lines long, Calyx smooth

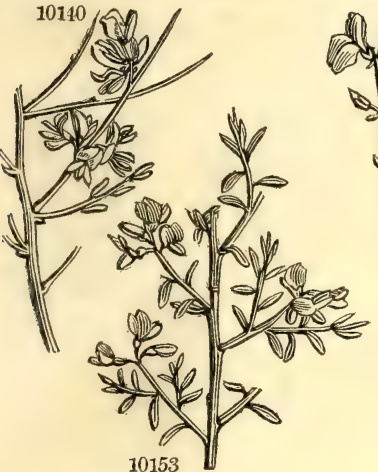

10153

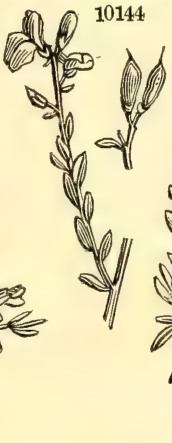

10155

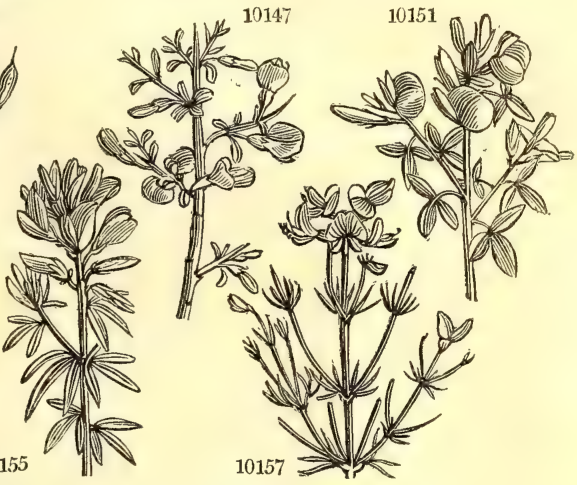

1015

and Miscellaneous Particulars.

S. scoparium, though in some places a troublesome weed in old pastures, is a very ornamental shrub in garden scenery: it is also useful in agriculture, domestic economy, and medicine. It is sometimes used as winter food for sheep, frequently for thatching cottages and ricks, and as litter. Bees are fond of the flowers : the flower-buds, just before they become yellow, are pickled in the manner of capers: the branches are said to be capable of tanning leather, and of being manufactured into coarse cloth; when tender, they are mixed with hops in brewing : the old wood furnishes the cabinet-maker with a beautiful material for veneering. The twigs, when bruised, smell disagreeably, which perhaps may be one reason why our broom is generally rejected by cattle (Curtis); but they have also a nauseous bitter taste. The plant when burnt affords a tolerably pure alkaline salt. Broom tops are diuretic and eathartic; the seeds are said to be emetic. The efferts of this plant have been very long known to the common people; and both Mead and Cullen found them useful in dropsy. The usual mode of exhibiting them is in the form of decoction, made by boil ing the green tops in water. Speaking of this decoction, of which two table spoonfuls were given every hour till it operated by stool, Cullen says, " it seldom fails to operate both by stool and urine, and by repeated exhibition every day, or every second day, some dropsies have been cured. (Thompson's London Dis-
pensatory, 514.)

1338. Genista. Gen, signifies, in Celtic, a small bush, whence also Gênet, French. The species are shrułs or undershrubs, some of them evergreen, and many with numerous flexible rush-like green twigs like the brooms. They are of easy culture and free flowerers. G. tinctoria is common in most parts of Europe, in unimproved pastures on dry gravelly soils. When cows feed on it, their milk, and the butter or cheese made from it, are said to be very bitter. A bright yellow color may be prepared from the flowers; and for wool that is to be dyed green with woad, the dyers prefer it to all others. A dram and a half of the powdered seeds operates as a mild purgative. A decoction of the plant is sometimes diuretic, and therefore 
10170 flórida $W$

10171 procámbens $W$ 10172 decúmbens $W$. 10173 pilósa $W$. 10174 diffúsa $W$.

10175 serícea $W$. 10176 ánglica $W$. 10177 germánica $W$ 10178 hispánica $W$. 10179 lusitánica $W$. 10180 bracteoláta Link.

1539. LEBECK'IA. 10181 contamináta $W$ 10182 serícea $\boldsymbol{W}$.

10183 cytisoídes $W$.

10184 subternáta Link.

1540. U'LEX. $W$. 10185 europæ $\mathfrak{x}^{\prime}$ us $\dot{W}$. 10186 nánus $W$.

1541. ONO'NIS, $W$ 10187 antiquórum $W$. 10188 spinósa $W$. 10189 hircína $W$. 10190 répens $W$. 10191 Colúmnæ $W$. 10192 mitíssima $W$. 10193 alopecuroídes $W$. 10194 variegáta $W$. 10195 pubéscens $W$. 10196 cérnua $W$.

10197 gemináta $W$. 10198 reclináta $W$ 10199 cenísia $W$. 10200 vaginális $\dot{P}$. $S$. 10201 Cherléri $W$. 10202 viscósa $W$. 10203 ornithopodioídes $W$. 10204 pinguis $W$ 10205 Nátrix $W$ 10206 hispánica $W$. $\beta$ oligophylla Tenor 10207 tridentáta $W$. 10208 críspa $W$. 10209 fruticósa $W$. 10210 rotundifólia $W$.
Spanish

or 6 jn.au Y trailing 2 or $1 \frac{1}{2} \mathrm{jn} . \mathrm{au} Y$

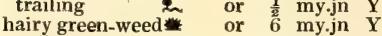
diffuse or 3 my.jn $Y$

silky

Petty whin

German

dwarf-prickly

Portugal

bracteolate

LEBECKIA. narrow-leaved
silky

Cytisus-leaved yellow-flowered

Furze.

common

dwarf

REST-HarRow.

tall

common

stinking

creeping

cluster-flowered

Fox-tail

variegated

downy

two-flowered un 2 jl.s $\quad \mathbf{Y}_{\mathbf{1}}$

spreading $\mathrm{O}$ un $\frac{1}{8}$ jn.au St

narrow-leaved $\ddagger \Delta$ un $\frac{1}{4}$ jn.au $\mathbf{P k}$

sheathed 青 $u$ un 2 jn.au Y

$\begin{array}{llll}\text { dwarf } & \$ \Delta \text { un } & 1^{\frac{1}{2}} \mathrm{jn} . \mathrm{jl} & \mathbf{P u} \\ \text { clammy } & \mathrm{O} \text { un } & 1^{\mathrm{jlau}} & \mathrm{Y}\end{array}$

Bird's-foot

greasy

yellow-shrubby w

Spanish

few-leaved

three-toothe

chrubby

round-leaved on 11 jlau

* un $11^{2} \mathrm{jl}$

— un $1 \frac{1}{2}$ my.s $\mathbf{Y}$

n. J or $1 \frac{1}{2}$ my.s

w.

n $\_$or $1 \frac{x}{2}$ jn.au $\mathbf{P u}$

* un 2 jn.au Y

pr 2 my.jn $\mathrm{Pl}$
Spain 1752。 S co Hungary 1816. C co France 1775. L p.l Bot. cab. 718 England san.he. S co Eng. bot. 208 Italy 1816. C co Jac. ic. 3. t. 555 Austria 1812. S s.l Jac. ic. 3. t. 556 Britain moi.he. $\mathbf{S}$ co Eng bot. 132 Germany 1773. Spain 1759. C co Cav. ic. 3. t. 211 Portugal 1771. C co Bot. rep.419 Sp. 4-12

$S p .4-12$.

C. G. H. 1774. S p.1

C. G. H. 1774. S p.l Com.hor.2.t.107

C. G. H. 1824. C co

Sp. 2.

Britain san.he. S co Eng. bot. 749

Britain dry he. S co Eng. bot. 743

Sp. 24-73.

S. Europe 1790, D co Lob. ic. 28

Britain $\ldots$ D co Eng. bot. 682

Italy 1596. D co Jac. vind. 1. t. 93

Europe $\quad . . .5$ co Dill.elt. t.25. f. 28

S. Europe 1732. D co Jac, aust.3. t.240

Portugal 1732. S co Dill.elt, t. 24 . f. 27

Portugal 1696. S co Lap. pyr. 1. t. 9

Spain 1784. S co Desf. atl.2. t.185

C. Europe 1680. S co

C. G. H. 1774. C co Com. hort.2.t.82 C. G. H. 1787. S p.1 . Europe 1800, S co Egypt 1815. C co Vent. cels. t. 32 S. Europe 1771. D 1.p S. Europe 1759. S s.l Barr. ic. 1239 Sicily 1713. S co Cav, ic. 2. t. 192 S. Europe 1739. C co

S. Europe 1683. S p.I Bot. mag. 329 Spain 1799. C p.1

Naples 1823. C p.l Bot. mag. 2450

Spain 1752. C p.l Cav. ic. 2.t. 152

Spain 1739. S p.l Magn.mons.t.17

S. France 1680. S s.1 Bot. mag. 317

Switzerl. 1570. C s.l Bot. mag. 335

1542. ANTHYLLIS. $W$. KidNeyVetch. Leguminose. Sp. 14-35.

10211 tetraphýlla $W$. four-leaved $O$ or 1 jl.au W S. Europe 1640. S co Bot. mag. 108

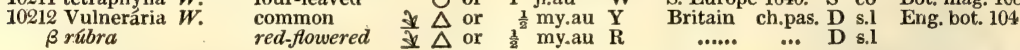
B rubra
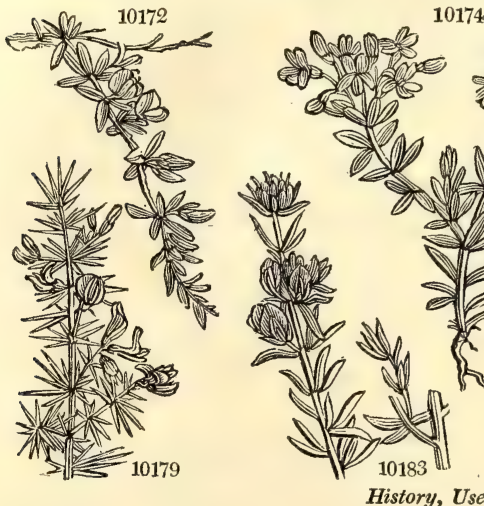

0174

s.1
10178

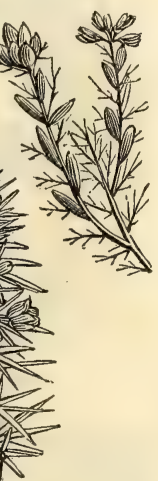

History, Use, Propagation, Culture,

has proved serviceable in dropsical cases. A salt prepared from the ashes is recommended in the same disorder.

G. triquetra is the handsomest hardy species : it is evergreen, and produces a vast profusion of bloom.

1539. Lebeckia. Named by Thunberg : possibly in honor of some forgotten botanist. Young cuttings root freely in sand under close cover.

1540. Ulex. A word of very obscure meaning. De Theis derives it from $a c$, a point in Celtic. U. europæus, Jonc-marin, Fr., is a beautiful evergreen shrub, which flowers freely, both when wild and cultivated, the greater part of the year. It abounds in some places, and there it is despised by the common people ; but the greatest botanists have admired its deep green shoots and leaves, brilliant yellow flowers, and tufted picturesque shape. About Petersburg, it forms one of their most valuable greenhouse plants, flowering in winter. Linnæus lamented that he could hardly preserve it alive in a greenhouse. Many parts of Germany winter. Linnæus lamented that he could hardly preserve it alive in a greenhouse. Many parts of Germany commons covered with its golden flowers. And Gerarde relates, that about Dantzic, Brunswick, and in Poland, there was not a branch of it growing, except some few plants and seeds that he sent, which were most curiously kept in their fairest gardens. As an agricultural plant the furze has been sown in several parts of the island as hedges; but excepting where it occupies a breadth of ten or twelve feet on a raised mound, it does not last long, getting naked below. Sown on a mound the sides may be out, and the prunings used as fuel or as green food, and the fence thus rendered close at bottom and durable. It is sown in fields, and 
10170 Leaves lanceolate silky, Branches striated round, Racemes 1-sided

10171 Leaves lanceolate acute, Pedunc, axill. 3 longer than leaves, Cor. smooth, Branches striated round 10172 Leaves lanceolate blunt silky beneath, Pedunc. axillary as long as leaf, Cor, silky, Branches angular 10173 Leaves lanceolate complicate, Pedunc. axill. very short, Cor. hairy, Stem warted striated procumbent 10174 . Leaves lanceolate smooth subciliate, Pedunc. axillary, Cor. smooth, Branches 3-cornered procumbent 10175 Leaves lanceolate silky beneath, Fl. terminal somewhat racemose, Cor. silky, Branches erect round 10176 Spines simple or compound, Flowering branches unarmed, Leaves oblong smooth, Racemes leafy term. 10177 Spines warted compound, Fl. branches unarmed, Lvs. lanc. hairy, Racemes term. naked, Keel pubesc. 10178 Spines compound pungent, Leaves lanceolate villous, Racemes terminal subcapitate

10179 Stem leafless, Spines crossing each other

10180 Leaflets ternate obovate, Racemes short, Bractes linear under the flower

10181 Leaves simple linear filiform smooth, Flowers umbelled 10182 Leaves ternate silky, Leaves linear, Flowers racemose

10183 Leaves ternate villous, Raceme long terminal

10181 Leaves simple binate or ternate sessile lanceolate acute rough

10185 Teeth of cal. conniving, Bractes ovate loose

10186 Teeth of cal. distant, Bractes minute appressed

$10187 \mathrm{Fl}$. solitary larger than leaflet, Lower leaves ternate lanceolate toothed at end, Branches spiny smooth 10188 Fl. twin axillary, Lower leaves ternate lanc. serrate, Branches spiny villous

10189 Fl. twin, Lower leaves ternate ellipt. serrate pubescent, Stem unarmed villous viscid

10190 Fl. solitary axill. Lower leaves ternate roundish serrate, Branches ascending spiny villous

10191 Fl. subsess. lateral, Leaves ternate obl. pubesc. Stipules lanc. toothletted, Cal, scarious longer than cor.

10192 Fl. sessile spiked, Bractes stipular ovate ventricose scarious imbricated

10193 Fl. subsess. lateral spiked, Leaves simple ovate blunt, Stipules dilated, Cal. larger than smooth corolla

10194 Fl. somewhat stalked axill. Lvs. simple obov. striated serrated, Stipules ovate toothed, Stem procumbent

10195 Pedunc. unarmed very short, Upper leaves simple, Stipules ovate lanc. entire

10196 Racemes straight, Leaves cuneiform, Pods nodding linear recurved

10197 Leaves ternate obovate, Pedunc. lateral 2-flowered

10198 Pedunc, unarmed 1-fl. Leaves ternate roundish crenate, Pods cernuous

10199 Pedunc. unarmed 1-fl. Leaves ternate cuneate, Stipules serrate, Stems prostrate

10200 Pedunc. 1-f. awned, Leaves sessile ternate, Stipules sheathing toothed

10201 Pedunc. 1-fl. awned, Leaves tern. cuneate toothed at end villous viscid, Cal. larger than corolla

10202 Pedunc. 1-f. awned length of leaves, Leaves simple oblong serrated viscid: lower ternate

10203 Pedunc. 2-fl. awned shorter than petiole, Leaves tern. oblong, Pods linear cernuous

10204 Pedunc. 1-fl. awned longer than leaf, Awns length of cor. Leaves ternate lanc. serrated at end

10225 Pedunc. 1-f. awned longer than leaf, Leaves ternate viscid obl. toothed at end

10206 Pedunc. awned about 1-fl. Leaves all ternate channelled recurved wholly serrated

10207 Shrubby, Leaves tern. linear fleshy 3-toothed, Pedunc. 2-flowered

10298 Shrubby, Leaves tern. roundish wavy toothed viscid, Pedunc. 1-flower unarmed

10209 Shrubby, Leaves sessile ternate lanceolate serrated, Stipules shcathing, Pedunc. 3-flowered

10210 Shrubby, Leaves tern. ovate toothed, Cal. with 3 bractes, Pedunc. 3-flowered

10211 Herbaceous, Leaves quaternate-pinnate, Flowers lateral

10212 Herbaccous, Leaves pinnated unequal, Head double
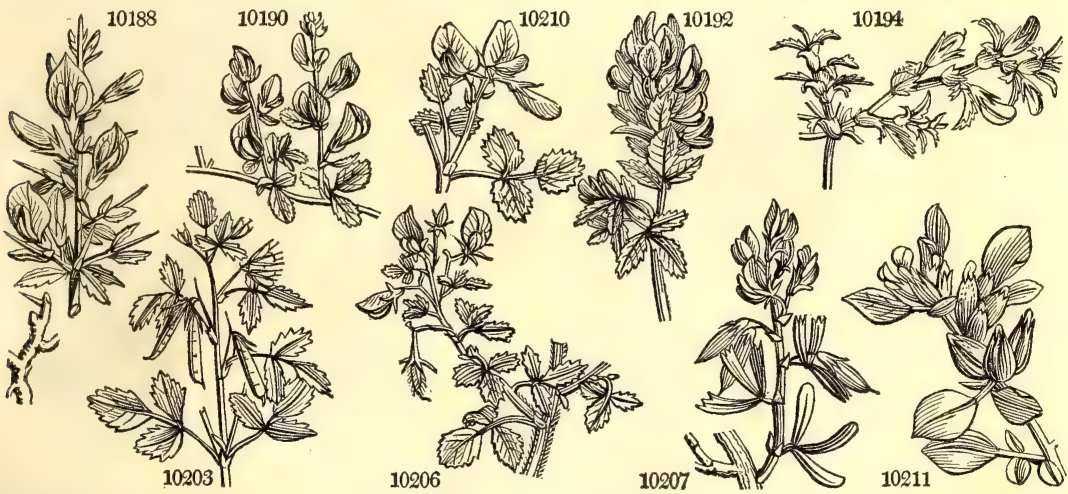

and Miscellaneous Particulars.

allowed to grow three or four years, and then it is cut down for fuel or for heating ovens : but the most profitable application of furze, whether sown or grown wild, is that of using it as green food for cattle. For this purpose, the shoots should not be more than two years old, and they require to be passed between rollers to bruise the ligneous parts and the thorns. It has been tried in this way by a number of agriculturists, and found a highly nutritive food for horses, oxen, and kine. Though a hardy plant and enduring the sea breeze, yet it is frequently killed by severe winters. It is never found on wet-bottomed clays, but generally on dry rocky or stony soils. There is a very luxuriant variety called the Irish whin, and one with double flowers found a few years ago in Devonshire, and now in propagation by cuttings in the nurseries.

U. nanus greatly resembles the common species, but is smaller in all its parts. It flowers from August to January, which renders it valuable in shrubberies as a successor to the other.

1541. Ononis. From ovos, an ass, because asses only feed upon so prickly a plant. O. spinosa, Arrète boeuf, Fr., Rest harrow, Eng,, was formerly very troublesome in corn fields, on account of its long ligneous roots obstructing the progress of the plough, and its thorny branches the harrow: but in all properiy cultivated lands the plant has disappeared. It is frequent in aboriginal pastures on dry soils, and is eaten by cows, sheep, and goats, but not freely by horses. All the species are of easy culture, and the greenbouse kinds are readily increased by young cuttings under a bell-glass in sand.

1542. Anthyllis. From $\alpha y, 95$, a flower, and bov $\lambda_{05}$, a beard. So called from the silky appearance of its heads of flowers; whence also one species is called Barba Jovis. A. Vulneraria is recommended as a herbage R $r$ 3: 
10213 montána $W$. 10214 serícea $W$. 10215 cornicína $W$. 10216 lotoídes $W$. 10217 Gerárdi $W$. 10218 Bárba-jóvis $W$ 10219 crética $W$.

10220 heterophýlla $W$. 10221 cytisoídes $W$.

10222 Hermánniæ $W$. 10929 Hraracanthil 10224 erinácea $W$. 1543. A'RACHIS. $W$ 10225 hypogæ'a $W$.

1544. LUPI'NUS. $W$. 10226 perénnis $P h$. 10227 nootkaténsis $P h$. 10228 álbus $W$. 10229 Thérmis $W$. 10230 várius $W$. 10231 hirsútus $W$ 10232 microcárpus $B . M$. 10233 mexicánus Lag.

10234 pilósus $W$

10235 angustifúlius $W$. 10236 linifólius $\boldsymbol{W}$. 10237 I ćteus $W$. 10238 villósus $W$ 10239 arbóreus $\dot{H} . K$

1545. AMOR'PHA. $W$. 10240 fruticósa $W$ $\beta$ emarginata 10241 microphýlla $P h$. 10242 pubéscens $P h$. 10243 canéscens $P h$. 10244 nána Nutt. 10245 cróceo-lanáta Wats. yellow_haired

1546. A'BRUS. $W$. WILD-LIquorice 10246 precatórius $W$.

1547. PHASE'O 10217 vulgáris $W$ 10248 multiflórus $W$. 10259 lunátus $W$. 1 250 inamœ'nus $W$. 10251 farinósus $W$. 10252 vexillátus $W$. 10253 hélvolus $W$.

10253 helvolus

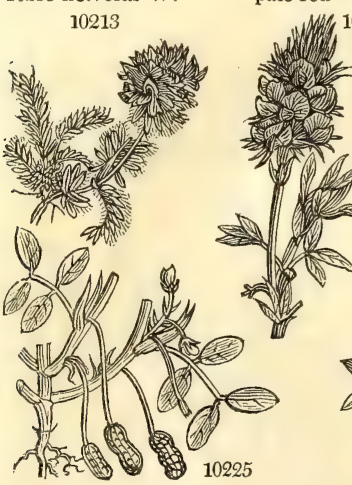

LUPine. white small-fruited Mexican

rose yellow vilious mountain $\quad \&$ or $\quad \frac{1}{4}$ jn.jl $\quad \mathrm{Pu} \quad$ S. Furope 1759. D s.l Bot. cab. 578 wing-leaved لـ or $\frac{1}{2}$ jl.au W Barbary 1786. C p.1 Desf.ac.par.1.t.3 horny $O$ or 1 jl.au $W$ Spain 1759. S p.1 Cav.ic.1.t.39. f.2 Lotus-like $\quad 0$ or ${ }_{1}$ jn.jl $Y$ Spain 1739. S co Cav.ic. 1. t. 40 Gerard's $O$ or $\frac{1}{2}^{\frac{1}{2}}$ jn.au W Proverce 1806. S co Ger. prov. t. 18 Jupiter's Beard L or 3 mr.my Pa.Y S. Europe 1640. C p.l Bot. mag. 1927 Cretan or $1 \frac{1}{2} \mathrm{jn} . \mathrm{jl}$ Pk Candia 1737. C p.l Bot. mag. 1092 various-leaved $\square$ or $1 \mathrm{jn} . \mathrm{jl} \quad \mathrm{Pk} \quad \mathrm{S}$. Europe 1768. C $\mathrm{C}$.1 downy-leaved $\square$ or 2 ap.jn W Spain 1731. C p.1 Barr. ic. 1182 $1 \frac{1}{2}$ ap.jl $\mathbf{Y}$ Barbary prickly or 1 ap.my $\mathrm{Pu}$ Spain 1759. C s.p Bot. mag. 676

Earth-Nut.
American

smooth-perenn. $7 \mathrm{t}$ or 2 my.jl B N. Amer. 1658. D p.l Bot. mag. 202 hairy-perennial $\$ \Delta$ or 6 jn.au Pu NootkaSo.1794. D p.l Bot. mag. 1311 or 3 jl.au great-blue or 2 jl.au O or 2 jl.au $1 \frac{1}{2}$ ap f Or 3 jl.au 2 jl.au Flax-leaved $\quad 0$ or 2 jl.au

W Levant 1596, S co W Egypt 1802. S co B.w S. Europe 1596. S co B S. Europe 1629. S co B Chili 1821. S co B Mexico 1819. S co F S. Europe 1710. S co B Spain 1686. S co B $\quad$-..... 1799. S co Y Sicily 1596. S co Pk Carolina 1787. R s.

Bot. mag. 2413 Bot. reg. 457

Knor.del.2.t.L.7 Roth. abh.14.t.5 Bot. mag. 140

Bot. mag. 682

\section{Leguminosa. Sp. 6.}

shrubby or 6 jn.jl Pu Carolina 1724. S s.p Bot. reg.427 emarginate-lvd. 歰 or 6 jn.jl $\mathrm{Pu}$ Carolina 1724. C s.p dwarf $\quad$ ft 2 jl.au Pu Missouri 1811. C $\quad$ s.p pubescent J or 3 jn.jl B Carolina 1803. C s.p canescent $\quad$ or 3 jl.au B Missouri 1812. C s.p

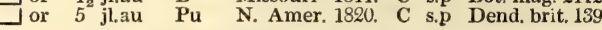
Leguminosa. Sp. 1

Jamaica g_ $\square$ or $12 \mathrm{mr}$ my Leguminosa. Sp. 20-55

common \$ 0 cul 1 jn.s W India 1597. S co Lob. ic. 2. p. 59

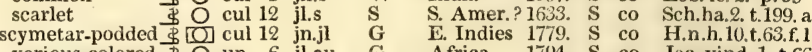
various-colored $\$ O$ un 6 jl.au $G$ Africa 1794. $S$ co Jac. vind. 1.t.66 mealy cor

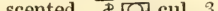
Pk F. Indies 1759. C co N.ac.p.1730. t.49 G W. Indies 1732 S co Jac vind 2.t.102 Pa.R Carolina 1732. S co Dil.el.t.233.f. 300 jl.au 
10213 Herbaceous, Leaves pinnated equal, Head terminal 1-sided, Flowers oblique 10214 Herbaceous, Leaves pinnated equal silky, Spike peduncled ovate

10215 Herbaceous, Leaves pinnated unequal, Head solitary stalked, Pods hooked blunt shorter than calyx 10216 Herbaceous, Cauline leaves ternate : radical pinnate unequal trifid or simple

10217 Herbaceous, Leaves pinnated unequal, Pedunc. lateral longer than leaf, Heads leafless

10218 Shrubby, Leaves pinnated equal silky, Bractes as long as globose many-flowered head

10219 Shrubby, Leaves pinnated equal and ternate villous, Flowers spiked

10220 Shrubby, Leaves pinnated: floral ternate

10221 Shrubby, Leaves ternate unequal, Calyxes woolly lateral

10222 Shrubby, Leaves ternate linear-cuneate somewhat stalked, Calyxes campanulate, Branches spiny

10223 Shrubby, Petioles spiny, Leaves pinnated, Flowers axillary subsessile, Cal. inflated

10224 Shrubby spiny, Leaves simple

10225 Leaves in fours cuneate rounded, Stipules undivided, Stem nearly smooth

10226 Cal. altern. without appendage : upper lip emarginate ; lower entire

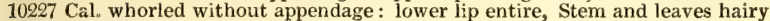

10228 Cal. altern. without appendage : upper lip entire; lower 3-toothed

$10229 \mathrm{Cal}$. altern. with an appendage : upper lip entire; lower 3-toothed

$10230 \mathrm{Cal}$. half-whorled with an appendage: upper lip bifid; lower about 3-toothed

10231 Cal. altern. with an appendage : upper lip 2-parted; lower 3-toothed

10232 Leaves digitate, Cal, whorled without append. Upper lip emarg. ; lower bifid, Pods 2-seeded

$10233 \mathrm{Cal}$. altern. with an appendage : upper lip half-bifid ; lower obscurely 3-toothed

10234 Cal. whorled with an appendage : upper iip 2-parted; lower entire

$10235 \mathrm{Cal}$, altern. with an appendage: upper lip 2-fid; lower entire, Leaflets linear-lanceolate flat

10236 Cal. altern. with an appendage : upper lip 2-fid; lower subtrifid, Leaflets linear channelled

$10237 \mathrm{Cal}$. whorled with an appendage : upper lip 2-parted; lower 3-toothed

10238 Cal. half-whorled with an appendage : upper lip 2-fid; lower undivided, Leaves simple obl, villous

10239 Shrubby, Cal, whorled without appendage stalked : lips acute entire

10240 Teeth of calyx 4 blunt, one acuminate

$\beta$ Leaflets emarginate, Caiyxes hoary

10241 Smoothish, Leaves on short stalks blunt at each end, Spikes solitary short, Pods 1-seeded

10242 Leaves on short stalks without a point obtuse smooth, Spikes long panicled downy

10243 Hoary, Leafiets subsessile ovate-elliptical acute mucronate, Spikes panicled hoary

10244 Said to be the same as A. microphylla

10245 Ferruginous, Spikes simple clustered, Leaflets ovate-lanceolate downy mucronate

\section{The only species}

10247 Raceme solitary shorter than leaves, Pedunc. 2, Bractes less than cal, spreading, Pods pendulous $10 \% 48$ Raceme solitary length of leaves, Pedunc. 2, Bractes less than cal. appressed, Pods pendulous 10249 Pods scymetar-shaped somewhat lunate smooth

10250 Vexillum of flowers revolute, Calyxes whole colored

10251 Peduncles subcapitate, Seeds 4-cornered cylindrical powdery

10252 Peduncles thicker than petiole capitate, Wings subfalcate deformed, Pods linear straight

10253 Flowers capitate, Cal, bracteate, Vexill. short, Wings expanded very large, Leatlets deltoid oblong

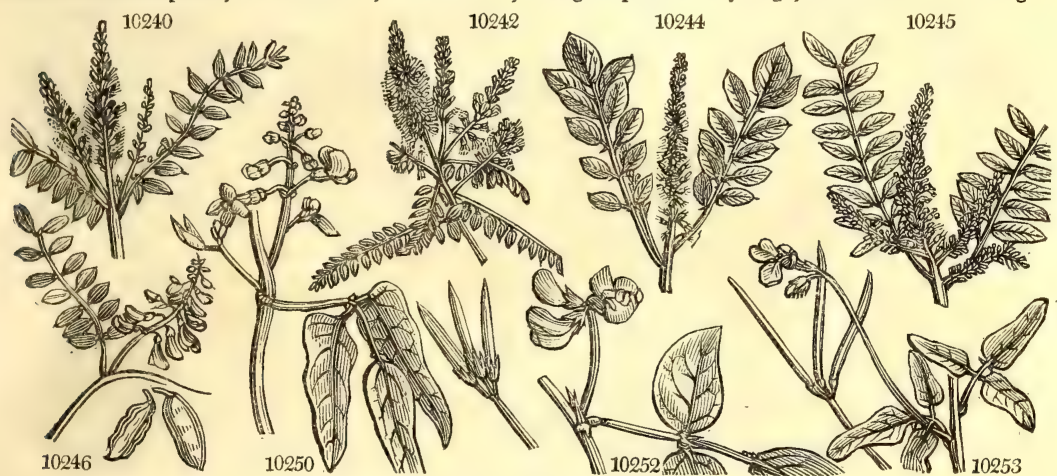

and Miscelianeous Particulars.

of the soil: but this is a very doubtful explanation. The species are border flowers, in much esteem for their velvet-like leaves and fine large flowers. They are vigorous growing plants, and most of them would afford the agriculturist a considerable bulk of herbage.

L. albus is supposed to be the species that was cultivated for this purpose by the Romarıs ; though L. luteus is what is at present grown in the fields in the south of Italy as human food. In the south of France, it is grown in poor dry extensive plains, as a meliorating crop to be ploughed in where no manure is to be had, and the ground is too sterile for clover or other better plants. (Villars.) The perennial and ligneous species may be increased by pieces of the root, but they all seed freely.

1545. Amorpha. From $\alpha$, privative, and $\mu \circ \oint \phi$, form, in allusion to the deformity of the corolla, which has neither alæ or carina. A. fruticosa was once used in Carolina as an indigo plant, but is now negiected. All the species are of easy cultivation, and increase by seeds or cuttings in sand.

1546. Alrus. From aßeos, elegant. The roots are used in the West indies similarly to those of our liquorice, and the seeds are strung and worn as beads for ormaments, and also as rosaries, whence the specific name precatorius. They are frequently thrown, with other West Indian seeds, on the north-west coast of Scotland. Linnzus affirms, that they are very deleterious; but they are eaten in Egypt, though the hardest and most indigestible of the pulse tribe. In our stoves the plant requires a good deal of room and heat in order to flower freely. It is generally raised from seed, but cuttings will root in sand plunged in heat.

1547. Phascolus. From phaselus, a little boat, which the pods may easily be supposed to resemble. $P$ vulgaris and multiflorus, Haricot, Fr., Schminkbohne, Ger., Faginoio, Ital., are well known culinary legumes, The dwarf kidney bean is earlier than the other, and better adapted for forcing; but much the largest crop R $r 4$ 
10254 semieréctus $W$. 10255 alátus $W$.

10256 Caracálla $W$.

10257 aconitifólius $W$.

10258 trílobus $W$.

10259 stipuláris $W$.

10260 nánus $W$.

10261 radiátus $W$

$10262 \operatorname{Max} W$.

10263 Múngo $W$.

10264 diversifólius $P . S$. trálobus $\mathbf{P h}$

. S. various-leave

W. Lathyrus-like

1548. TER AM'NUS. Browne. Teramus

10267 volábilis Sw.

1549. CARPOPO'GON. Rox. CarPopogon.

10268 gigantéus Rox. gigantic

10269 imbricátus Rox. $\quad$ imbricated

1550. DÓLichos. $W$. Dolichos.

10270 Láblab $W$. black-seeded

10271 sinénsis $W$.

10272 lutéolus $P h$.

10273 unguiculátus $W$.

10274 tranquebáricus $W$.
10275 gladiátus $W$.

10276 tetragonólobus $W$.

10277 sesquipedális $W$

10278 hirsátus $W$

10279 pilósus $W$.

10280 minimus $W$.

10281 tetraspérmus $W$.

10282 scarabæoídes $W$.

10283 reticulátus $W$.

30284 bulbósus $W$.

10285 purpáreus $W$

10286 lignósus $W$

10287 lúteus $W$.

10288 ensifórmis $W$.

10289 Sója $W$.

10290 Cat iang $W$.

10291 biflórus $W$.

10292 róseus $W$.
Chinese

yellow

Bird's-foot

Tranquebar

square-podded

long-podded

hirsute

hairy-podded

small

four-seeded

silver-leaved

net-leaved

bulbous

purple

yellow-flowere

scymetar-podded

Soy

small-fruited

two-flowered

Rose-colored
\$밈 2 jl un $3 \mathrm{jl}$

D $\mathrm{cul} 1 \frac{1}{2}$ au.s

$10 \mathrm{cu} 2 \mathrm{jn}$.au

[0] un 2 jl.au

$O$ un 2 jl.au

으 1 jn.s

$\bigcirc$ un 1 jn.jl

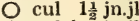

O cul $1 \frac{2}{2}$ jn.jl

$O$ un $1 \frac{1}{2} \mathrm{jn} . \mathrm{j}$

[0] or 2 jl.au

Q] un $1 \frac{1}{2} \mathrm{jl}$.au
R W. Indies 1732. S co Bot. reg. 743

Pu Carolina 1732. C s.l Dil.el.t.235.f.303

G India 1690. S r.m Bot. rep. 341

Pk E. Indies 1731. S s.1 Jac. obs. 3. t. 59

G E. Indies 1777. S s.1 Bur.ind, t.50. f.1

Y.Br Peru 1805. S s.l

Pu China 1732.

1758. S s. Dil.el.t.235.f.304

Y India 1790, S s.1

Pu N. Amer. 1806. S s.1

Sc Jamaica 1786. S $\quad$ s.l Slo. ja.1.t.116.f.1 Y Brazil 1824. S co

Jamaica 1824. C r.m

Leguminose. Sp. 2.

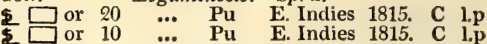
Leguminosa. Sp. 23-76.

B $Q]$ un 8 jn.jl Pu Egypt 1694. S s.l Bot. mag. 896 B $\mathrm{O}$ pr 6 jl.au $\mathrm{Pu}$ India 1776. $\mathrm{S}$ s.l Bot. mag. 2232 $\vec{B}$ O un 4 jl.au $Y$ America 1805. $S$ s.1 Jac.hort. t. 90 $B$ U] un 3 jn.jl $\mathbf{Y} \quad$ W. Indies 1780. S s.1 Jac. vind. 1. t. 23 $B \bigcirc$ un 3 jn.jl $Y$ E. Indies 1801. S s.l Jac. vind. 3. t. 70 B 010 pr 6 au Pk E. Indies 1790. S s.l Jac. ic.3.t.560 O un 4 s.n $\mathbf{Y}$ E. Indies 1816. S s.l B 0 un 6 au Pa.pk W. Indies 1781. S s.l tor 10 jin 10 un 3 au

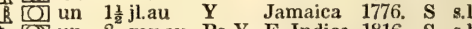
Q2) un 3 my.au Pa.Y E. Indies 1816. S s.1

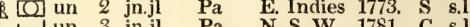
un 3 jn.jl Pa N.S. W. 1781. C s. $\overleftarrow{\triangle}$ or 12 au.s or 12 jl.au Pu W. Indies 1781 . S s.1 Pu E. Indies 1790 S 8 s.1

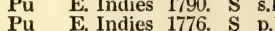

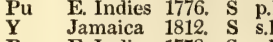
Pu E. Indies 1778. S 8.1

Jac. ic. 1. t. 145

$\mathrm{Pa}$ E. Indies 1793, S s.1 Rhee.mal.8. t.41

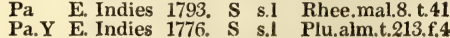
Pk Jamaica 1812. S 5 s.1
Jac. vind 1, t. 67

Jac. obs. 1. t. 22

Plu. alm.t.53. f.3

Rum.am.5. t.132

Bot. reg. 830

1551. STIZolo'BIUM. P. S. Cow-AGE, or Cow-rtch. Leguminosa. Sp. 3-8.

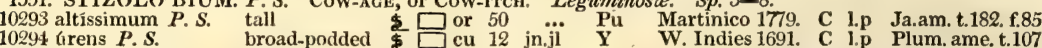

10295 prúriens $P$. S.

broad-podded common

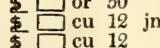

W. Indies 1691. C 1.p Plum. ame t.107

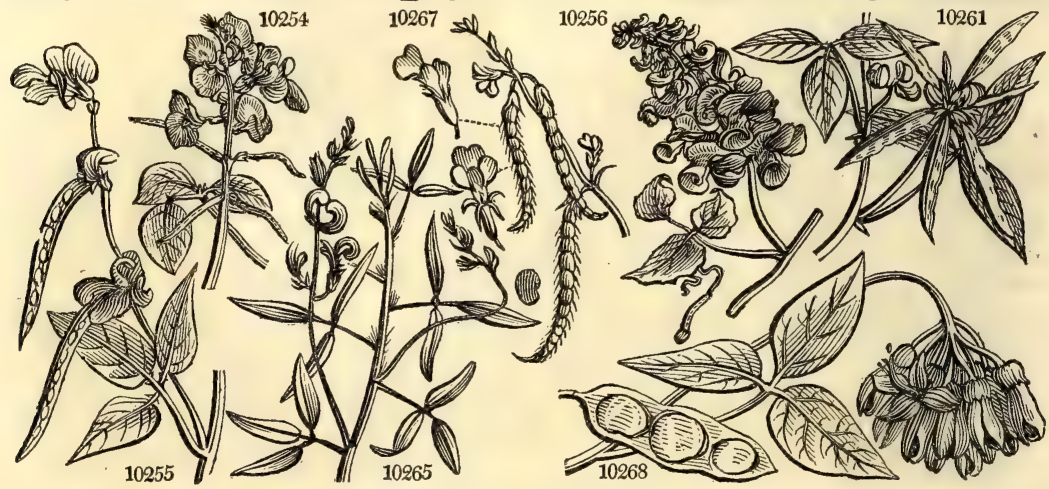

History, Use, Propagation, Culture,

is produced by the twining species. Neither sorts can be safely planted in the open air before the end of A pril, or first week of May, and the leaves are blackened by the first frosts of autumn. But in a stove or pit, green pods of the dwarf kinds may be gathered all the winter, and with this advantage over forced produc tions of the fruit kind required to be ripened, that the pods are as good from plants in the stove in midwinter, as from those in the open garden in midsummer. The garden culture of both species is so easy and universally known, that we shall not occupy ourselves with details. Though in this country the green pods only are used, on the continent the ripened seeds are as much the object of culture. In Holland, the twiner is grown in every cottage garden for both purposes ; and in France and Switzerland, it is grown chiefly for the ripened seeds : in the latter countries it grows on very poor dry soil. On the first blackening of the leaves with frost, the plants are pulled up, dried like tobacco leaves under the dripping eaves of the houses; and in winter threshed out for the seeds, to be boiled and eaten with cream or butter, stewed in haricots, or put in soups. According to the analysis of Einhoff, 3840 parts of kidney bean afforded 1805 parts of matter analogous to starch, 857 of vegeto-animal matter, and 799 parts of mucillage : from which is to be inferred, that it is the most nourishing of all the legumes.

The perennial stove species thrive best in a light rich soil, and may be propagated readily from cuttings or from seed P caracalla, or Snail-flower, is a very curious species, and will grow and flower freely, if kept clear from the red spiders. This species was so named by the Portuguese, who first brought it from South America, in consequence of its hooded flower. Caracalla (from the Celtic words car, a head, and cal, a eovering) was the name of a hooded dress much worn by the Gauls, and gave his nickname to the Emperor Marcus Aurelius Antoninus, who was accustomed to wear the dress. 
10254 Flowers spiked, Cal, without bractes, Wings expanded larger, Leaflets ovate 10255 Flowers loosely spiked, Wings the length of vexillum

10256 Vexillum and keel spirally twisted together

10257 Stem hairy, Lateral leaflets 3-lobed : terminal 5-parted, Segm. lanceol. Peduncles 3-fl. shorter than petiole 10258 Stem smooth, Lateral leafl. 2-lobed ; terminal 3-lobed: segments ovate, Pedunc. 3-f. longer than petiole 10259 Stem smooth, Leafl. blunt : lateral sinuose; terminal hastate 3-lobed, Peduncles longer than leaf spiked 10260 Stem smooth, Bractes larger than calyx, Pods pendulous compressed rugose

10261 Stem round, Flowers capitate, Pods cylindrical horizontal

10262 Stem angular hispid, Pods pendulous hairy

10263 Stem flexuose round hairy, Pods capitate hairy

10264 Downy, Lower leaves rhomboid oval : upper 3-lobed, Heads on long stalks, Pods round subulate

10265 Leaflets oblong acuminate, Peduncles elongated, Pods round subulate 10266 Leaflets about 3-lobed, Lobes acuminate, Racemes axillary

\section{Leaflets ovate-lanceolate downy}

\section{Leaflets ternate smooth, Flowers in heads, Calyxes hairy campanulate} 10269 Flowers imbricated

10270 Pods ovate acinaciform, Seeds ovate with a hilum curved towards one end

10271 Pods pendulous cylindrical torulose, Peduncles erect many-flowered

10272 Pods capitate many cylindrical, Seeds rounded

10273 Pods capitate subcylindrical with a recurved concave end

10274 Pods capitate few cylindrical with a mucronate straight point

10275 Pods racemose ensiform with 3 keels at back straight at point, Seeds with an arillus

10276 Pods membranous quadrangular

10277 Pods subcylindrical smooth very long

10278 Pods racemose compressed hairy, Outer leaflets 2-lobed

10279 Pods subracemose linear hairy, Leaflets ovate-lanceolate downy

10280 Pods racemose compressed 4-seeded, Leaflets rhomboid

10281 Pods racemose acinaciform 4-seeded, Leaflets rhomboid smooth

10282 Leaves ovate downy, Flowers solitary, Seeds 2-horned

10283 Leaves ovate acute rugose netted villous, Racemes few-flowered

10284 Leaves smooth toothed with many angles

10285 Stem smooth, Petioles downy, Wings of corolla spreading

10286 Peduncles capitate, Pods straight linear

10287 Flowers somewhat spiked, Pods subcylindrical smooth, Leaves roundish rhomboid blunt entire smooth

10288 Pods acinaciform with 3 keels

10289 Racemes axillary erect, Pods pendulous hispid about 2-seeded

10290 Pods twin linear nearly erect

10291 Stem smooth, Peduncles 2-flowered, Outer leaflets somewhat angular

10292 Stem creeping, Leaflets roundish shining, Fl. racemose, Pods with 3 keels at back

10293 Pods racemose hairy equal, Seeds surrounded by the nilum, Leaves smooth on each side 10294 Pods racemose with transverse lamellæ hairy, Seeds surrounded by the hilum

10295 Pods racemose : valves keeled hairy, Peduncles in threes

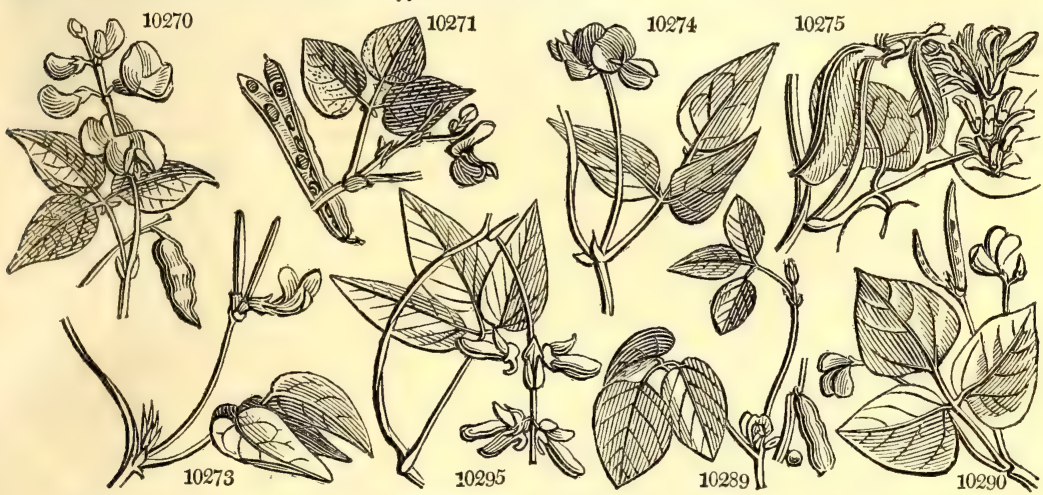

and Miscellaneous Particulars.

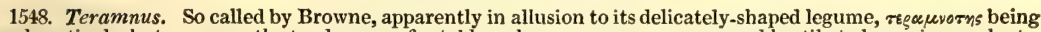
used particularly to express the tenderness of eatable pulse; $\alpha \tau \varepsilon \rho \alpha u$ os was a weed hostile to leguminous plants.

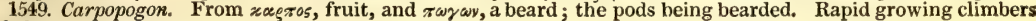
of the easiest culture.

1550. Dolichos. A name under which Dioscorides describes a plant supposed to have been the kidney bean of the moderns. The species are climbers, some of them to the height of the highest trees. The pods of most of them are eatable, but far inferior to the kidney bean. Some of them have tuberous roots which may be eaten. The seeds of D. Soja (Sooja, Jap.), which are usually called Miso in Japan, are put into soups, and are the most common dish there, insomuch that the Japonese frequently eat them three times a day. The Soja of the Japonese, which is preferred to the Kitjap of the Chinese, is prepared from these seeds, and is used in almost all their dishes instead of common salt. The Chinese also have a favorite dish made of these seeds, called Teu $h u$ or Tau $h u$, which looks like curd, and though insipid in itself, yet with proper seasoning is agreeable and wholesome. (Thunb. and Loureiro.)

The perennial kinds are easily increased by cuttings, and all the species seed freely. D. purpureus and lignosus have the handsomest flowers, but none of them can be considered of much beauty.

1551. Stizolobium. From $5 \zeta^{\zeta} \zeta \omega$, to prick, and $\lambda \circ \beta_{05}$, a pod. S. urens and pruriens produce on the outside of their pods the irritating substance used in medicine as a vermifuge, under the name of Cowhage. The species are twining shrubs of the West Indies, with long bunches of yellow scentless flowers. The seeds of S. urens are often seen in cabinets of curiosities: many qualities are attributed to them by the superstitious Crcoles. The French settlers call them Yeux bourrique, asses' eyes. S. pruriens is considered a powerful diuretic. 
1552. GLY'CINE. $L$. 10296 sarmentósa $W$ 10297 monóica $W$. 10298 angustifólia $W$. 10399 débilis $W$.

10300 comósa $W$.

10301 tomentósa $P h$. 10302 renifórmis $P h$

10303 suavéolens $W$. 10304 reticuláta $W$. 10305 caribæ'a $W$.

10306 bituminósa $W$

10307 parviflóra $P . S$.

10308 sagittáta W. en.

10309 rhombifólia $W$.

10310 vincentína Ker.

10311 phaseoloídes Swz.

10312 sinénsis B. M.

$10313 \mathrm{~A}^{\prime}$ pios $W$.

10314 frutéscens $P h$.

1553. KENNE'DIA. Ve

GLYcine.

$\mathrm{B} O$ un 2 jn.au $\mathrm{Pa}$

hairy

turted

\& un 6 jn.au

Q12) un $1 \frac{1}{2} \mathrm{jn} . j \mathrm{l}$

un $1 \frac{1}{2} \mathrm{jl.s}$

downy $\quad \beta \Delta$ un $1 \frac{1}{2}$ jn.s

Kidney-leaved
sweet-scented

net-leaved \$ $\square$ or 6 jl.s

trailing

clammy

\& $\square$ pr 2 s.o

$\$$ pr 4 ap.s

small-flowered \$ (0) un 3 jl

arrow-leaved $\square$ un 4 my.au $\mathbf{Y}$

rhomb-leaved $\$$ un 6 my.au ..

St. Vincent's

Kidn.-bean-like

Chinese or $\underset{15}{2} \mathrm{jn} . \mathrm{jl} \quad \mathrm{Br}$

tuberous-rooted $\Delta \mathrm{ft} 6$ aus

shrubby or $10 \mathrm{jn.s} \quad \mathrm{Pu}$

Leguminosa.

inda $V$

10317 prostráta $\dot{H}$. $K$

10318 Comptoniána $B$.

10319 monophýlla $V$

10320 ováta $B$. $M$.

1554. CYLIS'TA. $W$ 10321 villósa $H$. $K$. 10322 albifióra B. M. 10323 scariósa $W$.

1555. GALAC'TIA. Mi. dingy-flowered many-flowered single-flowerea ${ }^{\circ}$.

L or $10 \mathrm{mr}$.au $\mathrm{Br}$ or $4 \mathrm{mr}$.jn $\mathrm{S}$ Compton's \$山 or $12 \mathrm{mr}$.jn B

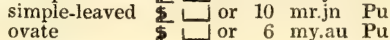

Crulsta Cape
white-flowered $\$$ or 6
or 6 ap.my Y Coromandel $\square$ or 4 ... Y

Leguminose. $\underset{\text { Jamaica }}{\text { Sp. }}$.

$\$ \square$ pr 6 jl.au R Jamaica 1794. C 1.p Bot. reg. 269 Leguminosa. Sp. 8-16.

10324 péndula Pers. pendulous 10305 Terńten $W$. Wing-leavied

10326 heterophýlla Lam.

10327 brasilianylla 10328 virginiána $W$. 10329 mariána $W$.

10330 arboréscens $H . K$ 10331 Plumiéri Pers.

10332 mexicána Link.

1557. O'ROBUS, $W$. 10333 lathyroídes $W$

10334 lateus $W$.

10335 digitátus Bieb.

10336 vérnus $W$.

10337 tuberósus $W$.

10338 palléscens Bieb.

10339 canéscens $L$

10340 álbus $W$

10341 várius Schneev.

10342 lácteus Bieb.

10343 hirsútus $L$
\$ or 4 jl.au B

1 jl.au

4 jl.au Pu

6 jl.au

au

au.s

s.n

s.in
E. Indies 1739. C s.p Bot. mag. 1542

E. Indies 1812. S s.p Bot. mag. 2111

$\mathrm{Pu}$ Brazil 1759. S s.p Breyn. cent. t. 1 America 1732. C s.p Par. lond. 51

W. R W. Indies ... $\quad$ C s.p Bot. reg. 268 BitTer-Vetch. Leguminose. Sp. 16-42.

upright $\Delta$ or $1 \frac{1}{2} \mathrm{jn} \quad$ L.B Siberia 1758. $R$ p.l Am.ruth. t.7.f.2 yellow $\Delta$ or $1 \frac{1}{2}$ jn.jl L.Y Siberia 1759. $R$ h.l Bot. cab. 783

digitate $\Delta$ or $1 \frac{1}{2} \mathrm{my} \quad \mathrm{Pu}$ Tauria 182S. $\mathrm{R}$ co Bux.cent.2. 38 spring $\Delta$ or 1 mr.ap Pu Europe 1629. R s.l Bot.mag.521 tuberous J $\triangle$ cul 1 my.jn $P u$ Britain heaths. $R$ p.1 Eng. bot. 1153 pallid $\Delta$ or 1 my W Tauria 1823. $\mathbf{R}$ co hoary $\Delta$ or $1 \frac{1}{2}$ my.jn W.B France 1816. R co

white-flowered $\Delta$ or 1 my.jn W Austria 1794. R s.l Sweet fl.g. 22 particolored d $\Delta$ or $1 \frac{1}{2}$ my.jn Y.R Italy 1759. $\mathbf{R}$ p.1 Bot. mag. 675 particolored milk-white $\quad \stackrel{2}{\Delta}$ or $1 \frac{1}{2}$ my.jn
hairy

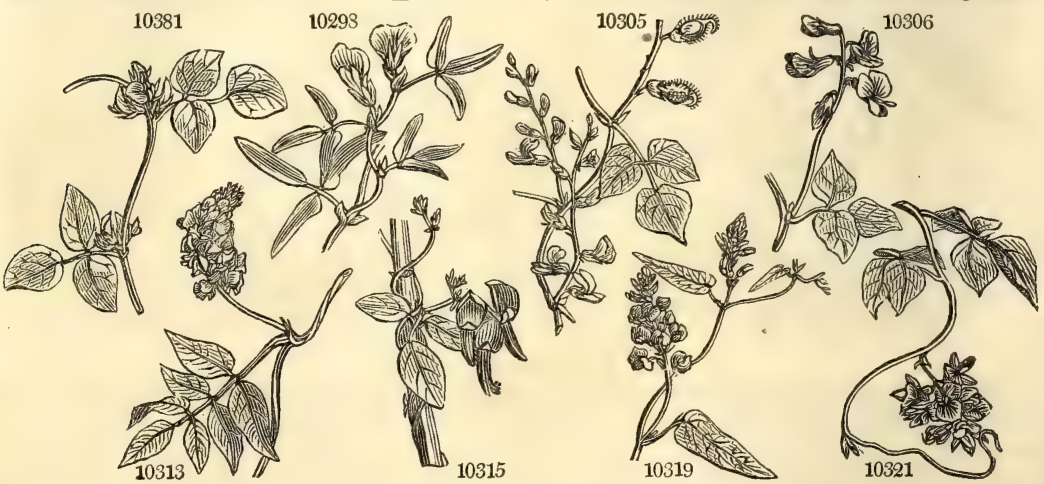

History, Use, Propagation, Culture,

1552. Glycine. From y $\lambda v \approx u \zeta$, sweet. G. monoica perfects its seeds under ground like Arachis hypogæa Trifolium subterraneum, and Lathyrus subterraneus. They are all of easy culture, like their preceding and following allies. G. frutescens, and especially G. sinensis, are most beautiful hardy climbing shrubs, with long Lendulous branches of blue flowers, like the Labum,

1553. Kennedia. Named after Mr. Kennedy, a nurseryman of celebrity in the vicinity of London. Handsome conservatory climbers of the easiest culture.

1554. Cylista. From $\approx \nu \lambda \iota \xi$, a calyx, that of the species so called being very large.

1555. Galactia. From $\gamma \alpha \lambda \alpha$, milk; the plant is milky in all its parts. A pretty fowering climber of easy culture in the soil indicated, and increased by cuttings in sand under a bell-glass.

1556. Clitoria. A name derived from an anatomical term, a resemblance to the subject of which has been fancist to islands, which induced Tournefort to adopt Ternatea as a generic appellation, and it was continued by Linnæus as a specific one. 
10296 Leaves ternate ovate smooth, Racemes filiform about 3-fl. Flowers apetalous, Pods oblong 2-seeded 10297 Leaves ternate ovate smooth, Stem hairy, Racemes pendulous, Fls. of stem with cor. of root apetalous 10298 Leaves ternate, Leaflets linear lanceolate silky, Fl. axillary solitary, Pods 2-seeded

10299 Leaves ternate, Leafl. oval hairy beneath, Pods subsolitary linear many-seeded, Style persistent straight 10300 Leaves ternate hairy, Racemes lateral

10301 Leaves ternate tomentose, Racemes axillary very short, Pods 2-seeded

10302 Downy, Leaves simple reniform rounded rugose netted, Racemes few-flowered

10303 Leaves ternate ovate acute hairy viscid, Peduncles jointed 1-2-fl. Pods oblong

10304 Leaves tern. ovate rhomboid pubesc. beneath netted tomentose, Racemes axillary, Pods subpubescent

10305 Leaves ternate ovate rhomboid beneath dotted with resin, Racemes longer than leaf

10306 Leaves ternate, Flowers racemose, Pods tumid villous

10307 Leaves ternate ovate somewhat hairy, Racemes axillary, Pods linear hooked at end

10308 Leaves simple sagittate, Petioles winged, Stem twining shrubby

10309 Leaves tern. roundish rhomboid smooth beneath dotted with resin, Racemes 1-sided longer than leaf

10310 Leaves pinnate, Leaflets 5 oblong apiculate, Flowers 3 axillary

10311 Leaves ternate villous beneath, Racemes terminal

10312 Leaves pinnated, Leaflets 11 ovate lanceolate silky, Raceme terminal nodding lax many-flowered

10313 Root tuberous, Lvs. pinn. Leafl. 5-7 ov. lanc. narrowed towards the end, Spikes dense shorter than leaves

10314 Leaves pinnated, Leaflets 9 ovate downy, Racemes dense terminal with bracteæ, Pods coriaceous

10315 Leaves ternate, Leaflets ovate, Pedunc. about 3-fl. Pods very hairy

10316 Leaves ternate, Leafiets obovate, Flowers capitate, Pods smoothish

10317 Leaves ternate, Leaflets obovate villous, Pedunc, 1-2-fl. Keel longer than obl. wings, Stem prostrate

10318 Leaves ternate, Leaflets ovate retuse netted, Racemes erect many-flowered

10319 Leaves simple smooth netted subcordate at base, Flowers racemose

10320 Leaves simple ovate, Racemos axillary few-flowered

10321 Cal, membranous, Upper segment bifid

10322 Down rusty, Cal. half 5-fid, Bractes ovate acuminate, Cor. larger than cal.

10323 Cal. scarious, Upper segment emarginate

10324 Leaves ternate, Raceme erect, Flowers pendulous

10325 Leaves quinate pinnate, Peduncles axilliary 1-flowered

10326 Leaves pinnate, Leaflets 5 round lanceolate or linear

10327 Leaves ternate, Calyxes solitary campanulate

10328 Leaves ternate, Calyxes twin campanulate

10329 Leaves ternate, Calyxies cylindrical

10330 Leaves ternate, Peduncles many-flowered, Ovary downy, Style villous

10331 Leaves ternate, Leaflets ovate-oblong acuminate, Cal. campanulate shorter than ovate bractes

10332 Leaves ternate, Leaflets mucronate glaucous beneath hairy, Cal. cylind. much larger than bractes

10333 Leaves conjugate subsessile, Stipules toothed

10334 Leaves pinnate in 4 or 5 pairs obl. glaucous beneath, Stipules half sagittate toothed at base

10335 Leaves of 2 pairs linear subulate approximating, Stip. half-sagittate subulate 1-toothed at base

10336 Leaves pinnate in 3 pairs ovate acuminate, Stipules half-sagittate entire, Stem simple

10337 Leaves pinnate in 3 or $\mathbf{4}$ pairs lanceolate, Stipules half-sagittate entire, Stem winged

10338 Leaves of 2 pairs linear-subulate downy, Stip. half-sagittate subulate nearly entire, Stem simple downy

10339 Stem branched, Leaves in 2 pairs linear, Stipules half sagittate subulate

10340 Leaves in 2 pairs ensiform stalked, Stipules simple, Stem simple

10341 Leaves in 4 pairs lin. lanc. Stipules half-sagittate entire, Stem winged branched upwards

10342 Leaves of 2 pairs lin-lanc. mucronate stalked nerved, Stipules half-sagittate toothed at base

10343 Leaves conjugate stalked, Stipules entire, Plant covered with long hairs

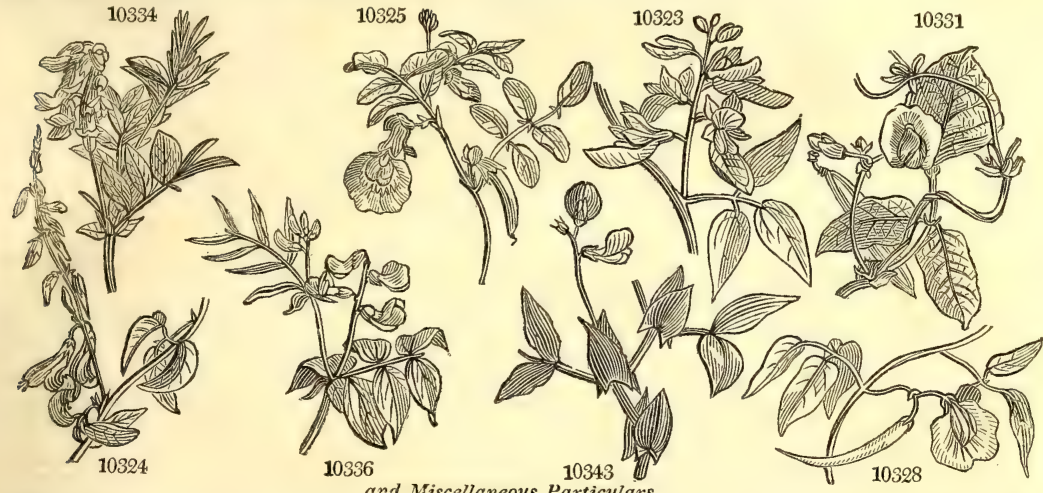

and Miscellaneous Particulars.

1557. Orobus. From oew, to excite, and $\beta 85$, an ox ; that is to say, a food nourishing to cattle Hand some plants, and free flowerers. O. luteus Haller considers as one of the handsomest of the papilionaceous tribe. O. tuberosus, according to Lightfoot, is in great esteem among the Highlanders of Scotland for the tubercles of the root; they dry and chew them in general to give a better relish to their liquor; they also affirm them to be good against most disorders of the thorax, and that by the use of them they are enabled to repel hunger and thirst for a long time. In Breadalbane and Ross-shire, they sometimes bruise and steep them in water, and make an agreeable fermented liquor with them. They have a sweet taste, something like the roots of liquorice, and when boiled are well flavored and nutritive, and in times of scarcity have served as a substitute for bread. (Lightfoot.)

Boiled well, a fork will pass through them, and dried slightly and roasted, they are served up in Holland and Flanders in the manner of chesnuts, which they resemble in flavor. Dickson (Hort. Trans. ii. 359.) recommends cultivating them in a bed or border of light rich soil, paved at the depth of twenty inches, to prevent their roots from running down. Plant the tubers six inches apart, and three inches below the surface; 
10344 angustifolius $W$. narrow-leaved $\neq \Delta$ or 1 my.jn W Siberia 1766. R s.l Gmel. sib. 4. t. 5 10345 niger $W$. $W$ black $\quad$ J $\Delta$ or 3 jn.jl Pu Europe 1596. R p.l Bot. mag. 2261 10346 pyrenáicus $W$. Pyrenean $\quad$ wood $\quad$ zor 2 my.jn Pu Spain 1699. R p.1 Pl.alm. t.210. f.2 10347 sylváticus $W_{i}$ wood $\frac{k}{B} \Delta$ or 2 my.jl $\mathbf{C r}$ Britain m.wo. $\mathbf{R}$ p.l Eng.bot. 518 10348 ochroleúcus $W . \& K$. sulphur-colored主 $\Delta$ or 2 my.jl Pa.Y Hungary 1816. R p.l Pl.rar.hu.2.t.118

1558. LA'THYRUS. $W$. LA'THYRUS. $\quad$ Leguminosa. Sp. $30-57$. 10349 Apháca $W$. 10350 Nissólia $W$. yell. Vetchling $B$ or Leguminose. Sp. $30-57$.

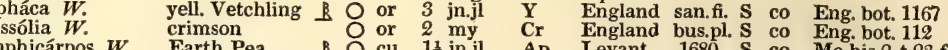
10351 amphicárpos $W$.

10353 sativus $W$.

10354 inconspícuus $W$

10355 setifólius $W$.

10356 coccíneus $P$. S .

10357 sphæ'ricus $W$.

10358 angulátus $W$.

10359 spúrius $W . e n$.

10360 monánthos $W$.

10361 articulátus $W$.

10362 odorátus $W$.

Earth Pea $\quad \&$ cu

flat-podded $\bar{B}$ O or

or 2 jn.jl $\quad \mathbf{p}$ S. Europe 1633, s co Geris.2. t.23.f.

ChicklingVetch $\bar{B} O$ ag $3 \mathrm{jn.jl}$ L.B S. Europe 1640. S co Bot. mag. 115

small-flowered $\frac{B}{O}$ un 1 jl.au Pu Levant 1739. S co Jac.vind.1.t.86?

scarlet $\frac{k}{B}$ or 1 jn.jl Sc S. Europe 1739. S co

round-seeded $\frac{k}{B}$ or 2 jn.jl Sc Italy 1800. S co

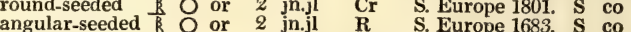

bastard $\hat{B}$ or 2 jn.jl $\mathrm{Pu}$

one-flowered $\hat{k}$ O or 2 my.jl Pk Russia 1731. S co

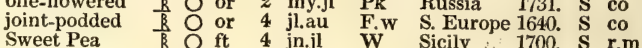

10363 grandiffórus $\boldsymbol{B}$. $\boldsymbol{M}$.

Bu.cen.3.t.42.f.2

10364 annuus $W$.

10366 Clymenum $W$.

10367 hirsútus $W$.

10368 magellánicus $W$.

10369 tuberósus $W$.

10370 túmidus $L$.

10371 rotundifólius $B i e b$.

(a)rennial

4 jn.jl

$\mathrm{Pu}$

Sicily 1700. S r.m

two-flowered $\bar{B}$ O or 4 jn.au $Y$ S. Europe 1621. S co

Tangier $\vec{B}$ O or 4 jn.au D.P Barbary 1680. S co

various-flower. $\bar{B}$ O or $4 \mathrm{jn} . \mathrm{jl} \mathrm{Pu}$ Levant 1713. S co

rough-podded $\vec{B} \bigcirc$ or $4 \mathrm{jl} \quad \mathrm{Pu}$ England bor.fi. $\mathrm{S}$ co

Ld.Anson's Pea $\mathrm{B}$ or $6 \mathrm{jn} . \mathrm{jl} \quad \mathrm{Y} \quad$ CapeHorn1744. S co

tuberous $\quad \vec{B} \Delta$ cul 2 jl.au

tumid $\quad \bar{O}$ or 1 jlau

10372 praténsis $W$.

round-leaved $\bar{B}$ O or

10372 praténsis $W$. Wo meadow $\frac{B}{B} \Delta$ or

10374 latifólius $W$. broad-lvd. Everlasting $\frac{B}{B} \Delta$ or

10375 heterophýllus $W$. various-leaved $\frac{B}{B} \Delta$ or

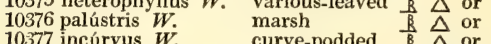

10377 incárvus $W_{\dot{ }} \quad$ curve-podded $\hat{k} \Delta$ or

11 $\quad R$ 1820. S co

Tauria 1822. S co

$\begin{array}{lllll}3 & \text { jn.au } & \mathbf{Y} & \text { Britain me.pa. R co Eng. bot. } 670 \\ \text { jl.s } & \text { Pu } & \text { Britain } & \text { moi.w. } \\ \text { co } & \text { Eng. bot. } 805\end{array}$

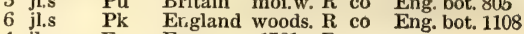

4 jl.s F Europe 1731. R co

4 jl.au B Britain moi.w. R co Eng. bot. 169

jl.au B Russia 1802. R co Bux. cent.4. t.46

10378 pisiformis $W$. Siberian $\quad B \Delta$ or $3 \mathrm{jn} . \mathrm{jl} \quad$ W. $\quad$ Siberia 1759. $R$ co Lin. fil. dec.t.20

1559. O'CHRUS. Bauh. Ochrus. Leguminose. Sp. 1

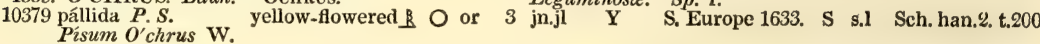

1560. Pí'SUM. $W . \quad$ Pea. $\quad$ B O cu 3 Leguminose. Sp. 3.

10380 satívum. $W . \quad$ common $\quad B O$ cu 3 jn.s W $\quad$ S. Europe ... $\quad$ S co Lam. ill. t. 633

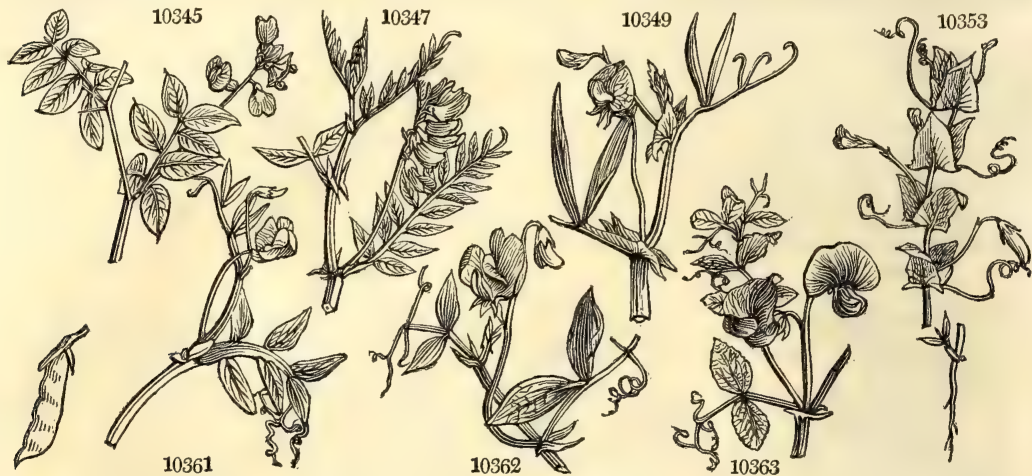

History, Use, Propagation, Culture,

the second year some will be fit to gather, and by taking only the largest, the bed will continue productive for several years, adding some fresh compost every year.

1558. Lathyrus. A name employed by Theophrastus to designate a leguminous plant. It is said by his commentator Bodæus a Stapel, to have been derived from $\lambda \alpha$, an augmentative particle, and $\theta$ oveos, any thing which is exciting; and to have been applied to this plant in consequence of certain aphrodisiacal qualities ascribed to it. I. sativus, Gesse, Fr., is frequently sown in Switzerland for soiling horses. In several parts of the continent, a white light pleasant bread is made from the flour of this pulse, but it produced such dreadful effects in the last century, that the use of it was forbid by an edict of George, Duke of Wurtemburg, in 1671 ; and this not being observed, was enforced by two other edicts under his successor Leopold, in 1705, and 1714 .

Mixed with wheat flour in half the quantity, it makes a very good bread, that appears to be harmless. But bread made with this flour only has brought on a most surprising rigidity of the limbs in those who have used it for a continuance; insomuch that the exterior muscles could not by any means be reduced, or have their natural action restored. These symptoms usually appeared on a sudden, without any previous pain; but sometimes they were preceded by a weakness and disagreeable sensation about the knees. Baths, both hot and cold, fomentations and ointments of various kinds have been tried without effect; insomuch that it is regarded as incurable, and being neither very painful nor fatal, those who are seized with it usually submit to it with patience.

Swine fattened with this meal lost the use of their limbs, but grew very fat lying on the ground. A horse fed some months on the dried herb, was said to have his legs perfectly rigid. Kine are reported to grow lean on it, but sheep not to be affected. Pigeons, especially young ones, lose the power of walking by feeding on the seed. Poultry will not readily touch it, but geese eat it without any apparent damage. In some parts of Switzerland, cattle feed on the herb without any harm. It would be worth enquiring, therefore, whether the soil may not contribute something to the ill qualities of the plant : and it is remarked that the seed from a strong, fat, moist soil, is much more deleterious than from a light dry one. (Duvernoy.)

Fabbroni, from Florence, in 1786, says, that the government there has cautioned the peasants against the 
10344 Leaves in 2 pairs ensiform, Stipules subulate, Stem simple 10345 Stem branched, Leaves in 6 pairs ovate oblong

10346 Stem branched, Leaves in 2 pairs lanceolate nerved, Stipules somewhat spiny

10347 Leaves pinnate hairy of many pairs ovate lanc. Stip. half-sagitt. Stem branched decumbent hairy

10348 Leaves pinnate smooth of many pairs elliptical, Stipules ovate lanceol. Stem branched erect hairy

10349 Peduncles 1-flowered, Tendrils leafless, Stipules sagittate cordate

10350 Peduncles many-flowered, Leaves simple, Stipules subulate

10351 Peduncles 1-flowered longer than calyx, Tendrils 2-leaved simple

10352 Peduncles 1-flowered, Tendrils 2-leaved, Pods ovate compressed channelled at back

10353 Peduncles 1-flowered, Tendrils 2-leaved and 4-leaved, Pods ovate compressed with 2 edges at back

10354 Peduncles 1-flowered shorter than calyx, Tendrils 2-leaved simple, Leaflets lanceolate

10355 Peduncles 1-flowered, Tendrils 2-leaved, Leaflets setaceous linear

10356 Peduncles 1-flowered as long as cal. Petioles 2-leaved, Leaflets lanc. Pods linear roughish mucronate

10357 Peduncles 1-flowered awned, Tendrils 2-leaved simple ensiform

10358 Peduncles 1-flowered awned, Tendrils 2-leaved simple, Leaflets linear

10359 Peduncles 1-flowered, Tendrils 4-leaved, Petioles winged, Pods compressed

10360 Peduncles 1-flowered awned, Tendrils many-leaved, Leaflets linear truncate mucronate

10361 Peduncles about 1-fl. Tendrils many-leaved, Leaflets alternate lanceolate, Petioles winged

10362 Peduncles 2-flowered, Tendrils 2-leaved, Leaflets ovate oblong, Pods hairy

10363 Peduncles 2-flowered naked, Tendrils 2-leaved, Leaflets obovate wavy, Stems rigid 4-angled

10364. Peduncles 2-flowered, Tendrils 2-leaved, Leaflets ensiform, Pods smooth, Stipules 2-parted

10365 Peduncles 2-flowered, Tendrils 2-leaved, Leaflets altern. lanc. smooth, Stipules lunate

10366 Peduncles 2-flowered, Tendrils many-leaved, Leaflets lanceolate, Stipules toothed

10367 Peduncles about 3-flowered, Tendrils many-leaved, Leaves lanc. Pods hairy, Seeds rough

10368 Peduncles long many-ft. Stipules broad cordate sagittate, Tendrils 2-leaved

10369 Pedunc. many-fl. Tendrils 2-leaved, Leaflets oval, Joints naked

10370 Pedunc. 1-f. shorter than stipules, Tendrils 2-4-leaved, Stip. toothed, Pods erect turgid and villous

10371 Pedunc. many-fl. Tendrils 2-leaved, Leaflets roundish, Joints membranous

10372 Pedunc. many-f. Tendrils 2-leaved quite simple, Leaflets lanceolate

10373 Pedunc. many-fl. Tendrils 2-leaved, Leaflets ensiform, Joints membranous

10374 Pedunc many-fi. Tendrils 2-leaved, Leaflets lanceolate, Joints membranous

10375 Pedunc many-fi. Tendrils 2-leaved and 4-leaved, Leaflets lanc. Joints membranous

10376 Pedunc. many-fl. Tendrils many-leaved, Leaflets linear lanc. acute

10377 Pedunc. many-fl. Tendrils many-leaved, Leafl. lanc. obl. blunt mucronate, Joints membran. Pods curved

10378 Pedunc. many-f. Tendrils many-leaved, Leafl. ellipt. blunt, Stipules half-sagitt. ovate broader than leaflet

\section{Petioles decurrent membranous 2-leaved, Peduncles 1-flowered}

10380 Petioles round, Stipules rounded below crenate, Peduncles many-flowered

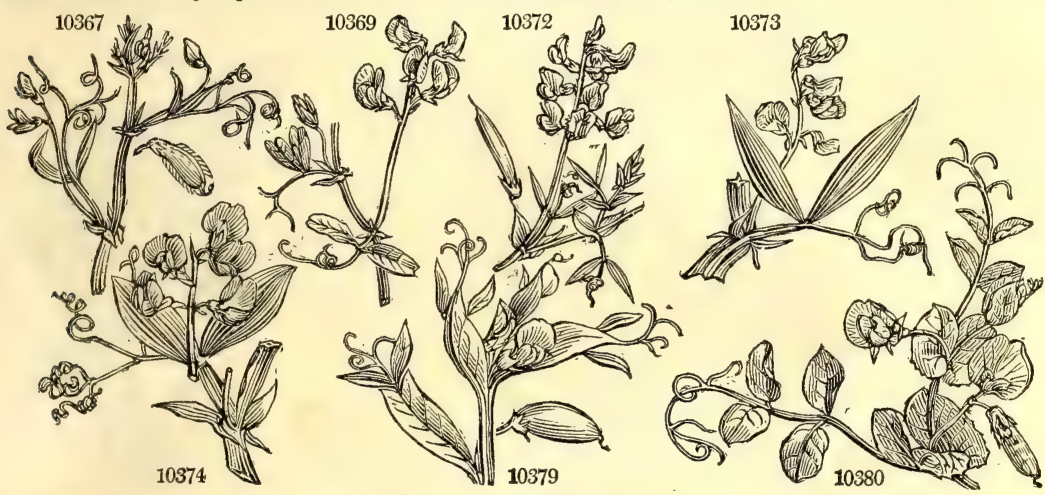

and Miscellaneous Particulars.

use of Lathyrus sativus; swine having lost the use of their limbs, and become pitiable monsters by being fed on this pulse exclusively. The peasants, however, eat it boiled, or mixed with wheat flour, in the quartity of one-fourth, without any harm.

The poisonous Lathyrus from Barbary, is $\mathbf{L}$. semine punctato of Casp. Bauhin, and seems to be only a variety; for in the crops of $\mathbf{L}$. sativus in Italy, they find black seeds striped with white, as in the African seed. Fabbroni suspects it to be a mule between $L$. sativus and Cicera, for the flower and seed partake of the characters of both; having a black seed marked with white; and a white banner with a red keel to the corolla. (Fabbroni's Letters in MSS. Banks.)

L. odoratus is one of our most esteemed border annuals, and is extensively grown in pots for decorating chambers and windows. L. tingitanus, articulatus, and annuus are also sown as border annuals.

L. tuberosus produces tubers on the roots, like those of the earth nut (Bunium bulbocastanum); these are sold in the markets of Holland, like those of Orobus tuberosus and Trapa natans, and their flavor is highly esteemed.

$\mathbf{L}$. latifolius is a very shewy plant for shrubberies, arbors, and trellis work, and yields a great quantity both of green fodder and seeds, which some botanists have suggested might be applied to agricultural purposes.

1559. Ochrus; oxeos, yellow, in allusion to the color of its flowers. A small annual plant with yellow flowers, native of hedges in the south of Europe.

1560. Pisum. From the Celtic pis, a pea. P. sativum, Pois, Fr., Erbse, Ger., and Pisello, Ital., is the most valuable of culinary legumes. Like most domestic plants of great antiquity, its native country is unknown, though it is commonly referred to the south of Europe. The varieties of the pea are numerous, and differ widely among themselves from the early frame, a low plant bearing only one white blossom on each footstalk, to the crown-bearing, having pink blossoms on a terminating corymb. The rouncival grows ten or twelve feet high, and the imperial not two feet. The sugar-pea has pods in which the inner film is wanting, or much less tough than usual, which admits of boiling the pods entire, and eating them in the same manner as kidney beans.

In the open garden, the pea is sown at intervals from January to the middle of July, and a succession of 
10381 arven'se $W$. 10382 maritimum $W$ 1561. VI'CIA. $W$. 10383 pisifórm:s $W$. 10384 dumetórum $W$. 10385 sylvática $W$. 10386 cassúbica $W$. 10387 atropurpúrea 10389 Crac'ca $W^{\prime}$ 10390 tenuifólia $\cdot W$. 10391 onobrychioídes $W$. 10392 biénnis $W$. 10393 nissoliána $W$. 10394 benghalénsis $W$. 10395 canéscens $W$. 10396 capénsis $W$. 10397 pellácida $W$ 10398 biflóra $W$. 10399 globósa $W$ 10400 satíva $W$ $\beta$ segetâlis $\gamma$ nemorális

10401 angustifólia $W$. 10402 amphicárpos $W$. 10403 lathyroides $W$. 10404 lútea $W$. 10405 hýbrida $W$. 10406 striáta Bieb. 10407 lævigáta $W$. 10408 megalospérma Bieb. 10409 articuláta $W$. en. 10410 pannónica $\dot{W}$. 10411 sórdida $W$ 10412 Michaúxii $W . e n$. 10413 peregrína $W$. 10414 monántha $W$. 10415 sépium $W$. 10416 bithýnica $W$. 10417 platycárpos $W$. 10418 narbonénsis $W$. 10419 serratifólia $W$. 10420 Fába $W$ $\beta$ equina

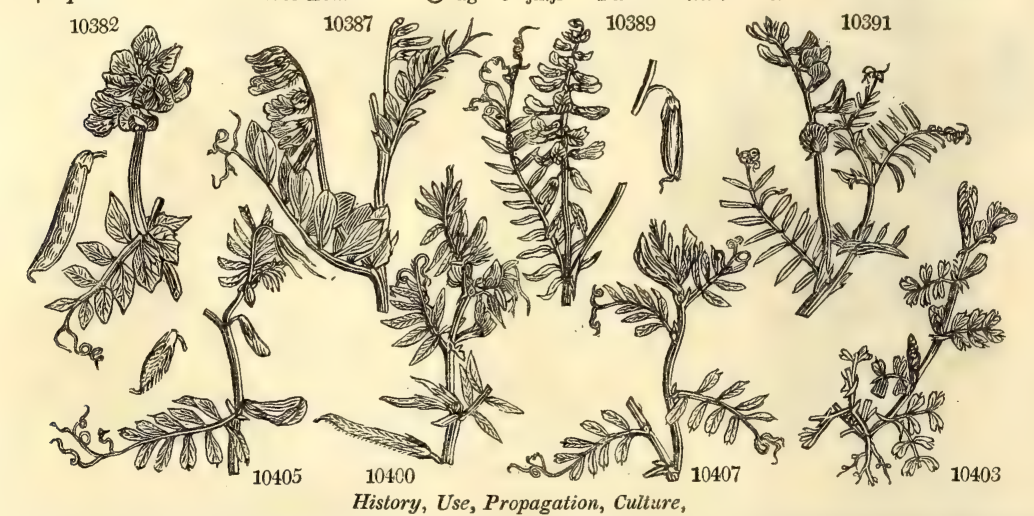

field

sea

B $O$ ag 3 jn.s

$\underset{\mathbf{B}}{\mathbf{R}}$

S. Europe $\ldots$ S $\quad$ co Englanḋ sea sh. D s.l Eng. bot. $10 \pm 6$

Vetch. great-wo at-wood common-w Cassubian dark-purple tufted slender-leaved

slender-leav biennial red-flowered Bengal hoary

Cape pellucid two-flowered globular common hedge wood

narrow-leaved subterraneous spring yellow hairy-flowered streaked smooth-podded

Taurian

Hungaria sordid white-flowered broad-podded single-flowered bush purple flat-podded broad-leaved saw-leaved Garden Bean Horse Bean

\section{Leguminosa. Sp. 38-100.}

B $\Delta$ or 2 jl.au Pa.Y Austria 1739. R co Jac. aust.4. t. 364 $B$ or 1 my.jn $\mathbf{P u}$ France 1752. $\mathrm{R}$ co Spreng,fi.hal, t.7 $\vec{B} \Delta$ or 6 jl.au W Britain moi.w. R co Eng. bot. 79 $\vec{B} \Delta$ or 3 jn.jl L.B Germany 1711. R co Jac. aust.3.t.229 k $\Delta$ or 3 jn.jl $\mathrm{Pu}$ Algiers 1815. R co Bot. reg. $87 \mathrm{l}$ k or 3 jn.jl D.Pu Germany 1815. S co B or 2 jn.au V Britain hed. $\mathbf{R}$ co $\mathrm{B} O$ or $2^{\frac{1}{2}} \mathrm{jn}$.jl $\mathrm{Pu}$ S. Europe 1789. S co $\mathrm{B}$ O) or 2 jl.s Pu Siberia 175s. S co B or 3 jn.jl D.Pu Levant 1773. S co

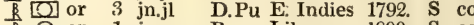
B O or 1 jn.au B Libanus 1800. S co

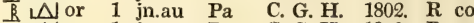
$\begin{array}{llll}\beta & \mathbb{N} \text { or } 1 \text { jn.au } & \mathrm{Pa} & \text { C. G. H. 1812. R co }\end{array}$ $\frac{B}{B}$ or $1 \frac{1}{2}$ jn.au $B$ Algiers 1801. S co $\frac{R}{B}$ O or $1 \frac{1}{2}$ jn.au $\underset{B}{B}$ Algiers 1804. S co $\mathrm{O}$ ag 3 my.jn $\mathrm{Pu}$ Britain corn fi. $\mathrm{S}$ h.l B O ag 3 my.jn Pu Britain corn fi. S h.l B. O ag 3 my.jn $\mathrm{Pu}$ Britain corn fi, $\mathrm{S}$ h.l Germany ... S co France 1815. S co Clus. exot. t. 88 Britain fall.fi. $S$ h.l Eng. bot. 30

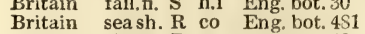
England thick. R co Eng. bot. 482 1 my.jn or $1 \frac{1}{2}$ ap.jn $\Delta$ or $1 \frac{1}{2}$ jn.au or $1 \frac{1}{2}$ jn.au $\Delta$ or $1 \frac{1}{2}$ jlau $\mathrm{Pu}$ Tauria 1823. R co Pa.Y England seash. $R$ co Eng. bot. 483 $\mathrm{Pu}$ Tauria 1798. S co $\mathrm{Pu}$ Pur... 1798. S co $\mathrm{Pu}$ Hungary 1658. $\mathrm{S}$ co Jac. aust. 1 t. 34 Y Hungary 1802. S co Pl.rar.hu.2.t.133 $\mathrm{Pu}$...... 1803. S co Pu France 1779. S co Plu.alm.t.233.f.6 $R$ Barbary $1790 . R$ Britain hed. R h.l Eng. bot. 1515 England san.fi. S co Jac.vind. 2.t.147 Germany 1723. S co Roth. abhan.t.1 France 1596. S co Roth. abhan. t.2 Hungary 1723. S h.l Jac.aust.app. t. 8

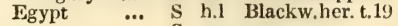

Eng. bot. 1168

Bot. mag. 2206

Her. lugd. t. 625

Jac.schœ.2.t.222

Eng. bot. 334

crops is thus obtained from the end of May to the beginning of November. By raising in hotbeds and transplanting, the first crop may be gathered in the beginning of May; and by raising and maturing in pits, pease may be gathered in April. The pea, however, does not force well, and requires extraordinary attention to giving air, otherwise the blossoms will not set. The culture of the pea is known to every countryman.

The grey pea, cultivated in agriculture, is by some considered as a species, though it is obviously a mere variety, not further removed from the frame pea than is the blue Prussian, or the crown pea. A dry soil and season is essential for a good crop, unless the plants can be supported by sticks like the garden crops. The seed is chiefly used for feeding pigs, and splitting for soup. In boiling split pease, some samples, without reference to variety, fall or moulder down freely into pulp, while others continue to maintain their form. The former are called boilers. This property of boiling depends on the soil ; stiff land, or sundy land that has been limed or marled, uniformly produces pease that will not melt in boiling, no matter what the variety may be. Pease straw cut green and dried, is reckoned as nourishing as hay, and is considered as excellent for sheep. The produce of pease in flour is as three to two of the bulk in grain, and husked and split for soups as four to two. A thousand parts of pea flour afforded Sir H. Davy 574 parts of nutritive or soluble matter ; viz. 501 of mucilage, or vegetable animal matter, 22 of sugar, 35 of gluten, and 16 of extract, or matter rendered insoluble during the operation.

P. maritimum has seeds of a bitterish disagreeable taste, but are reported nevertheless to have been eaten in times of scarcity. (Turner's Herbal.)

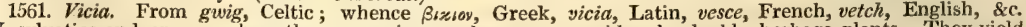
V. sylvatica and cracca, where they occur in meadows, are considered valuable herbage plants. They yield great bulk of fodder, which is allowed to be very nutritive. Some have proposed to cultivate them alone, but Curtis observes, they would probably in that case choke themselves for want of support.

V. sativa, the winter and summer tare, fetch or vetch, is a valuable agricultural plant. Some consider the winter variety as a distinct species; but Professor Martyn proved, by cultivating both, that they were not 
10381 Petioles 4-leaved, Stipules crenate, Peduncles 1-flowered

10882 Petioles flat above, Stem angular, Stipules sagittate, Peduncles many-flowered

10383 Peduncles many-fl. Petioles many-leaved, Leaflets ovate : lower sessile

10384 Peduncles many-fl. Leaflets reflexed ovate mucronate, Stipules somewhat toothed

10385 Peduncles many-fl. longer than leaf, Leaflets ellipt. Stipules lunate with setaceous teeth

10386 Peduncles many-f1. shorter than leaf, Leaflets oblong subpubesc. Stipules half sagittate entire lanceolate

10387 Peduncles many-fl. shorter than leaf, Teeth of calyx setaceous very villous, Leaflets lanceolate villous

10388 Peduncles many-fl. longer than leaf, Flowers imbricated, Leaflets obl. ovate villous, Stip. half-sagittate

10389 Peduncles many-fl. longer than leaf, Flowers imbricated, Leafl. lanc. blunt, Stip. half-sagitt. lin. subulate 10390 Peduncles many-fl. longer than leaf, Flowers imbricated, Leafl. lin. smoothish 3-nerved, Stip. lin. entire 10391 Peduncles many-f. longer than leaf, Flowers distant, Leaf. lin. Stip. half-sagitt. lin. lanc. toothed at base 10392 Peduncles many-fl. Petioles suleate 12-leaved, Leaflets lanc. smooth, Stip. half-sagittate stalked

10393 Peduncles many-11. Leaflets obl. Stipules entire, Pods villous ovate oblong

10394 Peduncles many-fl. Leaves entire, Stipules entire, Pods nearly erect

10395 Peduncles many-fl. long, Upper leaves subcirrhous, Stipules half-sagittate entire, Leafl. oval-obl. hoary 10396 Peduncles many-fl. long, Leaves not cirrhous, Leafl. obl. lanc. silky beneath, Stip. lanceol. entire

10397 Peduncles many-fl. shorter than leaf which is not cirrhous, Leaflets obovate emarginate, Stip. oblong 10398 Peduncles 2-flowered awned shorter than leaf, Leaflets linear narrowed at each end, Stip. half-sagittate 10399 Pods subsessile solitary, Leaflets ovate, Stipules marked 4-toothed

10400 Pods sessile sub-binate, Leaflets obl, ovate truncate mucronate, Stipules toothed marked

10401 Pods sessile sub-binate spreading, Lower leafiets ovate emarginate : upper lin. entire, Seeds globose 10402 Pods sessile : lower subterranean, Leaflets linear truncate, Stipules half-sagittate

10403 Pods sessile solitary erect smooth, Leaflets 6: lower subcordate

10404 Pods sessile solitary reflexed hairy, Stems diffuse, Stipules colored, Standard smooth

10405 Pods sessile solitary reflexed hairy 5 -seeded, Standard villous

10406 Pods stalked reflexed, Standard silky, Stipules lanceolate marked, Upper leaflets obl, elliptical acute

10407 Pods sessile solitary reflexed smooth, Stems nearly erect, Leaves quite smooth

10408 Pods sessile solitary reflexed downy, Leaflets linear blunt, Stipules half-sagittate entire

10409 Pedunc. 1-fl. in fruit longer than leaf and awned, Leaflets linear blunt mucronate, Stipules multifid

10410 Pods stalked about 3, and the standard hairy, Stipules lanceolate marked

10411 Pods subsessile twin reflexed smooth, Leaflets obl, ovate retuse, Stipules marked

10412 Pedunc. 1-fl. very short, Leaf. lin. lanc. truncate, Stipules lanc. undivided, Pods finely downy

10413 Pods subsessile pendulous smooth 4-seeded, Leaflets linear emarginate

10414 Pedunc. 1-fl. awned, Leaflets lanceolate blunt, Stipules bifid

10415 Pods stalked about 4 erect, Leaflets ovate entire

10416 Pods stalked solitary erect, Lreaflets 4 oval-lanceolate, Stipules toothed

10417 Pods subsessile solitary compressed somewhat inflated, Leaflets ovate toothed at end, Stip. cil. toothed

10418 Pods subsessile subternate compressed, Leaflets ovate entire, Stipules ciliate toothed at base

10419 Pods subsessile subternate, Leaves and stipules serrate

10420 Pods subsess, subtern, torulose, Leaflets ovate entire, Petioles not cirrhous, Stip. sagittate toothed at base

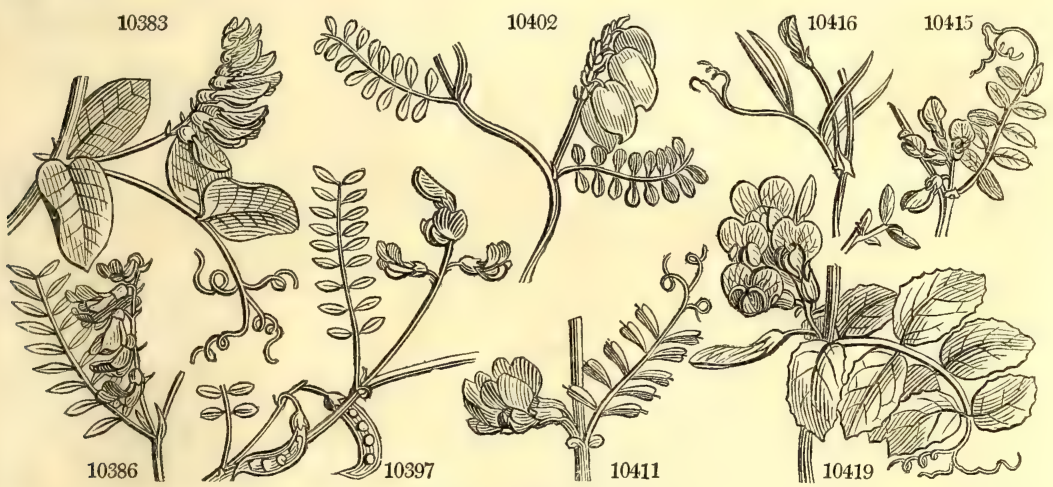

and Miscellaneous Particulars.

even very distinct varieties. The winter variety is sown in September and October, and the summer at different periods, from February to June, for successional cuttings. The soil requires to be in a good heart, otherwise they will produce but a poor crop of herbage: on a good soil they will yield ten or twelve tons, which is found excellent for milch cows and working stock. The crop is seldom left to ripen its seeds, but when seeds are wanted ; the only use made of them being for sowing or feeding pigeons.

V. narbonensis and serratifolia are cultivated in Germany in the same manner as our tare. Vicia sepium has been recommended to be sown among clover for mowing.

V. Faba is a well known legume both of the garden and the field. The garden varieties are numerous the earliest is a small seeded variety, the Mazagan, and the largest the Windsor. Beans are planted at the various times in which pease are sown; but the late sowings of this plant do not answer so well as those of the pea. When the ground is properly pulverised and in good heart, they succeed well when transplanted and where a first crop is injured by insects, if the stems are cut down to the ground during their flowering season, they will send up a succession of shoots, which will bear a crop. In this way, according to some, the bean may be rendered perennial, as it is certain the scarlet kidney bean may by merely protecting the roats from the frost.

The field bean, of which there is a larger and smaller sort, the latter called ticks, is sown in drills by a machine, so as to admit of horse hoeing, and otherwise ploughing or stirring between the rows. By this means a larger crop is produced, and the land cleaned and brought into a better state for a succeeding corn crop. Beans are excellent food for hard working horses, and for tatting hogs for bacon. The flower of beans and pease is more nutritive than that of oats, but less easy of digestion. A bushel of beans is surposed to yield fourteen pounds more of flour than a bushel of oats, and a bushel of pease eighteen pounds more, or according to some, twenty pounds. A thousand parts of bean flour were found, by Sir H. Davey, to yield 570 parts of nutritive matter, of which 426 were mucilage or starch, 103 gluten, and 41 extract, or matter rendered insoluble during the process. 
1562. ER'VUM. $W$. TARE 10421 Lens $L$. $W$ Lentil 10422 tetraspérmum $W$. smooth 10423 hirsútum $W$. hairy

10424 dispérmum $W$. two-seeded

1563. ERVI'LIA. Link. ERvilia. 10425 satíva Link.

1564. CI'CER. $W$. 10426 arietínum $W$.

1565. LIPA'RIA. $W$. 10427 sphæ'rica $W$. 10428 capitáta $W$. 10429 tomentósa $W$. 10430 vestíta $W$.

10431 graminifólia $W$. 10432 villósa $W$.

10433 hirsúta $W$

10434 serícea $W$.

1566. CY'TISUS. $W$. 10435 Labúrnum $W$. 10436 alpinus $W$. en 10437 tomentósus $B . R$. 10438 nígricans $W$. 10439 foliolósus $W$

10440 divaricátus $W$. 10441 sessilifólius $W$. 10442 wolgáricus $W$. 10443 Cájan $W$.

10444 nánus $W$. en 10445 hirsítus $W$.

10446 capitátus $W$.

10447 austríacus $W$. 10448 leucánthus ' $W$. 10449 purpúreus $W$. $\beta$ albiflórus

10450 supinus $W$

10451 biflórus $W$

10452 falcátus $W$. \& $K$.

10453 triflórus $W$.

10454 elongátus $W . \& K$.

10455 rhombifólius $P h$.

10456 proliferus $W$

10457 argénteus $W$.

10458 calycínus Bieb. pauciflórus W.

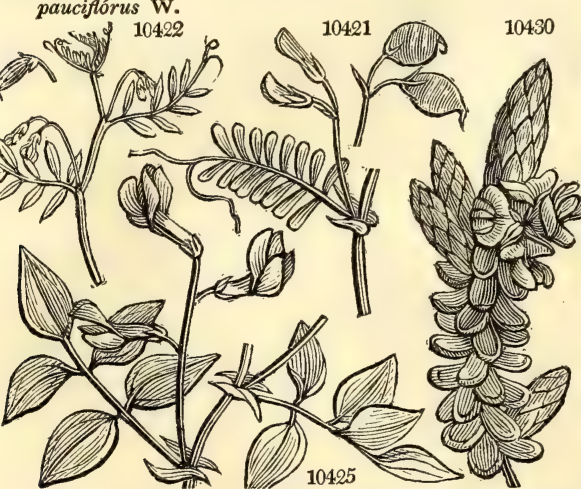

History, Use, Propagation, Culture,

1562. Ervum. From erw, tilled land, in Celtic; to which this plant is a pest. E. lens (from lentil, Celtic), Lentille, Fr, Lentze, Ger., and Lenticcia, Ital, is a legume of the greatest antiquity, being in esteem in Esau's time, and much prized in eastern countries ever since. In Egypt and Syria they are parched in a frying-pan and sold in the shops, and considered by the natives as the best food for those who undertake long journies. There are three varieties of lentils cultivated in France and Germany; the small brown, which is the lightest flavored, and the best for haricots and soups; the yellowish, which is a little larger, and the next best ; and the lentil of Provence, which is almost as large as a pea, with luxuriant straw, and more fit to be cultivated as a tare, than for the grain as human food. A dry warm sandy soil is requisite for the lentil ; it is sown rather later than the pea, at the rate of a bushel, or one and a half bushel, to the acre ; in other respects its culture and harvesting are the same, and it ripens sooner. The produce of the lentil in grain is about a fourth less than that of the tare; and in straw it is not a third as much, the plants seldom growing above one and a half foot high. The straw is, however, very delicate and nourishing, and preferred for lambs and calves; and the grain, on the continent, sells at nearly double the price of pease. Einhoff obtained from 3840 parts of lentils, 1260 parts of starch, and 1433 of a matter analogous to animal matter.

1563. Ervilia. A word with the same meaning as Ervum. See that word.

1564. Cicer. All authors agree in deriving the name from жsะv5, force; on account of the eminent qualities the ancients attributed to it. It grows naturally in the South of Europe, and is cultivated there for the same purposes as the lentil, but it is too delicate for field culture in this country. It is called Arietinum, because the young seed bears a very curious resemblance to a ram's head.

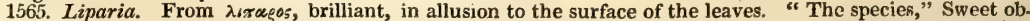
serves, "thrive very well in a mixture of loam and peat, and do not require so much water as some other genera of the order, L. villosa, vestita, sericea, and some others, if they get too much water over their leaves 
10421 Pedunc. 2-f. Seeds compressed, Leaflets entire

10422 Pedunc. about 2 -f. Pods smooth 4-seeded, Leaflets oblong truncate

10423 Pedunc. many-f. Pods hairy 2-seeded, Leaflets lin. blunt

10424 Pedunc. 2-fl. awned, Pods smooth 2-seeded, Leaflets lin. lanceolate downy

10125 Pedunc. awned shorter than leaf, Leaflets obl. truncate smooth, Stipules hastate

10426 Pedunc. 1-fl. Seeds globose gibbous, Leaflets serrated

10427 Flowers capitate, Leaves lanceolate nerved smooth

$10+28$ Flowers capitate: head erect, Leaves lanceolate smooth

10429 Flowers capitate, Leaves lanceolate downy

10430 Flowers capitate, Leaves ovate concave woolly beneath

10431 Flowers spiked hairy, Leaves lanceolate, and angular stem smooth

10432 Flowers fascicled, Leaves ovate villous downy

10433 Flowers racemose, Leaves obovate oblong smooth, Stem hairy

10434 Flowers somewhat spiked, Leaves ovate villous downy

10435 Racemes simple pendulous, Leaflets ovate oblong, Pods hairy

10436 Racemes simple pendulous, Leaflets ovate oblong rounded at base, Pods quite smooth

10437 Racemes lateral erect, Branches round spreading, Leaflets ovate downy

10438 Racemes terminal erect, Calyxes hairy : teeth minute, Leaflets ellipt. hairy

10439 Racemes terminal erect, Calyxes villous: segments falcate, Leafl. obovate oblong

10440 Racemes terminal erect, Calyxes and pods viscid, Leafiets oblong

10441 Racemes erect, Calyx with a triple bractea, Floral leaves sessile

$10+42$ Racemes terminal 1-sided, Leaves pinnated hoary, Leaflets roundish elliptical

10443 Racemes axillary erect, Leaflets sublanceolate downy : the middle one in a long stalk

10444 Raceme term. 1-sided 4-fl. Leaflets obovate downy beneath, Calyxes deeply 3-parted

10445 Redunc. aggregate subterminal, Calyxes hairy trifid, Leaflets obov. mucronate hairy beneath

10446 Flowers capitate, Branches straight round villous, Leaflets ovate ellipt. villous, Bract linear

10447 Fl. in term. umbels, Stems erect, Leaflets lanc. strigose pubescent

$10448 \mathrm{Fl}$. umbelled term. Stems erect, Leaflets ellipt. smooth acute

$10449 \mathrm{Fl}$. axillary solitary stalked, Stems procumbent, Leaflets obovate, Pods linear repand

$10450 \mathrm{Fl}$. stalked sub-binate axillary, Stem decumbent, Leaflets obovate blunt

10451 Pedunc. sub-binate axillary, Stems diffuse-erect, Leaflets oblong lanceolate

10452 Flowers stalked lateral about 3 erect, Stem declinate branched, Leaflets obovate mucronate

10453 Flowers stalked axillary about 3 , Calyx es campanulate, Leaflets obovate blunt hairy

10454 Flowers stalked lateral about 4, Stem erect, Branches long, Cal. tubular, Leaflets obovate

10455 Racemes term. erect, Leaflets obl. rhomboid biunt, Stipules rounded ovate oblique

10455 Flowers in lateral umbels, Stems erect, Leaves ellipt. erect silky beneath, Calyxes woolly

10457 Pedunc. about 3 term. Leaflets oblong lanceolate silky, Pods linear silky, Stems decumbent

10458 Flowers umbelled terminal, Cal. 3-parted: lower tooth trifid, Leaflets rounded obovate, Stems ascending
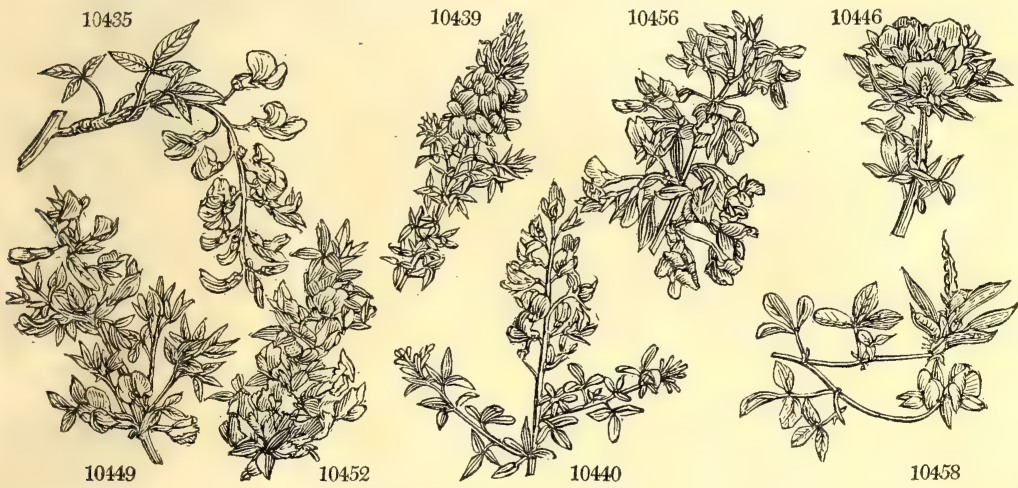

and Miscellaneous Particulars.

will be killed. Very young tops, taken off for cuttings, and planted under a bell-glass, in sand, are not difficult to root. (Bot. Cult. 217.)

1566. Cytisus. Pliny says it was so called because found in Cythnus, one of the Cyclades. The Cytisus of the ancients is believed to have been our Medicago arborea. A genus of ornamental trees and shrubs, of which the Laburnums, Cytise des alpes, Fr. Bohnenbaum, Ger., are well known and universally admired examples. There are two species of Laburnum, which are so much alike, that in most nurseries they are confounded together, or only one in cultivation. C. alpinus is the tree Laburnum, whose timber (the false ebony of the French) is much prized by cabinet-makers and turners, for its hardness, beauty of grain, and durability. The tree is frequently sown in plantations infested with hares and rabbits, who will touch no other tree as long as a twig of laburnum remains. "Though eaten to the ground in winter," as Boutcher observes, "it will spring again next season, and thus afford a constant supply for these animals, so as to save the other trees till of a size to resist their attacks. The timber has been sold for upwards of half a sovereign per foot." It becomes most valuable in light loams and sandy soils.

C. wolgaricus and purpureus are very handsome shrubs; and make a fine appearance when grafted on stocks of laburnum five or six feet in height.

C. cajan (an alteration of the Malay name, Catjang), Pois d'Angola, Fr., is frequently planted in the West India Islands, chiefly in rows as a fence to the sugar plantations, and will thrive on barren land The seed is much eaten by poor people and negroes, and is esteemed a wholesome pulse. In the island of Martinico even the better sort of people hold it in estimation, and prefer it to the European pea. The chief use of it in Jamaica is for feeding pigeons, whence its name. The branches, with the ripe seed and leaves, are given to feed hogs, horses, and other cattle, which grow very fat on them. (Sloane and Jacq, Obs.) 
1567. MULLE'RA, $W$ Mulleka

10459 monilifórmis $W$. bracelet

1568. ROBI'NIA. $W$. RoBINIA.

10460 Pseudacácia $W$.

$\beta$ inérmis W.

10461 viscósa $W$.

10462 violácea $W$.

10463 purpúrea Link.

$\beta$ rósea

\section{9 . C} ibírica Roy. Robinia Caragana I

10468 grandiflóra Bieb.

10469 Altagána $W$

10472 spinósa $W$

10473 Halodéndron $W$.

10474 Chamlágu $W$.

10476 pygmæ'a $W$.

smooth large-lv,

clammy

Ash-leaved

purple

Guinea

Rose-acacia

upright
10464 guineen'sis

1569. CARAGA

10467 arenária Downe san

10470 jubáta $W$.

10471 tragacánthoídes $W$.

10475 frutéscens $W$.

comm Acacia

Leguminosa. Sp. 1.

I $\square$ or $20 \quad \ldots . . . Y^{\prime}$ Guiana 1792. $\mathrm{C}$ 1.p Merian. sụr. t.35 Leguminosa. Sp. 6-10.

* tm 40 my.jn Pa.pu N. Amer. 1640. S s.l Schmid.ar.1.t.32 tm 40 my.jn Pa.pu N. Amer.

tm 30 jn.au Pk N. Amer. 1797. G s.l Bot. mag. 560 $\square$ or 12 ...... V V W. Indies 1759. S p.l or 15 jl.au Pu 跣 Pea-Tree. Leguminosa. Sp. 11-13.

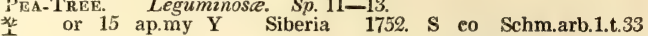
$\begin{array}{lllllll} & \text { or } 1 & \text { jn.jl } & Y & \text { Siberia } & \text { 1802. Sk s.l Bot. mag. } 1886\end{array}$

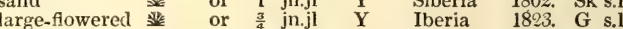
flat-podded $\quad$ or 3 ap.jn $\quad$ Y S Siberia 1789. G bearded or $1 \frac{1}{2} \ldots . \quad \mathbf{Y}$ or 4 ap.my $Y$ or 6 ap.my $\mathrm{Y}$ or 6 my.jn $\mathrm{Pu}$ or 4 my.jn $\mathbf{Y}$ $\begin{array}{llll}\text { or } & 4 & \text { my.jn } & \mathbf{Y} \\ \text { or } & 2 & \text { ap.my } & \text { Y }\end{array}$ or 1 ap.my $\mathbf{Y}$

Leguminosa.

Siberia 1816. G s.1 Bot. cab. 522

Siberia 1775. L s.p Schm arb.1.t.36

Siberia 1775. L s.p Nehm.arb.1.t.36

Siberia 1779. R s.1 Bot. mag. 1016

China 1773. G co L'her, stirp. t.77

Siberia 1752. L co Schm.arb. 1.t. 34

Siberia 1751. Sk s.p Schm,arb.1.t. 37

$\bullet$

10477 galegifólia $H . K$. red-flowered $\llcorner$ or 2 jl.au R R N. S. W. 1800. S s.p Bot. mag. 792

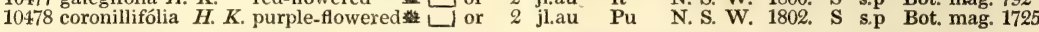
1571. SUTHERLAN'DiA. $H . K$. Sutherlandia. Leguminose. Sp. 1.

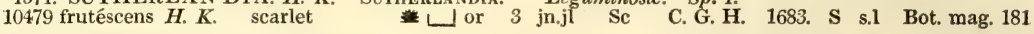
1572. LESSER'TIA. $\boldsymbol{H}$. $\boldsymbol{K}$. Lessertia. 10480 ánnua $H . K$. 10481 diffísa $H . K$. 10482 perénnans $H$. $K$ 10483 púlchra $B . M$. 1573. COLUTE'A. $L$ 10484 arboréscens $W$. 10485 média $W$. en. 10486 cruénta $W$. 10487 Pocóckii $W$. annual 이 or 1 jn.jl $R$ procumbent * * or 1 jl.au R $\begin{array}{ll}\text { perennial } & \text { لै } \\ \text { pretty } & \text { or }\end{array}$

Bladder-Senna. common smaller oriental

A.
$\begin{array}{lll}\text { pr } & 1 \frac{1}{2} \mathrm{my} & \mathbf{R}\end{array}$

$\begin{array}{llll}S p .4 . & & & \\ \text { C. G. H. 1731. S } & \text { s.l Ex. fl. } 84\end{array}$

C. G. H. 1792. S s.l Jac. ic. 3. t. 576 C. G. H. 1753. C s.l Jac. vind. 3. t. 3 Leguminose. Sp. 4-12.

or 10 jn.au $\mathbf{Y}$ France 1568. S co Bot. mag. 81 or 4 jn.jl Sc Levant 17ï. L co Schm. brit. 140 严 or 6 my.o $\mathbf{Y}$ Levant 1752. S co Schm. arb.t.120
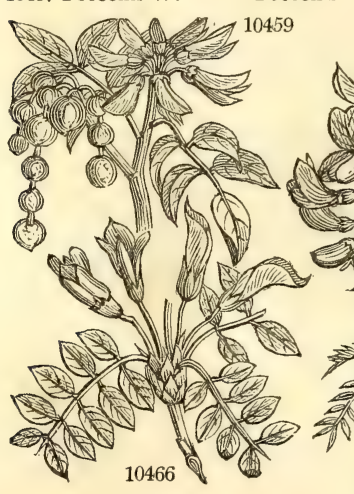

10460
10465 10461

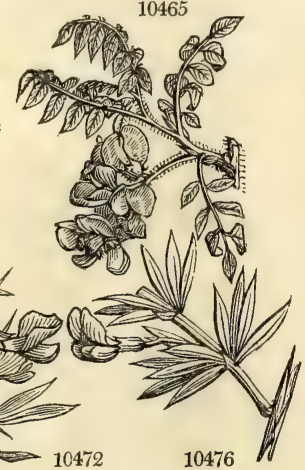

10470 170

History, Use, Propagation, Culture,

1567. Mullera. In honor of Otho Frederick Müller, a Dane, one of the editors of the Flora Danica. There have also lived four other Múllers, Germans, and botanists. The fruit is remarkable for its form, which is that of a necklace; a number of little balls being united by stalks, and not opening as in other leguminosæ, but always remaining closed. The flowers are pink, and the size of a bunch of Laburnum

1568. Robinia. In memory of Jean Robin, herbarist to Henry IV. of France, author of Histoire des Plantes, \&c., Paris, 1620. His son, Vespasian, was subdemonstrator at the Jardin de Roi, and was the first person who cultivated the $R$. pseudacacia in Europe.

R. pseudacacia is a thorny fast-growing tree, of middling stature, of no great beauty as a tree, but ornamental when young, and very well adapted for copse-wood and rough timber. The leaves come out late in spring, and fall off early in autumn, like those of the ash. The timber is much valued in North America, and said to be superior to that of the laburnum; "being close-grained, hard, and finely veined; and in America more valued by the cabinet-maker than any other native timber whatever. Pursh, in his Flora, asserts, that being nearly incorruptible, it is equally useful for posts and gates. We are informed by a friend, that gateposts of this timber, on a property near Baltimore, have remained fresh for nearly a century. The finest pinnated leaves, and pendulous white odorous flowers, add greatly to its beauty. Its value is scarcely known in this country." (Caled. Mem, ii 414.) It prefers a deep sandy soil, and rather sheltered situation ; being very apt to throw up suckers from the running roots, and as it stoles freely, it seems peculiarly calculated for coppice-woods. Beatson (Com. to Board of Agr.) has cultivated it in this way to great advantage.

In North America the use of the locust-tree has hitherto been confined to trenails, on account of its scarcity, but were it as plentiful as oak, it would be applied for more purposes by the shipwright, such as knees, floortimbers, and foot-hooks, being much superior to oak for its strength and duration, and, from the tree spreading into branches, affords full as large a proportion of crooks or compass timber as oak

A cubic foot of acacia, in a dry state, weighs from 48 to 53 pounds avoirdupois. If we compare its toughness in an unseasoned condition with that of oak, it will not be more than $8-100$ less. Its stiffness is equal to $99-100$ of oak; and its strength nearly $96-100$; but were it properly seasoned, it might, possibly, be found much superior to oak in strength, toughness, and stiffness. A piece of unseasoned acacia, two feet six inches long, and an inch square in the vertical section, broke when loaded with a weight of 247 pounds avoirdupois. Its medium cohesive force is about 11,500 pounds. (Dict. of Archi.) 
10459 The only species

10460 Racemes with 1-fl. pedicels, Leaves pinnated with an odd one, Stipules spiny, Pods smooth

10461 Racemes with 1-fl. pedicels, Leaves pinnated with an odd one, Branches and pods viscid with glands 10462 Racemes with 2-fl. pedicels, Cal, truncate, Leaves pinnated with an odd one, Stem unarmed 10463 Petioles somewhat spiny, Leaflets lanceolate mucronate downy, Pedic. 1-flowered

10464 Racemes axillary few-flowered, Calyxes and branchlets finely bristly

10465 Racemes axillary, Leaves pinriate with an odd one, Stem hispid

10466 Pedunc. simple several, Leaves in 4 pairs, Petioles unarmed, Pods cylindrical

10467 Leaves about 4 pair ; leaflets obcordate, Peduncles twin shorter than flower

10468 Pedunc. simple, Leaves 4 stalked hoary terminated by a weak spine, Pods downy

10469 Pedunc. simple solitary, Leaves in about 8 pairs, Stipules spiny, Pods compressed

10470 Pedunc. simple, Leaves in many pairs downy, Petioles filiform spiny, Branches villous

10471 Pedunc. simple, Leaves in 2 pairs, Leaf. obl. lanc. silky, Stipules and petioles spiny

10472 Pedunc. simple, Leaves in 4 pairs, Leafl. cuneate smooth, Stipules and petioles spiny

10473 Pedunc. 3-fl. Leaves in 2 pairs silky, Petioles spiny persistent, Pods bladdery

10474 Pedunc. simple, Leaves in 2 pairs, Leaflets obovate shining, Stipules and petioles spiny

10475 Pedunc. simple, Leaves about 4 somewhat petiolated terminated by a weak spine

10476 Pedunc. simple, Leaves 4 sessile

10477 Stalk of pod longer than persistent filaments

10478 Stalk of pod shorter than persistent filaments

10479 Leaflets obl, blunt hoary beneath, Stem shrubby, Branches silky with down

10480 Leaflets linear emarginate smooth, Stem weak, Raceme axillary

10481 Leaflets linear emarginate hairy, Cal. without bractes with black hairs

10482 Leafl, obl, downy, Stem erect, Racemes terminal

10483 Leaflets in 7 pairs ovate acute smoothish, Racemes axillary subcapitate 1-sided

10484. Leaflets ellipt, retuse, Prominences of the standard short

10485 Leaflets obcordate glaucous, Pedunc, about 6 -flowered, Pods closed at cnd

10486 Leafl. obovate emarginate glauc. Prom. of standard blunt very small, Pods open at end

10487 Leafl. roundish ellipt. very blunt mucronate, Prom. of standard long ascending, Stem shrubby

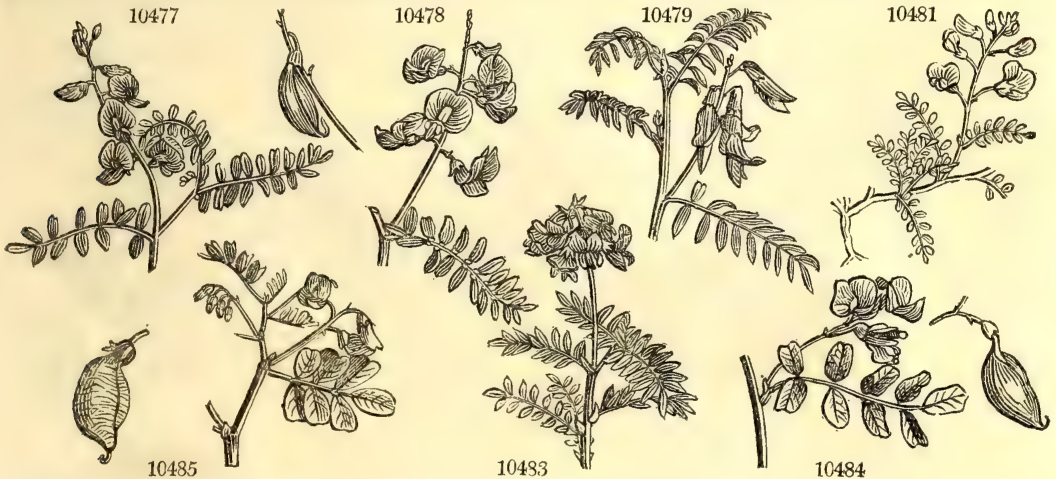

and Miscellaneous Particulars.

$\mathbf{R}$. hispida is a very handsome shrub, but it requires a sheitered situation, otherwise the branches are very liable to be shattered or blown off by high winds. In young trees grafted above ground, the fracture commonly takes place at the graft, so that a good preventative is to graft on the root a little below the surface. Grafts in this manner are also much more certain of success.

$\mathbf{R}$. viscosa resembles, in its leaves and flowers, the common acacia; but is, altogether, a much handsomer tree.

1569. Caragana. This genus has been confounded by Linnæus and his followers with Robinia. The name is derived from the appellation of the most common species in Tartary, where it is called among the Moguls, Carachaná. Altagana, the name of another species, is in like manner a slight alteration of the Tartar name Aldachaná.

C. spinosa, on account of the length and toughness of the branches, and its large stout thorns, is admirably adapted to form impenetrable hedges, and is sufficiently hardy to bear our climate. About Pekin, they stick the bushes in clay on the tops of their walls, to prevent persons from getting or looking over them. (Pallas.)

C. Halodendron is a handsome shrub, and grows in Siberia on dry naked salt-fields, and it is probably from the want of this principle in our garden soils, that it so seldom flowers here.

C. pygmæa is a weak low shrub, with a shining yellow bark, with wood of a deep bay, almost as hard as horn. C. frutescens is used by the Tartars for the same purposes as osiers, for which its tough shoots render it proper.

C. jubata is remrakable plant, its shoots always remaining covered by the persistent brown stipulæ of the fallen leaves. It is extremely difficult to propagate, and is rarely even seen in this country. The most successful cultivators of it are Messrs. Loddiges and Son.

1570. Swainsonia. Named after the late Mr. Isaac Swainson, who had a botanic garden at Twickennam.

1571. Sutherlandia. In honor of Mr. James Sutherland, who published, in 1683, an 8vo. catalogue of the Physic Garden at Edinburgh. This and the former genus seed freely, and may also be readily increased by cuttings.

1572. Lessertia. Named by Decandolle in honor of M. Stephen Delessert, to whose mother Rousseau's Letters on Botany were addressed.

1573. Colutea. An ancient name of a bush with sweet-scented flowers; probably similar to the genus now S s 2 
1574. GLYCYRRHI'ZA. W. GLYCYRRHIZA. 10488 echináta $W$ prickly-headed 2 $W$ glandulous

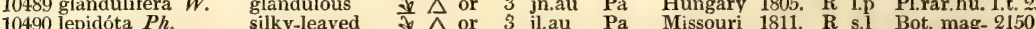
10491 aspérrima $W$ 10492 hirsúta $W$. silky-leaved rough hairy

量 $\Delta$ or is $\triangle$ clt

1575. LIQUORI'TIA. Mönch. LIQUORICE. 10493 officinális Mönch. common te

1576. CORONIL $/$ LA. $H . K$. Coronilla. 10494 E'merus $W$. 10495 júncea $W$. 10496 valentína $W$. 10497 glaúca $W$. 10498 viminális $H$. $K$. 10499 coronáta $W$. 10500 mínima $W$. 10501 argéntea $W$ 10502 vária $W$

10503 crética $W$. 10504 Securidáca $W$ 10505 ibérica Bieb. Scorpion Senna 业焉

Rush

nine-leaved seven-leaved slender large-headed least silvery-leaved purple purple Hatchet-Vetch or Iberian or

1577. HIPPOCRE'PIS. $\boldsymbol{W}$. HoRSESHOE-VETCH 10506 unisiliquósa $W$. 10507 multisiliquósa $W$. single-podded 10507 multisiliquósa $W$. many-podded 10509 comósa $W$. shrubby

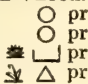

1578. ORNITHO'PUS. $W$. BIRD's-Foot 10510 perpusíllus $W$. 10511 ebracteátus Brot. O. durus Cav. 10512 compréssus $W$. 10513 scorpioídes $W$. 10514 repandus $P$. $S$. 10515 sativus $P . S$. common$$
\triangle \mathrm{pr}
$$
round-podded $\$ 0 \mathrm{pr}$ hairy Purslane-leav'd repand Serradilla

1579. SCORPIU'RUS. $\boldsymbol{W}$. Caterpillar. 10516 vermiculáta $W$. 10517 muricáta $W$ 10518 sulcáta $W$. 10519 subvillósa $W$. Caterpillar. common ${ }^{*} \bigcirc \mathrm{pr}$ three-flowered ${ }^{*} \bigcirc \mathrm{pr}$ four-flowered * $\bigcirc \mathrm{pr}$

1580. SMI'THIA, Salisb. Smithia. 10520 sensitiva Sal. annual

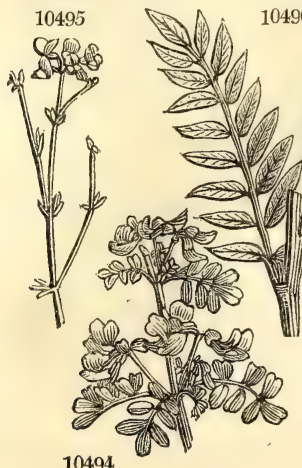

10490 $\begin{array}{lllllll}\text { Leguminosa. } & \begin{array}{c}\text { Sp. 5-6. } \\ \text { jn.s }\end{array} \text { Pa } & \text { Italy } & \text { 1596. } & \text { R } & \text { s.p } & \text { Bot. mag. 2154 } \\ \text { jn.au } & \text { Pa } & \text { Hungary } & \text { 1805. } & \text { R } & \text { 1.p } & \text { Pl.rar.hu. 1.t. 21 } \\ \text { jl.au } & \text { Pa } & \text { Missouri } & \text { 1811. } & \text { R } & \text { s.1 } & \text { Bot. mag-2150 } \\ \text { jl.au } & \text { L.B } & \text { Siberia } & \text { 1795. } & \text { R } & \text { s.p } & \text { Pall. i.ap.t.M.f.3 } \\ \text { jl.au } & \mathbf{P a} & \text { Levant } & \text { 1739. } & \text { R } & \text { s.p } & \end{array}$ Leguminosa. Sp. 1.

4. jl.au L.B S. Europe 1562. R r.m Lam. ill.t.625.f.2

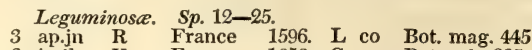
3 jn jl $\quad$ Y $\quad$ France 1656. C r.m Bot. cab. 235

2 mr.n Y S. Europe 1596. C r.m Bot. mag. 185

2 mys Y France 1792 C rm Bot mag. 13

2 my.s $Y$ F

3 my.n $\mathbf{Y}$ Mogador 1798. C 1.p Par.lond. 13

2 jn.jl $\quad Y \quad$ S. Europe 1776. C co Bot. mag. 907

$\frac{1}{2}$ jl $\quad Y \quad$ S. Europe 1658. C co Bot. mag. 2179

2 my.jn $Y$ Crete 1664. L s.1 Mil.ic.2.t.289.f.1

4. jl.n Pu Europe 1597. C co Bot. mag. 258

2 jn.jl St Candia 1731. C s.l Jac. vind. 1.t. 25

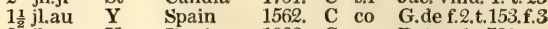

jl.au $\mathbf{Y}$ Iberia 1822. C co Bot. cab. 789

Leguminose. $S p .4-7$.

1 jn.jl. Y Italy 1570. S co Lam.ill.t.630

1 jl.au $\quad$ Y $\quad$ S. Europe 1683. S co Schk. ha. 2.t.206

2 my.jn $Y$ Minorca 1776. C r.m Bot, mag. 427

ap.au Y England ch.hil. D s.l Eng. bot. 31

Leguminose. Sp. 6-10.

my.au R Britain dry pas. S co Eng.bot. 369

$\frac{1}{2}$ my.jn Vy Portugal ... S co Cav.ic. 1.t. 41

$\frac{1}{3}$ jn.jl Vy S. Europe 1730 . S co

$\frac{1}{2}$ jn.jl Vy S. Europe 1596. S co Cav.ic. 1. t. 37

Leguminosa. Sp. 4. 2 jn.j $\quad Y \quad$ S. Europe 1621. S co Mor.hi. 2.t.11.f.

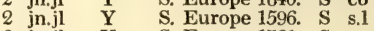
2 jn.jl Y S. Europe 1731. S co Mor.hi.2.t.11.f.2

Lcouminose. Sp. 1-2.
Barbary 1805. S co Lam.ill.t.631.f.
* [Q] un $\frac{1}{2}$ jl.s $\mathrm{Y}$ E. Indies 1785. S s.l Par.lond. 92 10488 
10488 Pods echinate, Fl. capitate, Stipules lanc. Leaflets smooth oblong mucronate

10489 Pods glandular echinate, Fl. racemose, Stipules withering, Leaf. oblong lanc. emarg. clammy beneath 10490 Leaflets oblong acute silky, Pods racemose oblong hispid

10491 Pods smooth moniliform, Raceme term. Stipules lanc. Leafl. obovate emarg. rough beneath

10492 Pods hirsute, Leafl. obl, lanc. Flowers racemose

10493 Pods smooth, Stipules O, Leaflets ovate retuse clammy beneath

10494 Pedunc. about 3-fl. Claws of cor. three times as long as calyx, Stem angular 10495 Leaves 5-nate and 3-nate linear lanceolate fleshy blunt

10496 Leaflets about 9, Stipules nearly round

10497 Leaflets 7 very blunt, Stipules lanceolate

10498 Leafiets 6-10 pair more or less obovate and retuse, Pods very long curved upwards

10499 Leaflets 9 ellipt. : inner close to stem, Stipules opp. the leaves lanceolate

10500 Procumbent, Leafl. 9 ovate, Stipule opp. the leaf emarg. Pods angular knotty

10501 Leaflets 11 silky : the outer the largest

10502 Leaflets several lanceolate smooth, Pods rounded erect

10503 Leaflets 15 cuneate retuse, Pods rounded erect 5 together

10504 Leaflets several obl. cuneate, Pods compressed ensiform

10505 Leaflets 9 very blunt somewhat emarginate, Stipules round toothletted

10506 Pods sessile solitary erect

10507 Pods stalked clustered circular : lobed on one edge

10508 Pods stalked clustered smooth lobed on the outer edge, Leaves and cal. hairy

10509 Pods stalked clustered arcuate rragh sinuated on one side

10510 Leaves pinnated, Flowers eapitate with a bractea, Pods roundish incurved

10511 Leaves pinnated, Flowers capitate without a bractea, Pods round incurved

10512 Leaves pinnated, Flowers capitate with a bractea, Pods compressed recurved rugose 10513 Leaves ternate subsessile : the odd one very large

10514 Leaves ternate or quinate: the odd one largest, Stipules large membranous 2-toothed 10515 Leaves pinnated, Pods rugose pendulous scarcely bowed, Joints compressed roundish

10516 Pedunc. 1-fl. Pods covered over with blunt scales

10517 Pedunc. 2-fl. Pods bluntly aculeate outwardly

10518 Pedunc, about 3-fl. Pods bearing outwardly distinct acute spines

10519 Pedunc. about 4-fl. Pods bearing outwardly clustered acute spines

10520 Lips of calyx entire, Racemes stalked few-flowered

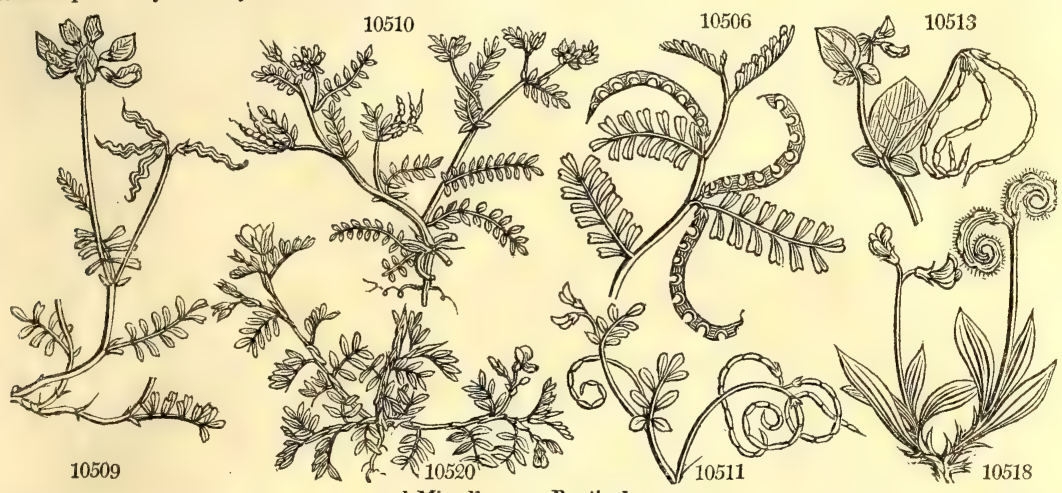

and Miscellaneous Particulars.

end of which the roots may be taken up by trenching over the ground. The roots are either immediately sold to the brewers' druggists, or to common druggists, or preserved, like carrots or potatoes, in sand, till wanted for use. They are used in medicine and porter-brewing.

1576. Coronilla. From corona, a crown. Its pretty flowers are disposed in little tufts like coronets. Handsome free-flowering shrubs, of easy culture. C. valentina, glauca, and viminalis are valuable as flowering in winter, and often all the summer. C. argentea bears a profusion of flowers, which have a strong sweet scent. The silvery color of this plant is occasioned by its growing on a poor dry soil; and if it is removed into better ground, it will take a glaucous color; and the contrary. C. emerus is a popular shrub of much beauty.

C. varia is a strong coarse-growing plant, and has been grown as an adjunct to clover, lucern, \&c. Curtis says, it is bitter; but others have found horses and cows to eat it greedily.

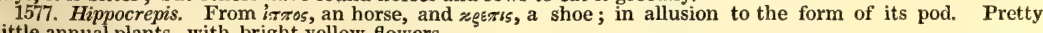
little annual plants, with bright yellow flowers.

1578. Ornithopus. From ogvis, a bird, and $\pi y_{s}$, a foot. The pods are twisted and curved in such a manner as to resemble the claws of a small bird. Curious on account of their jointed pods, but not worth culture as plants of ornament. O. sativus is a most valuable agricultural plant. It was introduced for purposes of fielc culture about the year 1818, from Portugal, under the name of Serradilla. Sown upon the barren, light, sandy downs of Thetford, in Norfolk, it produced an abundant crop of most excellent fodder, where nothing else would grow. It is exceedingly like 0 . scorpioides, except that it arrives at the height of two feet instead of as many inches.

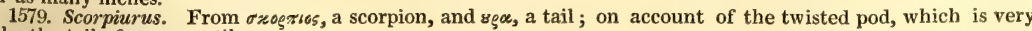
like the tail of some reptile.

1580. Smithia. In memory of Sir James Edward Smith, M. D., F. R. S., knight, president of the Linnean Society, possessor of the Linnean herbarium, and author of various elementary and other useful botanical works. These are inconspicuous worthless weeds, possessing little interest beyond their irritable foliage.

$$
\text { S s } 3
$$


1581. SESBA'NIA, $\boldsymbol{H}, \boldsymbol{K}$. Sesba'NiA.

10521 grandifiora $H . K$ great-flowered 10529 randifiora $H$. $K$. 10523 aculeáta $H . K$. 10524 cannabina $P$ S 10525 pícta Cav. great-flowered Egyptian Hemp painted

1582. ESCHYNO'MENE. $H . K$ 10526 sensitiva $W$. 10527 áspera $W$. 10528 híspida $W$. 10529 americána $W$. 10530 indica $W$. shrubby 整 $\square$ or 3 rough-stemmed $\square$ or rough-stemmed [0] or hispid hairy

Leguminosce. Sp. 5-9.

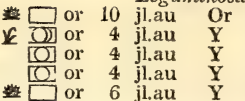

E. Indies 1768. C 1.p Rhee.mal.1.t.51 Egypt 1680. S co Al.ægypt.81.t.82 E. Indies 1690. S co Jac. ic. 3. t. 564 E. Indies 1800 . S co

W. Indies 1823. C co Bot. reg. 873

\section{Leguminosa. Sp. 5-27.}

W. Indies 1733. C s.1 Plum. ic. t. 149 E. Indies 1759. S s.l Breyn.cent.t.52 N. Amer. 1803. S s.l Jamaica 1732. S s.1 Sloa.h.1.t.118.f.3 E. Indies 1799. S s.1 Rhee. mal.9.t.18

1583. STYLOSAN'THES. Swz. Strlosanthes. Leguminose. Sp. 1-7.

10531 procúmbens Swz. procumbent $\square$ un 1 jl.au $\mathbf{Y}$ W. Indies 1821. S co Slo.jam.t.110.f.2

1584. HAL'LIA. Th. HaLlia.

10532 fláccida $W$.

10533 cordáta $W$.

10534 imbricáta $W$

DEZ M Mich, LESPEDEZA.

10535 fruticósa $P . S$.

10537 júncea $P$. $S$.

10538 capitáta $\mathrm{Ph}$.

10539 polystáchia $P h$

10540 violácea $P h . \quad$ violet-flowered $\frac{\Delta}{\Delta} \triangle \mathrm{pr}$

1586. FLEMIN'GIA. Rox. Flemingia.

10542 stricta $H$. $K$.

10543 semialáta $H$. $K$.

10544 congésta $H$. $K$.

10545 nána $H . K$

10546 lineáta $H . K . \quad$ branch-spiked 10547 strobilífera $H . K$. Beech-leaved un

1587. ZOR'NIA. Mich. Zornia.

$105+8$ pulchella $P$. S.

10549 diphýlla $P$. $S$.

neat-Indian
two-leaved

$W$. Hedysarum.

1588. HEDY'S

10552 nummularifólium $W$

10553 styracifólium $W$.

10554 gangéticum $W$

10555 triquetrum $W$

10556 maculátum $W$

10557 vaginále $W$.

10558 sagittátum $P . S$

10559 vespertiliónis $\mathscr{W}$.
105 t8 pulchella $P$. S

10550 Alhági $W$.

\section{()ㅣ un Leguminosa. Sp. 3-10.}

13 au.s Pu C. G. H. 1789. C $\quad$ l.p

$\triangle$ un 2 au Pu C. G. H. 1787. D l.p Jac.schœ.3.t.296

Leguminose. Sp. 7-14.

4 jl.au Pu Virginia 1739. C 1.p Jac, vind. 3. t. 89

3 jl $\quad$ Pu N. Amer.

2 jl.au W India 1776. D l.p Lin. fil. dec.1.t.4

2 jn.jl W N. Amer. 1789. D l.p

3 jn.au W N. Amer. 1789. D 1.p Mic.amer. 2.t.40

2 jlau $\mathrm{Pu} N \mathrm{Amer} 1789$.

2 jl.au Pu N. Amer. 1790. Leguminosce. $S p .6-10$.

jl.s Pu India 1798. D s.p

jl.au Pu Nepaul 1805. S p.1

3 jl.s $\mathrm{Pu}$ India 1802. C $1 . p$

$1 \frac{1}{2}$ au $\mathrm{Pu}$ India 1804. C l.p

2 jl.au Pu India 1793. C 1.p Bur. ind.t.53.f.1

jl.au Pu E. Indies 1787. C p.1 Bot. reg. 617

Leguminosa. Sp. 2-7.

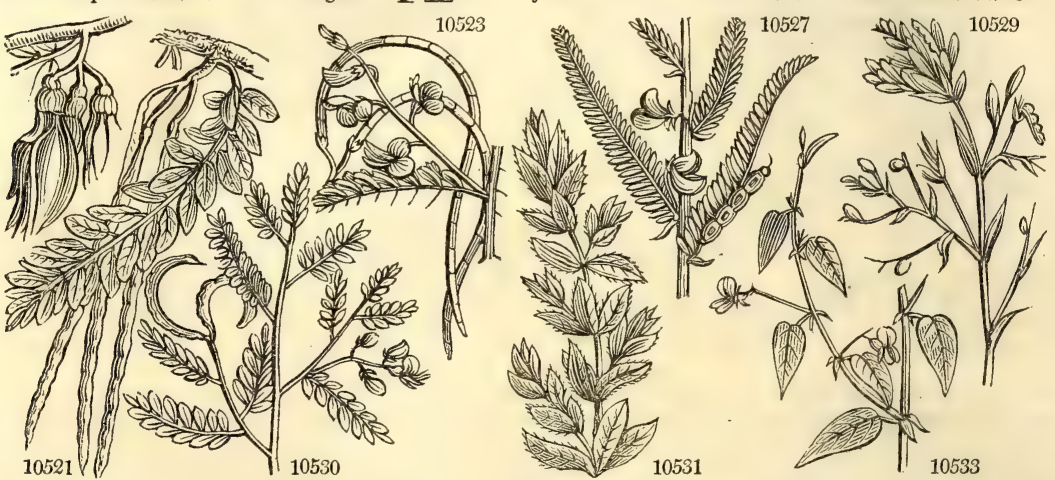

History, Use, Propagation, Culture,

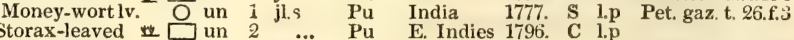
oval-leaved [O] un $1 \frac{1}{2}$ jl.au Pa.Y E. Indies 1762. S r.m Burzeyl t $49 . \mathrm{f} 2$ triangul.-stalk. 5 or 1 jl.au $\mathrm{Pu}$ E. Indies 1802. S l.p Bur. ind t.52, f. spotted sheathed $\quad\left[\begin{array}{llllll}\frac{3}{4} & \text { jl.au } & \text { R } & \text { E. Indies 1790. } & \text { S l.p } & \text { 1.p Bur.zeyl.t.49.f.1 }\end{array}\right.$ arrow-leaved in un 33 ... R R. Indies 1807. C l,p

W C. China 1780. C r.m Jac. ic. 3.t. 566 jl.au Pu India 1733. S 1.p Rheemal.9.t.82

Ieguminose $S p .56$ - 290

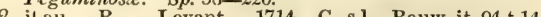

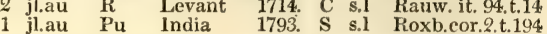


10521 Racemes about 3-f. Leafl. obl. emarg. smooth, Pods filiform straight compressed

10522 Racemes many-fl. Leafl. lin. blunt mucronate, Rachis of leaves smooth, Pods filiform round

10523 Racemes few-fi. Leafl. linear blunt mucronate, Rachis of leaves prickly, Pods filiform round

10524 Pedunc. 1-fl. Leafl. lin. biunt mucronate, Rachis of leaves smooth

10525 Racemes many-fl. pendulous, Leafl. lin. blunt, Pods filiform round moniliform

10526 Stem smooth, Leafl. lin. blunt, Racemes few-flowered, Pods smooth

10527 Stem rough below, Leafl. lin. blunt, Racemes comp. hispid, Joints of pod rough in middle 105०8 Stem hispid, Leafi. lin. blunt, Racemes simple, Pods hispid

10529 Stem hispid, Leafl. lin. falcate acuminate, Racemes simple, Joints of pods roundish distinct smooth

10530 Stem smooth, Pods smooth torose on one side and blunt, Leaflets blunt

10531 Leaves ovate lanc. sinooth, Spikes many-fl. Bractes smooth mucronate, Stem downy

10532 Leaves lanc. mucronate smooth, Pedunc. 1-fl, the length of leaves

10533 Leaves cordate obl. acute smooth, Pedunc. the length of leaves

10534 Leaves cordate ovate convolute imbricated, Flowers axillary sessile

10535 Leaf. subovate villous beneath, Flowers in sessile fasicles, Stem shrubby

10536 Leafl. oblong, Fasicles of flowers sessile numerous, Pods nearly naked acute

10537 Leafl. somewhat lin. hairy beneath, Racemes axillary, Pods smooth length of calys

10538 Simple, Leafl. ellipt. Spikes capitate on short stalks axillary and terminal, Cal, vill. length of cor.

10539 Branched villous, Leaf. round oval, Spikes axillary on long stalks, Cor. as long as calyx

10540 Branched diffuse, Leafl. ellipt. blunt hairy beneath, Racemes short umbelled

10541 Leaves ternate ovate, Racemes oblong, Pods inflexed, Calyx hairy

10542 Stem subsimple upright, Leafl. broad lanc, smooth, Racemes axill. sol. length of petiole

$105+3$ Branched nearly upright, Leafl. ellipt. smooth, Petioles winged, Racemes panicled term, and axillary 10544 Nearly erect, Leafl. broad-lanc. Racemes axillary clustered

10545 Somewhat branched, Leafl. obovate, Petioles winged, Racemes clustered, Pods gland. viscid

10546 Erect branched, Leafl, obovate cuneate, Racemes axill, on long stalks dichotomous

10547 Leaves simple, Spikes like cones, Bractes cucuilate foliaceous netted

10548 Leaves ternate large, Bractes numerous orbicular lined

10549 Leaves binate ovate-lanc. Bractes ovate acute

10550 Leaves simple lanc. blunt, Stem spiny

10551 Leaves simple lanc. acute, Stem unarmed, Stipules scarious

10552 Leaves simple obovate roundish, Stipules scarious shorter than petiole, Pods smooth netted

10553 Leaves simple cordate-roundish blunt smooth above downy beneath

10554 Leaves simple ovate acute with stipules

10555 Leaves simple cordate oblong stalked winged, Branches 3-cornered

10556 Leaves simple ovate blunt

10557 Leaves simple cordate oblong, Petioles simple, Stipules sheathing

10558 Leaves simple cordate lanc. sagittate, Flowers solitary, Pedunc capillary very long

10559 Leaves simple and ternate intermediate 2-lobed : lobes spreading lanc. Joints of pod wavy plaited

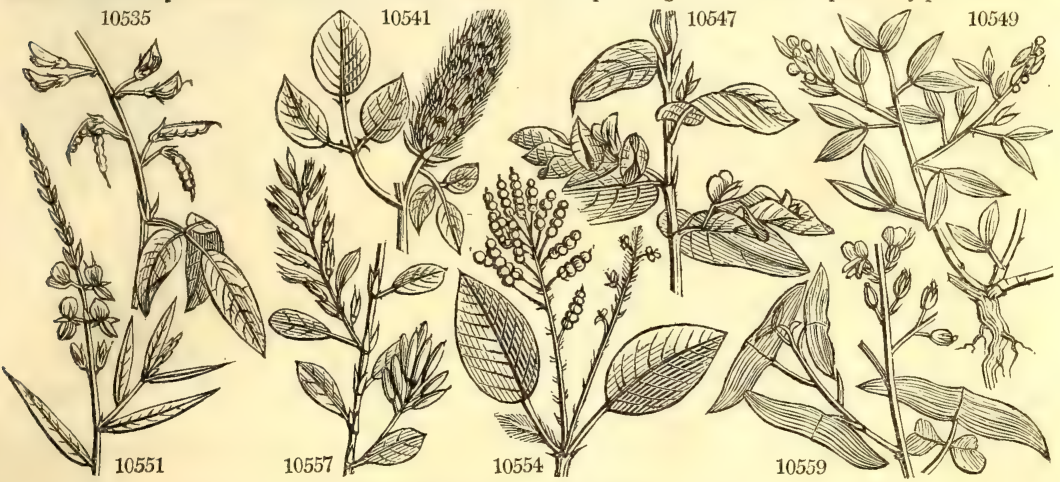

and Miscellaneous Particulars.

numerous genus, not remarkable for beauty, but containing two curious species, the manna plant, and the turning Hedysarum; and one of considerable importance in European agriculture, the Saint-foin.

H. Alhagi is a thorny shrub, with lanceolate leaves, and coriaceous, subcylindric, and scarcely jointed pods. It is on this plant that Manna Trungebeen is found in Mesopotamia (Russ. Alepp.) and other eastern countries. It is chiefly gathered about Tauris, where the shrub grows plentifully. Sir George Wheeler found it growing in Tinos; Tournefort also found it in many plains of Armenia and Georgia, and made a distinct genus of it, under the name of Alhagi, from the Arabic Aghul or Al-gul.

H. gyrans is a native of Bengal near the Ganges; and is called there Buram Chadali, or Burram Chandali. This is a wonderful plant, Linnæus observes, on account of its voluntary motion, which is not occasioned by any touch, irritation, or movement in the air, as in Mimosa, Oxalis, and Dionæa; nor is it so evanescent as in Amorpha. No sooner had the plants raised from seed acquired their ternate leaves, than they began to be in motion this way and that ; this movement did not cease during the whole course of their vegetation, nor were they observant of any time, order or direction; one leaflet frequently revolved, whilst the other on the same petiole was quiescent ; sometimes a few leaflets only were in motion, then almost all of them would be in movement at once: the whole plant was very seldom agitated, and that only during the first year. It continued to move in the stove during the second year of its growth, and was not at rest even in winter. (Supp. Linn.) Swartz observes, that the motion is irregular, and that it sometimes ceases entirely; that in a very hot day it is immoveable, being agitated only in the evening, and that slowly. In our climate, the leaves, in 
10560 tomentósum $W$. 10561 umbellátum $W$. 10562 biarticulátum $\boldsymbol{W}$. 10563 latifólium Roxb. 10564 uncinátum Jacq. 10565 lagocéphalum Link. woolly-headed 10566 aparines Link. 10567 malacophý 10568 gýrans $W$. 10569 trigónum $W$. 10570 canadénse $W$ 10571 canéscens $W$. 10572 marilándicum $W$ 10573 obtúsum $W$. 10574 capitátum $W$. 10575 tortuósum $W$. 10576 viridifórum $W$. 10577 paniculátum $W$. 10578 tuberósum $W$. 10579 cuspidátum $W$. 10580 glutinósum $W$. 10581 serotínum $W$. en. 10582 triflórum $W$. 10583 volúbile $W$. 10584 píctum $W$. 10585 argénteum $L$. 10586 fruticósum $W$. 10587 sennoídes $W$. 10588 alpinum $W$. 10589 obscúrum $W$. 10590 taúricum $W$. 10591 róseum $H$. $\dot{K}$. 10592 coronárium $W$. 10593 flexuósum $W$. 10594 húmile $W$ 10595 muricátum $W$. 10596 spinosíssimum $W$ 10597 Onobrýchis $W$. 10598 saxátile $W$. 10599 álbum $W$.

10600 ascéndens Swz. 3 cceruleum Linal. 10601 grandiflórum Bieb. 10602 cándidum Bieb. 10603 Cáput-gálli $W$. 10604 Crísta-gálli $W$. 10605 crinítum $W$

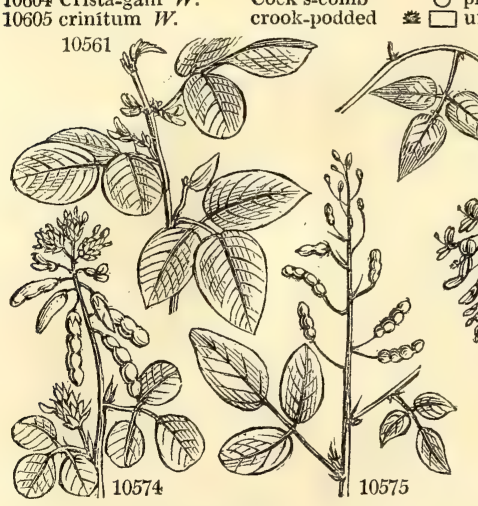
Bedstraw $k$. soft-leaved Moving-plan Canadian hoary

Maryland obtuse headed -flowered panicled tuberous sharp-pointed glutinous

late-flowering

three-flowered twining

painted-leaved

silver-leaved

Senna-like

alpine

creeping-rooted

Taurian Fr.Honeysuckle 0 () wave-podded dwarf prickly-podded

thorny

Saint-foin rock

white ascending blue white

Cock's-head Cock's-com

\section{f $\triangle \mathbb{N}$ un $1 \frac{1}{2} \mathrm{jn} . \mathrm{jl}$ in un 3 ... L $\quad 2$ au} v un 2 un ${ }_{2}$..

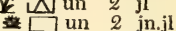
都 $\square$ un 3 ji twisted-podded $\square$ un 3 jl.au

Siberian-shrub. Rose-colored $\$ \vec{\Delta} \mathrm{pr}$

larcelowered white-flowered $\triangle$ un -2 jn.jl [O) $\mathrm{cu} 3$ jlau $\square$ un 1 jl.au $\rightarrow$ un 6 jlau $\Delta$ un 11 jla \& $\triangle$ un $1 \frac{1}{2}$ jl.o $\checkmark$ un $\quad 3$ jl un 3 ... $\frac{1}{4} \Delta$ un $1 \frac{1}{2}$ jl.ä

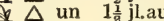
\& $\triangle$ un $1 \frac{1}{2} \mathrm{jl}$.s [य] un 2 jn.jl $\$$ un $3 \mathrm{jl} . \mathrm{s}$ $3 \mathrm{jl.s}$ jl. $\ddot{a u}$ 4 jn.jl jn.ji 4 jn.jl $\frac{1}{2}$ jl.au $\frac{1}{2} \mathrm{jl}$ $\frac{x^{\frac{1}{2}}}{2} \mathrm{jl} . \mathrm{au}$ 4 jn.jl jn.jl 1 jl.au * $\triangle$ un $\frac{1}{2}$ jl.au 角 $\mathrm{O}$ un 1 jl.au $\triangle$ ag 1 jn.jl $\triangle \Delta$ or 1 jn.au $\triangle \mathrm{pr} 1$ jn.au un $1 \frac{1}{2} \mathrm{jn} . \mathrm{au}$ ए un 2 in au $\rightarrow$ or or $1 \frac{1}{2} \mathrm{jn}$.au $\Delta$ pr $\frac{1}{2}$ my.jn O pr 1j.au 1 jn.au

Pu China 1782. C 1.p W E. Indies 1801. C 1.p Jac.schœ.3.t.297 Pu E. Indies 1808. C l.p Bur. zeyl.t.50.f.2 Pu China 1818. C l.p Bot. reg. 355 Pu Caraccas 1823. C co Jac. schön. t.298 Y Brazil 1824. C co Pu Mexico 1823. C p.l Pu Manilla 1822. C p.l Pu E. Indies 1775. S p.I Pu N Amer 1640. W.pu N. Amer, 1733. D s.1 $\mathrm{Pu}$ N. Amer. 1725. D s.1 V N. Amer. 1805. D s.l $\mathrm{Pu}$ Ceylon $\mathrm{C}$ s. 1 Pu Jamaica 1781. C s.l G N. Amer. 1787. D s.l Pu N. Amer. 1781. C s.I $\mathrm{Pu}$ E. Indies 1806. D s.1 V N. Amer. 1806. D s. Pu N. Amer. 1805. D s.

V ...... $\quad . . \quad$ D s.

$\mathrm{Pu}$ India 1796. S s.I Bur.ind, t.54.f.2

Pu N. Amer, 1727. C s.1 Dil el.t.143.f170

$\mathrm{Pu}$ E. Indies 1788. C p.l Jac. ic. 3.t.567

Pa.pu Siberia 1796. D s.1 Pall. it. 2. t. 9

$\mathrm{Pu}$ Siberia 1782. C s.l Pall. it. 3.t.5 f.1

Pu

1798. D s.l Bot. reg. 808

Pu Alps ofEu.1640. D s.1 Bot. mag. 282

Pa.pu Tauria 1804. D s.l

Pk Caucasus 1803. S s.l

Sc Italy 1596. S co

Pu Spain 1640. 1 D $\mathrm{s}$.

Y Patagonia 1793 . D

Pk Britain

L.Y S. Europe 1790. D s.1 All.ped.1.t.19.

W Hungary 1804. D s.l Pl.rar.hu.2.t.111

Pu Jamaica 1818, C s.

W. Indies 1818. C s.l Bot. reg. 815

Tauria 1821. D co Bieb cent.t. 63

Tauria 1824. D co

France 1731. S s.

S. Europe 1710 . S s. 10564

Pk E. Indies 1780. C s.1 Burm. ind. t. 53

History, Use, Propagation, Culture

general, only make a faint and feeble attempt towards the middle of the day at exerting their extraordinary faculty. (Shaw.)

This motion does not depend upon any external cause that we can trace, and we are not able to excite it by any art that we possess. It is not the action of the sun's rays, for this plant is fond of shade, and the leaves revolve well on rainy days, and during the night: exposed to too much wind or sun, it is quiet. Perhaps, says Linnæus, there may be some part in vegetables, as in animals, where the cause of motion resides.

H. coronarium, Sulla, or Sainfoin a bouquets, Fr., is an esteemed border biennial, and some speculative agriculturists recommend it for cultivation as a field plant. In Calabria it grows wild in great luxuriance, near four feet high, affording excellent nourishment to horses and mules, both green and made into hay: but it does not well bear the spring in the north of Italy : we may presume, therefore, that it will scarcely bear our climate well enough to answer the purposes of husbandry. Osbeck mentions, that he saw it brought into Cadiz in great bundles, as food for cattle.

H. Onobrychis, L'esparcet, Fr., Esparzette, Ger., and Cedrangolo, Ital,, is a deep rooting perennial, with branching spreading stems, compound leaves, and shewy red flowers. It is a native of many parts of Europe, but never found but on dry warm chalky soils, where it is of great duration. It has been long cultivated in France, and in other parts of the continent, and as an agricultural plant, a good deal in England, in the chalky districts; and its peculiar value is, that it may be grown on soils unfit for being constantly under tillage, and which would yield littie undergrass. This is owing to the long and descending roots of the saint-foin, which will penetrate and thrive in the fissures of rocky and chalky understrata. Its herbage is said to be equally suited for pasturage or for hay, and eaten green it is not so apt to swell or hove cattle as the clovers or lucern. Arthur Young says, that upon soils proper for this grass no farmer can sow too much of it, and in 
10560 Leaves ternate downy beneath, Stem angular downy, Racemes axillary

10561 Leaves ternate roundish ovate and branches 3-cornered hairy, Pedunc. umb. axill. shorter than petiole 10562 Leaves ternate oblong, Stem branched, Raceme terminal, Pods with 2 joints strigose

10563 Leaves simple reniform cordate repand, Racemes axillary with hooked hairs

10564 Leaves ternate ovate villous, Stem climbing, Racemes terminal

10565 Leafl. roundish hairy beneath, Panic. term. contracted bracteate, Pedunc. and cal, very hairy

10566 Leaves tern. Stem hairy rough, Leafl. roundish and obl. pale beneath somew. hairy, Racemes terminal

10567 Leaves tern. obl. subcordate pale and soft beneath, Raceme terminal

10568 Leaves tern. oval-lanc. blunt: lateral very minute, Panicle terminal, Pods repand below pendulous

10569 Leaves tern. ovate acute hairy, Stem climbing 3-cornered, Racemes very long axillary

10570 Leaves tern. obl. lanc. Stipules filiform, Fl. racemose, Pods hispid

10571 Leaves tern. roundish downy beneath, Stipules ovate acuminate, Stem angul. cil. hispid

10572 Leaves tern. oblong villous beneath, Stipules subulate, Racemes panicled, Pods with 3 joints

10373 Leaves tern. ovate blunt subcordate at base, Stipules lanc. subulate, Panicle terminal

10574 Leaves tern. roundish obovate downy beneath, Stipules lanc. Racemes axillary

10575 Leaves tern. ovate-obl. blunt smoothish, Racemes erect axillary, Pods tortuous

10576 Leaves tern. ovate-obl. rough beneath, Stip. lanc. cuspid. Racemes panicled with bractes

10577 Leaves tern. oblong lanc. smooth, Panic. term. Joints of pod rhomboid downy

10578 Leaves tern. ovate acute, Raceme term. very long, Pods repand villous

10579 Leaves tern. ovate acum. Panicle term. Joints of pod netted downy at edge

10580 Leaves tern. roundish ovate acuminate, Panicle scape-like from the base of stem, Peduncles viscid

10581 Leaves tern. ellipt. blunt beneath and petioles hirsute, Raceme term. simple

10582 Leaves tern. obcordate, Stem procumb. Pedunc. 1-fl. axillary, Pods with upper edge repand

10583 Leaves tern. lanc. blunt, Racemes axillary, Stem twining

10584 Leaves pinnate lanc. Raceme very long spiked, Joints of pod ellipt. plaited

10585 Leaves pinnate oval broader at base silky beneath, Cal. shorter than corolla, Joints of pod downy rough

10586 Leaves pinnate, Leaf. ellipt. blunt downy beneath alternate, Joints of pod netted

10587 Leaves pinn. Leafl. altern. smooth obovate retuse, Racemes axill. few-fi.

10588 Leaves pinn. ovate lanc. smooth, Racemes long axill. Bractes shorter than peduncle

10589 Leaves pinn. ovate smooth, Racemes axill. Bractes longer than peduncle

10590 Leaves pinn. lanc. linear downy beneath, Joints of pod roundish roughish

10591 Leaves pinn. in 7 pairs ellipt. Racemes capitate axillary stalked, Standard striped

10592 Leaves pinn. roundish ellipt. Joints of pod roundish aculeate naked

10593 Leaves pinn. oblong, Pods flexuose, Joints prickly

10594 Leaves pinn. linear cuneiform, Wings very short, Joints of pod roundish hairy prickly

10595 Leaves pinn. obovate emarg. hispid at edge, Raceme term. Pods with many joints muricated

10596 Leaves pinn. obovate emarg. Flowers in capitate racemes, Joints of pod round villous acuminate

10597 Leaves pinn. cuneate smooth, Wings as long as calyx, Pods smooth 1-seeded prickly

10598 Leaves pinn. linear smooth, Wings shorter than calyx, Pods smooth 1-seeded prickly

10599 Leaves pinn. linear silky beneath, Wings shorter than cal. Pods downy 1-seeded prickly-toothed

10600 Leaves ternate roundish downy beneath, Stem round, Branches declinate ascending hairy

10601. Leaves pinnate ellipt. silky, Cal, as long as wings, Joints of pod villous

10602 Leaves pinnate silky shining roundish ovate, Cal. length of corolla, Joints of pod rugose downy

10603 Leaves pinnate obl. smooth, Wings shorter than cal. Pods 1-seeded prickly, Teeth of crest subulate

10604 Leaves pinnate obl. smooth, Petals nearly equal, Pods 1-seeded prickly, Teeth of crest lanceolate 10605 Leaves pinnate, Racemes long, Pods inflexed

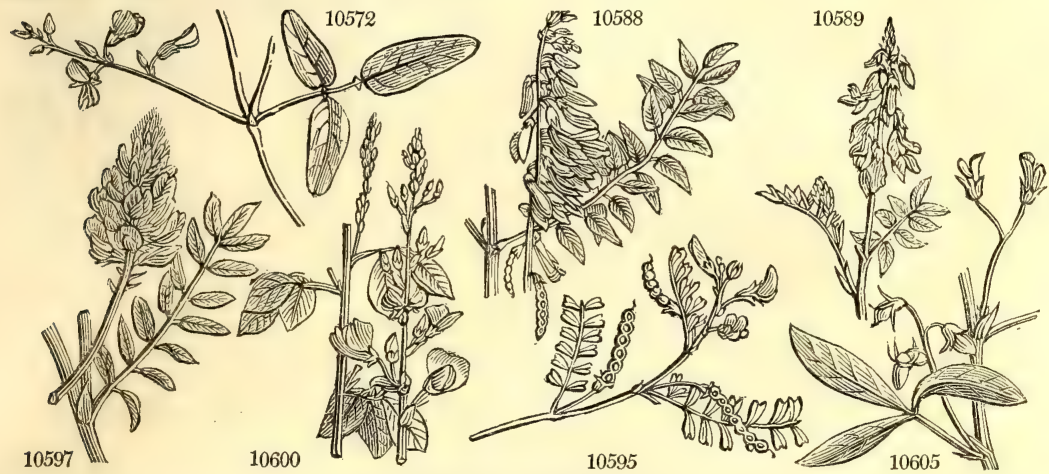

and Miscellaneous Particulars.

The Code of Agriculture, it is said to be " one of the most valuable herbage plants we owe to the bounty of providence."

The deeper the soil is stirred previously to sowing the better; the seed is generally put in broad cast, at the rate of three or four bushels the acre, and sometimes a little red clover is sown afterwards to produce a crop the second season, when the saint-foin plants are but small. When saint-foin is annually mown, it should be top-dressed with manure; but if only occasionally mown, the benefits derived from the grazing of sheep or eattle will, to a considerable extent, answer for surface dressings in a plant that derives a part of its nutriment from the subsoil. Saint-foin is highly nutritive, either cut green or made into hay. The produce, on a medium of soils and cultivation, may probably be estimated at from about one and a half to two tons the acre. And on the poorer and thinner staple sorts of land, it will perhaps seldom afford less than from a ton to a ton and a half on the acre. One thousand parts of saint-foin afforded Sir H. Davy thirty-nine of nutritive matter, which is the same as that afforded by the red and white clover.

The usual duration of saint-foin, in a profitable state, is from eight to ten years. It usually attains its perfect growth in about three years, and begins to decline towards the eighth or tenth on calcareous soils, and about the seventh and eighth on gravels. There are instances, however, of fields of saint-foin, which had been neglected and left to run into pasture, in which plants have been found upwards of fifty years from the time of sowing. It has been cultivated upwards of a century on the Cotswold hills, and there roots of it have been traced down into stone quarries from ten to twenty feet in length, and in Germany, Von Thaer found them attain the length of sixteen feet. In general, the great encmy to the endurance of saint-foin, is the grass which accumulates, and forms a close turf on the surface, and thus chokes up the plant. 
1589. INDIGOFERA. $W$. INDIGo.

\section{6 filifólia $W$}

10607 linifólia $W$.

10608 psoraloídes $W$

10609 cándicans $W$.

10610 amø'na $W$.

10611 incána $W$

10612 sarmentósa $W$

10613 denudáta $W$.

10614 trita $W$.

10615 microphýlla Lam.

10616 coriácea $W$.

10617 enneaphýlla $W$.

10618 cytisoídes $W$.

10619 stricta $W$.

10620 hirsúta $W$

10621 angustifólia $W$.

30622 austrális $W$.

10623 viscósa $W$.

10624 A'nil $W$.

10625 tinctória $W$

10626 argéntea $W$.

10627 endecaphýlla $W$

10628 stipuláris Link.

10629 aphýlla Link. naked-stalke.

Flax-leaved

long-piked

white-leaved

hoary

dwarf

smooth-leaved oyal-leaved

small-leaved

leathery-leaved

trailing

angular-stalked

upright

hairy

narrow-leaved

Botany-Bay

clammy

West-Indian

East-Indian

silver-leaved

eleven-leaved

large-stipuled

leafless

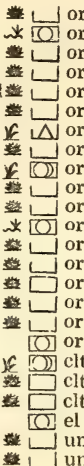

Leguminosa.

$\begin{array}{lll}1 & \text { jl.o } & \mathrm{Pu} \\ 1 & \text { jl.au } & \mathrm{Pu}\end{array}$ jl.s $\quad \mathrm{R}$

my.s R

mr.ap Sc

2 my.jl Pu

$\frac{1}{2}$ jn.jl $\mathrm{Pu}$

my.j

1 jn.jl

$\frac{1}{2}$ ja.d

3 jl.au

$\mathrm{Pu}$

jl.au Pu

3 jl.au Pu

jn... $\quad \mathrm{Pu}$

mr.jn Pk

1 jn.jl $\mathrm{Pu}$

3 jl.au Pu

3 jl.au

jl.au

4. jl.au

$1 \frac{1}{2} \quad \ldots$
C. G. $\overline{\mathrm{H}}$

C. G. H. 1812. C s.l Bot. reg. 104

C. G. H 1792. S s.l Rox. cor. 2.t.194

C. $H$ 1758. S s.p Bot. mag. 476

C. G. H. 1774. C s.p Bot. reg. 300

C. G. H. 1812. C s.p

C. G. H. 1786. C s.p

C. G. H. 1790. C s.p Bot. cab. 500

C. Indies 1802. C s.p

C. G. H. 1812. C $\quad$ s.p

E. Indies 1776 C s.p Bur ind 55 f

C. G. H. 1774. C s.p Bot. mag. 742

C. G. H. 1812. C s.p Jac. schœe.2.t 236

E. Indies 1759. C s.p Burm. zeyl, t. 14

C. G. H. 1774. C s.p Bot, mag. 465

N. S. W. 1790. S s.p Eot, cab 149

E. Indies 1806. C s.p Sert. han. 2.t. 12

W. Indies 1731. C s.p

E. Indies 1731. C s.p Rhe.mal. 1.t. 54

$\mathrm{Pu}$ W. Indies 17i6. C s.p L'Her. stirp.t.79

Sc S. Leone 1823. S co Bot. reg. 789

C. G. H. 1824. C s.p

C. G. H. 1825, C s.p

1590. TEPHRO'SIA. $P$. S. TePhrosia

10630 toxicária P.S. Fish-Poison

10631 virginiána $P h$.

10632 grandiflóra $P . S$

10633 strícta $P$. $S$.

10634 pállens $P$. $S$.

10635 villósa $P$. $S$.

10636 piscatória $P$. S

10687 purpúrea $P$. S

10638 capituláta Link.

Leguminosa.

\begin{tabular}{lllll} 
Virginian & $\square$ clt & 3 & $\ldots$ & $\mathrm{Pu}$ \\
\hline & or & 4 & $\mathrm{jn} . \mathrm{au}$ & $\mathrm{Pk}$
\end{tabular}

Rose-colored

straight-podded $\bigsqcup_{\text {or }} 3 \mathrm{my}$.jn $\mathrm{Pk}$

pale-flowered

villous

woolly

purple

capitellate

lance-leaved

S. Amer. 1791. S p.l Plum.ic.t. 135 . Amer. 1765. C s.p Plu. alm.t. 23.f.2 G. H. 1774. C p.l Bot. reg. 769 C. G. H. 1774, C p.1 Scop. insub. 1.t.3 C. G. H. 1787. C p.I E. Indies 1779. S p.l Plu. alm. t.59.f.6 India 1778. C $1 . p$ E. Indies 1768. C 1.p Burm, zeyl, t. 32 Owbyhee 1823. C co

1591. GALE'GA. P. S. GOA'T'S-RUE. 1.0640 officinális $W$.

$$
\beta \text { alba }
$$

10641 orientális $W$.

10642 caribæ'a $W$

10643 ochroleúca $W$

white-flowered

oriental

Leguminosa

Levant 1801. C p.l Bot. mag. 2192

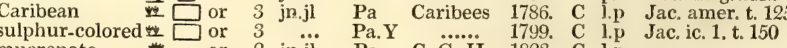

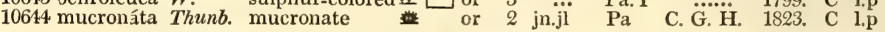

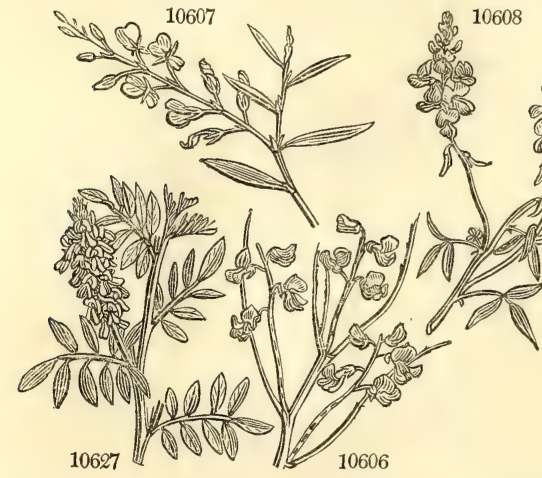

History, Use, Propagation, Culture, 10613

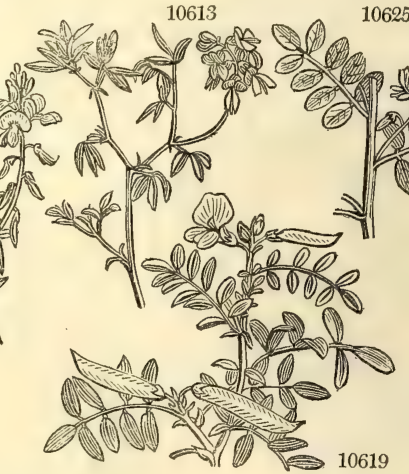

10625

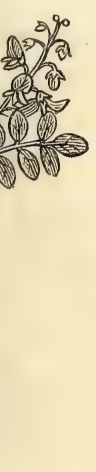
1589. Indigofera. That is to say, a plant bearing indigo. The species are elegant little shrubs, free-
fowerers, and of easy culture. Most of them will yield the dye, but those chiefly cultivated for this purpose are the I. Anil (Alnyl, Arab.), in the West Indies, and the I. tinctoria, argentea, and some other species in the East Indies. The indigo is one of the most profitable articles of culture in Hindustan; because an immense extent of land is required to produce but a moderate bulk of the dye ; because labor and land here are cheaper than any where else; and because the raising of the plant and its manufacture may be carried on without even the aid of a house. The first step in the culture of the plant is to render the ground, which should be friable and rich, perfectly free from weeds, and dry if naturally moist. The seeds are then sown in shallow drills about a foot apart. The rainy season must be chosen for sowing, otherwise if the seed is deposited in dry soil, it heats, corrupts, and is lost. The crop being kept clear of weeds, is fit for cutting in two or three months, and this may be repeated in rainy seasons every six weeks. The plants must not be allowed to come into flower, as the leaves in that case become dry and hard, and the indigo produced is of less value; nor must they be cut in dry weather, as they would not spring again. A crop generally lasts two years. Being cut, the herb is first steeped in a vat till it has become macerated and parted with its coloring matter; then the liquor is let of into another, in which it undergoes the peculiar process of beating, to cause the fecula to separate from the water. This fecula is let off into a third vat, where it remains some time, and is then strained through cloth bags, and evaporated in shallow wooden boxes placed in the shade. Before it is perfectly dry, it is cut in small pieces of an inch square; it is then packed in barrels, or sowed up in sacks for cale In sale. Indigo was not extensively cultivated in India before the British settlements were formed there; its profits were at first so considerable, that, as in similar cases, its culture was carried too far, and the market
glutted with the commodity. The indigo is one of the most precarious of oriental crops; being liable to be destroyed by hail storms, which do comparatively little injury to the sugar-cane and other plants.

The indigo cultivated in the West Indies, thrives best in a free rich soil, and a warm situation, frequently refreshed with moisture. Having first chosen a proper piece of ground, and cleared it, hoe it into little 
10606 Leaves simple filiform, Flowers racemose

10606 Leaves simple filfor hery,

10608 Leaves ternate lanc. silky beneath, Racemes longer than leaf, Pods pendulous

10609 Leaves ternate lin. lanc. silky beneath, Racemes longer than leaf few-fl. Pods straight

10610 Leaves ternate oblong downy beneath, Racemes longer than leaf, Pods reflexed appressed

10611 Leaves ternate obovate silky beneath, Raceme term. long, Stem decumbent

10612 Leaves termate, Leafl. ovate mucronate sessile, Pedunc. axill. about 2-fi. Branches filiform spreading

10613 Leaves ternate obcordate smooth, Racemes longer than leaf, Pods pendulous

10614 Leaves ternate ovate acute, Racemes short, Stem erect

10615 Leaves ternate obovate on short stalks, Pedunc. long filiform, Pods pendulous

10616 Leaves quinate obovate mucronate hairy, Stipules subulate, Pods straight smooth

10617 Leaves pinnate cuneate 7, Racemes as long as leaves, Pods 4-cornered 2-sceded

10618 Leaves pinnate 5 or 7 oblong narrowed at each end, Racemes longer than leaf

10619 Leaves pinnate 7 or 9 oblong downy beneath, Racemes about 5-flowered sessile, Stem straight

10620 Leaves pinnate of 4 or 5 pairs hoary beneath, Racemes length of leaves spiked, Pods 4-cornered villous

10621 Leaves pinnate linear, Racemes axillary, Stem shrubby downy

10622 Leaves pinnate smooth of many pairs oblong, Racemes shorter than leaf, Standard smooth

10623 Leaves pinnate of 6 pairs obovate strigose, Racemes shorter than leaf, Pods pendulous, Stem viscid

10624 Leaves pinnate oblong of 3 pairs, Racemes shorter than leaf, Pods falcate

10625. Leaves pinnated obl. smooth of 4 pairs, Racemes shorter than leaf, Pods round arcuate

10626 Leaves simple ternate and pinnate silky, Pods torulose pendulous

10627 Leaves pinn. obl. smooth, Racemes spiked shorter than leaf, Pods 4-cornered reflexed

10628 Stem muricate downy, Leafl. oval hairy, Stip. oval acute, Racemes longer than leaves

10629 Leaves about 3, Leafl. lanc. blunt mucronulate smooth deciduous, Petioles persistent

10630 Leafl. obl. lanc. blunt downy beneath, Raceme terminal long, Pods round spreading

10631 Pods falcate backwards compressed villous spiked, Calyxes woolly, Leafl. oval-obl. acuminate

10632 Leaf. obl. mucronate downy beneath, Stip. ovate acuminate, Raceme 4-fl. terminal, Pods pendulous

10633 Leaf. cuneate-obl. recurved mucronate villous beneath, Stipules subulate, Raceme few-fl.

10634 Pods straight spreading ciliated, Stip. subulate, Leafl. 9-11 obl. acute downy beneath

10635 Leaf. lanc. cuneate retuse silky beneath, Stip. setaceous, Pods falcate backwards villous pendulous

10636 Pods straight ascending villous, Stip. subulate, Pedunc. 2-edged, Leafl. obl. blunt

10637 Leafl. obl. cuneate emarg. mucronate smooth, Stip. subulate, Pods racemose straight ascending

10638 Leaf. inversely lanc. obtuse emarg. silky beneath, Racemes terminal short

10639 Leafl. inversely lanc. emarg. mucronate hairy, Stip. subulate, Racemes terminal

10640 Leafl. Ianc. mucronate smooth, Stip. lanc. sagittate, Pods erect straignt

10641 Leafl. ovate acuminate smooth, Stip. ovate, Flowers cernuous

10642 Leaf. obl. acute downy beneath, Stip. subulate, Pods smooth racemose pendulous

10643 Leafl. ovate acute downy, Stip. subulate, Pods straight pendulous smooth racemose

10644 Leaves pinn. ovate mucron. villous, Stem erect, Branches downy

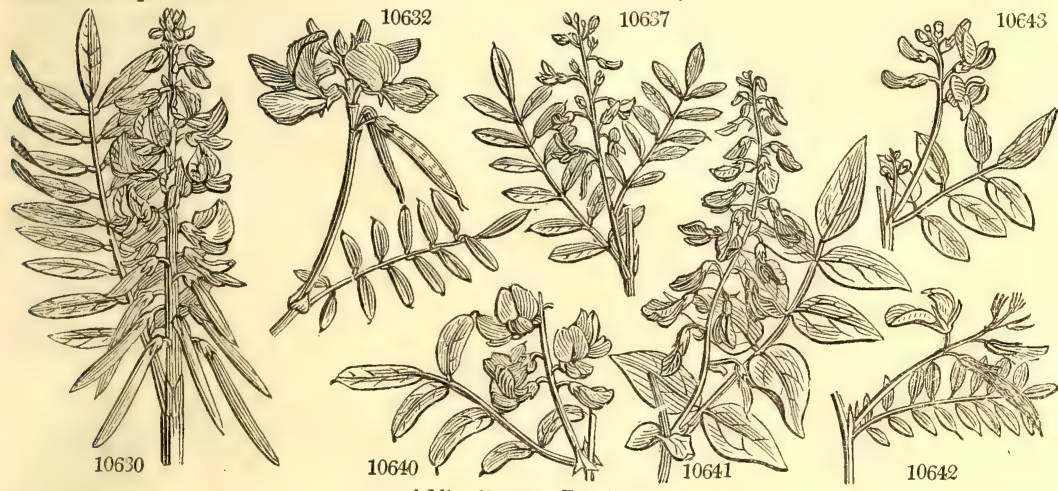

and Miscellaneous Particulars.

trenches, not above two inches, or two inches and a half in depth, not more than fourteen or fifteen inches asunder. In the bottorn of these, at any season of the year, strew the seeds pretty thick, and immediately cover them. As the plants shoot, they should be frequently weeded, and kept constantly clean, until they spread sufficiently to cover the ground. Those who cultivate great quantities, only strew the seeds pretty thick in little shallow pits, hoed up irregularly, but generally within four, five, or six inches of one another, and covered as before Plants raised in this manner, are observed to answer as well, or rather better, than the others; but they require more care in the weeding. They grow to full perfection in two or three months, and are observed to answer best when cut in full blossom. The plants are cut with reaping hooks, a few inches above the root, tied in loads, carried to the works, and laid by strata in the steeper. Seventeen negroes are sufficient to manage twenty acres of indigo; and one acre of rich land, well planted, will, with ood seasons and proper management, yield five hundred pounds of indigo in twelve months, for the plant ratoons (i. e, it sends out stolones), and gives four or tive crops a year; but must be replanted aiterwards.

Indigo has long been cultivated in Spain, but is on the decline in that country, owing to the more favorable circumstances of the East and West Indies. It was tried in the south of France and Italy, during the Buonaparte dynasty, but found not worth following for the same reason.

1590. Tephrosia. From $\tau \approx \phi \zeta o s$, ash-colored, in allusion to the color of the foliage. T. toxicaria is a spreading shrubby plant. The leaves and branches, well pounded, and thrown into a river or pond, very soon affect the water, and intoxicate the fish, so as to make them float on the surface, as if dead; most of the large ones recover after a short time, but the greatest part of the small fry perish on these occasions, It has been introduced to Jamaica, and cultivated there, on account of its intoxicating qualities. (Browne)

1591. Galega. A name of unexplained meaning. Ruellius says, it is the word Glaux, Italianized! G. officinalis was formerly accounted cordial and sudorific, but is now out of repute. The species are handsome border fiowers. 
1592. PHA'CA. $W$.

10645 bœ'tica $W$.

10646 frígida $W$.

10647 alpina $W$

10648 austrális $W$.

10649 arenária $W$.

10650 astragalina $P$. S.

1593. OXY'TROPIS. Dec

10651 montána Dec.

10652 Lambérti Ph.

10653 uralénsis $P$. $S$. Astrágalus ural

10655 campestris $\mathrm{Dec}$

10656 uncáta Dec.

10657 altáica Dec.

10658 cymbicárpos Dec.

10659 pilósa $\mathrm{Dec}$.

10660 dealbáta Dec.

10661 defíxa Dec.

10662 dichóptera Dec.

1594. ASTRA'GAL

10663 christiánus $W$.

10664 tomeritósus $W$.

10665 alopecuroídes $W$.

10667 narbonénsis $W$

10668 capitátus $W$

10670 melilotoídes $W$

10671 virgátus $W$.

10672 tenuifólius $W$.

10673 as'per $W$.

10674 galegifórmis $W$.

10675 chinénsis $W$.

10676 viréscens $D e c$.

10677 falcátus Dec.

10678 uliginósus $W$.

10679 caroliniánus $W$.

10680 canadénsis $W$.

1068ı semibiloculáris Dec.

10682 Cícer $W$.

10683 carnósus $P h$.

10684 caryocárpus $B$. reg.

10685 glycyphýllus $W$.

10686 microphýllos $W$.

10687 triméstris $W$.

10688 Búceras W. en

10689 hamósus $W$.

10690 canaliculátus $W$.en.

10692 contortuplicatus $W$. wave-podded $*$ or

10692 bœ'ticus $W . \quad$ triang.-podded $\boldsymbol{w}$. $\mathrm{O}$ or

10693 Stélla $W$.

10694 ægíceras $W$. en.

Star-podded $*$ or or

BASTARD VETCH. hairy

small Alpine $\frac{\$}{2} \Delta$

trailing $\frac{\mathrm{z}}{\mathrm{z}} \Delta \mathrm{pr}$

(n) procum

mountain

\& $\Delta$ pr hairy-mountain $\frac{\Delta}{B} \Delta r$ sis E. B.

Aleppo

dded

s. $\Delta$

O pr 1 jl.au

$\mathrm{O} \mathrm{pr}$

pale-flowered $\$ \Delta \mathrm{pr}$ small-flowered $\frac{d}{2} \Delta \mathrm{pr}$ pubescent w $\Delta \mathrm{pr}$

great-yellow $\not \Delta$ or downy-leaved $\triangle$ or

Fox-tail

French

headed

Melilot-like

twiggy

rough $\frac{\ddagger}{} \Delta \mathrm{pr}$

Goat's-Rue-lv. $\Delta$ or

upright Chinese $\downarrow \Delta$ or

green-flowered $\vec{x} \Delta$ or sickle-podded $\vec{\Delta} \Delta$

marsh

woolly

bladdered

Dै $\Delta$ or

* $\triangle$ or

考 $\Delta$ or

or

\& or

small-leaved

Egyptian

horned $\quad *$ or

or $2 \mathrm{jn} . \mathrm{j}$

1 jn.jl

$\begin{array}{ll}2 & \text { jn.jl } \\ 1 & \text { jl.au }\end{array}$

3 jn.jl

$\frac{1}{2} \mathrm{jl} . \mathrm{au}$

1 jl.au

10695 brachycárpus Bieb. $\begin{aligned} & \text { short-fruited } \\ & 10696 \text { stipulátus } B \text {. M. } \\ & \text { large-stipuled }\end{aligned}$

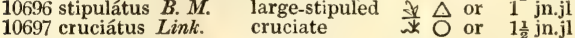

10698 verticilláris $W$.

10699 sesámeus $W$.

10700 annuláris $W$

10701 pentaglóttis $W$.

10702 epiglottis $W$.

whorled

* $\triangle$ or $1 \frac{1}{2}$ jn.jl

Bird's-foot w $O$ or 1 jn.jl ring-podded $w^{*} \bigcirc$ or $1 \frac{1}{2} \mathrm{jn}$.j

Leguminosa. Sp. 6-14.

$S_{\text {Spain }}{ }^{14 .} 1640 . \quad$ R s.1 Moris. s. 2.t.8.f.

Austria 1795. P s.l Jac. aust. t. 166

Austria 1759. R s.l Jac. ic. 1.t. 151

S. Europe 1779. R s.l Bot. cab. 490

Siberia 1796. R s.l Pal.it.3.t.cc.f.1.2

n.jl W.B N. Europe 1771. R s.l Bot. cab. 429

Leguminose. Sp. 12-21.

Pu Austria 1581. D s.1 Bot. mag. 843

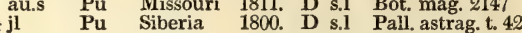

my.au Y.Pu Scotland ... D s.l Eng. bot. 466

Wu Germany 1778. S s.l Pl.r

Pa 1802. S co

Pa Portugal 1800. S co

Pa.Y Siberia 1732. D s.1 Bot. cab. 544

$\mathrm{Pu}$ Caucasus 1803. D s.l Pal, ast.t.23.f.2,3

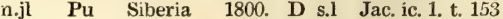

Leguminose. Sp. 63-110.

Y Armenia 1737. D s.1 Tourn. it.2.t.254

Y Egypt 1800. C p.1 Dec. astrag. t.29

L.Y Spain 1737. C s.l Pall. astrag.t. 8

L.Y Siberia 1815. C s.l Pall, astrag.t. 7

Pa.Y S. Europe 1789. C s.1 Pall. astrag. t.10

Pa.Y Levant 1759. C s.I

L.B Siberia 1785. C co Jac, vind. 3. t. 40

Pu Siberia 1785. C co Pall astrag t41

Vi Siberia 1806. C co Pall. astrag. t.18

Pu Siberia 1780. C p.l Sweet fl. g. 73

Pa.Y Astracan 1796. C p.l Jac. ic. t. 152

Y.G Siberia 1729. C s.l Pall. astrag. t.29

R China 1795. C p.I Linn. fil. dec.t.3

G.Y Siberia 1737. D p.1

Pa.Y Siberia 17. $D$ p. 1 Dec astrag. t. 26

L. B Siberia 1752. D p.1 Pall astrag. t. 26

G.Y N. Amer. 1732. D s.1 Dill. elt. t.39.f.45

Y N. Amer. 1732. D s.l Dodar.mem.t.64

Pa.Y Siberia 1804. D s.1 Dec. astrag. t.23

Y Europe 1570. D s.l Jac. aus. t. 251

W Louisiana 1811.

Pu N. Amer. 1811. D s.l

Bot. reg. 176

Y G Britain ch.wo. D s.l
Y Siberia 1773. D p.l

Y Egypt 1739. S co

Pa.Y Spain 1633. $\mathrm{S}^{*}$ co

W ….. 1816. S co

Y Siberia 1764 S co Pall, astrag 79

$\mathrm{Pu}$ S. Europe 1759. S co Bocc. sic.7. t. 4

$\mathrm{Pu}$ S. Europe 1658. S co Plu. alm, t.79. f.4

Pa.Y …... 1818, s co

$\mathrm{Pu}$ Caucasus 1820. D s.l Bot. mag. 2335

Y Nepal 1822. D s.l Bot. mag. 2380

Vi $\quad$....... 1820. S s.

Pk Siberia 1822. D s.1

Pa.B S. Europe 1616. S s.l

rough-Spanish * or $\frac{\Lambda}{2}$ jn.jl Pú Spain 1739, S s.l Cav, ic 2 t. 188

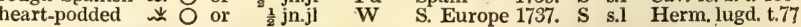

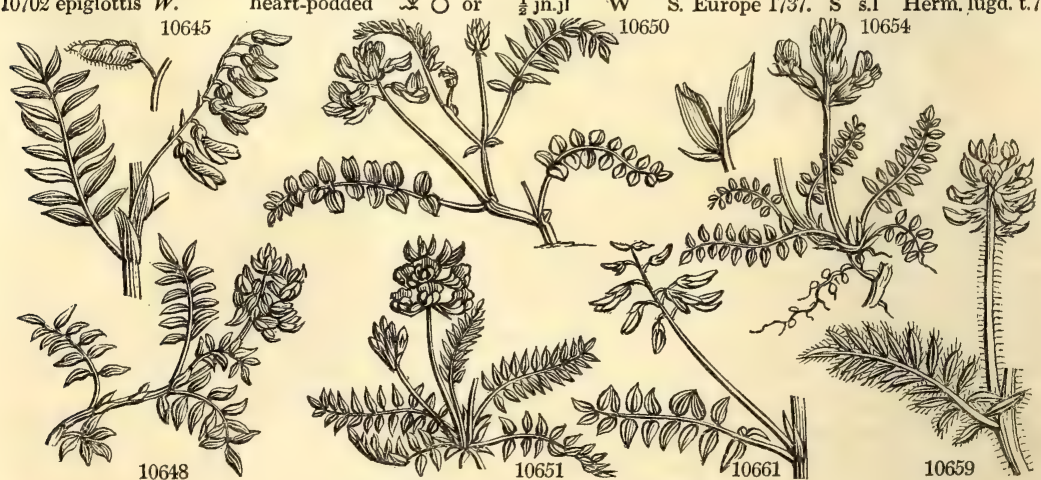

History, Use, Propagation, Culture,

1592. Phaca.

These are pretty herbaceous plants, with the habit of Astragalus.

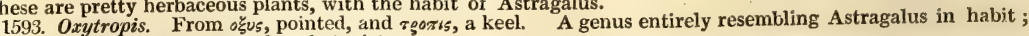
but considered distinct by modern botanists.

1594. Astragalus. This was a name given by the Greeks to one of their leguminous plants, but it is not

known to which. The modern genus is composed of plants, the greater number of which are very orna- 
10645 Erect hairy, Leafl. oval acute, Stip. lanc. Pods obl. cymbiform compressed

10646 Erect undivided, Leafl. 11 obl. blunt subciliated, Pods oblong inflated

$106 \pm 7$ Erect branched downy, Leafl. in many pairs obl. lanc. blunt, Pods half ovate acute

10648 Branched ascending, Leafl. about 17 lanc. : the odd one subsessile, Alæ bifid

10649 Branched ascending smooth, Leafl, about 11 lin.-lanc. : the odd one subsess. Pods obovate inflated erect

10650 Caulescent procumb. Fl. pendulous racemose, Pods acute at each end hairy

10651 Stemless villous, Pods erect roundish-obl. villous acuminate with style half 2-celled

10652 Stemless silky, Leafl. 19 lanc. ellipt. acute at each end, Spikes capitate

10653 Stemless villous silky, Pods erect ovate cylindr. inflated 2-celled

10654 Stemless, Leafl. lanc. silky, Scape longer than leaf and calyxes silky, Heads few-fl. cernuous

10655 Stemless, Calyx and pods villous, Leafl. lanc. acute, Stem decumbent

10656 Stemless, Pods subulate hooked longer than leaf, Leafl. obcordate

10657 Stemless, Leafl. lanc. smooth, Scapes as long as leaves hairy, Flowers in obl. heads

10658 Stemless, Leafl. cuneiform retuse subsessile, Pods smooth, Flowers nearly apetalous

10659 Caulescent erect hairy, Leafl. lanc. acute, Spikes stalked longer than leaf, Pods subulate hairy

10660 Caulescent erect hairy, Leafl. 3-pair lanc. acute, Stip. obl. acun. Spikes stalked longer than leif

10661 Caulescent ascending, Leafl. ovate lanc. deflexed hairy, Spikes stalked longer than leaf

10662 Caulescent diffuse downy, Stipules united, Wings emarg. Peduncles as long as leaf

10663 Caulescent erect, Leafl. ellipt. stalked, Stip. lin. subulate, Pedunc. about 3-fl. axill. clustered

10664 Caulescent erect, Leafl. roundish cordate sessile downy, Stip. ovate acuminate, Pedunc. 1-fl. axill.

10665 Caulescent erect, Spikes cylindrical subsessile, Cal. and pods woolly

10666 Caulescent erect, Heads of flowers stalked globose, Pods 4-seeded inclosed in woolly calyx

10667 Caulescent erect, Heads of flowers sessile axill. short, Corolla larger than calyx

10668 Caulescent erect, Heads globose, Pedunc. very long, Leafl. emarginate

10669 Caulescent erect striated, Leafl. lin. lanc. smooth, Stip. Ianc. Racemes longer than leaf

10670 Caulescent erect panicled, Leaves of 2 or 3 pair linear cuneate retuse smooth, Racemes filiform

10671 Caulescent erect shrubby, Leaves in 6 pairs lin. lanc. hoary, Racemes long spiked

10672 Caulescent erect, Leafl. linear lanc. Spikes obl. stalked Ionger than leaf, Standard twice as long as alø

10673 Caulescent erect rough, Leaf. lin. lanc. Spikes stalked longer than leaves straight, Pods 3-cornered

10674 Caulescent erect straight smooth, Leafi. ellipt. blunt, Fl. racemose pendulous, Pods 3-cornered smooth

10675 Caulescent erect straight smooth, Leafl. ellipt. blunt, Fl, racernose pendulous, Pods inflated rugose

10676 Caulescent erect smooth, Leaf. lanc. acute, Racemes longer than leaf, Pods falc. acute pendulous

10677 Caulescent erect, Peduncles as long as leaves, Leaflets 33-41, Pods about 3-cornered arcuate

10678 Caulescent erect, Leaf. obl. downy, Spikes stalked, Bractes obl. length of calyx

10679 Caulescent erect, Leafl. obl. downy beneath, Spikes stalked, Bractes lanc. length of peduncle

10680 Caulescent diffuse, Pods subcylindrical mucronate, Leafl. naked beneath

10681 Pedunc. as long as leaves, Leafl. 33-41 scarcely downy, Pods 3-cornered bowed nodding

10682 Pedunc. as long as lvs. Leafl. smoothish obl. blunt mucro. Stip. lanc. Racemes stalked longer than leaf

10683 Pedunc. as long as lvs. silky-white, Leafl, 21 ellipt. smooth above, Spikes subsessile, Pods fleshy

10684 Pedunc. longer than leaf, FI. erect closely spiked, Pods half 2-celled

10685 Caulescent prostrate, Leafl. smooth ovate mucronate blunt, Stip. ovate-lanceolate

10686 Caulescent erect spread. Leafl. ov. hairy, Stip. solitary opp. the lvs. 2-parted, Spikes stalked long. than leaf

10687 Caulescent, Scapes 2-fl. Pods hooked subulate with 2-keels

10688 Caulescent prostrate, Leafl. ellipt. cuneate emarg. Racemes few-fl. Peduncles longer than leaf

10689 Caulescent procumbent, Leafl. cuneate emarg. Stip. ov. Racemes few-fl. stalked shorter than leaf

10690 Caulescent erect, Leafl. obl, retuse, Fl. axill sol. subsessile, Pods deeply channelled

10691 Caulescent procumbent downy, Leafl. obovate emarg. Racemes stalked arcuate twisted

10692 Caulesc. procumb. Leafl. obl. blunt mucro. Spikes stalked few-fl. shorter than lvs. Pods obl. hooked at end

10693 Caulescent diffuse, Heads stalked lateral, Pods straight subulate mucronate

10694. Caulescent difluse, Leafl. ellipt. emarg. Racemes few-fl. stalked shorter than leaî, Pods hooked

10695 Stemless, Leaves ellipt, downy, Scapes racemose longer than leaf, Pods obovate the length of calyx

10696 Caulescent, Leaflets oval-oblong or obovate smooth, Stipules very large leafy

10697 Stem decumb. Leafl. obl, downy, Pedunc. axill. few-fl. Pods arcuate with elevated veins

10698 Stemless, Leafl. subulate 4 whorled pilose, Scapes spiked longer than leaf, Lower flowers remote

10699 Caulescent diffuse, Heads subsessile lateral, Pods erect subulate with a reflexed point

10700 Caulescent diffuse, Pods subulate incurved smooth, Leaf. obovate

10701 Caulescent procumb. Leafl. obl, retuse, Heads stalked shorter than leaf, Pods half ovate squamose at end

10702 Caulescent procumb. Leaf. lin. narrowed at base, Heads subsessile, Pods half ovate reflexed downy

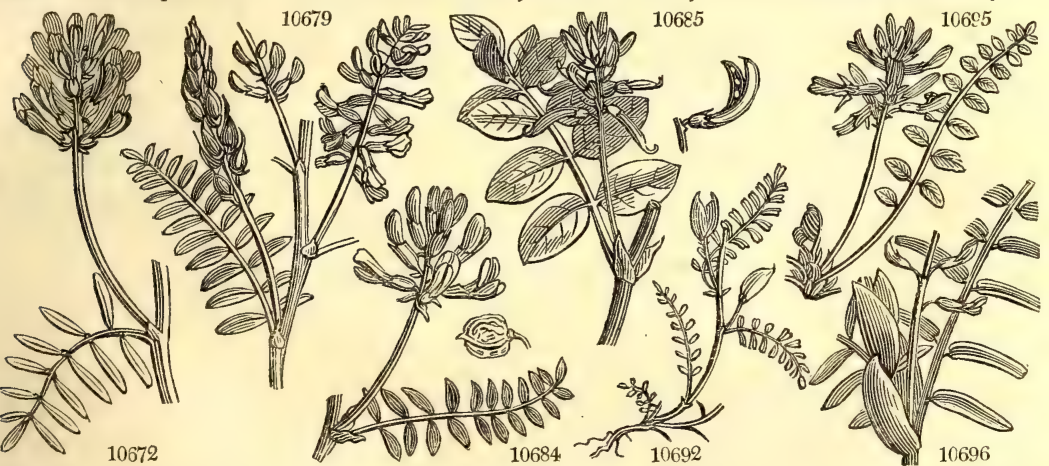

and Miscellaneous Particulars.

mental. A. glycyphyllos is the largest of the European species. The leaves are sweet, with a mixture of bitterness, and do not seem to be agreeable to cattle; at least the plant, in its wild state, is left untouched; otherwise it might have been desirable to cultivate it.

A. Tragacantha was formerly considered as the plant yielding the gum Tragacanth of commerce; but Olivier (Voyage dans l'Empire Ottoman, v. 342 . pl. 44.) discovered that it was generally procured from A. verus. It is probable that both species, and perhaps some others, yield this gum. A. verus is a native of the north 
10703 hypoglóttis $W$. 10704 austriacus $W$. 10705 fruticósus $W$. 10706 arenárius $W$. 10707 leucophæ' us $W$ 10708 depréssus $W$. 10709 leontínus Jac 10710 Glaux $W$. 10711 sínicus $W$. 10712 álbidus $W$. 10713 Onobrýchis $W$. 10714 Laxmánni $W$. 10715 physódes $W$. 10716 halicácabus Lam. 10717 caprinus $W$ 10718 longiflórus $W$. 10719 monspessulánus $W$. 10720 inćm $W$. 10721 exscápus $W$ 10722 tragacanthoi 10723 aristátus $W$. 10724 Tragacántha $W$. 10725 Potérium $W$.

1595. BISER'RULA. $W$. Hatchet Vetch.

1596. DA'LEA. $P$. $S$. Dalea

10727 Cliffortiána $W$. Vera Cruz 10728 alopecuroídes $W$. Fox-tail 10729 aírea $P h$.

10730 laxiflóra $P h$

10731 enneaphýlla $W$.

10732 citriodóra $W$

10733 Lagópus $W$.

10734 mutábilis $W$

10735 bícolor W. en

1597. PSORA'LEA. $W$ 10736 pinnáta $W$. 10737 odoratis'sima $\mathbf{W}$. 10738 verrucósa $W$. 10739 aculeáta $W$. 10740 bracteáta $W$. 10741 spicáta $W$. 10742 aphýlla $W$. 10743 multicaúlis $W$. 10744 tenuifólia $W$. 10745 decúmbens $W$ $107+6$ hirta $W$

10747 Stáchydis $W$. $107+8$ répens $W$. 10749 bituminósa $W$. 10750 glandulósa $W$ 10751 pedunculáta $B$. Mexican tea 10752 palnstina $W$.

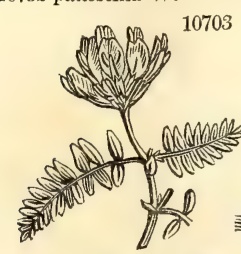
small-Spanish Plat-headed

purple-mountain $\star \star \Delta$ or Austrian sand

dwarf-white depressed Chinese-annual w* or white-Italian $* \Delta$ or purple-spiked * $\Delta$ el \ $\triangle$ or tpelier hairy-podded awned , Thern sm. Goat's Thornw

golden

loose-fiowered

leafy

downy-spiked changeable two-colored

Psoralea.
wing-leaved fragrant warted oval-spiked long-spiked leafless many-stalked fine-leaved trailing

hairy

Stachys-leaved creeping bituminous

祭 1 or $*$ or $1 \frac{1}{2}$ jn.j * or * or jn.j my.au my.jn $\frac{1}{2}$ jn.jl

$\frac{1}{2}$ jl.au

$1 \frac{x}{2}$ jn.jl

1 jn.au

$\frac{3}{4}$ jn.jl

$\frac{1}{2} \mathrm{jn}$

$1^{2}$ jn.jl

jn.jl

1 jl au

$\frac{j}{\mathrm{j} n} . \mathrm{jl}$

$\frac{1}{2} \mathrm{my} \cdot \mathrm{jl}$

$\frac{1}{2}$ my.jl

1 my.jl

$\frac{1}{2}$ jnj.l
$\$ \triangle$ or $\frac{1}{4}$ jn.jl or $1^{\frac{1}{2}}$ jn.jl $\frac{1}{4} \mathrm{my} \cdot \mathrm{jn} \quad \mathrm{V}$

Pu Britain sa.hea. D s.l Eng. bot. 274

Pa.B Austria 1640. D s.l Jac. aus. 2.t. 195

Vi Siberia 180t. D s.l Pall. astrag.t.19

Germany 1798. D s.l Retz. obs, 3, t 3

1776. D s.l Bot. cab. 111

Europe 1772. D s.l Bot. cab. 680

Austria 1816. D s.l Bot. cab. 432

Pu Spain 1596. S s.1 Clus. hist.2.t.241

Pu China 1763. S s.l Bot. mag. 1350

W.y Europe 1737. D s.l Pl.rar.hun.1.t.40

Pu Austria 1640. D s.l Jac. aus. 1. t. 38

Pu Siberia 1750. D s.1 Jac. vind, 3, t. 37

Pa.Y 1759. D s.1 Dec. astrag. t. 48

Pa.Y Barbary 1683. D s.I Schreb.decad.t.3

Y Tartary 1806 D s.l Pall astrag t 80

Pu France 1710. D s.l Bot. mag. 375

Pu Montpel. 1750

Montpel. 1759. D s.l

Hungary 1787. D s.l Jac. ic. 3. t.561

I Armenia 1791. D s.1 Bu.cen.3.t.38.f.2

Pu Pyrenees 1791. D s.l Pall. astrag, t. 3

Pa.Y S. Europe 1640. C s.p Dend, brit 8

Leguminose. Sp. 1

S. Europe 1640. S s.p Lam. ill. t. 622

Leguminose. $S p .9-19$.

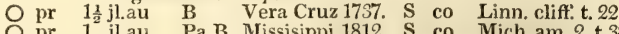

O pr 1 jl.au Pa.B Missisippi 1812, S co Mich.am.2.t.38 $\pm \Delta \mathrm{pr} \quad 2$ jl.au $\quad \mathrm{Y}$ Louisiana 1811. D co $\downarrow \Delta$ pr 6 jl.au W Louisiana 1811. D co [O] pr 5 jl.au Pk W. Indies 177\%. S co

[O] or 1 o.n Pk N. Spain 1780. S co Cav. ic. 3.t. 271 $\mathrm{Q}$ or 4 o.n Vi Mexico 1780. S co Cav.ic. 1. 86 a a $^{2}$ or $1 \frac{1}{2}$ o.n Pu Mexico 1818. C co Bot. mag. 2486 Y.B or 2 o.n Amer. 1817. C co Hook. ex. fl. 43 Leguminose. Sp. 28-62.

粪 L_J or 6 my.jl B C. G. H. 1690. C p.l Bot. rep. 474

* L or 6 my.jl Pa.B C. G. H. 1795. C p.1 Jac.schœ.2.t.229

L or 3 my.au B C. G. H. 1774. C p.l Jac.schc.2.t.226

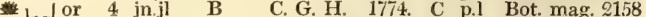

* 4 jn $\mathrm{ju} \quad \mathrm{C}$ G. H 1731 S p.l Bot mag. 416

L or 4 jl.au B C. G. H. 1774. C p.l Bot, rep. 411

L or 2 jn.jl B C. G. H. 1790. S p.l Bot. mag. 1727

$y$ f J or 3 au.o W.B C. G. H. 1793. C p.l Jac.schœ. 2.t.230

2 mr.jl W. B C. G. H. 1793. C p.l Jac.schœ. 2.t.225

2 ap.my W. B C. G. H. 1774. S pl Bot. cab. 282

3 my.au W.B C. G. H. 1713. C p.l Jac. schœ. 2.t.228

$\begin{array}{llllll}3 & \text { ap.my } & \mathrm{Br} & \text { C. G. H. } & 1793 \text {. C } & \text { s.1 }\end{array}$

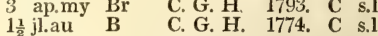

4 ap.s Pa.B S. Europe 1570. C p.l Lam.ill.t.614.f.1

4 my.au Pa.B Peru 1770. C p.l Bot. mag. 990

3 o.au Pu C. G. H. 1815. C p.l Bot. reg. 223

2 ap.s Vi Levant 1771. S P.I Jac. vind.2.t.184
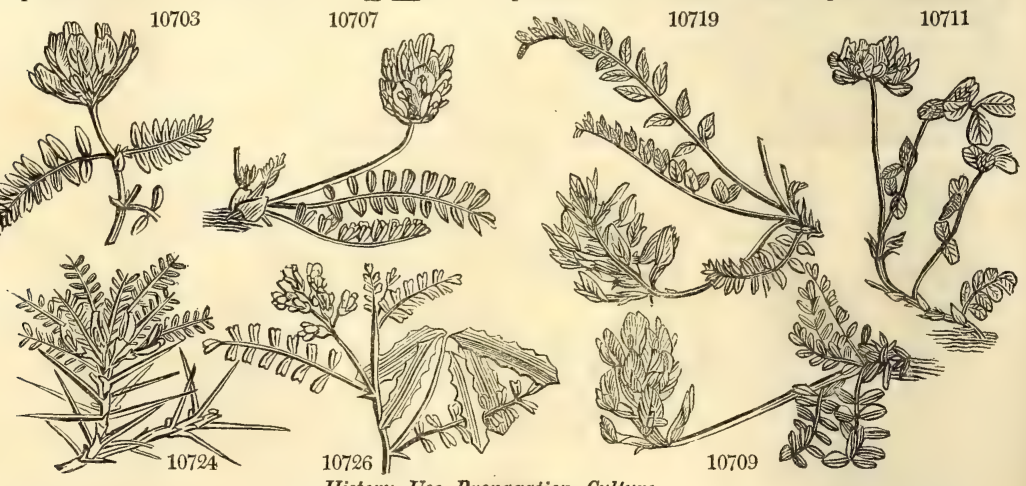

History, $U$ se, Propagation, Culture,

of Persia, flowering in July and August. It rises two or three feet only in height, on a stem about an inch in thickness; with many branches closely crowded together, and covered with imbricated scales and spines, formed from the petioles of the former year. The leaves, which scarcely exceed half an inch in length, are composed of six, seven, or eight pairs of opposite, villous, stiff, pointed leaflets; and the mid-rib is terminated with a sharp yellowish point. The flowers are small, yellow, and proceed from the axillæ of the leaves with cottony bractes. The calyx is five-toothed, and shorter than the corolla, which is papilionaceous. The gum exudes in summer, more or less copiously according to the heat of the weather, in tortuous filaments, which are allowed to dry on the plant before being collected. A large portion of the Tragacanth collected in Persia, is sent to India, Bagdad, Bassorah, and Russia. But what we receive is sent to Aleppo, whence it is exported, packed in cases.

Good gum Tragacanth is inodorous ; impressing a very slightly bitter taste as it dissolves in the mouth. Its mucilage differs from that of acacia gum, in being precipitated by the superacetate of lead, and oxymuriate of tin; and not by silicated potass (Bostock. Nich. Journ. Iviii. 30.), or the oxysulphate of iron. Medicaliy it is de- 
10703 Caulescent procumb. Leafl. obl. blunt, Spikes ov. stalked longer than leaf, Pods erect ovate channelled $1070+$ Caulescent procumb. Leafl. lin. trunc. emarg. Racemes stalked longer than leaf, Wings of cor. bifid 10705 Caulescent erect. Lvs. 7 pairs obl, bluntish subpubescent, Heads few-flowered stalked, Pods obi. villous 10706 Caulescent branched prostrate, Leafl. lin. lanc. silky complicate, Racemes 6-fl. longer than leaf 10707 Caulescent procumb. Leafl. obcordate silky beneath, Racemes stalked as long as leaves

10708 Subcaulescent procumb. Leafl, obovate, Racemes shorter than petiole, Pods round lanc. reflexed 10709 Caulescent decumb. Leafl. ellipt. blunt, Spikes obl. stalked longer than leaf

10710 Caulescent diffuse, Heads stalked imbricated ovate, Fl. erect, Pods ovate callous inflated 10711 Caulescent prostrate, Umbels stalked, Pods prismatical 3-cornered erect subulate at end 10712 Caulescent diffuse hoary, Leaves 5 pairs, Leafl. ellipt. blunt, Spikes stalked longer than leaf $10^{-1} 13$ Caulescent diffuse, Pedunc. spiked, Standard twice as long as flower

10714 Caulescent procumb. Spikes long, Pods oblong 3-cornered furrowed mucronate villous

10715 Stemless, Leafl. ov. glauc. Scapes longer than leaf, Fl. capitate, Pods inflated membranous smooth 10716 Stemless smooth, Calyxes bladdery contracted at mouth

10717 Stemless, Leafl. ov. obl. acute hairy, Scapes racemose erect twice as short as leaf, Pods ovate villous 10718 Stemless, Leafl. ellipt. retuse somewhat hairy, Scapes racemose few-fl. twice as short as leaf 10719 Stemless, Leafl. ellipt. blunt, Scapes racemose declinate longer than leaf, Standard long

10720 Stemless, Scapes decumb. Leaf. ovate subsessile downy beneath, Pods hoary

10721 Stemless, Leafl. obl. blunt hairy, Flower somewhat stalked aggregate, Cal. appressed hairy 10722 Nearly stemless, Fl. numerous radical subsessile

10723 Petioles spiny, Leafl. obl. mucro. hairy, Pedunc. very short about 4 -fl. Cal. teeth setaceous 10724 Petioles spiny, Leafl. ellipt. hoary, Pedunc. about 4-fl. as long as leaves, Cal. teeth ovate

10725 Petioles spiny, Leafl. obl. hoary, Pedunc. very short 2-flowered

\section{The only species}

10727 Pentandrous, Spikes obl. stalked terminal, Bractes length of cal. Leaves in 6 pairs lin. cuneate retuse 10728 Pentandrous, Spikes cylindric. stalked term. Bractes shorter than cal I,vs, in 10 pairs ellipt. retuse mucr. 10729 Spikes obl. term. sol. Lvs, about 3 pair obl, and obovate obtuse

10730 Spikes long panicled, Lvs, about 4 pairs linear

10731 Decandrous, Spikes capitate stalked axillary, Leaves in 4 pairs obl. blunt

10732 Decandrous, Spikes capitate stalked term. Lvs, in 10 pairs obovate

10733 Decandrous, Spikes cylindr. terminal, Lvs. of 15 pairs lanc. blunt

10734 Decandrous, Spikes cylindr. terminal, Lvs. of 10 pairs obcordate

10735 Decandrous, Spikes term. long, Lvs. of 5 pairs obovate

10736 Lvs. pinn. of 2 pairs lin. Pedunc. axill. 1-fl.

10737 Lvs. pinn. of 7 pairs lin.-lanc. Pedunc. 1-fl. axillary

10738 Lvs, pinn. and tern. lanc. Pedunc, axill. 1-3-flowered, Branches warted

10739 Lvs. tern. cuneiform recurve mucronate, Flowers axillary solitary approximated

10740 Lvs. tern. obovate recurve mucro. with pellucid spots, Spike term. capitate, Bractes ciliated

10741 Lvs, tern. obovate recurve mucronate dotted beneath, Spike terminal oblong

10742 Lvs. of the stem and branches ternate and simple; of the branchlets none, Stipules imbricated

10743 Upper lvs. simple ; rest ternate, Leafl. lin. lanc. mucronate, Pedunc, axill. clustered capitate

10744 Upper lvs, simple; rest ternate, Leafl. lin. lanc. mucro. Pedunc, axill. solitary

10745 Leaves tern. lanc. cuneate with a recurved mucro. Pedunc. axill. aggregate

10746 Leaves tern. obovate with a recurved mucro, Pedunc. axill. solitary

10747 Leaves tern. stalked obl. mucro. Spikes terminal interrupted, Calyxes villous

10748 Leaves tern. obovate emarg. Stem creeping, Flowers in umbels

10749 Leaves tern. Leafl. ov.-lanc. Petioles downy smooth, Spikes capitate stalked axillary

10750 Leaves tern. Leafl, ov,-lanc. acum. Petioles rough, Racemes axillary

10751 Leaves ternate silky beneath, Pedunc. axillary about twice as long as leaves, Heads depressed involucred

10752 Leaves tern. ovate, Petioles downy sulcate, Spikes capitate stalked axillary

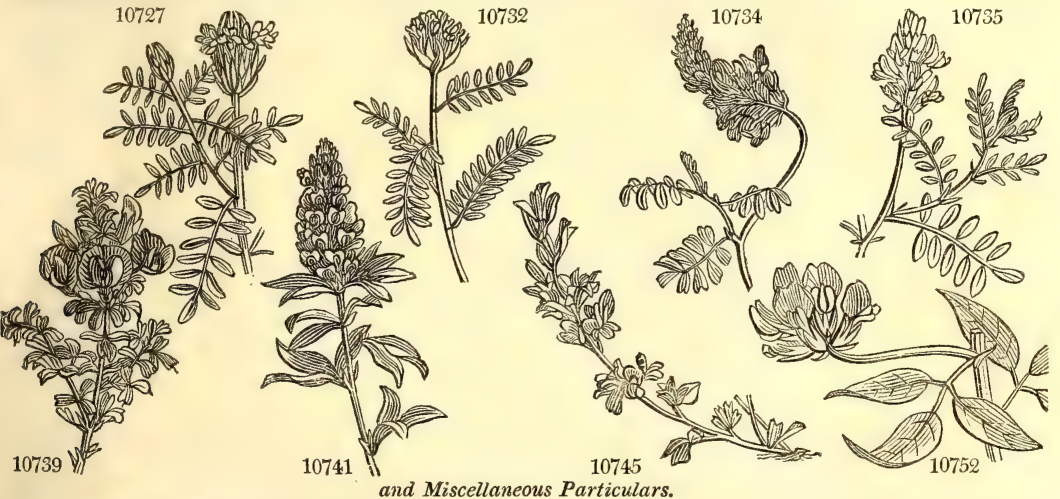

mulcent, and may answer the purposes of the acacia gum ; being even better adapted for allaying tickling cough, and sheathing the fauces in catarrhal affections, owing to its great viscidity. It is chiefly, however, employed for pharmaceutical purposes. (Thomson's London Dispensatory, 187.) The seeds of A. bœticus are roasted, ground, and used as a stubstitue for coffee in Hungary.

1595. Biserrula. From bis, twice, and serrula, a little saw. The pods are toothletted on each edge. Pelecinon was the name given by the Greeks to the plant called by the Latins Securidaca.

1596. Dalea. Named after Thomas Dale, an English botanist, who lived in the beginning of the last century. There was another Dale, an author of a Pharmacologia. These are pretty little plants, with the aspect of Psoralea.

1597. Psoralea. From $\psi \omega \rho \alpha \lambda \varepsilon \circ 5$, warted, on account of the numerous little tubercles with which most of the species are covered. The species are chiefly low shrubs; some of them are ornamental, and all are of easy culture and propagation by young cuttings in sand or seeds, which they produce in abundance. P. esculenta, the bread-root of America, is cultivated in Missouri, and other parts of that country. In this climate it will 

10754 capitáta $W$. 10757 cuspidáta $P h$. IC758 Lupinéllus 10760 arbórea $B . M$. 10761 onobrýchis Nutt. 10762 divaricáta $W$. en 10763 pubéscens $W$. en.

1598. MELILO' TUS. $J$ 10764 cærúlea $P$. S.

10765 indica $P . S$.

10766 rugulósa $W$. en. $M$. parviflora Desf

10767 messanénsis $P . S$. 10768 polónica $P$. $S$. 10770 dentáta $P$. S. 10771 officinális $W$. en 10772 vulgáris $W$. en.

10773 Kochiána $W$. en. 10774 Petitpierreána W.en. 10775 itálica $P$. S.

Cretan

10777 ornithopodioídes P.S. Bird's-foot

10778 mauritanica Schousb. Moorish M. sulcáta $\mathrm{P}$. S

10779 hamósa Link. hooked

$$
\text { hooked }
$$

1599. LUPINAS'TER. $P h$. Bastard-LUPine. 10780 pentaphýllus $P h$. five-leaved

1600. TRIFO'LiUM. $J$. Treforl. 10781 refléxum $W$.

10782 angulátum $W$.

10783 strictum $W$.

10784 hýbridum $\dot{W}$. reflexed angular upright mule

10785 Micheliánum $P$. S. Italian 10786 cæspitósum $W$. ${ }^{\text {turfy }}$ 10787 répens $W$.

10788 comósum $W$. 10789 alpínum $W$.

10790 palléscens $P$. S. 10792 globósum $W$. 10793 Cherléri $W$. 10794 píctum $W$. 10795 lappáceum $W$ 10796 diffüsum $W$.
10753 americánn $W$ 10755 corylifólia $W$. 10756 esculénta $\mathrm{Ph}$. 10759 melilotollos. 10769 macrorhiza $P$. $S$.

10776 crética $\dot{P}$. $S$.

10791 subterráneum $W$.

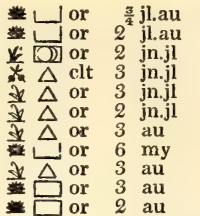

Pu Madeira 1640. C p.l Jac.schœ.2.t.227 $\mathrm{Pu}$ C. G. H. 1793. S p.l $\mathrm{Vi}$ India 1739. C p.l Bot mag. 665 B Missouri 1811. C p.l Pursh.amer.t.22 Pu Louisiana 1811. C P. B Carolina 1812. C p. Vi Carolina 1814. C p.1 Bot. mag. 2063 Pa.pu C. G. H. 1814. C p.l Bot. mag. 2090 $\mathrm{Pu}$ N. Amer. 1818. C p.l Bot. reg. 453

$\mathrm{Pu}$ S. Amer. 1820. C p. Leguminosa. Sp. $16-25$.

O $\mathrm{m} 3$ au.s L.B Germany 1562. S co Bot. xnag. 2283 O un 2 jn.au W India 1680. S co Plu.alm.t.45.f.4

un 3 jn.au W India 1798. S co

O un 3 jn.au Y Sicily 1680. S co O un 2 jn.au L.Y Poland 1778. S co $\checkmark$ un 3 jl.au Y Hungary 1801. D co P1.rar.hun.1.t.26 $\Delta$ un 3 jn.au Y Hungary 1802. D co Pl.rar.hun.1.t. O ec 1 jl.s $\quad$ Y $\quad$ Britain bus. pl. S s.l Eng. bot. 1340 Europe Germany 18̈16. S co Germany 1816. S co $\begin{array}{lll}\text { Germany } & 1816 . & \text { S } \\ \text { Italy } & \text { co } & \\ \text { 1596. } & \text { co }\end{array}$ Camer.hort. t. 29 Candia 1713, S co Bau.prodrt 14 Britain bar.hea. S co Eng. bot. 1047 Barbary 1798. S co

Tauria 1824. S co

Bux.ce.2.t.44.f.1 Leguminose. Sp. 1.

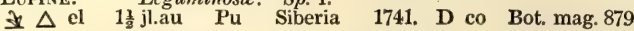
Leguminosa. Sp. 60-140.

类 $\triangle \mathrm{pr} \quad 1$ jn.au Pu Virginia 1794. D s.l O pr $1 \frac{1}{2} \mathrm{jn} . \mathrm{au} \quad \mathrm{R} \quad$ Hungary 1803. S s.l' Pl.rar.hu.1.t.27

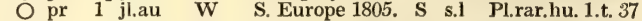
* pr $\frac{a}{4}$ jl.au $\mathrm{Pu}$ Europe 1777. D s.1 Mic.ge.t.25.f.2.6. $\mathrm{O}$ pr $\frac{3^{4}}{4}$ jl.au Pu Italy 1815. S s.l Mi.n.g.pl.t25.f.2 J $\triangle \mathrm{pr} \frac{1}{2}$ jn.au Pu Switzerl. 1815. D s.l Vill.delph. 3.t.41 * $\triangle$ ag $1 \frac{1}{2}$ my.s W Britain mea. D co Eng. bot. 1769 \ $\triangle$ pr $\frac{1}{2}$ jn.jl W America 1798. D s.l

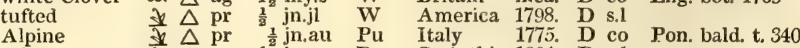

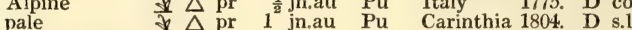

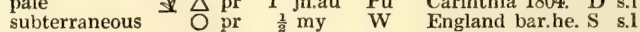
globular $\quad \mathrm{O}$ pr $1^{\frac{1}{2}}$ jn.au $\mathrm{Pu}$ Levant 1713. S $\mathrm{s}$ s.1 hairy $\quad \mathrm{pr} \quad \frac{1}{2} \mathrm{my} . j \mathrm{Pu}$ Montpel. 1750. S s.l painted O or 1 jl.au Pu $\quad$ Pu.... 1800. S diffuse $\quad *$ pr $\frac{2}{2}$ jl.au $\mathrm{Pu}$ Hungary 1801. S s.l Pl,rar, hu. 1.t.50

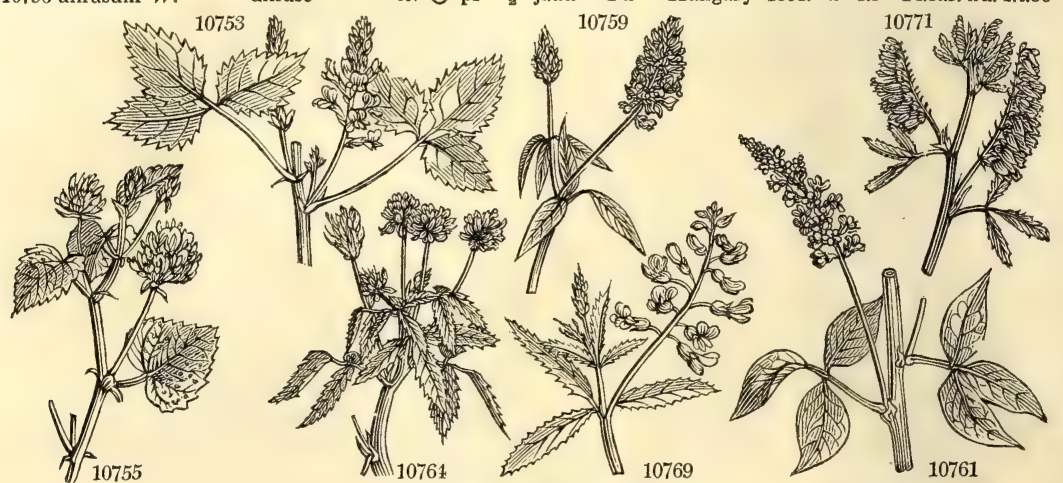

History, Use, Propagation, Culture,

grow in the open air, but requires the protection of a frame to produce abundant crops of roots, which are used like those of the potatoe in the countries where it is a native. (Pursh. Amer. t. 22.)

1598. Melilotus. From Mel, honey, and Lotus. These plants are similar to the Lotus, and are the favorite resort of bees. M. officinalis is the chief ingredient in flavoring the Gruyère cheese. This cheese no doubt owes its chief excellence to the mixture of herbs in the mountain pasturage which surrounds the valley of Gruyerre, but partly also to the flowers and seeds of this plant, which are bruised and mixed with the curd before it is pressed.

1599. Lupinaster. That is to say, Lupine-like. A pretty little herbaceous plant, with bright flowers.

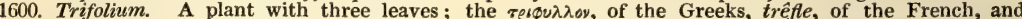
trefoil, of the English. This genus includes the two most valuable herbage plants adopted in European agriculture, the white and red clover. Notwithstanding all that has been said of the superiority of lucern to clover, and of the excellence of saint-foin, and various Leguminosæ of the pea kind, yet the red clover for mowing, and the white species for pasturage, are, and probably ever will be, found to excel all other plants in these respects. The yellow clover, $\mathbf{T}$. procumbens, and the cow or meadow clover, T. medium, are also in cultivation, but are far inferior to the others. 'The meadow clover is a useful addition to the white sort in laying down permament pastures; the yellow grows on poor soils, but the herbage is not much liked by cattle. The soil best adapted for clover is a deep sandy loam, which is favorable to its long tap-roots : but it will grow in any soil, provided it be dry. So congenial is calcareous matter to clovers, that the mere strewing of lime on 
10753 Leaves tern. roundish ovate repand at end, Spikes interrupted axillary 10754 Leaves tern, and simple linear, Head terminal

10755 Leaves simple ovate somewhat toothed, Spikes ovate

10756 Leaves digitate quinate lanc. unequal flat entire villous, Spikes axillary dense

10757 Leaves digitate quinate obovate mucro. entire, Spikes axillary dense

10758 Leaves digitate quinate very narrow, Spike few-flowered, Pods ovoid

10759 Leaves 3 lanc. Spikes obl. Bractes with long points, Pods round rugose

10760 Leaves pinnated of 5 pairs, Leaflets linear lanceolate, Pedunc, axillary 1-fl. longer than leaf

10761 Leaves ternate, Leaflets ovate-lanceolate somewhat downy, Racemes 1-sided on long stalks

10762 Leaves ternate lanc. smooth, Spikes interrupted stalked axill. longer than leaf

10763 Leaves tern. ovate-obl. downy, Spikes interrupted stalked axill. shorter than leaf

10764 Racemes obl. stalked, Stipules lanc. membranous

10765 Pods racemose naked smooth mucronate 1 -seeded

10766 Pods racemose about 4-seeded oblong rugose, Leatlets ellipt. toothed

10767 Pods 1-seeded ovate acute naked rugose, Racemes shorter than leaf 10768 Pods racemose naked 2-seeded lanceolate

10769 Pods racemose naked rugose 1-seeded, Stems and branches ascending, Leafl. linear

10770 Pods racemose naked 2-seeded somewhat rugose acute, Stipules toothed at base

10771 Pods racemose naked 2-seeded rugose acute, Stipules lanc, subulate undivided

10772 Pods racemose naked 1-seeded rugose obovate acute, Stipules setaceous

10773 Pods racemose naked 2-seeded smoothish ovate acute compressed, Stipules toothed

10774 Pods racemose naked 1-seeded rugose obovate, Stipules setaceous

10775 Pods racemose naked 2-seeded rugose blunt, Leaflets entire

10776 Pods racemose naked 2-seeded membranous oval, Stem nearly erect

10777 Pods naked 8-seeded about 3 times as long as calyx, Stems declinate

10778 Pods 1-seeded obovate blunt naked rugose, Racemes longer than leaf, Stems diffuse

10779 Pods racemose naked compressed 1-seeded nerved hooked, Stipules subulate

10780 Heads halved, Leaves quinate sessile

10781 Heads in fruit reflexed, Pods 3-seeded

10782 Heads umbelled: in fruit reflexed, Pods 4-seeded, Stem angular with furrows flexuose

10783 Heads globose, Pods 2-seeded, Cal. the length of corolla, Leafl. serrulate, Stipules rhomboid

10784 Heads umbelled, Pods 4-seeded, Teeth of cal, nearly equal, Leafl. ovate-obl. emarg. serrulate

10785 Heads umbelled stalked, Teeth of cal. subulate equal, Leafl. obcord. serrate

10786 Heads umbelled, Pods 4-seeded, Teeth of calyx equal, Leaf. obovate blunt serrated

10787 Heads umbelled, Pods 4-seeded, Teeth of calyx nearly equal, Leafl. ovate obl. emarg. serrulate

10788 Heads in globose umbels imbricated, Standards deflexed persistent, Pods 4-seeded

10789 Heads umbelled, Scape naked, Pods 2-seeded pendulous, Leaves linear lanc.

10790 Heads umbelled, Pods 2-seeded, Teeth of cal. unequal, Leafl. obovate blunt toothed

10791 Heads villous 5-flowered, Central tuft reflexed rigid wrapping up the fruit

10792 Heads villous globose, Upper calyxes without florets

10793 Heads villous globose terminal solitary, Teeth of calyx setaceous longer than corolla

10794 Heads villous globose terminal solitary, Teeth of calyx setaceous shorter than corolla

10795 Heads subglobose hispid, Teeth of calyx subulate as long as cor. Leafl. obovate retuse

10796 Spikes roundish ovate villous, Teeth of calyx unequal setaceous as long as corolla

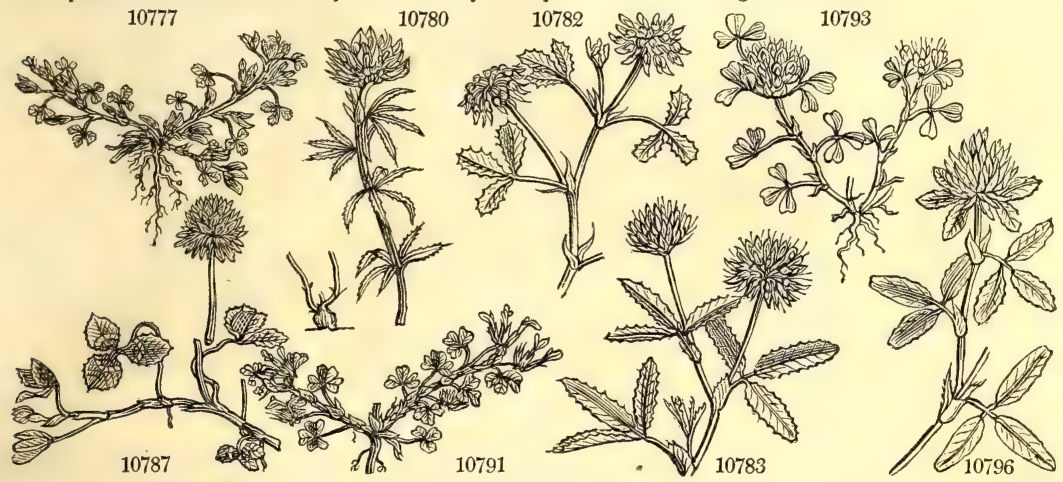

and Miscellaneous Particulars.

some soils will call into action clover-seeds, which it would appear have lain dormant for ages. At reast this appears the most obvious way of accounting for the well-known appearance of white clover in such cases.

The climate most suitable for the clovers, as of most plants natives of Europe, is one neither very hot nor very dry and cold. Most leguminous plants delight both in a dry soil and climate, and warm temperature; and the clover will be found to produce most seed under such circumstances; but as the production of seed is only in some situations an object of the farmer's attention, a season rather moist, provided it be warm, is always attended by the most bulky crops of clover herbage.

The time of sowing seeds is generally the spring, during the corn-seed time, or from February to May ; but they may also be sown from August to October; and when they are sown by themselves, that is, unaccompanied by any corn crop, this will be found the best season, as the young plants are less liable to be dried up and impeded in their progress by the sun, than when sown alone in spring, and remaining tender and unshaded during the hot and dry weather of July.

The manner of sowing is almost always broad-cast. When sown with spring corn, clover and grass-seeds are usually put in immediately after the land has been pulverized by harrowing in the corn-seed, and are themselves covered by one course more of the harrows; or, if the corn is drilled, the small seeds are sown immediately before or after hand-hoeing; and the land is then finished by a course of the harrows.

In the operation of sowing, some consider it best to sow the clover and rye-grass separately, alleging that that the weight of the one seed and lightness of the other, are unfavorable to an equal distribution of both. 


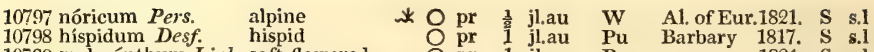
10799 malacánthum Link. soft-flowered $\quad \bigcirc$ pr 1 jl.au $\quad$ Pa 10801 rúbens $W$. 10802 praténse $W$. long-spiked $\frac{\$}{2}$ pr long-spiked $\Delta p$ 10802 praténse $W . \quad$ commo 10803 pensylvánicum $W$.en. Buffalo Clover $\$ \Delta p$ 10804 médium $W$. Cow-grass \$ $\triangle$ ag 10805 alpéstre $W . \quad$ oval-spiked $\$ \Delta p$ 10806 bracteátum $W$. en. large-bracted \$ () p

10807 pannónicum $W$. Hungarian 10808 canéscens $W$ 10809 maritimum $W$ 10810 squarrósum $W$ 10811 incarnátum $W$ 10812 pállidum $W$. 10813 ochroleúcum $I V$. 10814 angustifólium $W$. 10815 lasiocéphalum Link 10816 arvénse $W$ 10817 stellátum $W$. 10818 clypeátum $\dot{W}$. 10819 álbidum $W$ 10820 scábrum $W$ 10821 glomerátum $W$. 10822 striátum $W$. 10823 alexandrínum $W$ 10824 suffocátum $W$. 10825 involucrátum $W$. 10826 spumósum $W$ 10827 resupinátum $W$ 10828 recúrvum $\boldsymbol{P}$. $\boldsymbol{S}$. 10829 tomentósum $W$. 10830 fragíferum $\boldsymbol{W}$. 10831 montánum $W$ 10832 bádium $\boldsymbol{P}$. $\boldsymbol{S}$. 10833 spadíceum $W$ 10834 speciósum $W$ 10835 agrárium $W$. 10836 procúmbens $\boldsymbol{H} . \boldsymbol{K}$. 10837 minus $\boldsymbol{H} . \boldsymbol{K}$ 10838 filifórme $W$ 10839 phleoídes $W$ 10840 strictum $L$.

1601. LO'TUS. $W$ 10841 édulis $W$

10842 peregrinus $W$ gray

s pr

$\downarrow \Delta$

$\triangle \Delta$

O pr $\begin{array}{ll}\text { various-leaved } & \mathrm{O} \text { pr } \\ \text { fiesh-colored } & \bigcirc \mathrm{pr}\end{array}$

$\bigcirc$ pr lphur-colored se narrow-leaved $\_$s woolly-leaved Hare's-foot starry oriental white rough round-headed soft-knotted

Egyptian suffocated involucrated bladdered resupinate recurved

$\bigcirc$ pr

o w

* O pr $\bigcirc$ pr * $\mathrm{O} \mathrm{pr}$ * $\mathrm{O} w$ $\bigcirc \mathrm{w}$ pr $\mathrm{p}$ * $\mathrm{O}$ O pr 1 jn,jl * $O$ un 1 in.jl \& un $x^{2}$ jnjl or 3 jn.il woolly $\quad$ * $\mathrm{O}$ pr $\frac{3}{4} \mathrm{jn} . \mathrm{jl}$ Strawb.-headed $\mathcal{H}^{*} \mathrm{w} \frac{2}{4}^{\frac{3}{4}} \mathrm{jl}$. au mountain $\ddagger \Delta$ or $\overline{1}$ jl.au villous-stalked $\Delta$ pr $\frac{x}{2}$ in.au bay-colored large-flowered * $\triangle$ el golden $\bigcirc$ pr $\frac{1}{2}$ jri.jl Hop w 0 ag 1 jn.jl lesser-yellow w* $\mathrm{O}$ w $\frac{1}{8} \mathrm{jn} . \mathrm{jl}$

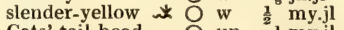
Cats'-tail-head. $\mathrm{O}$ un $\frac{1}{2} \mathrm{my}$.j upright

$\bigcirc$ pr $\frac{1}{2}$ my.jl teasel-headed Switzerl 1816 S s.l R N. Amer. 1811. D l.p $\mathrm{Pu}$ Morocco 1804. S s.l $\mathrm{Pu}$ C. G. H. 1823. S co W $\quad$...... 1796. S $s .1$ Pa.Y Egypt 1798. S s.l Pa.pu Morocco 1802. S co R France 1771. S $\mathrm{s.1}$

Pu Candia 1752. D s.l W.x Spain 1818. S co Leguminose. Sp. 24-60. esculent w $\mathrm{O}$ clt $\frac{1}{2}$ jl,au $\quad \mathrm{Y}$ Italy 1710. S s.l Cav, ic.2.t. 157

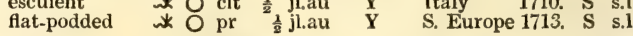

Desf.atl.t.209.f.1

All. ped, $t$ 59.f.3 D co Jac, aust, 4.t. 385 Pu Britain me.pa. D h.l Eng. bot. 1770 Pu England dr.pa. D h.l Eng. bot. 190 D.P Europe 1789. S co Jac. aust.5. t.433 W.Y Hungary 1752. S co Jac. obs. 2, t. 42 W.y Caucasus 1803. S co Bot. mag. 1168 Pa.pu Britain sal.m. S s.l Eng. bot. 220 Pa.pu Spair 1640 . S s.1 Mor.hi.2.t.13.f.1 F Italy 1596. S co Bot. mag. 328 W Hungary 1803. S s.l Pl.rar. hu. 1.t.30 Sul England dr.pa. D s.l Eng. bot. 1224 Pu S. Europe 1640. S s.l Barr. ic. t. 698 F Britain san.fi. S s.1 Eng. bot. 944 Pu England so.co. S s.l Eng. bot. 1546 W.x Levant 1711. S s.1 Alp. exot. t. 306 W Britain san.fi. S s.l Eng. bot. 903 Pk England gra.pa. S s.1 Eng. bot. 1063 Pu Britain bar.gr. S s.l Eng, bot. 1843 W England sea sh, S s.l Eng. bot. 1049 Pu Germany 1713. S s.1 Barr. ic. t. 872 W Hungary 1805, S s.1 Pl.rar.hu.2.t.165 Pu S. Europe 1640. S s l Mag. mons.t.264 F England moi.p. D s.l Eng. bot. 1050 W Europe 1786. D co Flor. dan.t.1179 Y Pyrenees ... D s.l Barr. ic. 1024 Br Europe 1778. D s.l Bot. mag. 557

Y Europe 1815. D s.l Flor, dan. t. 558 Y Britain dr.pa. S s.1 Eng. bot, 945 Y Britain gra.gr. S s.l Eng. bot. 1256 Y Britain gra.pa. S co Eng. bot. 1257 10802
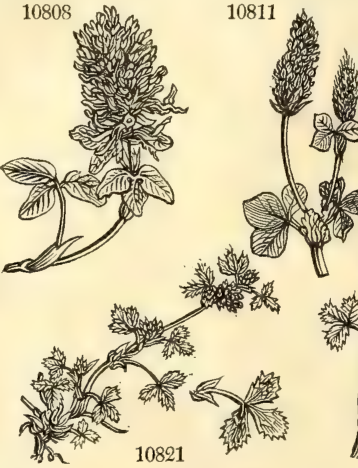

10813

History, Use, Propagation, Culture,

The quantity of seed varies from eight to fourteen pounds per acre, according to the intention of the crop, the quantity of grass-seeds sown, \&c. The after culture of clover and rye-grass consists chiefly of picking of any stones or rather hard bodies which may appear on the surface in the spring succeeding that in which it was sown, and cutting out by the roots any thistles, docks, or other large grown weeds. After this, the surface should be rolled once to smooth it for the scythe. This operation is best performed in the first dry weather of March. Some give a top-dressing of soot, gypsum, common lime, peat, or wood-ashes, at this time or earlier gypsum has been particularly recommended as a top-dressing for clovers and the other herbage legumes, because as their ashes afford that substance in considerable quantities, it appears to be a necessary ingredient of their food.

The taking of the clover, or clover and rye-glass crop, is either by cutting green for soiling, by making into hay, or by pasturing. It is observed in The Code of Agriculture, that it is a most important point to ascertain, in what cases cutting or feeding is most beneficial. If fed, the land has the advantage of the dung and urine of the pasturing stock; but the dung being dropt in irregular quantities, and in the heat of summer, when it is devoured by insects, loses much of its utility. If the dung arising from the herbage, whether consumed in soiling, or as hay, were applied to the land in one body and at the proper season, the operation would be more effectual. The smother of a thick crop, continued for any time upon the ground, greatly tends to promote its fertility; and it has been pretty uniformly found, after repeated trials, upon soils of almost every description, that oats taken after clover that has been cut, either for soiling or hay, is superior to the crop taken after clover pastured by sheep.

The produce of clover-hay, without any mixture of rye-grass, on the best soils, is from two to three tons per acre, and in this state in the London market it generally sells twenty per cent. higher than meadow-hay, or 
10797 Spikes term. globose hairy subsessile, Leafl. oval entire and stem densely villous 10798 Heads villous globose term. solitary, Teeth of calyx setaceous shorter than cor. Leafl. obovate entire 10799 Stem flexuose hairy, Leafl. obcord, hairy, Cal. camp. lined

10800 Leaves obovate hirsute, Heads lateral and terminal minute, Stem erect

10801 Spikes cylindr. obl. Teeth of cal. villous; lower as long as monopetalous unequal cor. 10802 Spikes dense ovate, Stipules awned, Leaf. oval nearly entire

10803 Leaf. ovate ellipt. blunt entire, Stipules awned, Spikes ovate cylindr. solitary dense

10804 Spikes lax subglobose sol. Stipules subulate, Leaf. ellipt. finely serrulate, Stems branched flexuose

10805 Spikes dense subglobose twin, Stipules setaceous, Leaf. lanc. finely scrrulate, Stems quite simple 10806 Spikes ovate conical dense sol. sessile, Corolla monopetalous, Leafl. ovate blunt

10807 Spikes dense obl. ellipt. solitary, Leafl. obl. lanc. entire emarg. vill. Stem simple straight 10808 Spikes ovate lax sol. Leafl, obovate emarg. villous, Stem simple ascending 10809 Spikes subglobose dense, Leafl. obovate lanc. serrulate at end hairy

10810 Spikes obl. somewhat hairy, Lower tooth of cal. very long reflexed, Stem herbaceous erect

10811 Spikes obl. villous blunt leafless, Leafl. roundish obcordate ovate crenate villous

10812 Spikes sol. roundish, Stipules membranous, Leafl. roundish, Edge of corolla bearded inside

10813 Spikes villous elliptical, Stem erect branched downy, Leafl. obl. : lower obcordate

10814 Spikes vill. conical obl. Teeth of cal. setaceous nearly equal, Leafl. linear

10815 Stem erect hairy, Leafl. linear, Calyx hairy with lanc. subulate spreading teeth

10816 Heads very hairy subcylindrical, Cal, teeth setaceous longer than the cor. Leafl. narrow obovate

10817 Spikes hairy ovate, Calyxes much spreading, Stem diffuse, Leafl. obcordate

10818 Spikes ovate, Calyxes spreading : lower tooth very large lanc. Leafl. obovate

10819 Spikes subglobose stalked, Cal. spreading: lower tooth subulate linear, Leafl, oblong

10820 Heads term. and axill. sess. ov. Cal. teeth unequal narr. lanc. rigid at length recurved, Leafi. obcor. serru. 10821 Heads round axill. sessile, Teeth of cal, equal subulate spreading rigid, Leafl, obovate serrulate

10822 Heads term. and axill, ov. subsol. subsess. Cal. striat. hairy with unequal straight teeth. Leafl. obcor. nearly 10823 Heads obl. stalked, Cal. vill. : teeth subul. unequal, Upper lvs. opp. Leafl ellipt. toothletted [entire pubesc. 10824 Heads sessile lateral roundish smoothish, Teeth of cal. lane, acute recurved longer than cor.

10825 Heads orbicular stalked in a round toothed involucre, Stipules awned

10826 Headis ovate, Cal. in fruit ovate ventricose smooth, Comm. involucre membranous 5-leaved

10827 Heads roundish, Cor. resupinate, Cal. of fruit inflated membranous downy, Leaf. obovate acute

10828 Heads ov. obl. Cal. of fruit inflated naked, Branches recurved, Leafl. setaceous serrulate

10829 Heads round, Cal. of fruit inflated membranous downy, Teeth obliterated [creep. Leafl. obcord. serrated 10830 Heads upon long stalks round. Cal. after flow, inflat. membran. pubesc. : two of teeth setaceous reflex. Stems 10831 Spikes about 3 somewhat imbricated, Standard subulate withering, Cal. naked

10832 Spikes round imbr. Standard deflexed persistent, Leaf, obcord. serrate, Stem hirsute 10833 Spikes oval imbr. Vexillum deflexed persistent, Leafl. obovate : intermediate sessile 1083 4 Spikes obl. with reflexed flowers, Standard roundish flat toothletted persistent, Stem flexuose 10835 Spikes oval imbr. Standard deflexed nersistent, Teeth of cal. subulate unequal smooth 10836 Spikes oval imbr. Standard deflexed persistent sulcated, Stems procumbent, Leafl. obovate 10837 Spikes capit. hemisphærical, Pedunc. straight, Standards smoothish, Stems procumb. Petiole lengthened 10838 Heads lax of few-f. Pedunc. capillary flexuose, Standards smooth, Stems procumb. Leafl. subsessile 10839 Heads obl. Cal. teeth subulate unequal rigid spreading, Leaf. obl. nearly entire emarg.

10840 Heads ellipt. Pods 2-seeded, Cal. length of cor. Leafl. lanc. blunt serrulate

10841 Pods subsolitary gibbous incurved

$108+2$ Pods súbbinate compressed lin. cernuous, Leafl. obovate hairy, Stem procumbent

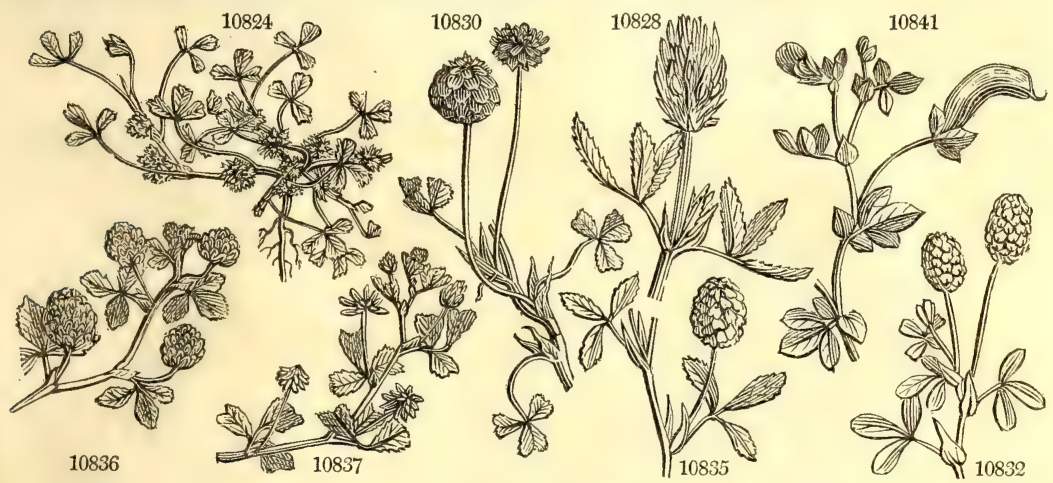

and Miscellaneous Particulars.

clover and rye-grass mixed. The weight of hay from clover and rye-grass varies according to the soil and the season, from one to three tons per English acre, as it is taken from the tramp-ricks; but after being stacked, and kept till spring, the weight is found to be diminished twenty-five or thirty per cent.

The value of clover and rye-grass hay, in comparison with the straw of beans or pease, may be in the proportion of three to two; and with the finest straw of corn crops, in the proportion of two to one. One acre of red or broad clover will go as far in feeding horses or black cattle, as three or four of natural grass. And when it is cut occasionally, and given to them fresh, it will probably go still much farther, as no part of it is lost by being trod down.

The saving of clover seed is attended by considerable labor and difficulty. Clover will not perfect its seeds, if saved for that purpose early in the year; therefore it is necessary to take off the first growth either by feeding or with the scythe, and to depend for the seed on those heads that are produced in the autumn.

The produce in seed may generally be from three to four or five bushels per acre, when perfectly clean, weighing from two to three hundred weight. But there is great uncertainty in the produce of clover-seed, from the lateness of the season at which it becomes ripe; and the fertility of the soil is considerably impaired by such a crop. Yet the high value of the seed is a great inducement to the saving of it, in favorable
buting situations.

T. incarnatum is sometimes sown as a border flower.

1601. Lotus. $\Lambda$ wros, in Greek. There were three sorts of Lotus distinguished by the ancients ; viz. their tree lotus, which was our Zizyphus lotus; the marsh lotus, which was our Nymphæa lotus; and the herbaceous lotus, which appears to have been the present genus.

The pods of $\mathbf{L}$. edulis are still eaten in Candia, by the poorer inhabitants. Lotus rectus has by some been $\mathrm{T}$ t 2 
10813 glaúcus $W$

10844 anthylloídes $V$.

10845 angustíssimus $W$ $10846^{-g r a b i l i s} W . \& K$. 10847 diffúsus $W$.

10848 coimbrénsis $W$.

10849 arábicus $W$.

10850 austrális $\boldsymbol{H}$. $K$.

10851 Dioscóridis $W$

10852 ornithopodioídes $W$. 10853 jacobæ'us $W$. $\beta$ lúteus

10854 créticus $W$. 10855 ténuis $W . \& K$ 10856 hirsútus $W$. 10857 réctus $W$. 10858 odorátus $\boldsymbol{H} . \boldsymbol{K}$. 10859 pedunculátus $W$. 10860 májor $E . B$ 10861 corniculátus $\boldsymbol{E} . \boldsymbol{B}$. 10862 cytisoídes $W$. 10863 parviflórus Desf. 10864 Gebélia Vent. glaucous $\quad 1$ pr 1 jn.au Anthyllis-like $\frac{1}{\mathrm{pr}} \frac{3}{4} \mathrm{jn.au} Y$ narrow-podded $\$$ ()) pr 1 jl.au slender

pr slender-podded $*$ \& Portugal red-flowered $*$ p New Holland 4 , el Dioscorides's Dioscorides's claw-podded
\& $\bigcirc$ pr dark-flowered jor yellow-flowered

silver-leaved

slender

hairy

upright

2. $1 \mathrm{pr}$

$\Delta$ pr

$\downarrow \Delta \mathrm{pr}$

sweet-scented $\$ \Delta \Delta \mathrm{ft}$

long-peduncled $\vec{x} \Delta \mathrm{pr}$ greater

1 jl.au

$1 \frac{1}{2}$ my.jn

$\frac{1}{4}$ jn.jl W

$\frac{1}{2}$ jl.s Pk

2 my.s

1 jn.jl

2 ja.d

$1 \frac{2}{2}$ jn.s

1 jn. au

Q jn.au W

3 jn.au

$1 \frac{1}{2} \mathrm{jn} . \mathrm{au}$

1 jn. au

$1 \frac{1}{2} \mathrm{jn} . \mathrm{au}$

$1 \frac{1}{2} \mathrm{jn.au}$

1\% jn.au Y
Madeira 1777. C s.l

C. G. H. 1812. S s.l Vent.malm. t.92 France 1683. S s.l Bauh. hist. 2. f. 2 Hungary

England rocks. S s.l Eng. bot. 925

Portugal 1800. S s.l

Arabia 1773. S s.i Jac. vind 2.t:155

N. S. W. 1803. S s.p Bot. mag. 1365

Crete 1658. S s.1 Al.ped.1.t.59.f.1 Sicily 1683. S s.1 Cav. ic. 2.t.163 D.Br C.Verd.Is.1714. C r.m Bot. mag. 79

Y Levant 1680. C p.l Cav. ic. 2. t. 156 Hungary 1816. D p.l Waldst. \& Kit.t. S. Europe 1683, C p.1 Bot. mag. 336 S. Europe 1640. D co Mor. s.2.t.18.f.13 Barbary 1804. D s.l Bot. mag. 1233 Spain 1814. D s.l Cav. ic. 2. t. 164 Britain w.sh.g. D s.l Eng. bot. 2091 Britain pas. D co Eng bot 2090 S. Europe 1752. D co All.ped.1.t.20.f 1 Barbary 1810. S co Desf. atl. t. 211 Aleppo ... D co Vent. cels. t. 57

1602. TETRAgONO'́lobUS. Roth. Tetragonolobus. Leguminose. Sp. 4.

10865 marítimus Roth. sea $\quad$ * $\Delta$ or 1 my.o Y Europe 1683. D co Fl. dan. 800

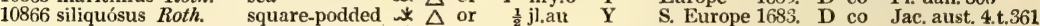
Lotus tetragonolobus $W$

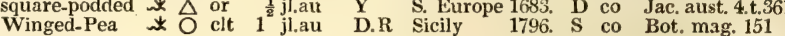
10868 conjugátus Link. twin-podded $*$ o or 1 jl.au $\mathrm{Y}$ Montpel. 1754. S s.l

1603. TRIGONEL/LA. $W$. Fenugreek. 10869 ruthénica $W$. 10870 platycárpos $W$. 10871 hýbrida $P$. S . 10872 polycérata $W$ 10873 hamósa $W$. 10874 spinósa $W$.

10875 corniculáta $W$. horse-shoe small small roundhybrid broad-leaved Egyptian thorny 10876 monspeliaca $W$

Morshoe cut-leaved

10878 Fœ'num-græ'cum $W$.common 10879 esculénta $W$. en. esculent 10880 índica $W$.

10881 striáta $L$

10882 cancelláta Desf.

10883 ténuis Bieb.

10884 flexuósa Bieb.

10885 callíceras Bieb.

10886 elongáta Link.

10887 gladiáta Bieb.

T. prostrata Dec.

1604. DORYC'NIUM. $W$. DORYCNIUM. 10888 monspeliénse $W$ shrubby

Indian

striated

slender

flexuose

neat-podded

long

\section{Leguminose. $\mathrm{S} p .19-32$.}

$\Delta$ un $1 \frac{1}{3}$ jn.jl $Y$ Siberia 1741. $S$ p.l Gmel. sib. 4. t. 8 (1) un 1 jn.s W Siberia 1741. S co Gmel sib 4. 9 * Un 1 jn.s W.Y France 1806. S s.l O un 1 jl.s Y S. Europe 1640. S s.1 * $\bigcirc$ un $\quad \frac{3}{4}$ jl.au $Y$ Egypt 1640. * un 1 jn * un to jum un $\frac{1}{2} \mathrm{jn} . \mathrm{au}$ ec 2 jn.au a clt $1 \frac{1}{2}$ jn.au un 1 jn.au * O un $\frac{3}{2}$ jnjt O un ${ }^{\frac{1}{2}} \mathrm{jn}$.jl un ${ }^{\frac{1}{2}}$ jn.j. Oด un $\frac{1}{2}$ un $\frac{1}{2} \mathrm{jn.j}$ O un $\frac{z^{2}}{4} \mathrm{jn} . \mathrm{j}$

S. Europe 1597. S s.l Mor. s.2.t.16.f.11 Montpel. 1710. S s.l Pl.rar.hu.2.t.142 Spain 1801. S s.1 Cav. ic. 1.t. 38 Montpel. 1597. S co Sch.s.ha.2.t.21 E. Indies 1815. S s. E. Indies 1793. S s.1 Plu.alm.t.200.f.7 Abyssinia 1800. S co

T...... 1823. S co

Tifliz 1824. 5 co

Tifliz 1820. S co

Tifiz 1823. S co

Tauria 1825. $\mathrm{S}$ co

业 $U$ or 3 jl.s W S. Europe 1640. S p.1 Par, thea.360.f 10889 herbaceum $W$. herbaceous \s or 2 jn.s W S. Europe 1802. co Vil, dauph.3.t 4

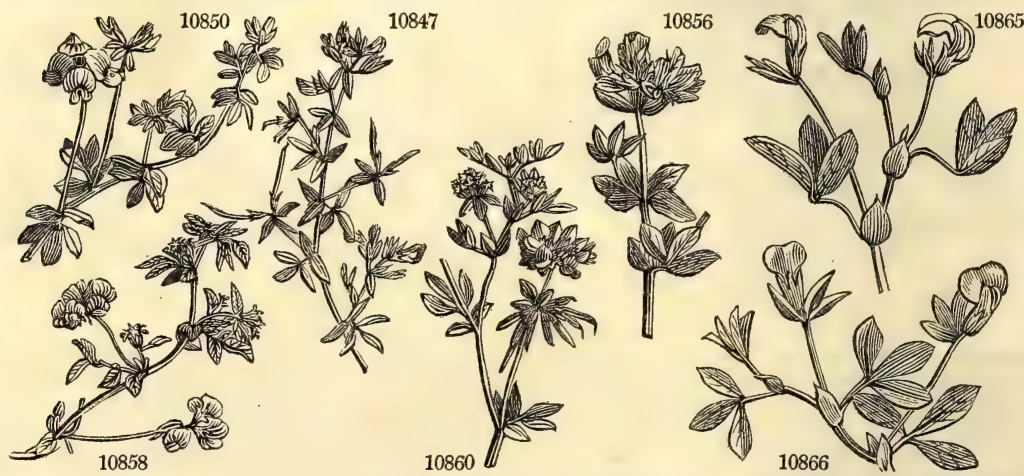

History, Use, Propagation, Culture,

supposed the Cytisus of Virgil, but, as other contend, without sufficient foundation. Lotus jacobæus is a valuable greenhouse plant, as flowering all the year. L major and corniculatus are very suitable to sow with white clover and cow-grass, in laying down lands to permanent pasture Dr. Henderson has written a good deal in their favor; Miller is against them; but Sinclair, in his work on the British Grasses, found it a valuable ingredient in meadows, especially where the soil was rather moist. (See Ency. of Agr. p. iii. b. 6, Gebelia is the Arabic name (Gébélié) of the species to which it has been applied.

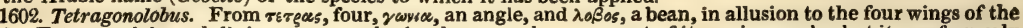
pods. Tetragonolobus edulis is now a popular border annual, on account of its curious pods; but it was formerly an esculent legume, these pods being used like those of the kidney bean, by the poor of Sicily and Spain.

1603. Trigonella. From retis, three, and rwusce, an angle. The standard of the flower is flat, and the keel very small and narrow, which gives the flower a triangular appearance. T. foenum-græecum, a plant cultivated by the Romans, is still occasionally employed in the agriculture of the south of Europe. The seeds have a strong 
10843 Pods subbinate cylindr. smooth, Leaf. subcuneif. fleshy hoary, Stip. leaf-shaped

10844 Heads few-f., Leafl. and bractes 3-leaved subspatulate

10845 Pods subbinnate lin. straight erect, Stem erect, Pedun. alternate

10846 Pods subternate round subulate straight, Cal. cil. Leafl. obl. Stem erect

10847 Pedunc. about 1 -fl. Stem much branched decumb. Pods round straight very slender

10848 Pedunc. about 1-f. Stem branched procumb. Leafl. obovate smooth, Pods lin. compressed

10849 Pods cylindr. awned, Fedunc. 3-fl. Bractes 1-leaved

10850 Heads few-fi. with bractes, Leafl. and stipules obovate cuneate equal, Pods cylindr. smooth

10851 Pods round torulose, Pedunc. 3-fl. Bractes 3-leaved

10852 Pods usually in threes arcuate compressed, Stems diffuse

10853 Pods usually in threes, Stem herbaceous erect, Leafl. linear

10554 Pods usually in threes, Stem half-shrubby, Leaves silky shining

10855 Pods about 4 rounded awned, Stem branched, Leaf. lin. lanc. smooth

10856 Heads roundish, Stem erect hairy, Pods ovate

10857 Heads roundish, Stem erect smooth, Pods straight smooth

10858 Hairy, Heads halved, Bractes 1-leaved, Pods straight torulose mucronate

10859 Heads depressed on long stalks, Leafl. obl. lanc. acuminate, Stipules ovate

10860 Heads depressed many-fl. Pods spreading cylindr. Claws of carina linear

10861 Heads depressed, Stems decumb. Legumes cylindr. spreading

10862 Heads halved, Stem diffuse much branched, Leaves downy

10863 Heads halved, Pods obl. compressed, Cal. as long as cor. Bractes 1-leaved

10864 Pods straight cylindr. mucronate, Stems decumb. smooth, Pedunc. few-fl

10865 Pods solitary, Leaves smooth, Bractes lanceolate

10866 Pods solitary, Leaves procumb. Leaves downy beneath

10867 Pods solitary, Bractes ovate, Intermediate leaflets somewhat toothed

10868 Pods in pairs, Bractes oblong ovate

10869 Pods stalked heaped obl. lin. straight, Leafl. obl. truncate mucronate 10870 Pods stalked heaped pendulous oval compressed, Leaflets roundish

10871 Pods stalked compressed ovate veiny, Leaf. cuneiform nearly entire smooth

10872 Pods subsessile heaped erect straightish long linear, Pedunc. not awned

10873 Pods stalked racemose hooked round, Pedunc. spiny longer than leaflet

10874 Pods stalked heaped declinate subfalcate compressed, Pedunc. spiny very short

10875 Pods stalked heaped declinate subfaicate, Pedunc. long somewhat spiny

10876 Pods sessile heaped arcuate divaricating inclined short, Pedunc. mucronate unarmed

10877 Pods sessile about 3 linear nearly erect, Leaves truncate cuneate pinnatifid toothed

10878 Pods sessile straight nearly erect a little falcate acuminate

10879 Racemes stalked, Common pedunc. longer than leaf, Pods linear falcate heaped pendulous

10880 Pods sessile subsolitary subfalcate, Leaflets entire

10881 Pods stalked longer than leaf, Leaves streaked

10882 Pods stalked umbelled erect incurved, Leafl. cuneate serrate, Stem much branched

10883 Pods about 4 arcuate erect, Pedunc. unarmed: when i. flower as long as leaf, Leafl. cuneate

10884 Pods about 6 arcuate erect wavy torulose, Pedunc. unarmed : when in fl. longer than leaf, Leafl. cuneate

10885 Pods stalked heaped declinate falcate furrowed, Pedunc. awned longer than leaf

10886 Pedunc. very short spiny, Pods short curved upwards

10887 Pods subsessile nearly erect falcate acuminate downy, Stem spreading

10888 Leaf. linear lanc. acute, Teeth of calyx ovate

10889 Leafl. obate blunt, Teeth of calyx ovate

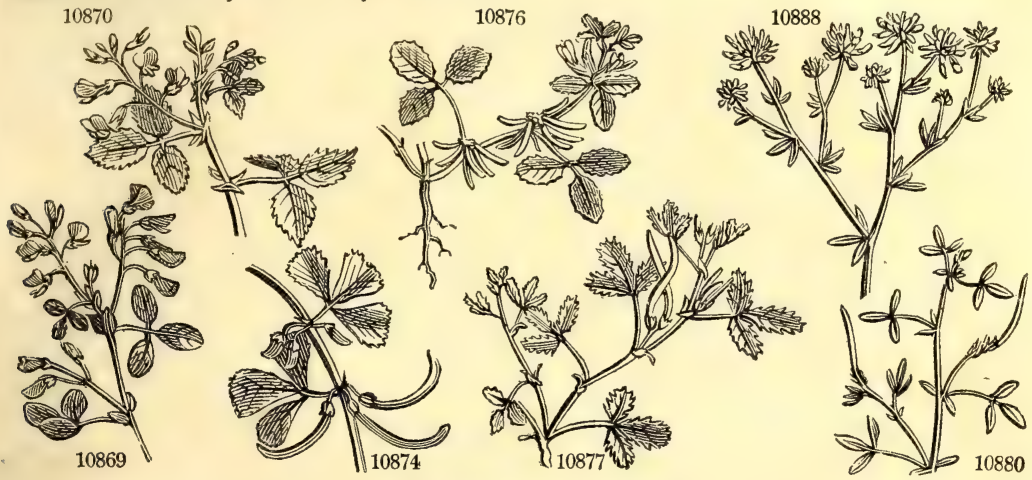

and Miscellaneous Particulars.

disagreeable smell, and an unctuous farinaceous taste, accompanied with a slight bitterishness. An ounce renders a pint of water thick and slimy. To rectified spirit, they give out the whole of their distinguishing smell and taste, and afterwards to water a strong flavorless mucilage. These seeds are never given internally, their principal use being in cataplasms and fomentations, for softening, maturating, and dispersing tumours and in emollient glysters. They were also an ingredient in the oleum e mucilaginibus; but this has no longer a place in the pharmacopæia. (Woodville and Lewis.) They are used by grooms and farriers for horses. Fenugreek has not been cultivated in any quantity for use in England, becaltse it is an uncertain crop, occasioned by the inconstancy of our weather.

1604. Dorycnium. The Greek name of an herb, supposed to be the Convolvulus Dorycnium of the moderns. The plant now called by the name has no resemblance to that of the ancients. D. hirsutum is a beautiful halfhardy shrub, well deserving cultivation. 
1605. MEDICA'GO, $W$. Menick. 10890 arbúrea $W$. Moon-Trefoil 10891 cretácea $W$. en. 10892 satíva $W$. 10893 glomeráta W. en. 10894 glutinósa Bieb.

10895 prostráta $W$.

10896 brachycárpa Bieb. 10899 obscúra $W$. 10900 orbiculáris $W$. 10901 margináta $W$. en. 10902 ếlegans $W$. 10903 scutelláta $W$ 10904. Hélix $W$. 10905 tornáta $W$. 10906 turbináta $W$ 10907 tuberculáta $W$. 10908 aculeáta $W$. 10911 intertéxta $W$. 10912 ciliáris $W$. 10913 carstiénsis $W$. 10914 maculáta $W$ 10915 coronáta $W$. 10916 apiculáta $W$ 10917 tentaculáta $W$.

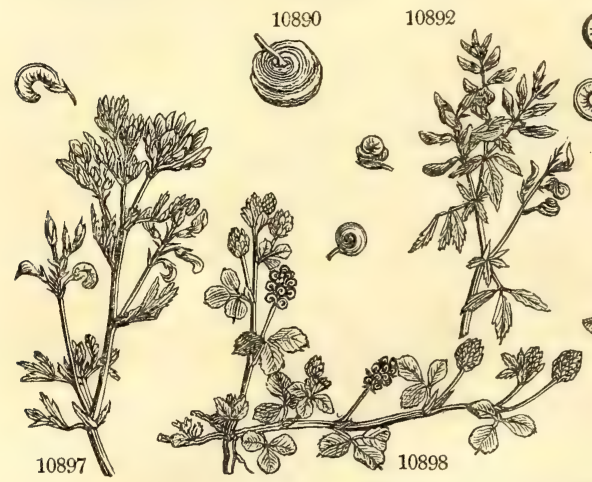
shrubby. Lucern clustered clammy prostrate short-podded yellow Nonesuch doubtful flat-podded margined elegant Snail many-fl._Snail smooth-podded Turban wart-podded spiny Spanish prickly hedgehog
fringed jo 1 jn.jl स $\mathrm{O}$ cu $\frac{1}{2}$ jn.jl * $\triangle \mathrm{cu} \quad \frac{\pi}{4} \mathrm{jn} . \mathrm{jl}$ * $\triangle \mathrm{ag}_{\mathrm{i}} \mathrm{jl}$ * O cu 1 jl.au * $\mathrm{O}$ cu 1 jl.au. * O cu 1 jlau * $\mathrm{O}$ cu 1 jl.au * O cu 1 jn.au * $\mathrm{O}$ cu 1 jn.au * O cu 1 jn.au * O cu 1 jn.au * $\mathrm{O}$ cu 1 jl.au creeping-rooted ${ }^{\prime} \mathrm{cu} 1$ ji.j! spotted spotted crowned tufted tufted 10897 falcáta $W$. 10898 lupulína $W$. 10909 granadénsis $W$.en. 10910 Múrex $W$.

Leguminosa. Sp. 40-76.

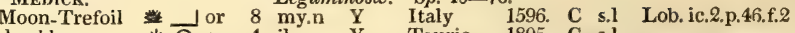

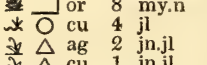
* $\mathrm{O}$ cu $\frac{x^{2}}{3}$ jn.jl * $O$ ag 1 my.au $Y$ * cu 1 jn.au * $\mathrm{O}$ cu 1 jn.au * $\bigcirc$ cu 1 jn,au * $\mathrm{O}_{\text {cu }} 1$ jn.au * $\mathrm{cu}_{\frac{3}{4} \mathrm{jn} \cdot \mathrm{au}}$ * $\mathrm{Cu}^{\frac{3}{4}}$ jn. au

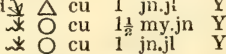
Tauria 1805. C s. England me.pa. D r.m Eng. bot. 1749

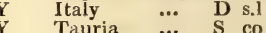
Y Tauria $7{ }^{2}$ S co a.Y Tifliz 1823. S co England bor.fi. S co Britain pas. S co Britain pas. S co S. Europe 1688. S S. Europe 1816. S co Sicily 1680. S co S. Europe 1562. S S. Europe 1562. S co S. Europe 1658. S co S. Europe 1680. S co S. Europe 1658. S co

...... 1802. S co Spain 1816. S $\quad$ s.1 Jac. coll. t. 15.f.2 T.... 1802. S s.1 S. Europe 1629. S co Moris.s.2.t.15.f.7 France 1686. S co Carinthia 1789. D co Bot. mag. 909 England gra.pa. S s.l Eng. bot. 1616 S. Europe 16त0. S s.l Mor.s.2.t. 15.f.16 S. Europe 1800. S s.t S. Europe ... S cu Gært. sem. t.155

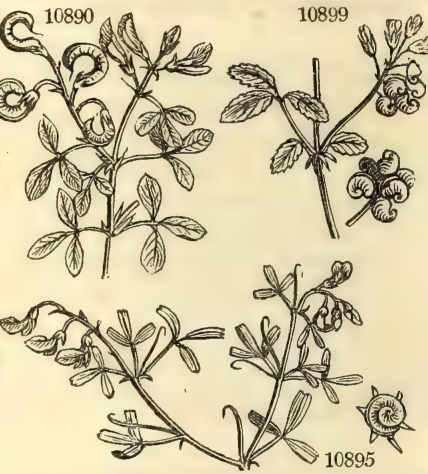

History, Use, Propagation, Culture,

1605. Medicago. A native of the country of the Medes, whence this plant was brought to Greece during the expedition of Darius. M. arborea, the Cytisus of the ancients, flowers great part of tne year, and when sheltered is seldom destitute of flowers. In the open air it begins to flower in April, and continues till December. Those flowers which appear early in summer, will have the seeds ripe in August, or the beginning of September, and the others will ripen in succession. It grows in great plenty in Abruzzo, and many parts of the kingdom of Naples, where the goats feed upon it ; and with their milk abundance of cheese is made there. It also abounds in several of the islands in the Archipelago, where the Turks use the wood to make handles for their sabres; and the caloyers, or Greek monks, form their beads of it. In old shrubs, the heart is of a dark color, and hard like ebony.

According to Miller, this shrub bids the fairest of any to be the Cytisus of Virgil, Columella, and the other ancient writers on husbandry ; and being celebrated by them as an excellent fodder, has been recommended for cultivation here. But however useful it may be in Candia, Rhodes, Sicily, Abruzzo, and other dry warm countries, yet it will never thrive in England, (where we have also many plants of this leguminous tribe far more succulent than this, so as to be of any real advantage; for in severe frost it is very subject to be destroyed, or at least so much damaged, as not to recover its former verdure before the middle or end of May; (and even after a mild winter, it will generally appear injured by our cold spring winds, even at that season; so that it cannot be of any use here for early spring fodder.) Besides, the shoots will not bear cutting above once in a summer, and then will not be of any considerable length : and the stems growing very woody, the cutting of it will be very troublesome. Upon the whole, therefore, it is not worth the trial; though in hot, dry, rocky countries, where few other plants will thrive, it may be cultivated to great advantage. But, howdry, rocky countries, where few other plants wil tree Medick may be for use as fodiler in England, yet for the beauty of its hoary leaves, abiding all ever unfit Tree Medick may be for use as fodrer in England, yet for the beauty of its hoary leaves, abiding all
the year, together with its long continuance in flower, it deserves a place in every good garden and plantation, with shrubs of the same growth. (Dict. in loco, and Martyn's Virgil.)

M. sativa, Foin de Bourgogne, Fr., Alfalfa, Span, and Lucerne, Eng., (from the Languedoc pâtois Lauserda), is a deep rooting perennial plant, sending up numerous small and tall clover-like shoots, with blue or violet spikes of flowers. It is highly extolled by the Roman writers ; it is also of unknown antiquity in old Spain, Italy, and the south of France; is much grown in Persia and Peru, and mown in both countries all the year round. It is mentioned by Hartlib. Blythe, and other early writers, and was tried by Lisle; but it excited round. It is mentioned by Hartlib, Blythe, and other early writers, and was tried by Lisle; but it excited
little attention till after the publication of Harte's Essays, in 1757. But though it has been so much extolled, it has yet found no great reception in this country. If any good reason can be given for this, it is, that lucern is a less hardy plant than red clover, requires three or four years before it comes to its full growth, and is for these and other reasons ill adapted to enter into general rotations. When the climate and soil suit, perhaps, a field of it may be advantageously sown, adjoining the homestall, to afford early cutting or food for young or sick animals, for which it is said to be well adapted; but though it will produce good crops for eight or ten years, yet from the time the farmer must wait till this crop attains its perfection, and from the care requisite to keep it from grass and weeds, we do not think it is ever likely to come into general culture.

There are no varieties of the lucern deserving the notice of a cultivator. What is called the yellow lucern, or Swiss lucern, is the Medicago falcata, a much more hardy and coarser plant, common in several parts of England, but not cultivated any where excepting in some poor soils in Switzerland. 
10890 Pods lunate entire at cdge, Stem arborescent

10891 Pedunc. many-fl. racemose, Pods reniform 1-seeded, Leafl. rhomboid roundish mucronate 10892 Pedunc. racemed, Legume smooth spirally twisted, Stipules entire, $\cdot$ Leafl. long toothed

10893 Pedunc. racemed, Pods twisted-falcate downy, Leafl. lin. truncate toothletted at end

10894 Pedunc. racemose, Pods twisted falcate and cal. viscid villous. Leafl, obovate toothed at end

10895 Pedunc. racemose, Pods smooth cochleate twisted, Stipules toothed at base, Leafl. lin. toothed at end

10896 Heads axill. sessile, Pods half orbicular acute lined 1-seeded

10897 Pedunc. racemose, Pods twisted falcate downy, Leafl. obl. toothed at end

10898 Spikes oval, Legumes renifirm 1-seeded, Stipules entire, Leafl. obovate

10899 Pods racemose reniform 2-seeded, Stip. toothed; Leafl. rhomboid ovate

10900 Pedunc. 2-fl. Pods unarmed cochleate orbicular flattish, Stip. setaceous multifid, Leafl. obov, toothed

10901 Pedunc. 2-fi. Pods unarmed cochleate orbicular very flat at each end; Folds loose .

10902 Pedunc. 2-f. Pods unarmed cochleate orbicular flat transversely rugose at edge, Stip. toothed

10903 Pedunc. 2-fl. Pods unarmed cochleate orbicular convex at base: flat above with concentrically spiral folds 10904 Pedunc. many-fl. Pods unarmed cochleate orbicular flat with distant fólds

10905 Pedunc. many-fl. Pods unarmed cochleate cylindr. flat at each end with distant folds

10906 Pedunc. 2-fl. Pods unarmed cochleate cylindr. convex at each end with imbricated folds

10907 Pedunc. 2-f. Pods unarmed cochleate cylindr. flattish at each end with tubercled folds

10908 Pedunc. about 2 -fl. Pods cochleate cylindr. flattish at each end, Folds muricated at edge

10909 Pedunc. about 2-fl. Pods cochleate cylindr. flat at each end, Prickles subulate appressed

10910 Pedunc. about 2-fl. Pods cochleate cylindr. convex at each end aculeate, Aculei straight

10911 Pedunc. about 2 -fl. Pods cochleate oval with downy pubescent setaceous appressed reflexed prickles

10912 Pedunc. about 2-fi. Pods cochleate oval with straight subulate downy prickles

10913 Pedunc. many-fl. Pods cochleate compressed at each end with subulate straight prickles

10914 Pedunc. about 2-fl. Pods cochleate compressed at each end with subulate arcuate prickles

10915 Pedunc. many-fl. Pods cochleate cylindr. flat at each end pubesc. with close-pressed subul. prickles

10916 Pedunc. many-fl. Pods cochleate flat at each end with 3 netted folds muricate at edge

10917 Pedunc. about 2-fl. Pods cochleate cylindr. flat at each end with smooth lanc. distich. close-pressed prickles

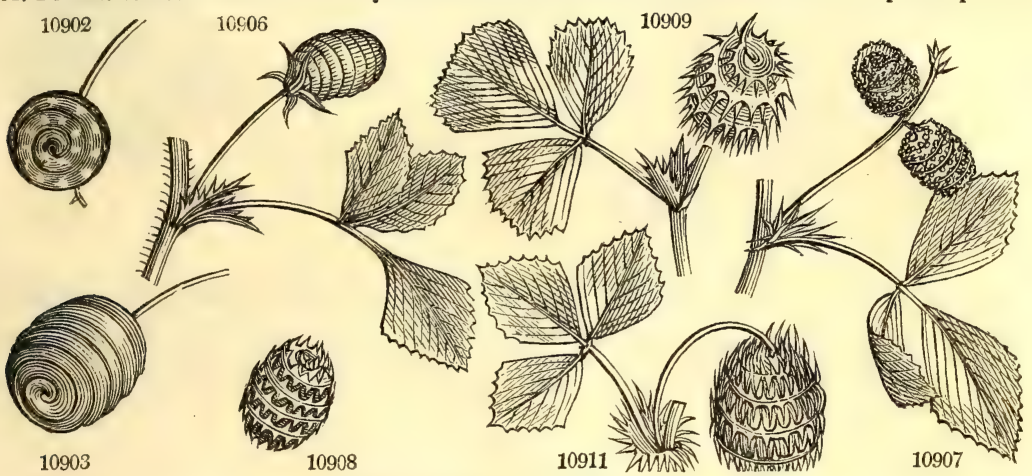

a

and Miscellaneous Particulars.

The soil for lucern must be dry, friable, inclining to sand, and with a subsoil not inferior to the surface; unless the soil be good and deep, it is in vain to attempt to cultivate lucern.

; The preparation of the soil consists in deep ploughing and minute pulverisation; and, in our opinion, the shortest way to effect this, is to trench it over by the spade to two or three feet in depth, burying a good coat of manure in the middle, or at least one foot from the surface. This is the practice in Guernsey, where lucern is highly prized.

The climate for lucern, as we have already hinted, must be warm and dry; it has been grown in Scotland and Ireland, and might probably do well in the southern counties of the latter country, but in the former it has not been found to answer the commendations of its admirers.

The season most proper for sowing lucern, is as early as can be done in the spring months, as in this way the plants may be fully established before the season becomes too hot. If the plants be intended to be transplanted out in the garden method, it will also be the best practice to sow the seed-bed as early in the spring as the frosts will admit, in order that they may be strong, and fit to set out about the beginning of August.

The manner of sowing lucern is either broad-cast or in drills, and either with or without an accompanying crop of corn for the first year. Broad-cast, and a very thin crop of barley or other spring corn, is generally, and, in our opinion, very properly preferred.

The quantity of seed, when the broad-cast method is adopted, is said to be from fifteen to twenty pounds per acre, and from eight to twelve if drilled. The seed is paler, larger, and dearer than that of clover; it is generally imported from Holland, and great care should be had to procure it plump and perfectly new, as two years old seed does not come up freely. The same depth of covering as for clover will answer.

The after-culture of lucern, sown broad-cast, consists in harrowing, to destroy grass and other weeds; rolling, after the harrowing, to smooth the soil for the scythe, and such occasional top.dressings of manure as the state of the plants may seem to require.

The top-dressings given to lucern may be either of the saline or mixed manures. Ashes are greatly esteemed, and also gypsum and liquid manure of any kind.

The taking of lucern by mowing for soiling, or hay, or by tethering, hurdling, or pasturing, may be considered as the same as for clover. Lucern frequently attains a sufficient growth for the scythe towards the end of April, or beginning of the following month; and in soils that are favorable for its culture, will be in a state of readiness for a second cutting in the course of a month or six weeks longer, being capable of under. going the same operation at nearly similar distances of time during the whole of the summer season.

The application of lucern is also the same as of clover. The principal and most advantageous practice, in the application of lucern, is that of soiling horses, neat cattle and hogs; but as a dry fodder, it is also capable of affording much assistance, and as an early food for ewes and lambs, may be of great value in particular eases. All agree in extolling it-as food for cows, whether in a green or dried state.

The produce of lucern, cut three times in a season, has been stated at from three to five and even eight tons per acre. In soiling, one acre is sufficient for three or four cows during the soiling season, and a quarter of an acre, if the soil be good, for all sorts of large stock, for the same period, or half an acre on a moderate soil.

The nutritive product of lucern, according to Sir H. Davy, is 2-3-tenths per cent, and is to that of the 


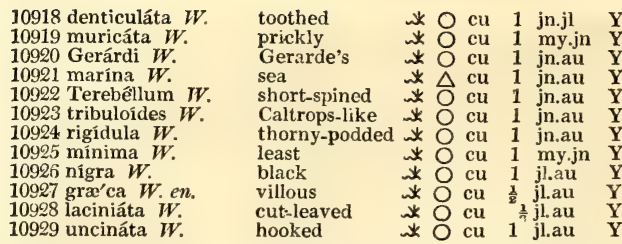

S. Europe 1800. S s.l England sea co. S co Mor. s.2.t.15.f.11 Hungary 1816. S co Mor.s.2:t. 15.f.18

S. Europe 1596. D s.1 Cav, ic. 2, t. 130 S. Europe 1798, S s.1 S. Europe 1798. S s.l S. Europe 1730. S 8. S. Europe 1730. S s.1 England ch.so. S co Greece 1804, S s.1

Surope 1683, S s.l Breyn cent t 34 S. Europe ... S S co
Fl. dan. 211

Breyn. cent. t. 34

1606. HYMENOCAR'PUS. $W$. HYMenocarpus. Leguminosa. Sp. 3.

10930 radiátus $W . \quad$ ray-podded $W^{*} O$ pr $\frac{1}{3}$ jn.jl Y Italy 1629 . S s.l Lob. ic.2.p.38.f.2 10931 circinátus $W$. kidney-podded ${ }^{*} O \mathrm{pr}{ }^{1}$ jl.au $\quad$ Y $\quad$ Italy 1640 . S co Gær. sem.2.t.155 10932 nummulárius $W$. en. money-leaved w $\mathrm{O}$ pr $\frac{1}{2}$ jl.au $\mathrm{Y}$ Italy $\quad 1640$. S co

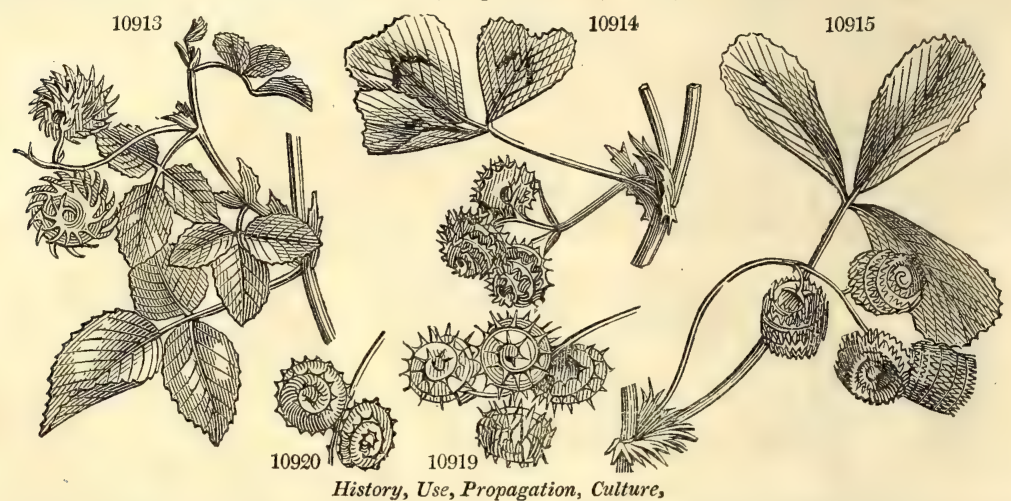

clovers and saintfoin as 23 to 39 . This result does not very well agree with the superior nutritive power attributed to lucern; and is one proof, among many, how little the analysis of the chemist agrees with the experience of the farmer.

To save seed, the lucern may be treated precisely as the red clover, and it is much easier threshed, the grains being contained in small pods, which easily separate under the flail, or a threshing machine, or clover mill.

M. lupulina, Hop-trefoil, sometimes called Shamrock, and in Norfolk Black Nonesuch, is cultivated occa- 
10918 Pedunc. many-fl. Pods cochleate flat at each end, Folds 2 reticulated with prickles of their edges diverging 10919 Pedunc. many-fl. Pods cochleate flat at each end smooth, Folds 5 with short subulate prickles 10920 Pedunc. about 2-fi. Pods cochleate flat at each end villous, Folds 5 with subulate hooked prickles 10921 Pedunc. many-fl. Pods cochleate roundish muricate, Leafl. downy obovate entire

10922 Pedunc. many-fl. Pods cochleate cylindr. flat at each end, Folds 5 with short subulate reflexed prickles 10923 Pedunc. 2-fl. Pods cochleate cylindr. flat at each end with conical distichous reflexed prickles

10924 Pedunc. many-fl. Pods cochleate cylindr. Prickles conical straight spreading

10925 Pedunc. many-fl. Pods cochleate hairy, Prickles subulate straight hooked

10926 Pedunc. 2-fl. Pods cochleate cylindr. with close folds, Prickles subulate straight hooked

10927 Pedunc. many-fl. Pods cochleate somewhat hairy, Prickles subulate straight hooked

10928 Pedunc. 2 -fl. Pods cochleate cylindr. with subulate straight hooked prickles, Leafl. lin. truncate

10929 Pedunc. many-f. Pods cochleate villous flat at each end with 5 folds, Prickles subulate straight hooked

10930 Pods toothed at edge, Leaves ternate

10931 Pods toothed at edge, Leaves pinnate

10932 Pods entire at edge, Leaves pinnate
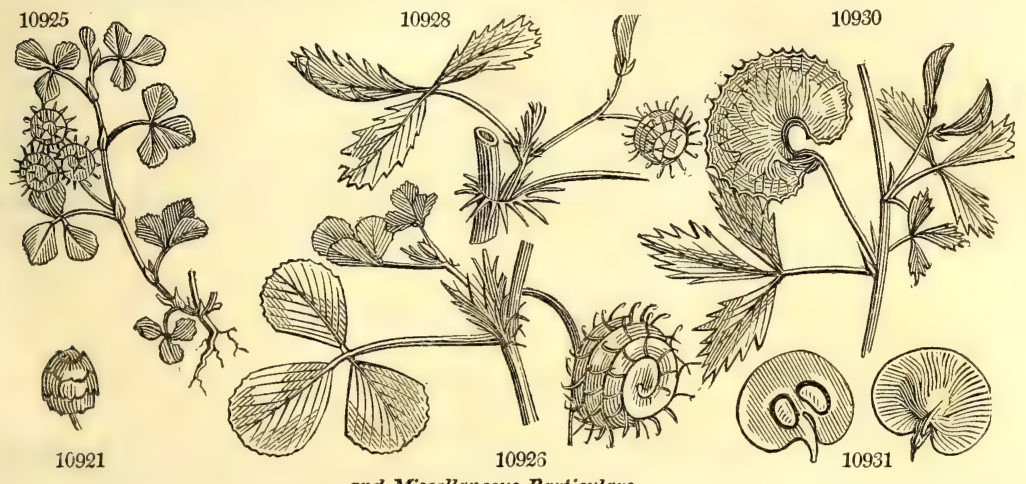

and Miscellaneous Particulars.

sionally along with the perennial clovers, and sometimes confounded with the common yellow clover, which is an annual and much smaller plant. Its treatment is the same as that of white clover; but its herbage is little relished by cattle, and both it and the yellow clover are going fast out of repute.

M. scutellata and intertexta are sown as border flowers for the curiosity of their pods.

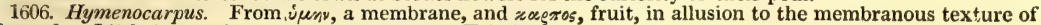
the pods. Little inconspicuous plants resembling Trifolium. 


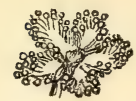

\section{Cr.ass XVIII. - POLYADELPHIA. Stamens united into several parcels.}

ONE of the smallest of the Linnean classes, characterized by the cohesion of the filaments in several parcels. It almost wholly consists of plants remarkable either for their beauty or importance otherwise. From the Theobroma the nutritious substance which forms the basis of Chocolate is procured. Melaleuca and its allies are among the most elegant of New Holland plants. The genus Symplocos contains a plant useful as a dye. To Citrus belong the Orange, Lemon, Lime, and all their delicious varieties; and the Loasa, with which the class is here concluded, consists of some of the most ornamental and curious of our garden annuals.

By some botanists this class is distributed among others, especially Icosandria and Polyandria.

Order 1. DECANDRIA.

Stamens 10 or 12.

1607. Theobroma. Cal. 5-leaved. Petals 5, fornicate. Nectary urceolate, with 5 horns. Filaments 5 , each with 2 anthers. Style filiform. Stigma 5-parted. Caps. 5-celled, without valves. Seeds in a buttery pulp. 1608. Bubroma. Cal. 3-leaved. Petals 5, 2-horned. Nect. campanulate, 5-fid. Filam. 5, attached to the outside of nectary; each with 3 anthers. Style simple. Capsule woody, warted, valveiess, bored with 12 rows of holes.

\section{DECANDRIA.}

1607. THEOBRO'MA. $W$. Chocolate Nut. 10933 Cacáo $W$. 10934 guianénsis $W$ Br Guiana 1803. C r.m Aub.gui,2.t.275 1608. BUBróma. $W$. Bastard Cedar. Bytneriacea. Sp. $1-3$ 10935 Guazúma $W$ Elm-leaved $\perp \square \operatorname{tm} 40$ au.s $Y$ J Jamaica 1739. C p.1 Trew.ehret.t.76 1609. ABRO'MA. $W$. AвRoma. Byttneriacea. Sp. 2-3. $\begin{array}{llllll}10936 \text { augústa } H . K . & \text { smooth-stalked } 9 \square \text { or } 10 \text { au } & \text { Pu } & \text { E. Indies 1770. C l.p Jac. vind. 3.t. } 1 \\ 10937 \text { fastuósa } H . K . & \text { prickly-stalked } 9 \square \text { or } 10 \text { jn.o } & \text { Pu } & \text { N.S. W. 1800. C l.p Par. lond. } 102\end{array}$
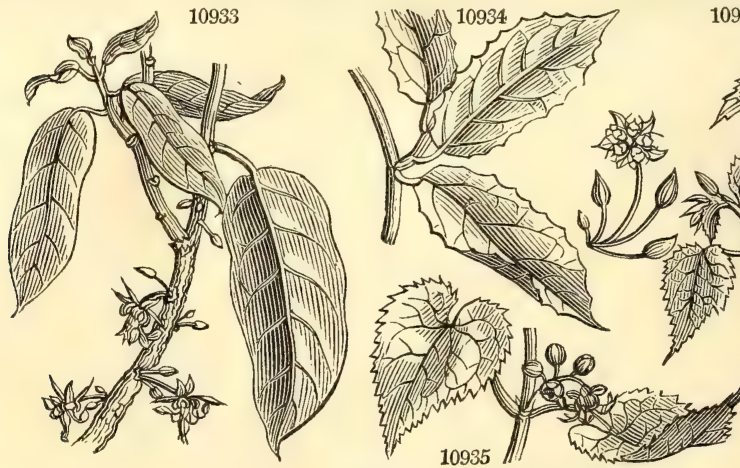

10936

History, Use, Propagation, Culture,

1607. Theobroma. From $\Theta_{\varepsilon}, \mathrm{s}, \mathrm{God}$, and $\beta_{\rho} \omega \mu \alpha$, food, in allusion to the excellent nature of its produce. The Mexicans call the beverage obtained from it Chocolatl. (Nieremb.) T. Cacao is a tree which grows in a very handsome form to the height of twelve or sixteen feet; the trunk is upright, and about as high as a man before the head spreads out; the wood is light and of a white color; the bark brownish. Leaves lanceolateoblong, bright green, quite entire; flowers small, reddish, inodorous. Fruits smooth, yellow, red, or of both colors, about three inches in diameter : rind fleshy, near half an inch in thickness, flesh-colored within : pulp whitish, the consistence of butter, separating from the rind in a state of ripeness, and adhering to it only by filaments, which penetrate it and reach to the seeds. Hence it is known when the seeds are ripe, by the rattling of the capsule when it is shaken. The pulp has a sweet and not unpleasant taste, with a slight acidity; it is sucked and eaten raw by the natives. The seeds are about twenty-five in number: when fresh they are of a flesh-color: gathered before they are ripe, they preserve them in sugar, and thus they are very grateful to the palate: they quickly lose their power of vegetation, if taken out of the capsule; but kept in it, they preserve that power for a long time. The tree bears leaves, flowers, and fruit all the year through; but the usual seasons for gathering the fruit are June and December. In two years from the seed it is above three feet high, and spreads its branches, not more than five of which are suffered to remain: before its third year is complete it shows for fruit. A tree yields from twc to three pounds of seeds annually. These seeds are remarkably nourishing, and agreeable to most people; which occasions them to be commonly kept in most houses in America, as a necessary part of the provisions of the family : they are generally ground or pounded very fine, a little arnatto added, and made into paste : they are much charged with oil, but mix well with milk or water, and are formed into rolls of one pound each.

This simple preparation of chocolate is the most natural and the best. It is in daily use amongst most 
1609. Abroma. Cal. 5-part. Petals 5, with saccate dilated claws Cup of stamens 10-fid ; with ju segments, each bearing 3 anthers; the other 5 petaloid. Styles 5 . Caps. 5 -celled; 5-winged, many-seeded.

\section{Order 2. POLYANDRIA.}

1610. Melaleuca. Parcels of stamens 5, opposite the petals, long; anthers incumbent. Caps. 3-celled, many-seeded, connate, and included in the thickened tube of the calyx which is grown to the branch.

1611. Tristania. Parcels of stamens 5, opposite the petals, and scarcely longer than they are; anthers incumbent. Caps. 3-celled, many-seeded, united with the turbinate stalked tube of the calyx.

1612. Calothamnus. Parcels of stamens 4-5, opposite the petals (some either connate or sterile). Anthers inserted oy the base, entire. Caps. 3-celled, many-seeded, connate, and included in the thickened tube of the inse which is grown by the base to the branch

1613. Beaufortia. Parcels of stamens 5, opposite the petals. Anthers inserted by the base, bifid at the end, with deciduous lobes. Caps. 3-celled, 1-seeded, connate, and included in the thickened tube of the calyx, which is grown by the base to the branch.

1614. Symplocos. Cal. 5-fid, superior. Petals 5-8; cohering at the base in a tube. Stamens united to the corolla in 4 rows. Drupe dry, 5-celled.

1615 Citrus. Cal, 5-fid. Petals 5, oblong. Anthers 20; the filaments variously divided. Berry 9-celled.

1616. Xanthochymus. Cal. 5-leaved. Petals 5. Nectaries 5. Stamens united in 5 parcels. Apple 1-5seeded.

1617. Hypericum. Cal. 5-parted. Petals 5. Filaments many in 3 or 5 parcels. Capsule superior.

1618. Ascyrum. Cal. 4-leaved. Petals 4. Caps. 1-celled, 2-3-valved.

1619. Loasa. Cal. 5-leaved. Petals 5. Nectary 5-leaved. Caps. $\frac{1}{2}$-inferior, 1-celled, $\frac{1}{2}-3$-valved, manyseeded.

\section{DECANDRIA.}

10933 Leaves entire smooth

10934. Leaves acuminate repand-toothed downy beneath

10935 Leaves cordate ovate acute with unequal serratures

10936 Leaves 7-angled : floral ov.-lanc. acuminate somewhat toothed, Pedunc. axill. Branches unarmed 10937 Adult lvs. with simple and stellate hair beneath, Wings of caps. subtruncate at end, Branches muricated
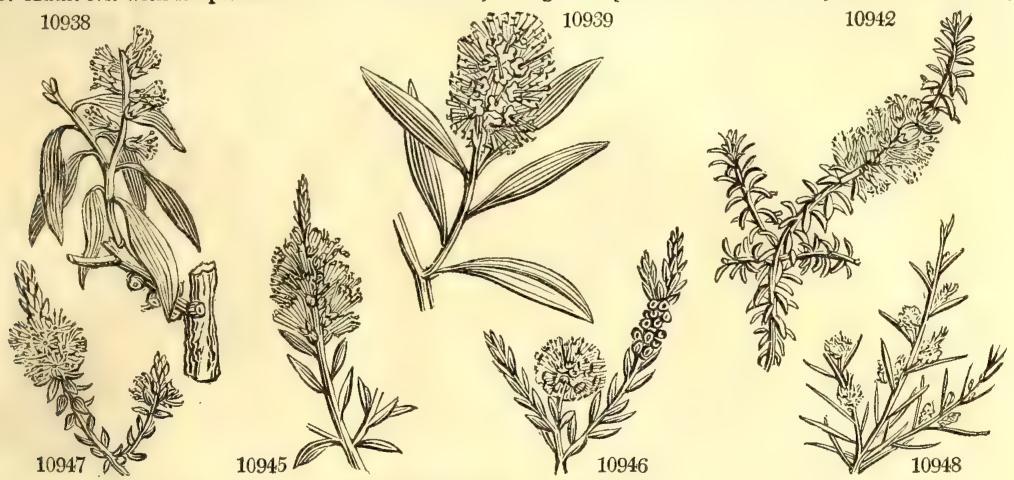

and Miscellaneous Particulars.

families in Jamaica, where the tree is largely cultivated, and affords a nutritious food for children, as well as adults. But as chocolate made abroad cannot by law be imported into this country, consequently all chocolate consumed in Britain ought to be made here. It is composed principally of the kernel of the cocoa, as above mentioned; but the art is in very few hands : and we believe that a small portion of soap is added to most British chocolate, in order to cause it to froth when it is dissolved in hot water.

Cocoa is a simple preparation made in Britain, from the cocoa-nut, or from the shells of it, or from a mixture of both. It is considered much easier of digestion than chocolate, and very nourishing.

In our stoves Theobromas thrive in light rich soil, and cuttings root in sand under a hand-glass.

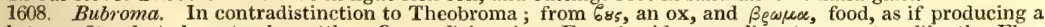
substance fit only to be eaten by cattle. Orme d'Amerique, Fr. A wide spreading tree, not unlike the Elm, with oblong heart-shaped leaves, which sleep hanging quite down, whilst the petioles remain entirely stiff and straight. It grows in the lowlands of Jamaica, forming a very agreeable shade for the cattle, and supplying them with food in dry weather, when all the herbage is burned up or exhausted. The seeds are very mucilaginous, but otherwise agreeable to the palate. The wood is light, and so easily wrought, that it is generally used by coachmakers in all the side pieces. (Browne.) It is also frequently cut into staves for casks. A decoction of the inner bark is very glutinous, and very like that of the elm. In our stoves it thrives well in a loamy soil, and cuttings root freely in sand under a hand-glass.

1609. Abroma. Still named with reference to the two preceding genera, from $\alpha$, privative, and $\beta \rho \omega \mu \alpha$, food ; as if unfit for either gods or oxen. This, Sweet observes, "is a hardy stove genus, and easily managed; the species flower freely at various seasons, and will grow in the common garden soil : but a mixture of good loam with a little peat is an excellent compost for them. They propagate freely by seeds and cuttings." (Bot. Cult. 10.) 


\section{POLYANDRIA.}

1610. MelaleU'CA. $\boldsymbol{H}$. $\boldsymbol{K}$. Melaleuca. 10938 Ieucadéndron $W$ Cajeputi Tree 10939 viridiflóra $W$. 10940 paludósa $B r$. 10941 globífera $B r$ 10942 diosmifólia $\mathrm{Br}$. 10943 stypheloides $B r$. 10944 genistifólia $B r$ 10945 striáta $B r$. 10946 thymoides $\mathrm{Br}$. 10947 squámea $B r$. 10948 nodósa $B r$. 10949 ericifólia $B r$. 10950 armilláris $\mathrm{Br}$. 10951 uncináta $B$. 10952 scábra $B$ 10953 pulchélla $B$; 10954 thymifólia $B r$. 10955 decussáta $B r$ 10956 fúlgens $B$ 10957 linariifólia $B r$. 109.58 hypericifúlia $\boldsymbol{B}$ r. 10959 squarrósa $B$ r 10960 calycína $B r$. 10961 dénsa $\mathrm{Br}$.

10962 incána $B r$.

Cajeputi Melaleuca. 15 Myrtacea. Sp. $25-30$ g. $10 \ldots . \quad$ G $\quad$ N. S. W. 1798. C s.l.p Cav. ic. 4. t. 333 long-leaved red Diosma-leaved Styphelia-leav. Broom-leaved striated yellow spear-l scaly-branched Whin-leaved Heath-leaved pale-flowered pale-flowered rough-leave nea

Thyme-leaved decussate splendid $\square$ or Hyd-Fax-lvd. Hypericum-lv. Myrtle-leaved permanent-cup whorl-leaved hoary

i611. TRISTÁNIA. $B \%$ TrISTaNIA. 10963 nereifólia $\mathrm{Br}$. Oleander-leav. $1096 \pm$ laurína $\mathrm{Br}$. 10965 conférta $B r$. Pittosporum-lv

1612. CALOTHAM'NUS. Lab. Calotilamés. 10966 quadrifida $\mathrm{Br}$. $\mathbf{1 0 9 6 7}$ villósa $B r$. hairy or

10968 grácilis $\mathrm{Br}$.

1613. BEAUFOR'TIA. 10969 decussáta $B r$.

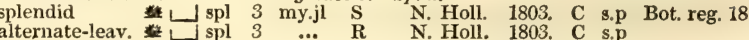
10970 spársa $\mathrm{Br}$ alternate-leav

1614. SYM'PLOCOS. $I$. SYMPLOCos. 10971 tinctória $W$. Laurel-leaved 10972 sinica $\mathrm{Ker}$. Laurel-leaved
Chinese

1615. CI'TRUS. $W$ 10974 Limétta Risso 10975 Aurántium Riss 10976 vulgáris Risso

\section{Orange-Tree. $\quad$ Aurantiacea, Sp. 8-15.}

Lemoñ \& $ـ$ fr $15 \mathrm{my} . j 1 \mathrm{~W}$ Asia 1648. B r.m Gæ.fr.2.t.121.f.2 Lime $\quad$ fr 8 my.jl W Asia sweet $\quad 9$ fr 15 my.jl W Asia Seville के 15 my.jl W Asia

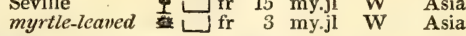

B r.m Lamill t.639.

\section{\& myrtifolia Hort. \\ Asia $\quad \ldots$ B r.m Bot. reg. 346}
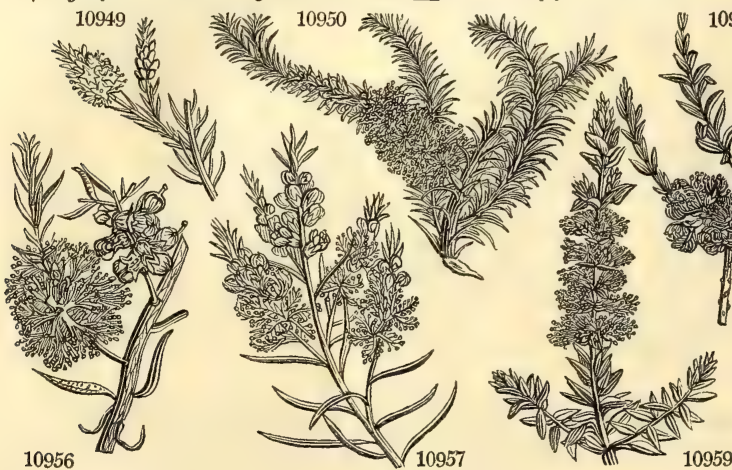

History, Use, Propagation, Culture.

1610. Melaleuca. From $\mu \varepsilon \lambda \alpha_{5}$, black, and $\lambda \varepsilon \nu \varkappa \varsigma_{5}$, white : because the original tree has black wood and white branches. A beautiful Australasian genus, which grows and flowers freely in equal parts of sandy loam and peat, with common greenhouse treatment. "Some cultivators," Sweet observes, "grow them entirely in peat, in which they will grow very well for a time; but they will not be strong and healthy, nor flower so well as in a mixture, Ripened cuttings, not too old, will root freely in sand under a bell-glass." (Bot. Cult. 223.)

The bark of Melaleuca Leucadendron is used by the Chinese as oakum, for making good the spaces between the timbers of their vessels. They also use it in the roofing their houses. From the same tree is obtained the Cajeputi oil, remarkable for its green color, its peppermint flavor, and turpentine smell. It is rarely to be procured in Europe in an unadulterated state. When pure it is one of the best preservatives of preparations of natural history, and is used externally with much success as a cure for rheumatic affections and pains in the joints.

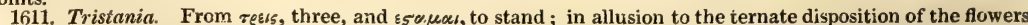
and ieaves. The species may be treated like Melaleuca, and are pretty little evergreen shrubs.

1612. Calothamnus. From $\approx \alpha \lambda \circ$, beautiful, and $\tau_{\alpha \mu \nu}$, a rod, in allusion to the splendid appearance of the branches covered with scarlet blossoms. The species are beautiful plants, and not difficult of culture or propagation in sand, and the air kent still and moderately moist by covering with a hand-glass. 


\section{POLYANDRIA.}

10938 Leaves alternate lanc. acuminate oblique 5-nerved, Branches and petioles smooti 10939 Leaves alternate ellipt. lanc. coriaceous 5-nerved, Branches and petioles downy

10939 Leaves linear-lanc. long equal-sided straight 3-nerved : lateral nerves close to the scabrous edge 10941 Leaves obl. 5-nerved equal-sided narrower at base, Heads spherical, Capsules connate

10942 Leaves oval or oblong obsoletely 1-nerved stalked flat close and branches quite smooth, Spikes obl. smooth

10943 Leaves ov. acuminate with a pungent point striated with many nerves sess. smooth, Spikes downy

10944 Leaves lin. lanc. obsoletely 1-3-nerved, Spikes lax leafy smooth, Parcels of anthers polyandrous

10945 Leaves lanc. lin. acute dotted obsoletely striated rigid subsess. Tube of calyx woolly

10946 Lvs. lanc. occasionally obl. 3-nerved stalked and branches smooth, Heads glob. or oval, Segm. of cal. acute

10947 Leaves ov. lanc. acuminate 3-nerved: young lvs, and branches villous, Heads globose downy

10948 Leaves subulate lin. mucro, rigid 1-nerved flat, Heads globose, Segm. of cal. membranous smooth

10949 Leaves lin.-subul. nerveless pointless spreading and subrecurved, Spikes oval smooth

10950 Leaves lin.-subul. mucro recurved at end, Spikes cylindr. very smooth

10951 Leaves angular filiform mucro. erect; hooked back at end, Branches virgate, Heads oval

10952 Leaves roundish mucro. rough clustered, Heads round, Parcels of stamens 4-6-androus

10953 Leaves scattered and somewhat opp. oval blunt obsoletely 3.nerved, Flowers subsolitary smooth

10954 Leaves opp. lanc. nerveless, Spikes few-fl. Parcels of stamens polyandrous

10955 Leaves opp. decussate oval-lanc. 3-nerved, Spikes oval quite smooth, Parcels of stamens polyandrous 10956 Leaves opp. lanc. lin. acute 1-nerved, Spikes oval quite smooth, Parcels of stamens multifid

10957 Leaves opp. lanc. lin. acute 3-nerved, Spikes obl. smooth, Parcels of stamens longitudinally pinnated 10958 Leaves opp. ellipt. obl. 3-nerved: lateral nerves obsol. and close to the recurved edge, Spikes quite smooth 10959 Leaves opp. ovate acute 5-7-nerved stalked, Spikes obl. and oval, Bractes leafy

10960 Leaves opp. ovate-lanc. 3-5-nerved subsess. Clusters few-fl. Segm. of cal. acute nerveless

10961 Leaves ternate obovate 3-nerved smooth, Spikes oblong or oval

10962 Leaves tern. lin. lanc. hoary on both sides, as are the branches, Spikes oval or oblong

10963 Leaves opp. lanc. Parcels of stamens 3-5..androus

10964 Leaves altern, cun. lanc. Branches and calyxes downy, Caps. half superior

10965 Leaves lanc. ellipt. acute alternate : terminal clustered, Segm. of calyx acute leafy

10966 Flowers 4-fid, Parcels of stamens distinct equal 12-15-androus, Old leaves and fruit smooth 10967 Flowers 5-fid, Parcels of stamens distinct equal polyandrous, Old leaves and fruit villous

10908 Flowers 5-fid, Parcels of stamens distinct equal 3-androus, Leaves very long and fruit smooth

10969 Leaves opp. decussate ovate or oval many-nerved

10970 Leaves scattered oval many-nerved

10971 Flowers clustered sessile, Leaves glaucous

10972 Leaves ellipt. lanc. downy on each side corrugate veiny, Sepals acuminate

10973 Peti. somew. winged, Lvs. obl. acute toothed, F1.35-androus, Fruit obl. with a thin rind and very acid pulp 10974 Petioles naked, Lvs, ov. rounded serrated, Fl. 30-androus, Fruit globose with a nipple and sweet pulp

10975 Petioles nearly naked, Lvs. ov. obl. and acute, Fl. 20-androus, Fruit globose with a thin skin and sweet pulp

10976 Peti. winged, Lvs. ellipt. acute crenulat. Fl. 20-androus, Fruit glob. with a thin rough skin and bitter pulp

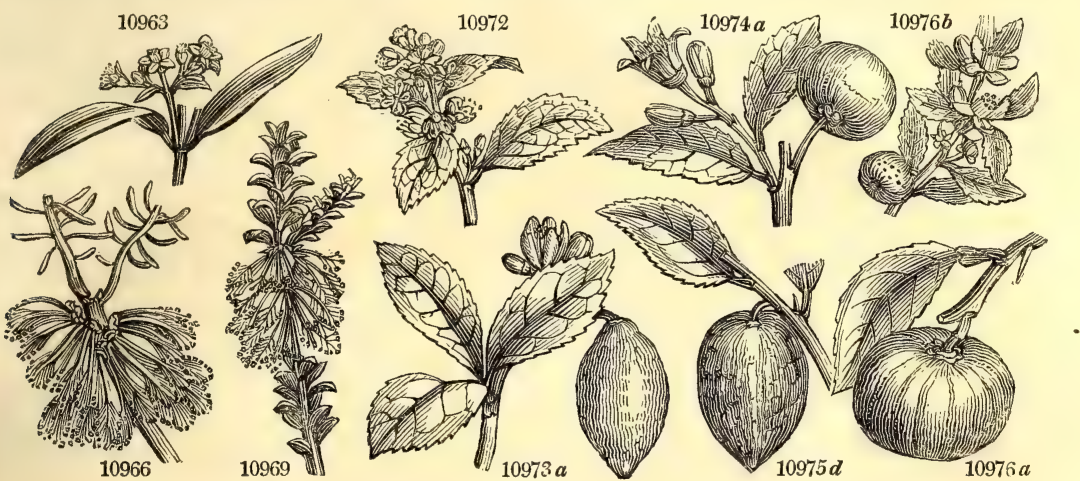

and Miscellaneous Particulars.

1613. Beaufortia. So called in honor of Mary, Duchess of Beaufort, who died January 7, 1714, in the 85th year of her age. She had a fine coilection of plants at Badmington, in Gloucestershire, during the life-time of her husband, Henry, first duke of Beaufort. Splendid plants, free-growers, and abundant flowerers, with common greenhouse treatment, in two-thirds peat, and one-third loam. Cuttings, Sweet found to answer best when "taken from nearly ripened wood, planted in sand, and covered with a bell-glass."

1614. Symplocos. From $\sigma \nu \mu \lambda$ orn, connection; union. The petals are naturally five, but united at the base so as to seem but one. A tree with oblong fragrant shining leaves, and sweet-smelling flowers, succeeded by subsessile drupes. A decoction of the leaves is used in North America for dying linen and silk of a bright yellow color.

1615. Citrus. The meaning of this word has escaped the ingenuity of etymologists. An ancient genus, combining in its species many excellencies, handsome evergreen shining tree-like forms, most odoriferous flowers, and brilliant, fragrant, delicious fruits. It is one of the most striking of fruit-bearing trees, and must have attracted the notice of aboriginal man long before other fruits of less brilliancy, but of more nutriment or flavor. The golden apples of the heathens, and forbidden fruit of the Jews, are supposed to allude to this family, though it is remarkable that we have no authentic records of any species of Citrus having been known; certainly none were cultivated by the Romans. The citron was introduced into Europe from Media, under the name of malus medica, and was first cultivated in Italy by Palladius, in the second century. The orange 
10977 buxifólia $P . S$.

10978 nóbilis $\boldsymbol{H} . \dot{K}$.

e mínor
10979 médica Risso

10979 médica Risso
10980 Decumána $W$.

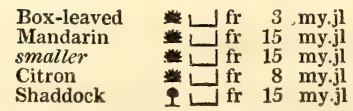

W China

China

China

Asia

Andia
1805, B r.m

B r.m Bot. rep. 608

B r.m Bot. reg. 211

17̈4 B r.m Ferr. hesp. t. 39

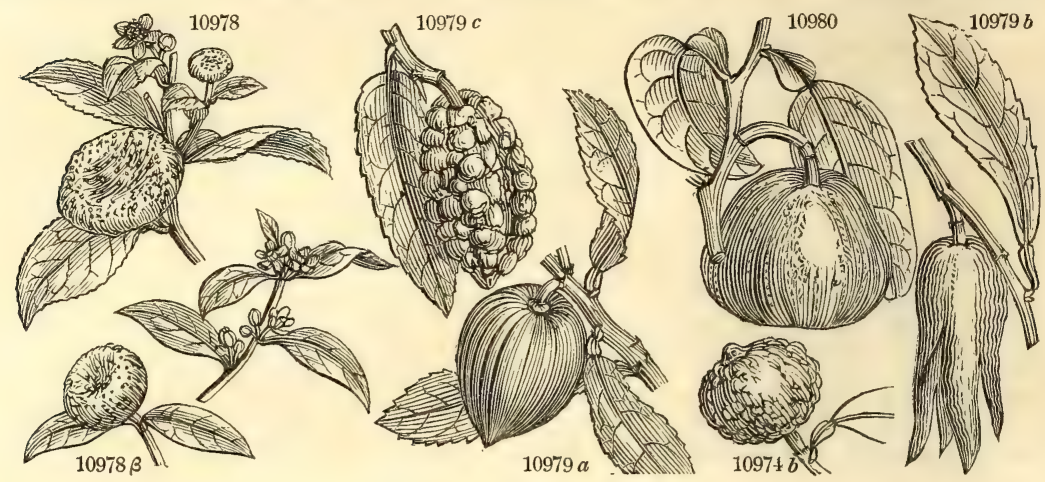

History, Use, Propagation, Culture,

is supposed to have been introduced into Italy in the fourteenth century, above a thousand years after the citron. In England, these trees have been cultivated since 1629. Parkinson, writing at that time, says, "6 the orange hath abiden with some extraordinary looking and tending, when neither citron nor lemon trees could be preserved any length of time." The orange trees he alludes to were those of Beddington, in Surrey, introduced from Italy by a knight of the noble family of the Carews (Gibion's edit. of Camb. Brit.), and the first that were brought into England; they were planted in the open ground and placed under a moveable cover during the winter months. It has been said that these trees were raised by Sir Francis Carew, from seeds brought to England by Sir Walter Raleigh: but as such trees would not have readily borne fruit, Professor Martyn thinks it much more likely that they were plants brought from Italy. Bradley says, they always bore fruit in great plenty and perfection; that they grew on the outside of a wall, not nailed against it, but at full liberty to spread; they were fourteen feet high, the girt of the stem twenty-nine inches, and the spreading of the branches one way nine feet, and twelve feet another. These trees, Evelyn informs us, were neglected in his time, during the minority of their owner, and finally entirely killed by the great frost in 1739-40; they were planted before 1595

During the latter end of the seventeenth and beginning of the eighteenth centuries, the orange tree was a very fashionable article of growth in conservatories, when there were but few exotics of other sorts kept there. The plants were procured from Genoa, with stems generally from four to six feet in height; they were planted in large boxes, and were set out during summer to decorate the walks near the house, in the manner still practised at Versailles and the Thuilleries. About the middle of the eighteenth century, when a taste for botany and forcing exotic fruits became general, that for superb orange trees began to decline; many of these large trees have decayed through neglect; and those which are now to be found in the greater number of greenhouses, are generally dwarf plants bearing few fruit, and those of small size. In some places, however, are still to be found large and flourishing trees. Those at Smorgony, in Glamorganshire, are the largest in Britain; they are planted in the floor of an immense conservatory, and bear abundantly. It is said that the plants were procured from a wreck on the coast in that quarter, in the time of Henry VII.

At Nuneham, near Oxford, are some fine old trees, planted under a moveable case, sheltered by a north wall. In summer the case is removed, and the ground turfed over, so that the whole resembles a native orange grove. At Wormleybury, Hertfordshire, and Shipley Hall, in Derbyshire, are very fine large orange and lemon trees grown in borders and in boxes. (Hort. Trans. vol. ii. 295, and iv. 306.)

At the Wilderness, Kent, are three trees in boxes, not surpassed by any trees so grown in Europe.

At Woodhall, near Hamilton, trees of all the species of Citrus are trained against the back walls of forcing houses, in the manner of peaches, and produce large crops of fruit

In the south of Devonshire, and particularly at Saltcombe, one of the warmest spots in England, may be seen, in a few gardens, orange trees that have withstood the winter in the open air upwards of a hundred years. The fruit is as large and fine as any from Portugal. Trees raised from seed, and inoculated on the spot, are found to bear the cold better than trees imported.

The common character of the Citrus family is that of low evergreen trees, with ovate or oval-lanceolate, entire or serrated leaves. On the ungrafted trees are often axillary spines. The flowers appear in peduncles, axillary or terminating, and one or many-flowered. The fruits are large berries, round or oblong, and generally of a yellow color. The species seem best distinguished by the petiole, which in the orange and shaddock is winged; in the citron, lemon, and lime, naked. The form of the fruit, although not quite constant, may also serve for a distinction. In the orange and shaddock it is spherical, or rather an oblate spheroid, with a red or orange-colored rind; in the lime, spherical, with a pale rind; in the lemon, oblong, rough, with a nipplelike protuberance at the end; in the citron, oblong, with a very thick rind. The flowers of the citron and lemon have ten stamens, and those of the orange more. It is very difficult to determine what is a variety, and what is a species in this genus; many of the sorts in cultivation are by buds.

Dr. Sickler, who spent several years in Italy, and paid great attention to the kinds and culture of the orange, published in 1815, Der Vollkommen Orangerie-Gartner (The complete Orange Gardener), in which he describes above seventy sorts of Citrus.

Gallesio (Traité du Genre Citrus, \&c. Savonna, 1818.) has given a synopsis of the forty principal sorts cultivated in Italy.

The most splendid work on oranges which has yet appeared is the Histoire Naturelle des Orangers, by Risso, of Nice, and Poiteau, of Versailles. (Paris, fol. 1818.) Here 169 sorts are described, and 105 of them figured, and their French and Italian culture given at great length. They are arranged as sweet oranges, of which they describe 42 sorts ; bitter and sour oranges, 32 sorts ; bergamots, 5 sorts ; limes, 8 sorts ; shaddocks, 6 sorts; lumes, 12 sorts ; lemons, 46 sorts ; citrons, 17 sorts.

All the species of Citrus endure the oper air at Nice, Genoa, and Naples; but at Florence and Milan, and often at Rome, they require protection during the winter, and are generally placed in conservatories and sheds. The largest conservatory in Italy is that of Prince Antonio Borghese, at Rome, which contains seventy select sorts of agrumi. The largest trees are at Sorenta, 'I'erracina, Gaeta, and Naples; but the most regular and garden-like culture of the orange, is in the orange-orchards at Nervi, Monaco, and other places in the neighbourhood of Genoa. At Nervi are also the orange nurseries which may be said to supply all Europe with trees; they are, in general, wretchedly cultivated, and the stocks inoculated in the most unscientific manner; but the fine climate, strong clavev soil. and abundant manurirgs, supply in a great degree the nicer practices 
10977 Petioles lin. very short, Lvs. ovate retuse, Flowers racemose

10978 Petioles sublinear straight, Branches ascending unarmed, Fruit depressed, Skin separated from flesh

10979 Petioles naked, Lvs. obl. acute, Fl. 40-androus, Fruit obl. rugose with acid pulp 10980 Petioles winged, Lvs. blunt emarg. Fruit very large with a thick skin

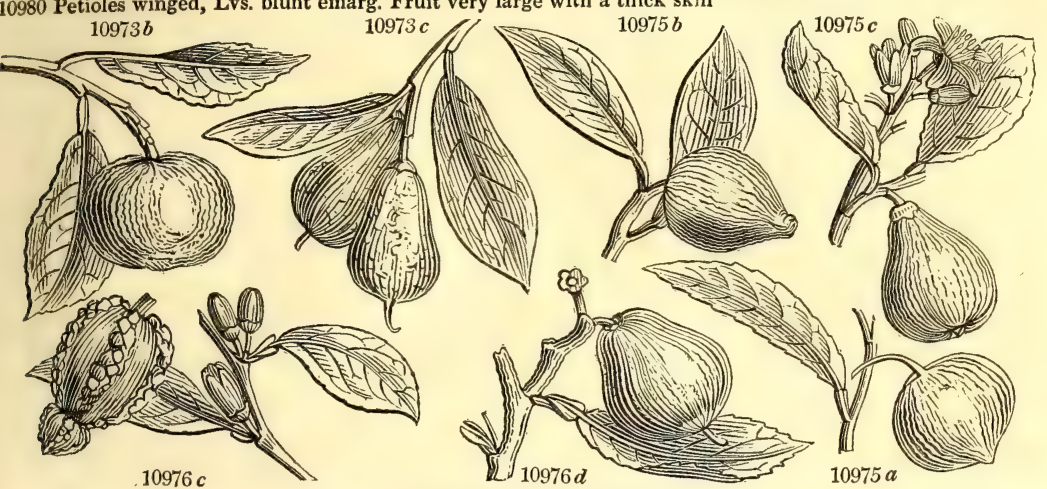

and Miscellaneous Particulars.

of gardening. There the names of varieties vary as much as those of gooseberries do in England; but from Good plants of the Maltese and other varieties of orange may be procured from Malta ; and some sorts also from Lisbon. From the nurseries at Paris about thirty sorts may be obtained, much smaller plants than those from the other places named, but more scientifically grafted or inoculated. The catalogues of London nurserymen enumerate above thirty varieties of oranges, twelve of lemons, and several varieties of the other species; the plants are partly Genoese, partly French, and partly propagated here.

The $\mathrm{C}$, aurantium, the common orange; orange, Fr, pomcranze, Ger., and arancio, Ital., is a middle-sized evergreen tree, with a greenish-brown bark; and, in its wild state, with prickly branches. The fruit is nearly round, from two to three inches in diameter, and of a gold color. It is now cultivated in most countries of Europe; in the open air in Italy and Spain; and in conservatories or greenhouses in Britain and the north of Europe.

The two principal varieties are the sweet or China orange, the orange douce of the French, and porto-gallo or poma de sino of the Italians: and the bitter or Seville, the bigarade of the French, and arancio volgaro of the Italians. The Maltese orange, distinguished by its red pulp, is also a noted and much-esteemed sort. The box-leaved, willow-leaved, and some others, are cultivated more as curious varieties than for their fruit.

C. Medica, the citron, citron, Fr., citronier, Ger., and cedrate, Ital., in its wild state grows to the height of about eight feet, erect and prickly, with long reclining branches. The leaves are ovate, oblong, alternate, sub serrate, smooth, pale green. The fruit or berry is half a foot in length, ovate, with a protuberance at the lip. There are two rinds, the outer thin, with innumerable miliary glarids, full of a most fragrant oil ; the inner thick, white, and fungous.

In China they have a variety of the $\mathbf{C}$. Medica, of very considerable size, quite solid, with scarcely any pulp or cells, and divided at the end into five or more long round lobes, on which account it is called $P$ hat thu, or finger-orange. The fruit is laid upon fine porcelain vessels in the sitting-rooms of the Chinese, for the sake of its agreeable perfume.

Dr. Sickler enumerates only about a dozen citrons and citronates as grown in Italy. The French nurseries have nearly twenty names in their lists. In England six are cultivated for sale.

C. Limonum, the lemon; limon, Fr., limonier, Ger., and limone, Ital., has the fruit less knobbed at the extremities, is rather longer and more irregular, and the skin is thinner than in the citron; the wood is more knotty, and the bark rougher.

Dr. Sickler enumerates twenty-eight varieties as grown in Italy. The French, according to Ville Hervé have eleven sorts ; in the London nurseries are cultivated twelve

C. Limetta, the lime, by some esteemed a variety of the C. Medica, lime, Fr., Ital., and Ger., grows to the height of about eight feet, with a crooked trunk, and many diffused branches, with prickles. The leaves are ovate lanceolate, almost quite entire. Berry an inch and a half in diameter, almost globular, with a protuberance at the top; the surface regular, shining, greenish-yellow, with a very odorous rind, enclosing a very acid juice.

The French have two sorts of lime; and, according to Dr. Sickler, the Italians have four varieties; five kinds are grown in the London nurseries.

C. decumana, the shaddock, orange pampelmouse, Fr., arancio massimo, Ital., is above the middle size, with spreading prickly branches. The leaves are ovate, subacute, seldom obtuse ; the petioles are cordate, winged the wings as broad as the leaves. The berry spheroidal, frequently retuse at each end, of an even surface, and greenish-yellow color; pulp red or white; juice sweet or acid; rind white, thick, fungous, and bitter. Thunberg says, the fruit in Japan grows to the size of a child's head, and Dr. Sickler states its weight as fourteen pounds, and its diameter as from seven to eight inches. It is a native of China and Japan, and was brought to the West Indies by Captain Shaddock, from whom it has derived its name.

The Italians, according to Dr. Sickler, have one, and the French, according to the Nouveau Cours, \&c., four sorts. Four are grown in the English nurseries.

All the sorts may be propagated by seeds, cuttings, layers, and grafting, or inoculation.

The object of raising plants from seed is either to obtain new varieties or stocks for grafting. To attempt raising new varieties in Britain will in general be found a tedious process, as the trees do not even in Italy show fruit for six or eight years or more; and there is now in the botanic garden at Toulon, a large handsome tree, of twenty-five years' growth, which in 1819 had not blossomed. Shaddock stocks are the strongest, and next to these the citron. Budding and grafting are performed at the usual season; but these operations may be performed at any time when the sap is in motion.

Henderson, of Woodhall, a most superior cultivator of the Citrus tribe, considers cuttings as the quickest mode of getting plants, and has practised it for thirty-seven years past: his directions are as follows : 66 Take the strongest young shoots, and also a quantity of the two years old shoots; these may be cut into lengths from nine inches to eighteen inches. Take the leaves off the lower part of each cutting to the extent of about five inches, allowing the leaves above that to remain untouched: then cut right across, under an eye; and make a small incision in an angular direction on the bottom of the cutting. When the cuttings are thus prepared, take a pot, and fll it with sand; size the cuttings, so that the short ones may be all together, and those that are taller in a different pot. Then, with a small dibble, plant them about five inches deep in the sand, and give them a good watering overhead, to settle the sand about them. Let them stand a day or two 
1616. XANTHOCHY'MUS. Rox. XaNTHochymus. Guttifera. Sp.2-4.

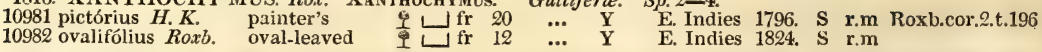

1617. HYPE'RICUM. $W$. ST. John's Wort. Hypericinea. Sp. 63-133.

10983 elátum $H . K$. tall $\quad$ or 5 il.au Y N. Amer. 1762. L s.l Dend. brit. $8 \tilde{5}$ 10984 frondósum Mich. green or 5 jl.au 10985 amœ'num Psh. elegant 10986 hircínum $L$. stirking 10987 foliósum $H . K$. shining 10988 floribúndum $\boldsymbol{H}, \boldsymbol{K}$. many-flowered 10989 olýmpicum $L$. Olympian 10990 canariénse $L$. Canary 10991 monógynum $L$. Chinese 10992 cordifólium Chois. heart-leaved 10993 pyramidátum $\boldsymbol{H} . \boldsymbol{K}$. pyramidal 10994 Ascýron $L$. Siberian 10994 Ascýron $L$. $W . \quad$ Siberian 10996 pátulum Thunb. H. Uralum B. M. 10997 Kalmiánum Lam. Kalmia-leaved 10998 calycínum $L$. large-flowered 10999 baleáricum $L$ warted

11000 Androsæ'mum $L$. Tutsan $\begin{array}{lll}\text { warted } & \text { or } 2 \frac{1}{2} \mathrm{jl} . \mathrm{s}\end{array}$

Canaries 1699. C p.1 Bot. cab. 953

China 1753. C p.l Bot. mag. 334

Nepal 1825. C co

Canada 1759. D p.1 Vent. malm. 118

Siberia 1774. Sk co Gmel. sib.4. t.69

$N$ Amer 1812 Sk co

Nepal 1823. C co Bot. mag. 2375

N. Amer. 1759. C s.

... Sk co Eng. bot. 2017

Majorca 1714. C r.m Bot. mạg. 157

Britain woods. Sk co Eng. bot. 1225

11001 cochinchinénseLour. red-flowered

L

China 1821. C co

11002 paludósum Chois. marsh

11003 virgínicum $L$. Virginian Elodea campanuláta $\mathrm{Ph}$.

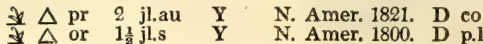

11004 angulósum Mich. toothed-flower. $\Delta$ or 2 jn.jl 11005 punctátum Lam. dotted 1 or $1 \frac{1}{9} \mathrm{jn} . \mathrm{jl}$ 11006 dolabrifórme Vent. hatchet-leaved $\Delta$ or 2 jn.jl 11007 procúmbens Micls, procumbent $1 \Delta$ or 1 aus 11008 rosmarinifólium Lam.Rosemary-1v. 亚 $\Delta$ or $2^{\frac{1}{2}}$ ju. au 11009 virgátum Lam. twiggy

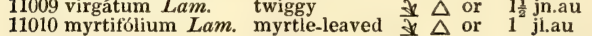
11011 prolificum $L$. prolific 武 or 4 jn.au 11012 glaúcum Mich. glaucous 业 - or $1 \frac{1}{2}$ jl.au 11013 lævigátum $H . K$ smooth $\quad \vec{\Delta}$ or $1 \frac{1}{\frac{1}{2}} \mathrm{jl.s}$

11014 nudiflórum Mich. naked-panicled $\frac{\Delta}{1}$ J or $1 \frac{1}{2} \mathrm{~s} .0$

11015 quadrángulum $L$. square-stalked $\vec{\Delta}$ or $1 \frac{1}{2}$ jl.au $\beta$ áubium W. imperforate $\mathbf{W} \Delta$ or 3 jl.au r maculátum All. spotted $\bar{\Delta}$ or 2 jl.au $\delta$ undulátum W.en. wave-leaved $\frac{\Delta}{\Delta}$ or 1 jl.au 11016 attenuátum Chois. narrow-leaved $\frac{1}{\Delta}$ or $1 \frac{1}{8}$ jl.au 11017 japónicum Thunb. Japanese $\frac{1}{\Delta} \Delta$ or $1 \frac{1}{\frac{1}{3}} \mathrm{jl}$.au

N. Amer. 1812. D p.l Plu.alm.t.245.f.6 N. Amer. 1823. D co N. Amer. 1821. D co N. Amer. 1822. D co Carolina 1812. L s.l N. Amer. 1820. D co N. Amer. 1818. D co N. Amer. 1758. S s.l Dend. brit. 88 N. Amer. 1812. C. p.l N. Amer. 1772. D p. N. Amer. 1811. C p.l Britain m. me C p.1 Eng. bot. 370 Britain m. thi. C p.l Eng. bot. 296 N. Amer. 1789. C p.l Barbary 1802. D p. Dahuria 1822. D p. Nepal 1823. D p.l

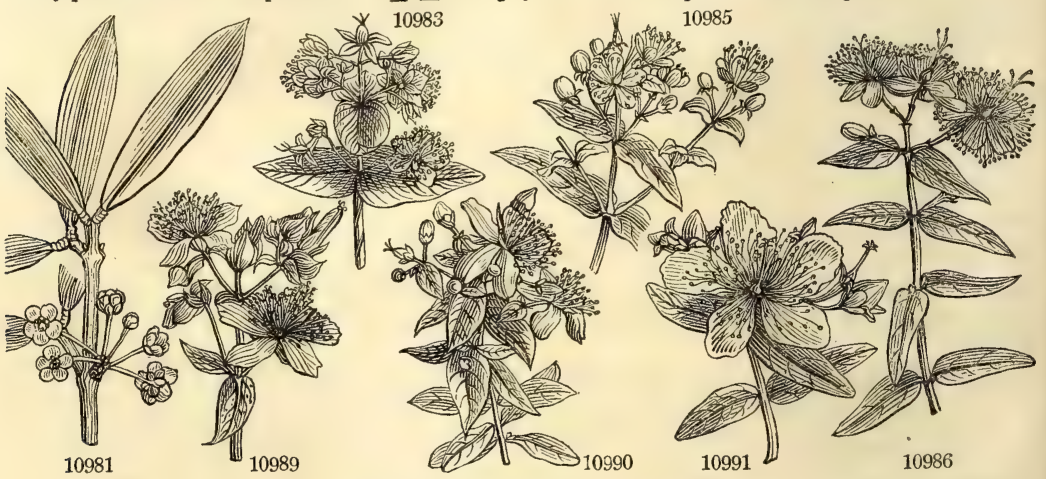

History, Use, Propagation, Culture,

in a shady place, and if a frame be ready with bottom heat, plunge the pots to the brim. Shade them well with a double mat, which may remain till they have struck root; when rooted, take the sand and cuttings out of the pot, and plant them into single pots, in the proper compost. Plunge the pots with the young plants again into a frame, and shade them for four or five weeks, or till they are taken with the pots; when they may be gradually exposed to the light. From various experiments, I found that pieces of two year old wood struck quite well ; and in place, therefore, of putting in cuttings six or eight inches long, I have taken off cuttings from ten inches to two feet long, and struck them with equal success. Although $I$ at first began to put in cuttings only in the month of August, I now put them in at any time of the year, except when the plants are making young wood. By giving them a gentle bottom heat, and covering them with a hand-glass, they will generally strike root in seven weeks or two months. The citron is most easily struck, and is the freest grower ; 1, therefore, frequently strike pieces eighteen inches long, and as soon as they are put into single pots, and taken with the pots, they are grafted with other sorts, which grow freely. I am not particular as to the time either of striking cuttings or of grafting." (Caled. Hort. Mem. iii. 308.)

At Genoa and Florence, citrus trees are grown in a strong yellow clay, which is richly manured; and this soil is considered by the first Italian gardeners as best suited to their natures.

The French gardeners, in preparing a compost for the orange-tree, endeavour to compensate for quantity by quality ; because the pots or boxes in which the plants are placed ought always to be as small as possible, relatively to the size of the tree. The following is the composition recommended : to a rresh loam, which contains a third of clay, a third of sand, and a third of vegetable matter, and which has lain a long time in a heap, add an equal bulk of half-rotten cow-dung. The following year turn it over twice. The succeeding year mix it 
10981 Leaves oblong

10982 Leaves smaller oval blunt

1. Sepals united at base and unequal. Stamens 00. Styles 3-5. Ascyreia.

10983 Young stem winged, Lvs. ov. obl. acute dilated at base somew. emarg, revolute at edge, Fl. corymbose 10984 Branches double-edged, Lvs. ov. elongated blunt at end narrow at base, Fl. large subsolitary 10985 Branches double-edged, Lvs, obl. ellipt. bluntish at end narrowed at base with a crisp revolute edge 10986 Branches winged, Lvs. emarg. at base dilated sess. acute at end ovate lanc. glandular at edge 10987 Branches winged, Lvs. sess. open ovate obl. somewhat acute slightly perforated 10988 Stem round, Lvs. sess. lanc. not dotted numerous, Peduncles dilated at end 10989 Stem round, Lvs. ellipt. ovate bluntish with pellucid dots, Calyx ovate acute 10990 Stem obsoletely quadrangular, Branches compressed, Ivs. ov.-lanc. acute, Cal. blunt ovate 10991 Stem round, Lvs, ellipt. blunt a little dotted with black, Styles united

10992 Stem round shrubby, Lvs. ov. amplexicaul. cordate not dotted clustered, Flowers few 10993 Stem winged, Lvs. amplexicaul. obl. lanc. acute revolute at edge, Pedunc. short thick 10994 Stem square herbaceous simple erect, Leaves amplexicaul lanc. acute with pellucid dots 10995 Stem winged at base square at end herbaceous simple, Lvs. obl. lanc. acute

10996 Stem round suffruticose purple, Lvs. ovate lanc. acute narrowed at base revolute at edge with pellucid dots

10997 Branches square, Lvs. lin. lanc. Flowers in terminal corymbs

10998 Styles 5, Fl. solitary, Segm. of the eal. unequal obovate obtuse, Lvs. obl. Stem shrubby branched square 10999 Stem square warted, Lvs. ovate blunt amplexicaul. warted

11000 Styles 3, Caps. pulpy, Stem shrubby compressed, Cal. leaflets unequal, Leaves ovate sessile

2. Sepals 5, equal, entire. Stamens deeply triadelphous; parcels pencilled at end. Styles 3. Tridesmos. 11001 Flowers trigynous, Leaves subpetiolate very dense, Pedunc. about 5 -fl. axillary

8. Sepals 5, equal, entire. Styles 3. Filaments definite in number, 9-15-18, deeply united. ElodeA.

11002 Stem herbaceous round, Leaves oblong blunt narrowed into a stalk with pellucid dots

11003 Stem round half-shrubby, Leaves oblong blunt amplexicaul. with pellucid dots

4. Sepals 5, equal, sometimes entire, sometimes toothed, or with glandular teeth, Stamens 00 . Styles usually 3. PERforaria.

* Sepals entire.

11004 Stem herbaceous square erect, Leaves distant long ovate amplexicaul sinuated at edge acute not dotted 11005 Stem round black dotted, Leaves ovate-lanc. somewhat acute amplexicaul, dotted with black 11006 Stem erect purple, Leaves lin. lanc. reflexed with pellucid dots, Flowers corymbose

11007 Stem procumbent square herbaceous, Leaves linear-lanceolate blunt revolute at edge with pellucid dots 11008 Stem round straight, Leaves amplexicaul. blunt ovate revolute at edge, Styles united

11009 Stem straight square, Leaves ovate-lanceol. slightly amplexicaul, dotted with black revolute at edge 11010 Stem round, Leaves ovate cordate amplexicaul. or cuneate lanc. revolute at edge

11011 Stem round, Branches angular, Lvs. linear lanc. revolute at edge with pellucid dots, Styles often united 11012 Stem round, Leaves cordate amplexicaul. blunt revolute at edge glaucous with pellucid dots

11013 Flowers trigynous, Styles united, Lvs. ovate subamplex. Sepals ov. acute, Middle flower of panicle sessile 11014 Stem square and winged, Leaves ovate obl. blunt needle-dotted not pellucid, Panicle naked

11015 Styles 3, Stem herbaceous 4-angular somewhat branched, Leaves ovate with pellucid dots, Cal. lvs. lanc.

$\beta$ Stem obsoletely quadrangular, Leaves elliptical ovate obtuse destitute of pellucid dots, Cal. lvs. elliptical

11016 Stem round dotted with black, Leaves ovate obl. blunt amplexicaul. dotted with black

11017 Stem weak square smooth, Leaves ovate subcordate blunt revolute at edge scarcely dotted beneath

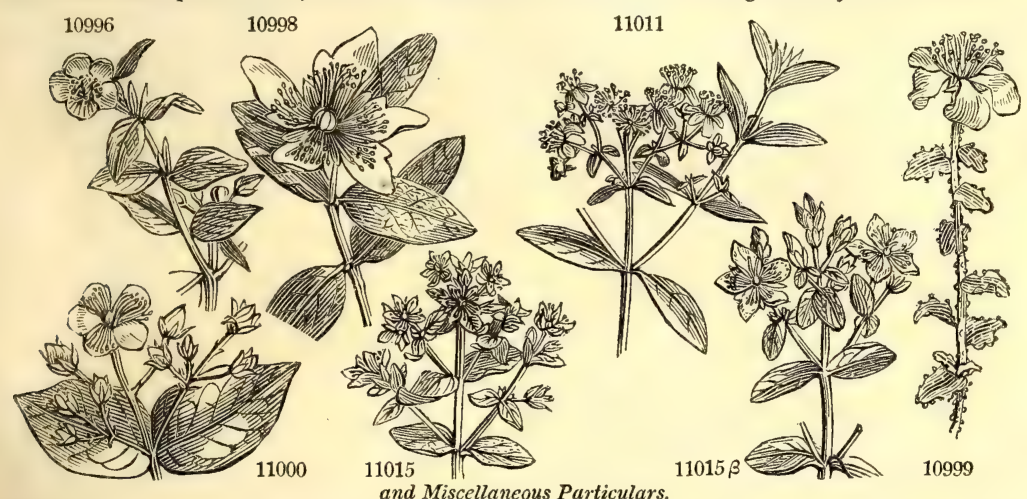

with nearly one-half its bulk of decomposed horse dung. Turn it over twice or three times, and the winter before using add a twelfth-part of sheep dung, a twentieth of pigeon dung, and a twentieth of dried ordure.

Henderson, already mentioned, takes one part of light-brown mould from a piece of ground that has not been cropped nor manured for many years; one part of peat earth, such as is used for growing heaths; two parts of river sand, or pit sand, if it be free irom mineral substances; and one part of rotted hot-bed dung, with one part of rotted leaves of trees, and mixes them all well together, so as to form a compost-soil of uniform quality. (Caled. Hort. Mem. iii. S02.)

Though orange-trees will grow exceedingly well in large pots and boxes, yet to have them produce the finest crop of fruit they should be planted in the ground like peach-trees, and trained like them, or as standard cherries in a conservatory. The latter has by far the best effect, especially when the stems of the trees are seven or eight feet high, and the head forms a handsome cone; but the largest fruit is produced when the trees are planted against the back-wall trellis of a narrow house, and treated like peach-trees. Henderson grows his largest fruit in this manner, and we have seen them fully as large as any we ever saw at Genoa or Naples.

1616. Xanthochymus. From $\xi_{\alpha \nu}$. juice which flows from the ripe fruit when wounded, and which, being inspissated, yields a material for watercolor painting which is as good as Gamhoge. Handsome plants, of the usual culture in light loam, and propagated by cuttings in sand under a hand-glass.

1617. Hypericum. A name of unknown meaning. The species are chiefly under-shrubs, generally with dotted leaves, and almost, without exception, yellow fowers. The hardy species are useful for the fronts of 
curl-leaved $\$$ or 1 jl.au 11019 setósum $H . K$. unbranched $\frac{1}{\Delta} \mathrm{N}$ or 1 jl.au 11020 heteroph fllum Vent various-leaved 11021 ægyptiacum $L$. Egyptian 1 or $2 \mathrm{jn.jl}$ 11022 humifúsum $L$. trailing $* \Delta$ or ${ }^{\frac{1}{2}} \mathrm{jl}$.au 11023 perforátum $L$. perfoliate \& $\Delta$ or $1 \frac{1}{2} \frac{1}{2} \mathrm{jl}$.au 11024 canadénse $L$. Canadian 11025 fasciculátum $W$. clustered

䟫 $\Delta$ or 1 jl.s

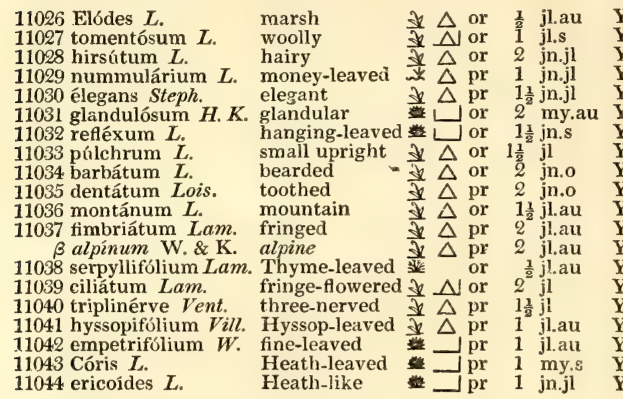

Y Greece 1688. C p.l Bocc. mus. t. 12 Carolina 1759. D p.l

Persia 1812. D p Vent cels t 68 Egypt 1787. C p.1 Bot. reg. 196 Britain pas. D co Eng. bot. 1226 Britain bu.pl. D p.1 Eng. bot. 295 N. Amer. 1770. D p.1 N. Amer, 1806. C s.1

Britain sp.bo. D p.l Eng. bot. 109 S. Europe 1648. C r.m

Britain ch.ba. D p.l Eng. bot. 1156

S. Europe 1823. D co Lam. ill. t. 643

Siberia 1822. D co Spreng.fl.hal.t.9

Madeira 1777. C p.l

Teneriffe 1778. C p.l

Britain woods. D p.1 Eng. bot. 1227

Scotland sc.thi. D co Eng. bot. 1986

Mediterr. 1820. D co Lois. fl. gall. t.17

Britain m.wo. D p.1 Eng. bot. 371

Pyrenees 1821. D p.l Vill. delph. t. 44

Hungary 1822, D p.l Wal. \& Kit. t.265

Levant 1688. C rm M.h.2, s.5.t.6.f.

Levant 1739. D l.p Bocc. mus. t.127

N. Amer. 1821. D co Vent. cels. t. 58

S. Europe 1823. D co Vill. delph. t. 44

S. Europe 1820. C p.l Dend. brit. 141

Levant 1640. C p.l Bot. mag. 178

Spain 1821. C p.l Cav. ic. t. 122

11045 aspalathoídes $W$. Aspalathus.like - or 1 jn.au $\quad$ Y $\quad$ Carolina 1811. C s.I

1618. ASCY'RUM. $W$. AscYrum.

dwarf J $\Delta$ pr

St. Andrew'sCross

11048 hypericoídes $P h$. Hypericum like

11049 stans $W$.

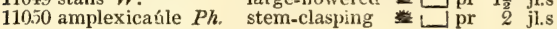

Hypericinea. Sp, $5-6$.

1619. LOA'SA. $L$. Loss

11051 Plácei Lindl. Place's

11052 nítida Lam. shining

$11 C 53$ volúbilis Juss. twining

11054 grandiflóra Lam. large-flowered

Loasece. Sp. 4-10.

2 jn.s $\quad$ Y Chile 1822. S co Bot. reg. 785

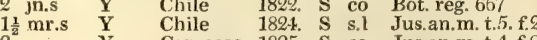

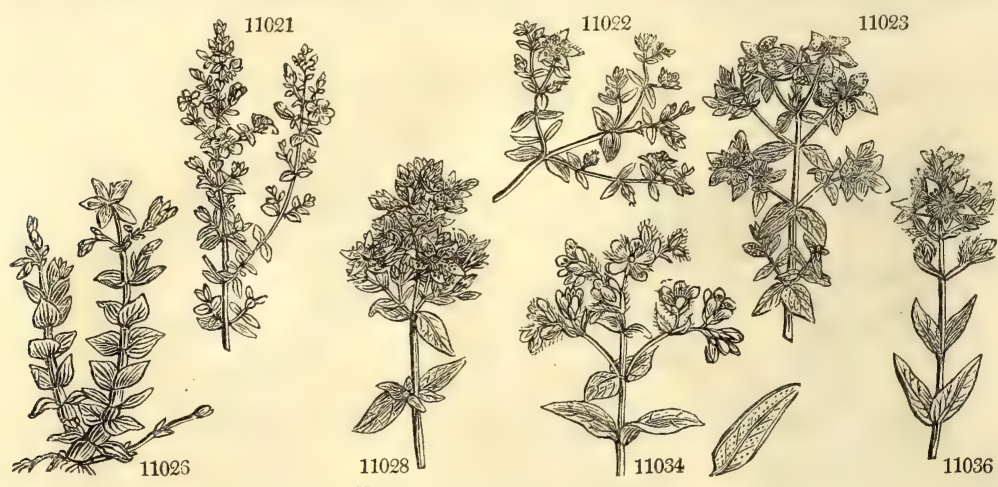

History, Use, Propagation, Culture,

shrubberies. H. calycinum soon spreads over a considerable surtace, and being evergreen, and growing under the shade, it is well adapted for covering bare spots under trees, and at the base of walls where few plants will thrive.

H. Androsæmum; from ayne, a man, and $\dot{\alpha} \iota \mu$, blood, because the fresh capsules, bruised between the fingers, give out a blood-colored juice, is called Tutsan from Toute-saine, Fr., from its bruised capsules being formerly applied to fresh wounds.

H. perforatum was formerly used in external wounds and hremorrhages as a balsamic, and was reputed to have other medical properties. The semi-transparent dots on the leaves are the receptacles of an essential oil. The flowers tinge spirits and oils of a fine purple color; and the dried plant, boiled with alum, dyes wool of a yellow color. The common people in France and Germany gather it with great ceremony on St. John's day, and 
11018 Stem round much branched, Lvs. sess. lanc. undul. wavy at base with pellucid dots, Cal. very small blunt 11019 Flowers 2-3-gynous terminal, Cal. lanc. entire, Leaves lanc. oblong and erect, Stem simple downy 11020 Stem round, Lvs. lin. lanc. with pelluc. dots : low. closely imbric. very short blunt, Cal. acute rather unequal 11021 Stem round, Leaves very small ovate close not dotted, Flowers few subsessile, Cal. acute lanceolate 11022 Styles 3, Flowers terminal subcymose, Stems comp. prostrate, Leaves oblong obtuse glabrous

11023 Styles 3, Stem compressed, Leaves elliptico-oblong obtuse with pellucid dots, Cal. leaves lanceolate

11024 Stem herbaceous upright 4-winged, Lvs. lin. somewhat blunt with fine pellucid dots and black dots beneath 11025 Stem round diffuse, Leaves lanceol. Iinear narrow at base revolute at edge, Calyx somewhat unequal

$$
\text { ** Sepals toothed, or toothed glandular. }
$$

11026 Styles 3, Cal, with (reddish) glandular serratures glabrous, Lvs, roundish pubesc. Stem rounded creeping 11027 Stem downy round ascend. Lvs. ovate blunt somewhat amplexicaul, with black dots at edge, Cal. acuminate 11028 Styles 3, Cal. with (black) glandular serratures, Stem erect rounded pubesc. Lvs. ov. slightly downy beneath 11029 Stem round ascending, Leaves orbicular stalked, Calyx ovate blunt

11030 Stem straight slightly wing. Lvs. ov.-lanc. subamplex. blunt. with pellucid dots, Anthers dotted with black 11031 Stem round straight branched, Lvs. ellipt. lanc. acute glandular at edge with pellucid dots, Cal. lanc. acute 11032 Stem round a little villous at end, Leaves amplexicaul, lanceol, acute generally reflexed, Panic. lax few-fl. 11033 Styles 3, Cal, with (black) glandul. serratures, Stem erect, Lvs. cord. glab. amplexicaul. [dots beneath 11034 Sty. 3, Corymbs term. Cal. fring. with long peduncul. glands, Stem erectround. Lvs. ov.with (black) scattered 11035 Stem round ascending, Leaves amplexicaul. oblong bluntish with pellucid dots : upper sometimes toothed 11036 Styles 3, Fis. paniculate-corymb. Cal. with glandul. serratures, Stem erect round. smooth, Lvs. ov. glabrous 11037 Stem round purplish simple, Lvs. amplexicaul. ovate dotted with black at the edge, Cal. ov. acute ciliated

11038 Stem round, Leaves ovate blunt with a small petiole revolute at edge, Calyx ovate blunt [with black 11039 Stem round slightly winged, Lvs. amplexicaul. subcord. ovate obl. blunt with pellucid dots, Anthers dotted 11040 Stem with 2 angles decumbent at base, Lvs. linear-lanc. spreading blunt revolute at edge, Cal. ovate acute 11041 Stem round ascending, Lvs. obl. lanc. bluntish narrowed at each end with pellucid dots, Cal, somewhat blunt 11042 Stem round, Branches somewhat winged, Leaves in threes linear revolute at edge, Calyx very small blunt 11043 Stem round ascending, Leaves whorled linear revolute at edge, Calyx linear somewhat blunt

11044 Stem round tortuous minute, Leaves round acute clustered dotted glaucous very small

$$
\text { 85. Sepals 5, entire, equal, like the leaves. Stamens 00. Styles 3-5. Brathys. }
$$

11045 Stem round compressed at end, Leaves dense not dotted channelled revolute at edge, Cal, equal straight

11046 Stem small simple quadrangular, Leaves oval blunt fascicled, Pedicels 6 lines long reflexed

11047 Stem round, Branches erect, Lvs. ovate linear blunt generally fascicled in the axillæ, Inner sepals orbicular 11048 Stem round, Leaves oblong linear blunt with 2 glands at base, Inner sepals somewhat orbicular 11049 Stem winged straight, Leaves ovate ellipt. blunt glaucous, Inner sepals cordate orbicular 11050 Stem dichotomous panicled, Leaves ovate cordate crisp, Corymb naked, Styles 3

11051 Sepals scarcely toothed reflexed as long as petals, in fruit reflexed and longer than the obovate capsule 11052 Sepals toothed shorter than petals, in fruit erect and shorter than the pear-shaped capsule 11053 Stem twining, Leaves bipinnatifid with narrow obtuse segments

11054 Hispid, Leaves opposite and alternate cordate ovate lobed, Petals flattish, Flower very large

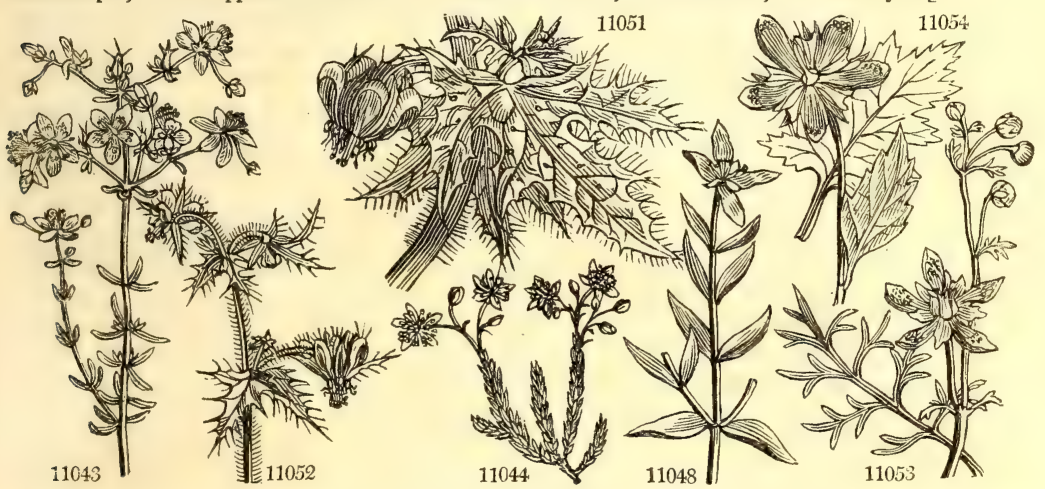

and Miscellaneous Particulars.

hang it in their windows as a charm against storms, thunder, and evil spirits ; mistaking the meanıng of some medical writers, who have fancifully given this plant the name of Fuga Damonum, from a supposition that it was good in maniacal and hypochondriacal disorders. In Scotland it was formerly carried about as a charm against witcheraft and enchantment.

$\mathrm{H}$. humifusum is one of the prettiest little plants of the genus, well adapted for growing in pots.

1618. Ascyrum. From $\alpha$, privative, and $\sigma \approx v \rho \circ$, roughness; that is to say, a smooth plant, Linn. Curious little plants, of the same culture as the Hypericums.

1619. Loasa. A name applied to these plants by Adanson, but of unknown meaning. Stinging, mostly annual plants; some of the species are handsome hardy annuals, remarkable for the beauty of their highly curious flowers. L. volubilis will not sueceed in the open air. 


\section{Class XIX. - SYNGenesia. Stamens 5. Anthers united by their edges.}

Tuis is one of the most extensive and best defined of all the Linnean classes. Its essential character depends, as its name indicates, ( $\sigma u v$, together, and $\gamma \varepsilon v \varepsilon \sigma i s$, generation, ) upon the adhesion of the antheræ or male organs of the flower into a single tube. It comprehends the whole of the Corymbiferæ, Cichoracer, and Cinarocephalæ of Jussieu; and, with the exception of Acicarpheæ, nothing else. The genera constituting the order Monogamia of Limnæus are excluded by Linnean botanists of the present day.

In addition to the cohesion of the anthers, upon which this class immediately depends, it is further characterized by the flowers, commonly called florets, being clustered together in heads, and inserted upon a common receptacle, which is surrounded by an involucrum, commonly, but very improperly, termed calyx. The few genera, such as Kuhnia, Euxenia, Acicarpha, \&c., in which a union of anthers either does not exist at all, or in a very incomplete degree, are therefore retained in Syngenesia, because of their congruity in the structure of their inflorescence.

The real nature of the various constituent parts of syngenesious inforescence being, from its complicated nature, very puzzling to the unlearned, and, as it would seem, to some professors also, it may be useful to explain briefy the analogy the various parts bear to the organs of other plants, and the terms employed in describing them.

The Head or Capitulum is a cluster of fiowers of the nature of an umbel, inserted upon a common rachis, which, by contraction or incomplete developement, assumes the form of a conical or flat body, out of which the tlowers proceed, and which is called a receptacle. This is surrounded by the involucrum. M. Cassini calls the head Calathide.

The Involucrum is the most external part of the head. It consists of a more or less considerable number of scales or leaves, placed in a single row, either distinctly from each other, or united at their edges, in which case the involucrum is called one-leaved; or placed in many rows, becoming gradually shorter as they are external, in which case they are called imbricated. If the external scales surround the internal at the base in a regular manner, then the involucrum is said to be calyculate. The involucrum was called common calyx by Linnæus, and has been more recently denominated a perianthium. M. Cassini names it Periclinium.

The Receptacle (Clinanthium of Cassini) is a cellular fungous surface surrounded by the involucrum, and bearing the florets. It is either columnar, conical, flat, or depressed; and naked, or covered with appendages called hairs or bristles, according to their nature, or paleæ, when they are dilated and have a glumaceous appearance. If naked, and merely scarred by the insertions of the florets, it is called dotted or puncticulate when the scars are more considerable and deeper, the receptacle is said to be scrobiculate; if the insertion are so deep as to appear to be divided by membranous partitions, it is cellular, or favose, or alveolate ; if furnished with hairs, it is villose; if with paleæ, it is paleaceous or chaffy.

The Palea are of the same nature as bractex, and exist in various degrees of developement. Occasionally they are as large as the scales of the involucrum, which they in that case closely resemble.

'The flower, usually termed Floret, consists of two parts, the ovarium and the corolla, each with its appen dages.

The Ovarium is always one-celled, but it occasionally has two additional obsolete cells, as in Arctotis. It is either naked, or covered with hairs in various degrees, occasionally becoming enveloped in fine wool, and it is surmounted by an organ named the pappus.

The Pappus has generally been esteemed a superior calyx, and it is the opinion of $\mathbf{M}$. Cassini that it is analo gous to the scales of the receptacle, and the leaves of the involucrum

The Corolla is placed on the top of the ovarium. It is either funnel-shaped, with a limb divided into four or five equal lobes, in which case, the florets are denominated tubular; or it is split on one side, and spread open into the form of a strap, when the florets are called ligulate; or it is divided into two portions, of which one is unequal to the other; this form is called bilabiate or two-lipped. Bilabiate corollas may be either ligulate c: flosculous, according to the species to which they belong. Occasionally the corolla appears to be absent.

The Stamens are attached to the orifice of the tube of the corolla, just below the limb. Their filaments are usually, but not always, distinct ; their anthers are adherent by their edges, and furnished with a little mem branous appendage at the tip, and sometimes with two spur-like processes at their base.

The Sty'e is filiform, and either split at the summit into two linear spreading stigmas, or consists of a single piece from the base to the summit. The form and surface of the stigma, and the upper part of the style are subject to a great diversity of appearances, which are of the utmost importance in determining the affinities of the genera.

The Florets are either hermaphrodite, unisexual, or neuter. Upon these differences of sex the orders of Linnæus are founded.

In Syngenesia aequalis the florets are all hermaphrodites.

In Syngenesia superflua, those of the disk or centre are hermaphrodite, of the circumference or ray female, (and superfluous.)

In Syngenesia frustranea, those of the disk are hermaphrodite, of the ray neuter, (and useless.)

In Syngenesia necessaria, those of the disk are male, of the ray female, (and necessary.)

Syngenesia segregata is only characterized by the heads themselves being clustered and surrounded by a common involucrum.

The genera of Syngenesia have always attracted much attention from systematic botanists, who have met with very unequal success in characterizing them. The older botanists comprised them all under a few general heads or names. 'Tournefort, with his usual happiness, pointed out a large proportion of the most natural geheads or names. Tournefort, with his usual happiness, pointed out a large proportion of the most natural ge-
nera. Vaillant established a considerable number. Linnæus, protiting by the labours of his predecessors, rejecting some genera, and dividing others, increased their number, and adapted them to his sexual system, in nearly the same order in which they exist at the present day. Jussieu, by applying to the genera the principles of his natural method, reduced them to an arrangement much superior in point both of facility and of natural affinity to that of his northern rival. But however meritorious the labours of these great systematists may have been, much remained to be effected, even among their own plants, by those who followed them. The indefat:gable Gærtner, who worked upon the only satisfactory or philosophical principle, that of strict analysis, soon discovered that the combinations of Linnæus and Jussieu were often too vague and ill defined to accord with his notions of accurate subdivision. Hence many other genera arose. But since his days, the extent of Syngenesia has, like all other parts of botanical science, increased exceedingly, and has arrived in our days at a state little short of absolute confusion. Injudicious or superficial botanists, impressed with the fear of innovation, and with a pious reverence even for the errors of those who went before them, have from time to time crowded the genera of Jussieu and Linnæus with the most incongruous species, and so have rendered many of those which were originally pure and simple, heterogenenus masses of species. Much has been done by our learned countryman, Mr. Robert Brown, to reduce to order this class of individuals, and, as far as his published observations have extended, with the happiest success. In France, an ingenious and accurate observer, Mr. Henry Cassini, has undertaken a revision of the whole class, upon principles peculiar to himself; and it must be ailowed, that what he has executed has given ample room for regret that he has not published more. Unfortunately, his observations are scattered over the face of many books, and are in no case in such a state of arrangement as to be extensively useful. It is hoped that a period will soon arrive when he, or at least some 
of his countrymen, will place in one view the result of his labours, so as to enable the world to judge with more accuracy, both of their extent, and of their real importance in defining the limits of the genera and their orders. The style and stigma, which had been previously almost overlooked, have furnished M. Cassini with what appear to be beautiful distinguishing marks of his orders; and it is upon these organs that much of the peculiarity of his arrangement depends. In the mean while, till it can be ascertained what the ultimate division of Compositæ is likely to be, it has been considered more prudent in this
of either M. Cassini, or of his fellow-labourers in France or elsewhere.

In a popular point of view, Syngenesia may be considered interesting in a high degree. It abounds in plants of ornament, all of which are, without exception, of easy cultivation. It is not necessary to particularize the merits of the brilliant varieties of the Dahlia, or of the Chinese Chrysanthemum, which are the chiefest orna. ments of every autumnal garden; nor to point out the beauty of the various tribes of Aster, Helianthus, Coreopsis, Xeranthemum, or Gnaphalium. These and an hundred others must be familiar to every lover of Coreopsis, Xeranthemum, or Gnaphalium. These and an hundred others must be familiar to every lover of
gardening. It is, however, worth remarking, that nearly all syngenesious plants are autumn flowers. In the tropics, many become trees of considerable dimensions; in temperate climates, they are mostly herbaceous or low bushes.

With regard to the qualities of syngenesious plants, considered economically or medicinally, it may be stated, that, whatever they may be, they consist in a bitter principle, and an oily secretion. But these vary in particular tribes. In some the bitter is combined with a resinous principle, by which its powers are increased in different degrees. In those plants in which the resin is found in small quantities only, and mixed with a bitter or astringent mucilage, tonic, stomachic, and febrifugal properties seem to be acquired, as in the camomile, the golden rod, the feverfew, and the Eupatorium perfoliatum; and the stimulant powers of these plants appear to increase in proportion as the resin is abundant. Some kinds are anthelmintic, as the wormwood and tansy ; others are emmenagogue, as the feverfew, the yarrow, and various kinds of wormwoods. Certain species possess sudorific qualities, as the Eupatorium, the yarrow, the wormwood, and the marigold; others, again, are powerful diuretics, as Liatris; while stimulating powers exist in considerable activity in others, as in the Sneezewort and Arnica. The Spilanthus, Anthemis, Pyrethrum, and some others, excite salivation. in the Sneezewort and Arnica. The Spilanthus, Anthemis, Pyrethrum, and some others, excite salivation.
The Eupatorium Ayapana of Brazil, and the Guaco of Peru, which is another species of Eupatorium, are most powerful alexiterics. According to the analysis of M. Braconnot, the wormwood owes its bitterness to an extremely bitter animalized matter, which forms a little less than one fifth of its weight; the same chemist also states that plant to contain a volatile oil, and an acid, apparently new, which is found in combination with potash. Before the perfect developement of the leaves. the bitter principle is so much diluted with insipid mucilage, that the young shoots of some of the thistle tribe, the Cardoon for example, are used for culinary purposes; and it is probable, that it is owing to the small proportion which the bitter bears to the whole mass,
that the receptacle of the artichoke, of the Onopordum, and of the cotton thistle, is found fit for food. The corollas of the Cardoon, and of many thistles, have the power of curdling milk. The juice of the lettuce and other cichoraceous plants is milky, bitter, astringent, and narcotic. In a wild state, the narcotic principle is so abundant, that the inspissated juice of Lactuca virosa has been used as a substitute for opium, and with much success. But under the effect of cultivation, the mucilage is so much more abundant than any other substance, that the same species often form well-known articles of wholesome and agreeable food and, indeed, under any circumstances, wild or domesticated, the young shoots, when the narcotic principle is scarcely developed, are frequently eaten with safety; it is for the same reason, namely, the incomplete formation of the bitter principle, and the superabundance of mucilage, on account of the absence of light, that the blanched leaves of cardoons and chiccory, and the white roots of the Scorzonera and the Salsafy, are capable of being eaten without inconvenience. The seeds of all syngenesious plants abound in oil, which is expressed from those of the Madia of Chili, the Verbesina sativa, and the common sunflower. Owing to the difficulty of procuring this oil in a pure state, its virtues are not ascertained with much accuracy. 'They are generally believed to be slightly purgative and diaphoretic.

\section{Order 1.}

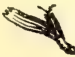

\section{EQUALIS}

Flowers of the disk and ray all hermaphrodite.

1620. Geropogon. Receptacle setose-paleaceous. Invol. many-leaved, simple, or with bracteolæ. Pericarps of disk with branched pappus, of the ray with five awns.

1621. Tragopogon. Involucre simple, of many leaves. Receptacle naked Pappus feathery, stipitate. Pericarps longitudinally striated.

1622. Troximon. Invol. oblong, conical, simple, or imbricated with unequal scales. Recept. naked, dotted.

Pappus sessile, hairy.

1623. Arnopogon. Recept. naked. Pappus feathery, stipitate. Involucre 1-leaved, 8-parted, turbinate.

1624. Podospermum. Recept. warted. Pericarps cylindrical on a long stalk. Leaves finely cut. Otherwise as Scorzonera.

1625. Scorzonera. Recept. naked. Pappus feathery, somewhat stalked. Invol. imbricated, with scales scarious at edge.

1626. Picridium. Invol. ventricose at base, imbricated with broadish scales, membranous at edge. Pappus sessile, villous, simple. Pericarps 4-cornered, warted across.

1627. Sonchus. Involucrè imbricated, swelling at the base. Receptacle naked. Pappus simple, sessile.

1628. Lactuca. Involucre imbricated, cylindrical, its scales with a membranous margin. Receptacle naked.

rapus simple, stipitate.

1629. Chondrilla. Receptacle naked. Invol, with bracteolæ. Pappus simple, stalked. Florets in many rows. Pericarps muricated.

1630. Prenanthes. Involucre with scales at the base. Receptacle naked. Pappus simple, sessile. Florets few.

1631. Leontodon. Involucre with scales that are frequently lax and flaccid. Receptacle naked. Pappus simple, stipitate.

1632. Apargia. Involucre imbricated with scales at the base. Receptacle naked, dotted. Pappus feathery, sessile, unequai.

1633. Thrincia. Recept. favose. Pappus of the ray membranous, multifid, of the disk stalked, feathery.

Invol. with 8 angles and 8 leaves.

1634. Picris. Cal. double, the inner equal, the outer lax. Receptacle naked. Pappus feathery. Pericarps transversely striated.

16:35. Hieracium. Involucre ovate, imbricated. Receptacle nearly naked, dotted. Pappus simple, sessile.

1636. Lagoseris has the characters of Crepis, but the pappus is stalked.

1637. Borkhausia. Invol. oblong in two rows, the outer much shorter than the inner. Recept. alveolate.

Pappus of the centre stalked, of the circumference sessile or subsessile.

1638. Crepis. Involucre surrounded with deciduous scales, and at length swelling into protuberances. Receptacle roughish. Pappus sessile.

1634. Helminthia Recept. naked. Invol. double : outer 8-leaved, equal ; inner 5-leaved, as long as outer.

Pericarps striated across. Pappus stalked, feathery.

1640. Myoseris. Recept. paleaceous. Paleæ capillary. Invol. calyculated. Pappus hairy, sessile.

1641. Tolpis. Recept. favose. Invol. with bracteolæ, which are subulate, and as long as invo! Pappus of

the ray toothed, of the disk with 2 or 4 awris.

1612. Andryale. Recept. villous. Invol. many-parted, nearly equal, rounded. Pappus simple, sessile. 
1643. Rothia. Recept. villous, chaffy at edge. Invol. many-ledved, equal. Pappus hairy, of the disk sessile,

of the ray nrigia. Recept. naked. Pappus membranous, 5-leaved, with 5 bristles between. Invol. many-leaved, simple.

1645. Hyoseris. Recept. naked. Invol. with bracteolæ. Pappus double : exterior capillary ; interior paleaceous, awned.

1646. Hedypnois. Recept. naked. Invol. with bracteolæ. Pappus of disk double : outer obsolete, of many bristles; inner paleaceous, 5-leaved; of the ray a membranous toothletted margin.

1647. Robertia. Invol. many-leaved, equal. Recept. scaly. Pappus feathery, the hairs being slightly membranous at base.

1648. Seriola. Recept. paleaceous. Invol. simple. Pappus somewhat hairy.

1649. Soldevilla. Invol. imbricated, in fruit ventricose at base, with scales crnniving at end. Recept. palea-

ceous; paleæ very short, setose. Pappus $O$.

1650. Hypochceris. Involucre oblong, imbricated. Receptacle chaffy. Pappus feathery, stipitate, or sessile. 1651. Lapsana. Involucre with scales at the base. Receptacle naked (its inner leaves equal, channelled, Sm.) Pericarps destitute of pappus (deciduous).

1652. Zacintha. Recept. naked. Pericarps of the ray incurved, of the disk straight. Pappus very short, somewhat feathery. Invol. with bracteolæ, which are membranous.

1653. Rhagadiolus. Recept. naked. Pericarps arcuate, spreading. Pappus O. Invol, with bracteolæ.

1654. Moscaria. Invol. 6-leaved, equal. Recept. flat, paleaceous. External pericarps with a short feathery

pappus; central with none.

1655. Catananche. Recept. paleaceous. Invol imbricated, scarious. Pappus paleaceous, 5-leaved; paleæ

awned. Triptilion. Invol. imbricated, the exterior scales somewhat squarrose. Florets bilabiate : the upper

1656. Triptilion. Invol. imbricated, the exterior scales somewhat squarrose.
lip 3 -toothed ; lower entire revolute. Recept. villous. Pappus with 3 feathers.

1657. Cichorium. Involucre surrounded with scales or smaller leaflets. Receptacle naked or slightly hairy.

Pappus sessile, scaly, shorter than the pericarp.

1658. Bacazia. Invol. imbricated, scarious. Florets, one in the middle large tubular; the others 4-toothed, with a revolute bristle inserted in the mouth of the tube. Recept. pilose. Pappus feathery.

1659. Scolymus. Receptacle paleaceous. Invol. imbricated, spiny. Pappus $\mathbf{O}$.

1660. Arctium. Involucre globose, each of its scales with an incurved hook at the extremity. Receptacle chaffy. Pappus simple.

1661. Serratula. Involucre cylindrical, imbricated with scales that are not spinous. Receptacle chaffy. Pappus roughish or feathery, rigid, persistent.

1662. Saussurea. Involucre imbricated, not spiny, outer scales acute, inner obtuse, membranous. Pappus feathery, in two rows, the exterior being shortest, the inner sornewhat united at base.

1663. Carduus. Involucre swelling, imbricated with spinous scales. Receptacle hairy. Pappus deciduous, roughish.

1664. Silybum. Invol, ventricose, imbricated: outer leaves with appendages at end; inner cochleate. Recept. chaffy. Pappus linear, chaffy, deciduous.

1665. Cnicus. Involucre swelling, imbricated with spinous scales. Receptacle hairy. Pappus deciduous, feathery.

1666. Onopordum. Involucre swelling, its scales spreading, and spinous. Receptacle cellular. Pappus deciduous, rough.

1667. Berardia. Invol. imbricated with linear unarmed scales. Recept. somewhat favose, naked. Pappus

hairy, generally twisted spirally, persistent.

1668. Cynara. Recept. setose. Invol. dilated, imbricated; scales fleshy, emarginate, with a point. Pappus sessile, feathery.

1669. Carlina. Involucre swelling: the exterior scales with numerous spines; the inner ones colored, scariose.

1670. Atractylis. Recept. paleaceous. Pappus feathery. Invol. imbricated with bracteolæ. Florets of ray 5-toothed.

1671. Acarna. Recept. paleaceous. Pappus feathery. Invol. imbricated with bracteolæ. Florets flosculous.

1672. Stokesia. Recept. naked. Pappus with 4 bristles. Invol, leafy, somewhat imbricated. Heads radiated; florets of ray funnel-shaped, irregular.

1673. Stobcea. Invol. imbricated, with toothed spiny scales. Florets flosculous. Recept. hispid, favose. Pappus paleaceous.

1674. Onobroma. Invol. ventricose: outer scales large, herbaceous, spiny, acuminate; inner coriaceous, unarmed. Recept. paleaceous. Pappus setaceous, rigid, unequal.

1675. Carthamus. Recept. paleaceous, setose. Invol. ovate, imbricated ; scales ovate, leafy at end. Pappus paleaceous, hairy, or none.

1676. Cardopatum. Invol. 6-8-fl. many-leaved, imbricated, the outer scales branched, spiny. Recept. paleaceous, with long fascieled paleæ. . Pericarps villous.

1677. Stchelina. Recept. with very short paleæ. Pappus feathery. Anthers awned at base. Invol. hemispherical, imbricated.

1678. Palafoxia. Invol. oblong, somewhat imbricated, 8 or many-leaved, many-flowered. Cor. flosculous, longer than calyx, with a 5-fid limb. Pappus chaffy. Receptacle naked. Fruit marginal, wrapped up in the involucre.

1679. Pteronia. Recept. paleaceous; paleæ many-parted. Pappus somewhat feathery. Invol. imbricated with keeled scales.

1680. Vernonia. Recept. naked. Invol. ovate, imbricated. Pappus double: outer paleaceons; inner capillary.

1681. Ammobium. Invol. imbricated, colored, radiant. Anthers with 2 bristles at the base. Chaffs of receptacle distinct. Pappus a tonthed edge.

1682. Liatris. Recept. naked. Invol. oblong, imbricated. Pappus feathery.

1683. Mikania. Recept. naked. Invol. 4-6-leaved, equal, 4 or 6 -flowered. Pappus hairy.

168t. Sparganophorus. Invol. subglobose, imbricated with unequal scales, recurved, spreading at end. liecept. naked. Pericarps crowned with a somewhat cartilaginous cup.

1685. Eupatorium. Involucre imbricated, oblong. Florets few. Receptacle naked. Pappus rough.

1686. Dumerilia. Invol. many-parted, equal. Receptacle paleaceous. Florets bilabiate. Anthers spurred

at base. Pappus feathery, sessile.

1687. Ageratum. Recept. naked. Pappus with 5 somewhat-awned paleæ. Invol. oblong in a doubie row.

Curollas $4-5$-fid.

1688. Caelestina. Invol. cylind. many-leaved, imbricated. Recept. convex, naked. Florets all tubular.

Stigmas very long, spreading. Pericarps truncate, 5-cornered. Pappus a membranous rim.

1689. Stevia. Recept. naked. Pappus paleaceous. Invol. cylindrical in a single row.

1690. Ccphalophora. Recept. naked, hemispherical. Pappus paleaceous, many-leaved. Invol. many-leaved, reflexed.

1691. Amphircpis. Invol. hemispherical, imbricated. Recept. flat, naked. Florets all tubular. Pericarps cylindrical, naked. Pappus hairy, deciduous.

1692. Hymenopappus. Invol. many-leaved, spreading; scales ovate, colored. Recept. naked. Pappus many-leaved, paleaceous.

1693. Melananthera. lecept. paleaceous, convex. Invol. many-leaved, in a deuble row. Pappus of from 2 to 18 rough bristles. Pericarps turbinate, angular. 
1694. Marshallia. Recept. paleaceous. Pappus of 5 membranous acuminate paleæ. Invol. imbricated; scales scmewhat lanceolate, incumbent.

1695. Spilanthes. Recept. paleaceous, conical. Pappus with 2 awns, one smaller than the other. Invol. nearly equal.

1696. Salmea. Recept. conical, paleaceous. Pappus with 2 awns. Pericarps depressed. Invol. imbricated.

1697. Bidens. Involucre of many leaves, with many foliaceous bracteas at the base. Receptacle plane, chaffy. Cor. sometimes radiant. Pericarps crowned with from 2.5 persistent awns, which are rough, with minute deflexed bristles.

1698. Platypteris. Invol. many-leaved, imbricated, squarrose. Recept. convex, paleaceous. Pericarps compressed, winged, with 2 awns at top.

1699. Lagascea. Invol. 1-leaved, tubular, 1-flowered, divided at end. Floret tubular, hermaphrodite. Pericarps linear, cuneate, compressed. Pappus a small fringed crown.

1700. Lavenia. Recept. naked. Pappus with 3 awns, glandular at end. Invol. ovate, somewhat imbricated.

1701. Cacalia. Recept. naked, Pappus pilose. Invol. cylindrical, oblong, at the base only with bracteolæ.

1702. Kleinia. Recept. naked. Pappus hairy. Invol, simple, equal, 5-leaved.

1703. Ethulia. Recept. naked. Pappus a very narrow rim. Invol. equal, in a double row.

1704. Piqueria. Recept. naked. Invol. equal, 4-leaved, 4-flowered, Pappus none. Pericarps pentagonal.

1705. Chrysocoma. Recept. naked. Pappus simple. Invol, hemispherical, imbricated. Style scarcely longer than florets.

1706. Tarchonanthus. Recept. villous, Pericarps enveloped in hair. Invol. 1-leaved, half 7-fid, turbinate.

1707. Calea. Recept. paleaceous. Pappus hairy. Invol, imbricated.

1708. Isocarpha. Recept. paleaceous conical, the outer paleæ forming the involucrum. Pappus O. Anthers not spurred at base. Stigmas with a long appendage.

1709. Petrobium. Recept. paleaceous, flattish. Invol. many-leaved, in 2 rows : outer row shortest. Pericarps angular. Pappus awned.

1710. Neurolcena. Recept. paleaceous, flattish. Pappus capillary, toothletted, persistent. Invol. imbricated, leafy. Anthers awnless at the base.

1711. Humea. Recept. minute, glandular. Pappus none. Invol. loosely imbricated, membranous. Florets about 3, tubular. Anthers awned.

1712. Cresulia. Recept. paleaceous : paleæ enveloping the pericarps. Pappus O. Invol. 3-leaved.

1713. Ixociia. Recept. paleaceous. Pappus O. Invol. imbricated: inner scales radiant colored

1714. Santolina. Recept. paleaceous. Pappus O. Invol. imbricated, hemispherical.

1715. Otanthus. Invol. hemispherical imbricated. Florets with 2 appendages at base. Recept. convex, paleaceous. Pappus $\mathbf{O}$.

1716. Caleacte. The same as Calea, but it has a radius of ligular female florets.

1717. Athanasia. Recept. paleaceous. Pappus paleaceous, very short. Invol. imbricated.

1718. Balsamita. Recept. naked. Pappus O. Invol. imbricated.

1719. Pentzia. Recept. naked. Pappus a membranous torn rim. Invol. imbricated, hemispherical.

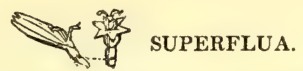

$\$$ Florets of the disk hermaphrodite: of the ray female.

1720. Tanacetum. Invol, hemispherical, imbricated. Recept. naked. Florets of the ray trifid, obsolete sometimes wanting. Pericarps crowned with a membranous margin or pappus.

1721. Artemisia. Invol. ovate or rounded, imbricated. Recept. naked (or downy, Sm.). Florets of the ray subulate. Pericarps crowned with a membranaceous pappus.

1722. Gnaphalium. Recept. naked. Pappus hairy or feathery. Invol. imbricated: marginal scales round, scarious, colored.

1723. Leontopodium. Heads sessile in the leaves. Invol, woolly. Florets 5-fid. Pappus pencilled or hairy. Otherwise Guaphalium.

1724. Evax. Heads surrounded by bracteæ. Invol. ovate, imbricated, with appressed acuminate scales. Florets of disk 4-toothed: of the ray not toothed. Recept. subulate, paleaceous. Pericarps of the female flowers without pappus.

1725. Antennaria. Recept. scrobiculate. Pappus capillary. Invol. imbricated, scarious, colored. Anthers spurred at base. Florets diøcious.

1726. Metalasia. Invol. cylindrical, radiant colored. Pappus deciduous, capillary, clavate. Florets few, hermaphrodite. Otherwise as Gnaphalium.

1727. Astelma. Recept. naked. Pappus feathery, sessile : rays connate at base. Invol. imbricated : with scarious scales; the interior of which are connivent.

1728. Athrixia. Heads radiant. Invol. obl. imbricated, awned, squarrose. Florets bilabiate. Pappus feathery. Recept. alveolate.

1729. Xeranthemum. Recept. paleaceous. Pappus paleaceous-setaceous. Invol. imbricated, radiated : with a colored ray.

1730. Elichrysum. Recept. naked. Pappus hairy or feathery. Invol, imbricated, radiated : ray colored.

1731. Carpesium. Recept. naked. Pappus O. Invol. imbricated, with the outer scales reflexed.

1732. Baccharis. Recept. naked. Pappus pilose. Invol. imbricated, cylindrical. Female florets mixed with the hermaphrodite ones.

1733. Molina. Invol. campanulate, imbricated. Pappus feathery. Recept. convex, naked, dotted. Flowers dicecious.

1734. Coryza. Invol roundish imbricated. Recept, naked. Florets of the ray 3 cleft. Pappus rough.

1735. Madia. Recept. naked. Pappus O. Invol. double: outer 8-10-leaved, equal, longer than the inner, which is many-leaved.

1736. Erigeron. Invol. imbricated. Recept. naked. Florets of the ray numerous, very narrow, mostly of a different color from the disk. Pappus simple.

1737. Tussilago. Invol. simple, equal, submembranaceous, swelling. Recept, naked. Pappus simple.

1738. Senecio. Invol. subcylindrical, equal, scaly below; the scales withered at the tip. Recept. naked.

Pappus simple.

1739. Aster. Invol. imbricated, its lowermost scales spreading (except in A. trifolium). Recept. naked. Florets of the ray more than 10 . Pappus simple.

1740. Solidago. Invol. imbricated, its scales connivent. Recept. naked. Florets of the ray (of the same colour as the disk) about 5 . Pappus rough.

174.1. Cineraria. Recept. naked. Pappus simple. Invol. simple, many-leaved, equal.

1742. Calotis. Recept naked. Pericarps crowned with two opposite paleæ and 1-3-barbed awns. 1nvol nearly equal, many-leaved, in a single or double row.

1743. Kaulfussia. Invol. simple: leaflets keeled. Recept. naked, convex. Pappus of the ray a minute fringed rim; of the disk stiff and feathery.

1744. Inula. Invol. imbricated. Recept. naked. Florets of the ray very numerous, linear. Anthers with 2 bristles at the base. Pappus simply composed of hairs.

1745. Pulicria. Invol roundish, imbricated: scales linear, àcuminate. Recept, nakcd. Pappus compound : outer a membranous cup; inner setaceous. Pericarps uniform.

1746. Grindelia. Recept. naked. Pappus setaceous, deciduous. Invol. imbricated, hemispherical.

$$
\text { U } 114
$$


1747. Podolcpis. Recept. naked. Pappus hairy. Invol. imbricated, scarious, hemispherical : scales unguiculate.

1748. Chatanthera. Invol. many-leaved, ciliated. Florets of ray linear, 3-toothed, with a fine bifid spiral segment at the divisions. Anthers spurred at base. Recept. naked, flat. Pappus hairy.

17+9. Arnica. Recept. naked. Pappus simple. Invol. with equal leaves. Florets of ray generally with 5 filaments without anthers.

1750. Girberia. Florets bilabiate, those of the ray ligulate. Invol. imloricated, coriaceous. Recept. flat, naked. Pappus with long bearded palex.

1751. Doronicum. Scales of the invol. in 2 equal rows, longer than the disk. Recept. naked. Pericarps of the disk crowned with a simple pappus, those of the ray without a pappus.

175\%. Perdicium. Recept. naked. Pappus hairy. Florets 2-lipped.

1753. Titragonothcca. Recept. paleaceous. Pappus O. Invol. 1-leaved, 4-cornered, 4-parted.

175t. Ximenesia. Recept. paleaceous. Páppus $O$. Pericarps of ray naked, emarginate; of the disk winged. Invol. many-leaved, nearly equal.

1755. Helenium. Recept. naked, of the ray paleaceous. Pappus 5-awned, Invol. 1-leaved, many-parted. Florets of ray half-tritid.

1756. Bcllis. Invol. hemispherical, its scales equal. Recept. naked, conical.

1757. Bcllium. Recept. naked. Pericarps conical, with a paleaceous 8-leaved crown and awned pappus. Leaves of invol. equal.

1758. Dahlia. Recept. paleaceous. Pappus O. Invol. double : outer many-leaved; inner 1-leaved, 8-parted.

1759. Babcra. Invol, double: outer many-leaved; inner 8-leaved. Recept. naked. Pappus hairy.

1760. Tagetes. Recept. naked. Pappus with 5 erect awns. Invol. simple, 1-leaved, 5-toothed, tubular. Florcts of ray 5 , persistent.

1761. Hetcrospcrmum. Recept. naked. Outer grains compressed with a membranous edge; inner oblong with two awns. Invol, double: outer 4-parted; inner many-leaved.

1762. Schkuhria. Recept. naked. Pappus paleaceous. Invol. 5-leaved. Florets of ray solitary.

1763. Pectis. Recept. naked. Pappus with 3 or 5 awns. Invol. 5-leaved. Florets of ray 5 .

1764. Longchampsia. Differs from Pectis and Leysera, in having a double pappus, the exterior of which is edged, the inner feathery.

1765. Leysera. Recept. somewhat paleaceous. Pappus paleaceous : of the disk feathery. Invol. scarious. 1766. Selloa. Invol. imbricated, ovate. Recept. naked. Pappus O. Female florets inconspicuous, mixed among the leaves of the involucrum.

1767. Rclhania. Recept. paleaceous. Pappus membranous, cylindrical, short. Invol. imbricated, scarious.

Rays numerous.

1768. Zinnia. Recept. paleaceous. Pappus with 2 erect awns. Invol, ovate, cylindrical, imbricated. Florets of ray 5 , persistent, entire.

1769. Chrysanthemum. Invol, hemispherical, imbricated with scales whose borders are membranous. Recept. naked. Pappus none.

1770. Pyrethrum. Recept. hemispherical, imbricated with scales whose borders are membranous. Recept. naked. Pericarps crowned with a membranous margin.

1771. Matricaria. Invol. hemispherical or almost plane, imbricated with scales whose borders are membranous. Recept. naked, almost cylindrical. Pappus none.

1772. Boltonia. Recept. favose, hemispherical. Pappus toothed, awned, somewhat 2-horned. Rays numerous. Invol. imbricated.

1773. Lidbcckia. Recept. naked. Pappus O. Pericarps angular, with the lowest joint of style persistent. Rays numerous. Invol. many-parted.

1774. Cenia. Invol. in fruit turbinate, multifid. Florets of ray very numerous, short. Recept. naked. Pericarps compressed.

1775. Cotula. Recept. nearly naked. Pappus margined. Florets of disk 4-fid, of the ray scarcely any.

1776. Grangea. Invol. imbricated, spreading. Marginal florets 3-toothed. Recept. hemispherical. Pericarps with a toothed edge at top.

1777. Anacyclus. Recept. paleaceous. Pappus emarginate. Pericarps with membranous edges.

1778. Anthemis. Invol. hemispherical, its scales nearly equal, their margins scarious, Recept. convex,

chaffy. Pericarps crowned with a membranous border or pappus.

1779. Centrospermum. Invol. hemispherical, of many imbricated, round, scarious scales. Recept. naked.

Pappus spiny. Outer pericarps cymbiform, smooth

1780. Sanvitalia. Recept. paleaceous. Pericarps of ray with 3 awns : of the side naked, warted; of the disk winged. Invol. imbricated, flat.

1781. Achillea. Invol, ovate, imbricated, unequal. Recept. plane, chaffy. Florets of the ray 5-10, roundish, obcordate. Pericarps naked.

1782. Tridax. Invol, cylindrical, imbricated, with ovate oblong scales. F'orets of ray 3-parted. Recept. paleaccous. Pappus hairy, simple.

1783. Amellus. Recept. paleaceous. Pappus simple. Invol, imbricated. Florets of ray undivided.

1784. Starkea. Recept. hirsute. Pappus sessile, hairy. Invol. imbricated.

1785. Columellia. Invol, cylindrical, imbricated. Florets of ray undivided. Recept. naked, favose. Pappus a toothed edge.

1786. Eclipta. Recept. paleaceous. Pappus O. Florets of disk 4-fid.

1787. Neyera. Invol. 4-leaved, the 2 inner smallest. Recept. small, paleaceous, 2 paleæ enveloping the pericarp, kecled. Pappus $\mathrm{O}$.

1788. Chrysanthcllum. Invol. cylindrical, about as long as florets, scaly at base. Recept. paleaceous. Florets numerous, linear, 2-toothed, short, of the centre few, and generally abortive. Pericarps naked, roundish, furrowed, with an entire edge.

1789. Siegesbeckia. Recept. paleaceous. Pappus O. Outer invol. 5-leaved, inner spreading. Ray halved.

1790. Verbesina. Recept. paleaceous. Pappus awned. Invol. in one row. Florets of the ray about 5.

1791. Synedrella. Invol. generally of 2 leaves. Florets flosculous. Recept. obsolete, paleaceous : paleæ

glumaccous; the outer or ate. Pericarys oval, flat, edged; the central dissimiar, inear, oblong, with 2 or 3 awns.

1792. Galinsogea. Recept. paleaceous. Pappus many-leaved, paleaceous. I. vol. imbricated.

1793. Acmclla. Invol. simple, with a few somewhat leafy divisions. Recept. oblong, paleaceous. Heads radiant. Pericarps 4-cornered, truncate at end, naked.

1794. Zaluzania. Invol. with distinct, somewhat ovate, equal segments. Head radiant. Recept. conical, paleaccous ; paleæ membranous, trifid, involving the pericarps, which are 4-cornered and naked.

1795. Pascalia. Recept. paleaceous. Pericarps drupaceous. Pappus a toothed rim. Invol. imbricated.

1796. Heliopsis. Invol. imbricated, with ovate lined squamæ. Cor. of ray linear, large. Recept. paleaceous, conical, with lanceolate palex. Pericarps 4-cornered. Pappus 0.

1797. Buphthalmum. Recept. paleaceous. Pappus an obsolete rim. Sides of pericarps, especially of the ray, eiged.

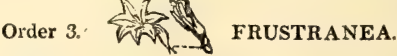

Florets of the disk fertile : of the ray sterile.

1798. Helianthus. Recept. paleacesus, flat. Pappus 2-leaved. Invol. imbricated, subsquarrose.

1799. Gymnolomn. Invol. hemispherical, loosely imbricated. Recept. convex, paleaceuus. Central forets sterile; marginal radiant. Pappus 0. 
1800. Rudbcclia. Recept. paleaceous, conical. Pappus with a 4-toothed rim. Invol. with a double row of scales.

1801. Galardia. Recept. paleazeous, hemispherical. Pappus paleaceous, many-leaved. Invol. imbricated, many-leaved, flat. Rays 3-parted.

1802. Tithonia. Invol, many-leaved, cylindrical, Rays 3-toothed. Recept. paleaceous, convex. Pappus paleaceous, 5-leaved.

1803. Cosmea. Recept. paleaceous. Pericarps 4-cornered. Pappus with 2 or 3 awns. Invol, double, each 1-leaved, 8-parted.

1804. Corcopsis. Recept. paleaceous. Pericarps compressed, emarginate. Pappus with 2 horns. Invol. double, each many-leaved.

1805. Simsia. Invol. subcylindrical, nearly equal, with linear lanceolate incumbent scales. Recept. palcatceous. Pericarps flattish, somewhat edged, each edge awned.

1806. Osmites. Recept. paleaceous. Pappus obsolete. Florets of ray ligulate. Invol. imbricated scarious.

1807. Encelia. Recept. paleaceous. Pappus O. Pericarps vertical, flat, with a ciliated edge. Invol. inbricated.

1808. Sclerocarpus. Recept. paleaceous. Pappus O. Invol. double, each 3-leaved.

1809. Cullumia. Recept. favose. Pericarps smooth. Pappus O. Invol. 1-leaved, covered with imbricated leaflets.

1810. Berckheya. Recept. favose. Pericarps villous. Pappus paleaceous (sometimes bristly-paleaccous, ciliated). Invol. 1-leaved, covered with imbricated leaflets.

1811. Didelta. Recept. favose, inclosing the pericarps. Pappus many-parted, setaceous, paleaceous, toothed. Invol. 1-leaved, covered with leaflets, the exterior very large

1812. Gorteria. Recept. scrobiculate. Pappus a ciliated edge. Invol, 1-leaved, covered with imbricated leaflets, of the fruit indurated, connivent, deciduous.

1813. Gazania. Recept. naked, or alveolate. Pericarps very villous. Papyus hairy-paleaceous. Invol.

1-leaved, the tube naked, or covered with imbricated leaflets.

1814. Cryptostemma. Recept. favose. Pappus paleaceous, covered by the entangled wool of the pericarp. Invol. imbricated.

1815. Arctotheca. Recept. favose. Pappus O. Invol. imbricated.

1816. Sphenogyne. Recept. with distinct palex. Pappus paleaceous, simple. Stigmas with a dilated truncated end. Invol. imbricated, the inner scales or all with a dilated scarious end.

1817. Zoegea. Recept. setose. Pappus setaceous. Rays ligulate. Invol. imbricated.

1818. Leuzea. Invol. imbricated, spherical, not spiny. Recept. bristly. Pappus feathery, in many rows. Florets all hermaphrodite.

1819. Centaurea. Invol. scaly. Recept. bristly. Corollas of the ray infundibuliform, irregular, longer than those of the disk. Pappus simple.

1820. Galactites. Invol. imbricated, with somewhat squarrose spiny scales. Recept. favose. Pappus feathery, deciduous.

1821. Wedelia. Invol. 5-leaved, with broad leafy segments. Recept. paleaceous. Florets of the centre generally abortive, of the ray many, oval, 2-3-fid. Stigmas setaceous. Pappus stipitate, membranous, toothletted.

\section{Order 4. N. NECESSARIA.}

Florets of the ray female fertile : of the disk male.

1822. Milleria. Recept. naked. Pappus O. Invol. of 3 valves. Ray halved

1823. Baltimora. Recept. paleaceous. Pappus O. Invol. cylindrical, many-leaved. Ray 5-flowered.

1824. Silphium. Recept. paleaceous. Pappus with a 2 horned edge. Invol. squarrose.

1825. Trixis. Invol. imbricated. Cor. of ray 3-fid. Recept. paleaceous. Pappus O. Pericarps villous at end.

1826. Polymnia. Recept. paleaceous. Pappus O. Invol. double : outer 4 or 5-leaved; inner 10-leaved, with common leaflets.

1827. Chrysogonum. Invol, 5-leaved. Recept. paleaceous. Pappus 1-leaved, 3-toothed. Pericarps with a little 4-leaved calyx.

1828. Melampodium. Recept. paleaceous, conical. Pappus 1-leaved, vulviform. Invol.5-leaved.

1829. Chaptalia. Recept. naked. Pappus capillary. Florets of the ray in a double row, deformed; of the disk bilabiate.

1830. Calendula. Recept. naked. Pappus O. Invo. many-leaved, equal. Pericarps of the disk membranous.

1831. Arctotis. Recept. setose-alveolate. Pericarps half 2-celled, or 2-furrowed at the back. Pappus paleaceous. Invol, imbricated, with scales scarious at end.

1832. Osteospermum. Recept. naked. Pappus O. Invol. many-leaved. Pericarps globose, colored, bony.

1833. Othonna. Recept. naked. Pappus hairy. Invol. 1-leaved, many-cut.

1834. Hippia. Recept. naked. Pappus O. Pericarps with very broad edges, naked. Invol, hemispherical, somewhat imbricated. Florets of ray 10, obsoletely trifid.

1835. Soliva. Invol. 7-leaved, leaflets with imbricated edges, the 3 outer largest. Ray none. Recept. very small, somewhat villous. Pericarps compressed, surrounded by a membrane, crowned by 2 prickles and the style.

1836. Psiadia. Recept. naked. Pappus hairy, sessile. Invol. imbricated, ovate. Florets of ray short.

1837. Eriocephalus. Recept. paleaceous. Pappus O. Invol, double : inner 1-leaved; outer 5-leaved.

1838. Filago. Recept. paleaceous. Pappus O. Invol. imbricated. Female florets mixed among the scales of involucre.

1839. Micropus. Recept. paleaceous. Pappus O. Invol, calyculate. Rays none. Femalc florets enwrapped in the scales of involucre.

1840. Parthenium. Recept. paleaceous, flat. Pericarps obovate, nearly naked. Invol. 5-leaved.

1841. Iva. Recept. pilose. Pericarps naked, blunt. Invol 3-leaved. Florets of ray 5. Styles 2, long.

1842. Acicarpha. Invol, 5-parted. Cor, all tubular. Recept. paleaceous, the palea being united with the pericarps after flowering. Pappus 0 . Stamens half-separate.

Order 5.

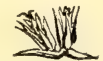

SEGREGATA.

Each floret having its own peculiar involucre.

1843. Elephantopus. Invol 4-flowered. Florets ligulate, hermaphrodite. Recept, nakcd. Pappus sctaccous. 1844. Edera. Invol. many-flowered. Tubular florets hermaphrodite, and one or more female and ligulate. Recept. paleaceous. Pappus with many palex.

1845. Flaveria. Partial invol. 2-5-leaved, 2-5-flowered. Common invol. imbricated with uncqual scales. Florets tubular, 1 often ligulate. Pappus O. Recept. naked.

1816. Stcebe. Invol. 1-flowered. Floret tubular, hermaphrodite. Recept. naked. Pappus feathery.

1847. Nauerbergia. Partial invol. 2-leaved, 1-flowered; common invol. leafy. Pappus O. lieceptacle sctose. 
1848. Cassinia. Invol. 2-flowered, 4-leaved. Florets hermaphrodite. Pappus paleaceous, pencilled. Recept. naked.

1849. Sphcranthus. Invol. 8-flowered. Florets tubular, hermaphrodite, and obsoletely female. Recept. scaly. Pappus $\mathbf{O}$.

1850. Echinops. Invol, 1-flowered. Florets tubular, hermaphrodite. Recept, setose. Pappus obsolete

1851. Rolandra. Florets fascicled in a head, with scales between. Invol, 2-valved, 1-Howered. Florets hermaphrodite. Pappus $\mathbf{O}$.

\section{EQUALIS.}

1620. GEROPO'GON. $W$. Old Man's Beard. 11055 . GEROPO

11055 giáber $W$. hirsute $\quad$ or $1 \frac{1}{2}$ jl.au Pk Italy

1759. co Bot. mag. 479

11057 calyculátus $W$. perennial $\Delta \triangle$

1621. TRAGOPO'GON. $W$. GOAT'S BEARD.

jl.au Pk Italy

759. S co Col. ecph.1. t.231

11058 cánus $W . \&$.

11059 angustifólius $L$.

11060 praténsis $W$.

11061 mutábilis Jac.

11062 undulátus $\mathrm{W}$.

11063 orientális $W W$

11064 májor $W$.

(1) or 1 jl.au

narrow-leaved $\frac{7}{20}$ or

yellow-leaved $\$$ of or

changeable $\frac{7}{2}$ or

wave-leaved 10

11065 floccósus $W . \&$. Woolly

11066 porrifólius $W$. Salsafy

11067 crocifólius $W$.

11068 villósus $W$.

Crocus-leaved

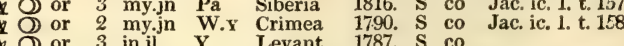

jl.au Pu fungary

$\frac{1}{4}$ jl.au Pu Italy

my.jn $\mathbf{Y}$ Britain past. S co

ria past. S r.m Eng. bot. 434

1622. TROX'IMON. Gertn. Troximon.

my.jn $Y$

(1) or

3 myjn $Y$ Hungary 1816 $S$ co Pl.rar hu $t 112$

Austria 1788. S co Jac. aust. 1. t. 29

Hungary 1816. S co Pl.rar.hu.2.t.1

Q or 1 jn.jl Pu Italy 1739. S co Col. ecph.1. t.230

11070 virgínicum $P h$. Virginian $\frac{\$ 1}{\Delta} \Delta$ or 1 jl.au Y N. Amer. 1799. D co

1623. ARNOPO'GON. $W$. SHEEP'S BEARD.

11071 Dalechámpii $W$. great-flowered ${ }^{2}$ pr

11072 picroides $W$.

11073 ásper $W$.

Composita. Sp.

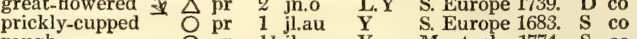
rough

O pr 1: $1 \frac{1}{2}$ jl.au $\mathbf{Y}$

Montpel. 1774. S co

1 jn.jl Y Y Sp. 3-6.

1 Podosperyum

11074 calcitrapifólium Dec. Centaury-lvd. $\downarrow \Delta p r$

11075 laciniátum Dec. $\begin{aligned} & \text { cut-leaved } \\ & 11076 \text { octanguláre Dec. } \\ & \text { octagon }\end{aligned}$

11076 octanguláre Dec. octagon

11077 tuberósa $W$

11078 tomentósa $W$.

11079 húmilis Jac.

11080 hispánica $W$

11081 glastifólia $W$

11082 caricifólia $W$

11083 purpúrea $W$

11084 rósea $W$

11085 graminifólia $W$

11086 angustifólia $W$

11087 eriospérma $W$.

11088 taraxacifólia $W$.

11089 taúrica Bieb.

11090 parviffóra Jacq.

11091 lanáta Bieb.

11092 ensifólia Bieb.

11093 hirsúta $L$.

tuberous

tuberous $\Delta$ pr

white $\quad \frac{\ddagger}{7} \Delta \mathrm{pr}$

a $\Delta$ pr 1 au

Woad-leaved of $\Delta$ cul 3 jn.s

Carex-leaved $\frac{ \pm}{\Delta} \Delta \mathrm{pr}$

purple-flowered $\frac{\Delta}{\partial} \Delta$

Rose-colored $\mathrm{z}$.

Grass-leaved $\frac{x}{\Delta}$ pr narrow-leaved $\mathrm{s}$ pr woolly-seeded $\frac{\Delta p r}{p r}$ Dandelion-lvd. \& $\Delta \mathrm{pr}$ Taurian $\Delta \mathrm{pr}$ small-flowered $\frac{1}{\Delta} \Delta \mathrm{pr}$ woolly sword-leaved $\$ \Delta$ pr hairy' ${ }^{\prime}$ is $\Delta$

1 jn.jl Y Levant 1820. D co Buxb.cent.2.t.22

1 jn.jl $\quad$ Y $\quad$ S. Europe 1818. S co Composita. Sp. 19-33.

光 jn $\mathbf{Y}$ Volga 1825. D co $\begin{array}{lll}\text { Volga } & 1825 . & \text { D co } \\ \text { Armenia } & 1789 . & \text { D co }\end{array}$ Europe 1597. D co Europe 1597. D co Spain 1576. D co Siberia 1805. D co

$\begin{array}{lllll}2 & \text { my.jn } & \mathrm{Pu} & \text { Austria 1759. D co } \\ 1 \frac{1}{2} \mathrm{jl} & \mathrm{Pk} & \text { Hungary } & 1807 . & \mathrm{D} \\ & & \end{array}$

$\begin{array}{lllll}2 & \text { my.jn } & \mathrm{Pu} & \text { Austria 1759. D co } \\ 1 \frac{1}{2} \mathrm{jl} & \mathrm{Pk} & \text { Hungary } & 1807 . & \mathrm{D} \\ & & \end{array}$

$2^{\frac{1}{2}}$ jn.au L.Y

$\frac{1}{2}$ jn.au Y

$1^{2}$ jn.au Y Siberia 1805. D co

$\frac{1}{2}$ jn.au $\quad Y \quad$ Bohemia 1801. D s.1

1 jn.au Y Tauria 1820. co

Austria 1819 D c0 Jacq aust t 305

1 jl.au Y Iberia 1824. D co Mor. se.7.t.6.f.17

1 my.jn $\mathrm{Y}$ Caucasus 1825. D co

S. Europe 1818. D co

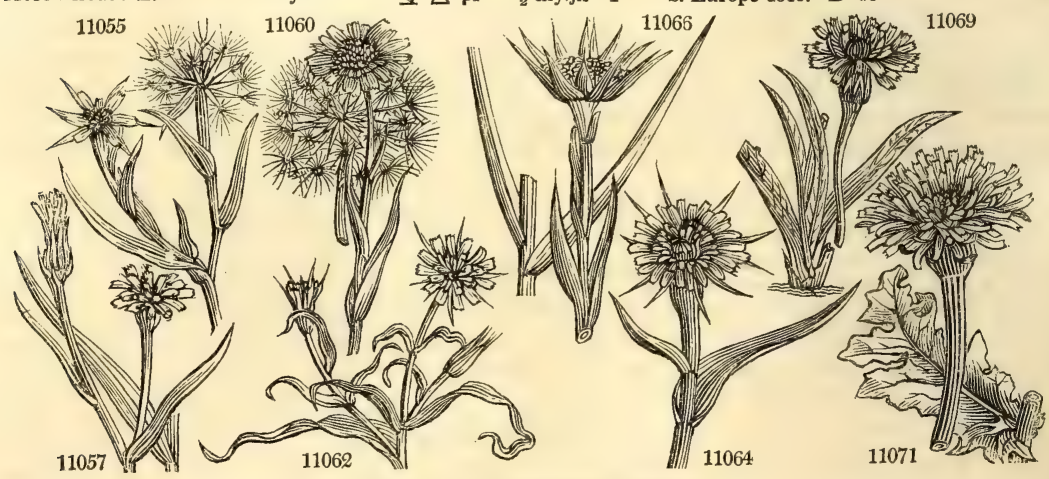

History, Use, Propagation, Culture,

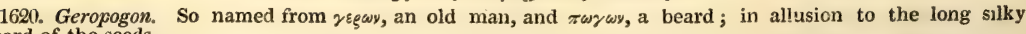
beard of the seeds.

1621. Tragopogon. From rearos, a goat, and $\pi \omega y$ cos, a beard; a name applied in the same way as Geropogon. T. porrifolius, or Salsafy, has a long tapering fleshy white root, which is used like carrots or parsneps, and cultivated in gordens for that purpose. The flavor of the root is mild and sweetish ; dressed like asparagus, there is some resemblance in taste. It is occasionilly grown in British gardens, and a good deal in those of France and Germany. It is raised and treated in all respects similarly to the carrot. T. praterisis answers equally vicll for culture as this species, and was formerly preferred to it. 
1852. Brotera. Partial invol. 1-flowered, many-leaved, common 6-8-flowered, imbricated, many-leaved. Florets tubular, uniform. Recept. naked. Pericarp covered by the adhering involucre.

1853. Gundelia. Invol. $O$. Hollows of the recept. 5-flowered. Florets tubular, male and hermaphrodite. Recept. paleaceous. Pappus $\mathrm{O}$.

1854. Euxenia. Invol. 1-leaved, 10-cleft, reflexed, two of the segments larger than the rest. Anthers dis-

tinct. Pappus none. Recept. chaffy.

\section{EQUALIS.}

11055 Leaves smooth

11056 Leaves hairy

11057 Involucrum with scales at the base

11058 Invol. 8-leaved as long as ray, and peduncles downy, Leaves linear straight

11059 Involucre 8-leaved longer than rays of corolla, Leaves entire straight smooth

11060 Invol. about as long as the cor. Leaves undivided glabrous acuminated channelled, Peduncles cylindirical 11061 Invol, 8-leaved as long as rays of cor. Leaves entire straight lanc. acuminate

11062 Invol. as long as rays of cor. Leaves entire sub-linear; those of the stem very wavy

11063 Invol. shorter than ray of cor. Leaves entire somewhat wavy

11064 Invol. longer than ray of cor. Lvs. entire straight, Pedunc. thickened upwards, Florets rourded at end

11065 Woolly with down, Invol. shorter than ray of cor. Lvs. linear channelled : cauline revolute

11066 Invol. much longer than the cor. Leaves undivided straight, Peduncle thickened upwards

11067 Invol. 5-leaved longer than ray of cor. Leaves entire, Radical and peduncles villous at base

11068 Invol. half as long again as ray of cor. Stem and leaves villous

11069 Scape 1-fl. Leaves of invol. imbricated cuspidate, Leaves linear entire glaucous on each side 11070 Smooth glaucous, Stem erect 2-3-fid somewhat naked, Leaves smooth : radical sublyrate

11071 Invol, downy unarmed, Leaves runcinate toothed

11072 Invol. hispid aculeate, Leaves runcinate toothletted : cauline dilated at base

11073 Invol. hispid aculeate, Leaves entire : cauline obl. attenuated at base

11074 Lower leaves lyrate with obl. mucronate segments : upper pinnatifid

11075 Lower leaves pinnatifid : upper linear, Invol. smooth : lower scales spreading mucronate

11076 Lower leaves decursively pinnatifid lanc. : upper linear-lanceolate, Invol. before opening 8 angular

11077 Stem 1-flowered leafy, Leaves linear downy beneath, Root tuberous

11078 Leaves ovate nerved downy entire sessile

11079 Stem somewhat naked about 1-flowered, and scales of invol. woolly, Leaves obl. lanc. nerved fiat

11080 Stem branched, Leaves amplexicaul. lanc. entire subserrulate at base

11081 Stem about 1-ff. leafy, Leaves lin. lanc. acuminate smooth nerved flat

11082 Stem about 1.f. leafy ascending, Leaves lanc. ensif. smooth nerved flat, Ray longer than invol

11083 Leaves lin. subul. channelled triquetrous, Stem branched

11084 Leaves lanc. lin. flat: cauline keeled linear, Stem 1-flowered

11085 Leaves lin. ensif, acum. rigid nerved keeled, Invol. villous leafy at base, Stem somewhat branched

11086 Leaves subulate entire, Pedunc. thickened, Stem villous at base

11087 Leaves lin. acum. keeled woolly at base, Stem branched, Invol, woolly, Fruit downy

11088 Leaves runcinate blunt smooth, Scape leafless branched, Peduncles thickened

11089 Stem leafy many-fl., and invol. downy, Lower leaves lanc. acuminate entire downy : upper lin. subulate

11090 Stem branched leafy at base, Leaves lanc. ensif. smooth nerved flat, Ray shorter than cal

11 (i91 Stem 1-fl. leafy at base, Leaves lin. lanc. wavy silky with cown all over

11092 Stem leafy many-flowered erect, Leaves nerved filiform acuminate, Invol. and seeds woolly

11093 Leaves linear and 1-flowered, Stem hairy

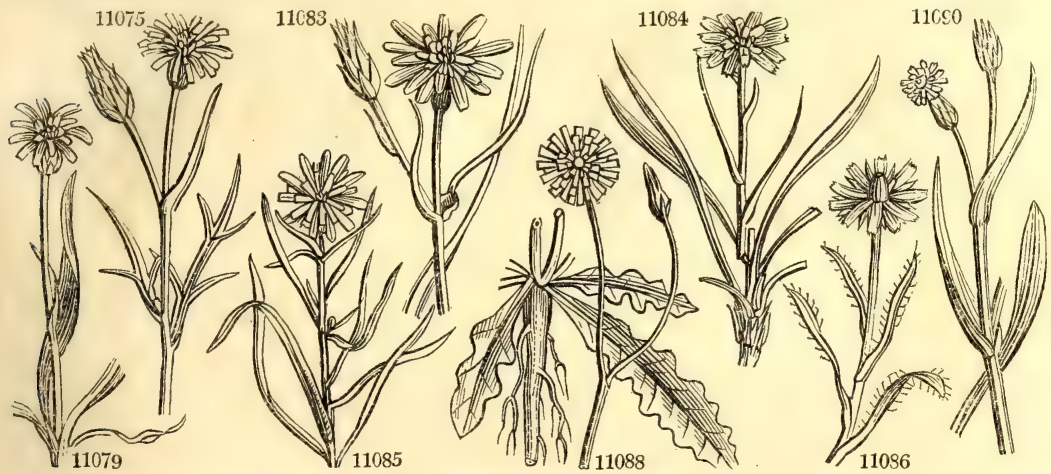

and Miscellaneous Particulars.

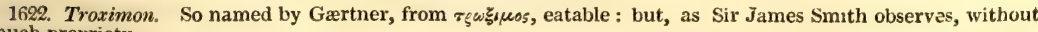
much propriety.

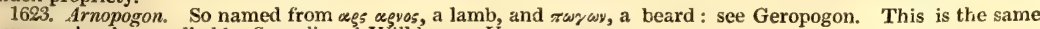
genus as has been called by Scopoli and Willdenow, Urospermum.

1624. Podospermum. From $\pi \tau_{5} \pi 0 \delta 05$, a foot, and $\sigma \pi \varepsilon \rho \mu \eta$, seed, on account of the long stalk of the fruit. Small herbaceous plants with the flowers of Scorzonera.

1625. Scorzonera. From scurzon, the Catalonian name of the viper. The plants are esteemed in Spain as a certain remedy for the bite of a viper; but it is believed that the slender tortuous form of the roots has 
11094 muricáta Dec. $\quad$ muricated $¥ \Delta \mathrm{pr}$ jn.au $\mathbf{Y} \quad$ S. Europe 1820. D co

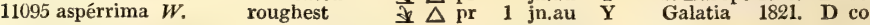

1626. PiCRi'dium. $P$. S. Picridium. 11096 vulgáre $P$. S.
Sónchus picroides W. various-leaved

11097 tingitánum $\boldsymbol{P}$. S. Tangier

11098 álbidum $P . S$. Crépis álbida W. Composita. Sp. 3.

$\begin{array}{ll}\text { Composita. } & S p .3 . \\ \text { jn.au } & \text { F }\end{array}$

1773. S co

All.ped.1.t.16.f.1

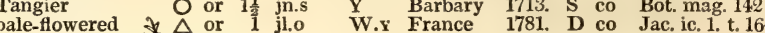

1627. SON'CHUS. $W$. 11099 maritimus $\not W$. 11100 fruticúsus $W$. 11101 pinnátus $W$. 11102 lævigátus $\boldsymbol{W}$.en. 11103 lyrátus W.en. 11104 radicátus $W$. 11105 palústris $W$. 11106 arvénsis $W$ 11107 oleráceus $W$ 11108 tenérrimus $W$. 11109 Plumiéri $W$. 11110 alpinus $W$. 11111 lappónicus $W$. 11112 floridánus $W$ 11113 caucásicus Fischer 11114 acuminátus $W$. 11115 pállidus $W$. 11116 sibíricus $W$ 11116 sibíricus $W$ 11118 divarićt 11119 uliginósus Bieb.

Sow ThistLe. sea shrubby wing-leaved smooth lyre-leaved tall marsh corn

common

clammy

Plumier's

blumier's Lapland small-flowered Caucasian acuminate Canadian Siberian

Tartarian divaricating swamp torn

11121 chondrilloídes Desf. spreading 11122 macrophýllus $L$ large-leaved

11123 leucopho'us $W$. shining

1628. LACTU'CA. $W$. LetTuce. 11124 sativa $W$. garden 11125 crispa $W$ 11126 palmáta $W$ 11127 intybácea $\boldsymbol{W}$. 11127 intybácea $\underset{W}{W}$. 11128 quercína $W$ 11129 stricta $W$. 11130 elongáta $W$ 11131 Scaríola 11133 angustána $W$ $111 S 4$ sagittata $W$. 11135 saligna $\underset{W}{W}$ 11137 altíssima Bieb. curled palmate Endive-leaved Oak-leaved upright elongated prickly Indian tallest y un 3 jn.jl strong-scented $\frac{1}{2} \mathrm{~m} \quad 3 \mathrm{jl}$.s entire-leaved $-\mathrm{O}$ un 2 jl.au arrow-leaved is 0 ) un 2 jl.au least

\section{Composita. Sp. 25-40.}

$\Varangle \Delta$ pr 2 jl.s $Y$ S. Europe 1748. D co All.ped.1.t.16.f.2 is or 3. ap.jl $\quad \mathbf{Y}$ Madeira 1777. S p.l Jac. ic. 1.t.161 * * 4 ... Y Y Madeira 1816. C co 는 $\longrightarrow$ Y $\triangle$ pr 6 jl.au $Y$ England riv.ba. D co $\Delta$ W 1 $\frac{1}{2}$ jl.au $\quad \mathbf{Y}$ Britain corn fi. D co W 2 jn.au Y \& $\triangle$ or 6 jl.au \$e $\triangle$ or 4 jl.au $\$ \triangle \triangle$ or 6 jl.au \) O or $6 \mathrm{jl}$ $\not \Delta$ or 3 au.s s or 2 au $\frac{ \pm}{7} \Delta$ or $2 \mathrm{jl.s}$ st $\Delta$ or 4 jn.jl \& $\Delta$ or 3 jlau O or 4 jn.jl $\checkmark$ O or $1 \frac{1}{2}$ jn.jl 7 or 6 jl.au I 0 or 6 jl.au

Britain corn fi. D co Eng. bot. 674

Eng bot. 84

1. S co Plu.alm.t.93. f.3

Pyrenees 1794. D co

Scotland al.pas. D co

Lapland 1804. S co

N. Amer. 1713. S co

Caucasus 1818. D co

N. Amer. 1812. D co

Canada 1704. D co

Rob. ic 148,151

L.B Siberia 1759. D co Siberia 1784. D co

Caucasus 1823. D co ..... 1820. S co Boc.sic.13.t.7.f. 4

Amer. 1823. D co N. Amer. 1821. S co - cul 4 Composita. Sp. 19-26.

Y.W $\mathbf{W}$.... 1562, S co O cul 3 jn.jl $\mathbf{Y} \quad \ldots . . .1570 . \quad$ S cul 3 jn.jl Y $\mathbf{Y}$ S..... 1683. S co

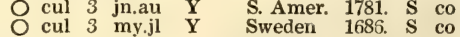
$\begin{array}{lll}\text { Sweden } & 1686 . & \text { S } \\ \text { Hungary } & 1805 \text {. S } & \text { co }\end{array}$ Pensylva. 1805. S co England rubble. $\mathrm{S}$ co Britain ch.ba. S co Italy 1791. S co Hungary 1805. S co England ch.ba. S co E. Indies 1784. S co
Pl, rar.hu.1.t. 48

Eng. bot. 268

Eng. bot. 1957

All.ped.1.t.52.f. 1 Eng. bot. 707
Jac. ic. 1. t. 162

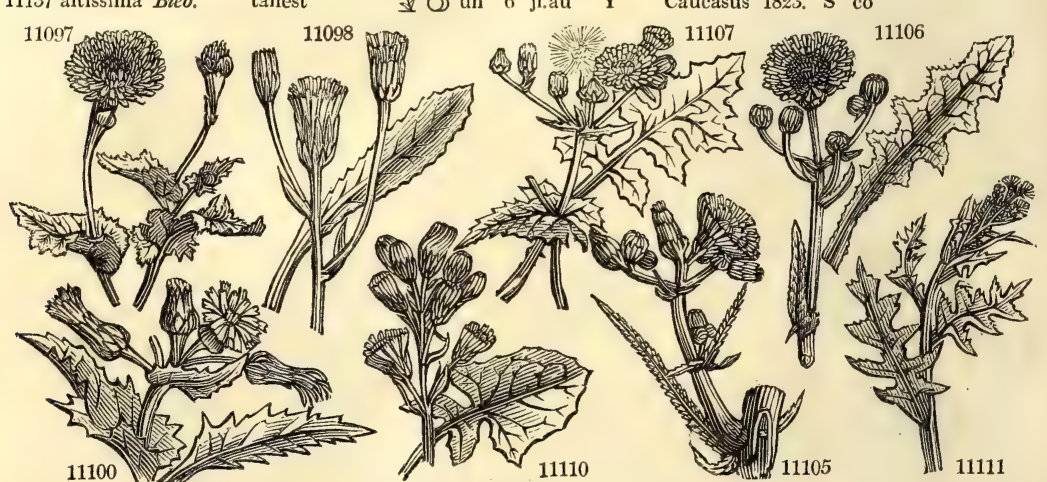

History, Use, Propagation, Culture,

given rise to this belief, rather than any quality inherent in the plant : for it is a rule to which there are few exceptions, that all plants used as food by man, possess very inactive qualities. If their action was powerful, they would be unfit for food.

Scorzonera hispanica is esteemed diuretic, stimulant, and sudorific. A drink is made from it for variola and a distilled water is also prepared from it. It is also an esculent of occasional culture. The root is carrotshaped, about the thickness of one's finger, tapering gradually to a fine point, and thus bearing some resemblance to the body of a viper. The outer rind being scraped off, the root is steeped in water, in order to abstract a part of its bitter flavor. It is then boiled or stewed in the manner of carrots or parsnep3. The roots are fit for use in August, and continue good till the following spring. Its culture is the same as that of carrot or salsafy.

1626. Picridium. A diminutive of Picris, which see. Picridium sativum, Picridium cultivé, Fr., is sown in the spring as a small salad, and, if not allowed to become too old before it is cut, is an excellent vegetable, with a pleasant delicate flavor, wholly devoid of the bitterness of endive, and of the insipidity of very young lettuces. $\mathbf{P}$. tingitanum is a favorite border annual.

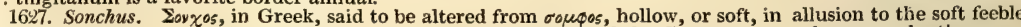
stem of the plants. Sonchus oleraceus, Sow-thistle, Eng. Hasenkohl, Ger., seems to have nearly the same properties as the Dandelion and Succory, but it is little regarded as a medicine It is a favorite food with proves and rabbits; young tender leaves are in some countries boiled and caten as greens: and it is even affirmed, that the tender 
11094 Lower leaves linear : upper pinnatifid, Lobes remote linear

11095 Leaves runcinate hispid, Stem about 2-fl. somewhat leafy hispid

11096 Cauline leaves amplexicaul. obl, nearly entire : radical sublyrate runcinate, Scales of invol. appressed

11097 Leaves amplexicaul, obl. pinnatifid toothed, Invol. squarrose

11098 Leaves scabrous, Scales of invol, membranous at edge ciliated

11099 Pedunc. subsol. term. naked, Leaves lanc. amplexicaul. undivided finely toothed backwards

11100 Pedunc. branched somewhat scaly, Leaves lanc. runcinate, Stem shrubby

11101 Pedunc. naked, Invol. smooth, Leaves pinn. Pinnæ lin.-lanc. somewhat toothed

11102 Pedunc. naked, Invol. turbin. smooth : lower scales reflexed at end, Leaves pinnatifid

11103 Pedunc. naked, Inv. turbin. smooth : low. scales reflexed at end, Lvs. lyrate pinnatif. Corymb divaricating

11104 Pedunc. naked and invol. smooth, Stem nearly naked, Radic. lvs. lyrate smooth on each side, Lobes triang.

11105 Pedunc. and invol. hispid somewhat umbelled, Leaves runcinate sagittate at base [ovate

11106 Peduncles and invol. hispid sub-umbellate, Leaves runcinate dentato-ciliate cord. at the base

11107 Peduncles sub-tomentose umbellate, Involucre glabrous, Lvs. runcinate dentato-ciliate amplexic. at base 11108 Pedunc. downy umbell. Invol. hairy, Leaves bipinnatifid cordate sagittate at base

11109 Pedunc. naked, Flowers panicled, Leaves runcinate

11110 Peduncles and involucre hispid racemose, Leaves sublyrate, Terminal lobe deltoid very large

11111 Pedunc. squarrose, Fl. racemose, Leaves runcinate acuminate smooth glaucous beneath

11112 Pedunc. sub-squarrose, Fl. panicled, Leaves lyrate-runeinate toothletted stalked

11113 Leaves sessile : lower cordate toothed; upper hispid entire, Peduncles scaly

11114 Pedunc. sub-squarrose, Fl. panicled, Radic. leaves sub-runcinate: cauline ovate acuminate stalked

11115 Raceme comp. terminal, Leaves lanc. ensiform amplexicaul. toothed

11116 Pedunc. squarrose, Fl. corymb. Leaves lanc. sessile: lower runcinate toothed; upper entire

11117 Pedunc. naked, Fl. in corymbose panicles, Leaves lanc. runcinatc narrowed at base

11118 Leaves pinnatifid with little white spiny teeth, Calyx slender

11119 Pedunc. and invol. smooth a little downy, Leaves sub-runcinate spiny-toothed amplexicaul.

11120 Pedunc. somewhat downy umbellate, Invol. smooth, Leaves pinnatif. toothed auricled cordate at base

11121 Radic. leaves unequally pinnatifid : cauline linear lanc. toothed, Pedunc. long 1-flowered

11122 Peduncles birsute naked, Fl. panicled, Leaves lyrate cordate at base hairy beneath

11123 Pedunc. scaly, Fl. racemose, Leaves runcinate acuminate, Stem panicled virgate

11124. Leaves rounded: cauline cordate, Stem corymbose

11125 Leaves sinuate-crenate toothed wavy curled : radical with a hairy keel, Florets 5-parted

11126 Lower leaves tripartite pinnatifid with obl. blunt segm. : upper cordate

11127 Leaves runcinate tooth-ciliated blunt amplexicaul. sagittate : radical obovate, Stem panicled

11128 Leaves smooth beneath: lower runcinate toothletted at base dilated and sagittate; upper lanc. sagittate

11129 Leaves smooth beneath : radical runcinate lyrate toothed; upper runcinate pinnatifid

11130 Leaves smooth beneath : lower runcinate entire amplexicaul. : upper lanceolate sessile

11131 I eaves vertical prickly at keel acute at end sagittate at base runcinate pinnatifid

11132 Leaves oblong toothed horizontal, their keel prickly, their apex obtuse

11133 Leaves smooth beneath obl. lanc. ciliate-toothed sagittate at base

11134 Leaves smooth beneath : lower oblong narrowed at base toothletted; upper lanceolate entire

11135 Leaves with a prickly keel : radical lanc. pinnatifid; cauline linear entire sagittate

11136 Leaves laciniate ensiform sessile unequally toothed

11137 Leaves toothletted smooth : lower sinuated; upper lanceolate sagittate acuminate, Pan. much branched

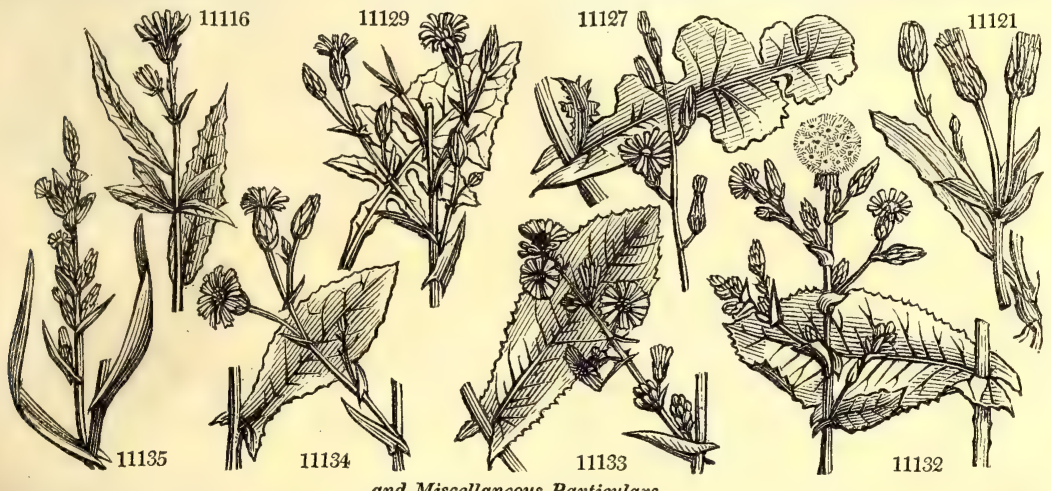

and Miscellaneous Particulars.

shoots of the smooth variety, boiled in the manner of spinach, are superior to any greens not in common use.

Nearly the same thing may be affirmed of S. arvensis, palustris, and other species.

Sonchus floridanus is used as a cure for the bite of the rattle-snake, in the same way as Prenanthes serpen-

taria. It is called by the American settlers Gall of the Earth.

$\mathrm{S}$. tenerrimus is eaten by the common people in Italy as a salad.

1628. Lactuca. From lac, milk, on account of the milky sap, which flows copiously when the plants are cut. Besides Lactuca sativa, the French cultivate as small salad both L. quercina, palmata, and intybacea, which are all excellently adapted for such a purpose. L. sativa is well known as furnishing among its numerous varieties the best vegetable of the salad kind grown in the open garden. Whoever has the command of lettuce, onions, and cucumbers, may well dispense with most other acetarious plants. It is questioned by some, whether the greater number of what are set down as species in this genus, are any thing more than variations of one type ; and, at all events, it is thought L. virosa, a poisonous plant, is the parent of our cultivated sorts ; which would not be more remarkable than the fact that the indigenous celery is one of our strongest poisons.

All the species of Lactuca abound in a milky juice, which is found to partake, in a considerable degree, of the qualities of opium. The production of this juice is lessened by culture, and especially by blanching. It is most abundant in plants in a wild state, and in both wild and cultivated lettuce during inflorescence. Of late years, this juice has been collected by incisions and scraping off the thickened juice, as in the collecting the opium of the poppy (See p. 461.), and an opium has been produced little inferior to that of the East. It is called 
11138 viminea Link. 11139 segusiána Balbis. 11140 sonchifólia $W$. 11141 tenérrima $W$. 11142 perénnis $W$. rushy-twigged \$ $\bigcirc$ un 1 jl.au Italian $O$ pr $\frac{1}{2}$ jl.au Sow-thistle-lvd. $\searrow \Delta$ un 2 jl.au purple-flowered $\$$ un $\frac{3}{4}$ jl.au $\frac{1}{2} \Delta$ un $a^{\frac{3}{4}}$ jl.au
Y Austria 1789. S co Pu Piedmont 1822. S co $\begin{array}{lll}\text { Pa.B Candia 1822. } & \text { D co } \\ \text { Pu S. Europe 1815. } & \text { D co }\end{array}$ Pu S. Europe 1815. D co Jac. aust. 1. t. 9

Bot. mag. 2130

1629. CHONDRILLA. $W$. Gun-Succory. Composita. Sp. 2-5.

11143 júncea $W$. common $\quad \forall \Delta$ un $1 \frac{1}{2}$ s.o $\quad \underset{Y}{\mathbf{Y}}$ France 1633. D co Jac. aust. $5 . t .427$

1630. PRENAN'THES, $W$. PRENANTHES.

11145 purpúrea $W$.

11146 álba $W$.

11147 altíssima $W$.

11148 cordáta $P h$.

11149 spinósa $W$.

11150 murális $W$.

11151 pinnáta $L$.

11152 arbórea Brouss.

11153 hieracifólia $W$

Crepis púlchra $\mathbf{L}$

1631. LEON'TODON. $W$. DANDELION.

11154 Taráxacum $W$.

11155 serótinus $W$.

11156 palustris $E$. $B$. lividus W.

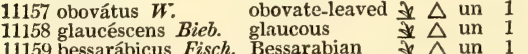

\section{APAR'GiA. $\boldsymbol{W}$. APARgIA}

11160 aurantíaca $W$.

11161 alpína $W$.

11162 hastílis $W$.

11163 dúbia $W$.

11164 tuberósa $W$.

11165 incána $W$.

11166 Taráxaci. $W$

11167 autumnális $W$

11168 críspa $W$

11169 híspida $W$

11170 áspera $W$.

11171 crócea $W$.

11172 caucásica Bieb.

11173 Villársi $W$. rough hairy un $\frac{7}{1} \mathrm{jn}$.j

\section{Composite. Sp. 9-13.}

purple-flowered $₫$ or 4 jl.s $\quad$ Pu Germany 1658. D co Jac. aust. 4. t.317 white-flowered $\vec{z} \Delta$ or 2 jl.au W N. Amer. 1762. D p.l Bot. mag. 1079 tall $\frac{\partial}{\Delta}$ or 6 jl.au L.Y N. Amer. 1696. D p.l Plu.alm.t.317.f.2 heart-leaved $\frac{1}{\mathrm{t}} \Delta$ or 4 jl.au Pa.Y N. Amer. 1816. D co prickly $\forall \Delta w \quad 2 j l \quad Y \quad$ Britain woods. D co

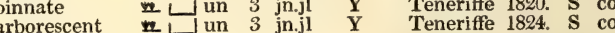
small-flowered $\mathrm{O}$ un $1 \frac{1}{2}$ jn.s $\quad \mathrm{Y}$ Scotland sc.roc. S co

Park.the.804, f.7

Eng. bot. 457

Eng. bot. 2325

common $\$ \Delta \quad w \quad 1$ ap.jl $\quad Y \quad$ Britain me.pa. D co Eng. bot. 510

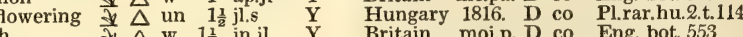

obovate-leaved $\neq \Delta$ un 1 jl $\quad$ Y Spain 1805. D co

Eng. bot. 553 Bessarabia1821. D co

Orange-colored $\downarrow \Delta$ pr $\frac{1}{2}$ my.jn Or Hungary 1816. D co Alpine $\frac{1}{2}$ my.jn Y Austria 1816. D co shining-leaved $\frac{\nabla}{\Delta} \Delta$ un 1 jlau $\quad$ Y $\quad$ S. Europe 1796. D co tooth-leaved $\$ \Delta$ un 1 au $\quad \mathbf{Y}$ Germany ... knotty-rooted $\frac{s}{\star} \Delta$ un 1 my.jl $\quad \mathbf{Y}$ France 1638 . D co hoary $\downarrow \Delta$ un 1. my.jn $Y$ S. Europe 1784. D co Dandelion-lvd. $\Delta \mathrm{w} \quad 1$ au $\mathbf{Y}$ Britain sc.alps. D co autumnal $\quad \Delta$ w 1 au $Y$ Britain me pa $\mathrm{D}$ co $\$ \Delta$ u 1 a \& $\triangle$ un $\frac{1}{2}$ jl.au $Y$ France 1303. D co Y Britain ch.pas. D co Hungary 1805. D co deep-yellow $\frac{\partial}{\Delta}$ un 1 jn.jl Or Hungary 1823. D co Dauphiny $\frac{\$}{\Delta}$ un 1 jn.jl Y Dauphiny 1821. D co

Bot. cab. 539

Jac. aust. 2. t. 164

Lob. ic. 232. f. 1 Jac. aust. 3. t. 28 Eng. bot. 1109

Vildauph 3 t 25

Eng. bot. 554

Pl.rar.hu.2.t. 110

Vill.delph.3. t.25

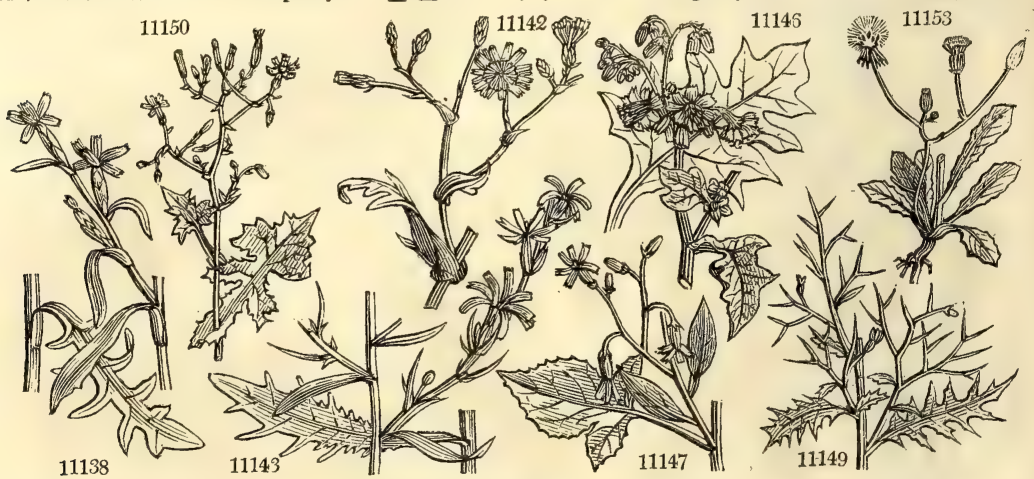

History, Use, Propagation, Culture,

Lactucarium, and was first brought into notice by Dr. Duncan, of Edinburgh, who finds it can be administered with effect in cases were poppy opium is inadmissible. Details of the process of collecting and preparing the article, will be found in the Caledonian Horticultural Memoirs. (Vol, i. 160-259. ii. 314. and iv. 153.)

The culture of lettuce as a salad plant is familiar to every one who has a garden. It is sown monthly, or oftener, throughout the year, in order to have a successional supply, and thinned out or transplanted to increase the size and succulency. The latter quality is greatly increased by watering in summer; and blanching, another desirable property, is promoted by tying up the leaves when the plant has attained about two-thirds of its usual size. Snails and slugs are very fond of this plant, and should either be watched and hand-picked, or the ground well watered with lime water, which effectually destroys them. The lettuce, unlike the cabbage and spinage, is a vegetable which can be grown to as great perfection in a warm as in a temperate climate, provided it be grown on rich soil, and abundantly supplied with water. Hence the lettuces of Paris, Rome, and Calcutta, are as large and tender as those of London and Amsterdam.

This genus is the type of the tribe Lactucea of M. Cassini. It differs essentially from all other tribes of Composita, in having a divided or ligulate corolla only, and from nearly all other tribes in its style, which can be compared to that of Vernoniex only. The radiant head of flowers is a character common both to Lactuceæ and Nassauvieæ. The greater part of Lactuceæ are found in Europe, a smaller number in Asia and Africa, very few in America, and in the southern hemisphere none at all.

1629. Chondrilla. Derived from xov gummy matter. But Theophrastus speaks of the grumous or tubercled roots of his Chondrilla. The plant now so called is an inconspicuous perennial plant, of no recordeci use.

1630. Prenanthes. From $\pi_{9}$. $y$ ys, drooping, and ex.tos, a flower. The heads of flowers of all the species are 
11138 Leaves decurrent : lower pinnatifid toothed outwards ; upper linear, Stem branched 1139 Lower leaves lanc: runcinate toothed narrowed at base and sessile : upper linear sagittate 1139 Leaves runcinate pinnatifid unequally toothed : floral lanceolate, Flowers racemose 11140 Leaves runcinate pinnatifid unequally toothed : floral lanceolate, Flowers racemose 11142 Leaves all pinnatifid: segments linear toothed upwards, Fl, in corymbose panicles

$111+3$ Radic. leaves runcinate : cauline linear entire

11144 Radic. leaves runcinate: cauline undivided filiform, Stem and invol. smooth

11145 Invol. 5-fl. Leaves obl. lanc. amplexicaul. cordate denticulate glaucous beneath 11146 Invol. many-fl. Leaves angular hastate toothed, Flowers nodding racemose panicled 11147 Invol. 5-f. Leaves 3-lobed stalked angular toothletted rough at edge, Racemes axillary, Fl. nodding 11148 Stem panicled upwards, Leaves stalked cordate toothed ciliated, Panicle lax racemose 11149 Leaves linear tooth-sinuated sessile, Stem shrubby much branched, Branches spiny 11150 Florets 5, Leaves lyrate-pinnatifid and toothed, the terminal lobe with about 5 angles 11151 Leaves pinnated, Leafl. linear filiform, Panicle corymbose stalked, Stem shrubby 11152 Leaves pinnatifid pinnate with linear segments

11153 Leaves pubesc. toothed, those on the stem subsaggitate, Stem panicled corymb. Invol. pyramidal glaibrous

11154 Outer scales of the involucre reflexed, Leaves runcinate glabrous toothed 11155 Outer invol, spreading, Leaves runcinate scabrous, Segments round toothletted 11156 Outer scales of the involucre erect appressed, Leaves sinuato-dentate nearly glabrous

11157 Outer invol, spreading, Scales ovate, Scape 1-fl. Leaves obov. bluntish toothed 11158 Outer invol. spreading, Scales ovate-lanceol. Lvs. runcinate pinnatifid glabrous with lin. falc. distant lobes 11159 Leaves pinnatifid to the nerve smooth, Leaves of invol. smooth reflexed

11160 Scape 1-fl. naked thickened and hairy upwards, Invol. hispid, Leaves lanc. obl. somewhat toothed 11161 Scape 1-f. squarrose thickened and somewhat hairy upwards, Invol. hispid, Leaves lanc. obl. smoothish 11162 Scape 1-fi. naked and invol. smooth, Leaves lanc. runcinate-toothed smooth

11163 Scape 1-f. nearly naked upward and invol. hairy, Leaves lanc. toothed at base with a few forked hairs 11164. Scape 1-fl. naked smooth. Scales of invol, acute hairy, Lvs, obov. runcin. hairy scabrous, Root tuberous 11165 Scape 1-fl. nearly naked and calyx pubesc. Lvs. lanceol. acute somewhat toothed hoary, Hairs multifid 11166 Scape single-flow, thickened upwards, Leaves glab, runcinato-dentate, Involucre very hairy

11167 Scape branched scaly upwards, Lvs, lanc. toothed or pinnatif. sub-glab. Pedunc. swelling beneath invol. 11168 Scape naked 1-f. and invol, hairy, Lvs. runcinate pinnatifid hairy, Segm. recurved tooth. Hairs 3-forked 11169 Scape single-flowered, Leaves dentate scabrous, Florets hairy at their orifice glandular at the tip 11170 Stem leafy somewhat branched hairy, Invol. smooth, Leaves lanc. runcinate hairy, Hairs forked 11171 Scape 1-fl. scaly thickened upwards and hairy, Invol. hispid, Leaves runcinate smooth

11172 Scape naked 1-fl. glabrous, Invol. hairy, Leaves runcinate toothed scab. somewhat hairy. Hairs prostrate 11173 Scape naked 1-fl. and invol. smoothish, Leaves pinnatifid-toothed hispid, Hairs simple subulate

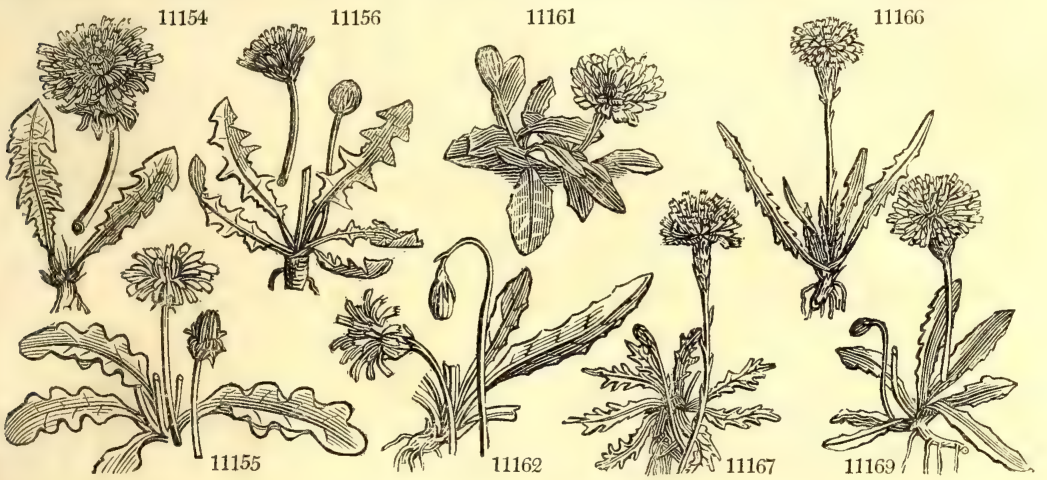

and Miscellaneous Particulars.

nodding. Prenanthes serpentaria grows to the height of two feet, bearing pale purple flowers. It is known by the inhabitants of Virginia and Carolina under the name of the Lion's Foot, and is in high esteem as a cure for the bite of the rattle-snake. The juice of the plant boiled in milk is taken inwardly, and steeped leaves, frequently changed, are applied to the wound. It must not be confounded with Prenanthes rubicunda, called False Lion's Foot, which is a less powerful plant

Prenanthes virgata has a very fine effect in large plantations.

1631. Leontodon. So named from $\lambda \epsilon \omega \nu$, a lion, and $0 \delta 85$, a tooth ; in reference to the deep tooth-like divisions of the leaves. The English name Dandelion, is a corruption of the French translation of this word, Dent de lion; in German Pfaffenröhrlein and Dotterbluhme. It has been recommended as a winter salad, blanched like Endive; but it possesses too much bitter principle to render it fit for table under any management. Dent de lion, Fr., from its cut leaves, and Piss-en-lit, in French, and most other European languages, from its diuretic qualities. The tender leaves in spring, used in compound salads, are equal to those of Endive or diuretic qualities. The tender leaves in spring, used in compound salads, are equal to those of Endive or
succory. The roots, which are fusiform, and abound in a milky juice, are eaten raw as a salad by the French, and boiled by the Germans, like Salsafy and Scorzonera. Dried and ground into powder, they afford a substitute for coffee, in all respects equal to that of Chicory roots. It is a difficult weed to extirpate, because every inch of root will form buds and fibres, and thus constitute a new plant. Swine are fond of it, and goats will eat it ; but sheep and cows dislike it, and by horses it is refused.

1632. Apargia. Aтcerice is the Greek name of a plant now unknown. It has been employed by Dalechamp and Scopoli for a species of Hieracium. At the present day it is given to a genus of weedy plants, with the appearance of I,contodon. 
1633. THRIN'CIA. $W$. THRINCIA.

11174 hírta $W$.

11175 híspida $W$ Hyóseris hispida $\mathrm{w}$.

1634. PI'CRIS. $W$.

11177 hieracioídes $W$.

11178 asplenioídes $W$

11179 hispida $H . K$.

11180 sprengeriána $\boldsymbol{P} . S$.

Ox-ToNGuE.
Hawkweed-like

hispid $\$ \Delta$ un $1 \frac{2}{1}$ jl.au

1635. HIER A'CIUM. $W$. HAWKWEED.

11189 alpinum $\mathrm{Al}$.

11183 alpéstre Jacq.

11185 bulbósum $W$.

11186 aúreum $W$.

rock

Alpine

mountain

bulbous

golden

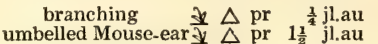

11187 dábium $L$.

11188 aurícula $\boldsymbol{L}$.

11189 fállax $W$. en.

11190 florentinum hairy spear-lvd. $2 \mathrm{\Delta}$ pr 1 jl.au

11191 cymósum $L$

Florentine $\frac{7}{2} \Delta \mathrm{pr} \quad 2$ jl.au

small-flowered d $\Delta$ pr 1 my.jn $Y$

11192 angustifólium Hoppe. narrow-leaved $\frac{1}{\Delta} \mathrm{pr} \quad \frac{2}{4} \mathrm{my} . \mathrm{jn} \quad \mathrm{Y}$

11193 staticifólium All. Thrift-leaved $\frac{\text { de }}{\Delta} \mathrm{pr} \quad 1 \frac{1}{2} \mathrm{jn.jl}$

11194 flagelláre $W$. en.

11196 bifidum $W$.

11197 Gmelini $W$.

creeping

forked

bifid

11198 præmorsum $L$.

Gmelin's

11201 Lawsóni Vill.

11203 Gronóvii $W$.

flesh-colored

orange

Lawson'

veined

Gronovius's

* $\Delta$ pr 1 my.jl

表 $\triangle \mathrm{pr} \quad 1 \frac{1}{2} \mathrm{jn}$

竞 $\triangle \mathrm{pr} 1 \frac{1}{2} \mathrm{jn}$

d $\Delta \mathrm{pr} \quad 1 \frac{1}{2} \mathrm{jn} . \mathrm{jl}$

7 $\triangle$ pr 1 jn.jl

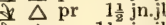

* $\Delta$ or $1 \frac{1}{2} \mathrm{jn} . \mathrm{j}$

\ $\triangle$ pr $\frac{1}{4} \mathrm{jn} . \mathrm{j}$

$\frac{7}{\Delta} \Delta$ pr $\quad \frac{1}{2} \quad$ jn.jl hispid

Spleenwort-lvd. $¥ \Delta$ un $1 \frac{1}{2}$ jl.au

11184 Pilosélla $L$.

11195 bifur'cum Bieb.

11200 aurantíacum $L$.

11202 venósum $W$

Composite. Sp. 3-6.

Britain gra.pa. D co Eng. bot. 555

S. Europe 1815. S co

Moroceo 1799 . S co

sp. 4-7.

England bor.fi. S co Eng. bot. 196

Barbary 1805. D co L'Her stirp. t.89

Levant 1789. D co

Portugal 1783. S co Moris.s.7.t.5.f.15

Sp. 75-117.

Switzerl. 1820. D co All.auct.1.t.1.f.1

Britain al. roc. D co Eng. bot. 1110

Switzerl. 1822. D co Jacq.austr.t.191

Britain dry pa. D co Eng. bot. 1093

Barbary … D co

Jac. aust.3. t.297

Britain hills. D co Eng. bot. 2332

England moun. D co Eng. bot. 2368

...... 1816. D co

Germany 1796. D co Bauh. pin t. 67

Europe 1739. D co Col.ecph.1.t.243

Switzerl. 1823. D co

Europe 1804. D co Vil.dauph.3.t.27

...... 1816. D co

Tauria 1820. D co

Hungary $\ldots .$. D co

Siberia 1798, D co Gmesib.2.t. 8. 2

Pa.Y Switzerl. 818 , D co Gm.sib.2.t.13.f.

Pk Carniola 1815. D co Jac. ic. t. 578

$\begin{array}{llll}\text { Pk Carmiola } & 1815 . & \text { D co Jac. ic. t. } 578 \\ \text { O Scotland sc.wo. D p.l Eng. bot. } 1469\end{array}$

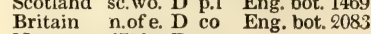

N. Amer. 1790. D co

N. Amer. 1798. D co

Canada '1800. D co

S. Europe 1807. D co

Austria 1801. D co

Switzerl. 1820. D co

Austria 1640. D co

France 1816. D co

Scotland sc.wo. D co

Scotland sc.roc. D co

Pyrenees 1739. D co

Pyrenees 1723. D co

Pyrenees 1723. D co

Pyrenees 1723. D co

Siberia 1755. D co

Switzerl. 1791. D co

a.Y Europe 1794. D co

Europe 1802. D co

Britain al roc $\mathrm{D}$ co

Scotland sc.roc. D co

Austria 1640. D co

S. Europe 1775. D co

Brita... ... D co

Scotland al.roc. D co

Europe 1820. D co

Europe 1820. D co

Hungary 1804. D co

Jac. ic. 1. t. 163

Jac. aust.5. t. 429

Eng. bot. 2210

Eng. bot. 2378

Ali. ped. t.15. f. 1

Her.parad. t.18*

Jac. aust.5. t.44.1

Gmel. sib. 2.t.10

Pl. rar. hu.1.t.99

Jac.aus.5.t.ap.4.

Vil.dauph.3.t.26

Eng. bot. 2121

Jac. aust.3. t. 28

Jac. aust.2. t.190

Eng. bot. 2031

Eng. bot. 2379

11224 villósum $L$. shaggy Alpine $\$ \Delta$ pr 1 jl.au

11226 trichocéphalumW.en. shaggy $\frac{ \pm}{\Delta} \Delta \mathrm{pr} \quad 1$ jl.au

11227 flexuósum $W$. bending-stalk'd $\frac{\not y}{\Delta} \Delta \mathrm{pr}$ pr $1 \frac{1}{2}$ jl.au

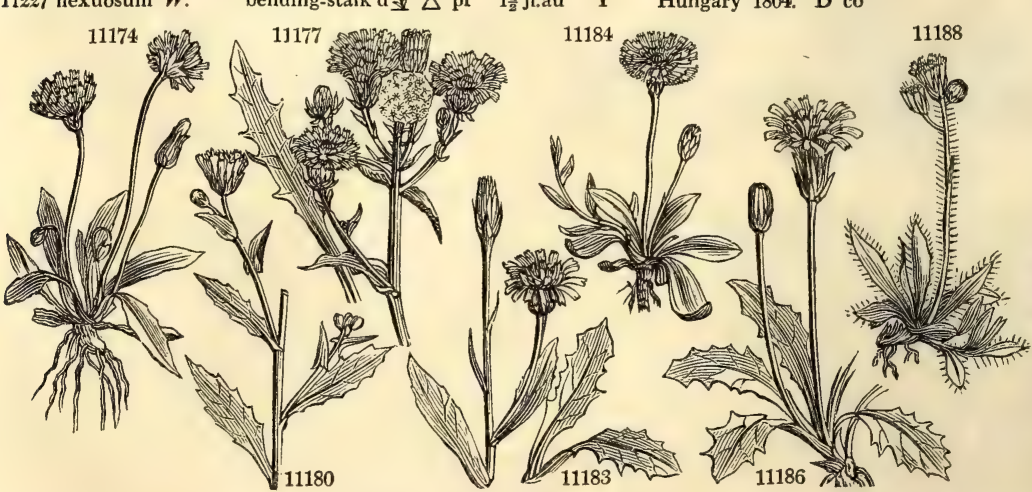

History, Use, Propagation, Culture

1633. Thrincia. From Teryzos, a feather; in allusion to the feathery pappus of the seeds. Small uninteresting weeds of no value or beauty.

1634. Picris. From $\pi$ izgos, bitter; a name given by the Greeks to some plant resembling Lettuce, on account of its bitterness. None of the species are remarkable for their qualities. 
11174. Scape single-fl. Leaves dentate scab. Involucre nearly glab. Outer pericarps with a scaly pappus 11175 Scape 1-f. pilose, Invol. hoary naked, Leaves lanc. blunt toothed, Hairs forked 11176 Scape 1-f. hispid, Ieaves obl. runcinate toothed hispid, Hairs forked

11177 Stem erect scabrous, Leaves amplexicaul. Ianc. toothed, Fl. corymbose, Outer invol. lax 11178 Stem ascending scabrous, Leaves obl. lanc. blunt sinuate pinnatifid, Pedunc. thickened 11179 Leaves obl. lanc. nearly entire sessile, and invol. hispid, Hairs glochidate 11180 Stem branched spreading leafy, Leaves amplexicaul. obl. repand hispid

11181 Scape 1-leaved, Invol, hairy, Leaves lanc. runcinate toothed subpubescent, Teeth recurved 11182 Scape somewhat naked villous, Invol. very villous, Leaves lanc. entire acute villous 11183 Scape 1-leaved downy upwards, Invol. cylindr. downy, Leaves lanc. toothletted

11184 Leaves entire ovate downy beneath, Stolones creepirg

11185 Scape naked thickened upwards hairy, Invol. smooth, Leaves lanc. obl. somewhat toothed smooth 11186 Scape nearly naked, Invol. hispid, Leaves lanc. spatulate runcinate-toothed smoothish \$2. Scape many-flowered, naked.

11187 Scape about 4-fl. naked, Leaves obl blunt entire, Stolones creeping

11188 Scape 1-leaved with about 6 fl. Fl. umb. Leaves lanc. acute entire, Stolones creeping

11189 Scape leafy pilose at base, Fl. corymbose, Peduncles downy, Leaves lanc. acute nearly entire pilose 11190 Scape leafy smoothish, Fl. in corymbose panicles, Pedunc. spreading, Invol. hairy

11191 Scape leafy hispid, Fl. in corymbose panicles, Pedunc. clustered, Invol. hispid

11192 Scape about 3-fl. 1-leaved hairy, Leaves lin. lanc, acute pilose

11193 Scape somewhat naked branched about 3-f. Pedunc. squarrose, Leaves lin. lanc, toothletted smooth

11194 Scape about 2-fl. Peduncles long, Leaves spatulate lanc. entire pilose, Stolones creeping

11195 Scape forked about 2-fl. and leafy at base, Leaves lanc. acute entire, Stolones $\mathbf{O}$

11196 Resembles $H$. murorum, but the stem is naked

11197 Scape naked corymbose, Leaves lyrate runcinate hairy

11198 Leaves ovate somewhat toothed, Scape naked racemose, Upper flowers opening first

11199 Scape naked scabrous at base, Fl. in racemose corymbs, Leaves oblong blunt toothletted hairy

11200 Scape leafy hispid, Fl. corymbose, Pedunc. clustered, Leaves obl. acutish pilose-hispid

11201 Scape somewhat naked branched, Invol. with glandular hairs, Leaves oblong acute entire woolly

11202 Scape naked branched, Invol. smooth, Leaves obovate acute entire ciliated, Veins colored

11203 Scape leafy in corymbose panicles, Invol. pubescent, Radic. leaves entire obovate blunt ciliated

\section{Stem leafy.}

11204 Stem erect, Leaves alternate lanc. naked toothed, Panicle capillary

11205 Stem erect branched, Leaves lanc. sessile somewhat toothed laucous narrowed at each end 11206 Stem erect branched, Leaves lin. lanc. nearly entire narrowed at each end ciliated at base 11207 Stem erect simple, Leaves lanc. cordate amplexicaul. toothletted downy, Fl. racemose corymbose 11208 Stem erect few-fl. Cauline leaves lanc. acum. runcinate : radical obl. lanc. undivided

11209 Stem erect pilose panicled, Leaves ovate oblong subcordate sessile remotely toothed entire at end 11210 Stem erect hairy, Fl. subcorymbose, Cauline leaves oblong lanceolate stem-clasping: radical toothed

11211 Stem erect villous, Lvs. pilose somewhat toothed : radic. obov.; caul. obl. half-amplexicaul, Inv. hirsute 11212 Stem erect branched, Lvs. ovate cord. amplexicaul. toothed towards the base, Pedunc. and invol. hirsute 11213 Stem erect simple furrowed smoothish, Rad. lvs. obl. deeply toothed at base; caul. hastate sagit. Inv. lax

11214 Stem erect panicled furrowed downy, Leaves rugose : upper lanceol. Invol. lax hispid

11215 Stem ascending simple furrowed viscid, Leaves lanc. with recurved teeth, Involucre hispid

11216 Stem erect branched hispid, Leaves lanc. toothed sessile narrowed at each end, Invol. lax hispid 11217 Stem erect about 2 -f. Leaves pllose toothed: radical oblong; cauline lanc. sessile, Invol. villous 11218 Stem cymose fistulous many-leaved, Leaves ovate-lanceolate toothed forwards

11219 Stem cymose solid few-leaved, Leaves lanceolate broadly toothed forwards

11220 Stem erect branched leafy, Leaves linear entire

11221 Stem erect simple leafy 1-fl. Leaves ovate-lanc. toothletted sessile

11222 Radic, leaves oblong and lanceolate bluntish narrowed at base toothletted woolly, Invol. hoary

11223 Stem leafy erect simple, Leaves oblong villous somewhat toothed, Fl. panicled

11224 Stem erect somewhat branched and lvs. villous : radic. obl. lanc. toothed; caul. ovate cord. amplexicaul 11225 Differs from H. villosum in having the involucrum covered with dense short brown hairs

11226 Radical lvs. lanc, narrowed into stalk: caul, sub-amplexic. toothed backwards acute smooth, Inv, villous

11227 Stem erect smooth below, Leaves sub-villous lanc. acute: racical toothletted, Invol. villous

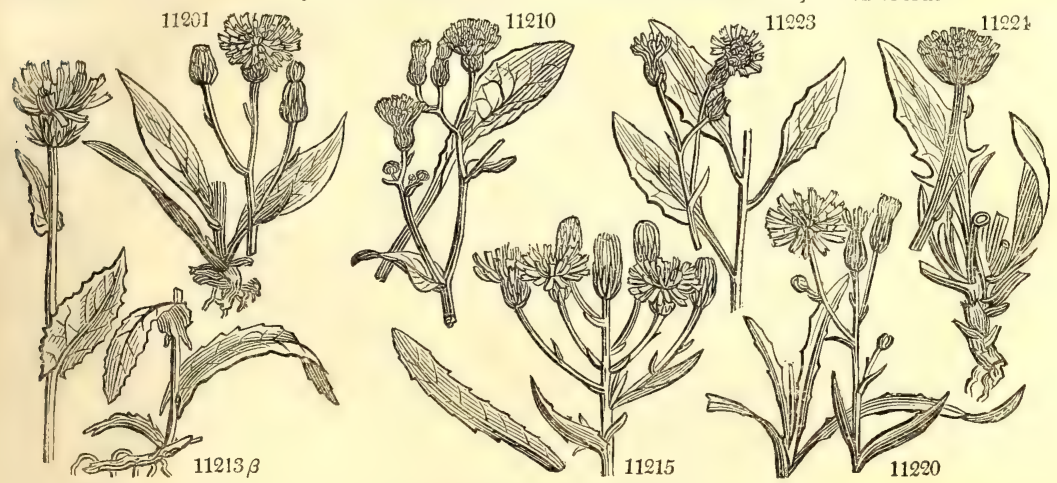

and Miscellaneous Particulars.

1635. Hieracium. It was believed formerly, that birds of prey made use of the juice of this kind of plant to strengthen their vision; whence it was called Hieracium, from isea z, a hawk; the French word Eperviére, to strengthen their vision; whence it was called Hieracium, from isga , a hawk; the French word Eperviere,
the English Hawk-weed. and the German Habichtskraut, all bear witness to the universal belief in this very strange opinion. An extensive genus of plants, many of which, especially $H$. aurantiacum, are objects 
11228 prostrátum W.en. s. prostrate

11099 .

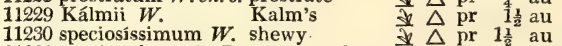
11231 denticulatum $E, B$. small-toothed $\frac{\$}{\ddagger} \Delta$ pr $1 \frac{1}{2}$ au 11232 Milléri Link. Miller's $\quad$ \& $\triangle$ pr 1 jl.au 11233 echioídes $W$ Viper's-bugloss $\frac{\Delta}{7}$ pr 3 jlau 11234 verruculátum Link, warted 11235 undulátum $H . K$. wave-leaved $\frac{ \pm}{\Delta}$ pr 1 jl.au

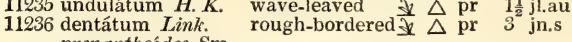
prenanthoides Sm.

11237 latifólium Link. broad-leaved \& $\triangle$ pr 2 jl.au 11238 foliosum $W . \& K$. leafy $\quad$ v $\triangle$ el 2 jl.au 11239 sabaúdum $W$. Savoy 11240 saviótum $\dot{W}$ Savoy

11240 læátum $W . \quad$ smooth $\triangle \Delta$ el 2 aus

11241 canéscens Link. hoary $\frac{1}{\Delta} \Delta$ el 2 au.s

11242 umbellátum $L$. narrow-leaved $\frac{1}{\Delta} \Delta$ el 3 jl.s

11243 bracteolátum Link. bracteolate $\frac{\neq}{} \Delta$ el $1 \frac{1}{2}$ jl.s

11244 longifólium Hornem. long-leaved $\frac{ \pm}{ \pm} \Delta$ el $1 \frac{1}{2} \mathrm{jl} . \mathrm{s}$

11245 fruticósum $W$. shrubby el 2 jn.jl

11246 húmile $W$. - small $\$ \Delta$ pr $\frac{1}{4}$ jl.au

11247 nigréscens $W$. dark-colored $\frac{\$}{\Delta} \Delta$ pr ${ }^{\frac{1}{4}}$ jl.au

11248 prunellifólium Gouan. Self-heal-leav. 文 $\Delta$ pr ${ }^{\frac{1}{3}}$ jl.au

$\begin{array}{ll}11249 \text { murórum } L . & \text { wall } \\ 11250 \text { paludósum } L . & \text { Succory-leaved } \frac{\Delta}{\Delta} \Delta \text { pr } 1 \frac{1}{2} \text { jl } \\ 1 \frac{1}{2} \text { jl.au }\end{array}$

11251 lapsanoídes $W$. Lapsana-like $\frac{1}{\Delta} \Delta$ pr $1 \frac{1}{2}$ jl.au

11252 ramósum $W . \& K$. branching $\ \triangle$ pr 2 au

11253 lyrátum $W$. Lyre-leaved \&\& $\triangle$ pr 2 jl.au

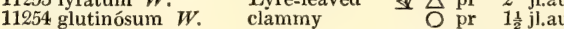

11255 fasciculátum $\dot{P}_{s h}$. bundled $\quad$ \& $\triangle$ pr 5 jl.au

1636. LAGO'SERIS, Link. LAGOSERIS.

Composita. Sp. $6-10$.

11256 bursifólia Link. Shepherd's-purse-lv. $\& \Delta$ un 2 jl.au $Y$ Sicily Crepis bursifolia $\mathbf{L}$.

11257 versicolor Fischer, changeable \& $\triangle$ un 2 jl.au

11258 leontodóntoídes Link. Dandelion-like $\frac{1}{2}$ () un 1 jl.au

11259 raphanifólia Link. Radish-leaved $\$ \Delta \Delta$ un 2 jn.jl

11260 taurinénsis Link. Turin $\mathrm{O}$ un 2 jn.jl

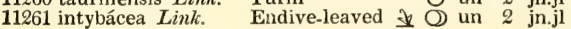

$\begin{array}{lllll}\mathbf{Y} & \text { Dauria } & 1820 . & \text { D co } \\ \mathbf{Y} & \text { Italy } & 1804 . & \text { S co } \\ \mathbf{Y} & \ldots . . . & 1816 . & \text { D co } \\ \mathbf{Y} & \text { Italy } & 1822 . & \text { S } \text { co } \\ \mathbf{Y} & \text { Portugal } & 1816 . & \text { S co }\end{array}$

1637. BORKHAU'SIA. Dec. Borkhausia.

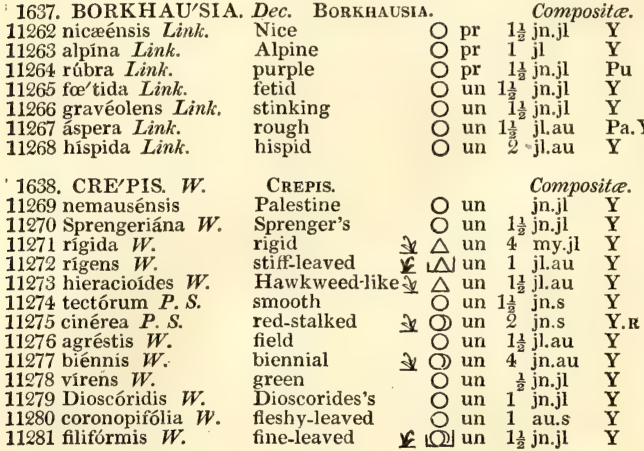

Portugal 1816. S co

S. Europe 1822, D co

Pensylva. 1794. D co

S. Europe 1821. D co

cotland sc.wo. D co

Hungary 1802. D co

Spain... 1821. D co

Scotland sc.wo. D co

Croatia 1820. D co

Hungary 1805. D co

Britain groves. D co

..... 1804. D co

Britain woods. D co

Europe 1823. D co

Ma.... 1821. D co

Germany 1804. D co Vill.delph.3.t.28

...... 1801. D co W. hort. ber. 10

Goua.ill. t.22.f.3

Pyrenees 1812. D co Goud.ill.t.21.f.3

Hungary 1805. D co

Siberia 1777. D co

S. Europe 1796. S co

$\begin{array}{ccc}\text { Sanada } & \text {... } & \text { D }\end{array}$

Gmel, sib. 2, t. 9

Sp. $7-9$.

Nice 1823. S co

Italy I632. S co

S. Europe 1824. S co

Gmel. sib. 2. t. 5

M. his. s.7.t.4.f.4

1797. S co

Pl. rar. hu.1.t.43

Sp. 13-23.

S. Europe 1794. S co All.ped.1.t.75.f.1

Italy 1823. S co M.his.s.7.t.5.f.17

Hugnary 1805. D co Pl, rar.hu.1.t.19

Azores 1778. D co

Hungary 1816. D co Pl. rar. hu.1.t.70

Britain past. S co Eng. bot. 1111

Europe ... S co

Hungary 1801 . S co

England ch.pa. S co Eng. bot. 149

Switzerl. 1796. S co

France 1772. S co Sch.han 3, t.220

Madeira 1777. S co Des, ac. pa.38.t.9 Madeira 1777. S co

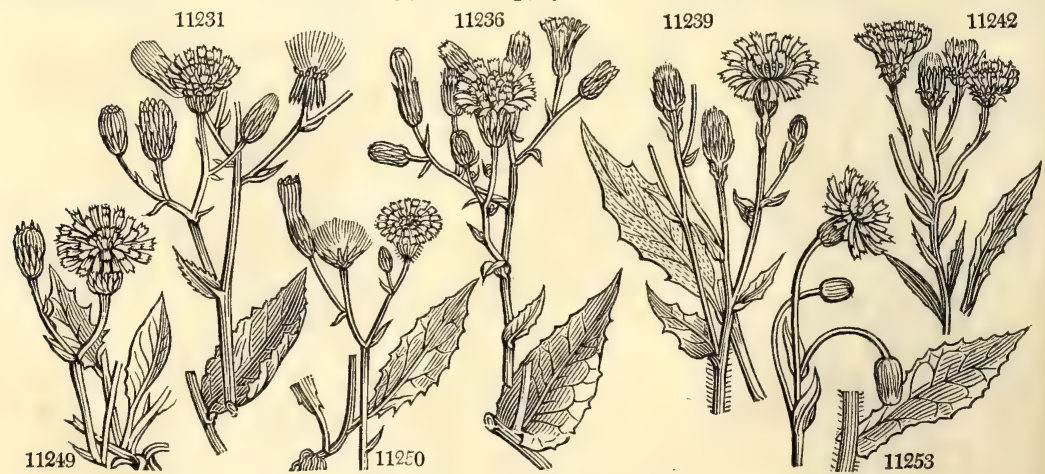

History, Use, Propagation, Culture,

deserving cultivation; others are of little interest; but all most difficult to distinguish or characterize. The species appear to intermix with the same facility as roses and willows.

Hieracium venosum, a very pretty plant, is called in America, Poor Robin's Plantain, and is believed to possess considerable medical powers.

1636. Lagoseris. From $\lambda \alpha$ yos, a hare, and $\sigma \varepsilon \rho s$, a lettuce. Obscure wced-like plants. 
11228 Near H. villosum, but the leaves are broader

11229 Stem erect many-fl. Leaves lanc. toothed, Peduncles downy

11230 Stem at base and lvs. here and there covered with hairs, Fls. smaller and inv. less vill. than in $H$. villosum 11231 Stem erect many-H. Leaves sessile ellipt. lanc. toothletted smoothish glaucous beneath

11232 Radic. Ivs. obl. narrowed at base acute : caul. sub-amplexic. lanc. Pedunc. glandular, Inv. glandul. hairy 11233 Stem erect strigose hispid, Leaves lanceolate nearly entire strigose hispid, Flowers corymbose

11234 Stem pilose warted glandular upwards, Leaves sub-amplexicaul, oblong acute with long hairs beneath

11235 Stem erect branched hoary, Leaves obov. obl. hoary toothed towards the base, Hairs feathery

11236 Stem erect many-f. Leaves amplexicaul, somewhat rough toothed at edge, Pedunc. downy

11237 Stem densely leafy, Leaves amplexicaul. 3 inches long $1 \frac{1}{3}$ inch wide toothed hairy

11238 Stem erect simple, Leaves ovate cordate amplexicaul, toothletted ciliated, Fl, panicled, Invol. smooth

11239 Stem erect simple, Lvs, ovate-obl, smoothish acute sess. sub-amplexic, toothed towards base, Fls, corymbose

11240 Stem erect branched, Leaves obl. lanc. smooth stalked deeply toothed in the middle, Fl. panicled

11241 Leaves narrowed at base sessile with long points toothed, Invol. downy hoary

11242 Stem erect simple, Leaves linear somewhat toothed, Fl. in corymbose umbels

11243 Leaves broader than in the last and less toothed, Stem few-flowered

11244 Leaves mostly radical with long points toothletted hairy, Invol. hoary with long white and black hairs

11245 Stem branched shrubby, Leaves oblong toothed stalked, Peduncles sub-corymbose, Invol. downy

\section{B. Leaves sublyrate, lyrate, pinnatifid.}

11246 Stem erect few-fl. Peduncles and invol. pilose, Leaves oblong sub-pinnatifid at base

11247 Stem naked few-fl. Pedunc, and invol. glandular downy blackish, Leaves oblong stalked toothed at base 11248 Stem procumb. branch. at base few-fl. Ped. and invol. downy, Lvs. ovate unequal at base toothletted stalked 11249 Stem erect leafy pilose simple, Fl. panicled, Leaves ovate deeply toothed at base

11250 Stem simple, Leaves smooth obl. narrowed at base runcinate toothed : caul. amplexicaul. Invol. hispid

11251 Stem simple, Cauline leaves lyrate runcinate amplexicaul. hairy, Fl. panicled, Invol. hispid

11252 Stem erect panicled, Leaves ovate stalked deeply toothed at base, Flowers panicled

11253 Stem simple, Leaves smooth : radical runcinate lyrate; cauline lanceolate, Invol. and pedunc. hispid

11254 Leaves lanc. runcinate roughish, Flowers in umbels

11255 Stem erect leafy simple smooth, Leaves sessile obl. acute finely toothed, Pedicels of panic. in bundles

\section{Leaves pinnatifid crenate, Scape naked few-flowered}

11257 Leaves long lanceolate acute repand smooth, Fl. cylindrical, Outer invol, very small

11258 Leaves runcin, toothed smooth, Scape naked many-fl. asceriding, Invol. dowriy : outer scales appressed 11259 Radic. leaves and lower cauline pinnated lyrate, Flowers corymbose, Invol, and pedunc. glandular

11260 Leaves scabrous : radic. lyrate runcinate; cauline lanc. amplexicaul. toothed at base, Invol. downy

11261 Lower lvs. runcin. pinnatifid: upper entire, Branches naked, Invol, downy with leaflets bristly at the back

11262 Leaves runcin. pinnatifid pilose scabrous, Stem panicled, Leaves of invol. keeled channelled downy 11263 Leaves ovate cordate-sagittate amplexic. toothed, Peduncles long 1-fl. Invol. hispid: outer membranous 11264 Radic. leaves runcinate-lyrate : cauline amplexicaul. lanceol.; lower pinnatifid, Invol. hispid

11265 Leaves runcinate pinnatifid scabrous sessile : upper lanceol. deeply cut at base, Invol. ovate angular 11266 Leaves amplexicaul. pinnatifid hairy, Leaves of invol. downy hoary flat

11267 Leaves amplexicaul. : lower obl. toothed; upper cut-toothed, Stem setose hispid, Inv. muricated in fruit 11268 Setose hispid, Leaves runcinate auricled at base : upper lanc, sagitt. hastate, lnvol. very hispid

11269 Leaves runcin. lyrate bluntly toothed, Scape naked many-fl. hispid, Lvs. of invol. membranous at edge 11270 Hispid-scabrous, Leaves oblong amplexicaul. remotely toothed, Stem divaricating branched

11271 Leaves rigid scabrous toothed : radic. obovate; caul. sagittate amplexicaul. Fl. in racemose panicles

11272 Leaves hispid ovate obl. finely and deeply biserrate, Scape naked corymbose

11273 Leaves smooth toothed : radical ovate-spatulate; cauline oblong sessile, Corymb terminal

11274 Lvs. glab. runcin.: the upper ones linear-sagitt. amplexic. Stem glab. Panic. subcorymb. Inv. pubescent 11275 Leaves lanc. : lower entire toothed smooth; cauline lanceolate amplexic. Stem furrowed branched 11276 Radic. leaves lanc. runcinate : cauline lanc. toothed at base sagittate, Panicles corymbose

11277 Leaves hispid runcinate pinnatifid : upper sessile lanc. toothed prickly upon the keel

11278 Leaves smooth : lower remotely toothed; upper nearly entire subsagittate, Invol, downy

11279 Radic. leaves lyrate runcinate : cauline hastate lanceolate, Branches divaricating, Invol. downy

11280 Leaves pinnatifid : segments linear; radical toothed; cauline entire, Stem panicled, Invol. downy

11281 Leaves linear-filiform entire smooth, Pappus sessiie

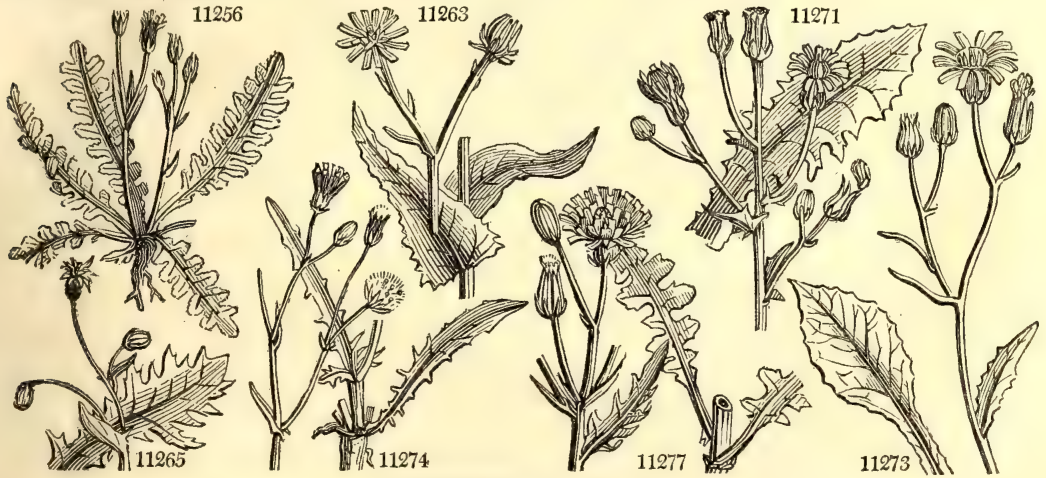

and Miscellancous Particulars.

1637. Borkhausia. Named after Moritz Borkhausen, a German botanist, author of some useful works, especially upon the useful plants of Germany, published in ome volume octavo, in 1790. Small anmual plants, formerly referred to Crepis.

1638. Crepis. A name made use of by Pliny, to designate a plant of which he gives no description. The plants of this genus are common weeds of the hedges of Europe. 
1639. HELMIN'THIA $J$. HELINTHIA 11282 echioides $W$. bristly 1640. MYO'SERIS. Link. MYoseris. 11283 purpúrea Link 1641. TOL'PIS. $W$. ToLPIS 11284 barbáta $W$. purple-eyed 11285 umbelláta Balbis. umbelled 11286 altíssima Pers. tall

1642. ANDRY'Ala. $W$. Andryala. 11287 cheiránthifólia $W$. various-leaved 11288 pinnatífida $W$. 11289 crithmifólia $W$. 11290 nígricans $W$. 11291 ragusína $W$. 11292 lanáta $W$.

1643. ROTHIA. $W$. 11293 andryaloídes $W$. 11294 cheiránthifólia $W$. 11295 runcináta $W$. 1644. KRI'GIA. W. 11.296 virgínica $W$ :

1645. HYO'SERIS. $W$. SWINE'S-SUCCORY. 11297 radius $W$. $W$. 11098 radiáta $W$ 11298 lúcida $W$. 11299 scábra $W$.

11300 arenária $W$.

11301 hispida $W$. wing-leaved Samphire-leav. dark-flowered downy woolly

\section{ROTHIA.} Andryala-like Stock-leaved hoary

KRIGIA. Virginian starry shining 妾 $\Delta$ un ${ }^{\frac{2}{4}}$ jn.jiu rugged sand hispid

1646. HEDYP'NOIS. $W$. HEDYPNOIS. 11302 monspeliénsis $W$. branching 11303 rhagadíoloídes $W$. Nipplewort 11304 crética $W$. Cretan 11305 coronopifólia Tenore. Buckshorn-leav'd 11306 tubæfórmis Tenore. tube-stalked 11307 mauritánica $W$. Moorish 11308 péndula $W$. pendulous

1647. ROBER'TIA. Rich. RoBERTIA. 11309 taraxacoídes Dec. Dandelion-lvd.

1648. SERI'Ola. $W$. Seriola. 11310 lævigáta $W$. smooth 11311 ætnénsis $W . \quad$ rough 11312 úrens $W . \quad$ stinging 11313 Alliátæ Biv. Alliata's

1649. SOLDEVILLA. Lag. SoldeviLl 11314 setósa $\mathrm{Lag}$ bristly

1650. HYPOCHE'RIS. W. CAT'S-EAR. 11315 helvética $W . \quad$ one-flowered 11316 maculáta

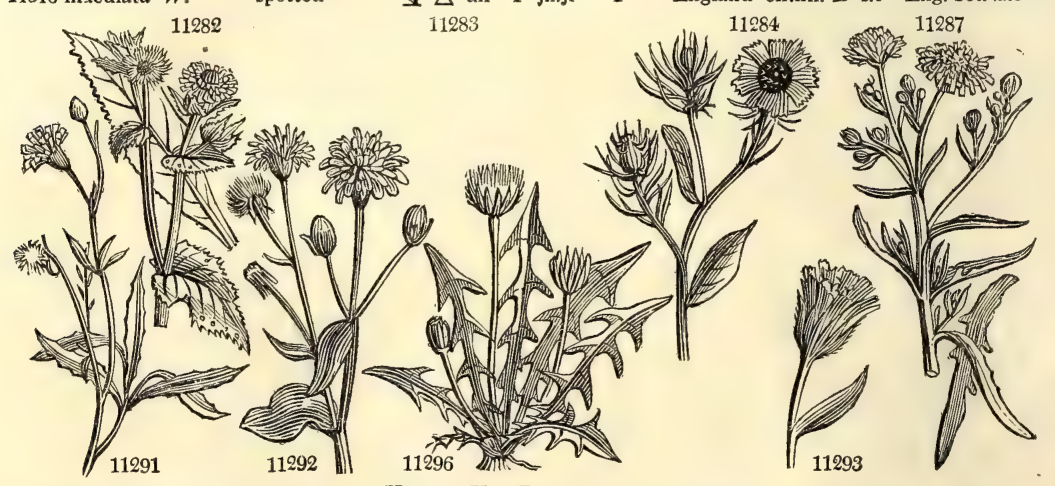

History, Use, Propagation, Culture,

1639. Helminthia. An abridgment of Helminthotheca, a name employed for this genus by Vaillant. It is derived from $\dot{\varepsilon} \mu_{\mu} v_{5}$, a worm, and $\nabla_{\eta \varkappa \eta}$, a case : in allusion to the corrugated seeds, which may be fancied to resemble bundles of little worms. The genus was united by Linnæus with Picris, but has been again separated by modern botanists.

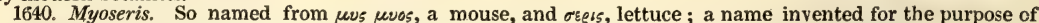
maintaining a resemblance in nomenclature with Hyoseris, Lagoseris, and other similar plants.

1641. Tolpis. A name invented by Adanson, ahd supposed to have no meaning. Handsome annual flowers.

1642. Andryala. A name, the meaning of which has not been discovered. Rather pretty plants, natives of the south of Europe and north of Africa.

1643. Rothia. Named by Schreber, in honor of Dr. A. G. Roth, author of a Flora Germanica, in 1788, Catalecta Botanica, in 1797, and other works. It has been united with Andryala by Richard.

1644. Krigia. Named after Dr. Krieg, a German botanist, who accompanied Mr. Vernon to America in search of plants. See Vernonia. A pretty little North American plant, with grassy leaves and bright yellow neat flowers. 
11282 Involucrum large prickly, Leaves repand

11283 Leaves runcinate pinnatifid : lobes oblong acute toothed spreading, Scape naked many-fl. smooth

11284 Leaves obl. toothed, Pedunc. 1-flowered

11285 Leaves lanc. oblong: lower sinuate-toothed, Pedunc. proliferous

11286 Leaves obl. linear scabrous toothed, Stem branched divaricating, Lower scales of invol, downy

11287 Leaves gland. downy : lower runcinate toothed; upper ovate lanc. entire, Stem and pedunc. glandular 11288 Leaves downy pinnatifid, Invol. downy pilose, Hairs rigid

11289 Leaves pinnated linear downy

11290 Leaves pinnatifid lyrate, Flowers corymbose aggregate, Pedunc, and invol. hispid

11291 Leaves downy oblong: lower toothed, Stem branched, Branches 1-flowered

11292 Leaves ovate woolly : lower somewhat toothed, Corymb terminal, Pedunc. about 2-flowered

11293 Stem branched at base diffuse, Leaves downy ovate lanceolate amplexicaul. nearly entire

11294 Stem erect corymbose, Leaves somewhat downy linear sinuate-toothed sessile : upper entire

11295 Stem erect corymbose, Leaves downy sessile : lower obl. runcinate, Pedunc. gland. villous

11296 The only species

11297 Scapes 1-fl. naked, Leaves smooth lyrate runcinate toothed : term. lobe trifid

11298 Scapes 1-fi. naked, Leaves smooth lyrate runcinate somewhat fleshy: segm. angular imbricated

11299 Scapes 1-fl. naked thickened at end, Leaves lyrate pinnatifid toothed ciliated roughish

11300 Stem branched leafy diffuse, Leaves amplexicaul. oblong toothed scabrous ciliated at edge

11301 Scapes 1-fl. hispid, Leaves obl. runcinate toothed hispid, Hairs forked

11302 Stem diffuse branched, Leaves obl. toothed narrowed at base sessile, Scales of invol. in fruit smooth

11303 Stem diffuse branched, Lvs. obl. toothed narr. at base sess. Scales of invol. in fruit hairy

11304 Stem diffuse branched, Lvs. obl. toothed subcordate amplexicaul. Scales of invol, in fruit smooth

11305 Related to the last, but the leaves are deeply toothed with 3-forked hairs

11306 Leaves somewhat toothed, Hairs simple, Pedunc. very thick

11307 Stem erect branched, Lvs. obl. somew, toothed subcordate amplex. Scales of invol. in fruit alternately setose

11308 Stem erect panicled, Lvs. obl. hispid deeply toothed, Scales of invol. in fruit smooth muricated at the end

11309 The only species

11310 Smooth, Leaves obovate toothed

11311 Hispid, Leaves obovate somewhat toothed

11312 Stinging, Stem branched, Leaves toothed

11313 Radical leaves spatulate toothed pilose, Stem ascending smooth, Pappus stalked

11314 Hairy with very short stellate hairs and bristles, Lvs. lanc. entire, Pedunc. term. thickened upwards 1-fl.

11315 Stem simple leafy $1-f$. Leaves lanc. toothed

11316 Stem almost leafless solitary, Leaves ovate-oblong undivided toothed (spotted above)

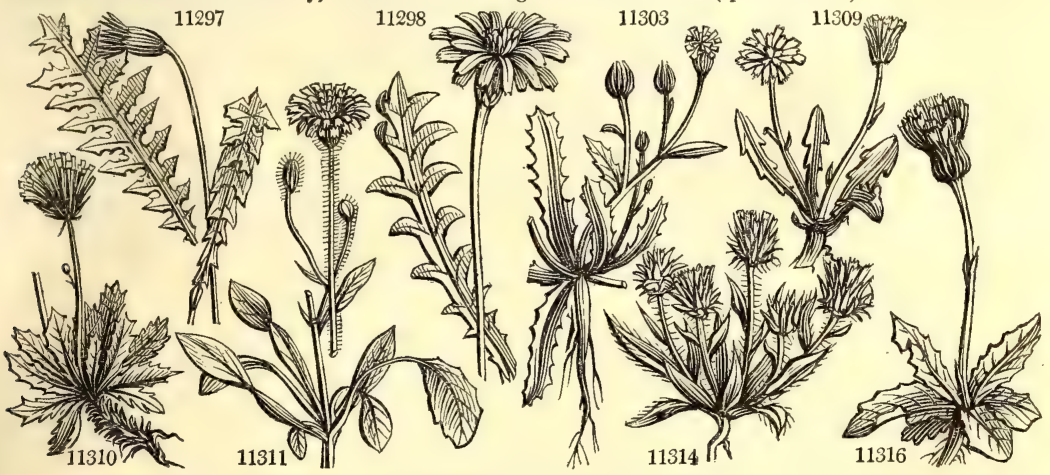

and Miscellaneous Particulars.

1645. Hyoseris. From vs vos, a hog, and $\sigma_{\varepsilon} \iota^{\prime 5}$, the Greek name of the Lettuce, or of a plant resembling it : hogs-lettuce, in allusion to the abominably fetid smell of the plant.

1646. Hedypnois. Under this name, a kind of wild endive, the medicinal qualities of which he much extols, is described by Pliny. Dalechamp, his commentator, rierives the word from id $\delta$, sweet, and $\pi y s \omega$, to breathe on account of a pleasant flavor communicated to other vegetables in cookery. But the modern genus, which consists of uninteresting weeds, has not been discovered to possess this quality.

1647. Robertia. Named by the authors of the Flore Française, after M. Robert, a Corsican botanist. A small weedy plant resembling Dandelion.

1648. Seriola. A diminutive of $\sigma \varepsilon \rho \delta s$, chicory. Small chicoraceous weeds of the south of Europe. S. Alliatæ is not, as its name would lead one to suspect, named from any smell of garlic which it possesses, but in honor of Prince Joseph Alliata, a Sicilian nobleman, and patron of Bivona Bernardi.

1649. Soldevilla. So named by Lagasca, apparently in honor of some botanist. A little Spanish weed with terminal solitary flowers.

1650. Hypocharis. From vro, for, and xosess, a pig; Porcelle, Fr., for the same reason, viz., that pigs eat the roots with avidity. All the species are uninteresting weeds. 
1651. LAPSA'NA $I T$
11317 minima $I V$. 11318 híspida $W . e n$

11319 glábra $W$.

11320 radicáta $W$.

11321 Balbísii $W$.

least

bristly

smooth

Balbis's Hyóseris fátida P.

11323 pusilla $W$. least

11324 commúnis $W$. common

11325 críspa $W$ curled

11326 intermédia $B i c b$. intermediate

11327 lyráta $W . e n$. lyrate

1652, ZACIN'THA. $W$. ZACINTHA 11328 verrucúsa $W$. warted

1653. RHAGADI'OLUS. $\boldsymbol{W}$. RHAGadiol lons-rooted

11322 fœ'tida $W$.

Hyóseris mínima E. B. $\begin{array}{r}\text { O un } \frac{1}{4} \text { jl.au } \\ \text { un } \\ \hline\end{array}$

$\triangle$ un 1 jlau $Y$

v un $1 \frac{1}{2} \mathrm{jn} . \mathrm{s} \quad \mathrm{Y}$

\) $\triangle$ un 1 jn.s

Compositce.

$\frac{1}{2}$ jl.au Y Y

$\$ \Delta$ un

O w $1 \frac{1}{2}$ jn.j1 $\quad Y$

-O un $1 \frac{1}{2}$ my.jn Y

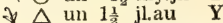

O $\frac{1}{4}$ my.jn $\mathrm{Y}$

Barbary 1797. S co

S. Europe 1804. D co W.hor.be.1.t.16

Britain sa hea. S co Fng, bot. 575

Britain me.pa. D s.1 Eng. bot. 831

Italy 1824. D co

Sp. 6-10.

Pl. rar.hu.1. t. 49

Britain gra.fi. S co Eng. bot.95

Britain clt, gr. S co Eng. bot. 84:

Tauria 1799. S co

1823. S co

Composite. Sp. 1

O un $\frac{z}{4}$ jn.jl Y.BR S. Europe 1633. S co Ga.se.2.t.157.f.7 Composite. Sp. 3-5.

un 1 jn.jl Y S. Europe 1633. S co

un 1 jn.jl Y Levant 1633. S co

11330 édulis $W$. $\quad$ heart-leaved

$\mathrm{O}$ un $\frac{3}{4} \mathrm{jl} \quad \mathrm{Y}$

Davuria 1788. S co

Sch, han.3. t.22:

Compositce. Sp. 1.

1654. MOSCA'RIA. $F l$. per. Moscaria. 11332 pinnatífida $\mathrm{Fl}$. per. pinnatifid

1655. CATANAN'CHE. $W$. Catananche. 11333 cærúlea $W$. blue yellow

\pm or 3 jl.o $B$ Chili

1823. S co

jl.o B S. Europe 1596. D co Bot. mag. 293

1656. TRIPTI'LION. Fl. per. TRIPTILION. 11335 cordifólium $\mathrm{Lag}$. cordate

1657. CICHO'RIUM. $W$. Succory.

11336 I'ntybus $W$. wild

11337 púmilum $\dot{W}$. dwarf

11338 Endivia $W$. Endive

11339 divaricátum $W$. branching

11340 spinósum $W$, prickly

1658. BACA'ZIA. $F l$.per. BAcazia.

11341 spinósa $F l$. per. prickly

1659. SCO'LYMUS. $W$. Golden Thistl. 11342 grandiflorus Desf large-flowered

11343 maculátus $W$. annual

11343 maculátus $W$

11344 hispánicus $W$. perennial

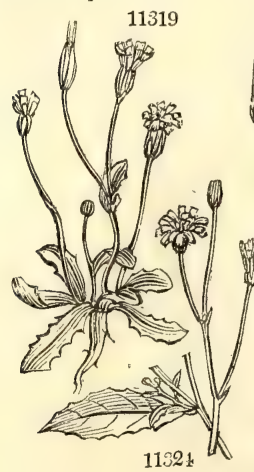

11320

i $\triangle$ or

Candia 1640. S co Alp, exot. t. 286

Compositce. Sp. 1-4.

$\frac{1}{9}$ my.au W Chili 1824. S co Bot. reg. 853

Composite. Sp. 5-7.

E. $\triangle$ ag 2 jn.au B Britain gra.so. D co Eng. bot. 539

1799. S co Jac. obs. 4, t. 80

E $O$ cul 2 jl.au B E. Indies 1548. S r.m

Candia 1633. S co Bauh.prodr.t.62

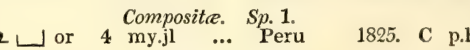

Compositce. Sp. 3-4.

my.jn $\mathbf{Y}$ Barbary 1820. S co Desf, atl, t. 218

jl.s $\quad \mathbf{Y}$

S. Europe 1633. S co Lam. ill, t. 659

S. Europe 1658. D co

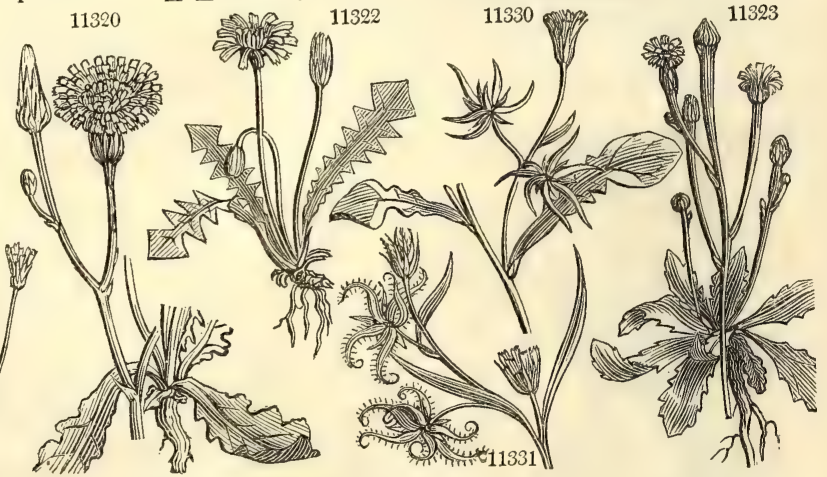

History, Use, Propagation, Culture,

1651. Lapsana. From $\lambda \propto \pi \propto \zeta \omega$, to purge. The Lapsana, says Pliny, gently relaxes the body. I. communis is called nipple-wort, in English, and herbe aux mamelles, Fr., having been formerly applied to the breasts of women to allay the irritation occasioned by nursing.

1652. Zacintha. A plant growing in the island of Zacintha or Zante. It was formerly included in Lapsaua, under the name of L. Zacintha.

1653. Rhagadiolus. From garas, a slit; each division of the calyx being hollowed out in the middle so as to resemble a furrow, or little gutter.

1654. Moscharia. This plant gives out an agreeable smell of musk. An annual plant, with stem-clasping pinnatifid deeply cut leaves, found in sandy waste places in Chili, where it is commonly called Almizelillo.

1655. Catananche. Vaillant explains the meaning of this word, by deriving it from the two Greek words,

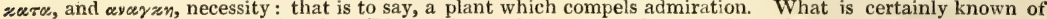
its origin is, that it was employed by Dioscorides to designate a plant used by the women of Thessaly, in philtres and love potions. The modern genus, which contains two or three species of ornamental border philtres and love potions. The modern genus, which contains two or three species of ornamental border
annuals, can have no reference to that of the ancients, one kind of which is believed to have been Ornithopus compressus, and another Astragalus pugniformis. John Bauhin cills Lathyrus Nissolia by the name of Catananche leguminosa.

1656. Triptilion. A genus instituted by the authors of the Flora Peruviana, and named from rgss, three, and $\pi \tau \varepsilon \lambda$ oy, a feather, on account of the three divisions of the pappus. The species mentioned above is a very pretty little annual, or rather biennial plant, flowering during all the winter months in any place whence frost is excluded, but it requires not to be kept too dry. There is a fine species in Chili, with bright blue flowers, but it has not been yet introduced. The inhabitants of South America employ the flowers of the different species as everlasting flowers, for which their dryness renders them very well adapted.

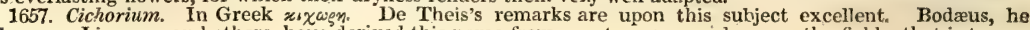
observes, Linnæus, and others, have derived this name from $\varkappa(\omega)$, to come, and xwclov, the field; that is to say, 
11317 Leaves toothed roughish, Invol. hispid, Pappus of disk stipitate plumose : of the ray sessile setose 11318 Hispid, Calyxes hairy, Stem branched, Lvs. lanc. toothed

11319 Nearly glab. Invol. obl. imbricated, Stem branched somewhat leafy, Radical leaves dentato-sinuate 11320 Stem branched leafless glab. Pedunc. with small scales, Lvs. runcinate obtuse seab.

11321 Different from the last in having a smooth involucrum

11322 Stemless, Scape 1-fl. Leaves runcinate pinnatifid, Terminal lobe rhomboid

11323 Scape branched very thick and fistulose upwards, Leaves obovate oblong toothed

11324 Invol. of the fruit angular, Stem panicied, Pedunc. slender, Lvs. ovate petiolate angulato-dentate 11325 Caulescent branched, Leaves ovate stalked doubly toothed

11326 Caulescent branched, Lvs. angular-toothed : lower lyrate-pinnatifid, Pedunc. and invol. smooth

11327 Caulescent panicled, Stem downy below, Radical leaves lyrate toothed : upper lanc. entire

11328 Rad. leaves lyrate acute, Cauline sagittate amplexicaul. toothed

11329 Fruit smooth spreading, Cauline leaves lanc. undivided

11330 Fruit smooth spreading, Leaves lyrate

11331 Fruit prickly spreading, Leaves linear lanc. entire

11332 Leaves amplexicaul. pinnatifid : segments deeply jagged

11333 Lower scales of invol, ovate mucronate, Leaves villous linear sub-bipinnatifid at base 11334 Lower scales of invol, lanc. Leaves lanc. toothed S-nerved

11335 Leaves cordate spiny

11336 Flowers sess. axill. in pairs, Leaves runcinate

11337 Flowers axillary twin sessile, Leaves obovate toothed

11338 Pedunc. axill. twin: one long 1-fl.; the other very short about 4-fl. Flowers capitate

11339 Pedunc, axill, twin : one long 1-fi. ; the other very short about 2-fl. Stem dichotomous, Rad. lvs. runcinate

11340 Flowers axill. solitary, Stem dichotomous, Branches naked spiny, Lvs. lanc. runcinate toothed

11341 Leaves obovate mucronate cartilaginous, Flowers solitary

11342 FI. solitary lateral sessile, Lvs. decurrent, Stem subsimple villous erect

11343 Fl. solitary, Lvs, roughish smooth, Stem winged toothed

$11344 \mathrm{Fl}$, subaggregate, Lvs. scabrous with the middle rib below hairy interruptedly decurrent

11332
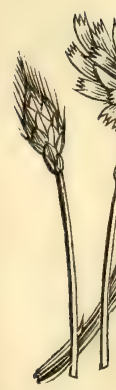

11333

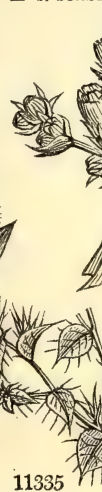

11335

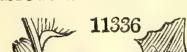

thine 11336
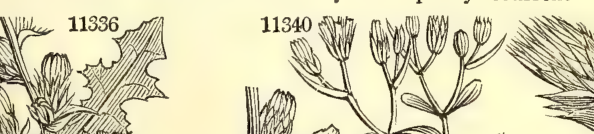

11341

it is a plant found wild in fields, - which grows every where : but this etymology is overstrained. It is much more natural to suppose that the Egyptians, who used this plant in great quantities, would have communicated to the Greeks, along with the manner of using it, the name by which it was known in Egypt, which appears from Forskahl to be chikouryeh. Pliny remarked, that the Egyptians made their chicory of much consequence, and it is very well known that, at the present day, chicory or similar plants constitute half the food of the common people in Egypt. In like manner, there can be little doubt that the specific terms Endivia and the common people in Egypt. In like manner, there can
Intybus, are both derived from the Arabic name hendibeh.

Intybus, are both derived from the Arabic name hendibeh.
The leaves of Cichorium Intybus are employed by the French under the name of Barbe du Capucine, as a kind of winter salad; for which purpose the leaves are blanched like Endive. The most common method of cultivating the plant, is to sow the seed in drills in the end of July, and to keep the plants about six inches apart, and quite free from weeds. In the winter the roots are taken out of the ground and packed up in a warm cellar among earth, in layers, like bottles in a wine cellar, the crowns only of the roots being exposed. In a few days, young leaves are produced in great abundance, from the situation in which they are cultivated quite blanched, and, if not grown too rapidly, with an agreeable taste. There is also a variety of C. Intybus, called Chichorée à café, which is cultivated extensively in France for the sake of its roots, which are taken up in the winter season, cut into squares, dried artificially, and afterwards, being roasted, are ground along with their coffee, for which they serve as an adulteration. There are those, however, who assert, that it is to this admixture of Succory root that the superior flavor of the French to the English coffee is to be attributed.

1658. Bacazia. Named by the authors of Flora Peruviana, in honor of George Bacas, professor of botany at Carthagena.

1659. Scolymus. The Greek name of a spiny plant, which appears to have been the modern artichoke. The word itself is derived from $\sigma \approx 0 \lambda, \sigma_{\text {, }}$ a spine. S. hispanicus has simple fusiform roots, soft and sweet like Scorzonera, and equally good to eat. The leaves and stalk also abound with a milky juice, and the people of Salamanca eat it in the same manner as Cardoons. The flowers are used for adulterating saffron. 
1660. ARC'TIUM. W. BURDock.

\section{Láppa $L V$.}

11346 Bardána $W$.

11347 minus Bieb.

1661. SERRA'TULA, $W$, SAw-WORT

11348 tinctória $W$

11349 coronáta $W$.

11350 quinquefólia $W$.

11351 pygmæ'a $W$.

11352 angustifólia $W$.

11353 saiicifólia $W$

11354 centauroides $W$.

11355 símplex $B$. $M$.

11356 argúta Fisch.

11357 radiáta Bieb.

11358 rayed

11358 xeran'themoides Bieb. smth.-headed $\downarrow \Delta \mathrm{pr}$

11359 heterophýlla Disf. various-leaved

11360 stæchadifólia Bieb.

11361 Pícris Bieb.

11362 áspera Link。

11363 aláta $W$.

woolly-h

rough

winged

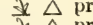

ty $\triangle \mathrm{pr}$

I $\triangle$ pr

\&. $\triangle \mathrm{pr}$

1662. SAUSSU'REA. Dec. Saussurea.

11364 elongáta Dec.

11365 alpina Dec.

11366 díscolor Dec.

long

discolored

d) $\triangle \mathrm{pr}$

$\frac{\Delta}{\Delta} \Delta$ pr

1663. CAR'DUUS. $W$, THISTLE.

11367 leucógraphus $W$. white-spotted

11368 crassifólius W. en. thick-leaved

11369 arábicus $W$.

11370 nútans $W$.

11371 earlinoídes $W$.

11372 argentátus $W W^{Y}$

11373 onopordoídes $B$ ieb.

11374 carlinæfólius $\mathrm{W}$.

11375 acanthoides $W$

11376 tenuiflórus $W$

11377 críspus $W$

11378 hamulósus $W$.

11379 cúndicans $W$.

11380 Personáta $W^{\prime}$

11381 polyánthemus $W$.

11382 orientális $W$.en.

11583 paniculátus $W$.

11384 pycnocéphalus

11385 cyanoídes $W$

11386 arctioídes $W$

11387 alpéstris $W$.

11388 deflorátus $W$.

11389 parviflórus $W$.

11390 nítidus $W$.

11091 cerinthoides $W$.

musk

Pyrencan

silvery

$\triangle \Delta \mathrm{pr}$

lender-flowered $O$ w curled \$2 (2) or

spiny-hooked D (D) or

hoary J O or

cut-leaved $\quad$ (2) or

many-flowered $\leq \mathrm{Q}$ or

oriental $\$ \Delta$ or

panicled $\$ \Delta$ or

Italian $\$ \Delta$ or

blue-bottle-lvd, $\$ \Delta$ or

pinnated \& $\triangle$ or

Alpine $\frac{\neq \Delta}{\Delta}$ or

various-leaved $\$ \Delta$ or

glossy $\bar{\Delta} \Delta$ or

Honevwort-lvd. $\frac{\partial}{\partial} \Delta$ or

Compositie.

Sp. 3-4.

jl.au Pu Britain wa. Su

$\begin{array}{llll}\text { jl.au P'u Europe } & \text {... } & \text { S co Schk.bot.3. t.227 }\end{array}$

Composite. Sp. 16-40.

jl.o Pu Britain woods. D co Eng. bot. 38

jl.au Pu Siberia 1739. D co Gmel. sib.2.t.20

jlau Pu Persia 1804. D p.1 Bot. mag.

jl.au Pu Austria 1816. D co Jac.aust. t. 440

$1 \frac{1}{2}$ jl.au Pu Siberia 1816. 1 co Gmel.sib.2.t.33

$\begin{array}{llll}\text { jl.au } & \mathbf{R} & \text { Siberia 1796. D co Gmel.sib.2. t.37 }\end{array}$

1 jl.au Pu Nepal 1821. D co Bot. mag.2482

3 jl.o Pu Hungary 1824. D co

Hungary 1800. S co

$1 \frac{1}{2} \mathrm{jl} \quad \mathrm{Pu}$ Caucasus 1825. D co Gmel.sib.t.47.f.1

2 jl.au Pu Dauphiny 1824. D co

$1 \frac{1}{2}$ jl.au Pu Tauria 1820. D co

1 jl.au Pu Caucasus 1822. D co

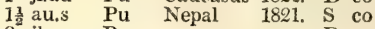

$\begin{array}{cccc}\text { Nepal } & 1821 . & \text { S } & \text { co } \\ & \ldots & \text { D } & \text { co }\end{array}$

Composite. $S p .3-6$

2 jl.au Pu Caucasus 1820. D co

jl.au Pu Britain al roc. $\mathrm{D}$ p.

jlau Pu

Composit:e. Sp. 26-100.

$\mathrm{O}$ or 2 jn.jl Pu Italy 1752. S co Jac. vind. 3. t. 23

\ $\triangle$ or 2 jl Pu $\quad$ Pl.... 1805. D co

$\mathrm{O}$ or $\frac{1}{2}$ jl.au Pu Arabia 1789. S co Jac. ic. 1.t. 166

Britain gra.fi. S co Eng. bot. 1112

Pyrenees 1784. S co Gouan. ill. t. 23

Egypt 1789. S co Jac.ho.vin.t.192

Iberia 1818. D co

Pyrenees 1804. S co

Britain wa.gr. S co

Europe 1804. S co

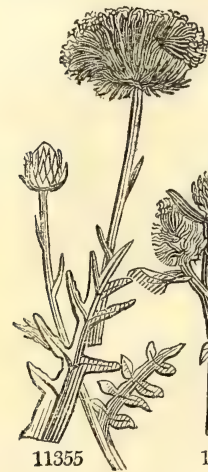

1136
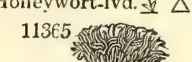

Pu

jl.au

jn.jl Pu

Hungary 1802. S co

Hungary 1805. S co

2 jn.jl Pk Rome 1739. D co Trium, obs.t.103

2 jl Pu Iberia 1804. D co

2 jn.jl Pu S. Europe 1781. D co

$1 \frac{1}{2}$ jl.s $\quad \mathrm{Pu} \quad \mathrm{S}$. Europe 1739 . S co

co Scop. carn. t. 53

jl.s $\mathrm{R}$ Austria 1570. D co Jac. aust. 1. t. 89

ji Pu S. Europe 1781. D co

ju S. Eur.h.1.52

Cav. ic. 3. t. 225

1134
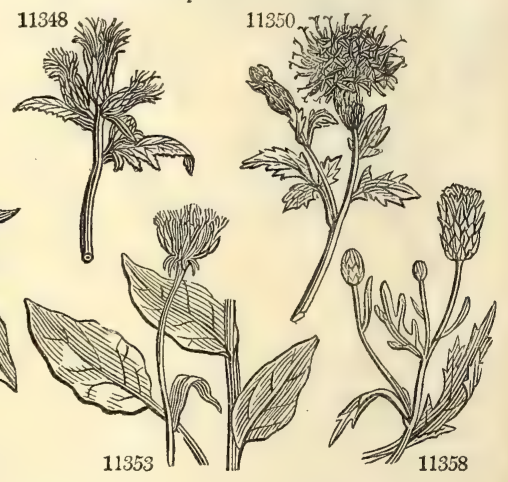

History, Use, Propagation, Culture,

1660. Arctium. From «esros, a bear, (arth, Celtic); on account of the rough bristly fruit, which may be compared to the coarse hair of a bear. Lappa is derived from llap, a hand, in Celtic, because it lays hold of every thing near it. The burdock is too familiar to every schoolboy to need illustration. It is equally common in Europe and Japan, by road sides and on ditch banks. Few quadrupeds, except the ass, will eat the plant ; but birds feed on the seeds, and snails and caterpillars on the leaves. The stems, stripped of their rind before the flowers appear, may be eaten, either boiled or raw, with oil and vinegar. Withering says, a decoction of the roots is esteemed by some equal to that of Sarsaparilla. Burnt green, between the time of flowering and seeding, three pounds of the ashes produced sixteen ounces of very white alkaline salt, as good as the best potash.

1661. Serratula. A diminutive of serra, a saw; the leaves being edged with cutting teeth. Plants with the habit and qualities of thistles. Serratula tinctoria dyes cloth of a yellow colour.

1662. Saussurea. Named in honor of the celebrated Swiss philosopher Horace Benedict de Saussure, who, among his other acquirements, possessed a considerable knowledge in botany. He died in 1799, in the fiftyninth year of his age.

1663. Carduus. This word appears to be derived from ard, a point, in Celtic, in allusion to the numerous 
11345 Lcaves cordate petiolate

11346 Cauline leaves cordate stalked entire, Invol, cobwebbed downy

11347 Invol. woolly : inner scales subulate somew. colored scarcely longer than outer, Racemes axill. panicled

11348 Leaves sharply serrate glab. pinratifid : the terminal lobe the largest, Flowers in a small clust. umbel 11349 Leaves serrated unequally pinnate of about 5-pairs, Pinnse confluent, Pedunc. 1-fl. Fl. rayed

11350 Lvs. serrated unequally pinn. of about 2-pairs, Pinnæ confluent, Pedunc. 1-f. Inner scales of invol. long

11351 Lvs. lin. lanc. hirsute revolute at edge, Stem 1-fl. vill. Scales of invol. ov.-lanc. appressed [colored

11352 Leaves lin. entire hirsute, Fl. terminal corymbose

11353 Leaves lin. entire downy beneath revolute at edge, Corymb fastigiate

11354. Leaves pinnatifid oblique acute smooth unarmed, Scales of invol. mucronate : inner scarious

11355 Leaves pinnatifid: lobes distant, Stem nearly simple 1-flowered, Invol. globose squarrose

11356 Like S. tinctoria, but the lower leaves are oval and entire

11357 Leaves pectinate-pinnatifid naked : segm. lin. unarmed; terminal ovate, Scales of invol. ov. mucronate

11358 Invol. unarmed somewhat awned radiate, Leaves pinnatifid

11359 Leaves ov. pinnatifid toothed unarmed hoary beneath : upper sess. Stem 1-fl. Scales of invol. ov. unarmed

11360 Leaves lin. entire downy beneath, Corymb nearly simple, Invol, ob!, ovate downy

11361 Invol. ovate: scales roundish scarious at edge, Leaves lanc. lower somewhat toothed at base

11362 Stem somewhat downy, Lvs, obl. acute narrowed at base serrated, Fl. subsessile, Invol. unarmed

11363 Lvs. downy beneath somewhat toothed: radical cord. stalked, Cauline lanc. decurient, Invol. squarrose

11364 Invol, corymb. somewhat downy, Leaves fleshy smooth : radical lyrate hastate, Cauline hastate

11365 Leaves villous beneath toothed: radic, ovate-lanc. Flowers terminal somewhat unhelled

11366 Lvs, downy beneath toothed: radic. ovate-subcordate; cauline ovate-lanc. Fl. terminal somew. umbelled

11367 Leaves decurrent toothed spiny, Pedunc. naked very !ong 1-fl. Invol. spiny inclining

11368 Lvs. half decurrent obl. spiny-toothed somewhat fieshy smooth glauc. beneath, Pedunc. very long 1-fl.

11369 Leaves obl. decurrent sinuate spiny with white veins villous beneath, Fl. sessile clustered, Invol. cylind.

11370 Leaves decurrent spinous, Fl. drooping, Scales of the invol. lanc. cottony : outer ones spreading

11371 Leaves decurrent pirnatifid downy : segments palmate spiny, Flowers clustered

11372 Leaves decurrent runcinate spiny, Pedunc, somewhat downy 1-fl. Invol, ovate mucronate unarmed

11373 Leaves decurrent sinuate spiny smooth, Pedunc. short subcorymbose downy

11374 L.eaves decurrent sipiny glabrous, Pedunc. erect 1-fl. unarmed

11375 Lvs. decur. sinuated spinous, Invol. globose nearly sess. : its scales lin. slightly recurved [lanc. erect

11376 Lvs. decurrent sinuated spinous somew. cottony beneath, Invol. nearly cylindr. clustered sess. their scales

11377 Lvs, decurrent obl. sinuated spiny at edge downy beneath, Fl. stalked clustered terminal

11378 Lvs. decurrent lanc. pinnatifid toothed spiny vill. beneath, Pedunc. 1-fl. downy, Scales of invol. sub. spiny

11379 Leaves half decurrent lanc. pinnatifid spiny downy beneath, Pedunc. scaly downy

11380 Caul. Ivs. half decurrent obl. undivided spiny toothed subvillous bencath : radic. pinnatifid at base

11381 Leaves decurrent sinuated ciliated naked beneath, Fl. stalked heaped

11382 Leaves half decurrent pinnatifid toothed spiny white with cown beneath, Fl. subsessile term. clustered

11383 Leaves half decurrent toothed sinuate spiny smooth, Flowers paricled

11384 Leaves decurrent pinnatifid sinuated downy spiny, Pedunc. naked downy, Invol. deciduous

11385 Lvs, downy beneath: upper finely decurrent lin. Stem 1-fl. Scales of invol. lanc. mucron. downy

11386 Lvs, decurrent deeply pinnatifid: segments toothed upwards spiny with setaceous ciliæat end

11387 Leaves half decurrent pinnatifid acuminate: segm. 2-lobed ciliated spiny, Pedunc. downy

11388 Leaves half decurrent pinnatifid-serrate somew, spiny ciliated naked : radic. undivided, Pedunc. very long

11389 Leaves adnate at base lanc. naked eroded ciliate-spiny unarmed

11590 Leaves unarmed: radic, ovate toothed somewhat cut at base; cauline sessile pinnatifid linear

11301 Leaves naked : radical obl. entire; cauline lanc. somcwhat toothed, Scales of invol, ovate mucronate

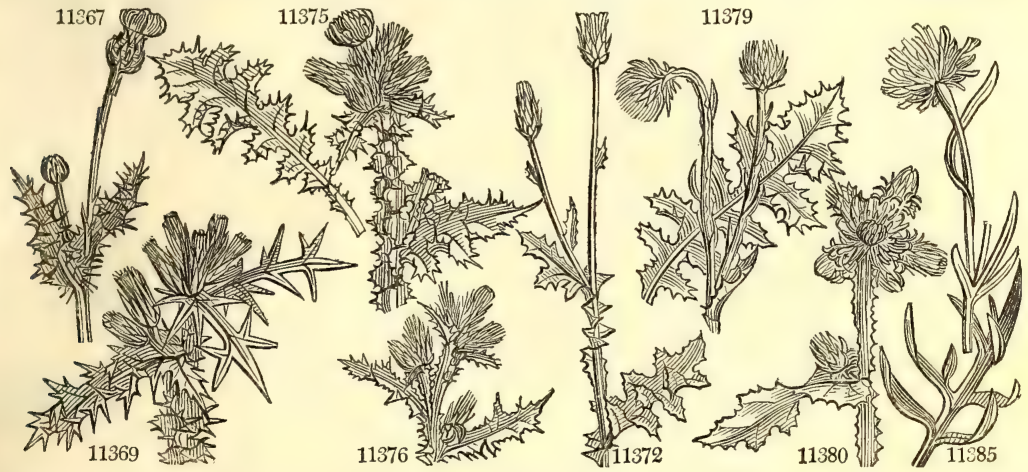

and Miscellancous Particulars.

points with which it is beset. C. marianus, the milk-thistle, derived its name from the Virgin Mary, some of whose milk is said to have fallen upon the leaves of the plant, and changed them to white An extensive genus of rather handsome weeds. C. Personata is said to have been so called, because its ample leaves were formerly used as a mask (persona). Some of the gigantic species make handsome ornaments for the shrubbery, but the greatest number are nuisances to the husbandman; some on account of their deep vivacious roots, which cannot be eradicated without extreme difficulty; but the greater number because of their bulky herbage, and the extensive dissemination of their seeds by the wind.

The footstalks of the leaves of most or all of the species of this and the allied genera might be eaten in the manner of Cardoons, if similarly blanched. The dried flowers of $C$. The seeds of all the species of Serratula, Cnicus, Onopordum, and similar genera, are greedily eaten by small birds, especially the finches.

The Carduineæ of M. Cassini differ from Carlineæ of the same author, in the filaments being bairy or papil. lose, from Centaurieæ in the structure of ovarium and of pappus, and from Echinopseæ, to which they bear a general resemblance, by many very important characters. The species inhabit Europe, Asia, and Africa ; there are scarcely any in America, and none in the southern hemisphere 
1664. SI'LYbuM. Gartn. Silybum. 11392 mariánum Gærtn. milk 11393 cérnuum Gertn. nodding 1665. CNI'CUS. $W$. 11394 palústris $W$. 11395 cánus $W$.

11396 Acárna $W$ 11397 monspessulánus $W$. 11398 lanceolátus $W$. 11399 férox $W$. 11400 ciliátus $W$. 11401 erióphorus $W$. 11402 díscolor $W$. 11403 altíssimus $W$. 11404 praténsis $W$. 11405 heterophýllus $W$. 11406 helenioídes $W$. 11407 serratuloides $W$. 11408 elátior Link. 11409 uliginósus Bieb. 11410 pannónicus $W$. 11411 stríctus Tenore. 11412 desertórum Fisch. 11413 serrulátus Bieb. 11414 laniflórus Bieb.

11415 arachnoídeus Bieb. 11416 strigósus Bieb. 11417 hórridus Bieb. 11418 scleránthus Bieb. 11419 echinátus $W$. 11420 inérmis $W$.

11421 ambíguus Pers.

11422 orgyallis $W$.

11423 setósus Bieb.

11424 carthamoídes $W$.

11425 arvénsis $P h$. Serrátula arvénsis $\mathrm{W}$ Carduus arvénsis $\mathrm{E}$. $\mathrm{B}$

11426 rivuláris $W$ 11427 paucifúrus $W$ 11428 tatáricus $W$. 11429 rigens $W$. 11430 carniólicus $W$. 11431 oleráceus $W$. 11432 munítus $W$.en 11433 obvallátus Bieb. 114.34. Erisíthales $W$. 11435 ochroleácus $W$ 11456 tuberósus $W$.

11437 acaúlis $W$

11438 Casabón $W$

11439 áfer $W$.
Horse Thistle marsh hoary Montpelie common prickly woolly-heade two-colored giant meadow melancholy

Elecampane-lv. Saw-wort-like tall

swamp

Hungarian

upright

desert

serrulate

woolly-flow

strigose

horrid

hard-headed echinate unarmed doubtful lofty catose corn or way $\$ \Delta$ or

river $\$ \Delta$ or 3 jl.au

few-flowered 0 or 2 jl.au Tartarian $\frac{j}{2} \Delta$ or $1 \frac{1}{2}$ jl. au upright Alpine $\frac{1}{2} \Delta$ or $1 \frac{1}{2}$ jl.au Carniolian $\frac{7}{\Delta} \Delta$ or 2 jl.au pale-flowered or 3 ilau bracteate 8 or 3 jl.au

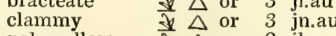
pale-yellow tuberous dwarf

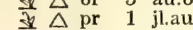
d 0 or 2 jn.au Barbary $\frac{D}{\partial j}$ or $2 \mathrm{jn} . \mathrm{jl}$
Composite. $S p, 2-5$.

jl Pu Britain banks. S co Eng. bot. 976 Composita. Sp. $50-114$.

3 jl.au Pu Britain m.pas. S co Eng. bot. 974 jl.au Pu Austria 1633. D co Jac.aust.1.t.42.3 jl.s Pu Spain 1683. S co Britain banks. S co S. Europe 1683. S co Siberia 1787. D co Britain ch.pa. $\mathrm{S}$ co N. Amer. 1803. S co N. Amer. 1726. D co Britain m.pas. D co Britain m.al.p. D co Siberia 1804. D co Siberia 1752. D co 1823. D co Caucasus 1820. D co Pa.pu Austria 1816. D co Pu Naples 1819. D co $\mathrm{Pu}$ Siberia 1824. D co Pu Tauria 1820. D co $\mathrm{Pu}$ Tauria 1819. D co Tauria 1818. D co Caucasus 1825. D co Iberia 1823. S co Caucasus 1820 . S co Barbary 1817. D co M..... 1824. D co Silesia... 1822. $\mathrm{S}$ co Siberia 1818. D co Britain ro.sid. D co Eng. bot. 975

Eng. bot. 107

All. ped. 1. t. 50 Mur.co.got.6.t.5 Eng. bot. 386

Dil. elt. t.69, f. 80

Eng. bot. 177

Jac. aust. 2.t.127

Hungary 1804, S co Jac aust. 1, t. 91 Hungary 1816. D co Pl.rar.hu.2.t.16 Siberia 1775. D co Jac. aust. 1. t. 90 Switzerl. 1775. D co Act. helv. 4, t.16 Pa.Y Carniola 1792. D co Sc.ca.n.1005.t.52 Pa.Y Europe 1570. D co Fl. dan. 860

$\mathrm{Pu}$ Caucasus 1816. D co

$\mathrm{Pu}$ Caucasus 1816. D co

$\mathrm{Pu}$ France 1752 D co Jac. aust. 4.t.310 Pa.Y Switzerl. 1801. D co

Pu England woods. D co Lob. ic. t. 10. f. 2 $\mathrm{Pu}$ Britain gra.pa. D co Eng, bot. 161

$\mathrm{Pu}$ S. Europe 1714, S p.l Schmd.ic.t.51,59 Pu Barbary 1800. S co Bot. mag. 2287

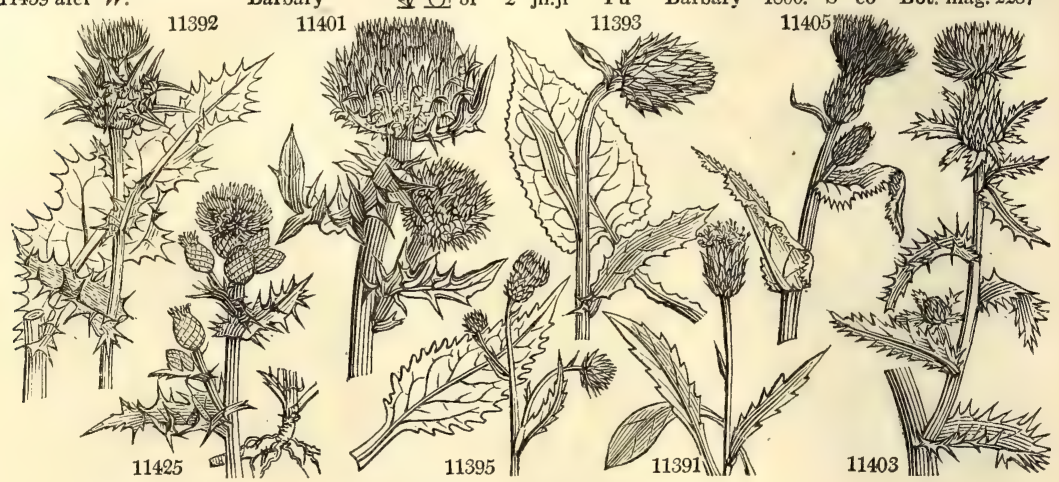

History, Use, Propagation, Culture,

1664. Silybum. A name under which Greek writers describe a plant not well known at present. Sprengel refers it to S. marianum. This plant was formerly cultivated, and the young leaves used in spring as a salad, or boiled as pot greens ; the young stalks, peeled and soaked in water, to extract a part of their bitterness, were also eaten, and were said to be excellent. In the spring of the second year, the root is prepared like salsafy or skirret; and the receptacle of the flower is pulpy, and eats like that of the artichoke. In Apulia the whole plant is much used as fodder for cattle.

1665. Cnicus. This is a name under which Dioscorides describes a prickly rough plant; derived from $z v i \omega \omega$ to prick. It is now referred to a tribe of plants having such characters in an eminent degree. Acarna and Erisithales are both names by which the ancients distinguished plants, either the very same as those now so called, or very similar to them. The tender stalks of C. palustris, as of most of the species, being peeled, are eatable either raw or boiled. C. arvensis is well known as one of the most troublesome weeds in arable land. It is never found, however, in very sandy, gravelly, or peaty soils; but generally in such as are loamy and dry. An instance is given in the Farmer's Magazine, of the descending roots of this plant having been about two inches of a root in his garden in April, and by November following it had thrown out under ground stolones on every side, some of them eight feet long; some of these stolones had thrown up leaves five feet 
11392 Lvs. anplexicaul. waved spinous : radic. ones pinnati. Scales of invol. subfoliac. recurved spinous at margin 11393 Leaves downy beneath ovate toothed : radical cord. Petioles winged toothed, Invol. subsolitary cernuous

11394 Lvs. decurrent scabr. pinnatif. spinous, Invol, ovate clustered their scales ovate-lanc. mucro. appressed 11395 Lvs. half decurrent somew. hoary lanc. ciliate spiny, Pedunc. naked downy solit. Scales of invol. appressed 11396 Leaves decurrent lanc. hoary toothed spiny, Fl. aggregate involucrate, Invol. with pinnated spines 11397. Lvs. decurrent lanc. smooth subrepand uneq. ciliated, Pedunc. naked downy alternate [lanc. spreading
[late 11398 Lvs. decurr. hispid pinnatif their segm. generally 2-lobed spreading spinous, Invol. ov. toment. their scales 11399 Lvs. subdecurr. pinnatif. : segm. 2-lobed spreading spiny vill. beneath, Invol. hemispher. sessile

11400 Lvs. amplexicaul. hispid pinnatif. : segm.2-lobed spreading spiny downy beneath, Invol. ovate

11401 Leaves sess. pinnatif. every other segm. pointing upwards spin. scabr. Involucres spherical woolly

11402 Leaves sess. pinnatif. hairy downy beneath: segm. 2-lobed spreading spiny, Invol. globose with cobweb down

11403 Leaves sess. obl. lanc. scabrous downy beneath toothed ciliated : radic. pinnatifid, Invol, bracteate ovate

11404 Leaves sess. lanc. waved at the edge and unequally spin. pubesc. cottony beneath, Flowers mostly solitary

11405 Lvs. amplexic. lanc. ciliato-dentate undivided or laciniated white and downy beneath, Fl. mostly solitary

11406 Lvs, subcordate amplexicaul. lanc. ciliated downy beneath : lower somewhat cut, Fl. clustered

11407 Lvs. lanc. sessile ciliated strigose beneath : radical sinuated, Scales of invol. recurved at end

11408 Lvs. pinnatifid with strong spines somewhat downy beneath, Fl. sess. aggregate, Lvs. of invol. spiny

11409 Lvs. half decurr. obl. sinuate toothed spiny hoary beneath, Heads close together with appressed scales

11410 Leaves half decurrent lanc. entire ciliated, Pedunc. very long 1-fl. woolly

11411 Very like $\mathrm{C}$, arvensis, but the leaves are decurrent

11412 Stem somew. downy, Lower lvs. sinuate-toothed with strong spines rough above finely downy beneath

11413 Lvs. amplexic. hispid pinnatifid: segm. 2-lobed spreading spiny downy beneath, Heads ov. glabrous spiny

11414 Lvs. amplexic. hispid pinnatif: segm. 2-lobed spread. spiny downy beneath, Heads ov. cobwebbed with down

11415 Lvs. amplexic. hispid pinnatif. : segm. 2-lobed spread. spiny beneath naked subvillous, Heads ov. cobwebbed

11416 Lvs. amplexic. hispid pinnatifid : segm. 2-lobed spreading spiny naked beneath, Heads ov. glabrous

11417 Lvs, amplexicaul. hispid pinnatifid prickly : segm. angular lobed spiny, Heads nodding cobwebbed

11418 Stem branched many-fl. Heads terminal solitary spiny at base, Lvs. amplexicaul. sinuate toothed spiny

11419 Leaves sess, pinnatifid hispid woolly beneath : segm. 2-lobed spreading spiny, Invol. ovate woolly

11420 Leaves sess. lanc. cut-toothed: radical. pinnatifid, Scales of invol. ovate lanc. membranous at edge

$11+21$ Leaves ciliate spiny downy beneath : lower stalked obl. acum. subsinuate; upper pinnatifid auricled

11422 Like the last, but the leaves of involucrum are reflexed

11423 Leaves obl. smooth serrulate with bristly ciliæe blunt mucro. Stem corymbose

$11+24$ Leaves unarmed sess. obl, toothed: radical undivided and pinnatifid, Invol. scarious villous

11425 Leaves sess. pinnati. spin. Stem panicled, Invol. ovate, Scales appressed mucronated

11426 Leaves toothed ciliated naked : cauline amplexicaul. : lower and radical pinnatifid, Fl. clustered capitate 11427 Leaves amplexicaul. ovate sublyrate ciliate serrate scabrous : radic. lyrate, F1, clustered

11428 Leaves amplexicaul. obl. lanc toothed ciliate-spiny, Pedunc. 1-fl. Invol. bracteate

11429 Leaves sess. pinnatifid : segm. cut serrate spiny at edge, Invol. bracteate: scales ovate appressed

11430 Leaves cordate amplexicaul. ovate obl. toothed ciliated: radical obl. blunt ciliated sinuate

11431 Leaves amplexicaul. cord. pinnatif. ciliate serr. Fl. terminal subracemose bracteate, Bractes colored ovate

11432 Leaves amplexicaul. obl. pinnatif. toothed spiny hispid above downy beneath, Term. fl. sess. axill. stalkec

11433 Leaves amplexicaul. pinnatif. toothed spiny glabrous, Fl. term. aggreg. sess. surrounded by colored bractes

11434 Leaves amplexicaul. pinnatifid ciliated, Pedunc. cernuous, Invol. glutinous : scales lanc. spreading

11435 Leaves amplexic. pinnati,-downwards ciliated: pinnæ la nc. 3-nerved ; upper confluent, Pedunc. cernuous

11436 Leaves amplexicaul. pinnatifid ciliate-spiny : segm. 2-lobed toothed upwards at the base

11437 Stemless, Invol, glabrous

11438 Leaves sess. lanc. entire downy beneath with triple spines at the edge, Fl, axill. sessile

11439 Leaves sess. lanc. downy beneath subrepand: lobes emarg. with 2 spines, Fl, stalked subcorymbose

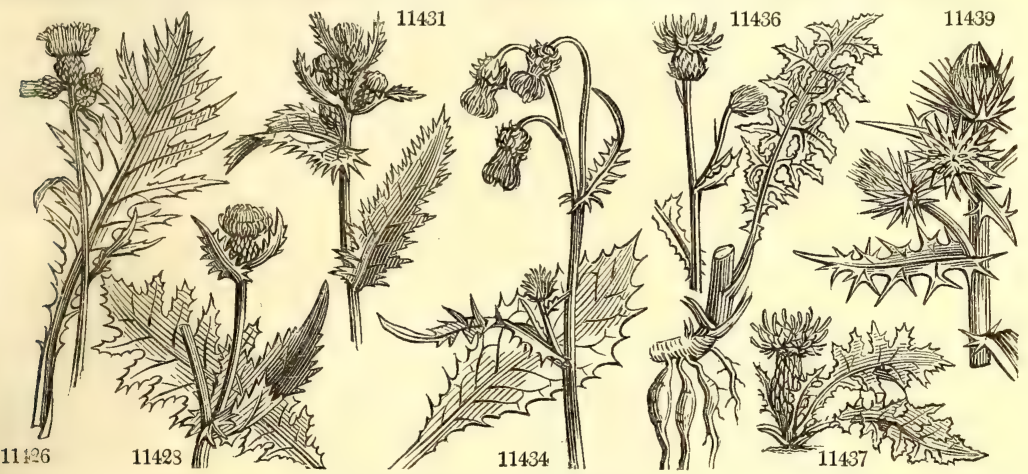

and Miscellaneous Particulars.

from the original root. The whole together, when dug up and washed, weighed four pounds. In the spring following, it again made its appearance, on or about where the small piece was originally planted. There were between fifty and sixty young plants, which must have sprung from fragments of the roots that had eluded the gardener's search, though he was particularly careful in extracting them. From these facts it may readily be conceived how difficult it is to eradicate this weed from arable land; a naked fallow, with frequent and deep ploughing, will not accomplish it, unless the season is more than usually dry. Laying land down to grass, keeping it in that state seven or eight years, and during the whole time pulling up every shoot as soon as it appears, is found fully more effectual than a naked fallow. But the plant is so common by road sides, and seeds so abundantly, that it is hardly possible to effect its extermination. In common field lands, and others indifferently cultivated, it often forms the larger half of the produce, and formerly used to be pulled when beginning to come into flower, and given as food to horses and cows. Those who pull this weed require to be furnished with strong gloves, or thistle pincers. (Ency. of Agr. \& 2394.) Some English botanists seem doubtful if horses and cows will eat it but those who know any thing of the history of agriculture in Scotland will recollect, that before the introduction of naked fallows and turnips, it formed the suppering of housed cattle, during five or six weeks of every summer. The ashes of the plant yield a very pure vegetable alkali. C. canus has fleshy white roots like the skirret, and may be dressed and eaten 
11440 diacánthus $L a \delta$. 11441 stellátus $W$ 11442 syriacus $W$. 11443 spinosíssimus $W$ 11444 centauroídes $W$. 11445 unitlórus $W$.

1666. ONOPOR'DUM 11446 Acánthium $W$.
11447 taúricum $W$. 11447 taúricum $W$. 11449 illýricum $W$. 11450 deltoídeum $W$. 11451 græ'cum $W$. 11452 cynaroídes Stev. 11453 arábicum $W$. 11454 acaúlon $W$.

1667. BERAR'DIA. Vill. Berardia 11455 subacaúlis $P . S$. round-leaved $A^{\prime}$ rctium lanuginosum Dec.

1668. CY'NARA. $W$. ARTichoKe. 11456 Scólymus iv

11457 hórrida $W$.

11458 Cardúnculus $W$.

11459 húmilis $W$.

11460 acaúlis $W$.

11461 glomeráta $T h$.

11462 pygmæ'a $W$.

1669. CARLI'NA, $W$ 11463 acanthifólia $W$.

11464 acaúlis $W$

11465 símplex $P$. $S$.

11466 aggregáta $W$.

11467 lanáta $W$.

11468 corymbósa $W$

11469 vulgáris $W$.

11470 racemósa $W$

11471 pyrenáica $W$.

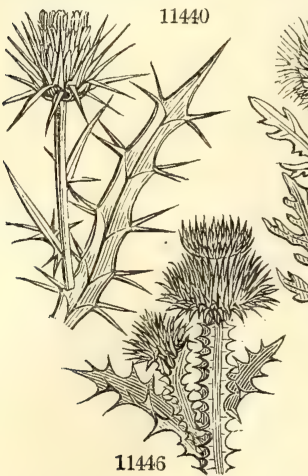

\section{garden}

Madeira

Cardoon

dwarf

stemless

pigmy

Carline Thistle

Acanthus-lvd $\triangle$ or ompositc. dwarf dwarf
single-flowered $\frac{j}{2} \Delta$ or ${ }^{\frac{3}{4}} \frac{1}{4}^{j n}$ clustered iे $\triangle$ or 2 jn.s woolly $\mathrm{O}$ or $3 \mathrm{jn.jl}$ corymbed $\$ \Delta$ or 3 jl.au $Y$ common $1 \mathrm{D}$ () $1 \frac{1}{2}$ jn.s $\mathrm{Pu}$ racemed $1 \mathrm{O}$ or ${ }_{2} \mathrm{j}$ jn.au Y $\pm \triangle$ or $2 \mathrm{jn}$

Pyrenean

\section{Pu Syria}

$\mathrm{Pu}$ Italy

1800. S co

1665. S co

W Levant 1771. S co

$\begin{array}{lll}\text { Pa.Y } & \text { Switzerl. 1759. D co } \\ \text { Pu Pyrenees } & 1640 . & \text { D co }\end{array}$

Vi Siberia 1796. D co Siberia

Compositce. Sp. $9-14$

$\forall$ or 6 jl.au Pu Britain gra.ba. $S$ co (D) or 12 jl.au Pu Tauria 1800. S co

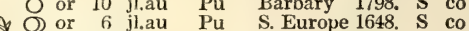
\& $\triangle$ or 12 au Pu Siberia 1784. D co Or 10 jn.jl Pu Levant 1799. D co 7 0 or $10 \mathrm{jn}$ W Caucasus 1823. S co J 1 or 8 jl $\mathrm{Pu} \quad \mathrm{S}$. Europe 1686. S co or $\frac{1}{2} \mathrm{jlau}$.a Composita.

S. Europe 1686. S co Sp. 1.

Italy

1791. D co

Lab.ic.pl.sy.2.t.s riumr.obs. t. 96 Camer.hort. t.10 Moris.s.7.t. 25. .f.2 Gmel, sib.2. ..38

Eng. bot. 977

Schou.maroc.t.5 Jac.vind.2. t. 148

Gouan. ill. t. 25

Jac. vind.2. t.149 Jac. ic. 1. t. 167

Vil.dauph.3.t.22

\section{Composite. Sp. 7-10.}

\$) $\triangle$ cul 8 aus $\mathrm{Pu}$

f $\triangle$ or 6 au.s Pu Madeira 1778. D co $\$ \triangle$ cul 5 au.s Pu Candia 1658. D co

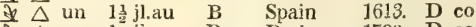
De un 1 ji Pu Barbary 1799. D co C. G. H. 1816. D co Spain 1820. D co

Blackw. t. 548

Tabern. ic. 1075 Plu.alm. t.81. f.2 Desf, atl.2. t. 223

Sp. 9-18.

Carniola 1818. D co All. ped. t. 51 Italy 1640. D co Knor. the.2.t.c.1 Hungary 1816. D co Pl rar.hu.2.t.152 Hungary 1804. D co S. Europe 1683. S co Garid. aix.t. 21 S. Europe 1640. D co Col.ecp.1.t.27.f.1

Britain dry pa. S co Eng, bot. 1144 Spain 1658. S co Pyrenees 1788. D co 11453

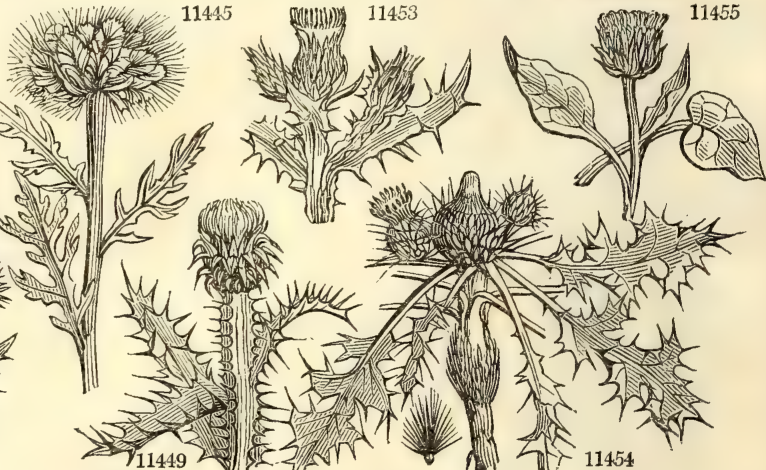

11455

History, Use, Propagation, Culture,

in the same manner. C lanceolatus is one of the most common and noxious weeds of the genus, chiefly on account of its great bulk, its numerous downy seeds, and the facility with which they are distributed by the wind: its dried flowers curdle milk. C. helenioides, used to be called the melancholy thistle, and was used by quacks as a cure for madness. C. Casaubonæ is so named after Casaubona, herbarist to the Grand Duke of Tuscany, who sent the seed to John Bauhin. C. syriacus is spotted with white, as are a number of Egyptian plants. C. oleraceus, according to Schreber, is not eaten by cattle; but the Russians are said to boil the leaves in the spring, and eat them as coleworts. The tender stalks of $\mathbf{C}$. cernuus are so used in Siberia.

1666. Onopordum A name employed by Pliny for a plant which he describes too imperfectly to be recognized uow. The virtues which he ascribes to it, and whence the name has been derived (oyos and $\left.\pi s \delta^{2} \omega\right)$, certainly have no existence in the modern genus, which consists of noble thistle-like plants, that, if allowed plenty of room, form very magnificent specimens of annual vegetation. $O$. acanthium (from its leaves being like those of the Acanthus) was formerly used like the artichoke and Cardoon. The seeds of this plant, unlike those of other thistles, are strongly defended by the calyx, and are not subject to be blown about by winds. The whole plant is white, tomentose, and one of the most magnificent of the family.

1667. Berardia. So named by Villars, after M. Berard, a botanist of Grenoble

1668. Cynara. Said to be derived from $\approx v \omega y$, a dog, on account of the stiff hard spines of the involucrum, which resemble the teeth of a dog. The English word Artichoke is said to be derived from the Celtic art, a spine, and chaulx, a cabbage; but it must be confessed that the word is very like the Arabic name of the plant, Carciofo or Kharchiof. C. scolymus is a well known garden esculent. In some parts of France and Italy it is eaten raw in its wild state by the common people. According to Gerarde, it was introduced into this country from Italy, but is become, "by reason of the great moisture which our country is subject unto," greater and better than those of Italy; a circumstance not to be doubted, and applicable to many other plants of culture; for it is a fact, that art can in many cases surpass nature; always, however, working upon nature's principles. The artichoke is one of those plants the most patient of drought, and in this unusually dry and hot season (1825) was almost the only vegetable procurable in the neighbourhood of Paris, during three or four weeks in July and August. Once in the seventeenth century, and again about 1759, most of the artichokes in England were destroyed by frost, but replaced from France. There are three varieties in cultivation, the conical, French, or oval; the globe, which has a large dusky purplish head; and the dwarf globe, a prolific variety, which is smaller. The parts used are the lower part of the leaves of the calyx; the fleshy receptacles of the flower, freed from the bristles and seed down, vulgarly called the choke; and some- 
11440 Leaves narr. pinnatifid downy beneath with strong spines, Fl. large solitary, Lvs. of invol. spiny recurved 11441 Leaves sess, lanc entire unarmed downy beneath, Spines axill, branched at base, Fl. axill. sessile

11442 Leaves amplexicaul. obl. toothed spiny with white veins, Fl. subsess. bracteate, Scales of invol. appressed

$114+3$ Leaves amplexicaul. pinnatifid toothed spiny pubescent, Stem simple, Fl. terminal clustered

11444 Leaves pinnatifid, Invol. scarious : scales acuminate

11445 Leaves pinnatifid, Invol. scarious villous

11446 Scales of invol. spreading subulate, Lvs. ov.-obl. sinuated and spin. decurrent woolly on both sides 11447 Scales of invol. much spreading, L.vs. decurrent smooth on each side sinuated toothed spiny

11448 Scales of invol. much spreading as long as invol. Lvs. decurr. downy sinuated toothed spiny : radic. pinnate

11449 Lower scales reflexed : upper much spreading, Lvs. decurrent downy sinuated toothed spiny

11450 Invol, squarrose with cobwebbed down, Leaves stalked ovate angular downy beneath

11451 Scales of invol. ovate-lanc. mucronate spreading, Lvs. decurrent downy subsinuate toothed spiny

11452 Stem and leaves tomentose: radical pinnatifid; cauline obl. adnate decurrent toothed spiny

11453 Scales of invol. ovate mucronate appressed, Lvs. decurrent somewhat downy sinuate toothed spiny

11454 Steml. Invol. glob. subsess. Scales of invol, lanc. spiny spreading, Lvs. stalked pinnatif. toothed spiny downy

11455 Stemless, Invol. obl. subsess. Scales of invol, obl. lanc. downy unarmed, Lvs. stalked roundish ovate

11456 Leaves somewhat spiny pinnate and undivided, Scales of invol. ovate

11457 Leaves pinnatifid downy beneath spiny, Spines of the base of leaves and pinnæ connate at base

11458 Leaves spiny : all pinnatifid, Scales of invol. ovate

11459 Leaves spiny pinnatifid downy beneath, Scales of invol. subulate

11460 Stemless, Leaves unarmed downy beneath pinnatifid : segm. cut-toothed, Scales of invol. lanc.

11461 Stemless, Leaves pinnatifid spiny

11402 Stemless, Leaves pinnated smoothish : segm. toothed spiny, Inner scales of invol. scarious at end

11463 Stemless, Leaves pinnatifid downy beneath : segm. toothed angular spiny

11464 Stem simple 1-fl. Lvs. pinnatifid naked: segm. cut-toothed spiny

11465 Stem simple 1-fl. longer than flower, Leaves deeply pinnatifid squarrose

11466 Stem simple 1-fi. numerous aggregate, Leaves pinnatifid smooth : segm. pinnatifid spreading spiny

11467 Stem subbifid, Middle flower sessile, Lvs. hoary lanc. toothed spiny

11468 Stem many-f. corymbose smoothish, Lvs. lanc. pinnatifid toothed smooth

11469 Stem many-fl. corymb. pubesc. Leaves lanc. unequally spin. and sinuated downy beneath

11470 Stem somewhat divided, Fl. axill, sess. Leaves lanc. toothed downy spiny pubescent

11471 Stem many-fl. Leaves decurrent

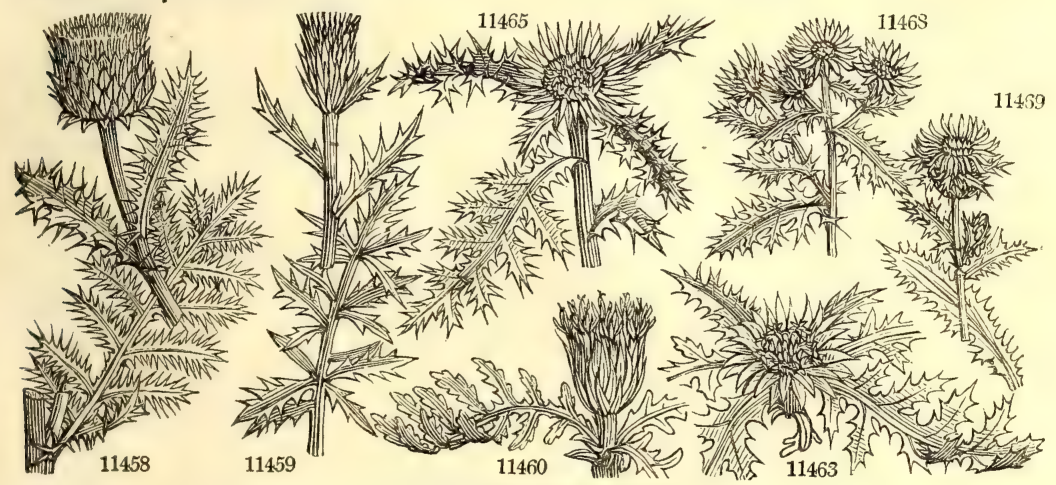

and Miscellaneous Particulars.

times the tender central leafstalk in a blanched state like the Cardoon. Medicinally, the plant is reputed to be aperient, stomachic, and somewhat heating. It is said to dye a good yellow, and the flowers curdle milk.

The plant is propagated by suckers in March and April, and requires a light rich soil, well dunged, and pulverised to a good depth. The leaves being large, the plants are placed in rows at four feet distance, and two feet apart in the row. They will produce some heads the first season, a full crop the next, and, if well manured, will last for five or six years. The plants require to be covered a foot thick with litter during winter, which is removed, and the ground dressed in March and April. The heads will appear in the beginning of June.

When the artichoke is to be cultivated as Cardoon, the plants are to be cut over by the surface about mid. summer; in September they will have produced leaves about two feet high; they are then bound close with a wreath of hay or straw, and earth drawn round them. The blanching will be perfected in a month or six weeks.

Bauhin thought the Cardoon a hybrid from the common artichoke, to which it bears a great resemblance. The tender stalks of the inner leaves, rendered white and crisp by earthing up, are used for stewing, and for soups and salads during winter, like celery. It requires the same soil as the artichoke, to be planted at three or four feet apart in May, or sown where it is to remain in March. In September the leaves may be tied together and earthed up, and in October and November they will be blanched from one to three feet in length.

With the florets of Cynara Cardunculus, which the Portuguese call Cardo do coalho, milk was formerly coagulated by the people of Portugal, as it is by rennet in England.

1669. Carlina. Olivier de Serres says, this plant was named after the famous Charlemagne, whose army was cured of the plague by means of this plant. Linnæus ascribes the the famous Charlemagne, whose army was army was relieved from the plague in Barbary in the same way. C, acaulis has black woody roots an inch thick, the upper part of which, with the receptacle of the flower, when tender, may be eaten, but the root of the adult plant becomes acrimonious, and is recommended as an alexipharmic. It contains an acrid resinous principle, by which it stimulates the solids, dissolves the humours, and promotes perspiration. C. vulgaris is found all over Europe in dry barren soils. The flowers expand in dry, and close in moist weather, retaining this property a long time.

Upon this and a few other genera M. Cassini has founded a tribe, which he denominates Carlineæ, which although possessing no very precise characters of difference, is, he believes, distinct from both his Centauriexe and Carduineæ, from which it may always be distinguished by the perfect smoothness of the filaments. The species of Carlineæ are found in every part of the world. 

10\%\% ATRAC'TYLIS, $W$. ATRACTYLIS. dwarf

1671. ACAR'NA. $W$. 11473 gummífera $W$.

11474 cancelláta $W$

1672. STOKE'SIA. $W$. 11475 cýanea $W$.

1673. STOB珑A. Th. 11476 pimnáta $T h$.

ACARna.

Composite. Sp. 1-4. cummy-rooted $\neq \Delta$ un Compositce. Sp. 2-6.

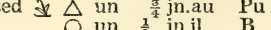
Composite. Sp. 1 . blue-flowered $E$ Lل J pr 2 au B Carolina 1766. D co L'He.ser.27. Sтовжа. Composite. Sp. 1-11.

$\begin{array}{lll}\text { Composita. } & \text { Sp. } 1-11 . \\ \text { ja.d } & \text { C. G. H. 1812, C co Bot. mag. } 178\end{array}$

1674. ONOBRO'MA. Gertn. Onoвroma. Composite. Sp. 2

11477 cærúleum Gartn. blue-flowered $\$ \Delta$ or 1 jn.jl B Spain 1640. D co Bot. mag. 2293 Carthamus caruleus W.

11478 salicifólium Link. Willow-leaved th or 3 au $\quad$ W Madeira 1784. C s.p

1675. CAR'THAMUS. $W$. Carthamus.

11479 tinctórius $W$. officinal

11480 lanátus $W$. woolly

$11+81$ créticus $W$.

11482 tingitánus $W$.

11483 mitissimus $\dot{W}$.

11485 arboréscens $W$. tree

\begin{tabular}{|c|c|c|}
\hline & & Compo \\
\hline or & 3 & jn.jl \\
\hline or & 3 & jl.au \\
\hline or & 2 & jn.jl \\
\hline or & $?$ & jn.jl \\
\hline or & & $\mathrm{jn} . \mathrm{jl}$ \\
\hline or & $\frac{3}{4}$ & my.jn \\
\hline
\end{tabular}

Sp. 7-20.

1676. CARDopa'TUM. Pers. Cardopatum.

11486 corymbósum Pers. corymbose

\section{c $\Delta$ u}

1677. STEHELI'NA. $W$. Steheliva.

11487 dúbia $W$. Rosemary-lyd

11488 arboré $W$ Storax leaved. 迸

11488 arborescens $W . \quad \begin{aligned} & \text { Storax-leaved } \\ & 11489 \text { chamæéuce } W .\end{aligned}$

1678. PALAFOX'IA, Lag. Palafoxia.

11490 lineáris Lag. linear-leaved

1679. PTERo'NiA. $W$. P'Teronia.

11491 camphoráta $W$.

11492 strícta $W$.

11493 flexicaúlis $W$.

11494 oppositifólia $W$.

11495 scariósa $W$.

aromatic

Composite

Egypt 1551. S s.l Bot. reg. 170

S. Europe 1596. S co Bot. mag. 2142

Candia 1731. S co

Barbary 1759. D co Cav. ic. 2. t. 128

France 1776. D co

France 1754. D co

Spain 1731. C s.p

Composita. Sp. 3-13.

3 jn.jl Pu S. Europe 1640. C p.l Lam.ill. t.666.f.4

6 jl.s Candia 1739. C p.1 Schreb.dec.1.t.1

jl.n Candia 1640. C p.1 Plu. alm.t.94.f.3

Composita. $S p .1$.

jn.jl W Mexico 1821. S co Bot. mag. 2132

Compositce. Sp. 5-33.

3 $Y$ C.jn $Y$.

C. G. H. 1812. C co

C. G. H. 1774, C p.1 Bre.prod.t.17.f.3

C. G. H. 1815. C co

Compositce. Sp. 9-18.

1680. VERNO'NIA. $W$. VerNonia

11496 noveboracensis $W \cdot$. long-leas

11497 præálta $W$

11498 angustifólia $P h$

11499 glaúca $W$.

11500 serícea Rich.

11501 flexuósa $B$. M

Composita

long-leaved $\$ \Delta$ or 6 s.n

$\mathrm{Pu}$

N. Amer. ${ }^{-1710, D}$ co Dil.el.t.26\$.f 342 narrow-leaved $\frac{\nabla}{\downarrow}$ or 4 s.n Pu N. Amer. 1817. D co glaucous-leav'd $\downarrow$ or 4 s.n Pu N. Amer. 1710. D co silky or 5 d Pa,pu Brazils 1823, C co

Dil.el.t.262.f.341 flexuose $\bar{D}$ or $1 \frac{1}{2}$

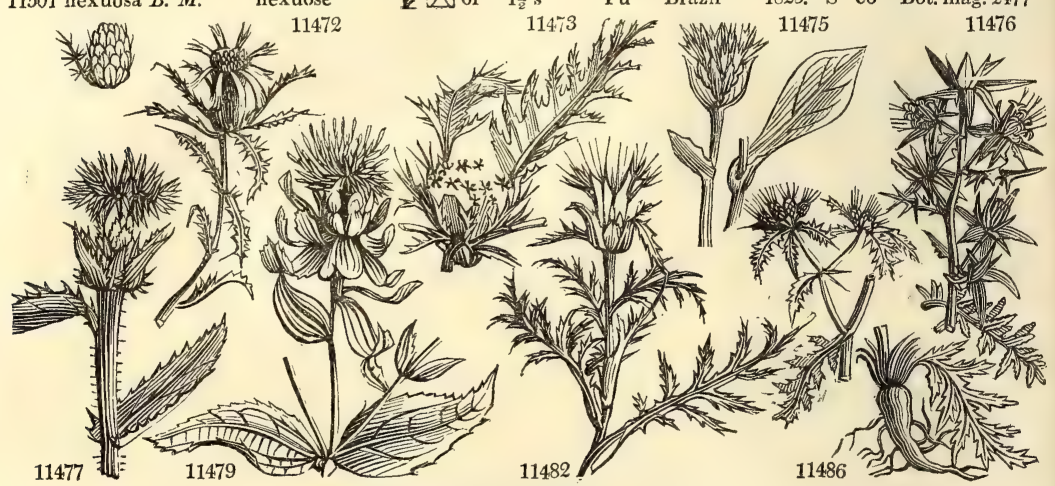

History, Use, Propagation, Culture,

1670. Atractylis. Vaillant (Mem. Acad. Sc. 1718.) derives this from orgarros, a distaff, because the light stems were very fit to make spindles.

1671. Acarna. A name under which Theophrastus describes a plant resembling a thistle. Willdenow applied it to the present genus, which consists of thistle-like plants.

1672. Stokesia. Named in honor of Jonathan Stokes, M.D., well known as the coadjutor of Dr. Withering in his botanical arrangement of British plants. A perennial plant, with large handsome blue flowers.

1673. Stobea. Named after Dr. Stobæus, of Lund, one of Linnæus's earliest patrons, and said to have been a practical naturalist.

1674. Onobroma. From ovos, an ass, and $\beta_{\text {gw }} \mu$, food, in allusion to the worthlessness of its herbage. Thistlelike plants of little beauty.

1675. Carthamus. From its Arabic name gortom, a word which signifies to paint, on account of the fine color yielded by the flowers. Tournefort, with little reason, derives it from the Greek The flowers of Carthamus tinctorius are used by the Chinese to give some of the fine rose, scarlet, purple, and violet colors to their silks. For this purpose, the flowers are thrown into an infusion of some alkali, and left to macerate; the colors are afterwards drawn out by the addition of lemon juice in various proportions, or of any other vegetable acid.

It is cultivated at present in many parts of Europe, and in the Levant, whence great quantities are annually imported into England for dyeing and painting. In Spain it is grown in gardens, as Marygolds are in England, to color soups, olives, and other dishes. The Jews in Poland are remarkably fond of it, and mix it with their bread, and most of their viands. According to Houghton, it was formerly cultivated in Gloucestershire, both for the flowers and seed. The common people took it for saffron, and used it in their puddings, cakes, and 
11472 Stem and leaves smooth

11473 Stemless, Leaves pinnatifid, Outer leaves of invol. tricuspidate

11474 Stem branched, Leaves lanc. ciliate toothed downy, Outer leaves of invol. setaceous pinnatifid conniving piarger than flower
[largen

11475 The only species

11476 Leaves downy pinnatifid : pinnæ linear terminated by a spine

11477 Stem about 1-fl. Leaves ovate lanc. spiny-toothed

11478 Stem shrubby, Leaves sessile lanceolate downy beneath spiny-toothed, Branches 1-flowered

11479 Stem quite smooth, Leaves ovate entire spiny toothed, Fruit naked

1179 Stem woolly, Lower leaves pinnatifid toothed : upper amplexicaul pinnatifid toothed spiny

11481 Stem smoothish, Invol. somewhat woolly, Lower leaves lyrate : upper half-amplexicaul.

11482 Radic. leaves pinnated: cauline pinnatifid, Stem 1-flowered

11483 Leaves unarmed: radical toothed; cauline pinnate

11484 Cauline leaves linear pinnated as long as plant

11485 Leaves ensiform sinuate toothed

11486 Spiny much branched with small blue flowers

11487 Leaves sessile linear toothletted downy beneath, Inner scales of invol. lanc. long 11488 Leaves stalked ellipt. blunt entire silky with down beneath

11489 Leaves lin. clustered very long revolute at edge hoary beneath, Branches downy

11490 The only species

11491 Leaves scattered and fascicled filiform ciliated, Leaves of invol. ciliated, Hairs of recept. clustered

11492 Lvs, scattered and fascicled filiform subciliate at base, Lvs. of invol. entire, Holes of recept. multipartite

11493 Leaves connate linear filiform glabrous, Scales of invol. ovate, Stem wavy, Fl, terminal in threes stalked

11404 Leaves ovate powdery downy, Scales of invol, ovate entire

11495 Leaves ovate smooth, Scales of invol. ovate mucronate membranous

11496 Leaves lanc. scabr. serrulate, Corymb fastigiate, Scales of invol. filiform at end

11497 Leaves ovate-lanc. serrate downy beneath, Corymb fastigiate, Scales of invol, ovate acuminate

11498 Stem simple, Lvs. many long and narrow lin. nearly entire, Corymb somewhat umbell. Scales of inv. stiff 11499 Leaves oblong acuminate serrate, Corymb fastigiate, Scales of invol. ovate acute rmucronate

11500 Leaves linear-lanc. silky beneath downy on each side nearly entire, Flowers alternate 1-sided sessile

11501 Stem straight dichotomous upwards : branches flexuose, Heads in the forks of the branches sessile

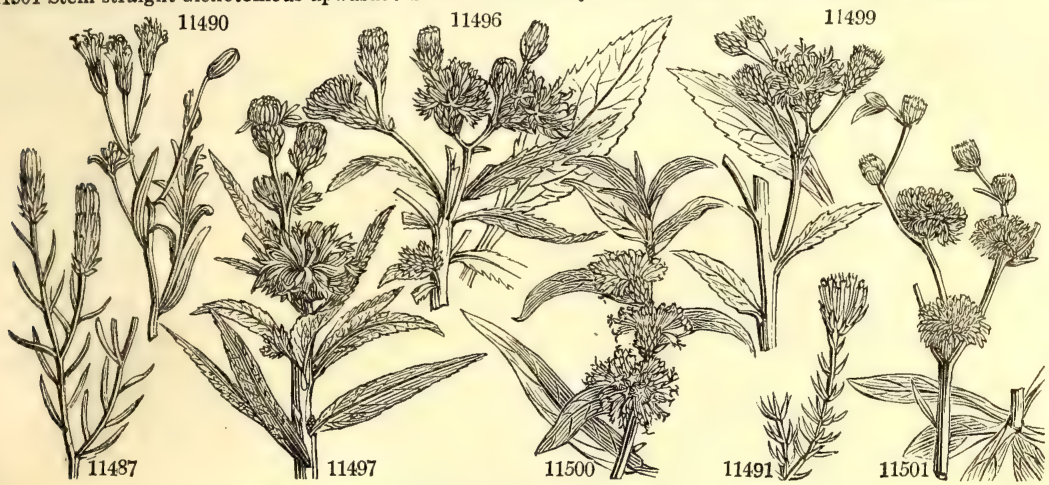

and Miscellaneous Particulars.

bread; but by putting in too great a quantity they found it communicate a purgative quality, and gave up its use. It is still, however, used in this way by some pastrycooks. In Germany it is cultivated on light land well pulverised; it is sown in rows about eighteen inches distance, and afterwards thinned to three or four inches apart in the row : in September the plants begin to flower, and the field is then gone over once a week, for six or seven weeks, to gather the expanded florets, which are dried in a kiln in the same manner as true saffron. Turkeys and geese are said to feed greedily on the seed, and in a short time become very fat.

C. lanatus is used by the women of the south of France and Spain for distaffs, and hence it had the name of distaff thistle. The root of C. carduncellus is eaten in A frica.

1576. Cardopatum. A name of unknown meaning. A spiny branched plant with little blue flowers, formerly referred to Carthamus.

1677. Stahelina. One Benoit Stæhelin, a Swiss botanist, published, in 1730 , an academical dissertation upon the Filicula saxatilis corniculata and the Equisetum. These are pretty half-shrubby thread-leaved plants, mostly deserving cultivation.

1678. Palafoxia. Named by Lagasca, after the Spanish General Palafox, of whose merits as a botanist we are uninformed. A small perennial plant with the habit of Stevia.

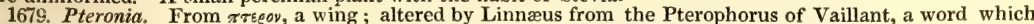
seems to allude to the feathery scales of the receptacle. A genus of humble rigid shrubs.

1680. Vernonia. Named after Mr. William Vernon, fellow of St. Peter's College, Cambridge, who travelled

in North America in search of plants, and left behind him an Herbarium, which came into the hands of Sir Hans Sloane, and contributed to enrich the third volume of Ray's Historia Plantarum. Vernonieæ con. stitutes the twentieth of M. Cassini's subdivisions of Compositæ. They are distinguished from Lactuceæ by 
11502 panduráta Jacq. fiddle-leaved $\forall \Delta$ or 4 s.n $\quad \mathrm{Pu} \quad \ldots . . . \quad 1825 . \mathrm{D}$ co 11503 arboréscens Cass. tree 1681. AMMO'BIUM. R. Br. Amмовium. Composite. Sp. 1.

11505 alátum $R . B r$. winged $\$ \Delta \mathrm{pr} 2 \mathrm{mr}$.s W N. Holl. 1822. S co Bot.mag. 2459

1682. LIA'TRIS. $W$. Liatris. Composite. Sp. 11-18.

11506 squarrósa $W$.

11507 scariósa $W$.

11508 sphæroídea $P h$.

11509 élegans $W$.

11510 pilosa $W$.

11511 cylindrácea $P h$.

11512 heterophýlla $P h$.

11513 pycnostáchya $P h$.

11514 spicáta $W$.

11515 odoratíssima $W$.

11516 púmila Hort.

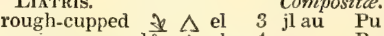

scarious-cupped $\$ \Delta$ el globular-cupp'd $\frac{1}{\Delta}$ el hairy-cupped + $\Delta$ el hairy-leaved $\frac{\Delta}{\Delta}$ el cylindrical-cup. is $\Delta$ el various-leaved $₹ \Delta$ el pubescent-lvd. $\frac{\nabla}{\Delta} \mathrm{el}$ long-spiked $\vec{x} \Delta$ el sweet-scented $\triangle \mathrm{el}$ dwarf

so $\Delta \mathrm{el}$

1683. MIKA'NIA. $\boldsymbol{W}$. MIKania.

11517 Houstóni $W$.

11518 hastáta $W$.

11519 scándens $W$.
3 au.o $\quad$ Pu

$1 \frac{1}{2}$ s.o Pu

4 au.o Pk

3 au.o Pu

6 au.o $\quad \mathrm{Pu}$

1 au.o
4 s.o Pu

3 jl.au Pu

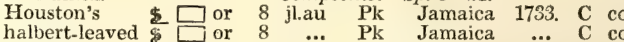
climbing

N. Amer. 1732. D p.1 Sweet fl. gard. 44 N. Amer. 1739. D p.1 Bot. mag. 1709 N. Amer. 1817. I co Sweet fl. gard.87 Amer. 1787. D p.1 Bot. reg. 267 N. Amer. 1783, D p.l Bot. reg. 595

N. Amer. 1811. D co

N. Amer. 1790 . D p.l

N. Amer. 1732. D co Dill. elt.t.72.f.83 N. Amer. 1732. D p.l Bot. rep. 401 Carolina 1786. R s.p Bot. rep. 633 N. Amer. ... R s.p Bot, cab. 147

Composite. Sp. 3-21.

1684. SPARGA No'PHORUS. Gertn. Sparganophorus. Composito. Sp. 2.

11520 Vaillántii Gertn. Vaillant's $\square$ un $1 \frac{1}{2}$ au $\underset{Y}{Y}$ India 1823. S co Gærtn.t.165. f.4 11521 Strúchium Sw.. Swartz's Un $2^{2}$ au Y Jamaica ... S co Bro.jam t.34.f.2

1685. EUPATO'RIUM. $W$. Eupatorium.

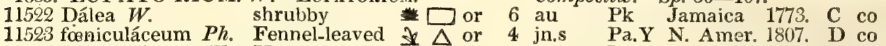

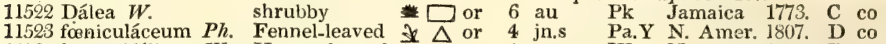

Composite. Sp. 30-107. 11524 hyssopifólium $W$. Hyssop-leaved $\$ \Delta$ or 1 au.s W N. Amer. 1699. D co

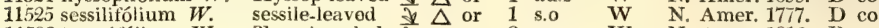
11526 teucrifólium $W$. Teucrium-lvd. $\frac{\Delta}{\Delta}$ or 2 au.n W N. Amer. 1816. D co 11527 rotundifólium $W$. round-leaved $\not \mathbf{y}$ or 1 jl.au W N. Amer. 1699. D co 11528 altíssimum $W$. tall 2 or 5 s.o 11529 trifoliátum $W$. three-leaved De $\triangle$ or 6 au.o 11530 cannabínum $W$. HempAgrimony 2 or 4 jl.o

11530 cannabinum $W$. HempAgrin

11531 syríacum $W$.

11532 purpúreum $W$.

11533 maculátum $P h$.

11534 punctátum $P h$.

11535 verticillátum $W$.

11536 perfoliátum $W$.

11537 coelestínum $W$

11538 urticæétium $i W$.

11539 aromáticuin $W$.

11540 ageratoídes $W$

11541 odorátum $W$.

11542 ivæélium $W$

Iva-leaved $\overline{\mathbb{\Delta}}$ or

B. $M$. Sage-leaved 4 or 4 au.s

11544 lamiifólium Link. Nettle-leaved $\Delta$ or 3 au.s

11545 ceanothifólium $W$. Ceanothus-lvd. \s $\Delta$ or 4 au.s

11546 iresinoides $K$ th. snowy $\quad \square$ or 2 au.o

$115 \$ 7$ paniculátum Mill. panicled $\quad \overline{\mathbb{Z}}$ or 6 au.o

Plu.alm. ber. 32 N. Amer. 1699, D co Jac.vind 2, 16 N. Amer. 1768, D co Britain wat.pl. D co Syria 1807. D co

1807. D co Jac, ic. 1. t. 170 purple-stalked $\Delta$ or 5 s.o Pk N. Amer. 1640. D co Corn. canad.t. 7 \& spotted-stalked $¥ \Delta$ or 3 au.s whorl-leaved $\frac{\not}{2} \Delta$ or 4 au.s Feverwort $\Delta$ or 2 au.o blue-tlowered $\frac{1}{\partial} \Delta$ or 2 jln Nettle-leaved $\mathrm{d} \Delta$ or 1 i jl.au aromatic $\underset{\text { a }}{\Delta}$ or 4 jl.au Ageratum-like 70 or 4 au.o

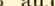
N. Amer. 1656. D co N. Amer. 1815. D co N. Amer. 1811. D co

N. Amer. 1699 D co Plu alm t. $87 . \mathrm{f} 6$ N. Amer. 1732 D to Dilel t 114 f 139 S. Amer. 1803. D co Smith. inerl t.68 N. Amer. 1739. D co Plu. alm, t.88.f.3 N. Amer. 1640. D p.1 Corn.canad, t.21 Jamaica 1752, C co Plu.alm.t.177.f. Jamaica 1794. D co

N. Amer. 1814. D co Bot. mag. 2010 ...... 1823. D co ..... 182t. D co

N.Grenad.1820. C co Kun.nov.g.t.340 Eriopáppus paniculatus Hort.
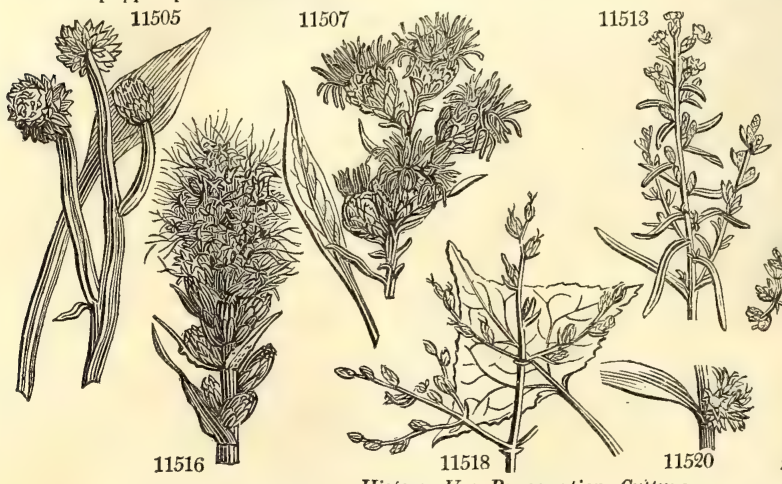

818. D co

Jac.schœ, 2.t.146

Dil.el.t.115.f.140

Herm.par, t.158

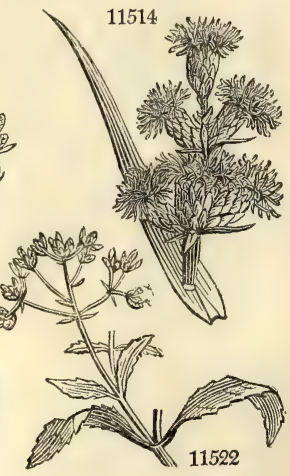

History, Use, Propagation, Cuiture,

their corolla, which is not ligulate, and from every other tribe by their style, which is absolutely the same as that of Lactuceæ. The greater part of Vernonieæ are found in America; a few in Asia and Africa, but none in Europe.

1681. Ammobium. From $\alpha \mu \mu \circ$, sand, and $\beta \iota \omega$, to live, in allusion to the places where it grows. A pretty half-hardy New Holland herbaceous plani, with dry white involucral scales, like a Gnaphalium.

168\% Liatris. A word of unknown meaning. A genus of charming North American herbaceous plants. They should be taken out of the borders in the autumn, and preserved in pots till the succeeding spring. Of Liatris odoratissima, the leaves when dry give out a very pleasant smell resembling Vanilla, and which lasts for years. It is called the Carolina Vanilla plaint.

I iatris squarrosa is a very handsome species, with large heads of most beautiful flowers of a rich purple. It and L. scariosa are known in North America under the name of rattlesnake's master. In case of being bitter by this reptile, the bruised bulbs of the plants are applied to the wound, while, at the same time, a decoction in milk is taken inwardly. 
11502 Leaves oval blunt serrate-crenate : lower with a winged amplexicaul. stalk, Fl. subcorymbnse 11503 Leaves ovate entire acute downy beneath, Spikes recurved 1-sided, Bractes reflexed 11504 Leaves ovate-lanc. narrowed at each end serrated roughish pubescent beneath, Fl. term. about 3

\section{Leaves oblong wavy decurrent}

11506 Stem simple pubescent, Leaves very long linear nerved roughish at edge, Racemes few-fl. leafy 11507 Stem simple pubescent, Lvs. lanc. narrowed at each end smooth rough at edge, Inv. squarrose at bottom 11508 Stem simple pubescent, Leaves smooth : lower stalked broad-lanc. Invol. subglobose with scarious scales 11509 Stem simp. vill. Lvs. lin. subfalc. dott. rough, Spike somew. leafy, Pedic. short, Inner scales ligul. colored 11510 Stem simple pubesc. Lvs. lin. pilose ciliated, Invol. racemose lax, Scales lin. obl. bluntish [mucronate 11511 Slender all over hairy, Lvs, grassy, Spike few-f. Inv. subsess. cylindr. few-fl. Scales round. at end abruptly 11511 Slender all over hairy, Lvs, grassy, Spike few-f. Inv. Subsess. cylindr. few-fl. Scales round. at end abre 11513 Stem simple hirsute, Lvs. straight narrow.lin. downy, Spike long, Fl. closely cluster. Inv. appress. squarrose 11514 Stem simple tall, Lvs. lin. smooth ciliated at base nerved and dotted, Spike very long, Fl. sessile [at end 11515 Quite smooth, Stem simple, Rad. leaves obl. : cauline amplexicaul. Panicle corymbose lax spreading 11516 Dwarf, Leaves linear, Stem simple, Flowers spiked

11517 Stem climbing, Leaves ovate entire, Flowers spiked

11518 Stem climbing, Leaves subcordate hastate toothed, Flowers in spikes

11519 Stem climbing smooth, Lvs. cord. repand toothed acuminate with spreading unequal lobes, Fl. corymbose

\section{Flowers sessile latera}

11521 Flowers axillary sessile, Corollas all trifid

11522 Leaves lanc. veiny obsoletely serrate smooth, Invol. 4-fl. Stem shrubby

11523 Stem panicled, Leaves smooth : lower pinnated; upper fascicled, all filiform

11524 Leaves opp. subverticill. linear entire pubescent 3-nerved dotted : radical somewhat toothed

11525 Leaves sessile amplexicaul. distinct ovate-lanc. rounded at base serrated smooth, Stem smoothish

11526 Leaves sessile distinct ovate scabrous : upper coarsely serrated at base ; uppermost entire

11527 Leaves sessile distinct roundish cordate bluntly serrate veiny

11528 Leaves subsessile lanceolate 3-nerved narrowed at each end downy : lower serrated in middle

11529 Leaves stalked 3 or 4-nate ovate narrowed at each end serrated roughish

11530 Leaves opposite subpetiolate tri-quinque-partite : their segments lanceol. deeply serrate

11531 Leaves petiolate ternate and simple downy beneath unequally serrate, Stem smooth

11532 Leaves stalked 4 or 5-nate ovate lanceolate serrate rugose veiny roughish, Stem hollow

11533 Leaves stalked 4 or 5-nate ovate lanceolate unequally serrate downy beneath, Stem solid furrowed

11534 Leaves stalked 4 or 5-nate ovate acuminate serrated scabrous on each side, Stem solid round

11535 Leaves stalked 3 or 4-nate ovate-lanceol. cuneate at base unequally serrate smoothish, Stem solid smooth

11536 Leaves connate perfoliate downy

11537 Leaves stalked cordate ovate bluntish 3-nerved bluntly serrate, Fl. corymbose

11538 Hispid, Leaves stalked cordate cut serrate, Panic. terminal, Invol. many-fl. subulate pungent

11539 Leaves stalked ovate acute 3-nerved bluntly serrate glabrous, Stem panicled upwards, Fl. corymbose

11540 Leaves stalked ovate acuminate 3-nerved unequally coarsely serrated smooth, Corymb many-fl. spreading

$115+1$ Leaves stalked triangular ovate serrated entire at end downy beneath, Corymbs spreading term. sessile

11542 Leaves narrow lanceol. 3-nerved subserrated, Invol. squarrose many-flowered

11543 Leaves amplexicaul. lanc. acuminate rugose serrated, Flowers panicled clustered

11544 Leaves stalked ovate acuminate unequally and bluntly crenated pubescent, Panicle contracted

11545 Leaves stalked ovate acuminate toothed 3-nerved glabrous

11546 Stem twining villous, Lvs. deltoid ovate acute 3-nerved soft beneath, Panicle term. trichotomous diffuse

11547 Like E. lamiifolium, but the flowers smaller and panicled

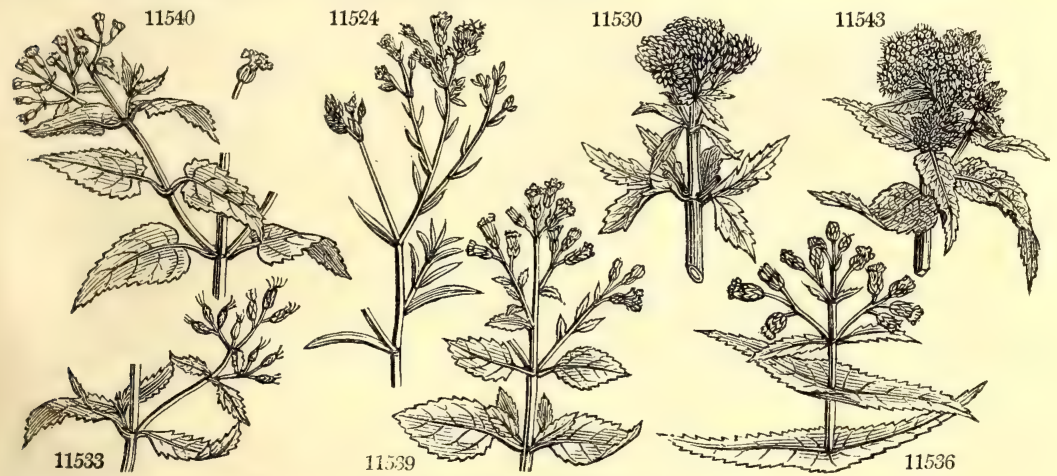

and Miscellaneous Particulars.

1683. Mikania. Named by Willdenow, after Professor Mikan, of Prague. Climbing tropical plants, one of which, M. Guaca, is employed in South American medicine as a powerful febrifuge.

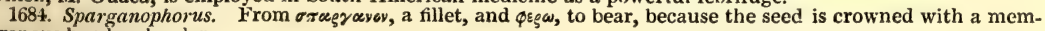
branous band or border.

1685. Eupatorium. This plant, says Pliny, derives its name from Eupator King of Pontus, who first used it in medicine. Aya-pana is the vernacular name of the species so called among the natives of the banks of the river Amazon. The tribe of Eupatorieæ is distinguished from Vernoniex by its style. They are chiefly found in America, very few inhabit Asia, scarcely any Africa, and not one has been found in Europe.

The Eupatorium perfoliatum has some reputation as a medicinal plant. A dissertation upon the subject of its merits was published a few years since by an American physician, from which it appears that the virtues of the plant reside chiefly in the leaves, and that the most efficient mode of exhibiting it is by means of a simple decoction. The medical powers of Eupatorium are, as its sensible properties would seem to indicate, those of a tonic stimulant. Given in moderate quantities, either in substance, or in cold infusion or decoction, it promotes digestion, strengthens the viscera, and restares tone to the system. Like other vegetable bitters, 

11548 pubéscens $W . \quad$ downy $\quad \downarrow \Delta$ or 4 jl.au W N. Amer. 1819. D co 11549 mólle Swz. 11550 deltoídeurn $\mathrm{Jacq}$ soft 11551 scándens Link.

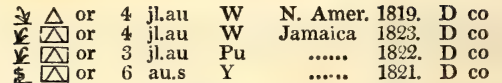
1686. DUMERI'LIA. Lag. Dumerilia. 11552 paniculáta Lag. panicled

1687. AGE'RATUM. $W$. Ageratum. 11553 conyzoídes $W$. hairy

11554 latifólium $W$. broad-leaved 11555 strictum $B . M$. upright 11556 mexicánum $B$. $M$. Mexican

1688. C Alest'Na. Cass. Calestina.

11557 ageratoídes Cass. blue-flowered

1689. STE'VIA. $W$. STEvia.

11558 purpúrea $\boldsymbol{W}$. en.

11559 Eupatória $W$.

11560 hyssopifólia $\dot{B} . M$.

11562 serráta $W$.

11563 ivæfólia $W$. en.

11564 ováta $W$.en.

11565 pedáta $W$.

11566 lanceoláta $\mathrm{Lag}$

11567 pubéscens Lag. purple

$\downarrow \Delta \mathrm{pr}$

entire-leaved $\frac{\Delta}{\Delta} \Delta$ pr

Willow-leaved

saw-leaved

Iva-leaved

oval-leaved

multifid

lanceolate

pubescent

$\frac{\Delta}{\downarrow} \Delta \mathrm{pr}$

$\downarrow \Delta \mathrm{pr}$

se $\triangle \mathrm{pr}$

$\checkmark \mathrm{O}$ pr

$\frac{\nu}{\Delta} \mathrm{pr}$

1690. CEPHAI glaucous

$\searrow \triangle \mathrm{U}$ U

1691. AMPHE'REPHIS. $K t h$. AMPHEREPHIS.

11569 intermédia Link. intermediate $\bigcirc$ pr

1692. HYMENOPAP'PUS. $J$. HYMENOPAPPUS.

11570 tenuifólius $P h$. slender-leaved $\underline{E}$ 이 un

Composite.

3 au $S p .1$

Composita. $S p, 4-8$.

1 jl.au L.B America 1714. S p.l Ex. ff. 15

$1 \frac{1}{2}$ jl.au W Peru 1800. S co Cav. ic. 4. t. 357

jn.jl W Nepal 1821. S co Bot. mag. 2410

$1 \frac{1}{2} \mathrm{jn} . \mathrm{jl}$ B Mexico 1822, S co Bot. mag. 2521 Composite. Sp. $1-2$.

1 jl.o B $10 . .$. .

$1 \frac{1}{2}$ au.s $\mathrm{Pu}$. $10-14$

$2^{2}$ jls $\mathrm{Pk}$

11 Mexico

$1 \frac{1}{2}$ au.s $\quad \mathrm{Pk}$ Mexico

$1 \frac{1}{2}$ jl.s F Mexico

$2 \mathrm{jl} . \mathrm{s}$

2 au.s

$1 \frac{2}{2}$ jl.s

1 jl.s

W Mexico

Mexico

Mexico

Mexico

Mexico

Composite. Sp. 1.

2 jl.au Y Chili

.. C co Bot. mag. 1730

Composita. Sp. $1-3$

$1 \frac{1}{2}$ jl.au Pu Brazil

1812. D co Bot. reg. 93

1798. S p.l Bot. mag. 1849

.... D co Bot. mag. 1861

1803. S p.l Cav. ic. 4. t. 354

1799. D s.p Jac.schue.3.t.300

1816. D s.p

1816. D s.p

1803. S s.p Bot. mag. 2040

1822. D co

1798. D co Cav. ic. 6. t. 599

Composita. Sp. 1-2

1821. S co Pla.sel.H.B.f.29

Louisiana 1811. S co

Sp. 2-5.

1593. MeLANANTHE'RA. Mi. Melananthera.
11571 hastáta $P h$. Composita. Bidens nivea W.

e panduríta

11572 deltoidea Mich. Calea áspera W.

1694. Marshal'Lia. $P h$. Marshallia.

fiddle-leaved $\mathrm{N}$ un 2 jn.jl $\mathbf{W}$

Amer. 1732. D co Dill.elt. t.47.f.55

N. Amer. 1732. D co Dill.elt. t.46.f.54 S. Amer. 1799. S co Jac. ic. 3. t. 583

11573 lanceoláta $P$.

11574 latifólia $P h$. pear-leaved 11 composita. Sp. 2-3.

$1 \frac{1}{2}$ jn.ji $\mathrm{Pu}$ Carolina 1812. D co

1695. SPILAN'THES. $\boldsymbol{W}$. SPILANThes.

11575 Pseudo-Acmélla $W$. spear-leaved

11576 álba $W$ esculent

1696. SAl'MEA. Dec. Salmea.

11578 scándens Dec. scandent

11579 hirsúta Dec. hirsute

\section{Compositce. Sp. 3-14.}

[0] un 1 jl $\mathrm{Y}_{\mathrm{W}}$ Ceylon 1768. S, s.l Pluk.al.t.159.f.4 O] un $1 \frac{1}{2} \mathrm{jn} . \mathrm{jl}$ W Peru 1783. S co L'He.stirp.7.t.4

Composita. Sp. 2-3. D pr 6 au W Jamaica 1823. S co
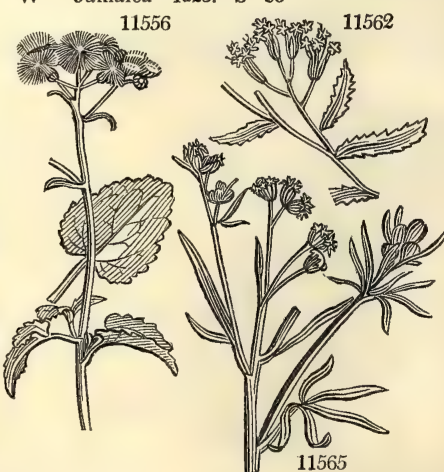

History, Use, Propagation, Culture,

If given in large quantities, especially in warm infusion or decoction, it proves emetic, sudorific, and aperient. Even in cold infusion, it tends to bring on diaphoresis. The plant is also stated to be an excellent remedy for the cure of intermittent fevers. When employed as a tonic, this plant may be taken in doses of twenty or thirty grains, or a teacup full may be used of the infusion rendered moderately bitter. When intended to act as an emetic, a strong decoction may be made from an ounce of the plant in a quart of water boiled to a pint. (Bigelow.)

1686. Dumerilia. Named after M. A. M. Constant Duméril, author of an Elementary Treatise upon Natural History, published in one volume octavo, at Paris, in 1804. Small half-shrubby South American plants, with firmi hairy leaves.

1687. Ageratum. A name employed by Dioscorides, and probably applied by him to some plants similar to what we call properly " everlastings;" it is derived from $\alpha$, privative, and rng , , old age, because it never grows old; that is to say, always preserves its color.

1688. Calestina. From calestis, blue, in allusion to the color of the flowers.

1689. Stevia. Dedicated by Cavanilles to the memory of Peter James Esteve, a Spanish physician of the

sixteenth century. He left behind him a dictionary of the plants natives of the kingdom of Valentia.

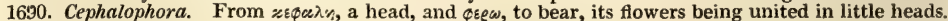

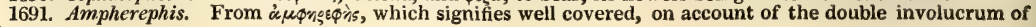
the genus, 
11548 Lvs. sessile distinct ovate scabrous veiny : lower doubly serrate; upper subserrate, Stem panicled downy 11549 Leaves stalked cordate acute subserrate villous beneath, Invol.8-15-fl. Stem shrubby

11550 Leaves stalked hastate triangular 3-nerved unequally serrate downy beneath, Panic. corymbose

11551 Stem twining, Leaves reniform ovate acuminate serrate-toothed, Panicle axillary

11552 Leaves roundish 7-lobed : lobes crenate, Panicle corymbose terminal

11553 Leaves ovate subcordate, Stem hairy, Palex of pappus awned toothletted

11554 Leaves ovate cuneate at base, Stem pilose, Paleæ of pappus lanceolate acute

11555 Stem erect simple scabrous, Leaves cordate rugose unequally serrated

11556 Hispid, Leaves cordate ovate crenate rugose, Corymb compound, Paleæ of pappus lanceolate awned

11557 Leaves stalked ovate acute rounded at base serrated pilose above hairy beneath

11558 Leaves lanc. channelled narrowed into the footstalk 3-ncrved, Corymb fastigiate 11559 Leaves lanc. 3-nerved entire. Corymb fastigiate, Pappus paleaccous and awned

11560 Leaves oblong ovate entire, Corymbs spreading, Paipus awned as long as corolla

11561 Leaves lanc. narrowed at each end serrated in the middle, Corymb spreading, Pappus with 2 awns

11562 Leaves lin. lanc. serrated at" end, Corymbs fastigiate, Papipus paleaceous and awned

11563 Leaves lanc. narrowed into the footstalk 3-nerved finely serrated at end, Corymbs fastigiate

11564 Leaves ovate 3-nerved serrated cuneate and entire at the base, Pappus chaffy and awned

11565 Leaves stalked digitate pedate entire, Pappus paleaceous. (Florestina, Cass.)

11566 Leaves sessile narrowed at base rough with minute hairs, Pappus with 3 awns

11567 Leaves 10 lines long 4 lines broad finely downy beneath, Flowers purple

11568 The only species

11569 Leaves of invol. foliaceous : inner ovate obl. rounded; outer awned

11570 Hoary, Leaves sub-bipinnatifid, Flowers in compound corymbs

11571 Leaves 3-nerved ovate acuminate scabrous unequally toothed

11572 Flowers solitary stalked winged, Leaves oblong triple-nerved unequally șerrated scabrous

11573 Leaves long-lanc. Leaves of invol. blunt, Paleæe spatulate

11574 Leaves lanc. oval acuminate 3-nerved, Paleæ narrow linear

11575 Leaves lanceolate serrate, Stem erect

11576 Leaves ovate repand: lower alternate, Stem branched ascending, Invol. many-leaved

21577 Leaves ovate subcordate serrated, Stem branched diffuse

11578 Leaves opp. ovate-acumin. serrate, Pedunc. panicled, Heads ovate

11579 Leaves opp. ovate-lanceolate entire downy, Pedunc. opp. diverging rnany-flowered

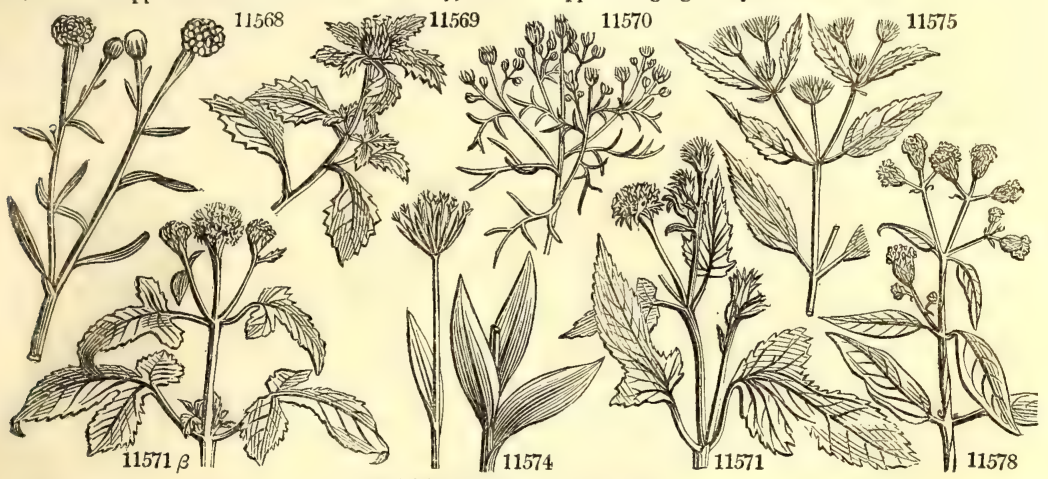

and Miscellaneous Particulars.

1692. Hymenopappus. From i $\mu$ ry, a membrane, and $\tau \alpha \pi \tau o s$, pappus, in allusion to the membranous pappus of its seeds.

1693. Melananthera. From $\mu \varepsilon \lambda \alpha_{5}$, black, and anthera. A plant with black anthers, a very unusual character in this tribe of plants, the anthers of which are usually either white or yellow, according to the color of the corolla.

1694. Marshallia. Named after Henry Marshall, an Englishman, author of a sort of history of the trees and shrubs of North America, published in 1778

1695. Spilanthes. From $\sigma \tau i \lambda_{05}$, a spot, and $\alpha$. 905 , a flower, in allusion to the heads of flowers of the original species, which are yellow with a brown disk. Jacquin says he so called it, because the flowers are spotted witl black points. S. salivaria is used by the natives of South America to relieve the tooth-ache by the salivation which it produces copiously. The flower-heads of S. oleracea are an excellent ingredient in salads, on account of their agreeable and lasting piquancy.

The leaves of Spilanthes tinctoria of Loureiro, which is said to be very similar to the Abcedaria figured by Rumphius, vol. ii. t. 65., give out when bruised a beautiful blue color, quite equal to indigo.

1696. Salmea. This name was originally given by Cavanilles to a genus related to Aloe, and was named after Prince Charles of Salm-Salm, a great promoter of botanical science. It was transferred to the genus which now bears the name by Professor Decandolle, in the appendix to his Hortus Monspeliensis. 
1697. BI'DENS. $W$. 11580 nodiflóra $W$. 11581 tripartíta $W$.

11582 cérnua $W$

11583 heterophýlia $W$.

11584 frondósa $W$.

11585 leucántha $W$.

11586 chinénsis $W$

11587 pilósa $W$.

11588 sambucifólia $W$.

11.589 bipinnáta $W$.

11590 bulláta $W$

11591 prócera B. Reg.

11592 luxúrians $W$.

11593 roliósa $W$.

11594 connáta $W$.

11595 parviflóra $W$.

11597 refléxa Link.

11598 croćta $K$ th. Spilanthus crocatus B. M.

1699. LAGAS'CA. Cav. Lagasca.

11599 móllis Cav.

11600 rúbra Kth. red

1700. LaVénia. $W$. Lavenia. 11601 erécta $W$. upright

1701. CACA'LIA. $W$. Cacalia 11602 papilláris $W$.

11603 Anteuphórbium $W$. oval-leaved

11604 Kleínia $W$.

11605 Ficoídes $W$.

11606 carnósa $W$.

11607 répens $W$.

i1608 Hawórthii Swcet tomentósa M.n. not

11609 articuláta $W$.

11610 tomentósa $T h$.

11611 appendiculáta $W$.
11612 bícolor $W$.

11013 ovális B. reg.

11614 sonchifólia $W$.

11615 salicina $L a b$.

11616 coccinea $H . K$

11617 sarracénica $W$

11618 hastáta $W$.

11619 rhombifólia $W$.

11620 suavéolens $W$.

11621 atriplicifólia $W$

11622 renifórmis $W$.

1 i623 alpina $W$.

11624 álbifrons $W$.

11625 scándens $W$.

11626 pinnáta $W . e n$

11627 sagittáta $W$.

flat-leaved

hairy tall tomentose

appendaged

의 un 1 jl.au

un 2 jls

nodding

smooth-stalked $\mathrm{O}$ un $1 \frac{1}{2} \mathrm{jl}$.au

white-flowered $O$ un $1 \frac{1}{2} \mathrm{jl}$.au

O un 2 jn.jl

un $1 \frac{1}{2} \mathrm{jl}$

Hemlock-leav. $₫$ o un ${ }_{2}$ jl.au

rough-leaved $O$ un 2 jl.au

luxuriant \$ $\triangle \mathrm{v}$ un 3 jl.au

connate $\quad O$ un 2 jn.jl

O un 1 jn.jl

\ $\triangle$ un $2 \mathrm{jn.jl}$

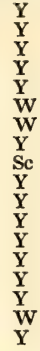

Composita. Sp.

2 ja.mr Or S. Amer, 1812. D co Bot. mag. 1627
Oleander-leav.

4 or 2 jn.s

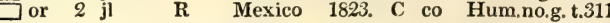

Composita. Sp.1-2.

[0] un 2 jl.s Y E. Indies 1739. S co Burm. zeyl.t.42 Composita. Sp. 26-60.

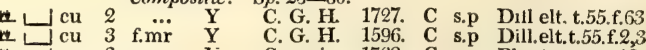
cu 3 s.o $\mathbf{Y}$ Canaries 1732. C s.p Plant, grass. 19 H cu 6 jn.n $\quad$ Y $\quad$ C. G. H. 1710. C s.p Plant. grass. 90 C. G. H. H. 1757. C S.p C. G. H. 1759. C s.p Plant. grass. 42 C. G. H. 1795. C co woolly-leaved w $\begin{array}{llll}\mathrm{cu} & 1 & \mathrm{jn} . \mathrm{o} & \mathrm{Y} \\ \mathrm{cu} & 2 & \ldots & \mathrm{Y}\end{array}$ of Thunberg.

jointed $\quad \sqcup$ cu $1 \frac{1}{g}$ s.n $\quad Y \quad$ C. G. H. 1775. C s.p Plant. grass, 18 two-colored $\begin{array}{llll}\text { or } & 2 \\ \text { oval-leaved } & \text { Pu } & \text { or } & 3 \\ \text { my.s } & \mathbf{Y}\end{array}$ Sow-thistle-lvd. Willow-leaved $\omega$ or 6 or jn.jl Y scarlet-flowered $O$ or $1 \frac{1}{2} \mathrm{jn}$.jl creeping-roted 1 4 au.o

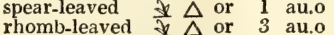
sweet-scented $\$ \Delta$ or 6 au.o Orache-leaved $\vec{x}$ or 4 au Kidney-leaved $\frac{1}{\Delta} \Delta$ or $1 \frac{1}{2}$ jl.an Alpine white-leaved $\not \Delta$ or 2 jlau climbing wing-leaved $\Delta$ or 2 jl.au sagittate 1 or 3 jlau
C. G. H. 1795. C s.p

Teneriffe 1815, C co

Teneriffe 1815. C co

E. Indies $\ldots$ C s.p Bot. reg. 101

U E. Indies 1768. S co Rhe,mal.10. t.68

N. Holl. 1820. C co Bot. reg. 923

O ...... 1799. S co Bot. mag. 564

Y France 1772. D s.p

W Siberia 1780. D co

Y Siberia 1816. D co

N. Amer. 1752. D co

. Amer. 1689. D co Pluk,al, t.101.f.2

$\mathrm{Pu}$ Austria 1739 .

.

Pk A. Tac. aust.3. t.235

Pk G. H. 1774. D co

Pk Iberia 1816. D co
E. reg. 110

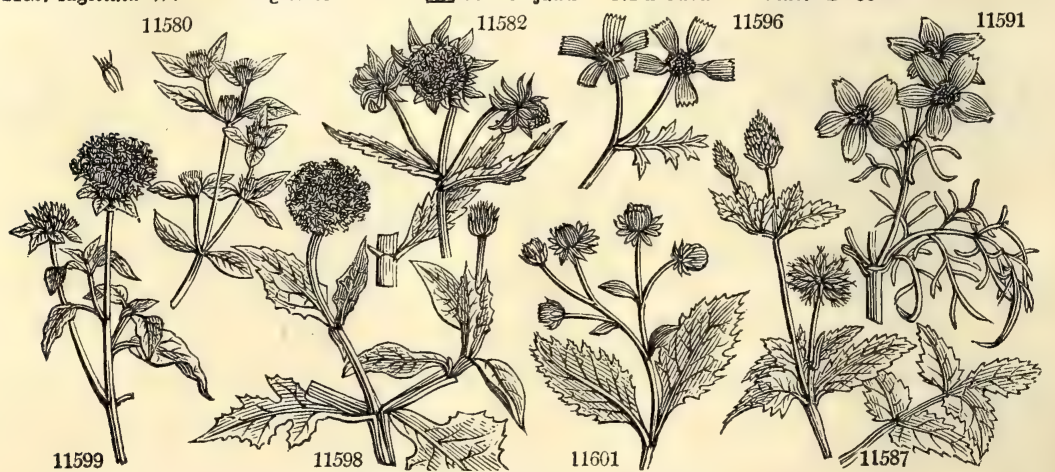

History, Use, Propagation, Culture,

1697. Bidens. So called because its seeds are surmounted with two teeth. Very worthless inconspicuous weeds.

1698. Platypteris. So called from $\pi \lambda \propto \tau u \zeta$, broad, and $\pi \tau \varepsilon$ eq, a wing, in allusion to the margin of the seeds. A sroall siove herbaceous plant of little merit.

1699. Lagasca. Named in honor of Don Mariãno La Gasca, professor of botany at Madrid, an amiable man and excellent botanist. He is, at the time of writing this, residing in England, whither he has fled from the dangers of persecution in his own country.

1700. Lavenia. A name of unknown meaning, originating with Sherard. Small useless annuals, natives of the East and West Indies.

1701. Cacalia. A name applied by Dioscorides to a mountain plant with large whitish leaves. By some it is believed to have been what is now called Cacalia alpina. To Sprengel it appears to be the Bupleurum 
11580 Flowers discoid stalked, Outer invol. 3 times as long as flower, Lvs. ovate with 1 or 2 teeth on each side 11581 Leaves tripartite, Leaflets lanceolate deeply serrated, Bristles of the pericarp 2-3

11582 Fls. droop. Bracteas lanc. ent. (longer than inv.) Lvs. lanc. serrat. undivid. Bristles of pericarp about 4 erect 11583 Flower radiant erect, Outer invol. longer than inner, Cauline leaves lanc. serrated : radical subternate

11584 Fls. discoid, Outer invol. 6 times as long as flower, Leaflets ciliated at base, Lower lvs. pinn.: upper ternate 11585 Fls. radiant, Outer inv, the length of inner, Lower leaves pinnate: upper ternate, Leaflets ovate serrated 11586 Fls. radiant, Outer inv. length of inner, Low. lvs. pinn. : upper tern. I.eafl. ov. subcord. serr. uneq. at base 11587 Fls. discoid, Outer inv. length of inner, Low. lvs. pinn. : upper tern. Term. leafl. twice as large as the rest 11588 Flowers radiant, Outer invol. longer than inner, Leaves decussively pinnated serrated

11589 Flowers subradiant, Outer invol. length of inner, Leaves bipinnate : leaflets lanc. pinnatifid

11590 Fls. discoid, Outer inv. longer than flower, Lvs. scabr. toothed: low. roundish ov. : upp. tern. Stem hairy

11591 Leaves bi-tripinnate : pinnæ linear acute channelled entire, Outer leaves of invol. blunt downy 11592 Flowers radiant erect, Outer involucre longer than inner, Leaves lanc. stalked equally serrate 11593 Leaves lanc. acute serrated subciliated, Outer involucre leafy

11594 Flowers discoid, Outer invol. 3 times as long as flower, Cauline leaves ternate: lateral connate 11595 Flowers discoid, Outer invol. longer than inner, Leaves ternate : leaflets S-parted cut-toothed 11596 Flowers radiant, Outer invol. length of inner, Leaves bipinnate, Leaflets cuneiform 3-toothed 11597 Leaves lyrate-pinnated: pinnæ ovate acute serrated pubescent, Flowers panicled

11598 Leaves hoary toothed, Stem with 4 wings

11599 Leaves stalked ovate acuminate subcrenate softly silky

11600 Leaves on short stalks elliptical blunt obsoletely toothed rigid

11601 Stem branched erect, Leaves elliptical finely serrated

11602 Stem shrubby with cylindr. truncate papilæ, Leaves lanc. flat

11603 Stem shrubby, Leaves ovate-oblong flat, Petioles with a triple line at base

11604 Stem shrubby, Leaves lanc. flat, Flowers corymbose

11605 Stem shrubby, Leaves compressed fleshy

11606 Stem shrubby, Leaves roundish fleshy incurved, Pedunc. terminal 1-fl. naked

11607 Stem shrubby, Leaves depressed fleshy

11608 Stem shrubby, Leaves depressed fleshy woolly

11609 Stem shrubby, Leaves fleshy flat ternate, Leaflets 3-lobed

11610 Stem suffruticose, Leaves ovate-lanc. toothed downy beneat

11611 Shrubby downy, Leaves cordate ovate acute angular downy beneath : stalks with leafy appendages

11612 Stem heriac. branched, Lvs. lanc. smooth toothed : of the stem amplexicaul.; of the branches stalked

11613 Ieaves thickish villous: lower oval repand-toothed stalked; upper sublyrate amplexicaul.

11614 Stem herbaceous, Leaves amplexicaul. tooched : lower lyrate ; upper sagittate toothed

11615 Leaves obl. lanceolate connate downy beneath, Racemes axillary

11616 Radical leaves ovate spatulate : cauline entire amplexicaul. crenate edged

11617 Stem herbaceous, Leaves sessile obl. lanc. serrated : at the base cuneate entire decurrent

11618 Stem herbaceous, Leaves stalked 3-lobed hastate serrate, Flowers racemose nodding

11619 Stem herbaceous, Lvs. stalked rhomboid hastate unequally toothed, Flowers corymbose spreading erect 11620 Stem herbaceous, Leaves stalked hastate-sagittate serrated, Flowers corymbose erect

11621 Stem herbaceous, Leaves stalked: radical cordate toothed; cauline rhomboid with 2 teeth on each side 11622 Stem herbaceous, Leaves stalked : radical cordate reniform repand toothed; cauline oblong toothed

11623 Stem herbaceous, Leaves stalked cordate toothed, Petioles naked, Corymbs fastigiate, Invol. 5-flowered 11624 Stem herbac. Leaves stalked corảite toothed hoary beneath, Petioles auricled at base, Corymbs fastigiate 11625 Stem twining, Leaves triangular sinuate-toothed

11626 Stem herb. Rad. Ivs. bipinnatifid : caul. pinn. Pinnæ toothed : upper confluent, Corymb comp. fastigiate 11627 Stem herbaceous, Leaves toothletted : lower stalked obovate; upper obl. lanc. sagittate amplexicaul.

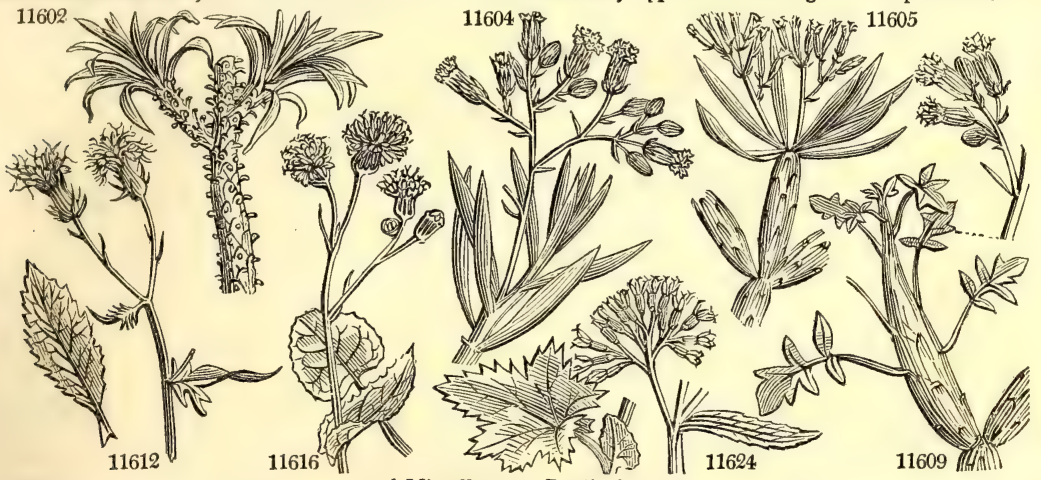

and Miscellaneous Particulars.

longifolium of the moderns. The species are nearly all objects of ornament. Some of them are remarkable for their fleshy awkward looking stems, others for their discolored leaves. The succulent kinds require to be grown in old rubbish, and to be treated as directed for Mesembryanthemums. The leaves of some species (C. procumbens and sonchifolia) are used as salad by the Chinese; and those of C. Ficoides are sometimes pickled by the French.

C. Kleinia is called cabbage tree, from the resemblance which the stalks have to those of the cabbage; and carnation tree, from the shape of the leaves and color of the flowers.

Upon Cacalia alpina, \&c., M. Cassini has founded his genus Adenostyles and tribe of Adenostyleæ; distinguished from Senecionez, to which Cacalia belongs, by the roughness of all che back of tre two lobes of the style. But we do not find the division adopted by other botanists. M. Cassini bimself suspects that Adenostyleæ may be united with Tussilaginea. 
1702. KLEI'NIA. $W$. 11628 ruderális Jacq. 11629 porophyllum $W$. 11630 suffruticósa $W$.

KLEINIA. dunghill perforated suffruticose

\section{Ethulia.} panicled spreading 1163! conyzoídes $W$. 11632 divaricáta $W$.

11633 braziliénsis Link.

1704. PIQUe'Ria. $W$. Piqueria. 11634 trinérvia $W$.

1705. CHRYSO'COMA. $W$, GoLDY-LocKs 11635 Comaúrea $W$. 11636 cérnua $W$. 11637 ciliáris $W$. 11638 scábra $W$.

11639 denticuláta $W$.

11640 Linosýris $W$

11641 dracúnculoídes $W$.

11642 biflóra $W$.

11643 villósa $W$.

1164 TARONAN'THUS. $W$. great-shrubby small-shrubby Heath-leaved rugged toothed German (1) hairy-leaved

1644 camphorátus $W$. shrubby

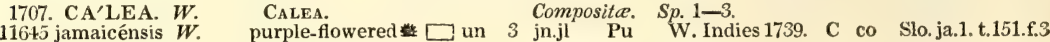

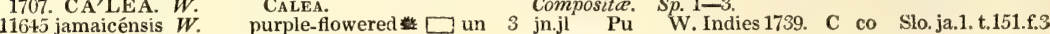

Composita. Sp. 3-5.

G] un 1 jl.au W Jamaica ... $\quad$ s co Jacq. am.t. 127

(O) un 11 jn.o W N. Amer. 1699. S co Cav, ic. 3. t. 222 th $\square$ un $\frac{3}{4}$ jn.o Pu Brazil 1820. C co Cav. ic. 3. t. 257

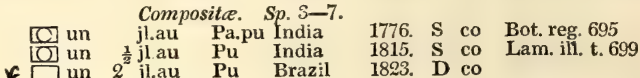
Composite. Sp. 1 -3.

jl.au W Mexico 1798. D co Cav. ic. 3. t. 235 Compositce. Sp. 9-18.

jn.au Y C. G. H. 1731. C p.l Bot. mag. 1972

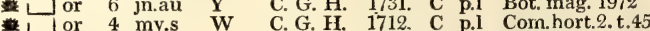

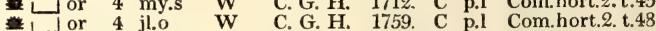
H. 1759. C p.1 Com.hort.2.t.48 1732. C p.1 Dil.elt.t.88.1.103

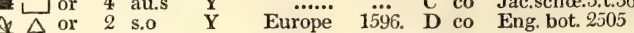
$\triangle$ or 2 s.o $\quad$ Y Siberia ... $\quad$ D co

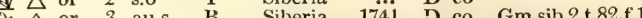
स $\Delta$ or $1 \frac{1}{2}$ au.s $\quad \mathrm{Y}$ Hungary 1799. D co Pl. rar.hu.1.t.53 Can Fleabane. Compositce. Sp. $1-7$. 1708, ISOCAR'PHA, $R, B r$. IsOCARPHA.

11646 oppositifólia $R$. Br. opposite-leaved $\mathbb{Q}$ ] un 3 jlar

1709. PETRo'BIUM. R. Br. White Wood Compositce. Sp.

11647 arbóreum $R . B r . \quad$ St. Helena $9 \square$ or 12 … Y Y St.Helena 1825. C co

1710. NeUrol ÉNA. $^{R}$. Br. Halberd-Weed. Composite. Sp. 1.

11648 iobáta $R . B r$. common $\square$ un 2 jn.jl $\quad$ Y W. Indies 1733. R s.p Bot. mag. 1734

1711. HU'Mea. Sm. Humea. Composito. Sp. 1.

11649 élegans $\mathrm{Sm}$. rose-colored $\quad$ لl 6 jn.o $\mathrm{R}$ N. S. W. 1800. S s.p Exot. bot.1.t.1

1712. Cesu'LIA. $W$. Cesula. Composita. Sp. 1-3

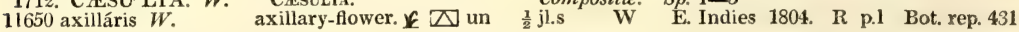

1713. IXO'DIA. H. K. IXodia. Composita. Sp. 1.

11651 achillæoídes H.K. Milfoil-like $\sqcup \mathrm{pr} 2 \mathrm{mr}$. W N. Holl. 1803. C s.p Bot. mag. 1534 1714. SANTOLI'NA. $\boldsymbol{W}$. Lavender-Cotton. Compositce. Sp. 7-16.

11652 Chamæ-Cyparíssus $W$. common or $2 \mathrm{jl}$ Y S. Europe 1573. C co Lam.ill. t.671.f.3 11653 suuarrósa $W$. hoary or $1 \frac{1}{2}$ jl.au Y S. Europe 1570. C co Mor. s.6.t.3.f.17 11654 viridis $W$. hoary or $1 \frac{1}{2}$ j. au $\mathrm{Y}$ S. Europe 1727 C co

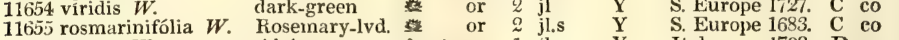
11656 alpina $W$. Alpine ${ }^{2} \Delta$ or $\tilde{1}$ jl.s Y Italy 1798. D co

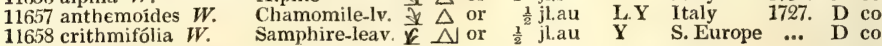

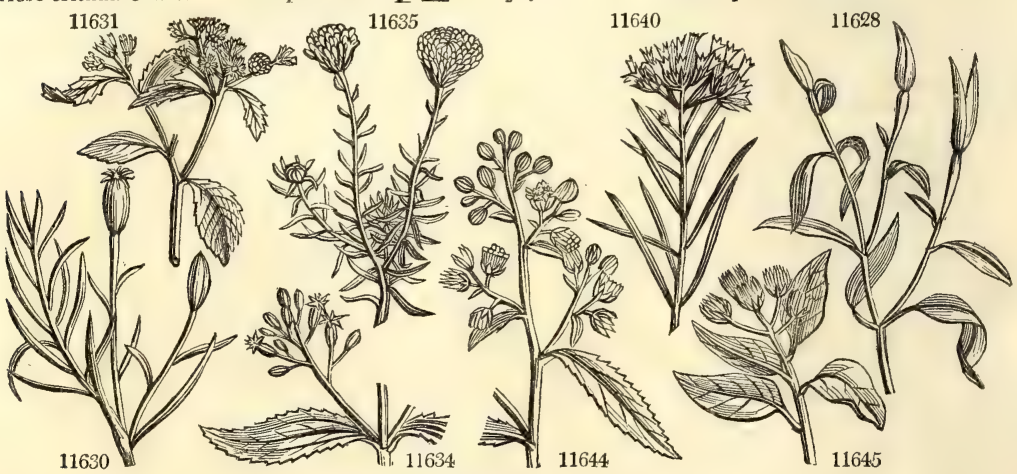

History, Use, Fropagation, Culture,

1702. Kleinia. Named after James Henry Klein, a German botanist, who published, in 1719, a dissertation upon the Juniper.

1703. Ethulia. A word formed by Linnæus without any explanation of its meaning. It is not easy to understand wherefore Vaillant's more ancient name of Sparganophorus should not have been adopted.

1704. Piqueria. So named by Cavanilles, in honor of Andreas Piquerio, a Spanish botanist, who published a translation of Hippocrates, in 1757.

1705. Chrysocoma. From xevoos, gold, and zoum, hair, in allusion to the tufts of yellow flowers with which the stems are terminated. The specific name Comaurea is a mere translation of the generic appellation. Linosyris, the name of another species, is so called from linum, flax, and osyris, an ancient name for a plant with long flexible branches and flax-like leaves, which is the character of C. linosyris; which, when handled sends forth a very fine aromatic smell.

1706. Tarchonanthus. Tarchon is a name given by the Arabian physicians to the Artemisia Dracunculus, and is the root of our English word Tarragon. Ay be Englished Tarragon-flower.

1707 Calea. Derived from rox $\lambda_{05}$, beautiful. The species are ornamental shrubs of South America, with undivided leaves, and corymbose, terminal, or axillary heads of yellowish purple flowers. Mr. Browr's histor' 
11628 Leaves obl. lanc. acute at each end nearly entire

11629 Leaves elliptical blunt mucronate repand with pellucid dots

11630 Leaves linear entire with pellucid dots, Stem suffruticose

\section{Flowers panicled}

11632 Leaves linear toothed decurrent, Pedunc. opposite the leaves 1-fl. Stem divaricating

11633 Stem winged, Leaves lanc. acute serrated downy decurrent, Flowers corymbose

11634 Leaves opp. ovate-lanc. serrated 3-nerved, Invol. with 4 flowers

11635 Leaves linear straight smooth decurrent at back

11636 Leaves linear recurved roughish, Flowers cernuous

11637 Leaves linear straight ciliated, Branches pubescent

11638 Leaves lanc, ovate recurved toothletted serrated, Peduncles pubescent

11639 Leaves oblong tapered at base toothletted wavy

11640 Leaves linear glabrous, Involucres lax

11641 Leaves linear-lanceolate 3-nerved scabrous, Flowers corymbose, Invol. lax

11642 Panicled, Leaves lanc. 3-nerved dotted naked

11643 Leaves lanc. villous, Involucres contracted

11644 Leaves oblong entire downy beneath

11645 Flowers about 3 stalked, Leaves ovate-oblong subserrate stalked

11646 Corymbs heaped, Peduncles very long, Leaves lanc. Stem herbaceous

11647 Leaves opp. undivided, Panicle terminal brachiate

11648 Corymbs heaped, Leaves alternate : upper ovate-lanceolate; lower toothed hastate sinuate serrate

11649 Panicles very large erect diffuse capillary

11650 Leaves lanc. narrowed at base serrated alternate

11651 The only species

11652 Pedunc. 1-fl. Leaves hoary toothed in 4 rows, Teeth blunt, Branches dowy, Invol. pubescent

11653 Pedunc. 1-f. Leaves hoary toothed in 4 rows, Teeth subulate much spreading, Branches downy

11654 Pedunc. 1-fl. Leaves smooth toothed in 4 rows, Teeth subulate straight, Branches and invol, smooth

11655 Pedunc. 1-fl. Leaves linear warted at edge: upper entire

11656 Pedunc. 1-f. Leaves bipinnate, Stems simple

11657 Pedunc. 1-fl. Leaves bipinnate, Stems much branched villous

11658 Like Santolina alpina, but segments of leaves are shorter and thicker

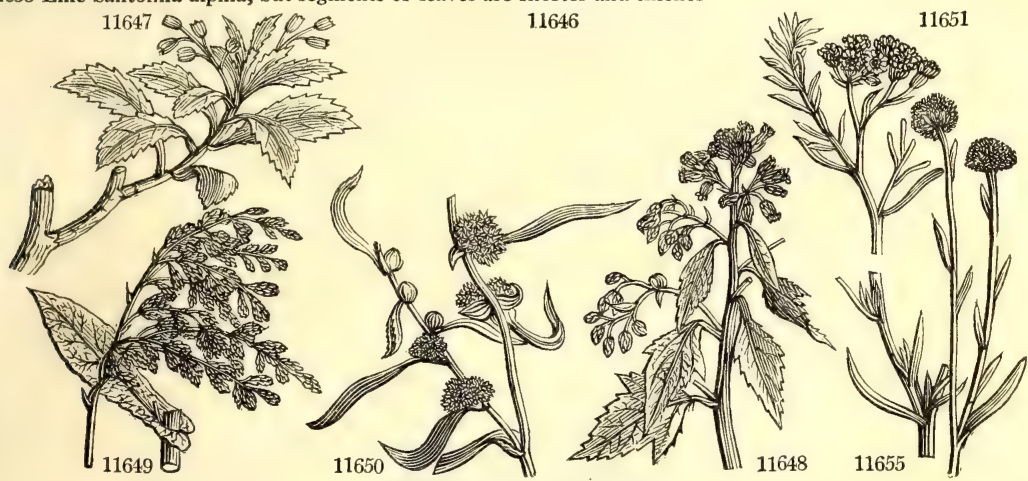

and Miscellaneous Particulars.

of this genus, in the twelfth volume of the Transactions of the Linnean Society, is a modei of botanical erudition and acuteness, such as has been rarely seen in modern days.

1708. Isocarpha. From $s \sigma \circ s$, equal, and $\approx \alpha \rho \emptyset$, chaff, in allusion to the equality of the chaff of the receptacle and the leaves of the involucrum. Herbs of South America, with opposite undivided leaves, and ovate terminal heads of whitish flowers.

1709. Petrobium. From $\pi \varepsilon \tau \rho \circ$, a stone, with reference, it is presumed, to the texture of the grains. A small tree, native of St. Helena, where it is called white wood.

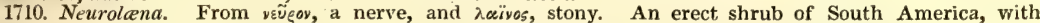
alternate, undivided, and lobed leaves, and terminal compound corymbs of yellow flowers.

1711. Humea. Named in honor of Sir Abraham Hume, Bart. of Wormleybury, in Hertfordshire, a gentleman whose whole life has been devoted to the protection and assistance of the arts and sciences, and especially of botany. A beautiful plant with immense capillary panicles of brilliant crimson flowers.

1712. Casulia. Meaning unknown. Little creeping weed-like plants, rooting at the joints.

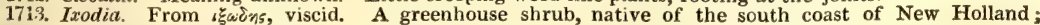
flowering most part of the year.

1714. Santolina. Supposed to be a diminutive of sancta; a holy little herb; in allusior to some reputed virtues. A genus of slightly shrubby somewhat aromatic plants, with yellow discoid flowers. 
1715. OTAN'THUS. Link. OxANThUs.

11659 marítimus Link. sea Santolina maritima $\mathbf{L}$.

1716. CAleaC'Te. $R . B r$. Caleacte

1766rticifólia $R, B r$ nettle-leaved Solidágo urticifólia Mill.

1717. ATHana'sia, $W$. Athanasia. 11661 capitáta $W$.

11662 pubéscens $W$.

11663 ánnua $W$.

11664 dentáta $W$.

11665 trifurcáta $W$.

11666 virgáta $W$.

11667 tomentósa $W$.

11668 filifórmis $W$.

11669 crithmifólia $W$.

11670 parvifióra $W$.

11671 pectináta $W$.

hairy

villous-leaved

annual

trifid-leaved

twiggy

Lavender-leav

fine-leaved

Samphire-leav.

small-flowered

pectinated

1718. BALSAMI'TA. $W$. Costmary.

11672 virgáta $W$

11673 ageratifólia $W$

11674 vulgáris $W$.

11675 ánnua Link.

twiggy

common

annual

1719. PENT'ZIA. Th. PENTZIA.

11676 flabelliformis $W$. fan-leaved

1720. TANACE'TUM. $W$. TANSY. 11677 linifólium $W$. Flax-leaved

shrubby

$\begin{array}{ll}11679 \text { argénteum } W . & \text { silvery } \\ 11680 \text { vulgáre } W . & \text { common }\end{array}$

$\beta$ crispum

curled

1791. ARTEMI'SIA, $W$. Wormwood

1721. ARTEMI'SIA. $W$. WORMWOOD.

11683 valentina $W$. Spanish

11684 subcanéscens $W$. hoary-leaved

11685 Abrótanum $W$.

11686 húmilis $W . e n$.

11687 tenuifólia $W$.

11688 arboréscens $W$

11689 argéntea $W$.

11690 glaciális $W$.

11691 mutellína $W$.

11692 prócera $W$.

11693 caucásica $W$.

11694 chinénsis Lour.

11695 spicáta $W$.

11696 pectináta $W$.

11697 tanacetifólia $W$.

11698 Santónica. $W$.

11699 scopária $W$.

Southernwod dwarf

slender-leaved

tree

silvery

silky

Alpine

lofty

Caucasian

Moxa

spiked

comb-leaved

Tansy-leaved

Tartarian

besom
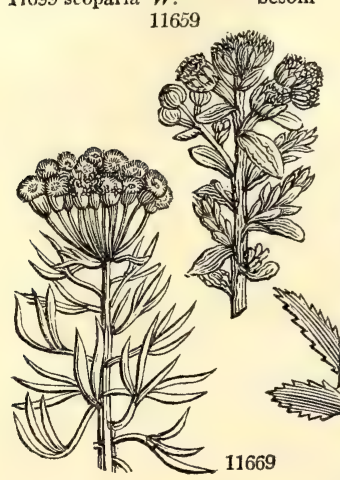

\section{.}

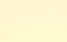

Composite. $S p .1$.

pr $\frac{\pi}{4} \mathrm{jl}$, s Y England sea sh. C s.l Eng. 3ot. 141

Composita. Sp. 1.

Compositae. Sp. 1.
jl.au Y Vera Cruz 1740. C co

Compositce. $\quad s p .11-28$.

$1 \frac{1}{2}$ ja.mr $Y$ C. G. H. 1774. C $1 . p$ Mor. s.6.t.3. f. 48

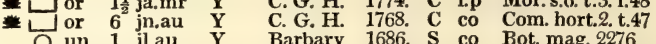
O un 1 jl.au $\mathbf{Y}$ Barbary 1686. S co Bot. mag. 2276

C. G. H. 1759. C 1.p Comm. rar. t. 41

C. G. H. 1710. C 1.p Com.hort.2. t.49

C. G. H. 1815. C co Jac.schœ.2.t.148

C. G. H. 1774. C l.p

C. G. H. 1787. C 1.p

C. G. H. 1723. C 1.p Com. hort.2.t.50

C. G. H 1731. C 1.p Jac.schœ.2.t.149

C. G. H. 1774. C co

$1 \frac{1}{2} \stackrel{\text { my.jn }}{Y}$

Composita. Sp. 4-6.

jn.jl Y.G Italy 1791. D co Jac. obs. 4. t. 81

jn.o Y.g Candia 1605. C co Alp. exot. t. 326

au.s Y.G Italy 1568. D co Sch han 3. t. 240

2 jl.au Y.G Spain 1629. S co Mil.ic.2.t.227.f.1

Composita. Sp. 1

ע or 3 my.au Y $\quad$ C. G. H. 1774, C p.l Bot. mag. 212

\section{SUPERFLUA.}

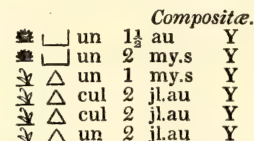

Sp. 5-21.

C. G. H. 1774. C p.l

1751. C p.l Com.hor.2. t. 100

Levant 1812. D co

Britain ro.sid. D co Eng. bot. 1229

Levant 18... 18 D co

Sp. 58-87.

Composita.

H or $1 \frac{1}{2}$ au $\quad$ Y

Levart 1683. C co Plu.alm, t.73. f.2

Spain 1739. C co Barr. ic. t. 485

S. Europe $\ldots$ C co

S. Europe 1548. C co Blackw, t. 555

Carniola $\quad \ldots . \quad \mathrm{C}$ co

China 1732. C co Dill. elt. t. 33.f. 37

Levant 1640. C co Lob. ic. 753

Madeira 1777. C co

Switzerl. 1739. D co Jac.aus.5.t.ap.35

Al. of Eur.1815. D co Vil.dauph.3.t.35

$\star \Delta$ or ${ }_{1}$ jl.au

or $\frac{1}{2}$ jlau

or 8 jlau

$\downarrow \Delta$ or $\frac{1}{2} \mathrm{jn} . \mathrm{jl}$

m 4 jn.jl

止 $\triangle$ or 1 jn.ji

๑ or 1 jl.au

0 or 2 jl.s

11660

Y.G S. Europe 1820. C co

Y.G S. Europe 1820 . C co

Y.G China 1818. C co

$\begin{array}{llll}\text { Y.G } & \text { China } & \text { 1818. } & \text { C co } \\ \text { Br } & \text { Switzerl. 1790. } & \text { D co }\end{array}$

$\mathrm{Br}$ Dac.aus.5.t.ap.34

Dauria 1806. S co Pal.it.3. t.Hh.f.2

W. Siberia 1768. S co Al.ped.1.t.10.f.3

Siberia 1596. C co Gmel. sib.2.t.51

G Hungary 1796. S co Pl. rar. hu.1.t.65 11662 frrm

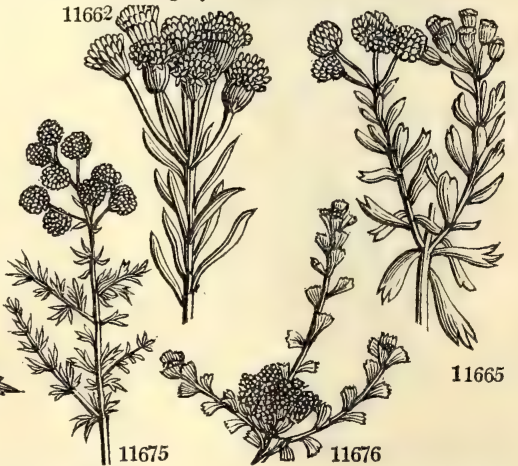

History, Use, Propagation, Culture,

1715. Otanthus. From $85 \omega \tau 05$, an ear, and $\alpha y$ 95 , a flower, in allusion to the appendages which are placed on each side of the base of the florets. An infusion of the leaves and stem is said to be employed successfully in the east in cases of stone and gravel.

1716. Caleacte. So called because it is the ornament of the sea coasts where it grows, and derived from zor 105 , beautiful, and $\alpha x \tau \eta$, the sea shore.

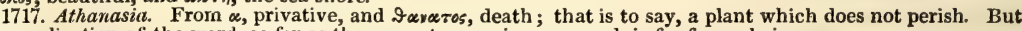
the application of the word, as far as the present genus is concerned, is far from obvious.

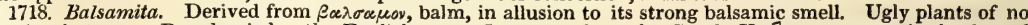
merit whatever. B. vulgaris has the English name Costmary, from the Greek Koolos, an aromatic shrub, and Mary ; the Virgin Mary's costus : from its being put into ale, it has our old English name of Ale-cost. It is more aromatic and has a pleasanter smell than tansy, to which it is nearly allied.

1719. Pentzia. Named by Thunberg, after his pupil Charles John Pentz. A bushy branching hoary shrub, with little yellow flowers. 
11659 Pedunc. corymbose, Leaves oblong blunt crenated densely woolly

\section{The only species}

11661 Leaves ovate villous, Heads terminal subsessile

11662 Leaves obov. lanc. blunt villous, Umbels terminal, Branches villous

11663 Corymbs simple contracted, Leaves pinnatifid toothed

11664 Corymbs compound, Leaves recurved: lower linear toothed; upper ovate serrate

11665 Leaves cuneiform cut-trifid, Flowers in umbels

11666 Leaves cuneiform : lower pinnatifid cut : upper 3 or 5-toothed, Flowers in umbels

11667 Leaves linear tomeritose, Panicle compound

11668 Leaves linear filiform smooth, Flowers panicled

11669 Leaves trifid with linear smooth segments, Flowers somewhat in umbels

11670 Leaves pinnated: pinnæ linear smooth, Panicle decompound

11671 Leaves pinnated: pinnæ linear smooth, Panicle compound

11672 Stem herbaceous branched at base, Branches 1-fl. Leaves sessile lanc. serrated

11673 Leaves obovate serrated sessile clustered, Flowers subcorymbose

11674 Leaves ellipt. toothed: lower stalked; upper sessile auricled at base, Flowers corymbose

11675 Radical leaves bipinnate: cauline many pinnated downy ; pinnæ linear acute mucronate

11676 Corymbs simple, Leaves deltoid serrated at end

\section{SUPERFLUA.}

11677 Leaves lanceolate channelled, Raceme terminal fastigiate

11678 Leaves pinnated : pinnæ linear toothed pubescent, Corymb fastigiate leafy at base

11679 Leaves pinnated silky with down, Pinnæ lanc. somewhat toothed at end, Corymb terminal

11680 Leaves bipinnatifid inciso-serrate

11681 Leaves pinnatifid : segm. lanceolate serrated, Corymb contracted, Invol, angular

11682 Leaves obovate blunt lobed small, Flowers panicled stalked

11683 Leaves hoary : lower pinnated with palmate pinnæ; upper palmate sessile, Heads panicled simple

11681 Cauline leaves pinnated smoothish : floral undivided linear, Panicle virgate, Heads glob. stalked nodding

11685 Stem upright, Lower leaves bipinnate : upper pinnated capillary, Invol. downy hemispherical

11686 Caul. Ivs, pinnat. very smooth : floral undivided setaceous, Involucres downy, Heads glob. stalk, nodding

11687 Stem upright, Leaves bipinnate capillary: floral simple, Invol. oblong

11688 Leaves tripinnatifid silky cinereous, Leaflets linear, Heads globose, Flowers branched simple

11689 Leaves bipinnatifid silky white, Leaflets lanc. linear, Heads globose, Flowers branched virgate

11690 Stem quite simple, Leaves all palmate multifid white, Heads terminal clustered

11691 Stem quite simple, Leaves all palmate multifid white, Lower heads stalked : upper sessile

11692 Stem branched spreading, Leaves all bipinnate capillary, Invol. smooth hemispherical

11693 Stem quite simple, Leaves all palmate multifid silky acute

11694 Leaves hoary : lower cuneiform obtuse 3-lobed; upper linear blunt, Flowers globose stalked cernuous

11695 Stem quite simple, Leaves hoary : radical palmate multifid; caul. pinnatifid; upper linear entire blunt

11696 Stem quite simple, Leaves pectinate pinnatifid glabrous, Pinnæ linear filiform, Pedunc. 1-fl. axillary

11697 Stem quite simple, Lvs. bipinnatifid subpub. beneath : segm. lin. lanc. acum. entire, Raceme naked term.

11698 Cauline leaves pinnated linear smooth, Branches undivided, Spikes 1-sided reflexed

11699 Cauline leaves vinnated setaceous smooth : radic. pinnated multifid silky, Stem erect, Branches divider

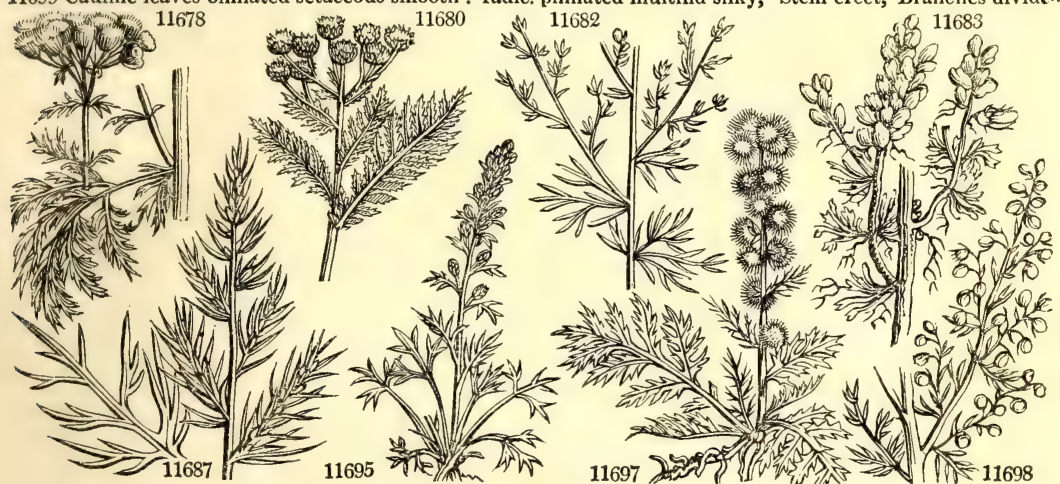

and Miscellaneous Particulars.

1720. Tanacetum. An alteration of Athanasia, which see. Tanaisie, Fr., Tansy, Eng., Reinfahren, Ger. The common Tansy has a strong aromatic smell, and an extremely bitter taste. It is stimulant and carminative; and its seeds are reckoned anthelmintic and sudorific. It is said to drive bugs away from a bed in which it is laid. A distilled water and a kind of stomachic bitter are prepared from it. The young leaves are shredded down and employed to give color and flavor to puddings; they are also used in omelets and cakes, and those of the curled variety for garnishing.

1721. Artemisia. Artemis was one of the names of Diana, the goddess of chastity. The plant is said to have been named after this goddess, on account of the purposes to which it was applied in bringing on precocious puberty. Pliny, however, informs us, that in his time, there was an opinion that the plant was named after Artemisia, the Queen of Mausolus, King of Caria.

A. Abrotanum, Santonica, maritima, and Absinthium, are included in the Materia Medica, but, according to Dr. Thomson, the latter species is the only one deserving to be retained. It is tonic, antispasmodic, and anthelmintic ; and when externally applied, is discutient and antiseptic. It has been used with advantage in inter- 
11700 campéstris $W$. 11701 áfra Jacq. 11702 pauciflóra $W$. 11703 palústris $W$. $1170+$ neglécta $W$.en. 11705 crithmifólia $W$. 11706 saxátilis $W$. 11707 glaúca $W$. 11708 monógyna $W$ 11709 laciniáta $W$. 11710 palmáta $W$ $117 ! 1$ nivea $W . e n$. 11712 marítima $W$. 11713 gállica $W$. 11714 frágrans $W$. 11715 álbida $W$. 11716 austriaca $W$. 11717 vallesíaca $W$. 11718 salína $W$. 11719 rupéstris $W$. 11720 sericea $W$. 11721 répens $W$. 11722 nútans $W$. 11723 saxátilis $W$. 11724 póntica $W$. 11725 chamæ'melifúlia $W$. 11726 ánnua $W$ 11727 camphoráta $W$. 11728 taúrica $W$. 11729 biénnis $P h$. 11730 Absinthium $W$ 11731 Sieversiána $W$. 11732 fasciculáta Bieb. 11733 vulgáris $W$.

11734 indica $W$

11735 integrifólia $W$. 11736 japónica $W$. 11737 cæruléscens $W$ 11738 inodúra $W$.en. 11739 Dracúnculus $W$.

field

African $\Delta \mathrm{w} \quad 1$ au

or $2 \frac{1}{2}$ au

45 or $\frac{1}{2}$ au

marsh

₹. $\triangle$ or

$\Delta$ or 2 jl.au

rock

glaucous

one-styled

torn

palmated

snowy

drooping-flow.

upright-flower.

Lavender-

(

Austria

downy

salt

nodding-flower

silky-leaved

creeping

nodding

rock

Roman

$\exists \Delta$ or

$\Delta$ or 2 jn.au

or $1 \frac{1}{2}$ jn.au

$\Delta$ or 2 jiau

留 1 or $1 \mathrm{jn} . \mathrm{jl}$

$\Delta$ or 2 jn.jl

or

$\Delta$ or 11

$\Delta$ or 1 jl.au

$\triangle$ or $1 \frac{1}{2} \mathrm{jl}$.au

$\triangle$ or $1 \frac{1}{2}$ au

$\Delta$ or $1 \frac{1}{2} \mathrm{jn} . \mathrm{jl}$

$\pm \Delta$ or $3 \mathrm{jn} . \mathrm{jl}$

ile-lv. \$s $\Delta$

annual

Camphorated

Taurian

biennial

common

Sievers's

fascicled

Mugwort

Indian

entire-leaved

Japanese

bluish

inodorous

Tarragon

11740 crísjum $W$. curled

11741 arbóreum $W$.

1174 arandifírum $W$.

11743 divaricátum Thunb

11744 tephrúdes Link.

11745 acuminátum Link.

11746 lasiocaúlon Lin

11747 congéstum $W$

11748 pátulum $W$.

11749 discolórum $W$.

11750 cephalótes $W$.

11751 fastigiátum $W$.

11752 milleflórum $W$.

11753 diosmæfólium $P$. S.

11754 ericoídes $W$

11755 teretifólium $W$.

11756 Stæ'chas $W$
ERASTING.

great-flowered

great-flowere

brown

acuminate

woolly-stemm.

ose-headed

spreading is or

large-headed or

close-flowered 贯 or

man-flowered

osma-leaved

Heath-leaved

round-leaved comm.-shrubby
2 or

$\frac{1}{2}$ jl.au

$\triangle$ or 2 jl.au

de $\triangle$ w 3 au.s

$\Delta$ or 2 jl.au

$\Delta$ or 3 o.n

$\downarrow \Delta$ or 2 jl.au $\checkmark$ or 3 s.o $\begin{array}{ll}2 & \text { jn.jl } \\ 1 & \text { au.s }\end{array}$

2 au.s

$1 \mathrm{jn} . \mathrm{jl}$

3 jn.jl

3 jn.jl

$3 \mathrm{~s}$

$1 \frac{1}{2} \mathrm{jl}$.au

4 jl.au

Br England san.fi. D co

Y Siberia 1800 . D co

Y Siberia 1804. S co

G.X Siberia 1815. D co

$\mathrm{Br}$ Portugal 1739. C co

W Hungary 1816. D co

Siberia 1806. D co

Hungary 1816. D co

G Siberia … D co

G.Y S. Europe 1739. C co

Bry Britain sea sh. D co

$\mathrm{Br}$ Britain mud.s. D co

L.Y Armenia 1739. D co

L.Y $\quad$...... $\quad \ldots$ D

$\mathrm{Br}$ Austria 1597. D co

L.Y Italy 1739. D co

W.G Hungary 1823. D co

$\begin{array}{lll}\mathrm{Br} & \text { Siberia 1748. D co } \\ \text { W } & \text { Siberia } & \\ & & \end{array}$

Br Siberia 1805. D co

Br.g Tartary ... $\quad$ D co

Br.G Hungary $\ldots . . . \quad$ D co

Austria 1570. D co
P. Br S. Europe 1739. D co

W.G Siberia 1741. S co

W.G Italy 1825. C co

W.G Tauria 1818. D co

Y.G Missouri 1804. S co

Y Britain rubble. D co

Br.G Siberia 1800. S co

Y.Pu Iberia 1823. D co

Y.G E. Indies 1796.0

Y.G Siberia 1759. D co

W Japan 1804. D co

Y England sea sh. C co

Y.G Siberia 1548. D co

\begin{abstract}
Compositce. Sp. 38-106.
\end{abstract}
$6 \quad \ldots \quad$ Pk $\quad$ C. G. H. 1809. C s.p

6 f.au W C. G. H. 1770. C s.p

3 jn.au W C. G. H. 173i. C s.p Bot. rep. 489

3 jn.au W C. G. H. 1820. C s.p Bre.prod.t.18.f.3

3 jn.au Y.w C. G. H. 1823. C s.p

3 jn.au W C. G. H. 1823. C s.p

S. G. H. 1823. C s.p

3 ja.au W C. G. H. 1791. C s.p

3 my.au Br C. G. H. 1815. C co

3 . G. H. 1789. C co Plu.phy.t.410.f.

1 my.au W

C. G. H. 1812. C co Pet.gaz.12.t.7.f 3

1 jn.s Pa.pu C. G. H. 1802. C s.p

1812. C co Vent.malm. t.74

C. G. H. 1774. C s.p Bot. mag. 435

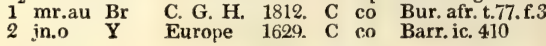

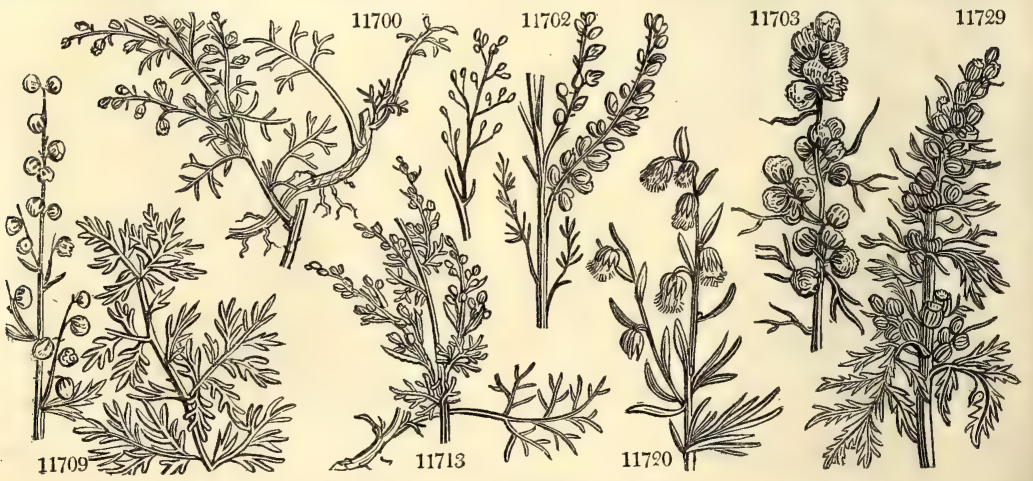

History, Use, Propagation, Culture,

mittents, gout, scurvy, and dropsy ; and although modern practitioners will scarcely rely on its efficacy in these complaints, yet it is undoubtedly of some value as a stomachic. (London Dispen. p. 182.) The seed of wormwood is used by the rectifiers of British spirits, and the species is a good deal cultivated on dry soil near Mitcham, in Surrey, for that purpose. A. vulgaris is used in some parts of Sweden instead of hops, in order to incease the plant is readily eaten by cattle and sheep, and is found in our best natural pastures on dry soils. It is said to be stomachic and slightly stimulating.

The species called Abrotanum, Garde-robe, Fr., derives its name from $\alpha$, privative, and beotos, mortal; on account of the great virtues attributed to it as a preservative of life; Absinthium, from $\alpha$, privative, and

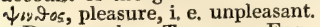

Dracunculus, Tarragon, Eng., Estragon, Fr., Dragon, Ger., and Dragoncelia, Ital, is said to have been so called on account of its tortuous roots, which may be likened to the sinuous tail of a dragon; but it is much 
11700 Caul. Ivs. pinnated setac. smooth : radic. pinnated with 3-fid hoary segm. Stem procumb. branched virgate 11701 Leaves bipinnatifid downy beneath : segm. lanceolate blunt, Panic. 1-sided, Heads nodding 11702 Cauline leaves pinnated or trifid filiform pubescent, Stem ascending somewhat divided

11703 Cauline leaves pinnated smooth : pinnæ filiform remote very long, Heads globose erect sessile

11704 Cauline lvs. pinnated smooth : lower and radic. 3-partite multifid, Stem panic. erect, Peduncles nodding 11705 Cauline lvs. pinnated smooth somewhat fleshy : pinnæ simple or bifid lin. blunt, Heads obl. stalked erect 11706 Cauline lvs. hoary pinnated linear filiform : floral undivided filiform, Heads roundish angular nodding 11707 Leaves glaucous downy : lower pinnated, Pinnæ linear-lanceolate, Heads globose stalked nodding

11708 Leaves multipartite hoary, Racemes erect 1-sided, Heads erect about 5-fl. Only one female floret or none 11709 Leaves pilose triply-pinnatifid, Stem simple with a leafless panicle, Heads globose nodding 11710 Leaves simply pinnate with some of the segments bifid subpalmate, Heads erect

11711 Leaves hoary-silky : lower pinnated, Stem nearly erect much branched, Heads sessile ovate

11712 Leaves downy pinnated : the uppermost undivided, Racemes drooping, Recept. naked, Flow. obl. sessile 11713 Leaves downy pinnate: the uppermost undivided, Racemes drooping, Recept. naked, Flowers obl. sessile 11714 Leaves hoary : radical bipinnate, Pinnæ close linear blunt : of the branches pinnated sessile 11715 Leaves pinnated white with down, Fascicles of flowers bracteate, Heads downy

11716 Leaves hoary : lower pinnated ; pinnæ linear 3-parted, Heads stalked roundish nodding

11717 Leaves snow-white : cauline bipinnate linear filiform; floral simple, Heads obl. sessile erect 11718 Leaves hoary : radical pinnated ; pinnæ 3-parted linear-filiform, Heads obl. stalked nodding 11719 Leaves subpubescent : cauline pinnated ; pinnæ linear acute, Heads globose stalked nodding 11720 Leaves silky : cauline pinnate ; pinnæ 3-parted linear runcinate, Heads globose nodding 11721 Leaves silky white, Pinnæ 3-parted linear acute, Heads roundish stalked cernuous

11722 Cauline leaves pinnated or trifid linear, Stem erect panicled, Branchlets nodding 1-sided

11723 Cauline lvs. hoary pinnated linear-filiform, Stem ascending branched panicled, Invol. roundish angular 11724 Leaves downy beneath : cauline bipinnate, Leaflets linear, Heads roundish stalked nodding

11725 Leaves smooth : lower tripinnate; upper bipinnate, Leaflets linear acute, Heads globose stalked nodding 11726 Leaves smooth triply pinnatifid, Stem straight, Heads roundish subsessile erect

11727 Cauline leaves pinnated hoary white : pinnæ trifid linear, Stem erect, Invol. hoary, Heads globose

11728 Leaves hoary : lower bipinnate, Pinnæ linear-filiform, Heads oblong sessile

11729 Leaves smooth : radic. triply pinnate ; upper undivided linear, Heads roundish subsessile erect

11730 Lvs. bi-tripinnatif. clothed with short silky down, Segments lanc. Heads hemispheric. droop. Recept. hairy 11731 Lvs. somewhat hoary : caul. bipinnatifid ; floral trifid or lanc. Heads globose stalked nodding, Inv. scarious 11732 Lvs, downy : lower decompound ; upper simple, Panicle corymbose, Heads fascicled ovate hoary

11733 Leaves pinnatifid : their segm. cut downy beneath, Heads somewhat racemed ovate, Recept. naked

11734 Leaves downy beneath : caul. pinnatifid ; floral undivided linear, Heads sessile obl. erect, Invol. smooth 11735 Leaves lanc. acuminate downy beneath somewhat toothed, Heads ovate subsessile erect

11736 Leaves smooth lanc. acute: cauline trifid at end, Heads roundish stalked nodding

11737 Leaves hoary lanceolate entire : radical cut ; floral oblong stalked nodding

11738 Lvs. smooth lanc. narrowed at each end, Heads roundish stalked erect, Scales of invol. membr. at edge 11739 Leaves smooth lanceolate narrowed at each end, Heads roundish stalked erect

11740 Leaves downy beneath scabrous above : radical stalked oblong; cauline amplexicaul. wavy

11741 Leaves sessile linear smooth above revolute at edge, Heads capitate, Pedunc. long

11742 Leaves amplexicaul. ovate oblong 3-nerved woolly above, Corymb. stalked, invol. cylindrical

11743 Leaves amplexicaul. panduriform spatulate blunt downy, Corymb and branches divaricating

11744 Branches downy, Lvs. linear revolute at edge smooth above downy beneath, Leaves of invol. lanc. acute

1174.5 Branches pubesc. Lvs. lanc. lin. acumin. smooth above finely downy beneath, Heads corymb. cylindrical 11746 Tomentose, Leaves linear acute curved, Heads in capitate stalked corymbs

11747 Leaves lanc. sessile 3-nerved naked above woolly beneath, Corymb contracted-capitate

11748 Leaves amplexicaul. spatulate downy acute, Corynub. term. Branches spreading

11749 Leaves sessile lanc. Involucres white : lower scales brown

11750 Leaves lin.-lanc. mucronate revolute at edge downy beneath, Heads sessile capitate terminal

11751 Leaves lanc. mucronate revolute at edge downy beneath, Heads corymbose

11752 Leaves obl. blunt downy, Corymbs fastigiate, Heads cylindrical

11753 Leaves lin. spreading recurved scabrous above, Corymb. dense, Invol. cinereous at base

11754 Leaves sessile linear, Outer involucre rough : inner flesh-colored

11755 Leaves clustered roundish, Corymbs branched, Involucres downy outside

11756 Leaves linear, Corymb commound, Branches virgate

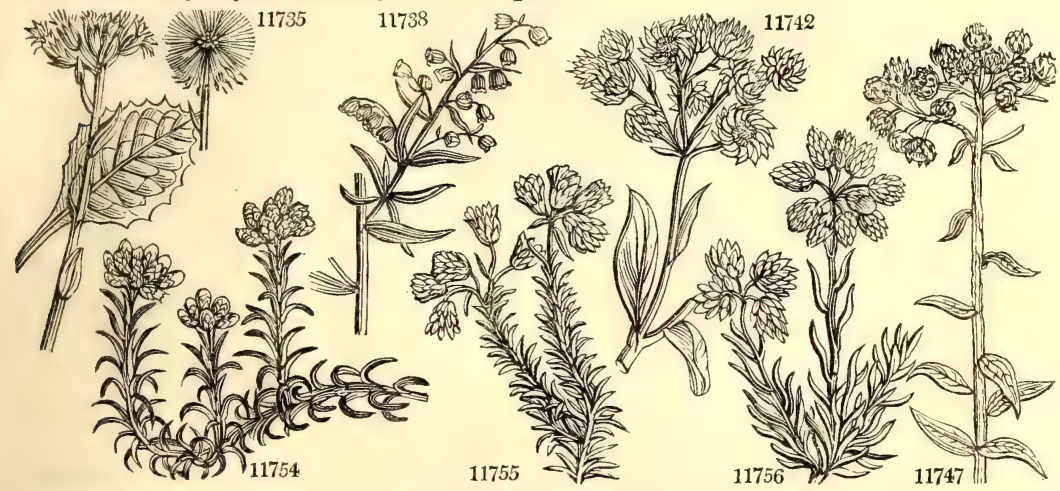

and Miscellanoous Particulars.

more probable that the word is a corruption of Tarchon, the Arabic name of the plant. See Tarchonanthus. The leaves and points of the shoots are used as an ingredient in pickles. A simple infusion of the plant in vinegar makes a pleasant fish sauce; it is eaten along with beef steaks, as horse-radish is with roast beef; and is employed, both in Europe and Persia, to correct the coldness of salad herbs, and season soups and other compositions. The plant is of the easiest culture, but, like other species of the genus, dislikes a wet soil.

From the acrid leaves of A. chinensis the drug called Moxa is obtained; a substance much in use among the Chinese as an actual cautery. For this purpose, the Moxa is laid upon the part affected and set on fire. The Cochin.Chinese, and also the Japanese, according to Kæmpfer, use Artemisia vulgaris for the same purpose, and it is said with great success, in removing tumours and rheumatic pains, or slight convulsions.

1722. Gnaphalium. A word under which Dioscorides describes a plant with soft white leaves, which served the purpose of cotton. It agrees pretty well with the modern genus, which consists of very pretty, sometimes 
11757 ignéscens $W$. 11758 crassifólium $W$

11759 marítimum $W$. 11760 dasyánthum $W$. en. 11761 orientále $W$. 11762 cymósum $\boldsymbol{W}$. 11763 rútilans $W$. 11764. arenárium $W$. 11765 angustifólium $P$ ers. 11766 lúteo-álbum $W$ 11767 albéscens $W$.

11768 apiculátum $L a b$. 11769 odoratissimum $W$. 11770 sanguíneum $W$. 11771 candidíssimum 11772 fo'tidum $W$. 11773 helianthemifólium 11774 squarrósum $\underset{W}{W}$. 11775 purpúreum $\boldsymbol{W}$. 11776 declinátum $\boldsymbol{W}$. 1723. LEONTOPO
11778 vulgáre $R$. Br.

\section{E'VAX. Lam.}

11779 pygmæ'a Lam.

1725. ANTENNA'RIA. $\boldsymbol{R}$. Br. ANTENNARI 11780 contórta $B, R$ twisted-leaved $A$

11781 triplinérvis $B . M$. three-nerved $\triangle \mathrm{pr}$ 11782 dioíca $R . B r$. diøecious $\quad$ \& $\Delta \mathrm{pr}$

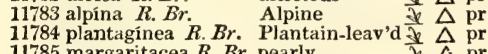
11785 margaritacea $R$. Br. pearly
11786 unduláta $R . B r$ wave-leaved $\$$.

11787 obtusifólia $R$. $\dot{B} r$. blunt-leaved $\mathrm{O}$ pr

1726. METALA'SIA. $R$. Br. MEtalasia.

11788 seriphioídes $R$. Br. Seriphium-like w $\downarrow$ pr

1727. ASTEL'MA. $\mathrm{R} . \mathrm{Br}$. Astelma.

11789 eximium $R$. Br. Br. Aste

11790 frúticans $\boldsymbol{R} . \boldsymbol{B r}$. shrubby

1728. ATHRIX'IA. Ker. A thrixia.

11791 capénsis $\mathrm{Ker}$. Cape

1729. Xera ${ }^{\prime}$ ThemUM. $W$. Xeranthemum.

11790 annum $W$.

$\begin{array}{lll}11793 \text { inapértum } W . & \begin{array}{l}\text { small-flowered } \\ \text { oriental }\end{array} & \mathrm{O} \text { or } \\ 11794 \text { orientále } W . & \mathrm{O} \text { or }\end{array}$

1730. ELICHRY'SUM. $W$. Elichrysum.

11795 vestítum $W$. upright

11700 spirále $W$.

11797 imbricátum $W \quad$ spiral-leaved

11708 spectábile Lodd inbricated

11799 speciosíssimum $W$. showy

11800 dealbátum $P$. S. herbaceous

11801 fúlgidum $W$. great-yellow

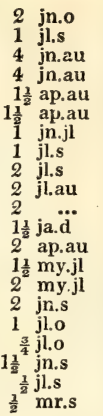

R C. G. H. 1731. C s.p C. G. H. 177k. C s.p W.x C. G. H. 1772. C co Bur. afr.t. 77. f.2 $Y$ C. G. H. 1812, C co Y Africa 1629. C s.p Com. hort. 2.t.55 Y Africa 1731. C co Dil.el.t.107.f.128 R.Y C. G. H. 1731. C s.p Dil. el.t.107.f.127 Y Europe 1739. D co Bot. mag. 2159 Y Naples ... D co Barr. ic. 1125 Y.w England san.pl. R s.l Eng. bot. 1002 W.y Jamaica 1793, C co Y V. Di. Isl. 1804. D co Bot. reg. 240 Cr C. G. H. 1691. C s.p Mil.ic.1.t.131.f.2 Pa.Y Caspian 1823. D co L.Y C. G. H. 1692. S s.l Bot. mag. 1987 W C. G. H. 1774. C co Volck.nori.t. 194 $\mathrm{Pu}$ C. G. H. 1816. C co Jac. frag. t. 3. f.4 $\mathrm{Pu}$ N. Amer. 1732. S co Dil.el.t.109. f.133 Br C. G. H. 1787. S co

Compositce. Sp. 1-2.

$\frac{1}{3}$ jn.jl Y Austria 1776. S p.l Bot. mag. 1958

Composite. Sp. $1-3$.

$\frac{1}{4}$ jl.au $\quad$ Br $\quad$ S. Europe 1629. C co Cav. ic. 1. t. 36 Composita. Sp. 8-11?

$2 \mathrm{jl} W$ Wepal 1821. D co Bot. reg. 605

I au W Nepal 1823. D co Bot. mag. 2468

$\frac{1}{4}$ my.jl Pk Britain … $\quad$ D p.l Eng. bot. 267

$\frac{1}{4}$ jn.jl Pk Al. of Eur.1775. D p.1 Flor. dan. t. 332

1 jn.jl W Virginia 1759. D p.I Plu.alm.t.348.f.9

$1 \frac{1}{2} \mathrm{jl}$.s $\quad$ England mea. D p.l Eng. bot. 2018

jn.s W Africa 1732. S s.l Dil.el.t.108.f.130

N. Amer. 1699. S co Dil.el.t.108.f.131 Composita. Sp. 1

3 … Y C. G. H. 1825. D p.l

Composita. Sp. 2-7.?

3 jl.au Cr C. G. H. 1793. S s.p Bot. reg. 532 jn.au Y C. G. H. 1779. C co Bot. reg. 726

Composite. Sp. 1

$\begin{array}{llll}\text { ap } & \text { C. G. H. 1821. C p.l Bot. reg. } 681\end{array}$ Composita. Sp. 3.

3 jl.au $\mathrm{Pu} \quad \mathrm{S}$. Europe 1570. S $\quad$ s.l Jac. aust. 4. t.388 2 jl.au Pu S. Europe 1620, S co Moris.s.6.t.12.f.9 l.au W Levant 1713. S co Compositre. Sp. 22-4.

2 jl.s W. C. G. H. 1774. S s.p Bur. afr. t. 66.f.1 b or $2_{2}^{2}$ jl.o W W. G. H. 1801. S s.p Bot. rep. 262 w or 2 jl.o W C. G. H. 1820. S s.p Pet. gaz. t. 5.f.10 * or 3 my.jn Pk C. G. H. 1810. S s.p Bot. cab. 59 $\begin{array}{llllll}\text { or } & 3 & \text { my.jn } & \text { Pk } & \text { C. G. H. 181. } & \text { S s.p Bot. cab. 59 } \\ \text { el } & 8 \text { jl.s } & \text { W } & \text { C.G. H. 1691. S s.p Bot. rep. 51 }\end{array}$ $\checkmark \mathbb{N}$ or $1 \frac{1}{2}$ ja.d $W$ V.Di.Isl. 1812. D co La.no.ho.2.t.190 C. G. H. 1774. S s.p Bot. mag. 414

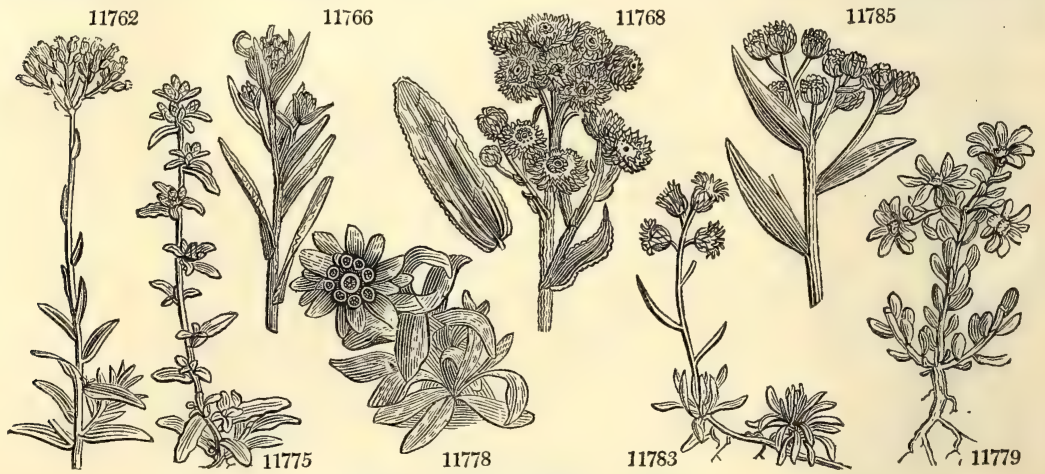

History, Use, Propagation, Culture,

beautiful woolly leaved shrubs or herbs, all of the description called Everlasting, on account of the permanence of the colors and form of their dry flowers.

1723. Leontopodium. From $\lambda \varepsilon \omega v$, a lion, and $\pi \varangle 5$, a foot. The soft tufted silky heads have been compared to the foot of such an animal as a lion.

1724. Evax. A name, the meaning of which has not been explained. A little white annual weed.

1725. Antennaria. In allusion to the awns of the pappus, which resemble the antenna of some insect. A genus founded upon the Gnaphalium margaritaceum of Linnæus. It consists of herbaceous plants, natives of Europe and North America, having the male and female flowers in distinct involucra, and on different individuals.

1726. Metalasia. Apparently so called from $\mu \sigma \tau \kappa \lambda \propto \sigma \sigma \omega$, to change or alter: but the application of the name is not evident. 
11757 Leaves sublanc. downy sessile, Corymbs altern. round, Heads globose

11758 Leaves broad-lanc. somewhat stalked coriaceous downy, Corymb. compound, Stem proliferous

11759 Much branched, Leaves lanc. acutish sessile, Inner scales of invol. yellow

11760 Leaves lanc. acute 3-nerved at base wavy pilose : beneath tomentose, Corymb contracted bracteate

11761 Leaves lin. lanc. hoary : radical blunt; cauline acute, Corymb compound, Pedunc. long

11762 Leaves lanc. 3-nerved smooth above, Raceme terminal, Stem branched below

11763 Leaves lanc. Corymb decompound, Stem branched below

11764 I eaves hoary downy blunt : radical spatulate lanc.; cauline lin.-lanc. Corymb compound

117651 aves linear long narrow downy replicate at edge, Corymb compound umbeliate

11766 Leaves half amplexicaul. linear-lanc. subrepand downy on each side : lower blunt, Corymb clustered

11767 White with down, Lvs. lin.-lanc. undivided below, Heads clustered conical

11768 Leaves subspatulate downy naked at end membranous or subulate, Flowers panicled

11769 Leaves decurrent blunt mucronate downy on each side flat

11770 Leaves decurrent lanc. downy flat with a naked point

11771 Leaves white silky-downy linear-lanc. acute, Corymb compound

11772 Leaves amplexicaul, entire acute downy beneath, Stem branched

11773 Leaves subamplexicaul. lanc. Corymbs compound, Scales of invol, plaited

11774 Leaves sessile lingulate very downy, Imner scales of invol. subulate recurved

11775 Leaves lin. spatulate downy beneath, Stem erect simple, Heads sessile terminal and axillary

11776 Leaves lin. lanc. Invol, with white lanceolate rays

11777 Stem herbaceous diffise, Lower scales of invol subulate naked, Leaves subamplexicaul.

11778 Head terminal enveloped in woolly bracteæ

11779 Stem branched at base, Bractes obovate

11780 Leaves lin. mucronulate reflexed, Corymbs few-flowered simple or proliferous, Scales of invol. blunt 11781 Stem erect simple, Lvs. ellipt. mucronate amplexicaul. 3-nerved [elongated obtuse colored 11782 Shoots procumb. Stems simp. Corymbs crowded, Rad. Ivs. spatulate, Fl.diœcious, Inner scales of invol. 11783 Stem simple, Rad. leaves lanc. : floral terminal aggregate sessile, Inner scales of invol. long

11784 Runners procumb. Rad. lvs. ov. nerved, Corymb contracted, Fl. diœecious, Inner scales of invol. long blunt 11785 Leaves lin. lanc. acuminate alternate, Stem branched upwards, Corymb fastigiate

11786 Leaves decurrent lanc. acute wavy downy beneath, Stem branched

11787 Leaves lin. lanc. acutish : smooth above ; pubescent beneath, Corymbs terminal contracted

11788 Leaves small fascicled lin. subulate downy above, Flowers lateral

11789 Leaves sessile ovate close erect downy, Corymb sessile

11790 Leaves amplexicaul, ovate-oblong 3-nerved acute woolly beneath on each side

\section{The only species}

11792 Scales of invol. blunt scariose : the inner ones of the ray lanc. blunt spreading

11793 Scales of invol. acute membranous at edge: the inner ones of the ray lanc. acute conniving 11794 Scales of invol. roundish scarious : the inner ones of the ray ovate acuminate erect

11795 Leaves sess. lanc. linear woolly acute: floral with a membrane at end, Branches 1-flowered 11796 Leaves sess. lanc. downy keeled spirally imbricated, Branches l-flowered

11797 Leaves obl.-lanc. silky imbricated, Branches 1-flowered, Peduncles squarrose

11798 Leaves linear subulate erect imbricated, Peduncle scaly l-flowered

11799 Leaves sessile lanc. obovate acute 3-nerved woolly, Branches 1-flowered

11800 Leaves lanc. white beneath silky recurved-spreading, Branches 1-fl. Peduncles nearly naked

11801 Leaves amplexicaul. ovate lanc. downy beneath tomentose at edge, Branches 3-flowered

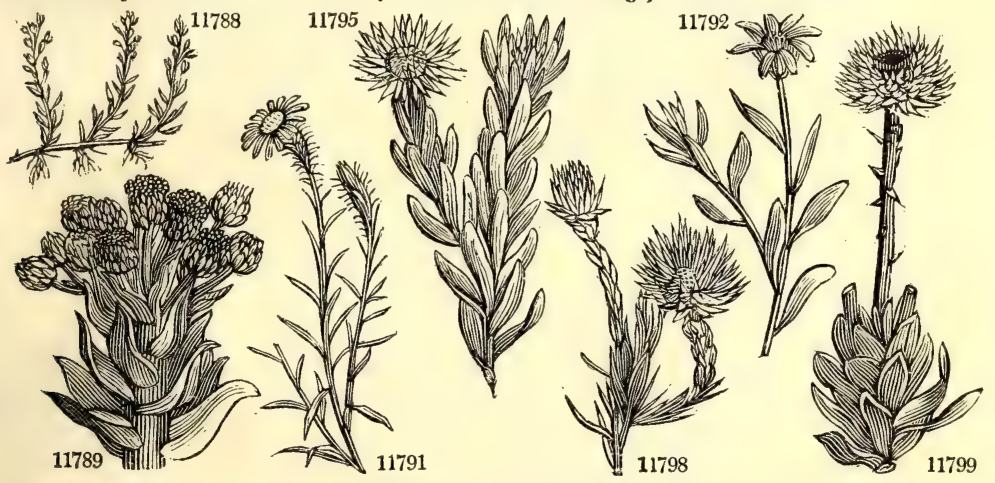

and Miscellaneous Particulars.

1727. Astelma. From $\propto$, privative, and $5 \varepsilon \lambda \mu \alpha$, a crown, in allusion to the construction of the fruit. Beautiful Cape shrubs with everlasting flowers.

1798. Athrixia. So called by Mr. Ker, we presume from $\alpha$, without, and Tes absence of hairs upon the receptacle and the stigmas of the ray. A pretty greenhouse shrub, with narrow lancelate haves, and bripht crimle a solitary heads of flowers.

1729. Xeranthemum. From $\xi$ nos, dry, and $\alpha \nu$. 05 , a flower, on account of the dry nature of the leaves of the calyx, which retain their color and form for years. The species are popular annual flowers, of easy culture in light rich soil. They are valued for their properties of retaining their texture and color, when gathered and dried, in the manner of Gnaphalium, Elichrysum, and other genera of what are vulgarly called everlastings.

1730. Elichrysum. From rinsos, the sun, and $\chi$ evoros, gold, in allusion to the brilliant yellow color of the flowers.

The species are much admired for the brilliancy of their flowers even in a dried state. $E$ bracteatum is the

handsomest annual species, and should be raised on a hotbed, and afterwards transplanted into a warm situation. 
1180 2 variegátum $W$. 11803 proliferum $\boldsymbol{W}$ 11804 canéscens $W$. 11805 argénteum $W$ 11806 retórtum $W$. 11807 sesamoídes $W$ 11808 fasciculátum $W$. $\beta$ álbum r rubrum

11809 rígidum $H$. $K$

11810 ericoides $P$. S. 11811 Stæhelina $W$. 11812 frágrans $B . R$.

11813 herbáceum $\boldsymbol{B}, \boldsymbol{R}$. spléndens B. M. 1773 .

11814 paniculátum $W$.

11815 bracteátum $W$.

1731. CARPE'SIUM.

W. Carpesium.

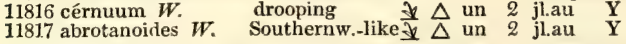

1732. BAC'CHARIS. $W$ 11818 angustifólia $P h$.

11819 ivæfólia $\boldsymbol{W}$.

11820 neriifólia $W$

11821 halimifólia $\boldsymbol{W}$

11822 adnáta $W$.en.

11823 Dioscóridis $W$

\begin{abstract}
Plowman's Spikenard.
\end{abstract} narrow-leaved

造 L pr

Oleander-leav 1 pr 2 aun

Groundsel Trees or 4. o.

adnate $\square$ un 6 au.n

Dioscorides's 4 au.n

1733. MOLI'NA Fl per MoLINA.

1731. CONY'ZA. $W$

11825 squarrósa $W$.

11826 marylándica $P h$

11827 axilláris $W$.

11828 camphoráta $P h$

11829 pátula $W$.

11830 balsamifera $W$.

11831 bífrons $W$.

11832 fástigiáta $W$.

11833 cándida $W$.

11834 chinénsis $W$.

11835 verbascifólia $W$.

11836 chilénsis Spreng.

11837 auríta $W$.

11838 hirsúta $W$.

11840 Gouáni $W$.

11841 amœ'na Link.

11842 sícula $W$.

1184.3 fo'tida $W$

11844 sórdida $W$.

11845 saxátilis $W$.

11846 rupéstris $W$.

11847 sericea $W$.

11848 inuloídes $W$.

11849 odoráta $W$.

11850 glomeráta Link.

11851 spatuláta Link.

11852 arboréscens $W$.

11853 incísa $W$.

118.54 thapsoides $W$

11855 virgáta $W$

Flea-bane.

great

Maryland

axillary

\า () $\mathrm{w} 2$ jl.au $\mathrm{Y}$

phor-scent. $\triangle \cup$ un 3 au.o

spreading $O$ un $1 \frac{1}{2} \mathrm{jl} . \mathrm{s}$

balsam-bearing of un 2 jls

oval-leaved $₹ \triangle$ un 1 au.s

fastigiate 0 un 2 jn.jl

woolly

Chinese

un 2 jlau

Mullein-leaved 1 un

Chil. $O$ un 3 au.o

auricled 1 un 1 au.o

shaggy $\quad$ in) un 2 au.s

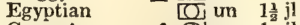

Gouan's [Q] un 1 jl.au

agreeable 0 un 3 jl.au

red-stalked $O$ un 1 au.s

stinking $\triangle \cup$ un 2 au.s

small-flowered

stone 1 jl.au

rock

snowy

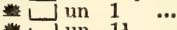

L un $1 \frac{1}{2}$ u...

sweet-scented $\mathrm{ft} 2 \mathrm{in}$ au

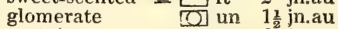

tree

[\] un 3 jn.au

$\square$ un 6 nd

ear-leaved,

un 2 jl.s

wing-stalked \& $\triangle \mathrm{J}$ un 2 au.s

11856 geminiflóra Tenore twin-flowered un $1 \frac{1}{2}$ au.s

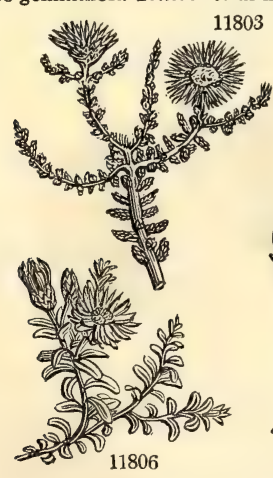

11806

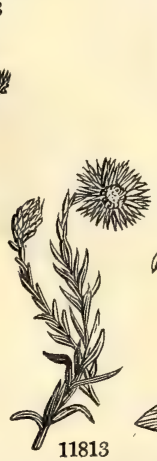

History

11812
Br.w C. G. H. 1801. S s.p

Cr C. G. H. 1789. C s.p Bot. reg. 21'

W C. G. H. 1794. C s.p Bot. mag. 420

W C. G. H. 1732. C s.p Dil. el.t.322.f.415

Pu.w C. G. H. 1739. C s.p Bot. mag. 425

W C. G. H. 1799. S s.p Bot. rep. 242

W C. G. H. 1799. S s.p Bot. rep. 279

C. G. H. 1799. S s.p Bot rep. 650

C. G. H. 1801 C co Bot rep 087

C. G. H. 1796. C co Lam. ill.t.693.f.2

C. G. H. 1801. C co Bot. rep. 428

C. G. H. 1803. C co Bot. rep. 561

C. G. H. 1802. D co Bot. rep. 487

W C. G. H. 1800. S co Bur. afr.t. 67.f.1 N. Holl. 1799. C co Bot. rep. 375 Sp. 2.

Austria 1739. D co Jac. aust. 3.t.204

China 1768. D co Osb, it. t. 10

Sp. $6-43$.

N. Amer. 1812. C co

America 1696. C J.p Sch.hand.3.t.244

C. G. H. 1752. C l.p

N. Amer. 1633, C co

S. Amer. 1823. C co

Sp. $1-37$.

S. Amer. 1824. C co

sp. $34-62$.

Britain ch.pa. S co Eng. bot. 1195

Pu N. Amer. ... S $\mathbf{S}$ co Dill.elt.t.88.f.104

Y $\quad$ ….. 1823. S co

Amer. 1704. D co Dilleit.t.89.f.105

Y.Pu China 1758, S co Mill ic 2.t. 247

$\mathrm{Br}$ E. Indies 1822. S co Rump.6.t.24.f.1

Y N. Amer. 1739. D p.1 Plu.alm.t.87.f.4

Pu Senegal 1820. S co

Candia 1714. C co Bar, ic. t. 217

1796. S co Ru, am.6.t.14.f 2

Y Sicily 1808, C co Bocc. sic.t.31.f.2

Y Chili 1816. D co

E Indies 1818, S co

Y.Pu China 1767. S co

Y Egypt 1778. S co Jac. vind. 3.t. 19

Y Canaries 1772. S co Jac. vind. 2, t. 79

$\mathrm{Pu}$ Congo 1824, S co

Y Sicily 1779. S co Bocc. sic.t.31.f.4

Africa 1724. D co Mill. ic. 2.t. 233

Br S. Europe 1570. C co Barr. ic. t. 368

Br S. Europe 1640. C co Schk han.3.t.24.1

Y Arabia 1790. C co Schmid.ic. t. 36

Y Canaries 1779. S p.l

Pu Teneriffe 1780, C co Jac. ic. 1.t. 171

$\mathrm{Pu}$ India 1759. C p.l Plum. ic. t. 97

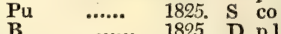

B $\quad$...... 1825. D p.l

Jamaica 1733. C p.

C. G. H. 1774. S p.l

Casp. Sea 1806. C co

America 1783. D co Slo.hi.1.t.152.f.5 
11802 Leaves ob.ong downy imbricated, Branches 1-headed, Heads nodding

11803 Diffuse proliferous, Leaves roundish ovate smooth convex closely imbricated, Heads sessile 11804 Leaves obl. blunt imbricated, Branches 1-fl. Scales of invol. ovate

11805 Leaves obl. silky recurved

11806 Decumbent, Leaves lanc. silky somewhat recurved, Branchlets 1-flowered, Peduncles squarrose

11807 Leaves acerose lin, keeled smooth appressed, Branches 1-fl. Flowers sessile

11808 Lvs. acerose lin. roundish downy above : lower spreading; upper appressed, Branches 1-fl. Pedunc. scaly

11809 Leaves linear lanc. channelled amplexicaul : adult smooth, Branches woolly

11810 Branches numerous very fine filiform, Leaves very small 3-cornered imbricated appressed

11811 Leaves obl, lanc, narrowed at base silky, Peduncles naked 1-flowered terminal

11812 Leaves wavy woolly reflexed at end, Heads small terminal few

11813 Leaves amplexicaul. oblong revolute at edge woolly, Flowers terminal solitary shining

11814 Leaves linear-lanc. silky, Corymb simple terminal

11815 Leaves lanc. acute at each end roughish, Peduncles 1-flowered long, Invol, bracteate

11816 Heads terminal solitary cernuous

11817 Heads axill, subsolitary

11818 Leaves narr. linear entire, Panicle compound many-flowered, Invol. small

11819 Leaves lanc. longitudinally toothed serrate

11820 Leaves lanc. serrated with one or two teeth forwards

11821 Leaves obovate emarginate crenate forwards

11822 Leaves lanc. serrate at end subdecurrent downy beneath

11823 Leaves obl. sessile toothed: teeth of the base deeper and stipule-like

11824 Leaves lanc. 3-nerved tooth-serrated, Corymbs terminal leafy

11825 Lvs. pubesc. ov.-lanc. serr. the upper ones ent. Stem herbaceous corymb. Scales of the invol. recurved leafy

11826 Leaves sessile broad-lanc. acute serrated, Corymbs terminal fastigiate

11827 Leaves ovate acute at each end toothed stalked pilose, Stem erect branched, Pedunc. many-headed

11828 Leaves stalked ovate lanc. very acute toothletted, Corymbs term. and axillary shorter than leaf

11829 Leaves ellipt. serrated villous beneath, Invol. subglobose, Leaves lanc. subulate, Branches spreading

11830 Leaves oblong lanc. doubly toothed acute downy beneath rugose veined, Petioles toothed

11831 Leaves spatulate oblong amplexicaul. serrated rugose

11832 Leaves sess. lanc. obl. : lower obovate-obl. subserrated at end, Branches corymbose-fastigiate

11833 Leaves ovate stalked entire obtuse downy, Pedunc. 1-fl. solitary term. axillary thickened

11834 Leaves lanc. ovate reflexed serrated downy beneath, Flowers terminal heaped

11835 Leaves ov. stalked crenate blunt downy rugose veiny, Pedunc. 1-fi. solitary terminal and axillary

11836 Leaves sublyrate : cauline entire, Stem downy panicled, Invol. campanulate

11837 Leaves toothed radical smoothish obovate : cauline obl. downy, Scales of invol. subulate

11838 Leaves oval entire hirsute beneath

11839 Leaves obl. spatulate tooth pilose, Heads panicled globose, Leaves of invol. subulate soft

11840 Lvs. lanc. serrated at end scabrous at edge : lower obov. Heads heaped, Lvs. of invol. membranous at edge

11841 Stem hairy, Leaves sessile oval blunt denticulate hairy, Panicle terminal contracted

11842 Leaves lin. lanc. scabrous nearly entire revolute at edge, Stem panicled, Scales of invol. lax

11843 Leaves lin. attenuate at base mucronate, Corymbs stalked contracted terminal

11844 Leaves lin. nearly entire, Peduncles long 3-headed

11845 Leaves lin.somewhat toothed, Peduncles very long 1-headed

11846 Leaves spatulate somewhat toothed and stem downy, Pedunc. long 1-f

11847 Leaves linear filiform and stems silky with down, Flowers panicled

11848 Leaves cuneiform lin. blunt crenate toothletted smooth, Stem shrubby, Anthers with two setæ

11849 Leaves ovate stalked hoary beneath serrated, Corymb terminal compound

11850 Leaves broad lanc. blunt serrulate downy scabrous, Heads clustered surrounded by bractes

11851 Stem branched with spreading hairs, Leaves subamplexicaul. blunt coarsely serrated hairy

11852 Leaves ovate entire acute downy beneath, Spikes recurved 1-sided, Bractes reflexed

11853 Leaves ovate subcordate pilose viscid toothed auricled at base, Recept. favose

11854 Leaves decurrent ovate mucronate downy : lower serrated, Flowers corymbose

11855 Leaves decurrent lin. lanc. serrulate downy beneath, Spike long terminal interrupted

11856 Stem white with down, Leaves lanc. serrulate downy beneath, Heads terminal

11824

11826

11831

11848

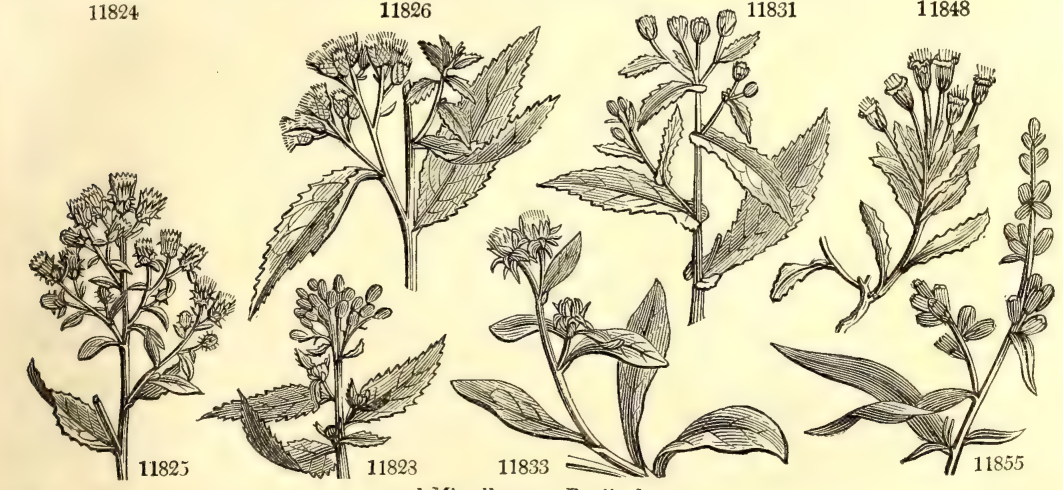

and Miscellaneous Particulars.

called B. Dioscorides is supposed to have been the Baccharis of the Greeks. An extensive genus of shrubby plants, few of which are deserving of cultivation.

1733. Molina. Named after John Ignatius Molina, a Spaniard, who published, in 1782, a Natural History of Chili.

1734. Conyza. This plant was believed to have the property, when suspended in a room, of driving away 
11857 carolinénsis $W$. 11858 rugósa $W$.

1735. MA'DIA. $W$. 11859 viscósa $W$.

1 i 860 mellósa $W$.

1736. ERI'GERON. 11861 gravéolens $W$. 11862 compósitum $\dot{P} h$.

11863 caroliniánum $W$.

11864 canadénse $W$.

11865 bonariénse $W$.

11866 linifólium $W$.

11867 philadélphicum $W$

11868 nudicaúie $P h$.

11869 purpúreum $W$.

11870 bellidifólium $W$.

11871 heterophýllum $W$

11872 jamaicen'se $W$.

11873 longifólium Desf.

11874 caucásicum Bieb.

11875 asteroídes Link.

11876 Villársii $W$.

11877 ácre $W$

11878 alpinum $W$.

11879 uniflórum $W$.

11880 glaúcum B. reg.

11880 glaúcum $B$. reg. shrubby delphinifólium $W . e n . L a r k s p u r-l e a v .4 \mathrm{pr}$

1737. TUSSILA'GO. $W$. Colt's Foot.

11882 nútans $W$.

11883 alpina $W$.

11884 díscolor $W$.

11885 sylvéstris $W$.

11886 Fárfara $W$.

11887 frígida $W$.

11888 frágrans $W$

11889 álba $W$.

11890 nived $W$.

11891 Petasites E.B. Com hýbrida E. B.

11892 spúria $W$.

11893 palmáta $W$

1738. SENE'CIO. $W$.

11894 reclinátus $W$ 11895 hieracifólius $W$.

11896 purpúreus $W$.

11897 cérnuus $W$

11898 erubéscens $W$.

11899 divaricátus $W$.

11900 croáticus $W$.

11901 Pseúdo-China $W$

Carolina

t. Helena

Madia.

clammy

: $\square$ un 5 jl.

Pu

Carolin

Brazil

O un $1 \frac{1}{2}$ jl.au $\underset{Y}{\mathbf{Y}}$ Chili

1821. C co

1794. S co

Erigeron.

strong-smellin

Daisy-flowered $\mathrm{O}$ p

Hyssop-leaved $\frac{\Downarrow}{2} \Delta \mathrm{pr}$

Canada

Buck's-horn

Flax-leaved

spreading

naked-stalked $¥ \Delta \mathrm{pr}$

Plantain-leav. $\frac{\partial}{\Delta} \mathrm{pr}$

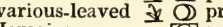
Jamaica [0 pr long-leaved $¥ \Delta \mathrm{pr}$ Aster-like $\stackrel{\Delta}{\Delta} \mathrm{pr}$ Villars's

blue

Alpine
dwarf

shrubby drooping-flow.

Alpine $\frac{1}{\Delta} \mathrm{pr}$

two-colored $\$ \overrightarrow{p r}$

wood Je $\triangle$ un

common $\quad \vec{\Delta} w$

Lapland d $\Delta$ or

White Butter Bur $\Delta$ pr downy-leaved \& $\Delta$ pr downy-leaved Burter Bur $\Delta$ hybrid $\frac{1}{\Delta} w$ lobe-leaved $\frac{7}{\Delta} \mathrm{pr}$ cut-leaved $\Delta \mathrm{pr}$

GroundSEI Grass-leaved Hawkweed

purple

drooping

blush-colored

straddling

Croatian

Chinese

11902 hæmatophýllus $W$.en.purple-leaved

11903 japónicus $W$.

jagged-leaved

12 jl.au Y S. Europe 1633. S co

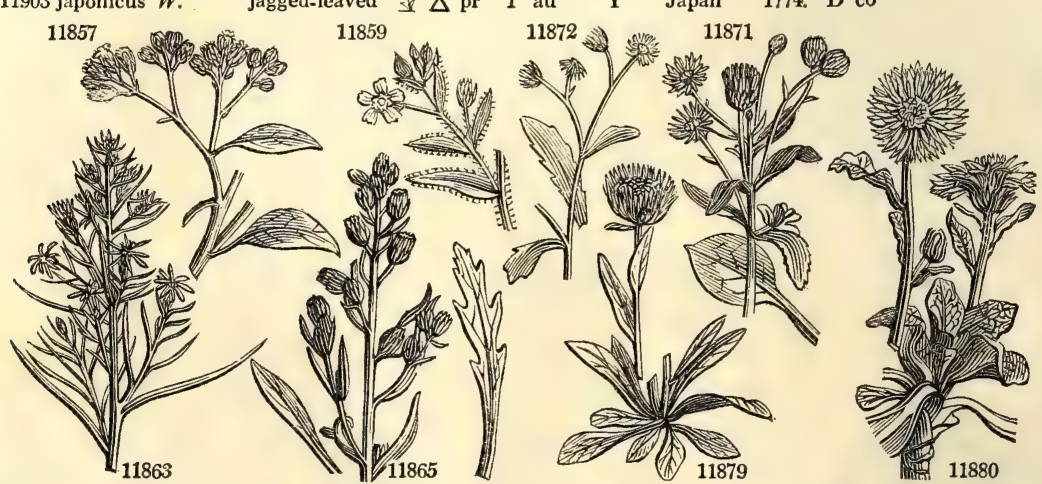

$\frac{v}{2} \Delta p$

¿ $\triangle \mathrm{pr}$

学 $\triangle$

₹ $\Delta \mathrm{pr}$

Composita. Sp. 21-53.

jl.au W.R N. Amer. 1811. D co

jl.au Pu N. Amer. 1727. D s.p

1 au.s W England rubble. S co

11 ji.au Pu S. Amer. 1732. S co

jl.au Pu S. Amer. 70 S p.l

$\begin{array}{llll}1 & \text { jl.au } & \mathrm{Pu} & \text { N. Amer. 1778. D co } \\ 1 \text { jl } & \mathrm{B} & \text { N. Amer. 1812. D co }\end{array}$

1 jl.au Pu Huds.Bay 1776. D co

$\frac{1}{2}$ jl.au Pu N. Amer. 1790. D co

1 jl.s W N Amer. 1640. S co

1 jl.s Pu Jamaica 1818. S co

2 jl.au Pu N. Amer. 1820. D co Caucasus 1821. D co ….. 1823. D co Piedmont 1804. S co Britain gra.pa. S co Scotland al.rills. D s.l Scotland highl. D co S. Amer. 1812. C co

$1 \frac{1}{2}$ jl. au

1 jl

$1^{4}$ ja.d $\mathrm{Pu}$

S. Amer. 1816, $\mathrm{S}$ co

Compositce. Sp. 12-17.

$\frac{1}{2} \mathrm{jn} . \mathrm{jl} \quad \mathrm{L}$.Pu W. Indies 1793. S co Plum, ic. t.41.f.1

$1 \frac{1}{2} \mathrm{mr} . \mathrm{my}$ L. $\mathrm{Pu}$ Austria 1710. D co Bot. mag. 84

$\frac{1}{2}$ ap.my L.Pu Austria 1633. D co Jac. aust. 3.t.247

1 ap.my L.Pu Austria 1816. D co Jac.aus.5.ap.t.12

$\frac{1}{2}$ mr.ap Y Britain moi.pl. D co Eng. bot. 429

my Pa Lapland 1710. D co Fl. dan. t. 61

ja.mr W Italy 1806. D co Bot. mag. 1388

1 ja.ap W Europe 1603. D co

1 mr.ap F Britain m. me. D co Eng. bot. 431

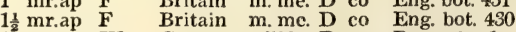

1 mr.ap W Germany 1790. D co Retz. obs. 1. t. 2

$\frac{1}{3}$ ap W Labrador 1778. D co Hort. kew.3.t.11

Composite. Sp. 62-171.

$\angle$ 이 or 2 jn.au Pu C. G. H. 1774. S co Jac. ic. 1.t. 174

or $1 \frac{1}{2}$ au W N. Amer. 1699. S co Her. parad.t.226

$\triangle \mathbb{V}$ or 2 jl.s Pu C. G. H. 1774. D co Jac. ic. 3. t. 580

O or 1 jl.au Vi E. Indies 1780. S co Jac. vind. 3.t.98

$\begin{array}{llll}4 & \text { or } 2 \text { jn.o } & \text { Pk } & \text { C. G. H. 1774. S l.p }\end{array}$

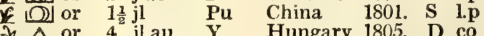
or $\frac{1}{2} \mathrm{jn} . \mathrm{au} \quad \mathrm{Y}$ E. Indies 1732. C co Dil.el.t.258.f.335

History, Use, Propagation, Culture,

gnats and fleas. From this imaginary property, its Greek name (from swver $\psi$, a gnat), its Latin name, pulicaria, its English name, flea-bane, and its French name, Herbe aux puces, are all derived. Conyza marilandica gives out a strong smell of camphor.

1735. Madia. Madi is the name of the plant in Chili. Clammy weeds, only seen in botanical gardens.

1736. Errgeron. A name synonymous with senecio, which is a translation of it. Named from $\dot{\eta} \rho$, the spring, and refw, an old man; because it becomes old in the beginning of the season. The name Senecio having been applied to another genus, the Greek term is preserved for this, which is related to it. E. viscosum is used to drive away fleas and gnats, probably from its strong scent, or, as some suppose, from the clammy juice of the leaves and stalks; hence the old name of Flea-bane, or Flea-wort.

1737. Tussilago. From tussis, a cough, for curing which the flowers are frequently employed at this day. Farfarus is the name under which the Greeks designated the White Poplar, the leaves of which are like the modern T. Farfara.

T Fariara is a certain indication of a clayey soil, and, according to Dr. Withering, is the first plant which vegetates in marle or lime stone rubble. The clayey part of the pestilential Maremmes of Tuscany, where scarcely any other plant will grow, is covered with common colts foot. The cotton of the leaves wrapped in a rag, 
11857 Leaves ovate-lanc. entire hoary downy beneath, Corymb compound terminal

11858 Leaves decurrent ellipt. crenate downy beneath, Heads capitate

11859 Leaves lanc. sessile viscid, Outer involucres 10-leaved

11860 Leaves amplexicaul, lanc. viscid

11861 Leaves sublinear entire, Branches lateral many-flowered

11862 Nearly stemless, Rad. leaves on long stalks triply 3-parted, cauline linear undivided

11863 Stem panicled, Flowers subsolitary terminal, Leaves linear entire

11864 Stem and flowers panicled hairy, Leaves lanc. ciliated

11865 Lower leaves lanc. laciniate : cauline line $\mathbf{r}$, Heads racemose

11866 Leaves scabrous : lower lanc. toothed in middle; upper linear, Heads corymbose

11867 Stem many-fl. Lvs. lanc. subserrate : cauline half amplexicaul. Florets of ray capillary the length of disk

11868 Radical leaves oval-lanc. acute somewhat toothed, Stem nearly leafless simple long

11869 Stem many-fl. pilose, Leaves obl. somew. toothed amplexicaul. Florets of ray capillary longer than disk

$11870 \mathrm{Rad}$. leaves obovate serrated : cauline lanc. entire, Stem about 2fl. Ray longer than disk

11871 Rad. leaves roundish ovate deeply toothed stalked: cauline lanc. toothed subserrated in middle

11872 Stem few-fl. subvillous, Leaves cuneiform lanc. Serratures 2 on each side

11873 Branches spiked, Scales of invol. long, Peduncles scaly, Leaves very long smooth sessile

11874 Leaves entire bluntly mucronate : radical oblong stalked; cauline cordate ovate sessile

11875 Stem nearly naked, Rad. leaves spatulate smooth dotted : cauline linear, Heads corymbose

11876 Leaves lanc. 3-nerved scabrous somewhat toothed sessile, Stem panicled, Ray shorter than disk

11877 Pedunc. alternate (scarcely racemose) single-fl. Pappus as long as the florets of the ray, Lvs. lanc. obtuse

11878 Stems with usually only one fl. Pappus much shorter than the florets of the ray, Lvs. lanceolate

11879 Stem 1-flowered, Invol. pilose

11880 Leaves ciliated glaucous clammy : radical with winged stalks and few teeth ; cauline sessile entire

11881 Leaves pinnatifid; segments of the cauline leaves linear entire; of the radical lanc. somewhat toothed

11882 Scape 1-fi. naked, Head radiated nodding, Lvs. stalked obovate toothed sinuated at base downy beneath 11883 Scape 1-fl. nearly naked, Head discoid, Lvs. reniform toothed smooth

11884 Scape 1-f. nearly naked, Head discoid, Lvs. reniform toothed downy beneath

11885 Scape about 1-fl. nearly. naked, Head discoid, Lvs, smooth reniform slightly 7-lobed

11886 Scape single-fl. imbricated with scales, Lvs. cordate angular toothed downy beneath

11887 Thyrsus fastigiate, Heads radiant, Lvs. roundish cordate unequally toothed downy beneath

11888 Thyrsus fastigiate, Heads radiant, Lvs. roundish cordate equally toothed downy beneath

11889 Thyrsus fastigiate, Heads discoid, Lvs, orbicular cordate doubly and finely toothed

11890 Thyrsus oblong, Heads discoid, Lvs. obl, cordate unequally toothed white beneath: lobes spreading

11891 Thyrsus ovate-oblong, Lvs. cordate unequally toothed with the lobes approximate downy beneath

11892 Thyrsus oblong, Heads discoid, Lvs. obl. cordate unequally toothletted snow-white beneath

11893 Thyrsus fastigiate, Heads obsoletely radiant, Lvs. roundish cordate half 7-lobed downy beneath

11894 Heads flosculous, Cor. naked, Invol. ventricose somewhat imbricated, Lvs. filiform lin. entire smooth

11895 Heads flosculous, Cor. naked, Lvs, obl. amplexicaul. unequally and deeply toothed, Stem virgate

11896 Heads flosculous, Cor. naked, Lvs. lyrate hairy : upper lanc, toothed

11897 Heads flosculous, Cor. naked, Lvs. ellipt. tooth-serrated hairy, Peduncles long many-flowered

11898 Heads flosculous, Cor. naked, Lvs. lyrate pilose on each side viscid

11899 Heads flosculous, Cor. naked, Lvs. lanc. toothed scabrous, Flowering branches spreading

11900 Heads flosculous, Cor. naked, Lvs. obl. lanc. finely serrated smooth, Heads corymbose

11901 Heads flosculous, Cor. naked, Lvs. lyrate pinnatifid toothed, Scape nearly naked

11902 Heads flosculous, Cor. naked, Lvs. obl. pinnatifid toothed acuminate stalked cuneate at base

11903 Heads flosculous, Cor. naked, Lvs. pinnatifid: segm. lanc. acute cut, Stipules leafy subpalmate

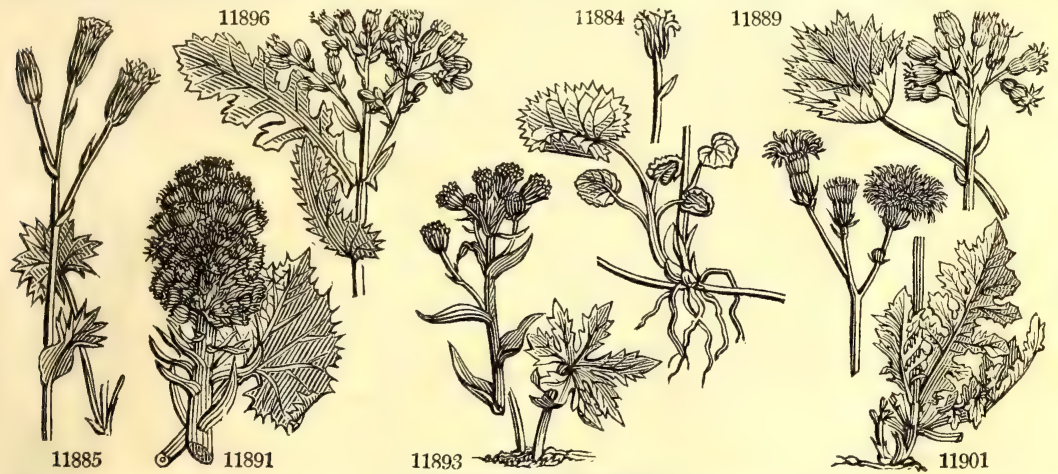

and Miscellaneous Particulars.

dipped in a solution of saltpetre, and dried in the sun, makes an excellent tinder. The leaves are the basis of the British herb tobacco ; they have been regarded as expectorant from the earliest ages, having been smoked through a reed in the days of Dioscorides, with the view of relieving the chest from accumulated mucus in catarrh, asthma, and phthisis. At present, though it occupies a place in the Materia Medica, very little reliance is placed on its powers. (London Disp. p. 542.)

T. Petasites, from the Greek $\pi \varepsilon \tau \ltimes \sigma o s$, a broad covering, in allusion to the leaves, which are larger than those of any British plant, and afford shelter from rain to poultry and other small animals. It is called Butter bur, in allusion to a former application, and Pestilent-wort, from its supposed efficacy in the plague. T. hybrida is by some considered, a variety of this species, as $\mathbf{T}$, alba is of $\mathbf{T}$ paradoxa. $\mathbf{T}$ fragrans is valued in gardens as an early and fragrant flower; like all the species, it is apt to run very much, and is therefore best kept in pots.

It is remarkable that no plant belonging to the tribe of Tussilagineæ, has been discovered with hermaphrodite flowers. They are distinguished from other tribes by their stigma, which occupies both surfaces of the lobes of the style. They are nearly all natives of Europe.

1738. Senecio. For the explanation of this word, see Erigeron. Most of these species are annual weeds, or 
11904 glomerátus Desf. 11905 cacalioídes Fisch. 11906 vulgáris $W$. 11907 arábicus $W$.

11908 dentátus Jacq.

11909 verbenæfólius $W$.

11910 triflórus $W$.

11911 ægyp'tius $W$.

11912 crassifólius $W$

11913 lividus $W$.

11915 cineráscens $W$

11916 squamósus $W$.

11917 viscósus $W$.

11918 sylváticus $W$.

11919 nebrodénsis $W$

11920 glaúcus $W$.

11921 hastátus $W$.

11922 vernális $W$

11923 artemisiæfólius $L$ an

11924 rupéstris $W$.

11925 venústus $W$.

11926 élegans $W$. a flere pléno

11927 squálidus $W$

11928 speciósus $W$.

11929 erucifólius $W$.

11930 uniflórus $W$.

11931 incánus $W$.

11932 abrotanifólius $W$.

11933 tenuifólius $W$,

11934 Jacobæ'a $W$.

11935 aquáticus $W$

11936 aúreus $W$.

11937 rosmarinifólius $W$.

11938 ásper $W$.

11939 rigéscens $W$

11940 linifólius $W$ :

11941 paludósus $W$

11942 riemorénsis $W$.

11943 sarracénicus $W$.

11944 ovátus $W$

11945 macrophýllus Bieb.

11946 solidaginoídes $W$.

11947 umbrósus $W$.en.

11948 coriáceus $W$

11949 Dória $W$.

11950 Dorónicum $W$

11951 lánceus $W$.

11952 longifólius $W$.

11953 halimifólius $W$.

11954 illicifólius $W$.

11955 rígidus $W$.

clustered

Cacalia-like

common

Arabian

$\Delta \mathbb{N}$ un 1 jl.au

three-flowered $\mathrm{O}$ pr ${ }_{1} \frac{1}{3} \mathrm{jl} . \mathrm{s}$

Egyptian $O$ pr $1 \frac{1^{2}}{2}$ ji.au

thick-leaved

livid

three-lobed

gray

squarrose

stinking

mountain

Sicilian

sea-green

$O$ pr $\frac{x}{2}$ jl.au

O un 1 jl.au

un 1 jn.au

\# un 6 my.jl

- L u un $_{1} 3$ my.jl

w 1 jl.au

un $1 \frac{1}{2} \mathrm{jn}$.au

un $1 \frac{1}{2}$ jn.au

halberd-leaved $\triangle \cup$ un $1 \frac{1}{2}$ my.au

spring $O$ un 1 ap.jn

Wormwood-lv. \$ $\Delta$ un $1 \frac{1}{2} \mathrm{jn} . \mathrm{jl}$ rock $\frac{1}{2} \mathrm{jn.jl}$ wing-leaved elegant $\mathrm{O}$ pr 2 jn.au double-flowered 4 el 2 ja.d inelegant $\mathrm{O}$ w $1 \frac{1}{2}$ jn.o red-flowered $\sim$ or $\frac{1}{2}$ jl.au Eruca-leaved $\frac{k}{\Delta}$ un ${ }_{2}^{2}$ jl.au Alpine

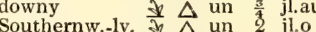

j $\Delta$ un ${ }^{\frac{1}{6}}$ jl.au lender-leaved $\vec{\Delta} \Delta$ un 2 jlau

Common Ragwort $\downarrow \Delta \mathrm{w} \quad{ }_{2}$ jl.au marsh \$ $\Delta$ un 3 my.jn golden Rosemary-lvd, $u$ pr 3 jl.au rough 4 pr 3 jl.au stiff-leaved 3 pr 33 jl.au Flax-leaved 4 un 2 jl.au bird's-tongue $\Delta$ pr 5 jin.au

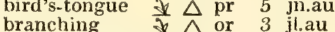
branching $\frac{5}{\Delta}$ or 3 jl.au or 3 jlo

late leaved $\Delta$ or 4 jlau Solidagolike $\Delta$ or a jlau various-leaved 4 or 2 jl.au leathery-leaved $\frac{1}{\Delta}$ or or 4 jl.au broad-leaved $\frac{\Delta}{\Delta}$ or 4 jl.s Leopard's Bane $\vec{x}$ or 1 jl.s spear-leaved 商 long-leaved or 3 aus succulent-leav, or $3 \mathrm{jl}$ Ilex-leaved hard-leaved

\section{STARWORT}

reflexed-leaved tooth-leaved silky-leaved Ivy-leaved Ivy-leaved fluted-stemmed

$\mathbf{Y}$
$\mathbf{Y}$
$\mathbf{Y}$
$\mathbf{Y}$
$\mathbf{Y}$
$\mathbf{Y}$
$\mathbf{Y}$
$\mathbf{P u}$
$\mathbf{Y}$
$\mathbf{Y}$
$\mathbf{Y}$
$\mathbf{Y}$
$\mathbf{Y}$
$\mathbf{Y}$
$\mathbf{P}$
$\mathbf{Y}$
$\mathbf{Y}$
$\mathbf{Y}$
$\mathbf{Y}$
$\mathbf{Y}$
$\mathbf{P u}$
$\mathbf{P u}$
$\mathbf{P u}$
$\mathbf{Y}$
$\mathbf{S} \mathrm{C}$
$\mathbf{Y}$
$\mathbf{Y}$
$\mathbf{Y}$
$\mathbf{Y}$
$\mathbf{Y}$
$\mathbf{Y}$
$\mathbf{Y}$
$\mathbf{Y}$
$\mathbf{Y}$
$\mathbf{Y}$
$\mathbf{Y}$
$\mathbf{Y}$
$\mathbf{Y}$
$\mathbf{Y}$
$\mathbf{Y}$
$\mathbf{Y}$
$\mathbf{Y}$
$\mathbf{Y}$
$\mathbf{Y}$
$\mathbf{Y}$
$\mathbf{Y}$
$\mathbf{Y}$
$\mathbf{Y}$
$\mathbf{Y}$
$\mathbf{Y}$
$\mathbf{Y}$
$\mathbf{Y}$

N. Holl. 1816, S co Brazil 1820. S co

Britain rubble. D co Eng. bot.747

Egypt 1804. S co

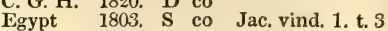

Egypt 1776. S co

Egypt 1771. S co

S. Europe 1815, S co Barr. ic. 261

Spain 1801. S co Schk. ha. 3.t.245

1728. S co

C. G. H. 1774. C p.I Jac.schœ.2.t.150

C. G. H. 1820. C p.l

Britain ch.ba. S co Eng. bot. 32

Britain woods. S co Eng. bot. 748

pu S. Europe 1704. S co Bärr. rar. 401

Egypt 1739. S co

C. G. H. 1722. D l.p Dil.el.t.152.f.184

Hungary 1803. S co Pl, rar. hu. 1.t.24 France 1816. D co

Hungary 1805, D s.l Pl.rar.hu.2.t.128 C. G. H. 1774. C p.l Bot. reg. 901 C. G. H. 1700. S co C. G. H. 1700. C s.l Bot. mag. 238 England walls. S co Eng. bot. 600 ...... 1789. D s.l Bot. reg. 41 Europe 1816. D co Barr. rar. t. 153 Al. of Eur.1799. D 1.p All. ped. t. 17.f.8 Al. of Eur.1759. D s.p Plu. alm. t.39.f.6 Al. of Eur.1640. D co Jac, aust. 1. t. 79 Britain woods. D 1.p Eng. bot. 574

Britain drypa. D s.l Eng. bot. 1130 Britain mar. D 1.p Eng. bot. 1131 N. Amer. 1758. D 1.p C. G. H. $\quad \ldots \quad$ C l.p Jac. ic. 3. t. 587 C. G. H. 1774. C p.1

C. G. H. 1815. D l,p Jac. coll.5.t.6.f.1 Spain 1820. D co Bocc. mus. t. 49 England fens. D p Eng. bot. 650 Austria 1785. D co Jac, aust. 2.t.184 Britain moi.pl. D co Eng. bot. 2211 Germany 1823. D co Caucasus 1818. D co C. G. H. 1824. C co

Hungary 1815. D l.p

Levant 1728. D l.p Dil.el.t.105.f.125 Austria 1570. D co Jac. aust. 2.t.185 S. Europe 1705. D co Jac.aus.2.t.ap.45 C. G. H. 1774, C p.I

C. G. H. 1775. C p.l Com. hort.2.t.71 C. G. H. 1723. C 1.p Dil.el.t 104.f.124 C. G. H. 1731. C 1.p Comm, rar. t. 12 C. G. H. 1704. C 1.p Com.hort. 2.t.75

1739. AS'TER. W.

11.956 refléxus $W$. 11957 tomentósus $W$

11958 sericeus $W$

11959 Cymbaláriæ $W$.

11960 lirátus $B . M$

11961 argophýllus $H . K$.
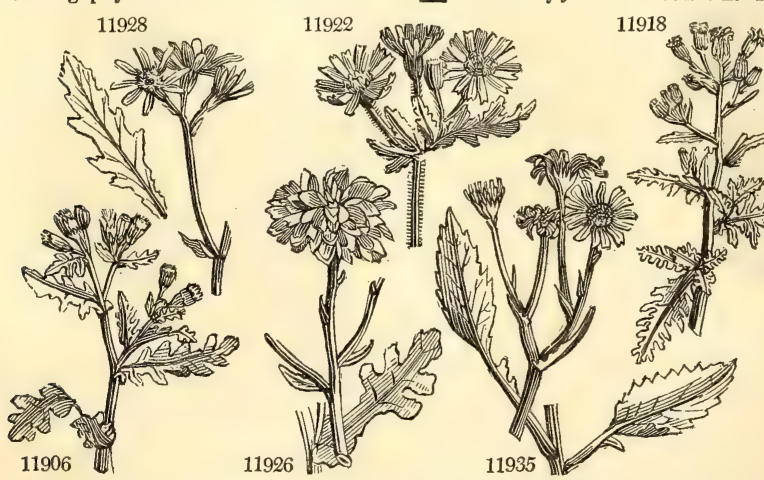

\section{Composite. Sp. 109-169.}

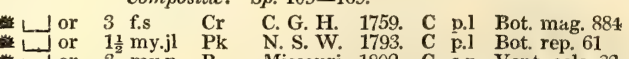

Missouri 1802 C s.p Vent cels. 33

C. G. H. 1786. C p.l Vent. malm. 95

N. S. W. 1812. C 1.p Bot. mag. 1509

V. Di. L. 1804. C s.p Bot. mag. 1563 11913

History, Use, Propagation, Culture,

rude gigantic yellow flowered autumnal perennials; S. venustus and cinerascens, however, are elegant plants with purple flowers. Of $\mathrm{S}$. elegans there is a double flowered variety, common in green houses, and readily propagated by cuttings.

Senecio hieracifolius is the pest of newly cleared ground in North America, as S. vulgaris is in Europe. It is known by the name of the Fire-weed

Senecio vulgaris is esteemed emollient and resolvative. It is employed in spitting of blood, in the form of a poultice, and against the gout and hæmorrhoids. It is given to horses suspected to be troubled with worms. 
11904 Herb downy upwards, Lvs. sinuate toothed and pinnatifid, Heads clustered, Invol. cylindrical

11905 Herb hirsute, Lvs. broad-lanc. sinuate-toothed and toothletted: teeth callous at end, Heads panicled 11906 Leaves semiamplexicaul. pinnatifid toothed, Heads in clustered corymbs destitute of a ray

11907 Heads tlosculous, Cor. naked, Leaves subbipinnate stalked smooth, Invol, not withered

11908 Heads radiant, Leaves half-amplexic. pinnatifid, Segments linear acute toothed distant, Peduncles long 11909 Heads flosculous, Cor. naked, Leaves obovate stalked cut-toothed, Pedunc. filiform 3-headed 11910 Heads radiate, Ray revolute, Ieaves stalked obl. sinuate, Pedunc. 3-headed, Invol. conical 11911 Heads radiate, Ray revolute, Leaves amplexic. lin. lanc. pinnatifid, Scales of invol. sphacelate in part 11912 Heads radiate, Ray revolute, Leaves amplexicaul. lanceolate-linear fleshy bluntly sinuated

11913 Heads radiate, Ray revolute, Leaves amplexicaul. lanceolate toothed, Scales of invol, all unwithered 11914 Heads radiate, Ray revolute, Leaves amplexicaul. obovate 3-lobed at end serrated

11915 Heads radiate, Ray revolute, Leaves pinnatifid downy revolute at edge, Panicle spreading 11916 Leaves amplexicaul. cut toothed scabrous above downy beneath, Heads racemose

11917 Ray revolute, Leaves pinnatifid and viscid, Scales of the involucre lax hairy

11918 Ray revolute, Lvs. sess. pinnatifid lobed and toothed, Scales of invol, very short glab. Stem erect straight 11919 Ray revolute, Leaves lyrate sinuate blunt stalked, Stem hirsute

11920 Ray revolute, Leaves amplexicaul. lanceolate blunt toothed entire

11921 Heads radiate, Petiole amplexicaul. Peduncles 3 times as long as pinnate sinuated leaves

11922 Heads radiate, Leaves amplexicaul. pinnatifid hirsute crisp-toothed, Stem woolly

11923 Cor, radiant, Leaves pinnated multifid : segm. filiform smooth, Heads corymbose

11924 Cor. radiant, Lvs, amplexic. pinnatifid glabrous above : segm. angular toothed, Stem and invol. glabrous 11925 Cor, radiant, Stem invol. and leaves glabrous, Leaves pinnatifid: segm. linear acute toothed

11926 Cor. radiant, Leaves pilose viscid pinnatifid equal spreading, Rachis narrowed below

11927 Cor. radiant, Leaves half-amplexicaul. pinnatifid : segm. linear subdentate distant 11928 Cor. radiant, Stem simple nearly naked, Radical leaves stalked oblong toothed ciliated

11929 Cor. radiant, Leaves pinnatifid toothed somewhat hairy, Stem erect

11930 Cor. radiant, Leaves tomentose oblong toothed, Stem leafy 1-flowered

11931 Cor. rad. Lvs. toment. on each side snow-white pinnatif. : segm. lin. blunt somew. tooth. Corymb contracted 11932 Cor, radiant, Leaves pinnate multifid linear naked acute, Peduncles about 2-flowered

11933 Cor. radiant, Leaves pinnate : pinnæ lin.-subulate somewhat cut downy beneath, Stem somewhat hairy 11934 Ray spreading, Leaves lyrate bipinnatifid divaric. toothed glabrous, Stem erect, Pericarps hairy

11935 Ray spreading, Florets elliptical, Leaves lyrate serrated : lower obovate entire, Pericarps glabrous 11936 Cor. radiant, Rad. Ivs. ovate-cordate serrated stalked : cauline pinnatifid toothed, Peduncles thickened 11937 Cor. radiant, Lvs. lanc. lin. nearly entire smoothish, Corymb contracted terminal stalked 11938 Cor. radiant, Lvs. lanc. lin. toothed rigid scatrous, Corymbs terminal and axillary stalked 11939 Cor. radiant, Lvs. lanc. lin. subtomentose glauc. finely toothletted or entire, Corymb contracted terminal 11940 Cor. Fadiant, Leaves linear entire, Corymb squamose, Stem herbaceous

11941 Cor. radiant, Lvs. half amplexicaul. lanc. finely serrate subvillous beneath, Corymb terminal spreading 11942 Cor. radiant, Lvs. ovate lanc. serrated ciliated at edge sessile unequal at base

11943 Ray spreading, Lvs. lanc. sharply serrated nearly glabrous, Corymbs of rather few flowers

11944 Cor. radiant, Lvs. ovate-lanc. finely serrated smooth on each side subsessile

11945 Cor. radiant, Outer scales of invol. subulate spreading, Lvs. subdecurrent obl. lanc. villous

11946 Cor. radiant, Lvs. sess. oborate toothed at end glaucous : younger silky, Corymb compound terminal

11947 Cor. radiant, Lvs. toothed : lower ovate decurrent in the stalk : upper cordate obl. amplexicaul.

11948 Cor. radiant, Scales of invol. appressed, Lvs. subdecurrent villous beneath lanc. serrated

11949 Cor. radiant, Outer scales of invol. spreading, Lvs. subdecurrent obl. lanc. glauc, serrate

11950 Cor. radiant, Stem undivided about 1-fl. Lvs. undivided serrated : radical ovate villous beneath

11951 Cor. radiant, Lvs. lanc. cordate at base amplexicaul. smooth finely serrated

11952 Cor. radiant, Lvs. lin. scattered

11953 Cor, radiant, Lvs, obovate fleshy somewhat toothed

11954 Cor. radiant, Lvs, obl. sessile toothed downy beneath : upper amplexicaul. toothed only at base

11955 Cor. radiant, Lvs. amplexicaul, spatulate repand eroded scabrous

\section{Shrubby.}

11956 Leaves ovate subimbricated recurved serrate-ciliated, Heads terminal

11957 Leaves ovate serrate spreading downy beneath, Heads terminal about 3

11958 Leaves obl. lanc, sessile entire 3-nerved silky with down, Flowers termina

11959 Leaves stalked roundish ovate hairy with 1 or 2 teeth on each side, Peduncles 1-headed long terminal 11960 Stem fluted, Leaves alternate stalked lanc. blistered repand-toothed downy beneath, Flowers panicler 11961 Leaves ovate lanc. toothed silky beneath, Panicles compound axillary, Rays 3

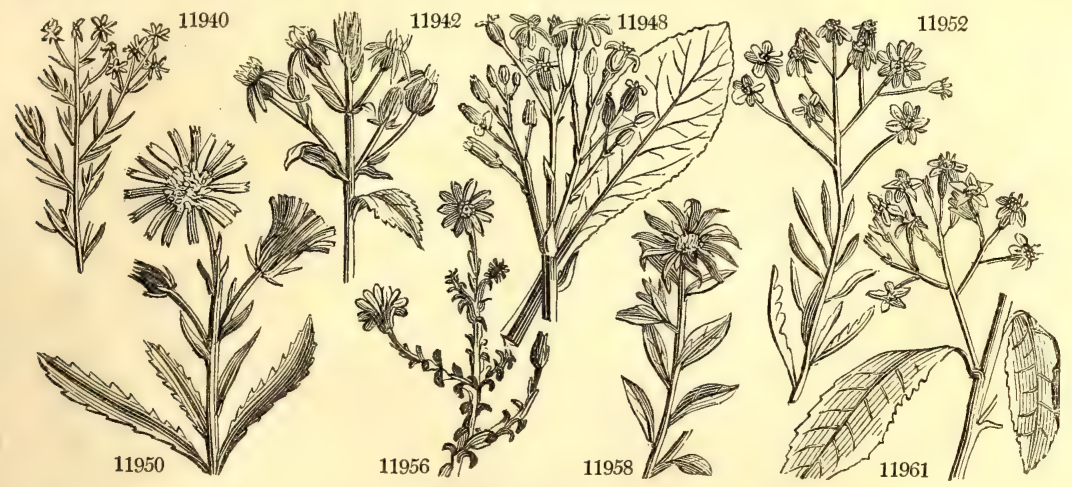

ences in ences in the style are insufficient to distinguish them. They appear, however, to be sufficiently well characterized by their other floral organs. They are found in every part of the world, especially in the south of Africa. Humboldt has observed, that they are very numerous in the the limits of eternal snow, where the sun has little influence, where huper region of the Andes, just below able to rear its head.

1739. Aster. The flowers of all the species of Aster resemble little stars, on account of the numerous rays 
11962 angustifólius $W$. 11963 villosus $T h$. 11964 obtusátus $W$.

11965 fruticulósus $W$ 11966 filifólius $V$.

11967 aculeátus $L a b$.

11968 exasperátus Link 11969 caroliniánus $W$.

11970 hyssopifólius $W$. 11971 solidaginoides $W$. 11972 tardifólius $\mathrm{Mich}$.

11973 nemorális $H . K$ ledifólius $\mathbf{P h}$

11974 rígidus $P h$.

11975 linarifólius $P h$.

11976 graminifólius $P h$.

11977 linifólius $W$.

11978 pilósus $W$.

11980 subulátus Mich.

11981 tenuifólius $W$.

11982 dumósus $W$

11983 ericoídes $W$.

11984 multiflórus $W$.

11985 ciliátus $P h$.

11986 canéscens $P h$.

11987 paludósus $W$.

11988 sparsiflórus $\dot{P} h$.

11989 coridifólius $W$.

11990 surculósus Mich.

11991 squarrósus $W$.

11992 argénteus Mich.

11993 cóncolor $W$

11994 myrtifólius Link.

11995 reticulátus $P h$.

11996 cornifólius $W$

11997 húmilis $P h$.

11998 amygdalinus $P h$. umbellaitus $\mathbf{W}$.

11999 salicifólius $W$

12000 æstivus $W$.

12001 Novæ An'gliæ $W$. $\beta$ rúber

12002 spúrius $W$. cyáneus $\mathbf{P h}$ rubricáulis Lam.

12003 grandiflórus $W$ 12004 phlogifólius $W$. 12005 pátens $W$.

12006 alpínus $W$.

12007 pủlchéllus $W$.

12008 punctátus $W$

12009 ácris $\boldsymbol{W}$.

12010 cánus $\dot{W}$.

12011 pannónicus $W$.

12012 Améllus $W$.

12013 sailignus $W$.

12014 longifólius $\boldsymbol{P} . \boldsymbol{S}$. narrow-leaved villous

obtuse-leaved

shrubby

thread-leaved

prickly-leaved

rough

tall

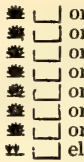

6 my.jl 4 my.jl 4 my.jl

$3 \mathrm{mr} . \mathrm{jl}$

3 mr.jl

$2 \mathrm{mr} . \mathrm{j}$

$3 \mathrm{mr} . \mathrm{j}$

8 au.s

Pa. B
W
W
W
W
W
W
Pu

B.

C. G. H. 1804. C 1.

C. G. H. 1812, C 1.p

C. G. H. 1793. C 1.p

C. G. H. 1759. C p.l Bot. mag. 2283

C. G. H 1812, C l,p Vent.malm.t. 89

N. Holl. 1818. C l.p Bot. cab. 830

C. G. H. 1823. C l.p

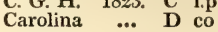

Hyssop-leaved $¥ \Delta$ or $1 \frac{1}{2}$ s.o

Solidago-like $\frac{\$}{\Delta}$ or 2 au.s

late-flowering $\$ \Delta$ or 1 au.s

wood $\pm \Delta$ or 1 au.s

stiff-leaved $\downarrow \Delta$ or $\frac{3}{4}$ au.o

Toad-flax-leav. $\frac{1}{\Delta} \Delta$ or $\frac{1}{2}$ s.o

grass-leaved $\downarrow \Delta$ or $2^{\frac{1}{2}}$ s.o

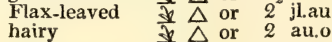

leafy

5 $\triangle 1$ or 3 a

subulate $\quad \vec{\Delta}$ or $2 \mathrm{s.o}$

slender-leaved $\$ \vec{\Delta}$ or $3 \mathrm{s.o}$

bushy $\$ \Delta$ or 3 s.o

Heath-leaved $\frac{7}{\Delta} \Delta$ or $3 \mathrm{~s}$

many-flowered $D$ or 3 s.o

ciliated $\quad \Delta$ or 3 s.o

iv or 2 s.o

canescent $\Delta$ or 2 s.o

scattered-flow. $\Delta$ or 3 s.n

Coris-leaved \& $\Delta$ or 1 au.n

rooting

ragged

$\triangle$ or 1 au.n

ilver-leaved

$\star \Delta$ el $1 \frac{1}{2}$ jn.jl

$\frac{\$}{\Delta} \Delta$ el 1 jl.s

myrtle-leaved $\frac{5}{\Delta}$ er 2 au.s

netted-leaved $\frac{\Delta}{\Delta}$ or 3 au.o

Cornus-leaved $\downarrow \Delta$ or 3 au.o

low $\triangle 4$ el 1 au.o

Almond-leaved $\frac{\$}{\Delta}$ or 2 jl.s

Willow-leaved $D \Delta$ or 6 s.o summer $\frac{1}{\Delta} \Delta$ or 2 jl.au New England $\frac{j}{\Delta} \Delta$ el 6 s.o

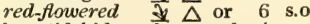
beautiful-blue $\vec{\Delta} \Delta \mathrm{spl} 4 \mathrm{s.o}$

great-flowered $2 \Delta$ or 2 o.n Phlox-leaved $\Delta \Delta$ or 13 jl.o spreading-hairy $\Delta$ or $1 \frac{1}{2}$ s.n

Alpine

pretty

$\frac{1}{4} \Delta$ or or $\frac{3}{4}$ my.au Pu

acrid

hoary-leaved

Hungarian

Italian

Sallow-leaved

W N Amer 1683. D

N. Amer. t.60

W N. Amer. 1899. D co

Li N. Amer, 1778, D co

Pu N. Amer. 1759. D co Plu, alm, t.14.f.7

Pa.B N. Amer. 1699. D co Pa.pu Huds. Bay ... D co W N. Amer. 173̈9. D co Pa.B N. Amer. 1812. D co $\mathrm{Pa}, \mathrm{B}$ N. Amer. 1732. D co Pa.B N. Amer. ... D co W N. Amer. 1725. D co W N. Amer. 1734. D co W N. Amer. 1758. D co

W N. Amer. 1732. I co Pa pu N. Amer. ... D co

B N. Amer 1784 D m Pa.pu N. Amer. 1798. D co B N. Amer. ... D co B N. Amer. ... D co B N. Amer. 1801. D co Pu N. Amer. 1801. D co Pu N. Amer. 1759. D co W 1812, D co W N. Amer. 1812. D co W N. Amer. 1811. D co W N. Amer. 1699. D co N. Amer. 1759. D co

F N. Amer. 1760. D co B N. Amer. 1776. D co Pu N. Amer, 1710. D co R N. Amer. 1812. D co Bot. reg. 183 $\mathrm{Pu}$ N. Amer. 1789. D co Hof.

$\mathrm{Pu}$ N. Amer. 1720. D co Bot. reg. 273

N. Amer. 1797. D co N. Amer. 1773. D co Al. of Eur.1658. D p.l Bot. mag. 199 Armenia ... D co Hungary 18ï. D co S. Europe 1731, D co Hungary 1816. D co Hungary 1815. D co Italy 1596. D co Germany 1815. D co N. Amer. 1798. D co

Pl.rar.hu.2.t. 109 Plu. al. t. 271.f. Pl. rar. hu.1.t. 30 Jac. vind. 1. t. 8 Bot. reg. 340

Mor.s.7.t.22. f.26

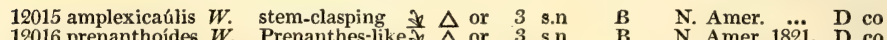
12016 prenanthoídes $W$. Prenanthes-like $\frac{j}{\mathrm{~S}} \Delta$ or 3 s.n $\quad$ B N. Amer. 1821. D co $\begin{array}{llllll}12017 \text { adulterínus } \boldsymbol{W} \text {. en. } & \text { bastard } \\ \text { smooth-stemm. 文 } \Delta \text { pr } & 3 \text { s.n } & \text { F } & \text { N. Amer. } & \text { N. Amer. 1794. } & \text { D co co }\end{array}$

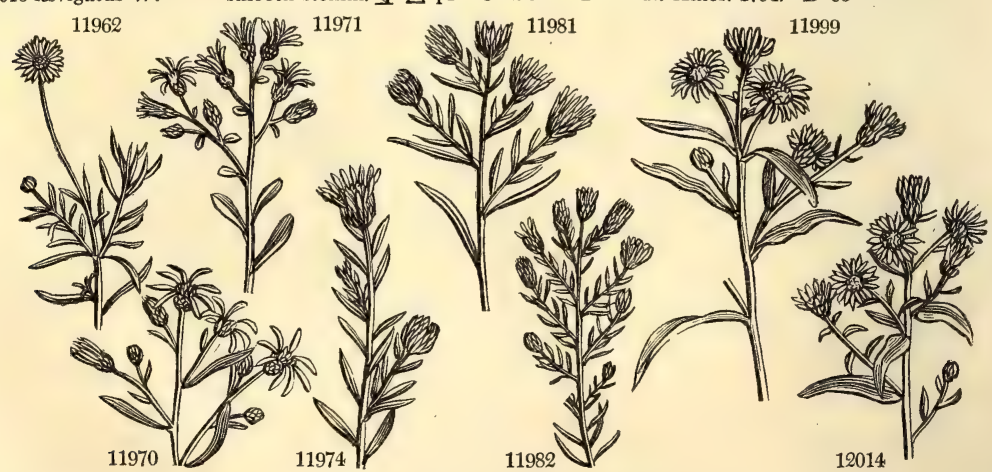

History, Use, Propagation, Culture,

of their circumference. A very numerous genus of plants, commonly called in England, Christmas Daisies, in allusion to the late period of the year at which they blossom. They are not very ornamental, and yet their flowers are acceptable at a seasor when few others are to be seen in open air. The species are extremely 
11962 Leaves linear acute not dotted somewhat hoary, Pedunc. term. solitary 1-fl. long

11963 Leaves linear filiform obtuse hairy, Invol, imbricated

11964 Leaves linear fleshy smooth dotted blunt, Pedunc. 1-headed, Invol. imbricated shorter than disk

11965 Leaves linear blunt glabrous dotted, Pedunc. 1-headed long, Invol. imbricated as long as disk

11966 Leaves linear filiform fasicled smooth dotted, Ligules entire

11967 Leaves linear scattered revolute at edge : prickly above; downy beneath, Heads in racemose panicles

11968 Stem and leaves rough, Leaves dense linear reflexed, Flowering branches short racemose

11969 Leaves obl. narrowed at each end sess. Stem somew. climbing, Branches downy, Scales of invol. squarrose

\section{\$2. Herbaceous.}

11970 Leaves lin. lanc. 3-nerved dotted acute scabr. at edge, Ray about 5-fl. Invol. imbric. twice as short as disk 11971 Lvs. lin. lanc. obsol. 3-nerv. blunt scab. at edge, Hds. in sess. clust. Ray about 5-fl. Inv. imbr. short. than disk 11972 Lvs. cuneate obov. acute nervel, scab. on each side twisted spread. Inv. cylindi. imbr. with 2 bractes at base 11973 Lvs. lin. lanc. narr. at base nerveless roughish revolute at edge, Inv. lax imbr. Branches filiform 1-headed

11974 Lvs. lin. mucro. somew. keeled rigid scabrous at edge : cauline reflexed; of the branches much spreading 11975 Lvs. many lin. mucron. nerveless not dotied keeled scabrous rigid, Branches fastigiate 1-headed

11976 Lvs. narrow lin. nerveless not dotted smooth erect, Branchlets term. nearly naked 1-headed

11977 Lvs. lin. nerveless dotted scabr. reflexed spreading, Branches corymb. fastigiate leafy, Invol. imbr. short

11978 Lvs. lin. lanc. hoary, Stem branched villous, Branchlets somew. 1-sided 1-headed, Invol. obl. lax imbricated

11979 Lvs. lin. lanc. narrowed at each end acum. Stem downy panicled erect, Branches few-headed, Intv. imbr.

11980 Very smth. with small fl. Stem panicled, Branch. many-head. Lvs. lin. subulate, Invol. cylindr. Ray minute

11981 Lvs. lin. lanc. narrow. both ways hispid at edge, Stem smth. branched erect, Branches 1-headed, Inv. imbr.

11982 Lvs. lin. glabrous: those of the branches very short, Branches panicled, Invol. cylindr. closely imbricated

11983 Lvs. lin. glab. : those of the branches subul. close together; of the stem long. Invol. subsquarr. Leafl, acute

11984 Lvs. lin. glab. Stem much branched diffuse downy, Branchlets 1-sided, Inv. imbr. : scales obl. squarr. acute

11985 Lvs. ciliat. : caul. lin. lanc. nerv. : those of the br. very short lanc. 3-nerv. Stem branch. downy, Br. panic.

11986 Hoary, Lvs. lin. Panic. corymb. much branched leafy, Invol. imbr. very acute longer than disk. aat base

11987 Lvs. remote lin. amplexicaul. erect very smth. scabr. at edge, Pedunc. almost naked, Inv. squarr. with 2 lvs.

11988 Very smth. Lvs. subul. lin. somew. fleshy subreflex. Stem slender much branch. Branchl. setaceous 1-head.

11989 Lvs. very numerous lin. blunt reflexed hispid at edge, Stem branch. diffuse smooth, Branches 1-headed

11990 Dwarf with creeping roots, Stems weak simple, Lvs. long lanc. smoothish, Invol. with lin. obl. blunt scales

11991 Lvs, very numerous ovate-acum. reflexed hispid at hedge, Stem branched hairy, Branches 1-headed

11992 Lvs, obl. lanc. silky sess. Stem slender decumbent loosely branched, Branchlets and branchlets 1-headed

11993 Lvs. obl. lanc. hoary on each side, Stem simple erect downy, Raceme terminal

11994 Cauline leaves amplexicaul. scaurous : of the branches small, Invol. imbricated : scales length of disk

11995 Hoary all over, Lvs. lanc. obl, acute at each end sess. revolute at end netted and 3-nerved beneath

11996 Smooth, Lvs, obl. ovate acuminate shortly stalked scabrous at edge, Panicles few-headed, Stem smooth

11997 Lvs. subrhomboid oval-lanc. acuminate at each end somew. stalked glabr. hispid at edge, Corymb diverging

11998 Lvs. lanc. narrowed at base acuminate scabrous at edge, Stem simple corymb. at end, Invol. loosely imbr.

11999 Lvs. lin. lanc. nearly entire smth. Stem smth. panicled at end, Invol. lanc. imbr. Scales acute spread. at end 12000 Lvs. lanc. somewhat amplexical. narrowed at end scabrous at edge, Stem erect hispid, Branchlets pilose

12001 Lvs. lin. lanc. pilose amplexicaul. auricled at base, Stem simple pilose straight, Heads sess. term. clustered

12002 Lvs. lin. lanc. amplexicaul. polished, Stem virgate panicl. Branches racemose, Inner scales of invol. colored

12003 Lvs. lin. rigid acute subamplexicaul. : those of the branches reflexed hispid at edge, Scales of invol. squarr. 12004 Lvs. lanc. cordate amplexicaul. downy beneath, Stem quite simple downy, Pan. term. lax few-headed

12005 Lvs. obl. lanc. ciliate cordate amplexicaul. scabrous on each side hairy, Stem branched hairy

12006 Stem l.fl. Rad, lvs, lanc. spatulate : cauline lanc. Scales of invol. nearly equal lanc. bluntish

12007 Stem 1-fl. Rad. lvs. spatulate: cauline lin.-lanc. Scales of invol. nearly equal linear acuminate

12008 Lvs. lin. remote 3-nerved acuminate dotted scabrous at edge, Branches corymb. fastigiate, Ray 10-fl.

12009 Lvs. lin. lanc. glabrous not dotted 3-nerved, Invol. imbricated twice as short as disk

12010 Lvs. lin. lanc. 3-nerved hoary on each side, Invol. twice as short as disk imbricated

12011 Lvs. lin. lanc. hispid at edge, Stem simple corymbose, Scales of invol. lanc. blunt equal

12012 Lvs, obl, lanc. scabrous, Invol. imbr. subsquarrose : lvs. blunt ; inner membranous colored at edge

12013 Lvs. lin. lanc. sessile scabrous at edge, Stem panicled smooth, Invol. lax imbricated

12014 Lvs. lin. lanc. rarely toothed long smooth, Heads terminal, Invol. squarrose

** Leaves lanceolate and ovate: lower serrate.

12015 Lvs, ov.-obl, acute amplexicaul. cordate serrated smooth, Stem panicled smooth, Branches 1-2-headed

12016 Lvs. amplexicaul. spatulate lanc. acuininate serrated in middle cordate at base, Branches pilose

12017 Lvs. amplexic. lanc. : lower subserr. smooth ; of the branches lin. squarr. Invol, squarr. shorter than disk

12018 Lvs, subamplexicaul. broad-lanc. subserrate smocth, Stem glabrous, Branches many-headed

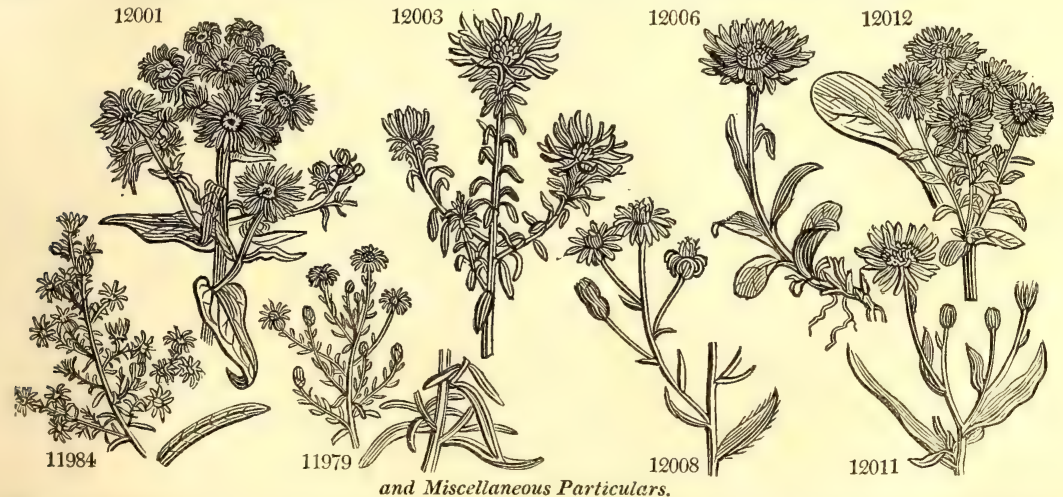

difficult to distinguish : the most ornamental are A. puniceus, Novæ Angliæ, pulchellus, and macrophyllus. A. chinensis is a well known border annual; of which there are varieties of different colors, and semi. double, and double. It is raised on a hotbed, and transplanted into the open ground in April or May. 
12019 versicolor $W$. 12020 mutábilis $W$. 12021 læ'vis $W^{\prime}$

12022 concinnus W.en. 12023 puníceus $W$ 12024 híspidus $W$. 12025 foribúndus $W$. 12026 Novi..Bélgii $W$. 12027 bellidiflórus $W$. 12028 spectábilis $W$ 12029 serotínus $W$ 12030 tardiflórus $W$ 12031 blándus $P h$. 12032 chinénsis $W$. 12033 acuminátus $P h$. 12034 conyzoídes $W$. 12035 Rádula $W$

12036 strictus $P h$.

12037 Tradescánti $\boldsymbol{W}$. M 12038 recurvátus $W$.

12039 éminens $P h$.

12040 láxus $P h$

12041 simplex $W$. en.

12042 polyphýllus $W$. en. 12043 júnceus $W$

12044 lanceolátus $W$.

12045 dracunculoídes $W$.

12046 frágilis $W$.

12047 míser $W$.

12048 divérgens $W$

12049 diffúsus $W$.

12050 péndulus $\dot{W}$.

12051 caucásicus $W$

12052 altáicus $W$. en

12053 tenéllus $W$.

12054 Tripólium $W$

12055 sibiricus $W$.

12056 élegans $W$.

12057 pállens $W$.en.

12058 præ'cox $\boldsymbol{W}$. en

12059 undulátus $W$.

12060 paniculátus $W$.

10061 cordifólius $W$.

12062 corymbósus $W$.

12063 macrophýllus $W$. changeable $\Varangle \Delta$ or 2 s.o smooth $\quad \Delta$ or 2 s.o neat $\quad \frac{1}{\Delta} \Delta$ or 2 pr $1 \frac{1}{2}$ s.o red-stalked $\quad \downarrow \Delta$ pr $\quad 1 \frac{1}{8}$ s.o rough-staiked $\frac{\Delta}{\Delta}$ or 1 s.o New-York $\vec{A}$ or 4 s.o Daisy-flowered $\frac{\partial}{\partial} \mathrm{A}$ or shorvy $\vec{A}$ el 2 au.s late-flowering $\frac{1}{2} \Delta$ or 3 s.n spear-leaved $\downarrow \Delta$ or 2 jl.s charming $\leq x \Delta$ or 2 o.n

Chinese

acurninate 2 or ${ }_{11} \mathrm{jl.s}$ Congratike $\Delta$ or 1 au

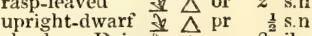
ichaelmas Daisy $\Delta$ or recurved $\Delta$ or eminent je $\triangle$ or loose-stalked $\$$ or single-stalked $\Delta$ or many-leaved $\frac{x}{\Delta} \Delta$ or 3 au.o slender-stalked $\downarrow \downarrow \Delta$ or lanceolate $\$ \Delta$ or Tarragon-like $\$ \Delta$ or meagre-flower. $\bar{\nabla} \Delta$ un preading-downy $\Delta$ un diffuse pendulous Caucasian dwarf slender sea

Siberian elegant pale-flowered $\frac{D}{d} \Delta$ or early-flowering $\vec{x} \triangle$ or various-colored ty $\triangle$ el 3 au.s abundant-fiow. $\downarrow$ or 4 s.o

Conyzalike $\frac{ \pm}{\Delta}$ or $1 \frac{1}{2}$ au.o brittle $\downarrow \Delta \Delta$ or

W.pu N. Amer. 1790. D co

$\mathrm{Pu}$ N. Ámer. 1710. D co Herm.lugd. t.67

B N. Amer. 1758. D co

Pu N. Amer. 1800. D co Pa.B N. Amer. 1800. D co B Siberia 1804. D co

wave-leaved $\& \Delta$ or 3 au.o panicled $\quad \&$ el 4 s.o heart-leaved $\downarrow \Delta$ or 2 jl.au corymbed $\frac{\downarrow}{\Delta} \Delta$ or $2 \mathrm{~s}$ large-leaved $\frac{\$}{\Delta} \Delta$ or 2 jl.s

12064 heterophýllus W.en. various-leaved $\downarrow \Delta$ or 3 jls. 12065 alwarténsis Lodd. fine rayed \$p $\triangle$ el $1 \mathrm{my}$

1740. SOLIDA'GO. $W$. Golven Rod.

12066 canadénsis $W$ 12067 frágrans $W_{0}$ e en. 12068 prócera $W$.

12069 serotína $W$. 12070 gigantéa $W$. 12071 ciliáris $\boldsymbol{W}$. 12072 refléxa $W$. 12073 lateriflór $W$ Canadian $\ \Delta$ pr 2 jl.s $\quad$ Y Sp. 48-61.

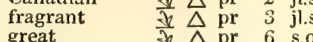
upright-smooth $\$ \Delta$ pr 4 jl.au Y gigantic $\quad$ t $\triangle \mathrm{pr} \quad 6$ au.s ciliated $\forall \Delta \mathrm{pr} 3$ au.s hanging-leaved $\forall \triangle \mathrm{pr} \quad 3$ au.s $\quad \mathrm{Y} \quad \mathrm{N}$. Amer, 1758. D co

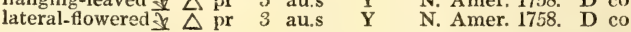

B N. Amer. 1710. D co

W China 1804. D co

$\mathrm{Pu}$ N. Amer. ... D co

P.B N. Amer. 1710. D co

Pa.R N. Amer. ... D co

B N. Amer. 1777. D co

B N. Amer. ... D co

P.B N. Amer. 1775. D co Pa.pu N. Amer. 1800. D co D.Pu China 1731. S co N. Amer. 1806. D co W N. Amer. 1778. D co W N. Amer 1785. D co Vi N. Amer. 1806. D co W N. Amer. 1633. D co $\mathrm{Li}$ N. Amer. ... D co W N. Amer. ... D co W.pu N. Amer.... D co W N. Amer... D co F N. Amer. $17 \ddot{5} 8$. D co W.pu N. Amer. 1811. D co W N. Amer. 1811. D co W N. Amer. 1800 . D co W N. Amer. 1759. D co W N. Amer. 1758. D co W N. Amer. 1777. D co W N. Amer. 1758. D co $\mathrm{Pu}$ Caucasus 1804. D co C. G. H. 1769 . C p.l Brition seash. D co Siberia 1768. D co ...... 1790. D co N. Amer. ... D co N. Amer. 1800. D co

Herm. lug. t. 651 Ic. Kæmpf, t. 29 Herm. lugd. t.69

Bot. cab. 959 Dill.elt. t.34.f.38

Mor. s.7.t.21.f. 12

Bot. mag. 33

Eng. bot. 87

Gm.sib.2.t.80.f.1

P.B N. Amer. 1699. D co

Herm. parad. 96

B N. Amer. 1640. D co Corn.canad. t.65 W N. Amer. 1765. D co W N. Amer. 1739. D co Pa.pu N. Amer. 1811. D co

Bot. mag. 2321
P.B N. Amer. 1759. D co

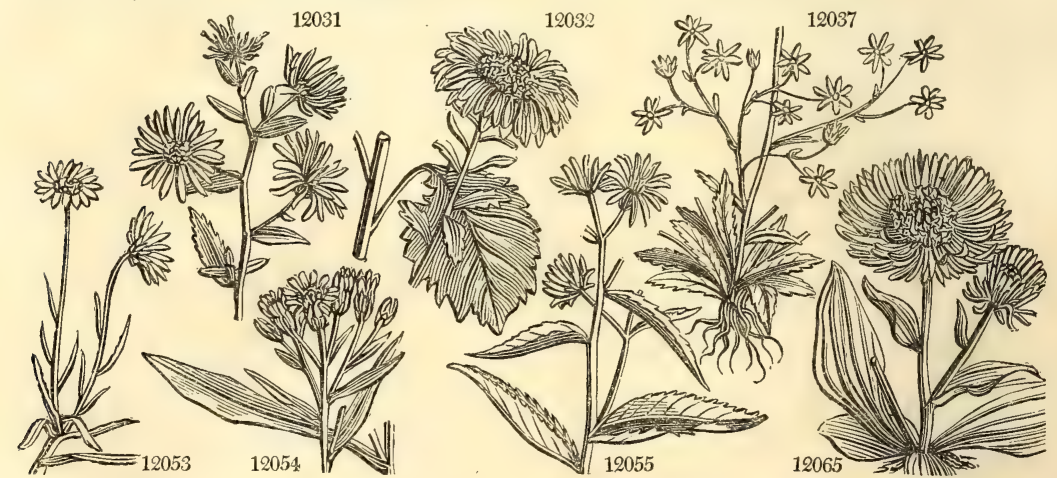

History, Use, Propagation, Culture,

Astereæ are chiefly characterized by their style, which, in its most complete state, is alone sufficient to distinguish them from every other tribe. They are found in every part of the world, but especially in North America and Africa.

1740. Solidago. From solidari, to unite, on account of the vulnerary qualitics of the plants. The species are all autumnal coarse-looking herbaceous plants with yellow flowers; in the shrubbery they make a pretty 
12019 Lvs. subamplexicaul. broad-lanc. subserrate smooth, Stem glabrous, Scales of invol. shorter than disk 12020 Lvs. subamplexic. : upper lanc. acumi, entire ; lower Janc. narrowed at base serrated, Branchlets virgate 12021 Lvs. subamplexicaul. remote obl. entire lucid : radic. subserrated, Invol imbr. with cuneiform leatlets 12022 Lvs, subamplexicaul. lanc. lower subserrate smooth, Stem simple panicled at end, Invol. closely imbricated 12023 Lvs. amplexicaul. lanc. serrate roughish, Branches panicled, Invol. lax longer than aisk

12024 Lvs. obl. lanc. scabrous ciliated: lower ovate, Stem hispid, Branches 1-headed, Scales of invol. obl. imbr. 12025 Lvs. subamplexicaul. lanc. : lower serrated, Stem smooth, Branches corymbose

12026 Lvs. subamplexicaul. lanc. glabrous scabrous at edge : lower subserrated, Branches divided

12027 Lvs. amplexicaul. narr. lanc. scabr. above lower subserr. Stem much branched, Invol, with spread. scales 12028 Lvs, lanc. roughish somewhat amplexicaul. : lower serrate in the middle, Scales of invol. lax leafy

12029 Lvs. obl. lanc. acuminate sessile smooth scabrous at edge: lower serrated, Branches corymbose smooth 12030 Lvs. sessile serrated smooth spatulate lanc. narrowed at base and bent down towards each side 12031 Lvs. subamplexic. obl. lanc. acuminate serrated smooth, Stem pyramidal, Racemes scarcely longer than lvs. 12032 Lvs. ov. coarsely toothed stalked : cauline sessile cuneate at base, Stem hispid, Branches with single heads 12033 Lvs, broad lanc, narrow, at base entire with a very long point, Stem simp. flexuose angul. Panic. corymb. 12034 Lvs. obl. 3-nerved narrowed at base acute : upper sess. nearly entire; lower stalked serrated, Stem corymb. 12035 Lvs. lanc. serrate acuminate rugose very rough, Stem erect angular simple

12036 Lvs. sess. narrow lanc. serrated scabrous, Stem 1 or few-headed

12037 Lvs. lanc. sess. serr. smooth, Branches virgate, Invol. imbricated, Stem round smooth

12038 Lvs. sess. narrow lanc. : lower serrated in middle, Stem branched smooth recurved, Invol. lax imbricated 12939 Lvs. lin. lanc. acumin. scabrous at edge: lower subserrated, Stem panicled, Branches 1-headed 12040 Lvs. lin. lanc. acumin. scabrous at edge : lower subserrated; cauline reflexed, Stem lax panicled 12041 Lvs. lanc. acum. scabrous at edge: cauline serrated at end; those of the branches entire, Stem panicled 12042 Lvs. lin. entire : radic. obl. subserrated, Stem much branched downy, Invol. loosely imbricated 12043 Lvs. lanc. lin, sessile smooth: lower subserrate, Stem panicled smooth, Invol. imbricated

12044 Lvs, lin. lanc. sessile entire smooth: lower lanc. subserrate, Stem branched diffuse smoothish

12045 Lvs. lin. acuminate entire : lower lin. lanc. subserrate, Branches corymbose, Invol. imbricated

12046 Lvs, lin. acuminate entire : radical obl, serr. Branches in corymbose panicles, Invol. imbricated

12047 Lvs. sess. lanc. serrated smooth, Invol. imbricated : leaflets acute, Stem rather villous

12048 Lvs. ellipt.-lanc. serrated smooth: cauline lan.-lanc. long, Branches spreading, Invol. imbr. Stem pubesc. 12049 Lvs. ellipt.-lanc. serrated smooth even-sized, Branches spreading, Invol. imbricated, Stem pubescent 12050 Lvs, ellipt.-lanc. serr. smooth: those of the branches distant, Branches much spreading pendulous 12051 Stem 1-f.. Lvs, ovate sessile scabrous, Scales of invol. nearly equal linear

12052 Lvs. lin. lanc. entire blunt mucronate 3-nerved at base veiny, Stem simple corymbose downy

12053 Lvs, filiform aculeate ciliate, Invol. hemispherical, Leaflets equal

12054 Stem glabr. corymb. Lvs. lin.-lanc. fleshy obscurely 3-nerv. Scales of invol. lanc. membran. obt. imbricated 12055 Leaves lanc. subamplexicaul. serrate pilose scabrous, Invol. lax : leafl. lanc. acuminate foliaceous hispid 12056 Leaves scabr. : caul. obl. lanc. acute; radical obl. stalked, Scales of invol. obl. cuneate blunt subsquarrose 12057 Leaves sessile obl. lanc serrate : floral ciliated, Stem branched glabrous, Invol closely imbricated

12058 Lvs. obl. lanc. serrat. narrow. at base, Stem hairy, Inv. imbric. nearly equal, Outer scales somew. spreading

\section{*** Leaves cordate and ovate, serrate}

12059 Leaves obl. cordate amplexicaul. entire, Petioles winged, Stem panicled hispid, Branchlets 1-sicled 12060 Leaves ovate-lanc. subserrated stalked smooth, Petioles naked, Stem much branched smooth, Invol. lax 12061 Leaves cordate pilose beneath finely serrated stalked, Stem panicied smoothish, Panicle spreading 12062 Leaves ov. finely serrated acum. smoothish : lower cord. stalked, Branches hairy, Seales of invol. blunt 12063 Leaves ovate stalked serrated scabrous : upper ovate cordate sessile, Stem branched diffuse, Scales acute 12064 Leaves smooth : cauline ovate subcord, acuminate deeply serrated entire at end, Stem panicled smovtl: 12065 Leaves ovate narrowed at base entire about 5-nerved, Invol. lax squarrose, Ray very fine

81. Racemes 1-sided, Leaves 3-nerved.

[exceeding disk 12066 Stem downy, Lvs, lanc. serrat. triple-ribb, rough, Clusters copious panicl. unilateral recurv. Radius hardly 12067 Leaves obl. 3-nerved subserrated, Racemes 1-sided, Ligulæ middling, Stem smooth, Peduncles dow ny 12068 Stem villous erect, Lvs. lanc. serrated triple-ribbed rough villous beneath, Clusters spiked erect drooping before flowering, Radius short

12069 Stem erect round very smooth, Leaves lin.-lanceol. smooth triple-ribbed serrated rough-edged, Clusters panicled unilateral, Stalks downy

12070 Stem erect smooth, Lvs. lanc. smooth serrated rough edged obscurely triple-ribbed, Clusters paniculated unilateral, Stalks hairy, Radius short

12071 Stem erect smooth, Leaves lanc. somewhat triple-ribbed smooth rough-edged slightly serrated, Clusters panicled unilateral, Stalks smooth, Bract. fringed, Radius short

12072 Stem erect vill. Lvs. lanc. somew. serrat. triple-ribbed rough reflexed, Clusters panicled slightly unilateral 12073 Stem erect rather hairy, Lvs. lanc. obscurely triple-ribbed smooth rough.edged: the lower ones slightly serrated, Clusters panicled unilateral somewhat recurved

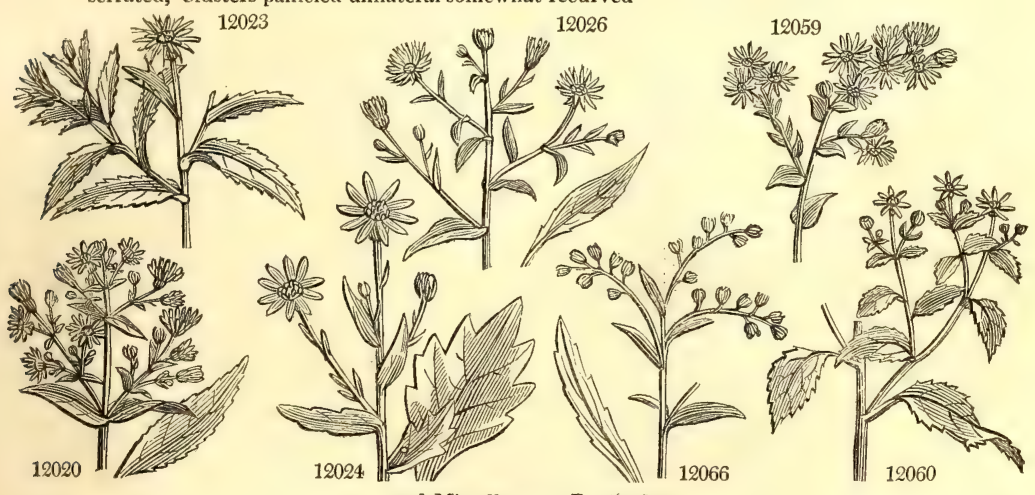

and Miscellaneous Particulars.

appearance among other coarse things, but there is not one of them which is worth a place in a choice collection of ornamental plants. The leaves of the Solidago odora have a delightfully fragrant odor, partaking of that of anise and Sassafras, but different from either. When subjected to distillation, a volatile oil, possessing the taste and aroma of the plant in a high degree, collects in the receiver. This oil apparently has its residence in the transparent cells which constitute the dotting of the leaves. The effects of the $\mathrm{S}$. odora are 
12074 áspera $W$.

12075 altíssima $P h$ 12076 rugósa $P h$.

12077 villósa $\boldsymbol{P h}$. 12078 scábra $W$. 12079 nemorális $W$ 12080 pátula $W$.

12081 ulmifólia $W$.

12082 argúta $W$.

12083 júncea $W$ 12084 ellíptica $W$ 12085 recurváta $W$. en 12086 sempervirens $W$ 12087 odóra $W$. tall $\neq \Delta$ pr 8 au.s

wrinkle-leaved $\$ \nabla$ pr 3 au.s

scabrous

ฟै $\triangle$ pr $\quad 2$ au.s

woolly-stalked $\frac{7}{\Delta} \Delta \mathrm{pr} \quad 3$ au.s

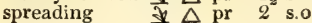

Elm-leaved $\ \Delta \mathrm{pr} \quad 2$ au.o

sharp-notched $\$ \Delta$ pr 4 jl.au

Rush-stalked $\forall \triangle$ pr 2 au.s oval-leaved $\quad$ \& $\Delta$ pr 3 au.s

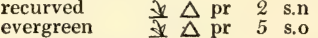

sweet-smelling $\frac{\$}{\Delta} \Delta \mathrm{pr} \quad 3$ jl.au

12088 pauciflósculósa $P h$. slender-flower. $\ \Delta$ pr 2 au.o

12089 bícolor $W$

12090 petioláris $W$.

12091 stricta $W$

12092 lanceoláta $P h$.

12093 tenuifólia $P h$.

12094 cæ'sia $W$.

12095 livida $\boldsymbol{W}$. en.

12096 hirta $W$. en.

two-colored

$\nexists \Delta$ pr

2 au.s

late-flowered \&\& $\triangle \mathrm{pr} \quad 4$ o.d

Willow-leaved $\$ \nabla$ pr 3

Grass-leaved $\not \triangle \textrm{pr} 5 \mathrm{O}$

slender-leaved $\& \Delta$ pr 2 s.o

Maryland $\neq \Delta \mathrm{pr} 2$ s.o

livid

hairy

$\not \Delta \Delta$ pr $\quad 2$ s.o

12097 lithospermif

12099 mexicána $\boldsymbol{W}$.

Gromwell-lvd

. $\Delta \mathrm{pr}$

2 au.o

Mexican

twiggy

10101 écta $P$.

12102 macrophýlla $P h$

12103 flexicaúlis $W$. 12104 latifólia

12105 ambigua $\boldsymbol{W}$.

12106 axilláris $P h$.

12107 Virgaúrea $W$

12108 cámbrica $W$.

12109 multiradiáta $W$.

12110 minúta $W$.

12111 húmilis $P h$.

12112 eláta $P /$.

12113 rígida $W$. upright
large-leaved

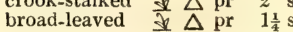

angular-stalked $\$ \Delta$ pr 2 jl.au

axillary

common

Welsh

Labrador

least

dwarf

tall-hairy

hard-leaved

\begin{tabular}{|c|c|}
\hline Q $\triangle \mathrm{pr}$ & 2 au.o \\
\hline$\Delta \Delta$ pr & 2 jl.s \\
\hline$\Delta \mathrm{pr}$ & $\frac{1}{2} \mathrm{jl} \cdot \mathrm{au}$ \\
\hline $\bar{\Delta} \mathrm{pr}$ & $\frac{1}{2}$ jl.au \\
\hline$\triangle \mathrm{pr}$ & $\frac{1}{4}$ jl.au \\
\hline$\Delta \Delta \mathrm{pr}$ & $1 \mathrm{jl} . \mathrm{au}$ \\
\hline$\Delta \mathrm{pr}$ & au,o \\
\hline
\end{tabular}

N. Amer. 1732. D co Dil.el.t.305.f.392

N. Amer. 1686. D co Mart. cent. 14

N. Amer. 1732. D co Dil.el.t.308.f.396

N. Amer. 1732. D co N. Amer. 1811. D co N. Amer. 1769. D co N. Amer. 1805. D co

N. Amer. 1805. D co

N. Amer. 1758. D co

N. Amer. 1769. D co N. Amer. 1759. D co N. Amer. ... D co N. Amer. 1699 . D co N. Amer. 1699. D co Pluk.al. t.116.t.6

N. Amer. 1811. D co

N. Amer. 1759. D co Pluk,al. t.114.f.8

N. Amer. 1758. D co

N. Amer. 1758. D co

N. Amer. 1758. D co Bot. mag. 2546

N. Amer. 1758. D co

N. Amer. 1732. D co Dil.el.t.307.f.395

N. Amer. $\quad \ldots \quad$ D co

N. Amer. $\quad \ldots$ D co

N. Amer. 1811. D co

N. Amer. 1699. D co

N. Amer. 1683. D co Dodar.ac.4.t.219

N. Amer, 1759, D co

N. Amer. $\quad \ldots \quad$ D co

N. Amer, ... D D co

N. Amer. 1725. D co Herm.parad.244

N. Amer. 1725. D co Pluk.al, t.235.f.4

...... 1759. D co

N. Amer. 1811. D co

Britain woods. D co Eng. bot. 301

Wales … D co Dil.el.t.306.f.393

Labrador 1776 . D co

Pyrenees 1772. D co Bot. cab. 189

N. Amer. 1811. D co

N. Amer. 1811. D co

N. Amer. 1710. D co Herm.parad.243

1741. Cinera'Ria. $W$. Cineraria.

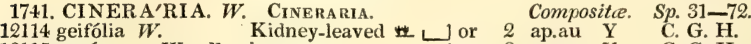

C. G. H. 1710. C p.l Com.hort.2.t.73

parviflora $\mathbf{H}, \mathbf{K}$. 12116 auríta $W$.

purple-flower'd $\omega_{2}$ or $i \frac{1}{2} \mathrm{jn} . \mathrm{jl} \mathrm{Pu}$

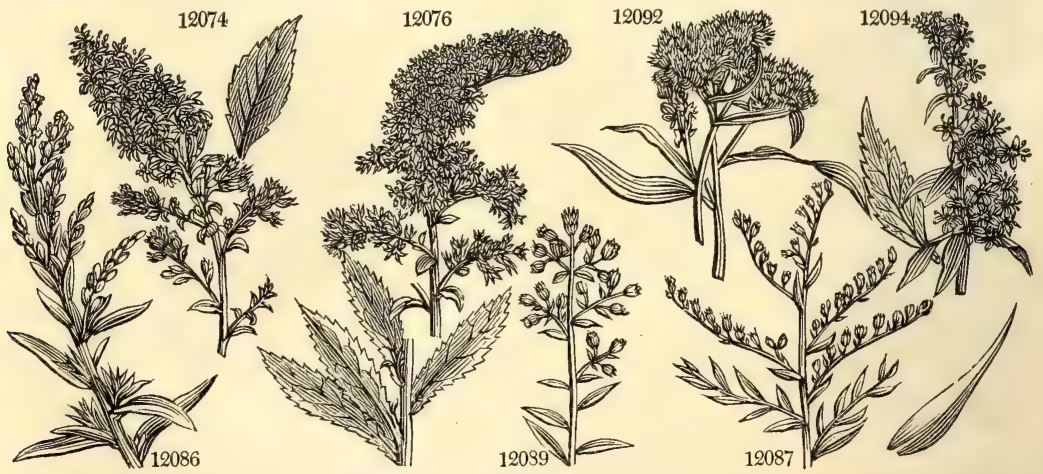

History, Use, Propagation, Culture,

aromatic, pleasant to the taste, gently stimulant, diaphoretic, and carminative. An essence made by dissolving the essential oil in proof spirit, is used in the eastern states as a remedy in complaints arising from flatulence, and as a vehicle for unpleasant medicines of various kinds. It has been employed successfully to allay vomit- 
8. Racemes 1-sided. Leaves not 3-nerved.

12074 Stem erect round hairy, Lvs. ov. rather ellipt. very rough rugged serrated without lateral ribs, Clusters panicled unilateral

12075 Stem erect hairy, Lvs. lanc. the lower ones deeply serrated very rough rugose, Panicles unilateral

12076 Stem erect hairy, Lvs. ovate-lanc. the lower ones closely serrated rugged very rough, Clusters panicled compound widely spreading unilateral

12077 Stem erect vill. Lvs. lanc. rather soft serrated without lateral ribs, Clusters panicled unilateral

12078 Stem erect hairy, Lvs. oblong pointed smooth above rugged and rough beneath, Clusters unilateral

12079 Stem erect downy, Stem lvs. lanc. hisp. ent. : radic. ones somew. wedge-shap. serrat. Clust. panic. unilateral 12080 Stem erect smooth angular, Lvs. ellipt. serrated smooth : the radic. ones obl.-spatulate, Clusters panicled unilateral spreading, Pedunc. downy

12081 Stem erect striated smooth, Lvs. ellipt. pointed deeply serrated vill. beneath : radicaì ones obovate, Clusters panicled unilateral, Pedunc. villous, Rays short

12082 Stem erect smooth, Lvs. smooth sharply and unequally serr. : those of the stem ellipt. ; radical ones ovateobl. Clusters panicled unilateral, Rays elongate

12083 Stem erect smooth, Lvs. lanc. smooth rough-edged : the lower ones serrated, Clusters panicled unilateral 12084 Stem erect smooth, Lvs. ellipt. smooth serrated, Clusters panicled unilateral, Rays of a middling length 12085 Stem erect downy, Lvs. lanc. serrated rough edged, Clusters elongated unilateral recurved panicled 12086 Stem erect smth. Lvs. lin.-lanc. rather fleshy smth. entire rough-edg. Clust. panic. unilateral, Ped. roughish 12087 Stem erect striated downy, Lvs. lin.-lanc. entire smooth rough-edged, Clust. panic. unilateral nearly simple

\section{Racemes erect.}

12088 Smooth somewhat shrubby, Lvs. lanc. obtuse without ribs, Panicle compound many-fl. tuft of flowers erect, Invol. narr.-oblong with 5 flor. in the disk and 1 in the radius

12089 Stem hairy, Lvs. ellipt. hairy : the lower ones serr. ; those on the fl.-branches entire numerous and small, Clusters erect, Scales of invol. obtuse

12090 Stem erect villous, Lvs. ellipt. roughish stalked, Clusters erect, Rays twice the length of the invol

12091 Stem erect smth. Stem-lvs. lanc. entire smth. rough-edg. : radic. ones serrat. Clust. panic. erect, Ped. smth.

12092 Stem smooth. furrowed much branched, Lvs, almost lin. ent. roughish nearly erect with 3 or 5 rough ribs, Rays not longer than the disk

12093 Stem rough angular branch. corymb. Lvs. spread. lin. very narr. slightly 3-ribb. rough with axilla tufts of smaller ones, Rays scarcely exceeding the disk

12094 Stem nearly erect very smooth and even, Lvs. lanc. smooth with roughish edges and ribs, Clusters erect, Rays rather longer than the disk

12095 Stem smooth panic. Ivs. lanc. serrat. smth. rough-edged, Branches racemose at the extremity, Rays elong. 12096 Stem panic. hairy, Lvs. lanc. rough on both sides : those of the stem serrat. ; of the branches ent. Clusters erect, Rays elongated

12097 Stem branch. downy, Lvs. lanc. rough on both sides tapering 3-ribb. entire, Clusters erect, Rays elongated 12098 Stem erect smth. Lvs. lanc. fleshy entire smooth in every part, Clusters panic. erect, Pedunc. scaly hairy, Radius twice the length of invol.

12099 Stem oblique smooth, Lvs. lanc. somew. fleshy entire smooth in every part, Clusters panic. erect, Pedunc. scaly smooth, Rays longer than invol

12100 Stem erect slightly downy, Lvs. lin lanc. smooth rough-edged tapering at the base : the lower ones somew. serrated, Clusters erect, Rays elongated

12101 Stem rather vill. Lvs. lanc. veiny smooth entire somewhat stalked

12102 Lower lvs. ov. pointed taper. unequally and sharply serr. smooth: those of the stem lanc. tapering at each end serr. nearly sess. Clusters axill. stalked leafy the length of the leaves

12103 Stem zig-zag roundish smooth, Lvs. lanc, pointed serrated smooth nearly sess. Clust. axill. erect

12104 Stem somew. zig-zag angular smooth, Lvs, ovate pointed strongly serrated smooth: tapering into a winged footstalk, Clusters axillary erect

12105 Stem slightly zig-zag smooth angul. branch. Lvs. ov.-lanc. pointed densely serrated rather hairy beneath tapering into a wing. footstalk : upper ones ent. Clust. axill. erect the upper ones much long. than the lvs.

12106 Stem smooth round erect, Lvs. lanc. serr. glabrous, Racemes axill. subglobose erect, Rays long

12107 Cauline leaves lanc. : the lower ones ellipt. Racemes panicled erect crowded

12108 Stem quite simple downy, Lvs. cuneiform lanc. downy, Racemes erect, Rays long

12109 Stem a little villous, Lvs. sessile lanc. smooth ciliated: lower serrated at end, Rays long numerous

12110 Stem quite simple pilose, Lvs. lanc. acute serrated smooth, Raceme term. simple erect, Rays long

12111 Stem simple erect smooth, Lvs. lanc. serrated smooth tapering and elongated at the base, Clusters erect

12112 Stem hairy round, Lvs. lanc. rather hairy beneath, Clusters erect, Rays elongated

12113 Lvs, ov,-obl, rough like the corymbose stem with minute rigid hairs : the lowermost serrat. ; upper entire,

[Clusters compact, Rays twice the length of the obtuse calyx

12114 Pedunc. branched, Lvs. reniform narrowed somewhat lobed downy, Petioles auricled at end

12115 Pedunc. branched, Lvs. cordate 5-lobed toothed woolly, Petioles with appendages, Ray 3-flowered

12116 Heads corymbose, Lvs, cordate somewhat angular downy beneath, Petioles auricled at base
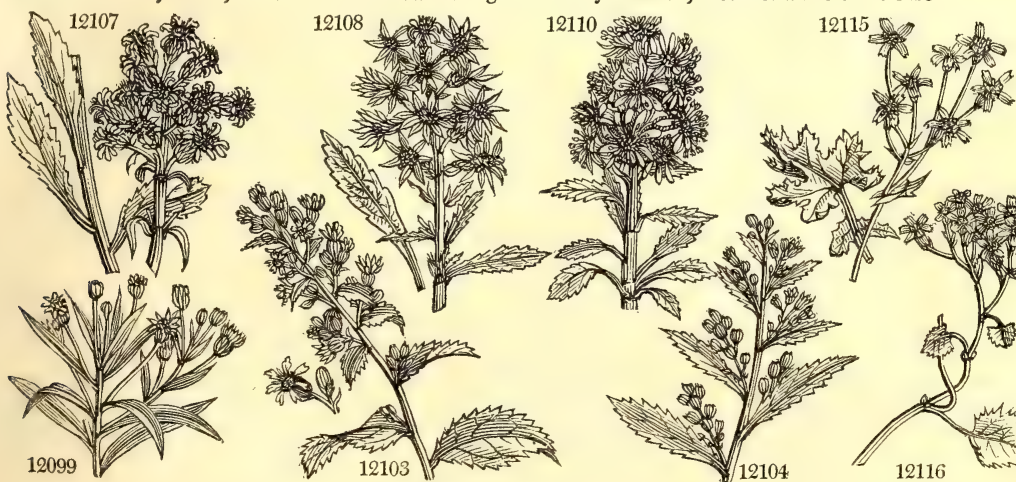

and Miscellaneous Particulars.

ing, and to relieve spasmodic pains in the chest of a milder kind. The leaves are also used in some parts of the United States as an agreeable substitute for tea. (Bigelow.)

1741. Cineraria. From cineres, ashes, in reference to the soft white down which clotles the lower, and 
12117 láctea $W_{\text {. en. }}$. 12118 cruénta $W$. 12119 hýbrida $W$.en. 12120 populifólia $H$. $K$. 12121 lobáta $W$.

12122 malvæfólia $W$. 12123 Petasites B. $M$. 12124 discolor $W$. 12125 elátior Bouché 12126 parviflúra Bieb. 12127 americána $W$. 12128 bícolor $L$. 12129 speciósa Schrad. 12130 sibírica $W$. 12131 gigantéa $\dot{H}$. $K$. 12132 glaúca $W$. 12133 palústris $W$.

12134 campéstris $W$. integrifólia E. B.

12135 longifólia $W$

12136 cordifólia $W$.

12137 alpína $W$.

12138 marítima $W$.

12139 canadénsis $W$.

12140 linifólia $W$.

12141 humifúsa $W$

12142 viscósa $W$

12143 lanáta $W$.

12144 amelloides $W$. purple-leaved purple-1ea

N J

Poplar-leaved

lobed

or 2 f.my

f L

Butter-bur-lvd

white-leaved $\square$ or

small-flowered

American $\triangle$ or

two-colored

shewy

Siberian

glaucous-leav'd $\frac{\downarrow}{\downarrow} \Delta$ or

marsh

mountain

¿ $\triangle$ or

long-leaved

Alpine

Sea Ragwort

Canadian

Flax-leaved

trailing

clammy

woolly

blue-flowered in or

1742. CALO'TIS $R, B r$. CALOTIS

12145 cuneifólia $R . B r$. wedge-leaved $\{\wedge \wedge \mathrm{pr}$

1743. KAULFUS'SIA. Nees. Kaulfuissia.

12146 amelloídes Nees. Cape Aster-likef $\triangle \mathrm{Vr}$

1744. I'NULA. $W$.

12147 Helénium $W$.

12148 O'culus-Christi $W$.

12149 británnica $W$.

12150 unduláta $W$

12151 indica $W$.

12152 squarrósa $W$.

12153 viscósa $W$.

12154 tuberósa $\dot{P} . S$ Erigeron tuberósum

12155 salicina $\boldsymbol{W}$

12156 glandulósa $W$.

12157 Bubónium $W$.

12158 hirta $W$

12159 suavéolens $W$

12160 Vaillántii $W$.

12161 móllis Bernhardi

12162 odóra $W$.

12163 mariána $W$.

12164 germánica $\mathrm{IV}$.

12165 ensifólia $W$.

12166 crithmifólia $W$.

12167 provinciális $W$

12168 montána $W$.

INULA.

Elecampane $\& \Delta$ or $\$ \Delta$ or or in or

f $\triangle$ or

(ब) or

L or

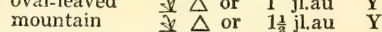

$1 \frac{1}{2}$ f.s $\mathrm{s}$

wave-leaved 0 or 1 jl.

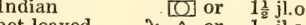

net-leaved $\forall \triangle$ or 1 jl.s

clammy

W.

Willow-leaved $\downarrow \Delta$ or 2 au.s

glandular \& $\Delta$ or 2 jl.au

Austrian $\downarrow \nabla$ or $1 \frac{1}{2} \mathrm{jl}$.s

hairy $\downarrow \Delta$ or 1 jn

woolly-leaved $\$ \Delta$ or $1 \frac{1}{4}$ jn.au $Y$

Vaillant's \& $\triangle$ or 2 jn.au $Y$

soft $\not \Delta$ or 2 jn.au $Y$

fragrant $\quad \frac{\partial}{\partial} \Delta$ or $1 \frac{1}{2}$ jn.au

American $\$ \Delta$ or 1 jl.au

German jo $\Delta$ or 4 jn.jl

sword-leaved $\$ \Delta$ or $\frac{3}{4} \mathrm{jl}$.s

Samphire-leav. $\downarrow \Delta$ or $2^{\frac{3}{4}}$ au.s w or 2 f.my $\mathbf{P}$

white-leaved is L

…... 1816. C 1.p

177. $\mathrm{C}$ p.

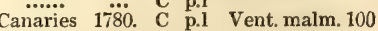

C. G. H. 1774. C p.1

Azores 1777. R p.l

Mexico 1812. C l.p Bot. mag. 1536

Jamaica 1804. C 1.p

Jamaica 1804. C C.p

Caucasus 1820. D l.p

Grenada 1825. C p.1

Siberia... 1815. $\begin{aligned} & \text { D } \\ & \text { co }\end{aligned}$ Bot reg. 812

Siberia 1784 C co Bot mag. 1869

Cape Horn1801. D co Exot. bot. 2. t.65

Siberia 1790. D co Gmel. sib. 2.t.74

England mar. D m.s Eng. bot. 151

England ch.pa. D co Eng. bot. 152

Austria 1792. D co Jac. aust.2. t.181

Austria 1739. D co Jac. aust.2. t.176

Austria 1683. D co Jac. aust.2. t.177

S. Europe 1633. C 1.p Lob. ic. t.227. f.2

Canada 1739. D co

C. G. H. ‥ C 1.p Jac.schœ.3.t.308

C. G. H. 1704, R p.l

C. G. H. 1774. C p.1 Ja.frag.12,t.7.f.2

Canaries 1780. C p.1 Bot. mag. 53

C. G. H. 1753. S p.l Bot. mag. 249

Composite. Sp. 1-2

N. Holl. 1819. D co Bot. reg. 504

Compositce. $S p .1$

1 jl.au B C. G. H. 1819. D co Bot. reg. 490

Compositc. Sp. 25-37.

4 jl.au Yritain m. me. D co Eng. bot. 1546

oary $\frac{1}{\Delta} \Delta$ or $1 \frac{2}{2} \mathrm{jl}$.s $\quad \mathrm{Y}$ Austria 1759. D co Jac. aust.3. t.223

creeping-rooted $\underset{\downarrow}{\Delta}$ or 2 jl.s $\quad Y$ Germany 1759. D co Fl. dan. t. 413
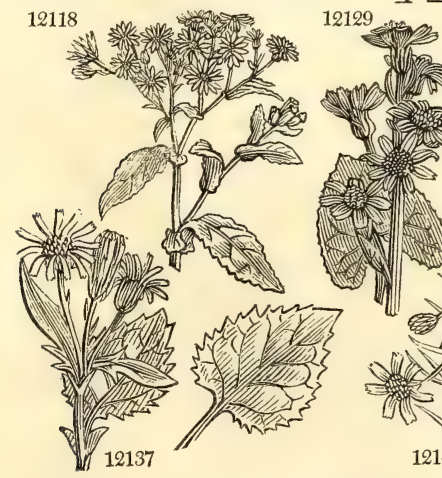

Y Egypt 1739. S co

E. Indies 1739. S co Burzeyl.t.55.f.2

L. Italy 1768. D co Plu.alm.t.16. f.1

Y S. Europe 1596, C p.l Jac.vind. 2, t.165 S. Europe 1640. D co Mor.s.7.t.19.f. 20

Georgia 1804. D co Bot. mag, 1907

Austria 1801 D co Jac.aus 5 apt 19

Austria 1759. D co Jac. aust.4. t.358

S. Europe 1758. D co Jac. vind. 3. t. 51

France 1739. D co

S. Europe 18̈21. D co M.h.3.s.7.t.21.f.

N. Amer. 1742. D co Mill.ic.1.t.57.f.1

Germany 1759. D co Jac. aust.2.t.134

Austria 1793. D co Jac. aust.2. t.162

England sal.m. D co Eng. bot. 68

France 1778. D co

S. Europe 1759. D co Garid. aix. t. 10
N. Europe 1648. D co Fl, dan, t. 786
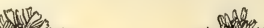
12117 Lvs, cordate angular downy beneath, Corymbs terminal panicled, Scales of invol, recurved at end 12118 Heads corymbose, Lvs. cordate angular toothed purple beneath, Petioles winged auricled at base

12119 Pedunc. about 1-headed, Branches corymb. Lvs. cord. angular toothed downy beneath, Petioles winged

12120 Heads corymbose, Lvs. cordate subangular downy beneath, Petioles with many appendages at end

12121 Heads subcorymbose, Lvs. roundish many-lobed smooth, Petioles auricled at base, Invol. calyculate

12122 Heads cymose, Lvs. cordate angular downy beneath, Petioles simple

12123 Leaves large round lobed downy and green on each side

12124 Heads corymbose, Leaves oblong lanc. acuminate toothletted smooth white beneath

12125 Lvs. cord. subangular smooth above downy beneath, Petioles with an appendage at top, Heads corymb. 12126 Stem simple, Heads panicled, Lvs. smooth tooth. : lower deltoid stalked : upper obl. lanc. amplexicaul.

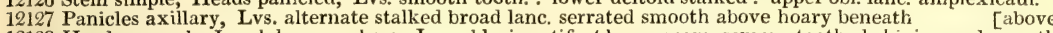

12128 Heads corymb. Invol. hoary pubesc. Lvs. obl. pinnatif. at base: segm. somew. toothed shining and smooth

12129 Raceme simple, Lvs, reniform toothletted, Petiole inflat. Stem simple leafy, Bractes in the midd, of stalk

12130 Raceme simple, Lvs, cordate blunt toothletted smooth, Stem simple 1-leaved

12131 Heads corymb. Lvs, cauline ov. acute finely serrated downy beneath : petioles winged at base ; radic. cord.

12132 Raceme simple, Lvs. spatulate cordate entire smooth, Stem simple

12133 Heads corymbose, Lvs. broad lanc. tooth-sinuated, Stem villous

12134 Heads umbellate, Stem simple, Lvs. downy : radical ovate subcrenulate; cauline lanc. entire

12135 Heads in corymbose umbels, Stem simple, Lvs. somewhat toothed : radic. spatulate; caul. obl. lanc.

12136 Panicle few-headed, Stem simple, Lvs. all stalked cordate doubly toothed, Petioles toothed at base

12137 Heads corymbose, Lvs. pinnated: term. pinnæ large cordate cut-toothed; lateral cuneate toothed at end

12138 Heads panicled, Invol. downy, Lvs. pinnatifid: segments blunt about 3-lobed downy beneath

12139 Heads panicled, Lvs. pinnatifid subvillous : segments sinuated, Stem herbaceous

12140 Pedunc. 1-headed axillary, Lvs. Jinear subulate glabrous, Stem shrubby

12141 Pedunc. 1-headed, Lvs, reniform somewhat angular, Petioles auricled at end or naked

12142 Pedunc. 1-headed, Lvs. pinnatifid lobed acute viscid fleshy

12143 Pedunc. 1-headed, Lvs, cordate roundish with 7 angles woolly beneath

12144 Pedunc. 1-headed, Lvs. opposite ovate naked

12145 Leaves cuneate cut-toothed at end

12146 The only species

12147 Lvs. amplexic. somewhat toothed ovate rugged downy beneath, Scales of the involucre downy

12148 Leaves amplexic. oblong entire hirsute, Stem pilose corymbose

12149 Leaves amplexic. lanc. serrated at base pilose beneath, Stem corymbose villous

12150 Leaves amplexic. cordate lanceolate wavy

12151 Leaves amplexic. cordate lanc. quite smooth serrated, Stem corymbose smooth, Pedunc. 1-headed filiform

12152 Leaves oval rigid sessile serrulate scabrous netted, Scales of invol. ovate reflexed

12153 Leaves sessile reflexed at base lanc. serrated, Stem downy clammy, Peduncles axillary leafy

12154 Leaves sessile lanc.-lin. Stem pilose branched, Branches spreading 1-headed, Root tuberous

12155 Leaves lanc. recurved serrate scabrous, Branches angular, Lower heads tallest

12156 Lvs. sess. obl. obsoletely serrated: serratures glandular, Stem hairy 1-headed, Scales of invol. lanc. villous

12157 Lvs. sess. obl. with cartilaginous teeth scabrous rigid, Stem corymbose, Scales of invol. blunt squarrose

12158 Lvs. sessile lanc. bluntly serrated rigid pilose, Stem villous 1-headed, Scales of invol. lanceolate

12159 Leaves ellipt. narrowed at base stalked pilose : lower toothed, Stem many-flowered

12160 Leaves sessile oblong lanc. serrated downy beneath, Heads stalked about 4 in terminal umbels

12161 Leaves lanc. acute serrulate hairy, Lvs. of invol. lanc. hairy outer reflexed

12162 Leaves amplexicaul. toothed very hairy : radical ovate; cauline lanceolate

12163 Leaves sessile oblong lanc. attenuated at base obtuse entire mucronate with a gland, Pedunc. fi if. viscid

12164 Leaves sessile obl. acute entire scabrous, Stem branched at top, Heads corymbose

12165 Leaves sessile lin. acuminate nerved smooth scattered, Stem about 1-headed

12166 Leaves linear fleshy generally 3-pointed

12167 Leaves subserrate downy beneath : radical stalked ovate, Stem erect 1-flowered

12168 Leaves lanc. hirsute entire, Stem 1-headed, Invol. short imbricated

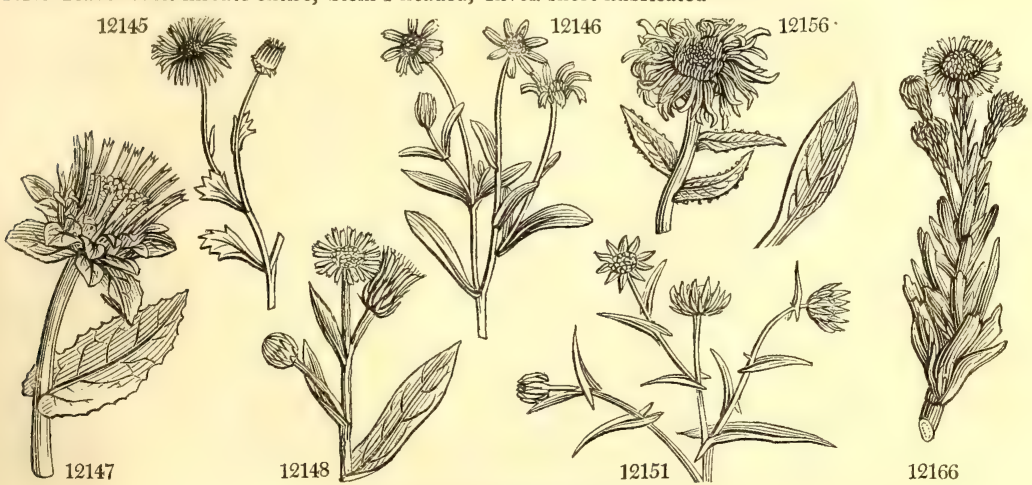

and Miscellaneous Particulars.

a preserve with sugar. Inuleæ in many respects resemble Anthemideæ, Senecioneæ, and Nassauvieæ, especially in their style; but they are perfectly well characterized by the peculiarities of their ovarium, pappus, stamens, and corolla. They are also related to Carlineæ. They are found in every part of the world, and especially in southern Africa; almost all the Composite of the southern latitudes being referable to them

I. Helenium, called Elecampane, from the officinal name Enula campana, is one of the larsest of British herbaceous plants. It was formerly esteemed a tonic, and is still retained in the Materia Medica, though little used. Bruised and macerated in wine, with balls of ashes and whortle berries, it dyes a blue color. The young branches of I. Crithmifolia are frequently sold in the London markets for samphire, to which they bear some resemblance in appearance, but none in virtues. 
12169 bífrons $W$. 12170 saturejoides $W$. 12171 fœ'tida $W$.

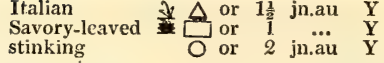

Compositce.

1745. PUliCA'RIA. Gartn. Pulicarin 12172 vulgáris Gertn Small Fleawort 12173 arábica Link. Arabian 12174 dysentérica Link. meadow

1746. GRINDE'LIA. W.en. Grindelia. 12175 glutinósa $\boldsymbol{H} . \boldsymbol{K}$. 12176 inuloídes $W$. en. 12177 squarrósa $P h$. 12178 angustifólia Kunth. 12179 ciliáta Nutt.

glutinous

Inula-like

or

$\Delta$ or ciliated

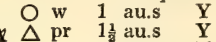

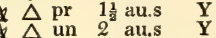

Composita 2 ja.d $\mathbf{Y}$ $1 \frac{1}{2} \mathrm{jn.s}$ $2^{2}$ jis

1 j.s

1 jl.s Y

jl.s $\quad \mathbf{Y}$

Composite.

jlau W Sp. my.au W N. S. W. 1803. C s.p Bot. mag.956

12180 rugáta $H . K . \quad \begin{aligned} & \text { wrinkle-scaled } \\ & \text { sharp-scaled }\end{aligned}$

1748. CH ET ANTHERA Flper. C 12182 ciliáta Fl. per. ciliated

$\forall \backsim$ or 2 jl.au

\section{Arnica.} mountain alternate-leav. Alpine 12183 montána $W$. 10185 Dorónicum $W$ 12186 Bellidiástrum $W$. 12187 glaciális $W$.

Alpine Dais u Chili

S. Europe 1713. D co Herm. par. t.127 Vera Cruz 1733, C 1.p Rel.Hous.8. t.19 Malta 1688. S co Boc. sic. 26. t. i3 Sp. 3.

England moi.h. S co Eng. bot. 1196 Arabia 1823. D co Pluk.al. t.149.f.4 England wat.pl, D co Eng. bot. 1115

Sp. 5-7.

Mexico 1803. C 1.p Bot. reg. 187

Mexico 1815. C l.p Bot. reg. 248

Missouri 1811. D l.p Bot. mag. 1706

Mexico 1822. D lp Bot. reg. 781

N. Amer. 1821. D 1.p Hook. ex. A. 45

2 .

p. 1-2.

1750. GERBE'RIA. Burm. Gerberis. 12188 crenáta Lindl. $\quad$ crenated

1751. DORO'NICUM. $W$. LEOPARD'S-BANE. 12189 Pardaliánches $W$. great 12190 scorpioídes $W$. mountain 12191 austríacum $W$. Austrian 12192 altáicum $W$

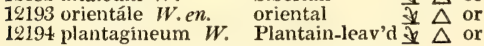

1752. PERdíCIUM. H. K. Perdiciun. 12195 Anándria $H . K$. Siberian

b $\Delta$ or

\section{Sp. 5-34.}

Austria 1816. D 1.p Jac. aust. 1. t. 92

Austria 1570, D p.1 Bot. mag. 1196

Switzerl. 1823. D p.1 Jacq. ic. t. 586

Composite.
Sp. $1-2$.
jl.au

Composita. Sp. 6-11.

$\Varangle \Delta$ or 3 my $Y$ Britain m.pas. D co Eng. bot. 630

$\Delta$ or 3 ap.jn $\mathbf{Y}$ Germany ... $\quad$ D co

or ap.jn $\quad Y$ Austria 1816. D co Jac. aust. t. 130

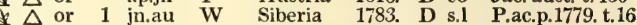

$\Delta$ or 1 jn.au $Y$ Caucasus 1815. D l.p

S. Europe 1570. D co

Sp. 1-12.

Siberia 1759. D co Gm.sib.2.t.68.f.1
1731. D p.l Bot. mag. 1749

Austria 1710. D p.l Bot. cab. 913

1753. Tetragonothe'CA. $W$. Tetragonotheca. Composite. Sp. 1

12196 helianthoídes $W$. Sunflower-like $₫ \Delta$ or 4 au.o $Y$ Virginia 1726. D p.1 Sch. han.3.t.263

1754. XIMENE'SIA. $W$. XIMENESIA.

12197 encelioídes $W$. Mexican

Composite. Sp. $\mathbf{1}$.

1755. Hele'NiUM. $W$. Helenium. 12198 autumnále $W$. 12199 pubéscens $W$. downy

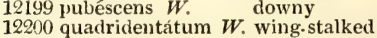
12201 quariripartítum Link:four-parted

$¥ \Delta$ or 3 au.o $\quad$ Y $\quad$ N. Amer. 1729. D p.l Sch.han.3.t.250 7 $\Delta$ or 3 au.s $\quad$ Y N. Amer. 1776. D p.l Louisiana 1730. D l.p Bot. reg. 598

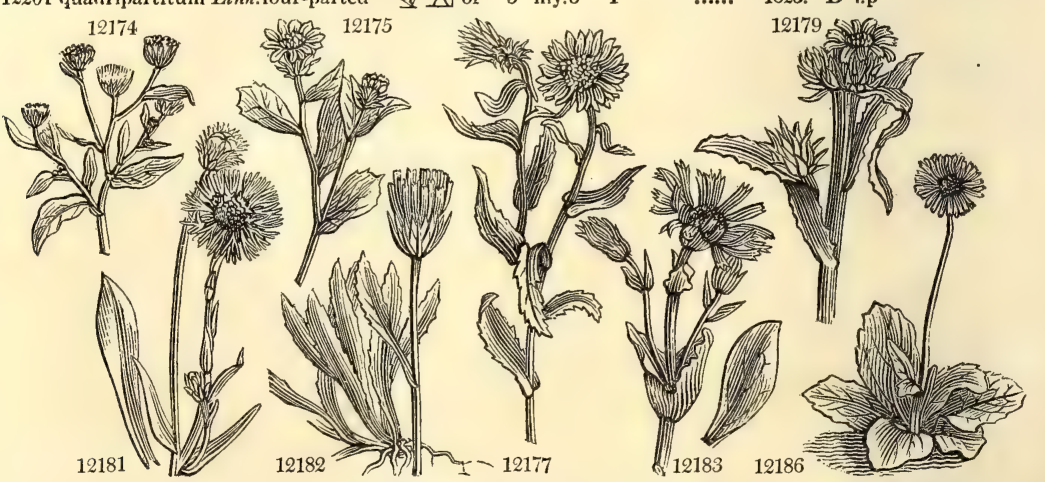

History, Use, Propagation, Culture,

1745. Pulicaria. So named in allusion to its property of driving away fleas, pulices. See Conyza. P. dysenterica has its specific name from having cured certain Russian soldiers of the bloody flux. It is called by our old authors middle flea-bane, and was supposed by its smoke in burning to chase away fleas and other insects. Forskahl says, it is named in Arabic Rara ejub, or Job's tears, from a notion that Job used a decoction of this herb to cure his ulcers. Of course it was formerly recommended to cure the itch. P. vulgaris is also said to drive away fleas and gnats.

1746. Grindelia. A handsome genus of herbaceous plants, with neat foliage, and pretty yellow flowers. They are sometimes called Donia.

1747. Podolepis. From $\pi 85$, a foot, and $\lambda \varepsilon \pi \iota 5$, a scale. The stalks of the flowers are covered with scales.

1748. Chatanthera. From $\chi \alpha i \tau \alpha$, hair, and $\alpha_{v}$ ing $\alpha$, an anther, the anther being furnished with a hairy tuft.

1749. Arnica. This is said to be a corruption of ptarmica, derived from $\pi \tau \alpha$ ş montana is a powerful sternutatory ; in the Vosges it is even called tabac on that account. The whole plant has important medicinal properties; it is fortifying, diuretic, emmenagogue, vulnerary, antiseptic, resolvative, and sternutatory. The root powdered is employed in diarrhcea, dysentery, and quartan fevers; it is also applied outwardly to bad ulcers, and in cases of gangrene. The flour is used in asthenia, rheumatic pains, 
10169 Leaves ovate-oblong decurrent toothed entire at end, Flowers corymbose clustered

12170 Leaves sessile opp. linear lanc. entire dotted beneath, Pedunc. long 1-headed

12171 Leaves lanceolate linear entire, Corymbs branched, Rays of flowers very short

12172 r.eaves amplexicaul. oblong wavy villous, Stem erect panicled, Pedunc. 1-fl. opposite the leaves 12173 Leaves oblong sessile, Pedunc. filiform, Invol. cylindrical

12174 Leaves oblongo-cordate amplexic. rugged downy, Stem woolly panicled, Scales of involucre setaccous

12175 Leaves ovate-obl, serrated, Involucres viscid

12176 Leaves sessile obl. lanceolate acute serrated at end not viscid

12177 Leaves obl. amplexicaul. serrated, Scales of involucre filiform at end revolute squarrose

12178 Stems simple, Lower leaves spatulate : upper linear-oblong serrated 1-nerved

12179 Leaves oblong blunt half-amplexicaul. ciliate serrated, Leaves of invol. linear flat bristle-pointed

12180 Scales of invol. rugose blunt, Stem quite simple

12181 Scales of invol, equal ovate acuminate, Stem nearly simple

\section{Leaves lanceolate ciliated}

12183 Leaves ovate entire : cauline twin opposite

12184 Leaves toothed, Teeth acuminate : radical stalked elliptical roundish ; cauline alternate oblong

12185 Leaves remotely toothed hirsute : radical stalked obl. narrowed at base; caul. alternate obl. lanceolate

12136 Scape 1-headed naked, Leaves stalked obovate repand

12187 Leaves somewhat toothed and hairy : radical stalked obl. rounded at base; caul. altern. obl. lanceolate

\section{Leaves obovate crenate smooth, Scape 1-headed}

12189 Leaves cordate repando-dentate : radical ones petiolate ; cauline ones amplexicaul.

12190 Leaves remotely toothletted : upper oblong amplexicaul.; lower ovate stalked, Petioles winged auricled 12191 Leaves toothletted : upper lanc. amplexicaul, ; lower spatulate ovate ; radical cordate stalked

12192 Leaves toothed obov, amplexic. : radical obov, spatulate narrowed into the stalk, Stem simple 1-headcd 12193 Smooth, Radical leaves cordate deeply toothed; cauline oblong amplexicaul. Stem about 1-headed 12194 Downy, Lower leaves stalked ovate with winged petioles : upper amplexicaul. ; all toothed

12195 Leaves stalked or ovate toothed subsinuate at base downy beneath : the eld ones quite smooth

12196 The only species

\section{The only species}

12198 Leaves serrated quite smooth

12199 Leaves serrated downy

12200 Lower leaves pinnatifid : upper entire smooth, Florets of disk 4-toothed

12201 Leaves lanceolate decurrent, Ray of corolla 4-parted

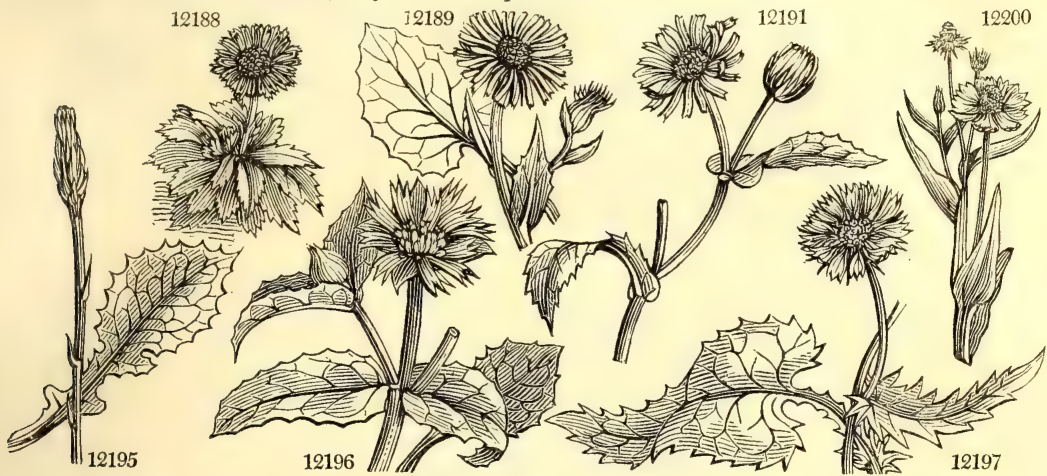

and Miscelianeous Particulars.

bruises, gutta serena, and paralysis of the bladder. The root is given in doses of six to twelve grains; the flowers of from three to four grains. Dr. Thomson observes, that in the hands of British practitioners it has not merited the eulogium of the French and German. (Lond. Disp. p. 169.)

1750. Gerberia. T. Gerber, a German naturalist, is only known as a traveller in Russia. A very pretty little greenhouse plant with neat purple flowers.

1751. Doronicum. Derived from the Arabic name Doronigi. Pardalianches is from $\pi \alpha \rho \delta 05$, a tiger, and ar $\chi_{\varepsilon i v}$, to strangle; on account of the use said formerly to have been made of the plant for the purpose of

1752. Perdicium. A name given by Pliny to a plant of which the partridge, perdrix, is very fond. The plant is not now recognized.

1753. Tetragonotheca. From $\tau \varepsilon \tau \rho \propto$, four, rwvis, an angle, and $9 \eta x \eta$, a capsule, in allusion to the four angles of the grains.

1754. Ximenesia. Named by the Abbé Cavanilles, after Joseph Ximenez, a Spanish apothecary, who is said to have attended to plants.

1755. Helenium. Named after the celebrated Helen, who is said to have availed herself of the cosmetic properties of the plant named after her. That is believed to be the modern Inula Helenium ; the ancient name being unoccupied, it has been applied to this American genus, which resembles the other. 
1756. BELLIS. $W$. 12202 perénnis $W$.

$\beta$ horténsis

₹ fistulósa

2203 sylvéstris $W$

12204 ánnua $W$.

1757. BEL/LIUN. $W$.

12205 bellidioídes $W$

12206 minútum $W$.

1758. DAH'LIA. Cav.

12207 supérflua $\boldsymbol{H}$. $K$.

12208 frustránea $H . K$.

$$
\begin{aligned}
& \beta \text { coccínea } \\
& \gamma \text { aurántia }
\end{aligned}
$$

olutea

1759. BCEBE'RA, $W$.

12209 chrysarthemoides $W$

1760. TAGE'TES. $W$.

12210 lúcida $W$.

12211 pátula $W$.

12212 erécta $W$.

12213 minúta $W$.

12214 tenuifólia $W$.

12215 clandestína Lag.

12216 micrántha Cav.

DaISY.

common

large-double

double-quilled

Hen \& Chicken

large Portugal

annual

Bellium.

small

dwarf

Dahlia.

fertile-rayed

barren-rayed

scarlet

yellow

Boerera.

列

1761. HETEROSPER'MUM. $W$. 12218 pinnátum $W$. wing-leaved

1762. SCHKUH'RIA. $W$. SchkUhria.

12219 abrotanoídes $W$. Wormwood-lvd.

1763. PEC'TIS. $W$.

12220 ciliáris $W$.

12221 linif́́lia $W$

Pectis.

ciliated

Flax-leaved
Orange-colored

Composita. Sp. 3-4.

$\frac{1}{4} \mathrm{mr}$.au W Britain past. D co Eng. bot. 424

$\frac{1}{4} \mathrm{mr}$.au $R \quad$...... ... $\mathrm{D}$ co Bot. mag. 228

$\frac{1}{4} \mathrm{mr} . \mathrm{au} \mathrm{R}$

$\frac{1}{4} \mathrm{mr} \cdot \mathrm{au} \mathrm{St}$

$\frac{3}{4}$ my.jl W

$\frac{1}{4} \mathrm{mr} . \mathrm{jl} \quad \mathrm{W}$

Composite. Sp. 2

pr $\frac{1}{4}$ jn.s W Italy

...... $\quad \cdots \quad$ D co

..... $\quad$... D co

Portugal 1797. D co Bot. mag. 2511

S. Europe 1759. S co Bot. mag. 2174

Italy 1796. S s.p Lam. ill. t. 684

Levant 1772. D co Sc.ac.up.1.t.5.f.2

Compositce. Sp. 2-3.

6 jl.n Pu Mexico 1789. R h.1 Cav. ic. 1. t. 80

6 s.n Sc Mexico 1802. R h.l Cav. ic. 2. t. 226

6 s.n Sc Mexico 1802. $R$ h.l Bot. mag. 762

6 s.n Or Mexico 1802 R h.1

6 s.n Y Mexico 1802. R h.1

Composita. Sp. 1.

$1 \frac{1}{2}$ o Y Carolina 1821. S 1.p

Composita. Sp. 8-12.

1 jl.n Y S. Amer. 1798. D p.1 Bot. mag. 740

2 jl.o Y.o Mexico 1573. S co Bot. may. 150

3 jn.s Y Mexico 1596. S co Lam ill t. 68

au.o PaY Chili 1728, S co Dilelt 280 . 362

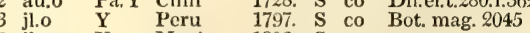

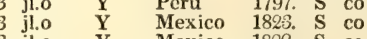

jl.o Y Mexico 1822. S co

S. Amer. 1819, S co

Composita. Sp. $1-3$.

au.s $\mathbf{Y}$ Composita. Sp.1.

\section{Composite. $\quad$ Sp. $2-7$.}

un 1 jl.au Y Jamaica 1732. S co Sl.jam.1.t.149.f.

1764. LONGCHAMP'SI A. Willd. Longchampsia. Composita. Sp. 1

12222 capillifólia Willd. hair-leaved $\mathrm{Opr} \frac{1}{2} \mathrm{jn} . \mathrm{jl}$ W Barbary 1822. S co

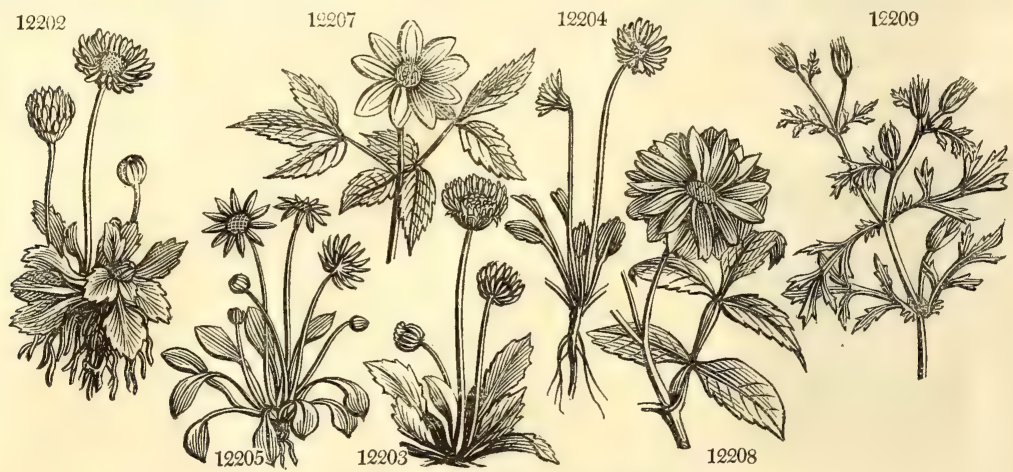

History, Use, Propagation, Culture,

1756. Bellis. So called from bellus, pretty. Every one knows the daisy.

1757. Bellium. See Bellis, from which this genus differs chiefly in the pappus of the grains.

1758. Dahlia. Named after Andrew Dahl, a Swedish botanist, and pupil of Linnæus. Continental botanists call the genus Georgina. This genus grows in Mexico, in sandy meadows, and till the peace of 1814 was more cultivated in France than in England : at present it is one of the most fashionable hardy plants. Though its leaves are coarse, resembling those of the common dwarf elder, yet the flowers are showy, and continue in beauty till late in auturn. The plants grow freely in any soil or situation; but the poorer the ground is, the smaller the size of the plant, and the earlier and more abundant the flowers. The single-flowered varieties of D. superflua are almost without end ; the double varieties of both species are much less numerous. Any number of the former may be raised from seeds, which ripen in abundance, and if sown in February on artificial heat, and transplanted in the end of April, they will flower in the July or August following. The double varieties are increased by dividing the roots, or by grafting, or by cuttings; they may also be sometimes raised from seeds. A very general way in which both kinds are propagated is by cuttings. They may be either taken from the root-shoots in spring, or the tops of the young shoots early in summer ; the lower end of each cutting should be cut smoothly off in the middle of a joint, and all the leaves left on, excepting those that would be buried in planting the cutting. If planted in sandy soil, on a gentle bottom heat, and covered with a hand-glass, they will soon strike root, and produce both flowers and tubers the same autumn. The double sorts are grafted on tubers of the single varieties much in the manner of whip-grafting, but without a tongue. There must be no buds on the tuber; cut off a slice from the upper part of it, in a sloping direction, and make, at the bottom of the part so cut, a ledge, whereon to rest the graft ; next, cut the scion sloping to fit, it should contain two joints, and be cut so that one of these may be at the bottom of it to rest on the ledge; from that joint the scion will occasionally put forth roots; from the other the future stem will be formed. Having tied the graft, clay it as in common grafting; then put the root in fine mould, burying half the graft, and place the pot in a gentle moist heat under a glass. If this be done in March, the plant may he shifted into a larger pot in April, and planted out in the end of May.

As the Dahlia is a bulky plant, it requires either to be grown in a very large pot, or in from three quarters to a yard and a half of surface. They look well in rows, or occurring singly in a shrubbery.

The treatment of the Dahlia bears a considerable resemblance to that of the potato and the marvel of Peru ; as soon as the frost has blackened the tops of these three plants, their roots require to be taken up, and 
12203 Scape naked single-headed, Leaves obovate crenate 3-nerved 12204 Stem somewhat leafy

12205 Stolones creeping, Scapes 1-headed, Leaves spatulate 12206 Stem leafy capillary

12207 Rachis of lvs. winged, Leafl. ovate acumin. serrated shining and smooth beneath, Outer invol. reflexed 12208 Rachis of lvs. naked, Leaflets ovate acuminate serrated roughish beneath, Outer invol, spreading

12209 Leaves pinnated : leaflets linear pinnatifid-toothed

12210 Leaves simple lanceolate finely serrated ciliate at base

12211 Leaves pinnated : leafl. lanc. ciliate-serrated, Pedunc. 1-headed thickened, Inv. smooth, Stem spreading 12212 Leaves pinnated : leaflets lanc. ciliate-serrated, Pedunc. 1-headed ventricose, Invol. angular, Stem erect 12213 Leaves pinnated : leaf. lanc. serrated; term. subdecurrent, Pedunc. many-fl. scaly, Flowers dense 12214 Leaves pinnated : leaflets linear serrated; lower serratures long, Stem panicled, Invol, clavate

12215 Leaves pinnated : leaflets filiform, Ray not longer than involucrum

12216 Leaves pinnated : leaflets filiform subulate entire, Stem branched diffuse, Pedunc. 1-headed solitary

12217 Leaves pinnated : lower segments lanceolate; upper linear, Serratures with intermediate glands

12218 Stem smooth, Leaves pinnated, Leaflets linear subulate entire

12219 Leaves attern. pinnate linear setaceous

12220 Leaves linear amplexıcaui. ciliated at base attenuated at end 12221 Leaves linear sessile acute ciliated at base

12222 Stem filiform branched, Leaves woolly subulate filiform, Peduncles naked axillary 1-headed

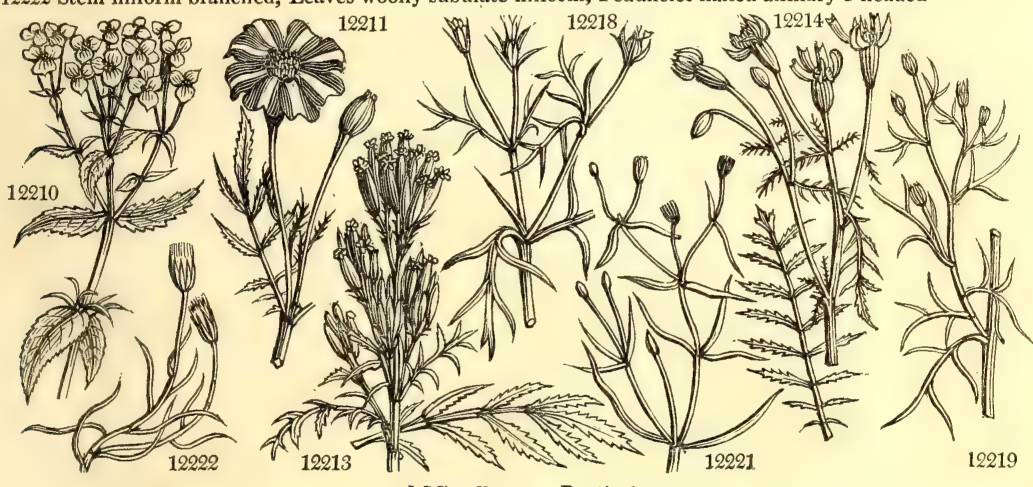

and Miscellaneous Particulars.

kept in a dry place, where the frost cannot get at them till spring. About April they may be divided, and planted in the open air where they are to flower; or, what is more common planted in large pots, and forwarded in heat till the middle of May, when they may be turned out of the pots where they are finally to remain. In this case they will flower a month or six weeks earlier than by the other method, and will, in general, continue fowering till they are destroyed by frost. Some care is requisite to preserve the roots suffigeneral, continue fowering till they are destroyed by frost. Some care is requisite to preserve the roots suffi-
ciently moist and plump to maintain the living principle, and yet not to rot, shrivel, or freeze them. The safest mode is to plant them in pots or boxes of dry earth, and place them in a shed or cellar, or under an ample covering of litter thatched over.

1759. Babera. Bueber is said by Willdenow to have been a learned Russian botanist.

1760. Tagetes. Named after Tages, a Tuscan divinity, the son of Genius, and the grandson of Jupiter. T. patula is a tender annual, deservedly popular, from the brilliancy and variegation of its flowers: it is cultivated in Japan, China, and many parts of India, but does not appear to be indigenous of those countries. The varieties of $\mathrm{T}$. erecta differ chiefly in the shades of the same color, but there are also double and quilled flowers. Both species are raised from seeds, upon a moderate hot-bed, in the beginning of April, and when they are three inches high, transplanted to where they are finally to remain. The varieties are very apt to degenerate, and can only be reproduced by the most careful selection and separation.

This genus serves for the basis of M- Cassini's Tagetinex, which do not appear to be at all distinct from Heliantheæ, from which they differ principally in the form of their ovarium. M. Cassini's principal motive for distinguishing them as a separate race, seems to have been his wish to reduce his tribe of Heliantheæ, which he finds too extensive. Nearly all the species are found in America.

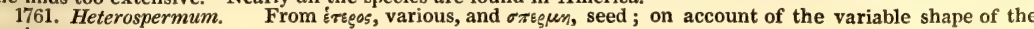
grains.

1762. Schkuhria. Named in honour of Christian Schkuhr, an acute German botanist, who has published some of the most accurate and useful, if not splendid, botanical works which the world has seen. It is to be regretted that their rarity makes them more generally unknown than they deserve to be.

1763. Pectis. From pecten, a comb, to which the teeth of the pappus may be compared

1764. Longchampsia. So named after Doctor J. L. A. Loiseleur Deslongchamps, a French botanist, author of a useful Flora Gallica, in two small duodecimo volumes, published at Paris, the first in 1806, the second in 1807 . 
1765. LEYSE'RA $W$. LEYSERA. 12223 gnaphalódes $W$. woolly 12224 squarrósa $W$. squarrose 1766. SELLO'A. Spreng. SelloA. 12225 glutinósa Spreng. clammy

1767. RELHA'NIA. $W$. RELHANIA. 12226 squarrósa $W$. $\quad$ cross-leaved 12227 púngens $W$. 12228 laterifléra $W$. 1768. ZIN'NIA. $W$. 12229 paucifóra $W$ 12230 muitiflóra $W$ 12231 verticilláta $W$ 12232 élegans $W$. 12233 tenuifióra $W$. 12234 hýbrida $B . M$

1769. CHRYSAN'T 12235 pinnatífidum $W$ 12236 atrátum $W$.

12237 heterophýllum $W$. 12238 Leucánthemum $W$.

12239 montánum $W$. 12240 ceratophylloídes $A l l$. 12241 graminifólium $W$. 12242 monspeliénse $W$ 12243 Achilléæ $W$. 12244 argénteum $W$. 12245 árcticum $W$. 12246 carinátum $W$. 12247 púmilum $W$. en 12248 sylvéstre $W$. en 12249 ségetum $W$. 12250 Mycónis $W$. 12251 itâlicum $W$. 12252 coronárium $W$. 12253 indicum $L$. 12254 sinénse $\mathrm{Sab}$. Montpelier Milfoil-leaved silver-leaved northern three-colored small field corn

tongue-leaved Italian garden Indian Chinese

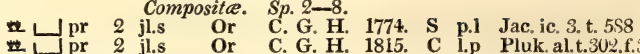
Composite. Sp. 1.

K $\square$ un $3 \underset{\mathrm{f}}{\mathrm{Y}}$ Brazil 1819. D co Bot. reg. 162 Compositce. Sp. 3-19.

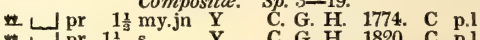

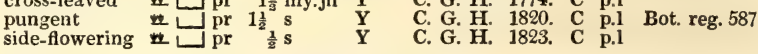
Zinnia. $\quad$ Composite. Sp. 6-8.

yellow-flowered $O$ or 2 jl.au Y Peru 1753. S r.m Mill.ic. 1.t. 64

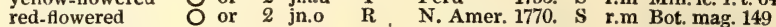
whorl-leaved O or 2 jl.au $\mathbf{R}$ Mexico 1789. S r.m Bot.rep. 189 purple-flowered $O$ or 2 jn.s Pu Mexico 1796. S r.m Bot. mag. 52 slender-flowered $O$ or 2 jl.au Sc Mexico 1799. S co Bot. mag. 555 hybrid $O$ or 2 jn.jl Sc S. Amer. 1818. S co Bot. mag. 2123

\section{MUM. $\boldsymbol{W}$. Chrysanthemum. Composite. Sp. 23-43.}

cut-leaved $u$ pr 3 my.au W Madeira 1777. C p.l fleshy-leaved $\Delta$ pr 1 jl.au W Austria 1731. D co various-leaved $\Delta \mathrm{pr} \quad 1$ jl.au W Switzerl. 1806. D co Ox-eye Daisy $\Delta \mathrm{pr} 2 \mathrm{jn} . \mathrm{jl}$ W Britain past. D co mountain $\Delta \mathrm{pr} 2 \mathrm{jn.jl} W$ France $1759 \mathrm{D}$ co Buckshorn $\Delta \mathrm{pr}{ }^{\frac{2}{3} \mathrm{jn} . \mathrm{jl}} \mathrm{W}$ Piedmont 1803. D co Grass-leaved $\Delta \mathrm{pr} 11 \mathrm{my} . \mathrm{jl} \quad \mathrm{W}$ Montpel. 1739. I co

$\checkmark \Delta$ pr $\frac{1}{2}$ jn.au W.pu Kamtsch. 1801. D co W.pu Barbary 1796. S co pot. mag. 508

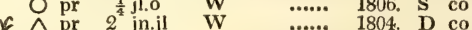
$\triangle \mathrm{pr} \quad 2$ jn.jl W N...... 1804. D co $\mathrm{W} 1 \frac{1}{2}$ jn.au $\mathrm{Y}$ Britain corn fi. $\mathrm{S}$ co Eng. bot. 540 O pr 1 jl.au Y Italy 1775. S co Jac. obs.4.t.94 * $\Delta$ pr 2 jn.jl Pa.Y Italy 1796. D co

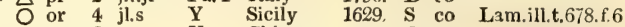
un 2 s.n spl 3 o.n

Garden Varieties.

1 Purple Bot. mag. 327

2 Changeable White Bot. mag. 2042

3 Quilled White Bot. reg. 4

4 Superb White Bot. reg. 455

5 Tasselled White

6 Quilled Yellow

7 Sulphur Yellow

8 Golden Yellow Bot. reg. 4*

11 Buff or Orange
9 Large Lilac

10 Rose or Pink

\section{Spanish Brown}

13 Ouilled flamed Yellow Hort, trans, 4, t. 14 14. Quilled Pink Bot. reg. 616

15 Early Crimson Hort trans, 5 , t 3

16 Large quilled Orange Hort. trans. 5. t. 3 17 Expanded light Purple 18 Quilled light Purple

19 Curled Lilac Sweet's fl. Garden, t. 7

20 Superb clustered Yellow Sweet's $f$. Garden, t. 14 21 Semidouble quilled Pink Hort. trans. 5. t. 17* 22 Semidouble quilled White

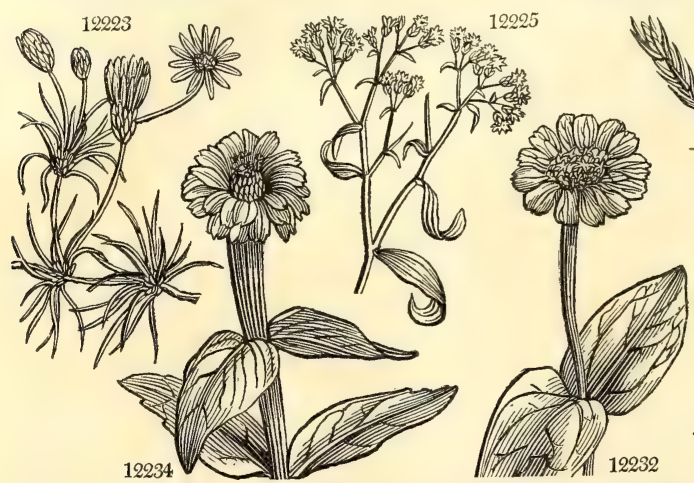

History, Use, Propagation, Culture,

1765. Leysera. So called in honor of Frederick William Leyser, a German, and author of a Flora Halensis in 1783.

1766. Sellox. Named after Mr. Sello, a German botanist, employed by the Prussian government in collecting materials for a natural history of Brazil. An uninteresting stove perennial plant, remarkable for having florets mixed among the leaves of the involucrum.

1767. Relhania. In honor of the Rev. Richard Relhan, an English botanist, and author of a Flora Cantabrigiensis. The genus was named by L'Heritier. Plants of no beauty and easy culture.

1768. Zinnia. John Godfrey Zinn, a German, published, in 1757, a Catalogue of the Plants in the Garden of Gottingen, \&c. Handsome border annuals, with persistent flowers, of the same culture as Tagetes.

1769. Chrysanthemum. From xevos, gold, and cy. 05 , a flower; because many of the kinds bear flowers of a yellow color. Chrysantème, Fr., Goldblume, Ger., and Crisantero, Ital. C. sinense is one of the handsomest of autumnal flowers, and of the easiest possible culture in any soil. It is a popular flower in China, whence all our numerous varieties have very recently been obtained, and chiefly through the exertions of the Horticultural Society. These are certainly a very great addition to the beauties of the flower garden in a dry autumn, and to the green-house or conservatory in the wet and foggy months of November and December, when scarcely any thing else is in flower. The plants are propagated by divisions, by suckers, and by cutting 6 
12223 Leaves linear subulate ciliate rough, Scales of invol lanceolate 12224. Leaves filiform downy, Scales of invol. membranous reflexed

\section{The only species}

12226 Leaves oblong acuminate nerveless recurved at end

12227 Leaves linear somewhat pungent striated beneath, Heads sessile

12228 Leaves linear villous, Pedunc. lateral shorter than leaf

12229 Heads sessile, Leaves opp. cordate-lanceolate amplexicaul. sessile

12230 Heads stalked, Leaves opp. ovate-lanceolate somewhat stalked

12231 Heads stalked, Leaves whorled ovate-lanceolate stalked, Ray double

12232 Heads stalked, Ieaves opp. cordate ovate sessile amplexicaul. Stem hairy, Paleæ serrated

12233 Heads stalked, Leaves opp. cordate lanceolate stalked, Ray linear-lanceolate reflexed

12234 Leaves cordate sessile rough at edge, Grains of disk with 2 awns : of the ray awnles 3

12235 Leaves smooth attenuated at base pinnatifid : segments cut

12236 Leaves all cuneiform oblong finely serrated, Stem simple 1-headed erect

12237 Leaves sessile : lower linear lanceolate serrated; upper spatulate

12238 Leaves amplexic. obl. obt. cut pinnatifid at base; radical ones obovate petiolate, Stem erect branched

12239 Lower leaves stalked spatulate serrate : upper lin. lanc. serrated, Stem 1-headed

12240 Leaves pinnated : pinnæ linear acute, Stem erect 1-headed

12241 Leaves linear nearly entire, Stem quite simple

12242 Lower leaves palmated: leaflets linear pinnatifid

12243 Leaves bipinnate: pinnæ oblong serrated, Heads corymbose

12244 Leaves bipinnate hoary : leaflets acute entire, Stem 1-headed simple

12245 Radical leaves 3-parted cut-toothed : cauline cuneiform 3-parted blunt

12246 Leaves bipinnated fleshy smooth, Scales of invol. keeled

12247 Leaves bipinnated linear subulate smooth, Stem erect sornewhat branched

12248 Very near $\mathrm{C}$. leucanthemum, but the lower leaves are more spatulate

12249 Leaves amplexic. glaucous inciso-serrate above toothed at the base

12250 Leaves lingulate blunt serrated, Scales of involucre equal

12251 Leaves bipinnate serrated, Rays length of disk, Stem procumbent

12252 Leaves bipinnatifid acute broadest externally, Stem branched

12253 Leaves flaccid stalked pinnatifid finely toothed : upper entire, Ray a little longer than flower

12254 Leaves coriaceous stalked sinuate-pinnatifid toothed glaucous, Ray very long

\section{Garden Varieties.}

23 Semidouble quilled Orange Hort. trans. 5. t. 17**

24 Late pale Purple

25 Quilled Salmon Color Hort. trans. 5. t. 17*

26 Small Yellow Hort. trans. 5. t. 17**

27 Paper White

28 Pale Buff

29 Early Blush

30 Blush Ranunculus-flowered

31 Changeable pale Buff

32 Two colored Red

33 Starry Purple

12246

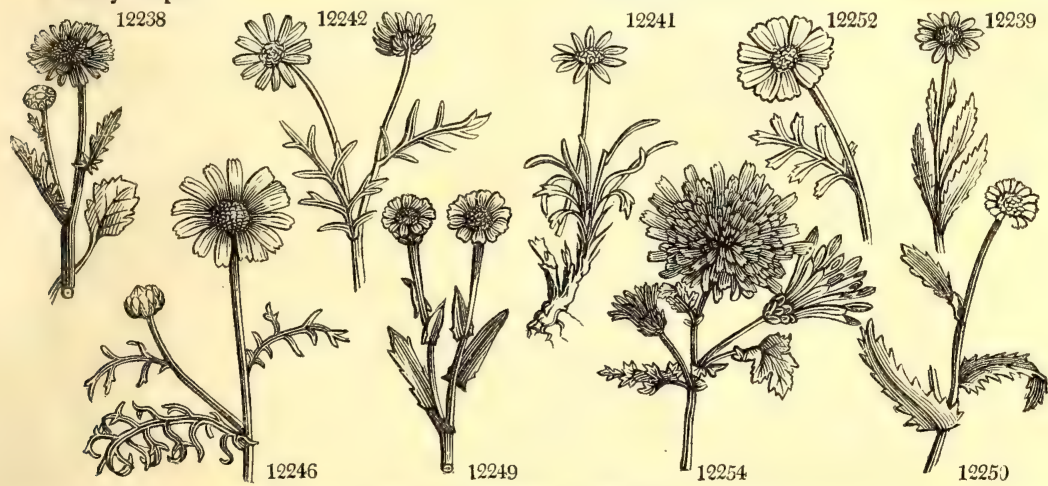

34. Brown Purple

35 Late quilled Yellow

36 Double Yellow Indian

37 Parkes's small Yellow

38 Tasselled Yellow

39 Tasselled Lilac

40 Semidouble quilled pale Orange

41 Golden Lotus-flowered

42 Two colored incurved

43 Yellow Waratah

44. Double White Indian

and Miscellaneous Particulars.

as they are very apt, in every case, to throw up suckers, the latter mode is decidedly the best. The cuttings may be taken from the side branches at any season from April to September; taken off before the end of May, they will flower the succeeding autumn; those taken off afterwards will not flower till next year. Chrysanthemums are so very prolific in suckers, that they soon become unsightly plants, and produce small and degenerate blossoms, unless frequently renewed from cuttings. The Chinese are said to do this every year they take off the cuttings in May, strike them as we do, and then put each plant in a very small pot, in which it flowers the succeeding autumn. The plants are thus kept in a dwarf state, and clothed with green foliage from the ground to the flower. In order that the blossoms may be strong. they leave only one or two This mode is now generally adopted with us; but sometimes the plants are retained a second, or even a third year, in which case care is requisite to leave no more stems, and to have no more suckers growing at one time than the roots can support in a vigorous state. As under this management the stems attain a great height, they require to be supported by a rod, and adjusted so as to form a symmetrical figure by a nice application of black threads, or small copper wires.

Sometimes the Chrysanthemum is grown in beds or borders, in which case the plants should be taken up every year and their superfluous suckers removed; or, which is better, they should be totally renewed hy cuttings. 
12255 paludósum Desf. marsh 12256 rotundifćlium $W . \& K$. round-leaved $\bigcirc \mathrm{pr} \quad 1 \frac{1}{2} \mathrm{jn} . j \mathrm{jl}$ pr $1 \frac{1}{2}$ jn.jl

1770. PYRE'THRUM. $W$. FEVERFEW. 12258 foeniculáceum $W$.en. Fennel-leaved 12259 crithmifolium W.en. Samphire-leav. 12260 anethifólium $\boldsymbol{W}$.en. Dill-leaved 12261 latifólium $W$. en. broad-leaved 12262 Halléri $W$. Haller's

12263 ceratophylloídes $W$. Buckshorn-lvd, 12264 frutéscens $W$. shrubby 12265 coronopifólium $W$ en. Horn-leaved 12266 grandiflórum $W$.en. great-flowered 12267 pinnatífidum $W$. pinnatifid 12268 pulveruléntum $W$. powdery 12269 sericeum Bieb. 12270 parviflórum $W$. small-flowered 12271 speciósum W.en. large-flowered 12271 speciosum W.en. $W$ large-flowered 12272 ptarmicæfólium $W$. Sneezewort-lv. 12274 uliginósum $W$. 12275 alpinum $W$.

12276 Balsarnita $W$. various-leaved

12278 róseum $W$. en. Ccariet-flower dy 12279 achilleæfólium Bieb. Milfoil-leaved 12279 achillexf 12280 corymbósum $W$. 12281 Parthénium $W$ $\beta$ flore plénn

double-flowered parthenifólium $W$. Parthenium-lv. 12283 caucásicum $W$. 12284 tenuifólium $W$. en. slender-leaved 12285 inodórum $W$. 12286 marítimum $W$. 12287 millefoliátum $W$. 12288 bipinnátum $W$. 12289 indicum $H . K$.

1771. MATRICA'RIA. $W$. Matricaria. 12290 suavéolens $W$. 12291 Chamomilla $W$ 12292 capénsis $W$. 12293 pusílla $W$. en. sweet WildChamomil cape

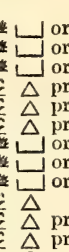

$\Delta \mathrm{pr}$

o un

$\triangle \mathrm{pr}$ $\Delta$ pr $\Delta p r$ $\Delta$ pr $\Delta p r$ $\Delta \mathrm{pr}$ $\Delta \Delta \mathrm{el}$ * $\Delta \mathrm{pr} \quad 2$ au.s $\triangle \mathrm{pr} \quad 1$ jn.au $\Delta \mathrm{w}$ $\triangle$ or 2 jn.s jn.s $\frac{1}{2} \mathrm{jlau}$ jl.au 1 au.s aved $\frac{1}{\Delta}$ pr $\Delta$ pr 1 jn.o many-leaved $\Delta$ pr 2 my.s r pr ${ }^{3} \mathrm{jn}$ jn.s

Compositce. O un $1 \frac{1}{2} \mathrm{jn} . \mathrm{au} W$ O w $1 \frac{1}{2}$ my.jl W un $\frac{x^{\frac{1}{2}}}{\mathrm{j}} \mathrm{jl.s}$ W

W Barbary 1810. S co Hungary 1817. D co Spain 1816. D co

Sp. 32-47.

Teneriffe 1815. C co Bot. reg. 272

Teneriffe 1815, C co Teneriffe 1815. C co Pyrenees 1820. D co Switzerl. 1819. D co Piedmont 1819. D co Canaries 1599. C p.l Canaries $\ldots . \quad$ C l.p Canaries 1815. C 1.p Caucasus 1823. D co Iberia 1823. D co ...... 1820. S co Canaries 1815. C 1.p Caucasus 1803. D co N. Amer. 1731. D co Hungary 1816. D co Switzerl. 1759. D co Levant 1779. D co Hungary 1803. D co Caucasus 180t D co Bot. mag. 1080

Caucasus 1823. D co Gm. sib. t.86. f.2 Germany 1596. D co Jac. aust.4. t.379 Britain rubb. D co Eng. bot. 1231

…... $\quad \ldots$ C $\quad$ r.m D co Vent. cels. t. 43 Caucasus 1804. D co Caucasus 1806. D co Britain dry fi. S co Britain sea sh, D co Eng. bot. 979 Siberia 17. 1. 9 E. Indies 1810. C p.1 Bot. mag. 1521

Sp. 4 .

Europe 1781. S co

Britain ro.sid. S co Fing. bot. 1232 C. G. H. 1699. S co Seb.th.1. t.16. f.2 ...... ... s co

Compositce. Sp. 2

1772. RolTo'NiA. $W$. Boltonia.

12294 asteroídes $W$. Starwort-flow. \& $\triangle \mathrm{pr} 2$ au.o $\mathrm{F}$ 12295 glastifólia $W$ glaucous-leav'd is $\Delta$ pr $1 \frac{1}{2} \mathrm{~s} \quad \mathrm{Pk}$

' 1773. LIDBECK'IA. $W$. LIDBECKIA. 12296 pectináta $W . \quad$ silver-leaved 12297 lobáta $W$. lobed

* J pr 2 my.jn Y

N. Amer, 1758. D s.l Bot. mag. 2554 N. Amer. 1758. D s.l Bot. mag. 2381

Compositce. Sp. 2-3.

1774. CE'NIA. 12298 turbináta $P$. S. ' 1775. CO'TULA. W. 12299 anthemoídes $W$. 12300 coronopifólia $W$.

\section{Cenra.} turbinated

Corula. Buckshorn-lvd.
Sp. 2-3. 1774 . C 1.p Ber.ca.306.t.5.fo C. G. H. 1800. C 1.p Lam, ill.t.701.f.3 Sp. 1.

C. G. H. 1713. S co Lam. ill.t.701.f.1 Sp. 5-29.

St. Helena1696. S co Dill elt. t.23.f.25 C. G. H. 1683. S co Lam. ill,t.700.f.1

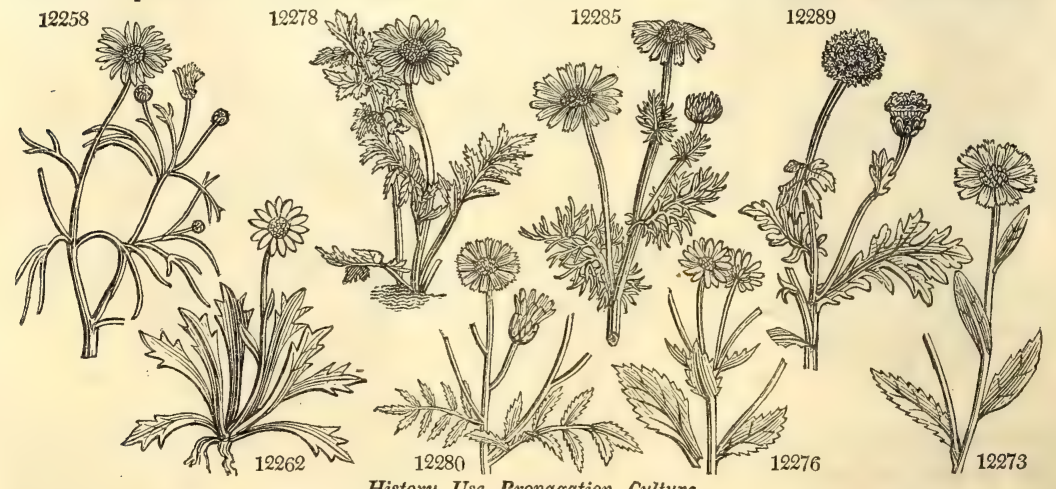

History, Use, Propagation, Culture,

Though these plants will grow in any soil, yet when in small pots they require a rich loam, and are the better for being watered, as in China, with liquid manure. The different varieties are well described by Mr. Sabine, in the fourth and fifth volumes of the Horticultural Transactions.

1770. Pyrethrum. An ancient Greek name, applied to this plant from its supposed resemblance to the rups gov of Dioscorides. That plant is believed to have been the Anthemis pyrethrum, or Pellitory of Spain, of the moderns, and to have received its name from the burning qualities of its root; rvo, fire. All the plant of Pyrethrum Parthenium has a strong unpleasant smell, and a bitter taste. It is used externally, in the form of lotion and of poultice, and internally as an infusion for colic, hysterical affections, and weak digestion. There are some double-flowering varieties, which are very ornamental.

1771. Matricaria. So named on account of the use which is made of it in disorders of females. Matricaire, Fr., Mutterkraut, Ger, and Matricaria, Ital. It excites menstruation. Chamomilla is an alteration of the 
12255 Leaves all cuneiform oblong bluntly serrated, Stem branched diffluse

12256 Leaves stalked serrated : lower roundish; upper ovate, Stem 1-headed

12257 Leaves with very narrow segments, Petioles very short connate

12258 Leaves pinnatifid fleshy : segments linear entire, Pedunc. long corymbose

12259 Leaves trifid fleshy; segments somewhat toothed linear blunt, Peaunc. long subcorymbose

12260 Leaves bipinnatifid linear acute, Pedunc. 1-headed terminal

12261 Leaves lanceolate serrated: radical oblong, Stem 1-headed

12262 Cauline leaves lanceolate deeply toothed : radical pinnatifid, Stem 1-headed

12263 Leaves pinnatifid: segments of the lower linear lanc. entire or bifid; upper linear entire

12264 Leaves fleshy pinnatifid linear toothed: upper linear trifid

12265 Leaves pinnatifid : segments lanc, somewhat 3-toothed fieshy, Pappus unequally toothed

12266 Leaves pinnatifid : segm. lanc. deeply toothed somewhat fleshy : upper lin. toothed, Pappus uneq. toothed 12267 Leaves downy glaucous subsessile lyrate pinnatifid unequally toothed, Heads corymbose

12268 Leave pinnate powdery, Leaflets pinnatifid blunt toothed, Pedunc. corymbose, Pappus toothed

12269 Leaves woolly bipinnate, Pinnæe and pinnules obl. imbricated, Stem 1-headed, Invol. woolly

12270 Leaves bipinnate : pinnæ lin.-filiform 2 or 3-parted, Stem erect branched, Pappus 2-lobed

12271 Leaves pinnatifid : segm. lanc. finely serrated, Grains subulate, Pappus unequally toothed

12272 Leaves linear serrulate, Heads corymbose

12273 Leaves lanc. : lower serrated at end; upper entire, Branches corymbose

12274 Leaves lanc. all deeply serrated, Stem erect branched at end

12275 Lower leaves pinnatifid toothed: upper linear entire, Stem 1-headed

12276 Leaves ovate obl. serrated : radical stalked; cauline sessile auricled at base, Heads corymbose

12277 Leaves hairy subsessile pinnatifid toothed blunt, Corymb terminal compound

12278 Leaves pinnated smooth : pinnæe once or twice pinnatifid with acute diverging segments, Invol. smooth

12279 Leaves bipinnate linear silky : pinnæ crossing, Pedunc. corymbose, Ray shorter than involucre

12280 Leaves pinnated, Pinnæ lanc pinnatifid finely serrated: upper confluent, Pedunc corymbose

12281 Lvs. petiol. flat bipinnate the segm, ovate cut, Pedunc. branch. corymb. Stem erect, Invol. hemispherical

12282 Leaves pinn. : pinnæ obl. obt. pinnatifid toothed; upper confluent, Stem virgate, Heads corymbubcent 12283 Leaves bipinnate: leaflets linear subulate, Stem 1-headed

12284 Rad. leaves bipinnate : pinnæ linear pinnatifid; cauline bipinnatifid, Heads corymbose

12285 Leaves sess. bipinnatifid with segm. capillary, Stem branched spreading, Pappus entire

12286 Leaves bipinnatifid the segm. linear fleshy awnless, Stem diffuse branched, Pappus lobed

12287 Leaves bipinnate linear blunt, Stem ascending somewhat corymbose, Ray length of invol

12288 Leaves hoary bipinnate linear blunt, Stem simple, Pedunc. twin, Ray shorter than disk

12289 Leaves pinnatifid : pinnæ cut-toothed, Pedunc. long nearly naked 1-headed, Scales of invol. blunt

12290 Leaves triply pinnate, Scales of invol, acute

12291 Leaves glabrous bipinnatifid the segments capillary, Invol. nearly plane: its scales obtuse

12292 Leaves glabrous bipinnatifid : stem branched suffruticose

12293 Leaves pinn. somewhat fleshy, Pinnæ linear blunt, Scales of invol. blunt, Grains margined on one side

12294 Leaves all entire

12295 Lower leaves serrated

12296 Leaves pinnatifid glaucous beneath

12297 Leaves stalked 5-lobed

12298 Ray short white : red on the lower surface

12299 Leaves pinnate multifid dilated, Ray none

12300 Leaves lanc. lin. amplexicaul, "pinnatifid toothed, Stem procumbent, Branches 1-headed
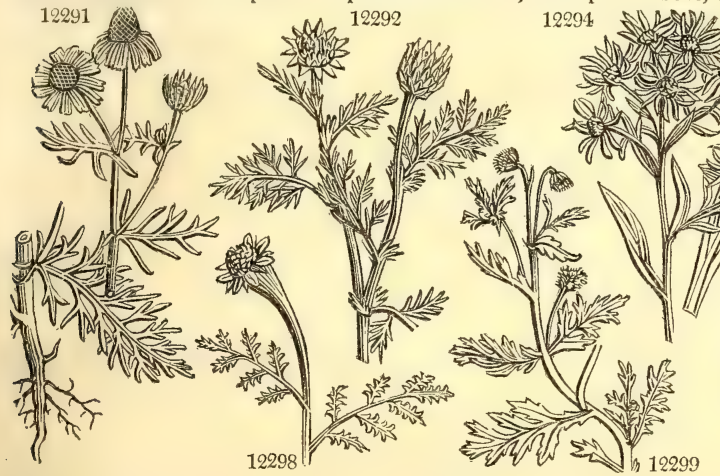

12294 AN

12298

and Miscellaneous Particulars.

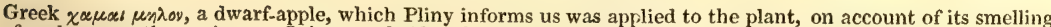
of apples, or rather quinces. It is remarkable, that the Spaniards call it mancinilla, which also means a little apple. The chamomile of medicine is another plant. See Anthemis.

M. Chamomilla is supposed to possess the same qualities with the officinal chamomile (Anthemis nobilis), but in an inferior degree. Most of the species, and chiefy this one, are rejected by quadrupeds.

1772. Boltonia. Named after I. B. Bolton, an English botanist, who wrote a work upon the Ferns of Great

Britain, and another upon the fungi growing about Halifax, published in 1788-9.

1773. Lidbeckic. E. G. Lidbeck, a German botanist, published some works upon agricultural matters.

1774. Cenia. From xevos, empty, in allusion to its inflated calyx.

1775. Cotula. A diminutive of Cota, an old name for some species of Anthemis, which this resembles in miniature. 
12301 viscósa $W . \quad$ clammy $\quad \mathbb{Z}$ un $\frac{1}{2}$ au $\quad$ W Vera Cruz 1739. D 1.p 12302 tanacetifólia $W$. Tansy-leaved $D$ un ${ }^{\frac{1}{2}}$ jn.au $\quad$ Y C. G. H. 1783. S co

12303 sphæránthus Link. round-headed $\&[\Delta]$ un $2^{4}$ my.jn $\mathbf{Y}$ Congo 1821. D co

1776. GRAN'GEA. $J$. Grangea.

12304 cuneifólia Lam. wedge-leaved

12305 minima $W$. least

12306 maderaspátana Lam. Madiras

12307 latifólia Desf.

1777. ANACY'Clus, $W$. Anacyclus.

12508 créticus $W$. trailing

10300 orientális $\mathcal{W}$ oriental

12310 aúreus $W$.

12311 valentinus $W$.

12312 radiátus Link. Anthemis valentina W.

golden-fowered

golden-flowered
fine-leaved fine-leaved

12313 clavátus Link.

clubbed

1778. A N'THEMIS. W: Chamomile.

12314 rigéscens $W . e n$. rigid

12315 Cóta $W$. Venetian

12316 altissima $W$. tall

12317 marítima $W$.

12318 tomentósa $W$.

12319 pubéscens $W$.

12320 mixta $W$.

12321 saxátilis W.en. rock 12322 Chamomilla $W$.en. various-leaved

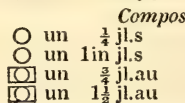

Sp. 4-6.

12323 chía $W$

12324 nóbilis $W$.

12324 nobilis - flore pleno

12325 arvénsis $W$.

12320 austríaca $W$.

12327 Cótula $W$.

12328 fuscáta $W$.

12329 montána $W$

12330 Pyréthrum $W$.

12331 globósa $W$.

12332 tinctória $W$.

12333 discoídea $W$.

12334 arábica $I V$

12335 apiifólia $R . R r$.

1233 punctáta $W$

12337 ruthénica Bieb.

downy

downy

pubescent

Composita. Sp. 6-11.

O pr 1 jn.au $\quad$ Y

jn.au $\mathrm{Y}$ Candia

O pr $\frac{1}{2}$ jn.au $\quad Y$

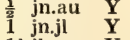

1759. S co

co Anus.11.t.22

$\mathrm{O}$ pr $1 \frac{1}{2} \mathrm{jl}$.au

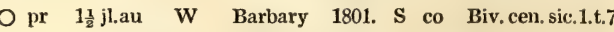
Composita. $S p$. 29-47.

E $\Delta$ pr 2 jl.s W Caucasus 1805. D co O pr 1 jlau W O pr 6 au

or 1 jlau

$\frac{1}{2} \mathrm{jl.o}$

Itaiy 1714. S co

W. hor. be.1.t. 62

England sea co. S s.I

Levant 1795. D co

S. Europe 1803. D co

France 1731. S co

Hungary 1807. D co

1 jl.au

1 jl.au

S. Europe 1807. D co

cut-leaved 0 pr 11 in.o W Chio 1731. S co

common

double

- $\triangle \mathrm{m} \quad \mathrm{j}$

Britain gra.pa. D co

Austrian $\quad 0$ w 1 my.au W

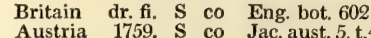

stinking O $\mathrm{w} 1 \mathrm{jn.s}$ W Britain cor.fi. S co Eng. bot. 1772

brown-scaled $\mathrm{O}$ pr 1 jl.au W Portugal 1805. S co

mountain $\& \Delta \mathrm{pr} \frac{1}{2}$ jl.o $\mathbf{P u}$ Italy 1759. D co

Pellitory of Spain $\frac{k}{E}$ or $1^{\frac{1}{2}}$ jio

1 jn.jl W S. Europe 1570. D s.p

glowe $\Delta$ el

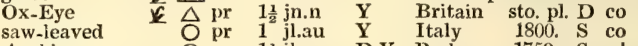
Arabian O pr 11 jl.au D.Y Barbary 1759. S s.I

Parsley-leaved $\triangle \mathrm{pr} 2$ au.s. W China 1819. D co

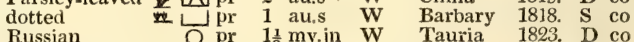

Russian $O$ pr $1 \frac{1}{2}$ my.jn W

Caucasus 1820. D co

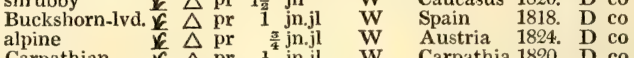

12340 alpina $W$.

12341 carpática $W$

Carpathian

$\Delta \mathrm{pr} \quad \frac{3}{4} \mathrm{jn} . \mathrm{jl}$

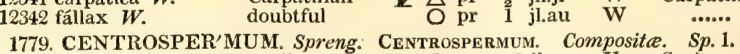

Carpathia 1820. D co

Bot. mag. 462

Eng. bot. 1472

Smith spic.9.t.10

ot. reg. 527

Desf. atl. t. 239

Jac.aust.app.t. 30

12343 chrysánthum Spreng. yellow $\quad \mathrm{O}$ pr $\frac{3}{4} \mathrm{jl}$.au $\mathrm{Y}$ Spain 1823. S co

1780. SANVITÁlia. Cav. Sanvitalia. Composita. Sp. 1.

12344 procúmbens $C a v$. trailing

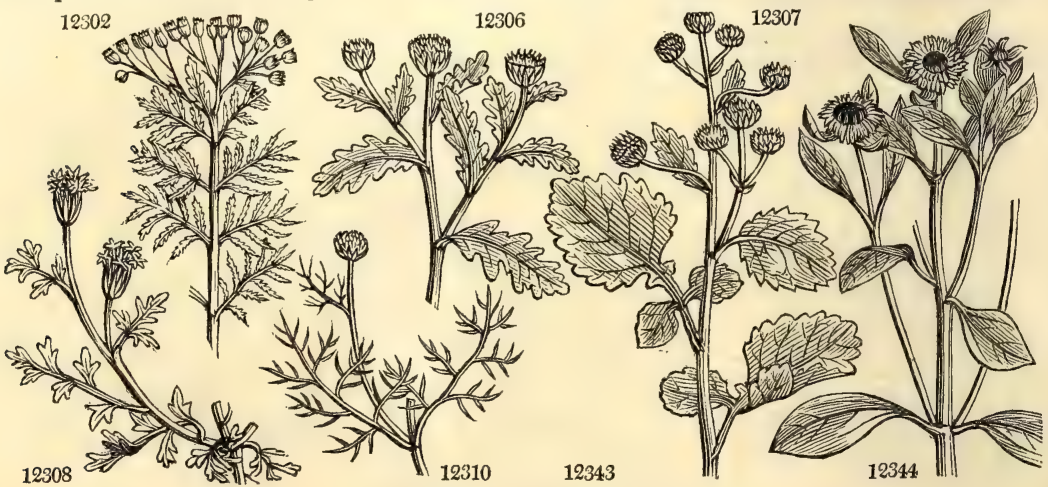

History, Use, Propagation, Culture,

1776. Grangea. A genus of Adanson's. The meaning of the word is unknown.

1777. Anacyclus. An abridgement of Ananthocyclus, which was the name originally proposed by Vaillant, and which does not appear to have been altered for the better. He formed it from $\alpha$, privative, ay.-5os, a flower, and zuzhos, a circle; on account of the rows of ovaries without flowers, which are placed in a circle round the disk.

1778. Anthemis. From cy. covered. A. nobilis is in considerable repute, both in the popular and scientific Materia Medica. The flowers, which are the parts used, have a strong and fragrant smell, and a bitter aromatic taste; both are extracted by water and alcohol. The active principles appear to be bitter extractive, resin, and essential oil. Medicinally, the flowers are considered tonic, carminative, and slightly anodyne: yet when a strong infusion of them is taken in a tepid state, it proves powerfully emetic. Given in substanee, united with opium and astringents, if the bowels be easily affected, they have been successfully used for the cure of intermittents ; and the infusion, in combination with ginger, or other aromatics, and the alkalies, is an excellent stomachic in dyspepsia, chlorosis. gout, flatulent cholic, and chronic debility of the intestinal canal. The tepid strong infusion is a ready emetic, and is often employed to promote the operation of other emetics. By coction in water, the essential oil is 
12301 Leaves lyrate pinnated, Flowers radiant

12302 Leaves tripinnate : segment acute, Stem erect, Heads flosculose corymbose

12303 Stem hirsute, Leaves lyrate pinnatifid hairy, Heads terminal hemispherical

1230 Leaves cuneiform smooth 3-toothed stalked, Heads axill. sessile 12305 Leaves obl. cuneate repand-toothed stalked, Heads axill, sessile

12306 Leaves obl. sinuate toothed downy, Stem branched procumbent, Pedunc. 1-headed opp. the leaves 12307 Leaves obovate toothed cut at base stalked, Peduncles branched

12308 Leaves bipinnate, Leaflets oblong, Stem procumbent

12309 Leaves bipinnate, Leaflets linear subulate flat, Stem ascending, Peduncle naked terminal 12310 Leaves bipinnate roundish hoary with excavated dots

12311 Leaves decompound linear: segm. divided roundish acute, Heads flosculose

12312 Leaves 3-pinnate, Pinn. linear-subulate downy, Stem branched divaricating, Pedunc. thick

12313 Leaves bipinnate linear, Pedunc. inflated, Grains winged

12314 Leaves bipinnatifid : segm. somewhat toothed rigid, Paleæ oblong acuminate

12315 Leaves bipinnatifid : segm. lin. subulate toothed, Palcæ round pungent dilated at base

12316 Leaves bipinnatifid : segm. lanc. somewhat toothed; lower teeth reflexed, Paleæ lanc. cuspidate 12317 Leaves bipinnatifid dotted beneath : segm. lanc. entire, Grains naked, Stem herbaceous 12318 Snow-white, Leaves pinnate : pinnæ 3 or 5 -fid, Invol. downy, Stem erect

12319 Leaves bipinnate : pinnæ linear, Stem erect and invol. downy, Inner scales sphacelate at end 12320 Leaves sessile pinnatifid : segments toothed, Stem erect branched

12321 Leaves pinnate : pinnæ linear entire subpubescent, Floral leaves simple, Branches 1-headed $12322 \mathrm{Rad}$. leaves bipinnatifid toothed: cauline pinnatifid somewhat toothed

12323 Leaves bipinnatifid stalked : segm. trifid oblong acute, Petioles sheathing, Sheaths toothed

12324 Lvs. bipinn. the segm. lin. subul, a little downy, Scales of recept. membranous scarcely long. than the disk

[entire pappus

12325 Lvs. bipinnatif. their segments lin. lanc. pubesc. Recept. conical its scales lanc. Pericarps crowned with an 12326 Recept, conical : paleæ obl. mucronate, Grains naked, Leaves bipinnate woolly

12327 Leaves bipinnatif. glabrous their segm. subul. Receptacle conical its scales setaceous, Pappus $\mathbf{O}$

12328 Recept. subconical, Paleæ obl. blunt, Grains naked, Lvs. bipinnate linear filiform 3-parted

12329 Leaves pinnated downy : pinnæ linear trifid bluntish, Stem ascending, Pedunc. long naked downy

12330 Leaves 3-pinnate : leaflets linear, Stem decumbent, Branches axillary 1-headed

12331 Leaves hairy bipinnatifid : segments trifid lanc. linear, Stem nearly erect divided

12332 Leaves bipinnatifid serrated downy beneath, Stem erect branched subcorymbose

12333 Leaves bipinnate serrated smooth, Stem erect branched, Pappus membranous toothed cut on one side 12334 Leaves pinnated : pinnæ linear 3-parted, Stem proliferous, Heads solitary axillary sessile

12335 Leaves smooth pinnatifid : lobes cuneate trifid or cut, Heads solitary

12336 Leaves bipinnatifid dotted beneath: segments entire, Crown of grains toothed

12397 Leaves woolly bipinnate : pinnæ lanc. acute, Flowering branches corymbose, Recept. conical

12338 Leaves stalked silky bipinnate: segm. linear acute, Invol, downy, Rays ovate

12339 Leaves linear sessile pinnatifid : segm, entire, Stem erect branched

12340 Leaves sessile pinnatifid : segm. linear subulate pectinate entire, Stem downy 1-headed

12341 Leaves pinnated : pinnæ linear entire blunt, Stem downy 1-headed

12343 The only species, resembling a Calendula

12344 Stem procumbent, Leaves ovate entire

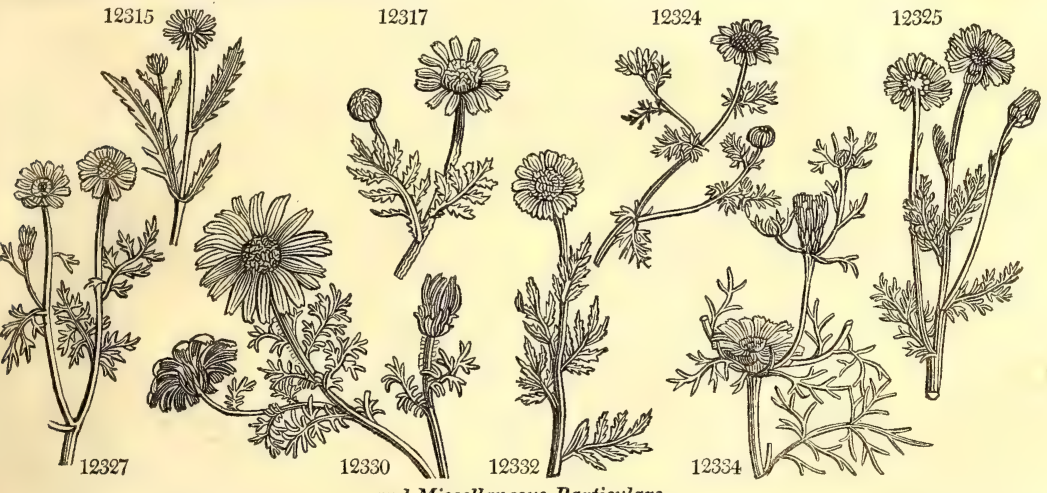

and Miscellaneous Particulars.

dissipated : chamomile flowers, therefore, ought never to be ordered in decoctions. Externally, they are used as fomentations in cholic, intestinal inflammation, and to phagedenic ulcers : and their infusion is also found to be an useful addition to emollient anodyne glysters in flatulent cholic, and in irritations of the rectumn producing tenesmus. (London Disp. p. 158.) There is a double variety generally grown for the apothecaries; it is more ornamental than the single, but much less efficacious as a medicine.

A. cotula is said by Linnæus to be a very grateful plant to toads; to drive away fleas, and to annoy bees. It is a very common weed on soft rich soils and dunghills, and increases by seeds with amazing rapidity. The tribe of Anthemidex, of which this genus is the example, are nearly related to Helianthea. In their style they resemble Inuleæ, Senecionex, and Nassauviex, but their floral organs are different. They inhabit Europe, Asia, and Africa, scarcely one has been found in America, or the southern parts of the world.

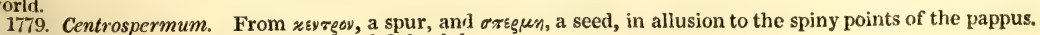

A small annual plant with the aspect of Calendula.

1780. Sanvitalia. Named by Lamarck without any explanation. A hardy annual plant, with flowers having a yellow ray and dark purple disk, like some species of Rudbeckia. 
1781. ACHILLE'A. $W$. MisfoIs 12345 linguláta $W$. tongue-leaved 12346 Hérba-róta $W$ 12347 grandiflóra $M . B$. 12348 Ptármica $W$. ß flore pléno 12349 cristáta $W$. 12350 Agératum $W$. 12351 decolórans W.en. 12352 speciósa $W$.en. 12353 alpina $W$. 12354 serráta $W$. 12355 Clavénnæe $W$. 12356 impátiens $\boldsymbol{W}$. 12357 pectináta $W$. ochroleúca Waldst. 12358 squarrósa $W$. 12359 falcáta $W$. 12360 tenuifólia $\boldsymbol{W}$. 12361 Santolína $W$. 12362 anthemoides $W$. 12363 atráta $W$. 12364 biserráta Bieb. 12365 coronopifólia $W$. 12366 álbida W. en . 12367 chamæ'melifólia Dec 12368 Gerbéri $W$. 12369 moscháta $W$. 12370 nána $W$. 12371 crética $W$. 12372 regyptíaca $W$. 12373 macrophýlla $W$. 12374 aúrea $W$. 12375 Eupatórium $W$ 12376 compácta $W$. 12377 pubescens $W$ 12378 crithmifólia $W$ 12379 tanacetifólia $\dot{W}$. 12380 dístans $W$. 12381 lanáta W. en. 12382 mágna $W$. 12383 Millefólium $W$. $\beta$ rúbra 12384 asplenifólia $P . S$. 12385 micrántha $W$. 12386 tomentósa $W$ 12387 ochroleúca $W$. 12388 microphýlla $W$. 12389 Ligústica $W$. 12390 nóbilis $\boldsymbol{W}$. 12391 myriophýlla $W$.en. 12392 odoráta $W$. 12393 setácea $W$ 12394 abrotanifólia $W$.

1782. TRI'DAX. $W$.

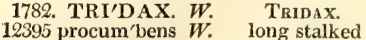
Herbarota great-flowered Sneezewort double-flowered slender-branch. Sweet Maudlin pale-yellow spear-leaved Alpine saw-leaved silver-leaved impatient comb-leaved

rough-headed sickle-leaved slender-leaved

avend.-cotton-lv. black-cupped biserrate Buckshorn-lvd whitish

c. dwarf musk dwarf Cretan Egyptian large-leaved golden-flower' Caspian compact downy

Samphire-leav. Tansy-leaved branching woolly great Yarrow red-flowered Rose-colored small-flowered tomentose cream-colored small-leaved Ligurian showy

any-leaved sweet-scented bristly Southernw.-Iv.

$\triangle$ or 1 jl.au $\frac{\Delta}{c}$ or $\quad 1^{\frac{1}{2}} \mathrm{jn}$ jl.au $\Delta$ or 1 jl.n $\triangle$ or 1 jl.n $\triangle$ or $\frac{1}{2} \mathrm{jl} . \mathrm{au}$ $\Delta$ or 2 au.o $\Delta$ or $1 \frac{1}{\mathrm{jn}} \mathrm{jl.s}$ $\Delta$ or $\frac{1}{2}$ jl.n

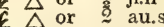
$\triangle$ or $\frac{1}{2} \mathrm{jn} . \mathrm{jl}$ $\triangle$ or 2 jn.s f $\triangle$ or $1 \frac{1}{2} \mathrm{au} . \mathrm{s}$

\section{\& $\triangle$ or 1 jl.au} $\Delta$ or $\frac{1}{2}$ jn.s $O$ or 1 jn.au $\triangle$ or 1 jn.au $\triangle$ or $2^{\frac{1}{2}}$ jn!.au $\triangle$ or 13 jn.jl

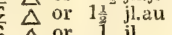
$\triangle$ or 1 jl $\Delta$ or $\frac{3}{4} \mathrm{jl}$ $\Delta$ or $1 \frac{1}{2}$ jl.au $\triangle$ or 2 jn.jl $\Delta$ or $1^{\frac{1}{2}}$ jn.au $\triangle$ or 1 jl.au $\Delta$ or 1 jl.s $\triangle$ or 3 jl.au $\Delta$ or 1 jin.s $\Delta$ or 2 jl.au $\triangle$ or 1 jl.au $\triangle$ or 1 jin.s $\Delta$ or 1 jl.au $\triangle$ or 3 jl.au $\triangle$ or 1 jl.au $\Delta$ or 3 jn.n $\triangle$ or 2 jin.o $\triangle \Delta$ or 2 jn.o $\Delta$ or $1 \frac{1}{3}$ jn.au $\triangle$ or 1 jn.o $\triangle$ or 2 my.o $\triangle$ or 2 jl.s $\triangle$ or 1 ji.s $\triangle$ or 2 in.au $\Delta$ or 11 jls $\Delta$ or $\frac{x}{2}$ jn.au W $\triangle$ or 1 jn.au
Sp. 50-69. Caunce 1640. D co Britain moi.pl. D co ...... $\ddot{17}$ C co S. Europe 1570. D s.p W. $\mathbf{Y}$ S. Europe 1798, D co W.X $\quad$ W...... 180. 1798. D co W Siberia 1731 . D s.p Y Switzerl. 1686. D co W Austria 1656. D p.1 Bot. mag. 1287 Pa.Y Hungary 1759. D co Gme. si.2.t.83.f.1 W $\quad$...... 1775. D p.l Pa.Y Levant 1739. D co Lam. ill. t.685.f.3 Y Levant 1733. D co 1759. D p. W Austria 1596. D co Jac. aust. 1.t. 77 W Albania 1820. D co Pa.Y Levant 1823. D co Pa.Y ...... 1819. D co W France 1825, D co Pa.Y Siberia 1821, D co Gmel.sib.t.83.f.2 W Itally 1775, D co Jac,aus.5.t.ap.33 W Italy 1759. D co All. ped.1.t.9.f.2 W Candia 1739. D p.1 Bocc. mus. t. 34 Pa.Y Levant 1640. R p.l Tourn. it. 1.t. 87 W Italy 1710, D co Triumf. obs, t.23 $Y$ Levant 1739. D co $Y$ Casp. Sho. 1803. D co Pa.Y ….. 1803. D co I.Y Levant 1739. D p.1 W Hungary 1804. D p.l Pl.rar.hun.1.t.66 Pk Switzerl. 1658, D co Moris.6.t.11.f.14 W Italy 1804. D co All, ped.t.53.f.1 W 1804. D co W S Europe 1683 . D W Britain pas, D co

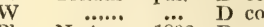

N. Amer. 1803 , D s.p Levant 1805. D p. Britain hea, D co Eng. bot. 2532 Pa.Y ….. 1804. I) co IV Spain 1810. 1) co Barr. ic. 1114 W Italy 1791. D co All.ped.1.t.53.f.2 W Germany 13\%0. D co Schk.han.3.t.255 W..... 179. D co Spain 1729. D co Jac. col 1 t 21 Hungary 1805. D p.l Pl.rar.hun.1.t. 80 Levant 1739. D p.l

1783. AMEL'LUS. $W$. AMellus. 12396 Lychnítis $W$. 12397 villósus $P h$. 12398 spinulósus $P h$.

\section{trailing} villous spiny

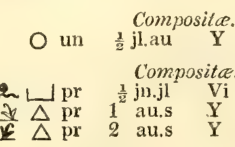

Mexico 1804. S co

C. G. H. 1768, C p.l Jac.co.su.t.10.f1 Missouri 1811. D co Missouri 1811. D co

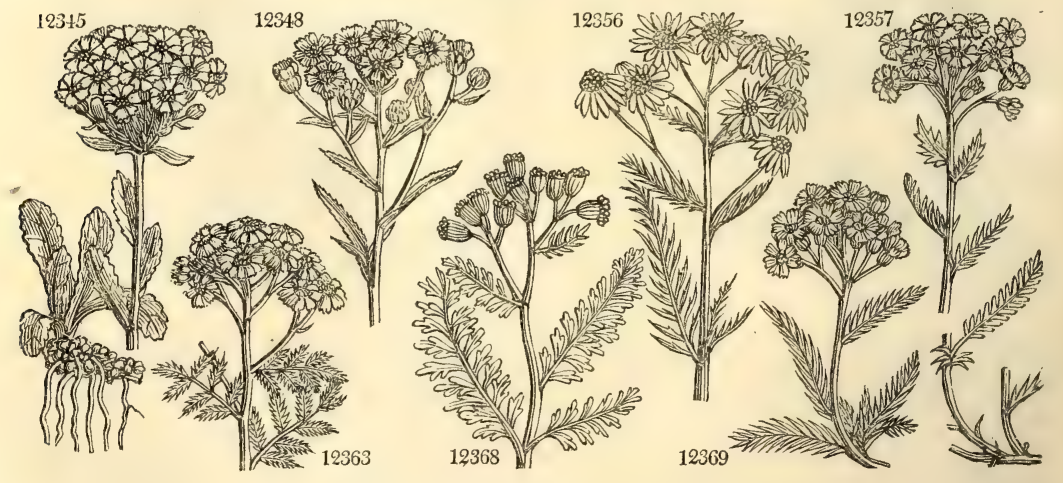

History, Use, Propagation, Culture,

1781. Achillea. Named after Achilles, a disciple of Chiron, and the first physician who used it in healing wounds. A. Ptarmica is called sneeze-wort, because the dried powder of the leaves snuffed up the nostrils provokes sneezing. In the spring, the young tender shoots were formerly put into salads, to correct the coldness of other herbs. There is a variety with double flowers, which is very ornamental, especially in pots. A. moschata, the Genipi of the,Swiss, is an excellent sudorific, aromatic, and acrid, and is a grateful food to cattle. 
12345 Leaves obl. linear blunt doubly serrulated downy clliated, Stem villous 12346 Leaves linear narrowed at base serrated and stem smooth

12347 Leaves lin. acute equally and finely serrulate smooth, Stem panicled, Corymbs few-headed, Palea bifid 12347 Leaves linear lanc. acuminate sharply serrated

$123+9$ Leaves lin. plane acuminate toothed : teeth emarginate transversely ciliated, Stem diffuse

12350 Leaves obl. blunt serrated narrowed into the petiole fascicled glabrous, Corymb compound contracted

12351 Leaves linear acuminate equally and finely serrated smooth : serratures of the base deepest, Paleæ entire

12352 Leaves lanc. equally and finely serrated downy, Serratures of base deepest, Stem panicled, Paleæ entire

12353 Leaves linear pectinate pinnatifid glabrous : segm. subserrated, Corymb compound

12354 Leaves downy linear lanc. pinnatifid : segments deepest at base

12355 Leaves downy pinnatifid smooth : segm. linear blunt : upper toothed at end, Corymb simple

12356 Leaves pectinate pinnatifid smooth : segm. linear acute ; lower 2-parted, Corymb simple

12357 Leaves pectinate pinnatifid: segm. linear subulate entire, Corymb compound contracted, Stem downy

12358 Leaves pinnatifid : segm. obl. cuneate unequally toothed vertically bent, Corymbs simple

12359 Leaves pinnated roundish pilose : pinnæ 3-parted toothed imbricated across, Corymbs simple

12360 Leaves pinnat. somew. downy, Pinnæ 3-part. blunt entire transversely imbr. Ray scarcely long. than invol

12361 Leaves pinnated somewhat downy, Pinnæ 3-parted transverse distant: segm. 3-toothed, Stem branched

12362 Leaves pinnated downy : pinnæ linear entire blunt ; lowest longest, Cymes simple

12363 Leaves pectinate pinnate smooth : pinnæ linear acuminate usually 3-parted

12364 Leaves linear-lanc. acuminate unequally and finely biserrate villous beneath

12365 Leaves downy pinnatifid : segm. lanc. serrated, Corymb compound

12366 Stem downy, Leaves pinnated minutely cut acute rigid bent upwards with a downy nerve

12367 Leaves pinnated : pinnæ long distant very narrow linear entire, Corymb compact branched

12368 Cauline lvs. pinnatifid with entire segm. : radic. pinnatifid with 3-fid segm. Ray scarcely larger than invol.

12369 Leaves pectinate pinnate smooth, Pinnæ linear bluntish entire dotted

12370 Leaves pinn. villous : pinnæ toothed linear; radical bipinnate, Stem quite simple

12371 Leaves pinn. downy : pinnæ roundish 4-fid concave spreading, Stem branched at end

12372 Leaves pinn. downy: pinnæ roundish bluntly toothed, Corymb compound

12373 Leaves pinn. smooth : pinnæ lanc. cut-serrated; outer confluent, Corymb compound

12374 Leaves bipinnate downy : pinnæ linear-lanc. toothed, Corymb simple, Peduncles long

12375 Leaves bipinnatifid hoary : segm. lin. lanc. serrated, Corymb compound globose, Flowers flosculous

12376 Leaves bipinnatif. setaceous villous: segm. lanc. entire, Corymb compound contracted, Flowers flosculous

12377 Leaves bipinnatifid pubescent : segm. linear lanc. unequal acute, Corymb compound

12378 Leaves downy : cauline bipinnatifid with linear blunt segm.; radical bipinnate, Corymbs compound

12379 Leaves bipinnatifid : segm. lanc. serrated, Corymb compound spreading

12380 Leaves bipinnatifid : segm. lanc. cut-serrated, Rachis winged cut-serrated, Corymbs fastigiate compound

12381 Leaves bipinnatifid villous. : segm. lanc. blunt, Corymbs fastigiate compound

12382 Ieaves thrice pinnatifid : segm. lanc. acute, Corymbs compound fastigiate

12383 Leaves bipinnate slightly hairy their segm. linear toothed acute, Stems furrowed

12384 Leaves pinnatifid downy beneath : segm. toothed, Stem branched fastigiate smooth

12385 Leaves bipinnatifid downy : segm. lanc. entire, Corymb compound

12386 Leaves bipinnatifid woolly : the segm. crowded linear acute, Corymbs repeatedly compound

12387 Leaves subbipinnatifid : pinnæ of the base undivided : segm. lin. lanc. Corymb compound, Invol. cylindr.

12388 Leaves bipinnatifid shorter than the intervals between them : segm. lin. entire, Corymbs comp. fastigiate

12389 Leaves bipinnatifid : segm. lin. finely serrated, Rachis winged entire, Corymb compound fastigiate

12390 Cauline leaves bipinnatifid : segm. lin. somew. toothed, Rachis winged toothed : radical thrice pinnatifid

12391 Leaves bipinnate downy: pinnæ pinnatifid, Segments linear-subulate, Corymbs compound fastigiate

12392 Leaves bipinnate pilose beneath : pinnæ linear entire, Corymb simple

12393 Leaves bipinnate : leaflets linear setaceous mucronate very compact pilose, Corymbs compound fastigiate

12394 Leaves bipinnate downy : pinnula very fine linear entire distant, Corymbs compound fastigiate

12395 The only species

12396 Leaves hoary linear lanc. opposite : those of the branches alternate

12397 Very villous, Leaves sessile oblong acuminate entire, Heads axillary on short stalks

12398 Hoary, Lvs. bipinnatifid cut-toothed, Segm. linear rigid mucronate, Heads lateral and terminal clustered

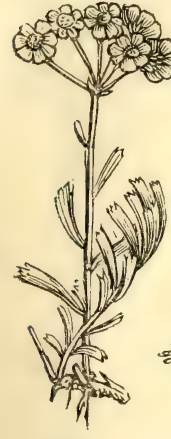

12346

\section{9}

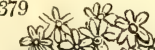

ond of
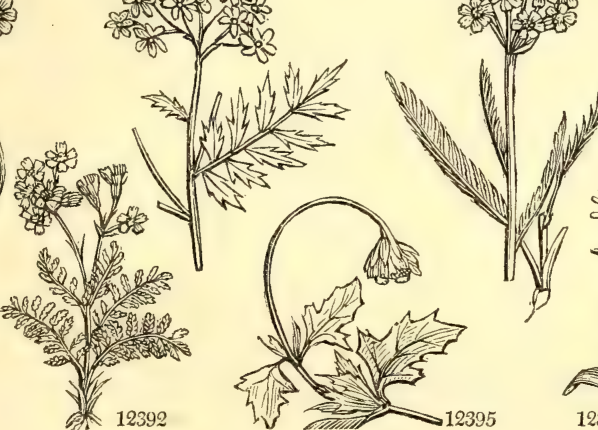

12392
12370

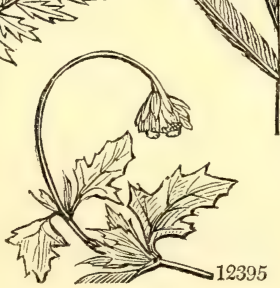

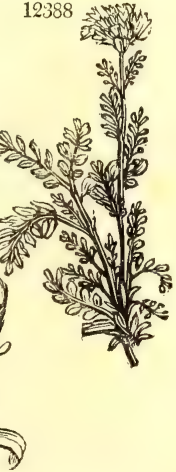

12396

and Miscellaneous Particulars.

1782. Tridax. From ressaxvos, cut into three pieces. The rays of the flower are divided in three.

1783. Amellus. A name used by Virgil for a beautiful flower growing on the banks of the river Mella. The

plant of Virgil is supposed to have been Aster Amellus. 
1784. STAR'KEA. $W$. Starkea. Composite. Sp. 1

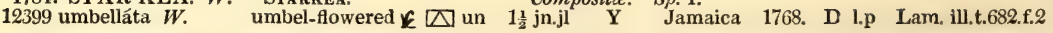

1785. COLUMEL'LIA. Jacq. Columellia. Composite. Sp. 1

12400 biénnis Jacq. biennial K 1 un 1 jn.jl $\quad$ Y C. G. H. 1821. S co Jac.schœ.3.t.301

1786. ECLIP'TA. $W$. EcLipta.

12101 erécta $W$. upright

12402 prostráta $W$. trailing

1787. MEYE'RA. Swz. MEYera.

12403 séssilis Swz. Sessile

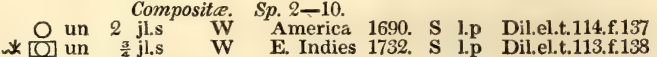

Composita. Sp. 1.

E [J] un 1 jl.au Y W. Indies ... D co Bot. rep. 429

1788. Chrysanthel/lUM. $P$. S. Chrysanthellum. Compositce. Sp. 1.

12404 procúmbens P.S. procumbent $\quad\left[\right.$ un $1 \frac{1}{2}$ jn.jl $\quad$ W. Indies 1768 . S co Sw. ob.314.t.8.f.1 Verbesina mútica $\mathbf{W}$.

1789. SIEGESBECK'IA. $W$. Siegesberia.

12405 orientális $W$ oriental Compositer. Sp. 2-5.

O pr \& au.o Y India 1730. S co Schk.han.3.t.256

12406 flosculósa $W . \quad$ small-flowered 0 pr 2 jn.jl Y Peru 1784. S co L'Her. stirp.t.16

1790. VERBESI'NA. $W$. Verbesina.

12407 aláta $W$. wing-stalked

12408 virginica

12409 gigantéa $W$. Compositce. Sp. 10-23.

12410 Siegesbéckia. $W$. American \ $\triangle$ un 3 o.n $\quad$ Y Virginia 1731. D co

1241 Coreópsis Ph, Coreopsis-like Jo pr 5 s.n Y N. Amer. 1640. D co Coreópsis alternifólia $\mathrm{W}$.

12412 serráta $W$.

12413 sativa $H$.

12414 calendulácea $W$. $\quad \begin{aligned} & \text { Oil-seed } \\ & \text { Ceylon }\end{aligned}$

12415 dichótoma $W$. forked

12416 fruticósa $W$. shrubby

$\leqslant \mathrm{N}$ un 3 jl.o Y

A mer, 1640. D co Jac. vind. 2.t.110

Mexico 1803. D 1.p Cav. ic. 3. t. 214

E. Indies 1806. S co Bot. mag. 1017

Ceylon 1739. S co Bur. zey. t. 22.f.1

E. Indies 1789. S co M. co.go.1779.t.4

W. Indies 1759, C co Plum. ic. t. 52

1791. SYNEDREL'LA. $P$. S. Sy NEDRELLA.

12417 nodiflóra $P . S . \quad$ sessile-flowered

1792. GAlinso'GEA. $W$. Galinsogea.

12418 parviflóra $W$. small-fiowered

12419 trilobáta $W$. three-lobed

1793. ACMEL'LA. P. S. ACMella.

12400 mauritiána P. S. Balm-leaved Spilanthes Acmella W.

12421 buphthalmoídes P.S. oval-leaved

1794. ZALUZA'NIA. P. S. Zaluzania. 12422 triloba $P . S$. three-lobed

1795. PASCA'LIA. $W$ Pascalia. Composite. Sp. 1.

12423 glaúca $W . \quad$ glaucous-leaved $\$ \Delta \Delta \mathrm{pr} \quad 1 \frac{1}{2} \mathrm{jn} . \mathrm{au} \quad \mathrm{Y}$ Chil

1796. HELIOP'SIS. P.S. Heliopsis. Composita. Sp. 1.

12424 læ'vis P.S. Sunflower-lvd. $¥ \Delta$ or 6 jl.o $\quad$ Y $\quad$ N. Amer. 1714. D co L'Her.stirp.t.45 Buphthálmum helianthoídes W.

1797. BUPHTHAL'MUM. $W$. Ox-Eve.
12425 frutéscens $W$.

shrubby $\bigsqcup_{\text {or }} 2$ jn.au $\mathbf{Y}$ America 1696. C p.l Dill.elt. t.28.f.4.

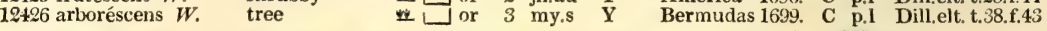

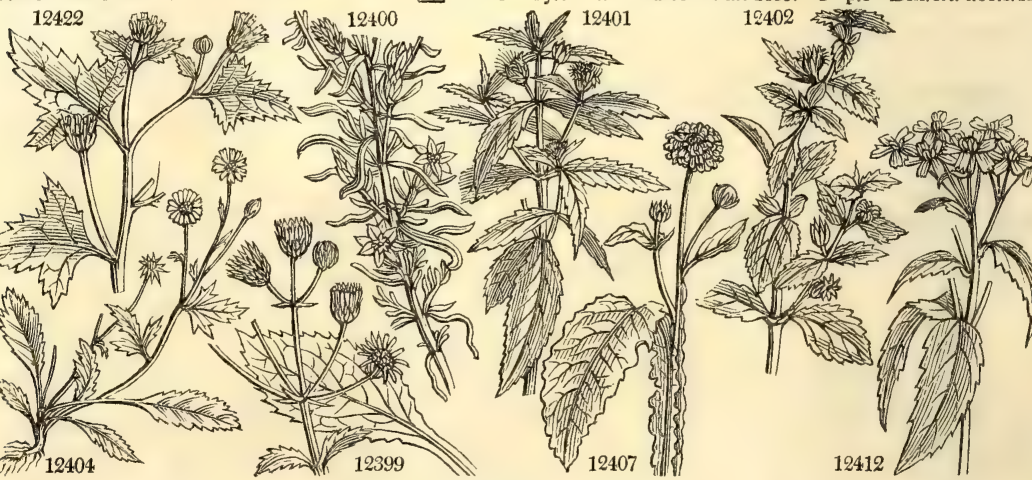

History, Use, Propagation, Culture,

1784. Starkea. Named by Willdenow, after the Rev. Mr. Starke, of Gros Tchirna, in Silesia, who paid much attention to the Cryptogamous plants of that country. This genus was included by Linnæus in Amellus, from which Willdenow remarks that it differs in habit, and in its hairy receptacle.

1785. Columellia. So called by Jacquin, after the celebrated Geoponic writer, Lucius Junius Moderatus Columella, a Spaniard, born forty-two years before Christ. A plant resembling Amellus annua. The flowers are yellow and sessile in the dichotomies of the branches. The Columellia of Loureiro is a different thing.

1786. Eclipta. A translation of the Malay name Wangi-wangi-maihg, which signifies an eclipse of the sun,

to which the form and disposition of the radiated flower has been likened. Worthless weeds with white flowers.

1787. Meyera. Named after Gottlieb-Andrew Meyer, a German, who published, in 1694, a dissertation upon the Sycomorus of Scripture.

1788. Chrysanthellum. A diminutive of Chrysanthemum, which see.

1789. Siegesbeckia. Dr. John George Siegesbeck, a German physician, director of the garden at St. Petersburgh, published in 1736, a catalogue of it under the title of Flora of St. Petersburgh. There was also a Botanosophia from his pen in 1737. 
12399 L waves opp. 3-nerved downy beneath, Heads in umbels

12400 The only species

12401 Stem erect strigose, Leaves oblong lanc. sessile remotely serrated

12402 Stem prostrate strigose, Leaves obl. lanc. somewhat stalked subserrate somewhat wavy scabrous

12408 Stem erect; Leaves amplexicaul, ovate toothed

12404 Leaves alternate 3-parted toothed : radical oblong serrated, Stem creeping

12405 Leaves stalked ov. unequally toothed subtriangular at base somewhat cut, Outer invol. longer than inner 12406 Leaves sessile ovate toothed, Florets of disk 3-toothed triandrous

12407 Leaves alternate decurrent wavy blunt

12408 Leaves alternate lanc. subserrate, Corymb compound

12409 Leaves alternate deeply pinnatifid, Stem shrubby

12410 Leaves opposite ovate lanc. serrated acuminate at each end decurrent

12411 Stem winged, Lvs. lanc. acuminate somewhat stalked serrated, Heads corymbose, Cor. of ray lanceolate

12412 Leaves opposite ovate-lanc. serrated downy beneath

12413 Leaves opposite cordate-lanc, amplexicaul. remotely serrated, Invol. simple 5-leaved

12414 Leaves opposite obl. lanc. bluntish strigose serrated at end, Pedunc. 1-headed long, Invol. simple

12415 Leaves opposite ov. acuminate serrated 3-nerved hairy, Pedunc. winged 1-headed, Invol. simple

12416 Leaves opposite ov. acuminate serrated 3-nerved scabrous on each side, Pedunc. 1-headed axillary

12117 Leaves opposite ov. serrated 3-nerved, Heads axillary subsessile, Invol. simple, Stem trichotomous

12418 Leaves ovate 3-nerved serrated

$12+19$ Leaves oblong lanceolate toothed 3-nerved : lower hastate 3-lobed

12120 Stem procumbent downy, Lvs. ovate entire, Pedunc. lateral, Ray shorter than disk

12421 Leaves ovate serrated 3-nerved downy beneath, Ray many-flowered

12422 Leaves ternate 3-lobed : lower opposite, Stem suffrutescent

12423 The only species

12424 Leaves opposite ovate serrated 3-nerved, Invol. leafy, Stem herbaceous

12425 Leaves opposite obovate hoary, Petioles with 2 teeth

12426 Leaves opposite lanceolate narrowed at base not toothed smooth

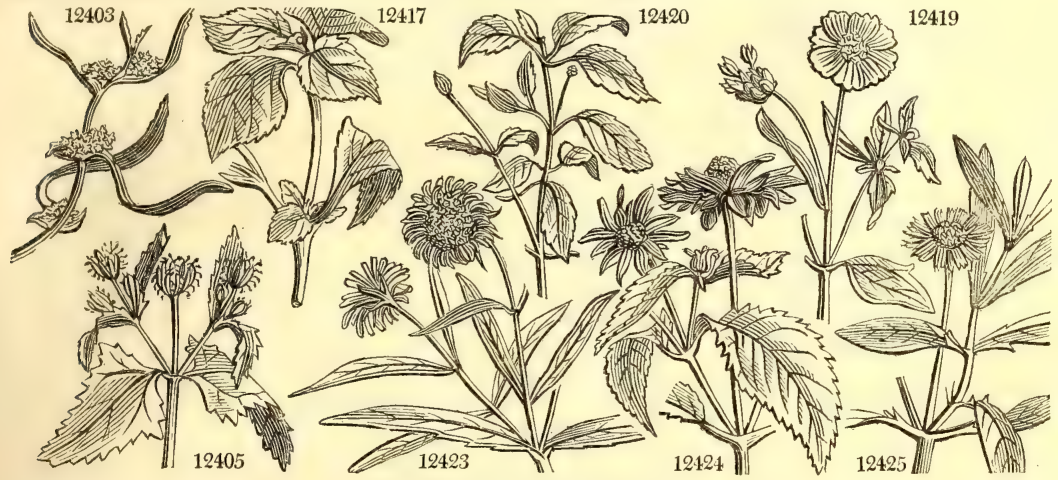

and Miscellaneous Particulars.

1790. Verbesina. A name with the same meaning as Verbena, which see. The V, alata resembles Vervain in the appearance of its foliage.

1791. Synedrella. A name of unknown meaning. A little worthless weed.

1792. Galinsogea. Named after after Mar. Ma. Galinsoga, first physician to the queen of Spain, and intendant of the garden of Madrid. One of the species, G. trilobata, is sometimes cultivated as a hardy annual. But it does not possess much merit.

1793. Acmella. From $\alpha=\omega n$, a point, on account of the pricking taste of the foliage.

1794. Zaluzania. Apparently an alteration of Zaluzianskia, a name applied in error to Marsilea trifolia, and formed in honor of an obscure Polish botanist.

1795. Pascalia. A genus dedicated by Ortega to Didan Pascal, doctor of medicine, and a professor at Parma.

1796. Heliopsis. A name with the same meaning, and a genus with the same habit, as Helianthus, which see.

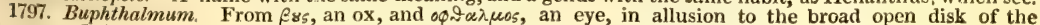

flowers. It is believed that the Buphthalmum of Pliny is a species of Anthemis. 
12427 seríceum $W$. 12428 spinósum $W$ 12429 aquáticum $W$. 12430 maritimum $\dot{W}$ 12431 salicifólium $W$.

12432 grandiflórum $W$.

12433 cordifólium $W$.

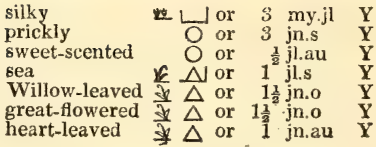

Canaries 1779. C p.l Bot. mag. 1836 Spain 1570. S co Barr. ic. 551 S. Europe 1731. S co Breyn. cent. t.77 Sicily 1640. D s.l Docc.mus. t.129 Austria 1759. D co Jac. aust. 4.t.370 Austria 1729. D p.l Moris.s.6.7. f.52 Hungary 1739. D !.1 Pl.rar.hu.2.t.113

\section{FRUSTRANEA.}

1798. HELIAN'THUS, $W$. SUN FlOWER. 12434 ánnuus $W$. 12435 indicus $W$ 12436 tubæfórmis $W$ 12438 multiflórus $W$. ß plénus

12439 tuberósus $W$ 12442 móllis $W$.

12443 decapétalus $W$. 12444 prostrátus $W$. 12445 strumósus $W$. 12446 altíssimus $W$. 12447 gigantéus $W$. 12448 iongifólius $P h$. 12449 diffúsus $B$. $M$. 12450 lineáris Cav. 12451 trachelifólius $W$. 12452 excélsus $W$

12453 missaricus Link. 12454 trilobátus Link. 12455 divaricátus $P h$, annual tube-flowered tooth-leaved many-flowered $\frac{y}{y}$ double-flowered \$ै Jerusalem Artich. narrow-leaved \% or 6 auto soft ten-petalled rough * or 2 jls. Carrot-rooted $\$ \Delta$ or 8 jl.s tall $\$ \Delta$ or 8 jl.s gigantic $\quad \vec{\Delta}$ or 10 s.o long-leaved $D$ or 6 au.o diffuse * $\Delta$ or 3 au.o linear $\vec{\Delta}$ or 2 au.o Trachelium-lv. $\frac{3}{4} \triangle$ or 6 s.o lofty $\not \Delta$ or 8 s.o Missouri $\vec{\Delta} \Delta$ or 3 s.o three-lobed $\overrightarrow{ }$ or 3 s.o divaricate $\frac{ \pm}{\Delta}$ or 3 or 6 au.

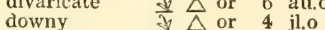
dark-purp.-eyed $\frac{1}{\triangle}$ or 3 jl.o 12437 dentátus $W$. 12440 angustifólius $P h$. 12441 macrophýllus $P h$. 12456 pubéscens $W$. 12457 atrorábens $W$. dwarf annual or 3 s.o

Composita. Sp. 24-31.

1596. S co Reneal.spec.t.83 Egypt 1785. S co Tabern. ic. 764 Mexico 1799. S co Jac.schœ.3.t.375 N. Amer. C 1.p Cav. ic. 3. t. 220 N. Amer, 1597. D co Bot. mag. 227

N. Amer. D co

1617. $R$ co Jac, vind.2.t.161 N. Amer. 1789. D co Bot. mag. 2051 N. Amer. 1800. D co W.hort. ber.t.70 N. Amer. 1805. N. Amer. 1759. D p.l Rob. ic. 235 N. Amer. 1800. D co N. Amer. 1710. D p.l Boc. sic. t. 27.f.4 N. Amer, 1731. D co Jac vind 2, t.160 N. Amer. 1714. D co Moris.s.6.t.7.f.66 Georgia 1810 D co N. Amer. 1821. D co Bot. mag. 2020 Mexico 1823. D co Bot. reg. 523 N. Amer. 1825. D co Mexico 1820. D co Cav, ic. t. 219 Missouri 1821. D co Mexico 1824. D co Nexico 1824. D co N. Amer. 175.9. D p.l Mo.h. s.6.t.7.f.66
N. Amer. 1795. D co Bot. reg. 524 N. Amer. 1732. D p.l Bot. reg. 508 Sp. 1.

12458 maculátum Kunth. spotted $\quad \square$ pr 3 jn.jl Y W. Indies 1821. D p.l Bot. reg. 662

1800. RUDBECK'IA. $W$. RUDBECKIA. 12459 pinnáta $P h$. 12460 digitáta $W$.

12461 laciniáta $W$.

12462 columnáris $P h$.

12463 subtomentósa $P h$.

12464 tríloba $W$.

12465 hirta $W$

12466 fúlgida $\dot{H} . K$

12467 lævigáta $P h$.

12468 amplexifólia $W$.

12469 purpúrea $P h$.

12470 serótina Sweet

\section{fragrant} $\triangle$ or 3 aus $Y$ hro.-jagged-lv. $y$ or 6 au.s $\quad X$ broad jagged-lv. $2 \downarrow \Delta$ or 6 jl.s $\quad$ Y downy-lobed $\$ \Delta$ or $S$ au.s $\quad$ Y three-lobed $\$$ O) or 4 au.s great-hairy $\$ \triangle$ or 2 jn.n small-hairv $\quad$ $\triangle$ or 3 jl.au

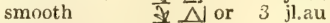
stem-clasping $\mathrm{O}$ or 3 jl.au

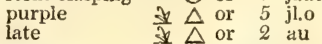

Sp. $12-20$ N. Amer. 1759. D p.l Moris.s.6.t.6.f.54 N. Amer, 1640. D p.I Moris.s.6.t.6.f.53 N. Amer. 1811. D co Bot. mag. 1601 N. Amer. 1802. D co

N. Amer. 1699. S co Bot. reg. 525 N. Amer. 1714. D p.l Sweet's fl.gar.82 N. Amer. 1760. D p.l Bot. mag. 1996 Carolina 1812. C co

Louisiana 1793. S co Jac, ic. 3, t. 592 D.P N. Amer. 1699. D p.l Bot. mag. 2

N. Amer. 1823. D co Sweet's fl.gard.4
N. Amer. 1803. D co Bot. mag. 2310

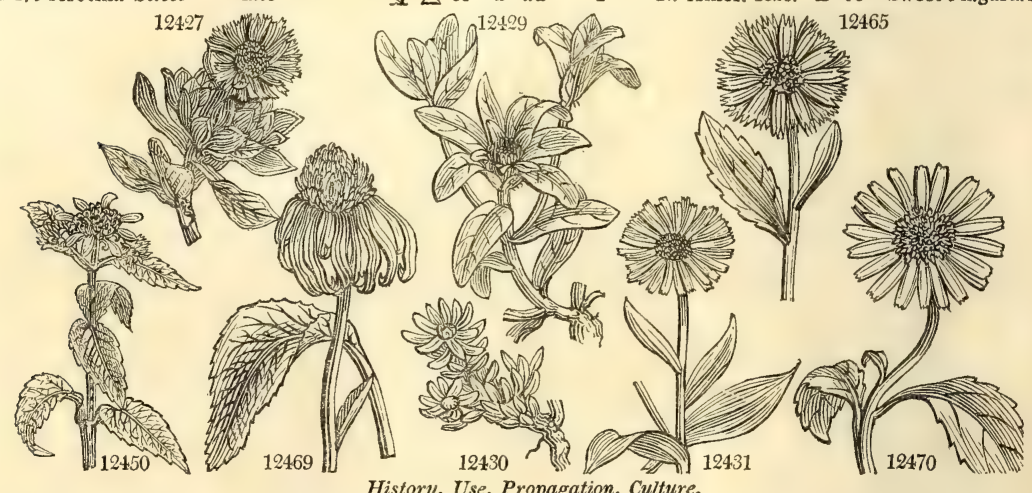

History, Use, Propagation, Culture,

1798. Helianthus. From $\eta \lambda .65$, the sun, and $\alpha y$. sentative of the sun, than the gigantic sun-flower, with its golden rays; it is dedicated with great propriety to the sun, which it never ceases to adore while the earth is illuminated by his light. When he sinks into the west, the flowers of Helianthus are turned towards him; and when he rises in the east, the flowers are again ready to be cherished by the first influence of his beams.

H. annuus is a well known border annual, which will grow in any soil. There are varieties with double flowers, the tubular florets being changed into ligular ones, like those in the ray. The whole plant, and particularly the flower, exudes a thin pellucid odorous resin, resembling venice turpentine. From the seeds an edible oil has been expressed, and they are also excellent food for domestic poultry. The flowers turning with the sun, is by some considered a popular error; Gerarde says he never could observe it; and Professor Martin has seen four flowers on the same stem pointing to the four cardinal points. H. tuberosus, Topinambour, Fr., Erdanfel, Ger., and Girasole, Ital., is called Jerusalem, from the corruption of the Italian word Girasole; and Artichoke, from the resemblance in flavor which the tubers have to the bottoms of artichokes. These tubers are in considerable esteem on the continent as a substitute for potatoes; and before the introduction of that vegetable, they were a good deal in use in this country. Their culture and treatment is the same as for that vegetable. H. multiflorus a showy autumnal flower. 
12427 Leaves opposite close spatulate oblong silky, Scales of invol, setaccous hirsute 12428 Leaves alternate obl. lanc. amplexicaul. entire hirsute, Invol. leafy mucronate 12429 Invol. bluntly leafy sessile axillary, Leaves oblong blunt alternate nearly entire, Stem dichotomous 12430 Invol. bluntly leafy stalked, Lvs. alternate spatulate, Stem herbaceous

12431 Leaves alternate obl.-lanc. subserrated S-nerved villous, Invol, naked, Stem herbaceous

124.32 Leaves alternate lanc. somewhat toothletted smooth, Invol. naked, Stem herbaceous

12433 Leaves alternate : lower stalked cordate doubly serrated: upper sess. ovate serrated, Stems herbaceous

\section{FRUSTRANEA.}

12434 Leaves all cordate 3-nerved, Pedunc. thick, Heads cernuous 12435 Leaves all cordate 3-nerved, Pedunc. evensized, Invol. leafy

$12+36$ Leaves cordate cuneate at base villous 3-nerved, Pedunc, thick fistular

12437 Leaves ovate acuminate narrowed at base unequally serrate scabrous, Pedunc. filiform, Rays obcvate

12438 Leaves 3-nerved scabrous : lower cordate; upper ovate, Ray many-fl. Scales of invol. lanceolate

12439 Leaves 3-nerved scabrous : lower cordate-ovate; upper ovate acum. alternate, Petioles ciliated at base 12440 Stems slender about 1-headed, Leaves linear revolute at edge rough

12441 Leaves ovate acuminate 3-nerved serrated scabrous above hoary beneath, Invol. squarrose

12442 Leaves ovate acuminate 3-nerved closely serrated scabrous above: hoary and soft beneath

12443 Lvs. ov. acum. remotely serrat. 3-nerv, scabr. Scales of invol. lanc. nearly equal subciliated, Rays 10 or 12 12444 Lvs. lanc. acuminate scabr, serrated 3-nerved : upper entire, Scales of invol. lanc. ciliated, Stem procumb. 12445 Lvs. ovate acuminate serrated S-nerved scabrous beneath, Scales of invol, lin. lanc. ciliated at base

12446 Lvs. altern. lanc. serr. scabr. 3-nerved narrow, at end stalked, Petioles ciliated, Scales of invol. lanc. ciliat. 12447 Lvs. altern. lanc. serr. scabr. obsol, 3-nerv. narrow. at each end subsess, ciliat. at base, Scales of inv. lanc. cil. 12448 Smooth, Stem panicled, Branches few-flowered at top, Lvs. sessile very long entire: lower serrated 12449 Stem hispid spreading, Leaves ovate rigid scabrous, Peduncles very long 1.fiowered

12450 Leaves altern. or opp. sessile linear revolute at edge entire 1-nerved, Heads corymbose

12451 Leaves ov. lanc, acuminate serrated 3-ncrved very rough on each side, Scales of invol, lin. lanc. ciliated

12452 Leaves altern. lanc. serrated scabrous 3-nerved narrowed at each end woclly at base, Stem vill, in 2 rows 12453 Leaves amplexicaul. Heads on long stalks, Disk of head dark purple

12454 Stem erect hairy, Lvs. stalked 3-lobed very rough, Invol. hairy, Pappus with 2 setæ

12455 Stem smooth much branched, Lvs. opp, sessile lanc. ovate 3-nerved, Panicle trichotomous slender few-ft. 12456 Leaves subsess, cordate ovate 3-nerved amplexicaul, closely serrated downy, Scales of invol. lanc. villous 12457 Leaves opp. spatulate crenate 3-nerved scabrous, Scales of invol, erect the length of disk

12458 Leaves oblong-lanceolate subserrate, Heads 1-3, Ray 8-flowered

rhispid

12459 Lvs, all pinnat. : one or other of the lower pinnæ2-parted; the rest undivided, Pappus ent. Stem furrowed 12460 Rad. Ivs, pinn. : leaflets sessile lanc toothed somewhat cut; upper confluent, Pappus entire

12461 Rad. Ivs. pinn. : leaflets ovate unequal at base about 3-lobed toothed, Pappus 4-toothed

12462 Stem upright simple few-fl. at top, Leaves pinnatifid cut: segm. linear, Invol. simple 5-leaved

12463 Stem branched, Branches erect many-f. Lvs. obl. lanc, acute serrated: lower 3-lobed

12464 Leaves spatulate: lower 3-lobed; upper undivided

12465 Leaves undivided spatulate ovate 3-nerved serrated hairy, Recept, conical, Palem lanceolate

12466 Leaves obl. lanc. toothletted hispid narrowed at base subcordate, Recept. hemispherical, Palea lanceolate 12467 Quite smooth, Peduncles long 1.headed, Lvs. ovate-lanc. acuminate cach way 3-nerved

12468 Leaves obl. lanc. cordate amplexicaul. : lower serrated, Disk cylindrical conical

12469 Leaves lanc. ovate alternate undivided, Rays bifid

12470 Stem hispid, Lower leaves broad-ovate tapered at base remotely toothed very rough, Rays 3-toothed

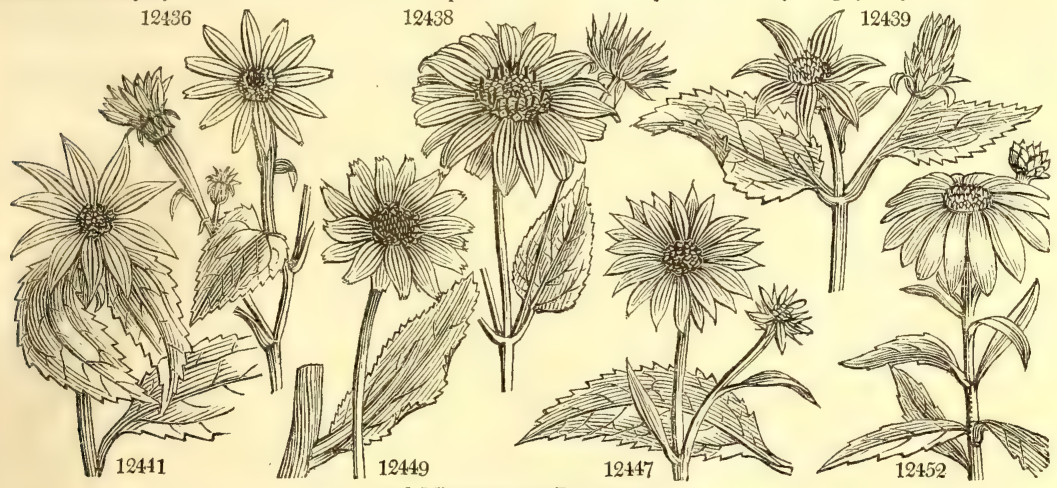

and Miscellaneous Particulars.

This genus has given rise to a most important and extensive tribe of plants, the Helianther, which is at once the most numerous of the various tribes of Compositæ, and on account of its strict affinity with several others, the most difficult to characterize with precision, Although it is perfectly natural, yet there is scarcely a character belonging to it which is not subject to many exceptions, and to more or less important modifications. Almost all the species of Heliantheæ are natives of America, several of Asia, a few of Africa, and scarcely any of Europe. They appear to be entirely unknown in the southern parts of the world.

1799. Gymnolomia. From rupyos, naked, and $\lambda \omega \mu \alpha$, an edge; in allusion to the nature of the margin of the grains.

1800. Rudbeckia. Named after the famous Olaus Rudbeck, professor of botany at Upsal, who died of grief in 1702 , at witnessing the destruction by fire of his laborious work, called Cammi Elysii, which was nevertheless published in 1701 and 2 , by the diligence of his son. He is also celebrated for having made the discovery that the Paradise of Scripture was situated somewhere in Sweden. Handsome border anmuals or perennials. $\mathbf{R}$. purpurea is remarkable for bearing purple flowers. 
1801. GALAR'DIA. $W$. Galardia 12471 bícolor $W$. two-colored

1802. TITHO'NIA. Desf. Tímonia.

12472 tagetiflóra $W$. Marigold-flow.

1803. COS'MEA. $W$. Cosmea.

12473 lútea $B$. $M$.

12474 sulphúrea $W$.

12475 bipinnáta $W$

12476 parviflóra $W$.

1804. COREOP'SIS 12477 ferulæfólia $W$. 12478 verticilláta $W$ 12479 tenuifólia $W$. 12480 chrysántha $W$ 12481 aúrea $W$.

12482 trípteris $W$.

12483 senifólia $\boldsymbol{W}$.

12484 álba $W$

12485 incísa B. reg.

12486 réptans $W$.

12487 lanceoláta $W$.

12488 tinctória Nutt.

12489 auriculáta $W$.

12490 latifólia $W$.

12491 argúta $P h$.

12492 crassifólia $W$.

12493 angustifólia $W$.

12494 aláta $W$.

12495 prócera $W$.

1805. SIM'SIA. Pers.

12496 ficifólia Pers.

yellow-flowered

لصا pr

purple-flowered $\mathrm{O}$ pr white-flowered $\mathrm{N}$ pr

\section{Coreopsis}

Fennel-leaved y $\Delta$ or whorl-leaved $\frac{\Delta}{\Delta}$ or whorl-leaved
slender-leaved
$\Rightarrow \Delta$ Angelica-leav. Hemp-leaved or three-leaved $\Delta$ or six-leaved climbing jagged-leaved jaggedtrailing Dyer's 7x $\Delta$ or 式 or 词 or \$ 0 or $\$$ Q ear-leaved hroad-ared sharp-notched $\frac{d}{\partial}$ or thick-leaved $\frac{\$}{\Delta}$ or narrow-leaved $\frac{7}{\partial}$ or narrow-leaved $\$ \Delta$ or wing-stalked $\Delta$ or tall Simsia
fig-leaf

12499 denta toothed ${ }_{\mathrm{pr}} 1 \frac{1}{2}$ ap.jl W

1807. ENCE'LIA Cav. ENCELIA.

12500 canescen Cav

1808. SCLEROCAR'PUS. $W$. Sclerocarpus.

12501 africánus $W$

African

1809. CUllu'Mia. $\boldsymbol{H} . \boldsymbol{K}$. Cullumia. 12502 ciliáris $H$. $K$.

12503 setósa $H . K$. ciliated h-lv, 此

1810. BERCKHE'YA. $H$. $K$. BERCKHEYA. 12505 cynaroídes $W$. 12506 obováta $W$ 12507 incána $W$

12508 cuné́ta $W$ 12509 palmáta $W$. 12510 grandiflóra $W$. 12511 uniflóra $W$. 12512 cérnua $H . K$.

1811. DIDEL'TA. $W$ 12513 carnósum $W$. 12514 spinósum $W$.

\section{K. BerCKHEYA.} Artichoke-cup, $\triangle$ or

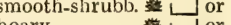
落 palmated or parge-flowered single-flowered $\mathbb{\Delta}$ or drooping-flow.

\section{DIDELTA.} 1 jn $\mathbf{Y}$
OsMites.

Composite. Sp. $1-2$.

Composite. Sp. 1.

1 jl.o Or Vera Cruz 1818. D co Bot, reg. 591 Compositce. Sp. 4-6.

2 o.n Y Mexico 1811. S co Bot. mag. 1689

2 jl.au $\mathbf{Y}$ Mexico 1799. S co Jac. ic. 3. t. 595

2 jl.au Pu Mexico 1799. C l.p Bot. mag. 1535

jl.au W Mexico 1800. S co Jac. schœ.3.t.374 Composita. Sp. 19-32.

3 o.n Y Mexico 1799. D 1.p Bot. mag. 2059

3 jl.o $\quad \mathbf{X}$ N. Amer. 1759. D p.l Bot. mag. 156

2 jl.au $\mathbf{Y} \quad$ N. Amer. 1780. D co Pl.man.t.344.f.4

2 jl.s $\quad \mathbf{Y}$ W. Indies 1752. S co Plum. ic. 53. f. 1

au.s $\mathbf{Y}$ N. Amer. 1785. D p.l

N. Amer. 1737. D p.I Moris.s.7.t.3.f.44

N. Amer. 1812. D co

Jamaica 1699. D lp Herm para 12

W. Indies .... D co Bot. reg. 7

W. Indies 1792 . S co Smith spic. t. 22

Carolina 1724. S co Bot. cab. 821

Missouri 1822. S co Bot. reg. 846

N. Amer. 1699. D p.l Plu.alm. t.83.f.5

N. Amer. 1786. D co

Carolina $\quad . . \quad$ D co

Carolina 1786. D p.

N. Amer. 1778. D p.

Mexico 1803. D co Cav. ic. 3.t. 260

N. Amer. 1765. D p.l Composita. Sp. 2-3.

Mexico 1799. S co Cav. ic. 1. t. 77 ......

1806. D p.l

C. G. H. 1794. C l.p Se. mu.1.t.90.f. 8

C. G. H. 1820. C l.p

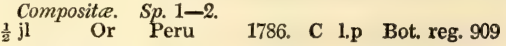

Composite. Sp. 1.

Guinea 1812 S co Jac. ic, 1. 176 Compositer. Sp. 3.

2 my.jn Y $\quad$ C. G. H. 1774. C p.l Bur. afr. t.54. f.1 jn.au $\mathrm{Y}$ Compositce. jn.au Y C. G. H. 1794. C l.p

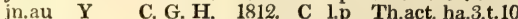
$\begin{array}{llll}\text { jn.au } & \text { C } & \text { C. } H & \text { 1800. C lp Th act.ha.3.t.13 }\end{array}$ jn.au Y C. G. H. 1812. C 1.p Bot. mag. 1844 C. G. H. H. 1815. D co Th. act. haf.3.t.7

Composite. Sp. 2.

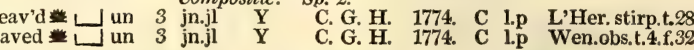

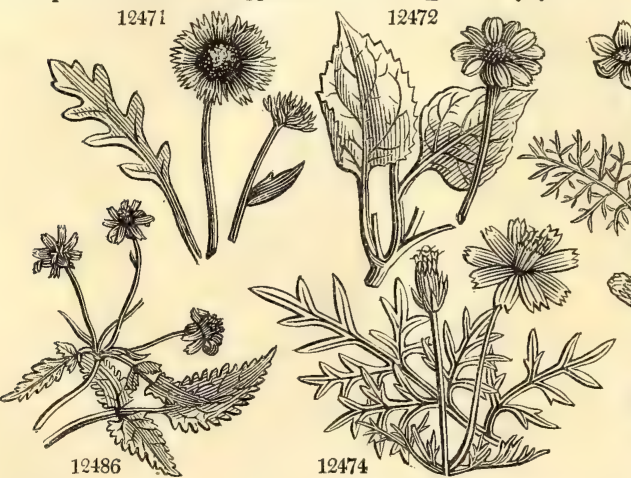

History, Use, Propagation, Culture, Ho.n.h.6.t.34.f. 2 Jac. ic. 3. t. 591 C. G. 1774, S co Meerb ic. 1, t.40

$\begin{array}{lllll}\text { C. G. H. } & \text { 1774. } & \text { C } & \text { l.p } & \text { L'Her, stirp.t. } 28 \\ \text { C. G. H. } & \text { 1774. } & \text { C } & \text { l.p } & \text { Wen.obs.t.4.f.32 }\end{array}$ (iv) 12477

C. G. H. 1780. C l.p

G. H. 1786, C 1.p Th. act. haf.3.t.5

Sp. 8-20

2 .

(1)


12471 Stem branched, Leaves lanc. Paleæ of pappus entire awned

12472 The only species

12473 Leaves pinnate and bipinnatifid, Pinnæ serrated somewhat decurrent, Ray few-flowered neuter 12474 Leaves bipinnatifid : segm. lanc. Segm. of exterior invol. lanceolate

12475 Leaves bipinnate, Leaflets linear subulate, Scales of outer invol. ovate

12476 Leaves bipinnate, Leaflets filiform, Scales of outer invol. lanceolate

12477 Leaves bipinn. Pinnüles lin. lanc. not broader than their rib

12478 Leaves whorled 3 or 5-pinnated : pinnæ lin. 3-parted and undivided, Disk discolored

12479 Leaves whorled 3 or 5-pinnated : pinnæe lin. 3-parted and undivided, Disk same color as ray

12480 Leaves ternate ovate-obl. serrated, Ray same color as disk

12481 Leaves serrated : radical 3-parted : cauline trifid or entire lanc. linear

12482 Leaves entire : radical pinnated; cauline in threes lanc. stalked

12483 Leaves entire ternate sessile

12484 Leaves subternate cuneate serrated

12485 Villous, Leaves stalked quinate and ternate : leaflets ovate-lanc. subpinnatifid or cut serrated

12486 Leaves serrated ovate : upper ternate, Stem creeping

12487 Leaves lanceolate entire ciliated

12488 Rad. leaves pinnate or bipinnate entire, Outer leaves of involucre short, Ray discolored at base

12489 Leaves entire ovate: lower ternate

12490 Leaves ovate acuminate crenate toothed, Grains naked

12491 Leaves stalked lanc. ovate by degrees acuminate finely serrated, Corymbs dichotomous term. and axillary 12492 Leaves obovate oblong entire downy

12493 Leaves alternate lin. lanc. entire smooth, Ray oblong trifid : middle segm. largest

12494 Stem winged, Leaves alternate scabrous roundish ovate cuneate at base 3-nerved

12495 Leaves ellipt. acuminate serrated stalked veiny decurrent : lower whorled; upper alternate

12496 Leaves 3-lobed toothed roughish, Petiole naked at base

12497 Hoary, Leaves somewhat palmate 3-lobed, Petiole leafy at base amplexicaul.

12498 Leaves lanc. obsoletely serrated toothed at base smooth

12499 Leaves obovate toothed villous

12500 Cor. of ray 4-fid nearly equal to disk, Leaves hoary with down

12501 The only species

12502 Leaves ovate smooth imbricated at the edge and rib ciliate-spiny, Spine of the end reflexed 12503 Leaves alternate obl. recurved smooth ciliate-spiny, Leaves of invol, ciliated

12504 Leaves altern. lanc. subulate recurved smoothish ciliat. spiny decurr. at base, Segm. of invol. ciliate spiny

12505 Cauline leaves altern. amplexicaul. ciliate spiny : radical entire unarmed, Scales of invol. entire 12506 Leaves opp. obl. lanc. narrowed at base spiny-toothed smooth, Scales of invol. ciliate spiny

12507 Leaves altern. ovate spiny-toothed 3-nerved netted hoary villous, Scales of invol. toothed spiny villous 12508 Leaves altern. obl. cuneiform spiny-toothed villous on each side, Scales of invol. toothed spiny 12509 Leaves altern. lanc. pinnatifid downy beneath : segm. entire spiny at end, Scales of invol. 3 or 5-fid 12510 Leaves opp. lanc. 3-nerved spiny-toothed downy beneath, Scales of invol. spiny-toothed

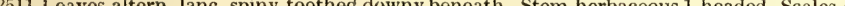
12512 Leaves altern. lanc. amplexicaul, spiny-toothed ciliated smooth on each side, Heads cernuous

12513 Leaves altern. lanceolate oblong fleshy

12514. Leaves opp, somewhat amplexicaul. ovate

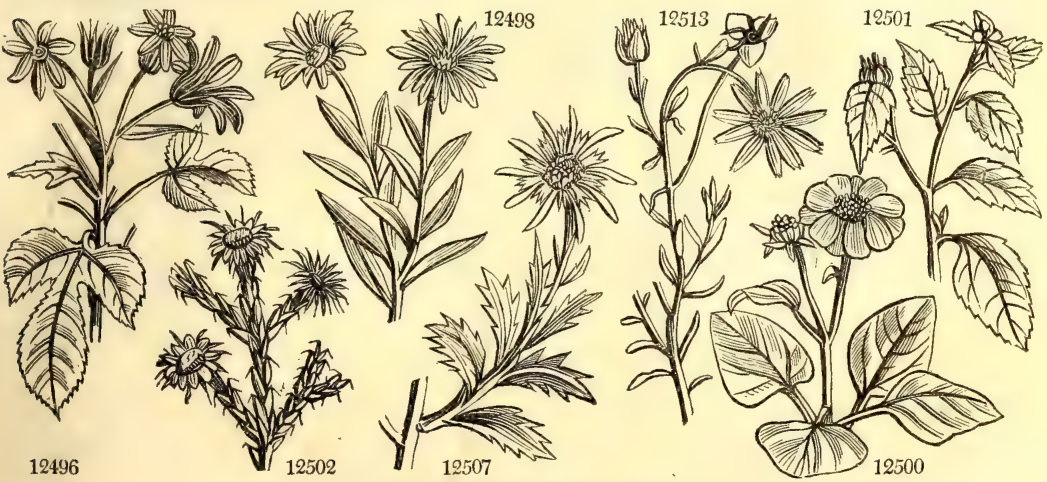

and Miscellaneous Particulars.

1806. Osmites. From orun, perfume. One of the species gives out a strong smell of Camphor.

1807. Encelia. A name of Adanson's, the meaning of which is unknown, A pretty half shrubby plant, with grey soft leaves.

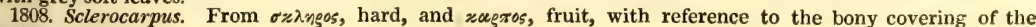
grain.

1809. Cullumia. Named after Sir Thomas Cullum, an English baronet, and one of the earliest promoters of the principles of Linnæus in this country. He is still living, at a very advanced age.

1810. Berckheya. Named after John Lefranc de Berckhey, a Dutch botanist.

1811. Didelta. From $\delta \varsigma$, , double, and $\delta \varepsilon \lambda \tau \kappa$, a Greek letter equivalent to the English $D$; because the receptacle resembles a double triangle. 
1812. GORTE'Ria. $W$. Gorteria. 12515 personátz $W$.

1813. GAZA'NIA. H. $K$. Gazania. 12516 rigens $H$. $K$. 12517 uniflóra $B . M$. 12518 Pavónia $\boldsymbol{H}$. $K$. 12519 subuláta $H . K$. great-flowere garden Peacock awl-leaved

1814. CRYPTOSTEM'MA. CRYptostemm 12520 calenduláceum $H . K$. Marygold-flow. 12521 hypochondriacum $H$.K. divided-rayed 12522 runcinátum $H, K$. Dandelion-lvd.

1815. ARCTOTHE'CA. $W$. Arctotheca. 12523 répens $W$. creeping

$\Delta \mathrm{or}$

1816. SPHENO'GYNE. $H . K$. SPHENOGYNE. 12524 anthemoides $H . K$. white-crowned $\bigcirc \mathrm{el}$ 12525 crithmifólia $H . K$. Samphire-leav. 12526 scariósa $\boldsymbol{H}$. $\boldsymbol{K}$ 12527 abrotanifólia $H . K$. Southernw -lv, 12528 dentáta $H . K$ 10529 odoráta $H . K$ 12530 pilífera $K e r$.

1817. ZWE'GEA. $W$ 12531 Leptaúrea $W$ 1818. LEU'ZEA. Dec 12532 conifera Dec. 12533 altáica Link.

لف or

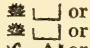

\& $\mathrm{N}$ or Nor

O or

O or smooth-seeded piliferous

\section{ZE'GEA.}

yellow-flowered. $\bigcirc$ un Altai or

jl.au $\quad \mathbf{Y}$

Composita. Sp.

1 jl.au Y C. G. H. 1793. D co Jac.schœ.3.t.306 Composita. $\mathbf{S p} .7$.

$\frac{1}{2}$ jl.s $Y_{Y}^{Y}$ C. G. H. 1774. S co Bot. mag. 544

1 ap.au $Y$ C. G. H. 1768. C l.p Bur.afr.t. 6 5.f.1

1 ap.au $\begin{array}{lll}\mathbf{Y} & \text { C. G. H. 1774. C l.p }\end{array}$

1 my.au Y $\quad$ C. G. H. 1789. C 1.p

$\begin{array}{llll}1 \frac{1}{2} \text { jn.jl } & \text { Y } & \text { C. G. H. } 1787 . & \text { C }\end{array}$

1 ap.jn Y $\quad$ C. G. H. 1774, C l.p

11 ap.jn

Composite. Sp. 1.

C. G. H 1821 C lp Bot. reg. 60 Leuzea. Composite, Sp. $2-5$.

S. Europe 1683, D l.p Ann. mu. 16.t.14

$\begin{array}{lll}\frac{2 y}{2} \Delta \text { or } & 3^{\frac{3}{4}} \mathrm{jn} . \mathrm{s} & \mathrm{Pu} \\ 4 & \mathrm{jn} . \mathrm{s} & \mathrm{Pu}\end{array}$
Composita. Sp. 101-182.

1819. Centaúrea. $\boldsymbol{W}$. Centaury.

12534 phrýgia $W$.

12535 salicifólia Bieb.

12536 pectináta $W$.

12537 austríaca $W$

125,38 uniflóra $W$.

12539 flosculósa $W$.

12540 nervósa W.en.

12541 trichocéphala $W$.

12542 rivuláris Brot.

12543 hyssopifólia $W$.

\section{feathery-caly.}

Willow-leaved

pectinate

Austrian

flosculous

nerved

$\forall \Delta$ or $1 \frac{1}{2}$ jn.o $\mathrm{Pu}$

支 $\triangle$ or $1 \frac{2}{3}$ jn.o $\mathrm{Pu}$

\& $\Delta$ or 1 jl.o

文 $\triangle$ or $1 \frac{1}{2}$ jn.o

is $\triangle \Delta$ or 1 jn.o

ty $\Delta$ or $1 \frac{1}{2} \mathrm{jn} . \mathrm{s}$

downy-calyxed $\frac{\checkmark}{2} \Delta$ or 1 jla $\quad \mathrm{Pu}$

river-side of $\triangle$ or 2 ji.s $\quad \mathrm{B}_{2}$

Hyssop-leaved ${ }_{2}$ or $\frac{2}{2}$ jl.au $\mathrm{Pu}$

12544 nígra $W$ 12545 nigréscens $W$.

Black Knapweed $¥ \Delta \mathrm{w} \quad 1$ my.au Pu dark $\frac{1}{\Delta}$ un $1_{3}^{\frac{1}{3}}$ jn.au $\mathrm{Pu}$

12546 Triumfétti $W$ 12547 montána $W$ 12548 axilláris $W$. 12540 Cý́nus $W$. 12550 paniculata $W$. $12 \tilde{5} 51$ spinósa $W$.

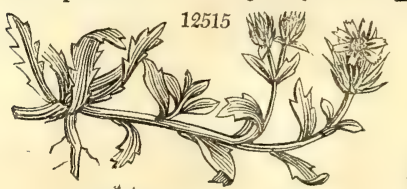
mountain

axillary

15 or jun.au Pu panicled $¥ \mathrm{O}$ or $1 \frac{1}{2} \mathrm{jl}$.au $\mathrm{Pu}$ prickly-branch. Is $\triangle$ or $2^{2}$ jl.s $\mathrm{Pu}$

\section{Switzerl. 1}

Caucasus 1823. D co

France 1727. D co

Austria 1815. D co

S. Europe 1819. D co

Italy 1818. D co

S. Europe 1815. D co

Siberia 1805. D co

Portugal 1812. D co

Gm.s.2.t.45.f.1.2

Spain 1812. C co Barr. jc. 306

Britain past. D co Eng. bot. 278

Hungary 1805. D co

M. Cenis 1820. D co

Austria 1596. D co Bot, mag. 77

Austria 1823. D co

Britain corn fi. S co Eng. bot. 277

Europe 1640. S co Jac. aust. 4.t.320

Candia 1640. C p.1 Bot. mag. 2493

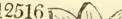

12517

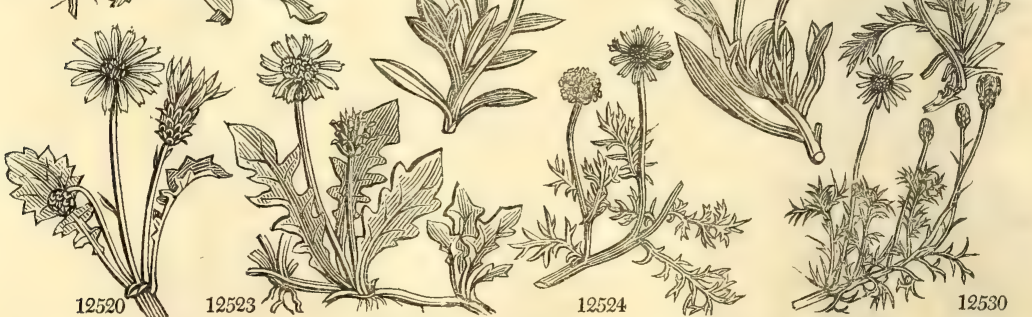

History, Use, Propagation, Culture,

1812. Gorteria Named after David Gorter, a Dutchman, professor of botany at Harderwych, and afterwards physician to Elizabeth. Empress of Russia. He published a Flora Belgica in 176\%, and assisted Kraschenninikoff in his Flora Ingrica. G. Rigens is a very showy plant when the flowers are fully expanded. All the species are of easy culture.

1813. Gazania. Supposed to have been so called from rasa, riches, in allusion to the splendour of the flowers.

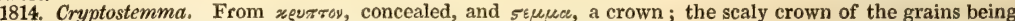
involved in wool. Tender annuals, natives of the Cape of Good Hope.

1815. Arctotheca. See Arctotis, from which this has been divided.

1816. Sphenogyne. So called from $\sigma \phi \eta v$, a wedge, and $\gamma v y \eta_{,}$a female, in allusion to the wedge-shaped stigmas. Pretty annual flowers.

1817. Zoegea. Named after Dr. J. Zoega, who published a Flora Islandica in 1775. Leptourex is an abbreviation of Lepto-centaurea, small centaurea.

1818. Leurea. Divided by M. Decandolle, from Centaurea, from which it differs in not having the outer florets barren, nor the pappus with simple hair, nor the insertion of the fruit oblique. He named it after his friend Deleuze. 
12515 Leaves lanc. entire and sinuater, Stem erect, Flowers stalked

19516 Leaves lanc. spatulate and pinnatifid entire white with down beneath, Pedunc. 1-headed terminal 12517 Stem shrubby decumbent, Leaves spatulate-lanceolate downy beneath, Ray same color as disk 12518 Leaves pinnatifid hairy above downy beneath : segm. oval-lanc. Scape 1-headed, Stem decumbent 12519 Stem leafy decumbent 1-headed, Leaves subulate linear revolute at edge downy beneath

12520 Ligulæ undivided, Leaves pinnatifid toothed downy beneath 12521 Ligulæ 3-5-parted, Leaves lyrate downy

12522 Ligulæ 3-5-parted, Leaves runcinate toothed downy beneath

12523 The only species

12524 Smooth, Lvs. bipinnatifid or pinnatifid linear-filiform, Lvs. of pappus white

12525 Smooth, Lvs. pinnatifid linear filiform, Outer leaflets of invol. subulate

12526 Leaves bipinnatifid or pinnatifid linear filiform smooth, Scales of invol, scarious blunt shining

12527 Leaves bitripinnatifid and invol. downy

12528 Leaves pinnatifid smoothish : segm. 2-3-toothed, Teeth piliferous, Outer scales of invol. lanceolate 12529 Leaves flat smooth cut pinnatifid at end, Outer lvs. of invol. scarious at end, Pappus obsolete 12530 Leaves fleshy linear pinnatifid and bipinnatifid, Pappus much shorter than the florets of disk

12531 The radical and lower cauline leaves pinnatifid

12532 Leaves tomentose : root ones lanceolate; stem ones pinnatifid, Stem simple 12533 Flower very large

\section{Cravus. Involucrum ciliated, unarmed.}

* Involucrum with feathery setce.

12534 Inv. recurved-feathery, Leaves oblong undivided scabrous mucronate serrulated

12535 Inv. recurved-feathery top_shaped, Leaves oblong undivided scabrous mucronate serrulated, Stem simple 12536 Invol. recurved feathery, Leaves mucronate-serrated : lower stem ones sinuate pinnatifid

12537 Invol. recurv, feathery, Lvs, egg-shap.undivid. scabr, gross. tooth. : upp. ones and those of branches undivid. 12538 Invol. recurved feathery, Leaves lanceolate sometimes toothed downy

12539 Invol. recurved feathery, Head without a neutral ray, Leaves hairy lanceolate remotely toothed

12540 Invol. recurved feathery, Leaves ovate lanceolate toothed at base nerved downy, Corollas flosculous

12541 Invol. recurved feathery pubescent, Leaves linear-lanceolate quite entire scabrous

12542 Invol. erect feathery, Lower lvs. lanc. attenuat. into the petiole serrul.; eaul, ov.-obl, downy on each side 12543 Invol, recurved feathery pubesc. Head without a neutral ray, Lvs. lin. quite entire, Stem somew, shrubby

\section{** Involucrum with ciliated appendages.}

12544 Scales of the invol, ovate ciliated with capillary teeth, Lower leaves angular lyrate : upper ones ovate 12545 Innermost invol. scales scarious, Root lvs. obsoletely pinnatif, : lower stem ones somew. tooth. at the base ; upper ones undivided quite entire

12546 Invol. serrated with white ciliæ, Leaves decurrent deeply pinnatifid, Pinnæ generally two

12547 Invol. serrated, Leaves smoothish lanceolate quite entire decurrent, Stem simple

12548 Invol. ciliated variegated, Leaves sessile linear downy, Stem 1-headed

12549 Scales of the involucre serrated, Leaves linear entire : the lowermost toothed

12550 Invol. ciliated egg-shaped, Scales flat close-pressed : Lower lvs. bipinnatif. : upper pinnatif. Stem panicled

12551 Invol, ciliated, Root lvs, undivided and pinnatifid smooth, Stem lvs. downy pinnatifid, Branches spinous

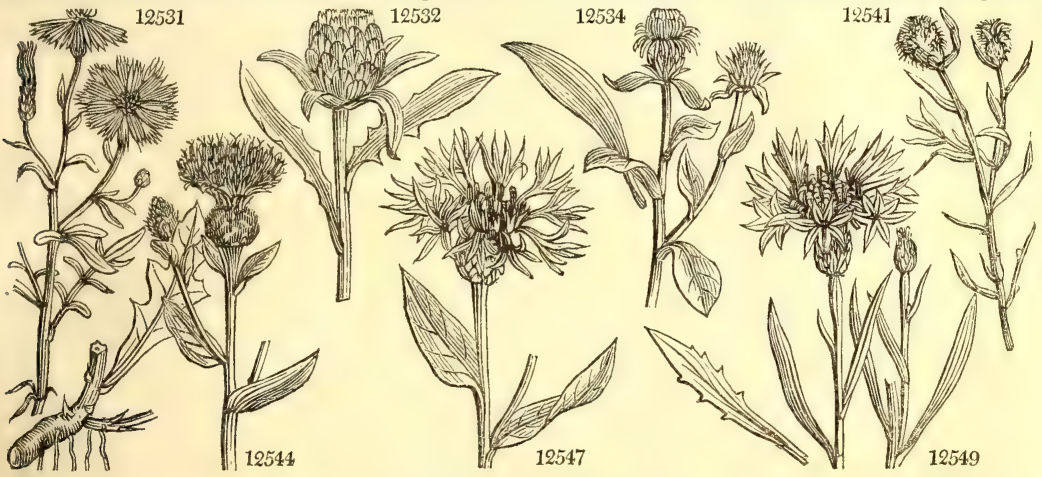

and Miscellaneous Particulars.

1819. Centaurea. It is said, that with this plant, the Centaur Chiron cured the wound in his foot made by the arrow of Hercules. Crupina is from the Dutch verb kruipen, which signifies to creep; because the dark multifid pappus resembles the legs of a creeping insect.

Phrygia signifies dry (థevyos), in allusion to its calyx.

Jacea is said to have been so named from jacere, to lie down, on account of its prostrate habit.

Calcitrapa, the Latin of a caltrop, or iron ball covered with stiff spines, formerly used in warfare to impede the operations of cavalry. Its calyx is very like one of these instruments.

Centaurea Crocodilium is so named, because the spines of the calyx have been fancifully likened to the claws of a Crocodile.

Verutum, the name of another species, is the Latin of a short javelin used by the Roman foot-soldiers. The spines on its calyx resemble a small dart.

C. nigra is a harsh stubborn weed in meadows and permanent pastures, seldom touched by cattle either green or in hay, and with difficulty extirpated. C. cyanus, Bluet, Fr., Kornblume, Ger, and Ciano, Ital., is a common weed in corn fields, on gravelly soils, throughout Europe, and also a popular border annual. The expressed juice of the natural florets makes a good ink; it also stains linen of a beautiful blue, but the coior is not permanent. C. benedicta was so called from its being supposed to possess extraordinary medical powers; it was 
12552 Cinerária $W$ 12553 cinérea $W$. 12554 dealbáta $W$. 12555 argéntea $W$. 12556 coriácea $W$ 12557 Fischéri $W$. en. 12558 macrocéphala $W$. 12559 átropurpúrea $W$. 12560 aláta $W$.

12561 elongáta $W$.

12562 Scabiósa $W$

12563 intybácea $H$. $K$.

12564 maculósa $P$. S

12565 Stoe'be $W$.

12566 ochroleúca $W$.

12567 ovína $W$.

12568 sempervírens $W$.

12569 ragusina $W$.

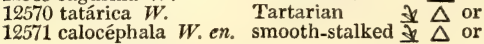

hoary-leaved

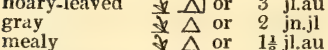
$\frac{7}{4} \Delta$ or $1 \frac{1}{2} \mathrm{jl.au}$ leathery Fischer's v 2 or 2 jn.jl large-headed $\frac{\neq}{\Delta} \Delta$ or 3 jn.au dark-purple $\Delta$ or 3 jn.au winged-stalked $\frac{7}{\Delta}$ or $1 \frac{1}{2}$ au.s long $\quad \Delta$ or 2 au.s

GreaterKnapw. $\frac{1}{4} \quad$ w $1 \frac{1}{2} \mathrm{jn} . \mathrm{au}$ Succory-leaved $\vec{A}$ or $11^{2} \mathrm{jl}$.s spotted-calyxed $\Delta$ or 1 jl.au wing-leaved $\Delta$ or $1 \mathrm{jn} . \mathrm{jl}$ Caucasian $\frac{\mathrm{j}}{\mathrm{a}} \mathrm{\Delta}$ or $1 \frac{1}{2} \mathrm{jl}$.au sheep's $\quad$ or 1 jl.n evergreen $\triangle$ or $1 \frac{1}{2} \mathrm{jl}$.au white-leaved or 2 in.jl Tartarian 2 or 2 jiau

\section{2 coronopifolia $W$ 12573 parviflóra $W$. \\ 12574 refléxa $W$ 12575 centauroídes $W$. 12576 collina $W$. 12577 rupéstris $W$ 12578 pubéscens $W$ 12579 Balsamíta $W$ 12580 aúrea $W$. \\ 12581 peregrína $W$ 12582 radiáta $W$ \\ 12583 sórdida $W$. 12584 hýbrida $W$ 12585 rigída $W$.}

12586 sonchifólia $W$. 12587 cruénta $W$. en 12588 Séridis $W$. 12589 romána $W$ 12590 férox $W$ 12591 sphærocéphala $W$ 12592 Isnárdi $W$ 12593 napif́́lia $W$. 12594 áspera $W$.

12595 pulláta $W$.

12596 polyacántha $W$. 12597 benedicta $W$. 12598 solstitiális $W$. 12599 meliténsis $\boldsymbol{W}$.

12600 sulphúrea $W$. en. 12601 sícula $W$. 12602 Adámi $\dot{W}$.

12603 stramínea $W$.

12604 erióphora $W$. 12605 Calcítrapa $W$. 12606 calcitrapoídes $W$. 12607 Verútum $W$.

12608 regyptíaca $W$.

Buck's-horn
small-flowered
crook-spined
lyre-leaved
hill
rock
downy
Syrian
great-golden
soft-leaved
rayed
sordid
hybrid
rigid

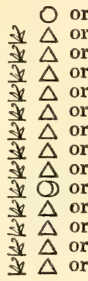

Sow-thistle-lvd. $\rightarrow \Delta$ or obovate-leaved $\$ \Delta$ or purple-flower'd $d \Delta$ or

Roman

hedgehog

\& 0 or

globe-headed

I $N$ or

Jersey

Turnip-leaved

$\Delta$ or

rough

OO or

various-colored $\nexists \triangle$ or

many-spined 10 or

Blessed Thistle

Barnaby's Thistle

cluster-headed

or jn.au

or $2^{\frac{1}{2}}$ jin.

O or 2 jl.au

$\mathrm{O}$ or $\frac{1}{3}$ jl.au

sulphur-colored

Sicilian

O or $\frac{1}{2}$ jl.au

O or $1 \frac{1}{2}$ jl.au

Adams

straw-colored

0 or

woolly-headed

Star-thistle

Phœnician

dwarf

Egyptian

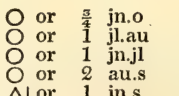

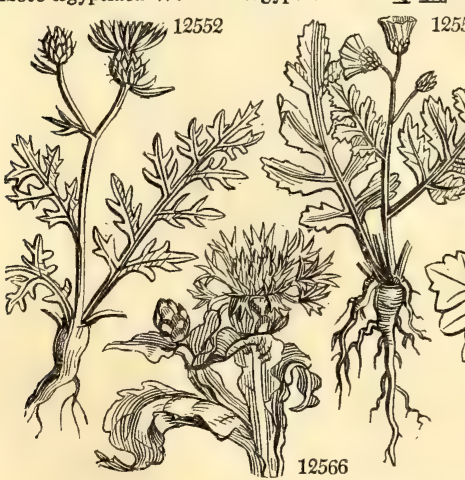

$\mathbf{P u}$
$\mathbf{P u}$
$\mathbf{P u}$
$\mathbf{P a} . \mathbf{Y}$
$\mathbf{P u}$
$\mathbf{V i}$
$\mathbf{Y}$
$\mathbf{P u}$
$\mathbf{Y}$
$\mathbf{V} \mathbf{}$
$\mathbf{P u}$
$\mathbf{P u}$
$\mathbf{P u}$
$\mathbf{Y}$
$\mathbf{P a}$
$\mathbf{Y}$
$\mathbf{Y}$
$\mathbf{Y}$
$\mathbf{Y}$
$\mathbf{Y}$

Italy

1710. D co 1710. D co

Candia 1739. C p.l Hungary 1804. D co Caucasus 1805. D co Hungary 1802. D co Tartary 1781. D co Britain 1823. D co S. Europe 1778. D co Siberia 1816. D co Austria? 1759. D co a.Y Caucasus 1801. D co Caucasus 1802. D co Spain ... 1683. C p.l Candia 1710. C p. Tartary 1801. D co Levant 1816. D co

Levant 1739. S co Barbary 1823. D co Iberia 1801. D co S. Europe 1739. D co S. Europe 1596. D co Italy 1804. D co ...... 1804. D co Syria 1820. D co S. Europe 1758. D co S. Europe 1749. S co Siberia 1804. D co 1818. D co Tauria 1822. D co ...... 1823. D co

Col. ecph. 1. t. 35 Co.ecp.1.t. et f.2

Bot. mag. 421

Gm.sib.2.t.47.f.1

Mediterr. 1780. D co …... 1816. D co Spain 1686. D co 1739. S co Barbary 1790. S p.l S. Europe 1683. D co Britain Jersey. D co Candia 1691. S co S. Europe 1772. S co S. Europe 1759. D co Portugal 1804. S co Spain 1548. S co England fields. S co

$\begin{array}{llll}\text { England fields. S } & \text { co } & \text { Eng. bot. } 243 \\ \text { Maita } & 1710 . & \text { S } & \text { co } \\ \text { Bocc. sic. t. } 35\end{array}$

1..... 1815. S co

Siberia 1804. S co

Egypt 1801. S co W. hort. ber. 26

Y Portugal 1714. S co

England gra.so. S co Eng. bot. 125 $\mathrm{Pu}$ Levant 1683. S co Y Levant 1780. S co Jac. ic. 1. t. 178 Egypt 1790. C p.l
Pluk.phyt.39. f.1

lu.alm. t.38. f.1 arr. rar. t. 504 Eng. bot. 2256

oc. mus. 35. t. 26

Bocc. sic. t. 8. f.1
Herm. par. t.189

History, Use, Propagation, Culture,

said not only to destroy worms and cure fevers, but also the plague, and the most putrid and stubborn ulcers and cancers. At present it is in no estimation whatever.

It has by some botanists been thought advisable to separate this genus into several others; but the differences upon which the separation has been made depend upon variations in the form of the involucrum, 
12552 Invol. ciliated, Leaves downy very white all compound : lowest bipinnatifid ; highest pinnate-laciniated 12553 Invol. ciliated, Leaves somewhat downy cinereous : lower ones pinnate-laciniate; upper ones simple

12554 Invol. ciliated, Lvs. downy undern. Root lvs. bipinnatifid : segm. lanceolate acute, Stem-leaves pinnatifid 12555 Invol. serrated, Leaves downy : root ones pinnated; upper l-eared

12556 Invol. ciliat. smooth, Lvs. pinnatif. scabr. Segm. obl. lanc. acute : highest root ones sometimes cut at base 12557 Invol. ciliated sphacelate, Scales spreading, Leaves obl. lanc. entire villous downy : cauline decurrent 12558 Invol. scales roundish egg-shaped ciliated, Leaves oblong lanc. undivided very scabrous acute serrated 12559 Invol. scales ovate lanceolate serrate-ciliated, Leaves bipinnatifid, Segments lanceolate

12560 Invol. egg-shaped smooth, Scales somew, scar. at tip, Lvs greenish decurr. undivided : radical ones lyrate 12561 Inv. scales scar. at tip serr. Lvs.scab. at edge : root ones obl. tooth.; stem ones lanc.somew.decurr. quite ent. 12562 Scales of the involucre ciliated ovate pubescent, Leaves pinnatifid roughish : the segm. lanceolate acute 12563 Invol. ciliated nearly globular, Leaves deeply pinnatifid, Segments linear

12564 Invol. ciliated ovate roundish beautifully spotted, Leaves slender bipinnatifid, Stem a little paniclea

12565 Invol. ciliated oblong, Leaves pinnatifid linear quite entire

12566 Invol. serrated, Leaves oblong serrated decurrent and undivided

[branched divaricated

12567 Invol. ciliat. Scales ovate-lanc. spread, at tip, Lower lvs. bipinnatif. lanc. lin. : upper ones pinnatifid, Stem 12568 Invol. ciliated, Leaves lanceolate serrated : lowest tooth elongated so as to appear like a stipule

12569 Invol. ciliated, Leaves downy pinnatifid, Segments obtuse egg-shaped quite entire : outer ones largest 12570 Invol. ciliated, Leaves scabrous : underneath pinnatifid, Segments lancenlate sometimes toothed

12571 Invol, scarious, Scales ovate lanceolate serrated ciliated, Leaves scabrous beneath : radical bipinnatifid

\section{\$2. Calcitrapa. Involucrum ciliated with spines.}

* Spines simple.

[panicled

12572 Invol erect feathery, Head without a neutral ray, Lower lvs. pinnatif: upper ones lin. All quite ent. Stem 12573 Invol. ciliate-spinous egg-shaped, Scales reflexed at tip, Lvs. hoary : root ones lyrate; stem ones linear

12574 Invol. ciliate-spinous at tip, Spines of lower scales reflex. Lvs. pinnat. Pinnælin.obt. Root leaves bipinnat. 12575 Invol. ciliate-spinous, Leaves lyrate-pinnated generally entire : terminal lobe large toothed 12576 Invol. ciliate-spinous, Stem-leaves pinnatifid : root ones bipinnatifid, Segments lanceolate 12577 Invol, ciliate-spinous, Stem-leaves pinnated : rost leaves bipinnated, Pinnæ linear-filiform

12578 Invol, ciliate-spin. at tip, Stem-lvs. pinnatif. lin. lanc. : root ones bipinnatif. Segm. lanc. terminal 1-toothed 12579 Invol. ciliate fringed with straight rigid white bristles, Lvs. obl. a little tootlied, Head yell. without a ray 12580 Invol. simply spinous, Spines spreading, Florets equal, Leaves hairy : lower ones pinnatifid 12581 Invol. bristly spinous, Leaves lanceolate petioled toothed near the base

12582 Invol. scarcely spinous somewhat awned rayed, Leaves pinnatifid

12583 Invol. ciliated spinous, Stem-leaves pinnated quite entire : root-leaves bipinnatifid

12584 Invol, ciliate spinous at the tip, Leaves hoary pinnatifid quite entire : upper ones linear-lanceolate

12585 Invol, ciliate subspiny, Leaves oblong downy sessile somewhat toothed; narrowed at base deeply toothed

** Spines palmate.

12586 Invoi. palm.-spin. Spines reflex. Lvs, obl. smooth, embracing the stem $\frac{1}{2}$ decurr, repand tooth. Tecth prickly 12587 Invol. palm.-spinous, Spines reflex. Lvs. obov, somew. tooth. stalked : floral somew. decurr. mucro.-toothed 12588 Inv. paim.-spin. Spines reflex. Lvs. obl. hoary embrac. stem $\frac{1}{2}$-decurr. tooth. cut at base, Teeth rather prickly 12589 Invol. palm. spinous, Lvs. decurr. not prickly : root ones pinnatifid; terminal lobe very large

12590 Inv. palm. spin. Spines reflex. larger than calyx, Lvs. hoary obl. sess. decurr. pinnatifid, Teeth not prickly 12591 Invol. palmate spinous, Lvs. ovate-lanc. petioled toothed

12592 Invol. palmate spinous solitary sess. Lvs. lanc. a little embracing the stem pinnatifid toothed

12593 Invol. palmate spinous, Stem lvs. lanc. toothed decurrent : root lvs. lyrate obtuse

12594 Invol. palmate spinous, Spines 3 or 5, Lvs. lanc. sessile toothed

12595 Invol. ciiiated surrounded by a whorl of long lvs. Lvs. lyrate toothed obtuse

12596 Invol. palmate spinous, Lvs. embracing the stem runcinate pinnatifid prickly : toothed root ones lyrate

12597 Invol. doubly spinous woolly bracteated, Leaves half decurrent toothed spiny

12598 Invol, palm. spinous term. solitary, Spines straight, Lvs. lanc. decurr. not prickly : root ones lyrate

12599 Invol. palm. spin. term. ones clustered sess. Spines straight, Lvs. lanc. scabrous decurr. not prickly : lower stem ones a little toothed; root ones sinuated

12600 Invol. palm. spinous solitary subsessile, Spines straight, Lvs. lanc. scabrous toothletted decurrent

12601 lnv. palm. spin. Spines spread. Lvs. scabr.: stem lvs. lanc. a little embrac. stem finely tooth.; root ones lyrate 12602 Invol, palm. spinous solit. Spines straight: inner scales scarious at the tip, Lvs. downy lanc. decurr. : lower ones finely toothed pinnatifid at the base

12603 Invol. palmate spinous terminal sess. glomerated, Leaves petioled pinnatifid cut-toothed

\section{*** Appendages of involucrum spiny-pinnate.}

12604 Invol, doubly spinous woolly, Lvs. half decurrent entire and sinuated, Stem proliferous 12605 Invol. doubly spinous sess. Lvs, pinnatifid toothed, Stem divaricated spreading hairy 12606 Invol, somewhat doubly serrated, Lvs, embracing the stem lanc. undivided serrated inve lanc. quite 12608 Invol. doubly spinous somewhat woolly, Lvs. sess. lanc. entire and toothed, Stem proliferous

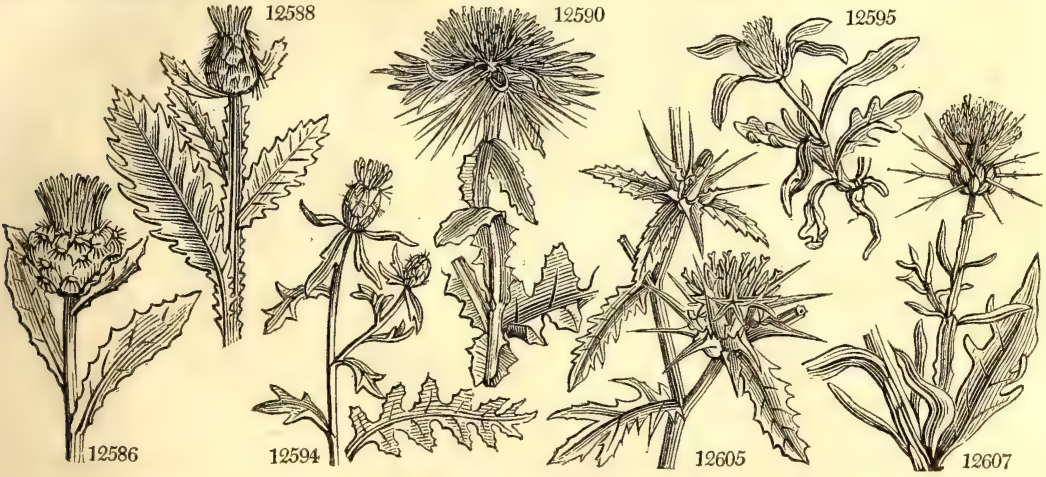

and Miscellaneous Particulars.

unconnected with differences of organization; they are therefore not adopted here. 'The tribe of Centaurca of M. Cassini is not distinguished from Carduinex by any very important characters, The greater part of the species are natives of Europe and Asia, several of Africa, a very few of America, and none of the southern parts of the world. 
12609 salmántica $W$. 12610 muricáta $W$

12611 Crocodýlium $W$.

12612 Rhapóntica $W$ $126 \mathrm{i} 3$ babylónica $W$.

12614 splendens $W$

10615 dilúta $H$.

12616 decúmbens $P . S$

12617 Jácea $W$.

12618 tagána $W$.

12619 álba $W$.

12620 amára $W$.

12621 nitens $\boldsymbol{W}$.

12622 sibirica $W$

12623 glastifólia $W$

12624 orientális $W$.

12625 Béhen $W$

12626 répens $W$.

12627 moscháta $W$.

12628 Centaúrium $W$

12629 ruthénica $W$.

12630 suavéolens $W$

12631 Crupína $W$

12632 Lippii $W$.

12633 glaúca $\bar{W}$

12634 alpina $\boldsymbol{W}$

1820. GALAC'TITES. $P$. $S$. Galactites.

12635 tomentósa $P$. S.

Swiss

Babylonian

shining

saw-leaved

creeping

Sweet Sultan

great

Russian

black-seeded

Lippi's

glaucous

woolly
Ragwort-leaved $\$$ or or 3 jl.au muricated $O$ or 1 jlau blush-flowered $\mathrm{O}$ or $1 \frac{1}{2} \mathrm{jl}$.au

$\frac{\partial}{\partial} \Delta$ or $1 \frac{1}{7}$ jl.au

pale-flowered $\vec{x}$ or 2 jl.au

decumbent $\downarrow \Delta$ or $1 \frac{1}{2} \mathrm{jl}$.s

Brown Knapw. $\frac{\ddagger}{\Delta}$ w $1 \frac{1}{2} \mathrm{jl.s}$

Portugal
white-flowered $\frac{\hbar}{\Delta} \Delta$ or 2
2

bitter $¥ \Delta$ or $1 \frac{1}{2}$ jl.au

shining $\mathrm{O}$ or 2 jl.au

Siberian $>$ or 1 jl.au

Woad-leaved $\vec{x} \Delta$ or 4 jn.s

oriental $\$ \nabla \Delta$ or $1 \frac{1}{2} \mathrm{jl}$.au

$\mathrm{O}$ or $1 \frac{1}{2} \mathrm{jl}$.au

$\exists \Delta$ or jn.au

O or 2 jl.o

Yellow Sultan or $1 \frac{1}{2} \mathrm{jl}$.o

or 3 jn.jl

$\bigcirc$ or 1 jn.j

$\downarrow \Delta$ or jn.jl

\. $\triangle$ or 3 jl.au

Composita. Sp. 1.

Levant 1710. D co Alp. exot. t. 282

Spain 1597. S co

$\mathrm{Pu}$ France 1815. D co

Pu England past. D co Eng. bot. 1678

Pu Portugal 1640. D co

Spain 1597. D co

Italy $\quad \ldots$ D co

1782. D co Gm.sib.2.t.42.f.2

Siberia 1731. D co Bot. mag. 62

Siberia

Levant 1797. S co

Pu Persia 1629. S $\mathbf{s . 1}$

Pa.Y Russia 1806. D co

Y Levant 1683. S s.l

F Italy 1596. S co

Pa.pu Egypt 1739. S co

Pa.Y Caucasus 1805. D co

1640. D co

$\bigcirc$ or $1 \frac{1}{2}$ jl.au $\mathrm{Pu}$ S. Europe 1738. S co
$\mathrm{Kn}$, thes.2, t. C.4

Gmel. sib. 2.t.41 Sweet fl. gard.51 Col.ecphr. 1. t. 34 Corn.can $69 . t .70$

An. mus.16, t, 9

\section{NECESSARIA.}

1821. WEDE'LIA $\boldsymbol{W}$. Wedelia.

12636 hispida $K t h$.

12637 radiósa $\mathrm{Ker}$.

12638 perfoliáta $\boldsymbol{W}$. perfoliate Alcina perfoliaita Cav.

1822. Mille'RiA. $P . S$. Milleria. 12639 quinqueflóra $W$. five-flowered 12640 biflóra $W$. two-flowered

1823. BALTIMO'RA. $\boldsymbol{W}$. Baltimora. 12641 récta $W$. upright

1824. SILPHIUM. $W$. SILPHIUM. 12642 laciniátum $W$. jagged-leaved 12643 compósitum $\dot{W}$, scollop-leaved 12644 terebinthináceum $W$.broad-leaved 12645 perfoliátum $W$. perfoliate 12646 conjúnctum $W$. en. conjoined 12647 connátum $W$. round-stalked 12648 Asteriscus $W$. hairy-stalked 12649 trifoliátum $W$. three-leaved 12650 ternátum $W$. various-leaved 12650 ternátum $W$. 12651 átropurpúreum $W$ varple-stalked
Compositce. Sp. 3-21.

f $\Delta$ or $1 \frac{1}{2}$ jn $Y$ N. Spain 1819. D co Bot. reg. 543

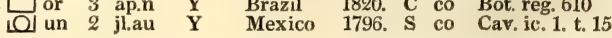

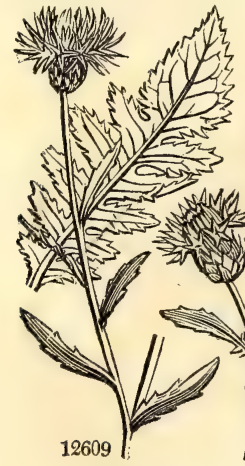

Composita. Sp. 2.

ए] un 2 jl.o $Y$ Vera Cruz 1731. S co Cav. ic. 1. t. 82

[O] un 1 jl.o $Y$ Campeachy1730. S co Mart. dec. 47. f. 1 Composita. Sp. 1.

O un 2 jn.jl Pa.Y Vera Cruz 1699. S co Sch.ha.3.t.261.C Composite. $S p .10-15$.

7 $\Delta$ w 12 jl.s Y N. Amer. 1781. D co Lin. fil. fas.1.t.3 $7 \Delta \mathrm{w} \quad 6 \mathrm{jl.s} \quad \mathrm{Y} \quad$ N. Amer. 1789. D co $\Delta$
$\mathrm{w}$ 6 au.s $\quad \mathrm{Y} \quad$ N. Amer. 1765. D co Jac. vind. 1. t. 43 \ $\Delta$ w 7 jl.o $\quad$ Y $\quad$ N. Amer. 1766. D co $\downarrow \Delta \mathrm{w} \quad 7$ jl.o $\quad \mathrm{Y}$ N. Amer. ... D co $\$ \Delta$ w 6 jl.o $\quad$ Y N. Amer. 1765. D co

$\triangle \quad$ W 5 jl.s $\quad$ Y $\quad$ N. Amer. 1732. D co Dill.elt. t.37.f 49 6 jl.o $\quad$ Y N Amer, 1755, D co Moris.s.6.t. 6.68 4 jl.o Y N. Amer. 1806. D co N. Amer. 1812. D co

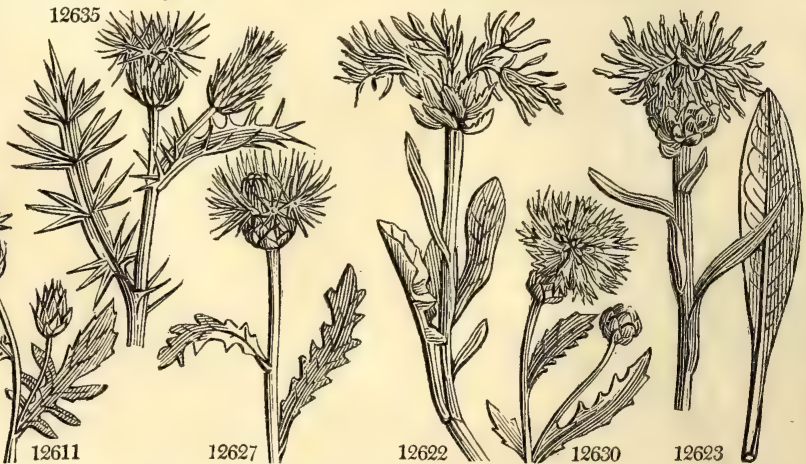

History, Use, Propagation, Culture,

C. moschata is a handsome border annual, of which there is a white-flowered variety. C. Centaurium, montana, splendens, and glastifolia, are among the most ornamental of the perennials.

1820. Galactites. A plant formerly included in Centaurea, and named on account of the milky veins of its leaves ( $\gamma \propto \lambda \alpha$, milk).

1821. Wedelia. Named after George Wolfgang Wedel, a German, born in 1625, died in 1721 . He was professor at Jena, and published many learned dissertations upon the plants of the ancients. There was also a John Adolphus Wedel, professor in the same university. 
\$3. Crocodylium. Involucrum not ciliated, but spiny at end.

12609 Invol. globul. smth. Spine very small weak a little reflex. Lvs. lanc.serrat. : root ones lyrate, Stem divaricat. 12610 Invol. simply spinous villous, Lower lvs. lyrate toothed: upper ones lanc. Peduncles very long 12611 Invol. scarious simply spinous, Lvs. pinnatifid quite entire terminal : segm. larger toothed

4. Rhaponticum. Leaves of involucrum with a round scarious appendage, which is often lacerated. 12612 Invol. scales lacerated, Lvs. ovate-obl. finely toothed tomentose

[ones lyrate 12613 Invol. conical hard, Scales ending in a patulous point, Lvs. somew, tomentose decurr. undivided : root 12614 Inv, egg-shap. Scales mucronat. Lower lvs, bipinnatif. lin. : upper one pinnat. Pinnælin. sometimes toothed 12615 Invol, ciliated, Scales acum. somew. thorny, Lvs. obl. pinnatif. Florets of the ray longer than those of disk 12616 Invol. scarious, Scales dilated cut, Lvs. linear-lanc.: radical cut

12617 Scales of invol, scarious torn : lower ones pinnatifid, Lvs. lin. lanc. : the lower ones broader and toothed 12618 Invol. scales roundish quite ent. Lvs, obl. smth. : root ones serrat. Stem ones sometimes slightly cut at base 12619 Invol. scales entire mucronated, Lvs. pinnate toothed : stem ones linear toothed at the base

12620 Stems decumbent, Lvs. lanc. quite entire

12621 Invol. cylindrical, Scales mucronated, Lvs. pinnated, Pinnæ lin. mucronated quite entire

12622 Invol. scales egg-shaped obtuse ciliated, Lvs. downy on both sides pinnatif. and undivided, Stem declining 12623 Leaves undivided quite entire decurrent

12624. Invol. scales pectinate ciliated, Lvs. deeply pinnatifid, Segm. linear lanceolate [the stem decurrent

12625 Invol. conical, Scales quite ent. Lvs. coriaceous reticularly veined : root ones lyrate; stem ones embracing 12626 Leaves lanc. toothed somewhat petioled, Peduncles filiform leafless

\section{\$5. Leaves of involucrum neither ciliated, nor spiny, nor with a scarious appendage.}

12627 Invol. roundish smooth, Scales egg-shaped, Lvs. lyrate toothed

12628 Invol. scales egg-shaped, Lvs. pinnated, Leaflets decurrent serrated

12629 Invol scales egg-shap. obt. Lvs. pinnat. smooth, Leafl. cartilagin. sharply serrat. termin. one obl. egg-shaped

12630 Invol. round. smooth, Lower lvs, broad somew, spatul, tooth. : upp. ones lyr, at base, Head yell. sweet-scent.

12631 Invol, scales linear awl-shaped, Leaves pinnated serrated

12632 Invol. scales mucronate, Leaves somewhat decurrent lyrate toothed

12633 Invol. pubescent, Scales roundish obtuse, Leaves deeply pinnatifid : lowest segments toothed

12634 Invol, scales egg-shaped obtuse, Leaves pinnated smooth quite entire odd one serrated

12635 Invol, bristly spinous, Leaves decurrent sinuated spinous downy underneath.

\section{NECESSARIA.}

12636 Leaves lanceolate acuminate serrated with a large tonth on each side at the base 12637 Leaves ovate-lanceolate, Invol, urceolate squarrose, Rays imbricated

12638 Stem herbacaous, Leaves rhomboid narrowed at base connate

12639 Leaves stalked roundish-ovate narrowed at base : floral subcordate, Pedunc. terminal dichotomous 12640 Leaves stalked oblong ovate ciliated, Pedunc. terminal aggregate

12641 Stem winged, Heads pale-yellow small

12642 Radical and cauline leaves pinnatifid, Stem hirsute

12643 Cauline leaves sinuate pinnatifid : radical ternate sinuate multifid

12644 Leaves alternate ovate serrated scabrous : radical cordate

12645 Leaves opposite deltoid stalked perfoliate, Stem square smooth

12646 Lvs. opp. conn. unequally toothed, Stem smooth square, Four outer sc. of invol. longer than the inner

12647 Leaves sessile stalked, Stem round scabrous

12648 Leaves opposite or alternate sessile oblong hairy : lower serrate, Stem round hispid

12649 Stems 6-angled, Leaves ternate ovate toothed, Panicle trichotomous

12650 Stems round, Leaves ternate somewhat toothletted, Panicle dichotomous

12651 Stems round, Leaves about 4 toothletted, Panicle dichotomous

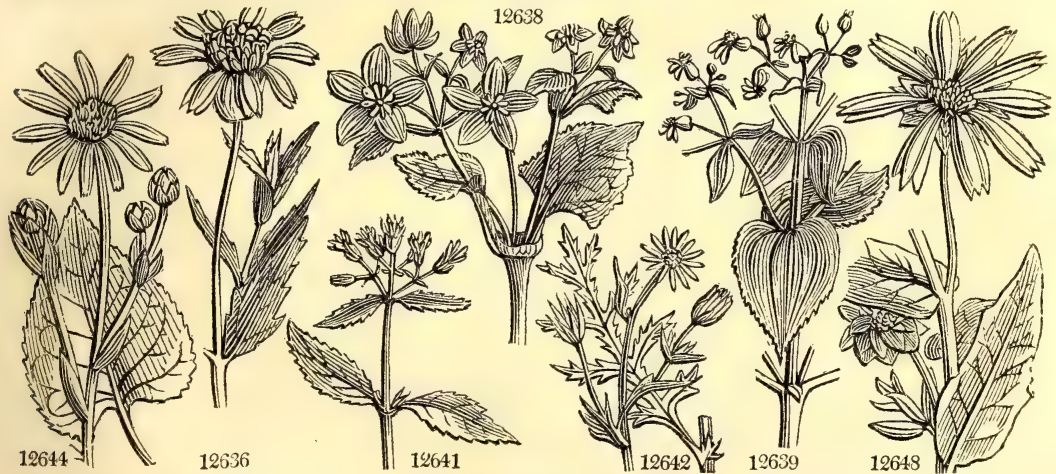

and Miscellaneous Particuiars.

1822. Milleria. So named by Linnæus, after Philip Miller, F. R. S., the well known author of the Gardener's

Dictionary, and considered the first botanical gardener of his time. He was born in 1692, and died in 1769.

1823. Baltimora. This plant grows in the neighbourhood of Baltimore.

1824. Silphium. D'Herbelot asserts, that silphi or serpi, was a name given by the natives of Africa to the plant which produced the laser of the Romans, a substance held in great esteem among them for its flavor and its medicinal properties. All the species are tall herbaceous plants with bright ycllow flowers, and are very proper ornaments for a shrubbery. 
1825. TRIX'IS. Dec. TRIXIS.

12652 senecioídes Hooker Groundsel-li

1826. POLYM'Nia. $W$. Polymia.

12653 canadénsis $W$. Canadian

12654 Uvedilia $W$

12655 abyssinica $W$

broad-leaved upright

Composita. $S p .1-5$.

1827. CHRYSO'GONUM L CHRYsocoNUM

12656 virginiánum $L$. Virginian $\$ \Delta \mathrm{pr}$

1828. MELAMPO'DIUM. $W$. Melampodium.
12657 americánum $W$. Compositas. Sp. 2-6.

- 1 un $1 \frac{1}{2}$ au.o W

1829. CHAPt ${ }^{\prime}$ Lia. Vent. Chaptalia.

12659 tomentósa $P h$. woolly

1830. CALEN'DULA. $W$. Marygold.

12660 arvénsis $W$. field

12661 sícula $W$. en. Sicilian

12662 stelláta $W$. starry

12663 officinális $W$.

B pléria

12664 sáncta $W$.

12665 incána $W$.

12666 pluviális $W$.

12667 hýbrida $W$

12668 nudicaúlis $W$

12669 graminifólia $W$.

12670 Trágus $W$. $\beta$ fláccida $\mathrm{V}$.

12671 viscósa $H . K$.

12672 oppositifólia $W$

12673 fruticósa $W$

12674 chrysanthemifólia $V$.

12975 arboréscens $W$.

12676 suffruticósa $W$.

12677 denticuláta $W$.

12678 muricáta $W$.

common

double-flowered

pale-flowered

hnary

Small Cape

Great Cape

naked-stalked

Grass-leaved
bending-stalk'd or

flaccid

viscous or

glaucous-leav'd $\square$ or

shrubby $\sqcup$ or

large-flowered $\downarrow$ or

rough-leaved
suffruticose

muricated

1821. S co Hook. ex. fl. 101

Composite. Sp 3-4.

1831. ARCTO'Tis. H. $K$. Anctotis.

12679 acaúlis $W$.

12680 trícolor $W$.

12689 gandinón $H$.

12683 glaucophýlla $W$.

12684 plantagínea $W$.

12685 argéntea $W$.

12686 rósea $\not V$.

12687 decúmbens $W$.

12688 angustifólia $W$

12689 fláccida $W$.

12690 decúrrens $W$.

12691 melanocícla $W$. en.

12692 réptans $W$.

12693 auriculáta $W$

12694 fastuósa $W$.

ored $\underline{N}$ or

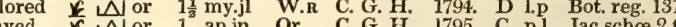

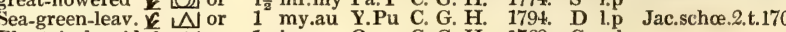

Plantain-leav'd $\mathbb{N}$ or 1 jn.au Or C. G. H. 1768. C p.1

silver-leaved 1 or 1 au Or C. G. H. 1774. D 1.p

Rose $\triangle$ or 1 jl.s Pk C. G. H. 1793. C 1.p Jac.schœ.2.t.162 decumbent $\mathbb{N}$ or 1 jl.s $\quad \mathbf{Y}$ C. G. H. 1790. D 1.p Jac.schœ.3.t.381 narrow-leaved $\begin{array}{llll}1 \frac{1}{2} \mathrm{jl} . \mathrm{s} & \text { Pu } & \text { C. G. H. 1739. C } 1 . \mathrm{p}\end{array}$ bending-stalked 1 or 1 my.jl W.r C. G. H. 1794. S 1.p Jac.schœ.2.t.163 decurrent or $1 \frac{1}{2}$ jn.jl W.R C. G. H. 1794. C l.p Jac.schœ.2.t.165 various-colored $\square$ or 1 jn.jl W.pu C. G. H. 1812. C 1.p

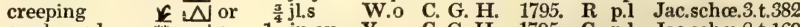
$\begin{array}{lllll}\text { ear-leaved } & \text { or } 1 \text { jn.au } & \text { C. G. H. 1795. C p.l Jac.schœ.2.t.169 }\end{array}$

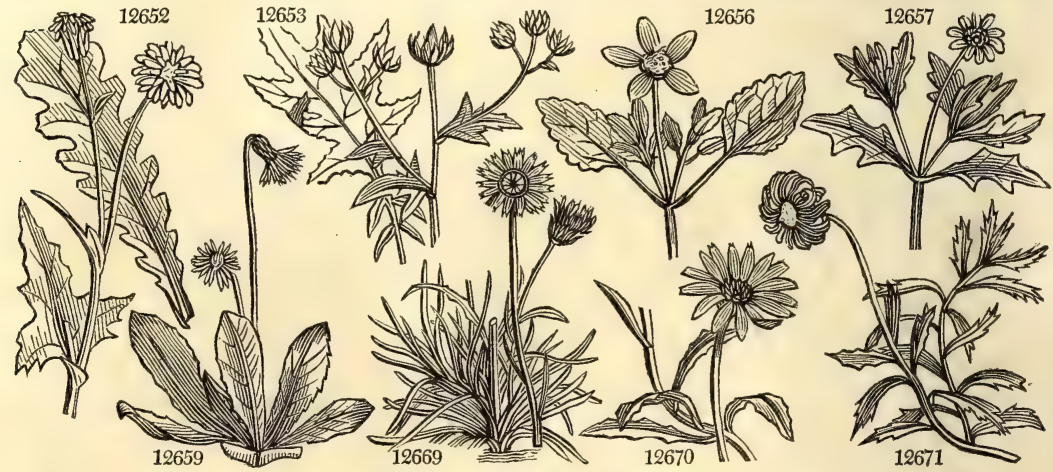

History, Use, Propagation, Culture,

1825. Trixis. From res

1826. Polymnia. Polymnia was the name of one of the Muses. Why it has been applied to this plant is not very obvious. A coarse broad-leaved weedy plant.

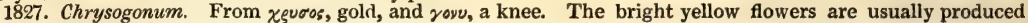
in the bends of the stems.

1828. Melampodium. One of the Greek names of black hellebore, with which the modern plant has no relation. The plant of the ancients was probably named from the blackness of the roots, ( $\mu \varepsilon \lambda \lambda_{\infty}$, black, and $\pi$ ss, a foot).

1829. Chaptalia. Dedicated by Ventenat to the famous French chemist, M. Chaptal. A pretty little North American herbaceous plant.

1830. Calendula. So named because it may be found in flower during the Calends of each month, or, which is the same thing, during every month in the year. C. pluvialis has been named from its flowers closing at the approach of rain. 
12652 Herbaceous downy, Leaves sinuate pinnatifid toothed: cauline amplexicaul.

12653 Leaves toothletted acuminate : lower pinnatifid ; upper 3-lobed or entire 12654 Leaves 3-lobed acute running down the petiole : lobes angular sinuated

12655 Leaves opposite sessile oblong lanceolate somewhat toothed, Invol, 5.-parted, Florets all femalc

\section{Leafstalks longer than leaves}

12657 Stem erect, Leaves somewhat linear 1-toothed on each side 12658 Stem erect, Leaves lyrate-toothed sessile

\section{Leaves ovate-oblong entire silvery beneath, Scape naked 1-headed, Head nodding}

12660 Pericarps cymbiform muricated incurved : outer lanceolate-subulate muricated at back

12661 Pericarps cymbiform muricated incurved : outer ovate with a membranous edge toothed crested at back 12662 Pericarps cymbiform incurved muricated : outer 5 ovate-lanceolate membranous toothed at edge

12663 Pericarps cymbiform all incurved muricated

12664 Pericarps urceolate obovate smooth, Involucre somewhat muricated

12665 Pericarps cymbiform smooth : outer subulate erect somew. muricat. Lvs. obl. spatul. downy on each side 12666 Leaves narrow lanceolate sinuate toothletted, Stem leafy, Peduncles filiform

12667 Leaves oblong lanceolate blunt toothed, Stem leafy, Peduncles thickened at end

12668 Leaves lanceolate sinuate toothed, Stem nearly naked

12669 Leaves linear nearly entire, Stem nearly naked

12670 Leaves linear somewhat toothletted muricate dotted beneath, Pericarps orbicular, Stem suffruticose

12671 Leaves cuneate cut toothed glabrous, Invol. downy ciliated, Stem shrubby weak

12672 Leaves opposite linear entire somewhat fleshy smooth

12673 Leaves obovate somewhat toothed, Stem fruticose decumbent

12674 Leaves obovate sublyrate roughish, Stem suffruticose erect

12675 Lvs, obl, toothed scabrous, Invol, in fruit cernuous, Pericarps nearly orbicular, Stem fruticose panicled

12676 Peric. cymbif. incurv. muricat. : outer lanc. subulate muricated erect, Lvs. obl. spatul. downy on each side

12677 Pericarps all uniform incurved cymbiform muricated, Leaves lanceolate toothletted acute smoothish

12678 Leaves oblong papillose scabrous: lower toothed; upper entire, Stem shrubby

12679 Radiant florets fertile, Stem very short decumbent, Leaves hoary on each side ternate lyrate

12680 Radiant florets fertile, Leaves downy beneath ovate entire or lyrate-toothed, Scape furrowed 1-headed

12681 Radiant florets fertile, Leaves downy beneath wavy-toothed ovate or lyrate, Scapes 1-headed

12682 Leaves pinnatifid toothletted cobwebbed 3-nerved

12683 Radiant florets fertile, Leaves hoary pinnatifid repand somewhat toothed, Outer scales of invol. reflexed

12684 Radiant florets fertile, Leaves lanceolate ovate nerved toothletted amplexicaul.

12685 Radiant florets fertile, Leaves lanceolate linear entire downy

12686 Radiant florets fertile, Stem procumbent, Leaves spatulate-lanceolate repand-tonthed hoary

12687 Radiant florets fertile, Stem procum. Leaves obl. lanc. unequally toothed hoary downy beneath $3-n e r v e d$

12688 Radiant florets fertile, Stem branched ascending, Leaves downy spatulate lanceolate 3-nerved pubescent

12689 Radiant florets fertile, Stem branched ascending, Leaves spatulate lanceolate entire 3-nerved downy

12690 Radiant florets fertile, Stem shrubby, Leaves hairy oblong undivided somewhat toothed

12691 Radiant florets fertile, Stem shrubby erect hoary, Lvs. obov. oblong vill. toothed decurr. down the petiole

12692 Radiant florets fertile, Stem ascend. Lvs. hairy hoary beneath : lower lyrate-toothed; upper lanc. tooth.

12693 Radiant florets fertile, Stem snow white, Leaves lyrate amplexicaul, downy toothed : term. lobe rhomb.

12694 Radiant florets fertile, Stem erect, Leaves hairy oblong toothed, Outer scales of invol. reflexed ciliated

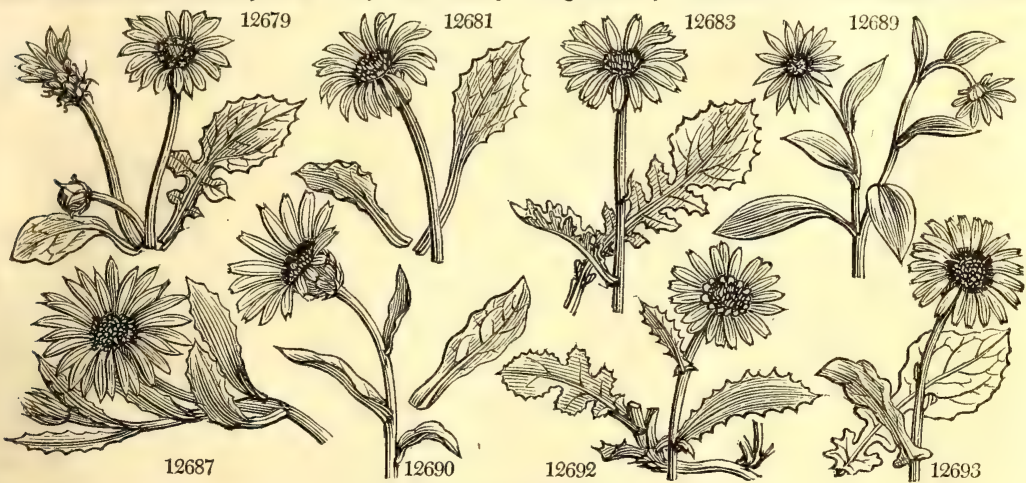

and Miscellaneous Particulars.

C. officinalis, Souci du jardin, Fr., Goldblume, Ger., and Furrancio, Ital., has been a garden plant time out of mind, and used in soups and broths, both to color them, and as comforters of the heart and spirits. formerly many virtues ascribed to it, but is now totally out of use in this country. the flowers are open from nine in the morning till three in the afternoon. There are double, lemon-colored, and prolific varieties. From the flowers of Calendula officinalis is obtained a distilled water, a kind of vinegar, and a conserve.

With this genus for his type, M. Cassini has formed a small tribe which he calls Calenduleæe, remarkable for a peculiar smell, very perceptible in the common pot-marygold, which is said to be confined to themselves alone. But this seems to be almost the only character by which they are distinguished from Helianthea. The greater part of Calenduleæ are found in the country of the Cape of Good Hope; but some are found in curope and Asia.

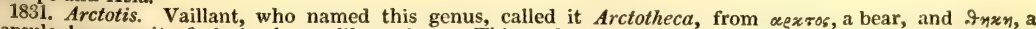
capsule, because its fruit is shaggy like $a$ bear. This and some neighbouring genera have given rise to $M$. 
12695 spinulósa $W$. 12696 maculáta $W$ 12697 áspera B. reg. 12698 auréola $B$. reg. 12699 bícolor $W$ en 12700 speciósa $\boldsymbol{B} . \boldsymbol{M}$. 12701 eiátior $W$.

12702 arboréscens $W$ 12703 cúprea $W$. 12704 Cinerária $W$.

1832. OSTEOSPER'MU 12705 corymbósum $W$. 12706 spinósum $\boldsymbol{H}$. $K$. 12707 spinéscens $\dot{H}$. $\boldsymbol{K}$ 12708 pisíferum $W$. 12709 moniliferum $W$. 12710 ilicifólium $W$. 12711 rígidum $W$. 12712 cærúleum $W$. 12713 polygaloídes $W$.

1833. OTHON'NA. $W$ 12714 pinnáta $W$. 12715 pectináta $W$. 12716 Athanásiæ $W$. 12717 abrotanifólia $W$. 12718 retrofrácta $W$. 12719 coronopifólia $W$ 12720 cheirifólia $W$. 12721 Tagétes $W$. 12722 flabellifólia $B$.C. 12723 crassifólia $W$. 12724 denticuláta $\dot{W}$ 12725 heterophýlla $\dot{W}$. 12726 Lingua $W$ 12727 tilicaúlis $W$. 12728 bulbósa $W$ 12729 perfoliáta Jac. 12730 parviflóra $W$. 12731 ericoídes $W$. 12752 tenuíssima $W$. 12733 arboréscens $W$ 12734 cacalioídes $W$.

1834. HIP'PIA. $W$ 12735 frutéscens $W$. 12736 integrifólia $\boldsymbol{W}$. 12737 anthemifólia $R$. Br. Chamomile-lvd. Gymnóstyles anthemifolia Juss.

1836. PSIA'DIA. $\boldsymbol{W}$. Psiadia. 12738 glutinósa $W$.

1837. ERIOCE'PHALUS. $W$. Eriocephalus 12739 a fricánus $W$ cluster-leaved to 12740 racemósus $W$. silver-leaved Cotton Rose. common 1838. FILA'GO. $L$ 12741 germánica $L$ 12742 gállica $L$ 12743 pyramidáta $L$.

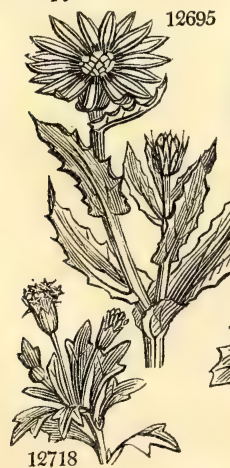
pyramidal
O un $\frac{\overline{3}}{4}$ jn.au Y.Br Britain san.fi.' S co Eng. bot. 948

잉 $1 \frac{1}{2}$ my au Or

C. G. H. 1795. S co Y C. G. H. 1710. C p.1 Bot. reg. 34 Or C. G. H. 1710. C p.l Bot. reg. 32 W.R C. G. H. 1812. C I.p Y C. G. H. 1812. C p.1 Bot. mag. 2182 Y.Pu C. G. H 1820 C p.l Jac sche 2.t.172 W.pk C. G. H. 1818. C p.l Jac.schœ.2.t.171 $\begin{array}{lllll}\text { Y.Pu C. G. H. } & 1823 . & \text { C } & \text { p.l } & \text { Jac.scho.2.t.176 } \\ \text { Y.o C. G. H. } & \text { 1824. } & \text { D p.l Jac.schœ.2.t.174 }\end{array}$ Composita. Sp. 9-27.

\begin{tabular}{lll}
\multicolumn{3}{c}{ Compositce. } \\
3 & au & $\mathbf{Y}$ \\
3 & f.o & $\mathbf{Y}$ \\
3 & mr.jn & $\mathbf{Y}$ \\
4 & mr.my & $\mathbf{Y}$ \\
3 & jl.au & $\mathbf{Y}$ \\
4 & jl.au & $\mathbf{Y}$ \\
3 & ap.jl & $\mathbf{Y}$ \\
3 & jn.s & $\mathbf{B}$ \\
3 & jn.s & $\mathbf{Y}$
\end{tabular}

Composita.

3 ap.jn $\mathbf{Y}$

3 n.d $Y$

ja.mr $Y$

2 jl.s.

$1 \frac{1}{2}$ ap.jn

1 ap jn

1 ap.jn

2 s.o

ap.j

2 ap.jl

$2 \frac{1}{2}$ my.s $\quad Y$

$1 \frac{1}{2}$ ap.my $Y$

11 my.jn $Y$

$1 \frac{1}{2}$ my.j

2 jl.au

$1 \frac{1}{3}$ ap.jl

2 jl.au $\mathbf{Y}$

Compositce.

$\begin{array}{ll}\frac{1}{2} \mathrm{f} . \mathrm{au} & \mathbf{Y} \\ \text { jl.au } & \mathbf{Y}\end{array}$

C. G. H. 1822. $\mathrm{C}^{-1}$ 1.p

C. G. H. 1700. S 1.p Corn. hort.2.t.43

C. G. H. 1793. C 1.p Jac.schce.3.t. 377

C. G. H. 1714. S 1.p Dil. elt. t.68. f.79

C. G. H. 1816. C l.p Bur.afr.172.t.62

C. G. H. 1774. C l.p

C. G. H. 1774. C 1.p Jac. ic. 1. t. 179

C. G. H. 1759. C J.p Pluk.mant.t.382 Sp. $21-39$.

C. G. H. 1759. C 1.p Bot. mag. 768

C. G. H. 1731. C p.l Bot. mag. 306

C. ${ }^{2}$ 1795. C p.1 Jac.schoe.2.t.2

C. G. H. 1812. C l.p Jac.schœ. 3.t.376

C. G. H. 1731. C p.l Com. hort.2.t.70

Barbary 1752. C p.l Bot. reg. 266

C. G. H. 1823. S co

C. G. H. 1821. C co Bot. cab. 728

C. G. H. 1710. C p.l Mil.ic.2.t.245.f.2

C. G. H. 1774. C p.l Bot. mag. 1979

C. G. H. 1812. C l.p

C. G. H. 1787. D l.p Jac.schœ.2.t.238

C. G. H. 1791. D l.p Jac sche.2.t.241

C. G. H. 1774, D l.p Breyn. cent. t.66

C. G. H. 1789. D 1.p Bot. mag. 1312

C. G. H. 1704. C p.l Volk.norib.t.226

C. G. H. 1815. C l.p

C. G. H. 1759. C 1.p Jac.schœ.2.t.239

C. G. H. 1723. C p.1 Dil.el.t.103.f.122

C. G. H. 1774. D I.p

Sp. $2-5$.

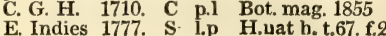

Compositce. Sp. $1-6$

Composita. Sp. 1.

Mauritius 1796. C p.I Jac schœ .2.t.152

Composita. Sp. 2-4.

3 ja.mr Y $\quad$ C. G. H. 1732. C p.1 Bot. mag. 833

mr.ap Y C. G. H. 1739. C

Composite. Sp. 16-21. un $\frac{5}{4}$ jn.au Y.Br Britain san.fi. S co Eng. bot. 2369 O un $\frac{1}{4}$ jn.au Br.Y S. Europe 1779. S co
3 ap.jn $\mathbf{Y}$

mr.au Y

C. G. H. 1757. S l.p Bot. cab. 470
12707
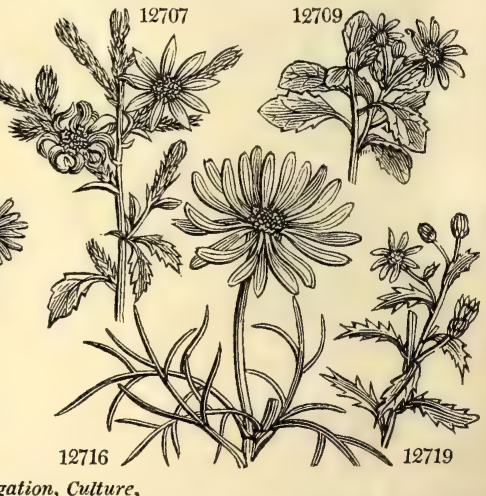

\section{History, Use, Propagation, Culture,}

Cassini's tribe of Arctotidex, which has the remarkable peculiarity of occasionally producing an ovarium with three cells. In the peculiarities of their style they approach the tribes of Echinopseæ, Carduineæ, Cen.taurex, and Carlineæ. They are entirely confined to the regions of the Cape of Good Hope.

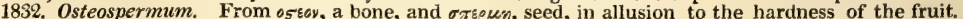

1833. Othonna. Dioscorides mentions this name as being applied to various things, but especially to a plant with a leaf like rocket, but perforated with little holes, whence it was called Othonna, from orovn, linen. The plant of the ancients can have had little affinity with that of the moderns.

1834. Hippia. A name applied by Cordus to the common Chickweed, because it was agreeable food for 
12695 Radiant florets fertile, Stem erect, Leaves hoary viscid oblong amplexicaul. mucronate-toothed 12696 Radiant florets fertile, Leaves pinnatifid lyrate angular toothed downy beneath

12697 Radiant forets fertile, Stem erect, Leaves pinnatifid scabrous downy beneath revolute at edge

12698 Radiant thorets fertile, Outer scales of invol. reflexed cuneate obl. with a broad short point somew. cobw. 12699 Radiant florets fertile, Stem erect, Leaves pinnatifid lyrate hoary downy beneath, Invol. imbricated 12700 Stemless, Leaves lyrate pinnatifid hoary beneath 3-nerved, Outer scales of invol. linear recurved 12701 Radi. flor. fertile, Stem erect, Branches downy hairy, Lvs. pinnatif. downy ben. : seg. lin. lanc. angul. downy 12702 Radiant florets fertile, Stem erect, Pedunc. hairy, Lvs pinnatif. hoary downy ben. : seg. lanc. angul. toothed 12703 Radiant florets fertile, Stem erect, Leaves downy beneath : segm. linear subpinnatifid wavy

12704 Radiant florets fertile, Leaves hoary downy long-stalked pinnatifid : segm. lanceolate blunt toothed

12705 Leaves lanceolate glabrous, Heads panicled

12706 Leaves obovate serrate downy, Spines branched

12707 Leaves lanceolate pinnatifid-toothed scabrous, Spines branched

12708 Leaves lanceolate mucronate somewhat stalked smooth serrated, Branches toothletted angular

12709 Leaves obovate serrated stalked subdecurrent

12710 Leaves oblong toothed-angular scabrous $\frac{1}{2}$-amplexicaul. Branches furrowed

12711 Leaves toothed pinnatifid hairy, Branches unarmed

12712 Leaves pinnatifid smooth, Segments lanceolate unequally serrated

12713 Leaves lanceolate scattered decurrent smooth entire, Axillæ woolly

12714 Leaves pinnatifid : pinnæ lanceolate entire decurrent

12715 Leaves pectinate-pinnatifid downy : segm. linear toothed at the edge

12716 Leaves pinnate filiform, Invol. hemispherical many-toothed

12717 Leaves multifid pinnated linear, Joints of stem villous

12718 Leaves lanceolate 1.toothed on each side in the middle or entire, Peduncles axillary, Stem divaricating

12719 Lower leaves lanceolate entire : upper sinuate toothed

12720 Leaves lanceolate 3-nerved entire, Stem suffruticose creeping

12721 Leaves deeply pinnatifid glabrous : segments linear somewhat toothed, Stem herbaceous

12722 Leaves pinnatifid very small, Peduncles long slender axillary 1-headed, Ray longer than disk

12723 Leaves lanceolate entire somewhat fleshy, Stem erect

12724 Leaves oblong toothletted smooth narrowed at base amplexicaul. Heads panicled

12725 Radical leaves ovate angular toothed : cauline lanceolate entire

12726 Leaves entire : radical lanceolate; cauline lanceolate subcordate $\frac{1}{2}$-amplexicaul. Stem erect

12727 Leaves entire : radical cordate; cauline ovate-lanceol. cordate at base amplexicaul. Stem flaccid filiform

12728 Leaves ovate somewhat toothed, Peduncles 1-headed very long

12729 Root tuborous, Leaves amplexicaul. Peduncles 1-headed

12730 Leaves lanceolate smooth amplexicaul. Heads panicled

12731 Stem dichotornous imbricated: leaflets acerose, Peduncle vंery long solitary in the divarications

12732 Leaves filiform fleshy, Stem shrubby

12733 Leaves oblong entire, Stem arborescent fleshy with woolly scars

12734 Fleshy naked smooth a span high, Leaves fascicled obovate sessile, Peduncle 1-headed

12735 Shrubby villous, Leaves pinnatifid, Heads corymbose

12736 Hispid erect, Leaves ovate serrated 5-nerved, Racemes terminal

12737 Leaves pinnated : leaflets linear many-times lobed acute, Pericarps cuneiform hairy

\section{The only species}

12739 Leaves entire and divided, Heads corymbose

12740 Leaves linear silky

12741 Stem erect prolifer. at summit, Lvs. lanc, downy acute, Fls, capitate in the axils of branches and terminal 12742 Stem erect dichotom. Lvs. lin. acum. downy, Fls. crowded axill. and term. Clust. much shorter than leaves 12;43 Stem erect subdichotomous, Leaves lanceolate spatulate downy, Flowers clustered axillary and terminal

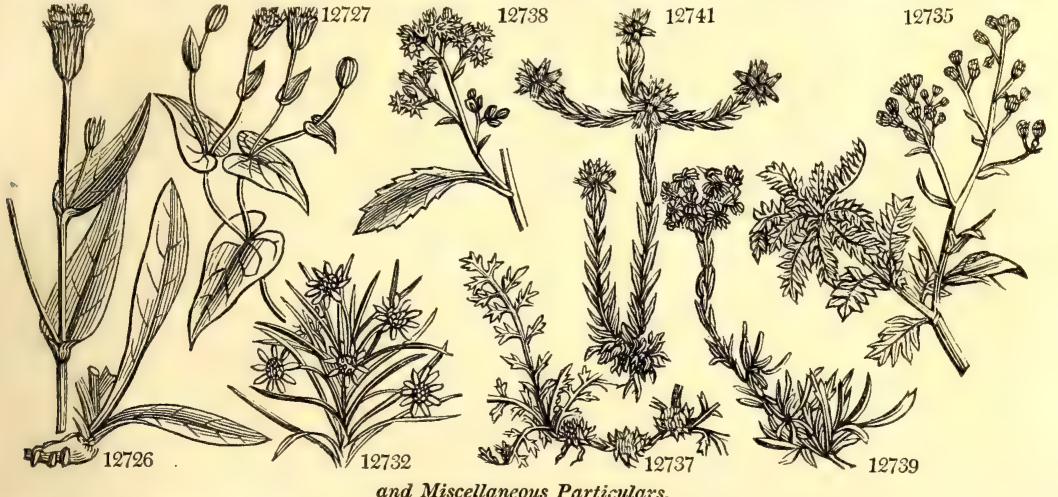

and Miscellaneous Particulars.

horses, i $\pi \pi 0$, a horse; and given to this plant by Linnæus for no reason whatever. Liitle plants resembling Tansy.

1835. Soliva. Named by the authors of the Flora Peruviana, after Salvator Soliva, a Spanish physician and botanist.

1836. Psiadia. From $\psi\llcorner\propto 5$, a drop of dew, in allusion to the dew-bespangled foliage of the plants.

1837. Eriocephalus. From sesoy, wool, and $\approx s \varnothing \alpha \lambda \eta$, a head, on account of the woolly grains collected in terminal heads.

1838. Filago.

All the paits of these plants are covered with delicate threads or fila 
12744 montána Pers 12745 minima Pers. 12746 arvénsis Pers. 12747 Lagópus Pers. 12748 rec'ta $^{\prime}$

12749 coarctáta

12750 americána

12751 supina $L k$

12752 pusílla Honke.

12753 sphæ'rica $L k$.

12754 cephaloídea $L k$.

12755 uliginósa

12756 sỳlvática

1839. MICRO'PUS. $W$.

12757 supinus $W$.

12758 eréctus $W$.

mountain

least

corn

Hare's-foot

upright-wood

contracted

Jamaica

dwarf

pygmy

spherical

large-headed

marsh

highland

\section{Micropus}

trailing

upright

1840. Parthe'NiUM. $W$. Parthenium. 12759 Hysteróphorus $W$. cut-leaved 12760 integrifólium $W$.

1841. I'VA. $W$.

1841. I'VA. $W$.
12761 ánnua $W$.

shrubby

Iva.
annual
shrubby

$\bigcirc$ un $\frac{x}{4}$ jn.au

O un ${ }^{\frac{1}{8}} \mathrm{jl.au}$

un ${ }^{2}$ jl.au

\$) $\triangle$ un $1^{2}$ au

O un 1 au

$\triangle$ un 1 jl.au

$\frac{\Delta}{\Delta}$ un $\frac{1}{4}$ jn.jl

\& $\Delta$ un 1 in jn.jl

O un $\frac{1}{2}$ jn.jl

On 1 au

\&) $\triangle$ un 1 au

Br.Y S. Europe 1820. S co Y.Br Britain sa.pas. S co Y.Br Europe 1804. S co Y.Br Siberia 1820. S co Y.Br Britain sa.pas. D co Br M.Video 1819. D co Pa.Y Jamaica 1815. D co Y.Br Scotland sc.alp. D co Y.Br Austria 1820. D co W N. Holl. 1819. D co Y.w N. Holl.? 1823. S co Y.Br Britain wat.pl. D co Eng. bot. 1194 Y.Br Britain al.pas. R s.1 Eng. bot. 913

Compositce. Sp. 2-3.

O un $\frac{1}{2}$ jri.s $\quad$ S. Europe 1710. S 1.p Sch.hand.3.t.267 On $\frac{3}{4}$ jn.s $\quad$ S. Europe 1683. S l.p Lof. hisp.t.1.f.3 Composita. Sp. 2.

O un 1 jl.o W Jamaica 1728, S 1.p Bot. mag. 2275 $\downarrow \Delta$ un 3 jn.o W Virginia 1661. D p.1 W. hort. ber. 4

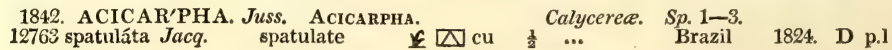

Compositce. $\mathrm{S} p, 2-5$.

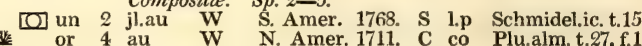
$\left[\mathrm{cu} \quad \frac{1}{2}\right.$...

\section{SEGREGATA.}

1843. ELEPHANTO'PUS. W. Elephants Foot. 12764 scáber $W$.

12765 caroliniánus $W$

12766 tomentósus $W$.

rough-leaved

Carolina

woolly

Compositce. Sp. 3-7.

1844. OEDE'RA. $W$. CEDERA. 12767 prolifera $W$. proliferous

1845. FLAVE'RiA. $J$. Flaveria

1845. FLA VE'RIA. $J$. Flaveria.
12769 contrayérba $W$. en. Peruvian

E: Indies 1695. C s.p Rhee.mal.10.t.7 W. Indies 1733. D 1.p

Composita. Sp. 1-3.

1846. STOE'BE. $W$. ST\&EE

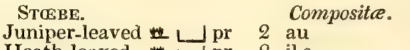
18769 . 12770 cinérea $W$. Heath-leaved 2 pr 2 jl.s

Eng. bot. 1157

Eng. bot. 124

Eng. bot. 1193

Krock.siles, t.41

(1)

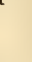

1847. NAUMbUR'GiA. $\boldsymbol{W}$. Naumburgia.

1847. NAUMbUR'GIA. $\boldsymbol{W}$. Naumburgia.
12771 trinerváta $W$. Brotera Contrayer'va Spr.

1843. CASSI'NiA. $H . K$. Cassinia. 12772 aírea $R$. Br. . 12773 spectábilis $\boldsymbol{R} . \mathrm{Br}$. shewy 12774 leptcphýlla $\boldsymbol{R}$. $R$ r. small-leaved

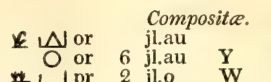

2. 4 pr

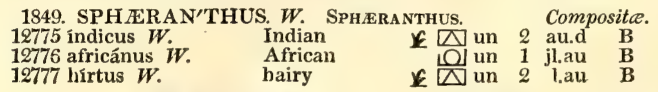

Sp. 3-11.

N. Holl. 1803. D 1.p Bot. reg. 764

N. Holl. 1818. S co Bot. reg. 678

N. Zeal. 1821. C co

Sp.3-8.

C. G. H. 1759. S co Pl.man.t.108.f.7 12777 hirtus $W$. bairy

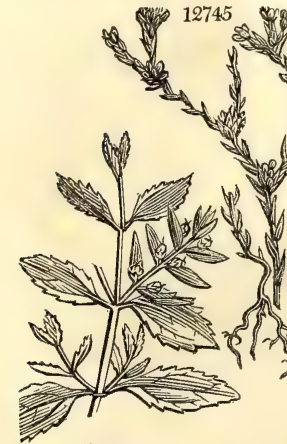

12762

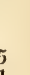


12744 Stem erect subdichotomous, Lvs. lin. lanc. appressed downy, Flowers clustered axillary and terminal 12745 Stem erect branch. Branch. sprdg. Lvs. Janc. acute cottony, Fls. conic. clust. lat. term. Clust. longer than lvs. 12746 Stem erect panicled, Leaves oblong lanceolate woolly, Heads clustered lateral and terminal downy 12747 Stem erect branched, Lvs. lanc. cord. at base amplexicaul. woolly, Heads clust. lat. and terminal downy 12748 Leaves nearly glabrous above, Spike longer more interrupted

12749 Stem herbaceous quite simple, Leaves oblong spatulate downy beneath hoary, Heads clustered 12750 Stem erect branched, Lvs. obov, spatulate downy beneath, Heads axillary and terminal clustered spiked 12751 Stem decumb. branch. only from base, Flower. stems erect, Fls, solit. or racem. Lvs. lin. downy on both sides 12752 Stem quite simple nearly erect about 3-fowered, Leaves linear acute downy, Runners procumbent 12753 Stem branched erect, Leaves linear 3-nerved acute very narrow at base downy beneath 12754 Stem simple, Leaves linear 3-merved acuminate silky beneath, Heads terminal clustered_ [ than Ivs. 12755 Stem very much branch. diffuse woolly, Lvs. lin.-lanc. downy, Fls. in term. crowded clust. which are shorter 12756 Stem simple nearly erect downy, Fls. axillary forming a distant leafy spike Leaves linear lanc. downy

12757 Leaves opposite obovate cuneate

12758 Leaves alternate lanceolate, Heads woolly

12759 Leaves bipinnatifid

12760 Leaves undivided oblong toothed

12761 Leaves lanceolate-ovate, Bractes lanceolate and petioles downy 12762 Leaves lanceolate dotted scabrous deeply serrated, Stem shrubby

12763 Leaves spatulate

\section{SEGREGATA.}

12764 Leaves scabrous : radical narrowed at base ; cauline lanceolate, Stem branched strigose 12765 Radical and cauline leaves owlong narrowed at base somewhat hairy, Stem simple hairy 12766 Leaves ovate downy

12767 Leaves lanceolate serrated reflexed

12768 Leaves somewhat stalked lanceolate 3-nerved mucronate-serrate

12769 Leaves mucronate subulate reflexed, Stem erect

12770 Leaves linéar subulate oblique, Spike cylindrical

12771 The only species

12772 Leaves lanceolate-linear smooth glandular beneath, Corymbs decompound

12773 Panicle decompound, Leaves lanceolate decurrent with their under surface and the branches woolly

12774 Corymb nearly sessile, Leaves small linear white beneath

12775 Leaves lanceolate serrate decurrent glabrous, Peduncles winged, Wings of stem and peduncles serrated 12776 Leaves decurrent ovate serrated, Peduncles round

12777 Leaves obovate serrated hairy decurrent, Peduncles winged, Wings of stem and peduncles serrated

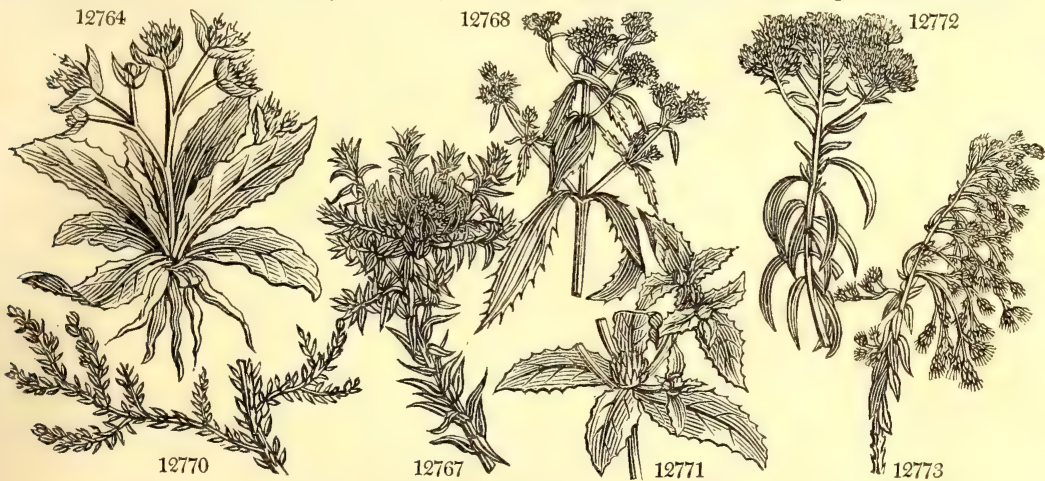

and Miscellaneous Particulars.

1846. Stoebe. The name under which Theophrastus and Pliny designate a plant of a rough and spiny habit. This is the character of the modern plant, which is very dissimilar to that of the ancients, which is believed to have been Poterium spinosum

1847. Naumburgia. Named by Willdenow without explanation; but we presume in honor of John Samuel Naumburg, author of a Dissertation upon Veronica Chamædrys, \&c., published at Erfurt in 1792

1848. Cassinia. Named after M. Henri Cassini, a celebrated French botanist, who has devoted much attention to the study of the very difficult tribe of plants to which this belongs, and with singular success. But his observations are scattered through so many different works, that it is almost hopeless to acquire a knowledge of their actual extent. Neat New Holland shrubs with white or yellow flowers.

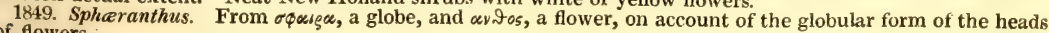
of flowers. 
1850. ECHI'NOPS. $W$. Globe Thistle.

12778 sphærocéphalus $W$.

12779 spinósus $W$.

12780 Rítro $\boldsymbol{W}$.

12781 strigósus $W$.

12782 lanuginósus $\boldsymbol{W}$.

12783 paniculátus Jacq.

Great thorny-headed small

annual

woolly

panicled upright

1851. ROLAN'DRA, $W$. ROLANDRA. 12785 argéntea $W$.

1852. BROTE'RA. $W$, Brotera. 12785 corymbósa $W$. umbelled

1853. GUNDE'LIA. $\boldsymbol{W}$ GUNDELIA 12787 Tournefórtii $W$. Tournefort's 1854 EUXE'NIA. Cham. EuXenia. 12788 gráta Cham. pleasant
Compositce. $S p .7-9$.

ฟ $\Delta$ or 4 jl.au W Egypt

I $\triangle$ or 3 jl.s B

O or 2 jl.s W Spain

$\downarrow \Delta$ or 2, jn.jl B Levant

$\pm \Delta$ or 3 jl.au

Pa.B Europe

Composite. $S p .1$

1.

\. $\Delta$ or

jl

Composite $\mathrm{Sp} 1$

1596. D co

1597. D 1.p Moris.s.7.t.35.f.4

1570. D co Bot. mag. 932

1729. S 1.p Bot. mag. 2109

1736. D l.p

1815. D 1.p Bot. reg. 356

1822. D l.p Bot. mag. 2457

Composita. Sp. 1.

$\pm \Delta$ un $1 \frac{1}{4}$ jn.au L.G Levant 1739. D s.p Mill. ic. t. 287

L L 2 pr 2 Compositce. Sp. 1.

1825 C p.l Hor.Phy.ber.t. 6

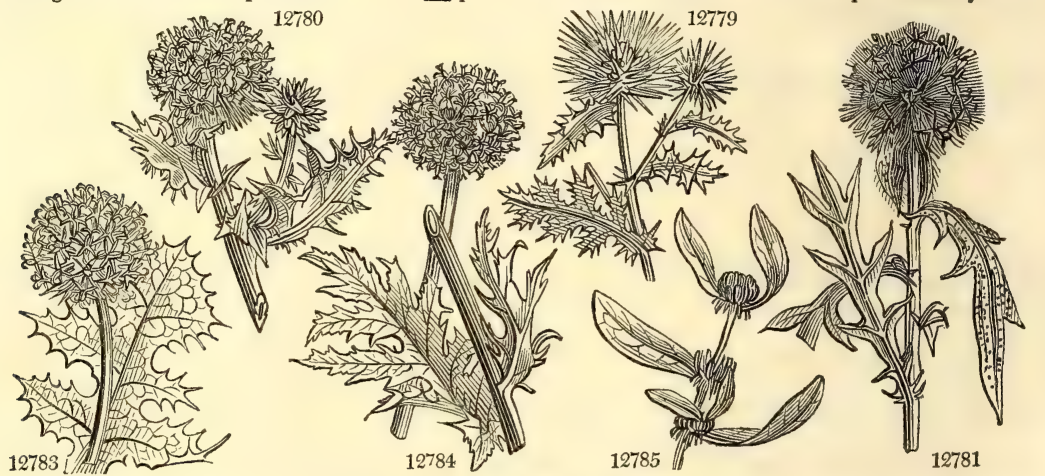

History, Use, Propagation, Culture,

1850. Echinops. From $\varepsilon$ xiyos, a hedgehog, and oq is, resemblance; because of the bristly round beads of flowers protected in every direction by stiff spines. The woolly leaves of Echinops strigosus are employed in Spain as tinder. Upon this genus M. Cassini has founded his tribe of Echinopseæ, which it must be confessed is entirely distinct from any other, and extremely remarkable on account of its very singular aberrations from the ordinary structure of Compositæ.

1851. Rolandra. After Daniel Rolander, a pupil of Linnæus, who visited Surinam. Nothing appeared from him except an account of Doliocarpus in the seventeenth volume of the Transactions of the Academy of Sciences of Stockholm. 
12778 Leaves pinnatifid downy above woolly beneath, Stem branched

12779 Heads scattered with long spines

12780 Head globose, Leaves pinnatifid smooth above

12781 Heads fascicled, Lateral invol. sterile, Leaves strigose on the upper side

12782 Stem branched woolly, Leaves subbipinnate : segments narrow smooth above, Head subsessile

12783 Leaves rugose squarrose pinnatifid smooth above glaucous with down beneath

12784 Stem simple upright 1-headed, Leaves eroded pinnatifid spiny-toothed smooth above downy beneath

12785 The only species

12786 Heads corymbose numerous

12787 Leaves long and spiny

12788 The only species

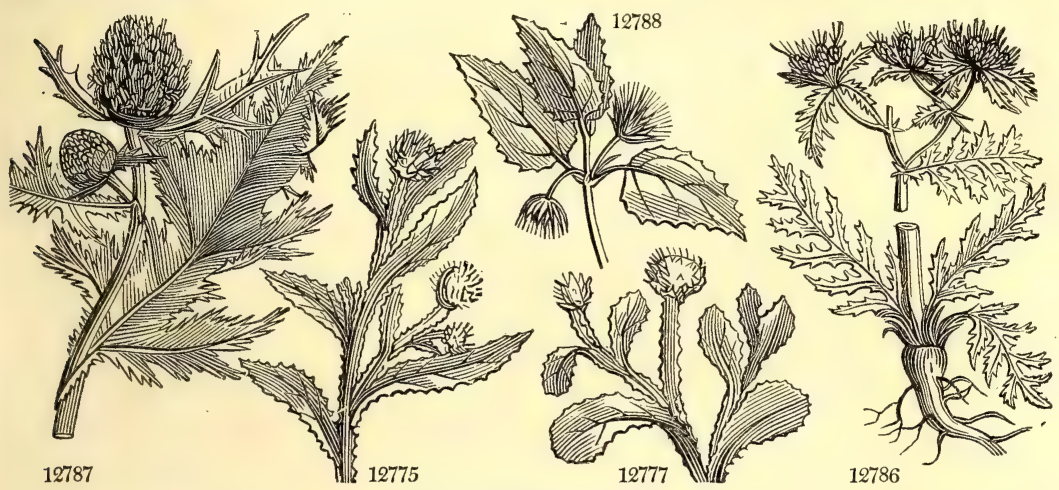

and Miscellaneous Particulars.

1852. Brotera. Named after Felix Avelhar Brotero, a Portuguese botanist, professor at Coimbra; author of a useful Flora Lusitanica.

1853. Gundelia. Named after Andrew Gundelsheimer, a German botanist, who accompanied Tournefort in his journey into the Levant in 1709.

1854. Euxenia. A name unexplained by its author. Apparently derived from Evక̌६yos, hospitable, but in what sense we do not pereeive. 


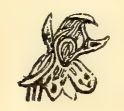

Class XX. - GYNANDRIA.

THE singular plants which constitute this class are distinguished from all others by the anomalous structure of their flowers. These do not, as is usually the case, contain a certain number of stamens surrounding a central ovarium or style, but on the contrary are furnished with a solitary fleshy undivided process, round which the sepals radiate, and which supplies the place of stamens and style. The nature of this process has heen variously explained : the modern opinion is that it is formed by the accretion of the stamens and style into a single mass, and this opinion seems to be confirmed by analysis and analogy. Omitting, therefore, a notice of such theories respecting its nature as are opposed to that which is now received as the most correct, it will suffice to explain a little in detail, the opinion which is adopted in this work. The central process, called the columna or column, is understood to be formed by the filaments of three stamens surrounding a style, and by mutual accretion firmly united with it and with each other into a solid mass. Of these three stamens, it most frequently happens that the two lateral are sterile, and not furnished with even the vestige of an anthera; and that their presence is not indicated by more than two irregular excrescences, as in Orchis, or by the same number of small appendages, as in Satyrium, or by two horn-like or tooth-like processes, present in several of the genera with waxy pollen-masses : it even happens, and not unfrequently, that no vestige whatever of them remains. But in Cypripedium both are fertile and bear perfect anthers, while the central stamen is barren and foliaceous. When the lateral stamens are, as above stated, abortive, which is the most common form of the columna, the central stamen bears at its upper extremity an anther, which is either moveable or fixed firmly in its place. The pollen which this contains, assumes three very distinct appearances in different tribes. It is either granular, dividing into many separable small pieces, as in Orchis ; or powdery, consisting of an infinite number of granules, as in Spiranthes ; or waxy, when it consists of a few large concrete masses, as in Epidendrum. The stigma is most frequently concave, and placed nearly under the anther, but in such a manner, that there is no contact between it and the pollen. In what way, therefore, fecundation can take place among truly Gynandrous plants, is one of those mysterious contrivances of nature which has not yet been explained. It is generally believed to take place by absorption in some undiscovered manner, before the flowers expand; but it is extremely difficult to understand how this can occur in many genera. The foregoing remarks apply only to the tribe of plants called Orchideous. The few genera attached to the latter part of the class are Gynandrous by the cohesion indeed of their stamens and style, but in a much more obvious manner.

Gynandrous plants are among the most interesting of the vegetable productions of the globe, whether we consider the vivacity of their colors, or the singularity of their organization, or the grotesque appearance of their tortuous roots, or the delicious perfume of their flowers. They are distributed in abundance over all the earth. In Europe and the temperate parts of the world, they are principally found in meadows and pastures among grass ; but in tropical regions they often constitute the chief beauty of the forest, occupying the forked among grass ; but in tropical regions they often constitute the chief beauty of the forest, occupying the forked
branches of living trees, or the prostrate trunks of fallen timber, over which, in company with ferns and parasitical Aroidex, they climb and trail in every direction, until they adorn the one with bright hues and rich odours foreign to their nature, and render the others more beautiful in death, than in the full vigour of their existence.

Order 1. MONANDRIA.

Stamen 1.

\$1. Anther terminal, erect. Pollen granular, cohering by an elastic thread.

1855. Disa. Flowers ringent: helmet with a spur or bag at the base. Inner sepals united to the column. Lip without a spur.

1856. Satyrium. Flower ringent : five anterior sepals united at base. Lip behind, fornicate with two spurs or bags at the base. Anther resupinate. Stigma 2-lipped.

1857. Platanthera. Flower vaulted. Lip entire with a spur. Cells of the anther widely divided at their base by the broad interposed stigma. Glands of pollen masses naked. Lips of stigma absent.

1858. Gymnadenia. Cor. ringent. Lip spurred at the base beneath. Glands of the stalks of the pollenmass naked, approximate.

1859. Orchis. Cor. ringent. Lip spurred on the underside at the base. Glands of the stalks of the pollenmass (1-2) contained in one common little pouch.

1860. Nigritella. Ovary straight. Flower spreading. Lip posterior, entire, with a scrotiform spur, Glands of pollen-masses distinct, and enclosed in a single 2-celled pouch.

1861 . Habenaria. Cor. ringent. Lip spurred on the upper side at the base beneath. Glands of the stalk of the pollen-mass naked, distinct, with the cells of the footstalks adnate or separated.

1862. Bartholina. Flower ringent: inner sepals united below with the lip. Lip spurred beneath at the base. Stalks of the pollen-masses long; cells united to the column : glands distinct, half covered by the exterior lobe.

1863. Glossuia. Sepals conniving in a galea: the upper without a spur. Lip anterior, spurred, 3-parted,

with an inflated spur. Pollen-masses 2, 2-parted, with 2 glands inclosed in distinct pouches.

1864. Anacamptis. The flower of Orchis, from which it differs in having the gland of the pollen-masses single, with inflexed edges, and enclosed in a pouch.

1865. Aceras. Flower ringent. Lip without a spur. Glands of the pollen-masses included in a common pouch.

1866. Ophrys. Flower somewhat spreading. Lip without a spur. Glands of the pollen-masses inclosed in two distinct pouches.

trist. Chamorchis. Ovary reclinate at end. Flower galeate. Lip without a spur, undividea. Glands of the pollen-masses naked. Upper lip of stigma divided. Anther of Orchis.

1868. Herminium. Flower somewhat spreading. Lip without a spur. Glands of the pollen-masses naked, distinct.

1869. Serapias. Flower ringent. Lip without a spur. Column sharp-pointed. Pollen-masses attached to a single gland inclosed in one pouch.

\section{\$2. Anther parallel with stigma. Pollen powdery.}

1870. Goodyera. Cor. ringent, with the 2 exterior or lateral segments of the perianth placed beneath the lip which is gibbous at the base and undivided the extremity. Column free. Pollen angular.

1871. Diuris. Flower irregular. Two outer linear sepals placed beneath the trifid lip: the inner clawed and spreading. Column with the lateral lobes petaloid. Pollen farinaceous.

1872. Ponthieva. Flower irregular. Lip behind, with the inner sepals inserted in the column. Pollen farinaceous. 
1873. Neottia. Flowers connivent. Lip sessile, 2-lobed, with no calli. Antber terminal, sessile. Stigma 2-lipped pervious; the front lip thickened.

1874. Spiranthes. Spike spiral. Ovary oblique at the end. Sepals connivent. Lip clawed, parallel with columna, with 2 calli at the base, entire. Anther terminal stalked. Stigma flat, cuspidate, membranous, finally split.

1875. Stenorhynchus. Like the last; but the lip adheres to the columna by means of the margins of its lateral lobes : it has no callosities. Stigma corneous, always entire.

1876. Listera. Flowers connivent. Lip 2-lobed, sessile, with no calli. Anther intramarginal, half covered over by the hooded clinandrium. Stigma closed, nearly flat, with a strong transverse furrow.

\section{\$3. Anther terminal, persistent. Pollen powdery.}

1877. Arethusa. Lip united at base with the columna, at the end hooded, in the inside crested. Sepals 5, united at base. Pollen angular.

1878. Calopogon. Lip at the back clawed, with a bearded inside. Sepals 5, distinct. Column separate.

Pollen angular

1879. Pogonia. Lip sessile, hooded, crested inside. Sepals 5, distinct, without glands. Pollen farinaceous. 1880. Epipactis. Lip ventricose below; the extremity either undivided or 3-lobed: the middle lobe the largest, connected as it were by a joint. Pollen farinaceous.

1881. Caleana. Lip unguiculate, placed at the back, with a peltate hollow lamina, having a perforation on the outside. Pollen farinaceous.

1882. Corallorhiza. Lip produced behind, adnate with the spur or free. Column free. Masses of pollen 4, oblique, not parallel.

\section{\$4. Anther terminal, opercular deciduous. Pollen waxy.}

1883. Rodriguezia. Perianth. 4-leaved ringent. Lip entire, unguiculate cornute at base; callous in the middle. Pollen-masses 2, with an elastic caudicula. Stigma with 2 horns.

1884. Gomeza. Like the last, but lip not cornute at base

1885. Cymbidium. Lip not spurred, concave, jointed with the simple base of the columna. Sepals spreading, distinct. Pollen masses 2, 2-lobed behind.

1885. Brassia. Lip expanded, undivided. Sepals spreading, distinct. Column not winged. Pollen-masses 2, 2 -lobed behind ; fixed by the middle to a common process of the stigma.

1887. Lissochilus. Pollen-masses 2, obliquely 2-lobed. Lip saccate at base, sessile, undivided, convex at the base, united with the apterous toothless column. Inner sepals divaricating, petaloid; outer refiexed, calycine

1888. Geodorum. Lip cucullate-ventricose, sometimes spurred at base, sessile, not jointed with the column. Sepals like the lip, 1-sided. Pollen-masses 2, lobed at back.

1889. Catasetum. Perianth. not inverted, generally globose. Lip saccate, concave, different from the sepals. Pollen-masses 2, 2-lobed behind, inserted on a large naked transverse caudicula, which finally separates with elasticity.

1890. Trizeuxis. Perianth. 2-parted; upper segment 2-lobed; lower 3-parted, inflated. Lip parallel with column, with a recurved dilated limb. Stigma excavated. Anther 1-celled, fleshy. Pollen-masses 2, adhering to a fusiform caudicula.

1891. Xylobium. Perianth. spreading. Lip behind jointed, with $\cdot$ an unguiform process of the column, 3-lobed, incumbent on columna. Outer lateral sepals united by their bases, with the process of column. Pollen-masses 2, furrowed on one side, seated on a broad caudicula.

1892. Maxillaria. Perianth. spreading. Lip in front 3-lobed, jointed with the unguiform process of the column. Lateral outer sepals united by their bases with the process of column. Pollen-masses 2, bipartite, united by their bases to a common gland.

1893. Notylia. Perianth. 4-leaved : upper sepals spreading. Lip divaricating entire. Columna acuminate. Pollen-masses 2, entire. Anther posterior, not terminal.

1894. Pleurothallis. Lip jointed with the simple or slightly lengthened base of column. The two anterior sepals united at base. Pollen-masses 2, not furrowed.

1895. Oncidium. Lip expanded, lobed, tubercled at base. Petals spreading, sometimes only 4. Colum winged. Pollen-masses 2, 2-lobed behind, fixed by the middle to the common process of the stigma.

1896. Cyrtopodium. Sepals 5, distinct. Lip 3-lobed, connected with a joint with the unguiform process of the base of the apterous column. Pollen-masses 2, 2-lobed behind.

1897. Coelogyne. Perianth. resupinate, spreading. Lip 3-lobed, cucullate, jointed with columna. Column winged. Anther lateral, 2-celled. Pollen-masses 2, 2-parted. Stigma funnel-shaped, 2-lipped.

1898. Macradenia. Lip sessile, cucullate, concave, undivided, acuminate. Sepals distinct, spreading. Column distinct, with the lobes of its end conniving. Pollen-masses 2, unfurrowed, seated on a long filiform caudicula.

1899. Dendrobium. I.ip without a spur, jointed with the unguiform process of the column, to whose edges the anterior sepals adhere. Pollen-masses 4, parallel.

1900. Anisopetalum. Flowers erect. Sepals conniving. The two lateral exterior large, cohering at end two inner very small subulate. Lip oblong, with 2 teeth near the base. Pollen-masses 4, without gland or caudicula.

1901. Camaridium. Perianth. resupinate, expanded. Sepals distinct. Lip distinct, sessile, cucullate, 3-lobed. Column round. Stigma arched. Pollen-masses 4, parallel, compressed, without a caudicula at the time of expansion.

1902. Ornithidium. Lip sessile, hooded, connate with the base of column. Sepals conniving. Pollenmasses 4 , oblique, furrowed at base.

1903. Isochilus. Lip almost of the same shape as the distinct, connivent, sepals. Pollen-masses 4, parallel.

1904. Pholidota. Flowers resupinate. Sepals uniform; the three outer erect, keeled at back. Lip ventricose.

Column dilated at end. Anther 2-celled. Pollen masses 4, each pair having a gland.

1905. Broughtonia. Column distinct, or at the very base united with the unguiculate lip, which is lengthened at the base into a tube, connate with the ovarium. Pollen-masses 4, parallel, with a granular caudicula reflexed npon the masses.

1906. Cattleya. Sepals spreading. Lip sessile, cucullate, surrounding the half round column. Pollen-masses 4, with as many powdery reflexed caudiculæ.

1907. Epidendrum. Column united with the claw of the lip, and forming a tube which sometimes runs down the ovarium. Pollen-masses 4, with as many powdery reflexed caudiculæ.

1908. Polystachya. Perianth. not inverted, cuneate, closed. Pollen-masses 4, placed on a simple naked caudicula with a gland.

1909. Cryptarrhena. Sepals 5, distinct, spreading. Lip not spurred, with a dilated flat lamina. Column distinct, not winged. Anther enclosed in the cucullate head of the column. Pollen-masses 4.

1910. Ornithocephalus. Flowers resupinate. Lip stalked. Sepals nearly equal; the two upper finally reflexed. Column short, with a very long beak. Pollen-masses 4 , adhering to a very long glandular caudicula. 1911. Bletia. Lip sessile, cucullate; sometimes spurred at the base. Sepals 5, distinct. Column separate. Pollen-masses 8 or 4 , 2-lobed.

1912. Eria. Perianthium woolly, conniving or expanded. Lip 3-lobed, jointed with an unguiform process of the column to whose sides the anterior sepals are united. Pollen-masses 8 , cohering at the end by means of a powdery substance.

1913. Octomeria. Lip jointed with an unguiform process, to the edges of which the anterior sepals adhere.

Pollen-masses 8. Perianthium quite smooth.

1914. Brassavola. Lip with a simple claw, undivided. Senals distinct, spreading. Pollen-masses 8 or more. 
1915. Sarcanthus. Lip fleshy, entire, calcarate; the spur furnished with various appendages in the interior. Sepals spreading equally. Pollen-masses 2 , seated on an elastic caudicula.

1916. Vanda. Lip saccate, continuous with the simple base of the apterous column, trifid, with the middle lobe fleshy. Sepals spreading, distinct. Pollen-masses 2, obliquely 2-lobed, attached to an elastic caudicula.

1917. Aerides. Lip spurred or saccate, inserted at the end of the unguiform process, to whose edges the anterior sepals are united. Pollen-masses 2, two-lobed behind, fixed by a common process to the middle of the stigma.

1918. Renanthera. Like the last, but sepals very long and spreading, and lip only a little saccate at base.

1919. Ionopsis. Sepals connivent, the anterior placed under the labellum. Lip spurred at base. Pollenmasses 2.

1920. Eulophia. Sepals 5, distinct, uniform, ascending, spreading. Lip spurred at base, with a sessile crested lamina, 3-lobed. Pollen-masses 2, two-lobed, with a posterior lobe attached to an elastic caudicula.

1921. Angracum. Sepals conniving, galeate. Lip spurred 3-lobed, jointed with column. Pollen-masses 2. Stigma concave, transverse.

1922. Aeranthes. Lip spurred, membranous, entire, jointed with an unguiform process of the column, to which the two front sepals are adherent. Pollen-masses 2, hollow, perforated on one side, with no caudicula, and two glands.

1923. Calanthe. Lip spurred, lobed, united with the columna. Perianth. spreading. Pollen-masses 8.

1924. Stelis. Lip of the same form as the inner dwarf vaulted sepals. Three outer sepals united at base.

Pollen-masses 2.

1925. Malaxis. Lip flat, expanded, regularly vertical. Column round. Pollen-masses 4, loose.

1926. Prescotia. Perianth. spreading. Two upper sepals connate at base. Lip behind, erect, fleshy, cucullate, entire, embracing the very minute column. Pollen-masses 2, twin, granular, united by the end to a gland. 1927. Microstylis. Lip flat, sagittate, or deeply cordate. Column very small, round. Pollen-masses 4, loose.

\section{MONANDRIA.}

1855. DI'SA. Sw. 12789 cornúta $W$. 12790 spatuláta $W$. 12791 prasináta B. Reg. 12792 bracteáta $W$. 12793 grandiflóra $W$. 12794 graminifólia Banks blue

1856. SATY'RIUM. $W$. 12795 cucullátum $W$. 12796 car'neum $\boldsymbol{H}$. $\dot{K}$. 12797 coriifólium $w$.

1857. PLATAN'T 12798 bifólia Rich 12799 dilatáta 12800 orbiculáta

1858. GYMNADE'NIA 12801 conópsea $\boldsymbol{R}$. $\boldsymbol{B r}$. 12802 viridis Rich. 12803 álbida Rich.

1859. OR'CHIS. $L$ 12804 Mório $W$. 12805 longicórnu $P$.S. 12806 máscula $W$.
Disa. horned

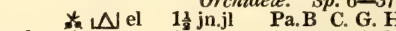
spoon-lipped $\triangle \mathrm{N}$ cu 1 jn.jl Papu C. G. H. 1805. R s.p Journ.sc.4.t.5.f.3 $\begin{array}{lllll}\text { green-flowered } & \Delta \text { cu } & \frac{3}{4} \mathrm{jn.jl} & \text { G.R } & \text { C. G. H. 1815. R s.p Bot. reg. } 210\end{array}$ small-flowered $\triangle \mathrm{cu} \quad \frac{3}{4} \mathrm{jn.jl} \quad \mathrm{G} \quad$ C. G. H. 1818. R s.p Bot. reg. 324 large-flowered $\triangle \mathrm{spl} 1 \mathrm{jl}$ jlau Sc $\quad$ C. G. H. 1825. R s.p Bot. reg. 926 Satyrium. cuculiate $\Delta$ cu $\frac{3}{4}$ jn.s Pa.Y C. G. H. 1787. R s.p Bot. reg. 416 great-flowered $\triangle$ el $1 \frac{1}{2}$ jn.s $\quad$ Pk C. G. H. 1787. R s.p Bot. mag. 1512 $\begin{array}{llll}\text { leathery-leaved } \triangle & \Delta \text { or } 1 \text { o } & \text { Y } & \text { C. G. H. 1820. R s.p Bot. reg. } 703\end{array}$

Orchidea. Sp. 3-11. ButterfyOrchis $\Delta$ pr 1 my.jn W Britain woods. $R$ p.l Eng. bot. 22 dilated $\Delta$ pr $1 \frac{1}{2}$ au $\quad$ W Canada 1823. R s.p Hook, ex. fl. 95 round-leaved $\triangle \mathrm{cu} 1$ ap.my $\mathbf{G}$ Canada 1823. R s.p Hook. ex. f. 145 Orchidea. Sp. 3-6. fragrant $\Delta \mathrm{pr} 1 \mathrm{jn} . \mathrm{jl} \quad \mathrm{Pu}$ Britain me.pas. $\mathrm{R}$ h.l Eng. bot. 10 Frog Orchis $\Delta$ pr $\frac{3}{4}$ jn.jl G $\quad$ Britain me.pas. $R$ l.p Eng. bot. 94 small-white $\Delta \mathrm{pr} \quad \frac{x^{4}}{2}$ jn.jl W Britain sun.hi. R l.p Eng. bot. 505 Orchidea. Sp. $19-84$.

meadow $\quad \Delta$ or $\frac{3}{4}$ my.jn Pu Britain me.pas. R l.p Eng. bot. 2059 flat-spurred $\mathbb{N}$ or $\frac{3}{4}$ ap.my $\mathbf{P u}$ Barbary 1815. R l.p Bot. reg. 202 early purple $\triangle$ or 1 ap.my Pu Britain woods. R l.p Eng. bot. 631
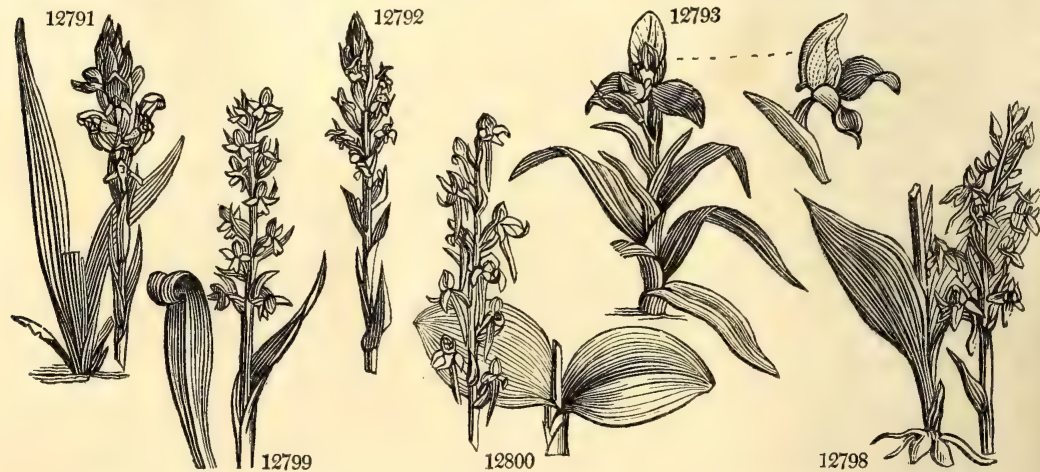

History, Use, Propagation, Culture,

1855. Disa. A name of unknown meaning, adopted by Linnæus from Bergius. Beautiful Cape herbaceous plants, with flowers of various colors, either growing singly, or in long spikes. Disa cornuta produces a spike, often a foot or a foot and a half long. D. grandiflora has large, nearly solitary flowers, of a brilliant scarlet color. The species are cultivated without difficulty in a stove or in a greenhouse, if the roots are planted in light sandy peat, mixed with a very little loam, and not overwatered. The same treatment is suitable to the other tender tuberous or fibrous-rooted Orchidex.

1856. Satyrium. The aphrodisiacal properties of Orchideous plants induced the ancients to give this name to almost all the species they knew ; from rotveos, a satyr. The bag-like appendages of the lip have perhaps assisted in the application of the name. The species are mostly handsome plants, with yellow or pink flowers. Mr. Salisbury says, he preserved Satyrium cucullatum some years, by attending to planting the bulb in a pot, nearly full of broken tiles, mixed with pure sandy loam, and keeping it quite dry when not vegetating. 
1928. Liparis. Perianth. spreading. Lip flat, expanded, entire, turned various ways. Column winged. Pollen-masses 4, with neither caudicula nor glands.

1929. Calypso. Lip ventricose, spurred beneath near the end. Sepals ascending, 1-sided. Column petaloid, dilated. Pollen-masses 4.

\section{Pollen granular. Seeds not arillate.}

1930. Vanilla. Flower jointed with ovary, and deciduous. Lip united at base with columna. Capsule fleshy.

\section{Order 2. DIANDRIA. Stamens 2.}

1931. Cypripedium. Lip ventricose, inflated. Column terminated by a petaloid lobe divining the anthers. Two anterior sepals usually united.

1932. Stylidium. Cal. 2-lipped. Cor. irregular, 5-fid; the fifth segment dissimilar. Column reclinate, with a double bend. Anthers with 2 spreading lobes. Caps.'2-celled.

1933. Gunnera. Cal. 2-toothed, superior. Cor. 0. Style 2-parted. Drupe 1-seeded, crowned by the teeth of the calyx.

\section{Order 3. HEXANDRIA. If Stamens 6.}

1934. Aristolochia. Cal, O. Cor. 1-petalous, ligulate, ventricose at base. Caps, 6-celled, many-seeded, inferiol.

\section{MONANDRIA.}

12789 Helmet blunt : spur conical deflexed, Inner sepals 2-toothed, Lip obovate velvety flat, Spike lax 12790 Helmet erect acute, Lip stalked dilated at end trifid, Stem few-flowered, Leaves linear

12791 Helmet blunt : spur obl, keeled convex at back, Lip linear acutish, Spike lax, Bractes shorter than fis. 12792 Helmet blunt : spur obl. Lip linear broadest at end, Spike cylindrical, Bractes erect longer than flowers 12793 Helmet acute erect: spur conical nodding, Lip linear blunt, Stem about 2-f.

12794 Leaves filiform shorter than 3-flowered scape, Spur blunt ascending

1279.5 Radical leaves twin cordate roundish concave : cauline remote cucullate bluntish

12796 Kadical leaves twin cordate roundish : cauline sheath-like close, Spike compact, Sepals keeled outside 12797 Leaves ovate acuminate somew. reflexed sheathing coriaceous crenated at edge, Fls. and helmet cernuous

12798 Horn filiform twice as long as ovary, Lip linear entire, Rad. leaves twin oblong narrowed at base 12799 Lip lanceolate obtuse dilated at base, Spur the length of lip a little shorter than the ovary, Stem leafy 12800 Lip linear lanceolate, Three upper sepals erect conniving : lateral reflexed, Leaves 2 orbicular

12801 Bulbs palmate, Lip trifid entire, Spur setaceous twice as long as ovary

12802 Horn short double, Lip linear 3-toothed : lateral teeth acute; middle very short

12803 Horm blunt 3 times shorter than ovary, Lip 3-parted : segments acute ; middle one largest

[ovary

12804 Lip 3-lob. : lobes cren. obt. midd. one emargin. Seg. of perianth ascend, obt. Spur conic. ascend. shorter tha 12805 Lip 3-lobed : lateral reflexed toothletted; middle shorter than blunt, Spur long comp. truncate ascending

$12506 \mathrm{Li}$, S.lob. crenul. obt. : the midd. lobe cleft, Seg. of the perianth cleft; exterior one reflex. Spur lin. ascend. compressed at the extremity rather longer than the ovary

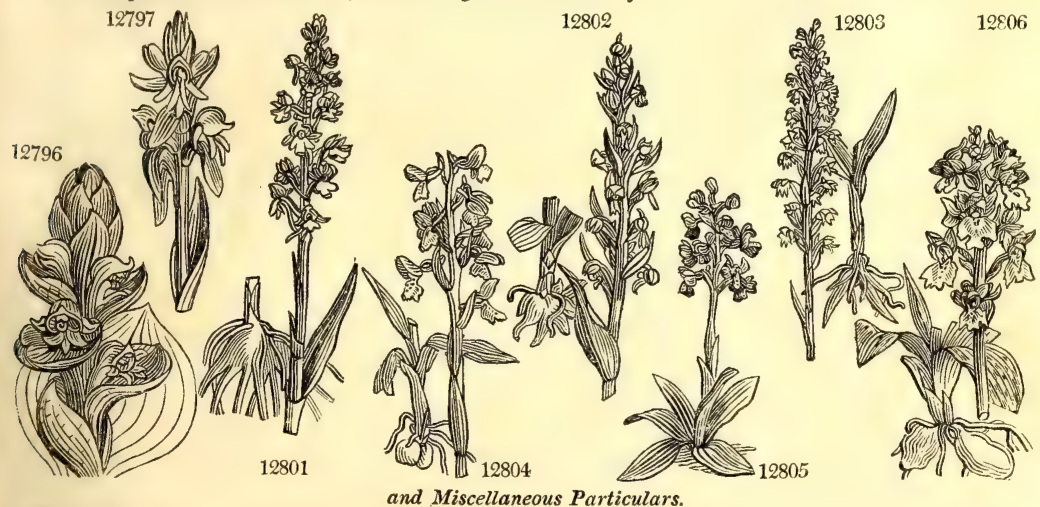

1857. Platanthera. So named from $\pi \lambda \alpha \tau v_{5}$, broad, and cy 9 roc, an anther, on account of the width of that organ, which is as broad or broader than the base of the labellum. Curious wood plants with greenish flowers.

Platanthera bifolia is one of our indigenous plants, which may be cultivated without any difficulty, if planted in pure loam from a lime-stone bottom. It succeeds in a pot, if filled half full of broken tiles; and when in the open ground, the border should be well drained, at least six inches in depth. No plant bears forcing better, or exhales a more delightful perfume. This species is never observed but in a lime-stone soil, and is exceedingly plentiful near Buxtơn.

1858. Gymnadenia. From queyos, naked, and $\propto \delta n y$, a gland; because it differs from Orchis in not having the glands enclosed in a pouch, but altogether uncovered. The principal species of the genus is the Orchis conopsea of old botanists.

1859. Orchis. The Greek name of the plant. In Arabic, according to Forskahl, it is called sahhleb, from 
12807 ustuláta $W$. dwarf 12808 fúsca $W$. brown

12809 tephrosan'thosDesf. fine-lipped 12810 militáris $W$. military

12811 unduláta Bivona

12812 acumináta $W$. 12813 globósa $W$. 12814 hircina $W$ 12815 latifólia $\mathscr{W}$

12816 maculáta $W$

12817 spectábilis $W$. 12818 papilionácea $W$. 12819 longibracteáta $\dot{B} i v$. 12820 variegáta All.

12821 sulphúrea Schrad.

1860. NIGRITELIA.

wavy-leaved

pointed-flower round-spiked Lizard marsh

* $\triangle$ or $\frac{1}{4}$ my.jn Pu England dr.pa. R l.p Eng. bot. 18 $\Delta$ or 3 my.jn Br.P England ch.hil, R l.p Eng. bot. 16

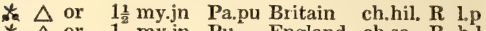
* $\triangle$ or 1 my.jn Pu England ch.so. R h.l Eng. bot. 1873 * $\Delta$ or 1 d Pa.pu Sicily

1818. R 1.p Bot. reg. 375 spotted-palmate $\Delta$ or $1 \frac{1}{2}$ jn.jl F Britain woods. $R$ h.l Eng. bot. 632 showy $* \Delta$ or $\frac{1}{2}$ jn.jl Pk N. Amer. 1801. R 1.p Bot. cab. 78 papilionaceous $\Delta$ or $\frac{1}{2}$ jn.jl Pa.pu S. Europe 1788. R 1.p Sicilian th $\triangle$ or $1 \frac{1}{2} \mathrm{~d}$ Pu Sicily 1818. R 1.p Bot.reg. 357 variegated $\mathrm{N}$ or $\frac{3}{4}$ ap.my Pa,pu S. Europe 1818. R 1.p Bot. reg. 367

12822 angustifólia Rich. dark-flowered $\Delta$ cu $\frac{1}{4}$ jn.jl Br.P Austria $1759 . \quad$ R l.p Flo. dan. $t .998$ 1861. HABENA'RI A, $R$. Br. Habenaria.

12823 bracteáta $R . B r$. long-bracted t $\triangle$ cu 1 my.jn G N. Amer. 1805. R 1.p Sweet tl. gar, 62 12824 hyperbórea $R . \dot{B r}$. northern $\Delta$ cu $\frac{1}{2}$ jn.ji G 12825 herbiola $R . B$. 12826 fimbriáta $\boldsymbol{R} . \boldsymbol{B r}$. 12827 cristáta $R$. Br. 12828 ciliáris $R, B r$. 12829 lácera $M i c h$. American $\triangle$ cu 1 jn.j purple-fringed $\nleftarrow \Delta$ el $1 \frac{1}{2} \mathrm{jn} . \mathrm{jl}$ yellow-crested yellow-fringed torn

12830 blephariglóttis $\boldsymbol{H}$ ook white-fringed 12831 tridentáta Hook. three-toothed

1862. BARTHOLI'NA. $R . B r$. BARTHOL 12832 pectináta $R$ Br. pectinated 1863. GLOS'SULA. Lindl. Glossula. 12833 tentaculáta Lindl. feeler-flowered t $\triangle \mathrm{cu}$ 1864. ANACAM'PTIS. Rich. ANACAMPTIS 12834 pyramidális Rich. pyramidal

1865. A'CERAS. $R . B r$. ACERAS. 12835 anthropóphora $R . B r$. Green Man 1866. O'PHRYS. $L$. OPHRYS. 12836 apifera $W$. 12837 Bee $\begin{array}{ll}12838 \text { aranifera } W \text {. } & W \text {. Saw-fiy } \\ & \text { Spider }\end{array}$

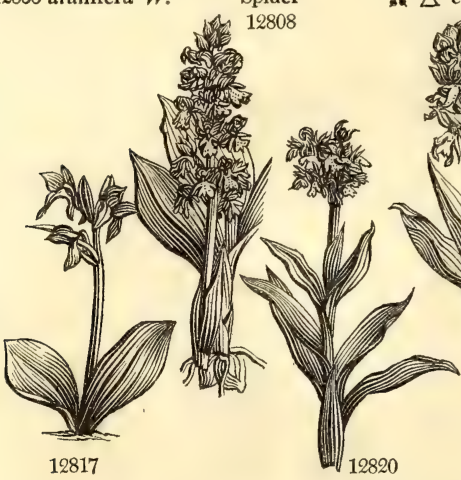
$*$ or $1 \frac{1}{2} \mathrm{jn} . \mathrm{jl} \mathbf{R}$ Britain dr.pa. $\mathbf{R}$ h.l Eng. bot. ilo

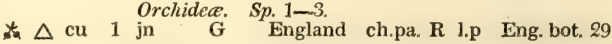
Orchidea. Sp. 6-14.

* $\triangle$ el $\frac{\pi}{4}$ jn.jl Pu England ch.pa. R h.l Eng. bot. 383 * $z^{\frac{3}{4}}$ ap.my Y.B Barbary 1815. R s.l Bot reg 205 $\frac{3}{4}$ ap.my $\mathrm{G}$ England ch.so. R s.l Eng. bot. 65 $12810 \quad 12812 \quad 12822$
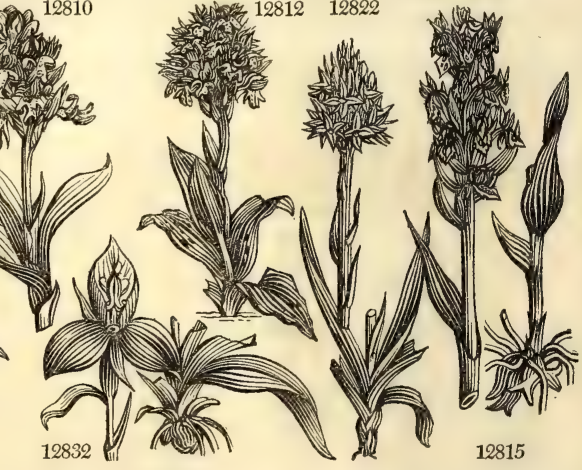

12815

whence doubtless our word salep has been obtained. This is a curious and beautiful genus, but rather difficult of culture. Few of the species produce seeds, but are propagated by their buibs or tubers, which, in most of the species, are of a peculiar structure and economy. An Orchis being taken out of the ground is found with two solid masses, ovate or fasciculated at the base of the stem, above which proceed the thick fleshy fibres which nourish the plant. One of these bulbs or tubers is destined to be the successor of the other, and is plump and vigorous, whilst the other or decaying one is always wrinkled and withered. From this withered one has proceeded the existing stem, and the plump one is an offset, from the centre of which the stem of the succeeding year is destined to proceed. By this means, the actual situation of the plant is changed about half an inch every year; and as the offset is always produced from the side opposite to the withered bulb, the plant travels always in one direction at that rate, and will in a dozen years have marched six inches from the place where it formerly stood.

In the garden, the Orchis can hardly be said to be propagated; the species are generally taken up from their native habitations with balls, and transferred to a shady border, where they remain for a year or two, but seldom increase. Those which grow in the open fields are generally found in calcareous soil, and those in bogs or woods thrive best in peat, or peat and loam mixed. The culture of this genus, however, has been very little attended to. According to Sweet, the best time to transplant the British Orchidex, is when they are in a growing state.

The Orchis affords the preparation known as Salep, imported from Turkey, and other parts of the Levant; and which has also been made in this country frorn 0 . mascula, and other species. The root is washed, the brown skin rubbed off, and then dried in an oven and ground into powder. This powder, as an article of diet, is accounted extremely nutritious, containing a great quantity of farinaceous matter in a small bulk. $O$. mascula is very abundant in the meadows of Gloucestershire, and Salep has been made from its bulbs, equal to that imported. (Encyc. of $\mathrm{Agr} .5527$.) 
12807 Lip 3-part. : seg. lin. dotted scabr.; midd. 2-parted, Sepals erect ac. Spur uncin. thrice as short as ovary 12808 Lip 3-part. dott. scabr.: later seg. obl.; midd. larg 2-lob. cren. with a point betw. Spur straightish thrice as short as ovary, Bractes 4 times as short as ovary

12809 Lip 4-parted very narrow : segm. filif.; middle longer with a tooth between, Spike conic. Bractes minute 12810 Lip 3-parted very narrow : seg. lin.; midd. 2-lob. blunt with a point between, Spur straight twice as short as ovary, Bractes obsolete

12811 Bulbs ovate, Stem leafy, Lip 3-parted scabr. : lat. seg. very narr. : midd, very long bifid with an appendage, Leaves wavy spotted

12812 Lip 3-lobed dotted : middle broadest with a tooth between, Spur compressed, Outer sep. subul. Spike dense 12813 Lip 3-part. : midd. seg. emarg. Sep. mucron. at end, Spur twice as short as ovar. Spike dense ov. Lvs. lanc. 12814 Lip 3-parted : lat. seg. lin. sub. : middle long bifid thrice as long as ovary, Spur very short conical double 12815 Lip slightly 3-lobed : sides reflex. Three inn. segm. of perianth conniv. Spur cylind. shorter than germen, Bract. longer than the flowers

12816 Lip plane 3 -lobed crenate : 3 inn. segm, of perianth conniv.; lat. ones patent, Spur cylind. shorter than the germen, Bract. as long as the germen

12817 Lip obov. undiv. cren. ret. Sep.straight : lat.long. Spur clav.short.than ovary, Bract. longer than fl. [ovary 12818 Lip obov. undiv, tooth. emarg. Sep. nerv. conniv. Spur subul, short. than ovar. Bract. membr. col, as long as 12819 Bulbs undivided, Sepals conniving, Lip trifid : middle segment projecting 2-lobed, Bractes longer than $\mathrm{A}$. $12820 \mathrm{Lip}$ trifid dotted: segments ovate serrulate ; middle broadest emarginate, Spike ovate compact 12821 Scape naked, Lip slightly 3-lobed at end, Spur ascending, Bractes as long as ovary

12822 The only species

12823 Spur short double, Lip linear retuse 3-toothed : lateral blunt ; middle obsol. Bractes twice as long as $\mathrm{fl}$. 12824 Spur cylindrical shorter than ovary, Lip entire linear oblong [than flower 12825 Spur filif. shorter than ovary, Lip obl. blunt toothed on each side at base, Palate 1-toothed, Bractes longer 12826 Spur filiform longer than ovary, Lip 3-parted with cuneiform fringed segments

12827 Spur filiform shorter than ovary, Lip lanceolate pinnatedly fringed, Inner sepals toothed cut 12828 Spur filiform longer than ovary, Lip lanceolate pinnatedly fringed, Inner sepals fringed cut

12829 Lip long 3-parted : segm. somewhat digitate filiform, Spur length of ovary, Spike obl. Flowers alternate 12830 Roots fascicled, Lip lanc. ciliated the length of upper sepals, Spur very long a little shorter than ovary 12831 Sepals conniving, Lip nearly equal broad ovate bluntly 3-toothed, Spur filiform curved longer than ovary

12832 The only species

12883 The only species

12834 Lip 3-cleft : lobes eq. ent. with 2 longitud. append. on upp. side near base, Seg. of perin. lanc. 2 outer ones

$12835 \mathrm{Lip}$ the length of ovary

12836 Lip 3-fid : middle lobe largest $\frac{1}{3}$-trifid ; middle segm. longest subulate deflexed

12837 Lip 2-lobed villous obovate appendaged, Sepals spreading : three outer oblong blunt ; inner very short 12838 Lip 3-lobed : lateral short blunt ; middle retuse

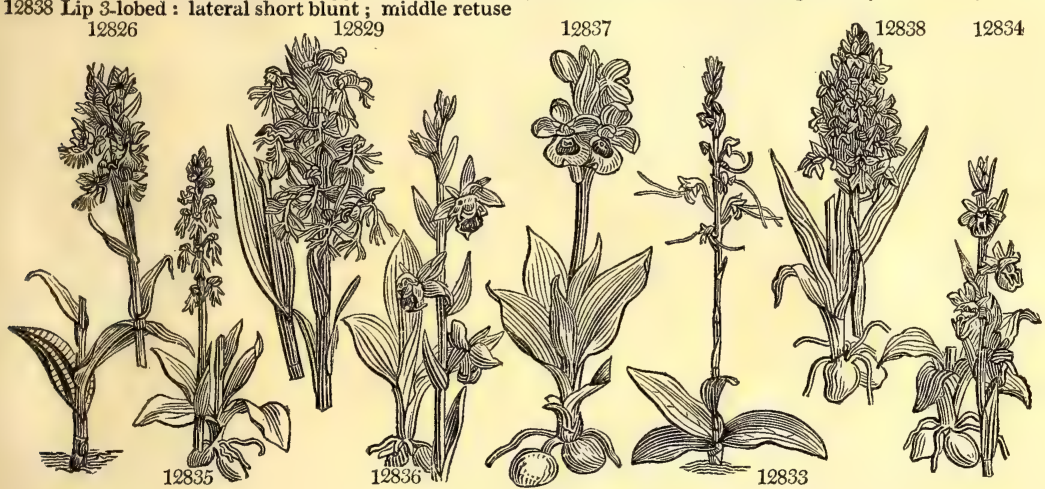

and Miscellaneous Particulars.

Orchis fusca and militarís, according to Salisbury, succeed best in chalky soil, free from all manure whatever; but they will endure more moisture than would be supposed; for he found them in a very wet part of the meadow below the terrace, at Mill Hill, where they had, no doubt, been planted by Mr. Peter Collinson. Gymnadenia conopsea affords another singular instance of this sort, which is found growing wild on the driest limestone, mixed with Anacamptis pyramidalis, and in bogs where one can hardly tread, mixed with Epipactis palustris.

1860. Nigritella. So named by M. Richard, from niger, black, in allusion to the color of the flowers.

1861. Habenaria. From habena, a thong or rein, on account of the long spur of the flower, which resembles something of that sort. Most of the species have white flowers, and natives of America. Some have bright yellow flowers, others purple ones.

1862. Bartholina. Named in honor of Thomas Bartholini, a Danish physician, who flourished at the end of the seventeenth century. A small Cape plant, with a beautifully fringed white flower.

1863. Glossula. So called by Mr. Lindley, from $\gamma \lambda \omega \sigma \sigma \alpha$, a tongue, in reference to the tongue-like segments of the labellum. An obscure Chinese plant, with pale green minute flowers.

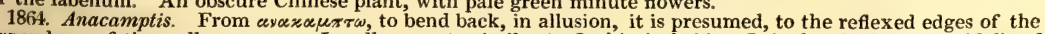
appendage of the pollen-masses. In all respects similar to Orchis in habit. It is the Orchis pyramidalis of Linnæus.

1865. Aceras. From $\alpha$, without, and $z e \rho e^{2}$, a horn, in allusion to the absence of the spur from the labellum, by which character it is chiefly distinguished from Orchis. Aceras anthropophora is difficult to cultivate. It can only be propagated by seeds, which thrive best in a mixture of sand, loam, and chalk.

1866. Ophrys. From the Greek word oøeys, which signifies an eye-lash, to which the delicate fringe of the inner sepals may be very well compared. $O$. apifera is a singularly beautiful plant, not uncommon on calcareous soils, near woods, and in open meadows. It ripens seeds plentifully, as will all the species, if care be taken, as 
12839 muscifera $H$. $K$. F 12840 mates $W$. Fy $\begin{array}{ll}12840 \text { aráchnites } W \text {. } & \text { villous } \\ 12841 \text { tátea } W \text {. } & \text { yellow }\end{array}$

1867. CHAMOR'CHIS. Rich.

12842 alpina Rich. alpine

1868. HERMI'NIUM. R. Br. 12843 Monórchis $R$. Br. musk

1869. SERA'PIAS. $R$. Br. Serapias 12844 Língua $W$.

12845 cordigera $W$. tongue-lipped

1870. GOODYE'RA. $H . K$. GoOdYERA 12846 répens $H$. $K$ 12847 pubéscens $H . K$. 12848 díscolor B. reg. 12849 prócera Hook.

12850 tesselláta Lodd.

1871. DIU'RIS. $S w$.

12851 aúrea $S w$.

1872. PONTHIE'VA 12852 glandulósa $R . \mathrm{Br}$. 12853 petioláta Lindl. 1873. NEOT'TIA. $L$ 12854 Nídus avis $W$. 12855 picta Lindl. 12856 eláta $L i n d l$. 12857 pudíca Lindl. 12858 bicolor Lindl. 12859 cérnua Rich. 12860 æstivális Rich.

1875. STENORHYN 12861 speciósus Rich. 12862 orchioídes Rich.

1876. LISTE'RA. $R$. 12863 ováta $H$. $\boldsymbol{K}$. 12864 cordáta $H . K$. 1877. ARETHU'SA. L. Arethusa. 12865 bulbósa $H . K$ bulbous stalked

NeOTTIA.

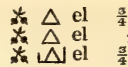

$\frac{3}{4}$ my.jn $\mathrm{Pu}$

my.jn $\mathrm{Br} \quad$ England ch.pa. R h.l Eng. bot. 64

$\frac{3}{4}$ ap.my $\mathbf{Y} \quad$ Spain 1818. $\mathbf{R}$ h.l Hook. ex. fl. 10 Orchidea. $\mathrm{Sp} .1$

$\frac{1}{2}$ ap.my Switzerl, 1824. R s.p $* \Delta$ pr $\quad \frac{1}{2}$ ap.my $\quad$ Orchidea. Sp. 1

$\checkmark \mathrm{cu}^{*} \frac{1}{2} \mathrm{jn} . \mathrm{jl} \mathrm{G}$ England ch.ba. R 1.p Eng. bot. 71 Orchidea. $S p .2-4$.

$\triangle \mathrm{Ncu} 1 \mathrm{my} . \mathrm{jn} \quad \mathrm{Br} \quad$ S. Europe 1786. R 1.p Bot. cab. 655 $\triangle \mathrm{cu} 1$ jl.au Br S. Europe 1806. R l.p Bot. rep. 475 Orchidece. Sp. 5-9. creeping $\Delta$ pr $\frac{3}{4}$ jl.au W Scotland al.wo. D l.p Eng. bot. 289

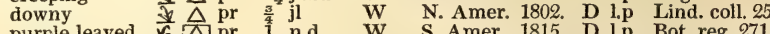
purple-leaved $\Delta$ pr 1 n.d W $\quad$ S. Amer. 1815. D l.p Bot. reg. 271 Nepal $\triangle \mathrm{pr}$ 2 jn.jl W Nepal 1821. D 1.p Hook. ex. f. 39

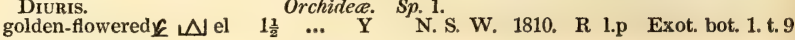
Orchidere. Sp. 2

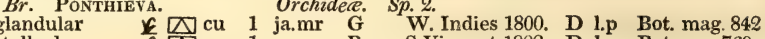

$\begin{array}{lllll}\square \mathrm{cu} & 1 \mathrm{au} & \mathrm{Br} & \text { S.Vincent 1822. D l.p Bot. reg. } 760\end{array}$ Orchidea. Sp. 1

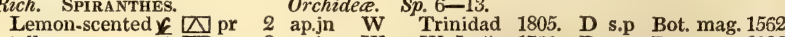
tall $\mathbb{N}$ pr 2 ap.jn W modest $\frac{2}{2} \mathrm{pr}$ in $\mathrm{pk}$ wo-colored $\triangle \mathrm{pr} 1$ ja.f W Trinadad 1819. D s.p Lindl. coll. 30

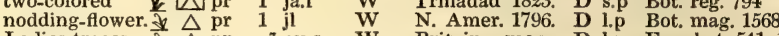
Ladies-traces $\Delta \mathrm{pr} \frac{3}{4}$ au.s W Britain me.pa. D l.p Eng. bot. 541

HUS. Rich. Stenorhynchus. Orchidea. Sp. $2-7$. showy
frosted-flower'd Orchidece. $\$ p .2$. common $\quad$ o $\mathrm{cu} \quad 1$ my.jn $\mathrm{G}$

Britain woods. R lp Eng bot 1548

$\begin{array}{lll}\text { Britain } & \text { woods. } R \text { l.p } & \text { Eng. bot. } 1548 \\ \text { Britain moi.h. R l.p Eng. bot. } 358\end{array}$ Orchidea. $S p .1-4$.

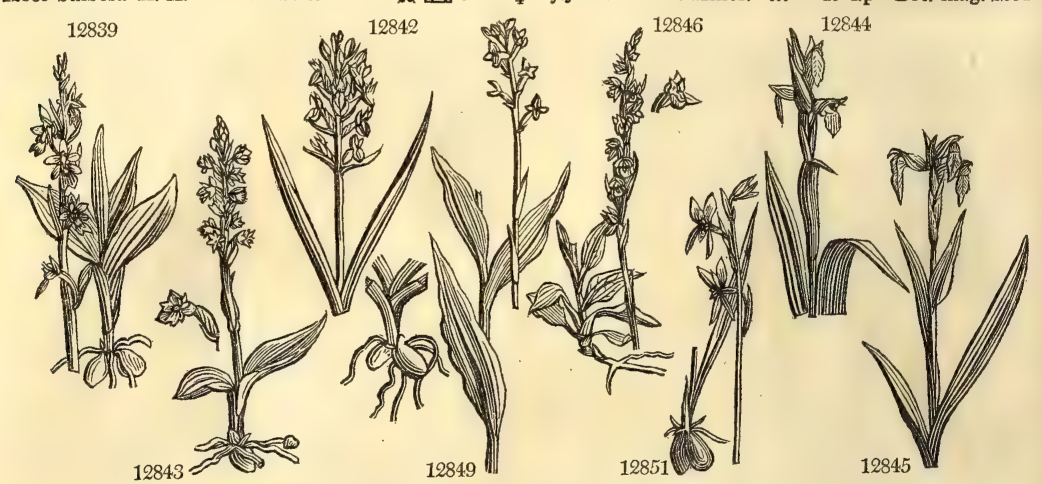

History, Use, Propagation, Culture,

Sweet directs, to "rub the pollen on the stigma." The seeds must be sown as soon as ripe, and the plant transplanted to where they are finally to remain, when of a small size. Several species of this genus, and of Orchis, were successfully cultivated by Collinson, in his botanic garden at Mill-Hill. His method was to place them in a soil and situation as natural to them as possible, and to suffer the grass and herbage to grow round them. $\quad 0$ aranifera, with a little attention and management, will grow and flower freely in pots. Curtis found the following method successful: " take up the roots carefully when in flower; bare them no more than is necessary to remove the roots of the other plants ; fill a large sized garden-pot with three parts choice loam moderately stiff, and one part chalk, mixed well together, and passed through a sieve somewhat finer than a common cinder sieve; in this mixture place your roots at about the depth of two inches, and three inches apart water them occasionally during summer, if the weather prove dry ; at the approach of winter place the pot in a frame under a glass, to keep it from wet and frost, which combined, destroy the beauty of the foliage, if not the plant itself; in the autumn, before any of the others make their appearance, this species emerges." (Curtis, Fl. Lond. n. 68.)

Salisbury says, that Ophrys muscifera, and most of its congeners, are very easily cultivated; but require the purest loam from a chalky bottom, and the border to be most effectually drained; for any permanent wet in summer makes them push too soon. On the hillocks and declivities where they grow wild, the slight showers are absorbed by the surrounding turf or long grass, and the heavy rains we usually have after midsummer-

day run off quickly. From xapes, dwarf, and Orchis. A pretty little alpine plant, exceedingly difficult to cultivate. Roots have been brought in damp moss from Switzerland, but they probably have perished ere now.

1868. Herminium. A name which is not explained by its author. It is the Ophrys Monorchis of old botanists.

1869. Serapias is the name of an Egyptian divinity, whose temples were notorious scenes of profligacy. In this sense, with reference to the uses of the plant, as also in Satyrium, the word seems to have been applied by Pliny. Rare herbaceous plants of the south of Europe, but cultivated in a frame.

1870. Goodyera. So called after Mr. John Goodyer, an obscure British botanist. The species grow freely in sandy peat, and, unlike most of the Orchidea, may be increased by dividing the roots. 
12839 Lip 3-fid : middle lobe large 2-lobed, Anther blunt

12840 Stem leafy, Lip vill. 3-lobed : midd. lobe obov, shortly 3-lobed at end, Inner sepals linear-lanc. very short 12841 Stem leafy, Lip downy obov. 3-lobed at end : lobes nearly equal, Inner sepals lanc. twice as short as outer

12842 Leaves linear setaceous, Scape naked

\section{The radical leaves lanceolate twin}

12844 Lip 3-parted : middle lobe oblong lanceolate acute smoothish hanging down 12845 Lip 3-parted: middle lobe ovate acuminate hanging down with a hairy disk

12846 Radical leaves ovate, Lip and petals lanceolate

12847 Radical leaves ovate, Lip ovate acuminate, Sepals ovate

12848 Leaves feshy chocolate-colored ovate without nerves

12849 Stem leafy, Leaves ovate-lanceolate stalked, Lip rounded glandular inside, Petals broad ovate

12850 A smooth variety of $G$. pubescens

12851 Leaves linear channelled shorter than scape, Middle segm. of lab. with a double keel inside

12852 Lip unguiculate acuminate, Inner sepals $\frac{1}{2}$-ovate

12853 Spike lax erect, Leaves stalked erect crisp smooth, Flowers discolored

\section{The only species}

$12855 \mathrm{Rad}$. lvs, obl. lanc. Scape with bractes, Anterior sepals decurrent placed under the $\frac{1}{2}$-inferior labellum 128.56 Lip obovate emarginate, Scape sheathed, Bractes shorter than flower, Leaves ovate stalked flat at edge 12857 Leaves linear-lanc. Lip subsessile crenulate at end, Sepals ovarium and rachis quite smooth

12858 Lvs. linear lanceolate 2-colored, Scape villous much longer than leaves, Fl. gibbous on its outside at base 12859 Leaves lanceolate 3-nerved, Stem sheathed, Flowers recurved cernuous, Lip oblong entire acute

12860 Rad. leaves oblong somewhat stalked, Spike twisted with the flowers on one side, Lip ovate

12861 Lip lanc. undivided, Scape bracteate, Bractes longer than flower, Leaves oblong wavy towards the end 12862 Rad. leaves broad lanceolate, Spike erect, Lip saccate at base with the sepals, Lip acuminate

12863 Stem with only a pair of ov.-ellipt. opp. Ivs. Col. of fructification having an appendage in which the anther 12864. Stem with only 2 cordate opposite leaves, Col. without any appendage behind, Lip with 2 teeth at the base

12865 The only species, Flower solitary large lilac

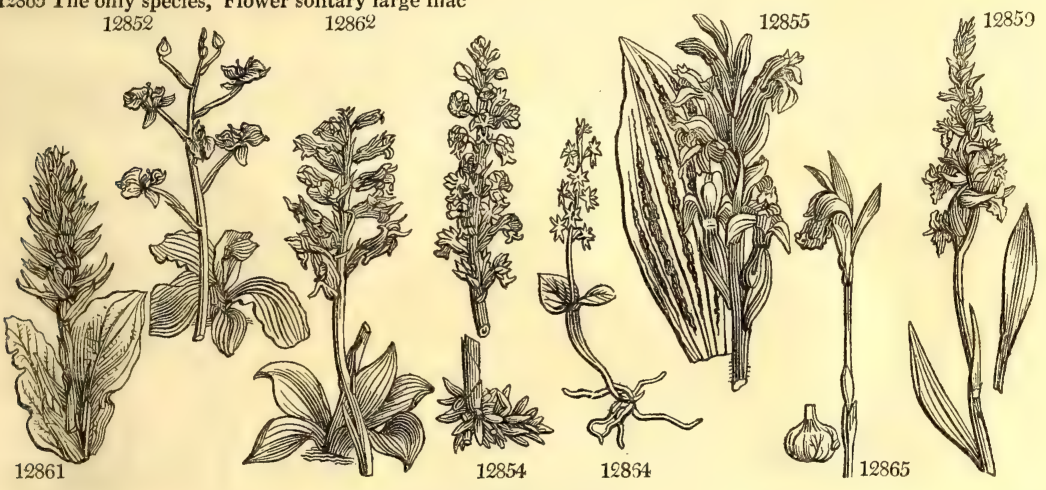

and Miscellaneous Particulars.

1871. Diuris. From $\delta 6 s$, double, and $8 \rho \alpha$, a tail, in allusion to the form of the sepals. Beautiful New Holland plants, which may be cultivated in the same way as Disa.

1872. Ponthieva. Named after De Ponthieu, who sent many specimens of West Indian plants to Sir J. Banks. The species may be cultivated in pots, well drained, and filled with sandy loam and peat. Water must be sparingly given when the plants are not in a growing state.

1873. Neottia. This word in Greek signifies bird's nest, and has been applied to the present plant on account of the interwoven fibres of its roots. No means of cultivating the only species has been yet discovered. It grows naturally in woods among decayed leaves, and is supposed to be parasitical.

1874. Spiranthes. From $\sigma \pi \varepsilon$ s ${ }^{2}$, a screw, or any thing spirally twisted; on account of the disposition of the flowers on their spike. Delicate little herbaceous plants with fibrous roots, and generally white flowers. S. restivalis has the germs on the flower-stalks placed regularly one above another, somewhat resembling tresses of plaited hair; whence its name of Ladies' traces or tresses. This species grows more readily in the garden than most of its tribe.

According to Salisbury, no plant whatever is more easy to cultivate than this. At Chapel-Allerton it propagated itself every where, springing up from seeds in the neighbouring pots, whatever soil or plants happened to be in them; and they were once found germinating on a dead root of a Persian Cyclamen, in a pot, which, for want of draining, was full of Jungermannias.

1875. Stenorhynchus. A splendid genus of evergreen stove herbaceous plants, with brilliant red or yellow flowers. They have been named from sevos, narrow, and pryxos, a beak, on account of the long pointed stigma. $\mathbf{N}$ orchioides is one of the most beautiful plants of this genus, introduced by $\mathbf{E}$. J. A. Woodford, Esq. in 1806, from the Island of Barbadoes, where it grows wild in the most arid places among grass. It requires, nevertheless, moderate waterings here while the leaves are green.

1876. Listera. Dr. Martin Lister was a celebrated English physician and naturalist, who died in 1711 The species require a shady situation and a light sandy soil, with some peat intermixed. They will grow on a bank under the drip of trees, or in small pots. They are increased by dividing the roots.

1877. Arethusa. A poetical name. Arethusa was a nymph of Diana, who was transformed into a fountain.

The species of this genus are all found in moist places. They are very impatient of cultivation. The best way to manage them, is to plant them in loose wet peaty soil, and to keep them in a frame well exposed to the sun. 
1878. CALOPO'GON. R. Br. Calopogon.

12866 pulchéllus $H$. $K$. tuberous-rooted $* \Delta$ el Limodórum tuberósum B. M.

1879. POGO'NIA. R. Br. Pogonia.

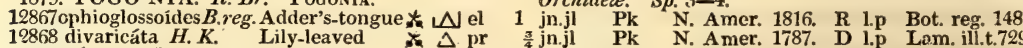

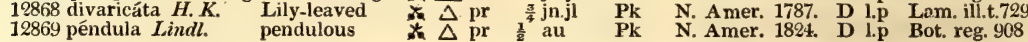

1880. EPIPAC'TIS. Sw. EPIPACTIS. 12870 latifólia $W$. broad-leaved 12871 palístris $W$ 12872 pállens $W$.

12873 ensifólia $W$

$1287+$ rúbra $W$.

marsh

white

narroly

1881. Calea'Na, R. Br. Caleana.

12875 mäjor $H . K$.

1882. CORALL smooth-lipped

12876 innáta $\boldsymbol{H}$. Z A. $H$. spurless

Orchidea. $S p$.

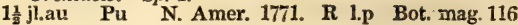

Orchidea. Sp. 5-9.

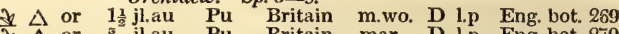
1 $\Delta$ or $\frac{5}{4}$ jl.au Pu Britain mar. D l.p Eng. bot. 270

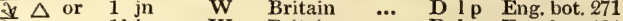
or 11 jn W Britain m.wo D l.p Eng bot 491 1) $\Delta$ or $1 \frac{1}{2}{ }^{j n . j l} \mathrm{Pu}$ Britain m.wo. D l.p Eng. bot. 437

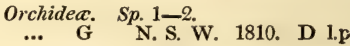

Cokallorrhiza. Orchidea. Sp. 1-4.

1883. RODRIGUEZIA. Fl.per. RodriguezIA. Orchidec. Sp. $1-2$ 12877 secínda Kunth. one-sided
Pleurothallis coccinea Hooker

1884. GOME'ZA $R$, $B$ r. GonezA. 12878 recúrva $B . M$. recurved

1885. CYMBi'DiUM. Swz. CYvaidium.

12879 tripterum $W$

12880 aloifólium $W$

12881 ensifólium $W$

12882 sinénse $W$. Aloe-leaved sword-leaved Chinese

12883 lancifólium Hook. lance-leaved 12884 depéndens Lodd. hanging-down 12885 xiphiifólium $L i n d l$. sword-leaved

1886. BR AS'SIA. $R$. Br. BRASSIA.

12886 maculáta $H . K$. spotted-flower.

12887 caudáta $L i n d l$ long_tailed

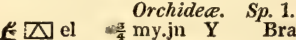 \\ $\frac{3}{4}$ my.jn Y Brazil 1814. D p.r.w Bot. mag. 1748}

Orchidea. Sp. 7-11.

$\frac{1}{2} \mathrm{jn} . \mathrm{jl}$ W Jamaica 1790. D p.r.w Smith ic. pict.14

1 my.jn Br E. Indies 1789. D 1.p Bot. mag. 387

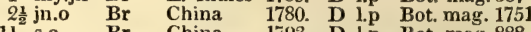

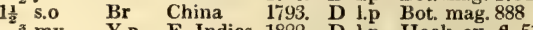

$\frac{3}{4} \mathrm{my} \quad$ Y.R E. Indies 1822. D l.p Hook. ex. fl. 51

4 1 my.au G.G China 1822. D p.r.w Bot. cab. 936

Orchidca. Sp. 2.

1 jn.jl Y.r Jamaica 1806. D p.r.w Bot. mag. 1691

1 jn.jl G.Y.R W. Indies 1823. D p.r.w Bot. reg. 832

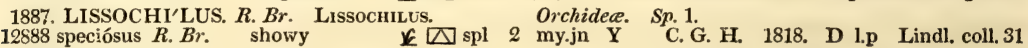

1888. GEODO'RUM. Jacks. GEODORUM.

1 jn.au Pu E. Indies 1800. D l.p Roxb. cor. 1.t.40

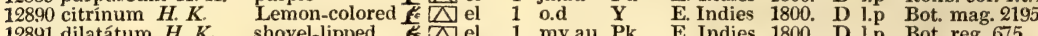
12891 dilatátum $H . K$. shovel-lipped $\mathcal{E}_{\mathbb{Z}} \mathrm{W}$ el 1 my.au Pk E. Indies 1800. D l.p Bot. reg. 675

1889. CATASE'TUM. Rich. Catasetum.

12892 tridentátum Hook. three-toothed, $E \square \mathrm{gr} 2$ jl.au Y.Br Trinidad 1822. D p.r.w Hook. ex. fl.90 12893 Claverin'gi Lindl. Capt. Clavering's $\triangle \mathrm{gr}_{2}$ jl.au Y.Br Brazil 1822. D p.r.w Bot. reg. 840 12894 floribúndum Hooker many-flowered $E \mathbb{E} \mathrm{gr}_{2} \mathrm{n} \quad$ Y.Br Trinidad 1824. D p.r.w Hook. ex. fl. 151
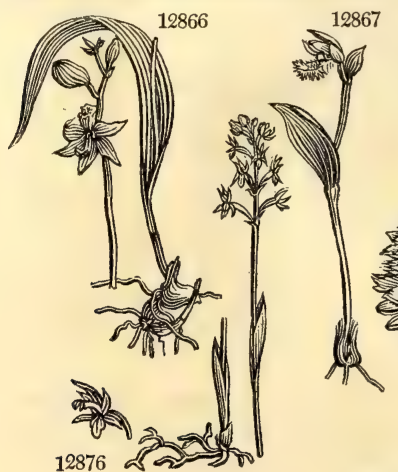

History, Use, Propagation, Culture,

$12875 \quad 12870 \quad 12874$

1878. Calopogon. From xanos, beautiful, and $\pi \omega y \omega v$, a beard, in allusion to the beautiful fringe of the lip. An eiegant plant, which was introduced accidentally, as Mr. Curtis informs us, by the laudable exertions of his gardener, who, in the spring of 1783 , examining attentively the bog earth which had been brought over with some Dionæas, found several tooth-like knobby roots, which, upon being planted in heat, afforded this plant: on the shelf of a stove, or on a bark pit it thrives exceedingly; and seems merely to require a longer and hotter summer than our climate affords.

1879. Pogonia. A name with the same derivation as the last genus. The species also require the same treatment.

1880. Epipactis. A name given by the Greeks to a sort of Hellebore, and used by Swartz to distinguish a tribe of plants previously called Helleborine. Pretty herbaceous hardy plants. "Some of its species thrive in the borders in the common garden soil, and most of them will do well in pots, in a mixture of loam and peat; they require but little water when in a dorrnant state, and are increased by dividing the roots." (Bot. Cult. 365.)

1881. Caleana. Named after Mr. George Caley, a most indefatigable and acute botanical collector, who resided several years among the natives of New South Wales, where he rnade a valuable collection of plants. The name has been subsequently changed by Mr. Brown to Caleya : which as being too similar to Calea, a very different plant, we cannot prefer to the original designation. The species require the common treatment of the tribe, and are increased by division of the roots.

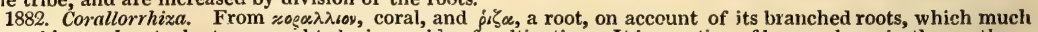
resemble coral. A plant supposed to be incapable of cultivation. It is a native of boggy places in the northern parts of the world. The three American species C. verna, multiflora, and odontorhiza, are said to have been introduced in 1824, but we have not heard of their having been cultivated with any success. 
12866 Leaves plaited long linear lanceolate. The only species

12867 Root fibrous, Leaf of the scape and bractea elliptical lanceolate, Outer sepals oblong-ovate 12868 Root subpalmate, Leaf and bractea of scape linear oblong, Outer sepals lariceolate linear 12869 Leaves ovate squamiform amplexic. Fls. subcernuous solitary, Middle lobe of lip obl. crisp, Stem angular

12870 Lvs. ov. amplexic. Lower bractes long. than fls. Fls. drooping, Lip entire acuminated shorter than petals 12871 Lws. lanc. amplexic. Bractes short. than fl. Fls. slightly drooping, Lip cren. obt. rather long. than perianth 12872 Leaves ovate-lanceolate sessile, Bractes longer than the flower, Lip obtuse shorter than perianth

12873 Lvs. lanc. much acum. subdistich. Bract. very minute subul. Fls. erect, Lip obt. much short. than perianth $1287+$ Lvs. lanc. Bractes longer than ovary, Flowers erect, Lip acute with wavy elevated lines, Ovary smooth

12875 Leaf lanc. lin. flat, Scape with a single bract in the middle, Lip smooth narrowed and $\frac{1}{2}$-ovate at each end 12876 Spur abbreviated adnate

12877 Spikes nodding 1-sided, Leaves lanceolate complicate

\section{Spikes nodding 1-sided, Leaves lanceolate flat}

12879 Stemless, Leaves growing on a bulb : radical sheathing, Scapes many-flowered, Ovary 3-winged 12880 Leaves radical broad-linear channelled fleshy retuse at end, Scapes many-flowered pendulous 12881 Leaves radical ensiform nerved, Scape round few-flowered, Lip ovate somewhat recurved spotted 12882 Leaves radical ensiform nerved, Scape few-flowered, Flowers 1-sided, Sepals striated : 3 outer reflexed 12883 Leaves radical lanceolate nerved narrowed at base, Scape round few-fl. Lip obl. recurved at end spotted 12884 Bulbous, Leaves plaited, Racemes divaricating pendulous radical

12885 Leaves thickish lin.-subulate channelled nerved crenate as long as scape, Spike few-fl. Lip not spotted

12886 Sepals lanceolate spreading not longer than ovary

12887 Sepals linear lanceolate acuminate: the lower caudate very much longer than ovary

12888 The only species. A tall plant with long rigid linear lanceolate leaves on a bulbous base

12889 Scape longer than leaves, Raceme pendulous, Flowers alternate, Lip ovate acute painted

12890 Scape shorter than lvs. Spike pendulous, Fls. close, Lip somewhat spurred at base blunt and entire at end 12891 Scape shorter than lvs. Spike pendulous, Fls. close, Lip somew. spurred at base dilated and crenul. at end

12892 Two inner sepals spotted, Lip galeate 3-toothed

12893 Spike shorter than leaves, Leaves galeate fleshy 3-toothed at end, Sepals oblong : inner spotted

12894 Spike short. than lvs. Lip gal. blunt. 3-tonth. Two inner sep. mott. with purple, others as well as col. green

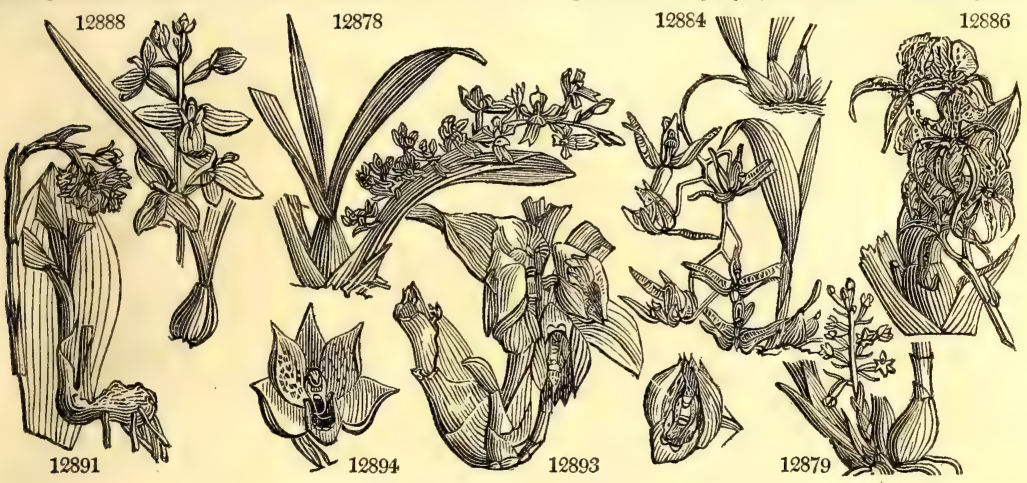

and Miscellaneous Particulars.

1883. Rodriguezia. Named by the authors of the Flora Peruviana, after Emanuel Rodriguez, a Spanish physician, and, as it is said, of considerable botanical merit. A beautiful herbaceous plant, growing upon decayed wood. Its flowers are placed in cernuous racemes of a lively pink color.

1884. Gomeza. So called by Mr. Brown, in honor of Senor Gornes, a Spanish apothecary. Mr. Lindley thinks it not distinct from the last. A bulbous epiphyte, with drooping spikes of yellow flowers.

1885. Cymbidium. From $\approx \nu \mu \rho_{n}$, a little boat, in allusion to the form of the labellum. All the genuine species of Cymbidium are terrestrial, and rarely are found growing upon trees. In cultivation the species grow in loam, chips of wood, potsherds, and other rubbish, broken small, and put in well-drained pots They are increased by dividing at the root.

1886. Brassia. Named after Mr. Brass, an intelligent gardener, who collected seeds and plants in Africa for

the Kew Garden. The two species now known are annong the most beautiful of the various tribes of Epidendrums. Prassia maculata has large pale yellow flowers, elegantly spotted with brown; B. caudata has similar flowers, with long tails to their lower segments.

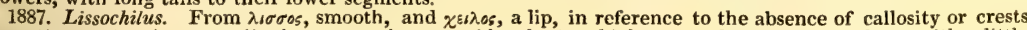
from that part. An exceedingly rare and very noble plant, which grows freely in sandy loam with a little peat. The flowers grow in long spikes of a bright yellow color.

1888. Geodorum. From rvs, the earth, and $\delta$ weov, a gift, in reference to the beauty of the blossoms lying on the earth. Handsome plants, succeeding with the treatment of Cymbidium.

1889. Catasetum. Apparently a word of hybrid extraction, from $\% \propto \tau \alpha$, and seta, a bristle, in allusion to the two long bristles or horns of the columna, which constitute one of the most remarkable characters of the genus. 3 C 3 

$\begin{array}{llllll}12895 \text { Hookéri Lindl. } & \text { Hooker's } & \text { F } \\ 12896 \text { cristátum Lindl. } & 1 \frac{1}{2} \mathrm{n} & \text { Y.Br Brazil } & \text { 1818. D p.r.w Lind. coll. bot. }\end{array}$

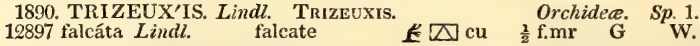

1891. XYLO'BIUM. Lindl. XYLobIur. Orchidea. Sp.1-uncertain.

$1 \approx 898$ squálens Lindl. dingy-flower'd $E \triangle \mathrm{cu} \quad \frac{3}{4}$ my.jn Y.Br Brazil 1822. D p.r.w Bot. reg, 732

1892. Maxillaria. Fl.per. Maxillaria. Orchidea. Sp. 2-uncertain.

12899 BarringtóniæLindl. large-flowered $\mathbb{Z} \mathrm{cu} 1 \frac{1}{2} \mathrm{jn.au}$ Y.G W. Indies 1790. D p.r.w Hook. ex. fl. 119

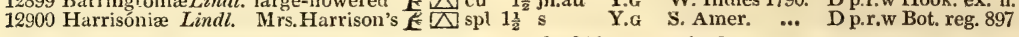

1893. NOTY'LIA. Lindl. NotYliA.

Orchidea. Sp. $1-2$

Pleurothallis punctata B. reg.

Gomeza tenuiflora Bot. cab.

1894. Pleurothal'Lis. $R$. Br. Pleurothallis. Orchidea. $S p .2-5$.

12902 racemifúra Lindi, racemose 12903 ruscifúlia H.K. Butcher's-broom-lv. E $\triangle \mathrm{k}$ cu $\frac{1}{2}$ my.jn G W. Indies 1791. D p.r.w Jac. am.t.133.f.3 1895. ONCI'DIUM. Sw. Oncidium. 12904 altissimum $W$ sharp-petaled 12905 carthaginénse $W$. Spread-eagle $F$ or 4 my.jn Ol 12906 bifólium $H . K$. two-leaved

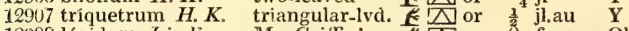
12908 lúridum Lindi. Mr. Grifin's 12909 barbátum Lindl. bearded 12910 flexuósum $B$. $M$. zigzag $\triangle$ el $1 \frac{1}{2}$ jn.jl Y 12911 pímilum 1 in 12912 Papílio Lindl. Er 1896. CYRTOPO'DIUM, $R, B r$ CYRTOPODIU⿴囗十 12913 Andersónii $H . K$ Anderson's 12914 Woodfórdii $B . M$. Woodford's $E[\triangle \mathrm{el}$ 1897. CGEL'GYNE. Lindl. CoELGXNe. 12915 purctuláta Lindl dot-flowered shining-leaved $\frac{\pi}{2}$ e 12917 fimbriáta Lindl. fringed 1898. MACRADE'NIA. $R . B r$. Macradenia. 12918 lutéscens $R \cdot B r$ yellowish

$1 \frac{1}{2} \frac{1}{2} \mathrm{jn}$.j $\quad$ Y. Orchidea. Sp.

2 my.au Y W. Indies 1804. D p.l Bot. mag. 1800 2 o $\quad$ Pk S. Amer. 1814. D p.l Bot. mag. 1814 Orchidere. $S p .3-7$.

$\begin{array}{lllll}\frac{3}{4} & \cdots & Y & \text { E. Indies 1822. D p.r.w }\end{array}$

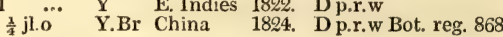
Orchidea. Sp. 1. 1899. ANISOPE'TALUM. Hooker. Anisopetalum. Orchidec. Sp. 1 12919 Careyánum Hooker Dr. Carey's E $\triangle \Delta \mathrm{cu}_{\frac{1}{3}}$ o Br.P Nepal 1823. D p.r.w Hook. ex. f. 149 1900. DENDRO'BIUM. $\boldsymbol{H} . \boldsymbol{K}$. Dendrobium. Orchidec. Sp.9-17.

T spl 1 jn au Pu N. S. W. 1801. D pl Exot bot. 1 t. 10

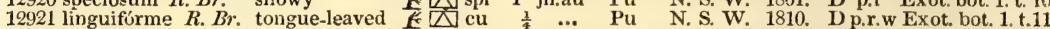
12922 cucullátum $R . B$ : cucullate $\quad \overline{\mathrm{F}}$ el $2^{4} \mathrm{mr} \quad$ Pk E. Indies 1815. C p.1 Bot. mag. 2242 12923 Pierárdi Roxb. Pierard's 12924 fimbriátum Hook. fringed $\mathbb{D}$ spl 2 ap $Y$ E. Indies 1823. C p.1 Hook. ex. f.71 12925 crumenátum $W$. sweet-scented E $\triangle \mathrm{ft} 2$ ap.ny W Sumatra 1823. C p.l Ru. am.6.t.47.f.2

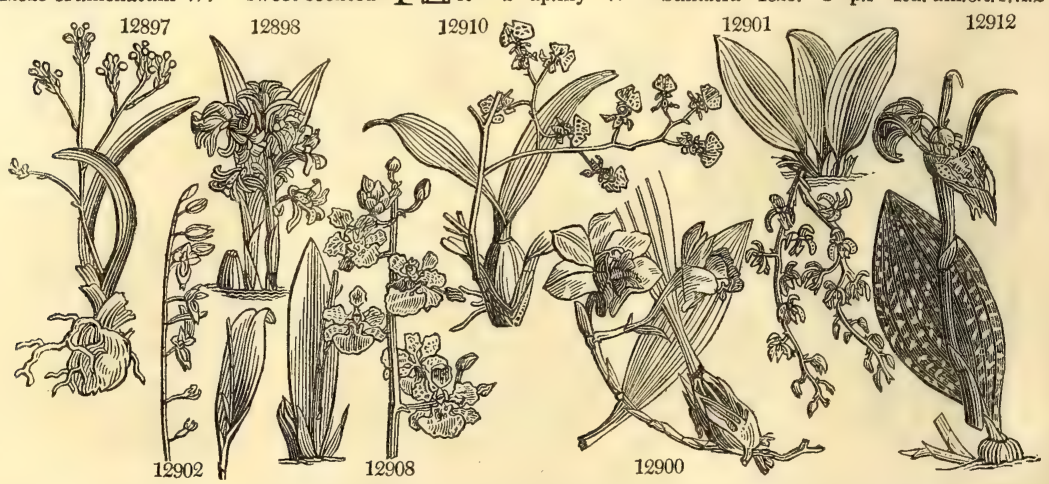

History, Use, Propagation, Culture,

Very fine epıphytes, with large bulbous roots, plaited leaves, and fine, often spotted, flowers of a greenish purple color. The bulbs contain a quantity of viscid juice, which is used, when fresh, in Brazil, for the purpose of sealing letters. The plants are there called Cebolleta.

1890. Trizeuxis. So called by Mr. Lindley without explanation. We suppose the name has been formed

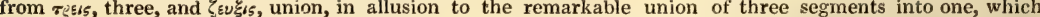
takes place in this genus. A very singular epiphyte, which is with difficulty kept alive in the stove by being placed in finely pulverised decayed wood.

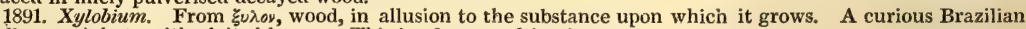
bulbous epiphyte with plaited leaves. This is of easy cultivation.

1892. Maxillaria. So called by the authors of the Flora Peruviana, as they inform us, because the labellum when looked at sideways, resembles the Maxillac of some insects. All fine South Ámerican plants, with plaited leaves and showy flowers. They are cultivated like other epiphytes, and not with much difficulty.

1893. Notylia. So called, we presume, from yaros, the back, and $\tau$. callosity at the back of the stigma, which Mr. Lindley, the author of the genus, considers very curious. An unostentatious epiphyte without bulbs, and with solitary leaves, out of the bosom of which grows a pendulous raceme.

1894. Pleurothallis. From $\pi \lambda \varepsilon v \rho \alpha$, a rib, and $9 \times \lambda . \lambda \varepsilon \omega$, to flower, in allusion to the one-sided disposition of the flowers. Singular little epiphytes with solitary leaves, no bulbs, and flowers of a green color. They grow rarely in decomposed wood. 
12895 Spike length of leaves erect, Flowers globose, Sepals rounded

12896 Perianth. spreading, Lip opened out saccate crested

\section{The only species. Flowers very small in little heads upon a branched scape}

12898 Bulbs conical truncate, Flowers close, Leaves lanceolate plaited about 3-nerved twice as long as scape

12899 Leaves about 3 oblong nerved seated on a bulb, Scape about 1-flowered sheathed

12900 Lvs. solitary lanc. plaited, Raceme 2-f. Perianth. very large wavy spreading, Lobes of lip recurved crisp

12901 Spikes pendulous lax as long as the narrow oval nerved leaves

12902 Stem long 1-leaved, Scape erect longer than obl. emarginate leaf, Fls. racemose 1-sided 12903 Stem long 1-leaved, Leaf ovate-lanceclate, Flowers clustered in the bosom of the leaf

12904 Sepals 5 lanceolate longer than lip, Scape panicled

12905 Sepals 5 obovate unguiculate a little shorter than lip, Scape panicled

12906 Sepals 4 obov. wavy, Lip long. than sep. : midd. lobe dilated reniform $\frac{1}{2}$-bifid, Scape racem. Bulbs 2 -leaved 12907 Sepals 4 acute, Middle lobe of lip roundish undivided, Scape racemose, Leaves 3-cornered

12908 Leaves ellipt. acute, Scape upright branched, Sepals wavy retuse spreading nearly equal, Lip reniform 12909 Lvs. fiat obl. lanc. Sepals 5 obovate undulate blunt, Lip transverse shorter than seg. bearded in the middle 12910 Lip 2-lobed spotted much longer than the sepals, Bulbs ovate comp. leafy at base and end, Scape panicled 12911 Lvs. rigid oval oblique, Panicle thyrsoid length of lvs. Sep. obov. Lip 3-lobed crested, Wings of col. ent. 12912 Lvs. solitary oval dotted spread. Scape jointed 2-edged few-fl. Upper sepals lin. very long, Col. 2-horned

12913 Lip narrow clawed : lateral lobes divaricating longer than the middle which is hollowed out 12914 Lip ventricose : lateral lobes shorter thar middie which is crested and callous

12915 Bulbs fascicled, Lvs. lanc. atten. at base, Sepals lanc. fineiy dotted, Midd lobe of lip acute, Crest obsolete 12916 Bulbs and leaves coriaceous and shining

12917 Lvs, twin obl. lanc. spreading, Fls. terminal sclitary, Inner sepals filiform, Lip fringed with two crests

12918 Bulbs 1-leaved : leafy at base, Leaves oblong 3-nerved, Spike erect shorter than leaves

12919 Leaves lanceolate keeled solitary on their bulb, Spike imbricated radical very little longer than the bulb

12920 Stems erect 2-3-leav. at end, Lvs. oval obl. shorter than many-fl. terminal raceme, Sepals narrow oblong 12921 Stems creep. Lvs, oval blunt depressed fleshy several times shorter than raceme, Sepals long linear acute 12922 Stems pendul. Lvs, bifarious lanc. acum. Ped. opp. the leaves about 2-fl. Lip undivided ov, cucul. at base 12923 Stems pendul. Lvs. bifarious broadly lanc. Pedunc. about 2-fl. Lip undivid. tubul. oblique almost truncate 12924 Leaves lanc. striated, Racemes many-f. Lip undivided obliquely campanulate fringed

12925 Stem branched somewhat compr. tubcrous at base, Leaves ovate-lanc. Spikes erect, Fls. remoie alternate

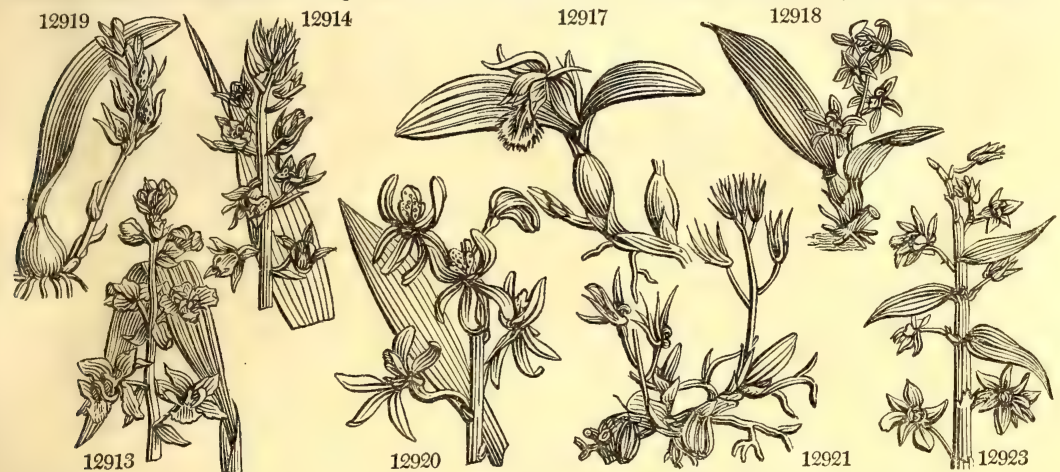

and Miscellaneous Particulars.

1895. Oncidium. From orzos, a tumour, on account of the callosities with which the disk of the labellum is covered. Among the most beautiful of epiphytous plants, conspicuous by their long loose panicles of olivecolored or yellow flowers. Oncidium altissimum grows to the height of three or folir feet. O. Papilio, the curious Butterfly-plant of Trinidad, has large yellow and red blossoms poised on slender footstalks, and dancing about in the air like some gaudy insects. All the species are cultivated without any difficulty in almost any soil, with plenty of heat and moisture.

1896. Cyrtopodium. From zеৎто5, convex, and $\pi 85$, a foot, in allusion to the labellum of the criginal species. These are handsome bulbous plants, growing either upon the ground or upon trees. They are rather difficult to manage well, and are seldom seen in collections. Their flowers, which are handsome, are rarely produced.

1897. Calogyne. So named by Mr. Lindley, from zosnos, hollow, and ruyr, a female, on account of the form of the stigma, which is peculiar for an Epidendrum. Some of the species, natives of Nepal, which have not yet been introduced into our gardens, are most beautiful bulbous epiphytes, with shining fleshy leaves, and spikes of gorgeous flowers proceeding from a rigid imbricated scaly base.

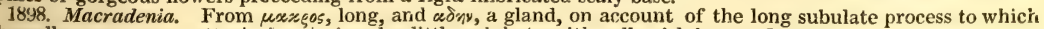
the pollen-masses are attached. A singular little epiphyte with yellowish brown flowers.

1899. Anisopetalum. From $\alpha$, without,,$\sigma \circ 5$, equal, and $\pi \varepsilon \tau \alpha \lambda \circ \nu$, a petal, on account of the inequality of the sepals, or petals as they commonly called. A curious Nepal plant, with bulbous roots, and little erect spikes of brownish flowers.

1900. Dendrobium. From $\delta \varepsilon \nu \delta \rho o v$, a tree, with reference to the habit of the species in growing upon trees, In the woods of the East Indies they climb and twist themselves about the branches of live trees, or throw 


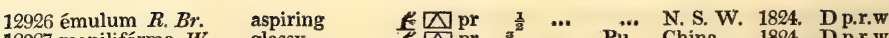

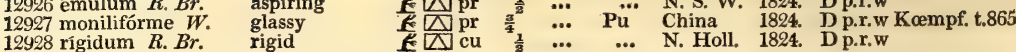

1901. CAMARY DIUM. Lindl. Camaridium. Orchider. Sp. 1.

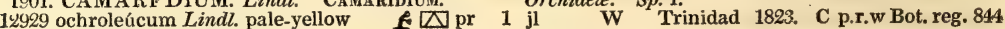
Dendróbium álbum Hook.

1902. ORNITHI'DIUM. Salisb. ORNITHIDIUM. 12930 coccíneum $H$. $K$. scarlet-flowered $\mathbb{E} \square$ or 1903. ISOCHI'LUS, $R$. $\boldsymbol{B r}$. IsochILUS.

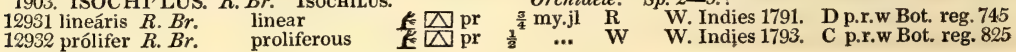

Orchidea. $S p .1$.

2 ja.d R W. Indies 1790 . C p.r.w Bot. mag. 1437 Orchidece. Sp. 2-5.?

1904. PHOLIdo'TA, Lindl. Pholidota. Orchidece. Sp. 1-2.

12933 imbricáta Lindl. imbricated E $\triangle$ or $1 \frac{1}{2} \ldots$ Br.w Nepal

1824. D p.r.w Hook, ex, fl. 138

1905. BRoUghto'NiA. $R$. Br. Broughtonia. Orchidea. Sp. 1.

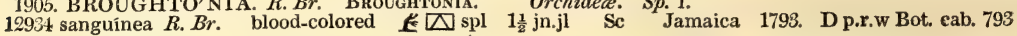

1906. CATT'LEYA. Lindl. Cattleya.

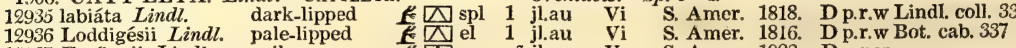

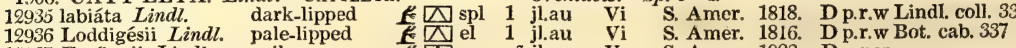

Orchidea. $S p .3-4$.

12937 For'besii Lindl. yellow

1907. EPIDEN'DRUM. $L$. Epidendrum. Orchidea. Sp. 14-67.

12938 cochleátum $W . \quad$ dark-purple $\& \square \mathrm{cu} \quad 1$ f.d $\quad$ Br.P W. Indies 1786. D s.p Bot. mag. 572

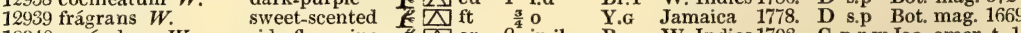

12940 secúndum $W . \quad$ side-flowering $E$ 过 or $2^{4}$ jn.jl $\quad \mathbb{R} \quad$ W. Indies 1793. C p.r.w Jac. amer. t. 137

12941 fuscátum $W$.

E. anceps Jacq.

10912 . anceps Jaco.

12043 umbellátum $W$.

1 1.914 nútans $W$.

brown

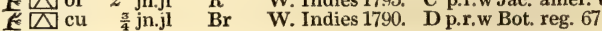

12945 conópseum $H$. $K$.

long-stalked

E $\triangle$ or 2 my.au $\mathbf{R}$

umbelled

nodding

12945 ciliáre $W$.

12947 cuspidátum Lodd. pointed

12948 diffus $W$.

12949 noctúrnum $W$. night

129050 moctir

12951 polybul'bon $S w$. many-bulbed

स $\mathrm{cu}^{\frac{3}{4} \mathrm{jn} . \mathrm{jl}}$

है or 13 jn.jl

F $\mathrm{Na} \mathrm{pr}^{\frac{1}{4}} \mathrm{au}$

R W. Indies 1798 . C p.r.w Bot. mag. 611

Y Florida 1775. D p.r.w

$\begin{array}{llll}\text { or } & 1 & \text { mr.au W } & \text { W. Indies 1790. D p.r.w Bot. reg. } 734 \\ \text { or } & 1 & \text { W. } & \text { W. Indies 1808. D p.r.w Bot. reg. } 783\end{array}$

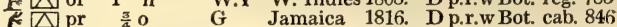

\& $\mathrm{D}$ or $1 \mathrm{O} \quad \mathrm{G}$ Jamaica 1816. D p.r.w Bot. cab. 713

EE $\mathrm{cu} \frac{1}{4}^{\frac{1}{4}} \mathrm{~d}$

G Jamaica 1816 . D p.r.w Bot. cab. 713

W Jamaica 1822. D p.r.w Hook. ex. f. 112

1908. POLYSTA'CHYA. Hooker. Polystachya. … Sp. $2-5$.

12952 lutéola Hook. smooth $\quad$ $\triangle \triangle \mathrm{cu} \quad \frac{3}{4}$ jl.a. $\quad$ Y.G W. Indies 1818. D p.r.w Lindl. coll.

12953 pubérula Lindl. downy E E $\begin{array}{llll}\frac{1}{2} & \text { o } & \text { Y.G S. Leone 1822. D p.r.w Bot. reg. } 851\end{array}$

1909. CRYPTARRHE'NA. $R, B r$. Cryptarrhena. Orchider. S $p .1$

12954 lunáta $R . B r$. crescent-lipped $E \square]$ de $\frac{1}{2}$ my.au Y W. Indies 1815 . D p.r.w Bot. reg. 153

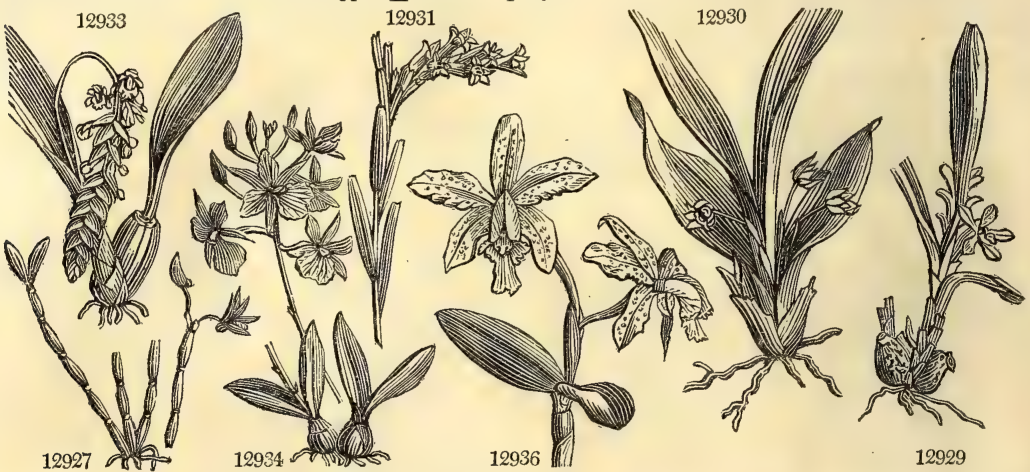

History, Use, Propagation, Culture,

down their long shoots almost in the same manner as the Miseltoe in England. The flowers are generally very beautiful, and frequently highly fragrant: they vary from a deep yellow to nearly white. All the species in the gardens are cultivated without the least difficulty by being planted in any light vegetable earth. Sometimes they are put in baskets among damp moss, but they do not succeed so well under that treatment as when planted in earth.

1901. Camaridium. Named by Mr. Lindley, from zuresoe, an arched roof. The stigma of this genus has the upper lip vaulted in a remarkable degree. An inelegant leafy caulescent bulbous epiphyte, with solitary white flowers.

1902. Ornithidium. From ogys ${ }^{\prime} \iota \xi$, a bird, in allusion to the resemblance which exists between the cuspidate upper lip of the stigma, and a bird's beak. The habit of this plant is like that of the last, but the flowers are red. They are both cultivated without difficulty in a stove, by being planted among rotten wood, or tan.

Mr. Salisbury says, Ornithidium coccineum is a parasite on old trees, near torrents, in the island of Martinico; its fibrous roots insinuating themselves into the crevices of their moist bark. Here it thrives exceedingly, in pots filled with the same, flowering at various seasons, but chiefly in October and November. During summer it should be placed in a shady part of the stove, and often sprinkled with water, but it requires little or none in winter, especially when plunged.

1903. Isachilus. From $6 \sigma^{\circ}$, equal, and $\chi_{\varepsilon} \iota_{\lambda}$.5, a lip, because the lip and the other divisions of the flower are of nearly equal breadth. The species grow in baskets of moss and old tan, or planted in pots' of sandy soil, and chips of wood, and other dry rubbish. They are increased by divisions at the root.

1904. Pholidota. A singular bulbous epiphyte, native of Nepal, remarkable for the close manner in which

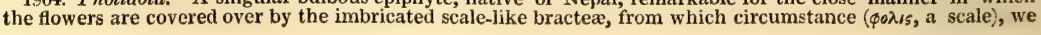


12926 Stems erect 2-3-leaved at end, Leaves oval obl. entire shorter than terminal many-fl. raceme 12927 Stem round jointed striatcd moniliform naked quite simple, Leaves oblong lanceolate 12928 Stems creeping, Leaves obl. lanceolate acute feshy the length of the few-flowered spreading raceme

12929 The only species

12930 Flowers small and appearing in the axillæ of the long leaves, Stems branched bulb-bearing

12931 Spike terminal, Leaves distichous linear blunt emarginate, Stem simple

12932 Flowers axillary, Leaves distichous lanceolate oblong, Stem proliferous, Bulbs axillary 2-leaved

12933 Lvs. solitary on a truncated conical naked bulb : lanceolate plaited, Raceme pendulous densely imbricated

12934 Leaves twin oblong seated on a bulb, Scape divided

12935 Outer sepals linear lanceolate acute 3 times as narrow as inner, Lip undivided

12936 Sepals nearly equal obtuse, Lip 3-lobed with the middle lobe saddle-shaped

12937 Sepals lanceolate: inner narrower wavy obtuse, Middle lobe of lip cordate lunate

12938 Leaves twin oblong seated on a bulb, Scape long, Lip cordate blunt

12939 Leaf lanceolate seated on a bulb, Scape short many-flowered, Lip cordate acuminate

12940 Stem simple, Leaves oblong emarginate, Peduncle terminal very long, Spike lax 1-sided

12941 Stem simple, Leaves obl. or acuminate, Peduncle terminal long, Spike globose, Col. shorter than sepals

12942 Stem simple, Leaves oblong, Peduncle terminal long, Spike lax, Lip toothed ciliated

12243 Stem simple, Leaves obl. somewhat emarginate, Flowers clustered in the bosom of a terminal leaf

12944 Stem simple, Leaves ov. lanc. amplexicaul. Flowers spiked nodding, Lip 3-lobed : middle lobe 3-toothed

12945 Stem simple, Fls, spiked erect, Lip 3-lobed: middle lobe retuse, Inner sepals narrower, Leaves lanceol

12946 Stem simple, Lvs. twin oblong veinless, Lip 3-parted : middle seg. subulate longest; lateral fringed

12947 Stem simple, Leaves 3, Spike remote few-fl. Lip 3-parted : middle segm. linear; lateral cut fringed

12948 Stem simple 2-edged, Leaves oblong, Panicle terminal much branched, Lip cordate acuminate

12949 Stem simple, Leaves obl. veinless, Flowers terminal, Lip 3-parted entire : intermediate segm. linear long

12950 Stem 1-leafed, Leaf ellipt. lanc. obt. Raceme few-fl. from the bosom of the leaf, Two inner sepals small

12951 Stem creeping bulbiferous, Bulbs 2-leaved 1-flowered, Lip cordate

12952 Spike compound : spikelets alternate erect, Flowers smooth

12853 Spike panic. thyrsiform, Leaves lanc. 7-nerved longer than scape, Fls. and ovaries downy, Bulbs ovate

12954 Leaves tufted lanceolate nerved shorter than erect spike

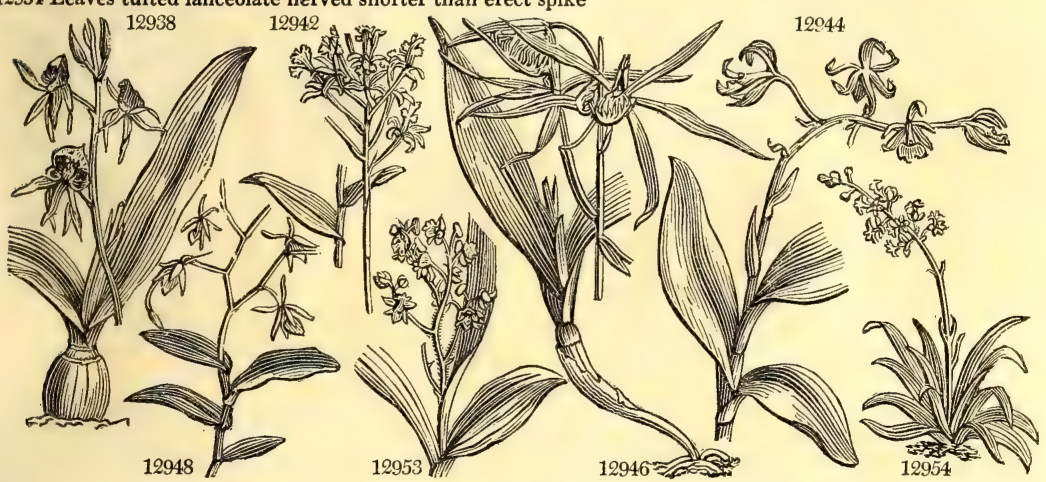

and Miscellaneous Particulars.

presume, Mr. Lindley has constructed the name. No explanation, however, of his names is ever given by this author, who seems to attach too little importance to the etymology of botany.

1905. Broughtonia. Named by Brown, in the Hortus Kewensis, without explanation. A handsome plant, with fine scarlet flowers. It is very rare, and cultivated with little success.

1906. Cattleya. Named by Mr. Lindley, after William Cattley, Esq. a munificent encourager of botany, and his early friend. A superb genus of bulbous epiphytes, with fleshy leaves growing in pairs, and large violet or yellow flowers.

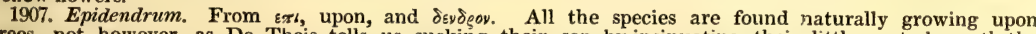
trees, not however, as De Theis tells us, sucking their sap, by insinuating their little roots beneath the bark, but vegetating in the soil which collects upon the forks of the branches. Many of the species have singular flowers, but none of those in the gardens are remarkable for their beauty. They are generally cultivated with less difficulty than most other epiphytes. Salisbury tells us, Epidendrum ciliare should be planted in pots, filled with porous stones, few decayed leaves, and knobs of bark taken fresh from the woods: it requires very little water; and if the leaves turn yellow, it is a sign that they have either too much wet, or too much sun. With such treatment, by keeping four or five pots of it, the stove will be enlivened with their long tubular flowers, slowly succeeding one another, at most periods of the year. It is easily propagated by dividing its stems.

1908. Polystachya. From rodes, many, and $s \propto x v_{5}$, a spike, on account of the compound nature of the inflorescence. Inconspicuous plants, requiring the treatment applied to similar kinds.

1909. Cryptarrhena. A pretty little stemless epiphyte with distichous leaves, and neat yellow flowers. It

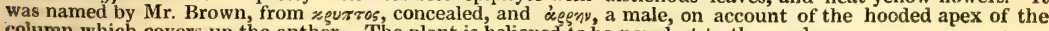
column which covers up the anther. The plant is believed to be now lost to the gardens. 
1910. ORNITHOCE/PHALUS. Hook. ORnithocephalus. Orchidea. Sp. 1.

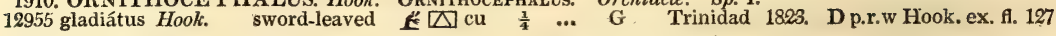

1911. BLE'TI A. Fl.per. BLETIA.

12956 Tankervilliæ $H$. K. Tankerville's

12957 verecúnda $H . K$. tall

Limodorum altum B. M.

12958 flórida $H . K$. purple

12959 hyacinthina $H . K$. hyacinthine

12960 capitáta $R$. Br. headed.

12961 pállida Lodd. pallid

1912. E'RIA. Lindl. ERIA.

12962 stelláta Lindl. stellate

12963 pubéscens Lindl. downy

1913. OCTOME'RIA. $R . B r$. OCTOMERIA.

12964 graminifólia $R$. Br. Grass-leaved

1914. BRASAVO'LA. $R$. Br. Brasavola.

12965 cuculláta $R . B r$. single-flowered $E \square$

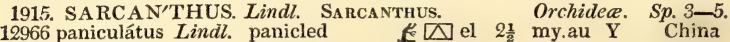

Orchidece, Sp. 6-8. 1778 , R p.I Bot. mag. 1924

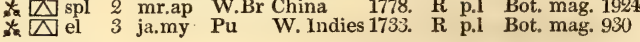

* W el 2 jl.au Pu W. Indies 1786. R p.l Redouté lil. 83 * $\backslash$ el- 1 mr.jn Pu China 1802. R p.l Bot. mag. 1492

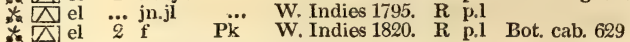

12967 teretifólius Lindl. slender-leaved $\mathbb{1}$ cu $1 \frac{1}{2} \mathrm{r}_{\mathrm{s}}$ Y.Pu China

12968 rostrátus Lindl. $\quad$ rostráte

1916. VAN'DA. R. Br. VANDA.
12969 multiflóra Lindl.
many-fiowered

12970) Roxbírghi $R$. Br. Roxburgh's

12971 trichorhiza Hooker hairy-rooted E $\mathrm{W}$ pr $\frac{3}{4}$ au Pu.G E. Indies 1822. C p.r.w Hook. ex. fl. 72

1917. A'ERIDES. Sw. AIr-Plant.

12972 odorátum $H . K$ fragrant $\mathrm{ft}{ }_{1}$ Orchidece. $S p .2-11$

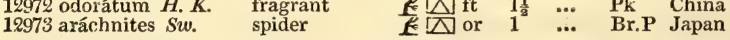

1918. RENANTHE'RA. Lour. Renanthera. Orchidece. Sp. 1.

12974 coccínea Lour. scarlet E[D] spl 5 … Sc Sp China

1800. C p.r.w

1793. C p.r.w Kæmpf.t.869.f.1

\section{IONOP'SIS. Kunth. IoNopsis.}

12975 utricularioídes Lindl. Small-flowered $E \square$ pr $\quad \frac{1}{2}$ o.n $\quad$ W.pu W. Indies 1822. D p.r.w Hook. ex. fl, 113 Jántha pallidiflora Hooker.

1920. EULO'PHIA. $R$. Br. EULOßHI.

12976 grácilis Lindl. slender $\$ \mathrm{pr} 2$ my.n G $\mathrm{G}$. 2 . Leone

数 2 pr 2 my.n G S. Leone 1822, R p.l Bot. reg. 742

12977 guineénsis $R . B r$. shovel-flower'd $\triangle$ el 1 my.n Pk $\quad$ S. Leone 1822. R p.l Bot. reg. 686

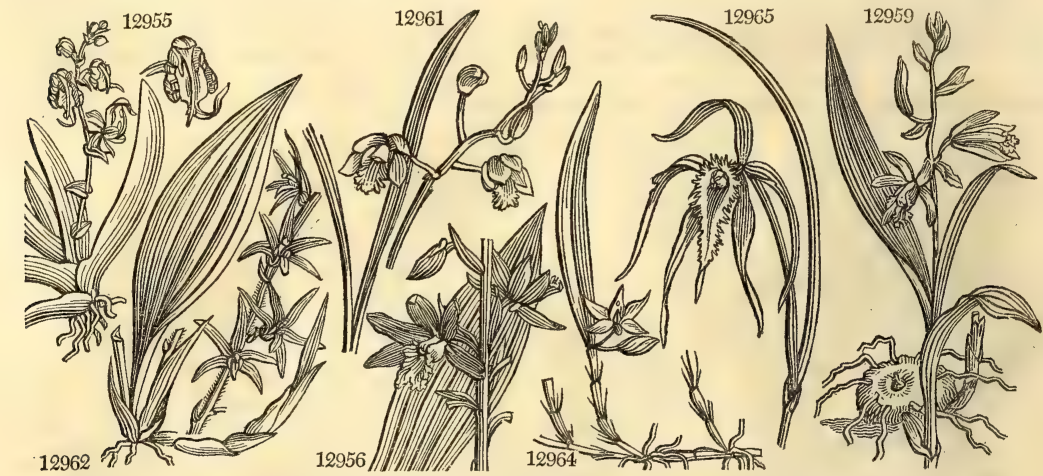

History, Use, Propagation, Culture,

1910. Ornithocephalus. A very curious little plant, only an inch or two in height, found in Trinidad growing upon rotten sticks in the woods. It bears two or three green flowers, which contain a column, the upper extremity of which is lengthened out into a fine subulate process, resembling a snipe's bill in miniature whence the name, from ogvi $9 t_{5}$, a bird, and $« \varepsilon \phi \lambda \eta$, a head. No successful method of cultivating this plant has yet been discovered

1911. Bletia. Dedicated to Luis Blet, a Spanish apothecary, who has always, as we are informed by the authors of the Flora Peruviana, distinguished himself in his botanical studies. Very noble plants, growing in the earth.

Bletia Tankervilliæ is a common but beautiful species. The first plant which flowered in this country, was cultivated at Apperly Bridge, near Bradford, in Yorkshire, in May 1776, and had been sent there to Mrs. Hird, by her uncle, Dr. Fothergill, in a black Chinese pot full of stiff loam, in which it had been imported. Many small bulbs, with leaves like those of a snow drop, grew near the edge of the same pot in a regular circle, and these afterwards proved to be Amaryllis Aurea. The Bletia Tankervilliæ delights in warmth, fresh loam, and plenty of water, by which treatment, and attention to fecundate the stigma, it will ripen fruit abundantly.

1912. Eria. From eesov, wool, on account of the woolliness of the flower of all the known species. Curious epiphytous plants, with bulbous roots, and flowers usually of a yellowish color. They differ from Dendrobium chiefly in the number of their pollen-masses, and in habit. E. stellata is a fine free-growing plant, with long broad fleshy leaves, and spikes of beautiful brown-yellow flowers nearly a foot and half in length.

1913. Octomeria. So called by Mr. Brown, with reference to the eight parts, oxto, and $\mu \varepsilon_{005}$, into which the pollen is divided. A singular little plant, with filiform leaves and small nearly solitary flowers. The true limits between this genus and the last remain to be determined. The two seem to be separated by nature.

1914. Brasavola. Named after Antonio Musa Brasavola, an Italian botanist, born at Ferrara in 1500 . Plants with long subulate fleshy leaves, and large white flowers. They are cultivated without difficulty in peat and sand, if good decomposed wood is not to be procured.

1915. Sarcanthus. A curious genus of plants not remarkable for their beauty. Their habit is various, but always caulescent ; their flowers either yellow or yellowish, marked with various shades of purple. The name 
12955 Leaves distichous obtuse compressed

12956 Lip spurred undivided : spur short, Leaves radical ovate lanceolate

12957 Lip not spurred : ribs of the disk branched; middle lobe broader than long, lateral narrower upwards

12958 Lip not spurred : ribs of the disk simple; middle lobe somewhat cuneiform, lateral broader at end 12959 Lip not spurred beardless, Pollen-masses 4, 2-lobed, Stem leafy, Flowers racemose

12960 Lip not spurred with a callus in the inside near the base, Stem leafy, Flowers capitate

12961 Leaves linear-lanceolate plaited, Sepals connivent, Scape higher than leaves

12962 Lvs. lanc. fleshy 5-nerved, Sep. ov. lanc. acum : midd. lobe of lip acum. Ovary and outer sep. ferruginous 12963 Bulb obl,-ov. Lvs, distich. lanc, smooth, Fls. loosely spik. Lip obl. 3-lobed, Three exterior sep. unit. at base

12964 Stem long 1-leaved, Leaf lanceolate, Peduncles twin 1-flowered, Root creeping

12965 Stem 1-flowered, Lip ciliated

12966 Stem panicled, Spur straight hanging down scarcely so long as ovary, Leaves bifid and unequal at end 12967 Leaves subulate, Lip spurred 2-celled, Raceme shorter than leaves

12968 Leaves lanc. flat somewhat recurved, Spike simple horizontal, Lip and anther rostrate

12969 Caulescent, Leaves remotely distichous broad linear channelled obtuse, Spikes opp. the leaves 12970 Sepals oblong obovate wavy, Leaves obliquely 3-toothed at end

12971 Lip without a spur, Sepals linear-lanceolate nearly equal, Leaves cylindrical

12972 Spur ascending conical subulate, Middle lobe of lip shorter than lateral ones, Leaves blunt

12973 Stem branched rooting, Leaves lanceolate, Sepals revolute dilated at the end, Lip bifid in front

12974. The only species

12975 Leaves lanceolate lined flat, Scape panicled, Sepals shorter than the lip

12976 Scape very slender 3 times as long as the lanceol. 3-nerved leaves, Spur clavate, Midd. lobe of lip obsolete 12977 Leaves lanceolate nerved, Spur ascending, Lip membranous complete

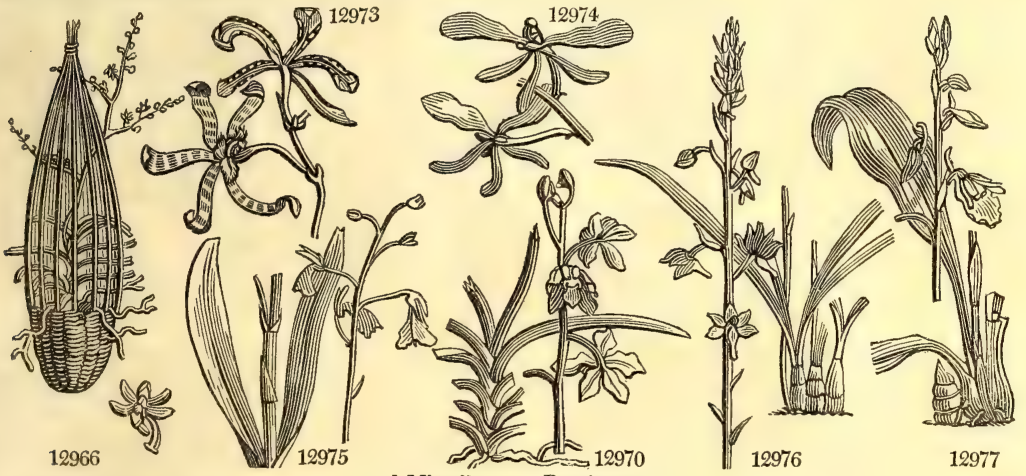

and Miscellaneous Particulars.

has been given by Mr. Lindley, from $\sigma \propto \rho \xi$, flesh, and $\alpha \nu \cdot 9 \circ 5$, a flower, in allusion to the texture of the sepals and labellum.

1916. Vunda. The Hindoo name of the original species. Noble caulescent plants adhering to old decayed arms of trees or fallen wood, by means of their tendril-like fleshy tortuous roots. The flowers of all the species are large and shewy. Their treatment is the same as the next.

1917. Aerides. Derived from aër, the air; in allusion to the peculiar property the species possess of existing many months suspended in that element. This genus and the two last are those to which the name of Air-plant is most properly applied, very few others being capable of enduring for any considerable period such a removal from their natural places of growth. The true species of this genus are beyond all comparison the most delightful productions of the vegetable world. Their flowers are arrayed in long spikes or racemes of delicate colors and delicious fragrance. Hung up in a room in their native country, a little before flowering, they continue to unfold their blossoms in gradual succession for many weeks. In this country they are rarely seen in flower. The only genuine species, the A. odoratum, should be planted in rotten wood with a little peat, or a few decayed leaves, or any light black vegetable mould, and kept in the hottest and dampest place of the stove. If put in baskets among moss and kept very damp, the plants will succeed for a short time, but they soon languish, and put on a yellow appearance, the certain indication of unhealthiness.

1918. Renanthera. A name contrived by Loureiro, to express the kidney-form or reniform shape of the pollen-masses. This plant is not uncommon in good collections, where it has sometimes acquired the height of six or eight feet; but it has never yet produced its flowers. These appear, in the native country of the plant, in large loose panicles, and are individually of considerable size and of a rich crimson color, a little mottled with yellow.

1919. Ionopsis. So called by Mr. Kunth, from soy, a violet, and oats, resemblance. I. utricularioides is a pretty little epiphyte, with purplish falcate leaves. It succeeds ill under any management which has hitherto been applied to it.

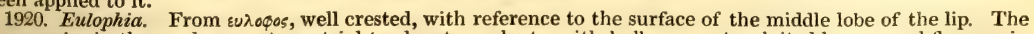
two species in the gardens are terrestrial tender stove plants, with bulbous roots, plaited leaves, and flowers, in E. exaltata, green and inconspicuous, in E. guineensis, whitish pink, and very handsome. They should be treated like Cymbidium. 
1921. ANGR F'CUM. Pet. Th. ANgracum. 12973 maculátum Lindl. spotted 12979 falcátum Lindl. falcate 12980 lúridum Lindl. lurid

\section{AERANTHES. Linal. AERANTHES}

F $\triangle$ pr 1 o.n Pk Africa

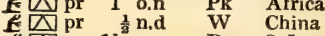

Br S. Leon

Orchidece. $S p .2-3$.

1819. D p.r.w Lindl. coll. 15

1815. D p.r.w Bot. mag. 2097

12981 grandiflóra Lindl. large-flowered $E$ S or $\quad \frac{3}{4} \quad$ G.x Madagasc.1823. D p.r.w Bot. reg. 817

1923. CaLAN'THE. R. Br. Calanthe. 12983 veratrifólia $R$. B 1924. STE'LIS, $S w$. plaitedeaved 12984 ophioglossoídes $W$. Adder's-tong.-lv. $\frac{K}{\mathbb{E}} \mathrm{cu}$
12985 micrántha $W$. small-flowered $E \nabla \mathrm{cu}$ 1925. MALAX' marsh

1926. PRESCO'TIA. Lindl. Prescotia. 12987 plantaginea $L i n d\}$. plantain-leaved $\mathbb{f}$ cu $1 \frac{1}{2}$ 1927. MICRO'STYLIS. Nutt. Microstymis. 12988 ophioglossoídes $N$. Snake's-tongue-lv. $\$ \Delta \Delta$ de $\frac{1}{4}$ 1928. LI'PARIS. Rich. LIPARIS. 12989 liliifólia Rich. Lily-leaved 12990 Lœesélii Rich. Loesel's 12991 bituberculáta Lindl. long-leaved 12992 foliósa $L i n d l$. leafy 12993 refléxa Lindl. reflexed 1929. CALYP'SO. Salisb. CALYPSO. 12994 boreális Salisb. northern 1930. VANIL'LA Siv. VANILla. $129 y 5$ aromática $H . K$. aromatic 12996 planifólia $H . K$. fragrant

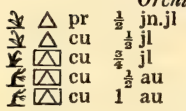
Orchidea. $S p .1-7$.

2 jn.jl W E. Indies 1819. R p.1 Bot. reg. 720 Orchidea. Sp. 2-10.

$\frac{1}{2}$ my.jn G W. Indies 1791. D p.r.w Bot. cab. 442

n.d G Jamaica 1805. D p.r.w Hook. ex. f. 158 Orchidea. Sp. $1-3$.

jl Y.G England tur.bo. R p.s Eng. bot. 79 Orchidea. $S p, 1-2$.

Orchidea. Sp. 1-2. jl Y.G N. Amer. 1824. R p.s Plu.am. t.434.f.4 Orchidea. Sp. 5-9.

jn.jl G.Pu N. Amer. 1758. R p.s Bot. mag. 2004 $\mathbf{Y}$ England sa.ma. $\mathbf{R}$ p.s Eng. bot. 47 G Nepal 1822. D p.r.w Hook. ex. fl. 116 G Isl.France 1823. D p.r.w Bot. reg. 882 Orchidea. Sp. $1-2$

$₫ \Delta \mathrm{pr} \frac{\lambda}{2}$ my.jn Y.R N. Amer, 1805. R s.p Hook. ex, fl. 12 Orchidece. $S p .2-3$.

\& $\square$ ec 10 jn.au W S. Amer. 1739. C p.l Plu. ic. 183. t. 188 I $\square$ or 10 ap.jn W W. Indies 1800. C p.1 Bot. cab. 733

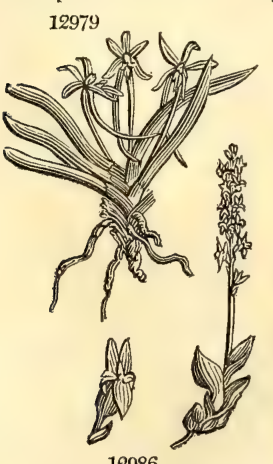

12986

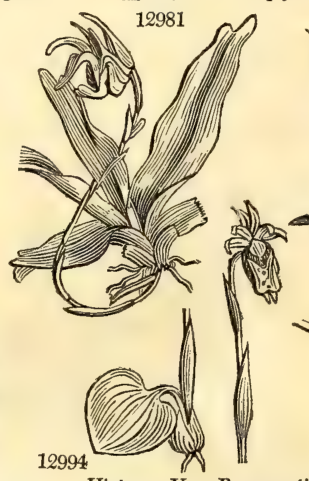

History, Use, Propagation, Culture,

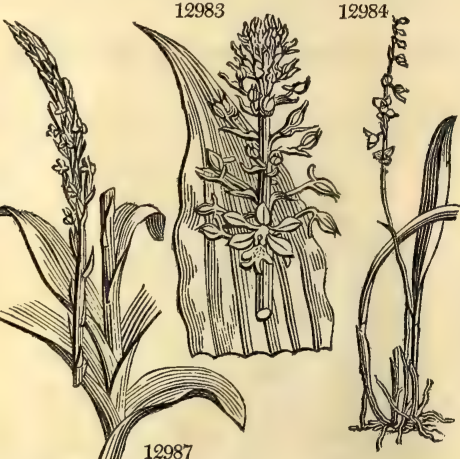

12987

1921. Angracum. A latinized form of the Malay appellation angrec, which is bestowed upon all epiphytous plants. This is a pretty genus, remarkable for the distinct spur to the lip. A. maculatum has handsome flat fleshy spotted leaves, and varies with flowers of a delicate pink and of a pale green color. A. luridum is an exceedingly rare species, with plaited leaves and conical bulbs covered with the vestiges of former leaves. A. falcatum is a little Japanese plant, whose flower has a spur nearly as long as the plant itself. It is easily grown among loose moss in a warm damp place, but there should always be some bits of rotten wood mixed among the moss for the tender roots to adhere to.

1922. Aeranthes. A word with the same meaning as Aerides. Fine Madagascar plants. A. sesquipedalis, which has not yet blossomed, bears in its own country very large white flowers, with a spur a foot and half in length. The species are not caulescent as in Aerides, and the flowers appear singly, or two or three together, not in long racemes.

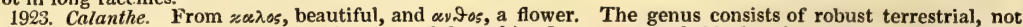
epiphytous, plants, with long plaited leaves, and fine white flowers, remarkable for the curious conformation of the labellum. They are easily cultivated as Cymbidium.

1924. Stelis. This was the Greek name of some parasitical plant found growing upon trees. The modern genus consists of little inconspicuous West Indian plants, with solitary leaves, and minute green flowers disposed in long filiform axillary spikes. They are not very easily managed; the best mode of cultivation is to plant them in very rotten wood with a little moss about them, and to keep them in a hot damp stove.

1925. Maiaxis. From $\mu \alpha \lambda \alpha \xi_{i 5}$, softness, in allusion to the delicate texture of the genuine species. They are natives of moist piaces in marshes, and are scarcely capable of successful cultivation.

1926. Prescotia. So called by Lindley in compliment to his friend John Prescot, Esq., an English gentleman resident at St. Petersburgh, and highly distinguished for his botanical acquirements. A curious little plant, with long spikes of green flowers. It is easily cultivated in peat and sand.

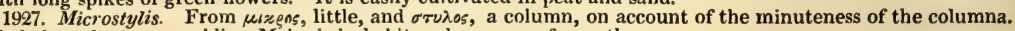
Little bog plants, resembling Malaxis in habit and manner of growth.

1928. Liparis Probably derived from $\lambda \epsilon \pi \propto \rho \circ$, unctuous, in allusion to the surface of the leaves of the original species, L. Loeselii. This genus consists of plants varying somewhat in habit, but agreeing in having pale green or greenish purple flowers, in terminal spikes or racemes. Part of the species are terrestrial, requiring the treatment of Malaxis; the remainder are epiphytes.

1929. Calypso. A poetical name, from $\approx \alpha \lambda \nu \pi \tau \omega$, to conceal; not merely alluding to the covering of the stigma, but preserving an analogy between this botanical beauty, so difficult of access, and the secluded goddess, whose isle was fabled to be protected miraculcusly from the observation of navigators.

1930. Vanilla. An alteration of vaynilla, which is a diminutive of vaina, a Spanish word, signifying a sheath. The fruit is a long cylindrical pod, very like the sheath of a knife. Vanilla aromatica produces the fruit of that name, which is used in England to flavor chocolate, and in Spanish America for that purpose, for perfuming snuffs, and as a medicine. The Spaniards have three different sorts, which they distinguish in com- 
12978 Leaves lanceolate spotted flat entire

12979 Leaves somewhat radical ensiform channelled falcate, Scapes few-fl. Spur filiform very long

12980 Stem compr. sheathing panicled, Branches quite simple spreading, Lip 3-lobed, Spur inflex. blunt emarg.

12981 Leaves 2-lobed and very unequal at end shorter than the weak radical sheathed scape, Spur emarginate 12982 Spur very long filiform, Spikes sheathed axillary

12983 Leaves lanc. plaited nerved, Spike dense many-flowered, Bractes small lanceolate

12984 Stem 1-leaved, Leaves oblong lanceolate the same length as raceme, Flowers 3-cornered 12985 Stem long 1-leaved, Leaf broad-lanceolate shorter than raceme, Flowers 6-cornered

12986 Lvs. about 4 at the base of the stem scabrous at the extremity, Scape pentagonal, Lip concave acute

12987 Leaves oblong cæsious flat nerved, Flowers in a long dense spike

12988 Scape 1-leaved, Leaf amplexicaul. Lip truncate emarginate

12989 Lvs. twin ovate-lanc. Scape 3-cornered, Inner sepals reflexed discolored, Lip concave obov. acute at end 12990 Leaves twin ovate-lanceolate, Scape 3-cornered, Lip ovate at end recurved

12991 Somewhat bulbous, Leaves 4-ovate plaited striated wavy, Lip reflexed with two tubercles at base

12992 Radical leaves unequal lanceolate entire acute fleshy about the same length as raceme, Lip oblong retuse 12993 Leaves lanceolate ensiform keeled, Raceme many-flowered, Lip 3-toothed at end

12994 Lip narr. at base somew. clawed, Spur $\frac{1}{2}$-bifid long. than lip with acute teeth, Pedunc. longer than ovary

12995 Leaves ovate oblong nerved, Sepals wavy, Lip acute, Caps. cylindrical very long 12996 Leaves oblong lanceolate flat obsoletely striated, Lip rețuse
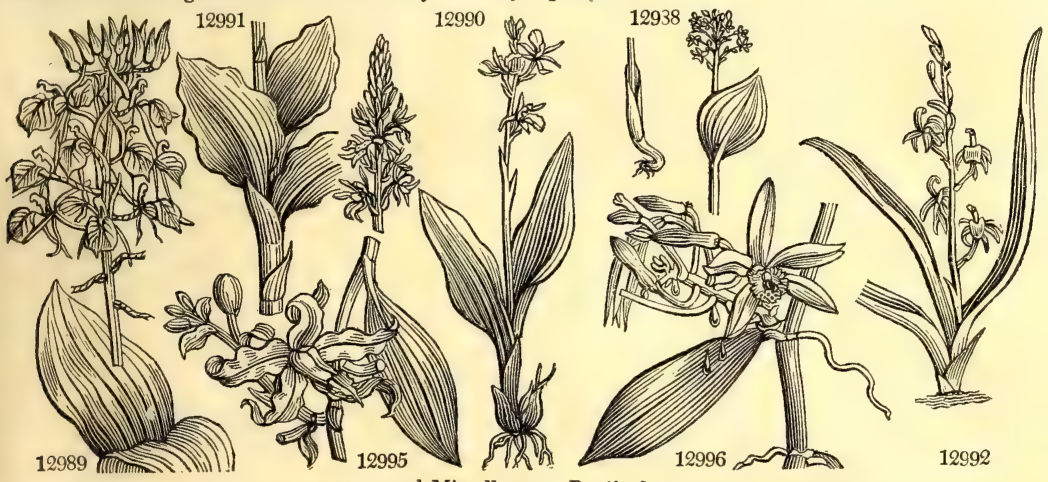

and Miscellaneous Particulars.

merce, viz.; the pompona, the ley, and the simarona. When the fruit begins to turn yellow, it is gathered and fermented in small heaps, in the same manner as is practised with the cocoa or chocolate pods (Theobroma) it is then spread in the sun to dry, and when about half dried, pressed flat with the hand and rubbed over with the oil of Palma Christi, or of the cocoa; it is then exposed to the sun to dry, the oiling repeated, and the pods covered with the leaves of the Indian reed to preserve them. The fruits which are brought to Europe are of a dark brown color, about six inches long, and scarce an inch broad ; they are wrinkled on the outside, and full of a vast number of black seeds, like grains of sand, of a pleasant smell, resembling Balsam of Peru.

The species of this genus, like many other Epidendreæ, are falsely called parasitical; but are no more so than our Polypodium vulgare, which is often found growing on the trunks of old trees. especially pollards, rooted in the decaying bark. The Vanillæ shoot out roots at every joint like the Ivy, and may be either grown on a piece of a rotten trunk of a tree, or planted in a pot of rotten tan mixed with rubbish, and the stem trained against any surface which it can root into. Like all the tribe, these plants require very little water.

Mr. Salisbury has the following observations upon Vanilla planifolia. "It was discovered by Father Plumier, in the island of St. Domingo, where it grows wild, climbing to the tops of the highest trees; and is easily preserved in our stoves, throwing out one or more roots at every leaf; but as it seldom flowers here, I would recommend the following treatment: - plant it at one end of a low bark stove, the temperature of which must be kept constantly hot and damp, never below sixty degrees of Fahrenheit in the night, during winter. Let the earth be fat loam, taken about an inch deep from the surface, in some old wood: mix this with a few decayed leaves and small pieces of rotten sticks, either in a tub bored full of holes, and sunk at the back corner of the bark pit; or pale off a space of two square feet for it, draining the bottom a foot in depth very effectually with hollow tiles and porous stones. Select a healthy young plant to place in this earth, and as soon as it pushes vigorously, divide the stem, by pinching off its top, into three or four principal branches, which train backwards and forwards over that end of the bark pit, at two inches and a half distance from each other, on stout rods of a rough-barked elm nailed firnly across; the roots which issue from the bottom of the stem or branches, must be suffered to penetrate into the earth, where they will swell and nourish the plants; but if those beyond attempt to strike downwards, wind them gently along the elm rods, to which they will soon cling by small fibres, like those of Ivy. When the principal branches have extended to fifteen or twenty feet in length, divide them again by pinching their tops, as you find it necessary, into about a dozen branches in all, which must be left to flower guiding them first horizontally, and afterwards in every possible direction, upon smaller rods of rough-barked elm, stuck into the bark pit at various angles. From the twentieth of March to the twentieth of September, shade that end of the stove by the light foliage of a Passiflora, trained all over the top, but pruned so thin as to admit the rays of the sun to play on the bed underneath: I prefer this method to a mat, for many reasons. Let the earth be always damp by gentle sprinklings of water, but never very wet, except in the great heats of summer, when I should be inclined to give the plant two or three drenching showers all over from a fine-nosed watering-pot, shutting up the house at night full of steam." 


\section{$D I A N D R I A$.}

1931. CYPRIPE'DIUM. $W$. LADIES-SLIPPER. 12997 Calcéolus $W$. 12998 parviflórum $W$. 12999 pubéscens $W$. 13000 spectábile $W$ 13001 húmile $W$.

13002 arietinum $H$. $K$ 13003 venústum $W$ all. 13004 insigne Wall. 13005 STI'DIUM. $R$. Br. STYLIDIUM. 13006 fruticó 13006 fruticósum $R$. Br. shrubby 13007 scándens $R . \quad B r . \quad$ climbing laricifólium Rich.

13009 adnátum $R . B r$. adnate

1933. GUNNE'RA. $W$. GunNerA.

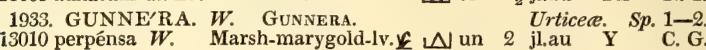

Orchidea. Sp. 8-14.

$\forall \Delta$ or 1 my.jl $Y$ England woods. R s.p Eng. bot. 1 yellow downy $\Delta$ or 1 my.jn $Y$ N. Amer. 1759. R s.p Bot. mag. 911 white-petalled $\frac{\Delta}{\Delta}$ or 1 my.jn $\mathbf{Y}$ N. Amer. 179. R s.p Bot. cab. 895 $\frac{1}{\Delta}$ or $\frac{1}{2}$ jn.j.jn Rw N Amer. 1786. R .p Bot. mag. 19 Ram's-head $\frac{1}{7} \Delta$ or ${ }^{\frac{1}{2}}$ my W W. Amer. 1808. R s.p Bot. mag. 1569 handsome $\frac{1}{4} \mathrm{el} \frac{1}{2}$ jl.au G.Pu Nepal 1816. D s.p Bot. reg. 788 ¿ $\triangle \mathrm{f}$ el 1 jl.au G.Pu Nepal 1819. D s.p Lindl. coll. 32 Stylidec. Sp. 5-45.

If $\triangle$ or 1 ap.au Pk N. S. W. 1803. S s.p Bot. reg. 90 w or 112 my.o Pk N. Holl. 1803. S s.p Par. lond.77 $\checkmark \mathrm{V}$ or $2^{2}$ jl.au Pk N. Holl. 1803. S s.p

E $\triangle$ or 1 jl.au Pk N. Holl 1818. S s.p Bot. mag. 2249 이 or $\frac{1}{2}$ jl.au Pk N. Holl. 1824. S s.p Bot. reg. 914

\section{HEXANDRIA.}

1934. ARISTOLO'CHIA. $W$. Birtirwort 13011 trilobáta $W$. 13012 máxima $W$ 13013 Sipho $W$

13014 tomentósa $B . M$ 13015 odoratissima $W$ 13016 barbáta $W$ 13017 índica $W$. 13018 bo'tica $W$ 13019 glaúca $W$ 13020 sempervirens $W$. 13021 lónga $W$ 13022 Serpentária $\boldsymbol{W}$. 13023 bracteáta $W$. 13024 Pistolóchia $W$ 13025 rotúnda $W$ 13026 pállida $W$.

13027 hirta $W$.

13028 Clematítis $W$. 13029 arbores'cens $W$ 13030 labiósa B. Reg. 13031 acumináta $W$ greatest bracteated small round-rooted pale-flowered
Aristolochice. Sp. 21-69 道 $\square$ or $20 \mathrm{jl} \quad \mathrm{Pu}$ New Spain1759. C l.p Jac, amer, t. 146 or 30 jn.jl Y.Br N. Amer 1763. L s p Bot mag. 534 downy-leaved $\bar{\beta}$ or 20 jn.jl Pu N. Amer. 1799. L s.p Bot. mag. 1369 sweet-scented $\square$ or 10 jl Pu Jamaica 1737. C p.l Slo. ja.1.t.104.f.1 bearded Spanish or 10 jn.jl $\mathrm{Pu}$ $\triangle$ or 6 my.jn $\mathbf{P u}$ glaucous-leav. $\mathrm{t} L$ or $6 \mathrm{jl} \quad \mathrm{Pu}$ evergreen 2 or 4 my.jn $\mathrm{Pu}$ long-rooted * $\triangle$ or $1 \frac{1}{2} \mathrm{jn} .0$ Pu $\mathrm{S}$. Snake-root $\quad$ * $\triangle$ or 1 jn.jl D.Pu N. Amer. 1632. R s.p Jac.scl:œe.3.t.385 c 4 or 2 mi.o or 2 my au W. or 2 my.jn Pu common $\Delta$ or 2 my.au $Y$ England woods. $R$ co Eng. bot. 398 tree $\quad$ or 20 jn.jl Y.Pu America 1737. C 1.p

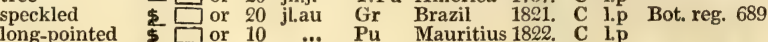

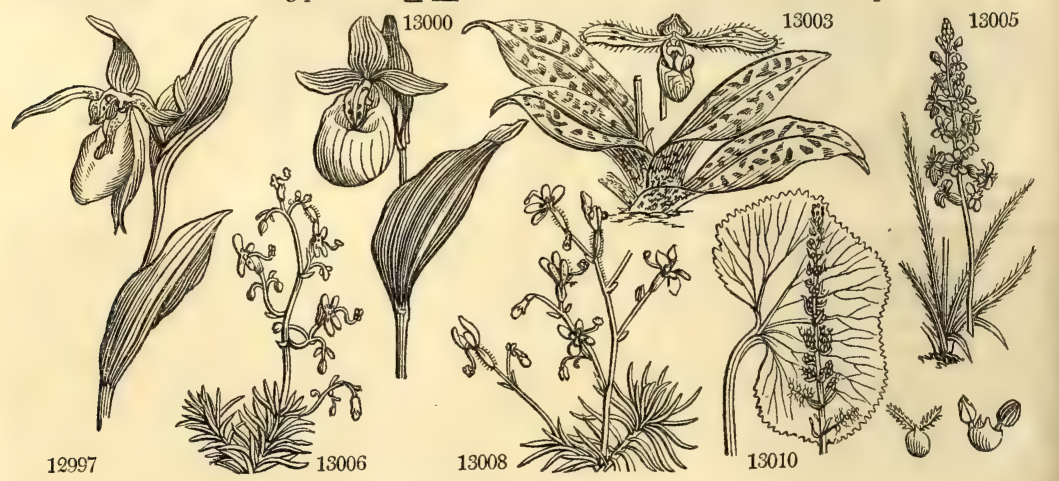

History, Use, Propagation, Culture,

1931. Cypripedium. From Kvтebs, Venus, and rodıv, a slipper, in allusion to the elegant slipper-like form of the labellum. Handsome plants "which will only thrive in a shady border in peat soil. The American species should be covered with some dry straw in very severe frosts, or if there should be too much wet; they are not easily increased, but will sometimes perfect seeds in favorable situations, particularly if pains be taken to apply the pollen to the stigma." (Bot. Cult. 358.)

1932. Stylidium. From $\sigma \tau \tau^{\circ}$ s, a column, in reference to the manner in which the stamen and style are united into one columnar mass. Beautiful little New Holland plants with pink flowers, remarkable for the singular elasticity of their column, which, being touched with a pin, starts with violence from the side to which it was turned when stimulated. The species grow in sandy loam and peat, and are increased by seeds, or dividing at the root; some of them by cuttings.

1933. Gunnera. So called after Ernest Gunner, bishop of Norway, who published a Flora of his country from 1766 to 1772. An uninteresting plant with orbicular leaves. May be planted in a pot of loam and peat, and plunged in water; it is increased by dividing at the root.

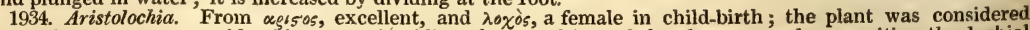
formerly to possess considerable powers in aiding the expulsion of the placenta, and in exciting the lochial 


\section{DIANDRIA.}

12997 Stem leafy, Lobe of column elliptical blunt, Lip shorter than sepals compressed 12998 Stem leafy, Lobe of column triangular acute, Lip shorter than sepals compressed 12999 Stem leafy, Lobe of column triangular oblong blunt, Lip shorter than sepals compressed 13000 Stem leafy, Lobe of column elliptical cordate blunt, Lip longer than blunt sepals, Spike ir front 13001 Stem leafless 1-flowered, Leaves 2 radical oblong blunt, Scape scarcely longer than leaves 13002 Flowers with 5 sepals, Lip saccate spurred, Stem leafy

13003 Leaves distichous fleshy nerveless spotted, Scape little longer than leaves 13004 Leaves cartilaginous ligulate not spotted twice as short as the hairy scape

13005 Leaves linear toothletted at edge, Raceme spiked simple and scape glandular 13006 Leaves narrow linear decurrent smooth, Throat $\frac{1}{2}$-crowned, Lip with an appendage

13007 Stem scandent, Leaves linear cirrhose, Throat crowned, Lip with an appendage, Column downy upwards 13008 Leaves setaceous linear sessile somewhat hairy, Orifice naked, Lip with an appendage

13009 Leaves linear, Spike subsessile divided : partial few-fl. Capsules adnate at base linear 1-celled

13010 Leaves reniform toothed shorter than the scape in fruit

\section{$H E X A N D R I A$.}

13011 Leaves 3-lobed, Stem twining, Corollas cylindrical broken saccate at base, Lip cordate cuspidate 13012 Lvs. obl. acum. 3-nerved, Stem twining, Peduncles many-flowered, Cor. incurv. Lip ovate mucronate 13013 Lvs. cord. acute, Stem twining, Pedunc. 1-flowered with an ovate bract. Cor. ascend. : limb trifid equal 13014 Stem twining, Lvs, stalked cord. downy beneath, Pedunc. sol. without bractes, Tube of cor. twisted back 13015 Lvs. cordate ovate, Stem twining, Pedunc. 1-fl. longer than leaf, Lip cordate lanceolate longer than cor 13016 Leaves cordate obl. Stem twining, Cor. straight : limb spreading, Lip spatulate bearded at end 13017 Leaves elliptical blunt somewhat emarginate slightly cordate, Pedunc. many-fl. Cor. erect 13018 Leaves roundish cordate acute, Stem twining, Peduncles about 3, Cor. incurved, Lip ovate 13019 Leaves cordate ovate blunt glaucous beneath, Stem twining, Cor. incurved, Lip ovate retuse 13020 Leaves cordate oblong acuminate, Stem prostrate flexuose somewhat climbing, Cor. incurved 13021 Leaves cordate ovate retuse, Stem prostrate flexuose somewhat climbing, Cor. erect, Lip lanc, acute 13022 Leaves cordate oblong acuminate, Stem flexuous ascending, Pedunc. radical, Lip of cor. lancenlate 13023 Leaves cordate blunt, Stem weak, Flowers solitary, Bractes cordate stalked

13024 Lvs. cordate ovate crenate scabrous netted beneath, Stem branched at base flexuose prostrate, Cor, erect 13025 Lvs. cordate ovate blunt subsess. Stem nearly erect and simple, Pedunc. sol. 1-f. Cor. erect

13026 Lvs. cordate ovate blunt emarginate stalked, Stem flexuose nearly erect, Pedunc. sol. 1-ff. Cor. erect

13027 Lvs. cordate ovate blunt downy stalked, Stem erect hairy, Pedunc. sol. 1-ff. Cor. recurved

13028 Lvs. roundish cordate bluntish stalked, Stem erect, Pedunc. 1-fi. heaped, Cor. erect

13029 Leaves cordate lanceolate, Stem erect shrubby

13030 Leaves reniform roundish cordate amplexicaul. Corolla incurved at base saccate: 2-lipped in the middle 13031 Leaves cordate acuminate, Flowers in racemes, Capsules acutely hexangular

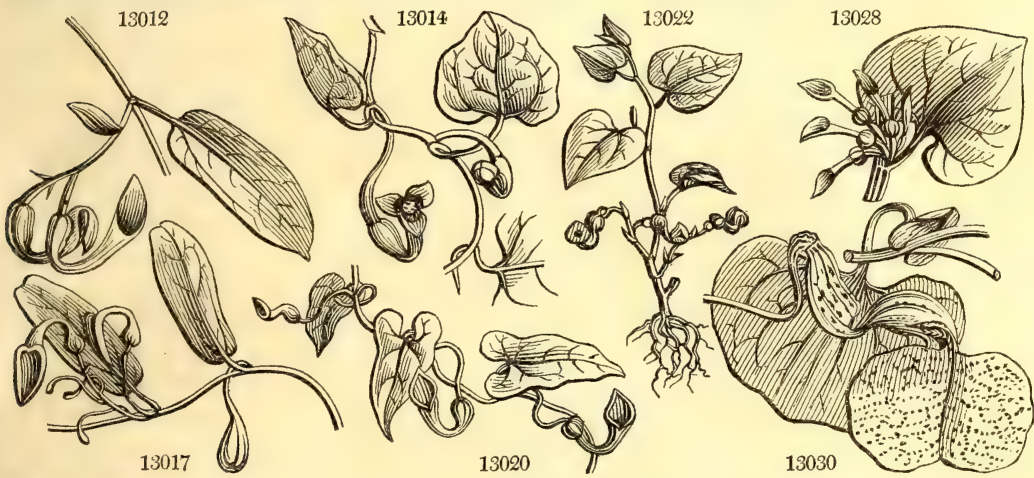

and Miscellaneous Particulars.

discharge. The root of A. serpentaria is said to be the substance which the Egyptian snake-juggiers chew, for the purpose of stupifying the snakes by the introduction of their saliva into the reptiles' mouths. A. clematitis (from $\approx \lambda \eta \mu \alpha$, a young shoot of the vine, in allusion to its appearance) is a species which furnishes one of the roots employed in European medicine. It is stimulant, stomachic, and emmenagogue; use has been made of it for various purposes, as for paleness of the countenance, fistula, sarcoma, \&c. A. pistolochia is also employed for the same purposes. It grows upon the dry stony places of Languedoc and Provence. It is used in cases of obstructed perspiration, and in disorders of the lungs. The roots should be chosen of a plump texture, and a yellowish color. They should be newly dried, and possess an aromatic flavor and a bitter taste.

Aristolochia trilobata and odoratissima have strong smelling roots, which are looked upon in Jamaica as powerful medicines, and used as stomachics by the slaves. The first species is called Contrayerva of the north side, from its growing in that part of the island; and the other Contrayerva of the south side, for a corresponding reason. The root of $\mathbf{A}$. serpentaria retains a place in the Materia Medica. The dried root is imported into this country from North America; it has an aromatic odor, not unlike that of Valerian; and a sharp, warm, bitter, pungent taste, resembling in some degree that of camphor. Medicinally, it is stimulating, diaphoretic, and tonic. 


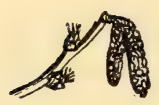

\section{Class XXI. - MONGEIA.}

\section{Male and female organs in distinct flowers, but upon the same plant.}

THIS class consists of a variety of plants of all kinds, natures, and affinities, combined by the character of having their flowers unisexual, but upon the same plant, in which respect Monœeia is distinguished from the next class, Diœeia. It contains nearly all the most important timber-trees of the temperate countries of the world, such as the oak, the pine, the birch, the beech, the walnut, the plane, the cypress, and many others. The bread-fruit, so important an article of food in some parts of the world, is placed in Monandria. Various palms occupy a station in other parts of the class. The dangerous Manchineel-tree, and many poisonous or medicinal plants, are also placed here. To Moncecia Polyandria belongs the famous Upas-tree of Java, to which so many fables are attached. It is described in Rumphius's Herbarium Amboinense (2. 87.), under the name of Ipo, and is now ascertained to be a species of Antiaris. From Siphonia elastica, a plant of Monœcia Monadelphia, and native of Brazil, one of the kinds of Caoutchouc or gum elastic of commerce is obtained.

Sprengel, and others, refer most of the genera of Monoecia to other classes, considering those only to be truly referable to it, of which the male and female flowers have some differences of structure.

\section{Order 1. MONANDRIA. Stamen 1.}

1935. Artocarpus. Male. A cylindrical catkin. Cal. O. Petals 2. Filament the length of cor. Female. Cal. O. Cor. O. Ovaries numerous, collected in a globe. Style filiform. Drupe compound.

1936. Casuarina. Male. Catkin filiform. Calyx 2-valved. Cor. O. Female. Catkin globose. Calyx an ovate scale. Cor. O. Caps, 2-valved, 1-seeded. Seed winged at end.

1937. Ceratocarpus: Male. Cal. 2-parted. Cor. O. Filament long. Female. Calyx 1-leaved, 2-horned, attached to the superior ovary. Cor. 0 . Style 2. Seed 1, tightly enclosed in the calyx.

1938. Zannichellia. Barren f. Perianth. none. Fertile fl. Perianth. single of 1 leaf. Germens 4 or more. Style 1. Stigma peltate. Capsules sessile.

\section{Order 2. DIANDRIA.}

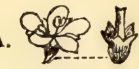
Stamens 2

1939. Lemna. Male. Cal. 1-leaved. Cor. O. Female. Calyx 1-leaved. Cor. O. Style 1. Capsule 1-celled, 2-seeded.

1940. Angwia. Näle. Calyx 5-fid. Petals 5. Female. Cal. 5-fid, Petals 5. Fruit inferior, 2-celled, many-seeded.

\section{Order 3. TRIANDRIA. St Stamens.}

1941. Comptonia. Male. A catkin. Calyx a scale. Petals 2. Filaments 2-forked. Female. A catkin. Calyx a scale. Petals 6 . Styles 2 . Nut ovate.

1942. Hernandia. Male. Calyx 3-parted. Petals 3. Female. Calyx truncate, entire. Petals 6. Drupe hollow, open at orifice, with a moveable kernel.

1943. Axyris. Male. Calyx 3-parted. Cor. O. Female. Calyx 5-leaved. Cor. O. Styles 2. Seed 1.

1944. Tragin. Male. Calyx 3-parted. Cor. O. Female. Calyx 5-parted. Cor. O. Style 3-fid. Caps. of 1944. Tragin. Male. Calyx 3-part
3 pieces, and 3 cells. Seed solitary.

1945. Typha. Flowers collected into cylindrical dense spikes or catkins. Barren fl. Perianth. O. Stam. 3. together, upon a chaffy or hairy receptacle, united below into 1 filament. Fertile fl. Perianth. 0 . Pericarp pedicellate, surrounded at the base with hairs resembling a pappus.

1946. Sparganium. Flowers in spherical dense heads. Barren fl. Perianth single, of 3 leaves. Fertile ff. single, of 3 leaves. Drupe dry, with 1 seed.

1947. Carex. Flowers collected into an imbricated catkin. Barren fl. Calyx of 1 scale, glumaceous. Cor. $O$. Fertile fl. Calyx of 1 leaf, glumaceous. Cor. of 1 leaf, urceolate, ventricose. Stigm. 2-3. Nut triquetrous, included withm the persistent cor.

1948. Cobresia. Flowers in an imbricated catkin. Male. Calyx a solitary scale. Cor. O. Female. Cal. generally a double scale; one flat, the other involving the ovary. Cor. 0 . Stigmas 3. Nut somewhat threecornered, naked.

1949. Uncinia. Flowers in an imbricated catkin, androgynous. Male. Cal. a solitary beardless scale. Female. Cal. bearded; beard hooked from the base of the inside of scale. Stigmas 3.

1950. Zea. Male in distinct spikes. Cal, a two-tlowered blunt glume. Cor. a blunt glume. Female. Cal a 2-valved glume. Cor. a 2-valved glume. Style 1, filiform, pendulous. Seeds solitary, immersed in an oblong receptacle.

1951. Coix. Male in remote spikes. Cal. a 2-flowered blunt glume. Cor. a blunt glume. Female. Calyx a 2 flowered glume. Cor. a blunt glume. Style 2-parted. Seed covered by the ossified calyx.

1952. Tripsacum. Male. Glume 2-flowered : outer male; inner neuter. Cor. a membranous glume. Female. Calyx a 1-f. glume, surrounded by a 1-leaved involucrum, perforated at the recesses. Cor. a 2 -valved glume. Styles 2 . Seed 1 .

1953. Heteropogon. Spike simple, monocious. Flowers male on one side, female on the other. Male. Cal. 2-valved. Cor. 2-valved, beardless : the inner valve setaceous. Nectary 2 -lobed, turgid. Female. Cal, twovalved. Cor. 2-valved, one thickish and bearded. Beard very long and hairy.

1954. Olyra. Male. Calyx a 1-flowered somewhat awned glume. Cor, O. Female. Cal. a 1-fl, spreading, ovate, awned glume. Cor. a 2 -valved blunt glume. Style bifid. Seed cartilaginous.

\section{Order 4. TETRANDRIA. to Stamens 4.}

1955. Alnus. Flowers collected into imbricated catkins. Barren fl. Scale of the catkin 3-lobed, with three flowers. Perianth. single, 4-partite. Fertile f. Scale of the catkin subtrifid, with 2 flowers. Perianth. $O$. Styles 2. Fruit compressed.

1956. Betula. Barren flower in a cylindrical catkin, its scales 3-fl. Perianth. O. Stam. 10-12. Fertile fl. Scale of the catkin imperfectly 3-lobed, 3-flowered. Perianth. O. Styles 2. Germens compressed, 2-celled, one abortive. Nuts compressed, with a membranaceous margin, 1-seeded. 
1957. Buxus. Male. Calyx 3-leaverl. Petals 2. Rudiment of an ovary. Female. Calyx 4-leaved. Petals 3. Styles 3. Caps. with 3 beaks and 3 cells. Seeds 2.

1958. Cicca. Male. Calyx 4-leaved. Cor. O. Female. Cal. 4-leaved. Cor. O. Styles 4. Capsule 4-coccous, not splitting, somewhat fleshy.

1959. Morus. Male. Cal. 4-parted. Cor. O. Female. Calyx 4-leaved. Cor. O. Styles 2. Calyx berried Seed 1.

1960. Boehmeria. Male. Cal. 4-parted. Cor. O. Nut O. Female. Cal. O. Cor. O. Style 1. Seed 1.

1961. Pilea. Male. Cal. 4-parted membranous. Stamens 4 elastic. Fernale. Calyx 3-leaved, with one sepal fleshy and gibbous. Stigma sessile fringed.

1962. Urtica. Barren fl. Perianth. single, of 4 leaves, containing the cup-shaped rudiment of a germen. Fertile fl. Perianth. single, of 2 leaves. Pericarp 1-seeded, shining.

1963. Pachysandra. Male. Calyx 4-leaved. Cor. O. Female. Calyx 4-leaved. Cor. O. Styles $3 . \quad$ Caps 3-horned, 3-celled. Seeds 2.

1964. Diotis. Male. Calyx 4-leaved. Cor. O. Female. Calyx 1-leaved, 2-horned. Style 2-parted. Seed 1 , villous at base, covered with the 2-horned calyx.

1965. Empleurum. Male. Calyx 4-fid. Cor. O. Female. Cal. 4-fid, inferior. Cor. O. Stigma cylindrical, seated on a lateral tooth of the ovary. Caps. splitting at side. Seed 1, with an arillus.

1966. Aucuba. Male. Cal. 4-toothed. Petals 4. Recept. with a square hole. Female. Cal. 4-toothed. Petals 4. Ovary inferior. Style 1, short. Nut ovate, 1-celled.

1967. Littorella. Barren f. Calyx of 4 leaves. Cor. 4-fid. Stam. very iong. Fertile fl. Calyx O. Cor. unequally 3. cleft. Style very long. Nut 1 .

1968. Serpicula Male Cal 4-toothed. Petals 4. Female. Cal. 4-parted. Pericarp a downy nut.

1969. Maclura. Male. A catkin. Female. Cal. O. Corolla O. Style 1, filiform, villous. Ovaries numerous, coalescing into a compound globose berry of many cells ; cells 1-seeded. Seed obovate, compressed.

\section{Orcier 5. PENTANDRIA. Stamens 5}

1970. Exocarpus. Male. Cal, 5-leaved. Cor. O. Stamens inserted in calyx, Female. Style simple, short. Stigma peltate. Drupe 1-seeded, placed on a fleshy receptacle.

1971. Nephelium. Male. Cal. 5-toothed. Cor. O. Female. Cal. 4-fid. Cor. O. Ovaries 2. Styles two to each. Drupes 2, dry, muricated, 1-seeded.

1972. Schizandra. Male. Cal. 9-leaved in a triple row. Cor. O. Anthers subsessile, cohering at, end. Female. Cal. of male. Cor. O. Ovaries numerous, capitate. Berries 1-seeded, inserted on a long filiform receptacle.

1973. Franzeria. Male. Cal, common, 1-leaved, many-toothed. Cor. 1-petalous, tubular, 5-toothed. Recept. naked. Female. Calyx many-leaved. Cor. O. Styles 4. Drupe dry, 4-celled, setose.

1974. X Xnthium. Male. Common calyx imbricated. Cor. monopetalous, 5-fid, funnel-shaped. Female. Cal. a 2-leaved, 1-flowered involucrum. Cor. O. Drupe dry, muricated, 2-fid. Nut 2-celled.

1975. Amaranthus. Male. Cal.3-5-leaved. Cor. O. Stamens 3-5. Female. Cal, of the male. Cor. O. Styles 3. Caps. 1-celled, cut round about.

1976. Luffá. Male. Cal. 5-parted. Cor. 5-parted, attached to calyx. Female. Cal. and cor. of male. Filaments 5, sterile. Ovary inferior. Stigma clavate. Gourd with a lid, 3-celled, furrowed

1977. Ambrosia. Male. Common cal. 1-leaved. Cor. 1-petalous, 5-fid, funnel-shaped. Recept. naked. Female. Cal. 1-leaved, entire, 5-toothed beneath, 1-flowered. Cor. O. Nut formed by the indurated ca!yx, 1-seeded.

1978. Securinega. Male. Cal.5-parted. Cor. O. Stamens 5, inserted under a rudiment of a pistillum. Female. Capsule 3-celled.

Order 6. HEXANDRIA

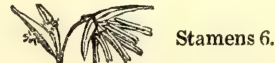

1979 Zizana. Male. Cal. O. Cor. a 2-valved blunt glume, mixed with the females. Female. Cal. O. Cor. a 2-valved glume, cuculiate, and awned. Style 2-parted. Seed 1, enveloped in the plaited corolla.

1980. Pharus. Male. Cal. a 2-valved 1-fl. glume. Cor. a 2-valved glume. Female. The cal, of the male Cor. a long involute 2-valved glume. Seed 1 .

1981. Guettarda. Male. Cal. cylindrical. Cor. 4-7-fid, funnel-shaped, Female. Cal cylindrical, Cor. 4-7-fid. Ovary 1. Drupe dry.

1982. Sagus. Common spatha 1-valved. Spadix branched. Male. Cal. 3-leaved. Cor. O. Filam. dilated. Female. Cal. 3-leaved, with two of the leaves bifid. Cor. O. Style very short. Stigma simple. Nut tessellated-imbricated, 1 -seeded.

1983. Cocos. Common spatha 1-valved. Spadix branched. Male. Cal. 3-leaved. Cor. 3 petals. Female. Cal. 2-leaved. Cor. 6 petals. Style 0 . Stigma a depression. Drupe fibrous.

1984. Elate. Common spatha 2-valved. Spadix branched. Male. Cal, 3-toothed. Petals 3. Anthers sessile. Female. Cal. 3-toothed. Petals 3. Stigmas 3. A drupe.

1985. Bactris. Common spatha 1-valved. Spadix branched. Male. Cal. 3-parted, Cor. 3-fid. Female

Cal. 3-toothed. Cor. 3-toothed. Style very short. Stigma capitate. Drupe fibrous, succulent.

\section{Order 7. POLYANDRIA.}

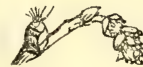

Stamens more than 6.

1986. Ceratophyllum. Barren fl. Cal. multipartite. Cor. O. Stam. 16-20. Fertile fl. Cal, muitipartite. Cor O. Stigma rearly sessile, oblique. Nut 1-seeded.

1987. Myriophyllum. Barren f. Cal. of 4 leaves. Petals 4. Stamens 8. Fertile fl. Cal, of 4 leaves. Petals 4. Stigmas 4, sessile. Nuts 4, subglobose, 1-seeded.

1988. Sagittaria. Male. Cal. 3-leaved. Petals 3. Stamens about 24. Female. Cal. 3-leaved. Petals 3. Oraries many. Seeds many, naked.

1989. Begonia. Male. Cal. O. Petals 4 : the two opposite the largest. Stamens numerous. Female. Cal. o. Petals 4 or 6 , like the male. Styles 3 , bifid. Caps. inferior, 3-angular, winged, 3-celled, many-seeded.

1990. Poterium. Barren $\mathrm{fl}$. Cal. of 4 leaves. Cor, 4-partite. Stamens 30.40. Fertile fl. Cal. of 4 leaves, Cor, 4-partite. Germens 2. Fruit 2-celled, invested with the cal.

1991. Amirola. Male. Calyx 5-fid : lower segm, cut down to the base. Cor. O. Stamens 8, declinate. Female as in the male. Style incurved. Caps. 3-coccous, inflated, 3-valved. Seeds globose.

1992. Acidoton. Male. Cal. 5-leaved. Cor. O. Stamens 35-40. Female. Cal, 6-leaved. Cor. O. Style 3-fid. Caps. 3-coccous.

1993. Thelygonum. Male. Cal. 2-fid. Cor, O. Stamens about 12. Female. Cal. 2-fid. Cor. O. Ovary 1. Caps, coriaceous, 1-celled, 1-seeded.

1994. Castanea. Barren fl. in a very long cylindrical catkin. Perianth. smgle, of 1-leaf, 6-cleft. Stamen 5-20. Fertile fl. 3, within a 4-lobed, thickly muricated involucrum. Perianth. single, urceolate, 5-6-lobed, $5-20$. Fertile fl. 3, within a 4-lobed, thickly muricated involucrum. Perianth. single, urceolate, 5-6-lobed,
having the rudiments of 12 stamens. Germen incorp. with the perianth. 6-celled, with the celis 2 -seeded, 5 of them mostly abortive. Styles 6 Nut 1-2-seeded, invested with the enlarged involucre. 
1995. Ostrya. Male, an imbricated catkin. Cal. a scale. Cor. O. Filaments branched, Female, a naked catkin. Cal. O. Cor. O. Caps. inflated, imbricated, 1-seeded at base.

1996. Carpinus. Barren $\mathrm{fl}$. in a cylindrical catkin, its scales roundish ciliated at the base. Stamens 8-20. Fertile fl. in a lax catkin, its scales large, foliaceous, 3-lobed, 1-flowered. Invol. O. Perianth. of 1 leaf, urceolate, 6-dentate, incorporated with the 2-celled germen, of which 1 cell is abortive. Styles 2. Nut ovate, striated, 1-seeded.

1997. Fagus. Barren fl. in a globose catkin. Perianth. single, of 1 eaf, campanulate, 6-cleft. Stamens 5-12. Fertile f. 2, within a 4-lobed prickly involucre. Perianth. single, urceolate, with 4-5 minute lobes. Germen incorporated with the perianth., 3-celled, two of them becoming abortive. Styles 3. Nuts 1-seeded, invested with the enlarged involucre.

1998. Corylus. Barren fl. in a cylindrical catkin, its scales 3-cleft. Perianth. O. Stamens 8. Anthers 1-celled. Fertile fl. Perianth. obsolete. Germens several, surrounded by a scaly involucre. Stizmas 2. Nut 1-seeded, surrounded at the base with the enlarged united coriaceous scales of the involucre.

1999. Juglans. Male, an imbricated catkin. Cal. a scale. Cor. 6-parted. Filaments 4-18. Female. Cal. 4-fid, superior. Cor. 4-fid. Styles 2. Drupe coriaceous, with a furrowed nut.

2000. Quercus. Barren fl. in a lax catkin. Perianth. single, somewhat 5-cleft. Stamens 5-10. Fertile fl. Invol cup-shaped, scaly. Perianth, single, incorporated with the germen, 6-lobed. Germen 3-celled, 2 of them abortive. Style 1. Stigmas 3. Nut (acorn) 1-celled, 1-seeded, surrounded at the base by the enlarged cupshaped involucre.

2001. Liquidambar. Male, a conical catkin, surrounded by a 4-leaved involucre. Cal. O. Cor. O. Filaments numerous. Female, a globose catkin, surrounded by a 4-leaved involucrum. Cal. 1-leaved, urceolate, 2-flowered. Cor. 0 . Styles 2. Capsules 2, surrounded at base by calyx, 1-celled, many-seeded.

2002. Platanus. Male, a globose catkin. Cal. O. Cor. scarcely any. Anthers growing about the filament. Female, a globose catkin. Cal. many-leaved. Cor. o. Styles with a recurved stigma. Seeds roundish, mucronate with the style, pappose at base.

2003. Salisburia. Male, a naked catkin. Cal. O. Cor. O. Anthers imbricated. Female. Cal. 4-fid. Drupe with a 3-cornered nut.

2004. Carludovica. Common spatha 4-leaved. Spadix cylindrical. Male. Common calyx a cubical 4-flowered receptacle: proper calyx many-toothed. Female. Cal. an edge. Styles 4, very long. Stigmas anther-like. Berry cubical. many-seeded.

2005. Caladium. Male. Cal. and cor. O. Anthers peltate, many-celled, disposed in a spike at the end of the spadix. Female. Cal. and cor. O. Ovaries inserted at base of spadix. Style O. Berry 1-celled, many-seeded. 2006. Arum. Spatha of 1 leaf, convolute at the base. Perianth. O. Spadix with germens at the base. Stem (sessile) near the middle of the spadix, which is naked above. Berry 1-celled, 1-seeded.

2007. Caryota. Common spatha compound. Male. Cal, 3-leaved, Petals 3. Female. Cal. 3-leaved. Cor. 3-parted. Style 1. Berry 1-celled, 2-seeded.

\section{Order 8. MONADELPHIA. (C)}

2008. Nipa. Paim. Male. Cal. O. Petals 6. Filament 1, 12-fid. Female. Stigma a lateral furrow. Drupe angular, 1 -seeded.

2009. Areca. Common spatha 2-valved. Male. Cal. 3-parted. Petals 3. Stamens 6, cohering at base, Female. Cal. 3-leaved. Petals 3. Nect. 5.toothed. Styles 3, very short. Drupe 1-seeded.

2010. Belis. Male. Anthers 2-celled. Female. Scales imbricated in a lupuliform cone, very short, crested, bracteate at back, trigynous. Lateral pericarps auricled, middle cuneate, deciduous with the cone.

2011. Agathis. Male. Anthers many-celled. Female. Scales imbricated in a round cone, naked at back, persistent monogynous. Pericarps winged, united to the inside of scale. Cotyledons 2.

2012. Pinus. Male. Anthers 2-celled, Female. Scales in a conical cone, bracteate at base, digynous. Pericarps attached to the inside of scale, more or less winged, deciduous. Stigmas 2-3.fid. Cotyledons 4-8.

2013. Abies. The same as Larix, excepting its habit and stigma, which is that of Pinus. Cotyledons 3-9.

2014. Larix. Male. Anthers 2-celled. Female. Scales imbricated in a round cone, bracteate at base, digynous. Pericarps attached to inside of scale, winged, deciduous. Stigma hemispherical, cupped, glandular. Cotyledons 5-9.

\section{MONANDRIA.}

1935. ARTOCAR'PUS. $W$. BREAD Fruit. 13032 incísa $W$ clt 30 Urticea. Sp. 2 Jaca Tree clt 30 in $\cdots \quad$ W.G S. Sea Isl. 1793. Sk r.m Rum.amb.1.t.33

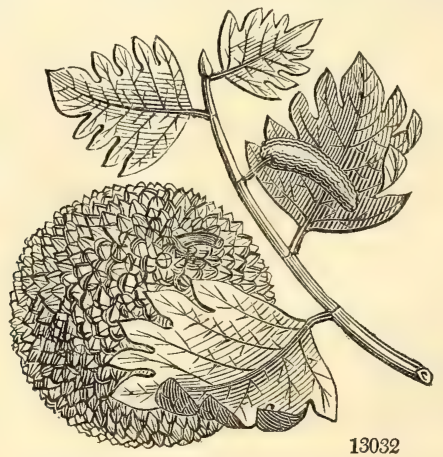

History, Use, Propagation, Culture,

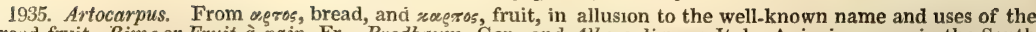
bread-fruit. Rime or Fruit-a-pain, Fr., Brodbaum, Ger., and Albero di pane, Ital. A. incisa grows ir, the South Sea Islands to the size of a moderate sized oak, with alternate leaves, deeply gashed, glaucous, and two feet long. The whole tree and the fruit before it is ripe, abound in a very tenacious milky juice. The fruit is about the 
2015. Schubertia.

2016. Podocarpus. Male. Cal.-leaflets of the bud imbricated. Anthers many, adnate, bilocular, rostrate, fixed to the lengthened column of the filament. Female. An ovate 1-celled nut, half immersed in a firm receptacle.

2017. Cupressus. Male, an imbricated catkin. Cal. a scale. Cor. O. Anthers 4, sessile, without filaments.

Female, a cone-like catkin. Cal. a 1-fl. scale. Cor. O. Stigma 2 concave dots. Nut angular.

2018. Thuja. Male, an imbricated catkin. Cal. a scale. Pet. 4. Anthers 4. Female, a cone-like catkin

Cal. a 2 -fl. scale. Cor. 0 . Nut 1 , surrounded by an edged wing.

2019. Trichosanthes. Male. Cal. 5-toothed. Cor. 5-parted, ciliated. Filaments S. Female. Cal. 5-toothed, Cor. 5-parted, ciliated. Style 3-fid. Gourd oblong.

2020. Momordica. Male. Cal. 5-fid. Cor. 5-parted. Filaments 3. Female. Cal. 5-fid. Cor. 5-parted.

Styles 3-fid. Gourd dropping off with elasticity.

2021. Cucurbita. Male. Cal. 5-toothed. Cor. 5-fid. Filaments 3. Female. Cal, 5-toothed. Cor. 5-fid.

Ovary 3 -fid. Seeds of gourd with a tumid edge.

2022. Cucumis. Male. Cal. 5-toothed. Cor. 5-parted. Filaments 3. Female. Cal.5-toothed. Cor. 5-parted. Ovary 3-fid. Seeds of gourd with a sharp edge.

2023. Sicyos. Male. Cal. 5-toothed. Cor. 5-parted. Filaments 3. Female. Cal. 5-toothed. Cor.5-parted.

Style 3-fid. Gourd 1-seeded.

2024. Bryonia. Barren fi. Cal. 5, dentate. Cor. 5-cleft. Filaments 3. Anthers 5. Fertile fl. Calyx 5dentate. Cor. 5-cleft. Style trifid. Berry inferior, globose, many-seeded.

2025. Andrachne. Male. Cal. 5-leaved. Petals 5. Stamens 5, inserted into the rudiment of a style. Female. Cal. 5-leaved. Cor. O. Styles 3. Caps. 3-celled. Seeds 2.

2026. Stillingia. Male. Cal. hemispherical, many-fl. Cor. tubular, eroded. Female. Cal. 1-flowered, inferior. Cor, superior. Style 3-fid. Caps. 3-coccous.

2027. Phyllanthus. Male. Cal. 6-parted. Cor. O. Filament columnar. Anthers 3. Female. Cal. 6-parted.

Cor. O. Disk with 12 angles. Styles 3. Capsule 3-coccous.

2028. Aleurites. Male. Cal. 3-fid. Petals 5. Scales 5. Filament columnar. Anthers numerous. Female. Cal. 3-fid. Petals 5. Scales 5. Style O. Stigmas 2. Berry dicoccous.

2029. Omphalea. Male. Cal. 4-parted. Cor. O. Disk a fieshy ring. Filament columnar. Anthers 2-3.

Female. Cal. 4-parted. Cor. O. Style very short. Stigma trifid. Caps.3-coccous, 3-celled: cells with a solitary nut. 2030. Hippomane. Male. Cal. campanulate, emarginate. Cor. O. Filament columnar. Female. Cal. 3-leaved. Cor. O. Style very short. Stigma 7-fid. Drupe with a 7-celled nut.

2031. Sapium. Male. Cal. 2-fid. Cor. O. Filament 2-fid. Female. Cal. 3-toothed. Cor. O. Style very short. Stigma 3-fid. Caps. 3-coccous.

2032. Croton. Male. Cal. cylindrical, 5-toothed. Petals 5. Stamens 10-15. Female. Cal. many-leaved. Cor. O. Styles 3, bifid. Caps. 3-celled. Seed 1

2033. Jatropha. Male. Cal, O, or 5-leaved. Cor. monopetalous, funnel-shaped. Stamens 10, alternately shorter. Female. Cal. O. Cor. 5-petalous, spreading. Styles 3, bifid. Caps. 3-celled. Seed 1.

2034. Ricinus. Male. Cal. 5-parted. Cor. O. Stamens numerous. Female. Cal. 3-parted. Cor. O. Styles 3, bifid. Capsule 3-celled. Seed 1.

2035. Hura. Male. An imbricated catkı.. Perianth. truncate, 2-leaved. Cor. O. Filament cylindrical, peltate at end, surrounded by many double anthers. Female. Cal, cylindrical. Cor. O. Style funnel-shaped. Stigma 12-fid. Caps. 12-celled. Seed 1.

2036. Sterculia. Male. Cal. 5-parted. Cor. O. Filament coiumnar, surmounted by numerous anthers. Female. Cal. 5-parted. Cor. O. Anthers sterile, surrounding the base of the stalked ovaries. Follicles 5 , many-seeded.

2037. Heritiera. Male. Cal. 5-toothed. Cor. O. Filament columnar, surmounted below the end with anthers. Female. Cal. 5-toothed. Cor. O. Sterile anthers at base of ovaries. Drupes 5, dry, 1-seeded

2038. Acalypha. Male. Cal. 3-4-leaved. Cor. O. Stamens 8-16. Female. Cal. 3-leaved. Cor. O. Styles 3. Caps. 3-coccous, 3-celied. Seed 1.

2039. Dalechampia. Common involucre outside, with 4 leaflets : inside with 2, trifid. Male. Umbel 10-fl. ; with a 2-leaved involucre and numerous paleæ. Cal. 5-leaved. Cor. O. Filaments many, connate. Female. Florets 3, with a 3-leaved involucre. Cal. 11-leaved. Cor. O. Style filiform. Caps. 3-coccous.

2040. Plukenetia. Male. Cal. 4-parted. Cor. O. Stamens 20. Female. Cal. 4-parted. Cor. O. Style very long, with a peltate 4-lobed stigma. Caps. 4-coccous.

\section{MONANDRIA}

13032 Leaves pinnatifid sinuated scabrous downy beneath

13033 Leaves oblong undivided narrowed at base scabrous beneath

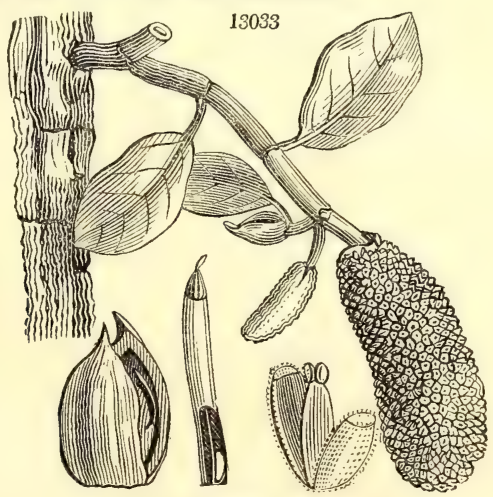

and Miscellaneous Particulars.

size and shape of a child's head, and the surface is reticulated, not much unlike a truffle; it is covered with a thin skin, and has a core about as big as the handle of a small knife; the eatable part lies between the skin and the core; it is as white as snow, and somewhat of the consistence of new bread. It must be roasted before it is eaten, being first divided into three or four parts; its taste is insipid, with a slight sweetness, somewlıat 
1936. CASUARI'NA. W. Casuarina. 13034 equisetifóiia $W$. 13035 strícta $W$ 13036 distyla $W$ 13037 torulósa $W$ 13038 quadriválvis $P . S$. 13039 muricáta Roxb. 13040 nodifíra $W$.

1937. CERATOCAR'PUS.

13041 arenárius $\boldsymbol{W}$.

1938. ZANNICH 13042 palústris $W$

1939. LEM'NA. $W$ 13043 trisulca $W$. 13044 mínor $W$. 13045 gíbba $W$. 13046 polyrhíza $W$.

1940. ANGU'RIA. $W$ 13047 trilobáta $W$

Horse-tail

upright

two-styled

Cork-barked

four-valved

knot-flowered

sand

marsh

Duck Weed.

Ivy-leaved

lesser

gibbous

greater
Pond Werdo u

EED.

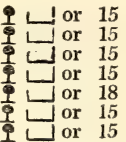

Casuarinec. Sp. 7-10.

o.n Ap S. Sea Isl. 1776. S s.p Bot. cab. 607

.n Ap N. S. W. 1775. S s.p Bot. rep. 346

Ap N. Holl. 1812. S s.p Ve.des.pl, n. t.62

Ap N. S. W. 1772. S s.p

N. S. W. 1812. S s.p La.no.ho.2.t.218

Ap

Tartary 1757. S s Bu.in.ac.pe.1.t.9 Naiades. $S p .1-3$.

\section{DIANDRIA.}

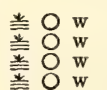

Aroidece. $S p .4-11$.

... my.jn Ap Britain sta.wa. S 1.p Eng. bot. 926

... jn.jl Ap Britain sta.wa. S l.p Eng. bot. 1095

... jn.jl Ap Britain sta.wa. S l.p Eng. bot. 1233

... my.s Ap Britain dit. S lp ny. bot. 2158

Cucurbitacece. Sp. 1.

且 $\mathbb{A}$ or 20 jn.jl Pk Carthag. 1793. R l.p Jac. amer. t. 156

TRIANDRIA.

1941. COMPTO'NIA. $W$. Comptonia. 13048 asplenifólia $W$. Fern-leaved

1942. HERNAN'DIA. $W$. JACK IN A Bo 13049 sonóra $W$

13050 ovígera $W$

1943. AXY'RIS. $W$. peltate-leaved egg-fruited

13051 amaranthoides $W$. simple-spiked 13052 hýbrida $W$. bastard 13053 prostráta $\dot{W}$. trailing

Myricece. Sp. 1.

韭 or 4 mr.my Br N. Amer. 1714. Sk s.p Dend. brit. 166 Laurinece. Sp. $2-3$.

9 or 20 ... E. Indies 1693. C p.l Rum.amb.2.t.85

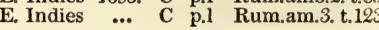

Chenopodece. Sp. 3-5.

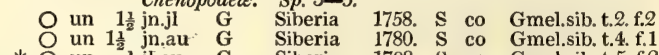
* $\mathrm{O}$ un ${ }_{\frac{2}{2}} \mathrm{jI} . \mathrm{au} \quad \mathrm{G} \quad$ Siberia 1798 . S co Gmel.sib.t.5.f.2

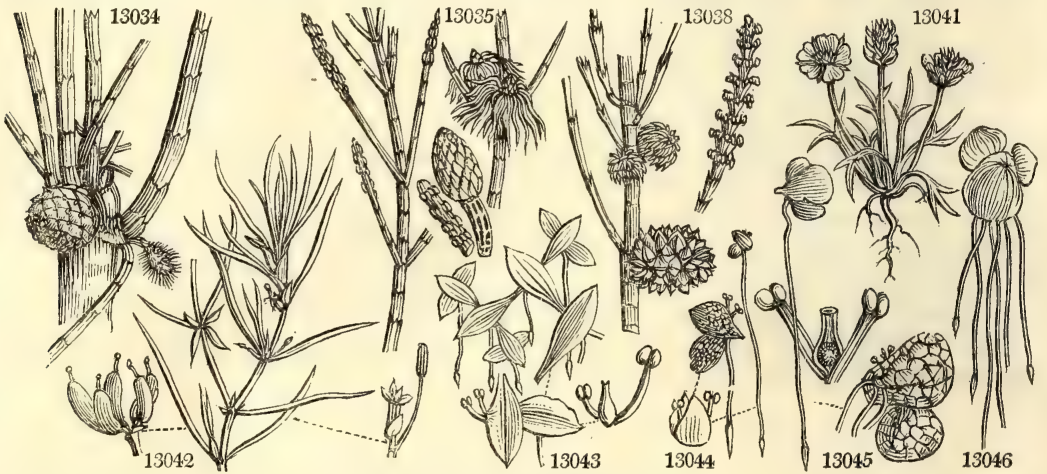

History, Use, Propagation, Culture,

resembling that of the crumb of wheaten bread mixed with Jerusalem Artichoke. The plant was first brought to England by the unfortunate Captain Bligh. A fresh supply has been more than once received, and there are now a number of plants in the nurseries about London. The bread-fruit, according to Sweet, is generally supposed to be difficult of cultivation in this country. He considers that the plants have been, in general,
treated too tenderly, and not allowed sufficient air. "They appear," he says, "to be of the same nature as the Fig, to which they are nearly allied. Large cuttings root freely in a pot of sand, plunged under a handglass, in a moist heat, with all their leaves entire: if the leaves are shortened, it is a great chance if they succeed." (Bot. Cult. 19.)

There are several varieties of the bread-fruit, as of all plants that have been long in cultivation. The principal of these varieties are without seeds ; the natives of Otaheite reckon at least eight, differing in the form of the leaf and fruit. A. integrifolia is also by many considered a variety of the other; for the leaves are sometimes lobed, and the situation of the fruit varies with the age of the tree, being first borne on the branches, then on the trunk, and finally on the roots.

The bread-fruit is ripe in December, and is used boiled, or fried in Palm oil. Besides the use of the fruit, the economical purposes to which the other parts of the tree are applied are various. The wood is used in building boats and houses; a cloth is made of the inner bark; the male catkins serve for tinder; the leaves for wrapping up food, and for wiping the hands instead of towels; and the juice for making bird-lime, and a cement for filling up the cracks of vessels for holding water. According to Forster, three trees are supposed to yield sufficient nourishment for one person.

The bread-fruit tree is distributed very extensively over the East Indian continent and islands, as well as the innumerable islands of the South Seas. In 1793 it was introduced to the West Indies, and subsequently to different parts of South America. Much has been said in praise of it by Europeans, and certainly, to the inhabitants of the South Sea Islands, it may be a valuable food, as the acorn was to the inhabitants of Britain, when they were in a certain state of civilization. But whether a civilized and refined people would esteem this fruit for their own use as highly as they do for the use of the semi-barbarians of the South Seas, is a point which may reasonably be doubted.

1936. Casuarina. The name under which the tree is described by Rumphius, who probably called it so from the resemblance its foliage bears to the plumage of the casoar or cassowary of the same country. By the Malays it is called filao, and by the South Sea Islanders club-wood, on account of the use of it for warlike weapons. Casuarina equisetifolia is a large spreading and lofty tree, with leaves, or rather branchlets, hanging down in bunches from twelve to eighteen inches in length, like a long head of hair, or a horse's tail, all jointed from top to bottom. The appearance of the whole tree is very remarkable. It was introduced by the first Lord Byron. 
13034 Branchlets flaccid round, Scales of cones unarmed villous

13035 Diœecious, Brancblets erect furrowed, Scales of cones unarmed smoothish

13036 Diøecious, Branchlets ovate round, Scales of cones unarmed ciliated

13037 Dicecious, Branchlets flaccid, Scales of cones villous and rough with tubercles

13038 Diøecious, Young branches somewhat flaccid, Scales of cones villous, Male sheaths submultifid ciliated 13039 Branches erect, Scales of cones mucronate pubescent, in which it chiefly differs from C. stricta

13040 Monoecious, Branchlets erect square, Scales of cones unarmed smooth

13041 Stem much branched diffuse making globose tufts

13042 Anthers 4-celled, Stigmas entire, Pericarps toothed on the back

\section{DIANDRIA.}

13013 Fronds thin elliptical-lanceolate caudate at one extremity, at the other serrate, Roots solitary 13044 Fronds nearly ovate compressed, Roots solitary

13045 Fronds obovate nearly plane above hemispherical beneath, Roots solitary

13046 Fronds obovate rotundate compressed, Roots numerous clustered

13047 Fruit small, Leaves 3-lobed

TRIANDRIA

13048 Leaves oblong alternately sinuated

13049 Leaves peltate

13050 Leaves cordate ovate acuminate flat. stalked at base

13051 Leaves ovate, Stem erect, Spikes simple

13052 Leaves ovate, Stem erect, Spikes panicled

13053 Leaves obovate, Stem somewhat divided, Flowers capitate

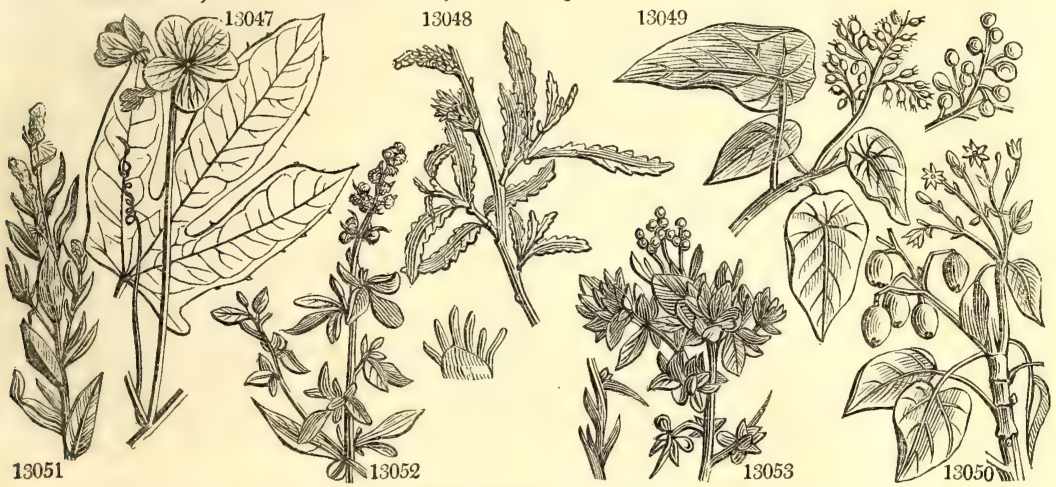

and Miscellaneous Particulars.

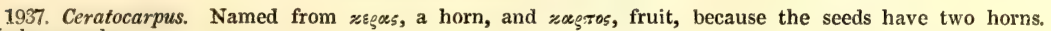
Useless weeds.

1938. Zannichellia. So called in honor of John Jerome Zannichella, a Venetian apothecary, who died in 1729. He left behind him a few works of little consequence. A plant found abundantly in the marshes of some parts of England.

1939. Lemna. Said to have been so called from $\lambda \varepsilon \pi \iota s$, a scale, in allusion to the form of the plants. Theophrastus describes under the same name an aquatic plant. Annual weeds, which float on stagnant water, their flowers are very obscure, and not produced freely in northern climates. L. trisulca has dichotomous, filiform, divaricated stems, having a lanceolate leaf at the angle of the branches, but proliferous ones terminating the branches; where these leaves are conjoined, there shoots out a pendant radicle, with a conical papilla at its base. Linnæus observes, that the stems are flatted and proliferous, crossing each other, and thus resembling in the mode of growth the opuntia or Indian fig. The leaves of $\mathbf{L}$. minor are very small, of a roundish ovate form, collected into heaps by twos or threes, and forming extensive green plats on stagnant waters; each leaf drops a single radicle. This plant affords nourishment not only to ducks, but to the fresh water polype, to Phalæna Lemnata, \&c. Its quick and extensive propagation makes it troublesome in some cases, but at the same time it is considered valuable as converting hydrogen gas into air adapted to respiration. L. polyrhiza is distinguished by its dropping bundles of thick black fibres from the lower surface of the leaves. The plants sink in the water in the winter season, and either these or new ones appear again in the spring.

1940. Anguria. One of the Greek names for the Cucumber. The plant now so called is also a kind of gourd The species grow freely on light soil, and are propagated by seeds or roots.

1941. Comptonia. Named in honor of Henry Compton, Lord Bishop of London, by whom the fine collection of plants attached to the episcopal palace at Fulham was formed. A handsome shrub, which thrives in peat soil, or sandy loam, and is increased by suckers or layers.

1942. Hernandia. So called in honor of Francisco Hernandez, a Spanish botanist, and first physician to Philip the second of Spain, by whom he was sent to Mexico for the sake of investigating the natural history of that country. Linneus is said to have named it in allusion to the large leaves and little flowers of the plant, which may be supposed to represent the great means and small advantages which attended the expedition of Hernandez. This is an upright lofty tree, with an elegant head. The fruit is a nut, sustained and partly enveloped by a yellow persisting calyx. The nuts are very large, and as they move in the wind, produce sound enough to alarm unwary travellers. In our stoves the plants grow freely in loamy soil, and ripened cuttings, with their leaves on, root in sand under a hand-glass.

1943. Axyris. A word of unknown meaning. Flants of little beauty and the easiest culture. 
1944. TR A'GI A. $W$. 13054 volúbilis $W$ 13055 involucráta $W$. 13056 úrens $W$.

13057 Chamæléa $W$.

13058 cannabína $W$

1945. TY'PHA. $W$. 13059 latifólia $W$.

13060 mínor $W$.

13061 angustifólia $W$.

1946. SPARGA'NIUM. $\boldsymbol{W}$. BUR REED 13062 ramósum $W$

13063 simplex $W$

13064 nátans $W$.

1947. CA'REX, $W$ 13065 dioíca $W$.

13066 Davalliána $W$
Tragra.

twining

involucr

stinging

lance-leaved

Hemp-leaved

CaT's-TaIl.

great

dwarf

lesser

branched

unbranched

floating

Carex.

diœcious

Davall's
Euphorbiacee. Sp. 5-9.

$\$$ un 6 jn.jl G W. Indies 1739. S co Tre.pl.rar.2.t.15 \$O un 3 jn.jl G E. Indies 1759. S co Jac. ic. 1. t. 190 \$ $\mathrm{O}$ un $3 \mathrm{au}$ G Virginia 1699. S co Pluk.al.t.107.f.5 स [0] un 2 jn.jl $G$ E. Indies 1793. D l.p Rhee.mal.2.t.34

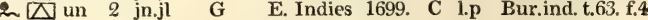
此 $\triangle$ ec 6 il Aroidece. Sp. 3-7.

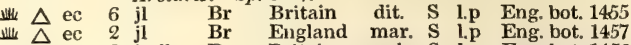
业 $\triangle$ ec 3 jn.jl Br Britain pools. S l.p Eng. bot. 1456
13067 pulicáris $\boldsymbol{W}$. 13068 pyrenáica $\boldsymbol{W}$.

13069 pauciflóra $W$.

13070 cyperoídes $W$. 13071 stenophýlla $W$. 13072 chordorhiza $W$. 13073 incúrva $W$

13074 fœ'tida $W$.

13075 arenária $W$. 13076 intermédia $W$ 13077 schœnoides $\boldsymbol{W}$. 13078 Schrebéri $W$ 13079 brizoídes $W$

13080 ovális $W$.

13081 lagopodioídes $W$. 13082 scopária $W$.

13083 nemorósa $\boldsymbol{W}$.

13084 vulpina $W$.

13085 stipáta $W$. 1 :086 divísa $W$.

13087 muricáta $W$

13088 norvégica $\boldsymbol{W}$. 13089 divúlsa $\boldsymbol{W}$. 13090 stelluláta $W$. 13091 rósea $W$. 13092 axilláris $\boldsymbol{W}$. 13093 remóta $W$.
Flea

Pyrenean

few-flowered$$
\text { 业 } \triangle \mathrm{cu} \quad 1 \frac{1}{2} \mathrm{jn} . \mathrm{jl}
$$$$
\text { 䛲证 } \triangle \text { un } 1 \frac{1}{2} \text { jn.jl }
$$

Ap

Ap

Bohemian

此 $\triangle$ un 2 in jl

narrow-leaved 制 $\triangle$ un 2 jn.jl

chord-rooted $\frac{114}{\Delta}$ un 1 jn.jl

curved

制 $\triangle$ un $\frac{1}{2}$ jl.au

stinking

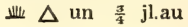

sand

soft-brown

rush-like

Schreber's

Briza-like

oval-spiked

址 $\Delta$ ec 1 in.jl Ap

业 $\Delta$ un $1 \frac{1}{2}$ my.jl Ap

䛲 $\triangle$ un 1 my.jl Ap

lill $\triangle$ un $1 \frac{1}{2}$ jn.jl Ap

制 $\triangle$ un 2 jn.jl Ap

Hare's Foot

Broom

wood

Ap

此传 $\triangle$ un $z_{2} \frac{1}{2} \mathrm{jn} . \mathrm{j}$

Ap

业监 $\Delta$ un 3 jn.jl Ap

great-spiked

此 $\triangle$ un 3 my.au Ap $\begin{array}{lllll}\text { propped } & \text { 址 } \Delta \text { un } 3 & \text { my.au } & \text { Ap } \\ \text { bracteated } & \text { un } 2 & \text { my.jl } & \text { Ap }\end{array}$ greater-prickly 业 $\Delta$ un 2 my.jn Ap

Norway 此 $\triangle$ un $1 \frac{1}{2}$ my.jn Ap gray $\frac{1}{\Delta} \Delta$ un 2 my Ap little-prickly $\stackrel{⿻ 上 丨}{\Delta}$ un $\frac{1}{2}$ my.jn Ap Rose 此 $\Delta$ un 2 my.jn Ap axillary 阱 $\triangle$ un $2 \frac{1}{2}$ my.jn Ap p. $3-5$.

p Britain dit. $S$ 1.p Eng. bot. 744 Britain sta.wa. S 1.p Eng, bot. 745 England fens. S 1.p Eng. bot. 272

Sp. $106-235$.

Britain sp.bo. Sk s.p Eng. bot. 543 Britain mar. Sk s.p Eng. bot. 2123

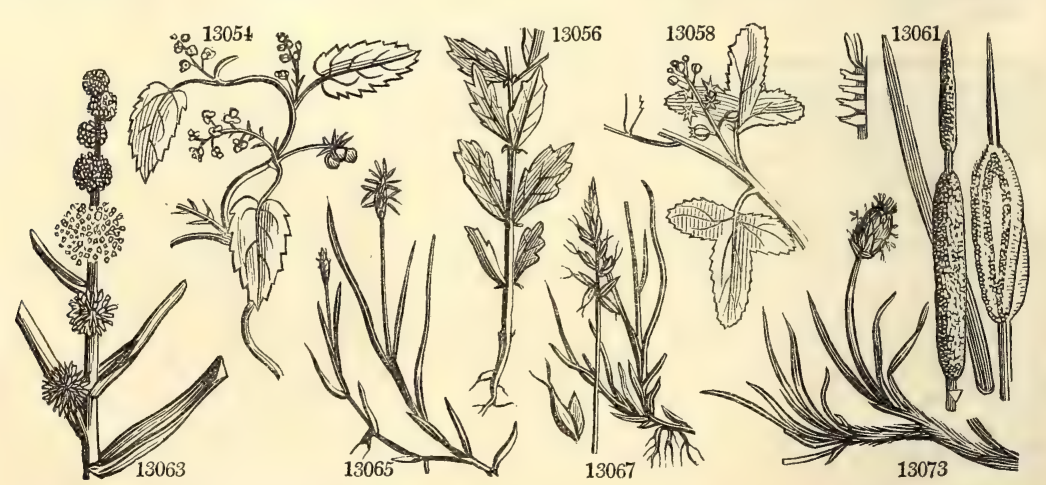

History, Use, Propagation, Culture,

1944. Tragia. In honor of a German botanist named Jerome Bock, born in 1498, and died in 1554; Tragus, which was the name he bore in science, being a Greek translation of his real name, both signifying a goat. He published a history of plants, or Kræuterbuch, and several other works. Twining plants of no interest.

1945. Typha. From $\tau$. handsomest aquatics of the reed kind; its leaves are of a bluish color, an inch in width, and three feet long; the pollen of the flower is very abundant, and a light being applied to it, a flash of fire is produced. Haller says, that the roots are eaten in salads, that cattle eat the leaves, and that the downy seeds serve for stuffing pillows. The leaves are sometimes used by coopers, and introduced between the staves of their casks; they are frequently used for making mats, baskets, chair bottoms, and sometimes for thatch. Rubens, and other 
13054 Leaves cordate ovate acuminate serrated smoothish, Petioles ciliated, Female sepals hairy entixe 13055 Leaves hispid ovate-acuminate serrated, Female sepals pinnatifid setose hispid

13056 Leaves ianceolate sessile blunt somewhat toothed at end; and stem, which is erect and branched, downy

13057 Leaves linear lanceolate stalked blunt mucronate, Stem branched diffuse

13058 Leaves deeply 3-lobed toothed, Middle lobe long

I3059 Leaves linear nearly plane, Sterile and fertile catkins close together

13060 Leaves linear plane twice as short as culm, Male and female catkins remote

13061 Leaves linear convex below, Sterile and fertile catkins a little distant from each other

13062 Leaves triangular at the base their sides concave, Common flower-stalk branched, Stigma linear 13063 Leaves triangular at the base their sides plane, Common flower-stalk simple, Stigma limear

13064 Lvs. floating plane, Common fl.-stalk simple, Stigma ovate very short, Head of sterile fls. mostly solitary

$\$$ Spikes dicecious.

13065 Spike simple diœcious, Fruit ascending ovate shortly acuminated striated rough at the margin upwards 13066 Spike simple diccious, Fruit ovate much acuminated recurvate-deflexed smoothish at the margin

\section{Spikes androgynous. \\ * 1. Spike simple.}

13067 Spike simple androgynous, Flowers few, Fruit distant oblongo-lanceolate acuminate reflexed, Stigmas 2 13068 Spike simple androgynous male at top, Stigmas 3, Fruit oblong with a short beak horizontal 13069 Spike simple androgynous of very few fls. Fruit distant lanceolate subulate patenti-reflexed, Stigmas

\section{* 2. Spikelets capitate.}

13070 Spikes androgynous male below collected in globose involucrated heads, Stigm. 2 , Fr. lanc. with 2 points 13071 Spikes androgynous male above collected in an oblong head, Stigm. 2, Fr, ovate comp, nerved with 2 teeth 13072 Spikes androgynous male above collected in an ovate form, Stigm. 2, Fr. ov.acumin. Culm branched at base 13073 Spikl. ster. at extrem. collected into a roundish head, Fruit broad. rotund.-ov. short acum. swell. on both sides nearly entire at the point, Culm obt. angular, Leaves channelled

13074 Spikes androgynous male above collected into an oval head, Stigm. 2, Fruit ellipt. roundish acuminate bifid

$$
\text { * 3. Spikelets spiked, many-flowered. }
$$

[Culm triang. Lvs, plane 13075 Lower spikel, fert. : upp, ones ster, all crowd. Fr. with membr marg. Bract. membranc.: low. ones subfoli. 13076 Inferior and term, spikelets fertile: intermediate ones sterile, Fruit acutely margined, Culms triangular 13077 Spike androgynous comp. Spikelets obl. altern. clust. male above, Stigmas 2, Fr. round. ov. edged 2 toothed 13078 Spike androgynous comp. Spikelets ovate alternate clustered male below, Stigmas 2, Fr. ovate 2-toothed 13079 Spike androg. comp. somew. distich. Spikel. about 5 altern. cun. obl. lanc. male bel. Stig. 2, Fr. ov. edg bifid 13080 Spikel. ster. at the base oval about 5 approxim. Fruit as long as the cal. ovato-acumin. convex on one side, concave on the other, with a membranaceous margin bifid at the point

13081 Spike androg. comp. Spikel. 12 altern. ellipt. blunt approxim. male below, Stigms.2, Fr. ov. lanc. edg.bicusp. 13082 Spike androgynous comp. Spikel. about 5 altern. ellipt. blunt somewhat approxim. male below, Stigmas 2 , Fruit ovate lanceolate edged bicuspidate

13083 Spike androgynous comp. Spikel. numer. collected in 3 s or 5 s ovate clustered male above, Stigmas 2 , Fruit spreading ovate acuminate 2-toothed edged compressed

13084 Spikel. ster. at their extremities thrice comp. collected into a cylind. crowded spike, Fruit ovate acuminat. convexo-plane acutang.-diverg. Stem very acute triang. Leaves rather broad

13085 Spike androg. comp. Spikel. about 5 obl. male above clust. Stigm. 2. Fr. spread. ov. acum. with 2 points nerv. 13086 Spikel. ster. at their extremities crowded into a somewhat ovate head: lover ones with a leafy erect bractea at their base, Fruit roundish ovate convex on one side slightly concave on the other

13087 Spikel. ster. at their extremities subcomp. collected into a ratherlong more or less interrupted spike, Fruit convexo-plaro ovato-acuminate acutangular divergent rough at the margin upward

13088 Spike androg. comp. Spikel. 4 altern. obl. male below somewhat approxim. Stigmas 2 , Fr. obl. acutish compr. 13089 Spike long somew. decompound branched at the base : lower spikelets remote, Fruit erect smooth at edge 13090 Spikel. ster. at base 3 or 4 dist. Fr.ov. much attenuat. convexo-plane acutangul. divaricat. rough at margins 13091 Spike androg.comp. Spikel, about 4 remote male above, Síigm. 2, Fr. ov.acum. 2-tooth. horiz. ciliat. at base 13092 Spikes subternate remote sessile, Bractes long, Fruit bifid at end

13093 Spikel. ster. at base dist. Fruit longer than cal. obl.-ovate acumina'e convexo-plane subacutang. obtuse at the marg. the point bifid, Bract. very narr. reaching beyond the culm

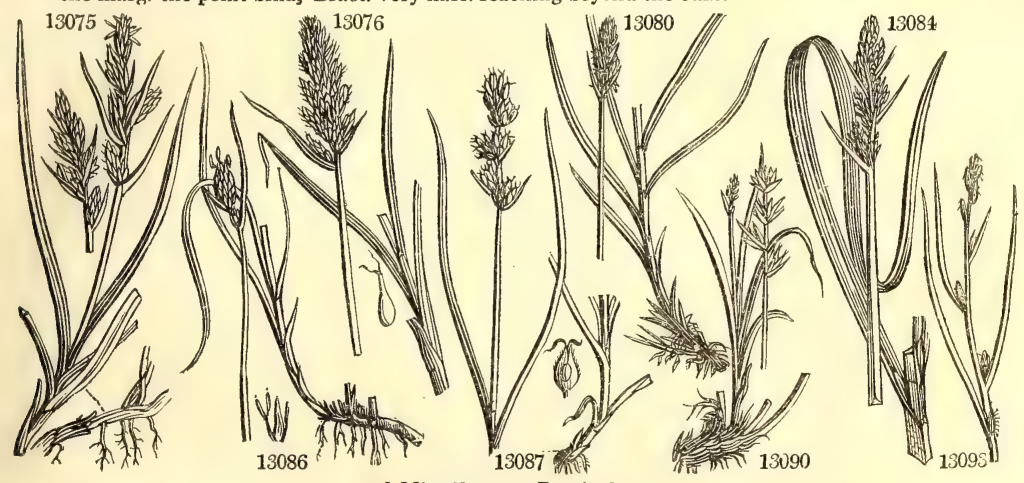

and Miscellaneous Particulars.

Italian painters after him, have put it into the hand of Christ as a sceptre, when he was saluted as a king in mockery by Herod's soldiers. The plant appears to be a native of every part of the world, in ponds, ditches, and by the sides of rivers and brooks.

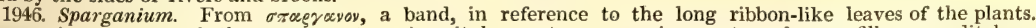
Sparganium ramosum is the commonest species: it has a strong creeping root, and soon fills up a ditch or pond, if suffered to remain unmolested. It is common not only in Europe, but in Barbary, Siberia, and North pond, if suft

1947. Carex. From the Latin carere, to want. The upper spikes of these plants are constantly without seeds, consisting only of male flowers. This numerous family of plants grow mostly in wet swampy grounds, 
13094 elongáta $W$. 13095 cúrta $W$.

13096 fo'nea $W$.

13097 loliácea $\boldsymbol{W}$.

13098 straminea $W$.

13099 multiflóra $\boldsymbol{W}$. 13100 teretiúscula $W$. 13101 paradóxa $W$.

13102 paniculáta $W$.

13103 appréssa $R . B r$.

$1310+$ bícolor $W$.

13105 atráta $W$.

13106 thuringiaca $W$.

13107 Buxbaúmii $W$

13108 glareósa $W$.

elongated white

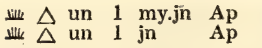

fodder

내 $\Delta$ un 2 jn

ray-grass-like 페 $\Delta$ un 2 jn

slender-stalked ill $\Delta$ un 2 jn.jl
England mar. Sk co Eng. bot. 1920 Britain pools. Sk co Eng. bot. 1386

N. Amer. 1818. Sk co Sweden 1810. Sk co Sc.ca.t.P.p. f.104 Ap N. Amer. 1803, Sk co S.ca.t.Xxx.f.174 many-flowered 业 $\Delta$ un 1 my.jn Ap lesser panicled paradoxical t此 $\triangle$ un $1 \frac{1}{2}$ my.jn Ap greater panicl. 址 $\triangle$ un 3 jn.jl Ap close-spiked 址 $\triangle$ un 2 my.au Ap

two-colored 峘 $\Delta$ un $1 \frac{1}{2}$ my.jn Ap black

业 $\triangle$ un $1 \frac{1}{2}$ jn.jl Ap

Thuringian 制 $\Delta$ un $1 \frac{1}{9}$ my.jn Ap

Buxbaum's

业 $\triangle$ un 1 my.jn Ap

sandy

址 $\Delta$ un 1 my.jn Ap
N. Amer, 1812, Sk co ,Sc.ca, t.Lll.f.144 Britain bogs. Sk co Eng. bot. 1065 Austria 1823. Sk co Host. gra.1. t. 57 Eugland bogs. Sk co Eng. bot. 1064 N.S. W. 1802 . Sk co

M. Cenis 1810. Sk co S.c. t. Aaaa.f. 181 Britain al.me. Sk co Eng. bot. 2044

Germany 1810. Sk co S.ca.t.P.pp.f.155

Sweden 1821. Sk co S.ca.t.X.Gg.f.76

Norway 1816. Sk co
13109 álba $W$

13110 clandestína $W$.

13111 digitáta $W$.

13112 plantagínea $W$.

13113 Fraseriána $\boldsymbol{H}$. $\boldsymbol{K}$.

13114 pilulifera $W$.

13115 lucórurn $W . e n$.

13116 collina $W$.

13117 ciliáta $W$.

13118 præ'cox $W$.

13119 tomentósa $W$.

13120 exténsa $W$.

13121 fláva $W$.

13122 CEdéri $E$. $B$.

13123 fúlva $W$.

13124 distans $W$.

13125 binérvis $W$.

13126 saxátilis $W$.

13127 púlla $W$.

13128 ferrugínea $W$.

white

dwarf silvery

fingered

broad-leaved

Fraser's

址 $\triangle$ un 1 my.jn Ap ille $\triangle$ cu $\frac{1}{2}$ ap.my Ap 亚 $\triangle$ un $\frac{1}{2}$ my.jn Ap

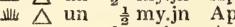
此有 $\triangle$ or $\frac{1}{2}$ ap.jn Ap

round-headed 嵖 $\triangle$ un 1 ap.jn Ap grove $\Delta$ un $1 \frac{1}{2}$ ap.jn Ap hill $\Delta$ un 1 ap.jn Ap ciliated $\frac{11}{\Delta}$ un $1 \frac{1}{2}$ ap.jn Ap vernal 业 $\triangle$ un 1 ap Ap

downy-fruited 制 $\triangle$ un 1 in $A p$ long-bracted 此 $\triangle$ un $\frac{3}{4}$ jn $\quad$ Ap yellow GErder's 址 $\triangle$ un $\frac{1}{2}$ jn.jl Ap

tawny 此 $\Delta$ un $\frac{3}{4}$ jn.jl Ap

loose

green ribbed

rock

russet

rusty

13129 Mielichhóferi $W$. loose-spiked

13130 umbrósa $\boldsymbol{W}$.

shady

hairy

grain-seeded

Pink-leaved

clustered
址 $\triangle$ un $1 \frac{1}{2} \mathrm{jn}$

此 $\triangle$ un 2 jn

典 $\Delta$ un $\frac{1}{2} \mathrm{jn}$

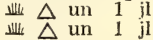

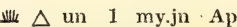

ille $\triangle$ un $1 \frac{1}{2} \mathrm{jn} . \mathrm{jl}$ Ap

with $\triangle$ un $_{\text {un }}$ my.jl Ap
13134 conglobáta $W$
Austria 1818. Sk co Sch.car. t.O.f.55 England sun.ro. Sk co Eng. bot. 2124 England woods. Sk co Eng. bot. 615 N. Amer. 1805. Sk co Sch. car. t.U.f.70 N. Amer. 1809. Sk s.p Bot. mag. 1391

Britain hea. Sk co Eng. bot. 885 N. Amer. 1825. Sk co Germany 1824. Sk co Sch.car. t.F.f.29 Germany 1812. Sk co Sch. car.'t.I. f.42 Britain dr.pa. Sk co Eng. bot. 1099

England mea. Sk co Eng. bot. 2046 Britain seaco. Sk co Eng. bot. 833 Britain bogs. Sk co Eng. bot. 1294 England m.me. Sk co Eng. bot. 1773

Britain mar. Sk co Eng. bot. 1295

Britain mar. Sk co Eng. bot. 1234

Britain dr.he. Sk co Eng. bot. 1235 Greenland1812. Sk co S.ca.t. I. \&'Tt f.40 Scotland sc.mo. Sk co Eng. bot. 2045 Austria 1822. Sk co Sch.car. t.M.f. 48

Scotland al.roc. Sk co Eng. bot. 2293

Austria 1810. Sk co S.ca.t.Uuu.f.165

Europe 1820. Sk co Sch.car.t.M.f.49 N. Amer. 1807. Sk co S.ca.t. Vvv.f.169 Britain moi.p. Sk co Eng. bot. 1505 Hungary 1812. Sk co
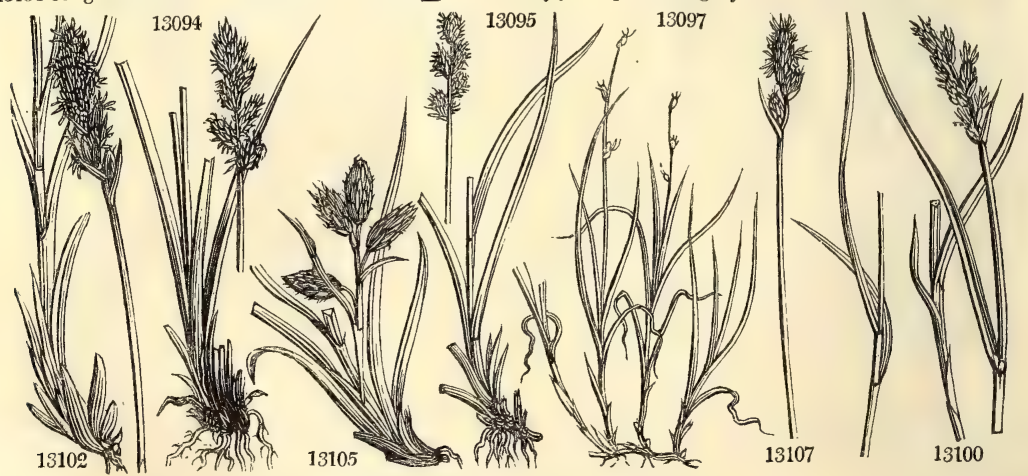

Hiistory, Use, Propagation, Culture,

in bogs, fens, marshes, or in moist woods, where they yield a very coarse grass scarcely touched by cattle. With the exception of two or three species, they are of little use or beauty. Some unfortunately situated husbandmen have recourse to them as cattle fodder, or as thatch or fuel. In Kent, the leaves of the larger 
13094 Spikes numerous obl. remotish naked, Fruit acuminate bifid recurved many-nerved longer than glumes

13095 Suikel. ster. at base about 5 rather dist. ellipt. Bracteas very minute, Caps. broadly ov. acum. conv, on one side and nearly plane on the other subobtusang. with 2 teeth at the extremity

13096 Spike androg. comp. Spikelets about 4 male below and close together, Fruit ovate acumin. edged 2-tooth 13097 Spike androg. comp. Spikel. about 4 male below and close together, Stigmas 2, Fruit elliptical blunt nerved 13098 Spike androg. comp. Spikel, about 5 roundish male below somew. approximated, Stigm. 2, Fr. round, ovate beaked 2 -toothed ciliated at edge

* 4. Spikelets panicled.

13099 Snikes andirog. narrow. panicl. male above obl. blunt, Stig. 2, Fr. ov. acum. with 2 points, Scales ov. mucron 13100 Spike supradecompound contracted acutish, Spikelets clustered, Fruit spreading gibbous, Culm roundish 13101 Spikes androg. narr. panic. male above, Low. branch. remote, Stig. 2 round. ov. beak. 2 -tooth. cil. ser. at base 13102 Spikel. ster. at extrem. thrice comp. and collect. into a panic. spike, Fr. broad. ov. acum. gib. on both sides 13103 Spike decomp. longish, Scales acute, Fruit ovate plano-convex nerved on each side

\section{* 5. Spikelets racemose.}

13104. Spikes androg. in thirees stalked terminal male below erect, Stigmas 2, Fr. obov. blunt, Scales ov. obtuse 13105 Fertile spikes pedunculated ovate pendulous : the terminal one with sterile fiowers at the base, Fruit roundish ovate depressed with a short beak bifid at the point

3. Terminal spikes male: the others androgynous.

13106 Male spike solitary stalked : androg. male above about 5 ellipt. remote sessile with a leafy bract, Stigm. 3 , Fruit roundish 3 -cornered downy

8. Terminal spike androgynous: the others female.

13107 Spike androg. pedunc. obov. male below : female about 3 remote somewhat stalked, Stigm. 3. Fr. ellipt. 3-cornered blunt slightly 2 -toothed

13108 Spike androg. pedunc. obl. male below : female 2 sessile close obl. Stigm. 2, Fr. oblong narrowed with an undivided mouth as long as ovate scale

\section{\$. Spikes of distinct sexes.}

* 1. Male solitary: female sessile and subsessile.

+1. Scape sheathed, with membranous bractes.

13109 Male spike solit, stalk. : fem, twin stalk, about 5-f. Stigm, 3, Fr, obov.-glob. furrow, beak. obliq. truncate 13110 Bractes membran. nearly leafless sheath. Fem. spikes remote few-fl. included in sheath, Lvs. channelled 13111 Bractes membranous nearly leafless sheathing, Spikes linear lax erect: male shorter, Leaves flat

13112 Male spike sol. stalk. : fem. 4 dist. stalk. Stig. 3. Fr. ellipt. 3-corner. stalk.smth. short. than obov. cusp. scale 13113 Leaves oblong lanceolate with a white scarious margin, Heads oblong, Scape not longer than leaves

$$
\text { †2. Culm leafy. }
$$

13114 Fertile spikes sess. roundish approxim. Scales mucron. Fr. obov.-glob. acute pubesc. Culms weak scabrous 13115 Female spikes 2-3 ellipt. sess. supported by a foliaceous bract, Fruit somewhat downy with a long beak 13116 Male spike solit. : fem. about 2 close ellipt. sess. Stig. 3, Fr. obl. with a short beak downy as long as ov. scale 13117 Male spike solit. : fem. about 2 close obl. sess. Stig. 3. Fr. roundish-obov. downy larg. than obl. blunt scale

13118 Sheaths short scarcely any equal to the flower-stalks, Fertile spikes oblong approximate, Scales ellipticooblong, Fruit obovate subtriquetrous acute pubescent

13119 Sheaths very short, Female spikes subsessile cylindrical blunt, Glumes elliptical acute, Fruit downy 13120 Fertile spikes subsess. obl. Fr. ov. scarcely beaked striated bifid at point, Lvs. very narrow, Culm glabrous 13121 Bracteas long foliaceous, Fert. spikes roundish oval, Fr. obov, with a long recurved beak bifid at the point 13122 Sheaths and peduncles very short, Female spikes roundish, Fruit spreading on each side globose, Beak straight, Culm smooth

13123 Bracteas foliaceous, Spikes oblongo-ov. distant rotundo-ov. inflated rostrate bifid at point, Culm scabrous * 2. Male spike solitary : upper female sessile and subsessile; lower stalked.

13124 Fertile spikes oblong erect, Scales mucronate, Fruit ovate somewhat inflated subtriquetrous depressed with rather a short beak bifid at the point

13125 Sheaths long shorter than peduncle, Spikes cylindrical remote somewhat compound, Fruit 2-nerved 13126 Male spike solit. : female twin; lower stalked obl. Stigmas 2, Fruit ellipt. blunt as long as blunt scale

13127 Fertile spikes ov.: the lower one pedunculated, Scales obl. Fruit subglob. apiculate with a short bifid beak 13128 Male spike solitary : female 3 distant ; two lower stalked, Stigmas 3, Fr. oblong compressed 3-cornered hispid at edge, Mouth membranous ?-lobed

13:29 Fertile spikes 1-3 somewhat drooping, Fruit scarcely longer than the scale lax especially the lower ones ovate with a short beak bifid at the point

13130 Male spike sol. obov. : female about 3 close; 2 lower on long stalks, Stigmas 3, Fruit compress. obov. downy beaked 2-toothed at end

13131 Male spike sol. : female about 3 distant ; two lower remote, Stig. 3, Fr. ov.beaked with a membran. mouth

13152 Male spike sol. : fem. 3 rem. : two lower stalked, Stigmas 3, Fr. glob. ovate nerved ventric. shortly beaked

13133 Fert. spikes subcylind, with dist. fls. Bract. foliaceous, Fr. subglob. somew. inflated obt. glab entire at point

13134 Male spike sol, : female about 4 remote; lower on a long stalk. the stalks of the others enclosed, Stigm. 3 , Fr. globose shining with a short beak 2-toothed at end

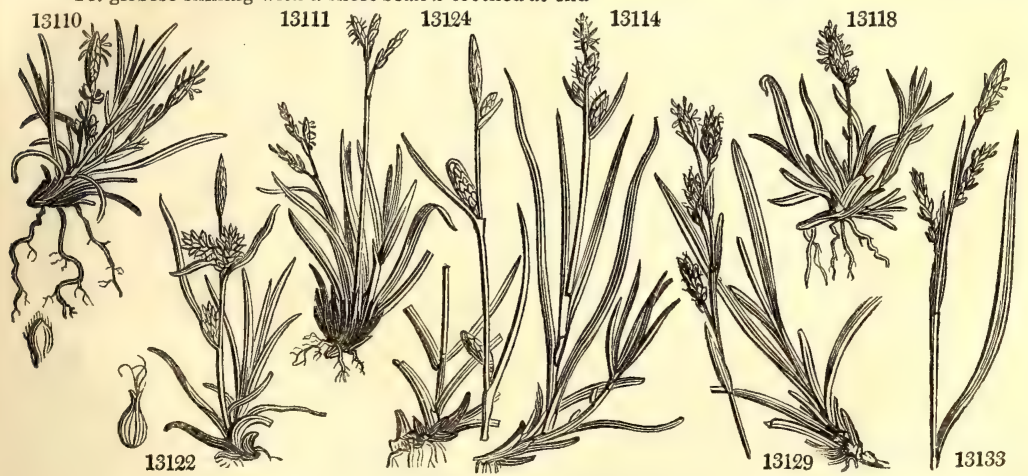

and Miscellaneous Particulars.

species are used for tying the vines of hops to the poles; in Italy they are put between the staves of wine casks to make them tight, wove over Florence flasks, or in chair bottoms. The Laplander combs and dresses some species of sedge, as we do flax, and in winter stuffs his shoes and gloves with it, as a defence against the 
13135 rostráta $W$.

13136 nítida $W$. 13137 ánceps $\boldsymbol{W}$. 13138 alpéstris $\dot{W}$.

13139 cæspitósa $W$. 13140 strícta $W$.

13141 péndula $I V$ 13142 rigida $W$.

13143 capilláris $W$. 13144 palléscens $H$ 13145 ustuláta $W$. 13146 rariffóra $E$. $B$

13147 limósa $W$.

13148 Pseudo-Cypérus $W$. Bastard Cyperus 步 $\triangle$ un 3 jn.jl Ap

13149 flexuósa $W$. 13150 sylvática $E . B$. 13151 júncea $W$. en. 13152 strigósá $W$.

13153 recúrva $W$ 13154 nútans $W$. 13155 acumináta $W$ 13156 filifórmis $W$. 13157 aquatilis $W$ 13158 acúta $W$.

13159 paludósa $W$. 13160 ripária $W$.

13161 vesicária $W$. 13162 ampullácea $W$. 13163 secalína $I V$. 13164 hordeiformis $W$. 13165 hírta $W$. 13165 hirta $W$. $W$ lævigáta $W$. 13167 crinita $W$. 13168 salina $W$. 13169 ambleocárpa $W$. 13170 bulláta $W$.

1948. COBRE'SIA. $W$. 13171 caricina $W$.

CI'NIA. Rich. Uncinia.

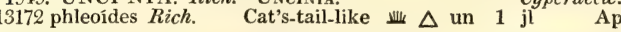
1950. ZE'A. $W$. Indian Corn. 13173 Maýs $W$. 1951. CO'IX. $W$. JoB's Tears. 13175 Láchryma $W . \quad$ common 13176 agréstis $W$. round-fruited $\frac{1 \omega}{\square} \mathrm{cu} 2$ jn.jl Ap acuminated $1+1 / \mathrm{H}$ un $1 \frac{1}{2} \mathrm{jn} . \mathrm{jl}$ Ap slender-leaved 此 $\triangle$ un 2 jn.jl Ap $\begin{array}{llll}\text { slender.spiked 䶕 } \triangle \text { un } & 1 \frac{1}{2} \text { jn.jl } & \text { Ap } \\ \text { my.jn } & \text { Ap }\end{array}$

lesser common 情 $\triangle$ un 2 my.jn Ap short-spiked 幽 un 2 my.jn Ap slender-beaked $\omega_{*} \Delta$ un 2 my.jn Ap rye-like Hitt $\triangle$ un 2 my.jn Ap Barley-formed mooth-stalked til $\triangle$ un 3 my.jn Ap haired 址 $\triangle$ un $1 \frac{1}{2}$ jn.jl Ap salt-marsh 滥 $\triangle$ un 1 jn Ap short-fruited 1 in $\triangle$ un $1 \frac{1}{2}$ jn.jl Ap
N. Amer. 1816. Sk co S.ca.t.Hhh.f.134

Austria 1805. Sk co Host. gra. 1. t.71 N. Amer. 1805. Sk co Sc.ca.t.Fff. f.128 Europe 1804. Sk co Sch.car.t.G.f.35

Britain bogs. Sk co Eng. bot. 1507 Britain mar. Sk co Eng. bot.914

Britain woods. Sk co Eng. bot. 2315 Britain moun. Sk co Eng. bot. 2047

Britain sc.mo. Sk co Eng. bot. 2069 Britain moi.p. Sk co Eng. bot. 2185 Scotland al.riv. Sk co Eng. bot. 2404 Scotland sc.al. Sk co Eng. bot. 2516

Britain sp.bo. Sk co Eng. bot. 2043

Britain mar. Sk co Eng. bot. 242

N. Amer. 1807. Sk co S.ca.t.Ddd.f.124 Britain woods. Sk co Eng. bot. 995 N. Amer, 1820 . Sk co England woods. Sk co Eng. bot. 994 nodding

England hea. Sk co Eng. bot. 1506 Austria 1815. Sk co Host. gra.1. t. 83 Istria 1818. Sk co Host. gra. 1.t.97 Britain bogs. Sk co Eng. bot. 904 Lapland 1813. Sk co Britain wat.pl. Sk co Eng. bot. 580

Britain wat.pl. Sk co Eng. bot. 807 Britain riv.ba. Sk co Eng. bot. 579

Britain mar. Sk co Eng. bot. 779 Britain bogs. Sk co Eng. bot. 780 Austria 1824. Sk co Schk.car.t.5.f.65 France 1805. Sk co S.ca.t.Ddd.f.121 Britain wat.pl. Sk co Eng. bot. 685 Britain bogs. Sk co Eng. bot. 1387 N. Amer. 1807. Sk co Sc.ca.t.Eee.f. 125 Norway ... Sk co

Britain $\quad \ldots$... $\quad$ Sk co Mi.g.62.t 32.f.12 N. Amer. 1811. Sk co S.ca.t.Uuu.f. 166 Sp. 1.

Switzerl. 1820. Sk co Sc.ca.t.Rrr.f.161 Sp. 1-4.

S. Amer. 1821. Sk co Cav. ic. t.464. f.1 Sp. 2.

America 1562. S r.m Lam. ill. t. 749 Chili 1824. S r.m Sp. 2-4.

E. Indies 1596. S 1.p Bot. mag. 2479 E. Indies 1812. S l.p Ru. am.6. t.9. f.1

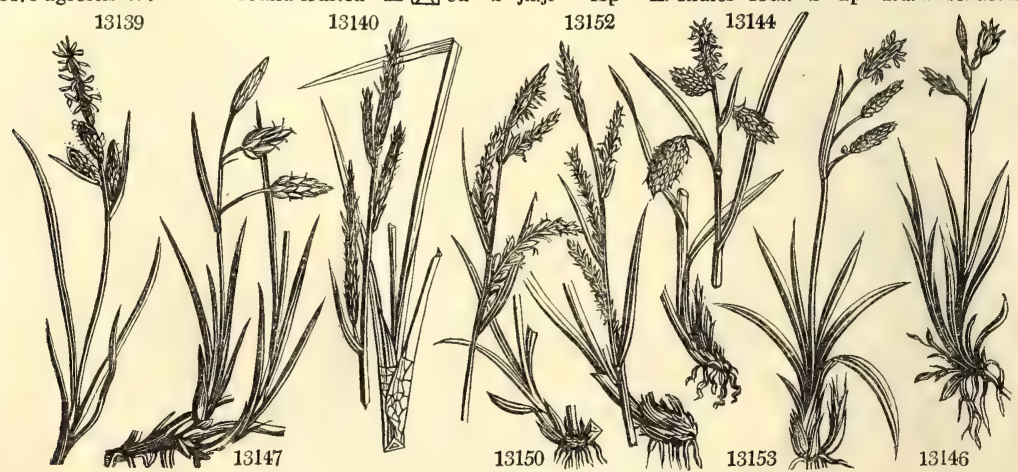

History, Use, Propagation, Culture,

extreme rigour of his climate. C. remota is a very elegant plant. C. paniculata grows in bogs in immense tufts, making a firm support for the heaviest bodies. C Fraseri is the handsomest species of the genus, resembling at a short distance when in flower, one of the Liliacex. C. riparia has leaves half an inch wide, and from one to three feet long; in Italy the leaves are used by the glass-makers to bind their wine flasks; by the chair-makers to bottom chairs; and by the coopers to place in the junctures in the heads of casks, in the same manner as the leaves of the Typha are used in the same country, and the stalks of Scirpus lacustris in England. C. arenaria increases rapidly in loose sand, and is sometimes planted with a view of fixing soils of this description, along with Elymus and Arundo.

1948. Cobresia. Named by Willdenow, after a German nobleman of the name of De Kobres, who is said to have been a great promoter of natural history. The plants resemble Carex. 
13135 Male spike sol. Scales obl. with very long beaks : female cylind. 2; stalk of the lower exserted, Stigm. 3, Fr. ovate inflated 5 -nerved beaked

13136 Male spike sol. : fem. 2 obl. close ; low. stalk. Stigm. 3, Fr. ellipt. glob. shin. bifid at end larg. than ov. scale

13137 Male spike sol. : fem. 3-rem. ; lower stalk. Stigm, 3, Fr. ov. nerv. memb. at mouth long, than mucron. scale

13138 Male spike sol. : fem. 3 few-fl. 2 close sessile; lower rad. on a very long stalk, Stigm. 3, Fr. obov, obl. 3-cornered with a very short beak

13139 Sheaths none, Bracteas foliaceous auric. at base, Spikes sess. obl. or subcylind. obt. Fruit broadiy elliptical

13140 Fertile spikes nearly sessile cylindric. filif. acumin. Fr. ovate somewhat acute plane above on each side, Culm acutely angular straight

13141 Fert. spikes cylind, very long droop. Fr. ov. short. acum. bif. at extremity closely imbricated, Iseaves broar! 13142 Digynous, Sheaths none, Spikes ovate: upper sessile, Leaves somewhat recurved rigid, Fruit compressed

\section{* 3. Male spike solitary, female all stalked.}

13143 Fert. spikes few-fl. lax drooping, Fr. as long as ovate membrarac. decid. scales oblongo-ovate acuminate 1314t Fert. spikes pedunculated oblongo-cylind. subpendul. Bract. subfoliac. Fruit ov.-ellipt. tumid obt. glabrous 13145 Sheaths elongated shorter than the flower-stalk, Fruit elliptical ovate beaked (black) bifid at the point

13146 Fert. spikes narrow obl. very few-fl. lax pendul. Bract. subsetaceous, Scales acute longer and broader than the fruit, Fruit ovate somewhat acumin. striated

13147 Fert. spikes oblongo-ovate pendulous, Bracteas subsetaceous, Scales acute as long as the fruit, Fruit ellipt. rotundate striated shortly mucronate

13148 Fertile spikes upon long footstalks cylind. pendul. Bract. very leafy, Scales setaceous, Fruit oblong very much acuminate cloven at the tips striated

13149 Male spike sol. : fem. about 4 remote filiform stalked cernuous, Stigm. 3, Fr, dist. altern. obl, beaked bifid 13150 Fert. spikes filif, rather slender slightly drooping, Fr. broadly ov. much acumin.cleft at point, Lvs. narrow 13151 Male spike solit. : fem. usually twin stalk. filif. Stigm. 3, Fr. lanc. hisp. scabr. 2-toothed long. than obl. scale 13152 Fert. spikes slend. filif. nearly erect, Fruit ov.-lanc. nerved slightly recurv. loose. imbric. Lvs. rather broad

* 4. Male spikes more than one.

13153 Fertile spikes subcylindrical drooping, Fruit obovato-globose obtuse rather downy entire at the poini

13154 Male spikes twin : fem. twin obl. sess. rem. Stigm.3, Fr. ov. nerved forked ventric. larg. than ov. lanc. scale

13155 Male spikes 3: fem, twin on short stalks nodd.cylind. Stigmas 3, Fr. ellipt. ventricose with a short ent. beak

13156 Fert. spikes short. peduncul. oblongo-cylind. their cal. subcusp. Fr. ov. short. beak. bif. at point very pubes.

13157 Lvs, subsessile sublim, thickened, Stigmas 2, Fr, ellipt with short beak ent. at end as long as rounded scales

13158 Fert. spikes long cylind. acum. slender erect when in fruit, Fr. oval swelling subacum. entire at point, Culm acutely angular scabrous

13159 Scal. of sterile spike obtuse, Fertile spikes cylind, obtuse, Fruit oblongo-ovate acute bifid at point striated

13160 Foliaceous, Scal. of sterile spike acum. Fertile spikes scarcely peduncul. broadly cylindrical acute, Fruit ovate subacum. bifid at the point

13161 Fert. spikes cylind. slightly droop. Scal. lanc. Fr. broadly ovate inflat. subulato-rostrate deeply bifid at point 13162 Fert. spikes cylind. long near. erect, Scal. lanc. Fr. crowd. subglob. inflat. setaceo-rost. slightly bif. at point 13163 Male spikes 2: female 3 obl. remote subsessile, Stigmas 3, Fr. obl. compr. rostr. bifid ciliate serrat. at edge 13164. Male spikes 2: female 3 obl. remote subsessile; lower subrad. Stigmas 3, Fr.ovate comp. 2-toothed hairy 13165 Bracteas long foliac. Fertile spikes short cylind. distant their scal. cuspidate, Fr. ov. with long beak hairy 13166 Fert. spikes droop, cylind, all the scal. acum. or mucr.Fr.ov.triang. with rather long acum. beak bif. at point 13167 Male spikes twin : fem. 4 dist. stalk. pendul. cylind. Stigm. 2, Fr. round, ellipt.ventric. with very short beak 13168 Male spikes 2: fem. 2 rem. on very long stalks erect obl. Stigm. 2 , Fruit ellipt. with short beaks ent. at end 13169 Male spikes about 4 : female 2 erect stalked cylind. Stigmas 3, Fr. obov. obt. shorter than obl. blunt scale 13170 Male spikes 3 : female 2 cylindr. stalked erect, Stigm. 3, Fr. ov. glob. beaked with 2 forks, Beaks hispid

13171 Spikes 3 or 4 alternate male above

\section{Fruit oblong 3-cornered smooth at edge}

13173 Leaves entire

13174 Leaves serrated

13175 Culm half round at top and obtuse, Flowers naked, Fruit ovate 13176 Culm round, Flowers naked, Fruit nearly round

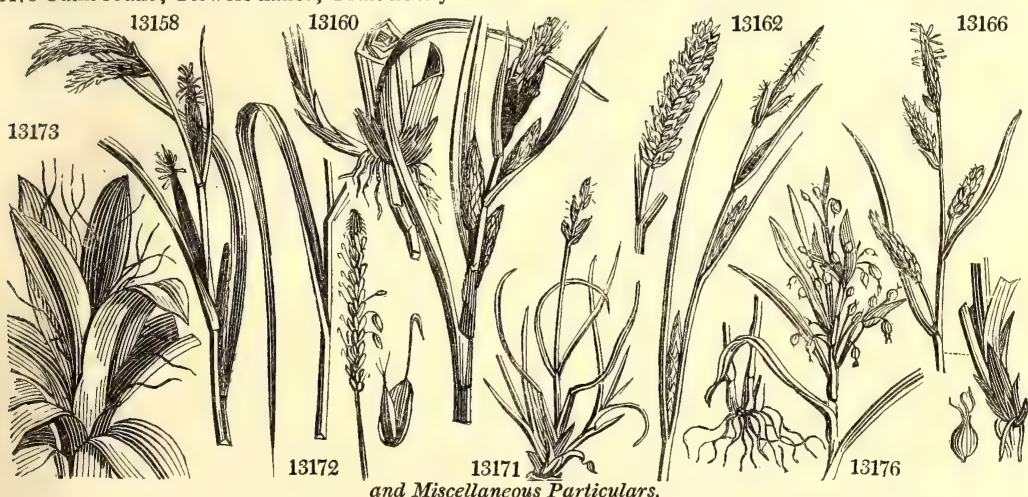

1949. Uncinia. So called from orxos, a hook, in allusion to the hooked awn, which in the fruic becomes hardened. Plants with the habit of Carex.

1950. Zea. The Greek name of corn of some kind. It is derived from కow, to live, and applied to this nutritive plant with propriety. The word Maize is the denomination of the vegetable among the South Americans. Zea Curagua is the curious Valparaiso corn, to which a sort of religious reputation is attached, on account of the grains, when roasted, splitting regularly into the form of a cross. Of the well known Indian corn, Z. Mays, there are numerous varieties, some of which are sufficiently hardy to thrive in this climate.

1951. Coix. A name used by Theophrastus to designate a kind of grass. C. Lachryma, commonly called Job's tears, derives its name from the appearance of its shining pearly fruit, which, when suspended on its slender pedicels, resembles in no inconsicierable degree a falling tear. Tropical grasses, which flower and seed plentifully in rich light soil 
1952. TRIP'SACUM. $W$. TRIPSACUM

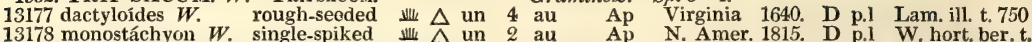
13178 monostáchyon $W$. single-spiked 业 $\Delta$ un 2 au Ap N. Amer. 1815. D p.l W. hort. ber. t.1 13179 hermaphroditum $W$. hermaphrodite 1 业 un 2 au.s Ap Jamaica 1776. D p.l

1953. HETEROPO'GON. Rich. Heteropogon. Graminea. Sp. 1-2.

13180 gláber Rich. smooth 业 $\Delta$ un 2 au Ap Switzerl

1954. OLY'RA. $W$ OlYra. Graminece. $S p .1-4$.

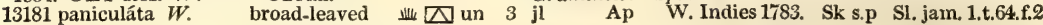

\section{TETRANDRIA.}

1955. AL'NUS. $W$ 13182 glutinósa $W$. $\beta$ laciniáta

13183 oblongáta $W$ $\beta$ ellíptica

13184 incána $W$. $\beta$ anguláta

13185 unduláta $W$.

13186 serruláta $W$.

13187 cordifólia Ten.

1956. BE'TULA. $W$.

13188 álba $W$

13189 pen'dula Roth.

13190 populifólia $W$.

13191 excélsa $W$.

13192 daúrica $W$

13193 nígra $W$.

13194 lanulósa Mich.

13195 papyrácea $W$.

13196 lénta $W$. carpinifolia Ehr.

13197 nána $W$.

13198 púmila $W$.

13199 póntica Hort.

13200 ováta $W$.

13201 fruticósa $W$.

13202 pubéscens $E h r$.

1957. BUX'US. $W$.

13203 baieárica $W$.

13204 sempervirens $W$

$\beta$ angustifólio r suffiruticósa

13205 chinénsis Link.

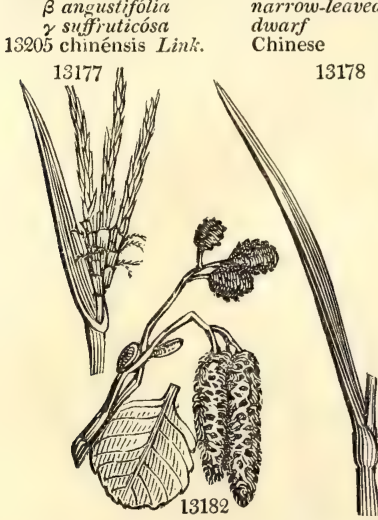

AlDER. common cut-leaved oblong-leaved elliptic-leaved hoary-leaved Elm-leaved curl-leaved rotch-leaved heart-leaved

Bircil. common Poplar-leaved tall

Daurian red woolly paper soft

smooth-dwarf hairy-dwarf Pontic ovate shrubby pubescent

Box Tree. Minorca common narrow-leaved
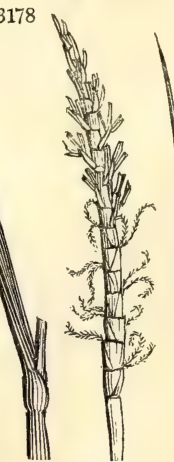

\begin{tabular}{llll} 
& \multicolumn{3}{c}{ Amentacea. } \\
ec & 25 & mr.ap & Ap \\
or & 25 & $\mathrm{mr} . a p$ & Ap \\
or & 20 & $\mathrm{jl}$ & $\mathrm{Ap}$ \\
or & 20 & $\mathrm{jl}$ & Ap \\
or & 20 & $\mathrm{jn}$ & $\mathrm{Ap}$ \\
or & 20 & $\mathrm{jn}$ & $\mathrm{Ap}$ \\
or & 20 & $\mathrm{my} . \mathrm{jn}$ & $\mathrm{Ap}$ \\
or & 20 & $\mathrm{mr}$ & $\mathrm{Ap}$ \\
or & 20 & $\mathrm{my} . j n$ & $\mathrm{Ap}$ \\
& \multicolumn{4}{c}{ Amentacee. }
\end{tabular}

Sp. 6-9.

in wat.pl. L m.s Eng bot. 1508

Britain $\ldots$ L m.s Willd. arb. 44

Europe 1780. L L 1.p

..... L l.p

N. Amer. 1782. L 1.p

N. Amer. 1769. L lp Abb. ins. 2.t. 92 Naples 1818. L co

Sp. 15-19.

tm 40 ap.jn Ap Britain moi.w. S co Eng. bot. 2198 or 40 ap.jn Ap Britain woods. $\mathrm{S}$ co or $30 \mathrm{jl}$ Ap N. Amer. 1750. L co tm 60 my Ap tm 30 jl Ap tm 60 jl.au Ap tm 70 jl.au Ap tm 50 jn Ap Mich. arb. 2, t. 2 N. Amer. 1767. S co Dend. brit. 95 Siberia 1786. L co Pall. ross. 1, t.39 N. Amer. 1736. L co Dend. brit. 153 N. Amer. 1817. $\mathrm{L}$ N. Amer. 1817. L co 8 my cu 8 my Ap or 6 ap.my Ap or 12 ap.my Ap or 15 ap.my Ap or 6 ap.my Ap
or 30 ap.my Ap

Scotland moi.h. L co Eng bot. 2326 N. Amer. 1762. L s.p Jac. vind.2.t.122 Turkey $\quad . . . \quad$ L s.p Dend. brit. 94 Hungary 1820 . L L co Dend. brit. 96 Siberia 1818. L co Dend brit. 97 Germany 1812. L co

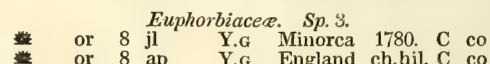

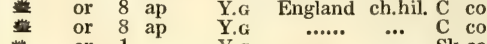

History, Use, Propagation, Culture,

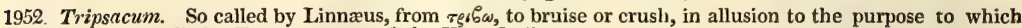
its grain may be applied. Forage grasses of the West Indies.

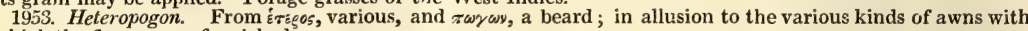
which the flowers are furnished.

1954. Olyra. A name under which Homer speaks of a grain which was used as the food of horses, and which has been thought analogous to Barley. The plant now so called is a native of America, and has no resemblance to that of the ancients.

1955. Alnus. From the Celtic word $a l$, near, and $l a n$, the edge of a river, in reference to the places where the species grow. A. glutinosa, Aulne, Fr., Eller, Ger., and Alno, Ital., is a well known timber tree, which will grow in marshy situations. The timber is applied to a variety of purposes, and in general for all works intended to be constantly under water, for turnery and furniture. The hark is used by dyers and tanners ; the sap being of a yellow color and very astringent. There is a variety with cut leaves sold by the nurserymen as

an ornamental tree, though it is more curious than showy.
1956. Betula. Betu is the Celtic word for the Birch. Bouleau, Fr, Birchenbaum, Ger., and Betulla, Ital.

B. pendula is the most graceful tree of the genus; it grows both in mountainous situations and bogs, from Lapland to the subalpine parts of Italy and Asia. B. lenta, the mahogany birch, mountain mahogany, or cherry birch of Canada, abounds in the middle states of Pennsylvania, New York, and the Jerseys ; but disappears altogether in the higher latitudes of the northern states. It is thought a very fit tree for planting in the valleys of the mountainous districts of Britain. Its growth is rapid, and the timber is close grained, beautifully variegated, and well adapted for cabinet work. The leaves, which appear early in spring, possess 
13177 Spikes 3 clustered : male above ; female below

13178 Spike solitary : male above; female below

13179 Spike solitary hermaphrodite flexuose, Spikelets somewhat distant

13180 Culm nearly simple, Sheath of leaves bearded at edge, Spike smooth

13181 Culm branched, Panicle terminal

\section{TETRANDRIA.}

13182 Lvs. roundish cuneiform obt. lobed at margin and serrat. somew. glutin. downy in axils of veins beneath $\beta$ Leaves oblong pinnatifid, Segments cut

13183 Leaves oblong bluntish glutinous, Axils of the veins naked

$\beta$ Leaves elliptical

13184 Leaves oblong acute downy beneath, Axils of the veins naked, Stipules lanceolate

$\beta$ Leaves green beneath, Petioles green

13185 Lvs. obl, acute rounded at base, Petioles and veins hairy beneath, Axils of veins naked, Stipules ov.-obl.

13186 Leaves obovate acuminate, Veins and axils of veins beneath hairy, Stipules elliptical blunt

13187 Leaves cordate acuminate entire lucid above

13188 Leaves ovato-deltoid acute doubly serrated glabrous

13189 Leaves ovate acuminate cut serrate smooth, Branches scabrous pendulous

13190 Lvs, delt, with long points unequal, serrat, quite smooth, Sce

13191 Leaves ovate acute serrated, Scales of cones with lat. lobes rounded, Petioles downy shorter than Petioles

13192 Leaves ovate narr. at base ent. unequally toothed smooth, Scales of cones ciliated: lateral lobes rounded

13193 Lvs. rhomb. ov. doubly serr. acute downy beneath entire at base, Scales of cones vill. with lin. uneq. lobes

13194 Leaves deltoid ovate small, Scales of female catkin densely woolly on the outside

13195 Leaves ovate acuminate doubly serrate, Veins hairy beneath

13196 Leaves cordate-ovate finely serrated acuminate, Scales of cones with blunt equal lobes and elevated veins

13197 Leaves orbicular crenate

13198 Leaves orbicular obovate serrated beneath with the branches downy, Female catkins cylindrical

13199 Petiole downy, Leaves rhomboid cut-toothed obtuse nearly smooth with tufts of hair in the axillæ beneath

13200 Lvs. ovate doubly serr. smooth, Fem. peduncles branched, Scales of cones with equal trunc. nerved lobes

13201 Leaves roundish ovate nearly equally serrate smooth, Female catkins oblong

13202 Lvs. deltoid acute subcord. doubly serr. beneath with branches pubesc. Scales of cones with lateral lobes

13203 Leaves oblong, Petioles smooth, Anthers sagittate linear

13204 Leaves ovate, Petioles hairy at edge, Anthers ovate sagittate

13205 Leaves opposite oblong : younger downy ; old ones smooth, Fl. axillary solitary

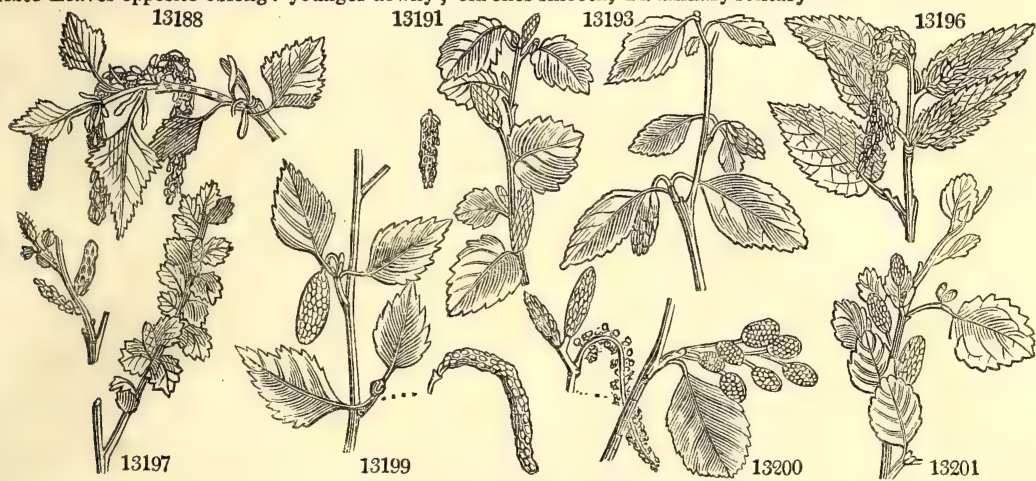

and Miscellaneous Particulars.

a peculiar fragrance, which they retain after being dried in a stove, affording by infusion an agreeable diluent, superior to some of the common teas of commerce.

B. populifolia and papyracea are elegant rapid growing trees, well deserving culture for their timber. All the species are ornamental, and more or less fragrant; and B. pumila and nana are pretty little shrubs. Of the Betula papyracea the North American Indians construct their large portable canoes, from which circumstance that species is known by the name of canoe birch. Betula lente is the canoes, from which circumon account of the excellence of its wood. It is known by the names of mountain mahogany, black birch, cherry birch, and sweet birch. This last appellation it has from the sweet scent the branchlets give when

1957. Buxus. An alteration of $\pi v \xi \%$, its Greek name. B. sempervirens, Buis, Fr., Buchsbaum, Ger., and Bosso, Ital. is one of the most useful of evergreen shrubs ; edgings of the dwarf variety are of univel.sal use in the walled gardens of Europe; and what is called the ; edgings of the dwarf variety are of universal use in which will grow under the he Britain southwards, and is very abundant in different parts of France and Switzerland. It abounds in many countries of Asia, as about Mount Caucacus, in Persia, China, Cochin China, and America. It was formerly very cominon in England, but has gradually disappeared as agriculture extended. Box-Hill in Surrey, Boxley in Kent, and Boxwell in Gloucestershire, are named from their abounding in this tree. The timber of the box tree is of considerable value. It is sold by weight, and being very hard and smee. The timber of the is very well adapted to a variety of nicer works. It is as extensively employed now as it appears to have been in the days of Evelyn, "for the turner, engraver, carver, mathematical instrument maker, comb and pipe or 
1958. CIC'CA. W. 13206 disticha $W$. 1959. MO'RUS. $W$. 13207 álba. $\boldsymbol{H}$ 13208 tatárica $W$ 13209 nígra $W$. 13210 rúbra $W$ 13211 tinctúria $W$.

1960. BEHME'RIA $\%$ BOEHUERIA 13212 cylíndrica $W$. 13213 rubéscens $W$. 13213 rubescens $W$. 13215 lateriflóra $W$.

1961. PI'LEA. Iindl. 13216 muscósa Lindl.

1962. UR'TI'CA. $W$. 13217 pilulífera $W$. 13218 baleárica $W$. 13219 convéxa Hort. 13220 Dodártii $W$. 13221 púmila $W$. 15222 involucráta $B . M$ 13223 grandifólia $W$.
Cicca. long-leaved

Mulberr. white Tartarian common

red

Fustick-wood cylindrical tree

branch-flower. side-Howering

Pilea. small-leaved

Netrthe. Roman Balearic convex Dodart's involucred great-leaved

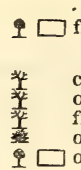

Euphorbiracer. Sp. 1 Urticea. Sp. $5-7$.

lt 30 jn Ap China 1596. I co Schk.han.3.t.290 or 20 jn Ap Tartary 1784. L co Pall.ros.2.t. 52 ir 30 jn Ap Italy 1548. L co Dend. brit. 159 or 10 jn.jl Ap N. Amer. 1629. L r.m

Urticea. Sp. 4-13.

$¥ \triangle$ un 4 jn.au $G$ Virginia 1759. Sk s.p Slo.jam.1.t.82.f.2 遢 10 or 10 f.my $G$ Canaries 1779. C s.p Jac. frag. t.5.f 1 造 un 8 f.my G $\quad$ Jamaica 1823. C co Jacq. amer.t.157 Urticece. Sp. $1-3$.

in $\triangle \mathrm{pr} \quad \frac{1}{\text { B }}$ ap.my $\mathrm{G}$ W. Indies 1793. C co Lind. coll. 4.

Urticea. Sp. 32-67.

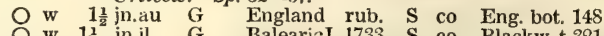

O $1 \frac{1}{2}$ jn.jl G BalearicI. 1733. S co Blackw.t.321.f.1

w $1 \frac{1}{2} \mathrm{jn} . \mathrm{jl}$

O w $1 \frac{1}{2}$ jl.au

O w $\frac{1}{2}$ jl.au

w un 1 jl.au

G S. Europe 1683. S co

N. Amer. .... S S co

$\begin{array}{lll}\text { N. Amer. } & \text { A. } & \text { S co } \\ \text { W. Indies } 1821 \text {. } & \text { C co }\end{array}$

Jamaica 1793. C co Bot. mag. 2481

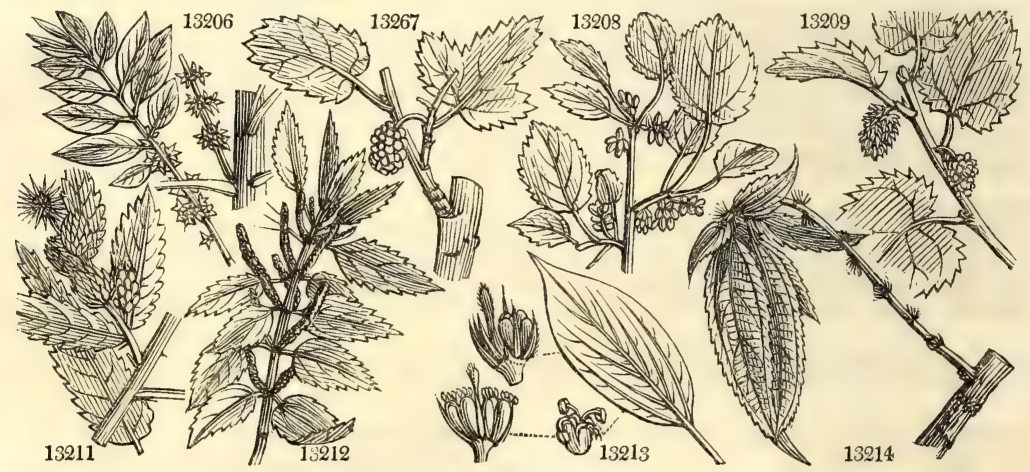

History, Use, Propagation, Culture,

flute maker; and the roots for the inlayer, and cabinet maker. Of box are made wheels and shivers, pins, pegs for musical instruments, nut-crackers, button-moulds, weavers' shuttles, hollar-sticks, bump-sticks, and dressers for the shoemaker, rulers, rolling-pins, pestles, mall-balls, beetles, tops, tables, chessmen, screws, bobbins for bone-lace, spoons, knife-handles, but especially combs.'

The English wood is esteemed inferior to that which comes from the Levant, and the American box is said to be preferable to ours, for most purposes; but the English is superior for the purpose of the engraver.

The ancients made combs of box, and musical instruments to be played upon by the mouth The Romans likewise clipped it into form, for which nothing, says Pliny, is more fit. And Martial mentions clipped box trees in the gardens at Bassus's country-house.

The tree box was second to the yew with us in former times for the purpose of being clipped into the shape of animals, \&c.; but the dwarf box stood unrivalled "for bordering up a knot, and was esteemed a marvellous fine ornament to the flower garden."

The branches were in request among our ancestors for decking up houses; they are still seen among other evergreens in churches at Christmas, and in some countries they are borne by attendants at funerals.

Box has been much celebrated as a medicine in the venereal disease, colicks, intermittent fevers, and even madness. According to Dr. Blaine, it is the principal ingredient in Well's Watford Drink, which is given as a preventive to canine madness.

Pliny affirms, that no animal will touch the seed of box. Gmelin relates, that the branches are fatal to the camels that eat them. None of our animals seem to touch this tree. Corsican honey was supposed by the ancients to owe its infamy to the bees feeding on the box.

1958. Cicca. A word of unknown meaning. Cicca disticha thrives in light loamy soil, and is increased by cuttings with their leaves on, planted in sand, and covered with a hand-glass.

1959. Morus. Moges was the Greek name of the Mulberry; it is derived from the Celtic mor, which signifies black. Murier, Fr, Maulbeerbaum, Ger, and Moro, Ital. M. alba is commonly cultivated in France and other countries for its leaves, to feed silk-worms; though in some parts of Spain and in Persia they are said to prefer the black mulberry. In China, it appears that both sorts are grown for the same purpose The most valuable variety of $\mathrm{M}$. alba is one grown in Italy, and especially in Lombardy, with vigorous shoots, and most valuable variety of $M$. alba is one grown in Italy, and especially in Lombardy, with vigorous shoots, and purpose of making a plantation in the south of Ireland, with a view to try the growth of silk in that country. In France the white mulberry is grown as pollard elms are in England; in Lombardy it is grown exactly in the same way as we grow willows for baskets, and in similar soil ; in China it is also grown in moist. loamy soil, and both there and in the East Indies as low bushes, and the plantation rooted up and renewed every three or four years. In many parts of the continent, when the leaves are wanted for the worms, they are stript off the young shoots, which are left naked on the tree; in other places the shoots are cut off, which is not so injurious to the tree, while the points of the shosts, as well as the leaves, are eaten by the worms. The plants are sometimes raised by seed, but more commonly by layers; the Italian variety is frequently grafted on seedling stocks of the common sort, in order to preserve it from degenerating. In the East Indies, the plants are raised from cuttings, three or four of which are placed together where they are finally to remain. (Encyc. of Agr. 884.)

The fruit of the white mulberry is white, and less acid than that of the black species.

M. nigra is naturally a stronger tree than the other; the fruit is of a dark blackish red, and of an agreeable aromatic and acid flavor. It has a place in the Materia Medica, as cooling and laxative, allaying thirst, and being grateful in febrile diseases. Young trees, like most others of the Moncecious class, ofien produce 
13206 Leaflets oblong, Racemes lateral

13207 Leaves deeply cordate unequal at the base ovate lobed unequally serrated smoothish 13208 Leaves slightly cordate equal at base ovate or lobed equally serrated smooth 13209 Leaves ccrdate ovate or lobed unequally toothed scabrous

13210 Leaves cordate ovate acuminate or 3-lobed equally serrate scabrous soft beneath, Fem. spikes cylinơrical 13211 Leaves oblong unequal at base, Spines axillary solitary

13212 Leaves opp. ovate-obl. acum. toothed smooth, Fl. diœcious, Male spikes clust. interrupt. : fem. cylincrical 13213 Lvs. altern. obl. narrow. at each end entire, Spikes axill. clustered interruptedly branched, Branches hairy 13214 Lvs. altern. broadly lanc. acum. serrated rugose, Fl. cluster. axill. and lateral moncecious, Males 3-audious 13215 Lvs. altern. ovate-lanceolate acuminate serrated scabrous, Fl. clustered lateral, Stem herbaceous

13216 Leaves ovate acute entire, Stem simple ascending

13217 Leaves opposite ovate or somewhat heart-shaped deeply serrated, Heads of fruit globose 13218 Leaves opposite cordate serrate, Fruit-bearing catkins globose

13219 Leaves opposite entire convex oblong, Fruit-bearing catkins globose

13220 Leaves opposite ovate nearly entire, Heads of fruit globose

13221 Leaves opp. ovate blunt-pointed 3-ribbed serrated, Fl.-stalks somewhat corymbose shorter than footstalks 13222 Leaves opposite ovate rugose obtuse, Flower-stalks in the axillæ of the upper leaves

13223 Leaves opposite ovate pointed copiously serrated, Stipulas elliptical entire glauc. Corymbs much branched axillary longer than the footstalks
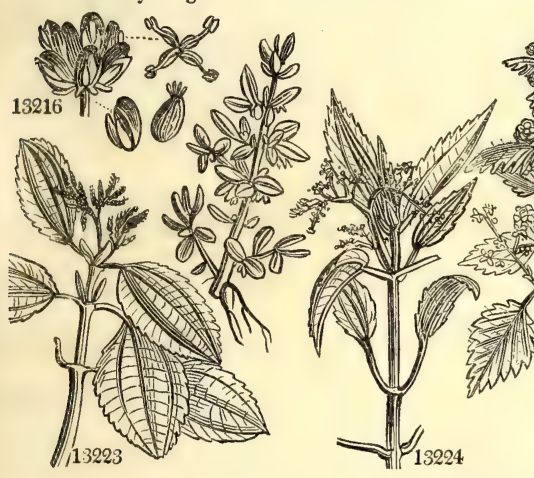

13217
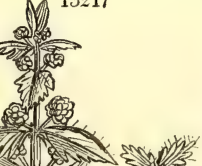

and Miscellaneous Partıculars.

only male blossoms for many years after they are planted, and yet afterwards become fruitful. As the tree increases in age, it increases in fruitfulness; and in full grown trees the fruit is much larger and better flavored than in young ones. In some of the old gardens near London, there are mulberry trees of a great age, which are very healthy and fruitful. Bradley says, that most of these were planted in the times of James $I_{\text {, }}$, who attempted unsuccessfully to set up a silk manufacture in England. The fruit of the mulberry, like that of the strawberry and raspberry, is said not to undergo the acetous fermentation in the stomach, and therefore it may be safely eaten by gouty and rheumatic persons. It is a mistake, however, to suppose that these fruits are lighter than others which have not the same antifermentative qualities.

The mulberry is generally propagated by layers, but it may also be increased by seeds, cuttings, or grafting. It is generally grown as a standard in orchards; but will produce fruit sooner as an espalier or wall tree.

M. rubra has black shoots, rougher leaves than the black mulberry, and a dark reddish fruit, longer than the common sort, and of a very pleasant taste. The tree is cultivated in China for feeding silk-worms, but not so generally as the white mulberry. M. indica is also cultivated for the same purpose. M. tatarica bears pale red berries of an insipid taste, but eaten in Russia fresh, conserved, or dried; a wine and a spirit are also made from them, and the leaves are used for feeding silk-worms.

M. tinctoria is a tall branching tree, with a fine head, smooth leaves, and awl-shaped solitary spines. The whole plant abounds in a slightly glutinous milk of a sulphureous color. The timber is yellow, and a good deal used in dying that color, for which it is chiefly imported into Europe, under the name of Fustick-wood. The berries are sweet and wholesome, but not much eaten, excepting by birds.

All the species of Morus are remarkable for putting out their leaves late; so that when they appear, gardeners may safely set out their greenhouse plants, taking it for granted, that all danger from frost is over.

1960. Bœehmeria. Named after George Rudolph Böhmer, a German botanist, and a member of the academy of Wittemberg. He published several works, besides an academical dissertation upon the cellular tissue of vegetables. Plants of little beauty, and easy cultivation and propagation.

1961. Pilea. So called by Mr. Lindley, from $\pi i \lambda \varepsilon 05$, a cap ; in allusion to the nature of one of the divisions of the periarthium. A neat little creeping plant, which makes a good cover to hide the earth of large pots of tropical plants.

1962. Urtica. A word formed from uro, to burn, in allusion to the stinging properties of most of the species. The English term Nettle seems to be the Anglo-Saxon Netel, which is itself an alteration of nadl, a needle, in the same language. U. dioica grows all over Europe, in Barbary, Siberia, and Japan, in hedges, neglected fields, gardens, and pastures. This species, U. urens, and pilulifera, with one or two others, are furnished with stings. The small projecting bristles or prickles with which they are covered are tubular, and stand on a bag filled with a poisonous juice; they are perforated at the point, and when they are gently pressed vertically, the pressure at once forces the poison to ascend the tube, and enables the point to lodge it in the skin. The tops of the tender shoots of U. dioica are sometimes used as a pot herb early in spring, and they have even been forced for that purpose. A strong decoction of the plant salted, will coagulate milk very readily and without any disagreeable flavor. The stalk is found to have a texture somewhat like that of hemp, and to be capable of being manufactured into cloth, ropes, and paper. The leaves are the only food of the caterpillars of three of our most beautiful butterflies, Atalanta, Paphia, and Urticæ, the principal food of the Io, and the occasional food of the Comma album; the caterpillars also of the urticata and verticalis moths feed on it: a great number of other indiscriminate feeders devour its foliage; and the bases of the leaves in autumn are frequently disfigured by tubercle;, w hich contain small maggots, probably producing Musca Urticæ. As a remedy for the 
13224 reticuláta $W$. net-leaved $\square$ un 2 jn.au G Jamaica 1793. C co Bot. mag. 2567

13225 rúfa $W$.

13226 úrens $W$.

13227 dioíca $W$.

13228 membranácea $W$.

13229 crassifólia

13230 árdens Link.

13231 cannabína $\boldsymbol{W}$.

13232 rugósa $W$.

13233 nudicaúlis $\boldsymbol{W}$.

13234 grácilis $W$.

13235 Parietária $W$.

13236 ciliáta $W$.

13237 pulchélla Link.

13238 scabrélla Rox.

13239 æ'stuans $\boldsymbol{W}$.

13240 canadénsis $W$

13241 nivea $W$.

15242 baccífera $W$.

13243 caracásana $W$

13244 caravellána Schrk. long-stalked 13245 elongáta Link. lengthened

13246 diversifólia Link. various-leaved

13247 hórrida Link.

13248 arboréscens Link. arborescent

rusty

- $\square$ un 1 jn.s

G

small

O w 1 jn.s

* $\triangle \mathrm{w} \quad 1 \frac{1}{2} \mathrm{jl} . \mathrm{s}$

Ap Britain clt.gr. C co Eng bot. 1236

Ap Britain wa.gr. C co Eng. bot. 1750

membranous

$\leftarrow \square$ un 2 jl.s

burning

$O$ un 1 jl.s

Hemp-leaved $\not \Delta$ un $3 \mathrm{jl} . \mathrm{s}$

rough-stalked 10 un 2 my.jl

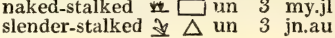

Pellitory-leav'd $\square$ un 1 jl.s

ciliated

证 $\square$ un 1 in ${ }_{1} \mathrm{jl.s}$

rough

Surinam

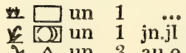

\$ $\triangle$ un 3 au.o

white-leaved $\$ \Delta$ un 2 au.s

berry-bearing $\square$ un 4 jl.au

—u uil 8 jl.au

Ap Spain 1820. C co

Ap S. Amer. 1822. C co

Ap Nepal 1821. S co

Ap Siberia 1749. S co Ám rut. 249.t.25

Jamaica 1793. C co

Jamaica 1793. C co

Ap Jamaica 1793. C co Slo.jam.1.t.93.f.1

Ap Jamaica 1815. C c6

Ap E. Indies 1820. C co

Ap E. Indies 1815. C co

Ap Surinam 1803. C co Jac.schœ.3.t.388

Ap Canada 1656. C co Pl.alm. t.237.f.2

Ap China 1739. C p.1 Jac.vind. 2.t.166

Ap S. Amer. 1793. Sk s.p Bot. rep. 454

Ap Caraccas 1824. C co Jacq. schœ.f.386

O un 4 jl.au Ap S. Amer, 1825. S co O un 3 jlau

Ap Philipp.1s.1823. S co

Ap Nepal 1821. S co

Ap Manilla 1822. C co

1963. PACHYSAN'DRA. Mi. Pachysandra.

13249 procúmbens $W$. trailing

Euphororbiacę. Sp. 2.

trailing $\quad \triangle \mathrm{pr} \quad \frac{1}{4} \mathrm{mr}$.ap W N. Amer. 1800. D s.p Bot. reg. 33

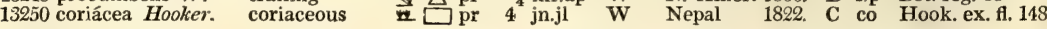

1964. DIO'TIS. $W$. Diotis. Chenopodea. Sp. 1.

13251 ceratoídes $W . \quad$ shrubby $\quad$ or $2 \mathrm{mr} \quad \mathrm{mp}$ Siberia $\quad$ 1780. L s.p Jac. ic. 1.t. 189

1965. EMPLEU'RUM. $W$. EMPLeURum.

1966. AU'CUBA. $W$. Aucuba.

13253 japónica $W$.

Diosmea. Sp. 1.

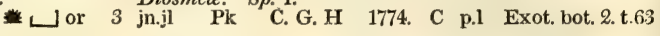

Rinamnea? Sp. 1.

1967. LitToreL/LA. $W$. Shore Weed.

13254 lacústris $W$. Piantain-leav'd 兰 $\Delta \mathrm{pr}$

Plantaginece. Sp. 1.

$\frac{1}{8}$ jn.au W Britain w.sa.p. S p.l Eng. bot. 468

1968. SERPI'CULA. $W$. Serpicula.

13255 répens $W$.

creeping

Onagraria. Sp.1-3.

1969. MACLU'RA. Nutt. Osage Orange.

13256 aurantiaca Nutt. common

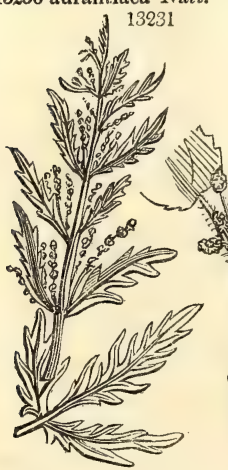

NGE. fr

Urticea. Sp. 1.

... Ap N. Amer. 1818. C p.l Lamb.pin. supp.
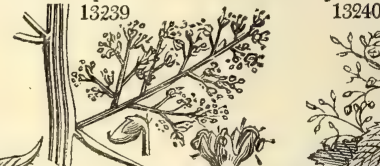

13240
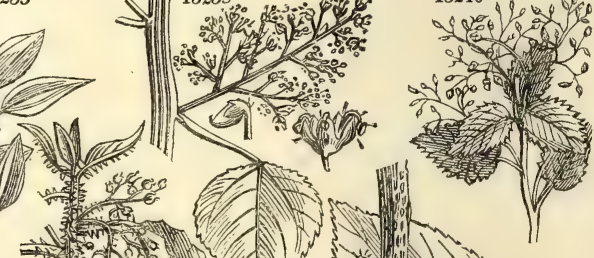

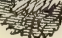
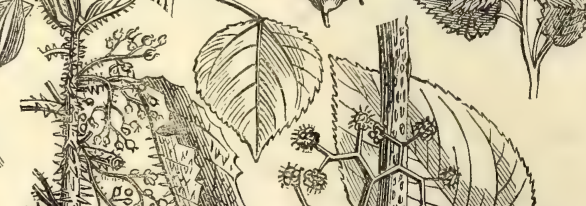

.

हो

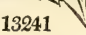

History, Use, Propagation, Cuilture,

sting of the nettle, its own juice, or that of the dock, may be applied. The exotic species are of easy culture.

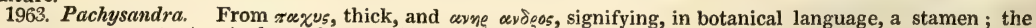
stamens are very stout. A plant of easy culture in common light soil, and freely increased by suckers from the roots.

1964. Diotis. From $\delta i s$, double, and $8 s w r o s$, an ear, on account of the two appendages which exist at the base of the florets. A shrub of no great beauty, which thrives in light soil, and is easily increased by layers or cuttings under a hand-glass.

1965. Empleurum. From $\varepsilon$, in, and $\pi \lambda \varepsilon v \rho \circ$, the pleura, or membrane which envelopes the lungs. The sceds of this plant are attached to a sort of coriaceous membrane.

1966. Aucuba. The Japanese name of the plant. It is a well known laurel-like evergreen shrub, with leaves mottled with yellow. Male flowers only have been produced in the gardens; but according to Kœmpfer, 
13224 Leaves opposite elliptic-oblong acute serrated towards the point reticulated beneath, Stipulas ovate-entirt, Clusters panicled about the length of the footstalks

13225 Leaves opposite elliptical acute serrated triple-ribbed their veins hairy, Stipulas roundish permanent, Clusters slightly branched, Stem shrubby shaggy with rusty hairs

13226 Leaves opposite elliptical with about 5 ribs, Clusters of flowers nearly simple

13227 Leaves ovate acuminate cordate at the base, Clusters of flowers much branched in pairs mostly diœcious

13228 Leaves opposite broadly ovate somewhat heart-shaped coarsely serrated, Fls. monœecious : male in twin upright unbranched stalked spikes with winged recept. : fem. in nearly sess. spikes shorter than footst.

13229 Leaves opposite ovate obl. acute 3-ribbed serrated thickish reticulated and pale beneath, Corymbs stalked forked longer than the leaves, Flowers tufted

13230 Stem petioles and lvs. covered with rigid dense stimuli, Lvs. ov. acum. doubly serrat. Spikes comp. whorled 13231 Leaves opposite in three deep pinnatifid segments, Clusters cylindrical in pairs erect

13232 Leaves opposite elliptical serrated 3-ribbed rugged, Clusters short dense terminal, Stem simple erect

13233 Lvs. chiefly term. opposite ellipt.-lanc. pointed 3.ribbed entire nearly smth. Stem angul. leaf. below, Cluster

lateral diœcious
13234 Leaves opposite ovato-lanc. serr. heart-shaped at the base, Stem and footstalks hispid, Flowers diœeious, Clusters in pairs somewhat branched about as long as the footstalks

13235 Leaves opposite ovato-lanc. entire, Stem much branched, Flowers diœcious

13236 Leaves opposite ellipt. 3-ribbed crenate fringed acute at each end entire at the base, Stem divaricated, Flowers aggregate on axillary stalks about the length of the footstalks

13237 Leaves long lanc. very rugose: glabrous above; beneath having a fine white down

13238 Stem downy roughish, Lvs, on long stalks ov. acute crenat. downy roughish 3-nerv. Stip. lanc. acute scar.

13239 Lvs, alternate ov. serrat. minutely heart-shap. at the base, Clusters axill. forked, Fruit in orbicular corymbs

$13240 \mathrm{Lvs}$. alternate ovate somewhat hairy serrated, Stipulas obtuse, Clusters axill. compound spreading shorter than the leaves: the lower ones male sessile; upper female stalked

13241 Leaves alternate roundish-ovate pointed toothed 3-ribbed snow white and downy beneath, Clusters axill. repeatedly compound, Fl. fasciculate

13242 Leaves alternate heart-shaped toothed prickly as well as the shrubby stem, Calyx of the fruit pulpy

13243 Leaves altern. heart-shaped acutely crenate rough above soft and downy beneath, Panicles lateral leafless forked divaricated, Flowers capitate dicecious, Stem arboreous

13244 Leaves on long stalks cordate acuminate acutely serrated stinging, Spikes panicled

13245 Leaves stalked cordate acuminate serrated stinging, Racemes axillary

13246 Leaves cordate entire and 3-lobed coarsely tooth-serrated, Petioles and stem with long strigose prickles 13247 Stem with very long stimuli, Leavos pinnatifid with finely toothed segments, Spikes axillary compound 13248 Stem downy, Leaves on long stalks ovate-lanceolate acuminate subcrenate rough above soft bencath

13249 Stem procumbent, Leaves short oval crenate toothed above, Calyx minutely ciliated 13250 Leaves ovate lanceolate acuminated nerved

13251 Leaves lanceolate downy, Female flowers woolly

13252 Leaves lanceolate ensate crenate smooth, Capsules 1-celled

13253 The only species

13254 The only species

13255 Flowers tetrandrous, Leaves alternate linear lanccolate entire rough

13256 A small lactescent tree with alternate entire leaves and spiny branches

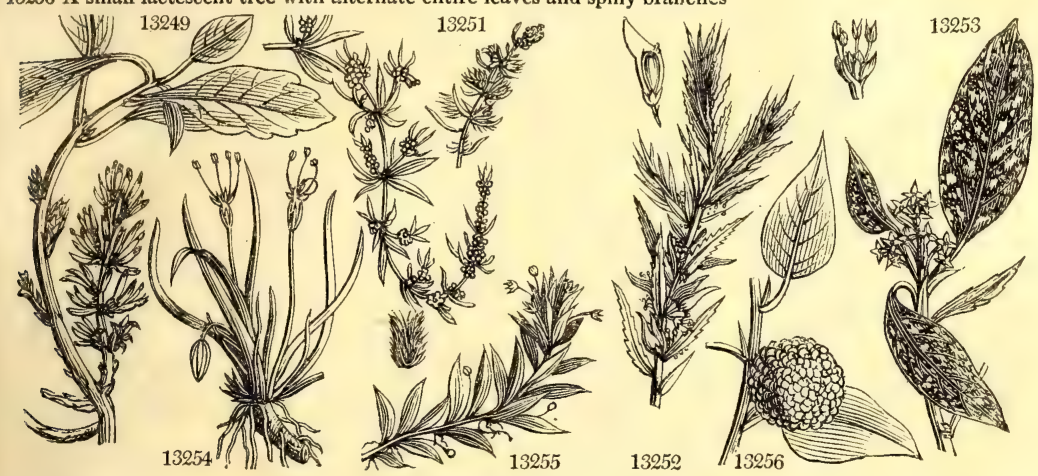

and Miscellaneous Particulars.

the fruit is a red oblong drupe, like a laurel berry, with a white sweetish pulp, and a kernel with a bitter taste.

1967. Littorella. From littus, the shore, in allusion to the places where it grows. A pretty little delicate plant, with long tremulous white stamens.

1968. Serpicula. From serpo, to creep, on account of the habits of the species.

1969. Maclura. Dedicated by Nuttali, to William Maclure, Esq. of the United States, a philosopher, whose devotion to natural history, and particularly to the geology of North America, has scarcely been exceeded by Ramond or Saussure in Europe. A spreading deciduous tree, about twenty or thirty feet high, with a yeliow axillary berry the size of an orange, nearly as succulent, and said to be as agreeable when fully ripe. It was originally found by Hunter and Dumbar, on the banks of the Little Missouri or Washita river, also near Natchitoches, and upon the banks of the Arkansa. 


\section{PENTANDRIA.}

'1970. EXOCAR'PUS. Lab. EXocarpus 13257 cupressifórmis $L a b$. Cypress-like \& $1 \mathrm{tm} 40$ Coniferce. $S p .1$ 1971. NEPHE'LIUM. $W$. RAMBUTAN.

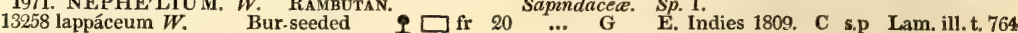
1972. SCHIZAN'DRA. $W$. SchizandRA. 13259 coccínea $W$. scarlet-flower'd 2

1973. Franzéria. Cav. Franzeria.

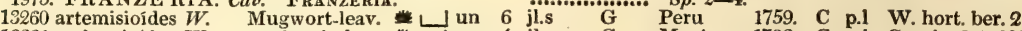
13261 ambrosioídes $W$. Ambrosia-leav, un 4 jl.s G Mexico 1796, C p.1 Cav. ic. 2.t.200 1974. XAN'THIUM. $\boldsymbol{W}$. XanthiUm. 13262 Strumb́rium $W$ Small Burdock 13263 orientále $W$. oriental 13264 spinósum $\dot{W}$. spiny 13265 echinátum $\dot{W}$. hedgehog

1975. 'A MARAN'TUS. $W$. Amaranth 13266 tenuifólius $W$. fine-leaved 13267 angustifólius $W$. narrow-leaved 13268 álbus $W$. 13269 græcízans $W$. Pellitory-leaved melancholy 13271 trícolor $W$ 13272 bícolor $W$. 13273 polýgamus $W$. 13274 gangéticus $W$ 13275 mangostánus $W$ 13276 polystáchyus $W$. 13277 tristis $W$.

13278 inamœ'nus $W$. 13279 unpleasant 139. shabby 13281 oleráceus $W$. livid 13282 bullátus Besser. $\quad$ blistered 13283 Blítum $W$. 13284 prostrátus $W$ 13285 spicátus $\boldsymbol{P} . \boldsymbol{S}$. 13286 víridis $W$. 13287 polygonoides $W$. 13288 scándens $\boldsymbol{W}$. 13289 defléxus $\boldsymbol{W}$ melancholy three-colored hermaphrodite oval-spiked rhomb-leaved many-spiked round-headed wild trailing spiked green

$\bigcirc$ un 3 ji.s $\mathbf{G} \quad$ England dungh. $\mathbf{S}$ co

un 3 jl.s $O$ un 3 jl.s S. Europe 1713. S co

Eng. bot. 2544 Menispermea. $S p .1$ jn.jl Sc N Amer, 1806. I s.p Bot mag. 1413 Amarantacece. $S p .37-45$

$\bigcirc$ un 1 jl.s $\mathbf{G}$ E. Indies 1801. S co un $1 \frac{1}{2} \mathrm{jl}$.s $\mathrm{G}$ Levant 1723. S co un $1 \frac{1}{2}$ jl.s G N. Amer.1778. S co O un $1 \frac{1}{2} \mathrm{jl}$. $\mathrm{O}$ or $1 \frac{1}{2} \mathrm{jn} . \mathrm{s}$ or $1 \frac{1}{2}$ jn.s or $1 \frac{1}{2}$ jl.s O or $1 \frac{1}{2} \mathrm{jl} . \mathrm{s}$ $\bigcirc$ un 2 jl.s O un 2 jl.s O un $\frac{3}{4} \mathrm{jl} . \mathrm{s}$ un 2 in.au un 2 jn.au un 2 jn.au 8 un 2 jn.a 0 clt 6 jl.au O un 4 jl.au * $\bigcirc$ un 2 jn.au O un 2 jl.s $O$ un 3 jl.s un 3 au.s spotted-leaved $*$ $\mathrm{O}$ un $1 \frac{1}{2} \mathrm{jl}$.au climbing $\quad \beta$ un 2 jl.au bending

$\mathrm{G}$ N. Amer. 1759. S co W ama.8.t.1.f.2 $\mathrm{Pu}$ E. Indies 1731. S co W.am.15.t. $\mathrm{S}$. 18

R.Y E. Indies 1548. S r.m Kn, th.2.t.A.3.6 R.Y E. Indies 1802. S r.m

G E. Indies 1780. S co Rum.amb.5.t.82 G E. Indies 1778. S co W.am.16.t.6.f.11 G E. Indies 1801. S co W. amar.13.t.12 G E. Indies 1816. S co China 1759. S co W am-21.5. 10 Japan: 1820. S co Hout.pfl.t.72.f.1 N. Amer. 1752. S co iner. 1759. so W. am. 20.t.1.f.1 Pa.R E. Indies 1764. S co W.am. 17.t.5.f.9 ...... 1822, S co

England dungh. S co France 1739. S co Europe .... S co Brazil 1768. S co Jamaica 1778. S co America 1796. S co ...... 1805. S co W.a.10.t.10.f.20

13290 cauliflórus Link. 13291 hýbridus $W$ 13292 strictus $W$. 13293 paniculátus $W$ 13294 sanguíneus $W$. 13295 retrofléxus $\boldsymbol{W}$. 13296 læ'tus $W$. 13297 flávus $W$ 13298 chlorostáchys $W$ 13299 hypochondriacus $W$. 13301 hécticus $W$ 13302 caudátus $W$ $\beta$ máximus

stem-flowering
clustered
upright
panicled
spreading
hairy
blunt-leaved
pale
nodding
Prince's Feather
various-leaved
oval-leaved
Love lies bleeding
tree

* $O$ un 1 jl.au

Eng. bot. 2212

W.am.18.t.8.f.16 W.am.11.t.6.f.12

O un 4 jn.s G Nepal 1821. S co un 2 jl.s $\mathrm{O}$ or 6 jl.s $\mathrm{O}$ or $3 \mathrm{jl}$.s $\mathrm{O}$ un $2 \mathrm{jl}$.s un 2 jl.s 8 or 4 jl.s 0 un 3 jl.s or 5 jls 0 or 3 jn.a or 3 au or 4 au.s

\section{G N..... 1793. S co G N. Amer. 1798, S co R BahamaI. 1775. S co G Pensylva. 1759. S co $\begin{array}{llllll}\mathbf{G} & \text { Pensylva. } & 1759 . & \text { S } & \text { co } & \text { W. a. 33.t.11.f.21 } \\ \mathbf{R} & \ldots \ldots . . . & 1799 . & \text { S } & \text { co } & \text { W.am.28.t.8.f.15 } \\ \text { L.Y } & \text { India } & \text { 1759. } & \text { S } & \text { co } & \text { W. am. 35.t.3.f.6 }\end{array}$ W. a. 34,t.10.f.19 D.R Virginia 1684. S co $\begin{array}{lllll}\text { D.R China } & \text { 1728. } & \text { S } & \text { r.m } \\ \text { Pk } & \text {........ 1796. } & \text { S } & \text { co W.am.25.t.7.f.13 }\end{array}$ R E. Indies 1596. S co \\ W.am.26.t.9.f. 17 W am 27.3 .5 W. am 32.t. 4 W. am. W. am, 35.t. $\mathrm{f} .6$ ..... 1820. S co}

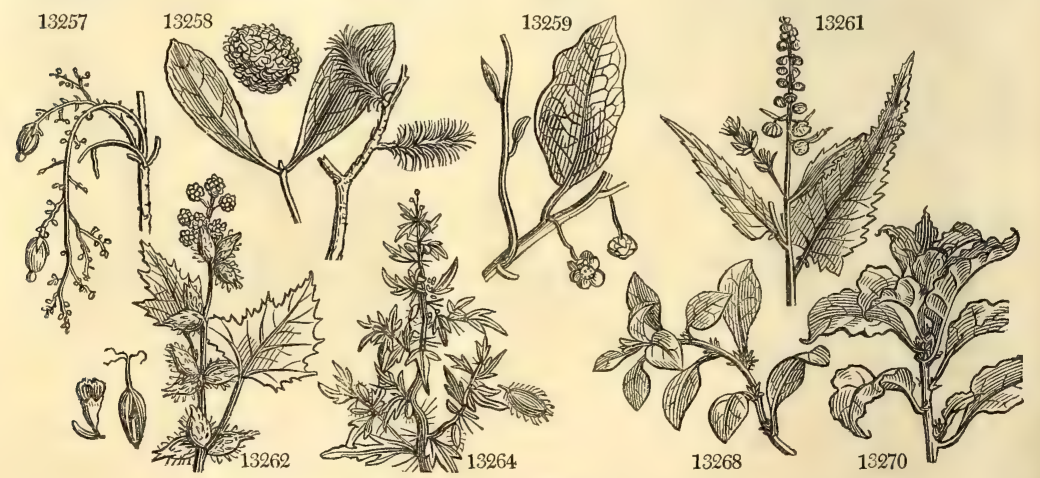

History, Use, Propagation, Culture,

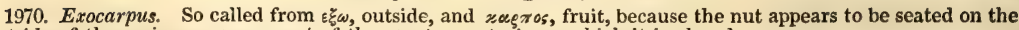
outside of the pericarp, on account of the great receptacle on which it is placed.

1971. Nephelium. According to Dodoens, Nephelion was a name anciently given to the Burdock. The modern plant bears bristly fruit like the involucrum of the Burdock. It is an excellent fruit, known in the islands of the Indian Archipelago by the name of Rambutan; grows in rich light loam, and is struck in pots of sand under a glass.

1972. Schizandra. From $\sigma \chi \zeta \omega$, to cut, and $\alpha y \eta \rho$, a stamen; its stamens are split. A handsome plant, which grows in light loam and peat, and ripened cuttings root in sand under a hand-glass. 


\section{PENTANDRIA.}

13257 The only species

13258 I.eaves alternate pinnated, Racemes erect shorter than leaves

13259 Leaves lanceolate oval acute at each end end, rarely somewhat toothed

13260 Leaves bipinnatifid toothed, Petioles winged

13261 Leaves ovate-lanceolate cordate toothed, Petioles with an appendage

13262 Stem unarmed, Leaves cordate 3-nerved

13263 Stem unarmed, Leaves cuneiform ovate somewhat 3-lobed

13264 Spines ternate, Leaves 3-lobed

13265 Stem unarmed, Fruit oval aculeate, Irickles hooked echinate at base

\section{Triandrous.}

13266 Clusters axillary, Leaves linear-lanceolate cuneate retuse, Stem branched diffuse 13267 Clusters axillary, Leaves linear-lanceolate acute mucronate, Stem branched erect 13268 Clusters axillary, Leaves obovate retuse, Stem square simple

13269 Clusters axillary, Flowers trifid, Leaves obovate emarginate, Stem roundish branched

13270 Clusters axillary stalked roundish, Leaves ovate-lanceolate colored

13271 Clusters sessile, Leaves oblong lanceolate colored

13272 Clusters sessile capitate, Leaves ovate acuminate blunt colored

13273 Clusters in short spikes, Cal, and bract. with hooked bristles, Leaves oblong lanceolate emarginate 18274 Clusters shortly spiked ovate, Leaves ovate lanceolate emarginate

13275 Clusters somewhat spiked axillary solitary, Leaves rhomboid roundish

13276 Clusters spiked, Spikes axillary and terminal, Leaves ovate-lanceolate emarginate

13277 Clusters spiked loosely, Leaves subcordate ovate emarginate shorter than petiole

13278 Clusters somewhat spiked and 3-leaved: axillary in pairs, Leaves rhomboid lanceolate

13279 Clusters spiked, Leaves rhomboid-ovate acute

13280 Clusters somewhat spiked rounded, Leaves elliptical retuse, Stem erect

13281 Clusters axillary branched, Leaves rugose oblong very blunt emarginate

13282 Leaves subrhomboid acute repard bellate, Spikes terminal, Sepals mucronate pungent

13283 Clusters somewhat spiked, Flowers 3-leaved, Leaves ovate retuse, Stem diffuse

13284 Clusters spiked, Flowers 3-leaved, Leaves rhomb.-ov. bluntish retuse, Stem prostrate branched

13285 Clusters spiked terminal, Leaves ovate-oblong, Stem erect somewhat branched

13286 Clusters axillary twin triandrous, Male flowers 3-leaved, Leaves elliptical emarginate wavy at edge

13287 Clusters 3-leaved, Female flowers funnel-shaped, Leaves rhomboid ovate emarginate

13288 Leaves ovate, Spikes interrupted compound, Spikelets inflexed, Stem weak

13289 Spike very short few-t. Leaves rhomboid lanceolate, Capsules not dehiscent

\section{Pentandrous.}

15290 Leaves oval acute somewhat wavy toothed, Clusters axillary cymose

13291 Raceme decompound clustered erect, Leaves ovate-lanceolate

13292 Raceme compound erect straight, Leaves ovate concave

13293 Racemes supradecompound, Branches spreading pubescent, Leaves ovate-lanceolate

13294 Racemes supradecompound erect, Branches spreading smooth, Leaves oblong acute

13295 Racemes supradeoompound erect clustered, Branches downy, Leaves ovate wavy

13296 Racemes compound erect, Leaves ovate blunt mucronate

13297 Racemes compound nodding, Leaves ovate lanceolate

13298 Racemes compound nodding, Leaves lanceolate

13299 Racemes compound erect clustered, Leaves oblong lanceolate mucronate

13300 Racemes decompound naked spreading, Leaves lanceolate ovate

13301 Racemes simply spiked, Flowers axillary clustered, Leaves ovate acute

13302 Racemes decompourd pendulous, Leaves lanceolate ovate, Stem nodding

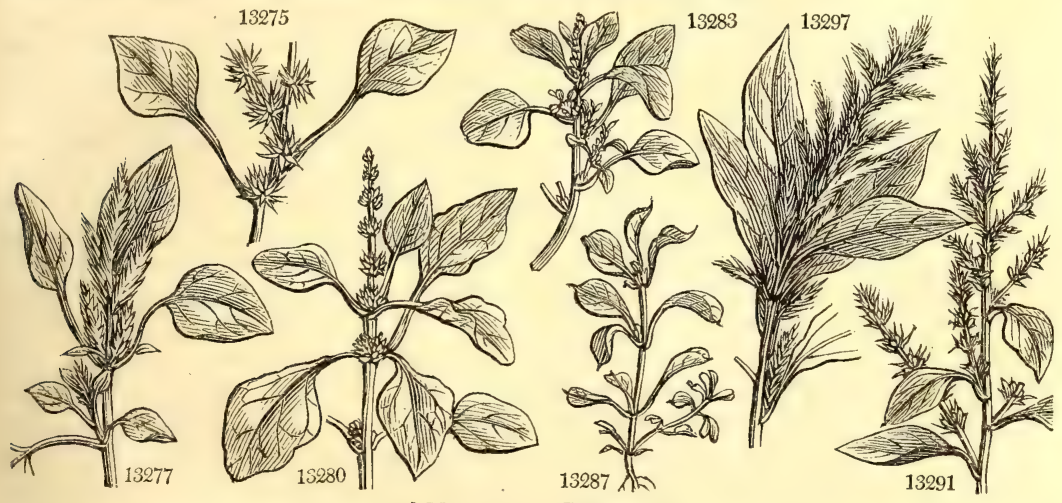

and Miscellaneous Particulars.

1973. Franzeria. A genus dedicated by Cavanilles to Antony Franzer, a botanical physician, whose merits are forgotten. Cuttings root in loam and peat under a hand-glass.

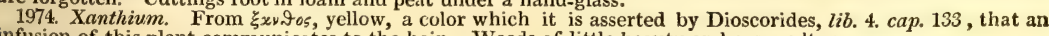
infusion of this plant communicates to the hair. Weeds of little beauty and easy culture.

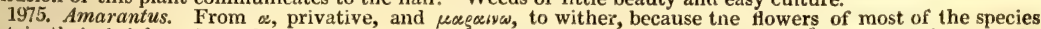
retain their bright colors when dead. Some of the species are very ornamental, and most of them might probably be used as spinage, as some sorts are in the East. A. polygamus is used in this way in Guiana and China, and A. oleraceus, tristis, and viridis, in India. A. melancholicus and tricolor are popular tender 
13303 spinósus $W$ 13304 speciósus $B$. $M$.

1976. LUF'FA. Cav. 13305 fo'tida Cav.

A. W. Ambrosia. 13306 integrifólia $W$. entire-leaved 13307 tríitia $W$. elátior $W$. 13309 artemisifólia $W$ 13310 paniculáta $W$.

1978. SECURINE' 13312 nítida $W$. prickly

shewy

LUFFA. tall

Mugwort-leav. panicled sea

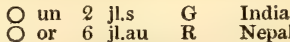
1683. S co W.am.38. t.4. f.8 Cucurbitacere. Sp. $1-2$
* ل् or 12 jn.o India 1812. S co Bot, mag. 1638 Sp. 6-10.

O un 3 jl.s G $\mathrm{G}$ N. Amer. 1816. S co

On 6 jl.s G N. Amer. 1699. S co Moris. s.6.t.1. f.4

O un 8 il.au $G \quad$ N. Amer. 1696. S co Herm. lugd, t.35

un 5 jlau G N Amer. 1759. S co

un 3 jls $G$ N. Amer. 1si1. S co Plu.alm.t.10. f.5

$O$ un 3 jl.au G Italy 1570. S co Sch.hand.3.t.292 Euphorbiacea. Sp. 1-2. shining-leaved $9 \square \operatorname{tm} 40 \mathrm{jn} . \mathrm{jl}$ W Mauritius 1793. C co Lindl.coll. 9

\section{HEX $A N D R I A$.}

1979. ZIZA'NYA. $W$. ZiZANIA 13313 aquática $H . K$. 1980. PHA'RUS. $W$. 13314 latifólius $W$.

Canada Rice

Pharus.

Graminea. Sp. $1-5$.

1981. GUETTAR'DA. $W$. GUETTARD 13315 speciósa $W$. 13316 rugóss $W$ 1982. SA'GUS. $W$. 13317 Rúmphii $W$. 13318 Rúffia $W$. 13319 vinífera Hort. 1983. $\mathrm{CO}^{\prime} \mathrm{COS} . W$. 13320 nucífera $W$. 13321 aculeáta $W$. 13322 fusifúrmis $W$. great-tlowered rough-leaved

Sago Pali. Rumphius's turbinate prickly

业 $O$ ec 6 jl.s G N. Amer. 1790. S co Lin.trans.7.t.13 ه or 6 jl.au Gramine. Sp.1-3. Cocon-NutT-Tree. Palmo Sp. 3-11. $\begin{array}{llccccc}\text { common } & \text { 全 } \square \text { clt } 50 & \ldots & \text { Pa.G } & \text { E. Indies } 1690 . & \text { S } & \text { r.m Roxb. cor. 1. t.73 } \\ \text { prickly } & \text { clt } 50 & \ldots & \text { Pa.G W. Indies 1796. } & \text { S } & \text { r.m Jac.am.278.t.169 }\end{array}$ Great Macaw-tree全若 clt 30 ... $\quad$ Pa.G Jamaica 1731. S r.m

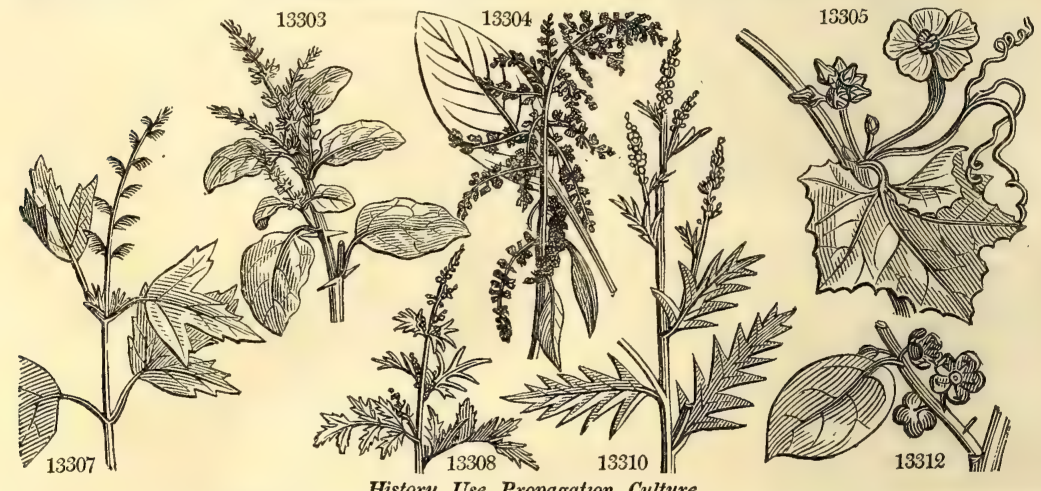

History, Use, Propagation, Culture,

annuals, and A. sanguineus and caudatus common border flowers; like all the species, they are of easy culture in light rich soil. Most of the species are very prolific in seeds, which preserve their germinating quality several years.

1976. Luffa. Its name in Arabic is loùff, according to Forskahl. A curious kind of gourd, not often seen on account of its offensive odor. It is cultivated in Arabia and China. It climbs up the Palm trees, covering and elegantly adorning their trunks. The fruit when young is pickled, like the Mango; but Europeans think it has a disagreeable taste, and is not very wholesome. L. Charantia has a fruit with a yellowish skin, but very red flesh, and when ripe, it bursts elastically. Culture as in Cucumis.

1977. Ambrosia. A poetical name. Ambrosia is the name of the food of the heathen divinities, as nectas was their beverage; of the former, the odor was delightful, whence its name has been applied to an herb, the leaves of which, when bruised, emit a grateful scent. Weedy plants of no beauty.

1978. Securinega. From securis, a hatchet. The name was given by Commerson, because the wood was so hard as to be capable of being manufactured into cutting instruments. It grows and flowers freely in loam and peat, and cuttings strike in sand under a hand-glass.

1979. Zizania. One of the Greek names of the rye-grass was ל̧¿avioy; according to Golius, the same plant was called by the Arabs Zoìa n. The modern plant has no relation to the ancient, being a native of Arnerica, where it is called Canada rice. This plant has been acclimated in Middlesex and Ross-shire; it grows on the margins of ponds, and is exceedingly prolific of bland farinaceous seeds, which afford a very good meal. It abounds in all the shallow streams of North West America, where its seeds contribute essentially to the support of the wandering tribes of Indians, and feed immense flocks of wild swans, geese, and other water fowl. Pinkerton says, this plant seems intended by nature to become the bread corn of the north.

1980. Pharus. From $\phi \propto \rho o s$, a covering. Brown gave this name to the plants, because their long broad leaves are employed as wrappers for various purposes by the natives of Jamaica. Fine stove grasses.

1981. Guettarda. Etienne Guettard was a French botanist, who published in 1747, a catalogue of the plants growing in the vicinity of Estampes. Splendid plants, which grow in loam, peat, and sand ; and are increased by cuttings in sand in a moist heat and covered.

1982. Sagus. So named in allusion to the nutritive properties of the substance obtained from it. From this palm is produced the Sago of the shops. The wood is full of white pith, like that of elder; the pith is taken out, bruised in a mortar, and then put into a cloth or strainer, held over a trough, and water being poured in, the pith is washed through the cloth into the trough; the water being then drawn off, the sago is taken out and dricd for use or transportation. The fruit is eaten by the Japanese, but the tree is chiefly esteemed for its highly nutritive pith.

1983 Cocos. Linnæus regards this name as of Greek origin. In that language, royros means a kind of fruit, but it does not appear that there was any relation between that and the modern cocoa nut. D'Herbelot 
13303 Racemes pentandrous terminal compound, Axillæ spiny

13304 Clusters densely spiked somewhat whorled, Spikes decompound erect colored, Lvs. obl. ellipt. red beneath

13305 Leaves cordate 5-lobed, Flowers large, Gourd a span long

13306 Leaves ovate sessile acuminate serrate ciliated at base

13307 Leaves 3-lobed serrated

13308 Leaves bipinnatifid smoothish, Petioles with long ciliæ, Racemes terminal panicled

13309 Leaves bipinnatifid hoary beneath : upper pinnatifid, Racemes 3 terminal

13310 Leaves smooth bipinnatifid : upper pinnatifid, Racemes terminal solitary, Branches fastigiate

13311 Leaves bipinnatifid blunt hoary beneath, Racemes terminal solitary, Branches villous

13312 Leaves alternate ovate, Flowers axillary clustered

\section{HEXANDRIA.}

13313 Panicle effuse, Giumes aristate : male and female mixed

12314 Panicle branched, Glumes awnless 6mooth, Leaves ovate-lanceolate

13915 Leaves obovate acute downy beneath, Flowers 7-androus 7-fid

13316 Leaves subcordate ovate acute scabrous downy beneath, Flowers hexandrous

13317 Branchlets of the spadix smooth

13318 Branchlets of the spadix annular

13319 Pinnæ spinulose, Fruit oblong furrowed

13320 Unarmed, Fronàs pinnated, Leaflets replicate ensiform

13321 Caudex cylindrical prickly upwards, Fronds pinnated prickly

13322 Aculeate spiny, Caudex fusiform, Fronds pinnated, Stems and spathes sping

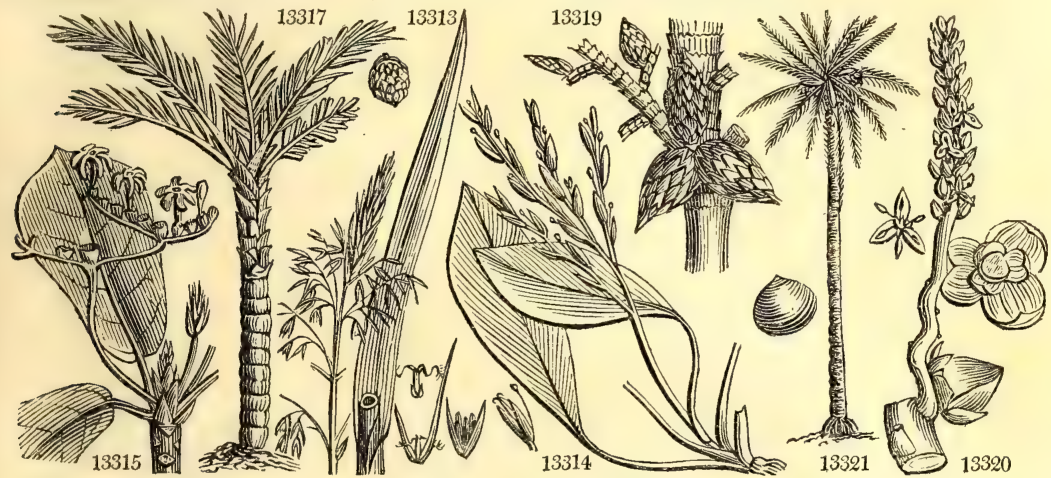

and Miscellaneous Particulars.

says, (Bibl. Or. 278.) that in India the fruit is called cozi, whence the Turkish name coz, for a nut: bu this requires confirmation. In Malabar it is called tenga, in the Moluccas calappa, and by the Brahmins medo. C. nucifera is a native of, and cultivated in, most places within the tropics. The trees grow to a great height, with a straight trunk, and, like almost every species of the Palm tribe, without branches. The leaves are from twelve to fifteen feet long; the flowers come out round the top of the trunk in large clusters, inclosed in a sheath, and the nuts succeed them, commonly ten or twelve together

There are few trees more extensively or variously useful. The leaves are employed as thatch to cover houses, and to make mats either for sitting or lying upon. The leaf, when reduced to fine fibres, is the material of which a beautiful and costly carpeting is fabricated for those in the higher ranks; the coarse fibres are made into brooms. After these useful materials are taken from this leaf, the stem still remains, which is about the thickness of the ankle, and furnishes firewood.

The wood of this palm, when fresh cut, is spongy; but becomes hard after being seasoned, and assumes a dark brown color. On the top of the tree a large shoot is produced, which, when boiled, resembles brocoli, but is said to be of a more delicate taste; and though much liked, is seldom used by the natives, because on is said to be of a more delicate taste; and though much liked, is seldom used by the natives, because on
cutting it off, the pith is exposed, and the tree dies. Between this cabbage-like shoot and the leaves, there spring several buds, from which, on making an incision, there distils a juice differing little from water, either in the color or consistence. It is the employment of a certain class of men to climb to the top of the trees in the evening, with earthen pots tied to their waists, which they fix there to receive the juice, which is regularly carried away before the sun has had any influence upon it. This liquor is sold at the bazaars by the natives under the name of toddy. It is used for yeast, and forms an excellent substitute. In this state it is drank with avidity, both by the low Europeans and the natives, and is reckoned a cooling and agreeable beverage. A A ter being kept a few hours, it begins to ferment, acquires a sharp taste, and a slight intoxicating quality. By boiling it, a coarse kind of sugar is obtained; and by distillation, it yields a strong ardent spirit, which being every where sold, and at a low price, constitutes one of the most destructive annoyances to our soldiers. The name given to this pernicious drink by Europeans, is Pariah arrack, from the supposition that it is only drank by the Pariahs, or out-casts, that have no rank.

The trees from which the toddy is drawn do not bear any fruit, on account of the destruction of the buds; but if the buds be left entire, they produce clusters of the cocoa nut. This nut in the husk is as large as a man's head, and when ripe falls with the least wind. If gathered fresh, it is green on the outside; the husk and the shell are tender. The shell, when divested of the husk, may be about the size of an ostrich's egg, and is lined with a white pulpy substance, which contains about a pint and a half of a liquor like water; and though the taste be sweet and agreeable, it is different to that of the toddy.

In proportion as the fruit grows old, the shell hardens, and the liquor diminishes, till it is at last entirely absorbed by the white milky substance, which gradually acquires the hardness of the kernei of the almond, S 3 
1984 E'L ATE 13323 sylvéstris $W$. 1985. BAC'TRIS. $W$. 13324 minor $W$ 13325 major $W$.
ELaTe.

prickly-leaved 尘 $\square$ or 14 ap.jn $\mathrm{G}$. E. Indies 1763 . S r.m Rh.mal.3.t.22.25 BACTRIS.

lesser greater
Palma. Sp. 2.

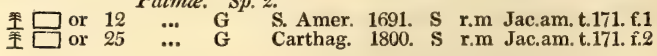

\section{POLYANDRIA.}

1986. CERATOPHYL'LUM. $W$. Hornwort. Fluviales. Sp. 2-

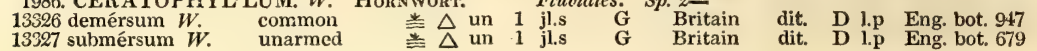
1987. MYRIOPHYL'LUM. $W$. Water MiLfoIL. Onagrarice. Sp Q-5. 13328 spicátum $W$. spiked $\Delta$ pr 1 jn.au $R$ Britain dit. D 1.p Eng. bot. 83 13329 verticillátum $W$. verticillate $\Delta \mathrm{pr} \quad 1$ jl $\quad$ G $\quad$ England ponds. D l.p Eng. bot. 218 1988. Sagittáni A. $W$. Arrow-Head. 13330 sagittifúlia $W$ 13331 sinénsis $B . M$ 13332 obtusifólia $W$ 13333 lancifólia $W$. 13334 rígida $B$. $M$. 13335 graminca $W$. 1989. BEGO'NIA. $W$ 13336 nítida $W$. 13337 dichótoma $W$. 13338 díscolor $H . K$ Evansiána B. R. 13339 macrophýlla $W$ 13340 tuberósa $W$ 13341 acumináta $W$ 13312 húmilis $W$. 13343 hirsúta $W$. 13344 ulmifólia $i v$. 13345 argyrostígma Fisc maculata Raddi 13346 spatuláta $V$. 13347 picta Lodd. 13348 paucifóra Lindley 13349 odoráta $W$. 13350 hirtélla Link. 13351 disticha Link. common Chinese

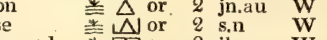
blunt-leaved $\bar{D}$ or 2 jl.au lance-leaved $\triangle \mathrm{N}$ or $1 \frac{1}{2} \mathrm{jn} . \mathrm{jl}$ brittle-leaved $\Delta$ or $1 \frac{1}{2}{ }^{2} \mathrm{jn} . \mathrm{jl}$

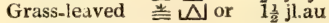
BEGONIA. shining-leaved $\square$ or $1 \frac{1}{2}$ my.d..........' Jamaica 1777. C s.p Par. lond. 72 forked or $2^{2}$ jl.au W Caraccas 1800. C s.p Jac. ic. 3. t. 619 two-colored $\square$ or 3 my.s W China 1804, R s.p Bot. mag. 1473

large-leaved $\square$ or 3 my.s W Jamaica 1793. C s.p Plu,ic.34.t.45. f.1 tuberous 0 or $\frac{1}{2}$ jl.s W Amboyna 1810. C l.p R.am.5.t.169.f.2 pointed-leaved $\square$ or $1^{\frac{1}{2}}$ my.d W Jamaica 1790. C s.p Bot. reg. 364 sinall or $\frac{3}{4} 0$ W W. indies 1788. C 1.p Lin.trans.1.t.15 shaggy-leaved 0 or 1 my.jn W W. Indies 1789. C l.p Aub.gui.2. t.348 elm-leaved wor 2 my.jn W S. Amer. 1822. C I.p Bot. cab. 638 3 jl.o W spatulate painted

few-flowered hairy distichous

1990. POTE'RIUM, $W$. BuRnet 13352 agrimonifólium Cav. Agrimony-lvd 13353 Sanguisórba $W$. common 13354 polýgamum $W$.

Hungarian

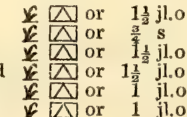
Brazils 1319. C 1.p Bot. reg. 656

Sp. 6-16. rivers. D 1.p Eng. bot 84

China 1812. D 1.p Bot. mag. 1631 W. Indies 1787. D l.p Bot. mag. 1792 N. Amer. 1806. D 1.p Bot. mag. 1632 Carolina 1812. D 1.p

\section{W. Indies 1819. C 1.p Bot. cab. 107}

Nepal 1818. C 1.p Bot. cab. 571

..... 1816. C 1.p Bot. reg. 471

..... 1824. C l.p

1..... 1824. C $1 . \mathrm{p}$

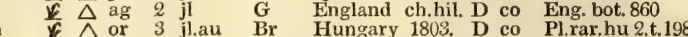

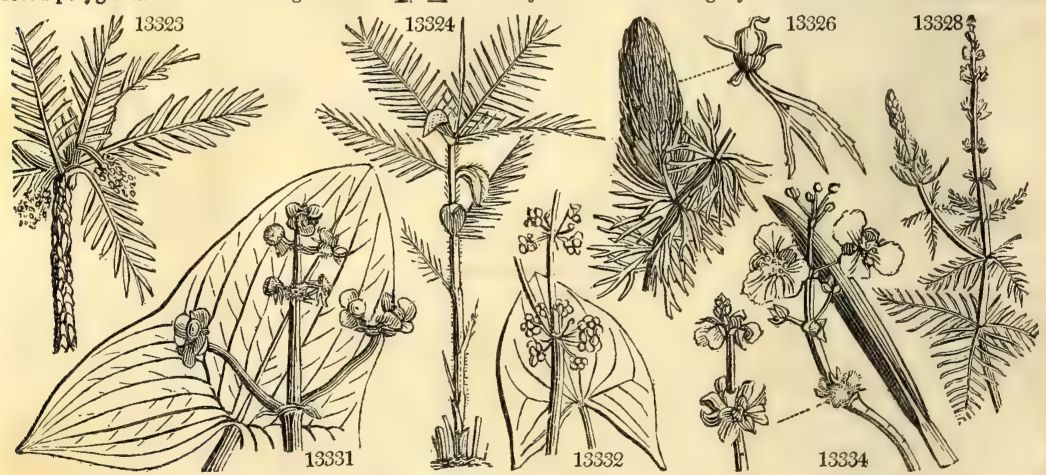

Iistory, Use, Propagation, Culture,

and is almost as easily detached from the shell. The natives use this nut as their victuals; and from it they also express a considerable quantity of the purest and best lamp oil. The substance which remains after this operation, supplies an excellent food for poultry and hogs. Cups and a variety of excellent utensils are made of the shell.

The husk of the cocoa nut is nearly an inch thick, and is, perhaps, the most valuable part of the tree ; for it consists of a number of strong fibres, easily separable, which furnish the material for the greatest part of the Indian cordage; but is by no means the only substitute which the country affords for hemp. This the natives work up with much skill.

Plants of the cocoa nut tree are frequent in our stoves, being easily raised from the nuts sold in the shops, planted in rich earth, and on a mcist heat; but the plants are seldom allowed room enough to come into flower; thcugh it has been observed, that this is almost the only palm that could be cultivated in this country for perfecting its fruit; all the others being diocious plants. Sweet observes, that they seldom succeed well in our collections ; perhaps from being too much exposed to the sun : he is " informed they thrive best in the shade in the West Indies, where cultivators of them plant tall trees near them for that purpose." (Bot. Cult. p. 42.)

C. aculeata has a trunk the thickness of the human body; the pinnæ of the fronds are longer than in the cocoa, and prickly like the bark of the trunk. The fruit is as large as a crab, and of the same shape ; under a green skin it has a thin sweetish astringent pulp; and within that, a nut full of a white sweet eatable kernel. The nut is said to yield the true palm oil. The outside of the trunk is made into laths, hows, and darts.

1984. Elate. This was one of the names given by the Greeks to the membrane which envelopes the female flowers of the date; that is to say, to its spatha. Modern authors have applied the word to a kind of Indian palm. The fruit of $\mathbf{E}$. sylvestris resembles a wild plumb. The poorer sort of people chew it in the same manner with the Areca nut, with the leaf of the betel pepper and quick-lime. The elephants are fond of the fruit-stalks, which are very sweet. In nur stoves the plants require a sandy loam, and a strong heat. 
13323 Fronds pinnated, Leaflets opposite

13324 Fruit roundish

13325 Fruit ovate

\section{POLYANDRIA.}

13326 Fruit armed with three spines 13327 Fruit unarmed

13328 Sterile flowers in interrupted leafless spiked whorls

13329 Leaves pinnated capillary : upper pectinate-pinnatifid, Flowers axillary whorled

13330 Leaves lanceolate acuminate sagittate : lobes lanceolate straight, Scape simple

13331 Leaves 3-fid and 3-parted: lobes nearly equal nerved, Scape branched angular, Male fl. solitary terminal

13332 Leaves ovate rounded blunt sagittate : lobes ovate acuminate spreading, Scape panicled

13333 Leaves ovate narrowed at each end, Scape branched below

13334 Leaves lanceolata ketled, Petioles 3-cornered, Scapes simple, Female flowers sessile

13335 Leaves lanceolate linear, Female heads small

13336 Shrubby erect, Lvs, very smooth unequally cordate obsoletely toothed, Wing of caps. very large roundish 13337 Shrubby erect, Lvs. unequally cord. subangul. toothletted smooth hairy ben. at the veins, Pan. dichotom. 13338 Leaves angular serrulate crimson beneath, Stem nodose, Wings of caps. unequal rounded

13339 Caulescent, Lvs. unequally cold. cren-tooth. : lower angular, Wings of caps. with obt. ang. one very large 13340 Creeping, Leaves unequally cordate angular toothed, Wings of capsule parallel

13341 Caulescent, Leaves hispid $\frac{1}{3}$ cordate acuminate unequally toothed, Largest wing of caps, obtusangular 13342 Caulescent erect, Leaves hispid $\frac{1}{2}$ cordate doubly serrate, Wings of caps. rounded nearly equal

13343 Caulescent, Leaves hispid $\frac{1}{2}$ cordate doubly serrated, Largest wing of caps. very large obtusangular

13344 Caulescent erect, Lvs. hisp. on each side unequally oblong doubly tooth. Largest wing of caps. obtusangul. 13345 Leaves long acuminate repand spotted with white above red beneath

13346 Leaves blunt obsoletely toothletted smoothish, Stipules spatulate unequal ciliated, Wings of caps. blunt 13347 Stemless, Leaves ovate cordate hirsute finely serrulated mottled, Capsules hairy

13348 Leaves nearly equally cordate very blunt crenate downy : upper cucullate, Stipules lanceolate scariose

13349 Leaves acuminate somewhat angular unequally obsoletely toothletted smooth on each side, Stip. scariose

13350 Leaves angular unequally serrulate-ciliated hairy beneath at the veins, Stipules scariose lanceol fringed 13351 Leaves acute crenulate smooth strigose beneath, Cyme distichous, One wing of capsule very large acute

13352 Hirsute, Leaflets lanceolate, Spikes oblong ovate

13353 Thorns none, Stem somewhat angular, Stamens much longer than the calyx

13354 Unarmed, Stems angular, Terminal flowers female: lower male; intermediate hermaphrodite

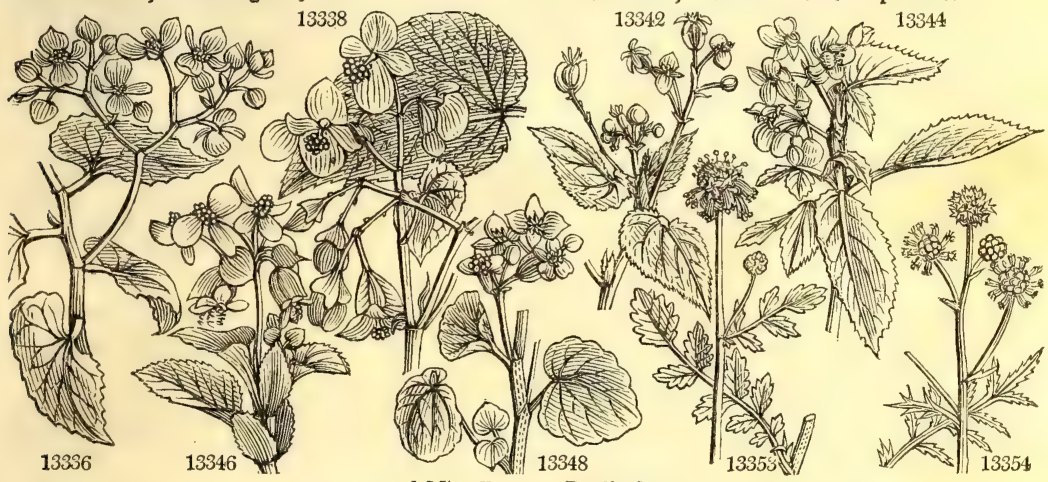

and Miscellaneous Particulars.

1985. Bactris. So called by Jacquin, from Ga»røoy, a cane, because the small stem is made into walkingsticks, which are much valued. B. minor produces a fruit of a dark purple color, the size of a common cherry, containing an acid juice, of which the Americans make a sort of wine. It is also eaten raw, but is not pleasant. Canes are made of the stem; they are dark-colored, shining, jointed, and very light; the French call them Cannes de Tobago. B. major has a large nut with a solid kernel, which is eaten in Carthagena. In our stoves they form handsome plants, and grow freely in sandy loam; like other palms, they are only to be increased by seed.

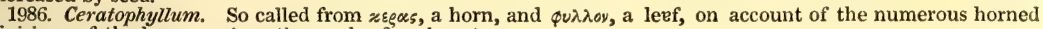
divisions of the leaves. Aquatic weeds of no beauty.

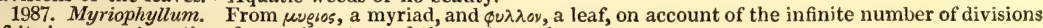
of its leaves. Aquatics of some heauty, and the easiest culture.

1988. Sagittaria. So called from sagitta, an arrow, in reference to the arrow-headed form of the leaves. S. sagittifolia is one of the handsomest of British aquatics, and is common in Siberia, China, Japan, and Virginia. The bulb, which fixes itself in the solid earth below the mud, constitutes an article of food among the Chinese, and upon that account they cultivate it extensively. The roots are larger in those countries than with us. All the species are of common culture.

1989. Begonia. Named in honor of Michael Begon, a Frenchman, born in 1638 ; he was an intendant of Marine, and a promoter of botany. These are universally plants remarkable for the neatness of their foliage, and their succulent habit. B. argyrostigma and discolor are the two most beautiful species. They are all cultivated without difficulty either from seeds or cuttings.

1920. Poterium. Literally, this word signifies a drinking vessel, and in the same scnse, a kind of beverage.
. L A drink was made of it, which was reckoned useful in many complaints; it is also an ingredient in cool tankards. P. sanguisorba is sometimes sown along with clover as an herbage plant; it is now, however, out cf 
13355 hýbridum $W$. 13356 caudátum $W$ 13357 spinósum $W$.

1991. AMIRO'LA

13358 nítida Pers.

1992. ACIDO'T

13359 úrens $W$

1993. THELY'GONU

13360 Cynocrámbe $W$.

1994. CASTA'NEA.

13361 vésca $W$

13362 púmila $i V$.

1995. O'STRYA. $W$.

13363 vulgáris $W$.

13364 virgínica $W$.

1996. CARPI'NUS. $W$.

13365 Bétulus $W$.

$\beta$ incisa

13366 americána $W V$

13387 orientális $W$.

1997. FA'GUS, $W$

13368 sylvática $W$.

$\beta$ atro-rúbens Duroi

S $\mathrm{S}$ incísa W.

13369 ferruginea $W$

1998. CO'RYLUS. $W$.

13370 Avellána $W$.

$\beta$ álba

r rúbra

$\delta$ grándis

e glomcrát

¿ cris'pa

13371 tubulósa $W$ sweet $\Delta$ or 2 jn.jl G France 1683. D co

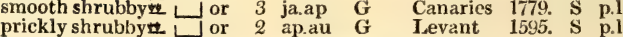

Terebintacea. $S p .1$

shining-leaved $9 \square$ or $24 \quad \ldots \quad \ldots$ Peru

Sp. 1.

Acinoron.

stinging Urticea. $S p .1$.

$\frac{3}{4} \mathrm{jl} \quad$ G S. Europe 1710. S co Lam. ill. t. 777

CHEsvit

Common

dwari

Hop-Honnbear

common

American

Hornbeam.

common

cut-leavcd

A merican

eastern

BEECH.

common

purple-leaved

Fern-leaved

American

NuT-Tree.

Common Hazel 造

White Filbert

Red Filbert

$\mathrm{Cob}$

clustered

frizzled

Lambert's
Amentacea. Sp. 2.

tm 50 my.jn $G \quad$ England woods. S $8.1 \quad$ Eng. bot. 886

or $12 \mathrm{jl}$ G.Y N. Amer. 1699. S p.l Mich. arb. 2. t.7

Amentacea. Sp. 2-4.

or $20 \mathrm{my}$ Ap Italy 1724. I. s.l Dend, brit. 143

or 20 my.jn Ap N. Amer. 1692. L s.1 Abb. ins. 2. t. 75

Amentacece. Sp. 3-5.

F tm 50 mr.my Ap Britain woods. S co Eng. bot. 2032

or $1.5 \mathrm{mr}$.my Ap

or $20 \quad \ldots$ Ap

1759. S co Dend brit. 157

Levant 1739. L co Dend, brit. 98

Amentacee. Sp. $\varepsilon$.

tm 70 ap.my Ap Britain woods. S co Eng. bot. 1846

or 30 ap.my $\mathrm{A}$

or 10 ap.my $\mathrm{Ap}$

or 30 my.jn Ap Amentacea.

fr 10 f.ap Ap

fr 10 fap

fr 10 fap

fr 10 f.ap

fr 8 f.ap

fr 8 f.ap

fr 8 fap Ap

fr 10 mr.ap Ap
T......... L co

….... G $\quad$ G 1

... L co
............ L L co

N. Amer. 1766. L s.1 Mich. arb. 2. t. 9

Sp. 5-7.

Britain woods. S co Eng. bot. 723

in

… l co

... $\quad$ r co

...... ... L L co

Fi........ L co

L co Lam. 1ll, t. 780

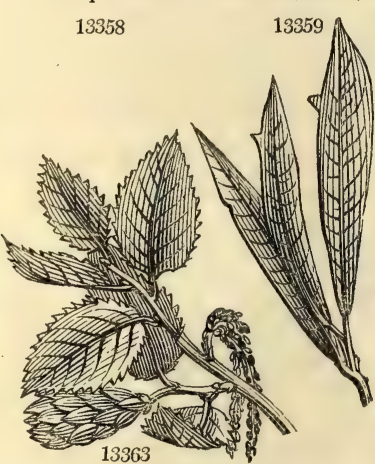

History, Use, Propagation, Culture,

repute. The leaves when bruised smell like cucumbers, and taste something like the parings of that fruit; they are sometimes put into salads. All the species are of the easiest culture.

1991. Amirola. A word with an unknown meaning. The Peruvians form the shining black seeds of Amirola nitida into rosaries.

1992. Acidoton. From aris wras, pointed; in allusion to the stinging pointed hairs of the leaves.

1993. Thelygonum. A name under which Pliny described a plant which appears to have been Mercurialis. It was derived from $2_{n \lambda u s,}$ a woman, and yove, a knee, because of its joints, which where thought to resemble a woman's knee. Cyno-crambe, literally interpreted dog-cabbage, was the Greek name of Mercurialis perennis.

1994. Castanea. A native of the territory of Castanea, a town of 'Thessaly, near the borders of the river Peneus, where magnificent chesnut trees still are found. The chesnut, Châtagnier, Fr., Castanienbaum, Ger., Castagno, Ital, is, like the walnut, both a timber and a fruit tree; some of the oldest trees in the world are of this species; as that mentioned by Brydone on Etna, and the chesnut at Tortworth, in Gloucestershire. The fruit is generally eaten roasted; abroad, it is not only boiled and roasted, but ground into meal, and puddings, cakes, and bread are made from it. The timber is thought to have been formerly in very general use for house carpentry, though some consider what is generally called chesnut in our old buildings as oak. It is one of the best trees for hop poles, and scarcely any other is now planted in Kent and other hop districts for that purpose. Some excellent fruit-bearing varieties have been lately imported from France; these are increased by grafting or budding in the usual methods, but the plants for coppice woods or timber are best raised from nuts. There is a variety with striped leaves which is very ornamental. The most esteemed of the French kinds are called Marron, a word which in old French literally signifies a substance, which it must be confessed the fruit is not unlike.

The American chesuut differs so little from the European, that no specific distinction can be drawn. It is one of the largest and most useful trees of the forests, the wood being extremely durable, and in high esteem for posts and rails to construct fences. The nuts are very delicious. The Castanea pumila or Chinquapin nut, is a small tree, or rather shrub, growing to the height of thirty feet in the southern states, but scarcely exceed. ing seven or eight in cold latitudes. The fruit is very sweet and agreeable to eat.

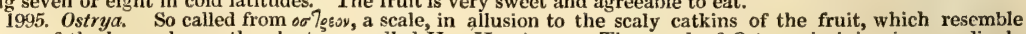
those of the hop, whence the plants are called Hop-Hornbeam. The wood of Ostrya virginica is exceedingly hard and heavy, whence it is generally known in America under the name of Iron-wood. In some parts it is called Lever-wood.

1995. Carpinus. From the Celtic words car, wood, and pin, the head; that is to say, wood fit for the yokes of cattle. The wood is white, and of a fine close texture, which makes it peculiarly fit to be wrought into the 
13355 Unarmed, Stems round striated

13356 Unarmed shrubby, Branches round villous, Spikes long loose

13357 Spiny shrubby, Spines branched, Branches villous somewhat angular, Spikes oblong loose

13358 Leaves simple and ternate ovate serrated, Petioles thickened on each side

13359 Leaves alternate lanceolate ovate, Flowers in racemes

13360 Leaves ovate, Stem diffuse

13361 Leaves oblongo-lanceolate acuminate mucronate serrate glabrous on each side 13362 Leaves oblong acute mucronate serrate white with down beneath

13363 Cones ovate pendulous, Leaves ovate acute, Buds blunt

13364 Cones oblong ovate erect, Leaves oblong ovate acuminate, Buds acute

13365 Scales or bracteas of the fruit oblong serrated with two smaller lateral lobes

133.36 Scales of cones 3-parted : middle segment oblique ovate lanceolate 1-toothed on one side 13367 Scales of cones ovate unequal at base undivided somewhat angular unequally serrated

13368 Leaves ovate glabrous obsoletely dentate, their margins ciliated

13369 Leaves ovate acuminate downy beneath coarsely toothed ciliated at edge

13370 Stip. obl. obt. Lvs. roundish-cordate pointed, Invol, of fruit campanulate rather spreading torn at margin

13371 Stip. obl. blunt, Cal. of fruit tubul. cylind. contracted at end cut toothed, Leaves roundish cord. acuminate

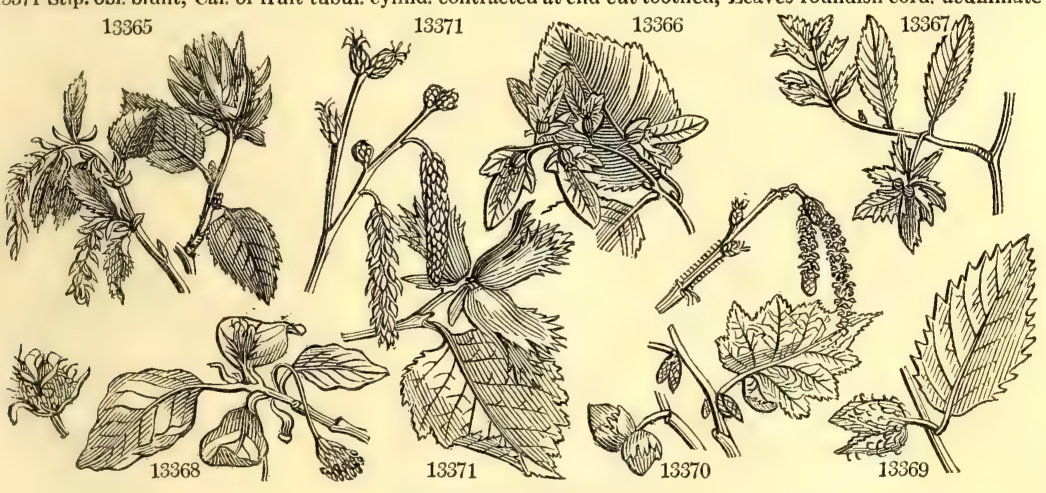

and Miscellaneous Particulars.

various forms with which the country people of all nations have delighted to ornament their yokes. Our English word Horn-beam has evidently the same meaning. C. Betulus is a tree of little merit or beauty, having persistent leaves like the beech; it is well adapted for hedges or separation, where the object is shelter.

1997. Fagus. From the Greek థnros, which also signifies eatable. We all know that mast was the original food of man. The Fagus of Virgil, was the Quercus Asculus. Hêtre, Fr., Büche, Ger, Faggio, Ital. F. sylvatica is a handsome tree in every stage of its growth. It seems to thrive best in a chalky clay or loam, rather sheltered. It is one of the handsomest single trees for parks, and is well adapted to form lofty hedges. The timber is brittle, and not of long duration; but it is much used by turners, joiners, and millwrights. The bark is remarkably thin, and has been used for making baskets and band-boxes. The leaves are used in France by the country people, on account of their elastic quality, instead of straw for the paillasse to used in France by the country people, on account of their elastic quality,
lay under their mattrasses. The mast is readily eaten by swine and deer.

F. cuprea, the copper colored, and F. purpurea, the purple beech, are two of the most striking of timber trees, from the color of their foliage. They are propagated by grafting, and grow as freely as the common beech.

Fagus ferruginea is distinguished by the Americans from the common kind by the name of Red Beech, the wood being of a darker color.

1998. Corylus. From zoevs, a bonnet; to which the enwrapping calyx may be very well compared, Our word Hazel is in like manner derived from the Anglo-Saxon Hasel, which signifies an head-dress. Noisette, Fr., Nussbaum, Ger, and Avellano, Ital. C. avellana has the specific name from Avellino, a city of the kingdom of Naples, near which, in a valiey, it grows to a great extent, and in Swinburne's time, brought in an annual profit of near $12,000 l$. sterling. It is said they were originally imported into Italy from Pontus, and known among the Romans by the appellation of nux Pontica, which in process of time, was changed into that of nux Avellana, from the place where they had been propagated with the greatest success. The common Hazel-nut is wild in many woods and coppices in Britain, whence the fruit is gathered in plenty and sent to the neighbouring markets. As underwood, the plant is of some value for hoops, fishing-rods, walking-sticks, the neighbouring markets. As underwood, the plant is of some value for hoops, fishing-rods, walking-sticks,
withes for faggoting, crate-making, hurdles, wattling-fences, and springles to fasten down thatch. Formerly the roots were used by the cabinet-makers; and where yeast was scarce, they twisted the twigs, steeped them in ale during its fermentation, hung them up to dry, and when they brewed put them into the wort

There are several varieties of the cultivated filbert. What is called the frizzled filbert is esteemed the best. The plants do not require a rich soil, but one with a dry bottom. They are generally propagated by suckers, and grown as dwarf standards, each plant with a single clean stem, from six feet high down to twelve inches. When allowed to throw up suckers from the root and form a thick bush, they cease to bear fruit in any When allowed to throw up suckers from the root and form a thick bush, they cease to bear fruit in any
quantity. The filbert bears principally upon the sides of the upper young branches, and from small shoots which proceed from the bases of side branches cut off the preceding year. Hence the spurring-in method of 
$133 \overline{7} 2$ americána $W$.

13373 rostráta $W$

13374 Colúrna $W$.

1999. JUG'LANS. $W$.

13375 régia $W$.

13376 nígra $W$.

13377 cinérea $W$.

13378 olivæfórmis $W$ angustifólia $\mathrm{H} . \mathrm{K}$

13379 sulcáta $W$, thick shell-bark Hickory

13380 álba $W$.

13381 compréssa $W$

13382 amára Mich.

13383 obcordáta $W$

13384 glábra $W$ porcína Mich.

2000. QUER'CUS. $W$.

13385 Phéllos $P h$.

13386 marítima $P h$.

13387 serícea $P h$.

13388 virens $P h$.

13389 cinérea $P h$.

13390 imbricária $P h$.

13391 laurifólia $W$ f obtúsa Mich. 13392 lútea $W$.

Dwarf Cuckold

Constantinople

WALNUT.

common

black

Butter Nut

Pekan Nut fl-bark Hickory

flat-fruited

bitter Nut

obcordate

OAK.

OAK.
Willow

sea

running

live

ash-colored

shingle

Llunt-leaved

yellow

Barbary

evergreen

common

notched-leaved

long-leared

Cork-tre

Kermes

Holly-leaved fr 6 mr.ap Ap

fr 5 mrap Ap N. Amer. 1798. L co

Terebintacea, $S p$. 10-14.

tm 50 ap.my Ap Persia 1562. S co Lam. ill.781

tm 30 ap.my Ap N. Amer. 1629. S co Dend. brit. 156

tm 30 ap.my Ap N. Amer. 1656. S co Jac. ic. 1. t. 192

tm 30 ap.my Ap N. Amer. ... S co Mich. arb. 1.it.

tm 30 ap.my Ap

tm 30 ap.my Ap

tm 30 ap.my Ap

$\mathrm{tm} 30 \mathrm{my}$ Ap

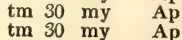

N. Amer. 180k S co

Mich. arb. 1. t. 8

N. Amer. 1629. S co Dend. brit. 148

N. Amer. 1730. S co Mich. arb. 1. t. 7

N. Amer, 1800. S co

N. Amer. 1812. S co M. arb.1.t.9.f.3,4

N. Amer. 1799. S co M. arb.1.t.9.f.,

Amentacece. Sp. 50-98.

tm $60 \underset{\text { my.jn Ap }}{\text { Am }} 6$ my.jn Ap

or 6 my.jn Ap

tm 40 my Ap

or 10 my.jn Ap

tm 40 my.jn Ap

$\operatorname{tm}_{\mathrm{tm}} 50 \underset{\mathrm{my}}{\mathrm{my}} \mathrm{Ap}$

tm 20 my Ap

N. A mer. 1723, S 8.1 N. Amer, 1811. S co N. Amer. 1724. S co N. Amer. 1739. S s.l N. Amer. 1789. S co

N. Amer. 1786. S co N. Amer. 1786. S co N. Amer. 1786. S co Mexico 1825. S co

Mich. arb. 1.t.12 Mi. quer, t.13.f. Mich. arb. 2.t. 15 Mich, arb. 2. t.11 Mich. arb. 2.t 14

Mich. arb. 2. t.13 Mich. querc.t.17 Mich. querc.t.18

tm 60 my.jn Ap Barbary _.. $\quad$ s $\quad$ s.l

tm 60 my.jn Ap S. France 1581. S s.1 Dend. brit. 90

tm 60 my.jn Ap S. France 1581. S s.1 or 60 my jn or 60 my.jn Ap clt 20 jn Ap clt $10 \mathrm{my}$ Ap

S. France 1581. G s.l

S. France 1581 . Duh. arb.t.123

S. France 1099. S s.1 Duh. arb.1 t.12

S. France 1699. S s.1 Dend. brit. 89

France 1730. G s.1 or 30 in Ap

Dend. brit. 91

13396 coccífera $W$.

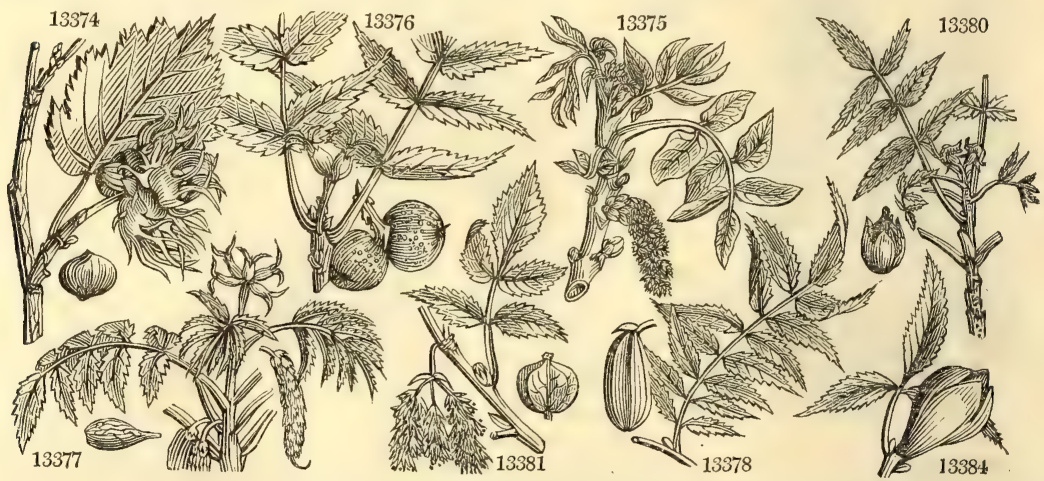

History, Use, Propagation, Culture,

pruning is the most successful in the production of fruit. C. Colurna may be treated in the same manner as the other, but the plants kept at a somewhat greater distance apart.

The nuts of the American Hazel-nut, Corylus americana, are very excellent.

1999. Juglans. That is to say, Jovis glans, the nut of Jove, on account of its excellence, which must have been great indeed, when gods had nothing but oak or beech-mast to eat. J. regia, walnut, from gaul-nut, the tree being introduced from France, Noyer, Fr., Walnussbaum, Ger., and Noci, Ital., is cultivated both as a fruit and timber-tree. The fruit in a green state, before the stone hardens, is much used for pickling, and also as an adulteration of soy sauce. An oil, which supplies the place of that of almonds, is expressed from the kernel in France. In Spain they strew the gratings of old and hard nuts, first peeled, into their tarts and other meats. The leaves strewed on the ground, and left there, annoy worms ; or macerated in warm water, afford a liquor, which from its bitterness may effect their death. The unripe fruit is used in medicine for the same purpose. Pliny says, "the more walnuts one eats, with the more ease will he drive worms out of the stomach." The timber is used in this country for gun-stocks, being lighter in proportion to its strength and elasticity than any other. It is used in cabinet-work in most parts of the continent: the young timber is held to make the finest colored work, but the old to be finer variegated for ornament. When propagated for timber, the nut is sown; but when fruit is the object, inarching from the branches of fruit-bearing trees is preferable Budding has also been successfully idopted by Mr. Knight; the buds succeed best when taken from the base of the annual shoots; ordinary-sized buds from the upper parts of such shoots generally fail. Walnut trees that have not been grafted or budded, may be induced to produce blossoms by ringing the bark.

Juglans nigra, the black walnut, is a tree of large size, and its nuts are eaten by men and several species of animals. The wood is put to various mechanical and economical uses. J. cathartica is known under the name of butter-nut, oil-nut, and white walnut; the nuts are used by the American Indians medicinally. The fruit of J. olivæformis, or the Pekan-nut, is delicious; sometimes it is exposed in the fruiterers' shops for sale. The nuts of J. sulcata, which is called thick shell-bark hickory, and Springfield and Gloucester nut, are large and well-tasted. The shell-bark hickory, shag-bark, or scaly-bark hickory, J. alba, is so called on account of its bark, which is torn lengthwise in long loose strips, as in J. sulcata. The wood of J. tomentosa, the Mocker-nut,
white-heart hickory, or common hickory, is excellent for mechanical purposes, and particularly esteemed as fire-wood; but the nuts are hard, with but little kernel in them. The Americans make very good and durable brooms by slitting into narrow slips the very tough wood of $\mathrm{J}$. glabra, which is called pig or hog-nut, also broom hickory. 
13372 Cal. of fruit roundish campan. larger than nut, Limb dilated tooth serrated, Lvs, roundish cord. acumin. 13373 Stip. lin. lanc. Cal. of fruit camp. tubul. larger than nut 2-parted : seg. cut toothed, L7s. obl. ovate acumin. 13374 Stip. lanc. acum. Cal, of fruit double : outer many-parted; inn. 3-part. Seg. palm. Lv3, roundish ov. cordate

13375 Leaflets about nine oval smooth subserrated nearly equal, Fruit globose

13376 Leaflets numerous lanceolate serrated beneath with the petioles downy, Fruit giobose dotted rough

13377 Leaflets numerous oblong lanceolate serrated soft with down beneath, Petioles viscid, Fruit oblong ovate

13378 Leaflets numerous lanceolate serrated, the odd one with a long stalk, Fruit oblong 4-cornered

13379 Leafl. about 9 lanceolate acuminate serrate downy beneath : the odd one sess. Fruit roundish with 4 keels 13380 Leaflets 7 'obl. lanc. acuminate serrated rough and downy beneath : the odd one sess. Fruit squarish smooth 13381 Leaf. 7 obl. lanc. acum. serr. downy beneath and soft: the odd one sess. Fruit ov. Nuts oblique compressed 13382 Leaflets about 9 ovate-oblong acum. finely serrated smooth on each side; the odd one with a short stalk 13383 Leaflets 7 ovate acuminate serrated smooth on each side with resinous dots beneath, Nuts obcord. smooth 13384 Leaflets 7 ovate acuminate serrated smooth on each side with resinous dots beneath, Fruit and nuts oblong

\section{A. Leaves entire, or little toothed.}

13385 Leaves membranaceous linear lanc. tapering at each end entire smooth with a small point, Nut roundish 13386 Leaves coriaceous elliptical-lanceolate entire smooth with a small point, Nut roundish

$13387 \mathrm{Lv}$ lanc-obl sornewhat wavy obt, at the base rather dilated upwards silky beneath, Nut almost globular 13388 Lvs. coriac. ellipt.-obl, revol, ent, pointless obt. at base clothed with starry down ben. Fr. stalk. Nut oblong 13389 Lvs, coriac. ellipt.-lanc. revol. ent. blunt. with a small point clothed with starry down beneath, Fruit sessile, Nut nearly globose

13390 Leaves elliptical oblong acute at each end entire almost sessile downy beneath, Nut nearly globose

13391 Leaves obovate entire smooth nearly sessile tapering at the base, Nut roundish even

13392 Leaves obovate entire shining somewhat heart-shaped at the base downy and yellow beneath

\section{B. Leaves toothed spiny.}

13393 Leaves elliptical coriaceous entire or serrated very downy beneath, Bark even, Nut cylindrical elongated 13394 Leaves ovate-oblong acute coriaceous entire or serrated hoary beneath, Bark even, Nut ovate

13395 Leaves ovate-oblong bluntish coriaceous entire or sharply serrated downy beneath, Bark cracked fungous 13396 Lvs, ellipt obl rigid smoth on both sides with spread brist. spin, teetb, Nut ov Cal with spread point se.

13397 Leaves roundish ellipt. nearly sess. undulated with deep spin, divaricat. teeth densely downy beneath somewhat heart-shaped at the base

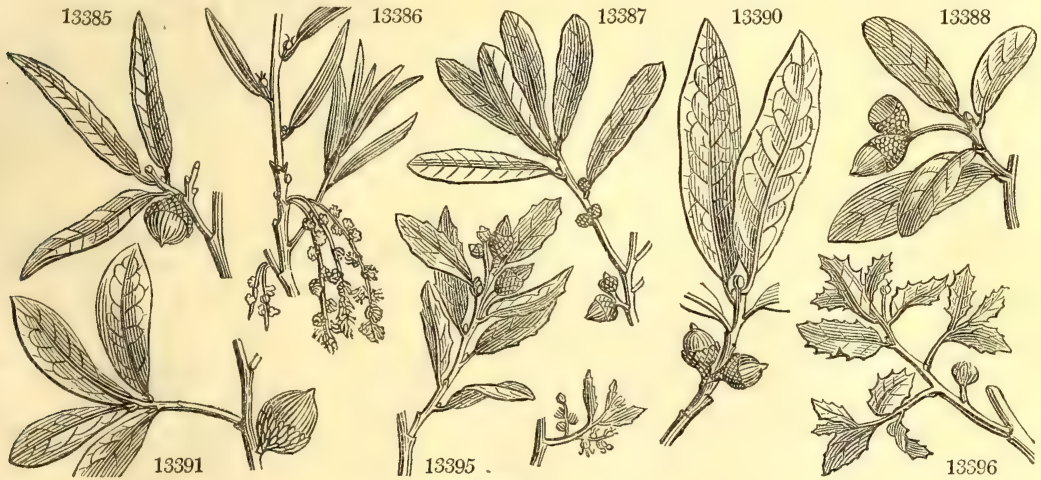

and Miscellaneous Particulars.

2000. Quercus. This name is derived from the Celtic quer, fine, and cuez, a tree; it was so called, in distinction to other trees, because the holy misseltoe grew upon it: otherwise the common name of the oak in Celtic was derw, whence druids, and the Greek devs. Phellos was the Greek name of the cork, $Q$. suber. Gramuntia has derived its name from growing in the wood of Grammont, near Montpelier. Suber is generally thought to have been formed from the Latin sub, under, because the bark was used by the Roman women as sandals, both for keeping their feet dry, and increasing their stature; but Vossius is of opinion, that it comes from wow the Greek name of bark of any kind. Coccifera has been so called because the little insect, coccus, which affords the well-known kermes dye, is found upon it. Kermes itself is an alteration of germex, which signifies in Arabic, a little worm; the same people called the red dye qermexy, whence our Norman-English word cramoisye. Robur is an alteration of rove, a Celtic synonym of the oak. Fgilops, literally goat's-beard, was so called on account of the long truss or beard-like lichens which were frequently found hanging suspended from it.

The oak is a genus of trees familiar to man in the temperate zones of both hemispheres, $O$. Robur, now valued for its timber and bark, and formerly for its acorns, is familiar to every Briton. There are two distinct varieties or subspecies; $Q$. sessiliflora and pedunculata, and another $Q$. pubescens. $Q$. pedunculata is thought to be the common oak of England, being much more frequent in natural woods than the others. The timber of this variety is said to be whitish and hard, while that of the sessile-fruited is reddish and brittle. The bark of this and all the hardy species of oak is or may be used by the tanner. Oak saw..dust is the principal indigenous vegetable used in dyeing fustian; and different shades of drab and brown are also made from it. Oak-apples are used in dyeing as a substitute for galls; the black got from them by the addition of copperas is more beautiful than that from galls, but not so durable. These galls are occasioned by an insect of the Cynips kind, which deposits its eggs in the substance of the leaf. When the bark of the oak has performed its office to the tanner, it is employed by the gardener to produce heat by its fermentation. Oak leaves are also used for the same purpose. When a great proportion of the island was in forest, acorns were of importance for feeding swine ; they are still valued for this purpose in districts where the oak abounds, as in Hampshire and Northamptonshire. Q. cerris is a very handsome tree, and the timber is considered nearly as valuable as that of the common oak. The Lucombe (from the name of the nurseryman who raised it) and Fulham (from the name of the nursery where it was first originated) varieties are nearly evergreens; they retain their verdure till Christmas, and remain on the tree in a brown or withered state till April or May following.

Q. coccinea is one of the handsomest of the American oaks; the leaves, which are six inches long, change in 
13398 lusitánica $W$ 13399 Prinoídes $W$ Chin'quapin $\mathbf{P h}$.

13400 infectória $W$. 13401 Turnéri $W$. 13402 Prinus $P h$. 13403 bícolor $\mathrm{Ph}$.

13404 montána $P h$.

13405 áquática $P$ h.

13406 nána $P h$.

13407 Castánea $P h$.

13408 nigra $\mathbf{P h}$.

13409 tríloba $P h$.

13410 stelláta $W$. obtusiloba Mich

13411 hemisphæ'rica $P h$.

13412 elongáta $W$. falcata Mich 13413 tinctória $P h$. 13414 discolor $P h$.

13415 rúbra $P h$.

13416 heterophýlla $P h$.

13417 coccínea $P h$.

13.18 Catesbæi $i$ 13419 palastris $P h$.

13420 macrocar'pa $P$ h 13421 Banistéri Mich. $13422 \Xi^{\prime}$ gilops $W$. 13423 álba $P h$.

$\beta$ repánda Mich. 13424 E'sculus $W$

13425 Róbur $W$ $Q$. sessilifióra $\mathrm{Sm}$.

13496 pedunculáta $W$ 13427 pubéscens $I V$. 13428 fastigiáta Lam. 13429 Taúzin Lam. 13430 Cérris $W$ $\beta$ bulláta sinuáta

\& sinuáta \& semperviren $\checkmark$ sempervire 13431 austriaca $W$.
Portugal
Dwarf Chesnut

Dyer's

Turner's

Rock Chesnut

water

dwarf

Yellow

black

downy-black

Iron

hemispherical

Spanish

Quercitron tm $70 \mathrm{my}$

champion

various-leaved

scarlet

barren scrub
marsh

over-cup white

Banister's

Velonia

white

repand-leaved

Italian

sessile-fruited

common

durmast

Cypress-oak

hoary

Turkey

rough-leaved

narrow-leaved

Lucombe

Fulham

toothed

Austrian $\operatorname{tm} 40$ jn

tm 40 my.Jn Ap

tm 40 my.jn Ap

tm 60 my.jn Ap

tm $50 \mathrm{my}$

$\operatorname{tm} 40 \mathrm{my}$

or $12 \mathrm{my}$

$\operatorname{tm} 60$ my

or $20 \mathrm{my}$

trm $90 \mathrm{my}$

tm 60 my

or $10 \mathrm{my}$

tm $60 \mathrm{my}$

tm 40 my

tm 40 my

tm 50 my

or $15 \mathrm{my}$

tm 60 my

tm 40 my

or $6 \mathrm{my}$

$\operatorname{tm} 60 \mathrm{my}$

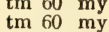

tm 40 my

tm 60 ap.my Ap

tm 60 ap.my Ap

tm 40 ap.my Ap

tm 40 ap.my Ap

tm 40 ap.my Ap

trm 50 my

tm 50 my

tm 50 my

tm 50 my

tm 50 my

tm 50 my
Ap Portugal 1824 G s.l Cav, ic. 2.t.129

Ap N. Amer. 1823. G s.1 Mi.querc.t.9. f.1

\section{Levant 1822. G co}

N. $\ddot{A}$ mer, 1730 . S s.l Mich, arb. 2.t.7

N. Amer. 1811. S s.1 Mich. arb. 2. t. 6

N. Amer. 1800, S s.l Mich. arb. 2. t. 8

N. Amer, 1723, S 6.1 Mich. arb.2.t.17

N. Amer. 1738, S 8.1 Abb. ins, 2. t. 59

Ap N. Amer. 1822. S 8,1

Ap N. Amer. 1739. S s.1 Mich, arb.2.t.18

Ap N. Amer. 1800. S s.1 Mich.querc. t.26

Ap N. Amer. 1819. S s.1 Mich. querc. t. 1

Ap N. Amer. ... S 6.1

Ap N. Amer. $\ldots$ S 8.1

Ap N. Amer. 1800. S s.l Mich.querc. t.24

Ap N. Amer. 1763. S 8.1 Mich.querc. t.25

Ap N. Amer. 1739. S s.1 Mich. arb.2. t.26

N. Amer. ... S s.l Mich. arb.2. t.16

A A s.l Mich. arb.2. t.23

Ap N. Amer, 1800. S s.1 Mich. arb.2. t.25

Ap N. Amer. 1800. S s.l Mich. arb. 2.t.3

Ap Amer. 1800, S s.l Mich arb.2, t.19

Levant 1731. S

N. Amer, 1724. S s.l Mich, arb. 2.t. I

N. Amer. A... S co

S. Europe 1739. S s.

Britain woods. S h.l Eng. bot. 1845

Britain $\ldots$ s h.l Eng. bot. 1342

Britain $\quad \ldots$ S h.l

S. Europe 1820 . G co

S. Europe 1822. G co

S. Europe 1735. S co Dend. brit. 92

S. Europe ... G co

Europe $\quad . . \quad$ G co

......

G co

$\because$ G co Dend brit, 93 Ap Austria 1824. G co Clus, hist.1. p.20

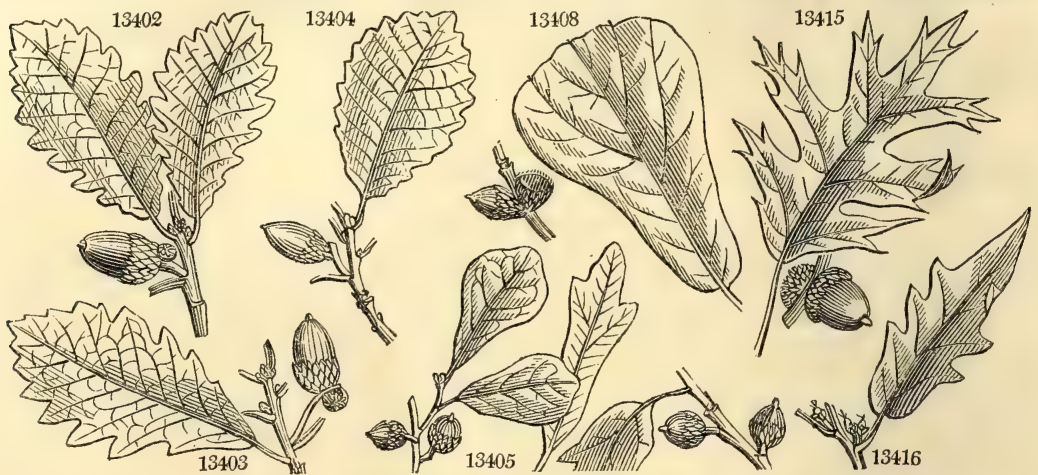

History, Use, Propagation, Culture,

cutumn to a beautiful scarlet color, and unless hard frost comes on early, they do not fall off the tree till near itutumn to a beaure beritron, Fr., has been recommended to be cultivated on account of its bark, which affords a valuable yellow dye. (Caled. Hort. Mem. iii. 378.

Q. suber is cultivated in Spain, Portugal, and the south of France, for its cork-bark. The exterior bark is the cork, which is taken from the tree every eight or ten years; but there is an interior bark which is left on to cork, the tree, so that stripping off the outer bark is so far from injuring the trees, that it is necessary to to protect the the bark is their continuation. Tres that are taken off for the first time when the tree is about fifteen years old; it soon grows again, and may be rebarked three times, the bark improving every time till the tree attains the age of thirty years. It is taken off in sheets or tables, much in the same way as oak or larch bark is taken from the standing trees in this country. After being detached, it is flattened by presenting the convex side to heat, or by pressure. In either case it is charred on both surfaces to close the transverse pores, previously to its being sold. The carionized surface produced by this charring, may be seen in bungs and taps; but not in corks, which being cut in the lengthway of the wood, the charring is taken off in the rounding. 
13398 Leaves elliptic. with deep point. serratures downy beneath, Fruit racemose, Cal. hemispherical, Nut obl. 13399 Lvs. on short stalks obov. acutely and coarsely toothed at base glaucous ben. Cup hemispheric. Acorn ov.

\section{Leaves sinuated.}

13400 Leaves oblong mucronate-toothed smooth on each side

134)1 Leaves oblong coarsely mucronate-toothed smooth on each side cuneate at base, Branchlets hairy

13402 Lvs. on long. stalks obov. ac. somew. downy ben. with near. eq. serrat. Cal. of fr. contract. at base, Nut ov. 13403 Lvs. nearly sess. obovate downy and white beneath with very broad unequal teeth, Fruit in pairs on long bristle-pointed stalks, Calyx hemispherical, Nut oblong ovate

13404 Lvs. on shortish stalks obovate acute downy and white beneath with nearly equal dilated short blunt serr. Cal. hemispherical with rugged scales, Nut oblong ovate

13405 Lvs. wedge-shaped smooth tapering at the base dilated and obscurely 3-lobed at the end: the middle lolse largest, Calyx nearly hemispherical, Nut roundish

13406 Lvs. obl. wedge-shaped smooth somew. sinuated 3-lobed at extrem. Iobes divaricated pointed : the middle one largest, Forks of the vein downy beneath

13407 Lv6. on long footst. obl. lanc. pointed somewhat downy ben. with numerous nearly equal dilated serratures, Cal, hemispherical, Nut round ovate

13408 Lvs, wedge-shaped somew. cord. dilated very slightly 3-lobed at the end, smooth above rusty beneath, Cal. hemispherical with membranous scales, Nut round ovate

13409 Lvs. wedge-shaped with 3 terminal bristly-pointed lobes : the midd. one longest downy beneath, Cal. of the fruit flattish, Nut nearly round

13410 Leaves oblong sinuated downy beneath : lobes blunt ; upper dilated 2-lobed, Cups hemispherical

13411 Leaves evergreen oblong-lanceolate undivided 3-lobed or sinuated smooth on both sides, Lobes pointed 13412 Lvs, downy ben. sinuat. with 3 or more somew falc. brist.-point. lobes : term. one elong. jagg. Cal. hemispl.

13413 Lvs, downy ben. obov, obl. dilat. wide. sinuat. Lobes short obt. slight. toothed bristle-pundern. Nut globose 13414 Leaves downy beneath oblong pinnatifid toothed bristle-pointed, Calyx turbinate-point. Cal. of fruit flat 13415 Lvs. smooth obl. sinuat. on long stalks, Lobes ac. sharply tooth. bristle-point. Cal of fr. ovate

13416 Lvs, on long stalks ovate lanc or obl, entire or unequally lobed, Cup hemispherical, Acorn nearly Nut ov. 13417 Ivs. smooth obl deeply and widely sing $13418 \mathrm{Lvs}$. sm th. obl. wedge-shap. at base deeply and widely sinuat. on short stalks, Cal. of fr. turbin. $\frac{1}{3}$ as long as nut $13+18$ Lvs. smth. obl. wedge-shap. at base deeply and widely sinuat. on short stalks, Cal. of fr. turbin. $\frac{1}{2}$ as long as nut
13419 Lvs. smooth obl. deeply and widely sinuateri on long stalks, Forks of the veins densely woolly beneath, Cal. of the fruit flattened, Nut nearly globose

13420 Lvs, obl. lyr. downy ben. : term. lobe very large 3-cleft sinuat. Cal, of fr. hemisph. scaly fring. with bristles 13421 Leaves obovate cuneiform 3-5-lobed, Lobes setaceous mucronate downy beneath [elong. spread. sca!es 13422 Lvs, ov, obl with bristle-pointed tooth-like lobes hoary ben. Cal of fr very large hemispherical with lane.

13423 Lvs. obl. deeply pinnatif. glaucous ben. Lobes lin, obl, obt. ent. dilated upw. Fr. stalked, Cal, depress. warty

$\beta$ Leaves slightly lobed green on each side

[hemispherical

13424 Lve. ov, obl. sinuat. smooth paler ben. : segm. bluntish somew. angular at base, Fruit nearly sess. Cal. scaly 13425 Lvs, decidu. oblong smooth dilated upwards stalked, Lobes obtuse, Stalks of fruit elongated, Nut oblong

13426 Leaves oblong subsessile smooth sinuated: lobes round, Fruit oblong stalked [Fruit nearly sessile 13427 Lvs, obl, obov, stalked sinuat. downy ben. : lobes obt. angul, wavy somew. heart-shap. and unequal at base, 13498 Leaves subsessile smooth oblong ovate pinnatifid sinuated blunt, Branches ascending

13429 Leaves softly villous deeply pinnatifid : segm. oblong blunt sinuated, Cups warted

$13430 \mathrm{Lvs}$, on very short stalks obl, deeply and uneq. pinnatif. hairy ben. Stip. longer than footst Casph. bristly

13431 Lvs. on longish stalks ovate obl. slightly but copiously sinuated downy and hoary ben. : lobes short ovate acute entire, Stipules shorter than the footstalks, Cal. of the fruit hemispherical bristly

13419
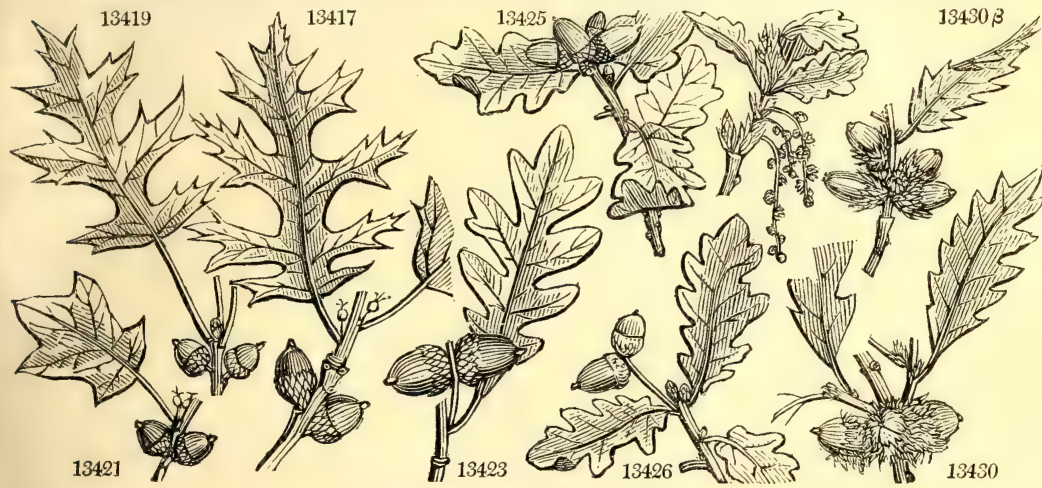

and Miscellaneous Particulars.

The uses of cork in Britain are well known. It was used as sandals by the Greeks, whence our cork soles, and probably the Venetian choppings (cioppini, Ital.), or shoes so high heeled, as to raise the women above the men. The poor people in Spain lay broad planks of it by their bed-side to tread on, as great persons use
Turkey and Persian carpets to defend thern from the floor; and sometimes they line the walls and insides of their houses built of stone with this bark, which renders them very warm, and corrects the moisture of the air. Both in Spain and Barbary bee-hives are made of cork; for this purpose, they roll the bark into a cylinder of five or six feet long, and six inches in diameter, boring holes for the entrance and exit of the bees, as in the Polish hive. (Encyc. of Gard. 1738.)

Q. coccifera, Cusoja, Span., has prickly leaves like those of the holly, or $Q$. ilex, from this species is collected the kermes or scarlet grain, a little red gall, occasioned by the puncture of the Coccus ilicis. With these galls scarlet color was dyed, till the discovery of America, when another species of Coccus, the cochinillifer, was found in the Mexican woods upon the Cactus.

Q. phellos is remarkable for the form of the leaves, which differ in character from those of the rest of the species. Q. ilex, the holly, or holm oak, Chêne verd, Fr., Elice, Ital, and Enzina, Span, is a handsome evergreen tree, and the timber is supposed equal to that of the common oak. $Q$. gramuntia is thought by some 
13432 Pseudo súber Desf. false Cork 13433 olivæfórmis $P h$. mossy-cup 13434 lyráta $P h$. Swamp-post

2001. LIQUIDAM'BAR. $W$. LIQUIDA

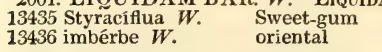

2002. Pla'tanus. $W$. Plane-Tree

13437 orientális $W$

13438 cuneáta $W$.

13439 acerifólia $W$.

13440 occidentális $W$. Plane-T oriental Maple-leaved

2003. SAlisbu'RiA. L. T. Salisburia. 13441 adiantifólia $L . T$. Maiden-hair-lv.

2004. CARLUdo'vica. Fl.per. Carludovica. 13442 angustifólia $F$. per. narrow-leaved $\square$ or 13443 latifólia Fl. per. broad-leaved 13444 palmáta Fl.per. palmate

2005. CAla'dium. $W$. Caladium. 13445 helleborifólium $W$. Hellebore-lvd. 13446 bícolor $W$. two-colored 13447 nymphæifólium $W$. Water-lily-lvd. 13448 esculéntum $W$. 13449 sagittifólium $W$. 13450 pinnatífidum $W$. 13452 grandif́lium $W$ 13453 arboréscens $W$. 13454 tripartítum $W$ 13455 aurítum $W$. 13456 lácerum $W$. 13457 odorátum Roxb. 13458 maculátum Lodd. 13459 scándens $W$

13460 xanthorhizum Jacq. yellow-rooted tm 40 my Ap S. Europe 1824. G co Sant.itin.156.t.4 tm 50 my Ap N. Amer. 1811. S h.l Mich. arb. 2.t. 2 or $15 \mathrm{my}$ Ap N. Amer. 1786. S h.l Mich. arb. 2.t.5 Amentacea. Sp. 2.

tm 60 mr.ap Ap N. Amer, 1683. S s.l Mi.ar.3.p.194.t.4 or $6 \quad \ldots$ Ap Levant 1759. L s.l Amentacea. Sp. 4-5.

tm 50 ap.my Ap Levant 1548. C co Dend. brit. 101 or 6 ap.my Ap tm 70 ap.my Ap tm 70 ap.my Ap

Amentacece.

or 20 ap.my Ap

pan

3 ... W W Sp. 3 -5.

3 jl.au W W Peru

Peru

Levant 1739. C co

N. Amer. 1640. C co

Sp. 1.

1754. C s.l Dend. brit. 168

1818. Sk p.1

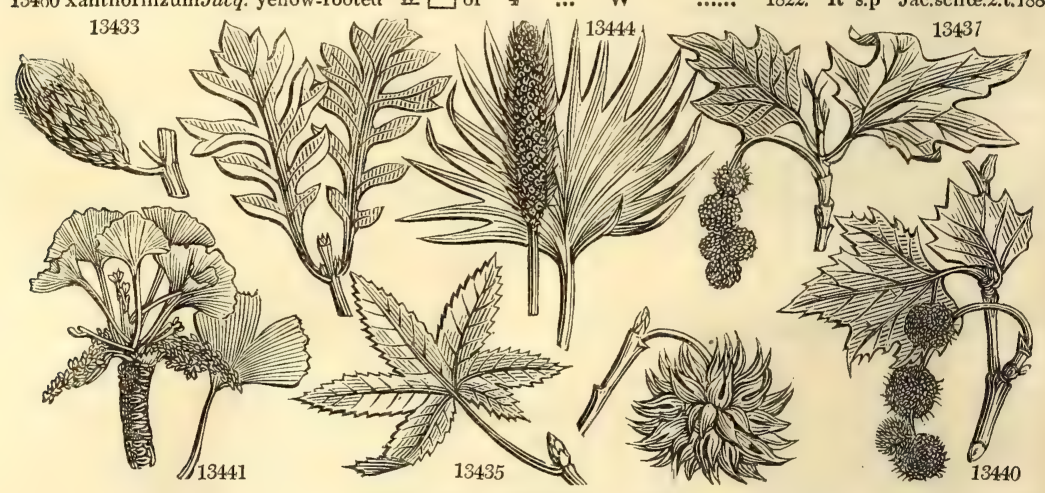

History, Use, Propagation, Culture,

to be only a variety of this species. The acorns of $Q$. esculus are sweet, and, it is said, are frequently eaten by the poor in the south of France : the tree very much resembles the common English oak.

The willow oak grows to the height of about fifty or sixty feet. The $O$. virens, or live oak, grows to the height of forty or fifty feet, spreading its branches, when in open places, extremely wide; it yields the finest and most durable ship-timber of any species known; for which reason it is considered one of the most valuable trees in America. The laurel.oak, or, as it is sometimes called, swamp willow oak, is about fifty or sixty feet high ; its wood, according to the elder Michaux, is very valuable, and almost preferable to that of $Q$. virens. The water oak, $Q$. aquatica, is about forty feet high when full grown: its wood is but little valued. Its leaves vary according to the soil and age, ad infinitum. There is scarcely one tree found having leaves like the other; and the same tree is almost as variable in its different branches. The downy black oak, $Q$. triloba, is from twenty to forty feet high, according to Michaux, of very rapid growth, and extremely well calculated for inclosing land. The barren oak, or black jack of the Virginians, O nigra, is of low growth, especially in the more northern states; it bears very abundantly, and furnishes a fine mast for hogs ; the wood is small, but excellent for fuel. The black oak, or Quercitron, Q. tinctoria, is one of the largest trees of the American forest, and highly valuable on account of its timber as well as bark, which is very superior for tanning to any other oak. O. falcata is a very large tree, commonly called Spanish oak. The wood of the upland white oak, or iron oak, is of great value in ship-building. The fruit of the $Q$. Prinus, known by the name of the chesnut white oak, swamp chesnut oak, and, in the southern states of North America, white oak, is large, and of a sweet taste. The bark of the rock chesnut oak, $Q$. montana, is excellent for tanning. The yellow oak, $Q$. castanea, is a large and beautiful tree with eateable acorns.

2001. Liquidambar. From this tree flows a strong balsamic substance, which has been compared to ambergris, and named from Ambar, amber, and liquidum, fluid. L. styraciflua, in its general form and leaves, bears a considerable resemblance to the lesser Maple, (Acer campestre) as the wood is good timber and beautifully variegated. Between the wood and the bark issues a fragrant gum, which trickles from the wounded trees, and by the heat of the sun congeals into transparent drops, which the Indians chew as a preservative to their teeth. It smells like the balsam of Tolu. The species are propagated by layers, or from seeds.

The sweet gum-tree, or Liquidambar styraciflua, is sometimes found of an immense size, particularly in the southern states; its wood is of an exquisite hard texture and fine grain, and furniture made of it has a handsome appearance.

2002. Platanus. From $\pi \lambda \alpha \tau v$, ample, broad, in allusion to the shadow afforded by the foliage. The species are trees of peculiar grace and elegance, and from that circumstance, and the classical associations attached to them, they are eminently adapted for pleasure grounds. The chenar, or eastern plane, is very much employed 
13132 Leaves oblong sinuate serrated downy beneath, Bark fungous

13433 Lvs. obl. smooth glaucous ben. deeply and unequally pinnatif. Fruit ellipt.-ovate, Cal. cup-shaped fringec 13434 Lvs. obl. deeply sinuated smooth much contracted in the middle: lobes acute; the upper ones dilated angular and abrupt, Calyx of the fruit globose muricated nearly covering the nut

13435 Leaves palmate-lobed, Recesses at the base of the veins villous

13436 Leaves palmate-lobed, Recesses at the base of the veins smooth

13437 Leaves 5-lobed palmate cuneate at base, Segm. lanceolate sinuated, Stipules nearly entirc

13438 Leaves 3-5-lobed toothed cuneate at the base smoothish

13439 Leaves cordate 5-lobed remotely toothed truncate at base

15440 Leaves 5 angular obsoletely lobed toothed cuneate at base downy beneath

13441 The only species

13442 Fronds forked: segments ensiform narrow, Stems round 13443 Fronds forked: segments lanceolate, Stems channelled 13444 Fronds flabelliform 3-5-parted

13445 Stemless, Leaves pedate entire, Spadix as long as spathe

Contracted in the middle 13446 Stemless, Lvs. pelt.-cordate sagittate colored in the disk, Spadix shorter than the hooded spathe, which is 13447 Stemless, Lvs. peltate-cordate sagittate, Spadix longer than the cylindrical spathe sagittate at end

13448 Stemless, Leaves peltate-cordate, Spadix shorter than ovate-lanceolate spathe

13449 Stemless, Ieaves sagittate acuminate, Spadix shorter than ovate-cucullate spathe 13450 Stemless, Leaves pinnatifid

13451 Caulescent suberect, Leaves oblong cuspidate, Spadix shorter than oblong spathe

13452 Caulescent rooting, Leaves cordate sagittate, Spadix as long as the cucullate ovate spathe

13453 Caulescent erect, Leaves sagittate, Spadix shorter than the cucullate ovate spathe

13454 Caulescent rooting, Leaves ternate, Petioles naked, Spadix as long as the cucullate ovate spathe

13455 Caules, root. Lvs, tern. : lat. leaflets eared at base on outside, Petiol. winged bel. Spad. shorter than spathe 13456 Caulescent rooting, Leaves cordate sinuate

13457 Caulescent, Leaves cordate with rounded lobes, Spadix as long as cymbiform spathe

13458 Caulescent suberect, Leaves oblong acuminate cuspidate cordate at base finely spotted with clear white

13459 Caulescent scandent, Leaves ovate oblong acuminate, Spadix longer than cucullate spathe

13460 Caules. erect, Lvs. cord. sagittate, Spadix shorter than spathe, which is cucullate and contracted in middle
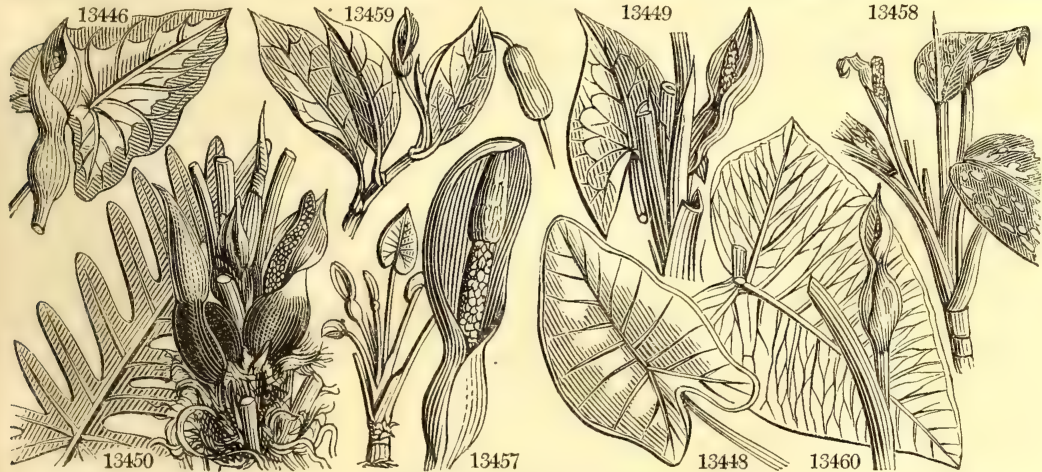

and Miscellaneous Particulars.

in the gardens of Persia and India; it was highly esteemed by the Greeks and Romans, and was planted near their houses in the form of avenues and groves. Groves of these trees are still equally revered in India, and are commonly found near the native temples and burial places of the princes. The timber is considered of similar quality to that of sycamore. All the species are of easy culture by layers, and they will also grow by cuttings.

The Platanus occidentalis is known in America by the name of the button-wood, water beech, sycamore, and plane-tree; in Canada it is called cotton-tree. It is, perhaps, the largest tree in North America; on the fertile banks of the Ohio and Mississipi there are trees measuring from ten to sixteen feet in diameter.

2003. Salisburia. So called in honor of Richard Anthony Salisbury, F. R. S., a modern distinguished botanist. A large tree remarkable for its fan-shaped leaves, cloven like some of the Adiantum species. The fruit is a pale brown drupe of a globular form; it has never been produced in this country, though there are trees of a considerable size. The fruit is yellow when ripe, with a fleshy, juicy, white pulp, adhering closely to the druye, which is like that of an apricot. The kernel is white, rather firm, sweet, with a mixture of austerity or bitterness when raw, but agreeable when roasted. Dr. Abel says, he saw the fruit exposed in the markets in China, but could not find out to what purpose it was applied.

2004. Carludovica. Named by the authors of the Flora Peruviana, in honor of Charles IV., king of Spain, and Luiza, his queen; both of whom were noble patrons of botany, and deserving of a finer genus to commemorate their virtues. The species are low palm-like herbs, of little beauty, but of great hotanical interest.

2005. Caladium. A name originally employed by Rumphius, to designate some species of Arum, and revived by Ventenat. Its meaning is unknown. The species have the appearance of Areca, and are only revived by Ventenat. Its meaning is unknown. The species have the appearance of Areca, and are only accidents to which other stove plants are liable. The species are plants of the same general appearance as Arum. C. sagittifolium, Chou-de-Bresil, Fr., and Essbare Arum, Ger, bears a near resemblance to Arum Colocasia, and is carefully cultivated in the West Indies for the leaves, which are boiled and eaten as coleworts, being extremely pleasing to the taste. The roots are also eaten there, but they are in less esteem than the leaves. This is generally supposed to be the species of the Arum family the most universally cultivated. It is found in the East and West Indies, China, Japan, New Zealand, and the South Sea Islands. The root is extremely acrid, and when eaten raw, will excoriate the mouth; but baked in hot ashes, it looses its acrimonious quality, and becomes mild and well tasted; it is, however, heavy on a weak stomach, and is apt to occasion costiveness. The leaves, which are very soft, glaucous, and covered with a very fine silky nap, are used in many places instead of plates and dishes. 
2006. A'RUM. $W$. 13461 crinitum $W$. 13462 Dracúnculus $W$. 13463 Dracóntium $W$ 13464 venósum $I V$. 13465 triphýllum $W$. 13466 atrorúbens $W$. 13467 ternátum $W$. 13468 Colocásia $W$. 13469 macrorhízon $W$. 13470 divaricátum $W$. 13471 trilobátum $W$. 13472 maculátum $W$. 13473 orixénse $R$. $B r$. 13474 itálicum $W$ 13475 minútum $W$. 13476 virgínicum $W$. 13477 Arisárum $W$. $134-8$ tenuifólium $W$. 13479 cucullátum Lour 13480 indicum Lour. 13481 obtusilóbum $\dot{L}$ ink 13482 sagittifólium Link. (3184 intearum Lodd. 13485 ramósum Iink. 13486 hederáceum $\vec{W}$ 13488 bulbíferum $B$. $M$. 13489 spirále $W$.

13490 flagellifórme $\operatorname{Lodd}$. 2007. CARYO'TA. $W$. 13491 úrens $W$. 13492 mítis Lour. 13487 lingulátum $W$.
A Rum. hairy-sheathed do $\mathrm{V}$ cu 1 Aroidea. Sp. 30-45. Comm. Dramon 1777 . R 6.1 Bot. reg. 831 or 3 jn.jl $\mathrm{Br}$ or purple-flower'd $\bar{x} \nabla \overrightarrow{c u}$ three-leaved $\Delta \mathrm{cu}$ purple-stalked $\frac{}{\Delta} \Delta \mathrm{cu}$ Japan Egyptian long-rooted divaricated three-lobed common Orixian Italian small

Virginian

Friar's Cowl Grass-leaved hooded Indian blunt-lobed arrow-headed viviparous entire-leaved branched Ivy-leaved tongue-leaved spiral

whip-lash

Caryota. torn-leaved unarmed 然 不 $\mathrm{cu} 2$ jn...j * $\nabla \mathrm{cu} 1$ my.jn Pu $\triangle \mathrm{w} \quad 1$ my.jl W 苍 or 1 au.o

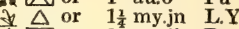
* $\triangle \mathrm{cu}$ my.jl $\mathrm{Pu}$ $\nabla \mathrm{cu} 1$ jn.jl L $\triangle$ cu 1 ap.jn W w $\begin{array}{llll}\mathrm{cu} & 2 & \mathrm{k} & \mathrm{G}\end{array}$ $\square \begin{array}{cccc}\mathrm{cu} & 5 & \ldots . & \mathrm{Br}\end{array}$

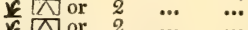
or $1 \frac{1}{3} \mathrm{my}^{\circ}$ or 3 my.jn $G$ or 3 my.jn ... E㐫 cu 6 my.jn $\mathbf{P u}$ E $\square$ cu 㳦 or 3 my 这

Bengal 1819. R i.p Bot cab. 996

N. Amer. 1759. F s.l Bot. reg. 668

...... 1774. R s.l

Japan 1774. R s.1

Levant 1551. R s.p

Ceylon 1714. R s.p Bot.mag. 339

N. Amer. 1759. R s.p

S. Europe 1570, R s.p Bot. reg. 512

China 1824. R s.p

China 1824. R s.p

...... 1824. R $1 . p$

1817. R l.p

1810 $R$ ip

China 1820. S r.m
1 jn.jl $\mathrm{Br}$ 作 $\mathrm{cu}^{\frac{3}{4} \mathrm{my} . \mathrm{jl} \quad \mathrm{Pu}}$

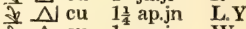
$\square$ or 20 Palma. $S p .2-3$.

Europe 1548. R s.l Mor. s.13.t.5.f.46

N. Amer. 1664. R s.1 Bot. mag. 950

N. Amer. 1758: R s.l Pluk.al, t.148.f.6

E. Indies 1803. R s.p Herm parad 73

E. Indies 1759. R s.p Rhe.mal.11. t.20

Britain sha.pl. R co Eng. bot. 1298

Italy 1683. R co Bot. mag. 2432

E. Indies 1812. R co Rhe.mal.11.t.17

S. Europe 1596. R s.I Jac.schœ.2.t.192

W. Indies 1793. R 1.p Jac. amer. t. 152 W. Indies 1793. R l.p Plum. ic. 26̈. t.57 Bengal 1813. R l.p Bot. mag. 2i17

里

\section{MONADELPHIA.}

2008. NI'PA.Thunb. 13493 fruticans Thunb. 2009. ARE'CA. $W$. 13494 Cátechu $W$. 13495 húmilis $W$. 13496 olerácea $W$

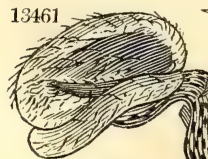

Nipa.

shrubby

生 $\square$ or ${ }_{10} \begin{aligned} & \text { Palma. } \\ & \text {... }\end{aligned}$ W. 1 E. Indies 1822. S r.m Rumph.1. t. 16
Cabbage-Tree. medicinal dwarf esculent 年 $\square$ clt 30 Palma. S Sp. $5-$...

E. Indios 1690. S r.m Rox.cor. 1. t. 75 W. Indies 1656, S r.m Jac. amer. t.170
13463 13465

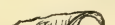

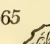

13471 $\cdots \quad$ W E. Indies 1814. S r.m liump.amb.1.t.7

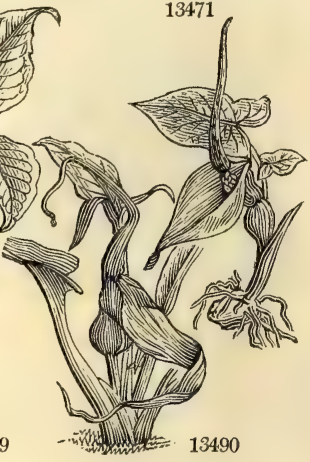

13473

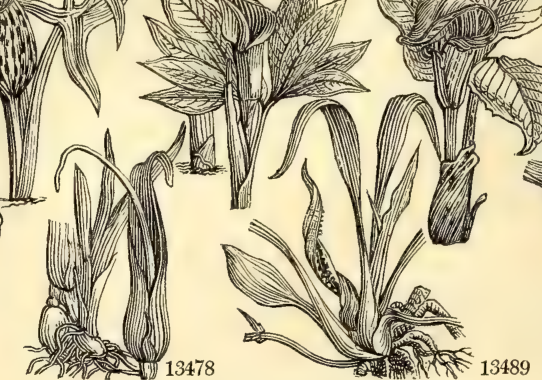

History, Use, Propagation, Culture,

2006. Arum. Formerly aron; supposed to be an ancient Egyptian word by which the A. colocasia was known. The last mentioned name is an alteration of its Arabic denomination qolq $\hat{s}$, according to Forskahl. Perennial herbaceous plants, mostly natives of hot climates. The roots are fleshy, hot, and acrid, but in many species eatable; they are generally without stems, and altogether, with the Caladiums, form a very singular family. A. Dracunculus, Serpentaire, Fr., Drachenwarz, Ger., and Dracunculo, Ital., is a very remarkable plant ; the stalks of the leaves being spotted with brown and purple, like the belly of a snake. The flower, which, like others of the genus, has a very singular appearance, smells so strongly of carrion, that few persons can endure it. It might be used in medicine and domestic economy for the same purposes as A. maculatum. A. Colocasia has a tuberous thick large oblong root, and leaves resembling those of the water-lily. In Egypt and the Levant, this plant is esteemed a wholesome food, though not very delicate. The roots and petioles are boiled, and the leaves when young are sometimes eaten raw. A. trilobatum, and various others, are similarly used in the West Indies. There and in Europe the culture of all the species is of the simplest kind.

A. maculatum, Gouet, Fr., Aronswartzel, Ger., and Aro, Ital., has a tuberous whitish root about the size of a large nutmeg, which is used both as food and medicine. On tasting them, they seem to be merely mucilaginous and insipid, but they soon affect the tongue with a pungency as if pricked by needles; this uneasy sensation may be alleviated by milk, butter, or oil. The acrimony is lost in drying, and the roots become farinaceous, insipid, and fit for boiling or baking. In the Isle of Portland, where the plant is very abundant, the roots are generally eaten by the country people ; they are macerated, steeped, and the powder so obtained is dried and sent to London, and sold urider the name of Portland sago. Medicinally, the root in its recent state is stimulant, diaphoretic, and expectorant. Though retained in the Materia Medica,' it is seldom used. The berries which succeed the flower are devoured by birds; and Mr. Curtis thinks, that even the roots are eaten by them, particularly pheasants. Dried and powdered, they are used by the French as a wash for the skin, under the narne of cypress powder.

2007. Caryota. The Greeks gave this name to a kind of cultivated date. Pliny says, it was so called, 
S461 Leaves pedate entire, Spadix cylindrical shorter than ovate flat spathe, which is hairy inside

13462 Leaves pedate entire, Spadix lanceolate shorter than the ovate flat smooth spathe

13463 Leaves pedate entire, Spadix subulate longer than the oblong convolute spathe

13464 Leaves pedate entire, Spadix shorter than lanceolate spathe

13465 Stemless, Leaves ternate entire, Spadix clavate shorter than ovate acuminate flat stalked spathe

13466 Stemless, Leaves ternate ovate twice as short as spadix

13467 Stemless, Leaves ternate, Spadix longer than spathe

13468 Stemless, Leaves peltate ovate repand emarginate at base

13469 Stemless, Leaves paltate cordate repand 2-parted at base

13470 Stemless, Leaves cordate hastate, Spadix subulate longer than the reflexed ovate-lanceolate spathe

13471 Stemless, Leaves sagittate 3-lobed, Flowers sessile

13472 Leaves all radical hastato-sagitate: lobes deflexed, Spadix club-shaped obtuse shorter than the spathe

13473 Leaves hastate 3-parted, Spathe stalked 2-colored longer than spadix : the end lanceolate and deflexed

13474 Stemless, Lvs, veiny with white hastate sagit. : lobes auricled diyaricating, Spad. clav, shorter than spathe 13475 Stemless, Lvs. hastate sagittate mucronate : lobes deflex. Petioles dotted, Spad. cylind. shorter than spathe 13476 Stemless, Leaves hastate cordate acute : angles obtuse

[cucullate spathe

13477 Stemless, Lvs, hast. sagittate mucron. : lobes deflexed oblong obtuse, Spadix cylind. incurved shorter than

13478 Stemless, Leaves linear-lanceolate, Spadix subulate longer than lanceolate spathe

13479 Caulescent erect, Leaves peltate cordate : auricles cucullate

13480 Caulescent suberect, Leaves ovate bifid at base rounded, Spadices axillary

13481 Caulescent, Leaves peltate cordate acute cut out at the base with a wide recess

13482 Leaves sagittate acute rounded at base

13483 Leaves peltate cordate sagittate, Spathe roundish oblong acute, Spadix obtuse much shorter than spathe

13484 Leaves lanceolate acute entire, Edge of petiole sheathing, Spathe cucullate

13485 Leaves peltate cordate

13486 Caulescent rooting, Leaves cordate oblong acuminate, Petioles round

13487 Caulescent crecping, Leaves cordate lanceolate, Petioles with a membranous edge

13488 Stemless, Leaves decompound bulbiferous, Spadix oblong ovate shorter than the obtuse veiny spathe

13489 Stemless, Leaves linear lanceolate, Spadix lanceolate shorter than the oblong lanc. spirally twisted spathe

13490 Steml. Lvs. ov. ent. or S-lob. Spathe urceol, at base : reflex. and taper-point. at end, Spadix length of spathe

13491 Unarmed fronds bipinnate, Leaflets cuneiform obliquely bitten off

13492 Fronds bipinnate, Petioles nodding, Fruit 1-seeded

\section{MONADELPHIA.}

13493 Frond pinnated, Female flowers terminal capitate : male lateral with dichotomous peduncles

13494 Fronds pinnated, Leaflets plaited terminal bitten off, Stems and spadices smooth

13495 Fronds pinnated, Leaflets cuneiform truncate, Fruit globose ovate acute

13496 Fronds pinnated, Leaflets linear acute, Fruit oblong incurved

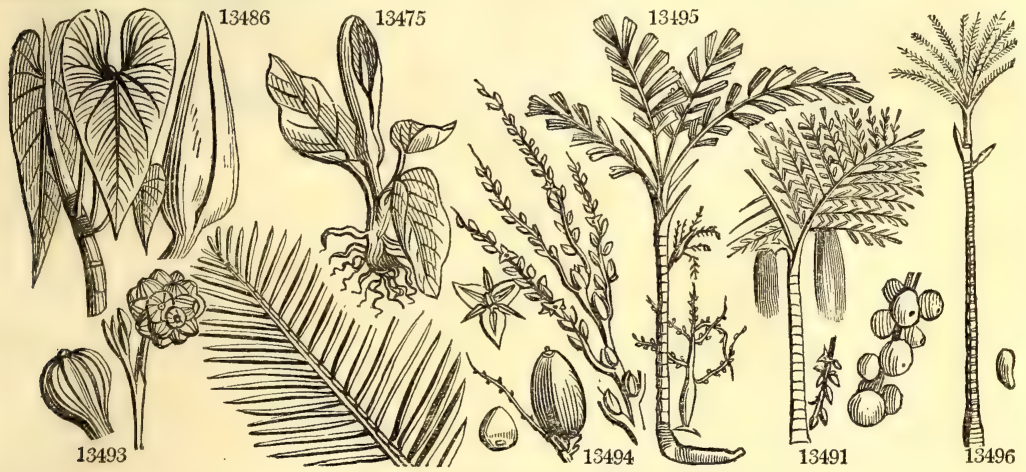

and Miscellaneous Particulars.

because a wine was prepared from it which soon got into the head, *apo, head. C. urens, a fine specie of palm, produces flowers in long pendulous spikes, which are succeeded by strings of succulent globular berries, dark red when ripe, with a thin skin, soft pulp, and very sharp and acrid to the taste. In Ceylon, it yields a sort of liquor, sweet, wholesome, and no stronger than water. It is taken from the tree twice or thrice a day, and an ordinary tree will yield three or four gallons. They boil this liquor, and thus make a kind of brown sugar of it, called Jaggory. The fruit is not eatable. When the tree has come to maturity, there comes out a bud from the top; this bud they cut and prepare by putting salt, pepper, lemons, garlick, leaves, \&c. over it which keep it from ripening. They daily cut off a thin slice from the end, and the liquor drops into a vessel, which they set to catch it. The buds, like those of the Cocoa and Betel-nut, are excellent in taste, resembling walnuts or almonds. C. mitis is a very beautiful palm, with fronds four feet long and a branched spike of flowers, succeeded by berries, round, coriaceous, smooth, black, the size of a musket bullet, but not eatable. Both species grow freely in sandy loam.

2008. Nipa. The name given to this fine palm in the Moluccas.

2009. Areca. The name which this palm bears in Malabar is, when it is an old tree, Areec; when young it is called Paynga. A. Catechu produces the nut which is cut in slices, wrapped in the aromatic leaves of the betel-pepper, and chewed as we do tobacco. These leaves are previously covered with a thin layer of shelllime (Ehunam), to preserve the flavor longer in the mouth. In most parts of the East Indies the natives are continually chewing it, swallowing their saliva tinctured with the juice, and spitting out the rest. The inside of their mouths appears as red as blood, and it gives their teeth a dark color: but it preserves the teeth, sweetens the breath, and is a stomachic and diuretic. This palm is very generaliy cultivated in the East Indies.

A. oleracea is the highest of the American palms, and is very distinct from the East Indian Areca. The sheaths of the leaves are very close, and form the green top of the trunk a foot and a half in length. The 
13497 criníta $W$

13498 lutéscens $W$.

2010. BE'LIS, Salisb.

13499 jaculifólia Salisb. Pinus lanceoláto

2011. A'G ATHIS. Saliso. Dammar Pine.

13500 loranthifólia Salisb. common Pinus Dam'mara

13501 austrális Hort.

2012. PI'NUS. $W$. 13502 sylvéstris $W$. 13503 Pumílio $W$. 13504 Larício $P$. S. 13505 púngens $\dot{P} h$ 13506 Banksiána $P h$. 13507 Mághus $W$. 13508 Pinaster $\mathscr{W}$. 13510 marítima $W$. 13511 halepénsis $W$. 13512 inops $P h$. 13513 resinósa $P h$. 13514 variábilis $P h$. 13515 Tæ'da $P h$ 13516 excélsa Wail. 13517 serotina $P h$. 13518 rigida $P h$.

\section{Kawrie Pine}

PINe. Scotch dwarf Corsican pungent Scrub Pine Mugho cluster cluster stone maritime Aleppo Jersey pitch two and 3-leav. frankincense Nepal Fox-tail three-leaved

\section{乎 $\square$ or $20 \quad \ldots \quad$ W $\quad$ I. France 1824. S r.m} Coniferc. $S p .1$.

1804. C p.l Lam.pin.52, t.34

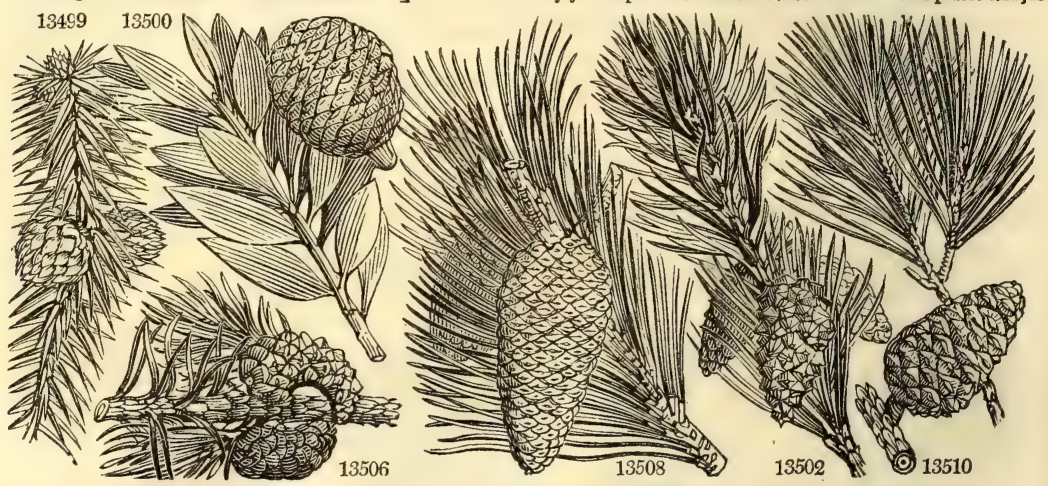

History, Use, Propagation, Culture.

inhabitants cut off this top, take out the white heart of two or three inches in diameter, consisting of the leaves closeiy folded together, ard eat it, either raw with pepper and salt, or fried with butter like the artichoke.

2010. Belis. Named by R. A. Salisbury, in the Transactions of the Linnean Society, from $6 \varepsilon \lambda .5$, a javelin, on account of the form and texture of the leaves, which are not unlike a javelin head, B. lanceolata is a beautiful evergreen shrub, with distichous neat leaves, easily cultivated in any good conservatory.

2011. Agathis. From arcents, a cluster, because the flowers are collected in clusters. This genus is formed of the Dammar Pines, of which the A, australis, or New Zealand Cowdie Pine, is one of the finest trees in the world, often growing perfectly straight to the height of 100 feet or more, and yielding one of best descriptions of wood for masts.

2012. Pinus. This name is of Celtic origin, and is the same in all the dialects of that tongue. Pin or pen, a rock or mountain, has given rise to pin, in Armorican; reinge, in Erse; pinua, in Welsh; pinu, in AngloSaxon; pine, in English; pynbaum, in German; all signifying the fir-tree: hence also the Appennines (Alpes pennines), Penuafiel, Pennaflor, \&c. towns of Spain embosomed in mountains. The fruit of P. Pinea was formerly called Nux pinea, the pine nut. Pinaster is Pliny's name for the wild pine. Cembra is an alteration of the word cembro or cirmolo, the name given by the inhabitants of Trentin and Valteline to the plant. Tæda is derived from the Greek $\delta \omega_{s} \delta \alpha_{0}$, which signifies a torch, for which the wood of P. tæda is particularly adapted. Strobus is a name employed by Pliny for an eastern tree, which was used to perfume apartments. The moderns have applied it to a noble North American species.

The trees which compose this genus are not less remarkable for their grandeur and beauty, than for their valuable timber. They are all evergreens, and of lofty and erect growth. The trunk of the Scoteh pine is more generally employed and more universally applicable as timber than any other tree in the temperate zone of the northern hemisphere. P. sylvestris, Pin, Fr., Keifer or Föhre, Ger., and Pina, Ital., is erroneously called a fir; and has the term Scotch applied to it, because it is the only species of the genus indigenous to Britain, and there only in the northern parts of Scotland. It is also indigenous in the Alps, in the north of Germany, Russia, and abundantly so in Sweden and Norway. The finest pine woods in Britain, are at Invercauld in Inverness-shire, and Gordon Castle in Aberdeenshire. The timber of the Scotch pine is the red or yellow deal of the north of Europe, and is the most durable and valuable of any of the genus, unless we except, in point of durability, the larch. That grown in cold elevated situations in the highlands of Scotland, is tound to be not inferior in quality to any imported from Norway; but that which has been planted in the low districts, is greatly inferior in point of durability, and can seldom be used in house carpentry and joinery. The tree is of great value as a nurse plant to others less hardy. The trunk of the tree produces resin by. incision, and the roots tar by distillation. Several varieties of the wild pine have been noticed by botanists. According to Sang, the variety commonly cultivated is least worth the trouble, "The P. sylvestris, var. montana," he says, " is the variety which yields the red wood. even young trees of this sort are said to become red in their wood and full of resin very soon. The late Mr. Don, of Forfar, exhibited specimens of cones of each variety to the Highland Society of Scotland, and likewise to the Caledonian Horticultural Society. The variety preferred by Don, is distinguished by the disposition of its branches, which are remarkable for their horizontal direction, and for a tendency to bend downwards close to the trunk. The leaves are broader and shorter than in the common kind, and are distinguishable at a ỏistance by their much lighter and beautiful glaucous appearance. 
13497 Fronds pinnated, Stems hirsute, Spadixes branched spiny, Spines incurved

13498 Fronds pinnated, Leaflets plaited bitten off, Stems and spadixes branched smooth, Fruit roundish gibbous

13499 Leaves solitary lanceolate flat spreading, Cones round, Scales acuminate

13500 Leaves elliptical lanceolate striated

13501 Leaves ovate oblong smooth not striated

13502 Leaves in pairs rigid, Cones conico-ovate acute as long as the leaves, generally in pairs

13503 Leaves in pairs, Trunk ascending, Cones ovate erect

13504 Jvs. twin very long of two forms, Cones ovate, Scales narrowed at base very thickened at end not angular 13505 Leaves twin short acute, Cones ovate conical, Prickles of scales long subulate incurved: lower reflexed 13506 Leaves twin divaricating oblique, Cones recurved twisted, Crest of anthers dilated

13507 Leaves double or triple rigid, Cones oblong generally in pairs rounded at base

13508 Leaves twin roughish at edge, Cones oblong conical shorter than leaf narrowed at base, Scalcs cchinate

13509 Leaves twin : the first ciliated, Cones ovate blunt somewhat unarmed longer than leaf, Nuts hard

13510 Leaves twin very fine, Cones ovate-conical very smooth solitary stalked

13511 Leaves twin, Cones ovate-conical rounded at base somewhat shorter than leaf, Scales blunt

13.512 Leaves twin, Cones oblong-conical the length of leaves solitary rounded at base, Scales echinate

13513 Leaves twin, Cones ovatc-conical rounded at base solitary half as short as leaves, Scales unarmed

13514 Leaves twin or ternate, Cones ovate-conical subsolitary, Prickles of scales incurved

13515 Leaves long, Cones deflexed : spines inflexed, Sheath of leaves long

13516 Leaves in 5 s very long slender lax toothletted, Cones cylindrical smooth pendulous longer than leaves 13517 Leaves 3 very long, Cones roundish ovate mucronate

13518 Leaves 3, Cones ovate clustered, Spines of scales reflexed, Sheath of leaves short

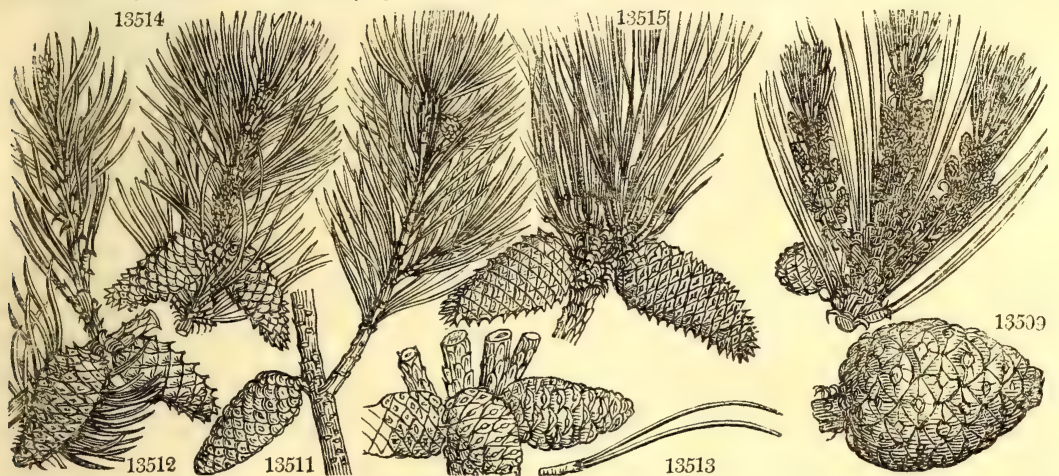

and Miscellaneous Particulars.

The bark of the trunk is smoother than in the common kind. The cones are thicker, and not so much pointed. The plant is more hardy than the common sort, grows freely in almost any soil or situation, and quickly arrives at a considerable size."

P. laricio is said to be nearly allied to the Scotch pine, but a much handsomer and finer tree. Professor Thouin considered it equally hardy with P. sylvestris; its wood is more weighty and resinous, and consequently more compact, stronger, and flexible. It grows wild on the summits of the highest mountains in Corsica. $\vec{P}$. resinosa, the red Canadian pine, is not unlike the Scotch pine, but rather redder in the bark. The timber of this resinosa, the red Canadian pine, is not unlike the Scotch pine, but rather redder in the bark. The timber of this
tree is frequently imported as masts, and is considered valuable. Grown on a damp and fertile soil, it is much less durable than from elevated situations; it is equally hardy with $\mathbf{P}$. sylvestris. $\boldsymbol{P}$. pinasier is a grand and picturesque tree, and is a great favorite with the Roman and Florentine painters. The timber is of less value than that of any of the others that have been mentioned; in Switzerland it is cut into shingles for covering their houses. It is highly deserving of culture as an ornamental tree, but not for timber.

$P$. Pinea is very common in the south of $J$ taly; there is an immense forest of them at Ravenna, and they are much planted in the gardens of the villas of Rome and Florence. The seeds of this and the list species are eaten throughout Italy, both by the poor and rich. They are as sweet as almonds, but with a slight flavor of turpentine. The wood is not so resinous as that of most of the other sorts, and the tree can only be consiciered as deserving culture for its pictorial effect. P. Cembra, the Tannenbaum of Lord Fyron (Childe Harolde), and the Aphernousli pine of Harte (Essays), grow's higher up the Alps than other pines, and is even found at elevations where the larch will not grow. The wood is very soft, and having scarcely any grain, is very fit for the carver. The peasants of the Tyrol, where this tree abounds, make various soris of carved works with the wood, which they dispose of in Switzerland among the common people, who are fond of the resinous sinell which it exhales.

P. Tæda has longer leaves than the wild pine, and larger cones than P. Pinea; the tirnber is like that of the Scotch pine, but has more resin. There are a number of these trees at Woburn Abley, which grow as frecly as the Scotch pine, and the timber, as far as it bas been tried, is superior.

$P$. palustris is remarkable for the length of its leaves, which often excced a font, and hang down in tufts at the end of the branches, having a singular appearance. It grows in a warmer climate than most other pines; produces a valuable timber in America, but has teen but little cultivated in this country. P. strobus forms the connecting link between the pine and the larch tribe, and is the tallest tree of the genus. The bark is smooth and elegant, and the leaves numerous, soft, and of a bluish green. The timber is imported in vast quantities under the name of white pine; it is much used in house carpentry, but is considered less durable than the red deal of Norway (P. sylvestris), or the pitch pine of Canada (P. resinosa). 'The tree seems to be of so delicate a habit, as to prevent our expecting it ever to become very large or valuable in Britain. It has teen a goo' deal cultivated, having formerly been supposed the most valuable tree of the genus, next to the common pine.

The Pinus canariensis seems never to have been well described or unclerstood. Some have taken it for the Pinus Larix, others for the Pinus tæda, whilst others had confounded it with the Pinus maritima, Von Buch, and the late Christian Smith, named it in their catalogue of the veretation of Tenerifi, Pinus canariensis, and they state, that it mhabits that island from the edge of the sea to an elevation of 6700 Parisian feet above the level of the sea; but that the region where it is most abundant may be reckones at frem 4080 
13519 palústris $P h$. 13520 canariénsis Buch. 13521 longifólia $W$. 13522 Strúbus $W$ 13523 Cémbra $W$

2013. A'BIES. Salisb. 13524 Fraséri $P h$. 1352:5 Pícea $W$. 13526 Balsámea $W$. 13527 canadénsis $P h$. 13528 orientális $W$. 15529 clanbrasilián 13530 commúni 13531 álba $P h$. swamp iong-leaved Weymouth Siberian

Fin. Double Balsam Silve Balm of Gilead Hemlockspruce Oriental

Oriental Norway spruce White spruce

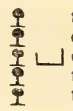
or 40 ... Ap or 4) tm 50 ap Ap

N. Amer. 1730. S s.I Lam.pin.27. t. 20 Pl. r. gen. c. ic. G p.1 I am.pin.29. t.21 Siberia 1746. is s.l I, Li. pi.t.23,24 or $30 \begin{aligned} & \text { Conifcre. } \text { my } S p .10-12 . \\ & \text { Ap Pensylv. 1811. C s.l }\end{aligned}$ tm 30 my Ap Germany 1603. L s.l Lam.pin.46. t. 30 or $50 \mathrm{my}$ Ap N. Amer. 1696. S s.l Lam.pin.48. t.31 or 30 my Ap N. Amer. 1736. S s.l Lam.pin.50, t.32 or 30 my Ap Levant 1825. S co Lam.pin.c. ic.

or $6 \mathrm{my}-\mathrm{Ap}$ tm 100 ap A tm 50 my.jn Ap N. Amer. 1700. S s.J Lam.pin.39.t.26
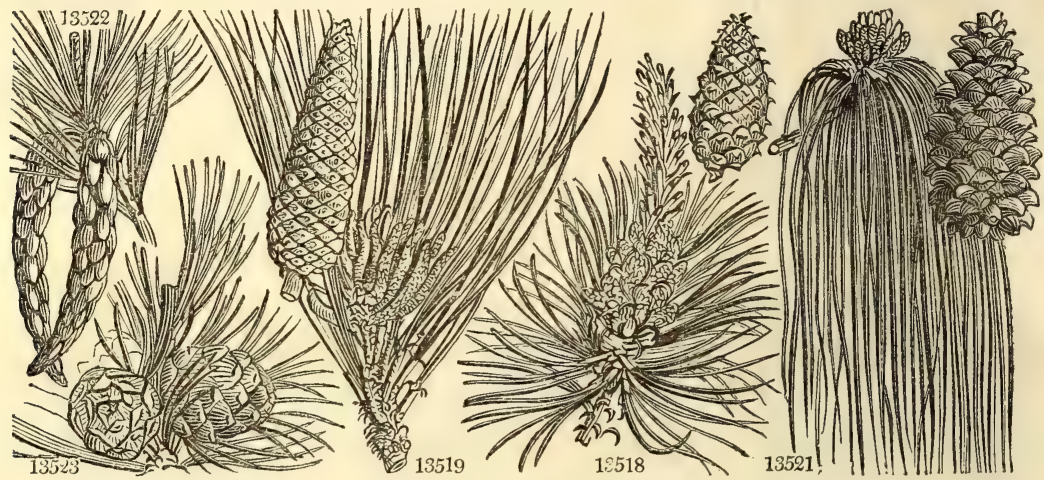

History, Use, Propagation, Culture,

to 5900 feet, where snow falls for about a month. The temperature of the zone M. Decandolle estimates to be similar to that of Scotland, or to the north of France, or of Germany. The wood is resinous, highly inflammable, and is excellent for constructing buildings, being known to continue sound for ages.

The Pinus inops, Jersey pine, pitch or scrub pine, is of middle size, straggling growth, and full of resin. Its branches are tougher than those of any other pine, and might be used for many purposes if its wood were not subject to so early a decay. The pitch pine, $\mathrm{P}$, resinosa, is generally known in its native country by the name of Norway pine; sometixies, particularly among the Canadian French, red pine. It grows in close forests, is very tall, and its bark remarkably smooth and red: the timber is very heavy; for which reason it is rejected for masts, though its shape and size appear to recommend it for that purpose. The scrub pine, P. Banksiana, is a small straggling tree, which in some instances, when growing among barren rocks, does not rise above five or eight feet high, though it will grow to a considerable size when by accident or culture it is brought on geod soil : trees of this species now in Englaind exude a great quantity of resin from their branches. The yellow pine, $P$ variabilis, is most in use for building houses as well as shipping. P. tæda, the loblolly or Oldfield pine, is found in large tracts in the southern states of North America : all the woods seem to be filled with its seeds; for when any piece of cleared land is neglected for any space of time, it will be covered with these pines. It is difficult, and in some cases almost impracticable, to recover lands so run over, as the ground appears to have lost all fertile properties for other vegetation. The long leaved, yellow, pitch, or brown pine, P. palustris, is a beautiful as well as very useful tree. The white or Weymouth pine grows in the state of Vermont to an enormous size; it is the best timber in America for masts.

2013. Abies. According to Bullet, this name is derived from one of the dialects of the Celtic, abetoa, whence abete, Italian, abeto, Spanish, \&c. Hesychius, the Greek grammarian, calls it ably.

Abies communis, Sapin, Fr., Fichtenbaum, Ger., and Abiete, 1tal., is one of the tallest of European firs, with a very straight but not thick trunk. It is a native of the north of Germany and Russia, and particularly abundant in Norway ; its timber being the white deal, and, at an earlier age, the long spars imported from that country and the Baitic. The timber is inferior to that of the common pine in durability and bulk; and being often knotty, is not proportionally strong for horizontal bearings with that timber. White Norway deal, however, is used for a great variety of purposes in building; and the entire trees are more prized than any other
for masts for small craft, for spars both for marine parposes and on land. What constitutes the value of this fir is, that its timber is equally durable at any age, like that of the larch; and what renders it peculiarly adapted for masts, spars, scaffolding, poles, \&c. is its habit, almost in every case, whether standing single or detached, of growing perfectly erect and straight. The tree may be cut for rods, stakes, and scythes, or other implement handles, when the trunk at the base is not more than two inches in diameter, and the bark being kept on it, it will prove almost as durable as the larch. Pontey says, that poles of spruce are so far inferior to those of larch, that they are more apt to crack when exposed whole to the influence of the sun and air: but in ali other respects they are nearly equal to it, and in straightness surpass it. The tree is peculiarly valuable as a nurse, from being evergreen and closely covered with branches, by which radiated heat is retained ; from its conical shape and rigid stem, by which it does not suffocate or whip the adjoining trees ; from its being valuable at whatever age it is thinned out; and from its being an excellent shelter for the most valuable game. It will not, however, grow in elevated situations, where the common pine and larch will flourish. It is also an excellent hedge plant for shelter, but is deficient in point of defence and durability. By incision, it yields a resin, from which, by various preparations, turpentine and Burgundy pitch are formed. The tops or sprouts give the flavor to what is called spruce heer.

A. alba, rubra, and nigra, are American firs of the spruce kind, resembling in their general properties those of Europe. The black spruce is reckoned the most durable : in America it is used for knees for ship_building. where neither oak nor larch can be easily obtained. These knees are not prepared from two diverging branches, as in the oak, but from a portion of the base of the trunk connected with one of the largest diverg ing roots. The timber of the red spruce is universally preferred throughout the United States for sail yards, and, indeed, imported for this purpose into Liverpool from Nova Scotia, where it is also used for constructing casks for salted fish. It is chiefly from the decoction in water of young shoots of the black spruce, and not exclusively from those of the white species, as supposed by Lambert, that the celebrated beer is prepared by fermentation, with a due proportion of sugar and molasses. The essence of spruce of the dealers is prepared by evapolating this decoction to the consistence of honey.

A. picea displays a more stable and majestic form than any of the firs. The upper surface of the leaves is of a fine vivid green, and their under surface has two white lines running lengthwise on each side of the 
13519 Leaves 9 very long, Cones subcylindrical muricated, Stipules pinnatifid ragged persistent 13520 Lvs. very tine and slender of a bright glaucous green, Cones oblong pendulous, Scales obtuse spreading 13521 Leaves 3 very fine very long, Sheath long, Stipules entire deciduous, Crest of anthers convex entire 13522 Leaves quinate, Cones cylindrical longer than leaf lax

13523 Leaves quinate, Cones ovate obtuse, Scales appressed, Nuts hard

13524 Leaves solitary glaucous beneath emarginate, Cones ovate obl. erect, liractes oblong reflexed emarginate 13525 Leaves solitary flat emarginate pectinate, Scales of cone very blunt appressed

13526 Leaves solitary flat emarginate subpectinate suberect above, Scales of the cone in fl. acuminate reflexed 13527 Leaves solitary flat toothletted somewhat distichous, Cones ovate terminal scarcely longer than leaf 13528 Leaves solitary 4-cornered, Cones ovate cylindrical, Scales rhomboid

13529 This is a stunted variety of Abies communis

13530 Leaves solitary 4-cornered, Cones cylindrical, Scales rhomboid flattened repand at end eroded

13531 Leaves solitary 4-cornered incurved, Cones subcylindrical lax, Scales obovate entire

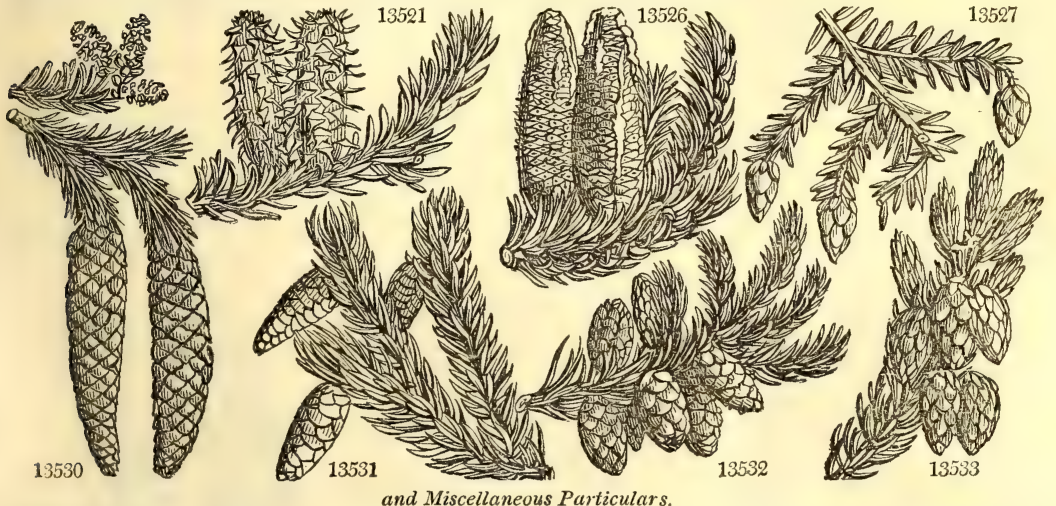

and Miscellaneous Particulars.

midrib, giving the leaves that silvery look which has given rise to the name. The timber is reckoned much inferior in value to that of the common pine, or of the white spruce. It should not be cut till after forty or fifty years growth; at this age, if it has grown in a sheltered rocky steep or dell, it will be found to have produced a great bulk of timber. It is more prolific in resinous matter than any other tree of the fir hind.

A. balsamea is a tree of more delicate habits than the silver fir: its timber is of little value, and the balm or resin procured from it possesses no medical properties superior to those of common turpentine. During summer, the tree sends out a pleasing terebinthinate odor.

A. canadensis is a drooping low evergreeu tree, elegant in appearance, and valuable as growing under the shade or drip of other trees.

All the species of the pine, fir, and larch families, with the exception of one or two, as yet rare in this country, are raised from seeds. The cones are gathered in the winter season, and exposed to the sun, or to at gentle heat on a kiln, in order to facilitate the separation of the seeds. The cones of the cedar shoula be kept for a year at least after they are taken from the tree, before the seed be attempted to be taken out. This is necessary on account of the soft nature of the seeds, and the great quantity of resinous matter which the cones contain when growing, and which is discharged by keeping. Cedar cones are generally imported from the Levant, and the seeds retain their vegetative powers for many years. The cones of the Scotch pine, spruce, and larch, are the principal kinds which are opened by kiln heat. The cones of the Weymouth pine, silver fir, and balm of Gilead fir, give out their seeds with very little trouble. April is the best season for sowing all the species. The soil should be soft and rich, well mellowed by the preceding winter's frost and snow, carefully dug and raked with a long toothed rake as finely as possible. The rarer sorts are generally sown in pots, but the more common in beds. The manner of sowing is by first drawing off the surface of the bed to the depth of half an inch; then drawing a light roller along it to render the surface perfectly even; next depositing the seed ; and afterwards replacing the earth drawn off with a spade as evenly as possible. This is what is technically called bedding in, and is one of the nicest operations of nursery culture. The seed of the Scotch pire and Pinaster require a covering of half an inch in depth; those of the Weymouth pine, three quarters of an inch; and those of the stone pine, an inch and a quarter. The Cedar is generally sown in broad pots, or boxes of light sandy loam, and covered half an inch. The seeds of the larch require a covering of only a quarter of an inch; those of the spruce fir, an inch; those of the silver fir and balm of Gilead fir, from half to three quarters of an inch. The seeds of the American spruce fir are smaller than those of any of the preceding kinds, and therefore require a lighter covering than any of them; one-fifth of an inch is quite sufficient. The strictest attention is required, both in regard to quality of soil, and thickness of covering the seed; for though resinous trees are extremely hardy when grown up, yet they are all very tender in infancy. In sowing the seed, a considerable loss will be sustained by the suffocation of young plants if it is deposited too thick, and by the want of plants if too thin. The judicious gardener will be regulated by the goodiness of the seed, and the size of the foliage of the different species. The raising regular crops of the pine family is reckoned a master piece of nursery culture in the open ground; and as it has been most extensively practised in the Scotch nurseries, it is generally considered as best understood there. (See Sang. Plant. Kal.)

The pine, fir, and larch families benefit less by transplanting in the nursery than the non-resinous trees. And in general, where circumstances admit, the better plan is to remove them at once from the seed-bed at two years old, to where they are finally to remain. The more delicate species, including the cedar and most of the pines, are best transplanted into pots, unless they can be placed at once where they are to remain. The more common pines and firs are transplanted at two years of age into nursery lines, about the middle of April for all the tribe, excepting the larch, which, being deciduous, should be transplanted in February. No description of tree-plants receive so much injury as this tribe from the loss of roots, from the roots being exposed to the air by being kept long out of the soil, or from compression and exclusion of air and moisture by being kept in close bundles, or thick layers. They should, therefore, be finally planted as soon as possible after removal from the nursery; and, indeed, whenever it is practicable, no more should be taken up in one day than can be planted that day or the next. Nor are any plants more easily deprived of the vital principle, by packing and carriage either by sea or land; though, being all evergreens, excepting the larch, they do not readily show it. This has been stated to us by experienced planters in Wales and different parts of lingland, as the reason why so few trees are finally produced from the immense numbers of Scotch pine and larch fir annually sent to the south by the Scotch nurserymen.

Abies Balsamea forms an elegant tree forty or fifty feet high. It grows in high and cold situations in the northern states of North America, where it is called balsam of Gilead fir, fir balsam, and American silver fir. 
13552 rúbra $P h$. 13533 nigra $P^{\prime} / 6$.

2014. LA'RIX. Salisb. 135't commúnis 13535 péndula $W$. 13535 microcárpa 13537 Cédrus $V$. Red spruce Black tm $50 \mathrm{my}$

LARCi. common white * Black
Red
Cedar of Lebanon $\frac{1}{y}$

2015. SCHUBER'TIA. Mirb. SchUBERTIA 13538 dísticha Mirb. deciduous Cypress Cuprés'sus disticha $\mathrm{L}$.

2016. PODOCAR'PUS. L'Her. PODOCARPUS 13539 macrophýllus Hort. long-leaved 13540 verticillátus Hort. whorl-leaved 13541 elongátus $P . S$. African 13542 núcifer $P . S . \quad$ nut-bearing 2017. CUPRES'SUS. $W$. CYPRESS 13543 sempervirens $W$. common. « stricta 135+4 lusitánica $W$ $135+5$ thyoides $W$. 13546 juniperoides $W$. 13547 austrális $P . S$. 2018. THU'JA. $W$. 13548 occidentális $\boldsymbol{I}$. 13549 orientális $I Y$.

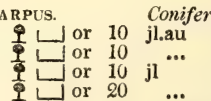
甲 1 or 20

\section{tm $50 \mathrm{my}$}

Ap N. Amer, 1755. S s.1 Lam.pin.43, t.28 tm 50 mr.ap Ap. Germany 1629. S s.1 Lam.pin.53.t.35 tm 30 my Ap N A mer 1739 S s.l Lampin 56. 35 $\mathrm{tm} 80 \mathrm{my}$ Ap N. Amer. 1760. S s.1 Lam.pin.58.t.37 or 60 riay Ap Levant 1683. S s.l Lam.pin.59.t.57 Conifere. $S p .1$.

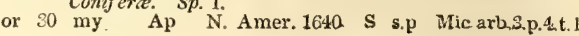
Conifera. $\quad S p .4-6$

$\begin{array}{llllll}\text { Ap } & \text { China } & 1804 . & \text { C } & \text { 1.p } & \text { Bank.ic. Kæ.t.24 } \\ \text { Ap } & \text { Japan } & \ldots . . & \text { C } & \text { 1.p } & \\ \text { Ap } & \text { C. G. H. } & 1774 . & \text { C } & \text { l.p } & \\ \text { Ap } & \text { Japan } & 1822 . & \text { C } & \text { 1.p } & \text { Kæ.amœn.t.815 }\end{array}$
Coniferce. Sp. 5-9.

o or $20 \mathrm{my}$ Ap Candia 1548. S co Dend. brit. 155 upright spreading Cedar of Goa White Cedar $\begin{array}{llll}\text { White Cedar } & \text { or } & 0 & \text { ap.my } \\ \text { African } & \text { Ap } \\ \text { slender-branch. } 9 \text { or } 6 \text { ap.my Ap }\end{array}$ -branch. 9 or 10 ap.my Ap

Arbor Virs

American 9 or 25 my Ap N. Amer. 1596. L co Mi.arb.3.p.29.t.3

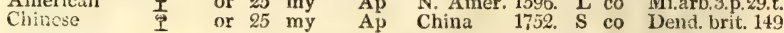

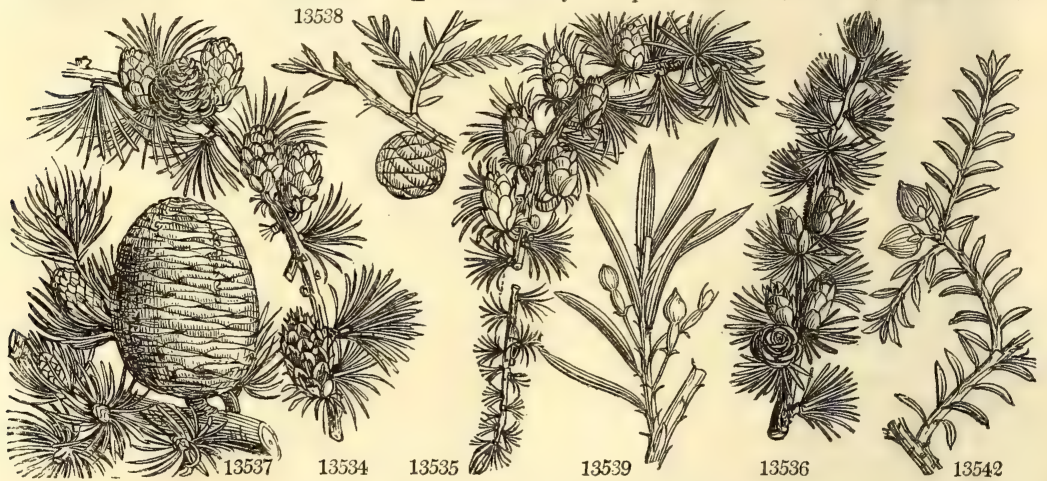

History, Use, Propagation, Culture,

The hemlock spruce is a very elegant tree, and grows in some situations to an enormous size : its bark is a fine substitute for oak-bark in tanning.

2014. Larix. This has also for its root the Celtic word lar, which signifies fat, in allusion to the abundance of resin afforiled by the plant. Even Dioscorides remarks, that Larix is the Gallic name for resin. The authors of the Dictionary of Trevona make the word Cedrus come from zuwjen, sweet-scented, on account of the balsamic odor exhaled by the wood when burned.

L. Cedrus, Cédre, Fr., Cederbaum, Ger., and Cedro, Ital., is unquestionably the most celebrated tree of the genus, and not less remarkable for the irregular grandeur of its form. The general character of its shoot, even when the tree is young, is singularly bold and picturesque, and quite different from that of every other species of the tribe. It is a native of the coldest parts of the mountains of Libanus, Amanus, and Taurus ; but it is not now to be found in those places in great numbers. Maundrell, in his journey rrom Aleppo to Jerusalem, in 1696 , could reckon only sixteen large trees, though many small ones; one of the largest was twelve yards six inches in the spread of its boughs. The forest of Libanus never seems to have reeovered the havoc made by Solomon's forty score thousand howers: so that we have now, as Professor Martyn observes, probably more cedars in England than there are in Palestine.

From the branchy head of this tree, and its aversion to pruning, it is not likely ever to become valuable as timber in this country. When planted for that purpose, it should, as Sang recommendt, be sown in groves, and thus by proximity drawn up with few branches. Much has been said of cedar timber, which borders on the miraculous; as far as experience has gone, it is greatly inferior to that of the common larch, or the wild pine. 'The great use of the cedar is to plant singly on lawns, or in the margin of plantations, where one or two specimens will give force and character to the duilest front of round-headed trees.

L. Communis, Mélexe, Fr., Lerchenbaum, Ger., and Laricio, Ital., is a deciduous tree, and there are two or three species or varieties not yet distinctly ascertained. There is a variety with red and another with white flowers; one with cinerous bark, called the Russian larch, and one with pendulous branches, $\mathbf{L}_{\text {; }}$ pendula and L. microcarpa are considered species or subspecies; the timber of both is said to be harder than that of the common white larch; but these trees have never yet had a fair trial in this country. As there are a few large specimens at Dunkeld and Athol, seeds will probably soon be obtained, and from their progeny a practical estimate rnay be formed of their merits in this country. The red larch trees on the Athol estates do not contain one-third as many cubic feet of timber as the white larch of the same age. The wood is so ponderous that it will scarcely swim on water. (Hort. Trans. iv, 416.) The timber of the white larch has been as much extolled as that of the cedar, and with much more reason. 'The rapidity of its growth is not less remarkable than the durability of the timber. Both have been experimentally proved in the Highlands of Scotland. It is stated by the Duke of Athol, that on mountainous tracts there, at an elevation of 1500 or 1600 feet, the larch, at eighty years of age, has arrived át a size to produce six loads ( 300 cubic feet) of timber; appearing in durability and every other quality to be likely to answer every purpose both of civil and naval architecture. (Hort. Trans. iv. 416.) The tree will arrive at a timber size in almost any situation or soil. Sang, a forest manager of extensive practice, has paid great attention to this tree. "It bears," he says, "the ascendancy over the Scotch pine in the following important circumstances : that it brings double the price, at east, per measureable foot; that it will arrive at a useful timber size in one-half, or a third part of the time, in general, which the pine requires; and, above all, that the timber of the larch, at thirty or forty years old, 
13532 Leaves solitary subulate, Cones oblong blunt, Scales rounded somewhat 2-lobed entire at edge 13533 Leaves solitary 4-cornered erect straight, Cones ovate, Scales elliptical wavy at edge erect

13534 Leaves fascicled deciduous, Cones ovate-oblong, Edges of scales reflexed lacerated, Bractes panduriform 1353.5 Leaves fascicled deciduous, Cones oblong, Edges of scales inflexed, Bractes panduriform sharply actimin. 13536 Leaves fascicled deciduous, Cones roundish few-tl. Scales reflexed, Bructes panduriform bluntly ucuminate 13537 Leaves fascicled rigid evergreen acute, Cones roundish, Scales truncate apprcseed

13538 Leaves distichous spreading

13539 Leaves solitary lanceolate remote

13540 Leaves whorled linear falcate

13541 Leaves lanceolate, Branches whorled

13542 Leaves solitary linear cuspidate remote

13543 Branches quadrang. Lvs. imbric. in 4 rows blunt appr. convex, Cones glob. Scales un:um. Branches straigit

13544 Branches quadrang. Lvs. imbric. in 4 rows appr. glauc. keel. Cones subglob. Sc. mucron. Branches pendulous 13345 Branches compressed, Leaves imbricnted 4 ways ovate warted at base

13546 Leaves linear much spreading decussate

13547 Leaves linear crossing appressed, Branches very slender

13548 Branches 2-edged, Leaves imbricated in 4 rows ovate rhomboid appressed naked warted, Cones obovate 1.549 Branches 2-edged, Lvs. imbricat. in 4 rows ovate rhomboid appressed furrowed in middle, Cones elliptical

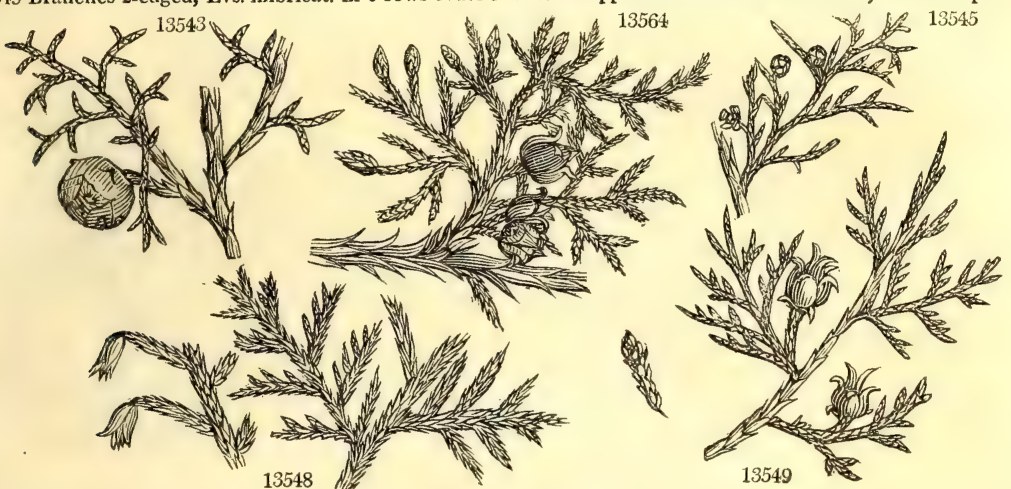

and Miscellaneous Particulars.

when it has been planted in a soil and climate adapted to the production of perfect timber, is in every respect superior in quality to that of the pine at 100 years old. In short, it is probable, that the larch will supersede the Scotch pine in most situations in this island, at no very distant period."

The chief objections to the timber of the larch are its liability to warp and twist; but this Monteath and others have proved may be effectually prevented by barking the trees in spring while growing, and not cutting them down till the following autumn, or even for a year afterwards. This is also said to prevent the timber from being attacked by the dry rot. The bark of the larch is more than half as valuable as that of the oak in tanning; turpentine is extracted from it in the Tyrol by incision; but that being always injurious to the timber, can never be recommended for adoption in this country. (See Encyc. of Gard. 7053. Monteath's Forester's Guide, 2 d edit. p. 234.)

Like all other trees, and especially the resinous tribe, the timber of the larch is much affected by climate and soil. A certain elevation of surface, coldness of climate, and inferiority of soil, is absolutely necessary to pro. duce the timber in perfection. Sang has known it in many places make the most rapid progress for thirty or thirty-five years, and though there was no external signs of disorder, yet when it was felled, the wood had begun to rot in the hearts of the trees, and some were quite hollow a good way upwards. (Plant. Kal. 59.)

Larix pendula, black larch, Tamarack or Hackmatack of the Americans, is a beautiful tree, resembling the European larch in appearance, as well as in the excellent qualities of its wood and bark.

2015. Schubertia. Named in honor of M. Schubert, a Polish botanist. The deciduous cypress grows in extensive swamps, and on the banks of large rivers, from Indian river, Delaware, to Florida, and on the Mis. sissipi ; it is one of the largest trees of the new continent, and one of the most valuable timbers that country produces; it grows to a considerable height in this country, though the extremities of the young shoots are almost every autumn destroyed by frost. The finest specimens are at Sion-house and Blenheim.

2016. Podocarpus. From $\pi 85$ todos, a foot, and zcestos, fruit; in allusion to the stalk of the fruit. The species are increased by ripened cuttings in sand under a hand-glass.

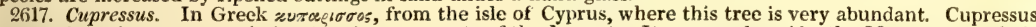
sempervirens is a common timber tree in some parts of the Levant. It was employed by the Moors round their palaces, and both by the ancient and modern Romans in their villas and gardens. The timber of this tree is said to resist the worm, and to be of great durability. The doors of St. Peter's church at Rome were formed of this material, and have lasted eleven hundred years. The Greeks made their cothins of it ; and the mummy chests of Egypt are many of them of this wood. In Crete, Malta, and other places, it is used for the common purposes of building; and when imported into this country it is employed by the cabinet-maker and turner. purposes of building, and when imported into this country it is employed by the cabinet-maker and turner. it is also considered an appropriate tree for burial places. C. Thyoides is an abundant tree in the swamps of New Jersey and Pennsylvania. It is used for fencing and house-building, and is in the highest esteem for shingles and pipe staves. C. lusitanica is a native both of Goa and Japan, and the handsomest tree of the genus. It is easily distinguished from all the evergreens of the Coniferæ by its abundance of very long dichotomous pendent branchlets. The culture of the hardy species of this genus, and also of Thuja, is the same as tomous pendent

2018. Thuja. An alteration of thya, its real name; from $9 v \omega$, to sacrifice. Its wood, which gives out when burnt an agreeable perfume, was used in sacrifices. Thuja occidentalis, Cédre blanc, Fr., is a well known 3 F 4 
13550 articuláta $W . \quad$ jointed $\quad$ or 15 f.my Ap Barbary 1815 . S co Bot. cab. 844 13551 cupressoídes $W$. African $\quad$ I $\square$ or 10 ... Ap Ap C. G. H. 1799. S p,I 2019. TRICHOSAN'THES. $\boldsymbol{W}$. SNAKE Gourn. Cucurbitacee. Sp. 3-12. 13552 Anguína $W$. common OJ $^{*} 4$ my.jn W China 1755. S co Bot. mag. 72 13553 cucumerina $W$. Cucumber-like $*$ J or 4 jn.jl Y E. Indies 1804. S co Rhee.mal.8.t.15 13554 tuberósa $W$. tuberous $\$ \Delta$ or 6 jn.jl $\quad \mathbf{Y} \quad$ W. Indies 1810 . D co Plum. ic. t. 24

2020. MOMOR'DICA. $\boldsymbol{W}$. MOMORDICA. 13555 Balsámina $\boldsymbol{W}$. 13556 Charántia $W$.

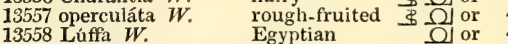

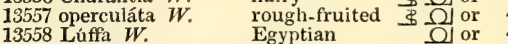
Balsam Apple hairy Cucurbitacee. $S p .5-17$. 13559 Elatérium $\boldsymbol{W}$. Squirting Cucumber* $*$ or 2021. CUCUR'BITA. $W$. Gourd. 13560 ovífera $W$. 13561 lagenária $W$. 13562 aurántia $W$. 13563 Pépo $W$. 13564 verrucósa $W$. 13565 subverrucósa $W$. 13566 Melopépo $W$. ' 2022. CU'CUMIS. $\boldsymbol{W}$. 13568 Colocýnthis $W$. 13569 prophetárum $W$. 13570 Angúria $W$. 13571 africána $W$. egg-shaped egg-shaped
bottle Orange-fruited لم clt 3 jn.au Pumpkin $\quad *$ o clt 16 in.au warted pimpled squash w $O$ clt 12 jn.jl O clt 3 my.s Cucumber. bitter bitter globe African

4 jn.jl Y
Y India
Y
E. Indies 1710. S co

jn.jl Y $\quad$ E. Indies 1710. S co Bot. mag. 2455 jn.s $\quad$ W. Indies 1731. S co Comm rar t 92 jl.au L.Y E. Indies 1739 S co Rum am $5 . t .147$ jn.jl Y S. Europe 1548. D r.m Bot, mag. 1914 Cucurbitacece. $\quad S p .8-13$.

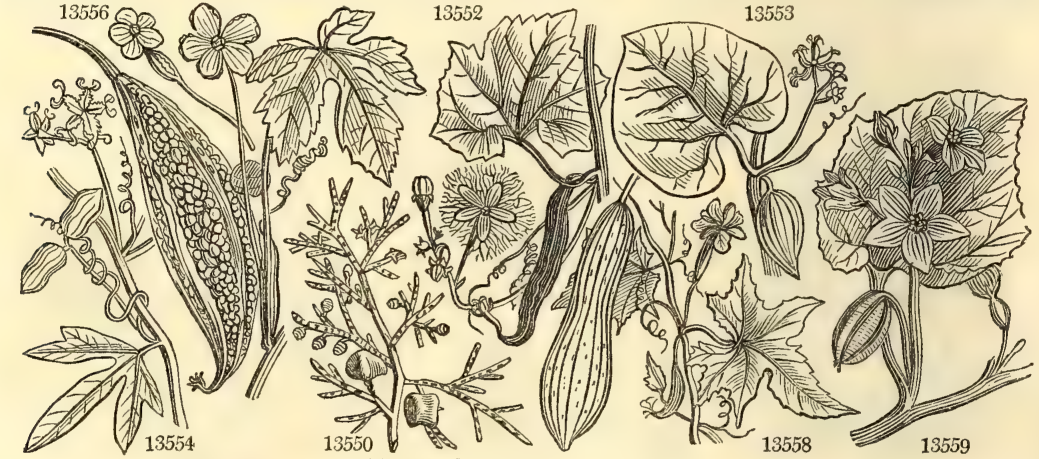

Hiistory, Use, Propagation, Culture,

$\begin{array}{llll}\text { my.s } & Y & \text { S. Europe 1597. S } & \text { co Rum.am.5.t.140 }\end{array}$

$\begin{array}{lll}\text { Cucurbitacea. Sp. } 13-19 . & \\ \text { my.au Y } & \text { C. G. H. 1551. S r.m }\end{array}$

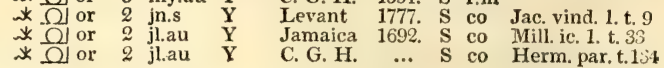

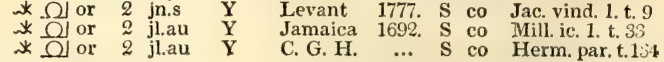

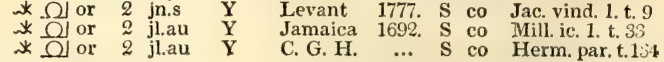

popular evergreen, which, thongh it seldom rises above the height of a shrub here, yet in Upper Canada attains the height of a timber tree, and the wood is considered more durable than any other. The trunk is sawn up into planks and boards for houses and boat-building, and the branches used for posts and fencing. The smaller branches and spray form besoms, and the leaves, made into a salve, are used by the Indians to cure the rheumatism. In England, the timber has been chiefly employed by the turner and cabinet-maker. In its native country the Arbor-vitæ succeds best in soils where the roots have abundance of moisture. It grows tallest in swamps and marshes; in very dry places it never comes to any degree of perfection. The first tree of this species sent to Europe, was planted in the royal garden of Fontainbleau, in the reign of Francis the first. $T$. orientalis is a shrub resembling the other in general appearance. Both these species are readily increased by seeds, cuttings, or layers.

2019. Trichosanthes. From $9 \varphi_{\zeta}$, hair, and $\alpha_{1} \vartheta_{05}$, a flower. The limb of the flower is divided into ten parts, of which the five outer are reversed and acute, the five interior ciliated. T. Anguina is a popular annual, with the habit of the common cucumber. The flowers are cut into many small threads, and the fruit is taper, and nearly a foot long. $T$. cucumerina has smooth fruit of a red or orange color, the size of a pear. In the popular medicine of Malabar, the seeds are used for disorders of the stomach and bowels. Culture as for the common gourd.

2020. Momordica. From mordeo, momordi, to chew; its seeds have an irregular rugose surface, and the appearance of having been chewed. M. elaterium has a large fleshy perennial root, somewhat like that of Bryony. The stems are thick, rough, trailing, branching, with rough leaves on long footstalks. The fruit is an inch and a half in length, swelling like a cucumber, of a grey color like the leaves, and covered with short prickles. When fully ripe, it quits the peduncles, and casts out the seed and juice with great force and to a considerable distance through the hole in the base, where the footstalk is inserted. For medicinal use, the fruit is athered in September, just before it is ripe; and the clear juice which runs from it and that obtained by the expression of the fruit are inspissated, and form the elaterium of the shops. This fruit is a very violent cathartic. It was much employed by the ancients, who regarded every part of the plant as purgative; but Dr. Clutterbuck has proved that this is an error. (Thomson's Lond. Disp. 388.)

M. balsamina has a fleshy ovate fruit, remotely tubercled in longitudinal rows, smooth in the other parts, red when ripe, bursting irregularly, and dispersing the seeds with a spring. This fruit in Syria is famous for curing wounds. They cut it open when unripe, and infuse it in sweet oil, exposed to the sun for some days, until the oil is become red. It may then be applied to a fresh wound dropped on cotton. M. operculata has a green fruit, the top of which falls off when it is ripe like a lid; within it has no pulp, but is dry, and filled with netted fibres, very much interwoven.

2021. Cucurbita. A Latin word signifying a vessel. It is said to be derived from the Celtic cuce, a hollow thing. C. lagenaria has a fruit shaped like a bottle, with a large roundish belly, and a neck very smooth when ripe of a pale yellow color, some near six feet long and eighteen inches round; the rind becoming hard, and being dried contains water; seeds quadrangular oblong, cut off and emarginate at top, three-cornered and beaked at bottom; edge keeled with a double raised line, smoothish, of a pale bay color. The Arabians call the bottle gourd Charrah. The poor people eat it boiled, with vinegar, or fill the shell with rice and meat, and thus make a kind of pudding of it. It grows in all parts of Egypt and in Arabia, wherever the mountains are covered with rich soil. In Jamaica, the shells are generally used for water cups, and frequently serve for bottles among the negroes and poorer sort of white people in the country. A decoction of the leaves 
13550 Branches compressed, Lvs. imbricated in 4 rows lanc. acute appressed warted under end, Cones 4-cornered 13551 Branches round, Leaves imbricated in 4 rows oblong appressed smooth, Cones 4-cornered roundish

13552 Fruit rounded oblong incurved, Leaves cordate repand mucronate toothletted 13553 Fruit ovate acute, Leaves roundish cordate angular repand 13554 Fruit oblong acute, Leaves 5-lobed palmated entire

13555 Fruit roundish ovate narrowed at each end angul. warted, Bract cordate toothed above midd. of pedunc. 13556 Fruit oblong acuminate angular warted, Bract cordate entire below the middle of the peduncle 13557 Fruit elliptical angular warted beaked, Beak deciduous forming a lid 13558 Fruit cylindrical oblong, Furrows chain-like, Bract cordate entire at the base of the peduncle 13559 Fruit elliptical hispid, Leaves cordate hispid blunt toothed, Stem without tendrils

13560 Leaves cordate angular 5-lobed toothletted downy, Fruit obovate striped with lines lengthwise 13561 Leaves cordate roundish obtuse downy toothletted with 2 glands at base beneath, Fruit woody clavate 13562 Leaves subcoraate about 3-lobed cuspidate finely toothletted rough, Fruit globose smooth

13563 Leaves cordate obtuse about 5-lobed toothletted, Fruit roundish or oblong smooth

13564 Leaves cordate deeply 5-lobed : the midale lobe narrowed at base, Fruit roundish elliptical warted

13565 Leaves cordate deeply 5-lobed: middle lobe narrowed at base toothletted, Fruit clav. ellipt. somew. warted 13566 Leaves cordate obtuse about 5-lobed toothletted, Fruit depressed umbonate tumid at edge 13567 Leaves 5-lobed, Lobes sinuate pinnatifid blunt, Fruit elliptical smooth

13568 Leaves multifid, Fruit globose smooth

13569 Leaves cordate 5-lobed toothletted blunt, Fruit globose spiny muricated

13570 Leaves palmate sinuated, Fruit round echinate

13571 Fruit oval echinate, Leaves palmate sinuated, Stem angular

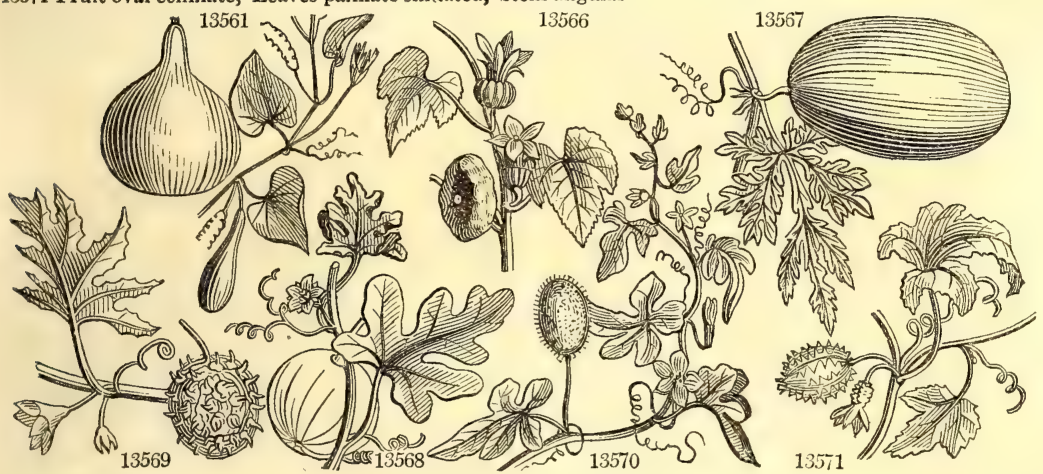

and Miscellaneous Particulars.

is recommended much in purging clysters; and the pulp of the fruit is often employed in resolutive poultices : it is bitter and purgative, and may be used instead of Coloquintida.

C. pepo, Patisson, Fr., has hispid branchy tendril stems, which in good soil will extend forty or fifty feet in a season, and cover an eighth part of an acre. The fruit is oblong, ovate, varying in form and size; some not less than four feet in circumference. In some parts of England the pompion (corruptly pumpkin) is sometimes planted by cottagers on dunghills, and suffered to trail at length over the grass of an orchard. When the fruit is ripe, they cut a hole on one side, and having taken out the seeds, fill the void space with sliced apples, adding a little sugar and spice, and then, having baked the whole, eat it with butter, under the name of pumpkin pie. On the continent the fruit, both unripe and ripe, is used in soups, stews, and fried in oil or butter. The tender tops of the shoots boiled as greens are much more delicate than the fruit. C. aurantia is more tender than the common pompion. The fruit is small, round, of a bright yellow when ripe, and may be used like those of the other species. C. verrucosa has a small round fruit, with a woody rind In America it is gathered when half grown, and boiled to eat as a substitute for greens; but for this purpose this and most of the species are inferior to the succade Gourd.

C. melopepo, Potiron, Fr., Pfebin Kürbiss, Ger, and Popone, Ital, has a large fruit, reddish yellow or yellowish-white within and without, roundish, but often flatted at top and bottom; torulose, and sometime warted. It is cultivated in America as a culinary vegetable. C. Citrullus, Pastèque, Fr., Wassermelone, Ger, and Cocomero, Ital., is readily distinguished from all the other species by its deeply cut leaves. 'The fruit is roundish, large, smooth, often a foot and a half in length, with a white icy flesh, streaked with dark red and black seeds. It is much cultivated in the warm countries of Europe, and also in Asia, Africa, and America, for its cooling quality. It serves the Egyptians for meat, drink, and physic. It is eaten in abundance during the season, which is from the beginning of May until the overflowing of the Nile; that is, to the end of Julv or beginning of August. It is the only medicine the common people use in ardent fevers. For this purpose they have a variety that is softer and more juicy than the common sort: when this is very ripe, or almost putrid, they collect the juice, and $\mathrm{mix}$ it with rose-water and a little sugar. This fruit should be eaten by Europeans with great caution; when taken in the heat of the day, whilst the body is warm, colics and other bad consequences often ensue, and it is well known that persons are much troubled with worms at the time this fruit is in season.

The Succade Gourd, a variety of C. ovifera, has an elliptic oblong pale-yellow fruit, by far the best for culinary purposes of any species of the genus. When very young, it is good tried with butter; when about half grown, it is excellent either boiled as a substitute for greens, or stewed in slices with rich sauce; when full grown, it is used for pies. Sabine, who has cultivated most species of Cucurbita, considers the vegetable marrow without a rival. (Hort. Trans. vol. ii. 255.)

All the species may be raised on a hot-bed in April, and transferred to the open garden at the end of May, under a warm aspect and in a rich soil ; or they may be sown in a trench filled with hot dung, where they are finally to remain. Their after culture is of the easiest description.

It is not very generally known, that the tender tops of all the species of the Cucurbita and Cucumis families, whose fruit may be eaten, when boiled form a very tender substitute for greens.

2022. Cucumis. A word with the same derivation as the last. C. Colocynthis has fruit the size and color of orange ; the pulp light, spungy, and white, and most intolerably bitter. When ripe, it is peeled and dried in a stove, and in this state it is imported from the Mediterranean under the name of coloquintida. Medicinally, it 
13572 acutángulus $W$ : 13573 Mélo $W$. 1357. Ducláim $W$. 13575 Cháte $W$. 13576 pubéscens $W$. 13577 satívus $W$. 13578 flexuósus $W$. $13 \tilde{7} 79$ anguínus $W$. 13580 maderaspátanus 2023. SIC'YOS. $W$ 13581 anguláta $W$. 13582 vitifólia $W$. 2024. BRYO'NIA. W 13583 scábra $W$. 13584 tríloba $W$. 13585 verrucósa $W$. 13586 grándis $W$. 13587 epigæ'a $W$. 13588 scabrélla $W$ 13589 latebrósa $\boldsymbol{W}$. 13590 dioíca $W$. 13591 álba $W$. 13592 nítida Link. 13593 crética $W$. 13594 quinquéloba $T h$ 13595 ticifólia $W$. 18596 palmáta $W$. 13597 laciniósa $W$. 13598 africána $W$ 13599 dissécta $W$

2025. ANDRACH'NE 13600 telephioídes $\boldsymbol{W}$.

2026. STILLIN'GIA. $W$ 13601 sylvática $W$ 13602 ligustrina $W$. 13603 sebífera $W$. acute-angled Melon

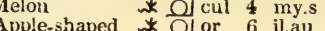
* 6 jl.au pubescent $\quad *$ \& or 3 jin.s common $\quad *$ O cul 4 jl.s Snake $\quad *$ ل Serpent * 의 or 6 my.s * Oل or 3 jl.au

$\mathbf{Y}$
$\mathbf{Y}$
$\mathbf{Y}$
$\mathbf{Y}$
$\mathbf{Y}$
$\mathbf{Y}$
$\mathbf{Y}$
$\mathbf{Y}$
$\mathbf{Y}$

.

India 1092. \& co Jac.vin.3.t.73,7t ….. 1570. S r.m Sabb. hort. t. 65 1705. S r.m Bot. rep. 548 Levant 1759. S co Alp.ægypt. t.117 E. Indies 1573. S r.m Sabb. hort. t. 63 E. Indies 1597. S r.m Ger.herb.763.f.3 E. Indies $\ldots$ S r.m Rumph. 5. t. 148 E. Indies 1805. S co Pluk.al, t.170.f.2 Single-seeden Cucunber. Cucurbitacea, Sp. 2-6. angular-leaved $\$ 0$ cul 3 jl.s $Y$ Y N. Amer. 1710. S co Plu.phyt.t.26.f.4 Vinc-leaved \$ $\mathrm{O}$ cul 3 ji.s $\quad \mathrm{Y} \quad \ldots . .$. ... $\mathrm{\text {S }}$ co BRYoNy.

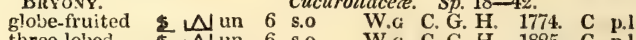
$\begin{array}{llllll}\text { three-lobed } 5 \mathbb{N} \text { un } 6 & \text { s.o } & \text { W.G C. G. H. 1825. C } & \text { p.1 }\end{array}$ rough \$ $\mathbb{N}$ un 4 ... W.G Canaries 1779. D co great-flowered $\$$ un 8 my.au W. E Indies 1783, C p.l R.am.5.t66 f bristly

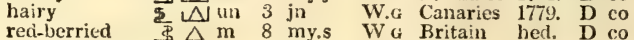
redi-berried $\$ \Delta \mathrm{m} 8$ my.s WG Britain hed, D co Eng. bot. 439 black-berried $\$ \Delta m \quad 8$ jn.jl W.g Europe 1807. D co Lam. ill. t. 796

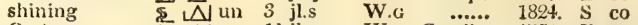

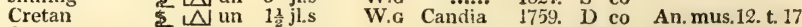
five-lobed $\quad \mathbb{N}$ un 3 jn.o Br C. G. H. ... D co Bot. reg. 82

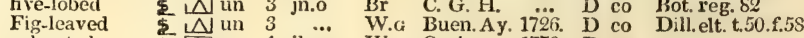
palmated 5 un 4 jl.au W.a Ceylon 1778. D co

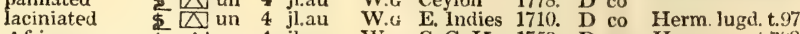

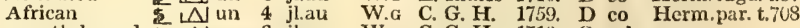
smooth-leaved $2 \mathbb{L}$ un 3 jl.au W.g C. G. H. 1710. C p.I

Euphorbiacea. Sp. 1-2.

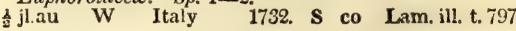

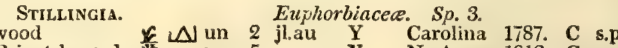

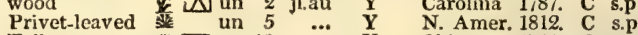

Tallow-tree $\square$ ec $10 \mathrm{~s} \cdots \quad$ Y China 1703. C 8.p Plu.am. t.390.f.2

2027. Phyllan'Thus. $W$. Puyllanthus. Euphorbiacea. Sp. 16-60.

13604 obovátus $W$. annual O un $\frac{a}{4}$ jl.au Ap N. Amer. 1803. 13605 maderaspaténsis $\boldsymbol{W}$. Madras

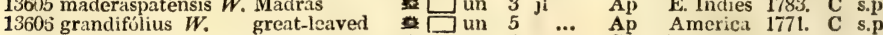
E Indies 1802. C s.p 13608 turbinátus $B, M$ shining-leaved $\quad$ pr 2 jl G G China … C s.p Bot. mag. $186^{\circ}$ 13609 reticulátus Hort. netted $\square$ pr 3 au.s $R \quad$ E. Indies … 13610 fraxinifólius Hort. Ash-leaved $\quad$ pr au.s G E. Indies 18\%9. C s.p Bot. cab. 839 13611 mimosoídes $W$. Mimosa-like pr $^{10}$ au.s G Caribbees 1817. C s.p But cab. 721 13612 Conámi $W$. Brazilian $\square$ pr 6 ji 13613 racemósus $W$. racemed $\square$ pr $1 \frac{1}{2} \mathrm{ji}$.au 13615 polyphýllus $W . \quad \begin{aligned} & \text { Indian annual many-leaved } \\ & \text { pr }\end{aligned}$

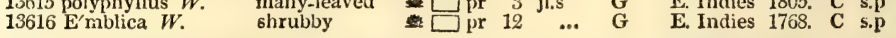
Aub. gui.2. t. 354 Rhe.mal.10.t.15

Bot. cab. 548

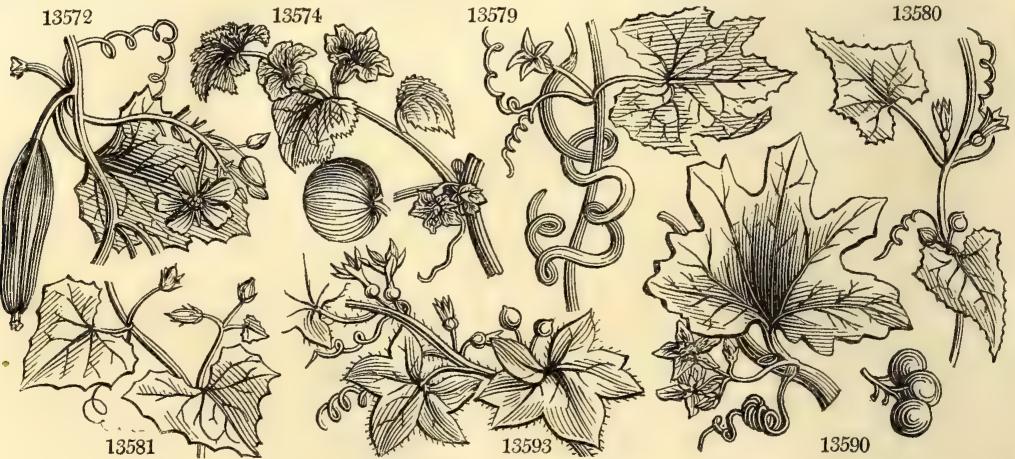

History, Use, Propagation, Culture,

is a very powerful drastic cathartic, requiring to be employed with caution, on account of its violent effects. When given alone, even in moderate doses, it purges vehemently, producing violent gripings, bloody ejections, and not unfrequently convulsions and inflammations of the bowels. (Thom. Lond. Disp. 271.)

C. sativus and Melo ( $\mu \varepsilon \lambda$ iov, an apple) are too well known to require farther notice in a work of this description. C. anguria has hispid angular stems, and small flowers like those of Bryony. The fruit is of the size and shape of a pullet's egr, of a dark-green color, and prickly like a hedgehog. It is eaten green, or with other herbs in soups in the West India Islands, and is esteemed an a reeable and wholesome ingredient. C. propheherbs in soups ine fruit smaller than a melon; the odor nauseous, and the taste as bitter as Coloquintida. tarum has a roundish The fruit of $\mathrm{C}$. acutangulus is very insipid, but in India is eaten boiled and pickled. C. Chate has a roundish fruit almost like that of the melon; the taste is somewhat sweet and cool, but not so cool as the water melon. apprehend. The culture of all the species is similar to that of the common cucumber.

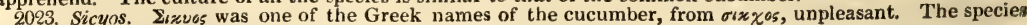
are trailing plants like those of Cucumis, but with much smaller fruits.

2024. Bryonia. From Gevw, to push or grow rapidly, in allusion to the manner of its growth. B. alba and dioica, differ in little else besides the color of the berries, and by some are considered one species. Goats are 
13572 Leaves roundish angular, Fruit with 10 acute angles

13.73 Argles of leaves rounded, Fruit torulose

13574 Angles of leaves rounded, Fruit spherical with a retuse nipple

13575 Hirsute, Angles of leaves entire toothed, Fruit fusiform narrowed at each end hairy

13.576 Leaves cordate subangular acutish finely toothed scabrous, Fruit elliptical blunt downy

13.577 Angles of leaves straight, Fruit oblong rough

13578 Leaves angular somewhat lobed, Fruit cylindrical furrowed curved

13579 Leaves lobed, Fruit cylindrical very long smooth doubled up

13580 Leaves cordate entire toothletted, Fruit globose smooth

13581 Leaves cordate with an obtuse angle, 5-angular toothletted smooth

13582 Leaves roundish-cordate with a recess 5-lobed toothed hairy viscid

13583 Leaves cordate angular toothed rough with callous dots above and hairs beneath, Fl. in umbels 13584 Leaves 3 -lobed smooth above rough beneath

13585 Leaves cordate angular above and the veins beneath covered with callous dots, Tendrils simple

13586 Leaves cordate angular entire smooth with callous dots above and 5 glands at the base beneath

13587 Leaves 3-lobed rough toothed, Lateral lobes angular somewhat 2-lobed, Fl. axillary somewhat umbellate 13588 Lvs. S-lobed tcothed hispid on each side, Lat. lobes dilated angular : middle elong. Stem muricato-hispid 13589 Leaves somewhat 3-lobed hairy narrowed at base

13590 Leaves cordate palmate 5-lobed toothed with callous dots, Fl, racemose diceious

13541 Leaves cordate 5-lobed toothed rough with callous dots, Flowers racemose

13592 Leaves cordate 5-lobed apiculate hairy, Peduncles in uimbels

13593 Leaves cordate 5-lobed entire with callous asperities on each side

13594 Leaves 5-lobed toothletted scabrous above, Peciuncles 1-flowered

13595 Leaves 5-lobed somewhat toothletted, Lobes obtuse, Petioles and stem hispid

13596 Leaves palimate smooth 5-parted: segments lanceolate repand serrated

13597 Leaves 5-parted palmate, Segm. oblong lanc. acuminate serrated, Petioles muricated, Peduncles 1-flowered 13598 Upper leaves 5-parted palmate, Segments oblong cut-toothed : lower cordate angular toothed

13599 Lvs. 5-parted palmate, Segm. pinnatifid linear revolute at edge rough, Flowers in umbels, Berries acute

\section{Procumbent herbaceous}

13601 Leaves sessile oblong blunt narrowed at base serrulate, Stem herbaceous 13602 Leaves petiolate lanceolate narrowed at each end entire, Stem shrubby 13603 Leaves stalked rhomboid acuminate entire, Stem arborescent

13604 Leaves obovate bluntish, Flowers twin axillary stalked, Stem branched round erect 13605 Leaves lanceolate cuneate blunt mucronate, Flowers solitary stalked axillary, Stem shrubby branched 13606 Leaves ovate-oblong blunt mucronate, Flowers axillary in threes, Branches compressed 3-cornered 15607 Leaves elliptical ovate blunt narrowed at base, Fls. axillary aggregate diœcious, Branches square compr. 13608 Leaves simple orbicular-ovate lucid, Flowers axillary: male turbinate nodding 13609 Leaves oblong obtuse netted with red veins beneath, Flowers racemose and fasciculate 13610 Leaves elliptical acute at each end, Stipules ovate acute as long as petiole, Flowers fascicled

13611 Lvs. pinn. flower-bearing : leaflets oblong attenuated at base and narrower on one side, Fls. axill. aggreg. 13612 Lvs, ovate acute, Fls. axill. somew. umbelled, Pedunc. filiform with 2 bractes at base, Branchlets compr. 13613 Leaves lanceolate acute, Flowers terminal about 3, Branches pinnæform 2-edged

13614 Lvs. pinn. fl. bearing : leaf. elliptical obtuse, Pedunc. axill. lower usually twin and male; upp. solit. fem. 13615 Lvs. pinn. fi. bearing: leaflets linear obtuse mucronate, Flowers axillary solitary; the female uppermost 13616 Leaves pinnate fl. bearing : leaflets linear sharpish, Flowers axillary clustered, Petioles round downy

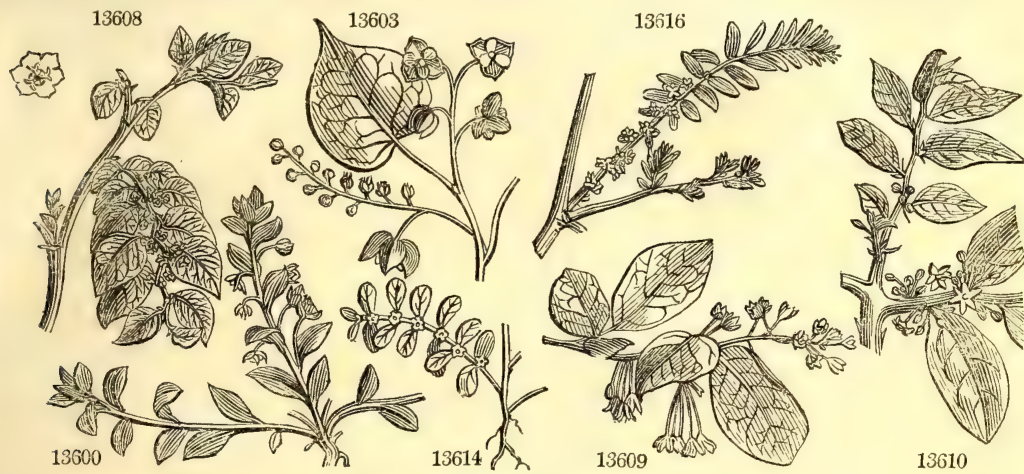

and Miscellaneous Particulars.

the only quadrupeds said to eat this plant. The root grows to a vast size. Gerarde says, "the queene's chiefe chirurgeon, Master William Goodorous, shewed me a roote heereof, that waied halfe an hundred waighte, and of the bignesse of a childe of a yeere old." To this Linnæus ascribes the quickness of its growth, though it springs late. The roots have been formerly by impostors brought into an human shape, carried about the country, and shewn for mandrakes to the common people. The method which these people practised, was to open the earth round a young thriving Bryony plant, being careful not to disturb the lower fibres of the root to fix a mould such as is used by those who make plaster figures close to the root, fastening it with wire to keep it in its proper situation, and then to fill in the earth about the root, leaving it to grow to the shape of the mould, which is effected in one summer. This root is a famous bydragogue, and highly purgative and acrid.

2025. Andrachne. The Greek name of the Purslane. The modern plant bears some analogy to that of the Greeks, in its thick and fleshy leaf. Plants of little beauty, and the easiest culture.

2026. Stillingia. Named after Dr. Benjamin Stillingfleet, an English botanist. S. Sebifera is the tallow-tree of China. An oil is expressed from the kernel, which hardens by cold to the consistence of common tallow, and by boiling becomes as hard as bees' wax. Stillingia sylvatica is considered a specific in cases of syphilis.

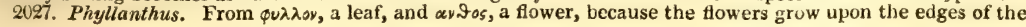


13617 latifólius $W$.en. Sea-side Laurel $\square \mathrm{pr} \quad 2$ au o $\quad \mathrm{R} \quad$ Jamaica 1783, C s.p Bot. mag. 1021 Xylophýlla latifolia W.

13618 angustifólius $W$. en. narrow-leaved $\square$ pr 2 jl.au $\quad \mathrm{R} \quad$ Jamaica 1789. C $\mathrm{\text {s.p }}$ 13619 falcátus W. en. $\quad$ sickle-leaved $\square$ pr 2 jl.au $\quad$ R $\quad$ Bahama I.1699. C 8.p Bot. rep. 331 2028. AlEURI'TES. $W$. Aleurites 13620 tríloba $W$ 2029. OMPHA'LEA. $W$. Omphales. 13621 triándra $W$ long-leaved

2030. HIPPO'MANE, $W$. MANCHINEEL 13622 Mancinélla $W$ common

2031. SA'PIUM. $W$ 13623 aucupárium $W$

2032. CRO'TON. $W$ 13624 variegátum $W$. 13625 lineáre Jac. 13626 maritimum $W$ 13627 palústre $W$. 13628 glabéllum $W$. 13629 tinctórium $W$. 13630 argénteum $W$ 13631 Tiglium $W$. 13632 Eleutéria $W$ 13633 micans $S w$. 13634 púngens $W$ 13635 penicillátum $W$ 13636 aromáticum $W$ 13637 húmile $W$ two-glanded Euphorbiacea. Sp. 1-4.

$9 \square \mathrm{ft} 10 \quad \ldots$ Ap Society Is. 1793. S r.m Euphorbiacere. Sp. 1-3.

$\square$ or $15 \mathrm{jn} . \mathrm{jl} \mathrm{G}$ Jamaica 1763. C p.l Bot. cab. 519 Euphorbiacece. Sp. 1.

Croton. variegated
or 10
prosemary-leav sea-side leav. pr 6 jl marsh Laurel-leaved $\square$ or 6 ... officinal $\mathrm{O}$ dy 3 jl silver-leaved [0] un 2 jl.au purging $\square \mathrm{m} 10 \mathrm{au} . \mathrm{s}$ Sea-side Balsam Sea-side Balsam
glittering pungent pencilled aromatic humble Molucca moiuccánum $W$. $\mathbf{P}$. 13639 Astroítes $W$. woolly un 6 jl.au 13640 lobátum $W$. various-leaved [0] un 2 jl.au painted $\square$ or 4 jl.au ... G W. Indies 1690 . L r.m Jacq.amer. t.159 13642 tomentósum Link, downy 13643 napæifólia $W$. 13644 gossypifólia $W$ 13645 integérrima $W$ 13645 integerrima $W$ panduræfólia $W$ 13646 panduræéolia Napæa-leaved Cotton-leaved spicy

fiddle-leaved angular-leaved 13648 multífida $W$. multifid

\section{Euphorbiacea. Sp. 9-21.}

数 $\square$ or 3 on 3 my.au G $\quad$ W. Indies 1690. S 1.p Bot. cab. 117 - $\square$ or 3 my.au R Cuba 1809. S r.m Bot.mag. 1464 or 4 my.au S Cuba 1800. S r.m Bot. mag. 6(44 $\square$ or 4 ... G $\quad$ S. Amer. 1731. S r.m Jac.vind. 3. t. 63 $\square$ or 3 jn.au G S. Amer. 1731. S r.m Jac.vind. 3. t.
S. Amer. 1690. S r.m Par. lond. 91

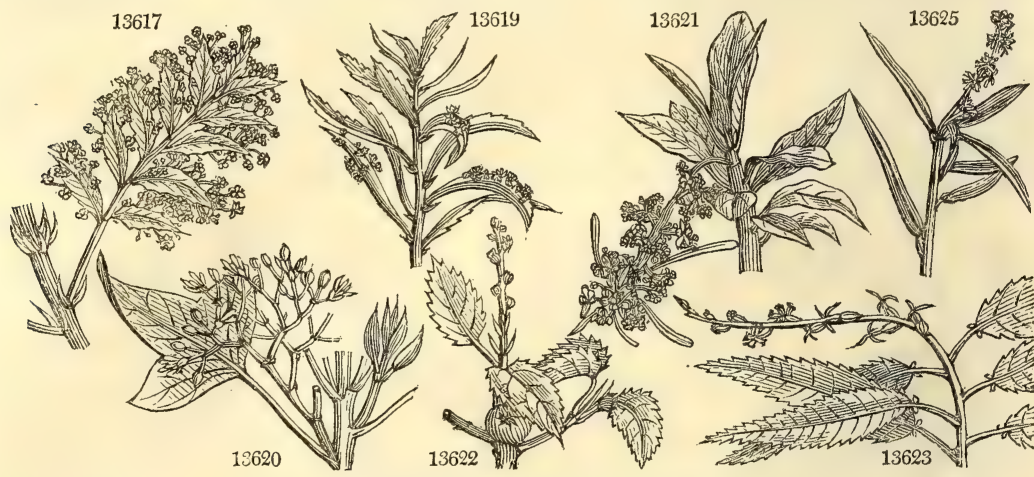

History, Use, Propagation, Culture,

leaves. Many of the species of this genus are remarkable for the neatness of their foliage and general aspect. The abolished genus Xylophylla, which is now included in Phyllanthus, is very generally cultivated on account of the pretty and at the same time singular appearance of its leafless leaf-like branches, covered over at the edges with multitudes of pink flowers. All the species require common stove culture.

2028. Aleurites. From $\alpha \lambda \varepsilon ; \alpha \rho$, flour, all the parts of the plant seeming to be dusted with a farinaceous substance. A handsome plant of easy culture, and ripe cuttings with their leaves untouched, root in sand under a hand-glass.

2029. Omphalea. A curtailment of Omphalandria, a name under which Dr. Patrick Browne, in his History of Jamaica, first described the plant. He formed it from oupoios, a navel, and avme, a stamen. because the male organs are collected in a fleshy navel-like mass occupying the centre of the flowers. It grows freely in light loamy soil, and cuttings, with their leaves uninjured, root in sand under a hand-glass.

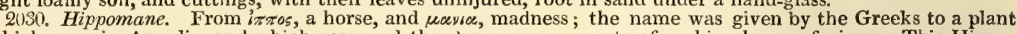
which grew in Arcadia, and which possessed the dangerous property of making horses furious. This Hippomane must not, however, be confounded with that of Virgil (third Georgic), which is an animal substance.

The Manchineel-tree grows to a vast size on the sea coast of the Caribbee Islands and neighbouring continent. The leaves are ovate, serrated, acute, and very shining. The fruit fall off from the tree spontaneously, and pave all the ground with their numbers. They are highly poisonous, and are said to be eaten by the sea-crabs, which collect about the trees in vast numbers. But this is supposed by Jacquin to be a vulgar error. The whole tree abounds with a white milk, which is highly poisonous, and so very caustic, that a single drop placed upon the skin instantly causes the sensation of a hot iron, and in a short space raises a blister. It is a common belief that to sleep beneath the branches is death; but Jacquin and his companions reposed under it for three hours at a time without inconvenience. The wood is a most beautiful material for furniture, being finely variegated with brown and white, and susceptible of a high polish. The workmen who fell the trees, first kindle a fire around the stem, by which means the juice becomes so much inspissated as not to follow the blows of their axes. Whole woods on the sea-coast of Martinique have been burnt, in order to clear the country of such a dangerous pest. 
15617 Leaves pinnate lanceolate acuminate subcrenate coriaceous, Flowers stalked

13618 Leaves pinnate linear-lanceolate lined crenate, Flowers stalked hermaphrodite

13619 Leaves scattered linear-lanceolate subfalcate crenate, Flowers subsessile

\section{Leaves 3-lobed}

13621 Leaves oblong blunt very smooth, Flowers triandrous, Stem arborescent

\section{Leaves ovato-serrated}

13623 Leaves oblong acuminate serrulate, Petioles with 2 glands at the end

13624 Leaves lanceolate entire smooth variegated stalked

13625 Leaves linear entire stalked downy beneath

13626 Leaves elliptical entire bluntish hoary downy beneath stalked, Spikes terminal few-flowered

13627 Leaves ovate lanceolate plaited serrated scabrous

13628 Leaves ovate bluntish entire smooth, Fruit stalked

13629 Leaves ovate rhomboid repand entire at base hoary on each side, Pedunc. terminal about 3-ft.

13630 Leaves ovate serrated at end hoary downy beneath, Stipules ciliated, Spikes terminal subcapitate bracteate

13631 Leaves ovate acuminate serrated smooth with 2 glands at base, Petioles shorter than leaf, Racemes term.

13632 Leaves ovate acuminate entire smooth silvery with scales ben. Racemes comp. axillary, Stem arborescent

13633 Leaves cordate ovate attenuate somewhat toothletted warted and green above, silvery and shining beneath

13634 Leaves cordate acuminate serrulate rough above downy beneath with 4 glands at the base

13635 Lv, round

13636 Leaves oblong subcordate serrulate scabrous downy beneath with 2 glands at the base, Raceme terminal

13637 Leaves ovate acute subcordate entire scabrous above downy beneath

13638 Leaves subcordate angular blunt repand scabrous downy beneath

13639 Leaves obl.-lanc. subcordate scabrous downy beneath and with 2 glands at base, Branches densely downy 13640 Leaves 3-5-lobed serrated with hairy petioles, Stem herbaceous

13641 Leaves oblong-lanceolate obtuse at base variegated and stained with red, Spikes axillary suberect

13642 Downy, Leaves cordate roundish blunt repand greenish above hoary beneath

13643 Ieaves palmate 7-lobed hispid beneath stinging: lobes pinnatifid, Petiole with 1 gland at end

13644 Lvs. cord. 5-lobed serrated fringed with glands, Branched glandular hairs in axillæ of leaves and petioles 13645 Leaves ovate acuminate entire very smooth, Racemes subcymose

13646 Leaves oblong subpanduriform acuminate entire angular at base with 2 teeth on each side

13647 Leaves cordate angular

13648 Leaves palmate 11-lobed smooth : lobes pinnatifid cuneate, Stipules setaceous multifid

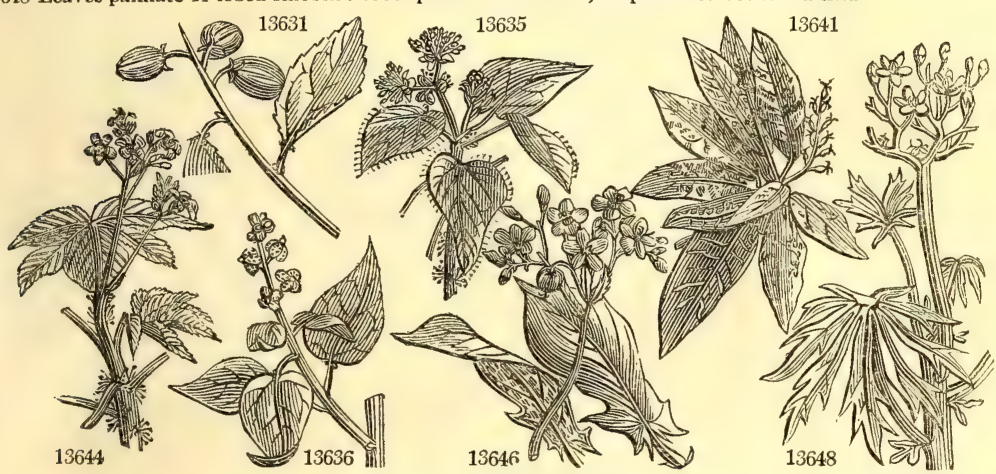

and Miscellaneous Particulars.

2031. Sapium. A name unaer which Pliny indicates a sort of pine, so named from the abundance of resin which it produces; from sap, fat or greasy in Celtic. The Americans employ the juice of Sapium aucuparium as bird-lime, for catching parrots and other birds. For this purpose they cut oft a limb of the tree, and the next day collect the sap which has flowed out and become inspissated. They call it Mangle cautivo. The juice is also burned in lamps. Cuttings root freely in sand under a hand-glass.

2032. Croton. The Greek name of a certain insect called ricinus by the Latins, which the fruit of Croton resembles.

Croton 'Tiglium affords an oil used in medicine, which is so powerfully irritating, that a small drop placed upon the tougue, has the effect of exciting an irritation along the whole intestinal canal, which does not soon upon the tongue, has the effect of exciting an irritation along the whole intestinal canal, which does not soon
subside. It is usually employed in mixture with oil of almonds, in order to weaken its too violent powers. C. lineare in its general appearance resembles rosemary, and is called wild rosemary in Jamaica. C. tinctorium is used to dye both silk and wool of an elegant blue color, and the juice is used to color wines and jellies. The substance for this purpose is called Turnsol, and is made of the juice which is lodged between the calyx and the seeds : this, if rubbed on cloths, appears at first of a lively green, but soon changes to a blueish purple; if these cloths are put into water, and afterwards wrung, they will dye the water of a claret color; the rags thus dyed are brought to England, and sold in the druggists' shops by the name of Turnsol.

C. Eleuteria furnishes the Cascarilla bark, which is chiefly imported from Eleutheria, one of the Bahama Islands. It consists of pieces of about six or eight inches long, scarcely one-tenth of an inch thick, quilled, and covered with a thin whitish epidermis. It has a pleasant spicy odor, and a bitter warm aromatic taste. It is very inflammable, and is easily distinguished from all other barks by emitting, when burnt and extinguished, a fragrant smell resembling that of musk. Medically, this bark is a valuable carminative and tonic, and is an excellent adjunct to the Cinchona bark in fevers. C lacciferum, a plant not yet in gardens, is one among several species on which the gum lac is said to be produced. Some of the spines we are in possession of, are several species on which the gum lac is said to be produced. Some of the spines we are in possession of, are
much admired for their variegated leaves: all of them are freely propagated by cuttings with the leaves on, planted in sand, and plunged in moist heat under a hand-glass.

2033. Jatropha. From iøлৎov, a remedy, and $\varphi \propto \gamma \omega$, to eat. The J. Manihot (Mandioka, Brazilian) or Cassa- 
13649 Mánihot $W$. 13650 úrens $W$. 13651 herbácea $\boldsymbol{W}$.

2034. RI'CINUS. $W$. 13652 commúnis $W$ 13653 viridis $W$ 13654 africánus $W$. 13655 lívidus $W$. 13656 inérmis $W$. 13657 armátus $B . R$. 13658 Tanárius $W$.

2035. HU'RA. $W$. 13659 strépens $W$ en 13660 crépitans $\dot{W}_{\text {. }}$ en

(STERCU'IIA 13661 Balánghas $W$ $13 b^{\circ} 62$ crinita $W$. 13663 úrens $W$. 13664 platanifólia $W$. 13665 foe'tida $W$ 2037. HERITIE

2058. ACA'LYPH 13667 virgínica $W$. 13668 caroliniána $W$. 13669 ciliáta $W$. 13670 pauciflúra $\boldsymbol{W}$.en. 13671 brachystáchya $\boldsymbol{W}$.en 13672 índica $W$

13673 alopecuroídea $W$. 13674 diversifólia Jacq. 13675 integrifólia $I V$. 13676 rúbra $W$. 13677 hispida $W$. 13678 cuspiciáta $W$ 13679 virgáta $W$.

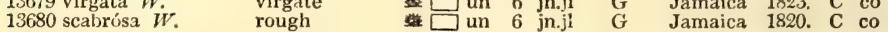
Cassava stinging

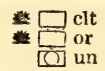
\begin{tabular}{lll}
3 & jl.au & G \\
3 & my.jl & G \\
\hline
\end{tabular}
annual

Palma-Ciristi.

Castor-oil plant

green

African

livid-leaved

smooth-capsul.

rough-capsuled

scollop-leaved

Sandbox-Tree. unequal-tooth. equal-toothed

. Sterculia.

coronet-flower. hairy-capsuled stinging

Plane-tree-lvd $\$$ or $10 \ldots$ fetid

의 $\mathrm{m} \quad$ jl.au G

S. Amer. 1739. S r.m Sloan.jam.1.t.85 Brazil 1690. S r.m Bot. cab. 478

VeraCruz 1759. S r.m Reliq,hou.6.t.15

2039. IALECHAM'PIA. $\boldsymbol{W}$. DALECIA MPIA. Euphorbiacece. Sp.1-17.

13681 scándens $\boldsymbol{W}$. climbing $\square$ un 12 jn.j1 G $\quad$ W. Indies 1739. C l.p Jac.am.252.t.160

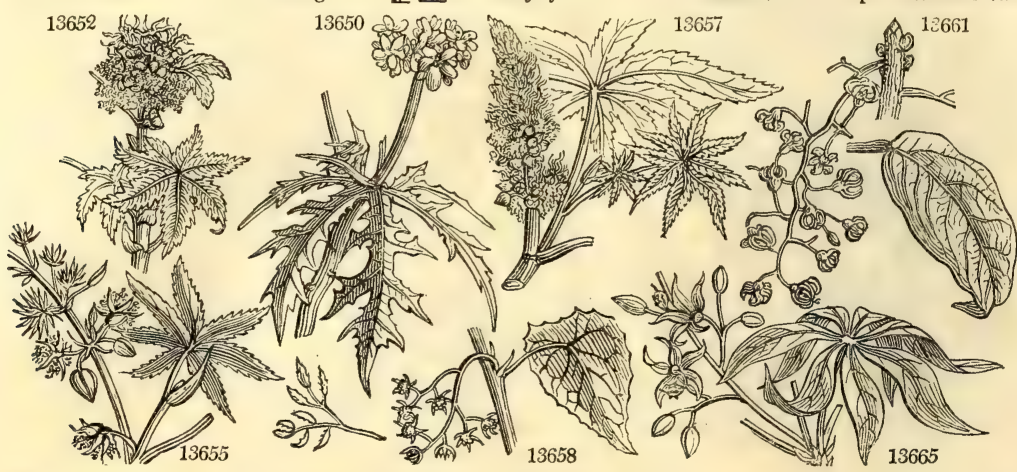

History, Use, Propagation, Culture,

root, yields an excellent nutritious article of food when the juice has been expressed, which is a strong poison. J gossypifolia is considered a beneficial plant in the West Indies, on account of the seeds, which are much relished by and very nourishing to poultry. J. Manihot, the Cassava of the West Indies, and the Mandioca and Tapioca of Brazil, formerly supplied the greater part of the nourishment of the natives of South America, and is now very generally cultivated there and in the West Indies. It yields an agreeable wholesome food; is of rapid growth, the roots arriving to perfection in about eight months, and it will thrive in any soil or situa tion The juice of the root is sweetish, and when swallowed, or when the root is eaten without preparation, it brings on convulsions, and occasions violent retching and purging. It acts only on the nervous system; it produces no inflammation on the stomach; but the stomach of a man or other animal poisoned by it, apuears produces no inflammation on the stomach; but the stomach of a man or other animal poisoned by it, appears
to be contracted one half. A little mint-water and salt of wormwood, timely administered, will prevent all bad consequences. In preparing the roots for use as food, they are washed, scraped, and grated to a pulp: this pulp is then pressed, and when dried is a powder resembling starch or flower fit for use. It is generally baked as bread, and bears a considerable resemblance to that made from wheat flour. The roots entire, or in a powdered state, form an article of considerable export from different parts of Brazil. All the species thrive well in our stoves, and are increased by cuttings, which Sweet states, succeed best when stuck in the $\tan$ in a good heat.

2034. Ricinus. A name with the same derivation as Croton, No. 2032, which see. R. communis, though an annual and herbaceous plant in our gardens, becomes a tree in Africa of several years' standing. In Candia it continues many years, and, according to Belon, requires a ladder to come at the seeds. The seeds furnish the well known Castor-oil of medicine. This oil is obtained both by coction and expression. The former method is performed by tying up the seeds, previously decorticated and bruised, in a bag, which is suspended in boiling water, till all the oil is extracted and rises to the surface, when it is skimmed off. Oil so obtained is apt to become rancid, and, therefore, the better mode is to subject the seeds to the press, in the same manner as is done with almonds to procure almond oil. (See Amygdalus.) The oil obtained is equal to one fourth of the weight of the seeds employed. It is often adulterated with olive oil, linseed oil, and poppy oil. The great value of eastor oil as a purgative is the mildness and rapidity with which it operates. It is peculiarly adapted for infants, 
13649 Leaves undivided 3-5-lobed palmate entire glaucous bencath

$\left.136{ }^{5}\right)$ Leaves 5-lobed cordate toothed hispid stinging

13651 Prickly, Leaves 3-lobed, Stem herbaceous

13652 Leaves peitate palmate: lobes lanceolate serrated, Stem herbaceous frosted, Capsules prickly

1365 . Lvs. pelt. palm. : lobes oblong toothed; middle obsoletely 3-lobed, Stem herbaceous frosted, Caps. prickly

13654 Leaves peltate palmate : lobes oblong serrated, Stem shrub!y smooth, Stigmas 6 , Caps. prickly

13655 Leaves peltate palmate colored: lobes obl. scrrate-toothed, Stem shrubby smooth colore?, Caps. prickly

IS 556 Leaves peltate palmate : lobes oblong serrated, Stem shrubby frosted, Capsules unarmed

13657 Leaves peltate deeply palmate 9 cut serrated, Petioles glandular, Caps. with herbuceous spines

13658 Leaves peltate ovate acuminate repand toothed, Caps. prickly

13659 Leaves ovate oblong slightly cordate toothed : lower teeth long entire at end

13660 Leaves ovate deeply cordate equally serrate, Male catkin ovate

15661 I.eaves ovate lanceolate, Capsules obovate

13662 Hermaphrodite, Leaves ovate entire, Flowers panicled decandrous, Caps. smooth

13663 Leaves 5-lobed : lobes acuminate, Calyxes campanulate, Caps, ovate hispid

136 tht Leaves palmate 5-lobed, Calyxes rotate reflexed

1350 is L.eaves digitate

\section{Leaves ovate simply veiny}

13567 Female flowers at base of male spike, Invol. ovate acuminate toothed, Leaves obl. lanc. remotely toothed $13668 \mathrm{Fem}$. Hs. at base of male spike, Invol. cordate toothed, Leaves subrhomboid ovate serrated entire at base 13669 Spikes axill. male upwards : female downw. Invol. cordate acuminate with imbricated serratures ciliated 13670 Female flowers solitary or $t w i n$ at base of the male spike, Invol. cordate serrate, Leaves rhomboid ovatc 13671 Female flowers at base of the male spike without an involucre, Leaves roundish ovate subcordate serrated 13672 Spikes axill. male above female below, Invol. smoothish serrated, Leaves ovate acum. serr. cumcate at base 13673 Female spike cylind, solitary terminal, Invol, 3-parted awned ciliated, Leaves roundish-ovate acuminate $1567+$ Female flowers twin axillary, Involucres entire, Leaves ovate acuminate serrulate, Stem shrubby 1367.5 Flowers diøeious : male spiked; female axillary, Invol. rouiadish entire, Leaves smooth lane. subcord. 15676 Spikes male above; fem. below, Invol. cuneiform toothed at edge, Styles multifid, Lvs. obl. subcoril. serr. 13677 Spikes axillary male above; female below, Invol. cordate hispid, Leaves ovate acute hispid 13678 Male spikes axillary female at base, Invol. O, Leaves ovate cordate acuminate serrated

13679 Spikes axillary erect, Female invols. cordate toothed very large, Leaves ovate-lanceolate serrated smonth 13680 Flowers diøecious spiked, Spikes axill. Invol. of females cordate cut, Leaves obl. lanceolate serrated smooth

13681 Leaves 3-lobed serrated : lobes oblong serrated, Bractes 3-lobed ciliated, Petioles shorter than pediuncle

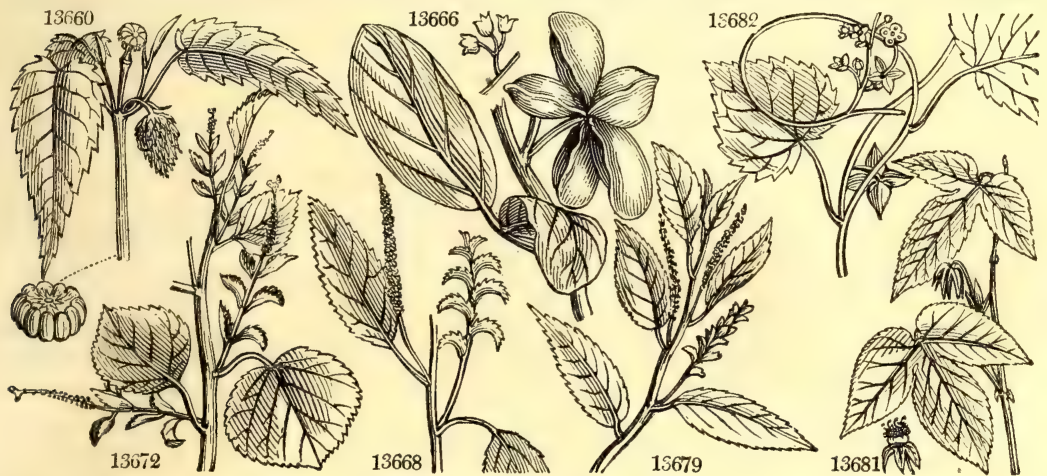

and Miscellaneous Particuars.

women in childbed, and persons bed-ridden. Sown in pots on heat early in the season, and transplanted as soon as the frosts are over into a mass of light rich soil, the plant makes one of the most magiificent of border annuals, often attaining the height of ten or twelve feet.

2035. Hura. Its American name. H. crepitans is a rapid growing tree. From the quickness of its vegetation, its parts are of so loose a texturc, that a loud clap of thunder, or a sudden gust of wind, frequently cause the largest boughs to snap asunder. The wood is only fit for joists and spars: the sap of the leaves and bark is corrosive, and the seeds when roasted purge both upwards and downwards. The species are propagated by large ripcned cuttings, planted in sand, plunged in heat, and covered with a hand-glass. Its fruit when ripe bursts with a loud crack, whence the specific name of crepitans; they are of a very elegant form, resembling a depressed sphere with many rounded ribs, arranged with the utmost symmetry.

2036. Sterculia. Sterculius was the god of the privy, from stercus, excrement. It has been well observed by a French author, that the Romans, in the madness of paganism, finished by deifying the most immodest objects and the most disgusting actions. They had the gods Sterculius, Crepitus, Priapus; and the goddesses Caca, Pertunda, \&c. \&c. The flowers of one species and the leaves of the other are highly fetid. The species are lofty trees with large leaves, and some of them very showy flowers: they all tirrive in light loamy soil; and ripened cuttings, with their leaves on, root in sand, plunged in moist heat, and covered with a handglass. The famous Cola nut of Guinea is the produce of $\mathrm{S}$. acuminata.

2037. Heritiera. Named in honor of Charles Louis L Heritier de Brutelle, a distinguished French botanist, who was unfortunately assassinated in a street of Paris in 1800 . He published many works, which will always have a high reputation for the excellence of their text, and the magnificence of their illustrations. A fine tree, which may be treated like Sterculia.

2038. Acalypha. A Greek name for the nettle, which this genus much resembles. It is compouncied of a, privative, $\approx c \lambda 0 s$, beautiful, and $\alpha p \eta$, touch. Plants of no beauty and the easiest culture.

2039. Dalechampia. So called after James Dalechamp, a French botanist, born in 1513, died in 1588. He left a General History of Plants, and some commentaries upon Pliny. May be treated is Plukenetia. 
2040. Plukene'tia. $W$. Plukenetia

6 jl.au G $\begin{aligned} & \text { Euphorbiacea, } S p .1-5 \\ & \text { W. Indies } 1739 .\end{aligned}$

13682 volúbilis twining

$\$$

C. p.1 Plu. ic. $220 . t .226$

History, Use, Propagation, Culture,

2040. Plukenetia. Named after Leonard Plukenet, an English botanist, who published some valuable works, with an immense number of copperplates, of singular merit for their time. The names of two of these works are so singular as to deserve explanation. One was called Amaltheum botanicum. This word in Greek, A $\mu \alpha \lambda \theta_{\varepsilon i \alpha}$, was the name of the goat which suckled Jupiter. As its milk was exquisite and abundant, the word came to signify, among the ancients, the symbol of richness and abundance. The famous library of Atticus was called Amaltheum, on account of the number and variety of the books which it contained. In

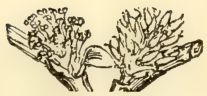

Class XXII. - DIGeCIA.

Male and female flowers upon different plants.

To this class many of the observations made upon the last are equally applicable. Like it, the genera would have been more conveniently distributed among previous classes. 'The genera it contains are chiefly trees, and many of them form the most valuable portion of the forests of all parts of the world.

In Monandria is found the celebrated Pandanus or screw pine, which, with its strange spiral branches, constitutes one of the most singular features of the vegetation of the Isle of France. Diandria contains the valuable Salix; Pentandria, the hop, the hemp, and the spinage. The black Bryony, and various palms have a station in Hexandria; the poplar in Octandria ; the Papaw and the Bonduc tree in Decandria. Monadelphia is richly endowed with valuable trees, such as the yew, the Norfolk Island pine, the juniper, the nutmeg; and it also contains the wonderful pitcher-plant of Chira.

\section{Order 1. MONANDRIA.}

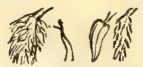

Stamen 1.

2041. Pandanus. Male. Cal, O. Cor. O. Anthers cuspidate. Female. Cal. O. Cor. O. Style bifid. Drupe compound or simple.

Order 2. DIANDRIA.

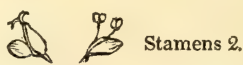

2042. Salix. Barren fl. Scales of the catkin single-flowered, imbricated, with a nectariferous gland at its base. Perianth. O. Stam. 1-5. Fertile fl. Scales of the catkin single-flowered. Perianth. O. Stigmas 2, often cleft. Caps. 1-celled, 2-valved, many-seeded. Seeds comose.

2043. Cecropia. Male. Spatha falling off. Catkin cylindrical. Cal. turbinate 4-cornered scales. Cor. $\mathrm{O}$ Female, as in the male. Style 1. Stigma torn. Ovaries imbricated. Berry 1-seeded.

2044. Borya. Male. Cal. 4-leaved, Cor. O. Stamens 2-3. Female. Stigma capitate. Berry 1-seeded.

\section{Order 3. TRIANDRIA.}

2045. Empetrum. Barren fl. Cal, tripartite. Cor. of 3 petals (7 in E. B.). Stam. 3 (9 in E. B.), upon long filaments. Fertile fl. Cal. tripartite. Cor. of 3 petals. Style very short. Stigma with 6-9 rays. Berry superior, globose, with 6-9 seeds.

20+6. Willenovia. Male. Cal. of many glumes. Petals 6. Nectary fleshy, 6-parted, surrounding the corolla. Female. Ovary superior. Style 1. Stigmas 2-3, Drupe 1-seeded.

2047. Restio. Spike imbricated. Cal. 6 equal glumes. Cor. O. Female. Styles 2-3. Nut stony, 1-celled, 1-seeded.

2048. Elegia. Cal. 6 unequal glumes. Female. Styles 3. Caps. 6-celled. Seeds solitary. 
13682 Angles of capsules compressed keeled

and Miscelianeous Particulars.

this sense Plukenet applied it to a work in which a great variety of curious plants was assembled. The other work was called Almagestum. This also came originally from the Greek. Claudius Ptolomæus, an astronomer and mathematician, published about the middle of the second century a work on astronomy, called

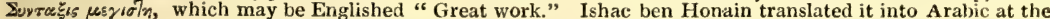
beginning of the ninth century, by order of the Caliph Mahmoun; to its title he added the Arabic artic:c Al, and so formed the word Al-magesti or Almaghesti.

2049. Phanix. Cal. 3-parted. Petals 3. Ovary 1. Drupe ovate-oblong.

2050. Stilago. Male. Cal. tubular, 3-4-toothed. Cor. O. Stamens 2-3. Female, an annular disk at tl:e base of the ovary. Stigmas 2, one bifid. Drupe 1-seeded.

2051. Osyris. Male. Cal, 3-fid. Cor. O. Female. Style 1. Stigma roundish. Berry 1-celled.

\section{Order 4. TETRANDRIA. Stamens 4}

2052. Aulax. Male. Flowers racemose. Cal. O. Petals 4, staminiferous. Female. Stigma oblique. Nut exserted, ventricose, bearded.

2053. Leucadendron. Male. Flowers capitate. Cal. O. Petals 4, staminiferous. Female. Stigma oblique.

Nut or samara 1-seeded, included in the scales of the cone.

2054. Viscum. Barren fi. Cal. O. Petals 4, dilated at the base, connate, resembling a cal. Anthers sessile, adnate with the petals. Fertile fi. Cal. submarginate. Petals 4, dilated at the base. Style 1. Drupe inferior, 1-seeded.

2055. Myrica. Barren fl. Scales of the catkin concave. Perianth. O. Fertile fl. Scales of the catkin concave. Perianth. O. Styles 2. Drupe 1-celled, 1-seeded.

2056. Nageia. Cal. 4-leaved, Cor. O. Style bifid. Drupe 1-seeded.

2057. Shepherdia. Male flowers in a catkin, 8-androus. Female racemose at the ends of the branches. Limb of calyx flat, regular, 4-parted. Disk with 8 glands. Fruit of Hippophae.

2058. Hippophae. Male flowers in a catkin, tetrandrous. Female solitary in the axillæ of the leaves. Calyx tubular, bifid at end, closed. Disk $O$. Fruit formed of a berried calyx and akenium.

2059. Broussonetia. Male. A cylindrical catkin. Cal. 4-parted. Female A globose catkin. Cal. tubular, 3-4-toothed. Ovaries becoming fleshy, clavate, prominent. Style lateral. Seed 1, covered by the calyx.

2060. Schafferia. Cal. 4-leaved. Petals 4 or O. Berry 2-celled. Seeds solitary.

2061. Brucea. Male. Cal. 4-parted. Petals 4. Disk 4-lobed. Female. Pericarps 4, 1-seeded.

2062. Anthosfermum. Male. Cal. 4-toothed. Cor, with a short tube, and 4-parted limb. Female. Ovary inferior. Styles 2, reflexed. Fruit bipartible.

2063. Trophis. Male. Cal. O. Petals 4. Female. Cal. O. Cor. O. Style 2-parted. Berry 1-seeded.

2064. Montinia. Male. Cal, 4-toothed. Petals 4. Female. Style bifid. Stigmas reniform. Capsule inferior, 2-celled, many-seeded.

\section{Order 5. PENTANDRIA. Stamens 5.}

2065. Pistacia. Male. Cal. 5-fid, Cor, O. Female. Cal. 3-fid. Cor. O. Styles 5. Drupe 1-seeded.

2066. Xanthoxylum. Male. Cal. 5-parted. Cor. O. Stamens 3-5. Female. Ovaries 5. Caps. 3-5, one-

reeded.

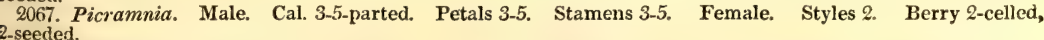

2068. Antidesma. Male. Cal, 5-leaved. Cor. O. Anthers bifid. Female. Stigmas $5 . \quad$ Berry cylindrical, 1-seeded.

2069. Iresine. Male. Cal. 2-leaved. Petals 5. Scales 5-7. Female. Stigmas 2, sessile. Caps, with downy seeds.

2070. Spinacia. Male. Cal. 5-parted, Cor. O. Female. Styles 4. Seed 1, within the indurated calyx.

2071. Fluggea. Male. Cal. 5-leaved. Cor. O. Rudiment of an ovary. Female. Style 2-parted. Stigmas recurved, bifid. Berry 4-seeded. Seeds with an arillus.

2072. Acnida. Male. Cal. 5-parted. Cor. O. Female. Cal. 3-parted. Styles O. Stignas 3, sessile. Caps. 1-sceded. 
2074. Cannabis. Male. Cal. 5-parted. Femaie. Cal. 5-leaved, entire, opening at the side. Styles 2. Nut 2-valved within the closed calyx.

2074. Humulus. Barren fl. Perianth. single, of 5 leaves. Anthers with 2 pores at the extremity. Fertile f. Scales of the catkin large, persistent, concave, entire, single-flowered. Perianth. O. Styles 2 . Seed 1.

2075. Modecca. Cal. 5-fid. Petals 5, inserted in the calyx. Scales 5-10, rarely O. Male. Stamens 5. Anthers erect. Female. Caps. stalked, 1-celled, 3.valved, many-seeded.

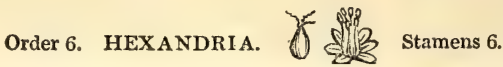

2076. Xerotes. Cor. 6-parted, somewhat colored. Male. Stamens 6. Anthers peltate. Female. Stamens abortive. Ovary 3-celled, with 1-seeded cells. Caps. cartilaginous, 3-celled, 3-valved. Seeds peltate.

2077. Elais. Cal, 6-leaved. Cor. 6-fid. Style 1. Stigmas 3. Drupe 1-seeded, fibrous. Nut 3-valved.

2078. Chamcedorea. Cal. 3-parted. Cor. 3-parted. Stamens 6. Rudiment of a style. Female. Scales 3.

Stỳles 3. Drupe succulent, 1-seeded.

2079. Borassus. Cal. 3-leaved. Cor. hypocrateriform, with a 3-parted limb. Female. Cal. 8-9-leaved, im. bricated. Cor. O. Style O. Drupe with 3 stones.

2080. Mauritia. Cal. cyathiform, somewhat 3-toothed. . Petals 3. Drupe 1-seeded, tessellated.

Q081. Smilax. Cal. 5-leaved. Cor. O. Styles 3. Berry 3-celled. Seeds 2.

2082. Tamus. Cal. 6-parted. Cor: O. Styles 3-fid. Berry 3-celled, inferior. Seeds 2.

2083. Testudinaria. Perianth. 6-parted, spreading: segments linear, nearly equal. Male. Stamens 6, inserted in the base of the segments. Female. Styles 3, united. Capsule membranous. Seeds winged.

2084. Rajania. Cal. 6-parted. Cor. O. Styles 5. Samaræ 1-seeded.

2085. Dioscorea. Cal. 6-parted. Cor. O. Styles 3. Capsule 3-celled, compressed. Seeds 2, membranous.

Leaves generally alternate.

2086. Maba. Cal. 3-fid. Cor. tubular, trifid. Drupe 2-celled. Cells 2-seeded.

Order 7. OCTANDRIA

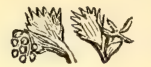

Stamens 8.

2087. Populus. Barren fl. Scales of the catkin lacerated. Anthers 8-30, arising from a turbinate, oblique, entire, single perianth. Fertile f. Scales of the catkin lacerated. Perianth. turbinate, entire. Stigmas 4. Caps. superior, 2-celled, 2-valved, many-seeded. Seeds comose.

\section{Order 8. ENNEANDRIA. 2⿺辶卬}

2088. Mercurialis. Barren fl. Perianth. single, tripartite. Stam. 9-12. Anthers globose, 2-lobed. Fertile fl. Perianth. single, tripartite. Styles 2. Caps. 2-celled. Cells 1-seeded.

2089. Hydrocharis. Barren fl. Cal. tripartite. Petals 3, "the three interior filaments beaked" Sm. Fertile fl. Cal. tripartite. Petals 3. Styles 6, each with 2 stigmas. Caps. inferior, coriaceous, roundish, sixcelled, many-seeded.

2090. Triplaris. Cal. 3-parted. Petals 3. Stamens 9. Styles 3. Capsule 1-seeded, 3-valved.

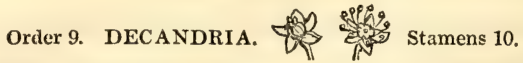

2091. Coriaria. Cal. 5-parted. Cor. O. Scales 5. Anthers 2-parted. Styles5. Caps. 5, 1-seeded, covered by the enlarged scales.

2092. Kiggelaria. Cal. 5-parted. Petals 5; glands 5, 3-lobed. Anthers perforated. Styles 5. Capsule onecelled, 5-valved, many-seeded

2093. Schinus. Cal. 5-fid. Petals 5. Berry 3-coccous.

2094. Gymnocladus. Cal. 5-toothed. Petals 5. Style 1. I.egumen 1-celled, pulpy inside.

2095. Carica. Male. Cal. hardly any. Cor. 5-fid, funnel-shaped. Filam. in the tube of the cor. Female.

Cal. 5-toothed. Petals 5. Stigmas 5. Berry furrowed, 1-celled, many-seeded.

\section{Order 10. DODECANDRIA. Sffry 12.}

2096. Stratiotes. Male. Spatha 2-leaved. Cal. 3-parted, Petals 3. Stamens 11-13, perfect, 20 atortive. Ovary inferior, 6-angular. Styles 6, 2-parted. Berry 6-celled, many-seeded.

2097. Hyananche. Cal. 5-7-leaved. Cor. O. Stamens 10-20. Style 1. Stigmas 3. Caps. 3-celled, 3-coccous. Cells 2-seeded.

2098, Euclea. Cal. 5-toothed. Cor. 5-parted. Stamens 15. Ovary superior. Styles 2. Caps. berried, 3-horned, 3-celled. Seeds solitary, with an arillus.

2099. Datisca. Male. Cal. 5-leaved. Cor. O. Anthers sessile. Female. Cal, 2-toothed. Styles 3. Capsule 3-angular, 3-horned, 1-celled, pervious, inferior.

2100. Menispermum. Male. Cal. 2-leaved. Petals 4 or 6 on the outside, 8 inside. Stamens 16. Female. Stamens 8, sterile. Ovaries 2-3. Berries 2, 1-seeded.

2101. Cocculus. Sepals and petals ternate, usually in two, rarely in three rows. Male. Stamens 6, distinct, opposite the petals. Female. Drupes berried, 1-6, generally oblique, reniform, somewhat compressed, 1-seeded. Cotyledons distinct.

\section{Order 11. ICOSANDRIA.}

2102. Flacourtia. Cal. 5-parted. Cor. O. Stamens 50-100. Stigma stellate, sessile. Berry m ny-celled, with 2-seeded cells.

2103. Peumus. Male. Cal. campanulate, 5-fid. Petals 5, inserted in the calyx, reflexed. Stamens about 46, glandular. Female. Scales 5, subsagittate. Ovaries 2.9. Style 0. Drupes oval, acuminate.

2104. Geionium. Cal. 5-leaved, Cor. O. Stamens 12. Stigmas 3, lacerated. Caps. 3-celled, 3-valved, 3-seeded.

2105. Rottlera. Male. Cal, 2-parted. Cor. O. Stamens 30-40. Female. Cal. 4-toothed. Styles 3. Caps. 3-celled, tricoccous, 3-seeded. 


\section{Order 12. FOLYANDRIA. ऊन्य Stamens numerous, inserted under the ovarium.}

2106. Cliffortia. Cal. 3-leaved. Cor. O. Stamens about 30. Styles 3. Caps. 3-celled. Seed 1

2107. Cycas. Male. Catkin imbricated. Cal. a spatulate scale. Cor. O. Anthers globose, sessile, on a scale. Female. Spadix compressed, 2-sided. Cal. O. Cor. O. Style 1. Drupe 1-seeded.

2108. Zamia. Catkin like a cone. Male. Calyx an obovate scale. Cor. $\mathrm{O}$. Anthers globose, opening by a slit, sessile on the scale. Female. Cal. peltate scales. Ovaries 2. Style O. Berries 2, 1-seeded.

\section{Order 13. MONADELPHIA.}

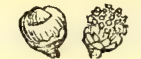

Stamens united into one body.

2109. Latania. Spadix many-leaved. Calyx 3-leaved. Petals 3. Stamens 15-16. Drupe coated, with three stones.

2110. Leptocarpus. Cal. 6-leaved, glumaceous. Cor, O. Stamens 3. Ovary superior. Style 1. Stigmas 2 or 3. Utricle or nut crustaceous, crowned by the base of the style.

2111. Ruscus. Cal, 6-leaved. Cor. O. Male. Rudiment of ovary ovate, perforated at end. Female. Style 1. Berry 3-celled. Seeds 2.

2112. Araucaria. Male. Catkin imbricated. Cal, a woody scale. Anthers 10-12, united in a scale Female. Catkin cone-shaped. Cal. a lanceolate 2-flowered scale. Style O. Stigma 2-valved. Nut coriaceous, cuneiform, winged at end.

2113. Juniperus. Barren fl. Scales of the catkin subpeltate. Perianth. O. Stam. 4-8, 1-celled. Fertile fl. Scales of the catkin few, united at length, fleshy, and surrounding the 3-seeded berry.

2114. Taxus. Barren fl. Perianth. single at the base. Stam. numerous. Anthers peltate, 6-8-celled. Cells opening beneath. Fertile fl. Perianth. single, urceolate, scaly. Style O. Drupe fleshy, perforated at the extremity.

2115. Ephedra. Male. A catkin. Cal. 2-fid. Stamens 7. Anthers 4 inferior, 2 superior. Female. Cal. 2-parted, quintuple. Ovaries 2. Seeds 2, covered by the berried calyx.

2116. Cissampelos. Male. Cal. 4-leaved. Cor. O. Disk rotate. Stamens 5. Filaments connate. Female. Cal, 1-leaved, ligulate, roundish. Styles 3. Berry 1-seeded.

2117. Excecaria. Male. Catkin cylindrical. Cal, a scale. Filament 3-parted. Female, Calyx 3 scales. Caps, 3-coccous.

2118. Adelia. Male. Cal, 3-parted. Cor. O. Stamens 00. Female. Cal. 5-parted. Styles 3, torn. Capsule 3-coccous.

2119. Loureira. Male. Cal. 5-parted. Cor. tubular, campanulate, 5-fid. Stamens 8-13, cohering at base. Female. Stigmas 3-4. Capsule dicoccous, 2-celled, with 1-seeded cells.

2120. Myristica. Male. Cal. O. Cor, campanulate, trifid. Filament columnar. Anthers 6-10, connate. Female. Style 1. Stigmas 2. Drupe with an arilled 1-seeded nut. Seed large, veiny, variegated in the inside.

2121. Nepenthes. Cal. 4-parted, spreading, colored inside.

connate. Stigma peltate, sessile. Caps. 4-celled, many-seeded.

2122. Cluytia. Male. Cal. 5-leaved. Petals 5. Disk glandular. Stamens 5, inserted into the rudiment of an ovarium. Female. Styles 3. Capsule 3-celled. Seed 1. 
MONANDRIA.

2041. PANDA'NUS, $W$. Screw-Pine. 13683 odoratíssimus $W$. green-spined 13684 útilis $W$. en. red-spined 13685 spirális $R$. 13685 spirátis $R . B r$ spiral

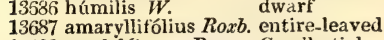
13688 candelábrum Beauv. Candlestick 13689 fasciculáris $W$. fascicled

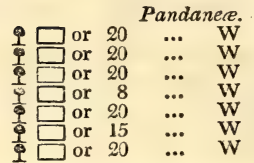

Sp. 7-25.

E. Indies 1771. S r.m Rox.cor.1. t.94-6 Bourbon … S r.m Ja.fra.t.13,14.f.1 N. S. W. 1805. S r.m

Mauritius ... S S r.m Jac.frag.t.14.f.2 E Indies 1820, S r.m Guinea 1822, S r.m Fl. d'Oware,t.21 E. Indies 1822. S r.m Rheede. 2. t. 6

\section{$D I A N D R I A$.}

2042. SA'LIX. $W$. 13690 triándra iW.

13691 lanceoláta

13692 Hoppeána $W$.

13693 unduláta $W$.

13694 Villarsiána $W$.

13695 amygdalina $W$.

13696 decípiens $E . B$. 13697 Russelliána $W$. 12698 Humbolcitiána

13700 nigra $W$.

13701 pentándra $W$.

13702 nígricans $I V$. 13703 phylicifólia $W$.

13704 Wulfeniána $W$.

13705 silesíaca $W$.

13706 Pontederána $W$.

13707 laurina $\boldsymbol{W}$. 13708 tenuifólia $W$. 13709 Ammanniána $W$

13710 hastáta $W$.

13711 serruláta $W$
Wiliow. long-leaved sharp-leaved

Hoppe's wave-leave $]$

Villars's

Almond-leaved 齿

varnished

Bedford

Humboldt's

four-sseded

black

Bay-leaved

dark broad-lvd, si

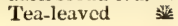

Wulfen's

Silesian

Pontedera's

two-colored

thin-leaved

Ammann's

halbert-leaved

serrulate -2.
Amentacea. Sp. 125-163.

先 $t \mathrm{~m} 30$ my.au Ap Britain riv.ba. C m.s Eng. bot. 1435

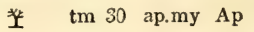

* tm 30 ap.my Ap

England mea. C m.s Eng. bot. 1436

Austria 1820. C m.s

Germany ... C m.s

S. France 1818. C m.s

Britain mar. C m.s Eng. bot. 1936

England woods. C m.s Eng. bet. 1937

England mar. C m.s Eng. bot. 1808

Peru 1823. C ms

E. Indies 1796. C in.s Rox.cor. 1. t.97

N. Amer. 1811. C m.s An.bot.2. t.5. f.5

Britain riv.ba. C m.s Eng. bot. 1805

or 15 mr.jn Ap

or 10 ap

or $1 \frac{1}{2} \mathrm{my}$

Ap

England os.hol, C m.s Eng. bot. 1213

Scotland sc.alp. C m.s Eng. bot. 1958

or $6 \mathrm{my}$

Ap

Carinthia 1818. C m.s

Silesia 1816. C m.s

Switzerl, 1821. C m.s

or $3 \mathrm{my} \quad \mathrm{Ap}$

England $\quad \ldots \quad$ C m.s Eng. bot. 1806 Britain sto.hi. C m.s Eng. bot. 2186

or 8 ap.my $\mathrm{Ap}$ or 20 my.jn Ap Austria 1821. C m.s H. sal. t.17,18,19 or 15 my Ap Lapland 1780. C m.s Fl. lapp.t.8.f. $g$

or 8 my Ap Lapland 1810. C m.s Fl. dan. t. 1238

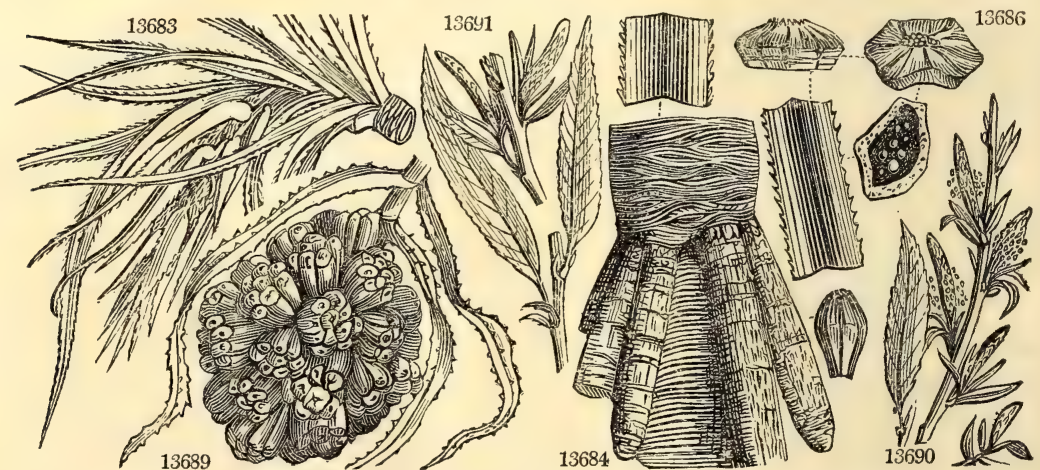

History, Use, Propagation, Culture,

2041. Pandanus. The Malay name of the genus is Pandang, which is said to signify, being interpreted, something to be regarded, and to have been so named on account of the beauty of the tree, and its exquisite odor. P. odoratissimus is a large spreading branching bush, with stem-clasping imbricated leaves, bearing some resemblance to those of the pine-apple; from three to five feet long, and placed in three spiral rows round the extremities of the branches. It grows in all soils and situations in the warmer parts of Asia, and is much employed there for hedges. It grows readily from branches, whence it is rare to find the full-grown ripe fruit. The tender white leaves of the flowers, chiefly those of the male, yield that most delightful fragrance, for which they are so generally esteemed, and for which the plant is cultivated in Japan. Of all the perfumes, it is by far the richest and most powerful. The lower pulpy part of the drupe is sometimes eaten by the natives in times of scarcity and famine. 'The tender white base of the leaves is also eaten raw or boiled, at such melancholy times. The taste of the pulpy part of the drupe is very disagreeable. The roots are composed of tough fibres, which basket-makers use to tie their work with; they are so soft and spongy as to serve the natives for corks. The leaves are composed of longitudinal, tough, useful fibres. In the South Sea Islands, where the Pandanus is also a native, this or some other species or variety is used for making mats. The leares are beautifully white and glossy. In the Sandwich islands these mats are handsomely worked in 


\section{MONANDRIA}

13683 Leaves at back and edges spiny-toothed, Fruit globose solitary

13684 Leaves at back and edges spiny-toothed, Fruit globose, Branches ternate dichotomous

13685 Stem without stolones, Clust. of drupes with from 9 to 20 cells obtuse depressed and tessellate at end

13686 Leaves at back and edges spiny-toothed, Fruit globose aggregated

13687 Leaves quite entire

13688 Leaves at edge and back serrate-spiny, Branches of stem erect

13689 Leaves and edges spiny-toothed, Spines distant, Drupe oblong solitary, Fruits fascicled

\section{DIANDRIA.}

1. Leaves smooth-serrated.

13690 Leaves lin. obl. serr. smooth rather unequally sloping at base, Catkins accompanying the leaves triandrous, Ovary stalked ovate compressed smooth, Stigma nearly sessile

13691 Leaves lanceolate tapering toward each end serrat. smooth Footst. decurr. Catk. accompanying the leaves triandrous, Ovary stalked oblong constricted smooth

13692 Leaves lanceolate tapering at each end serrated glaucous beneath, Catkins accompanying the leaves triandrous polygamous, Ovary stalked oblong lanceolate smooth, Stigmas sessile

13693 Leaves lanceolate pointed obtuse at the base smooth wavy and serrated, Footstalks decurrent, Catkins accompanying the leaves triandrous, Ovary stalked elliptic oblong, Style elongated

13694 Leaves elliptical roundish at the base serrated pointed glaucous white beneath, Catkins accompanying the leaves triandrous, Ovary stalked ovate smooth, Stigmas sessile

13695 Leaves ovate unequal at the base serrated smooth, Catkins accompanying the leaves triandrous, Ovary stalked ovate compressed smooth, Stigmas nearly sessile, Young branches furrowed

13696 Lvs. lanc. serrate quite smooth, Petioles somew. glandular, Ovary narrowed stalked, Branches varnished

13697 Leaves lanceolate acuminate serrated smooth, Ovaries pedicellate subulate smooth

13698 Lvs. lin. pointed finely serrat. smooth, Stam. about 6, Ovary stalked round.-ovate smooth, Stigmas sessile

13699 Leaves elliptic-lanceolate pointed finely serrated smooth glaucous beneath, Catkins following the leaves, Stamens about 6 deflexed, Ovary stalked ovate smooth, Style elongated

13700 Leaves ovato-lanc. pointed serrated green on both sides smooth with a downy rib and footst. Catkins accompanying the leaves vill. Stam, about 5 bearded at base, Ovary stalked ov. lanc. smooth, Stigm. divid.

13701 Leaves elliptic-lanceolate or ovate pointed crenate glandular srnooth, Footstalks glandular at the top, Catkins following tne ieaves, Stam. 5 or more hairy, Ovary ovate smooth nearly sessile

13702 Leaves ellipt. lanc. acute cren. smooth glaucous beneath, Catkins before leaves, Ovary stalked lanc. downy

13703 Leaves elliptical lanceolate with wavy serratures smooth glaucous beneath, Stipules somewhat lunate glandular on the inside, Ovary stalked silky, Style longer than the stigma

13704 Leaves obovate bluntish serrated smooth glaucous beneath, Catkins dense with fringed scales, Ovary staiked awl-shaped nearly smooth, Style longer than the stigmas

13705 Leaves elliptical acute at each end smooth serrat. green on both sides : midrib footstalks as well as young foliage downy, Catkins before the leaves, Ovary ovato-lanceolate long stalked smooth

13706 Leaves elliptical acute serrated smooth obtuse at base glaucous beneath : midrib footstalk as well as young foliage hairy, Ovary oblong downy

13707 Leaves elliptical acute tooth-serrated smoothish glaucous beneath, Ovary lanceolate silky

13708 Livs. ellipt. acute serrat. smoothish glaucous ben. Stip. small or none, Catk. hairy, Caps. sess. very smooth

13709 Leaves oblong elliptical acute serrated smooth glaucous beneath, Footstalks elongated downy, Stipules ovate toothed permanent, Catkins before the leaves, Ovary lanceolate smooth

13710 Lvs. ovate acute serrated undulate crackling smooth heart-shaped at the base glaucous beneath, Stipules unequally heart-shaned longer than the broad footstalks, Catkins very woolly, Ovary lanc. smooth

13711 Lvs. ovate acute serrated smooth glaucous beneath, Footstalks very short smooth, Stipules ovate serrated permanent, Catkins accompanying the leaves, Ovary lanceolate nearly sessile

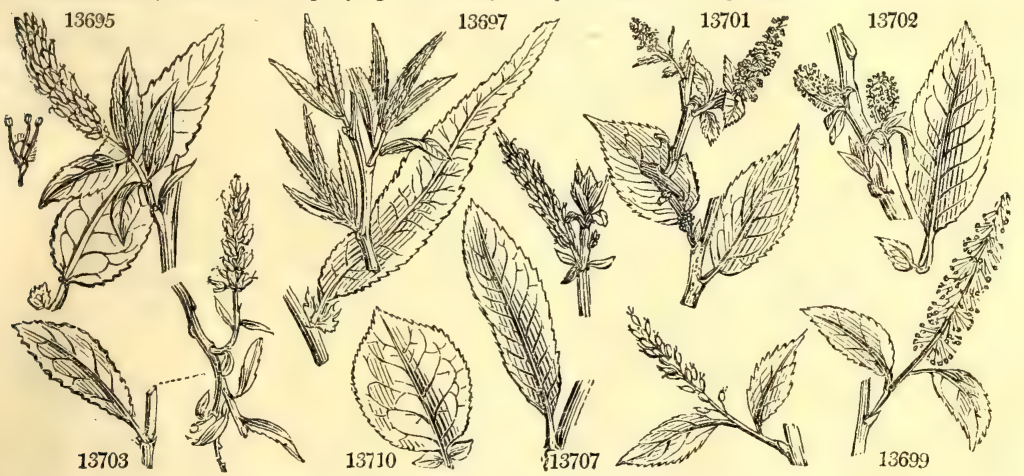

and Misccllaneous Particulars.

a variety of patterns, - and stained of different colors. 'The branches being of a soft spongy juicy nature, cattle will eat them very well when cut into small pieces. They call it Wharra tree at Otaheite. (Hawksw. Voy. ii. 217)

2042. Salix. From the Celtic sal, near, and lis, water Our common name osier, seems to be a slight alteration of the Greek os $\iota_{\infty}$, which means the same thing. This is a numerous and difficult genus of trees and shrubs, with one or two exceptions limited in their range to the temperate regions of Europe and America. Many of the species are distinguished by such delicate shades, that only the most acute botanists can recognize them. Soil, situation, and climate produce so considerable a change in their appearance, as to render it difficult to determine what are species and what varieties. Those species which attain a timber size, are chiefly valued for the rapidity of their growth; they produce a great bulk of trunk and lop in a short time, and the bark of most of the species has recently been used in tanning; being, at an average of sorts, about half as valuable as that of the oak. S. alba is considered the most valuable timber tree of the genus; it has a branching stem, and tapering flame-shaped head. It may be seen pollarded by way-sides in mos $t$ parts of Europe, in which state it is very productive of poles, fence wood, crate ware, fuel, and bark for the tanner, which is considered nearly as good as that of the oak. A variety of this species, called by Pontey, the red 
13712 prinoides $P h$.

13713 discolor $\boldsymbol{W}$.

13714 angustáta $P h$.

13715 petioláris $W$.

13716 myricoídes $\boldsymbol{W}$.

13717 cordáta $W$.

13718 rígida $W$.

13719 lúcida $W$.

13720 ambígua $P$ sh.

13721 acutifólia $W$

13722 vitellína $W$

13723 frágilis $W$.

137.24 præ'cox $W$.

13725 Meyeriána $W$. 13726 babylónica $W^{\prime}$

13727 purpúrea $W$. 13728 pomeránica $W$. en. 13729 Hélix $W$.

Prinos-like narrow-leaved dark long-leav. $¥$

Gale-like 还

heart-leaved

rigid

shining

douttiul

芷

sharp-leaved yellow-branch.

cracking

early

Meyer's

weeping

bitter purple

Pomeranian

Rose

13730 Lambertiána $W$ Boyton 13731 tetra'pla Link.

13732 rúbra $W$

13733 Forbyána $W$.

Boyton

pretty

Basket Osier

Crowe's

Apple-leaved

13735 malifólia $W$.

13736 Houstoniána $\mathbf{P} /$.

1.3737 falcáta $P h$.

13738 Starkeána $W$.

13739 prunifólia $W$.

13740 myrsinites $W$.

辈

sickle-leaved

Starke's

Plum-leaved

Whortle-leav'd brown-branch, 缕

or 10 mr.ap Ap

or 8 ap

Ap

or $10 \mathrm{mr}$.ap Ap

or 10 ap

Ap

or 8 ap

Ap

or 6 ap.my Ap

or 15 ap.my Ap

or $8 \mathrm{my} \quad$ Ap

or 20 ap

Ap

or 8 ap Ap

clt 15 miny Ap

or 15 ap.my Ap

or 20 ap.my Ap

or 20 ap.my Ap

$8 \mathrm{mr} \quad \mathrm{Ap}$

$\begin{array}{lll}\text { or } 10 & \text { my } & \text { Ap } \\ \text { or } & 10 & \text { mr.ap }\end{array}$

clt 10 mr.ap Ap

or 4 mr.ap Ap

clt 8 ap.my Ap

clt 8 ap Ap

clt 8 ap.my Ap

or 3 ap Ap

or 4 ap.my Ap

or 4 ap.my Ap

13741 Waldsteiniana $W$. Waldstein's

13742 venulósa $E . B$. veiny-leaved 13743 planifólia $P h$

13744 fuscáta $P h$.

1374 brown-stemm'd

13746 carináta $W$.

13747 corúscanś $W$

folded-leaved glittering 缕
N. Amer. 1811. C m.s

N. Amer. 1811. C m.s Ann.bot.2.t.5.f.1

Pensylv. 1811. C m.s

England mar. C m.s Eng. bot. 1147

N. Amer. 1811. C m.s Ánn.bot.2.t.5.f2

N. Amer. 1811. C m.s Ann.bot.2.t.5.f.8

N. Amer. 181I. C m.s Ann.bot.2.t.5.f.4

N. Amer. 1811. C m.s Ann.bot.2.t.5.f.7

N. Amer. 1821. C m.s

Casp. Sea 1823. C m.s

England mar. C m.s Eng. bot. 1389

Britain mar. C m.s Eng. bot. 1807

Austria 1820. C m.s

Germany 1822. C m.s

Levant 1692. C m.s Rauw.it.183.t.25

England mar. C m.s Eng. bot. 1388

Pomeran. 182\%. C m.s

Britain mar. C m.s Eng. bot. 1343

England riv.ba. C m.s Eng. bot. 1359 ...... 1825. C m.s

England os.hol. C m.s Eng. bot. 1145 England os.hol. C m.s Eng. bot. 1344

England mar. C m.s Eng. bot. 1146 England moun. C m.s Eng. bot 1617

Virginia $\quad \ldots \quad$ C m.s

N. Amer. 1811. C m.s

Silesia 1820. C m.s

Scotland sc.alp. C m.s Eng. bot. 1361

Scotland sc.alp. C m.s Eng. bot. 1360

Croatia 1822. C m.s

Scotland sc.alp. C m.s Eng. bot. 1362 Labrador 1811. C $\mathrm{m} . \mathrm{s}$

N. Amer. 1811. C $\mathrm{m} \mathrm{s}$

Scotland s. of sc. C m.s Eng. bot. 2341

$\begin{array}{llllll}\text { or } & 3 & \text { ap.my } & \text { Ap } & \text { Scotland sc.alp. C } & \text { m.s Eng. bot. } 1363 \\ \text { or } & 3 & \text { ap.my } & \text { Ap } & \text { Germany 1818. C } & \text { m.s Jacq. aust. t. } 408\end{array}$

$\begin{array}{lllllll}\text { or } & 3 & \text { ap.my } & \text { Ap } & \text { Scotland sc.alp. C } & \text { m.s } & \text { Eng. bot. } 1363 \\ \text { or } & 3 & \text { ap.my } & \text { Ap } & \text { Germany 1818. C } & \text { m.s Jacq. aust. t. } 408\end{array}$ or 2 ap Ap Switzerl. 1823. C m.s
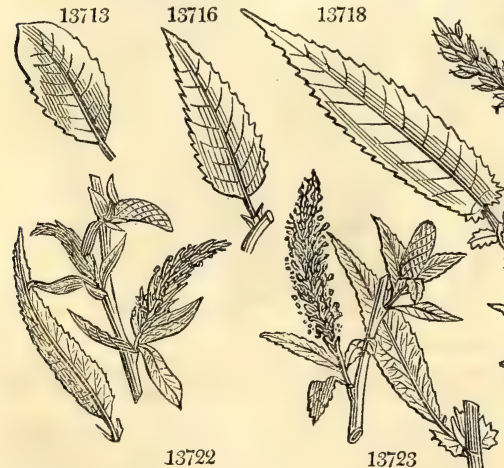

History, Use, Propagation, Culture,

\section{5}

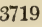


13712 Lvs oval-obl. acute with distant wavy serratures smooth glauc. ben. Stipules $\frac{1}{2}$ heart-shaped deeply toothed, Catkins villous before the leaves, Ovary stalked ovate pointed silky, Style elongated, Stigma cloven

13713 Leaves ovato-lanceolate smooth bluntly serrated glaucous beneath, Catkins before the leaves, Scales short rounded hairy, Ovary awl-shaped silky on a stalk thrice the length of the scale

13714 Lvs. lanc. acute very long gradually tapering at base finely serrated quite smooth scarcely paler beneath, Stip. $\frac{1}{2}$ heart-shap. Catkins before lvs. erect smooth, Ovary stalk. ov. smooth, Style divid. Stigm. 2-lobed

13715 Leaves lanceolate serrated smooth glaucous beneath somewhat unequal at base, Stipules lunate toothed, Catkins lax, Ovary stalked ovate silky, Stigmas sessile divided

13716 Lvs, ovato-lanc. bluntly serr. smooth ac. glauc. ben. gland. at base, Stip. ov. with gland. serrat. Catk. wool. Ovary lanceolate smooth its stalk longer than the scale, Style the length of the divided stigmas

13717 Lvs. ovato-lanc. serrat. smooth paler ben. heart-shaped at the base, Stip. rounded finely toothed, Catk accomp. Ivs. mostly triand. Sca. lanc. woolly, Ovary stalked lanc. smooth, Style length of divided stigm.

13718 Lvs. ellipt. lanc rigid smooth sharply serrat. two lowest serratures elongated, Footst. hairy, Stip. dilated round. with glandul. serrat. Catk. accomp. lvs. mostly triand. Sc. woolly, Ovary lanc. smth. on long stalk

13719 Lvs. ov taper-point. smooth shining with glandul. serrat. mostly crowded at stip. tooth. Catk. accomp. lvs. mostly triand. Scales hairy at base obt. serr. and smooth at end, Ovary stalked lanc. awl-shaped smooth, Style divided, Stigma obtuse

13720 Leaves lanceolate pointed smooth green on both sides with gland. serr. Catkins accomp. lvs. Nect. double rather large: its lobes lanceolate smooth toothed at the summit; the terminal flowers triandrous

13721 Lvs. lanc, acum. uneq. and bluntly serrated smooth somew, glauc. ben. Branches dark purple with a bloom

13792 Leaves lanc. acute with cartilaginous serrat, smooth above glaucous and somew, silky ben. Stip. small and deciduous smooth on their inside. Ovary sessile ovato-lanceolate smooth, Stigmas nearly sessile:2-lobed

13723 Leaves ovato-lanc. pointed serrated throughout very smooth, Footstalks glandular, Ovary ovate nearly sessile, Male flowers with an abortive ovary

13724 Leares broadly lanc. pointed smooth with glandular serrat. glaucous beneath, Footstalks slightly hairy without glands, Catkins before the leaves, Ovary sessile ovate smooth, Style elongated

1372 ) Triandrous, Stamens reflexed, Leaves about four inches long and one broad smooth and green beneath

13726 Leaves lanceolate taper-pointed sharply serrated smocth glaucous beneath, Stipules $\frac{1}{2}$ ovate taper-pointed revolute, Catkins naked accompanying the leaves, Ovary ovate sessile smooth, Branches pendulous

13727 Decumb. Stam. 1, Leaves obovato-lanc. serrated smooth narrow at base, Stigm. very short ov. nearly sess.

13728 Lvs. downy serrulate acum. glaucous beneath, when old becoming smoother, Catkins before lvs. Style long

13729 Erect, Stamen 1, Leaves mostly opposite oblong lanc. pointed slightly serrated smooth linear at base, Style nearly as long as divided stigmas

13730 Erect, Stam. 1, Lvs, obov. lanc. ac. serrat. smth. round, at base, Stip. none, Stig. very short ov. notched obt.

13731 Branches downy, Leaves elliptical acute glaucous beneath: the young ones downy

13732 Stam. combined below, Leaves linear lanc. elongated acute smooth with shallow serrat. green on both sides

13733 Erect, Stamen 1, Leaves alternate with small stipules lanceolate acute with shallow serratures smooth rounded at base glaucous beneath, Style nearly as long as the linear divided stigmas

13734 Stamens combined below, Leaves elliptical slightly serrated quite smooth glaucous beneath

13735 Leaves elliptic-oblong toothed waved thin and crackling very smooth, Stipules heart-shaped about the length of the footstalk, Catkins very woolly, Ovary lanceolate smooth on a short stalk

13736 Leaves linear lanceolate acute very finely serrated smooth shining and green on both sides, Stipules none, Catkins accompanying leaves cylindrical villous, Scales ovate acute, Stam. 3 to 5 bearded half way up

13737 Leaves very long linear-lanc. closely serrated tapering gradually and somewhat falcate upwards acute at the base smooth on both sides : the young ones silky, Stipules crescent-shaped toothed deflexed

13738 Leaves elliptical nearly orbicular smooth somewhat serrated in the middle rather glauc. beneath, Catk. after the leaves, Capsules ovato-lanceolate stalked downy

13739 Leaves ovate serrated naked smooth and even above glaucous beneath, Branches rather downy, Capsules ovate silky, Style as long as the stigmas

13740 Leaves elliptical serrated smooth veiny polished on both sides, Young branches hairy, Ovary awl-shaped clothed with silky hairs, Style as long as the cloven stigmas

13741 Leaves obovate-elliptical smooth rather acute serrated in the middle shining above somewhat glaucous beneath, Ovary lanceolate silky, Young branches smooth

13742 Lvs. ov. serrat. nak. reticul. with promin. veins above rather glauc. ben. Ovary ellipt. silky, Style very short 13743 Somew. erect straggling, Branches polished, Lvs. obl. lanc. acute at each end serrul, in midd. very smooth 13744 Leaves obovate lanceolate acute smooth subserrated glaucous beneath, Stipules small, Ovaries ovate silky 13745 Leaves ovate serrated smooth even above glaucous and silky beneath, Ovary ovate silky, Style as long as the stigmas, Stems decumbent

13746 Leaves ovate finely toothed smooth minutely veined folded so as to form a keel, Ovary ovate downy

13747 Lvs. ov. ellipt. ac. serrat. smooth tapering at base glauc. ben. : lower serrat. glandular, Caps. ov. lanc. smth.

13748 Leaves oblong acute serrulate whole colored beneath, when old quite smooth

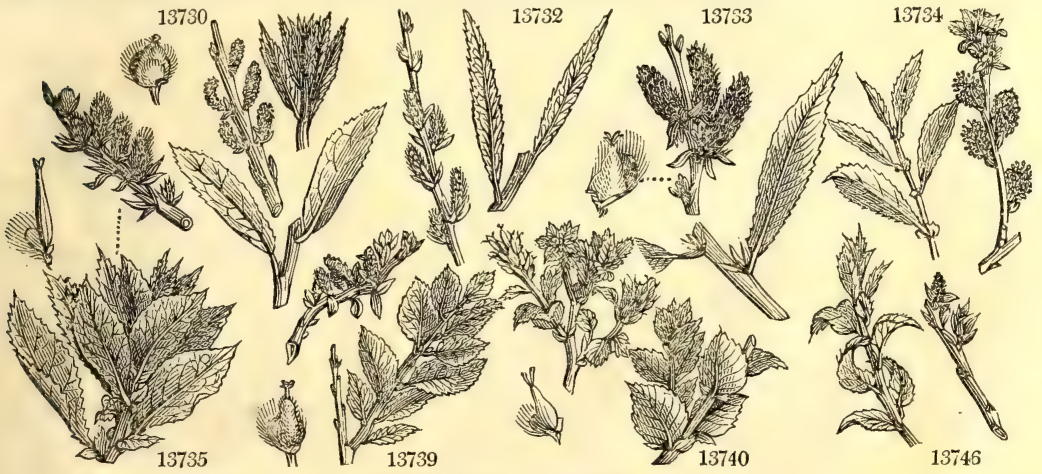

and Miscellaneous Particulars.

a century in Scania. Few of the willow species can be considered ornamental, though the maie plants of S, pentandra and amygdalina produce numerous showy catkins of a bright yellow color, and very odoriferous. The leaves of $\mathrm{S}$. pentandra are also fragrant, exuding a copious yellow resin from their serrated edges. $T$. down of the seeds of this and other species, mixed with the third part of cotton, has been found a useful adulter. ation, especially for stuffing cushions and forming candle-wicks. Goldfinches and other birds line their nests with this material.

The wceping-willow is generally admired; it grows wild on the coast of Persia, and is common in China. It is sometimes said to have been introduced by Pope, but the celebrated specimen of that tree which stood in 3 G 4 
13749 arbúscula $W$. 13750 húmilis $W$.

13751 herbácea $W$ 13752 ulmifólia Thuill 13753 arbutifólia $W$.

13754 Kitaibeliána $W$. 13755 retísa $W$ 13756 serpyllifólia $W$. 13757 reticuláta $W$.

13758 myrtilloídes $W$. 13759 recurváta $P h$. 13760 Uva-úrsi $P h$.

13761 cordifólia $P h$.

13762 pedicelláris $\boldsymbol{P} h$.

13763 glaúca $W$. 13764 serícea $W$ 13765 lanáta $W$.

13766 Lappónum $W$.

13767 arenária $\boldsymbol{W}$.

13768 cinérea $W$.

13769 obtúsa Link. 13770 bícolor $\boldsymbol{W}$

13771 MuhlenbergiánaPh. Muhlenberg's

13772 Jacquiniána $W$. Jacquin's 소

13773 tristis $W$.

linear-leaved

13774 argéntea $W$

13775 leucophýlia $W$.

silky sand

white-leaved

13776 elæagnoídes Schlei. Elæagnus-leav.

13777 répens $W$.

creepin

13778 fúsea $W$

brown

13779 prostráta $W$.

prostrate

13780 Schraderiána $W$.

Schrader's

Pyrencan

13781 pyrenáica $W$.

hairy-branched 䏠

13782 hírta $W$

13783 Dicksoniána $\boldsymbol{W}$.

13784 parvifólia $E . B$. 13785 adscéndens $\boldsymbol{E} . \boldsymbol{B}$. 13786 incubácea $W$

Dickson's 歪

small-leaved

ascending

trailing

齿

13787 rosmarinifólia $W$. Rosemary-lvd, 楈

$\begin{array}{lll}\text { or } & 2 \text { ap } & \text { Ap } \\ \text { or } & 1 \frac{1}{2} \text { ap } & \text { Ap } \\ \text { or } & \frac{1}{3} \text { jn } & \text { Ap } \\ \text { or } & 1 \text { my } & \text { Ap } \\ \text { or } & \frac{1}{2} \text { ap.my } & \text { Ap }\end{array}$

Ap

Scotland sc.aip. C m.s Eng. bot. 1356 Britain sc.alp. C m.s Eng. bot. 1907 Switzerl. 1821. C m.s Switzerl. 1818. C m.s

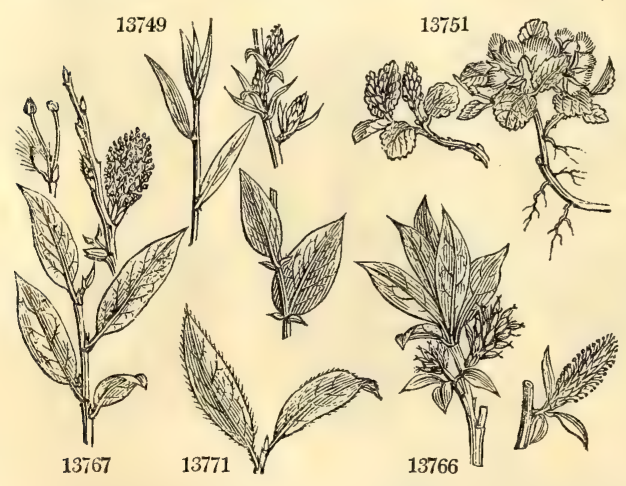

\section{or $\frac{1}{2}$ ap.my $A$ or $\frac{1}{2} \mathrm{my} \quad \mathrm{Ap}$ or $\frac{1}{2} \mathrm{jn} . \mathrm{jl} \quad \mathrm{Ap}$ or 2 my Ap or 3 ap $\mathrm{my}$ or $3 \quad \ldots \quad$ Ap \\ or 3 ap}

Carpathi. 1823. C m.s Italy 1763. C m. Switzerl. 1818. C m. Britain scalp. C co Eng. bot. 1908

Sweden 1772. C m.s Vil.da.3.t.50.f.11 N. Amer. 1811. C m.s Labrador ... C $\mathrm{cm} . \mathrm{s}$

N. Amer, 1811, C m.s

N. Amer. 1811. C m.

or $1 \mathrm{my}$

or 1 my

or $2 \mathrm{my}$

or 3 my.jn Ap

or $15 \mathrm{my}$

or $4 \mathrm{my}$

or $5 \mathrm{my}$

or 3 ap

or 2 ap

or 4 ap

or $3 \mathrm{my}$

or $4 \mathrm{my}$

or $4 \mathrm{my}$

or $2 \mathrm{my}$

or $1 \mathrm{my}$

$2 \mathrm{my}$

$1 \mathrm{my}$

or 15 ap.my Ap

or 1 ap Ap

or 2 ap.my Ap

or $3^{\frac{1}{2}}$ ap.my Ap

or 2 ap.my Ap
Ap Scotland sc.alp. C m.s Eng. bot. 1810

Ap S. Europe 1820. C m.s Vil.de.3.t.51.f.27 Lapland 1818. C m.s

Lapland 1812, C m.s Fl.lappon.t.8.f.T

Scotland sc.alp. C m.s Eng. bot. 1809

Britain woods. C m.s Eng. bot. 1897

Switzerl. 1820. C m.s

Ap Hercynia 1820. C m.s

Ap N. Amer, 1811. C m.s Ann.bot.2.t.5.f.9

Ap Austria 1818. C m.s Jac. aust.1. t.409

Ap N. Amer. 1765. C m.s

Ap Britain san sh C m.s Eng. bot. 1364

Ap Europe 1824. C m.s

Ap Europe 1824. C m.s

Aritain sa.hea. C m.s Eng. bot. 183

Ap Britain m.hea. C m.s Eng, bot. 1960

Ap Britain m.al.p. C m.s Eng. bot. 1959

Ap Germany 1820. C m.s

p Pyrenees 1823. C m.s

England woods. C m.s Eng. bot. 1404

Scotland sc.alp. C m.s Eng. bot. 1390

England moi.h. C m.s Eng. bot. 1961 England moi.h. C m.s Eng. bot. 1962 Europe 1775. C m.s

Britain san.pl. C m.s Eng. bot. 1365

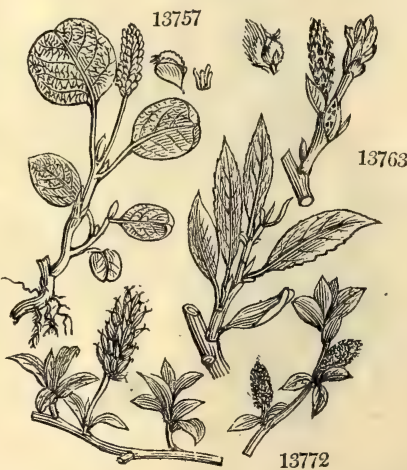

History, Use, Propagation, Culture,

the poet's garden at Twickenham, was a cutting from some rods employed in a package which came from Spain. Pope being present when the package was opened, observed that the pieces of stick appeared as if they had some vegetation, and added, perhaps they may produce something which we have not in England. Under this idea he planted it in lis garden, and it produced the willow tree that has given birth to so many others; not as the parent tree of all the willows in the country, but as an admired and celebrated specimen. S. herbacea is not properly an herbaceous plant, but possesses the Linnean character of a tree, and is the smallest yet 
13749 Lvs. lanc. acut. serrul. smooth glauc. ben. Catkins appearing with lvs. Caps. ov. lanc. smooth, Styles twin 13750 Lvs. obl, lanc. acute crenul.-serr. glaucous beneath, Stipules obsolete, Scales short round with long hairs 13751 Lvs. orbicul. somew, retuse serrated shining on each side, Fem. catkins about 5-fl. Caps. ov. lanc. smooth

13752 Lvs. obl. and ovate acute toothletted glaucous beneath, Stipules large toothed, Catkins short, Styles long

13753 Leaves lanc. acute obscurely serrated smooth and shining on both sides reticulated with veins beneath, Ovary lanceolate hairy, Style elongated, Stigmas deeply divided

2. Leaves smooth entire.

[lanceolate smooth ovary

13754 Leaves obovato-lanc, ent. emarg. smooth shining above, Catk. cylind. many-fl. Scales shorter than ovato13755 Leaves obovate entire smooth shining above, Fem. catk. obl of few-fl. Scales length of obl. smooth ovary 13756 Lvs. ov. or ovato-lanc. acute ent. smooth shin. above, Catk. obl. of few-fls. Caps. ellipt. smooth, Stigm. sess.

13757 Leaves orbicular somewhat ellipt. obt. entire coriaceous smooth with reticulated veins glaucous beneath, Stigmas nearly sessile, Capsule shaggy

13758 Lvs. ovate entire bluntish smooth glaucous beneath, Ovary ovato-lanc. smooth its stalk longer than scale 13759 Leaves obov. lanc. acute entire glandular at edge smooth glaucous ben.: young ones silky, Stipules none

13760 Stem depressed, Leaves spatulate obovate obtuse entire smooth shining above gland. at margin beneath, Stip. none, Catk lax, Scales obl. fringed, Ovary stalked ovate smooth, Style deeply divid. Stigm. 2.lobed

13761 Stem depressed, Leaves oval rather acute entire reticulated with veins heart-shaped at the base smooth above pale with a hairy rib and margin beneath, Stipules $\frac{1}{2}$ heart-shaped 13762 Stem erect, Branches smooth, Lvs. obov. lanc. acute entire smooth, Stip. none, Catk. stalked very smooth,
Scales oblong scarcely hairy, Ovary ovate obl. smooth its stalk twice as long as scale, Stigm. sess. divided

8. Leaves villous.

[ovate woolly

13763 Leaves nearly entire ellipt.-lanc. even and nearly smooth above woolly ben. Footst. decurrent, Ovary sess.

13764 Leaves oblong lanceolate entire obtuse silky on each side, Caps. ovate oblong villous sessile

13765 Leaves roundish ovate acute entire shaggy on both sides hoary beneath, Capsules sessile smooth, Style four times as long as the blunt divided stigmas

13766 Leaves lanceolate entire bluntish clothed on both sides with long silky hairs, Ovary sessile very woolly, Style about the length of the deeply separated cloven blunt stigmas

13767 Leaves nearly entire ovate acute reticulated and somew. downy above veiny and densely woolly beneath, Ovary sessile very woolly, Style about the length of the deeply separated linear divided stigmas

13768 Stem erect, Lower leaves entire : upper more or less serrated obovate lanc. reticulated with veins glaucous and downy ben. Stip. half heart-shaped serr. Ovary lanc. stalked silky, Style as long as blunt stigmas

13769 Leaves ovate acute serrulate smooth above hairy beneath, Stipules minute, Catkins long

13770 Leaves elliptical acute waved and slightly serrated nearly smooth glaucous beneath, Footstalks dilated at the base, Catkins before the leaves, Ovary stalked lanceolate silky

13771 Leaves lanceolate sharpish nearly entire downy revolute veiny and rugose beneath, Stipules lanc. decid. Scales of the catk, oblong fringed, Ovary ovato-lanceolate silky stalked, Style short, Stigmas divided

13772 Leaves elliptical entire tapering at each end polished : the veins beneath as well as the margin hairy, Ovary elliptical downy, Style elongated

13773 Leaves entire elliptical somewhat revolute with a recurved point rather downy above silky and shining beneath as well as the branches, Ovary stalked ovato-lanceolate silky, Style shorter than the stigmas

13774 Leaves elliptical entire recurved acute above downy beneath silky, Ovary ovate lanceolate villous

13775 Leaves brown above downy with short hairs hoary beneath acute nearly entire

13776 Leaves obtuse brown smooth and opaque above silky beneath [ovate downy, Stem depressed

13777 Lvs, ellipt.-lanc, straight somew, point nearly ent almost naked above glauc and silky ben. Ovary stalked

13778 Leaves elliptic-obl. acute straight flat with a few glandular teeth glaucous and silky beneath, Footstalks slender, Stem erect much branched, Stipules none

13779 Leaves elliptical acute convex rarely toothed glaucous rugged and silky beneath, Stem prost. Branches elongated straight, Ovary stalked ovate silky, Style shorter than the stigm.

13780 Leaves elliptical acute finely downy on both sides glaucous beneath slightly serrated towards the point, Stipules very small, Catkins rather before the leaves ovate hairy

13781 Leaves elliptical entire acute at each end reticulated with veins glaucous beneath most hairy at margin, Ovary somewhat stalked ovato-lanceolate villous, Style the length of the deeply divided stigm

13782 Leaves elliptical heart-shaped pointed finely notched downy on both sides, Stipules half heart-shaped flat-toothed nearly smooth, Branches hairy

13783 Leaves elliptical acute slightly-toothed smooth, Young branches very smooth, Catkins ovate short erect, Ovary stalked ovate silky, Stigmas ovate obtuse nearly sessile

13784 Lvs, ellipt. nearly ent. with recurv, points glaucous and silky ben. Stem decumbent, Stipules ovate entire 13785 Lvs. ellipt.-obl. somew. serrat. with recurv. points glauc. and silky ben. Stem ascend. Stipules ovate serrated 13786 Leaves lanc. pointed straight somewhat elliptical entire convex smooth above glaucous and silky beneath, Catkins oval erect, Ovary stalked lanceolate, Style the length of the stigma

13787 Leaves linear-lanceolate pointed straight entire silky beneath, Stem erect, Stipules upright flat, Catkins recurved, Ovary stalked lanceolate silky

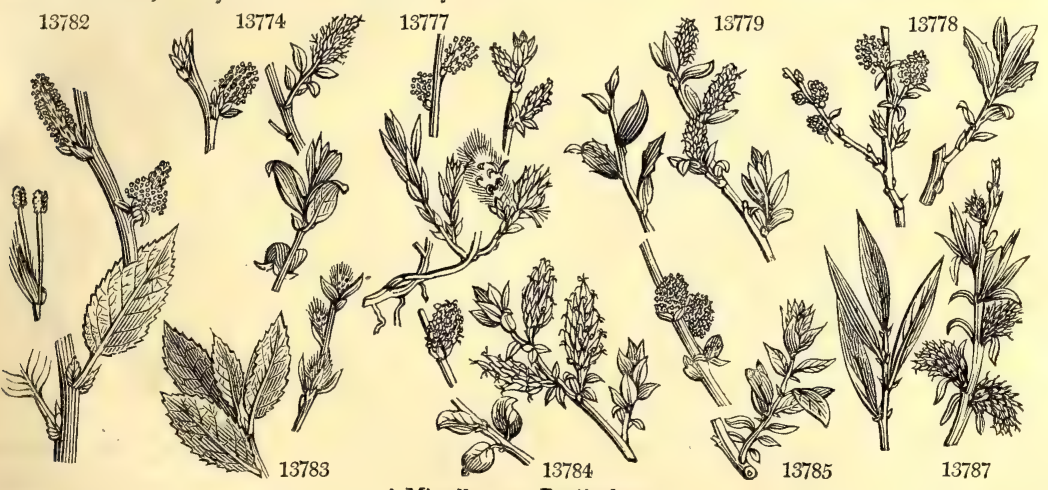

and Miscellaneous Particulars.

known; being only from one to three inches in height. S. retusa is nearly as little as $\mathrm{S}$. herbacea. S. vitellina with its brilliant yellow bark, planted in shrubberies, contrasts well with evergreens and the purple twigged dogwood.

Almost all the willows are of the easiest propagation and culture. Plantations for basket-work or hoops should be made on deep loamy soil on the banks of rivers, within reach of water, but by no means saturated with it. Few willows are either bog or marsh plants. The cultivated species require as much attention as 
13788 ripária $W$.

13789 angustifólia $W$. 13790 grisea $W$.

13791 spatuláta $W$.

13792 auríta $W . e n$. 13793 uliginósa W.en. aurita $\mathrm{E} . \mathrm{B}$ 13794 aquática $W$. 13795 oleifília $W$ 13796 cotinifólia $W$ 13797 sphaceláta $W$

13798 cáprea $W$.

13799 Stuartiána $E . B$.

13800 acumináta $W$.

13802 viminális $W$.

13803 mollíssima $E$. $B$.

13804 stipuláris $W$.

13805 cándida $P h$.

13806 Fluggeána $W$ 13807 álba $W$.

13808 cærúlea $E . B$ 13809 rupéstris $E . B$.
13801 conífera $P h$

bank

narrow-leaved grizzly

spatulate

eared

marsh

water

Olive-leaved

Quince-leaved

withered-point. 亚

greatround-Ivd. 萑

Stuart's 鉴

acuminate

Cone-bearing

Common Osier 䦕

Smith's

花

auricled

hoary Flugge's whe
common white

blue

silky root

18810 Andersoniána $E$, B. Anderson's

13811 Forsteriána E. B. Forster's

13812 finmar'chica $W$.

13813 holosericea $W$

Finmarck

velvety

2043. CECRO'PIA. $W$. SNAKE-WOOD. 13814 peltáta $W$.

2044. BO'RYA. $W$. 13815 porulósa $W$. 13816 ligustrina $W$. 13817 acumináta $W$ 13818 prinoídes $W$. 13819 nítida $W$. 13820 retúsa $W$. peltated

Borya. Florida Privet-leaved pointed Prinos-like shining glaucous or

or 6 ap.my sp

or 3 ap.my Ap

or 6 ap.my Ap

or 5 ap.my Ap

clt 2 ap.my Ap

or 10 ap Ap

or 4 mr Ap

or 2 ap.my Ap

or 30 ap.my Ap

or 4 jl.au Ap

or 15 ap

Ap

or $10 \mathrm{my}$

Ap

clt 12 ap.my Ap

or 20 ap.my Ap

clt 6 mr.ap Ap

or 10 ap.my Ap

or 10 ap.my Ap cit 40 ap.my Ap

or 40 ap.my Ap

or 3 ap Ap

签 or 3 ap.my Ap

花 or 10 ap.my Ap

藍 Urticea. Sp. 1-3.

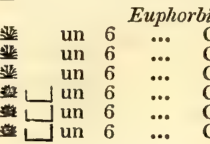

Germany 1821. C m,s

Caspian 1825. C m. Pensylv. 1820. C m.

Germany 1818. C m.s

Europe 1820. C m.s Hof.sal.1.t.22.f.1 Britain woods. C m.s Eng. bot. 1487

ritain w.thi. C m.s Eng. bot. 1437 Britain thick. C m.s Eng bot. 1409 Britain woods. C m.s Eng. bot. 1403 Scotland sc.alp. C m.s Eng. bot. 2333

Britain dr.wo. C m.s Eng. bot. 1488 Scotland sc.alp. C m.s Eng. bot. 2586 Britain moi.w. C m.s Eng. bot. 1434 N. Amer, 1820. C m.s Wa.am.t.31.f.72 Britain os.gro. C m.s Eng. bot. 1898 England os.gro. C m.s Eng. bot. 1509 England os.gro. C m.s Eng. bot. 1214 N. Amer, 1811. C m.s

S. France 1820. C m.s Vi.del.3 t.51.f. 28 Britain woods. C m.s Eng. bot. 2430

England m.me. C m.s Eng. bot. 2431 Scotland sc.alp. C m.s Eng. bot. 2342

Scotland sc.mo. C m.s Eng. bot. 2343

Scotland sc.wo. C m.s Eng. bot. 2344

Sweden 1825. C m.s

-3. Sp. 6.

Florida 1806. C m.s

N. Amer, 1812. C $\mathrm{C}$.s Mich.ame.2.t.28

N. Amer. 1824. C m.s

N. Amer. 1824. C $\mathrm{ms}$

N. Amer. 1824, C m.s

\section{TRIANDRIA.}

2015. EMPE/TRUM. $\boldsymbol{W}$. Crow Berry. 13821 álbum $W$. 13822 nígrum $\boldsymbol{W}$.

white-berried black-berried

or $\ldots . . . . . . . . . . . . .5$ Sp. 2-3.

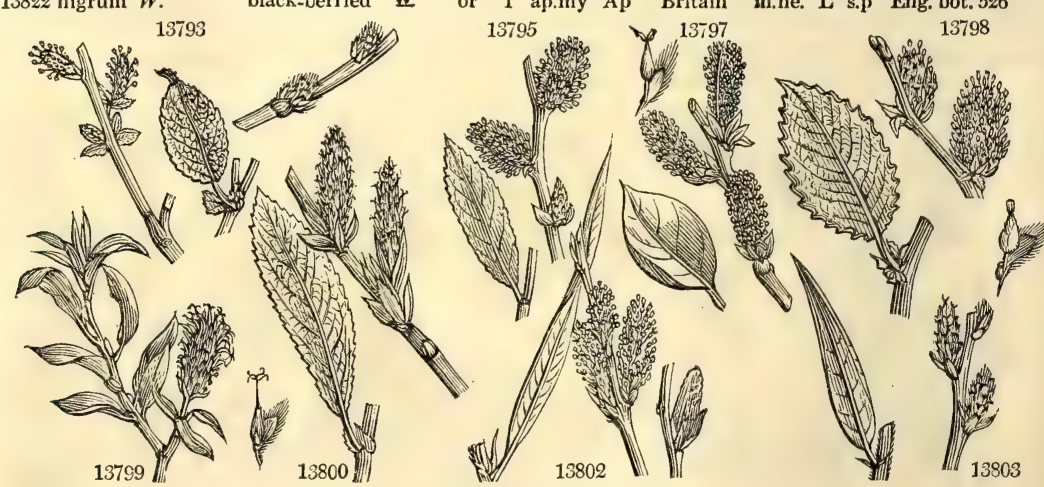

History, Use, Propagation, Culture,

young trees in a nursery, otherwise they will soon become stunted and of irregular growth. Excellent directions for their culture may be found in Sang's Planter's Kalendar.

2043. Cecropia. From *sะe $2 \omega \omega$, to cry out, a sort of translation of the English word trumpet-wood, This tree has the trunk and branches hollow every where, and sloped from space to space with membranaceous septas, and answering to so many annual marks in the surface. The leaves are large, peltate, lobed like those of Carica Papaya, and placed at the ends of the branches. The fruits rise four, five or more, from the very top of a comrnon peduncle, and shoot into so many oblong cylindrical berries, composed of a row of little acini, something like our raspberry, which they resemble in flavor when ripe, and are agreeable to most European palates on that account. The wood of this tree, when dry, is very apt to take fire by attrition. The native Indians have taken the hint, and always kindle their fires in the woods by rubbing a piece of it against some 
13788 Leaves linear-lanceolate with small glandular teeth entire at the base clothed with close-pressed hairs above downy and rugged with veins beneath, Ovary ovate smooth

13789 Leaves linear very narrow without stipules nearly entire ovate at the base hoary above silky beneath

13790 Leaves lanceolate pointed serr. smooth above glauc. and silky beneath, Stipules linear deflex. deciduous, Catk, before the leaves, Scales hairy, Ovary stalked oblong silky, Stigm. nearly sessile

13791 Leaves lanceolate-obovate with a recurved point serrated at the end clothed with depressed hairs above rugged veiny and downy beneath, Stipules lanceolate

13792 Leaves obovate lanceolate obtuse mucronate with a hooked point subserrate green above hoary beneath

13793 Leaves obovate with a recurved point with wavy serrat. at end green and downy above hoary and shaggy with rugged veins beneath, Stip. $\frac{1}{2}$ heart-shaped toothed, Caps. lanceolate stalked, Stigm. nearly sessile

13794 Lvs. slightly serrat. obov.-ellipt. downy flat rather glauc. ben. Stipules rounded tooth. Stigm. nearly sess.

15795 Lys, obov, lanc. flat rather rigid minute. indent. ac. undern. glauc. and hairy, Stip. small notch. Catk, ellipt.

13796 Lvs. ellipt. almost circular slightly tooth. downy with rectang. veins ben. Style as long as notched stigmas

13797 Leaves entire elliptical acute even downy on both sides somewhat withered at the point, Stipules obsol. Ovary lanceolate silky on a long hairy stalk, Stigmas nearly sessile

13798 Leaves ovate pointed serrated waved downy beneath, Stipules somewhat crescent-shaped, Ovary ovate downy on a long hairy stalk, Stigmas undivided nearly sessile

13799 Leaves nearly entire lanceolate acute shaggy above densely silky beneath, Stigmas capillary deeply divided, Style as long as the ovary

13800 Leaves lanc. oblong pointed waved slightly downy beneath, Stipules kidney-shaped, Ovary ovate silky, Style the length of the linear stigmas

13801 Leaves oblong lanceolate acute distantly serrated smooth above flat and downy beneath, Stipules lunate somewhat toothed, Ovary stalked lanceolate silky, Style elongated, Stigm. deeply cloven

13802 Leaves linear inclining to lanceolate very long pointed entire somewhat wavy silky beneath, Branches straight and slender, Ovary sessile, Style as long as the undivided linear stigmas

13803 Leaves lanceolate pointed obsoletely crenate whitish and silky beneath, Stipules crescent-shaped minute, Stigmas linear deeply divided about the length of the style

13804 Leaves lanc. pointed obscurely crenate downy beneath, Stipules half heart-shaped very large, Nectary cylindrical, Stigmas linear undivided longer than the style

13805 Leaves linear lanceolate pointed revol. obscurely toothed downy above snow-white and cottony beneath, Stip. lanc. about the length of the footstalk, Scales of the catk. with hairs as long as the stamens

13806 Lvs. obl. lanc. ac. at each end nearly ent. without stipul. smooth. above downy ben. Ovary ovate lanc. silky

13807 Leaves elliptic-lanceolate acute serrated permanently silky on both sides : the lowest serratures glandular, Stamens hairy, Stigmas deeply cloven

13808 Lvs. lanc. taper-point. serrat. : under-side at length almost naked; lowest serrat.gland. Stigm. deeply cloven 13809 Leaves obovate serrated flat even silky on both sides, Stipules hairy, Branches minutely downy, Ovary stalked awl-shaped silky, Styie as long as the undivided stigmas

13810 Leaves elliptic obl. acute finely notched slightly downy paler beneath, Stipulas half-ovate nearly smooth, Branches minutely downy, Ovary stalked smooth, Style as long as the cloven stigmas

13811 Leaves elliptical obovate acute notched slightly downy glaucous beneath, Stipules vaulted, Branches minutely downy, Ovary stalked silky, Style longer than the thick undivided stigmas

13812 Lvs. obl. acute entire silky on each side hoary ben. Ovaries long-pointed lax, Scales very blunt smooth 13813 Lvs. lanc. acum. toothl. at end smooth above rugose and soft beneath, Caps. downy lanc. Stigmas sessile

13814 Leaves 9-lobed : lobes oblong bluntish hispid and rough above white and downy beneath

13815 Leaves oblong lanceolate obtuse sessile coriaceous revolute at edge dotted beneath

13816 Leaves ovate-lanceolate acute subsessile somewhat membranous

13817 Leaves ovate-lanceolate narrowed at each end stalked membranous serrulated

13818 Leaves $2 \frac{3}{4}$ inches long 1 broad serrated

13819 Leaves acute serrulate very smooth shining oppositc and alternate

13820 Leaves alternate tapered into a short stalk retuse emarginate mucronulate very smooth glaucous

\section{$T R I A N D R I A$}

13821 Erect, Branches downy, Leaves linear revolute at edge roughish above

13822 Procumbent, Leaves linear oblong

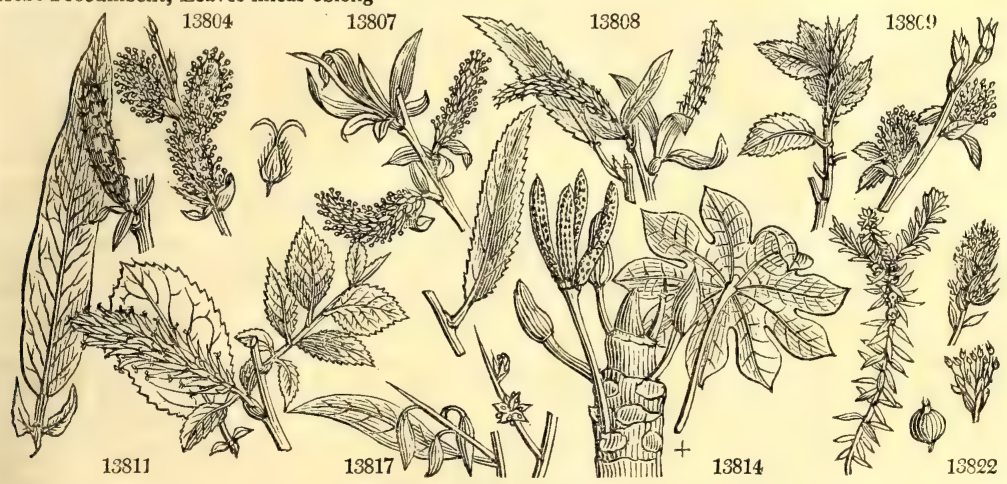

and Miscellaneous Particulars.

harder wood. The bark is strong and fibrous, and is frequently used for all sorts of cordage. The trunk is very light, and for that reason much used for bark-logs and fishing-fioats. The smaller branches, when cleaned of the septums, serve for wind instruments. Both trunk and branches yield a great quantity of fixed salt, which is much used among the French, to despumate and granulate their sugars. The fruit is much fed upon by pigeons and other birds, and thus the tree is much spread and propagated. (Browne.) It may be increased like Brosimum.

2014. Borya. Named in honor of M. Bory de St. Vincent, a distinguished French traveller and naturalist, known out of the scientific world by the violence of his liberal opinions. Small bushes of North America, of little beauty. Sir James Smith has altered the name to Bigelovia.

2045. Empctrum. So called from the places of its natural growth, $\varepsilon y$, in, and $\pi \varepsilon \tau \rho \circ$, a stone. E. nigrum is 
2046. WILLDENO'VIA. Th. WILLdenovia.

13823 téres $W$.

2047. RES'TIO. $W$.

13824 tectórum $W$

13825 virgátus $W$.

13826 dichótomus $W$

13827 paniculátus $W$.

13828 vaginátus $W$.

2048. ELE'GIA. $\boldsymbol{W}$. 13829 júncea Thunb.

13830 racemósa Lam.

2049. PHOE'NIX. $W$. 13831 dactylífera $W$. 13832 recl náta $\boldsymbol{W}$. 13833 farinítera $i V$. 13834 acaúlis Roxb.

2050. STILA'GO. $W$ 13835 Búnius $W$. 13836 diándra $W$

2051. OSY'RIS. $W$. 13837 álba $W$.

DATE PAI common reclining small

stemless

StILAgo.

Poet's Cassia. round-stalked 証 $\Delta \mathrm{p}$

Rope Grass.

thatch

twiggy

dichotomous

panicled

sheathed

Elegia.

Rush-like

racemed
Restiacer. $S p .1-3$

2 jn.jl Ap C. G. H. 1790. R s.p Ac.h.1790.t.2.f.2

Restiacea. Sp. 5-47.

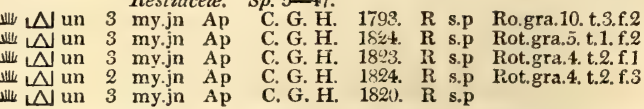

C, G, H. 1820, R s.p

Restiacece. Sp. 2-3.

此 $\triangle \mathrm{J}$ un 1 jl.au Ap C. G. H. 1789. C 1.p Rot.gra.8. t.3. f.4 嶫 $\triangle$ un 1 my.jn Ap C. G. H. 180t. C l.p Lam.ill.t.804.f.4

Palma. $\mathrm{Sp} .4$

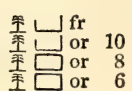

... W.G Levant 1597. S r.m K.amæ.e86.t.1,2 ... W. G C. G. H. 1792. S 1.p Jac.frag. 27. t. 24 ... W.g E. Indies 1800. S r.m Rox. cor. 1.t. 74 ... W.G E. Indies 1816. S r.m

Laurel-leaved is $\square$ un 20 au $\mathrm{Ap}$ E. Indies 1757. C p.l Rhee.mal.4.t.56 diandrous $\$$ un 20 ... Ap E. Indies 1800. C p.1 Rox.cor.2.t.165

Santalacea. Sp $1-2$

Santalacea. Sp 1-2.

\section{TETRANDRIA.}

2052. AU'LAX. R. Br. AULAX. 13838 pinifólia $R, B r$. Pine-leaved 13839 umbelláta $R$. Br. umbelled
Proteacea. $S p .2$.

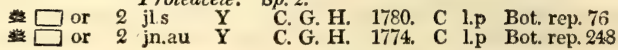
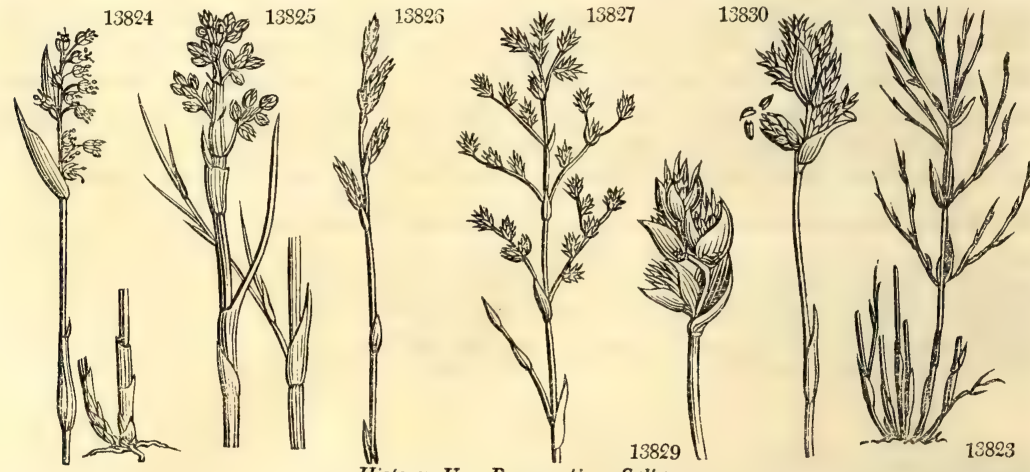

History, Use, Propagation, Culture.

very common in the northern parts of Europe, in elevated situations, on dry, barren, moorish, or boggy soils. It is more patient of cold than even the common heath. The Highlanders' children eat the berries, but they are no very desirable fruit; and taken in large quantities, are said to bring on a slight head-ache. The Russian peasants, however, eat them, and the Kamtschadales gather great quantities of them to boil with their fish, or to make a sort of pudding with the bulbs of their lillies. They are esteemed antiscorbutic and diuretic. Grouse and heathcocks feed upon them, and they give the excrement a tinge of purple. Boiled in alumwater they afford a dark purple dye; and boiled with fat, they are said to be used in dying otter and sable skins black. Cattle do not seem to browse on this shrub. The French word Camarine, is an alteration of Camarinhas, the Portuguese name of $\mathrm{E}$. album.

2046. Willdenovia. A rush-like plant, with long flexible slender shoots, named in honor of Charles Louis Willdenow, a celebrated Prussian botanist, whose edition of Linnæus's Species Plantarum is not only the best which has been published in modern days, but excellent in itself

2047. Restio. From restis, cord; the supple shoots of many species are used as withs at the Cape of Good Hope. The houses of the Cape of Good Hope are commonly thatched with this plant both in town and country, and sometimes whole huts are built with it. A roof thatched with it will last twenty or thirty years, and would last much longer, if the south-east wind did not blow much dirt into it, which causes it to rot.

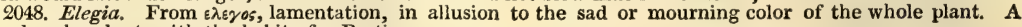
hard rushy plant, with the habit of a Restio.

2049. Phoenix. The Greek name of the date, and probably so called from Phœnicia, whence the best dates were brought. Dactylifera is the Greek version of Palma, both signifying the hand, to the fingers of which the ancients likened the bunches of dates. P. dactylifera is a lofty palm, with a rugged trunk, on account of the persisting vestiges of the decayed leaves. These leaves, when the tree is grown to a size for bearing fruit, are six or eight feet long, with pinnæ three feet long, and a little more than an inch broad. The flowers of both sexes come out in very long bunches from the trunk between the leaves, and are covered with a spatha, which opens and withers; those of the male have six short stamina, with narrow four-cornered anthers filled with farina. The female flowers have no stamina, but have a roundish germ, which afterwards becomes an oval berry, with a thick pulp enclosing a hard oblong stone, with a deep furrow running longitudinally. The fruit of this tree makes a great part of the diet of the inhabitants of Arabia and part of Persia. In Upper Egypt many families subsist almost entirely upon it. They make a conserve of it with sugar; and even grind the hard stones in their hand-mills for their camels. In Barbary they turn handsome beads for paternosters of these stones. The date is said to strengthen the stomach and intestines, to stop looseness, and promote expectoration, for which purpose it is given in pectoral decoctions. It is also recommended in the pring in is also recom. In Egyn piles, given in red wine. From the leaves of the tree they make baskets or bags in Barbary. In Egypt they make fly-flaps of them, and brushes to clean their sofas or clothes. The hard boughs are used as fences to their gardens, and cages to carry their fowls to market. The trunk is split for the same purposes, and is even used in small buildings. It serves likewise for firing. The threads of the web-like integument between the 
13823 Culm and branches round smooth

13824 Culm simple leafless, Spikes racemose somewhat 1-sided roundish triquetrous cernuous with bracteæ 13825 Culm dichotomous leafy, Branches compressed, Spikes panicled pendulous

13826 Culm dichotomous leafy decumbent, Branches round, Spikes solitary and alternate

13827 Culm dichotomous leafy, Branches compressed, Spikes sessile alternate erect

13828 Culm simple leafless, Spikes alternate erect, Scales acuminate

13829 Culrn simple nearly naked, Spathes very large ovate nearly acute, Spikes clustered thyrsoid 13830 Culm channelled, Spathes large ovate obtuse, Spikes racemose

13831 Fronds pinnated unarmed, Leaflets folked together linear-lanceolate straight

13832 Fronds pinnated unarmed, Leaflets folded together linear-lanceolate loosely spreading

13833 Fronds pinnated unarmed, Leaflets linear-subulate folded together, Flowers hexandrous

13834 Pinnæ linear-ensiform folded together : lower spiny

13835 Flowers triandrous

13836 Flowers diandrous

13837 The only species

TETRANDRIA.

13838 Leaves filiform channelled

13839 Leaves flat spatulate-linear

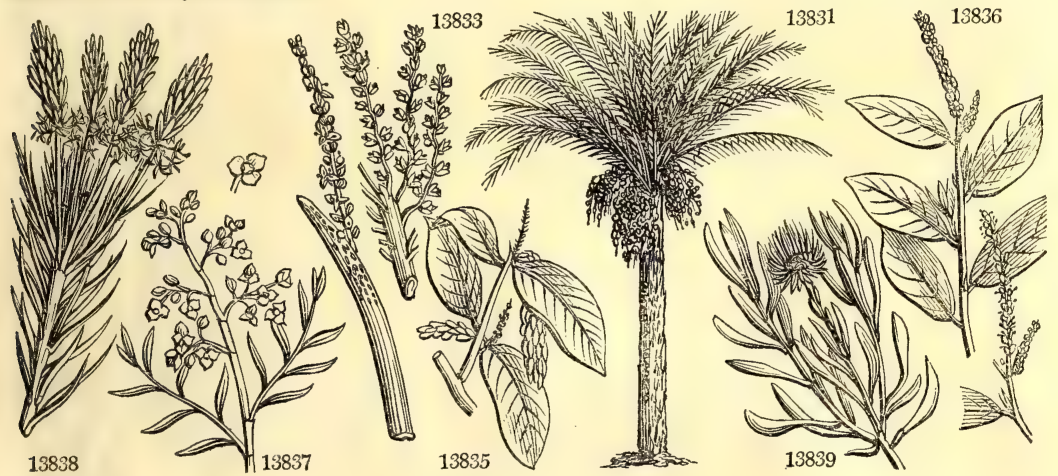

and Miscellancous Particulars.

boughs make ropes and the rigging of smaller vessels. The juice of the date tree is procured by cutting of the head or crown of the more vigorous plant, and scooping the top of the trunk into the shape of a basin; where the sap in ascending lodges itself, at the rate of three or four quarts a day, during the first week or fortnight; after which, the quantity daily diminishes, and at the end of six weeks or two months the tree becomes dry, and serves for timber or firewood. This liquor, which has a more luscious sweetness than honey, is of the consistence of a thin syrup, but quickly becomes tart and ropy, acquiring an intoxicating quality, and giving upon distillation an agreeable spirit or araky, which is the general name in the East for all hot liquors extracted by the alembick.

P. farinifera produces black drupes of the size of a large kidney bean; these the natives of Coromandel eat as gathered from the bush without any preparation. The leaflets are wrought into mats; the common petioles are split into three or four, and used for making ordinary baskets of various kinds ; but they are not so proper for this purpose as the bamboo. The small trunk, when divested of its leaves, and the strong brown fibrous web that surrounds the trunk at their insertions, is wenerally fifteen or eighteen inches long, and six in diameter at the thickest part; its exterior or woody part consists of white fibres matted together, which envelope a large quantity of farinaceous substance, used as food by the natives in times of scarcity; but to separate this from the fibres, the trunk is split into six or eight pieces, then dried, beaten in wooden mortars, and afterwards sifted: the rest of the preparation consists in boiling the meal into a thick gruel, or, as it is called in India, congee. It seems to be much less nutritive than sago, and is less palatable.

2050. Stilago. Perhaps so called from the length of the style; but the name is unexplained by its author. S. diandra produces an eatable fruit used by the natives, but not esteemed by Europeans. The species thrive in sandy loam, and cuttings root in sand under a hand-glass.

2051. Osyris. The Greek name of a tree with long supple branches, which were used for brushes and similar purposes. The modern shrub has also slender flexible branches, of which packing materials are formed throughout the south of Europe

2052. Aulax. From $\alpha \nu \lambda \propto \xi$, a furrow ; in allusion, we presume, to the furrows on the under-side of the leaves of the original species. Neat shrubs with narrow leaves; nearly allied to Protea. This, Sweet observes, is " a pretty genus belonging to the Proteacez, which thrives best in a very sandy loam, with a great many potsherds broken small at the bottom of the pot, to let the water drain off freely, as they frequently get too much water, which makes the mould sodden, and stagnates their growth. Ripened cuttings, taken off at a joint, and planted in a pot of sand, will strike root, if placed under a hand-glass in the propagating house, and the glass to be occasionally left off, an hour or two at a time, to give them air, and keep them from damping; which should be done in a morning bere raised from seeds, which should be sown in a mixture of two-thirds loam and one-third sand: as soon as they come up, they should be planted off in small pots, in the same kind of soil, as they are very apt to die, if left too long in the seed-pot." (Bot. Cult. 143.) 
2053. LeUCADEN'DRON. R. Br. Leucadendron. Proteacee. Sp. 24-37.

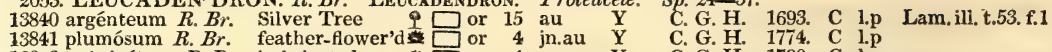
13842 imbricátum $R$. Br. imbricated 0 or 4 ... Y 13843 buxifólium $R$. Br. Box-leaved 13844 Leviśnus $R$. Br short-leaved 13845 linifólium $R . B r$. Flax-leaved or 4 ap.jn $\mathbf{Y}$ 13846 fusciflórum $R$. Br r. starred $\square$ or 4 my.jn $\mathbf{Y}$ Prótea stelláris B. M.

13847 tórtum $L . T$. twisted-leaved 13848 cinéreum $L$. $T$. 13849 corymbósum $L . T$. $\begin{aligned} & \text { gray } \\ & \text { corymbed }\end{aligned}$ 13850 decórum $L . T$. $T$. decorous 13851 cóncolor $L . T$. one-colored 13852 grandiflórum $L . T$. great-flowered 13853 decúrrens $L . T$. 13854 stríctum $L$. $T$. 13855 virgátum $L$. $T$. 13856 adscéndens $L . T$. 13857 concínnum $L . T$. 13858 salígnum $L$. $T$. 13859 uliginósuin $L$. $T$. 13860 flóridum $L . T$. $13861 æ^{\prime}$ mulum $L . T$. 13862 abietínum $L$. $T$. 13863 scábrum $L . T$. decurrent
upright slender pale neat Willow-leaved swamp florid incurved Pine-leaved rough

C. G. H. 1774. C l.p

C. G. H. 1790. C 1.p

C. G. H. 1812. C

C. G. H. 1774. C l.p Bur.afr.t. $100 . f 2$

C. G. H. $\quad \ldots$ C l.p Jac schœ1. t. 26

C. G. H. $\quad \ldots$ C $1 . p$ Bot. mag. 881

C. G. H. 1790. C 1.p Bot. reg. 826

C. G. H. 1774. C 1.p

C. G. H. 1790. C 1.p Bot. reg. 102

C. G. H. 1790, C

C. G. H. 1774. C l.p Bot. rep. 307

C. G. H. 1789. C 1.p Par. lond. 105

C. G. H. 1812. C i.p

C. G. H. 1795, C l.p Par. lond. 75

C. G. $\mathrm{H} . \quad \ldots \quad$ C $1 . \mathrm{p}$

C. G. H. 1774. C 1.p Pl.man.t.229.f.6

C. G. H. 1800. C l.p

C. G. H. 1774. C 1.p Boer.lug.2.t.204

C. G. H. 1795. C 1.p Breyn.cen 21.t.9

C. G. H. 1795. C 1.p Bot.rep. 572

C. G. H. 1789. C 1.p Bot. rep. 429

C. G. H. 1789. C l.p Bot. rep. 461

C. G. H. 1812. C 1.p

2054. VIS'CUM. $W$. Misletoe.

13864 álbum $W$.

MrsLETOE
common

2055. MYRI'CA. $W$. 13865 Gále $W$.

13866 cerífera $W$.

13867 carolinénsis $W$

13868 pensylvánica $P h$

13869 Fáya $W$.

13870 æthiópica $W$.

13871 serráta $W$.

13872 laciniáta $W . e n$.

13873 quercifólia $W$. en.

13874 cordifólia $W$.

13875 mexicána $W$.

13876 segregáta Jacq.

Candleberry Myrtle.

common

broad-leaved

Pensylvanian

Azorian

African

saw-leaved

smooth Oak-lv.

hairy Oak-lvd.

heart-leaved

Mexican

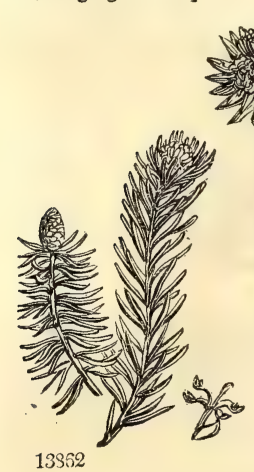

netted

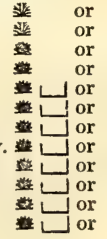

Loranthea. Sp. 1.

gland trees. S m.s Eng. bot. 1470

Sp. 12-21.

- my Ap Britain sp. bo. L s.p Eng. bot. 562

my.jn Ap N. Amer. 1699. S s.p Cat. car. 1. t. 69

N. Amer. 1730. S s.p Cat. car. 1. t. 13

N. Amer. ... C s.p Du.ar.e.n. 2.t.55

6 jn.jl Ap Azores 1777. L s.l Du.ar.e.n.2.t.56

8 jn.jl Ap C. G.H. 1795. I s.l Plu.alm. t.48.f.8

C. G. H. 1793. L s.1 Plu.am.t.424.f.3

C. G. H. 1752. L s.1 Jac.frag.2.t.1.f.4

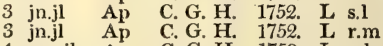

4 my.jl Ap C. G. H. 1759. L p.l Plu.alm.t.319.f.7

8 f Ap Mexico 1823 $\mathrm{L}$.

Mexico 1823. L p.l J 13847

13861

13862

13846

$6 \quad$... A
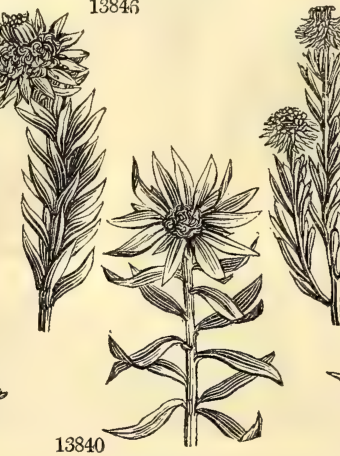

History, Use, Propagation, Culture,

2053. Leucadendron. From $\lambda \varepsilon v * 05$, white, and $\delta \varepsilon y \delta \rho \circ y$, a tree, in allusion to the appearance of the most com mon species, No. 13,840. The species are evergreen shrubs, with handsome foliage; they grow in light soil well drained and not over watered, and are increased by ripened cuttings in sand under a hand-glass.

2054. Viscum. From the Latin viscus, clammy, on account of the sticky nature of the berries. Gui, Fr. Mistl, Ger, and Visco, Ital. This may be considered the only true parasitical plant indigenous to Britain, as at no period of its existence does it derive any nourishment from the soil like Orobanche, or from decayed bark or wood like certain Fungi, and other epiphytes. The root of the misletoe insinuates its fibres into the woody substance of the tree; the shoots are dichotomous, round, smooth, and even; and of a pale green, like the leaves, which are tongue-shaped and entire. The whole forms a pendant bush of from two to five feet in diameter, evergreen, and in winter covered with small white very glutinous berries. The British species of misletoe is commonly found on fruit trees; but it will grow on various others, as the thorn, oak, maple, poplar, lime, ash, \&c. ; and in the neighbourhood of Magdebourg it is abundant on Pinus sylvestris. It is not difficult to propagate by inserting the berries in slits in the bark early in spring, and tying a shred of mat over the slit to protect them from the birds. The Druids sent round their attendant youths with branches of the misletoe to announce the entrance of the new year; and something like the same custom is still continued in France. In England branches of it are hung up in most houses at Christmas, along with other evergreens. The berries are devoured by several birds of the thrush kind, and esnecially by the Misletoe Thrush. Birdlime is made from the berries, and also from the bark, boiled in water, beaten in a mortar and washed. It is, however, more commonly manufactured from the bark of the holly.

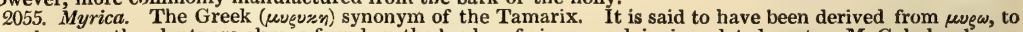
flow, because the plants are always found on the banks of rivers, and in inundated spots. M. Gale has leaves of a bitter taste, but fragrant like those of the myrtle. Their essential oil rises in distillation. The northern nations formerly used this plant instead of hops, and it is still in use for that purpose in some of the western isles, and a few places in the Highlands of Scotland. Unless it be boiled a long time, it is reported to occasion head-ache. The catkins or cones boiled in water throw up a scum resembling bees' wax, which gathered in sufficient quantities would make candles. It is used to tan calf-skins. Gathered in the autumn it dyes wool 
13840 Arborescent, Leaves lanceolate silky, Branches villous, Bractes short downy, Cal. silky

1:3841 Shrubby, Leaves linear lanceolate oblique smoothish, Male cal. smooth: female feathery, Fruit villous 13842 Lvs. lanc. lin. smooth rounded at base, Branches vill. Scales of cone silky cuneate, Fruit comose mucronate 13843 Leaves oval lanceolate : when old smooth, Scales of cone dilated-cuneate silky

13844 Leaves spatulate callous at end, and branches villous, Fruit comose pointless

13845 Leaves linear spatulate tapering at base and branches smooth, Male head sessile larger than leaves

13846 Leaves linear lanceolate smooth : the younger straight tapering at base, Female head shorter than leaves

13847 Leaves linear bluntish twisted smooth, Branchlets somewhat silky, Cal. silky, Fruit comose pointless 13848 Leaves spatulate linear silky with a callous beard at end, Cal. very shaggy, Fruit cuneate downy 13849 Lvs. lin. acute channelled imbricated erect smooth, Scales of cone acute recurved, Fruit obcord. ciliated 13850 Lvs. obl. veiny callous at end recurved smoothish : floral colored $\frac{1}{2}$ scarious, Scales of cone downy outside 13851 Leaves spatulate obl. callous at end smooth, Branches downy, Scales of cone retuse ciliated downy at base 13852 Lvs. lanc. obl, callous at end smooth : floral colored, Branches somewhat downy, Scales ovate obt. smooth 13853 Lvs. spatul. lanc. call. at end subdecurrent concave and branches smooth, Scales of cone roundish smoothish 13854 Lvs. lin. lanc. mucron. finally smooth, Invol. ov. ac. longer than head, Scales of cone round. dilated smooth 13855 Lvs. lin. acute with transparent edges and branches quite smooth : floral lin. lanc. long, Fr. winged emargin. 13856 Leaves linear lanceolate acute : floral lanceolate colored concave, Shrub low with ascenaing branches

13857 Lvs. obl. lanceolate bluntish veinless and branches quite smooth : floral $\frac{1}{2}$-colored, Fruit winged emarginate 13858 Leaves linear lanceolate cuspidate somewhat silky : floral lanceolate colored, Fruit very narrow winged 13859 Leaves lanc. lin. silky with down on each side with callous points at end, Branches downy, Calyx hairy 13860 Lvs. lanc. lin. silky with down on each side with call. points at end, Branches shag. Cal. of male hairy in lines 13861 Upp. Ivs. lanc. spatul. ac. rugose, Cones ov. Scales cohering at base distinct above with recurv. beardl, edges 13862 Lvs, all filiform chann. bluntish smooth spreading incurved, Scales cohering at base distinct above 2-lobed 13863 Lvs. all filiform channelled acute imbric. straightish ciliated, Scales cohering at base distinct above 2-lobed

13864 Leaves lanceolate obtuse, Stem dichotomous, Heads of flowers axillary

13865 Leaves lanceolate broader upwards serrated, Stem shrubby

13866 Leaves oblong narrowed at base subserrate at end, Scales of male catkins acute, Berries globose 13867 Leaves oblong narrowed at base coarsely serrated, Scales of male catkins acute, Berries globose 13868 Leaves oblong acute at each end entire or slightly serrated at end revolute at edge

13869 Leaves elliptical lanceolate subserrate, Male catkins compound, Drupe with a 4 celled nucleus 13870 Leaves elliptical toothed : the lowest quite entire

13871 Leaves lanceolate unequally acuminate serrated, Catkins long lax

13872 Leaves oblong deeply sinuated smooth

13873 Leaves oblong oppositely sinuated hairy

13874 Leaves subcordate serrate sessile

13875 Leaves oblong lanc. cuneate tapered at base neariy entire smooth shining with the middle nerve downy 13876 Leaves lanceolate entire netted with veins, Catkins few-flowered lax

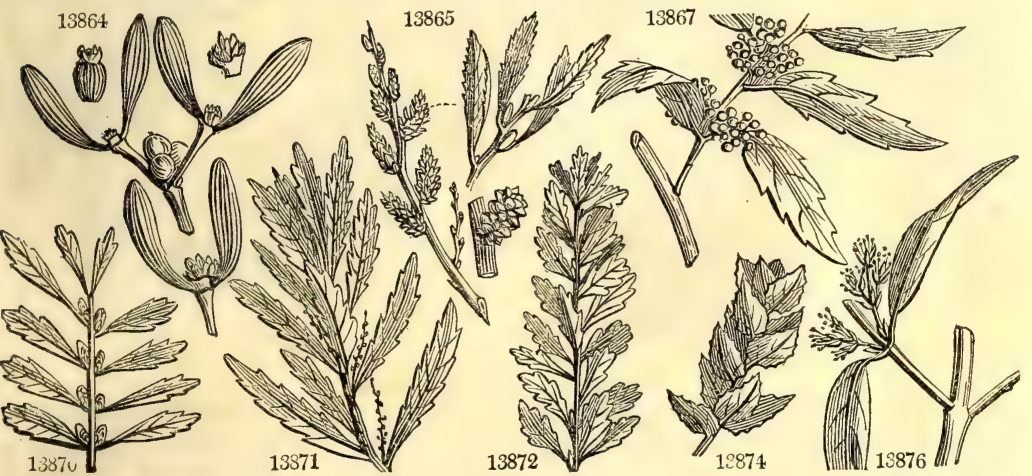

and Miscellaneous Particulars.

yellow, and is used for that purpose both in Sweden and Wales. The Swedes sometimes use a strong decoction of it to kill bugs and lice, and to cure the itch. The Welsh lay branches of it upon and under their beds to keep off fleas and moths, and give it as a vermifuge in powder and infusion, applying it also externally to the abdomen. In most of the Hebrides, as well as in the Highlands of Scotland, an infusion of the leaves is fre quently given to children to destroy the worms. In Isla and Jura the inhabitants garnish their dishes with it, and lay it between their linen and other garments to give them a fine scent, and to drive away moths. When it grows within reach of a port, the sailors make besoms of it for sweeping their ships. In the isle of Ely they make faggots with it to heat their ovens. Linnæus was induced to suspect, from the smell of this shrub, that camphor might possibly be prepared from it. Horses and goats eat; sheep and cows refuse it.

M. cerifera may be used for most of the purposes of the former species. Candles are made from the berries in North America, whence it is called there the tallow shrub or candleberry tree; some also name it the bayberry-bush. It grows abundantly on a wet soil, and seems to thrive particularly well in the neighbourhood of the sea does it secm ever to be found high up in the country. The berries intended for making candles are gathered late in autumn, and are thrown into a pot of boiling water; their fat melts out, floats at the top of the water, and may be skimmed off. The fat when congealed looks like tallow or wax, but has a dirty green color; it is therefore melted again and refined, by which means it acquires a fine and pretty transparent green color. It is dearer than common tallow, but cheaper than wax. They usually mix some tallow with it. Candles of this kind do not easily bend or melt in summer as common candles do ; they burn better and slower, nor do they cause any smoke, but rather yield an agreeable smell when they are extinguished. At present not many candles of this kind are used, the animal tallow is readily come at, it being very troublesome to gather the berries. They are chielly used by poor people, who live near where the bushes grow, and have not cattle berries. They are chielly used by poor people, who live near where the bushes grow, and have not cattle
enough to supply them. A soap is made from the fat which has an agreeable scent, and is excellent for shaving; and it is used by surgeons for plasters. In Carolina they likewise make sealing-wax from these berries. The root is accounted a specific in the tooth-ache.

All the species grow well in peat soil or sandy loam, in a moist situation. Thcy are increased by seeds or layers, but not readily by cuttings. 
2056. NAGE'IA Gartn. Nagera. 13877 Putranjiva Roxb. grey-barked

Amentacea. Sp. 1-3.

2057. SHEPHER'Di A. Nutt. Surpierdia. 13878 canadénsis Nutt. Canadian

2058. HIPPO'PHAE, $W$. SEA BuckthoRN 13879 rhamnoídes $W$. common 花

2059. BROUSSONE'TIA. $\boldsymbol{W}$. Broussonetia. 13880 papyrífera $W$. Paper Mulberry 13881 spatuláta Hort. entire-leaved

2060. SCHIEFFE'RIA. $\boldsymbol{W}$. SCHAFTERIA. 13882 compléta $W$. white-

2061. BRU'CEA. $W$. BRUCEA. 13883 ferruginea $W$. 1388 ferruginea Hor. Sumatra

2062 A NTHOSPER'MUM $W$ A $W$ TRE 13885 æthiópicum $W$. Ethiopian un $12 \quad \ldots \quad$ Ap $\quad$ F.. Indies 18æ2. C r.m Elcagnea. Sp. 1.

or 10 ap.my Ap N. Amer. 1759. L co Elaeagnee. Sp. 1.

or 12 ap.my Ap England seaco. L co Eng. bot. 425 Urticea. Sp. 2.

or 12 f.s Ap Japan 1751. C co Kæm.amœ.t.472 or 12 f.s Ap $\mathrm{s}$...... 1824. C co

................. Sp. 1 -2.

Terebintacece. Sp. 2-3.

2063. Tro'phis. $W$. Ramoon Tree. 13886 americána $W$. 13887 áspera $W$. American rough-leaved

2064. MONTI'NIA. $\boldsymbol{W}$. Montinia. 13888 caryophyllácea $H$. $K$. Sea Pursl.-lvd.

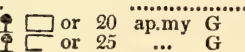

ap.my G E. Indies 1820. C $\begin{array}{lll}\text { p.l } \\ \text { G. }\end{array}$

1793. C p.l Lam. iil. t. 809

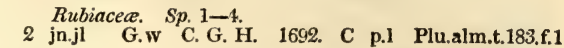
Sp. $2-4$.

. Indies 1789. C 1.p Bro.jam, t.37. f.1 E. Indies 1802. C l.p

Onagrarie. Sp. 1

sp. 1.

\section{PENTANDRIA.}

2065. PISTA'CIA. $W$ Pistichin Tree.

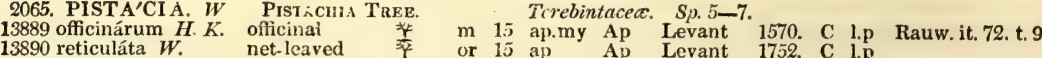
narbonen'sis $\mathbf{L}$.

13891 Terebinthus $W$ 13892 atlántica $\boldsymbol{W}$.

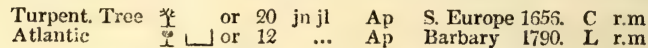

or 15 ap Ap Levant 1752. C l.p

13882
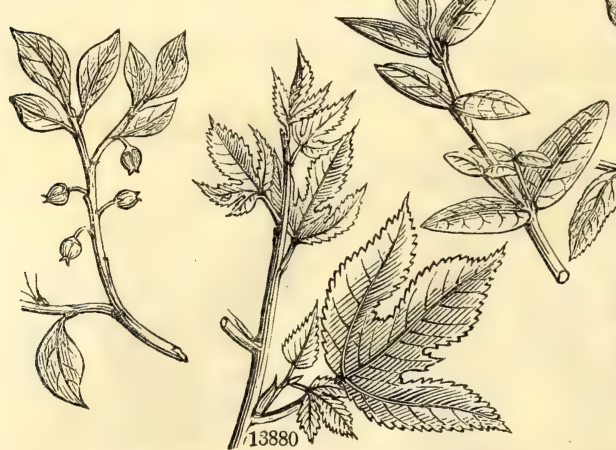

History, Use, Propagation, Culture,

13879

2056. Nageia. Nagi is the Japanese name of one of the species. That in the gardens is an uninteresting shrub with a loose elegant foliage, and a light grey bark. Ripened cuttings strike freely in a bark pit.

2057. Shepherdia. A name given by Nuttall to the Hippophae canadensis of our gardens, in honor of Mr. William Shepherd, the worthy curator of the Liverpool botanic garden. A small inelegant tree; with dark green deciduous leaves, covered over with brownish silvery scales on the lower side.

2058. Hippophae. An ancient name given to some plant now unknown, which was applied medicinally to horses; from i itros, a horse, and фaw, to give light. H. rhamnoides is very prolific in berries, which are yellow when ripe, succulent, smooth, and gratefully acid to the taste. They are much eaten by the Tartars; and the fishermen of the Gulph of Bothnia prepare a rob from them, which imparts a grateful flavor to fresh fish. Every part of the plant will dye yellow. The species grow in common soil, and are readily increased by layers or cuttings of the roots.

2059. Broussonetia. Named by L'Heritier, in honor of his countryman P. N. V. Broussonet, a well known naturalist, who travelled in Barbary, and published an Ichthyologia in 1782. This is a vigorous growing shrub or low tree, with large lobed leaves, variously shaped; the foliage of the male and female plant differing so much from each other that they might easily be taken for distinct species. The fruit is little larger than peas, and from the bark the Chinese make paner, and the Otaheitans cloth.

B. papyrifera, though a low tree, produces vigorous shoots, furnished with large leaves. The fruit is little larger than peas, surrounded with long purple hairs, when ripe changing to a black purple color, and full of sweet juice. In China and Japan it is cultivated as we do osiers, for the sake of the young shoots, from the bark of which the inhabitants of the east countries make paper. The bark being separated from the wood is steeped in water, and the inner bark separated from the outer; the former making the whitest and best paper. The bark is next slowly boiled, then washed, and afterwards put on a wooden table and beaten into a pulp. This pulp being put in water, separates like grains of meal. An infusion of rice and the root of manihot is next added to it. From the liquor so prepared, the sheets of paper are poured out one by one, and when pressed, the operation is finished.

The juice of this tree is sufficiently tenacious to be used in China as a glue, in gilding either leather or paper. The finest and whitest cloth worn by the principal people at Otaheite and in the Sandwich Islands is made of the bark of this tree. The cloth of the Bread-fruit tree is inferior in whiteness and softness, and worn chiefly by the common people.

2060. Schefferia. So called after James Christian Schæffer, a German naturalist of celebrity, who is best known by his excellent work on the Fungi of Bavaria, published in 1762. An inelegant shrub with green flowers. 
13877 Leaves ovate lanceolate oblique at base finely and simply serrated smooth

13878 Leaves oblong stellate-hairy above brownish white and scaly beneath

13879 Leaves linear-lanceolate smooth above white with scales beneath

13880 Leaves 3-5-lobed acuminate serrated scabrous

13881 Leaves cucullate entire

13882 Flowers tetrapetalous axillary

13883 Leaves opposite stalked pinnated with an odd one of 5 or 6 pairs 13884 Leaflets serrated villous beneath, Racemes often compound

13885 Leaves somewhat whorled linear smooth

13886 Unarmed, Leaves oblong acum. entire smooth, Fruit 1-seeded cornute, Horns reflexed shorter than fruit 13887 Unarmed, Leaves obovate oblong acuminate unequally serrate very scabrous on each side

13888 Leaves alternate oblong oval, Fl. solitary

\section{PENTANDRIA.}

13889 Leaves pinnated with an odd one, Leaflets 5 ovate tapered at base rather acute and mucronate at end 13890 Leaves pinnate and ternate, Leaflets roundish narrowed at base netted with veins retuse mucronate

13891 Leaves pinnate with an odd one, Leaflets about 7 ovate-lanceolate rounded at base acute mucronate 13892 Leaves pinnate with an odd one, Leaflets lanceolate about 9, Petiole winged between the terminal pairs

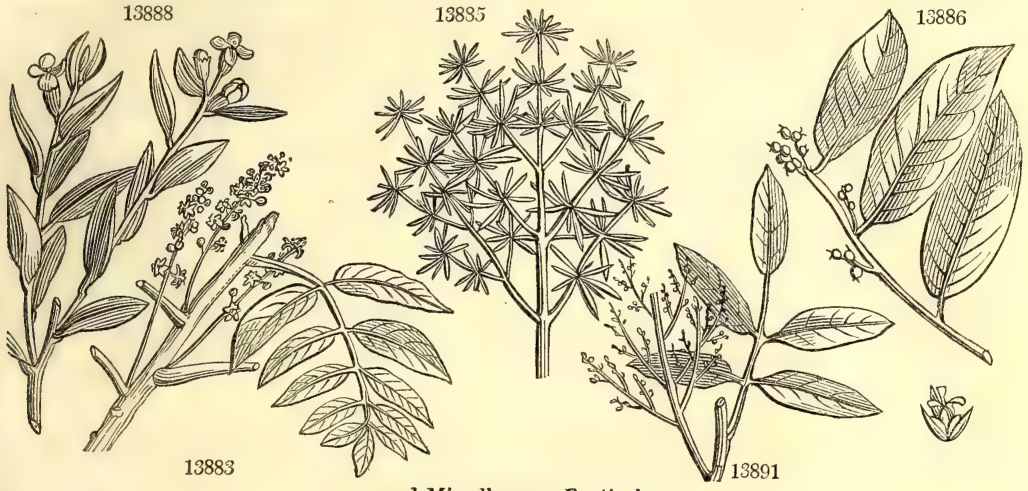

and Miscellaneous Particulars.

2061. Brucea. Named in honor of James Bruce, a celebrated Scotch traveller in Abyssinia, who discovered the plant.

2062. Anthospermum. From av. $\%$, , a flower, and $\sigma \pi \varepsilon \rho \mu \eta$, seed ; its female flower is entirely naked, consisting of a single ovarium; whence its name. A heath-looking evergreen, the leaves of which are fragrant when bruised, and the propagation and culture of the easiest description.

2063. Trophis. From $\tau \rho \in \varphi \omega$, to nourish. T. americana produces berries about the size of large grapes, and of an agreeable pleasant flavor. The leaves and twigs are used as fodder for cattle when grass is scarce. Cuttings root in sand under a glass.

2064. Montinia. In honor of Laurence Montin, a Swede, who published a little tract upon Splachnum. The specific name seems to hint at the nature of his disposition. A little worthless weed-like Cape plant.

2065. Pistacia. Said by Forskahl to have been altered by the Latins from its Arabic name foustaq $\mathbf{P}$ officinalis abounds in Sicily, where it is cultivated for its nuts. The male flowers come out from the side of the branches in loose bunches, and are of an herbaceous color. The female flowers come out in the same manner in clusters. The male puts forth its flowers first, and some gardeners pluck them whilst yet shut, dry them, and afterwards sprinkle the pollen over the female tree : but the method usually followed in Sicily, when the trees are far asunder, is to wait till the female buds are open, and then to gather bunches of male blossoms ready to blow; these are stuck into a pot of moist mould, and hung upon the female tree till they are quite dry and empty. This operation is called tuchiarare, and never fails to produce fructification; sometimes the gardeners ingraft the male bud upon the female tree.

P. Terebinthus (from $\tau \varepsilon g \varepsilon \omega$, to cut) furnishes the Cyprus turpentine. It is procured by wounding the bark of the trunk in several places, during the month of July, leaving a space of about three inches between the wounds; from these the turpentine is received on stones, upon which it becomes so much condensed by the coldness of the night, as to admit of being scraped off with a knife, which is always done before sunrise : in order to free it from all extraneous admixture, it is again liquified by the sun's heat, and passed through a strainer; it is then fit for use. The quantity produced is very inconsiderable; four large trees, sixty years old, only yielding two pounds nine ounces and six drachms; but in the eastern part of Cyprus and Chio, the trees afford somewhat more, though still so little as to render it very costly, and on this account it is com. monly adulterated, especially with other turpentines. The best Chio turpentine is generally about the consistence of thick honey, very tenacious, clear, and almost transparent, white, inclining to yellow, and of a fragrant smell, moderately warm to the taste, but free from acrimony and bitterness.

P. Lentiscus (lentiscere, to be sticky) produces the mastick, which is obtained most abundantly, by making transverse incisions in the bark of the tree, whence the mastick exudes in drops, which are suffered $3 \mathrm{H}$ 

13893 Lentiscus $W$.
\& massiliénsis $\quad \begin{aligned} & \text { Mastick Tree } \\ & \text { narrow-leaved }\end{aligned}$ I ec $15 \mathrm{my} \quad$ Ap $\quad$ S. Europe 1664. L r.m Bot. mag. 1967 \& massiliénsis 2066. ZANTHOX'YLUM. $W$. ToOTH-Ach TreE. Rutacee. Sp. 5-43.

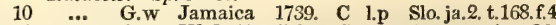
13895 Clava Hérculis $W$. Lentiscus-leav. $\omega^{-} \downarrow$ or 10 ap.my G.w W. Indies 1739. C 1.p Cat. car. 1. t. 26 13896 fraxíneum $W$ common or 6 mr.ap G.w N. Amer. 1759. L s.l Duh. arb. 1.t. 97 13897 tricárpum $H . K$. three-capsuled 韭 or 6 … G.w N. Amer. 1806. L l.s 13898 nítidum Dec. shining \& or $_{\text {or }} 6$ ap.my G.w China 1823. L r.m Bot. mag. 2558

2067. PICRAM'NiA. $W$. Picramia.

13899 Antidésma $W$.
2068. ANTIDES'MA. $W$. Ash-leaved Anridesma.
13900 alexitéria $W$ Laurel-leaved

13901 paniculata $W$.

2069. IRE'SINE. $W$

13902 celosióides $W$.

13903 elongáta $W$.

panicled

$\square$ un 10 my.jn Ap E. E. Indies 1793. C p.l Rhee.mal.5. t.11 IRESINE. Florida long-leaved

13904 diffúsa $W$. straggling

2070. SPINA'CIA. $W$. SPINAge. 13905 olerácea $W$. common

a spinósa

$\beta$ glabra Mill. prickly

2071. FLUG'GEA. $W$. FLUGGEA. 13906 leucopýrus $W$. 2072. ACNI'DA, $W$ 13907 cannabina $W$. white un $10 \quad \ldots$ Ap E. Indies 1800. C p.l Amaranthacee. $S p .3-8$.

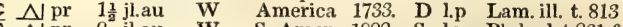

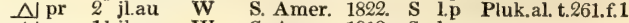
$\begin{array}{lllll}\Delta \mathrm{pr} & 1 \frac{1}{2} \mathrm{j} \text { jlau } & \text { W } & \text { S. Amer. 1818. S } & \text { 1.p }\end{array}$ Chenopodea. Sp. 1.

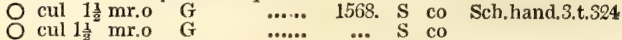
O cul $1 \frac{1}{3}$ mr.o G

cul $1 \frac{1}{2}$ mr.o G Euphorbiacee. Sp. 1.

$\square$ un $6 \quad \ldots \quad$ Ap $\quad$ E. Indies 1825. C r.m Virgintan Hemp. Chenopodece. Sp. 1-3.

2073. CAN'NABIS. $W$. HeMP. 13908 sativa $W$. common

un 2 jn.jl G.x N. Amer. 1640. S co Urticece. Sp. 1.

2074. HU'MULUS. $W$ Hop. 13909 Lúpulus $W$. common

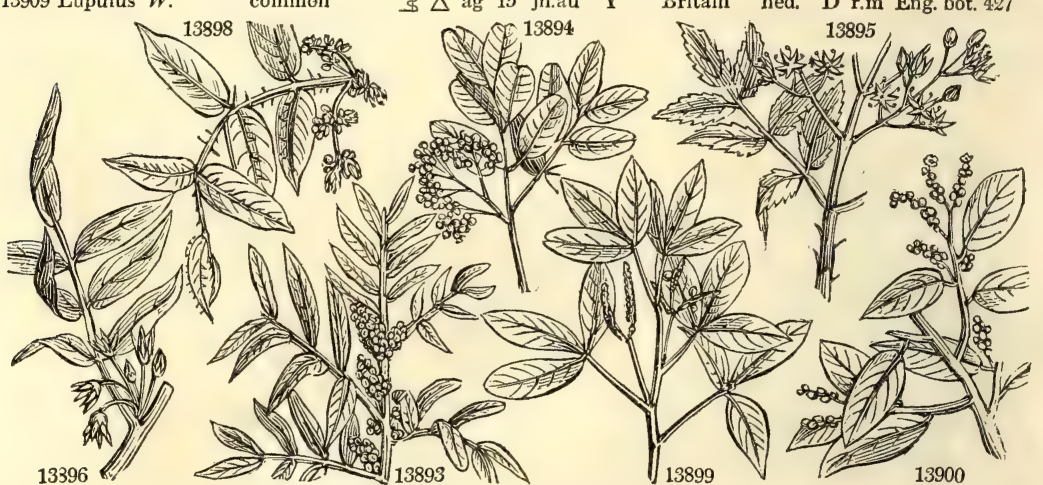

History, Use, Propagation, Culture,

to run down to the ground, and after they are concreted they are collected for use. These incisions are made at the beginning of August, when the weather is very dry, and are continued till the end of September.

Turpentine and mastick are considered as astringent and diuretic; but though they retain a place in our Materia Medica, they are not much used by modern practitioners. Mastick is used by the Turkish and Armenian women as a masticatory for cleaning the teeth and giving an agreeabie smell to the breath. It is also employed to fill the cavities of carious teeth. (Thom. Lond. Disp. 444.)

2066. Xanthoxylum. From kxy tree in Jamaica, and an infusion of the leaves is used to cure the tooth-ach there and in Carolina. All the species may be increased by ripened cuttings, or by cuttings of the roots.

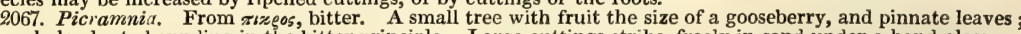
the whole plant abounding in the bitter principle. Large cuttings strike freely in sand under a hand-glass.

2068. Antidesma. So called from the use of the bark in making ropes ; from $\propto y \tau l$, like, and $\delta \varepsilon \sigma \mu \circ \xi$, a bond, A alexiteria is a middle-sized evergreen tree, with leaves resembling those of the lemon, and fruit in racemes, red and acid like the barberry. A decoction of the leaves is reputed to be an antidote against the bite of serpents, and the bark is used for making ropes. All the species require a rich loamy soil, and ripened cuttings with their leaves on root in sand in a moist heat.

2069. Iresine. Suppliants were accustomed among the Greeks to present themselves before the altar with a

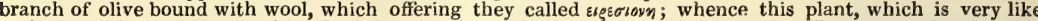
such a branch, on account of its close clusters of woolly flowers, has been named. Herbaceous plants not of great beauty.

2070. Spinacia. From spina, a prickle, on account of the processes of the seed. A well known annual esculent of the easiest culture in any rich soil.

2071. Fluggea. Named by Willdenow, in honor of _ Flügge, a German Cryptogamic botanist. A shrub with round ash-colored spiny branches. The spines are from one and a half to three inches long, very strong and numerous, whitish, and covered with leaves.

2072. Acnida. From $\propto$, privative, and $z y \delta \delta$, a Greek name of the nettle; that is to say, a nettle-like plant, which does not sting.

2073. Cannabis. According to Bullet, this name is taken from the Celtic can, a reed, and $a b$, small. But Golius says, the plant has been known by the Arabs from time immemorial under the name of qaneb. The hemp is a manufactorial plant of equal antiquity with the flax. It grows to a great height on rich soils under a warm climate; in some parts of Italy it has been found eighteen feet high (Cruds. Agr.); the common height in Lombardy and the Bolognese territory is twelve feet; in this country it seldom exceeds six feet, and the fibre of British hemp is no finer than where it is three times the length. The culture, management, and uses of hemp are nearly the same as those of flax ; but and the male plant decaying long before the female, the former requires to be pulled up as soon as the setting of the seed in the females shews that they have effected their purpose. Hemp is sown on well prepared 
13893 Leaves abruptly pinnate, Leaflets lanceolate about 8 , Petiole winged

13894 Unarmed, Leaves pinnate of 2 or 3 pair, Leaflets ovate emarginate villous, Racemes terminal

13895 Prickly, Leaves pinnate of 4 pair, Leaflets ovate repand-toothed unequal at base sessile, Panicles terminal 13896 Lvs. pinn. with an odd one of 4-5 pair, Leaf. ov. obsoletely serrul. equal at base, Petiol. rounded unarmed 13897 Lvs. pinn. with odd 1 of 3-5 pair, LeaA. stalkl. obl. oval acum. serrul.obliq. at base, Petiol. and branch. prickly 13898 Branches petioles and ribs prickly, I eaves pinnate with an odd one of $2-3$ pairs, Leaflets oblong shining with remote glandular crenatures

13899 Racemes filiform pendulous, Flowers triandrous, Styles 2 recurved

13900 Lvs. obl. narrowed at base acumin. at end smooth shining on each side, Racemes axillary twin or solitary 13901 Lvs. roundish ellipt. rounded at each end retuse emarginate at point downy beneath, Racem. term. panicled

13902 Leaves dotted scabrous : lower oblong acuminate ; upper ovate-lanceolate, Panicle branched compact 13903 Leaves ovate-oblong acute, Panicle erect, Branches simple, Stem furrowed 13904 Leaves ovate smooth cuspidate, Panicle diffuse branched, Stem furrowed

13905 Leaves sagittate, Fruit sessile

13906 The only species. Leaves alternate orbic ovate entire smooth, Spines 2 or 3 inches long

13907 Leaves lanceolate, Capsules smoothish acutangular

13908 The only species

13909 The only species

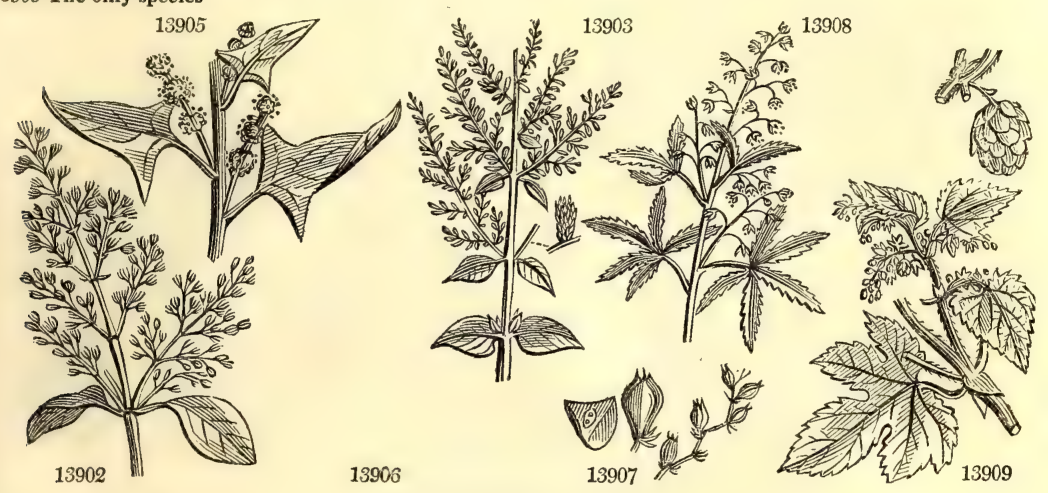

and Miscellaneous Particulars.

loamy soil about the end of April : the male plants are generally pulled about the beginning of July, and the females four or five weeks after them, when they have ripened their seeds. The plants being tied in bundles, are watered and bleached, in the same manner as flax; or they are dried and stacked without having gone through this process, and the fibres separated when wanted by the flax-breaking machine of recent invention, or by steeping in hot water and soft soap. The produce of hemp in fibre varies from three to six hundred weight per acre ; in seed, from eleven to twelve bushels. The fibre produces a cloth stronger than that from flax, and the best of all cordage and ropes. An oil is extracted from the seeds of hemp, which is used in cookery in Russia, and in this country by painters. The seeds themselves are reckoned a good food for poultry, and are supposed to occasion hens to lay a greater quantity of eggs. Small birds in general are very fond of them, but they should be given to caged birds with caution, and mixed with other seeds. A very singular effect is recorded, on very good authority, to have been sometimes produced by feeding bullfinches and goldfinches on hemp-seed alone, or in too great quantity; viz. that of changing the red and yellow on these birds to a total blackness. (Ency. of Agr. 5327.)

2074. Humulus. From humus, fresh earth; the hop grows only in rich soils. Our English word hop, seems to be the Anglo-Saxon hoppan, to climb. Lupulus is a contraction of Lupus salictarius, the name by which it was, according to Pliny, formerly called, because it grew among the willows, to which, by twining round and choking up, it proved as destructive as the wolf to the flock.

The hop has been cultivated in Europe an unknown length of time for its flowers, which are used for preserving beer. Its culture was introduced from Flanders in the reign of Henry VIII., though indigenous both in Scotland and Ireland: it is little cultivated in those countries, owing to the humidity of their autumnal season. Like other plants of this sort, the hop bears its flowers on different individuals ; the female plant, therefore, is alone cultivated. There are several varieties grown in Kent and Surrey under the names of Flemish, Canterbury, Goldings, \&c. ; the first is the most hardy, differing little from the wild or hedge-hop; the Goldings is a very improved and highly productive variety, but more subject to the blight than the other. The hop prefers a deep loamy soil on a dry bottom; a sheltered situation exposed to the south or south-west, but at the same time not so confined as to prevent a free circulation of air. The soil requires to be well pulverized and manured previously to planting. In hop districts, the ground is generally trenched either with the plough or spade. The mode of planting is generally in rows, six feet apart, and the same distance in the row. Five, six, or seven plants are generally placed together in a circular form, and at a distance of five or six feet from each other. The plants or cuttings are procured from the most healthy of the old stools; each should have two joints or buds; from the one which is placed in the ground springs the root, and from the other the stalk. Some plant the cuttings at once where they are to remain, and by others they are nursed a year in a garden. An interval crop of beans or cabbages is generally taken the first year. Sometimes no poles are garden. An interval crop of beans or cabbages is generally taken the first year. Sometimes no poles are
placed at the plants till the second year, and then only short ones of five or six feet. The third year the hop generally comes into full bearing, and then from four to six poles from fourteen to sixteen feet in length are placed to each hill. The most durable timber for poles is that of the Spanish chesnut, which is much grown 
2075. MODEC'CA. Lam. ModeccA. 13910 lobáta Jacq.

Passiflorea. Sp. 1.
月 or 12 au G S. Leone 1812, C r.m Bot. reg. 433

HEXANDRIA.

2076. XERO'TES. $R$. Br. Xerotes. 13911 longifólia $R . B r$. long-leaved 13912 rígida $R . \mathrm{Br}$. rigid

2077. ELA'IS, $W$. OILY PALM.

13913 melanocócca Ġertn. black-seeded 13.91 occidentális $W$. West Indian

13915 guineénsis $W . \quad$ Guinea 全 $\square$ or $30 \quad \ldots$ G.w Guinea 1730. is r.m Jac. amer. t. 172

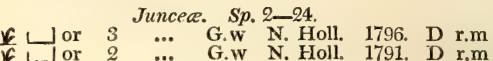

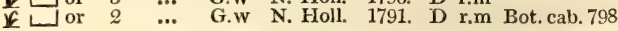

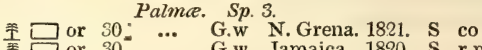

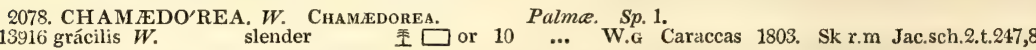

2079. BORAS'SUS. $W$. BorassUs. 13917 flabellifórmis $W$. fan-leaved

2080. MAURI'TIA. W. MaUritia. 13918 flexuósa $W$. wavy-spiked

2081. SMI'LAX. $W$. Smilax.

13919 áspera $W$.

$\beta$ auriculáta

13920 excélsa $W$.

13921 zeylánica $W$.

13922 quadranguláris $W$.

13923 Sarsaparilla $W$.

13924 China $W$

13925 rotundifólia $W$.

13926 laurifúlia $W$.

Rough Bindw. ear-leaved

ear-le

tall

square-stalked medicinal

Chinese

round-leaved

Laurel-leaved

Palmae. Sp. 1.

生 $\square$ or $30 \quad \ldots$ W.G E. Indies 1771. S r.m Rox.co.1.t.71,72

\section{$\square$ or 40 Palma. Sp. 1.}

Smilacea. Sp. 22-68.

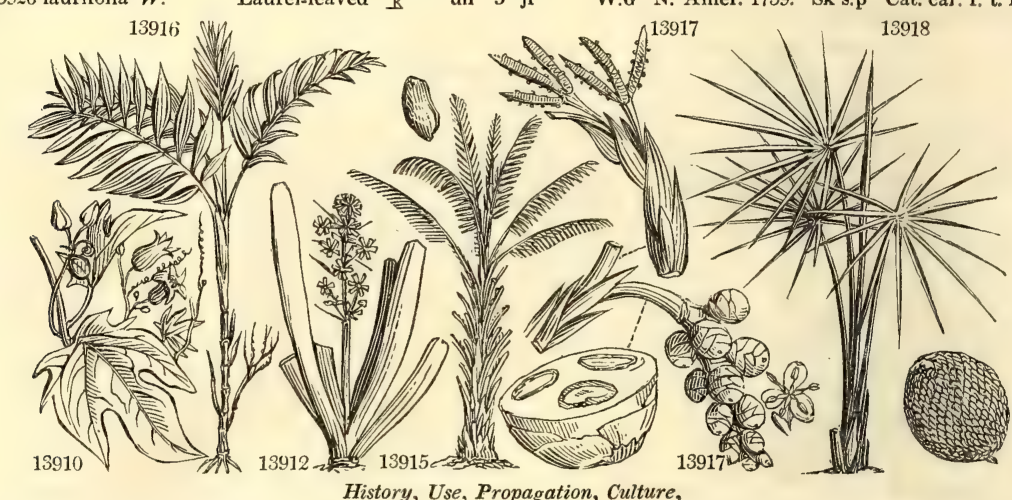

History, Use, Propagation, Culture,

W.G S. Europe 1648, Sk s.p Sch.hand.3.t.328

B un 8 s W.g S. Europe 1648. Sk s.p Pluk.al.t.110.f.3

1 un 12 au.s W.G Syria 1739. Sk s.p Buxb.cen.1.t.27

B un 6 jn.ji W.G ${ }_{\mathbf{N}}$. Indies 1778. Sk p.I Rum.arn.5. t.16

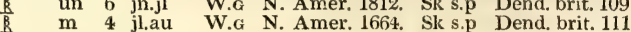

8. $\square \mathrm{m} \quad 6 \quad \ldots \quad$ W.G China 1759. Sk s.p Kæm.amæ.t.782

W. N Amer. 1760. Sk s.p

Cat 1.15

13918

in Kent as coppice wood for that purpose. The after-culture of the hop consists in stirring the soil, and keeping it free from weeds; in guiding the shoots to the poles, and sometimes tying them for that purpose with withered rushes; in eradicating any superfluous shoots which may arise from the root, and in raising a small heap of earth over the root to prevent any more shoots from arising.

Hops are known to be ready for gathering, when the chaffy capsules acquire a brown color, and a firm con. sistence. Each chaffy capsule or leafed calyx contains one seed. Before these are picked, the poles with the attached stalks are puiled up, and placed horizontally on frames of wood, two or three poles at a time. The hops are then picked off by women and children. After being carefully separated from the leaves and stalks, they are oropped into a large cloth hung all round withinside the frame on tenter-hooks. When the cloth is full, the hops are emptied into a large sack, which is carried home, and the hops laid on a kiln to be dried. This is alwrays done as soon as possible after they are picked, as they are apt to sustain considerable damage, both in color and flavor, if allowed to remain long in sacks in the green state in which they are pulled. In very warm weather, and when they are pulled in a moist state, they will often heat in five or six hours : for this reason the kilns are kept constantly at work, both night and day, from the commencement to the conclusion of the hop-picking season. The operation of drying hops is not materially different from that of drying malt, and the kilns are of the same construction. The hops are spread on a hair-cloth, from eight to twelve inches deep, according as the season is dry or wet, and the hops ripe or immature. When the ends of the hopstalks become quite shrivelled and dry, they are taken off the kiln and laid on a boarded floor till they become quite cool, when they are put into bags.

The bagging of hops is thus performed : in the fioor of the room where hops are laid to cool, there is a round nole or trap, equal in size to the mouth of a hop-bag. After tying a handful of hops in each of the lower corners of a large bag, which serve afterwards for handles, the mouth of the bag is fixed securely to a strong hoop, which is made to rest on the edges of the hole or trap; and the bag itself being then dropped through the trap, the packer goes into it, when a person who attends for the purpose, puts in the hops in small quantities, in order to give the packer an opportunity of packing and trampling them as hard as possible. When the bag is filled, and the hops trampled in so hard as that it wiil hold no more, it is drawn up, unloosed from the hoop, and the end sewed up, other two handles having been previously formed in the corners in the manner mentioned above. The brightest and finest colored hops are put into pockets or fine bagging, and the brown into coarse or heavy bagging. The former are chiefly used for brewing fine ales, and the latter by the porter brewers. But when hops are intended to be kept two or three years, they are put into bags of strong cloth, and firmly pressed so as to exclude the air.

The stripping and stacking of the poles succeeds to the operation of picking. The shoots or bind being stripped off', such poles as are not decayed are set up together in a conical pile of three or four hundred, the centre of which is formed by three stout poles bound together a few feet from their tops, and their lower ends spread out.

The produce of no crop is so liable to variation as that of the hop; in a good season an acre will produce 20 cwt. ; in a bad season none, or only 2 or $3 \mathrm{cwt}$. From 10 to $12 \mathrm{cwt}$. in a season is considered a tolerable average 
13910 Leaves entire 3-7-lobed without glands cordate at base

\section{HEXANDRIA.}

15911 Stemless, Lvs, long lin. coriaceous straight toothed at end rough at edge, Panicles lanceolate contracted 13912 Scapes and spikes short, Lvs, distichous cartilaginous convex beneath $\frac{1}{2}$ truncate at end, Stem very short

13913 Stem ascending, Stalks spiny serrated, Anthers and fruits ovate acute 13914 Fronds pinnated, Leaflets sheathed, Stems unarmed

13915 Fronds pinnated, Stems toothed spiny diverging: upper teeth recurved

13916 Fronds pinnated 2 feet long : pinnæ alternate oblong narrowed at base pointed at end

13917 Fronds palmate plaited cucullate, Stalks serrated

13918 Fronds flabelliform, Male spadix flexuose a foot long and more

13919 Stem prickly angular, Leaves hastate cordate lanceolate 7-9-nerved prickly toothed coriaceous

13920 Stem prickly angular, Leaves unarmed ovate slightly cordate about 7-nerved

13921 Stem prickly somewhat square, Leaves unarmed 3-5-nerved ovate-oblong cordate

13922 Stem prickly square, Leaves unarmed ovate acute 5-nerved

13923 Stem prickly nearly square, Leaves unarmed ovate-lanceolate cuspidate about 5-nerved glaucous beneath

13924 Stem prickly rounded, Leaves roundish-cordate acute at each end 5-nerved

13925 Stem prickly rounded, Leaves roundish-ovate acuminate slightly cordate 5-nerved

13926 Stem prickly rounded, Branches unarmed, Leaves ellipt. or elliptical-lanc. obtuse recurved acute 3-nerved

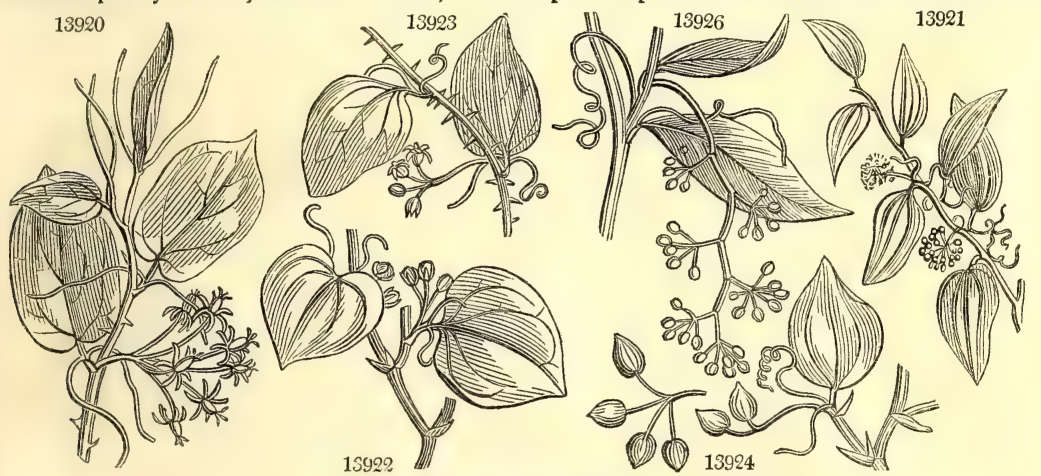

and Miscellaneous Particulars.

crop. The quality of hops is estimated by the abundance or scarcity of an unctuous clammy powder which adheres to them, and by their bright yellow color.

The expences of forming a hop plantation are very great; but once in bearing, it will continue so for ten or fifteen years before it requires to be renewed. The hop culture in England, like that of the culture of the vine in France, is only calculated for cultivators of considerable capital, who can retain the produce from years of abundance to years of scarcity. It is calculated on an average, that the hop crop fails almost entirely every fifth year, when the price will rise from two to thirty pounds per cwt. To those who can cuitivate and preserve the hop with a view to such a rise, few crops will be equally profitable.

The hop is peculiarly liable to diseases; when young it it devoured by fleas of different kinds; at a more advanced stage it is attacked by the green fly, red spider, and otter moth, the larvæ of which prey even upon its roots. The honey dew often materially injures the hop crop; and the mould, the fireblast, and other blights injure it at different times towards the latter periods of the growth of the plants.

The use of hop in brewing is to prevent the beer from becoming sour, and this is the grand purpose for which

it is cultivated. But the young shoots both of the wild and improved hops are eaten early in the spring as asparagus, and were formerly brought to market for that purpose. The stalk and leaves will dye wool yellow. From the stalks a strong cloth is made in Sweden, the mode of preparing which is described by innæus in his

Flora Suecica. A decoction of the roots is said to be as good a sudorific as Sarsaparilla; and the smell of the Alowers is soporific. During the illness of George the third, in 1787, a pillow filled with hops was used instead of opiates.

2075. Modecca, is an Indian word by which two or three species of this genus appear in the Hortus Mala.. baricus, and has been adopted as a generic name by Lamarck. A curious plant resembling a bryony, of easy culture and propagation.

2076. Xerotes. From $\xi$ nos, dry, on account of the aridity of the herbage and of the situations in which it grows.

2077. Elais. The natives of Guinea express oil from the fruit of this, as the Greeks from their olives, $\varepsilon \lambda \propto \iota$, whence its name. This palm bears a fruit about the size of a large plum. The inhabitants of the West India Islands draw an oil from it, by the same process used in extracting oil from olives. From the sap an inebriating liquor is fermented, and the negroes weave the leaves into mats, on which they repose.

2078. Chamedorea. Named, we presume, from $\chi \propto \mu \alpha$, dwarf, and $\delta$ weg sense in which the name has been applied.

2079. Borassus. This is one of the names which were applied to the spatha of the date; and was applied by Linnæus to the designation of this family of palms. The fruit of this palm is of the size and shape of a child's head; a wine and a sugar are made from the sap of the trunk.

2080. Mauritia. Named in honor of Prince Maurice of Nassau, the patron of Piso, for whom he obtained the necessary aid towards publishing his Natural History of Brazil. A fine genus of palms.

2081. Smilax. From $\sigma \mu i \lambda$, a grater; the stems are rough with stiff prickles. S. aspera has roots not unlike those of the Sarsaparilla. They have the same qualities, but in an inferior degree; and may be distinguished by 3 H 3 
13927 tamnoídes $W$ 13928 austrális $R . B$ r. 13929 cadúca 13930 Bona nóx $W$. 13931 latifólia $\boldsymbol{B} . \boldsymbol{P}$ 13932 herbácea $\boldsymbol{W}$. 13933 lanceoláta $\boldsymbol{W}$. 13934 glycyphýlla $\dot{B} . P$ 13935 pábera $W$ 13936 Pseudo-china $W$ 13937 pedunculáris $W$. 13938 glaúca $B$. $M$. 13939 rúbens Wats. 13940 longifólia $W$. 2082. TA'MUS. $W$. 13941 commúnis $W$. 13942 crética $W$.

Tamus-leaved $B \triangle$ un 6 jn.jl $\begin{array}{lllll}\text { oblong-leaved } & \frac{\mathrm{A}}{\mathrm{B}} \\ \text { deciduous } & \square \text { un } & 6 & & \\ \text { un } & 6 & \text { jn.j } 1\end{array}$ ciliated broad-leaved $\bar{B}$ un 6 jn.jl herbaceous $\frac{1}{B}$ un 8 un spear-leaved $\frac{k}{B} \Delta$ un $\frac{1}{5}$ l Botany Bay Tea $\frac{k}{\text { a }}$ un 5 m.j. $\begin{array}{llll}\text { Botany Bay Tea } \frac{1}{B} L \text { un } & 6 & \ldots \\ \text { downy } & 5 & \ldots\end{array}$ BastardChinese $\frac{\widehat{B}}{\hat{B}}$ un 6 my.jn glaucous-leav'd $\vec{B}$ un 2 my.jl pink un 6 jl

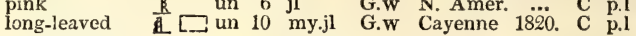

W. N. Amer. 1739. Sk s.p Cat car. 1, 59 W.G N. S. W. 1815. Sk s.p W.G N. Amer. 1759. Sk s.p W.g N. Amer. 1739. Sk s.p Pluk.al. t.111.f.1 G.w N. Holl. 1791. Sk s.p

G N. Amer. 1699. Sk s.p Bot. mag 1920 G.w N Amer 1785 Sk pat car 1.8 G.w N. S. W. 1815. Sk s.p G.w N. Amer. 1806. Sk s.p G.w America 1739. C p.l Slo. ja.1.t.143.f.1 G.w N. Amer. 1812. C p.l G.w N. Amer. 1811. C p.l Bot. mag. 1846 G.w N. Amer. ... C p.l Dend. brit. 108 Black Bryony. Smilacea. Sp. 2-3.

common $\quad$ D $\triangle \mathrm{m} 10$ my.au $\mathrm{G}$ England hed. $R$ s.p Eng. bot. 91 Cretan $\quad \$$ un 5 jl.au G Candia 1739. R p.l

2083. TESTUdina'RIA. Burch. Elephant's Foot, or Hottentot's Bread. Dioscorece. Sp. 1-2.

13943 elephan'tipes Burch. common $\quad B \quad$ cu 8 jl.au Y C. G. H. 1774. R p.l Bot. mag. 1347 20S4. RAJ'NIA. $W$. 13944 cordáta $W$. Tamus-leaved Dioscorec. Sp. $1-14$.

2085. DIOSCO'REA. $\boldsymbol{w}$. YAM. Dioscorece. Sp. 12-42 13945 pentaphýlla $W$. 13946 aculeáta $W$. 13947 aláta $W$.

13948 bulbifera $W$. 13949 sativa $W$. 13950 triphýlla $W$ 13951 brasiliénsis $\boldsymbol{W}$. 13952 coriácea $W$. 13953 altíssima $\boldsymbol{W}$. 13954 angustifólia $W$. 13955 villósa $W$. quaternata Ph. 13956 oppositifólia $W$. five-leave prickly-stemm wing-stalked bulb-bearing common three-leaved Brazilian leathery tallest narrow-leaved pubescent

* $\square$ cul $10 \quad \ldots \quad G$ E. Indies 1768. R r.m Rhee. mal.7.t.35

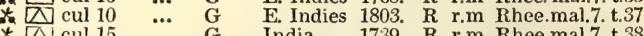

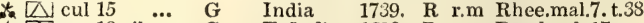
* \J esc 12 jl.au G E. Indies 1692. R r.m Par. lond. 17 * clt 20 au G W. Indies 1733. R .m Phee.mal. * $\triangle 1$ clt 20 au $G$ W. Indies 173s. R r.m Rhee.mal.8. t.51

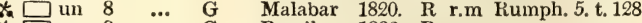
* $\square$ esc 8 … G G Brazil 1823, R r.m *a $\square$ un $8 \quad \ldots \quad$ G $\quad$ S. Amer. 1818. R r.m th $\square$ ur $20 \quad \ldots \quad$ G Martiniq. 1821. R r.rn Plum. ic.117.f.1

N. Amer. 1752. R s.p Jac. ic. 3, t. 626

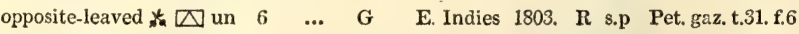

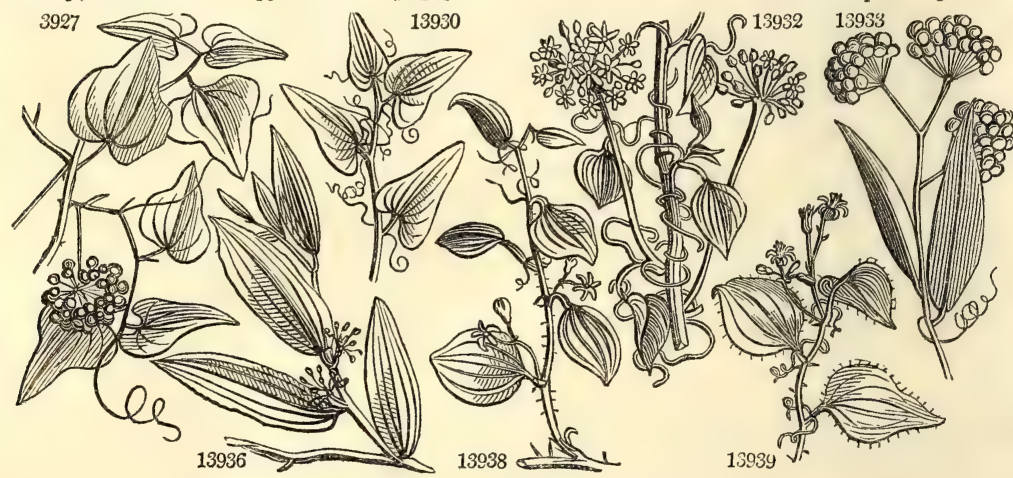

History, Use, Propagation, Culture,

being larger, more porous, aud much less compressed. S. Sarsaparilla (zarza, furze, Spanish) has long slender roots covered with a wrinkled brown bark, white within, and having a small woody heart. It is inodorous and has a mucilaginous very slightly bitter taste. Medicinally it is demulcent and diuretic. It was brought to Europe about the year 1530, and introduced as a medicine of great efficacy in the cure of lues venerea; but it fell into disrepute and was little used, till it was again brought into esteem by Dr. William Hunter and Sir William Fordyce, about the middle of the last century; not, however, as a remedy fitted to cure syphilis, but of much efficacy in rendering a mercurial course more certain, and after the use of mercury. Experience, however, has not verified the encomiums bestowed on it; and the extensive observations of Mr. Pearson have fixed the degree of benefit which is to be expected from this root in syphilitic complaints. The contagious matter and the mineral specific may, he observes, jointly produce, in certain habits of body, a new series of symptoms, which, strictly speaking, are not venereal, which cannot be cured by mercury, and which are sometimes more to be dreaded than the simple and natural effects of the venereal virus. Some of the most formidable of these appearances may be removed by sarsaparilla, the venereal virus still remaining in the system ; and when the force of the poison has been completely subdued by mercury, the same vegetable is also capable of freeing the patient from what may be called the sequelæ of a mercurial course. Sarsaparilla is also recommended in scrophula, elephantiasis, or cutaneous affections resembling it, and in chronic rheumatism; but its efficacy is doubtful. (Thom. Lond. Disp. 505.)

S. China has roots as long as a child's hand, twisted, full of knots, reddish on the outside, flesh-colored in the heart, and destitute of smell. It is employed both as food and medicine in China, and to feed hogs in the West Indies. None of the species are of much beauty or worth growing, but as objects of curiosity.

2082. Tamus. This name was employed by Columella and others, for a plant resembling a vine, and bearing fruit not unlike grapes; a description which does not apply badly to the modern plant. T. communis has very large tuberous black coated masses attached to its roots. These are so acrid, that the pulp has been formerly used as a stimulating plaster. The young shoots, how ever, are so mild as to be good eating when dressed like asparagus. The Moors eat them boiled with oil and salt. The flowers of the female plant are succeeded by ovate smooth berries.

2083. Testudinaria. So called from the resemblance which the great rugged cracked root of this plant bears to the shell of a tortoise (testudo). The rootstock is a large fleshy mass, covered with a thick bark cracked deeply in every direction. The Hottentots in time of scarcity make use of the fleshy inside of the root as a sort of yam.

2084. Rajania. Named in honor of our distinguished countryman John Ray, a distinguished naturalist, 
13927 Stem prickly rounded, Leaves ovate oblong acute subpanduriform obsoletely cordate 5-nerved 13928 Stems prickly rounded, Leaves oblong acute unarmed 5-nerved smooth, Petioles with tendrils 13929 Stem prickly rounded, Leaves ovate mucronate 5-nerved

139.30 Stem unarmed angular, Leaves cordate ovate acute ciliate prickly 7-nerved

13931 Stem unarmed angular, Leaves ovate 5-nerved smooth subcordate or obtuse at base, Petioles with tendrils 13932 Stem unarmed angular, Leaves ovate acuminate 7-nerved, Common pedunc. of umbel longer than leaf 13933 Stem unarmed rounded, Leaves unarmed lanceolate

13934 Stem unarmed rounded, Leaves obl. lanc. acute 3-nerved smooth glaucous beneath. Petioles with tendrils 13935 Stem unarmed rounded, Leaves oblong acute cordate about 5-nerved soft with down beneath

13936 Stem unarmed rounded, Leaves unarmed : cauline cordate; of the branches ovate-oblong 5-nerved

13937 Stem unarm. round. Lvs, roundish ov. cord. acum. 9-nerv. Peduncles of fr.-bear. umbel longer than leaves 13938 Stem prickly, Lvs. unarmed rounded ovate mucronulate about 7-nerv. glauc. beneath, Pedunc. about 2-fl. 13939 Stem angular prickly, Leaves ovate subcordate rather obtuse mucronate coriaceous 5-nerved denticulate 13940 Stem prickly square, Leaves unarmed hastate oblong obtuse mucronate about 7-nerved

$139 \pm 1$ Leaves cordate undivided

13942 Leaves 3-lobed

\section{Leaves reniform entire}

13944 Leaves ovate lanceolate cordate 7-nerved

13945 Leaves alternate digitate, Leaflets 5 oblong acuminate veiny, Stem aculeate bulbiferous

13946 Leaves alternate roundish cordate acuminate 7-nerved, Stem aculeate bulbiferous

13947 Leaves opposite ovate cordate-sagittate cuspidate 7-nerved, Stem winged bulbiferous

13948 Leaves alternate cordate roundish ovate acuminate about 9-nerved, Stem smooth bulbiferous [round

13949 Lvs. altern. cord. round. ov. cuspid. about 9-nerv. : lobes of base close together, Caps. obov. Stem smooth

13950 Leaves alternate ternate, Leaflets obl. acuminate nerved, Stem prickly

13951 Leaves alternate cordate S-lobed : middle lobe acuminate, Stem compressed round naked

13952 Leaves alternate cordate oblong acuminate coriaceous 7-nerved, Stem round smooth

13953 Leaves opposite cordate roundish ovate acute 7-nerved, Stem round smooth

13954 Leaves alternate cordate lanc. narrow 3-nerved longer than petiole, Stem smooth

13955 Leaves opposite and whorled cordate acuminate 9-nerved downy beneath, Stem round

13956 Leaves opposite ovate acuminate 7-nerved, Stem ruund smooth

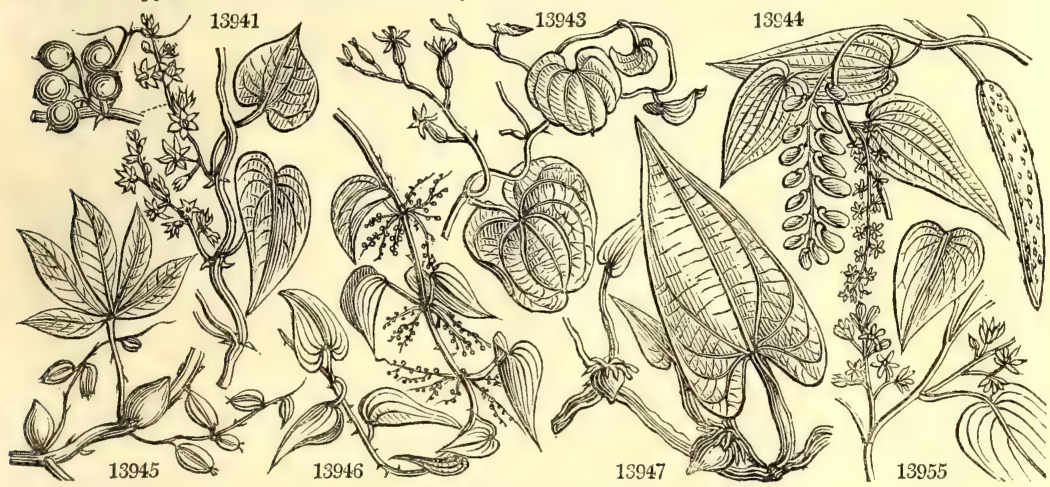

and Miscellaneous Particulars.

born in 1628, died in 1705, and author of many works of the highest reputation. His zoological arrangement is still regarded with much respect. Twining plants resembling the Yam.

2085. Dioscorea. In memory of Pedacius Dioscorides, a Greek physician, born at Anazarba, in Cilicia. He is generally believed to have lived under Nero, but this is very uncertain. Abulfarrage makes him to have flourished under Ptolemæus Physcon; but he is not generally credited. D. sativa, Iguame, Fr., and Inhame, Portug., has large thick tubers, a foot broad, and palmated like some Orchises. The stalks are slender, and with the leaves bear some resemblance to black bryony. The yam is largely cultivated for food in Africa and the East and West Indies, especially in the latter for the negroes. The roots grow to a great size, are mealy, and esteemed to be easy of digestion; they are palatable, and not inferior to any roots now in use, either for delicacy of flavor or nutriment. They are eaten instead of bread, either roasted on the embers or boiled; the flower is also made into bread and puddings. In Otaheite they make a dish, which they esteem very delicious, from the roots of the yam, with the kernel of the cocoa-nut scraped, and the pulp of the Musa or Banana. The juice of yam-roots fresh is acrid, and excites an itching on the skin. There are many varieties of these roots, some spreading out like the fingers (Rumph. t. 121.); others twisted like a serpent (Rumph. t. 122.); others again very small, scarcely weighing more than a pound, with a whitish ash-colored bark, whereas the bark is commonly black. The flesh of the yam is white or purplish, and viscid, but becomes farinaceous or mealy when dressed.

D. aculeata, by some considered only an improved variety of the sativa, is universally cultivated in the East and West Indies, in Africa, and in all the islands of the southern ocean within the torrid zone, and even as far as New Zealand. The tubers are frequently three feet long, and weigh thirty pounds. All the edible species and varieties are propagated in foreign countries like the common potatoe, but they arrive much sooner at maturity. The buds of the roots are not apparent, but still a small piece of skin is left to each set. for from this piece of bark alone the shoots proceed. Holes are made in rows two feet apart, and at eighteen inches distant in the row; into those holes two or three sets are put, first covered with earth, and then with a little haulm or rubbish to retain moisture. The only after-culture consists in hoeing up the weeds. They are commonly planted in August, and are ripe about the November or December following. When dug up, the greatest care is taken not to wound them, as that occasions them to sprout much earlier than they otherwise would do. They should be rubbed over with ashes, and piled regularly on beds or hurdles raised above the floor, that the air may come easily between them; or, if they be piled in heaps, some ashes should be strewed between the layers. None of the species are worth cultivating as ornamental plants; but some of the edible sorts have been raised in hotbeds in the Paris garden, and being transplanted early into a warm situation, have produced tubers of a considerable size. 
2086. MA'BA. $J$. 13957 buxifólia $P . S$
MABA.

Box-leaved

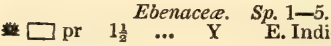

\section{OCTANDRIA.}

2087. PO'PULUS. $W$. Poplar 13958 álba $W$.

13959 canéscens $W$. 13960 trépida $W$. 13961 trémula $W$. 13962 lævigáta $W$ 13963 græ'ca $W$ 13964 nígra $W$.

13965 betulifólia $P h$. hudsonica Mich. 13966 dilatáta $W$. 13967 monilifera $W$. $P$. grandidentata Mich. 13968 aclades'ca Lindl. black Italian 13970 balsamifera $W$. Carolina 13971 macrophýlla Lindl. Ontario 13972 cándicans $W^{*}$. heart-leaved 13973 heterophýlla $\boldsymbol{W}$. various-leaved
Abele Tree

gray Aspen smooth Athenian black American Lombardy

\begin{tabular}{ccc}
\multicolumn{4}{c}{ Amentacea. } \\
tm 40 & mr.ap & Ap \\
tm 40 & mr.ap & Ap \\
tm 30 & $\ldots .$. & Ap \\
tm 50 & mr.ap & Ap \\
tm 80 & mr.ap & Ap \\
tm 40 & mr.ap & Ap \\
tm 50 & mr.ap & Ap \\
tm 40 & mr.ap & Ap \\
tm 70 & mr.ap & Ap \\
tm 70 & my & Ap \\
tm 70 & my & Ap \\
tm 80 & mr & Ap \\
tm 70 & ap & Ap \\
tm 70 & $\ldots .$. & Ap \\
tm 50 & mr & Ap \\
tm 70 & ap.my & Ap
\end{tabular}

E. Indies 1810. S s.p Rox. cor. 1. t. 45

\section{ENNEANDRIA.}

2088. MERCURIA'LIS. $W$. Mercury.
13974 perénnis $W$.

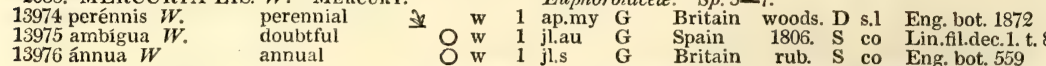

Sp. 16.

Britain moi.w. Sk co Eng, bot. 1618 N. A mer. 1819 . Sk co Eng. bot. 1619 Britain 1812. Co Mic.arb.3.t.8.f.1 N. Amer. Archipel. 1779 C co Mich.arb.3. t.11 Britain watpl C co Eng bot 1910 N. Amer. ... C co Mi.arb.3.t.10.f 1

Italy 1758. C co Canada 1772. C co Dend. brit. 102

N. Amer. ... C co Carolina 1738, C co Mi.a.3.p.302.t.12 N. Amer. 1692. C co Mic.ar.3. t.13. f.1 N. Amer. 1820 . C co N. Amer. 1772, G co

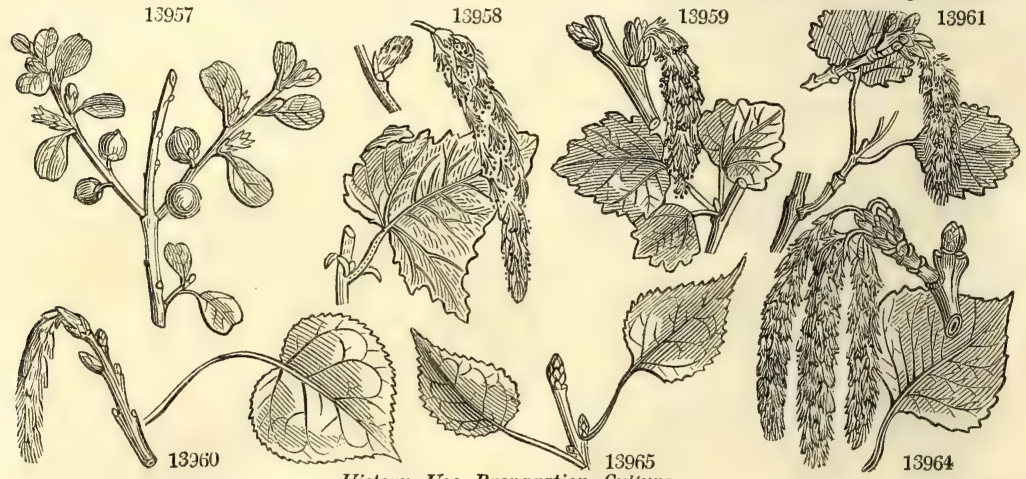

History, Use, Propagation, Culture,

2085. Maba. The name given to the plant by the natives of Tonga-Tabu, according to Forster. (Gen.61.) This shrub or small tree produces edible berries very well tasted. The wood is dark colored, remarkably hard and durable, and where its size will admit, is employed for such uses as require the most durable, compact, and heavy timber.

2086. Populus. In ancient times the public places of Rome were decorated with rows of this tree, whence it came to be called arbor populi, as being a tree peculiarly appropriated to the people. But Bullet asserts, that the Poplar has obtained its name from the constant motion of the leaves, which are in a perpetual state of agitation like the populace. All the species are rapid-growing soft-wooded timber trees, some of which attain a very great size. P. alba is one of the most valuable of the British species. The leaves of the common gray poplar are of a blackish-green above, but having a thick white cotton underneath; they are mout three inches long, on petioles a foot in length. The leaves of the Abele are about double the size, and divided into three, four, or five lobes. The leaves of the gray poplar are also larger more deeply lobed, and divided into three, four, or five lobes. The leaves of the gray poplar are also larger more deeply lobed, and been introduced from Flanders, and the hoary poplar to have been originated in this country. The timber is of great value for all sorts of wooden vesseis, especially butchers' trays. It is of quick growth, soft, white, and stringy, and little subject to swell or shrink. It makes beautiful floors and turners' ware. Some of the finest Abeles in England are at Hartwell near Aylesbury.

$\mathbf{P}$. tremula is commonly called the asp, from the German espe, which is the general name for all poplars, is a rapid-growing tree in almost any soil or situation: but the numerous shoots of the roots spread so near the strface that they will not permit any thing else to grow there. The wood is extremely light, white, smooth, soft, and durable in the air. It may be used for the same purposes as that of the. Abele. The bark is the favorite ood of beavers. On the leaves and leafstalks may sometimes be seen red glandular substances about the size of a pea, which are the nests of Tipula juniperina. P. nigra has a naked lofty trunk covered with an ash-colored bark, and a regular handsome head. It is a tree of quick growth, and on the banks of rivers and in moist situations it grows up to a great height in a short time. The bark is light like cork and is sometimes used by fishermen to float their nets. The timber is light and soft, fit for the turner and pattenmaker, and excellent for flooring-boards. These boards are much siower in taking fire than those of resinous trees; they smoke a long time before they burst into a flame: of course the wood is bad for fuel. Many species of insects are supported by this and the other poplars. The red substance like berries upon the leafstalks of this species are occasioned by the Aphis Bursonia. The leaves and ycung shoots are gathered in Sweden and other parts of Europe during the month of October and dried, to be given as fodder to the sheep in winter The practice is as old as the time of the Romans; who, as well as the modern Italians, planted this tree for their vines to run on. In Kamchatka the inhabitants are sometimes reduced to the necessity of converting the inner bark into bread. Scheffer made paper from the cotton down of the seeds. The buds both of this and the white poplar smell very pleasant early in the spring, and being pressed between the ingers yield a balsamic resinous substance, which, extracted by spirits of wine, smells like storax. A drachra of this tincture in broth is administered in internal ulcers and excoriations.

The black Italian poplar, so much recommended by Pontey, and said by him to have been intro- 


\section{$O C T A N D R T A$.}

13958 Lvs. roundish cord. lobed toothed glab. above downy and very white beneath, Fert. catkins ov. Stigmas 4 13959 Leaves roundish angular-repand toothed hoary beneath, Catkins cylindrical lax

13960 Leaves roundish toothed with 2 glands at base acuminate smooth : younger silky

13961 Lvs. nearly orbicul. broadly tooth. glab. on both sides, Petioles compressed, Stigmas 4 auricled at base

13962 Lvs. roundish ov. acum. subcord. unequally serrat. smooth, Petioles compressed, Branches round smooth

13963 Lvs, round. ov, acute slightly cord. with equal close serratures smooth a little ciliat. Branches round smooth

13964 Leaves deltoid acute serrated glabrous on both sides, Fertile catkins cylindrical lax, Stigmas 4

13965 Leaves rhomboid acumirate toothed smooth, Younger branches hairy

13966 Leaves smooth on each side acuminate serrate deltoid, broader than long

13967 Lvs. subcord. smooth glandul, at base, Serrat. cartil. hooked hairy, Nerves spread. Branchl. slightly winged towards end compound

13968 Lvs, subcord smooth glandul at base, Serrat cartil, hooked hairy, Nerves spread. Branchl. wirged simple 13969 Leaves cordate deltoid acuminate bluntly hook-toothed, Branches winged angular

13970 Leaves ovate acuminate with close serratures white and netted beneath, Buds resinous

13971 Leaves cordate ovate large somewhat entire pale beneath

13972 Lvs. cordate ovate acumin. bluntly and unequally serrated white beneath 3-nerved netted, Buds resinous

13973 Leaves cordate roundish-ovate blunt hook-toothed : younger downy beneath

\section{ENNEANDRIA}

13974 Stem perfectly simple, Leaves rough, Root creeping perennial

13975 Stem herbaceous brachiate, Leaves ovate-oblong smocth ciliated, Fls. whorled: male and female mixed

13976 Stem branched, Branches opposite, Leaves glabrous, Root fibrous annual

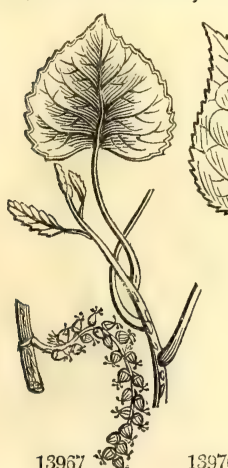

13970
13969

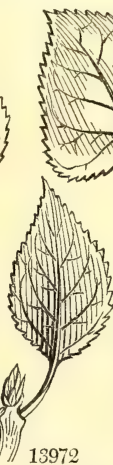

13972
13973

13975

and Miscellaneous Particulars.

uluced from America, seems intermediate between P. nigra and dilatata; indeed, all the three sorts are by some considered as but one species. P. dilatata differs from the common black poplar chiefly in its close conical manner of growth, which resembles the cypress. The leaves are greater in breadth than length; whereas in the black poplar the longitudinal diameter is the greatest. Though it generally attains a great height, the increase of the trunk is by no means so rapid as in most of the other poplars. It cannot, therefore, be highly recommended as a timber tree. In ltaly it is considered peculiarly adapted for packing-boxes : nails do not split it; and if cases of this wood fall or are thrown carelessly on the ground, it gives way a little, and returns to its former position without splitting, which oak and other heavy woods will not do. In Lombardy all the vessels in which the grapes are carried home in carts from the vineyards, are of poplar plank, about two inches thick, and in them the grapes are squeezed. Such vessels last thirty or forty years; and by their lightness are manageable, however large and long. A four-wheeled cart is in general covered with one of them, and it contains about fifteen hundred weight of grapes, each hundred being a hundred pounds of thirty ounces. The conic form of the Lombardy poplar, as a deciduous tree, is peculiar. Among evergreens we find the same character in the cypress; and both trees, in many situations, have a good effect. The cypress often, among the ruins of ancient (and the buildings of modern) Rome, breaks the regularity of a wall or a pedirnent; and the poplar has the effect among deciciuous trees of the round-headed kind. One beauty the Italian poplar possesses which is almost peculiar to it; and that is the waving line it forms when agitated by the wind. Most trees, in these circumstances, are partially agitated; one side is at rest while the other is in mo. tion; but the Italian poplar waves in one single sweep from the top to the bottom, like an ostrich-feather on a lady's head. All the branches coincide in the motion, and the least blast makes an impression upon it when other trees are at rest.

P. balsamifera is a moderate sized conical tree, a native both of Siberia and America. The buds of this tree, from autumn to the leafing season, are covered with abundance of a glutixous yellow balsam, which often collects into drops, and is pressed from the tree for medical use. This balsam is brought to Europe from Canada in shells. It is smooth, of an even texture, a yellowish color, and a fragrant scent. In Siberia a medicated wine is prepared from the buds, which is diuretic, and esteemed by the inhabitants serviceable in the scurvy. The grouse and other birds of that family feeding on these buds during winter, acquire a flavor which is much esteemed by epicures. P. candicans bears a general resemblance to the preceding species; and, like it, the buds are covered with a resinous tenacious balsam. The other American species are rapid-growing bulky timber-trees, well calculated for immediate effect and utility; but all the species being short-lived when compared with oaks, elms, and other slower-growing hard-wooded trees, confer a temporary premature character on landscape; for nothing can be great and lasting but what advances by degrees. Such poplars as do not grow freely from cuttings of the shoots, are most rapidily increased by cuttings of the roots; but the largest plants are produced from layers.

2087. Mercurialis. Mercury is said to have discovered the virtues of this plant. Böhmer, indeed, in his Lexicon, says, after Ambrosinus, that the name is a corruption of muliercularis, as being useful to women; but the Greeks call it हqus zoce, which is the same as Mercurialis in its mythological sense. M. perennis is not eaten by any quadruped, and is poiscnous to men and sheep. The plant on being dried turns blue, and steeped in water it 


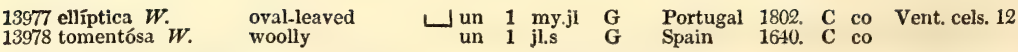
2089. HYDRO'CHARIS. $\boldsymbol{W}$. FROG-BIT. Hydrocharidea. Sp. 1.

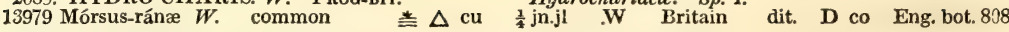
2090. TRIP'LARIS. $W$. Triplaris. 13980 americána $W$. American

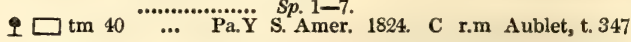

\section{DECANDRIA.}

2091. CORI A'RIA. W. Corlaria. 13981 myrtifólia $W$. Myrtle-leaved 13982 sarmentósa Forst. running

2092. KIGGELA'RIA. $\boldsymbol{W}$. Kiggelaria. 13983 africána $W$. 2093. SCHI'NUS. $W$. 13984. Mólle $W$

13985 dentáta $\dot{H}$. $K$ entire-leaved Amýris polýgama W.

2094. GYMNOCLA'DUS. $W$ GrMNochadus

2094. GYMNOCLA'DUS. $W$. GrmNocladus.
13987 canadénsis $W$.
Canadian

2095. CA'RICA. $W$. Papaw Tree.

13988 Papáya $W$

13989 cauliflóra $W$

13990 spinósa $W$.

13991 microcárpa $W$

$\beta$ monoica Desf.
Coriariece. $\quad S p .2-7$.

or 6 my.au G S. Europe 1629. L co Dend. brit. 103 N. Zeal. 1823. L co Bot. mag. 2470

Euphorbiacea. Sp. 1-2

my.jn W.G C. G. H. 1683. C s.l Lam. ill. t. 821 Terebintacea. Sp. 3-7.

jl.au G Peru 1507. I r.m Mill, ic. 2. t. 246

my.jl G Owhyhee 1795. L r.m Bot. rep. 620 Cucurbitacee? Sp. 4-6.

$\square$ cul 20 jl G India 1690. S r.m Bot. reg. 459

or $20 \quad \ldots \quad$ G Caraccas 1806. S r.m Jac.schœ.3.t.31 prickly $\quad$ or $20 \quad \ldots$ W.G Guiana 1821. S r.m Aublet, t. 346

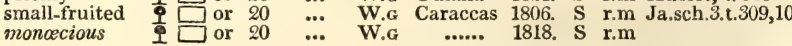

\section{DODECANDRIA.}

2096. STRATIO'TES. $W$. WATER Soldier. Hydrocharidece. $S p .1$.
13992 aloídes $W$ Aloe-like
$\Delta \mathrm{e}$
jn.jl W England
dit. D 1.p Eng. bot. 379

2097. HYENAN'CHE. $\boldsymbol{H}$. $\boldsymbol{K}$. HYana Poison. 13993 globósa $\boldsymbol{H}$. $K$.

2098. EU'CLEA. $W$.

13994 racemósa $W$ 13995 unduláta $W$.

Euclea.

$S p .1$.

L or 8 ap.s W.G C. G. H. 1783. C l.p Lam.cinc.52.t.10 round-leaved J or 5 n............... Sp. $2-5$.

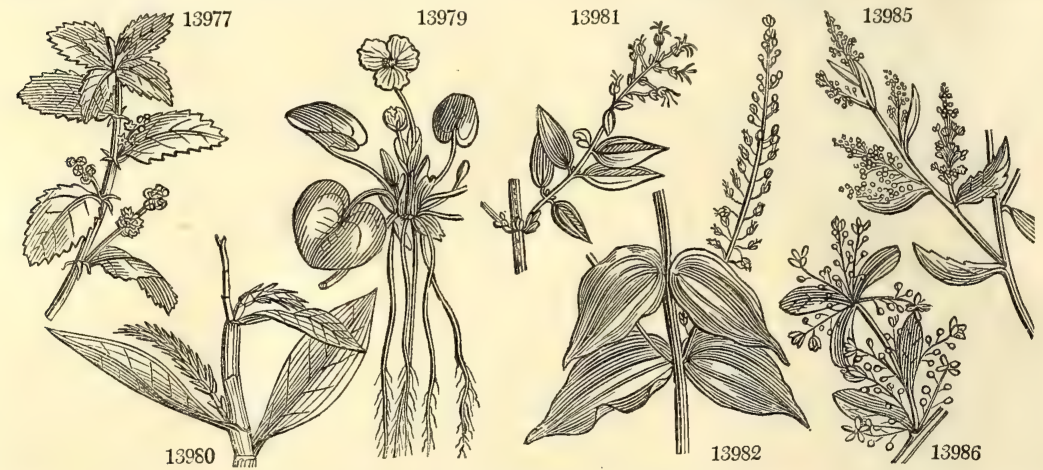

History, Use, Propagation, Culture,

affords a fine deep blue color, destructible, however, both by acids and alkalies. It has been observed that the male and female plants are seldom found intermixed, each sort usually growing in large patches; whence it is probable that this plant, which increases much by the root, rarely produces perfect seeds. M. annua was formerly accounted medicinal ; its seeds taste like those of hemp.

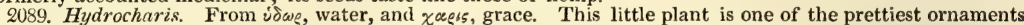
of still waters. This plant increases by runners, which shoot out to a great length, and at the joints drop down long roots, which penetrate deep into the mud. The joints are furnished with pendulous buds, supported on long footstalks. The buds consist of two stipulaceous scales folded together, within which are curiously enveloped the embryo leaves of the future plant.

2090. Triplaris. All the parts of the fructification are in threes or triple. T americana is a tree forty feet high, with a dense pyramidal head. The leaves are oblong, entire, smooth, a span long The branches are often hollow, and are then filled with an innumerable quantity of little red ants, which are often showered down upon any incautious traveller who may stand under the shade of the tree, and whom they bite severely. (Bredemeyer.)

2091. Coriaria. A tanner's plant ; from corium, a hide. Coriaria myrtifolia has handsome leaves, but very little beauty in the flowers. It is considerably astringent, and is used not only in tanning leather, but in dying black colors. It produces abundance of suckers.

2052. Kiggelaria. Named after Francis Kiggelar, an obscure botanist, who lived at the end of the seventeenth century. An uninteresting plant. Ripened cuttings strike in heat under a hand-glass.

2093. Schinus. This was the Greek name of the Pistacia Lentiscus. It is now applied to an American genus which resembles Pistacia in sensible properties. The word molle, applied to one species, does not allude to any softness in the plant which bears the name, but is a slight alteration of the Peruvian word mulli. Fragrant shrubs with beautiful foliage, easily cultivated in a cold conservatory or out of doors in a warm sheltered place.

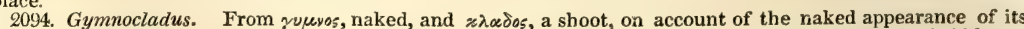
strange rigid shoots during the winter. This tree or shrub has pinnate leaves nearly a foot and a half long; both leaves and stalks are armed with thorns. The stalks at first grow erect, but afterwards twine about the neighbouring trees and shrubs. It is best propagated by cuttings of the roots. 
13977 Stem suffruticose brachiate, Leaves elliptical acute at each end smooth glandular serrated 13978 Stem suffruticose, Leaves oblong downy with serratures on each side at the end

\section{The only species}

13980 Racemes terminal and axillary brachiate

\section{DECANDRIA.}

13981 Leaves ovate-lanceolate 3-nerved stalked

13982 Procumbent diffuse, Leaves cordate-ovate acuminate entire 5-nerved stalked, Racemes noduing

13983 Leaves oblong unequally serrated

13984 Leaves pinnated, Leaflets serrated : the odd one very long, Petioles equal 13985 Leaves simple toothed

13986 Leaves simple entire and trifid, Flowers generally octandrous

13987 Leaves bipinnate very large deciduous, Flowers equal diœcious

13988 Leaves palmate 7-lobed : middle lobe sinuated; segments oblong acute, Male flowers corymbose 13989 Leaves palmate 5-lobed : middle lobe sinuated; segments lanc. acum. Male fis. from excrescences of trunk 13990 Leaves digitate, Leaflets 7 oblong acuminate entire, Trunk spiny

13991 Leaves 3 or 5-lobed: middle lobe 3-lobed, Male fiowers corymbose

$\beta$ Lower leaves entire : cauline 3-lobed; upper 5-lobed, Flowers monœcious subracemose erect

\section{DODECANDRIA.}

13092 Leaves linear tanceolate keeled prickly toothed

13993 Branches diffuse cinereous scarred, Leaves opposite 3 or 4-nate oblong retuse coriaceous

13934 Leaves oblong or obovate flat

13995 Leaves obovate wavy

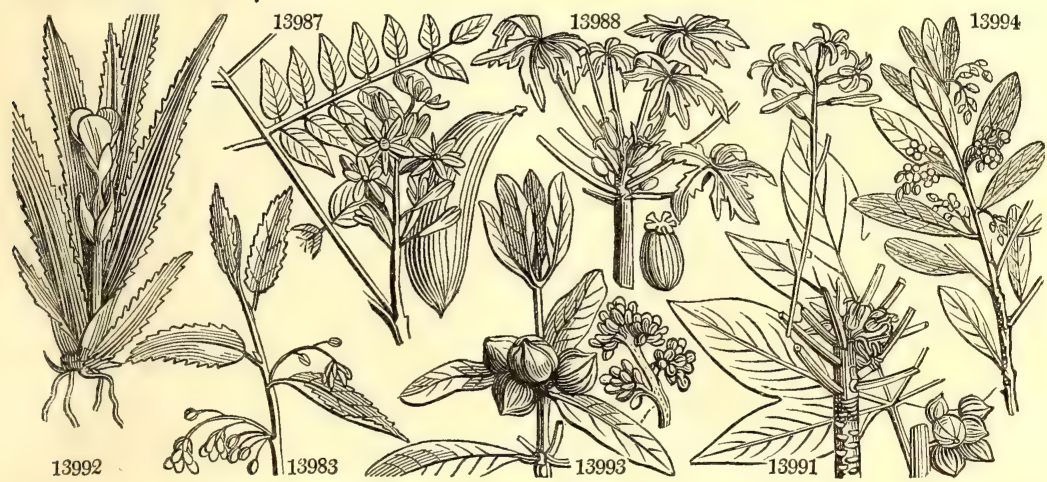

and Miscellaneous Particulars.

2095. Carica. According to Linnæus, because a native of Caria; but as the plant has no relation to that country, it would be better to adopt, with Jussieu, the specific name Papaya for the genus, C. Papaya rises with a thick soft herbaceous stem to the height of eighteen or twenty feet, naked till within two feet of the top, and having marks of the fallen leaves great part of its length. The leaves have long footstalks, are very large, and divided into many lobes. The whole plant abounds with a milky acrid juice, which is esteemed good for the ringworm. The male flowers, which are in loose clusters on long peduncles, are of a pure white, and have an agreeable odor. Sometimes these are succeeded by a small fruit about the size of a pear, which has occasioned some to suppose the male plant a distinct species. The flowers of the female have short peduncles; they are large and bell-shaped, composed of six yellow petals. When these drop off, the germ swells to a large fleshy fruit the size of a small melon. When ripe it is eaten by the inhabitants of the Caribbee Islatids, but its flavor is very indifferent. The most common use of them is when they are about half grown, to soak them in salt water, to get out the milky juice, and pickle them as mangoes, for which they are considered a good substitute. The plant generally is said to have the property of intenerating animal fibre by suspension under its leaves or branches; but this quality wants confirmation. In our stoves the plants grow freely in loamy soil, and are increased by large cuttings with their leaves on in a moist heat.

2096. Stratiotes. From नle $\alpha$ ros, a camp; in English, water-soldier; both names alluding to the military appearance of the plant, with its long sword.-like leaves, and flowers which may be liked to plumes of white feathers. An aquatic plant, remaining the greatest part of the year immersed in water, but rising to flower. It increases with such rapidity as to become a troublesome weed in artificial pieces of water in which it is planted.

2097. Hycenanche. From hycna, and $\alpha \gamma \times \eta$, pain; because the fruit is used at the Cape of Good Hope to poison hyænas. A small tree, six or seven feet high, also called Toxicodendron capense. The flowers grow in axillary branched yellowish panicles, and are succeeded by smooth nuts, which, being pounded, are used to poison the carcases of lambs, by which the hyænas are infallibly destroyed.

2098. Euclea. From $\varepsilon \nu * \lambda \varepsilon \varsigma \alpha$, glory or beauty; in allusion to the permanent beauty of the neat evergreen foliage of the plants. Shrubs or small trees, natives of the Cape of Good Hope. Of one species the berries are brought to the market of Cape Town for sale, and is the only kind of native fruit, except that of Cissus capensis, which is there eaten. Ripened cuttings root in sand under a glass. 
2099. DATIS'CA. $W$. DAtisca.

13996 cannabina $W$. Hemp-like $¥ \Delta$ or 4 jl.s Y Y Candia 1640. D co Alp. exot. t. 298 2100. MENISPER'MUM. $D$. MoON SEed. 13997 canadénse $W$. Canadian 13998 virgínicum $\boldsymbol{W}$. Virginian or 20 jn.jl G.Y N. Amer. 1732. R s.p Dil.el.t.178.f.219 Cissampelos smilacina W.

2101. COC'CULUS. Dec. Cocculus.

14000 Plukenétii Dec. officinal

$1+001$ carolinus $W$. Carolina Wendlandia populifolia

14002 orbiculátus Dec. round-leaved 14003 villósus $\mathrm{Dec}$. $\beta$ hirsútus Dec. hairy

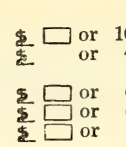
Menispermece. Sp. 4-46. Menispermec. Sp. 3-6.

or 10 jn.jl G.y N. Amer. 1691. R s.p Bot. mag. 1910 G.Y Carolina 1776, R 1.p Jac. ic. 3. t. 629

\section{ICOSANDRIA.}

2102. Flacour'Tia. $W$. Flacourtia. 14004 Ramóntchi $W$. 14005 flavéscens $W$. 14006 cataphrácta $W$. 14007 sápida $\boldsymbol{W}$. shining-leaved yellow-flower'd many-spined esculent

2103. PEU'MUS. Pers. Peumus. 14008 frágrans Pers. fragrant 2104. GELO'NIUM. Roxb. GeloniUM. 14009 bifárium Roxb. oval-leaved 2105. ROTTLE'RA. Roxb. Rottlera. 14010 tinctória $R_{\theta x b}$. dyer's

\section{Tiliacea. $S p .4-7$.}

$\square$ fr 12 jn.jl $\underset{\text { W }}{\square}$ Madagasc.1775. C p.1 L.He.stir.59.t.30

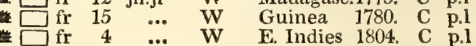

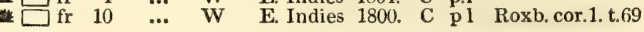
30............... Sp. 1. Euphorbiacea. Sp. 1-2.

$\square$ un 6 jn.au Ap E. Indies 1793. C p.l Euphorbiacec. Sp. 1.

$\square$ un $15 \quad \ldots \quad$ Ap $^{2}$ E. Indies 1810. C p.l Roxb.cor.2.t.168

\section{POLYANDRIA.}

2106. ClifFoR'TIA, $\boldsymbol{W}$. Cliffortia 14011 cuneáta $W$. 14012 ilicifólia $W$. 14013 tridentáta $\boldsymbol{W}$. 14014 ruscifólia $W$. 14015 cinérea $W$. 14016 pulchélla $W$ 14017 crenáta $W$. 14018 ericæfólia $W$. wedge-leaved $\begin{aligned} & \text { or } \\ & \text { llex-leaved } \\ & \text { three-toothed } \\ & \text { Ruscus-leaved } \\ & \text { cinereous } \\ & \text { beautiful or } \\ & \text { notched-leaved } \\ & \text { Heath-leaved } \\ & \text { Hol or } \\ & \square\end{aligned}$ or
or
or Rosacea. Sp. 11-24.

ap G.W C. G. H. 1787 C

my.s $G$ C. G. H. 17.14. C p.1 Dill. elt.t.31.f.35 $\begin{array}{llllll}\text { my.s G.w C. G. H. } & \ldots & \text { C } & \text { p.l }\end{array}$ 3 jn.jl G.w C. G. H. 1752. C p.l L'hort. cliff.t.31 4 jn.jl G.w C. G. H. 1800. C p.l

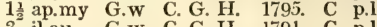
3 jl.au G.w C. G. H. 1791. C pl

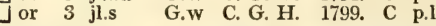

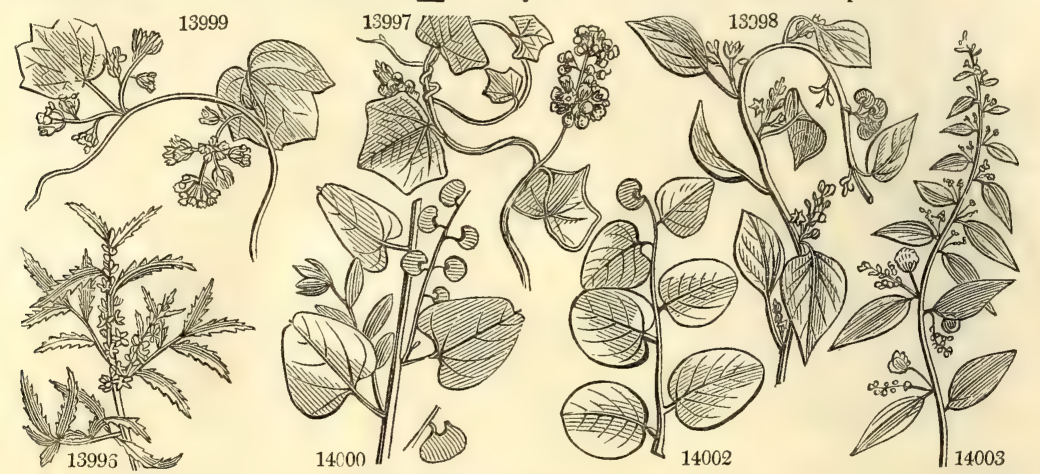

History, Use, Propagation, Culture,

2099. Datisca. A word the meaning of which is unknown. The plant is of no beauty, and of the easiest culture. 2100. Menispermum. From $\mu$ ry the fruit. All the species are of the easiest propagation and culture.

The M. palmatum produces the famous Colombo root, which is so remarkable for the intenseness of its bitter taste, and valuable on this account in dyspepsia, diarrhcea, dysentery, and as a wash for putrid sores.

2101. Cocculus. This word is derived from coccus, the name of the weli-known dyers' insect, and has been applied to this yenus on account of the resemblance which has been found to exist between that insect and the scarlet berries of the plant. A genus with the habit of Menispermum.

Cocculus Plukenetii produces berries and bunches like grapes, but smaller; first white, then red, and finally blackish purple. In the East Indies they are made up into a paste, and used to intoxicate fish, birds, and different sorts of vermin.

2102. Flacourtia. Named in honor of Etienne de Flacourt, a director of the French East India Company, and the commander of an expedition to Madagascar in 1648; of which he afterwards wrote an account, containing considerable details upon the botany of the country. L'Heritier dedicated to him the first species of the genus, which was found by him in Madagascar, where it is called Ramontchi. It is a thorny shrub or tree, with leaves and fruit resembling those of the plum. The fruit is green when young, of a beautiful red when ripe, and finally of a dark violet color: the skin is very thin, and the flesh transparent red, of the same consistence with our common plums : in the middle are a dozen or fourteen small kernels, the size of those in the apple, and nearly of the same shape; they are bitterish like our apricot kernels, and covered with a tender shell. The natives eat the fruit; it is sweet, but leaves a slight sharpness in the mouth. An island on the coast of Maciagascar is covered with these trees; and because they resemble the European plum-tree, the sailors have named the island Isle aux Prunes, or Plum-tree Island. All the species grow freely in a mixture of loam and peat, and cuttings root in sand, plunged and covered.

2103. Peumus. The Chilian name of this plant is Peumo. It is the Ruizia of the Flora Peruviana, and forms an evergreen tree among the woods upon the sandy shores of Chili ; it is valuable for its wood, which is very fragrant. 
13996 Stem smooth

13997 Leaves peltate cordate roundish angular

13998 Leaves peltate cordate lobed

13999 Leaves peltate smoothish cordate-roundish bluntly angular glaucous beneath, Racemes simple

14000 Leaves ovate subcordate at base bluntly truncate at end with a little point, Fem. racemes axillary simple 14001 Leaves cordate villous beneath

14002 Leaves orbicular subcordate obtuse 5-7-nerved mucronulate ash-colored beneath, Peduncles very large 14003 Leaves ovate or lanceolate 3-5-nerved: younger villous; old ones downy, Branchlets vill. Pedicels few. fi.

\section{ICOSANDRIA.}

14004 Leaves roundish ovate acute crenate

14005 Leaves oblong obtuse serrated narrowed at base

14006 Leaves ovate oblong acuminate serrated

14007 Leaves elliptical bluntish repand serrated obtuse at base

14008 Leaves ovate oblong with pellucid dots, Racemes short pellucid

14009 Leaves elliptical sharp-pointed

14010 Leaves alternate oblong elliptical acute at each end

\section{POLYANDRIA.}

14011 Leaves alternate cuneiform truncate 5-toothed at end streaked with veins

14012 Leaves altern. roundish ellipt. amplexicaul. from the middle to end mucronate toothed streaked with veins 14013 Leaves alternate oblong cuneiform entire and 3-toothed nerved downy beneath

14014 Leaves alternate lanceolate smooth nerved terminated by a spine : floral 3-toothed, Branches downy 14015 Leaves connate ovate 3-cornered hoary

14016 Leaves opposite orbicular entire appressed many-nerved

14017 Leaves opposite or ternate orbicular appressed toothletted 7-nerved 14018 Leaves fascicled rounded furrowed smooth

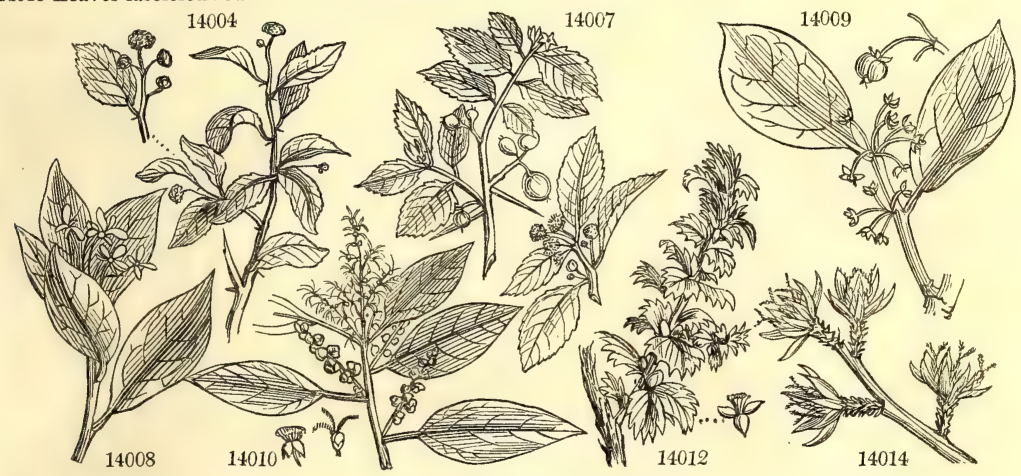

and Miscellaneous Particulars.

2104. Gelonium. So named by Roxburgh; but it is not known with what meaning. East Indian trees, with alternate leaves, the tubular stipular of a Ficus, and axillary flowers.

2105. Rottlera. Named by Roxburgh, in honor of the Rev. Dr. Rottler, an East Indian botanist of reputation, who resided many years at Tranquebar in the character of a Danish missionary. Rottlera tinctoria is a native of the inland mountainous parts of the Circars of Hindostan, flowering in the cold season. Dr. Roxnative of the inland mountainous parts of the Circars of Hindostan, flowering in the cold season. Dr. Rox-
burgh never found it any where else. This is a middle-sized, erect, branching tree. Leaves alternate, stalked, elliptic, oblong, acute, entire, from four to eight inches in length, three-ribbed, and veiny; nearly smooth above; downy beneath, furnished at their base with two brown glands. Footstalks round, downy, from one to three inches long. Flowers small, in clusters about the tops of the branches, axillary, and terminal ; the latter branched. Capsules the size of a small cherry, clothed with abundance of deep red granular powder, easily rubbed off. This powder is a valuable article of commerce, being much esteemed, especially among the Moors, for dyeing silk of a deep, bright, very beautiful and durable, full orange or flower color. When the capsules are ripe, in February or March, they are gathered, and the powder carefully brushed off. It is preserved without any further process, and is sold to the merchants trading to Hydrabad and other inland parts. This substance is but little acted upon by water, except with the admixture of alkaline salts, when it gives out a very deep blood-red color. To spirits it communicates a rich, deep, reddish flame color ; but in neither instance does it dissolve, the grains remaining entire, like sand. The inhabitants know this powder by the name of Wassunta-gunda, and use it in the following manner:- To four parts of Wassunta-gunda are added one of alum, and two of salt of soda, native barilla. These are rubbed well together, with a portion of expressed oil of Sesamum, so small as hardly to be perceived. When well mixed, the whole is put into boiling water, in quantity proportioned to the silk which is to be dyed, and kept boiling smartly, more or less time, according to the shade required. The silk is turned frequently, to render the color uniform.

2106. Cliffortia. Named in honor of George Cliffort, a Dutch gentleman; a great lover of plants, and one of the earliest of Linnæus's patrons. He had a superb garden at Hartcamp, of which Iinneus published the catalogue in one volume folio, in 1737. Shrubs of little beauty, except C. pulchella, which is exceedingly pretty; they are easily cultivated in a good greenhouse. 
14019 obcordáta $W$. 14020 trifoliáta $W$. 14021 sarmentósa $W$. 2107. CY'CAS. $W$. 14022 circinális $W$ 14023 revolúta $W$.

2108. Z A'MI A. $W$. 14024 púngens $W$. 14025 cycadifólia $W$. 14026 angustifólia Jac. 14027 média Jac. 14028 débilis $W$. 14029 integrifólia $W$. 14030 pygmæ'a $B . M$. 14031 furfurácea $W$. 14032 spirális $W$. 14033 hórrida $\dot{W}$. 14033 horrida $W$. 14035 púmila $B$. $M$. 14036 lanuginósa $W$ 14037 longifólia $W$. 14038 tridentáta $W$. heart-leaved three-leaved twiggy

Cycas.

broad-leaved narrow-leaved

ZAMIA.

needle

Cycas-leaved

narrow-leaved

intermediate

long-leaved

dwarf

least

broad-leaved

spiral

gray

Cycas-like

pygmy

woolly

long-leaved

three-toothed
*

警 $\rightarrow$ or 10 ap.jt

迷 $\longleftarrow$ or 4 jn.au

G.w C. G. H. 1790. C p.1

G.w C. G. H. 1752, C p.l Pluk.al.t.319.f.4

Cycadec. $S p .2-4$.

$\square$ cu 3 ... Ap E. Indies 1700. Sk r.m Rh.mal.3.t.13.21 $\square$ cu 3 jl.au Ap China 1737. Sk r.m Lin.trans.6.t.29 Cycadea, Sp. 15.

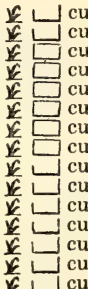

... Ap C.

$\begin{array}{lllll}\ldots . . & \text { Ap } & \text { C. G. H. } & \text { 1775. Sk l.p Till. pis.129. t.45 }\end{array}$ jl.. .0 Ap Bahama 1775. Sk 1.p Ja.frag.1.t.25, 26 jlau Ap W. Indies $\cdots$ Sk p.l Bot ma

jl.au Ap W. Indies $\%$... Sk p.1 Bot. mag. 1838

jl.au Ap W. Indies 1777. Sk p.1 Bot. cab. 155

my A W. W. 1851 3 my Ap W. Indies $\ldots$. Sk p.l Bot. mag. 1741 jl.au Ap W. Indies 1691. Sk p.l Bot. mag. 1969

Ap C. G. H. 1800. Sk p.l Jac.fr. 27. t. 27,28

Ap C. G. 1775. Sk p. Jac.fr.27.t.27,28

Ap C. G. H. 1775. Sk p.1 Th.act.ups.2.t.5

$\begin{array}{lllll}\text { Ap } & \text { C. G. H. } & 1812 . & \text { Sk p.l } & \text { Bot. mag. } 2006 \\ \text { Ap } & \text { C. G. H. } & \text { 1812. } & \text { Sk p.l } & \text { Jac. frag. t. } 27,28\end{array}$

Ap C. G. H. 1818. Sk p.l Jac. fragm. t. 29

C. G. H. 1814. Sk p.l

\section{MONADELPHIA.}

2109. LATA'NIA, $J$. Bourbon PaLM

14039 rábra $W$.

14040 borbónica $W$.

$\begin{array}{ll}\text { red } & \text { 等 } \square \text { or } 15 \\ \text { or } 20\end{array}$

Palma. Sp. 2.

2110. LEPTOC AR'PUS. $R$. $B r$. LeptocanpUS. Restiacece. $S p .1-7$.

14041 ténax $R$. Br. tough Schæenódum ténax $\mathrm{Lab}$.

2111. RUS'CUS. $W . \quad \begin{gathered}\text { Burcher's Broom. } \\ \text { prickly }\end{gathered}$
14042 aculeátus $W$.

$\beta$ láxus L. T.

14043 Hypophýllum $W$.

14044 Hypóssum $W$. broad-leaved

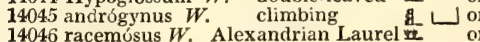

14046 racemósus $W$. Alexandrian Laure

2112. ARAUCA'RIA. J. Araucaria.

14047 imbricáta $W . \quad$ Sir J. Banks's

Norfolk Island 9 tm $100 \ldots$ Ap Norfolk I. 1793. C p.l Lam.pin.t.39,40

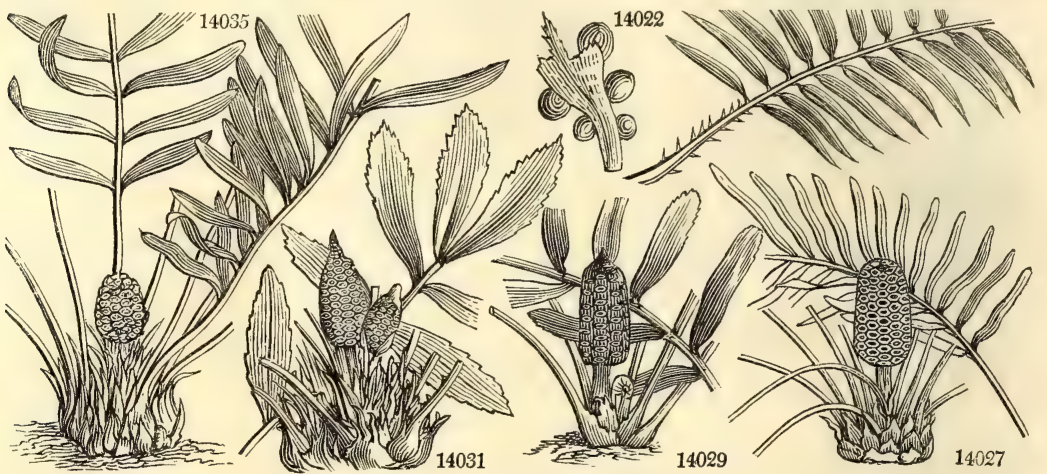

History, Use, Propagation, Culture,

2107. Cycas. A name employed by the ancients to designate a little palm which grew in Ethiopia. The modern plant is analogous to it. This genus, which seems intermediate between palms and ferns, produces the nutritive granulated power called sago, from sagu, the name of a sort of bread made from the pith of the trunk in Tonquin. It is cultivated in China and Japan, and the fruit is eaten in the latter country. The tree, however, is chiefly valued for the pith of its trunk, which is full of white pith like that of the elder. The tree being cut down, this pith is beaten with a wooden pestle in a great mortar or trough; it is then strained, and the sediment, without farther preparation, constitutes sago. The native Indians live wholly upon it for three or four months in the year. That which is transported is dryed and granulated. In our stoves these plants require the culture common to all the palm tribe; a rich loamy soil, plenty of pot-room, and a strong moist heat. 2108. Zamia. From $\zeta \eta \mu s \alpha$, loss or damage. Pliny applied the name to the pine-cones of the fir, which, when suffered to decay upon the tree, injured the succeeding crop. The modern genus bears heads of fowers very like pine cones.

2109. Latania. The name of this plant in the Isle of Bourbon is Latanier. L. borbonica is a middle-sized palm with plaited fan-like fronds, which from the elongation of the axis and terminal lobe, seems as if pinnate. When young their middle nerve is downy; it afterwards becomes naked. The stalks of the leaves are spiny. The other species, $\mathbf{L}$. rubra, is a much smaller plant, and is remarkable for its red livid leaves.

2110. Leptocarpus. From $\lambda_{\varepsilon \pi \tau 05}$, smooth, and $\approx \infty \rho \pi 05$, fruit; with reference to the polished surface of the seeds. Rushy plants allied to Restio, and all natives of New Holland and the South Seas.

2111. Ruscus. Anciently bruscus, and derived, it is said, from beus, box, and kelem, holly, in Celtic ; boxholly. The French at this day call one species buis-épineux and petit-houx. R. aculeatus has thick white twining roots, which strike deep into the ground, and send out fibres like those of asparagus. The stem is suffruticose, tough, stiff, and dark green; having many stiff sharp prickly pointed leaves. From the middle of the leaf above, comes out a singl- flower, on a very short pedicel: when it first appears it is the size and shape of a small pin's head; when expanded, composed of three outer calyxed leaves, and three inner ones con- 
14019 Leaves ternate veinless smooth roundish elliptical : the middle one smaller obcordate

14020 Ieaves ternate fascicled veiny hairy : lateral lanceolate entire; middle one obovate 3-toothed

14021 Leaves ternate linear villous

14022 Fronds pinnated, Leaflets lanceloate linear acute 1-nerved flat

14023 Fronds pinnated, Leaflets linear mucronate 1-nerved revolute at edge

[unarmed

14024 Fronds pinnat. Leafl. subul. spread. straight rigid mucron. : outer margin of base rounded, Stalk roundish 14025 Fronds pinnated, Leaflets linear mucronate distichous : lower opposite, Stalk $\frac{1}{2}$-round channelled downy 14026 Fronds pinnated, Leaflets linear entire with a callous end twice emarginate obtuse, Stalk $\frac{2}{2}-$ round

14027 Fronds pinnated, Leaflets linear lanc. blunt obsoletely serrulate at end and flat, Stalk 3-cornered smooth 14028 Fronds pinnated, Leaflets lanc. acute pointless serrated at end, Stalk 3-cornered smooth

14029 Fronds pinnat. Leaf. lanc. rounded blunt narrow, at base serrul. on outside at end, Stalk smooth nearly sq. 14030 Very smooth, Leaflets of 16 pairs ovate oblique imbr. serr, at end, Stem round, Ament ovate nodding

14031 Fronds pinnated, Leafl. lanc. ac. pointless serrat. from middle to end chaffy ben. Stalk roundish spiny below 14032 Fronds pinnated, Leaflets in 30-40 pairs falciform outwards with 3 or 4 prickly teeth at the end [smooth 14033 Fronds pinnat. Leafl. frost. glauc. lanc. ac. point. with spiny teeth in midd. on outside, Stalk sq. and trunk 14034 Leaflets oblique linear-lanceolate subulate hairy curved with 1 or 3 spines at the end and none on stalk

14035 Leaflets linear entire obtuse of 20 pairs, Stem round unarmed scurfy at base [woolly 1403ถ Leafl. oblique lanc. acute mucron, in midd. on outside with 2 spiny teeth smooth, Stalk squ. smooth, Trunk

14037 Leaflets oblique lanceolate distichous acute pointless entire, Stalk smooth bluntly 4-cornered

14038 Leaflets oblique linear somewhat sulcate 3-toothed at end smooth, Stalk $\frac{1}{8}$ round channelled

\section{MONADELPHIA.}

14039 Fronds plaited flabelliform, Leaflets spiny serrulate, Stalk unarmed

14040 Fronds plaited flabelliform elongated in the middle, Leaflets smooth at edge, Stalk spiny

14041 Spike divided, Catkins oblong somewbat squarrose, Scales cartilaginous acuminate, Culm simple

14042 Leaves mucronate pungent flower-bearing on their upper side and naked

$\beta$ Leaves elliptical acute at each end, Branches weak

14043 Leaves bearing flowers on their underside naked

14044 Leaves bearing flowers on their upper side under a leaflet

14045 Leaves bearing flowers at their edge

14046 Raceme terminal hermaphrodite

14047 Leaves about 8 imbricated ovate-lanceolate mucronate perennial 14048 Old leaves closely imbricated inflexed pointless

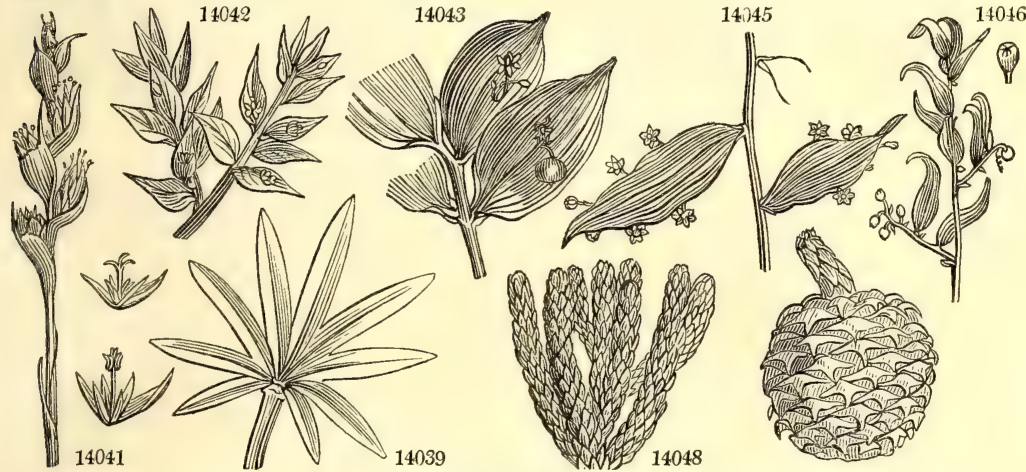

and Miscellaneous Particulars.

sidered as petals. Mr. Woodward remarks, that the flower does not properly grow out of the leaf, but on a pedicel from the bosom of the leaf, which is immersed beneath the outer coat, whence it may with ease be dissected. The female flowers are succeeded by red berries, almost as large as some cherries; they are sweet tasted, with two large orange-colored seeds in each. The green shoots were formerly used by butchers for sweeping their blocks, whence the common English name of the plant. It is still made into besoms in Italy. The tender growths, soon after they have sprung up from the root in spring, have been gathered and eaten by the poor like those of asparagus; and the branches, with the ripe fruit on them, were formerly stuck up in sand, with the stalks of Peony and Iris, displaying their capsules of ripe seeds; the three together made a sort of winter nosegay for rooms. In landscape gardening the plant is valuable as an evergreen, which will grow under the shade and drip of other trees. It harmonizes well with Daphne Laureola, and Ulex nana, and Vaccinium vitis idæa. R. hypophyllum has the flowers on the under side of the leaves, which are succeeded by small red berries about the size of those of Juniper. R. racemosus is an elegant evergreen shrub, by some supposed to be the plant with which the ancients crowned their victors; but the more general opinion is in fupposed to be the plant with which the ancients crowned their victors; but the more

2112. Araucaria. The inhabitants of Chili call this noble ornament of their forests araucanos. A. excelsa, the Norfolk Island pine, is a most superb plant, growing to all enormous size, and never losing the bright imperishable foliage with which it is covered, as with a coat of mail. This genus, Sweet observes, " may be termed the handsomest genus of plants with which we are acquainted. A. imbricata, in particular, is certainly one of the grandest plants known. It will thrive well in the open air, with the protection of a mat or two in very severe weather, and when got pretty large, will, no doubt, be perfectly hardy. A. excelsa, or Norfolk Island pine, is also a beautiful tree, but will not do without the protection of a greenhouse. An equal mixture of sandy loam and peat will suit them very well; and cuttings may be rooted, though with difficulty, taken off at a joint in ripened wood, and planted in a pot of sand, which must be put under a hand-glass, in the propagating house, but not plunged in heat." (Bot. Cult. p. 136.) 
2113. JUNI'PERUS. $W$. JUNIPER. 14049 thurifera $W$. $W$. Junish

14050 bermudiána $W$. Bermudas Cedar

14051 chinénsis $W$

14052 excélsa $W$.

14053 Sabina $W$.

\& tamariscifólia

14054 prostráta $P$. S.

14055 daúrica Pall.

14056 virginiána $W$

14057 commúnis $W$.

ß suécica

14058 nána $W$.

14(1)59 Oxycédrus $W$.

14060 phoenicea $W$.

14061 lýcia $W$.

14062 barbadénsis $W$.

2114. TAX'US. $W$ 14063 baccáta $W$.

3 hibérnica $W$.

2115. EPHE'DRA. $W$. EPHEdra.

14064 distáchya $W$. great

14065 monostáchya $W$. smal

14066 altíssima Desf. , lofty

Coniferce. Sp. 14-17. or 10 my.jn Ap S. Europe 1752. L s.l $\Delta \mathrm{tm} 20$ my.jn Ap Bermudas 1683. S p.1 Herm. lug. t.347 $\Delta$ or 10 my.jn Ap China 1804. L p.1 tm $20 \quad \ldots$ Ap Siberia 1806. L s.1 or 4 my.jn Ap S. Europe 1548. L s.l or 4 my.jn Ap S. Europe 1562. L s. or 3 my.jn Ap N. Amer.... S st or 8 my.jn Ap N. Amer. $\ldots$ i s s. Dauria 1791 , L s.l 584 tm 30 my.jn Ap N. Amer. 1664. S s.p Mich. arb. 3. t.5 tm 15 my.jn Ap Britain heaths. S s.1 Eng. bot. 1110 or 15 my.jn Ap N. Europe $\quad . . . \quad$ L $\quad$ s.l or 2 my.jn Ap Siberia $\ldots$. $\mathrm{s}$ 1.p Pa.r.2.t.54.f.A.B or 15 my.jn Ap Spain 1739. C s.l Duh.arb.1.t. 128 $\begin{array}{llllll}\text { brown-berried } & \text { or } 15 \text { my.jn Ap } & \text { S. Europe 1683. C } & \text { s.1 } & \text { Pall. ross. 2. t. } 57 \\ \text { Phoenician } & \text { or } 10 \text { my.jn Ap } & \text { S. Europe 1693. L } & \text { s.1 Pall. ross. 2.t. } 56\end{array}$ $\begin{array}{llllll}\text { brown-berried } & \text { or } 15 \text { my.jn Ap } & \text { S. Europe 1683. C } & \text { s.1 } & \text { Pall. ross. 2. t. } 57 \\ \text { Phoenician } & \text { or } 10 \text { my.jn Ap } & \text { S. Europe 1693. L } & \text { s.1 Pall. ross. 2.t. } 56\end{array}$ Barbadoes Cedar $9\llcorner$ or 20 ... Ap Florida 1811. L s.1 Pluk.al, t.197.f.4

Yew-Tree. Coniferce. $S p$. 1.

9 $\begin{array}{llll}\text { or } 20 & \text { f.ap Ap Britain m.wo. S co Eng. bot. } 746\end{array}$ Coniferce. Sp $3-5$.

cu 2 jn.jl Ap France 1570. L co Sch.han.3. t.339

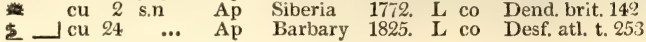

2116. Cissa M'Pelos. Dec. Pareira Brava Root. Menispermece. Sp. 3-28.

14067 Paréira Dec. genuine \& $\quad$ or 6 jl.au G $\quad$ S. Amer. 1733. C s.p Lam. ill. t. 830
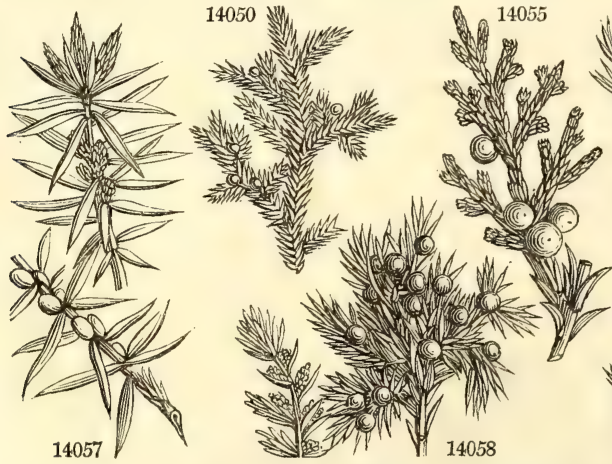

History, Use, Propagation, Culture,

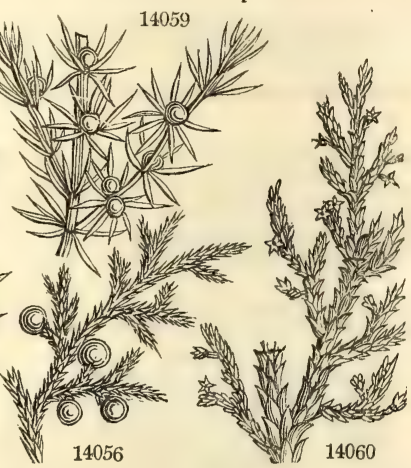

14060

2113. Juniperus. From the Celtic jeneprus, which signifies rough, or rude. Sandarach, the name of a resın produced by the Juniper, is, according to Golius (p. 1225.), an alteration of the Arabic word sandarous. The species, with only one or two exceptions, are close conical-growing evergreen shrubs or trees. The timber of $\mathbf{J}$ Barbadensis and Bermudiana is imported from the West Indies under the name of Bermudas Cedar. $J$. Virginiana grows in the West Indies, the North American continent, and in Japan. It is one of the highest timber trees in Jamaica, affording very large boards of a reddish brown colar, close and firm contexture, shining, very odoriferous, and bitter to the taste. It is imported into this and various other countries for the purposes of the cabinet-maker, as it is offensive to most insects. J. communis is common in all the northern parts of Europe, in fertile or barren soils, on hills or in vallies, in open sandy plains, or in moist and close woods. On the sides of hills its trunk grows long, but on the tops of rocky mountains and on bogs it is a tufted shrub. In England it is found chiefly on open downs in a chalky or sandy soil. In Scotland it is found in granite, trap. and schistous hills and mountains; but not in the highest summits of the latter. In the south of Europe it is only found in elevated situations; it abounds in the Alps of Switzerland, but is not very common in the Appenines. In our shrubberies it forms a respectable looking conical bush, grouping and combining very well with cypresses, American cedars, and various species of the pine and fir tribe. It is easily transplanted, and bears cropping. Grass will not grow beneath it, but the Avena Pratensis is said to destroy it. The wood is hard and durable; the bark may be made into ropes; and ardent spirits, impregnated with the essential oil of these berries, forms the true Juniper water or gin. Various insects feed on this shrub; and it is eaten by horses, sheep. and goats, when they can get nothing better. A gum oozes spontarieously from the trunk of old plants, which is Sanda. rach, and in its powdered form is known under the name of pounce. Juniper berries require to remain two years on the tree before they are fully ripe. The greater quantity of those which are used in Britain, are brought from Germany, Holland, and Italy. They have a peculiar aromatic odor, and a sweetish, pungent, bitterish taste when chewed. In distillation with water, they yield a volatile terebinthinate oil of a greenish color, on which their virtues depend. The flavor and diuretic properties of hollands depend on this oil ; it is also supposed to be used for flavoring English gin, but for this purpose oil of turpentine is used. Medicinally, Juniper berries are diuretic and cordial. They have been long known as a remedy in hydropic affections ; but they cannot be depended on alone, although they form an excellent adjunct to foxglove and squill. The tops yield the same essential oil as the berries, and may therefore be substituted for them. (Thom. Lond. Disp.)

J. suecica is by some considered only a variety. J. sabina seldom produces flowers or seeds in our gardens. Professor Pallas says, that in the Chersonesus Taurica, where it is very common, the savin is often found a foot and a half diameter; that it grows upright there, like a cypress, whereas by the Tanais it is procumbent. the branches extending on the sand several fathoms; that the wood very much resembles that of $J$. iycia, but has a more cadaverous smell, and the leaves are more fetid. The leaves and tops of common savin have a strong, heavy, disagreeable flavor, and a bitter hot taste, with a considerable degree of acrimony. These qualities depend on an essential oil, which is obtained in considerable quantity by distillation with water. Both water and alcohol extract its active principles; and Lewis found that on inspissating the spirituous tincture, there remains an extract consisting of two distinct substances, of which one is yellow, unctuous or oily, bitterish, and very pungent; the other black, resinous, tenacious, less pungent, and subastringent. Medicinally, savin is a powerful stimulant, posssesing diaphoretic, emmenagogue, and anthelmintic properties. It has certainly, however, a considerable effect on the uterine system; but, on account of its stimulating properties, is suited to those cases only of amenorrhoea which are unattended by fever, and in which the circulation is 
14049 Leaves imbricated in 4 rows acute

14050 Lower leaves ternate : upper binate decurrent subulate spreading acute

14051 Leaves decurrent imbricated spreading closely packed, of the stem in threes of the branches in fours

14052 Leaves opposite bluntish glandular in the middle imbricated in 4 ways, Stem arboreous

14053 Lvs. opp. blunt glandular in the middle imbricated in 4 ways : the younger acute and opp. Stem shrubby

14054 Leaves opp. acute imbricated in about 4 rows smooth glaucous, Branches horizontal prostrate 14055 Leaves opposite acute imbricated decurrent : occasionally spreading and subulate

14056 Leaves in 3 s adnate at base : younger imbricated ; old ones spreading

14057 Leaves ternate spreading mucronate longer than the berry

14058 Leaves ternate falcate somewhat imbricated the length of berries 14059 Leaves ternate spreading pointed shorter than berry

14060 Leaves ternate obliterated imbricated blunt

14061 Leaves ternate imbricated all ways ovate blunt

14062 Leaves all imbricated in 4 rows : younger ovate; old ones acute

14063 Leaves thickly set linear distichous flat, Male receptacles globose

14064 Sheaths of joints 2-toothed blunt, Catkins 2-3 opposite stalked, Peduncles shorter than catkins 14065 Sheaths of joints 2-toothed blunt, Catkins solitary scattered or opposite, Peduncles longer than catkin 14066 Sheaths of joints bifid acum. Male catkins clustered sessile or stalked, Fem. solit. stalk. Branches spreading

14067 Leaves peltate subcordate ovate-orbicular silky beneath, Female racemes longer than leaves

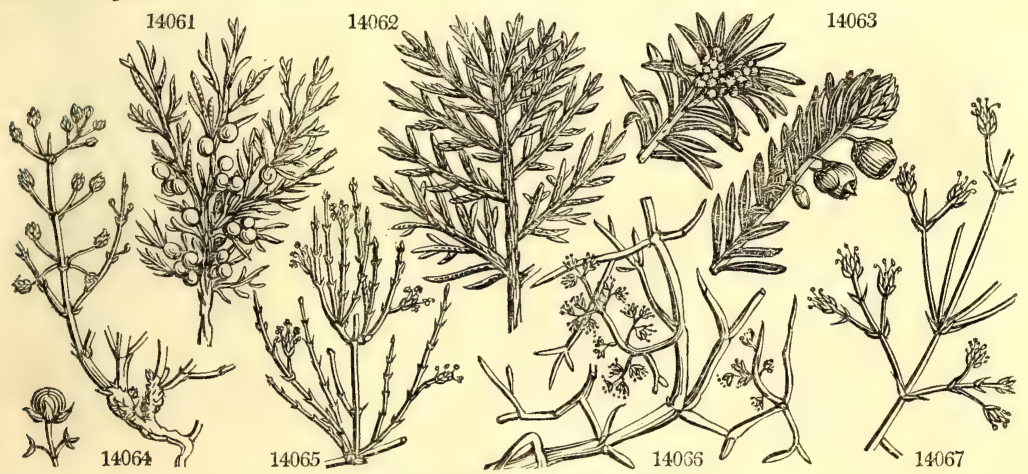

and Miscellaneous Particulars.

languid. In plethoric habits, its use should be preceded by repeated bleedings; and at all times its internal exhibition requires caution. It has been given in gout and worm cases also, but is seldom used. As an external local stimulant or escharotic, the dried leaves in powder are appiied to warts, flabby ulcers, and carious bones; and the expressed juice diluted, or an infusion of the leaves, as a lotion to gangrenous sores, scabies. and tinea capitis, or mixed with lard and wax as an issue ointment. (Thom. Lond. Disp. p. 342.)

$\mathrm{J}$, Lycia, which greatly resembles the savin, is commonly thought to produce the gum resin called Olibanum; though Dr. Thomson and others consider the Boswellia Serrata of Roxburgh as the true plant. Olibanum is supposed to have been the incense used by the ancients in their religious ceremonies; it is much employed by the Roman Catholics in their churches, and generally as a perfume in sick rooms.

2114. Taxus. According to Vossius this word is derived from rogos, an arrow, because that weapon was formerly poisoned with the juice of the plant. Yew seems to be an alteration of the Celtic iw, green. $T$. baccata inhabits mountainous woods in Europe, North America, and Japan. Cæsar mentions it as very common in Gaul and Germany. In Britain and Ireland there was formerly great abundance in a wild state, and planted in church-yards. Ray says that our ancestors planted the yew in church-yards because it was an evergreen tree, as a symbol of that immortality which they hoped and expected for the persons there deposited. Hence a custom, which still exists in a few places of Wales and Ireland, of carrying twigs of this and other evergreen trees in funerals, and throwing them into the grave with the corpse. According to some, the yew was planted in church-yards on account of its utility in making bows; but this is by no means likely, when the tree was so common in a wild state, and when a single one would have afforded so very scanty a supply. The bow was considered an engine of military warfare, at least up to the time of Henry VIII. ; so great was the demand for yew in the days of archery, that our own stock could not supply the demand; it was obliged to be imported, and various laws were passed concerning it from the time of Edward IV. to Elizabeth. The wood of the yew is red and veined, very hard and smooth, used by turners, cabinet-makers, millwrights, and a variety of other artisans. Flood-gates for ponds made of it, are said to be of incredible duration. The twigs and leaves of yew, eaten in a very small quantity, are certain death to horses and cows; but deer, it is said, will crop these trees with impunity, and sheep and goats are said by Linnæus to eat them. Turkeys, peacocks, and other poultry and birds eat both the leaves and fruit. A few of the berries are not deleterious to the human species, but the leaves are fatal. The tree is very patient of the shears, and was much employed in the ancient style of gardening for verdant architecture and sculpture. Allowed to take its natural shape, and when advanced to a considerable age, it forms one of handsomest of British evergreens, harmonizing admirably with the holly, the box, and the juniper. The yew is generally propagated from seeds, which are either sown as soon as they are ripe, without clearing them from the pulp, or mixed with sand, and laid in a heap to be turned over two or three times during the winter, and in spring, the seeds from which the pulp will have rotted sown in beds of light loamy soil. By either mode, a part of the plants will come up the first season, and the remainder in that following. The Irish yew is probably a distinct species.

2115. Ephedra. This was a name given by the Greeks to our Equisetum, which the plant now called Ephedra strongly resembles. E. Distachya abounds in the southern parts of Russia, and from thence southwards to Persia and India. The berries ripen in July and August: they are sweetish, muroms, and leave a little heat in the throat. They are eaten by the Russian peasants, and by the wandering horaes of all Great

Tartary.

2116. Cissampelos. From « 


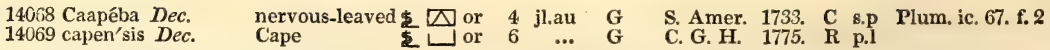

2117. EXCÆCA'RIA. $W$. EXacARIA.

14070 serráta $H$. $K$.

2118. ADE'LIA. $W$.

14071 Bernárdia $W$.

14072 Ricinélla $W$. saw-leaved

Adelia.

Euphorbiacea. Sp. 1-6.

14073 Acidóton $W$

smooth.-leaved

Box-leaved

2119. LOUREI'RA. $W$. LoureIRA

14074 glandulósa $W$. glandulous

2120. MYRIS'TICA. $\boldsymbol{W}$. NuTMEG.

14075 moscháta $W$.

14076 fátua $W$.

true

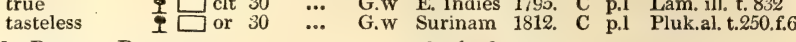

曾 L or 6 f.n W Chili

1796. C p.l

Euphorbiacea. Sp. 3-6.

6 jl.au G Jamaica 1768. C p.l

or 6 jn.au G.w Jamaica 1768. C p.1

3 jn.jl G.w Jamaica 1768. C p.l

Euphorbiacea. Sp. 1-2.

14077 distillatória $W$. Chinese

2122. CLUY'TIA. $W$. CLUYTIA

14078 alaternoídes $W$.

14079 polygonoides $\dot{W}$.

14080 daphnoides $W$

14081 ericoídes $W$.

14082 polifólia $W$.

1408 s tomentósa $W$.

14084 pulchélla $W$.

14085 collina $W$.

narrow-leaved

Polygonumedike

Daphno-leaved

Heath-leaved

Poley-leaved

tomentose

broad-leaved

hili

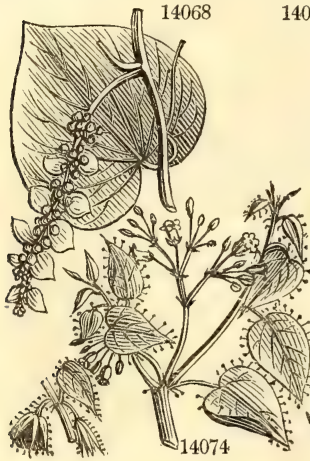

14070

$\checkmark \square \mathrm{cu}$

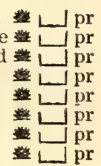

2 ap.my G

Euphorbiacece. $S p .8-11$

2 mr.d W C. G. H 1692. C pl Bot mag 1321

$2 \mathrm{mrd}$ W C. G. H. 1790. C p.l W. hort. ber. 51

3 my.jn W C. G. H. 1731. C p.l W. hort. ber. 52

2 ap.jn W C. G. H. 1790. C p.I

2 ap.jn W C. G. H. 1790. C p.l Jac. schœ.2. t. 50

3 ap.jn W C. G. H. 1812, C p.l

C. G. H. 1812. C p.I Bot mag 1915

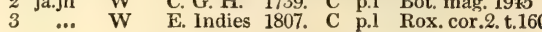

14072

14077
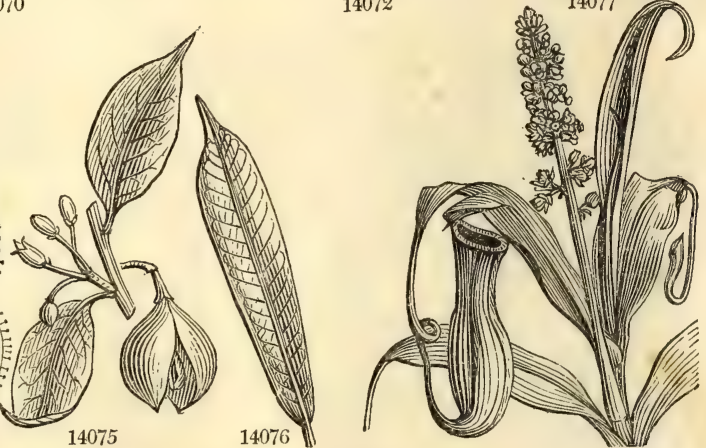

History, Use, Propagation, Culture,

nature of the former in its foliage, and of the latter in its fruit. The roots of several species are said to have powerful medicinal qualities. That of the C. pareira, or Pareira brava, is bitter, diuretic, and aperient; of C. caapeba more mucilaginous.

2117. Exccearia. From excacare, to blind. The juice of this plant is so acrid as to cause loss of sight whenever it touches the eyes. Agallochum, the produce of one of the species, was the name given by the the Greeks to an aromatic wood they obtained from India. In Arabia it is called, according to Golius, âghâloùdjy.

2118. Adelia. From $\alpha$, privative, and $\delta \eta \lambda_{05}$, visible. The parts of fructification are so minute as to be hardly visible. A. Bernardia derives its name from having been considered a distinct genus, and dedicated to the celebrated Bernard de Jussieu. Bernardia is the name which ought to have been adopted for the genus. Ugly uninteresting shrubs.

2119. Loureira. Dedicated by Cavanilles to John de Loureiro, a Portuguese missionary, who travelled in China and Cochin-china, of which he published the Flora in 1790 .

2120. Myristica. From $\mu$ e $\rho \alpha$, myrrh, on account of the odor of the fruit. M. moschata produces spheroidal drupes, fleshy, smooth, and finally drying up into a coriaceous crust, and opening on one side. Each berry contains an ovate, globular, serrated nut. The arillus or cover, which is commonly called mace, is fleshy, coriaceous, and reddish-saffron colored. Under this are two shells, the outer thin and brittle, and reticulated by the impressions of the mace : the inner shell is membranaceous, and adheres very closely to the kernel. The fruit would be a drupe was it not for the arillus.

The nutmeg-tree yields three crops annually; the first in April, which is the best; the second in August, and the third in December; yet the fruit requires nine months to ripen it. When it is gathered, the outer coriaceous covering is first stripped off, and then the mace carefully separated and dried in the sun. The nutmegs in the shell are next exposed to heat and smoke for three months, then broken, and the kernels thrown into a strong mixture of lime and water; after which they are cleaned and packed up. This process is necessary for their preservation, and with the same intention the mace is sprinkled with salt water. There are several varieties of the tree; but that denominated the queen nutmeg, which bears a small round nut, is the best. They are imported in chests, which contain each from 100 to $140 \mathrm{lbs}$. weight; the mace comes in chests also of different sizes. The essential oil which is obtained in Banda by the distillation of the nut is brought 
14068 Leaves somewhat orbicular cordate at base 7-nerved or little downy, Fem. racemes the length of leaves 14069 Lvs. ovate bluntish smooth on short stalks, Racemes much branched, male? scarcely longer than petiole

\section{Monœcious diandrous, Leaves oblong serrated}

14071 Leaves oblong downy serrated

14072 Leaves obovate entire

14073 Leaves oblong blunt entire fascicled, Spines axillary

14074 Leaves cordate glandular on the limb

14075 Leaves oblong acuminate smooth, Veins simple, Fruit solitary smooth

14076 Leaves oblong lanceolate with starry down beneath, Veins simple, Fruit racemose downy

14077 Leaves sessile, Pitchers cylindrical, Flowers panicled

14078 Leaves sessile linear lanceolate acute, Flowers axillary solitary

14079 Leaves sessile obovate acute, Peduncles about 3 -fl. axillary

14080 Leaves subsessile lanceolate obovate, Flowers axillary solitary

14081 Leaves subsessile linear-lanceolate acute thickish, Flowers axillary twin

14082 Leaves stalked linear blunt mucronate revolute at edge, Flowers axillary subsolitary on long stalks

14083 Leaves elliptical blunt densely downy on each side, Flowers axillary solitary sessile

14084 Leaves stalked ovate acute smooth, Flowers in 5 s axillary

14085 Leaves stalked elliptical blunt somewhat retuse smooth shining, Flowers axillary polygamous about 3

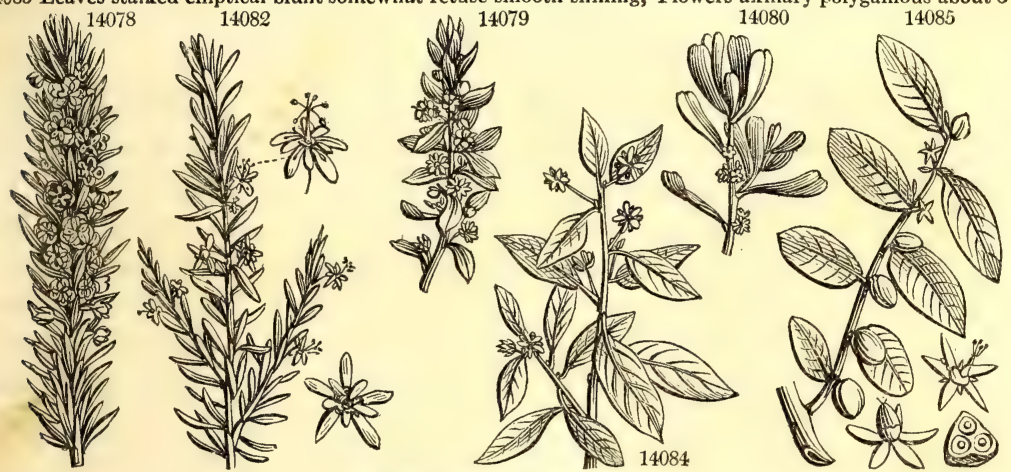

and Miscellaneous Particulars.

in bottles, and the expressed oil in stone jars. Nutmegs are frequently punctured and boiled in order to obtain the essential oil, and the orifices afterwards closed with powdered sassafras. The fraud is detected by the lightness of the nutmeg. The nutmeg has a fragrant, agreeable, spicy odor, and a warm aromatic taste.

As the medical properties of nutmeg and mace depend on the essential oil they contain, they agree in these circumstances; and both are stimulant, carminative, and, in large doses, narcotic. Mace is more generally used as a culinary spice; but the nutmeg and its volatile oil are in frequent use to cover the disagreeable taste of other medicines, and are sometimes ordered in cases of languor, vomiting, and diarrhea, and in flatulent colic. On account of the narcotic property of the oil, nutmeg should be cautiously employed in apoplectic and paralytic habits. In India its dangerous effects have been frequently felt; and in this country instances have occurred in which the nutmeg, taken in large quantity, produced drowsiness, great stupor, and insensibility, and on awakening delirium, which alternated with sleep for several hours. (Thom. Lond. Disp. p. 395.)

M. fatua is a branching lofty tree; the branches long, tortuous and declining; the leafy and flowering branches downy and ferruginous, and the flowers in axillary and terminal clusters. The fruit varies in size and form on different trees; but is generally oblong, and about as long as a pigeon's egg. From the kernel is extracted a species of yellowish suet or fat, which serves for various medical and economical purposes, and is made into candles. From the wounded bark flows a red acrid juice. The plants are at present rare in British collections : they grow in light loam and peat, and may be increased by cuttings in sand under a bell-glass.

2121. Neperthes. The name under which Homer speaks of a substance, which appears to have been opium. It is impossible to conceive in what sense the word has been applied to the plants now bearing the name. They are the famous pitcher-plants of China and the East Indies, which bear leaves, the extremities of which are are the famous pitcher-plants of China and the East Indies, which bear leaves, the extremities of which are
hollowed out into cup-like appendages, which are generally filled with water, which seems as if confined within them by a little lid, by which the pitchers are surmounted. The cultivation of the plants is extremely difficult. It requires a very damp atmosphere, much heat, and perhaps, not much light. They are managed more successfully by Loddiges of Hackney, than by any cultivators in this country.

2122. Cluytia. Named by Boerhaave, after Outgers Cluyt, or Augier Clutius, a Dutchman, and professor of botany at Leyden. He published, in 1634, a little tract upon the Cocoa-nut of the Maldives, which he called nux-medica. The species are of little beauty or interest, and of the easiest propagation and culture. 


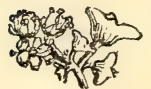

\section{Class XXIII. - POLYGAMIA.}

Flowers either male, female, or hermaphrodite, upon the same or different plants.

Tris class differs from the two preceding in having not only the sexes in different flowers upon the same individual as in Monœcia, or upon separate individuals as in Diœcia, but also combined in one flower, mixed among those which are unisexual. It may, therefore, be considered to contain those genera which are in a state of transition from the common hermaphrodite structure to absolute unisexuality.

To the first of its orders are referred several grasses, which are excluded from the early classes on account of the separation of their sexes; it also contains the numerous tribe of Mimosas, so well known for their various properties as objects of food, of ornament, of medicine, or of curiosity. The maple is also stationed in the first class, as are a few genera of palms.

The most important genera of the second class, besides the poetical Palmetto, are the ash and the fig. Gleditschia and Ceratonia, two families of Leguminosæ, are valuable, the former for its light, airy, elegant foliage, and the latter for its sweet pods, which are used in Spain, in great quantities, as fodder for cattle.

\section{Order 1. MONCECIA. .}

2123. Inga. Hermaphrodite. Cal, 5-toothed. Cor. tubular, 5-fid. Stam. 100, monadelphous. Pod 2-valved. Seeds enwrapped in pulp, or in an arillus. Male. Cal, 5-toothed. Cor. tubular, 5-fid. Stam. 100, monadelphous.

2124. Mimosa. Hermaphrodite. Cal. 5-toothed. Cex. O. or 5-toothed. Stam. 8. Pod separating into oneseeded joints. Male. Cal. 5-toothed. Cor. O. or 5-toothed. Stamens 8.

2125. Schrankia. Hermaphrodite. Cal. 5-toothed. Cor. 5-fid. Stamens 8-10. Pod 4-valved. Male. Cal. 5-toothed. Cor. 5-fid. Stamens 8-10.

2126. Desmanthus. Hermaphrodite. Cal. 5-toothed. Cor. 5 petals. Stamens 20. Pod 2-valved. Male. Cal. 5-toothed. Cor. O. Stamens 20.

2127. Acacia. Hermaphrodite. Cal. 5-toothed. Cor. 5-fid. Stamens 4-100. Pod 2-valved. Male. Cal. 5-toothed. Cor. 5-fid. Stamens 4-100.

2128. Veratrum. Hermaphrodite. Cal. O. Cor. 6-petalous. Stamens 6. Ovaries 3. Caps. 3, manyseeded. Male. Same as hermaphrodite, but no ovary.

2129. Andropogon. Hermaphrodite. Cal. 1-f. Paleæ glume bearded, either at base or tip. Stamens 3. Styles 2. Seed 1. Male. Ovary none.

2130. Chloris. Flowers 1-sided. Cal. 2-valved, with 2 or 6 florets : one sessile, hermaphrodite; the other stalked, male. Hermaphrodite. Paleæ with a terminai beard. Stamens 3. Styles 2. Seed 1. Male. Cal, O, Paleæ one or two, bearded. Stamens 3.

2131. Sorghum. Flowers panicled. Glume coriaceous-cartilaginous, 2-fowered closed. Paleæ of the hermaphrodite bearded; of the neuter single, beardless. Male. Glume 1-fi. stalked. Paleæ 2, beardless.

2132. Holcus. Hermaphrodite. Cal. glume 1-2-flowered. Paleæ bearded under the end. Stamens 3. Styles 2. Seed 1. Male. Cal glume 2-valved. Paleæ O. or 2. Stamens 3.

2133. Ischæmum. Hermaphrodite. Cal. glume 2-flowered. Paleæ 2. Stamens 3. Styles 2. Seed1. Male Cal. and palea as in hermaphrodite. Stamens 3.

2134. Agilops. Hermaphrodite. Cal glume about 3-flowered, cartilaginous. Palea terminated by a triple beard. Stamens 3. Styles 2. Seed 1. Male, Cal, and pal, of hermaphrodite. Stamens 3.

2135. Manisuris. Hermaphrodite. Glume 1-f. Paleæ2. Stamens 3. Style bifid. Male. Glume 1-fl. Paleæ 2. Stam. 3. All the valves of calyx emarginate at end and sides.

2136. Valantia. Hermaphrodite. Cal. O. Cor, 4-parted. Stamens 4. Style 2-fid. Seed 1. Male. Cal. 0. Cor. 3-4-parted. Styles 3-4.

2137. Parietaria. Hermaphrodite. Cal, 4-fid. Cor. O. Stam. 4. Style 1. Seed 1. Female. Cal. 4-fid.

Cor. O. Style 1 . Seed 1.

2138. Atriplex. Perfect fl. Perianth. single, 5-partite, inferior. Stam. 5. Style bipartite. Fruit depressed, 1-seeded, covered by the cal. Pistilliferous fl. Perianth. single, 2-partite. Stam. O. The rest as in the perfect flower.

2139. Rhagodia. Hermaphrodite. Cal. 5-parted. Cor. O. Stamens 5, or fewer. Acinus depressed. Male. Cal., cor, and stam. of the hermaphrodite.

2140. Terminalia. Hermaphrodite. Cal. 5-parted. Cor. O. Stam, 10. Drupe inferior. Male. Cal, fiveparted. Cor. $O$. Stamens 10.

2141. Fusanus. Hermaphrodite. Cal, 5-fid, Cor, O. Stamens 4. Ovary inferior. Stigma 4. A drupe.

Male. Fruit abortive. Cal., cor., and stam. of hermaphrodite.

2142. Brabejum. Hermaphrodite. Cor. of catkin 4-parted. Stamens 4. Style 2-fid. Drupe with a fleshy round nut. Male. Cor. of catkin 4-parted. Stamens 4. Style 2-fid, abortive.

2143. Acer. Hermaphrodite. Cal, 5 -fid. Cor. 5 petals. Stamens 8 . Styles 2 . Samara winged at end, oneseeded. Male. Cal. 5 -fid. Cor. 5 petals. Stamens 8.

214t. Negundium. Cai. very small, unequally 4-5.toothed. Pet. O. Male. Flowers fascicled. Anthers 4-5, linear, sessile. Female, Flowers racemose

2145. Celtis. Hermaphrodite. Cal, 5-parted. Cor. O. Stamens 5. Styles 2. A drupe. Male. Cal. sixparted. Cor. O. Stamens 6.

2146. Gouania. Hermaphrodite. Cal. 5-fid, superior. Cor. O. Stamens 5. Style 3-fid. Fruit 3-cornered, 3-parted. Male. Cal. 5-fid. Cor. O. Stamens 5.

2147. Hermas. Hermaphrodite. An umbel. Cor. 5 petals. Stamens 5, sterile. Male. An umbel. Cor. 5 petals. Stamens 5 , fertile. Styles 2 . Seeds 2 , inferior, cordate, orbicular.

2148. Bridelia. Hermaphrodite. Cal, 5-parted Petals 5, inserted in calyx. Stamens 5, monadelphous. styles 2, bifid. Berry 2-seeded. Male. Cal. 5-parted. Petals 5, inserted in the calyx. Filam. columinar, bearing 5 anthers. Female. Cal, and corolla of male. Styles 2, bifid, Berry 2-seeded.

2149. Feronia. Hermaphrodite. Cal. 5-toothed. Cor. 5 petals. Stamens 10. Style 1. Berry 5-celled, many-seeded. Male. Cal, 5-toothed. Cor. 5 petals. Stamens 10.

2150. Ailantus. Hermaphrodite. Cal. 5-parted. Cor. 5 petals. Stamens 2-3. Ovaria 3-5. Styles lateral. Samaras 1-seeded. Male. Cal. 5-parted. Cor. 5 petals. Stamens 10 . Female. Cal. 5-parted. Cor. 5 petals. Samaras 1-seeded. Male. Cal. 5-parted. Cor. 5 petals. Stamens 10. Female. Cal. 5-parted, Cor. 5 petals.

2151. Clusia. Hermaphrodite. Cal. 6-leaved. Cor. 4-6 petals. Anthers clustered. Stigmas 4-6. Caps. 6-celled, many-seeded. Male. Cal, 4-6-leaved. Cor. 6 petals. Stamens numerous.

2152. Ophioxylon. Hermaphrodite. Cal, 5-fid. Cor. 5-fid. Stamens 3. Ovary 1. Male. Cal. 2-fid. Cor. 5-fid. Stamens 2. 
2153. Rhapis. Hermaphrodite.

Cal. 3-fid. Cor. 3-fid. Stamens 6. Ovary 1. Drupe 1-seeded. Male.

Order 2. DIGEIA.

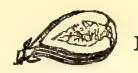

Flowers diœcious.

2154. Gleditschia. Hermaphrodite. Cal. 4-fid. Cor. 4 petals. Stamens 6. A pod. Male. Cal. 3-leaved. Petals 3. Stamens 6. Female. Cal. 5-leaved. Petals 5. A pod.

2155. Ceratonia. Hermaphrodite. Cal. 5-parted. Cor. O. Stamens 5. Style 1. Pod coriaceous, manyseeded. Male. Cal, 5-parted. Cor. O. Stamens 5. Female. Cal. about 5-toothed. Cor. O. Style 1. Pori coriaceous, many-seeded.

2156. Fraxinus. Hermaphrodite. Cal, O. or 4-parted. Cor. O. or 4 petals. Stamens 2. Samara 1-seeded. Female. Cal. O. or 4-parted. Cor. O. or 4 petals. Samara 1-seeded.

2157. Brosimum. Hermaphrodite. Catkin globosc, with a solitary ovary at end. Cal. a scale. Cor. O. Anthers peltate, solitary. Style 2-fid. Female. Cal. O. Cor. O. Ovary imbricated with scales. Style 2-fid. Berry coated, 1-seeded.

2158. Diospyrus. Hermaphrodite. Cal. and cor. 4-fid. Stam. 8., Style 4-fid. Berry 8-seeded. Male. Cal. and cor. 4-fid. Stamens 8.

2159. Myrsine. Cor. half 5-cleft, conniving. Ovary filling the corolla. Drupe 1-seeded. Nut 5-celled.

2160. Nyssa. Hermaphrodite. Cal. 5-parted. Cor. O. Stamens 5. Ovary 1. Drupe inferior. Male. Cal. 5-parted. Cor, O. Stam. 10.

2161. Hamiltonia. Hermaphrodite. Cal. 5-fid. Cor. O. Nect. a 5-toothed disk. Stamens $5 . \quad$ Ovary 1. Drupe inferior. Male. Cal. 5-fid. Cor. O. Nect. a 5-toothed disk. Stamens 5.

2162. Laurophyllus. Hermaphrodite. Cal. 4-leaved, Cor. O. Stamers 4. Ovary superior. Style 1. Male. Cal. 4-leaved. Cor. O. Stamens 4.

2163. Bursera. Hermaphrodite. Cal. 5-toothed. Petals 5. Stamens 10. Style O. Caps. 3-valved, oneseeded. Male. Cal. 5-toothed. Petals 5 . Stamens 10.

2164. Arctopus. Male. An umbel. Petals and stamens 5. Hermaphrodite. An umbel. Petals 5. Styles 2. Seeds 2. Involucre very large.

2165. Panax. Hermaphrodite. An umbel, Cal. 5-fid. Petals 5. Stamens 5. Styles 2. Berry 2-seeded. Male. An umbel. Cal, entire. Petals 5. Stamens 5.

2166. Ficus. Common receptacle turbinate, closed, fleshy. Female. Cal. 5-parted. Cor. O. Ovary 1. Seed 1. Male. Cal, 3-parted. Cor. O. Stamens 3. 


\section{MONECIA.}

2123. IN'GA. $W$. 14086 dúlcis $W$.

14087 Unguis-Cáti $W$. 1488 biglobósa $W$. 14089 macrophýlla $W$. 14090 véra $W$.

14091 rhoifólia $W$. en 14092 álba $W$.

14093 margináta $W$. 14094 mellifera $W$. 14095 nodósa $W$. 14096 latifólia $W$. 14097 purpúrea $W$ 14098 circinális $W$

2124. MIMO'SA. $W$. 14099 viva $W$. 14.100 cásta $W$.

14101 sensitíva $W$. 14102 latispinósa $L a m$ 14103 obtusifólia $W . e n$ $1+104$ pudíca $W$. 14105 polydáctyla Humb. 14105 pigra $H . K$ 14107 rubicaúlis $W$. 14108 asperáta $W$. 14109 concínna $W$. 14110 polystáchya $W$. en. many-spiked

2125. SCHRANK'IA. $W$. Schrankia.

14111 aculeáta $W$. Vera Cruz 14112 uncináta $W$
INGA. sweet

four-leaved

two-headed large-leaved common

villous

white

margined

honey-bearing knobbed

broad-leaved spiral-podded

Mimosa.

lively

chaste

Sensitive Plant

broad-spined

blunt-leaved

Humble Plant

many-fingered

ramble-staik.

rough

hooked
Leguminosa. Sp. 13-112.

\begin{tabular}{|c|c|c|}
\hline & $g u r$ & \\
\hline 20 & & $\mathrm{Pk}$ \\
\hline 20 & ... & Pk \\
\hline 30 & & 1 \\
\hline 20 & & \\
\hline 30 & jl.au & W \\
\hline 12 & $\cdots$ & \\
\hline 20 & & \\
\hline 20 & & $\mathrm{PH}$ \\
\hline 20 & ... & $P$ \\
\hline 20 & $\ldots$ & $\mathrm{PK}$ \\
\hline 10 & mr.ap & $\mathrm{Pl}$ \\
\hline 6 & mr.ap & $\mathbf{F}$ \\
\hline 10 & & \\
\hline
\end{tabular}

E. Indies 1800, C p.l Roxb. cor.1. t.99 W. Indies 1690 . S p.1 Jac.schoe.3.t.392 Martiniq. 1823. S p.l Ja.am. t.179.f.87 Cumana 1815. S s.p W. Indies 1739. S s.p Sl.jam.2.t.183.f.1 Brazil 1815. S s.p E. Indies 1804. S p.1 W. Indies 1759 S s.p Pluk al t.141 f Arabia 1822. S p.l Ceylon 1690. S s.p Pluk.al.t.211.f.5 W. Indies 1768. S p.1 Plum. ic. t.9 W. Indies 1733. C p.l Bot. reg. 129 W. Indies 1726. C p.l Plum, ic. t. 5

\section{Leguminosa. Sp. 12-71.}

区 1 or $1 \frac{1}{2} \mathrm{jl} . \mathrm{s} \quad \mathrm{Pu}$ Jamaica 1739. S p.l Sl.jam.2.t.182.f.7

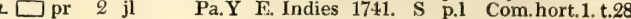

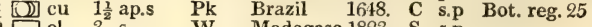
3 s W Madagasc.1823. S s.p $3 \quad \ldots \quad$ Pu Brazil 1816. S . s.p 1 ap.s W Brazil 1638. S r.m Bot. rep. 544

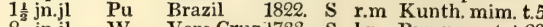
2 jn.jl W VeraCruz 1733. S 1.p Breyn. cent t.20 3 jn.jl Pa.Y E. Indies 1799. S lp Roxb.cor $2 . t 200$ 2 jn.jl W W. Indies 1823. S 1.p Dec. legum. t.63 $3 \quad \cdots \quad$ Pu E. Indies 1794. S p.l ... W Martinico 1816. S p.l Dec.leg.tt.61,62

\section{Leguminosa. $S p .2-5$.}

$\star$ ॠ $\triangle$ cu 2 il.au Pk VeraCruz 1733. S p.1 Mil.ic.2.t.182.f.1 * $\triangle$ cu 2 jl.au Pk N. Amer. 1789. S p.1 Vent. choix. 28

14090

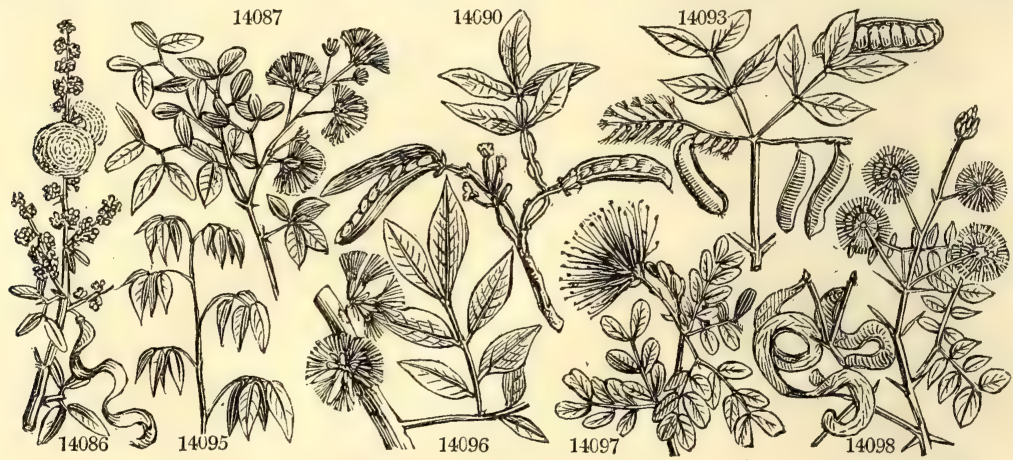

History, Use, Propagation, Culture,

2123. Inga. This is an American name adopted by Marcgraaf. A fine genus of plants, remarkable for their beautiful foliage and flowers; but in cultivation they seldom blossom. I purpurea is a remarkably elegant plant, and so is Inga biglobosa. I. unguis.Cati, the Cat's claw, Mimosa, is so called from the form of its curved plant, and so is Inga biglobosa. 1. unguis-Cati, the Cat's claw, Mimosa, is so called from the form of its curve

2124. Mimosa. Said to be derived from $\mu$ ses, a buffoon, because the leaves of the sensitive species appear as if to play with the hand that touches them

The cause of the well known motion in the leaves of the sensitive plant, has been the subject of many ingenious explanations; but it has not been treated by any botanist with so much ingenuity and address as by Dr. Dutrochet, whose theory we give, as explained by Mr. Lindley in the Botanical Register. M. Dutrochet states, that having ascertained hot nitric acid to possess the power of separating and reducing to its simplest form the whole mass of vegetable tissue, and that the action of the same acid produced other effects equally advantageous for the examination of the most obscure parts of vegetable structure, he was induced to give his attention to that of the Mimosa pudica, in the hope of gaining some evidence respecting the cause to which its sensibility is to be ascribed. Beginning with the pith, he observed a considerable number of minute globules of a greenish color, intermingled among the cells, and adhering to them in an irregular manner. After attempting to shew the probability of these globules having deceived M. Mirbel in various points of his analysis of vegetation, and especially in regard to the pores, which that botanist supposes to exist in the cellular tissue of plants, Dr. Dutrochet proceeds to remark, that the application of hot nitric acid to these globules renders them perfectly opaque, whence he concludes, that they are, in fact, minute cells filled with a particular renders them perfectly opaque, whence he concludes, that they are, in fact, minute cells filled with a particular
fluid, which is subject to become concrete by the application of acids. Now, it is known, that such fluids as are thus altered by acids, are usually dissolved and liquefied again by the application of alkalies. A few drops, therefore, of a solution of hydrate of potash were suffered to fall upon a portion of the pith on which nitric acid had been acting, and the mixture was exposed to the heat of a lamp. Being examined after a few minutes, the globules were found to have resumed their natural appearance. This curious fact indicated, in the opinion of Dr. Dutrochet, a strong and unexpected point of analogy between plants and animals. According to the microscopical researches of some modern observers, it has been ascertained that all the According to the microscopical researches of some modern observers, it has been ascertained that all the
organs of animals are composed of a conglomeration of minute corpuscles, similar to those just described; the corpuscles which constitute the muscles are soluble in acids, but those which compose the nervous system are insoluble in the same acids, and only soluble in alkalies. Now, as the chemical properties and the external appearance of the particles scattered among the cellular tissue of plants, and constituting the nervous system of animals, are the same, the author is induced to infer, that the spherical particles of plants are, in fact, the 


\section{MONOECIA.}

14086 Spines stipulary very short straight, Leaves of two pairs halved oblong obt. Panicle simple long terminal 14087 Spines stipulary straight, Leaves of two pairs roundish elliptical halved emarginate, Raceme terminal 14088 Unarmed, Leaves bipinnate, Spike double of two globes pendulous

14089 Unarm. Lvs, bipin of 2 pairs, Leaf. ov, ac smooth shining above, Glands betw. every pair, Petiole winged 14090 Unarm. Lvs pinn of about 5 pairs, Leafl. ov. obl. acum. smooth, Gland between every pair, Petiole winged 14(.91 Leaf. of 5 pairs obl. acumin. hairy above and shining villous beneath, Branches covered with rusty down 14092 Unarmed, Lvs. of 3 pairs, Leaflets obl, acuminate equal smooth, Gland between each pair, Fetiole winged 14093 Unarm. Lvs, pinn. of 2 pairs, Leafl. obl. lanc. acum. smooth, Gland between each pair, Petiole wing. at end 14094 Spines stipulary recurved, Leaves of $\mathcal{L}$ pairs, Leaflets halved obovate. Pod ensiform straight

14005 Unarm. Lvs, pinn. of 2 pairs, Leafl. obov, obl. unequal sided smooth, A gland between the lowest small ones 14.,96 Unarmed, Lvs. conjugate pinnate, Leaflets ov. obl. term. opp. lateral alternate, Flowers in lateral umbels 14097 Unarmed, Lvs. conjugate pinnate, Leafl. obl. blunt uneq. at base, Petioles without glands, Heads stalked 14098 Spines stipular, Lvs. conjugate pinnate, Pinnæe of 3 pairs, Leaflets ovate acute smooth, Pods spirally twisted

14099 Unarmed herbaceous, Leaves conjugate pinnate, Pinnæ 4 pairs, Leaflets roundish, Pods with one joint 14100 Prickles of branches and stems scattered hooked, Lvs. bipinn. ciliat. and rough, Sutures of pods very spiny 14101 Stem and petioles prickly, Leaflets nearly halved ovate acute hairy beneath smooth above

14102 Spines of petiol. scatter. very broad compr. straight, Lvs. bipinn. finally smooth without glands, Leaf. 10-15 14103 Stem and petioles prickly, Leaflets halved cordate ovate blunt smooth

14104 Stem prickly more or less hispid, Leaves digitate-pinnate, Pinnæ 4 of many pairs, Leaflets linear

14105 Stem aculeate smooth hairy upwards, Leaves digitate-pinnate, Pinnæ 8 of many pairs, Leaflets linear 14106 Like M. asperata, but less hairy

14107 Prickles of branches and stems scattered hooked, Leaves bipinnate, Pinnæ of 5 pairs, Leaflets $20-25$ lin.

14108 Leaves bipinnate, Pinnæ of 8-12 pairs, Leaflets of many pairs bristly ben. Peduncles twin as long as head

14109 Prickly, Leaves bipinnate : partial of 6 pairs ; proper of many pairs cultrate, Gland of petiole depressed

14110 Lvs. bipinnate terminated by a tendril, Pinnæ of $2-3$ pairs, Leaflets oval emarg. Spikes numerous fascicled

14111 Prickly, Leaves bipinnate : partial of 3 pairs ; proper of many pairs, Pods acute, Stem 4-cornered 14112 Prickly, Leaves bipinnate: partial of 6 pairs; prcper of many pairs, Pods acute, Stem 5-cornered

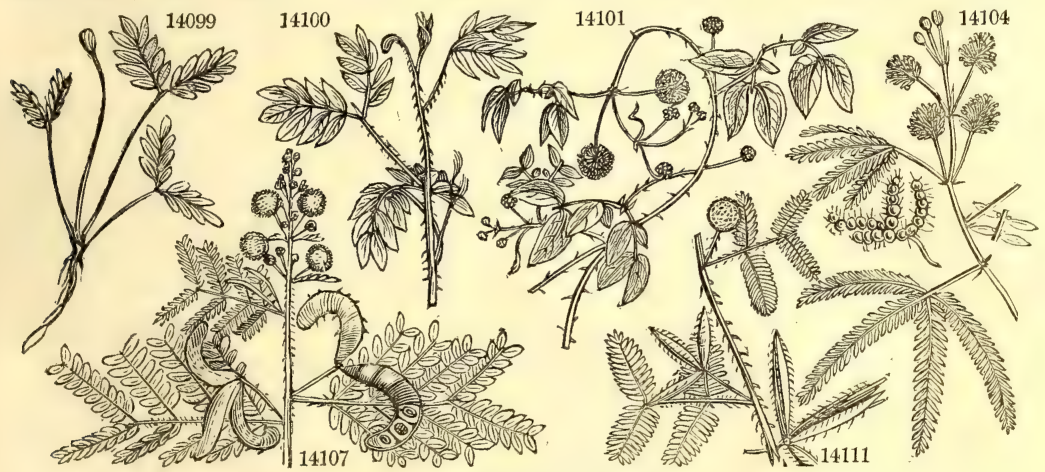

and Miscellaneous Particulars.

scattered elements of their nervous system. This hypothesis receives additional strength from the great similarity which exists between the medullary substance of the brain of Mollusca Gasteropoda and the cellular medullary tissue of plants. In pursuit of this idea, Dr. Dutrochet made a variety of experiments upon the sensitive plant, the results of which seem to be these. - The principal point of locomotion, or of mobility, exists in the little swelling which is situated at the base of the common and partial petioles of the leaves; this swelling is composed of a very delicate cellular tissue, in which is found an immense number of nervous corpuscles; the axis of the swelling is formed of a little fascicle of tubular vessels. It was ascertained by some delicate experiments, that the power of movement, or of contraction and expansion, exists in the parenchyma and cellular tissue of the swelling, and that the central fibres have no specific action connected with the motion. It also appeared that the energy of the nervous powers of the leaf depended wholly upon an abundance of sap, and that a diminution of that fluid occasioned an extreme diminution of the sensibility of the leaves. Prosecuting his remarks yet further, the author ascertained, that in the motion of the sensitive of the leaves. Prosecuting his remarks yet further, the author ascertained, that in the motion of the sensitive
plant, two distinct actions take place, the one of locomotion, which is the consequence of direct violence offered to the leaves, and which occurs in the swellings already spoken of; the other of nervimotion, which depends upon some stimulus applied to the surface of the leaflets, unaccompanied by actual violence, such as the solar rays concentrated in the focus of a lens. As in all cases, the bending or folding of the leaves evidentiy takes place from one leaf to another with perfect continuity; it may safely be inferred, that the invisible nervous action takes place in a direct line from the point of original irritation, and that the cause by which this action of nervimotion is produced, must be some internal uninterrupted agency. This was, after much curious investigation, determined by the author to exist neither in the pith, nor in the bark, nor even in the cellular tissue filled with nervous corpuscles, and on which, he supposes, the locomotion of the swelling at the base of petioles to depend. It is in the ligneous part of the central system, in certain tubes supplied with nervous corpuscles, and serving for the transmission of the sap, that Dr. Dutrochet believes he has found the true seat of nervimotion, which he attributes to the agency of the sap alone, while he considers the power of locomotion to depend upon the nervous corpuscles alone.

to depend upon the nervous corpuscles alone. planted in sand and kept closely covered.

The pods of M. fagifolia contain a sweet whitish pulp, which the natives of Martinique suck; they call the tree and its fruit Pois Doux, or sweet pea.

2125. Schrankia. Named by Willdenow, in honor of his countryman, Francis de Paula Schrank, a well

known German botanist. Herbaceous prickly shabby-looking plants, with the habit of Mimosa 
2126. DESMAN'THUS. $W$. Desmanthus. 14113 nátans $W$. 14114 plénus $W$. 14115 diffísus $W$. 14116 virgátus $W_{\text {. }}$ 14117 punctátus $W$ cinéreus $W$.

14119 divérgens $W$. en 2127. ACA'CIA. $W$. 14120 verticilláta $W$ 14121 juniperína $W$. 14122 aciculáris $H . K$. 14123 genistifólia $\operatorname{Link}$. 14124 sulcáta $H . K$. 14125 suavéolens $W$. 14126 glaucéscens $W$. 14127 floribúnda $W$. 14128 linifólia $W$. 14129 lineáris $B . M$. 14130 calamifólia Lindl. 14131 strícta $W$. 14132 longifólia $W$. 14133 falcáta $\boldsymbol{W}$. 14134 laurifólia $W$. 14135 diffúsa $B$, Re A. prostrata Bot. Cab. 631

14136 l. prostrata Bot. Cab. 631 in 14137 unduláta Lindl. 14138 melanóxylon $H, K$. black-wooded 14139 Sophóræ $H . K$ Sophora-podd. 14140 margináta $H$. 14141 marginátia $H$. $K$. 14141 myrtifólia 14143 angustifólia Werdl. narrow-leaved 14144 hispídula $W$. $1+145$ decipiens $H . K$. 14146 biflóra $H$. $K$. 14147 armáta $H, K$ 14148 aláta $H$. $K$. 14149 vestita $B . R e g$. floating double-yellow prostrate spotted-stalked Ash-colored
divergent

Acacia.

whorl-leaved Juniper-leaved needle-leaved furze-leaved furrowed-leav. sweet-scented many-flowere Flax-leaved linear

reed-leaved double-headed long-leaved sickle-leaved Laurel-leaved wavy-leaved marginate-lea Myrtle-leaved lunate

little harsh paradoxical two-flowered simp.-lv.-prick wing-stalked wing-stal
clothed long-twigged
Leguminosa, Sp.7-19. * $\square$ un 2 jl.s W $_{\text {W }}^{\text {China }}$ 1800. C p.l Bot. rep. 629

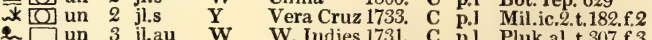
W W.Indies 1731. C p.1 Pluk.al, t.307.f. an 3 illau un 3 jn.jl Y W. Indies 1774. S p.1 Bot. mag. 2454 W Jamaica 1686. C p.l Com.hort.1.t.3 W E. Indies 1739. C p.l Rox.cor. 2.t.174 Abyssinia 1816. C p.1 Bruce Abys. t. 6 Leguminosce. Sp. 83-258. \begin{tabular}{lrlllll} 
or & 10 & mr.my Y & V. Di. Isl. 1780. S & s.p & Bot. mag. 110 \\
\hline or & 6 & mr.jn Y & N. S. W. 1790. & C & s.p & Bot. cab. 388
\end{tabular} N. S. W. 1796. S s.p N.S. W. 1825. S s.p N. Holl. 1803. S s.p Bot. reg. 928 N. S. W. 1790. C s.p Bot. cab. 730 N. S. W. 1790. S s.p N. S. W. 1796. C s.p Vent, choix. 13 N. S. W. 1790 S s.p Bot. mag. 2168 N. S. W. 1820. S s.p Bot. mag. 2156 N. S. W. 1819. S s.p Bot. reg. 839 N. S. W. 1790. C s.p Bot. rep. 53 N. S. W. 1792. S s.p Bot. mag. 2166 N. S. W. 1790. C s.p Tanna 17i5. S s.p N. S. W. 1818. s.p Bot. reg. 634

N. S. W. 1819 . s.p Bot. reg. 680 N. S. W. $1817 . \quad$ s.p Bot. reg. 843 V. Di. Isl. 1808. S s.p Bot. mag. 1075 V. Di. Isl. 1805. S s.p Lab.no.h.2.t.237 N. S. W. 1803, S s.p

N. S. W. 1789. C s.p Bot. mag. 302 N. S. W. 1810. S s.p Bot. cab. 384 N. S. W. 1816. S s.p Bot. cab. 763 N. S. W. 1794. S s.p Bot. cab. 823 N. Holl. 1803. C s.p Bot. mag. 1745 N. Holl. 1803. S s.p

N. Holl. 1803. S s.p Bot. mag. 1653 N. Holl. 1803. C s.p Bot. reg. 396 N. Holl. 1820. S s.p Bot. reg. 698

14150 scándens $W$. climbing 14151 Lambertiána 14152 ciliáta $H . K$. 14153 nigricans $H$. $K$. 14154 guianénsis $W$ 14155 Houstóni $W$. 14155 Houstón $W$. 14156 odoratissima $W$. 14157 venústa $W$. 14158 aruórea $W$. Cowan's $\square$ or 10 f... $\quad$ Pu ciliate-winged ${ }^{2}$ or $8 \mathrm{mr}$.jn $Y$ unequal-wing.

Guiana

Houston's

fragrant charming tree Silk tree

India 1780. S s.p Rh.mal.8.t.32.34 Mexico 1818. S s.p Bot. reg. 721 N. Holl. 1803. S s.p

N. Holl. 1803. S s.p Bot. mag. 2188

Cayenne 1803. C l.p Aub.gui.2. t.357 Vera Cruz 1729. C p.1 Bot. reg. 98

E. Indies 1790. S p.I Rox. cor. 2, 120 S. Amer. 1816. C 1.p Jamaica 1768. S p.1 Plu.al.6.t.25l.f.2 Levant 1745. C 1.p Scop. in. 1. t. 8

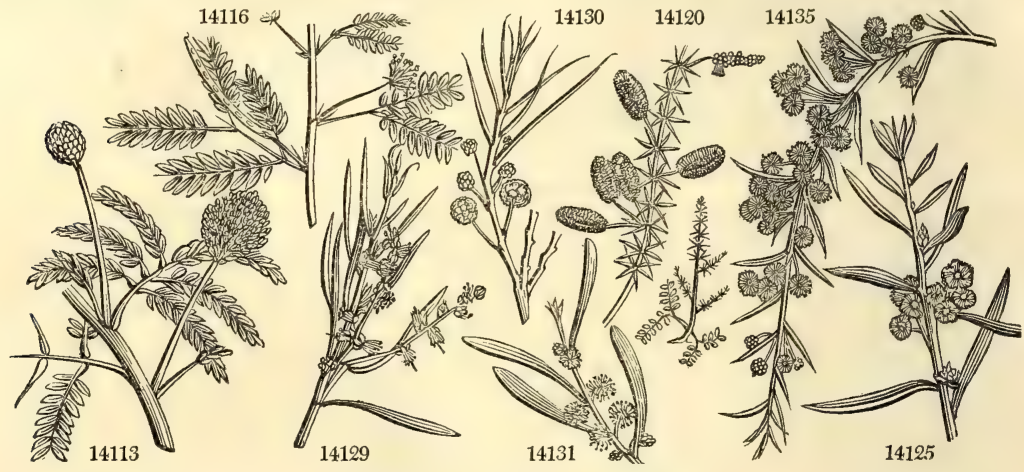

History, Use, Propngation, Culture,

3126. Desmanthus. From $\delta \varepsilon \sigma \mu \eta$, a bond, and ay. seem as if bound up together. These plants are chiefly aquatic; a few are prickly; and they all have the habit of Mimosa. D. natans is used in China as a pot-herb; and is described by Loureiro, under the name of Neptunia oleracea. Willdenow, the author of the genus, observes, that the neuter florets have always a different color from that of the hermaphrodites, whence the spikes appear parti-colored, by which character the genus may be known at a distance. Culture as in Mimosa. D. natans should be grown in water.

2127. Acacia. This was the Greek name of some plant of the present genus, and not being appropriated, was taken by Willdenow, in his reformation of the old genus Mimosa, as the designation of one of his new divisions. This is one of the most ornamental families of the greenhouse plants, and some are curious as well as beautiful. A Julibrissin, the Gul ebruschim, or rose of silk of the Persians, and the Gazia of Italian gardeners, is an elegant hardy tree with beautiful tufts of pink colored flowers, which resemble tassels of silken threads.

A. Catechu and vera are used in medicine. The inner wood of the former tree is of a brown color, from which the catechu is thus prepared. "After, felling the trees, the manufacturer carefully cuts off all the exterior white part of the wood. The interior colored part is cut into chips, with which he fills a narrowmouthed unglazed earthen pot, pouring water upon them until he sees it among the upper chips; and when 
14113 Unarmed, Leaves bipinnate : partial of 3 pairs ; proper of many pairs, Spikes ovate, Pedunc. with bractes 14114 Unarmed, Leaves bipinnate : partial of 3 or 4 pairs : proper of 12 pairs, Spikes ovate, Stem prost. compres. 14115 Unarmed, Lvs. bipinnate : partial of 4 or 5 pairs; proper of 12 pairs. Spikes few-fl capit pentand. Pods lin. 14116 Unarmed, Lvs. bipinnate : partial of 4 pairs ; proper of 12 pairs, Spikes few-fl. capitate decand. Pods linear 14117 Unarmed, Leaves bipinnate; partial of 4 or 5 pairs ; proper of many pairs, Spikes ovate, Pods obl. blunt 14118 Spines solit. Lvs. bipinn. : partial of about 9 pairs ; proper of many pairs, Spikes cylind. atten. at base cernu. 14119 Spines solitary, Leaves bipinn. : partial of 8 pairs; proper of many pairs, Spikes cylindrical twin pendulous

\section{Leafless.}

14120 Unarmed, Petioles linear subulate mucronate rigid pungent whorled, Spikes cylindrical solitary 14121 Unarmed, Petioles linear subulate mucronate rigid pungent alternate clustered, Spikes globose solitary 14122 Petioles round subulate mucronate scattered rigid, Stipules deciduous, Spikes globose solitary 14123 Stipules spiny very minute, Petioles linear subulate-pungent close together, Peduncles solitary 14124 Petioles filiform furrowed on each side : point harmless, Heads twin, Pods wavy

14125 Unarmed, Petioles linear narrowed at base mucron. Spikes globose stalked racemose, Branches 3-cornered 14126 Unarmed, Petioles lanceolate subfalcate narrowed at base blunt about 2-nerved glaucous, Spikes axillary 14127 Unarm. Petioles lin. narrowed at each end mucron. arcuate striat. Fls. interruptedly spik. Branches round. 14128 Unarm. Petiol. lin. narrow. at base straight mucron. Spikes glob. stalk. racem. Racemes nearly as long as lys 14129 Petioles narrow lin. very long 1-nerved erect entire, Spikes several axillary generally branched

14130 Stip. scarcely any, Petioles filiform compressed cernuous spreading with an incurved point, Pods torulose 14131 Unarmed, Petioles linear lanceolate narrowed at base obtuse, Spikes globose axillary stalked double

14132 Unarmed, Petioles lin. lanc. narrowed at each end 3-nerved striated, Spikes axillary double cylindrical

14133 Unarmed, Petioles oblong falcate narrowed at base acute veiny, Branches 2-edged

14134 Unarmed, Petioles ovato-acute many-nerved, Spikes globose stalked, Pods falcate

14135 Stip. very small decidu. Petiol. lin. 1-nerved with an oblique point, Branches procumb, diff. smooth angul.

14136 Petioles very long filiform 1-nerved spreading, Spikes several axillary generally branched 14137 Petioles half oblong wavy : their inner edge a little truncate, Stipules spiny, Branches smooth 14138 Petioles lanceolate oblong nerved somewhat falcate, Heads racemose, Young shoots furred 14139 Petioles oblong equal-sided nerved, Spikes twin sessile, Corollas 4-petals, Pods torose

14140 Petioles long lanc. somewhat falcate edged 1-nerved: the anterior edge with 1 gland, Heads racemose 4-fl 14141 Unarmed, Petioles oblong acuminate veiny, Spikes globose stalked racemose

14142 Petioles half obl. somew. falcate tapered at base with a little gland on the convex side, Branches smooth 14:143 Petioles linear tapered at base acute mucronate 1-nerved entire, Heads racemose many-flowered 14144 Unarmed, Petioles sessile oblong cuspidate toothletted scabrous, Spikes globose solitary axillary

14145 Petioles triangular: outer angle spiny ; inner bearing glands, Stip. setaceous caducous, Branchlets smooth 14146 Petiol. triangul. : outer angle spiny; inner bearing glands, Stip. setaceous spiny persist. Branchlets downy 14147 Petiol. halv. obl. smooth mucronul. 1-nerv. : never parallel with inner edge, Stip. veiny, Branches hirsute 14148 Stem winged two ways, Petioles decurrent 1-nerved terminated by a spine, Stipules spiny

14149 Petioles half elliptical lanceolate mucronate aristate 1-nerved in middle and branches hispid

$$
\text { * Leafy. }
$$

14150 Leaves conjugate pinnate terminated by a tendril, Pinnæ of 4 pairs, Spikes filif. Petals 5, Stem climbing 14151 Unarmed, Leaves bipinnate: partial of 2 pair ; proper of 2 pair vill. Petiole without glands, Head globose 14152 Unarmed hairy, Lvs. bipinnate : partial of 2 pair ; proper of 2 or 3 pair, Stip. somew, setaceous deciduous 14153 Unarmed smooth, Leaves bipinnate : partial of 2 pair; proper of 2 to 7 pair, Stip. subulate setaceous

14154 Lvs. bipinnate: partial and proper of 10 pairs ellipt. blunt, Gland of petiole convex, Spikes filif. solit. axill. 14155 Leaves bipinnate: partial of about 6 pairs; proper of many, Petioles downy, Spike terminal interrupted 14156 Leaves bipinnate : partial of 4 pairs; proper of 10.12 , lowest very minute, Spikes globose term. panicled 14157 Unarmed, Leaves bipinnated, Pinnæ of 3 or 5 pair, Leaflets of 15 or 20 pair falcate acute smoothish

14158 Lvs. bipinn. : partial of 7 pair; proper of 17 pair halv. acute, Spikes glob. stalk. axill. Pods arcuate twisted 14159 Lvs. bipinn, : partial of 11 pair; proper of many pair halved acute, Spikes subglobose terminal aggregated

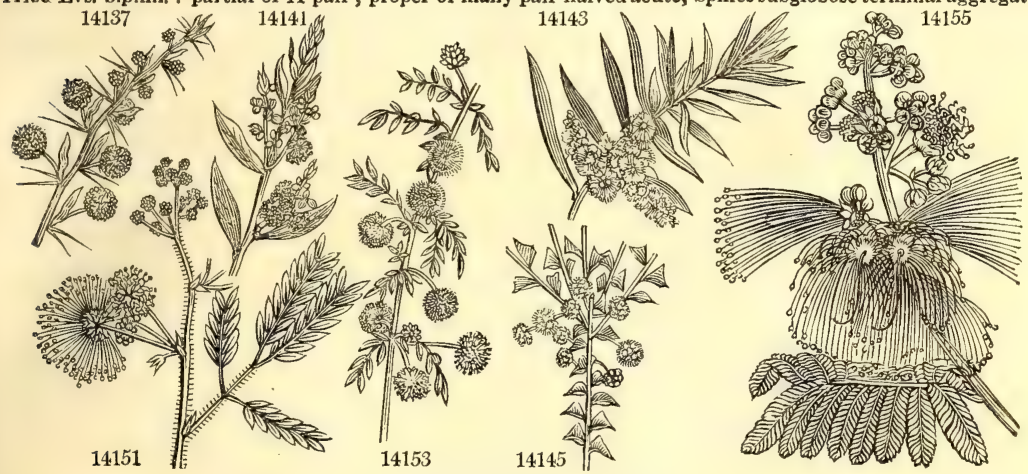

and Miscellaneous Particulars.

this is half evaporated by boiling, the decoction, without straininz, is poured into a flat earthen pot, boiled to one-third part, and then set in a place to cool for one dav. The decoction is afterwards evaporated by the heat of the sun, stirring it several times in the day; and when it is reduced to a considerable thickness, it is spread upon a mat or cloth, which has previously been covered with the ashes of cowdung. The mass is lastly divided into square or quadrangular pieces by a string, and completely dried by turning them in the sun, until they are fit for sale. This extract, when first introducd as a medicine into Europe, was named Terra Japonica, from the supposition that it came from Japan and was an earth."

Medicinally catechu is one of the most valuable of the vegetable astringents ; and as the dark colored contains the greater quantity of tannin, on which its astringency depends, it is to be preferred for medicinal use. It is employed with the best effects in dysentery and diarrhcea, when the use of astringents is admissible; in alvine and uterine hæmorrhages, leucorrhœa, gleet, and in obstinate catarrhal affections. As a local astringent, it is used in sponginess of the gums, and aphthous ulcerations of the mouth and fauces, and we have found the slow solution of a small piece of it in the mouth, a certain remedy for the troublesome cough induced by a relaxed uvula hanging into and irritating the glottis. Dr. Paris recommends it as a dentifrice, especially when the gums are spongy.

$A$. vera produces the gum arabic of the shops. The tree is found in almost every part of $\Lambda$ frica, but those 
14160 speciosa $W$. 14161 latisíliqua $W$ 14162 Leb'beck $W$ 14163 discolor $W$. 14164 pubéscens $H . K$. 14165 lophántha $W$. 14166 brachýloba $W$ 14167 glandulósa $W$. 14168 decúrrens $W$. 14169 móllis B. Reg. 14170 peregrina $W$. 14171 grandiflóra $W$

14172 glaúca $W$.

14173 glaucous

14173 leucocephala Pers. white-headed

14174 portoricénsis $W$. Padranguláris $L_{i n k}$. quadrangular

14176 dealbáta Link. whitened 14178 reticuláta $W$. en.

14179 pulchélla $\boldsymbol{H}$.

14180 juliflóra $W$

14181 Sénegal $W$.

14182 Giráffæ W. en.

14183 Cátra $W$.

14184 Chúndra $W$.

14185 Cátechu $W$.

14186 leucophlæ'a $W$.

14187 cornigera $W$.

14188 ebúrnea $W$.

14189 hæmatóx ylon

14190 farnesiána $W$.

14191 véra $W$.

14192 arábica $W$. 14193 cæ'sia $W$.

14194 pennáta $W$

14195 I'ntsia $W$

14196 Ceratónia

14197 tamarindifólia $W$.

14198 hórrida $W$.

14199 flexuósa $\dot{W}$.

spiral-podded

netted

zigzag spiny

long-flowered

Arabian

camelopard's

Hottentot

hook-spined

medicinal

panicled

Cuckold Tree

ivory-thorned

hoary

Sponge Tree

Egyptian Thorn

Gum Arab. tree

gray $\square$ or 15

angular-stalked $\square$ or 12 angular-stalked $\square$ or 12

round-leaved $2 \square$ or 3

horrid

flexuose

14200 brachyacántha $W$.en.short-spined

14201 ciliáris $W$.en. ciliated

14202 peruviána $W$. en. Peruvian

2128. VERA'TRUM, $\boldsymbol{W}$. Veratrum.

14203 álbum $W$

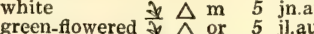

14204 víride $W$.

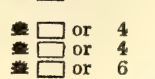

E, Indies 1742. C 1.p Jac. ic. 1. t. 198 W. Indies 1777. C 1.p Plum. ic. 3. t. 6 Egypt 1823. C 1.p Pl.man.p.331.f.1 N. S. W. 1788. S s.p Bot. rep. 235

N. S. W. 1790. R s.p Bot. mag. 1263

N. Holl. 1803. S s.p Bot. mag. 2108

N. Amer. 1803. C s.p

N. Amer. 1806. C s.p Vent. choix. 27

N. S. W. 1790. S s.p

N. Holl. 1810. C s.p Bot. reg. 371

S. Amer, 1780, C s.p

F. Indies 1760 C s.p Bot rep 590

America 1690. S s.p Cat. car. 2, t 49

S. Amer. 1823. S s.p

S. Amer. 1824. S s.p Jacq. ic. t. 633

..... 1825. S s.p Bot. mag. 2651

1824, C s.p

Peru 1825. S s.p

C. G. H. 1816. C s.p Pluk.al, t.123.f.2

Y N. Holl. 1803. S s.p Bot. cab. 212

W Jamaica 1793. C s.p

W Arabia 1823. C s p Alp. ægypt. t. 15

... C. G. H. 1816. S p.l

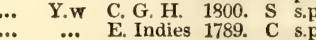

... Pa.Y E. Indies 1790, s p.l Rox.cor.2.t.175

.. Pa.Y E Indies 1812. C p.1 Kox. cor.2. t.150

.. Pa.Y S. Amer. 1692. C p.1 Plu.al.3.t.122.f.1

.. Y E. Indies 1792. C p.1 Rox. cor.2.t.199 Y.W C. G. H. 1816. C p.l

W Egypt 1596. C p.l Pluk.al, t.123.f.1

... W E. Indies 1820. S p.1 Pluk.al.t.251.f.1

... Y E. Indies 1773, S p.l Pluk. t. 330. f. 1

.. Y E Indies 1773, S p.l Burm. zeyl.2.t.1

Y W E Indies 1778, S p. Rheed mal.6.t.4

... W S. Amer. 1800. S p.l Plum. ic. t. 8

W W. Indies 1774. S p.1 Jac.schœ.3.t.396

... $\quad .$. Africa 1823. S p I Pluk.al, t.121.f.4

... ... Cumana 1824. S p.l

$\ldots \quad$... S. Amer. 1824. C p.1

$\ldots \quad \ldots \quad$ S. Amer. 1822. C p.l

... Peru 1820. C p.l

Melanthacea. Sp. 5-7.

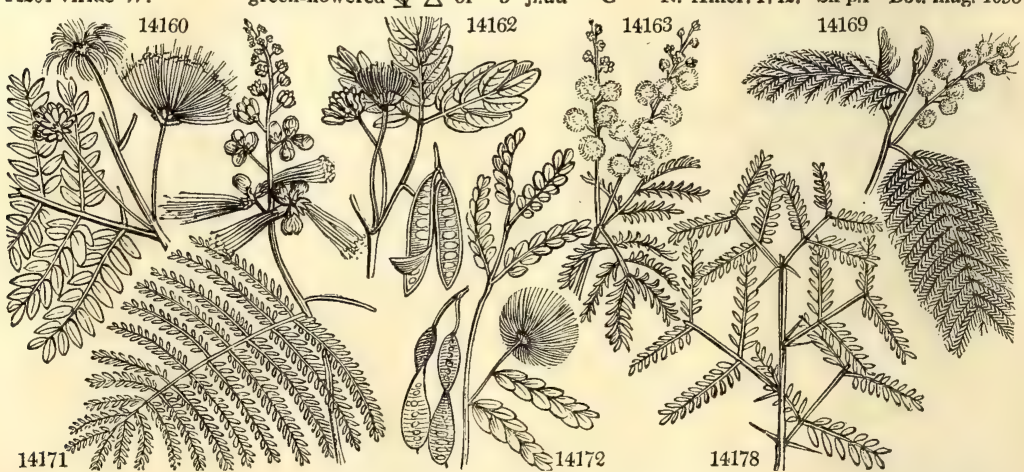

History, Use, Propagation, Culture,

which yield the gum which is exported from Barbary to Great Britain, grow principally in the Atlas moumtains. It is a hard withered looking low tree, with a crooked stem, and a grey bark. The gum exudes naturally from the bark of the trunk and the branches, in a soft, nearly fluid state, and hardens in the air without losing its transparency. It is collected about the middle of December. It has a faint smell when first stowed in the warehouses, and is heard to crack spontaneously for many weeks.

Medicinally gum exerts no action on the living system, but is a simple demulcent, serving to lubricate abraded surfaces, and involve acrid matters in the primæ viæ. In the solid form it is scarcely ever given, unless to sheath the fauces, and allay the tickling irritation which occasions the cough in catarrh and phthisis pulmonalis; in which cases a piece of it is allowed to dissolve slowly in the mouth. It is chiefly used in a state of mucilage.

According to Sweet, all the species of Acacia are of easy culture. Those of the hothouse he recommends to be grown in loam and peat. "Cuttings," he says, "of most kinds will strike root. From the strongest growing kinds, take off large cuttings at a joint, and plunge them in a pot of sand under a hand-glass in the bark-bed. 
14160 Lvs. bipinn. : partial of 4-5 pair : proper of 7-11 pair halved blunt smooth, Spikes subcapitate axill. aggregate 14161 Lvs. bipinn. : partial of 5 pair ; proper of 10 pair ellipt. blunt, Spikes globose stalked termin. with bractea 14162 Lvs. bipinn. : partial of 4 pair; proper of many pair oblong halved blunt, Spikes subglobose term. aggregate 14163 Lvs. bipinn. : partial of 5 pair ; proper of about 10 pair discolored beneath, Spikes globose stalked racemose 14164 Lvs, bipinn. : partial of 8 pair; proper of about 15 pair, Racemes axillary solitary, Heads globose stalked 14165 Lvs. bipinn. : partial of $9-12$ pair; proper of 20 pair lanc. veinless, A gland on stalk and betw. 2 term. petiol. 14165 Lvs. bipinn. : partial of $9-12$ pair ; proper of 20 pair lanc. veinless, A gland on stalk and betw. 2 term. petiol.
14166 Lvs. bipinn. : partial of 8 pair ; proper of many pair, A gland between the lowest pair of the partial ones 14167 Lvs. bipinn. : partial of 12 pair ; proper of many pair, A gland betw. every pair of partial ones, Spikes glob. 14168 I.vs. bipinn. : part. of 11 pair; prop. of many pair, A gland betw. every pair of part. ones, Part. petiole marg. 14169 Lvs. bipinn. : partial of 8-18 pair ; proper of many pair lin. very close downy, A gland between every pair 14170 Ivs. bipinn. : partial of 16 pair ; proper of about 40 pair, A gland on petiole, Spikes glob. stalked axill, in 3s 14171 Lvs, bipinnate: partial of 17 pair; proper of about 40 pair, Spikes subcapitate stalked racemose terminal 14172 Leaves bipinnate: partial 5-6 pairs ; proper of 18 distant pair, Spikes globose stalked axillary

14173 Leaves bipinnate, Pinnæ of 4 or 5 pair, Leaflets of 12 or 15 pair oblong linear acute, Petiole downy 14174 Lvs. bipinn. : partial of 5 pair; proper of many pair lin. acute, Spikes glob. axill. about 3 , Cal. ciliat. at edge 14175 Lvs. of 5 pair, Pinnæ of many pairs, Leafl. lin. acute ciliat. Rachis of lvs. downy, Heads axill. on long stalks 14176 Leaves of 15 pair, Pinnæ of many pair, Leaflets equal-sided minute downy, Racemes lateral

\section{* Spiny.}

14177 Spines stipulary, Leaves conjugate pinnate, Pinnæ of 4-6 pair, Pods spirally twisted

14178 Spines stipul. straight almost length of leafl. Leaflets oblong linear obtuse dist. Petiole with a gland at end 14179 Lvs. conjugate pinnate, A stalked gland betw. pinnæ which consist of 5-7 pair, Stip. spiny as long as leaves 14180 Spines stipulary twin, Lvs. bipinn. : partial of 2 pair; proper of 20 pair, Spikes axill. $2-3$ cylind, pendulous 14181 Spines stipul, in $3 \mathrm{~s}:$ midd. one reflex. Lvs. bipinn.: part. of 5 or 6 pair : prop. of many pair, Spikes axill. cylind. 14182 Spines stipul. twin con. as long as lvs. Lvs. bipinn. Pinnæ 3 or 6 pair, Leafl. 20 pair, Gland betw. every pinnæ 14183 Spines stipulary twin incurv. Lvs. bipinn. : partial of 12 pair ; proper of many pair, A gland on the petiole 14184 Spines stipulary twin hooked, Leaves bipinnate : partial of $9-13$ pair; proper of many pair, A gland on the petiole and between the three terminal outer leaflets

14185 Spines stipulary twin hooked, Leaves bipinnate: partial of 10 pair ; proper of many or downy, A gland on the petiole and between the two terminal outer leaflets

14186 Spines stipulary twin connate, Leaves bipinnate : partial of 6-10 pair ; proper of many, A gland between the 2 pair of partial leaves

14187 Spines stipulary connate compressed, Leaves bipinnate : partial of 6 pair : proper of 20 pair smooth, A gland on the petiole

14188 Spines stipul. connate twin, Leaves bipinnate : partial of 4 pair ; proper of 6 pair, Spikes globose aggregate 14189 Spines double slender and branches smooth, Branchlets, leaves, peduncles and fls. hoary

14190 Spines stipulary setac. dist. Lvs. bipinn. : partial 16 pair ; proper many pair, A gland on netiole and between 2 term. pair of partial leaves

14191 Spines stipulary twin spreading, Leaves bipinnate : partial of 2 pair ; proper of 8-10 pair, A gland betw. each pair of partial leaves

14192 Spines stipul. twin spread. Lvs. bipinn. : partial of 5 pair ; proper of many pr. Spikes globose axill. stalked 14193 Prickly, Lvs. bipinn. : partial of 7 pair; proper of 16 pair, A gland on petiole, Spikes globose panic. term. 14194 Prickly, Lvs, bipinn. partial and proper of many pr. A gland on petiole, Com. ped, and petioles prickly at 14195 Prickly, Leaves bipinnate : partial of 6 pair; proper of about 12 pair incurved, Petioles prickly [base 14196 Prickly, Leaves bipinnate : partial of 5 pair; proper of 3 pair obovate 3-nerved

14197 Prickly, Leaves bipinnate : partial of 5 pair; proper of 15 pair, Gland on petioles stip. and bractes cordate 14198 Spines stipul. twin nearly as long as lvs. Lvs. bipinn. of 2 or 3 pr. : partial of about 10 pr. Spikes gleb. stalked 14199 Spines stipulary twin connate, Leaves bipinnate: partial of 16 pair ; proper of many pair, A gland on the petiole and between the two terminal pair of partial leaves

14200 Spines stipulary twin hooked, Leaves bipinnate, Pinnæ of about 10 pair, Leaflets of 10 or 12 pair ciliated 14201 Spines stipul. twin straight subulate, Leaves bipinnate, Pinnæ of 3 or 4 pair, Leaflets of 13 pair ciliated 14202 Spines stipulary setaceous double, Leaves bipinnate, Pinnæ of 2 pair, Leaflets of $11-15$ pair blunt smooth

14203 Racemes panicled, Bractes of branches oblong: partial as long as downy peduncle, Flowers erect 14204 Racemes panicled, Bractes of branches oblong-lanceolate : partial longer than downy petiole

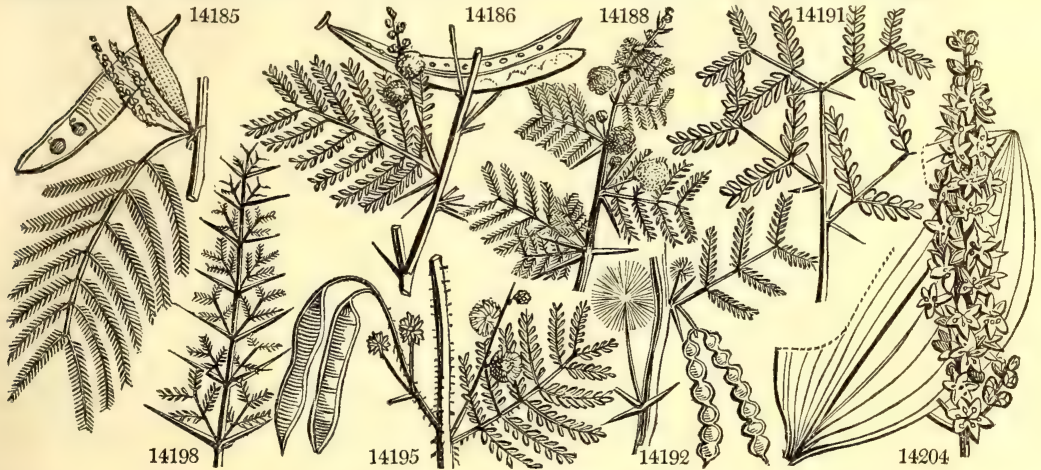

and Miscellaneous Particulars.

Of the smaller kinds take younger cuttings, and put them under a bell-glass, also plunged in heat. The sooner the plants are potted off after they are rooted the better. If they stay too long, the sand injures their roots: they should be kept under a close glass, and shaded for a few days after potting off, and exposed to the air by degrees." (Bot. Cult. 11.)

The greenhouse species are particularly valuable as flowering for the most part in winter, or early in spring ; they are very hardy and grow freely in loam, peat, and sand well drained. Cuttings of most kinds, Sweet observes, will root pretty freely, taken off in the young wood and planted in sand, under a bell-glass, and plunged in a little bottom heat. The kinds that do not root readily from cuttings may be increased by taking off roots, as large pieces as can be spared, and planting them in the same kind of soil as the old plants, when they should be plunged under a hand-glass in a little bottom heat. Most of the kinds might be propagated by that means. (Bot. Cult. 126 .

2128. Veratrum. Said by Lemery to be so called, because its root is vere-atrum, truly black. V. album has a fleshy fusiform root, beset with strong tibres, gathered into a head; this root and every part of the plant is 
14205 virgínicum $\boldsymbol{H} . \boldsymbol{K}$. Virginian $\quad \Delta$ or 2 jn.jl Br N. Amer. 1768. D 1.p Bot. mag. 985 14206 nigrum $W$. $W$ dark-flowered $\frac{\$}{\$} \Delta$ or 3 jn.jl D. Pu Siberia 1596. D p.1 Bot. mag. 963 14207 parvifiórum $W$. small-flowered $\frac{\downarrow}{\Delta} \Delta$ or 2 jn.jl $G$ Carolina 1809. D p.l

2129. ANDROPO'GON. $W$. ANDRopogon. 14208 striátus $W$. 14.209 contórtus $W$. 14210 Schænánthus $W$. 14211 distáchyos $W$. 14212 múticus $W$. 14213 Ischæ'mum $W$. nerve-glumed twisted

Graminece. $S p .6-66$.

2130. CHLO'RIS. $W$. 14214 petræ'a $W$. 14215 ciliáta $W$. 14216 radiáta $W$. 14216 radiáta $W$. 14218 curtipéndula $W$. Lemon-grass 业 $\triangle \mathrm{ft} \mathrm{1}_{\frac{2}{2}} \ldots$ two-spiked 业 $\Delta$ un $1 \frac{1}{2}$ jl.au smooth-spiked $\frac{1 \omega}{\|} \Delta$ un $\frac{1}{2}$ jl.s woolly 址 $\triangle$ un $1^{2}$ au

Ap
Ap
Ap
Ap
Ap
$A$

E. Indies 1793. D co E. Indies 1779. D co E. Indies 1786. D co S. Europe 1805. D co C. G. H. 1794. D co S. Europe 1768. D co

Sch.ha.3.t.342.a. Ru.am.5. t.72.f. Fl. græc. 1. t. 69 Sch. gram.2. t.33

ChLORIS. flat-stalked ciliated many-spiked bearded short-spiked

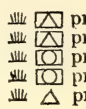

Graminere. Sp. 5-24.

$\frac{1}{2}$ jl.au Ap Jamaica 1779. D co $\frac{3^{\frac{1}{4}}}{\mathrm{j}} \mathrm{jl.s}$ Ap Jamaica 1779. D co $\frac{1}{2}$ au.s Ap W. Indies 1739. S co Moris.s.8.t.3.f.15 Ap E. Indies 1777. S co

业 $O$ clt 3 jl Araminea. Sp. 5-9. 2131. SOR'GHUM. W.en. Sorghum. 14219 bícolor $W$. en two-colored 14220 vulgare $W$.en. 14221 rúbens $W$. en 14292 saccharátum $W$. en yeded 14223 halepénse $P . S$. two-colored red-seeded 14224 Grýllus $R . B r$. 14225 móllis $W$. 14226 lanátus $i V$ 14227 avenáceus $W$.en. 14228 bulbósus $W$.en. 14229 odorátus $W$.

2133. ISCH $\mathbb{E}^{\prime}$ MUM. $W$. 142.30 aristátum $W$ 14231 rugósum $W$. purple-flower'd meadow bulbous-rooted 业 $\triangle$ ag 3 jn.jl Ap sweet-scented 址 $\triangle \mathrm{ft} 1 \frac{1}{2} \mathrm{jn} . \mathrm{jl}$ Ap

Graminea.
制 $\mathrm{O}$ clt $4 \mathrm{jl}$ Ap India

址 [0] $\mathrm{clt} 6$ jl.au Ap India

址 $\triangle$ un 3 jl.au Ap Syria
1731. S co M.ac.he.8.t.4.f.4

1596. S co M.ac.he.8.t.4.f.3

1817. S co

1759. S co A.ac.pa.1.t.4.f.9

1691. D co Fl.græc. 1. t. 68

\section{Sp. 6-8.}

S. Europe 1791. D co Fl. græc. 1.t. 67

Britain corn fi. D h.l Eng. bot. 1170

Britain me.pa. D co Eng, bot. 813

N. $\ddot{A m e r}, 17 \ddot{7}$. D D co

\section{Sp. 2-21.}

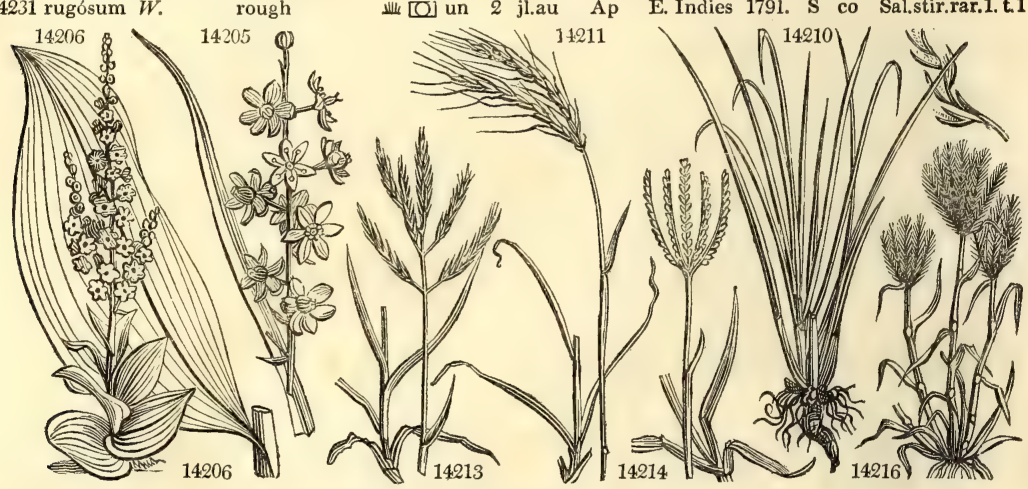

History, Use, Propagation, Culture,

extremely acrid and poisonous. It is used in medicine, and its properties are found to depend on veratrine, the same alkaline principle which is the active ingredient of colchicum. Medicinally it is violently cathartic and sternutatory. When taken internally, even in moderate doses, its operation is violent and dangerous; producing besides hypercatharsis, with bloody stools and excessive vomiting, great anxiety, tremors, vertigo, syncope, sinking of the pulse, cold sweats, and convulsions, terminating, if the dose be large, in death. Its external application to an ulcerated surface also produces griping and purging. Notwithstanding these effects, Veratrum has been exhibited internally, and with advantage, in mania, epilepsis, scabies, lepra, and obstinate herpetic eruptions. But the most ordinary use of white hellebore is as a local stimulant. When taken internally as a poison, the best antidote is a strong infusion of nut-galls. (Thom. Lond. Disp. p. 545.)

V. nigrum is very nearly allied to album, but differs in color, and seems not to be so strong and acrid in its qualities; for when both sorts are placed near each other, snails will entirely devour the leaves of this species, when they will scarcely touch those of the other.

2129. Andropogon. From eyne, a man, and $\pi \omega \gamma \omega y$, a beard. A hyperbolical comparison of the little tuft of hairs upon the flower to the beard of a man. A. schæenanthus has an agreeable smell, with a warm, bitterish, not unpleasant taste. It was formerly brought over from Turkey in bundles about a foot long, and kept in the shops to be employed as a stomachic and deobstruent, but it is now little used. All the species are of the easiest culture.

2130. Chloris. Derived from $\chi \lambda$ weos, green, on account of the color of its herbage. Pretty little grasses, with beautiful one-sided spikes of silky flowers.

2131. Sorghum. Sorghi is the Indian name, according to Bauhin. S. vulgare, grand millet, Fr., Saggeno or Sorgo, Ital., and alcandia, Span., is much cultivated in Arabia and most parts of Asia Mincr. It has been introduced into Italy, Spain, Switzerland, and some parts of Germany; also into China, CochinChina, and the West Indies, where it grows commonly five or six feet high or more, and being esteemed a hearty food for labourers, is called Negroe Guinea corn. Its long awns or bristles defend it from the birds. In England, the autumns are seldom dry and warm enough to ripen the seeds well in the field. In Arabia it is called Dora or Durra. The flour is very white, and they make good bread of it, or rather cakes, about two inches in thickness. The bread which they make of it in some parts of Italy is dark and coarse. In Tuscany it is used chiefly for feeding poultry and pigeons; sometimes for kine, swine, and horses. Brooms are made of the spikes, which are also sent to this country for the same purpose. The Indian millet, as well as the common sort (Panicum), is cultivated in some parts of North America, and has been tried in this country, but it is only in the warmest autumns that it ripens its seeds. It might probably, however, be country, but 
14205 Racemes panicled, Bractes shorter than peduncle, Petals with 2 glands at base

14206 Racemes supradecompound panicled, Bractes of branches linear-lanceolate very long

14207 Racemes panicled, Petals bearing the stamens on their claw

14208 Spike simple, Flowers twin : hermaphrodite sessile awned; male stalked, Outer valve of cal. nerved 14209 Spike simple, Lower flower beardless, Male and hermaphrodite calyxes hairy, Awns very long hirsute 14210 Spikes imbric. conjug. panic. bract. Fls. in 3s : midd. hermap. beard. : beard smooth : lat. stalk, male beardl. 14211 Spikes twin terminal, Florets twin bearded: hermaphrodite sessile; male bearded, Culm undivided 14212 Spikes digitate about 3 , Florets alternate sessile beardless

14213 Spikes digitate about 8, Florets twin woolly at base : hermaphrodite sessile bearded; male stalked bearded

14214 Spikes 4-5-6 straight erect, Florets imbric. nearly smooth beardless, Outer valve of cal. beard. Culm compr. 14215 Spikes digitate about 5 erect, Glumes ciliated

$1+216$ Spikes many fascicled nearly erect, Florets subulate smooth

14217 Spikes many fascicled, Glumes ciliated bearded, Male valves ventricose bearded

14218 Spikes many alternate panicled pendulous, Spikelets 4-flowered

14219 Panicle contracted ovate, Florets strigose with down black, Seeds white round 14220 Panicle contracted oblong, Florets obovate shining hairy, Seeds compressed 14221 Panicle spreading, Florets oblong acute shining ciliated

14222 Panicle effuse, Branches spreading, Florets villous oblong, Leaves broad lanceolate

14223 Panicle spreading, Branches rough, Florets lanc. acute silky shining, Leaves lanceolate rough at edge

14224 Panicle effuse spreading, Branches whorled 3-fl. Peduncles bearded, Leaves and sheaths hairy 14225 Glumes 2-fl. hermaphrodite, Sessile floret beardless stalked bearded, Beard longer than flower 14226 Glumes 2-fl, : hermaphrodite beardless, Beard of the male much shorter than flower recurved 14227 Male flowers with a jointed beard twice as long as calyx, Joints of culm smooth, Root nodose 14228 Male flowers with a jointed beard twice as long as calyx, Joints of culm villous, Root bulbous

14230 Leaves lanc. Florets naked, Outer valve of cal, with 2 nodules on each side, Beard of cor. long twisted 14231 Leaves lanceolate, Neuter florets intermediate wrinkled across : two lateral smooth
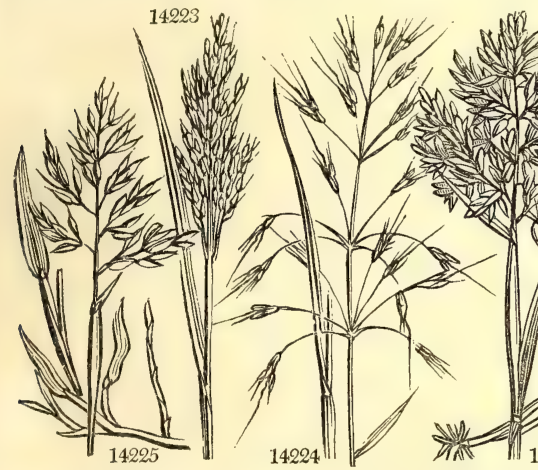

14227

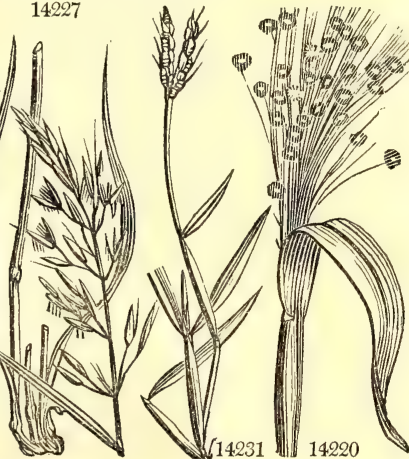

and Miscellaneous Particulars.

2132 Holcus. From $\dot{\varepsilon} \pi \omega$, to extract. It was a popular notion among the ancients, that the leaves of the plant they called Holcus, which seems to have been a grass of some kind, had the property of extracting thorns from the flesh. H. mollis is distinguished by its creeping roots, which, when once in possession of the soil, as Mr. Sinclair observes, can hardly be again expelled without great labor and expence. It is the true couchgrass of light sandy soils, and underground stolones have been found five feet in length, the growth of a few months only. These root-shoots contain a very considerable quantity of nutritive matter, which has the flavor of new made meal. Pigs are very fond of the roots, and dig them up with eagerness; but the herbage is disliked by eattle, more than that of any other species of the genus, being extremely soft, dry, and tasteless. The best mode of banishing this weed from light arable lands, is to collect the roots with the fork after the plough. (Sinclair, Hort. Gram. 167.)

H. lanatus has a fibrous root, and grows on all soils from the richest to the poorest, but attains to the highest degree of luxuriance on light moist peaty soils. Cattle prefer almost any other grass to this ; it is seen in pastures with fill grown perfect leaves, while the grasses that surround it are cropped to the roots. Its nutritive matter consists entirely of mucilage and sugar; while the nutritive matters of grasses most liked by cattle are either sub-acid or saline. Mr. Sinclair suggests, that this grass might probably be made more palatable to cattle, by being sprinkled over with salt. (Hort. Gram. 164.)

$H$. avenaceus, the Avena elatior of Linnæus, Curtis, and Host, is a bulky productive grass, eaten by horses, cattle, and sheep, but less nutritious than many other grasses. It pushes rapidly after being cropped; and though later in flowering than many other species, produces an early and plentiful supply of herbage in the spring. These properties would entitle it to rank high as a grass adapted for the alternate husbandry, but its nutritive matter contains too large a proportion of bitter extractive and saline matters to warrant its cultivation, without a considerable admixture of different grasses; and the same objection extends to its culture for permanent pasture. It is always present in the composition of the best natural pastures, and, as before mentioned, eaten in common with other grasses. It does not, however, constitute a large proportion of the herbage, but rather the least of any of the more valuable grasses that have been mentioned. (Hort. Gram. p. 171.) This grass and Triticum repens are the two species eaten by dogs to excite vomiting. One variety has bulbous roots, and is a noxious weed in arable lands.

$\mathbf{H}$. odoratus is one of the earliest flowering grasses; but it is tender, the spring produce of herbage is inconsiderable, and its powerful creeping roots render it unfit for agricultural purposes. (Hort. Gram. 169.)

2133. Ischamum. From $\iota \sigma \chi \omega$, to stop, and $\alpha \iota \mu \alpha$, blood. Pliny says, that the Thracians first discovered that the woolly seed which is borne by the Ischæmum, if introduced into the nostrils, has the power of stopping the bleeding at the nose. Useless grasses. 


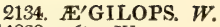
14232 ováta 14233 triunciális $W$. 14234 cylíndrica $W$. 14235 squarrúsa $W$. 14236 caudáta $W$.
Hard-Grass. oval-spiked long-spiked cylindrical rough-spiked Cretan
Graminece. Sp. 5 . 业 $\mathrm{O}$ un $\frac{3}{4} \mathrm{jn} . \mathrm{jl}$ Ap S. Europe 1683. S co Fl. græc. 1. t. 93 址 O un ${ }^{\frac{1}{2}} \mathrm{jl}$.au Ap S. Europe 1739. S co Sch.gr.1.t.10. f.1 业 $\mathrm{O}$ un 1 jn.jl Ap Hungary 1805. S co Host.gram.2. 7 业业 un $1 \frac{1}{2} \mathrm{jn} . \mathrm{jl}$ Ap Levant 1794. S co 3ch.gr.2 tof. fo 此 O un 1 jn.jl Ap Candia 1739. S co Fl. græc.1.t. 95

Graminea. Sp. $1-2$.

2135. MANISU'RIS. $W$. MANISURIS. 14237 granuláris $W$. round-graine

2136. VALAN'Tia. $W$. Valantia, 14238 Cruciáta $W . \quad$ Crosswort

14239 murális $W$.

14240 híspida $W$.

14941 filif́rmis $W$.

14242 pedemontána $W$. Piedmont

14243 Cucullária $W$. hooded

14244 A parine $W$. warty-fruited Gálium verrucósum E. B.

14245 articuláta $W . \quad$ jointed

14245 articula $W$.

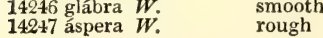

$\frac{1}{2}$ jn.jl Ap E. Indies 1794. S co Roxb.cor.2.t.118

Rubiacea. Sp. 10.

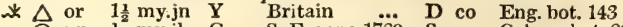

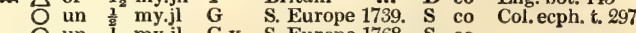

O un 1 my.jl G.Y S. Europe 1768. S co

O un $\frac{1}{2}{ }^{\frac{1}{4}} \mathrm{jl}$ G.s Hungary 1799. S co Pl.rar.hu.1.t. 33

O un my.jn G.Y Levant 1780. S co Bu.cen.1.t.19.f.2

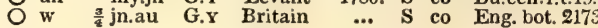

* $O$ un 1 jl.au G.x Egypt 1752. S co

G S. Europe 1731. D co Pl.rar.hu.1.t.32

G.Y Siberia 1804. D co

2137. PARieta'Ria. W. Pellitory.

14248 indica $W$.

14248 indica $W$. $W$ Indian

14250 judáica $W$.

14251 pensylvánica $W$.

14252 urticæéfólia $W$

14253 lusitánica $W$.

Basil-leaved

Pensylvani

Pensylvanian
Nettle-leaved 0 un $1^{\frac{1}{2}} \mathrm{jl}$
jn.s

Chickweed-lvd. $*$ $O$ un $\frac{1}{2} \mathrm{jl}$.au

Urticex. Sp. 7-19.

$\square$ un 112 ap.my G E. Indies 1790. D co

$\Delta \mathrm{w} 1^{2}$ jn.s G Britain walls. D co Eng.bot. 879

G Germany 1728. S co Pensylva. 1821. S co Bourbon 1700. S co Armenia 1728. S co

2138. A'TRIPLEX. W. ORAChe.

14255 Hálimus $W$.

14256 portulacoides $W$. $\quad$ dwarf shrubby

14257 glaúca $W$.

14258 álbicans $W$.

14259 rósea $W$.

14260 sibírica $W$.

14261 tatárica $W$.

14262 horténsis $W$. B rúbra

14263 laciniáta $W$

14264 pátula $W$.

14265 angustifólia $W$.

14266 erecta $W$.

14267 littorális $W$

14268 pedunculáta $W$. pedunculated

white

Rose

Siberian

Tartarian

garden

red garden

frosted sea

spreading

narrow-leaved

upright

Grass-leaved

14269 microspérma $W$. small-seeded

2139. RHAGO'DIA. $R$. Br. Rhagodia. 14270 hastáta $R . B r$. halberd-leaved in

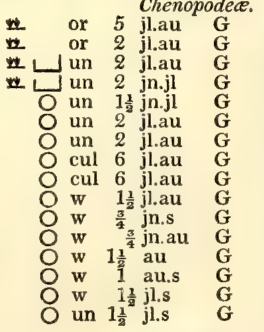

Sp. 15-37.

Spain 1640. C co Par.thea.724.f.2

Britain mud.s. C co Eng. bot. 261

S. Europe 1732. C s.l Dill.elt. t.40. f.46

C. G. H. 1774. C s.1

S. Europe 1739. S co Sch.hand.3.t. 350

Siberia 1783. S co S. h.3.p.538.t.350

Tartary 1778. S co S.h.3.p.539.t.349

Tartary 1548, $\mathrm{S}$ co

Tartary 1518, $\mathrm{S}$ co

Britain san.sh. S co

dungh. S co Eng. bot. 9.36

Britain rub. S co Eng. bot. 1774

England fields. S co Eng. bot. 2223

Britain mud.s. S co

England sal.m. S co Eng. bot. 232

Hungary 1800. S co

Chenopodea. Sp. 1-7.

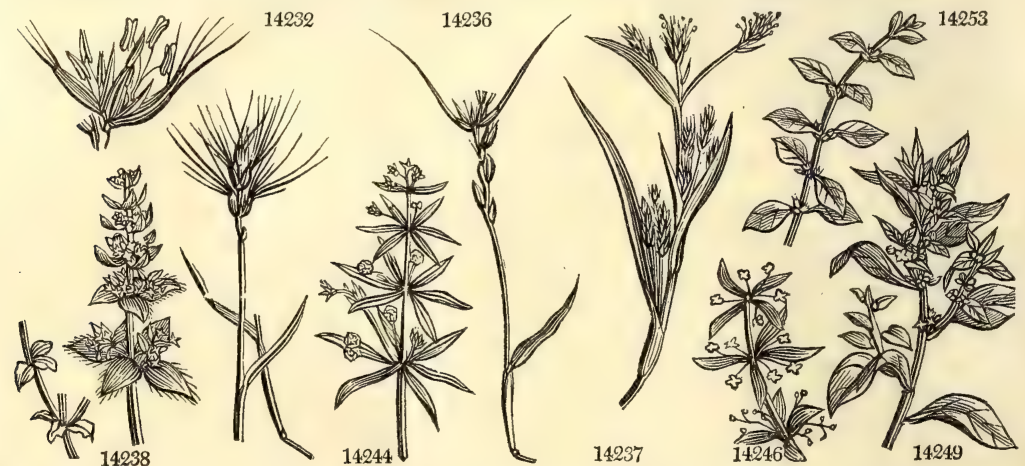

History, Use, Propagation, Culture,

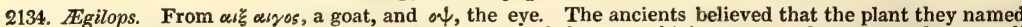
EEgilops had the power of curing a disease of one corner of the eye, which seems to have been what we call Fistula lachrymalis. The Ægilops ovata is a common Sicilian grass; when ripe, it is gathered by the peasantry, who tye the heads up in bunches, and set them on fire; they burn with rapidity, and so give the grains a slight roasting, which are then considered agreeable food.

2135. Manisuris. Said to be so called, from wavos, relaxed, and yea, tail, or, in botanical langnage, a head of grass; because the spikes are loose, and not compact. A curious little plant remarkable for its wrinkled grains.

2136. Valantia. Miserable weeds of no beauty or use ; called by their present name by Linnæus in reference to Sebastian Vaillant, a learned and excellent French botanist, who died in 1722. The author of the name would have employed his time better in considering the botanical writings of Vaillant, than in identifying with the most worthless part of vegetation an author whose merits he was not able to understand. No man was more given to sneers of this kind than Linnæus; and yet his followers manifest a most extra. ordinary degree of sensitiveness whenever he is retorted upon in a similar way; although few ever deserved criticism in some things in a higher degree than himself

2137. Parietaria. From paries, a wall. Weeds which are commonly found upon old walls, or rubbish heaps.

P. officinalis presents some curious anomalies in its inflorescence and fructification. To obtain a perfect idea of 
14232 Spike ovate, Cal. all with 4 beards scabrous, Culms ascending

14233 Spike cylind. Lower cal. with 2 beards : the rest with 3 , Beards of 2 terminal florets longer than the rest 14234 Spike cylindrical, Cal. with 1 beard, Cor. beardless, Terminal beards very long

14235 Spike cylindrical, Cal. 2-toothed beardless, Co.r with 1 beard

14236 Spike cylindrical, Cal. 2-toothed: teeth urequal beardless, Valves of terminal floret with 1 valve only

14237 Valves of female fl. globose tessellated warted, Culm erect branched, Sheaths hairy

14238 Leaves 4 ellipt. obl. 3-nerved netted hispid, Peduncles branched smooth bracted, Fruit smooth 14239 Leaves 4 elliptical netted smooth, Male fl, trifid attached to the base of the hermaphrodite

14240 Leaves 4 obovate-oblong veinless roughish, Male fl. trifid attached to the base of the hermaphrodite

14241 Leaves 4 oblong ciliate toothletted netted smooth, Ovary oblong chaffy longer than pedicel

14242 Leaves 4 oblong ciliate hispid, Pedunc. subbifid ciliated, Male fl. trifid, Ovary smooth

1424: Leaves 4 oblong, Peduncles protected by the ovate deflexed bractea, Stem erect

14244 Leaves 6 linear lanceolate hispid at edge, Pedunc. 2-fl. naked, Male fl. trifid, Fruit warted

14245 Male fl. 4-fid, Pedunc. dichotomous leafless, Leaves cordate

14246 Leaves 4 elliptical ciliated, Pedunc. branched naked and fruit smooth

14247 Leaves 6 linear very rough at edge, Stalk and fruit hispid

14248 Leaves lanceolate, Stem erect

14249 Leaves oblong ovate acuminate at each end with pellucid dots, Pedunc. dichotomous, Cal. 2-leaved

14250 Leaves ovate, Stem erect, Invol. 3-flowered, Male corollas long cylindrical

i4251 Leaves oblong lanceolate veiny with opaque dots, Involucre longer than flowers

14252 Leaves opposite stalked ovate serrated veiny downy, Flowers axillary

14253 Leaves roundish ovate obtuse the length of petiole, Stems tiliform procumbent

14254 Leaves linear lanceolate subsessile hairy, Invol, longer than flower

14255 Stem shrubby, Leaves alternate or opposite oblong subrhomboid entire

14256 Stem shrubby, Leaves obovate-lanceolate entire silvery white

14257 Stem half-shrubby procumbent, Leaves ovate sessile entire : lower a little toothed

14258 Stem shrubby erect, Leaves hastate entire acute, Spikes terminal

14259 Stem herb, spreading, Leaves triangular hoary unequally toothed, Cal, of fruit quadrang. toothed

14260 Stem herbaceous spreading, Leaves rhomboid somewhat toothed, Cal. of fruit muricate toothed

$1+261$ Stem herbaceous erect, Leaves oblong sinuated cuneate at base hoary beneath, Cal. of fruit toothed

14262 Stem herbaceous erect, Leaves triangular toothed whole-colored, Cal. of fruit ovate netted entire

14263 Stem herbaceous diffuse, Leaves ovato-deltoid dentato-sinuate very mealy beneath [tuberculat. at side 14264. Stem herb, spreading, Lvs triang, hast, glab above irregul, tooth. : upp ones ent Cal of fr. more or less 14265 Stem herb. spread. Lvs. lanc. ent. : lower ones somew. hast. Cal of fruit hastate slightly tuberculat. 14266 Stem herbaceous erect, Leaves ovate-lanceolate; lower sinuated, Cal. of seeds muricated

14267 Stem herbaceous erect, Lvs. all linear ent. or toothed, Perianth. of fruit sinuated and muricated on back $14 \div 68$ Stem herbaceous flexuose spreading, Leaves obovate entire, Female flowers stalked cuneiform

14269 Stem herbaceous erect, Leaves triang. hastate acutish a little toothed, Cal, of fruit ovate acute entire

14970 Branches diffuse, Leaves nearly opposite rhomboid-hastate entire smooth, Spikes terminal leafless

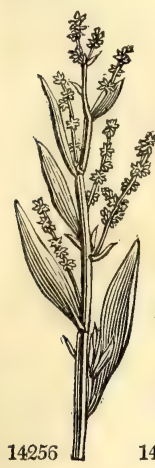

14266

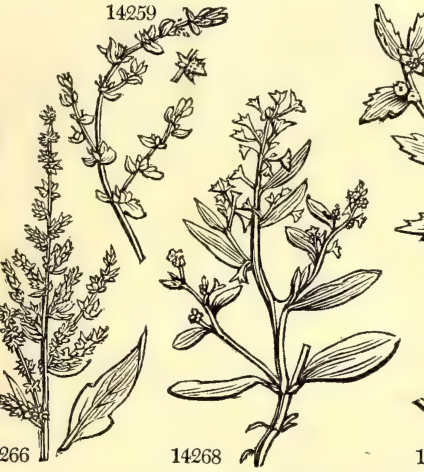

ticulars.
14263
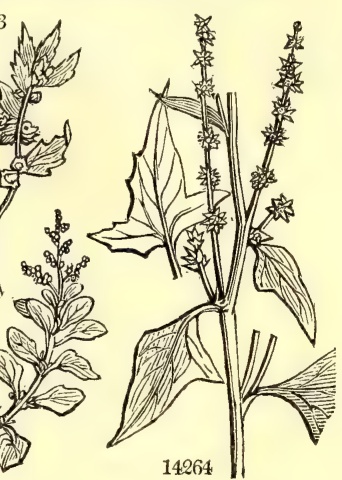

14264

the manner in which this is carried on, the flowers should be examined at a very early period of their expansion. The manner in which the stamens shed their pollen is curious. The filaments on their first appearance all bend inwards; as soon as the pollen is arrived at a proper state to be discharged, the warmth of the sun, or the least touch from the point of a pin will make them instantly fly back, and discharge a little cloud of dust. This process is best seen in a morning, when the sun shines on a plant in July or August : if the plant be large, numbers will be seen exploding at the same instant. Mr. Curtis remarks, that the same degree of cold (thirtyone Fahrenheit) which strips the mulberry of its leaves, will destroy the herbage of Parietaria. The ashes of the plant are said to contain a considerable quantity of nitre.

2138. Atriplex. The same name as Atraphaxis, which see. A. Halimus ( $\dot{\alpha} \lambda, \mu_{1} 05$, maritime) grows on the sea-coast of the south of Europe, and in this country its silver-colored foliage adds to the variety of our shrubberies. A. portulacoides requires to be planted on a poor gravelly soil; in its native state it prefers the seashore and salt marshes. A. hortensis, sometimes called mountain spinach, was formerly cultivated as a culinary herb, and is still grown to a considerable extent in the neighbourhood of Paris, and the leaves gathered as spinach. There are several varieties more or less tinged with red or purple. The leaves of all the species may no doubt be used as pot-herbs.

2139. Rhagodia. From jarwins, bearing berries. New Holland shrubs with alternate leaves, and flowers growing in racemose spikes. 
2140. TERMINA'LIA. $W$. Terminalis. 14271 Catâppa $W$ 14272 moluccána $W$. 14273 Chébula $W$. 14274 angustifólia $W$.

2141. FUS A'NUS. $I$ 14275 compréssus $L$.

2142. BRABE'JUM. $W$. 14276 stellátum Thunb.

2143. A'CER. $W$ 14277 heterophýllum $W$. 14278 tatáricum $W$. 14279 Pseúdo-Plátanus 14280 rúbrum W. 14281 dasycárpum $W$. 14282 barbátum $P h$. 14283 saccharínum $W$. 14284 nígrum $P h$. 14285 platanoídes $W$. B laciniátum

14286 stríatum $P h$.

14287 montánum $P h$.

$1+288$ campéstre $W$. 14289 O'palus $W$. 14290 opalifólium Vill. 14291 monspessulanum $W$. 14292 obtusátum Kit. 14293 créticum $W$ broad-leaved $\square$ or 20
Molucca
oval-leaved
narrow-leaved $9 \square$ or 20
or 20
or 20

Combretacea. Sp. 4-11.

... W.g E. Indies 1778. S p.l Jac. ic. 1. t. 197 ... W.G E. Indies 1804. C p.I ... W.G E. Indies 1796. C p.l Rox. cor.2.t.197 ... W.G E. Indies 1692. S p.l Jac.vind.3. t.100 Colpoon. Santalacee. Sp. 1

flat-stalked $L_{\text {un }} 1 \frac{1}{2} \quad \ldots \quad$ G.w C. G. H. 1776. C 1.p Ber.ca.38.t.1.f.1 African-Almond Proteacece. Sp. 1.

common 1 or 15 mr.ap W C. G. H. 1731. C 1.p Breyn.cent.1.t.1 Maple. evergreen Tartarian Sycamore Red or Swamp Sir C. Wager's Sir C. Wager's bearded Sugar black

Norway cut-leaved striped-barked mountain mountain common Italian blunt-leaved 2144. NEGUN'DIUM. Dec. Box-Elder. 14294 americánum $D_{c} c$. Ash-leaved 2145. CEL'Tis. $W$. Nettle Tree. 14295 austrális $W$. 14296 Tournefórti $W$. 14297 occidentális $W$. 14298 lævigáta $W$. 14299 crassifólia $W$. 14300 púmila $P h$. European Tournefort's American polished Hoop-Ash

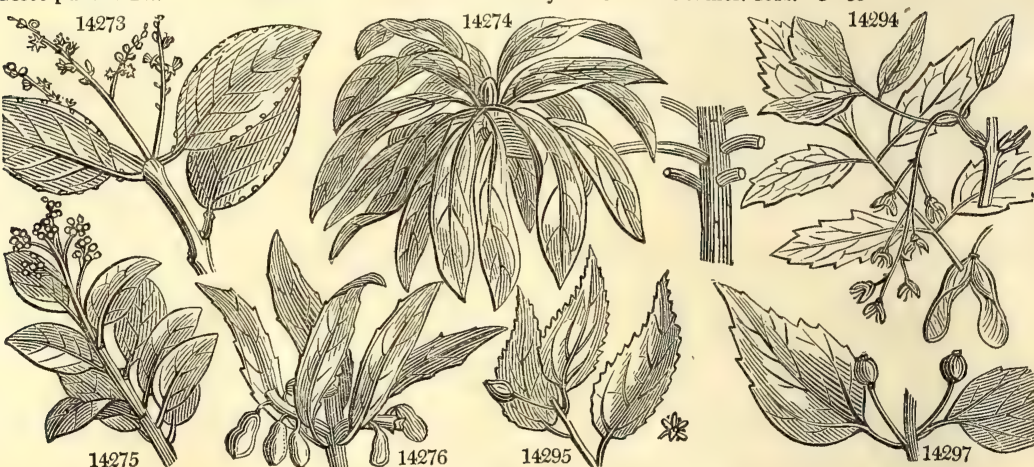

History, Use, Propagation, Culture,

2140. Terminalia. Because the leaves grow in bunches at the termination of the branches. The species row in loam and peat, and ripened cuttings, with their leaves on, will root in sand closely covered.

2141. Fusanus. The ancient name of the Euonymus. This plant resembles it in foliage. A little Cape shrub, formerly included in Thesium.

2142. Brabejum. From Geabsiov, a sceptre. The elegant racemes of splendid flowers may well be compared to a sceptre.

2143. Acer. A Latin word signifying vigorous or sharp. The wood was formerly manufactured into the heads of pikes and other weapons. The species consist of trees, most of them yielding a saccharine juice from the trunk, branches, and leaves. A. Pseudo-Platanus, Plane tree, Scot,, grows wild in Switzerland, Germany, Austria, and Italy. It is remarkably hardy, and will grow with an erect stem, exposed to the highest winds, or to the sea-breeze. It is in leaf by the middle of April; and on their first appearance the leaves are of a pleasant green, but they exude a clammy juice so abundantly, that they attract a variety of insects, which soon perforate and disfigure them. The flowers of none of the species are of any beauty. The shade of the tree is said to do less damage to pasture than most trees. The timber was formerly much used by the turner, and is still in repute by the saddle-tree maker and the millwright. In spring and autumn, if the trunk be pierced, it yields abundance of juice, from which a good wine may be made, or sugar to a certain extent procured by evaporation. A. rubrum grows in swamps in Pennsylvania, where the natives use it for almost all sorts of wood-work; with the bark they dye a dark blue, and make a good black ink. The Canadians tap the tree for the juice, of which they make sugar and treacle. The scarlet flowers of this species come out in spring before the leaves; they are without petals, and have not more than six stamens.

A saccharinum bears a considerable resemblance to A. platanoides, especially when young. From this tree, and probably also from other species, the inhabitants of North America make a very good sort of sugar. The trees are tapped in February, March, and April, during warm days and frosty nights. The incision is made with an axe or auger, or about two inches deep. A spout of sumach or elder is introduced, through which the sap flows, from four to six weeks, into a trough, whence it is carried daily to a larger receiver; from which it is conveyed after being strained to the boiler. The boiling and refining process is or should be carried on in the same manner with that for the cane sugar in the West Indies. A tree of an ordinary size yields in a good season from twenty to thirty gallons of sap, from which are made from five to six pounds of granulated sugar.

A. platanoides grows on the mountains of the northern counties of Europe, descending in some places of 
14271 Leaves onovate without glands at base blunt obsoletely toothletted : beneath soft with down

14272 Leaves obovate without glands at base blunt entire smooth on each sicic

14273 Leaves obovate oblong blunt entire smooth on each side, Petioles with 2 glands above

14274 Leaves linear-lanceolate repand downy beneath

14275 The only species

14276 The only species

14277 Leaves evergreen entire and 3-lobed obsoletely toothletted smooth on very short stalks

14278 Leaves cordate somewhat cut unequally toothed, Corymbs erect, Fruit smooth

14279 Lvs. cord. 5-lobed glauc. and smooth beneath : lobes unequally tooth. Racemes pendulous, Fruit smortl,

14280 Lvs. on long stalks subcordate 5 -fid smooth glauc. beneath : segm. acuminate cut-toothed, Umbels erect

14281 Lvs. cordate 5 -fid whitish and smooth beneath : segm. acuminate cut-toothed, Fl. in capitate umbels

14282 Lvs. shortly 3-lobed serrated smooth on each side: male peduncles branched; female simple

14283 Lvs. subcord, acutely 5-lobed downy beneath : lobes nearly entire, Corymbs before the lvs. loose nodding

14284 Lvs. cordate 5-lobed downy beneath, Corymbs sessile nodding, Fruit smooth

14285 Lvs. cordate 5-fid smooth : segm, acuminate cuspidate somewhat toothed, Corymbs nearly erect

14286 Lvs, cordate 3-fid acuminate serrated smooth, Racemes simple long pendulous, Branches striated 14287 Lvs. about 5-lobed acute serrated downy beneath, Racemes compound erect

14288 Lvs. cord. bluntly 5-lobed shining smth. beneath : lobes nearly ent. Corymbs erect, Wings of fruit divaricat.

14289 Lvs. on long stalks round. coriac. bluntly 5 -lob. pale ben. : lobes bluntly tooth. Corymbs erect, Fruit smt 2.

14290 Lvs. cord. 5-lobed glauc. beneath netted : lobes blunt crenate-tooth. Umb. pendul. Pedun. and fruit smooth

14291 Lvs. annual cordate 3-lobed : lobes nearly entire equal, Corymbs few-fiowered erect, Fruit smooth

14292 Lvs, cordate slightly and very bluntly 5-lobed downy beneath: lobes repand, Umbels pendulous

14293 Lvs. evergreen tapered at base 3-fid : segments toothletted; lateral shortest, Corymbs few-flowered erect

14294 Leaves ternate and pinnate cut serrate, Male flowers corymbose : female racemose

14295 Leaves oblong-lanceolate acumin. finely serrated scabrous above beneath soft with down unequal at base 14296 Leaves ovate acute serrated unequal at base roughish above: younger somewhat cordate

14297 Leaves ovate acuminate serrated unequal at base rough above hairy beneath

14298 Leaves unequally cordate acuminate nearly entire smooth on each side

14299 Leaves ovate acuminate serrated unequally cordate at base subcoriaceous rough on both sides

14300 Leaves unequal at base ovate acuminate serrated smoothish on each side.

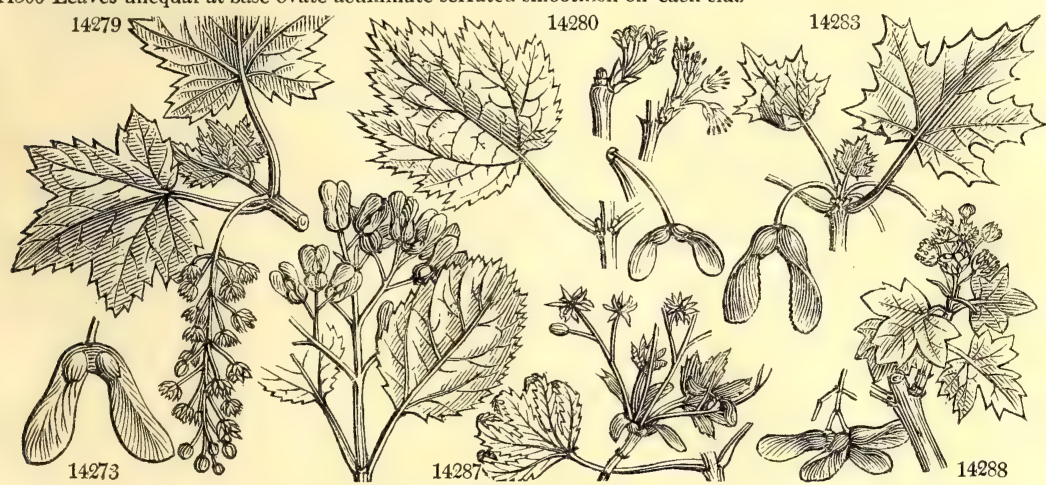

and Miscellaneous Particulars.

Norway to the sea-shore. It abounds in the north of Poland and Lithuania, and is common through Germany, Switzerland, and Savoy. On a tolerable soil it attains a large size, and the leaves being smooth and of a shining green, as large or larger than those of the sycamore, and being seldom eaten or defaced, because the tree abounds in a sharp milky juice disliked by insects, they have a much better appearance than those of the sycamore; and in the spring, when the flowers are out, which are of a fine yellow color, this tree has great beauty. Hanbury observes, that in the autumn the leaves die to a golden yellow color, which produces a good effect at that season, when the different tints of the decaying vegetable world are displayed. He says further, that it is a quick growing tree, arrives at a great bulk, and is one of the best trees for sheitering habitations. Linnæus recommends it for sheltering walks and plantations; as yielding a juice from which sugar may be made, if it be wounded in the winter; and as cutting out into a white smooth wood, fit for the stocks of guns, the joiner and the turner. Dr. Hunter observes, that it is a quick grower, arrives at a great bulk, and answers all the purposes of the sycamore; the raising it for use, as well as ormament and variety, should not be neglected. (Mill. Gard. Dict.)

A striatum has a slender stem, with a smooth bark beautifully varied with green and white stripes, the boughs of a shining red in winter. The thickness of the shade, the beauty of the bark, and the tree not being liable to insects, render it very desirable for ornamental plantations; the only objections to it are, that it is subject to be injured by storms, and that the abundance of its foliage and seeds occasions a great litter in autumn.

A. campestre forms a very picturesque little tree, and the timber is said to be far superior to that of the beech or the sycamore for the purposes of the turner. It is also frequently substituted for that of the holly and box by the mathematical instrument maker.

A. Opalus is a noble tree, with large and beautiful foliage, throwing an extensive shade; it is much prized in Italy for planting by avenues and public walks. All the species are easily raised from seed, though the ashleaved and some other species are occasionally propagated by layers and cuttings; the cuttings should be cut off at a joint, and, as in the case of most hardy trees and shrubs, they succeed best when planted in the autumn in a sheltered situation in the open ground.

2144. Negundium. A genus obviously distinguished from Acer by its pinnated leaves. A fine ornamental tree, called in North America black ash. There is another species in China.

2145. Celtis. One of the names ancientiy given to the Lotus. Tournefort first applied the name to the modern genus, which may be said to resemble both in fruit and foliage the shrubby Lotus of the ancients, 
14301 sinénsis Pers.

14303 aculeáta $W$.
14302 micrántha $W$.
Chinese

smooth

prickly

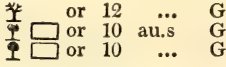

Rhamnea. , $S p$. 2-20.

Chaw-stick 2 $\square$ or $10 \quad \ldots \quad$ G $\quad$ W. Indies 1739. C p.l Pluk.al.t.201.f.

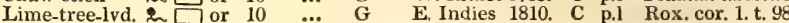

14305 tiliæfólia $W$

2147. HER'M AS. $W$ 14306 depauperáta $W$. 14307 gigantéa $W$.

Hermas.

hairy

gigantic

2148. BRIDE'LIA. $W$. BRIDELIA.

14308 spinósa $W$.

prickly

Umbelliferce. $S p .2-5$.

$\checkmark \mathrm{N} \mathrm{cu} 2 \mathrm{j}$ j.jl $\mathrm{G} \quad$ C. G. H. 1795. D 1.p Bur. afr.t.71.f. \& $\triangle \mathrm{cu} \quad 4$ jn.jl G $\quad$ C. G. H. 1794. D l.p T.in.ac.p.14.t.11

\section{Euphorbiacea. Sp. $1-5$.}

* J or 6 jn.jl Ap E. Indies 1823. C 1.p Roxb. cor.t. 172

2149. FERo'NIA. Correa. Elephant Apple.
14309 elephántum Corr. Indian

2150. Ailan'TUS. $W$. Ailantus.

14310 glandulósa $W$. C. Arla

14311 excélsa $W$.

Indian

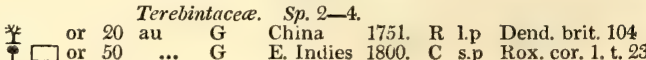

Balsam TreE.

Rose-colored

white-flowered

14312 rósea $W$.

14313 álba $W$.

14314 flava $W$.

14315 venósa $W$.

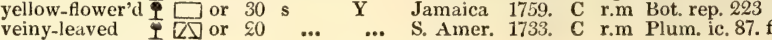

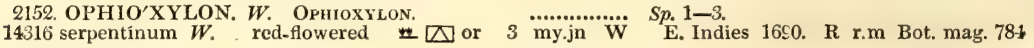

2153. RHA'PIS, $W$.

14317 flabellifórmis $\mathscr{W}$

14318 arundináceà $W$.

\section{RHAPIS.}

creeping.rooted主 $\square$ or 6 au $\mathrm{G}$ China 1774. R p.1 Bot. mag. 1371 simple-leaved 星 $\triangle$ or $6 \mathrm{~s} \quad \mathrm{G} \quad$ Carolina 1765. $\mathrm{R}$ p.l

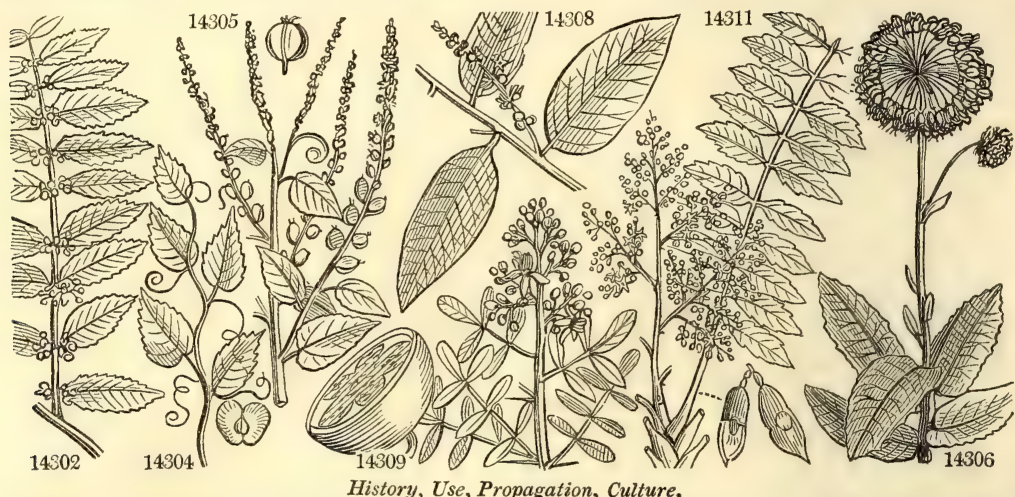

C australis, sometimes called the lote tree, is reckoned among the largest timber trees of the south of Europe. The wood is one of the hardest we are acquainted with; it is also very tough and flexible. In France, the forked branches are peeled, and cut so as to resemble rude hay-forks, and in that state used for various agricultural purposes. The leaves have a cheerful light green color; the berries are the size of a small cherry, first yellow and then black; they are eaten by birds and children.

C. occidentalis bears a great resemblance to the first. The leaves come out late in the spring, but they are also the latest in fading of any of the deciduous sort; the timber is tough and pliable, and imported by coachmakers for the frumes of their carriages. It grows more freely in this country than the European species, and in some years bears abundance of fruit.

C. orientalis is a low-spreading tree or bush; the timber is white, aud yields a gum like that of the cherry. C. aculeata is an inelegant little tree, with a drupe double the size of a pea, which is eaten by the natives of the Caribbee Islands and the neighbouring continent. All the species are easily increased by layers or seeds.

2146. Gouania, Antoine Gouan was professor of botany at Montpellier in the middle of the eighteenth century, and was a good botanist. The species are increased by ripened cuttings under a hand-glass in heat.

2147. Hermas. A name, the meaning of which is wholly unknown. An inconspicuous starved-looking plant of no known use; whence it is called depauperata.

2148. Bridelia. Named in honor of Professor Bridel, the celebrated muscologist. Small bushes or trees, with little beauty to recommiend them.

2149. Feronia. Elegantly named by the classical Correa de Serra, after Feronia, the goddess of the forests.

This is a noble Indian timber tree, bearing a fruit not unlike an orange, to which it is botanically related.

2150. Ailantus. Derived from Ailanto, the name of one species in the Moluccas. The usual way of writing it, Ailanthus, is therefore incorrect. A. glandulosa is a tree which may be compared to a gigantic stag's-horn sumach; it has very large leaves, unequally pinnate, with foot-stalks from one to two feet in length, and numerous flowers in a terminating pedicel, which exhale a disagreeable odor. The tree grows very fast, and on very poor soil, especially if it be calcareous. If the bark be wounded, a resinous juice flows out, which hardens in a few days. The wood is hard, heavy, glossy like satin, and susceptible of a very fine polish. It is proin a few days. The wood is hard, heavy, glossy like satin, and susceptible of a very fine polish. It is pro-
pagated by cuttings of the roots. In general the trees bear only male flowers; but in France it has produced both male and female flowers, and fruit twice in ten years.

2151. Clusia. So called, in honor of the celebrated Charles de l'Ecluse, born at Artois in 1526, and died in 1609. He was one of the most excellent botanists who ever lived, and author of many works whose value will only cease with the world. But he is not more known for his mental excellence, than for his personal calamities. In his early youth he undertook to travel through Portugal, Spain, England, Hungary, and other countries in pursuit of plants; no easy task in those days. By excessive fatigue he contracted, so soon as in his twenty-fourth year, a dropsical complaint, of which he was afterwards cured with chicory by the celebrated 
14301 Leaves broad ovate acuminate serrate smooth on each side

14302 Leaves ovate oblong acuminate serrulate unequally cordate at base rough above hairy bencath

14303 Lws. ovate obl. acum. equally cordate at base entire obsoletely serrated at end smooth, Branches prickly

14304 Leaves ovate acuminate bluntly serrated smooth

14305 Leaves cordate-ovate with glandular serratures roughish, Racemes terminal downy

14306 Stem downy, Leaves oblong sessile toothed downy beneath

14307 Leaves lanceolate ovate woolly above downy beneath entire

14308 Shrubby erect spiny, Leaves ovate entire acute glabrous

14309 The only species

14310 Leaves pinnated with an odd one, Leaflets toothed at base, Teeth glandular 14311 Leaves abruptly pinnated, Leaflets serrated

14312 Leaves obovate blunt veinless, Cor. hexapetalous twice as large as calyx 14313 Leaves obovate blunt veinless, Cor 5-7 petalous half as large again as calyx 14314 Leaves obovate blunt veinless, Cor. 4-petalous twice as large as calyx

15315 Leaves obovate blunt veiny, Flowers tetrapetalous

14316 Leaves in fours

14317 Fronds palmate plaited, Plaits and margins prickly

14318 Fronds simple 2-parted, Lobes acute plaited, Plaits roughish

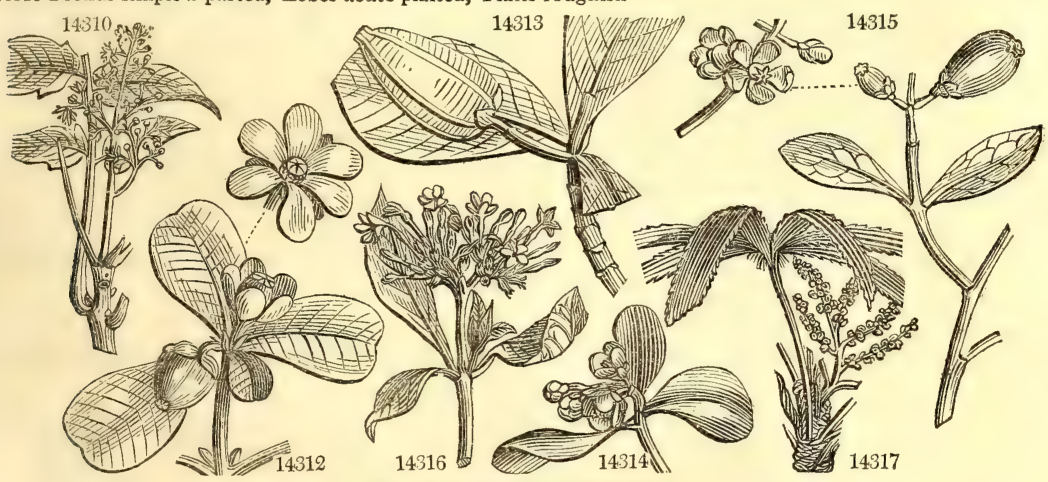

and Miscellaneous Particulars.

Rondelet. See Rondeletia. At the age of thirty-nine he broke his right arm, during one of his botanical rambles; and a short time afterwards his right thigh. When fifty-five, he dislocated his left ancle while at Vienna; and eight years after his right hip. . Having been unskilfully treated, he was ever after obliged to walk with crutches. The consequent deprivation of his natural exercise brought on other diseases, among not the least distressing of which were calculus and hernia. After having been the director of the Imperial Gardens of Vienna for fourteen years, he finally returned to his native country, Flanders. He was narned professor of botany at Leyden, where he gave botanical lectures for sixteen years, when he died overwhelmed by the multitude of his bodily infirmities, but retaining his faculties unimpaired to the last.

The species are trees abounding in a tenacious glutinous juice, of a balsamic flavor, whence the English name. C. rosea has handsome flowers, in which the stamina and pistillum are covered with a gelatinous gluten. The fruit is green and of the size of a middling apple, with eight lines running, like meridians on a globe, from the stalk to the crown of it- When it ripens, it opens at these lines, and divides into eight parts, disclosing many mucilaginous scarlet seeds, resembling those of the pomegranate. The whole tree is exceedingly beautiful, and the structure of the fruit is a most exquisite piece of mechanism. It grows on rocks, and frequently on the trunk and limbs of trees, occasioned by birds scattering or voiding the seeds, which being glutinous, like those of the misletoe, take root in the same manner; but the roots not finding sufficient nutriment, spread on the surface of the tree till they find a decayed hole, or other lodgment, wherein is some small portion of soil; the fertility of this being exhausted, a root is discharged out of the hole till it reaches the ground, where it fixes itself, and the stem becomes a large tree. Roots have been known to do this at forty feet from the surface. The resin is used to cure sores in horses, and instead of tallow for boats.

C. alba is an elegant tree, and epiphytical on other vast trees, like the foregoing; the trunk is frequently a foot in diameter, and supports a spreading head. The whole abounds in a balsamic juice, of a green color, but becoming of a brownish color on being exposed to the air. The flowers are white, and of no great beauty; the fruit scarlet, with a scarlet pulp; the birds are very fond of them, hang over them on the wing, and pluck out the seeds with the pulp adhering.

C. flava bears in all respects a considerable resemblance to the former. A very good idea of the progress of culture since Miller's time, may be formed by comparing his directions for propagating this plant, and those of Sweet. Mr. Miller says, the best way is to have them brought over in tubs from the West Indies : according to sweet, the pots should be well drained, the soil for rooted plants should be a light sandy loam, and ing to Sweet, the pots should be well drained, the soil

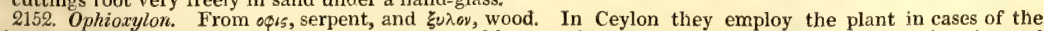
bite of serpents. It grows freely in a mixture of loam and peat, and may be increased by cuttings in sand under a hand-glass.

2153. Rhapis. So named by Loureiro, from ea $\phi i 5$, a needle, on account of the acute awns of the corolla, which stick into the clothes. Culture as in the other palms; that is, abundance of heat and room, both for the roots and top. 


\section{$D I O E I A$}

2154. CHAM E'ROPS. $W$. ChameroPs

Palma. Sp. 4.

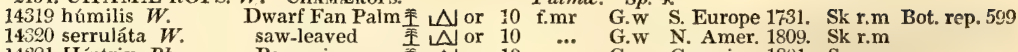

14321 Hýstrix $P h$.

G.w N. Amer. 1809. Sk r.m

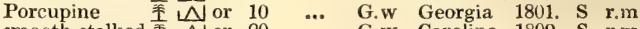

2155. GLEDITS'CHIA. $W$. Gleditschia.

14323 triacánthos $P h$. Honey-locust Tree

$\beta$ inérmis

$\begin{array}{cccc}\text { R inérmis } & \begin{array}{c}\text { smooth } \\ \text { curved-spined }\end{array} & \text { or } 30 \text { jn.jl } \\ 14324 \text { brachycárpa } P h . & \text { or } 30 \text { jn.jl }\end{array}$

Leguminose. Sp. $5-7$.

14326 hórida $W$. SW . S

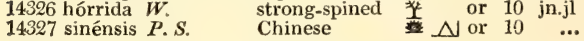

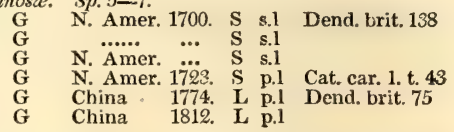

2156. Ceratónia. $W$. Carob Tree. Leguminose. Sp. 1.

14328 Siliqua $W$. St.John's Bread $\mathcal{N} \cup$ ec 15 s.o R.x Levant 1570 . S s.I Bot. rep.567

2157. FRAX'INUS. $W$ Ash Tree. Oleince. Sp. 34-37.

14329 americána $W$. white $\quad$ tm 20 my G N. Amer. 1723. G

14330 acumináta Lain. Green $\quad \frac{1}{1}$ tm 40 my G N. Amer. 1723.

14332 caroliniána $W$.

14333 pubéscens $W$. nigra Duroi

14334 pannósa Vent.

14335 epiptera $W$.

14336 quadranguláta $W$.

14337 platycárpa $W$.

14338 expánsa $W$.

14339 mixta Bosc.

14340 pulverulénta Bosc.

14341 rubicúnda Bosc.

14342 longifólia $B o s c$

14343 víridis Bosc.

14344 cinérea Bosc.

14345 álba Bosc.

14346 Richárdi Bosc

14347 ováta Bosc.

14348 elliptica Bosc.

14349 nígra $B o s c$.

14350 fúsca Bosc.

14351 rúfa Bosc.

14352 pállida Bosc.

14353 excélsior $W$

$\beta$ péndula Hort.

y jaspídea W. en.

s atrovirens $\mathbf{P} . \mathbf{S}$.

shining or 30 my.jn

Red or black $\quad$ or 20 my

cloth-leaved

cut-winged

N. Amer. 1783 . G co

Catesb.

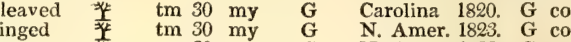

broad-fruited or 30 my G N Amer 1820 G

expanded $\frac{1}{4}$ or $30 \mathrm{my}$ G N. Amer. 1824. G co

mixed or 30 my

or $30 \mathrm{my}$

or 30 my

or 30 my

or $30 \mathrm{my}$

or $30 \mathrm{my}$

or 30 my

long-leaved

green

or $30 \mathrm{my}$

or 30 ap.my $\mathbf{G}$

or 30 ap.my $\mathrm{G}$

or 30 ap.my $\mathrm{G}$

or 30 ap.my $\mathbf{G}$

or 30 ap.my $\mathbf{G}$

or 30 ap.my $\mathbf{G}$

or 30 ap.my $\mathbf{G}$

or 30 ap.my $\mathbf{G}$

tm 80 ap.my $G$

or 20 ap.my $G$

or 30 ap.my $\mathbf{G}$

or 4 ap.my $\mathbf{G}$

$\begin{array}{llll}14354 \text { verrucósa Link. } & \text { warted } & \text { or } 60 \text { ap.my } \mathbf{G} \\ 14355 \text { heterophýlla } V \text { ahl. } & \text { various-leaved } & \text { tm } 30 \text { ap.my } \mathbf{G}\end{array}$

N. Amer. 1824 . G co
N. Amer. 1824. G co

N. Amer. 1824. G co

N. Amer. 1824. G co

N. Amer. 1824. G co

N. Amer. 1824. G co

N. Amer. 1823. G co

N. Amer. ... G co

N. Amer. .... G co

N. Amer. 1825 . $G$ co

N. Amer. ... G co

N. Amer. 1823. G co

N. Amer. 1822. G co

N. Amer. ... G co

Britain woods. S s.l

...... ... G $\mathrm{G}$ co

...... $\quad$... G $\mathrm{G}$ co

England Norf. $G$

England woods. G s.1 Eng. bot. 2476

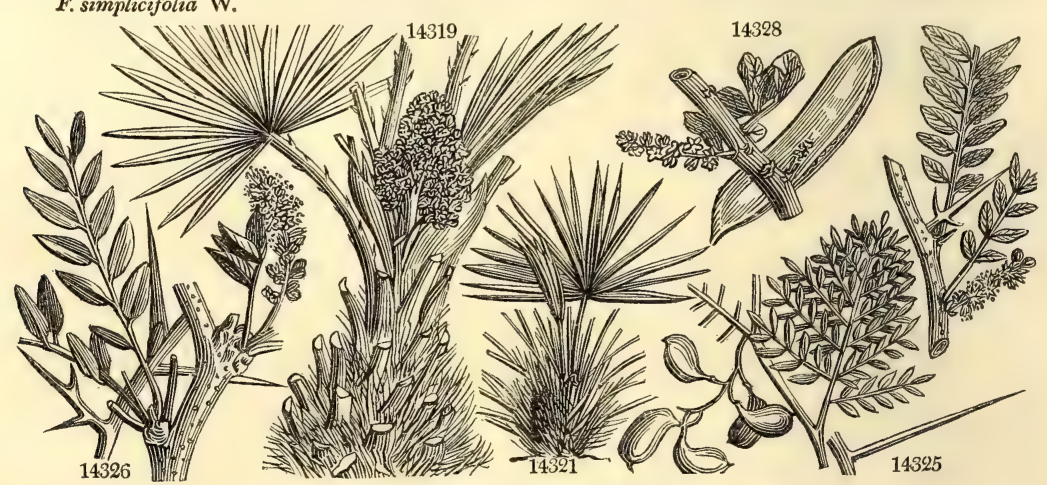

History, Use, Propagation, Culture,

2154. Chamorops. This word is said by etymologists to be synonymous with $\chi \propto \mu \alpha s \delta e u s$, or $\chi \propto \mu \propto s \delta \rho \omega \varkappa$ a dwarf oak. The modern genus consists of ornamental palms, which are fine hardy greenhouse plants.

2155. Gleditschia. Called in honor of John Gottlieb Gleditsch, a native of Leipzig, and member of the academy of Berlin, and the author of several works, among which his Arrangement of Fungi, published in 1753, and his Botanical System, are the most remarkable. G. triacanthos, the honey locust of North America, attains the size of a large tree, but very seldom flowers and ripens its seeds in this country. All the species grow in common garden soil, and are generally raised from seeds.

2156. Ceratonia. This name has been derived from «ве as, a horn, in allusion to the long horn-like pods of this plant, which contain a sweet foecula, for the sake of which they are often imported from Spain under the name of the Algaroba bean. This last word is a slight alteration, by the prefix of the article al, of the Arabic name of the tree, Kharroùb, whence also our English name Carob-tree. This is generally considered the locust-tree of scripture; and in Spain, where the seeds are eaten, it is called Saint John's bread. Ignorance of eastern manners and natural history, Professor Martin observes, induced some persons to fancy that the locusts on which John the Baptist fed, were the tender shoots of plants, and that the wild honey was the pulp of the pod of the Carob, whence it had the name of Saint John's bread. There is better reason to suppose, he adds, that the shells of the carob pod might be the husks which the prodigal son desired to partake 


\section{DICECIA.}

14319 Fronds palmate with spiny stalks, Spathe simple

14320 Fronds palmate with spiny stalks, Caudex creeping

14321 Stem creeping, Stalks with very long entangled prickles, Fronds palmate

14322 Fronds palmate with unarmed stalks, Spathes double, Stem arboreous

14323 Branches spiny, Spines thick triple, Leaflets linear oblong, Pods many-seeded

14324 Spines short thick triple, Leaflets oblong blunt, Pods oblong short

14325 Branches somewhat spiny, Leaflets ovate-oblong, Pods 1-seeded

14326 Trunks spiny, Spines branched, Leaflets oval-oblong

14327 Spines robust alternately branched, Leaflets elliptical smooth

14328 The only species

14329 Leaflets stalked oblong shining acuminate entire glaucous beneath, Buds yellowish

14330 Leaflets quite entire with long points glaucous beneath, Buds tawny

14331 Leafl. stalked ovate opaque serrated glaucous ben. Axils of veins downy, Branches smooth, Buds fusceus 14332 Leaflets stalked lanceolate serrulate shining smooth, Branches smooth, Buds fuscous

14333 Leafiets stalked elliptical ovate serrated beneath with the petioles and branchlets downy

14334 Lvs. of 3 pair shining above vill. with down ben. Leafl. stalk. ov. ent. taper. toward each end, Buds tawny 14335 Leaflets oblong lanceolate subserrated, Wing of fruit stalked cuneate emarginate, Buds fuscous

14336 Leaflets subsessile lanc. ellipt. serrated downy beneath, Branches square with winged angles, Buds grey 14337 Leaflets subsessile serrated outwardly and fruit lanceolate elliptical

14338 Leaflets ovate oblong unequally serrate about 11 smooth stalked, Branchlets smooth, Buds fuscous 14339 Leaves of 5 pair smooth above, Veins above hairy, Leaflets oblong subsessile unequally toothed

14340 Lvs. of 6 pair somew. downy ben. Leafl. on long stalks oblong acute sinuated, Petioles somew. powdery

14341 Lvs. of 3 pair coriac. a little downy ben. Leafl. obl, acute somew hat toothed, Veins and petioles ben. pink 14342 Lvs. of 3 pair shining above ben. with the petioles downy, Leaflets obl. lanc. acuminate, Branches hirsute 14343 Lvs. of 3 pair shining above with veins downy ben. Leaflets oblong acute finely serrated, Branches green 14344 Lvs. of 3 pair smooth, Veins ben. rather hairy, Leaflets lanc. unequally toothed, Buds lin. cinereous hairy 14345 Lvs. of 3 pair beneath and petioles hirsute, Leafl. lanc. unequally and finely toothed acum. Branches grey 14346 Lvs. of 3 pair smooth, Veins ben. rather hairy, Leafl. obl. acute toothed, Branches cinereous hairy at base 14347 Leaves of 3 pair downy beneath, Leaflets ovate acute equally toothed, Buds tawny

14348 Lvs. of 3 pair hairy ben. Leaflets oblong mucronate somew. toothed, Branches brownish-black, Buds tawny 14349 Leaves of 3 pair smooth, Leaflets oblong acute subsinuate toothed, Branches blackish

14350 Lvs. of 3 pair smooth above, Veins beneath villous, Leafl. obl. mucron. equally toothed, Branches fuscous 14351 Leaves of 2 pair with rufous hairs beneath, Leaflets lanceolate acuminate cuspidate unequally toothed 14352 Leaves of 3 pair smooth, Leaflets subsessile ovate lanceolate toothed, Branches yellow

14353 Leaflets somewhat stalked lanceolate acuminate serrated smooth cuneate at base, Branches flat smooth

14354 Leafl. somewhat stalked lanceolate acuminate serrate smooth, Branches round warted 14355 Leaves simple and compound tooth-serrated, Buds black

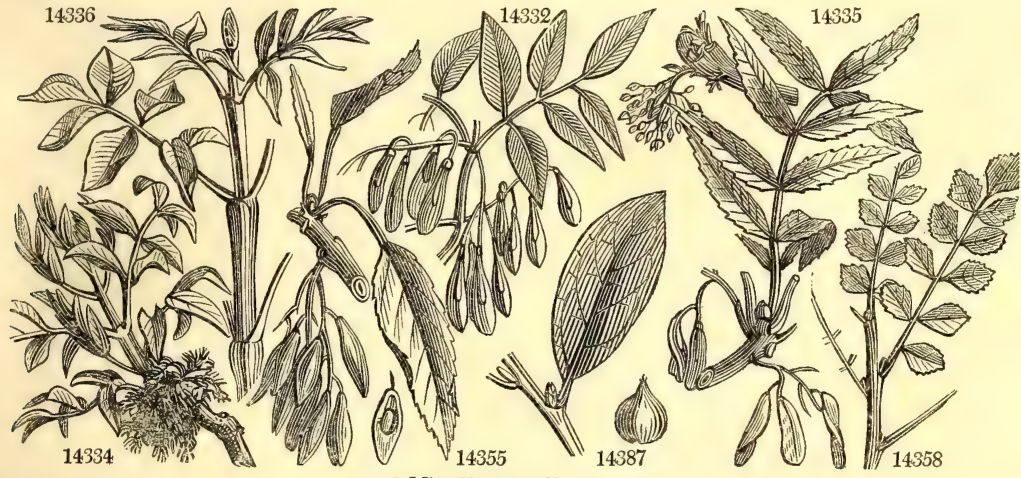

and Miscellaneous Particulars.

of with the swine. The tree is very common in the south of Spain, and the seeds or beans, as they were there called, often formed the principal food of the British cavalry horses during the war of 1811 and 1812 . In our greenhouses the plant seldom flowers, but it grows very well in loam and peat, and ripened cuttings root in sand under a hand-glass.

2157. Fraxinus. The origin of this word is far from certain. Linnæus says, it has been taken from the Greek $\phi_{\text {cec }} \xi_{15}$, a separation, in allusion to the facility of splitting its wood. De Theis remarks, that M. A. Dureau de la Malle has proved, in a learned dissertation published in 1804, that the Fraxinus of the Latins and the Melia of the Greeks are our Ornus europæus, while the Ornus of the Latins and the Boumelia of the Greeks are, in fact, our Fraxinus excelsior, or common ash. Le Frêne, Fr., Esche, Ger., and Frassino, Ital. The English name is from the Celtic esc, a pike. F. excelsior is one of the most useful of our native timber trees. It is peculiarly adapted for implements of husbandry, and the coachmaker and wheeler : it makes excellent fuel, with very little smoke; good hop-poles and hoops, excellent handles for tools, and very good walking-sticks. Its period of leafing is very late, being seldom earlier than the last week of April, and not unfrequently about the middle of May : the leaves have been used to adulterate tea; they are bitter, and said to communicate a rank taste to the milk and butter of cows which eat them. The roots spread to a great extent, and lie very near the surface; and these, together with the shade of the head, are found very injurious to hedges and pastures. The variety of this species, F. pendula, was first discovered in a field at Gamblingay, 
14356 macrophýlla Thouin large-leaved 14357 parvitólia $W$. small-leaved 14359 argéntea Lois. 14360 sambucifólia $W$. 14361 nána Bosc. 14362 ox ycárpa $W$

$\beta$ oxyphýlla $\mathrm{F}$.

2158. BRO'SI MUM $W$

14363 Alicástrum $W$. W. BrEad Nut.

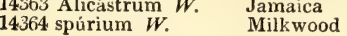

2159. Diospy'ROS. $W$. Date Plum. 14365 Lótus $W$.

14366 virginiána $W$.

14367 pubéscens $P h$.

14368 sylvática $W$.

14369 E'benum $W$.

14370 Káki $W$.

Aleppo

silvery

Water

dwarf

Caucasian

narrow-leaved

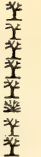
European American pubescent wood smooth
...... 1823, G co

Aleppo 1710. G co Pluk.al.t.182.f.4

Corsica 1825. G co

N. Amer. 1800. G s.l

...... G co

815. G co

S. Europe 1821. G co

14371 Embryópteris Pers.

14373 discolor $W$

14374 montána $\dot{W}$.

14375 cordifólia $W$

14376 obováta $W$ polyindrous

\section{Sp. 2-4.}

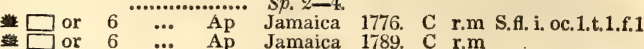

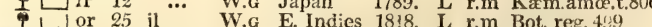
Vaccinium-like $\_$pr 2 ap.my W China 1823. C r.m Hook. ex. H. 139 Mabolo-fruit mountain heart-leaved four-seeded

2160. MYRSI'NE. $R . B r$. MYrsine. 14377 africána $W$.

14378 retúsa $W$.

14379 Samára $\dot{R} . R r$ r. round-leaved Samára pentándra W.

14380 melanóphleos $R . B r$. Laurel-leaved Sideróxylon melunophleum W.

2161. NYS'SA, $W$

14381 villósa $W$.

14382 biflóra $W$

14383 capitáta $H$. $K$

14384 tomentósa $W$. grandidentata Mich.

14385 can'dicans $W$.
14386 denticuláta $W$.

2162. HAMILTO'NIA. $W$. OIL Nut 14387 olétera $-\boldsymbol{W}$. Pyrulária púbera Mich.

TUPELO Sour-gum mountain downy-headed wn

Ogechee lime Olive-bearing

Ebenacee. Sp. $12-29$.

* clt 20 jn.jl Y.G Italy 1596. L s.1 Mill. ic. t. 116 clt 20 jn.jl Y.G N. Amer. 1629. S s.l Dend. brit. 146 clt 20 ap Y.G N. Amer. 1812. C s.1 $\square$ or $20 \quad \ldots \quad$ W E. Indies 1812. C s.l Roxb.cor.1.t.47 - $\mathrm{tm} 30 \quad \ldots \quad$ W E. Indies 1702 C s.1 Ro... L f f 12 ... W.g Japan 1789. L r.m Kxmamœ.t.806

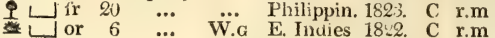
9 5 or $15 \quad \ldots$ W.G E. Indies 1794. G co Roxb.cor.1.t.50 ... W. W W. Indies 1796. G co Jac.schœ.3.t.312

Myrsinea. $S p .4-13$.

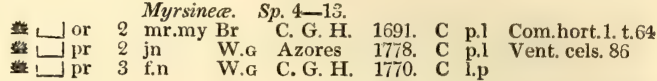

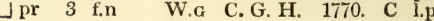

$\begin{array}{lllll}\text {... W.G } & \text { C. G. H. 1783. C } & \text { 1.p Jac.vind.1.t.71 }\end{array}$

Santalacea? Sp. 5-9.

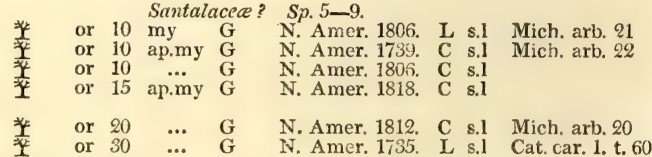

II

2163. LAUROPHYL'LUS, $W$. LAUROPHYLLUS,

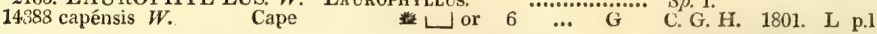

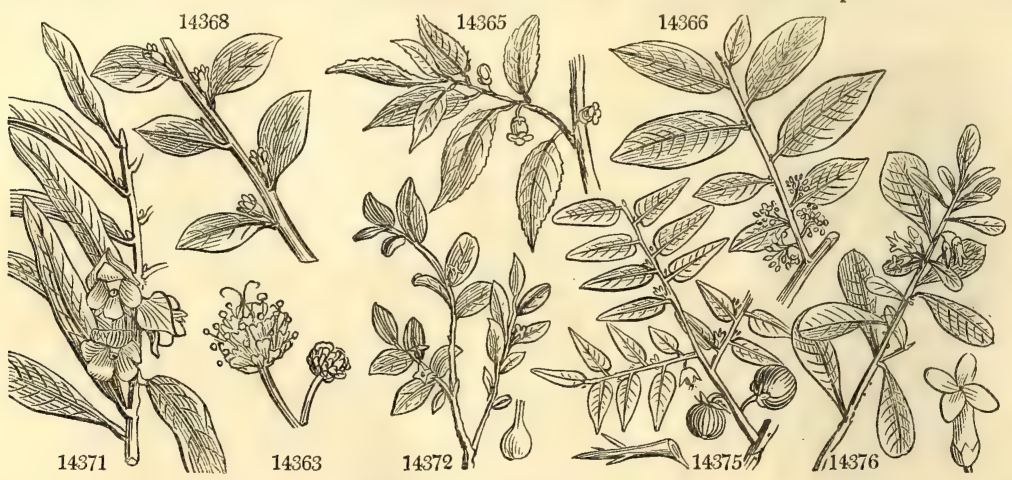

History, Use, Propagation, Culture,

in Cambridgeshire. There are other varieties with curled leaves, striped leaves, variegated bark, \&c. and some consider F. simplicifolia only a variety. F. Americana is a lofty tree, in few respects different from the common ash. Those species which do not produce seeds, are readily increased by grafting.

Little is known of the qualities of the greater part of the numerous varieties of American ash, distinguished by Bosc. They probably all form fine trees; the young plants in our gardens grow freely, and exhibit indications of valuable properties as ornamental trees.

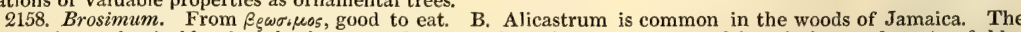
timber is not despicable; but the leaves and younger branches are more useful, and a hearty fattening fodder for all sorts of cattle. The fruit, boiled with salt tish, pork, beef, or pickle, has been frequently the support of the neoroes and poorer sort of white people in times of searcity, and proved a wholesome, and not unpleasant food, when roasted, it eats something like our European chestnuts, and is called bread-nut. The leaves and younger shoots are full of gum, which renders them disagreeable to most cattle at first, but they soon grow very fond of them.

B. spurium is also common in woods in the West Indies, but its timber is of little value. In our stove both species thrive well, and like loamy soil ; and old cuttings, with their leaves on, root in sand in moist heat.

2159. Diospyros. From $\Delta$ wos rugos, the fruit of Jove, or heavenly fruit It has been fancied that the European species of this plant produced that fumous fruit, which, according to ancient romancers, caused oblivion. D. Kaki is a valuable Japanese tree, which bears the fruit sometimes received from China in a dried form under the name of dates. D discolor also bears a fine fruit. D. lotus produces fruit the size of a 
14356 Leaves simple blistered ovate coarsely serrated dark-green quite smooth

14357 Leafl, ovate subsessile acute mucronate serrate smooth cuneate at base

14358 Leafl, oblong stalked acute at each end mucronate serrated smooth

14359 Leaves unequally pinnated of 3 pair, Leaflets stalked lanceolate acuminate serrated silvery

14360 Leafl. sessile ovate lanc. serrated rugose-shining rounded at base unequal, Axils of veins villous beneath

14361 Lvs. of 3 pairs smooth, Leafl, obl, acum, tooth Com. petiole winged at base, Branches ciner. Buds blackish

14362 Leaflets subsessile lanc. acuminate serrated smooth, Fruit lanc. narrowed at each end with a long point

14303 Leaves ovate lanc. evergreen, Catkins globose stalked twin axillary, Fruit coated

14364 Leaves lanceolate-ovate acuminate, Catkins subsessile ovate axillary twin, Fruit soft

14365 Leaves obl. acuminate downy beneath, Buds hairy inside

14366 Leaves ovate bluntish shining smooth netted with veins, Petioles downy, Buds smooth

14367 Leaves obl. acute downy beneath, Petioles long, Fruit few-seeded

14368 Lvs. obl. acute at base and end smooth on each side, Fl. trigynous erect, Hermaphrodite cor. as long as ca!.

14369 Leaves ovate-lanc. acuminate, Buds hairy

14370 Leaves ovate-elliptical acuminate acute at base downy beneath, Branches downy

14371 Leaves lanc. oblong, Flowers axillary polyandrous, Berry 8-seeded

14372 Lvs. simple fleshy nerveless cover. on each side with scatter. stell. scales, Sterile obl.-lanc. Fert. lin.-lanc.

14373 Leaves oblong acute rounded at base acute at end : smooth above; silky and glaucous beneath

14374 Leaves oblong rounded at base acute at end smooth on each side

14375 Spiny, Leaves oblong acuminate cordate downy beneath

14376 Leaves obovate blunt smooth on each side

14377 Leaves obovate elliptical acute serrated at end, Pedunc. umbelled axillary, Stamens exserted

14378 Leaves obovate retuse toothletted, Flowers axillary clustered, Stamens included

14379 Leaves ellipt. Corymbs axillary aggregate

14380 Leaves oblong lanc. subcoriaceous entire, Flowers axillary clustered

14381 Leaves oblong entire acute at each end, Petiole middle rib and edge villous, Female peduncles about 3-fl. 14382 Leaves ovate-oblong entire acute at each end smooth, Female peduncles 2-flowered

14383 Leaves cordate ovate slightly serrated glaucous beneath, Flowers in globose heads, Drupes oblong

14384 Leaves on long stalks obl. acuminate remotely serrate downy beneath, Female peduncles 1 -flowered

14385 Leaves on short stalks obl. nearly entire cuneate at base whitish beneath, Female peduncle 1-f

14386 Leaves on long stalks obl. acuminate remotely serrated smooth on both sides, Female pedunc. 1 -ft.

14387 Leaves oval-oblong acuminate entire

14388 Leaves stalked oblong acute serrated coriaceous veiny smooth

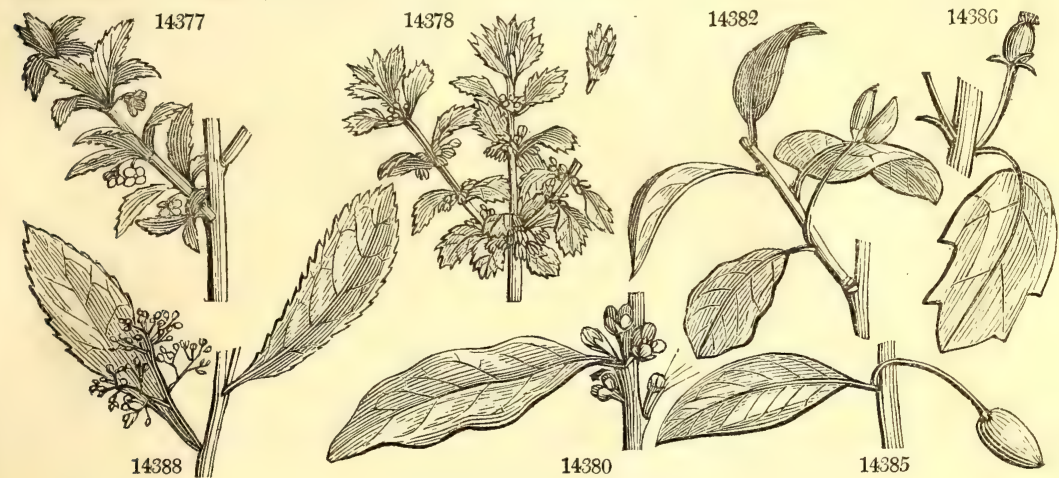

and Miscellaneous Particulars.

cherry, yellow when ripe, sweet, and somewhat astringent; they are recommended as a cure for the diarrhœa. D. virginiana has a white brittle wood, covered with a dark brown bark. The fruit is in form and bigness like a date, very firm, like that fruit, and almost as sweet, with a large kernel.

2160. Myrsine. A Greek word synonymous with Myrtle. Modern botanists have applied the name to a genus of African myrtle-like shrubs. The species grow freely in loam and peat, and are increased by young cuttings in sand under a hand-glass.

2161. Nyssa. A name of a nymph, according to Linnzeus. The species are large shrubs, which grow freely in any soil or situation, but prefer moisture. N. denticulata grows naturally in wet swamps in Carolina and Florida, and rises there to the height of eighty or hundred feet. Marshall, in his American Grove, describes it as a tree of great singularity and beauty. It produces fruit about the size and shape of small olives, which are preserved like them by the French inhabitants of the Mississipi, where it greatly abounds, and is called the olive-tree. The timber is white and soft when unseasoned, but light and compact when dry, which renders it very proper for the carver and turner. All the species are readily propagated by layers or seeds.

2162. Hamiltonia. Dedicated by Muhlenburg, to Mr. Hamilton, an American botanist. A shrub growing to the height of from three to six feet. The flowers grow in terminal racemes from an inch to an inch and a half long.

2163. Laurophyllus. An hybrid name created by Thunberg, to express the resemblance of the leaves, $\phi \cup \lambda \lambda \alpha$, to a laurel. A shrub with stalked, oblong, acute, serrated, coriaceous leaves, and minute flowers growing in panicles three or four inches long. 
2164. BURSE'rA. W. Buraela. 14389 gummífera $W$. Jamaica 2165. ARCTO'PUS. $W$. Arctopus. 14390 echinátus $W$. rough 2166. PA'NAX. $W$. PANAX. 14391 quinquefólium $W$. Ginseng 14392 trifólium $W$. lesser 14393 aculeátum $W$. prickly

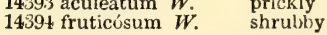

2167. FI'CUS. $\boldsymbol{W}$. 14395 Cárica $W$ 14396 rubrinérvia Link. 14397 aquática $W$. 14398 nymphæifólia $W$. 14399 crassinérvia $W$. 14400 religiósa $W$ 14401 benghalénsis $W$. 14402 venósa $W$ 1440)3 Bras'sii Sabine 14404 coriácea $W$. 14405 lasiophýlla Link. 14406 costáta $W$. 1440) 7 lúcida $W$.

14408 oblongáta Link. 14409 martinicénsis $W$. 14410 infectória $W$. 14411 superstitiósa $\operatorname{Link}$. 14412 pedunculáta $W$. 14413 ulmifólia $\boldsymbol{I V}$. 14414 cordáta $W$. 14415 macrophýlia $P . S$. 14416 obtusáta Link. 14417 Mun'tia Link. 14418 austrális $W$. 14419 elástica $R o x$ 14420 microcárpa $\mathrm{Vahl}$. 14421 ciliolósa Link. 14422 stipuláta $W$. 14423 púmila $W$. 14424 tinctúria $\dot{W}$ 14425 brasiliénsis Link. 14426 benjámina $W$. 14427 Lichtensteínii Link. 14428 pertúsa $W$. 14429 nítida $W$. 14430 índica $W$. 14431 popul'nea $W$. 14432 lævigáta Vahl. 14433 racemósa $W$. 14434 retúsa $W$. 14435 répens $W$ 14436 péndula Link.
Fig Tree. common red-nerved rough-leaved Water-lily-lvd. thick-nerved

Poplar-leaved Bengal vein-leaved Brass's Jeathery-leaved woolly-leaved rib.leaved

shining-leaved oblong-leaved round-fruited veiny

superstitious heart-leaved large-leaved largedoubtful ferruginous Elastic-gum small-fruited ciliated trailing dwarf Otaheite

Brazilian oval-leaved

Lichtenstein's Laurel-leaved glossy-leaved Banyan Tree poplar-leaved polished clustered blunt-leaved blunt-leaved creeping-stem

pendulous Willow-leaved

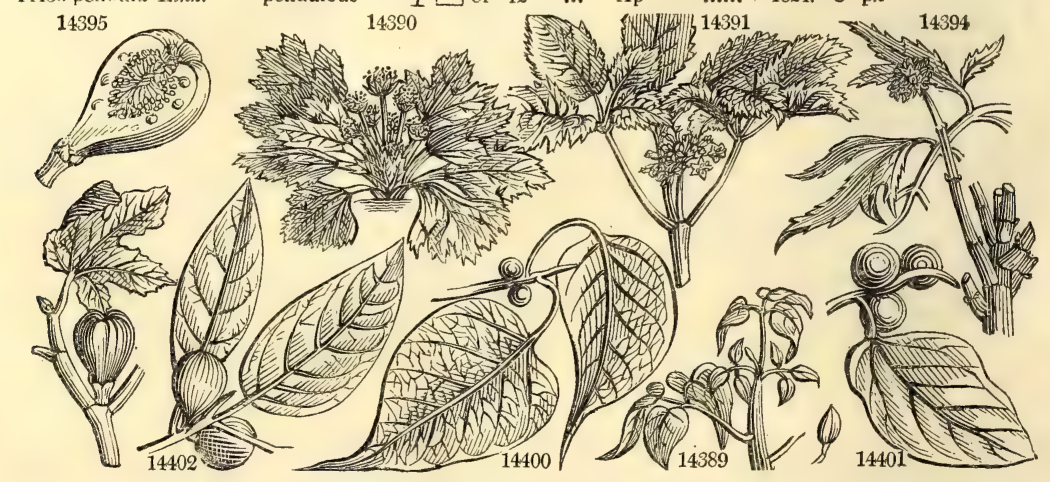

Terebintacea. Sp. 1.

1690. S p.l Jac. amer. t. 65 Umbelliferc. $S p .1$.

$\begin{array}{llllll}1 \mathrm{~m} & 1 & \text { my.jn } \mathrm{G} & \text { C. G. H. 1774. D p.1 Bot. reg. } 705\end{array}$

\section{Araliaces. $S p .4-16$.}

$\frac{1}{4}$ pr $1 \frac{1}{2}$ jn L.Y N. Amer. 1740. D s.p Bot. mag. 1333

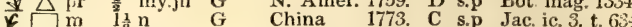

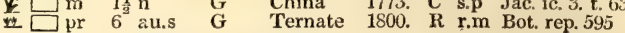

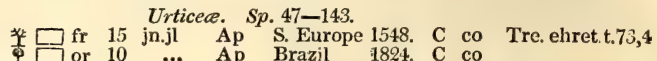

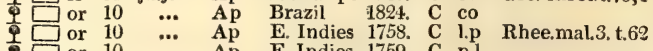

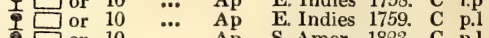

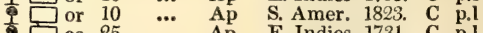

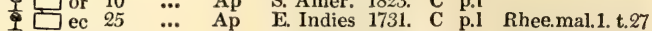
9 $\square$ or 25 ap Ap E. Indies 1690. C p.1 Rheemal.1. t.28 $\begin{array}{llllll} & \text { Ap } 10 & \ldots & \text { A. Indies } 1763 \text {. C } & \text { p.l W.ho.ber.1. t. } 36\end{array}$

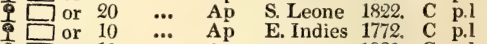
... Ap E. Indies 1772. C p.l

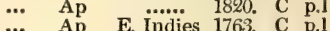
$\cdots$ Ap F. Indies 17 ... Ap E. Indies 1772. C p.l $\ldots \quad$ Ap C. G. H. 1825. C p.l

... Ap W. Indies 1759. C p.1 Sloa.jam.2.t. 223 ... Ap E. Indies 1763. C p.l Rhee.mal.3. t.64 ... Ap $\ldots . . .1763$. C p.1

... Ap S. Amer. 1776. C p.l Pluk.al. t.178.f.4 ... Ap Phillipin. 1813. C p.l

... A Ap C. G. H. 1802. C p.l Thunb.diss.c.ic. $\begin{array}{cccccc}\ldots & \text { Ap } & \text { C. G. H. } & 1802 . & \text { C } & \text { p.l } \\ \ldots & \text { Ap } & \text { N. Holl. } & \ldots & \text { C } & \text { p.l }\end{array}$

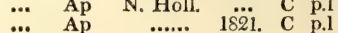

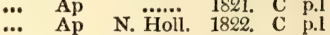
mr.jn Ap N. S. W. 1789. C p.I ... Ap E. Indies 1815. C p.l ... Ap Guinea 1819. C p.l

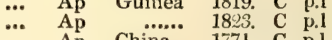

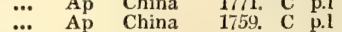
my.jn Ap Society I. 1793. C p.1 ... Ap Brazil 1823. C $p .1$ ... Ap E. Indies 1757. C p.I ... Ap C. G. H. 182џ. C p.l ... Ap S. Amer. 1780. C p.l mr.jn Ap E. Indies 1759. C p.1 hihee.mal,s.t.63 ... Ap S. Amer. 1812. C p.l $\ldots$ Ap W. Indies 1823. C p.l ... Ap E. Indies 1793. C p.l $\begin{array}{cccccc}\ldots & \text { Ap } & \text { E. Indies } & 1805 . & \text { C } & \text { p.1 } \\ \ldots & \text { Ap } & \ldots . . . & 1824 . & \text { C } & \text { p.I }\end{array}$ C pil Hook ex, f. 111 C p.I Rhee.mal.1.t.25

Ven.malm, t.114.

Kæm.amœ.t.8C4 Rhe?.mal.1.t.26

History, Use, Propagation, Culture,

2164. Bursera. So called after Joachim Burser, a disciple and friend of Caspar Bauhin, and professor of botany at Sara, in Naples. He is said to have left behind him an Herbarium, in twenty-five volumes. B. gummifera is a large tree with a fine leafy head, and abounds in copious watery balsamic fluid, which soon becomes inspissated by exposure to the air. The rost is said to possess the same vroperties as Quassia. Hedges are made of it by the Spanish residents in South America, who call it Almacigo.

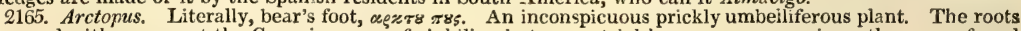
are used with success at the Cape, in cases of siphilis; but upon trial here some years since, they were found to be less efficient than Sarsaparilla.

2166. Panax. A high-sounding title, meaning little less than that the plant which bears it is the long 6ought universal elixir; the name has been taken from rov, and $\alpha=0$, a remedy; a remedy for all things. P. quinquefolium is a native of Chinese Tartary, and also of North America. In the former country it has been gathered as an invaluable drug from time immemorial. The roots, which are said to bear some resemblance to the human form, are gathered and dried, and enter into almost every medicine used by the Tartars and Chinese. Osbeck says, that he never looked into the apothecaries' shops, but they were always selling Ginseng, that both poor people and those of the highest rank made use of it, and that they boil half an ounce in their 
14389 Racemes axillary, Leaves pinnated with an odd one, Leaflets ovate acute

14390 Leaves prickly with stellate spines

14391 Stem herbaceous, Leaves ternate or quinate, Leafl. ovate acuminate serrated. 14392 Stem herbaceous, Leaves ternate or quinate, Leafl. oblong lanc. serrated

14393 Leaves ternate: the upper near the flowers clustered simple, Petioles and branches prickly

14394 Leaves supradecompound toothed-ciliated, Stem shrubby

14395 Leaves cordate 3-5-lobed repand-toothed : lobes blunt rough above downy beneath

14396 Ieaves ovate with a short point netted beneath very smooth

14397 Leaves oblong 3-lobed and sinuated entire rough on each side

14398 Leaves cordate roundish mucronate entire glabrous glaucous beneath

14399 Leaves ovate oblong entire acute blunt at base smooth

14400 Leaves subcordate ovate with very long points

14401 Leaves ovate entire very blunt rounded at base subcordate 5 nerved

14402 Leaves oblong ovate entire acute subcordate at base impressed with dots on the upper surface

$1+403$ Leaves oblong pointed smooth on both sides widely toothed, Branches covered with brown hairs

14404 Leaves oblong smooth narrowed at base cordate coriaceous, Veins immersed

14405 Leaves ovate blunt soft with down beneath

14406 Leaves ovate-cordate with a deep narrow sinus quite entire smooth acute green on each side

14407 Leaves ovate-cordate entire smooth blunt 3-nerved at base, Branches erect

14408 Leaves cordate oblong with a short point obtuse smooth with parallel nerves

14409 Leaves oblong-lanc. entire narrowed and acute at end rounded at base with white dots above

14410 Leaves obl. quite entire narrowed and acute at end rounded and subcord. at base: with punctures above

14411 Leaves ovate tapered at the base with a long point

14412 Leaves ovate-obl. entire acuminate blunt obsoletely cordate at base

14413 Leaves ovate unequal-sided toothed acuminate rough on each side

14414 Leaves ovate-lanc. entire slightly cordate at base

14415 Leaves cordate oblong entire nerved shining

14416 Leaves ovate-oblong bluntly serrate crenate hairy on each side

14417 Leaves oval acute serrated rough above soft beneath

14118 Leaves ellipt. entire rounded at each end smooth : young ones rusty with down beneath

14419 Leaves smooth elliptical entire shining very large

14420 Leaves oblong ovate blunt smooth, Fruit twin globose sessile

14421 Leaves oblong acuminate blunt tapered at base netted beneath, Stipules scarious

14422 Leaves ovate blunt entire cordate unequal at base, Stipules membranous twin persistent, Stem creeping

$14+23$ Leaves ovate bluntish entire netted beneath

14424 Leaves obliquely ovate blunt

14425 Leaves broad lanc. with a short point tapered at base shining very smooth netted beneath

14126 Lvs. ellipt. obl. ent. narrow. at base bluntly acum. at end with fine parallel veins; dotted with white above

$14+27$ Leaves cordate lanc. repand toothed obtuse downy beneath

14428 Leaves obl. acuminate entire narrowed at base about 3-nerved with parallel veins

14429 Leaves obovate entire with very short points and fine parallel veins shining smooth

14430 Leaves ovate acuminate entire acute at base

14431 Leaves obl, with short points entire smooth

14432 Leaves cordate ovate acuminate veiny very smooth, Fruit stalked globose smooth

14433 Leaves oblong-lanc. acute quite entire somewhat narrowed at base 3-nerved veiny dotted beneath

14434 Leaves obovate entire blunt smooth, Branchlets furrowed

14435 Leaves cordate ovate acute serrated unequal at base scabrous above hairy beneath, Stem creeping

14436 Leaves oblong acuminate tapered at base, Branches pendulous

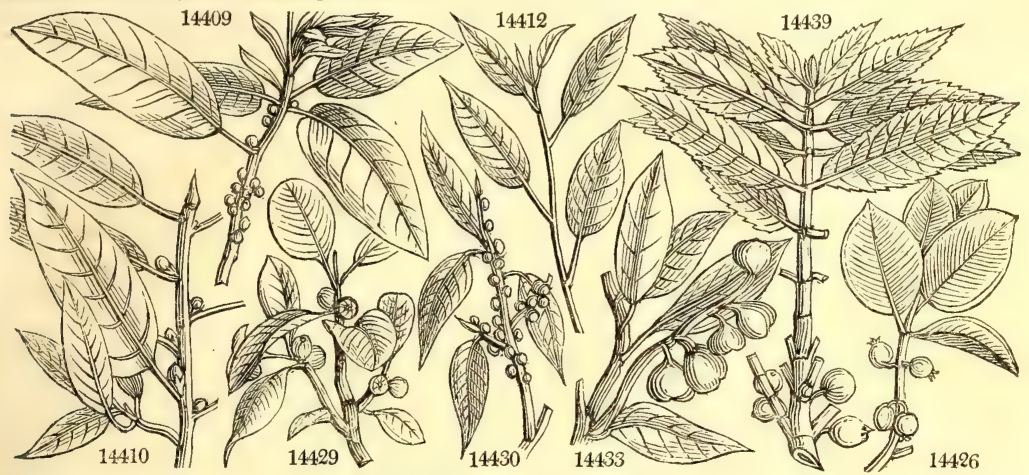

and Miscellaneous Particulars.

tea or soup every morning, as a remedy for consumption and other diseases, Jartoux relates, that the most eminent physicians of China have written volumes on the medicinal powers of this plant, asserting that it gives immediate relief in extreme fatigue, either of body or mind, that it dissolves pituitous humours, and renders respiration easy, strengthens the stomach, promotes appetite, stops vomiting, removes hysterical, hypochondriacal, and all nervous affections, giving a vigorous tone of body even in extreme old age. The French in Canada use this root for curing the asthma, and as a stomachic. After all, our physicians say, that we have no proofs of the efficacy of Ginseng in Europe, and that from its sensible qualities it seems to possess very little power as a medicine. The hardy species thrive well in light rich soil; the others grow in loam and peat, and are increased by cuttings in sand under a hand-glass

2167. Ficus. It is not known what the derivation of this word is; but in most languages it is nearly the same. In Greek it is ovxn, in Latin Ficus, in Celtic Figuezen, in Teutonic feige, in Sclavonic fige, in Hungian fwge, in Anglo-saxon fic. The species are trees or shrubs, abounding in a milky juice The fruit is turbinate, fieshy, soft, and hollow within. All the species are natives of warm countries. F. Carica, le figuier, Fr., Feigenbaum, Ger, and Fico, Ital., is supposed to be originally from Caria, in Asia, though it is now acclimatized, and in some respects naturalized in the Levant and 
14437 myrtifólia Link. 14438 áspera $W$

14439 oppositifólia $W$ scábra P. S.

14440 arbutifólia Link. 14441 capénsis $W$.

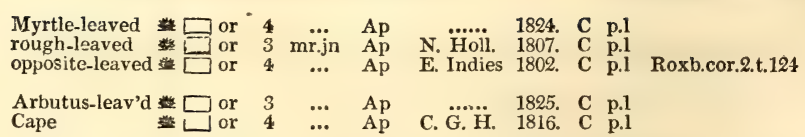

History, Use, Propagation, Culture,

the south of Europe. In these countries the fruit green and dried forms an important part of the food of the inhabitants. In this country it is cultivated as a fruit tree, but not generaliy or extensively. It is only in very warm situations that it will ripen its fruit in the open air, even though trained against a wall; though there are one or two exceptions in Sussex on the sea-coast, where it ripens its fruit on standards. The only certain mode, however, is to grow it in houses built on purpose. No tree is more robust or more prolific. Even plants in pots or tubs kept in a temperature adapted for the orange-tree will fruit freely, and ripen two crops a year. Kept in the temperature of the pine-apple, Mr. Knight has proved, that the fig will go on growing and ripening fruit without intermission. A variety of curious and important matter respecting this tree will be found in the Transactions of the Horticultural Society, and in the Encylo-

\section{Class XXIV. - CRYPTOGAMIA.}

\section{Sexual organs hidden; either imperfect, or not existing.}

THrs class differs essentially from all the preceding in the peculiar conformation of the organs of reproduc tion, which are not formed of male and female parts, like those of the higher classes of plarits, but are of a nature altogether different, consisting either of buds under a particular form, or of vessels containing vegetable substances analogous to seeds, but differing in not being the result of impregnation, and in having the power of striking root indifferently from any point of their surface. The internal composition of these vegetable substances, which are denominated sporules, is, on account of their extreme minuteness, unknown. Willdenow describes Cryptogamous plants to be vegetables without any visible flower, and differing from other plants in their external characters, in which respect they also differ from each other. By more modern botanists they their external characters, in which respect they also differ from each other. By more modern botanists they
are said to be distinguished from other plants by the absence of lymphatic vessels, and of pores of the epidermis; but the latter character has been disputed, and neither apply to the three first orders of Cryptogamia. For the purposes of this work, which follows the system of Linnæus, the definition, if it can be so called, of Willdenow is most applicable. In the arrangement of the orders of Cryptogamia, it has been found advisable to adhere to the divisions of modern writers, who, by extensive observations, and great powers of perception, have brought this most abstruse part of botany to a considerable degree of perfection.

The orders which are here adopted, are

I. FILICES. Reproductive organs uniform. Thecæ naked, or covered by an involucre, placed on the back of a frond, which is either foliaceous, or contracted in such a way as only to cover the clusters of thecæ, and always circinate when young.

II. Equisetace I. Reproductive organs uniform, in terminal spikes, composed of peltate, several-sided scales, producing on their under surface 4-7 elongated involucres containing the seeds. Branches whorled, rigid.

III. LxcopoDINEÆ. Reproductive organs axillary, sometimes apparently spiked. Thecæ? of two kinds, the one containing granules, the other larger bodies. Stems covered with many small leaves.

IV. Ma RsileaceA. Reproductive organs radical, uniform. Sporules? contained in roundish, one or manycelled indehiscent heads. Plants simple, aquatic.

V. Misci. Reproductive organs of two kinds. Thecæ many-seeded, solitary, furnished with an operculum and columella. Plants leafy.

VI. HEPATICE. Reproductive organs of two kinds. 1st. Thecæ without an operculum, either naked or sessile, or furnished with a veil, through which they are, more or less, protruded. Sporules naked, or mixed with spiral threads. 2d. Minute, roundish, or oblong bodies variously situated. Plants frondose, of a cellular structure, not submersed.

VII. Alg.E. Reproductive organs of two kinds. 1st. Thecæ or tubercles variously situated. $2 \mathrm{~d}$. Sporules or granules naked, or immersed in the frond. Plants always aquatic, and submersed.

VIII. Licienes. Reproductive organs uniform. Sporules deposited in receptacles of various forms, distinct in substance from the thallus, which is either pulverulent, erustaceous, membranous, foliaceous, or branched and shrub-like.

IX. Fungr. Reproductive organs uniform. Sporules arranged in tubular cells, placed in some part of the external surface. Substance various, mostly thick and fleshy, sometimes vesicular. Thallus none.

A few other divisions, such as Hypoxyla, \&c., which have been proposed by some writers of authority, nct having appeared to possess characters of sufficient importance, are here merged in others.

In consequence of the wide difference which exists between the lower orders of vegetables and the higher, and the impossibility of subjecting the former to cultivation, it has been found requisite, with the exception 
14437 Leaves oblong acute subcordate at base netted beneath

14438 Leaves ovate unequal-sided sinuate-toothed cordate at base rough on each side

14439 Leaves opp. obovate oblong serrated acute scabrous above hairy beneath

14440 Leaves oblong acuminate blunt tapered at base netted beneath, Stipules scarious smooth 14441 Leaves ovate-oblong acute sinuate toothed smooth

and Miscellaneous Particulars.

pædia of Gardening. ( $\$$ 4839.) F. elastica as well as some other plants produce the gum known as Indiarubber.

F. indica is an immense tree, spreading very wide, the branches ash-colored, and throwing down roots into the soil. Marsden mentions one of these growing near Memgee, twenty miles west of Patna, in Bengal, which was in diameter 370 feet; the circumference of the shadow at noon was 1116 feet, and there were fifty or sixty stems. It is called the priest's tree, and held in so much veneration by the Gentoos, that if any one cuts or ops off a branch, he is looked upon with as great abhorrence as if he had broken a cow's leg. F. religiosa is so called, because it is sacred to the idol Vishnu. The horizontal branches root into the soil like the other; all the species are of remarkably easy culture, and root easily from large cuttings.

of Filices and their nearest allies, to introduce some alterations into the form of the pages of this work. These alterations commence with Musci.

The orders of Cryptogamia being equal in importance to the classes of flowering plants, they will be treated of as the classes have hitherto been treated. Each order will, therefore, stand by itself, and will have its genera and species arranged under it, without immediate connection with any other order.

Order 1.

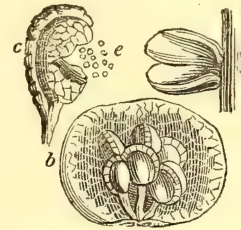

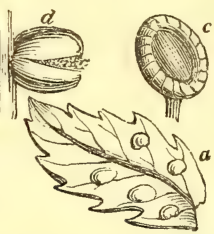

FILICES.

Reproductive organs uniform. Thecx naked, or having an involucre placed on the back of a frond, which is either foliaceous, or contracted so as only to cover the clusters of theca, and always circinate when young.

This is the most beautiful of all the orders of Cryptogamic plants, and has always been a favorite tribe, to which the most celebrated botanists of all modern times have given their attention. Till some time, however, after the death of Linnæus, ferns shared the fate of all other departments of botany, being viewed rather as objects of elegant form than of scientific examination. Sir James Edward Smith was the first author who attempted to distribute them into genera, by characters derived from a minute inspection of their organs of reproduction; and his arrangement, however imperfect it may now be considered, is certainly that upon the principles of which the more precise divisions of recent authors have been effected. He was succeeded by Swartz, Willdenow, Brown, and many others, and lastly by Dr. George Frederick Kaulfuss, Professor of Botany at Halle, whose arrangement of 1824 is chiefly here adopted as being the most recent which has been published.

The principal distinction which exists between ferns and other orders of Cryptogamous plants is found in the situation of what are called their sori, or patches of reproductive organs, which are in all cases inserted upon the back surface of the leaf, or, as it is called in ferns, the frond, sometimes appearing only in the form of little spots, sometimes covering the whole of the under side of the frond, and sometimes contracting the substance of the frond, so as to give it the appearance of a single mass of fructification, bursting in a determinate manner, as in Ophioglossum, Schizea, \&c. Besides this character, the fronds are always rolled up in a circinate manner when they are first developed

That part of the frond which occupies the place of the petiole of a compound leaf is called the rachis. The groups of thecæ forming the organs of reproduction are called sori $(a)$, which are either naked or covered with an involucrum, or, as it is more frequently termed, indusium. (b) This latter organ, when present, either bursts outwardly towards the margin of the frond, or inwardly towards the midrib or rachis. It may also be either single or double; the latter term signifying, that there is a cover on each side the sorus. The bodies which are called thece by some authors, and capsules by others, are constructed in two ways; they are either surrounded 
by an elast.c furrowed ring, when they are called Annulate (c), or they are destitute of such a ring, in which case they are termed Exannulate $(d)$. They contain the minute powdery matter, which is that by which ferns are reproduced; the constituent parts of this matter are called sporules $(e)$, and are analogous to seeds in more perfect plants.

\section{Tribe I. POLYPODIACEE.}

Thece 1-celled, with an articulated, elastical, longitudinal ring, bursting across in an irregular manner.

2168. Polybotrya. Thecæ closely covering the whole surface of the pinnules of an altered frond. Indusium none.

2169. Acrostichum. Thecæ scattered, occupying all the lower surface of the frond, or a part of it. Indusium none.

2170. Hemionitis. Thecæ seated on the reticulated veins of the frond. Indusium none.
2171. Gymnogramma. Thecæ seated on the forked veins of the frond. Indusium none.

2172. Meniscium. Sori linear, lunulate, somewhat parallel, placed across the spaces between the veins of the fronds. Indusium none.

2173. Xiphopteris. Sori oblong, oblique, placed on the reflexed points of the frond. Indusium none.

2174. Cetercich. Sori linear, transverse, concealed under paleæ. Indusium none.

2175. Polypodium. Sori in little round scattered convex spots. Indusium none.

2176. Tanitis. Sorus linear, longitudinal, placed between the midrib and margin of the frond under the end. Indusium none.

2177. Nothochlana. Sori almost marginal, continuous, covered by the scales, setæ, or hairs of the frond. Indusium none.

2178. Onoclea. Sori globose, inserted upon columnar receptacles, inclosed within the berry-like pinnules. Indusium double: common placed on the edge of the pinnule, and united into the form of a berry; proper membranous enwrapping the sori.

2179. Struthiopteris. Sori linear, crossing, inserted upon crested receptacles, included in a double row within the somewhat articulated pinnæ. Indusium double: common marginal opening inwards in a rugged manner; proper membranous, and resembling a partition.

2180. Allosorus. Sori placed on the transverse forked veins of spike-like pinnules, finally becoming confluent. Common indusium very narrow, arising from the revolute margin which is rolled inwaris.

2181. Ellebocarpus. Thecre globose, irregularly attached to the longitudinal veins of the frond. Indusium transparent, discolored, arising from the revolute edge of the frond, continuous, and opening by a longitudinal suture.

2182. Lomarix. Sori linear, continuous, occupying the surface of the linear pinnæ of a particular frond

Indusium marginal or submarginal, conniving, involute.

2183. Blechnum. Sori linear, continuous, (sometimes interrupted) contiguous to the midrib. Indusium membranous, superficial, continuous, opening inwards.

2184. Woodwardia. Sori oblong, distinct, in rows, parallel, contiguous to the midrib. Indusium membranous, superficial, vaulted, opening inwards.

2185. Doodia. Sori lunulate, distinct, parallel with the midrib. Indusium membranous, superficial, flat, separating inwardly.

2186. Asplenium. Soli linear, placed upon lateral veins. Indusium membranous, flat, separating inwardly.

2187. Allantodia. Sori oblong, oblique with respect to the midrib. Indusium membranous, vaulted, cylindrical, adhering to a vein, opening inwards, finally spreading outwards.

2188. Scolopendrium. Sori linear, oblique, opposite, double, parallel. Indusia membranous, opening in opposite pairs.

2189. Diplazium. Sori linear, double alongside the veins. Indusia double, narrow, placed between the sori, fixed lengthwise by the middle, with their exterior margin separate.

2190. Pteris. Sori continuous, linear, marginal. Indusium from the inflexed edge of the frond, opening inwards.

\section{POLYPODIACEA.}

2168. POLYbótiry A. $\boldsymbol{H}$ \& $\boldsymbol{B}$. Polybotrya. 14442 cervina Kaulf.

\section{Sp. $1-17$.}

s. ap.my Br

History, Use, Propagation, Culture,

2168. Polybotrya. So called in allusion to the numerous bunches of the fertile divisions of its frond; from

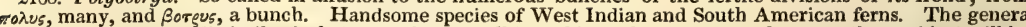
of ferns are not very dissimilar in habit, so that it will be seldom that any remarks upon that subject will be found in these notes, which must necessarily consist chiefly of the etymology of the names. The medical properties are probably the same in all the genera; such as appear of any consequence are, however, inserted in the proper places. We will here take occasion to remark, that the cultivation of ferns is nearly the same in all cases, and that the soil best adapted for their growth is light peaty earth with a little loam. They are propagated by division of the roots, or by seeds or sporules. The latter plan has been practised at Liverpool, 
2191. Vittaria. Sori solitary, continuous, linear, marginal or submarginal, immersed. Indusium double, superficial.

2192. Lonchitis. Sori lunate, marginal, placed under the recesses of the frond. Indusium from the margin of the frond, inflexed, opening inwards.

2193. Antrophyum. Sori linear, continuous, immersed in the reticulated veins of the frond, Indusium double, opening in the middle.

2194. Adiantum. Sori inserted into the indusium, linear, contiguous, or roundish. Indusium marginal, opening inwards, either nearly continuous, or squamiform, or reniform.

2195. Cheilanthes. Sori dot-like, separate, marginal in the recess of the indusium. Indusium either reflexed crenules of the frond, or squamiform, membranous, and arising from the margin, or nearly continuous, opening inwards.

2196. Davallia. Sori roundish, nearly terminal and marginal, distinct. Indusium superficial, attached inwards, and opening outwards.

2197. Dicksonia. Sori dot-like, marginal, solitary in the recesses of the frond. Indusia membranous, nearly globose, marginal, adnate, opening unequally with lacerated orifices, and spreading back in all directions.

2198. Balantium. Sori oblong-linear, nearly terminal and marginal, transverse. Indusium coriaceous, reniform, 2-valved, opening outwards : upper valve marginal, patera-shaped; lower nearly flat.

2199. Aspidium. Sori roundish, scattered. Indusium solitary, orbicular, peltate, or reniform.

2200. Woodsia. Sori dot-like, scattered. Indusium membranous, placed under the sori, somewhat paterashaped and ciliated.

2201. Cyathea. Sori globose, scattered, inserted upon an elevated receptacle, which arises from a division of the vein. Indusium spherical, opening in the middle, and finaliy becoming patera-shaped.

2202. Trichomanes. Sori marginal, inserted upon a long setaceous receptacle. Indusium erect, campanulate. 2203. Hymenophyllum. Sori marginal, inserted upon a claviform receptacle. Indusium erect, 2-valved.

\section{TRIBE II. OSMUNDACER.}

Thece without a ring, netted, pellucid, with radiating stria upon their top, bursting lengthwise on one side.

2204. Todea. Sori oblong, seated upon forked veins of an unchanged frond. Thecæ globose, stalked, netted, opening from their base as high as a pellucid dorsal projection. Indusium none.

2205. Osmunda. Sori nearly globose, alternately arising from the margin of a frond, which becomes changed into a panicle. Thecæ globose, stalked, netted, opening from their base as high as a pellucid dorsal projection. Indusium none.

2206. Lygodium. Thecr oblong-ovate, striated at the end in a radiate manner, seated in two rows upon 1-sided marginal spikelets, fixed by their backs and opening lengthwise in front. Indusium funnel-shaped, covering up each capsule.

2207. Anemia. Thecæ ovate, striated at the top in a radiated manner, disposed in compound unilateral spikes, attached by the base, and opening lengthwise. Indusium none.

\section{Tribe III. OPHIOGLOSSEE.}

Thece 1-celled, adnate at base, roundish, coriaceous, opaque, without a ring, not vascular, sometimes fastened together, half-bivalved.

2208. Botrychium. Thecæ naked, globose, distinct, attached to the rachis of a compound spike, half 2 -valved, opening nearly at one side.

2209. Ophioglossum. Thecæ naked, connate in a distichous jointed spike, half 2-valved, opening at the side.

2210. Marattia. Sori oval, somewhat marginal. Thecæ united in a double row, opening inwards by a cleft Indusium arched, opening lengthwise above, 2 -valved, inclosing on each side a row of thecæ.

\section{POLY PODIACEAE.}

$144\{2$ Ster. fronds pinnat. Pinn. ov. lanc. ent. margin. Fert. fr. bipinn. Pinnæ lin. Pinnul. obl. flatt. runn. together

and Miscellaneous Particulars.

by $\mathrm{Mr}$. H. Shepherd, with so much success, that his method has been made the subject of a communication to the Horticultural Society, of which the following is an extract. "Having provided a common garden-pot four and a half inches in depth, and three and a half wide, let the bottom part, to the height of one inch, be filled with fragments of broken pots, by way of drain. Over these should be spread a stratum of such soil as is commonly used for potting greenhouse plants, of the depth of two inches; the remaining inch and half should be filled with brown loamy earth sifted through a hair-sieve, the surface being made perfectly smooth, and on this the seeds are to be scattered as evenly as possible. Care must be taken that the wind be not suffered to blow the seeds away, leaving nothing but empty capsules. The seeds being sown, no other covering is 
2169. ACROS'TICHUM. $L$. ACrostichUM. 14443 simplex $W$. 14445 alcicórne $W$. 14416 sorbifólium $W$

14447 aúreu'n $L$. simple hairy $\mathbb{D}$ or 1 or $\quad \cdots \quad B$ Br

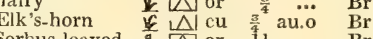
$\begin{array}{lllll}\text { Sorbus-leaved } & \frac{1}{\Delta} \text { or } & 1 \frac{1}{2} & \cdots & \mathrm{Br} \\ \text { golden } & \text { or } & 4 & \text { au } & \mathrm{Br}\end{array}$ golden

2170. HEMIONI'TIS, $L$. HeMIONITIS.

14448 palmáta $L$. palmated

$S p .1-$

$\frac{3}{4}$ jn.au Br

2171. GYMNOGRAM'MA. Desv. Grmnogramma. S $\mu, 6-26$.

14449 pedáturn Kaulf. pedate $f \Delta \mathrm{pr}$ i jn.jl $\mathrm{Br}$

14450 rúfum Desv. rusty-haired $\triangle$ pr $\frac{x^{2}}{j n}$.au Br Hemionítis rúfa W.

14451 trifoliátum Desv. three-leaved

14452 sulpháreum Desv. sulphury

$14+53$ tartáreum Desv. sultened Hemionitis dealbata W.

14454 calomélanos Kaulf. mealy Acrostichum calomelanos W.

Y $\triangle$ or 1 jl.au Br

$\triangle$ el 1 jn.jl $\mathrm{Br}$

$\triangle \mathrm{el} 1 \mathrm{au} \quad \mathrm{Br}$

f $\triangle$ el 1 jl.au $\mathrm{Br}$

2172. MENIS'CIUM. Schreb. Meniscium.

14455 reticulátum Schr. netted

2173. XIPHOP'TERIS. Kaulf. SwORD-FERN.

14456 serruláta Kaulf. serrulate $\mathbb{E} \bowtie \mathrm{pr}$ Grammitis serrulata W.

2174. CE'TER ACH. $W$. Ceterach.

2175. POLYPO'DiUM. L. Polypony.

14458 piloselloídes $W$. Mouse-ear

14459 lycopodioídes $\dot{W}$. Club-moss

14460 phyllitidis $W$.

14461 Lin'gua $W$

14462 aúreum $W$.

$\beta$ cámbricum

14464 virginiánum $W$

14465 pectinátum $W$.

14466 asplenifólium $W$

14467 incánum $W$.

14468 Phegópteris $W$.

14469 hexagonópterum $W$.

14470 pruinátum $W$.

14471 effúsum $W$.

14472 Dryópteris $W$.

14473 calcáreum $W$.

14474 crassifólium. $W$.

Hart's-tongue

tongue-leaved

golden

common

Welsh

Virginian

comb-leaved

$4 \Delta$ or

d. $\triangle$ or

riangular

white-leaved

spreading

\& $\Delta$ or

ved or

thick-leaved $\frac{3}{4}$ ap.my $\mathrm{Br}$ Sp. 1-2.

$\frac{1}{4}$ jn.jI Br

Sp. 1-4.

$\frac{3}{4}$ my.o $\mathrm{Br}$

Sp. 27-160.

$\frac{\pi}{4}$ au $\quad \mathrm{Br}$

2 jn.s $\quad \mathrm{Br}$

$1 \mathrm{my} . j \mathrm{Br}$

3 mr.ap $\mathrm{Br}$

my.o $\mathrm{Br}$

1 my.o $\mathrm{Br}$

$1 \frac{1}{2}$ jn.s $\mathrm{Br}$

2 jl Br

$\frac{1}{2} \mathrm{jl} \quad \mathrm{Br}$

jn.jl $\mathrm{Br}$

${ }_{2} \mathrm{jl} \quad \mathrm{Br}$

$\begin{array}{lll}2 & \mathrm{~s} & \mathrm{Br} \\ 3 & \mathrm{n} & \mathrm{Br}\end{array}$

1 jn.s $\mathrm{Br}$

$\frac{3}{4} \mathrm{jl} \quad \mathrm{Br}$
Jamaica 1793. D 1.p Bot. cab. 709 W. Indies 1793. D l.p Plum. fil. t. 125 N. S. W. 1808. R s.p Bot. reg. 262-3 Indies 1793. D l.p Plum. fil. t. 117 W. Indies 1815. D l.p Plum. fil. t. 104

W. Indies 1793. D l.p Hook, ex. fl. 33

N. Spain 1822. D l.p Sw.syn.fil.t.1.f. Jamaica 1793. D 1.p Schk. fil, t.17.21

Jamaica 1810. D 1.p Plum. fil. t. 144 Jamaica. 1808, D l.p Schku, crypt. t. W. Indies 1817. D l.p

W. Indies 1790. D s.p W. hort. ber. 41

Martinico 1793. D l.p Plum. fil. t. 110

W. Indies 1823, D 1.p Schku. crypt. t.7

Britain cal.ro. D 1.p Eng. bot. 1244

W. Indies 1793. D 1.p Plum. fil. t. 118 W. Indies 1793. D l.p Schk. fil. t. 8. c.p W. Indies 1793. Sk s.p Plum. fil. t. 130 China 1817. D l.p Thunb. jap. t. 38 W. Indies 1742. Sk s.p Plum. fil. t. 76 Britain sha.ba. D l.p Eng. bot. 1149 Britain ... D l.p Bolt. fil. t.2. f.5.a N. Amer. ... D 1.p Plum. fil. t. 77 W. Indies 1793. Sk s.p Bot. cab. 748

Martinico 1790. Sk s.p Plum.fil.t.102.A N. Amer. 1811. D l.p Schk, fil.t. 11. b Britain moun. D l.p Eng, hot, 2224 N. Amer. 1811. D 1.p Pluk.al. t.284.f.2 Jamaica 1793. D l.p

Jamaica 1769. Sk s.p Slo.jam.1.t.57.f.3 Britain moi.pl. D l.p Eng. bot. 616

Britain cal.ro. D 1.p Eng. bot. 1525

W. Indies 1823. D l.p Plum. fil. t. 123

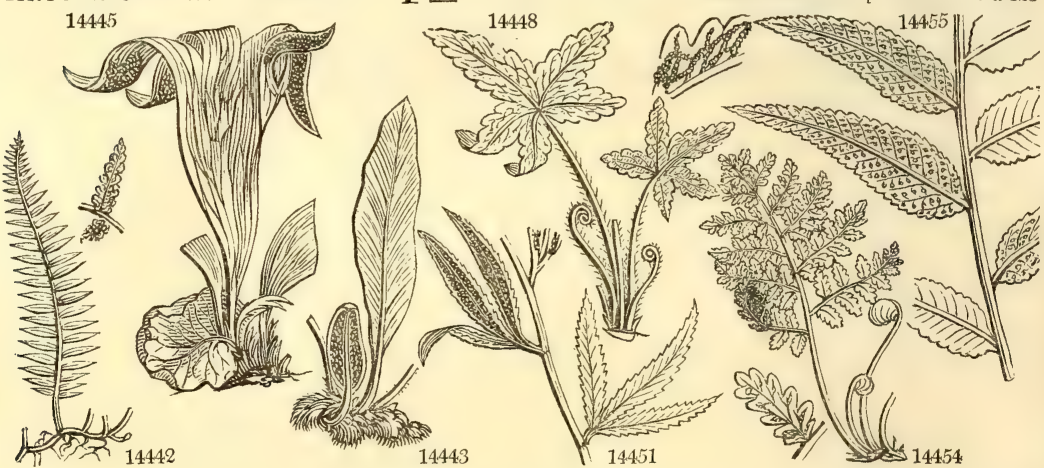

History, Use, Propagation, Culture,

required than a bell-glass, which should just fit within the rim of the pot, so as to exclude all air. The pot is then to be kept in a pan always half full of water, and set in a shady part of the stove or hot-house, being always regularly watered as above directed. When the young plants have acquired their second leaf, it is proper to give them a little air, by placing a small piece of wood under the edge of the glass, at one side. In a short time afterwards the glass may entirely be removed."

The vegetation of ferns appears to be less tardy than botanists have supposed. Specimens of Gymnogramma tartareum having been brought from Jamaica to Liverpool, on the tenth of July 1817, a few seeds were brushed off them and sown immediately. Several plants thus obtained perfected seeds by the fifth of August 1818, which being committed to the earth, had produced young plants, covering the surface like a fine moss, by the eighth of September following. Specimens of Pteris cretica, and another marked Pteris acrostichoides, from William Jackson Hooker, Esq., afforded seeds which have vegetated and produced very fine plants of both species. Dr. William Carey sent from Serampore specimens of Polypodium giganteum, and what appears to be a new Diplazium. These reached Liverpool, July the tenth 1818; their seeds being immediately sown, had produced ycung plants by the eighth of September. A small fern from Sicily, with several others of this tribe, collected in the Brazils by William Swainson, Jun., Esq., afforded ripe seeds, which being sown in the spring of 1818 , had partly vegetated, and in September had produced Polypodum decumanum, as well as Gymnogramma calomelanos. Mr. Shepherd obtained two plants of the latter from seeds brushed from the specimens in the Herbarium of Dr. John Reinhold Forster, now belonging to the botanic garden at Liverpool, and perhaps fifty years old. He made the experiments on other ferns in that collection, but without success, which, indeed, is not wonderful.

The seeds of this order of plants are of course liable to damage from damp or other accidents, like those of plants in general. It seems, moreover, that they are very soon shed by the bursting of their capsules, so that 
14443 Fronds lanceolate tapered each way smooth : fertile linear lanceolate, Stalks very short naked 14444 Fronds elliptical obtuse at each end hairy villous at the edges, Stalk villous

14445 Ster, fronds renif, somew. lobed entire horizontal : fert, ereet palmate dichotom. bearing fr. on lanc, segm. 14446 Fronds pinnated : pinn. lanc. acumin. serr. cuneate at base, Fert. pinn. : pinn. linear entire, Stem climbing 14447 Fronds pinnated: pinn. altern. obl. lanceolate ent. cuneate and equal at base, all acum. : the upper fertile

14448 Fronds cordate 5-lobed toothed ciliated, Stalk long

14449 Fronds pinnate : pinnæ pinnatifid acuminate hairy

14.50 Fronds pinnate: pinnæ oblong acutish subcordate subserrate on each side as well as the stalk hairy

14451 Fronds pinnate : pinnæ ternate in pairs and solitary stalked lin. crenul, ; fertile yellow with meal beneath 14452 Fronds bipinnate: pinnulæ pinnatifid; segm, cuneate truncate at end toothletted yell. with meal beneath 14453 Fronds bipinnate : upper pinn. confluent obl. obt. serrul, ; lower somew. pinnatif. white with meal beneath

14454 Fronds bipinnate : pinn. lanc. white with meal beneath ; lower pinnatifid auricled at base, upper confluent

14455 Fronds pinn. : pinn. lanc acuminate cuneate at base all repand : lower opposite, Stem none

14456 Fronds linear toothed when fructifying entire at the end, Stem filiform ascending simple

14457 Fronds pinnatifid : segm. oblong obtuse chaffy with entire paleæ beneath

14458 Fronds hairy : sterile oblong ovate entire ; fertile lanceolate, Sori solit. Stem filiform rooting chaffy 14459 Fronds lanceolate entire smooth, Sori solitary, Stem filiform creeping with bristly paleæ

14460 Fronds lanceolate margined acute tapered at base smooth, Sori in two rows

14461 Fronds oblong obtuse entire smooth above rusty with down beneath, Sori contiguous copious

14462 Fronds deeply pinnatifid glaucous: segm. lanc. acuminate entire, Lower sori scattered ; upper solitary

14463 Fronds deeply pinnatifid : segm. lin. lanc. blunt crenul. contig. : upper smaller by degrees, Sori solitary

14464 Fronds deeply pinnatifid : segm. lanc. blunt entire contig. ; upp. smaller by degrees, Sori solit. Stalk naked 14465 Fronds deeply pinnatifid : segm. lanc. acute entire parallel smooth; upper and lower smallest, Sori solitary 14466 Fronds pinnatifid hairy : segments half ovate blunt, Sori solitary

14467 Fronds deeply pinnatifid : segm altern. lin. ent. obt.; upper smaller by degrees ben. as well as stalk chaffy 14468 Fronds bipinnatif. : 2 lower pinnæ defl.; segm. lin..lanc. blunt ent. ciliat. Veins hairy, Sori solit. marginal 14469 Fronds downy and ciliated bipinnatifid, Membranes connecting the opposite pinnæ oblong hexagonal

14470 Fronds 4-pinn. Branches and branchlets lanc. Pinnæ lanc. pinnatifid, Segm. ovate acute glaucous beneath 14471 Fronds 3-pinn. : pinnulæ pinnatif.; segm. lin. serrat. acute, Rachis edged naked, Sori solit. Stalk smooth 14472 Fronds ternate bipinnate spreading deflexed: segments blunt nearly entire, Sori marginal, Root filiform 14473 Fronds ternate bipinnate straight rigid: segments bluntish nearly entire, Sori marginal confluent

14474 Fronds oblong smooth entire margined acute at each end, Sori in rows

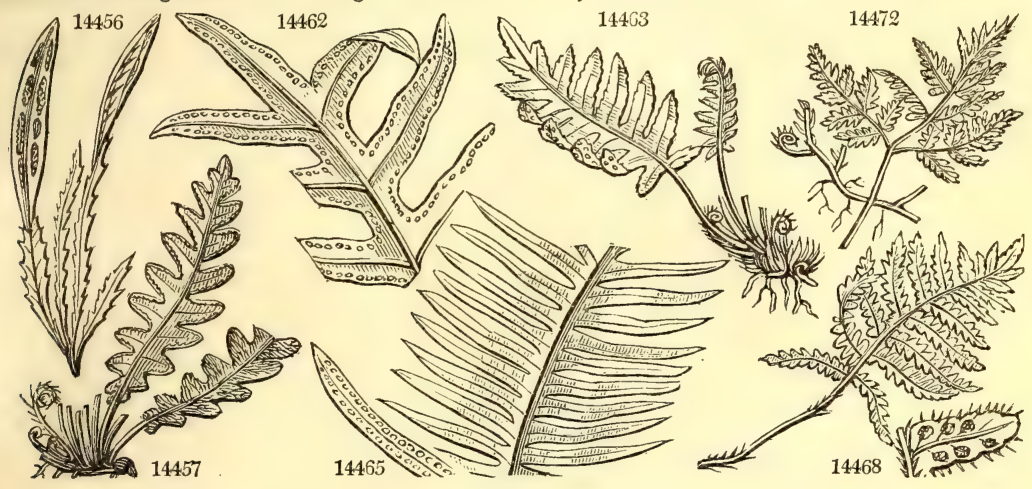

and Miscellaneous Particulars.

they are more likely to be found in such specimens as are just beginning to turn brown in their fructification, than in others more advanced.

2169. Acrostichum. Said to be formed from the words azoos 56\%os, the commencement of a verse, and to have been so called because the reverse of their leaves indicates traces of lines, resembling the beginning of lines of poetry. These are fine, chiefly tropical, ferns, one of which, A. aureum, sometimes grows to the height of five or six feet.

2170. Hemionitis. Said by Dioscorides to be so called from the resemblance of its nature to that of a mule, ทं usovos; it was always considered sterile, bearing neither flowers nor fruit.

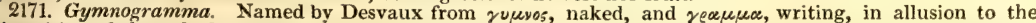
disposition of the naked sori upon the forked veins of the frond, whence they seem to resemble Roman letters. The species have been separated from Hemionitis and Acrostichum.

2172. Meniscium. From $\mu$ nv, the moon; the sori are crescent-shaped. These ferns are remarkable for the arrangement of their veins. The little veins which unite the transverse veins of the sterile frond are usually at right angles, and generally united with each other by a little branch which sets off from one or other of their angles. In the fertile fronds the veins on which the sori are placed are either curved or straight.

2173. Xiphopteris. Divided from Grammitis by Kaulfuss, who seems to have named it from $\xi \iota 05$, a sword, and $\pi \tau \varepsilon e v \xi$, a fern, on account of the sword-like form of their fronds.

2174. Ceterach. The name employed by the Arabian and Persian physicians for this plant was Chetherak. (Gaxoph. Ling. Pers. p. 377.) They employed the plant in obstructions of the viscera, for the jaundice, and for disorders of the spleen.

2175. Polypodium. From roגes, many, and r8s rodos, a foot, on account of the multitude of the roots which form close entangled patches. Many of the species of this genus are noble plants. They are mostly epiphytic 

14481 sérpens $\dot{W}$.
14475 decumảnum $W$. 14476 fraxinifólium $W$. 14477 lanceolátum $W$. 14478 phymatódes $W$. 14479 quercifólium $W$. 14480 répens $W$ 14482 tæniósum $W$ 14483 pertúsum 14484 crenátum $W$

tall

ash-leaved

lauceolate

red

oak-leaved

creeping

gliding

jointed

2176. T⿸广 ${ }^{\prime}$ NITIS. Swz. Tenitis. 14485 lanceoláta Kaulf. lanceolate

2177. NOTHOCHLE'NA. $R . B r$.

14486 lanuginósa Desv. woolly Acróstichum vel'leum W.

2178. ONOCLE'A. L. ONOCLEA. 14487 sensibilis $W$. 14488 obtusilobáta $S c h k$. obtuse-lobed
Tothochlana. Sp. $1-16$.

14489 germánica $W$. Russian or 2 jl.au

14490 pensylvánica $W$. Onoclea-like $\quad \neq \Delta$ or 2 au $\quad \mathrm{Br}$

2180. Alloso'RUS. Bernh. Allosorus.

14491 crispus Bernh. Pteris críspa L.

curled

2181. ELLOBOCAR'PUS. Kaulf. PoD-Fern.

14492 oleráceus Kaulf. eatable

2182. LOMA'RIA. $W$. Lomaria.

14493 longifólia Kaulf. long-leaved

2183. BLECH'NUM. $L$. BLECHNUM.

14494 boreále $W$.

14495 austrále $W$. northern

Cape

2184. WOODWAR'DIA. $S m$. WoODWARDIA

14497 rádicans $W$ rooting-leaved $\mathcal{N}$ or

14498 virgínica $P h$. Virginian $\$ \nabla$ or

Sp. $1-3$.

2186. ASPLE'NIUM. $L$. SPleEnwort. Aspídium fontánum E. B.

14501 Filix-fo'mina $R$, Br female 14502 Adiántum-nígrum $W$. black

14503 montánum $W$. mountain

14504 lanceolátum $\dot{W}$. Janceolate

14505 frágrans $W$. fragrant

14506 Ruta-murária $W$. Wall-rue
\& $\mathrm{D}$ el 5 au

N 2 au

夜 or $\frac{1}{2}$ jn.au

If $\square$ or $1 \frac{1}{2}^{2}$

․ 1 my.jn $\mathrm{mr}$

을 2 my.jn Br

Tit pr ja.d Br

I $\square$ pr $1 \frac{1}{2}$ au $\mathrm{Br}$

ํㅠ $\left[\mathbb{Z}\right.$ pr $1 \mathrm{au}^{S p .1-5 .} \mathrm{Br}$

If $\triangle$ or $\quad \frac{3}{4}$ au.s $\quad B r$

$\downarrow \Delta$ or $1 \frac{1}{2} \mathrm{au}^{2 .} \mathrm{Br}$

Sp. 2.

jl.au $\mathrm{Br}$

Sp. 1-2.

c $\triangle \square$ or

au B

Sp. 1-20.

in $\square$ or 2 jn.jl Br

Sp. 3-29.

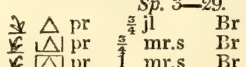

Britain hea. D l.p Eng. bot. 1159

C. G. H. 1691. R s.p Schk. fil. t.110. b

S. Amer. 1777. R s.p Jac. ic. 3. t. 644

Sp. $2-7$.

$1 \frac{1}{2} \mathrm{~s} \quad \mathrm{Br}$

1 au.s Br

mr.s $\mathrm{Br}$

Sp. 27-117.

$\frac{3}{4} \mathrm{jn} . \mathrm{au} \quad \mathrm{Br}$

Brazil 1818. D l.p

Caraccas 1817. D l.p Jacq. ic. t. 639

Indies 1812, D l.p Plum. fil. t. 137

E. Indies 1823. D l.p Plu. phyt.404.f.5

D l.p Rumph.6. t. 36

W. Indies 1816. D 1.p Plum. fil 121

S. Amer. 1815. D 1.p

1821. D 1.p Hook. ex. fl. 162

W. Indies 1818. D l.p Plum. fil. t. 132

Madeira 1778. R s.p Desf. atl.2.t. 256

Virginia 1799. D l.p Schk. fil. t. 102 . Amer. 1812. D l.p Schk. fll. t. 103

Europe 1760. D l.p Schk. fil, t. 105 N. Amer. 1812. D 1.p Schk. fil. t. 111

Madeira 1779. R s.p Schk. fil. t. 112 N. Amer. 1774. D 1.p Plu.alm.t.179.f.2 N. S. W. 1808. R s.p England w. \& r. D l.p Eng. bot. 2024

$\$ \Delta$ or 2 jn.s Br Britain w.sh.pl. D l.p Eng. bot. 1459 \} \triangle \text { pr } 1 \text { ap.o Br Britain sha.pl. D l.p Eng. bot. } 1 9 5 0 \& $\triangle \mathrm{pr} \frac{1}{3} \mathrm{jl} \quad \mathrm{Br} \quad \mathrm{N}$. Amer. 1812. D l.p $\triangle \triangle$ pr $\frac{1}{2}$ jn.s Br England rocks. D l.p Eng. bot. 240

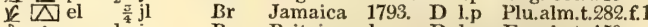
₹ $\triangle$ cu $\frac{2}{3}$ jn.o Br Britain sh.roc. D l.p Eng. bot. 150

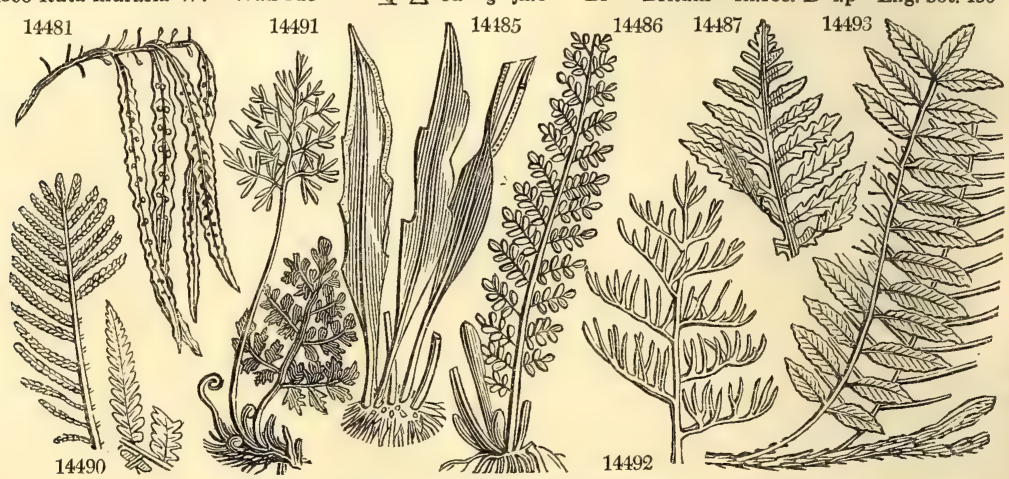

History, Use, Propagation, Culture,

upon trees. Polypodium vulgare is sometimes burnt for the sake of its ashes, which contain a large proportion of carbonate of potash, which is employed in the fusion of flint for some kinds of glass-ware.

2176. Tanitis. From the resemblance of the interrupted line of sori to the tania or tape-worm.

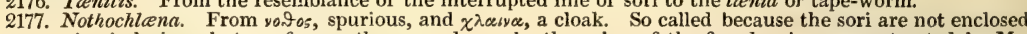
in a genuine indusium, but are frequently covered over by the paleæ of the frond. A genus extracted by Mr. Robert Brown from the ancient Acrostichum.

2178. Onoclea. A name given by Dioscorides, Pliny, and Galen, to a Boragineous plant, and strangely appliec by the moderns to a genus of ferns. $O$. sensibilis has been so called from the delicacy of its frond, which is so impatient of injury as to perish with almost the least violence.

2179. Struthiopteris. Named from Flovitos, an ostrich, and $\pi \tau \varepsilon \rho$, a fern, on account of the similarity between its fine fronds and the feathers of an ostrich. A genus divided from Osmunda by Willdenow.

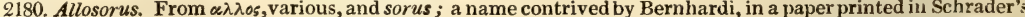
Journal, we presume in allusion to the different states of the sori at different periods. A curious little rock ylant.

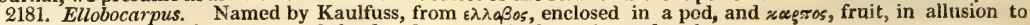
the pod-like form of the divisons of the fronds on which the sori are placed. 
14475 Fronds deeply pinnatifid glaucous : segments lanceolate acuminate repand serrate, Sori in rows 14476 Fronds pinnate, Leaflets lanceolate acuminate repand wavy distant

14477 Fronds lanceolate entire smooth or somewhat scaly rigid erect, Sori solitary

14478 Fronds simple 3-lobed and pinnatifid: segments lanceolate acuminate opposite, Sori scattered immersed 14479 Sterile fronds sessile ovate sinuated : fertile pinnatifid; segments lanceolate

14480 Fronds on a creeping stem lanceolate acuminate entire sublucid with flexuous veins, Sori scattered

14481 Sterile fronds oblong entire : fertile linear lanceolate repand, Sori solitary, Stem paleaceous rooting

14482 Fronds linear lanceolate much tapered at the base somewhat repand quite smooth, Sori scattered

14483 Ster. fronds obl. lanc. taper, at base : fert. lin.-lanc. bear, sori on upp. half, Sori oval immers. in dense wool

14484 Fronds pinnate, Pinn. somewhat stalked oblong acuminate coarsely and bluntly serrated, Sori in rows

14485 Fronds simple lanceolate acute at each end nearly entire fructifying at end

14486 Fronds bipinnate woolly : pinnules elliptical obtuse covered all over with long wool

14487 Pinnæ lanceolate acute cut toothed: pinnules and rachis smooth

14488 Pinnæ pinnatifid with rounded lobes : pinnules villous, Rachis scaly

14489 Sterile fronds bipinnatifid : segments entire acute equal

14490 Sterile fronds bipinnatifid : segments entire obtuse ; lower long acute

14491 Fronds supradecompound, Pinnæ alternate roundish cut

14492 Alternate pinnæ pinnulate on the upper-side linear : lower 2-parted

14493 Sterile pinnæ long-lanceolate acuminate cuneate at base repand-toothed : fertile linear

14494 Fronds pinnated smooth, Pinnæ linear bluntish entire nearly equal at base

14495 Fronds pinnated, Pinnæ linear-lanceolate mucronate auricled at base scabrous at edge

14496 Fronds pinnated, Lower pinnæ opposite lanceolate entire subcordate at base : upper alternate united

14497 Fronds pinnate-pinnatifid : segments lanceolate acuminate somewhat repand finely serrulate

14498 Fronds very smooth pinnate, Pinnæ sessile lanceolate pinnatifid, Segments oblong blunt crenulate

14499 Fronds lanceolate pinnatifid : segm. linear ensiform acuminate spinulose, Sori lanceolate in two rows

14500 Fronds pinn. : pinnæ cordate pinnatifid; segm. ovate rather acute, lower and terminal usually 3-lobed

14501 Fronds bipinn. : pinnules obl. lanc. cut serrated : serratures 2 or 3-toothed nearly acute, Sori obl. straight 14502 Fronds bipinn. : pinnæ obl. lanc. acute ; pinnules oblong pinnatifid cut, Sori becoming confluent

14503 Fronds bipinn. : pinnules pinnatifid; segments 3 or 2-toothed

14504 Fronds bipinn. : pinnules obovate blunt cuneate at base acutely toothed at end, Sori becoming confluent 14505 Fronds bipinn. : pinnules oblong acute at each end serrated at end : upper confluent

14506 Fronds alternately decompound : pinnæ rhomboid cuneiform spreading bitten at end

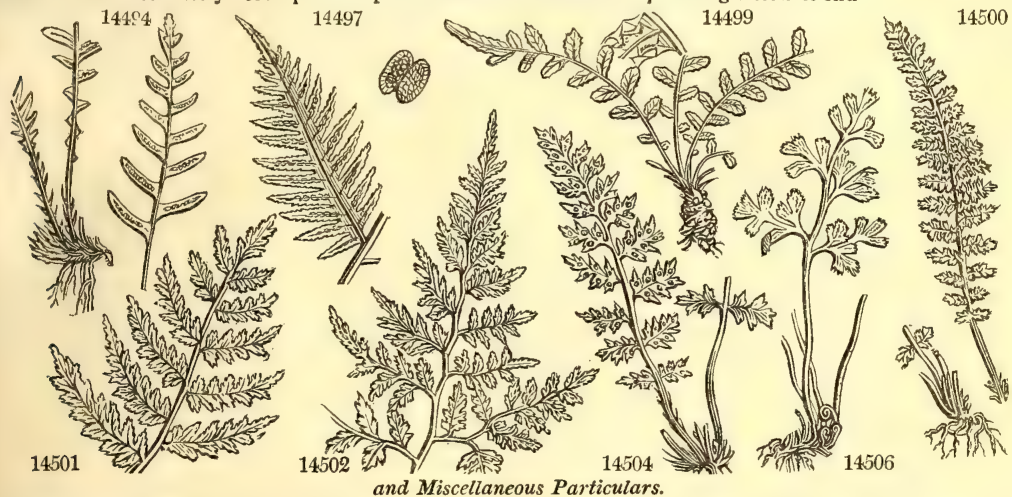

2182. Lomama. From $\lambda \omega \mu \alpha$, an edge, on account of the marginal position of the indusia. These are fine plants, resembling Acrostichum in habit

2183. Blechnum. One of the Greek names of the fern was $\beta \lambda \varepsilon \chi$ yoy. Athenæus writes it $\beta \lambda \propto \chi v o y$, and derives it from $b_{\lambda \omega \xi}$, powerless, insipid.

2184. Woodwardia. Named by Sir James Smith, after his friend Thomas Jenkinson Woodward, Esq., a good practical English botanist. One of the species produces little hairy bulbs at the axillæ of the leaves, which either fall off and strike root in the ground, or vegetate while attached to the parent plant. This property is common to many other ferns, and in one instance, the young plants so produced have been mistaken in Pteris cornuta for parasites by an acute cryptogamic botanist.

2185. Doodia. So called in honor of Samuel Doody, a London apothecary, who was almost the first investigator of British cryptogamic plants. Small rough-leaved ferns of rigid texture.

2186. Asplenium. From $\alpha$, privative, and $\sigma \pi \lambda \eta y$, the spleen. This plant was formerly held to be a sovereign remedy for all diseases of this organ, and to be so powerful as even to destroy it if employed in excess. 
14507 præmórsum $W$. 14508 striátum $W$. 14509 rhizóphorum $W$. 14510 víride $W$.

14511 melanocaúlon $P h$. 14512 Trichómanes $W$. 14513 alternifólium $\mathrm{Sm}$. 14514 ebéneum $P h$. 14515 monánthem
14516 Nidus $W$. 14517 marínum $W$.

14518 angustifólium $W$ 14519 septentrionále $W$ 14520 rhizophýllum $W$ 14521 serrátum $W$. 14522 biséctum $S w z$ 14523 púmilum $W$. 14524 zamiæfólium $w$. 14525 acútum $W$. 14526 palmátum $W$.

snip-leaved striated root-bearing green

f $\square$ el $\frac{3}{4}$ au $\mathrm{Br}$

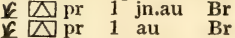
$\triangle$ pr $\frac{1}{3 n} . \mathrm{s}$. Br $\triangle \mathrm{pr} \quad \mathrm{x} \mathrm{jl} \quad \mathrm{Br}$ $\Delta \mathrm{pr}$ my.o $\mathrm{Br}$ $\triangle \mathrm{cu} \frac{\mathrm{x}}{9}^{2}$ jn.o $\mathrm{Br}$ $\triangle$ or ${ }^{\frac{3}{4}} \mathrm{~s} \quad \mathrm{Br}$ $\triangle \mathrm{Al} \mathrm{cu} \quad 1^{2} \mathrm{jl} \quad \mathrm{Br}$ $\triangle \mathrm{D}$ el 2 au $\checkmark \Delta$ or $\frac{1}{2}$ jn.o $\Delta$ el 1 jn.jl or 1 jno $\mathrm{Br}$ $\triangle$ cu $\frac{3^{\frac{1}{2}}}{4} \mathrm{jn} . \mathrm{jl} \quad \mathrm{Br}$ $\triangle \mathrm{pr} \quad \mathrm{A}_{\frac{2}{2}} \quad \ldots . \mathrm{Br}$ $\triangle \mathrm{D}$ or $1 \frac{1}{2}$ au एٓ pr ${ }^{\frac{1}{2}} \mathrm{jn} . \mathrm{jl}$ $1 \frac{1}{2}$ jn.s $\mathrm{Br}$ $\triangle \mathrm{N}$ or $\frac{3}{4}$ au.s $\mathrm{Br}$ 2187. Allan'TO'DIA. $\boldsymbol{R}$. $\boldsymbol{B} r$. Allantodia. 14527 axilláris Kaulf. 14528 umbrósa $R$. Br. Madeira

2188. SCOLOPEN'DRIUM. Smith. 14529 officinárum Swz.

$\begin{array}{ll}\beta \text { crispum } & \text { common } \\ \gamma \text { undulátum } & \text { wave-leaved } \\ \delta \text { multifidum } & \text { clustered } \\ \varepsilon \text { ramósum } & \text { branching }\end{array}$

2189. DIPLA'ZIUM. Swz. Diplazium.

14530 grandifólium $W$. large-leaved 14531 auriculátum Kaulf, auricled

2190. PTE'RIS. $L$. 14532 longifólia $W$. 14533 grandifólia $W$ 14534 serruláta $W$. 14535 atropurpúrea $W$. 14536 argúta $W$. 14537 aculeáta $W$. 14538 esculénta Swr. 14539 caudáta $W$. 14540 aquilína $W$. 14541 podophýlla $W$. 14542 crética $W$. 14543 hastáta $W$. 14544 palmáta $W$. 14545 pedáta $W$.

14546 Plumiéri Link.

BRAKE.

\section{long-leaved}

large-leaved

various-leaved purple

sharp-notched prickly-stemm.

esculent

American

common

pedated

Candian

hastate

palmate pedate

Plumier's

2191. VITTA'RIA. Sm. Vittaria.

14547 lineáta $W$.

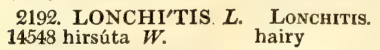
Hemionitis lanceoláta $\mathbf{L}$.
Hart's Tongue. Sp. 1.

\& $\triangle$ cu $1 \frac{1}{2}$ jl.au

$\triangle 1$, $\mathrm{Br}$

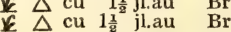

$\triangle \mathrm{cu} 1 \frac{1}{2} \mathrm{jl} . \mathrm{au} \quad \mathrm{Br}$ $S p .2-13$. $\Phi$ or 10 au $\quad \mathrm{Br}$ (c) $2 p .15-37$. D or 2 au $\quad \mathbf{B r}$ $\triangle$ pr $1 \frac{1}{2}$ au.s Br $\frac{1}{6} \Delta$ pr $\frac{x}{1}$ au.s $\quad \mathrm{Br}$ $\square$ or 10 au.s $\mathbf{B r}$ $\checkmark \mathrm{N}$ or 3 au.s $\mathrm{Br}$

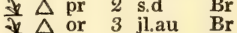
v $\triangle$ or or ${ }_{1} \frac{1}{2}$ jn.jl $\quad$ Br $\checkmark \mathrm{cu} 1 \mathrm{jl}$.au $\mathrm{Br}$ N $\triangle$ or 2 jl.s Br D or $\frac{3}{4}$ jn.au Br

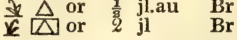
Sp. 1-10.

$\triangle \mathbb{c u} \quad 2$ au $\mathrm{Br}$ Sp. $1-5$, $\mathbb{1} \square$ pr 1 jn.s Sp. $1-8$.
Jamaica 1793, R s.p Plu.alm.t.73, f.5 W. Indies 1793. R s.p Plum.fil.t.18, 19 Jamaica 1793. D 1.p Sl.ja.I.t.29,30.f.1 Britain al roc. D l.p Eng. bot. 2257 N. Amer. 1812, D l.p Britain sh.roc. D 1.p Eng. bot. 576 Scotland ... D l.p Eng. bot. 2258 N. Amer. 1779. D l.p Schk. fil. t. 73 C. G. H. 1790. D l.p Smith ined. t. 73 E. Indies 1820. D l.p Breyn. cent. t.99 Britain rocks. $R$ s.p Eng. bot. 392 N. Amer. 1812. D l.p Schk.fil. t. 67.69 Britain rocks. D l.p Eng. bot. 1017 N. Amer. 1680. D j.p Pluk.al. t.105.f.3 W. Indies 1793. D 1.p Schk, fil, t. 64 Jamaica 1821. D 1.p W. Indies 1823. D l.p Plum.fil. t.66. A. Caraccas 1820. D 1.p Teneriffe 1818. D l.p S. Europe 1816. D 1 p Bot. cab. 868

Madeira 1779. D 1.p

Madeira 1779. D 1.p Schk. fil. t. 61

$\begin{array}{cccc}\text { Britain } & \text { m.s.pl. D l.p } & \text { Eng. bot. } 1150 \\ \text { Britain } & \ldots & \text { D l.p } & \\ \text { Britain } & \ldots & \text { D l.p } & \text { Plu.phyt.248. f.1 } \\ \text { Britain } & \ldots & \text { D l.p } & \\ \text { Britain } & \ldots & \text { D l.p } & \text { Plu.phyt.248. f.1 }\end{array}$

Jamaica 1793. D 1.p Caraccas 1820. D l.p

W. Indies 1770. Sk s.p J.sch.3.t.399,400 W. Indies 1793. Sk s.p Schk. fil. t. 89 India 1770. Sk s.p Schk. fil. t. 91 N. Amer. 1770. D l.p Schk. fil. t. 101 Madeira 1778. D 1.p Plu.alm.t.290.f.2 W. Indies 1793. D 1.p Plum. fil.t.5.et11 N. S. W. 1815. D 1.p La.n.hol.2. t.244 N. Amer. 1777. D l.p Jac. ie. 3. t. 645 Britain hea.w. D l.p Eng. bot. 1679 Jamaica 1793. D 1.p Brow. jam.89.t.1 Candia 1820. D l.p Schku.crypt.t.90 C. G. H. 1823. D 1.p Pl. phyt.t. $403 . f .5$ Caraccas 1821. D l.p

Virginia 1820, D l.p Plum, fil t. 152 S. Amer, 1818. D 1.p

America 1793. D l.p Schk, fil.t. 101.b. W. Indies 1793. D 1.p Schk. fil. t. 86

W. Indies 1793. D l.p Schk. fil, t. 6

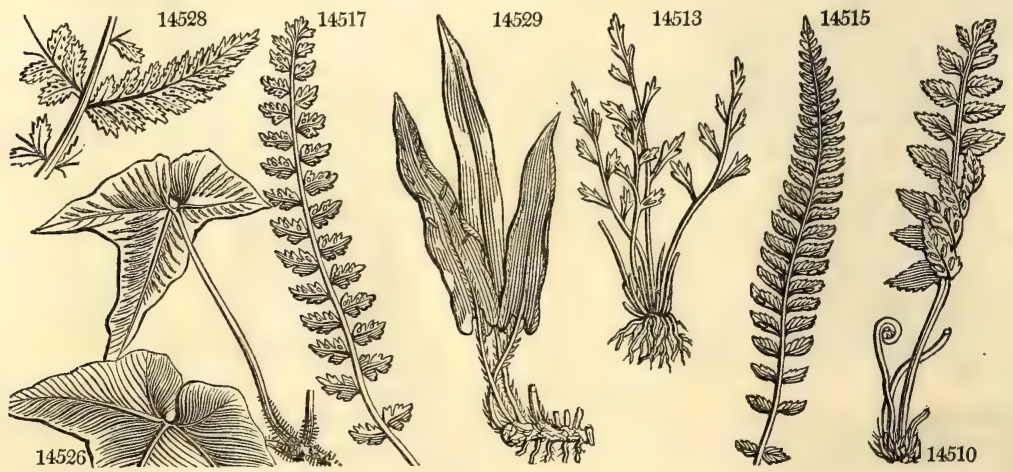

History, Use, Propagation, Culture,

2187. Allantodia. So named from $\alpha \lambda \lambda \alpha \nu \tau \circ 5$, a sausage, or sort of small pudding, to which the cylindrical arched indusia bear considerable resemblance.

2188. Scolopendrium. On the lower surface of the fronds of this plant are to be seen little marks which bear a likeness to the insect called Scolopendra. It is probable that the supposed varieties of this plant are distinct species. One of them has been ascertained not to alter in being raised from seed.

2189. Diplazium. From $\delta \iota \pi \lambda \omega \sigma i s$, double; the indusia are double. Handsome ferns of large size; one forms a small tree.

2190. Pteris. The Greeks called ferns in general by this name, because they generally resemble plumes, covert for game, and for serving for many household purposes in the north of England. It is used as litter for 
14507 Fronds pinnated : pinnæ cuneate ovate acute deeply pinnatifid; segments lanc. cuneate unequally toothed 14508 Fronds pinnated: pinnæ stalked oblong acuminate pinnatif ; segments lanc. cuneate unequally toothed 14509 Fronds pinnated : pinnæ ovate repand somew. auricled; term. remote small entire, Fronds rooting at end 14510 Fronds pinnated : pinnæ alternate elliptical roundish crenate, Rachis flattened beneath

14511 Fronds pinnated : pinnæ roundish blunt crenated cuneate at base, Stalk discolored

14512 Fronds pinnated: pinnæ ovate-roundish crenate, Rachis shining keeled beneath

14513 Fronds pinnated : pinnæ alternate cuneiform erect eroded at end

14514 Fronds pinnated: pinnæ sessile lanceolate serrulate cordate at base auricled upwards

14515 Fronds pinnated : pinnæ lanceolate blunt equally and bluntly serrated, Sorus one on each pinna

1516 Fronds broad-lanceolate subsessile, Sori very near parallel contiguous to the midrib

14517 Fronds pinnated : pinnæ ovate oblique serrated obtuse unequal at base cuneate

14518 Fronds pinnat. : pinnæ altern.; upp. usually opp. lin.-lanc. subrepand truncat. at base above rounded below 14519 Fronds pinnated trifid : pinnæ alternate linear torn at end

14520 Fronds lanceol. stalked rather crenate auricled cordate at base at the end very long linear-filiform rooting

14521 Fronds lanceolate on short stalks acuminate serrated tapered at base and entire, Sori contiguous parallel

14522 Fronds pinnate : pinnæ lanceolate taper-pointed at end pinnatifid; segments bifid, Stalk shining glabrous

14523 Fronds ternate : middle leaflet pinnatifid; lateral 3-parted toothed

14524 Fronds pinnated : pinnæ obl. lanceolate acuminate coriaceous serrated at end tapered at base, Stalk chaffy

14525 Fronds 3 pinnated: pinnæ oblong lanceolate with very long points, Sori becoming confluent

14526 Frond 5-lobed cordate, Three middle lobes acuminate

14527 Fronds bipinnate : pinnules oblong pinnatifid; segments lanceolate finely bidentate, Sorus solit. at base 14528 Fronds 3-pinnate: pinnules lanceolate decurrent cut serrated, Sori contiguous finally becoming confluent

14529 Frond simple cordate-lingulate smooth beneath

14530 Fronds pinnat. : pinnæ lanc. serrat. at end truncate at base above rounded and somew. wedge-shaped below 14531 Fronds pinnat. : pinnæ lanc. coarsely toothed; teeth rounded serrated at end tapered and finely toothed

14532 Fronds pinnated : pinnæ linear auricled cordate at base serrulate, Stalk and rachis paleaceous hairy

14533 Fronds pinnated : pinnæ oblong lanceol, on short stalks entire cuneate at base, Stalk and rachis smooth

14534 Fronds pinnated : pinnæ lin. decurrent ; lower 3-parted, Sterile acutely serrated : fertile ent. serrul. at end

14535 Fronds decompound : lover bipinnate; pinnules lanceol. retuse at base, terminal longer, Stalk pubescent 14556 Fronds bipinnatifid, Lower branches twin 2-partite below, Pinnules lanceolate subfalcate sharply serrated 14537 Fronds supradecompound : pinnæ broad-lanceolate pinnatifid, Stem and branches prickly

14538 Fronds tripinnate: pinnules linear decurrent downy beneath; those at the end longest, Rachis smooth

14539 Frond 3-parted, Branches bipinnate, Pinnules linear elongated blunt entire : lower bipinnatifid

14540 Frond 3-parted, Branches bipinn. Pinnules lin. lanc. : upper undivided; lower pinnatif. Segm. obl. blunt 14541 Frond pedate, Branches pinnate, Pinnules obl. lanceolate acumin. pinnatifid, Segm, oblong acute serrated 14542 Fronds pinnat. : pinnæ lanc. acum. on short stalks tapered and serrated at base ; lowest 2-parted or ternate 14543 Fronds bipinn. : pinnules somew. stalked ovate-lanc. blunt crenulate; lower hastate 3-lobed, Stalk smooth 14544 Fronds deeply 5-lobed palmate, Lobes pinnatifid: segments linear lanceolate acumin. Recesses rounded 14545 Fronds deeply 5-lobed palmate, Lobes pinnatifid: segments linear lanceolate acute, Recesses acute

14546 Pinnæ opposite pinnatifid, Nerve above a little strigose, Pinnules lanceolate blunt entire, Petiole smooth

14547 Fronds linear very long pendulous, Sori solitary within the margin

14548 Fronds bipinnate hairy : pinnæ pinnatifid acuminate; segments blunt, Stalk and rachis villous

14549 Fronds linear-lanceolate tapered at each end ribbed, Sori reticulated

14535

14530

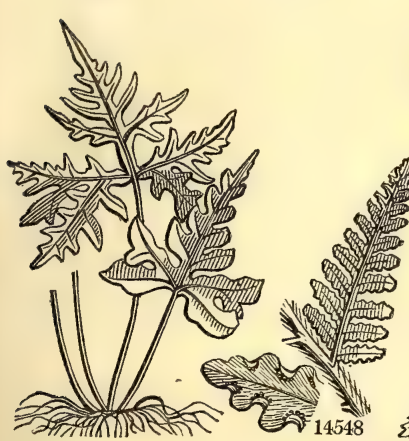

14547

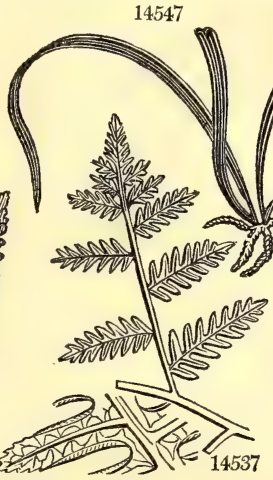

14549

and Miscellaneous Particulars.

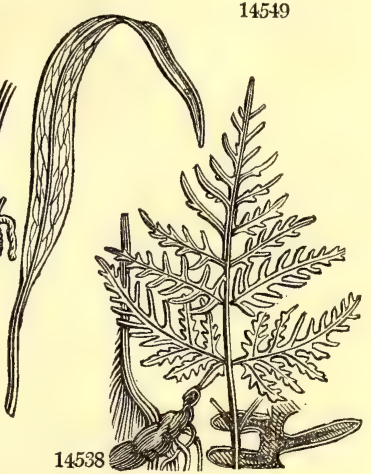

cattle, and very frequently for the purpose of thatching cottages. The ashes are employed in the manufactory of soap and glass. Its astringent quality has recommended it in dressing and preparing kid or chamois leather. The country people take it medicinally to destroy worms, and a bed made of the green plant is esteemed a sovereign cure for the rickets in children.

2191. Vittaria. From vitta, a ribband, on account of the narrow ribband-like appearance of the fronds. Small simple-leaved grass-like plants, of difficult cultivation.

2192. Lonchitis. From $\lambda$ ov $\eta$, a lance, on account of the form of the fronds of some species. The Greeks had a plant named $\lambda_{0 y} \chi^{i} \tau i s$, but it must have been very different from that of the moderns.

2193. Antrophyum. A genus divided by Kaulfuss from Hemionitis, and named from ayţos, a cavern, and Quw, to grow, in reference to its native places of habitation. 
2194. ADIAN'TUM. $W$. Maideviair.

14550 renifórme $W$. Kidney-leaved

14552 macrophýllum $W$.

14553 pedátum $W$.

14554 villósum $W^{\circ}$

14556 trapezitórme $W$. rhomb-leaved

14557 Capíllus-véneris $W$. true

14558 ténerum $W$. tender

14559 serrulátum $W$. serrulate

4560 pterta $W_{-}$THES. SWz. CheILANTHES.

14560 pteroídes $W_{0} \quad$ Pteris-like $\quad \Delta \sim \mathrm{pr}$

14561 vestíta $S w z$

14562 frágrans $W$

14563 lentígera Swz. sweet-scented $\frac{1}{4}$ (

2196. DA VA L'Lia. Sm. Dayallia.

1456 pyxidáta $W$. shining

14565 canariénsis $W$. Hare's-foot

2197. DICKSO'NIA. L'Her. Dicksonia.

14566 arboréscens $W$. tree

14567 dissécta $W$. cut-leaved

14568 pilosiúscula $W$. hairy

2198. BALAN'TIUM. Kaulf. BaLANTIU 14569 Cúlcita Kaulf.
Dicksónia Culcita W.

2199. ASPI'DIUM. Swz. Shield FerN.

14570 dentátum $W$.

14571 bulbiferum

14572 frágile $W$.

14573 régium $\boldsymbol{W}$.

14574 rhæ'ticum $W$.

14575 irriguum $E$. $B$.

$14576 æ^{\prime}$ mulum $W$.

14577 trifoliátum $W$

14578 Lonchítis $W$.

14579 auriculátum $W$.

14580 exaltátum $W$.

14581 unítum $W$.

14582 propínquum Kaulf.

14583 pátens $W$.

14584 downy

14585 Oreopteris

Oreopteris $W$.

14586 Thelýpteris $W$

14587 cristátum $W$.

14588 aculeátum $W$.

14589 marginále $W$ 14590 Fílix-mas $W$ 14591 lobátum $W$. hairy chaffy

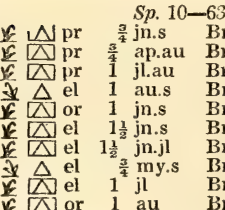

Sp. $4-30$.

Sp.
1 $\mathrm{jl}$.s

$\frac{2}{4}$ au $\quad \mathrm{Br}$

au $\quad \mathrm{Br}$

Sp. $2-39$.

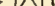

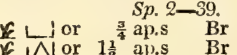

Sp. $3-23$.

I $\square$ or 15 jn.d ${ }_{3} \mathrm{Br}$

\& $\triangle \mathrm{pr} \quad 2 \mathrm{jl} . \mathrm{s} \quad \mathrm{Br}$

Sp. 1-2.

$3 \mathrm{au} \quad \mathrm{Br}$

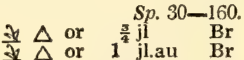

bulbiferous

brittle

stone

brook

three-leaved

rough Alpin

eared

lofty

river-side

Heath

Lady-fern

lesser-crested

com.-prickly

marginal-flow.

\& or 2 jn.s $\mathrm{Br}$

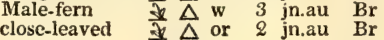

Madeira 1699. R s.p Bot. cab. 841

W. Indies 1776. D 1.p Plum. til. t. 100

Jamaica 1793. D l.p Bro. jam.t. 38 . .

N. Amer. 1640. R s.p Schk fil t 115

Jamaica 1775. D s.p Schk fil t. 120

W. Indies 1793. D s.p Schk, fil. t 119

W. Indies 1793. R s.p Schk. fil. t. 112

Britain rocks. R s.p Eng. bot. 1564

Jamaica 1793. D s.p Pluk. al. t.354.f.1

Jamaica 1822. D l.p Pluk. al.t.125.f.2

C. G. H. 1775. D 1.p Ho.n.his.t.96.f.3

N. Amer. 1812. D l.p Schk. fil. t. 124

Madeira 1778. D l.p Sw. syn.fi.t.3.f.6

N. S. W. 1808. D 1.p

Canaries 1699. R s.D Jac. ic. 1. t. 200

St. Helena 1786. D 1.p

Jamaica 1793. D l.p

N. Amer. 1811. D l.p Schk, fil, t. 131

Madeira $\quad . . \quad$ D l.p

Wales rocks. D 1.p Eng. bot. 1588

N. Amer. 1638, D l.p

Britain walls. D 1.p Eng. bot. 1587

Britain al.roc. D l.p Eng. bot. 163

Britain rocks. D l.p

Britain w.sh.p. D l.p

Madeira 1779 .

W. Indies 1769 . D l.p Jac. ic. 3. t. 638

Britain al.roc. D l.p Eng. bot. 797

E. Indies 1793. D 1.p

Jamaica 1793. D l.p Schk, fil, t. 32, b.

E. Indies 1793. D l.p

E. Indies 1793. D Ip

Jumaica 1784. D l,p Schk, fil. t. 334

N. Amer, 1812. D ip Schk fil t 40

Britain hea. D l.p Eng. bot. 1019

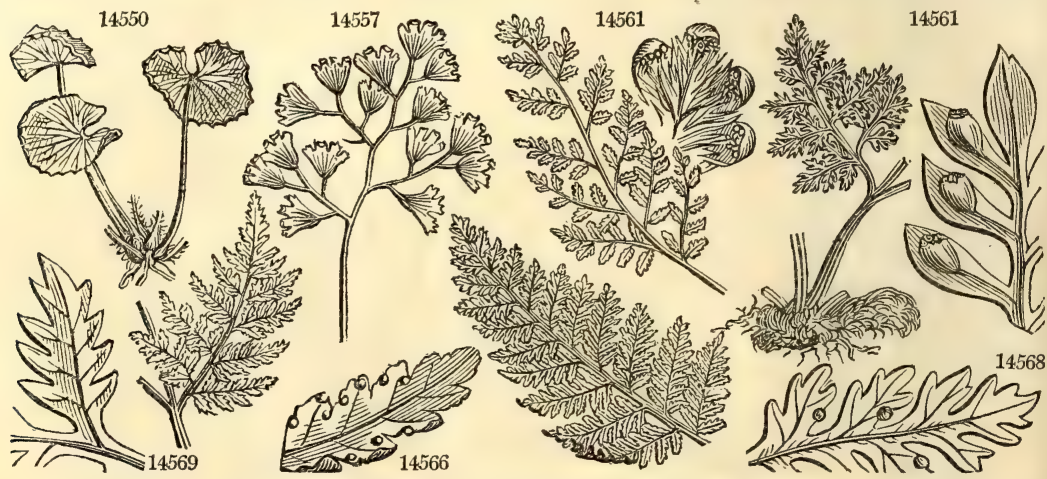

History, Use, Propagation, Culture,

2194. Adiantum. From asıcyros, dry. In vain you plunge the Adiantum in water, says Pliny, it always remains dry. The prettiest of all ferns, on account of the delicate slender stalks on which the pinnules are balanced in the air; one species on this account is called Capillus Veneris, or in English, Maiden's Hair.

2195. Cheilanthes. From $\chi_{\varepsilon b} \lambda_{05}$, a lip, and $\alpha_{\nu} A_{05}$, a flower, in allusion to the lip-like form of the indusium. Pretty plants, formerly referred to Pteris.

2196. Davallia. Named by Sir James Smith, after his friend M. Davall, a Swiss botanist, who sent him large collections of plants. D. canariensis is popularly called the hare's-foot fern, on account of the peculiar form of its rootstock, which curves over the side of the pot in which it grows, and, being covered with close brown hairs, resembles very perfectly the foot of a hare.

2197. Dicksonia. In honor of the late Mr. James Dickson, a celebrated British cryptogamic botanist. A noble genus containing several arborescent species, among which the tree-fern of St. Helena is placed. This plant is often brought in a living state to this country, but the mode of cultivating it being unknown, it rarely survives more than a few months.

2198. Balantium. A genus of Madeira ferns, divided from Dicksonia by Kaulfuss, on account of its transverse two-valved indusium; and named from e ex «urıov, a purse, on account of the form of the indusium. 
14550 Fronds simple reniform-orbicular crenate, Both diameters equal

14551 Frond digitate, Branches pinnate, Pinnæ linear-oblong obtuse nearly halved crenate, Stalk smooth 14552 Fronds pinnate : pinnæe ovate acuminate cuneate at base toothed at end, Sori continuous upon each edge 14553 Frond pedate, Leaflets pinnate, Pinnæ rhomboid-oblong somewhat lunate cut-lobed

14554 Fronds bipinnate: pinnules trapezoid-obl. blunt, Sori oblong at the end of the upper edge, Stalk villous 14555 Fronds bipinnate: pinnules rhomboid oval serrated at end, Sorus lin. solitary on upper edge, Stalk hairy 14556 Fronds supradecomp. : pinnules trapezoid acum. cut crenate towards end of upper edge, Sori on crenatures 14557 Frond alternately decompound: pinnules stalked cuneiform lobed

14558 Fronds supradecompound : pinnules rhomboid blunt cut lobed on upper edge, Lobes toothl. bearing sori 14559 Fronds pinn. or bipinn.: pinnæ obl. lanc. halved truncate at base serrul. Sori on upper edge, Stalk smooth

14560 Fronds bipinnate, Lower pinnæ bipinnate : pinnules ovate-ellipt. obtuse obsoletely subcordate crenulate 14561 Fronds bipinn. hairy on each side: pinnules pinnatif.; segments obl. blunt entire, Stalk and rachis hairy 14562 Fronds bipinnate smooth : pinnules obl. lanc. obtuse pinnatifid cut ; segments subbifid, Stalk paleaceous 14563 Fronds tripinnate somewhat villous, Leaflets orbicular very small

14564 Fronds bipinnate alternate, Leaflets lanceolate pinnatifid, Sori linear oblong

14565 Fronds 3-parted alternately decompound: segments lanceolate; those bearing sori obovate

14566 Fronds supradecompound villous, Leaflets nearly entire, Stem arboreous

14567 Fronds tripinnate: pinnæ tapered; pinnules oblong blunt pinnatifid, Segments blunt toothed

14568 Fronds bipinnate: pinnæ pinnatifid; segments toothed, Rachis somewhat hairy

14569 Fronds tripinnate smooth : pinnules ovate oblong cuneate cut-toothed

14570 Fronds pinnate : pinnæ ovate-oblong pinnatifid; segments oblong blunt toothletted

14571 Fronds pinnate remotish : pinnules oblong serrated bulb-bearing beneath ; lower pinnatifid

14572 Fronds bipinnate: pinnules oblong blunt cut-serrated, Serratures blunt toothletted, Rachis winged

14573 Fronds bipinn. : pinnules ov. obl. lobed pinnatif.; segm. linear-oblong blunt nearly entire, Rachis winged

14574 Fronds bipinn. : pinnules lanceolate acuminate pinnatifid; segments linear acute serrated, Rachis winged 14575 Frond lanceolate pinnate: pinnæ deeply pinnatifid cut toothed, Rachis quadrangular, Sori lateral

14576 Fronds tripinnate: pinnules pinnatifid; segments linear toothed at end

14577 Fronds simple cordate 3-lobed or ternate : middle larger; lateral auricled at base

14578 Fronds pinnate: pinnæ ciliate serrate, Stalk strigose

14579 Fronds pinnate: pinnæ falcate lanceolate serrate truncate at base auricled above

14580 Fronds pinn. pinnæ lanc. subfalcate cordate at base gibb, and somew, serrul. on upper. 14581 Fronds pinnate : pinnæ ensiform serrated, Serratures half ovate ovate nerved

14582 Fronds pinn.: pinnæ ensiform attenuated at end downy ben. cut. pinnatif. Sori almost marginal contiguous 14583 Fronds pinn.: pinnæ pinnatif.; segm. lanc. ac. Lowest of last pinnæ longest pinnatif. cut, Veins hairy ben. 14584 Pinnæ pinnatifid somewhat linear: pinnules oblong nearly entire, Sori in rows near the edge of pinnm

14585 Fronds pinnate: pinnæ lanceolate glabrous resinous glandulose beneath pimnatifid; the segm. lanceolate obtuse entire, lowermost ones longer, Sori marginal

14586 Fronds pinn. : pinnæ lin.-lanc. pinnatif. glab. : segm. ov. ac. ent. Sori marginal contigu. at length confluent 14587 Fronds pinnate : pinnæ subcordate oblong pinnatifid; segments oblong obtuse dentato-serr. Stalk chaffy 14588 Fronds bipinnate: pinnules rigid ovate sublunate acum. aristate oblique and cuneate at base and decurr. the margins faintly serrated spinulose with a tooth near the base on upper side, Stalk and rachis chaffy

14589 Fronds bipinnate: pinnules oblong obtuse decurrent crenate. Crenatures of base deepest, Sori marginal

14590 Fronds bipinn. : pinnules obl. obt. serrat. mutic. Sori near the central nerve, Stalk and rachis chaffy

14591 Fronds bipinnate : pinnules scarcely rigid ovate rather obt. aristate truncate at base which has a lobe on the upper margin shortly petiolate; the margin deeply serrated and spinulose, Stalk and rachis chaffy

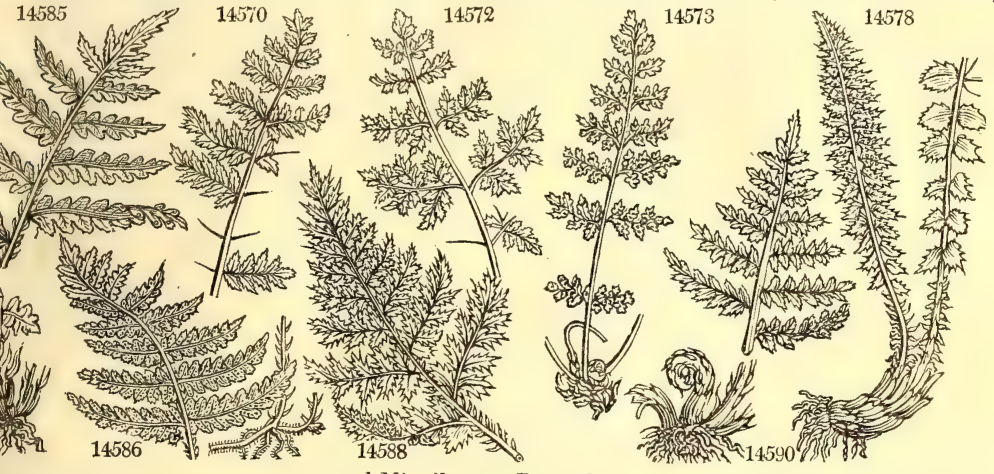

and Miscellaneous Particulars. 2199. Aspidium. From arrss, a little buckler, on account of the form of the indusia. Fougère, Fr,
Johannis wurtzel, Ger., Feli Maschia, Ital, and Polypodio Helecho Masculino, Span. The male fern is common to Europe, in shady places and woods. The root consists of many matted fibres, forming a turfy is cæspitose head, of the thickness of the finger, blackish and scaly. It has been celebrated from time immemorial as a specific for worms. It appears to have been used as such by Theophrastus, Dioscorides, and Galen; but seems to have been neglected by the moderns, with the exception of empiric practitioners, until the publication of Madame Nufer's specific for the tape-worm by the French gorernment again brought it into notice. According to her plan of administering it, from one to three drachms of the powdered root were directed to be taken in a large cupful of water in the morning, while the patient was in bed; and two hours afterwards, a strong cathartic of calomel and gamboge, proportioned to the age and strength of the patient, was given; and if necessary, the further operation was promoted by a dose of purging salts ; nothing but broth being taken till the worms came away. If this, however, did not happen on the same day, the process was ordered to be re peated on the next day. In the present state of medical science, oil of turpentine is considered a certain specific for expelling tænia. (Thom. Lond. Disp. 186.)

Aspidum Baromez is the famous Scythian lamb, of which so many fables have been related. Although it 
14592 spinulósum $W$. 14593 dilatátum $W$.

14594 elongátum $W$.

14595 villósum $W$

14596 mólle $W$

14597 acrostichoídes $W$. 14598 intermédium $W$.

14599 asplenioídes $W$.

2200. WOOD'SIA. R. B

14600 hyperbórea $R$. Br. hairy Alpine

14601 ilvénsis $R . B r$. rock

2201. CYathe'A. Sm. Cyathea.

14602 arbórea $W$. tree

crested-prickly
great-crested $\frac{\Delta \text { or }}{1} \quad 1$ jn.au cut-leaved

villous

soft

$\Delta$ or 2 jl.au

Nor

ए

$3 \mathrm{jl}$

2 au.s

$1 \frac{1}{2} \mathrm{jl}$.au

2 jn.s Br

$1 \frac{1}{3}$ jn.s $\quad$ Br Sp. 2-4.

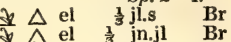

$S p .1-22$.

๑ $\square$ or $15 \quad \ldots . \mathrm{Br}$

2202. TRICHO'MANES. $L$. Trichomanes. Sp. $1-40$.

14603 brevisétum $\boldsymbol{H} . \boldsymbol{K}$. short-styled $\& \Delta \mathrm{el} \frac{1}{3}$ my.jn $\mathrm{Br}$

Hymenophýllum alatum E. B.

2203. HYMENOPHYL'LUM. Sm. Filmy-Leaf. $S p .1-38$.

14604 tunbridgénse $W$. Tunbridge \& $\Delta$ el $\frac{1}{4}$ my.jn $\mathrm{Br}$
Britain mar. D l.p Eng, bot. 1460 Britain w.sh.p. D 1.p Eng. bot. 1461

Madeira 1779. D l.p

W. Indies 1793. D l.p Schk. fil, t. 46. b. Caraccas 1824. D 1.p Jacq. ic. t. 640 N. Amer. $\ldots$ D l.p Schk. crypt. t. 30 N. Amer. 1823. D l.p

N. Amer. 1823. D 1.p Schk, crypt. t. 78

Scotland al.roc. D 1.p Eng. bot. 2023 N. Amer. 1812. D 1.p Schk. fil. t. 19

W. Indies 1793. D 1.p Plum, fil, 1. t.1,2

Britain moi.ro. D 1.p Eng. bot. 1417

Britain moi.ro. D l.p Eng. bot. 162

\section{OSMUND ACEAE.}

2204. TO'DEA. $W . \quad$ ToDeA.

14605 africána $W$ African

2205. OSMUN'DA. $L$. OSMUNDA.

14606 cinnamómea $P h$.

14607 regális $W$.

14608 Claytoniána $W$.

14609 interrúpta $W$.

14610 spectábilis $W$.

2206. IYGO'DIUM Swy.

14611 scándens Swz. climbing

14612 circinátum Swz.

14613 palmátum Swz.

circinate

palmate

woolly

Clayton's

interrupted

$\Delta \Delta$ or
$\frac{1}{\Delta} \Delta$ or
$\frac{\Delta}{\Delta} \begin{aligned} & \text { or } \\ & \text { or } \\ & \text { or } \\ & \text { el }\end{aligned}$

Sp. 1.

my.au $\mathrm{Br}$

$S p .5-8$.

2 jn $\mathrm{Br}$

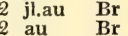

2 jn.jl $\quad \mathrm{Br}$

Sp. 3-18.

NGUE.

恶 $\mathrm{el} 3 \mathrm{au} \quad \mathrm{Br}$

严 $\triangle$ el $\quad 3$ au.s $\quad \mathrm{Br}$

2207. ANE'Mia. Suz. Anemia.

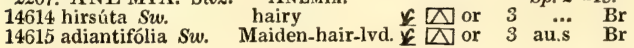

\section{G. H. 1805. D 1.p Schk, fil. t. 147}

N. Amer, 1772. D l.p Schk. fil. t. 146 Britain sha.bo. D l.p Eng. bot. 209 N. Amer. 1772. D I.p N. Amer. ... D l,p Schk. fil. t. 144 N. Amer. 1811. D 1.p Plu.alm.t.184.f.4

E. Indies 1793. D 1.p Bot. cab. 742 E. Indies 1823. D 1.p Rum. amb.6.t.33 N. Amer. ... D 1.p Ac.E.1802.t.1.f.2

Jamaica 1794. D 1.p Plum. fil.t. 162 W. Indies 1793. D p.1

\section{OPHIOGLOSSEAE.}

2208. BOTRY'CHIUM. Swz. MoONWORT

14616 Common $W$. 5-10.

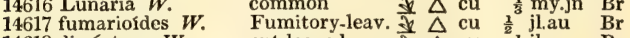
14618 disséctum $W_{\dot{H}} \quad \begin{gathered}\text { cut-leaved } \\ \text { Rattlesnake }\end{gathered}$

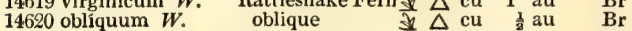

Britain hil.pa. D p.l Eng. bot. 318 Carolina 1806. D p.l Schk, fil.t. 157 N. Amer. 1806. D p.l Schk. fil. t. 158 N. Amer, 1790. D p.l Schk. fil. t. 156 N. Amer, 1821. D p.1

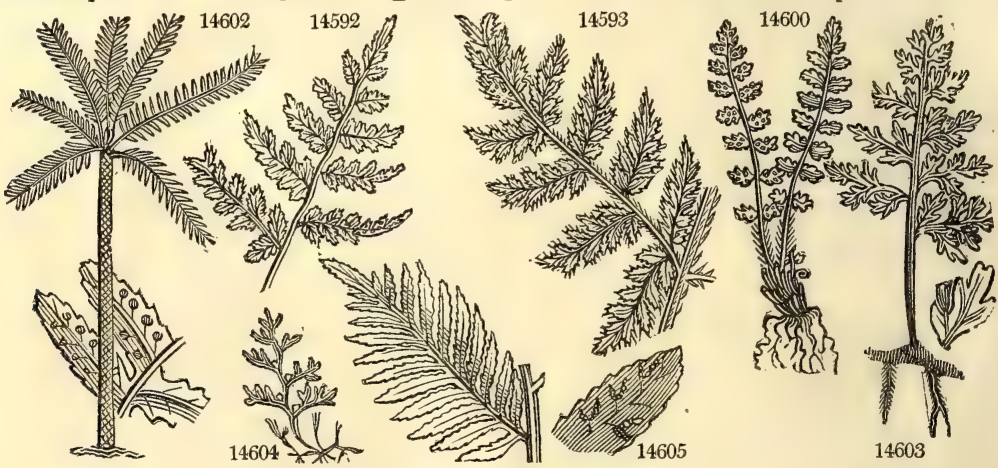

History, Use, Propagation, Culture,

is often brought in a fresh state to the markets of Macao, as an article of medicine, no plants have ever reached this country alive. Its name has arisen from the resemblance which its brown hairy rootstalk bears to a little rufous dog couching; and the belief in its animal nature has been confirmed by the color of the juice, which is of a rich blood color, and soon becoming thick by exposure to the air. It is needless to add, that the stories about no plant being able to grow near it are mere fables. Kæmpfer says, that borannek is the name which the people on the borders of the Caspian Sea give to a kind of sheep of that country.

2200. Woodsia. Small ferns formerly referred to Polypodium, Aspidium, and Nephrodium, by various writers ; and distinguished from all these by Mr. Brown, who named the genus after Mr. Joseph Woods, an ingenious British botanist.

2201. Cyathea. From wuer os, a cup; on account of the cup-shaped form of the indusia. A fine tropical genus of ferns, which does not appear to have been well understood by its author, who confounds it with little British plants referred by all other botanists to Aspidium. Nearly all the species are arborescent, and arrive at the greatest height of which ferns are susceptible. C. glauca forms a lofty tree in the Island of Bourbon, and $C$. speciosa and excelsa are not less than twenty-four feet in height.

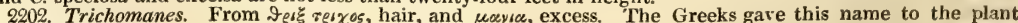
now called Asplenium trichomanoides, on account of its fine shining stems, which resemble hairs. Elegant plants with almost transparent foliage. 
14592 Frond somew. bipinn. : pinnules decurrent ellipt. pinnatifid serrul. spiny, Rachis smooth, Nerves flexuose 14593 Fronds bipinnate: pinnules oblong distinct inciso-pinnatifid; segments mucronato-serrate, Stalk chaffy 14594 Fronds bipinnate: pinnæ pinnated bipinnatifid below; pinnules lanc. blunt, Segments ovate toothletted 14595 Fronds 3-pinnate: pinnules oblong blunt hairy above, toothed, Stalk and rachis bristly chaffy

14596 Fronds pinnate : pinnælanc. hairy on each side pinnatifid; segm. oblong blunt entire, lowest nearly equal 14597 Fronds pinn. : pinnæ altern. subsess. subserr. ciliat. auric. at base on upp. edge, Upp. pinnæ bear. sori, Stalk 14598 Fronds bipinnate : pinnules lin. pinnatifid cut; segm. mucronate serrate at end, Stalk chaffy [chaffy 14599 Fronds bipinn. : pinnules lin. lanc. cut serr. Serrat. 2 or 3 toothed: those at end most ac. Sori obl. lunate

14600 Frond lanceolate pinnate : pinnæ cordate pinnatifid hairy on each side, Lobes rounded repand 14691 Fronảs bipinnatifid : pinnæ oblong blunt ; lower repand, upper entire

14602 Fronds bipinnate : pinnules lanceolate serrate sharpish; upper confluent, Stalk smooth, Stem arboreous

14603 Frond tripinnatifid lobed smooth : segments linear entire, Stalk winged, Columella included

14604 Frond alternately bipinnatifid : segments and invol. serrated, Sori solitary axillary

\section{$O S M U N D A C E A E$.}

\section{The only species}

14606 Fronds pinnat. : ster. bipinnatif.; segm. ov. obl. obt. entire, Stalk woolly, Fertile fronds bipinnate woolly 14607 Frond bipinnate bearing the spike at end : pinnules cordate-lanceolate smooth

14608 Fronds bipinnatifid rusty with down contracted and fertile at the end

14609 Fronds bipinnatifid entire smooth interrupted in the middle by 3 pair of fertile pinnated racemes

14610 Fronds bipinn. : pinnules lanc, sharply serrat. cune, at base; all altern. A fert. bipinn. panic. at end of frond

14611 Stem flexuose round, Fronds conjugate pinnate, Leaflets bearing spikes on each edge

14612 Stem flexuose climbing, Fronds conjugate 3-4-lobed palmate, Lobes lanceolate acute entire

14615 Stem flexuose climbirg, Fronds conjugate cord. 5-lobed palmate, Lobes lanc. ent. obt. obscurely sinuated

14614 Frond bipinnatifid hirsute : segments cuneate lined blunt and serrated at end

14615 Frond 3-pinnatifid triangular: segm. ovate acute toothletted at end, beneath and the rachis downy

\section{OPHIOGLOSSEAE.}

14616 Scape with a simple frond above, Frond pinnate : pinnæ lunate entire

14617 Scape none, Fronds radical 3-parted bipinnate : pinnules lunate crenate

14618 Scape with a simple frond at bottom, Frond 3-parted bipinnatifid: segm. linear 2.parted 2-toothed at end 14619 Scape frondose in midd. Frond subtern. 3-parted bipinnatifid, Leaflets cut pinnatif. Segm. obtuse 3-toothed 14620 Scape with a simple frond at bottom, Frond mostly bitern. Leaflets obl. lanc, serrul, unequally cord. at base

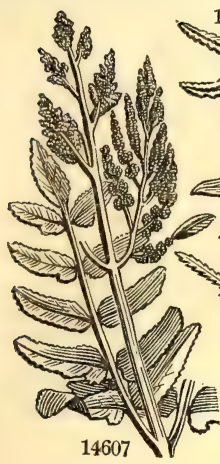

14607

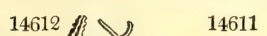

14611

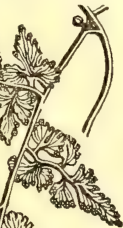

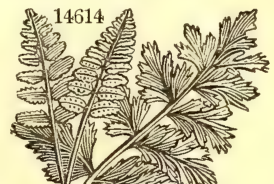

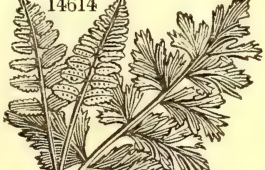

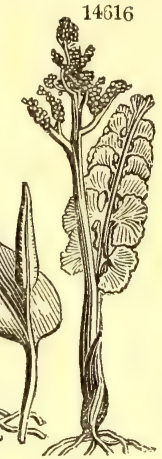

and Miscelianeous Particulars.

2203. Hymenophyllum. From iunv, a membrane, and $\varphi v \lambda \lambda \circ \nu$, a leaf, in allusion to the tenuity of the foliage This and the last are the most elegant of all ferns; they generally grow in damp shady places amcng moss, and have hitherto refused cultivation under any plan which has been devised.

2204. Todea. Named after Tode, an experienced mycologist, author of Fungi Mecklenburgensis. Mr. Brown unites this genus to Osmunda, but Kaulfuss keeps them distinet.

2205. Osmunda. A word said to be of northern origin, and to have received its name on account of its potential qualities in medicine. Osmunder was one of the names of Thor, a Celtic divinity, and mund, in Anglo-Saxon, is expressive of force or power. These are noble species of hardy ferns. $O$. regalis is the finest of all our native species.

2206. Lygodium. From turos, a band. The species are elegant twining plants, which bind together the grass or small shrubs near which they chance to grow. L. palmatum, although a North American plant, must have the protection of a good frame.

2207. Anemia. From $\alpha \nu \in \varphi \omega \omega$, naked; in allusion to the naked spikes of inflorescence; whence some authors write the word Aneimia.

2208. Botrychium. Derived from Botevs, a bunce, on account of the bunch-like form of its fructification. Botrychium virginicum is the largest of the American kinds, and is called the rattle-snake fern, from the circumstance of its generally growing where these venomous reptiles are usually found.

$$
3 \mathrm{~L} 4
$$


2209. OPHIOGLOS'SUM. $L$. ADDER's-TONGUE.
14n21 vulgátum $W$. common

14622 reticulátum $W$.

14623 bulbósum $W$.

common

netted

bulbous

2210. MARAT'TiA. Swz. Marattia,

14.624 aláta $W$.

winged
$\$$ cu
$\frac{1}{2} \mathrm{my} . \mathrm{jn} \quad \mathrm{Br}$ 运 $\mathrm{pr}$ 这 my.jn $\mathrm{Br}$

Britain m.me. D p.l Eng. bot. 108 W. Indies 1793 . D p.1 Plum. fil. t. 164
N. Amer. $\quad$ D D l.p

History, Use, Propagation, Culture,

2209. Ophioglossum. From $0 \varnothing \varsigma$, a serpent, and $\gamma \lambda \omega \sigma \sigma \eta$, a tongue. The little green narrow-pointed leaves, seated on a narrow stalk or neck, and peeping up from among the grass, may be not unaptly compared to a snake's tongue. 
14621 Frond ovate veinless

14622 Spike cauline, Frond cordate acute reticulated

14623 Spike cauline, Frond subcordate ovate obtuse, Root bulbous

14624 Fronds bipinnate : pinnules acutely serrate, Rachis scaly : partial winged

and Miscellaneous Particulars.

2210. Marattia. In honor of J. F. Maratti, a writer upon ferns. He lived at Vallombrosa, in Tuscany. Kaulfuss considers this, Danæa, and Angiopteris as constituting a particular tribe, which he calls Marattiaceæ, but of which he has not given the characters. 
Order 2.

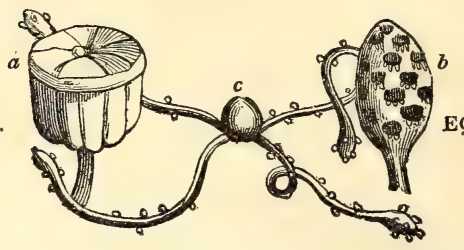

EQUISETACEF.

Reproductive organs uniform, in terminal spikes, composed of peltate, several-sided scales, producing on their under surfice 4-7-elongated involucres containing the seeds. Branches whorled, rigid.

THIs order contains one genus only, which is among the most puzzling of all the anomalous formations which are so frequently met with among the lower orders of vegetation. Both the stems and branches are regularly articulated, and arise from a tubular sheath. There are no leaves, and the reproductive organs are arranged in a terminal spike $(b)$, on all sides of which are inserted many peltate scales $(a)$ with several sides or angles. Several wedge-shaped hollow bodies project from the surface of these scales, and bursting inwardly, discharge their contents, which are not yet well understood. They consist of a number of green roundish bodies, surrounded by minute granules, and furnished at the base with four elastic filaments (c), thickened at their apex. By some observers the granules have been considered pollen, the filaments stamens, and the green bodies ovaries; by others the granules have been called naked seeds; by Kaulfuss the wedge-shaped hollow bodies are considered capsules, and the green bodies, seeds. It is probable that none of these theories are true.

2209. Equisetum. Character the same as of the order.

2211. EQUISE'TUM. $L$, HoRSE-TAIL. 14625 arvénse $W$.

14626 fluviátile $W$.

14627 sylváticum $W$. 14628 limósum $W$. 14629 palústre $W$. 14630 variegátum $W$. 14651 hyemále $W$. corn

great-water

wood

smooth naked

marsh

variegated

Dutch Rush

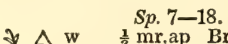

\) $\Delta$ w 6 ap.my $\mathrm{Br}$

$\star \Delta \Delta \mathrm{w} \quad 1$ ap.my $\mathrm{Br}$ $\$ \Delta \mathrm{w}^{2} \quad{ }_{12}$ jn.jl $\mathrm{Br}$ t $\triangle$ or 3 jijl $\frac{\nabla}{\mathrm{E}} \triangle \mathrm{ec} 1 \frac{1}{2} \mathrm{jl}$.au $\mathrm{Br}$
Britain moi.fi. D p.l Eng. bot. 2020 Britain wat.pl. D p.1 Eng bot. 2022

Britain m.s.pl. D p.l Eng. bot. 1874 Britain wat.pl, D p.l Eng. bot. 929 Britain bog.pl. D p.l Eng. bot. 2021 Scotland sc.sh. D p.l Eng. bot. 1987 Britain moi.w. D p.l Eng. bot. 915

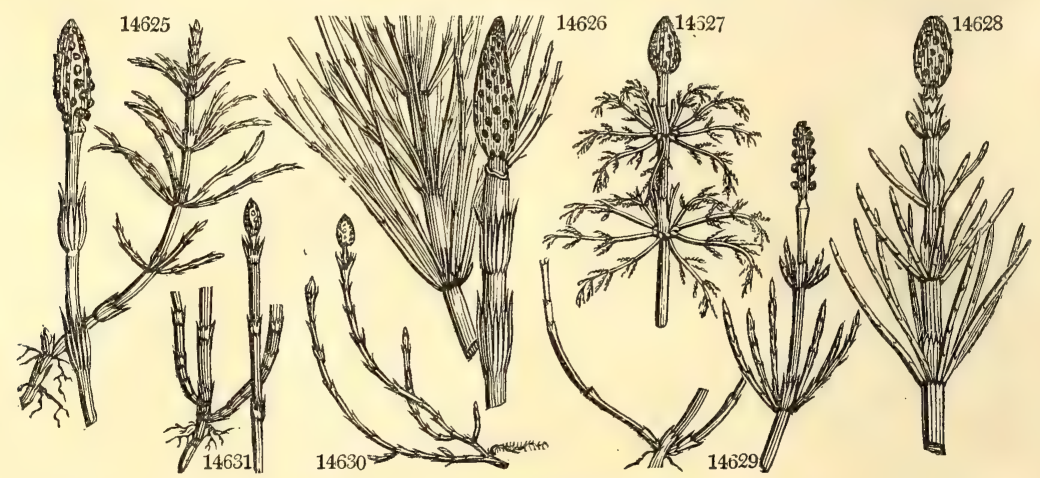

History, Use, Propagation, Culture,

2211. Equisetum. Literally, horse-hair, from equus, a horse, and seta, hair; so called, in allusion to the fine branches of all the species. The first five species are noxious weeds on deep loamy soil, especially such as has been gained from rivers or lakes. E. fluviatile rises three or four feet high, the thickness of a finger, with numerous branchlets or leaves proceeding from the whorls; according to Haller, this species was eaten by the common people among the Romans. Linnæus affirms, that rein-deer, who refuse hay, will, however, eat this : 
14625 Ster. stems decumb. with simp. branches, which are rough. tetragon. : fertile ones erect simp. their sheaths cylind, inciso-dentate

14626 Sterile stems with very numerous simple branches, which are roughish octagonal : fertile ones simple; the sheaths infundibuliform laciniato-dentate, their teeth setaceous

14627 Sterile and fertile stems with their branches comp. roughish deflexed 4-sided, Branchlets subtriquetrous 14628 Stems branch. upw with branches about 12 in a whorl simple pentagon. smooth, Spike or catkin terminal 14629 Stems branched glabrous sulcate, Branches simple pentagonal, Spike terminal

14630) Stems naked very rough branched at base, Sheaths black with white membran. lanc. teeth, Spike terminal 14631 Stems simple erect very rough bearing spikes at the extremity, Sheaths whitish black at base and summits, Teeth aristate deciduous
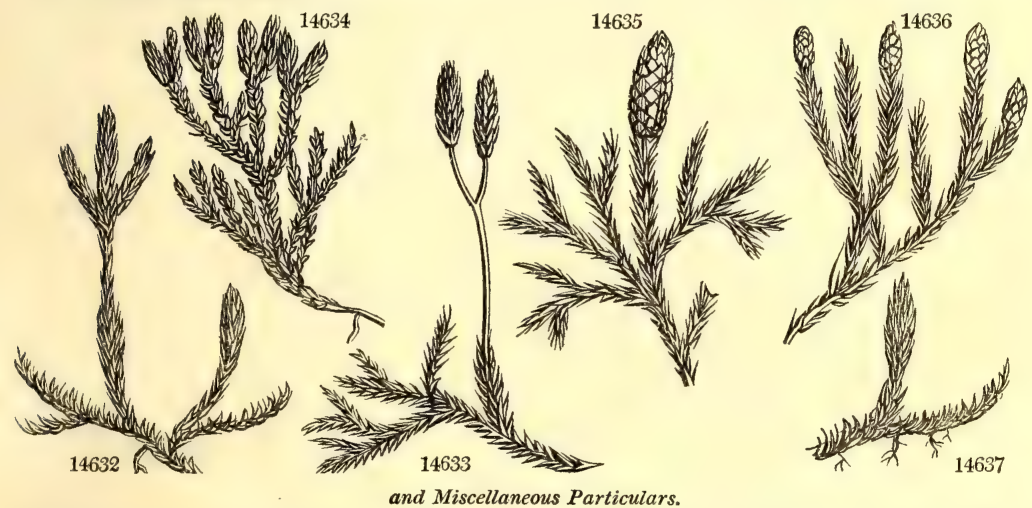

and Miscellaneous Particulars.

that it is cut as fodder for kine, but that it is not so acceptable to horses. E hyemale is the best species for polishing wood and metal, and is imported from Holland for that purpose under the name of Dutch rushes. It is much used by whitesmiths, cabinet-makers, and comb-makers, and formerly it was in demand for scouring pewter and wooden things in the kitchen. 


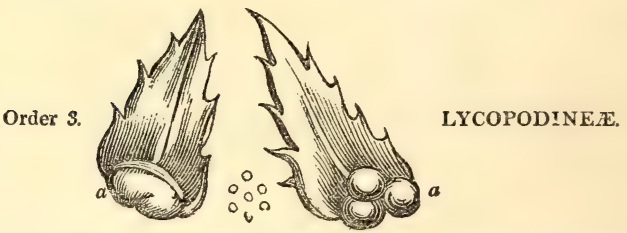

Reproductive organs axillary, sometimes apparently spiked. Theca? of two kinds, the one containing minute granules, the other larger bodies. Stems covered with many small leaves.

THE reproductive organs of these plants are always axillary, the apparently spiked arrangement which they occasionally present being caused by the partial abortion of the leaves, at the base of which they are seated. The thecæ $(a)$ ? the nature of which is very doubtful, and which have accordingly been called by different writers capsules, conceptacula, and cocci, are formed of from one to three valves, and of a similar number of cells, and contain either a mass of minute powdery granules, or some corpuscles of a larger size. The nature and properties of both these are uncertain. Decandolle imagines that one may be the means of fertilizing the other.

2210. Lycopodium. Thecæ reniform, 1-celled, 2-valved, wich many sporules. Sporules very minute, powdery.

2211. Psilotum. Thecæ 3-coccous, 3-celled; cells opening,upwards, half 2-valved.

2212. LYCOPO'DIUM. $L$. CLUB-Moss.
14632 clavátum $W$ common

14633 complanátum $W$. Arbor-vitæ-lvd. $\quad \Delta$ cu $\quad \frac{3}{4}$ jl.au $\quad \mathrm{Br} \quad$ N. Amer. 1770. D p.l Fl. dan. 78

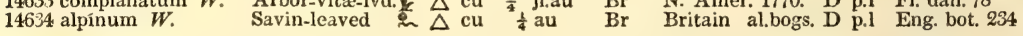

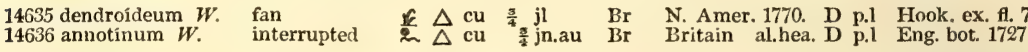

14637 inundátum $W$. marsh \& $\Delta$ cu $\frac{1}{4} \mathrm{jn} . \mathrm{jl} \quad \mathrm{Br}$ Britain tur.bo. D p.l Eng. bot. 239

14638 Selaginoídes $W$ prickly $\quad$ 2 $\Delta \mathrm{cu} \quad \frac{3}{4}$ au $\quad \mathrm{Br} \quad$ Britain w.al.h. D p.l Eng. bot. 1148

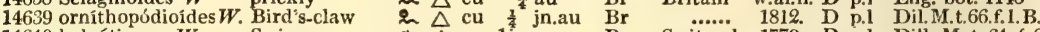
14640 helvéticum $W$. Swiss $\Delta \mathrm{cu} 1 \mathrm{in} \ldots \mathrm{Br}$ Switzerl. 1779. $\mathrm{D}$ p.l Dill. M. t. 64. f. 2

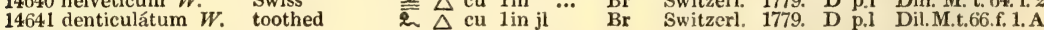

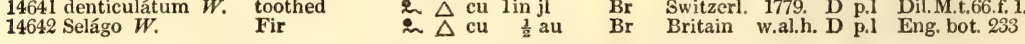

14643 rupéstre $W . \quad$ rock $\quad$ 2 $\Delta$ cu $\quad \frac{1}{4}$ au $\quad \mathrm{Br} \quad$ N. Amer. . ... D p.l Schk. fil. t. 165

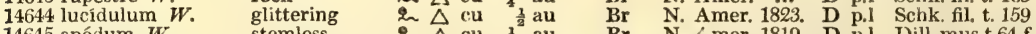

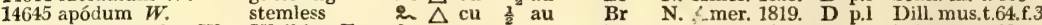

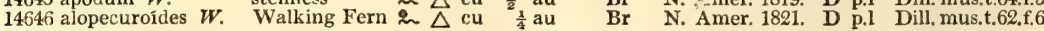

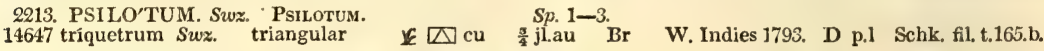

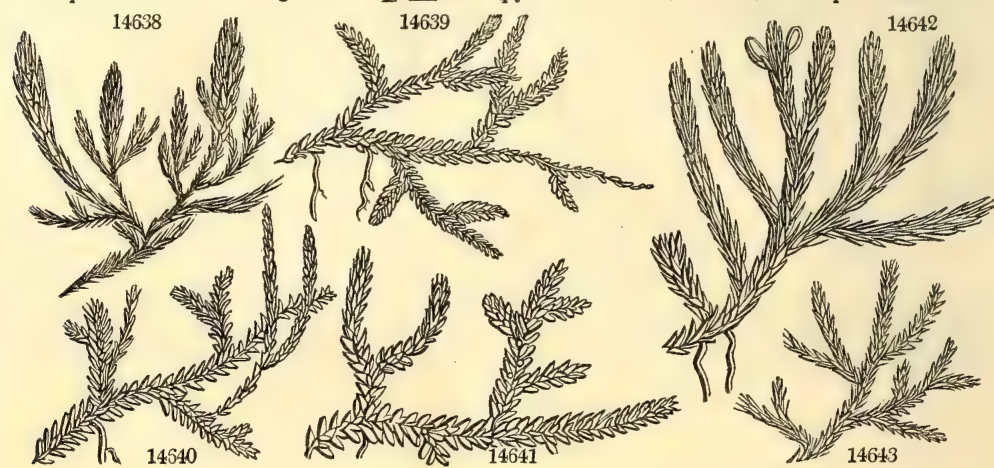

History, Use, Propagation, Culture,

2212. Lycopodium. From $\lambda v \% \circ$, a wolf, and $\pi 8 s$, a foot; on account, as Dalechamp assures us, of the resemblance the roots bear to a wolf's foot. Selago is an ancient word applied to some succulent plant, and derived, according to De Theis, from the Celtic sel, sight, and jach, salutary, as being useful for complaints in the eyes. From the same root sel, was formed selma, the name of Fingal's hall, which in modern language would be called Belle-vue. The species are neat little evergreen moss-like herbaceous plants, some of which are found in all parts of the world. $\mathrm{L}$ helveticum is a pretty prostrate plant, with small bright green leaves ; for the beauty of which it is often cultivated in hothouses on the edge of the aquarium or in pots set in for the beauty of which it is often cultivated in hothouses on the edge of the aquarium, or in pots set in
pans of water. L. Phlegmaria is a fine species found in various parts of the East Indies, but hitherto a stranger to our gardens. It is a parasite upon the trunks of trees, whence it hangs down in tufts from six inches to a 
14632 Stem creeping, Branches ascending, Leaves scattered incurved and hair-pointed, Spikes geminate cylindrical pedunculate : their scales ovate acuminate eroso-dentate

14633 Stem erect, Branches altern. dichotom. Leaves bifarious connate spreading at end, Spikes 4 round cylind. 14634 Stems prostrate, Branches dichotomous and fasciculated, Leaves quadrifarious oblong convex acute appressed, Spikes terminal solitary sessile short cylindrical

14635 Stem erect, Branches alternate compact dichotomous spreading, Spikes solitary terminal sessile

14636 Stem creeping, Branches ascending dichotomously branched, Branchlets simple, Leaves in 5 rows linear lanceolate mucronate serrulate patent, Spikes oblongo-cylindrical solitary sessile terminal

14637 Stem creeping, Branches simple solitary erect with a single sessile leafy spike at its extremity, Leaves linear scattered acute entire curved upwards

14638 Stem creep. Branches ascend. simple, Lvs. scattered lanc. subpatent ciliato-denticul. Spikes term. solitary 14639 Leaves bifarious spreading ovate acute : of the surface distichous ciliated flat, Spikes roundish sessile

14640 Lvs. bifar. $\frac{1}{2}$-cord. blunt. : of surface altern. distichous ovate-obl. blunt, Spikes stalked term. mostly in pairs

14641 Lvs. bifarious ovate subcord. acute toothletted : of surface altern. ovate acute, Spikes terminal short sessile 14642 Stems dichotomously branched erect fastigiate, Leaves scattered in 8 rows linear-lanceolate acuminate entire imbricated rigid, Capsules scattered not spiked

14643 Stem creeping branched, Leaves scatt. imbric. ciliated with a hair at end, Spikes solitary sessile terminal 14644 Leaves in 8 rows linear-lanceolate toothletted acute spreading reflexed, Stem ascending bifid

14645 Lvs. bifarious roundish ovate acute flat toothl. Stem branched rooting at base, Spikes term. sess. subsolit. 14646 Branches nearly simple long ascend. with one spike at top, Lvs.lin.-subul. toothed at base, Spike sess. leafy

14647 Stem dichotomous, Branches 3-cornered

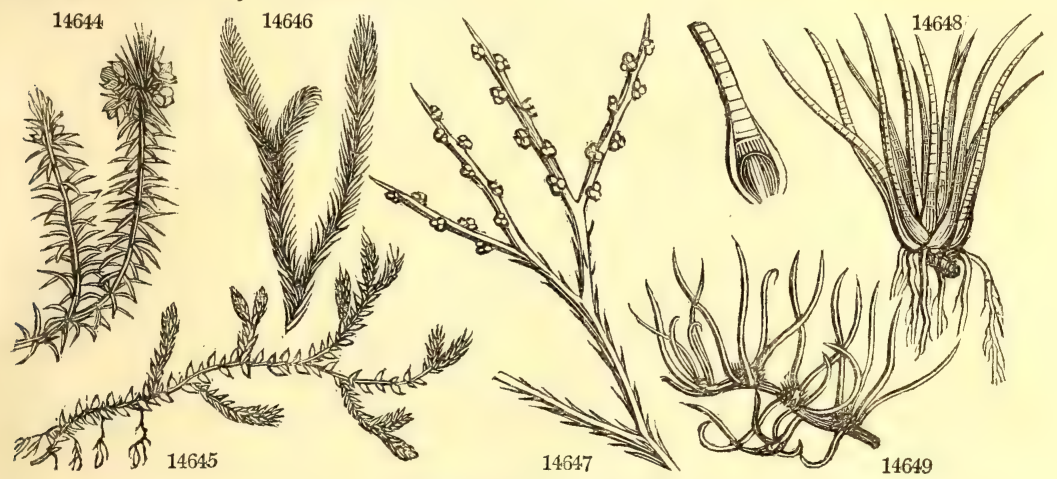

and Miscellaneous Particulars.

foot in length. I. Selago is used in Skye, and some other places, to fix colours in dying, instead of alum. The Highlanders employ it in infiusion as an emetic and cathartic; but it operates violently, and, unless taken in a small dose, brings on giddiness and convuisions. Linnæus says, the Swedes use a decoction of it to destroy lice on swine and other animals. All the species may be cultivated in a light peaty soil, but they require an abundance of moisture.

2213. Psilotum. From \&iخos, naked. This is a little bushy evergreen herbaceous plant of no beauty. Its branches are 3-cornered, and altogether destitute of leaves. The thecæ apvear from the little indentations of the branches, and are of a whitish-yellow color. It is easily cultivated in a little peat and sand, but it has no merit except as an object of curiosity. 
Order 4.
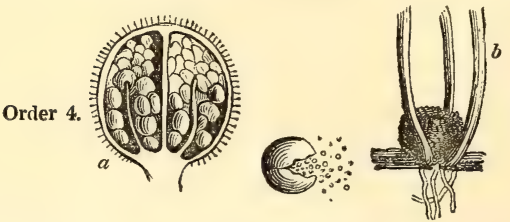

MARSILEACEÆ.

Reproductive organs radical, uniform. Sporules contained in roundish one or many-celled indehiscent heads. Plants simple, aquatic.

VERY few plants are found in this order. Their vegetation is various; they are at most a few inches high, and are more or less aquatic. In Isoetes the leaves resemble those of a young rush. The organs of reproduction are always near the root, and are variable, and their nature is by no means understood. In Pilularia $(a)$ it consists of a roundish head, divided internally into 1-4-cells, each cell containing small bodies of two kinds. In Isoetes $(b)$ the fructification is even less known and understood.

2214. Isoetes. Head membranous, not opening, immersed in the base of the frond, 1-celled. Sporules angular, inserted upon many filiform receptacles.

2215. Pilularia. Heads imbricated, solitary, nearly sessile, globose, coriaceous, 4-celled. Cells containing two kinds of bodies.

2214. ISOE'TES. $L$. 14648 lacústris $W$.

2215. PILULA'RIA L Pinwort 14649 globulífera $W$. Pepper-grass
QUILLWORT.

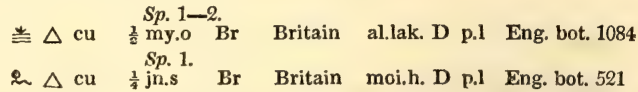

History, Use, Propagation, Culture,

2214. Isoetes. From 1605 , equal, and हros, the year; a plant which remains the same through all the seasons. A very curious little submersed aquatic, which grows at the bottom of some of the Scotch lakes. The leaves are long and cylindrical, whence the English name Quill-wort.

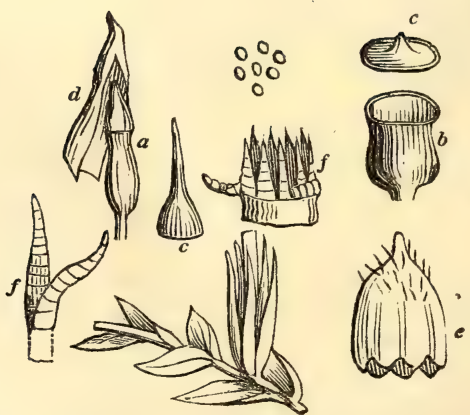

MUSCI.

Reproductive organs of 2 kinds. Theca many-seeded, solitary, furnished with an operculum and columella. Plants leafy.

Mosses are distinguished from all other similar plants, by the peculiar nature of the reproductive organs, which Mosses are disting The principal and the most obvious is a theca $(a, b)$, which is furnished with an operculum or are of two kinds. The principal and the most obvious is a theca $(a, b)$, which is furnished with an operculum or
lid $(c)$, by means of which the sporules are retained in the theca, and a columella, or central axis, to which they are attached. The other consist of minute spherical pedicellated organs, concealed in the axils of some of the leaves, and called anthers by Hedwig. The theca is either entire, or split into four valves, as in Andreæa; when in a very young state it is enclosed in an indusium, which is torn asunder as the theca is elongated, and being carried up with it, remains upon the summit of the theca in the form of a little extinguisher called 
14648 Fronds subulate half-cylinđrical, Heads roundish 2-celled

14649 Filiform branched creeping, Heads brown

and Miscellaneous Particulars.

2215. Pilularia. From pilula, a pill. The little heads in which the reproductive organs are enclosed resemble pills. An obscure little plant found creeping among grass in meadows in many parts of England, and especially in damp places which are overflowed during winter.

calyptra $(d)$; if the calyptra is slit up one side it is called dimidiate $(d)$, if divided at the base into many short clefts, it is termed mitriform $(e)$. The orifice of the theca, when the operculum is removed, is either covered by a simple membrane, or by various processes called the peristome $(f)$, either annular, or in the form of teeth, and arranged in a single or double row. These processes vary in number, and in the manner of their division; from such differences excellent characters for the genera have been obtained

The minute attention which mosses have recelved in modern times has brought their arrangement to a degree of perfection unknown in other Cryptogamic orders. This has been effected by the labor of Hooker, Greville, and Brown in our own country, and of Hedwig, Swartz, Bridel, Schwaegrichen, Palisot de Beauvois, Nees von Esenbeck, and Hornschuch abroad. The arrangement of the two last authors is chiefly adopted here from their excellent Bryologia Germanica.

With this order, the alteration in the form of our page, of which we have already spoken, commences. The columns indicating the habit, habitation in the garden, propagation, and soil, are necessarily omitted ; and their place is supplied by a more extended popular character, and more detailed references to plates. The heights indicated are to be understood as in inches, and not as feet; and the colors as the general color of the plant. In the figures it has been also found necessary to represent the plants in many cases much magnified; whenever this has taken place, the figures which are larger than nature are distinguished by $a *$ affixed to their number. The popular synonyms of this and the succeeding orders have been rendered as complete as possible, number. The popular synonyms of this and the succeeding orders have been rendered as complete as possible, index even in Cryptogamia.

Theca entirely sessile; its receptacle stalked, and without perichatial leaves.

2216. Sphagnum. Receptacle of theca stalked. Peduncle resembling a fruitstalk. Theca sessile on the receptacle. Mouth naked.

Tribe II. VAgINULATI OLOCARPI.

Theca more or less stalked: with perichatial leaves; not valvular.

$$
\text { A. Theca terminal. }
$$

2217. Phascum. Theca entire, adnate with the persistent lid. Calyptra shorter than the theca. 
** Theca dehrscent. Peristome absent.

2218. Schistostega. Fruitstalks terminal ; mouth of theca naked. Lid laciniated, with deciduous segments. 2219. Gymnostomum. Fruitstalk terminal. Calyptra dimidiate. Mouth of theca naked.

*** Theca dehiscent. Peristome present.

+ Peristome single.

2220. Hymenostomum. Fruitstalk terminal. Peristome destitute of teeth, but having an inner horizontal membrane perforated in the middle.

2221. Tetraphis. Fruitstalk terminal. Peristome of 4 erect teeth.

2222. Encalypta. Fruitstalk terminal. Peristome single of 16 teeth. Calyptra cylindrico-campanulate, wholly concealing the nature of the theca.

2223. Grimmia. Fruitstalk terminal. Peristome single, of 16 entire or perforated rarely cleft teeth.

Calyptra mitriform. Wruitstalk terminal. Peristome single, of 16 entire equidistant teeth. Calyptra dimidiate. 2225. Dicranum. Fruitstalk terminal. Peristome single, of 16 bifid equidistant teeth. Calyptra dimidiate. 2226. Trichostomum. Fruitstalk terminal. Peristome single, of 16 equal teeth divided to the base, or 32 in pairs. Calyptra mitriform.

2227. Cinclidotus. Fruitstalk terminal. Peristome single, of 32 filiform twisted teeth anastomosing at their base. Calyptra mitriform.

2228. Tortula. Fruitstalk terminal. Peristome single, of 32 filiform twisted teeth, nearly free, or more or less united by a tubiform membrane. Calyptra dimidiate.

2229. Pterogonium. Fruitstalk lateral. Peristome single, of 16 entire equidistant teeth. Calyptra dimidiate. 2230. Didymodon. Fruitstalk terminal. Peristome single, of 16 bifid equidistant teeth. Calyptra dimidiate.

2231. Splachnum. Fruitstalk terminal. Peristome single, of 8 geminate teeth. Theca with an evident apophysis. Columella exserted, capitate. Calyptra mitriform.

2232. Conostomum. Fruitstalk terminal. Peristome simple; teeth solitary, entire, separate at base, 16 in number, united at the tips.

\section{+ Peristome double.}

2233. Orthotrichum. Fruitstalk terminal. Peristome mostly double ; outer one of 16 teeth, approaching in pairs ; inner one of 8-16 ciliary processes or none. Calyptra mitriform. Columella capitate.

2234. Zygodon. Fruitstalk terminal. Peristome double or simple; teeth in pairs. Calyptra cucullate.

2235. Diphyscium. Fruitstalk terminal. Peristome always double; outer with 16 teeth : teeth obscure.

Theca subsessile.

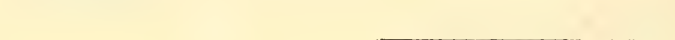

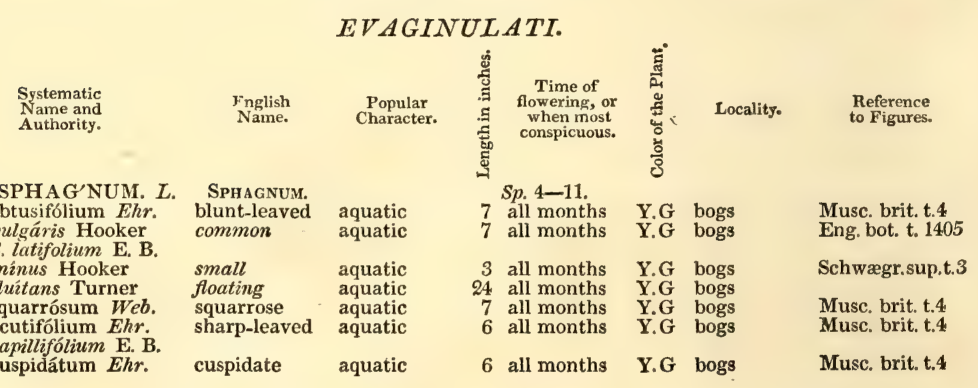

\section{VAGINULATI OLOCARPI.}

2217. PHAS'CUM. $L$. Phascum.

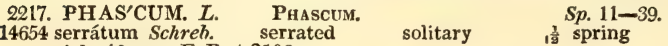

stoloniferum E, B. t.2106
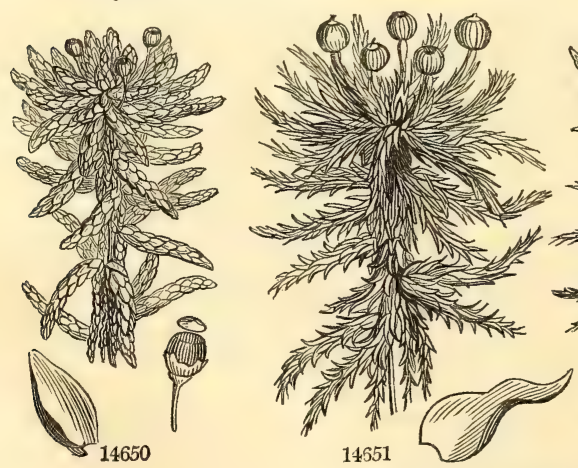

Pa.G shady banks Musc. brit.t.5

History, Use, Propagation, Culture,

2216. Sphagnum. A name employed by Pliny to distinguish some kind of moss that grew upon trees. In this genus the theca is sessile, being entirely destitute of a real fruitstalk. That which appears like one is the footstalk of the receptacle, which in most of the Sphagna is so much lengthened out as greatly to exceed the perichretial leaves. All the species agree in the peculiar structure of the leaves, of which the reticulation is 
2236. Buxbaumia. Fruitstalk terminal. Stem none. Theca oblique, gibbous. Peristome double : outer one of many filiform, torulose processes; inner one of a conical plicate membrane. Calyptra mitriform

2237. Funaria. Fruitstalk terminal. Peristome double, oblique; outer and inner ones each of 16 teeth, opposite to each other.

2238. Bartramia. Fruitstalk terminal. Theca subglobose. Peristome double: outer one of 16 teeth; inner one of a membrane cleft into 16 bifid segments. Calyptra dimidiate.

2239. Pohlia. Fruitstalk terminal. Peristome double: teeth separate acute; membrane with 16 processes, which are entire at the end without ciliæ.

2240. Bryum. Fruitstalk terminal. Peristome double : outer one of 16 teeth; inner one of a membrane cut into 16 equal segments, with filiform processes often placed between them. Calyptra dimidiate.

2241. Polytrichum. Fruitstalk terminal. Peristome double : outer one of 32 or 64 equidistant incurved teeth; inner one of a dense horizontal membrane connected with the outer teeth. Calyptra dimidiate.

\section{B. Theca lateral.}

2242. Anictangium. Fruitstalk lateral. Calyptra mitriform. Mouth of theca naked.

2243. Fissidens. Fruitstalk lateral. Peristome simple. Calyptra smooth. Teeth bifid.

2244. Leucodon. Fruitstalk lateral. Peristome simple, with bifid processes.

2245. Fontinalis. Fruitstalk lateral. Peristome double: outer one of 16 teeth ; inner one of 16 ciliary processes formed by transverse bars into a reticulated cone. Calyptra mitriform.

2246. Anomodon. Fruitstalk lateral. Peristome double: the first of 16 teeth; the second of 16 ciliary processes arising from the teeth. Calyptra dimidiate.

2247. Neckera. Fruitstalk lateral. Peristome double : outer one of 16 teeth ; inner of 16 ciliary processes, connected only at the base by a short membrane Calyptra dimidiate.

2248. Daltonia. Fruitstalk lateral. Peristome double : membrane figured, with 16 ciliæ and reflexed teeth. 2249. Hookeria. Fruitstalk lateral. Peristome double: outer one of 16 teeth; inner one of a membrane cut into 16 entire segments. Calyptra mitriform.

2250. Leskea. Fruitstalk lateral. Peristome double. Membrane with 16 entire processes. Teeth erect or reflexed. Calyptra cucullate.

2251. Hyprum. Fruitstalk lateral. Peristome double : outer one of 16 teeth; inner of a membrane cut into 16 equal segments, with filiform processes often between them. Calyptra dimidiate.

Tribe III. VAGINULATI SCHISTOCARPI.

Theca more or less stalked, with perichatial leaves, valvular.

2252. Andreac. Theca 4-valved : valves cohering at apex, and adnate with the persistent lid.

\section{EVAGINULAT'I.}

14650 Branches tumid, Leaves ovate obtuse

$\propto$ Stems loosely tufted, Leaves closely imbricated

$\beta$ Stems densely tufted, Leaves closely imbricated

$\gamma$ Stems much lengthened, Leaves scattered remote

14651 Branches attenuated at their extremities, Leaves ovato-acuminate squarrose recurved 14652 Branches attenuated, Leaves ovate-lanceolate crowded

14653 Branches attenuated, Leaves lanceolato-subulate lax

\section{VAGINULATI OLOCARPI.}

* Shoots creeping, leafless, articulated, branched.

14654 Shoots branched conferva-like, Perichatial leaves lanceolate serrated nerveless

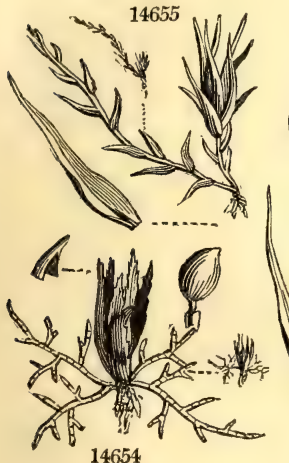

14654

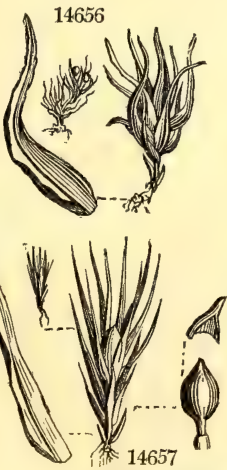

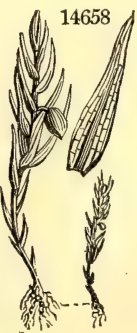

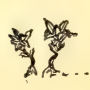

14661
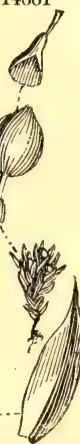

large, and the interstices or areolæ oblong, interr

2217. Phascum. One of the ancient Greek names of the moss was parkov. This genus contains species 


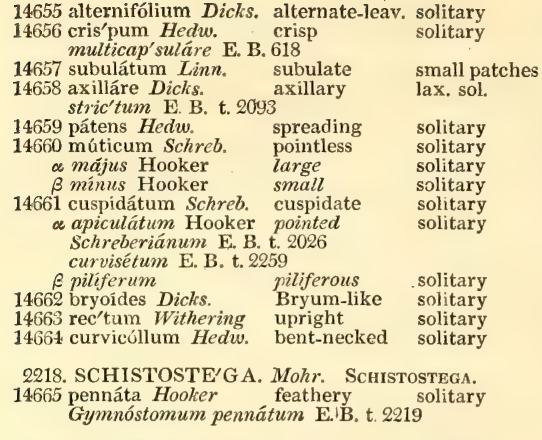

2219. GYMNO'STOMUM. Hedw. Gymnostomum. 14667 astivum Hedw. Lapland a $\begin{aligned} & \text { dense tufts } \\ & \text { thick tufts }\end{aligned}$ lutéolum E. B. t. 2201 14668 viridis'simum E. B. very green tufts

14669 curviróstrum Hedw. bent-pointed tufts stellígerum E. B. t. 2202

14670 rupes'tre $S$ chwagr: rock aruginósum E. B. t. 2200

\section{Griffithsiánum E. B. Griffith's 14672 ovátum Hedw. ovate \\ a vulgáre Hooker common \\ $\beta$ gracile Hooker slender \\ 14673 truncátulum Hoffm. truncate intermédium E. B. t. 1976 \\ 14674 Heímii Hedw. Heim's obtüsum E. B. t. 1407 \\ 14675 cónicum Schwagr. conical 14676 fasciculáre Hedw. bundled 14677 pyrifórme Hedw. pyriform 14678 tenue Hedw. slender paucifólium E. B. t. 2506}

14679 Donniánum Smith Donn's
$1 \frac{1}{2}$ spring $\frac{1}{4}$ spring

Pa.G moist banks Musc. brit. t. 5

T. $\frac{1}{3}$ spr. and sum. Y.G moist banks Musc. brit. t.5

$\frac{1}{2}$ spr. and sum. Pa.G clay fields Musc, brit. t.5 spr. and sum. Bt. G moist banks Musc. brit. t. 5

$12 \frac{1}{2}$ spr. and sum. Bt. G moist banks Eng. bot. t. 2027

12 spr. and sum. Bt.G sea coast Musc. brit. t.5

${ }^{\frac{1}{2}}$ spr. and sum. Bt. G sum. Gr hed. moi. ba. Musc. brit. t. 5

$7_{3}$ spr. and sum. Gsh hed. moi. ba. Eng. bot. t. 2025

$\frac{1}{1}$ spr. and sum. Hoa sandy downs Eng, bot. $t .1888$ 1 spr and sum G banks and fi. Musc, brit t. 5

$\frac{1}{4}$ spr. and sum. G ${ }_{\frac{7}{8}}$ spr. and sum. L.G moist banks Musc. brit. t. 5 $\frac{1}{2}$ spr. and sum. L.G moist banks Musc. brit. $t .5$

Sp. 1.

$\frac{1}{4}$ spring $\quad$ L.G banks, Dev. Musc. brit. t. 8

Sp. $13-47$.

1 spring

$1 \frac{1}{2}$ spring

$\frac{3}{4}$ summer

alpine rocks Musc. brit. t.

Bt.G wet rocks Musc. brit.t.6

11 spring Pa.G moist rocks Musc. brit.t. 6

$1 \frac{1}{2}$ spr. and sum. D.G moi.mou. ro. Schwæg.sup.t.11

2220. HYMENO'STOMUM, $\boldsymbol{R}$. Brown. Hצmenostomum. $S p .1$

14680 microstómum $R$. Br. small-mouthed little-patches $\frac{1}{8}$ spring Gymnóstomum micróstomum E. B. t. 2215

\begin{tabular}{|c|c|}
\hline $\begin{array}{l}\text { little spots } \\
\text { broad patches } \\
\text { broad patches } \\
\text { broad patches } \\
\text { patches }\end{array}$ & $\begin{array}{l}\frac{1}{\frac{1}{2} \text { summer }} \\
\frac{1}{2} \text { all months } \\
\frac{1}{2} \text { all months } \\
\frac{1}{2} \text { all months } \\
\frac{1}{3} \text { all months }\end{array}$ \\
\hline small patches & 1 summer \\
\hline $\begin{array}{l}\text { little spots } \\
\text { patches } \\
\text { dense patches } \\
\text { little patches }\end{array}$ & $\begin{array}{l}\frac{1}{8} \text { summer } \\
\text { summer } \\
\frac{1}{2} \text { summer } \\
1 \frac{3}{4} \text { spring }\end{array}$ \\
\hline
\end{tabular}

little spots

patches
Pa.G mountains Musc. brit.t.7

Gr ba. \& wa.tops Musc, brit. t.7

Gr ba. \& wa.tops Eng. bot. t. 1889 Gr ba. \& wa.tops

Bt.G fields \& ban. Musc. brit. t. 7

Rsh marit. banks Musc. brit. t.7

Pa.G fields, S. Jrel. Musc. brit. t.7 Y.G clayey banks Musc. brit. t.7 Bt. G moist places Musc. brit. t.7 Bt. $G$ sandst. rocks Musc. brit. t.7

Pa.G Scotch rocks Musc. brit. t.7

2221. TE'Tra PHis. Hedw. Tetraphis.

14681 pellácida Hedw. pellucid wide tufts 1 all months Pa.G dry banks Musc. brit.t.8

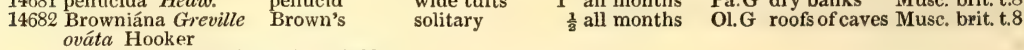
Grim'mia Broumiána E. B, t. 1422

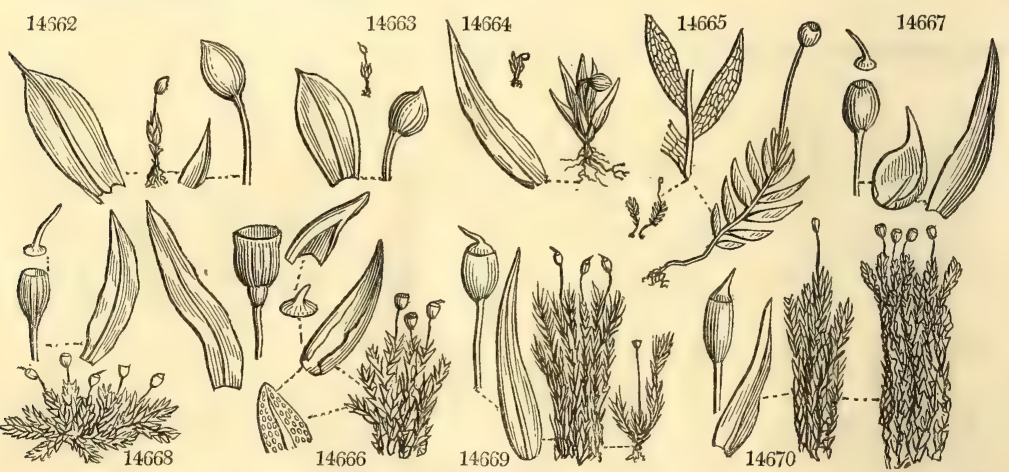

History, Use, Propagation, Culture,

which are not only amongst the minute of mosses, and often scarcely discernible to the naked eye, but also extremely dissimilar in appearance to each other

2218. Schistostega. From $\sigma \chi \chi^{2} \omega$, to split, and $s \varepsilon y n$, a covering, in allusion to the singular character of the lid splitting at the margin. The only known station for this minute moss is said by Dr. Hooker, from whose Muscologia Britannica, many of the remarks in this work upon the genera of mosses are borrowed, to be in the road from Zele to South Tawton church, near Okehampton, Devonshire.

2219. Gymnostomum. From ruuvos, naked, and sore, the mouth, in allusion to the processes called teeth, from the orifice of the theca. Very minute plants, many of which are barely distinguishable by the naked eye. 
14655 Leaves entire lanceolato-subulate, Innovations elongated

14656 Leaves lanceolato-subulate flexuose crisped when dry

14657 Leaves subulato-setaceous straight : their nerve disappearing below the point

14658 Leaves lanceolato-subulate straight : their nerve disappearing below the point, Fruit at length lateral

14659 Leaves patent narrow-ovate serrated : their nerve disappearing below the point

14660 Leaves ovato-rotundate acuminate concave connivent : the nerve reaching to the point

¿ Leaves sharply serrated at point

$\beta$ Leaves entire

14661 Leaves ovato-acuminate erect : their nerve reaching to the point

$\propto$ Leaves apiculate

$\beta$ Leaves hair-pointed

14662 Leaves ovate apiculate, Thecæ elliptical

14663 Leaves ovate with a short point, Thecæ globose, Fruitstalk nearly erect

14664 Leaves narrow-ovate acuminated, Thecæ globose, Fruitstalk curved

14665 The only species

\section{* Stem long, branched.}

14666 Leaves linear lanceolate crisped when dry : perichætial broadly ovate, Thecæ turbinate striated 14667 Lvs. lanc. twist. when dry : the perichætial ones broadly ovate ; their marg. involute, Thecæ obl, smooth

14668 Leaves broadly lanceolate, Thecæ ovate, Lid obliquely rostrate

14669 Leaves subulate, Thecæ turbinate ovate, Lid obliquely rostrate

14670 Lvs. lin. subul, spreading flexuose twisted when dry, Thecæ ovate, Lid conical rost. shorter than thecæ

** Stems short simple.

14671 Lvs. obov.-rotund, reticul. : their nerve disappear. below summit, Fruitstalk carnose thick, Lid hemispher. 14672 Lvs. ovate erect concave piliferous : their nerve furnished with a granuliferous membrane, Lid rostrate

œ Thecæ ovate

14673 Leaves ovate apiculate patent nearly plane, Lid obliquely rostrate

14674 Leaves lanceolate serrated at the point, Thecæ ovato-oblong, Lid obliquely rostrate

14675 Leaves oblongo-obovate apiculate, Thecæ ovate, Lid conical obtuse

14676 Leaves oblongo-acum. nearly plane subserrated margined, Thecæ pyriform, Lid plane submammillate

14677 Leaves ovato-acum. concave serrated not margined, Thecæ roundish obovate, Lid convex shortly rost.

14678 Stem scarcely any, Outer leaves very short ovate lanceolate : inner ones linear lanceolate; all erect obtuse with a strong nerve disappearing below the summit, Thecæ oblong

14679 Stem very short, Leaves subulate straight, Thecæ turbinate

[subulate incurved

14680 Lvs. broadly subul, : marg. invol, above flexuose crisped when dry, Thecæ ellipt. contracted at mouth, Lid

14681 Stems elongated, Leaves ovato-acuminate : those of the perichætium lanceolate, Thecæ cylindrical 14682 Stems very short, Lvs. few lin. slightly incrassated upw. : those of perichætium ovate obtuse, Thecæ ovate
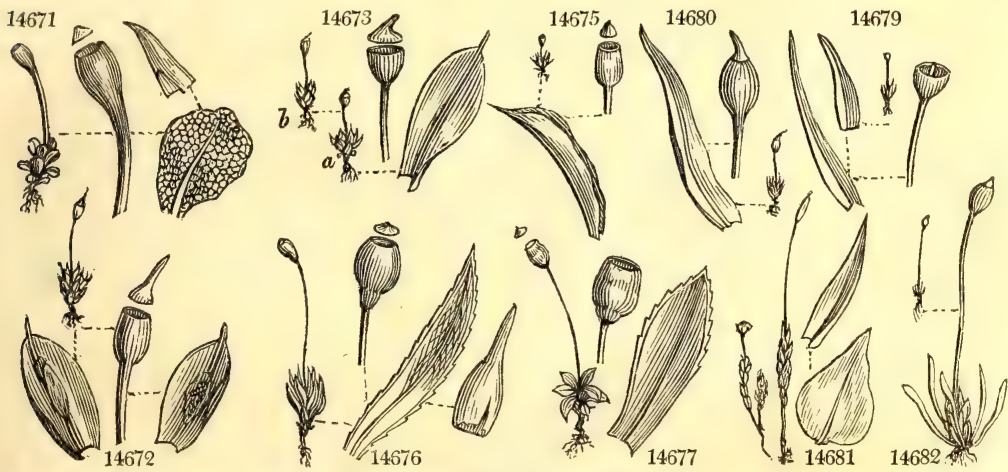

and Miscellaneous Particulars.

2420. Hymenostomum. From i unv, a membrane, and sore, a mouth. This genus differs from the last in having a membrane stretched across the orifice of the theca, a character first discovered by Mr. Brown. Minute plants, with the habit of Gymnostomum.

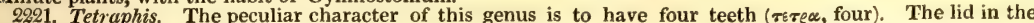
only known species of this genus is remarkably thin and scariose in texture, and the teeth are reticulated, not striated as in most mosses. The calyptra is striated or furrowed; the leaves are rigid. 
2222. ENCALYP'TA. Hedw. Encalypta.

14683 streptocárpa Hedw. twisted-fruited tufts

14684 vulgáris Hedw. common wide patches Brýum extinctórium E. B. t. 558

14685 ciliáta Hedw.

a cóncolor Hooker whole-colored tufts

$\beta$ alpina Hooker alpine

14686 rhaptocárpa Schwag. straight-fruit. tufted

2223. GRIM'MIA. Hedw. Grimmia

14687 apocárpa Hedw. alpine

a nigro-víridis Hooker dark-green

$\beta$ stric'ta Turner straight

14688 marítima Turn. sea-coast

14689 saxícola Hooker rock

14690 pulvináta $E . B$.

cushion

14691 leucophæ'a Grev. mottled

14692 Daviésii Turn. Welsh Encalyp'ta Daviésii E. B. t. 1281

14693 ováta Web. \& Mohr. ovate Dicránum ovále E. B. t. 2165

14694 trichophýlla Greville hair-leaved

14695 Doniañ Smith Don's

dense tufts

tufts

loose tufts

tufted

subsolitary

round tufts

broad tufts

little patches

tufts

tufts

little tufts

2224. WEIS'SIA. Hedw. Weissia.

14696 splachnoídes Schwaeg. Splachnu.-like broad tufts Grim'mia splachnoides E. B. t. 2164 Splach'num lingulátum E. B. t. 2095

14697 Templetóni Hooker Irish Funaria Templetóni E. B. t. 2524

Sp. 4-7.

$1 \frac{1}{2}$ all months Bt. $\mathrm{G}$ moist rocks Musc. brit. $t .13$ $\frac{x}{4}$ all months

$\frac{1}{2}$ spring

$\frac{1}{2}$ spring

spring

Sp. 9-29.

$1 \frac{1}{2}$ all months

$1 \frac{1}{2}$ all seasons $\quad$ D.Ol rocks \& trees Eng. bot. t. 1134

3 all seasons Ruf mountains Tu.mu.hi.t.2.f.

$\frac{3}{4}$ spr. and aut. Br.G marine rocks Musc. brit. t.13

$\frac{1}{8}$ summer Bt.G rocks Musc. brit. t.13

$\frac{3}{4}$ all seasons Br.G house-tops Musc. brit. t.13

$\frac{1}{2}$ all seasons D.Ol subalp. rocks Wer. trans.4.t.6 spring Br.G marit. rocks Musc. brit. t.13

$\frac{\pi}{4}$ spr. and sum. D.G alpine rocks Musc. brit. t.13

$\frac{3}{4}$ summer Hoa stone w., Sc.

D.G loose stones Musc. brit. $t .13$

3 summer $19-54$.

D.G Scotch bogs Grev.cryp.fl.145

little patches $\frac{x}{4}$ spring

L.G banks, Irel. Musc. brit. t.14

14698 núda Hooker

naked Grim'mia núda E. B. t. 1421

14699 nigrita Hedw. Grim'mia nigríta E. B. t. 1825

14700 latifólia Schwaeg. broad-leaved

14701 Starkeána Hedw. Starke's Grim'mia Starkeána E. B. t. 1490

14702 affínis Hooker kindred

14703 lanceoláta Hook. lanceolate Grim'mia lanceoláta E. B. t. 1408

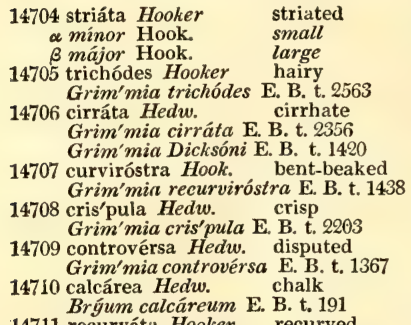

little patches $\quad \frac{1}{2}$ summer

tufts

tufted $\frac{1}{4}$ autumn

subsolitary $\quad$ I $\frac{1}{2}$ spring

subsolitary $\frac{1}{2}$ summer

round tufts $\frac{1}{4}$ spring

round tufts

$\frac{1}{4}$ spring

tufts $\frac{1}{5}$ summer

1 all seasons R.G roc. and ban. Musc. brit. t.14

tufts

dense tufts

dense patches

$\frac{1}{2}$ sum. and aut. D.G rooks

Musc. brit. t.15

subsolitary $\quad \frac{2}{8}$ spring

solitary spring

L.G clayey soil Musc. brit. t.14

Br.G mount. ban. Musc. brit. t.14

Pa.G Scot. mount. Grev. cryp.fi.149

D. G banks and ti. Musc. brit. t.14

Pa.G fields Musc. brit. t.14

L. $G$ moist banks Musc. brit. t.14

Bt. $\mathrm{G}$ alpine banks Musc. brit. t.15

Bt.G alpine banks Hed.sp.mus.t.13

Bt. G alpine banks Schwæo sup t 19

L. G decay. wood Musc. brit. t.15

Ol. G chalk cliffs Musc. brit. t.15

L. G rocks Musc. brit. t.15
Bt.G granite roc. Musc. brit. t.15

14711 recurváta Hooker recurved Grim'mia recurváta E. B. t. 1489
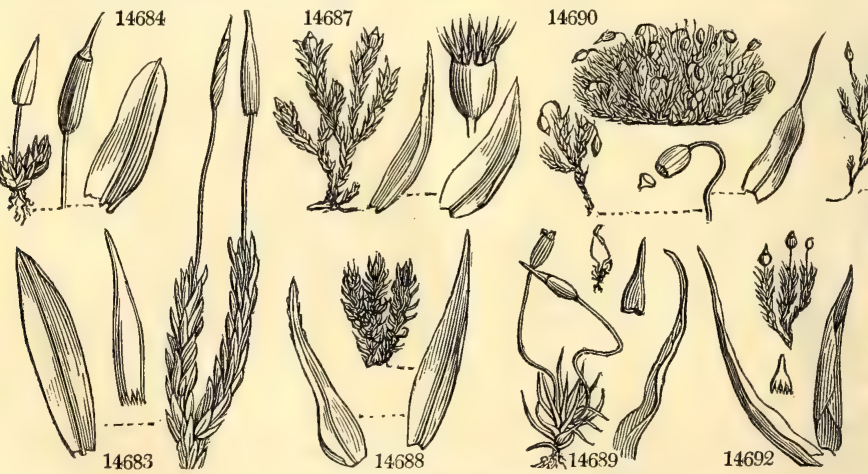

History, Use, Propagation, Culture,

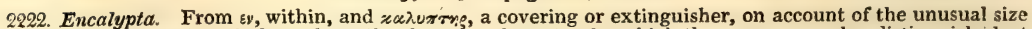
of the calyptra, which entirely encloses the theca; a character by which the genus may be distinguished at first sight. Small plants, forming imperfect tufts of green among moist rocks, or on mud-capped walls.

2293. Grimmia. Named in honor of I. F. C. Grimm, a German botanist, who published a Flora of Eisenach. 
[Calyptra toothed at the base

14683 Stems elong. Lvs. elliptico-lanc. somew. obt. : nerve not produced beyond sum. Thecæ cylind. spiral. striat. 14684 Stems short, Leaves oblongo-elliptical obtuse : their nerve produced a little beyond the summits, Theca cylindrical smooth, Calypt. entire at the lase

14685 Stems short, Lvs. obl. acum. : nerve produced considerably bey. summ. Thecæ cylind, Calyp. tooth. at base $\propto$ Leaves apiculate : their points of the same color, Theca smooth

\& Leaves much acuminate : their points diaphanous, Theca smooth

14086 Leaves oblong acute : nerve as long or longer than the leaves, Theca straight striated

14687 Stems branched, Leaves ovato-lanceolate recurvo-patent any.

(heir margins reflexed; the perichætial ones « Leaves broad dark-green

$\beta$ Stem long, Leaves narrow and rufous

[running beyond summits, Theca ov. sess. Lid shortly rost. 14688 Stems short pulvin. Lvs. lanc. acum. nearly erect crisp. when dry : marg. recurv.; perich. ones with nerve ** Fruitstalks longer than leaves.

14689 Stem scarcely any, Lvs. lin.-subulate crisped when dry, Theca ovate, Fruitst. geniculate, Lid rost. straight 14690 Stems short pulvinate, Leaves narrow elliptical : their margins recurved; points diaphanous piliform, Theca ovate striated, Fruitstalks curved, Lid conical acuminate

14691 Stem rather short, Lvs. ov. with long white pilifer. points, Footst. very short, Theca ov. Lid obscurely rost. 14692 Stems short, Leaves lanceolate acuminate carin. entire much crisped when dry : their margins recurved; those of the perichætium broad and convol. Theca turbinate, Lid rostrate

14693 Stems slightly branched, Leaves lanceolate-subulate gradually produced into long diaphanous hair-like points : their margin incurved, Theca ovate, Teeth of the peristome often perfora. and split, Lid rost.

14694 Lvs, lanc. subul, carin, recurv, at edge with a hair-like point, Seta curv, and flex. Theca ov, ellipt. Lid rost.

14695 Stems short, Ieaves lanceolate-subulate produced into long diaphanous hair-like points : their margin incurved, Theca ovate, Teeth of the peristome quite entire, Lid shortly rostrate

* Theca with an apophysis.

14696 Lvs. lingul, rounded at top : nerve disappear, before summ. Theca obov. Apophy. obcon. Lid convex acum.

14697 Leaves ovato-lanceolate acute, Theca (with the apophysis) narrowly pyriform, Lid nearly plane

\section{** Theca destitute of an apophysis.}

1. Leaves ovate or lanceolate.

14698 Stems scarcely any, Leaves ovato-lanceolate nerveless, Theca ovate gibbous on one side cernuous

14699 Stems elongat. Lvs. lanc. acum. Theca obovate cernuous gibbous sulcate, Lid hemispheric. obtusely point. 14700 Stem simple short, Leaves broad and bluntly ov. with a short point imbric. Nerve shorter than leaf, Theca 14701 Stems very short, Lvs. ov. with an excurr. nerve, Theca ov. erect, Lid conical, Teeth of perist. subul. acute

14702 Stems very short, Lvs. ov. with an excurr. nerve, Theca ov. erect, Lid conic. Teeth of perist. subulate acute 14703 Stems somew. elongat. Lvs. ov. with an excurr. nerve almost piliferous, Theca ovate, Lid obliquely rostrate

\section{Leaves linear or subulate.}

14704 Leaves linear denticul, crisped when dry, Theca ovato-turbinate sulcate erect, Lid obliauely subulate $\propto$ Leaves linear-subulate subserrulate

$\beta$ Leaves broad-linear denticulate

14705 Stems scarcely any, Leaves subulato-setaceous entire, Theca ovate striated, Lid rostrate

14706 Leaves broadly subulate crisped when dry : their margins recurved, Theca ovate, Lid rostrate

14707 Leaves linear-subulate, Theca ovate cylindraceous, Lid rostrate

14708 Stems divid. Lvs. from a broad base lanc.-subul. crisp. when dry : marg. incurv. Theca ov. ellipt.Lid rostrate 14709 Stems nearly simple, Lvs, lin. -subul. crisp. when dry : their marg. incurv. Theca ovato-ellipt. Lid rostrate 14710 Stems scarcely any, Lvs. from a broad base lin. obt. thick with a very broad nerve, Theca turbin. Lid rost. 11711 Stems scarcely any, Leaves subulate, Theca broadly ovate, Fruitstalks curved, Lid rostrate

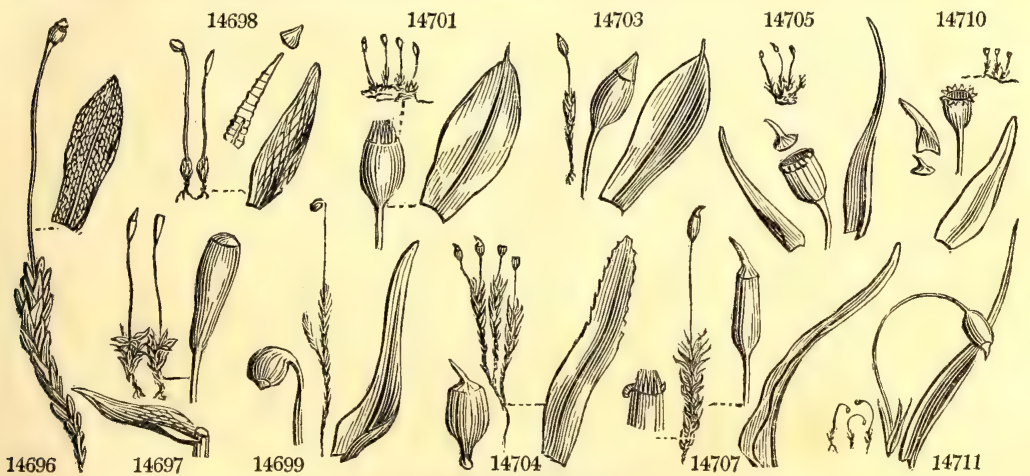

and Miscellaneous Particulars.

Plants growing in roundish tufts, and nearly related to Trichostomum. G. pulvinata is the moss which forıns those little cushion-like dark brownish green lumps which are so commonly spotted over the tops of old walls and houses.

2224. Weissia. In honor of J. W. Weiss, a German cryptogamic botanist. There was also a John 
14712 pusilla Hedw. dwarf Grim'mia pusílla E. B. t. 2551

14713 verticilláta Schwæg. whorled Grim'mia verticilláta E. B. t. 1258

14714 acúta Hedw.

Grim'mia acúta $\mathbf{E}, \mathbf{B}$.

2225. DiCRA'NUM. Hedw. Dicranum.

14715 glaúcum Hedw. glaucous

14716 latifólium Hedw. broad-leaved
Trichóstomum piliferum E. B. 2536

14717 longifólium Hedw. long-leaved

14718 flexuósum Hedw. flexuose

14719 flavéscens Smith yellowish

14720 squarrósum Schrad. squarrose

14721 pellácidum Swz. pellucid

14722 spúrium Hedw. spurious

14723 cris'pum Hedw. crisp

14724. Scottiánum Turn. Scott's flagelláre E. B. t. 1977

14725 polycárpon Ehr.
Bruntóni E. B. t. 2509

14726 undulátum $E h r$ wave-leaved

14727 scopárium $\boldsymbol{H}$ du. a május Hooker large $\beta$ fuscéscens Turner brownish

14728 várium Hedw. various

a viride Hooker green

callis'tomum Smith Fi. Brit.

$\beta$ ruféscens brown

$\gamma$ luridum Hooker lurid

14729 fulvéllum Smith tawny

14730 heteromállum Hedw. interrupted

14731 subulátum Hedw. subulate

14732 cerviculátum Hedw. hooked pusillum E. B. t. 2491

uncinátum E. B. t. 2261

14733 vírens Hedw. green tuft

14734 strumiferum Smith thick-necked tufts

14735 falcátum Hedw. falcate

14736 Schreberiánum Hedw. Schreber's

14737 Stárkii Web. \& Mohr. Starke's

Trichostomum. 14738 pátens Schwaegr. spreading
Dicránum pátens E. B. t. 1990

Tr. obtusum Fl. Brit.

14739 lanuginósum $\mathrm{Hedw}$. woolly

14740 canéscens Hedw. hoary T. ericoídes E. B. t. 1991

14741 heteróstichum Hcdw. branched tufts dense patches $1 \frac{1}{2}$ spring

Bt. G calcar. rocks Musc. brit. t.15

tufts

s. summer

Bt.G moist rocks Musc. brit. t.15

1 sum, and aut. Ol.G moist rocks Musc. brit. t.15 Sp. $23-47$.

4 autumn W.G moors Musc. brit. t.16 $\frac{3}{4}$ spring Bt.G moun. banks Musc. brit. t.16

3 win. and spr. Bt.G wet rocks Musc. brit. t.16

3 win. and spr. D.G peat bogs Musc. brit. t.16

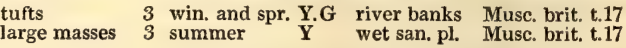

$1 \frac{1}{2}$ spr. and sum. D.G wet san. pl. Musc. brit. t.17 dense masses 4 summer Bt.G bogs Musc. brit. t.17 loose patches all months Bt.G moist banks Musc. brit. t.17 large masses $2 \frac{1}{2}$ sum. and aut. Bt. G mount.rocks Musc. brit. t.18 $\begin{array}{llll}\text { round tufts } & \frac{1}{2} \text { all seasons } & \text { Bt. G rocks } & \text { Musc. brit. t.18 }\end{array}$ tufts $\quad 2 \frac{1}{2}$ summer $\quad$ Bt. $G$ woods $\&$ roc. Musc. brit. t. 18 patches $\quad 3$ win. and spr. Dp.G woods $\&$ ban. Musc. brit. t.18 patches $\quad 3$ win. and spr. Dp. G woods \& ban. Eng. bot. t. 354 tufts 2 spring Brsh heathy plac. Eng. bot. t. 1597 oose patches $\frac{1}{2}$ spring $\quad$ D.G moist banks Musc. brit. t.17 oose patches $\frac{1}{2}$ spring D.G moist banks Eng. bot. t. 1215

loose patches $\frac{x}{2}$ spring $\quad$ Rsh moist banks Eng. bot. t. 1216 loose patches

$\begin{array}{lll}\text { dense tufts } & \frac{3}{4} \text { spr. and sum. Bt. G crev.of rocks Grev. cryp.fi.188 } \\ \text { large patches } & \text { Bt. G moist banks Musc. brit. t.18 }\end{array}$ spring Bt.G moist banks Musc. brit. t.18 small spots $\quad$ Str bring bogs $\quad$ Musc. brit. t.16

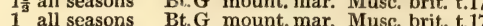

large patches 2 spr. and aut. Bt.G alpine rocks Hoo.mus.br.t.17 tufted ${ }^{\frac{1}{4}}$ spring $\quad$ Bt.G moi.pl., Scot. Grev. cryp.fl.116 tufts $\quad 1^{\frac{1}{4}}$ spring $\quad$ Bt.G alpine rocks Musc. brit. t.17

Sp. 9-18.

deep patches 6 all seasons Hoa mountains Musc. brit. t.19 deep tufts $\quad 4$ all seasons

Hoa stonymount. Musc, brit. t.19 tufted creep. $1 \frac{1}{2}$ all seasons Y.G heaths Musc. brit. t.19 broad tufts 1 all seasons Hoa ston. on mo. Musc. brit. t.19 14742 microcárpon Hedw. small-fruited deep patches 2 all seasons 01 rocks Musc. brit. t.19
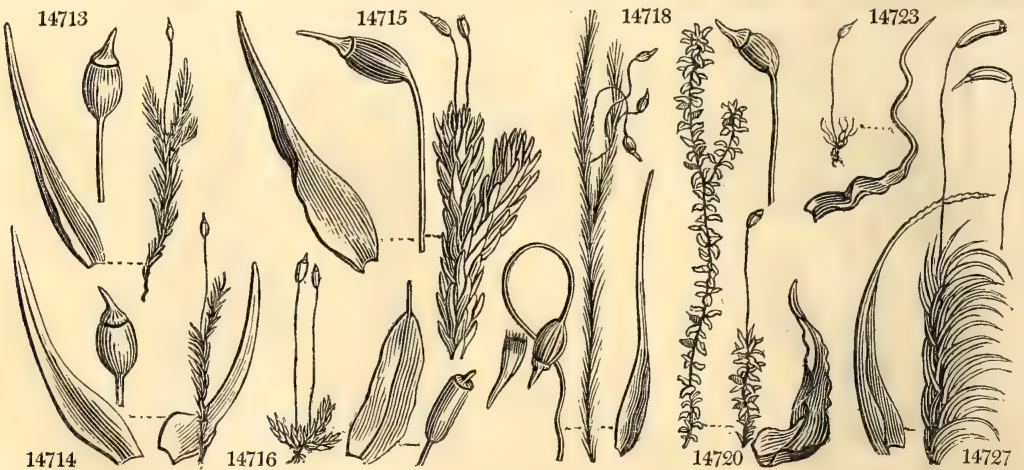

History, Use, Propagation, Culture,

Christopher Weiss, who published, in 1712, a Dissertation on the pomegranate. These plants are chiefly found in wet places, most frequently in alpine countries ; in habit they resemble Gymnostomum.

2225. Dicranum. Named by Hedwig, from dixeavos, forked, in allusion to the division of the teeth. This is one of the finest genera of mosses, containing many species which form broad masses of turfy vegetation, giving a decided character to the face of the varth where they grow. Like most of the genera of this order, 
14712 Stems scarcely any, Leaves subulate, Theca ovate, Fruitstalks always erect, Lid rostrate

14713 Stems branched, Leaves broadly subulate nearly flat rather flaccid, Theca ovate, Lid rostrate

14714 Stems branched, Leaves subulate-setaceous subsecund rigid canaliculate, Theca turbinate, Lid rostrate

* Theca without a struma.

14715 Stems branched fastigiate, Lvs. erecto-patent ov. lanc. straight nerveless ent. Theca ov. cern. Lid ros $^{4}{ }^{2}$ ate 14716 Stems short, Leaves oblong concave entire apiculate or piliferous, Theca erect ovato-oblong, Lid rostrate [nearly erect, Lid rostrate

14717 Stems elongat. Lvs. very long subul.-setace. falcato-secund serrul, : nerve very broad, Theca oblongo-ovate 14718 Stems nearly simple rigid, Leaves lanceolato-subulate acuminated straight: their nerve very broad, Fruitstalks flexuose, Theca ovate striated, Lid rostrate

14719 Stems branched, Lvs, long lanc. serrul. point, in all directions crisp. when dry, Thecæ obl. crect, Lid rost. 14720 Stems somewhat branched, Leaves from a broad sheathing base lanceolate obtuse recurved and patent directed to every side crisped when dry, Theca ovate subcernuous, Lid rostrate

14721 Stems branched, Leaves lanceolate : their margins slightly undulated serrated rather obtuse pointing in all directions, Theca ovate subcernuous, Lid rostrate

14722 Stems elongated, Leaves fasciculated concave erecto-patent directed to every side ovate : the superior ones lanceolate serrulate, Theca oblong curved, Lid rostrate

14723 Stems short, Leaves from a sheathing base setaceous nearly distichous flexuoso-recurved crisped when dry, Theca erect ovate, Lid with a long beak

14724 Stems branched, Leaves erecto-patent directed to every side subulate: their margins plane subserrated crisped when dry, Theca ovate cylindraceous nearly erect; Lid with a long beak

14725 Stems branched, Lvs. patent directed to every side lanceolate-subulate : their margins recurved flexuose subserrulate crisped when dry, Theca obovate subcernuous, Lid rostrate

14726 Stems elongated, Leaves nearly plane lanceolate attenuate serrulate at the points transversely undul. Theca cylindrac. cernuous, Lid with a long beak

14727 Stems elongated, Lvs. narr. subul, canalicul. sec. Theca cylindrac. arched cernuous, Lid with a long beak

$\propto$ Leaves falcato secund

$\beta$ Leaves subsecund narrow crisped when dry

14728 Stems short, Leaves narrow hastato-lanceolate, Theca ovate, Lid rostrate

1 $\alpha$ Leaves pointing all ways lanceolate green, Theca subcernuous

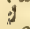

$\beta$ Leaves subsecund lanceolate subulate reddish, Theca erect

$\gamma$ Leaves subsecund subulate lurid, Theca subcernuous

[stalk, Lid short rostrate

14729 Stem near, simp. Lvs, very long subul setac. : nerve obsolete percurr. Theca obov, erect striat. with a short 14730 Stems branched, Leaves subul falcato-secund nearly ent. Theca ovate subcernuous, Lid with a long beak 14731 Stems branch. Lvs, from a broad sheath, base subul. setace. sec. ent. Theca ov, subcern. Lid with long beak ** Theca with a struma.

14732 Stems short, Lvs. lanc. subul. ent. subsec. : nerve very broad, Theca ovate subcern. strumose, Lid rost.

[tions, Theca furrowed oblongo-ovate subcern. strum. Lid rost 14733 Stems elongat: Lvs. from a broad sheath. base subul. ent. : marg. plane crisp. when dry pointing in all direc14734 Stems elongated, Leaves from a broad sheathing base subulate entire : their margins piane crisped when dry pointing in all directions, Theca furrowed oblongo-ovate subcernuose strumose, Lid rostrate

14735 Stems nearly simple, Lvs. long lanc.-subul. falcato-secund nearly ent. Theca ov. subcern. strum. Lid rost. 14736 Stem erect simple, Lvs, spread long subul, dilated and amplexic at base, Theca ov, cernu. strum, Lid rost. 14737 Stems somew. branch. Lvs. lanc. subul. falcato-secund entire, Theca oblongo-ov. suberect strum. Lid rost.

14738 Stems elongat. Lvs. lanc. acuminated carinated : margins recurv. Theca ovate, Fruitst. curved, Lid conic.

14739 Stems elongated subpinnate, Leaves lanceolato-subulate acuminate : their long diaphanous points serrat. ; margins recurved, Theca ovate, Fruitstalk short on lateral branches, Lid rostrate

14740 Stems elongated irregularly branched, Leaves ovato-lanceolate: their diaphanous acuminated points slightly serrated, Theca ovate, Teeth of the peristome very long and filif. Lid subulate

14741 Stems elongated branched, Leaves ovato-lanceolate: their diaphanous acuminated points slightly serrat. Theca oblong, Teeth of the peristome rather short, Lid rostrate

14742 Stems elongated branched, Leaves lanceolate: their diaphanous acuininated points slightly serrated, Theca oblong, Teeth of the peristome rather short, Lid rostrate
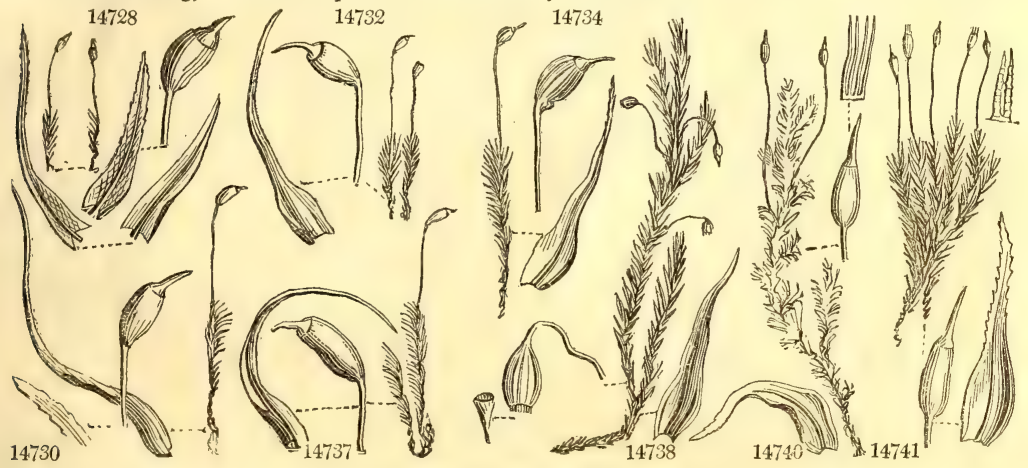

and Miscellaneous Parizculars.

there are species included in this which vary considerably from the common appearance of the group. The most distinct of these forms is, however, removed, after the example of the German muscologists, to Fissidens; which see.

2226. Trichostomum. From $9 \rho 6 \tau_{5}$. being very fine. The species are for the most part dark green mountain plants, with hair-pointed leaves, 
14743 aciculáre Beauv needle-pointed loose tufts $1 \frac{1}{2}$ summer Dicránum aciculáre E. B. t. 1978

14744 fasciculáre Schrad. bundled.

14745 proad patches 2 all seasons Dicránum polyphýlum E. B. t. 1217 Tr. cirrátum F1. Brit.

14746 ellipticum Hook. elliptical little tufts Dicránum ellípticum E. B. t. 1901

2227. CINCLIDO'TUS. Pal. de Beauv.

14747 fontinaloídes Beauv, water Fontínalis minor E. B. t. 557

2228. TOR'TULA. Ehr.

14749 murális Hedw.

rigid Tortula.

14750 rurális $E h r$.

country

14751 subuláta Hedw.

subulate

14752 cuneifólia Roth.

wedge-leaved

14753 stelláta Smith.

14754 tortuúsa Hedw.

14755 fállax. Swz.

B. t. 2316

T. imber'bis E. B. t. 2329

14756 revolúta Brid. revolute T. nervosa E. B. t. 2383

14757 unguiculáta Hooker unguiculate

IT. mucronuláta E. B. t. 1299

T. aristáta E, B. t. 2392

T. barbáta E. B. t. 2391

T. humilis E. B. t. 1663

T. apiculáta E. B. t. 2494

convolute

Cinclidorus.

floating

summer

sp. $11-38$.

small patches
tufts

D.G rocks \& walls Musc. brit. t. 19 D.G everywhere Musc. brit, t.12 deep patches 2 all seasons

D. G trees \& ban. Musc. brit. t.12 thick tufts

$1 \frac{1}{2}$ all seasons

Y.G banks

Musc. brit. t. 12

spring

Y.G banks

Musc. brit. t.12

Y.G riv. sides, Sc. Musc. brit. t.12 solitary broad masses $\frac{1}{4}$ spring L.G limest. rocks Musc. brit. t.12 $1 \frac{1}{2}$ all seasons L,G everywhere Musc. brit. t.12

tufts

tufts

송 spring

L. $G$ banks

Musc. brit. t.12

tufts

3) spring

Dp.G ban. \& hedg. Musc. brit. t.12

2229. PTEROGO'NIUM. Swx. Pterogonium

loose patches

$\frac{3}{4}$ spring

Y.G moist banks Musc. brit. t.12

$\begin{array}{lll}14759 \text { Smith'ii Swx. } & \begin{array}{l}\text { Smith's } \\ \text { slender }\end{array} & \text { creepin } \\ \text { creepin }\end{array}$

Sp. 3-7

3 all seasons

11. all seasons

Bt. G trees, S. Eng. Musc. brit. t.14 Bt.G subalp. rocks Musc. brit. t.14

14761 filifórme Hedw. filiform creeping

$1 \frac{1}{2}$ all seasons

Bt.G mountains Musc. brit. t.14

Sp. 10.

all seasons Rsh moist rocks Musc. brit. t.20

. Hedw. DIDYMODON.

14762 purpúreum Hedw. purple large patches Brgum bipartitum E. B. t. 2357 Dicránum stríctum E. B. t. 2294

Dicránum Cel'sii E. B. t. 2414

Trichóstomum papillósum E. B. t. 2533

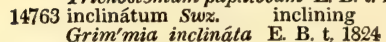
Grim'mia inclináta E. B. t,

Grim'mia atrovirens E. B. t. 2015

spots

loose patches

loose tufts

Trichostomum flexifólium E. B. t. 2490

14766 rigidulum Hedw. rigid B. tuft Trichóstomum rigídulum E. B. t. 2178

14767 trifarium Swz. three-rowed tufted

Trichóstomum trifárium E. B. t. 1707

Trichóstomum linoídes E. B, t. 2295

14743

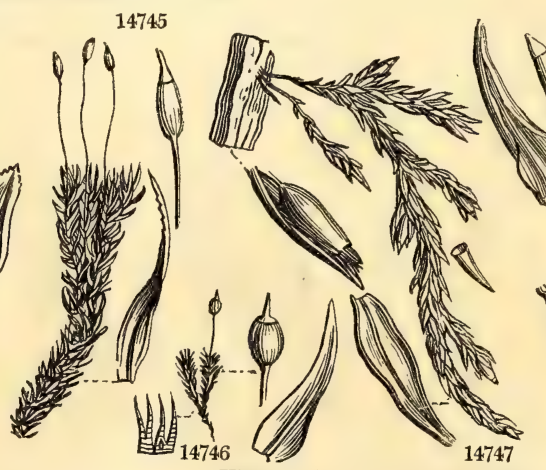

$\frac{3}{4}$ spring

L. $\mathrm{G}$ moun. rocks Musc. brit, t. 20

$\frac{1}{3}$ spring

Dp. G dry banks

Musc. brit. t. 20

$\frac{3}{4}$ spr. and sum. Bt.G banks

Musc. brit. t.20

$\frac{3}{4}$ spr. and sum. Br walls \& roc. Musc. brit. t.20

$\frac{3}{4}$ spr. and sum. Bt.G moist banks Musc. brit. t.20
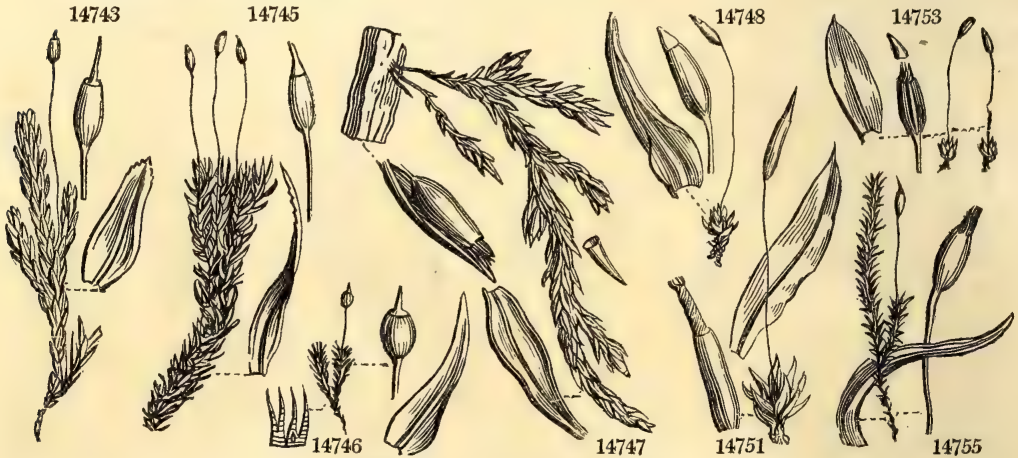

History, Use, Propagation, Culture,

which give them the appearance of being hoary. The genus is nearly related to Grimmia both in natural and essential characters.

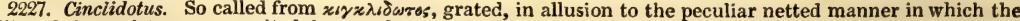
ciliæ of the peristome are united in parcels. A plant from four to six inches long, growing on stones and wood in streams of water, in many places exceedingly common. Its general appearance is that of Trichostomum, whilst the peristome more resembles that of a Tortula.

2228. Tortula. From torqueo, to twist, in allusion to the singular manner in which the teeth of the peristome are twisted together. Small plants, frequently forming thick tufts, and common in almost all situations from 
14743 Stems elongat. branch. Lvs. lanc. obt. serrulat. at points : nerve vanish. before summ. Theca obl. Lid rost.

14744 Stems elongat. branch.'Lvs. lanc. ent. : summ. never diaphan. ; margins recurv. Theca ovato-obl. Lid rost. 14745 Stems branch. Lvs. lanc.-subul. : marg. recurv.serrat.above very much crisp. when dry, Theca obl. Lid rost.

14746 Stems short nearly simple, Lvs. lanc. acum. straight : nerve broad ; margins plane, Theca ellipt. Lid rost.

\section{The only species}

14748 Stems scarcely any, Lvs. patent obl. rigid : marg. much inflex. Nerve broad, Theca obl. Lid conic. acum. 14749 Stems short, Leaves patent linear-oblong : their margins recurved, Nerve produced beyond the leaf into a white hair-like point, Theca oblong, Lid conical acuminate

14750 Stems elongated, Leaves oblong carinated patent and recurved, Nerve terminating in a long generally diaphanous serrated point, Theca oblong, Lid subulate, Teeth of the peristome united below in a tube

14751 Stems very short, Leaves oblongo-lanceolate acuminate : the nerve excurrent often forming an apiculus, Theca cylindrical, Lid conico-subul. Teeth of the peristome united nearly to the apex into a long tube

14752 Stems scarcely any, Lvs. broadly obov. conc. Nerve terminating beyond top of leaf in a rather long and frequently serrulated point, Theca oblong, Lid shortly rost. Teeth of the peristome united at the base

14753 Stems scarcely any, Leaves ovate concave, Nerve running beyond points, Theca ovate striated, Lid rost. 14754 Stems elongat. branch. Lvs. lin.-subul. carinate undulate much twisted when dry, Theca cylind. Lid rost. 14755 Stems elongat. branch.Lvs.lanc. subul. pat. or recurv. : marg. refl. Theca obl.Lid rost. nearly as long as theca

14756 Stems short, Leaves lanceolate acum. : the margins of those of the stem remarkably revolute; perichætial leaves sheathing, their sides involute, Theca oblong, Lid rostrate shorter than the theca

14757 Stems branched, Leaves linear-lanceolate obtuse : their nerve produced into an apiculus; the marg. nearly plane, Theca oblong, Lid rostrate nearly as long as the theca

14758 Stems short, Lvs. obl, rather obt. : nerve not protruded; perichat. remarkably convol. Theca obl. Lid rost.

[above half-way up, Fruitstalks very short, Lid rostrate 14759 Stems much branch. Branches pinn. Lvs. lingul. obt. ent. crisp. when dry : marg. recurv.; nerve reaching 14760 Branches fascicled curved, Leaves broadly ovate acute concave : their margins plane; summits serrated, faintly 2-nerved at the base, Lid conical

14761 Stems irregularly branched curved, Leaves ovate subacuminated concave : their margins recurv. serrated; nerve single or forked : shoots faint, Lid conical

14762 Stems scarcely branched, Leaves lanceolate acuminate carinate: their margins recurved entire, Theca ovato-cylindraceous oblique substrumose furrowed when dry, Lid conical

14763 Leaves bifarious from a sheathing base subulate, Theca ovate inclined, Lid conical

14764 Leaves obovate shortly apiculate: their nerve incrassated above, Theca ovate erect, Lid shortly rostrate 14765 Stems more or less elongat. Lvs. oblon.-ov. flexu. strongly serrat. at point, Theca erect cylindrac. Lid rost.

14766 Leaves closely imbricated on all sides lanceolate much acumin. carinate with the rigid nerve running beyond the point, Theca oblongo-ovate erect, Lid rostrate

14767 Leaves rather distant somewhat trifarious lanc. rather obtuse carinated with the nerve scarcely reaching to the point, Theca oblongo-ovate erect, Lid rostrate

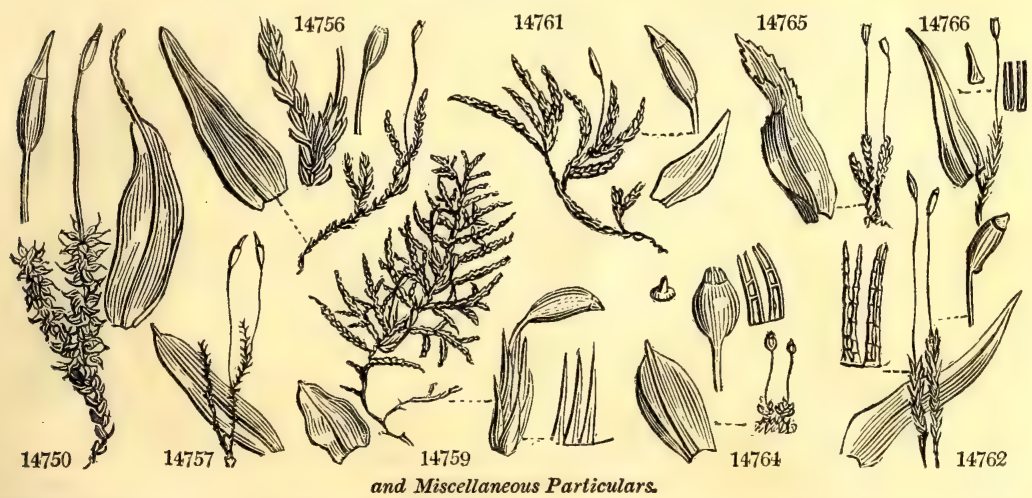

and Miscellaneous Particulars.

the banks of the sea-shore to the limits of perpetual snow. The character from which the genus has received its designation, will always indicate the species with perfect truth.

2299 Pterogonium. A name altered by Swartz from the Pterigynandrum of Hedwig, which was contrived to express that the male and female flowers of this genus of mosses are both present on a pinnated stem. An elegant collection of species, generally found in subalpine countries, where they enliven the trunks of trees and rocks with their bright green trailing entangled stems, which have altogether the habit of Hypnum. P Smithii has only been found in this country upon trees in the southern counties, especially in Devonshire.

2230. Didymodon. So called, by Hedwig, from $\delta$ ivipos, double, and $0 \delta 8 s$, a tooth, in reference to the geminate 
14768 capilláceum Schrad. hairy Trichóstomum capilláceum E. B. t. 115

14769 heteromálium Hook. variable Grim'mia heteromálla E. B. t. 1899 14770 obscúrum Kaulf. obscure 14771 glaucéscens Greville glaucous

2231. SPLACH'NUM. $L$. Splachnum.

14772 sphæ'ricum Linn. spherical ovátum E. B. t. 1590 rugósum E. B. t. 2094

14773 ténue Dicks. ${ }^{2094}$ slender Grim'mia splachnoides Fl. Brit.

14774 mnioides Linn. clustered \& minus Hooker small \& minus Hooker large $\beta$ május Hooker fastigiátum E. B. t. 786

14775 angustátum Linn. narrowed

14776 ampulláceum Linn. bottle-headed solit Turneriánum E, B. t. 1116

14777 vasculósum Hedw, vascular tufts rugrosum E B. t 2094 ?

14778 Frölichiánum Hedw. Frölich's little tuft reticulátum E. B. t. 2507 patches

solitary

tufts

tufts

turts

solitary

dense tufts 4 all seasons Bt.G moun, banks Musc. brit. t. 20

产 spring

Y.G mountains Musc. brit, t. 20

broad tufts $\quad 1$ spr. and sum. L,G alpine rocks Grev, crypt. 193 closely tufted 1 sum.and win. Gl Scot. moun. Grev. crypt. 127

$$
\text { Sp. 7-19. }
$$

2 summer

Pa.G dung, of ani. Musc. brit. t. 9

subsolitary $\quad 1 \frac{1}{2}$ summer

Pa.G Scot. moun. Musc. brit. t. 9

2 all seasons

1 ail

Bt. G mountains

D. G mountains

Musc. brit. t. 9

1 spring

Pa.G eow-dung

i.cry.2.t.11

$3^{2}$ sum. and aut. Pa.G bogs

Musc. brit. t. 9 Musc. brit. t. 9

2 spring

Pa.G mountains

Grev, cryp.t. 179

$1 \frac{1}{2}$ summer

Pa.G mountains

Musc. brit. t. 9

2232. CONOS'TOMUM. Swz. Conostomum.

14779 boreále Swa. northern small tufts Grim'mia conóstoma E. B. t. 1135

2233. ORTHO'TRICHUM. Hedw. Orthotrichum. $\begin{array}{ll}14780 \text { Drummóndi Hooker } & \text { Drummond's } \\ 14781 \text { anómalum Hedw. } & \text { anomalous } \\ \text { broad tufts }\end{array}$

14782 cupulátum Hoffim. naked tufted núdum E. B. t. 1325 anómalum E. B. t. 1423

14783 críspum Hedw. crisp

round tufts

Sp. 1-4.

1 summer

Bt. G moun,, Scot, Musc. brit, t. 10

Sp. $13-49$.

$1 \frac{1}{2}$ summer Drk trun. of trees Grev, crypt. 11

$\frac{3}{4}$ all seasons $\quad$ D. O1 rocks \& walls Musc. brit. t. 21 1 all seasons $\quad$ D.Ol wo. \& stolies Musc. brit. t. 21

14784 Ludwígii Bridel Ludwig's $\quad$ creep., branc. 3 sum. and aut. Pa.G smth. branc. Grev. crypt. 133 14785 rupíncola Funck rock branched, lax 1 may to july Br rocks \& walls Grev. crypt. 105 14786 Hutchínsiæ Smith Miss Hutchins's tufts 1 spring Br.G rocks

$\begin{array}{cllrl}14787 \text { affíne Schrad. } & \text { akin } & \text { tufts } & 1 \frac{1}{2} \text { spring } & \text { Pa.G trun. of trees Musc. brit. t. 21 } \\ \alpha \text { május Hook. } & \text { large } & \text { tufts } & 1 \frac{1}{2} \text { spring } & \text { Pa.G trun. of trees Eng. bot. } t .1323 \\ \beta \text { púmilum E. B. } & \text { dwarf } & \text { tufts } & \frac{1}{2} \text { spring } & \text { Pa.G trun. of trees Eng. bot. t. 2168 }\end{array}$

14788 diáphanum Schrad. transparent tufts $\quad \frac{1}{2}$ spr. and sum. Hoa trees \& walls Musc brit.t. 21 aristátum Turn. hib.t. 9. f. 2

14789 pulchéllum Smith pretty

14790 rivuláre Turn rivulet floating

$\frac{1}{2}$ all seasons $\quad$ L, G trun, of trees Musc. brit. t. 21

2 all seasons Ol.G roc, in strea. Musc. brit. t. 21

14791 striátum Hedw. striated tufts 2 all seasons Bt.G trees $\quad$ Musc. brit.t. 21

14792 Lyéllii Hook. Lyell's branched 3 all seasons Y.G trees $\quad$ Musc. brit.t. 22

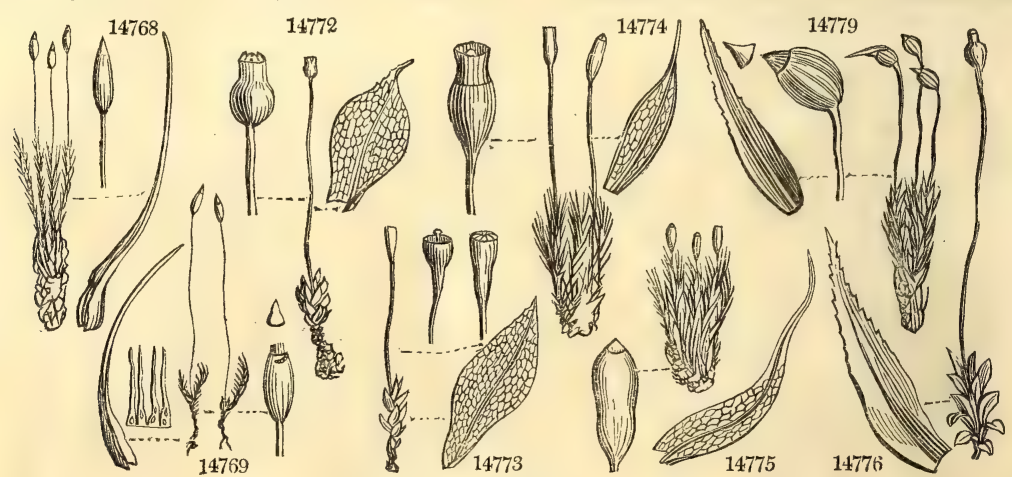

History, Use, Propagation, Culture,

arrangement of the teeth of the theca. In natural habit, the plants of this genus approach on the one hand to Weissia, and on the other to Dicranum. With the former, Dr. Hooker observes that two species are liable to be confounded, viz. Didymodon inclinatum, and I). heteromallum, each of which has but sixteen teeth, and their approximation in pairs is with difficulty discoverable. D. inclinatum is a very rare plant, having been scarcely found any where in this country, except upon the mountains of Cunnemara, in Ireland.

2231. Splachnum. $\Sigma \pi \lambda a r$ yoy was one of the Greek names of moss. Generally elegant little plants, with thecæ of exquisitely beautiful forms. The annual species are usually found growing upon dung, while the perennial are found in more permanent situations. They are in all cases of rare occurrence. S. Frcelichianum was found on the summit of Ben High, in the Scotch Highlands.

2232. Conostomum. From wavos, a cone, and sopa, a mouth, the teeth of the theca being always united at 
14768 Stems elongated, Leaves nearly distichous subulato-setaceous, Theca erect ovato-cylindrace. Lid conical 14769 Stems rather short, Leaves subsecund subulate, Theca ovate cylindraceous, Lid conical

$1+770$ Leaves lanceolate subulate tortuose when dry, Nerve strong, Theca suberect ovate, Lid obliquely rostrate 14771 Stem branched erect, Leaves lanc. acum. spreading, Nerve reaching apex, Theca oblong with a short lid

14772 Leaves obovato-rotundate acuminate slightly serrated, Apophysis ovate globose wider than the theca

14773 Leaves obovato-acuminate serrated, Apophysis obconical narrower than the theca, Columella exserted

14774 Leaves ovato-lanceolate much acuminat. concave entire, Apophysis obovate nearly as narrow as the theca $\alpha$ Deeper color with shorter stems

$\beta$ Paler color with longer stems

[than the leaves

14775 Lvs. ovato-lanc. much acuminat. serrat. Apophy. obov. somew. narrow. than theca, Fruitst. scarcely longer 14776 Leaves ovato-lanceolate acuminated serrated, A pophysis inversely flagon-shaped twice as wide as theca

14777 Lvs. rhombo-rotund. obt. : the nerve disappearing before point, Apophysis globose much wider than theca 14778 Lvs. ov. rounded at points : nerve disappear. before summ. Apophysis obovate much narrower than theca

14779 Stems rather short, Leaves lanceolate acuminated carinated slightly toothed

\section{* Peristome without ciliary processes.}

14780 Lys. obl. lanc. slightly curl. Theca clav. furrow. Lid with a long beak, Teeth 16 simple, Calyptra very hairy 14781 Leaves lanceolate erecto-patent, Fruitstalks exserted, Peristome of 8 double teeth, Calyptra slightly pilose 14782 Leaves lanc. erecto-patent, Theca nearly sessile, Peristome of 16 double teeth, Calyptra slightly pilose

* Peristome with 8 ciliary processes.

14783 Leaves lanceolato-subulate much crisped when dry, Fruitstalk much exserted, Theca striated, Peristome with 8 ciliary processes, Calyptra very pilose

14784 Leaves erect spreading narrow-lanceolate crisp when dry, Theca pyriform smooth plaited and contracted at orifice, Calyptra very hairy

14785 Lvs. erect rigid broad-lanc. Theca somew. immersed striat. toward mouth, Teeth 16, Calyptra very hairy 14786 Leaves lanceolate erect and nearly straight when dry, Fruitstalks much exserted, Theca striated, Perist. with 8 ciliary processes, Calyptra very pilose

14787 Leaves patent broadly lanceolate, Theca sessile, Peristome with 8 ciliary processes, Calyptra subpilose

\section{*** Peristome with 16 ciliary processes.}

14788 Stems short, Lvs. lanc. acum. : points diaphan. Theca sess. Perist. with 16 ciliary process. Calypt. subpilose

14789 Stems short, Lvs. pat. narr. lanc. crisp when dry, Footst. exserted, Perist. with 16 slender ciliary processes, Calyptra subpilose

14790 Stems elongated much branched, Leaves broadly lanceolate obtuse, Theca sessile, Peristome with 16 slender ciliary processes, Calyptra smooth

14791 Stems elongated brancied, Leaves lanceolate-patent slightly twisted when dry, Theca sess. ovate smooth, Peristome with 10 torulose ciliary processes, Calyptra subpilose

14792 Stems elongated much branched, Leaves long linear lanceolate recurvo-patent rnuch crisped when dry, Theca obl. striat. Peristome with 16 rather broad distinctly jointed ciliary processes, Calypt. very hairy

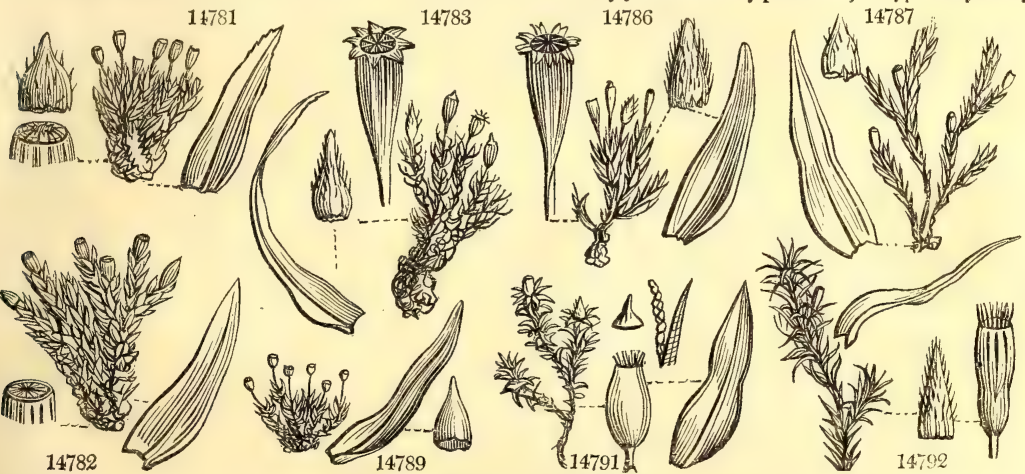

and Miscellaneous Particulars.

the points. A curious genus, first established by Swartz, in Schrader's Journal. The British species approaches in habit to Bartramia fontana. It is quite an alpine plant, not growing in Switzerland at a lower elevation than 7 or 8000 feet. With us it inhabits the summits of the highest Scotch mountains, particularly in the Breadalbane district.

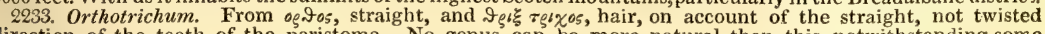
direction of the teeth of the peristome. No genus can be more natural than this, notwithstanding some variations in the peristome of some of the species from the ordinary structure. Thus $\mathbf{O}$. decipiens and anomalum have no ciliary processes; and 0 . striatum has them of a peculiar shape and beaded appearance. Many of the plants referred to this genus are common occupants of the aged trunks of trees, where they vegetate among the soft earth which collects in the clefts of the dead bark. O. Lyellit, which is the finest of our species, is only found on trees in the New Forest. 
2234. ZY'GODON. Hook. ZYYGoDoN.

\section{$S p .1$.
small tufts $\quad \frac{1}{2}$ spring}

Mníum conoideum E. B. t. 1239
14793 conoídeum Hooker conical

Pa.G trun. of trees Musc. brit. t. 21

Sp. 1.

2235. DIPHYS'CIUM. Mohr. DiPHYscium. 14794 foliósum Mohr.
Buxbaumia foliosa E. B. t. 329 matt. patches $\frac{1}{8}$ spring

2236. BUXBAU'MIA. $L$. BuxBauma. 14795 aphýlla $L$. leafless solitary

sp. 1.

1 summer

Br Fir-woods

Musc. brit. t. 8

D.G woods

Sp.

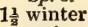

$\frac{3}{2}$ spring

$\frac{3}{4}$ spring

Sp. 6-11.

2 summer

$1 \frac{1}{2}$ summer

1 summer

apple-fruited tuft

« minor Hooker

14800 ithyphýlla Brid.

14801 grácilis Flarke

14802 fontána Swz.

a májor Hooker

large turts

stifflegved tufts

stiff-leaved

deep patches 3 summer

$\begin{array}{lll}\text { slender } & \text { deep patches } & \text { summer } \\ \text { fountain } & \text { thin tufts } & \text { summer }\end{array}$

thin tuits

large

e márchica Swz.

dwarf

tufts

6 summer

1 summer
Pa G everywhere Musc brit, $t, 20$ Pa. G cottage roofs Musc. brit. t. 20

Bt. $G$ heaths Musc. brit. t. 23 Bt.G alp. heaths E. b.1526.B.cris Bt. G dry banks Musc. brit. t. 23 Dp. G alpine rocks Musc. brit. t. 23 Bt.G wet places Musc. brit. t. 23 Bt.G wet places Dill mus.t.44.f.?

Bt.G wet places Eng. bot. t. 2074 Pa. G rocks Musc. brit. t. 20 Bt.G heaths Eng. bot. 998
14803 Halleriána Hedw. Haller's 14804 arcuáta Brid. arcuate

2239. POH'LiA. Hedw. Pohlia. 14805 inclináta Schwagr. inclined Brýum turbinátum E. B. 1572 Brýum nígricans E. B. 1528 14806 elongáta Hedw. long Brýum elongátum E. B. t. 1663 14807 cæspiticia Schw. tufted a májor Hooker large $\beta$ minor Hooker

14808 ventricósa Schw. ventricose Brýum ventricósum E. B. t. 2270 Bry̆um bimum E. B. t. 1518 Brýum cubitäle E. B. t. 2554

2240. BRY'UM. Hedw. BRYUM. 14809 andrógynum Hedw. androgynous patches 14810 palústre Swartz. deep patches 6 sum. and aut. Bt.G moun. rocks Musc. brit. t. 23 loose tufts 4 sum. and aut, Bt.G mountains Musc. brit. t. 23 Sp. 4-13.

thin tufts $\quad 2$ summer $\quad$ Pa.G wet sandy pl. Musc. brit. t. 29 subsolitary $1 \frac{1}{2}$ summer Bt. $\mathrm{G}$ mountains Musc. brit. t. 30 patches $1 \frac{1}{2}$ all seasons Bt.G everywhere Musc. brit. t. 29 patches $\frac{1}{2}$ all seasons Bt.G everywhere Eng. bot. t. 1904 patches 1 all seasons Bt.G everywhere Eng. bot.t. 1601

deep tufts 4 spr. and sum. Br mar. ground Musc. brit. t. 30

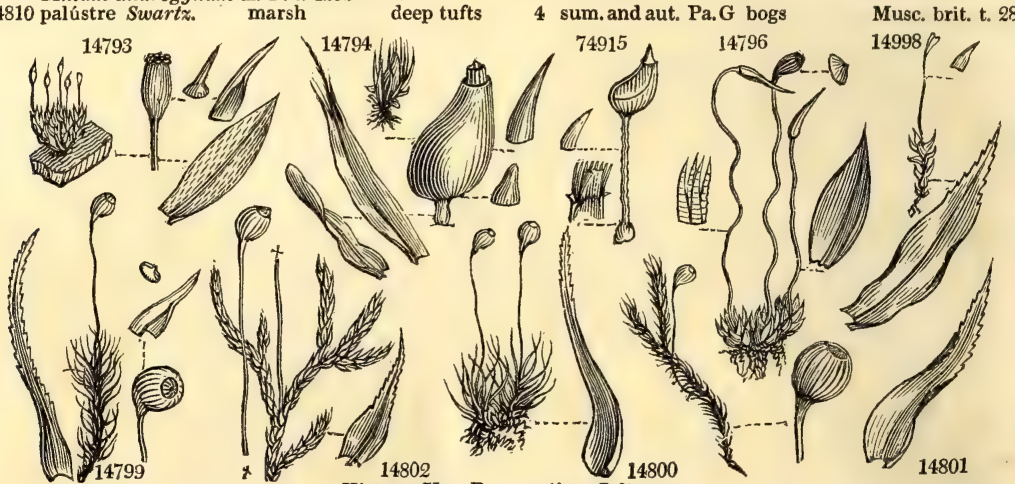

History, Use, Propagation, Culture,

Sp. 22-43.

1 spring

Y.G wo. and ban. Musc. brit. t. 28 4 sum. and aut. Pa.G bogs
Musc. brit. t. 28 14998

2234. Zygodon. From 'uros, a yoke, and $0 \delta 85$, a tooth, and so called, we presume, in allusion to the yoking together by pairs of the outer teeth; but the name is unexplained by its authors. A singular plant, which was referred to Bryum by Dickson, and to Mnium by Smith. The stems grow in a tufted manner like Gymnostomum viridissimum, but rarely exceed half an inch in length. The peristome is double; the outer consisting of sixteen short obtuse teeth approaching in pairs, which at length become recurved; inner of as many alternate ciliæ lying horizontally over the mouth of the theca.

2235. Diphyscium. From $\delta 15$, twice, and $\phi v \sigma x i o v$, a vesicle, in allusion to the double nature of the shell of the theca. A little plant found in woods, and on rocks in alpine situations. The stems are exceedingly short, and grow in densely matted patches. The theca is large, ovate, gibbous, and oblique. Dr. Hooker denies the existence of a double peristome, while Hornschuch asserts its presence.

2236. Buxbaumia. A very singular plant, destitute of apparent leaves, and resembling a minute fungus rather than a moss. It was named in honor of John Christian Buxbaum, a German botanist, who published, in 1728, an account of the plants of Asia Minor in five centuriæ of figures of little merit.. This plant was originally discovered in the vicinity of Astrachan, afterwards in a fir-wood near Norwich, and lately in two stations in Scotland. Its minute size and want of foliage may have caused it to be overlooked.

2237. Funaria. From funis, a rope, in allusion to the twisted nature of the strongly hygrometrical fruit. stalk. This genus, though sufficiently characterized by the interior teeth or ciliæ being oblique and placed 
14793 The only species

14794 The only species

14795 The only species

14796 Leaves very concave ovate apiculate entire, Nerve excurrent, Fruitstalk curved flexuose

14797 Stems short, Lvs. conc. ov. suddenly acuminat. serrat. : the nerve disappear. below point, Fruitst. straight 14798 Stems elongat. Lvs. plane ov.-lanc. gradually acuminat. serrat. Nerve disappear, bel. point, Fruitst. straight

* Fruitstalks long, not curved.

14799 Leaves patent subulate strongly serrated : the nerve reaching to the summit twisted when dry $\propto$ Leaves flexuose

$\alpha$ Leaves flexu

[into the substance of the leaf straight when dry, Fruitstalks much elongated 14800 Stems short, Leaves rigid erecto-patent subulate-setaceous almost entire : the nerve half-way up passing 14801 Stems elongated, Leaves recurvo-patent lanc. canaliculate serrat. Fruitstalks lateral from innovations

14802 Stems fastig. Lvs. closely imbricat. rig. erect broadly ovate or lanc. acuminat. nearly plane serr. Fruitst. lat.

Leaves broad ovate acuminate

[from innovations

** Fruitstalks very short, curved.

1480 Stems much elongat. prolifer. Lvs. long subul. flexu. serrat. above, Fruitst. lat. from innov. very short curv. 14804 Stems much elongated proliferous, Leaves horizontally patent ovato-lanceol. acuminated serrat. striated, Fruitstalks very short arcuate at length lateral, Theca smooth

14805 Stems short branched with innovations, Leaves ovate acuminated nearly entire: the margins slightly recurved ; the nerve running beyond the points, Theca elong.-pyrif. pendulous

14806 Stems short, Lvs. erect elong.-lanc. acuminat. serrat. Nerve reaching to point, Theca elongato-elev. inclined 14807 Stems short, Leaves ovate acuminated entire or very obscurely serrated at the points : the marg. slightly recurved; the nerve reaching to or beyond the point, Theca between ovate and pyriform pendulous

14808 Stems elongated branched with innovations, Leaves oblong acuminated scarcely serrul. : margins recurved nerve reaching beyond the point, Theca oblongo-obovate pendulous

* Theca sulcated.

14809 Stems nearly simple, Lvs. lanc. serrat. : their marg. recurv. Theca nearly erect cylind. sulcat. Lid conical 14810 Stems much branch. Lvs. lanc. obt. ent. : their margins revolute, Theca ovate oblique sulcat. Lid conical

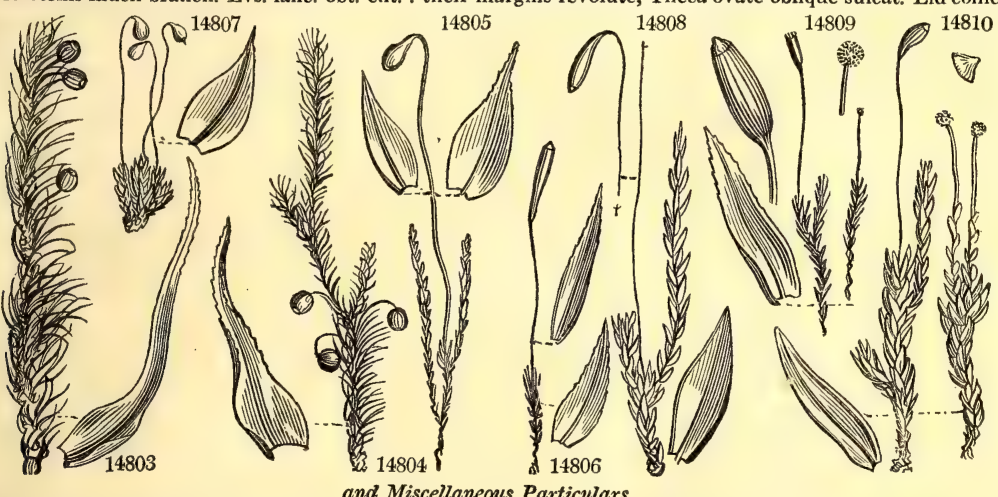

opposite to those of the outer, is further remarkable in these teeth lying horizontally over the mouth of the theca. In the male flowers of Hedwig, the succulent filaments are remarkabl ; clavate, jointed, pellucid, the joints containing greenish granules. Funaria hibernica has been found only on the roof of a thatched cottage at Blarney, near Cork, Ireland. The long flexuose fruitstalk of F. hygrometrica, one of the commonest of mosses in almost every situation, possesses strong hygrometrical qualities.

2238. Bartramia. So called in honor of John Bartram, an Anglo-American, to whose researches in North America the gardens of Europe owe many of their finest trees. He had a son William, who published in 1773, an account of a journey in the interior of North America. This is an elegant genus of mosses, remarkable for their fine capillary light green leaves, and spherical capsules. The genus approaches nearly to Bryum, but differs in almost every species having a spherical capsule; and the sixteen broad segments of the inner peristome, instead of being entire or only perforated, are cleft like the teeth of a Dicranum

2239. Pohlia. Named in honor of I. E. Pohl, a German botanist. Small plants, often refered to Bryum, with which they entirely agree in habit.

2240. Bryum. One of the ancient Greek names of moss. These are all dwarf plants producing capsules in abundance, and generally found growing in wet places. In B. palustre are found terminal capitular bodies, which much resemble what are called the anthers of B. androgynum; but in B. palustre they are considered gemma, and arise not only from the main stems, but also from the innovations. B. triquetrum has only been 
14811 trichódes $\boldsymbol{L}$. 14812 demissum Hooker. 14813 triquetrum Turn. 14814 dealbátum Dicks. patches loose patch patches
4 summer Y.G highl.moun. Musc. brit. t. 28 1 july, august Y.G Scot. moun. Grev,crypt. 1.99 9 july, august $\mathbf{L}, \mathbf{G}$ bor, of lakes Musc brit $t .28$ $1 \frac{1}{2}$ summer Cæs. mount. bogs Musc. brit. t. 28

\begin{tabular}{|c|c|c|c|c|c|c|}
\hline $\begin{array}{l}14815 \text { pyrifor'me Swz. } \\
\text { B. aureum E. B.t. } 389 \\
14816 \text { iuláceum Schrad. }\end{array}$ & $\begin{array}{l}\text { pyriform } \\
\text { iuliform }\end{array}$ & $\begin{array}{l}\text { patches } \\
\text { patches }\end{array}$ & $\begin{array}{l}2 \text { summer } \\
1 \frac{1}{2} \text { summer }\end{array}$ & $\begin{array}{l}\text { Y.G } \\
\text { Y.C }\end{array}$ & $\begin{array}{l}\text { rocks } \\
\text { mountains }\end{array}$ & $\begin{array}{l}\text { Musc. brit. t. } 28 \\
\text { Musc. brit. t. } 28\end{array}$ \\
\hline 4817 crúdum Huds. & simple & tufts & 1늘 summer & Bt. G & rocks & Musc. brit. t. 28 \\
\hline $\begin{array}{l}4818 \text { car'neum } L . \\
4819 \text { argen'teum } L \text {. }\end{array}$ & $\begin{array}{l}\text { carneous } \\
\text { silvery }\end{array}$ & $\begin{array}{l}\text { patches } \\
\text { patches }\end{array}$ & $\begin{array}{l}\frac{1}{6} \text { summer } \\
\frac{1}{6} \text { spring }\end{array}$ & $\begin{array}{l}\text { L. G } \\
\text { Gl. }\end{array}$ & $\begin{array}{l}\text { banks } \\
\text { on ground }\end{array}$ & $\begin{array}{l}\text { Musc. brit. t. } 29 \\
\text { Musc. brit. t. } 29\end{array}$ \\
\hline 4820 Ziérii Dicks. & Zier's & patches & $\frac{1}{c}$ spring & Gl. & mountains & Musc. brit. t. \\
\hline $\begin{array}{l}14821 \text { róseum Schreb. } \\
14822 \text { capilláre } L \text {. } \\
\text { B. stellare E. B. } 2434\end{array}$ & $\begin{array}{l}\text { rose-colored } \\
\text { capillary }\end{array}$ & $\begin{array}{l}\text { tufts } \\
\text { patches }\end{array}$ & $\begin{array}{ll}2 & \text { summer } \\
1 & \text { summer }\end{array}$ & $\begin{array}{l}\text { Pk } \\
\text { Bt. G }\end{array}$ & $\begin{array}{l}\text { heaths } \\
\text { heaths }\end{array}$ & $\begin{array}{l}\text { Musc. brit. t. } 29 \\
\text { Musc. brit. t. } 29\end{array}$ \\
\hline $\begin{array}{l}14823 \text { nútans Schreb. } \\
\text { Brýum compáctum E } \\
\text { 14824 alpínum L. }\end{array}$ & $\begin{array}{l}\text { nodding } \\
\text { B. t. } 1527 \text { ? } \\
\text { alpine }\end{array}$ & $\begin{array}{l}\text { little patches } \\
\text { tufts }\end{array}$ & $\begin{array}{l}3 \text { summer } \\
2 \text { summer }\end{array}$ & $\begin{array}{l}\text { Bt. G } \\
\text { Pu }\end{array}$ & $\begin{array}{l}\text { walls \& hea. } \\
\text { subalp. rocks }\end{array}$ & $\begin{array}{l}\text { Musc. brit. t. } 29 \\
\text { Musc. brit. t. } 28\end{array}$ \\
\hline 14825 punctátum Schreb. & dotted & solitary & 3 sum. and aut. & L. $G$ & mar. places & Musc. brit. \\
\hline 14826 ligulátum Schreb. & ligulate & solitary & 4 sum. and aut. & L. G & moist banks & Musc. brit. t. 3 \\
\hline 14827 rostrátum Schrad. & rostrate & solitary & 2 summer & L. G & subalp.coun. & Musc. brit. t. 30 \\
\hline 14828 marginátum Dicks. & edged & tufts & 2 summer & Y.G & shady banks & Musc. brit. t. \\
\hline 14829 hórnum Schreb. & lurid & deep tufts & 5 summer & Y.G & mar. places & Musc. brit. t. 3 \\
\hline 1830 cuspidátum Schreb. & cuspidate & subsolitary & 2 summer & L. G & wo. \& walls & Musc. brit. \\
\hline
\end{tabular}

2241. POLY'TRICHUM. L. Polytrichum.

14831 undulátum Hedw. wave-leaved solitary 14832 hercýnicum Hedw Hercynian solitary

14833 piliferum Schreb. hair-pointed 14834 juniperinum Willd.
$P$. stríctum E. B. 2435

14835 septentrionále Swz. northern P. sexanguláre E. B. 1906

14836 commúne $L$.

common

« yuccafólium Ehr. Aloe-leaved $\beta$ attenuatum Menz. narrowed $\boldsymbol{P}$. gracile E. B. t. 1827

14837 alpinum $L$. alpine

14838 urnigerum Menz. urn-bearing

14839 aloídes Hedw. stiff-leaved

a májor Hooker $\begin{gathered}\text { large } \\ \boldsymbol{P} \text { rubéllum E. B. t. } 1939\end{gathered}$

P. rubéllum E. B. t. 1939
Sp. $10-22$

4 autumn

3 autumn

3 autumn

4 autumn

3 autumn

solitary

broad masses 9 all seasons

broad masses 9 all seasons broad masses 4 all seasons

patches

4. summer

scattered

4. summer

scattered

$1 \frac{1}{2}$ autumn

$1 \frac{1}{2}$ autumn

scattered

1 autumn
Ol.G moist banks Musc brit t 10 Ol.G mountains Musc. brit. t.10

Ol. G heaths

Musc. brit. t.10

Ol.G heaths Musc. brit. t.10

Ol. G Scot. moun. Musc. brit. t.10

Ol. G heaths

Musc. brit. t. 10

Ol G heaths Eng. bot. t. 1197 Ol. G heaths Eng. bot. t. 1198 Ol. G alp. regions Musc. brit. t.11 G1. sides of stre. Musc. brit. t.11 Br.G heaths Musc. brit. t.11 Br.G heaths Eng. bot.t. 1649 Br.G heaths Eng bot. t. 1605

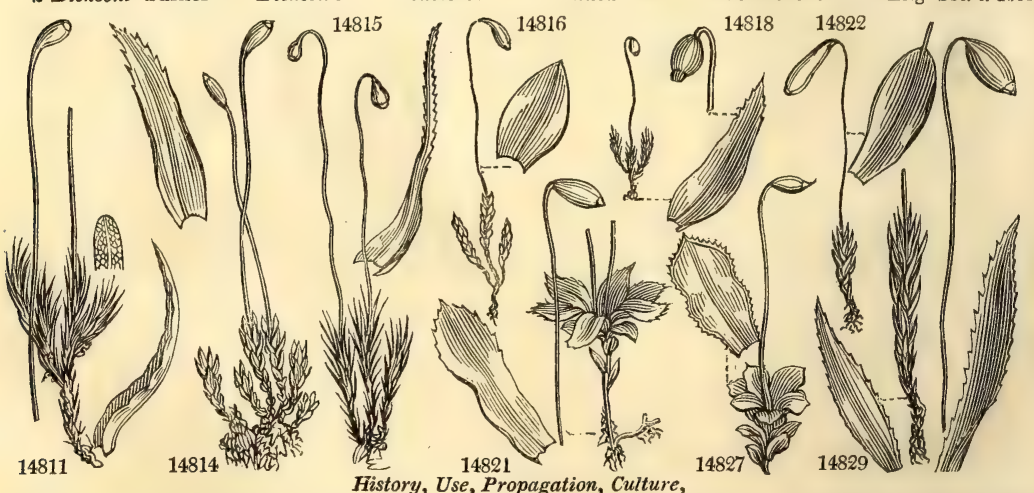

found in Great Britain upon the borders of some lake in the north of Ireland. By Mohr it is considered : distinct genus, and called Diplocomium. 
** Theca destitute of furrows.

A. Exterior peristome shorter than interior.

14811 Stems somew. branch. Lvs. lin. obt. ent. reticulat. 'Theca obovate recurved subcernu. Fruitstalk very long 14812 Stems branched, Leaves ovate cuspidate reticulated shorter than nerve, Theea curved pyriform pendulous 14813 Stem elongat. branch. Lvs. lanc. carin. ac. serrated reticulat. Theca pyrif, erecto-cernu. Fruitst. very long 14814 Stems short, Leaves lanceolate acute plane serrated at the points reticulated, Theca pyriform nearly erect

\section{B. Peristomes equal.}

1. Leaves without a thickened margin.

14815 Stems slightly branched, Leaves subul.-setaceous flexuose serrated: nerve very broad, Theca pyrif. pendul.

14816 Stems branched, Leaves closely imbricated broadly ovate concave entire obtuse : nerve running nearly to the point, Theca obovato-cylindraceous pendulous

14817 Stems simple, Leaves rigid lanceolate : the upper ones the narrowest and longest; all of them plane serrul. nerve disappearing below the summit, Theca oblong-subpyriform cernuous

14818 Stems simple, Lvs. lanc. reticulat. slightly serrul, at point : nerve disappear. bel. summ. Theca obov. pendul. 14819 Stems branched, Leaves closely imbricated broadly ovate suddenly and sharply acuminated subserrulate very concave: nerve disappearing below the point, Theca ovato-pyriform pendulous

14820 Stems branch. Leaves closely imbricated more or less broadly ovate acuminulate very concave reticulated entire : nerve running nearly to the point, Theca clavate cernuous

14821 Lvs. obovato-spathulate acute serrated undul. : nerve running to the point, Theca oblongo-ovate pendul. 14822 Stems short, Leaves obovate twisted when dry entire : their nerve produced into a hair-like point; their margins slightly thickened, Theca oblong pendulous

14823 Stems short, Lvs. erect lanc. acuminated serrated above : nerve reach. to point, Theca oblon.pyrif. pendul.

14824 Stems rig. elongat. branch. Lvs. closely imbricat. erect lanc. somew. obt. subserrul. at apex : marg. revolute; nerve reaching to the points, Theca oblongo-ovate pendulous

\section{\$2. Leaves with a thickened margin.}

14825 Stems elongated, Leaves obovato-rotundate very obtuse reticulated: their margins thickened entire; nerve disappearing below the point, Theca ovate pendulous, Lid shortly rostrate

14826 Stems elongated, Leaves undul. ligul, reticulated: their margins thickened denticul. ; nerve reaching a little beyond the point, Theca ovate pendulous, Lid conical

14827 Stems elongated, Leaves broadly ovate reticulated: their margins thickened denticulated; the nerve reaching a little beyond the point, Theca ovate pendulous, Lid rostrate

14828 Stems elongated, Leaves ovate acute reticulated : their margins thickened serrated; nerve reaching a little beyond the point, Theca ovate pendulous, Lid shortly rostrate

14829 Stems elongated,'-Leaves lanceolate acute reticulated : their margins thickened denticulate: nerve generally disappearing below the summit, Theca oblongo-ovate pendulous, Lid hemisph. mucronulate

14830 Stems elongated, Leaves obovate acute reticulated : their margins thickened denticulated above; nerve running beyond the point, Theca ovate pendulous, Lid conico-hemispheric. obtuse

\section{* Calyptra naked.}

14831 Lvs. lanc. undul. : their margins plane denticulat.; their nerve winged, Theca cylind. curved, Lid subul. 14832 Lvs. lanc. rig. ent. : their sides invol.; their nerve broad impress. with furr. Theca obl. suber. Lid conical ** Calyptra hairy.

14833 Leaves lanceolate-subulate : their margins involute ent. terminating in a pellucid hair-like point, Theca

ovate obtusely quadrangular furnished with an apophysis, Lid conical
14834 Leaves lanceolate-subulate : their margins involute entire; their points acumin. colored subserrated, Theca ovate obtusely quadrangular furnished with an apophysis, Lid conical

14835 Leaves lineari-subul. obtuse : their margins especially towards the top invol. subserrulate, Theca ovate subangulate furnished with a minute apophysis, Lid conical acuminate

14836 Stems elongated, Leaves patent lineari-subulate: their margins plane serrated as well as the points of the keels, Theca erect ovate quadrangular with an evident apophysis

$\alpha$ Leaves with their margins of the same color

$\beta$ Leaves shorter with their margins pellucid

14837 Stems elongated branched, Leaves patent subulato-lanceolate: the margins plane serrated as well as the points of the keels, Theca subovate with an indistinct apophysis

14838 Stems elongated branched, Leaves erecto-patent lanceolate acute: their margins plane serrated, Theca erect cylindrical destitute of an apophysis

14839 Stems short, Leaves linear-lanceolate obtuse : their margins plane serrated principally at the extremity and at the summit of the keels, Theca nearly erect cylindrical without an apophysis

œ Fruitstalks 2 inches long, Stems simple

B Fruitstalks very short, Stems branched
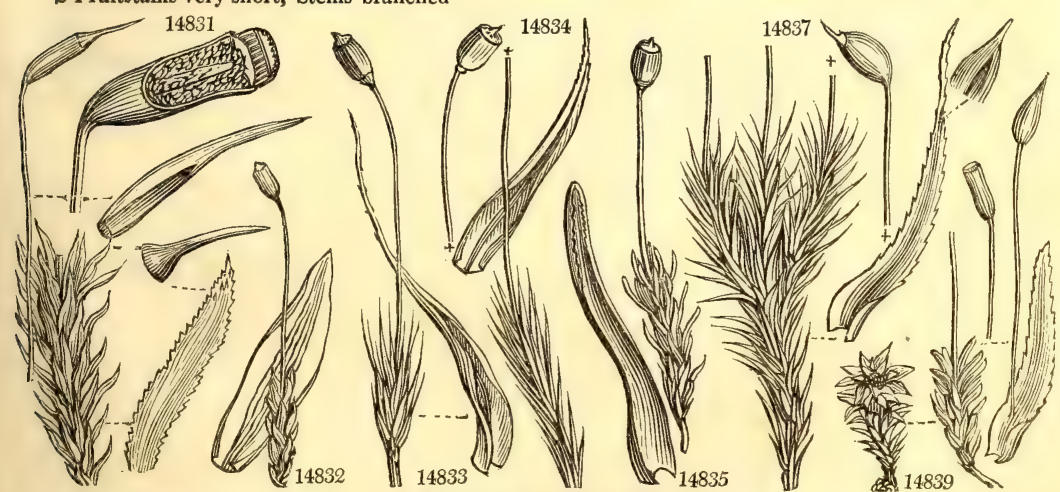

and Miscellaneous Particulars.

2241. Polytrichum. From rodus, many, and $2 \rho \iota \xi$ reเxos, hair, on account of the numerous hairs of the calyptra. Easily distinguished by the rigidity of the leaves and the square form of the theca, which is gene- 
14840 nánum Hedw. dwar

scattered 1 autumn

Br. G moist banks Musc. brit. t.11

2242. ANICTANGI'UM. Hedw. Anictangium.
14841 ciliátum Hodw. Gymnóstomum ciliátum E. B. t. 1179

14842 imbérbe Hooker beardless
Gymnóstomum imbérbe E. B. t. 2237 Gymnóstomum imbérbe E. B. t. 2237 depress. tufts 1 summer

Hoa. rocks Musc. brit. t. 6

2243. FIS'SIDENS. Hedw. Fissidens.

2243. FIS'SIDENS. Hedw. Fissidens.
14843 bryoides Hedw.
Bryum-like patches

Dicránum bryoídes E. B. t. 625

Dicránum viridulum E. B. t. 1368
Dicránum osmundioídes
E. B. t. 1669 14844 incúrvus Schwagr. incurved patches

14845 adiantoídes Hedw. Maidenha.-lv. patches Hýpnum adiantoídes E. B. t. 264

14846 taxifólius Hedw. Yew-leaved tufts Hýpnum taxifólium E. B. t. 416

2244. LEU'CODON. Schwagr. LeUcodon.

14847 sciuroides Schwagr. Squirrel-tail creeping Dicránum sciuroides E. B. t. 1903

2245. FONTINA'LIS. $L$. FonTinalis.

14848 antipyrética $L$. nerveless floating

14849 squamósa $L$. scaly floating

14850 capillácea Dicks. capillary floating

2246. ANO'MODON. Hooker. ANOMODON.

14851 curtipéndulum Hook. dark green pinnate Neckéra curtipéndula E. B. t. 1444

14852 viticulósum Hook. pale green creeping Hýpnum viticulósum E. B. t. 265

2247. NECKE'RA. Hedw. Neckera. 14853 púmila Hedw.

14854 crispa Hedw. $\quad \begin{aligned} & \text { crisp } \\ & 14855 \text { pennáta Hedw. }\end{aligned}$

pigmy

Pa.G Irish moun. Musc. brit. t. 6

2248. DALTO'NIA. Hooker. Daltonia.

14856 splachnoides Hooker long stalked Neckéra splachnoides E. B, t. 2564

14857 heteromálla Hooker short-stalked tufts Neckéra heteromálla E. B. t. 1180

\section{creeping}

creeping

$\frac{1}{4}$ spring

Pa.G moist banks Musc. brit. t. 16

$\frac{2}{4}$ spring

L.G moist banks Schw. suppl.t.49

2 summer

L, G wet pastures Musc. brit. t.16

$\frac{3}{4}$ summer

L G moist banks Musc. brit. t.16

Sp. $1-17$.

3 summer

D.G trun. of trees Musc. brit.t. 20

Sp. 3-9.

12 summer

6 summer

6 summer

Sp. 2-8.

8 summer

6 spring

Dl.G rivers Musc. brit. t. 22 O1.G rivulets Musc. brit. t. 22 Br. G alp. rivulets Musc. brit. t. 22

D.Ol roc. \& trees Musc. brit. t. 22

Sp. 3-24.

2 spring

Y.G trees \& roc. Musc. brit. t. 22 creeping 6 summer Bt.G trees \& roc. E.b. t.616. Hypn.

Pa.G woods

Eng. bot. t. 1443 um. Bt. G trun. of trees Gre.sc.cry.t. 109 Sp. 2-5.

Lummer $\quad$ L. G Irish moun. Musc. brit. t. 22

$\frac{1}{4}$ summer L.G trun. of trees Musc. brit. t. 22

2249. HOOKE'RIA. Smith. HoOKERIA.

14858 lúcens Smith shining procumbent 3 summer

14859 læate-virens Hook. $\quad \begin{array}{lll}\text { bright-green } & \begin{array}{l}\text { procumbent } \\ \text { procumbent }\end{array} & 3 \text { summer } \\ \text { summer }\end{array}$

Pa.G moist banks Musc. brit. t. 27 Bt.G Irish bog Musc. brit. t. 27

2250. LES'KEA. Ehrhart. LESKEA.

14860 trichomanoides Hedw. scymitar-shap. entangled $\quad 2$ spring 43.

14861 complanáta Hedw. flattened entangled 4 spring

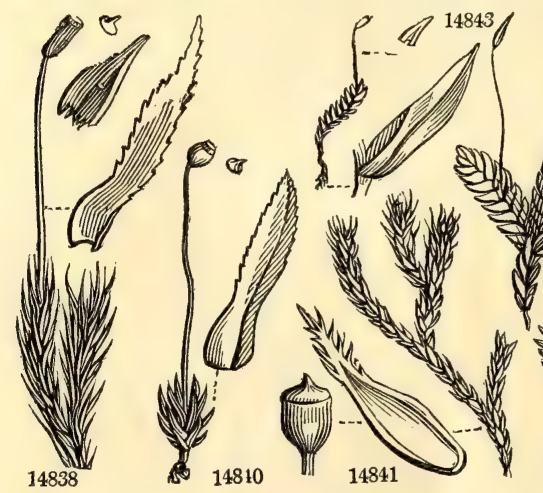
$14845 \quad 14847$

Y. G trun. of trees Eng. bot. t. 1498 Y.G trun. of trees Eng. bot. t. 1492

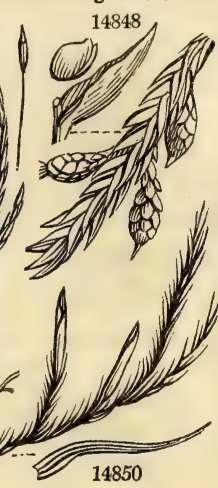

History, Use, Propagation, Culture,

rally covered by a very hairy calyptra : this organ is in some species smooth, by which character they have been distinguished by the accurate Ehrhart, under the name of Catharinea; but Dr. Hooker is of opinion that the genus is not tenable.

2242. Anictangium. From aysur os, open, and arysıy, a vase, on account of the open nature of the theca, which is not enclosed by a peristome. The only British species are two plants with nerveless leaves, and the habit of Trichostomum.

2243. Fissidens. From fissus, split, and dens, a tooth, in allusion to the structure of the peristome. Plants 2243. Fissidens. From fissus, split, and dens, a tooth, in aflusion to the structure of the peritish botanists, but differing from that genus entirely in habit, and suffigeneraly refres is highly curious, and totally ciently in char and unlike that of any other plant with which he is acquainted. Besides being vertical, their upe equal lainella, the the nerve for the line of separation) is, from the base beyond the middle, composed of two equal lainelia, the lower part of which embraces the stem, and the rest very often embraces a portion of the leaf placed immediately above it.

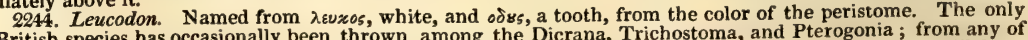
British species has occasionally been thrown among the Dicrana, Trichostoma, and Pterogoniate calyptra, will keep its genus distinct. The stems are long, and creeping over the bark of trees.

its genus distinct. The stems are long, and creeping over the bark of trees. 2245. Fontinalis. From fons, a fountain, in allusion to the places where it grows. F. antipyretica is a
commen 
14840 Stems short, Lvs. lin. lanc. : marg. serrat. principally at extrem. as well as summit of keels, 'Theca nearly [erect subglobose

14811 Leaves ovate much lengthened out and diaphan. at points : those of perichætium laciniated at extremity 14842 Leaves ovato-acuminate colored at the points : those of the perichrtium serrated at the extremity

14843 Fruitstalks terminal, Perichætial leaves resembling the cauline ones

1484t Like the last, but theca drooping

14845 Fruitstalks lateral, Perichætial leaves ovate slightly convolute pointed

14846 Fruitstalks radicular, Perichætial leaves ovate sheathing involute pointed

14847 Leaves closely imbricated ovate-cordate acuminate striated, Theca oblong

14848 Leaves nerveless for the most part complicato-carinate

14849 Leaves nerveless plane or very slightly concave

14850 Leaves furnished with a nerve slightly concave

14851 Lvs. ov. acum. serrul. : the nerve disappear. below point, Fruitst. twice as long as perichætium, Theca ov.

14852 Leaves ovato lanceolate obtuse entire : the nerve reaching to the point, Fruitst. very long, Theca cylind.

14853 Lvs, ovato-acum. slightly conc. : marg. recurv. Fruitst. scarcely longer than perichæt. lvs. Theca oblon.-ov. 14854 Leaves oblong acuminulate transversely rugose, Fruitstalks much exserted, Theca ovate

14855 Lvs. bifar. ov. lanc. transversely undul, serrul, at point, Theca ovate subsess. shorter than perichætial lvs.

14856 Leaves oblongo-lanceolate, Fruitstalks long, Calyptra fimbriated at the base

14857 Leaves broadly ovate acute, Theca sessile impressed, Calyptra nearly entire

14858 Leaves broadly ovate entire obtuse nerveless

14859 Lvs, ov. acuminul. margin. very obscure. serrat. at extrem. with 2 nerves nearly reach. their whole length

14860 I.vs. broadly scymitar-shaped serrat. at point : nerve reach. to middle of leaf, Theca ovate erect, Lid rost. 14861 Leaves oblong apiculate entire nerveless, Theca ovate erect, Lid rostrate

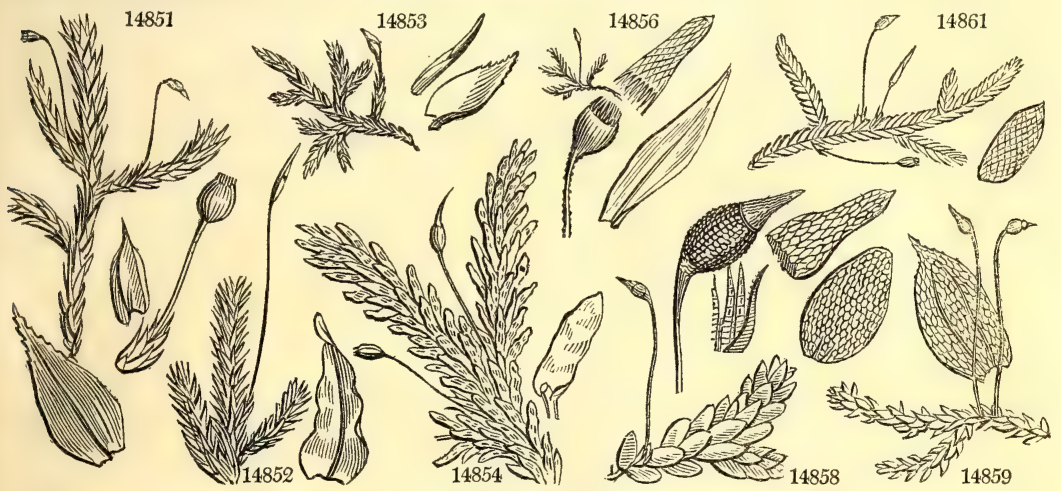

and Miscellaneous Particulars.

it is employed by the Swedes to fill up the spaces between the chimney and the walls, and thus, by excluding the air, to prevent the action of fire.

2246. Anomodon. So called by the authors of Muscologia Britannica, on account of the peculiar nature of the peristome, which has narrow fringed processes arising from the very same range, and from between the

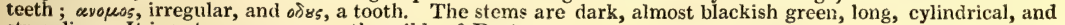
straggling. It is not uncommon on the wilds of Dartmoor.

2247. Neckera. Named after N. J. Necker, a German botanist, who published in 1791, his Elements of Botany, a work which contained more useful imformation than many of his detractors have been pleased to allow. Beautiful mosses, found in woods and upon trees and rocks. N. crispa has more the appearance of some fine tropical moss, than of those of our own country, where it is far from uncommon in mountainous districts, frequently covering a great extent of surface upon the trunks of old forest-trees.

2248. Daltonia. Named in honor of the Rev. James Dalton, a skilful English muscologist. The mitriform calyptra separates this from Neckera. D. splachnoides has only been found by the side of a streamlet on the Secawn mountain, near Dublin, where it grows sparingly in pale green tufts.

2249. Hookeria. This beautiful Hypnum-like genus was named by Sir James Edward Smith, in honor of Dr. William Jackson Hooker, F. R. S., \&c. professor of botany in the university of Glasgow, one of the most distinguished of modern eryptogamic botanists, and a gentleman whose public reputation is only exceeded by his private excellence. The Hookera of Salisbury, must give way to this on every account. H. lxte-virens has hitherto been discovered only in a hog near Cork.

2250. Leskea. N. G. Leske was an obscure German botanist, of whom little is known, except that be gave $3 \mathrm{~N}$ 
14862 polycárpa Eh many-fruited entangled 3 spring Lur. trun, of trees Eng. bot. t. 1274 Hypnum mêdium $\mathbf{E} \mathbf{B}$ Hy̆pnum inundátum E. B. t. 1922

14863 iulácea Moh; $:$ round-leaved Pterogónium? rotundifólium E. B.

14864 pulchêlla Hedw. pretty

14865 ruféscens Schwagr: rufous 14866 serícea Hedw. silky

14867 dendroídes Hedw. tree-like

3 spring

Y.G ground

Eng. bot.t. 2525 dense turts $\frac{1}{2}$ spr. and surn. Bt. G moist banks Eng. bot. t. 2006 creeping 4 spr. and sum. Rsh moun. rocks Eng. bot. t. $2296^{\circ}$ entangled $\quad 3$ spr. and sum. Y.G roc. \& trees Fing. bot. t. 1445

14868 incurváta Hedw. incurved erect

3 spr. and̀ sum. Y.G wo. and bogs Eng. bot. t. 1565

Hýpnum atrovirens E. B.

procumbent 3 spr. and sum. D.G trees \& rocks Eng. bot. t. 2422 14869 polyántha Hedw. Inany-flowered creep. tangled 3 summer

Y.G trun. of trees Gre.cryp. f.t.151

2251. HYP'NUM $I$

14870 ripárium $L$ 14871 undulátum $L$ 14872 denticulátum $L$

HYPNuM.

water

wavy

toothletted loose patches lax masses prostrate

Sp. 53-119.

4 sum. and aut. Bt. G ban. of ditc. Eng. bot. t. 2060 6 sum, and aut. W.G heathy plac. Eng. bot. t. 1181 $1 \frac{1}{2}$ suin. and aut. Bt. G roots of trees Eng. bot. t. 1260

angustifólium Hook, narrow-leaved prostrate $\beta$ obtusifólium Hook. blunt-leaved prostrate

$1 \frac{1}{2}$ sum. and aut. Bt. G roots of trees Hed.sti.cr.4.t.31 $1_{2}$ sum, and aut. Bt.G mountains Eng. bot. t. 1446

14874 sểrpens $L$. creeping subtile E. B. t. 2496
popúleum Hedw. matted

patches 1 spring

Dp. G roc. \& old w. Eng. bot. t. 1859 impléxum E. B. t. 1584 14876 refléxum Weber \& Mohr reflexed entang. patch. 2 spring Bt. G roots of trees Eng, bot, t. 1037

14877 mólle Dicks. soft

loose masses

2 spring

D.G trees \& ston. Tur.mus.hi. t.16

much tufted 3 sum. and aut. Lur. alp. rivulets Eng. bot. t. 1992

14878 Schrebéri Willd. Schreber's

lax tufts

9 summer

Rsh wo. and ban. Eng. bot. t. 1621

14879 catenulátum Schwag. chained

close tufts

2 spr. and sum. D.G wet rocks

Brid. mus.t.5.f.4

14880 stramineum Dicks. straw-colóred loose patches $1 \frac{1}{2}$ summer $\quad$ Pa.G wet places Eng. bot.t. 2405

14881 murále $\mathrm{Hedw}_{\mathrm{e}}$ wall confértum E. B. t. 1038

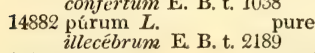

14883 flúitans $L$. floating

14884 plumósum $L_{\text {. }}$, 1496

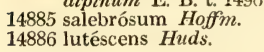

feathered

patches

$1 \frac{1}{2}$ all seasons

L. G walls \& ston. Dil.mu. t.41.f.52

broad masses 7 spring

wo. and ban. Eng. bot. t. 1599

aquatic 6 spr. and sum. Var. pools $\&$ stre. Eng. bot. t. 1448

derise mat 4 spr. and sum. Y.G moist rocks Eng. bot. t. 2071

smth.-stk. shi. decumb. bran. 4 summer

yellowish patches 3 summer

Bt. G roc. \& groun. Grev.cryp.t. 184

14387 nitens Schreb.

shining

branched

3 summer

Go.Y bogs

Eng. bot. t. 1646

14888 al'bicans Neck.

whitened patches 2 spring

W.G hea. \& bogs Eng. bot. t. 1500

14889 alopecúrum $L$.

fox-tail

loose masses

3 spr. and sum. D.G moist woods Eng. bot. t. 1182

14890 curvátum Swz.

curved

14891 spléndens Hedw. glittering

3 spr. and sum. Bt. G trees \& roc. Eng. bot. t. 1566

14892 prolíferum $L$. proliferous loose patches 6 all masses Du.G wo. and ban. Eng. bot. $t .1494$

lax cufts

9 all masses

Y.G hea. \& banks Eng. bot. t. 1424 14893 prælóngum $L$. B. 1 . 149 prokésii E. B. t. 2036 Swártzii E. B. t. 2334

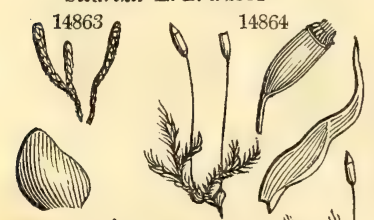

loose tufts 6 all masses

Du.G woods

Eng, bot. t. 2035

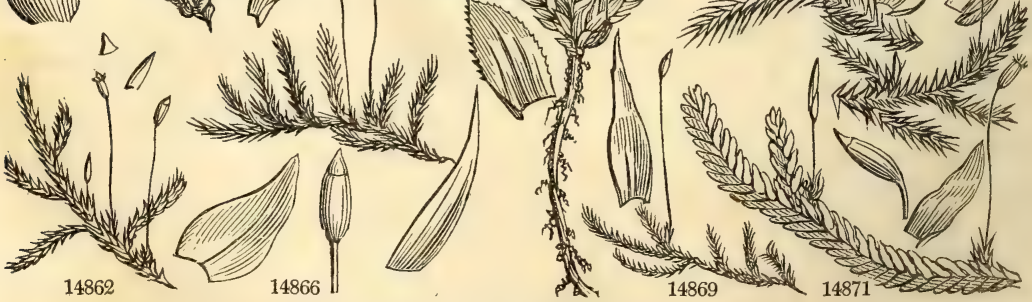

History, Use, Propagation, Culture,

occasion to Hedwig to name this genus after him. It has entirely the habit of the next, with which it is frequently united. 
14863 Leaves closely imbricated rotundato-ovate obtuse very concave ventricose nerveless, Theca ov. nearly erect

14864 Leaves loosely imbricated : the upper ones subsecund; all of them lanceolate acuminate entire nerveless, Theca ovato-cylindrical nearly erect, Lid conical

14865 Lvs, erecto-pat. lanc, acuminat, ent. striat. faintly 2-nerved at base, Theca ovate nearly erect, Lid conical 14866 Leaves erecto-patent lanceolate acuminated entire striated; nerve running to three fourths of the length, Theca ovate cylindrical erect, Lid conical

14867 Stems erect below simple and naked fascicled above, Leaves ovate more or less lanceolate striatod serrat. at the point: nerve reaching nearly to the summit, Theca erect ovate cylindrical, Lid rostrate

14868 Stems variously branched procumbent, Lvs. all of them slightly secund broadly ovate with an attenuated obtuse point : nerve running nearly to the summit, Theca ovate cernuous, Lid conical

14869 Leaves 1-sided imbricated erect spreading ovate lanceolate acum. entire obscurely 2 nerved at base, Fruitst. numerous, Theca erect ovate, Lid acutely conical

$$
\text { * Stems plane. }
$$

14870 Lvs, ov,-lanc. acuminat. ent. : the nerve reaching nearly to summit, Theca oblong cernuous, Lid conical 14871 Lvs. ov. ac. transversely undulat. with two faint nerves at base, Theća obl. furrow. arcuato cern. Lid rost. 14872 Leaves ovate sometimes approaching to lanceolate more or less acuminated having two short nerves at the base, Theca oblongo-cylindraceous inclined, Lid conical

$\propto$ Leaves ovate lanceolate distant quite plane

$\beta$ Leaves ovate more or less obtuse slightly concave

** Leaves spreading on all sides of the stem.

14873 Lvs, fascicul, erect lanceolato-subul, ent. : nerve reaching to summit, Theca ovate cernuous, Lid rostrate 14874 Leaves ovato-lanceolate rather obtuse patent entire: their nerve for the most part reaching to the summit, Theca cylindrical curved cernuous, Lid conical

14875 Leaves lanceolate acuminated serrated: margin slightly reflexed: nerve reaching to the point, Theca ovate nearly erect, Fruitstalks rough, Lid conical

14876 Leaves cordato-acuminate serrated: their nerve reaching to the point; their margin slightly reflexed, Theca ovate cernuous, Fruitstalks rough, Lid conical

14877 Leaves loosely imbricated rotundato-ovate obtuse concave entire faintly two-nerved at the base or with one short nerve, Theca ovate cernuous, Lid conical

14878 Leaves closely imbricated nearly erect elliptical apiculate concave entire faintly two-nerved at the basc, Theca ovate cernuous, Lid conical

14879 Leaves subpatent ovate subacuminated papillose on the back and margin with a very short nerve, Theca ovate inclined, Lid conical acuminated

14880 Leaves loosely imbricated erecto-patent oblongo-ovate obtuse entire: their nerve reaching half way, Theca oblongo-ovate curved cernuous, Lid conical

14881 Leaves nearly erect imbricated oval with a very short point concave entire: nerve reaching about half way up, Theca ovate cernuous, Lid rostrate

14882 Leaves closely imbricated oval with a very short point very concave : their nerve reaching half way up, Theca ovate cernuous, Lid conical

14883 Leaves loosely imbricated, the upper ones falcate secund; all of them lanceol.-subul. scarcely serrated at their points : their nerve reaching more than half way, Theca ovate obl. curved cernuous, Lid conical

14884 Leaves erecto-patent : the upper ones sometimes secund; all of them ovato-lanceolate acuminated subserrated: the nerve reaching above half way, Theca ovate cernuous, Lid conical

14885 Lvs. nearly erect lanc. acum. serrul. tow. end : nerve disappear. beyond end, Theca cern. Lid acute conical

14886 Leaves erecto-patent lanceolate acuminated entire striated : nerve disappearing below the point, Theca ovate cernuous, Fruitstalks rough, Lid conico-acuminated

14887 Leaves erecto-patent narrow lanceolate acuminated nearly entire striated : nerve running nearly to the summit, Theca oblongo-ovate curved cernuous, Fruitstalks smooth, Lid conical

14888 Leaves erecto-patent ovato-lanceolate acuminated striated entire: nerve reaching half way up, Theca ovate cernuous, Fruitstalks smooth, Lid conical

14889 Stems erect below simple and naked, fascicled above, Leaves concave ovate ellipt. acute serrated : nerve running nearly to the point; marg. reflexed, Theca ovate cernuous, Lid rostrate

14890 Branches fascicled curved, Leaves ovato-elliptical concave serrated at the points : nerve disappearing beyond the middle, Theca ovate erect, Lid rostrate

14891 Stems tripinnate, Leaves ovate with a suddenly acuminated serrated point concave faint!y two-nerved at the base: margin below recurved, Theca ovate cernuous, Lid rostrate

14892 Stems tripinnate, Leaves serrated papillose on the back : the cauline ones cordato-acuminate striated with a nerve running nearly to the point; those of the branches more ov. with a sing. or double nerve at base 11893 Stems subbipinnate, Leaves distantly placed patent cordate or ovate acuminated serrated : nerve disappearing below the summit, Theca ovate cernuous, Lid rostrate

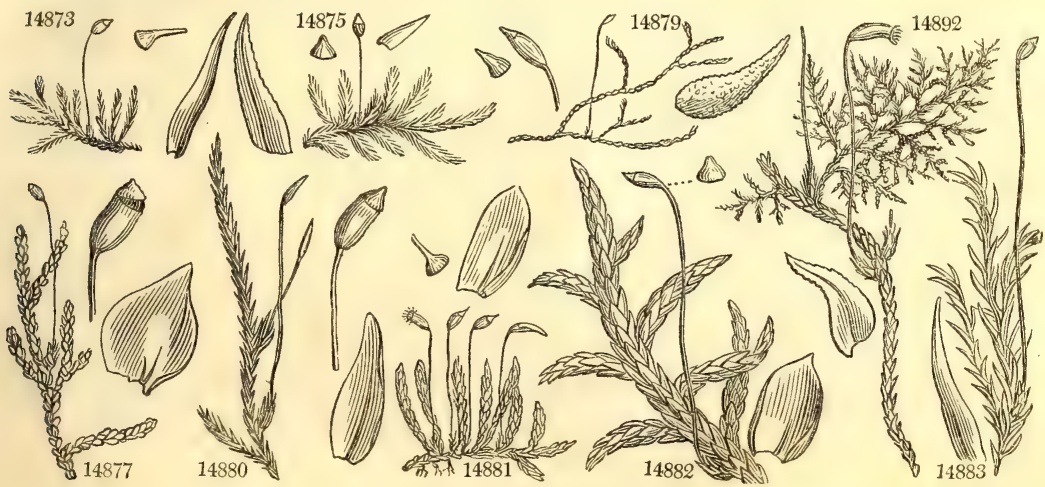

and Miscellaneous Particulars.

2251. Hypnum. One of the names of moss among the Greeks was ixyoy. This is the most extensive genus among mosses, and is readily known by its prostrate pinnated bright green branches, which form a thick mat$3 \mathrm{~N} 2$ 
14894 flagelláre Dicks. shady

14895 abietínum $L$.

14896 Blandóvii Web.

fir-leaved

Blandoff's

14897 pilíferum Schreb.

hair-pointed

14898 rutábulum $L$. poker crenulátum E. B. t. 1261

14899 velutínum $L$. velvety intricátum E, B. t. 2421

14900 Halléri $L$. Haller's

14901 dimórphum Brid. two-formed

14902 stellátum Schreb. stellate

$\beta$ squarrósulum E. B. squarrose

14903 loreum $L$

14904 ruscifólium Neck.

strap-shaped

14905 striátum Schreb. striated H. serrulátum E. B. 1262

14907 cuspidátum $L$. $\quad$ cuspidate

14908 cordifólium Hedw. heart-leaved 14909 polymórphum Hedw. variable

14910 tríquetrum $L$

14911 squarrósum $L$.
14906 confértum Dicks. compact

broad patches 6 summer

straggling $\quad 6$ summer

Bt. G alpine rocks E.b.t. 2565 H.umbr. tum

br.tum t. 2037

broad masses 5 spr. and sum. Bt.G alpine rocks dense mats 3 all seasons Bt.G everywhere E.b.t.1647H.bredense patches $1 \frac{1}{2}$ all seasons $\quad$ Y.G hedge banks Eng. bot. t. 1568 creep. dense 2 summer $\quad$ Y.Br Scotch rocks Grev.cryp.fi.174 lax procumb. 3 summer Pa.G shady places Grev.cryp.fi.160

broad tufts 3 spr. and sum. Y.Br marshes Eng. bot. t. 1302 patches $1 \frac{1}{2}$ spr. and sum. Dp. G stone walls Eng. bot. t. 1709 broad masses 9 spring Bt.G wo. and hea. Eng. bot. t. 2072 floating 6 spr. and sum. D.Ol in rivulets Eng. bot. t. 1275 loose tufts 6 spring Bt.G woods Eng. bot. t. 1648 small patches $1 \frac{1}{2}$ spring $\quad$ Pa.G trun. of trees Eng. bot. t. 2407

loose tufts 5 summer Y.G bogs Eng. bot. t. 1425

loose tufts 4. summer Pa.G bogs Eng. bot. t. 1447 matt. patches 5 win. and spr. Bt.G limest. rocks Hed.sp.mus.t.66 three-cornered branch. tufts 9 all seasons Y.G wo. and ban. Eng. bot. t. 1622 squarrose patches 7 all seasons Bt.G wo. and hea. Eng. bot. t. 1953

14912 filicínum $L$ dúbium E. B. 2126 fállax E. B.

14913 palústre $L$. marsh fluviátile E. B.t. 1303 adnátum $\mathrm{E}$. B. 2406

14914 adúncum $L$. hooked

ßrugósum E. B. rugose 14915 uncinátum Hedw. uncinate 14916 rugulósum $\mathrm{Web}$. wrinkled 14917 commutátum Hedw. changed

14918 scorpioídes $L$. creeping 14919 silesiánum Beauv. Silesian

Y.G wo. and ban. Eng. bot. t. 1622
Bt.G

Eng. bot. t. 1570

small masses 3 spr. and sum. Rsh. bogs

Li. G ban. of stre. Eng. bot. t. 1665

creeping tufts 2 spring

broad patches 3 spr. and sum. Var, bogs

E.b.t.2073.H.revolvens

broad patches 3 spr. and sum. Var bogs Eng. bot. t. 22.50 thick patches 3 spr. and sum. Y.G moist banks Eng. bot. t. 1600 dense tufts $\quad 3$ spr. and sum. Y.G heath. places Musc. brit. t. 26 droop. masses 9 all seasons Dp.G marg. of stre. Eng. bot. t. 1569

dense masses 9 summer Rsh. wet bogs Eng. bot. t. 1039 broad patches 7 summer Bt.G mountains Eng. bot. t. 2016

14920 cupressifórme $L$. Cypress-leaved thick mass 4 all seasons Bt. $G$ trees $\&$ rocks Eng. bot. t. 1860 nigroviride E. B. t. 1620

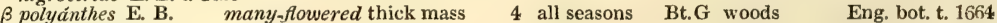
14921 crista castrénsis $L$. crested lax tufts 6 suminer Bt.G woods $\quad$ Eng. bot. t. 2108 14922 mollúscum Hedw. soft entangl. tufts 2 summer $\quad$ Y.G rocks $\quad$ Eng. bot. t. 1327

\section{VAGINULATI SCHISTOCARPI.}

2252. ANDRE形A Hedio. ANDRETA

$\begin{array}{lllr}\text { 2252. ANDREAE'A. Hediv. ANDREAEA. } & & \text { AND. } \\ \text { 14923 alpina Hedw. } & \text { alpine } & \text { loose tufts } & \text { summer } \\ \text { 14924 rupéstris Hedw. } & \text { rock } & \text { dense tufts } & \frac{1}{2} \text { summer } \\ \text { 14925 Róthii Mohr. } & \text { Roth's } & \text { dense tutts } & \frac{3}{4} \text { summer } \\ \text { 14926 nivális Hooker } & \text { snow } & \text { deep patches } & 1 \frac{1}{2} \text { summer }\end{array}$

4.

summer

$\frac{1}{2}$ summer
D.Br rocks $\quad$ Musc. brit. t. 8

D. Br rocks \& ston. Musc. brit. t. 8

D. Br rocks \& ston. Musc. brit. t. 8

D. Br mountains Musc. brit. t. 8

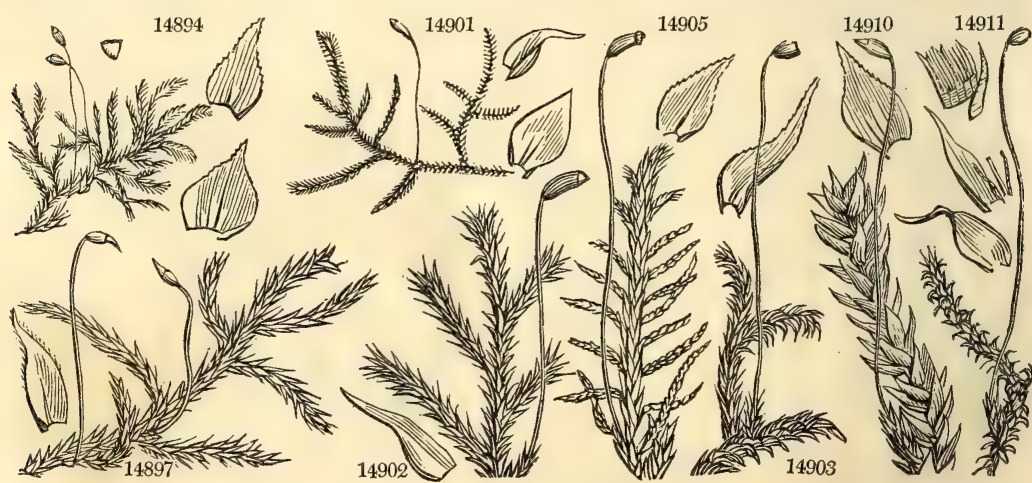

History, Use, Propagation, Culture,

like covering to the surface on which they grow. H. crista-castrensis is at once the most beautiful and most rare of British species.

2252. Andrecea. Named by Hedwig, in honor of J. G. R. André, a German botanist, author of Letters upon Switzerland. There was also a Portuguese Andreas de Castro, who published in 1636, a work upon plants. He was physician to one of the dukes of Braganza. There was besides a celebrated physician of antiquity 
14994 Stems pinnate (or irregularly bipinnate), Leaves thickly set cordato-acuminate serrated very faintly twonerved at the base, Theca oblong cernuous, Lid conical

14895 Stems pinnate, Leaves serrated papillose on the back: the margins reflex.; nerve running nearly to the point ; the cauline ones cordato-acuminate : those of branches cord. ac. Theca cylind, inclined, Lid rost.

14896 Stems pinn. Lvs. serrated smooth on the back : marg. reflexed; cauline ones cordato-acute with a short nerve, those of branches ovate acum. with nerve disappear, bey. midd. Theca cylind, inclin, Lid conical

14897 Stems somewhat pinnate, Leaves ovate with a long narrow acumination serrated: nerve disappearing below the middle, Theca ovate cernuous, Lid rostrate

14898 Stems variously branched, Leaves patent ovate acuminated serrated at the points striated: their nerve reaching half way, Theca ovate cernuous, Fruitstalk rough, Lid conical

14899 Stems variously branched, Leaves erecto-patent ovate often approaching to lanceolate acuminat. serrated striated : nerve reaching half way, Theca ovate cernuous, Fruitstalks rough, Lid conical

14000 Stems pinn. Branches short erect, Lvs, all recurv, cord, acum, obsol 2-nerv, at base, Lid obtusely conical

14901 Stems somewhat pinnate, Leaves serrulate two-nerved at base: primary cordate acuminate; of branches broad ovate, Theca ovate cernuous, Lid conical

14902 Leaves loosely set squarrose cord. much acuminated ent. nervel. Theca oblongo-ov, curv. cern. Lid conic.

14903 Leaves recurved squarrose lanceolate much acuminated concave serrated striated faintly two-nerved at the base, Theca globoso-ovate cernuous, Lid conical

14904 Leaves loosely imbricated spreading broadly ovate acute serrated concave with a nerve nearly as far as the middle, Theca ovate cernuous, Lid rostrate

14905 Lvs. spread, cord.-acum. serrat. striat. : nerve reach. beyond midd. Theca obl. ovate cernu. Fruitst. smooth 14906 Lvs. erect. spread. ov. acum. concave serrat. : their nerve reach. half way, Theca ov. cernu. Fruitst. smcoth

14907 Leaves loosely set ovate concave nerveless entire : lower squarrose ; upper imbricated in a cuspidate point, Theca oblong curved cernuous

14908 Lvs. loosely set squarr. cord.-ov. obt. concave ent. : nerve running nearly to point, Theca obl. curv. cernu. 14909 Lvs. loosely set squarr. cord. much acum. entire : nerve disappear. half way up, Theca obl. ov. curv. cernu. 14910 Lvs. squarr, cordato-acum. serrat. faintly striated with two nerves at base, Theca globoso-ov. Lid conical 14911 Leaves squarrose widely cordate very much acuminated and recurved serrated faintly two-nerved at the base, Theca ovato-globose cernuous, Lid conical

*** Leaves secund.

14912 Stems subpinnate, Leaves especially the upper ones falcato-secund broadly ovate acuminated serrated : their nerve reaching to the point, Theca oblongo-ovate curved cernuous, Iid conical

14913 Leaves secund ovate somewhat acuminate concave entire : margins incurved above; nerve short often forked sometimes obsolete, Theca oblongo-ovate cernuous, Lid conical

14914 Leaves falcato-secund lanceolato-subulate concave or almost semicylind. entire: the nerve disappearing below the summit, Theca oblongo-ovate curved cernuous, Lid conical

$\beta$ Leaves wider less falcate

[cernuous, Lid conical

14915 Lvs. falcato-secund lanceolato-subul. serrat. striat. : nerve disappearing below point, Theca cylind. curv.

14916 Lvs. sec. ovato-lanc. serrat. nearly plane crisp, transverse. when dry : marg. recurv.; nerve reach. half way

14917 Stems pinnated, Leaves falcato-secund cordate very much acuminated serrated : their margins reflexed; nerve disappearing below the summit, Theca oblongo-ovate curved cernuous, Lid conical

14918 Leaves secund broadly ovate ventricose obtuse ent. nervel. Theca oblongo-ovate curv. cernu. Lid conical

14919 Leaves loosely imbricated secund narrow-lanceolate acuminated serrated nerveless or very obscurely twonerved, Theca subcylindrical erecto-cernuous, Lid conical obtuse

14c 20 Leaves closely imbricated more or less falcato-secund lanceolate acuminated entire, except at the points, which are usually serrated very faintly two-nerved at base, Theca cylind. erecto-cernuous, Lid conical

14921 Stems closely pectinated, Leaves falcato-secund ovato-lanceolate acuminated serrulate striated faintly two-nerved at the base, Theca oblongo-ovate curved cernuous, Lid conical

14922 Stems pectinated, Leaves falcate secund cordate acuminated serrated not striated faintly two-nerved at base, Theca oblong ovate curved cernuous, Lid conical

\section{VAGINULATI SCHISTOCARPI.}

14923 Stems branched, Leaves obovate suddenly acuminate straight imbricating the stem on every side 14924 Stems branched, Leaves ovate gradually acuminated : the upper ones falcate

14925 Stems almost simp. Lvs. lanc. subul. falcate secund fragile : perichætial obl. nervel.; their marg. involute 14926 Stems slightly branched, Leaves loosely imbricated lanc. subfalcate secund : perichætial similar to cauline

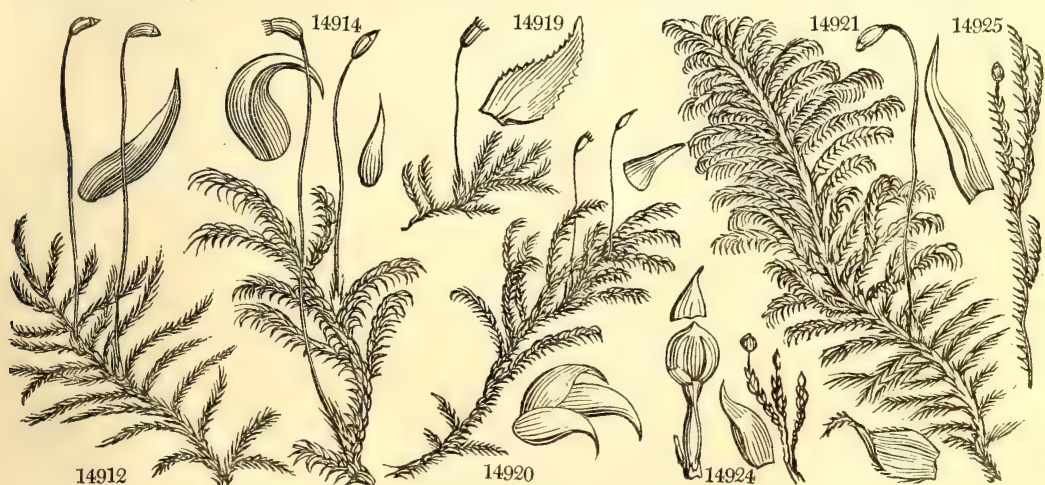

and Miscellaneous Particulars.

named Andreas, who was cited honorably by Pliny. This remarkable genus differs from all other mosses, in having a theca which splits into four valves, cohering at their ends by means of the persistent lid; it agrees with Sphagnum in having no fruitstalk, but in its room an elongated receptacle, and appears to be a transition from Musci to Hepatice. This is, however, only apparent. All the species are natives of rocks or nountains, and are remarkable for their nearly black or dark irrown color. 


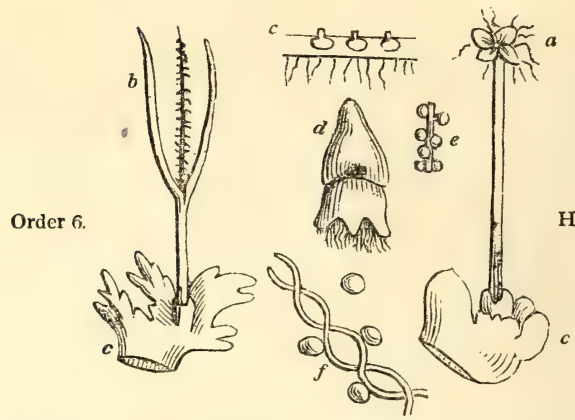

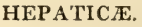

Reproductive organs of two kinds. 1. Thece without an operculum, either naked or sessile, or fur"nished with a veil through which they are more or less protruded. Sporules naked(e), or mixed with spirai threads (f). 2. Minute roundish or oblong bodies variously situated. Plants frondose of a cellulose structure not submersed.

THIs order is distinguished from Algæ, with which it was formerly united, by the nature of the theca ( $a, b)$, and of the foliaceous frond $(c)$ which is never submersed, and which bears a greater affinity to that of Musci. From

\begin{tabular}{|c|c|c|c|c|c|c|}
\hline 14927 trichophýlla Wahl. & hair-leaved & loose tufts & $\begin{array}{l}\text { Sp. } 81-15 \\
1 \frac{1}{3} \text { summer }\end{array}$ & $\mathrm{Br}$ & turfy heaths & Hook. jung. t. \\
\hline 14928 setácea $E . B$. & setaccous & dense tufts & 2 spring & $\mathbf{P a} . \mathbf{G}$ & bogs & t. 8 , sup. $t$ \\
\hline 14929 julácea Hook. & crecping & dense patches & $\frac{1}{2}$ summer & Pa.Ol & mountains & Hook. jung. t. 2 \\
\hline 14930 laxifólia Hook. & loose-ieaved & cush.-like pat. & $\frac{1}{3}$ spr. and sum. & Pa.G & mountains & Hook. jung. t. 5 \\
\hline rína $\mathrm{Hoo}$ & rigid & crowded tufts & ? summer & R. $\mathrm{Br}$ & mountains & ook. jung. t. \\
\hline & & small pat & $\frac{1}{2}$ wint & & ditche & is 0 \\
\hline
\end{tabular}

14933 asplenioides Hook. 14.934 spinulósa Hool. 14985 decipiens Hook.

14936 Doniána Hook.

14937 púmila Hook. 14938 lanceoláta Hook.

14939 corciifólia Hook. 14910 Sphágni Hook, 14941 crenuláta Hook. 14942 sphærocárpa Hook $149+3$ liyalina Hook.

14944 compréssa Hook.
Asplenium-like loose patches 3 all season spinulose crowded tufts 3 all seasons deceitful

Don's

dwarf

lanceolate

heart-leaved Sphagnum crenulate

round-fruited transparent

compressed

entangl. tufts $2 \frac{1}{2}$ september dense tufts 2 august dense tufts 4 jume

small patches $\frac{1}{2}$ wint. and spr. 01 rocks Hook, jung. t.17 entangl. patc. 3 autumn Y.G marshy plac. H.ju, t.33.su. t.2

D.Ol mountains Hook. jung. t. 32 Hook. jung. t, 37 early spring Pa G Irish bogs Hook jung t 7 broad tufts 1 early spring D.G bogs Hook. jung. t. 63 Pu rivulets, Irel. Hook. jung. t.58

14945 emaryináta Hook. 14946 concinnáta Hook. 14947 orcadénsis Hook. 14948 infláta Hook. 14949 excísa Hook. 14950 ventricúsa Hook.

emarginate notched Orcades inflated bitter ventricose
Ol.G moist woods Hook jung t.13 Y G mountains Hook jung, $t .14$ OI.G Irish heaths Hock. jung, t.50

P.Br Scot. mount. Hook. jung. t. 39 large patehes $\frac{3}{4}$ may, june $\mathrm{Br}$ wet pl. on $\mathrm{m}$. Hook. jung. t.2 thick tufts Sil wet pl. on m. Hook. jung. t. 3 loose patches 1 may, june Bt.G mountains Hook. jung. t.71 dense patches $\frac{1}{4}$ jan. to july Ol.G boggy places Hook. jung, t. 38 scatter, patch. I spring D.G shady woods Hook jung t $\begin{array}{ll}\text { dense patches } & \text { spug., novem. Pa.G woods } \\ \text { Hook. jung. t.28 }\end{array}$

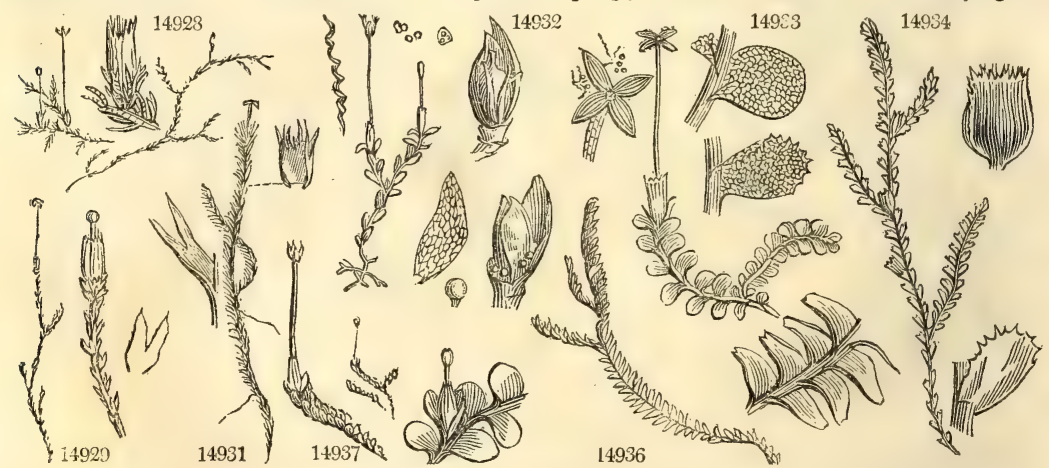

History, Usc, Propagation, Culture,

2258. Jungcrmannia. Named by Ruppius, to perpetuate the memory of Louis Jungermann, a German 
these Hepaticr differ in being destitute of an operculum or lid to the theca, and, with the exception of Marchantia $(d)$ and Jungermannia, of a calyptra. The order is composed of seven genera, all very different from each other, and forming an assemblage which is only natural in regard to the organs of vegetation. It does not appear possible to reconcile those of reproduction. The herbage consists of a variously dilated frond lying flat upon the substance on which it grows, generally naked, but in many Jungermannias covered with small flat upon the substance on which it grows, generally naked, but in many Jungermannias covered with small dilatations of the frond: the substance is generally loosely cellular, sometimes compact, as in Marchantia, in which Hooker asserts that pores of the epidermis exist.

2253. Jungermannia. Theca 4-valved, supported on a peduncle longer than the calyx. Valves free.

2254. Marchantia. Theca on the under surface of a common peltate pedunculate receptacle. Anthers im bedded in the disk of distinct peltate pedunculate or sessile receptacles.

2255. Riccia. Thecaspherical, immersed in the frond (not opening), crowned with the style, which is alone protruded.

2256. Anthoceros. Theca stalked, linear, 2-valved, with a central columella to which the sporules are attached.

2257 Targionia. Perianth? globose, arising from the underside of the extremity of the frond, at length opening vertically into 2 -valves. Theca globose, nearly sessile, included in the perianth, opening irregularly at the extremity, and filled with spiral filaments.

2258. Spherocarpus. Thecæ minute, spherical, seated upon obpyriform receptacles, and filled with mirute sporules unmixed with filaments.

\author{
A. Leafy. \\ + Stipules none.
}

* Leaves inserted many ways.

14927 Stem creep, irregul. branch. Lvs. imbricated on all sides setace. joint. straight, Fr. term. : mouth contract. 14928 Stem creep, pinnated, branch. Lvs, imbricat. on all sides setace joint incurv, Fr. term. : mouth expanded 14929 Leaves quadrifarious ovate closely imbricated erect acutely bifid, Theca terminal plaited at end

14930 Stem erect nearly simple filif. Lvs, dist. quadrifar, ov, somew. keel, acutely bif. Fr. term. Cal. somew. plait. 14931 Lvs. quadrifarious falcato-secund lin.-lanc. bipart. : segments straight acum. Fr. terminal, Cal. ovate leafy 14932 Leaves imbricated on all sides ovate or oblong-ovate here and there lobed and angled, Fr. term. Cal, none

** Leaves bifarious.

14933 Leaves obovate roundish ciliate toothed subrecurved, Fruit term. and lateral, Cal. obl. compressed oblique 14934 Lvs, obl. recurv. with margin on one side and apex dentato-spinul. Fr. lat. and axill. Cal, round. compr. 14935 Stem erect flexuose nearly simple, Lower leaves smaller ovate entire: upper rounded-ovate or nearly square, with one or more spiniform teeth

14936 Stem erect nearly simple filiform flexuose, Leaves closely imbricated nearly horizontal oblong ovate concave 2-toothed at end falcate 1-sided

14937 Leaves elliptical ovate, Fruit terminal, Cal. oblong ovate acuminate : mouth contracted denticulated

14938 Leaves spreading ovate-rounded, Fruit terminal, Cal. oblong cylindrical depressed and flat at the extremity: mouth much contracted cut and toothed

14989 Lvs, erect concave cord, circumvol. Fr, term. and axill. Cal, obl, ov, subplicate: mouth minute toothed 14.940 Lvs orbicul. Fr, upon short prop. branches, Cal, obl, attenuat, at each extrem. : mouth contracted toothed

14941 Lvs, orbicular margin. Fruit term. Cal. obov. compressed longitudin. quadrang. : mouth contract. toothed 14942 Stem ascending simple, Leaves orbicular, Fruit terminal, Cal, obl, ovate cylind. quadri. Theca spherical 1494 Stem ascending flexuose dichotomous, Leaves rounded somewhat wavy, Fruit terminal, Cal. ovate angul. with a contracted 4-toothed orifice

14944 Stem erect divided, Leaves orbicular : upper reniform appressed, Fruit terminal, Cal. immersed oblong fleshy with an open 4-toothed orifice

b Leaves emarginate or bifid: segments equal.

14945 Leaves loosely imbric. spreading obcordate emarginate, Fruit term. Cal. ovate toothed immersed in lvs. 14946 Leaves very closely imbricated erect concave ovate obtuse emarginate, Fruit terminal, Cal. $\mathrm{O}$

149.7 Leaves closely imbric, erect or spreading cordate ovate plane notched at extremity: their marg. recurv.

14948 I.vs. roundish concave acutely bifid: segm. straight obt. Fruit term. Cal. obpyrif. ; mouth contract. tooth.

14949 Leaves spreading subquadrate deeply emarginate, Fruit terminal, Cal. oblong : mouth plaited toothed

14,950 Leaves spreading subquadrate obtusely and broadly emarginate: their sides incurved, Fruit terminal, Cal. oblong : mouth contracted plaited toothed
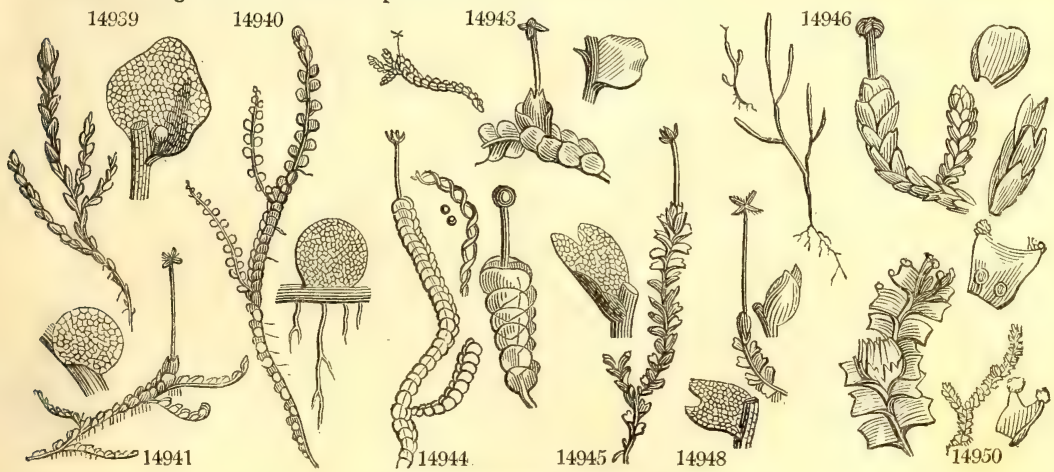

and Miscellaneous Particulars.

botanist, who was born in 1572, and died in 1653, after having published a catalogue of the plants of the neigh 
14960 nemorósa Hook. 14961 planifólia Hook.
14951 Turnéri Hook.

14952 bicuspidáta Hook. 14953 byssácea Hook.

14954 connivens Hook.

14955 curvifólia Hook.

14956 capitáta Hook.

14957 incísa Hook.

14958 pusilla Hook.

14959 setifórmis Hook. 14.962 umbrósa Hook.

14963 unduláta Hook.

14964 resupináta Hool. 14965 álbicans Hook.

14936 obtusifólia Hook 14967 Dicksóni Hook.

14968 minúta Hook.

14969 exsécta Hook.

Turner's

two-pointed Byssus-like connivent

curve-leaved

capitate

cut

dwarf

bristly

grove

flat-leaved

shady

wavy

resupinate

whitish

blunt-leaved

minute

scooped out

14970 cochlearifórmis Hook. cup-shaped

14971 complanáta Hook. flattened
Dickson's

small patches $\frac{\hat{\theta}}{\mathrm{b}}$ march

Pa.G Irish rivul. Hook. jung, t.29

large tufts 1 march, april Pa.G damp banks Hook.jung, t.11 dense tufts 1 march, april D.Ol heaths Hook. jung, t.12 loose patches $x_{2}$ april, may Y.G wet places Hook.jung. t.15 small patches $\frac{3}{4}$ april, may Dp.P mountains Hook. jung. t.16

very smll, pat. $\frac{2}{4}$ septem., jan. Pa.G bogs Hook. jung. t.80 sml.dense pat. $\frac{1}{4}$ july Pa.G heaths Hook. jung. t.10 sol. or thk.pat. $\frac{2}{4}$ october, may Bt.G moist banks Hook. jung. t. 69 dense tufts 2 spring

G. Br mountains Hook.jung. t.20

matted tufts $2 \frac{1}{2}$ july, october $\mathbf{P u}$ woods Hook.jung.t.21 crowded patc. $2^{2}$....... Din. Brmountains Hook. jung. t.67 dense tufts $\frac{1}{4}$ march, april G.Br shady places Hook. jung, t.24 large tufts 3 may, june Bt.G wet places Hook. jung. t.22

verysml.tufts $\frac{1}{3}$ may, june Br.G heaths Hook, jung. $t 23$ broad tufts $1 \frac{1}{2}$ april, july Pa.G hedgebanks Hook. jung. t.25

little tufts $\frac{1}{4}$ march, april Pa.G damp places Hook. jung. t.26 dens, mat. tuf. $\frac{1}{3}$ august Ol.Br mountains Hook. jung. t.48 loose patches $\frac{3}{4}$ spr. and sum. Ol.Br mountains Hook. jung, t.44 small patches $\frac{1}{\frac{1}{k}}$ summer $\quad \mathrm{Pa} . \mathrm{G}$ heaths Hook.jung. t.19 large patches 4 summer R. Br mount. bogs Hook. jung. t. 68 cush.-like pat. $1 \frac{1}{2}$ summer Pa.G trun. of trees Hook. jung. t.81

-

14972 anómala Hook. 14973 Taylóri Hook. 14974 scaláris Hook. 14975 polyánthos Hook. 14976 cuncifólia $\mathrm{Hook}$. 14977 viticulósa Hook. 14978 trichómanis Hook.

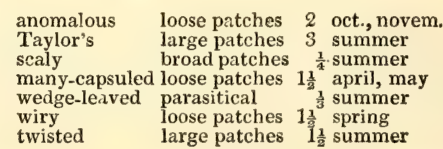

Br.G bogs

Hook. jung. t. 34 Pk mountains Hook. jung. t.57 Pa G loamy soil Hook jung. t.61 $\mathrm{Pa} . \mathrm{G}$ wet places Hook, jung. t.62 $\mathrm{Br}$ inland $\quad$ Hook. jung. t.64 $\mathrm{Br}$ inland Hook. jung. t. 64
$\mathrm{Y} . \mathrm{Br}$ ear. damp pl. Hook. jung. t. 60 Bt.G moist places Hook. jung. t.79

14979 bidentáta Hook. 14980 heterophýlla Hook.

14981 stipuiácea Hook.

14982 Francísci Hook.

14983 barbáta Hook. 14984 albéscens Hook. 14985 réptáns Hcok.

14986 trilobáta Hook.

two-toothed crowded patc. $1 \frac{1}{2}$ oct., novem. Pa.G moist places Hook. jung. t.30 various-leaved small tufts $\quad \frac{1}{2}$ april, novem. Pa.G stemsof trees Hook. jung. t.31

large-stipuled cush.-liketuf. $\frac{x}{4}$ summer

Francis's

bearded

whitened

creeving

three-lobed crowded patc. $\frac{1}{9}$ april, july

crowded patc. $1 \frac{1}{2}$ spring

loose patches $\frac{1}{2}$ summer

dense tufts 1 summer

large patches 3 summer
Pa.Ol shady places Hook. jung. t.41

$\mathrm{Pk}$ moist places Hook. jung. t.49

Ba.G woods \& hea. Hook. jung. t.70 Pa.G Ben Nevis H.jun t.72.su.t.

Pa.G woods Hook. jung. t.75

Ol.G rocks Hook. jung. t.76
14987 platyphylla Hook. 14988 lævigáta Hook. 14989 ciliáris Hook.

14990 Woúdsii Hook. broad-leaved polished ciliated

Woods's

downy wide patches 2 march, aug. Br.G old walls H.jun.t.40.su.t.3 $\begin{array}{lll}\text { loose tufts } 2 \frac{1}{2} \text { summer Br.Ol woods Hook. jung. t. } 35 & \end{array}$ dense patches 2 spr. and sum. R. Pr rocks \& hea. Hook. jung. t. 65 crowded tufts 5 spr. and sum. R. Br Irish mount. Hook. jung. t.66 broal patches 3 march, oct. Pa.G moist places Hook. jung. t. 36

14992 Mackáii Hook. Mackay's dense patches 1 febr,, novem. Bk.G trees \& rocks Hook. jung. t.53

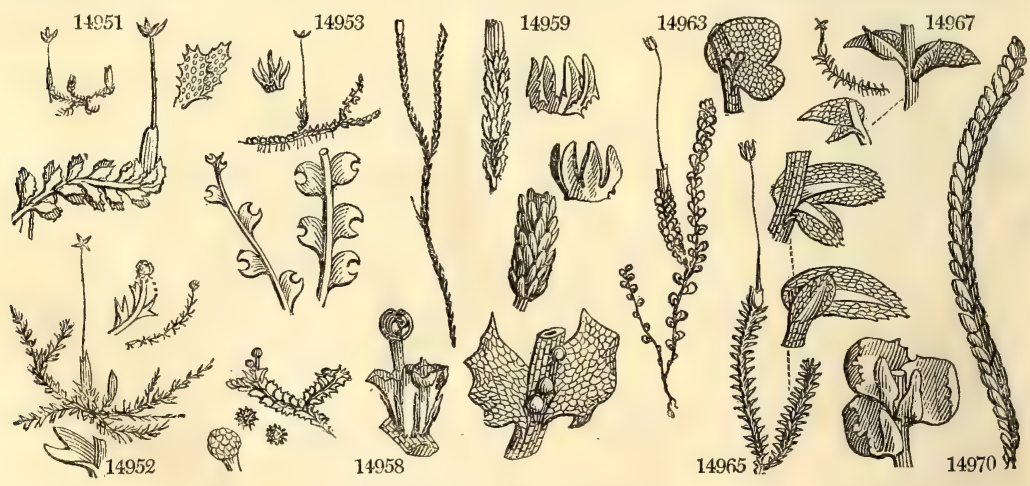

History, Use, Propagation, Cuiture,

bourhood of Altdorf, and a work called Cornucopia Floræ Giessensis. A genus of obscure plants, forming by their creeping stems little patches upon trees or rocks, or on the earth in damp places. The British 
14951 Stem procumbent flexuose branched in a starry manner, Leaves broad-ovate acutely 2-parted : segments folded together with spiny teeth, Fruit terminal

14952 Lvs. subquad. acutely bifid : segm. acute straight ent. Fruit terminal, Cal. obl. plaited : mouth toothed 14953 Leaves subquadrate obtusely bifid: segments acute, Fruit terminal, Cal, oblong plaited. mouth toothed 14954 Lvs. orbicul. concave at extrem. lunul. emarg. Fruit term. upon short prop. central branches. Cal, obl. ov. 14955 Lvs. round. very conc. bif. : segm. long acum. incurv. Fr. term. upon short prop. branch. Cal. obl. subplicate c Leaves 3-4-fid: segments equal.

14956 Stem prost. nearly simp. Lvs, round square : lower bifid; upp. 3-4-fid, Fr. term. Cal, obl, ov, somew, plait. 14957 Leaves subquadrate waved subtrifid; segm, "equal here and there toothed, Fruit terminal, Cal. obovate 14958 Leaves spreading horizontally quadrate waved obtusely bitricrenate, Fruit terminal, Cal. campanulate, Theca spherical bursting irregularly

14959 Leaves bifarious closely imbricated erect quadrate quadrifid : their inferior angles here and there spinul toothed, Fruit terminal and lateral, Cal. oblong plicate : the mouth open

d Leaves hifid: segments unequal folded together.

14960 Lvs. unequally 2 -lobed $\frac{1}{2}$-bifid tooth. cili. Lobes fold. together : lower ones larger obov. ; upp. subcord. obt. 14961 Stem erect nearly simple, Leaves unequally 2-lobed as deep as base : tooth ciliated, Lobes folded together 14962 Lvs. uneq. 2-lob. Lobes folded together serrated at extrem. acute : lower ones larger ov.; upp. round. ov. 14963 Leaves unequally 2-lobed wavy entire, Lobes roundish folded together; lower ones largest, Fruit term. Cal. oblong incurved compressed

14964 Leaves roundish nearly equally 2 -lobed entire, Lobes folded together, Fr. term. Cal, obl. incurv, compres. 14965 Leaves unequally 2-lobed folded together with a pellucid line in the middle serrated at the extremity, Fruit terminal, Cal. obovate cylindrical

14966 Lvs, unequally 2-lobed folded together obtuse entire, Fruit term. Cal, obov. : mouth contracted toothed 14967 Lvs. unequally 2-lobed folded together narr, ov, acute, Fr, term. Cal, ov, plaited : mouth contract. toothed 14968 Leaves horizontally spreading somewhat folded together: upper equally, lower unequally 2-lobed, All the lobes rather acute, Cal, obovate

14969 Stem prostrate nearly simple, Leaves unequally 2-lobed, Lobes folded together: lower larger ovate concave acute; upper minute tooth-like

14970 Leaves imbricated on the upper side unequally 2-lobed folded together : upper lobes the larger convex bifid and toothed at the extremity

14971 Lvs. distich. imbricat. above unequ. 2-lobed : upp. lobes larger orbicul. ; lower ov. appres. flat, Cal. truncat. 十† Furnished with stipules.

* Leaves entire or rarely emarginate.

14972 Leaves orbicular and ovate acuminate, Stipules broadily subulate

14973 Lvs, all rounded, Stip. broadly subul. Fruit term. Cal. ovate compressed at the extremity truncate 2-lipped 14974 Lvs. round concave entire and emarg. Stipules broadly subul, Fruit terminal, Cal. immersed in the leaves 14975 Lvs, horizontal rounded quad. plane ent. and emarg. Stip. obl. bifid, Fr. upon very short proper branches 14976 Stem creeping simple, Lvs, rather rem. cuneiform ent. or bluntly emarg. at end, Stip. minute ovate bifid 14977 Leaves horizontal plane ovate entire, Stipules broadly ovate toothed lanc. Fr. lat. Cal, subterr, obl. fleshy 14978 Leaves horizontal convex ovate ent. Stipules round lunate-emarg. Fruit lat. Cal. subterr, obl, fleshy hairy

* Leaves 2 or 3 cleft : segments equal.

14979 Leaves broadly ovate decurrent bifid at the apex : segm, very acute entire, Stipules bitrifid and laciniate 14980 Stem creeping branched, Leaves round-ovate decurrent rarely acutely often obtusely emarginate or entire, Stipules bitrifid, Fruit terminal, Cal, ovate

14981 Leaves round acutely emarginate: segments acute straight, Stipules large ovate acuminate with a single tooth at the base on each side

14982 Stem nearly erect simple or branched, Leaves ovate concave acutely emarginate, Stipules minute ovate bifid, Fruit terminal, Cal, oblong cylindrical little plaited

14983 Leaves rounded quadrate 3-4-fid, Stipules lanceolate acutely bifid : their margins lacerated

14981 Lvs. very concave nearly hemispherical emarg. Stip. ovate lanc. obtuse, Fruit term. upon short branches $1498 \tilde{~ L e a v e s ~ i m b r i c a t e d ~ a b o v e ~ s u b q u a d r a t e ~ i n c u r v e d ~ a c u t e l y ~ 4-t o o t h e d, ~ S t i p . ~ b r o a d l y ~ q u a d . ~ 4-t o o t h . ~ F r . ~ r a d i c a l ~}$ 14986 Lvs. imbricat. above ov. convex obtusely trident. Stip. broadly subquad. cren. Fr. from lower part of stem

** Leaves bifid: segments unequal folded together. a Lower segments or smaller ones flat.

14987 Lvs, unequal. lob. : upper lobes round, ov, nearly ent. ; lower and stip. ligulate quite entire, Fruit lateral 14988 Lvs, unequal. 2-lobed spinul-toothed: upper lobes roundish ov, ; lower ligul. Stip. obl, quad spiny toothed 14989 Leaves very convex unequally 2 lobed: lobes and lobules ovate bipart. fringed with long and slender cilia 14990 Stem procumbent bitripinnate, Leaves very convex unequally 2-lobed: upper lobes 2-parted spiny toothed lower very minute oblong entire

14991 Leaves nearly flat unequally 2-lobed cut into numerous capillary segments : upper lobes 2-partite; lower minute, Stipules subquadrate laciniate

$b$ Lower segments or smaller ones involute.

14992 Stem creeping unequally branched, Leaves unequally 2-lobed: upper lobes rounded; lower minute invol. Stipules large rounded obcordate

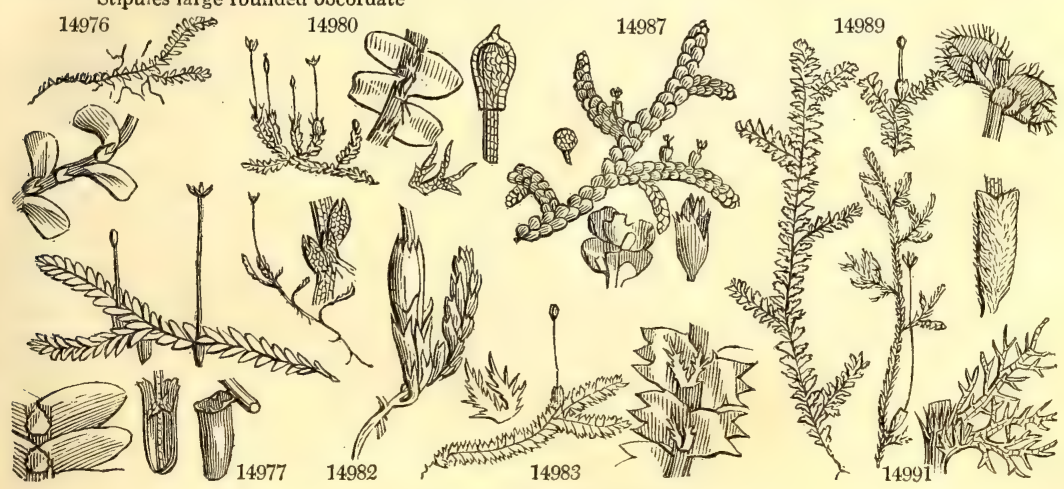

and Miscellaneous Particulars.

species have been admirably illustrated by Hooker, to whose Monograph no other botanical work can be compared. 
14993 serpyllifólia Hook. 14994 hamatifólia Hook. 14995 minutíssima Hook.

14996 calyptrifólia Hook. thyme-leaved imbric.masses $\frac{1}{2}$ april, june hook-leaved very smll.pat. $\frac{1}{8}$ spring very minute little patches ${ }^{\frac{1}{8}}$ april, may calyptra-leav. little tufts $\frac{1}{8}$ summer
Pa.G trun of trees Hook, jung, t. 42 $G$ rocks Hook. jung. t.51 Y.G bark of trees Hook. jung. t.52 Pa.G on Ulex nan. Hook. jung. t. 43

14997 Hutchínsiæ Hook. Miss Hutchins's loose patches 1 summer

14998 dilatáta Hook 14999 Tamarísci Hook. dilated.

Tamarisk round patches $\frac{3}{4}$ winter large patches $3^{4}$ april, sept.
D.Ol damp pl., Ir. Hook. jung. t. 1

Br.P trun. of trees Hook. jung. t. 5 Br.G on the earth Hook. jung. t. 6

\section{0 pinguis Hook. \\ 15001 multífida Hook}

15002 Blásia Hook. 15003 epiphýlla Hook.

15001 furcáta $H o o k$.

15005 pubéscens Hook. 15006 Lyéllii Hook.

15007 hibérnica Hook fat

many-cut

loose patches 2 summer crowded tufts 1 spring

Pa.G moist sha. pl. Hook. jung. t.46 Pa.G moist pl. hea. Hook. jung. t. 45

Blasia epiphyllou patches 1 spring

D.G moist heaths H. jun.t. $82,83,8$ forked

downy

Mr. Lyell large patches

spr. and aut.

Pa.G moist hedges Hook, jung. t.47

patches

loose patches

oct., march

Pa.G trun. of trees Ho. jung. t.55,56 loose patches

\section{1 spring}

Gl rocks

Hook. jung. t.73

Hook, jung, t.77

Pa.G shores of Ir. H.ju. t.78.s.t4.f.1

2254. MARCHAN'TIA. Mich. Marchantia. Sp. 4-7. 15008 polymórpha $E . B$. variable broad patches 2 winter 15009 hemisphæ'rica $E$. $B$. hemispherical broad patches $1 \frac{1}{2}$ winter 15010 cónica $E$. B. conical broad patches 2 winter

15011 andrógyna $E . B$. androgynous broad patches $1 \frac{1}{2}$ winter

2255. RIC'CIA. E.B.

15012 glaúca $E . B$

15013 nátans $E . B$.

15014 flúitans $E$. B.

15015 spúria Dicks.

Sp. 4.

Riccia.

glaucous

floating floating

spurious patches

$\frac{1}{2}$ spring

$\frac{1}{9}$ spring

$\frac{2}{8}$ spring

$\frac{1}{2}$ spring

Sp. 3-5.

$\frac{1}{2}$ summer

15016 multífidus Dicks.

15017 punctátus $E . B$. $\quad$ dotted $\quad$ patches

$13^{\frac{1}{2}}$ summering

large broad patches $\frac{1}{2}$ spring

D.G moist rocks Eng. bot. t. 210

D.G moist rocks Eng. bot. t. 503

D. G shady banks Eng. bot. t. 504

Pa.G wet rocks Eng. bot. t. 2545

Gl rocks Eng. bot. t. 254

$\mathrm{G}$ ditches Eng. bot. t. 252

Pa.G ditches Eng. bot. t. 251

Pa.G mount. mar. Dick.cr.t.11.f.16

G crev. in roc. Dill.mus.t.68.f. 4 Pa.G damp places Eng. bot. t. 1537 D.G damp places Eng. bot. t. 1538

15019 hypophýlla E.B. flat-leaved broad patches $\frac{1}{4}$ wint. and spr. D.G wet places Eng. bot.t. 287 2258. SPHEROCAR'PUS. E. B. SPherocarpus. Sp. 1-4.

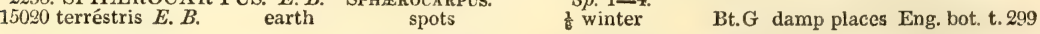

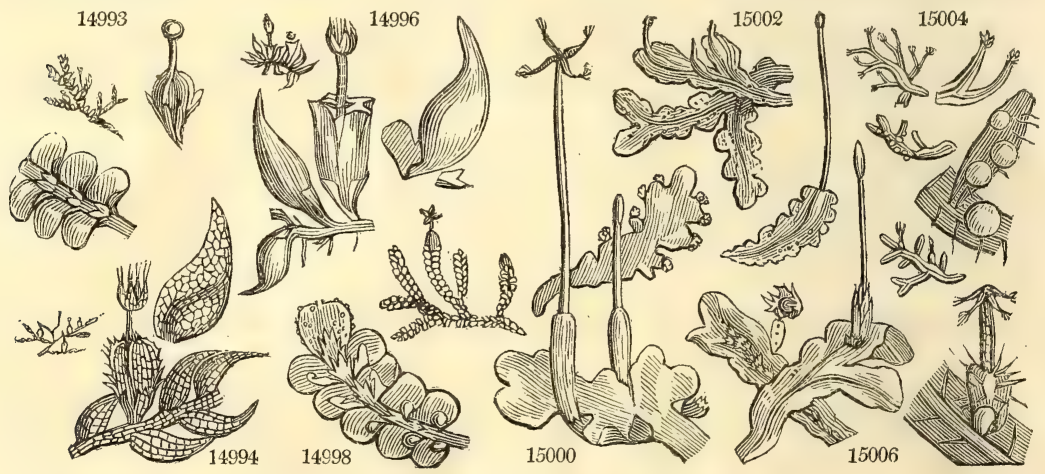

History, Use, Propagation, Culture,

2254. Marchantia. Named by Nicholas Marchant, in honor of his father John Marchant, the first botanist whom the Academy of Sciences of Paris admitted among its members, in 1666 . Soft-leaved creeping plants, with green cellular fleshy fronds spreading over the surface of the ground in wet places. M. hemisphærica and polymorpha are often the pest of the florist, whose flower pots are overrun by them, and continually disfigured.

2255. Riccia. Pietro Francisco Ricci, was a Florentine botanist, who left some of his works to the academy of Florence. Little, generally floating, simple plants, of the nature of which very little is known. Only one kind has been observed in fructification, and that is of a very ambiguous character. The thecæ, or the organs so called, are little round bodies immersed in a cavity of the frond, and containing minute sporules.

2256. Anthoceros. From ay 705 , a flower, and zsexs, a horn, on account of the horn-like form of the theca, which old botanists considered to be the flower. Minute frondose plants, with a linear 2 -valved theca, containing a columella to which the sporules are attached. In habit they resemble Jungermannia. 
14993 Lvs. unequal. 2-lobed: upper lobes rounded; lower minute invol. Stip. roundish acutely bifid, Fruit latera 14994 Lvs. unequally 2-lobed : upper lobes ovate-acum. mostly curved at extremity; lower ovate acutely bifid 14995 Stem creeping unequally branched, Leaves unequally 2-lobed : upper lobes hemispherical ; lower minute almost obsolete, Stipules ovate rounded bifid, Fruit lateral

14996 Stem creeping branched, Leaves unequally 2-lobed: upper lobes larger calyptriform; lower bluntly square circumvolute, Fruit lateral

c Lower segments or smaller ones saccate.

14997 Stem creeping branched, Leaves unequally 2-lobed: upper lobes ovate spiny-serrated: lower minute saccate generally 1-toothed at base, Fruit lateral

14998 Lvs. unequally 2-lobed: upper lobes ovate rounded; lower rounded saccate, Stip. rounded flat emarginate 14999 Lvs. unequally 2lobed: upper lobes ovate roundish; lower minute obov. saccate, Stip. subquadrate emarg.

$$
\begin{aligned}
& \text { 2. Frondose. } \\
& + \text { Nerveless. }
\end{aligned}
$$

15000 Frond obl. decumb. nervl. fleshy nearly plave above: swell. ben.; irregularly branch. The margin sinuated 15001 Frond lin. nerveless fleshy compressed branched in a pinnated manner, Fruit marginal, Cal, very short

$$
++ \text { Nerved. }
$$

15002 Frond obl. submemb. dichot, costate having scattered scales on the underside, Cal, and calyptra within frond 15003 Frond obl. submembranous irregularly divided obsoletely ribued : the margin entire or lobed and sinuated, Fruit from upper part of frond near the apex

15004 Frond lin. dichotomous membranous costate glabr. above : more or less hairy beneath and on the margin, Fruit from the lower surface of the nerve

15005 Frond lin. dichotomous membranous costate pubescent in every part [of the fronds 15006 Frond obl. somew, branch. memb. costate : the margin nearly entire, Fruit arising from the superior surface 15007 Frond obl, dichotomous membranous costate with the margin entire, Fruit arising from the upper surface of the frond

15008 Recept. of thecæ deeply cut in a stellated manner into about ten narr. segm. : that of the anthers pedunculat. 15009 Recept. of thecæ hemispherical cloven into about 5 oval segments

15010 Recept. of thecre entire conical ovate somewhat angular: that of the anthers sessile

15011 Recept. of thecæ hemispherical half 4-cieft of 4 cells

15012 Frond small obl, somew. divid. : the segments 2-lobed at the end fleshy glaucous dotted on the surface

15013 Frond triangular cordate covered with long linear lanceolate segments on one side

15014 Frond membranous dichotomous, Lobes retuse

15015 Fronds membranous lobed pellucid, Theca beneath the sinuses of the lobes solit. exserted turbinate tooth.

15016 Fronds bipinnatifid linear

15017 Fronds multifid lobed sinuated, Theca subulate half bifid

15018 Fronds lobed rounded flat, Theca short

\section{Frond flat imbricated lobed, Lobes rounded retuse}

15020 Frond simple ovate, Thecæ pyriform clustered at the base of frond
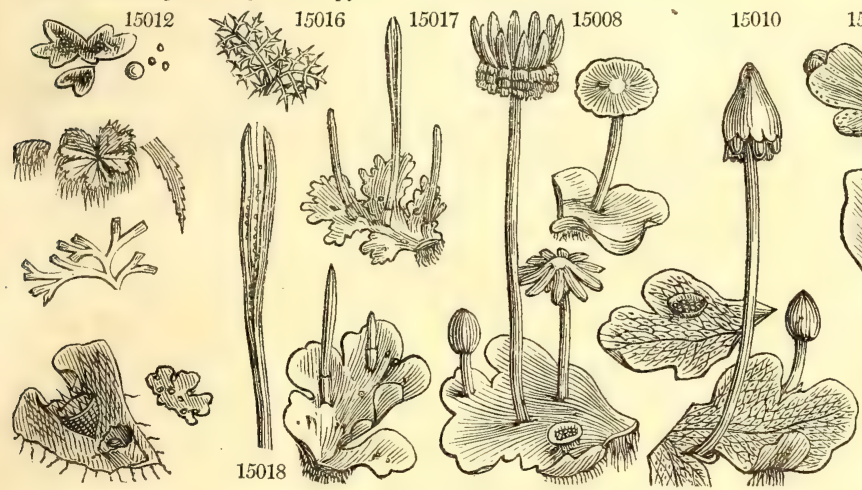

15017

and Miscellaneous Particulars.

2257. Targionia. So called in remembrance of John Anthony Targioni, a meritorious Florentine botanist, who published in 1734 a work for the purpose of shewing the importance of botanical lectures, with reference to a course of studies in medicine. There was also another Florentine physician called John Targioni Tozzetti, after whom Tozzettia has been named. This genus consists of only one species, which is frondose and lobed. The theca is concealed and almost sessile within the involucre, globose, bursting at the apex, and discharging its sporules mixed with spiral filaments. This genus is very near Jungermannia.

2258. Spharocarpus. From $\sigma \phi a s c$, a globe, and $\approx \alpha \xi \pi$, , fruit, in allusion to the form of the fruit. The plant consists of a roundish delicate membranous frond, bearing on its disk a cluster of obpyriform receptacles each of which has a globose transparent finely membranous seed-vessel, filled with minute sporules unmixed with elastic filaments. 
Order 7. ALGE
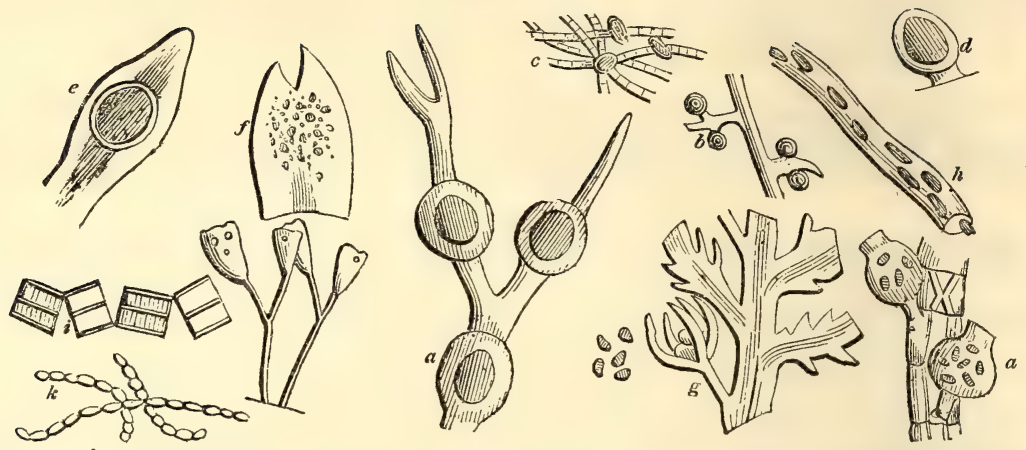

Reproductive organs of two kinds. 1. Thece or tubercles variously situated. 2. Sporules or granules naked or immersed in the frond. Plants always aquatic and submersed.

This order is constituted of the sea-weeds of our ocean, and of the floating scum-like substances of our ditches and rivers. Little is known of the functions which what are called their reproductive organs perform. The nature and structure of those organs are so various as to render it improbable that they should all be destined for the same purposes. The bodies which are called sporules are variously situated; now filling distinct thecæ $(a)$, or even tubercles $(b)$, which are either free $(b, c, d)$, or imbedded in the substance of the frond $(e, f)$; now appearing to be naked and surrounded by an involucre $(g)$; now scattered or arranged in some determinate manner in the interior of the frond. $(h)$ The fronds are either cylindrical $(h)$, or plane $(i)$, sometimes little more more than a mere membrane, sometimes hard and horny, and extended to the length of many feet. Many are articulated $(i, k)$ : their line of separation is then called a joint, and the space between two joints an articulation

Professor Agardh, of Lund, one of the most celebrated of modern cryptogamists, and whose disposition of Algæ is adopted here, in his latest work, called Systema Algarum, published at Lund, in 1824, defines the order thus:

“ Aquatic plants destitute of cotyledons and of sexual organs; gelatinous, membranous, or coriaceous; filamentous, laminose, or even leafy; in color green, purple, or olivaceous; jointed or continuous; bearing sporidia" (little transparent bodies containing sporules), " either included in pericarps or scattered over the surface."

The Algæ form one of the three forms of the lowest order of vegetation, Lichens and Fungi the two other. of the former, many are considered by some botanists to be animalcula, and others, to be the young seedling plants of mosses.

Tribe I. DIATOME无.

Bodies of various forms, flat and crystalline, and separating into fragments.

2259. Achnanthes. Frond stalked, vexilliform. Marine.

2260. Diatoma. Filaments jointed, hyaline, rigid, simple, united in pairs longitudinally, at length separating into articulations cohering by their alternate angles.

2261. Fragillaria. Filaments jointed, simple, gelatinous, compressed, fragile, separating at the joints.

2262. Meloseira. Filaments jointed, contracted at the joints, very fragile, and easily separating.

2263. Desmidium. Filaments transversely and densely striated, mucous, flexible, green, half separated into articulations, and in that state pinnatifid.

2264. Schizoncma. Filaments bead-like, composed of narrower cohering filaments inclosing elliptical granules, into which they are finally dissolved. Marine.

\section{Tribe II. NOSTOCHINÆ.}

Individuals numerous, globular or filiform, suspended in a gelatine of a definite form.

2265. Palmella. Minute or small, somewhat diaphanous gelatinous plants, filled with solitary granules unmixed with filaments.

2266. Echinella. A roundish gelatine crammed with elliptical radiant corpuscles. Marshy.

2267. Alcyonidium. A spongy fleshy lobed frond filled with granules. Marine.

2268. Nostoc. Plants roundish or shapeless, gelatinous. Substance composed of curved moniliform simple filaments, lying irregularly in a gelatinous nidus.

2269. Corynephora. A gelatinous roundish puckered frond filled with jointed filaments, bearing here anc there clavate processes.

2270. Rivularia. A gelatinous subglobose frond filled with filaments, radiating from a ccmmon centre, continuous, placed on a globule, and marked with annulations inside.

2271. Chcetophora. Plant elongated or globose gelatinous. Substance composed of branched articulated filaments.

2272. Scythymenia. A coriaceous tough stratum, formed of fibres and granules mingled together.

TRIBE III. CONFERVOIDEE.

Filaments jointed either ezternally or internally, separate, and not combined in any definite form.

2273. Byssocladium. Filaments like cobwebs, scattered externally with sporidia. Slightly inundated.

2274. Mycinema. Filaments membranous, opaque, tenacious, colored (usually tawny). Slightly inundated.

2275. Chroolepus. Filaments rigid, nearly solid, opaque, crumbling into powder, torulose On rocks or bark

2276. Trentepohlia. Filaments flexible, colored, bearing capsules, which generally proceed from the last articulation, which is inflated. Inundated or fluviatile.

2277. Scytonema. Plant not gelatinous, coriaceous. Filaments short, forming dark dense tufts, beaded internally, or filled with annular transverse bodies. On rocks or inundated, rarely marine.

2278. Stigonema. Filaments continuous, coriaceous, naked, marked inside with dots disposed in rings. On rocks.

2279. Protonema. Filaments somewhat jointed, rooting very minute

2280. Hygrocrocis. Filaments hyaline, arachnoid, obsoletely articulated, floating in a shapeless gelatine or in a colored membrane.

2281. Leptomitus. Filaments hyaline or slightly colored, arachnoid, obsoletely articulated, separate, erect, not entangled. 
2282. Mesogloia. Frond filiform, cylindrical, gelatinous, with compact somewhat moniliform branches radiating from a medullary pith, and bearing capsules.

2283. Batrachospermum. Frond filiform, gelatinous, sending out from the primary filament moniliform gemmiferous branches.

2284. Draparnaldia. Filaments green, jointed, very gelatinous. Ramuli penicillate fascicled. Fructification a granular mass in the articulations of the main filaments.

2285. Oscillatoria. Plants gelatinous. Filaments simple, continuous, membranaceous, filled internally with transverse parallel striæ.

2286. Calothrix. Filaments destitute of a mucous matrix, stiffish, straight, motionless, with a continuous tube annulated inside.

2287. Lyngbya. Filaments without a mucous matrix, freely floating, flexible, motionless, with a continuous

tube annulated inside.

2288. Bangia. Filaments capillary, mostly simple, tubular, continuous. Fructification; granules disposed in regular transverse series or strata.

2289. Zygnema. Filaments jointed, simple, gelatinous, compressed, fragile, separating at the joints.

2290. Mougeotia. Filaments articulated, connected like a net, with irregularly placed granules, and thecæ attached to the angles of the meshes.

2291. Hydrodictyon. Filaments articulated, connected like a net. Articulations viviparous, including young individuals.

2292. Conferva. Filaments uniform, jointed, membranaceous, simple or branched, mostly green. Fructification, granules scattered in the articulations. Salt and fresh water.

2293. Bulbochate. First filament articulated, sending out from the apex of the articulations an accessory branchlet. Thecæ alternating with the accessory branches. Marshy.

2294. Nitella. Filaments consisting of a single tube, membranous, jointed, with whorled branches. Organs of fructification twofold and separate; first nucules spirally striated, without bractes, and not crowned second, colored globules. Sea and marshes.

2295. Chara. Filaments spirally striated, jointed, with whorled branches. Organs of fructification twofold, and close together; first, nucules spirally striated, furnished with bracteæ, and crowned; second, colored globules. Sea and marshes.

2296. Ceramium. Filaments jointed, subdichotomous, red, articulations veined or diaphanous. Fructification; capsules with an involucre of short ramuli. Marine.

2297. Griffithsia. Filaments jointed, rose red, branched. Articulations marked with one broad tube-like line, the joints pellucid. Fructification; pedunculated capsules on the ramuli. Marine

2298. Chretospora. Filaments obsoletely articulated, rosy, covered by axillary articulated fruit-bearing branches, which either include in the middle a globe of sporules, or change to a lanceolate receptacle covered with setæ, among which the sporules nestle. Marine.

2299. Polysiphonia. Filaments jointed, longitudinally striated, with internal parallel tubes. Fructification double ovate capsules, and granules in swollen branchlets. Marine.

230\%. Rytiphlaea. Frond flattened, distichous, transversely striated, becoming black when dry, with incurved ramenta. Fruit twofold ; first, spherical capsules with pyriform sporidia; and second, lanceolate pods with roundish sporidia. Marine.

2301. Ectocarpus. Filaments jointed, much branched, fuscous. Fructification; lanceolate pods or ovate capsules solitary or racemose. Marine.

2302. Sphacellaria. Filaments jointed, branched, olivaceous, distichous or dichotomous; apex of the branches sphacellate or hyaline, abrupt. Fructification; granules in the sphacellated apex, or capsules. Marine.

2503. Cladostephus. Plant olivaceous. Main filaments opake, inarticulate; branches jointed, mostly whorled with ramuli. Fructification; capsules. Marine.

\section{Tribe IV. ULVACET}

Frond membranous, continuous, tubular or flattened, never ribbed, herbaceous, or very rarely purple. Fruit a heap of sporules, either naked, or forming scattered granules covered by coniocystas.

2304. Vaucheria. Filaments dichotomous or irregularly branched, somewhat rigid. Fructification; a granulated mass within the frond, and external dark vesicles variously sinuated.

2305. Codium. Frond spongy, of a determinate figure formed of filaments densely packed, which are tubular and continuous, and colored by a granular green powder. Coniocystas clustered at the surface of the frond.

2306. Bryopsis. Root minutely scutate. Filaments tubular, continuous, aggregated, branched, pinnate, or imbricated upwards with branchlets. Fructification a dark internal granular mass.

2307. Solenia. Frond tubular, membranous, with a striated areolated surface. Sporidia very minute and compact.

2308. Ulva. Root scutate. Frond plane, ribless, flabelliform or wedge-shaped, or linear and dichotomous. Fructification naked immersed; granules distributed in fours throughout the frond.

2309. Porphyra. Frond flat, purple, with the membrane of equal texture. Fruit twofold; first, sori of oval sporidia collected in a disorderly manner; second, two parallel lines marked on each side by a globule.

\section{Tribe V. FLORIDE⿸厂}

Frond coriaceous or rarely membranous, flat or filiform, continuous, purple or pink. Sporidia purple, included in capsules or clustered in sori.

2310. Polyides. Frond filiform, fastigiate, cartilaginous, softish, composed of radiating fibres. Fruit, spongy warts composed of fibres supporting sporidia.

2311. Ptilota. Root scutăte. Fronds compressed or plane, pinnate. Fructification; a cluster of naked granules surrounded by a linear cleft involucre

2312. Rhodomela. Frond either flat or foliaceous, and somewhat ribbed or filiform. Fr uit twofold; first, lomenta filled longitudinally with globules of sporaceous matter; second, capsules with a few pyriform sporidia sessile in the capsule (blackish when dry).

2313. Chondria. Frond continous, gelatinoso-cartilaginous. Fructification double; naked granules im mersed in the substance of the ramuli and external tubercles.

2314. Spherococcus. Root scutate. Frond submembranaceous or cartilaginous. Fructification uniform tubercles or capsules.

2315. Halymenia. Frond flat or tubular, somewhat membranous. Fruit, dot-like tubercles half immersed in the lamina of the frond.

2316. Bonnemaisonia. Frond filiform, compressed, pectinate, ciliated. Fruit, capsules with pyriform sporidia fastened together in a chain-like manner.

2317. Delesseria. Root scutate. Frond plane, membranaceous, with or without ribs. Fructification double, tubercles and clusters of naked immersed granules.

\section{Tribe Vi, FUCOIDE无.}

Frond coriaceous, rarely membranous, continuous, olive-green, flat or filiform, Sporidia black, included in capsules, which are either ovate, and surrounded by a hyaline border, and nestling in a peculiar receptacle, or pyriform, and immersed in the frond.

2318. Lemanea. Frond filiform, torulose, tubular. Chains of sporæ adhering to the inner surface of the filament, pencilled moniliform. In fresh water. 
2319. Chordaria. Root scutate. Frond filiform of an olive color and cartilaginous substance. Fructification; clavate, pyriform, concentric filaments constituting the whole frond.

2320. Scytosiphon. Root scutate. Frond tiiform, tubular, subcoriaceous. Fructification; naked pyriform granules covering the whole frond.

2321. Sporochnus. Root mostly scutate. Frond plane, with distichous branches, bearing, in most instances, delicate pencil-like deciduous tufts of confervoid filaments. ("Receptacles composed of concentric, clavate, articulated corpuscules.")

2322. Haliseris. Frond flat, linear, ribbed, membranous. Capsules heaped in sori.

2323. Encrelium. Frond tubular or bladdery, dotted. Fruit, the tips of the frond filled with a black sporaceous matter.

2324. Zonaria. Root downy. Frond plane, ribless, flabelliform or wedge-shaped, or linear and dichotomous. Fructification, adnate tubercles collected into parallel lines on the frond.

\section{DIATOMEAE.}

2259. ACHNAN'THES. Agh. Achnanthes. 15021 lóngipes $\mathrm{Ag}$. 2260. DI A'TOMA. Ag. Dratoma 15022 flocculósum 15023 marulosum 15024 Biddulphiánum $\mathrm{Ag}$. Miss Biddulph's 15025 striátulum $A g$. striated 15026 obliquátum $A g$. oblique

2261. FraGiLLA'ria, $A g$. Fragilla 15027 pectinális $\mathrm{Ag}$. silvery 15028 hyemális $A g$ winter 2262. MELOSEI'RA. $A g$. Meloseira. 15029 nummuloídes $\mathrm{Ag}$. necklace 15030 lineáta $\mathbf{A g}$. striated

15031 discígera $\mathrm{Ag}$. 2263. DESMI'DIUM. Ag. DEsMidium. 15032 Swártzii $A g$. 2264. SCHIZONE'MA Ag. SCHIZONEM 15033 Smithii $\mathrm{Ag}$. Smith's 15034 lacústre $A g$. 15035 Dillwýnii Ag

15036 apiculátum $A g$.

15037 dichótomum Grę pointed lax tufts

erect tufts
Sp. $1-2$.

$\mathbf{1}^{\frac{1}{2}}$ july Gsh dit., sea coast E.b.t.2488. Conf stipitato Sp. 5-16.

${ }_{1 \frac{1}{2}}$ sum. Y. Br ditches $\quad$ E. bot. t. 1761. Confervo $t^{\frac{1}{2}}$ febr. Y.G ocean E.b.t.1883. Conf.taniaf $1^{\frac{1}{2}}$ nov.d. G sea coast E. bot. t. 1762. Conferva $1^{\frac{1}{2}}{ }^{\frac{1}{2}}$ april G ocean E. bot. t. 1928. Conferva Lt.Br ocean $\quad$ E. bot. t. 1869. Conferva Sp. 2-3.

$\frac{1}{2}$ march Y.G on wat. plan. E. bot. t. 1611. Conferve 3 april O.Br rivulets Lyngb. phyt. dan. t. 63 Sp. 3-5.

$\frac{1}{2}$ march Ysh salt marshes Eng. bot. t. 2287

$1^{\frac{1}{2}}$ march Ysh rivulets Dil.con.24, t.B.Conferve $\frac{1}{2}$ sum. Brsh lvs, of aquat. Di.co.25.t.B.C.nummul Sp. $1-2$.

$1 \frac{1}{2}$ sum. $G$ still waters E.b.t.2464.Con.dissiliens Sp. 5-9.

$\frac{3}{4}$ sum. Brsh sea coast $\quad$ E. b. t.2101. Conf. faetida $\frac{3^{4}}{4}$ sum. Brsh lakes

$1 \frac{1}{2}$ sp. su. Ol.G sea coast Di.co.t.104.Conf. faetida $\frac{3}{4}$ spring Y.G sea in basins Grev. crypt. t. 30 sum. Y.G sea in basins

\section{NOSTOCHINE.}

2265. Palmel/LA, $A g$. Palmella. 15038 protúberans $\mathrm{Ag}$. 15039 botryoides $\mathrm{Ag}$. bunched 15040 adnáta $\mathrm{Ag}$. adnate

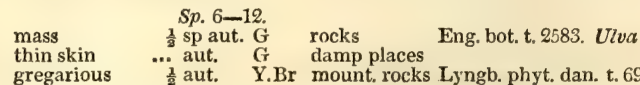

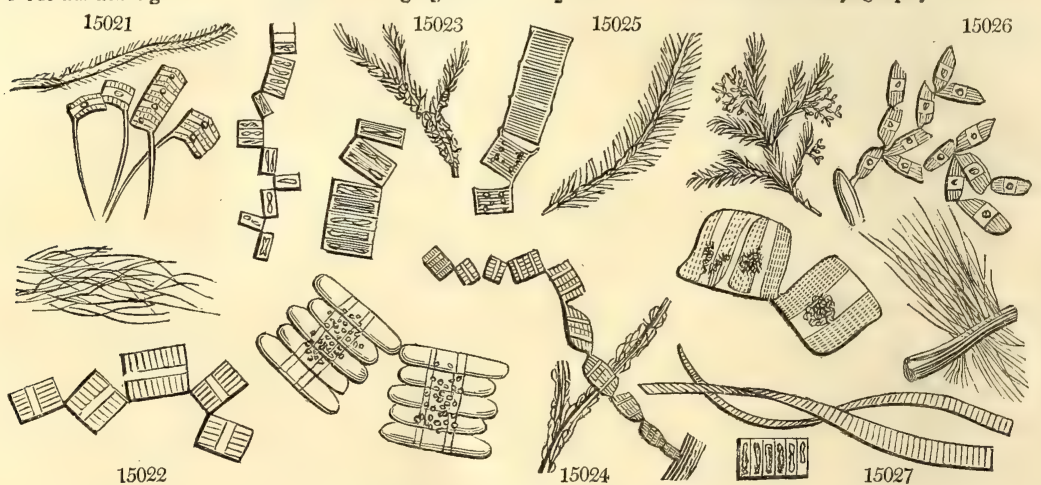

History, Use, Propagation, Culture,

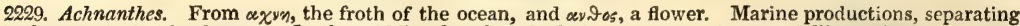
into fragments, but by degrees. In the middle of each articulation are one or two crystalline points.

2230. Diatoma. From diaroun, incision, in allusion to the curious manner in which the filaments are divided into joints cohering alternately by their angles.

2231. Fragillaria. So named on account of their fragile nature, which is more remarkable than that of other Confervæ. The filaments when complete are flat and composed of little fragments glued together crosswise. These are very narrow, and when once separated do not cohere again.

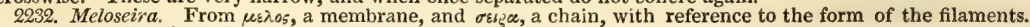
This genus differs from the last, as Conferva from Oscillatoria.

2263. Desmidium. From $\delta \varepsilon \sigma \mu \circ$, a bond, in allusion to the singular manner in which the parts cohere when in a state of dissolution. At that period the articulations become half separated one from the other in such a way as to represent a pinnatifid appearance.

2264. Schizonema. From $\sigma x$ L $^{2} \omega$, to divide, and ynus, a filament; the filaments are finally divided into com pound granules. These plants have entirely the habit and flexible substance of Confervæ When fresh they are sparkling and brown, when dry olive-green, and very shining. They are composed of many filiform individuals, which include nearly the same corpuscles as are visibl; in the foreign genera Frustulia and Meridion. 
2325. Laminaria. Root fibrous. Stipes dilated into a plane frond. Fructification, naked granules iminersed and forming irregular groups in the frond.

2326. Lichina. Fronds minute, tufted, greenish-black when growing. Fructification solitary tubercles with a pore, at length scutelliform.

2327. Furcellaria. Frond cylindrical. Fructification concealed in the swollen extremities of the frond, capsules in the centre, and pyriforme granules in the circumference.

2228. Fucus. Root scutate. Frond plane or compressed, (rarely filiform) dichotomous. Fructification, tubercles contained in a common mucose receptacle, and filled with sporules and filaments.

2329. Cystoseira. Root scutate. Stipes cylindrical. Lower leaves plane, upper ones filiform, furnished with pinnate vescicles. Fructification, tubercles in common receptacles, the receptacles with several loculaments.

\section{DIATOMEAE.}

15021 Articulations with one dot, Stem long

15022 Filaments striated, Articulations nearly equal in diameter with parallel striæ 15023 Articulations half as long again as wide granular transversely

15024 Filaments greenish, Articulations square striated

15025 Filaments arcuate transversely striated, Articulations nearly square with pellucid joints

15026 Articulations half as long again as wide oblique marked with a pellucid transverse band and a dot

15027 Filaments tapering very rigid with parallel transverse dense striæ

15028 Filaments tapering orange-colored, Articulations twice as short as their diameter

15029 Filaments unequal containing nearly circular moniliform globules in rows

15030 Joints contract. Articulations transversely striat. with 1 or 2 very fine lines about 3 times as long as wide 15031 Articulations shorter than broad finally changed into somewhat oval close moniliform heaps

15032 Filaments after copulation pinnatifid traversed by a longitudinal green streak, Articulations 2-toothed

15033 Filaments somewhat branched cæspitose acute, Granules parallel clustered

15034 Filam. somew. branched cæspitose acute, Granules clustered appressed, Membrane of filam. inconspicuous 15035 Filaments densely branched virgate, Granules elliptical

15036 Filaments minute continuous erect branched containing cylindrical oblong scattered granules

15037 Filaments slender erect dichotomous, Branches swollen here and there into roundish knobs : interior gelatinous with numerous cylindrical oblong granules

\section{NOSTOCHINAE.}

15038 Frond thick angular-lobed, Granules elliptical

15039 Fronds aggregate minute globose, Granules globose

15040 Frond deformed rugose, Granules globose brown

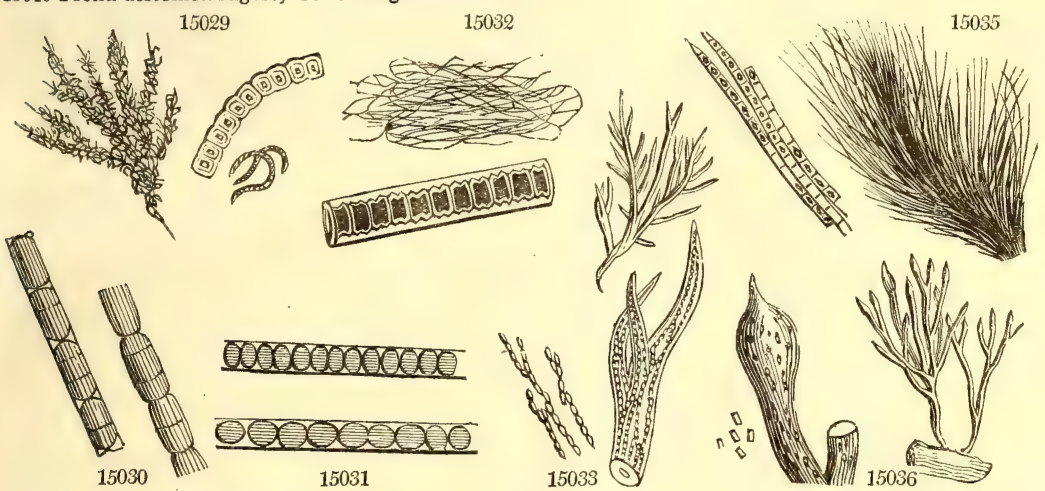

and Miscellaneous Particulars.

2265. Palmella. Apparently a diminutive of Palma, a little palm; but the application of the name is not obvious in that sense. The plants are found in marshy or inundated places, and consist of globules nestling in a gelatine; in which respect the genus differs from Protococcus, the Red Snow plant. It is supposed that many of the species are only the ova of animalcules.

The Red Snow plant, which, as we have just said, is nearly related to this genus, has not hitherto been noticed in this country, but as it has been found in many countries similar to our own regions of snow, it is so probable that it exists in Great Britain, that we insert some particulars of it here, especially as it may be con-
sidered to have been introduced at least in 1819, by Captain Ross's expedition to the North Pole. When viewed under the highest powers of a simple microscope, it appears to consist of globules containing a red fluid. We select the following observations upon its history, from a communication made to the News of Literature and Science, on the twenty-first of January, 1826

"Our scientific readers will remember the interest which was excited on the subject of this natural production, upon the return of Captain Ross from his Polar expedition, some years since. At that time it was examined by three of the most acute observers in this country, especially of microscopical objects, Wollaston, Brown, and Bauer, who all formed a similar conclusion in one respect, that it was of vegetable origin, but were of different opinions as to its precise nature : Dr. Wollaston supposing it to be the seed of a moss ; Mr. Brown, a substance belonging to Algæ, and nearly related to Tremella cruenta, a common British plant; and $\mathrm{Mr}$. 
15041 rósea Lyngb.

15042 mol

15042 montána $A s$

rosy

gregarious

leaf-like

2266. ECHINEL'LA. $A g$. Echinella.

15044 articuláta $\mathrm{Ag}$. jointed thin film

2267. AlCyOni'DiUm. $\mathrm{Ag}$. Alcyonidium.

15045 diáphanum $\mathrm{Ag}$.

15046 flavéscens $\mathrm{Ag}$.

15047 defráctum $\mathrm{Ag}$.

2268. NOS'TOC. $A g$.

15048 commúne $\mathrm{Ag}$.

15049 prunifórme $\mathrm{Ag}$.

15050 sphæ'ricum $A g$.

15051 verrucósum $A g$. treshy mass

yellowish fleshy mass

vermicular

\section{Nostoc}

$\begin{array}{ll}\text { common } & \text { lobed mass } \\ \text { plum-shaped } & \text { little balls }\end{array}$

spherical little balls

gregarious plum-shaped little balls
... sum. Pk on lichens Grev. crypt. t. 51

1․․

... all sea. R.Br shady places E. bot.t. 1800. Tremella

2269. CORYNE'PHORA. $A g$. CoRYNephora.

15052 marína $\mathrm{Ag}$. marine lobed mass Rivularia tuberiformis E. B.

$\begin{array}{lll}\text { Sp. } 1-3 . & \text { jn.jl G lakes } \quad \text { E.b.t.1378. C.echinulata }\end{array}$

6 sum. $3-7$. Y occan

3 sum. Y ocean

Fl, dan. t. 1245. Ulva

Eng. bot. t. 1626. Ulva

Sp. $4-22$

2 sum. Ol.G damp places E. bot. t. 461. Tremella

$\frac{1}{4}$ sum. Ol.G lakes

$\frac{\frac{1}{2}}{2}$ sum. Ol. G still waters

april Ol.G rocks

Sp.1.
$1 \frac{1}{2}$ aug.

2270. RivUla'ria. $A g$. Rivularia.

15053 átra $\mathrm{Ag}$.

15054 angulósa $A g$. angular

15055 calcárea $E$. $B$. calcareous

Sp. 3-11.

Linckia dura Lyngb.

2271. CHæTO'PHORA. Ag. Chætophora.

15056 tuberculósa $A g$ warty balls

15057 endiviæfólia $A g$. $\quad$ endive-leaved branched

$\beta$ crassa Ag.

$T^{\frac{1}{2}}$ oct. D.G sea plants Eng. bot. t. 1798

1 ${ }^{\frac{2}{4}}$ sum. Di.G ditches Eng. bot. t. 968

2272. SCYTHYME'NIA. $A g$. SCYTHYMENia.

15058 rupéstris $\mathrm{Ag}$. rock broad mass

\begin{tabular}{ccrl}
\multicolumn{2}{c}{ Sp. 2-12. } & \\
\multicolumn{2}{c}{ sept. } & G & ditches \\
2 & sum. & G & still waters \\
2 & sum. & G & lakes
\end{tabular}

Sp. 1.

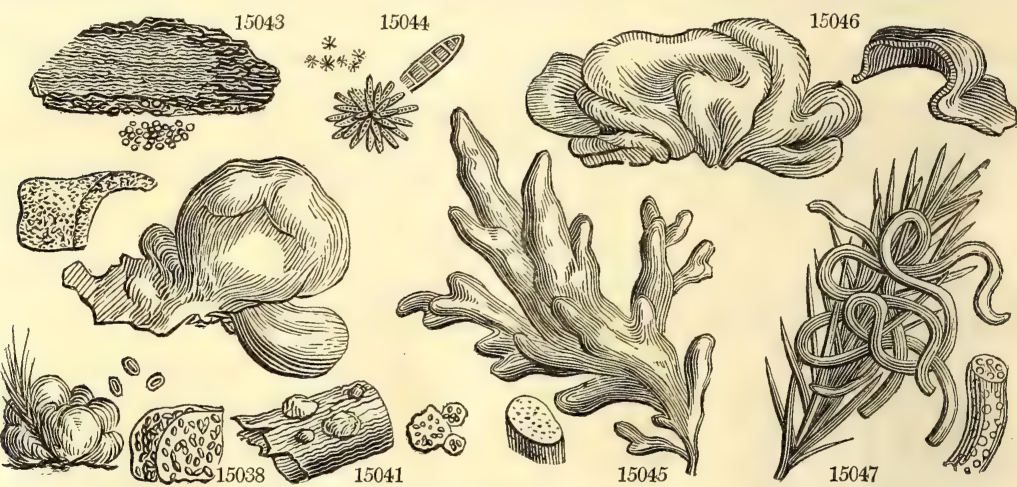

History, Use, Propagation, Culture,

Bauer refering it to a genus of Fungi, called Uredo. We have lately seen a curious paper upon this subject, by Professor Agardh, of Lund, whose opinions upon all matters connected with the lower orders of vegetation demand deep attention.

" That snow occasionally assumed a red color, had long been a fact of which there could be no doubt; and that water was also under particular circumstances stained with red, we have the popular traditions of showers of blood, and water changed to blood, to attest. In the year 1608, a shower of blood fell near Aix, in France, which was examined by Peiresc, and found to be caused by insects; and to the same eause was undoubtedly to be ascribed the bloody rain that fell at Schonen, in 1711, which the learned Bishop Swedberg looked upon as a supernatural phenomenon, and a direct sign of the anger of the Divinity. The red pools which are occasionally met with, even in this country, are generally stained by the presence of an immense number of animalcules, called Daphinia Pulex, or Cyclope quadricornis. The red stains sometimes seen upon the sea. shore are occasioned by a particular sort of Fucus. Professor Agarih proceeds to observe, that the red snow is very common in all the alpine districts of Europe; where it is probably, for the most part, of the same nature as that brought from the North Pole by Captain Ross. Saussure saw it in abundance upon Mount Brevern, in Switzerland, and elsewhere; Ramond found it on the Pyrenees, and Sommerfeldt in Norway. In March, 1808, the whole country about Cadore, Belluno, and Feltri, was in a single night covered to the depth of twenty centimetres with a rose-colored snow; at the same time a similar shower was witnessed on the mountains of Valtelin, Brescia, Carinthia, and Tyrol. But the most remarkable red-snow shower was that which fell on the night between the 14th and 15th of March, 1823, in Calabria Abruzzo, in Tuscany, and at Bologna, and upon the whole chain of the Appennines. We may add, that both snow and ice were seen stained with red, green, and blue, by the late expedition under Baron Wrangel to the Frozen Ocean.

" With this information before him, Professor Agardh proceeds to consider the nature of this remarkable substance, which he concludes, with Brown, to be referable to the lowest order of Algæ, and to stand as a distinct genus, which he calls Protococcus, upon the very limits of the animal and vegetable kingdoms. Saussure, indeed, from finding that the red snow of the Alps gave out, when burnt, a smell like that of plants, concluded that it was of vegetable origin; but he supposed it to consist of the farina of some plant, although he could neither account for its having ascended to such elevated regions, nor mention a plant whose farina was of that color.

"Besides the plant called Palmella cruenta, which is similar in its structure to the red-snow plant, other low vegetable productions have been noticed by different authors, as possessing a similar color. Such are the Lepraria Kermesina, which, by the way, is considered only a particular state of the red-snow plant itself, and the Byssus cobaltiginea. These are always found in situations in which they are exposed to the intense action of light, such as vast plains of snow, or masses of glittering limestone. Whence it is inferred, that the color of the red snow is attributable to the action of light, modified in some mysterious manncr, by the nature of the body on which it strikes. In confirmation of which hypothesis, it is remarked, that when the Lepraria 
15041 Minute roundish soft rose-colored containing extremely minute sporules 15042 Frond deformed rugose, Granules ovate red

15043 Frond crust-like crimson

15044 Corpuscles radiant lanceolate jointed

15045 Branches elongated

15047 Frond filiform simple

15048 Frond expanded deformed plaited wavy

15049 Frond globose watery inside, Integument coriaceous very smooth

15050 Frond globose solid smooth

15051 Frond bladdery subcoriaceous hollow plaited smooth

15052 The only species

15053 Frond hemispherical hard, Filaments very dense branched by apposition

15054 Frond globose hollow, Filaments simple

15055 Filaments intermingled with calcareous particles hard and crustaceous when dry

15056 Frond tubercular hollow, Filaments distributed in many little orbs

15:57 Frond linear flattish dichotomous at base much pinnated at end

$\beta$ Branches very short

15058 The only species

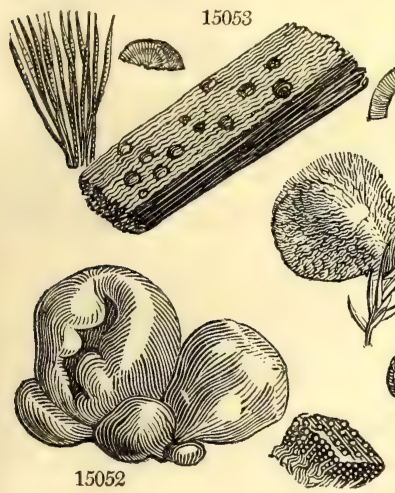

15054

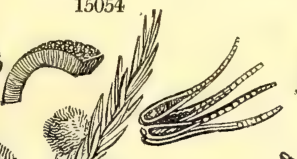

1505
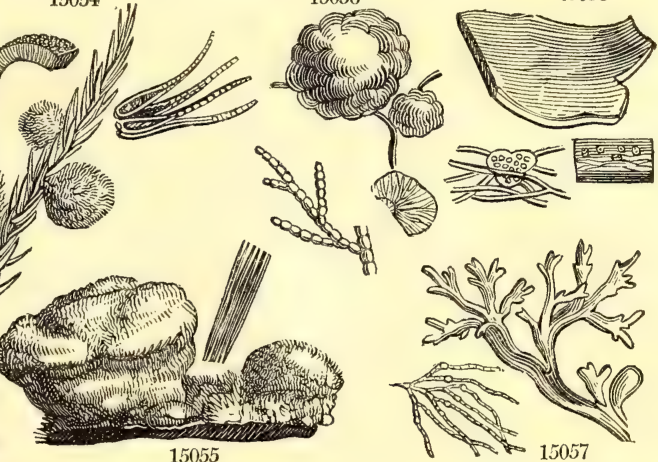

15055

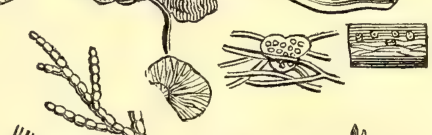

and Miscellaneous Particulars.

Kermesina is found under stems, stones, or in crevices of limestone, where light can scarcely gain admittance, its color gradually passes from red to green.

"The only difficulty in the way of this explanation of its nature is in the statements of so many olsservers, that the red snow falls from the air. But Professor Agardh shrewdly remarks, that all the persons agree that it fell in the night, which is as much as to say, that no one saw it fall. He is of opinion that the Protococcus, or Red Snow, is called into existence by the vivifying power of the sun's light, after its warmth has caused the snow to dissolve, and accompanied by that incomprehensible power in white snow, of producing a color and, moreover, that it first attracts the eye when there is a considerable quantity, in the same way that we do not see the color of drops of water till they have accumulated in the ocean."

2266. Echinella. From echinus, an hedgehog, in allusion to the bristly appearance presented by its radiant particles. Many naturalists believe the bodies referred to this genus to be animalcula.

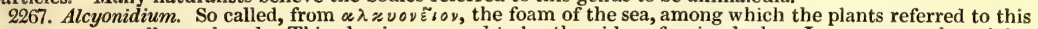
genus are naturally produced. This also is supposed to be the nidus of animalcula. Lamouroux who origin-" ally fixed it here, afterwards referred it to Zoophytes; in which last opinion Gaillon agrees with him, declaring that he has actually seen the animalcula nestling in it. D'Orbigny and Ellis consider it the ova of a testaceous animal.

2268. Nostoc. A name first used by Paracelsus, without an explanation of its meaning. Agardh thinks this singular substance changes into the genus Collema among the Lichens.

2269. Corynephora. From z found on different parts of it. The species are found in the ocean."

2270. Rivularia. So named on account of the places in which the species grow. They have a globose frond, of a gelatinous but toughish texture. Their color is dark-green, and not as in the next genus, pale-green. The filaments are very singular, seated on a globule, simple, cylindrical, and terminated by a very fine point; they are densely compact, continuous, and filled with a green annular matter.

2271. Chatophora. From $\chi \propto\llcorner\tau \eta$, a bristle, and $\phi \varepsilon \rho \omega$, to bear; the filaments are terminated by a bristle-like point. This genus is chiefly distinguished from Confervoideæ by its gelatine. The color is bright green, and the texture softer than in the preceding. The manner of propagation, which has been noticed in so small a number of Algæ, has been observed by Agardh in two species of this genus. In Chætophora pisiformis little hard crystalline corpuscles, like grains of sand, may be seen, which separate from the mother plant and produce young filaments. But in C. clavata, the points of the filaments fall off and sink to the bottom of the water, where they unite by three, four, five, or by a greater number at a time, in a common point, which is first green, afterwards blackish, and apparently inorganic. From this beginning new individuals arise.

2272. Scythymenia. Derivation unknown. A very singular plant, formerly referred to Ulva. It has the habit of a fungus, and grows upon damp walls. It is supposed to be most nearly related to Palmella. 


\section{CONFERVOIDER.}

2273. BYSSOCLA'DIUM. Ag. BysSOCLADIUM

15059 fenestrále $\mathrm{Ag}$. window fine tuft

2274. MYCINE'MA. Ag. Mxcinema.

15060 arachnoídeurn $A g$, cobweb

15061 fúlvum $A g$. tawny

15062 rubiginósum $A g$. rusty

phosphoreum $\Lambda g$. phosphoric patches

15064 pulvereum $\mathrm{Ag}$. powdery

15065 Jolithus $A g$.

15066 odorátus $\mathrm{Ag}$.

15067 lichenícola $A g$.

15068 rubicúndus $A g$.

15069 ebéneus $\mathrm{Ag}$.

\section{purple}

patches

eet-scented patches

Lichen down

pink patches

ebony patches

2276. TRENTEPOH'LIA. $A g$. Trentepohlia

15070 purpúrea $\mathrm{Ag}$. purple patches

15071 aúrea $A g$. golden patches

$\beta$ ilicícola Ag. Holly branch. patc.

$\beta$ chalýbea Ag.

2277. SCYTONE'MA. Ag. Scy'tonema.

15073 compáctum Ac.

15074 byssoideum $4 g$ byssus-like tufts

15075 myochrous

$\beta$ ocellátum Ag.

$\gamma$ inundátum Ag.

15076 Bángii Lyngb.

15077 Sowerbyánum $\mathrm{Ag}$.

15078 comoídes $A g$.

2278. Stigone'MA. $A g$. Stigonema.

15079 atrovirens $A g$. dark green bushy tufts

2279. PROTONE'MA. Ag. Protonema.

15080 répens $\mathrm{Ag}$.

15081 umbrósum $A g$

15082 velutinum $A g$.

15083 frágrans $A g$

15084 cryptárum $\mathrm{Ag}$.

15086 muscícola $\mathrm{Ag}$.

creeping patches

shady patches

velvety patches

fragrant patches

vault patches

Orthotrichum dense tufts

HYGROCRO'CIS. Ag. Hygrocrocis

15087 barýtica $A g$.

15088 atraménti $\mathbf{A g}$.

15089 typhlodérma $\mathrm{Ag}$.

15090 pállida $\mathrm{Ag}$.

15091 Rósæ $\mathrm{Ag}$.

15092 sanguínea $\mathrm{Ag}$

15093 víni $\mathbf{A g}$.

Barytes

tufts

ink tufts

Gum Arabic fine tufts

pallid fine tufts

blood-colored fine tufts

Wine fine tufts

2281. LEPTOMI'TUS. Ag. LEPTomitus.

15094 minutíssimus $A g$. very minute little tuft

15095 lácteus $\boldsymbol{A g}$. milky patches

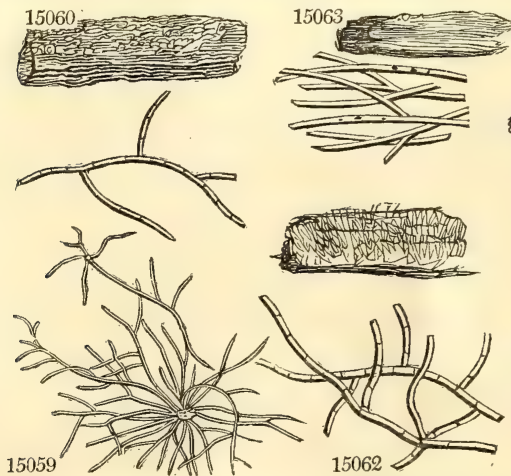

History, Use, Propagation, Culture,

on windows Dillw. conf. t.94

Sp. 5-6.

$\tau^{\frac{1}{2}}$ all sea $\mathrm{Pa} . \mathrm{G}$ dead trees Dillw.conf.t.C.Conferva

is aut. $\mathrm{Br}$ rotten

$\frac{1}{8}$ all sea. Rust rotten wood Dillw. conf. t. 68 . Conf.

$\tau^{\frac{1}{2}}$ all sea. V rotten wood Dillw. conf, t. 88. Conf.

$\tau \frac{1}{2}$ all sea. G rotten wood Dillw.conf.78.t.D.Conf

Sp. 5-6.

$\tau \frac{1}{2}$ all sea. Pu rocks Fl, dan. t. 899. f. 1

$\tau \frac{1}{2}$ wint. $\mathrm{Br}$ trees Lyngb.hydrop. dan. $\mathrm{t} .57$

sum. R on lichens Eng. bot. t. 1609

-1 sum. R.Br bark of ap.tr.

$\frac{1}{d}$ all sea. $\mathrm{Bk}$ rocks $\quad$ E. b.t.702. Byssus nigra

Sp. 3-4.

$\div \frac{1}{2}$ all sea. $\mathrm{Pu}$ sea coa, roc. Eng. bot. t. 192. Byssus $\tau \frac{1}{2}$ all sea. Y roc. \& sub.w. Eng. bot. t. 212. Byssus $\tau^{\frac{1}{2}}$ spring $Y$ holly bark En.bot.t.1639. Conferva

spring R.Br on Confervæ Eng. bot. t. 2585. C.nana $\frac{1}{2}$ sept. D.Ol fresh water Eng. bot. t. 1996

$$
\text { Sp. 5-17. . }
$$

1 sum Bksh mountains Lyngb.hydrop dan t 28

1 sum B rocks Dillen, t. 1. f. 18

1 sum.

1 sum. D. Br aquat. plants Eng. bot. t. 2530

1 sum. D. Br inund. places Eng. bot. t. 1555

$1 \frac{1}{2}$ sum. Ærug subalp.banks Lyngb.hydrop.dan. t. 28

sum. Ol.Br ocean $\quad$ E.b.t.2219. C.mirabilis

1 oct. Rs.br ocean Eng. bot. t. 1700. Conf.

Sp. 1-3.

1 sum. Bk G rocks

Dillw. conf, t. 25. Conf.

Sp. 7-10.

$\frac{1}{4}$ sum. $G$ pots in hoth.

$\frac{1}{4}$ sum. G

$\frac{\pi}{2}$ nov. G

nov. G

$\frac{1}{6}$ sum. Br

$r^{\frac{1}{3}}$ april $\mathrm{Br}$

Sp. 7-9.

$\frac{1}{8}$ all sea. Tr

$i \frac{1}{2}$ all sea. Wsh surf.

$\bar{\tau}^{\frac{1}{2}}$ all sea. Tr

$\frac{1}{8}$ all sea. Y

Sp. 4-15.

$-\frac{2}{2}$ all sea. $\mathrm{Tr}$ on mar, algæ

$\tau \frac{1}{2}$ wint. Tr pools Dillw. conf. t. 79. Conf.

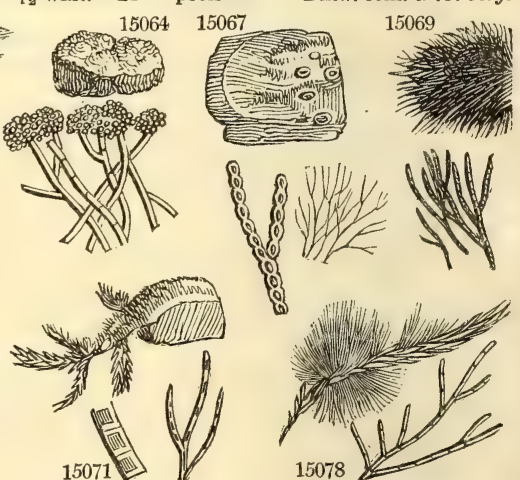

2273. Byssocladium. From byssus, a kind of fungus, and $\approx \lambda \propto \delta 05$, a branch; the filamentous branches of this plant being very similar to those of Byssus. These plants grow in places occasionally overflowed with water. 2274. Mycinema. From $\mu \nu x \eta 5$, a kind of minute fungus, and $v \eta \mu \alpha$, a thread; in allusion to the resemblance of the filaments to those of some Fungi.

2275. Chroolepus. So called on account of the change which is undergone by the exterior membrane, which changes to powder; from $\chi \omega 005$, skin, and $\lambda \varepsilon \pi \omega$, to decorticate.

2276. Trentepshlia. So named, in honor of an obscure German botanist. This is an ill-defined genus, which is much in need of reformation.

2277. Scytonema. From o\%vros, leather, and vnus, a filament; in allusion to the coriaceous nature of the filamentous frond. The species grow chiefly on stones in inundated places, and are rarely found in salt water. 


\section{CONFERVOIDEAE.}

15059 Filaments appressed very minute short radiant cobweb-like branched sinuous wavy

15060 Filam. thin entangled in a cobweb-like membr. Branches scatter. rem. simp. Articulat. of various lengths 15061 Filam. decumb. long membran. equal branched entangled in a soft layer, Articulat. thrice as long as broad 15062 Filaments much branched rigid erect entangled in a nearly solid mass, Articulat. 4 times as long as broad 15063 Filain. branch. ascend. very short entangled in a dense unif. crust, Articulat. about $\frac{1}{2}$ as long again as broad 15064 Filam. branch, dichotom, creeping very minute having caps.at end and ærugin. Dissepiments nearly obsol.

15065 Filaments cæespitose erect very short dichotomous, Articulations half as long again as broad 15066 Filaments caspitose branched short erect, Branches spreading stiffish, Articulations as broad as long 15067 Filaments erect fascicled alternately branched rigid, Articulations tumid as broad as long

15068 Filam. cæespit. rig. short ascend, curved densely branched, Artic. as broad as long by a line except granules 15069 Filaments cæspitose branched erect rigid somewhat cartilaginous obtuse, Articulations as broad as long

15070 Filam. dichotomous cæspitose entangled very minute, Artic. about twice as long as broad

15071 Filam. flexu. collect. in a dense soft cushion-like tuft, Branch. long spread, rig. Artic. twice as long as broad $\beta$ Much smaller, Articulations as broad as long

15072 Filaments virgate cæspitose, Branches straight, Artic. twice as long as broad, Thecæ racemose

15073 Filaments decumbent rigid flexuose branched entangled in a crustaceous layer, Branches appressed 15074 Filaments simple erect very short flexuose-crisp entangled in a black layer

15075 Tuft with olive-yellow filaments, Branches double 1-sided

15076 Filaments simple erect flexuose spirally twisted into pointed masses greenish above brownish below 15077 Tuft loose, Filaments netted branched, Branches divaricating

15078 Tuft loose, Filaments flexuose, Branches solitary remote ascending

15079 Filaments rigid branched, Branches slender, Granules disposed in rings

15080 Runner creeping transparent emitting round green erect branches, Artic. cylindrical, Joints obsolete 15081 Layer velvety, Filaments erect obtuse clustered brittle, Articulations gibbous

15082 Layer velvety, Runner creeping rooting sending out erect obtuse branches, Artic. cylind Joints obsolete 15083 Layer velvety, Filaments erect blunt rigid, Branches alternate, Articulations oval twice as long as broad 15084 Filaments dichotomous, Branches divaricating acuminate, Artic. thrice as long as broad

15085 Filaments olivaceous branched blunt erect in a cushion-like tuft, Artic. about as broad as long

15086 Filaments branched, Branches alternate divaricating subulate, Artic. three times as long as broad

15087 Tuft globose, Filaments very fine like cobweb hyaline much entangled without joints wavy branched 15088 Filam. dichot. branch.very min. decumb. very densely entang. in a whit. layer, Artic. twice as long as broad 15089 Filam. somewhat branched densely entangled in an olive-green pellicle, Artic. as broad as long

15090 Filam. dichot. curved flexuose entangled in a coriaceous gelatin. pellicle, Axillæ round, Artic. very long 15091 Filam. hyali. somew. branch. entang. cobw.-like entang. in a pucker. cloud-like memb. or a comp. gelatine 15092 Filam. branched densely ertangled in a gelatin. pellicle, Branches divaric. Artic. half as long again as broad 15093 Filaments hyaline entangled branched, Branches tapered acute, Artic. as long as broad

* Growing on vegetables.

15094 Filam. somew. branched minute hyaline, Branches scattered forked bluntish, Joints obsol. Artic. various 15095 Filam, at every joint branched and clustered in a shapeless gelatinous mass, Articulations very long

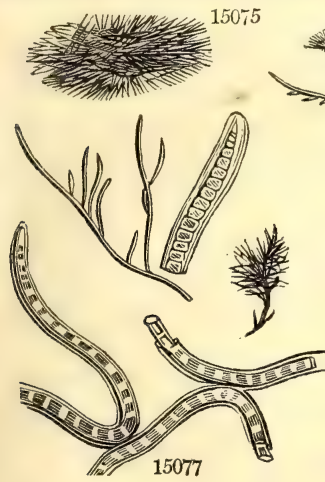

15079
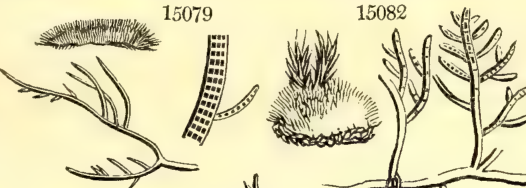

15089
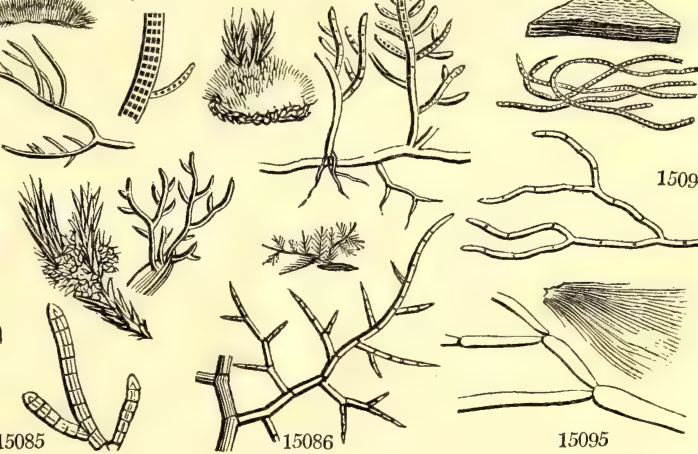

and Miscellaneous Particulars.

2278. Stigonema. So named in allusion to the regular annular dots of the filaments ; from surwy, dotted, and у пек, a thread. This genus is similar in habit to the Lichens. The color is opaque and brown; the filaments are branched with spines, and marked internally with distinct dots.

2279. Protonema. It is uncertain whether this genus is not rather the young state of germinating mosses; it is named in allusion to the simplicity of its structure, from reoros, first, or primary, and y $\mu_{\mu \alpha}$, a thread.

2280. Hygrocrocis. From irgos, any thing belonging to water, and « «oxis, a little tuft. These plants are round in chemical solutions of vegetable matter, as in ink, \&c.

2281. Leptomitus. Substances floating in the water, and produced by animal matter in a state of decay. They consist of exceedingly fine intertangled fiaments, whence the name, $\lambda \varepsilon x \tau$, slender, and $\mu$, sos. a thread. 
15097 clavátus $\mathrm{Ag}$. clavate minute

2282. MESOGLO'IA, $A g$. Mesogloia.

15098 multifida $\mathrm{Ag}$. multifid tufts

15099 Hudsóni $\mathrm{Ag}$. Hudson's $\quad$ branched

15100 coccinea $\mathrm{Ag}$. $\quad$ scarlet $\quad$ bushy

Rivularia verticillata E. B.

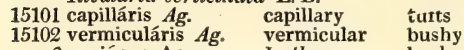

$\beta$ coriácea Ag. leathery
Rivularia vermiculata E. B.

2283. BATRACHOSPER'MUM. Ag. Batrachospermum. Sp. 2-6.

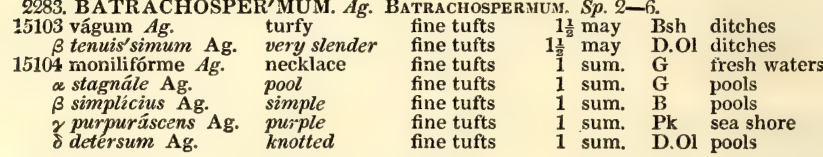

$\tau \frac{1}{2}$ aut. Tr dead fishes Lyngb. hydroph. t. 22

Sp. $5-8$

6 aut. R ocean $\quad$ E. b. t. 1627. Ulva rubra

4 sum. $R$ ocean Eng. bot. t. 2466

3 sum. $\mathbf{R}$ ocean

Lyngb. hydroph. t. 12

Lyngb. hydroph. t. 65

5 august Brsh oc:an

Eng. bot. t. 1819

84. DRAPARNAI'DIA $A g$. DraparNaLDA.

15105 ténuis $A g$. fine fine tufts

15106 plumósa $A g$. $\quad$ feathery $\quad$ broad tufts

Sp. 3-6.

s all sea. Dl. G pools

2285. OSCILLATO'RiA. Ag. Oscilinatoria.

15108 tenuíssima $\mathrm{Ag}$. very fine patches

15109 autumnális $\mathrm{Ag}$.

$\beta$ vagináta Ag.

15110 nigra $\mathrm{Ag}$.

15111 Córium $\mathrm{Ag}$.

15112 subfúsca $\mathrm{Ag}$.

15113 spléndida Grev.

15114 ténuis $\mathrm{Ag}$.

15115 limósa $A g$.

15116 cyánea $\mathrm{Ag}$.

15117 decórticans $\mathrm{Ag}$.

15118 ochrácea Lyngb.

very fine

sheathed

black

brownish

splendid

fine

mud

floating laye

thin film

unbarking thin flakes

2286. CA'LOTHRiX. Ag. Calothrix.

15119 nivea $A g$. snowy

15120 confervicola $\mathrm{Ag}$. conferva

15121 scopulorum $\mathrm{Ag}$. $\quad$ rock

15122 fasciculáta $\mathrm{Ag}$.

15123 mirábilis $\mathrm{Ag}$.

15124 distórta Ag.

15125 lanáta Ag.

$\beta$ fuscéscens $\mathbf{A g}$.

rock

wonderful

distorted

woolly

fulvous

fine tufts

minute tuft

patches

tufts

Lyngb. hydroph. t. 64

E. bot. t. 690 . Conf. atra

2287. LYNG'BYA. Ag. LYNGBYA 15126 murális $\mathrm{Ag}$.

LYNGBYA. patch
wall floating patc. $1 \frac{1}{2}$ sum. B.G lakes $\quad$ E. bot. t. 2577. Conferva floating patc. $1 \frac{1}{2}$ sum. G springs on st.

floating patc. $1 \frac{1}{2}$ sum. Taw pools $\quad$ E.bot.t. 2577. fig.sinistr.

2288. BAN'GIA. Ag. BANGIA.

15127 lamináriæ $\mathrm{Ag}$. Laminaria broad tufts 15128 atropurpúrea $\mathrm{Ag}$. dark-purple silky tufts

B fúsco-purpúrea Ag. brown-purple silky tufts

Sp. 11-47.

$\frac{1}{8}$ sum. Pa. G warm springs Eng. bot. t. 2584. Conf

$1 \frac{1}{2}$ sum. Ol.G on the earth

$1 \frac{1}{2}$ sum. Ol. G on the earth Dillw. conf. t. 99

D.G still waters Dil.co. t.64.O.fontinali

$\frac{1}{2}$ spring Ysh rocks in wat.

$1^{2}$ all sea. Br.V stones in riv.

spring $\mathrm{Pa}$. G still waters Dill. conf. t. 20.C.limosa

6 all sea. Frug mud bot. po. Fl. dan, t. 1549. f. 2

.. all sea. B church walls E. bot. t. 2578 . Conferva

$\frac{1}{8}$ march B.G damp wood Dillw. conf. t. 26

Sp. 7-12.

1 all sea. Pa.Y sulph. sprin. Dill conf, t. C. Conferva

Gla marine algm $\mathrm{E}$ bot $t$ 2576. Conferva

2 sum marine algæ $\mathbf{E}$ bot. $\mathrm{t}$. 2171. Conferva

Sp. $1-7$.

$\div \frac{1}{2}$ all sea. G damp earth Eng. bot. t. 1554

Sp. $2-5$.

$\frac{1}{2}$ sum. $G$ on $\mathrm{L}$. escul. Lyngb.hydrop.dan. $t .24$

$2^{2}$ sum. D.Pu marine rocks Dill. con t.103. Conferva 2 sum. Br.pu sea coast Dill. conf. t.22. Conferva

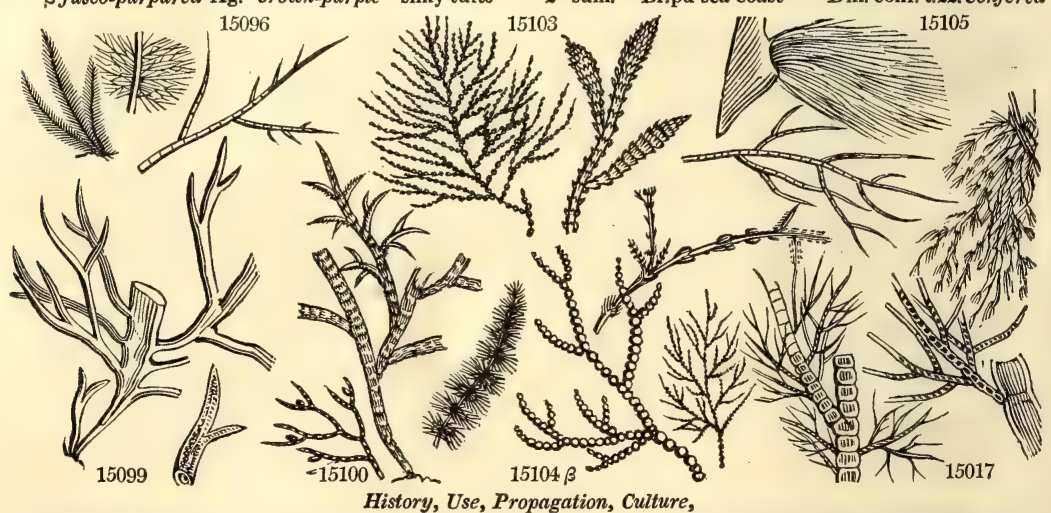

2282. Mesogloia. From $\mu \varepsilon \sigma^{\circ} \circ$, the middle, and ynotos, viscid: the spines of little branches radiating from a common centre, and forming what appears to be a solid mass. These plants were formerly referred to Chætophora, from which they differ in the want of any fixed gelatine.

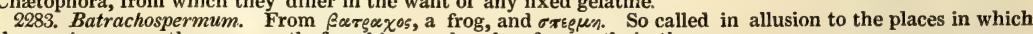
the species grow; they are mostly found in marshes, less frequently in the sea.

2284. Draparnaldia. James Philip Ralph Draparnaud, was a French botanist, who wrote some memoirs on the subject of botany in the beginning of this century. He is also known for his acquaintance with freshwater Confervæ.

2285. Oscillatoria. The singular motion of these curious plants has suggested their generic name. The oscillation of the filaments seems almost of an animal nature, although it frequently arises from mechanical 
15096 Filam. branched very minute, Branches and branchlets acuminate, Joints pellucid, Artic. cylindrical 15097 Filaments simple hyaline clavate at ${ }^{* *}$

\author{
** Growing on animals.
}

15098 Frond dichotomous, Axillæ rounded : upper spreading

15099 Frond virgate with all the branches divaricating

15100 Frond somewhat moniliform virgate filiform, Branches scattered obtuse spreading

15101 Frond much branched, Branchlets tapering at each end divaricating

15102 Frond yellowish-brown, Branches divaricating

15103 Frond dichotomous cylindrical equal, Branches thickened at end

$\beta$ Frond setaceous minute

15104 Frond moniliform much-branched, Branches rather acute, Cauline whorls nearly distinct globose a Filaments thick, Whorls of stem confluent : those of the branches distinct

$\beta$ Thinner bluish with distant whorls

15105 Branches simple clustered, First filament nearly homogeneous

15106 Pencils of branches lanceolate acute erect

15107 Pencils of branches ovate blunt spreading

15108 Filaments hyaline very fine tufted entangled in nearly parallel lines

15109 Filaments rigid straight entangled in a gelatinous black layer which has short rays

$\beta$ Filaments twisted in bundles

15110 Filaments rigid straight entangled in a gelatinous black sayer with long rays

15111 Filaments stiffish curved entangled in a compact somewhat coriaceous layer

15112 Filaments transparent rigid straight entangled in a compact brownish-violet layer with short rays

15113 Filaments very minute densely entangled: transverse striæ wholly invisible

15114 Filaments stiffish straight entangled in a gelatinous green layer with short rays

15115 Filaments rigid rapidly oscillating straight entangled in a gelatinous layer with long rays

15116 Filaments covered with a deciduous crust entangled in a blue layer

15117 Filaments very slender flexuose densely interwoven into thin masses

15118 Filaments very slender simple greenish lying in a thick very tender fragile ochraceous stratum

15119 Filaments very fine rigid snow-white packed in a dull-yellow tuft

15120 Filaments glaucous erect minute subulate fascicled at base separate at end

15121 Filaments curved-wavy erect minute entangled in a dense layer

15122 Filaments stiffish erect acuminate simple at the beginning finally branched

15123 Filaments curved variously united entangled in a lax globule

15124 Filaments mucous stiffish erect branched tufted

15125 Filaments stiffish erect branched packed in a dark-green tuft

\title{
15126 Filaments stiffish curved wavy thickish with lax rings
}

15127 Filaments tufted fastigiate equal, Bands approximating in pairs many-dotted 15128 Filaments dark-purple straight, Bands 5-dotted
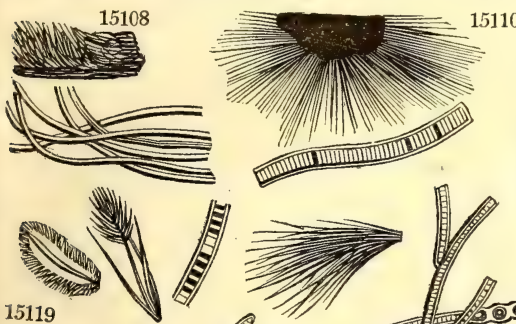

15119
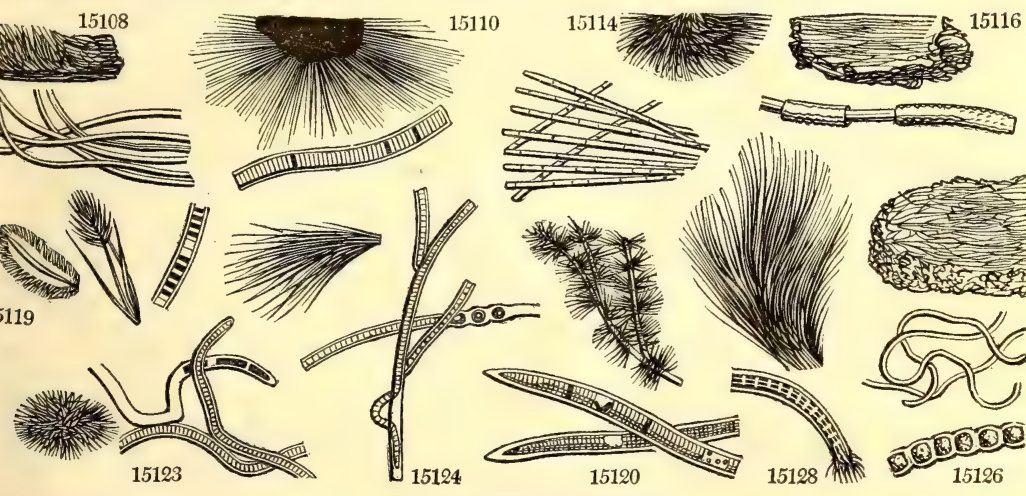

and Miscellaneous Particulars.

causes, as from the elasticity of the filaments, from the motion of minute animalcula. Agardh, however, declares that $O$. curviceps has naturally the motion of an animal, but of a creeping not oscillatory nature.

2286. Calothrix. From $\approx \alpha \lambda .5$, beautiful, and $\lambda_{\rho} \zeta$, hair, in allusion to the beauty of the entangled filaments; the latter appear as if branched, by the singular juxta-position of small filaments.

2287. Lyngbya. H. C. Lyngbye, a Danish botanist, is the author of an excellent work on Algæ, which he calls Hydrophytologiæ Danicæ Tentamen, published at Copenhagen, in 1819, in one volume quarto. This genus differs from Oscillatoria in the absence of a mucous matrix, and from Calothrix in being curved and quite distinct. In habit it approaches Conferva.

2288. Bangia. So called in honor of Christian Frederick Bang, the author of a dissertation upon the plants of sacred history, published in 1767. 
2289. ZYGNE'MA. Ag. ZYGNema.

15129 cruciátum $A g . \quad$ crossed

breving. mass. $\gamma$ brevi-articulatum Ag. short jointed entangl. mass.

15131 bicolor $\mathrm{Ag}$. two-colored

15132 pectinátum $\mathrm{Ag}$. pectinate

floating tufts floating tufts

april Y.G ditches

april Ysh rivulet

G ditches

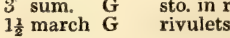

15133 curvátum $\mathbf{A g}$.

15134 quinínum $\mathrm{Ag}$.

15135 decimínum $\mathrm{Ag}$.

15136 nítidum $\mathrm{Ag}$.

curved

quinate

decimate

shining

dotted

9290. MOUGEO'TIA Ag MOUGEOTIA

15138 genufléxa $\mathrm{Ag}$. knee-jointed

15139 cæruléscens $\mathrm{Ag}$. blueish

2291. HYDRODIC'TYON. Ag. HrorodictXon.

15140 utriculátum $\mathrm{Ag}$. bladdery floating web

2292. CONFER'VA. $A g$. Conferva.

15141 ericetórum Roth heath fine web

15142 alpina Bory alpine fine web

15143 fasciáta Dillw. $\quad$ banded fine web

15144 bombycina $A g$. silky

15145 floccósa $\mathrm{Ag}$. floccose

15146 mucósa Mert. mucous

15147 zonáta $W e b . \&$ Mohr zoned

15148 dissíliens Dillw. elastic

15149 impléxa Dillw. entangled

15150 tumídula $E . B$. tumid $\begin{array}{cc}15151 \text { vesicáta } \mathrm{Ag} . & \text { blistered } \\ \text { B fuscéscens Ag. } & \text { brownish }\end{array}$

15152 rivuláris $L$.

$\beta$ an'glica $\mathbf{A g}$.

15153 capilláris Ag.

15154 linum Roth.

15155 intricáta Grev.

15156 tortuósa Dillw.

15157 crássa $\mathrm{Ag}$.

15158 melagónium $\mathrm{Web}$.

15159 æ'rea Dillw.

15160 Youngána Dillw.

15161 hormoides Lyngb.

15162 collábens $\mathrm{Ag}$.

15163 flácca Dillw.

15164 isogóna $E . B$.

15165 fucórum Roth.

15166 flac'cida Lyngb.

rivulet

English

Flax

matted

tortuous

thick

patches

arge masses

$1 \frac{1}{2}$ march $\mathrm{G}$ rivulets

$\frac{2}{4}$ sp. su. Dl.G still waters

$\frac{1}{4}$ sum. Bt.G still waters

2 sum. Bt.G ditches

$\frac{3}{4}$ sum. Bt.G pools

Sp. 2-6.

$-\frac{1}{2}$ april Y.G ditches

$\frac{1}{2}$ july Pu.B ditches

Sp. 1-2.

6 jn. sep. G

riv. \& lakes E.b.t.1687. C. reticulato

Sp. 52-130

1 sp. su. Br.pu dry bogs $\quad$ E. b. t. 1553. Conferva

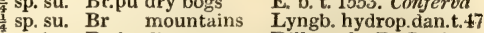

$\frac{1}{4}$ spring Pu.br dit. on carr. Dill,conf. t.B. Conferva

floating cloud $\frac{3}{4}$ sum. G pools \& dit. Dill.con.t.60. C.sordida

float masses $1 \frac{1}{2}$ spring $\mathbf{G}$ ditches E.b. $\mathbf{t}$.2303. C. sordida float. masses $1 \frac{1}{2}$ spring $G$ long tuft 3 all sea $G$

tufts 3 sum.

broad mat 3 sum. G

Dill conf t. B. Conferva

sto in rivul. Dill conf t 47 . C. lucens

ditches Eng, bot. t. 2461

sea-shore $\quad$ E. b. t. 2309 . C.implexa

fine film 1 march $\mathrm{G}$

float. masses 6 march $G$ ditches

float. masses 6 march $\mathrm{G}$ ditches

long tufts 24 sp. su. G rivers

long tufts 24 sp. su. G

long tufts

long tuft

sinall tur

crisp masses

crisp masses

black-jointed tufts

verdigrease

Young's

pencilled

slippery

flaccid

equal-jointed

Fucus

drooping

long tufts

minute tufts

minute tufts

floating tufts

tufts

sp. su. G

竞 sp. su. G

$\frac{1}{4}$ spring $\mathrm{G}$

$2 \frac{1}{2}$ april G

1 april

4 sum. G

6 all sea. $G$

sum.

4 sum. G

2 all sea. $\mathbf{G}$

float. patches $\mathbf{1}$ - spring $\mathbf{G}$

ditches

ditches

ocean

sea shore

sea shore

salt marshes Dillw. conf. t. 9

ocean Dillw. conf, t. B.

ocean Dillw, conf t. 80

sea shore Dillw conf $t .102$

sea shore Lyngb hydroph $t, 49$

Germ. ocean Eng.bot.t.1929. C. ciea

on Hutchins. Dillw. conf. t. 49

on F. vesicul. E.b.t.1930. C. youngana

$\frac{1}{2}$ sum. Brsh on Fuci Dill.con.t.C. C. flaccida

$\frac{1}{2}$ may Brsh on Fuci Eng, bot. t. 2310

$\begin{array}{llll}\text { rusty } & \text { tufts } & 1 & \text { all sea. Rus. on Fuci } \\ \text { cropped } & \text { minute tufts } & \text { sum. Ol.Br on Fuci }\end{array}$

Dill.con.t.66. C. fucicols

Dillw. conf. $t$. 76

1 $\frac{1}{2}$ aut. $\quad \mathrm{Pk}$ on Algæ

Dillw, conf, t. 84

cropped
pink

tufts

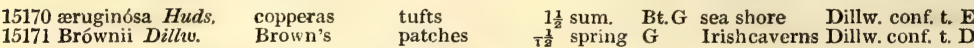

$\begin{array}{lllcl}15170 \text { æruginósa Huds, } & \text { copperas } & \text { tufts } & 1 \frac{1}{2} \text { sum. Bt. G sea shore Dillw. conf. t. E } \\ 15171 \text { Brównii Dillw. } & \text { Brown's } & \text { patches } & \tau^{\frac{1}{2}} \text { spring } \mathbf{G} \text { Irishcaverns Dillw. conf. t. D. }\end{array}$

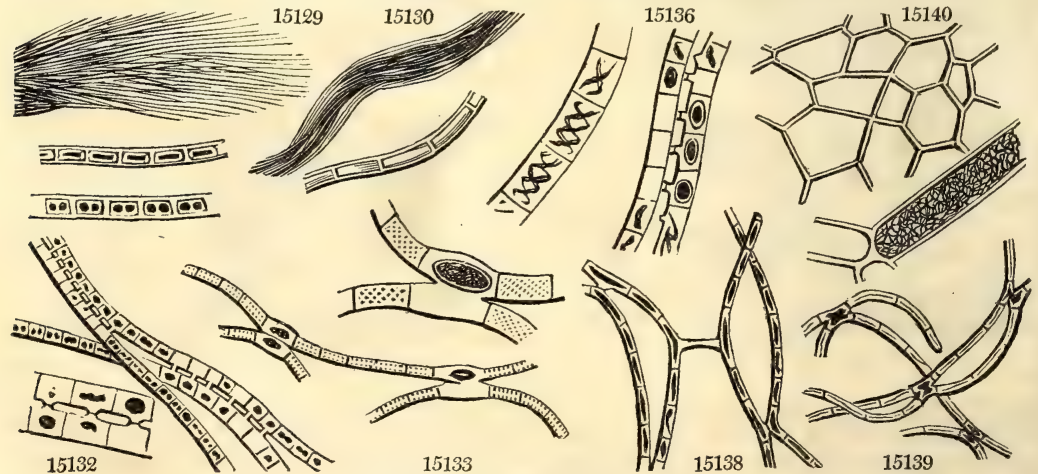

History, Use, Propagation, Culture,

2289. Zygnema. From ¿vyos, a yoke, and ın the filaments are jointed together in pairs.

2290. Mougeotia. Named in honor of J. B. Mougeot, the coadjutor of Nestler, in the publication of their useful work, the Stirpes Cryptogamæ Vogeso-Rhenanæ, which, we believe, is still continued. 
* Two dotted.

15129 Articulations twice as long as broad, Stellæ roundish, Fruit spherical

$\beta$ Articulations thrice as long with two approximated stellæ in the middle

$\gamma$ Articulations about as long as broad

15130 Articul. 4 times as long as broad: in fruit convolute, Sporaceous matter continuous obscure on each side 15131 Articulations about as broad as long, Stellæ transversely linear-oblong parallel, Rays obsolete

15132 Filam. adnate, Articul. half as long again as broad, Stellæ transversely obl. pectinated, Fruit spherical ** Marked with spires.

15133 Filam. equal curved and flexuose conjugate at angles and twice as long as broad, Spires simple 15134 Filam. equal, Spires simple contracted in beginning, at length arcuate, Artic. 3 times as long as broad 15135 Artic. 4 times as long as broad : in fruit elliptical, Spires cruciate lax, Crosses about 4, Fruit elliptical

15136 Articulations about as broad as long, Spires cruciate thin contracted, Fruit elliptical

15137 Filaments simple slippery very fine, Dissepiments obscure, Articulations shortish cylindrical

15138 Filaments knee-jointed, Articulations six times as long as broad

15139 Filaments purple-blue, Sporidia of the crosses of the filaments green

15140 Spots 5-cornered

\section{A. Simple.}

1. Floating, arachnoid, colored.

15141 Filaments simple creeping entangled in a brownish purple layer, Joints half as long again as broad 15142 Filaments simple very fine adnate straight brown, Articulations four times as long as broad

15143 Filam. simple fine mucous, Articulations about as long as broad marked in the middle with a narrow band

2. Floating, arachnoid, mucous, green.

15144 Filaments arachnoid simple very long in an uniform puckered layer, Artic. thrice as long as broad : when young dotted in the middle

15145 Filam. arach. simp. very muc. entang. in a puckered layer, Artic. about as long as broad or $\frac{1}{2}$ as long again 15146 Filam. simple mucous slippery capillary, when dry traversed by a longitudinal band, Artic. as long as broad 15147 Filaments simple fine gelatinous tapered marked by a transverse band, Artic. about as long as broad

15148 Filaments simple very fine gelatinous equal, Articulations twice as broad as long

15149 Filaments simple fine curled entangled smooth, Artic. half as long again as broad

3. Capillary or setaceous. Articulations filled with globose granules, when dry alternately compressed. 15150 Filaments simple tine, Artic. 5 times as long as broad infiated elliptical

15151 Filaments simple fine, Artic. half as long again as broad with globular inflations at intervals

15152 Filam, simp, capill, very long straight equal, Artic. grain-bear. 2 or 4 times as long as broad shin. when diry $\beta$ Artic. half as long again as broad

15153 Filam. simple variously bent and loosely entangled, Artic. about as long as broad, Granules scattered

15154 Filam. simple filiform rigid crisp loosely entangled, when dry variegated, Artic. turgid dotted

15155 Filam. simple very short and minute entangled tortuous, Artic. twice as long as broad

15156 Filam. simple stiffish curled entangled fine, Artic. 3 times as long as broad

[moniliform

15157 Filam. simple filif. rigid crisp loosely entang. when dry variegated, Artic. about as long as broad, when dry

15158 Filam. simple thicker than a bristle adnate straight rigid erect, Artic. elliptical when dry

15159 Filam. simple thicker than a bristle adnate rigid erect, Artic. cylindrical 3 times as long as broad

15160 Filam. simple very fine adnate stiffish curved, Artic. about as long as broad somewhat moniliform

15161 Filam. simple very fine adnate straight pendulous, Artic. about as long as broad moniliform

15162 Filam. simple fine adnate mucous, Artic. as long as broad and variable, Interstices pellucid

15163 Filam. simple very fine, Artic. rather shorter than broad, Joints pellucid

15164 Filam. simple very fine adnate mucous straight, Artic, as long as broad, Interstices pellucid

15165 Filaments simple straight minute, Articulations oval half as long again as broad

15166 Filaments simple very fine adnate rigid tapered, Lower artic. shorter than broad: upper as long as broad

4. Adnate, pencilled, fastigiate, colored.

15167 Filaments simple rigid fastigiate, Artic. twice as long as broad

15168 Filaments simple fascicled rigid short attenuated at each end, Artic. somewhat longer than broad

15169 Filam. simple fine short, Artic. torose about 3 times as long as broad, Sap contained in a central globule

\section{B. Branched.}

15170 Filam. branched flexuose short, Branches scattered spreading blunt, Artic. half as long again as broad 15171 Filam. branched densely tufted rigid short, Branches 1-sided, Artic. generally thickest at the end about 3 times as long as broad

15141
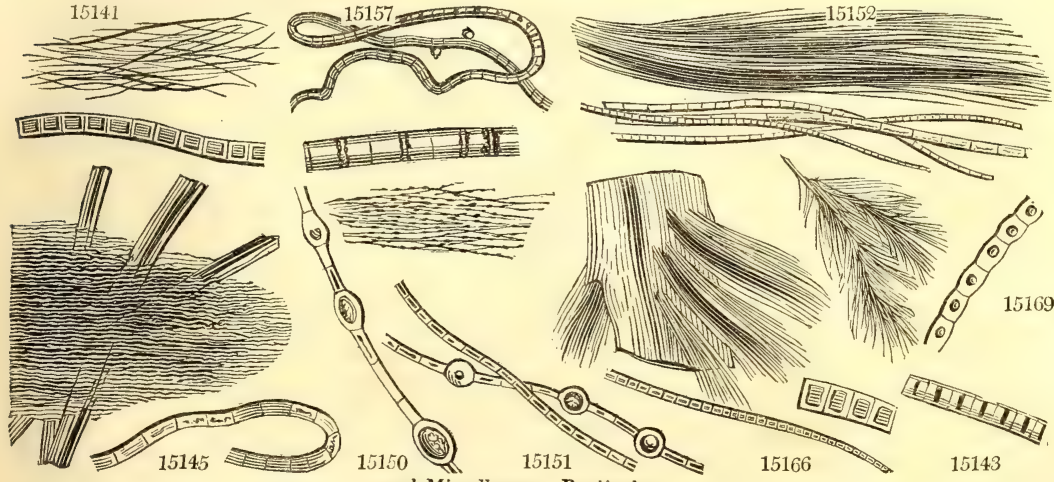

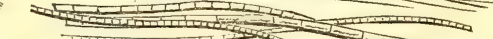
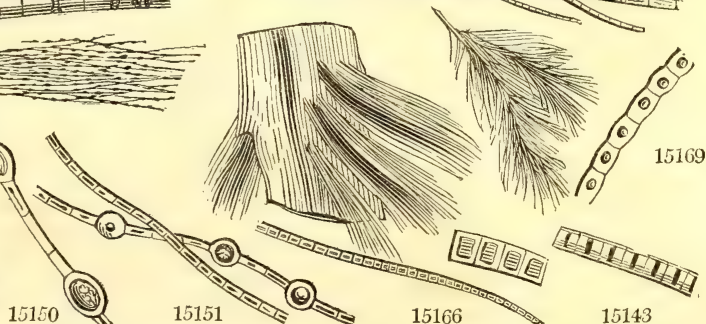

and

15151

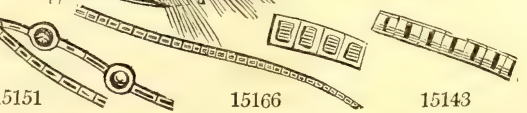

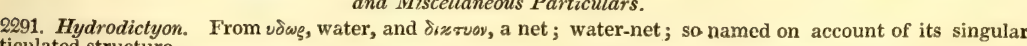
reticulated structure

2292. Conferva. A syncope of the Latin conferruminare, to consolidate. Plants of this kind were formerly 
15172 stelláris Fl. Dan.

15173 ripária Dillw.

15174 glomeráta $L$.

15175 crispáta Roth.

15176 frácta Dillw.

15177 pátens $\mathrm{Ag}$.

$\beta$ prolifera Ag.

15178 congregáta $\mathrm{Ag}$.

15179 lanósa $A g$.

15180 flavéscens Dillw.

15181 serícea Huds.

15182 refrácta Roth.

15183 as pera $\mathrm{Ag}$.

15184 heterochló $\mathrm{Ag}$.

15185 rupéstris $L$.

15186 ægogrópila

15188 Vaucheriæfó

15189 catenáta $L$.

15190 Hutchinsim Dillu.

15191 pellúcida Huds.

15192 dístans $A g$.

2293. BULBOCH王E

15193 setígera $\mathrm{Ag}$.

2294. NITEL'LA. $A g$.

15194 translúcens $\mathrm{Ag}$.

15195 fléxilis $\mathrm{Ag}$.

15196 opáca Ag.

15197 nidífica $\mathrm{Ag}$.

15198 grácilis $\mathrm{Ag}$.

2295. CHA'RA. $L$

15199 híspida $L$.

15200 vulgáris $\mathcal{L}$

starry

bank

clustered

floating tufts 2 sum.

G ins.ofwa.ves. Fl. Danica, t. 660 . f. 1

$\begin{array}{llll}\text { curled patches } 2 \text { sp. su. G lakes Eng. bot. t. } 2350 & \end{array}$

$\begin{array}{llll}\text { broken large tufts } 6 \text { sp. su. G pools } & \text { Eng. bot. t. } 2338\end{array}$

spreading large tufts $\Rightarrow$ 音 sum. G ditches

proliferous large tufts ditches

Dil.con.t.10. C. flexuos $\alpha$

heaped

woolly

yellowish

silken

whitish

rough

dense

rock

VegetableBall close

tufts

tufts

tufts

1 sum.

1 sum.

6 sum.

G roc. sea coa

$\mathrm{G}$ on Algæ

Y.G salt ditche

shining tufts 3 sum. Y.G sea shore

crispent.tufts 4 jn.jl. Pa.G ocean

tufts

tufte

dense tuft

s all sea. G ocean

$\frac{3}{4}$ all sea. D.G ocean

4 sum. Gi. ocean

3 sum. G lakes

floating tuft 3 sum. Tran. ocean

branched $\quad 1 \frac{1}{2}$ sum. G ocean

chain-like patches 1 sum. Br ocean

Miss Hutchins's dense tufts 4 sum Gl

pellucid finely branch. 5 august $\mathrm{Pa}$.G ocean

distant loose bundles 6 aut. Pa.G ocean

Sp. 1

setigerous delicate tufts

2296. Cer A'MiUM. $\boldsymbol{A g}$. Ceramium.

15201 lanuginósum $\mathrm{Ag}$. wooll

15202 floridulum $\mathrm{Ag}$.

15203 répens $A g$.

15204 plúma $A g$.

15205 Daviésii $\mathrm{Ag}$.

15206 Róthii $\mathrm{Ag}$.

15207 diáphanum $\mathrm{Ag}$.

$\beta$ pilosum Ag.

15208 rúbrum $\mathrm{Ag}$.

15209 tetragónum $\mathrm{Ag}$.

15210 pedicellátum $A g$.

15211 Hookéri $\mathrm{Ag}$.

15212 arbúscula $\mathrm{Ag}$.
Nitella

transparent

flexible

opaque

nest-like

slender

Cuara.

hispid

common

branched

branched

branched

branched

much branch.

branched

branched

woolly

lowering

creeping

feather

Davies's

Roth's

diaphanous

pilose

red

square

stalked

Hooker's

little tree aut.

Sp. 5-11.

2 sum. Y.Ol pools

1 sum. F.Ol pon. \& rivul

1 jl. aug. Y.Ol pools

1 jl. aug. Y.Ol pools

$\frac{3}{4}$ sept. Y.Ol pools

Ly.hy.d.t.56. C. uncialis

Dillw. conf. t. E.

t. 2088

E. b. t. 2327. C. albida Dil.con.t.E. C.nigricans

Eng. bot. t. 1699

Eng. bot. t. 1377

Eng. bot. t. 2098

Dillw.conf.t.E. C. $a r c t a$

Dillenius, t. 5. f. 27

Dillw, conf. t. 109

Eng. bot. t. 1716

Dill.con.t. 21. C. diffusa Sp. 2-16.

Eng bot.

fine down $\quad T^{\frac{1}{2}}$ all sea. Br on Algæ Dill.conf.t.45. Conferva

little tufts $\quad \frac{1}{2}^{\frac{1}{2}}$ all sea. Pa.G roc. sea shor. Dillw. conf. $t$. F

short down $\quad \frac{1}{12}$ july $\mathrm{Pk}$ on large Alg. E. b. t. 1608. Conferva

fine tufts $\quad \frac{1}{8}$ sum. $\mathbf{R}$ on large Alg. Dillw. conf. $t . f$.

small tufts $\frac{1}{8}$ july $\quad \mathbf{R}$ sea shore Eng. bot. t. 2329

broad tufts $\frac{2}{4}$ sum. Vi sea shor. roc. Eng. bot. t. 1702

$\begin{array}{llll}\text { diffuse } & 5 & \text { sum. Var. ocean } \\ \text { diffuse } & 5 & \text { sum. Var. }\end{array}$

solitary weak 10 sum. Pu ocean

Eng. bot. t. 1742

E. b. t. 2128. Conferva

tufts 3 sum. $R$ ocean Eng. bot. t. 1690

dense tufts 4 sum. Or sea shor

fine tufts $\quad 1 \frac{1}{2}$ sum. Pa.br sea shore

illw conf $t$. 108

Dill. conf. t. 106

bushy tufts 3 all sea. D.R sea shore Eng. bot. t. 1916

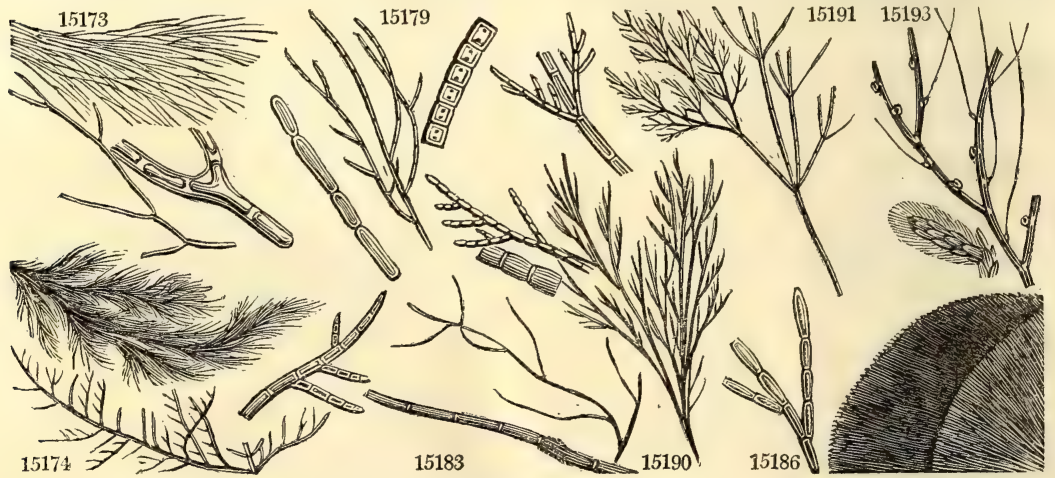

History, Use, Propagation, Culture,

held to he efficacious in healing fractured limbs. Pliny declares, he was witness to a cure of this kind. Some of the species of this genus are believed to be merely the young of mosses.

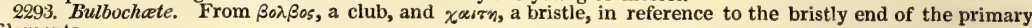
filaments.

2294. Nitella. From niteo, to shine. A genus separated by Agardh from Chara, because the stem is composed of a simple tube, and not of one spirally striated. The plants have the habit of Chara.

2295. Chara. The origin of this word is unknown. It first occurs in Casar's Commentaries, where it is mentioned as the name of a plant, the root of which was used by the Roman soldiers as food. That plant could have had no relation to the plant of the moderns. Various opinions have been held with regard to the station of this genus. Linnæus referred it to the perfect plants, and he has been followed by many botanists. Dr. Hooker and Mr. Lindley, in the former's Flora Scotica, formed it into a particular order, placed between Dr. Hooker Algæ and Hepaticæ; and with this opinion Dr. Greville coincides. But Professor Agardh thinks it cannot even be separated from true Algæ, in the midst of which he has placed it. The nature of the fructification is so paradoxical, that it is scarcely possible to trace an aralogy between it and the fructification of any other plant. 
15172 Filam, branched very minute equal parallelly exserted from an orbicular base

15173 Filam. branched remotely capillary very long, Branches short divaricating, Artic. twice as long as broad 15174 Filam. branched capillary, Branches alternate : those at the end clustered one-sided erect; Artic. cylind. about twice as long as broad

15175 Filam. branch. Branches altern. rem. Artic. cylind. 6-10 times as long as broad alternately compr. when dry 15176 Filam. branch. capill. Branch. divaricat. 1-sid. : upp. numer. somew. recurv. Artic. 4 times as long as broad 15177 Filam. branched capillary. Branches spreading somewhat alternate, Artic. 3 times as long as broad

B Artic. elliptical proliferous, Pullulating filaments very fine

\section{Heaped.}

15178 Tufts fascic. clav. form. a hemisphere, Filam: intric. branch. Branch. ascend. Artic. about as long as broad 15179 Filaments tufted, Branchlets long remote, Artic. oblong oval 3 times as long as broad

15180 Filaments much branch. capillary, Branches spreading somew. alternate, Artic. 6 times as long as broad

15181 Filaments much branch. capillary dichotom. at base, trichotom. in middle, Artic. 5 times as long as broad 15182 Filam. much branch. capill. Branches divaricat. somew, recurv. very numer. Artic. twice as long as broad 15183 Filam. dichotom. setac. rigid finally becoming blackish, Branc. erect rem. Artic. 3 times as long as broad

15184 Filaments opposite much branched : first branches blackish; second greenish [as broad

15185 Filam. much bran. setac. when dry dot. with black, Bran. erect, Joints pelluc. Artic. cylind. 3 times as long 15186 Filam. from a common centre forming a globe rigid branched obtuse, Artic. 5 times as long as broad

15187 Filam. branch. straight virg. capil. Branch. erect somew. hyal. and thicken. at end, Artic. of various lengths 15188 Filam. branched straight virgate capillary mucous, Branches erect when dry black at the ends

15189 Filam. more than bristly trichotom. shin. when dry dott. with black at joints, Artic. 3 times as long as broad

15190 Filam. much branch. flexuose somew. cartilaginous fragile, Branches and branchl. scatter. Artic. torulose

15191 Filam. much branched straight rigid, Branches generally in threes obtuse, Articul. very long

15192 Filam. setac. dichotom. flexuose, Branch. rem. Branchl. short blunt, Artic. cylind, 4 times as long as broad

15193 The only species

15194 Stem long, Branchlets blunt, Nucules nearly naked in heaps at the joints of the stem 15195 Stem trichotomous pellucid, Branchlets forked, Nucules axillary solitary

15196 Stem 2-3-chotomous opaque, Branchlets forked or with broken joints, Globules solitary

15197 Fruit branches filiform with other long jointed ones between, Nucules clustered axillary

15198 Stem slender long, Branches acute forked, Fruit solitary

15199 Stem twisted furrowed strigose, Strigæ reflexed, Bractes aculeate

15200 Stem twisted ash-colored, Branches not jointed, Bractes linear twin thrice as long as nucule

\section{Filaments short, fastigiate.}

15201 Filam somew, branch. minute ferrug. Branch, scatter, blunt, Artic. pelluc. in mid, 3 times as long as broad 15202 Filam. branched fine tufted, Branches scattered simple remote, Articul. 3 times as long as broad

15203 Filam. creeping rooting densely entangl. much branch. Joints somew. contract. Artic. narrowest in middle 15204 Filam. creeping minute branched, Branches erect naked at base pinnat. upw. Artic. twice as long as broad 15205 Filam. much branch. fastig. short, Branc. erect acute, Artic. thrice as long as broad, Caps. lateral clustered 15206 Filam. short cæspitose pulvinate, Branches and branchlets fastigiate erect, Artic. twice as long as broad

2. Filaments dichotomous, Branchlets forked, Joints obscure, Thece involucred.

15207 Filam. dichotom. much branched somewhat membranous variegated with purple and hyal. Joints elevated $\beta$ Joints hairy

15208 Filam. dichotom. much branched somewhat cartilaginous, Branchlets forked, Artic. ovate opaque

3. Branches furnished with branchlets, which are more or less dense and shortened. 15209 Filam. branched virgate, Primary articulations twice as long as broad

15210 Filam. setaceous dichotomous, Artic. thickened upwards about 5 times as long as broad

15211 Filam. much branch. : prim. thick and contiguous, Altern. pinnules with artic. half as long again as broad

15212 Filam, much branched: primary without joints, Artic. as long as broad

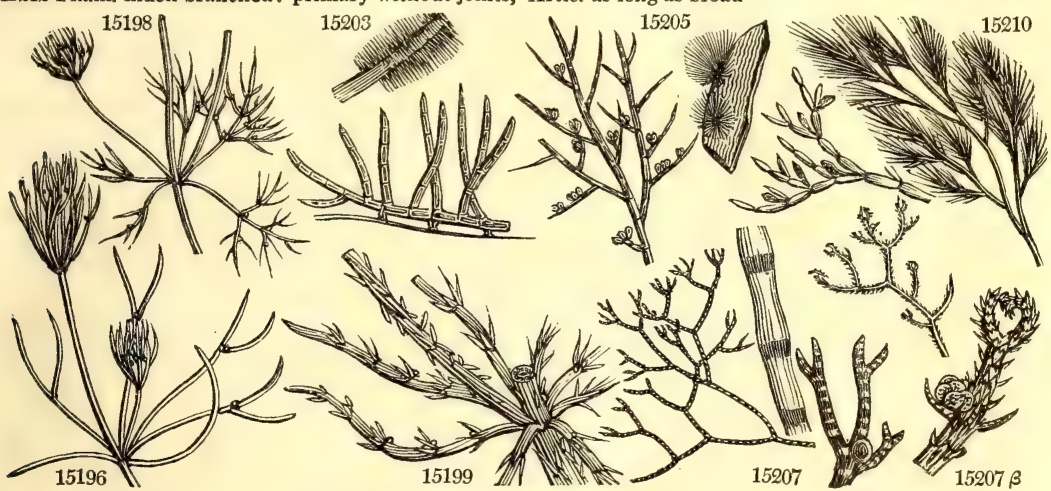

and Miscellaneous Particulars.

Greville observes, "This is a most curious tribe of plants, whose structure, I am convinced, is by no mean well understood. At present, I have only minutely examined the fruit of C. vulgaris. Under a high power of the microscope, the globule is found to consist of seven triangular scales, which in maturity separate from each other, and produce the dehiscence of the globule. Each of these scales has a vacant portion in its centre, but the margin, which has a fluted appearance under a small magnifier, consists of a number of parallel, linear oblong, hyaline, hollow tubes, placed at small intervals from each other, those forming the angles of the scale being branohed. Within these tubes are a profusion of orange, globular, minute bodies (exactly similar to the sporules of many cryptogamic plants), arranged in no order, and escaping on the least injury to the tubes. It is these little bodies which give the orange color to the globule. Within the globule is a mass of elastic white filaments, much convoluted, and distinctly either jointed or transversely rugose."

The calcareous matter of the stem and branches is not an adventitious incrustation, but is the result of some peculiar economy in the plant itself, as it evidently originates from within, and is covered with the cuticle. It is supposed to be analogous to the siliceous deposit beneath the cuticle of Equisetum.

2296. Ceramium. So called from жвраноs, a little measure, in reference to the appearance of the capsules. All the species are found in the sca, and among the substances cast up upon the shore. 
15213 corymbósum $A g$.

$15 \% 14$ róseum $\mathrm{Ag}$.

15215 thujoídes $\mathrm{Ag}$.

15216 versícolor $A g$.

15217 Borréri $\mathrm{Ag}$.

15218 tétricum $\mathrm{Ag}$.

15219 interrúptum $\mathbf{A g}$.

15120 Turnéri $A g$.

15221 plúmula $A g$.

2297. GRIFFIT

15222 multífida $\boldsymbol{A g}$.

15223 equisétifolia $\mathrm{Ag}$.

15224 setácea $\mathrm{Ag}$.

15225 barbáta $\mathrm{Ag}$.

15226 corállina $\mathrm{ig}$

2298. CHATOSPO

2299. POI

15228 parasítica $\mathrm{Ag}$.

15229 spinulósa Grev.

15230 coccínea $\mathrm{Ag}$.

15231 divaricáta $\Lambda g$.

15232 grácilis $\mathrm{Ag}$.

15233 vioiácea $\mathrm{Ag}$. 3 májor Ag.

15234 nigréscens $\mathrm{Ag}$.

$\beta$ pectináta $\mathrm{Ag}$. 15235 urceoláta $\mathrm{Ag}$. 15236 elongáta $\mathrm{Ag}$.

15237 allochróa

15328 Brodiæ'i $A g$

15329 atrorubéscens $\mathbf{A g}$.

15240 fastigiáta $\mathrm{Ag}$. $15 \& 41$ bádia $A g$.

15242 recúrva $\mathrm{Ag}$.

15243 byssoídes $\mathrm{Ag}$. 15244 fruticulósa $\mathrm{Ag}$.

15245 filamentósa $\mathrm{Ag}$. corymbose

rosy

Arbor-Vitæ

changeable

Borrer's

livid

interrupted

Turner's feather-like

Ag. Griffithsi

multifid

fine tufts $\quad 3$ july ${ }_{\mathrm{R}}$

bristly lax tufts $\quad 4$ all sea. $\mathrm{R}$ sea shore bearded flocculent $1 \frac{1}{2}$ july $\mathrm{C}$ sea shore coralline branch, tufts 3 july Or.R sea shore Ag. Chatospora. Sp. 1 .

Wigg's finely branch, 5 sum. R.Br sea shore Grev. - Grev. Polysipuonia. Sp. 18-49.

sinall patches $1 \frac{1}{2}$ sum. R.Br on Fuci rough-stemm. sinall patches $1 \frac{1}{2}$ sum. R. Br sea shore scarlet bushy tufts 4 all sea. $\mathrm{S}$ ocean

divaricating tufts

3 sum. R ocean

slender

long tufts

4 all sea. $\mathrm{Pu}$

ocean

violet

large

blackish

pectinate

urceolate

elongated

various

Brodie's

dark red

fastigiate

brown

little bushes

9 sum

Vi ocean

bushy tufts

6 sum.

D.Pu sea shore

fine tufts,

6 sum

D.Pu ocean

little tufts

long branches $\frac{1}{2}$ sum. D.Pu ocean

shrubby

8 all sea. R.Br ocean

$1 \frac{1}{2}$ all sea. Vi ocean

little bushes 2 sum. D.Br ocean

fine tufts 3 sum. D.Br ocean

recurved

byssus-like shrubby

fine tufts

3 sum. D.Br sea shore

slender tufts 6 spring $\mathbf{R}$ sea shore finely branch. 4 sum. $\mathrm{Br}$ ocean

branch. tufts 4 march $\mathrm{R}$ ocean equisetum-lv'd sponge-lik.tuf. 6 sum, $\mathrm{R}$ sea shore

2300. RYTIPHLE'A. $A g$. RYTIPHLAa.

15246 tinctória $\mathrm{Ag}$. dyer's masses

dyer's

2301. ECTOCA R'PUS. Ag. LCTOCARPUs.

5247 siliculósus $\mathrm{Ag}$.

$\beta$ atrovirens Ag.

15248 brachiátus $\mathrm{Ag}$.

podded bushy

dark-green bushy

fcrruginous

bushy

floating tufts

Sp. 1-3.

6 all sea. Ol.G ocean

Sp. 4-8.

6 spring D.G ocean

6 spring Rus. ocean

6 spring Rus. ocean

3 april $\mathrm{Pa}$. br ocean

granular flocculent 3 july OlG on Fuci

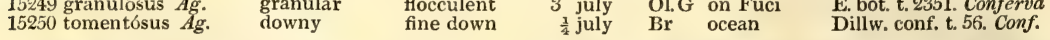

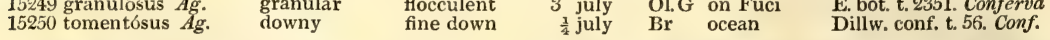

Eng. bot. t. 2352

Dillw. conf. t. 17

E.b.t.2465. C. purpuras

Eng.bot. t. 966 . C. rosea

Eng. bot. t. 1741

Eng. bot. t. 1915

Eng. bot. t. 1838

Eng. bot. t. 2339

E.bot.t.1637. C. Turneri

E. bot. t. 1816. Conferva Eng. bot. t. 1479

Eng. bot. t. 1689

Eng bot. t. 1814

Eng. bot. t. 1815

Eng. bot. t. 1165. Fucus

E. bot. t. 1429. Conferva

Grev. crypt. 90

E. bot. t. 1055. Conferva

Lyngb. hydroph. t. 34

Dill.conf.t.40. C. stricta

Lyngb. hydrop.dan.t.35

Eng.bot.t.2340. C. nigra

E. bot. t. 1717. Conferva

E. bot. t. 1239. C. fibrata Dill. con. t. G. Conferva Dill. con. t. 33. Conferva Dill. con. t.G. C. fibrata Dill.con.t. 107. Conferva

Dill, con, t.70. Conferva

E.b.t.1764. C. polymorp. Dill.con. t. G. Conferva

Dill. con. t. G. C. patens

Eng.bot.t.597. Conferva E. b. t. 2312. C. Gruffith.

Turn. fuci, t. 224. Fucus

Dillw. conf. t. E. Conf.

E. b. t. 2319. C.siliculosa

E. b. t. 2290. C.littoralis E. bot. t. 2571. Conferva

E. bot. t. 2351. Conferva

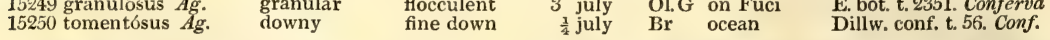

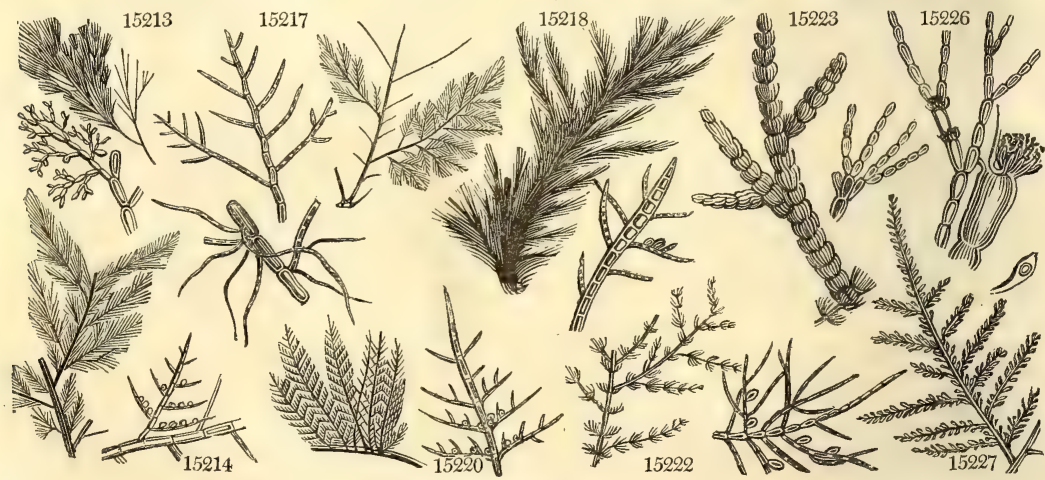

Fistory, Use, Propagation, Culture,

2297. Griffithsia. Named after Mrs. Griftiths, of Devonshire, whose many discoveries in marine vegetation truly entitle her to this distinction : the highest which one botanist can bestow upon another.

2228. Chetospora. From $\chi \alpha \iota \tau \alpha$, a bristle, and $\sigma \pi \circ \propto$, a sporule: the latter are placed upon fine capiliary divisions of the filaments.

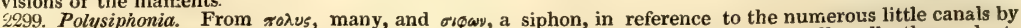
which the colored matter is carried from one end of the plant to the other. Agardh calls these plants 
4. Branches pinnulate, Pinnula alternate.

15213 Filam. branch. Branches virg. surround. by short cory mbose fastig. branchl. Artic. 3 times as long as broad 15214 Filam, branched, Branchlets alternate rigid spreading subulate, Artic. 3 times as long as broad

15215 Filam. branched, Branchlets scattered decompound-pinnate, Artic. 3 times as long as broad

15216 Filam. branched, Branchlets scattered virgate, Artic. 8 times as long as broad

15217 Filam. virgate with many simple or multifid pencilled ramuli, Artic. 3 times as long as broad 15218 Primary filaments downy, Branches straight decompound pinnate, Artic. 3 times as long as broad 15219 Filam. much branch. Artic. 4 times as long as broad by degrees becoming thickened, Caps. stalked ellipt.

5. Filaments pinnated, Pinna opposite.

15220 Filam. pinnated, Pinnæ opposite nearly simple, Artic. many times longer than broad

15221 Filam. with irregular branches, having at each joint short slender opposite spreading recurved branchlets 1. Branches fascicled.

15222 Filam. branched, Branchlets subternate distant short multifid, Artic. much longer than broad [broad 15223 Filam. branch. cover. all over with somew. whorl. imbricat. short multif. branchl. Artic. much longer than 2. Dichotomous, chained.

15224 Filam, dichotom, straight, Branches erect long, Articulations cylindrical about 5 times as long as broad 15225 Filam. dichotom. Fibres multifid very fine, Articulations thickened upwards about 5 times'as long as broad 15226 Filaments dichotomous slippery, Articulations thickened 2-4 times as long as broad

15227 The only species

a. Purple or scarlet, flnt, somewhat pinnated.

15228 Filaments bipinnate veiny rigid, Pinnæ and pinnules alternate, Articulations rather shorter than long 15229 Dark-red, Branches divaricate rigid, Articulations 3-tubed as long as broad, Stem rough with tubercles 15230 Filam. very much branch. Primary not jointed, Branches decomp.-pinn. Pinnules heterogen. multif. fascic. b. Creeping, Branches divaricating, often one-sided.

15231 Filaments entangled with scattered branches, Branches divaricating, Articulations twice as long as broad c. Purple, whole-colored, adhering to paper.

15232 Filaments nearly equal branched virgate, Branches erect, Lower articulations 5 times as long as broad

$d$. Pencilled, black above, generally rose-colored above, adhering to paper.
15233 Filam. much branched diffuse, Branches virgate spread. Lower artic. obsol. Artic. much longer than broad

15234 Filarnents much branched at end diffuse, Lower articulations very short when dry nodulose : upper about as long as broad with $S$ veins

e Filaments short somewhat pectinated, Branches nearly simple

15235 Filaments much branched diffuse, Branchlets spreading short, Articulations half as long again as broad 15236 Filam. dichotom. pencilled much branched, Articulations shorter than long netted veiny : lower obsolete 15237 Filam. much branched diffuse, Lower artic. 5-veined 4 times as long as broad: upp. 3-veined twice as long 15238 First filament not jointed spirally veiny, Articulations as long as broad, Capsules axillary

15239 Filaments branched veiny, Branches long, Artic. of stem long, of the branches thrice as short e. Black or blackish-brown when dry, rigid, scarcely adhering to paper.

15340 Filam. dichotomous nearly equal fastigiate, Artic. shorter than broad with a black point in the middle 15241 Filaments dichotomous irregularly branched at end, Branches and branchlets very straight : upper artic. 3 times as long as broad

15242 Filam. much branched long diff. Branchl. short spread squarr. recurved, Lower artic. long: upper short f. Branchlets lateral, short, fascicled.

15243 Filaments decompound pinnated, Branchlets very short and fine, Articulations 3 times as long as broad 15244 Filaments branched virgate, Branch, alternately pinnated, Branchlets short multifid, Theca sessile ovate 15245 Filam. much branched covered with heterogeneous hair-like simple branchlets, Artic. very short obsolete

15246 Frond somewhat cartilaginous compressed transversely rugose bipinnated, Pinnules in fruit incurved

15247 Filam. nearly separate, Branches erect subulate, Artic. rather longer than broad, Pods linear subulate

15248 Filam. much branched very tine, Branches and branchlets opposite spreading attenuated acute, Artic half as long again as broad

15249 Filam. much branch. Branches scatt. spread, taper. ac. : at tips hyal. Artic. as long as broad finaliy tumid 15250 Frond rope-like somew. spongy divid. into branches, Filam. densely entang. A rtic, 4 times as long as broad

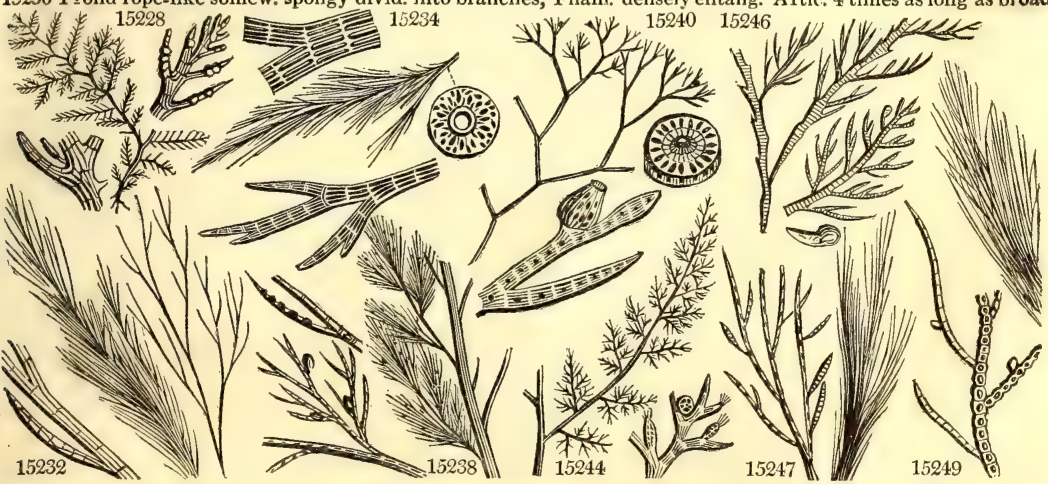

and Miscellaneous Particulars.

Hutchinsias, not being aware that the name of Miss Hutchins had previously been applied to a genus of Cruciferæ, by Mr. Brown. The species of this genus are, perhaps, the most beautiful of all the tribes of Conferva.

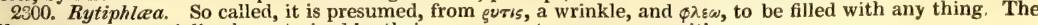
filaments are essentially characterized by their numerous transverse rugosities.

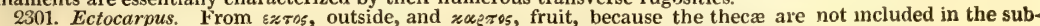
stance of the frond, as in the next genus, but placed on the outside. Marine plants. 
2302. SPHACELLA'RIA. Ag. Sphacellaria. 15251 racemósa 15252 cirrhósa $\mathrm{Ag}$. 15253 rádicans $\mathrm{Ag}$.

15254 plumósa $\mathrm{Ag}$. 15255 Merténsii Ag. 15256 scopária $\mathrm{Ag}$. racemose rooting

dense tufts fine tufts

plumose flaccid Mertens's rock dense tuft

2303. Cladoste'phus. $A g$. Cladostephus.

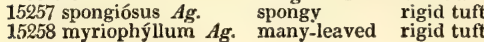

Sp. 6-14.

1 febr. Ol.G sea shore

sum. Ol.G ocean Dillw. conf. t. 86. Conf

$\frac{3}{4}$ sum. Br.Ol marine roc. Dillw. conf. t. C. Conj.

3 spring G.Br ocean E.bot. t.2330. C.pinnata 4 sum. Ol.Br sea shore E. bot. t. 999 . Conferva 3 sum. Br ocean $\quad$ E. bot. t. 1552. Conferva Sp. 2-7.

3 sum G ocean 5 sum G ocean
E.b. t.2427. f.1. Conferva E.b.t.1718.C.verticillata

UL VACEA.

2304. VAUCHE'RIA. Ag. VAUCHERIA 15259 dichótoma Ag. 15260 Dillwýnii Ag. 15261 radicáta $\mathrm{Ag}$. 15262 gemináta $\mathrm{Ag}$.

$\begin{array}{ll}15263 \text { racemósa } A g . & \text { racemose } \\ 15264 \text { multicapsularis } A g & \text { many-fruited }\end{array}$ 2305. CO'DIUM. 15265 tomentósum $\mathrm{Ag}$ 15266 Bur'sa $\mathrm{Ag}$. submarine Dillwyn's rooting double

2306. BRYOP'SIS. $A g$. 15267 plumósa $\mathrm{Ag}$. 2307. SOIE'NIA. $1 g$ 15268 intestinális $\mathrm{Ag}$. $\beta$ max ima Ag.

15269 Lin'za Ag. 3 lanceolátá Ag. 15270 compréssa $A g$. $\beta$ crinita Ag. 15271 clathráta $A g$ $\beta$ uncináta Ag. 2308. UL'VA. $L$. 15272 lactúca $\dot{L}$. 15273 bullósa Roth 15274 crispa Lightf. Codium. downy purse

BRYOPSIS. feathery

Solenia. intestinal very large crisp

lanceolate compressed crinite grated booked

Ulva. Green Laver puckered crisp

2309. POR'PHYrA. $\mathrm{Ag}$. Porphyra 15275 laciniáta $A g$. torn 15276 purpúrea Ag. $\quad$ purple large tufts large tufts thin mat patches ge masses patches

\section{coralloid} spongy mass

fine tufts

simple simple simple simple simple compound branched irregul branc.

\section{soft leaves soft leaves} broad mass

soft leaves soft leaves
Sp. 6-29.

12 sum. D.G ditches E. bot. t. 932. Conferva 12 sum. D.G submar. ditc. Lyng.hydrop. dan. t.20 1 sp. su. D.G on the earth Dill. conf. t.16. C. frigida $\frac{1}{8}$ sept. D.G dry ditches E.b. t.324.Trem.granul. 6 sum. D.G still waters Eng. bot. t. 1766

4 su. au. D.G ditches Lyng. hydrop dan. t.23 $i^{\frac{1}{2}}$ su. au. D.G dry banks Dill, conf. t.71. Conferva Sp. 2-7.

6 june G ocean Eng. bot. t. 712. Fucus 3 all sea. $\mathbf{G}$ ocean Eng. bot. t. 2183. Fucus

Sp. $1-7$.

2 sept. Dp. G ocean

E.b.t.2375.Ulv.plumosa Sp. 4-18.

24 sum. G ditches

24 sum. G ditche

18 sum. G ocean

Dillenius, $t .9$. 6

ocean Dillenius, $t, 9$. 5

Eng. bot. t. 1739. Ulve

sum. Ysh ocean

Dillenius, $t, 2, f$

E.b.t.2137. Ulv. ramul.

12 su.

on the earth Dillenius, t. 10. f. 12

Sp. 2-3.

2 sum. Pu sea shore Lightf, fl scot, $t .23$

sum, Pu sea shore

\section{FLORIDEAE.}

23i0. POLYI'DES. Ag. Polyides. 15077 lumbrílis

2311. P'TILO'TA Ag. PTILOTA

15078 ptilo'

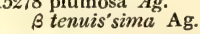
$\begin{array}{ll}\text { feathery } & \text { fine tufts } \\ \text { delicate } & \text { fine tufts }\end{array}$

coralloid

Sp. 1.

6 nov. Br ocean

E.b.t.1738. Fuc.rotund. fine tufts

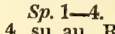

4 su. au. $\mathrm{R}$

ocean

Eng. bot. t. 1308. Fucus

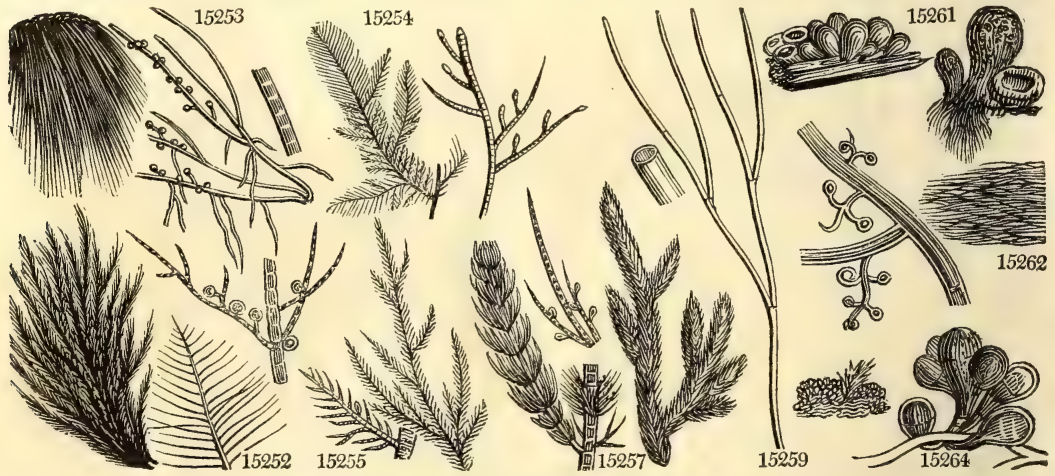

History, Use, Propagation, Culture,

2302. Sphacellaria. This name has been suggested by the sphacelated appearance of the truncated extremities of the shoots, in which the reproductive organs are immersed.

2303. Cladostephus. From $* \lambda \propto \delta \circ 5$, a branch, and s\&ф०s, a crown, in allusion to the manner in which the first stem is crowned as it were by the little compound whorled branches.

2304. Vaucheria. So named, in honor of M. Vaucher, of Geneva, an indefatigable collector of submersed Algæ.

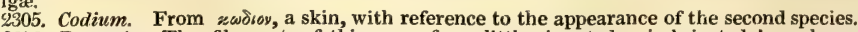

2306. Bryopsis. The filaments of this genus form little pinnated or imbricated branches, resembiing bits of

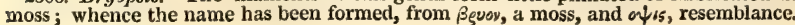


15251 Filam. twice or thrice dichotom. Artic. as long as broad, Tubercles ovate racemose on branched peduncles 15252 Filam. mich branched fine striated, Branches alternate somew. pinnated, Articulations as long as broad 15253 Filaments branched rocting straight rigid, Branches scattered simple erect obtuse tapering at the base, Artic. about twice as broad as long

15254 Primary filaments branched not jointed surrounded by pectinated spreading branchlets

15255 Filaments bipinnate very fine, Pinnæ and pinnules opposite, Artic. very short, Theca ovate stalked

15256 Stem covered with confervoid filam. Branches somew. bipinnate, Pinnæ pectinate, Altern. pinnules subul.

15257 Setæ simple densely imbricated

15258 Setæ incurved forked or crested imbricated

\section{ULVACEAE.}

15259 Filaments setaceous dichotomous fastigiate, Thecæ globose sessile solitary

$\beta$ Filaments finer, Thecæ lanceolate and ovate

15260 Filaments flexuose, Thecæ sessile lateral globose

15261 Filaments descending rooting, Thecæ solitary terminal globose

15262 Filaments dichotomous, Theca obovate stalked opposite on a common cornute pedic

15263 Filaments branched cæspitose, Thecæ racemose

15264 Filaments branched creeping, Branches erect nearly simple, Thecæ heaped towards the tips

15265 Frond dichotomous fastigiate cylindrical

15266 Frond globose hollow

15267 Filam. branched naked below, pinnated in the middle, Branchlets opp. nearly simple approximating

15268 Frond tubular inflated simple

15269 Frond lanceolate ensiform much tapered at each end wavy crisp

15270 Frond tubular lined clathrate branched filiform compressed, Branches simple tapering at base

15271 Frond tubular irregularly clathrate filiform, Branches tapered

15272 Fronds obovate or lanceolate flat wavy laciniate-crisp

15273 Frond obovate slippery sinuous blistered finally expanded

15274. Fronds blistered plaited-crisp rugose heaped in an expanded layer

15275 Frond flat with numerous dilated segments

15276 Frond flat ovate lanceolate flat wavy crisp at the edge

\section{FLORIDEAE.}

15277 The only species

15278 Jugament filiform compressed, Pinnules opposite pectinate-cut

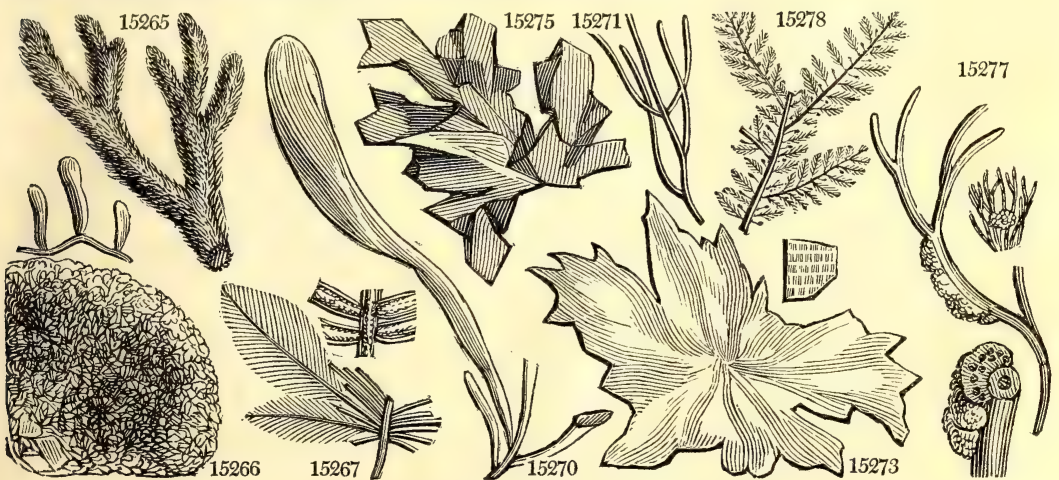

and Miscellaneous Particulars.

2307. Solenia. So called, from $\sigma \omega \lambda \eta$, a tube, in allusion to the tubular nature of the frond

2308. Ulva. This was the common name applied by the Latins to all kinds of marine plants. The word is said to have been derived from the Celtic $u l$, water. The green laver which, stewed with lemon juice, is so much esteemed in England, is the U. lactuca.

2309. Porphyra. This genus has received its name from zoøфuৎos, purple, on account of its being remarkable among Ulvacex for possessing that color.

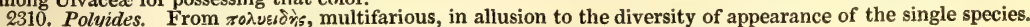

2311. Ptilota. Named in allusion to the form of the frond: from $\pi \tau i \lambda \omega \tau 05$, pennated. 
2312. RHODOME'LA. Ag. Rhodomela. 15280 lycopodioides $\mathbf{A g}$. lycr 15282 scorpioídes $\mathrm{Ag}$. toothed ycopodium-like 15283 pinastroídes $\mathrm{Ag}$. lat branchei

Sp. 5-21

2313. CHON'Dria. $A g$. Chondria. 15284 pusílla Hook. 15285 pinnatífida $\mathrm{Ag}$. 15286 obtúsa $\mathrm{Ag}$ 15287 ovális Ag. 15288 dasyphýlia $A g$. 15289 tenuíssima $A g$ 15290 clavellósa $A g$. 15291 Kalifórmis $A g$. 15292 articuláta $\mathrm{Ag}$. Pepper dulse blunt blunt thick-leaved slender clavellose Kaliform jointed

2314. SPHAROCOC'CUS. $A g$. Spherococcus.

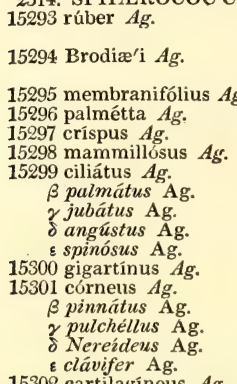
red

Brodie's tufts loid

4 sum. Ol. Br sea shore 6 sum. acicular 3 sum. $\mathrm{Br}$ ocean Sp. 9-38.

entangled bushy bushy rigid branch Sedum-like asparagoid gelatinous coralloid $\frac{3}{4}$ sum. Psh marine roc. 6 sum. Psh ccean 4 sum. Y.Pk ocean 4 sum $\mathrm{Br}$ ocean .ll sea $\mathrm{Pu}$ - all sea. Pu jli sug. Papk 5 june Dl.P ocean Sp. 17-128.

4. wint. Psh ocean

4 su.au. Psh ocean $\begin{array}{llll}\text { membranous } & \text { branched } & 6 & \text { oc. jan. } \\ \text { Palmetto } & \text { flat branched } & 3 \text { sum. } & \text { Dl.P sea shore }\end{array}$ Palmetto crisp teated ciliated palmated maned narrow spiny branched corneous pinnated pretty pretty club-bearing branched 4 s. my. R.Br ocean 4 all sea. R. Br ocean 6 wint. R. Br ocean

6 wint. R. Br ocean
6 wint. R. $\mathrm{Br}$ sea shore

6 wint. R.Br sea shore

6 wint. R.Br sea shore

6 wint. R. Br sea shore

3 all sea. R.Br sea shore finely cut coralloid

3 sum. dp.pk ocean $\begin{array}{llll}\text { finely pinnat. } & 3 & \text { sum. dp.pk ocean } \\ \text { finely pinnat. } & 3 & \text { sum. dp.pk sea shore }\end{array}$ $\begin{array}{llll}\text { finely pinnat. } & 3 & \text { sum. dp.pk sea shore } \\ \text { finely pinnat. } & 3 & \text { sum. } & \text { dp.pk sea shore }\end{array}$ finely pinnat. 3 sum. dp.pk sea shore 3 sum. dp.pk sea shore 8 all sea. di. $\mathrm{Br}$ ocean 6 sum. Dp.R ocean

15303 corónopifólius $\mathrm{Ag}$.

15304 laciniátus $\mathrm{Ag}$. jagged

\section{flat lobed}

3 f. may $\mathbf{P k}$ ocean

15305 bifidus $\mathrm{Ag}$.

15306 cristátus $A g$.

15307 confervoídes $A g$.

15308 plicátus $A g$.

bifid

crested

bushy lobed

conferva-like small tuft

2 f. may pu.pk sea shore

$1 \frac{1}{2}$ sum. Pk ocean

2315. HALYME'NIA. Ag. Dulse. 15310 renifórmis $\mathrm{Ag}$. 15311 édulis $\mathrm{Ag}$. ß média Ag.

15312 palmáta $A g$. $\beta$ marginifera Ag. $\gamma$ sarniénsis Ag. 15313 liguláta $\mathrm{Ag}$.

15314 furcelláta $\mathrm{Ag}$. 15315 opúntia $\mathrm{Ag}$. 13516 purpuráseens reniform true

intermediate common margined Guernsey strap-shaped

much branch 6 aut wi Ol.G ocean coarse bush 3 all sea. $\mathrm{Ol} . \mathrm{Br}$ ocean thinly branc. 6 all sea. Pa.Y ocean Sp. $7-21$.

broad leaves 8 aut. $\mathbf{R}$ sea shore broad leaves 8 aut. DI.R ocean broad leaves 8 aut. $\mathbf{R}$ sea shore broad leaves 8 oc. ap. psh. $R$ ocean broad leaves 8 wint. $\mathrm{Pu}$ ocean broad leaves 8 wint. $\mathrm{Pu}$ sea shore 8 wint.
4 wint. $\mathrm{Pu}$ ocean

forked much lobed 3 wint. Pu ocean Indian Fig matted 1 sp. aut. Pa.pu ocean much branch. 6 sum. Psh ocean
Eng. bot. t. 1241. Fucus Eng bot. t. 1163. Fucus Fng bot t 1164. Fucus Eng, bot. t. 1428. Fucus Eng. bot. t. 1042. Fucus

Greville crypt. t. 79 Eng. bot. t. 1202. Fucus Eng. bot, t. 1201. Fucus Eng. bot. t. 711. Fucus Eng. bot. t. 847. Fucis Eng, bot. t. 1882. Fucus Eng. bot. t. 1203. Fucus Eng. bot. t. 640. Fucus Eng. bot. t. 1574. Fucus

Eng. bot. t. 1053. Fucus

Lyngb, hydrop. dan, t.3

Turn. fuci, t. 74. Fucus Eng. bot. t. 1120. Fucus Turn. fuci, t. 216. Fucus Eng. bot. t. 1054. Fucus Eng, bot. t. 1069. Fucus

Lin.trans.3.t.17.f.2.Fuc.

Eng. bot. t. 908. Fucus Eng. bot. t. 1970. Fucus Turn fuci, t. 257 . f. d Turn. fuci, t. 257 . f. p.

'Turn. fuci, t. 257. f. 9

Eng. bot. t. 1477. Fucus Eng. bot. t. 1478. Fucus

Eng. bot. t. 1068. Fucus

Eng. bot. t. 773. Fucus Greville crypt. t. 85

Eng. bot. t. 1668. Fucus Eng bot. t. 1089 . Fucus Eng. bot. t. 1243. Fucus

Turn. fuci, t. 113. Fucus Eng. bot. t. 1307. Fucus Turn. fuci, t. 113. f. g. E.b.t. 1306, F palmatus Stackhouse, fuci, t. 12 Turn. fuci, t. 44. Fucus Eng. bot. t. 421 . Ulva

Eng. bot. t. 1881. Ulva E. bot.t.1868, Rivularia Eng. bot. t. 641 . Ulva

2316. BONNEMAISO'NIA. $A g$. Bonnemaisonia. Sp. $1-3$.

15317 asparagoídes $A g$, Asparag.-like finely branch. 4 ji. to n. Dl.pu sea shore Eng. bot. t. 571. Fucus

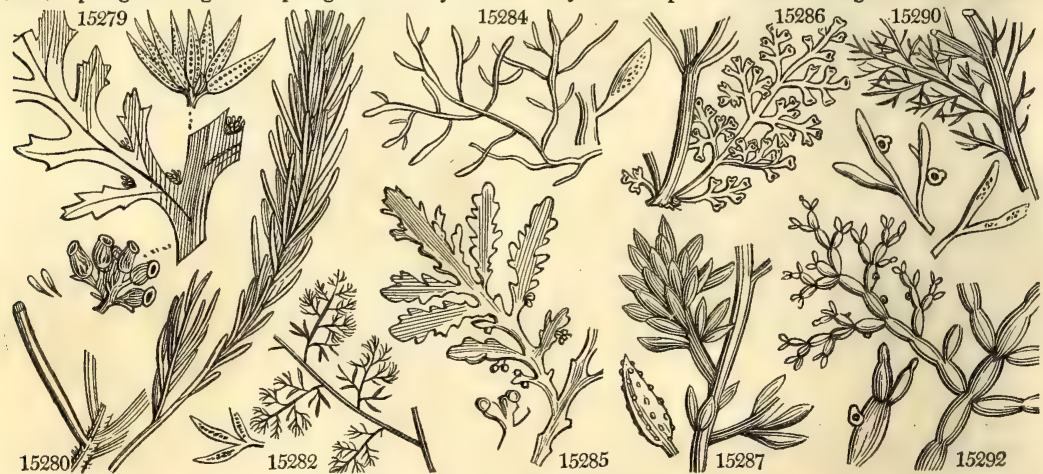

History, Use, Propagation, Culture,

2312. Rhodomela. From podos, red, and $\mu \in \lambda \circ 5$, a limb; in allusion to the color of the fronds.

2313. Chondria. The fronds of this genus are particularly cartilaginous, on which account its name has been

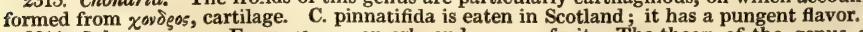

2314. Sphcerococcus. From $\sigma$ фeifo, an orb, and xoxжos, fruit. The thecæ of the genus are round, and contain a globose nucleus full of round sporidia. 
15279 Frond flat obsoletely ribb. alternately bipinnatifid, Pinnæ linear cuneate, Pinnules cut, Thecæ urceolate 15280 Stem filiform covered with setaceous densely imbricuted ramenta

15981 Frond filiform much branched, Branchlets setaceous subulate pinnate fascicled

15282 Frond filiform attennuate flexuose branched, Branches bipinnate: upper involute

15283 Frond filiform equal, Ramenta simple about one-sided clustered involute

15284 Frond compres. filif. somew. contract. here and there, Fructif. either min. tuberc. or scatter. spor. in ramu't 15285 Frond compressed 2-3-pinnate, Pinnæ alternate, Pinnules obtuse callous

15286 Frond round filiform many-times pinnated, Pinnæ opposite cylindrical clavate short horizontal

15287 Stem roundish filiform dichotomous, Ramenta elliptical scattered much attenuated at base

15288 Stem round filiform much branched, Ramenta clavate much attenuated at base

15289 Stem round filiform irreguiarly branched, Ramenta setaceous much tapered at base

15290 Stem filiform much pinnated, Ramenta linear-lanceolate distichous tapering at base

15291 Frond filiform contracted in joints tubular, Branches whorled

15292 Frond filiform chain-like in joints tubular, Branches fastigiate dichotomous and whorled

15293 Stem scarcely any, Laminæ chained obsoletely ribbed cuneate 2-forked or larıceolate, Thecæ rugose sessile in the disk of the frond

15294 Stem filiform somewhat dichotomous, Branches terminating in oblong 2-forked somewhat proliferous laminæ, Thecæ spherical subulate terminal

15295 Stem filiform dichotom. Branches expanded in cuneiform multifid laminæ, Thecæ stalked ovate cauline 15296 Stem filif, nearly simple expanded into a cuneif. palm. laminæ: segm. ligulate, Thecæ hemisph. sess. in disk 15297 Frond flat dichotomous, Segments linear-cuneiform. Thecæ hemispherical sess, on the disk of the frond 15298 Frond somew, channel, dichotom. Segm. lin. cuneif. Thecæ spheric, scatter. on short stalks on aisk of frond 15299 Frond membran. leathery flat somew. lanc. somew. branched ciliat. Ciliæ subulate bearing thecæ at end

15300 Frond cartilagin. compressed lin. somew, dichotom. Segm. ciliated, Ciliæ bear. thecæ either at sides or ends 15301 Frond cartilagin. corneous distich. branched, Segm. compressed flat linear bipinn. Pinnæ opp. spread, obt.

15302 Frond cartilagin. filif. compress. decomp. pinnated, Pinnæ horizontal altern. Pinnules bearing thecæ at end 15303 Frond cartilaginous much branched dichotomous pinnated, Segments tapered at base: lower compresed 2-edged; the last furcate acute

15304 Frond cartilaginous membranaceous dichotomous or palmate, Segments obtuse somewhat proliferous, Theca immersed in minute unequal processes

15305 Frond membranous dichotomous, Theca spherical marginal sessile

15306 Frond membranous dichotomous, Segm. linear : upper palmate crested entire, Theca margin. immersed

15307 Frond cartilagin. round filif. Branch. long simp. surround. by little branch. Theca hemispher. sess. scatter.

15308 Frond filif. corneous rigid equal with entang. branches, Branches horizontal 1-sided cluster. forked at end

15309 Fronds filif. much branch. Branchl. setaceous tapered at each end setac. Theca speric. attach. to branchl.

15310 Stem filiform dilated into a cartilaginous reniform or orbicular entire frond

15311 Frond fleshy flat simple cuneiform tapered at base into the footstalk rounded at end

15312 Frond coriaceous flat palmate entire, Segments cuneate oblong nearly simple

15313 Frond membranous tubular flat dichotomous, Axillæ rounded, Segments linear narrow by degrees sending out from the margin many simple ramenta

15314 Frond gelatinous coriaceous dichotomous, Segments filiform : end membranous dilated elliptical lanceol. 15315 Frond filiform with contracted articulations

15316 Frond subgelatinous filiform, Branches remote long, Sporules naked in the substance of the branches

15317 Frond filiform compressed much branched, Branchlets setaceous distichous simple pectinate on each side

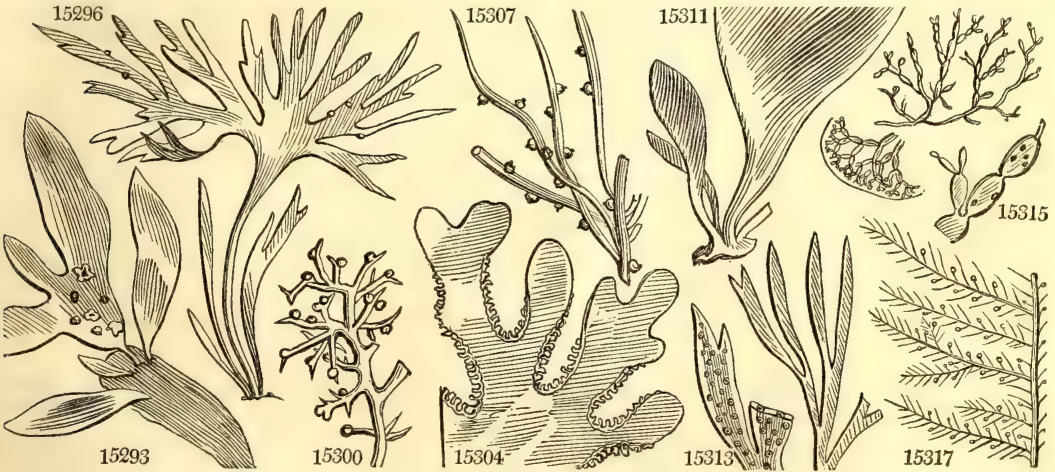

and Miscellaneous Particulars.

2315. Halymenia. From $\dot{\alpha} \lambda$, the sea, and $\dot{v} u n v$, a membrane. Marine plants with flat or tubular membranous fronds. H. edulis is the true Dulse, and H. palmata the common Dulse, both of which are eaten in Scotland.

2316. Bonnemaisonia. So called in honor of M. Bonnemaison, a French cryptogamic botanist, who particularly attended to Confervæ. 
2317. DeLesse'ri A. Ag. Delesseria. 15318 sanguínea $A g$. blood-colored bushy 15319 ruscifólia $A g$. 15320 hypoglóssum $\mathrm{Ag}$. 15321 aláta $\mathrm{Ag}$.

$\beta$ dilatáta $\mathbf{A g}$

$\gamma$ angustissima Ag. 15322 plocámium $\mathrm{Ag}$. 15323 laceráta $\mathrm{Ag}$. 15324 punctáta $\mathrm{Ag}$. ruscus-leaved fiat lobed proliferous

winged dilated very narrou scarlet torn dotted
Sp. 7-24.

6 ja. my. Fi.Pk ocean

4 ja. feb. Ri.pu ocean

3 jn. sep. Ri.pk ocean finely branch. 6 jan au dp.pk ocean finely branch. 6 jan.au. dp.pk sea shore finely branch. 6 jan.au. dp.pk sea shore finely branch. 4 su.aut. dp.pk ocean nearly simple 6 jl. oct. Pa.R ocean very tender 4 sum. Bt.pk sea shore
Eng. bot. t. 1041. Fucus Eng. bot. t. 1395. Fucus Eng. bot, t. 1396. Fucus Eng. bot. t. 1387. Fucus

E. b.t.1242. F. coccineus Eng. bot. t. 1067. Fucu Eng. bot. t. 1573. Fucus

\section{FUCOIDE AE.}

2318. LEM A'NEA. Ag. Lemanea. 15325 fluviátilis $\mathrm{Ag}$. \& média Ag. 15326 torulósa $\mathrm{Ag}$. fluviatile lax tufts torulose tufts

2319. Chorda'ria. Ag. Chordaria. 15327 flagellifórmis $\mathrm{Ag}$. flagelliform long masses

2320. SCYTOSI'PHON. Ag. ScrtosiphoN.

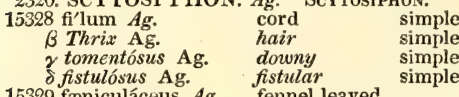

15329 fæniculáceus $\mathrm{Ag}$. fennel-leaved

2321. SPOROCH'NUS, $A g$. SporochNus

15330 pPOROCH NUS. 15330 pedunculátus $\mathbf{A g}$.

15332 viridis $\mathrm{Ag}$.

1530 villosus Ag.

major

15335 ligulátus $\mathrm{Ag}$.

Ag. SpOROCHNUS.

aculeate

green

villous

warted

large

ligulate

2322. HALI'SERIS. Ag. Haliseris

15336 polypodioídes $\boldsymbol{A g}$. polypodi.-like

2323. ENCE'LliUM. Ag. Encolium.

15337 bullósum $\mathrm{Ag}$. blistered

2324. ZONA'RIA. Ag. Zonaria. 15338 pavónia $\mathrm{Ag}$. 15339 dichótoma $\mathrm{Ag}$

Turkey fe

15340 multífida $A g$.

dichotomous multifid

2325. LAMIN A'RIA. $A g$. Laminaria 15341 agárum $A g$ 15342 esculénta $A g$. 15343 digitáta $\mathrm{Ag}$. 15344 bulbósa $A g$. 15345 saccharina $A g$. B bulláta Ag. 15346 phýllitis Ag. saccharine tender much branch. 24 sum. Lt. su. sea shore very finely br. 18 sum. OIG ocean downy 6 sum. $\mathrm{Pa}$.Y sea shore smth. branch. 2 sum. Y.Br ocean smth. branch. 3 sum. Y.Br ocean much branch. 48 sum. Ol.G ocean

$$
\text { Sp. 1-5. }
$$

$6 \begin{aligned} & \text { Sp. 2-5. DI G stones in riv. } \\ & \text { sum. DI G }\end{aligned}$

6 sum. Dl.G rivers Sp. 1-5.

Sp. 2.

24 sum. Br.Ol ocean

60 sum. Br.Ol sea shore

120 sum Brol ocean

E. bot. t. 1763. Conferva Act. holm. 1814, t. 2. f.

Eng. bot. t. 1222. Fucus

Turn. fuci, t. 86. Fucus Stackh. fuci, t.12. Fucu Lyng.hydroph.dan.t.19 Eng. bot. t. 642. Ulva

Tu.fuci,t.234. F.subtilis

Eng. bot. t. 545. Fucus Turn. fuci, t.187. Fucus Eng. bot. t. 1669. Fucus Eng.bot.t.546. Conferva Lyngb. hydrop. dan.t.13 E.b. 1688 . C verrucosa

Eng. bot. t. 1636. Fucus

E.b.t.1758, F. membran

simple tubul. $6 \underset{\text { sum. }}{\mathrm{Sp.1}}$ Ol. $\mathrm{G}$ sea coast

E. b. t. $2570 . U$. Turneri

$$
\text { Sp. 3-34. }
$$

3 sum. Br.G occan

4 sum. Ol G ocean

3 aug. $\mathrm{Pa} . \mathrm{Ol}$ ocean

Sp. 6-25.

perforated large masses 60 sum. Br ocean esculent large masses 60 sum. $\mathrm{Br}$ ocean digitate large masses 60 all sea. Ol.G ocean bulbous large masses 60 all sea. Ol $\mathrm{Br}$ ocean large masses 48 all sea OlG ocean 48 all sea. Ol.G ocean
Eng. bot. t. 1276. Ulva Eng. bot. t. 774. Ulva Eng. bot. t. 1913. Ulva

Turn. fuci, t. 75. Fucus Eng. bot. t. 1759. Fucus Eng. bot, t. 2274 . Fucus Eng. bot. t. 1760. Fucus Turn fuci, t.163. Fucus E. b. t.1376. F sacchari. Eng. bot. t. 1331. Fucus

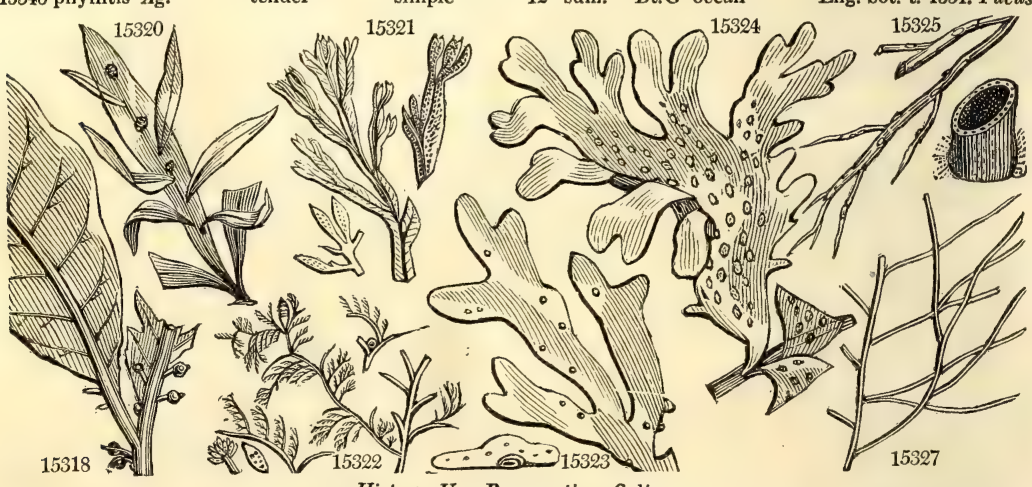

History, Use, Propagation, Culture,

2317. Delesseria. The most beautiful of the Fucus tribe, so named in honor of M. Benjamin Delessert, a distinguished French patron of botany; and now holding the same station among the scientific men of Paris, as was lately occupied in London by Sir Joseph Banks.

2318. Lemanea. Named in honor of M. Leman, a French botanist, who possessed a considerable knowledge of Algæ. This genus is the puzzle of writers upon Algæ. It differs from all the Nostochinæ in its substance, being in no way gelatinous, and in its compound structure, and separate fruit ; from Confervoideæ it is distinguished by its continuous frond, olivaceous color, and leathery texture. To Fucoideæ it most nearly distinguished by its continuous frond, olivaceous color, and leathery texture. To Fucoideæ it most nearly
related in color, substance, and structure, but it is akin to no other genus, and its habits are entirely different from those of Fucoideæ; the species being all found floating in fresh water.

2319. Chordaria. So called from the cord-like appearance of the species.

2320. Scytosiphon. The fronds of this genus are tubular and coriaceous; whence the name has been con

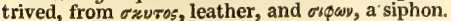


15318 Stem distinct, Ieaves ovate stalked entire costate, Nerves transverse parallel

15319 Stem winged, Leaves linear oblong subsessile proliferous from the costa, Veins diaphanous nearly parallel 15320 Stem winged, Leaves linear-lanceolate costate veinless proliferous from the mibrib netted

15321 Frond ribbed obsoletely nerved linear dichotomous alternately pinnatifid towards end, Pinnæ rather lingul.

15322 Frond pinnated dichotomous much branched, Last branches falcate inwards and pectinate

15323 Frond very fine linear irregularly split entire at end, Segments rounded at end not veined, Sori marginal 15324 Frond very thin veinless roundish irregularly split at the end, Sori on the disk of the frond

\section{FUCOIDEA.}

15325 Filaments simple papillose, Papillæ usually ternate, Articulations 5 times as long as broad $\beta$ Branched torulose in a moniliform manner here and there 15326 Filaments simple moniliform incurved 1-colored

15327 Frond much branched, Branchlets virgate somewhat distichous spreading at base

15328 Frond quite simple

15329 Frond setaceous branched in an irregular manner

15330 Recept. elliptical lateral as long as peduncle

15331 Branches spiny alternate

15332 Frond many times pinnated, Pinnæ opposite capillary

15333 Frond many times pinnated nodose, Pinnæ opposite, Nodi villous

15334 Frond irregularly branched, torulose and rugose in every direction

15335 Frond flat membranous scarcely nerved bipinnate, Pinnæ and pinnules opp. lin.-lanc. tapering at base

15336 Frond linear dichotomous entire, Sori heaped about the costa

15337 Frond inflated clavate

15338 Fronds reniform flabelliform smooth membranous, Zones concentric

15339 Dichotomous entire, Segments erect linear rounded blunt, Thecæ scattered on the disk

15340 Frond dichotomous entire, Segments long slender acute

15341 Stalk running through the lamina which is riddled with holes

15342 Stalk winged with pinnæ and running through the ensiform lamina

15343 Stalk round expanded into a roundish digitate split entire lamina

15344. Root inflated-bulbous, Stalk flat expanded into a digitate split entire lamina

15345 Stalk compressed expanded into an entire linear-oblong laminæ

15346 Stalk compressed expanded into a thin linear-lanceolate entire lamina

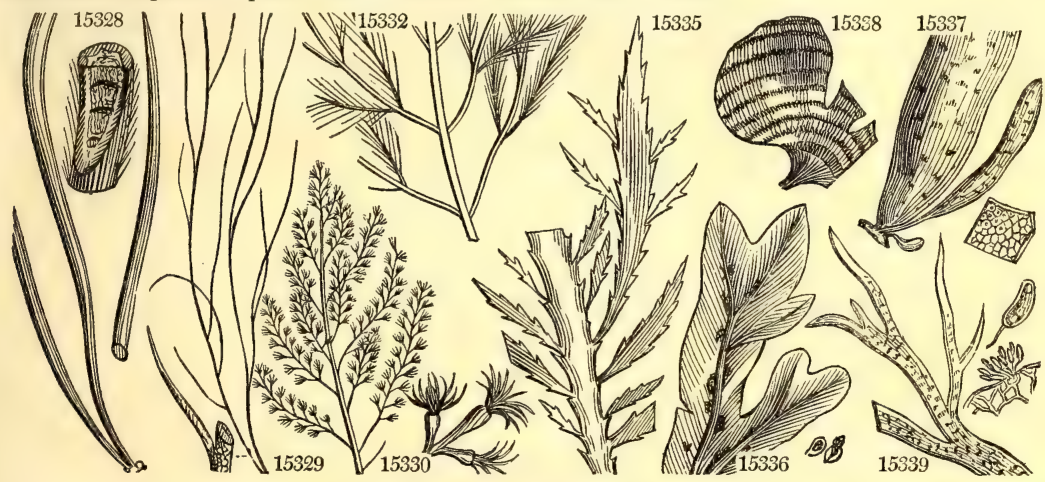

and Miscellaneous Particulars.

2321. Sporochnus. The meaning of this word is not explained. The genus is remarkable for the nature of the reproductive organs, which consist of a minute receptacle formed by some clavate corpuscles, which are jointed and arranged in a concentrical manner, and crowned with tufts of hair.

2322. Haliseris. This name literally signifies sea-cabbage ; from $\dot{\alpha} \lambda s$, the sea, and $\sigma \varepsilon \rho \xi$, a sort of cabbage

The broad membranous fronds are not unlike the leaves of cabbage.

2323. Encolium. From $\varepsilon y$, within, and zoi ${ }_{05}$, hollow. The fronds are all tubular and bladdery.

2324. Zonaria. Beautiful marine plants marked with transverse zones of lines, in which the organs of reproduction are supposed to exist.

2325. Laminaria. The reproductive organs of this genus are situated in the form of large sori upon the lamina of the frond. L esculenta is eaten in Scotland, where it is called Badderlocks. From L. saccharina, when dried in the sun, exudes a dry white sweetish substance, which is eaten as sugar by the poor inhabitants of Iceland. L. buccinalis furnishes the singular vegetable production called the sea-trumpet. 
2326. LICHI'NA. Ag. Lichina. 15347 pygmæ'a $\mathrm{Ag}$.
15348 confi'nis $\mathrm{Ag}$. 2327. FURCELLA'RI A. Ag. Furcellaria
15349 fastigiáta $\mathrm{Ag}$. 2328. FU'CUS. $\boldsymbol{L}$. 15350 nodósus $L$.

15351 vesiculósus $L$. $\beta$ longifrúctus Ag. $\gamma$ lineáris Ag. 15352 ceranoídes $\boldsymbol{L}$ 15353 dis'tichus $L$. 15354 serrátus $L$.

15355 canaliculátus $L$. 15356 tuberculátus Esp.

15357 lóreus $L$. Fucus. knotty Mackay's bladdery long-fruited linear horn-like distichous serrated channelled warted strap-like 2329. CYSTOSE'IRA. $\mathrm{Ag}$. Cystoseira.
15358 ericoídes $\mathrm{Ag}$. 15358 ericoídes 15359 barbáta $\mathrm{Ag}$. 15360 dis'cors Ag. 15361 fibrósa $\mathbf{A g}$.

15362 siliquósa $\mathrm{Ag}$. $\beta$ minor Ag. $\gamma$ denudáta Ag. heath-lik bearded variable fibrous podded small naked $\beta$ Mackáii Turn.

small patches $\begin{array}{ll} & S p .2 . \\ \text { sum. } & \end{array}$ small patches $\frac{1}{1} \frac{1}{2}$ sum.

Sp. 1.

Sp. 8-18

leathery bran. 36 dec. Ol.G ocean leathery bran. 24 dec. D.Br ocean loose masses 24 sp. su. Ol.G ocean loose masses $24 \mathrm{sp}$. su. Ol.G ocean loose masses $24 \mathrm{sp}$, su. Ol.G ocean bushy $12 \mathrm{sp}$. su. Ol.G ocean bushy $\quad 12 \mathrm{sp}$. su. Ol.G ocean masses $\quad 36 \mathrm{sp} . \mathrm{au}$. D.Ol ocean small masses 6 sp, au. Y.Ol ocean branch, wart, 6 june Y.Ol ocean masses 36 sum. D.Ol ocean Sp. $5-45$.

coralloid 6 su.au. Ol.Br ocean much branch. 6 su. au. Ol.Br ocean bushy 6 su. wi. Ol. Br ocean bush. deform. 6 su. wi. Ol.Br ocean loose masses 24 au. sp. D.Ol ocean loose masses 8 au. sp. D.Ol ocean

loose masses 24 au. sp. D.Ol ocean

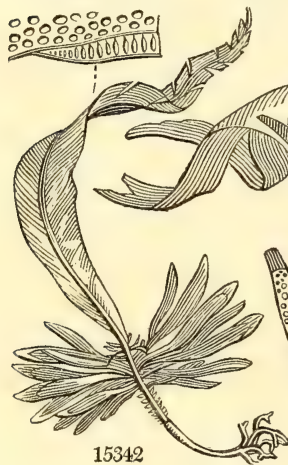

15344

15342

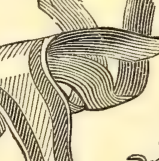

\section{E.b.t.824. F.lumbricalis}

Eng. bot. t. 570

Eng. bot. t. 1927

Eng. bot. t. 1056

Esper fuci, t. 146

Eng. bot. t. 2115

Turner fuci, $t .4$

Eng. bot. t. 1221

Eng. bot, t. 823

Eng. bot. t. 726

Eng. bot. t. 569

Eng. bot. t. 1968. Fucus Eng. bot. t. 2179 . Fucus Eng. bot. t. 2131. Fucus Eng. bot. t. 1969. Fucus Turn. fuci, t.159. Fucus Stackh. fuci,t.11. Fucus

History, Use, Propagation, Culture,

to its supposed convertibility into some one of the Lichen tribe. Sir James Smith has made one species a Lichen and the other a Fucus.

2327. Furcellaria. Named on account of the dichotomous forked or furcellate arrangement of the fronds. 2328. Fucus. So called by the Greeks. In Latin, the word signifies paint of any kind; a pigment staining red is afforded by certain species of Fucus. Fucus vesiculosus is much employed in the manufacture of kelp. It is common in great variety upon all the sea-coasts of these islands. It is known at first sight by its spherical vesicles filled with air. When the plant is dried, it becomes brittle, and of a dull black color, and sometimes it is covered with a saline efflorescence. Medically it is considered deobstruent, and has been found efficacious in scrofulous swellings. (Thom. Lond. Disp. 308.) 
15347 Frond flat with spherical tubercles

15348 Frond roundish with elliptical tubercles

15349 The only species

15350 Stem compressed here and there inflated with internal vesicles, Receptacles lateral distic. stalk. pyriform

15351 Frond flat ribbed lin. dichotom. entire, Vesicles spherical innate upon frond in pairs, Recept. term. elliptical

15352 Frond lin. costate ent. somew. dichotom. without vesicles, Lateral segm. narrowest multif. fruit-bearing

15353 Frond linear entire dichotomous without vesicles ribbed, Receptacles linear-elliptical

15354 Frond dichotomous ribbed serrated, Recept. solitary flat serrated

15355 Frond linear nerveless channelled dichotomous, Recept. terminal

15357 Cup radic. circular plano-convex emitt. from its centre a frond terminat. in a very long dichotom. recept.

15358 Lvs. densely spiny all over, Vesic. ellipt. somew. term. crown. solit. Recept. warty from inflat. base of spines 15359 Lvs. filiform dichotom. unarmed, Vesicles lanceolate chained, Recept. terminal ovate ellipt. mucronate 15360 Lower leaves thin costate pinnate, Pinnæ lanceolate crenulate, Vesicles lanceolate somewhat solitary

15361 Lvs. unarmed filif. much branched, Vesicles innate ovate-elliptical somew. chained, Recept. filif. terminal 15362 Stem compressed pinnated, Leaves distichous flat linear entire, some bearing vesicles, others receptacles

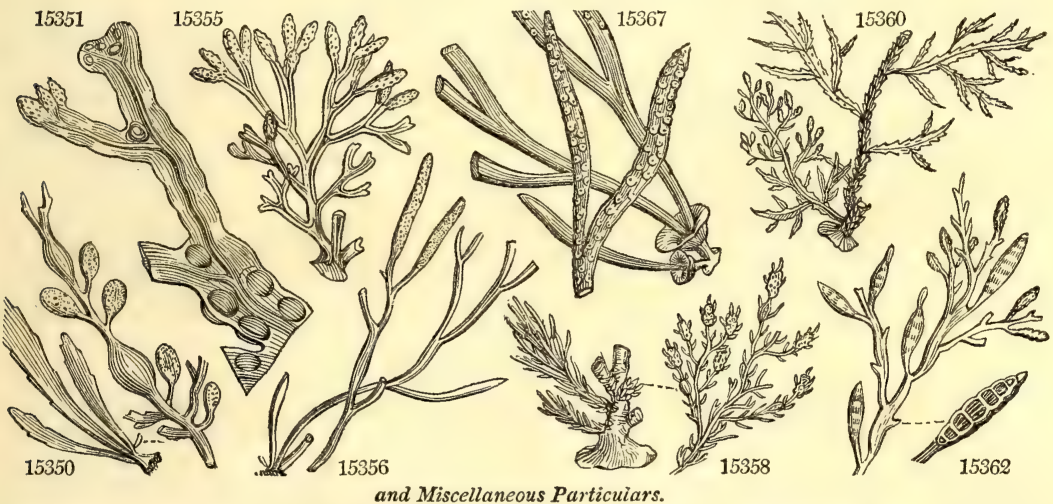

For rural economy, this and other species of Fucus are burned for their ashes, which produce the kelp or potash of commerce. On those shores of the sea where these plants do not abound, and where the water is sufficiently saline, the different species of fuci are raised artificially, by depositing stones at regular distances, on which the fuci spring up of themselves, and in four years yield a crop fit for cutting. Those who are interested on this subject will find ample information in the Transactions of the Highland Society of Scotland (vol. viii.), and in Headrick's Survey of Forfarshire. A condensed view of what is known on the subject will be found in the Encyclopædia of Agriculture in loco.

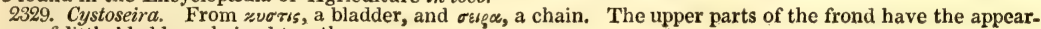
ance of little bladders chained together. 


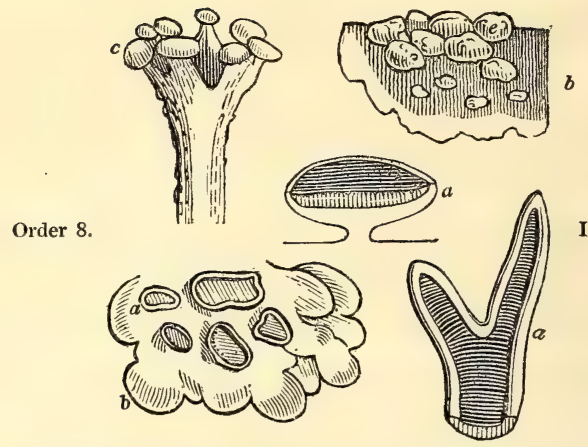

I.ICHENS,

Reproductive organs uniform. Sporules deposited in receptacles of various forms, distinct in substance from the thallus or frond, which is either pulverulent, crustaceous, membranous, foliaceous, or branched and shrub-like.

Tuis, Algæ, and the collateral order Fungi, may be said to exhibit the lowest stage of vegetable developement, and to contain the simplest forms of which plants are susceptible. Indeed it seems that each is resolved into the other when in the least stage of composition. Of this order, the lowest tribe, Pseudo-Lichenes, are considered Fungi by some authors, and have been formed into a distinct order by others, under the name of Hypoxyla. Here it seems best to consider them Lichens.

The fructification is usually in the form of shields or cup-like receptacles $(a)$, dispersed over the surface of the frond or thallus $(b)$, and bearing various names according to their nature. Apothecia is the common term used to designate the fructification. Podetia are the stalk-like processes of the frond $(c)$, which bear the apothecia on their summit. Scyphce are cup-like apothecia. Cyphella are pale tubercular spots on the under side of the frond. Lacunae are small hollows or pits on the upper surface of the frond. Soredia are little heaps of free, pulverulent bodies, mostly of a whitish color, placed on various parts of the frond (e). Pulvinuli are spongy, excrescence-like bodies arising from the frond, and often resembling minute trees. Nucleus proligerus, or kernel, is a distinct cartilaginous body coming out entire from the apothecia and containing sporules. Lamina proligera is a distinct body containing the sporules, separating from the apothecia, often very convex and variable in form, and mostly dissolving into a gelatinous mass. The arrangement of Acharius, which is the most celebrated, is here followed.

\section{Tribe I. IDIOTHALAMI.}

Apothecia differing in color from the rest of the plant, and formed of a distinct substance.

1. Apothecia simple, entirely formed of a sub-uniform, pulverulent, or cartilaginous substance. HомоGENIX.

* Apothecia destitute of a raised margin.

2330. Spiloma. Plant crustaceous, spreading, plane, adnate, uniform. Apothecia composed of minute bo dies, collected into a compact, homogeneous, subpulverulent, naked, and shapeless colored mass.

2331. Solorina. Plant foliaceous, coriaceous, lobed, separate beneath, and veiny or fibrous with down Recept. adnate, roundish, not edged, covered by a colored membrane, and containing a solid, cellular, bladdery parenchyma.

** Apothecia with a raised border.

2332. Lecidea. Plant various, crustaceous, spreading, adnate, and uniform or foliaceous. Apothecia scutelliform, sessile, surrounded by a cartilaginous membrane; the disk of the same nature as the raised border.

2333. Calicium. Plant crustaceous, plane, spreading, adnate, uniform. Apothecia cup-shaped, sessile, or stipitate, cartilaginous, containing a compact pulverulent mass, plane or convex, and forming a naked disk.

2334. Gyrophora. Plant foliaceous, coriaceous, or cartilaginous, peltate, mostly monophyllous, free beneath. A pothecia subscutelliform, sessile, or adnate, covered with a black cartilaginous membrane; the disk warty or plaited in circles, and bordered.

\section{\$2. Apothecia subsimple, included, formed of a single covering, containing a capsular body or nucleus. HETEROGENI.}

2335. Endocarpon. Plant crustaceous, adnate, of some determinate figure, or foliaceous and peltate. Apo. thecia globose, concealed in the substance of the plant, surrounded by a thin membrane, furnished with a slightly prominent orifice, and containing a nucleus.

\section{Tribe II. CoENothalami.}

Apothecia partly formed from the substance of the plant.

51. Apothecia included in wart-like processes, formed from the substance of the plant. PHYMatoIder.

2336. Thelotrema. Plant crustaceous, cartilaginous, plane, spreading, adnate, uniform, with wart-like receptacles, furnished with a wide pore, and bordered. Apothecia included, and containing a nucleus within a double covering.

2337. Pyrenuila. Plant crustaceous, plano-expanded, adnate, uniform. Recept. wart-like, formed of the thallus, enclosing or surrounding at the base a solitary thalamium, with a simple, thick, papillose perithecium, containing a globose cellular nut.

2338. Variolaria. Plant crustaceous, plane, spreading, adnate, uniform. Apothecia wart-like, forme from the crust (resembling soredia), submarginate, white, including a naked nucleus.

\section{Apothecic scutelliform, subsessile, the disk of a peculiar color different from the border, which is formed from} the crust. DiscoIDEI.

2339. Urceolaria. Plant crustaceous, spreading, adnate, uniform. Apothecia shield.like, the disk concave, colored, immersed in the crust ; border formed from the crust, and the same color.

2340. Lecanora. Plant crustaceous, spreading, adnate, plane, uniform. Apothecia shield-like, thick, adnate, ai:d sessile, the disk plano-convex, colored; border thickish, somewhat free, formed from the crust, and the same color

2341. Parmelia. Plant foliaceous, between coriaceous and membranaceous, spreading, appressed, orbicular, lobed, and stellate, variously divided, fibrous beneath. Apothecia shield-like, attached by a central point; the disk concave, colored, with a border formed from the crust. 
2342. Borrera. Plant cartilaginous, branched, and laciniate, the segments free, channelled beneath, and ciliate at the margin. Apothecia shield-like, with a colored disk; the border formed from the frond.

2343. Cetraria. Plant cartilagino-membranaceous, ascending or spreading, lobed, smooth, and naked on both sides. Apothecia shield-like, obliquely adnate with the margin, the disk colored, plano-concave; border inflexed, derived from the frond.

2314. Sticta. Plant foliaceous, coriaceo-cartilaginous, spreading, lobed, free and pubescent beneath, with little cavities or hollow spots. Apothecia shield-like, fixed by a central point, the disk colored, plane ; border formed from the crust.

2345. Peltidea. Plant foliaceous, coriaceous, spreading, subadnate, lobed, with woolly veins beneath. Apothecia orbicular, adnate, on produced portions of the frond, the disk colored; border very thin, formed from the frond.

2346. Nephroma. Plant foliaceous, coriaceous, membranous, expanded, lobed, beneath separate, and naked or villous. Recept, resupinate, formed of the ascending lengthened lobes of the thallus. Fertile lamina reniform, entirely attached to the thallus and its lower side, and surrounded by an elevated inflexed margin.

2347. Roccella. Plant coriaceous, cartilaginous, branched, laciniated, round or flat, erect or pendulous, woolly inside. Recept. shield-like, thick, growing into the thallus. Fertile lamina forming a disk, plano-convex, colored, and cartilaginous, in the inside hyaline, and of a similar nature, surrounded by a margin, which is elevated, sessile, and as deep as the disk, and which contains a compact black powdery mass, which is hidden within the substance of the thallus.

2348. Evernia. Plant branched, laciniate, angular, or compressed, suberect or pendulous, with a central filament within. Apothecia shield-like, sessile, the disk concave, colored; border formed the frond

\section{Apothecia subglobose, terminating the branches or podetia, or scattered, sessile, and emarginate.} CEPHaLOIDEI.

* Apothecia covered by the mass of the fructification.

2349. Cenomyce. General receptacle subcartilaginous, foliaceous, laciniate, subimbricated, free (rarely adnate, uniform, or wanting). Apothecia on podetia, orbicular, immarginate at length, capituliform, bearing thick colored masses of fructification.

2350. Baeomyces. Plant crustaceous, spreading, plane, adnate. Apothecia on short, soft, solid, simple podetia, capituliform, solid, immarginate, colored, convex, reflexed at the margin.

2351. Isidium. Plant crustaceous, plane, spreading, adnate, uniform. A pothecia on very short solid podetia, orbicular, convex, solid, terminal; the disk subimmersed, having a border formed from the substance of the podetia.

2352. Stereocaulon. Plant shrubby, cartilaginous, branched. Apothecia turbinate, sessile, solid, plane above, at length subglobose, with a border formed from the frond.

** Apothecia clothed with the substance of the frond, and containing a pulverulent mass.

2353. Spharophoron. Plant cartilaginous, fibrous within, solid, shrubby, branched. Apothecia sessile, terminal, subglobose, bursting irregularly, and containing a black, globular, pulverulent mass.

\section{Tribe III. HOMOTHALAMI.}

Apothecia entirely formed of the substance of the frond, and of a similar color.

2354. Alectoria. Plant cartilaginous, subfiliform, fibrous, and somewhat fistulose within, branched, prostrate, or pendulous. Apothecia shield-like, thick, sessile, bordered, wholly formed from the frond.

2355. Ramalina. Plant cartilaginous, fibrous, and nearly solid within, branched, somewhat shrubby, mostly sorediferous. A pothecia shield-like, thick, subpedicellate and subpeltate, plane, bordered, wholly formed from the substance of the frond.

2356. Cornicularia. Plant cartilaginous, fibrous, and nearly solid within, branched, shrubby. Apothecia orbicular, terminal, obliquely peltate, at length convex, somewhat inflated; the border dentate.

2357. Usnea. Plant much branched, filiform, mostly pendulous, furnished within with a bundle of elastic fibres. Apothecia orbicular, terminal, peltate, often ciliate at the border.

2358. Collema. Plant subgelatinous, homogeneous, crustiform, foliaceous, or somewhat branched, membranaceous or cartilaginous when dry. Apothecia shield-like, bordered, formed from the substance of the frond; the disk sometimes differing in color when dried

Tribe IV. ATHALAMI.

Lichens destitute of apothecia, and whose fructification is unknown.

2359. Lepraria. Whole plant crustaceo-pulverulent, spreading, adnate, uniform. Apothecia unknown.

Tribe V. PSEUDO-LICHENES.

Apothecia black, corneous, imbedded in a receptacle. Sporules in slender tubular cells, lying in a mulp, not spontaneously emitted.

2360. Opegrapha. Plant crustaceous, flat, expanded, adnate, uniform. Receptacle oblong and elongated, sessile, covered with a cartilaginous dark membrane, enclosing a solid parenchyma. Disk linear,'edged on each side.

2361. Verrucaria. Plant crustaceous, plane, expanded, adnate, uniform. Recept. hemispherical, roundish at the base, growing into the thallus, with a double perithecium; exterior somewhat cartilaginous and thick, having above a little pimple or perforation; inner very fine, and membranous. Kernel cellular.

2362. Porina. Plant crustaceous, cartilaginous, plano-expanded, adnate, uniform. Recept. wart-like, formed out of the thallus, and not margined. Thalamium imbedded in the substance of the wart, with a simple very thin perithecium, and a colored orifice thicker at the surface of the wart. Kerne! roundish, cellular.

2363. Arthonia. Plant crustaceous, plano-expanded, adnate, uniform. Recept. innate, sessile, of an irregular roundish figure, without an edge, covered by a somewhat cartilaginous membrane, and containing a solid uni. form kernel.

2364. Graphis. Plant crustaceous, plano-expanded, adnate, uniform. Recept. long, immersed in the thallus, with a simple cartilaginous perithecium, which forms an edge all round the linear kernel, which is naked at top and bottom, and cellular inside. 


\section{IDIOTH AL AMI.}

2330. SPILOMA. Ach. SpIloma. 15363 tumidulum Ach. tumid

15364 versícolor Ach. changeable

15365 microclónum Ach. fine-branched 15366 melanópum $E$. $B$. sooty 15368 murále $E$. $B$. wall scattered 15370 decolórans $E$. $B$. staining

15371 punctátum $E$. B. dotted 1537.2 variolósum $E . B$. speckled 15373 aurátum $E$. $B$. golden 233I. SOLORI'NA. Ach. Solorina. $\begin{array}{ll}15375 \text { crócea } \text { Ach. } & \text { yellow } \\ 15376 \text { saccáta } \text { Ach. } & \text { bagged }\end{array}$

2332. LECIDE'A. Ach. Lecidea. 15377 atro-cinérea $E . B$. dark-grey

15378 corácina Ach. raven

15379 atro-álba $A c h$.

(a)
black \& white

15380 fusco-átra $A c h$. dark-brown

15381 fumósa $\mathrm{Ach}$. smoky Lichen athrocar 15382 lapícida Ach. E. B. 1829. stone-splitting broad patches 3 all sea. G brick walls $\quad$ E. bot. 821. L.contiguus 15383 petræ'a Ach. 15384 cónfluens $A c h$. rock thin crust confluent tartareous

$1 \frac{1}{2}$ all sea. W roc. \& stones Eng. bot. 245

15385 paraséma Ach.

black-fruited

15386 sanguinária Ach. red-fruited

15387 sabuletórum Ach. heath

$\beta$ geochróa Ach. earth-skin

15388 miscélla $\mathrm{Ach}$. mixed

15389 escharoídes $E$. B. scarred

$S p .12-20$

thin skin 4 all sea. $O$

bark of trees Eng. bot. $215 i$

spotted crust 3 all sea. Gr bark of trees Eng. bot. 2070

cloudy

obl. patches

crust

$1 \frac{1}{2}$ all sea. Wsh aged oaks Eng. bot. 2150

2 all sea. Bl apple trees Eng. bot. 2358

$1 \frac{1}{2}$ all sea. Sea $\mathrm{G}$ old boards Eng. bot. 2396

3 all sea. Ysh old mortar Eng. bot. 2397

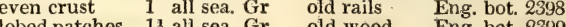
lobed patches $1 \frac{1}{2}$ all sea. Gr old wood Eng. bot. 2399

crust

cracked crust 2 all sea. Wr Wh old trees 2472 $\begin{array}{llll}\text { tumid crowd. } & 1 \frac{1}{3} \text { all sea. Wsh old walls } & \text { Eng. bot. } 2077 \\ \text { Eng. bot. } 2078\end{array}$ even patch 3 all sea. Cæs. sandst. rocks Eng. bot. 2555

Sp. 2-10.

leafy frond $1 \frac{1}{2}$ sp. su. Ol.G tops of mou. Eng. bot. t. 498 leafy frond 2 sum. Grsh on the earth Eng. bot. t. 288

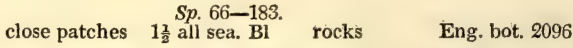

tessellated 2 all sea. Gr.Bl graniterocks E. b.t.2335. L.coracinus cracked crust 3 all sea. Bl rocks Eng. bot. t. 2336 thin crust 2 all sea. Bl rocks E.b.t.1734. L.dendritic. tessellated 3 sum. Br.Gr alpine rocks E.b.t.1830.L.cechumeñ. membranous 3 aut. Wsh bark of trees Eng bot. 14 rugose crust 2 all sea. Wsh rocks Eng. bot. 155 thin cuticle $1 \frac{1}{2}$ all sea. Wsh bark of trees lobed crust $\quad 2$ all sea. Pa.Ol whinst.rocks Eng. bot. 1831 granul, crust $1 \frac{1}{2}$ june $\quad$ D. Br earth \&rocks Eng. bot. 1247 lobed crust $1 \frac{1}{2}$ all sea. Ol old walls Eng. bot. 1777 15367 microscópicum $E . B$. microscopic 15374 tuberculósum $E$. B. warted

15390 aromática Ach. aromatic thin cuticle $1 \frac{1}{2}$ all sea. $\mathrm{Gr}$ bark of trees E. b. 1450. L.parasemus 15391 dolósa Ach. $\quad$ rusty spongy-crust. broad cuticle 4 all sea. Cæs. rocks $\quad$ Eng. bot. 2581 15392 atro-vírens $A$ ch. dark-green thin coat $\quad 2$ all sea. $\mathrm{Bl}$ rocks

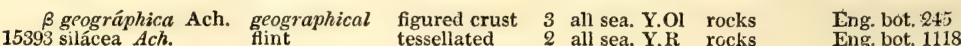
15394 Edéri Ach. OEder's tessellat.powd. 2 all sea. Rsh rocks $\quad$ Eng. bot. 1117

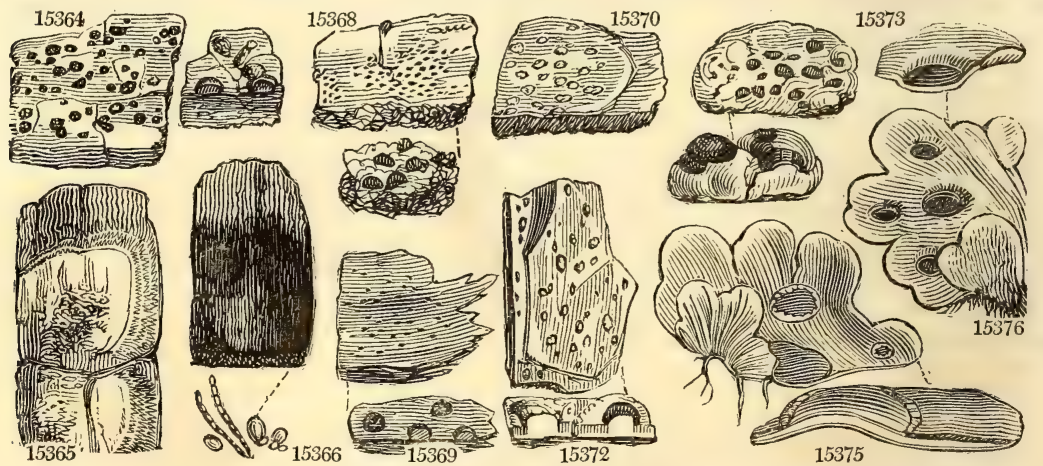

History, Use, Propagation, Culture,

2530. Spiloma. This word signifies in Greek, a spreading discoloration of the cuticle, and well expresses the general character of the genus. 


\section{IDIOTHALAMI.}

15363 Crust somewhat cartilaginous whitish, Apothecia crowded tumid oblong varying in figure roughish reddish at length brownish black and somewhat pruinose

15364 Crust somewhat cartilaginous powdery cracked variegated with cinereous and yellow, Apothecia immersed superficial roundish finally confluent

15365 Crust very thin glauc. Apothecia burst. forth min. convex cluster. and conflu somew. branch. dark-color. 15366 Crust very thin greyish, Apothecia flat diluted irregular somewhat confluent black

15367 Crust spread. widely very thin membran. greyish, Apothecia dot-like very min. black lead-color. when dry 15368 Crust obsolete or white, A pothecia very minute black confluent without bristles

15369 Crust filmy very thin green. grey, Apothecia mostly dispers. hemispher. sooty : internally yellowish green 15370 Crust spreading widely very thin; for the most part membranous greyish white, yellowish green when rubbed, Apothecia minute Hat confluent blueish grey

15371 Crust thin somew. powd. white, Apoth. scatter. min. dot-like solid black with superfic. dark-brown powder 15372 Crust tartar. rugg. greyish-white cracked, A pothecia convex round, very black : their centers often decid. 15373 Crust tartar. rugged greyish or greenish-white, Apothecia convex rounded black orange-colored within 15574 Crust calcareous greenish-white, Apothecia scattered somew. confluent unequal elevaied granulat. black

15375 Thallus green. (brown when dry) lobed : ben. veiny and of a fine saffron-col. Apothecia somew. tum. brown 15376 Thallus lobed grey.-green whiter and fibrous ben. Apothecia at length sunk into deep pits or hollows brown

\section{+ Thallus crustaceous reniform.}

* Apothecia constantly black, naked, (not pruinose).

15377 Crust tessellated greyish-black smooth, Apothecia several together depressed brownish-black with a paler border, at length crowded elevated the border being obliterated

15378 Crust continued tessellat. greyish-black, Apothecia immersed between the areolæ plane at length convex somewhat angular black of the same color within

15379 Crust spreading very thin cracked black with swelling whitish scattered areolæ, Apothecia plane or slightly convex often in the interstices black, of the same color within

15380 Crust very thin black cracked and tessellated areolæ chesnut-brown plane marginated shining scattered, Apothecia rather convex black margined white within

15381 Crust subcartilaginous tessellat. smoothish brownish grey, Apothecia buried in the crust plane margined at length convex clustered and losing their margin black within greyish-black

15382 Crust tartareous cracked whitish ash-color, Apothecia within the spaces of the crust depressed flat finally convex somewhat confluent dark with a thin edge

15383 Crust thin roundish very finely cracked somewhat powdery white, Apothecia grown into the crust thick protuberant somewhat concentrical dark-colored with a tumid elevated contracted margin

15384 Crust tartareous somew. spreading tessellated nearly even greyish-brown, Apothecia sessile at length irregular convex subglobose confluent black emarginate within having a thin greyish stratum ben. disk

15385 Crust thin submembranaceous greyish-white bordered with black at length spreading somew. granulated, Apothecia nearly plane sessile margined black blackish within

15386 Crust rugose and warted grevish-white, A pothecia at length convex hernispherical somew. tuberculated black horny and black within having beneath a powdery bright red stratum

15387 Crust scattered granular irregularly lobed cinereous whitish, Apothecia clustered convex sessile planoconvex hemispherical somewhat confluent dark powdery inside

$\beta$ Crust scattered granular somewhat cohering white cæesious or cinereous brown, A pothecia hemispherical somewhat globose often clustered shining

15388 Crust tartareous broken into cracks with wart-like smooth cracked cinereous areolæ, Apothecia deepiy immersed convex aggregate scarcely edged dark-colored

15389 Crust tartareous brownish ash-colored composed of granulated warts, Tubercles convex irregular black with an obsolete black border

15390 Crust somewhat cartilaginous scaly granular glaucous cinereous, Granules flattish crenulated, Apothecia sessile plano-concave erged finally wavy

15391 Crust rugose somewinat granular ferruginous ash-colored, Apothecia superficial flat edged finally fexuose and convex, Edge finally obliterated

15392 Crust spreading thin black scattered with plareish subcontiguous bright-yellow areolæ, Apothecia plane or slightly concave black of the same color within

\& Areolæ bright-yellow plane angular black between and with a black margin

15393. Crust tartareous tesse!lated yellowish-red, Apothecia sessi'e plane at length convex irregular confluent black internally cernuous and black

15594 Crust granulated and tessellated somewhat pulverulent ochraceous red, Apothecia minute elevated with the margin tumid: the disk depressed black nearly of the same color internaily

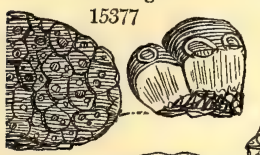
15379
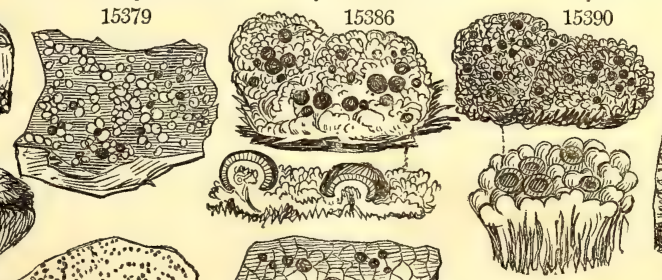

15393

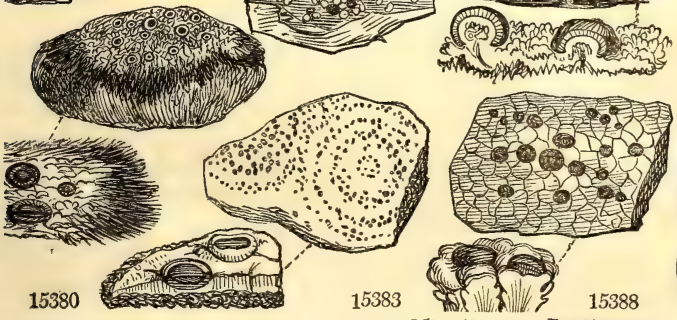

and Miscellaneous Particulars.

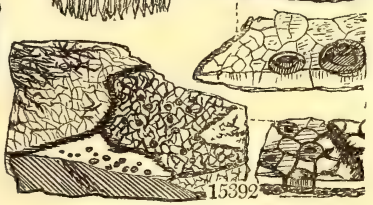

2331. Solcrina. From rodos, solid, and gryos, a skin, in allusion to the firm texture of the fond.

2332. Lecidea. An unexplairied name contrived by Acharius for the Lichenes tuberculati of Linnaus, whose shields have no border from the substance of the frond or crust. 
15395 alba Ach.

15396 citrinélla Ach. 15397 uliginósa Ach.

15398 scabrósa Ach.

15399 immérsa $\mathrm{Ach}$.

15400 rivulósa $A c h$ white

membranous 3 aut. W

bark of trees E. bot. 1349. Lepraria

lemon-peel-crust. cracked coat 3 spring Y.G sand.ground Eng. bot. 1877 marsh whole colored 3 spring Bi sandy heaths Eng. bot. 1466 rugged-shield, lobed patches 2 all sea. Pa.G tiled roofs Eng.bot. 1878

\section{immersed even crust $\quad 4$ all sea. Pa.Y calcar. rocks Eng. bot. 193}

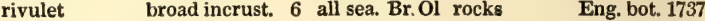

15401 albo-cæruléscens $A c h$. whitish-blue tartare. crust 3 sum. Wsh Scotch alps E. b. t.2244. L.pruinosus

$\beta$ turgida Ach turgid sinuated crust 3 sum $W$ stone walls E.b. 820 L.multipunct.

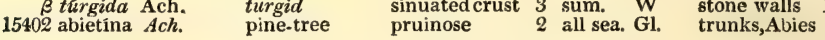

15403 speírea Ach. wavy sinuated crust 4 spring W.Y flint. pebbles Eng. bot. 1864

15404 epipólia Ach. thick tartare. crust 2 sum. W Scotch alps Eng. bot. 1137

15405 cortícola Ach. black \& white bark small verruc. 1 aut. Cæs. old trees $\quad$ Eng. bot. 1892

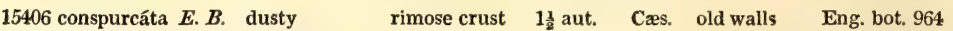

15407 Lightfo6tii Ach. Lightfoot's sinuat. patch. $\frac{3}{4}$ all sea. Pa.G smooth bark Eng.bot. 1451

15408 quérnea Ach. oak thin crust 3 all sea. Y.G clefts of bark Eng. bot. 485

15409 viridéscens Ach. greenish thin crust $1 \frac{1}{2}$ all sea. Pa.G dead trees

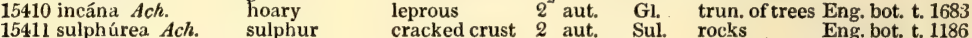

15412 orósthea Ach. downy toment. crust 3 all sea. Lt.G trees \& pales Eng. bot. t. 1549

15413 decolórans Ach. discoloring granular 2 sum, Grsh on earth

Bgranulosa Ach. granular. granular 2 sum. Grsh on earth E.b.t.1185.L.quadricol. $\begin{array}{llll}\text { Lichen escharoides E. B. } 1247 & & \end{array}$

15415 rupéstris Ach. $\quad$ rock

15416 lutéola Ach. $\quad$ yellowish thin crust 3 all sea. Wsh bark of trees Eng.bot.845. L. vernalis

15417 carnéola Ach. horny-cupped papillosecrust 3 all sea. Wsh on oaks Eng.bot.965. L. corneus

B arceutina Ach. Griffithian smooth coat 2 all sea. W.Br bark of trees E.bot.1735. L.Griffithii 15418 fusco-lítea Ach. yellow-brown thin crust 3 sum. Grsh mountains Eng. bot. 1007.

15419 cinéreo-fúsca $A c h$. cinereo.-brown cracked crust 3 all sea. Grsh trun. of trees

15420 anthracina Ach. dark scaly crust 2 sum. D.Br rocks \& trees E. bot. t.432. L. byssinus

15421 cæ'sio-rúfa Ach. bluish-brown tessellat. crust 3 sum. D. Gr rocks \& trees E.b.16j0. L. ferrugineus 15422 icmadophila Ach. Heath leprous crust 2 all sea. G.W on ear. in he. E.b.t.372. L. ericetorum

15423 marmórea Ach. marbled thin crust 3 all sea. Gr.W bark of trees Eng. bot. t. 739

15424 alabástrina Acl. Alabaster thin crust 2 sum. Gr.W Scotland E. bot.t.1651. L. rosellus

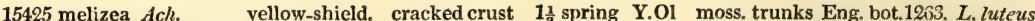
15426 Ehrhartiána Ach. Ehrhart's cartilag. crust 2 all sea. Gsh rocks Eng. bot. 1136

15427 polýtropa Ach. variable tessellated s 2 all sea. Pale rocks Eng. bot. 1264

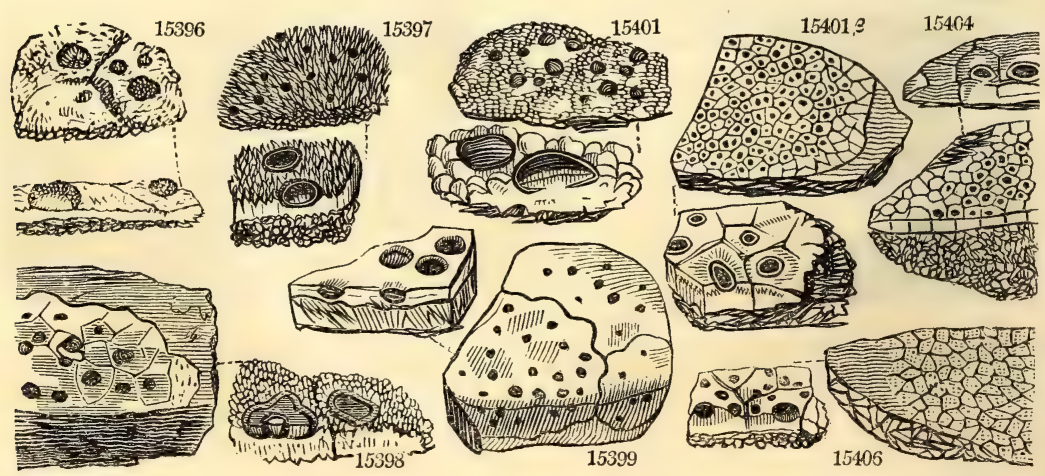


15395 Crust membranaceous white with a greyish or whitish-grey powdery substance scattered over it in small clusters, Apothecia minute appressed plane black

15396 Crust leprous granul, powdery green.-yell. A pothecia sess. margin. finally convex dark : of same col. inside 15397 Crust granular somewhat gelatinous greenish-brown, Apothecia appressed margined finally hemispherical clustered dark : of the same color inside

15398 Crust globose warted powdery cinereous yellowish, Apothecia convex scabrous

** Apothecia black, naked : when moistened becoming-red or brown.

15399 Crust thin whitish, Apothecia plano-convex immersed in the stone margined dark: disk pruinose;

when moistened crimson, white inside
15400 Crust cracked into areolæ brownish ash-color edged with dark lines, Apothecia sessile flat becoming convex edged irregular black

\section{*** Apothecia black with a grey bloom.}

15401 Crust tartareous contiguous even at length somewhat tessellated and whitish, Apothecia sessile and elevated plane black with a grey bloom and a black smooth border

$\beta$ Crust of a regular figure contiguous whitish cæsious, Apothecia immersed : disk depressed hollowish

15402 Crust spreading very thin smooth glaucous : fructification subsessile plane black with a grey bloom; the border raised and swelling

15403 Crust tartareous contiguous very white, Apothecia sessile thick black powdery margined becoming convex with an ash-colored layer under the disk

15404 Crust tartareous defined tessellated white areolæ swelling, Apothecia sessile hemispherical with a grey bloom black within with a thin persistent margin

15405 Crust somewhat tartareous granular areolated uneven very white, Apothecia minute somew. immersed cæsious becoming subglobose not margined dark cinereous inside

15406 Crust thick greyish-white cracked rugose at length mealy very white within, Apothecia numerous scat. tered minute: at first prominent and pale-brown; then concave and black

**** Apothecia black-brown, brownish, or deadened by some other color.

15407 Crust somewhat effuse granular cinereous greenish, Apothecia appressed flat dark-brown: inside dirtywhite with a thin flexuose edge paler than the disk

15408 Crust lep. granul. pale yellow,-brown, Apoth. somew, immers. becom. conv, not margin. brown and black

15409 Crust thin granulat. somew. farin. green or green.-brown : fructific. conv, rug. irregul. conflu. black.-brown

15410 Crust spread. leproso-farin. soft uneven glauc. green, Apothecia scatter. sess. brown with marg. ent. paler

15411 Crust tartareous cracked and broken uneven smoothish pale sulphur-color, Apothecia adnate plane scarcely margined brown and scarcely paler in the margin, at length irregular and convex

15412 Crust cracked areolated uneven somewhat powdery sulphureous, Apothecia minute sessile convex not margined whole-colored becoming hemispherical

15413 Crust granulated greyish-white, Granules becoming pulverulent, Apothecia nearly plane red fleshcolored livid or brown with the elevated margin paler, at length flexuose

15414 Crust firmer granulat. and subpapill. Apothecia at length hemispheric. rug. brown.-black and black conflu.

15415 Crust thin tartareous contiguous greyish-white, Apothecia immersed plane margined, at length convex : the margin persistent glabrous reddish-brown; of the same color within

15416 Crust thin whit. cover. with somew. globul. pale gran. at length grey. Apoth.sess. becom. conv. yel.-brown

15417 Crust thin membranous hoary finally granular powdery, Apothecia sessile concave thick tumid brown flesh-colored with an edge of the same color

B Crust very thin naked whitish, Apothecia flattish scarcely margined waxy purple brown and black

15418 Crust spreading very thin membranaceous white or greyish somew. shining subgranulose, Apothecia plane yellow-brown, at length red-brown with the margin paler elevated, at length flexuose

15419 Crust thin somewhat cracked uneven greyish-white : fructification plane, at length angular and irregular yellowish or reddish-brown; the border narrow persistent

15420 Crust spreading somewhat scaly uneven roughish darkish-brown, Apothecia minute plane reddish yellow with the margin paler, at length somewhat convex and brownish

\section{***** Apothecia dark-red, or whitish flesh-color.}

15421 Crust tessellated rugose darkish-grey, Apothecia plane rusty orange : the margin sometimes crenulate, at length convex with the margin obsolete blackish-red

15422 Crust leprose uneven somewhat granulated greenish-white, Apothecia nearly sessile plane flesh-colored, at length waved roughish in the disk: margin scarcely any

15423 Crust thin grey.-white, Apothecia somew. glob. at length urceol. white : disk flesh-color. ; marg. tum. ent.

15424 Crust thin smoothish minutely granulated greyish-white, Apothecia slightly convex entire whitish rosecolor paler at the margin

\section{****** Apothecia pale, yellowish, waxen or orange-colored.}

15425 Crust thin white powdery, Apothecia plano-convex smooth edged pale-yellow

15426 Crust cartilaginous cracked rugoso-plicate granulated white or greenish, Apothecia nearly sessile plane at length slightly convex waved unequal clustered pale yellowish

15427 Crust subtartareous tessellated pale, Apothecia nearly plane with the margin lobed waved clustered, at length subglobose destitute of margin yellowish flesh-color

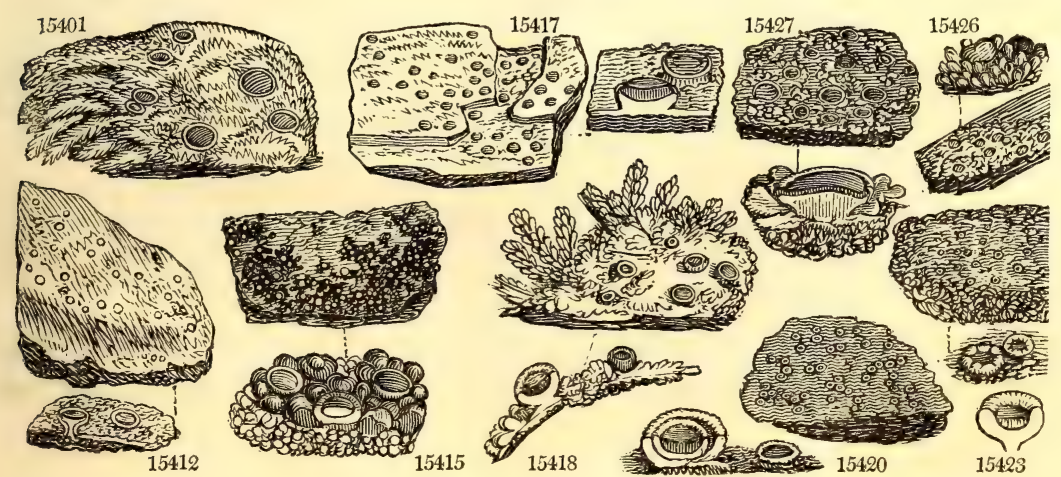


15428 licida Ach 15429 atro-fiáva $A c h$ 15430 luteo-álba $A c h$.

15431 cándida Ach.

15432 vesiculáris $A c h$.

15433 lúrida $A c h$. 15434 atro-rúfa $\mathrm{Ach}$.

15435 scaláris Ach.

shining

soft crust

2 sum. G.Y rocks

black \& yellow ragged crust 2 all sea. $\mathrm{Br}$

yellow-white smooth crust $1 \frac{1}{2}$ all sea. W

expos,

Eng. bot. 1550

$\begin{array}{llll}\text { hoary } & \text { sinuous } & 3 \text { all sea. Wsh old walls } & \text { Eng. bot. } 1138\end{array}$

blistered

imbricate

lurid

red-brown

imbricated

imbricated

3 sum.

3 sum.

4 sum.

scaly

15436 verruculósa $E$. B. warted

15437 rubifórmis $A c h$.

blackiberry

15438 decípiens Ach.

deceitful

scaly

15439 pholidióta $A c h$.

small-leaved

$\begin{array}{ll}15441 \text { canéscens } A c h . & \begin{array}{l}\text { hoary } \\ \text { intricate }\end{array}\end{array}$

$\begin{array}{ll}15441 \text { canéscens } A c h . & \text { hoary } \\ 15442 \text { dæedálea } E . B . & \text { intricate }\end{array}$

2333. CALI'CiUM. Ach. Calicium.

$\begin{array}{ll}15443 \text { tigilláre } \text {. Ach. } & \text { rail } \\ \text { 15444 stigonéllum } A c h . & \text { black sessile }\end{array}$

15445 microcéphalum Ach. small-headed

15446 claviculáre Ach. club-headed

15447 sphærocéphalum $A c h$. pin-headed 15448 hyperêllum Ach. convex

15449 chrysocéphalum $A c h$. yellow-head.

15450 trabinéllum Ach. brown 15451 cantheréllum Ach. cinnamon

154.52 capitellátum Ach. sulphureous 15453 aciculáre Ach. acicular

15454 ferrugíneum $E$. B. rusty

15455 in'quinans $E$. $B$. sooty-knobbed to $1545^{\circ}$ ró quidum $E$. $B$.

15457 débile $E . B$. weak

15458 æruginósum $E$. $B$. verdigrease

imbricated

irregul. patch. 1 aut.wi. Bl hard rocks Eng. bot. 2317

patches $\frac{3}{4}$ wint. Pa.G turfy earth Eng. bot. 2112

$\begin{array}{llll}\text { imbricated } & -2 & \text { spring } \mathrm{F} \text { earth } & \text { Eng. bot. } 870\end{array}$

leafy crust 4 spring Cæs. quartz, rocks E. b. 1955. L. glebulosus

broken patch. 2 spring Gr.G trees

Eng. bot. 2128

round. patch. $1 \frac{1}{2}$ spring W bark of trees Eng. bot. 582 leafy lobed $\frac{3}{4}$ spring Y.G rocks $\quad$ Eng. bot. 2129

soft crust $\quad 2$ aut. Gi. $_{\text {a. }}$ trees $\quad$ Eng. bot. 1530

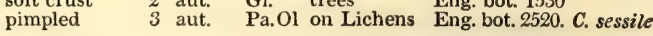
cloudystreaks $\frac{5}{4}$ dec. Ol. G oak rails Eng. bot. 1865 granul, crust $\frac{3}{4}$ aut. Grsh naked wood

thin crust $\frac{1}{2}$ spring Grsh old pales Eng. bot. 414 irregular coat 2 spring Bt.G old oak Eng. bot. 1832

patches $\quad 3$ aut. Lem trun. of trees Eng. bot. 2501

dense granul. 4 aut. Br.Ol boards Eng. bot. 1540 obscure crust $\frac{1}{2}$ aut. Wsh decay, wood Eng. bot. 2557

regularpatch. $\frac{1}{2}$ july $\quad$ G.Y sandy soil Eng. bot. 1539 irreg. incrust. 3 sum. Ol Scotch firs Eng. bot. 2385

lobed crust $\quad 4$ aut. $\quad \mathrm{Pa} . \mathrm{Ol}$ pales $\quad$ Eng. bot. 2473

tessellat.crust 4 wint. W.Br dead wood Eng. bot. 810 mealy coat 4 all sea. $\mathrm{G}$ old boards Eng. bot. 1464 close-set patc. $\frac{1}{2}$ aut. $\quad \mathrm{Br}$ old timiber Eng. bot. 2462 granular $1 \frac{1}{2}$ wint. Dl.G old boards Eng. bot. 2502

15459 cúrtum E. B. $\quad$ short-stalked crowd. patch. 112 wint. Dl.G decay.wood Eng. bot. 2503

2334. GYRO'FHORA. Ach. Gyrophora.

Sp. 8-19.

15460 glabra Ach

3 polyphýlla Wahl. many-leaved leafy thallus 2 sum. D.Ol rocks

$1546 \mathrm{i}$ proboscidea Ach. snouted netted frond 3 spring Sino. rocks

B arc'tica Acn. arctic smooth lobed $1 \frac{1}{2}$ wint. $\mathrm{Br}$ rocks

15462 cylindrica Ach. cylindrical folded frond 2 spring Gr.Ol rocks

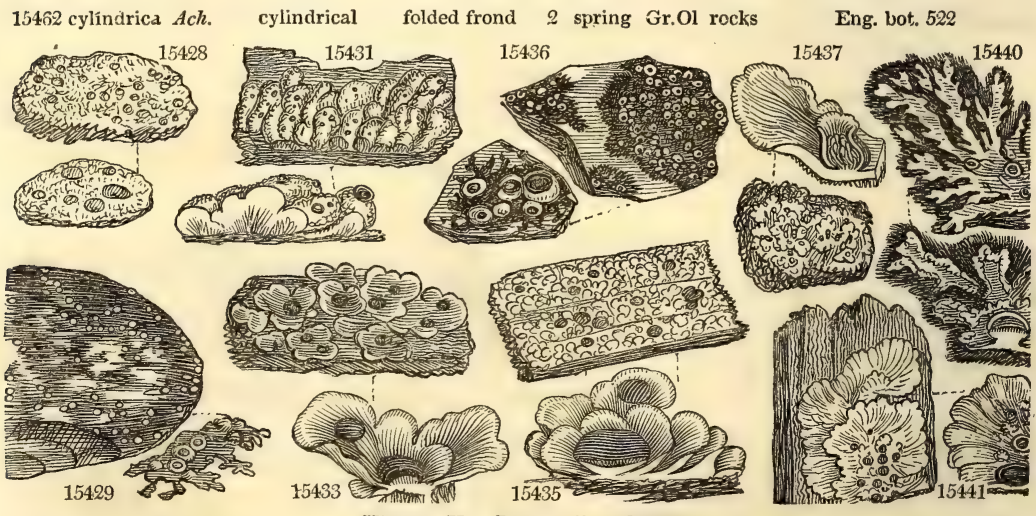

History, $\boldsymbol{U}_{3}$ e, Propugation, Culture,

2333. Calicium. From «civesoy, a little cup, well expressing the appearance of the organs of reproduction All the species form grey, white, or yellow patches, of various extent, on old wrought wood, or boards exposed to the weather.

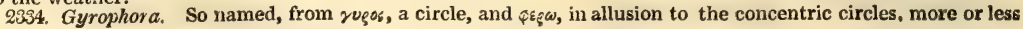

Eng bot. t. 1289 Eng. bot. t. 2483

Eng. bot. 2485

Eng. bot. 522 
15428 Crust thin leprose powdery soft pale green.-yellow, Apothecia slightly convex pale yellowish: marg. obsol. 15429 Crust thin effuse somew. granul, black, Apothecia min. cluster, flat yellow. with an elevat. ent. paler marg. 15430 Crust thin smooth. white, Apoth. crowd. at length convex hemispher. margin. orange-color. white within +t Thallus crustaceous, of a regular figure or leaf. LEPIDOMA.

15431 Crust somewhat imbricated white hoary, Lobes crenate reflexed tumid, Apothecia appressed black glaucous; edge finally wavy

15432 Crust somewhat imbricated brownish-black covered with a greyish powder, Lobes entire swelling, A pothecia black naked, at length hemispherical with the margin obsolete

15433 Crust imbricat. green,-brown, Lobes round, cren. paler ben A pothecia plane, at length somew. conv, biack

15434 Crust somewhat contiguous lobed areolate and imbricated cinereous brownish-lurid, Lobes becoming flexuose cut-crenate, Apothecia appressed not edged flattish finally confluent

15435 Crust imbricated pale olive-green, Lobes distinct reniform nearly erect beneath and the margin powdery, Apothecia plane margined glaucous black

15436 Crust indeterminate very thin fibrous black with white convex crowded smooth warts, Apothecia solitary in each wart depressed coal-black with a border of the same color

15437 Crust somewhat imbricated, Lobes rounded crenate livid-brownish white beneath surrounding the apothecia, which are hemispherical clustered reddish not margined

15438 Crust subimbricated, Lobes distinct subpeltate roundish flesh-colored and red brown whitish bensath, Apothecia in their border convex and subglobose black: inargin obsolete

15439 Crust imbricated glaucous white, Lobes minute rounded convex, Apothecia convex rufous brown becoming blackish : margin thin entire

15440 Thallus slightly imbricated fragmentary grey,-green on a dense black fibrous cushion : its segm. somewhat linear lobed crenate and granular at the margin, Apothecia scattered tawny paier at the.marg. at length convex brown obliterating the margin

15441 Crust orbicul. rugose plait. hoary lobed-plait. in circumfer. Apothecia central plano-convex dark-colored

15442 Closely imbricated radiated membranous very smooth brownish-grey pale with black fibres below: its segments linear obtuse undulated, A pothecia black with a black border of their own substance

15443 Crust areolated-warted smoothish wavy, Apothecia sessile dark upaque, Disk flat tumid at edye

15444 Crust somewhat contiguous unequal whitish or none, Apothecia sessile subgiobose dark smooth: disk dot-like becoming flattish with a thin shining margin

15445 Crust somewhat tartareous contiguous wrinkled olive-green, Apothecia roundish dark shining: disk depressed opaque, and stalks short whole-colored

15446 Crust effused greyish somewhat pulverulent: fructification subglobose, at length flattened gre ${ }^{-1}$ ish-black with a cylindrical thickish-black peduncle

15447 Crust very thin grey. smooth, A pothecia subglob. : disk dark-brown; margin greyish, Stripes filif. black 15448 Crust cartilaginous areolate rugose smooth yellow-green, Apothecia lentiform ferruginous powdery, Stems short cylindrical dark-pitch color thicker at base

15449 Crust lemon-yellow granulated and conglomerated: fructification subturbinate; disk brown convex, the border yellow and pulverulent, Peduncle filiform blackish and shining at the base

15450 Crust thin white ash-color. Apothe. becom. lentif. : disk black.-brown ciner. pruin. with a yell.-green marg.

15451 Crust thin whitish powdery, Apothecia lentiform: disk flesh-colored becoming brown powdered, Stalks filiform naked pale becoming brownish or black

15452 Crust effuse powdery greenish-yellow, A pothecia globose, and stalks filif. very long flexuose yellow.-green

15453 Crust leprous powdery pale yellowish-green, Apothecia hemispherical globose and stalks tapering upwards straight powdered with fulvous

15454 Crust thin granulated tartareous rusty white, Apothecia on short stalks thick black often compound with a pale rusty disk

15455 Crust white granulat. Tuber. a little prominent round flatt. gray.-black powdery with a smooth black edge $15+56$ Crust granulated smooth greyish-white, Tubercles scattered roundish black polished wrinkled irregular without a border mostly sessile

15457 Crust membran. very thin white, Tuber. black convex with recurv. marg. on long slend. wavy black stalks

15458 Crust thin tartareous somewhat granulated of a verdigrease-grey, A pothecia on slender black stalks black hemispherical with a convex brownish-black disk

15459 Crust filmy very thin whitish, Apothecia on thickish black stalks obovate or hemispherical black with black prominent loose powder

15460 Thallus smooth blackish-green : ben. smooth black and naked, Apothecia at length conv, rough and plait. $\beta$ Thallus of many lvs, or lobes variously fold. black, -green quite black ben. on each side naked and smooth.

15461 Thallus membranaceous with elevated reticulations, at length of a smoky ash-color rough smoother paler and subfibrillose beneath, A pothecia turbinate, at length convex variously plaited

$\beta$ Thallus thick hard rigid with elevated dots rugose olive-brown becoming black naked smooth paleyellow beneath, Apothecia globose

1546 Thallus somewhat naked dark greenish-grey folded and lobed strongly ciliated beneath smooth pale with branching fibres, Apothecia elevated nearly plane with concentric and plaited lines

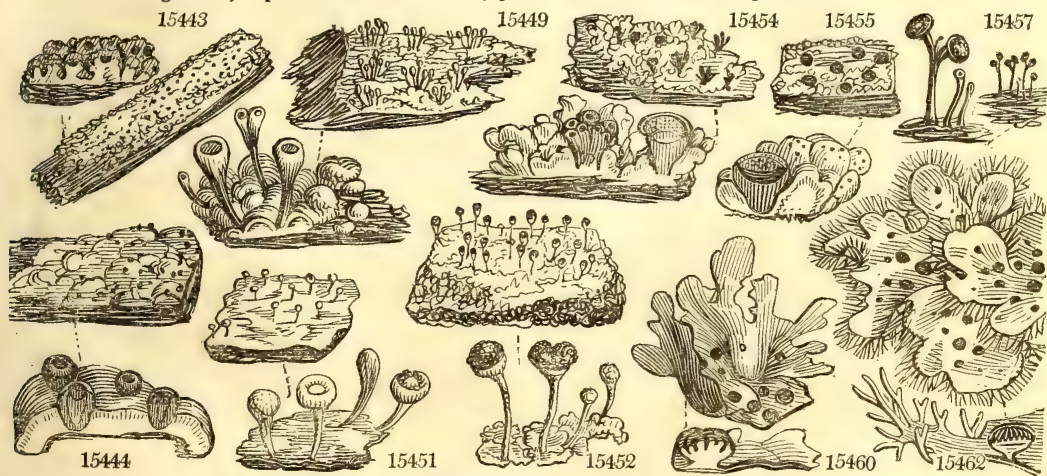

and Miscellaneous Particulars.

complicated, observable in the disk of the receptacles of the shields. The species grow chiefly upon exposed alpine rocks, chiefly on granite or volcanic stones. The vitrified forts in the Highlands of Scotland produce some of them. 


\begin{tabular}{|c|c|c|c|c|c|}
\hline 15463 erósa $A c h$. & knawed & ragged & 3 all sea. $\mathrm{Ol} . \mathrm{Br}$ & rocks & Eng. bot. 2066 \\
\hline 5464 deústa $A c h$. & scorched & rough leafy & 3 all sea. $\mathrm{Ol} . \mathrm{Br}$ & rocks & Eng. bot. 2483 \\
\hline 15465 pustuláta Ach. & pimpled & blister'dfrond & 2 spring Cin. G & rocks & Eng. bot. 1283 \\
\hline 15466 pellíta $A c h$. & furred & sinuated & 2 all sea. G.Br & rocks & Eng. bot. 931 \\
\hline 15467 murina Ach. & mouse-skin & irregular lob. & 1 all sea. $\mathrm{Br}$ & rocks & Eng. bot. 2486 \\
\hline $\begin{array}{l}\text { 2335. ENDOCAR'PON. } \\
15468 \text { sinópicum Ach. }\end{array}$ & $\begin{array}{l}\text { Ach. EN } \\
\text { cracked }\end{array}$ & $\begin{array}{l}\text { RPON. } \\
\text { tessellat. mass. }\end{array}$ & $\begin{array}{l}S p p_{1} 10-22 . \\
1 \text { sum. Or }\end{array}$ & schist & Eng. bot. 177 \\
\hline 15469 smarágdulum $A c h$. & yellow & little patches & $\frac{3}{4}$ sum. $\quad$ Y.G & rocks & Eng. bot. 1512 \\
\hline $\begin{array}{l}15470 \text { tephroídes Ach. } \\
\text { Lichen fuscellus } \mathrm{E} \text {. } \\
15471 \text { Hedwigii Ach. }\end{array}$ & $\begin{array}{l}\text { brownish } \\
\text { B. } 1500 \\
\text { Hedwig's }\end{array}$ & $\begin{array}{l}\text { little patches } \\
\text { crowd. patch. }\end{array}$ & $\begin{array}{ll}1 \text { sum. } & \text { Gl. } \\
\frac{1}{4} \text { sum. } & \text { Ol }\end{array}$ & $\begin{array}{l}\text { earth } \\
\text { on the earth }\end{array}$ & $\begin{array}{l}\text { Eng. bot. } 2013 \\
\text { E. b.t.595. L. tra }\end{array}$ \\
\hline $\begin{array}{l}\text { B lach'neum Ach. } \\
15472 \text { pálidum Ach. }\end{array}$ & $\begin{array}{l}\text { black-woolled } \\
\text { pallid }\end{array}$ & $\begin{array}{l}\text { crowd. patch. } \\
\text { finely lobed }\end{array}$ & ${ }_{\frac{1}{4}}^{\frac{1}{4}}$ sum. all sea. $\mathrm{Pa} \cdot \mathrm{O}$ & $\begin{array}{l}\text { on the } \\
\text { rocks }\end{array}$ & $\begin{array}{l}\text { Eng. bot. } 1698 \\
\text { Eng. bot. } 2541\end{array}$ \\
\hline 15473 parasíticum Ach. & parasitical & round. patch. & sum. Cop. & on Lichens & Eng. bot. 1866 \\
\hline 15474 miniátum Ach. & vermilioned & thick crust & 1 all sea. Grsh & rocks & Eng. bot. 593 \\
\hline 15475 leptophýllum Ach. & fine-leaved & round patches & $\frac{8}{4}$ spring $\mathrm{Br}$ & rocks & Eng. bot. 2012 \\
\hline 15476 complicátum Ach. & entangled & coriaceo & $\frac{3}{4}$ all sea. Grsh & rocks & E.b.593.f.2.L.amphibius \\
\hline 15477 Webéri $A c h$. & Weber's & cartilaginous & win.sp. G.Br & wet rocks & E. bot. 594. L. aquaticus \\
\hline
\end{tabular}

\section{CEENOTHALAMI.}

2336. THELOTRE'MA. Ach. Thelotrema. Sp. 5-19.

15478 lepadinum Ach. enclosed smooth crust $1 \frac{1}{2}$ all sea. Wsh holly bark Eng.bot.678. L.inclusus

15479 exanthemáticum $A c h$. pallid tartareous 2 all sea. Grsh calcar. rocks Eng. bot. 1184

15480 variolarioides $\mathrm{Ach}$. Variolaria-like tessellated 2 all sea. $\mathrm{Pa} . \mathrm{Ol}$ bar. of trees

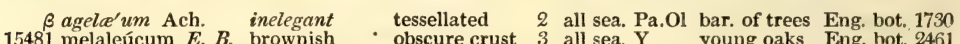

15482 hyménium $E$. B. wrinkled granular $\quad 4$ all sea. G old oaks Eng. bot. 1731

2337. PYRE'NULA. Ach. Pyrenula.
15483 nitida Ach.
shining

15484 nigréscens $A c h$. blackish tartareous $\quad 1 \frac{1}{3}$ all sea. Br.Bl rocks $\quad$ E. b. 1499. Ver.umbrina

15485 tesselláta Ach. tessellated circular dots 2 all sea. Ol.G slate rocks $\quad$ E. b. 2455. L. viridulus

15486 umbonáta $A c h$. nipple shielded even coat $\quad 1 \frac{1}{2}$ all sea. $\mathrm{Br}$ rocks $\quad$ E.b.2153. L.thelostomus

2338. VARIOLA'RIA. Ach. VARiolaria.
15487 veláta Ach.

15488 multipúncta Ach. much dotted granular 2 win. Gl. beech trees Eng. bot. 2061

15489 globulifera $A c h$. globuliferous uneven crust $1 \frac{1}{2}$ all sea. Grsh trees \& rocks Eng. bot. 2008

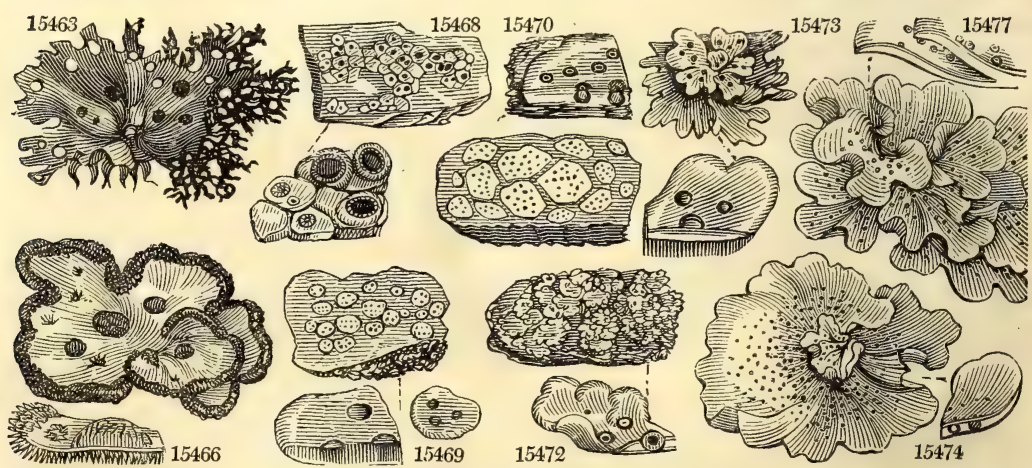

History, Use, Propagation, Culture,

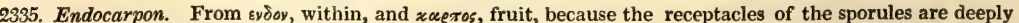
imbedded in the substance of the frond. The species form small roundish or angular plants, commonly closely sessile upon earth or stone; of a grey or olive hue; their fructification appearing like little black dots over the surface.

2336. Thelotrema. From $\uparrow \eta \lambda \eta$, a nipple, and $\tau \rho \eta \mu \alpha$, an orifice. The protruberances of the thallus are perforated. This genus has been reduced to Endocarpon by Sir James Smith. 
15463 Thallus rugged olivaceous brown, its circumference perforated and laciniated dark-grey : beneath glabrous somewhat granulated and fibrous, Apothecia somewhat convex variously plaited

15464 Thallus roughish olivaceous brown with a brown scattered dust smooth beneath with pits and reticulations naked of the same color, A pothecia plane with circular plaits, at length convex

15465 Thallus blistered and warty greenish ash-color ben. deeply pitted smooth palish-brown naked, Apothecia few plane margined : disk somewhat even papillose and plaited

15466 Thallus smooth sinuato-lobate of a greenish coppery-brown : beneath black with dense pulvinate fibres, Apothecia sessile, at length somewhat globose variously plaited intricate

15467 Thallus very rig. mouse-col. ben. black.-brown rough with elevat. paler spots, Apoth. conv. various. plait.

15468 Thallus crustaceous cracked into areolæ figured somewhat lobed greenish rubiginous depressed at the circumference, Orifices depressed black

15469 Thallus crustaceo-cartilaginous somewhat foliaceous minute subpeltate appressed plane roundish entire yellow-green, Orifices of the apothecia depressed reddish-brown

15470 Thallus crustaceous submembranaceous spreading and subfoliaceous contiguous wavy cracked glaucous ash-col. irregul. lob. and crenat. at marg. ben. black somew. spongy, Orifi. elevat. conv. black perforat.

15471 Plant subcartilaginous roundish or somewhat angular lobed of an olive-green : beneath pale at margin; the rest blackish and fibrillose, Orifice of the fructification subprominent dark-brown

$\beta$ Lobes of thallus aggregat. somew. imbricat. : margin elevated repand-lobed wavy with black wool beneath 15472 Thallus coriaceous membranous pallid leafy greenish crenate-lobed becoming irregularly ragged, Orifices hemispherical pale with a black dot

15473 Thallus coriaceous convex rounded lobed copper-colored, at length rugged black and shaggy beneath, Orifices scattered sunk minute coal black, at length convex

15474 Thallus thick crustaceo-cartilaginous foliaceous orbicular peltate greyish spread at marg. somewhat lobed and waved beneath smooth, at length rugose and tawny, Orifices minute slightly prominent brownish

15475 Thallus cartilaginous foliaceous orbicular peltate brown or greyish : the border spread and wavy smooth naked rough and black beneath, Orifices of the apothecia very minute slightly prominent black

15476 Thallus coriaceo-cartilaginous lobed greyish : beneath brownish-black; the lobes nearly erect rounded plicate and convolute, Orifices of the apothecia numerous convex black

15477 Thallus cartilagineo-coriaceous lobed greenish-brown olivaceous : beneath rather tawny or blackish on both sides smooth; the lobes laciniated waved plaited and crisped crowd. Orifices rather convex black

\section{COENOTH AL $A M I$.}

15178 Crust smooth whitish, Warts of the apothecia smooth somewhat cone-shaped with the margin of the aperture thin simple somew, inflexed and contracted covered at bottom with a membrane which bursts

15479 Crust subtartareous thin contiguous greyish, Warts of the apothecia convex half immersed whiter, Orifices much contracted radiated with fissures concealing the flesh-colored apothecia

15480 Crust nearly regular smooth rugulose cinereous, Warts of apothecia clustered irregular whitish with a large black aperture and a thick somewhat angular lacerated edge

$\beta$ Crust white powdery with granul. and min. soredia, Warts of apothecia appres. few and immers. in crust

15481 Crustaceous cream-colored with scattered rather convex warts opening by an irregular inflexed orifice, Apothecia immersed depressed brown

15482 Crust cartilaginous uneven somewhat polished greenish-grey, at length extremely tumid and uneven, Apothecia elevated crowded hollow very irregular

15483 Crust cartilaginous membranous polished pale brownish cinereous, Warts of apothecia closed closing surrounding the upper projecting part of the thalamium

15484 Crust tartareous somewhat tessellated unequal brownish-black, Warts of the apothecia spreading at the base depressed somewhat rugose surrounding the greater part of the prominent apothecia

15485 Crust tartareous unequal cracked into areolæ cinereous yellowish, Warts of apothecia enlarged at their base depressed closed clustered about the edged orifice

15486 Crust tartareous regular finely cracked cinereous rufous, Warts of apothecia smooth reddish depressed above forming a margin to the papilla-like prominent orifice

15487 Crust determined somewhat cartilaginous smooth very white plaited in rays, Warts of apothecia polished compressed tumid : kernel covered with a thin powdery skin

15488 Crust subcartilaginous cracked into areolæ granular cinereous, Warts of apothecia convex clustered granular: kernel lentiform enclosed

15489 Crust subcartilaginous greyish uneven with granules and soredia scattered in an irregular manner, Warts of fructificat. subglob. smooth, at length depressed above and soredifer. and contain. a concavenucleus
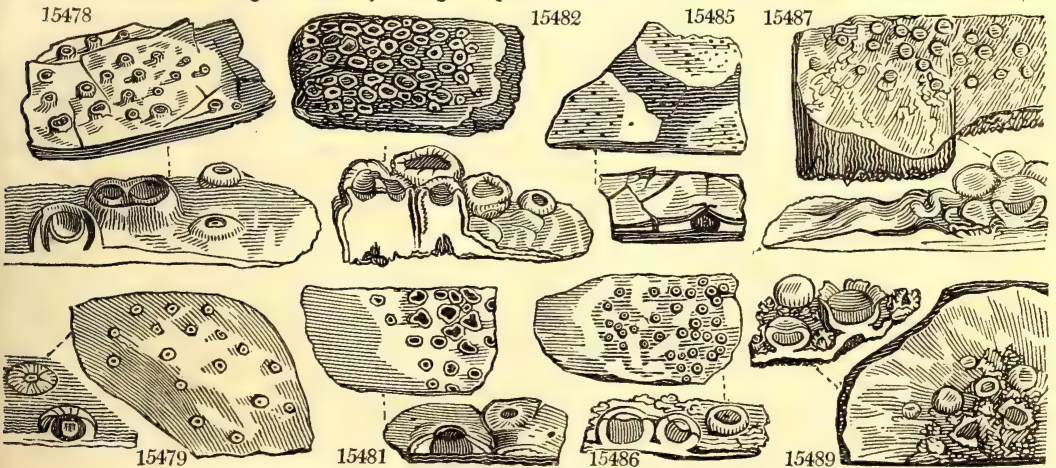

and Miscellaneous Particulars.

2337. Pyrenula. A diminutive of ru९nv, a kernel; in allusion to the manner in which the receptacle is enclosed in the thalamium, as a kernel within its shell. Crustaceous plants, found chiefly upon the bark of trees.

2338. Variolaria. The shields of these plants resemble the eruptive spots of the variolæ or measles. The whole genus was referred by Linnæus to his Lichen fagineus and lacteus. The species are of a crustaceous nature, found upon the trunks of trees, rocks, walls, or the ground. 
15490 commúnis Ach. common radiated $1 \frac{1}{2}$ all sea. Dl.W trees

$\beta$ aspergélla Ach. sprinkled radiated $1 \frac{1}{2}$ all sea. Y.Ol rails Eng. bot. 2401

15491 amára Ach. bitter

$\beta$ discoídea Ach. discoid pulverulent 2 all sea. $W$ bark of trees Eng. bot. 1714

15492 láctea Ach. milky tartar. crack. $1 \frac{1}{2}$ wint. W rocks Eng. bot. 2410

15493 griseo-vírens $E . B$. greyish green tukercular $1 \frac{1}{3}$ aut. D.Ol smooth bark Eng. bot. 2400

15494 dealbáta E. B. whitened cracked crust 3 all sea. Lt.Br hard rocks Eng. bot. 2519

1.5495 cinérea $E$. B. cinereous tubercular 2 all sea. Ol.G whinstone Eng. bot. 2411

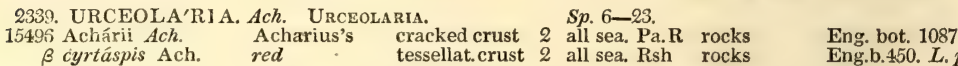

15497 gibbósa $A c h$ gibbous fringed patch. 3 all sea. $\mathrm{Br}$ flints

Eng.b.450. L. punctatus

15498 cinérea $A c h$. cinereous concent.zones 3 all sea. G.Br flints

Eng. b. 1732. L. fibrosus

15499 scrupósa Ach. rock

15500 Gágii $E$. B. Gage's

solid crust 1 all sea. Grsh rocks

Eng. bot. 1751

15501 calcárea $A c h$.

calcareous

obscure crust $1 \frac{1}{2}$ all sea. $\mathrm{Pa} . \mathrm{Y}$ rocks

Eng. bot. 266 ,

Eng. bot. 2580

$\beta$ Hoffmánni Ach. İ̈offmann's sinuous patc. $1 \frac{1}{2}$ all sea. Cæs. roc. \& stone Eng. bot. 1940

2340. LECANO'RA. Ach. Lecanora. 15502 átra Ach. dark

15503 argópholis Ach. pallid

15504 oculáta Ach. 15505 coarctáta Ach.

15506 pericléa $A c h$.

$\beta$ exígua Ach.

15507 sophódes Ach. obscure

mottled

contracted

rough

diminutive

brownish

15508 subfúsca $\mathrm{Ach}$.

15509 ventósa $A c h$.

15510 frustulósa $\mathrm{Ach}$.

15511 effúsa $A c h$.

15512 chloroleuca Ach. 15513 vária $A c h$.

15514 apocræ'a Ach. leprous

exposed

broken

scattered brownish

whitish green Leprous variab. shield. crowded

cartilaginous 2 all sea. Grsh trun. of trees Eng. bot. 2109

Sp. $46-79$.

granulated $1 \frac{1}{2}$ all sea. Grsh bark of trees Eng. bot. 949

warted crust 2 sum. Pale rocks

smooth. crust 2 spring W roc. \& earth Eng. bot. 1833 broad patches 4 all sea. Br brick walls Eng. bot. 534

little spots $\frac{1}{3}$ all sea. Wsh old posts Eng. bot. 1850

little spots $\quad \frac{1}{2}$ all sea. $\mathrm{Br} \quad$ old pales

Eng. bot. 1849

mealy crust $1 \frac{1}{2}$ aut. $\mathrm{G}$ on trees Eng. bot. 1791
Eng. bot. 906

Eng. bot. 2273
3 aut. G bark of firs Eng. bot. 1863

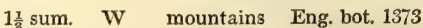

$\frac{3}{4}$ all sea. Lt. G old walls Eng. bot. 1666

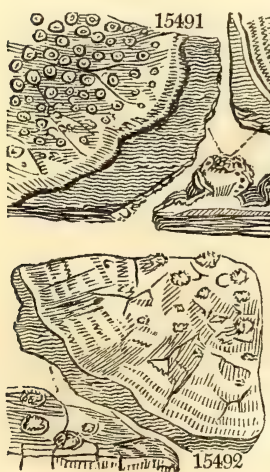

cloudy crust $1 \frac{1}{2}$ wint. Lt. $\mathrm{G}$ old posts

wint. Lt. G old posts Eng. b. 2075. Sp.Vitiligo
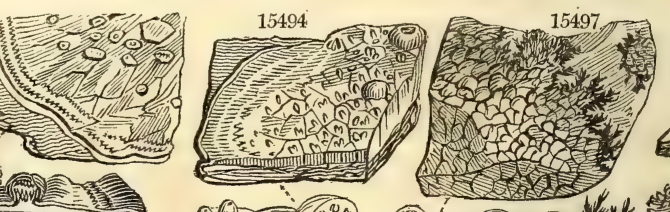

15500
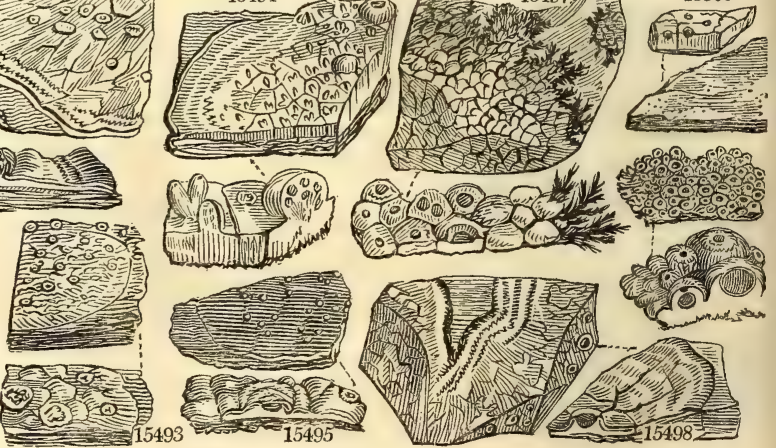

Fistory, Use, Propagation, Culture,

2339. Urceolaria. From urceolus, a little pitcher, with reference to the form of the shields, which are sunken in the crust. Natives of hard stones occasionally inundated, or upon naked exposed rocks; occasionally upon the trunks of trees. The crust of $U$. esculenta, a native of Tartary, is eatable.

2340. Lecanora. An unexplained name. Lecanora perellus affords a purple dye, and is called in the south of France, where it is employed in lieu of the L. tartarea, Perelle d'Auvergne, whence the specific name, as Smith 
15490 Crust cartilaginous polished whitish becoming unequal and ash-colored scattered with white soredia having no margin, Warts of apothecia spheroidal powdery

$\beta$ Crust tartareous cartilaginous determined glaucous with a polished radiated cracked circumference, Soredia scattered superficial flat not margined

15491 Crust rugose cracked uneven subpulverulent white or greyish, Warts of the apothecia appressed planoconcave margined bearing soredia of the same color as the crust

$\beta$ Crust pulverulent white, at length greyish naked, Soredia crowded, at length spreading waved planoconcave with the margin raised swollen

15492 Crust tartareous distinctly bordered cracked smooth white: the circumference somewhat zoned crenato lobate, Warts of the apothecia crowded margined very white and pulverulent

15493 Crust elliptical thin slightly tartareous rugged grey scarcely limited, Apothecia rounded with a narrow border, Powder greenish

15494 Crust tartareous thickish greyish-white cracked tumid papillary and rugged obscurely zoned at the cir. cumference, Apothecia orbicular prominent white

15495 Crust orbicular tartareous thin ash-colored cracked : its circumference indeterminate, Apothecia orbicular very small white with an elevated margin and flesh-colored disk

15496 Crust with a rather decided edge smooth with narrow cracks pale brick-colored : disk redd, ; marg. tum.

$\beta$ Crust bordered smooth tessellated reddish, at length white, Apothecia becoming elevated with the disk rather convex reddish-brown reaching the margin of the crust

15497 Crust papillose warted polished white ash-color : disk concave black immersed in the tip of the warts, Border contracted protuberant crenated entire

15498 Crust cracked areolate warted cinereous bordered with black : disk somewhat concave dark immersed among the warts becoming elevated, Border thickish projecting

15499 Crust rugoso-plicate granulated white or greyish : fructification urceolate; the disk black, the border swelling inflexed subrugose covering the disk

15500 Crust continued calcareous smooth brownish-white irregularly cracked when dry, Apothecia very minute blackish sunk in the crust

15501 Crust determined finely cracked somewhat powdery very white becoming cinereous : disk minute concave black powdered with white, Border prominent discoid thin

$\beta$ Crust thin cracked into areolæ equal dull ash-colored, Fertile areolæ raised in the middle whitish leadcolor: disk somewhat concave dark cæesious powdery

\section{+ Thallus adnate uniform. Rinodina.}

* Disk of apothecia constantly dark and black.

15502 Crust with a somewhat decided eige granulated and cracked greyish-white, Disk of the apothecia plane at length swelling and black : the margin free raised, at lerigth waved and crenulate

15503 Crust smooth uneven warted pale, Warts at length subimbricated somewhat lobed and deformed, Disk of the fructification concave brownish-black : the border sharp crenulate contracted

15504 Crust glab. papill. and branch. white, A pothecia sess. scattered : disk slightly concave black ; marg. tumid

15505 Crust effuse thin cracked rugose unequal cinereous, Disk of apothecia somewhat immersed finally elevated flat dark with an elevated inflexed powdery border

15506 Crust thin somewhat leprous and dispersed whitish, Disk of apothecia plano-convex dark dotted rough. Border obscure powdery

$\beta$ Crust uneq. obscure. ciner. black. Apothecia min. aggreg. flat with a white cren. border and brown. edge

** Disk of apothecia black, naked, brownish when moistened.

15507 Crust verrucose-granular from cinereous brownish-green, Apothecia heaped with a flat coarse dark disk brown when moistened, Border tumid inflexed entire

*** Disk of apothecia black, brown, brownish, or clouded with other colors, naked.

15508 Crust cartilaginous smooth, at length granulated unequal white or greyish, Disk of the apothecia planoconvex brown or almost black: margin tumid entire, at length waved and crenate

15509 Crust tessellated with tumid warts yellow green or grey, Apothecia appressed, at length irregular with the disk plane or swelling red brown, at length rising above the entire margin

15510 Crust tartareous very much cracked variegated with black and white (yellowish-white in dispersed tumid warts), Apothecia pale-brown, at length convex dark-brown : margin white

15511 Crust effuse thin powdery cinereous aruginous, Apothecia minute appressed : disk flat becoming convex pale-brown, Border thin obscure

15512 Crust thin leprose white, Apothecia crowded elevated : disk plane olive; the margin waved

15513 Crust unequal granular somewhat warted pale-green, Apothecia clustered: disk flat pale-brown and variegated, Border raised inflexed finally crenulate

15514 Crust effuse very thin polished whitish sometimes bearing soredia, Apothecia sessile ; disk flattish pale livid-brown, Border pale becoming crenulate

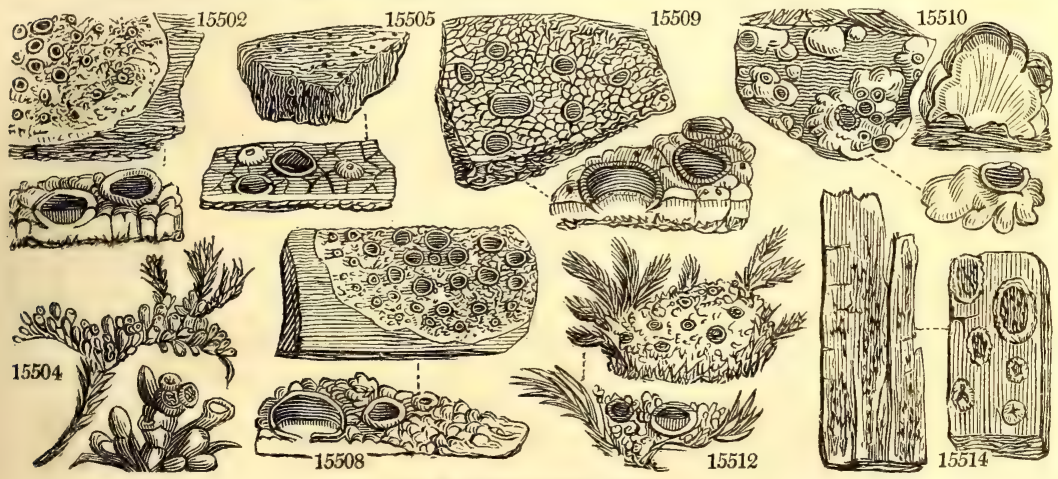

and Miscellaneous Particulars.

tells us, though generally spelled Parellus. L., Turneri is probably only a variety growing upon the bark of trees.

Lecanora candelaria derives its name from the circumstance of the Swedes employing it to stain the candles that are used in their religious ceremonies.

Lecanora tartarea is the famous Cudbear (so called after a Mr. Cuthbert, who first brought it into use) 
15515 rubricósa Ach.

15516 tuberculósa $A c h$. 15517 glaucóma Ach.

15518 Hagéni Ach.

$\beta$ crenuláta Ach. 15519 albélla $E . B$.

15520 parélla Ach.
15521 upsaliénsis Ach.
15522 Turnéri Ach.

15523 carneo-lútea $A c h$. 15524 tartárea Ach.

\section{Bfrigida Ach. 15525 cerina Ach.} 15526 Stónei Ach.

15527 vitellina $\mathrm{Ach}$.

15528 salicina Ach.

15529 erythrélla $A c h$.

15530 rúbra $\boldsymbol{A c h}$. red shielded

warted

glaucous

Hagen's

crenulated

E.t.1040. L. casio-rufus

equal warted 2 all sea. W rocks Eng. bot. 727

Upsal

membranous 2 all sea. Gl.W rocks

Eng. bot. 1634

Turner's

mealy crust 3 aut. Dl.G old trees

Eng. bot. 857

yell.-flesh-col. cracked crust 1 sum. Wsh trun. of elms Eng. bot. 2010 Cudbear tartareous 2 all sea. Grsh rocks Eng. bot. 156

northern thincrust 2 aut. Gl. earth Eng. bot. 1879 waxen oblong patch 2 wint. G trun. of trees Eng. bot. 627

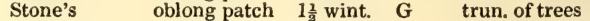

yolk of egg granular $1 \frac{1}{2}$ all sea. $Y \quad$ pales Eng. bot. 1792

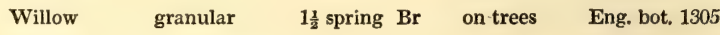

reddish crack. rugose 2 all sea. Gsh stone walls Eng. bot. 1993

15531 hæmatom'ma Ach. bloody spotted powdery

trun, of trees Eng. bot.t.2218, L. Ulmi

ß porphýria Ach.

15532 epigéa Ach. eart

15533 lentigera Ach. white

15534 saxícola $\mathrm{Ach}$. rock

15535 murórum Ach. wall

15536 élegans Ach.

elegant

15537 ful'gens $\mathrm{Ach}$.

refulgent

15538 circináta Ach.

circled

15539 gélida Ach.

frozen

2 sum. Wsh rocks

Eng. bot. 486

15540 galáctina Ach. milky

thin crust

2 sum. Gl. rocks

Eng. b.223. L. coccincus

plaited $1 \frac{1}{2}$ all sea. W earth

E. b. $1778 . L$. candicans

round. patch. $1 \frac{1}{2}$ all sea. Wsh dry heaths Eng. bot. 871

scaly crust

2 all sea. Pa.G roc. \& walls Eng. bot. 1695

cracked crust $1 \frac{1}{2}$ all sea. Y.Or rocks

Eng. bot. 2157

imbricated 1 all sea. Tawn. rocks

Eng. bot. 2181

small patches $\frac{1}{2}$ sum. $\mathrm{X}$ rocks -

Eng. bot. 1667

cracked crust $\frac{1}{3}$ aut. Grsh flat stones Eng. bot. 1941

cracked crust 1 all sea. R.Gr rocks

Eng. bot. 699

rugose crust $1 \frac{1}{2}$ all sea. Wsh roc. $\&$ walls

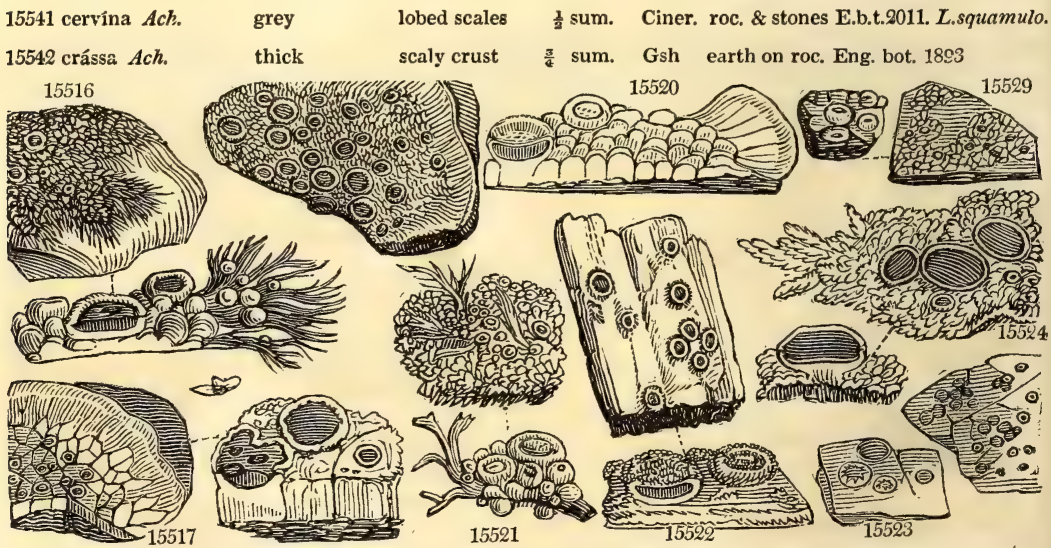

History, Use, Propagation, Culture,

employed to produce a purple for dying woollen yarn; and no where, perhaps, used to so great an extent as in the manufactory of Mr. Mackintosh, at Glasgow. The manufacturers import it largely from Norway, where 
15515 Crust cracked and areolate somewhat granular whitish, Disk of apothecia rufous becoming brown, Border white or yellowish becoming flexuose

**** Disk of apothecia black, casious, glaucous, or variously colored, always pruinose

15516 Crust greenish ash-color with roundish warts, Circumference fibrous, Apothecia mixed : disk concave becoming flat blackish-glaucous; border elevated thick

15517 Crust tartareous tessellated even greyish-white, Apothecia immersed in the crust : the disk plane, at length convex subglobose glaucous and powdery ; margin entire afterwards obliterated

15518 Crust cartilaginous membranous whitish ash-color, Apothecia clustered minute : disk flat becoming convex variegated with brown and black; border entire naked persistent

$\beta$ Crust becoming unequal somewhat granular ash-colored or blackish, Apothecia much clustered : disk flat brown and black; border crenulate powdery

15519 Crust thin leprous continuous cream-colored somewhat polished, Apothecia sessile whitish-buff uneven with a thin white wavy border

***** Disk of apothecia somewhat flesh-colored, pale, testaceous, waxen, or orange-colored.

15520 Crust granulated or somewhat warted white, Apothecia thick crowded by pressure angular: the disk concave, and as well as the tumid entire margin of the same color as the crust

15521 Crust very thin membranaceous smooth glaucous white bearing awl-shaped bristles, Disk of the apothecia at length spreading plane pale-yellowish

15522 Crust leprous granular powdery whitish-grey, Apothecia scattered thick powdery: disk concave pale flesh-colored; border tumid entire and flexuose

15523 Crust thin polish. hoary, Apothecia somew. inn. : disk flat fleshy-yell, ; border thin somew. inflex. crenat.

15524 Crust tartareous with clustered granules greyish white, Apothecia scattered : disk plano-convex a little wrinkled flesh-color; the margin inflexed, at length waved

$\beta$ Crust thin glaue us white running out into papillæ and spiniluferous branches [becoming black

15525 Crust granul. ciner. Disk of apothecia flat convex yellowish wax-colored; border elevated inflexed hoary

15526 Crust leprous-tartareous granular powdery dirty-white, Apothecia scattered : disk waxen covered by the powdery inflexed border becoming convex and dilated

15527 Crust granulated bright-yellow, Apothecia crowded : the disk plane of the color as the crust, at length convex deeper colored and powdery ; the margin elevated thin, at length waved pulverulent

15528 Crust granular unequal dirty-yellow, Disk of apothecia fat becoming convex somewhat orange-colored ; border thin crenulated becoming entire and flexuose

15529 Crust cracked subrugose greenish-yellow, Apothecia at length subglobose deep orange shining when the entire margin becomes obliterated

****** Disk of apothecia red, scarlet, or purple, and sanguine.

15530 Crust submembranaceous smooth, at length unequal pulverul, and granular white, Apothecia crowded : the disk concave red; margin tumid inflexed crenulate

15531 Crust tartareous pulverulent whitish, Apothecia imbedded scattered subconfluent: the disk scarlet rather convex; the margin sometimes obliterated

$\beta$ Crust tartar. granul. powd. whit. A pothecia sess. : disk flat deep sanguine ; bord. elevat. thick rug. persist.

t+ Thallus adnate, radiate, stellate, and lobed in the circumference. Placodium.

15532 Crust plaited and wrinkled white : the circumference smooth lobed, Disk of the apothecia at length rather convex brownish-black : the margin thin entire

15535 Crust somewhat imbricated white, Lobes somewhat concave flexuose cut-crenate, Disk of apothecia flat yellowish-brown : border elevated tumid

15534 Crust subimbricated scaly somew. rugose uneven pallid_green radiated and lobed in the circumference : fructification extremely crowded; the disk plane yellowish-brown or subochraceous with a border, at length crenate waved

15535 Crust plaited and lobed cracked bright-yellow orange pulverulent : the circumference plicate and rayed ; segm. lin. convex cut, A pothecia crowd. : disk at length convex of a deeper orange; marg. ent. waved

15536 Crust somew. imbricated plaited and rugose tawny orange naked, Lobes lin. lanc. waved convex somew. distant radiatıng. Disk of the apothecia concave of the same color with the crust marg. somew. inflex. ent.

15537 Crust somew. contigurus pale yellow with a plaited lobed edge, Lobes flexuose flat, Apothecia scattered, Disk very red plano-convex

15538 Crust cracked greyish plaited and rayed in the circumference lin.-laciniate, Apothecia much crowded at at length angular : disk plane brownish black even with the margin of the crust

15539 Crust cracked pale reddish grey the circumference rayed and lobed having brown warts in the centre cracked and rayed : disk of the apothecia depressed reddish margin thick elevated entire

15540 Crust subimbricat, rugulose whitish lobed and cren. at the circumference : fructification crowd. angular ; the disk plane brownish flesh-color pruinose with a raised and at length crenate flexuose border

+t+ Thallus imbricated throughout.

15541 Crust with lobed scales of a brownish ash-color : disk of the apothecia immersed nearly plane blackish brown with the margin at length prominent

15542 Crust scaly greenish, Lobes imbricated inciso-crenate waved irregular, Disk of the apothecia slightly swelling brownish orange margin thin entire at length obliterated
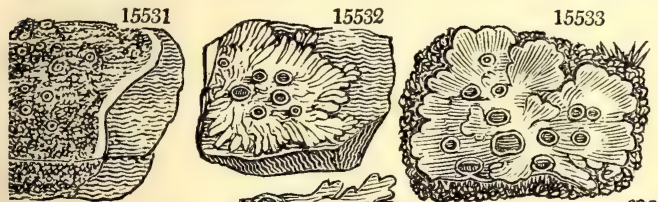

15535

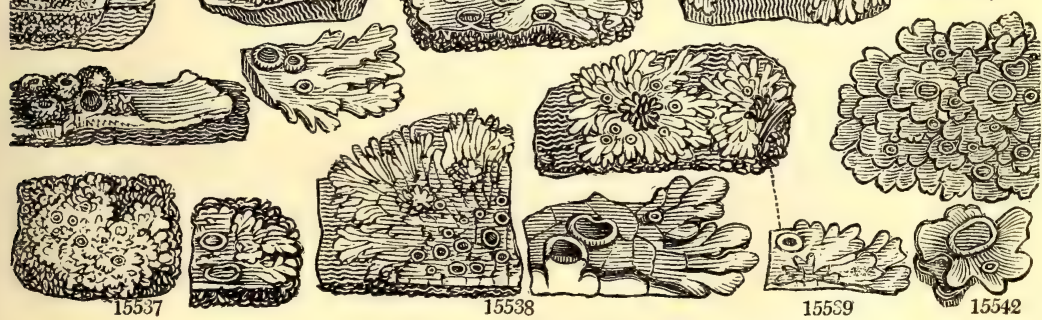

and Miscellaneous Particulars.

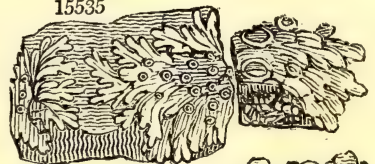
it grows more abundantly than with us; yet, in the Highland districts, mary an industrious peasant gets a
living by scraping this Lichen with an iron hoop, and sending it to the Glasgow market. When I was in the $3 \mathbf{Q}$ 
15543 virêlla $A c h$.

15544 candelária Ach.

ß polycárpa Ach. 15545 hypnórum Ach. 15546 brun'nea Ach.

15547 Hookéri greenish multifid patc. 1 all sea. Bt.G. trees \& pales Eng. bot. 1696 Candle-dyeing scaly crust 1 all sea. Y trees \& pales Eng. bot. 1794 many-shielded toothed lobed $\frac{1}{4}$ all sea. Gr.Y old posts Eng. bot. t. 1795 Hypnum scaly crust 1 wint. Gr.Br woods Eng. bot.t.740 brown lobed crust 1 spring $\mathrm{Ci}$. Br on the grou. Eng. bot. t. 1246 Hooker's imbricated 1 spring Grsh wet rocks Eng. bot. 2283
2341. Parme'lia. Ach. Parmelia. 15548 glomulífera $\mathrm{Ach}$. warted

15549 caperáta Ach. 15550 scórtea Ach. 15551 perláta $A c h$. 15552 perforáta $A c h$. 15553 herbácea Ach. 15554 corrugáta Ach. 15555 olivácea Ach. 15556 parietína Ach. 15557 elæína $A c h$. 15558 pitýrea $A c h$. 15559 clementiána Ach. 15560 tiliácea $\mathrm{Ach}$. 15561 Borréri Ach. 15562 lanuginósa $\mathrm{Ach}$. 15563 plúmbea $A c h$. 15564 rubiginósa $A c h$.

wrinkled leathery grey perforated herbaceous rugose imbricated 3 all sea. D.G on trees Eng. bot. 1652 olive wall Sp. $38-77$.
round patch. $\quad 1 \frac{1}{2}$ spring Gi

trun. of trees Eng. bot. t. 293 round patch. $\quad \frac{3}{4}$ spring Y.G trun. of trees Eng. bot. t. 654 obed patches $1 \frac{1}{2}$ all sea. Br trees \& pales Eng. bot. 2065 round patch. 2 all sea. Grsh trun. of trees Eng. bot. 341 crisp patches 3 all sea. Y.G old trees Eng. bot. 2423 round patch. $1 \frac{1}{2}$ all sea. Bt.G trun. of trees Eng. bot. 294 orbicular olive small patches $\frac{1}{2}$ all sea. Ol bark of trees Eng. bot. 2158 scurfy flat-warted $1 \frac{1}{2}$ july Gl. walls

Eng. bot. 2064

Clementi's flat radiated $1 \frac{1}{2}$ all sea. W. Gr trees

Eng. bot. 1779

Linden flat imbricat. 6 sum. $G$ rocks

Eng. bot. 700

Borrer's foliaceous 4 aut. Ol.G trun. of trees Eng. bot. 1780

woolly

leaden

rusty

15565 omphalódes Ach. navel

15566 saxátilis $A c h$. rock

15567 fahlunénsis Ach.

Iron mine

pitchy

lacerated

round patch. 3 all sea. Y.W rocks

round patch. 2 aut. Bl.Gr trun. of trees Eng. bot. t. 353

round patch. 3 sum. Br.Gr trun. of trees Eng. bot. t. 983

shining dott. 4 all sea. $\mathrm{Pu} . \mathrm{Br}$ rocks

Eng. bot. t. 604

rough \& pitt. $2 \frac{1}{2}$ all sea. Grsh stones

Eng. bot. t. 603

smth. thallus 3 all sea. Pitch. rocks

Eng. bot. t. 653

15568 stýgia Ach.

15569 áquila Ach.

multifid lobes 4 sum. $\mathrm{Br}$ rocks

Eng. bot. t. 982

15570 encaústa Ach. griesly

recurved stellated dott. 3 sum. Pa.Gr rocks

warted 2 sum. $\mathrm{Pa} . \mathrm{G}$ rocks
Eng. bot. t. 2049

Eng. bot. t. 1375

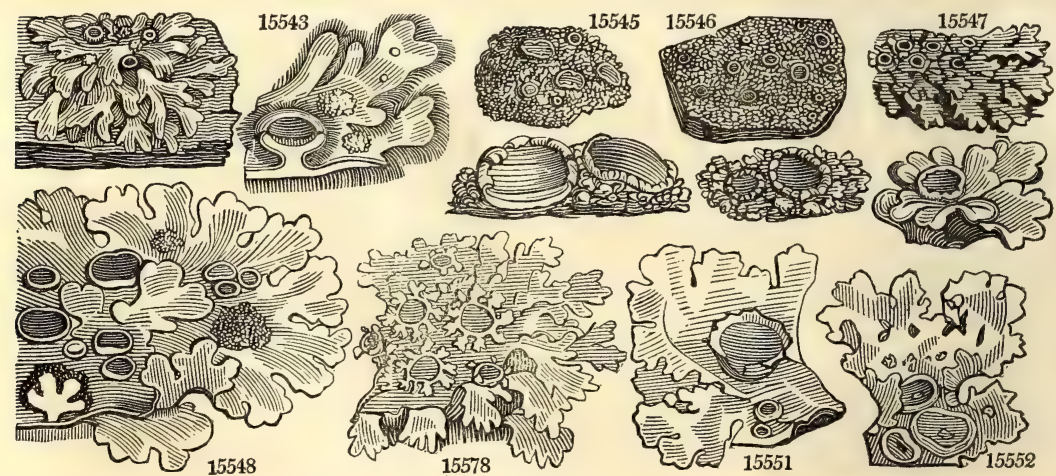

History, Use, Propagation, Culture,

neighbourhood of Fort Augustus, in 1807, a person could earn fourteen shillings per week at this work, selling the material at three shillings and fourpence the stone of twenty-two pounds. The fructified specimens are reckoned the best. 
15543 Crust somewhat scaly greenish ash-colored becoming powdery, Lobes repand cut wavy with irregular margins, Disk of apothecia flat brownish black

15544 Crust scaly yellow, Lobes very much crowded cut and laciniated imbricated their margins minutely granular, Apothecia nearly of the same color as the crust margin elevated entire

$\beta$ Crust formed of lobes with many crowded teeth and segments greyish yellow, Apothecia crowded waved: disk plane dilated of the same color as the crust at length fulvous and the margin crenulated

15545 Crust scaly greenish-brown, Lobes minute somew. rounded with margin granular and crenulat. Apothecia submembran. : the disk concave at length dilated plane reddish brown the marg. elevated inflex. crenate

15546 Crust imbricated greyish lobed and granulated ash-colored brown, Apothecia imbedded in the crust crowded irregular: disk rather convex red-brown the margin elevated crenulated persistent

15547 Crust imbricated greyish, Lobes minute appressed blunt, Disk of the apothecia plane black margin elevated and crenate

+ All the divisions of the thallus equal at end.

15548 Thallus cartilaginous rigid obicular livid and glaucous smooth bearing dark green scattered tufted excre scences: tawny beneath and downy, the lobes waved and laciniated angular, Apothecia reddish brown rugose at the margin

15549 Thallus orbicular pale yellowish green rugose at length granulated black and hispid beneath the lobes waved laciniated round. nearly entire, A poth. scatter. brown their margin incurv. entire at length pulverulent

15550 Thallus roundish subcoriaceous white smooth finely dotted with black : hispid beneath, Lobes longish sinuate-crenate cut, Apothecia rufous brown

15551 Thallus orbicular greyish white smooth blackish brown and hairy beneath, Lobes rounded cut plane their margin waved entire, Apothecia brown their margin thin entire

15552 Thallus orbicular glaucous green naked with black fibres on the under side, Lobes rounded cut flat somewhat plaited at the edge, Apothecia rufous

15553 Thallus orbicular membranaceous hright green above, beneath pale brown almost white and downy, Lobes waved and cut, the segments rounded subcrenate, Apothecia red, the margin inflex. rugose and crenate

15554 Thallus orbicular membranaceous finely rugose glaucous green, beneath blackish brown fibrous, Lobes cut rounded lax plaited entire

15555 Thallus orbicular olive brown rugged with elevated points paler beneath and fibrous, Lobes radiating appressed plane dilated rounded and crenate, Apothecia dark-brown : the margin crenulated

15556 Thallus orbicular bright yellow : berieath paler and fibrillose; the lobes radiating appressed plane dilated round. crenate and crisped at the extremity, Apoth. of the same colour as the crust their margin entire

15557 Thallus orbicular somewhat membranous contiguous plaited umber-olive colored cut crenate in the circumference with flat somewhat truncate lobules

15558 Thallus orbicular cinereous powdery : beneath white with black fibres, Central segments plaited eroded crisp powdery at edge, Apothecia concave blackish brown

15559 Thallus orbicular white hoary granular powdery : beneath of the same color with obsolete blackish fibres, Segments of the circumference flat cut crenate, Apothecia appressed flat brownish black

15560 Thallus orbicular membranous glaucous ash-colored : blackish brown beneath, Lobes sinuate-cut; the end ones rounded crenated, Apothecia brownish with an entire edge

15561 Thallus orbicul. cinereous, Soredia grey margined, beneath brownish spongy and fibrous, Lobes concrete plaited : those of the circumference rounded cut crenate, Apothecia red with a tumid edge

15562 Thallus orbicular yellowish white pulverulent greyish black and downy beneath, Lobes imbricated plane rounded slightly crenated, Apothecia reddish ("of the same color as crust") their margin pulverulent

15563 Thallus orbicul. blueish-grey, beneath having a very thick spongy down, Lobes of circumference rounded and crenate, Apothec. scattered at length convex rusty-brown, their margin of same color and entire

15564 Thall. orbic. brownish-grey, ben. having a blueish-grey spongy down, Lobes of circumf. obtusely notched elevated pale, A pothecia plane crowded central reddish-brown with tumid incurv. crenul. whit. margins

15565 Thallus orbicular dark purplish-brown shining dotted with black, beneath black and fibrillose : the segments sinuato-multifid linear plane truncated crenate in the circumference, Apothecia dark-brown, the margin slightly crenulate

15566 Thallus orbicul. greyish rough and pitted beneath black and fibrillose : the segments imbricated sinuated plane subretuse, Apothecia bright chesnut-brown, their margin subcrenulated

15567 Thallus orbicular pitchy-brown smooth beneath black and scarcely fibrillose : the segm. sinuated multifid divergent plane or slightly grooved, margins elevat. lacerat. Apothec. dark-brown, margin granulated

15568 Thallus stellated shining pitchy-black, beneath black and almost naked: the segments nearly linear mul tifid and somewhat palmate convex, the margins and extremity recurved, Apothec. of the same color at length black with the margin creriated

15569 Thallus orbic. tawny-brown paler beneath with blackish fibres : the segment multipartite nearly lin. convex, those of the circumfer. dilated nearly plane and crenate, Apothecia dark-brown, their margin crenated

15570 Thallus stellat. pale-grey, beneath black uneq. naked: the segments often uniting convex and almost round. lin multifid roughish dotted with black, Apothecia reddish-brown, their margin somewhat crenulated

15571 Thallus stellat. pale-greenish bear. powdery warts, beneath black with spongy fibres : segments of circum ference multifid very narrow convex and almost rounded, Apothecia reddish-brown, marg. nearly ent.

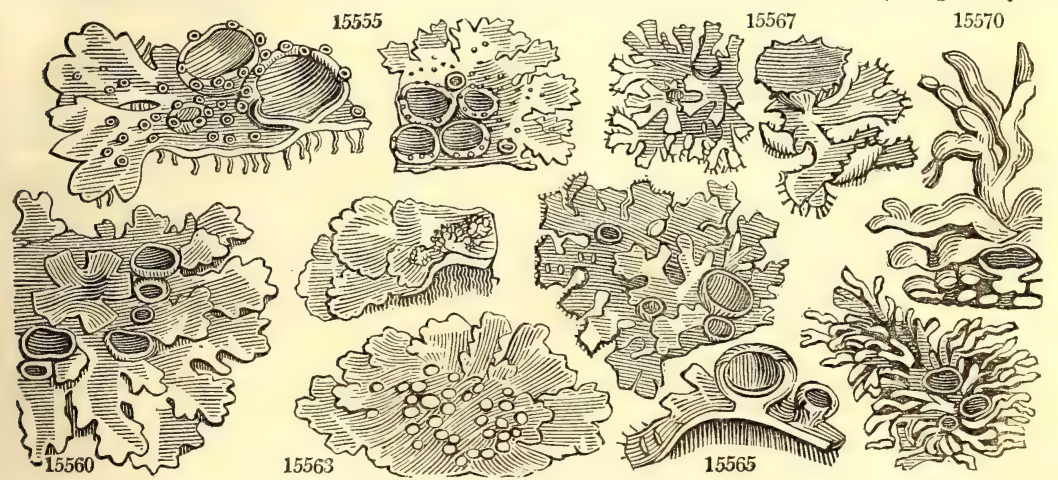

and Miscellaneous Particulars.

2341. Parmelia. Named from $\pi \propto \rho \mu n$, a sort of small shield, and $\varepsilon \_\delta \varepsilon \omega$, to enclose. On the thallus cf these plants scattered powdery warts are commonly found. These Hedwig has determined to be anthers, apparently for no other reason than that they are powdery, and that he could fix the title to nothing better. 
15572 sinuosa Ach. sinuous starry 2 all sea. Pa.Y moorstones Eng. bot. t. 2050

15573 aleurites Ach. rugose $\quad$ round patch. 3 aut.wi. Pa. Gr trun. of trees Eng. bot. t. 858

15574 ambígua Ach. ambiguous starry warted 2 aut.wi. Pa.G trun. of trees

starry glabr. 2 spring G.W woods $\quad$ Eng. bot. t. 1979

15577 lævigáta Ach. polished starry 3 spring Grsh on trees $\quad$ Eng. bot. t. 1852

15578 pulverulénta $A c h$. powdery

pruinose mul. 2 spring Dp.G trun. of trees Eng. bot. t. 2063

15579 stelláris $A c h . \quad$ stellate

15580 cæ'sia Ach. $\quad$ cæsious

rugged frond 2 spring Grsh trun. of trees Eng. bot. t. 1697

$\beta$ dúbia Ach.

dubious

sorediferous $\frac{3}{4}$ all sea. Grsh roc. \& stones Eng. bot. t. 1052

15581 cyclosélis Ach.

circular round patch. 1 all sea. Li.Gr trees \& pales Eng. bot. 1942

15582 diacápsis $E . B$.

twofold-shield. tumid crust $1 \frac{1}{2}$ all sea. Wsh stones Eng. bot. 1954

15583 physódes Ach.

bladdery

multif, smth. 2 all sea. Wsh rocks

Eng. bot. t. 126

15584 diátrypa Ach. warted

multif. smth. 2 all sea. Gr.G wet rocks

Eng. bot. t. 1248

2342. BORRE'RA. Ach. Borrera.

15585 tenélla $A c h$. slender

Sp. 7-23.

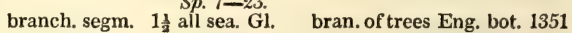

15586 leucoméla Ach. black \& white dense tufts $1 \frac{1}{2}$ feb. Wsh on the earth Eng. bot. 2548

15587 furfurácea Ach. mealy farinaceous $1 \frac{1}{2}$ all sea. G.Gr trun. of trees Eng. bot. 984

15588 chrysophthálmaAch. yellow-eyed bushy $\quad 1$ all sea. Or apple trees Eng. bot. 1088

15589 flávicans Ach. yellowish branched 1 all sea. Y trun. of trees Eng. bot. 2113

15590 ciliáris Ach. ciliated bushy $1 \frac{1}{2}$ all sea. Gl. trun. of trees Eng. bot. 1352

15591 atlántica Ach. Barbary iushy tufts $1 \frac{1}{2}$ april $\quad$ G.Ol elms $\quad$ Eng. bot. 1715

2343. CETRA'RIA. Ach. Cetraria. 15592 juniperína Ach. ${ }_{\text {juniper }}$

bushy $\quad \begin{aligned} & S p .5-14 . \\ & 1 \frac{1}{2} \text { all sea. Pa.Y trun. of trees }\end{aligned}$

$\begin{array}{cll}\text { B pinástri Ach. } & \text { Pinaster } & \text { bushy } \\ \text { bushy waved } & 1 \frac{1}{2} \text { all sea. Pa.Y trun. of trees Eng. bot. t. } 2111 \\ 15593 \text { sepincola Ach. } & \text { hedge } & \text { Ol. Br ston. \& trees Eng. bot. t. } 2386\end{array}$

15594 glaúca Ach. glaucous bushyshining 2 all sea. Gl. on the grou. Eng. bot. t. 1606

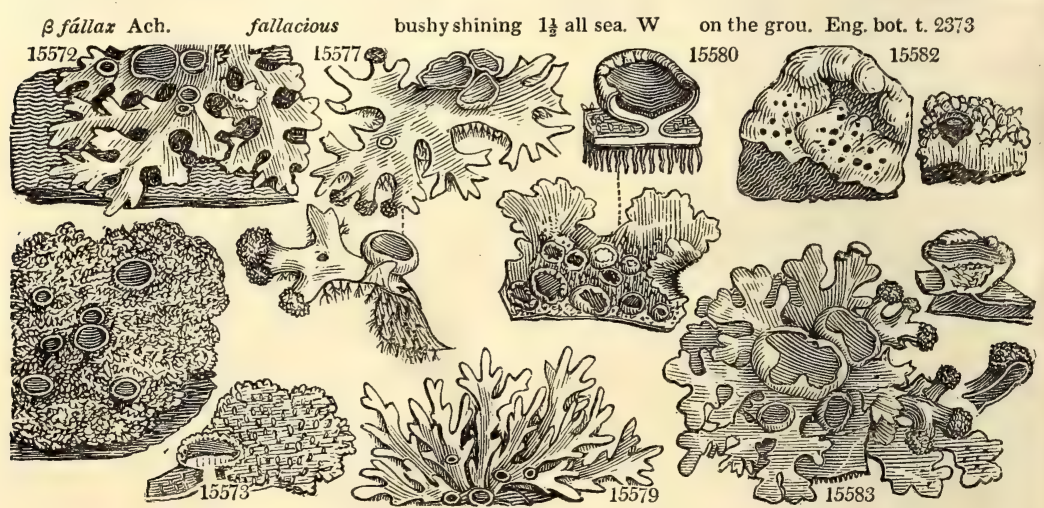

History, Use, Propagation, Culture,

2342. Borrera. Dedicated by Acharius, to Mr. William Borrer, F. L. S., one of our most eminent British cryptogamic botanists. This genus is very natural in habit, including the Linnean genus Lichen and its allies.

2343. Cetraria. An unexplained name. C. islandica is common in Iceland and in the north of Germany, and is also found in the mountains of Asturias. It grows to the height of two or three inches only, and has a rugged bushy aspect. In Iceland and Lapland it is used as an article of diet; being boiled in broth or milk, after being freed from its bitter by repeated maceration in water, or dried and made into bread. It has of late years been brought in considerable quantities to this country for medicinal purposes. The dried plant differs very little from its appearance in a recent state. Medicinally it is tonic and demulcent; it has also been found useful in debilities after acute diseases, and in emaciations, particularly those arising from the great discharge 
15572 Thallus stellat. pale-yellowish grey smooth, black and fibrous beneath : segments broadly lin. sinuato-pinnatifid, their sinuses broad and circular, A pothecia nearly plane dark-brown, their margin thin entire

15573 Thallus orbicular continuous rugose pale-grey pulverulent, beneath of the same color with blackish fibres : segments in the circumference distinct plane rounded waved inciso-crenate, Apothecia plane reddishbrown, their margin at length crenulate and pulverulent

15574 Thallus stellated pale-yellow green smooth bearing powdery warts, beneath brownish-black and fibrillose : the segments linear appressed plane dichotomous somewhat truncated, Apothecia subcentral small nearly plane brown, their margin entire

15575 Thallus orbicul, greenish-yell. smooth with blackish dots, brown and fibrillose beneath : segments sinuatolobate rounded crenate nearly plane, Apothecia central chesnut-brown with the margin nearly entire

15576 Thallus stellated glabrous greenish-white, beneath snowy-white with greyish fibres: the segments imbricated linear plane cut and branched crenate, their extremities ascending and powdery, Apothecia central brown with a tumid singularly rough and crenate border

15577 Thallus stell. smooth greyish-white, beneath black and fibrillose : segm. multif. lin. broader upwards cut divaricated acute in the circumference frequently bearing powdery warts, Apothecia concave chesnut color with the margin entire

15578 Thallus stellated deep glaucous green cæsious and pruinose when dry, beneath black and downy and hispid : the segment linear multifid in the circumference plane appress. waved retuse at the extremities, Apothecia glaucous black, the margin entire and waved at length leafy

15579 Thallus stellat. at length rugged and granulat. greyish-green, beneath with grey fibres: the segm. sublin. rather convex cut multifid, A pothecia glauc. black, their margin entire, at length waved and crenate

15580 Stellate greyish-white and glaucous sorediferous, ash-colored beneath with black fibres: segments linear cut multif. convex but plane at extremities : fructification subconcave black with a subinflexed border

$\approx$ Thallus stellate cinereous: segments branched separate recurved at edge roundish, some broader than the rest and powdery at the edge

15581 Orbicular greenish-grey, fibrous and black beneath, Lacinæ imbricated nearly plane multif. erosa-crenate somewhat ciliate: the margin sometimes raised; fructification very dark, the border raised entire

15582 Crust blueish-white tartareous minutely undulated, Apothecia clustered somewhat sunk : disk flat black or brown ; margin thick externally black

15583 Thallus substellated glaucous white : beneath brownish black; the segm. sinuato-multifid convex glabrous inflated and ascending at the extremity, Apothecia red brown, their margin entire

15584 Thallus substellate greyish-green: beneath rugose blackish and white; segments sinuato-multifid nearly plane smooth bearing powdery warts and perforated; the extrem. inflated, Apoth. redd. : marg. entire

15585 Thallus greyish-white naked on both sides and of the same col. substellat. : segm. pinnatif. ascend. dilat. arched and ciliated at the extremity, Apothecia scattered : disk plane cæsious black; its marg. entire

15586 Thallus palish : segments erect linear multifid attenuated ciliated : beneath very white powdery and channelled, Apothieca with a flat black casious disk

15587 Thallus greenish-grey farinaceous: the segments linear attenuated branched grooved naked rugose and blackish beneath, Apothecia somewhat marginal cup-shaped with their margin thin inflexed

15588 Thallus yellow naked and of the same color on both sides : segments linear flattish pinnatifid branched fibrous at end, Apothecia somewhat terminal with an orange-colored disk

15589 Thallus yellow naked: segments dichotomously branched slightly compressed atten. divaricated complicated, Apothecia scattered : their disk plane orange-red; their margin entire naked

15590 Thallus greenish : segments linear branched attenuated ciliated at end whitish and channelled beneath, Apothecia somewhat terminal : disk concave becoming flat with a fringid border

15591 Thallus pale rufous downy : segm. divaricating tortuous linear tapering channelled on the under surface, Apothecia scattered : disk flattish brownish-black with a thin entire border

15592 'Thallus pale-yellow very yellow beneath : the segments plane ascending erose crenate and crisped, Apothecia elevated: their disk brown; the margin crenulated

$\beta$ Thallus with segm. depressed: the lobes rounded crenate; margins crisped pulverulent and very yellow 15593 Thallus olive-brown paler beneath; the segments plane ascending lobed waved subcrenate, Apothecia elevated of the same color : their margin rugose and crenulate

15594 Thallus glaucous somewhat shining sinuated and lobed brown beneath: the segments cut and jagged curled ascending, A pothecia elevated chesnut-brown : their margin wrinkled

$\beta$ Thallus white on each side or with occasional black spots beneath

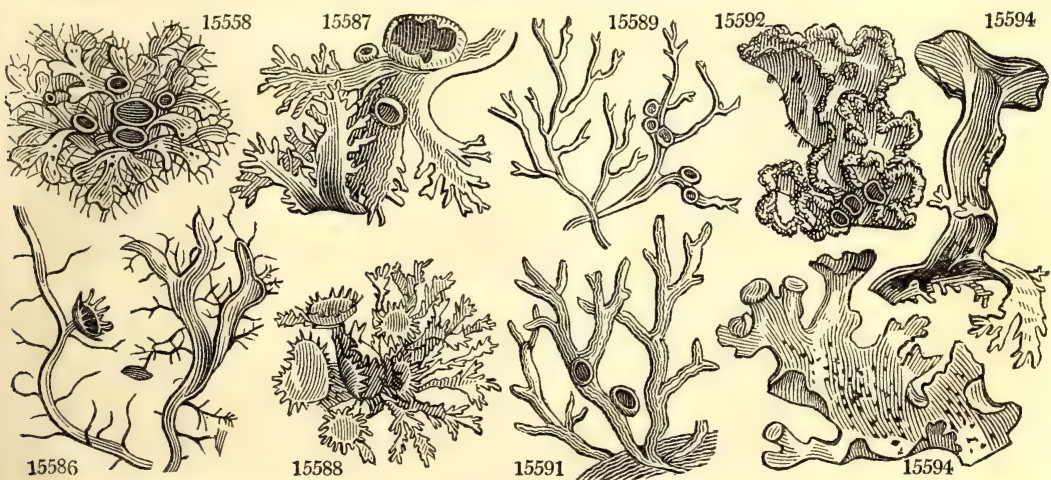

and Miscellaneous Particulars.

of ulcers; and diarrhœeas, dysentery, and hooping cough. Its virtues, however, have been greatly overrated.

(Thom. Lond. Disp. 365.)

Though plentiful with us, it is scarcely sufficiently so to form an article of commerce. A great proportion of what comes to our shops, where it is in great request as a medicine in coughs, consumptions, \&c. is procured from Norway or from Iceland. Immense quantities are gathered in the latter country, not only for sale, but for home consumption, as an article of common food. The bitter and purgative quality being extracted by steep. ing in water, the lichen is dried, reduced to powder, and made into a cake, or boiled and eaten with milk; and eaten with thankfulness, too, by the poor natives, who confess " that a bountiful Providence sends them bread out of the very stones." An ample account of the nutritive qualities of this plant may be found in the Memoir of Professor Proust, inserted in the Journal de Physique, for August, 1806. 


\begin{tabular}{|c|c|c|c|c|c|}
\hline 15595 nivális $A c h$. & snow & bushy tufts & 2 all sea. Sul. & rocks & Eng. bot. t. 1994 \\
\hline 15596 islándica $A c h$. & Iceland Moss & bushy & 2 all sea. O1.Br & rocky places & Eng. bot. t. 1230 \\
\hline $\begin{array}{l}\text { 2344. STIC'TA. Ach. } \\
15597 \text { crocáta Ach. }\end{array}$ & $\begin{array}{l}\text { STICTA. } \\
\text { orange }\end{array}$ & yellow warts & $\begin{array}{l}S p .7-18 . \\
\text { all sea. Gl.Br }\end{array}$ & rocks & Eng. bot. 2110 \\
\hline 15598 auráta $A c h$. & golden & foliaceous & 6 all sea. Br & trun. of trees & Eng. bot. 2359 \\
\hline 15599 pulmonácea $A c h$. & liverwort & reticulated & 2 all sea. Oliva. & trun. of trees & Eng. bot. 572 \\
\hline 15600 scrobiculáta $A c h$. & pitted & roundish pat. & 3 all sea. Grsh & trun. of trees & Eng. bot. 497 \\
\hline 15601 limbáta $A c h$. & bordere.l & smooth lobed & 4 all sea. Gl.Br & rocks & Eng. bot. 1104 \\
\hline 15602 fuliginósa $A c h$. & smutty & round patch. & 3 all sea. Lu.gr & moist rocks & Eng. bot. 1103 \\
\hline 15603 sylvática $A c h$. & wood & pitted fronds & 3 all sea. Ru. Br & shady woods & Eng. bot. 2298 \\
\hline $\begin{array}{l}\text { 2345. PELTIDE'A. Ach. } \\
15604 \text { venósa } A c h \text {. }\end{array}$ & $\begin{array}{l}\text { Peltidea. } \\
\text { veiny }\end{array}$ & much veined & $\begin{array}{l}\text { Sp. 9-21. } \\
\text { sum. Gsh }\end{array}$ & on the earth & Eng. bot. 887 \\
\hline 15605 scutáta Ach. & shielded & crisp & $1 \frac{1}{2}$ all sea. Cin. & bark of trees & Eng. bot. 1834 \\
\hline 15606 horizontális Ach. & horizontal & shining, cren. & 2 all sea. Br.G & shady rocks & Eng. bot. 888 \\
\hline 15607 aphthúsa Ach. & Thrush & warted & 2 aut. & among moss & Eng. bot. 1119 \\
\hline 15608 ruféscens $E . B$. & brownish & incurved & 2 ail sea. $\mathrm{R} . \mathrm{Br}$ & on the earth & Eng. bot. 2300 \\
\hline 15609 canina $A c h$. & dog & broad-lobed & 2 all sea. Grsh & on the earth & Eng. bot. 2299 \\
\hline
\end{tabular}

15610 membranácea Ach. membranous broad-lobed $1 \frac{1}{2}$ all sea. Grsh thatch

15011 spúria $E . B$. imperfectly veined lobed frond $1 \frac{1}{2}$ july Ol.Br thatch Eng. bot. 1542

15612 polydáctyla Ach. multifid smooth-hood. $1 \frac{1}{2}$ july Gl. on the earth Jacq. coll. t. 14. f. 2

2346. NEPHRO'MA. Ach. NePhroma.
15613 resupináta Ach.

15614 párilis Ach. chocolate foliaceous 3 all sea. $\mathrm{Br}$ stonequarr. Eng. bot. 2360

2347. ROCCEL'LA. Ach. ORChall.
15615 tinctória Ach. $\quad$ Sp. 2-7.
true dyer's $\quad$ bushy tufts $1 \frac{1}{2}$ all sea. Y.Br marit. rocks Eng. bot. 211

15616 fucifórmis Ach. flat-leaved bushy tufts 4 all sea. Gl. graniterocks Eng. bot. 728

2348. EVER'NIA. Ach. EvERnia.
$\begin{aligned} & \text { Stag's Horn } \\ & 15617 \text { prunástri Ach. }\end{aligned} \begin{aligned} & \text { Sp. 1-6. } \\ & \text { L. stictoceros } \text { E. B. t. } 1353\end{aligned}$

2349. CENOMY'CE. Ach. CENomyce. Sp. 20-43.

15618 papiliária Ach. pimpled $^{2}$ granul. crust $\frac{1}{2}$ wint. Grsh dampearth Eng. bot.907

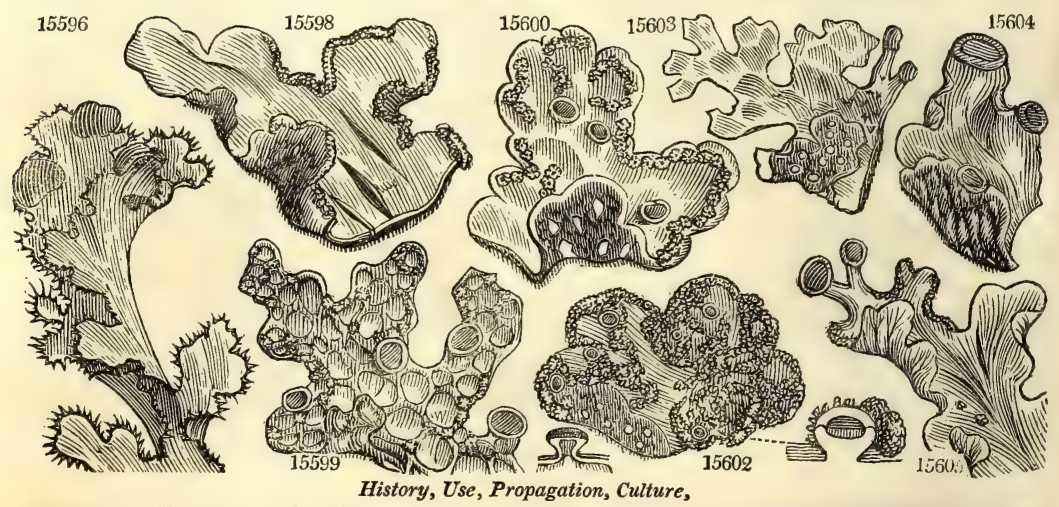

2344. Sticta. From sเ\%ros, dotted, on account of the numerous little pits on the under surface of the fronds. One of the most handsome genera of Lichens, growing almost wholly upon trees. Sticta pulmonacea is sup-

posed to possess the same qualities as the famous Iceland moss, Cetraria islandica.
2345 . Peltidea. So called in allusion to the form of the shields, from $\pi \varepsilon \lambda \tau \eta$, a target. Peltidea aphthosa, a large handsome species, has its name from the circumstance related by Linnæus, that the Swedish peasants boil it in milk as a cure for the aphtha, or thrush, in children.

2346. Nephroma. From $\nu \in \Phi \rho \circ$, a kidney ; the apothecia are of a reniform figure. N. polaris is remarkable for being common to both the arctic and antarctic circles.

2347. Roccella. This is a slight alteration of the Portuguese Roccha, signifying a rock, in allusion to the 
15595 Thallus sulphur-colored orange at the base pitted and reticulated erect nearly plane laciniated : 1 ts segm multifid crisped crenato-dentate and often warted at points, Apothecia plane flesh-col. : marg. crenulat.

15596 Thallus olive-brown paler beneath : the segments erect sublinear multifid channelled smooth dentatociliate; fert. branches spreading, Apothecia appressed plane of the same color : margins elevated entire

15597 Thallus dark glaucous brown pitted with broad rounded spreading entire lobes, having bright lemoncolored powdery spots upon the margin and on the elevated parts between the pits : downy and tawny beneath with min. lemon-colored little hollows, A pothecia scattered black.-brown : their margin entire

15598 Thallus glaucous shining very broad woolly beneath, Soredia minute yellow: segments rounded sinuated cut; margin wavy crisp inflexed yellow-powdery

15599 Thallus olivaceous pitted and reticulated downy beneath with smooth prominences : the segm. sinuatolobate truncated, Apothecia submarginal plane reddish : their margin rugose

15600 Thallus suborbicular glaucous greyish-green very broad somew pitted and having mealy warts : beneath downy tawny with white naked spots; the segments rounded and lobed irregular, Apothecia scattered nearly plane reddish-brown: their margin somewhat crenate

15601 Thallus orbicular glaucous brown roundly lobed smooth grey and powdery at the margin : downy beneath with white hollow spots, Apothecia brown

15602 Thallus orbicular dark lurid-grey rough with brown granules : beneath grey.-brown with white concave spots ; the segments roundly lobed nearly entire, A pothecia scattered dark-brown : their marg. entire

15603 Thallus wide rusty brown naked and pitted: brown and downy beneath with small pale excavations; segments lobed and obtusely cut unequal, Apothecia marginal dark-brown

15604 Thallus greenish ash-color white beneath having dark brown prominent branched veins, Lobes rounded cut somewhat entire. A pothecia marginal plane rounded swelling brown scarcely crenulate at the margin

15605 Thallus ash-colored whitish and veiny beneath : the lobes rounded sinuated and cut crenate and crisped; fertile lobules very short, Apothecia orbicular ascending nearly plane brown somewhat entire

15606 Thallus glaucous and brownish green lobed cren. and shining pale ben. with numerous brown branching reticulated veins : fertile lobules abbreviated, A pothecia terminal plane horizontal transversely oblong reddish brown with a nearly entire margin

15607 Thallus green smooth roundly lobed sprinkled with brown warts whitish beneath with brown branching veins : fertile lobules very long contracted in the middle their sides reflexed, Apothecia terminal large ascending red brown with a lacerated margin

15608 Thallus coriaceous concave even dark reddish-brown pale downy with obsolete veins beneath, Lobes rounded with numerous fruit-bearing processes

15609 Thallus greyish green with broad rounded lobes white beneath with brownish branching veins: fertile lobules rather long with their sides reflexed, Apothecia terminal nearly erect revolute reddish-brown with a subcrenulated border

15610 Thallus thin membranous somewhat downy with rounded lobes beneath whitish and netted with veins of the same color, Fertile lobes short, A pothecia minute

15611 Leathery ash-colored and even above: whitish smooth with indistinct pale veins beneath, Apothecia ascending roundish dark reddish brown

15612 Thallus glaucous green naked glabrous with brown reticulated veins beneath : fertile lobules very nume. rous elongate and as well as the brown terminal, Apothecia cucullato-revolute

15613 Thallus greyish brown pale pubescent and granulated beneath : fertile lobules very short, Apothecia large numerous reddish

15914 Thallus livid brown beneath naked wrinkled blackish, Fertile lobes short, Face of the apothecia brownish

15615 Thallus rounded glaucous green somew. branched nearly erect, Apothecia scattered elevated : disk flat cresious pruinose as broad as the border

15616 Thallus flat cinereous greenish with dichotomous divisions, Segments attenuated, Apothecia marginal

15617 Thallus greenish white segments dichotomous multifid ascending linear-attenuate plane pitted grooved and white beneath, Apothecia bright brown concave

\section{+ Thallus subcrustaceous uniform. Podetia hollow. Pycnothelia.}

15618 Subcrustaceous uniform granulated greyish, Podetia ventricose glabrous white simple or branched, the branches very short confluent and subfastigiate, Fructification minute reddish-brown

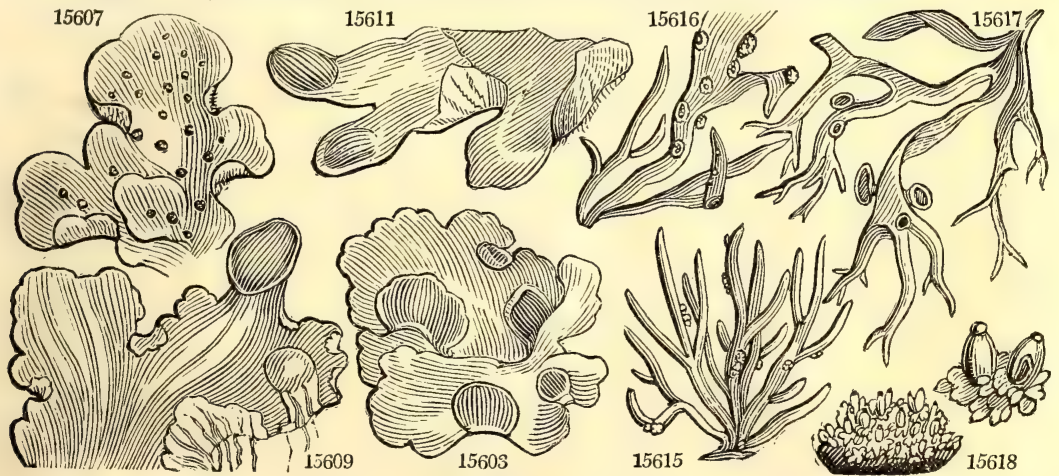

and Miscellaneous Particulars.

places where this plant is commonly found. This plant is the Orchall or Argol of the dyers, so celebrated for yielding a fine purple color, for which Cudbear is but a poor substitute.

2348. Evernia. Evepyns signifies tall, or well branched. The name has been well ccntrived to express the habit of the species, which all form bushy, erect, or pendulous tufts.

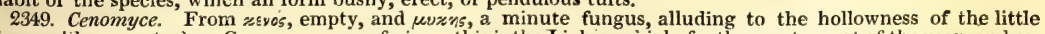
fungus-like receptacles. Cenomyce rangeferina : this is the Lichen which, for the greater part of the year, and es . pecially in winter, is the support of the vast herds of rein-deer, in which consists all the wealth of the Laplanders. No vegetable, Linnæus tells us, grows throughout Lapland in such abundance as this, especially in woods of scattered pines, where, for very many miles together, the surface of the sterile soil is covered with it as with 
15619 alcicórnis Ach. buckshorn tufts $\frac{1}{2}$ wint. Gl. heaths Eng. bot. t. 1392

15620 endiviæfólia Ach. endive-leaved multifid tufts $\frac{3}{4}$ wint. Y.G dryplaces Eng. bot. t. 2361

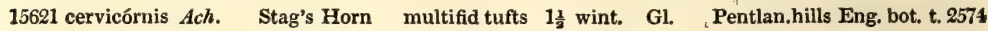

15622 pyxidáta Ach. cupped tufts $\frac{3}{4}$ spring GI. banks $\quad$ Eng. bot. t. 1393

15623 fimbriáta Ach. Pringed coralloid tufts $1 \frac{1}{2}$ spring Gl. moors \& hea. Eng. bot. t. 2138

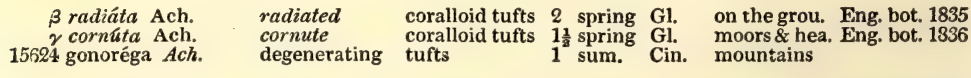

Banoma'a Ach. variable brittle tufts 1 spring Cin. hills $\quad$ Eng. bot, 1867

15625 ecmocýna Ach. leafy fine tufts $\frac{\pi}{4}$ spring $\mathbf{G r}$ hea.\& moun.

B grácilis Ach. slender fine tufts $\frac{3}{4}$ spring $\mathrm{Gr}$ hea.\& moun. Eng. bot. 1284

15626 bacilláris Ach. rod-like branched 2 all sea. Wsh woods $\quad$ E. b. t. 2028. L.fliformis

15627 digitáta Ach. fingered powdery $1 \frac{1}{2}$ all sea. Y.G woods $\quad$ Eng. bot. 2439

15628 deformis Ach. deformed branch. tufts 3 all sea. Sul. roots of trees Eng. bot. 1394

15629 coccifera Ach. coccus-bearing long tufts 3 wint. Gr.G moors \& hea. Eng. bot. 2051

$\beta$ cornucopioides Ach. cornucopia-like short tufts $1 \frac{1}{2}$ wint. Gr. G moors \& hea.

15630 bellidifóra Ach. $\quad$ daisy-flowered stiff scaly $\quad 2$ wint. Pale lofty mount. Eng. bot. 1894

15631 sparássa Ach. ventricose branch. tufts 2 .all sea. Gl. in woods Eng. bot. 2362

15632 delicáta $\mathrm{Ach}$. delicate mealy patch $\frac{2}{2}$ wint. G rotten rails Eng. bot. 2052

15633 racemósa Ach. racemose loosely branc. $1 \frac{1}{3}$ all sea. Gsh heaths Dill. musc. t. 16. f. 25

15634 furcáta Ach. forked smooth tufts $2 \frac{1}{3}$ all sea. Liv.br woods

Dil.musc. t.16.f.27.A-D $\begin{array}{cll}\text { B subuláta Ach. } & \text { subulate } & \text { slightly bran. } 2 \text { all sea. Liv.br woods } \\ 15635 \text { unciális } A c h . & \text { stiff } & \text { rigid smooth } 1 \frac{1}{2} \text { wint. Pa.G moors }\end{array}$

Dil. musc. t.16. f.21. A.B

15636 rangiferina Ach. rein-deer much branch. 2 all sea. Hoa. woods

Eng. bot. t. 174

Eng. bot. t. 173

B pun'gens Ach. pungent branched tuft 2 all sea. Gr commons Eng. bot. 2444

15637 vermiculáris Ach. vermicular little tufts 1 sum. W high mount. Eng. bot. t. 2029

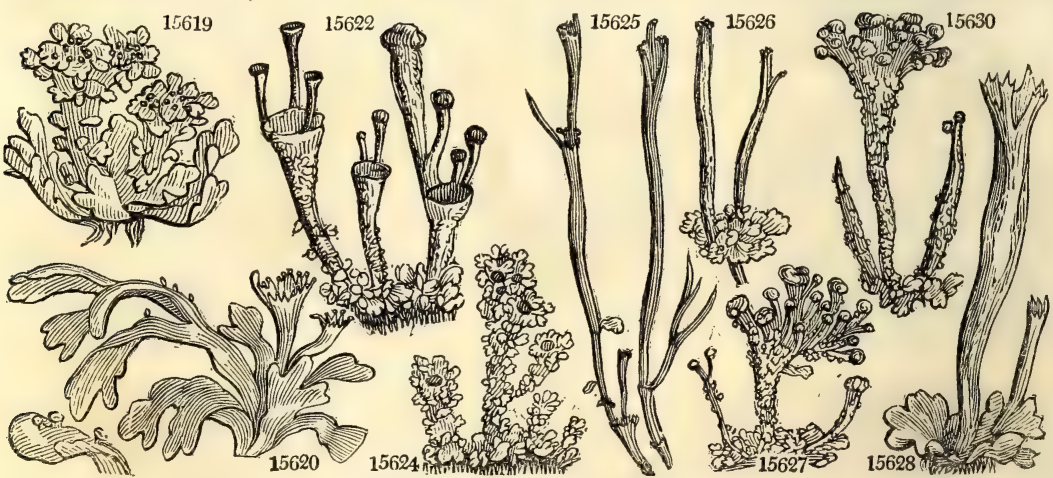

History, Use, Propagation, Culture,

snow. On the destruction of forests by fire, when no other plant will find nutriment, this Lichen springs up and flourishes, and, after a few years, acquires its greatest size. Here the rein-deer are pastured, and whatever may be the depth of snow during the long winters of that climate, thev have the power of penetrating it, and 
+ Thallus foliaceous. Podetia fistular dilated upwards and fertile, or sterile and subulate. Apothecia closed with a membrane. ScY PHOPHORA.

* Apothecia fuscous or pallid.

15619 Thallus foliaceo s very pale glaucous green the segments subpalmated ascending obtuse and incurved, Podetia elongated turbinate all cup-bearing smooth the cups regular crenate with the margin at length leafy and proliferous, Apothecia brown

15620 Thallus foliaceous large glaucous yellow green white beneath the segments muitifid waved crenate crisped, Podetia turbinate elongate mostiy simpie, Apothecia marginal reddish-brown

15621 Thallus foliaceous glaucous green: segments erect multifid narrow repando-subdentate, Podetia cylindrical short glabrous dingy at length black all of them cup-bearing: cups small regular dilated entire nearly plane proliferous from the centre, Apothecia marginal sessile brownish-black

15622 Thallus foliaceous : segments crenulated ascending, Podetia all turbinate elongate cup-shaped glabrous at length granulat. warty rough grey. green: cups regular; the margin at length proiifer. Apoth. brown

15623 Thallus foliaceous: the segments small crenate, Podetia elongate cylindrical cup-bearing sometimes subulate slightly pulverul. white: cups regular their margins ent. and crenat. at length prolifer. Apoth. brown

$\beta$ Podetia elongated powdery white, Scyphæ radiant at edge

$\gamma$ Podetia elongate subulate simple or branched pulverulent white sterile or with reddish apothecia

15624 Thallus foliaceous, Segments broadish crenulate cut, Podetia longish smooth somewhat warted glaucous or whitish green, Apothecia irregular torn into rays proliferous at edge

\& Thallus foliaceous ash-colored brittle : segments imbricated minute crenate, Podetia cylindrical rough and foliaceous : cups turbinate closed at length dilated and radiated, Apothecia marginal sessile or stalked brownish-black

15625 Thallus foliaceous, Segments small crenate, Podetia long subulate sterile and fertile smooth livid-brown, A pothecia cup-shaped toothed at edge occasionally proliferous

$\beta$ Thallus foliaceous very minute, Podetia elongate subulate sterile and cup-bearing smth. greenish brown : cups toothed at the margin at length proliferous, Apothecia brown

$$
\text { ** Apothecia scarlet or deep red. }
$$

15626 Thallus foliaceous small : segm. inciso-lobate crenate, Podetia cylindr. simple and somew. branch. at the extremity greenish white granulated rarely cup-bear.; cups narr. at length radiat. Apoth. minute scarlet

15627 Thallus foliaceous small : segments expanded rounded crenate beneath as well as on the cylindrical yeltow green cup-bearing, Podetia pulverulent: cups narrow small at length large with the often branched numerous digitate or rayed prolifications tipped with the bright scarlet apothecia

15628 Thallus foliaceous minute : segments broadish cut crenate naked beneath, Podetia long thick subventricose sulphur-colored slightly pulverulent cup-bearing : cups narrow crenato-dentate at length dilated and jagged, Apothecia sessile and pedunculate scarlet

15629 Thallus foliaceous minute: segm rounded crenate nak beneath, Podetia elongated turbinate naked neariy pale yellow or greyish green all cup-bearing, cups with their margins spreading fertile, Apothecia large

at length stalked scarlet
$\beta$ Pode. rather short cup-bearing: cups dilat. crisp. and foliac. term. by the scarlet stalk. Apoth. ai leng. prolif.

15630 Thallus foliaceous minute : the segm. inciso-crenate naked beneath, Podetia elongate cylindr. rigid glaur. foliaceo-squamose pale all cup-bear.: cuys narr. their margins fertile and prolifer. A poth. crowd. scarlet

+t+ Thallus foliaceous. Podetia fistular dilated upwards and fertile. Apothecia pervious. ScHasMa RIA.

15631 Thallus foliac. minute lobed and crenated, Podetia elongated branch. subventr. granulat. rough with leafy scales cup-bearing : cups irregular pervious dentato-radiate proliferous, Apothecia stalked pale brown

+t+t Thallus foliaceous. Podetia somewhat fistular, cylindrical, simple, split at end or digitate. Rays all fertile. HELOPODIA.

15632 Thallus foliaceous with minute granular lobes, Podetia smooth granular pallid divided at end : divisions very short, A pothecia clustered brownish black

$+1+++$ Thallus foliaceous, scarceiy any. Podetia cartilaginous, rigid, fistular, all tapering subuiate branched. Axille generally bored through. CLADONiA.

15633 Podetia elongated smooth at length scaly greenish white inflated curved branched, Branches lax subsecund their extremities divergent spinulose, Apothecia pale brown

15634 Podetia elongated smooth livid brown dichotomous, Axils not perforated, Branches narr. subulate curved the extremities forked divergent : fertile ones with brown apothecia

f Podetia elong. slender sparingly branch. Branches nearly erect : fertile bran. with brown capitate apoth.

15635 Podetia elongate glabr. pale dichotomous : the axils perforated open; extremities of the braisches patent short acute and rigid, Apothecia small terminal brown

15636 Podetia elongate cylindr. erect roughish hoary branched : axils often perforated, Branches scattered very much divided spreading the ultimate ones subradiate or drooping. A pothecia subglobose clustered browr,

B Podetia cinereous dichotomously branched rigid forming a cushion-like tuft, Axillæ rut bored through, End of branches mucronate diverging brownish

$+++1+$ Thallus none. Podetia soft, subsolid, subulate, somewhat branched. Axilla not bored through. CERANIA. 15637 Podetia subulate nearly simple smooth very white subfistulose flexuose prostrate

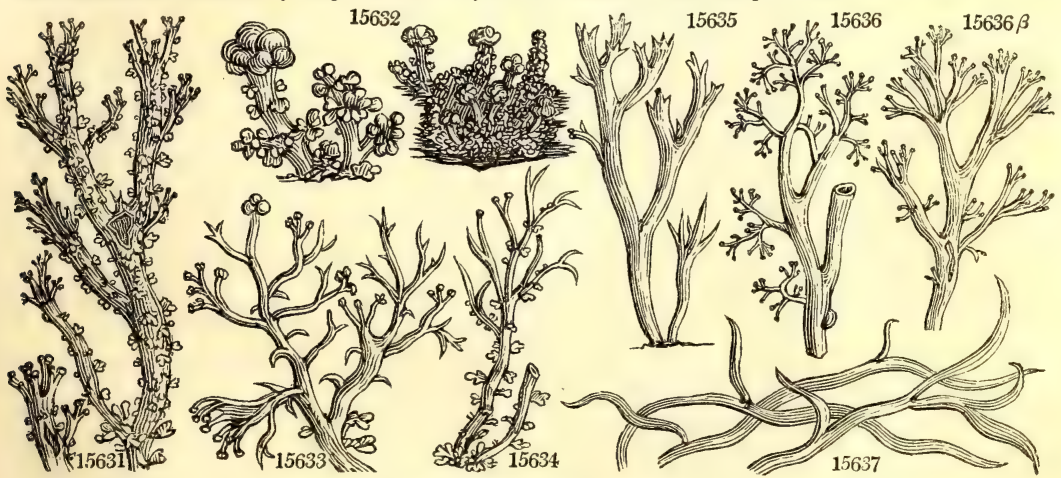

and Miscellaneous Particulars.

obtaining their necessary food. Linnæus has given a beautiful description of this Lichen, and of the animals whose support it is, in the Flora Lapponica, p. 332

C. pyxidata is somctimes employed by the poor in the cure of the hooping-cough. 
2350. B AO'MYCES. Ach. BEOMYCES.

15638 róseus $A c h$

15639 rúfus $A c h$.

rosy

rufous

15640 microphýllus $E . B$. small-leaved 15641 cæspitítius $E . B$. turfy

2351. ISI'DIUM. Ach. IsIDIUM. 15642 microstícticum Hoo. small

15643 corállinum Ach. coralloid 15644. Westrin'gii Ach. Westring's

15645 phymatódes Ach. bladdery

B phragma'um Ach. buff 15646 coccódes Ach. cracked

15647 paschále Ach. Easter

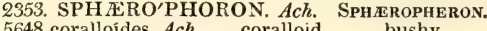

coralloid bushy

15650 compréssum Ach. compressed bushy
Sp. 4-10.
sum. Gsh powdery $\frac{1}{2}$ sum. Gsh

imbric. patch 3 wint. D.G wet heaths leafy tuft 3 aut. Pa.G oaks

tartareous $\quad$ Sp. $5-11$. $\frac{1}{4}$ aut. Brsh rocks

crowded patc. $\frac{x}{4}$ aut. Grsh rocks Eng bot 1541 cracked crust $\frac{1}{4}$ aut. Grsh rocks Eng. bot. 2204

powderycrust 3 wint. Pa.Su, stems, old tr.

powderycrust 3 wint. Y.OI stems, old tr. E.b.1529.Lepr.lutescens powderycrust 2 aut. Pa.Ol park pales Eng. bot. 1511

Sp. 1-6.

2 all sea. Grsh mountains Eng. bot. 282

Sp. 3-14.

$1 \frac{1}{2}$ all sea. $\mathrm{Pa} . \mathrm{Br}$ rocks

1 all sea. Grsh rocks

Eng, bot. t. 115

Eng. bot. t. 2474

E. bot. t. 114. L. fragilis

\section{HOMOTHALAMI.}

2354. AleCto'ria. Ach. Alectoria mane-like long tufts

3 wint. $2-7$.

on fir trees Eng, bot. t. 1880

3 chalybiifórmis Ach.

15652 sarmentósa Ach. sarmentose

long tufts 3 wint. Gr. Bl on fir trees

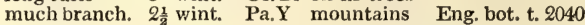

2355. RAMALI'NA. Ach. Ramalina.

15653 fraxinea $A c h$. ashen loose tufts

Sp. $\tilde{5}-19$

15654 fastigiáta Ach. clustered loose tufts 2 all sea. Gl. rocks \& trees Eng. bot. t. 890

$\beta$ calicáris Ach. calyx-like loose tufts $1 \frac{1}{2}$ all sea. Gl. rocks \& trees

15655 scopulórum Ach. ivory loose tufts $1 \frac{1}{2}$ all sea. Y. Gr marinerocks Eng. bot. t. 688

15656 farinácea $A c h$. mealy bushy tufts 2 all sea. Grsh trun. of trees Eng. bot. t. 889

15657 pollinária Ach. powdery bushy patch 3 all sea. Bt.G old oaks Eng. bot. 1607

2356. COrnicula'Ri A. Ach. Cornicularia. Sp. 7-16.

15658 trisétis Ach. dingy shrubby $1 \frac{1}{2}$ all sea. Dp.Br alpine rocks Eng. bot. t. 720

15659 aculeáta $A c h$. prickly shrubby 1 all sea. Ches. Highl. mou.

B spadicea Ach. brown shrubby 1 all sea. Ches. Highl. mou. E. bot. t. 452. L.hispidus

15660 bícolor Ach. two-colored shrubby 1 all sea. Bl Highl. mou. Eng. bot. t. 1853 15661 ochroleúca. Ach. pale-yellow shrubby $1 \frac{1}{2}$ all sea. Pa.Y Highl. mou. Eng. bot. t. 2374

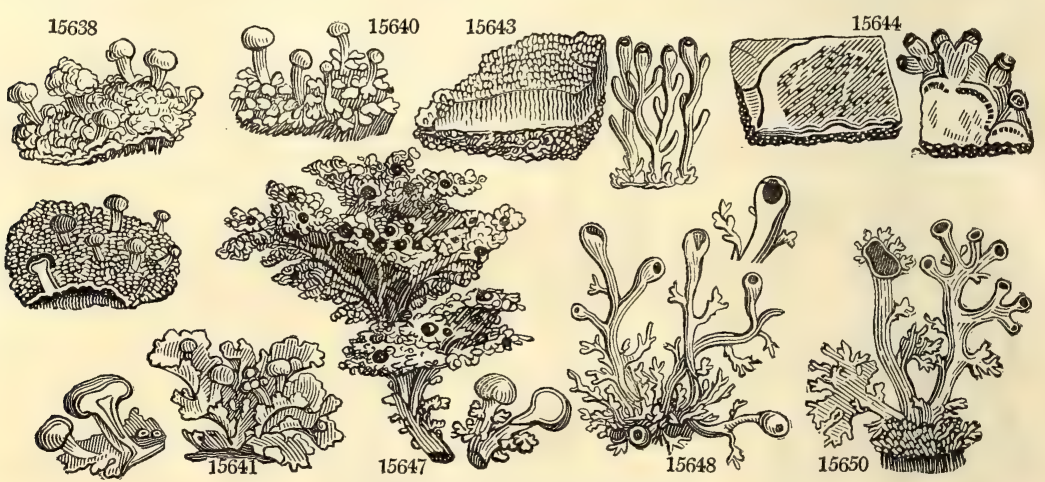

History, Use, Propagation, Culture,

2350. Baeomyces. From kasos, small, and uv*ns, a fungus, a name well applied to this genus, which much resembles some minute kinds of Ägaricus or Helvella.

2351. Isidium. From soos, equal, in allusion, we presume, to the small difference which exists in size between the podetia and the substance of the frond.

2352. Stereocaulon. From 5 Esos, hard, and liarities of this genus. Its firm branching frond is fitted to occlipying the interstices of crumbling granite, and the cells of volcanic scoriæ. It is the first of its tribe which clothes the lava of volcanoes in a state of decay.

2353. Spharophoron. From $\sigma \phi \alpha \rho \propto \alpha$, a globe, and $\phi \varepsilon \rho \omega$, to bear, in reference to the globular fructification. The most elegant genus of Lichens, at once known by its branched bushy smooth habit, like that of a coralline. 
15638 Crust unif. grazulat. greenish white, Podetia very short cylindr. Apoth. subglob. wrinkl. pale flesh-color 1.5639 Crust uniform rugose granulat. and pulverulent greenish white, Podetia very short somewhat compressed, Apothecia flattish at the top sometimes conglomerate reddish brown

15640 Leaves minute somewhat imbricated rounded nearly entire, Podetia simple tubular smooth

15641 Thallus clustered ascending leafy pinnatif. cut and crisped : bright green above; white beneath, Tubercles from the disk of leaves convex reddish brown

15642 Crust tartareous cracked smoothish nearly even of a brownish cream-color thinner towards the edges, Podetia scattered short hemispherical simple of the same color as the crust, Apothecia brownish

15643 Crust tartareous greyish white, Podetia at length elongat. round. simple or branch. Apeth. brownish-grey

15644 Crust tartarecus thin unequal cracked and greyish, Podetia subglobose at length cylindrical simple and branched, Apothecia dark-brown

15645 Crust cracked areolate warty a little powdery unequal pale sulphur-color, Podetia becoming cylindrical simple and branched, A pothecia yellowish brown

$\beta$ Crust powdery sulphureous-green, Podetia roundish of the same color, Apothecia pale yellow

15646 Crust somewhat cracked powdery and hoary, Podetia subglobose papillæform very close together, Apothecia brown hoary

15647 Thallus greyish branch. and rough with granulat. excrescences, Branches crowded and very much divided, Apothecia scattered and terminal at length convex conglomerate blackish brown

15648 Thallus palish-brown, Branches lateral elongate lax divaricat. and forked acumi. Apoth. subglobose smth.

15649 Thallus greyish branched, Branches dichotomous short crowded fastigiate naked rounded rather obtuse, Apothecia globoso-turbinate somewhat warted

15650 Thallus whit branch. Branc. compress. ramulose subfibrill, naked, A poth. subglob. depress, and smth. above

\section{НОМОТН ALAMI.}

15651 Thallus rounded somewhat shining livid-brown very much branched, Branches filiform compressed at the axils, Apothecia of the same color, at length convex entire at the margin

$\beta$ Thallus and subsimple branches flexuose or tortuose complicated rather rigid greyish-black decumbent

15652 Thallus roundish angular somewhat pitted dichotomous pale-yellowish : the extremitles much branched lax and slender, Apothecia rather concave livid pruinose, at length flattened

15655 Thallus plane linear laciniated greyish-white glabrous but rugose and pitted subreticulated : the ultimate branches attenuated, Apothecia mostly marginal plane pale flesh-colored

15654 Thallus compressed glabrous pitted branched glauc. white, Branches thickened and fastigiated upwards, A pothecia numerous terminal peltate subsessile white

$\beta$ Thallus and branches elongated, Branchlets cylindrical attenuated pitted and channelled, Apothecia subterminal appendiculated beneath

15655 Thallus compressed glabrous somewhat pitted branched yellowish-grey, Branches linear attenuated, A pothecia scattered on short stalks of the same color as the thallus

15656 Thallus compressed glabrous somewhat pitted bearing powdery warts rigid branched greyish or greenishwhite, Branches linear attenuated, Apothecia scattered on short stalks plane somew. margin. whitish

15657 Thallus flat somewhat membranous smooth a little pitted white torn, occasionally powiery with dilated flat soredia, Apothecia nearly terminal very large

15658 Thallus deep pitchy-brown rounded or subcompressed smoothish distichously dichotomous, Branches fastigiate black above, Apothecia plano-convex blackish-brown somew. marginated entire and toothed 15659 Thallus glabrous chesnut-brown round. angular pitted and subcompressed naked, Branches and branchl divaricated flexuose aculeated, Apothecia reddish-brown : the circumference somewhat toothed

$\beta$ Thallus glabrous chesnut-colored plano-compressed somewhat pitted with the margins denticulate, Branches and branchlets short patent attenuated, Apothecia spinose-radiate reddish-brown

15660 Thallus black rounded capill. suberect branched, Branches fine short. scatter. pat. : extrem. curved grey.

15661 Thallus glabrous pale yellowish-white roundish suberect branched, Branches short attenuated blackish at the points, Apothecia brownish pale in the circumference

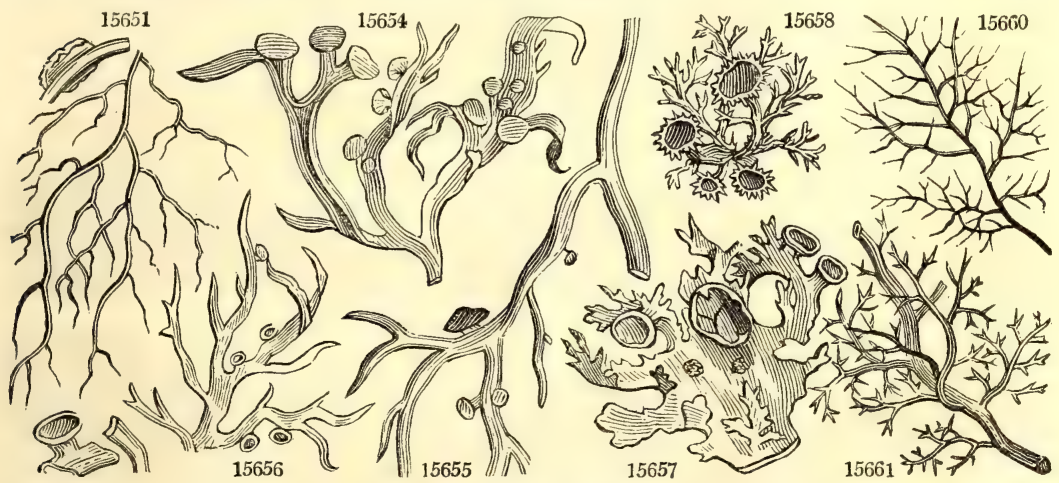

and Miscellaneous Particulars.

2354. Alectoria, seems to derive its name from $\alpha \lambda \varepsilon \approx \tau \omega \rho$, unmarried, because nothing has been made out respecting the male flowers. A. usneoides is a species which grow on trees in warm countries, such as Asia, Africa, and America, hanging down in branches from six to eighteen inches long: it was used by the Arabian physicians as a cordial, and also for the purpose of procuring sleep. A. juoata occasionally supplies the reindeer with food; for which purpose the Laplanders cut down the trees, that the Lichen may be devoured from the topmost branches.

2355. Ramalina. This name does not appear to have any obvious meaning. The species are little bushy tufts generally covered with soredia. They are found in all parts of the world upon trees and rocks; but chiefly upon the former.

2356. Connicularia. So called in allusion to the multitude of little horn-like divisions into which the thallus

is divided. Crustaceous branched tufts, with a solid axis. 


\section{2 lanáta Ach. woolly}

15663 pubéscens $A c h$. pubescent

1566 t heteromálla $E . B$. variable

2357. US'NEA. Ach. UsNea.

15665 forida Ach. $\quad$ flowering

15666 plicáta Ach.

\section{B hirta Ach.}

15607 barbáta Ach.

$\beta$ articulata Ach.

2358. COlle'mA. Ach. Collema 15668 nígrum Ach.

15669 cheíleum Ach. lipped

15670 frágrans $A c h$ fragrant

15671 críspum Ach. crisp

15672 ténax Ach. tough

15673 plicátile $A c h . \quad$ plaited

15674 fluviále Ach. $\quad$ floating

15675 melæ'num Ach. blackish

$\beta$ marginále Ach. marginal

15676 fasciculáre Ach. fascicled

15677 cretáceum Ach. cretaceous 15678 corrugátum Ach. $\quad$ wrinkled

15679 palmátum Ach. palmated 15680 granulátum E.B. granular 15681 multipartítum E.B. many-parted shrubby $\quad \frac{\pi}{4}$ all sea. Gr.Bl rocks

Eng. bot. t. 846

entangl. tufts 3 aut. Bl rocks Eng. bot. t. 2318

rough patch 3 aut. Bl bark of trees Eng. bot. 2246

erect

Sp. 3-10.

pendulous 4 wint. Gsh old trees

Eng. bot. t. 872

nearly erect 2 wint. Gsh old trees

g. bot. t. 257

Eng. bot. t. 1354

pendulous 4 wint. Gsh old trees Eng. bot. t. 258. f. 2

pendulous 4 wint. Gsh old trees Eng. bot. t. 258. f. 1

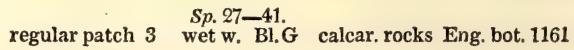

round, patch $1 \frac{1}{2}$ wet $w$. Bl.G roots of trees

small patches $\frac{1}{2}$ wet w. D.Ol trun. of clms Eng. bot. 1912

round. patch. $\frac{1}{2}$ wet w. Gl. on the grou. Eng. bot. 834

lobed tuft 1 wet w. G moist places Eng. bot. 2349

lobed tuft 1 wet w. Ol.G wet rocks Eng. bot. 2348

many-parted $\frac{1}{2}$ wet w. Br calcar. rocks Eng. bot. 2039

starry $\quad \frac{1}{3}$ wet $w . B r$

imbric. lobes 1 sum. Ol Highlands Eng. bot. 1924

roundish $\quad 2$ aut.wi. $\mathrm{Br} \quad$ trun. of trees Eng. bot. 1162

minute dots $-\frac{1}{2}$ wint. $\mathrm{Br} \quad$ chalk stones Erg. bot. 738

small patches $\frac{1^{2}}{4}$ wint. D.G rocks, sea co. Dillenius, t. 19. f. 19

lobed patch $\quad$ i spr. su. Br sand. ground Eng. bot. 1635

imbric. patch $1 \frac{1}{2}$ wet $\mathrm{w}$. $\mathrm{Br}$ gravel walks

lobed patch 3 sum. Ol.G rocks \& walls Eng. bot. 2582

eafy

2 all sea. Bl.G trun. of trees Eng. bot. 1980

15684 nigréscens $A$ ch. blackish leafy 2 all sea. D.G trun. of trees Eng. bot. t. 345

15685 fáccidum Ach. flaccid leafy smooth 2 all sea. D.G Scotland Eng. bot. t. 1653

15686 fúrvum Ach. rough rugese memb. 2 all sea. D.G trun of trees Eng. bot. t. 1757

15687 scotinum Ach. naked flat patches $1 \frac{1}{2}$ sum. Ol oldwalls

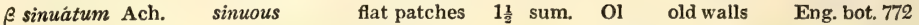

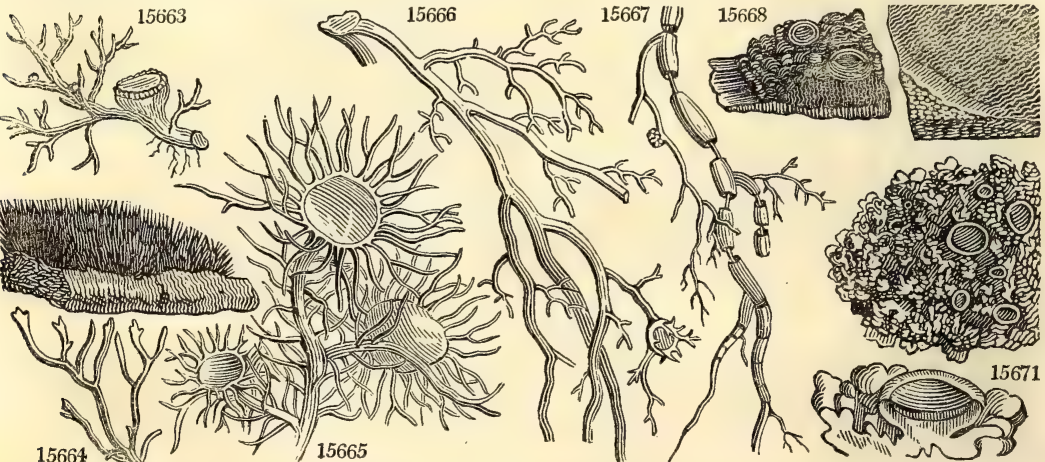

History, Use, Propagation, Culture,

2357. Usnea. This word is said to have originated in the Arabic âchneh or âchnên, which is, according to Golius, the name by which the Arabian physicians designate Lichens in general. Crustaceous branched tufts, usually hanging down from the substances on which they grow 
15662 Thallus decumbent rounded smoothish dichotomous greyish-black, Branches and branchl, flexuose intricate forked at the extremity, Apothecia somew. margined plane: circumference naked and granulated

15663 Thallus decumbent rounded roughish black, Branches intricate capillaceous : the ultimate ones simple, A pothecia of the same color entire in the circumference

15664 Minutely shrubby densely tufted erect entangled cylindrical corymbose black with palish notched tips

15665 Thallus nearly erect roughish greenish-grey with very numerous fine horizontal fibres, Branches patent subsimple, Apothecia plane very broad whitish ciliated: the cilize radiating long

15666 Thallus pendulous smooth pale, Branches lax much divided subfibrillose: the ultimate ones capillaceous, A pothecia plane broad ciliated, Ciliæ slender very long

$\beta$ Thallus nearly erect somewhat shrubby pale greenish-white very much branched subpulverulent and roughish, Branches very much divided flexuose intricate attenuated subfibrillose

15667 Thallus pendulous smoothish rounded thickish pale greenish-grey, Branches divergent here and there fibrillose capillary at their extremity articulated below

$\beta$ Thallus glabrous greenish-grey glabrous, Branches elongate dichotomously divided articulated, Articulations swelling distinct : ultimate branches capillary fibrillose

+ Thallus crust-like, irregular, or uniform. Placynthivm.

15668 Thallus crustaceous roundish brown-black: lobes of the circumference cut crenate; central granular a little branched, Apothecia becoming convex black-edged

+t Thallus imbricated, plaited, roundish, composed of minute lobes, becoming very turgid when wet. ENcHYLIrM. 15669 Thallus suborbicular imbricated: lobes thick; all minute rounded crenulated ascending, Apothecia nearly plane aggregated of the same color as the thallus : the margin crenulated subevanescent

15670 Thallus roundish : lobes rounded expanded naked thickened at edge crenate asceriding, Apothecia scattered minute concave dull yellow-brown : exterior margin tumid and unequal

15671 Suborbicular : the central lobes somewhat erect granulated; those of circumference depressed larger obt. crenulate, Fructification scattered rather concave reddish with a granulated margin

15672 Suborbicular imbricated : lobes thickish flat incumbent roundish cut lobed and crenulate, Apothecia scattered immersed in the lobes and concave rufous with an entire edge

15673 Suborbicular imbricated : lobes all thick rounded lobed plaited in circles wavy suberect entire, Apothecia scattered concave whole-colored

15674 Thallus cushion-like formed of thick close blunt complicated lobes, Apothecia somew. marginal roundish whole-colored : disk urceolate with a double edge

15675 Thallus orbicular sornewhat stellated imbricated : lobes cut and laciniated ; margins elevat. waved crisp. and crenulated, A pothecia marginal nearly plane of same color as thallus : their margin granulated

$\beta$ Lobes of the thallus deeply laciniated narrow multifid spreading flexuose nearly plane crenate and lobed, A pothecia marginal and scattered dark-brown their margin entire

15676 Thallus suborbicular imbricato-plicate : plaits central erect flexuose, Lobes of the circumference rounded inciso-crenate, Apothecia marginal turbinate fasciculate: disk rather convex reddish

15677 Thallus Jobed starry dark green, Apothecium central elevated brownish pink with a paler entire margin

15678 Thallus thick dark-green with elevated intestine-like convolutions

+++ Thallus somewhat foliaceous irregular, formed of naked, expanded, thick, turgid, naked lobes. ScrTinıum.
15679 Thallus subfoliaceous green-brown-glaucous: lobes thick close palmate cut; segments somewhat linear round, Apothecia rufous brown

15690 Leafy gelatinous fleshy granulated on both sides of a blackish-olive color, its lobes crowded rounded plaited crisp and cut, Apothecia scattered dark brown

15681 Frond radiating fieshy : segments repeatedly forked fan-shaped crenate convex above concave beneath, Shields prominent at length blackish and flat

++++ Thallus foliaceous: lobes rounded, downy or fibrous beneath. MaLLotium.

15682 Thallus foliaceous blackish-green glaucous and downy beneath, Lobes rounded waved entire, Apothecia scattered elevated plane reddish : their margin entire

15683 Thallus foliaceous somew. imbricated glauc. greenish-brown pubescent and somew, spongy beneath, Lobes rounded sinuated crenulat. and crisped, Apoth. depressed planish brown : their margin foliaceous crisped ++++ Thallus foliaceous : lobes somewhat membranous, lax, naked, dark-green. LATHAGRum.

15684 Thallus foliaceous membranous submono-phyllous orbicular depressed plaited rounded and lobed blackgreen, Apothecia central crowded at length convex reddish brown their margin entire

15685 Thallus foliaceous membranaceous smooth blackish-green : lobes distinct rounded entire lax waved, Apothecia scattered nearly plane reddish : their margin thin entire

15686 Thallus foliaceous membranaceous somew. wrinkled complicate blackish-green granulated on both sides : lobes round. unequal waved and crisp. ent A poth. scattered plane dark-brown: their margin entire

15687 Thallus foliaceous membr. imbr. naked black: lobes small roundish cut nearly entire suberect plaited, Apoth. scattered sessile whole-colored with an entire edge

B Lobes sinuate cut crisp toothletted
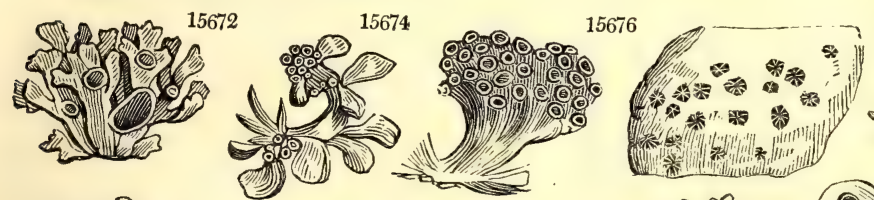

15677
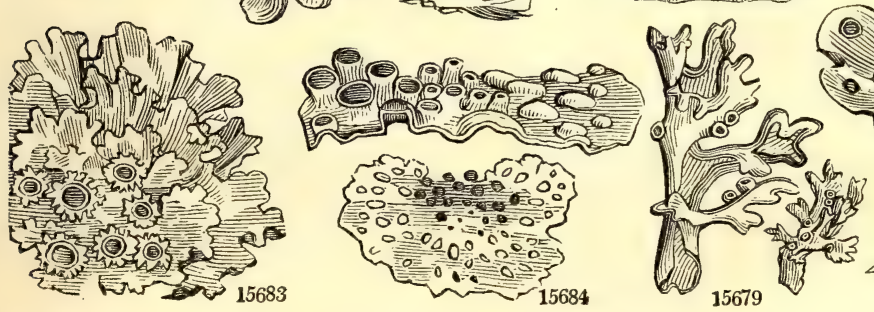

15679

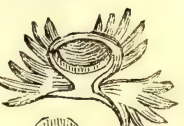

and Miscellaneous Particulars.

2358. Collema. A Greek word signifying a glutinous substance. All the species are gelatinous, and are supposed by Fries to be Algæ in a Licheniform state. Nostoc cæruleum has been positively stated to be convertib!e into Collems limosum. 
15688 tremelloides Ach. tremella-like half transpar. 1 spring Lead rocks 15689 lácerum Ach.

15690 súbtile Ach.

15691 tenuíssimum $A c h$. very fine 15692 Schradéri Ach.

15693 muscícola Ach.

15694 spongiósum Ach. lacerated

half transpar. $1 \frac{1}{2}$ spring $\mathrm{Gl}$. earth

starry

$1 \frac{1}{2}$ sum. D.G earth

Eng. bot. t. 1981

Eng. bot. t. 1982

Eng. bot. t. 1008

fat patch 2 jul.au. D.Ol dry banks

Schrader's small tufts

$\frac{1}{2}$ june Y.G old walls

Eng. bot. 1427

moss-covering cushion-like $\frac{3}{\frac{3}{4}}$ spring $\mathrm{Br}$ among moss Eng. bot. 2264

spongy

large fruit

3 all sea. $\mathrm{Ol} . \mathrm{Br}$ rocks

Eng. bot. 1374
2359. LEPra'Ria. Ach. Lepraria. 15695 chlorina Ach. 15696 fláva Ach.

15697 ochrácen $E . B$.

15698 viréscens $E . B$. brimstone

yellow

ochre-colored

greenish

\section{ATHAL AMI.}

Sp. 4-13.

cushion-like 2 wint. Sul. rocks

thin coat 2 wint. Bt.Y old pales

scatter. warts $\frac{1}{4}$ wint. G.Y old trees granular $\frac{3}{4}$ wint. Y.G elm trees
Eng. bot. 2038 Eng. bot. 1350

Eng bot. 2408

Eng. bot. 2149

\section{PSEUDO-LICHENES.}

2360. OPE'GraPha. Ach. Opegrapha.

15699 nimbora 15700 venósa $E$. $B$.

15701 Persoónii Ach.

$\beta$ apórea Ach.

15702 calcárea Ach.

15703 maculáris Ach.

15704 herpética Ach.

$\beta$ disparáta Ach.

15705 vulgáta Ach.

15706 epipásta Ach. 15707 stenocárpa Ach.

$\beta$ denigráta Ach. black

veiny

rough

limestone

spotted

eruptive

reddish

common

\section{Sp. 10-35.}

variegated flat patch

$1 \frac{1}{2}$ all sea. Pa.Y old trees

$1 \frac{1}{2}$ all sea. pa.Oc. beeches

Eng. bot. 2346

tartareous

2 all sea. Wsh stones

leprous

2 all sea. Wsh slate \&stones

angular dots $1^{\frac{1}{2}}$ all sea. Bl mort., old w. Eng. bot. 1790

largish spots

$\frac{1}{2}$ all sea. Brsh bark of trees E. bot. 2282. O. epiphega

dotted crust

1 all sea. Pa.Ol bark of trees Eng. bot. 1789

scaly

1 all sea. Pa.Ol bark of trees E. bot. 2347. O. rubeila

$1 \frac{1}{2}$ all sea. G.W bark of trees Eng. bot. 1811

dotted smooth skin 3 all sea. Gr smooth bark Fng. bot. 1828

\section{microscopical smooth skin 3 all sea. Ol} narrow-fruited smooth patch. $1 \frac{1}{2}$ all sea. Ol

smooth bark Eng. bot. 1911 smooth bark

15708 nótha Ach. spurious dotted crust 3 all sea. Wsh old trees Eng. bot. 1896

$\beta$ diáphora Ach. various-fruited dotted crust 3 all sea. Gr trun. of trees Eng. bot. 2280

2361. VERRUCA'RIA. Ach. Verrucaria.
15709 maúra Ach.
blackamoor cracked crust 2 aut. Bl $\begin{array}{lll}S p .11-56 . & \text { rocks } & \text { Eng. bot. t. } 2456\end{array}$

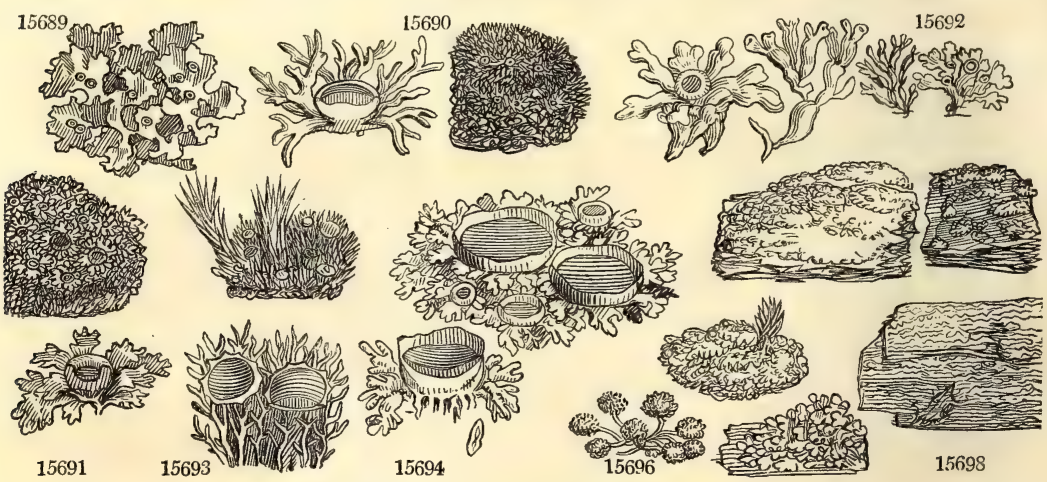

History, Use, Propagation, Culture,

2359. Lepraria. Because the plants upon which these substances grow have the appearance of being diseased with leprosy.

2360. Opegrapha. From orn, a chink, and reaфw, to write. The shields or apothecia are cracks upon the surface of the thallus resembling Hebrew or oriental characters upon a pale ground. 
H+1+1 Thallus foliaceous: lobes rounded, membranous, thin, naked, cinereous, glaucous, somewhat transparent. Apothecia slightly stalked. LEPTOGIUM.

15688 Thallus foliaceous membranaceous thin subdiaphanous lead-color obsoletely rugose and dotted: lobes rounded somewhat cut, Apothecia scattered subpedicellate plane reddish-brown : their margin pale

15689 Thallus nearly erect foliac. membr. subdiaphan. subrugose with obscure reticulations glauc. : lobes small subimbr. cut and laciniat. and somew. fringed, Apoth. scattered rather concave red : their margins pale ++++++ Thallus very finely laciniated and branchletted.

15690 Thallus substellate : the segments very narrow linear appressed very much branched obtuse, Apothecia central nearly plane of the same color as the crust : their margin thin entire

15691 Thallus subimbricated : segm. minute linear multifid unequal granular acute much clustered, Apothecia scattered fleshy rufous margined

15692 Thallus subcæspitose : segm. linear flat irregularly subdivided rugose obtuse; margins repand obsoleteiy crenated, Apothecia scattered of the same color

15693 Thallus pulvinate brown, Branches rounded nearly erect flexuose uneven subfastigiate rather obtuse, Apothecia nearly terminal plane brown margined

15694 Thallus dull-green : segm. aggregate branched granular cylindrical obtuse, Apothecia scattered concave brown : externally spongy and pale with an erect thin margin

\section{ATHALAMI.}

15695 Crust thick pulvin. bright sulphur-color composed of a dust-like substance collect. into somew. hairy glob. 15696 Crust spreading equal thin somewhat cracked bright-yellow composed of subglobose granules

15697 Crust not discernible, Fructification of an ochrey-yellow collected into thin scattered patches

15698 Crustac. granulated continuous somewhat gelatin. : greyish dull-green when dry ; bright-green when wet

\section{PSEUDO-LICHENES.}

+ Disk of apothecia very narrow, crack-like, somewhat covered in by the conniving tumid margins. HYsTERINA. 15699 Crust somew. cracked unequal very white, Apothecia clustered minute oval-oblong turgid : disk closed 15700 Crust tartareous determined reddish-white, Clefts immersed convex without any elevated border repeatedly branched curved parallel and equidistant

15701 Crust tartareous smoothish cohering uneven whitish, Apothecia innate oblong: disk resembling a cleft, at length rugose waved plaited dissimilar rather confluent with the disk irregular somewhat dehiscent

$\beta$ Crust tartareous or leprose uneven pulverulent, Apothecia roundish dissimilar waved plaited tortuose and variously expanded in the disk

15702 Crust tartareous powdery very white, Apothecia longish straight swelling opaque collected in a stellate manner : disk like a crack

15703 Crust very thin brownish-black, Apothecia minute much crowded roundish elliptical, at length rugose irregular: disk very narrow

15704 Crust somewhat membranous very finely cracked rugose roughish cinereous-brown, Apothecia minute innate clustered convex elliptical oblong straight with a crack-like disk

$\beta$ Crust membranous smoothish pale-olive or green and rufous-brown, Apothecia variable roundish oblong straight and curved

15705 Crust between cartilaginous and membranaceous somewhat scaly smoothish greyish-white, Apothecia sessile long or roundish waved somewhat shining with the disk very narrow

15706 Crust very thin of a regular figure polished cinereous, Apothecia innate minute convex rugulose opaque various : smaller dot-like; longer very slender flexuose somewhat branched

$\beta$ Crust very thin shin. pale-olive, Apothecia subellipt. simp. somew. parallel becoming stellate and angular

15707 Crust membranous polished somewhat bordered whitish, Apethecia sessile various: the smaller globose or oblong; larger very long narrow roundish flexuose

$\beta$ Crust regular membranous whitish, Apothecia sessile close together somewhat shining longish flexuose simple and branched : disk somewhat channelled

t+ Disk of apothecia concave, channelled, or flat, appearing between the separated margins. Auxxoria.

15708 Crust cartilagi:n. lep. white, Apothecia scatter. sess. round. and oval deform. : disk flat becorning convex

\& Crust cartilaginous membranous dirty-white ash-color, Apothecia variable sessi?e oblong and tapering at each end opaque : disk flat

t+† Thallus cartilaginous, membranous, contiguous, polished. LiccPhLEA.

15709 Crust very thin smooth much cracked very black, Apothecia very minute subglobose immersed: the extremity prominent umbilicated; nucleus blackish

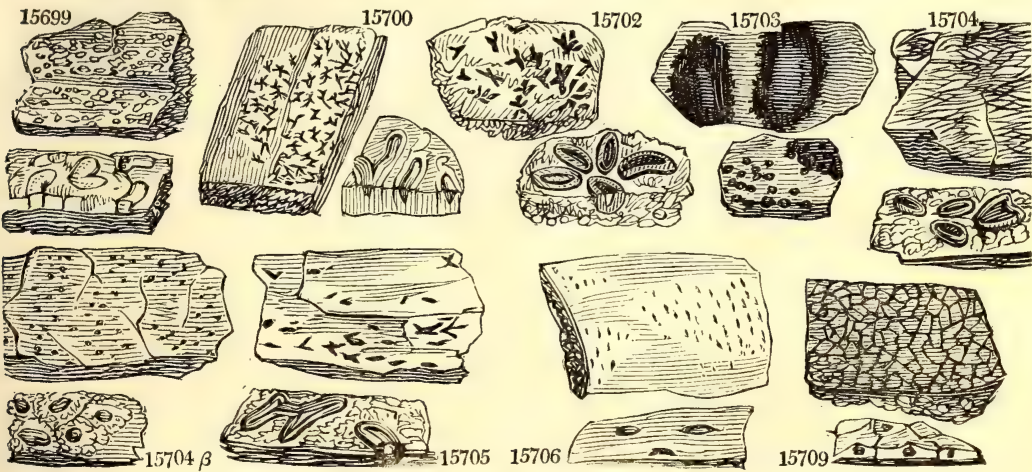

and Miscellaneous Particulars.

2361. Verrucaric. Thus called, from verruca, a wart, on account of the verrucose nature of the shields. Schrader says, this genus differs from the similar Eudocarpon in having the shields always closed, while the latter explodes its contents by a small but distinct orifice. 
15710 punctifórmis $A c h$. 15,11 analépta $A c h$.

15712 epidérmidis Ach.

15713 stigmatélla Ach.

15714 ceuthocárpa Ach. cracked

15715 Schradéri $A c h$. 15716 Harrimánni Ach.

15717 plúmbea Ach.

15718 striátula Ach.

$\beta$ acrotélza Ach.

15719 epigéa Ach.

2S62. PORI'NA. Ach.

15720 pertúsa $A c h$.

2363. ARTHO'NIA. Ach.

15721 impulita $E . B$. du

15722 Swartziána Ach. Swartz's

15723 astroidca Ach. $\quad$ astroid

1572+ ol iscúra Ach. obscure

15725 lýncea Ach.

2364. GR A'PHIS. Ach. GraphIS.

15726 scripta Ach.

$\beta$ pulverulénta Ach. powdery

$\gamma$ Cérasi Ach. Cherry-tree

15727 dendrítica Ach. Tree-like

15728 serpentina Ach. serpentine

15729 Lyélli Ach. Lyell's

15730 élegans Ach. elegant thin coat

thin coat

thin coat

thin coat
2 all sea. Br

1 all sea. W birch bark

3 all sea. Pa.Br smooth bark Eng. bot. 1891

tessellated

4 all sea. Pa.01 slate rocks Eng. bot. 2372

dotted crust \& all sea. Wsh calca. stones Eng. bot. 1711 small pitches 1 all sea. Br.Ol hard rocks Eng. bot. 2539

lobed patches $1 \frac{1}{2}$ all sea. Ol limest. rocks Eng. bot. 2540 cloudy spots $\frac{\frac{s}{4}}{4}$ all sea. Pa.G flints

cloudy spots $\frac{\pi}{4}$ all sea. Pa.G flints

Eng. bot. 1712

mealy tessell. $1 \frac{1}{2}$ all sea. G dry banks $\quad$ E. b. 1 (161. L. terrestris

crust $\quad \begin{aligned} & S p .1-19 . \\ & \text { aut. }\end{aligned}$

Sp. 4-14.

spotted patch. $\frac{1}{2}$ all sea. Rsh trun. of trees Eng. bot. 981

cracked crust $1 \frac{1}{2}$ all sea. Wsh smooth bark Eng. bot. 2079 membranous $\frac{2}{4}$ all sea. Cin. smooth bark Eng. bot. 1847 warty 3 all sea. D.Ol bar. of old tr. Eng. bot. 1752 broad masses 3 all sea. Wsh bar. of old tr. Eng. bot. 809 Sp. $5-16$.

shining crust $1 \frac{1}{2}$ all sea. Grsh smooth bark Eng. bot. 1813 thin crust 2 all sea. Pa.Y trees Eng. bot. 754 thin crust $\quad 3$ all sea. $\mathbf{Y}$ old cher. tre. Eng. bot. 2301 smooth patch. $1 \frac{1}{2}$ all sea. $Y \quad$ sinooth bark Eng. bot. 1756 even crust $\quad 3$ all sea. Pa.Ol smooth bark Eng. bot. 1755 cracked crust 4 all sea. Pa.Ol rugged bark Eng. bot. 1876 uneven crust 3 all sea. Pa.Y smooth bark Eng. bot. 1812
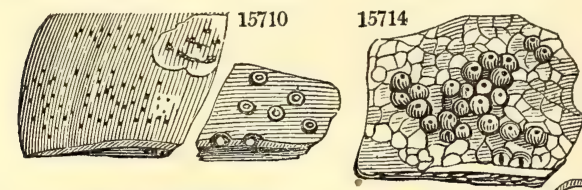

157150
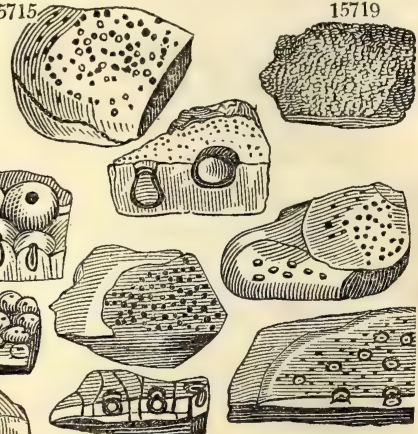

15716

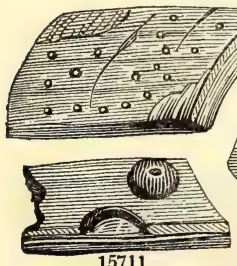

15711

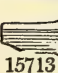

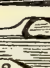

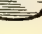

2362 Porina. From twesvos, any thing that crumbles away, a name applied in consequence of the nature of the crist of these plants, which, indeed, is common to them with other Lichens.

2363 Arthonia. A name, the meaning of which is unexplained. The species are similar in habit to Spitoma and Opegrapha. 
15710 Crust very thin determined polished brown. Apothecia min. hemisph. glob. without orifices : kernel white 15711 Crust membranous determined shining somewhat olive-colored, A pothecia subsessile scattered hemispherical conoid papillose: kernel compressed somewhat membranous white

15712 Crust exceedingly thin spreading quite white, Fructification minute roundish subelliptical, Tubercles semi-immersed : the interor white

15713 Crust thin cartilaginous membranous polished becoming cracked whitish, Apothecia minute hemispherical clustered subconfluent with scarcely any orifice

+† Thallus nearly solid, somewhat gelatinous. Blennorina.

15714 Crust somewhat gelatinous roundish broken dark crenate cut radiated in the circumference, Apothecia subglobose immersed papillose at end

+十 Thallus subtartareous, crustaceous, contiguous, cracked into areole, or powdery. Lithocia.

15715 Crust tartar. contig. whitish, Apothecia minute clustered immersed subglobose dirty transparent inside

15716 Crust tartareous contiguous bordered finely dotted mouse-color, Apothecia minute subglobose immersed with a prominent papilla : dirty-white inside

15717 Crust tartareous contiguous finely cracked subrugose lead-color, Apothecia subglobose innate finely becoming depressed and scutelliform

15718 Crust with the figure of a tree greenish-black bordered, Areolæ nearly separate somewhat branched radiating, Apothecia conoid becoming concave above

$\beta$ Areolæ of the crust dispersed deformed brownish-black

$++1+$ Thallus soft, cottony, somewhat spongy, or thin and arachnoid. INoDERMA.

15719 Thallus thin somew. fibrous uneq. pale-yell. Apothecia minute globose immersed with a prominent orifice

15720 Crust equal polished whitish ash-colored, Warts ot apothecia subglobose, Orifices several depressed black

15721 Crust white powdery and cracked, Tubercles numerous depressed oblong irregular obtuse yellowishbrown clothed with deciduous mealiness

15722 Crust cartilagin. membr. white, Apoth. sess, broad. tum. round. rep. irreg. and confl. dark with elevat.dots 15723 Crust membr. pale cinereous and glaucescent, Apoth. flatten. upon the crust plane angular substell. black 15724 Crust membr. somew. olive-col. A poth. min. flat concav, somew. membr. oval-ellipt. and renif. wrink. dark 15725 Crust thin subtartareous equal somewhat cracked white, Apoth. clustered flat somewhat immersed round oblong and curved black cæsious

15726 Crust membranac. smooth somew. shining white or greyish-brown bordered with black, Apothecia half immersed naked flexu, simple or branch. : disk very narr marg. formed of the thallus raised membranac.

8 Crust effuse membr. whitish, Apoth. emerging flexuose with a channelled dehiscent cæesious disk with an elevated tumid margin

$\gamma$ Crust very thin hoary glaucous shining, Apothecia emerging straight long nearly simple acuminate somewhat parallel : disk channelled

15727 Crust somewhat cartilaginous unequal very white, Apothecia immersed flexuose branched black : branches divergent forked acute, Disk broad flat naked

15728 Crust cartilaginous membranous unequal rugulose of a regular figure white and cinereous, Apothecia immersed long clustered flexuose nearly simple and branched

15729 Crust membranous polished pale-olive, Apothecia clustered nearly simple curved turgid obtuse : disk broad convex cinereous pruinose with a thick powdery white margin

15730 Crust orbicular granular smooth white, Apothecia immersed scattered short straight nearly simple margin of the perithecium with a longitudinal furrow
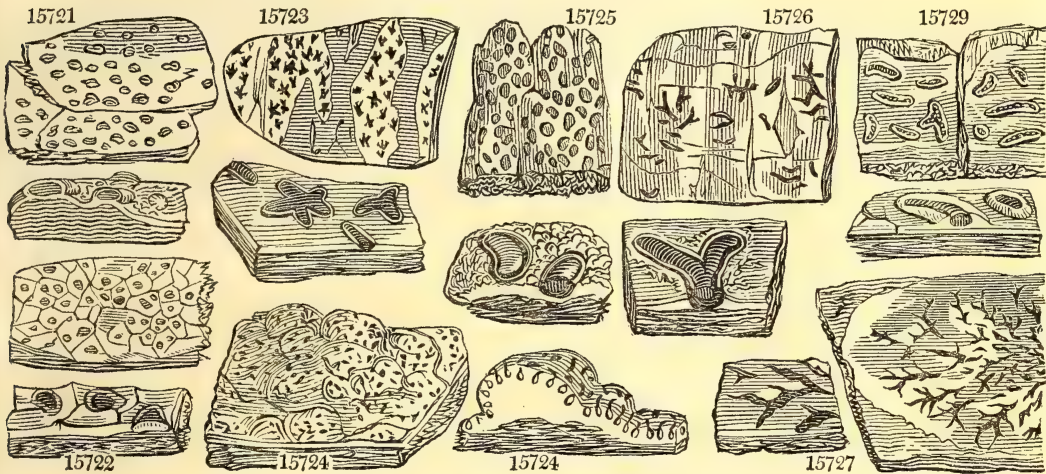

and Misceilaneous Particulars.
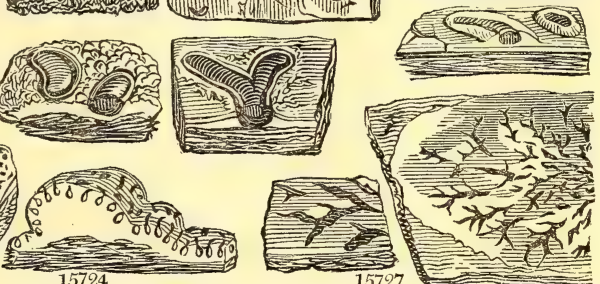

15727

2364. Graphis. From yea $\phi$, to write. The apothecia are extremely similar in form to the characters of some strange language. It is very near Opegrapha from which it does not at all differ in habit. 

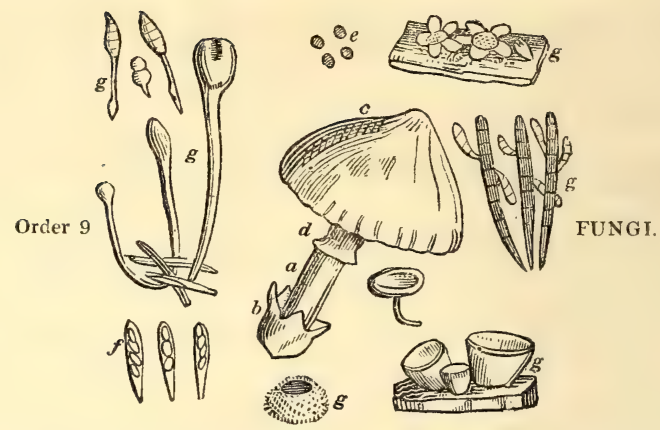

Reproductive organs uniform. Sporules (e) arranged in tubular cells $(f)$ placed in some parts of the external surface." Substance various $(\mathrm{g})$, mostly thick and fleshy, sometimes vesicular. Frond none.

IN speaking of the eighth order, Lichens, it has been observed, that they, Algæ and Fungi, might be considered collateral. But perhaps Fungi should be estimated as still lower in the scale of creation than Lichens. From some passages in the writings of a celebrated Swedish author upon Fungi, Mr. Fries, whose mode of arrangement is almost entirely adopted here, it would seem as if he considered the three orders to consist of the same beings altered by the material on which they grow, and organized according to the different elements upon which they depend for support. Algæ, he observes, which are much extended in their native element, water, when exposed to the air, contract and become Lichens. Thus Nostoc muscorum becomes Collema limosum, \&c. ; and Sir James Smith has even decided, that Lichina pygmæa when growing under water is an Alga, and when above water a Lichen. But the differences between Fungi and Algæ, or Lichens, are greater, and arise out of their essence; that of Fungi being always reproductive, of Algæ primitive. In Algæ, the thallus is the most essential part, and the reproductive organs of secondary importance ; in Fungi, the whole plant is generally a mass of reproductive matter, and the thallus always accidental. Fungi always grow upon dead vegetable matter; Lichens always upon living vegetation. The bark which, when living, bears Lichens, produces Fungi as soon as it begins to decay : and even on the same half-dead branch, the living side will be found occupied by Lichens, and the dead by minute Fungi. The lowest Fungi are considered by Fries, to bear the same relation to plants as Entozoa to animals; for which reason, he is of opinion, that all infusorial plants are Fungi, and not Algæ. But this may be doubted. The number of Fungi which may be conceived to exist is incalculable. Multitudes have been discovered by the researches of modern observers, and multitudes still remain to be detected, especially in extra-European countries. In Sweden, in the small space of a square furlong, where the number of Phænogamous plants was 420, and of Lichens and Algæ 430, Fries discovered more than 2000 species of Fungi.

The most celebrated writers on Fungi are Micheli, Schæffer, Bulliard, Bolton, Sowerby, and Greville, for figures; and Persoon, Link, Nees von Esenbeck, Fries, and Greville, as systematists.

Link defines the essence of a Fungus to be sporules disposed in a series, in elongated tubular cells; the cells situated in some part of the external surface. 'The part in which the reproductive organs are placed is called the hymenium $(a)$, the hollow base from which the stem or stipes $(a)$ arises is named the volva (b) or wrapper'; the upper part is the cap or pileus $(c)$, which is provided on the inferior surface with thin radiating expansions, which are termed gills or lamella, among which the sporules are situated. Many Agarics have a delicate fringe connecting the margin of the pileus at a certain age with the stem; this is called the veil $(d)$, and is either general (universale), when adnate with the surface of the pileus, but becoming obsolete with age; or it is partial when it extends only from the margin of the pileus to the stipes. The annulus $(d)$ is a kind of veil, which is sometimes fixed to the stem, at others free and capable of being moved upwards and downwards. The Peridium, Perithecium, or Perisporium, are different names for the envelope immediately enwrapping the sporules.

\section{Tribe I. HYMENOMYCETES.}

Hymenium naked.

Class I. Hymenini $v$. Agaricine.

Hymenium distinct. Receptacle long or expanded, superior.

Division I. Pileati.

Receptacle dilated, occasionally branched, having a tendency to an orbicular form. Hymenium inferior. Asci fixed.

2365. Agaricus. Hymenium in lamellæ. Lamellæ sìmple, parallel.

* Stem central, with a veil. Gills unchangeable. Sporidia white.

8 1. Amanita. Veil double, universal separate, partial annular somewhat persistent.

\$ 2. Lepiota. Veil simple, universal, concrete, annular, somewhat persistent.

Observations.

Tribe I. Hymenomycetes. This tribe is readily distinguished from the others by its hymenium containing sporules within the surface, and not naked; from the Pyrenomycetes by the want of a perithecium and a reproductive nucleus; from Gasteromycetes by the want of a peridium inclosing the sporules, which constitute the mass of the fungus, and from the Hyphomycetes and Coniomycetes by the sporidia not being exposed.

Division I. Pileati. This constitutes the most extensive division in Fungi, and includes almost every thing which was known to the ancients. Dioscorides mentions one or two species distinctly, comprehending the remainder among his eatable and unwholesome kinds. Pliny talks of the very numerous kinds of fungi, but describes very few. C. Bauhin knew about sixty, which he chiefly obtained from Clusius; Tournefort had two genera and eighty-seven species; Micheli six genera and about 800 species; Linnæus three genera and fifty species; Persoon, in his Synopsis, mentions nine genera and 683 species; finally, Fries describes more than a 1000 species arranged under many genera and subgenera.

The species are widely scattered over all Europe, but the extra European fungi, with the exception of thase 
8. Armillaria. Veil simple, partial, separate, annular, 6omewhat persistent.

4. Limacium. Veil very fugacious, viscid. Lamellæ adnate, decurrent.

5. Tricholoma. Veil very fugacious, flocculose, marginal. Lamellæ emarginate or rounded.

** Stem central, naked. Gills unchangeable. Sporidia whitc.

86. Russula. Pileus fleshy, becoming depressed. Lamellæ equal, juiceless.

7. Galorhreus. Pileus fleshy, becoming depressed. Lamellæ unequal, milky.

8. Clitocybe. Pileus fleshy, when young convex. Lamellæ unequal, juiceless.

9. Collybia. Pileus fleshy-membranous, flattish. Small, dry.

10. Mycena. Pileus membranous, campanulate. Slender. Stipes hollow.

11. Omphalia. Pileus membranous or fleshy-membranous, when young umbilicated

*** Stem out of the centre, none. Gills unchangeable. Sporidia white.

\$12. Pleurotus. Pileus out of the centre or lateral.

**** Stem always central. Veil 0 . Gills changing color. Sporidia rose-colored.

13. Mouceron. Pileus fleshy, becoming depressed. Lamellæ long, decurrent. Odor of new flour.

14. Clitopilus. Pileus fieshy, convex.

15. Leptonia. Pileus fleshy, membranous, from convex becoming plane. Small.

16. Nolanea. Pileus membranous, campanulate. Slender. Stipes hollow.

17. Eccilia. Pileus umbilicate. Lamella adnate.

***** Stem always central. Veil like cobweb. Gills changing color, becoming dry. Sporidia ochre-colored.

8 18. Telamonia. Veil annular, woven, somewhat persistent. Lamellæ distant.

19. Inoloma. Veil fugacious, Lamella emarginate. Stipes bulbous, Color something of violet.

20. Dermocybe. Veil fugacious. Lamellæ closely packed. Stipes equal.

****** Veil distinct, not like a cobweb. Gills discolored, somewhat persistent. Sporidia ferruginous.

21. Pholiota. Veil diry, annular.

22 Myxacium. Veil viscid, fugacious. Lamellæ affixed.

23. Hebeloma. Veil marginal, fugacious. Lamellæ emarginate.

******* Veil very fugacious or spurious, not like a cobweb. Gills discolored, somewhat persistent. Sporidia ferruginous.

\$24. Flammula. Pileus fleshy, convex, smooth, somewhat viscid. Lamella not emarginate.

25. Inocybe. Veil formed of the longitudinal fibres of the fleshy convex pileus. Lamella whitish.

26. Naucoria. Pileus fleshy, membranous, flattish, squamulose. Smail. Lamella cinnamon-colored.

27. Galera. Pileus membranous, campanulate. Slender. Stipes hollow.

28. Tapinea. Pileus umbilicate, villous at edge.

29. Crepidotus. Pileus out of the centre or sessile.

******** Veil present, not unlike a cobweb. Gills becoming discolored, cloudy, dissolving. Sporidia brownish-purple.

80. Volvaria. Veil universal, separate. A volva.

31. Psalliota. Veil annular.

32. Hyph́oloma. Veil marginal, fugacious. Lamellæ emarginate. Stipes bulbous.

33. Psilocybe. Veil very fugacious. Pileus somewhat fleshy, and stipes equal, tenacious.

34. Psatyra. Pileus somewhat membranous, and stipes brittle

35. Coprinarius. Lamellæ with a tendency to deliquesce. Veil partial. Sporidia black.

2366. Coprinus. Hymenium in lamellæ, which finally become deliquescent. Asci separate with sporidia in four rows.

2367. Gomphus. Hymenium in lamellæ, which are long branched and decurrent. Pileus turbinate, umbonate.

2368. Cantharellus. Hymenium veined. Veins dichotomous, subparallel, sometimes anastomosing

2369. Merulius. Hymenium veined. Veins flexuose, or forming very irregular pores. Plants sessile, resupinate or effused.

2370. Schizophyllum. Hymenium in lamellæ. Lamellæ bifid, lengthwise revolute.

2371. Dadalea. Hymenium sinuous, composed of anastomosing lamellse or flexuose elongated pores

2372. Polyporus. Hymenium porous, not separable from the substance of the pileus nor the pores from each

other. Pores sometimes lacerating in age. Pileus very rarely with a central stipes.

1. Favolus. Pores ample, with four or six angles resembling an honeycomb.

2. Microporus. Pores minute, roundish.

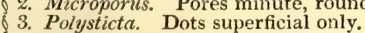

2373. Boletus. Hymenium tubular. Tubes separable from the pileus and from each other. Pileus always with a central stipes.

2374. Fistulina. Hymenium tubular. Tubes loose, the young ones closed

2375. Hydnum. Hymenium subulate. Subulæ loose

2376. Sistotrema. Pileus carnose, irregularly stipitate. Hymenium composed of dentate, interrupted lamellæ.

2577. Plilebia. Hymenium rugose, formed of long or confluent papillæ.

2378. Thelephora. Plant with very few exceptions more or less aduate, thin, coriaceous, very rarely infundibuliform. Hymenium covering the outer surface

2. Phyiacteria. Sporidia four in a row. Resupinate and groving on the earth.

3. Himantia. Effuse resupinate, when young byssoid. Sporidia few, immate in the hymenium, which 15 smooth and naked in the middle.

4. Leiostroma. Resupinate, somewhat contiguous, smooth, or with spuricus papillæ. Asci none.

Observations.

on the coasts of Barbary, and a few from North America, are almost universally distinct from the European kinds. They are found growing on the earth, or in decayed wood, or similar substances; never upon iocks Those which have been described as natives of vaults and places underground, are believed to be mere monstrous formations. They are in greatest perfection in warm rainy weather, being chiefly the creations of summer and autumn; a few only appear in the spring, and scarcely any in the winter. The duration of the pileate fungi is often only ephemeral; some last from a week to a fortnight; and a few for a longer time. The Dædalex and Polypori are often called perennial, but it is the opinion of Fries, that their substance decays, and is only covered yearly by a fresh layer of pores. The roots of many of those which grow upon trees is perennial; of others merely annual.

When crude they are mostly poisonous, with a mucilaginous taste, which is often acrid, but they become less dangerous by cooking. The dangerous qualities of some of the kinds is attributable to the larvæ with which they are infested. 
Division II. Clavati.

Receptacle long, simple, or branched, with a tendency to a cylindrical form, not margined. Hymenium superior. Asci fixed.

* Hymenium occupying the whole surface. Asci distinct. No distinot stem.

2379. Clavaria. Plant carnose, cylindrical, simple or branched. Hymenium smooth, occupying almost the whole surface, confluent with the stipes.

2380. Caloccra. Plant branched or simple, cylindrical, homogeneous, corneous, gelatinous, viscid. Growing on wood.

\footnotetext{
** Hymenium only occupying the end. Asci long. Head separate from stem, simple.
}

2381. Geoglossum. Hymenium short, club-shaped, mostly compressed, stipitate. Stipes elongated, smooth or hairy. Plants black or dull green. 2382. Spatularia. Hymenium club-shaped, separate, compressed, running down the stipes on each side,
hearing the asci at the upper end.

2383. Mitrula. Hymenium clavate, ovate, closely surrounding at the base the stipes, which is distinct.

*** Hymenium only occupying the end. Asci obsolete. Head separate from stem.

2384. Typhula. Hymenium thin, subcylindrical, persistent, terminating the capillary stipes.

**** Hymenium covering the whole surface, but bearing sporules at the end only, without asci.

2385. Pistillaria. Simple, contiguous, linear or clavate. Sporidia emerging at end.

Class II. Uterini $v$. Elvellacee.

Hymenium distinct, superior, margined. Receptacle urceolate or reflexed, alway's inferior.

Division 1. Mitrati.

Receptacle pileiform, bullate, never closed. Hymenium neither margined nor discoid.

2386. Morchella. Pileus lacunose, confluent with the stipes either at the margin or a little above it. Hymenium occupying the whole outer surface.

2387. Helvella. Pileus submembranaceous, irregular, smooth on each surface, deflexed at the sides. Hymenium occupying the whole outer surface.

2388. Verpa. Pileus conical-deflexed, equal. Hymenium smooth or rugose

2389. Leotia. Pileus ovate-conical or orbicular, wholly occupied by the hymenium, the margin free, but closely embracing the stipes. Division II. Cupulati.
Receptacle cupulate, equal. Hymenium discoid, when young somewhat closed, surrounded by the margin of the
receptacle.

2390. Peziza. Pileus mostly carnose, sessile or stipitate, more or less cup-shaped at length sometimes plane. Hymenium occupying the disk.

earth.

8 2. Lachnea. Waxy, hairy or villous externally. Usually on wood.

3. Phialed. Waxy or membranous, rarely gelatinous, smooth, naked, On wood.

4. Helotium. Plano-convex. On wood.

2391. Ascobolus. Pileus carnose, cup-shaped or hemispherical. Sporuliferous cells in the disk, forming prominent points filled with a fluid intermixed with the eight sporules.

\section{Observations.}

Division II. Clavati. Scarcely any traces of these fungi can be discovered in the writings of the ancients. Clusius described a few. Tournefort confounded them with corals and Lycoperdons. Holmskioid and Persoon are the principal modern writers upon this tribe.

Almost all the species of which there is any certain knowledge are European. The genuine kinds are terrestrial; those which are found upon wood, being transitious to other orders. In vaults or caverns they become unusually developed, and the asci, on account of the excessive supply of moisture, expand and become flocculent. Most are found in the autumn ; the branched kinds are often what are termed meteoric, that is to say, spring up suddenly after heavy falls of rain. They seldom last more than fourteen days.

In qualities they are mild, some having a bitter taste, but the greatest number are almost entirely destitute of smell, color, or taste. Many of the large kinds are used in cookery, and are eaten by various herbivorous animals.

Class II. Uterini. The natural form of the receptacle is cupulate, but in the most perfect kinds, the cupula is reflexed, and is called a mitra; in the least perfect, which are innate in the matrix, the receptacle is almost wholly obliterated. The resupinate Pileati are distinguished from these by their immarginate form, and by their asci.

Division I. Mitrati. A small division, apparently wholly unknown to the ancients. The species are almost entirely European; a few are found in North America and Siberia. It is probable, however, from the evidence of Loureiro and others, that some peculiar genera and species exist within the tropics. They are generally fond of a humid shady station. None are found in subterraneous places. If an individual is occasionally produced upon wood, it is upon such as is wholly decayed. Many spring up in the autumn and spring; they are rarely meteoric, but some appear in greater abundance in one kind of season than in another. Most of them last for a fortnight, and retain their form when dry

Their qualities are generally mild, nutritive, and juiceless; one is said to be bitter. They are little infested by larvæ. Several are used as food.

Division 1I. Cupulati. These are included in the Fungoides of the old botanists. The species which are separate from their thallus and much developed, are little changed by the places in which they grow, and are therefore the same in the most remote countries; but the eruptive or innate species, which are more affected by the nature of the substance by which they are fed, are liable to greater changes when their matrix is altered. For it is a general rule, that the more a fungus is innate in the substance which produces it, the more it is not only imperfect, but affected by its situation, and vice-versâ. Hence Cæoma, which is of a very low order, consists of as many species as the plants upon which it grows, just as a vowel forms as many distinct words as it is combined with distinct consonants.

The Clavati and Pileati, which chiefly depend upon the access of light, are in perfection from spring to autumn; the Elvellaceæ from autumn to spring. The Cupulati also depend much upon the operation of light, for in caverns or cellars they remain closed and sphæria-like. Such is the case with Peziza cerina, which in dark places, undergoes many metamorphoses; and Cenangium under similar circumstances, when some obstacle is offered to the developement of its hymenium, becomes deliquescent. Generally the terrestrial sorts agree in habitude with the preceding divisions; but those which are eruptive are often in perfection for half a year together.

Class III. Trcmellini. These are nearly akin to the Pileati and Clavati, especially to Thelephora and Calocera; and also to Elvellaceæ, more particularly to Hygromitra, Peziza, Mollisia, Bulgaria, and Ditiola, but they are distinguished without difficulty by the characters assigned to them.

Formerly all the genera were confounded under one, along with various species of Lichens and Algæ. These 
2392. Bulgaria. Cupula closed at first. Asci immersed, with paraphyses, becoming separate and bursting out. Gelatinous.

2393. Ditiola. Hymenium becoming plaited and deliquescent. Cupula open. Veil universal. Corky.

2394. Cenangium. Hymenium smooth, persistent, rarely deliquescent. Cupula closed, but opening finally. Somewhat coriaceous.

2395. Stictis. Hymenium smooth, immersed. Cupula obliterated. Hymenium persistent.

2396. Cryptomyces. Spreading, quite adnate, emerging, nearly plane, carnose. Hymenium covering the

whole surface. Thecæ erect. Sporidia large, oval.

\section{Class III. Tremeluini.}

Hymenium confounded with a gelatinous receptacle. Sporidia separate. Asci none.

2397. Tremella. Receptacle gelatinous homogeneous, fructifying in all directions, without papilla. Sporidia nearly emerging.

\footnotetext{
1. Coryne. Fleshy gelatinous, somewhat clavate.
}

Somewhat cartilaginous, expanded, leafy.

2398. Exidia. Receptacle gelatinous, homogeneous, covered on the upper surface only by a papillose hymenium. Sporidia emitted with elasticity.

2399. Dacrymyces. Receptacle gelatinous, homogeneous, filled with assurgent flocci, and sporidia placed in layers inside. When young compact, but finally deliquescent.

2400. Agyrium. Receptacle spherical, smooth, compact, waxy, when humid gelatinous, finally crumbling away in sporidia.

2401. Hymenella. Recep acle flattened, adnate, smooth, like soft leather, very thin, persistent.

2402. Nematelia. Receptacle gelatinous, surrounding a compact heterogeneous nucleus. Sporidia emerging.

Class IV. Sclerotiace.

Hymenium confounded both with the fleshy receptacle and the sporidia. Asci none.

2403. Acrospermum. Elongated, somewhat clavate, with a coat of a similar substance, distinctly fructifying at the end.

2404. Sclerotium. Subglobose, or without regular form within, homogeneous, vesiculose, carnose, or corneous. Sporules unknown.

2405. Rhizoctonia. Deformed, united with a similar persistent coat by means of root-like fibres proceeding from all points of its surface.

2406. Periola. Rootless, fleshy, covered entirely by a villous persistent coat.

2407. Acinula. Rootless, smooth, with a distinct farinaceous granular coat.

2408. Erysiphe. Sporangium epiphyllous, very minute, globose, furnished with white radiating subjacent filaments, and containing sporuliferous bodies.

\section{Tribe II. GASTEROMYCETES,}

Fungus entirely closed, and bearing sporidia in the centre; and so forming an uterus.

Class I. Angiogastres.

Uterus finally bursting forth, separate from the receptacle. Sporidia lodged in the receptacle.

Division I. Phalloidece.

Receptacle separate, open on account of the bursting of the uterus. Sporidia placed in a mucous layer.

2409. Phallus. Stipes issuing from a volva. Pileus furnished with large cells filled with a sporuliferous slimy substance.

\section{Observations.}

are by modern writers now referred to their proper stations. The genus Mycoderma of Persoon, to which are referred those tough skin-like coatings which are found upon vegetable extracts enclosed in bottles, and which is generally placed among Tremellini, is thought by Fries to be not of a vegetable nature.

The species at present known are found in Europe, Asia, and North America, but no material difference seems to be caused in them by their native country. All the species, with one exception, are epiphytes; the most perfect bursting forth from the bark of trees; the least perfect occurring on decorticated wood, the stems of herbs, \&c. \&c. The more the wood is dried, the nearer the species approach to Lichens; the more it is humid to Algæ. They are in perfection in the latter part of autumn, winter, and early spring, but scarcely any are found in the summer. Some live for a month or more; others appear to be perennial. When dry they are not to be recognized; they may nevertheless be preserved, and if moistened, they recover their original appearance. It must be observed, that they are in all cases to be examined in a wet and tumid state.

Their qualities are refrigerant, and but little known. They are destitute of smell and taste, for which reason, and on account of their mucilaginous texture, scarcely any species is eatable. Many of the large kinds were formerly used in medicine in cases of ophthalmia, under the name of the "Jew's ear." Vinegar in which they had been steeped was also used as a gargle in tumors of the throat, according to Clusius. Tremella fimbriata is said to furnish a dye, and the sporidia of $T$. mesenterica to dye yellow. Dacrymyces destroys timber.

Class IV. Sclerotiacee. The affinity of this class is complex; for the lower we descend, the less differences are to be found between natural bodies. Thus Sclerotiacei are not only closely connected with the preceding divisions, but have a more or less obvious relation to all the hymenine and epiphytous classes of other tribes.

Before the time of Tode, a most sagacious observer, who was the first to distinguish the Sclerotia from other fungi, a very few species only were known, which were confounded with Lycoperdon, Sphæria, Tuber, and other genera. He was followed by various other mycologists, and especially by Decandolle, who described thirtynine species. Tode, Persoon, and Link, have been unable to detect any fructification; Decandolle, Ehrenberg, and Fries, declare that the sporidia are scattered through the whole mass of the fungus, and emerge from it like hoar-frost.

Most of the known species are epiphytes, either upon living or recently dead plants. When growing in cellars and subterraneous places they undergo no alteration, but they do not fructify. They flourish most in the winter, late in the autumn, and early in the spring; and are exceedingly common just at the retreat of winter. A very few Spermodia only are found in the summer. Their odor and smell are either inconspicuous or nauseous. None of the species at least are eatable. Those which grow on rotten seeds are exceed. ingly poisonous. Some feed on the roots of living plants, which they destroy; others infest sickly herbs, whence they are a pest to the farmers.

Tribe II. Gasteromycetes. These fungi consist of concrete cells; they have a determinate figure and a tendency to a spherical form; at first they are closed, but finally are furnished with an orifice ; or burst in an irregular manner, and emit an internal mass of reproductive matter, which either crumbles to pieces or deliquesces. The integument is of various natures, either a volva, a peridium, or perithecium, of a somewhat bladdery texture; and is simple or double, but rarely multiple. They almost all, when young, are fluxile or soft, or have some part or another of a fluid nature; afterwards they become indurated and rigid, and assume their true forms.

Class I. Angiogastres. These are fungi of remarkable forms, and most unusual mode of fructifying; they were well known to Clusius, not to mention the celcbrated Truffle of which Theophrastus had knowledge They are found in different climates; but the most perfect only in temperate regions. The latter are also 
2410. Batarrea. Head hemispherical, crumbling to pieces under the vertex into a little tuft of hairs bearing sporules. Stipes smooth. Involucrum triple, flowing with mucilage.

Division II. Tuberacec.

Sporangia membranous, scattered in an hymenium which is often grated with verns, and inclosed in the uterus. Sporidia pulpy at first.

2411. Tuber. Uterus closed, marbled with veins inside. Sporangia stalked, scattered among the veins. Subterraneous.

2112. Rhizopogon. Uterus sessile, bursting with irregularity, with anastomozing veins inside. Sporangia sessile. Above ground.

\section{Division III. Nidulariacea.}

Uterus filled with separate sporangia.

2413. Nidularia. Common peridium simple. Sporangia lenticular, fleshy, with sporidia in heaps in the middle.

2414. Myriococcum. Peridium simple, flocculent-furfuraceous, disappearing. Sporangia globose, with sporidia in round heaps.

2415. Polyangium. Peridium simple, membranous. Sporangia oblong, filled with a grumous mass.

\section{Division IV. Carpoboli.}

\section{Uterus protruding a solitary separate sporangium.}

2416. Atractobolus. Peridium cupulæform, with a lid. Sporangium fusiform, with mucous sporidia

2417. Thelebolus. Peridium sessile, urceolate-ventricose with an entire orifice. Sporangium papillæform, with mucous sporidia.

2418. Pilobolus. Stipes or receptacle pellucid, watery. Peridium a roundish vesicle, bursting elastically, placed on the apex of the receptacle.

24.19. Spharobolus. Peridium double, both stellate; the inner membranous by inversion throwing out with elasticity a globose sporangium, bearing in the middle heaped sporidia.

\section{Class II. Pyrenomycetes.}

Uterus genuine, forming the receptacle. Sporidia disposed in asci in regular rows.

Division I. Spheriacei.

Perithecium closed, perforated by an orifice, filled by an ascigerous somewhat deliquescent mucleus.

2420. Xylaria. Receptacles stipitate, carnose or suberose. Spherules immersed in the receptacle, and containing a gelatinous sporuliferous mass.

2121. Stromatospheria. Receptacle sessile, free, or bursting from beneath the bark of dead wood. Spherules immersed.

2422. Cucurbitaria. Spherules tufted, free, fixed on a receptacle, rarely at first included. Receptacle burst ing through the bark.

2423. Ciyptosphcria. Receptacle O. Spherules scattered or aggregate, lying beneath the epidermis or bark, orifice various more or less exserted.

2424. Heterospheria. (See Notes.)

2425. Spheria. Receptacle O. Spherules sessile on the surface or slightly immersed.

2426. Lophium. Perithecium vertical, compressed, dehiscing by a longitudinal somewhat closed cleft. Asci crumbling away.

\section{Division II. Cytisporei.}

Closed, perforated by an orifice. Asci none; sporidia surrounded by a little bag or thin cellule, deliquescent.

2427. Spheronema. Perithecium opening by a pore, enclosing in a very thin bag some mucous sporidia, which burst forth and become indurated in a globose form. Naked.

2428. Septaria. (See Notes.)

2429. Cytispora. Cellular-many-celled; cells deformed, membranous, united at ends. Nucleus gelatinous, filled with sporules, propelled through the common elongated orifice

2430. Phoma. Nucleus grumous, enclosed in a tubercle. Sporidia emitted by a simple orifice without regularity.

Division III. Phacidiacei.

Perithecium finally bursting, with an open disk. Asci erect, fixed.

2431. Dothidea. Nucleus inclosing immersed cellules. True perithecium obliterated, Asci erect, remaining for a long time.

2432. Rhytisma. Perithecium deformed, bursting into transverse fragments by means of a flexuose crack

2433. Phacidium. Receptacle $O$. Perithecia sessile, depressed, bursting from the centre towards the circumference in several acute segments. Sporuliferous cells elongated, fixed.

2434. Hysterium. Perithecia mostly oblong, black, corneous, bursting by a longitudinal slit. Sporuliferous tubes erect. (Crust none.)

Division IV. Xylomacei.

Asci obsolete. Sporidia innate.

2435. Actinothyrium. Perithecium buckler-like, with radiating fibres covering the fusiform sporidia.

2436. Leptostroma. Perithecium uniform, without an orifice, but entirely separating and exposing a very thin disk.

2437. Xyloma. Black, corneous. Perithecia single, solitary and minute, or united and confluent, irregularly dehiscent.

\section{Observations.}

terrestrial; the imperfect kinds being inhabitants either of plants or of the dung of animals. Many are meteoric, flourishing most in "Jove tonante, densisque cadentibus imbris ;" others are ephemeral; some exist for a month and more.

The Phalloideæ are generally very fætid, cold, and venomous; one species is accounted in China a vulnerary, and also a food, but of doubtful quality. The old physicians had some peculiar notions about their use in arthritis, \&c. but they are not worth repeating. The Tuberaceæ have a peculiar smell, which is often grateful; their taste is irritating; their qualities esculent, nutritive, and aphrodisiacal.

Class II. Pyrenomycetes. The affinity of this class is very complex, for which reason there is much Class II. Pyrenomycetes. The affinity of this class is very complex, for which reason there is much
difference of opinion among authors as to its limits. In fructification it approaches fungi of a higher degree of developement; on one hand resembling the Angiogastres, from which it is readily distinguished by its separate receptacle; on the other hand, the Cupulati, whose differences depend upon the definition of their perithecium. In point of vegetation it descends, first, to Sclerotiacex, which are entirely different, in the absence of an uterus and nucleus; secondly, to Perisporia, which have no distinct perithecium, and no asci ; and thirdly, to several genera of Coniomycetes. 
2438. Lasiobotrys. (See Notes.)

2439. Asteroma. Black, minute, epiphyllous. Receptacle radiate, filamentous, very adnate, at length tubercled here and there.

Class III. Trichosperm.

Uterus genuine, forming a receptacle. Sporidia intermixed with flocci.

Division I. Lycoperdinei.

Uterus of a determinate figure, fleshy when young. Flocci copious.

2440. Onygena. Subglobose with a fibrous stipes. Peridium crustaceous, fragile, with interwoven fibres, Sporules naked, compactly clustered.

2441. Tulostoma. Globose stipitate. Involucrum none. Peridium opening by a bordered pore in the summit. Sporules scattered in it.

2442. Scleroderma. Sporangium globose or prolonged into a stipes. Peridium single, coriaceous, mostly warty, bursting at the apex or subdehiscent. Sporules collected into little contiguous distinct globules mixed with filaments.

2443. Lycoperdon. Sporangium globose. Peridium single, membranaceous, scaly, with warts or soft spines bursting irregularly at the apex, and containing a mass of sporules and filaments.

2444. Bovista. Sporangium globose. Peridium double; the outer one adnate, cracking, somewhat fugacious ; inner one bursting at the apex, and containing a mass of filaments and pedicellated sporules.

2445. Geastrum. Globose sessile. Involucrum coriaceous, stellate. Peridium membranous. Sporules on stalks from the first.

\section{Division II. Trichocisti.}

Uterus regular, when young pulpy. Sporidia having numerous flocci scattered among them.

2446. Craterium. Peridium oblong, stipitate, operculate, containing a cellulose, filamentous, sporuliferous mass.

2447. Stemonitis. Cylindrical or subglobose. Peridium fugacious. Filaments forming a reticu ated mass, perforated by the stipes to which they are attached. Sporules intermixed.

2448. Cribraria. Globose stipitate. Peridium crumbling to pieces at the summit in cracks.

2449. Dictydium. Globose stipitate. Peridium crumbling to pieces entirely or for the most part.

2450. Arscyria. Mostly cylindrical. Peridium fugacious, except a small portion at the base. Filaments abundant, reticulated, fixed at the base. Sporules intermixed.

2451. Leangium. Minute subglobose. Peridium single, membranaceous, bursting into subregular, persistent, expanding segments. Filaments attached at the base and surrounding a columella.

2452, Trichia. Minute subglobose or irregular. Peridium single, membranaceous, bursting. Filaments involute attached at the base, and expanding elastically.

2453. Diderma. Minute subglobose. Peridium double; the outer one fragile and fugitive. Sporules mixed with a few filaments and surrounding a roundish columella.

2454. Physarum. Sporangium minute, mostly stipitate, subglobose. Peridium single, membranaceous, bursting and deciduous in distinct portions. Sporules mixed with a mass of filaments.

2455. Leocarpus. Minute. Peridium single, fragile, bursting, sessile or substipitate, containing a black mass of sporules mixed with a few filaments. Columella $O$.

\section{Division III. Fuliginoidei.}

Uterus somewhat deformed, sessile, when young pulpy. Sporidia separated by flocci.

2456. Iycogala. Sessile globose or subirregular, pulpy when young. Peridium single, fragile, variously dehiscent. Sporules mixed with a few filaments.

2457. Spumaria. Form irregular, roundish, effused. Peridium soft, at length membranaceous, fragile. Sporules contained in the folds of branched, elongated, membranaceous, persistent processes.

\section{Division IV. Liceoidei.}

Flocci obsolete.

2458. Dichosporium. Flattened hemispherical, Peridium membranous, coated with a layer of granules, Sporules in globose masses.

2459. Licea. Peridium membranaceous, sessile, fragile, inclosing a pulverulent mass of sporules unmixed with filaments. (No subjacent membrane.)

Class IV. Múcorolder.

Peridium formed of flocci loosely woven together, vanishing in the middle. Sporidia in heaps.

2460. Mucor. Peridium membranaceous, globose, stipitate, pellucid, at length opake. Pedicel simple or branched, tubular, articulated.

2461. Thamnidium. Stipes branched at base; branches bearing solitary globules at their end. Peridium globose.

2462. Ascophora. Peridium membranaceous, stipitate, bursting at length, turned inside out, convex and subpersistent. Pedicel simple or branched, tubular, pellucid, articulated.

Class V. Perisporia

Perisporium thin, somewhat membranous, bursting. Sporidiaimmersed, scarcely distinct.

2463. Eurotium. Peridia membranous, subglobose, with an articulated floccose innate receptacle. Sporules naked in masses.

2464. Amphisporium. Subglobose. Peridium membranous, thin. Sporules naked of two forms.

\section{Observations.}

Its extent is very great, ascending from the most simple forms to those which are very compound, but at the same time connected with the former by the most strict natural ties. The true place of the genera in the system has been a subject of doubt. Many authors have taken them for fungi in the most perfect state. Decandolle excludes them from fungi, and, with some analogous Lichens, refers them to a peculiar intermediate dolle ex
family.

They are found in every part of the world in which vegetation exists ; for every perfect plant and all its decaying parts nourish Pyrenomycetes. The chief families of trees in the European Flora upon which they flourish are Coniferæ, Amentaceæ, Rosaceæ, Ericeæ, Rhamnoideæ, Acerinæ, and Tiliaceæ, and of herbs, Graminex Umbelliferm, and Liliacex. Many are peculiar to certain species of trees, and others are common to many species. For example, on the Betula alba may be found about ten peculiar, species, and from for to many species. For example, on the Betula alba may be found about ten peculiar species, and from forty to fifty which are common to it and other trees. Their qualities are unknown. Many species which are included by Fries under the name of Ectostroma, are probably not vegetables, and are here omitted. 


\section{TRIBE III. HYPHOMYCETES.}

\section{Thallus flocculent.}

\section{Class I. Cephalotrichi.}

Receptacle distinct, covered over with flocci, with sporidia scattered among them.

2465. Ceratium. Filaments very short, pellucid, simple, minute, attached to a membranaceous, plicate, simple or branched, filiform receptacle.

2466. Isaria. Filaments minute and pellucid, attached to an elongated, simple or branched, clavate, carnose receptacle.

\section{Class II. StrilboideI.}

Fibres grown together upon the receptacle. Sporidia inclosed in a separate naked head.

2467. Stilbum. Minute. Stipes slender, bearing a little round solid head, which is pellucid and semifluid at first, at length more dense and opake.

Class III. INOMYCETES.

Fibres genuine, somewhat separated by divisions. Receptacle none. Upon putrescent organic matter.

\section{Division I. Byssacei.}

Opake fibres, bearing sporce inside, when fertile jointed, when sterile contiguous. Repel moisture. 2468. Torula. Thallus composed of branched, rigid, fragile, moniliform, subopake filaments, the articulations minute, globose.

2469. Monilia. Fibres numerous, erect, opaque, distinctly articulated, permanent. Articulations ovate.

2470. Racodium. Thallus composed of branched, decumbent, interwoven, jointless, persistent, subopake filaments, among which are sometimes granules of moniliform filaments.

2471. Dematium. Fibres decumbent or ascending, rigid, opake, branched, continuous in all directions, permanent.

2472. Cladosporium. Thallus composed of erect, rigid, subopake, jointed, simple or branched, aggregate filaments. Sporules ovate, attached in a series to the filaments, deciduous.

2473. Helicosporium. Fibres erect, rigid, nearly simple, opake. Sporules spiral, remotely jointed, some that are fugacious scattered among them.

2474. Oxonium. Thallus composed of decumbent, branched, entangled filaments: primary ones thick, irregular ; ultimate ones fine-jointed.

2475. Khizomorpha. Receptacle much branched, elongated, coriaceous or ligneous. Perithecia arising from the branches, mostly clavate, dehiscent at the apex.

Division II. Mucedines.

Flocci pellucid, with dissepiments, bearing sporce on the outside.

2476. Sepedonium. Thallus formed of entangled filaments, spreading within putrefying fungi. Sporidia scattered, globose. (Bright yellow.)

2477. Acremonium. Thallus composed of decumbent, entangled, branched, pellucid filaments. Sporidia globose, solitary, pedicellate.

2478. Sporotrichum. Thallus minute, tufted or expanded. Sporidia scattered among the branched, tubular jointed filaments.

2479. Trichothecium. Filaments minute, branched, forming a tufted thallus. Sporidia scattered, subglobose, didymous.

2480. Acrosporium. Thallus composed of minute, tufted, pellucid, moniliform, simple filaments, the upper. most joints (sporidia) separating spontaneously.

2481: Botrytis. Thallus composed of decumbent, entangled, branched, pellucid filaments. Sporidia globose,

solitary, pedicellate. Thallus composed of minute, pellucid, scattered or tufted filaments, apex of the rain
2482. Aspergillus. Thas filament mostly clavate, on which is a head of (often beaded) sporidia.

2483. Stachylidium. Thallus composed of tufted, pellucid filaments : sterile ones procumbent; fertile ones erect, whorled, with ramuli near the top, among which the sporidia are collected.

2484. Penicillium. Thallus composed of tufted, pellucid filaments : sterile ones procumbent ; fertile ones erect, bearing a terminal pencil-like tuft of erect ramuli, to which the sporidia are attached.

2485. Trichoderma. Sporidia collected in the centre, free, the filaments woven into a web-like covering, at length opening at the apex and discharging the globose sporidia.

\section{Class IV. Phylleriacen.}

Fibres spurious, contiguous, bearing spora inside. Receptacle none. On living leaves.

2486. Rubigo. Fibres infundibuliform or clavate, twisted, situated in patches upon sickly leaves.

2487. Erineum. Peridia flocciform, subdiaphanous, various, subsimple, aggregato-cæspitose, parasitic on living leaves. Sporules sometimes, but rarely evident.

\section{Tribe IV. CONIOMYCETES.}

Sporidia naked, without any heterogeneous receptacle.

Class I. Tubercularia.

Sporidia naked, simple, scattered over the receptacle.

2488. Tubercularia. Sporangium subglobose, sessile, or somewhat stipitate, carnoso-vesiculose (not gelatinous). Sporidia towards the circumference'(color mostly red).

2489. Fusarium. Minute, subglobose, naked, almost wholly formed of fusiform, free, jointless sporidia.

2489. Fusarium. Minute, subglob. Exosporium. (See Notes.)

\section{Observations.}

Tribe III. Hyphomycetes. Distinguished from other tribes by their flocculent thallus. In no other tribe do flocci occur in so perfect a state of developement, although they undoubtedly exist as subordinate organs in the Uterini and Hymenomycetes.

Class IV. Phylleriacee. These are perhaps morbid states of the outer integuments of plants. This at least seems obvious in Phyllerium Rubi, Gei, \&c. which are nothing but the hairs of the leaves in a clustered and sumewhat altered form. This also may be the reason why there are no sporidia.

Tribe IV Coniomycetes. To this are referred those fungi in which the sporidia are of a more obvious nature than the other parts of the plant, and so constitute the essence of the fungus. Hence they are more evolved than in any other class. The receptacle, if present, arises either out of united pedicels, or of united sporidia, 
Class II. Entophy're.

Sporidia naked, separate, without a receptacle.

Division I. stilbosporei.

Entophytes growing upon dead plants.

2491. Fusidium. Thallus plane, effused. Filaments short, branched. Sporidia fusiform, scattered.

2492. Polythrincium. (See Notes.)

2493. Stilbospora. Black. Receptacle $O$ ? or a pulverulent mass intermixed with naked sporidia, the whole bursting through the bark in the manner of a Stromatosphæria.

2494. Sporidermium. (See Notes.)

2495. Namospora. Receptacle O. Spherules obvious, or somewhat obsolete, dischargirg sporuliferous pulp through the bark in the form of tendrils.

\section{Division II. Hypodermia.}

\section{Parasites upon living plants.}

2496. Cylindrosporium. Very minute, parasitic on the surface of living leaves. Sporidia pellucid, cylindrical, truncate, free, not divided.

2497. Uredo. Epidermis of the leaf forming a pseudo-peridium. Sporidia 1-celled, free, mostly globose.

2498. Acidium. Peridium membranaceous, bursting through the epidermis, and dehiscent at the apex, with a dentate or lacerate orifice.

2599. Puccinia. Epidermis of the leaf forming a pseudo-peridium. Sporidia fixed by a pedicel, one or many-celled.

\section{Observations.}

and is homogeneous with the immature sporidia. The thallus is never flocculent. The organs of nutrition and reproduction are the same

Division II. Hypodermia. The genera of this division are furnished with a caliculus, which must not be confounded with the receptacle or thallus, \&c. of other tribes, because it does not constitute part of the fungus, but is formed out of the epidermis of the plant on which the fungus grows. 


\section{HYMENOMYCETES.}

\section{Class I. Hrmenini, - Dir. I. Pileati.}

2365. AGA'RiCUS. $L$. Agaric.

1. Amaníta. Pers.

15731 vérnus Bull. vernal

15732 phalloídes Fries. Phallus-like

$\beta$ verrucósus $\mathrm{Fl}$. Lond, warted

$\gamma$ viréscens Fl. Dan. greenish

15733 porphýrius Fries. porphyry

15734 vaginátus Bull.

a plumbeus Schæff.

r hyalínus Schæff.

$\delta$ pulvinátus Bolton

$\varepsilon$ fúlvus Schæef.

15735 nivális Grev.

sheathed

lead-colored

transparent

cushioned

tawny
alpine

15736 muscárius $L$

\section{fly-blown}

15737 pantherinus Dec. mottled

poisonous

warted

Sp. 308-715.

stinking

scentless

scentless

eatable

eatable

eatable

eatable

eatable

delicate
3-6 spr. su. W

4 jul.oct. Y woody places Bull. t. 2.577. bulbosus

jul.oct. $\mathrm{Pa}$. Gr woody places Fl.lo.t.312.f.dex.verruc

4 jul.oct Livid among moss

6 aut. W waste places Bulliard, t. 512

6 aut. Lead waste places Schæffer, tt. 85,86

6 sum. Cæs. waste places Schæffer, t. 244

6 sum. Br waste places Bolton, t. 49

6 sum. Tawn. waste places Bolt. t. 38. f.2. trilobatus

5 aug. W Scotch mou. Greville crypt. 1. 18
15738 rubéscens Pers. flesh-colored nauseous

15739 ásper Alb. \& Schwe. rough stinking

\section{Lepiótra. Pers.}

15740 procerus Scop. Perontic

15741 excoriátus Schaff: flayed

15742 clypeolárius Bull. buckler

B felinus Pers.

1574 meleagris Sowerb. variegatco esculent

esculent

insipid

insipid

insipid

fotid
4 au. oc. Or. R woods

Greville crypt. 1.54

3 au. oc. Ol moun; woods Schæff. t. 90. maculatus

3 jul.sep. F.Col. heaths Schæff, t. 91. pustulatus 3 jul.oct. Rsh open woods Bull. t. 316 . verrucosus

10 au. no. W.Br gardens Sowerby, t. 190 7 jul. au. Wsh fields $\quad$ Schæff, t. 18, 19

2 au. oc. Wsh beech woods Sowerby, t. 14

2 au. oc. Wsh hot-houses

2 au. oc. Wsh pine woods Sowerby, t. 171

$1 \frac{1}{2}$ au.no. Wsh grassy places Greville crypt. 3. 176

15744 illinitus Fries besmeared mucilaginous 3 jul.uct. Wsh meadows Fl. dan.t. 600

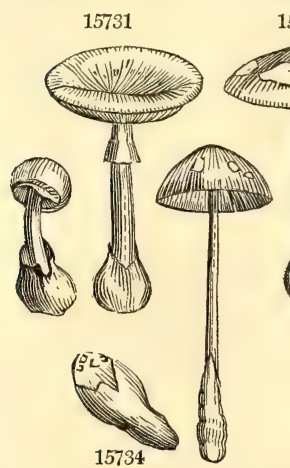

15734
15732

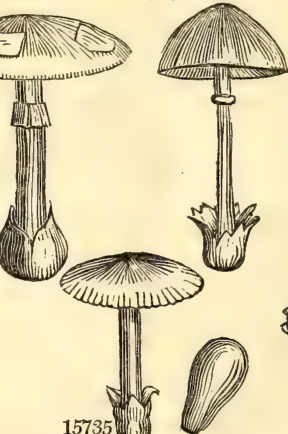

History, Use, Propagation, Culture,

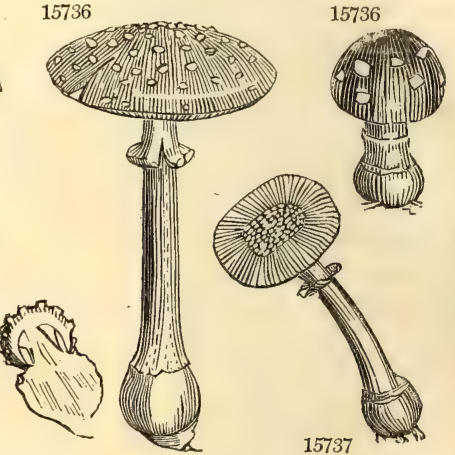

15737

2365. Agaricus. This, the most extensive genus in the vegetable kingdom, derives its name from Agaria, a kingdom of Sarmatia. The species are determined upon various principles. Some writers have mixed together species of the most different kinds, as Gleditsch; and a few writers only have really taken pains to ascertain the species. If it is divided into many genera it would be necessary to break up Boletus also, which would scarcely be judicious. An accurate and simple mode of division is, however, of the utmost moment, and several methods have been proposed, the greater part of which are artificial, and therefore objectionable ; such, for example, as that of Villars, from the magnitude of the species; of Linnæus, from the color of the pileus of Haller, from the color of the lamellæ or gills; of Withering, from the nature of the stipes and the color of the lamellæ taken together; or of Otto, from the position of the lamellæ. The divisions of Fries, which are all named as subgenera, depend upon the characters of the veil, the lamellæ, the sporidia, and the pileus. Our notes will follow these in their order of succession.

\&. Amanita. This name was applied by Galen to some eatable fungus, and has been restored in modern days by Persoon. Most of the species are poisonous. They do not perish quickly, and are found for the most part on damp earth in shady woods, never upon wood or the dung of animals. They are in perfection about the end of summer.

A. vaginatus is eaten by the Muscovites; but in the Jena Literary Gazette of 1819, it is declared to be poisonous. A. ovoideus is said to be delicious.

A. muscarius, or reddish mushroon, has a large pileus, varying much in color, white, red, or crimson, convex, sprinkled with downy warts, which are raised, compact, and angular, or thin, flat, and ragged, turning up with age, from two to seven inches over; flesh white, reddish in decay : gills fixed, white, yellowish with age, mostly uniform, but a shorter one sometimes intervening; the shorter gills varying much in length, but rarely less than one-third the length of the long ones: the stem solid and cylindrical, but the internal substance shrivelling with age leaves irregular hollows; scaly, bulbous at the base, from three to five inches high, and from three quarters to one and a half inch in diameter; ring broad, permanent, and turned down upon the stem. This plant rises out of the ground inclosed within its brown studded wrapper. It is found in pastures. The juice rubbed on the walls and bed-posts destroys.bugs; and in the North of Europe, the inhabitants infuse it in 


\section{HYMENOMYCET'ES.}

Class I. Hrmenini. - Div. I. Pileati.

* Volva loose: edge of the cap smooth. UNwhoLesome.

15731 Cap somewhat scaly : edge smooth, Stipes solid nearly equal, Volva loosely sheathed 15732 Cap somewhat scaly : edge smooth; Stipes hollow at top, Volva connate bulbous

15733 Cap naked : edge smooth, Stipes somewhat fistular equal, Volva booted

**Volva loose: edge of the cap striated. Eatable.

15734 Cap furrowed at edge, Gills white, Stipes tistular tapering nearly naked, Volva sheathing

15735 Whole plant white, Cap plane or slightly umbonate : the centre often pale ochraceous; margin striatopectinate, Lamella somewhat distant, Stipes solid naked bulbous

*** Volva obliterated: edge of the cap striated. Poisonous.

15736 Margin of the cap striated orange-red shining warty rarely naked, Volva vanishing scaly, Stipes bulbous 15737 Cap equally warted : edge striated, Stipes nearly solid equal, Volva booted adnate

**** Volva obliterated : edge of the cap smooth. UNwholesome.

15738 Warts of cap mealy unequal : edge smooth, Flesh pink. Stipes solid somewhat scaly and bulbous

15739 Cap somewhat umbonate rough with acute warts : edge smooth, Stipes solid somew. taper. squarrulose

$$
\text { * Veil finally separate, Gills distant. Eatable. }
$$

15740 Large, Cap scaly, Lamella distant white, Stipes very long bulbous, Collar free

15741 Skin of cap contiguous, Lamella remote, Stipes equal, Collar free

** Veil fixed, Skin of the cap peeling off, Gills separate.

15742 Inodorous, Cap with the epidermis broken into ferruginous scales, Lamella white numerous, Stipes subsquamose, Collar mostly fugacious

15743 Highly odor. Surface of cap white with reddish scales, Lamella distinct, Stipes smooth, Collar fugacious *** Veil fixed, Gills separate, Skin of the cap adhering.

15744 Cap glutinous striated at edge, Lamella loose, Stipes viscid on account of the veil

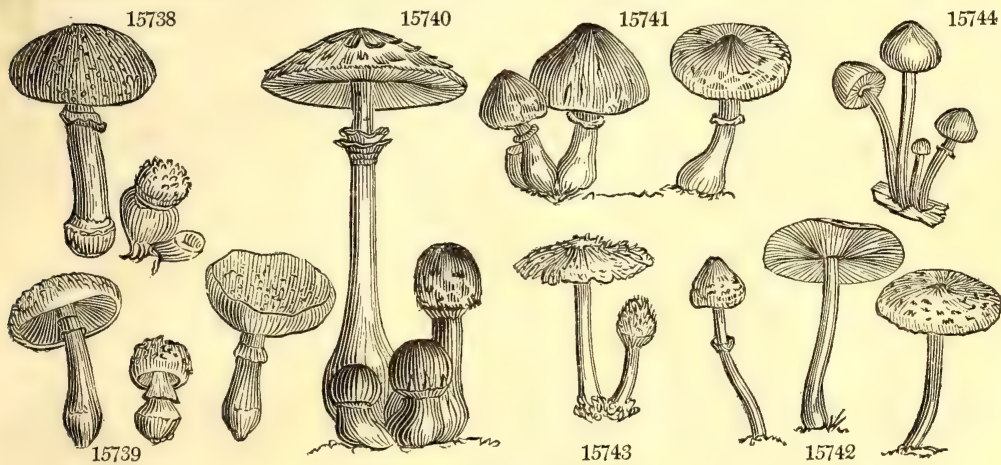

and Miscellaneous Particulars.

milk, and set it in their windows in order to poison the flies who taste it. This is moucho-more of the Russians, Kamtchatlales, and Koriars, who use it for intoxication. They sometimes eat it dry, and sometimes immerse it in a liquor made with the epilobium; and when they drink this liquor, they are seized with convulsions in all their limbs, followed with that kind of raving which attends a burning fever. They personify this mushroom; and if they are urged by its effects to suicide, or any dreadful crime, they pretend to obey its commands. To fit themselves for premeditated assassination, they recur to the use of the moucho-more. A powder of the root, or of that part of the stem which is covered by the earth, is recommended in epileptic cases, and externally applied for dissipating hard globular swellings, and for healing ulcers. The dose is from half a scruple to one, taken thrice a day in water; but a dram administered once a day in vinegar has been thought more efficacious. Murray, App. Med, vol. v. p. 560. Dr. Withering enumerates ten varieties of this species.

12. Lepiota. Terrestrial, solitary, persistent, autumnal fungi, none of which are noxious. Named from $\lambda \varepsilon \pi i s$, a thin membranous layer or cuticle. The A. procerus, or tall mushroom, is not uncommon on hedge banks and dry pastures, and is sometimes exposed to sale in Covent Garden market. It may be distinguished from the genuine sort by the sponginess of its flesh; and from others by its fine and large horizontal ring. The gills are white, uniform, and fixed to a collar; the pileus is a broad cone, bossed white-brown, and scaly; the stem is scaly, and the ring loose. This plant, when preserved in pickle, is very apt to run into the vinous fermentation.

A. xerampelinus is the most splendid of all the agarics. Its gills are fixed, bright golden-yellow, and nearly orange under the edge of the pileus, regularly disposed four in a set; fleshy, brittle, and serrated at the edge with a paler cottony matter : the pileus is a fine lake-red, changing with age to a rich orange and buff, and every intermediate shade of these colors, which render it very beautiful; convex, center bossed, edge turned down, three to four inches in diameter, clothy to the touch; flesh pale-buff: stem solid, nearly cylindrical, but gradually tapering upwards, rich buff, shaded with fine rose-red, three to five inches high, half inch in diameter; flesh pale, buffy, spongy, and elastic. This is common in Italy, and brought to the markets for sale. The ancient Romans esteemed it one of the greatest luxuries for the table. It was made the vchicle for poison to Claudius Cæsar by his wife Agrippina, and has therefore been celebrated by Juvenal and Martial. 
15745 granulósus Pers. granular
A. croceus Sowerb.
15747 mélleus Bolton honey-like
$\beta$ laricinus Bolton Larch
$\gamma$ elásticus Bolton elastic

84. Lima'crum, Fries.

15748 chrýsodon Batsch yellow-toothed noxious

15749 carnósus Sowerb. fleshy noxious

15750 ebúrneus Bull. ivory shining

$\beta$ nitens With. shining shiniog

15751 oliváceo-álbus Fries olive-white

15752 hypothéjus Fries slug

15753 aromáticus Sowerb. aromatic

\section{viscid}

clustered

glutinous
15746 múcidus Schrad. mucid

2 jl. dec. $Y \quad$ heaths

2 jl. dec. W old trees

Fl, dan, t. 773. roitidus

4 au. oc. DL.Y trun. of trees Sowerby, t. 101. stipitis

4 au. oc. Di.Y trun. of trees Bolton, t. 19

4 au. oc. Di.Y trun. of trees Bolton, t. 15

$\frac{\pi}{4}$ sep.oc. Pa.Y beech woods Batsch cent. 2. f. 212

3 sep.oc. Pa.Pk among grass Sowerby, t. 246

4 au.no. Vy woods Sowerby, t.71. nitens

4 au.no. W woods Sowerby, t. 121. cossus

4. jul.oct. Ol pine woods Schæff. t.312. limacunus

4 oc.dec. Ysh heaths Sowerby, t. 8. limacinus

3 oc.dec. $\mathrm{Pa} . \mathrm{Br}$ woods Sowerby, t. 144

3. au. oc. Br fir leaves Schæff. t. 38. striatus 4 au.sep. Tawn. thickets. Schæft. t.62. incertus 4 au.sep. Tawn. thickets

15754 albo..brúnneus Pers. whitish-brown glutinous

15755 fulvas Dec. tawny

15757 Russula Schaff: $\quad$ rosy

15758 aurántius Schaeff: orange

15759 prasinus Schceff: $\quad$ pea-green

smells of

scentless

delicious

bitter

tuberous

mild

aut. Pk woods Schæff. t. 58

3 aut. Or pine woods Schæff. t. 37

3 aut. Y.G mossy places Schæff. t. 218

15761 lúridus Schaeff.

painted
lurid

gregarious

2 sep oc. Lurid way sides

2 sep.oc. DI.R pine woods Schæff. t. 69
15762 equéstris $L$

15763 rútilans Schaff.

15764 vaccinus Schaef: 15765 myomýces Pers.

15766 Columbétta Bauh. white-headed eatable

\section{noble mild 2 sep.d. Y.Br way sides Schæff. t. 41. aureus \\ glittering splendid 3 au. oc. Y roots of trees Sow. t.31. xerampelinus \\ cow scaly 3 oc.dec. Ruf. damp places Schæff. t. 25}

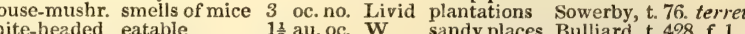

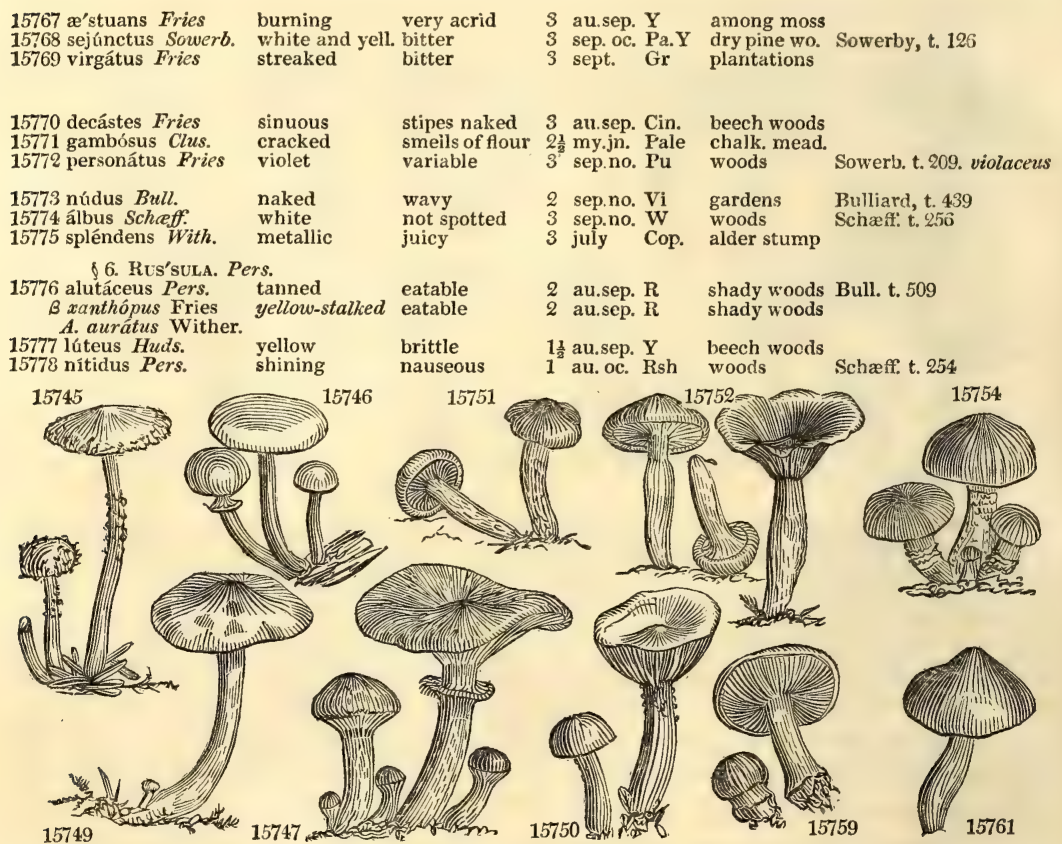

History, Use, Propagation, Culture,

Schæffer and Clusius have recited several curious circumstances respecting it. Dr. Withering apprehends that these authors have mistaken the species, and that their account should be transferred to the A. deliciosus, The A. xerampelinus is eatable, but its taste is not at all agreeable. It is the A. cæsareus of Schæffer, and first found by Dr. Withering's daughter on the red rock plantations at Edgbaston, July 6th, 1791, and afterwards in September 1793; and in July 1792, among moss in the fir plantations at Tettenhall, Staffordshire. Dr. W. enumerates five varieties.

§3. Armillaria. From armilla, a necklace. Atitumnal species, of permanent duration, firm, and esculent. 
****Veil fixed. Cap covered, Gills somewhat united.

15745 Cap with furfuraceous scales reddish-yellow, Lamella fixed white, Stipes subsolid covered below the veil with squarrose scales

* Cespitose, Cap smooth.

15746 Somew. cæepit. Cap thin glutin. Lamellæ annex. dist. Stipes bulb. Collar reflex. and then erect furrowed * Caspitose, Cap not sinooth.

15747 Cap dull-yell, rough with black. hairy scales, Lamellæ adnate-decurr. dist. Stipes fibrous, Coll. tum. spread.

* Cap smooth, floccose at edge. UNwholesour.

15748 Cap smooth whitish, Margin and top of stipes yellow-flocculent with crisp lamellæ

15749 Cap smooth whitish-pink : edge involute downy, Lamellæ straight, Stipes thickened upwards scaly

** Cap smooth, Stalk scaly. Eatable.

15750 White, Cap smooth umbon. Lamelli broad dist. very decur. Stipes white scurfy solid becom. hoil. in age

*** Cap finally depressed, Stalk spotted.

15751 Cap umbonate smooth olive-brown, Lamellæ connected white, Stipes solid mottled with brown [yellow 15752 Cap obt. smooth yellow. covered by an olive-colored gluten, Lamellæ distinct and stipes (which is spotted) 15753 Cap smooth cinnamon-col. Lamellæ somewhat decurrent and hollow, Stipes spotted rufous

* Cap truly fleshy, somewhat blunt, humid, viscid; with an involute downy edge, Gills white or sellow, emarginate, Stalk clothed, separate from the cap.

15754 Cap smooth viscid umber-col. Lamellæ annexed white, Stipes solid smooth scaly at end 15755 Cap viscid virgate rufous brown discoidal, Lamellæ annexed yellow, Stipes hollow equal fibrous 15756 Cap smooth viscid red-brown, Lamellæ emarginate white, Stipes equal solid fibrous

15757 Cap somew. depress. visc. granul. and solid stipes eq. scaly at end rose-color. Lam. somew. separate white 15758 Cap somewhat scaly viscid yellow-orange, Lamellæ adnate white, Stipes solid covered with orange scales 15759 Cap scaly viscid yellow-green, Lamellæ separate yellow, Stipes solid thick tuberous

15760 Cap flexuose virgate viscid lurid, Lamellæ emargin. broad and solid, Stipes somew. scaly yellowish-white 15761 Cap flexuose smooth greenish ash-colored, Lamellæ emarginate narrow yellowish, Stipes solid scaly pallid ** Cap always dry, scaly, with the young edge involute, douny, or villous, Gills separate or emarginate, Stalk scaly, separate from cap.

15762 Cap comp. flexuose somew. scaly yellow.-brown, Lamellæ emarg. comp. and solid, Stipes scaly sulphure. 15763 Cap obt. convex deep-yellow more or less covered with crimson red squamulose fibres, Lamellie rounded numerous yellow, Stipes solid or partly hollow streaked with red

15764 Cap umbon. rufous, Skin torn with hairy scales downy at edge, Lamellæ affixed whit. Stipes holl. fibrous 15765 Firm, Cap dry smooth a little scaly brownish-livid, Lamellæ emarg. somew, dist. whit. Stipes solid uneq. 15766 White, Cap irregular becoming scaly and cracked, Lamellæ emargin. compact, Stipes solia short smooth *** Cap always dry, smooth, but often fibrillose, with a naled edge, Gills separate or emarginate, Stalk solid, smooth, striated, separate from the cap.

15767 Cap umbonate dry yellow-brown fibrous towards edge, Lamellæ emarg. broad and solid striat. Stipes yell. 15768 Cap somew. umbon. dry yellow streaked with black hairs, Lamellæ emargin. broad and solid, Stipes white 15769 Cap umbonate dry grey streaked with black, Lamellæ emargin. broad hoary, Stipes solid striated whitish **** Cap always dry, smooth, with a thin, floccose, frosted, involute edge, Flesh soft, Gills rounded, clustered, obliterated in front, Stalk united with cap.

15770 Somew. cæspitose, Pileus smooth unequal cinereous, Lamellæ round. white, Stipes solid powdery at end 15771 Somew. cæspitose, Pileus compact smooth mouse-colored, Lamellæ emarg. and solid downy, Stipes white 15772 Cap somewhat compact smooth with a villous frosted margin, Lamellæ rounded loose and solid somew. bulbous villous, Stem rather violet

15773 Gregarious, Cap thin smooth lilac-brown, Lamellæ rounded pale violet, Stipes solid equal naked

15774. White not spotted, Cap equal smooth, Lamellæ rounded dense, Stipes solid elastic

15775 Cap conical shining, Lamellæ loose white, Stipes solid white

* Gills all equal, Sporidia yellow.

15776 Cap somewhat compact : the margin finally furrowed, Lamellæ broad equal tanned $\beta$ Stipes yellow

15777 Middle-sized, Margin of cap smooth, Lamellæ narrow compact equal : the color of yolk of egg 15778 Cap thin with a sulcate margin, Lamellæ broad subảistant equal yellow
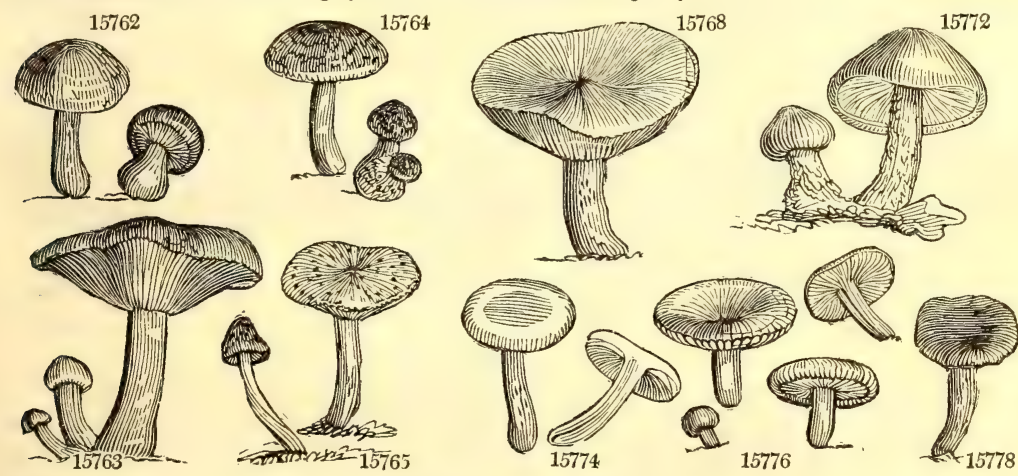

and Misccllaneons Particulars.

They differ much in habit among each other. The annulus is either superior, that is reflexed from the top of the stipes; or inferior, that is contiguous to the middle; or even proper, being inserted above the middle.

4. Limacium. So called from A. limacinus, a name which has been indiscriminately applied to almost all the species of this subgenus. They are fungi of a middle size, solitary, terrestrial, autumnal, and permanent.

5 . Tricholoma. From $9 \rho \rho_{\xi}$, hair, and $\lambda \omega \mu \alpha$, a margin. The species are large, robust, and permanent, solitary or gregarious, and terrestrial. Many are eatable; some have an acrid bitter flavor. A. Russula is
said to be of excellent quality. 


\section{9 eméticus Schaff} $\beta$ Geórgii L.

15780 depállens Pers.

15781 rúber Lam.

15782 foe'tens Fries

15783 furcátus Fries

15784 adústus Pers.

$\beta$ elephántinus Bolt. elephantine

\$7. Galarha'us. Fries

15785 controvérsus Pers. controverted

15786 scrobiculátus $S c \circ p$. pitted

15787 torminósus Schaeff. bearded

15788 necátor Bull. destructive

15789 cilicioídes Fries downy

15790 lúridus Pers.

15791 ácris Bolton

15792 úvidus Fries

15793 viétus Gleditsch

15794 hýsgynus Fries

15795 blénnius Fries

15796 pálidus Pers.

15797 deliciósus $L$.

15798 aurantiacus Pers.

15799 mitíssimus Fries

15800 quiétus Fries A. serósus Wither.

15801 subdúlcis Pers.

15802 thejogálus Bull.

15803 Tithymalinus Scop tellow-milked

1580 ruth scoptaceous rútus Scopoli
A. rubéscens With.

15805 hélvus Fries

15806 glycyósmus Fries

15807 plúmbeus Bull.

15808 pyrogálus Bull.

15809 Alexuósus Pers.

15810 piperátus Scop.

15811 velléreus Fries

15812 dúlcis Hudison

15813 depréssus Wither.

$\begin{array}{ll}\text { lurid } & \text { flattened } \\ \text { hot } & \text { very acrid } \\ \text { moist } & \text { brittle } \\ \text { variable } & \text { very acrid } \\ \text { firm } & \text { variable } \\ \text { verdigrease } & \text { very acrid } \\ \text { pallid } & \text { gregarious } \\ \text { delicious } & \text { eatable }\end{array}$

acrid

sweet

sweet

nauseous

poisonous very milky scentless

acrid

esculent

insipid

red-nilked

flexuose

peppery

peppery

Lister's

depressed

very acrid compact

eatable

gregarious

rious

gregarious

variable $\begin{array}{llll}3 & \text { sum. } & \text { Rsh } & \text { woods } \\ 3 & \text { sum. } & \text { Y } & \text { woods }\end{array}$

$1 \frac{1}{2}$ jul.sep. R.Br heaths

2 jul.sep. $\mathrm{R}$

2 woods

2 jul.oct. Ol woods

3 jul.oct. Y.Br woods
2 ausep $\mathrm{Y}$ woods

Sowerby, t. 201. integer Bulliard, t. 509. f. R.

Bulli t 49 san uineus Bulliard,t.292.piperatus Bulliard, t. 26. bifidus Bulliard, t.212.nigricans Sowerby, t. 36

2 sep. oc. Var. beech woods Bulliard, t. 538, acris

4 au. oc. Y damp woods Schæff. t. 227

2 jn. oc. Pk way sides Sowerby, 103

1 au oc Ol Br woods Bulliard, 14

3 sept. Dl.Pk pine woods

$1 \frac{1}{2}$ sep. oc. Lurid heaths

2 au. no. Ciner. groves

$1 \frac{1}{2}$ au. oc. Li.Pk dampgroves

2 au. no. Livid woods

$2 \frac{1}{2}$ au. oc. $\mathrm{Pk}$ grassy places

$1 \frac{1}{2}$ jul. oc. Gsh beech woods

11 aul oc Pa Y beech woods

$1 \frac{2}{2}$ jul.no. Or pine woods

3 au. oc. Or woods Batarra, t. 16. f.

3 au. no. Or woods

3 aut. $\mathrm{Pk}$ oak woods Fl.dan.t.1069. rubescens

3 sum. Brsh woods

Sower. t. 204. lactiflorus

$2 \frac{1}{2}$ sep. oc. Fulv. shady woods Bulliard, t. 567. f. A

3 sep. oc. Pa.Y shady woods Bats.cont.f.60. ichoratus 2 jul. oc. $\mathrm{Br}$ pine woods

$2 \frac{1}{2}$ jul. no. R.Oc. damp places

3 jul. oc. Lurid thickets

4 au.sep. Lead damp places Sowerby, t. 245. Listeri
$1 \frac{1}{2}$ au. oc. Livid groves Bulliard, t. 529. f. 1

1 jul. oc. Br grassy places Bul.t 559.f.1. A. azonites

2 sep. oc. W woods Bolton, t. 21

2 au.no. W thickets Sowerby, t. 104. Listeri

au. no. W thickets

$2 \frac{1}{2}$ au. oc. $\mathrm{Pk}$ grassy places

88. Clito'cybe. Fries

15814 gigantéus Leysser. gigantic
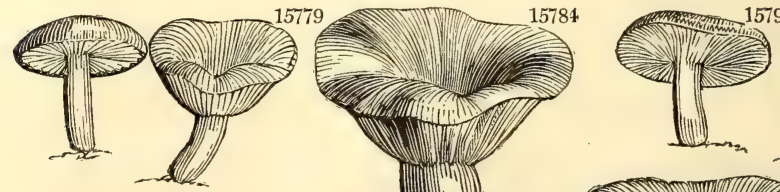

5790

15791
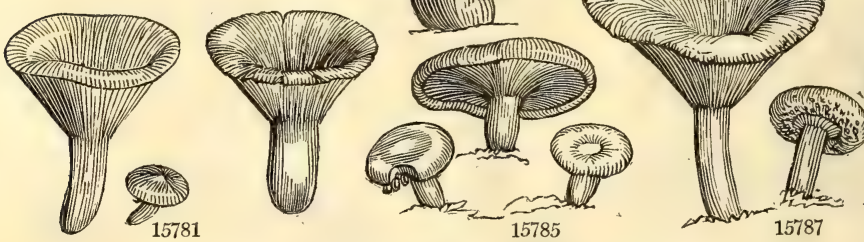

15787

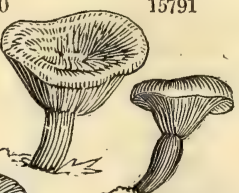

History, Use, Propagation, Culture,

8. Russula. So named from the russet color of the original species. The species are all large, or of middle size, rigid, persistent, solitary, terrestrial, chiefly appearing in the autumn.

7. Galarhaus. From $\gamma \propto \lambda \varkappa$, milk, and $\rho \omega \omega$, to flow ; many of the species being lactescent ; some are juiceless. These are fungi of the summer and autumn, possessing an aromatic smell and acrid flavor. They all grow upon the ground A torminosus, in times of scarcity, is eaten by the Russians, mixed with salt, oil, and vinegar. Buxb. A. controversus is stated by Persoon to be eatable ; but Fries thinks it must be in mistake A. deliciosus has gills decurrent, flame-colored, narrow, regularly branched; pileus rich, red, brown; flesh nearly flat, but somewhat hollowed at the centre, and the edge turned in from one and a half to three inches over; orange-color; stem orange, solid, tapering downwards, from one to two inches high, and a quarte to three-eighths high: hollow with age. The juice is rich yellow, which soon turns green. It is found in the fir plantations of Scotland, and in those of the barren hills at Barr, in Staffordshire. Dr. Smith also found it at Hillingdon, Middlesex, under some fir trees; it also grows near Guildford. It is much esteemed in Italy, and exposed in the markets, and supposed to have been the A. cæsareus mentioned by some authors. 
15779 Cap cornpact somew. depressed in centre with marg. at length sulcate, Lamellæ broad subeq. very white

** Gills nearly equal, Sporidia white.

15780 Cap deformed opaque pallid : margin finally striated, Lamellæ distinct whitish, Stipes finally cinereous

*** Gills forked, and many of them halved.

15781 Very hot, Cap very red : margin smooth, Lamellæ forked white

15782 Acrid stinking, Cap yellow : margin warted furrowed, Lamellæ connected and hollow, Stipes white

15783 Scentless, Cap greenish : margin smooth, Lamellæ forked white [thick. Stipes short solid very robust

15784 Large, Pileus depres. ash color. olive at length dark and as if burnt : marg. smth. Lam. uneq. dist. white

$\beta$ Cap brownish-yellow, Lamellæ yellowish-white, Stipes solid white

\section{* Edge of the cap rolled inwards, downy. Hot. Porsonous.}

15785 White, Pileus villous blood-red variegated downy at edge, Stipes solid

15786 Cap yellow without zones: margin bearded, Milk yellowish, Stipes hollow spotted

15787 Cap glabr. pale with a yellowish brownish or greyish tinge: marg. toment. Stipes most. holl, in part smth. 15788 Cap smooth zoned olive-brown : margin villous, Stipes solid

15789 Cap downy dull flesh-colored, Lamellæ yellowish, Stipes rather hollow

** Cap smooth, viscid, with a naked edge. Hot. EatABLE.

15790 Cap viscid zoned lurid, Lamellæ white, Milk reddish, Stipes hollow

15791 Cap viscid not zoned cinereous-sooty, Lamellæ yellow, Milk turning red, Stipes solid

15792 Cap viscid not zoned fleshy livid or brownish, Lamellæ white, Milk whitish-lilac, Stipes hollow

15793 Cap thin smooth somew. viscid not zoned livid pale, Lamellæ and milk whit. Stipes somew. hollow fragile

15794 Cap viscid not zoned smooth flesh-colored, Lamellæ and milk white, Stipes hollow spotted

15795 Cap viscid somewhat dripping not zoned greenish, Lamellæ and milk white

15796 Cap viscid smooth not zoned and stipes (which is short) hollow and firm pallid, Lamellæ and milk white 15797 Cap glutinous obscurely zoned dingy-orange or reddish very pale when dried, Lamellæ and juice orange, Stipes becoming hollow glabrous

15798 Cap somew. viscid not zoned orange-colored, Lamellæ compact yellowish, Milk white, Stipes long smooth

*** Cap dry, naked at edge, Gills close, when young white, afterwards yellow. EataBle but Acrid. 15799 Sweet, Cap papillose smooth dry orange-colored, Lamellæ paler, Milk white, Stipes long hollow 15800 Sweet, Cap obtuse smooth dry opaque, Lamellæ testaceous rufous, Stipes solid firm brownish

15801 Cap glabrous polished reddish, Lamellæ flesh-colored at length ferruginous, Juice white not changing color, Stipes firm smooth becoming hollow

15802 Somewhat acid, Cap dry smooth somewhat zoned rufous brown, Milk yellow, Stipes solid 15803 Acrid, Cap dry smooth obsoletely zoned pale-yellow, Lamellæ pale flesh-color, Stipes solid 15804 Very acrid, Cap dry umbonate polished reddish-brown, Lamellæ rufous, Milk white, Stipes solid

15805 Acrid, Cap bluntish scaly ảry red-ochre-colored, Lamellæ ochraceous, Stipes nearly solid 15806 Cap thin scaly dry opaque somewhat lurid

15807 Cap large dry zoneless dark fuscous or deep dingy-grey, Lamellæ yellowish rather numerous, Juice white

**** Cap dry, naked at edge, Gills not altering, Substance compact, tough. VERY Acrin. 15808 Cap dry smooth somewhat zoned livid, Lamellæ distant yellow, Stipes hollow cinereous 15809 Cap repand dry smooth, Lamellæ distant pallid, Stipes short pallid

15810 Cap depress, becom infundibulif glab whit. Lamel very narrow crowded, Stipes solid white thick acric 15811 White, Cap umbilicate downy rigid, Lamellæ narrow distant, Milk white, Stipes solid thick

15812 All white sweet, Cap convex, Stipes long

15813 Seems to be a green variety of A. hysgynus, with a solid stipes

$$
\text { A. Gills equally narrowed backward, acute. }
$$

1. Cap dry, smooth, Gills close, decurrent or acutely adnate.

* Cap more or less fleshy; when young convex-deflexed, when oider depressed, Gills truly decurrent

15814 Very large whitish or very pale brown, Cap becoming infundibuliform, Lamellæ numerous decurrent becoming reddish, Stipes solid very thick

15798

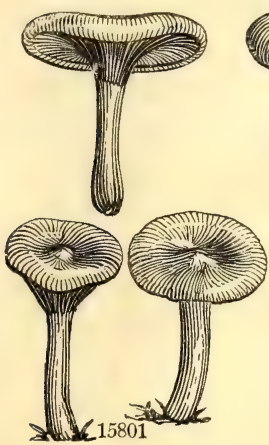

15808

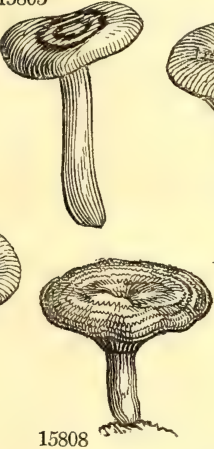

15807

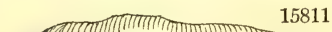

15811

and Miscellaneous Particulars.

Dr. Withering enumerates three varieties, one of which affords, from every part of it when wounded, a copious discharge of yellow acrid juice. They are gathered in woods and dry pastures in September and October.

Lösel asserts in his Flora Prussica, p. 82., that " the juice of A. piperatus, mixed with the syrup of mallows, is a certain cure for calculus, and a powerful diuretic." Almost all the venemous fungi, and especially those of the present group, are said to be the favorite food of the goat, during the rutting season. It is sometimes monstrous and irregular. Withering mentions their attaining the diameter of ten inches. The stipes is not unfrequently thicker than it is long. It has been used in medicine, and thought useful in dissolving calculi ; a property we may safely venture to deny it.

8. Clitocybe. From $\approx \lambda \epsilon \tau 05$, inclined, and $z v \ell_{\eta}$, a head. Most of the species are harmless, and of the larger size. A. nebularis is eatable, so also is A. fusipes. A. giganteus is one of the species which form those circles known by the name of Fairy-rings, the origin of which is still as obscure as ever.

A. orcades has loose gills, with the part attached to the pileus jutting up very close to the stem, so as to give 
15815 gil'vus Pers. A. pileolarius Sowerb.

15816 fláccidus Sowerb.

15817 gíbbus Pers.

15818 turfósus Sowerb. turfy

15819 diatrétus Fries perforated

fragrant

scentless

tough

15820 nebuláris Batsch

A. cáseus With.

15821 túrgidus Grev.

clouded

turgid

gregarious

solitary

slender

15822 viridis Wither.

15823 odórus Bull.

green

anise-scented

15824 cándicans $P$ ers.

anise-sc

whitened

A. agréstis Wither. A variety.

15826 grammopódius Dec. stinking

15827 míllus Sowerb. Dog's-collar

15828 inornátus Sowverb. neat

15829 fimbriátus Bolton fringed

15830 lignátilis Fries wood

15831 adhæsivus Wither. sticking

15832 œdemátopus Schæff: fusiform

$\beta$ coralloides Dicks. coralloid

15833 obésus Wither. squat

15834 opácus Wither. opaque

15835 pistilláris Wither. pistillary

15836 camarophýllus Fries arched

15837 praténsis Pers. meadow

A. fulvus Wither

$\beta$ clavafórmis With, clavate

$\gamma$ ericeus With. heathy

15838 virgineus Wulfen virgin-white

eatable

shaggy

gregarious

shaggy

depressed

pretty

gregarious

irregular

irregular

tufted

tufted

tufied

cracking

crooked

brictle

eatable

eatable

eatable

eatable

15839 psittácinus Schaff: parrot-colored pretty

15840 ceráceus Sowerb. waxen gregarious

15841 cónicus Schaff: conical watery

$\begin{array}{lll}15842 \text { puníceus Fries } & \text { crimson } & \text { beautiful } \\ 15843 \text { coccineus Pers. } & \text { scarlet } & \text { beautiful }\end{array}$

3 au. no. Dl.Y among moss. Grev. crypt. 1.41

3 sep, oc. W

1 nov plains

2 sep.no. Pk woods

Bolton, t. 185

3 sep. oc. Ciner. heaths

Bulliard, t. 573. 1.2

Sowerby, t. 210

2 aut. Sooty dry woods

Bolton, t. 40. mollis

Grev. crypt. t. 9

$\begin{array}{ll}2 \frac{1}{2} & \text { aug. G } \\ 3 & \text { woods } \\ & \text { Ciner, woods }\end{array}$

au. no. Wsh Bolton, t. 17

3 oct. W grassy grov. Sower, t.281. graveolens

3 jan. Brsh woods Sowerby, t. 184

2 aut. Liv $\mathrm{G}$ upon earth Sowerby, t. 342

1 au.sep. Wsh rotten wood Bolton, t. 61

2 au.dec. Wsh rotten wood

3 sept. W.Br plantations

2 sp. aut. Ruf. woods Schæff. t. 259

2 sp. aut. Ruf. hollow t. ees Battarra, t. IX. f.

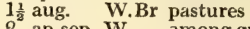

2 ap.sep. W among grass Sowerby, t. 142

$\frac{3}{4}$ aug. Wsh among grass

4 au. oc. Sooty damp woods Sowerby, t. 172. elixus

$1 \frac{1}{2}$ au. no. Ysh way sides Grev. crypt. 2, 91

$1 \frac{3}{2}$ au. no. W way sides S Schæff, t. 307

$1 \frac{1}{2}$ sep.no. W heaths Bull. t. 467 . ericetosus

2 sep.no. W heaths Grev. crypt. 3. 166

2 oc. no. Gsh.Y meadows Grev. crypt. 2. 74

$2 \frac{1}{2}$ au.no. $Y$ pastures Sowerby, t. 20

4 my.oc. Ysh meadows Sow.t.381.aurantiacus

3 au. oc. Or. $\mathrm{R}$ among grass Bull t 202 coccinus

2 au. oc. Sc meadows Sowerby, t. 381

15844 baccátus Scop. varnished handsome

$\beta$ amethýstinus Huds. amethystine handsome

15845 ovínus Bull. sheep mild

15846 sulphúreus Bull. sulphureous foetid

15847 tórtilis Bolton twisted distorted 15848 ovális With. oval satiny
2 jn.nov. Ros. $\mathrm{R}$ on earth Sower. t.208. farinaceus

2 jn.nov. Viol. shady places Sowerby, t. 187

2 au. oc. Brsh meadows Bulliard, t. 580

4 sep. oc. Test. trees\&woods Sowerby, t. 44

$\frac{1}{4}$ aut. $\mathrm{Br}$ gard, mould Bolton, t. 41

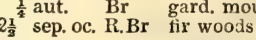

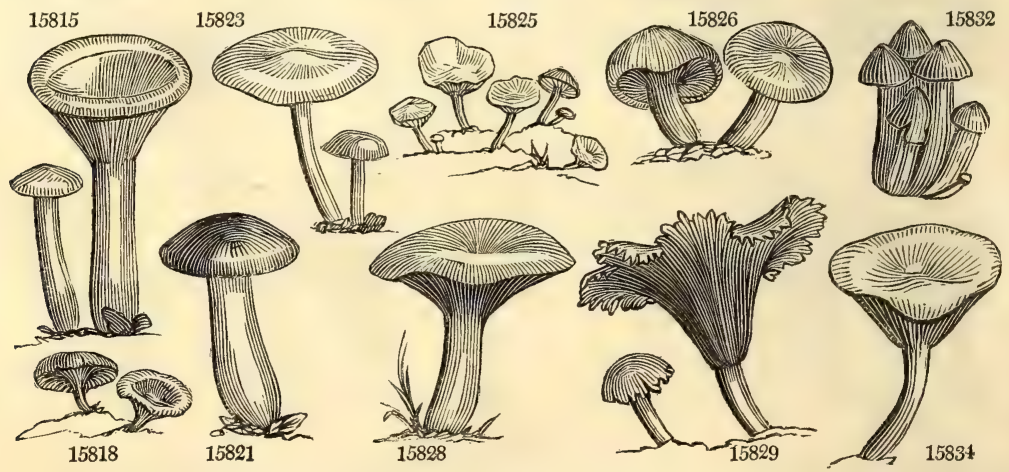

History, Use, Propagation, Culture,

them almost the appearance of being fixed, watery, brownish-white, two or four in a set, the small ones very minute, and the large ones sometimes splitting at the outer end; not numerous, rather broad for the size of the plant, frequently connected to the pileus by ligaments ; pileus pale, buffy-brown, convex, irregular, with a sudden depression of the border at some distance from the centre, often giving the appearance of a large rounded boss in the middle; central color generally deeper; from one to one and three-quarters inch over; and the edge turning up with age: stem solid, white, changing to watcry-brown, cylindrical, but thicker and and the edge turning up with age: stem solid, white, changing to watcry-brown, cylindrical, but thicker and
flattened just under the pileus, very tough, mostly crooked, twisted when dry, rarely central, one and half inch high, and thick as a crow-quill. This is the twenty-seventh fungus of Ray's Synopsis, ed. 3. p. 6. ; A. pratensis of Hudson, and coriaceus of Lightfoot. There are two varieties; one with eream-colored gills, buff pileus, and mealy stem; and another with yellow-brown, more fleshy, and more regularly convex pileus, found in groves. Mr. Woodward says, that this species has a much higher flavor than the common mushroom, but he suggests, 
15815 Large, Cap convex umbonate at length infundibuliform smooth firm yellowish-white, Lamellæ numerous decurrent whitish, Stipes straight solid subradicating

15816 Cap thin funnel-shaped obt. smooth flaccid, Lamellæ decurr. whit. Stipes solid thickened at base villous 15817 Cap umbonate smooth becoming funnel-shaped, Lamel, decurr, white, Stipes solid elastic taper. upwards 1581 Cap depressed broad zoned brown irregular, Gills decurrent pallid, Stipes solid

15819 Cap flatt. somew. umbilic. smth. a lit. flesh-color, : when dry whit. Lam. decurr. and solid eq. Stipes white

** Cap closely fleshy, convex, opening out flat, Gills truly dccurrent, Stalk stiong. Eatable. 15820 Cap compact smooth cinereous, Lamellæ slightly decurrent compact whitish, Stipes solid tapering upw.

15821 Cap plano-convex very smooth greyish-brown, Lamellæ narrow numerous pale, Stipes hollow stout

*** Cap truly but not firmly fleshy, flattish or slightly depressed, Gills adnate, not properly decurrent, Stalk slender.

15822 Cap smooth green, Lamellæ adnate narrow, and stipes (which is solid and smooth) white

15825 Fragrant smooth dull bluish-green umbonate convex becoming plane, Lamellæ numer, adnato-decurrent 15824 Shining-white, Cap smooth convex then umbonate, Lamel. adnate then decurr. Stipes fistulous smooth 15825 Scentless white, Pileus unequal thin smooth, Iamellæ adnate numerous, Stipes solid equal glabrous

15826 Cap obsoletely umbonate smooth, Lamellæ adnate close white, Stipes solid furrowed smooth 15827 Cap somew. umbon. smooth brown. Lamel. affixed with hind end recurv. Stipes solid equal strigose 15828 Cap obtuse smooth somewhat repand greenish-livid, Lamellæ adnate, Stipes solid smooth 15829 Dirty-white, Cap becom. funnel-form. smth. : marg. sinuat. and lob. Lam. adnate very tender, Stipes solid **** Tufted, variable, some growing on wood, some on earth.

15830 Cap irregular rather out of centre vill. whit. Lamel. adn. compact white, Stipes solid flexu. vill. at base 15831 Cap flat discoid viscid, Yamellæ decurrent and solid tapering, Stipes white

15832 Cap conical powdery rufous, Lamella decurrent and solid ventricose powdery, Stipes rufous

15833 Cap whit.-brown, Stipes solid obconic. scarcely broader at top than bottom, Lamel. decurr. branch. white 15834 Cap dead white nearly flat, Lamellæ white numerous, Stipes white with brown pith 15835 Whitish, Cap convex, Lamellæe decurrent, Stipes solid subconical

\section{Cap somewhat compact dry, Giils very distant, arcuate, decurrent.}

15836 Cap somewhat compact streaked sooty, Lamellæ decurrent white-glaucous, Stipes long stout fibrous

15837 Firm, Cap compact convex becoming partially expanded smooth brownish-buff with a pink tinge Lamellæ decurrent thick, Stipes short solid attenuated below

$\beta$ All white

$\gamma$ Cap thinner with a striated margin

15838 Viscid, Cap campanul. expand. when humid striated, Lamel. adnate somew. distant, Stipes equal smooth

3. Cap thin, viscid, wet, Gills variable, Stalk hollow. Terrestrial.

15839 Green chang. to yell. Pileus campanulate spreading, Lamellæ adnate rather distant, Stipes equal smooth 15840 Cap nearly plane slimy substriate yellow, Lamellæ adnate decurrent distant, Stipes rather unequal gradually attenuated towards the base

15841 Cap conical glutin. mostly yell. or crim. Lamel. crowd. ventric. attenuat. and free, Stipes substriate splitt. 15842 Cap campanul. obt. lob. orange-red, Lamel. affixed ascend. yellow, Stipes thick ventricose white at base 15843 Cap conv. expand. visc. becom. depres. Lam. adn. versicolor connect. by decurr. tooth, Stipes compr. scarlet

B. Gills unequal at the back; that is, toothed; or arcuate, decurrent, sinuate, emarginate, \&c.

4. Cap dry, minutely scily, Gills generally arcuate, decurrent, rarely adnate. Frвм.

15844 Gregarious, Cap scarcely fleshy tough farinaceous with minute scales pale or deep flesh-color : disk de pressed in age, Lamellæ distant, Stipes long elastic

$\beta$ Cap convex becoming depressed somewhat squamulose purple, Lamellæ distant thick violet-purple, Stipes purple, hollow when old

15845 Cap fleshy plano-convex șomew. scaly brown. Lamel. arcuate affix. connect. whit. Stipes solid short firm 15846 Cap fleshy somewhat umbonate slightly silky testaceous, Lameliæ arcuate adnate somewhat distant and solid equal, Stem sulphur-colored

15847 Lamellæ brown changing to purplish, Cap red-brown convex turning up with age, Stipes brownish 15848 Lamellæ bro:vnish-white, Cap cinnamon bossed, Stipes brownish-white cylindrical

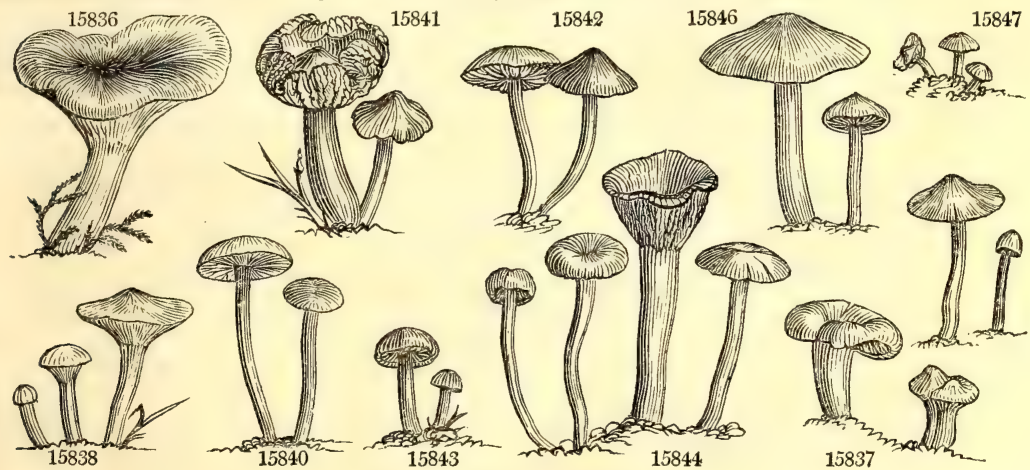

and Miscellaneous Particulars.

that from its leathery nature it is indigestible, except in the form of powder, in which it is admirable. Dr. Withering, however, observes, that he has seen the pileus and gills of this agaric very brittle and tender when fully saturated with moisture in rainy seasons, and in that state it is sufficiently digestive. Professor Martyn informs us that he has eaten these mushrooms for forty years without injury, and without perceiving that toughness, like leather, of which others have complained, except in very dry weather, or when they are in too advanced a state. They should be gathered young, and early in a morning, and properly dressed. They are found in hedge banks, upland pastures, and sheep commons, particularly in those patches called Fairy rings. Those that are found in woods and hedges are of inferior flavor to such as are gathered in dry pastures, which have a very pleasant smell and luscious flavor, either when stewed alone or in ragouts, \&c. This sort makes excellent ketchup, and is much valued in the form of powder. It is in season during September and October, but may be dried so as to be in use for the table all the winter. Mr. Lightfoot supposes that this species is the 
15849 pelieánthinus Fries toothltted beautiful 3 au.sep. Pu roots of trees Bolt.t.4.f.1.denticulatus

15850 melaleúcus Pers. black \& white elegant

15851 compréssus With. compressed pellucid 15852 murináceus Bull. nitric-acid-scent. fragile

15853 platyphýllus Pers. broad-headed large

\begin{tabular}{|c|c|c|c|c|c|c|}
\hline $\begin{array}{l}15854 \text { radicátus Relh. } \\
15855 \text { grácilis With. } \\
15856 \text { velútipes } F l \text {.Lond. }\end{array}$ & $\begin{array}{l}\text { rooting } \\
\text { slender } \\
\text { velvet-footed }\end{array}$ & $\begin{array}{l}\text { gigantic } \\
\text { more slender } \\
\text { cæspitose }\end{array}$ & $\begin{array}{l}1 \frac{1}{2} \text { jn.sep. } \\
1 \frac{1}{2} \text { jn.sep. } \\
2 \text { oc. mr. }\end{array}$ & $\begin{array}{l}\text { W } \\
\text { Wulv. }\end{array}$ & $\begin{array}{l}\text { trun. of trees } \\
\text { trun. of trees } \\
\text { trees }\end{array}$ & Sowerby, t. 384 . f. 3 \\
\hline 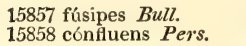 & $\begin{array}{l}\text { thick-footed } \\
\text { confluent }\end{array}$ & $\begin{array}{l}\text { eatable } \\
\text { cæspitose }\end{array}$ & $\begin{array}{l}2 \text { jul. no. } \\
4 \text { au. oc. }\end{array}$ & $\begin{array}{l}\text { W } \\
\text { Wsh }\end{array}$ & $\begin{array}{l}\text { woods } \\
\text { shady woods }\end{array}$ & sines \\
\hline 5859 collinus $S$ & oak-lovin & æspitose & $\begin{array}{l}4 \text { sep. oc. } \\
2 \text { oc. no. }\end{array}$ & $\begin{array}{l}\text { Pallid } \\
\text { Wsh }\end{array}$ & $\begin{array}{l}\text { among grass } \\
\text { heaps of lvs. }\end{array}$ & $\begin{array}{l}\text { Bul. t.403. arundi } \\
\text { Sowerby, t. } 127\end{array}$ \\
\hline
\end{tabular}

3 au. no. Sooty damp places

3 june $\mathrm{Br}$ among grass Sowerby, t. $66^{\circ}$

2 au. oc. Ciner. pastures Sowerby, t, 106

4 jul.oc. Wsh trun. of trees Bul. t.594.grammoceph.

$\begin{array}{llll}15861 \text { peronátus Bolton } & \text { woolly } & \text { changeable } & 2 \frac{1}{2} \text { jul. no. Test. dead leaves Sowerby, t. } 37 \\ 15862 \text { oréades Bolton } & \text { twisted } & \text { eatable } & 3 \text { my.no. Pa.Rf. grassy places Sowerb. t. 247.pratensis }\end{array}$

15863 pórreus Fries $\quad$ Garlic-scented stinking

15864 fúsco-purpúreusPers. brown-purple cæspitose

3 oc. no. W plantations Sowerb. t. 81. alliaceus $2 \frac{1}{9}$ jul.sep. D.Pu beech leaves Pers. ic. t. 4 . f. 1

$$
\text { \$ 9. Collybia. Fries }
$$

15865 scorodónius Fries Onion-scented strong smell, 11 au oc Wsh heaths Schreft 99. 15866 cárneus Bull. puniceus With.

15867 esculéntus Wulfen eatable esculent

15868 tuberósus Bull. tuberous.

$$
A \text {. alumnus Bolton }
$$

15869 racemósus Sonuerb. racemose

15870 clávus Bull.

racemose compound

15871 rameális Bull. branch-living $\begin{aligned} & \text { gregarious } \\ & \text { gregarious }\end{aligned}$

$\begin{array}{lll}1 \frac{1}{3} & \text { au. oc. Wsh heaths } & \text { Schæff. t. 99. alliatus } \\ \mathbf{1} \text { au.sep. } \mathbf{R} & \text { grassy places Bull. t. 533. f. } 1\end{array}$

$1 \frac{1}{2}$ ap. my. Clay way sides Schæff. t. 59. clavus

$\frac{2}{8}$ au.no. W on fungi Grev. crypt. 1.23

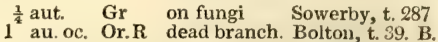

1 au. oc. Or.R dead branch. Bolton, t. 39 . B.

\begin{tabular}{|c|c|c|c|c|c|}
\hline $\begin{array}{l}15873 \text { Vaillántii Fries } \\
\text { Merúlius androsá }\end{array}$ & $\begin{array}{l}\text { Vaillant's } \\
u \text { With. }\end{array}$ & tough & 1 au.sep. W & dead branch. & Vail,bot.par. t.11.f,21-24 \\
\hline 15874 Rótula Scop. & black-footed & gregarious & 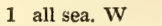 & woods & Sowerby, t. 95 \\
\hline 15875 androsáceus $L$. & Androsace-like & tough & $1 \frac{1}{2}$ all sea. W.Br & dead leaves & Bolton, t. 32 \\
\hline $\begin{array}{l}15876 \text { fo'tidus Fries } \\
15877 \text { pérforans Fries } \\
15878 \text { epiphýllus Pers. }\end{array}$ & $\begin{array}{l}\text { stinking } \\
\text { boring } \\
\text { shrivelled }\end{array}$ & $\begin{array}{l}\text { gregarious } \\
\text { stinking } \\
\text { gregarious }\end{array}$ & $\begin{array}{l}1 \text { au.sep. Br } \\
1 \text { all sea. Pallid } \\
\frac{3}{4} \text { sep. d. W }\end{array}$ & $\begin{array}{l}\text { fallen branc. } \\
\text { dead fir lvs. } \\
\text { dead leaves }\end{array}$ & $\begin{array}{l}\text { Sow. t.21. Merulius foet. } \\
\text { Sower.t.94. androsaceus } \\
\text { Sowerb. t.93. squamula }\end{array}$ \\
\hline
\end{tabular}

15872 parasíticus Bull. parasitical meteoric $\frac{1}{4}$ au. oc. Gr on fungi Sowerby, t. 343

15879 Hudsóni Pers. Hudson's hairy $\quad \frac{3}{4}$ aut. Wsh holly leaves Sowerb. t. 164. pilosus

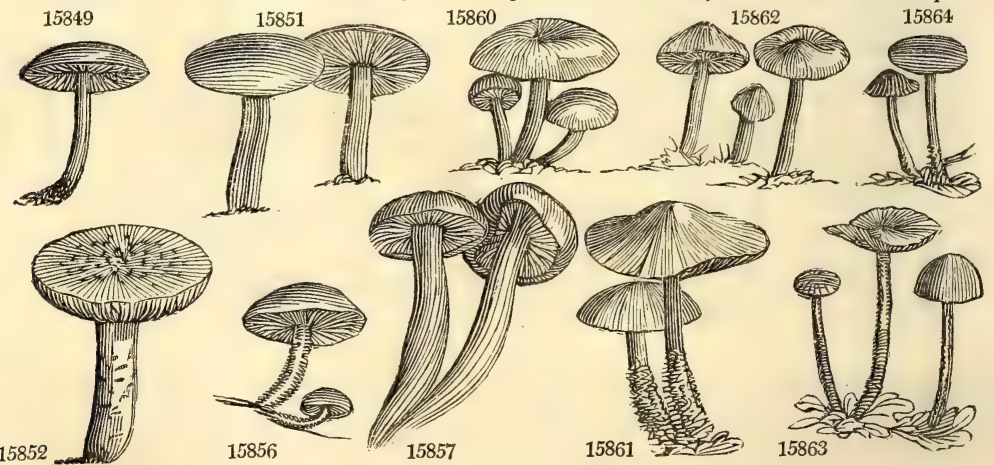

History, Use, Propagation, Culture,

mouceron of the French, who use it in ragouts instead of that, and acknowledge it to be equal in flavor, but more tough. The mouceron, however, has a very thick and fleshy pileus; its gills are very narrow and numerous, and fixed to the stem, and the stem is thick and short. Dr. Withering has carefully distinguished severa! other species from this fairy-ring agaric, or Scotch bonnets, as it is called by Mr. Ray. 
5. Cap smooth, somewhat humid, Gills arcuate at their connection with the edge, reticulated at their union with each other, with appendages at edge.

15849 Cap convex livid-purple striat. at edge, Lamel. arcu.-annex. purple with black teeth, Stipes fistular equal

$$
\text { 6. Cap thin, dry, Gills emarginate. BRITTLE. }
$$

* Cap fleshy, smooth, and stem regular. Terrestrial.

15850 Cap fleshy soft flatt. smooth, Lamel. clustered somew. ventricose white, Stipes somew. holl. long and thin

** Cap somewhat fleshy, and stem, which has no roots, irregular. Terrestrial.

15851 Cap subcarnose irregular smooth thin fuscous, Lamellæ distant white, Stipes hollow-whitish compressed 15852 Cap fleshy deform. crack. scaly cinereous, Lamel. glued together dist. and deform. holl. Stipes cinereous

*** Cap somewhat fleshy, and stem, which has roots, regular. Growing on Wood.

15853 Cap fleshy flat somew. streaked cinere.-whit. Lamel. very broad dist. and solid equal striat. Stipes white

\section{Gills equal, behind blunt}

7. Cap fleshy, glutinous, Gills somewhat united, Stem rooted.

15854 Cap rugose glutinous tough, Lamellæ white, Stipes tall rigid with a long fusiform root

15855 More slender, Lamellæ sinuated with a decurrent tooth, Stipes very long [blackish towards base 15856 Cap nearly plane brown orange glutin. Lamel. ventric. yellow. Stipes incurv, velvety and redd.-brown or

8. Cap tough, dry, Gills separate, close, white.

15857 Gregarious, Cap fleshy loose, Lamel. somew. separate serrat. Stipes hollow ventricose furrow. whit. root. 15858 Confluent cæspitose, Cap somewhat fleshy whitish, Lamellæ loose compact, Stipes fistulous somewhat compressed red villous powdery

15859 Cap somew. fleshy campanul. expanded umbonate pallid, Lamel. loose, Stipes fistulous smooth glabrous 15860 Variable, Cap thin watery smooth plane sometimes depressed, Lamellæ free soft, Stipes hollow splitting becoming thicker towards the base pinkish or yellowish-white more colored at the summit

\section{Cap somewhat leathery, dry, Gills separate, distant, pallid}

* Capfleshy, Stem solid.

15861 Cap dry leathery convex at length plane, Lamella distant pale-reddish or buffish, Stipes solid clothed towards the base with a woolly or strigose mass

15862 Cap tough subumbonate reddish becoming buffish or very pale opake, Lamellæ distant whitish, Stipes solid firm cylindrical thickest under the pileus pale

** Cap fleshy, Stem fistulous

15863 Strong smell. Cap somew. fleshy smth. and lamellæ somew. loose white, Stipes fistular long downy rufous 15864 Cap somewhat fleshy wrinkled dark-purple becom. pale, Lamellæ loose rufous, Stipes fistular rubiginous

1. Cap slightly fleshy, smooth, scarcely umbilicate, Gills true, Stem hollow, or somewhat fistulous.

15865 Strong smell. Cap somew. fleshy, and lamellæ adnate crisp whitish. Stipes fistular short glabrous rufous 15866 Cap somewhat fleshy smooth pinkish-red, Lamellæ attached white, Stipes nearly solid short scaly

15867 Cap somew. fleshy obt. clay-colored, Lamellæ attached lax white, Stipes fistular rooting smooth yellow. 15868 Cap plane or somewhat umbonate, Lamellæ adnate numerous, Stipes subfistulose slightly tomentose at the base and springing from a reddish tuberous roct

15869 Cap membranous papillose grey, Lamellæ white, Stipes racemose

15870 Cap plano-convex reddish-orange, Lamella white rather broad fixed, Stipes very slender subsolid whitish 15871 Gregarious, Cap nearly plane white sometimes changing to reddish, Lamella adnate white, Stipes short minutely furfuraceous marked within with a white line

15872 Cap somewhat fleshy convex becoming flat pruinose pale-grey, Lamellæattached thick distant more obscure, Stipes fistular villous

2. Cap thin, membranous, flat, becoming depressed, plaited, rugose, Gills veiny, of the same substance as the cap, Stem horny, black.

15873 Cap flat plaited, and lamellæ (which are very broad adnate and distant) white, Stipes solid smooth brownish thicker and paler towards the extremity

15874 Cap conv. umbilic. plicate, Lam. attach. to a collar surround, stipes white, Stipes holl. striate black below 15875 Cap convex plicate white sometimes tinged with brown, Lamellæ simple adnate white, Stipes hollow furrowed very glabrous purplish-brown or black except at the summit

15876 Cap convex umbilicated plicate redd.-brown, Lamel. adnate pale-yellow. Stipes holl. redd,-brown velvety 15877 Cap flatt. rugul. pall. Lam. adnate simp. many being halved, Stipes smth. fistular velvety blackish-brown

15878 Cap nearly plane rugose, Lamellæ few adnate resembling white prominent veins, Stipes hollow very minutely velvety reddish-brown below

15879 Cap convex-expanded whitish and rufous, Stipes covered with straight red hairs, Lamellæ whitish

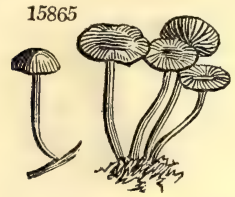

$15869 \quad 15870$

15872
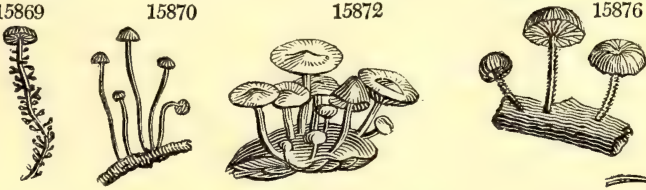

15878
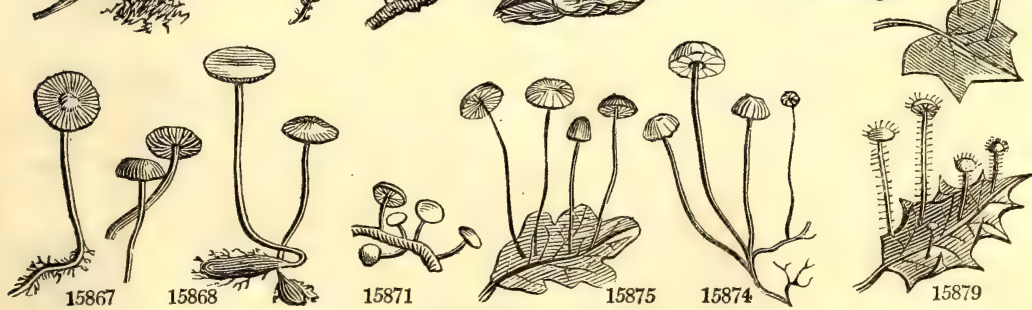

and Miscellaneous Particulars.

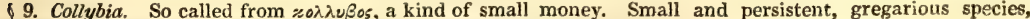
frowing either on earth or wood. Some of the species may be used as food. 
10. MrCE'NA, Pers

15880 alliáceus Jacq. onion-scented fotid

15881 atro-álbus Bolton black-white scentless

15882 alcalinus Fries alkaline

15883 galericulátus Scop various várius With.

prolzferus Sower. t. 169

15884 polygram'mus Dec. mariked

15885 gálopus Pers. 15886 hæmátopus Pers.

15887 cruéntus Fries

white-footed red-footed bloody

15888 élegans Pers.

elegant 15889 strobilinus Pers. Pine-cone

15890 róseus Pers.

rosy

15891 párus Pers. pure

15892 Adónis Bull. Adonis

15893 luteo-álbus Bolton yellow-white

15894 lácteus Pers. milky

15895 pílipes Sonverb. hairy-footed

15896 epip'terýgius Scop. nodding

15897 vulgáris Pers. common

15898 pellúcidus Bull. transparent thick

15899 corticális Bull. bark delicate

15900 pterigenus Fries rosy

rosellus With.

spiny-footed gregarious

15901 spinipes Sowerb.

\section{11. Омpнa'́la, Pers.}

15902 stellátus Fries stellate

$\begin{array}{ll}15903 \text { fibula Bull. } & \text { button } \\ 15904 \text { pyxidátus Bull. } & \text { box-like }\end{array}$

15905 murális Sow. wall

15906 ericetórum Pers. heath

15908 epichýsium Pers. dirty

15909 obliquus Pers. oblique

15910 frágrans Sowerby fragrant

15911 cæspitósus Bolt. $\quad$ cæspitose

15912 cyathifórmis Bull. cyathiform $A$. clavatus Wither.

15913 murinus Sowerby mouse-scented solitary

15914 tigrinus Bull. $\quad$ mottled
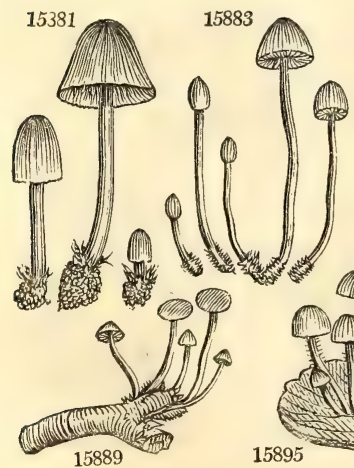

gregarious

15884
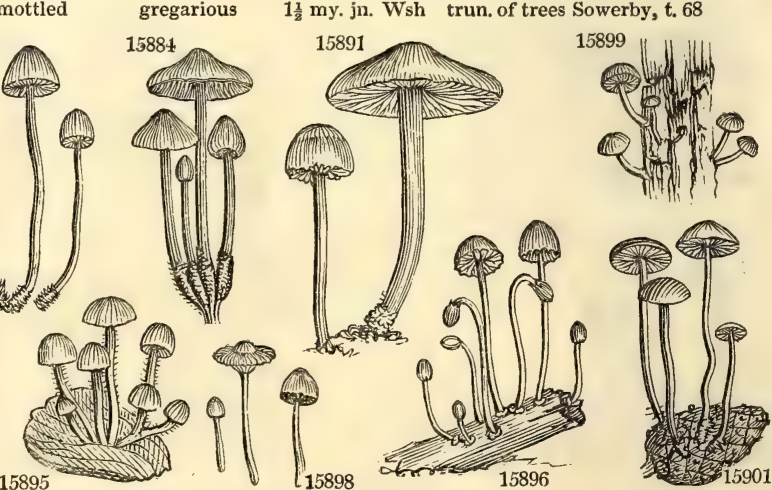

10. Mycena. From uuxns, a kind of small fungus. The species are of the smaller kind, at least they are thin and slender, and tolerably permanent. None of them are fit for food; many are distinguishable by their smell, which is always powerful. 
1. Dry, Cap generally umbonate, not depressed, Gills separate or adnate, not decurrent. * Stem rooting, smooth, juiceless, Gills separate, whole-colored.

15880 Cap becoming nearly plane subcoriaceous, Lamellæ free whitish, Stipes tall covered with a sort of bloom dark purplish-brown below velvety at the base

15881 Cap smooth blackish. Margin and lamellæ loose whitish, Stipes tumid at base, strigose

** Stem smooth, juiceless, somewhat rooting, Gills adnate, whole-colored.

15882 Cap obtuse striated cinereous, Lamellæ adnate glaucous white, Stipes smooth firm villous at base

15883 Cap brown. Lamel. whit. adnate with a decurrent process, Stipes smth. tenacious strig. at base and radicat,

*** Stem juiceless, striated, Gills whole-colored.

15884 Cap obscurely striate blue.-grey, Lamel. attenuated and subadnate whit. Stipes long rigid striate glisten.

**** Stem smooth, milky, somewhat rooting, Gills attenuated, united at the edge.

$15 \varepsilon 85$ Cap striated blackish glaucous, Lamellæ affixed white, Stipes filled with white juice

15886 Cap fleshy-membranous whitish-red, Lamellæ affixed, and stipes filled with dark-red juice

15887 Cap striated reddish-brown, Lamellæ adnate whole-colored at the edge, Stipes filled with red juice

***** Stem smooth, juiceless, somewhat rooting, Gills adnate, discolored at edse.

15888 Cap striated livid-yellow, Lamellæ adnate linear livid : margin yellow, Stipes rigid smooth fibrous at base

15889 Bright-red, Cap acutely umbonate with a striate marrin, Lamellæ fixed dilute reddish, Stipes firm strigose and pale at the base

15890 Cap between fleshy and membranaceous convex pale rose-purple, Lamellæ ventricose rather paler than pileus, Stipes smooth villous at the base

****** Stem smooth, juiceless, scarcely rooting, Gills affixed, whole-colored. CoLor PURE.

$15891 \mathrm{Cap}$ between fleshy and membranous obtuse somewhat rose-colored, Lamellæ round ventricose pallid, Stipes smooth villous at base

15892 Cap obtuse smooth, Lamellæ adnate white, Stipes smooth rootless

15893 Cap umbonate striated and slender, Stipes yellow, Lamellæ adnate white

15894 Cap somew. umbonate striated yellowish-white, Lamel. affixed distinct, and stipes rigid smoothish white ******* Stem juiceless, rootless, but swollen at base into a globe, Cap blunt.

15895 Pale-brown, Cap conical smooth, Lamellæ loose compact, Stipes thickish hairy

$$
\text { 2. Cap or stem viscid, Gills adnate or decurrent. }
$$

15896 Cap obtuse striated and elongated, Stipes yellow viscid, Lamellæ uncinate

15897 Cap umbonate becoming depressed striated cinereous, -Lamellæ decurrent white, Stipes short firm viscid

$$
\begin{aligned}
& \text { 3. Dry, Cap finally depressed, Gills decurrent. } \\
& \text { * Firm, persistent, with a firm stem. }
\end{aligned}
$$

* Firm, persistent, with a firm stem.

15898 Cap somewhat membranous campanulate striated at edge, Lamellæ decurr. very broad, Stipes solid thin

$$
\text { ** Delicate, withering, with a capillary stem. }
$$

15899 Cap thin hemispher, becom. unbilicat, and striat. Lamel. uncin. decurr. dist. Stipes short incurv. smooth 15900 Thin rosy, Cap campanulate smooth, Lamellæ broad distant, Stipes capillary with a strigose bulb

15901 Slender, Stipes slender with stiff wool at base, Cap depressed hemispherical

1. Cap somewhat membranous, Gils decurvent.

$$
\text { * Small, Cap membranous. }
$$

15902 White, Cap convex smooth, Lamellæ distant, Stipes attached to the base of a convex radiat. membrane 15903 Cap convex glabrous orange-yellow, Lamellæ whitish distant, Stipes yellowish

15904 Testaceous rufous pallid, Cap funnel-shaped: disk smooth, Lamellæ narrow, Stipes firm

15905 Cap convex umbilicated striate, Lamellæ broad pale, Stipes solid short thickish

[at the base 15907 Stipes solid thickened at base ferruginous downy

\section{* Large, Cap somewhat membranous.}

15908 Tender cinereous blackish, Cap funnel-shaped striated, Lamel. lin. Stipes somew. solid tough vill. at base 15909 Thin pale cinereous, Cap somewhat funnel-shaped smooth oblique, Stipes thick

2. Cap fleshy, membranous, Gills adnate.

15910 Odor. Cap nearly plane pale yellow. or brown.-white when dry, Lamel. numer. whit. Stipes holl. white 15911 Livid, Cap somewhat membranous plane striated, Lamellæ distant, Stipes fistular [attenuat, above 15912 Cap somew. fleshy funn.-shap. smooth dark-brown grey : marg, reflexed, Lamel. dist. grey. Stipes elastic

15913 Cap thin campanulate green at centre brown and plaited at margin, Stipes smooth hollow

3. Cap fleshy, coriaceous, somewhat corky, soft, Gills decurrent.

15914 Cap regular umbilicat. whitish with black. hairy scales, Lamel. denticul. white, Stipes thin minutely scaly

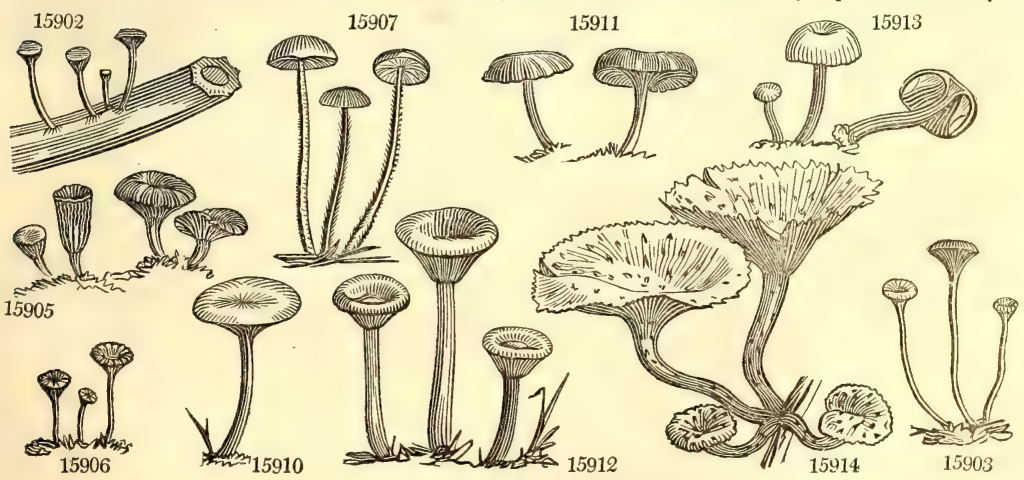

and Miscellaneous Particulars.

11. Omphalia. From ousarios, the navel, in reference to the young form of the pileus. Many of the species are of the smallest size. None are eatable. 
15915 lepíceus Fries scaly

B monstrósus Fries monstrous

15916 cochleátus Pers. cochleate

\$ 12. Pleuro'tus. Frics.

15917 dryinus Pers. oak

\section{8 torulósus Pers.}

15919 conchátus Bull.

15920 ostreátus . Iacq.

\section{knotted} oyster shell-shaped

variable deformed cæspitose

solitary

very tough

gregarious

eatable

gregarious imbricated

thin

15922 pórrigens Pers. pine

15923 flabellifórmis Bolt. flabelliform

\section{4 ulmárius Bull.}

Elm

15925 palmátus Bull. 15926 serotinus Pers. 15927 stip'ticus Bull. ficoídes With.

palmate late stiptic

15928 nidulans Pers.

15930 móllis Pers.

15931 variábilis Pers.

prickly

soft

15932 laterális Fl. Dan. lateral

15933 trémulus Schaff. tremulous 15934 sep'ticus Fries pubescent

15935 applicátus Batsch cup-shaped 8 13. Mou'Ceron. Bauh.

15936 Prúnulus Casalp. French Mushr. esculent 15. Clitropílus. Fries. 15938 rhodopólius Fries repand 15939 fértilis Pers. prolific 15940 sinuátus Bull. burnt sugar. 15941 maritimus With. seashore

15942 leoninus Schaef: tawny 15943 Plúteus Batsch. sooty 1.944 phlebóphorus Ditt. wrinkled reticulátus With.

8 15. Leptón Nia. Fries.

15945 griseocyáneus Fries blue-gray solitary 15946 chalýbeus Pers. dove-colored pretty

16. Nolane'a. Fries.

15947 majális Fries early

15948 pas'cuus Pers. cæaspitose

\$17. Eccíla. Fries.

15949 aspréllus Fries roughis 15950 áquilus Fries $\quad$ exposed 15951 politus Fries polished subsolitar

15952 carneo-albus With salmon-color'd gregarious
1 my. jn. pa. Oc. pine trunks Schæff. t. 29. squamosus 3 my. jn. pa.Oc. pine trunks Sower.t.382. tubceformis

3 sp. aut. Wsh old trunks Sower. t. 168. confluens

1 au. no. Wsh oak trees Schæff.t.233.dimidiatus

$1 \frac{1}{2}$ jl. oct. Rsh birch trees Nees pilze, f. 176

1 jl. sep. Cinn. birch trees Bull. t. 298

$\frac{1}{9}$ sp. aut. Cin. trun. of trees Sowerby, t. 241

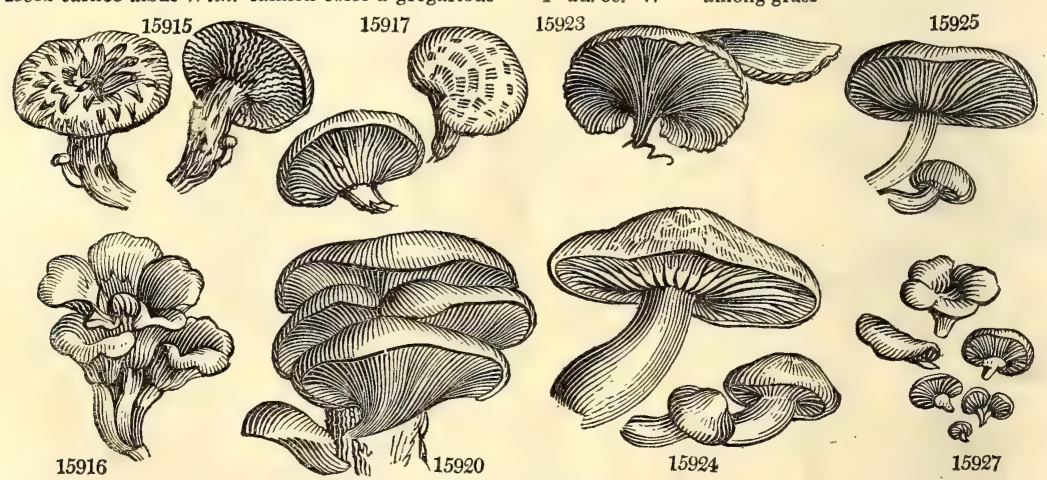

History, Use, Propagation, Culture,

12. Pleurotus. From $\pi \lambda$ sveov, the side; the pileus is always inserted out of the centre. A tribe of perennial, innocuous, often eatable fungi ; always found upon trees.

13. Mouceron. An old French name of certain eatable fungi. This, no doubt, is the origin of our word Mushroom. A. prunulus is said to be one of the very best of mushrooms ; it is common in woods, among grass.

$\$ 14$. Clitopilus. A name analogous to Clitocybe, $\$ 8$, as the group is also. Species of the middle size, nearly destitute of smell, mild, but not used as food. 
15915 Cap compact unequal pale ochraceous, Scales spot-like more opaque, Lamellæ torn, Stipes stout scaly 3 Stipes long curved, Cap small

15916 Cap tough somewhat lobed twisted smooth rufous, Lamellæ toothed pallid, Stipes firm furrowed rufous

1. Veil universal, Cap compact, horizontal.

15917 Hard, Cap oblique smoothish whitish, Scales brownish, Veil fugacious

$$
\text { 2. Veil none, Cap fleshy, Gills decurrent. }
$$

$$
\text { * Cap always entire. }
$$

15918 Cap tough depressed reddish tan-color, Lamellæ rather crisp paler, Stipes short grey downy

$$
\text { ** Cap entire or halved. }
$$

15919 Cap tough deformed pink cinnamon-color, Lamel. entire and short irregul. Stipes downy at base and pallid 15920 Tufted, Stipes sublateral or none, Cap smooth fleshy pale blueish-grey or brown, Lamellæ whitish often anastomosing at the base

*** Cap always halved, somewhat ascending.

15921 Ascending, Cap spatulate whitish-brown, Disk and stipes somewhat villous, Lamel. compact lin. white 15922 White, Cap ascending sessile ear-like glabrous, Lamellæ narrow linear quite entire 15923 Cap flattish smooth pale-brown, Margin and lamellæ crenate, Stipes short or none

3. Veil none, Cap fleshy, when young horizontal, Gills terminating in a determinate manner.

15924 Cap compact smooth pale whitish, Lamellæ adnate or subdecurrent whitish, Stipes strong ascending incrassated at the base excentrical

15925 Cap smooth rufous, Lamellæ adnate of the same color, Stipes out of the centre smooth whiter

15926 Cap comp. somew. visc. olive-green, Lamel. adnate comp. pallid, Stipes short rather on one side sooty scaly 15927 Cap coriaceous reniform rather tan-colored, Epidermis separating into scurfy scales, Lamellæ veiny connected, Stipes lateral frosted

4. Cap fleshy, when young resupinate, Gills running together in a point out of the centre.

15928 Cap fleshy renitorm downy yellowish, Lamellæ orange-yellow

15929 Cap fleshy scaly mouse-color, Upper stratum gelatinous, Lamellæ greyish-white

15930 Cap soft smooth gibbous pale-yellow brown, Lamellæ pale reddish-brown somew: ventricose, Stipes none 15931 Cap membranaceous white cottony at first subresupin. at length reflexed, Lamel. whit. afterw. pink.-buff 15932 Cap Heshy smooth umber-colored ; the upper layer gelatinous, Lamellæ pale becoming yellow

$$
\text { 5. Cap membranous, Gills adnate, or running together in one point. }
$$

15933 Cap reniform diaphanous, Lamellæ linear, Stipes marginal ascending villous

15934 Cap at first resupinate : afterw, reflex, smooth downy, Lamel radiat. Stipes thin incurved dowe Byssus 15935 Cap subsessile : at first resupinate; afterwards reflexed frosted villous at base, Lamellæ lax

15936 Cap compact flattish white, Lamellæ white becoming pink

\section{Gills affixed. Terrestrial.}

15937 Cap somewhat umbonate sooty black. Lamel. flat decurr twist. whit. Stipes hollow thickened downwards 15938 Cap somewhat umbonate silky livid, Lamellæ adnate whitish rose-colored, Stipes hollow smooth white 15939 Cap somew. umbon. smooth livid pale, Lamel. annexed flesh-colored, Stipes solid smooth somew. bulbous 15940 Broad, Cap smooth yellowish-white, Lamellæ loosely attached very broad rufous, Stipes solid equal white 1594 I Snall, Cap convex and stipes white, Lamellæ adnate

$$
\text { 2. Gills altogether distinct. UPON WooD. }
$$

$159+2$ Cap somewhat membranaceous smooth yellow, Stipes solid striated

15243 Cap fleshy smooth blackish soot-color, Stipes firm with black fibres

15944 Cap convex at length plane clear olive or yellowish-brown smooth but minutely rug. as if veined towards the centre, Stipes hollow rather twisted, Lamellæ ventricose

15945 Cap scaly grey-lilac colored, Lamellæ loose, Stipes hollow fibrous cæsious

15946 Cap somewhat squamose blue, Lamellæ bluish-white adnate at length purple, Stipes solid smooth bluish

15947 Cap irregular smooth somew. cinnamon-colored, Lamel. loose toothed rosy, Stipes hollow twisted striated 15948 Cap campanul. expanded black, soot-color when dry paler and silky, Lamel. almost loose dirty flesh-col.

15949 Cap fibrous scaly livid-grey, Lamel. adnate and fistular, Stipes (which is white with wool at the base) paler 15950 Cap squamulose umber-colored, Lamellæ sinuate affixed purplish, Stipes solid short

159.51 Cap smooth with a striated edge and the fistular equal, Stipes livid, Lamellæ decurrent

15952 Lamellæ salmon-colored not numerous, Cap and stem white

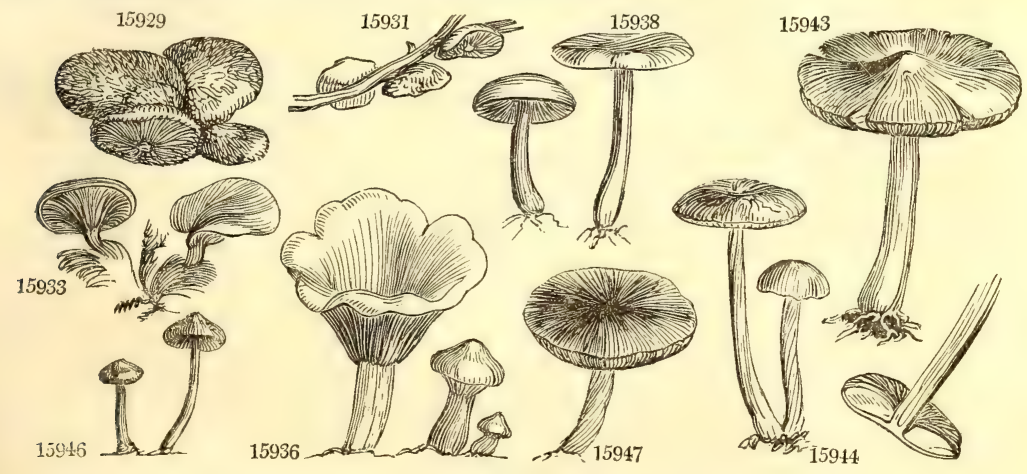

and Miscellanéous Particulars.

15. Leptonia. From $\lambda \in \pi \tau$ s, slender. Small permanent, elegant, scentless, insipid, not used for food. They are in perfection at the end of summer.

16. Nolanea. From nola, a bell. Terrestrial, various, of a thin watery substance, insipid, not eatable. Easily distinguished by their habit.

\$17. Eccilia. From єxะoi ${ }_{0} \circ$, to excavate. Small, terrestrial, inodorous, insipid. 
8 18. Telamónia. Fries. 15953 tórvus Fries tawny $\begin{array}{ll}15953 \text { torvus Fries } & \text { tawny } \\ 15954 \text { brun'neus Pers. } & \text { brown }\end{array}$ spongiosus With.

15955 everhius Fries dismal

159.56 sublanátus Sowerb. half-woolly

15957 bulbósus Sowerb. bulbous

15958 viola. INOLO'MA. Fries.

15958 violáceus $L$. violet

15959 pholidius Fries cobwebbed

15960 spiloméus $F r$ spotted

15961 scaúrus Fries curved

15962 callochróus Pers. fine-skinned

15963 glaúcopus Schrff. blue-footed

15964 várius Schaeff. thick-footed

15965 turbinátus Bull. stron 3 scent. 4 jul. oc. Br damp woods Bull, t. 600. araneosus weak scented 4 jl. nov. $\mathrm{Pa}$.U. pine woods

solitary $\quad 5$ jl. nov. $\mathrm{Pu} . \mathrm{Br}$ pine woods Sower, t. 125. impuber radish scent. 3 au. oc. Ol. Br woods Sowerby, t. 224:

radish scent. 4 au. oc. $\mathrm{Br}$ among grass Sowerby, t. 130

\section{shewy $\quad 4$ au. oc. $\mathrm{Vi}$ groves Bolton, t. 52}

solitary 4 au. oc. Cin. woods Bul.t.586.f.1.psammoce -

solitary $\quad 3$ au.sep. $\mathrm{Pa} . \mathrm{Br}$ woods

phalus

Sow, t.384, f.1. araneosus

\section{soft 3 jan. oc. $\mathrm{Ol}$ woods Batsch cent. 2. f. 184}

insipid 4 au. oc. Psh wood's Bat.cent.1.f.74. subpurp.

gregarious 3 au. oc. Ol woods \& hea. Sowerby, t. 223

variable $\quad 4$ au. oc. $Y$ everywhere Sower. t. 102.turbinatus soft

4. sep.no. Y

80. Dermócye. Fries.

15966 sanguineus Wulf. bloody

15967 cinnamómeus $L$. cinnamon

handsome

$1 \frac{1}{2}$ jn.nov. Crim. woods Sowerby, t. 43

variable $\quad 3$ jn. dec. Cinn. everywhere Sowerby, t. $20 j$

15968 hel'volus Pers. brownish dirty

2 jn. dec. Cinn. woods

Sow. t. 173, hinnulcus

15969 Cúcumis Pers. Cucumber-scented strong smell. 3 au. oc. Pu.Br woods

Sower. t. 344. fuscipes

15970 Armeniacus Schaff. A pricot-color. softish 15971 castáneus Bull. Chesnut-color. gregarious

3 jl, nov, $\mathrm{Pa}, \mathrm{Br}$ woods

2 jl. nov. Ches. woods
Schæeff. t. 81

Bulliard, t. 268

$\begin{array}{llllll}15972 \text { hýbridus Sowerby } & \text { hybrid } & \text { variable } & 2 \text { my.no. Or } & \text { fir leaves } & \text { Sowerby, t. 221 } \\ 15973 \text { testáceus With. } & \text { testaceous } & \text { crooked } & 4 \text { sept. Y } & \text { plantations } \\ 15974 \text { flávidus Sowerby } & \text { yellowish } & \text { soft } & 2 & \text { sept. Ysh among grass Sowerby, t. S66 }\end{array}$

\section{5 aúreus Pholio'ta. Fries.}

15976 caperátus Pers golden

15977 aurivéllus Batsch tilamentous

15978 squarrúsus Pers. squarrose

15979 flam'mans Batsch flame-colored rheoides With.

15980 muricátus Fries scariósus With.

$\beta$ incequalis Batt.

unequal
changeabl

changeable subcæspitose 6 sep. oc. Fulv. damp earth Sowerby, t. 77 solitary $\quad 5$ jul.oct. Lem. mount. woo. Fl. dan. t. 1675 solitary $\quad 3$ oc.no. Y old trees Schæ.t.209.filamentosus cespitose 2 au.dec. Ferr. roots of trees Gre.cryp. fl.t.2 floccosis

3 jul.oct. Y pine trees Batsch el. f. 30

2 jul.oct. Dl.Y commons

2 jul.oct. Dl.Y commons Bolt. t. 50. luteus 3 my.no. Pa.Ci. on trees Schæff. t. 9

15982 constric'tus With. contracted watery

$\frac{3}{4}$ sept. Y.Br rotten wood
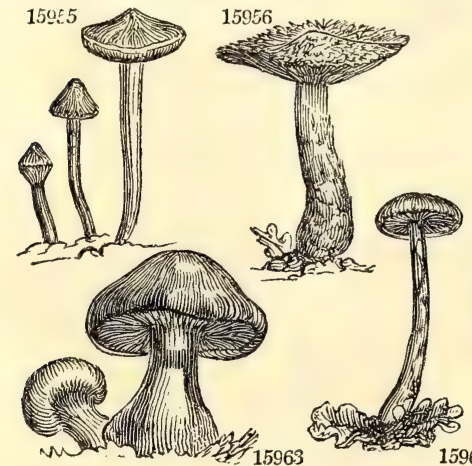

15960

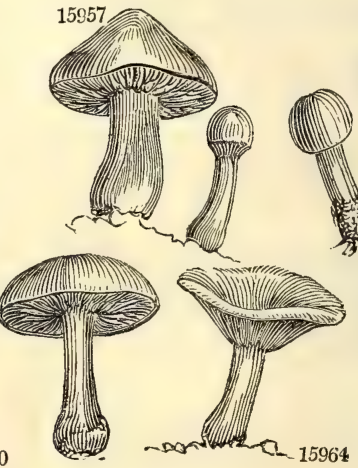

15958
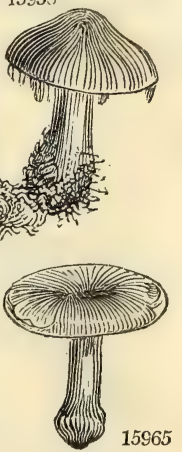

History, Use, Propagation, Culture,

18. Telamonia So named on account of their gigantic stature. The species are among Agarics what Ajax Telamonius was among men. Large, terrestrial, firm species, none of which are eaten. The species of this and the next subgenus are extremely difficult to determine; not only on account of their size, but of their colors, which vary exceedingly at different periods of their growth, as well as according to their situation. Their colors are also intermediate between fulvous, testaceous, cinnamon, \&c., which are very difficult to describe. The most constant marks are, first, smell; second, surface of pileus being fibrous or viscid; third, the situation of the lamellæ, whether they are compact or distant; and fourth, their color in the young state, in which it must be observed, that they are always described.

The A. bulbosus of Hudson and Ray is referred by Withering to A. violaceus of Linnæus ; which has fixed purple gills, numerous, eight in a set; long gills, sometimes cloven, and a few of them decurrent: purple pileus, soft, smooth, firm, convex, but centrally depressed with age, and cracking at the edge, which is somewhat turned down, from half an inch to five inches over : stem solid, cylindrical, purple, bulbous at the base, from one to four inches high, and from a quarter to one inch in diameter; and curtain like a cobweb. In maturity it plentifully emits a powder of the color of Spanish snuff. It is not uncommon from October to December, in Edgbaston and Barr plantations, in the woods near Bath, and at Powick, near Worcester. With much broiling and duly seasoned, it is esteemed as delicious as an oyster. Another variety, which is the A. varius of Bolton, is found on grass-plats and new-mown fields in July. It has chocolate gills, from brown to black, 
15953 Cap obt. fibrous hoary testac. Lamellæ adn. purple, An annulus sheath. stipes which is violet at upp. end 15954 Cap bluntly umbon. somew. fibr. pale umb.-color, Lamel. adnate umb.-col. Stipes somew. bulb. striat. paler

1595.5 Cap somew. fleshy purp.-brown becom. fibrous testac. and hoary, Lamel. violet-pur. Stipes long eq. violet 15956 Cap scaly testaceous olive-color, Lamellæ yellowish cinnamon, Stipes bulbous scaly, Veil fuscous

15957 Cap obtusely umbon. smth. bright-brown when dry testac. Lamel. cinnam. Long bulb. stipes and veil white 1. Cap always dry, scaly, or fibrous, obtuse or umbonate, never depressed.

15958 Cap very convex dull or brownish-violet, Lamellæ distant violet, Stipes spongy greyish violet within

15959 Cap umbonate squarrose with hairy sooty scales, Lamellæ compact violet becoming clay-colored, Stipes scaly transversely banded with black

15960 Cap umbon. smooth. pale-brown, Lamel, compact violet discolor. Stipes taper. varieg. with brown scales 2. Cap smooth, humid, viscid, always obtuse, finally depressed, Stem bluc, becoming white.

15961 Cap equal viscid, Lamellæ compact olive-purple, Stipes attenuated bulbous

15962 Cap equal viscid smooth, Lamellæ compact violet-purple, Stipes bulbous becoming white from violet

15963 Compact rounded, Cap olivaceous or brownish-grey glutinous while young, Lamellæ reddish-brown tinged with violet, Stipes thick tinged with violet

15964 Firm, Cap yellow somew. scaly humid viscid, Lamel. compact serrat. whit.-cæsious, Stipes tapering white 15965 Cap smooth viscid yellow or tawny, Lamellæ compact quite entire yellowish-cinnamon, Stipes bulb. white

1. Cap scaly or fibrous, Stem same color as the cap or paler. Growing ON THE EARTH.

15966 Cap slightly fleshy somew. scaly, and stipes (which is thin and eq.) dull sarg. Lamel. affix. more dull-color. 15967 Cap glabrous subcarnose obtusely umbonate cinnamon-color, Lamellæ numerous adnate yellow-cinnamon, Stipes yellowish rarely straight

15968 Cap pale reddish-buff umbonate subfarinaceous, Lamellæ cinnamon-color broad numerous, Stipes whitish often with a few remains of the veil attached

** Cap somewhat fleshy, at first campanulate.

15969 Cap somew. fleshy becom. umbon. smoothish brown-purple, Lamel. affix ventric. ferrugin. Stipes fuscous

2. Cap smooth, but with a few surface-fibres, Stem white. Growing on THE EARTH.

15970 Cap bluntly umbonate pallid, Lamellæ compact cinnamon-colored, Stipes solid tapering upwards white

15971 Cap somewhat fleshy convex becoming bluntly umbonate chesnut-colored, Lamellæ affixed compact violet-testaceous, Stipes short firm

3. Cap smooth, dry, Gills affixed.

15972 Cap convex humid orange-colored or fulvous, Lamellæ yellow, Stipes hollowish

15973 Lamellæ brown-yellow, Cap dcep-yellow bossed in the centre, Stipes scored yellow thickset downwards

15974 Lamellæ reddish-buff, Cap pale-yellow bossed, Stipes pale-yellow

15975 Fulvous, Cap fleshy: scales few hairy, Lamelle annexed, Stipes solid smooth, Annulus small

15976 Cap pitted lemon-colored : hairs white; disk uniform with scatter. scales towards disk, Stipes solid white 15977 Compact, Cap yellow : scales scattered appressed, Stipes solid fibrous long-rooted

15978 Cap fleshy brownish or reddish-yellow scaly with fasciculat. filam. : scales revol. Stipes squarr. with scales 15979 Cap fleshy dry yellow: scales hairy scattered, Lamellæ at first yellow, Stipes equal squarrose

15950 Cap slightly fleshy obt. fulvous-yellow vill, with stalked scales, Lamel. adnate : at first yell. Stipes fistul.

15981 Cap scarcely fleshed glabrous striate: when moist dull cinnamon-color becommg pale, Lamellæ subdecurrent numerous reddish-brown, Stipes hollow subincurved

15982 Cap yellow-brown bluntly conical, Lamellæ brown, Stipes brown scurfy, Veil permanent

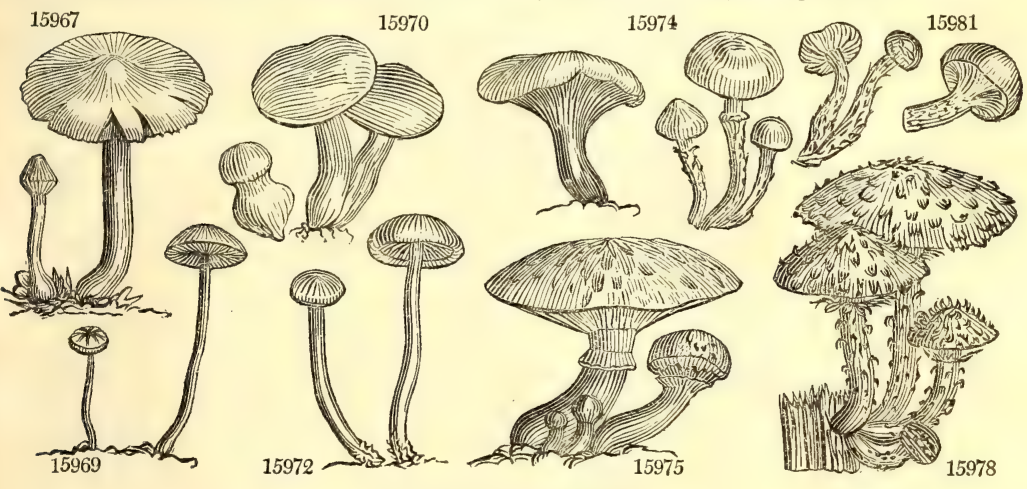

and Miscellaneous Pariziculars.

mottled, and in pairs ; pileus mouse-color, conical, and pointed ; stem of the same color, cylindrical, and firm. This, though a common, is a very beautiful species. In a summer morning it is covered with a bloom like that of a plumb, having often a glittering spangled appearance ; its form is regular, and the fringe of the curtain that of a plumb, having often a glittering spangled appearance; its form is regular, and the fringe of the curtain
peculiarly delicate. Another variety, with the stem of a dark mulberry color, is found in wet gravel where no grass grows, and sometimes on cow-dung, in which case the stem, under the shelter of long grass, is covered with a white hoariness which is easily rubbed off.

19. Inoloma. A name with the same meaning as Tricholoma, $\$ 5$, to which the species are analogous. They are large, firm, somewhat succulent, autumnal, and terrestrial, but not as far as is known, eatable.

8 20. Dermocybe. From sseun, a skin or membrane, and pileus. Analogous to Clitocybe, 8 . Of middle size, or small; scarcely eatable. A. cinnamomeus has gills, four in a set, broad about the middle, deep tawny red, and fixed by claws; pileus convex, but bossed, of a rich cinnamon color, from one and a half to three and a half inches diameter; the stem hollow, cylindrical, silky, shining, two inches high, thick as a goose-quill, of a fine full yellow color. This is a species that is readily distinguished by its cinnamon color. It is found in woods in September and October, and has a good flavor.

121. Pholiota. From $\phi \circ \lambda, s$, a scale. Species of various habits. Some are terrestrial, others grow upon wood; some large, others of a smaller size. 
22. MYXa'crum. Fries.

15983 collinitus Sowerby besmeared 15984 longicaúdus Fries long-tailed flexuósus With.

\$ 23. Невецо мa. Fries.

15985 fastíbilis Pers. multiform

824. Flan'mula. Fries.

15986 flavidus Sch Pff. yellowish

15987 inopus Fries $\quad$ connate connátus With.

15988 spumósus Batt. frothy

15989 scáber Sowerby rough

15990 plumósus Bolton feathery

15991 lanuginósus Bull. woolly

15992 rimósus Bull. cracked

15993 geophýllus Sowerby earth-leaf

15994 furfurósus With. scurfy

8 26. Nauco'ria, Fries.

15995 conspérsus Pers. sprinkled

15996 furfuráceus Pers. mealy viridárius With.

15997 hippopinus With. $\quad$ rounded 827. GalE'RA, Fries.

15998 cólus With.
15999 téner Schaeff.

$\begin{array}{ll}15999 \text { téner Schaff: } & \text { tende } \\ 16000 \text { hypnórum Schrank Moss }\end{array}$

16001 atrorúfus Bolton dark-brown slender 16002 núceus Bolton hazel-nut slender \$28. Tapine'A. Fries.

16003 involítus Batsch involute adustus With.

\$29. Crepido'trus. Fries.

16004 auránt.-ferrugi. Wi. orange-brown solitary

16005 fo tidus With. fetid

16006 vulpínus Sow. foxy

16008 haustelláris Fries

gregarious

solitary

resupinátus With.

16009 variábilis Pers. $\quad$ variable

\$ 30. Volv' 'rIA. Fries.

16010 bombycínus Schaff. silky

16011 cepæ'stipes Sow. patchy 531. Psallio'ta, Fries.

16012 cretáceus Bull. chalky Mushr. eatable 16013 eampéstris $L$. comm. Mushr, eatable $\begin{array}{llll}5 & \text { jl.nov. } & \text { Or } & \text { woods } \\ 4 & \text { oct. } & \text { Tann. pine woods }\end{array}$

$2 \frac{1}{2}$ jl.nov. Wsh everywhere Schæff. t. 221. gilvus

$\begin{array}{lllll}\text { caspitose } & 2 & \text { au.no. Ysh } & \text { trun. of trees Schæff. t. } 35 \\ \text { subcæspitose } & 2 & \text { sep.oc. Ysh } & \text { trun. of trees Bol.t.148.radicato-ram. }\end{array}$

gregarious 3 au.no, Ysh on earth, \&c. Battarra, t. 22. C.

solitary $\quad 1 \frac{1}{2}$ aug. Sooty pine woods Sowerby, t. 207

woods Bolton, t. 33

jul.sep. Brsh way sides Bulliard, t. 370

jn.sep. Y.Br woods

Grev. crypt. 3. 128

2 jul.oct. Wsh woods Sowerby, t. 124

1 june Y.Br hedges

11 jn.oct, Cinn damp woods Pers. ic. $t, 12$, f. 3

2 au.oc. Cinn dead lvs. \&c. Sch.t.226. pulverulentus

$\frac{1}{2}$ aut. Pa.Br Sco. fir cones

jl.oct. $\mathrm{Pa} . \mathrm{Br}$ hea. of rubb.

4 my.no. Y.Br grassy places Sowerby, t. 33.

1 jl.nov. Ferr. among moss Sch. t.63. campanulatus

3 aut. $\mathrm{Br}$ pastures Bolton, t. 51. f. 1

4 oct. Pa.Br fir woods Bolton, t. 70

3 au.no. Ferr. woods Sower. t. 98. contiguus

$2 \frac{1}{2}$ aut. Or. Br roots of oak

2 aut. Dl. Br old willows

2 aut. Tawn. hollow trees Sowerby, t. 361

$\frac{1}{4}$ au. oc. pa.Cin trun, of trees Sowerby, t. 98

$\frac{1}{2}$ au.oc. Pa.tar rotten branc.

$\frac{1}{2}$ aut. W rotten trees Sowerby, t.97. niveus

\section{eatable $\quad 6$ jl.aug. W trun, of trees Schæff, $t, 98$}

4 sum. W bark of trees Sowerby, t. 2

3 au.no. W meadows Bull. t. 374

2 my,oc. Wsh meadows Grev, crypt. t. 161
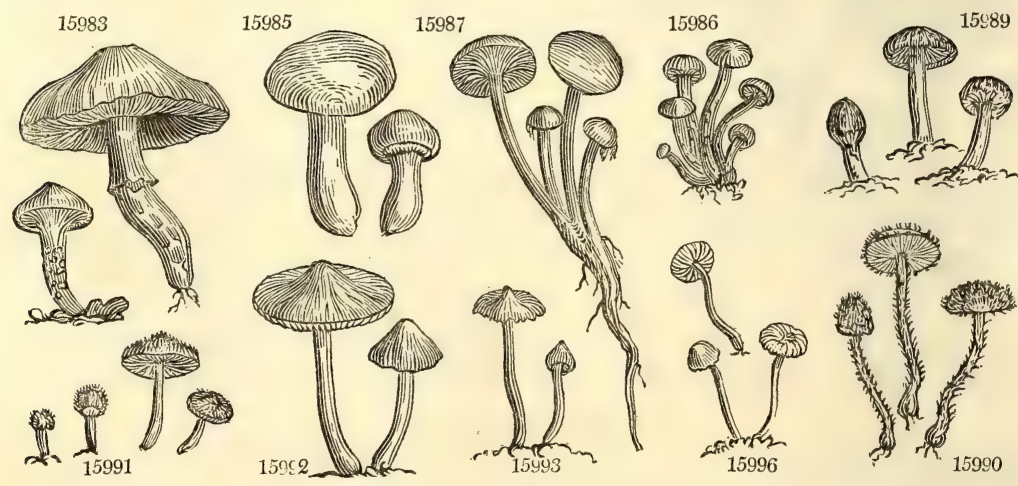

History, Use, Propagation, Culture,
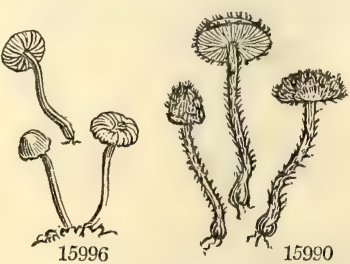

\$22. Myxacium. So called from $\mu \nu \zeta \alpha$, mucus, on accoun

23. Hebeloma. From $\dot{n} \hat{e} \eta$ down, and $\lambda \omega \mu \alpha$, a margin. The only species has a nauseous taste. Its lamellæ are serrated, and distil drops of a peculiar fluid. Its varieties are infinite. Common in woods.

24. Flammula. So named in allusion to theil color, which is a pale yellow, the color of a weal flame. The species are gregarious, subcæspitose, firm, persistent, rather bitter, and all eatable. A. socialis and ilicinus are both eaten at Montpellier, where they are known by the names of Pivoulade d'eouse and Frigoule.

srom

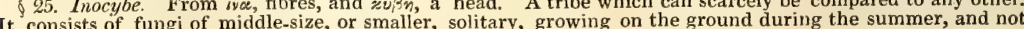
known to be poisonous; although, on account of their nauseous odor, they are suspicious.

$\$ 26$. Naucoria. Small gregarious epiphytous fungi, growing upon stipules, leaves, wood, and even muddy earth, fragile, and without any smell. Their stature is that of Collybia, but their veil is of the same nature as that of Lepiota, resembling the kernel of a nut (naucum), whence they are named. 
15983 Cap fleshy smth. orange-brown, Lamel. pur. : then ferrugin. Stipes part. across into bluish gelatin. scales 15984 Cap somewhat fleshy smooth, Lamellæ cinnamon-colored, Stipes long smoothish

15985 Cap somewhat repand opaque, Stipes scaly white, Sporidia clay-color

1. Cap dry, Gills adnate, Tufted. Growing on wood.

15986 Cap smooth yellowish, Lamellæ adnate yellow-ferruginous, Stipes fibrous 15987 Cap smooth yellowish, Lamellæ aftixed yellow, Stipes fibrous pallid solid

2. Cap viscid, Gills adnate, Not tufted. Growing UPON Both Wood and Earth. 15988 Yellowish, Cap smooth viscid, Lamellæ adnate, Stipes hollow tapering at base

$$
\text { 1. Siem fibrous or scaly with fibres. }
$$

15989 Cap fleshy obtuse scaly brownish-grey, Lamellæ free or nearly so, Stipes solid fibrillose

15990 Cap somew. fleshy hemispherical mouse-color, Stipes solid thin long scaly squarr. Lamel. somewhat loose 15991 Cap somewhat fleshy convex scaly-villous, Lamellæ loose and solid: then fibrous, Stipes solid

$$
\text { 2. Stem nearly at the top with white scales. }
$$

15992 Cap dry campanulate at length nearly plane: surface splitting longitudinally pale shining-brown, Stipes solid somewhat tuberous at the base

15993 Cap conical at length expanded umbonate silky, Lamellæ subadnate, Stipes solid slender sprinkled with white pulverulent particles

15994 Cap yellow-brown scaly, Gills watery white irregular, Stem yellow-brown crooked scored

15995 Cap somew. fleshy scurfy scaly rufous cinnam.-color. Lamel. emarg. lin. cinnam.-color. Stipes scaly at end 15996 Cap somew. fleshy : then umbilicat. scaly or silky, Lamel. somew.decurr. cinnam.-color. Stipes fistul. scurfy

15997 Cap dark-brown convex, Lamellæ light-brown, Stipes light-brown

15998 Cap somewhat membranous smooth pallid, Lamel. somewhat loose saffron-color. Stipes long villous white 15999 Cap obtusely conical stri. when moist : when dry smth. ochrac. Lamel. adnate lin. Stipes long glab. fragile 16000 Minute, Cap campanulate striate: when moist reddish-buff becoming pale, Lamellæ adnate rather broad distant, Stipes somewhat crooked filiform

16001 Cap somewhat conical: when dry elastic, Lamellæ few trifid, Stipes very long and slender

16002 Cap globose chesnut-color lobed and incurved at edge, Lamel, trifid wavy, Stipes slender white fistulous

16003 Compact, Cap depressed ochrey-brown with a tomentose involute margin, Lamellæ mostly dichotomous, Stipes thick often excentrical

16004 Cap convex scaly cracked and irregular, Lamellæ orange-brown, Stipes stout somewhat lateral 16005 Cap conv. viscid becom. wrinkled dull-brown : marg. invol, Lamel, adnate yellow. Stipes hard thick black 16006 Imbricated sessile fulvous, Cap fleshy obovate scaly towards the margin

16007 Cap subsessile smooth flaccid pale, Lamellæ watery cinnamon-colored

16008 Cap reniform villous pale tan-color, Lamellæ rounded ferruginous, Stipes lateral tapering upwards white 16009 Cap membranous reflexed silky downy white, Lamellæ whitish

16010 Cap silky white, Lamellæ flesh-colored, Stipes solid tapering incurved, Volva lax 16011 Cap campanulate with scattered scales, Stipes hollow ventricose smooth below

16012 White, Cap dry smoothish, Lamella loose broadest in front, Stipes hollow smooth, Annulus ascending 16013 Cap white fleshy dry subsquamose or sericeous, Lamellæ free ventricose pink changing to dark-fuscous, Stipes solid white with an annular veil
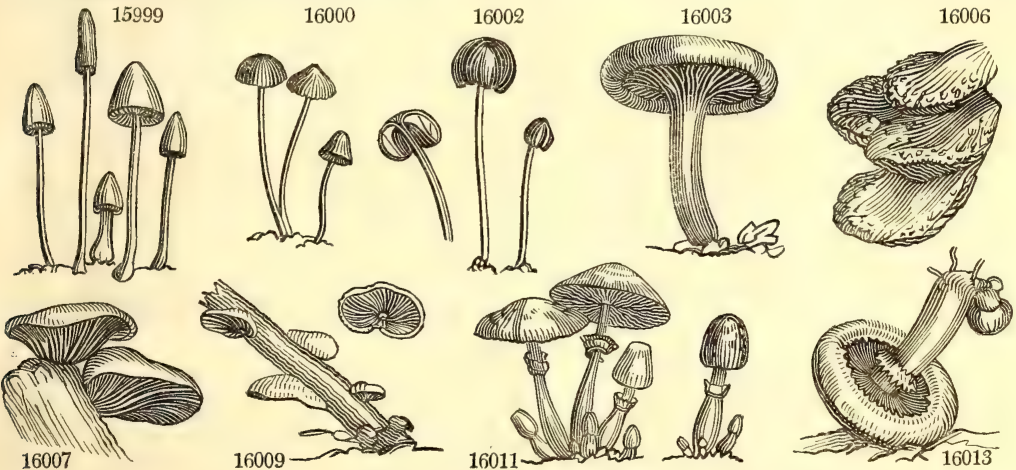

16007
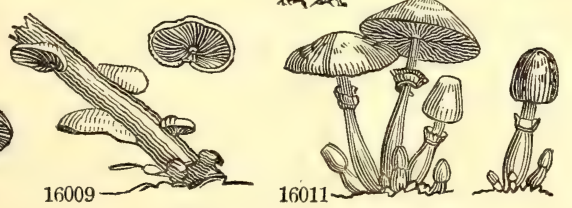

and Miscellaneous Particulars. 27. Galera. From galea, a helmet, in reference to the figure of their pileus. The species are slender,
fragile, tolerably permanent, mostly growing on the ground, and for the most part choosing humid stations. They have neither smell nor use.

28. Tapinea. Fungi of various natures, deriving their name from rarєayow, to depress. Mostly terrestrial and permanent, but scarcely fit for food

829. Crepidotus. These plants form a transition to Pratella. They grow on wood or trees, and are hardly eatable. phosphoric appearance in the night. A. translucens, a French species, is eaten by the poor of Montpellier. $\$ 30$. Volvaria. So called from the magnitude of their volva. The species grow in fertile manured spots, or on wood, are soft and soon perishable. The larger are fit for food.

31. Psalliota. Mostly eatable. Named from $\psi a \lambda \lambda$ sov, a chain-bit, in the same sense as Armillaria. To this place belongs the common Mushroom, A campestris, so called from Mouceron, the French name of another eatable kind. It is found all over Europe, the north of Asia, and of Africa, and in North America. 
16014 Geórgii Sowerby

16015 præ'cox Pers.

St. George's

eatable

s appendiculátus Sow.appendaged tufted 16016 semiglobátusBatsch half-rounded gregarious 16017 squamósus Pers. scaly solitary 16018 versícolor With. changeable-col. spongy 16019 æruginósus Fl.lond, verdigrease pretty 16020 littoreus With. $\quad$ sea-shore 32. Hypholo'ma. Fries.

16021 lachrymảúndusSow.weeping

16022 laterítius Schaff: one-sided 16023 fasciculáris Hids. bundled 833. Psilo'cyib. Fries. 16024 myosótis Fries. olive 16025 stercorárius Sehum. adnate adnátus Hudson

16026 erica'us Pers. heath 16028 callósus Fries callous $\beta$ várius Bolton various \$34. Psathína. Fries. 16029 stipátus Pers. stalked 16030 tentáculum Sower. slender

16031 cuspidátus Bolton cuspidate 85. Coprina'rius. Fries. 16032 semiovátus Soweröy half-ovate coronátus With.

16033 fimipútris Bull shield-headed fragile

16034 papilionáceus Bull. butterfy

16035 Boltóni Pers. Bolton's 16036 títubans Bull.

16037 papyráceus Pers. papery 16038 disseminátus Pers. scattered 2366. COPRI'NUS. Link. Coprinus. 16039 comátus Link. maned̉ A. cylindricus Sowerby, t. 189 16040 picáceus Fries ventricose 16041 atramentárius Link inky

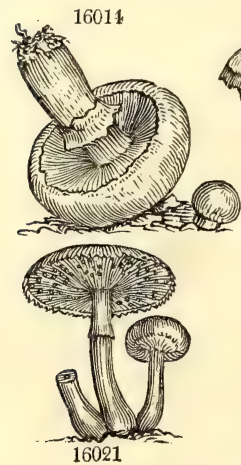

16021

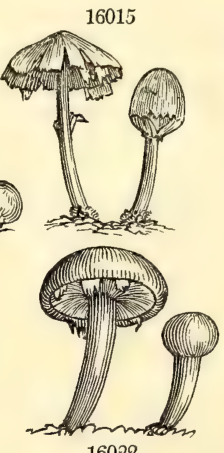

16022 fragile

cæspitose cæspitose

gregarious

brittle

twisting

gregarious

gregarious

tufted

fragile

thin

upright

\section{rragile}

unpleasant

fragile

semitranspar. gregarious

gregarious

subsolitary tufted
4 aut. Wsh mead.\& woo. Sowerby, t. SC4

$2 \frac{1}{2}$ spr. su. Ysh among grass

$2 \frac{1}{2}$ spr. su. Ysh among grass Sowerby, t. 324 3 my.no. $Y$ meadows Sowerby, t. 218 4. sep.no. Y 2 july. 11 july G.Br grove

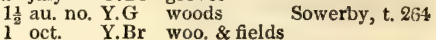

2 au. no. W.Br on ground Sowerby, t. 41

2 my. oc. Fulv. trun. of trees Bolt. t. 5. pomposus $1 \frac{1}{2}$ my.no. Ysh decay. trees Sowerby, t. 285

3 sep.no. G.Ol damp places

4 jul.oct. Liv.Y cow dung

4. jul.oct. $\mathrm{Br}$ damp places Schæff, t. 210. helvolus 2 aut. $\mathrm{Pa} . \mathrm{Br}$ among grass

Sow. t.248.f.1. semiglob.

Bolton, t. 66. f. 1

3 jl. nov. Br trun. of trees Bolt. t. 15. concinnus $3 \frac{1}{2}$ au. no. Brsh gardens Sowerby, t. 385. f. 1

\section{4 aut. R. Br pastures Bolton, t. 55}

6 sum. Wsh cowdung

Sowerby, t. 131

4 au. oct. Ciner. horse dung Bolt. t. 57. clypeatus

3 my.no. Sooty dunghills Bulliard, t. 58

3 spring $\mathrm{Y}$ dunghills Sower. t.96. Jlavidus

3 au.sep. Y dunghills Sowerby, t. 128

3 aut. Wsh oak trees Bolt. t.11. membranace. 1 spr. au. Ysh trun, of trees Sowerby, t.166. striatus Sp. 10-24.

2 au. oct. W gardens Grev. crypt. fl. t. 119

5 sep. oc. Wsh shady woods Sowerby, t. 170

$6 \mathrm{jn}$. dec. $\mathrm{Br}$ trun. of trees Sow. $\mathrm{t}$ 188. A. fimetarius

History, Use, Propagation, Culture,

of all the species of agaric, one only has been selected for cultivation in our gardens, viz, the A. campestris, or common mushroon, or champignon. The gills of this species are loose, pinky red, changing to a liver-color, in common mushroon, or champignon. The gils of thics sect, irregularly disposed, some forked next the stem, contact with the stem, but not united to it; very thick set, irregularly disposed, some forked next the stem,
some next the edge of the pileus, some at both ends, and in that case generally excluding the intermediate smaller gills. The pileus is white, changing to brown when old, and becoming scurfy; regularly convex, fleshy, flatter with age, from two to four inches, and sometimes nine inches in diameter, and liquefying in decay; the flesh white. The stem is solid, white, cylindrical, from two to three inches high, half an inch in diameter; the curtain white and delicate. When this mushroom first makes its appearance, it is smooth and almost globular; and in this state it is called a button. This species is esteemed the best and most savoury of the genus, and is much in request for the table in England. It is eaten fresh, either stewed or boiled, and of the genus, and is much in request for the table in England. It is eaten fresh, either stewed or boiled, and
preserved either as a pickle, or in powder; and it furnishes the sauce called ketchup. The field plants are better for eating than those raised on artificial beds, their flesh being more tender; and those who are accustomed to them can distinguish them by their smell. But the cultivated ones are more sightly, may be more easily collected in the proper state for eating, and are firmer and better for pickling. The wild mushrooms are found in parks and other pastures, where the turf has not been ploughed up for many years ; and the best time for gathering them is August and September. Dr. Withering mentions four varieties.

The A. Georgii of Linnæus resembles the former, but is much inferior to it in flavor. Its gills are yellowish white; the pileus yellow, convex, hollow in the centre; the stem yellow, thickish, and smooth; the juice yellow, which flows plentifully from it when wounded. It is gathered in September in woods and pastures. A variety of this is found on the sea-coast of Cornwall, of a large size, with the button as big as a potatoe; 
16014 Cap very fleshy convex white or pale-yellowish mostly smooth, Lamellæ broad whitish at length deep purple-brown, Stipes thick with a persistent collar

16015 Cap fleshy smooth yellowish tan-color, Lamellx annexed with a decurrent tooth pale-brown, Stipes nearly solid smooth white

16016 Cap hemispher. smooth glutin.redd.-yell. Lamel. adnate mostly horizont. darkly mott. Stipes holl. squam. 16017 Cap somewhat viscid yellow: scales scattered concentrical, Lamellæ adnate blackish, Stipes solid 16018 Cap scaly greenish-brown, Lamellæ decurrent becoming rufous-brown, Stipes solid bulbous [squamose 16019 Cap fleshy yell. but being cover. with a blue slime appear. green. Lamel. adnate purple-brown, Stipes holl. 16020 Stipes solid white, Annulus persistent, Cap yellow-brown, Lamellæ adnate reddish-grey

16021 Cap fieshy very fibrous pale yellow-brown, Lamellæ dull reddish-brown exuding a thin grey fluid, Stipes hollow fibrillose thickest at the base

16022 Cap fleshy obt. brown-orange, Lamel. slightly green. Stipes filled with a spongy mass stained by the veil 16023 Cap somew. fleshy umbon. ochrace. or redd.-orange, Lamel. green. numer. Stipes holl. rather long slender

16024 Cap convex viscid, Lamellæ adnate whitish-brown, Stipes long fibrous

16025 Cap obtuse smooth viscid livid-yellow, Lamellæ broad decurrent brown, Stipes long naked

16026 Cap convex smooth shining, Lamellæ broad adnate blackish, Stipes long naked

16027 Cap light-brown semiglobular, Lamellæ purplish-brown broad thin, Stipes reddish-brown

16028 Cap conical dry, Lamellæ adnate ascending dark-purple, Stipes tough smooth pale

16029 Cap somew. feshy smooth fuscous-brown pallid, Lamel. adnate numer. brown. flesh-color. Stipes smocth 16030 Cap somewhat membranous campanulate obtuse, Lamellæ very broad at back adnate cinereous-blackish margin pink, Stipes thin smooth

16031 Cap cinnamon-color conical, Lamellæ dusky-brown, Stipes brownish cylindrical smooth

16032 Cap somewhat fleshy obtusely campanulate glutinous yellowish or brownish-white, Lamelle adnate greyish-black, Stipes long white, Veil annular entire

16033 Cap somewhat fleshy campanulate humid cinereous pallid, Lamellæ adnate cinereous-black wholecolored at edge, Stipes long rufous, Annulus ragged

16034 Cap somewhat fleshy campanulate dry blackish soot-colored pallid, Lamellæ adnate cinereous-dark white at edge, Stipes long rufous striated at end

16035 Cap convex somewhat umbonate viscid yellow, Lamellæ annexed pallid, Stipes attenuated smooth yellow 16036 Cap membranaceous plicate viscous yellow, Lamellæ scarcely attached to the stipes pale purplish at length brown flesh-color, Stipes equal shining

16037 Cap hemispherical smoothish whitish, Lamellæ loose blackish-purple, Stipes naked white

16038 Gregarious small, Cap ovato-campan. plicate, Lamel. subadnate whit. at length grey, Stipes incurv. glab.

16089 Cap somewhat fleshy white scaly, Lamellæ white changing to red-purple and to black, Stipes subbulbous, Veil annular moveable

16040 Cap membranous white separating into broad scales, Lamellæ blackish, Stipes bulbous naked

16041 Tufted, Cap somewhat fleshy grey becoming reddish-brown smooth scaly at the apex, Lamel. ventricose white changing to purplish-brown, Stipes equal naked
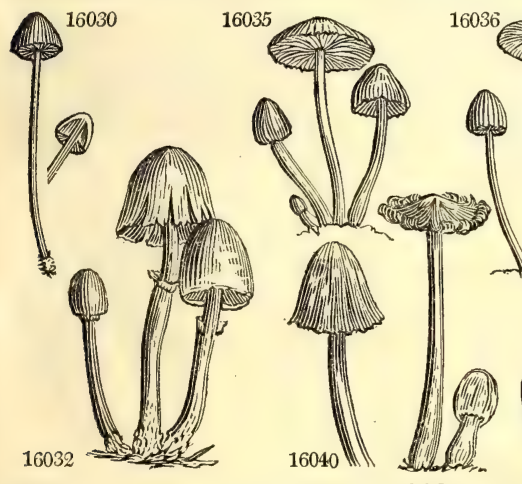

and Misccllaneous Particulars.

16038
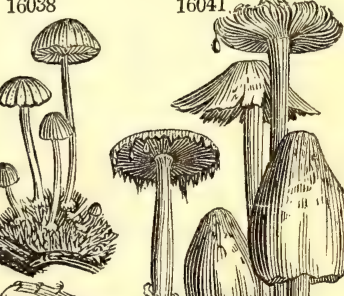

did.
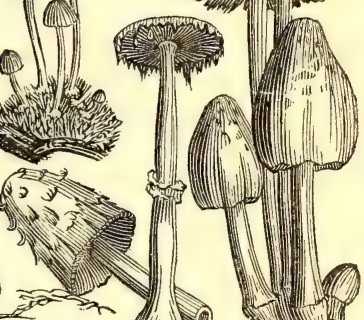

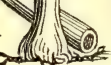

simen

the expanded pileus eighteen inches over, the stem as thick as a man's wrist, the gills very pale, the curtain tough, and thick as leather, and the juice yellowish. A plant of this kind, as Dr. Withering jnforms us, was gathered on an old hot-bed in a garden in Birmingham, which weighed fourteen pounds.

Greville says," A. Georgii derives its name, according to Parkinson, from springing up about the time of St. George's day. It is unquestionably the largest of the British agarics. It has been known to weigh fourteen pounds. Mr. Hopkirk mentions one that weighed five pounds six ounces, and measured forty-three inches in circumference; but Mr. Stackhouse found it to attain the enormous size of eighteen inches in diameter, which is fifty-four in circumference, having a stem as thick as a man's wrist. 'The best distinguishing marks are, the extreme paleness of the lamellæ at the period of the bursting of the veil, compared with the true mushroom; the greater convexity and thickness of flesh at the same period; and shortly afterwards, the more yellowish and tough pileus."

832. Hypholoma. So called, from iфøs, a cup, and $\lambda \omega \mu \alpha$, an edge. Wood species growing in patches.

33. Psilocybe. From $\psi\left\llcorner\lambda_{05}\right.$, thin, and $\chi v \beta \eta$, a head. A very natural assemblage. The species are for the most part terrestrial, inhabiting fertile and somewhat fenny places, growing either solitary or in groups, not eatable, and subject to much variety of appearance.

$\$ 34$. Psathyra. So called, from $\psi \propto 2$. are found upon moist wood, and in grassy places on a fertile soil

85. Coprinarius. All the species are found on dung, whence their name, from worew, dung.

2366. Coprinus. Named for the same reason as the last. The species are gregarious and fugacious. They are found on dunghills, rich grassy places, and in the hollow trunks of decayed trees. The taste of the 
16042 congregátus Fries clustered 16043 niveus Pers. snowy 16044 cinéreus $F \cdot$.ies 16047 ephémerus Pers. ephemeral 16048 radiátus Bolt. radiated

2367. GOM'PHUS. Fries. GompHus. 16050 rútilus Fr. $\quad$ sparkling

2368. CANTHAREL'LUS. Adans. 16051 umbonátus Pers. umbonate 16052 aurantíacus $\mathrm{Fr}$. orange 16053 cibárius Fries. $\begin{array}{ll}16053 \text { cibárius Fries } & \text { eatable } \\ \text { 16054 cinéreus Fries } & \text { cinereous }\end{array}$ 16055 cornucopioídes Fries purplish Merúlius purpurátus With.

16056 undulátus Fries wavy

16057 lobátus Fries lobed

16058 lutéscens Fries yellowish 16049 gompH tufted

variable

solitary

pretty

tender

fugacious

very aelicat

solitary

solitary

\section{Chantarell.} gregarious poisonous esculent

tufted

elastic

tough

tough

spirit-scented
3 my. no. Ferr. trun. of trees Sowerby, t. 261

3 au.no. W horse dung

4 jul oct. Cin dunghilis Bolt $t$. 156 tomentosus

3 wet w. Sooty walls Bolton, t. 26

2 sum. Cin. damp places Sowerby, t. 364

2 my. oc. $\mathrm{Br}$ dungbills Sow. t. 262. stercorarius

2 my, oc. Cin. dung Bolton, t. 39. f. C.

Sp. 2-4

3 jl. nov. Pu pine woods Sowerby, t. 7

3 au. oct. Brsh pine woods Sowerby, t. 105

Sp. 8-43.

3 au. no. Cin. among moss Jacq. coll. 2, t. 16, f. 1

2 au. no. Or.Y fields Jacq. coll. 2. t. 14. f. 5

$1 \frac{1}{2}$ jl. nov. $\mathrm{Y}$ fields Sow t.46. A cantharellus

$1 \frac{1}{2}$ oct. Blsh among moss Bolt.t.34 infundibularis

$2^{2}$ au.no. Br woods Sowerby, t.74

$\frac{3}{4}$ all sea. Pale on ground Sower. t. 75. floriformis spring Brsh humid places Bo.t.177. membranaceus jul, no. Ysh humid places Sow.t.47.A.cantharelloi.

Sp. $1-10$

* all sea. Y.Br decay. wood Sowerby, t. 113

parasite

4 all sea. Y.Br decay. wood Bolton, t. 74

Sp. 1.

2 wet w. Grsh trun. of trees Grev. crypt, t. 61

Sp. $7-30$.

2371. DADA'LEA. Pers. Dedalea. 16062 biénnis Fries. $\quad$ biennial

16063 betulina Pers. 16064 confragósa Pers. 16065 unícolor Fries

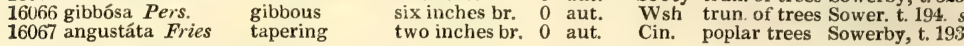
three inch. br.

0 all sea. $\mathrm{Pa}$

HIZOPHYLLUM. gregarious

smaller woody

0 all sea. Pallid birch trees Sowerby, t. 182

0 all sea. Brsh service trees Bolton, $t, 160$

0 aut. Sooty trun. of trees Sowerby, t. 325

2372. POLYPO'RUS. Micheli. Polyporus. Sp. 35-143.

$$
\text { 1. Favólus. Beauv. }
$$

16068 squamósus Fr. scaly

$3-18$ inc. wide 2 jn.nov. Ochr. trun. of trees Grev. crypt. 207

16069 heteróclitus $F r$ variable

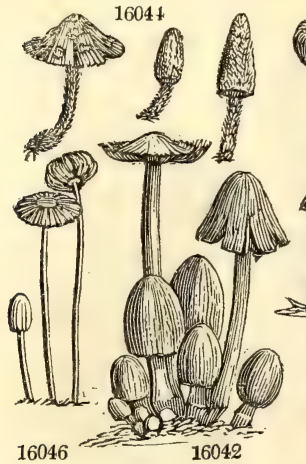

$2 \frac{1}{4}$ inches wide 0 aut. Or on earth Bolton, t. 164
16058

16056
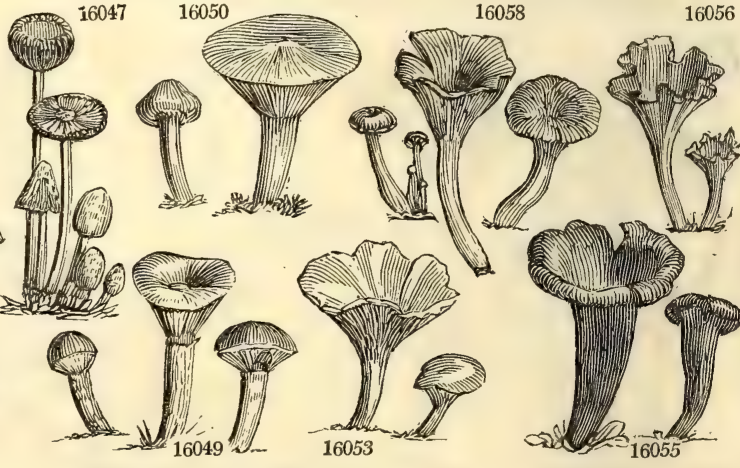

History, Use, Propagation, Culture,

European species is watery and nauseous ; they are therefore not eatable. But in the spice islands, two species, C. moschocaryanus, which is found on the nutmegs, and C. saguarius, which inhabits the pith of the Sago palm, are said to be most delicious. C. cinereus is extremely rapid in its growth, attaining perfection and dissolving in the course of a few hours. At its first appearance, it is covered with the delicate frosted remains of the veil. 2367. Gomphus. So named from their form, from rouфos, a club. Large Fungi, scarcely fit for food, with little taste or smell.

2368. Cantharellus. An alteration of the French Chantarelle. C. cibarius is one of the best of our eatable mushrooms. The best way of preserving the plants for use is to string them in rows, after they have become flaccid, and to hang them in a dry place where they can have plenty of air. They then form a delicious ingredient in rich gravies, \&c.

2369. Merulius. A name applied by the ancients to the common morel, Morchella esculenta. Natives of rotten wood, which they soften and finally destroy. M. lacrymans, the dry rot, is a pest to the wood of dwelling houses, which it speedily destroys. It is said to be destroyed by a wash of diluted sulphuric acid. The whole plant is generally resupinate, soft, tender, at first very light, cottony and white. When the veins appear, they are of a fine yellow, orange, or reddish-brown, forming irregular plicæ, most frequently so arranged as to have the appearance of pores, but never any thing like tubes. Sometimes the pileus or substance of the plant, from its situation, produces pendent processes like inverted cones. "The whole fructification often forms a circle of $1-8$ inches in diameter." Except in favorable situations, it does not produce fructification, and resembles a dry pithy cottony substance, whence it has been called the dry rot. When in a perfect state, its sinuses contain drops of clear water, which have given rise to the specific name.

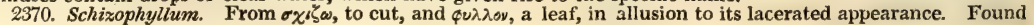


16042 Tuft. Cap membranac. furrow. furfurac. brown-orange, Lamel. pale chang. to black, Stipes equal fragile 16043 Cap campan. farin. with min. scales, Stipes snow-white tomentose, Lamel. narrow.at length brown.-black 16044 Cap furrowed subtomentose cinereous smooth on the summit, Lamel. lin. Stipes tall attenuated upwards 16045 Cap obtuse scaly scurfy wavy-furrowed sooty, Lamellæ numerous linear blackish, Stipes somewhat silky 16046 Very tender, Cap conical at length plane umbilicated plicate, Lamellæ not reaching to the stipes distant dark-grey, Stipes smooth weak

16047 Ovato-campanulate scaly while young afterwards glabrous becoming expanded and revolute grey or tinged with brown very thin splitting, Lamellæ distant

16048 Very delicate and fugacious, Cap grey furfuraceous at length splitting in a radiated manner glabrous brownish in the centre, Stipes filiform

16049 Cap obtuse giunınous purplish-brown, Lamellæ whitish cinereous

16050 Cap umbonate somewhat viscid rufous-brown, Lamellæ purple umber-colored

16051 Cap slightly fleshy umbonate cinereous-blackish, Stipes solid paler, Plaits straight white

16052 Cap fleshy rather depressed downy and solid, Stipes orange-yellow, Plaits straight orange-colored

16053 Rich buff yellow, Cap fleshy irregular smooth : veins tumid, Stipes solid attenuated at the base

16054 Cap funnel-shaped pervious scaly and hollow, Stipes blackish, Plaits distant cinereous

16055 Cap tubeform pervious scaly black umber-color : wrinkles obsolete

16056. Cap coriaceous membranous depressed wavy pallid rugose beneath, Stipes solid

16057 Horizontal sessile lobed membranaceous dilute brown, Veins branched

16058 Cap submembranac. funnel-shap. waved yellowish or olivac. brown, Veins anastomosing, Stipes holl, yell.

16059 Effused large yellow ferruginous or deep orange : margin white and cottony, Veins large forming irregular pores by their sinuosity

16060 The only species

16061 Sessile pale with a woody aspect, Cap suberose rugose glab. Hymenium contorted sinuose anastomosing 16062 Cap somewhat corky depressed rather velvety subferruginous, Hymenium composed of labyrinth-like pores grey flesh-color, Stipes irregular central or nearly lateral

16063 Sessile pallid, Cap coriaceous banded downy, Lamellæ straight somewhat branched

16064 Sessile, Cap corky-coriaceous banded rough brownish, Recesses labyrinth-like cinereous

16065 Sessile cinereous, Cap coriaceous villous banded, Recesses unequal somewhat flexuose becoming ragged

16066 Sessile whitish, Cap corky villous projecting and gibbous at base, Pores linear straightish

16067 Sessile, Cap corky downy banded brownish-cinereous, Pores long narrow olive-yellow

16008 Large, Cap fleshy pale dirty-yellowish with broad dark-colored scales, Pores large angular whitish becoming mere reticulations at the base, Stipes very short

16069 Sessile orange-colored, Cap imbricated lobed villous, Pores large deformed

16059

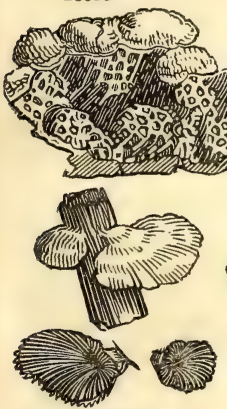

16060
16062
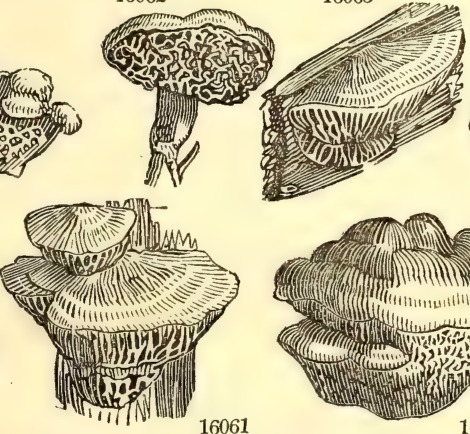

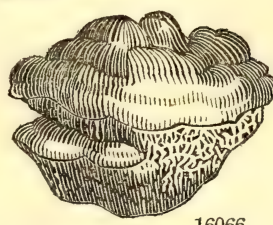

16066
16068
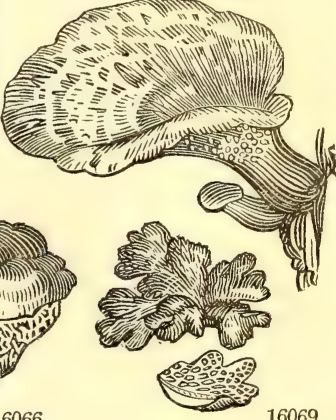

16069

and Miscellaneous Particulars.

upon the trunks of leafy trees through all Europe and Asia, the Gold Coast, Cape of Good Hope, North America, the Antilles, and South America.

2371. Dadalea. So called from its sinuosities, which appear as if arranged with Deedalean art. Most of the species grow upon wood. The dried substance of $\mathrm{D}$. quercina is a good styptic. D. suaveolens has, according to Bolton, a smell like aniseed; and Linnæus mentions, that the Laplanders carry it about them when they visit their mistresses, in order to render themselves more agreeable. From the powder of the plant is prepared an electuary which is said to have been used with success in cases of phthisis. The dose from a scruple to a drachm.

2372. Polyporus. From zodvs, many, and zoeos, a pore, on account of the multitude of pores which constitute its hymenium. P. squamosus is a common species on trunks of willows, oaks, walnuts, \&c. From this was extracted, by Braconnot, the Fungic acid. It is colorless, does not crystallize, has a very sour taste, and when evaporated to dryness, deliquesces upon exposure to the air. The fungates of potash and soda do not crystal lize, are very soluble in water, but not in alcohol. The fungate of ammonia crystallizes in regular six-sided prisms. The fungate of lime is not altered by exposure to the air, and is soluble in about eighteen times its weight of water at seventy-three degrees.

$P$. Tuberaster, a speeies common in Italy, in various parts of the kingdom of Naples, and the Pontifical states, is held in the highest esteem as an article of Neapolitan cookery. P. annosus, a Swedish species, is used by the peasantry as a cure for the bite of snakes. Fries says, that he saw the blocd which was flowing from the mouth of a kid which had been hurt stopped in a short space of time by its application. From P dryadeus, the Boletus pseudo-igniarius of Bulliard, Braconnot obtained his Boletic acid. The color of this principle is white ; it is not altered by exposure to the air, and its crystals are regular four-sided prisms. Its 
6. Micropo'rus. Beauv.

16070 leptocéphalus Jacq. small-cappe 16071 brumalis Pers. winter 16072 perénuis Fr. 16073 strobilifórmis Dicks, cone-like 16074 pellúcidus With. pellucid 16075 variegátus Sower. variegated

$\beta$ várius Pers. variable

B. lateralis Bolt. 83 r nummulárius Bull. moneywort 16076 lícidus $F r$ : 16077 frondónin 16078 leafy 16079 gigantéus $\mathrm{Fr}$. $\quad$ gelvety 16080 sulphúreus $F r$. 16081 betulinus $F$ 16081 betulinus $F r$. 16082 spúmeus $F$ 16083 cæ'sius $F r$.
16084 hispidus $F r$. Bol. velutinus Sowerby, \$45 16085 cuticuláris $F r$. cuticular 16086 adústus $\mathrm{Fr}$. scorched 16087 ulmárius $\mathrm{Fr}$. 16088 suavéolens Fr. $\beta$ salicinus Fr. 16089 versícolor $F$ r. 16090 radiátus $\mathrm{Fr}$. 16091 palléscens $\boldsymbol{F r}$. 16092 abietinus $F ;$. sulphur-color. tufts birch acid

one inch wide 1 aut. $\mathrm{Gr}$ on wood Jacq misc, $t, 12$ $1-4$ inch. wide 2 all sea. Sooty trun. of trees Schreff. t. 281. pileus thin 3 aut. Cinn. trun. of trees Sowerby, $t .192$ lumpish $\quad 2$ aut. $\quad \mathrm{Br}$ trun. of trees Crypt. brit. t.3. f. 2 two inch. br. $\frac{\pi}{3}$ aug. $\mathrm{Br}$ old wood patches $\quad 2$ all sea. Br trun. of trees Sowerby, t. 368 patches $\quad 2$ all sea. Grsh trun. of trees Grev. crypt. 202

patches 2 all sea. Wsh trun of trees Sower, $t .368$, fig. min variable $1 \frac{1}{2}$ or 0 sum. Ysh trun. of trees Sowerby, t. 134 broad patches 2 sep. oc. Sooty roots of oaks Schæffer, t. 127 thin 2 spr.au. Wsh trun. of trees

24 sum. Pa.Br beech trees Sow. t. 86, imbricatus 24 sum. Rsh.Y oak trees Grev. crypt. 113 thick spongy

$\begin{array}{llll}2 & \text { sum. Brsh birch trees Sowerby, t. } 212 \\ 3 & \text { aut. } & \text { Wsh trun. of trees Sower. t. 211. stipitatus }\end{array}$

3
2 aut. Wsh trun. of trees Sower. t. 211 , stipitatus

6 sum. Ferr. oak trees Grev. crypt. 14

imbricated 3 aut. Ferr. trun, of trees Sower. t. 195. impuber imbricated $\quad 2$ aut. Pa.Br trun, of trees Sower, t. 231. carpinus elm 3-4 inch. wide 0 aut. Pallid elm trees Sowerby, t. 88 Anise-scented fragrant $\quad 3$ aut. W willow trun. Sowerby, t. 228

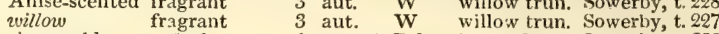
changeable tufted 1 su. aut. Bsh trun. of trees Sowerby, t. 229 radiated imbricated 1 aut. Y.Br trun. of trees Sowerby, t. 190 pallid imbricated 2 aut. pa.Oc. trun. of trees Sow. t. 250. pelleporus pine-tree imbricated $1 \frac{1}{2}$ aut. Wsh. dead pines Dicks, crypt. t.9. f. 9 16093 fomentárius Fr. soft tinder spongy $\quad 6$ all sea. Sooty beech trees Sowerby, t. 133 16094 igniárius hard tinder hard

6 all sea. Ferr. trun. of trees Sowerby, t. 132

16095 spongiósus $\mathrm{Fr}$. spongy tufts 16096 medúlla pánis $\mathrm{Fr}$. bread-crumb thick 16097 vulgáris $F r$. common fragile 16098 ferruginósus $F r$ rusty $\quad \begin{array}{ll}\text { common } & \text { unequal }\end{array}$ 16099 mollúscus $F r$. slippery variable 16100 incarnátus $F r$ pink firm

2 aut. Ferr. trun. of trees Bolt. t. 165. resupinatus 4 aut. W fallen timber Bolton, t. 166. f. 1

12 all sea. W fallen timber Bolt. t. 166 , proteus

1 sum. Ferr, alder trees Grev, crypt. 155

3 all sea. W dead trees Sow. t.326. Medul. panis 3 sum. Pk pine wood

16101 reticulátus Polic'Ta.

16101 reticulatus Nees. netted. very delicate 2 sum. W pine wood Nees crypt. f. 225

decay. trun. Grev. crypt. 224

2373. BOLE'TUS, Dill. Boletus. 16103 lúteus $L$

16104 lactifluus With. yellow 16105 piperátus Bull. peppery 16106 subtomentósus $L$. downy $\beta$ sanguineus With. bloody 16107 láridus Sehaff: lurid B. rubeolus Sower. 150 16108 esculéntus Per.: esculent

$$
\text { Sp. } 8-20 \text {. }
$$

3 inch. broad 2 aut. $\quad \dot{Y}$ old tree 2-4 inches br. $2 \frac{1}{2}$ aut. Buff pasture $2 \frac{1}{2}$ inch. broad $1 \frac{1}{2} \mathrm{su}$. aut. Ysh woods cracked 2 jn, oct. Ol woods cracked 2 jn oct. Crim, woods 6 inches broad 2 su.aut. Ol.G groves cracked $\quad 4$ su.aut. Sooty woods 3 inchesbroad 4 su.aut. W woods 16109 scáber Fr. rough $\quad$ orange-colored 3 inchesbroad \& aurantiacus Sow. orange-colored 3 inches broad 4 su,aut. Ruf. woods $\gamma$ bovinus Schæff. glutinous 3 inches broad 4 su.aut. Sooty woods 16110 cyanéscens Fries bluish $\quad$ frosted 3 su.aut. Straw woods

Sp. 1.

6 aut. Crim. oak trees Sowerby, t. 58 16111 hepática Bull. liver-like patches

Grev. crypt. 183

Sowerby, t. 34

Bulliard, t. 393

Sow. t. 225 , commutatis Grev. crypt. 121

Sowerby, t. 111. edulis

Bolt. t. 86. procerus Sowerby, $t, 110$ Sowerby, t. 175. scaber Bulliard, t. 369

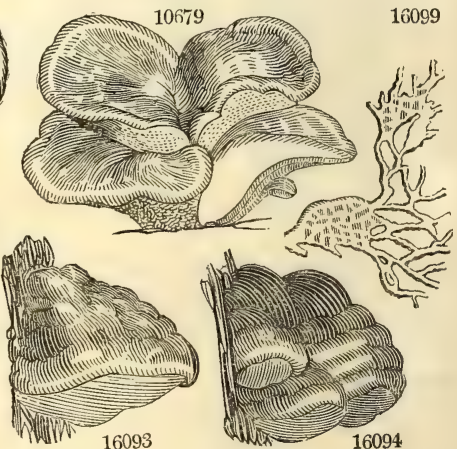

16093

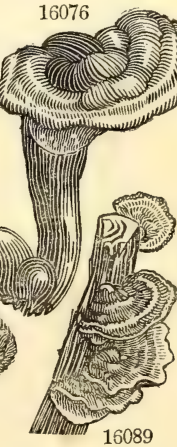

16089 16072

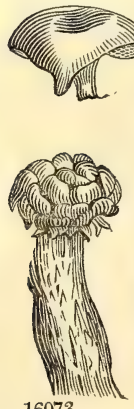

16073
16084

History, Use, Propagation, Culture,

taste is similar to that of tartar. It is soluble in 180 times its weight of water, at a temperature of sixty-eight degrees, and in forty-five times its weight of alcohol. The aqueous solution reddens vegetable blues. It combines with the different bases forming boletates, which have been but little examined. The boletate of ammonia crystallizes in flat four-sided prisms, and is soluble in twenty-six times its weight of water at sixtyeight degrees. The boletate of potash is very soluble in water, and erystallizes with difficulty. The boletate of lime crystallizes in flat four-sided prisms, and is soluble in about 110 times its weight of water at seventytwo and a half degrees. Polyporus fomentarius is much used on the continent for making Amadou ; also very generally in the Highlands of Scotland for the same purpose by the shepherds, who manufacture it for themselves. 
16070 Cap fleshy coriaceous thin smooth brownish, Pores very small roundish white, Stipes short pallid 16071 Cap soft fleshy somewhat umbilicated villous sooty pallid, Pores somewhat angular white, Stipes pallid 16672 Cap coriaceous velvety zoned, Pores minute at length lacerated, Plant cinnam.-col. Stipes central 16073 An obscure species scarcely known

16074 Cap concave rich brown scaly, Pores white very short, Stipes whitish thick short

16075 Cap rigid glab. smooth, Pores minute round. pallid, Stipes short smooth pallid abruptly black downwards $\beta$ Cap rigid glab. smooth, Pores small round. pale, Stipes short smooth pale becom. suddenly black at base

\% Cap yellow ochre-color or whitish

16076 Cap corky and stipes smooth shining, Pores minute round pale

16077 Much branched, Caps halved rugose scoty-grey, Pores white [Pores excessively short min. round whit. 16078 Imbricated scarcely reflex. whit. or brown.-grey, Cap betw. corky and coriac. thin velvety obscure. zoned, 16079 Imbricated multiplied, Caps very broad somewhat banded pale-brown, Pores unequal pale

16080 Multiplied subsessile, Caps broad imbricated smoothish reddish-yellow, Pores minute flat sulphur-colored 16081 Cap subsessile not dimidiate compact smooth pale whitish-brown, Pores white small unequal 16082 Whitish, Cap fleshy rugose hispid obtuse, Pores short roundish

16083 Cap fleshy subsericeous white changing to bluish, Pores minute white irregular lacerated

16084 Cap dimidiate large somew. fleshy thick villous ferrugin. Pores yellowish pale and fringed at the orifices

16085 Caps fleshy corky downy ferruginous, Pores shining greyish ferruginous

16086 Caps fleshy tough villous pale: margin straight blackish, Pores minute round cinereous

16087 Cap fleshy corky not banded glabrous pallid, Pores small equal

16088 Cap fleshy corky not banded villous white, Pores largish brownish

[brown short irregular

$B$ Sess. or dimid. bet. suber. and coriac. round. smooth white at length brown. Pores white becom. yellow. 16089 Cap mostly reflexed coriaceous villose variegated by zones of different colors, Pores round white short 16090 Caps coriaceous streaked in rays somewhat velvety brownish-ye!low, Pores minute

16091 Caps coriaceous smooth not banded pale ochre-color, Pores equal

[lacerating

16092 Effused but at length mostly reflex. Cap thin coriac. vill, white, Pores violet at length brown. and toothed 16093 Cap subtriangular glabrous dark brownish-grey soft within: margin pale glaucous as well as the pores (which are very minute) but at length ferruginous

16094 Hard, Cap thick obtuse smoothish mostly ferruginous blackish at the base banded: margin convex, Pores minute greenish at length cinnamon-color

16095 Effused coriaceous-spongy ferruginous, Pores straight round minute

16096 Effused somewhat wavy hard smooth dry white, Pores middle-size

16097 Broadly effused thin dry smooth white, Pores minute subequal

16098 Effused thick portions sometimes growing out horizontally ferrugin. Pores round. very uneq. Flesh none

16099 Effused thin soft white with a fibrous circumference, Pores thin unequal

16100 Effused coriaceous very thin submarginate, Pores orange flesh-color minute round suboblique

16101 Very fine resembling byssus fugacious white, Pores distant cupulæform powdery

16102 Effus, entirely resupin. very thin white: marg. membran. laciniat. Pores min. subhexagonal very shallow

16103 Cap glutinous varying from bright-yellow to fulvous : tubes adnate yellow, Stipes firm with an annular veil 16104 Cap red-buff, Pores yellow, Stipes bright-yellow, Juice like milk

16105 Cap redd. or brownish-yell. smooth : tubes adnate somew. decurr. large ferrugin. Stipes smooth deep-yell. 16106 Cap round. dry subtoment. reddish or olivaceous : tubes adnate large angul. yell. Stipes very firm smooth

16107 Cap convex subtomentose mostly olivaceous : tubes nearly free round yellow ; the orifices crimson-red, Stipes thick reticulated with crimson-red

16108 Cap convex smooth cinereous yellow or brown : tubes nearly free roundish minute whitish at length yellowish, Stipes thick reticulated: flesh white not changing color

16109 Cap convex glabrous : tubes free round whitish, Stipes firm attenuated upwards scabrous

$\beta$ Cap somewhat rufous with black scales

y Cap slightly glutinous reddish-brown thin : tubes adnate compound yellowish, Stipes smooth

16110 Cap compact somewhat downy : tubes loose round equal, Stipes solid smooth ventricose

16111 The only species
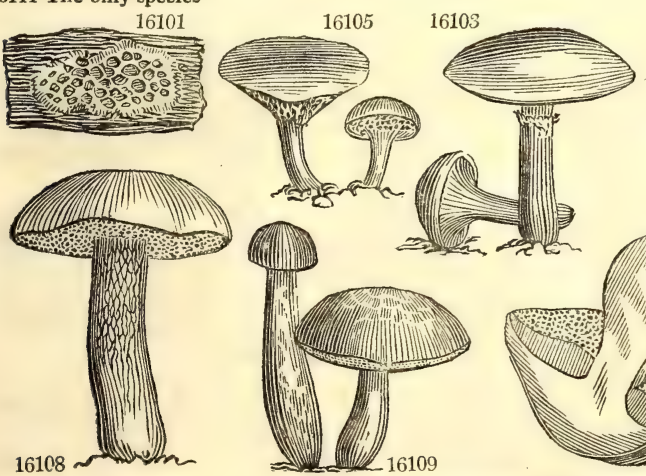

16106

16111
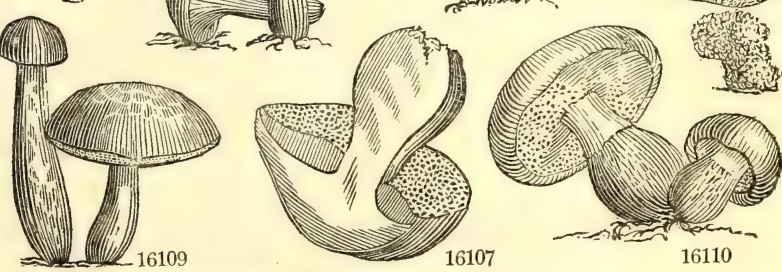

16110

and Miscellaneous Particulars.

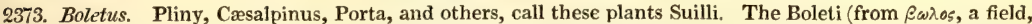
in allusion to the places where they are found) of the Romans were terrestrial Fungi, and more particularly Agaricus cæsareus. By Tournefort these were called Phalloidei ; by Micheli, Morchellæ. The species grow singly upon the ground, are succulent, and have their parts in the greatest perfection of any fungi. B. granulatus is eatable, according to Persoon; so is Boletus subtomentosus. Boletus edulis is excellent when cooked.

2374. Fistulina. So called from the fistulous nature of its tubes; the genus is just intermediate between

Boletus and Hydnum, to the former of which it bears the same resemblance as Schizophyllum to Agaricus. There is only one species, and it is said, by Persoon, to be eatable. 
2375. HYD'NUM. $L$. 1611 s repándum $L$. $\beta$ squamósum Fr. 16114 ruféscens Pers. 16115 auriscálpium $L$

16116 gelatinósum Scop . 16117 erináceum Bull.

16118 coralloídes Scop.

16119 críspum Schaeff. 16120 ochráceum Pers. 16121 minimum Bolton 16112 imbricátum $\dot{L}$.
Hronum. imbricated repand scaly brownish ear-pick

\section{gelatinous} Hedge Hog

coralloid

crisp least escuient esculent esculent

eatable

curious

curious

variable
4 inches wide

Sp. 13-87.

1 sep. oc. Umb. pine woods Greville crypt. 71

$1 \frac{1}{2}$ su. aut. Ysh woods Greville crypt. 44

$1 \frac{1}{2}$ su. aut. Ysh woods Bolton,t.88.imbricatum

su. aut. Pksh beech woods Bolton, 89 repandum

$2 \frac{1}{2}$ all sea. Bl pine cones Greville crypt. 196

$\frac{1}{3}$ aut. Fusc. pine woods Jacq. aust. t. $23 y$

3 oct. W beech trees Bulliard, t. 34

1 aut. W trun. of trees Sowerby, t. 252

0 oct. Brsh dead wood Schæff. t. 147, f. 1

2 all sea. Ysh pine wood Sowerby, t. 15. Daviesii

aut. Taw. rotten oak Bolton, $t$. 171

$\begin{array}{lllll}16122 \text { membranáceumBull.membranous } & \text { effused } & 0 & \text { sum. } & \text { Ferr. pine wood Sowerby, t. } 327 \\ 16123 \text { Bárba Jóvis Bull. Jew's Beard } & 12 \text { inches wide } & 0 & \text { sum. Whh hollow trees Sowerby, t. } 328\end{array}$ 16124 spatulátum Fr. 1 spatulate very delicate 0 all sea. W pine trees Nees syst. f. 231

2376. Sistostre'MA. Fries. Sistostrema. Sp. 1.

2376. SISTOSTRE

2377. PHLE'Bi A. Fries. Phlebia.

$S p$. 1-4.

16126 vága Fries wandering

membranous 2 sep.no. Sul. alder trees

2378. THELE'PHORA. Ehr. THELEPHORA.

16127 pannósa Fr.
16128 caryophyllæa Fr. clove
clove

2 sep.no. Sul.

2 aut. Pallid on ground Sowerby, t. 155

1: $\frac{1}{8}$ aut. Psh among grass Schæffer, t. 325

16129 terréstris $\mathrm{Fr}$. terrestrial gregarious $1 \frac{1}{2}$ aut. Brsh on ground Bul. t.268, caryophyllaa

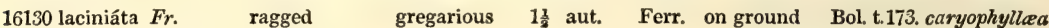
\$1. Merisma. Fr.

16131 palmáta $F r$ palmate stinking $\beta$ anthocéphala $\mathrm{Fr}$. flower-headed stinking 16132 cristáta Fr. crested crust-like 16133 tuberósa dwarf tuberous solitary

2 wet au. Psh pine woods Greville crypt. fl. t. 46 2 wet au. Ferr. pine woods Sowerby, t. 156

3 au. oct. Pallid damp places Sow. t. 158. laciniata $1 \frac{1}{9}$ aut. Rsh bare ground Greville crypt. 178

2 all sea. Bt.Br old oaks Sow. t. 26. Au. ferrugin.

16134 rubiginósa Schr. rusty woody

16135 tabacína Fr. Tobacco Auric. nicotiána Bolton, t. 174

16136 hepática $\mathrm{Fr}$. Liver

16137 hirsúta $W$. hairy

16138 ochroleúca $F r$. pale-yellow

16139 purpúrea Schum. purple

16140 intybácea Pers. $\quad$ endive-like

elegant

imbricated 4 aut. Dl.Br trum, of trees Sow.t.388.f.2. Aur.lavis firm 3 all sea. Ysh trun. of trees Sow. t. 27. Au. reflexa

membranous 3 aut. Wsh trun. of trees Sow.t.349.Au.papyrinus wavy 3 aut. $\mathrm{Pu}$ trun. of trees So.t.388.f.1.A.persistens very irregular 6 au. spr. Rsh stumps of tr.

16141 sinuans Pers. $\quad$ sinuous gregarious 1 au. wi. Y. Br oak branches 16142 corýlea Pers. Hazel-Tree imbricated 6 all sea. Ochr. decay. hazel 16143 córium Pers. leathery thin 6 aut. Buff dead trunks Greville crypt. 147

16144 ochrácea $F r$. yellow-ochre very broad 12 aut. Ochr. rotten trun. 16145 radiáto-rimósaGrev. cracked confluent 4 aut. $\mathrm{R} . \mathrm{Br}$ dampfir tim.

16146 sanguinolénta Fr. bloody very gregar. 2 nov. Psh dead trees Greville crypt. 225
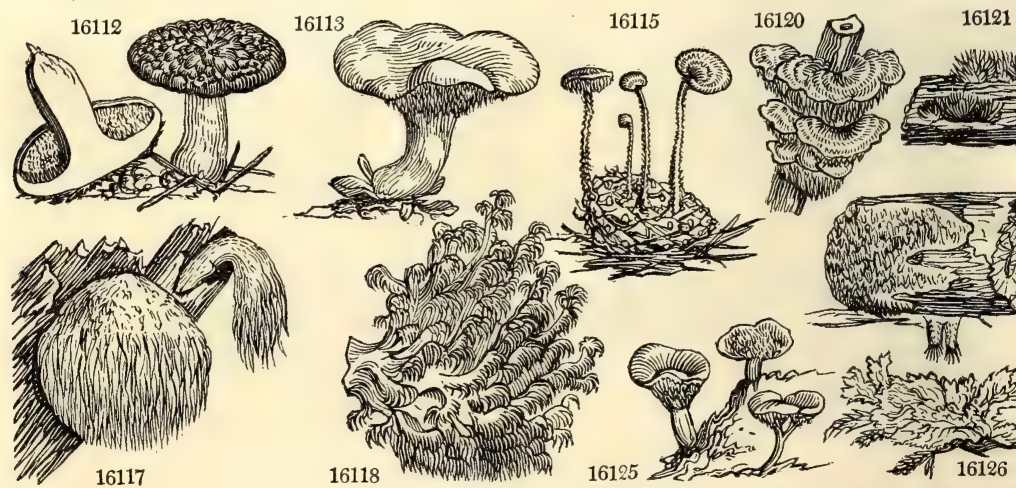

History, Use, Propagation, Culture

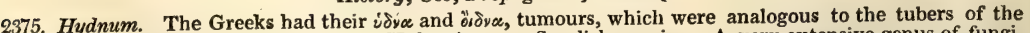
2375. Hydner. $\mathrm{H}$. corloides is eatable ; so is $\mathrm{H}$. leoninum, a Swedish species. A very extensive genus of fungi, Romans. H. coralloides is eatable so the trunks of trees. The pileus is furnished on its lower surface with chiefy found in moist situations upon the trunks of trees. The prickles of a hedgehog; they are soft, solid, numerous awl-shaped bodes, emitting sporules from every part of their surface.

conical or cylindrical substances, emitting sporules from every part of their surface. an orifice, in allusion to

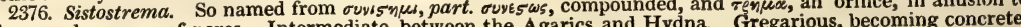
the regular rows of pores. Intermediate between the Agarics and Hydna. Gregarious, becoming concrete, 
1. Stem perpendicular, Cap distinct, round, nearly entire. GROWING ON THE GROUND. 16112 Cap fleshy flat tessellated scaly not banded umber-colored, Processes buffish-cinereous, Stipes short 16113 Cap fleshy smooth subrepand buffish, Subulate processes of hymenium unequal pale, Stipes unequal thick

16114 Cap fleshy orbicular somewhat tomentose brownish-flesh-color, Processes nearly equal, Stipes thin equal 16115 Cap coriaceous tomentose, Stipes lateral tomentose

2. Stem simple, somewhat horizontal, Cap halved, or out of the centre. Fleshy. GRowing ON wooD. 16116 Cap gelatinous papillose, Processes soft pyramidal glaucous, Stipes short lateral

16117 Very large heart-shaped white becoming rather yellow, Cap subsessile fibrous torn, Processes very long 3. Cap confounded with the stem, obliterated. Fleshy. Growing on wood.

16118 Much branched white becoming yellow, Branches entangled tapering, Processes unilateral subulate

4. Cap sessile, lateral. Growing on woop.

16119 Cap coriaceous lobed scaly plaited rufous brown projecting behind, Processes imbricated pale rufous

16120 Effuse-reflexed, Cap coriaceous thin banded ochre-colored, Processes minute numer. ochre-flesh-colored

16121 Coriaceous woody spherical orange-color, Processes short erect

5. Cap resupinate, effuse. Growing on wood.

16122 Effused thin glabrous tawny-ferruginous, Processes in the middle straight

16123 Effused downy pale-white, Processes rounded pubescent at the end bearded with orange

16124 Effus. white at length yellow. with a byssoid marg. Process of hymen. oblique subent. compr, vill. at apex

16125 The only species

16126 Effused soft sulphur-colored : the circumference expanded and byssoid, Plaits distant irregular

1. Cap entire, with a stem. Terrestrial.

16127 Corky pale, Cap depressed scaly beneath smooth somewhat pilose

16128 Somew. tuft. stipit. or sess. Cap irregul, rarely quite ent. striato-fibr. purplish-brown : marg. often laciniate

2. Cap lateral, somewhat stipitate. TERRESTrial.

16129 Irregularly tufted dark fuscous, Cap rather thick striato-fibrous sessile often imbricated sometimes with a very short lateral stipes

16130 Ferruginous brown, Caps fibrous scaly ragged and crisp at their edges

3. Cap and stem confounded, running into compressed branches. Terrestrial. Merisma. Pers.

16131 Erect purple-brown, Branches compressed palmate folded paler at the summit

$\beta$ Somewhat ferruginous, Branches glabrous obtusely ragged fastigiate

16132 Subdecumbent pale greyish or yellowish, Branches effused plane expanding fimbriato-laciniate

16133 Erect distinct stipitate reddish-grey, Cap with branches of nearly equal length, Stipes bulbous at base

4. Cap sessile, lateral. Growrng on wood.

16134 Imbricated rigid somewhat zoned purplish reddish-brown glabrous, Hymenium papillose minutely velvety rubiginous paler at the margin

16135 Effuse-reflexed thin silky ferruginous margined downy beneath

16136 Somewhat imbricated bandless smooth on each side very smooth dull-brown

16137 Effuse-reflexed coriaceous strigose, Hymenium smooth yellowish or orange-buff

16138 Effuse-reflexed somewhat membranous striated pubescent beneath smooth and ochraceous

16139 Imbricated subcoriaceous zoned hirsute, Hymenium smooth purple

16140 Imbricated velvety zoned pale reddish-buff, Hymenium smooth irregularly papillose buffish at length ferruginous sometimes shooting out into rude stems anastomosing and producing irregularly caps

16141 Round thick often conflu. Marg. waved splitting, Hymenium tuberculose yellow. or reddish-brown crack. 16142 Broadly effused thickish, The margin slightly reflexed, Hymenium ochraceous uneven unequally papillose 16143 Coriaceous broad thin, Margin free with the surface tomentose, Hymenium smooth minutely reticulated buff becoming darker in age

16144 Effus. very broad thin, Hymen. somew, of an ochrey pale-yell. smth. or with scatter. uneq. false papillæ 16145 Resupinate, Margin free whitish hirsute, Hymenium fuscous smooth somewhat shining and faintly zoned towards the margin cracking in a radiated manner

16146 Circular effused, Margin sometimes free rarely reflexed, Hymenium pale whitish-brown pruinose silky and minutely byssoid at the margin turning red when wounded
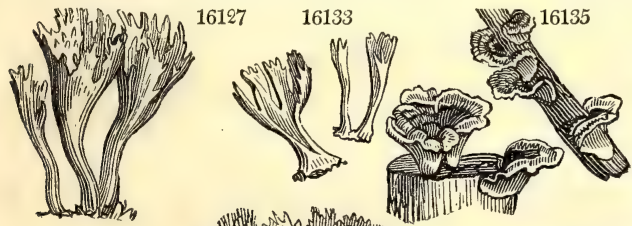

16136

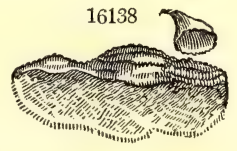

16130
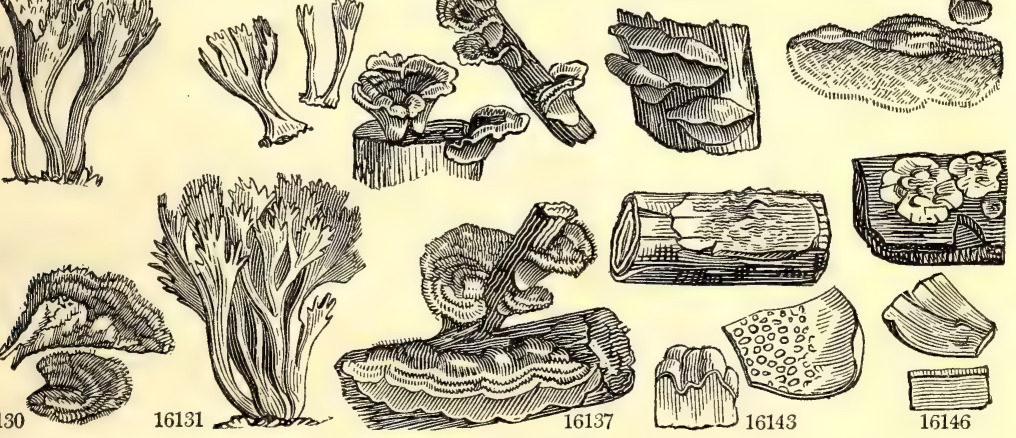

and Miscellaneous Particulars.
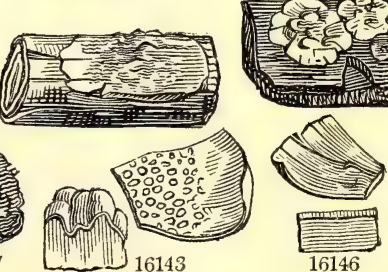

broad, somewhat depressed, flexuose, and apt to grow to one another. The only species is found in August and November by the side of sandy paths in pine-groves.

2377. Phlebia. So called, from $\phi \lambda s \psi$, a vein. As the last was intermediate between Agaricus and Hydnum, so is this between Cantharellus and Thelepnora. As that differed from Drolea, does this from Merulius, The species are all found upon bark, late in the year. No species was described before the writings of Fries. P. merismoides is an elegant little plant, distinguished by its reddish-flesh-colored hues. It is found occasionally spreading over wood and smooth bark; and sometimes runs with its papillose veiny branches among mosses.

2378. Thelephora. So called, from $\vartheta_{n \lambda \eta}$, a nipple, and $\phi \varepsilon \rho \omega$, to bear, in allusion to the papiliose surface of $3 \mathbf{T} 2$ 
16147 quercína Pers. 16148 fraxínea Pers.

16149 Tíliæ Pers.

16150 epidérmea Pers.

$\begin{array}{ll}\text { oak } & \text { brittle } \\ \text { ash } & \text { thin } \\ \text { lime } & \text { irregular } \\ \text { bark } & \text { irregular }\end{array}$

16151 incrústans Pers. incrusting

16152 cálcea Pers.

chalky

\section{Sambúci Pers. Elder Tree}

16154 2. Phylacte'ria. Pers.

16154 biénnis $F r$ biennial

3. Himan'tia. Pers.

16155 doméstica Pers.

16156 fúsca $F r$. hers. househ

16157 láctea $F r$. $\quad$ milk-white

H. cándida Pers.

8. Leiostróma. Fr.

16158 cinérea $\mathrm{Fr}$. cinereous

uneven

\author{
brittle \\ irregular \\ cracked $\quad 3$ aut. Ysh earth,tr., \&c. \\ membranous 4 aut. W decay. elders \\ plaited \\ 4. aut. Wsh on ground Bulliard, t. 436 \\ smooth 6 wet w. $\mathrm{Br}$ da. pla. in ho \\ rugose $\quad 2$ aut. Vi.Br trun. of trees \\ very thin $\quad 2$ aut. W $\quad$ W trun. of trees Sow.t. 387.f.1. F. stellate \\ Greville crypt. 142 \\ aut. Grsh dead ashes \\ 3 nov. Pa.Bu dead trunks
}

4 spr. au. Cin. elder tree Sowerby, t. 388

Division II, Clavati.

2379. CLAVA'RIA. Vaill. Clavaria. 16159 Bótrytis Pers. bunched

16160 fláva Pers. $L$ coralloídes $L$. coral-like

16162 abietína Pers.

pine-wood

16163 cristáta Pers. $\quad$ crested

16164 cinérea Pers. cinereous

16165 córnea Pers. corneous

Sp. 23-66.

much branch. 3 sum. Wsh beech woods Sch.t.176 acroporphyria delicious 3 aug. $\quad \mathbf{Y}$ woods Schæffer, t. 175

very smooth 3 aut. W on ground Sowerby, t. 278. fig. sup. gregarious 3 aut.

Ochr. fir woods Greville crypt. 117

polymorph $2 \frac{1}{2}$ aut. W woods Greville crypt. 190

tufted 3 sum. Cin. damp places Greville crypt. fl. t. 64

16166 stric'ta Pers. $\quad$ erect

16167 praten'sis Pers. meadow

16168 corniculáta Schœef. horned

16169 rugósa Bull. rugose

gregarious $\frac{3}{2}$ aut. $\mathbf{Y}$ deadfirtrees

16170 pistilláris $L$. pistillary

16171 Ardénia Sowerby flexuose

16172 fusifórmis Sowerby fusiform

16173 ceranoídes Pers. wrinkled

16174 inæquális Fries unequal

16175 frágilis Pers. brittle

C. gracilis Sowerby, 232

16176 acúta Sowerby acute

16177 fimbriáta With. fringed

16178 hélvola Pers. pale-red

16179 vermiculáris Fries worm-like

16180 unciális Grev. dwarf

bristle-footed

2380. CAlo'CERA. Frics. Calocera.

16182 tuberósa Fries tuberous

thin 1 au. oc. Brsh trunks Schæffer, t. 286. pallida

viscid

solitary

toughish

$\begin{array}{ll}1 & \text { aut. } \\ 3 & \text { aut. }\end{array}$

3 aut.

Y meadows

Bolton, t.114. muscoicics

largest

12 au. no. Ysh beech woods Sowerby, t. 277

opaque $\quad 6$ sep. Brsh bran, of lime Sowerby, t. 215

regular tufts 3 sep. $\quad$ Y among grass Sowerby, t. 234

much tufted 3 aut. Ysh upon trees Sowerby. t. 235. rugosa

gregarious $2 \frac{1}{2}$ aut. $\quad \mathbf{Y}$ meadows Sow. t. 253. vermicularis

gregarious $\quad 1$ aut. Ysh damp places Greville crypt. 37

gregarious 2 aut. W upon trees Sowerby, t. 333

polymorph. 2 aut. W upon trees

flexuose $1 \frac{1}{2}$ aut. $Y$ meadows

crowded tufts 3 aut. W mea. \& past.

very gregar. 1 aut. W rotten twigs Greville crypt. 98

dead leaves Greville crypt. fi, t. 49

root roundish 2 aut. $\mathrm{Y}$

16183 córnea Fries horny tufted $\frac{1}{4}$ jl, dec. Y

und.ba. of tr. Sowerby, t. 199

various trees Sowerby, t. 40

2381. GEOGLOS'SUM. Pers. Earth-tongue. Sp. 4-9. Clavaria Sow.

16184 hirsátum Pers. hairy $\quad 2$ aut. . Bl bolitary \& mea. Greville crypt. 185

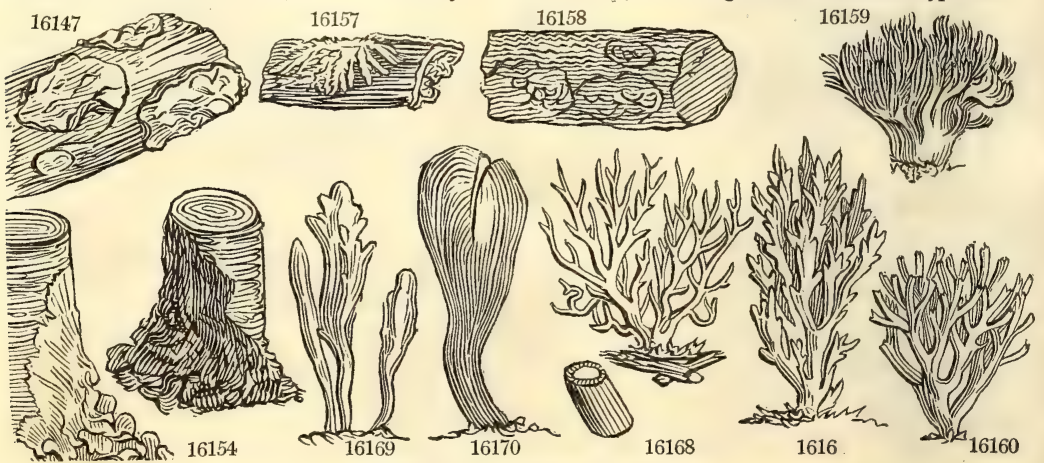

History, Use, Propagation, Culture,

of the pileus of all the species. T. caryophyllæa is very common upon the exposed roots of old firs in the autumn. The substance is tough and somewhat woody; the color a chocolate brown. The plants often grow in masses, attached by their upper side to sticks, old bark, \&c. and are from one to three inches in diameter.

2379. Clavaria. So called, from the simple clavate form of the species. Some are eatable; as for instance C. flava, which is said to be delicious; C. cinerea, which is frequently eaten in France; C. pyxidata is said by Persoon to be tolerably good. Loureiro has' also an eatable species found in Cochin-China, growing upon elephant's dung. 
5. Cap obliterated, resupinate. Growing on wood.

16147 Resupinate rigid nearly black beneath, Hymenium flesh-color rugose and papillose at length cracking 16148 Very thin effused cracking and becoming invol, very dark ben. Hymen. brown.-grey minutely farin. papill. 16149 Effus, extremely thin, Marg. appress, minutely vill. Hymen. purp.-grey cover. with small uneq. papillæ 16150 Effused thin smooth, Margin delicate and byssoid, Hymenium whitish at first at length very pale-buff; Papillæ scattered or none

16151 Effused spreading over moss, \&c., Margin fibrous, Hymenium very unequal tuberculose yellowish

16152 Effused unequal in thickness hard, Hymenium white glabrous cracked in different directions so as to be often tessellated obtusely papillose

16153 Effused membranaceous thin, Margin entire, Hymenium very white glabrous subpapillose

16154 Membranous smooth plaited at base whitish becoming blackish

16155 Effused membranous smooth pale beneath white with cobweb-like down

16156 Effused somewhat rugose soft of a violet-brown: at the margin and beneath downy

16157 Mostly on dead leaves, Filaments very fine white radiating dilated at the extremities in a plumose manner

16158 Broadly effused thin dry smooth glabrous cinereous

\section{Division II. Clavati.}

* Much branched, Stem thick.

16159 Deformed, Stipes decumbent very thick pale, Branches short somewhat wrinkled red at ends 16160 More erect, Stem thick white, Branches straight round fastigiate yellow

16161 White erect, Stipes thick, Branches elongated irregular unequal mostly acute

16162 Dull ochrey-yellow much branched white and tomentose at the base turning green when bruised, Branches erect crowded slightly rugose with acute often forked summits

16163 White or ciner. tuft. branch. smooth, Branch, dilat at summ, and jagged or shortly but acutely laciniate 16164 Grey often with a bluish or a purplish tinge much branched unequally incrassated rugose often subcompressed, Summits either very obtuse or somewhat acuminate

16165 Yellow half an inch high branched or neariy simple viscous, Stipes of several plants connected at the base

$$
\text { ** Branched, Stem thin. }
$$

16166 Much branched pale brownish, Branches and branchlets straight appressed acute

16167 Yell. tuft. Stipes short producing numer. short geniculate divaricate branches : the ramuli subfastigi. obt.

16168 Yellow erect much branched in a dichotomous manner, Branches slender with acute summits

16169 White gregarious incrassated rugose simple or branched, Branches few short obtuse

$$
\text { *** Simple, clavate. }
$$

16170 Solitary large glabrous yellowish-brown thickened upwards and obtuse

16171 Very long hollow thickened upwards brownish downy at base

16172 Heaped fascicled yellow, Branches nearly equal incurved yellow

16173 Fascicled unequal subdivided hollow yellowish-brown at end

16174 Yell. or yell.-white tuft, or gregarious fragile uneq. ventric dirregular at the apex 16175 Yellow or white gregarious sometimes subcrespitose solid or hollow very brittle rather firm attenuated at the base subrugose in age and often crooked

16176 Straight white, Head distinct round acuminate as long as stipes

16177 Stem slender villous, Branches long compressed, Branchlets numerous setaceous cut

16178 Yellow gregarious cylind. equal smooth obt. slender below and paler, apex frequently of a cinnamon-color

16179 Pure white tuft. crowd. subul. flexuose solid but with a small perforat. mostly somew. connected at base

16180 White gregarious round club-shaped obtuse much attenuated at the base smooth not brittle

16181 White minute, Hymenium oblong or ovato-clavate passing suddenly into a filiform pilose stipes

16182 Tough yellowish nearly simple, Stem tuberous long-rooted

16183 Tufted smaller simple and branched viscid yellow connate at base

16184 Stipes hirsute deep-black, Hymenium somewhat plicate

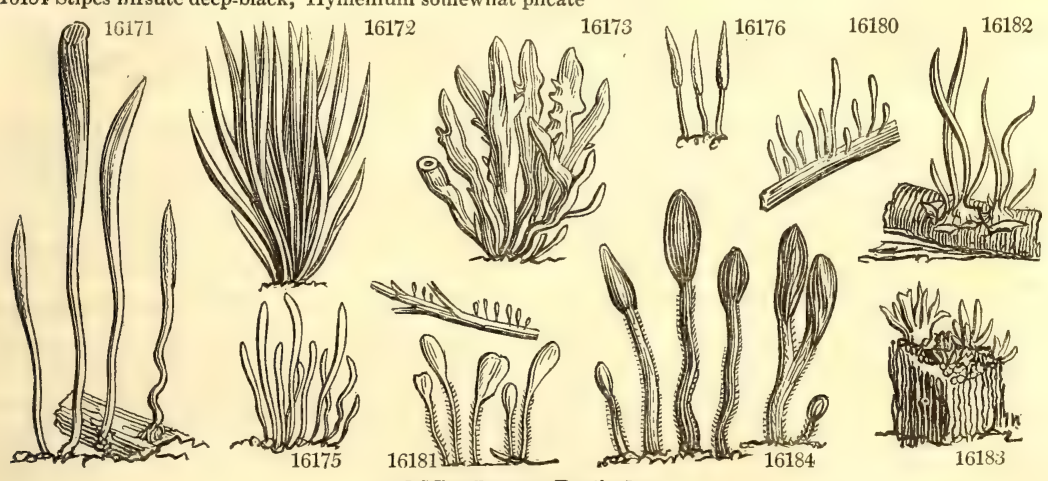

and Miscellaneous Particulars.

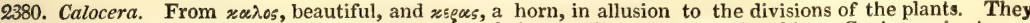
grow on wood, and are either brown or yellow; but their sporidia are generally white. C. viscosa is at once distinguishable by its beautiful gold color. Some of the species adhere to paper when dry.

2381. Geoglossum. From $\gamma \eta$, the earth, and $\gamma \lambda \omega \sigma \sigma \alpha$, a tongue; earth-tongue : in allusion to the simple form of the species, which all grow upon earth, and are of a blackish or dark-green color. Fries considers the genus to be scarcely distinct from Clavaria. 

16186 viscósum Pers.

smosth

viscid

green
16185 glábrum Pers. 16187 víricle Pers. gregario. 1 sum. cylindric. $1 \frac{1}{2}$ aut. gregario. 2 aut.
Bish among grass Bl moist meadows G moist meadows

2382. SPatula'RIA. Pers. Spatularia. Sp. $1 . \quad$ Clavaria Sow.

2383. MI'TRUla. Fries. Mitrula. Sp. 1-5. Clavaria Sow. Leotia Pers. $16.81 \mathrm{~J}$ paludósa Fries. marshy hollow $1 \mathrm{my} . a u$. Y wet ditches 16190 minúta Fries $\quad$ minute gregario. 1 sum. Y $\mathbf{Y}$ brac.of Dips. 16191 abítis Fries fir-wood dry Leotia mitrula Grev. 81

2384. TY'PHULA. Fries. Typhula. 16192 phacorhíza Fr. 16193 erýthropus $\mathrm{Fr}$.

16194 ténuis $\mathrm{Fr}$.

16195 filifor'mis $\boldsymbol{F r}$.

\section{tuberous}

red-footed

thin

filiform
Sp. 4-11.

gregario. $\frac{1}{2}$ aut. W sticks and leaves

gregario. $\frac{2}{4}$ sum. Blsh on wood

Cin. dead leaves
Bolton, t. 111. fl. f. 2

Greville crypt. f. t. 55

Greville crypt. 211

Greville crypt. 165

Sowerby, t. 293

Sowerby, t. 391

Sow. t. 84. ferruginea

Sowerby, t. 253

Gre.cry.43. Phacorhiza

Sowerby, t. 386. f. 5

Gre. cry.93. Phacorhize

2385. PISTILLA'RIA. Fries. Pistrllaria. Sp. 1-7. Clavaria Sow.

16196 quisquiliáris Fr. obtuse $\begin{gathered}\text { gregario. } \frac{3}{4} \text { aut. } \\ \text { lo }\end{gathered}$

Class II. Uterini $v$. Elvellace - Division 1. Mitrati.

2386. MORCHEL'LA Dill MOREL 16197 esculénta Pers. a rotúnda Pers. e vulgáris Pers.

16198 pátula Pers.

16199 semilíbera $D$ Pe.

\section{Dill. Mons} esculent common eatable spreading eatable half-separate cap brown
3 spring $\mathrm{Sp}$. 3-14.

3 spring Wsh on the earth 3 spring Wsh on the earth 3 spring Wsh on the earth 3 spring Ysh on the earth 4. spring Wsh woods
Greville crypt. 68 Sow. t. 51. fig. sinistr. Sower. t. 51. fig dextr. Sower, t. 51. fig. med. Grev. crypt. 89. hybridı

\section{Helvel'LA. $\boldsymbol{L}$. Helvelea.} 16200 crispa $F r$. 16201 lacunósa $A f z$. 16202 esculénta Pers. 16903 In'fula Schaff: crisp

pitted

esculent

brown

\section{Sp. 5-15.}

4 aut. Ysh borders of fields

4 aut. Livid hedge banks Grev.crypt. fl.t.36. Mitru
Schæffer, t. 160

Gre. cry. 143. leucophaea $\begin{array}{llll}\text { eatable } & 3 & \text { mr. my Brsh pine woods } & \text { Schæffer, t. } 160 \\ \text { eatable } & 4 & \text { aut. } & \text { Cinn. damp scorch. places Flora danica, t. } 835\end{array}$

16204 elástica $\mathrm{Fr}$.

elastic slender

4 su. aut. Blsh damp places

Sower. t. 154. fuliginoso

2388. VER'PA. Swz. 16205 cónica Swz.

Verpa.

conical.

$$
\text { fistular } 3 \text { aut. } \stackrel{S p, 1-6 .}{\mathrm{Br}} \text { on ground }
$$

Sowerby, t. 11. Relhani
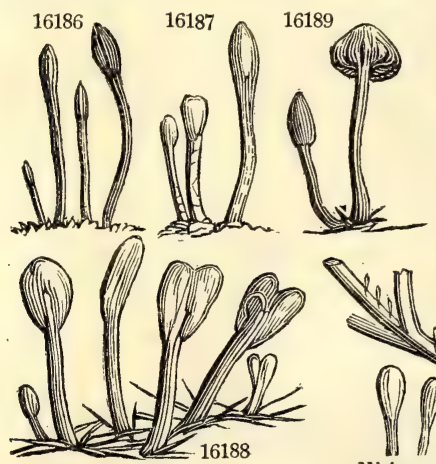

\section{0}

$$
16191
$$
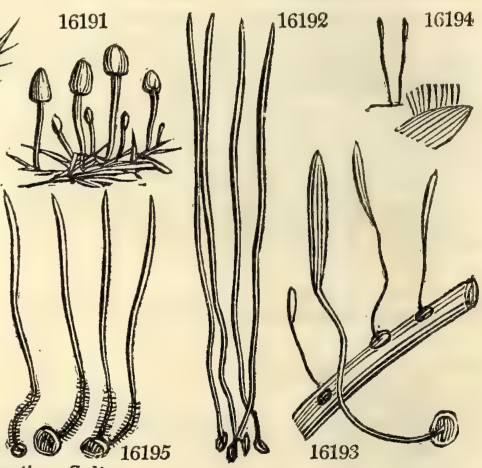

History, Use, Propagation, Culture,

2382. Spatularia. A very distinct genus, named from its spatulate form. The only species known is an autumnal epiphyte, common on fallen leaves, decaying mosses, \&c. Iis color is at first pallid; afterwards it becomes yellow and ferruginous: but the stipes retains its paler color. It is found in plantations in various parts of England. In a state of perfect maturity, the head, on being touched, throws up its sporules in the form of smoke, which rises with elastic force, and glitters in the sunshine like particles of silver.

2383. Mitrula. So called from its mitrate form. The species are small epiphytes with a simple stem.

2384. Typhula. A diminution of Typha, a well-known marsh plant, the heads of fructification of which this genus resembles in miniature. All the species are delicate, and are found upon decayed leaves, or even occasionally upon Sclerotias.

2385. Pistillaria. So called from its pistil-like form. The species are all small, delicate epiphytes, appearing in the autumn.

2386. Morchella. A name altered by Dillenius from Morchel, the German name of the plant. Fungi of a large size, appearing in the spring upon the earth. The eatable morel is one of the most valuable of fungi for purposes of cookery; but is more frequently used in a dried state for sauces, than when fresh. It is found in greatest abundance in places where trees have been burned, which led in Germany to a practice of burning down masses of forests for the sake of the future morels. This practice proved so injurious, that it became necessary to suppress it by law. The morel is subject to many variations of figure and color, which are all necessary to suppress it by law. The morel is subject to many variations of figure and color, which are all
referable to four principal forms. But there are also some legitimate species which have been distinguished by modern botanists. Of these it is not ascertained which are natives of England; but it is probable, that they are all to be found if sufficiently sought for. Without, therefore, absolutely inserting them in the list of British species, it cannot be otherwise than useful, considering the importance of an accurate knowledge of the eatable fungi, to enumerate the two principal in this place.

1. M. Deliciosa is found in the spring, among grass and bushes by the sides of fields in France, and is said to be much superior in flavor to the M. esculenta. Its stipes is hollow, and shorter than the pileus, scarcely ever so much as an inch long, about three or four lines thick, nearly equal in the whole length, but sometimes thickened and compressed at the base; under a lens covered with a slight downiness. Pileus is conical-cylindrical, from one inch to two inches and an half long, with nearly parallel ribs, which can scarcely be said to 
16185 Glabrous dry blackish, Stipes somewhat scaly

[thin and attenuated downwards 15186 Smooth very slimy in moist weather black, Hymen. cylind. round. at apex confluent with stipes which is 16187 Green somewhat fasciculate, Hymenium distinct, Stipes minutely scaly

16188 The only spocies

16189 Yellow subgregarious, Cap orange-yellow obtuse hollow : margin connate wath the stipes 16190 Very small, Head lanceolate yellow, Stipes equal paler

16191 Gregarious solid, Hymenium ovate yellow cinnamon, Stipes slender dark-brown flexuose at the oase

16192 White filiform elongated somewhat villose at the base radicular tuber dark fuscous lenticular 16193 Gregarious min. Hymenium smooth white short terminat. in an elongated filiform dark pink-red stipes 16184 Simple smooth dark thickened at end

16195 Somewhat branched spadiceous, Heads thickened whitish

16196 Thickened towards the extremity white confluent with the stipes

Class II. Uterini $v$. Elvellaces. - Division 1. Mitrati.

16197 Cap round. or oval : marg. contract. round the stipes, Areolæ much hollow. Stipes white dilat. tow. base $\propto$ Cap and areolæ round

$\beta$ Cap oval, Areolæ quadrangular

16198 Cap obtuse separate as far as the middle, Areolæ rhomboid, Stipes smooth

[thick white 16199 Cap short conic. spread. at base, Areolæ shall. partly formed by longitudin. parallel ribs, Stipes long equal

* Cap waxy, membranous, at first united, afterwards wavy in plaits.

16200 Cap irregularly deflexed free often variously lobed yellow.-white, Stipes deeply sulcate and lacunose white 16201 Cap dark-livid inflated deflex. and partially adnate with stipes, Stipes deeply furrow, and lacunose white 16202 Cap inflated deformed wavy wrinkled in circles brown, Margin villous adhering to the smooth stipes 16203 Cap deflexed lobed adnate about cinnamon-colored, Stipes smoothish villous pale

* * Cap somewhat membranous, smooth, always separate. 16204 Cap loose smooth inflated becoming sharply lobed, Stipes long thin tapering pruinose

16205 Cap campanulate smoothish fuscous somewhat sinuated at the edge : beneath and the stipes yellow

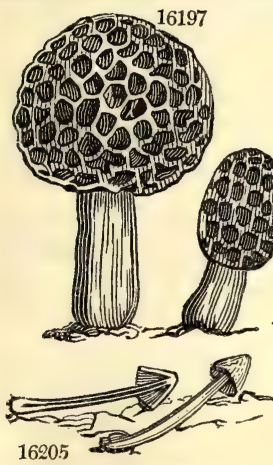

16205

\section{8}
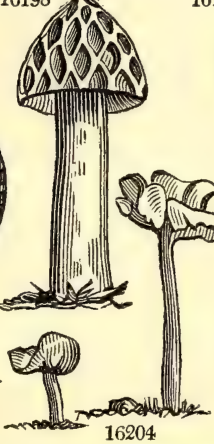

16199

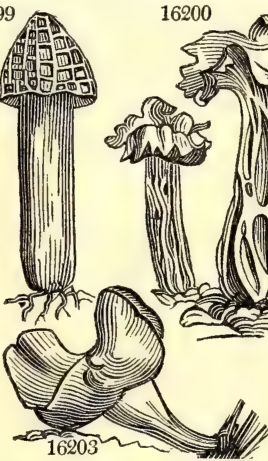

$16203 \sim$

16201

\section{anastomo}

2. M. elata has a longer stipes than the last, an inch and more thick, very hollow and brittle, with irregular cavities. The pileus is ovate-conical, two or three inches long, but of a far more delicate texture than any of the others. The longitudinal ribs are much elevated, membranous, flaccid, with very few anastomoses, but united by transverse costr, which give the spaces between a sort of misshapen rhomboidal figure. The color is a soft brown. The flavor is watery and vapid, and in decay becomes so fetid as to be unfit for food. This is found in pine-woods, expecially in humid places. It is a rarer kind than the last and like it, appears in the spring.

M. patula and semilibera are readily known from the true morels by their pileus not being attached to the stipes by the base, but altogether separate from it. They are distinguished from each other by the latter having a much longer stipes, and a shorter pileus, which is more conical and acute. M. patula is considered by Fries to have been confounded, in Mr. Sowerby's fine work on Fungi, with Helvella esculenta.

2387. Helvella. A name employed by Cicero, as the name of a fungus. The species of the modern genus are permanent, somewhat fragile fungi, with little odor or taste, but always innocuous. They grow on the are permanent, somewhat fragile fungi, with little odor or taste, but always innocuous. They grow on the

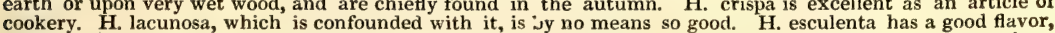
and is commonly eaten, but is far inferior to Morchella esculenta. Its qualities are nearly the same as those of the latter plant, and it is popularly confounded with it under the name, in Sweden, of Stenmurkla, and in Germany, of Gemeine Morchel, Stumpf Morchel, and Stockmorchel. H. infula, a large species, with an inflated smooth pileus of various hues of brown, is also esculent. This last plant is the true $\mathbf{H}$. Mitra of Ruppius, and old botanists; a name which, having been applied by one writer or other to every species of Helvella, is now abandoned altogether in order to avoid further confusion.

2388. Verpa. An old Roman name synonymous with Phallus, and restored to modern science by Swartz. The species are meteoric, terrestrial, and intermediate between the Morels and Leotia. The hymenium is covered, as is the case with many Mitrati, with a frost-like flocculence, which Swartz mistook for sporules, but which more recent observation has shewn to have been a mistake. 
2389. LEO'TIA. Hill. LEOTIA.

16206 infundibuliformis $r$ funnel-for 16207 nána With. 16208 lábrica Pers. dwarf slippery

solitary 3 oct. Sp. 3-11. subsessile 1 act. Cin. on groun gregario. 2 aut ol moist woods

\section{Division II. Cupulati.}

$S p .45-300$.

\section{PEZI'ZA. Dill. Peziza.}

\section{Aleu'ria. Fries.} 16209 acetábulum $L$. saucer

16211 leporina Batsch hare's-ear 16212 onótica Pers.

16213 aurántia Fl.dan. orange 16214 concínna Pers. neat 16216 cérea Sowerby 16217 vesiculósa Bull. 16218 repánda $\boldsymbol{F r}$.

\section{Sowerby, t. 153}

Greville crypt. 56 16210 bádia Pers. brown 16215 cochleáta Huds. cochleate bladdery

repand

\section{clustered spring Sooty damp woods tufted 1 su. aut. Br grassy places gregario. 1 aug.oc. Brsh on ground gregario. 11 aug.oc. Brsh dead leaves beautiful $\frac{3}{4}$ aut. Or sandy places very broad 1 sum. Lem. dead leaves brittle $2 \frac{1}{2}$ su. aut. Y.Br fields gregario. $\frac{1}{2}$ sum. Sooty dunghills crowded $2 \frac{1}{2}$ aut. Wsh dunghills fleshy $1 \frac{1}{2}$ aut. Wsh on ground}

16219 mácropus Pers. large-footed solitary 2 su.aut. Cin. shady woods

16220 tuberósa Bull. tuberous slender $2 \mathrm{mr}$. ap. $\mathrm{Br}$ shady woods

16221 cupuláris $L$. cupped fringed $\frac{1}{4}$ aut. $\mathrm{Pa} . \mathrm{Br}$ scorched earth

16222 argillácea Sowerby argillaceous scattered ${ }^{\frac{1}{4}}$ aut. Ysh clay

16223 granuláta Bull. granular gregario. $\frac{1}{2}$ sum. Or.R cow dung

16224 reticuláta Grev. netted very fine 4 spring $\mathrm{Br}$ on ground

$\begin{array}{llll}16225 \text { erécta Sowerby } & \text { erect } & \text { patches } \\ 16226 \text { humósa Fries } & \text { carth } & \text { scattered } \frac{1}{8} \text { aut. } & \text { Ysh shady woods } \\ & & \text { Crim. damp earth }\end{array}$

Sowerby, t. 59

Bolton, t. 99. cochleata

Schæffer, t. 156

Sowerby, t. 79. leporina

Sowerby, t. 78. coccinea

Bolton, t.175. vesiculosa

Sowerby, t. 5

Sowerby, t. 3

Greville crypt. 107

Greville crypt. fl. 59

Bolton, t. 96. hispida

Sowerby, t. 63

Bull. t. 396. f. 3

Sowerby, t. 148

Bull. t. 438 , f. 3

Greville crypt. 156

Sowerby, t. 369. f. 10

Sowerby, t. 369. f. 2

Greville crypt. 171

Sowerby, t. 149

Sowerby, t. 114

Sowerby, t. 147. hispida Sow. t. 369. f. 1. hybrida

Sowerby, t. 24

Bolton, t. 108, f

Sowerby, t. 352. equino

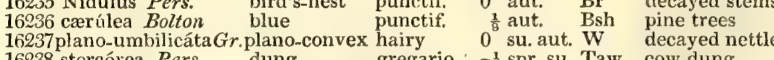

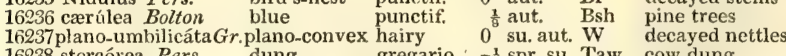
16238 stercórea Pers. dung gregario 16239 albo-spadicea Grev pallid 16240 sulphárea Pers. sulphur handsome $\frac{1}{19}$ aut. R.R. bare earth pretty $\quad 0$ aut. Y decay.herbac.stems Greville crypt. fl. 83

16241 virginea Batsch 16242 bículor Bull.

16243 variécolor Fries.

$$
\text { virgin }
$$
solitary $\frac{1}{1 \frac{1}{2}}$ aut. W rotten sticks

Sowerby, t. 65. nivea two-colored beautiful $\frac{1}{2}$ aut. W larch twigs Sowerby, t. 17 variable gregario, 0 all sea. Ysh rotten wood Sower. t. 178. hydnoidea $\begin{array}{ll}16244 & \text { papilláris Bull. } \\ 16245 \text { villósa Fries } & \text { villous }\end{array}$ gregario, 0 all sea. W upon wood 16246 plúmbea Grev. $\quad$ leaden crowded 0 aut. Fu. ol. rotten wood Greville crypt. fl. 11

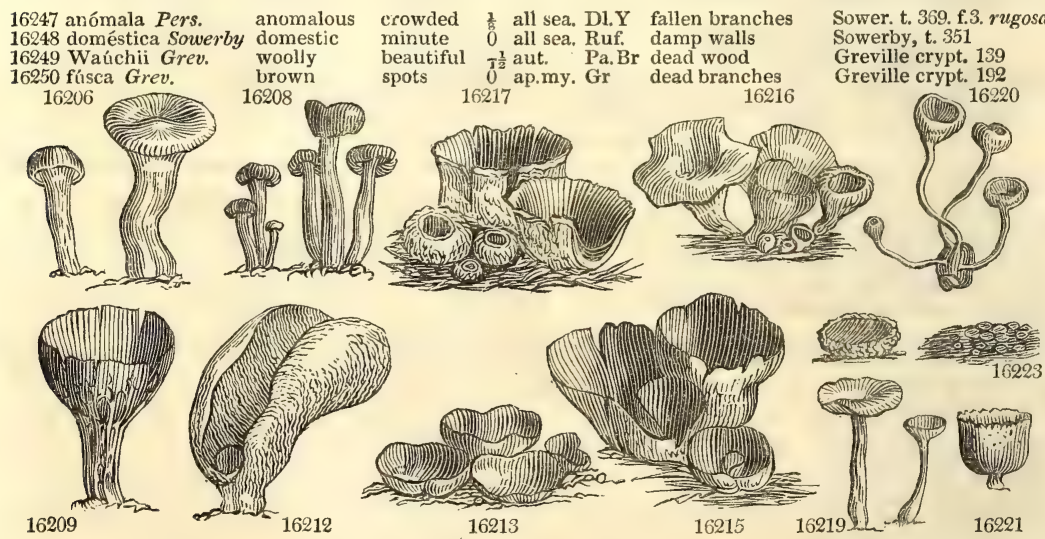

History, Use, Propagation, Culture,

2389. Leotia. Named by Sir John Hill, of famous memory, for no known reason. Gregarious terrestrial substances of the middle size, appearing in summer or autumn, without smell or taste. They are most nearly akin to Helvella and Verpa, from which they differ in form and substance. The species are not known to be eatable, with the exception of $\mathrm{L}$. amara, a native of Cochin-China, which is capable of being deprived of its native bitterness by long stewing. 
16206 Cap depressed cinereous livid smooth on each side, Stipes solid smooth

16207 Dwarfs, Cap rugose white beneath smooth brown, Stipes solid cylindrical white

16208 Tremellose, Cap tumid spread. olivac. : margin rounded, Stipes orange-cylindr. or unequally compressed

\section{Division II. Cupulati.}

1. Cupule always open, or when young conniving, Veil superficial, Sporidia with two smaller sporidia. HELVELLOIDEA.

16209 Cyathiform sooty veiny on the outside arising from a short fistulous pitted stipes

16210 Subsess. ent. flexuose brown, Margin at first involute externally pruinose paler and somew. olive-colored 16211 Substipitate lengthened on one side ear-shaped somew. ferrugin. mealy outside smooth inside at the base 16212 Substipitate lengthened on one side ear-shaped farinaceous outside pink inside becoming rugose at base 16213 Gregarious fiexuose very brittle white externally, Hymenium fine orange

16214 Cæspitose large very brittle externally lemon-colored becoming wrinkled pale flesh-color inside

16215 Gregarious cæspitose variously contorted externally yellowish-brown, Hymenium dull reddish-brown

16216 Large funnel-shaped repand yellowish villous and whitish outside and upon the stipes-like base [base

16217 Gregar. cæspit. glob, at first with mouth conniv, at length campan, splitt. externally whit, and toment, at

16218 Sessile solitary or somewhat tufted large at first hemispherical and concave at length nearly plane sub rugose and brown within the outer surface farinose whitish, Margin crenate

2. Cupule at first closed, Veil innate, Sporidia simple. GEopyxis.

16219 Subgregarious large: the pileus hemispherical slightly hairy and verrucose ash-colored; the hymenium mouse-colored at length pale, Stipes very long incrassated below

16220 Thin, Cupule funnel-shaped brownish pallid, Stipes long seated on a black deformed root

16221 Subsessile thin globose campanulate brownish or pale mealy outside crenate at edge

16222 Sessile yellowish smooth at first urceolate afterwards cracked and torn with hairs about the root outside 16223 Sessile minute flattish orange-red externally granulated with pimples [Stipes usually short and thick 16224 Centre plicate and reticulat. without whit. and pruin. Cap invol. at margin variously split somew. spread.

3. Cupule a little fleshy, small, Veil floccose only at the edge, or fugacious, Sporidia with a solitary little sporidium. Humaria.

16225 Sessile clustered subcylindrical smooth somewhat yellow becoming dilated with an erect subciliated orifice 16226 Sessile fleshy plano-convex smooth crimson entire at margin

\section{Membranaceous, bursting forth with a separating veil, Sporidia simple. ENCALIA.}

16227 Subcæspitate sessile coriac. membran. Margin split ragged externally scurfy and brown, internally white

1. Cupule fleshy, or fleshy-membranous. Crust none. SARcoscYpHe. 16228 Stipitate large subinfundibuliform externally white and tomentose, Hymenium crimson-red

16229 Cupule fleshy, Disk urceolate black externally rubiginous-flocculent, Stipes short down dense dark strigose 16230 Subcæspit. fleshy sess. from hemispher. becom. flatten. Disk sulph. external, and thick root white and vill. 16231 Sessile hemispherical wavy brownish externally covered by dense fascicled hairs, Disk glaucous white 16232 Sessile subhemispher. externally fuscous hairy with a somewhat inflexed margin, Vermilion colored inside 16233 Min. sess. or subsessile hemispher. externally tomentose-pulverulent yellowish-olive, Hymen. dull ochrac. 16234 Sessile gregarious or scattered nearly plane : external surface of the margin hispid with black rigid hairs, Hymenium orange-red

16235 Sessile gregarious very minute orbicular somewhat depressed substrigose brown or nearly black 16236 Plane ciliated blackish externally, Hairs pale, Disk blue [at margin, Hymenium gently umbonate 16237 Small sess. gregar. whole plant white glob. concave at length quite plane ciliate with horizont. white hairs 16238 Gregarious concave tawny externally surrounded near the edge with straightish brown hairs [white 16239 Sess. gregar. glob. at length quite plane, exter. surface and marg. strig. with redd.-brown hairs, Hymen. 16240 Sessile gregarious small globose at length plane: the strigose external surface yellow, Hymenium white 2. Cupule waxy, dry, villous, Crust none. Epiphytes. Dasyscyphe. 16241 Stipitate gregarious small, Stipes rather long, Pileus hemispherical subpatulose villous, whole plant white 16242 Subsess. small gregar. externally very white vill. Mouth contract. Hymen. varying from dil. yeil. to orange 16243 Sessile hemispherical orbicular rather firm flocculent, Disk urceolate whitish

16244 Sessile distinct concave villous hairy milk-white on each side granulated at edge

16245 Sessile very minute gregarious white subglobose villous, Mouth more or less connivent

16246 Sessile minute gregarious depressed externally fusco-olivaceous villose, Hymenium smooth bluish-grey

$$
\text { 3. Cupule waxy or coriaceous, seated on a downy crust. TAPESIA. }
$$

16247 Substipitate much crowded form. a crust, Cupules turbinate vill. light bistre-colored : disk urceol, whitish 16248 Sessile gregarious obovate strigose rufous

1624.9 Sessile gregarious ovate globose golden-yellow strigose with a subjacent woolly paler web 16250 Carn. sess. Cup. concave brown at length plane grey : marg. glab. attach. by fibres to a wide toment. wel

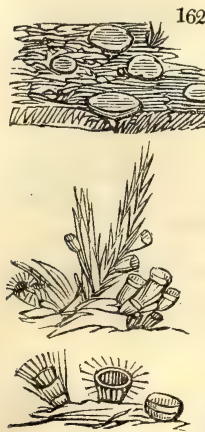

16225

\section{6}

16228

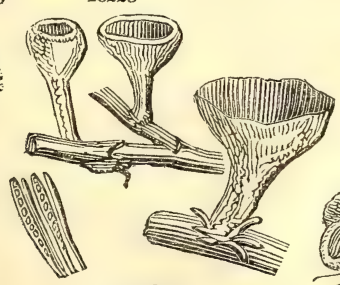

16229

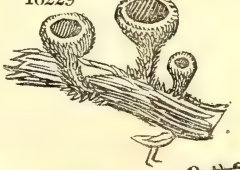

16242

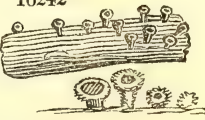

16243

2390. Peziza. Pliny had a tribe of Fungi which he called Pezica, from which the modern name has been corrupted. The present genus is very extensive, but almost wholly of modern creation. The species are found in various situations, but chiefly on decayed wood. They are remarkable for their leathery texture, and for emitting their sporules in the form of smoke from the bottom of their cup. 
83. Phíálea Pers.

16251 fir'ma Pers. firm

16252 Persoónii Moug. Prm

16252 Persoónil Moug. Perso

16253 fructigena Bull. fruit

16255 infléxa Bolton

16256 pedicelláta Sow.

16257 túba Bolt.

16258 calýculus Sow.

16259 æruginúsa $F l$. da Ugelevcd Swed.

16260 Aspegrénii $\mathrm{Fr}$.
16261 citrina Batsch
cyathoídes Wither 16262 yalléscens Pers.

16263 trícolor Sow.

16264 campánula Nees

16265 cribrósa Grev.

16266 clarofláva Grev.

16267 punctáta Grev.

16268 herbárum Pers.

16269 conigéna Pers.

16270 chrysócoma Bull.

16271 cinérea Batsch

16272 vulgáris Fries albella With.

$\beta$ diáphana Sowerb

16273 erúmpens Grev.

16274 ochrácea Grev.

16275 atrovírens Pers.

16276 Abbottiána Sow.

infiexed

stalked

tubular

cupped

pallid

Herb

cinereous

common

ochrey

gregario 1 aut

aggreg. 1 aut.

clustered ${ }_{\frac{1}{4}}$ aut

clustered $\frac{3}{4}$ sprin

gregario.
solitary

aut.

su aut. Bt.G dam

Aspegren's gregario. $\frac{1}{4}$ aut. Ysh damp wood

lemon-color, crowded ${ }^{\frac{1}{6}}$ aut. $\mathbf{Y}$ fallen branches

numer. $x$ aut.

Pa.Y old trees

three-color. scattered 0 aut. Sooty trunks of trees

delicate $\frac{x}{2}$ aut.

porous curious $1 \frac{1}{2}$ aut.

bright-yell. punctif. 0 aut.

dotted punctif. 0 aut.

crowded

$\frac{1}{2}$ aut.

gregario. 0 au. sp. W pine cones

yellow-hair. crowded 0 aut. Fu. Or posts \& rail

patche

0 wint. Wsh dry bark

transparent scattered 0 wint Sycam.-peti. scattered 0 aut.

puckered 0 aut.

Tran. rotten wood

Cæs. stalks of Sycamore Gre

Sowerby, $t, 64$

, t. 389.7

Sea G wood

Greville crypt. 5

Sowerby, t. 389 , f. 8

i 4. Helótium, Pers.

16277 fibulifórmis Fries button-shap.

16278 aciculáris Pers.

Ascobolus.

2391. AS'COBOLUS. Pers.
16279 furfuráceus Pers. scurf

Y truniss of elm

Bolton, t. 176

Sow. t.57. agariciformis

Sp. $1-11$.

gregario. 0 all sea. Brsh old cow dung

2392. BULGA'RIA. Fries. Bulgaria.

16280 in'quinans Fries dirty gelatino. 0 au. wi. Umb.

polymor, a aut. Pu.R. dead oaks

2393. Diti'Ol. Fries, Ditrola.

16282 radicáta $F r$. rooting

Sp. $1-5$.

gregario. $\frac{1}{4}$ ap. jn. Gold. barked pines

Sowerby, t. 428

Bolton, t. 101, f.

2394. CENA N'GIUM. Fr. Cenangium.

16283 quercínum $\boldsymbol{F r}$. oak

Spho'ria collápsa Sow.

16284 Prunástri Fr. Plum crowded 0 aut. Bl dead plum branches

16285 Cérasi Fr. Fr. Cherry crowded 0 all sea. R.Bl dead cherry branches

16286 Aucupáriæe Fr. Mount. Ash tufted 0 aut. BI dead mountain-ash branches

16287 ferruginósum $F r$. ferruginous patches 0 aut. R.Bl Scotch fir branches Greville crypt. 197

2395. STIC'TIS. Pers. STICTIS. Sp. $1-23$.

16288 radiáta Pers. $\quad$ radiating spots 0 au. spr. W bark of trees Sowerby t. 16

16251

16264
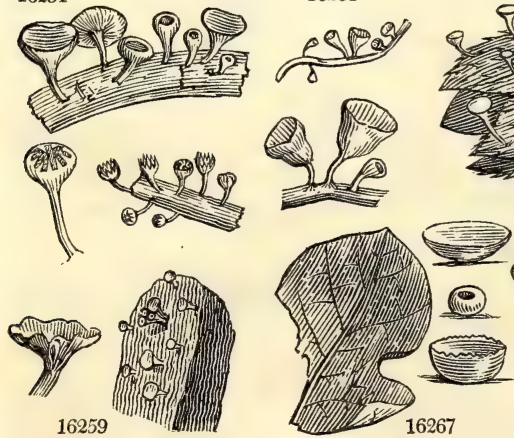
16253 16273

History, Use, Propagation, Culture,

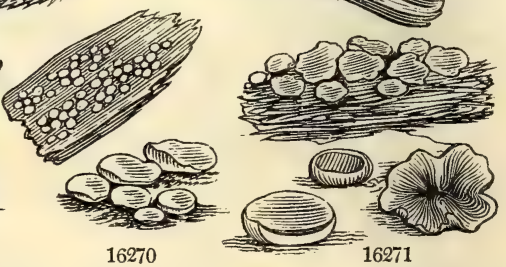

16270
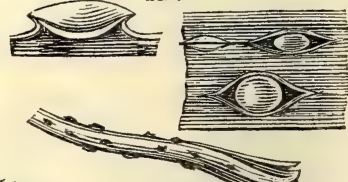

2391. Ascobolus. From ascus, one of the forms of theca in which the sporules are retained among Fungi, and $\varepsilon_{\alpha \lambda \lambda} \omega$, to emit, in allusion to the principal peculiarity of the genus. Small gregarious soft plants, without roots, but not very perishable, growing upon dung, and most obvious during rainy weather.

2.392. Bulgaria An intermediate genus between Peziza and Exidia, named from bulga, a leather bag, on account of the saccate form of the species. Scentless, insipid, mucilaginous, rootless, soft fungi, tolerably permanent, and generally breaking forth in clusters from the bark of trees during the winter and autumn. Miller is said to have succeeded in obtaining glue from B. inquinans, but subsequent attempts have failed of success.

2393. Ditiola. From $\delta 15$, double, and $10 \lambda .5$, down, in allusion to the nature of the pubescence of the velum. The species of this genus are gregarious, firm, permanent, without smell, flourishing upon dry wood from the 
1. Cupule somewhat membranous, distinctly stalked, Hymenium distinct. HrmenoscYpHE.

16251 Rather large ochrey-brown infundibulif. at length concavo-rep. or very plane, Stipes elongat. dark at base 16252 Cap smooth urceolate orange-color with a prominent membranous pale margin, Stipes cylindrical pink 16253 Gregar. yell. or redd.-white subinfundibulif. : surface of hymen. plane, Stipes long subflexu. and attenuat. 16254 Bright-yellow, Cupule plano-convex thinnish, Stipes short firm thickish

16255 Stipit. glab. white or yellow. subinfundibulif. Margin fringed with inflexed teeth, Stipes elongated curved 16256 Stipitate campanulate, Margin smooth, Stipes straight

2. Cupule flchy, waxy, firm, obconical, somewhat stalked, Hymenium distinct. CaLYcINa.

16257 Yellow, Cupule turbinate : disk flat; margin tumid, Stipes long slender [orange-brown 16258 Gregarious globoso-infundibulif. slightly concave, Stipes rather short attenuat. whole plant ferrugin. or 16259 Eruginose, Cupule turbinate becoming expanded and flexuose: disk whitish, Stipes short

16260 Cupule subrepand smooth : disk yellow exteriorly white as well as the somewhat ascending stipes 16261 Yell. crowd. apparently sess. but having a short thick obconical stipes carnose, Hymenium plano-concave

16262 Crowded smooth pale-yellow or whitish, Cupule concave, Stipes short thickish pallid 16263 Hemispherical margined, Disk yellowish externally sooty, Stipes very short whitish 16264 Gregarious white rather small very membranaceous campanulate unequal, Stipes filiform short 16265 Black solitary rather large very concave, Hymen. cribriform or full of lacerat. irregular pores or sinuses 16266 Yellow gregarious minute obconical at length somew. plane, Margin raised obt. externally somew. paler 16267 Yellow very minute gregarious punctiform globular at length plane or subconvex, Margin minutely cren. 16268 White gregar. carnose at length convex but sometimes depress. in centre turning reddish in age and decay

3. Cupule waxy, soft, watery, sessile or obconical, Hymenium confluent. MoLlisia. 16269 White gregarious excessively minute orbicular subimmarginate

16276 Fulvous orange gregarious crowded minute nearly plane subtremella-like

16271 Grey gregarious depressed waved subtremellose, Margin obsolete

16272 Sessile somewhat tufted membranous soft smooth whole-colored all over and whitish

B Scattered flattish-urceolate whitish transparent

[in wet weather 16273 Minute ceraceous glab. sess. grey connate within the semiputrid petioles of the Sycamore and burst. forth

4. Cupule waxy, dry, sessile, flat at base or innate edged. Patellea.

16274 Ochrey-brown min. gregar, carnose thick obconic. Hymen. minutely granul. at length plane or subconvex 16275 Green gregarious minute subtremellose hemispherical at length plane becoming black in decay

16276 Sessile diry patellate cæsious on the outside, Disk yellow

16277 Firm, Head convex yellow black-brown beneath, as is the short thick villous stipes 16278 White smooth, Head convex, Stipes long equal

16279 Sessile gregarious somewhat concave olive-green or brownish externally furfuraceous

16280 Turbinate firm, externally rugulose scaly umber-colored, Disk flattish blackish

16281 Polymorphous crespitose subgelatinous somew. firm purplish.red externally subvenose, Hymen. concave

16282 Disk flattish golden-yellow, Stipes thick villous white long-rooted

16283 Simp. gregar. long flexu. at first closed pruin. and blackish-cinereous, afterw. open with a broad pale disk

16284 Substipitate opake rigid black marginate, Hymenium concave

16285 Coriaceous reddish-black at first closed at length expanded and plane

16286 In round. tufts, Caps stipit subturbin. concave with round. marg. intermix. with digit. or subul. processes

16287 Gregarious between membrane and leathery subsessile rugose somewhat pruinose, The orifice compressed inflexed: when moist spreading

15288 Immersed orbicular, Limb snow-white ragged pulverulent

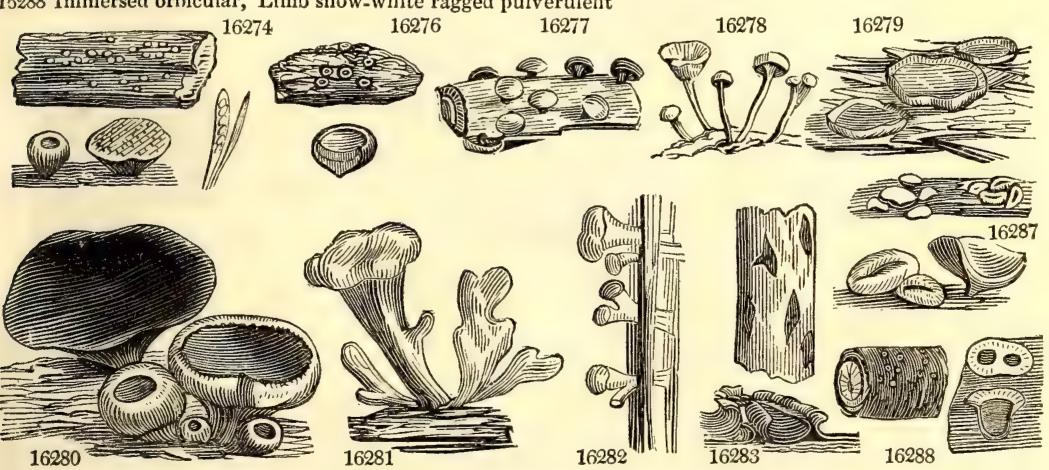

and Miscellaneous Particulars.

autumn until the spring. They are to be considered noxious fungi from the injury they bring to the timber upon which they vegetate. Their mucilaginous roots insinuate themselves between the fibres of the wood, and separate and soften them. Their tubercles burst forth, and filling the wood with clefts, and rendering its interior accessible to wet, soon destroy it. D. radicata is one of the species of dry rot:

2394. Cenangium. From *syas, hollow, and urysoy, a capsule or vessel, in allusion to the hollow nature of the receptacle. Chiefly distinguished from Peziza by substance, and the coriaceous nature of the cupules. From Tympanis it is distinguished by its closed cupules and smooth permanent hymenium. The species are small and deformed, growing upon the bark of trees, either singly or in tufts, and mostly produced in winter.

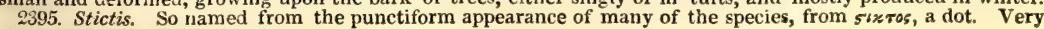
simple, minute, gregarious fungi. 
2396. CRYPTOMY'CES. Grev. Crypromyces.

2396. CRYPTOMY'CES. Grev. CRYPromyces.
16289 Waúchii Grev.

Class III. Tremellini.

2397. TREMEULA. $L$. Tremella.

Sp. 4-18.

16290 mesentérica $R t z$. Mesent.-like subsolit. 2 aut. sp. Y fallen branches 16291 al'bida Huds. whitish clustered 1 aut. Wsh fallen branche 16292 intuméscens $E$. B. tumid twisted lobes 2 wet w. Br trunks of trees 16293clavariæfórmisPers. Clavar--like gregarious 1 su. aut. Dl.Or juniper stems \$1. Co'RXNe. Nees. 82. Phyllop'ta. Fries.

16295 biparasítica Fries parasitical deformed $\frac{2}{4}$ sept. Bl dead Agaric 2398. EXI'DI A. Fries. Exidia. 16296 aurícula Júdæ Fries Jew's-ear

$\beta$ rubescénti-fúsca $\mathrm{Fr}$. redd.-brow 16297 recisa $F r_{.}$ 16297 recisa $F r$. cut-back

16299 glandulósa $\mathrm{Fr}$. glandular verygelat. 2 aut. $\mathrm{Br}$ dead trees 2399. DACRYMY'CES. Nees. DACRYMYces. Sp. $2-7$. 16300 morifórms $\mathrm{Fr}$. mulberry-like sessile 0 aut. $\mathrm{Bp}$. 2 .7 dead wood 16301 stellátus Nees trickling very soft $\frac{1}{8}$ all sea. Or.Y rotten wood T. deliquéscens Grev 2400. AGY'RIUM. $F r$. AGYrium.
16302 cæ'sium Fr. punctif. 0 all sea. Cæ. $\begin{aligned} & \text { A-6. } \\ & \text { cæious }\end{aligned}$ 2401. HYMENEL'LA. Fr. HYMenella. 16303 vulgáris $\mathrm{Fr}$. common tumid Sp. $1-4$.

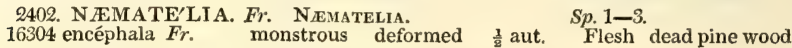

Eng. bot. t. 709

Eng. bot. t. 2117 Eng. bot. t. 1870 Jacq. ic. t. 648

Eng. bot, t. $2+50$

Bolton, t. 107

Eng. bot. t. 2447 E.b. t.1819. boletiformis Eng. bot. t. 2452

E. b. t. 2448, T. arborea

Eng. bot. 2446 Grev. crypt. 159

Class IV. Sclerotiacei.

2403. ACROSPER'MUM. Tode. Acrospermum. Sp. 2-5. 16305 cornútum $\mathrm{Fr}$. cornute $\begin{gathered}\mathrm{AcR} \text { gregarious } \frac{1}{4} \text { aut. } \\ \mathrm{Sp} .2-\end{gathered}$ 2404. SCLERO'TIUM. Tode. ScLerotium. 16307 sémen Tode Mustard Seed hard \& Bras'sice Bolt. Turnip Seed hard 16308 fungórum 1 Fungus roundish $S p$. 12-60. $\frac{1}{8}$ wi.spr. W.Y dead leaves

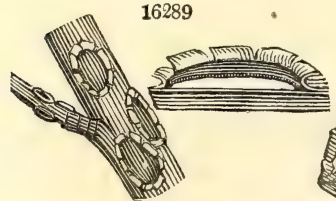
16291 0 aut. $\mathrm{Br}$ gills of dead Agarics t. 393

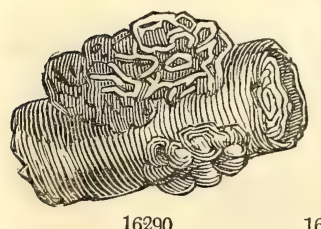

16290

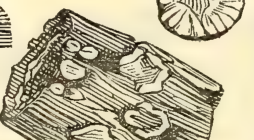

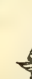

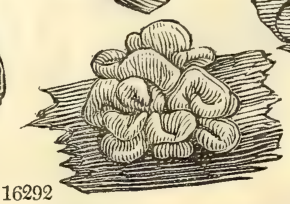

History, Use, Propagation, Culture,

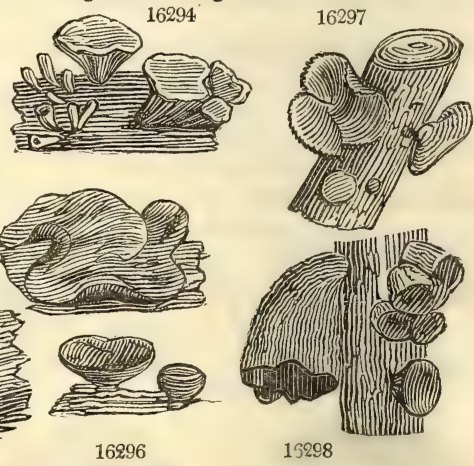

2396. Cryptomyces. Upon this curious addition to the British Flora, Dr. Greville has the following remarks. " This very curious plant, I have little hesitation in placing as a new genus among the true Fungi. It is difficult to say, with what it has nearest affinity. In general habit, it might be supposed to resemble some species of Thelephora, but there the comparison stops. Our plant, besides being produced under the epidermis, seems to belong to a more perfect group, when its structure is examined. The hymenium is a quite distinct substance from that of the receptacle. The fructification is fully and beautifully developed, a good deal similar to that of the Helvellæ. The receptacle is carnose and white; and the whole exhales a very strong odor, precisely like what is universaily known under the name of a fungus-like smell. Till the plant is perfected, it remains concealed beneath the epidermis; and on this account, I have named the genus Cryptomyces. The epidermis, in fact, scarcely seems to crack by the swelling of the fungus, more than by the natural consequence of being killed by its separation from the subjacent bark. A cluster of willows, which was attacked in the beginning of the season by this plant, has been nearly destroyed by it; and, from the rapidity of its progress, 1 have no doubt that a whole plantation might, in the course of a couple of seasons, be rendered good for nothing. At a little distance, the affected branches look as if they were dry, scorched, and rotten"

2397. Tremella. Large or middle-sized fungi, rooting at the base, which is considerably contracted between the bark and the wood of trees. Dillenius named the genus on account of its soft, tenacious, tremulous substance, but his name was applied in a far more extensive sense than at present. - The section called Phyllopta is an aberrant form of the genus, and should perhaps be separated.

2398. Exidia. From $\varepsilon \xi \xi \varepsilon \mu$, to proceed from a thing; with reference to the manner in which the sporidia exude as it were from their receptacle. This genus differs from Tremella, to which it is nearest; in its horizontal Peziza-like receptacle ; in its hymenium being superior, the lower surface being dissimilar and either 
16289 Suborbicular olivaceous at length nearly black white within, Thecæ elorigated obtuse

\section{Class III. Tremellini.}

16290 Sessile roundish orange-yellow variously lobed and plicate

16291 Sessile roundish or spreading and somewhat expanded obtusely lobed and plaited whitish

16292 Sessile clustered tumid plaited shining-brown

16293 Gregarious distinct tender gelatinous simple lingulate dull-orange pulverulent towards the apex

16294 Sessile gelatinous reddish-purple at first club-shaped then rounded lobed plaited or curled finally blackish

16295 Cartilaginous lobed somewhat wrinkled black

1. Pezizoid, plicate, villous beneath, or dotted with roughness, Tubes half inferior, distinct. Auricula.. 16296 Sessile concave flexuose blackish plaited on each side with veins : beneath downy olive-grey

16297 Very soft truncate-flat subrepand fuscous beneath dotted scabrous, Stipes very short oblique out of centre 16298 Thin flaccid very dark, externally opaque, internally wrinkled

2. Somewhat flattened, wavy, rugose beneath, Tubes half-inferior, obsolete. Glandulose.

16299 Sess. round, rather spread. thick not goyrose plicate ben. : the surface bear. min. white-headed processes

16300 Conglobated sinuous dark opaque fleshy and purple inside

16301 Gregarious entire round depressed pulpy orange-yellow

16302 Gregarious nearly separate convex whitish cæsious

16303 Long various smooth whitish when dry becoming brown : the circumference adhering

16304 Subsessile pulvinate plaited-rugose pale flesh-color becoming dry

\section{Class IV. Sclerotiacei.}

16305 Horn-like smooth when dry furrowed rufous becoming paler at the end

16306 Stipitate mostly lanceolate somewhat obtuse subcompressed of a dark olivaceous color

16307 Separate spherical whitish-yellow becoming wrinkled and black, white inside

$\beta$ Clustered somewhat immersed pale inside

16308 Deformed lobed smooth pale becoming tawny, whitish inside
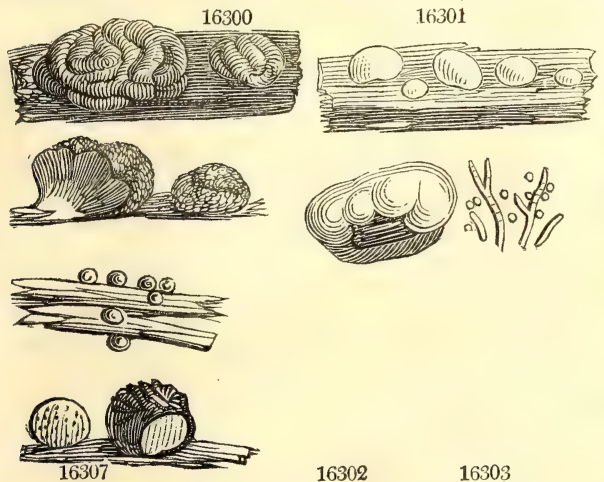

16302

16303

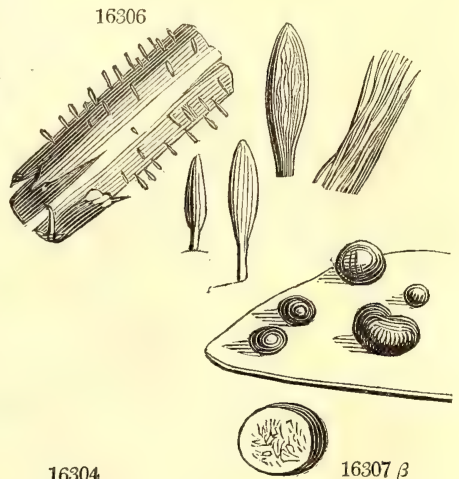

and Miscellaneous Particulars.

villous or rugose, and ribbed in a peculiar manner; in the conoid papillæ of the disk; in the tubes, which must be esteemed rudimentary asci, containing the sporules; and in the elastic manner in which the sporidia are produced. The species are simple, rarely growing in patches, of a large or middle size, and generally inhabiting wood; when dry they are membranous, but nearly regain their original form upon being moistened.

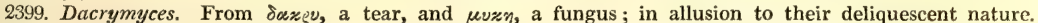
Tremella deliquescens of Bulliard, a yellow confluent mass found chiefly upon pine-timber in the spring, is the type of the genus.

2400. Agyrium. Apparently from arvoss, a crowd, in allusion to the clustered disposition of the individuals; although Fries, the author of the name, expressly declares that it has been named " ob superficiem nunquam non levem.". Small dot-like gregarious plants growing upon wood, perennial, seated upon a crust-like spot, and resembling some species of Lecidea.

2401. Hymenella. This genus consists of plants growing upon plants, generally upon the stem, having the habit of Sclerotium durum, but softer, more tender, and bearing sporidia within their surface, for which reason they seem as if they consisted only of a kind of elementary hymenium, whence their name.

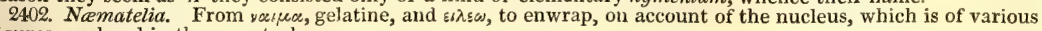
figures, enclosed in the receptacle.

2403. Acrospermum. Minute fungi of a rigid habit, parasites upon decaying vegetables. From $x \approx 05$, the summit, and $\sigma \pi$ icum, seed, on account of the apex of the plants becoming tumid, and emitting the sporules.

2404. Sclerotium. From $\sigma * \lambda$ neos, hard, in allusion to the remarkably firm substance of the species. All the species are parasites upon other plants, and some are very destructive. 
16309 muscórum Pers. 16310 salicinum Pers.

16311 popúlneum Pers.

16312 Ptéridis Pers.

16313 scutellátum $A l b$.

16314 nitidum Pers.

16315 dúrum $F r$.

16316 bullátum $D e c$.

16317 ouercínum Pers.

16318 trúctuum Grev.

\section{Moss}

Willow

Poplar

Bracken

shield-like

shining

hard

blistered

Oak

Fruit irregular $\frac{2}{4}$ spring Or.Y stems of mosses

patches 0 aut.wi. Rsh Salix caprea leaves

patches 0 all sea. Rsh

punctiform 0 aut. sp. Bl

button-like 0 spring $\mathrm{Br}$

less crowd. 0 wi.spr. B

corneous 0 wi.spr. Bl

confluent 0 aut $\mathrm{Bl}$

conter aut. Bl

crowded 0 aut.

Bl

Wsh

Sp. $1-4$.

Crocus-blight clustered 0 all sea. Ruf. saffron roots

Populus tremula lvs

dead Pteris aquilina

leaves of trees

dead herb. stems

ead herb. stem

otten gourds

ead leaves

ev. crypt. 14

Grev. crypt. 1

Grev. crypt. t. 77

Nees syst. f. 135 Thanatóphyta crocórum Nees

2406. PERI'OLA. Fr. Periola.

16320 tomentósa $F r$. downy

2407. ACI'NULA. $F r$. ERGot. 16321 Clávus $F$;

common

scattered $\frac{S p .1-3 .}{8}$ wi. spr. W ${ }^{\text {. }}$ potatoe roots

2408. ERY'SIBE. Rebentisch. MILDEW.

16322 Artemisiæ Grev. Wormwood patche

16323 Trifólii Grev.

16324 Berbéridis $D e c$

16325 Láthyri Grev.

16326 Bétulæ Dec.

16327 Robiniæ Grev.

15328 Arc'tii Grev.

15329 Aquilégiæ Dec

16330 AlchemíllæGrev.

15331 Pisi Dec.

Berberry

Vetch

Birch

Acacia

Columbine patches

spots

powdery

powdery

16332 A'ceris Dec. $\quad$ Sycamore scattered

16333 Lonicéræ Dec. Honeysuckle powdery

16531 Asperifoliárum Grev. Borage powdery

16335 Ranúnculi Grev. Crowfoot scattered
Sp. 1.

0 sum. Blsh glumes of grasses

$$
\text { Sp. 14-37. }
$$

0 aut. Wsh Artemisia vulgaris

0 aut. Bl Trifolium

0 aut. Rsh berberry

0 aut. R. Br Lathyrus pratensis

0 su.aut. Blsh birch leaves

0 aut. Wsh Robinia viscosa

0 su.aut. Rsh Arctium Lappa

0 aut. Wsh Aquilegia vulgaris

0 su. aut. Ysh Alchemilla vulgaris

0 aut. W garden pea

0 aut. Blsh maple \& sycamore

Grev. crypt. 134

Glau. honeysuckles

Wsh Asperifolix

Wsh Ranunculi

\section{GASTEROMYCÊTES.}

Class I. Angiogastres. - Division I. Phallondea.

2409. PHA L'LUS. Mich. Phallus,

Sp. 2-9.

16336 impudicus $L_{0} \quad$ Stinking Morel very fetid 8 su. aut. Wsh woods and hedges Gr.cry.213, 214. fatidns 16337 canirus Huds. scentless smaller 4 au.sep. Pk rotten hazel trunks Sow. t. 330 . inodorus

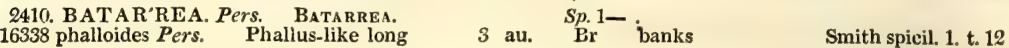

Division II. Tuberacece

2411. TU'BER. Plin. Truffle. Sp. 2-6.

16339 cibárium Sibth. common esculent $1 \frac{1}{2}$ winter $\mathrm{Br}$ under ground Nees pilz syst. f. 147 16340 al'bidum Casalp. pale less fragrant $\frac{3}{4}$ su.aut. Wsh under ground

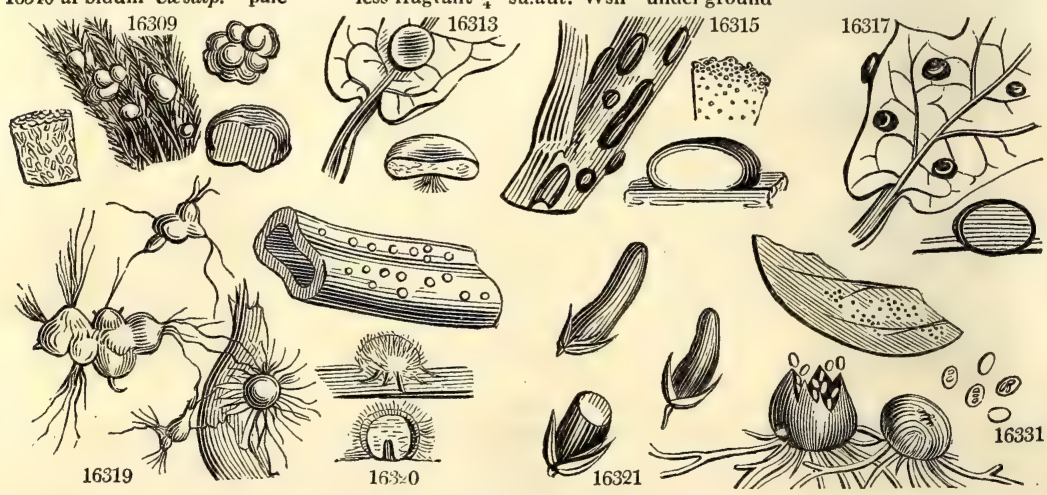

History, Use, Propagation, Culture,

2405. Rhizoctonia. Subterraneous fungi, reposing upon the roots of living plants, which they destroy. The species appear in the summer or autumn, and are very destructive. They have received their name from their habits; $\varrho^{b} \alpha$, a root, and $z \tau \varepsilon \downarrow \omega$, to destroy. They are very nearly related to the subterraneous Sclerotia. $\mathbf{R}$. crocorum grows parasitically on the roots of the cultivated Saffron, Crocus sativus, in France, and is so pernicious as to have acquired the name of la mort du safran. It is very destructive, soon causing the bulb to perish, and spreading with great rapidity over a whole field of that valuable crop, if not speedily stopped by a trench fifteen to eighteen inches deep, to cut off the communication between the infected and the sound plants. The smallest quantity of earth from an infected field is said to be capable of communicating this plague, even if the ground were not planted with saffron till twenty years afterwards. "Hitherto this de. structive parasite has not been heard of but in France. The plants are of an irregular knobbed figure, from half an inch to an inch long, of a light reddish brown, scarcely bursting; granular and paler within. Long branching capillary roots are sent out in all directions, propagating the plants very extensively and readily by offsets which attach themselves to the saffron, and multiplying in the substance of the bulbs soon destroy them." (Smith)

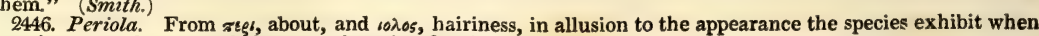
growing upon the roots of plants, or decaying fungi. 
16309 Gregarious roundish but very irregular tuberculose orange-yellow within and without or whitish 16:310 Depressed epiphyllous scattered or very confluent reddish fulvous

16311 Minute on both sides of the leaf numerous dark mostly angular and subconfluent

16312 Black very minute roundish or oval numerous depressed

16313 Epiphyllous orbicul. flattened at length somew. concave in middle fixed ben. by a central filamentous point

16314. Minute somewhat scattered or partially aggregate very black orbicular depressed

16315 Deep-black oval or elongated cernuous at length substriate or rugose white within

16316 Roundish or oval confluent corneous externally and black paler within and concave

16317 Epiphyllous scattered globular or subdepressed smooth pale at length black, Substance very corneous

16318 Rounded or oblong sometimes confluent white at length brown or black corneous externally, within somewhat hollow and carnose

16319 Rufous, Filaments few spreading over the bulb in the form of a disk

16320 Round deformed downy white

16321 Horn-like cylindrical powdery and purple-black outside, white inside

16322 Very minute on both surfaces of the leaf, Filaments forming a dense whitish web

16323 On both sides of the leaf very globular nearly black, Filaments giving the leaf a farinose aspect

16324 On both sides of leaf form. circular pulverul, spots at length conflu. Filam. dichotom. at their extremities 16325 Red-brown minute, Filaments spreading over the whole leaf pulverulent

16326 On the under-surface scattered very visible blackish, Filaments few simple not rendering the leaf whitish 16327 On the upper-surface finely pulverulent, Receptacles minute congregated here and there

16328 On the under-surface thickly covering the whole leaf, Filam. simple granuliferous : bodies pyriform small 16329 On both sides of the leaf forming a light pulverulent surface, Recept. few scattered distinct

16330 On under-surface very numer. min. Filam. few forming no filament. or pulverul, appear. to the naked eye 16331 On both sides of the leaf so crowded as to darken its color, Filaments very long and slender

16332 On the under-surface scattered at length concave, Filaments elongated interwoven

16333 On both sides the leaf very numerous scattered minute, Filaments presenting a glaucous powdery surface 16:334 On both sides the leaf scattered becoming confluent pulverulent, Recept. aggregated here and there

16335 Chiefly on under-surface partially scatter. Filam. long flexu. Granulifer, cells oval contain. mostly 4 gran.

\section{GASTEROMYCETES.}

Class I. Angrogastres. - Division I. Phalloidece.

16336 Volva large, Stipes very cellulose white, Cells of the head containing a fetid dull-green sporuliferous slime 16337 Head close to the stipes ovate warted impervious pink

16338 Stipes cylindrical straight mucilaginous

Division II. Tuberacece.

16339 Very rough with warts blackish

16340 Very rough with warts whitish

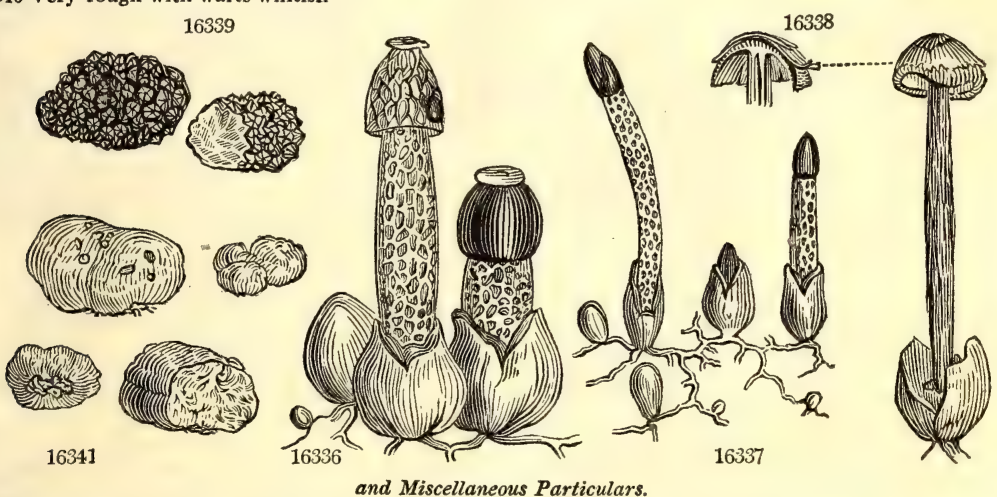

2007. Acinula. Very similar to Sclerotium or Periola ; but distinguished by the diffluent coat, containing a nucleus resembling an acinus in a berry, whence the name. A. Clavus is the Ergot of corn.

2408. Erysibe. A Greek name of mildew. Most of the productions arranged under this head are known by the popular name of mildew. They are better characterized by the plants on which they grow, than by their peculiar differences, which, it is probable, depend very much upon the former circumstance.

2409. Phallus. Large terrestrial fungi, sometimes growing upon rotten wood, not clustered, appearing in the summer after thunderstorms, fetid, and highly poisonous. Their form is so similar to that of the $\varphi \alpha \lambda \lambda$ os of the Greeks, as not to be overlooked.

2410. Batarrea. So named by Persoon, in honor of Antonio Batarra, professor of botany in the Lyceum at Rimini, and author of a Historia Fungorum Agri Ariminensis, published at Faenza, in 1759, in quarto, with forty plates. A very curious plant found only in England, where, however, it is exceeding rare. The volva or wrapper is about the size of a hen's egg, originally of three slightly coriaceous layers, hollow internally, when a spongy stalk is formed which rises suddenly to its full height of about twelve inches. This stalk carries up on its summit full half the innermost layer of the volva, which is white and smooth within, and covered externally with copious brown sporules intermixed with fibres.

2411. Tuber. An ancient Roman name. T. cibarium is the famous truffle, so celebrated in the annals of 
2412. RHIZOPO'GON. Fr. RHzOPOGON. Sp. 1-4.

16341 álbus Fr.
Lycopérdon gibbósum Dicks.

Division III. Nidularacea.

2413. NIDULA'RIA. Bull. Nidularia. Sp. 3-13.

16342 striáta Bull. striated gregarious $\frac{1}{2}$ au. no. Brsh on rotten leaves 16343 campanuláta Sibth. bell-shaped flocculent $\frac{1}{2}$ su.aut. Ciner. shavings of wood 16314 Crucíbulum Hoffm. crucible coriaceous ${ }^{\frac{1}{4}}$ su.aut. Oc.fer pine bark

Sow. t. 29. hirsuta Sow. t. 28

Grev. crypt. 34

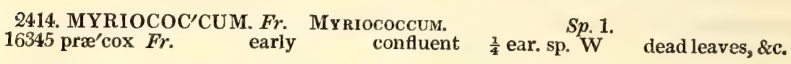

2415. POLYAN'GIUM. Lk. Polyangrum. S $S \tilde{p}_{\dot{q}} 1$.

16346 vitellinum $L k$. yolk of egg gregarious 0 au.oct. ${ }_{\mathbf{Y}}$. damptrunks

Nees syst. f. 131

Division IV. Carpoboli.

2416. ATRACTO'BOLUS. Tode. 16347 ubiquitárius Tode common

Atractobolus. Sp. 1.

2417. THELE'BOLUS. Tode. Thelebolus.
16348 stercóreus Tode
dung $\begin{gathered}S p .1-2 . \\ \text { gregarious } \frac{1}{12} \text { w. aut. Ysh cow dung }\end{gathered}$

wood,oones,stones,\&c. Fung.meckl.p. 45. f.9

2418. PIlo'bolus. Tode. Pilobolus.

Sp. 1-2.

16349 crystallinus Tode transparent very fugac. $\frac{1}{4}$ cool w. Bl horse dung
$\beta$ ro'ridus Pers.
frosted very fugac. $\frac{1}{6}$ cool $w$. Pellu. horse dung

Nees syst. f. 363

2419. SPHERO'BOLUS. Tode. SPHærobolus. Sp. 1 -2.

16350 stellátus Tode starry remerging 0 su. aut. Pa.Y wood, \&c.

Bolton, t. 133. f. 1

Bolton, t. 132. f. 4

Grev. crypt. 158

Class II. Pxrenomycetes, - Division 1. Sphcriacei.

2420. XYLA'RIA. Hill. XYlaria. 16351 hypóxylon Grev. wood

various 2 all sea. $\mathrm{Bl}$ stumps of trees

16352 digitáta Pers. fingered tufted 2 all sea. Bl stumps of trees

16353 polymórpha Grev. polymorph. variable 2 aut. $\quad \mathrm{Bl}$ stumps of trees $\quad$ Sow. t. 69. digitata

16354 grácilis Grev. $\quad$ slender 16355 entomorhiza Dicks. insect-root. stalked $\quad 3$ aut. Br moist places Grev. crypt. 86

16355 entomorhíza Dicks. insect-root. stalked 2 aut. Fusc. dead larvæ of insects Dicks. erypt. 1.t. 3.f.3

16356 capitáta Holmsk. capitate tufted 3 sep. oc. Br on Scler. cervinum Sow.t.354.agariciformis

$\begin{array}{llll}16357 & \text { alutácea Pers. } & \text { tan-like } & \text { brittle } 2 \frac{1}{2} \text { au.oct. pa.tan dead pine leaves Sow. t. 159. clavata } \\ 16358 \text { hypóxylon Ehr. } & \text { wood } & \end{array}$

B cupressifórmis Woodv. cyps $\begin{array}{lll}\beta \text { cupressifórmis Woodv. cypress-like gregarious } \frac{1}{2} \text { aut.sp. Wsh old trunks } & \text { Bolton, t. 129. f. g } \\ 16359 \text { punctăta Sowerby dotted } & \text { gregarious } \frac{3}{4} \text { all sea. Sooty animal dung } & \text { Sow. t.54 }\end{array}$

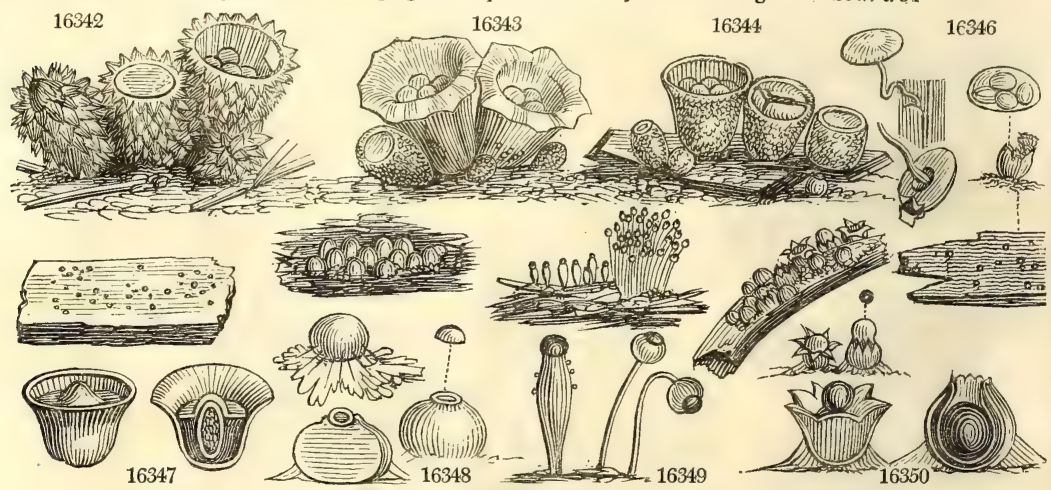

History, Use, Propagation, Culture,

cookery. Dogs are taught to find this fungus by the smell, and to scratch it up out of the earth. An instance is recorded of a man having possessed this power. It is brought to table either simply boiled, or stewed in various forms. It is reported to have a stimulating aphrodisiacal quality, which perhaps renders them more popular than their flavor, which is trifling. Truffles are found under the surface of the ground in various parts of Europe, where the soil is light and dry; as well as in Japan and the East Indies. There are said to be numerous varieties of color.

2412. Rhizopogon. Large or middle-sized Fungi, emerging from the earth, and resembling potatoes; scarcely eatable; but, according to Gleditsch, possessing aphrodisiacal qualities. On the outside covered with netted corymbose rooting fibres, whence the name, from $\rho \zeta \alpha$, a root, and $\pi \omega \gamma \omega \nu$, a beard.

2413. Nidularia. A diminution of nidus, a nest. The plants consist of a leathery cup containing several lenticular bodies supposed to contain sporules, and all together resembling a bird's-nest with eggs.

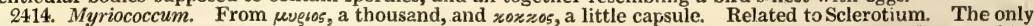
species consists of superficial deformed confluent tubercles, 2-4-lines broad, at first sight resembling a white

compound Sphæria with prominent brown orifices.
2415. Polyangium. Named by Link, from $\pi 0 \lambda v 5$, many, and $\propto \gamma \gamma$ rov, a capsule. Easily distinguished from the last by the internal grumous substance, which Nees and Fries consider unequal sporidia.

2416. Atractobolus. From $\alpha \tau \rho_{\alpha}=\tau 05$, a spindle, and $\beta \omega \lambda \lambda \omega$, to cast. The bladder which contains the sporules, is fusiform and closed, and is ejected from the base of the cupule as soon as the operculum is thrown off.

2417. Thelebolus. From $9 \eta \lambda \eta$, a nipple, and $\beta_{\alpha \lambda \lambda \omega}$, to emit. The uterus protrudes a glubose papilliform vesicle. This is found on the dung of swine, after rainy weather in June and July. Tode compares it to the 
16341 Round somewhat rugose whitish-brown slightly fibrous at base

\section{Division III. Nidulariacce.}

16342 Obconical hirsute bright-brown striated inside

16343 Campanulate villous cinereous-brown lead-colored and shining inside

$163+4$ Campanulate-cylindrical truncate at each end somew. downy ochrey-brown smooth and pale-yellow inside

16345 Tubercles superficial deformed confluent, at first sight resembling some kind of compound sphœria

16346 About the size of a grain of sand

Division IV. Carpoboli.

16347 Resembling to the naked eye flour scattered about

16348 Subglobose saffron-color gregarious sessile

16349 Stem-like receptacle inflated upwards (rarely filiform) Pointed capitular vesicle round depressed black

$\beta$ Stem-like receptacle globose, Stipes oblong filiform, Capitular vesicle dot-like black

16350 Globose pale-yellow, Orifice regular stellate toothed

Class II. Pyrenomycetes. - Division I. Spheriacei.

16351 Gregarious branched compressed black white and farinaceous towards the apex downy at the base 16352 Gregarious somewhat tufted black, Peduncles glabrous more or less united at their base, Receptacle cylindrical terminated by a sterile acuminate apex

16353 Black gregar. simp. or divid. Pedunc. pass. into a ventric. recept. contain. spherules ben. its whole surface 16354 Stipes elongat. cylindr. equal somew. flexuose, Recept. smooth roundish-ovate brown, Spherules obl. pale 16355 Fleshy, Head globose fuscous, Stipes thin very long

16356 Fleshy, Head ovate globose brown, Stipes yellow becoming blackish

16357 Fleshy soft, Head clavate pale tan-color confluent with the stipes

16358 Corky simple and branch. compressed at first whitish powdery afterwards naked and black, Stipes villous \& Smaller simple, Head distinct cylindrical conical acuminate

16359 Stipitate turbin. Disk truncate white dotted with black blackish externally

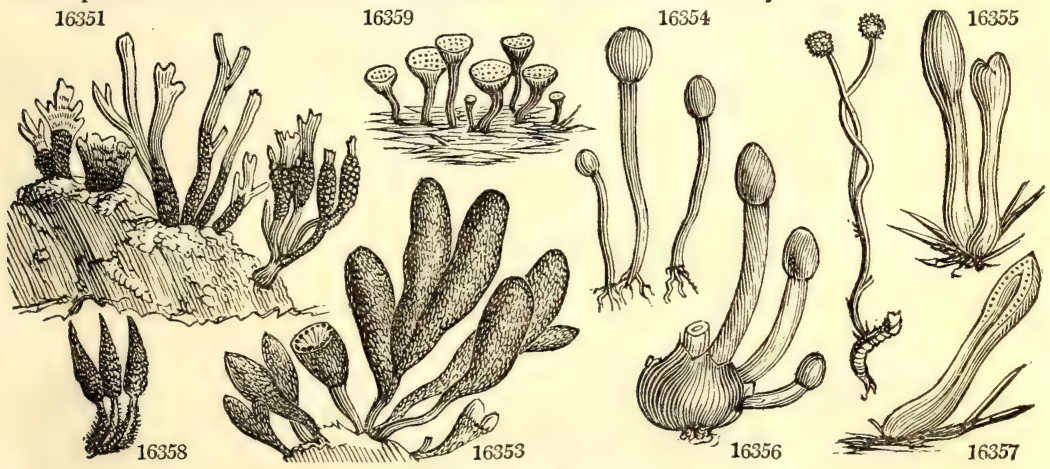

and Miscellaneous Particulars.

roe of a fish in appearance, and to poppy-seed in size. The color is a tawny yellow. Each individual is globular, attached at the bottom by capillary roots, and crowned by a small papillary tubercle of a more orange or golden hue than the rest.

2418. Pilobolus. Named from $\pi i \lambda \circ$, a cap, and $\beta \propto \lambda \lambda \omega$. A very natural genus, consisting of gregarious little fungi, of a very fugacious nature, inhabiting dung, appearing in the summer and autumn; when full grown they resemble species of Mucor, but in a younger state they are more evidently interwoven, and resemble Sphæria or Sclerotium.

2419. Spharobolus. From $\sigma \phi \alpha \iota \alpha$, a globe, and $\beta \propto \lambda \lambda \omega$. The peridium is double, membranous inside, at length becoming elastically inverted, and emitting a globose solid sporangium, filled with sporidia clustered in the centre. Epiphytous persistent plants, generally appearing in the autumn. S. stellatus is found in various parts of Europe in autumn upon rotten wcod or branches of trees, heaps of sawdust, or in the tan-pits of hothouses. In an early state each plant consists of a pale yellow globe larger than a mustard seed. Several such grow crowded in patches, bound down as it were by a fine cottony web. After a while each plant bursts into several starry rays, and by a momentary explosion, frojects to the distance of six or eight inches a whitish globular starry rays, and by a momentary explosion, $\mathrm{I}$ rojects to the distance of six or eight inches a whitish globular
mass of powdery seeds from its internal cavity. Sometimes this ball of seeds remains sticking to the points of the rays. When fallen to a distance, the skin of this ball is found empty, the seeds having flown out, in its passage, through a hole in its base. (Smith.)

2420. Xylaria. From zonov, wood, in allusion to their station, or to their woody and durable texture. Once included in Sphæria. 
2421. STROMATOSPHA'RIA. Grev. Stromatospharia. Sp. 24-58. 16360 concéntrica Grev. concentric suberose 1 aut. Bl ash trunks

16362 fúsca Grev. fuscous suberose 0 all sea. Br dead hazel

16364 striæformis Grev. striated gregarious 0 aut. Bl herbaceous stems

16365 múlticaps Grev. many-head. masses $\mathbf{I}^{\frac{1}{2}}$ aut. Bl dead branches

16366 fragifórmisGrev. Strawberry-like clustered to aut. R. Br dead beeches
16361 deústa Grcv. scorched fleshy z all sea. Brsh rotten stump

16363 unduláta Grev. wavy broad $\overline{7}^{\frac{1}{2}}$ aut. Bl decayed branches

Sow. t. 160. fraxinea

Sow, t. 338. maxima

Grev. crypt. 223

Sower. t. 394. f. 8

Grev. crypt. 136

dead hazel, \&c. Grev. crypt. 223

dead hazel, \&c. Sow, t 137

wood and deadtrees Sow.t.373.f.9. fuliginosa

16369 láta Grev.

broad spreading 0 all sea. Bl

punctiform 0 all sea. Gr.Bl elm leaves

disk-shaped gregarious 0 all sea. D.Br dead hazel, \&c.

Sower. t. 374, f. 3

Sow. t. 216. depressa

Sow. t. $372, \mathbf{f}, 10$

Grev. crypt. 114

Sow. t. 374. f. 4

Sow. t. 374. f. 1

Grev. crypt. 110
16378 rubiginósa Grev. purplish crusts 0 all sea. $\mathrm{Br}$ dead trunks snow-white gregarious 0 all sea. W

Plum

Oak

16382 ferrugímea Grev. rusty

16383 corniculáta Grev. horned

2422. CUCUREITA'RIA. Gray. Cucurbitaria. Sp. 5-13.

16384 Berbéridis Grev Berberry crowded $\tau^{\frac{1}{2}}$ all sea. Bl dead herbbranches Grev, crypt $\mathrm{Al}$

16385 pinástri Grev. Pinaster gregarious $0^{T^{2}}$ all sea.

16386 coccínea Grev.

16387 decolórans Grev.

16388 elongáta Grev. $\begin{array}{lllll}\text { scarlet } & \text { variable } & 0 & \text { all sea. Sc } & \text { dead branches } \\ \text { discoloring } & \text { larger } & 0 & \text { all sea. Pa.R dead branches }\end{array}$

long black eracks 0 all sea. Blsh furze branches
Gr.cry.135. cinnabarina Grev, crypt. 195

2423. CRYPTOSPHE'RIA. Grev. CRYPTOSPHZRIA. Sp. 30-48.

16389 fagíne Grev. Beech-wood protruded 0 all sea. Bl dead beeches

16390 pulchélla Grev. pretty broad patc. 0 all sea. Bl dead birches

tiro-fronted dry spots 0 wi.spr. Bl

Grev, crypt. fl. $t .67$

So, t.373. 4. circumval. lata

16392 Gnómon Grev. Gnomon yellow spots 0 all sea. BI

16393 Lonicéræ Sonverby Woodbine longit.cracks 0 all sea. Bl

hazel leaves Sower. 373 . f. 6

honeysuc. branches Sower, t. 393. f. 6 dead nettle stems

16395 Héderæ Sowerby Ivy leaf innate 0 all sea. Wsh dry ivy leaves

Sower. t. 371. f. 5 dead ashes

Grev, crypt. 201

16396 millepunctáta Grev. punctulated punctiform 0 all sea. B

16397 subcónfluens Sower. subconfluent patches 0 spring Bl upon leaves 16398 Táxi Grev.

Sower. t. 370 , 7

Grev. crypt. il. t. 13

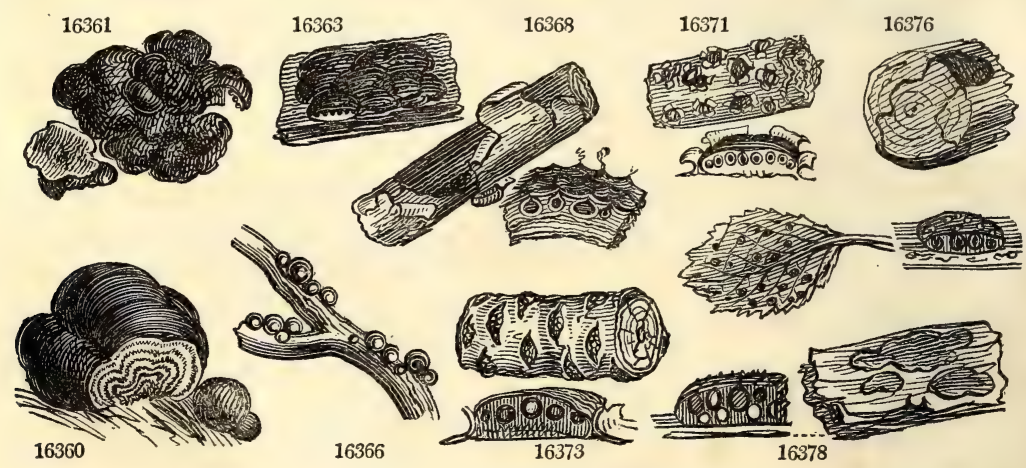

History, Use, Propagation, Culture,

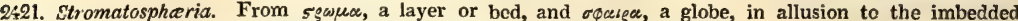
character of the species. Apparently well divided by Dr. Greville from Sphæria.

2422. Cucurbitaria. So named in reference to the form of the sporules, which resemble little flasks. Sphæria 
* Receptacle free, not bursting through bark.

16860 Large black somewhat hemispherical, Surface smooth, Orifices of the spherules scarcely at all ralsed within composed of regular concentric strata

16361 Large pale and carnose at length brownish-black and rigid spreading thick undulato-rugose: the surface dotted with raised points

16362 Brown hemispher. depress, somew. conflu. when crowd. interior of same col. Spher, very slightly promin. 16363 Black thickish undulato-rugose whitish within, Mouths of the spherules round and somewhat prominent 16364 Black gregarious forming limear or oblong striæ smooth, Spherules very minute without obvious mouths 16365 Black irregular mostly free but sometimes bursting through the bark spreading confluent thickish-green within, Mouths of the spherules obtuse granulated prominent

16366 Globose purplish-red shining black within, Spherules in circumference with more or less promin. orifices

\section{** Receptacle bursting through bark.}

a. Orifices of the spherules plane, or slightly prominent.

16367 Black plane spread transversely on branch, smooth: inside whitish, Mouths of spherules not prominent 16368 Black plane spreading longitudinally white within, Mouths of the spherules somewhat prominent conical 16369 Black plane widely sprearling somewhat rugose at first subdistinct at length confluent and united by a kind of irregular crust, Mouths of the spherules conical and angular

16370 Grey.-black scattered plano-conv. round. parasitic on elm leaves, Surface papill. with mouths of spherules 16371 Scattered distinct very gregarious round elevated plane dark-brown dotted with the orifices of the spherules, Orifices nearly plane

16372 Scatter. broadly thin, Perithecia immers. scatter. cover. with a dark membran. crust, Orifices burst. forth 16373 Scattered gregarious rather large elliptical rusty-brown smooth minutely pulverulent blackish and friable within, Moutlıs of the spherules quite concealed

16374 Short of a determinate figure emerging dark, Perithecia somewhat ovate, Orifices obtuse-unequal

16375 Rather small roundish elliptical dull-black bursting transversely through the bark depressed rugososulcate, Surface minutely rough with the mouths of the spherules

16376 Innate-immersed effused smooth black, Perithecia ovate immersed, Orifices prominent somew. depressed 16377 Gregar. distinct bursting through the bark which is marked with a narrow black ring, Disk small covered by an evanescent membr. ben. white pulverul. dott. with the black orifices of the immersed spherules

16378 Thickish purplish-brown black within covered with a min. pulverul. substance, Spher. conceal. Spor. oval

\section{b. Orifices of the spherules more or less spinous.}

16379 Scattered very gregarious somewhat conical roundish : the disk pulverulent white, Orifices of the spherules somewhat prominent and converging

16380 Deep black bursting transversely through the vark oblong elevated, Orifices of the spherules crowded level-topped acutely 4 -sided and grooved

16381 Black round much elevated very gregarious : the orifices thick irregular 4-sided

16382 Black gregarious sometimes subconfluent bursting transversely through the bark ferruginous within, Orifices of spherules erect straight cylindrical spinose

16383 Receptacle very small black, Spherules few crowded with thickish cylindrical elongated obtuse coarctate orifices umbilicate at their apex and piercing the bark

16384 Black ellipt-obl. burst. longitudin. through the bark, Spher. seat. on recept. crowd. rugose somew. tessellat.

16385 Clustered, Spherules globose dotted red at length black at first immersed in the receptacle, Tubes containing the sporules attenuated at each extremity

16386 Very gregarious, Spherules minute clustered scarlet oval irregular in size smooth : the mouth papilliform

16587 Dull pale-red scattered or crowded on the receptacle, Spherules globose tuberculated and rugose

16388 Black, Stroma very long, Perithecia at first immersed at length sessile crowded globose, Orifice papilliform with a circular depression around it

\section{* Spherules collected into circular clusters.}

16389 Black, Spherules few : the mouths elongated rough converging

16390 Black spherules aggregated forming a dense circle, Mouths filiform flexuose converging depressed

16391 Innate grow. on both sides, Leaf arrayed in round spots flat black, Perith, convex promin. becom. bossed ** Spherules more or less scaltercd, or simply asgregated.

$$
\text { a. Spherulcs with an orifice. }
$$

16392 Spherules few aggregated globose black : the orifice suberect filiform shining style-like

16393 Gregar. burst. forth, Perithecia glob. nearly separate fine black becom. ragged and cup-shap. Orifice simp.
16394 Black shining very numerous ovate conical : the mouth short thick cylindrical piercing the epidermis like a black point, After the decay of the epidermis the spherules are naked

16395 Scattered, Perithecia prominent convex smooth black, Orifice open white

16396 Spherules black minute very numerous globose white within immersed in the substance of the bark: the mouth very short scarcely picrcing the epidermis which seems covered with imnumerable dots

16397 Upon leaves, Perithecia innate prominent punctiform globose black clustered in unequal spots

16398 Minute scattered, Spherules depressed : the mouth very short not exserted, Epidermis of the leaf convex and slightly ruptured, Sporules naked extremely minute

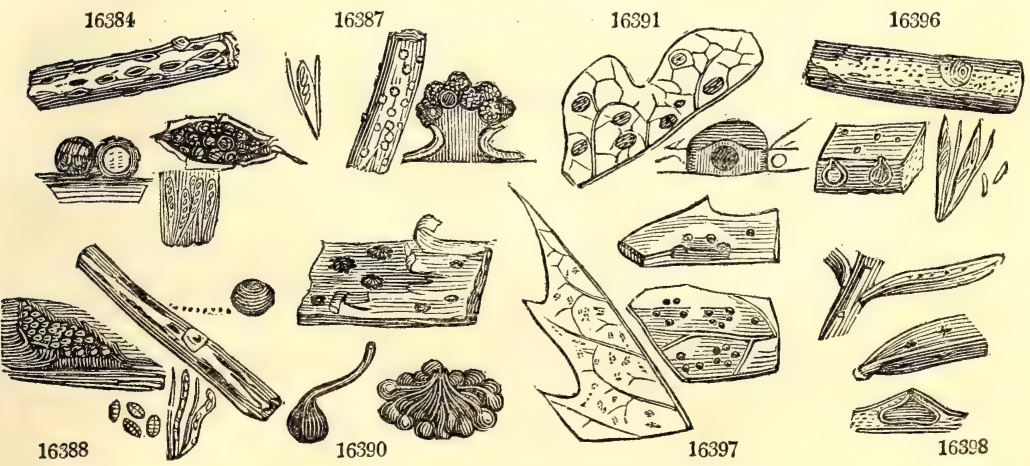

and Miscellaneous Particulars.

Cucurbitula of Tode, seems to have afforded the type of the genus, which contains most of the species constituting the seventh section of Spharia in Persoon's system.

2423. Cryptospharia. A genus formed by Dr. Greville, to include those plants formerly refered to Spharia, 
16399 strobilina Grev. 16400 Laúri Grev. 16401 dúplex Sowerby 16402 bítrons Grev.

16403 aurántia Grev.
Pine-cone Laurel scattered 0 all sea. Blsh variable 0 all sea. BI two-fronted scattered 0 all sea. Bl

orange

succulent 0 all sea. Ysh

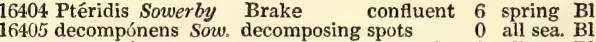

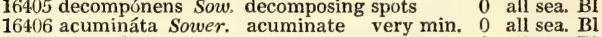

16407 curviróstra Sower. curv.-beaked very min. 0 all sea. Bl

16408 Tamaríscinis Grev. Tamarisk patches 0 all sea. Bl

16409 semi-immérsaGrev. $\frac{1}{2}$-immersed shining 0 all sea. Bl

16410 herbárum Grev. Herbaceous punctif. 0 winter Bl

16411 nebulósa Grev. cloudy spots 0 winter B1 dead fir cones

dead laurel leaves Sower, $t$. 371 , f 4

Spargan. stems, \&c. Sower. t. 375, f. 4 dead holly leaves Sower. t. 316

dead fungi

Grev. crypt. 78

$P$ aquilina stems Sower, $t$. 394. f. 10 dead poplar branc. Sower. t. 217

thistle stems Sower. t. 394, f. 3

Umbellifer. stems

dead Tam. german. Grev, crypt. fl. t. 45

dead honeysuckle

dead herbac. plants

dead herbac. plants

16412 capilláta Grev. hairy very min. $\quad 0$ all sea. Br.Bl dead lvs,of Holcus mollis Grev. crypt.f.t.69

16413 Egopódii Grev. $\quad$ Egopodium spots $\quad 0$ all sea. Blsh living lvs. of Æggopod. Podagraria 16414 punctifórmis Grev. dot-like white spots 0 all sea. Bl dead oak and other leaves

16415 microscópica Grev. microscopic cld.-lik. sp. 0 all sea. Bl dead Port. laurei lvs.

16416 glauco-punctátaGr. glauc. dotted cld.-lik. sp. 0 all sea. B.Bl dead Rusc. aculeat. Ivs.

16417 arundinácea Sow. Reed minute 0 spring Bl reed stems $\quad$ Sower. t. 336

16418 arbutícola Sower. arbutus polymorp. 0 spring Bl dead Uva ursi lvs. Sower. t.370. f. 6

2424. Heterosphéria. Grev. Heterospheria. Sp. 1. 16419 patélla Grev. collapsed shining 0 all sea. Bl dead herbac. stalks Grev. crypt. 103

2425. SPHÆ'RIA. Haller. SPHERIA. Sp. 38-63.

. 0 all sea. Bi $38-63$.

16421 Peziza Pers.

16422 Dolíolum Pers. tub contiguous 0 all sea. Bl dead herbac. stalks

web-like pretty 0 aut. $\mathbf{R}$

aut.wi. Y on rotten wood, \&c. Grev. crypt. 215

0 aut. Blsh upon trees Bolton, $t, 180$

16426 tuberculósa Bolton warted superficial 0 all sea. Fusc. bark of trees Bolton, t. 12S. f. 1

16427 sérpens Pers. $\quad$ creeping broad pat. 0 spr.wi. Bl dead wood Sow.t.372.f.11.crustad

16428 réptans Sowerby branched superficial 0 aut. Dark dead wood $\quad$ Sower. t. 395. f. 1

16429 vis Sowerby smooth immersed 0 aut. Bl dead wood

16430 nummularia Fries moneywort orbicular 0 aut.wi. Dark dead wood

16431 enteroleúca Fries white-heart. crustace. 0 all sea. Wsh drybranches

Sower. t. 395 , f. 1
Sower, t. 394 . f. 5

Sower. t. 373. diffusa

Sow. t.120. ? tentaculata

16433 oblónga Sowerby oblong in circles 0 all sea Bl birch bark

$\mathbf{1 6 4 3 4}$ convérgens Sover. converging patches 0 all sea. Bl smooth bark

16435 Nidula Sowerby bird's nest spots 0 aut. Dark bean roots 16436 hydróphora Sower. pitcher small 0 aut.sp. Or.R soft beech wood
S. Peziza Tode

16437 sanguínea Sibth. blood-red minute 0 spring Crim. naked wood

16428 papillósa Sozverby pimpled gregarious 0 all sea. Dark rotten wood

(ung

16440 episphæ'ria Tode parasitic

Sower. t. 218. Saturnus

Sower. t. 374. f. 7

Sower. t. 374 . f. 6

Sower. t. 394. f. 2

Sower. t. 23

Grev. crypt. 175

Sower. t. 236

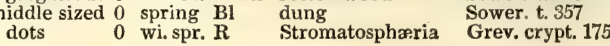

16441 byssiséda Pers. byssoid spread. wide 0 all sea. Br.Bl dead branches

16442 hirsúta Pers. hairy shining 0 all sea. Bl dead branches

16443 pilósa Pers. pilose shining 0 all sea. Br dead branches

16444 cálva Pers. bald punctif. 0 all sea. BI dry rotten branches

16445 alirea Grev. golden crowded 0 all sea. Or decay. large fungi Grev. crypt. t. 47

16446 rosélla $A l b$. rosy spots 0 aut. $R$ red

16400

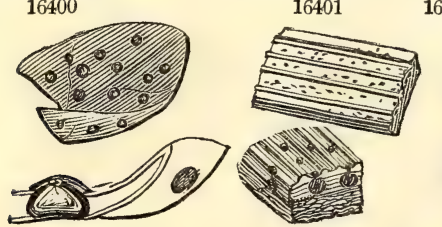

0 aut.

Grev. crypt. 138 16403

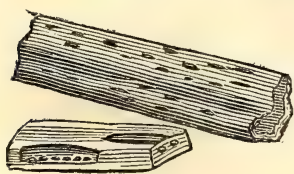

16404

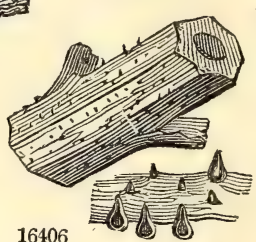

16406
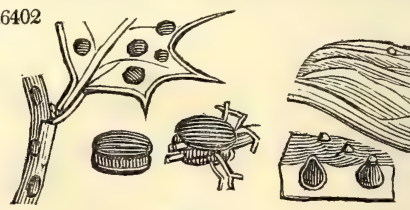

History, Use, Propagation, Culture,

which are destitute of a receptacle and remain concealed ( $x \rho$ rros, hidden, whence the name) beneath the epidermis of vegetables, which is only perforated by their mouths. They are further characterized by having their spherules not enclosed in filiform tubes as in true Sphæria. 
16399 Black roundish oblong scattered bursting through the epidermis, Orifice Irregular papillose [minute 16400 Scatter, rather min. plano-convex black. splitt. Epider, in centre and becom. umbilicat. Spor. naked very 16401 Scattered, Perithecia immersed globose black concealed, Orifices dilated naked hemispherical

16402 Scattered black shining plane : the margin slightly raised; the epidermis united with the plant and bursting at the centre into 3-5 acute segments, Sporules naked oblong in 3-5 distinct masses

16403 Gregarious often crowded, Spherules yellowish globose somewhat fleshy, Orifices short cylindrical surrounded by an orange web

16404. Somew. innate parallel conflu. shin. black burst. with paral. slits, Thallus black, Perith in rows connate 16405 Scattered, Perithecia imimersed globose, Orifices min. convex peeping out of a black spot becom. bossed 16406 Gregarious, Perithecia somewhat immersed ovate black, Orifice bursting conical acute

16407 Gregarious, Perithecia covered ovate black, Orifices bursting equal smooth longer

16408 Scattered under the epidermis which is very convex and ruptured in the centre, Mouth very short obtuse not exserted, Sporules oval in filiform tubes

16409 Scattered globose with a very short rounded umbilicated mouth : at first the mouth only visible at length the spherule itself semi-exserted falling out in decay and leaving a cavity

16410 Spherules minute scattered very numerous black round depress. Orifice papilliform piercing the epidermis like minute dots at length naked when it decays

16411 Spherules excessively minute scattered forming dark greyish cloud-like longitudinal spots on the smooth stalks of plants : the orifice somewhat acute penetrating the epidermis

b. Spherules without an evident orifice.

16412 Parasitic on the leaves of dead grasses scattered brown black white within flat hemispherical : the apex furnished with a tuft of black rigid diverging hairs

16413 Scattered or in small groups minute blackish roundish producing pale spots on the leaf

16414 Scattered very gregarious fructiform somewhat shining rarely dehiscent

16415 Excessively minute very gregarious so as to form dark cloud-like irregular spots on the leaf

16416 Spherules very numerous punctiform glaucous or blueish-black rendering the leaf pale

16417 Bursting forth lin. black with hardly any thallus, Perithecia in 1 or 2 rows somew. connate black inside

16418 Gregar. conflu. cover. with a blackened epider. Perith. deform. black : disk finally burst. forth and opaque

16419 Forming nearly equidistant spots upon the stems of large dead herbaceous plants, Very common

\section{* Spherules with an orifice, not hairy.}

16420 Black globose nearly smooth crowded: the orifice minute slightly papilliform

16421 Fine red min. smooth gregar. glob. with a very min. papill. orifice, Spher. at length collapsed and concave

16422 Black scattered gregarious roundish ovate acute shining : the mouth papilliform

16423 Subgregar. or scattered sessile orange-colored smooth glob. destitute of orifice whit. and filament. at base 16124 Perithecia glob. subimmers. Orifices promin. convex furnish. with an effused filament. strat. of a yell. color 16425 Globose deformed brownish-black banded within with concentric layers, Perithecia oblong immersed

16426 Convex pulvinate fuscous whole-colored inside, Perithecia globose, Orifices bossed

$16+27$ Effused thin flattened black, Perithecia subglobose prominent pimpled

16428 Dark, Layer diffused branched, Perithecia oblong smooth pimpled

16429 Elliptical smooth black white inside, Perithecia immersed ovate without orifice

16430 Of a regular figure very flat contigu. dark extern. and internally, Perith. immers, ov. Orif. gloo. promin. 16431 Orbic. conv. separ. Layer white, Perithecia min. Orifices numer. disengaged glob. and rostell. somew. rug. 16432 Pustular, Layer adhering to the bark and emerging, Disk palish, Orifices exserted oval and rostellate 16433 Perithecia subovate, Orifices long thickened at end united in an opaque disk bursting transversely

16434 Minute circinate, Perithecia about 6 ovate and converging, Orifices round somewhat tapering emerging 16435 Cæspitose growing to the surface, Perithecia stalked ovate acute smooth dark

16436 Gregarious soft, Perithecia globose smooth somew. pimpled orange-red becoming concave by collapsion

16437 Scattered soft very small, Perithecia ovate smooth pimpled crimson 16438 Dark, Perithecia thin globose smooth, Orifice papillæform

16439 Black shining, Perithecia globose rigid smooth, Orifice papillæform

16440 Sess. min. soft aggregated or scattered smooth blood-red, Perithecia subglob. collapsıng, Orifice papilliform

** Spherules with an orifice, hairy.

16441 Rather large brownish-black shining globose with a papilliform orifice arising from a dense brown filamentous stratum which sometimes partly envelopes the sperules

16442 Gregarious somewhat clustered quite black, Spherules roundish ovate somewhat tuberculate with short rigid scattered hairs, Orifice obtuse

16443 Spherules minute crowded roundish : when young appearing like one mass of diverging brown hairs at length almost naked towards the apex and black, Orifice minute papilliform

16444. Black gregar. hemispher. minutely granulat. : the apex naked somew. shin. ; the base hairy, Orif. papill.

1644.5 Gregar.very crowd. ov. somew. acum. orange, Orifice indist. but the spherules escape in a pulverul. form 16446 Gregarious rose-colored, Spherules ovato-globose subacute or papillose placed on a paler colored web
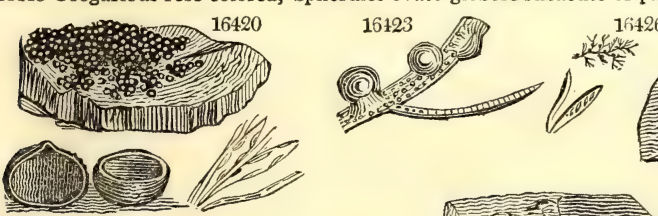

$$
16426
$$

16436

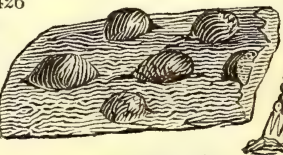

60436
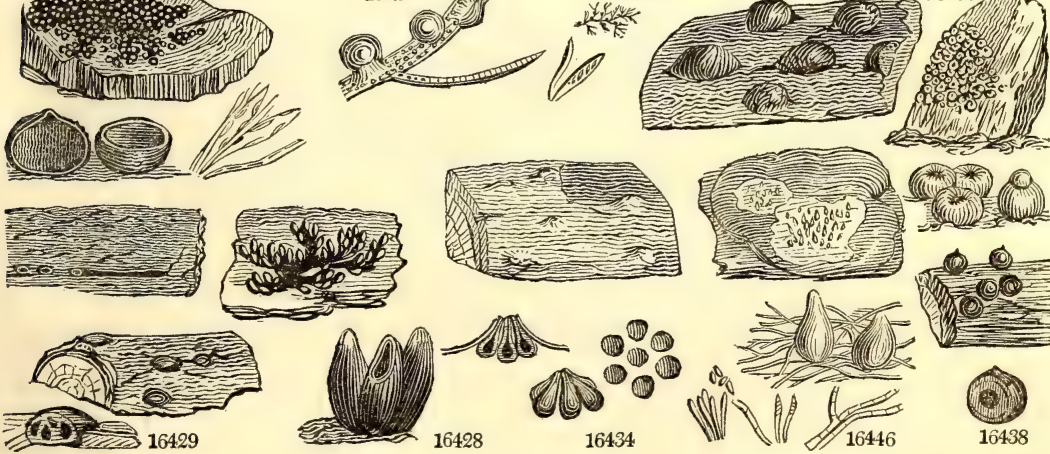

16434

16438

and Miscellaneous Particulars.

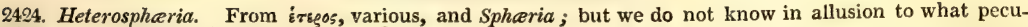
liarity. A small black dot-like plant.

2425. Spharia. In allusion to the spherical figure of the species, which are exceedingly numerous and diffi- 
16447 bifrormis Pers. e terréstris Sow.

16448 morifórmis Pers. 16449 lignária Grev. $16+50$ rugósa Grev. 16451 Pisi Sowerby

16452 púlvis-pýrius Pers. Pea

(6) small black

16454 Vaccínii Sower.

16455 myriocárpa Fries

16456 verrucósa Grev.

16457 hirsúta Sowerby

2426. LO'PHIUM. Fries.

16458 elátum Gren.

16459 mytilinum $F r$.

Mulberry LOPHIUM. $\begin{array}{lllll}\text { two-formed scattered } & 0 & \text { spring } & \text { Bl } \\ \text { terrestrial } & \begin{array}{l}\text { Blustered } \\ \text { clusing }\end{array} & \text { Bl }\end{array}$ black wood punctiform 0 all sea. Bl rugose tessellated 0 all sea. $\mathrm{Bl}$ scattered 0 wi. spr. BI seed-like 0 all sea $B 1$ $\begin{array}{llll}\text { irregular } & \text { pulvinate } & 0 & \text { aut. Prsh } \\ \text { Cranberry } & \text { patches } & 0 & \text { wi.spr. Dark }\end{array}$ Cranberry patches 0 wi.spr. $\mathrm{Bl}$ warty areolated $\frac{2}{4}$ aut.wi. Bl hirsute clustered 0 all sea. BI Sp. $2-3$. elongated scattered
muscle-shap. crustaceous 0 all sea. $\mathrm{Bl}$ rotten wood gravelly soil

dead wood dead wood dead Polypor Grev. crypt. 8\%

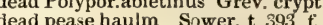
dead dry wood Grev crypt 150 dead wood Sower. t. 374. f. liveVacc.Vitis idæa Sower. t. 373 f 1 dead wood Grev. crypt. 159 cup of fungi Grev. crypt. 39 plaster pine bark pine bark
Sower. t. 386. f. 3

Grev. crypt. 177

Pers. syn. t. 2. f. 14 Sower, t. 373. f. 7

Grev, crypt. 177

Division II. Cytisporei.

2427. SPHÆRON Æ'MA. Fries. Spherontma. Sp. $1-15$.

16460 subulátum Fries awl-shaped spiculiform $\frac{1}{12}$ aut. Ciner. on Agarics $\quad$ Grev. crypt. 189

2428. SEPTA'RIA. Fries. Septaria.

2429. CYTISPO'RA. Ehrenb. CytisPora. Sp.2-18. : Spharia. Sowerby

16462 Chrysospérma $F r$, yellow-seed, spots 0 all sea. Blsh poplar bark

Grev. crypt. 112

$16+63$ Rosărum Grev. Rose twig pustular 0 aut. Pallid dead rosebranches Grev. crypt. 20

2430. PHO'M A. Fr

16464 saligna $\mathrm{Fr}$.

Phомa. Sp.2-5. Spharia. Sowerby

16165 Pópuli $\mathrm{Fr}$ poplar leaf pimpled 0 wi. spr. Test. dead poplar leaves Sower. $\mathrm{t}$. $374, \mathrm{f}$.

Division III. Phacidiacei.

2431. DOTHIDE'A. Fr. Dothidea, Sp. 7-54. Spharia. Sowerby

16466 typhina $F$ r. Bull-rush Sphceria spiculifera Sower. 270

16467 Ul'mi Fr.

Elm.

16468 Robertiána Fr. shining Cryptospheria nitidix Grev.

16169 al'nea Pers. alder Xyloma alneum Pers.

16470 rúbra $\mathrm{Fr}$. alder

16471 fúlva $F$ r red tawny

2432. RHYTIS'MA. Fries. RhYTISMa. Sp. $1-22$.

16473 corrugátum $\mathrm{Fr}$. wrinkled gregarious 0 all sea. $\quad$ crusts of lichens E.b.14.64.L.graniformis 2433. PHaCi'DiUm. Fries. Phacidium. Sp. 2-20.

16474 coronátum Grev. crowned black spot 0 all sea. Bl dead oak leaves Grev. crypt.f. t. 52 16475 dentátum $\mathrm{Schm}$. toothed white spot 0 all sea. Bl oak leaves

\section{HYSTE'RIUM. Tode. Hysterium. Sp. 12-52.}

16476 lineáre Fries linear lines 0 all sea. Bl dead wood

16477 maculáre Fries pale spot blotches 0 aut. Bl dead leaves

Grev, crypt. 200

Grev. crypt. 167 Grev. crypt. 129

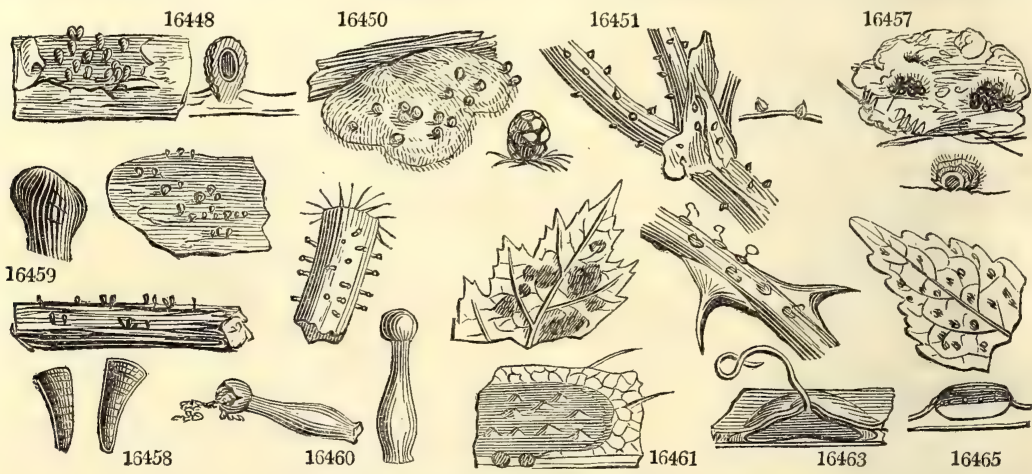

History, Use, Propagation, Culture,

cult of determination. Most of them are highly curious objects when minutely examined, and some even beautiful. Sphæria militaris is a fine species, about an inch in height. the head being ovate, of a beautiful scarlet, granulated like orange-peel.

2426. Lophium. So named from noфos, a little elevation. Differs from Sphæria in being completely evolved, dehiscent, compressed, without a veil, and having a nucleus crumbling to pawder. The plants are very similar to the valves of a bivalved shell.

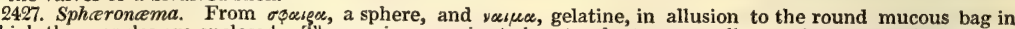
which the sporules are enclosed. The species are minute innate plants, generally growing on wood, very permanent, and often cohering by their base.

2428. Septaria. Growing upon dead leaves, in the form of clouds or spots. Named upon account of the septa of the sporidia.

2429. Cytispora. From zurıs, a little chest, and $\sigma \pi \omega \rho \alpha$, a sporule. The species are very common, growing upon plants, immersed, soft, bearing fruit during damp weather, and even by watering only, within doors. The most essential character consists not in the cirrhi, common to many fungi, but in the deformed cellular perithecia, by which it may be easily known in any state. 
16447 Perithecia somew. ov. rather wart. black cover. with strigose hairs of same col. Orifice rather lengthened $\beta$ Perithecia numerous seated on a little strigose villous crustaceous stalk

$$
\text { *** Spherules without an evident orifice. }
$$

16448 Gregarious obovate deep-black smooth tuberculated

16449 Spher, minute solitary or somew. cluster. black ovate setoso-rugose mouthless, Spor. ovate in cylindr. tubes 16450 Minute black scattered globose very rugose and tuberculated parasitic on the pileus of Polyporus abietinus 16451 Scatter. Perith. ellipt. rounded depress. plaited lengthwise opaque black, Orifice hidden somew. compress. 16452 Spher. black min. very numer. crowded roundish somew. tuberculated and often with a transverse furrow 16453 Emerging prominent irregular brownish-black rufous brown internally, Oritices concealed

16454 Tufted innate on the surface, Perithecia subglobose solid without orifice at first villous afterwards naked 16455 Naked more or less crowd, ovate-glob. black shining, Perith. very small smooth at first without an orifice 16456 Minute black scattered globose very warty, Parasitic on the cap of Polyporus abietinus

$\mathbf{1 6 4 5 7}$ Perithecia subglobose ovate tuberculate black covered with scattered hairs of the same color

16458 Stipit. compress. black transverse. striat. dilat. gradual. from stipes into an elongat. wedge-shap. peritheci. 16459 Somewhat stalked dilated upwards striated across shining

Division II. Cytistorei.

16460 Perithecia conico-subulate acute yellowish somewhat pellucid, Globule very pale

16461 Spherules aggregated, Sporidia 3 or 4 times divided, Cirrhi often becoming effused

16462 Cells impressed on the receptacle, Disk emerging blackish, Cirrhi yellow [with a cottony margin 16463 Sporulifer. tendr. white simp. Spher. waved: when divid. horizontal. manifest under epider. Orifice black.

16464 One or many-celled convex brownish-black somewhat umbonate in the centre 16465 Generally many-celled roundish fiat brownish-testaceous, Orifices obsolete

Division III. Phacidiacei.

16466 Long, surrounding the culms whitish becoming dark-yellow at length rendered granular by the orifices

16467 Epiphyll, round. conflu. convex cinereous-black : internally black with white cells, Orifices like granulat. 16468 Epiphyllous subgregarious hemispherical smooth shining very black white within

16469 On both sides of the leaf regularly scattered roundish black shining collapsed rugose and plaited

16470 Plane orange-red, Sporules unequal globose

16471 Plane pale fulvous

16172 Epiphyllous somewhat angular and irregular in form subconfluent tuberculose black shining black within : the cellules white

16473 Minute innate on the surface rugose plaited opening with many flexuose cracks

16474 Orbicul. subhemispher. depressed black dehiscent in numer. acute segm. Disk pale greenish or yellowish 16475 Four-sided small black or whitish spots on the leaf splitting in 4-5 acute segments, Disk dingy

16476 Subimmersed crowded parallel linear black, Lips of the orifice tumid smooth, Disk linear 16477 Collected on pale defined spots roundish elliptical black : the margin depressed and paler

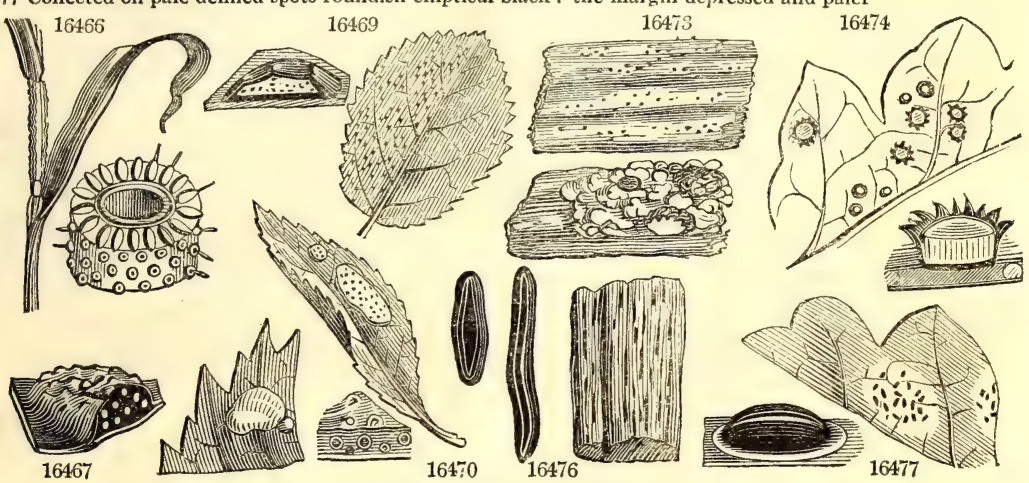

and Miscellaneous Particulars.

2430. Phoma. Said by its author to be named in allusion to the pustular appearance of the plants, which are of a brownish color, and grow within the substance of leaves.

2431, Dothidea. A genus which has been named from jontov, a tubercle, and $\varepsilon i \delta \delta_{5}$, similar, and appears to be very distinct. The species are numerous, growing upon plants; many of them are innate and dark, a few colored.

2432. Rhytisma. From puzis, a wrinkle. R. corrugatum, the Lichen graniformis of English botany, is 3 gregarious, subcorneous, shining flattish plant, referred to Lichens by Acharius, but considered by Fries and Ehrenberg to belong to Fungi. It is common upon the crusts of Lichens and upon dry wood.

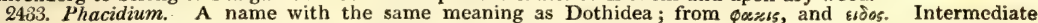
between Rhytisma and Hysterium, but differing from both in the manner of dehiscence. The species are somewhat innate, epiphytous, tolerably permanent, blackish, and with a kernel which becomes softish.

2434. Hysterium. From isegnois, penury, in allusion, perhaps, to the diseased and squalid appearance which trees attacked by this fungus assume. Minute plants, resembling Opegrapha, and like that genus, found occupying the bark of trees; but destitute of a crust. 


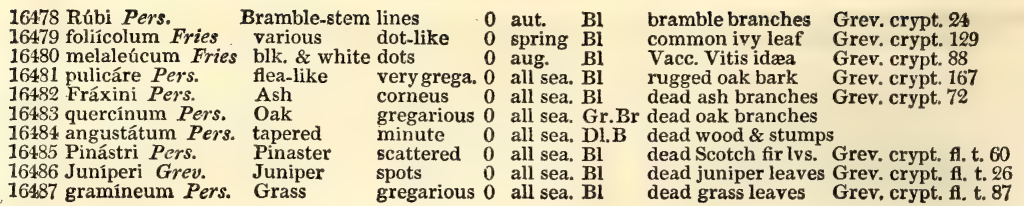

Division IV. Xylomacei.

2435. ACTINOTHY'RIUM. Kunz. ACtinothyium. Sp. 1. 16488 gráminis Kunz. grass gregarious 0 spring $\mathrm{Bl}$

culms of grasses Grev, crypt. 218

2436. LEPTOSTRO'MA. Fr. LePtostroma. $\quad S p .1$.

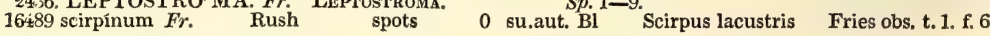
2437. XYLO'MA. Pers. XÝoma. Sp. 8-14. 16490 acerinum Pers. Maple broad spots 0 all sea. Bl living sycamore leaves

16491 salicínum Pers. Willow $\quad$ solid spots 0 all sea. Bl living Sal.capræa lvs. Grev. crypt. 118 16492 salígnum Pers. Sallow yell. spots 0 all sea. Br decaying Sal.capræa lvs. Grev. crypt.118 $16+93$ populínum Pers. Poplar small spots 0 all sea. Brsh aspen leaves

16494 Geránii Grev. Geranium crowded 0 all sea. Dl,Bl living Geran.sylv.lvs.

16495 fagíneum Pers. Beech very min. 0 all sea. Bl dead beech leaves

16496 concávum Grev. concave scatt. spots 0 all sea. Bl dead holly leaves Sow. t.317. Sphcria

$16 \pm 97$ pezizoídeum Pers. Peziza-like punctiform0 all sea. Bl dead oak leaves So.t.118. Pez. comitialis

2438. LASIOBO'TRYS. Kunze. LASIOBotrys. $\quad S p .1-?$.

16498 Lonicéræ Kunze Woodbine spots 0 sum. $\quad$ Bl ${ }^{2}$ honeysuckle leaves Grev. crypt. 191

2439. AsterómA. Dec. Asteroma. Sp. 2-?

$16499 \mathrm{Ul} / \mathrm{mi}$ Grev. Elm pale spots 0 all sea. Bl living elm leaves

16500 Alchemílla Grev. Lady's Mantle pale spots 0 all sea. Bl living Alchemilla lvs.

\section{Class III. Trichospermi. - Division I. Lycoperdinei.}

2440. ONYGE'NA. Pers. OnYGena.

2441. TUlo'stoma. Pers. Tulostoma. Sp. 1-3.

16502 brumále Pers. winter subsolitary 1 au.oct. W.Br pastures

decaying hoofs, and Willd. fl. berol. f. 20 similar substance

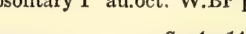

16503 verrucósum Grev. warty $\begin{array}{r}\text { handsome } 5 \text { aut. } \\ \text { Y } . \text { Y. } \mathrm{Br} \text { plantations }\end{array}$

Bulliard, t. 471. f. 2

16504 cépa Grev. solid surf.variab.2 aut. Y.Br plantations

Grev. crypt. fi. t. 48 Tuber solidum With.

16505 citrinum Pers. Iemon-color, tessellated 2 aut. $\mathrm{Pa}$. about oak roots 16506 spadíceum Pers. brown tessellated 1 sum. Pa.Br beech trunks

Grev. crypt. fl. t. 60

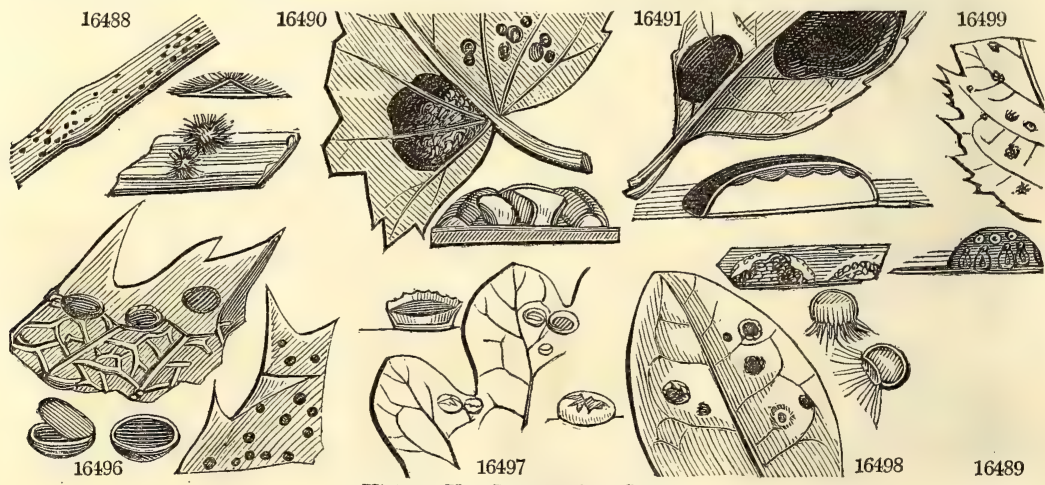

History, Use, Propagation, Culture,

2435. Actinothyrium. So called from $\alpha x \tau i v$, a ray, and gveow, to enclose, in allusion to the radiated integument of the sporidia. The only known species is innate, growing upon plants, orbicular, almost black, and appearing in the early part of the year.

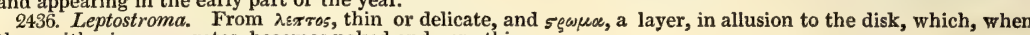
the perithecium separates, becomes naked and very thin

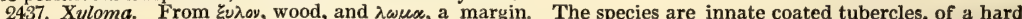
vesicular substance, but which does not produce fructification. One of the most common kinds, X. acerinum, has a ragged border.

2438. Lasiobotrys. From $\lambda \alpha \sigma i o s$, wool, and ßorevs, a bunch. This plant originates beneath the epidermis of the leaf, during its green and living state. When mature, it is of a very black color, and regular circular form, from one to two lines in breadth, very slightly convex, the surface uniformly granulated, and the whole generally situated on a paler or colorless portion of the leaf. On the bursting or laceration of the epidermis of the leaf, which takes place in the centre, our plant is foumd to consist of a multitude of distinct perithecia of a roundish form, closely arranged side by side destitute of orifice, and the summits of which produce a granulated appearance to the naked eye or a small magnifier. These perithecia are fixed to the leaf by a number of short filaments radiating from their base, and are not to be detached without some 
16478 Ellipt.or obl. atten. each end black somew. shin. obscure. striat. Sum. of sporulifer. cells obtuse. club-shap. 16479 Innate scattered elliptical obtuse rather trmid smooth naked black with a longitudinal depression 16480 Minute black irregularly gregarious oval or roundish convex, Sporuliferous tubes club-shaped 16481 Gregarious black oblong or roundish-elliptical obtuse somewhat striate

16482 Convex tumid oblong-elliptical very black disposed in a subconcentric manner, Sporules large obl. yellow 16483 Bursting throagh the bark oblong elliptical flexuose somewhat ventricose greyish-brown

16484 Gregarious linear narrow parallel smooth of dull black

16485 Minute oval elliptical very black disposed in a subconcentric manner, Sporules large oblong yellow 16486 Very min. oval shin. somew. plane growing longitudinally on leaf, Sporulifer. tubes clavate acum. at apex 16487 Very minute linear elliptical black mostly on the ribs of the leaf or culm

Division IV. Xylomacei.

16488 Scattered or gregarious orbicular $\frac{1}{3}$ to $\frac{1}{6}$ line broad very dark a little ribbed and elevated in the centre

16489 Orbicular opaque bossed in the centre at length entirely separating, Disk whitish

16490 Black spreading in large irregular spots which are either uniform or composed of somewhat distinct dots dehiscence irregular and rugose

16491 Large irregular very thick black white within

16492 Gregarious sometimes crowded roundish slightly convex brown at length blackish

16493 Gregarious rarely scattered over the whole surface flattish irregular smooth dull-brown

16494 Scattered black unequal in size plane : the surface rugose and somewhat papillose in the centre

$16+95$ Minute crowded often in circular groups round black shining plane rugose

16496 Minute roundish regularly scattered black shining smooth : the upper half separating

16497 Clustered orbicular black becoming open, Margin erect somewhat crenate, Disk pale

16498 Perithecia even much crowded black : the radiating fibres simple

16499 Filam. black radiat. subdichotom. at length covered with confluent rugoso-plicate shining black tubercles 16500 Filam. very min. extremely fine branch. at length subdist. black, Tubercles producing a pale spot on leaf

Class III. Trichospermi. - Division I. Lycoperdinei.

16501 Stipes short somewhat fibrous, Peridium scabrous always closed, Sporules ovate

16502 Stipes smoothish, Peridium globose, Orifice flat

16503 Large gregarious subglobose yellowish-brown, Scales small numerous, Stipes subelongated incrassated below lacunose and variously divided at the root

16504 Globose subdepressed very firm smooth or warty sess. or with a very short thick stipes, Root scarcely any

16505 Middle-sized roundish long-rooted pale lemon-color obsoletely scaly, Scales thickish

16506 Gregarious smaller somewhat spotted smooth brown, Root hard fibrous
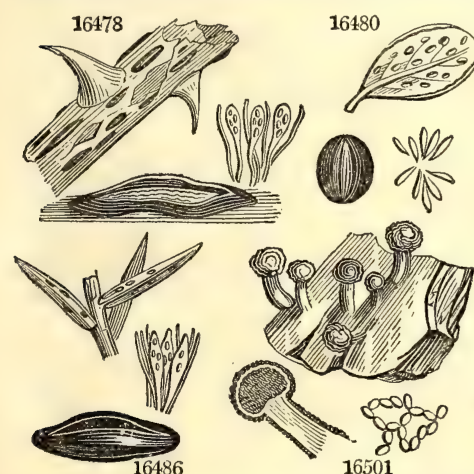

16486

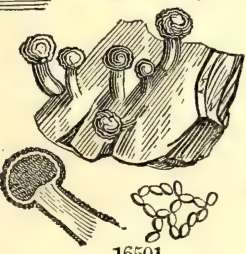

16501

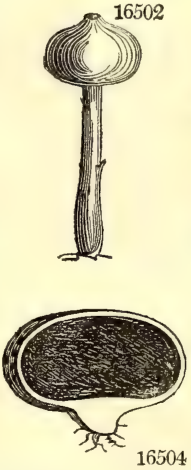

16504
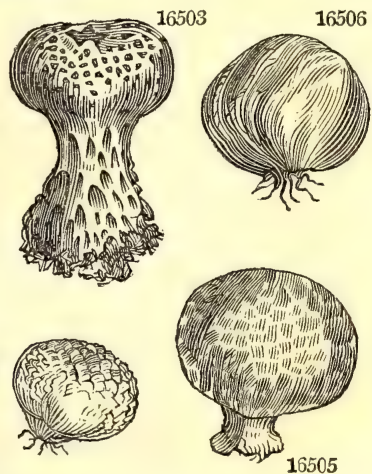

and Miscellaneous Particulars.

force. Their surface is smooth black. Within they are replete with a somewhat gelatinous granulose mass, containing subglobose sporidia. The above is a description of the usual appearance of this plant.

A variety, however, occurs in the form of a ring or annulus, the centre being unoccupied. Sometimes the perithecia are scattered in irregular groups, a few together, and may even occur solitary.

2439. Asteroma. So named by Decandolle; but we know not with what meaning. Many of the substances referred to this genus are believed to be merely young states of various kinds of Dothidea; some are the black limes by which certain Pyrenomycetes are bounced; others are merely darkened veins of leaves. To this the whole of Actinonema of Persoon, and several of his Capillarias are to be referred.

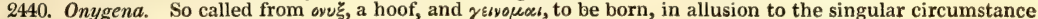
of the original and only species being always found on old horse-hoofs in shady woody places.

2441. Tulostoma. From $\tau v \lambda_{05}$, a wart, and $\sigma \tau o \mu \alpha$, the mouth, in reference to the nature of the orifice by which the seeds of this plant are dispersed. $T$. brumale is found on the mossy tops of walls about London in the winter and spring. It may easily be overlooked for some unexpanded Agaric.

2442. Scleroderma. So called from $\sigma x \lambda$ neos, hard, and $\delta$ s $\mu \alpha$, skin, in allusion to the hardness of the coat of the species. S. spadiceum is found on heaths in England, but is very rare; it is about the size of a chesnut, rather depressed at the top. 
2443. LYCOPER'DON. Mich. PuFf-Ball. Sp. 4-11.

16507 bovista Pers. large turbinate $\mathbf{s}$ aut. ${ }^{S p \text {. Wh }}$ pastures 16.508 praténse Pers. meadow $\frac{1}{3}$ subterra. 2 su.aut. W pastures 1650 excipulifórme Pers. chan.tobr. 2 aut. W pastures

Sower. t. 332. Proteus Bulliard, t. 435. f. 2 Bulliard, t. 450 . f. 2

16510 pyrifórme Pers. pear-shaped tufted $1 \frac{1}{2}$ su. aut. $\mathrm{Pa} . \mathrm{Br}$ abøut tree stumps Bulliard, t. $435 . \mathrm{f} .3$

2444. BOVIS'T A. Pers. Bovista.
16511 nigréscens Pers. blackish becom. blk. 2 su. aut. W W $2-4$. 16512 gigantéa Grev.

2445. GEAS'TrUM. Mich. Geastrum. Sp 4-5.

16513 colifórme Pers. purse-shap. subsolitary 2 aut. Brsh pastures 16514 Woodwárdi Pers. Woodward's subsolitary 1 aut. $\mathrm{D}$. Br dry banks 165015 quadrifidum Pers. quadrifid subsolitary 2 aut. Wsh pine woods 16516 stellátum Bolt. stellated subsolitary sp. aut. Br moors

Lycoperdon recolligens Woodw,

Division II. Trichocisti.

2446. CRATE'RIUM. Trent. Craterium. 16517 leucocéphalum Trent. white-head. pretty 16518 vulgáre Dittm. common pretty Cýathus minútus Sowerby

2447. STEMONI'TIS. Pers. Stemonitis, 16519 fasciculáta Pers. fascicled dense Trichia núda Sow. 2448. CRIBra'RIA. Schrad. Cribraria. Sp. 1-?. 16521 micropus Schrad. small stalk. pinheaded $\tau_{\tau} \frac{1}{2}$ aut. $\mathrm{Br}_{\text {pine }}$ trunks 2449. DICTY'DIUM. Schrad. DictÝdum. Sp. 1-?

165.2 cérnuum Nees cernuous pinheaded $\tau \frac{1}{2}$ all sea. Bl rotten wood 2450. ARSCY'RTA. Pers. Anscyria. Sp. 2-?.

16523 punícea Pers. crimson gregar. $\frac{1}{4}$ su. aut. Crim. rotten wood $\begin{array}{lll}\text { Tríchia denudáta } & \begin{array}{c}\text { Sowerb } 29 \\ \text { nútans Grev. }\end{array} \text { nodding } & \text { weak }\end{array}$ 16524 nútans Grev. nodding weak $\frac{1}{2}$ su.aut. Pa.Y
2451. LEA N'GIUM. Link. LEANGIUM. 16525 florifórme Link. flower-like scattered $-\frac{2}{2}$ aut. $\quad \dot{Y}$. 2 decaying trunks 16526 Trevelyáni Grev. Trevelyan's scattered $\tau^{\frac{1}{3}}$ aut. Pa.Br leaves of mosses 2452. TRI'CHIA. Pers. Trichia. 16527 reticuláta Pers. 16528 ováta Pers. pulpy 0 aut. Sp. 3-? 16529 falláx Pers. variable 0 aut. Pish rotten wood Spharocárpus frágilis Sowerb.

2453. DIDER'MA. Pers. Diderma. Sp. 1-?

2454. PHY'SA RUM. Pers. Physarum. 16532 nútans Pers. 16533 nigripes Link. 16534 viride Pers. 16534 viride Pers. 16536 aúreum $\mathrm{Per}$.

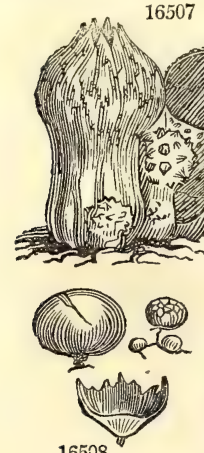

16508 furrowed weak nodding weak black stem. firm $\frac{1}{4}$ aut. D. Gr rotten wood green rather weak $\frac{1}{4}$ aut. Y.G rotten wood white stem. very stiff' $\frac{\frac{1}{6}}{6}$ aut. Gl. dead beech wood golden yell. gregar. $\frac{1}{2} \frac{1}{3}$ sp. aut. Y decaying trunks

Sower. t. 331

Bulliard, t. 447

Dic.cr.t.3.f.4. Lycoperd Bry.hist.f. 19. Lycoperd. Sch.t.183. L fornicatum Bolt. t. 179. Lycoperdon

Grev. crypt, t. 65 Sower. t. 239

Greville crypt. 170

Nees syst. t. 10. f. 118

Schrad. gen. t. 2. f. $1-2$

Greville crypt. 153

Greville crypt. 130

Sower. t. 260. Trichia

Bulliard, t. 371

Grev. crypt. 132

Nees syst. t. 10. f. 111

Sower. t. 85. turbinata Sower, t. 279

Grev. crypt. 122

Bull. t. 407. f. 3 Sturm's Deuts, fun.t. 42 Bull. t. 481. f. 1

\section{Grev. crypt.}

2443. Iycoperdon. So called by Tournefort, from $\lambda v \approx \sigma$, a wolf, and $\pi \_\rho \delta \omega$, to explode backwards, that author certainly having improved upon the foolish old name, Crepitus lupi, by making it less generally intelligible. (Smith.) These are roundish tuber-like plants, when ripe, exploding and emitting the sporules in the form of smoke, whence country people call the species puff-balls.

2144. Bovista. A name of barbarous origin, having been formed by Dillenius, from the German Bofist. Bovista furfuracea, an Italian species, is said by Micheli, to be common on heaths near Florence, where it is sold with others of its tribe, as an article of food. Bovista gigantea is the largest of the genus, and, indeed, of the whole order, measuring not unfrequently nearly 2 feet in diameter. Bulliard mentions having seen many of eighteen, twenty, and twenty-three inches in diameter, and on the authority of others, affirms them to attain the enormous bulk of nearly nine feet in circumference. The flesh is at first white, afterwards of a greenish-yellow, lastly of a brown-grey. The outer peridium cracks and peels off in large flakes on being handled.

2445. Geastrum. So called from $\gamma$ \%, the earth, and $\alpha s n$, a star, in allusion to the stellate appearance of the species when burst and lying on the ground. A genus formed by Micheli upon the Puff-balls with a stellated volva.

2446. Craterium. So nar.ed from zৎcrne, a cup, in allusion to the form of the peridium, which in C. vulgare is formed like a small goblet. This is a minute subsolitary plant, with the habit of Calicium. 
16507 Large obconical soft whitish plicate beneath, Scales broad often indistinct

16508 White soft hemispherical subsessile somewhat smooth, Warts scattered

16509 I arge white variable, Peridium subglob. cover. with spinul. warts, Stipes somew. smooth long and plicate 16510 Caspit. pyrif. umbon. pale-brown, Scales in form of min. slender spin. process. Root consist. of long fibres

16511 Large white becoming blackish-brown plicate beneath

16512 Almost sessile very large globular yellowish-white, with scattered rearly obsolete scales

16513 Volva multifid, Peduncles and oscula of the peridium numerous

16514 Smaller, Head flat above, Orifice acuminate with longer ciliæ

16515 Peridium globose stalked, Orifice hoary, Radii somewhat quadrifid arched

16516 Volva multifid spreading, Laciniæ equal, Head depressed spherical sessile, Orifice acuminate

\section{Division II. Trichocisti.}

16517 Cup-shap. redd.-brown, Operculum convex whit. very thin evanescent, Filam. white, Sporules very dark 16518 Campanulate chesnut-color, Operculum firm white, Stipes orange, Sporules blackish

16519 Crowded cylindrical, Stipes black arising from a shining subjacent membrane, Peridia very fugacious blackish-brown, Stipes continued to the summit of the peridium

16520 Dark-brown globose stipitate, Stipes penetrating through the summit of the peridium

16521 Gregarious roundish, Stipes short blackish

16522 Gregar. brownish-purple nodding umbilicated, Membrane of peridium deciduous, Flocci persistent robust

16523 Gregarious often cæspitose stipitate dull crimson, Sporules abundant crimson-red

16524 Pale-yellow substipitate cylindrical long weak drooping

16525 Yellow globose stipitate, Peridium splitting into holes which are beautifully expanded and reflexed 16526 Sporangium sess. Peridium splitting into many regular reflexed segm. Colum. very min. Spor. pedicellat.

16527 Effused forming an irregular sort of reticulation yellowish or pale-brown 16528 Crowded obovate ochrey-yellow bursting at the summit

15529 Shortly stipitate reddish at length yellowish bursting at the apex plicate beneath

\section{Sessile subglobose smooth greyish-white: both of the peridia fragile, Sporules globular}

16531 Head globose flattish beneath grey inclined, Stipes rather long pale weak sulcate, Sporules dark-brown 16532 Head glob, flatt. ben. blueish-grey nodd. Stipes thin weak whit. not furrow. Spor. and filam. dark-brown 16533 Head globose dark-grey, Stipes long firm black, Sporules and filaments very dark

16534 Subglob, umbilicate ben. yellowish-green, Stipes slender rather weak brown. Sporules and filam. very dark 16535 Head globose depressed pale-glaucous, Stipes very short thick pale at length brownish

16536 Peridium subglobose fine yellow, Stipes slender rather long greyish-brown, Sporules globose

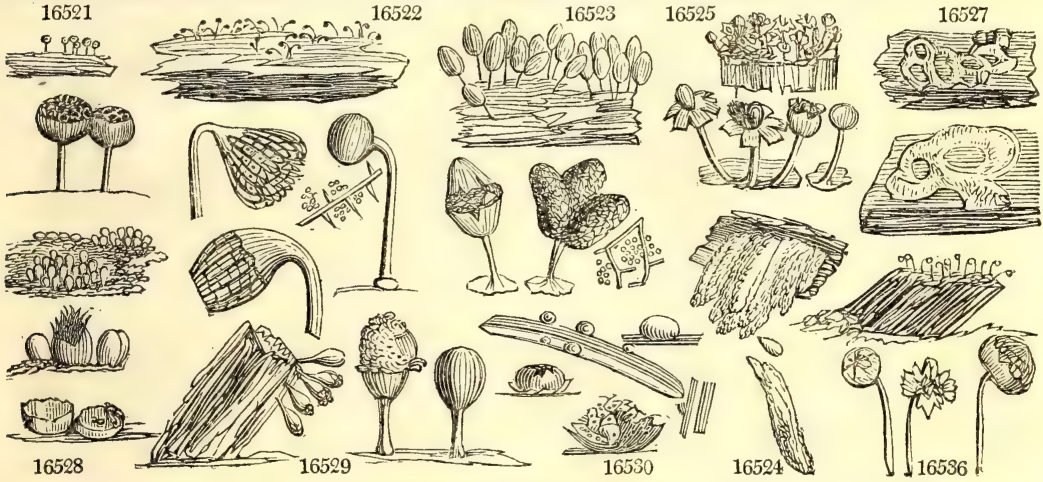

and Miscellaneous Particulars.

2447. Stemonitis. From snuav, a stamen, in allusion to the form of some of the species, which may be compared to the male organ of a flower, taking the stipes for the filament, and the head for the anthera.

2448. Cribraria. A genus formed by Schrader out of the Sphærocarpi of Bulliard. It has for its essential character, a peridium, the upper part of which has numerous apertures, whence the name, from cribro, to perforate. All the species are found in autumn upon rotten wood.

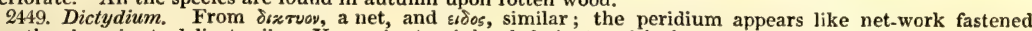
together by minute delicate ribs. Very minute pinheaded plants, with the appearance of Calicium.

2450. Arscyria. From $\propto \rho \varkappa v$, , a net. The sporules are fastened together by a net-work of fibres. Beautiful little minute fungi, found upon wood.

2451. Leangium. From $\lambda_{\text {eios, }}$ smooth, and arysos, a vessel, in reference to the smoothness of the peridium. Small wart-like plants, resembling a minute Lycoperdon.

2452. Trichia. From $\theta_{\rho} \zeta \tau^{\prime} \chi^{\circ} \circ$, hair, in allusion to the internal mass of elastic fibres gradually expanding after the head bursts. These are pin-headed plants, growing upon old wood, and very rarely seen in this country.

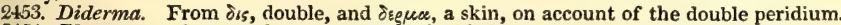

2454. Physarum. So named, on account of the bladdery appearance of the peridium, from $\varphi \cdot \% \mathrm{n}$, a resicle. 
- 2455. LEOCAR'PUS. Link. Leocarpus 16537 vernicósus Link. varnished enc Lycopérdon frágile Sowerb. t aut. Sp. R. Br stems of grasses Grev. crypt. 111

Division III. Fuliginoidei.

2456. LyCOGA'LA. Mich. Lycogala.

Mich. LYCogala. 3 -?

16538 mincenta granular 0 sp. aut. R rotten wood

Wsh rotten wood Reticulária Lycopérdon Sowerb.

16540 minúta Grev. minute gregario. 0 aut. W decayed leaves

Grev. crypt. fl. t. 38

Grev. crypt. t. 106

Grev. crypt. fl, t. 40

2457. SPUMA'RIA. Pers. SPUMaria. 16541 alba Grev.

Division IV. Liceoidei.

2458. Dichospo'RIUM. Nees. Dichosponium. Sp. 1

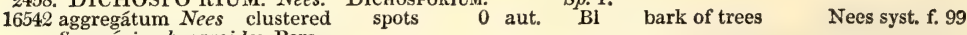
Spumária physaroides Pers.

2459. LI'CEA. Schrad. LICEA. 16543 circumscis'sa Pers. pared

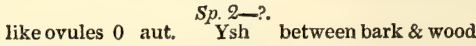

16544 fragifórmis Nees strawberry-like pulpy $\quad 0$ aut. Dl.R rotten wood Nees syst. t. 8. f. 102

Class IV. Mucoronder.

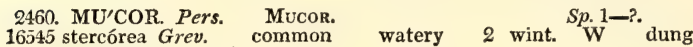
Hydróphora stercórea Tode.

2461. THAMNi'DiUM. Link. Thamnidium.

16546 élegans Link. elegant

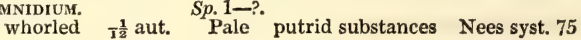

2462 ASCO'PHORA. Tode. Ascophora. $S p$. 1-?.

16547 mucédo Link. mouldy veryslend. $\frac{1}{6}$ all sea. W' putrid substances Sow.t.378.f.5,6,7.Mucor

Class V. Perisporia.

2463. EURO'TIUM. Link. EURotIUM. 16548 herbariórum Link, herbarium punctiform0 all $S p_{.}$.2-?.

16549 Rosárum Grev. rose patches 0 sum. W dried plants

2464. AMPHISPO'RIUM. Link. AMPHISPoriUm.
16550 versícolor Link.
changeable

\section{HYPHOMYCETES.}

Class I. Cephalótrichi.

2465. CERA'TIUM. Albertini. CERatium.
16551 hydnóides $A l b$. Hydnum-like fugacious $\mathrm{r}^{\frac{1}{2}}$ aut.

Berl. mag. v. 3. t. 1. f. 33

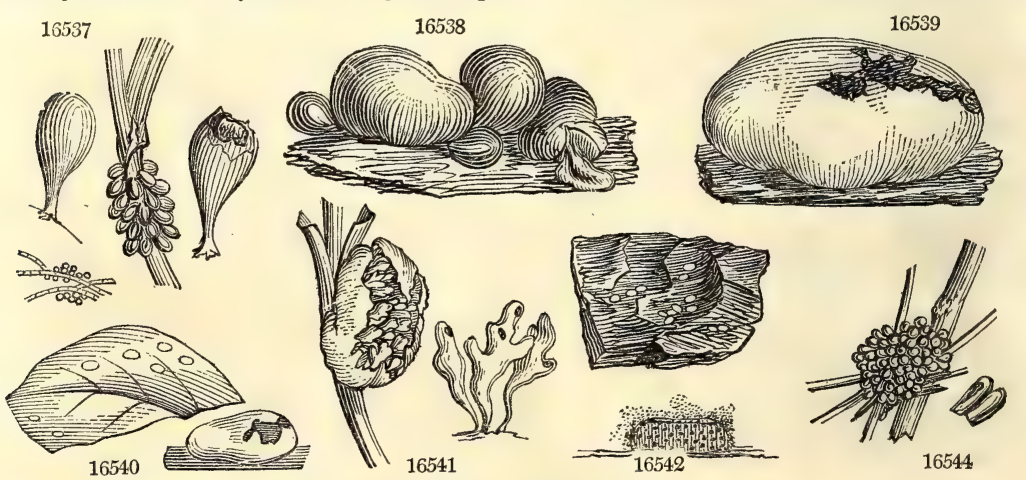

History, Use, Propagation, Culture,

2455. Leocarpus. A word with the same meaning as Leangium; which see. L. vernicosus appears as if varnished over with vermilion. The plants grow in clusters upon bits of rotten wood, and are each formed of a pear-shaped stalked peridium, bursting at the end, and letting fall out a nucleus of sporules held together by fibres.

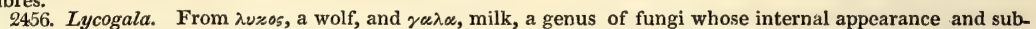
stance in an early state are like a mass of thick cream. It is included under Mucor by Linnæus, Schreber, and others. L. argenteum is found upon rotten wood in the autumn. It is about an inch or more in diameter, brown and pulpy when young, of a brilliant white when arrived at maturity, discharging, by one or more irregular accidental openings, a mass of rich dark snuff-colored powder.

2457. Spumaria. From spuma, froth. S. muclago is spread in the autumn over the leaves and stems of living plants, or over dead branches, when it resembles in some measure stiffened foam or froth.

2458. Dichosporium. From $\delta \iota x \alpha$, double, and $\sigma \pi_{00} \omega$, a seed ; in allusion, we presume, to the double coat of he peridium, the innermost of which is formed of granules like sporules. The only species known is found upon the bark of the oak.

2459. Licea. The meaning of this word is unexplained. The species have been referred to Trichia, Didy- 
10537 Shortly stipitate obovate reddish-brown shining crowded, Stlpes whitish

\section{Division IIl. Fuliginoidei.}

16538 Globular gregarious red changing to brown, Sporules orange-red at length purple-grey 16539 Large suboval very fragile silvery-white, Sporules profuse deep-brown, Filaments few

16540 Minute white roundish depressed rarely confluent fragile, Sporules black intermixed with a few filaments 16541 Effused frothy, Peridium furnished internally with horn-like grey processes inclosing brown sporules

Division IV. Liceoidei.

16542 The only species

16543 Gregarious sessile yellowish or chesnut-brown subglobose : the upper half of the peridium separating like a lid, Sporules rarely mixed with one or two filaments

16544 Peridia cylindrical very fragile densely crowded forming a roundish or hemispherical mass dull-red changing to pale-brown, Sporules brown in the form of minute abundant dust

\section{Class IV. Muconoidei.}

16545 Byssus-like white becoming yellowish, Stipes erect or lax simple bearing a minute subglobose head

16546 Filaments branched whorled, Peridium elevated

16547 Stipes simple, Heads inflated spherical dark-grey bursting close to the stipes which is long and filiform

Class V. Perisporia.

16548 Gregarious punctiform yellow, Filaments whitish branched

16549 Tufted, Peridia gregar. greenish covered by the filam. which are elongat. simple profuse somew. erect in [centre

16550 Changes from yellow to grey

\section{HYPHOMYCETES.}

Class I. Cephalotrichi.

16552 Growing in small tufts, Filaments subconfluent simple or branched and fasciculated

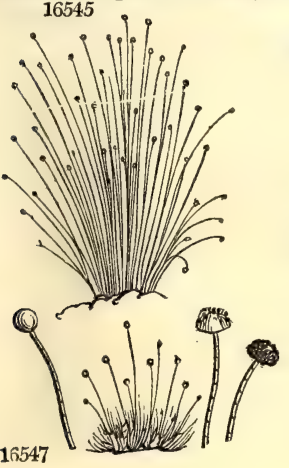
16546

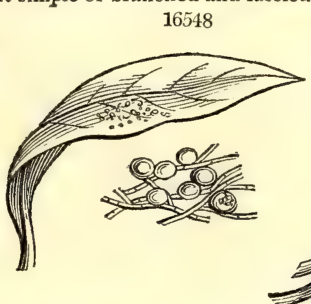

16550
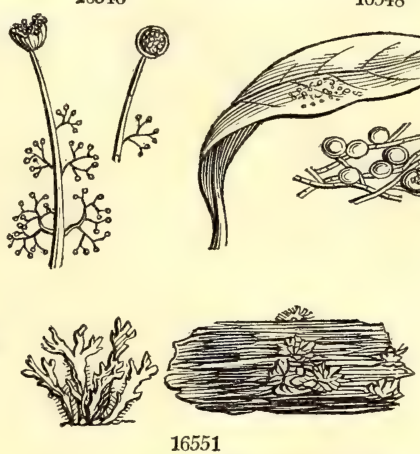

16551

000

$165 \div 0$

; and Miscellaneous Particulars.

mium, \&c. by various writers. They are minute productions scarcely bigger than pins' heads, found chiefly on rotten wood of the fir kind.

1.2460. Mucor. An alteration of $\mu \nu \%$ s, the name of a small fungus. To this genus are referable the greater part of the substances which form the mould upon cheese and other materials.

2461. Thamnidium. From Tapyos, a rod or twig, in allusion to the appearance of the plants under the microscope. Minute plants, with a bushy branched stipes, and a head like that of Mucor.

2462. Ascophora. From a $\%$ \%os, a term used by mycologists to denote a peculiar kind of receptacle of sporules, and $\phi \varepsilon \rho \omega$, to bear. These are pin-headed fungi, with the habit of Mucor, from which they chiefly differ in their peridium being turned inside out after bursting, and being somewhat persistent.

2463. Eurotium. Eugws was the Greek name of a sort of mouldiness, and has been with a sufficient reason applied to this genus of plants.

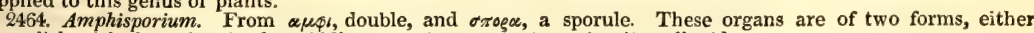
roundish with three dots in the middie, or ovate acuminate, and quite pellucid.

2465. Ceratium. So named from «kpas, a horn, on account of the cornute appearance of the plants under a microscope. 
2466. ISA'RIA. Pers. IsARIA.
16552 microscópica Grev. microscopic very min. 0 spring ${ }^{S p}$ W ${ }^{1-}$. Trichia clavata

2466. ISA'RIA. Pers. Isaria.
16552 microscópica Grev. microscopic very min. 0 spring $\mathbf{W p}$. ${ }^{\text {I-? }}$ Trichia clavata

Grev. crypt. ff. t. 3

Class II. STLLoidei.

2467. STIL'BUM. Tode. STILBUM. very min. 0 aut. $\quad S p .1-$ ? ? decayed stems

Tode fun, meckl.t.2.f.16

Class III. Inomycetes. - Division I. Byssacei.

2468. TO'RULA. Link. Torula.
16554 herbárum Link
herbaceous fragile 0 aut. ${ }^{S p .1-\text { Bl }}$ dead stems

2469. MONI'LiA. Pers. Monilia. $S p$. 1-?.

16555 aúrea Pers. $\quad$ golden yell. stalked $\tau^{\frac{1}{2}}$ all sea. ${ }^{1-?}$ rotten wood

2470. RACO'DIUM. Pers. Raconium. Sp. 1-?

16556 celláre Pers. wine-cellar shaggy 3 all sea. Sooty cellars Fibrillária vinária Sowerb.

2471. DEM A'TIUM. Pers. Dematium.
16557 articulátum Pers. articulated minute 0 aut. $S p .1-$ Blsh

2472. CladosPo'RIUM. Link. Cladosportum. Sp.2-?.

16558 herbárum Link herbaceous very min. 0 su. aut. Ol.G dead stems

16559 velutínum Grev. velvety patches 0 spring G.Bl rotten wood

2473. HELICOSPO'RIUM. Nees. Helicosporium. Sp. 1.

2474. OZO'NIUM. $t k$. Ozonium. Sp. 1-?

16561 auricomum Link yell.-headed byssoid 3 aut. ${ }^{S p}$. 1 - ? rotting wood

2475. RHIZOMOR'PHA. Roth. RHIzomorpHA. Sp.5-?.

247. RHIZOḾ RHA. Roth. RHrzomorPHA. 72 all sea. Br-?

16563 divérgens Grev. diverging creeping 24 aut. Rsh beneath bark

$\begin{array}{llll}16564 \text { farinácea Grev. } & \text { mealy much branc. } 36 \text { all sea. W } & \begin{array}{l}\text { decayed trunks } \\ 16565 \text { subterránea Pers. }\end{array} \text { subterrane. filament. } 24 \text { all sea. Bl mines }\end{array}$

16566 medulláris $\mathrm{Sm}$. medullary much branc. 144 all sea. W cellars

Sower. t. 432

Pers. disp. t. 4. f. 2

Nees syst. t. 5 . f, 64

Nees syst. 66

Sow. 392. r. 1 \& 2. patens Grev. crypt. 154

Linn. trans.12. t. 20

Grev, crypt. 198

Schm. mycol. 1. t. 2. f.23

2476. SEPEDO'NIUM. Link. SEPEDONIUM. Sp. 1-? 16567 mycóphilum Link yellow cloudy

0 aut. Or 1 -? dying fungi

2477. ACREMO'NIUM. Link. ACREMonIUM. $\quad S p .1-$ ?

16568 fúscum Schmidt brown patches 0

Sp. 6-?

16569 macrospórumGrev. large grained blotches 0 spr. su. Hoa. apple leaves

$\begin{array}{lllll}16570 \text { minútum Grev. } & \text { minute } & \text { tufts } & 0 \text { aut. w. W } & \text { dung } \\ 16571 \text { sulphúreum Grev. sulph.-color. tufts } & 0 \text { all sea. Y } \text { casks in cellars } \\ 16572 \text { aurantiacum Grev. orange-col. tufts } & 0 \text { all sea. Or } & \text { damp cellars } \\ 16573 \text { stercorárium Link dung } & \text { tufts } & 0 \text { all sea. Or } & \text { damp cellars } \\ 16574 \text { tenuis'simum Grev. thin } & \text { thin coat } & 0 \text { aut. W }\end{array}$

Wern. trans. 4. t. 5 . f

Wern. trans. 4. t. 5 . f.

Wern. trans. 4 , t. 5 . f.

16574 tercorsium fink dung turts
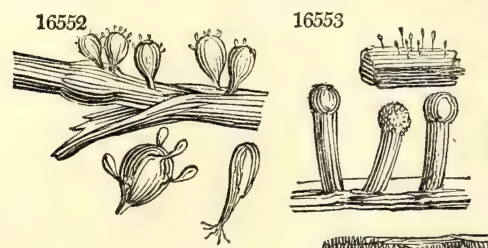

16554

Wern. trans, 4. t. 5. f. 2
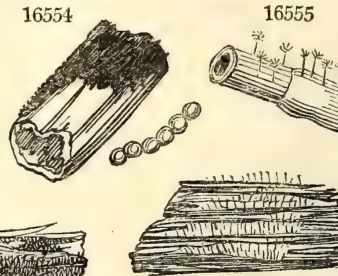

Q0, 800 $0.0,0.0000$
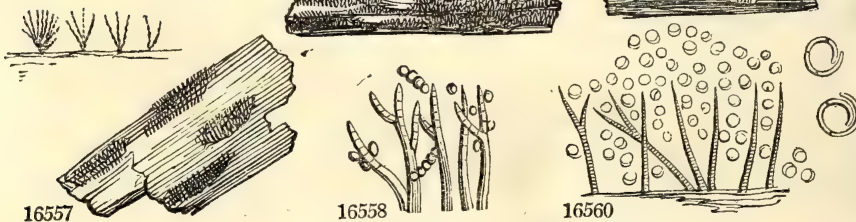

내르 16556

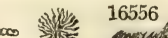

.


16552 Extremely minute scattered sImple club-shaped very white, Filaments and sporidia indistinct

\section{Class II. Struboider.}

16553 Head roundish whitish semifluid becoming firmer and yellowish, Stipes rather thick cylindrical

Class III. Inomycetes. - Division I. Byssacei.

16554 Filaments densely crowded so as to form a black crust

16555 Tufted gold color

16556 Very soft lax much interwoven of a greenish black color, Filaments intermixed with irregular granules

16557 Minute blackish fascicled, Bristles diverging sometimes jointed

16558 Tufted extremely minute of an olive-green color becoming blackish and rigid in old age

16559 Very minute spreading on old wood in wide velvety patches greenish-black, Filaments simple or branched jointed somewhat thickened upwards

16560 The only species

16561 Very irregular rigid diverging : when young from a common centre; afterwards straggling, Filaments tawny orange-color compressed of various sizes

16562 Compressed brown or black shining anastomising often broad and very extensive [regularly patent 16563 Stem pale redd. cylind. subflex. never anastomis. Branches spread. in all directions free, Fructific. clavate 16564. Stems covered with a mealy substance

16565 Long branched roundish somewhat separate black

16566 Round much branched snow-white, cellular and yellow inside

\section{Division II. Mucedines.}

16567 Spreading widely within putrefying Agarici and Boleti, Filam. white, Spor. profuse bright orange-yellow

16568 Filaments spreading branched olive-brown, Pedicels of the sporules numerous alternate

16569 Forming a pulverulent hoariness interspersed with very minute tufts, Filaments few branched straggling, Sporules large obtusely ova

16570 Tufts roundish minute very white, Filaments loosely entangled, Sporules very numerous oval

16.571 Tufts yellow irregular roundish, Filaments lax entangled, Sporules numerous subglobose

16572 Tutts of a reddish orange-color, Filaments very slender much entangled, Sporules glob. extremely minute 16573 Differs from the last, chiefly in its paler color

16574 Very white forming a web, Filain. densely interwoven very fine, Sporules globular scattered very minute
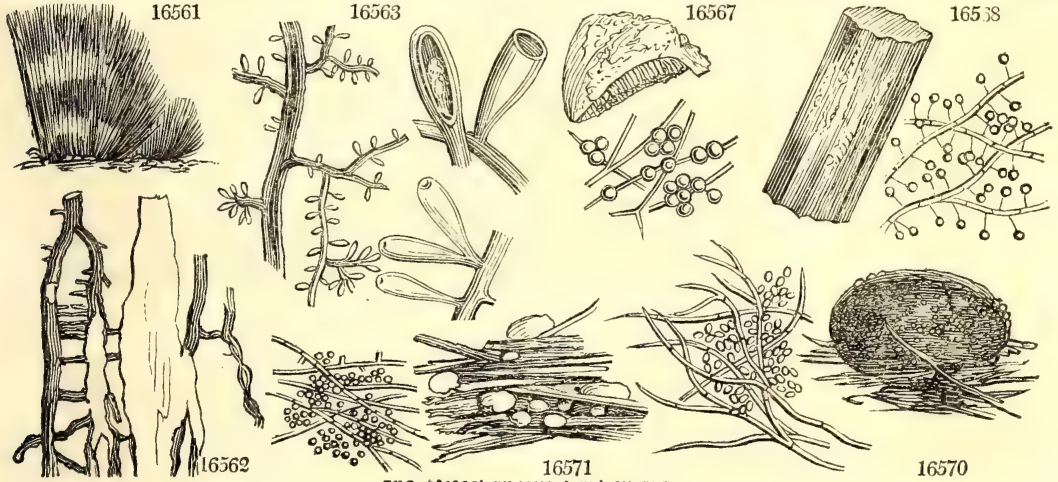

2474. Ozonium. We presume, from olos, a branch, in allusion to the manner in which the filaments branch or diverge from a common centre. This genus has been extracted from Dematium by Link.

2475, Rhizomorpha. So called from its resemblance to the branching fibrous roots of various plants. All the productions referred to this genus are very obscure and uncertain. R. phosphorea, the Clavaria phosphorea of Sowerby, is a plant sometimes existing as a parasite between the wood and bark of trees, or in wine-cellars among saw-dust, and is, when fresh, remarkably luminous in the dark.

2476. Sepedonium. From $\sigma \eta \pi \delta \delta \omega$, putrescence. The species grow among the decaying parts of fungi, and other putrid substances.

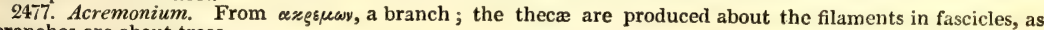
branches are about trees.

2478. Sporotrichum. From $\sigma \pi \circ \propto$, and $3 \varrho \iota \xi$, hair, in allusion to the filamentous nature of the sporules. A very destructive parasite in some seasons, and probably of general distribution, for it has been detected on a great variety of plants. To gardeners it is well known as a kind of mildew or blight, and is commonly taken for an insect. The leaves of the peach-trees, even when protected by glass, are often attacked by it, nor does the fruit itself always escape, in which case it frequently drops off. The leaves are more or less distorted by it. As its production is probably the result of a peculiar state of the atmosphere, there is little chance of any means being discovered for its prevention. 
2479. TRICHOTHE'CIUM. Link. Trichothecium. $s p .1$-?

16575 róseum Link rose-colored tufts 0 aut. w

2480. ACrOSPO'RIUM. Nees. Acrosporium. Sp. 2-?.

16576 monilioídes Nees Monilia-like spots 0 sp. aut. W leaves of grasses Grev. crypt. fl. t. 73

16577 fasciculátum Grev. fascicled patches 0 spring Gl. rotten oranges

2481. BO'TRYTIS. Mich. BOTRYTIS.

16578 diffúsa $A l b$. diffuse broad tufts $\frac{1}{4}$ aut. Sp. 4-?

16579 agaricína Link Agaric wool.coat 0 aut. W decaying fungi

spots 0 aut. Pu.Gr underside of live lvs.

16581 parasítica Pers. parasitic lax 0 spr. su. W on shepherd's purse Sower. t.359

2482. ASPERGIL'LUS. Mich. Mouldiness. $S p .4-?$.

16582 glaúcus Link blue patches 0 all sea. B rotten substances Berl. mag. 3.t.1. f. 23

16583 láneus Link. white patches $\tau^{\frac{1}{2}}$ aut. Wsh putrid fungi

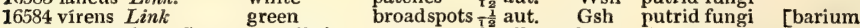

16585 penicillatus Grev. pencilled spots 0 all sea. D.Gr damp specimens in Her- Grev.crypt.f.t.32 2483. STACHYLI'DIUM. Link. STACHYLInIUM. $S p .1-?$ ? 2484. PENICIL'LiUM. Link. Penicillium. $S p$. 2-?.

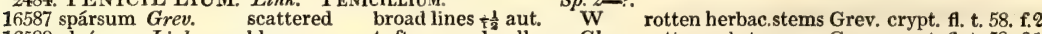
16588 glaúcum Link blue tufts $\frac{1}{\frac{1}{a}}$ all sea. Gl, rotten substances Grev, crypt. fl. t. 58. f.1

2485. TRICHODER'MA. Pers. Trichoderma. Sp. 1-?.

Class IV. Phylleriaces.

2486. RUBI'GO. Link. RUBigo. 16590 al'nea Pers. alder

2487. ER I'NEUM. Pers. ERINEUm.

\section{2 gríseum Pers.} grey

16593 acerínum Pers.

\section{Sycomore}

16594 pyrínum Pers. Pear

16595 tortuósum Kunze tortuous

16596 Juglondis Dec. 16597 claglandis Dec.

16598 róseum Kunze rose-colored depress.tufts 0 sum. Crim. on birch lvs.

16599 betulinum Rebent. Birch depress.tufts 0 spr. su. Wsh on birch lvs.
Sp. 1-?.

$$
S p .9-\text { ? }
$$

velvety spots 0 sum. Bt.Y lvs. Populus nigra Edin.phil.jour. 6.t.3.f.15 velvety spots 0 spr.su. Dl.Pu under oak leaves Ed.ph.jo.6.t.3.f.17.minu depress.tufts 0 sp. aut. R.Br und, sycomore lvs. Edin.phil.jou.6.t.2.f.1\&6 depress.tufts 0 aut. R. Br on crab-tree lvs. Grev, crypt. fl. t. 22

Grev. crypt. fl. t. 94

Ed.ph. jo.6.t.2.f.4. suburl. Edin. phil. jour. 6.t.2.f.8

Grev. crypt. fl. t. 21

Edin.phil. jour.6.t.3.f.16

\section{CONIOMYCETES.}

\section{Class I. Tubercularien.}

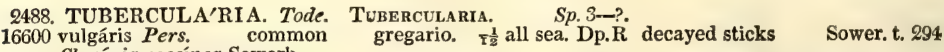
Clavária coccínea Sowerb.

16601 cónfluens Pers. confluent gregario. 0 aut. sp. F.R dead sycomore branches

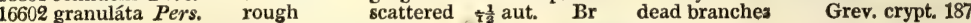

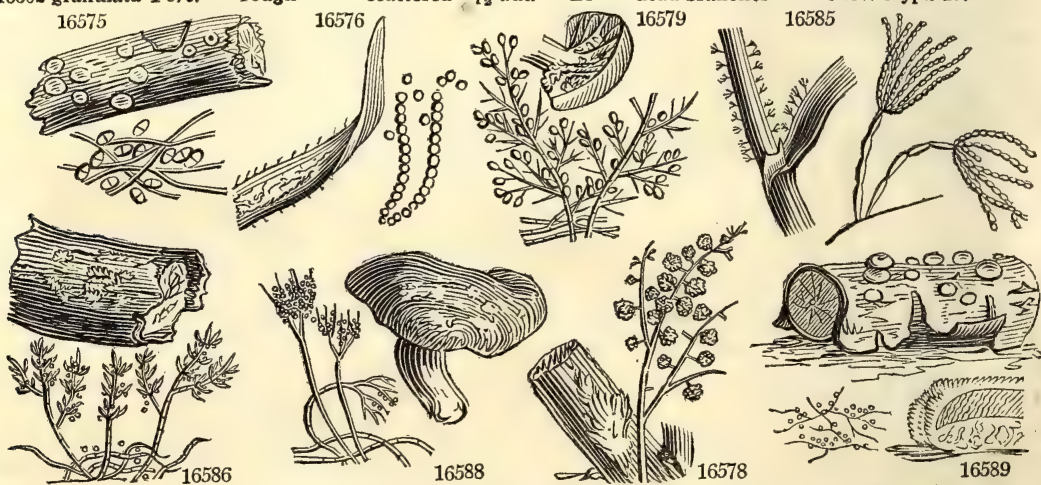

History, Use, Propagation, Culture,

2479. Trichothecium. The thecæ are intermixed among a mass of hair-like filaments; whence the name. 2480. Acrosporium. From cesos, the top of any thing, and $\sigma \pi \circ \sigma_{0}$, a sporule; the latter occupying the summit of the simple filaments.

2481 . Botrytis. So called from forevs, a bunch of grapes, in allusion to the clusters of little globular seeds or seed vessels.

2482. Aspergillus. This is the name of the brush with which the holy-water is scattered in Catholic ceremonies. The little plant, consisting of a stem and a cluster of sporules at the top, is not unlike a little brush with its handle.

2483. Stachylidium. From $\sigma \tau \alpha \chi \cup 5$, a spike, and $\varepsilon \delta \sigma s$, similar. The sporules are dispersed in a sort of spiked manner on the filaments. 
16575 Tufted, Tufts distinct at length sometimes confluent, Filam. white, Sporules pink very numerous oval

16576 Filaments simple forming white spots of one or two lines in length on the living leaves of grasses 16577 Filam. branched somew. fasciculated erect in spreading tufts white at first at length a fine glauc. color

16578 Very lax tuft. white branch. Branch. few long spread. set with short patent ramuli bear. round clust. of spor. 16579 Tufted confluent white, Filaments one line high, Branches divaricate, Sporules numerous ovate large 16580 Pale purpl.-grey spread. Filam. branch. towards summit, Branch. divaric. short, Spor. large oval numerous 16581 Somewhat tufted lax white not much branched, Sporules roundish

16582 Tuft. min. formed of white erect filaments with little heads at first white but when mature of a glauc, color 16583 In dense tufts composed of whitish or yellowish suberect entangled filaments with yellowish heads 16584 Tufts rather dense, Filaments entangled suberect heads as well as the filaments greenish

16585 Filaments scattered gregarious about a line high supporting an elongated tuft of beaded sporidia

16586 Filaments branched erect remotely jointed scattered white, Sporules globular

16587 Barren filaments effused interwoven : fertile ones simple somewhat scattered, Heads of sp rules white 16588 Densely tufted spreading, Heads of sporules at length glaucous

16589 Tufted, Tufts roundish composed of snow-white interwoven filaments, Sporules profuse green at length giving the whole a green-color

\section{Class IV. Phylleriacee.}

16590 Irregularly tufted or effused and confluent whitish at length reddish-brown, Peridia shortly branched, Branches thick bearing several round or ovate lobes

16591 On the surface of the leaf bright gold-color effused sometimes spreading over the whole leaf, Peridia simple crowded club-shaped, Sporules evident excessively minute yellow

16592 Hypophyllous, so minute as scarcely to be raised above the surface of the leaf pale obscure purple widely effused, Peridia simple obtusely club-shaped

16593 On the under surface of the leaf depressed distinct or confluent pale becoming reddish-brown $\mathbf{P e r i d i a}_{\mathbf{3}}$ club-shaped very rarely turbinate flaccid, the upper half often inclined

16594 Mostly on the under surface of the leaf scattered subeffused rich reddish-brown, Peridia compressed lin. somewhat lax with the apex club-shaped and often truncate

16595 Mostly on the under surface irregularly tufted whitish becoming ferruginous, Peridia linear cylindrical twisted with rounded summits

16596 Hypophyll. silky or toment. pale or quadrangular, Peridia erect cylindric. long and attenuated to a point 16597 On the under surface whitish-pink becoming subferruginous rarely in the form of spots or tufts but con. fluent at the margin of the leaf which is rolled inwards and conceals it, Peridia short

16598 Mostly on the upper surface unequally scattered confluent fine crimson, Peridia polymorphous turbinate club-shaped or capitate, the summit frequently truncate

16599 Mostly on the under surface whitish at length dark ferruginous often confluent, Peridia short polymor. phous sometimes turbinate but generally with two blunt horn-like patent summits

\section{CONIOMYCETES}

Class I. Tubercularie.

16600 Gregarious deep-red rugose furnished with a very short thick pale stipes

16601 Gregarious confiuent depressed flesh-red small somewhat plane

16602 Somewhat round somewhat shortly stipitate dull-red at length black, Surface tuberculate wrinkled

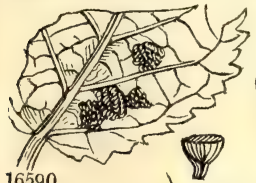

16591

16592
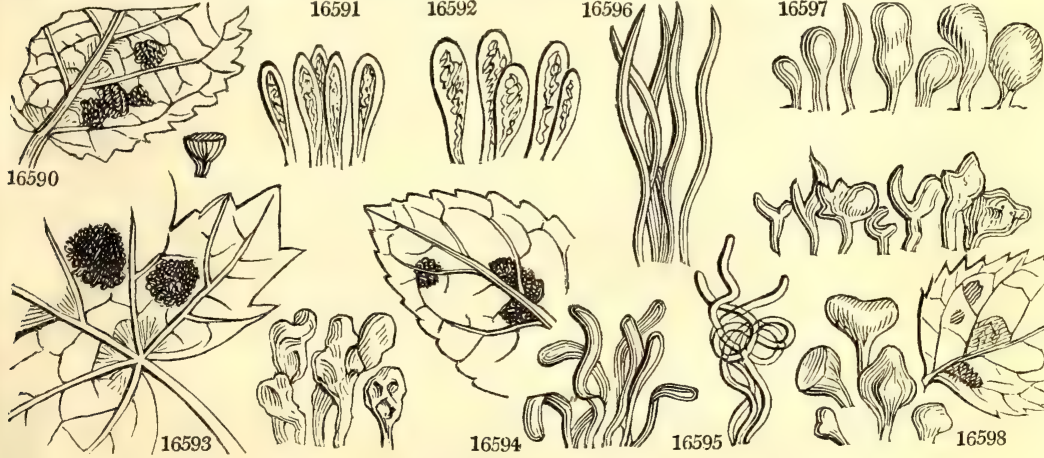

2484. Penicill
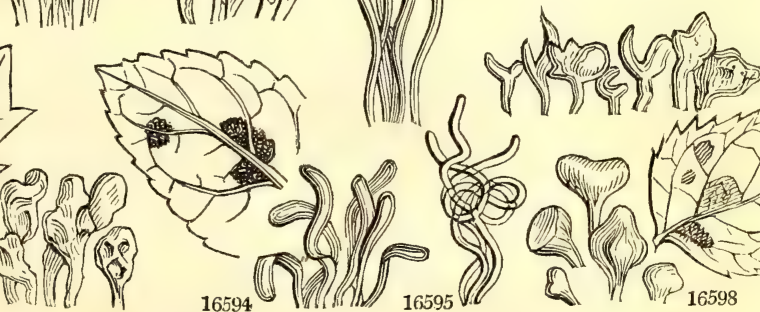

in appearance.

A name with the same mich the sporules are attached spread round, radiating through the powdery mass in little tufts from a subjacent membrane.

2486. Rubigo. An ancient Latin name of blight. There was a inferior deity whom the Romans acknowledged under the name of Rubigus, and whom they propitiated in bad seasons. All the productions referred hither are popularly called mildew or blight.

2487. Erineum. So named in reference to its hispid appearance, which resembles the common hedge-hog,

Erinaceus. Found growing upon leaves in little tufts.

2488. Tubercularia. So named in allusion to its warted appearance 
2489. FUSA'RIUM. Link. FUSARIUM.

Sp. 1-?.

16603 tremelloídes Grev. gelatinous very small 0 spring Pksh dead nettle stems Grev. cryp. fl.t. 10

2490. EXOSPO'RIUM. Link. EXOSPORIUM. Sp. 1-?

16604 Tiliz Link Linden punctif. 0 sept. Bl linden branches Grev. crypt. 208

Class II. ENTophyтe. - Divisıon I. Stilbosporei.

2491. FUS' DIUM, Link. Fusidium.

16605 gríseum Grev. grey effus. spo. 0 aut. $S p$. 2-?.

16606 . Wsh dead beech leaves Grev. crypt. ft. $t .109$

2492. POLYTHRIN'CIUM. Kunze. Polythincium. Sp. 1.

16607 Trifólii Kunze Trefoil punctif. 0 aut. Bl clover leaves

2493. STILbOSPO'RA. Hoffm. Stilbospora. Sp. 4-?. 16608 profúsa Grev. profuse spots 0 spring $\mathrm{Br}$ sycamore branches Grev. crypt. 212 16609 microspérma Pers. small grain. emerging 0 all sea. BI dead beech bran.

16610 ováta Pers. ovate dots 0 aut. Br dead branches Grev. crypt. 212

16611 biloculáta Grev. two-celled emerging 0 all sea. Bl dead furze branch.

2494. SPORIDER'MIUM. Link. SPoridermium. Sp. 1-?

16612 atrum Link. $\quad$ dark $\quad$ parasitic 0 aut. ${ }_{B 1}$ on species of Thelephora Grev. crypt. 194

2495. NEMASPO'RA. Pers. Nemaspora. Sp. 3-?.

16613 Carpíni Sowerb. Hornbeam irregular 0 all sea. Bl dead hornbeam Sower. t. 376

16014 filamentósa Grev. filamentous tortuous 0 all sea. Gr.Bl dead branches

16615 Rosárum Grev. Rose slightly prom. 0 all sea. Bl dead rose branches Grev. crypt. fl.t. 20

Division II. Hypodermia.

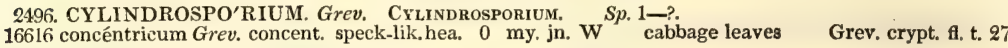

2497. URE'DO. Pers. UREDo. Sp. 45-?.

16617 Geránii Dec. Geranium scattered 0 sum. D.Br on Geranium lvs. Grev. crypt. fl. t. 8

16618 Fí́riae

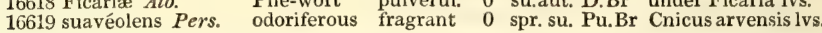

16620 Polygonórum Dec. Polygonum spreading 0 su.aut. Pa.Br under Polygonum lvs. Grev. crypt. fl. t. 80 16621 Prímulæ Dec. Primrose scattered 0 sum. Pa.Br under primroselvs.

16622 CichoraceárumDec. Syngenesious spots $\quad 0$ su.aut. D.Br on Compositæ lvs.

16623 Heráclei Grev. Cow-Parsnep patches 0 sum. Pa.Br under Sphondylium Ivs.

16624 bifrons Grev. two-sided spots $\quad 0$ aut. $\quad \mathrm{Pa} . \mathrm{Br}$ both sides of sorrel leaves

16625 Rúmicum Dec. Dock small 0 aut. $\mathrm{Br}$ on Rumex leaves

16626 Fábæ Pers. Bean patches 0 aut. Pa.Br on bean leaves Grev. crypt. f. t. 95

16627 Labiatárum Dec. Mint pustular 0 aut. $\quad$ Y.Br on mint leaves

16628 intrúsa Grev. depressed scattered 0 aut. $\quad$ R.Br on Alchimella lvs.

16629 oblongáta $L k$. oblong pustular 0 sum. R.Br on Luzula leaves Grev. crypt. fl. t. 12

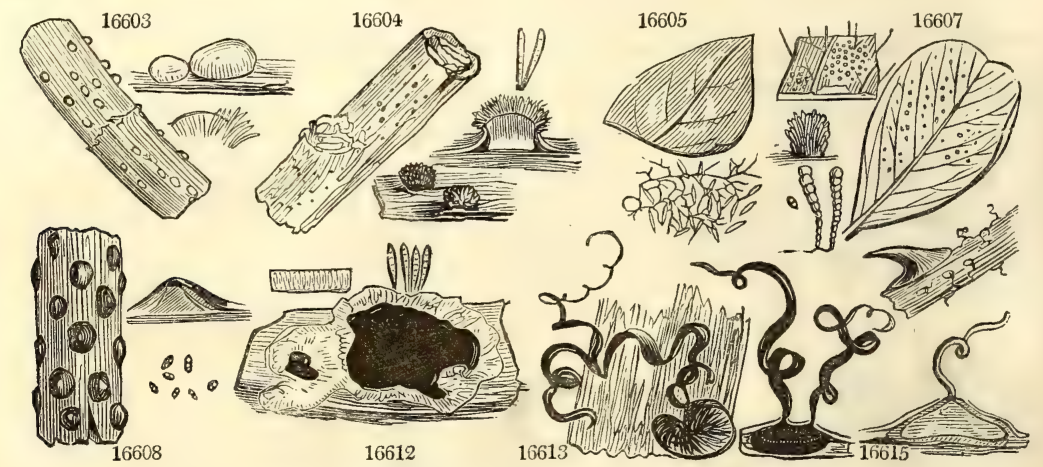

History, Use, Propagation, Culture,

2489. Fusarium. The sporules are remarkable for their regular fusiform figure.

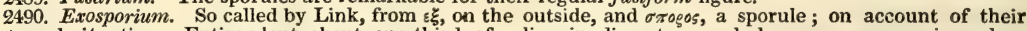
external situation. Entire plant about one-third of a line in diameter, rarely larger, very gregarious, deep black, convex, bursting from beneath the epidermis, and appearing bristly under a pocket magnifier. Sporidia very crowded, elongated, obtuse at the apex, subopake, divided transversely about five times, fixed at the base upon a roundish dark-colored, solid receptacle, and there persistent.

2491. Fusidium. A name with the same meaning as Fusarium.

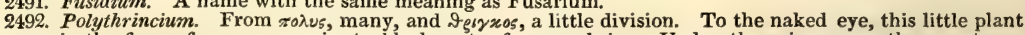
appears in the form of numerous minute black spots of unequal size. Under the microscope, these spots are each found to consist of a number of distinct little roundish tufts of filaments, nearly equidistant from one another, and becoming smaller towards the circumference. The filaments are densely crowded, semitransparent, gradually thickening upwards, somewhat moniliform from the numerous articulations, erect, simple; the sporidia oval, two-celled, scattered among the filaments.

2493. Stilbospora. From $5 i \lambda 6 \omega$, to shine, and $\sigma$ sogos, a sporule. Asci or sporules naked, imberded in a black substance flowing from the branches of trees. 
16603 Minute roundish or oval subgelatinous, Sporules long slender slightly curved

16604 Gregarious black minute convex, Sporidia elongated obtuse about 5 times transversely divided

\section{Class II. Entophytai, - Division I. Stilbosporei.}

16605 Mass thin irregular of a whitish or grey color 16606 Mass irregular thin bright-yellow or greenish

\section{The only species}

16608 Heaps rather large, Sporidia extremely minute nearly equally 2-celled

16609 Black granulated irregularly ovate at length shapeless, Sporules ovate attenuated at each extremity 16610 Heaps small, Sporidia ovate unilocular

16611 Heaps roundish bursting through the bark, Sporules ovate obtuse 2-celled

16612 Black very crowded, Filaments linear-oblong 4 or 5 times divided

16613 Spherules depressed black immersed, Sporules large ovate escaping in the form of thick black tendrils 16614 Spherules very small grey black, Sporules excessively minute dust-like under a high magnifying power escaping in the form of long capillary entangled dull-orange tendrils

16615 Spherules waved when divided horizontally elevating the epidermis, Orifice blackish with a cottony margin, Sporules very minute forming a single short slightly tortuous whitish tendrils

16616 The only species

Division II. Hypodermia.

16617 Hypophyllous scattered dark fuscous round very pulverulent sometimes confluent, Sporidia globose

16618 Aggregated deep-brown chiefly hypophyllous confluent, Sporidia oval sometimes with a very min. stipes 16619 Hypophyllous scattered becoming confluent reddish or purplish-brown, Sporidia globose greenish under a high power of the microscope

16620 Hypophyllous circular scattered rarely disposed in a circle round a pale-brown centre, Sporidia globular

16621 Hypophyllous scattered single or disposed in a circle round a central one light-brown, Sporidia globular subovoid and rarely furnished with a minute pedicel

16622 On both sides of leaf dark fuscous minute round scattered, Sporidia globular rarely with a minute pedicel 16623 Hypophylious scattered sometimes subconfluent roundish light-brown girt by the remains of epidermis, Sporidia oviform sometimes furnished with a very short blunt pedicel

16624 On both surfaces of the leaf and opposite to each other scattered round light-brown girt with the remains of the epidermis, Sporidia globose

16625 On both surfaces of the leaf brown round minute often not bursting : the epidermis rarely disposed in a circle, Sporidia ovoid sometimes with minute pedicels

16626 Scattered round depressed light-brown girt with the remains of the epidermis, Sporidia rounded or suboval rarely with minute pedicels

16627 Hypophyllous pale yellowish-brown sometimes disposed in a circle round : a central one minute rarely confluent, Sporidia roundish or egg-shaped and rather hyaline

16628 Hypophyllous scattered or partially aggregated reddish-brown rounded somewhat prominent minute very unequal, Sporidia roundish or oval rarely pedicelled

16629 On both sides of the leaf scattered distinct oblong reddish-brown girt by the ruptured epidermis, Sporidia subglobose rarely subpedicelled

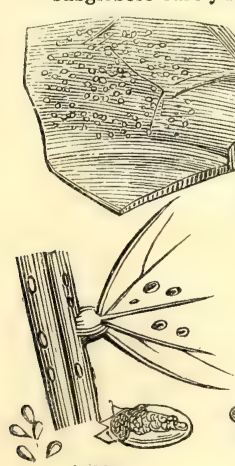

16626 16616

$$
D^{1}
$$
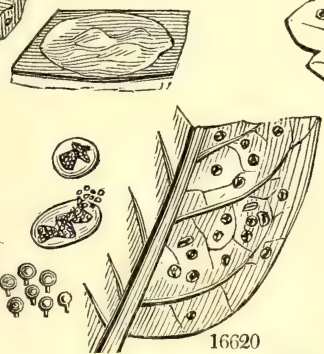

and Miscellaneous Particulars.
16617
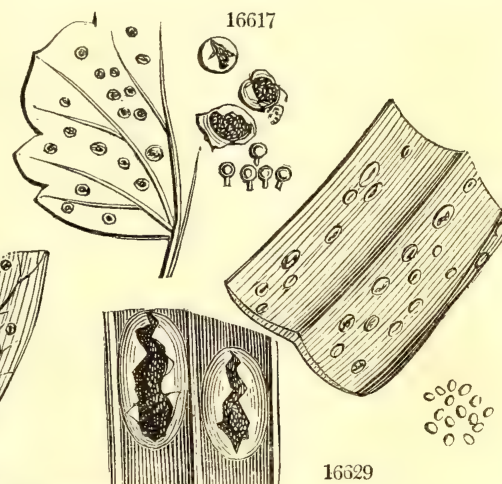

16029

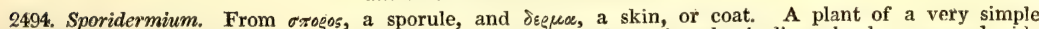
structure, composed entirely of linear-oblong or club-shaped semi-opake bodies, closely arranged side by side, exactly of the same height, and transversely divided by three or four dissepiments. When viewed with the naked eye, it resembles an intensely black thin crust, creeping over the surface of Thelephora. Specimens from Captain Carmichael, as well as those found by Dr. Greville, occurred on Thelephora vulgaris.

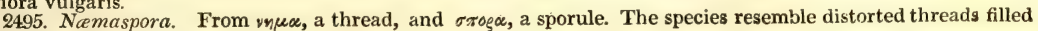
with minute sporules.

2496. Cyiindrosporium. In allusion to the cylindrical form of the sporules. Found on both surfaces of living cabbage leaves (Brassica oleracea). Frequent in May and June. A very extraordinary plant, forming minute speck.like heaps of an oblong shape, but otherwise very irregular, and projecting into little angles and processes. They are disposed in a concentric manner, are pure white, and change in decay to a dirty yellow. Sporules naked, very numerous, cylindrical, truncate at each extremity, pellucid.

2497. Uredo. An old Latin name, from uro, to burn or scorch, applied to those occasional discolorations of the surfaces of plants which were attributed to blasts or injuries of the atmosphere or heavenly bodies, and are 
16630 Sálicis Dec. 16631 Vitellinæ Dec. 16632 farinósa Pers. 16633 Tussiláginis Pers

1663 Seneciónis Dec. 16635 cónfluens Pers. 16636 Potentíllæ Dec. 16637 Rósæ Pers. 16638 Rubórum $\mathrm{Dec}$. 16639 eff'isa $G$ roy. 16640 gyrósa Rebent

\begin{tabular}{|c|c|c|c|c|c|}
\hline $\begin{array}{l}\text { Willow } \\
\text { Golden Osier } \\
\text { powdery } \\
\text { Colt's-foot }\end{array}$ & $\begin{array}{l}\text { mottled } \\
\text { mealy } \\
\text { gyrose }\end{array}$ & $\begin{array}{l}0 \\
0 \\
0 \\
0\end{array}$ & $\begin{array}{l}\text { aut. } \\
\text { my.aut } \\
\text { aut. } \\
\text { sum. }\end{array}$ & $\begin{array}{l}\mathbf{Y} \\
\mathbf{Y} \\
\mathbf{P a} . \mathbf{Y} \\
\text { Or }\end{array}$ & $\begin{array}{l}\text { under Salix pentandra lvs. } \\
\text { under Sal. vitellina lvs. } \\
\text { under Sal. Caprea lvs. } \\
\text { under coltsfoot lvs. }\end{array}$ \\
\hline $\begin{array}{l}\text { Ragwort } \\
\text { confluent } \\
\text { Cinquefoil } \\
\text { Rose } \\
\text { Bramble } \\
\text { effused } \\
\text { concentric }\end{array}$ & $\begin{array}{l}\text { blotches } \\
\text { gyrose } \\
\text { powdery } \\
\text { mottled } \\
\text { very powd. } \\
\text { spreading } \\
\text { gyrose }\end{array}$ & $\begin{array}{l}0 \\
0 \\
0 \\
0 \\
0 \\
0 \\
0\end{array}$ & $\begin{array}{l}\text { sum. } \\
\text { sum. } \\
\text { sum. } \\
\text { sum. } \\
\text { sum. } \\
\text { sum. } \\
\text { spr. su. }\end{array}$ & $\begin{array}{l}\text { Or } \\
\text { Y } \\
\text { Gol.Y } \\
\text { Or } \\
\text { Gol.Y } \\
\text { R.Or } \\
\text { Y }\end{array}$ & $\begin{array}{l}\text { under Senecio lvs. } \\
\text { on Mercurialis lvs. } \\
\text { on Fragaria sterilis lvs. } \\
\text { under rose lvs. } \\
\text { under bramble lvs. } \\
\text { under Rosaceæ lvs. Grev. crypt. f. } \\
\text { on raspberry lvs. }\end{array}$ \\
\hline
\end{tabular}

Willow mottled 0 aut. $Y$ under Salix pentandra lvs.

Osier pimpled 0 my.aut $Y$

Ragwort blotches 0 sum Or under Senecio lvs.

Cinquefoil powdery 0 sum. Gol.Y on Fragaria sterilis Ivs.

Bramble very powd. 0 sum. Gol.Y under bramble lvs.

concentric gyrose 0 spr. su. Y on raspberry lvs.

16641 AlchemillæPers. Lady's Mantle spreading 0 my. jn. Or under Alchemilla lvs. 16642 Rhinanthaceárum Dec. bt-yellow spots 0 su. aut. R.Y Scrophularineæ

16643 Líni Dec. Flax shining 0 sum. Or. Y Linum cartharticum Grev, crypt. A t 31

16644. Saxifragárum Dec. Saxifrage brilliant 0 sum. Or Saxifrage

16645 Campánulæ Pers. Campanula bright 0 sum. Or under Campanula lvs.

16646 Py'rolæ Grev. Winter Green minute 0 sum. Gold. under Pyrola lvs.

16647 Helioscópiæ Dec. Euphorbia round 0 aut. Gold. under Euphorbia lvs. 16648 lineáris Pers.

16649 æcidiifórmis Grev. Ecidium-like pustular 0 spring $\mathrm{Y}$ on Sphondylium lvs.

16650 Cerástii Grev. Cerastium punctif. 0 sum. Gold. on Cerast. viscosum lvs.

16651 pustuláta Pers. pimpled punctif. 0 spring $\mathbf{Y}$ on Epilobium palustre lvs.

16652 Súnchi Pers. $166 \tilde{3}$ Petasites Dec.

Sow Thistle spreading 0 sum. R.Or under Sonch. olerac. lvs. Petasites gyrose 0 aut. Or under Petasites lvs.

16654 Populina Pers. Poplar beautiful 0 aut. Gold. under Populus nigra lvs. Ann.wett.2.t.11.f.5

16655 ováta Strauss Aspen spots 0 aut. Tawn. on Populus tremula lvs. Ann.wett.2.t.11.f.6 16656 cándida Pers. white spreading 0 aut. W Cruciferæ $\quad$ Sower. t. 340. Thlaspi

16557 ségetum Pers. Smut Brand spreading 0 sum. Bl within grains of corn

16658 urceolórum Dec. sedge spreading 0 sum. Bl on fructif. of Carex

cankering

$\mathrm{Bl} . \mathrm{Br}$ within grains of wheat Deutschl. fl. t. 34

16650 antherárum Dec. Anther

16661 flosculósum Dec. Floret

spreading 0 sum. Pu on Caryophylleæ

spreading 0 sum. Pu. Br on Scabiosa arvensis Sow. t.396.f.2. Scabros

Sp. 21-?.

2498. ECI'DIUM. Pers. EcIDIUM.

16662 Pini Pers.

Pine

scattered $\frac{1}{6}$ sum. Pa.Or on Pinus sylvestris Grev. crypt. fi. t. 7

16663 Epilóbii Dec.

Epilobium

Violet

0 sum. W

on Epilobium montanum lvs.

16664 Violárum Dec.

whitish

crowded 0 sum.

Wsh under Viola canina lvs.

16665 albéscens Grev.

16666 Taráxaci Grev.

Dandelion

beautiful 0 april W

Adoxa moschatellina

16667 Periclýmeni Dec. 16668 Búnii Dec. under Leontodon Taraxacum lvs. under woodbine lvs.

Ground Nut deformed 0 spring Ysh on Bunium lvs.

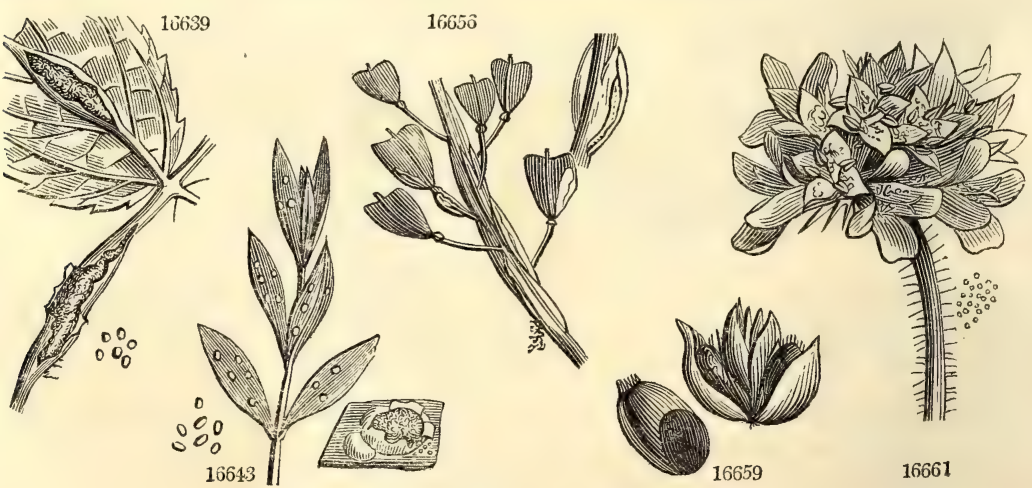

IIistory, Use, Propagation, Culture,

called mildew or blight. All the species are obscure and require further examination. They are in the hands of Bauer, whose knowleige and pictorial powers cannot be better employed than in illustrating this obscure part of vegetation. 
16630 Hypophyl. scatter, very min. rounded becom. contigu. but not confluent, Sporidia pyriform subpedicellate 16631 Hypophyl. very min. convex orbicular scattered becom. confluent, Sporidia very min. globul. transparent 16632 Hypophyl. pale ochrey-yell. distinct at first soon bursting becom. conflu. and very pulverul. Sporidia oval 16633 Hypophyllous bright orange-yellow prominent crowded generally forming circles and becoming very confluent, Sporidia very numerous obovate

16634 Hypophyllous orange-yellow oblong irregular becoming confluent, Sporidia numerous

16635 Hypophyllous depressed yellow oblong concentric becoming confluent, Sporidia nearly oval

16636 Chiefly hypophyllous golden-yellow scattered irregular convex becoming contluent, sporidia subspherical

16637 Hypophyllous small scattered effused orange-yellow, Sporidia suboval sometimes with a minute pedicel

16638 Hypophyllous golden-yellow suborbicular becoming effused, Sporidia very numerous irregularly spherical

16639 Bright reddish-orange broad pulverulent hypophyl. and on nerves and petioles, Sporidia numer. subglob.

16640 Epiphyllous much scattered rather large yulow thick elevated from the leaf and bursting in a gyrose manner, Sporidia subglobose

16641 Hypophyl. lin. obl. crowded arranged in a subparallel manner orange-yell. becom. pale, Sporidia spherical 16642 Hypophyllous and on the petioles and calyx oblong thickish sometimes partly disposed in a circular manner and subconfuent deep reddish-yellow, Sporidia spherical

16643 On hoth sides of the leaf and stem suborbicular prominent bright orange-yellow scattered, Sporidia oval or even oblong transparent

16644 Hypophyllous and on the calyces rather large oval with an indurated disk after the sporidia have escaped, Sporidia bright orange spherical and granular within

16645 Hypophyllous scattered round depressed rarely confluent, Sporidia yellowish-orange spherical surrounded by the remains of the ruptured epidermis

16646 Hypophyllous punctiform scattered or collected into small clusters golden-yellow scarcely bursting, Sporidia ovate or oblong somewhat transparent and granular within

16647 Hypophyll. golden-yell. scatter, distin. surround. by remains of ruptur. epidermis, Sporidia subglob. minute

16648 On both sides of the leaf oblong or lin. sometimes forming long lines yellow becoming reddish or brownish in decay, Sporidia globular or suboval

16649 Hypophyllous and on the petioles somewhat aggregated but generally following the course of the veins, bullated yellow bursting in the centre

16650 Chiefly hypophyllous very minute regular numerous convex late in bursting golden-yellow, Spcridia roundish oval or even oblong

16651 Chiefly hypophyllous very minute pale-yellow subrotund convex scattered or collected into clusters scarcely bursting, Sporidia suboval

16652 Hypophyll. depressed regular in form redd, orange scattered becoming partially conflu. Sporidia egg-shaped

16653 Hypophyllous depressed minute spreading somewhat aggregated subconfluent irregular in form of a deep orange or orange-red, Sporidia oval

16654 Hypophyllous scattered or crowded distinct convex roundish large compared with the following mostly closed pale becoming golden-yellow, Sporidia very long obtuse at each extremity

16655 Hypophyllous punctiform prominent or papilliform numerous tawny yellow mostly closed, Sporidia ovate

16656 Polymorphous of various forms sometimes disposed in a circular manner quite white frequently never bursting, Sporidia in great profusion globular

16657 Within the fruit and glumes of corn and various grasses spreading and in a short time filling the whole with a profuse black dust, which under the microscope consists of minute spherical sporules

16658 Attacking the fructification of Carices and forming a black compact slightly pulverulent mass composed of a pale solid nucleus surrounded by the naked sporidia which are small and globular

16659 Always inclosed within the grain and filling it with uniform dense fetid blackish-brown mass composed of very minute spherical sporidia

16660 Attack. anth. and ovary of the Caryophyllee, fine purp. Spori. very plentiful pulverul. min. and globul.

16661 Sporidia very min. purpl.-brown plentiful produc. within florets and often filling them with pulverul, mass

16662 Large oblong or conical much scattered pale-orange bursting with an irregular orifice, Sporidia excessively abundant bright-orange

16663 Hypophyllous numerous distinct, Sporidia very white toothed, Teeth beautifully rolled back brittle and vanishing, Sporidia pinkish-orange

16664. Hypophyllous and on the petioles scattered or subaggregated numerous, Peridia whitish split into many small deciduous teeth, Sporidia orange becoming obscure brown

16665 Hypophyllous and on the petioles scattered distinct, Peridia very white split into a few comparatively large teeth, Sporidia yellowish-white, Surface of the leaf blistered whitish

16666 Hypophyllous very numerous subsessile scattered or collected into little clusters, Peridia white split into subrevolute teeth, Sporidia fine orange

16667 Hypophyllous, Peridia distinct but decidedly clustered and crowded prominent becoming subelongated; the mouth with a few broad very delicate decidious teeth, Sporidia fine orange

16668 Hypophyllous and on the petioles irregularly clustered and deforming the parts on which it grows, Peridia somewhat indistinct round prominent and yellowish with a subentire orifice

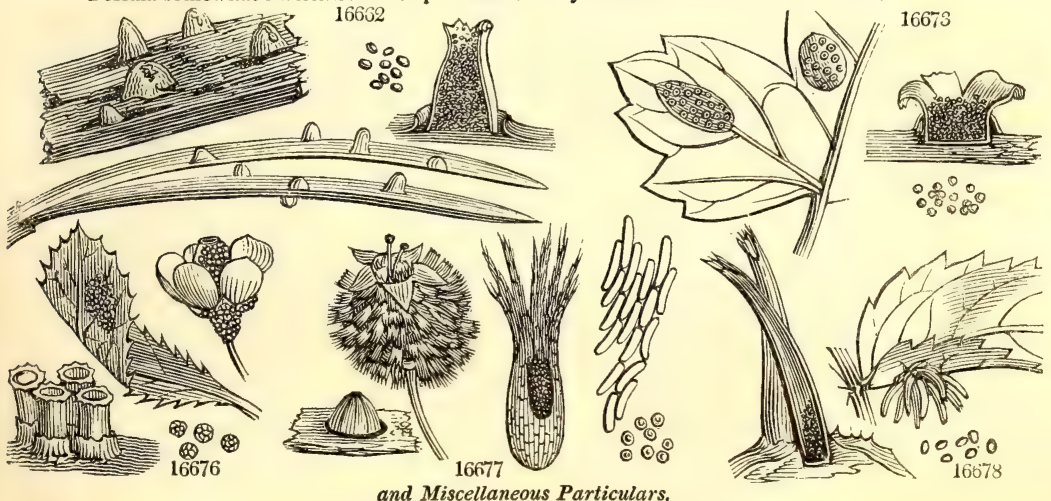

and Miscellaneous Particulars.

2498. Ecidium. These plants are found upon the leaves of other vegetables, and one of them is known to agriculturists under the name of Red Gum. This species usually grows inside the glumes of the calyx, under the epidermis, which, when the plant is ripe, bursts and emits a powder of a bright orange color. It does not 
16669 Jacobæ'æ Grev.

16670 Prenánthis Pers.

16671 Urtícæ Dec.

16672 confértum Dec.

16673 Grossuláriæ Dec.

16675 Cal'thæ Grev.

Caltha

bright

0 spring Or

16676 Berbéridis Pers. Berberry blight spreading 0 sum

16677 lacerátum Dec. $\quad$ ragged $\quad$ swollen 0 sum.

16678 cornútum Pers. cornute spots $\frac{1}{6}$ sum.

16679 Tussiláginis Pers. Coltsfoot concentrical 0 sum.

16680 rubéllum Dec. pink

16681 Al'lii Pers.

16682 Thalíctri Grev.

Allium concentrical 0 sum.

Thalictrum clustered 0 sum.

2499. PUCCI'Nia. Mich. Puccinia.

16683 Rósæa Grev. Rose

16684 Rúbi Dec. Bramble

many-cell. 0 aut.

16685 grácilis Grev.

slender

many-cell. 0 aut. many-cell. 0 aut.

16686 Potentíllæ Pers. Potentilla many-cell. 0 aut. 16687 Aspáragi Dec. Asparagus two-celled 0 aut. 16688 Circæ'æ Pers. Circæa two-celled 0 aut.

16690 Aviculáriæ Dec. knot grass two-celled 0 aut. 16691 ÆEgopódii Strauss Ægopodium two-celled 0 aut. 16692 túmida Grev.

tumid

16693 Men'thæ Pers. Mint

16694 Polýgoni Pers.

16695 Centauréæ Dec.

Polygonum two-celled 0 aut.

Centaury two-celled 0 aut.

16696 Umbelliferárum Dec. Umbellifer. two-celled 0 aut. 16697 Sanículæ Grev. Sanicle two-celled 0 aut.

16698 variábilis Grev. variable two-celled 0 aut.

16699 Heráclei Grev.

Cow Parsnip two-celled 0 sum.

Epilobium two-celled 0 june

Betony

16701 Betónicæ Dec.

two-celled 0 aut.

two-celled 0 sum.
Ysh under Sen. Jacobæa Ivs.

W under Hierac. sylvat. Ivs.

Ysh on Urtica dioice

Wsh on Ficaria

R under gooseberry lvs. Grev, crypt. fl, t. 62

Wsh under Ranunc. lingua lvs.

under Caltha palustris lvs.

Or on Berb.vulgaris Grev، crypt. ft. t. 97

$\mathrm{Br}$ on hawthorn Grev. crypt. 209

Y.Br on mountain-ash Grev. crypt. 180

Psh under Farfara lvs. Sower. t. 397. f.

Crim. under Rumex lvs. Sow.t.405. Rumicis

Y under All. ursinum lvs.

Or Thalictrum alpinum Grev. crypt. 4 Sp. 30-?.

Bl under rose leaves Grev. crypt. fl. t. 15

Bl under bramble lvs.

Bl under raspberry lvs.

B1 under Potentilla lvs. Grev. crypt. fl, t. 57

Bl dead asparagus

Pk.Br under Circæa lvs.

Pa.Br under Chrys. opp. Ivs.

Bl under Polygonum Ivs.

B. Gr on Egopodium 1vs.

Br.Gr on Bunium Bulbocastanum

Bl under Mentha Ivs.

R. Br under Polyg. amphib. lvs.

B1. on Centaurea nigra

Ve.D on Umbelliferæ lvs.

Bl.Br under Sanicula lvs.

Blsh on Leont. Taraxacum Grev, crypt. fl. t. 75

Blsh under Sphondylium lvs. Grev. crypt. f., t. 42

Br under Epilobium palustre lvs.

Ferr. under Beton. offic. lvs.

D. Br under Epilobium lvs.

16703 Adóxæ Dec. Moschatel two-celled 0 sum. D.Br on Adoxa Moschatellina

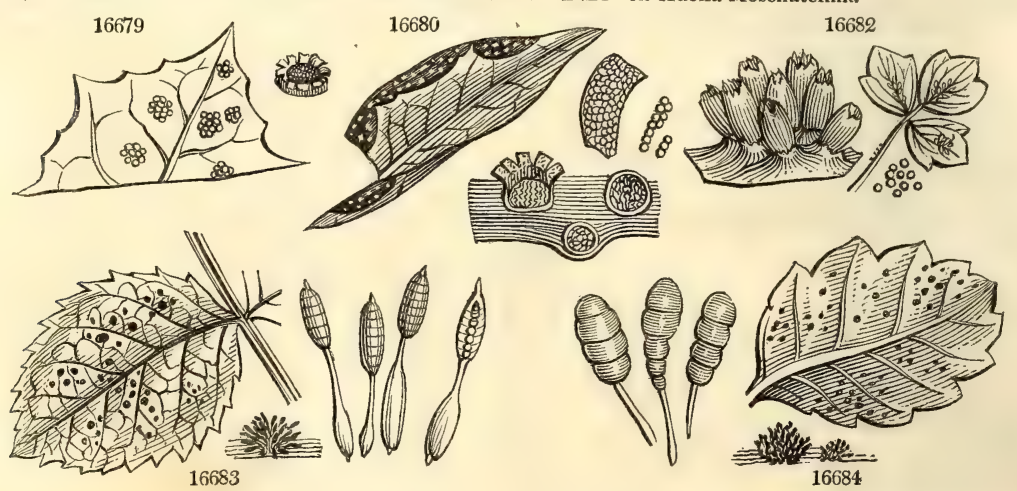

History, Use, Propagation, Culture,

appear to be materially injurious to the grain, if at all. Ears full of it have been found with very plump grains; and it has also been found upon branded ears. Before the cuticle which covers the fungus bursts, it has much the appearance of a pustule upon the human body. 
16669 Hypophyllous at first prominent pustular soon becoming agglomerated very numerous, Peridia splittirig into short brittle yellowish-white teeth, Sporidia pale-orange

16670 Hypophyllous in widely scattered agglomerated clusters but not very crowded, Peridia subsessile split into very white exceedingly brittle teeth, Sporidia pale

16671 Hypophyllous and on the petioles and stem, Peridia campanulate agglomerated rarely single split into many short recurved teeth, Sporidia ochre-yellow numerous ovate

16672 Hypophyllous and on the petioles, Peridia in dense agglomerated clusters whitish split into revolute teeth, Sporidia yellowish : the leaf whitish around the clusters

16673 Hypophyllous upon a thickened portion of the leaf, which on the upper surface is of a fine red color with a yellow border, Peridia densely crowded splitting into yellowish-white teeth, Sporidia pale

16674 Hypophyllous, Peridia agglomerated in scattered clusters of various sizes whitish with a brittle dentated margin, Sporidia yellow

16675 Hypophyllous and on the petioles aggregated short somewhat campanuiate with numerous very minute marginal teeth, Sporidia bright-orange subglobose or oval

16676 Hypophyllous and on the fruitstalk, seed-vessel, calyx, and even petals, Peridia short or elongated cylindrical densely crowded fine orange, Sporidia yellow under the microscope

16677 Hypophyllous and on the petioles and young fruit, Peridia elongated agglomerated brown splitting to the base in capillary segments, Sporidia numerous light-brown

16678 Hypophyllous, Peridia 2-12 long cylindrical slightly curved yellowish-brown springing from an orangecolored thickened portion of the leaf, Sporidia numerous greyish becoming brown

16679 Hypophyllous marked on the upper surface of the leaf by a yellow or purplish spot, Peridia partly immersed short splitting into white revolute teeth, Sporidia pink-orange

16680 Hypophyllous producing a crimson spot on the upper surface of the leaf, Peridia minute subimmersed splitting regularly into small revolute white teeth, Sporidia yellowish-white

16681 Hypophyllous marked by a pale spot on the upper surface of the leaf and a pale ring round the peridia, which are small not numerous splitting into small brittle yellowish-white teeth, Sporidia pale

16682 Hypophyllous somewhat clustered, Clusters of a roundish form, Peridia oblongo-cylindrical brightorange, Mouth paler and bursting irregularly

16683 Hypophyllous, Sporidia mucronated 5-7-celled with a white filiform stipes incrassated towaràs the base which is furnished with a yellow gland

16684 Hypophyllous deep-black tufted, Sporidia 4-celled obtuse mucronate, Stipes slender incrassated at the base

16685 Hypophyllous tufted of various sizes black rather lax scattered, Sporidia 7-9-celled somewhat attenuated mucronate with a slender stipes incrassated at the base

16686 Somewhat tufted scattered black, Sporidia cylindrical 3-4-celled obtuse never mucronated, Stipes filiform 16687 Round. or ov. obl. scatter. black somew. convex, Sporidia densely crowded obl. obt. firmly fix. by pedicels 16688 Hypophyl. deep pinkish-brown promin. consist. of a number of distinct aggregat. tufts, Sporidia obl. acute

16689 Hypophyllous small of various sizes few together and confluent pale-brown, Sporidia long somewhat waved much attenuated at each extremity with an elongated stipes

16690 Hypophyllous punctiform minutely tufted subrotund blackish-brown, Sporidia crowded obtusely eggshaped with a long flexuose filiform pedicel

16691 Chiefly hypophyllous minute aggregated rendering the nerves and petioles swollen dark bluish-grey before bursting, Sporidia nearly black oval not contracted in the centre, Stipes short

16692 Hypophyllous and on the petioles conglomerated confluent brownish-grey before bursting, Sporidia nearly black obtuse scarcely contracted in the centre: the upper cell sometimes divided

16693 Hypophyllous round scattered nearly black, Sporidia of an obtuse irregular figure with a short filiform stipes somewhat incrassated at the base

16694 Hypophyllous minute round very crowded reddish-brown : upper cell of the sporidia thick globose; the lower one long and narrow, Stipes short

16695 On both sides of the leaf and on the stem in small nearly black scattered tufts surrounded by the remains of the ruptured epidermis, Sporidia oval the two cells nearly equal, Stipes very short

16696 Hypophyllous minute very dark scattered, Sporidia short with both cells obtuse and a short stipes

16697 Hypophyllous circular very variable in size blackish-brown scattered rarely confluent, Sporidia very obtuse with a subelongated stipes

16698 On both sides of the leaf in minute tufts nearly black circular bordered by the remains of the epidermis, Sporidia variable very obtuse rounded 2 -celled both often subdivided, Stipes very short

16699 Hypophyllous blackish-brown irregular in figure girt by ferruginous remains of epidermis, Sporidia crowded obtuse divided but scarcely contracted in the middle, Stipes short

16700 Hppophyllous scattered closely over the whole surface small round brown depressed, Sporidia much contracted in the centre nearly resembling figure 8 : the upper cell largest

16701 Hypophyllous very thickly scattered and becoming contiguous but very rarely confluent minute at first and ferruginous after bursting, Sporidia short : upper cell obtuse, Stipes very short

16702 Hypophyllous dark-brown scattered or sub-confluent often concentric, Sporidia crowded pulverulent obtusely oval slightly contracted in the middle : the lower cell terminating in an abrupt and short stipes

16703 On the leaf and petiole crowded confluent, Sporidia dark-brown puiverulent : upper cell obtuse, Stipes somewhat lengthened
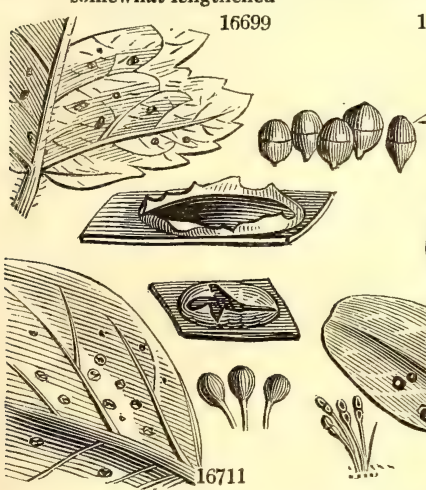

16698
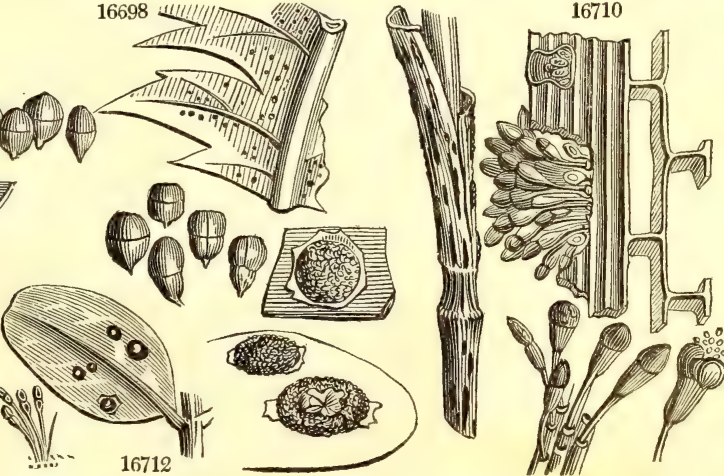

and Miscellaneous Particulars.

2499. Puccinia. A name of obscure meaning; possibly derived from $\pi \dot{x} x \alpha$, closely packed, in allusion to the crowded manner in which the little plants are placed. 
16704 Primula Grev.

16705 Víolæ Dec.

16706 Valántiæ Pers. 16707 glomeráta Grev. 16708 Ulmáriæ Dec. 16709 caricína Dec. 16710 Gráminis Pers. 16711 globósa Grev. 16712 Búxi Sow.
Primrose

Violet

Cross-wort heaped

Ulmaria

Sedge

Grass

globose Box two-celled 0 sum. D.Br uiader primrose Ivs.

two-celled 0 sum. D.Br under Viola canina lvs.

two-celled 0 sum. Dp. Br on Galium verum

two-celled 0 spr. su. Dp.Br under Senecio Jacobææ lvs.

two-celled 0 aut. Pu.Bl under Ulmaria Ivs

two-celled 0 aut. BI on Carex leaves

two-celled 0 aut. Bl on corn \& grasses Sow. t.140. U.Frumenti

one-celled 0 aut. $\mathrm{Bl}$ on bean leaves two-celled 0 sum. $\mathrm{Br}$ leaves of box

Grev. crypt. fi. t. 29

Grev. crypt. fi. t. 29

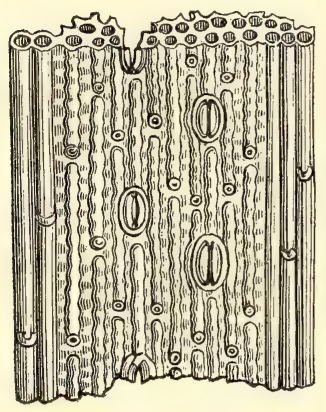

16710

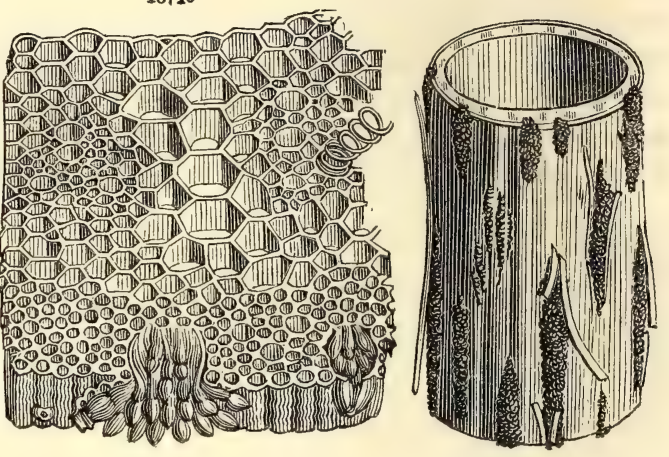


ORD. IX. TRIBE IV.

16704 Hypophyllous deep brown solitary scattered or concentric and subconfluent, Sporidia rather slender with the lower cell attenuated into a short stipes

16705 Hypophyllous minute scattered sometimes confluent irregular in form nearly black, Sporidia short obtuse small with a short stipes

16706 Hypophyll. very min. scatter. deep-brown, Sporidia thick obt. variable in shape with lower cell fusiform 16707 Hypophyllous tufts circular depressed broad dark fuscous composed of many smaller ones confluent at the centre, Sporidia oblong with lower cell somewhat attenuated

16708 Hypophyllous purplish black scattered in tufts, Sporidia variable generally very obtuse two rarely 3-celled frequently also divided perpendicularly, Stipes short

16709 Epiphyllous brown eventually black oval often confluent and forming long lines, Sporidia oblong with a white filiform stipes firmly fixed at its base

16710 Tufts dense oblong often confluent and forming long parallel lines changing from yellowish-brown to black, Sporidia elongated : the upper cell the shortest, Stipes filiform

16711 Epiphyllous minute scattered nearly black, Sporidia globose with a filiform slender stipes

16712 Scattered reddish-brown round very convex surrounded by the ruptured epidermis, Sporidia oblong 2-celled yellow with a long filiform stem
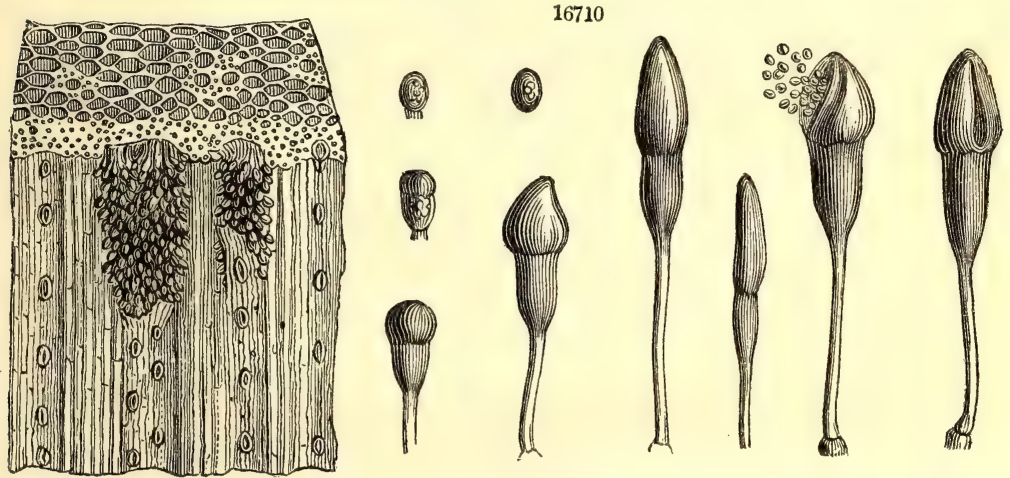



\section{ENCYCLOPADIA OF PLANTS.}

\section{PART II.}

\section{NATURAL ARRA.NGEMENT.}

First grand Division, VASCULARES

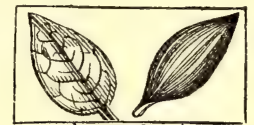

(vas, a vessel ; plants with woody fibre and cellular tissue).

First Class, Dicotyledones

Subdivision I. Dichlamydece

Subclass 1. Thalamifloræ

Subclass 2. Calyciflorre

Subclass 3. Corollifloræ

Subdivision II. Monochlamydece

Second Class, Monocotyledones

Second Class, MonocotyledoN

First Class, Foliacese

Second Class, APHylle

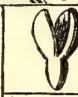

(dis, two, and cotyledon; cotyledons two).

(dis, two, and chlamys, a coat or covering; calyx anc: corolla distinct).

(thalamus, a bed or receptacle, and flos, a flower; stamens under the pistillum).

(calyx and flos; stamens on the calyx),

(corolla, and flos; stamens on the corolla).

(monos, one, and chlamys, a coat or covering; calyx and corolla not distinct).

(monos, one, and cotyledon; cotyledon one).

(cellula, a little cell ; plants with cellular tissue only).

(foliaceus, leafy ; habit).

(a, priv., and phyllon, a leaf; leafless).

THE difficulties connected with the adoption of the natural system of plants are these, that the characters of many of the orders are at present imperfectly known, and that they depend upon a consideration of many points of structure which are not to be determined without much labor and a considerable degree of practical skill in the use of the microscope and the dissecting knife. But the facilities which the habit of viewing all natural bodies with reference to the relations they bear to other bodies, and not as insulated individuals merely possessing certain peculiarities by which they may be referred to some station in an artificial system, merely possessing certain peculiarities by which they may be referred to some station in an artificiat system,
ultimately gives to the investigations of the naturalist, are so great, that difficulties of the nature just alluded to ought not to be suffered to influence the botanist in determining which line of study he will follow, whether that pointed out by Linnæus, or that traced by the hand of nature. By the artificial system of Linnæus, indeed, no great difficulty exists in determining the number of stamens or styles possessed by a given plant, or the nature of their combination, and from the knowledge so obtained, in referring them to their class and order in the Linnæan system. But when this step has been gained, what more has been acquired than the bare knowledge that the plant in question possesses a certain number of stamens and styles? No possible notion can be formed of the relation it bears to other plants of the same nature, of the qualities it probably possesses, or of the structure of those parts not under examination, the fruit for example; and, finally, if it were wished to convey an idea of the plant to a stranger, no means would be in the possession of the Linnæan botanist of doing so, except by stating that the plant belonged to Pentandria Monogynia for example, which is stating nothing. But what would be the condition of the student of the natural affinities of plants in a similar case? It is true he would be obliged to consult more characters than the two uninfluential ones of Linnæus - it would be necessary to ascertain if his subject was Vascular or Cellular; if Vascular, whether it was Monocotyledonous or Dicotyledonous ; if Dicotyledonous, whether the leaves were opposite or 
alternate, stipulate or exstipulate, whether the flowers were monopetalous, polypetalous, or apetalous, the nature and station of the stamens, the condition of the ovarium, and so on. But when he has ascertained thus much, only let it be remembered, for a moment, how much he has gained indirectly as well as directly. Perhaps he has discovered that his plant belongs to Rubiaceæ; he will then have learned that all vegetables with opnosite entire stipulate leaves, and a monopetalous superior corolla, are also Rubiaceous ; if a fragment of the leaves and stem only of such a plant were afterwards submitted to him for examination, he would recognise its affinities, and remember that it was Rubiaceous, and being aware of that fact, he would be able safely to infer that its calyx and corolla would be of a particular nature, that if the roots afforded any color for dying, it would be red; that the medicinal properties of the bark, if any, would be tonic, astringent, and febrifugal, and that its seeds would be of the same nature as those of coffee, and finally, its geographical position would be tolerably certain to him.

The really important obstacle which exists in the way of acquiring this kind of knowledge, is undoubtedly the want of any introduction to the study of it, accompanied by the distribution and characters of the natural orders into which plants are divided. It is to be hoped that English readers at least will not long have to regret this deficiency in their elementary works. In this place, it must suffice to point out the characters upon which the great divisions depend, under which the orders themselves are arranged; and it is to be hoped, that even this small aid will be found to smooth the way, and to remove some of the obstacles that at present are supposed to exist at the very threshold of the temple.

Plants considered with reference to their general structure, are separated into two grand divisions called Cellulares and Vasculares.

The Cellulares answer to the Linnæan Cryptogamia, and are also called Acotyledonous; the Vasculares answer to the rest of the Linnæan system, which is sometimes called Phanerogamia and Cotyledonous.

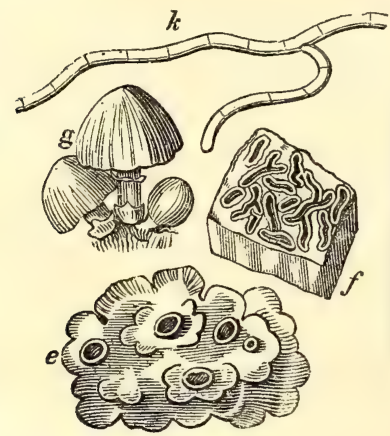

$a$, Longitudinal section of a stem

$b$, Transverse section of a stem.

c, Stem of a moss, with leaves and theca, or seed-case.

magnified.

Ieafy thallus of a lichen, with shields.

Cellulares, Cryprogamous, or Acotyledonous plants are all, therefore, different terms denoting the same combination of vegetables. The first term is here adopted in preference to the others as expressing the most obvious character upon which the division depends, namely, the cellular, not vascular, structure of the plants composing it. Cellular plants are formed entirely of cellular tissue ( $\mathrm{fig}$. 1.), without woody fibre or spiral vessels ; or in more familiar terms by having no veins in their leaves if foliaceous, and not forming wood they also are destitute of perfect flowers. The lower tribes, such as Fungi and Algæ, are destitute of leaves, and in some points approach the animal kingdom so nearly as to be scarcely distinguishable. In the highes tribe, Ferns, apparent veins are formed in the leaves; but as they are imperfectly supplied with spiral vessels, they cannot be considered more than analogous to the veins of other plants. Ferns, however, hold the intermediate station between Cellulares and Vasculares, and are chiefly retained among the former on account of their perfect accordance in other respects. In the whole of Acotyledones, it is unnecessary to examine the seed for the purpose of determining whether it has one cotyledon, several cotyledons, or none, the structure of the perfect plant giving the most obvious and satisfactory evidence.

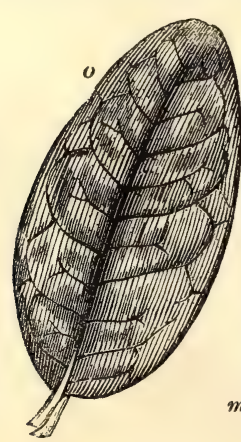

$l$, Vertical section of a vascular stem. $m$, Woody fibre
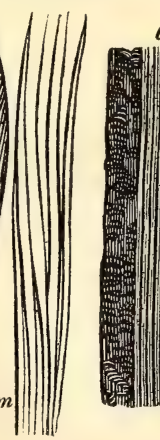

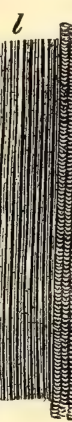

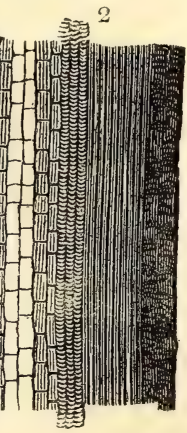

o, Leaf of a dicotyledonous plant.

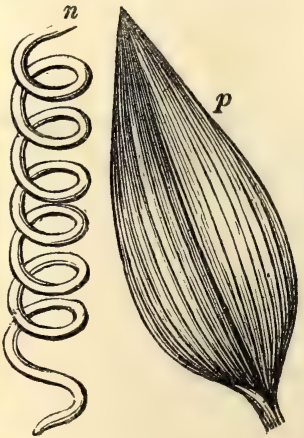

$p$, Leaf of a 
Vasculares, Phanogamous, or Cotyledonous plants, are also separated into two great classes called Endogenes or Monocotyledones, and Exogenes or Dicotyledones, both which are distinguished as accurately by their obvious physical structure as they are by the minute and obscure peculiarities of the seed. They are all formed with cellular tissue, woody fibre, and spiral vessels ( $f g .2$.), and their leaves are traversed by veins; the last character is sufficient for practical purposes, if it is remembered that they also bear perfect flowers, (that is, flowers furnished either with stamina, or pistillum, or both, which will always prevent their being confounded with the highest tribes of Cellulares.

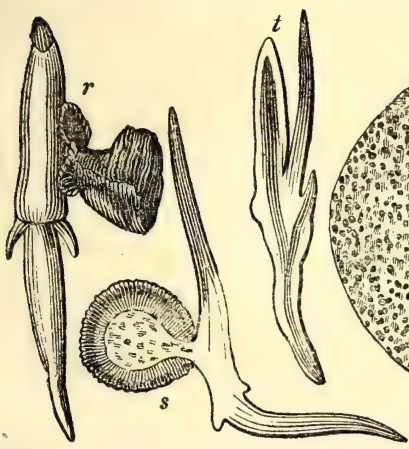

$q$, Transverse section of a monucotyledonous stem. $r$, Germination of a monocotyledonous seed $s$, section of ditto, to show the cotyledon remaining in the
3

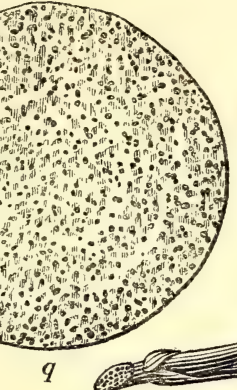

$t$, Section of a germinating embryo of a grass, to show the two alternate cotyledons of unequal size; the back and front lobes $u$, Stem and leaves of a monocotyledoncus plant.

Endogenes, or Monocotyledonous plants, are the first remove from Cellulares, and hold an intermediate rank between them and Exogenes or Dicotyledonous plants, in which vegetation acquires its highest form of developement. They were formerly characterised by having a single cotyledon, but this circumstance is not only not absolute but difficult of determination, except after minute analysis. The real difference in the seed of them and Dicotyledones is this, that in Monocotyledones there is only one Cotyledon ( $f i g .3 . s)$; or, if two, that they are alternate with each other $(t)$, while in Dicotyledones they are always opposite, and more than one, sometimes several, as in Pinus ( fig. 4.y). The physiological structure of the two classes is, however, that by which they are familiarly distinguished, and exhibits a beautiful proof of the harmony that exists between the great features of vegetation and their first principle, the seed from which they originate. In Endogenes, or Monocotyledones, there is no distinction between wood and bark ( fig. 3. q); in Exogenes, or Dicotyledones, the wood and bark are distinctly separated (fig. 4. v). In Monocotyledones the wood and cellular tissue are mixed together without any distinct annual layers of the former being evident; in Dicotyledones the wood and cellular tissue have each their particular limits assigned them, a distinct layer of the former being annually deposited. In Monocotyledones there are no radiations from the medulla to the bark; in Dicotyledones the radiations are distinctly marked. In Monocotyledones there is generally no articulation between the leaves and the stem, while in Dicotyledones the leaves are always jointed with the stem from which they fall off, leaving a scar behind. In Monocotyledones the veins of the leaf pass in parallel lines from the base to the apex, in Dicotyledones they diverge from the midrib towards the margin at various angles; in the former they are unbranched, the principal veins being connected by nearly simple secondary veins; in the latter they are much branched, ramifying in many directions, and giving the surface of the leaf a netted appearance.

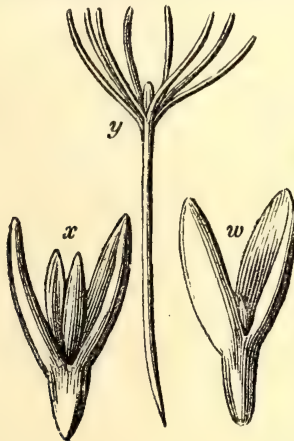

$v$, Transverse section of a dicotyledonous stem. $w$, An embryo with two cotyledons.

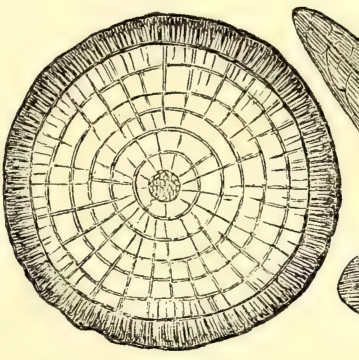

$v$

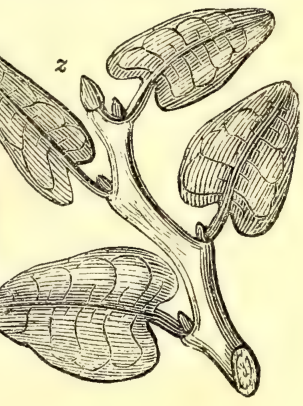
$y$, An embryo with many cotyledons.
$z$, Stem and leaves of a dicotyledonous plant.

Such are the very obvious distinctions of the two great classes of Phænogamous, or flowering, plants ; and so far is it from there being any necessity for dissecting a seed in order to ascertain its structure, that this point is one of the most easy determination, and about which there cannot be in one case in five hundred the slightest cause of doubt or difficulty. It is almost impossible to take even a morsel of a plant in the hand without instantly being in possession of the knowledge of the structure of its seed, with respect to the sotyledons.

Thus far have we advanced without a single obstacle to impede us. In all farther investigation no greater degree of able to ascertain the genus of a plant. Many of the orders do not depend upon the minute characters of the seed so much as is believed; the structure of the ovarium and position of the ovuia, are aids which frequently make amends for the absence of fruit: and the nature of the foliage and inflorescence are guides which, though sometimes treacherous, are often as faithful as the fructification itself. But as it is not intended to give the characters of the orders in this place, neither is it necessary to advance farther in an explanation of the manner of determining them; upon that point each order would require a particular note. It may, how- 
ever, be confidently believed, that there are no greater impediments in the road to an acquaintance with the natural relations of plants than those that have been already removed; and that although neither the science of botany, nor any other science, is to be taken by storm, yet that the fortress is sure to be reduced by silent and patient approach.

It only remains to explain briefly upon what principles the names of the orders, suborders, \&c. are formed. It is usual, in the school of Jussieu, to give to a natural order a name derived from that of the genus which is understood to be the type of the order; as Ranunculaceæ from Ranúnculus, Rosaceæ from Rósa, and so on. But several deviations from this principle had been admitted by Jussieu, in favor of certain groups of plants, long known by other popular names, derived from certain peculiarities; such as Labiatæ, because their corollas are labiate; Compositæ, because their flowers are what is commonly called compound; Guttiferæ, on account of the resinous juice in which they abound, and some others. It would, perhaps, have been better, if uniformity in nomenclature had not thus been sacrificed to a dread of innovation; but it is now too late to remedy the evil, if such it be ; nor would the advantage of alteration be at this day equivalent to the inconvenience. For the purpose of making it at once apparent, whether, in speaking of a group of plants, reference is had to an order or a suborder, it has of late years been thought convenient to terminate the name of the natural order in acea, and of the suborder in ea. Thus, in speaking of the whole mass of which Ranúnculus is the representative, the word Ranunculacee is used; but in speaking of the particular division, or suborder, of which Ranúnculus forms a part, the term Ranunculea is employed. This manner of speaking is, however, at present, very partial in its application, and is of little importance, except in a few cases, of which Ranunculaceæ is one of the most striking examples. In those orders, the titles of which, necessarily, from their grammatical construction, end in ea, as Orchideæ, it is obviously inapplicable, without a total change in a great part of the nomenclature of natural orders, a measure which cannot be too much deprecated.

It may, perhaps, be finally expected, that these remarks should be concluded by a recommendation of some work, from which those who are anxious to become fully acquainted with the principles and distinguishing characters of the Natural System of Botany, may derive the necessary information. Unfortunately, however, such a work has at present no existence. M. Decandolle's Théorie Élémentaire de la Botanique explains the principles upon which the orders of plants are constituted; and M. de Jussieu's Genera Plantarum contains their characters, as determined in 1789: but the latter is now too obsolete to be very useful to the tyro. In our own language, the only work that can be consulted upon the subject with advantage, is the Flora Scotica of Professor Hooker, in which the characters of the natural orders of Scottish plants are concisely indicated by Mr. Lindley. We understand a work upon the subject is in preparation by the latter gentleman, by which this great desideratum in the science of Botany will be supplied. It may be expected to appear in the course of 1829, previously to which, however, the division Botany, in the forthcoming Encyclopæedia of Natural History will have been published, in which much information may be expected upon this important subject.

\section{VASCULARES.}

\section{Class I. Dicotyledones.}

\section{Subdivision I. DICHLAMYDEE.}

This subdivision comprehends all the Dicotyledonous plants, that have both a calyx and corolla, by which they are distinguished from Monochlamydeæ, in whioh the calyx only exists. It is in consequence of this high developement of the floral envelopes, that the greater part of flowering trees and shrubs are found in Dichlamydeæ, it rarely happening that those with a single floral covering only have any brilliant coloring.

\section{SUBCLASS I. THALAMIFLORE.}

\section{Petals inserted into the receptacle.}

The insertion of the petals and stamens into the receptacle is the great character of this subclass, which, therefore, contains all the polyandrous plants of Linnæus, as the Calycifloræ contain the icosandrous genera of the same botanist.

\section{Section 1. Carpella numerous, or stamens opposite the petals.}

Order I. RANUNCULACEÆ.

The greater part of the plants of this order are objects of interest with gardeners, containing, as it does, many of the most eiegant or showy of the tribes of hardy plants. It is here that the graceful Clematis, the lowly Anemóne, the glittering Ranúnculus, and the gaudy Pæony are found; differing, indeed, in external appearance, but combined by all the essential characters of the fructification. It is remarkable, however, that the acrid and venomous properties of these plants are nearly as powerful as their beauty is great. They are all caustic and in many of them the deleterious principle is in dangerous abundance. M. Decandolle remarks, that its nature is extremely singular; it is so volatile, that, in most cases, simple drying in the air or infusion in water is sufficient to destroy it: it is neither acid nor alkaline; but its activity is increased by acids; honey, sugar, wine, or alcohol; and it is, in reality, destructible only by water. The crowfoots of our European pastures, and the Anemónes trilobáta and triternáta, of those of South America, are well known poisons of cattle. Blistering plasters are made in Iceland of the leaves of Ranúnculus ácris. The foliage of some species of Clématis is supposed to afford the means employed by beggars of producing artificial ulcers. Some of the Aconites are diuretic, especially Napéllus and Cámmarum. Delphínium Consólida is said to be an ingredient in those French cosmetics which are so destructive of the surface of the skin. The Helleborus, famous in classical history for its drastic powers, and the Nigélla, celebrated in ancient housewifery for its aromatic seeds, which were used for range of this order, in a geographical point of view, is very extensive. A great number has been discovered in Europe, but they are so abundant in all parts of the world that an order can scarcely be found more universally and equally dispersed. It is singular, that, with the exception of the climbing species of Clematis and of Xanthorhiza, scarcely an instance occurs in Ranunculaceæ of a shrubby stem.

Tribe 1. Clematinea.

Clématis $L$.

1228 Naravélia Dec.

1229 Thalictrum $W$

1226 Anemóne $W$
Tribe 2. Anemones.

1225 Hepática $W$. en.

1241 Hydrástis $W$.
1231 Knowltónia Sal.

1230 Adónis $L$.

Tribe 3. Ranunculea.

707 Myosúrus $W . \quad 708$ Ceratocéphalus $\boldsymbol{P} . S . \quad 1233$ Ranúnculus $\boldsymbol{W}$.

1239 Cáltha $W$.

1234 Tróllius $W$.

1286 Eránthis Sal.
708 Ceratocéphalus $P . S . \quad 1233$ R
Tribe 4. HELLEBorez.

1235 Isopýrum $W$. 1053 Garidélla $W$.

1237 Helléborus $W$. 1209 Nigélla $W$.

1239 Cóptis Sal. 1208 Aquilégia $W$.
1232 Ficária Pers.

1204 Delphinium $W$

1205 Aconitum $W$ 
1164 Actæ'a $P h$. 1207 Cimicífuga $P h$.

Tribe 5. PeONIEA

\title{
Order II. Dilleniace.e.
}

Fine plants, almost exclusively confined to tropical countries. Dillénia speciósa, a native of India, is a most noble tree with large yellow flowers, rivalling those of a Magnólia. Hibbértia volúbilis is a green-house plant well known for the beauty of its blossoms, and their powerfully fetid smell. The medical properties of this order are scarcely known; a decoction of their leaves or bark is astringent, and used for gargles; and the acid juice of the fruit of some of the species of Dillénia is used in India, mixed with water, as a pleasant beverage in fevers. The foliage of many of the species is extremely scabrous, whence the dried leaves are used for the same purposes as fish-skin and sand-paper in Europe; those of Trachytélla áspera are even employed in China for polishing works of metal.

1201 Curatélla $W$.

1212 Tetrácera $L$

\section{Trachytélla Dec.}

1214 Dillénia $W$.
1203 Hibbértia $H . K$.

1211 Colbértia Sal.

\section{Order III. MAGNOLIACEE.}

No one is ignorant of the grandeur of Magnolias, or of the delicious, though sometimes dangerous, fragrance of their blossoms; but it is less generally known, that, from their affinity to the trees that produce the famous Winter's bark and Melambo bark, they possess medicinal qualities of no common power. The bark of all of them is said to have a bitter flavor without any astringency, and combined with a hot aromatic principle. In the United States, the bark of Magnólia glaúca and Liriodendron tulipífera, is employed for the same purposes as Jesuit's bark, and from the fruit of Magnólia acumináta, a tincture is prepared which has some reputation for removing attacks of rheumatism. The fruit of Illícium anisátum, is the material which flavors the liqueur called Anisette de Bourdeaux. The Magnolias are exclusively inhabitants of Asia and America, no species having hitherto been found either in Europe or in Africa. 1215 Illicium $W$. 1216 Liriodéndron $W$.

1218 Michélia $W$.

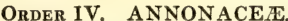

The plants of this order are closely allied to Magnoliaceæ, from which they are principally distinguished by the absence of stipulæ, and by the structure of their anthers and seeds. The latter consist of a hard mass of albumen, ruminated, as the botanists call it, that is to say, perforated by the substance of the seed-coat, in every direction. They are all trees or shrubs, and chiefly inhabitants of the hottest parts of the tropics, but a few have been discovered straggling into the temperate zones of America. The fruit of the Annóna is in many species highly esteemed as an article for the dessert, especially that of the Cherimoyer, which has the many species highly esteemed as an article for the dessert, especially that of the Cherimoyer, which has the
reputation of being the finest fruit in the world, next to the Mangosteen. The hard fruits of the species of Uvária are highly aromatic; those of one of them furnish the Piper æthiópicum of the shops. The genus Asimina is the only one which contains any hardy species, and these are so delicate as to be seen very rarely in this country. In Brazil, the bark of Xylópia sericea is used for cordage; for which it is admirably adapted.

\author{
1219 Uvária $W$. \\ 1220 Annóna $P$. $S$.
}

1221 Artabótrys $R$. Br.
1223 Asímina Ad.

1224 Xylópia $W$.

Order V. MENISPERMEF.

The order of Menispermex consists entirely of twining shrubs with minute flowers. They are extremely dissimilar in habit from the orders which are placed near them, and occupy their present station entirely on account of certain minute but important characters in their fructification. With the exception of Schizándra coccínea none of them are worth cultivating as plants of ornament. The berries of Lardizabála biternáta are sold in the markets of Chile, under the name of Aguilboquil, Guilbogui, or Coguill-Vochi, according to different travellers. The bitter, diuretic, and aperient sorts of Pareira brava, are produced by a species of Menispérmum, as is also the famous Columbo root, so much esteemed for its intense bitterness, and for its use in diarrhoea and dysentery. The poisonous drug, called Cocculus indicus in the shops, is the seed of Menispérmum Cócculus. Several Brazilian species of Cócculus are said to possess powerful febrifugal properties. No species of Menispermeæ is found in Europe; they are chiefly natives of tropical America and Asia.
858 Wendlándia $W$
2100 Menispérmum $D$.
2116 Cissámpelos Dec.
¿101 Cócculus Dec.

1972 Schizándra $W$.

Order VI, BERBERIDE存.

With the exception of Bérberis this order does not contain any genus of much interest; most of the others are low, inconspicuous, herbaceous plants; Nandína is an elegant Japanese shrub. The Berberises are all shrubs of much beauty and interest, especially the species with pinnated leaves, which are sometimes called Mahonias. These are all inhabitants either of Europe, Asia, or North and South America; none have ever been seen in Africa or New South Wales. Many of the finest species from Chile and India yet remain to be introduced. The berries of the Berberises are acid and astringent; the latter quality is especially abundant in the stem and bark.
297 Epimédium $W$
826 Caulophýllum Mich.
829 Bérberis $W$
825 Leóntice $W$.

827 Diphylléia Mich.
830 Nandína $W$

Order Vit. PODOPHyllaceæ.

Little interesting herbaceous North American plants, nearly related on the one hand to Nymphæaceæ, and, on the other, to the herbaceous genera of Berberidea. Their juice is heid to be purgative.
1166 Podophýllum $W$.
896 Jeffersónia $P h$.

ORDER VIII. HYDROPELTIDEE.

This order differs from Nymphæaceæ chiefly in having a definite number of seeds. It consists of only two genera, each containing a single species. Both are little floating plants of tropical and northern America. Nothing is known of their properties.

\author{
1240 Hydropéltis $H$. $K$.
}

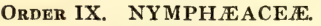

Like the last, these are all floating plants, and, to gardeners, possessed of great interest, on account of the elegant form and various hues of their flowers Three species are known as the lilies of our own streams and ponds, and the remainder occupy similar stations in other couritries. Some of the Indian species of Nymphæ'a are delightfully fragrant. The holy Cyamus, or Pythagorean bean of antiquity, is the produce of the Nelúmbium, a stately aquatic, which abounds in all the hotter countries of the East, where its roots are frequently used as an article of food. The ditches, about Pekin and other Chinese cities, are literally choaked up with its abundance. The pericarpia or beans are oblong, hard, smooth bodies, and possess the power of vege tating after having been dried for even thirty years. The flowers and roots of the common white Nymphæ' have been long celebrated for their sedative and antiaphrodisiacal qualities, which are, however, now considered doubtful. In Sweden, in years of scarcity, the roots of Núphar lútea are pounded into cakes along with the inner bark of Pinus sylvéstris. 
This order has been the cause or much difference among botanists, as to its true station in a natural classification, its structure being of so doubtful a character as to leave room for disputing whether it belongs to Dicotyledones or Monocotyledones. Upon this subject M. Decandolle has the following remarks : " Gærtner declares that the embryo is undivided, and therefore monocotyledonous. In 1802, I remarked in the Bulletin Philomathique, that the embryo both of Nymphæ'a and Núphar is enclosed in a peculiar integument, and that a dicotyledonous structure is apparent when that integument is removed; shortly after, M. Mirbel declared that the embryo of Nelúmbium has two thick cotyledones; in 1806, M. Turpin gave an accurate description of the fruit of Nelumbium líteum, without however removing the doubts about the real structure of the embryo, and two years afterwards his colleague, M. Poiteau, described the seed and germination of the same plant, pointing out that the embryo consisted of two thick cotyledons enclosed within a stipular membrane, but destitute of radicula: this was subsequently confirmed by $\mathbf{M}$. Mirbel after very minute anatomical examination; that observer compared the seed of Nelúmbium to the seed of Amýgdalus, and also to that of Piper and Saurúrus, and also demonstrated that the structure of the stem was analogous to that of exogenous or dicotyledonous plants. A very different opinion was shortly afterwards held by $\mathbf{M}$. Correa de Serra, an observer of the highest order, who admitted indeed that Nymphæaceæ are exogenous, but contended that the parts which had been taken by previous observers for cotyledons were, in fact, a mere expansion of the radicle, and that cotyledons were as entirely absent in Nelúmbium as in Cúscuta. In the meanwhile M. de Jussiєu adhered to the old opinion, that Nymphæaceæ are monocotyledonous; in which he was supported by the late Professor Louis Claude Richard, a name for ever memorable in the annals of Carpology, who published a new view of their structure, in which he differed materially from all his predecessors; this botanist considered the stipulary membrane of Poiteau a simple cotyledon, and the cotyledons of that writer the hypoblastus, or body of the radicula; he also refused to admit any evidence derived from the anatomical structure of the stem. In this conflict of opinions, I have determined to station Nymphæacer among Exogenes, for the following reasons: 1st, because the structure of their stem is that of Exogenes rather than of Endogenes; $2 \mathrm{dly}$, because the two opposite bodies, enclosed within the little bag or stipulary membrane, described by Poiteau, appear to be undoubtedly cotyledons, which is confirmed by the presence of a plumula between them in Nelímbium; 3dly, because of the structure of their flower, which has a great affinity with that of Pæónia, Magnólia, and Papáver; 4thly, on account of the similarity between their fruit and stigma and that of Papáver; 5thly, because of their milky juice and convolute leaves, two characters which are not known to exist among Endogenes." These who are interested in pursuing this curious discussion any farther, will find many remarks and illustrative figures in the English edition of the Analyse du Fruit, published by Mr. Lindley in 1819.
1174 Nymphæ'a $W$.
1176 Núphar $H . K$.
1177 Eurýale $\boldsymbol{H} . \boldsymbol{K}$.
1213 Nelúmbium $J$.

Section 2. Carpella solitary or connate; Placente parietal.

Order X. PapaveraceE.

These plants are better known for their medicinal properties than for their beauty. Some of them are the cornmon pests of corn fields, and with grain have been disseminated over all the world. Sanguinária is a neat little American plant well known for its crimson juice, and the emetic purgative powers of its roots. Saracénnia is a genus of very doubtful affinity; consisting of curious little American marsh plants of difficult culture, and remarkable for the singular pitcher-like form of its leaves. The peculiar power of the poppy is, as is well known, narcotic; a property which pervades all the order, although in a less intense degree in all than in the officinal P. somniferum, from which exclusively the drug opium is obtained. The Mexicans use the expressed officinal of the seeds of Argemóne mexicána for polishing furniture.
oil
1170 Papáver $W$.
1165 Sanguinária $W$.
1168 Röméria Med.
1169 Glaúcium $\boldsymbol{J}$.
1172 Argemóne $W$.
313 Hypécoum $W$.
1073 Boccónia $W$.
1167 Chelidónium $W$.
1171 Meconópsis $V$ ig.
? 1173 Saracénia $W$

\section{Order XI. FUMARIACE无.}

Tender herbs, with fineiy cut leaves and annual stems, abounding in a watery juice ; without any appearance of milkiness. They are reckoned slightly diaphoretic and aperient, but their medical properties are trifling. Formerly they were combined with Papaveraceæ, from which they are now universally distinguished. The greater part of them are natives of hedges or thickets in the cooler parts of the northern hemisphere; two are natives of the Cape of Good Hope. Many of the species are beautiful ornaments of the flower-garden.

1502 Corýdalis Vent.
1503 Cysticápnos $W$. en
1504 Diclýtra Dec.

1505 Adlúmia Raf.
1506 Sarcocápnos Dec. 1507 Fumária $P . S$.

\section{Order XII, CRUCIFERE}

The importance of this order to mankind, and the singular nature of its botanical characters, render it expedient to speak very fully upon it: in which the remarks of the learned $M$. Decandolle, who has paid Cruciferæ particular attention, will be chiefly followed. The order consists wholly of annual or pererinial, often biennial herbs, occasionally assuming a suffrutescent habit; then, however, never exceeding the height of three feet. The roots are either thick and perennial, or annual or biennial and slender, almost always perpendicular and undivided. The young roots are tipped with a little sheath, called the coleorhiza, which is pendicular and undivided. The young roots a curious character, and deserves attention. The stems are round or somewhat angular, branched, and often, even in character, and deserves attention. The stems are round or somewhat angular, branched, and often, even in
the annual species, indurated at the base. The branches proceed from the axilla of the leaves, but the uppermost ones are abortive in most cases. The racemes are always opposite to the leaves; sometimes the terminal branch is abortive when the raceme appears to be terminal; but this is merely owing to that circumstance. The leaves are simple, generally radical or alternate, rarely opposite. The flowers are either white, yellow, or purple, or in a few Cape species bright blue. The fruit is called either a siliqua or silicula, the former being linear pod this order, which is the same as the Linnæan class Tetradynamia, is divided by Linnæus into two parts, called this order, which is the same as the Linnæan class Tetradynamia, is divided by Linnæus into two parts, called
Siliquosæ and Siliculosæ. In the seed, the radicle and cotyledons are applied to each other in different ways, from which the suborders of M. Decandolle derive their characters. When the edge of the cotyledons is pressed close to the radicula, so that a cross section would be thus $\mathrm{O}=$, the cotyledons are said to be accumbent, as in all Pleurorhizeæ; when the side of the cotyledons is pressed to the radicula thus 011 , the former are called incumbent, as in Notorhizeæ. If the cotyledons are incumbent, and at the same time half folded together or conduplicate, thus $O>>$, the suborder Orthoploceæ is formed; when the cotyledons are incumbent and spirally twisted, so that a section would resemble this $O\|\|$, they constitute the suborder Spirolober; and finally, when the cotyledons are incumbent, and doubled twice in their length, thus 0\|\| , we have Diplecolobeæ.

The whole order is preeminently European; 166 species are found in the north and middle of Europe, and 178 on the sea-shores of the Mediterranean; 45 are found between Mogadore and Alexandria; 184 in the countries of the East, that is to say, Syria, Asia Minor, Tauria, and Persia; 99 in Siberia; 35 in China, Japan, and India; 16 in New Holland and the South Sea islands; 6 in the Mauritius and adjacent countries; 70 at the Cape; 9 in the Canaries; 2 in Saint Helena ; 2 in the West Indies; 41 in South America; 48 in North America; 5 in Kamtchatka and the bordering islands; and finally, 35 are common to several parts of the globe. From this it appears that there are about 100 species in the southern hemisphere, and about 800 in the northern: or, if they are considered with reference to the zones of temperature, 205 are natives of the frigid zone of the northern hemisphere; 30 of the whole of the tropics; 548 of the temperate zone of the northern hemisphere; and 86 of thie southern. The forty-first degree of north latitude may be considered the equa- 
torial line of Cruciferæ, about half being found on one side of it, and half on the other. Their station is very variable many inhabit open sandy places, some form the vegetation about the limits of the perpetual snows of lofty mountains, and many follow the footsteps of man through all parts of the world.

The useful qualities of the turnip, the radish, the rape, and the cabbage, and its multiform varieties, are all well known. The greater part of the order consists of plants possessing high antiscorbutic powers. These appear to depend upon a certain acrid volatile oily principle, the chemical nature of which is imperfectly known. It is particularly abundant in the seeds of mustard and the roots of horseradish, and the leaves of Lepidium latifolium, which latter exercise a violent influence upon the organs of digestion. The same sort of acrimony, but in less degree, is found in the herbage of the scurvy-grass and the roots of the radish, which act much more mildly when taken inwardly ; thus, when any cruciferous plants are found to be eatable, either from culture or other circumstances, it is to be understood to depend upon a reduction of this acrid principle. The exciting powers of this last, are what render the horse-radish, the scurvy grass, and others, so remarkably useful as antiscorbutics; they are also believed to possess diuretic and diaphoretic properties. It is to be remarked, that Cruciferæ are always eatable when their texture is succulent and watery, as in the roots of the radish and the turnip, and the leaves of the cabbage tribe. A further diminution of the acrid principle is produced by blanching. Cruciferæ are said to possess a greater share of azote than any other tribe of plants ; as is apparent in their fetid smell when fermented. The embryo of all the order abounds in oil, whence many species are employed with much advantage for expressing, either for eating or for feeding lamps. Some of the species are extremely beautiful and fragrant, as the Stocks, the Gillyflowers, the Hesperides, the Candytufts, and many others. The Hutchinsias, Drabas, Cardamines, \&c. are among the most interesting of alpine plants

Suborder I. PLEURORHIZEAE. O =

Tribe 1. Arabide.E.

1381 Mathiola $R$. Br. 1382 Cheiránthus $L$ 1383 Nastúrtium $R$. Br.

1384 Leptocarpæ'a Dec. 1389 Turritis $R . B r$

1385 Notóceras $R . B r . \quad 1390 \mathrm{~A}^{\prime}$ rabis $L$

1391 Macropódium $R, B r$. 1394. Dentária $L$.

Tribe 2. ALYSSINEE.

1395 Lunária $L$.

1396 Ricótia $L$

1397 Farsétia Turr

1399 Aubriétia Adans. 1402 Clypéola $W$.

1400 Vesicária Lam. 1403 Peltária L

1401 Alýssum $L . \quad 1404$ Petrocállis $R . B$

1405 Drába $L$

1406 Erúphila Dec.

1407 Cochleária $L$.

Tribe 3. Thlaspide

1411 Teesdália $R . B r$. 1413 Biscutélla $L$.

1408 Thláspi $L$.

1410 Hutchínsia $R$. $B r$.

1412 Ibéris $L$.

Tribe 4. Euchidiex.

1414 Euclídium $R$. $B r$

1415 Ochthódium Dec.

Tribe 5. Anastaticew.

1416 Anastática $L$

Tribe 6. Cakilinex.

1417 Cakíle Tourn. 1419 Choríspora Dec.

SUborder II. NOTORHIZEFE. O II

Tribe 7. Sisymbryez.

1424 Erýsimum $L$. 1422 Sisýmbrium $L$. 1423 Alliária Adans.

1420 Malcómia $R . B r$.

1421 Hésperis $L$.

1425 Camelína Crantr

Tribe 8. Camelinee.
1427 Corónopus Sm. 1428 Lepídium $L$

Tribe 9. Lepidines

$\begin{array}{ll}L . & 1409 \text { Capse } \\ \text { Tribe 10. } & \text { Isatide.e. }\end{array}$

1430 Isátis $L$

1431 Mýagrum $L$.
1429 ÆEthionéma $R . B r$.

SUBORDER III. ORTHOPLOCEAE. $\bigcirc>>$

Tribe 11. Brassices.

1432 Brássica $L$.

1433 Sinápis $L$.

1437 Vélla $L$.

1440 Zílla Forsk.
1434. Moricándia Dec.

1435 Diplotáxis Dec.

Tribe 12. VelleE.

1438 Carrichtéra Adans.

Tribe 13. ZILLEE

1441 Calepina Adans.

Tribe 14. RAPHANEE.

1418 Rapístrum Desv.

1443 Ráphanus $L$
1436 Erúca Tourn.

1439 Succówia Mönch.
442 Crámbe $W$
SUBorder IV. SPIROLOBEE. O \|\|

Tribe 15. Buniadeas.

1444 Búnias $L$.

Tribe 16. ERticarte.

1445 Erucária Gartn. 
Tribe 18. Subularinge 1447 Subulária $L$

$\$$ of doubtful station.

1380 Schizopétalon Sims.

Order XIII. FLACOURTIANEF

A very small order formerly comprised in Tiliaceæ. It is remarkable on account of the structure of its fruit, to the inner lining of which the seeds are attached upon a branched placenta. Nothing is knowri of the properties of the Flacourtias. The berries of Flacoúrtia Ramóntchi are eaten in Madagascar. The order
consists entirely of small tropical trees or bushes.

\author{
2102 Flacoúrtia $W$
}

Order XIV. CAPPARIDEA.

These are nearly related to Cruciferæ, of the properties of which they partake. Many are very pretty plants, especially Cleóme rósea, and the various species of Cratæ'va. The common caper is an elegant bush, remarkable for its large white flowers and long purple stamens. The species are found occasionally in various parts of the world. The different kinds of Capparis are reputed to be stimulating, antiscorbutic, and aperient. The bark of the root of the common caper passes for a diuretic medicine. Several species of Cleóme have an acrid taste, which has been compared by travellers to that of mustard. The root of Cleóme dodecándra is employed as a vermifuge in the United States; and the leaves produce an inflammation of the skin, whence they are used in Cochin-china as a sinapism. Dec.

1162 Cápparis $W$.

1086 Cratæ'va $W$.

1448 Cleóme $W$.

Order XV. VIOLARIEE.

This is one of the most favorite orders with gardeners ; consisting, as it chiefly does, of the Violet genus, from which most of the others are recenc dismemberments. Tine greater part are hardy herbaceous plants, some of which are remarkable for their perfume, others for their brilliant colors, and all for their neatness. They are natives of the temperate or cold zones of both hemispheres, often growing at great elevations above the sea. A mong them is a tribe called Alsodineæ, consisting of suffrutescent tropical plants; but none of them have been introduced into the gardens of this country. The attention of collectors should be directed to procuring the shrubby Violaceæ of Brazil, some of which possess great interest. The medical properties of the order are found principally in their roots, which appear to possess, in all cases, emetic properties, in a greater or less degree. One of the Ipecacuanhas is the root of a Brazilian violet. M. Decandolle has the following observations upon the affinities of the Violarieæ: - They are very nearly akin, he observes, to the Polygaleæ and Droseraceæ, and especially to the Passiflorea. From the first they are distinguished by their unilocular fruit, leaves furnished with stipules and two-celled anthers; from Droseracee by their solitary style, lengthened embryo and stipulate leaves, the vernation of which is involutive, not circinate. From Passiflorea they differ in their fruit being capsular, not berried; in their albumen being compact and shining, not pitted; in their stamens being hypogynous, not perigynous; in their anthers being attached along their whole length, not fixed by their middle; finally, in their stigmas being one and not three. The genus Calýptrion approaches Passifloreæ in its twining stem, and Hymenanthéra vorders upon Polygaleæ on account of its monospermous pericarpium with solitary pendulous seeds.

541 Ionídium Vent.

540 Víola $W$.

539 Sauvagésia Jacq.

Order XVI. POLYGalez.

Most of the plants of this order are interesting, and deserving the attention of the gardener, some for their neatness, some for their beauty, and some for their use in medicine. They are natives of most countries, and are either low herbaceous plants, occasionally less than an inch in height (small specimens of Polygala purpúrea), or shrubs varying from a dwarf, rigid, spiny habit, to a tall, graceful, drooping appearance. Polygalex are remarkable for the union of their stamens into a single body, their one-celled anthers opening with a pore, and their irregular flowers, one of which is often keel-shaped, and beautifully crested or bearded. The leaves have generally a bitter astringent taste, which is much more abundant in the roots, combined with an acrid and somewhat resinous flavour: these properties are particularly sensible in $P$. sénega, which is reputed a sudorific, diuretic, sialagogue, cathartic, or mild emetic, according to the manner in which it is administered. The Yelhoi of South America, the root of a species of Monnina, has the same properties as P. sénega, and is particularly used as a remedy for dysentery. The well known Rattany, or Ratanhia root, of Chile, is the produce of a plant of this order, and possesses powerful tonic and astringent qualities. According to the analysis of a French chemist, it contains gallic acid, but neither tannin nor resin.

1508 Polýgala $W$. 1509 Muráltia Neck.

1510 Múndia Kunth.

1511 Securidáca. $L$.

Order XViI. DROSERACEE.

The order of sun-dews is a small group of plants, natives of marshes or inundated grounds in all the temperate parts of the world. The species are very remarkable for the abundance of glandular hairs with which all the parts of the foliage are covered. Only two species are in any degree frutescent. The young leaves are always rolled up in the circinate manner, so remarkable in ferns. 'Their medicinal properties appear to be trifling: the leaves have the power of curdling milk.

702 Drósera $W$.

1009 Dionæ'a $W$

Order XVIII. BIXINEF

The plants of this order are few in number, and not remarkable either for beauty or use. The Bixa orellana is chiefly known for producing the seed called in the shops Arnotta (Rocon, Fr.), and used for coloring cheese; the properties of the Arnotta are slightly purgative and stomachic. They are all bushes or small trees, and mostly tropical. Azaras, Chilian shrubs with fragrant flowers, are not yet known in the gardens of Europe.
1178 Bíxa $W$.
1179 Prockia $L$.

Order XIX. CISTINEF.

The common rock roses of our gardens give an accurate idea of this order, which contains little else. They are all very ornamental, and particularly well calculated for covering rockwork. The species of Cístus and Heliánthemum have been multiplied by Dunal in an extravagant manner, as has been well demonstrated by Mr. Bentham. They are natives of most parts of the world in dry elevated places. The gum called Ladanum is the produce of some kinds of Cistus; it exhales a fragrant perfume when burnt, and possesses slightly tonic and stomachic properties. 1089 Hudsónia $\boldsymbol{W}$.

1197 Cístus J.

1198 Heliánthemum $J$.
222 Lechea $W$. 


\title{
Section 3. Ovarium solitary. Placenta central.
}

Order XX. CARYOPHYLlEE.

These consist of herbs or low undershrubs, inhabiting the mountains and pastures of all parts of the world. In Europe and Siberia they are particularly abundant, and least so in Africa and South America. Many are common weeds, as most of the Cerástiums, Spérgulas, and others. Several of the Silénes are very ornamental, and among the Arenárias are to be found some dwarf species of considerable elegance. But it is in Diánthus that the pride of the order consists : this genus is almost unrivalled for the brilliancy of its colors, the neatness of its foliage, and the perfume of its flowers. From the finest of its species the title of the order has been derived. The virtues of Caryophylleæ are slight. Saponária officinális, and one or two others, have been praised for possessing antisyphilitic properties; the root of Siléne virginiána is reputed anthelmintic; and the Arenária peploídes, being fermented, is used by the Icelanders for food.

\section{Gypsóphila $W$. 1046 Diannthus $W$ 1045 Saponária $\mathscr{W}$.}

Tribe 1. Silenede.
1017 Cucúbalus $L$.
1048 Siléne $L$.
1067 Lýchnis $W$.
1066 Agrostémma $W$.
604 Velézia $W$.
687 Drýpis $W$.

\begin{abstract}
91 Ortégia $W$.
311 Buffónia $\boldsymbol{W}$.

319 Sagína $\boldsymbol{W}$.
\end{abstract}

920 Mœhríngia $\boldsymbol{W}$.

Tribe 2. Alsinen.
931 Elátine $W$. 225 Mollúgo $W$. 691 Pharnáceum $W$ 220 Holósteum $W$.

1050 Arenária $W$. 1068 Cerástium $\boldsymbol{W}$ 1051 Cherléria $W$.

Order XXI. LINEF.

Separated by M. Decandolle from Caryophylleæ, from which it is well distinguished by its fruit having several cells, or in the language of the botanist just named, being formed by the cohesion of several carpella. Most of the species are pretty plants, bearing yellow, blue, or white flowers. They are of immense importance in the world, on account of the tenacity of their fibres when made into flax. The seeds of common flax are between mucilaginous and oily; the leaves of Linum cathárticum and $L$. selaginoides, the latter a native of Peru, are purgative.
701 Línum $W$.
321 Radíola Sm.

\section{OrDer XXII. FrANKENIACEE.}

Distinguished from Caryophylleæ by the fruit not having a central separate placenta, but bearing the seeds on the inner margin of the valves. The species are natives of arid situations in Europe, Africa, and South America. They have not much beauty, and no known medical properties. Besides the genus here recorded, there are two others mentioned by $M$. Decandolle.

\author{
835 Frankénia $W$
}

\section{Order XXIII. MALVACE}

Before this order was dismembered of Bombaceæ and Byttneriaceæ, it contained most of the grandest flowers in nature. Even now, the splendour of the various species of Málva, Althæ'a, to which the hollyhock belongs, and Hibiscus, renders it one of the most remarkable groups of plants. With the exception of the numerous genus Sída, nearly all Malvaceæ are objects worthy of the gardener's care, particularly those which are hardy. In stoves or greenhouse, the softness of their branches and leaves render them peculiarly liable to the attacks of the red spider, mealy bug, and scale, from which few collections are free; a circumstance which makes them less generally esteemed than the surpassing beauty of many of them merits. The greater part of the order is clothed with stellate pubescence, and a reniform one-celled anther is a character common to the whole. clothed with stellate pubescence, and a reniform one-celled anther is a character common to the whole.
These two peculiarities, together with the alternate stipulate leaves, distinguish Malvacea from all the rest of These two peculiarities, together with the alternate stipulate leaves, distinguish Malvaceæ from all the rest of
Dichlamydeæ. All the species abound in a nutritive mucilage; a quality which renders the young heads of the Ochro, or Hibiscus esculentus, an object of great value within the tropics, as an ingredient in soups. In Brazil, the Abritilon esculéntum serves the same purposes. The emollient properties of Althæ'a officinális, or Guimauve of the French, are well known to physicians, as a remedy for catarrhs and pulmonary complaints. A decoction of the leaves of Sphærálcea cisplatina is used for similar objects in Brazil. A species of Pavónia A decoction of the leaves of Sphæralcea cisplatina is used for similar objects in Brazil. A species of Pavonia micrántha are employed as rocket-sticks at Rio Janeiro. The chewed leaves of Sída carpinifólia allay the inflammation occasioned by the stings of wasps. The tough fibres of many Malvaceæ are manufactured into cordage. Their petals are astringent; whence those of Hibíscus Rósa sinénsis are used in China to blacken the eyelashes and the leather of shoes. The fibrous threads in which the seeds of Gossýpium are enveloped furnish the valuable cotton, an article of immense importance to the world; these threads when examined by the microscope, will be seen to be finely toothed, which explains the cause of their adhering together with greater facility than those of Bombax and several Apocineæ, which are destitute of teeth, and which cannot be spun into thread without an admixture of cotton.
1471 Málope $\boldsymbol{W}$.
1472 Málva $W$,
1475 Lavatéra $W$.
1476 Maláchra $W$.
1477 Uréna $W$.
1484 Cristária Cav.
1487 Sida $W$.
1474 Althæ'a $W$.
1479 Achánia $W$.
1480 Hibíscus $W$.
1482 Redoutéa Vent.
1483 Palávia $W$.
1488 Lagunéa $W$.
1486 Períptera Dec.
1481 Gossýpium $W$.

\section{Order XXIV. BOMBACEA}

Distinguished from the last by the imbricate æstivation of the calyx, and the arrangement of the stamens in five sets, or, in Linnæan language, brotherhoods. The species are mostly fine trees with large showy flowers, and natives of the tropics. Some of them are among the largest trees in the world; Adansonia, the Baobab of Senegal, has been seen with a diameter of twenty-five feet, and specimens of Bómbax Ceíba, and Eriodéndron anfractuósum, are not uncommon an hundred feet in height. The wood of all the species is light and soft, as in Malvaceæ, from which this order probably does not differ in its medicinal properties.
1458 Ochróma $W$.
1490 Carolínea $W$.
1492 Bómbax $W$.
1466 Helicteres $W$
1491 Adansónia $W$.
1493 Myródia $W$.

\section{Order XXV. BYTTNERIACER.}

Much the same kind of plants as those of the two last orders, from which they were not formerly dis. tinguished; and from which they scarcely differ, except in their bilocular anthers. Many of the Sterculias are fine umbrageous trees, the seeds of which are large and eatable; especially those of the famous Kola, which possess the property, being chewed, of rendering bad water pleasant to the palate. The seeds of the Chicha, another and very noble species of the genus, are highly esteemed in Brazil for the dessert. Astrapæ'a, and several other genera related to it, are among the most beautiful in the world. The flowers of a species of Pentapétes, called by the Indians, Machucunha, give out a mucilaginous refrigerant juice, which is employed in gonorrhæa. Guaźma ulmifólia has its fruit filled with a pleasant mucilage, which is sweet and very agreeable; an extract of the bark of the same plant is used in Martinique to clarify sugar; its old bark is 
employed in the form of a strong decoction, as a sudorific. Walthéria Douradinha contains a great deal of mucilage, and is employed by the Brazilians as an antisyphilitic.

Tribe 1. SterculiaceE.

2036 Stercúlia $W$. 2037 Heritiéra $W$.

Tribe 2. BytTNERIEA.

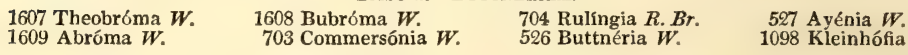

525 Seríngia Gay.

1445 Hermánnia $W$

1489 Ruízia $W$. 1468 Pentapétes $W$.
Tribe 3. Lasiopetalee. 524 Thomásia Gay.

528 Lasiopétalum Sm.

Tribe 4. Hermanniacee.

1456 Melóchia $W$.

1454 Walthéria $W$.

Tribe 5. Dombeyaces.

1467 Dombéya $J$.

1457 Melhánia $J$.
1469 Astrapæ'a Lindl. 1470 Pterospérmum $W$.

ORDER XXVI. TREMANDREE.

A very small order containing only seven species, all small bushes, natives of New Holland, and remarkable for the peculiar neatness of their appearance. In habit, they may be compared to heaths, with which they agree in the anthers bursting by a pore at the end. Nothing is known of their properties.

879 Tetrathéca $\mathrm{Sm}$.

\section{Order XXViI. TILI ACEF}

Trees, shrubs, or herbs, in general not remarkable for their beauty, the greater part of the last being the commonest weeds of the tropics. The Lime, from which the order derives its name, is a genus of fine trees with fragrant flowers, and Sparmánnia and Enteléa are handsome broad-leaved greenhouse arborescent plants. The inner bark of 'Tilia is tough and separable, and supplies the material whence the Russia mats used by gardeners and others are prepared. Córchorus olitórius is cultivated in Egypt as a kitchen-garden vegetable; the fibres of the bark of Córchorus capsularis are twisted into fishing lines; and the roasted nuts of the Lime tree are reported to bear some resemblance to chocolate.
1087 Triumfétta $W$.
1100 Heliocárpus $\dot{W}$
1181 Apeíba $W$
1182 Sparmánnia $W$
1184 Muntíngia $W$
1186 Tília $W$
1180 Sloánea $W$.
1183 Enteléa $R$. Br.
1185 Gréwia $W$
1187 Córchorus $W$

Order XXVIII. EL EOCARPEE.

These differ from Tiliaceæ in nothing except their lobed petals and anthers opening by two pores at the apex. The flowers of some of the species of Elæocárpus are fragrant, the fruit eatable, and the hard rugose stones manufactured into necklaces.

1192 Elæocárpus $W$.

Order XXIX. SAPINDACEE.

One of the distinctive peculiarities of this order consists in the petals having an auditional lobe in the inside, or a tuft of hairs instead. Nearly all the plants have compound leaves, and bunches of white flowers ; a few of them are twining herbs, but the greater part are trees or shrubs, all natives of the warmer parts of the world, and in a great proportion, of the East. The only genus which will bear the climate of England is Kolreutéria, a fine shrub or small tree, with panicles of white or pale yellow flowers. Nephélium and Dimocárpus are both genera bearing excellent fruit. The rind of the berry of Sapindus saponária is of a soapy quality, as the name of the plant indicates. The pulp of Melicócca, the arillus of Blighia sápida, and the kernel of Berthollétea and Pékea are all excellent eating.

$\begin{array}{cccc}926 \text { Sapindus } W . & 832 \text { Ornítrophe } W . & 887 \text { Kolreutéria } W . & 925 \text { Cardiospérmum } W . \\ 1971 \text { Nephélium } W . & 884 \text { Melicócca } W . & 923 \text { Paullínia } W . & 897 \text { Dodonæa } W . \\ 883 \text { Dimocárpus } W . & 885 \text { Blíghia } H . K . & 924 \text { Seriána } W . & 1991 \text { Amiróla Pers. }\end{array}$

831 Cossignia Juss. $\quad 886$ Metáiba Aubl 
for the prurient hairs produced on the surface of their leaves; their fruit is eatable, their timber of a deep red color, and their bark a febrifuge. Their showy pink or yellow flowers, and firm neat foliage, render all this order worthy of cultivation, except Aspicárpa, which is a weed.
1054 Malpighia $W$.
1056 Hiræ'a $W$.
29 Aspicárpa Rich.
1007 Gærtnéra $W$.

Order XXXV. HYPERICINEE.

The whole of these abound in a resinous juice, and are in most cases glandular in some degree. Their leaves are all dotted, and which is very remarkable, the dots are often black, even upon the yellow petals. These latter have a singular obliquity, which is not indicated by their outline, but by the arrangement of their veins. The juice just noticed as abundant in this order is yellow, viscid, rather bitter, often purgative or anthelmintic and so very analogous to Gamboge, that the juice of Hypéricum baccátum, and some other Guiana species, has received the name of American Gamboge. Most Hypericineæ are bitter, and slightly astringent, whence they have been used as febrifuges. A small part of the order is tropical; but in its most genuine form it consists of herbaceous or undershrubby plants, delighting in the shade of groves and thickets in the coler parts of Europe and Asia. Nearly all the flowers are yellow; those of $\mathrm{H}$. cochinchinénse are dull re?.

694 Parnássia $W$.

\section{Order XXXVI. GUTTIFER}

Trees or shrubs found in the hottest parts of the world, and well known by their thick entire opposite leaves and resinous juice. In the countries where they grow they are of great importance. One, the Garcinia mangostána, bears a fruit, the equal of which is supposed not to exist. The well known Gamboge is the inspissated juice of Garcínia Gambógia, and, perhaps, other species; the juice of others is found an efficacious vermifuge, and also a remedy for the chiggers, one of the worst pests of equinoctial America. The bark and fruit of many Garcinias are astringent. The unripe fruits of Grías cauliforra are pickled. The flowers of all the order being showy, the foliage good, and the properties interesting, every species deserves cultivation.
1079 Garcínia $W$
1190 Mamméa $W$.
2151 Clúsia $W$.
1616 Xanthochýmus Roxb.
1188 Grías $W$

1085 Canélla $W$.

\section{Order XXXVII. VINIFER Æ.}

The vine is the type and representative of this order. Císsus and Ampelópsis differ little from it in botanical characters, and not at all in habit. The common grape is the only species that bears really good fruit the American kinds, with large fleshy berries, being spoiled by a disagreeable foxy flavor, which is not found to be removed by cultivation.

\section{Vitis $P$. $S$.}

502 Ampelópsis $W$.

305 Císsus $W$.

454. Lééa $W$.

Order XXXIII. GERANIACEE.

The Gerániums are well known to all gardeners for their beauty, and the facility with which hybrid varieties are produced among them. Geranium and Eródium are chiefly natives of the northern hemisphere and Pelargónium of the southern. Different as they appear from Viniferæ in most respects, there are some points in which a curious resemblance may be found between the two orders. The young stems of both are articulated and separable at the articulations; and the lower leaves are opposite, while the upper ones are alternate. In Geraniaceæ no tendrils are produced, but the peduncles are opposite to the leaves, as in Vítis, and occupy the place of tendrils. M. Decandolle observes, that of the true Geraniacex, some are slightly acid, especially those of which the leaves and bark are succulent; several exhale a resinous smell which is sometimes agreeable, but occasionally so powerful as to be unpleasant. The resinous principle is so abundant sometimes agreeable, but occasionally so powerful as to be unpleasant. The resinous principle is so abundant
in Geránium spinósum, that its stem burns like a torch, and exhales an agreeable perfume. The most common property of European geraniums is to be astringent, which is chemically determined by their juice being blackened by sulphate of iron; this is particularly remarkable in G. Robertiánum and sanguineum, which are both accounted vulnerary, and in G. moschátum, praténse, and others, in which it is united to a slight aromatic principle, whence they have been recommended for various purposes, and among others for removing calculous disorders. The astringent property of the geraniums is also present in G. maculatum, which grows in much abundance about Philadelphia; the root of this plant, boiled in milk, is used for the cholera in children. Barton is of opinion, that it would be a good substitute for gum kino in nephritis and obstinate diarrhœas.
1460 Eródium $W$
1461 Pelargónium $W$.
1463 Geránium $W$
1465 Monsónia $W$.

Order XXXIX, OXALIDEE.

Formerly confounded with the last order. It is the opinion of modern botanists, that the species are more nearly allied to Rutaceæ or Zygophylleæ, and that their character and peculiar habit is quite sufficient to distinguish them. The beauty of the genus $O^{\prime} \times$ xalis is very great, and the readiness with which the species may be cultivated and caused to flower, would have been expected to make them universal favorites; they are not, however, much seen in cultivation. Their properties are well known : all of them have a slightly acid taste, whence some have occasionally been employed as salad; their acidity is very agreeable and depends upon the presence of a small quantity of oxalate of potassa. In some of the species of equinoctial America oxalic acid exists in great abundance. Several species are employed in Brazil as a remedy for certain fevers of that country.

Order XL, TROPEOLER.

These are climbing or trailing herbs with handsome solitary axillary fowers, and fleshy stems and leaves. They are distinguished from Geraniacex by their starnens being separate, and not agreeing in number with the petals; by their axillary flowers, and fleshy indehiscent fruit. It is very curious, that this is the only order in which the peculiar acrid flavor of Cruciferæ is found to exist. 'Tropæ'olum pentaphyllum, with probably other species, is a powerful antiscorbutic. All are natives of shady places in various parts of South America. The roots of some are fleshy and eatable.

\section{Tropæ'olum $W$.}

ORDER XLI. BALSAMINEE

The flower of this order has been remarked by a learned botanist to be that of Fumariaceæ, the capsule of $\mathbf{O}^{\prime} \mathbf{x}$ alis, the embryo of Linum, and the habit peculiar. The well-known elastic spring with which the secas are ejected, constitutes a principal character of the order. All the species are annuals, with the exception of Impátiens fruticósa; they delight in moist hot situations, generally within the tropics; and are remarkable for the singularity and varied colors of their flowers.

538 Impátiens $\boldsymbol{W}$.

OrDER XIII. ZYGOPHYLLE

The hardness of the wood of the shrubby species of this order is most remarkable, if the softness of the stems of the herbaceous ones is remembered. To this the extreme difficulty of propagating Guaiacum is to 
be attributed. Zygophýllum Fabágo is employed as an anthelmintic, but it is in the Guaiacum that the great medical virtues of the order are found: all the genus is extremely exciting; the wood and bark of Guai acum officinále and sánctum have a rather bitter acrid flavor, and are principally used as sudorifics, diaphoretics, or alteratives; they have been found to contain a particular substance differing both from gum and resin, which has been called guayacine. Many of the species bear beautiful flowers, especially the Tríbuluses, which with their brilliant yellow Cistus-like blossoms, enliven many a barren rock in the tropics, None are found in the colder latitudes of the world.
994 Zygophýllum $W$.
995 Fagónia $W$.
996 Tríbulus $W$.
993 Guaíacum $W$.

Order XLIII. MELIACEE

The nearest affinity of this order is probably with Sapindaceæ. It is particularly distinguished by the stamens being united into a tube bearing the anthers. The leaves are usually pinnated, and most of the species, which are all either trees or shrubs, are natives of tropical forests. Mélia bears bunches of fine lilac colored flowers, but few of the genera are interesting on account of their inflorescence. The qualities of the different species are little known. Canélla álba is aromatic, and is used in equinoctial America as a spice. The bark of Guárea trichilioídes is said by Aublet to be purgative and emetic. The pulpy fruit of Mélia Azedarách is said to be poisonous; both this part and the inner bark have been used as anthelmintics either in substance or in decoction. It is asserted by Michaux, that the pulp that surrounds the kernel is considered in Pekin a specific in scrophulous cases. The oil expressed from the seeds of the same plant is said to have strong antispasmodic powers.

888 Guárea $W$

987 Trichilia $W$

988 Mélia $W$

989 Quivísia Cav.

991 Ekebérgia $W$.

992 Heýnea Roxb.

\section{Order Xliv. CenREleE.}

Some of the finest trees of the tropical regions of the globe are comprehended in this order, as the well known mahogany, and the New Holland cedar, which is a species of Cedrela. Their winged seeds distinguish them from Meliaceæ. The bark of Cedréla Túna is employed in the East Indies as a febrifuge, as is also that of the mahogany in the West. But the most powerful remedy for fevers in the whole order is the Soymida of the West Indies, which is the produce of Swieténia febrifuga; its taste is bitter and nauseous, and its virtues are extolled as equalling those of Cinchóna.

\section{Swieténia $W$. 531 Cedréla $W$.}

\section{Order XLV. AURANTI ACEE.}

These are also known under the name of Hesperidex. They consist of trees or shrubs of the greatest beauty and utility. The well-known orange and lemon are the representatives of the order, the characters of which are so well defined that there is no material deviation from the type afforded by those species. The thick leaves, articulated with their petiole, and abounding in transparent reservoirs of odoriferous oil, are the most obvious peculiarities. The flowers are fragrant, and the fruit in all cases fleshy, and generally eatable. The

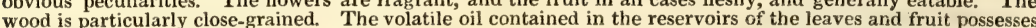
powerful tonic and stimulating properties. M. Decandolle thus explains the singular structure of the fruit of the orange. In the opinion of this learned botanist it consists, first, of a thick, valveless, indehiscent indusiun or coat, which is most likely to be considered a continucus torus. Secondly, of several carpella, verticillate around an imaginary axis, often separable without laceration; membranous, and either containing seeds only, or filled with pulp, lying in innumerable little bags proceeding from the inner coats of the cells.
500 Triphásia Lour.
1004 Glycósmis Corr.
1005 Murraýa $W$.
1196 Æ'gle Corr.
1003 Limónia $W$ 1615 Cítrus $W$.
1006 Coókia $W$.
2149 Ferónia Corr.

Order XLVI. TERNSTROMIACEÆ.

A very small order, consisting wholly of trees or shrubs, bearing handsome white or yellowish fiowers. They are rearly related to Camellieæ, from which they do not differ at all in habit. Nothing is known of their properties. Noronha states that a species of Saurauja found in Java has a subacid fruit, in flavor resembling the Tomato, and that it is eaten by the Javanese under the name of Koleho.

1083 Eúrya $T h$

1494 Gordónia $W$.

1495 Stuártia $W$.

Order Xlvit. Camellie.e.

Camellias are too well known in our gardens to render it necessary to say much upon their peculiarities. The Camellia is one of the most beautiful, and the tea one of the most useful, plants in the world. Both are natives either of China, Japan, or Nepal. The tea is well known for the stimulating influence of its decoction upon the nerves, which is attributed by Cullen to the presence of a narcotic principle. The seeds of Caméllia oleifera yield a fine oil. None of the species bear fragrant flowers. Their nearest affinity is with Ternströmiaceæ, from which they probably ought not to be separated.

1496 Caméllia $\mathrm{Ker}$

Order Xlvili. olacineß.

Smooth trees or shrubs, with simple stalked exstipulate alternate entire leaves, and little axillary flowers. Botanists doubt whether what is called a calyx is not rather an involucrum, in which case the corolla would become a calyx, and the station of the order among Monochlamydex, rather than in this place.

890 Ximénia $W$.

Order Xlix. RU'TACEE.

An interesting and extensive, but rather heterogeneous, group of plants, natives of all countries and all situThe species are either fetid northern herbaceous plants, as the garden rue, or neat heath-like southern shrubs, with an aromatic odor, as the Cape Diósmas; broad or long-leaved Australasian shrubs, with a stellate shrubs, with as Phebálium, or tropical trees with panicles of pallid minute flowers, as the Cuspárias and Xanpubescence, as Phe order contains nearly 300 species, of which but a small proportion is in our gardens. The medical properties of many genera are considerable. Rúta and Péganum are emmenagogue, anthelmintic, and sudorific. Diósma abounds in a volatile oil of an agreeable smell, but acrid flavor; several of its species are reputed antispasmodics. The Xanthóxylums are said to possess acrid, stimulating, or tonic qualities; Cláva Hérculis and fraxíneum are said, in America, to be powerful sudorifics and diaphoretics. According to Barton, they possess a remarkable power of exciting copious salivation, not only when applied to the mouth, Barton, they posses a both been found powerful remedies in paralysis of the muscles of the mouth. Xanthóxylum caribæ'um is regarded in Guiana as a detersive vulnerary and febrifuge. The famous febrifugal Angostura bark is the produce of Cuspária febrifuga.

Tribe 1. RUTEE.

998 Rúta $W . \quad 1088$ Péganum $W$. 1293 Meliánthus $W . \quad 905$ Jambolífera 
997 Dictámnus $W$. 528 Calodéndrum $W$. 880 Corræ'a $W$.

Tribe 2, DIOSMEe.

999 Crówea $\mathrm{Sm}$. 878 Borónia $S m$.

304 Ziéria Sm.

\section{Diósma $W$. en.}

518 Adenándra $W$. en

519 Baryúsma $W$. en.
520 A gathósma $\boldsymbol{W}$ en. 1965 Empleúrum $W$.

303 Fagára $W$

Tribe 3. ZanthoXYLFe.

Tribe 4. Cuspariex.

41 Galipéa Aubl. $\quad 1500$ Monniéria $W$.

Order L. CORIARIEE.

Five species constitute the whole of this order, distributed in South Europe, New Zealand, Peru, and Mexico. They possess no beauty, and are only interesting on account of their problematical station in a botanical arrangement. The leaves of C. myrtifólia are astringent, and are employed in dying black. It berries are very poisonous. On one occasion, during the Spanish war fifteen French soldiers were taken ill after eating them, and three died from their powerful narcotic effects.

\section{Coriária $W$.}

\section{Section 4. Fruit (gynobasic) inserted into a fleshy receptacle, with which the style is continuous.}

\section{Order LI. OCHNACEF。}

Beautiful yellow-flowered tropical shrubs or trees with lucid leaves. The roots and leaves of Walkéra serráta a Cingalese plant, are bitter; a decoction of them, either in water or milk, is used in Malabar as tonic, stomachic, and antiemetic. The bark of Gómphia hexaspérma is found useful in healing sores produced in cattle in Brazil by the stings of insects.
1001 Gómphia $W$.
1191 O'chna $W$.

ORDER LII. SIMARUBACEE.

Thirteen plants, found in equinoctial America, constitute this order. They are trees or shrubs, with an intensely bitter bark, a milky juice, and pinnated leaves. The Quassia is well known as the most pure and intense bitter hitherto discovered; the same property exists, in a milder degree, in the rest of the order. Quássia amára is a very ornamental plant, but rare, at present, in collections.

\section{Quássia $W$.}

\section{Subclass II. CALYCIFLOREE.}

\section{Petals separate, inserted into the calyx.}

\section{Order liII. Cellastrineæ.}

This order differs from the succeeding, in having the stamens alternate with the petals; the sepals imbricated in xstivation; and the ovarium wholly superior. It consists entirely of shrubs or small trees, with simple, rarely compound, alternate or opposite leaves, and inconspicuous flowers of a greenish or white color. Several are favorite ornaments of our shrubberies, as the Staphyléa, the Celástrus, and the Euónymus; the Several are favorite ornaments of our shrubberies, as the Staphyléa, the Celástrus, and the Euonymus; the
latter of which is valued on account of its beautiful-colored fruit. The fruit of Euónymus europæ'us is a brisk purgative, as is also the inner bark, and in strong doses powerfully emetic. The famous Paraguay tea is the foliage of a species of I'lex. The bark of Prínos verticillatus possesses such active, astringent, bitter, tonic, and febrifugal qualities, that it is used in North America, with success, as a substitute for Cinchóna. A decoction of the twigs of Maýtenus boária is used to bathe the swellings produced by the poisonous shade of the tree Lithi.

Tribe 1. Staphyleacez.

684 Staphyléa $\boldsymbol{W}$.

Tribe 2. Euonymes.

509 Euónymus $W$.

682 Cassine $\boldsymbol{W}$. 301 Hartógia $W$ 300 Curtísia $W$.
507 Celástrus $\boldsymbol{W}$.

31 Maýtenus $\mathrm{Mol}$.

Tribe 3. Aquifoliaces. 605 Bumálda $T \%$. 314 Mygínda $W$ 315 I'lex $\boldsymbol{W}$.

\section{Order LIV, RHAMNE尼}

In nabit, this altogether agrees with the last, from which the medical properties of the species are not widely different. Throughout the order, as far as it has been examined, there is a remarkable agreement between the fruit and the inner bark, especially in Rhámnus cathárticus, frangula, and others, in which they both are purgative and emetic. Some, as the Jujuba, and the African Lote, nevertheless, yield a wholesome and agreeable fruit ; and the berries, of the greater number, yield, under the chemist's hands, green or yellow dyes of much importance in manufactures. The leaves of Rhámnus theézans are substituted for tea by the poorer sort among the Chinese. The bark of Ceanóthus carúleus is esteemed in Mexico as a good febrifuge.
506 Zizyphus $W$.
505 Paliurus Gart
504. OEnóplia Mich. 503 Rhámnus $\boldsymbol{W}$. 510 Ceanóthus $W$.
512 Pomadérris $W$.
542 Phýlica $W$
2146 Gouánia $\dot{W}$. 532 Hovénia $T h$. 2060 schæfféria $\boldsymbol{W}$.

828 Prínos $W$

543 Plectrónia $\boldsymbol{W}$.

514 Schrebera Retx.

\section{ORDER LV. BRUNIACEE.}

Small heath-like shrubs, all natives of the Cape of Good Hope, and extremely ornamental, both in flower and foliage. Their properties are unknown.

533 Brúnia $W$.

511 Stáavia $\boldsymbol{W}$.

ORDER LVI. SAMYDEE.

Tropical shrubs or small trees, with entire, stipulate, alternate leaves, covered with pellucid dots, and axillary flowers of little shew. Some of the species of Samyda are pretty, but very rare. Their properties are unknown. M. Decandolle remarks, that in their fruit they approach Bixineæ and Flacourtianeæ; but on ac count of the position of their stamens must be arranged in the vicinity of Rhamneæ and Rosaceæ.

$$
\text { 1034 Samyda } W \text {. }
$$


Order LVII. HOMALINE⿸⿻

Evergreen handsome shrubs, with alternate leaves and deciduous stipulæ; they are readily known by their parietal placentæ, an unusual character among the orders that surround them. Blackwellia fagifolia has fine bunches of starry white fragrant flowers. A ristotélia is an evergreen half hardy shrub, with eatable berries. Little is known of their medical properties; the root of Homálium Racoubea is used in Guiana as a cure for
gonorrhœa.

\section{Order LVIII. TEREBINTHACE死.}

This order is, notwithstanding the labors of several botanists, in a very confused state; from want of suffi cient knowledge of many of the genera, which have been hitherto imperfectly described, it is difficult either to determine the value of the characters assigned to the tribes, or the dignity of the tribes themselves. All the species are shrubs or trees, with alternate exstipulate leaves, and inconspicuous flowers, and abound in the samiferous resin, which is chiefly present in the leaves and bark, and from wowers, and abound in a bal order has been derived. Notwithstanding the minuteness of their flowers, many of the species are valuable as ornamental plants, on account of the beaty of thir fire valuable as cine, and others for their for the sake of their utity in arts or medicine, and others for their fruit. 'The walnut, the Cashew nut, and the Pistachio are valuable for their nuts, which are well known articles of the markets of Europe. The Spóndias and Mángo are equally famous in the tropics. The well-known balsam of Tolu is the produce of the Toluifera; the balsam of Amýris gileadénsis; and balm of Acouchi, of the I'cica acuchíni; gum comes from Amýris elemifera and I'cica leptophýlla; mastich from Pistácia atlántica and lentíscus; and Venetian turpentine from Pistácia terebínthus. Schínus Mólle produces a resin which in Peru is used as a dentrifice, as myrrh is with us. Some of the best varnishes are prepared from the exudation of Amýris guianénsis, Rhus vérnix, copallína, and others; the finest kinds of incense are also afforded by plants of this order, such as the wood and resin of the different species of I'cica, of Amýris balsamifera, and of Canárium commune, the Coumia, which is used in Guiana for such purposes, and finally, tho Boswellia thurifera, which is the true frankincense of use temples. But among the fragrant and wholesome plants of bich the order others in which acrid and poisonous qualities which produces bister af To conclude this To conclude this long list of the uses and dangers of Terebinthaceæ, the bark of Brúcea is used as an astringent in dysenteries, that of Rhus glábra as a febrifuge and as a mordant for red colors, and that of Rhus coriária as a powerful means of tanning skins of animals. It is curious to remark how strongly Terebinthacea
are connected with Amentaceæ through Júglans.

\begin{abstract}
935 Anacárdium $W$. 513 Mangífera $W$.
\end{abstract}

681 Rhus $W$.
Tribe 1. Anacardiex.

\section{Pistácła $W$.}

85 Comocládia

2067 Picrámnia $W$

Tribe 2. Sumachinex.

2093 Schinus $W$.

Tribe 3. SpondiaceE,

1059 Spóndias $W$.

Tribe 4. Burseracea.

2164 Burséra $W$.

1010 Garúga $R o x b$.

Tribe 5. Amyridee.

889 Amýris $W$.

Tribe 6. Pteleacez.

298 Ptélea $W . \quad 529$ Toddália Lam. $\quad 84$ Cneórum $W . \quad 683$ Spathelia $W$.

Tribe 7. Connaracese.

1057 Cnéstis Lam

2061 Brícea $W$.

Tribe 8. JuglandeE.

1999 Júglans $W$.

Order LIX. I.EGUMiNOSE.

The farnily to which the various kinds of pulse belong is one of the most familiar to the world, and at the same time one of the most useful to mankind. Their papilionaceous flowers characterise a large number, and their pods and pinnate leaves the remainder, with a few exceptions, which it is not necessary to particularise. As objects of ornament, many are possessed of unrivalled beauty, for example, among hardy fiowering trees, the Robínia and the Labúrnum; among shrubs, for decorating the borders of the flower-garden, the various tribes of Cýtisus, Caragána, Colutèa, Amórpha, and others; among hardy climbers, the far-famed Glýcine of China, and its sister of North America, with the species of the herbaceous genera Vicia and Lathyrus; and, lastly, among hardy herbaceous plants, the numerous species of Lupínus and Astrágalus. Great, however, as is the beauty of the Leguminosæ which can brave the inclemencies of the seasons of Northern Europe, it must give way before the splendor and elegance of their brethren of the tropics. The flowers of the Erythrina, or Coral tree, are of the deepest crimson, and borne in profusion upon some of the loftiest trees of the forest. The Bauhinias, with their snake-like stems and twin leaves, hang in festoons of flowers from branch to branch The Bauhinias, with their snake-like stems and twin leaves, hang in festoons of flowers from branch to branch
of other trees, and are only rivalled by the less vigorous and elegant, but more richly colored blossoms of the Carpopógons. But all these, with their broad heavy foliage and gaudy colors, are far surpassed by the rugged trunks, trembling airy foliage, and golden flowers of the Mimósa, which cast a charm over even the most sterile deserts of burning A frica. While the forests of hot countries are thus indebted to species of this order for their timber, the meadows and pastures of the same latitudes are enamelled with the flowers of myriads of Hedýsarums, and animated by the wonderful motion of sensitive plants. As in our own country, the gayest part of our scenery is in many places indebted to the yellow flowers of our furze and broom, so in other countries the same effect is produced by other genera of Leguminosæ; by Lipária, Borbónia, and Aspálathus, at the Cape of Good Hope, and by the Pultenæ'as, Daviésias, Aótuses, and multitudes of similar genera in New Holland. The wood of the order is very hard and durable, with a yellow tinge, sometimes changin into green, as in the Labírnum of Europe, and in the better known Brazil wood of commerce, produced by Cæesalpinia. The following useful remarks upon the properties of the order are made by M. Decandolle:-

c The family of leguminous plants, though established upon characters of primary importance, offers, never-
"Thia. The following useful remarks upon the properties of the order are made by $\mathbf{M}$. Decandolle :theless, so large a number of species and such singular botanical anomalies, that it is easy to foresee that its properties will exhibit little uniformity. Still more exceptions may be anticipated if one reflects, that the chemical principle which is found most abundantly in every part of leguminous plants, and to which we must attribute their principal properties, is the extractive. It is probable that this principle, either from its own narure, or from its peculiar power of uniting with different matters, or perhaps instead of being a simple principle, it is rather a compound of different matters; it is probable, I say, that the extractive principle exhibits 
much less uniformity in its results than any other. It is, without doubt, to the presence of the extractive principle, in considerable quantities, that many leguminous plants owe their purgative properties, which are common to several extracts, and which many chemists attribute to the acetate of potash, which they are almost universally found to contain. Thus the leaves and foliaceous pods of Cássia sénna Lin., of Cássia lanceoláta Forsk, of Cássia emargináta of the Antilles, of the Cássia marylándica employed in the United States, of Colùtea arboréscens, of Spártium púrgans, and perhaps also of Coronilla émerus, act as brisk purgatives, and often cause wind and pain in the bowels. The juice of Coronilla vária excites vomiting, and may even become often cause wind and pain in the bowels. The juice of Coronilla varia excites vomiting, and may even become
poisonous when taken in too large quantities. It is, perhaps, from a different cause that the pulp which is poisonous when taken in too large quantities. It is, perhaps, from a different cause that the pulp which is
contairied in the husks of leguminous plants operates upon the human body; it purges gently without causing the least pain, and ought to be considered as laxative rather than purgative. Such is the character of the juicy pulp that exists in the Cássia fístula Lin., in the Tamaríndus índica Lin., in the Ceratónia siliqua Lin., and probably in the Mimósa inga and the M. fagifólia, which are eaten in small quantities in the Antilles, but which, taken more copiously, would have the same effect as our Carobs. There are some fruits of Leguminosæ, for example, the Sophóra and the Gledítschia, with tumid pods, in which is found a juice which surrounds, it is true, the seeds, as in the plants just mentioned, but which differs from them altogether in its very astringent and nauseous flavor; the nature and properties of this juice deserve to be examined by chemists, and would undoubtedly throw some light upon the nature of Leguminosæ. I am induced to think, that the astringent juice of the Sophora is a secretion of the pericarp, whilst the sweet and purgative juice of the Cássia would be a secretion of the external part of the seed; but this hypothesis requires to be verified : what leads me to this opinion, is the flavor commonly found in husks ; in the Carobs, for example, the husk is leads me to this opinion, is the flavor commonly found in husks; in the Carobs, for example, the husk is the extractive principle. It is undoubtedly from some one of these modifications that the singular property of the Piscídia and many Galégas is derived, which are employed in America to stupefy fish, which are taken by this means as readily as with Nux vómica. The decoction of the root of Galéga virginiana is considered in America as a powerful vermifuge. It is, perhaps, indeed, to the very same cause that the rubefacient powers of the fresh leaves of some Leguminosæ are to be ascribed, which act readily upon the skin if applied as plasters ; as, for example, in Ornithopus scorpioides among ourselves, and Hyperanthera moringa elsewhere. It appears to me, that it is to the greater or less considerable mixture of the extractive principle with the fæcula contained in the seed, that the different properties of the pulse of leguminous plants may be attributed. If found in small quantities, the seed may serve as food for man and animals, as we see in French beans, peas, lentils, chick peas, beans, and many others, \&c. If found in a more considerable quantity, it will render them purgative or emetic, as in the Cýtisus labúrnum, the Anagýris fœ'tida, and even in most Coronillas. It is remarkable that the botanical characters of Leguminosæ should so strictly agree with the properties of their seeds : the latter may be divided into two sections; namely, first, those of which the cotyledons are thick and filled with fæcula, and destitute of cortical pores, and which, moreover, in germination do not undergo any change, but nourish the young plant by means of that supply of food which they already contain; secondly, those of which the cotyledons are thin, with very little fæcula, and furnished with cortical pores, and which change at once into leaves at the time of germination for the purpose of elaborating food for the young plant. All the seeds of the first section are employed as food in different countries; none of those of the second section are ever so employed; the Cajan, which has long been classed among the Cýtisi, was apparently an excep. tion to this general rule; but observation has proved the contrary. Bearing in mind its known properties, $I$ formerly paid particular attention to its structure, and I have shown in a note, which accompanies my catalogue of the Montpelier garden, that the Cajan forms a particular genus much more nearly allicd to the French bean than to the Cýtisi, and that it, in fact, belongs to the first of the sections which I have just described. The seeds of Leguminosæ present also many other anomalies more difficult to reduce to any fixed laws: thus some are found which contain a rather large portion of fixed oil; such as the seed of the A'rachis hypogæ'a, lately introduced into European agriculture, and that of Guilandina moringa which produces oil of ben ; there are some, of which the flavor and smell are rather powerful; as the seed of Dipterix or Coumarobna odora of Aublet, which, under the name of Tonquin bean, is used for perfuming snuff; there are others which, like the chick pea, have rather a bitter taste and exciting properties, and are on that account administered for the jaundice. There are others again, like those of the Andira, which are so bitter as to be used in Java and Brazil as tonic, alexiteric, and vermifuge. In a word, are not the aperient and diuretic properties which are observable in the herbage and the roots of many leguminous plants, such as broom, beans, Onónis, Guilandina rínga and morínga, Anthýllis crética, \&c. to be attributed to a modification of this extractive principle? There are, in another view, roots which are furnished with tubercles, that is to say, with reservoirs of fæcula which furnish mankind with wholesome food, as we see in the Láthyrus tuberósus, which is eaten in Holland, the Dólichos tuberósus, and the D. bulbósus, which the Indians use as food. The roots of the liquorice have a sweet and mucilaginous taste, which is well known by every body, and which, united to an acrid and rather exciting principle, causes it to be employed as a pectoral; the analysis of this root, published by M. Robiquet, proves principle, causes it to be employed as a pectoral; the analysis of this root, published by M. Robiquet, proves
that independently of its woody skeleton, the same kind of amylaceous frecula is found as in the tuberous roots of which we have just been speaking; it is thence seen that the acrid flavor of decoctions of liquorice depends on the small quantity of resinous oil which it contains, and that its sweet properties are by no means analogous to common sugar, since it is insoluble in cold water, soluble in warm water or in alcohol, not capable of fermentation, and does not yield to the action of nitric acid any of the known products of sugar. It may here be added, that the sugary flavor of liquorice, and its other properties, are not confined to this genus; they are found equally in the roots of Trifolium alpinum, vulgarly called Mountain liquorice; in those of the $A^{\prime}$ brus precatórius, from which a pectoral draught is prepared in Hindoostan, called Velti, and in others. The barks of some trees of the leguminous class, are remarkable for their bitterness, and are used as febrifuges ; the different kinds of Geoffroya possess this bitter and febrifugal quality in a remarkable degree; in India, the bark of the Eschynómene grandiflora and of the Cæsalpinia bonducella are employed for the same purpose. 'The barks of many leguminous plants are also remarkable for their astringent qualities, caused by the quantity of tannin which they are found to contain; this is observable in the Acácia Cátechu, and in the Acácia arábica, which is used for tanning leather, and elsewhere. It is well known that almost all coloring matter proceeds from the extractive principle; and as it appears that this principle abounds in Leguminosæ, we ought to find in them a considerable number of the colors which are used by dyers : to this family, in fact, belong the principal blue colors, known by the name of indigo, extracted from every kind of Indigófera and from some Galégas ; and the red colors, which are yielded by all the species of Cæsalpinia and of Hæmatóxylon. We may add the red juice, which is drawn from the Pterocárpus dráco and Santalinus, under the name of sandal and of dragon's-blood; from Erythrína monospérma, under the name of gum lac; and also from Dalbérgia monetária. These juices appear to differ in many particulars, but their history and analysis are at present so far from being known, that it is impossible to form a true estimate of the nature of their differences. But anomalies of this nature are far from being confined to the plants just mentioned. Among the exotic drugs employed in the arts they are very common: such, for example, are the balsam of Capivi, produced by the Copaifera; the balsam of Peru, which, Mutis says, is obtained from Myróxylon; the Cachou, which has been found to be almost pure tannin, and which is supposed to be produced by Acácia Cátechu; of the same character is that remarkable resin that is yielded by Hymenæ'a Courbaril; gum Arabic, produced by the bark and roots of Acácia senegalénsis, nilótica, arábica, and others; gum tragacanth obtained from Astrágalus créticus, gummifera, and vérus ; and finally, manna, secreted by Hedýsarum alhági.

The arrangement of this tribe of plants has been found to be attended with much difficulty. By Linnæus, and the writers who succeeded him, the number of genera was much smaller than those admitted by botanists of the present age; many additions have been made in consequence of the discovery of New Holland, and a large number of subdivisions in old genera have been from time to time introduced by one writer or another. To combine these scattered improvements under one uniform system has lately been attempted by the learned botanist, from whom the foregoing extract has been taken. This was not executed at the time when those parts of the present work, in which leguminous plants are found, were written; for which reason the names 
of the suborders will not be found in the body of the work. M. Decandolle's method, however, being here adopted, it will be useful to explain the principles upon which it is founded. He divides Leguminosæ into two grand divisions, the first of which consists of plants, the radicle of whose seed is curved back upon the edge of the cotyledons, and the second of those whose radicle and cotyledons are straight: the former are CuRvEMBRIE, the latter RECTEMBRIE. In the Curvembria, certain diversities in the structure of the calyx and corolla again divide into two principal forms, one of which, comprehending all the genera with papilionaceous flowers, is called Papilionaceæ, and the other, consisting of a very small number of species, with one or two petals or more, and an obscurely lobed calyx, is called Swartzieæ. The last is not subdivided, but the Papilionacex resolve thernselves into the two great tribes pointed out by $\mathbf{M}$. Decandolle, namely, those with fleshy cotyledons and eatable pulse, Sarcoloba, and those with foliaceous cotyledons and seeds which are not eatable, Phylloloba. Each of these is divisible by three, upon slight differences in the fructification. In Rectembrice two suborders, Mimoseæ and Cæsalpineæ, are formed upon variations in the æstivation of the calyx and corolla; in the former, it is valvate, in the latter, imbricated; the first constitute a single tribe, the latter divide into three, distinguished by less momentous peculiarities of structure. Having premised thus much, the following tabular explanation will be intelligible:

\section{CURVEMBRI $\mathrm{E}$. \\ Papilionaceis.}

a. Phyllolobæ. $\{$ Tribe 2. Lotee. Pod continuous. Stamens united by the filaments.

3ribe 3. Hedysarea. Pod with transverse articulations. Stamens mostly united by the filaments.

Tribe 4. Viciea. Pod polyspermous, dehiscent. Leaves cirrhous, the first alternate.

b. Sarcolobæ. $\{$ Tribe 5. Phaseolea. Pod polyspermous, dehiscent. Leaves not cirrhous, the first opposite.

Tribe 6. Dalbergiea. Pod one or two-seeded, indehiscent. Leaves not cirrhous.

2. Swartziex. Tribe 7. Swartziea.

II. RECTEMBRIEE.

1. Mimosef.

2. Ciesalpinee.

Tribe 8. Mimosece.

Tribe 9. Geoffrea. Sepals and petals imbricated in æestivation. Stamens variously connected by the filaments.

Tribe 10. Cassiece. Sepals and petals imbricated in æstivation. Stamens distinct.

Tribe 11. Detariea. Sepals before expansion indistinct, calyx bladder-like. Petals 0.

Suborder I. PAPILIONACEAE.

\section{Tribe 1. SOPHOREA}

941 Sophóra $\boldsymbol{H} . \boldsymbol{K}$. 940 Edwárusia Sal. 942 Ormósia Jacks. 945 Virgília Lam. 943 Anáris $W$. 944 Thermópsis $\boldsymbol{R} . \boldsymbol{B r}$. 947 Baptísia $R$. Br.
946 Cyclópia $R$. Br. 948 Podalýria $R$. Br. 949 Chorozémia Lab. 950 Podolóbium $\boldsymbol{H}, \boldsymbol{K}$ 951 Oxylóbium $\boldsymbol{H}$. $K$. 952 Callístachys Vent. 953 Brachyséma $\boldsymbol{H}$. $\boldsymbol{K}$.
954 Gompholóbium $\boldsymbol{H} . \boldsymbol{K}$. 955 Burtonia $\boldsymbol{H}$. $\boldsymbol{K}$. 956 Jacksónia $\boldsymbol{H}$. $\boldsymbol{K}$. 957 Viminária $H . K$ 958 Sphærolóbium $\boldsymbol{H} . \boldsymbol{K}$. 959 Aútus $\boldsymbol{H}$. $K$ 960 Dillwýnia $\boldsymbol{H}$. $\boldsymbol{K}$.
961 Eutáxia $\boldsymbol{H} . \boldsymbol{K}$

962 Sclerothámnus $\boldsymbol{H} . \boldsymbol{K}$. 963 Gastrolóbium $\boldsymbol{H}$. $\boldsymbol{K}$ 964 Euchílus $H$. $K$. 965 Pultenæ'a $\boldsymbol{H}$. $\boldsymbol{K}$. 966 Daviésia $L . T$.

967 Mirbélia L. T.

\section{Tribe 2. LOTEA.}

Subtribe 1. Genistea.

1536 Hóvea $\boldsymbol{H} . \boldsymbol{K}$ 1525 Platylóbium Sm. 1531 Bossiæ'a Sm. 1534 Goódia $R$. Br. 1532 Scóttia $R$. Br

1533 Templetónia $\boldsymbol{H}$. $\boldsymbol{K}$.

1605 Medicágo $W$. 1603 Trigonélla $W$. 1598 Melilótus $J$

1597 Psorálea $W$. 1589 Indigófera $W$.

1501 Petalostémum Mich.

1596 Dálea $P$. $S$.

1574 Glycyrrhiza $W$.

1575 Liquorítia Mönch.

1591 Galéga $P$. S

1592 Pháca $W$.

1579 Scorpiurus $W$.

1587 Zórnia Mich. 1583 Stylosánthes Swz.

\section{Cícer $W$.} 1561 Vícia $W$.

I643 Róthia $W$.

1546 A'brus $W$

1548 Terámnus Browne
1527 Ráfnia $T h$. 1526 Borbónia $W$ 1565 Lipária $W$.

1584 Hállia $T h$. 1530 Crotalária $W$.

1523 Vibórgia $W$.
1535 Loddigésia $\boldsymbol{B} . \boldsymbol{M}$. 1539 Lebéckia $W$. 1529 Sarcophýllum $T h$ 1528 A spálathus $W$ 1540 U'lex $W$.
Subtribe 2. Trifoliece.

1600 Trifólium $\boldsymbol{J}$.

1599 Lupináster $P h$.

1604 Dorýcnium $W$

Subtribe 3. Clitoria.

1556 Clitória $W$.

1555 Galáctia $M x$

Subtribe 4. Galegece.

1590 Tephrósia $\boldsymbol{P}$. S. . $^{\dagger} \quad 1568$ Robínia $\boldsymbol{W}$.

1545 Amórpha $W . \quad 1581$ Sesbánia $\boldsymbol{H} . \boldsymbol{K}$

1512 Nissólia $W$. 1524 Piscídia $W$

1524 Piscí $W . \quad 1570$ Swainsónia $H . K$

1569 Caragána Royen. $\mathbf{1 5 7 1}$ Sutherlándia $\boldsymbol{H} . \boldsymbol{K}$.

1537 Spártium $W$.

1538 Genista $W$

1566 Cýtisus $W$.

1541 Ononis $W$.

1542 Anthýllis $W$.

1567 Mulléra $W$

1601 Lótus $W$

1602 Tetragonólobus Roth.

1606 Hymenocárpus $W$.

1552 Glýcine $\boldsymbol{L}$.

Subtribe 5. Astragalea.

1593 Oxýtropis Dec. 1594 Astrágalus Dec.

1595 Bisérrula $W$.

Tribe 3. Hedysarea.

Subtribe 1. Coronillec.

1576 Coronílla $\boldsymbol{H} . \boldsymbol{K} . \quad 1578$ Orníthopus $W$.

1577 Hippocrépis $W$.

Subtribe 2. Euhedysarea.

1582 Æschynómene $\boldsymbol{H}$. $\boldsymbol{K} . \quad 1588$ Hedysarum $\boldsymbol{W}$.

1580 Smithia Sal. 1585 Lespedéza Mich.

1586 Flemíngia Roxb.

Tribe 4. VICIEE.

1562 E'rvum $W . \quad 1560$ Pisum $W . \quad 15570^{\prime}$ robus $W$.

Tribe 5. Phaseolex.

1558 Kennédia Vent. 1551 Stizolóbium $\boldsymbol{P} . S$.

1547 Phaséolus $W$. 1550 Dólichos $W$.

1549 Carpopógon Roxb. 1544 Lupinus $W$.

1554 Cylista $W$.

1521 Erythrina $W$.

1522 Bútea $W$. 
1514 Pongámia Vent. 1513 Dalbérgia $W$.

2124 Mimósa $W$. 2123 I'nga $W$.

1543 A'rachis $W$.

2155 Gledítschia $W$. 2094 Gymnocládus $W$. 979 Guilandína $H, K$ 978 Cæsalpínia $H$. $K$. 977 Poinciána $H . K$. 981 Hoffmanséggia $\mathrm{Cav}$.
Tribe 6. Dalbergiex.

1515 Pterocárpus $W$.

1516 Ecastaphýllum Rich.
1520 Amerimnum $W$

SUBORDER II. or Tribe 7. MIMOSE AE.

2125 Schránkia $W . \quad 982$ Adenanthéra $W$

2127 Acácia $W$. 2126 Desmánthus $W$. 984 Prosópis Roxb.

SUBorder III. CAESALPINEAE.

Tribe 8. Geoffred.

1517 Geoffroýa $W . \quad$ 1464 Brównea $W$.

1518 Dipterix $W$.

Tribe 9. CASSIEA

985 Hæmatóxylon $W$. 974 Cássia $W$.

974 Cássia $W$.
975 Cathartocárpus P. S.
9719 Parivóa Aubl.

983 Cádia $W$.

2156 Ceratónia $W$.

867 Jonésia $W$.

971 Afzélia $\mathrm{Sm}$.

969 Schistia $W$.

986 Copaífera $W$.

972 Hymenæ'a $\boldsymbol{W}$

970 Bauhinia $W$.

968 Cércis $W$

30 Codárium Vahl.

980 Hyperanthéra $W$.

\section{ORDER LX. ROSACEE.}

With the exception of Chrysobalaneæ and Sanguisorbeæ, this order is so uniform in its appearance, that Rósa, the type from which all the other genera are to be considered variations, when justly understood, will be found to contain every form of structure which is essential to the order. Having stated this, it will be at once obvious, that if the other genera have such close affinity to Rósa, they must also bear a great analogy in beauty. And this is, indeed, the fact. Amýgdalus and Prúnus among trees, and Potentilla, Géum, and others, among herbaceous genera, rival the rose in their blossoms, and, in many particulars, surpass that most lovely of all flowers in foliage and general appearance. But it is not for charms alone of smell, or blossom, or foliage, that this order has fixed itself so high in the estimation of mankind. It has also the rare merit of comprehending all the most important of the fruits of the temperate regions of the world. Thus the apple and the pear belong to Pýrus, the plum and the apricot to Prúnus, the peach and the nectarine to Amýgdalus; Eriobótrya produces the loquat, Méspilus the medlar, and finally, the quince is borne by the Cydonia. The medical powers of many plants of this order are not less active than their fruit is excellent. The principal of these is the well-known Prussic acid, which exists in abundance in the leaves and kernels of many genera, especially of Prúnus and Amýgdalus : it is the basis of Laurel water, which, when taken in small doses, acts either as a violent purgative or as an emetic; and, in stronger doses, is said to destroy irritability without exciting inflammation; these properties, however, although thus dangerous in the distilled water of the laurel and other similar plants, can scarcely be said to exist in any important quantity in the plants in a state of nature. The kernel of the bitter almond, for example, in which the Prussic acid is more abundant than usual, is used for many culinary and other purposes without any bad effect. There are, however, cases in which it is said to be dangerous to eat the fresh leaves or kernels; as in the Pronus virginiana, the leaves and fruit of which are reputed in the United States to be poisonous to certain animals. Besides the Prussic acid, there are several other principles which abound in the order. All Drupacex yield a gum which is nearly allied to gum Arabic, and which affords a strong evidence of the affinity that exists between Rosaceæ and Leguminosæ. A great deal of astringency is found in many species, whence different parts have been occasionally employed as febrifuges, and as remedies for hæmorrhage, diarrhœa, and dysentery. The root of the Tormentilla is used for tanning in the Ferro Isles; and that of the Capollim cherry in Mexico. The bark of Pranus virginiána is used as a febrifuge in the United States; Potentílla réptans has been praised for the same properties. The root of Géum urbanum has been found, by Milandi and Moretti, to contain one eleventh of its weight of tannin; it has been used both in America and Europe as a substitute for Jesuit's bark. The leaves of Drýas octopétala in the north of Europe, of Rúbus árcticus in Norway, of Prúnus spinósa and ávium, and of Rósa rubiginósa have been manufactured into a sort of substitute for tea. The bark of the root of Gillénia trifoliáta is remarkable in having, in addition to the astringency already mentioned, an emetic property, on which account it is employed in North America as Ipecacuanha. It is said, that a similar power exists in other Spiræ'as.

It must not be omitted, that the order Rosaceæ nearly answers to the Icosandria of Linnæus.

Tribe 1. Chrysobalaneet.

1130 Chrysobálanus $W . \quad 870$ Parinárium Juss. $\quad 499$ Hirtélla $W . \quad 1080$ Grangéria Lam.

Tribe 2. Amygdalines.

1128 Amýgdalus $W$. 1129 Pránus $W$.

'1156 Kérria Dec.

Tribe 3." SpIracee.

1141 Spiræ'a $W$.

1142 Gillénia Mönch.

Tribe 4. Neuradfes

1063 Griélum $W$.

1159 Drýas $W$.

1161 Sievérsia $W$.

1155 Géum $W$.

1160 Colúria $R . B r$.

Tribe 5, Dryadex.

$\begin{array}{lcc}1140 \text { Waldsteínia } W . & 1154 \text { Tormentílla } L . & 1101 \text { Agrimónia } W \text {. } \\ 1149 \text { Rábus } W . & 1153 \text { Potentíla } L . & 1152 \text { Comárum } W: \\ 1150 \text { Dalibárda } M i c h . & 710 \text { Sibbáldia } W . & \end{array}$

1151 Fragária $W$.

710 Sibbáldia $W$.

Tribe 6. Sanguisorbee.

$\begin{array}{ll}255 \text { Alchemílla } W . & 1190 \text { Potérium } W . \\ 256 \text { Sanguisórba } W . & 2106 \text { Cliffórtia } W .\end{array}$

68 Ancistrum $L$.

Tribe 7. Roses.

1148 Rósa $W$.

Tribe 8. Pомacex.

1132 Cratæ'gus $L$.

1136 Raphiolépis Lindl.

1137 Eriobótrya Lindl.

1139 Cotoneáster Lindl.

1135 Photínia Lindl.

1138 Amelánchier Lindl.

1131 Méspilus Lind

1133 Pýrus Sm.

1134 Cydónia Juss. 
Order ixi. SAlicariet.

Most of these are very showy plants, in particular the genera Lýthrum and Lagerstrœ'mia, which are the representatives of the order. They are chiefly natives of temperate climates, on mountains and among bushes. Glaux and Péplis are common shore plants in England. Heimia is remarkable for its yellow flowers. Little is known of the properties of Salicariæ; they are mostly astringent; the common Salicária is used in inveterate diarrhœas; a species of Lythrum is used in Mexico as a vulnerary and astringent, and Lawsónia, which is used by the Turkish women to stain their nails, is also supposed to possess similar properties. There is a plant of this order called Hanchinol in Mexico, which is said to possess much more remarkable powers than any of the preceding; its expressed juice, taken in doses of four ounces, excites violent perspiration and secretion of urine, and is said to cure venereal disorders in an incredibly short space of time.
877 Gríslea $W$.
1094 Lýthrum $W$.
1097 Cúphea Jacq
1095 Nesæ'a Kunth.
302 Ammánnia $W$.
898 Lawsónia $W$.
1195 Lagerstro'mia $W .1096$ Heímia $L k$.
836 Péplis $W$.
1031 A cisanthéra $J$

\section{Order LXII.' MELASTOMACE死,}

All these are remarkable as handsome tropical shrubs or trees, with large purple or white flowers, and leaves with several costæ, or nerves as they are incorrectly termed. The genera admitted in the body of the work are those received by the greater part of previous writers; they have been much increased, and apparently with great propriety, by Mr. D. Don. The species are generally ill treated in collections, where they are not unfrequently to be found under the form of sickly stunted plants, instead of noble broad-leaved spreading shrubs, with masses of brilliant flowers. To be grown well they require much heat, much moisture during the summer, and much pit-room and head-room. The fruit of true Melástomas is a fleshy insipid juicy berry, which is for the most part eatable, and is often so deep a black as to dye the teeth and mouths of those who eat it. They are nearly related to Myrtaceæ, from which they differ in the want of essential oil, and of the dot-like reservoirs of the leaves which contain it. The juice of the leaves of $\mathbf{M}$. succósa and aláta is used as a lotion for recent wounds by the inhabitants of Guiana.
899 Osbéckia $W$.
1029 Melástoma $W$
1075 Blákea $W$

1030 Petalóma $W$

ORDER LXIII. MYRTACEE.

Dotted leaves, with marginal ribs, and an inferior ovarium and single style, are the great features of Myrtaceæ. They are all fine evergreen shrubs or trees, generally bearing white flowers, and in the first section producing fleshy fruit. It is there that the Allspice, the Clove, the Rose-apple, and the Guava find their station, by the side of the common myrtle and pomegranate of Europe. The section with capsular fruit comprehends, with the exception of the gigantic Eucalýptuses, almost wholly, handsome hard-wooded New Holland or South Sea shrubs, with white or crimson flowers and stamens; yellow flowers are very uncommon. The volatile oi contained in the little reservoirs of the bark, the leaves, and the floral envelopes, gives these plants the fragrance which has caused them to be celebrated by poets of all ages. It is very aromatic, a little acrid, and slightly tonic and stimulant, whether it is under the form of Cajeputi oil, the produce of Melaleúca leucadéndron, or of oil of cloves or of myrtle. In the clove this oil is so abundant as to constitute nearly a fifth of the whole weight of the calyxes that produce it. There is also a considerable proportion of astringent principle in these plants; in the bark of the pomegranate it is very obvious; and in Mýrtus régni and lúma of Chile, Eugénia malaccénsis, it is so abundant as to render a decoction of those plants of great use in cases of dysentery Eucalýptus resinifera produces an astringent resinous substance resembling gum Kino. The leaves of the Chilian myrtles, Leptospérmum scopárium, and some other species, have been used as substitutes for tea.

Tribe 1. Baccate.

$\begin{array}{llll}1193 \text { Alángium } J . & 1120 \text { Caryophýllus } P . S . & 1123 \text { Piménta Lindl. } & 1499 \text { Cáreya Roxb. } \\ 1118 \text { Psídium } W . & 1121 \text { Mýrtus } W . & 1124 \text { Olýnthia } L i n d l . & 1082 \text { Decumária } W . \\ 1119 \text { Eugénia } W . & 1122 \text { Calyptránthes } W . & 1127 \text { Pánica } W .\end{array}$

1119 Eugénia $W$.

1122 Calyptránthes $W$. 1127 Púnica $W$.

891 Bæ'ckia $S m$.
1115 Leptospérmum $W$.
1116 Fabrícia $W$.

1125 Stravádium Juss.
Tribe 2. Capsulares.

1117 Metrosidéros $W$.

1126 Eucalýptus $W$.

1610 Melaleúca $\boldsymbol{H} . \boldsymbol{K}$.

Tribe 3. LecrthideE.

1497 Barringtónia $W$.
1611 Tristánia $B r$.

1612 Calothámnus $L a b$.

1613 Beaufórtia $\mathrm{Br}$.

1498 Gustávia $W$

Order LXIV. COMBRETACEF,

Combrétum and Quisquális are among the most splendid of the climbing plants of the tropics, adorning the trees from which they depend with garlands of white and crimson, and yellow. The bark of Búcida Búceras is used with success in Guiana for tanning leather. The juice of Terminalia vernix is employed by the Chinese as a varnish ; it is, however, caustic, and its exhalation dangerous; benzoin is the produce of Terminália Benzóin. The kernel of several species is eaten as a nut, and the expressed oil has the remarkable quality of not becoming rancid.

514. Conocárpus $W$.

916 Combrétum $W$.
1027 Getónia Roxb.

1028 Quisquális $W$
2140 Terminália $W$.

Order LXV. PASSIFIlorEE.

The beauty of Passifloras is well known; they are remarkable for the singular arrangement of the stamens and pistillum, upon a column surrounded by several lines of circumvallation, formed by as many rows of barren thread-like colored stamens, which are popularly called the rays. The fruit of several species of passionflower is filled with a pleasant acidulated pulp, on which account they are eaten as dessert fruit. It is not known that they possess any medical properties. The station of the order is not settled; it is undoubtedly known that they possess an

1459 Passiflóra $W$.

2075 Modécca Lam.

\section{Order LXVi. CUCURBITACEF.}

Here is the station of the gourd, the melon, and the cucumber, succulent climbing vegetables, the fruit of which administers to us many of cur comforts and necessities. The importance of the gourd in hot countries is of the highest degree, where, from the nature of the climate, few of those culinary vegetables that are 60

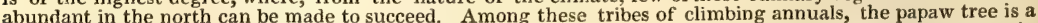
abundant in the north can be made to succeed. Among these tribes of climbing annuals, the papaw tree is a
remarkable deviation from the ordinary character of the vegetation. Its fruit, however, and flowers are in remarkable deviation from the ordinary character of the vegetation. Its rruit, however, and flowers are in
all respects those of Cucurbitaceæ. The fruit is mostly sweet, watery, refreshing, and pleasant to the palate; but the coloquintida gourd, the spirting cucumber, and the Trichosánthes amára, are all possessed of violent bitter, drastic, purgative qualities, which are, indeed, to be found, in a slight degree, even in the mildest of the mildest of the order depends upon the different proportions between these two substances. The seeds of the gourd, like those of the 
passion-flower, possess none of the properties of the pulp; they are sweet and nutty, and readily form an emulsion. The roots of the bryony are purgative, but also contain a wholesome frecula. It is said that the roots of a species of bryony are eaten in Abyssinia, after being merely boiled. There are some Cucurbitacer, the roots of which are intensely bitter; those of one of this description are used in Peru, to remove the pains roots of which are intensely bitter; those of
attendant upon inveterate venereal disorders.
551 Gronóvia $W$
2019 Trichosánthes $W$
2022 Cúcumis $W$
2024 Bryónia $W$.
1976 Lúffa Cav.
2020 Momórdica $W$.
2023 Sícyos $W$.
2095 Cárica $W$.

Order lxvil. loasee.

Nothing is known of the qualities of this order. It consists of succulent cut-leaved plants, generally covered with asperities or rigid stinging hairs, and yellow or white flowers. They are all natives of America, and handsome annuals. A very few of them are climbers.
1113 Bartónia $\mathrm{Ph}$.
1194. Mentzélia $W$.
1619 Loása $I$

Order LXVIII. HALORAGE尼

Obscure weeds, chiefly distinguished from Onagrariæ, by their naked and solitáry ovula. They are natives of moist places or ponds, in various parts of Europe and North America. Some of the species of Halorágis are tropical. They are not known to possess any medicinal properties.
23 Hippúris $W$.
932 Halorágis $W$.
1987 Myriophýllum $W$.
309 Ludwígia $\boldsymbol{W}$.
1968 Serpicula $W$.
258 Isnárda $W$.

Order LXIX. ONAGRARIA.

A very well defined order, generally known by its pollen cohering, by a sort of filamentous substance, an inferior polyspermous ovarium, a tetrasepalous tetrapetalous flower, with a definite number of stamens, and a single style. From this form there are some anomalous variations, such as Circæ'a and Lopézia, which are, however, easily reconciled to the usual structure of the order. Most of the genera are pre-eminently beautiful; as Epilóbium, Enothéra, and Fúchsia, which are old favorites among gardeners. The properties of Onagrariæ are little known, and probably very weak. The leaves of Jussiæ'a peruviána are used as an emol. lient pouitice, the seed of Trápa nátans as an eatable nut, and the root of CEnothéra biénnis as a sort of salad.
71 Circæ'a $W$.
18 Lopézia Cav.
903 Epilóbium $\boldsymbol{W}$.
904 Fúchsia $W$
308 Trápa $W$.
1026 Jussiæ'a $W$
902 Gaura $W$.

\section{Order LXX. FICOIDEÆ.}

These are all plants with a greater or less degree of succulence; the Mesembryánthemums and Hymenógyne are well-known dry-stove plants, many of which are beautiful in the highest degree. Of the former of these two, the flowers are of all colors, many of the most vivid hues, and remarkable for expanding only beneath bright sunshine; this phenomenon, indeed, is common to the whole order. Tetragonia expánsa, Sesávium portulacástrum, and Mesembryánthemum edéle, are excellent substitutes for summer spinach. A large quantity of saline matter is contained in all of them; in Reaumúria vermiculáta, a sub-

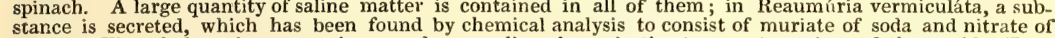
potash. The whole order grows in very dry or saline places, in the temperate regions of the world. Four fifths of the whole are natives of the Cape of Good Hope. The leaves of the different species of Mesembryánthemum, offer the most remarkable instances of figure known in the vegetable world.
1090 Nitrária $W$.
1143 Sesúvium $W$
1145 Tetragónia $W$.
1146 Mesembryánthem
1147 Hymenógyne Haw.
1107 Glínus $W$.
1144 Aizóon $W$.

Order lXXi. portulace⿸.

With the exception of Turnéra, Támarix, Talinum, and a few species of Claytónia, the whole of this order consists of insignificant weedy plants, of no beauty, and little use. Claytónia perfoliáta and common purslane, which are occasionally used as salads, being the only species of a useful kind. They are chiefly herbaceous plants, frequenting dry barren situations, or the sea-shore of all parts of the world; all are insipid and inodorous, and destitute, as far as is known, of medicinal properties. Some of the kinds of Támarix have an astringent tonic bark, and yield, when burnt, a large proportion of sulphate of soda. Turnéra resembles a Cístus.

224 Móntia $W$.

537 Claytónia $W$.

1091 Portuláca $W$.
1092 Talínum Haw.
1093 Anacampséros $L$.
871 Limeum $W$
692 Portulacária $W$.
690 Corrigíola W.
686 Turnera $W$.
685 Támarix $\boldsymbol{W}$.

\section{Order LXXil. CACTI.}

All succulent plants destitute for the most part of leaves, the place of which is supplied by fleshy stems of the most grotesque figure; some angular, and attaining the height of thirty feet, others roundish, covered the most grotesque figure ; some angular, and attaining the height of thirty feet, others roundish, covered
with stiff spines, like the hedgehog, and not exceeding the stature of a few inches. Their flowers are in many cases large and remarkably specious, varying from pure white to rich scarlet and purple, through all the intermediate gradations of colors. The species are chiefly natives of the hottest and dryest parts of the tropics, and are cultivable with little care, in pots filled with rubbish, in a dry-stove. Their fruit is fleshy and watery, and generally insipid, but it is eaten in their native countries for the sake of its refreshing moisture and coolness. Two species of Opuntia are hardy in Great Britain. The characters of this order and the next are very similar, although their habit is so widely different. Cacti are sometimes called Nopaleæ.

$$
1111 \text { Cáctus } W
$$

1112 Rhípsalis Gert.

\section{ORDER LXXIII. GROSSULACEÆ.}

Distinguished from the last by the definite number of their stamens and woody leafy stems. The utility and excellence of the gooseberry and currant are known to every one. None of the other species equal these, although the fruit of several possesses considerable excellence. The berry of most of these is sweet, watery, and acid, but that of Ribes nigrum, and a few more, is tonic and stimulant, which appears to have some connection with the presence of glands upon the leaves of those species.

$$
550 \text { Ríbes } W \text {. }
$$

\section{Order LXXIV. SEMPERVIVEæ.}

Still another order of succulent plants, but with a habit very different from that of those which have gone before. The species are often characterised by the rosulate or densely imbricated arrangement of their leaves, but this is not by any means a universal character. They are natives, for the most part, of dry barren places in Europe, North Africa, and the Cape of Good Hope, and are cultivable with ease in pots of dry rubbish. Many of them have extremely beautiful flowers, especially those of the genera Sempervivum and Crássula, which are either white, yellow, or deep rose color. Their leaves are used medicinally as refrigerant and abstergent; they are also, in a slight degree, astringent, and in Sédum ácre so acrid, that, taken internally, 
they operate violently both as purgatives and emetics. The leaves of Sédum teléphium are occasionally eaten as a vegetable, but they are always found to leave behind a slight and unpleasant taste of burning.
1061 Sédum $W$
927 Vérea $\boldsymbol{W}$.
874 Séptas $W$.
1062 Penthórum $W$.
699 Crássula $W$.
1110 Sempervivum
698 Róchea Dec.
928 Bryophýllum Sal.
320 Till $\mathfrak{a}^{\prime} \mathbf{W}$.

\section{Order LXXV. SAXIFrAGEÆ.}

The whole of these plants constitute the glory and delight of the cultivator of alpine plants. This is to be attributed to the neatness and perpetual verdure of their leaves, and the exquisite simplicity and elegance of their flowers, rather than to any striking attractions, of which they are wholly destitute: their blossoms being generally white or pale pink, occasionally becoming brownish-purple. All the genuine species are humble herbaceous plants, affecting mountainous situations, but occasionally found in marshes by the sides of springs, and even upon dry walls. All are natives of cold regions, or of the most temperate mountainous situations of hot ones. They are slightly astringent; some of them, as Heuchéra americána, eminently so. Infusions of the leaves have been reckoned lithontriptic, and the powdered root of the last-named plant is used with success in cancerous disorders. Hydrángea, which is shrubby, is not a legitimate inhabitant of the order.
1041 Saxífraga $W$
1043 Mitélla $W$.
606 Heuchéra $W$.
930 Adúxa $\boldsymbol{W}$
1040 Chrysosplénium $W$.
361 Gálax $W$.
1039 Hydrángea $W$.

Order LXXVi. PHILAdELPHE⿸.

This consists at present of a single genus, which was formerly referred to Myrtaceæ, but which has lately been separated with much acuteness by Mr. Don. The species are hardy ornamental shrubs, natives of North America, with white flowers; in some cases fragrant. Nothing is known of their properties.

1114 Philadélphus $W$.

Order LXXVII. CUNONIACEE.

These were formerly included in Saxifrageæ, from which Mr. Brown first distinguished them. They are shrubs of the southern hemisphere, mostly with pinnated leaves and white flowers. Callicoma and Bauéra, which have simple leaves, are elegant green-house shrubs. The bark of a species of Weinmánnia is employed in Peru for tanning leather, and is said to be also used for adulterating the quinquina. Nothing is known of the properties of the remainder.
1038 Cunónia $W$.
1099 Callícoma $B . R$.
1199 Bauéra H. $K$.
919 Weinmánnia $L$.

Order LXXVIII. ARALIACEÆ.

Araliaceæ are a slight divergence from the well-known Umbelliferæ, with which they nearly agree in habit, except in being frutescent, and from which they are obviously distinguished by their 5-celled fruit. Their flowers have no beauty, but the foliage of many is extremely fine, especially of the species of Actinophyllum that of our common ivy must not be omitted. Their medicinal properties are much the same as those of Umbelliferæ, except the fruit, which differs in virtues as it does in botanical structure. Theirbark exudes an aromatic gum resin, as in Arália umbellifera. Their roots are tonic, with, in some cases, the flavor of parsnep. The famous ginseng, which is produced by a Pánax, is reputed to have powerful tonic, restorative, and even aphrodisiacal qualities; but it is probable that these have been greatly exaggerated.
607 Cussónia $L$.
697 Actinophýllum $R$. \& $P$.
1109 Gastónia Juss.
696 Arália $W$.
549 Hédera $W$
2166 Pánax $W$

Order LXXIX. UMBELLIFERA.

One of the least attractive groups of plants, and at the same time one of the most important to the world. They are not more useful as food than they are dangerous as poison; while in their native ditche they are often suspicious lurid weeds, but under the influence of cultivation they lay aside their venom, and become wholesome food for man. They are generally recognised by their hollow stems and cut leaves, with what botanists call a sheathing petiole; that is to say, with a petiole, the base of which wraps round the stem. Their flowers are mostly white or greenish, rarely, as in Astrantia, some species of Caúcalis, and others, of a seeds, which are held together by a common axis, and a thickened discus. All are natives of damp ditches or way-sides, in cool parts of the world; in the tropics they are either extremely rare or wholly unknown, and when present, have generally a character unlike that of our European species. The simplicity of their structure, and uniformity of their appearance, has rendered their classification a matter of very great difficulty. It has been attempted in modern days by Lagasca, Sprengel, and Koch, all of whom have added something to our knowledge; but much still remains to be done. The arrangement of Professor Sprengel, objectionable as it is many points, is here adopted as the most perfect, upon the whole, of any yet published. The culinary and agricultural importance of many species is well known; the parsnep and carrot form a large part of the staple winter store of the inhabitants of Europe, as the Arracachas do of those of South America ; and the Prangos of Thibet is supposed to be the most important and productive of any in the whole worid, as a forage plant. The medicinal properties of Umbelliferæ are not more powerful than they are at variance with each other. While the seeds of some are aromatic, and stimulating in the highest degree, the fresh roots and leaves of others are not less narcotic. This has been supposed to arise from the difference in the state of the sap in different parts of the plant; and it has been thought that the narcotic principle is only to be found in the ascending sap, while the aromatic stimulant properties are found in the juices, which are fully elaborated and matured. It has been already observed, that their dangerous properties are often removed by cultivation; the common celery is a familiar instance of this ; but the most remarkable, that of OEnanthe pimpinelloídes, a most dangerous species when wild, which is cultivated about Angers for the sake of its roots, which are there called Jouanettes, and about Saumur, where they are known by the name of Méchons. The roots of some Umbelliferæ contain a large proportion of sugar; those of the carrot, when dried, more than an eighth; those of the parsnep just an eighth; and those of the chervil about eight parts in 100. Galbanum, Upopanax, and Assafœetida, are all the produce of different species of Umbelliferæ.

Tribe 1. Desciscentes.
2165 Arctópus $W$ 622 Erýngium $W$. 644. Actinótus $L a b$
548 Lagöécia $W$. 624 Echinóphora $W$. 623 Sanícula $\boldsymbol{W}$. 637 Dóndia Spreng.
674 Astrántia $W$.

\section{Tribe 2. HYDROCOTYLINA} 658 Hydrocótyle $W$. 659 Spanánthe Jacq.

Tribe 3. Bupleurin A. 657 Bupleúrum $W$.

2147 Hérmas $W$.

Tribe 4. Pimpinellex

635 Pimpinélla $w$. 629 Ledebúria $L k$. 642 séseli $W$.
647 Síson $W$

652 Ægopódium $W$.

655 Cárum $W$.
656 Cnídium Cuss.

632 Enánthe $W$

636 Phellándrium $W$
651 A'pium $W$.
653 Meum Jacg. 
650 Smyrnium $\boldsymbol{W}$ 633 Crithmum $W$ 660 Ulospérmum $L k$.
Tribe 5. SMYrniex. 677 Cáchrys $W$. $\quad 648$ Cicúta $W$. 678 Hippomárathrum $L k . \quad 661$ Æthúsa $\dot{W}$.
618 Coriándrum $W$.
666 Hasselquístia $\boldsymbol{W}$. 673 Tordýlium $\boldsymbol{W}$.
626 Caucalis $W$. 625 Daúcus $W$. 627 'Tórilis Gert.
Tribe 6. Caucalinea.
628 Olivéria Vent. 628 Olivéria Vent. 638 Trachyspérmum $L k$.
640 Búbon $W$.

631 Búnium $W$

676 Rúmia Hoffm.

Tribe 7. SCANDicineE.

619 Scándix $\boldsymbol{P} . S . \quad 630$ Mýrrhis $P . S . \quad$ e21 Chærophýllum $\boldsymbol{P} . \boldsymbol{S} . \quad 620$ Anthríscus $\boldsymbol{P} . \boldsymbol{S}$.

Tribe 8. АмміNeA.

639 A'mmi $W$ 641 Cúminum.
646 Sium $W$

649 Cónium $W$.
665 Ligústicum $W$ 645 Trínia Hoff $m$.

Tribe 9. SElineæ.

663 Selínum $W$, 670 Peucédanum $W$. 672 Herácleum $W$.

\section{Zosimia Hoffm. 1 Pastináca $W$.} 668 Férula $W$.

\section{Angélica $W$. \\ 662 Imperatória $W$. \\ 643 Thápsia $W$.}

669 Laserpitium $W$.

667 Artédia $W$.

654 Anéthum $W$.

Order LXXX, RHIZOPHORE正.

The mangroves are plants of arborescent stature, which are remarkable, in tropical countries, for growing upon the shores of the sea, even as far as low water. The seeds have the singular property of germinating, while enclosed within the capsule, and adhering to their parent, and pushing forth a long thread-like radicle, which lengthens till it reaches the soil, where it takes root, and forms a new individual. The bark of Rhizóphora gymnorhíza, which is very astringent, is used in India for dying black.

1078 Rhizóphora $W$.

ORDER LXXXI. HAMAMELIDEÆ.

Hardy American deciduous shrubs, with the appearance of Amentacex, to which they are undoubtedly closely allied notwithstanding their situation here, which must be considered quite artificial. Nothing is known of their medicinal qualities.
1200 Fothergilla $W$.
312 Hamámelis $W$.

\title{
Order LXXXil. CAPrifoliace
}

This is an eminently beautiful order, consisting either of twining or erect shrubs with clusters of trumpetshaped fragrant flowers, or of fine bushes having cymes of white blossoms. The honeysuckle is the representative of the former, the dogwood of the latter. Here too is found the modest and delicate Linnæ'a, which, however inferior its attractions for the vulgar eye may be to those of its more ostentatious neighbours, yields to none of them in elegance or interest for the botanist. All the genera have a more or less astringent bark; that of Lonicéra corymbósa is used in Chile for dying black; that of Córnus fírida in North America in intermittent fevers, as is also the bark of Córnus sericea, which, according to Barton, is scarcely inferior to Quinquina. The Elders are the link between honeysuckles and umbelliferous plants, to the latter of which they are allied by their stinking divided foliage and half herbaceous habit; their flowers are sudorific and soporific in a high degree, their leaves and inner bark are emetics and drastic purgatives. Triósteum perfoliátum is intermediate between this order and Rubiaceæ, with the former of which it agrees in its purgative, and with the latter in its emetic, qualities, which resemble those of ipecacuanha. All Caprifoliáceæ love shady cool places in both hemispheres; but few have been found in such as endure a very severe climate.
474 Caprifólium R. S.
477 Diervílla $J$.
475 Lonicéra $R$. $S$.
478 Triósteum $W$
306 Córnus $W$.
476 Symphória $P h$.
292 Linnæ'a $W$.
679 Vibúrnum $W$
680 Sambúcus $W$.

\section{ORDER LXXXIII. LORANTHE⿸⿻}

None of these are cultivable; they are all genuine parasites rooting beneath the bark of the trees on which they grow, and deriving from their juices the whole of their nutriment. The Viscums have little or no beauty, but the Loranthi are among the most lovely of plants, hanging in clusters of rich scarlet flowers from the branches of trees in the tropics, which they often clothe with a beauty not their own. The misletoe of the Druids is supposed to have been the Loránthus europæ'us, the common V'scum never being seen upon the oak, while the Loránthus inhabits no other tree. If this be so, the latter must have once existed in this kingdom although now extinct. It has been suggested, that all vestiges of their religion were extirpated with the Druids, which will account for the Loranthus having disappeared wherever that religion formerly held its sway.

\author{
2054 Viscum $W$.
}

\section{Order LXXXIV. RUBIACE玉.}

Opposite entire leaves with intervening stipulæ, a monopetalous superior corolla, with a definite number of stamens and a bilocular ovarium, are the great characteristics of Rubiaceæ; an order of such extent that it embraces a very large proportion of the whole of phænogamous plants, including within its limits humble weeds and lofty trees, plants with important medicinal qualities and flowers of varied dyes, and herbs of neither value nor beauty as far as has yet been ascertained. The sections into which the order has been divided are merely artificial, with the exception of Stellatæ, which are the representatives of the order in northern regions. Among these the Rubia, or madder, is the most important on account of its dye; Galium also possesses some qualities of minor consequence, which have been already indicated in the body of this work. Among the other sections, the plants of beauty or value are innumerable : of the former description, the genera Ixóra, Bouvárdia, Catesbæ'a, Portlándia, Coutárea, Gardénia, Mussæ'nda, Haméllia, Cephaélis, Cephalánthus, and many others, are notable examples; to the latter, every genus has a contribution of one kind or another. The root of Oldenlándia umbelláta is employed in India for staining nankin; that of Morínda umbelláta in the Moluccas, and of Morínda citrifolia in India, is used for dying red and brown. The potent febrifugal properties of the Cinchóna need not be insisted on; it is less generally known that the bark of Pincknéya púbens, Macrocnémum corymbósum, Guettárda coccínea, and Portlándia grandiflóra, possesses similar, but weaker powers. The bark and roots of Antirhóa are used, in the Isle of Bourbon, to stop hæmorrhage; and that of Morínda Róyoc is used for ink. Astringent properties of a very marked character are found in the juice of Naúclea Gámbir of Hunter, and the Uncária Gámbir of Roxburgh, both which are often improperly confounded with Gum kino, which is the produce of a very different plant. Some of the species formerly comprehended under the genus Cinchóna, but since separated by the name of Exostémma, possess strong emetic powers. The same qualities exist in Psychótria emética Cephaélis, Ipecacuánha, 
and Psychótria herbácea, which are often used as ipecacuanha. The seed of the Cofféa furnishes the valuable beverage which is so much esteemed in Europe and the East, under the name of coffee.

SECTION I. STELLATE.

266 Gálium $W$.

267 Rúbia $W$.

270 Spermacóce $W$. 285 Chomélia $\boldsymbol{W}$.

288 Ixóra $W$.

292 Siderodéndrum $W$
268 Aspérula $W$.

269 Sherárdia $\boldsymbol{W}$

\section{.} 291 Ernódea Swr. 294. Mitchélla $W$ 439 Pædéria $W$.
271 Crucianélla $W$.

2136 Valántia $W$.

617 Phýllis $W$.

483 Psychótria $W$.

495 Plócama $W$

833 Richárdia $\dot{L}$.

\section{Cofféa $W$.}

480 Chiocócca $W$.

482 Cánthium Pers.

494 Webéra $W$. $\begin{array}{ll}287 \text { Bouvárdia } H . K . & 456 \text { Dentélla } W \\ 261 \text { Houstónia } W . & 457 \text { Macrocnémum } W . \\ 293 \text { Coccocýpsilum } W . & 460 \text { Rondelétia } W . \\ 295 \text { Oldenlándia } W . & 455 \text { Spermadíctyon } R o x b . \\ 296 \text { Manéttia } W . & 8: 32 \text { Hillia } W . \\ \text { 406 Ophiorhíza } \dot{L} . & \text { 289 Catesbæ'a } L .\end{array}$

Section IV.

493 Erithalis $W$

486 Vanguiéra $W$.
485 Posoquéria Aubl.

458 Exostémma Rich. 462 Portlándia $W$. 462 Portlándia $W$. 461 Coutaréa Aubl. 488 Genípa $\boldsymbol{P} . \boldsymbol{S}$.
489 Oxyánthus $D e c$

490 Rándia $\boldsymbol{P}$. $S$.

491 Mussæ'nda $W$

492 Pincknéya Mich.

481 Seríssa $W$.

1981 Guettárda $W$.

SECTION V.

484. Haméllia $W$

Section VI.
497 Cephaélis $\boldsymbol{W}$.
498 Sarcocéphalus Afz.
286 Adína Sal.
459 Burchéllia $R$. $B r$.
496 Morínda $W$.
521 Naúclea $W$.
275 Cephalánthus $\boldsymbol{W}$.
2060 Anthospérmum $W$.

Order LXXXV. opercularinez.

- Exotic weeds, nearly related to Rubiaceæ. Their properties are unknown. M. de Jussieu has remarked that their affinity to Valerianeæ is supported by the curious circumstance, that birds devour the young shoots of the Opercularias as they do those of the Corn-salads. 250 Operculária $W$.

251 Cryptospérmum $\boldsymbol{P} . S$.

Order LXXXVI. VALERIANEA.

Small herbaceous plants, more interesting for the sake of their symmetry and neatness, than on account of any particular attractions: they may be considered a connecting link between Rubiaceæ and Dipsaceæ. Many of the Valérians, and all the Patrinias, are pretty plants. The Valerianéllas are useful esculents, known under the name of corn-salads. Their medicinal properties are of a decisive character. The roots of Valeriána officinális, Phu, and others, are bitter, tonic, aromatic, antispasmodic, and vermifugal of Valeriana officinalis, Phu, and others, are bitter, tonic, aromatic, antispasmodic, and vermifugal;
they are occasionally used as febrifuges. The odour of Valerian is not generally agreeable, but the Orientals collect with care, on the mountains of Austria, the roots of Valeriána céltica, with which they perfume their baths; and the natives of India, at this day, employ the Valeriána jatamánsi, the spikenard of old times, as a perfume, and against hysterics and epilepsy.
20 Centránthus Mich.
78 Valeriána $W$.
80 Valerianélla $D e c$.
72 Fédia $D e c$.
79 Patrinia $W$.

Order LXXXVII. DIPSACEF

Very nearly akin to Compositæ, of which they have nearly the habit. All are herbaceous plants with flowers growing in heads. Some of the Scabiosas are very handsome, and popular border flowers. The whole tribe is cultivated with great facility. Some of the species of Scabiosa have been employed as diaphoretic anc antisyphilitic, but are now neglected.
70 Morína $W$.
263 Cephalária $S c h r$
265 Knaútia $W$.
262 Dípsacus $W$. 264 Scabiósa $\boldsymbol{W}$.

Order LXXXVIII. CALYCEREE.

Obscure weedy South American plants, differing from Compositæ, chiefly in the position of their ovula. 1842 Acicárpa Juss.

ORDER LXXXIX. COMPOSITÆ.

A most extensive and natural order, obviously characterized by the cohesion of their anthera, and the arrangement of their florets in involucrated heads, or calathidia, as they are now called. Most of them may be said to be ornamental plants, and yet but a very few hold that station in the opinion of the public. It is difficult to account for this circumstance, nor is this the place to enter upon such an investigation; certain, however, it is, that with the exception of Dáhlias, the varieties of Chrysanthemum sinénse, and a féw Caléndulas and Arctótises, and perhaps Tagétes, scarcely a single Composita now finds a place in a fashionable flower garden. The prevailing color of the flower in the order is yellow ; red, purple, or scarlet, being comparatively uncommon. The species inhabit every part of the world, and in all, perhaps, in nearly equal proportions:- in Europe and the north of the world they are chiefly herbaceous ; but within the tropics, they are more frequently frutescent. Their medical properties are very important; Tussilágo fárfara, Chamomile, I'nula, Solidágo Vircaúrea. Matricária Parthénium, Stévia febrifuga, and Eupatórium perfoliàtum, are instances of the presence of tonic and febrifugal properties; Tanacétum and Santolina are anthelmintic ; Matricária and the Achilléas emmenagogue ; some Eupatóriums, Achilléas, Artemísias, and Caléndulas, are sudorific ; certain Liátrises are diuretic, and Erígeron philadélphicum is both sudorific and diuretic. Ptármica and A'rnica are sternutatory, and Spilánthes, Siegesbéckia orientális, A'nthemis pyréthrum, and others, powerfully excite salivation; finally, unany Achilléas, Chamomile, Tanacétum, and Eupatóriums, are tonic and antispasmodic Others seem to possess all these properties combined, and are reckoned among the best alexiterics, as the Ayapana of Brazil, and the Guaco of Peru. Every one knows the excellent and refreshing alexiterics, as the A yapana of Brazil, and the Guaco of Peru. Every one knows the excellent and refreshing Artemísia glaciális, rupéstris, and spicáta. Some species of Achilléa, Béllis, and Artemísia have been used as substitutes for tea. The seeds of many Compositæ, as Mádia and Verbesína, yield a copious oil ; and the.fleshy roots of Heliánthus tuberósus, a wholesome food for man. The juice of Lactúca virósa is highly narcotic, and has been even employed with extraordinary advantage as a substitute for opium. It is not necessary to mention the utility of the leaves of the lettuce, the endive, the succory, the cardoon, or the roots of Scorzonera and Salsafis, as culinary productions; they must be familiar to all our readers; as also the fleshy receptacle of the artichoke and some other plants. The flowers of Echinops strigosus are used as a kind of tinder; those 
of the artichoke, the cardoon, and others, have the power of curdling milk. The arrangement of Compositæ is attended with extreme difficulty; the greatest progress that has yet been made in reducing them to order has been with M. Cassini, by whom they are called Synanthereæ: but unfortunately, the remarks of that learned botanist are so scattered and unconnected, that the public has hitherto been able to derive little benefit from his labors. His general arrangement is here adopted, but for the reasons now given, his genera have not been enquired after, as, until they shall have been more completely systematized the adoption of them would necessarily be full of errors, which would only add to the confusion that already too extensively exists. Those necessarily be full of errors, which would only add to the confusion that already too extensively exists. Those consult the Opuscules phytologiques of M. Cassini, and Mr. Brown's elaborate essay on the structure of Compositæ, in the Transactions of the Linnean Society.

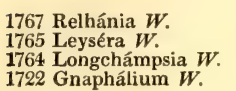

1722 Gnaphálium $W$.

\section{SUBORdER I. INULE ZE.}

1848 Cassínia $H . K . \quad 1747$ Podolépis $H . K$. 1681 Ammóbium R. Br. 1725 Antennária $R . B r$ 1713 Ixúdia $H . K . \quad 1726$ Metalásia $R . B r$. 1727 Astélma $R . B r . \quad 1846$ Stæ`be $W$.
1844 odéra $W$.

1723 Leontopódium R. Br 1728 Athríxia $\mathrm{Ker}$

1730 Elichrýsum $W$.

Tribe 1. Archetrpe.

1838 Filágo $L$. 1724 E'vax Lam. 1839 Micrópus $W$.
1734. Conýza $W$

1744 I'nula $W$.

1745 Pulicária Gert.
1731 Carpésium $\boldsymbol{W}$.

1785 Columéllia $J a c$.

1710 Neurolæ'na $R$. $B$ r

Tribe 2. BuphthalmeE.

1797 Buphtnálmum $W . \quad 1849$ Sphæránthus $W$.

Suborder II. LACTUCETE.

Tribe 3. Prototy pe.

1659 Scólymus $W$. 1623 Arnopógon $W$.
1626 Picridium P.S.

1627 Sónchus $W$.

Tribe 4. CrepideE.
1639 Helminthia $J$. 1634 Pícris $\boldsymbol{W}$. 1651 Lapsána $W$.

1630 Prenánthes $W$. 1635 Hierácium $\boldsymbol{L}$.

1647 Robértia Rich. 1648 Seriola $W$ 1620 Geropógon $W$.
1650 Hypochæiris $W$.

\begin{abstract}
1653 Rhagadiolus $W$. 1629 Chondrilla $W$. 1632 Apárgia $W$.
\end{abstract}

1628 Lactúca $W$. 1637 Borkhaúsia Dec 1636 Lagóseris $I h$.

Tribe 5. Hieracies.

$$
\begin{array}{lll}
1641 \text { Tólpis } W . & 1649 \text { Soldevilla Lag. } & 1643 \text { Róthia } W . \\
1644 \text { Krigia } W . & 1654 \text { Moscária Fl. per. } & 1642 \text { Andrýala } W .
\end{array}
$$

Tribe 6. Scorzonereas.

$\begin{array}{lll}1621 \text { Tragopógon } W . & 1625 \text { Scorzone'ra } W . & 1655 \text { Catanánche } W . \\ 1633 \text { Thríncia } W . & 1622 \text { Tróximon Gert. } & 1657 \text { Cichórium } W . \\ 1631 \text { Leóntodon } W . & 1645 \text { Hyóseris } W . & \end{array}$

1624 Podospérmum Dec. 1646 Hedýpnois $W$
1638 Crépis $W$ 1640 Myśseris $L k$.

\section{SUboRder III. ADENOSTYLEAE.}

1678 Palafóxia Lag.

\section{SUBORDER IV. EUPATORIEAE.}

1689 Stévia $W$. 1687 Agératum $W$
Tribe 7. Ageratez.
1688 Cælestína Cass.

1700 Lavénia $W$.

Tribe 8. ARCHETYPA. 1685 Eupatórium $\boldsymbol{W}$.

1704 Piquéria $W$. 1683 Mikánia $W$.

Tribe 9. Liatride 1682 Liátris $W$.

Suborder V. AMBROSIEAE.

Tribe 10. IVEA. 1841 I'va $W$.

Tribe 11. ARCHETYPE.

1974 Xánthium 1977 Ambrósia

SUborder VI. ANTHEMIDEAE.

1721 Artemísia $W$ 1711 Húmea Sm. 1835 Soliva Fl. per. 1834 Híppia $W$.
1774 Cénia $J$. 1775 Cótula $W$. 1718 Ralsamita $W$. 1776 Grángea $W$.

\author{
1719 \\ 1719 Pentzia $T h$. \\ 1720 Tanacétum $W$. \\ 1788 Chrysanthéllum $P . S$.
}

1769 Chrysánthemum $\boldsymbol{W}$.

1771 Matricária $W$. 1773 Lidbéckia $W$.

Tribe 13. Santolinea.

1717 Athanàsia $W$. 1715 Otánthus $I k$.

\section{Anacýclus $W$.}

1778 A'nthemis $W$

1837 Eriocéphalus $W$
1781 Achilléa $W$.

1806 Osmites $W$.

1816 Sphenógyne $R$. Br.

Suborder VII. ARCTOTIDEA.

Tribe 14. Gorteriek. 1811 Didélta $W$.

1812 Gortéria $W$. 1801 Galárdia $\dot{W}$.

1809 Cullúmia $H$. $K$.

1810 Berckhéya $\boldsymbol{H} . \boldsymbol{K}$.

Tribe 15. ARchetYPa. 1814 Cryptostémma $R, B r .1815$ Arctothéca $W$. 
SUborder VIII. CALENDULEAE.

Tribe 16. ARchetype. 1830 Caléndula $W$.

Tribe 17. Osteospermez 1832 Osteospérmum $W$.

Suborder IX. MUTISIEAE.

Tribe 18. ARCHETYPE.

1748 Chætanthéra Fl. per.

Tribe 19. Gerberiee.

1750 Gerbéria Burm. 1829 Chaptália Vent.

SUborder X. TUSSILAGINEAE. 1737 Tussilágo $W$.

SUborder XI. NASSAUVIE EE.

Tribe 20. Trixidee.

1686 Dumerilia Lag. 1825 Tríxis Dec.

Tribe 21. ARChETYPE.

1656 Triptílion Fl. per.

1671 Acárna $W$ $16 \%$ () A tráctylis $W$. 1658 Bacázia Fl. per.
SUborder XII. CARIIINEAE.

1676 Cardopátum Pers. 1677 Stæhelína $W$ 1659 Carlína $W$.

1677 Stæhelina $W$.

1729 Xeránthemum $\boldsymbol{W}$

Suborder XIII. CENTAURIEAE.

1819 Centauréa $W$

1665 Cnícus $W$

1817 Zœ'gea $W$

Suborder XIV. CARDUINEAE.

$1660 \mathrm{~A}^{\prime}$ rctium $W$

1663 Cárduus $W$.

1675 Cárthamus $W$

1668 Cýnara $W$

1666 Onopórdum $W . \quad 1661$ Serrátula $W$.

1667 Berárdia Vill.

1664 Silybum Giert. 1818 Lé́zea $D e c$.

SUborder XV. ECHINOPSEA.

1850 Echínops $W$.

1699 Lagásca Cav.

Suborder XVI. TAGETINEAE.

\begin{tabular}{|c|c|c|}
\hline $\begin{array}{l}1749 \text { A'rnica } \underset{W}{W} \\
1702 \text { Kleínia } W \text {. }\end{array}$ & $\begin{array}{l}1763 \text { Péctis } W \text {. } \\
1766 \text { Sellóa Spreng. }\end{array}$ & $\begin{array}{l}1760 \text { Tagétes } \underset{W}{W} \text {. } \\
1759 \text { Boebéra } W \text {. }\end{array}$ \\
\hline \multicolumn{3}{|c|}{ SUBorder XVII. HELIANTHEAE. } \\
\hline \multicolumn{3}{|c|}{ Tribe 22. Heleniez. } \\
\hline $\begin{array}{l}1782 \text { Trídax } W . \\
1707 \text { Cálea } W . \\
1716 \text { Caleácte } R . B r .\end{array}$ & $\begin{array}{l}1690 \text { Cephalóphora } \boldsymbol{W} \text {. } \\
1792 \text { Galinsógea } W \text {. } \\
1755 \text { Helénium } W \text {. }\end{array}$ & $\begin{array}{l}1692 \text { Hymenopáppus } J . \\
1694 \text { Marshállia } P h . \\
1762 \text { Schkúhria } W .\end{array}$ \\
\hline \multicolumn{3}{|c|}{ Tribe 23. COREOPSIDEA. } \\
\hline $\begin{array}{l}1697 \text { Bídens } W \text {. } \\
1804 \text { Coreópsis } W \text {. } \\
1803 \text { Cósmea } W \text {. }\end{array}$ & $\begin{array}{l}1758 \text { Dáhlia Cav. } \\
1761 \text { Heterospérmum } W \text {. } \\
1840 \text { Parthénium } W \text {. }\end{array}$ & $\begin{array}{l}1824 \text { Sílphium } W . \\
1791 \text { Synedrélla } \dot{P} . S . \\
1753 \text { Tetragonothéca }\end{array}$ \\
\hline
\end{tabular}

Tribe 24. ARCHETYPE.

1793 Acmélla $P$. S . 1807 Encélia Cav.

1798 Heliánthus $W$.

1708 Isocárpha $R$. $\dot{B}$ r.

1823 Baltimóra $W$ 1786 Eclipta $W$.

1852 Brotéra $W$.

17.12 Cæsúlia $W$.

1787 Meyéra Swz.

1779 Ceritrospérmum Spr.

1783 Améllus $W$.

1743 Kaulfússia Nees.

$17.39 \mathrm{~A}^{\prime}$ ster $W$

1740 Solidágo $W$.
1693 Melananthéra Mi. 1780 Sanvitália Cav. 1709 Petríbium $R . B r . \quad 1805$ Símsia Pers. 1698 Platýpteris $K t h$. 1695 Spilánthes $W$ 1696 Sálmea Dec.

1700 Verbesina $W$ 1754. Ximenésia $W$ 1768 Zínnia $W$

Tribe 25. RudBEckie玉.

1799 Gymnolómia Kth. 1795 Pascália $W . \quad 1802$ Tithónia Desf 1796 Heliópsis $P$. S. 1800 Rudbéckia $W$. 1821 Wedélia $W$.

Tribe 26. MILLERIEA.

1827 Chrysógonum $L . \quad 1735$ Mádia $W . \quad 1808$ Sclerocárpus $W$ 18 活 Euxénia Cham. 1828 Melampódium $W$. 1789 Siegesbeckía $W$. 1847 Nauenbúrgı́ $W . \quad 1892$ Milléria $P . S . \quad 1794$ Zaluzánia $P . S$. 1845 Flavéria Juss. 1826 Polýmnia $W$.

SUborder XVIII. ASTERE

17.32 Báccharis $W$.

$173: 3$ Molina $\mathrm{Fl}$. per.

1756 Béllis $W$

1742 Calótis $R . B r$
1784. Stárkea $W$

18.36 Psiádia $W$

1746 Grindélia $W$. en.

1679 Pterónia $W$

SuborDER XIX SENECIONES.

\begin{tabular}{lll}
1701 Cacália $W$. & 17.51 Dorónicum $W$. & 1738 Senécio $W$. \\
1741 Cinerária $W$. & 1833 Othónna $W$. \\
\multicolumn{3}{c}{ Sưonden XX. VERNONIEAE. } \\
1843 Elephantópus $W$. & 1851 Rolándra $W$. & 1706 Tarchonánthus $W$. \\
1703 Ethúlia $W$. & 1684 Sparganóphorus Gertn. & 1680 Vernónia $W$. \\
1853 Gundélia $W$. & 1672 Stokésia $W$. & 1691 Ampheréphis $K t h$.
\end{tabular}


Order XC. CAMPanulacee.

These differ from the last in not having the flowers in heads, in their usually distinct antheræ, which are, however, syngenesious in Lobélia, in their polyspermous fruit, and also in exuding a milky juice. All the genera are pretty, and some highly ornamental. They are mostly herbaceous, and by far the greater number are extra-tropical, abounding especially in the woods and coppices of the North. The roots of Campánula Rapúnculus are used as a vegetable under the name of Rampion. The juice of some of the Lobélias is highly caustic and inflammatory; when taken internally, producing vomiting and even death : nevertheless, the root of Lobélia siphilitica, in small doses, acts as a diaphoretic, in greater quantity as diuretic or purgative, and, if taken in considerable quantities, as an emetic. An infusion of Lobélia inflata is used in North America as a remedy for leucorrhœa ; and the root of Lobélia cardinális is employed in the same country as a vermifuge.
46t Lobélia $W$.
466 Trachélium $W$.
467 Roélla $W$.
8.34 Canarína $W$.
463 Campánula $W . \quad 546$ Lightfoótia $L$ 'Her. $\quad 545$ Cỹphia $W$.
547 Jasione $W$.

465 Phyteúma $W$. 895 Michauxía $W$.

Order XCI. GOODENOV1玉.

New Holland and South Sea herbs or undershrubs, very nearly akin to the last, from which they differ more in artificial characters than in habit. All of them are pretty, and deserving culture. .Nothing is known of their properties.

468 Goodénia $R$.

470 Dampièra $R . B r$.

$\$ 73$ Scæ'vola $R . B r$.

469 Eutháles $R . B r$. 472 Velléia $S m$.

Order XCII. STYLIDEE.

Like the last, the properties of this very small but curious order are, if any, undiscovered. All are inhabitants of New Holland, and either herbs or half-herbaceous shrubs. They have pink flowers, ornamented with glittering glands; their stamens are united into a column, which is terminated by a sessile stigma, and which is irritable in so high a degree, that, if touched with a pin, it instantly starts from its place with great elasticity.

\author{
1932 Stylidium $R$. Br.
}

Order XCIII. GESNERIEE.

Fine tropical herbs, with broad, fleshy, downy leaves, and purple or scarlet flowers. They all require stove heat, and decayed vegetable soil; in their native country, which is chiefly equinoctial America, they are found growing in the woods, where the earth is little more than a bed of rotten leaves and bark.

$$
1290 \text { Gesnéria } W \text {. } 1291 \text { Gloxínia } W \text {. }
$$

\title{
Order XCIV. ERICEE.
}

These are distinguished from the neighbouring orders by their polyspermous fruit, aristate anthers, and dry shrubby habit. Every genus is eminently beautiful, and worthy of the most assiduous cultivation. 'Ihe first tribe is a native of hill-sides and open plains, chiefly of the extra-tropical regions of the earth. Some are famous for their beauty, some for their fragrance, and many for their foliage. The heaths are the glory of the Cape, the Arbutuses of Europe, the Andrómedas of America, and Cléthra of the Canaries. The second tribe is distinguished from the rest by its inferior berry, and is not less valuable for its fruit than conspicuous for its beauty. The species are principally North American. Monotropeæ stand in their systematic station as they grow in their native woods, lowly herbs among thickets of bushes and trees. Rhodoraceæ, once conthey grow in their native woods, lowly herbs among thickets of bushes and trees. Rhodoraceæ, once conbut their habit is not materially different; here the Azálea the Kálmia, and the Rhododéndron, the pride of European gardens, as they are of their native woods, find their station. The utility of the fruit of Vaccinium is well known; its bark is reckoned tonic, stimulant, and astringent, and their fruit slightly styptic. The berries of $A^{\prime}$ rbutus úva-tirsi are considered lithontriptic; its leaves have also been employed successfully in infusions in obstinate cases of gonorrhœea. Extract of Chimáphila umbellata, in the form of pills, in doses of five seruples a day, has been found successful in cases of dropsy. Some of the species are possessed of narcotic qualities; this is the case with Lédum, Rhododéndron chrysánthum, and especially Azálea púntica; honey obtained from the juice of which is said by Xenophon, to have caused the death of many soldiers in the famous retreat of the ten thousand. An infusion of Rhododéndron máximum is used in America in cases of chronic rheumatism, and that of Rhododéndron pónticum in Asia, against gout and rheumatism.

Tribe 1. ERICEA VERE.

$\begin{array}{lcll}284 \text { Blæria } W . & 535 \text { Itea } L . & 1018 \text { Gaulthéria } W . & 1020 \text { Cléthra } W . \\ 892 \text { Erica } W . & 536 \text { Cyrílla } L . & 1019 \text { A'rbutus } W . & 1021 \text { Mylocáryum } W . e n . \\ \text { 534 Brossæ'a } L . & 1016 \text { Andrómeda } W . & 1017 \text { Enkiánthus } B . M . & \end{array}$

Tribe 2. VACCINIEE.

906 Oxycóccus $P . S$. 907 Vaccínium $L$. 1023 Chimáphila $P h . \quad 1008$ Monotrópa $W$

Tribe 4. RHODORACEN.

$\begin{array}{lll}403 \text { Azálea } W . & 1011 \text { Kálmia } W . & 1014 \text { Rhododéndron } W . \\ 404 \text { Chamælédon } L k . & 1012 \text { Lédum } W . & 1015 \text { Epigæ'a } W . \\ 893 \text { Menziésia } S m . & 1013 \text { Rhodóra } W . & 1076 \text { Bejária } P h .\end{array}$

\section{Subclass III. COROLLIFLORÆ.}

Petals cohering in the form of a hypogynous corolla, which is not attached to the calyx.

To this subclass are to be referred all genera which have a monopetalous corolla, with the stamens inserted into it, and a superior ovarium.

\section{Order XCV. MYRSINEE}

Showy shrubs, with evergreen undivided leaves, and cymes of white or red flowers. Theophrásta is a very rare stove plant, with a simple stem, and undulated spiny toothed leaves. The Ardisias are common in col. lections. None are natives of Europe, but are found in the hot parts of Asia, Africa, and America. Nothing is known of their properties.

408 Theophrásta $L$. 409 Clavija $\mathrm{Fl}$. per.
4.35 Ardísia $W$

2160 Myrsíne $\boldsymbol{R} . \boldsymbol{B r}$.

$3 \mathrm{Z} 2$
443 Bæobótrys Vahl. 
Order XCVI. SAPOTEA.

These are also shrubs, which are mostly evergreen, and natives of the warmer regions of the world. Some of the Bumélias are found in the southern states of $\mathrm{N}$. America, but none of the order exists in Europe. They are chiefly valuable for their fruit, which, in many cases, contributes richly to the dessert. Mímusops eléngi, Imbricária malabárica, Sideróxylon spinósum, are all of this description; the star apples of the West Indies, the produce of several species of Chrysophyllum, and particularly of C. cainito, are esteemed delicious ; and the Medlars, Lucumas, and Sapotillas of equinoctial America, all the fruit of different kinds of $A^{\prime}$ chras, are among the most valuable productions of the western world. The seeds of all the order are oily : those of A'chras sapóta are accounted diuretic and aperient. Their oil is not fluid, but so concrete as to have the appearance and consistence of butter, whence the name of butter-tree has been applied to different species both in Africa and India. The most famous of this description is the Indian mava, mahva, or madhuca, the Bássia butyrácea of botanists; the seeds of which are so oleaginous, that a single tree has been known to produce three quintals of oil; the dried flowers of the same tree are mixed by some Indians with their food, and a kind of spirit is distilled from them by others. The juice of all the sapotas is milky, but not acrid and poisonous like that of most other lactescent orders, but, on the contrary, yielding a wholesome beverage or food. Here is supposed to belong the famous Palo de Vaca, or Cowtree of South America, the trees of which are regularly milked by the inhabitants of the districts in which it grows. According to Brown, the bark of some of the $\mathbf{A}^{\prime}$ chrases is so astringent and febrifugal as to be substituted for quinquina.
423 Bumélia $\boldsymbol{W}$.
426 Jacquínia $W$
424 Chrysophýllum $W$.
427 A'chras $W$.
433 Sersalísia $R$. $B r$.
434. Manglílla Juss.
1024 Inocárpus $W$.
425 Sideróxylon $\boldsymbol{W}$.

\section{Order XCVII. SYMPLOCACEA.}

Shrubs with serrated leaves, turning yellow in drying, and small white flowers which are sometimes fragrant. The leaves of most of them are astringent; those of Alstónia tinge the saliva greenish yellow, of Sýmplocos tinctúria are used in America under the name of Sweet-leaf, for dying yellow.

1614 Sýmplocos $L$.

Order XCVIII. EBENACEA.

Some of these are hardy trees or shrubs, with deciduous leaves and white flowers, natives of woods, mountains, and banks of streams in North America and Europe; others are tropical evergreens. Among the former, the best known are the Snow-drop tree, or Halesi, with pendent shewy white blossoms; and the different species of Stýrax : of the latter, many of the Diospýruses' produce are eatable fruit; as, for example, the Mabolo of the Phillippine Islands, which is as big as a peach, and the Kaki of Japan, which resembles an apricot. All these fruits are remarkable for their extreme austerity before maturity, and the necessity of letting them decay, like our medlars, before they are fit for table. These are also distinguished for the excessive hardness of their wood, and for the black colour it sometimes acquires when old, as the Ebony. The bark of Diospýros virginiana is used in North America in intermittent fevers.
1035 Royéna $W$
2159 Diospýros $W$.
1025 Stýrax $W$.
1081 Halésia $W$.
1105 ? Visnea $W$.
2086 Mába $J$.

Order XCIX. oleine.

The olives are known by their monopetalous corolla, with a valvular æstivation, two stamens alternate with the segments, a bilocular ovarium with no discus at the base, and pendulous collateral ovula. They were formerly combined with the jasmines. They have all simple opposite leaves; their flowers are either white, yellow, or purple, and frequently fragrant. The Phillyréas are among our finest evergreens, and the Lilac or Syringa perhaps at the head of hardy deciduous bushes. The ash is an anomalous genus which hardly belongs to the order. The seed of the olive contains so large a proportion of fixed oil, that it has long been one of the most important objects of cultivation in the South of Europe. The bark and leaves of many Oleinæare bitter and astringent; these properties are particularly apparent in the ash, which has often been employed successfully as a febrifuge. From the exudation of many species of that genus, the mild purgative called manna is formed; it is most commonly found upon the $U^{\prime}$ rnus. M. Decandolle remarks, that in proof of the natural affinity of the plants here combined, and of the propriety of separating the jasmines from them, it has been found that all the olives as now restricted, will bud or graft upon one another, but not on the jasmines. Thus the lilac will graft on the ash, the Chionánthus, and the Fontanésia, and even upon Phillyréa latifólia. and the olive will take upon the Phillyréa, and even on the ash.
32 O'lea $W$.
34 Chionánthus $\boldsymbol{W}$
67 Linociéra $B . P$.
69 O'rnus $P$. S.
35 Notelæ'a $\boldsymbol{B} . \boldsymbol{P}$
36 Ligústrum $W$.
66 Fontanésia $W$.
2157 Fráxinus $W$

\section{Order C. JASMINEE}

Fragrance is the predominant property of the jasmine, and has made it for ages the favourite of poets and of the people; this arises from the presence of an oil which can be extracted so as to retain its perfume. In medicinal qualities, the jasmines do not differ materially from the last; they are neatly distinguished by botanists by the direction of their ovula which are erect in Jasmineæ, and pendulous in Oleinæ.
38 Nyctánthes $W$.
39 Jasminum $\boldsymbol{W}$.

\section{Order CI. APOCYNEF.}

We now turn from the contemplation of plants ondued with mild and agreeable properties and fragrant flowers, and often bearing food for man, to others which are among the most dangerous and fatal poisons; whose juices, milky indeed, like the Cowtree, are not a wholesome and delicious beverage like those of Sapotex, but on the contrary acrid, caustic, or bitter. They are readily known by the twisted direction of the segments of the corolla, which have been compared to the rays of a Catherine's wheel, whence they were called by Linnæus, Contortæ. By far the greatest part of the order consists of tropical trees and shrubs: a few Apócynums, Amsónias, and Vincas, are natives of the colder zones of the earth. Many are elegant climbers, as the different species of Echítes and Melodinus. The splendid Oleánder belongs to Nérium; the different species of Plumiéria, Camerária, Strophánthus, and Arduína are stove plants of the greatest beauty. The medicinal action of these plants is highly powerful. The Strychnos, or nux vomica tree, is remarkable for its bitterness and acrid deleterious effects, which are indicated not only when introduced into the stomach, but still more violently when absorbed into the system by inoculation. In general, the Apocyneæ are acrid, stimulating, and astringent; these principles, when in excess, act so powerfully on the nerves as to produce stupefaction. The root of Ophióxylon is very bitter and purgative : under the name of snake-root it is used in India as an antidote to the bites of serpents. The bark of Cérbera Mánghas is purgative; of Echítes antidysentérica, and the Wrightia of the same name, astringent and febrifugal; the leaves of the Vinca are so astringent, that they have been used successfully in tanning; those of Nérium oleánder are said to abound in free gallic acid. The inspissated juice of a species of Cérbera, known in Mexico under the name of Ycotli, is a fatal poison.

407 Allamánda

410 Vinca $W$
411 Nérium $R$. $B$ r.

412 Wrightia $R$. $B$ r
413 Echites $R, B r$.

414 Ichnocárpus $\boldsymbol{R} . \boldsymbol{B r}$.
415 Plumiéria $W$.

416 Strophánthus Dec. 
417 Camerária $W$. 418 Tabernæmontána

2152 Ophióxylon $W$.

419 Amśnia Mich.
420 Cérbera $W$.

436 Arduína $W$.
438 Caríssa $W$.

440 Gelsémium $J$.

441 Rauwólfia $W$.
572 Apúcynum $R$. Br. 573 Melodínus Forst. 299? Monétia $W$.

Order CII. ASCLEPIADEE.

These differ from the last only in having the stamens united into a sort of fleshy crown, and the pollen coherent in masses of a waxy substance like that of Orchider; their properties, habit and geographical range, are much the same. Periplóca is a singular instance of an asclepiadeous plant being a hardy shrub, every other frutescent species of the order being natives of countries where frost is unknown. Hoýa comprehends climbing plants, with waxen, clustered, odoriferous flowers distilling honey. Pergulária is valued for its fragrance, Ceropégia for its singularity, and Asclépias for beauty and hardiness. But the most extraordinary genera of the order are Stapélia, Piaranthus, and Huérnia, in which the place of leaves is supplied by fleshy short stems of various forms, and whose flowers are not less singular for their curious and complex organiza. short stems of various forms, and whose flowers are not less singular for their curious and complex organiza-
tion, than they are remarkable for their strange coloring and spotting, and offensive for their foetor. The root tion, than they are remarkable for their strange coloring and spotting, and offensive for their fœetor. The root countries for ipecacuanha. An infusion of the root of Asclépias decumbens has the singular property of exciting general perspiration; whence it is successfully used in Virginia for pleurisy. It is very singular that, in a tribe of plants so generally poisonous as these are, the young shoots of some species should be an article of food: of this nature are Pergulária édulis, Periplóca esculénta, Apócynum índicum, and several more.

574 Periplóca $\boldsymbol{R}$. Br. 581 Cynánchum $R$. Br.

575 Cryptostégia $R$. Br.

576 Hemidésmus $R$. Br.

577 Secamóne $R$. Br.

579 Microlóma $\boldsymbol{R}$. $\boldsymbol{B r}$.

584 Calótropis $R$. $B r$.
585 Dischídia $R . B r$

580 Dæ'mia $R . B r$.
581 Cynánchum $R . B r$

583 Gymnéma $R$. Br.

585 Dischidia $R . B r$. $B$ Xysmalobium $R$. $B r$

592 Hoýa $R . B r$
587 Gomphocárpus $\boldsymbol{R}$. Br. 593 Ceropégia Roxb.

588 Asclépias $R$. Br:

589 Gonólobus $R$. $B$ r

590 Pergulária $R$. Br.

591 Marsdénia $R$. $B r$
594 Stapélia $R$. Br.

595 Piaránthus $R$. Br.

596 Huérnia $R$. Br.

597 Brachystélma $R$. $B$

598 Caralluma $R . B r$

An order in some degree intermediate between Polemoniaceæ and Scrophularineæ, from both which it is distinguished both by habit and fruit; some of the genera border closely upon A pocyneæ. 'The species are natives of cool or mountainous regions or pools in all parts of the world. The Gentians are mostly dwarf herbaceous plants, with deep blue flowers; the latter color, and different shades of orange, being the prevailherbaceous plants, with deep blue flowers; the latter color, and different shades of orange, being the prevail-
ing hues. They are all pretty, and many beautiful in the highest degree; but, with a few exceptions, they are impatient of cultivation. The medicinal properties of the root of Gentiánalatea, rábra, and purpúrea, are eminently tonic, stomachic, and febrifugal; their bitterness is second only to Quássia. Similar, but more feeble virtues, are found in most of the order, especially in Villársia ováta, Gentiána peruviána, Chirayíta Fraséra Wálteri, \&c. Spigélia anthélmia is used as a vermifuge; and the root of Spigélia marylándica infused in water as anthelmintic, and in wine as febrifuge. Potália amára is used in Guiana as an emetic. A kind in water as anthelmintic, and in wine as febrifuge. Potalia amara is used in Guter istilled in Switzerland from the roots of Gentiana, macerated in water.
281 Sebæ'a $R$. Br.
365 Eústoma $P$. $L$.
600 Gentiána $\boldsymbol{W}$.
282 Fraséra Walt.
366 Erythræ'a $P$. $S$
599 Swértia $W$.
379 Spigélia $W$
378 Lisiánthus $W$.
368 Logánia $R . B r$.
367 Sabbátia $P$.
362 Menyánthes $W$
353 Villársia $R$. Br.

Order CIV. BIGNONIACE死.

The showy trumpet-shaped flowers and broad leaves of these plants, render them objects of general admiration. The greatest number is found in the equinoctial regions, a few only passing beyond those limits to the north Bignónia rádicans is a hardy climbing plant, of exceeding beauty; and the Jacarandas are resplendent with flowers of blue or purple, and leaves which emulate the elegance of the Acácia. Nothing important is known of their qualities. Their wood is said to resist the attack of worms.

64 Catálpa Juss.

1294 Bignónia $W$.

1295 Jacaránda Juss.

Order CV. COBEACE无.

A climbing genus with large purple flowers, recently separated from the Bignónias by Mr. Don. Nothing is known of its medicinal properties.

388 Cobæ'a Cav.

Order CVi. polemoniace死.

Herbaceous plants with showy blue, red, or white flowers, and often with pinnated leaves. They are natives of cool or mountainous parts in Europe and America. Nothing is known of their properties.

369 Phlox $W$

70 Polemónium $W$.

389 Cántua $W$.

390 Hoítzia Cav.

Order CViI. CONVOLVUlaCE⿸⿻ 丿亅

Nearly the whole of these are twining plants, with shewy flowers expanding beneath the influence of bright sunshine. A few are shrubs, but the greater part are herbaceous, and very many annual. They are frequently, also, weeds, which, from their creeping roots, are difficult to extirpate. All parts of the world produce them, from the cold regions of the north to the burning soil of the equator. Cúscuta is a singular produce them, wholly destitute of leaves. The root of many is filled with a milky acrid juice, which is very purgative. parasite, wholly destitute of leaves. The root or many is tilled with a milky acrid juice, which is very purgative. flóridus and scopàrius, and Ipomæ' a quamóclit, is stimulatory; that of Convólvulus batátas, which is the sweet potato of America and Southern Europe; and Convólvulus édulis are wholesome articles of food.

Hydroleæ are little known, pretty, herbaceous plants, mostly with blue flowers, native both of cold and tropical countries. Diapénsia lappónica being an inhabitant of Lapland mountains, and Hydrólea spinósa of West Indian marshes. Their botanical characters are very nearly the same as those of Polemoniacex. The roots of Hydrólea spinósa are reputed bitter, and slightly purgative.

383 Ipomæ'a $R$. $B r$.
384 Convólvulus $\boldsymbol{W}$. 384 Convólvulus $W$.
385 Argyréia Lour.

601 Hydrolea $W$
Tribe 1. GENUINA.

387 Calystégia $\boldsymbol{R}$. $\boldsymbol{B r}$.

602 Fálkia $\boldsymbol{L}$.

695 Evólvulus $L$.

Tribe 2. HydroleE.

358 Diapénsia $\boldsymbol{W}$
310 Cúscuta $W$.

603 Dichóndra $W$

391 Rétzia $T h$.

359 Pyxidanthéra $\mathbf{M i}$

\section{Order CVIII. BORAGINEE.}

True Boraginex are chiefly herbaceous plants, with alternate exstipulate leaves, the surface of which is covered over with minute asperities, and with flowers arranged in one-sided spikes or racemes, occasionally solitary. Each flower has also four distinct little nuts or seeds, as they are commonly called. Some E'chiums 
and a few more are shrubs. They are found abundantly in Europe, Siberia, and the North of Africa, less commonly in India, and the equinoctial parts of the world; in some quantity in North America, and in tolerable abundance in New Holland. Within the tropics the order is principally represented by Heliotrópiums and Tournefórtias; in colder latitudes by Anchúsas, Cynoglóssums, herbaceous E'chiums, and the like. Some are mere weeds, quite unworthy of culture; others are eminently beautiful, as many E'chiums, Onósmas, Onosmódiums, Sýmphytums, and others. In general they are mucilaginous and emollient, qualities which are especially abundant in the root of Symphytum and Cynoglóssum. Pure nitre has been found in several plants of the order. A red color is given out by Anchúsa tinctória, Lithospérmum tinctórium, and Onósma echioídes, which is used in dying. Several plants are employed on the same account in America. The Hydrophyllex are often considered as distinct, on account of their capsular fruit and cartilaginous albumen. One or two of these are pretty plants, but most of them mere weeds.

\section{Tribe 1. Asperifolie.}

316 Coldénia $W$ 325 Heliotrópium $L$ 326 Myosótis $\boldsymbol{B}$. $\boldsymbol{P}$. 327 Echinospérmum $S w$. $\$ 28$ Máttia $S c h$

329 'Iiarídium $\mathrm{Lehm}$.

\author{
330 Lithospérmum $W$. \\ 331 Bátschia Mich \\ 332 Onósma $W$. \\ 333 Anchúsa $W$ \\ 334. Sýmphytum $W$. \\ 335 Onosmódium Mich.
}

336 Cynoglóssum $\boldsymbol{W}$.

337 Omphalódes Lehm

338 Pulmonária $\boldsymbol{W}$.

339 Cerinthe $W$

340 Borágo $W$

341 Trichodésma $R . B r$.
342 Asperúgo $W$.

343 Nónea Mönch.

344 Lycópsis $W$.

345 E'chium $\boldsymbol{W}$.

346 Tournefúrtia $R, B r$.

347 Nolána $W$.

372 Hydrophýllum $W$.

Tribe 2. HYDROPHYLLEE.

373 Phacélia Mich. $\quad 386$ Nemóphila Nutt. 432 Ellísia $W$.

\section{Order CIX. CORDiACEæ.}

Trees formerly referred to the last order, from which their habit, plaited cotyledons, and dichotomous style divide them. Little is known of their properties, except that the flesh of their fruit is emollient and mucilaginous. The nuts of Córdia Sebesténa are employed sometimes as laxatives.
428 Córdia $\boldsymbol{W}$.
429 Varrónia $W$
430 Ehrétia $W$.
431 Bourréria Giert

Order CX. SOLANEA.

The baneful nightshade represents this order, which participates very generally in its qualities, although they are frequently hidden beneath a fairer form, and often much mitigated, Many of the Solánums are very handsome. The Verbáscums, Datúras, and Solándras are all plants of great beauty, although the former, on account of their frequency, are despised in gardens. Cápsicums are famous for their pungent fruit and seeds ; Brunsfélsias for their fragrance, and Nicotianas, or Tobacco, for their fœetor. The leaves indeed of the whole order are disagreeably scented. The usual effect of Sulaneæ is narcotic; but it is thought that this has been exaggerated, on account of the intense and deleterious properties of A'trona belladónna. These, accord. ing to the observations of Vauquelin, depend upon the presence of a bitter nauseous matter which is soluble in spirits of wine, forming with tannin an insoluble compound, and giving out ammonia when decomposed by fire. Notwithstanding the narcotic power of the roots of the Mandrake, the Belladónna, and others, those of the potato are found to contain an abundant facula, which is among the most valuable food of man. The leaves of many Solaneæ are exciting and narcotic, but in very unequal degree, as in Tobacco, Phýsalis, Henbane, \&c. ; those of the Nightshade excite vertigo, convulsions, and vomiting. The juice of Stramónium is given in North America, in doses of from twenty to thirty grains, in cases of epilepsy. The fruit of Phýsalis Alkekéngi is a veterinary diuretic ; that of P. édulis is used in tarts; that of Solánum Lycopérsicum, and Melongena, is served at table in various forms, under the name of Tomatoes and Aubergines.
375 Verbáscum $W$.
374 Ramónda $P$.
1377 Alonsóa $H$. $K$
1376 Célsia $W$.
376 Datúra $W$
377 Brugmánsia $P . S$
381 Hyoscýamus $L$.
273 Witheríngia $W$.
1336 Crescéntia $W$.
382 Nicotiána $W$.
447 Mandragóra $W$. en. 451 Solánum $W$.

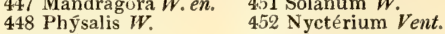
1375 Brunsfélsia $\dot{W}$
445 Solándra $W$.
446 Céstrum $W$.
452 Cápsicum $W$.
1378 Anthocércis $\boldsymbol{R} . \mathbf{B r}$
1000 ? Códon $W$

380 Nicándra $J$

\section{Order CXI. OROBANCHEE.}

Leafless parasites on roots, with brown or colorless scaly stems and flowers. 1335 Orobánche $W$.

1339 Lathræa $\boldsymbol{W}$.

ORDER CXII. SCROPHULARINEE

A great part of Linnæus's Didynamia Angiospermia is found here, capsular fruit and didynamous stamens being among the most obvious characteristics of the order. The species are generally herbs with opposite leaves, very rarely shrubs ; and natives of mountains, valleys, ditches, woods, and waysides, in all parts of the world. The Personatæ have the palate so prominent as to close up the orifice of the corolla. Ringentes have the palate open. Some are highly ornamental, as Digitális, Pediculáris, Calceolária, \&c., others are mere weeds, as is the case with a large proportion of them. Most of them have a weak unpleasant smell, a bitterish taste, and acrid and suspicious properties; but this odor is sweet and aromatic in the Ambúlia of Lamarck; the taste is refreshing in Mimulus luteus, which is a culinary plant in Peru, and the ordinary acrid properties become emollient in some Antirrhinums. The Rhinanthaceæ are remarkable for their astringent tonic bark and leaves. 'T he leaves and roots of Scrophulária aquática, Gratíola officinális and peruviána, and Calceolária, act as purgatives, or in strong doses produce vomiting: these properties exist, in a high degree, in Digitalis purpurea. The leaves of this plant, reduced to powder, excite vomiting and vertigo, excite urine and saliva, and lower the pulse: in too strong doses they cause death; in moderate doses they are useful in scrophula, dropsy, asthma, \&c.

1343 Antirrhínum $J$.

$13+4$ Linária $J$

1345 Anarrhínum Desf.
Tribe 1. Personate (or Rhinanthace e). 1346 Nemésia Vent. 1347 Maurándya $W$. 1349 Pediculáris $W$.
1342 Euphrásia $\boldsymbol{W}$.

1340 Rhinánthus $W$. 1341 Bártsia $W$.
1337 Castilléja Sm. 1299 Tourréttia $J$. 1298 Chelóne $\boldsymbol{W}$.

Tribe 2. Ringentes

40 Verónica $W$.

43 Gratíola $W$.

51 Calceolária $W$

276 Scopária $W$.

279 Búddlea $W$.

1297 Pentstémon $W$.

863 Disándra $\boldsymbol{W}$.

1338 Halléria $W$.

1348 Gerárdia $W$
1350 Erínus $W$. 1351 Mímulus $W$. 1352 Hornemánnia $W$. en. 1353 Mázus Lour. 1354 Isopléxis Lindl. 1355 Digitáis $W$. 1355 Digitális $W$. 1357 Vandéllia $L$. 1358 Sibthórpia $\boldsymbol{W}$.
1359 Limosélla $W$. 1360 Browállia $W$. 1361 Stemódia $W$. 1362 Trevirána $\boldsymbol{W}$. en. 1363 Colúmnea $W$. 1364 Russélia $W$ 1365 Dodártia $W$. 1366 Lindérnia $\vec{R}$. $B r$. 1367 Herpéstis $\boldsymbol{R}$. $\boldsymbol{B} \boldsymbol{r}$
1868 Caprária $P$. $S$. 1369 Buchnéra $\boldsymbol{B} . P$. 1370 Manúlea $W$. en. 1371 Angelónia $K t h$. 1372 Schizánthus $R$. \& $\boldsymbol{P}$. 1373 Besléria $W$.

1379 Cymbária $\boldsymbol{W}$. 


\section{Tribe 3. Melampyraces.}

1315 Melampyrum $W$.

\section{Order CXIII. LABI AT TE.}

A portion of Diandria Monogynia, and the whole of Didynamia Gymnospermia of Linnæus, make up Labiate, which are characterized by their didynamous stamens, four little nuts or naked seeds, single style, and irregular corolia. They are mostly natives of extra-tropical countries, although under the form of Hýptis, Anisoméles, Leúcas, $O^{\prime} c y m u m, \& c$, they are found in the hottest zones of the world. Many are extreinely odoriferous in the leaves, some bear handsome flowers, but by far the greater part are no better than weeds. They are all remarkable for their tonic, cordial, and stomachic virtues: they contain both a bitter and an aromatic principle, in different proportions. The bitterness which is given out in decoctions, resides in a gumresinous secretion, abounding in some Teicriums, which are particularly employed as stomachics, and someresinous secretion, abounding in some Tencriums, which are particularly employed as stomachics, and some-
times as febrifuges: those which abound in essential oil, and which are consequently aromatic, are used as stimulants. From the different degree of combination of these principles in different plants, they have obtained various uses ; such as savory, thyme, marjoram, for seasoning of fond; sage, balm, ground ivy for tea ; marum, marjoram, lavenuer, and thyme, for sternutatories; others, such as lavender, miut, balm, and rosemary, for periumes. It is a remarkable fact, that the essential oil of all contains camphor, which exists in such quantity in sage and lavender, that it has been supposed that the separating of it might become an object of commerce.

55 Lýcopus $W$ 56 Amethýstea $W$ 57 Zizíphora $W$.

\section{Diandra.}

58 Cúnila $P$. S.

59 Hedeóma $P$. S

60 Monárda $W$.
61 Rnsmarinus $W$.

62 Sálvia $W$

63 Collinsónia $W$
1242 A'juga $W$

1243 Anisoméles $R$. $B r$.

12+4 Teúcrium $W$.

1245 Westringia $\mathrm{Sm}$.

1246 Saturéja $W$

1247 Thýmbra $\dot{W}$

1248 Hyssópus $W$

1249 Népeta $W$.

1250 Elshóltzia $W$.

1251 Lavándula $W$

125: Sidéritis $W V$

1253 Bystropógon $W$.

\section{Tetrandra.}

1254 Méntha $W$

1255 Perilla $W$.

1256 Hýptis Poit.

1257 Horminum ort.

1258 Gléchoma $W$

1 ¿59 Lámium $W$

1260 Galeópsis $W$.

1261 Galeóbdolon, $E$. $B$

1262 Betónica $W$.

1263 Stáchys $W$.

$126+$ Zieténia Pers.

1265 Ballóta $W$.
1266 Marrúbium $W$.

1267 Leonúrus $R . B_{i}$.

1268 Phlómis R. Br.

1259 Leúcas $R$. $B r$.

1270 Leonótis $R$. $B r$.

127. Moluccélla $W$.

1272 Clinopódium $\boldsymbol{W}$.

1273 Pycnánthemum $T h$.

$127+$ Origanum $W$.

1275 Thýmus $L$.

1276 A cynos Pers.

1277 Calamintha $P h$.
1278 Melíssa $W$

1279 Dracocéphalum $W$

1280 Melittis $W$.

$12810^{\prime c y m u m} W$.

1282 Plectrárithus $W$

$12 \times 3$ Trichostéma $W$

1284 Prostanthéra $R . B r$.

1285 Scutellária $W$.

1286 Prunélla $W$

1287 Cleónia $W$.

1288 Prásium Wr.

1289 Phrýma $W$.

Order CXIV. PEDALIN

Herbaceous plants, formerly included in Bignoniaceæ, from which they are distinguished by the small number of seeds in each cell of the fruit. Natives of the tropics, with shewy trumpet-shaped flowers. The seeds of Sésamum abound in oil, which is easily expressed, for which the common species is extensively cultivated in hot countries.

1296 Sésamum $\boldsymbol{W}$.

1300 Martýnia $W$

1331 Pedálium $W$.

Order CXV. MYOPORINEF.

South Sea and New Holland shrubs, with scarcely any hair. The leaves are simple, alternate, or opposite, with no stipulæ. The flowers, scarlet, white, or blue, axillary without bracteæ. These are very near Verbenaceæ. Stenochílus is the handsomest genus of the order: the Avicénnias are shore plants, growing in the place of the mangroves, and shooting their long roots to a great distance ainong the mud, sometimes to the length of six feet along the surface before they fix themselves. Their medicinal properties, if any, are unknown.

1323 Avicérnia L. 1332 Myopórum Forst. 1333 Stenochílus $R . B r$. $\quad 1334$ Búntia $R . B r$.

Order CXVi. VERBENACEF.

A mixture of weeds and shewy herbs, of humble creeping plants and of lofty timber trees. Some of the Vitexes and Clerodéndrums are handsome shrubs: Aloýsia is esteemed for the fragrance of its flowers, and Holmskióldia for the refulgent scarlet of its enlarged calyxes. Téctona produces the famous Indian teakwood. No properties of consequence have been attributed, by medical men, to any plant of the order, those formerly ascribed to the vervain and chaste-tree being now disregarded. The species are natives of waysides in Europe, and of woods and barren plains in the tropics.

1322 Verbéna $L$ 54 Stachytárpheta $V a h l$

$131^{\circ}$ Zapánia $J$.

132) Priva $P . S$.

1314 Líppia $L$.

272 Callicárpa $W$

65 Ghínia $W$.

\section{$27+$ Egíphila $W$}

1309 Hebenstréitia $W$.

1310 Hósta Jacq.

1317 Vitex $W$.

1318 Cornútia $W$
1313 Aloýsia Fl. per.

1316 Selágo $W$

1312 Iantána $W$

1311 Gmelína $\boldsymbol{W}$.

1321 Spielmánnia $W$

1324 Caldásia $W$
1325 Clerodéndrưom $\boldsymbol{B}, \boldsymbol{P}$. 1326 Volkaméria $H$. $K$.

1327 Holmskióldia $\boldsymbol{H} . \boldsymbol{K}$. 1328 Petréa $W$.

1329 Citharéxylum $W$

1330 Duránta $W$.

Order CXVII. ACANTHACEÆ.

These are known by the elastic dehiscence of their capsules, and the hooked processes of the seeds. They are almost entirely tropical herbs or shrubs, with the pubescence, if any, simple or capitate, but never stellate. Their leaves are opposite, occasionally arranged in fours, simple and undivided, or very seldom loled. The flowers are either in imbricated heads or open racemes, always enclosed in their bractex; and are white, blue, yellow, scarlet, or purple. Some of the species are very shewy, but few of them are cultivated commonly; a large proportion are mere weeds. The Thunbérgias are fine climbers, and the Acánthus móllis, the foliage of which gave rise to the classical acanthus of architecture, is, perhaps, except Morina pérsica, one of the most interesting of hardy herbaceous plants. It is also one of the few species to which any medical properties are ascribed, being used sometimes as an emollient by reason of its mucilage. Justicia biflóra is employed in Egypt as a poultice, J. Ecbólium as a diuretic, and J. pectorális as a vulnerary.
45 Elytrária $M$.
46 Hypoéstes $R$. Br.
1304 Ruéllia $\boldsymbol{J}$.
47. Justícia $W$.
1302 Barléria $W$. 1305 Bléchum $R$. Br.
1306 Aphelándra $R . B r$.
1303 Phaylópsis Juss. 1301 Acánthus $W$
1307 Crossándra $P$. $L$
1308 Thunbérgia $W$.

\section{Order CXViII. LENTIBUlariæ.}

Very pretty interesting aquatics, which are scarcely susceptible of cultivation, except in a few cases. The Pinguículas are either European or North American, inhabiting elevated patches in bogs: the Utriculárias are floaters, found in most countries in marshes and little rills : their flowers, are white, yellow, or blue. 
Order CXiX. PRimulace

Beautiful dwarf herbs, inhabiting the mountains and meadows of all parts of the world, but especially in the northern hemisphere. Nothing can be more lovely than the little delicate alpine Prímulas, Androsáces, Arêtias, and Soldanéllas, with their little modest blossoms, sometimes rivalling the whiteness of the surrounding snow, sometimes emulating the intense blue of the empyrean, as if the one had borrowed its hues from heaven, and the other from the spotless mantle of the earth. Hottónia is a naiad of the stream, inhabiting several parts of England, in ponds and ditches, which are enlivened for many a month with its rosy flowers, peeping from among the sedge and under grass, by which it is environed. All the genera are familiar to gardeners, except Centúnculus and Schwénckia, of which the former is singular in the order, as being an obscure minute weed, and the latter has inelegant green flowers, curious to the botanist but ungrateful to the florist. The prominent botanical character is the one-celled fruit, with a central placenta, and the stamens opposite the petals. The properties of Primulacer are feeble and of little consequence; they appear to be slightly astringent and bitter; the root of Cýclamen is acrid, and only eaten by wild boars; the flowers of the primrose and cowslip are fragrant, and mildly sudorific and soporific. Cortúsa Mathíola has been used in nervous disorders.

\begin{tabular}{|c|c|c|}
\hline $\begin{array}{l}350 \text { Prímula } W \text {. } \\
349 \text { Androsáce } W \text {. } \\
\text { S48 Arétia } W \text {. } \\
351 \text { Cortùsa } W \text {. }\end{array}$ & $\begin{array}{l}352 \text { Soldanélla } W \text {. } \\
353 \text { Dodecátheon } W \text {. } \\
354 \text { Cýclamen } W \text {. } \\
355 \text { Hottónia } W \text {. }\end{array}$ & $\begin{array}{l}356 \text { Lysimáchia } W \text {. } \\
392 \text { Lubínia Comm. } \\
357 \text { Anagállis } W \text {. } \\
360 \text { Córis } W \text {. }\end{array}$ \\
\hline
\end{tabular}

277 Centúnculus $W$. 42 Schwénckia $W$ 471 Samólus $W$. 862 Trientális

Order CXX. GlobUlarin

Pretty alpine plants with blue flowers. The leaves of Globulária A'lypum are very bitter and powerfully purgative, giving at the same time a tone to the stomach and intestines.

260 Globulária $W$.

Order CXXI. PLUMBAGINEE.

These are properly placed at the limit between Monochlamydeæ and Dichlamydeæ, to either of which they are referable in the minds of some botanists, although it appears, upon the whole, to be most convenient to station them where they are now arranged. They are low shrubs or herbaceous plants, with shewy red or blue flowers of an arid texture, inhabiting salt marshes and subalpine tracts, in the temperate latitudes of both the northern and southern hemispheres. All the Státices and Armérias are fine plants worth cultivating. The root of Státice Limónium is astringent and tonic; of the Plumbágos, the root and whole plant are acrid and caustic, and employed as vesicatories.
324 Plumbágo $W$.
705 Arméria W. en.
706 Státice $W$. en.

\section{SuBdivision II. MONOCHLAMYDE ÆE.}

Perianthium simple.

The absence of corolla characterizes this subdivision of dicotyledonous vegetation; but as the term corolla is subject to frequent misunderstanding, it should be borne in mind, that whenever there is only one floral envelope, that envelope is to be considered calyx, whether green, as in most cases, or colored, as in the Marvel of Peru.

Order CXXII. PLANTAGINEA.

Little inconspicuous herbs found in waste places all over the world. The leaves are stellate, and occasionally ternate; the pubescence is jointed; the flowers are brownish, and arrayed in dense spikes. Their leaves are rather bitter and astringent; their seeds mucilaginous and rather acrid; those of Plantágo arenária are imported in large quantities from the south of France, for the purpose of forming an infusion in which muslins are washed. P. média is sometimes cultivated by farmers under the name of ribgrass.
278 Plantágo $W$.
1967 Littorélla $W$.

Order CXXIII. NYCTAGINEA.

With the exception of Mirábilis, in which the colored calyx has a shewy effect, all the order consists of weeds, growing often among the loose sand on the sea coast of the tropics and western hemisphere; none are found in Europe. The Abrónias are curious, neat, and often fragrant. The root of Mirábilis Jalápa was formerly considered the jalap, which is now known to be an error; it is however purgative, although in a less degree. Boerhaávia tuberósa is also a reputed purgative.
19 Boerhaávia $\boldsymbol{W}$.
81 Calyménia $R . P$. 322 Mirábilis $W$.
323 Abrónia Juss.
864 Pisónia $W$.

Order CXXiv. AMARANTHACEE.

Upon this order Dr. von Martius has the following remarks : Leaves, especially when young, of a lax soft (the seeds texture, abounding virtues are nutritive, emollient, demulcent are farinaceous, consisting chiefly of starch and mucus. Their virtues are nutritive, emollient, demulcent; mostly diffuse and villous, and existing in dry stony exposed places, or erect and reclining on other vegetables, with little pubescence, when found on the skirts of ancient forests; a few are found in saline coast places; finally, they are more common in low land, little elevated above the surface of the sea, than in mountainou regions. They are met with in both hemispheres; rarely under the equator, but increasing both northregions. wards and southwards as we plants deserving to affect all regions of the world. Among an abundance of weeds, we distinguish a few fine plants deserving cultivation, as the Globe Amaránthus, the Cockscombs, and a few species of Amaranthus, one of which, under
the name of Love-lies-bleeding, is commonly reared for the sake of its long, tail-like, pendent masses of crimson flowers. Amaránthus oleráceus, and a few others, are occasionally cultivated as potherbs.
552 Achyránthes $W$.
553 Philoxérus $R$. $B r$.
556 Alternanthéra $R . B r$. 563 Deeríngia $R$. Br.
560 Ærúa Juss
563 Deeríngia $R$. Br.
565 Celósia $R$. Br.
918 A phanánthe $L k$.
554. Desmochæ'ta Dec.
561 Lestibudésia $R$. Br.
566 Gomphréna $\boldsymbol{R}$. $B r$.
1975 A maránthus $W$

Order CXXV. ILLECEBREE

Weeds distinguished from Amaranthaceæ by their membranous stipules. They are found in dry barren places, for which they are better fitted than for a garden, unless as objects of curiosity.
555 Illecébrum Juss.
569 Mollia $\boldsymbol{W}$.
614 Herniária $W$.
82 Loéflingia $W$.
557 Paronýchia Juss.

Order CXXVI. CHENOPODEE.

The habit of this order is a better distinction from Amaranthaceæ, than any artificial character which it is easy to point out. While Amaranthaceæ have a dry perianthium with a dense infloresccnce, Chenopodeæ on the contrary have a fleshy perianthum and a very effuse inflorescence. In the former, the stamens are usually 
inserted under the ovarium ; in the latter into the calyx, but this mark is not constant. None of them, unless Phytolácca is excepted, can be esteemed plants of ornament; on the contrary, they have a weedy uninviting appearance, which is not improved by the fetid smell of some of them. But, although their appearance is less attractive than that of the Amaranths, their use to man is far more considerable. Their qualities are very various; Camphorósma has the smell of camphor; Petivéria stinks like onions; Phytolácca roots, leaves, and berries, are violent purgatives and emetics; the latter are esteemed in North America nearly equal to Guaiacum, and are employed in chronic rheumatisms, and in rheumatic pains following venereal diseases; an extract of the berries has been employed in scrophula and cancerous ulcers; and the young shoots of the plant are eaten in the United States as asparagus. Some of the Chenopódiums, as A mbrosioides, Bótrys, \&c., possess antisuasmodic and tonic properties; the leaves of Spinácia, and of many Chenopódiums, are eaten as spinach; as are those of Basélla in China and India. Salsóla and Salicórnia are often employed as pickles. Beet roots are equally valuable as a culinary and agricultural production, and the leaves are an excellent vegetable when boiled. But the most remarkable feature in the properties of the order is the abundant production of soda, which is obtained from many of the species, as from all the Salsólas, Salicórnias, Anabásis, many species of A'triplex, several salt marsh Chenopódiums, and others. The seeds of Chenopódium anthelmínticum are used as a vermifuge, those of $A^{\prime}$ triplex horténsis excite vomiting, frequently attended with acute pain; those of Chenopódium quinóa are said to be used as rice. To conclude this list of remarkable properties in one of the most vile of all assemblages of plants, the roots of beet yield an abundance of sugar.
21 Pollichia $W$.
22 Salicórnia $W$.
92 Polyenémum $W$.
608 Anabásis $W$
558 Chenólea $W$
613 Bósea $W$.
28 Blítum $W$.
254 Camphorósma $W$.
693 Bas $\leq 1 l a ~ W$.
865 Petivéria $W$
609 Salsóla $W$.
6 I0 Kóchia Roth.
26 Corispérmum $W$.
917 Galénia $W$.
1071 Phytolácca $W$
1937 Ceratocárpus $W$.
1943 Axýris $W$
1964 Diótis $W$
2070 Spinácia
$2138 \mathrm{~A}^{\prime}$ triplex
2139 Rhagódia $\boldsymbol{R} . \boldsymbol{B}$,

612 Béta $W$.

\section{Order CXXViI. POLYGoneF}

Herbaceous or suffrutescent fleshy-leaved plants, chiefly natives of the northern hemisphere; a few Polýgonums and Coccolobas are found to the south, the former in barren places, the latter on sea shores. A great part of the order consists of worthless weeds. Some of the Polýgonums, and all the Eriógonums, are handsome plants; the Rhéums are famous in medicine. The root of Rheum is tonic and purgative; most of the Rúmexes and Polýgonums are also tonics. The juice of the Coccolóbas is very astringent. The young leaves and shoots of several species of Rúmex and Rhéum are eaten either raw or baked, under the name of sorrel, French sorrel, and tart rhubarb. For the sake of its seeds, Polygonum Fagopýrum is cultivated by farmers under the name of buck-wheat; the seeds of $P$. aviculare are very emetic and purgative. The fleshy calyx of the Coccolóbas is colored; and, the fruit growing in clusters, the genus has received the name of the sea-side grape.

228 Kœnígia $W$.
838 Atrapháxis $W$.
856 Rúmex $W$.
857 Oxýria Dec.
921 Polýgonum 921 Polýgonum $W$
937 Eriógonum $\mathbf{M i}$.

938 Rhélim $W$.

1052 Brunnichia $W$.
1106 Calligonum $W$ 2090 Tríplaris $W$.

\section{Order CXXVIII. BEGONIACEß.}

The acid qualities, sheathing stipules, and alternate leaves of these tropical herbs approximate them to Polygoneæ, notwithstanding the very different structure of their fructification. Most of the species are pretty, some very handsome; all requiring great heat and humidity to be grown in perfection.

1989 Begónia $W$

\section{Order CXXIX. LAURINEÆ.}

Noble trees or shrubs with handsome foliage and inconspicuous flowers. They are chiefly natives of hot countries, where they constitute some of the most valuable of the productions known under the name of spice. By botanists they are readily recognized by the singular circumstance of their anthers having each four cells, the valves of which are hinged as it were to the upper edge of each cell, and do not open longitudinally like those of most other plants. It is well known that the cinnamon is the produce of the Laúrus cinnamómum, and that its properties are eminently aromatic, warm, and stomachic. The same peculiarities, but in a less áegree, exist also in Laúrus cássia, L. malabáthrica, and L. culilában, which are all occasionally substituted for true cinnamon; they are found in the leaves of Laúrus parvifólia, in the bark of the species which produces the Pichurim bean; ir that of $L$ cupuláris, which is the Isle of France cinnamon; of L. quixos, which yields the Peruvian cinnamon; in L. Benzoin, which was used as spice in the United States during the American war; and finally, in the common bay tree of our plantations. Laúrus sassafras yields the sassafras chips of the shops, but its bark is much more powerful. The fruit of many Laurinez are extremely aromatic; that of Laúrus Pérsea is an agreeable West Indian fruit, called the alligator pear. Camphor is the produce of Laúrus cámphora, and of another or two; this substance is found indeed in small quantities in the roots of almost all the order; one of the cinnamons is even named Capuru Carundu, which quantities in the roots of almost
signifies camphorated cinnamon.
934 Laúrus $W$.
936 Cassýtha $W$
1942 Hernándia $W$.
1077 Agathophýllum $W$

\section{ORDER CXXX. MYRISTICEF.}

Closely allied to the last, especially in sensible properties. The arillus of Myristica is the mace of the shops, and its nut, the famous nutmeg. It is well known that this abounds with oil ; in Viróla sebífera the oily secretion is so copious, that it is readily separated by immersion in boiling water under the form of fat.

$$
2120 \text { Myrística } W \text {. }
$$

\section{Order CXXXI. PRO'TEACEA}

Favorite shrubs with gardeners, both on account of the neatness of their foliage and the beauty of their flowers, With very few exceptions, they are confined to the southern promontory of Africa, and to New Holland, where they adorn large tracts of country. They are shrubby or arborescent plants with an arid habit. The leaves are simple, evergreen, narrow, entire or serrated. The flowers generally grow in clusters, and are green, yellow, or red, sometimes in true Proteas surrounded by colored bracteæ with dark hairy margins. Their stamens are four, with distinct anthers, which rarely adhere together. The pollen is triangular; the stigma undivided and usually oblique. Their fruit is of various kinds, either a solitary nut or a sort of cone consisting of many nuts immersed among the indurated remains of abortive flowers. Of their properties, little is known. Some of the Rhópalas afford tolerable timber; the bark of Prótea speciósa and grandifóra is astringent and useful in diarrhœas. The seeds of Embóthrium tinctórium yield a powder which is employed for dying pink. The Próteas of the Cape, and the Banksias and Dryandras of New Holland, are the finest plants of the order.

229 Petróphila $R, B r$

230 Isopógon $R . B r$.

231 Prótea $R$. Br.

234 Serrúria $R$. Br.

052 Aúlax $R . B r$

2053 Leucadéndron $R$. Br.
233 Mimétes $R$. $B r$.

235 Nivénia $R$. $B r$.

237 Spatálla $R . B r$.

238 Persoónia $\boldsymbol{R}, \boldsymbol{B}$ r.
239 Grevíllea $R$. $B r$

240 Hákea $R$. $B r$.

241 Stenocárpus $R$. $B r$.

242 Lambértia $R$. Br.

243 Xylomélum $\boldsymbol{R}$. $B$

244 Telopéa $R . B r$.
245 Lomátia $R, B r$

246 Rhópala $R . B r$

247 Bánksia $R$. Br.

248 Dryándra $R$. Br.

2142 Brabéjum $W$. 
Order CXXXII. THYMELÆE.

Nearly all shrubby plants, found in all parts of the world, but most abundantly in the south of Africa. The flowers are white. yellow, or red, most commonly in clusters, and often fragraut ; the foliage is entire, either smooth or silvery, and generally very neat. Their wood is particularly soft ; their inner bark easily separable, and in Dáphne Lagetta, pulls out by the division of the vertical fibres into a sort of network resembling lace. Their bark is extremely acrid, acting as a vesicatory when applied to the skin, and if chewed, producing extreme heat and torture in the mouth; a decoction of it has been used with some success in venereal diseases. The seeds of these plants are poisonous to man, but birds eat them with impunity. The fibres of Dirca and Lagétta are used for cordage; those of Dáphne gnídium and Passerina tinctória are employed in the south of Europe for staining wool yellow, which is converted into green by the addition of Isátis.
73 Pimeléa B. $P$.
910 Dáphne $\boldsymbol{H}$.
913 Stelléra $W$.
911 Dirca $W$.
914 Passerina $L$.
915 Lachnæ'a $W$.
909 Lagétta $J$.

\section{Order CXXXIII. SANTALACE⿸.}

Trees or dwarf herbs, with inconspicuous or unattractive flowers. They are chiefly natives of the Cape, New Hollard, ard India, a few only being found in Europe and North America. Their virtues are few. The wood of Sántalum álbum has a sweet aromatic flavor, and a slightly bitter taste : it is chiefly known as a perfume, although it is said to possess mild sudoritic properties. The leaves of Myoschilos are purgative, of Osýris japónica eatable as salad; 'Thésium is slightly astringent.
569 Thésium $W$. 908 Memécylon $W$
2051 Osýris $W$.
2161 Nýssa $W$ 1033 Bucída $W$.
2141 Fusánus $L$.
216: Hamiltónia $W$.

Order CXXXIV. ELEAGNEA.

Hardy shrubs or small trees, with deciduous leaves, covered, as well as the bark, with minute silvery scales : their flowers are inconspicuous, but sometimes agreeably fragrant. They occupy but little space; a few inhabiting China and Japan, and the remainder Europe, North America, and Guiana. The berries of Hippóphae rhamnoides, which are slightly acid, are used as a kind of sauce by the Swedes.

259 Elæágnus $W$.

2057 Shephérdia Nutt.

2058 Hippóphae $W$ :

Order CXXXV. ARISTOLOCHIæ.

Here we are on the limits of Monocotyledones and Dicotyledones. The species are herbaceous or half shrubby plants, with simple, often reniform, leaves; and mottled grotesque flowers, usually brownish purple. Their roots are all bitter, and possessed of tonic and stimulating properties; but the degree in which they exist in different species is not at present ascertained. The A ristolóchias have been in former days praised as emmenagogues, and many are still used in South America as a remedy for the bite of serpents. A'sarum europæ um is a purgative ard emetic when fresh, but its powers are much diminished by drying; its dried leaves are occasionally used by the country people in some parts of England as a sternutatory.

$$
1072 \text { A'sarum } W \text {. } 1934 \text { Aristolóchia } W .
$$

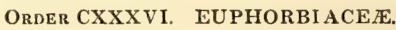

Weeds and lofty trees, of such varied appearance and property, that it is scarcely possible to frame a brief character by which they can be expressed. Their vegetation in cold countries is mostly herbaceous, in hot countries frutescent or arborescent; their juice is milky, and their flowers mostly inconspicuous. It is for their medicinal properties that they are chiefly known, and these are as various as their aspect ; mostly, however, dangerous, and always to be suspected. In a few of them, the smell and taste are aromatic; but in most, there is either no smell or it is nauseous, and the taste constantly acrid and pungent. Some possess also an acrid limpid fluid, which is given out by the leaves when touched. Many of them act strongly upon the kidneys, as several species of Phyllánthus, the leaves of Mercuriális ánnua, and the root of Rícinus commúnis. Many are said to be powerful medicines in cases of dropsy. The bark of several Crótons, the wood of Cróton Tiglium and Búxus, the leaves of the same, and also of Cícca dísticha, several Euphórbias, and others, are recorded as sudorifics, and useful against syphi'is; as emetics, we find the roots of the Euphórbias, the juice of Cómmia, A'nda, Mercuriális perénnis, \&c. A great number are purgative, especially the leaves of Búxus and Mercuriális, the juice of Euphórbia, Cómmia, Húra, the seeds of Rícinus, Cróton Tíglium, A'nda, and and Mercuriális, the juice of Euphorbia, Commia, Hura, the seeds of Ricinus, Cróton Tiglium, A'nda, and
Játropha. The effects of some others are so dangerous, particularly Hippímane, that it is not advisable to administer them even in very small doses; even in many Euphorbias it is difficult to draw a line between the quantity in which they are poisonous, and that in which they are harmless or useful. The nature of their poi-on is mostly acrid, occasionally, however, mixed with something narcotic, as is apparent from the effect of those which are used for poisoning or rather stupifying fish. The purgative oil in which the seeds of many are found to abound, has been determined to reside wholly in the albumen; hence the embryo of some, as Omphálea diánidra, is eaten as nuts. Boiling or roasting has also the effect of dissipating their noxious effects ; Omphálea diándra, is eaten as nuts. Boiling or roasting has also the effect of dissipating their noxious effects ;
thus Játropha Maníhot, than which there scarcely exists a more dangerous poison, affords a food when submitted to fire, called cassava, the flour of which is often used in London as a luxury for making puddings, than which few are reputed to be more wholesome. But the most curious of all the products of Euphorbiaceæ is the Caoutchouc, that singular substance which, although the produce of dangerous acrid trees, possesses no nothing whatever wich which is unalterable either in air, in water, or in spirits, although it softens at a high temperature. It is chiefly produced by Siphónia elástica, but also exists in the juice of very many others, as Excæcária Agallócha, Hippómane Mancinélla, Húra crépitans, Sápium aucupárium, Plukenétia volúbilis, the Játrophas, Mábea Ompháleas, and many others. Tournesole, another curious chemical preparation, is the juice of Cróton tinctórium, but is also found in several others. Many other properties belong to this order, which it would be too $M$. Adrian de Jussieu's monograph of the order, from which most of the foregoing remarks are taken.

Section I.

1963 Pachysándra Mi. 1957 Búxus $W . \quad 1978$ Securinéga $W . \quad 2071$ Flúggea $W$.

Section II.

1958 Cícca $W . \quad 2092$ Kiggelária $W . \quad 2122$ Cluýtia $W$. Phyllánthus $W . \quad 2025$ Andráchne $W . \quad 2148$ Bridélia $W$.

SEction III.

2032 Cróton $W$. 2118 Adélia $W$. 2044 Bórya $W$.

2105 Rottléra Roxb. 2104 Gelónium Roxb. 2119 Loureíra $W$.
2034 Rícinus $W$.
2033 Játropha $W$.
2028 Aleurites $\boldsymbol{W}$.

2097 Hyænánche $\boldsymbol{H}$. $\boldsymbol{K}$.

\section{Section IV.}


2031 Sápium $\boldsymbol{W}$. 2026 Stillingia $\boldsymbol{W}$.
Section V.

\author{
$\begin{array}{ll}2030 \text { Hippómane } W . & 2035 \text { Húra } W \text {. } \\ 1992 \text { Acidóton } W . & 2117 \text { Excæeária } W .\end{array}$
}

2029 Omphálea $W$.

SEction VI.

2039 Dalechámpia $W . \quad 1103$ Euphórbia $W$

$110+$ Pedilánthus Neck.

Order CXXXVit. resedacez.

Weeds of no interest, except the Réseda odoráta for its delicious fragrance. R. lutéola, a common annual in waste places, yields a yellow color fit for dying.

1102 Réseda $W$.

2099 Datísca $W$.

Order CXXXViII. CALYCÁNTHEe.

Handsome grateful deciduous shrubs, with deliciously fragrant flowers, natives of North America and Japan. They are not known to possess any medicinal virtues, but their odour insures them a place in every garden, notwithstanding the uninviting look of the blossoms themselves.
1157 Calycánthus $L$.
1158 Chimonánthus Lindl.

Order CXXXIX. ATHEROSPERMEA.

Allied to the last in sensible and botanical qualities : they are shrubs, natives of America and New Holland, of which little is known either to gardeners or botanists. 2103 Peúmus Pers.

\section{Order CXL. EMPETREE}

Dwarf heath-like shrubs, with obscure flowers and berries, natives of Europe and North America. 2045 Empétrum $L$.

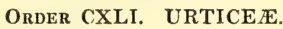

Few are the objects in this order deserving the care of the cultivator; it is rather extraordinary, however, Few are the objects in this order deserving the care of the cultivator; it is rather extraordinary, however,
that those few are abundantly so. Among worthless weeds and shabby half herbaceous shrubs, some of which are covered with rough points, and others defended by stinging hairs, we find the fig, the mulberry, the hemp, the hop, and the bread-fruit, all objects of the first consequence to the world. Here also is placed the half fabulous Upas, with which lying travellers and credulous naturalists have long deluded Europe. The Upas tree is now known to be the Antiáris toxicária, the inspissated juice of which is indeed a frightful poison, but the baneful effects of whose branches are purely imaginary. Similar, though inferior, qualities have been found to exist in Ficus toxicária, and some of the Artocárpuses. The root of the black mulberry is bitter, acrid, and purgative; of Dorsténia brasiliénsis, emetic; of D. contravérba, bitter, aromatic, hot, and stimulant. A decoction, or the dried leaves, of hemp, is eminently narcotic, and forms the basis of the well known intoxicating Turkish drug called Bang or Haschisch. 'The tenacious nature of the fibres of the hemp is also found in other plants of the order, especially Urtica cannabina, the hop, the bread-fruit tree, the common stinging-nettle, and others.
1962 Urtíca $W$.
1961 Pílea Lindl.
1960 Parietaria $W$.
933 Forskóhlea $\boldsymbol{W}$.
1993 Thelýgonum $W$. 2059 Broussonétia $W$. 2073 Cánnabis $W$. 2074 Húmulus $\boldsymbol{W}$. 2167 Fícus $W$.
2043 Cecrópia $\boldsymbol{W}$. 1979 Maclúra Nutt. 1959 Mórus $W$.
1935 Artocárpus $W$
257 Dorsténia $W$.

\author{
75 Gunnéra $W$.
} 2158 Brósimum $W$. 1973 Franzéria Cav. 2063 Tríphis $W$. 2050 Stilágo $W$.

\section{Order CXLII. aMeNTACEE.}

Here is the group in which all the timber trees of Europe, and most of those of all cold countries, are stationed. Every genus consists of plants important to the wants of man. The alder, the birch, the willow, the poplar, the oak, the chesnut, the hornbeam, and the plane, are all collected in this place, to which they have been brought by the coincidence of similar fructification existing in all of them. This similarity depends upon their producing flowers of one sex only, the males of which are always arrayed in catkins, of which the flowers are destitute of calyx or corolla, in the place of which is produced a single scale. Their bark is furnished with an astringent principle, which has rendered them valuable either for staining black, as in the alder and the oak gall; or for tanning, as in the oak; or as febrifuges, as the alder, the birch, the oak, most of the willows, and also Populus tremuloides, which is well known in North America as a tonic and stomachic febrifuge. The substance called tacamahaca was formerly supposed to be produced by some of the poplars, but it is now believed to be obtained from a very different plant, Fagára octándra. The fruit of many Amentáceæ contains a considerable proportion of fæcula, which renders it fit for the food of man and other animals, as the acorns of the oak, the mast of birch, the nut of Castánea and Córylus, \&c.
1955 A Inus $W$.
1956 Bétula $W$
2042 Sálix $W$.
2001 Liquidámbar $W$
2002 Plátanus $W$
2003 Salisbúria $\dot{L}$. $T$.
1995 O strya $W$.
1996 Carpinus $W$.
1994 Castánea $W$.
1997 Fágus $W$.
2000 Quércus $W$.

\section{ORDER CXLIII. ULMACEE.}

Many of the observations upon the last order are also applicable to this, which differs rather in certain technical characters, than in any arrangement of nature. The elm is its representative, from which the others only slightly differ.
616 Planéra Mich.
615 U'lmus $L$.
2145 Céltis $W$.

Order CXliv. CASUARINEF.

These are nearly related to Coniferæ, than which they are dwarfer, and of far less importance. By various writers they have been tossed about between Amentaceæe and Coniferæ, and have at last settled in a place by themselves. The leaves of Comptónia asplenifólia are employed in the United States against diarrhœa. The berries of Myríca cerifera yield, on boiling, an abundance of wax which is manufactured into candles; the nuts of Ephédra distáchya are eatable ; the wood of some of the Casuarinas is remarkably hard and durable. $\begin{array}{ll}1936 \text { Casuarína } W . & 1941 \text { Comptónia } W . \\ 2115 \text { Ephédra } W . & 2055 \text { Myrica } W .\end{array}$

Order CXLV. CONIFERE.

These bear the same relation in point of consequence to resinous trees, that Amentaceæ bear to those that are not resinous. They are well known as lofty timber, yielding valuable wood and abundance of resin. 
Among them is now numbered the loftiest tree in the world, a species of pine found by $\mathrm{Mr}$. Douglas in California, which grows 220 feet high, with a circumference of 60 feet. Pitch, turpentine, Venice turpentine, are produced by various species. Gum Sandarach, by Thúja quadriválvis ; a matter like olibanum, by Juniperus lýcia; a sort of liquid storax, by Altíngia excélsa. The Juniperuses in which the resin is "incompletely oxygenized," are more fragrant, and also stimulating in a greater degree; as the savin for example. The berries of many of these plants possess similar qualities. Their seeds are all oily; those of Pinus Pínea, Cémbra, and Lambertiána, and Salisbúria adiantifólia, are eatable as nuts. The fleshy fruit of the ivy, which is poisonous, is an exception to the general innoxious character of the order. Coniferæ are mostly inhabitants of the northern parts of the world, where they form immense forests, and supply with their dense persistent leaves the place occupied by the evergreen trees of warmer climates. $A$ few are found in the southern hemisphere.

2012 Pinus $W$.

2013 A'bies Salisb.

2014 Lárix Salisb.

2015 Schubértia Mirb.

\section{Cupréssus $\boldsymbol{W}$. 2018 Thúja $W$.}

2113 Juniperus $W$.
2112 Araucária $J$. 2010 Bélis Salisb.

2011 A'gathis Salisb.
1970 Exocárpus $L a b$. 2016 Podocárpus L'her. 2114 Táxus $W$.

Order CXlvi. chloranthez.

Obscure Asiatic weeds of no known use, and wholly destitute of interest for gardens.

25 Chloránthus $W$.

Order CXlvil. PIPERACEE.

The peppers are far more valuable in commerce than interesting in cultivation, their flowers being in all cases very insignificant, and their leaves so uniform in appearance, as to create but little variety Nearly the whole indeed of the herbaceous species or Peperómias, as they are sometimes called, are mere weeds. The berry of the pepper is well known to be hot, aromatic, pungent, and stimulating; not only in the common peppers of the shops, but also in $\mathbf{P}$. cubéba, carpúnga, and heterophýllum. The Píper anisátum yields a strong smell of anise; a decoction of its berries is used in Spanish America for washing ulcers. The Piper Bétel and Siribóa afford the Malays a powerfully acrid and exciting preparation, which, they suppose, invigorates and enables them to withstand the debilitating influence of their climate. In the South Sea Islands, an inebriating beverage is procured by the mixture of the leaves and stems of $\mathbf{P}$. inébrians with water. No pepper has yet beverage is procured by the mixture of the leaves and stems of P. inebrians with water. No pepper has yet
been found beyond the limits of the tropics. Saururus is the representative of the order in extra-tropical countries.

\section{Píper $W$. $\quad 872$ Saurúrus $W$}

Order CXLVIII, CYCADEF.

The true station of this very curious order is extremely uncertain. Although placed here in conformity with the common practice, it is to be supposed that its true station is in the immediate vicinity of ferns, with which the species agree in vernation, and in many curious particulars. All are natives of countries beyond the reach of frosts, chiefly of the Cape of Good Hope and equinoctial America. With a lnw trunk which rarely exceeds the height of a few inches, they have the fronds and appearance of pigmy palms, and the inflorescence of gigantic Equisétums. The trunk of Cýcas contains a great quantity of fæcula, which is manufactured into a kind of spurious sago; and a similar substance, it has lately been ascertained, may be obtained from the stem of Cýcas. (Gard. Mag., vol. iv.) 2107 Cýcas $W$.

2108 Zámia $W$.

\section{Crass II. MONOCOTYLEDONES.}

The physiological peculiarities of this class of plants have been already explained in the general remarks which precede this arrangement of natural orders. To what is there stated, little remains to be added, except that in these northern regions, every thing included in it is herbaceous, and that in hotter latitudes, few deserve the name of either bush or tree, except the palms, and a few Aroideæ and Asphodeleæ.

\section{SECTION I. STAMENS EPIGYNOUS.}

\section{Order CXLIX. HYDrocharidefe}

Floating white-flowered plants, of which Stratiótes is the most majestic. They possess no known properties, but have the singular character in Monocotyledones of being in some cases lactescent. The species are natives but have the singular character
of various parts of the world.
308 Trápa $\boldsymbol{W}$.
859 Damasónium $\boldsymbol{W}$.
2089 Hydrocháris $W$
2096 Stratiótes $W$

\section{Order CL. ORCHIDEX.}

Of all tribes of plants, this is the most singular, the most fragrant, and the most difficult of culture. The flowers are often remarkable for their grotesque configuration, which has been likened to heads and bodies of animals, and for the strange character of their stems, which are sometimes attenuated into a degree of gracefulness scarcely equalled even among grasses, and sometimes contracted into a clumsy goutiness of figure such as is known no where else. The species are found inhabiting the mountains and meadows of the cooler such as is known no where else. The species are found inhabiting the mountains and meadows of the cooler
parts of the globe, or adhering by their tortuous roots to the branches of the loftiest trees of the tropical parts of the globe, or adhering by their tortuous roots to the branches of the loftiest trees of the tropical
forest, to which their blossoms often lend a beauty not their own. Vulgarly, this last description of plants is called parasitic ; they are, however, not so, deriving no support from the juices of the plants on which they grow ; but on the contrary, are epiphytes, merely adhering to other plants for support, and vegetating amidst the rich black soil which collects at the foot of all trees growing in a hot humid climate. It is very singular that the pollen of these plants has no parallel, except among the very different and distinct order of Asclepiader. The only medical properties of the order exist in the roots of some of the O'rchises, from which the nutritious substance called salop is prepared. The Vanilla of the shops is the pod of the genus called Vanilla. From the boiled stems of some of the Brazilian species a tenacious glue is obtained, which is employed in many useful purposes.

Tribe 1. NeotTies. Lindl.

$\begin{array}{lll}1870 \text { Goodyéra } R . B r & 1872 \text { Ponthiéva } R . B r . & 1876 \text { Listéra } R . B r \\ 1871 \text { Diúris } S w . & 1873 \text { Neóttia } L . & 1874 \text { Spiránthes Rich. }\end{array}$

1875 Stenorhýnchus Rich.

Tribe 2. Arethusea. Lindl. 1879 Pogónia $R$. Br. 1881 Caleána $R$. $B r$.

1880 Epipáctis-Sw. 1882 Corallorrhiza Haller.

Tribe 3. Gastrodies. $R . B r$. 
Tribe 4. Ophrydes. Lindl.

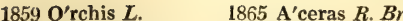

1863 Glóssula Lindl. 1866 O'phrys $L$.

1864 Anacámptis Rich. 1869 Serápias $R$. Br.

1860 Nigritélla Rich. 1855 Dísa Sw.
1861 Habenária $R . B r$.

1858 Gymnadénia $R \cdot B$

1857 Platanthéra Rich.

1867 Chamórchis Rich.
1868 Hermínium $R$. $B r$.

1862 Bartholina $R . B r$

1856 Satýrium $W$.

\section{Tribe 5. Vandfe. Lindl.}

1923 Calánthe $R . B r$. 1913 Octoméria $R$. Br. 1892 Maxillária Fl. ner.

1001 Camaridium Lind. 1902 Ornithídium Salisb. 1904 Pholidóta Lindl. 1919 Ionópsis Kth. 1910 Ornithocéphalus Hook. 1918 Renanthéra Lour.
1887 Lissochílus $R$. Br. 1888 Geodórum Jacks. 1895 Oncídium $S w$ 1898 Macradénia $R$. $B$ r. 1916 Vánda $R$. 1915 Sarcánthus Lindl. 1886 Brássia $R . B r$ 1896 Cyrtopódium $R$. Br. 1889 Catasétum Rich.
1920 Eulóphia $R$. Br. 1891 X ylóbium Lindi. 1908 Polystáchya Hooker 1890 Trizeúxis Lindl.

1883 Rodriguézia $\mathrm{Fl}$. per. 1884. Goméza $R$. Br. 1893 Notýlia Lindl.

Tribe 6. EpIDENDrex, Lindl.

1911 Blétia $F$.per. 1907 Epidéndrum $L$. 1914 Brassavóla R. Br. 1906 Cáttleya Lindl.
1905 Broughtónia $R$. Br 1903 Isochílus $R$. $B r$.

Tribe 7. Malaxidez. Lindl.

1912 E'ria Lindl.

1900 Dendróbiưm $\boldsymbol{H} . \boldsymbol{K}$. 1897 Cælógyne Lindl. 1925 Maláxis $L$.

1927 Micróstylis Nutt.
1928 Líparis Rich.

1929 Calýpso Salisb.
1894 Pleurothállis $\boldsymbol{R} . \mathrm{Br}$. 1924 Stélis $S w$.

\section{Tribe 8. CYPRIPEDIEA}

1931 Cypripédium $W$.

\section{Order CLI. SCITAMINEE.}

These are distinguished from the last by their pollen not cohering in masses, their seeds not being winged, and their plurilocular ovarium. Their sensible qualities are also widely different. The species are natives only of the tropical parts of the world, where they form stemless or caulescent herbaceous plants, with long broad leaves, and flowers of white, yellow, or red, often possessing great fragrance, arid generally much beauty. Their sensible qualities reside either in the root or the seeds. The former is the part used of the Ginger, the Galangale, the Cóstus, Turmeric, Zedoary, and others, all of which are more or less aromatic. The root of turmeric is also well known as affording a yellow dye, a property which it possesses in common with some others. The seeds of Cardamom are well known for their aromatic stimulating powers.
6 Hedýchium $W$.
9 Hellénia $\boldsymbol{R}, \boldsymbol{B r}$.
12 Kæmpfëria $W$.
15 Glóbba Rosc.
7 Roscúea $\mathrm{Sm}$.
10 Zíngiber Ros.
13 Amómum Rosc.
16 Mantísia Sim
8 Alpínia $W$.
11 Cóstus Rosc.
14 Curcúma $W$

Order CLII. CANNEE.

Differing from the preceding, in the absence of aromatic principles, in the petaloid nature of the filament, and the single cell of their anther, they wholly resemble them in external appearance and geographical distribution. The Cánnas are well known for their beautiful flowers, and the Maránta arundinácea is celebrated for the abundance of nutritive fæcula which is prepared from it, and imported to Europe under the name of arrow-root.
1 Cánna $W$.
4. Thália $W$.
3 Calathéa Meyer
2 Maránta $W$.
5 Phrýnium $W$.

Order CLIII. MUSACE正.

A noble order of plants, resembling the two last in appearance, but of far more gigantic stature, different geographical distribution, and sensible qualities. All the species, without exception, are among the grandest in the vegetable world, whether the breadth and beauty of their foliage, or the surpassing grandeur of their flowers, be considered. They are not, like Scitamineæ and Canneæ, confined to the tropics, but approach in many points towards the cooler latitudes of either hemisphere. While the Strelítzias, resplendent with orange and scarlet and white, are peculiar to the Cape of Good Hope, the plantain is laden with its enormous masses and scarlet and white, are peculiar to the Cape of Good Hope, the plantain is laden with its enormous masses forests of Madagascar and Guiana. The fruit of the Músa is, as just stated, pleasant and wholesome; the leaves of the same plant form a valuable thatching for cottages; and the fibres of a particular species are manufactured into a fine hemp, from which the most delicate muslins of India are prepared.
570 Helicónia $\boldsymbol{W}$.
571 Strelítzia $H . K$
721 Músa $W$.
722 Uránia $\boldsymbol{W}$.

\section{ORDER CLIV. HEMODORACEE.}

The name of this order, derived from «in , blood, indicates its most striking peculiarity ; the roots of several species of Hæmodórum, Wachendorfia, and Heritiéra yielding a brilliant crimson dye. The species have equitant leaves, and six stamens, with anthers turned towards the ovarium; in which last character they differ from the closely allied order of Iridex. They are found, with very few exceptions, in the Cape of Good Hope and New Holland.

108 Xiphídium $W$. 111 Hæmodórum Sm. 718 Lophíola $B . M . \quad 720$ Anigozánthos $L a b$.

110 Wachendórfia Ker 113 Dilátris Ker 719 Argolásia Juss.

\section{Order CLV. IRIDEF.}

The peculiarity of this order exists in the superior six-cleft perianthium, three stamens opposite the outer segments, and the anthers so inserted that the line of their bursting is towards the outside of their flower. Occasionally, they are still called by the old appellation of Ensatæ. Most of the species are extremely beautiful ; and as they are generally very easily cultivated, they have become universal favorites in gardens. Many of the species are found by the side of streams, or in rich pastures in Europe, Siberia, and America; others adorn the most barren deserts of the same countries, with their perishable flowers; a third set, consisting for the most part of Sisyrinchium and its allies, are found in cool parts of the islands in the South Seas; and, lastly, a large proportion of the order contributes to the herbage of Southern Africa, that indescribable charm which has captivated all observers. Their medicinal virtues are trifling. I'ris florentína and germánica have roots, which, when dry, smell like violets, and are slightly stimulant, acting as sternutatories or purgatives, according as they are employed. The stigmas of the Crócus form the well-known saffron, which differs from the general character of the order, in being aromatic, and possessing a valuable coloring matter, which has the singular property of entirely disappearing under the influence of the sun's rays.
93 Crócus $\mathrm{Ker}$
95 I'xia $\mathrm{Ker}$
97 Geissorhiza Ker
94 Witsénia Ker
96 Trichonéma $\mathrm{Ker}$
98 Hesperántha Ker 
101 Watsónia Ker

102 Babiána Ker

103 Lapeyroúsia Ker

104 Melasphæ'rula Ker

\author{
105 Gladiolus $\mathrm{Ker}$ \\ 106 Anomathéca Ker \\ 107 Antholýza Ker \\ 112 Aristéa Ker
}

\author{
115 I'ris $\mathrm{Ker}$. \\ 116 Moræ'a $\mathrm{Ker}$ \\ 117 Márica Ker \\ 118 Pardánthus Ker.
}

1450 Patersúnia $R$. Br.

1451 Ferrária $\mathrm{Ker}$

1452 Tigrídia $J$.

1453 Galáxia $W$

\section{Order CLVI. amARYLLIDEF}

Here we have arother group of vegetation so lovely as to have ex cited admiration from the days of Solomon, who called them the lilies of the field, down to our own period. Their roots are all bulbous. In stature the seldom exceed a foot or two : in Doryánthes, and some species of Crínum alone, much surpassing such a size in foliage they possess a uniformity of figure which is very singular ; in color they vary from white and yellow to deep scarlet and azure blue; in fragrance they vie with the violet and the primrose. Some of the species are natives of thickets in the cooler provinces of Europe and Asia; others are found deep rooted in the burning shores of islands where scarcely a blade of grass interposes itself between them and the torrid rays of a scorching sun; many spring up in the gloomy, damp, and sultry woods of equinoctial America; and another set intermingles with the Ixias and Gladioluses of Southern A frica. Several of the Narcissi, independent of their beauty, possess emetic qualities ; from the viscid juice of Hæmánthus toxicárius, the Hottentots procure a poison wherewith to smear their arrows.

\begin{tabular}{|c|c|c|c|}
\hline $\begin{array}{l}711 \text { Narcíssus } W . \\
712 \text { Pancrátium } W . \\
713 \text { Eucrósia } B . R e g . \\
714 \text { Eúrycles Salish. } \\
715 \text { Calostémma R. Br. } \\
716 \text { Chlidánthus Herb. } \\
717 \text { Chrysiphíala Ker }\end{array}$ & $\begin{array}{l}731 \text { Hemánthus } W . \\
732 \text { Galánthus } W . \\
733 \text { Leucójum } W \text {. } \\
73 \pm \text { Strumária Jacq. } \\
7: 35 \text { Crínum } W \text {. } \\
736 \text { Cyrtánthus } \boldsymbol{H} . \boldsymbol{K} \text {. }\end{array}$ & $\begin{array}{l}737 \text { Brunsvígia Heist. } \\
738 \text { Neríne Herb. } \\
739 \text { Amarýllis } W \text {. } \\
740 \text { Valtóta Herb. } \\
741 \text { Griffínia Ker } \\
7+2 \text { Sternbérgia } W \text {. }\end{array}$ & $\begin{array}{l}743 \text { Zephyránthes' Herb } \\
744 \text { Habránthus Herb. } \\
745 \text { Doryánthes } R . B r^{\circ} \\
746 \text { Gethýllis } H \text {. } K \text {. } \\
748 \text { Alstroeméria } W \text {. } \\
749 \text { Conanthéra } F l \text { per. }\end{array}$ \\
\hline
\end{tabular}

Order CLVII. HYPOXIDEA

America, New Holland, the Cape of Good Hope, Polynesia, and the Indian Archipelago give birth to these plants, which have sweet yellow flowers and linear leaves, protected by long weak hairs. Nothing is known of their medicinal qualities.
750 Hypóxis $W$.
751 Curcúligo $H . K$.

Order ClViII. Dioscore玉.

A climbing stem, and broad, cordate, or angular leaves, inconspicuous yellowish flowers, and a large fleshy root, are the obvious characteristics of this order, of which the yam is the representative; the roots of this plant yield one of the most important articles of food in the tropical countries.
2083 Testudinária Burch.
2084 Rajánia $W$
2085 Dioscórea $\boldsymbol{W}$.

\section{SECTION II. STAMENS PERIGYNOUS}

\section{Order CliX. HEMEROCALLIDEX.}

These are fine shewy plants, bearing their flowers in umbels or racemes, either white, yellow, red, or blue ; they are mostly inhabitants of temperate zones, and are of little utility, with the exception of the Aloe, the purgative powers of which need not be insisted on. This genus is, besides, remarkable among Monocotyledonex for its fleshy leaves, in which, and its woody stem, it offers a striking deviation from the usual structure of these plants.

\section{Poliánthes $L$. \\ 767 Agapánthus $W$. \\ 768 Blandfórdia $R$. $B r$. \\ 769 Hemerocállis $W$. \\ 770 A'loe $W$. \\ 776 Alétris $W$.}

777 Trítoma $\boldsymbol{B} . \boldsymbol{M}$.

779 Sanseviéra $W$.
780 Tulbághia $W$. 792 Brodiæ'a $S m$.

\section{Order CLX. ASPHODELEE}

Different from Hemerocallideæ in their expanded flowers and dark crustaceous seed-coat ; the only characters which have yet been discovered to distinguish them. The species are all pretty, many very handsome some bulbous, some with fasciculated roots, a few with arboresent stems. They are uncommon in tropical countries, very abundant in temperate latitudes, and not unfrequent in the cooler regions of the world. Among the prettiest are Gágea, Scilla, and Hyacinthus; the least interesting are Chlorophýtum and Zuccágnia. Aspáragus and Dracæ'na have berried fruits; the former is diuretic, and when young is employed as a favorite food; the same properties are possessed by Scilla and A/llium. The stamens of Arthropódium are remarkable for their tuft of yellow hairs, of Dianélla for the thickening of the filaments. Many of the A lliums are very pretty, and admired notwithstanding their unpleasant odor; their roots are all eatable, and those of some among the most useful articles of food. Thysanotus, the fringed violet of New Holland, has rich purple some among the most useful articles of food. Thysanotus, the fringed violet of New Holland, has rich purple
blossoms, with long delicate fringes which sparkle in the sun, as if continually bedewed with minute particles of water. From Phórmium ténax the strong fibrous substance called New Zealand flax is prepared. Xanthorrhæ a has an arborescent stem which abounds in resin.
808 Asphódelus $\boldsymbol{W}$
807 Bulbíne $W$. en.
806 Eremúrus Bieb.
815 Eustréphus $\boldsymbol{R} . \boldsymbol{B r}$.
805 Massónia $W$.
803 Scilla $W$
804 Puschkinia Bieb.
810 Arthropódium $R . B r .802$ Ornithógalum $W$.
811 Chlorophýtum $\mathrm{Ker} \quad 801$ Gágea Sal.
$812 \mathrm{Cæ}^{\prime s i a} R . \mathrm{Br}$. 800 Eriospérmum $W$.
813 Narthécium $B . M$.
797 Albúca $W$.
705 Sowerbæ'a $L, T$.
798 Xanthorrho'a $\boldsymbol{R} . \boldsymbol{B r} . \quad 819$ Hyacinthus $\boldsymbol{B} . \boldsymbol{M}$.
791 Eúcomis $W$. 820 Zuccágnia $T h$.
799 Thysanótus $R . B r$
794 Aphyllánthes $W$
775 Phylloma $B . M$
774 Dracæ na $W$.
816 Aspáragus $L$
817 Drímia Jacq.
821 Muscári $B$. $M$.
822 Lachenália $W$.
823 Phórmium $W$
824. Cyanélla $W$.
793 Peliosánthes $\boldsymbol{B} . \boldsymbol{R}$
2111 Rúscus $W$.

\section{Orner ClXi, SMILACE瓜.}

These scarcely differ from the baccate Asphodelex, except in their usually trifid style, and the membranous integuments of the sred. Many are interesting plants, especially the lily of the valley, a species of Convallária, the odor of which is perhaps the most grateful in the vegetable kingdom. Several others, as Uvulária, Smilacína, Polygonátum, and Tríllium are objects of ornament. Smílax is remarkable for its twining stems, and its leaves, which resemble those of Dicotyledones; the roots of several species form the sarsaparilla of the shops, a drug, the nature of which is mucilaginous and rather bitter, and which is employed as diaphoretic and diuretic. Medéola is also an active diuretic. The roots of Támus are purgative and dangerous.
785 Uvulária $W$.
$\begin{array}{ll}788 \text { Smilacína Desf. } & 843 \text { Myrsiphýllum } \\ 789 \text { Polygonátum Desf. } & 846 \text { Medéola W.en. }\end{array}$
$\begin{array}{ll}788 \text { Smilacína Desf. } & \mathbf{8 4 3} \text { Myrsiphýllum } \\ 789 \text { Polygonátum Desf. } & \mathbf{8 4 6} \text { Medéola W.en. }\end{array}$
786 Streptópus $M$.
787 Convallária Desf. 790 Ophiopógon Ker
2081 Smílax $W$.
2082 Támus $\boldsymbol{W}$.
729 Páris $W$.

\section{OrDER CLXII BROMELIACE雨.}

Of these the eatable pine-apple is the representative, from which the other genera differ more in the want of a fleshy fruit than in general appearance. Their habit is acid, their leaves rigid and toothed with spines, and covered with minute scales, their bracteæ often colored with scarlet, and their flowers either white or blue. 
They are all natives of tropical countries, with the exception of Tillándsia, which, in the humid woods of Carolina, forms dense festoons among the branches of the trees; this, like many others of the order, is an epiphyte, vegetating among the black mould that collects upon the bark of trees in hot damp countries; others are inhabitants of deep and gloomy forests; and others form, with their spiny leaves, an impenetrable herbage in the extensive pampas of Buenos Ayres and Brazil. From the Agáve mexicána a fermented, beverage. is prepared, from which a strong colorless spirit, resembling the best Scotch whiskey, is distilled.
726 Bromélia $W$.
727 Guzmánnia Fl.per.
723 Bonapártea $F . P$.
725 Furcræ'a $V$
728 Pitcaírnia $w$.
729 Tillándsia $W$.
724. Agáve $H$. $K$.

\section{Order CLXIII. LILIACE无.}

It is doubted whether several of the preceding orders are not rather sections of this; until, however, the combination of these shall be effected by some hand yet more masterly than those by which they have been divided, it is best to let them remain as they are. The beauty of the plants composing the Liliaceæ, strictly so called, is universally acknowledged; the rich colors of the branching lilies, the vivid hues of the painted tulip, the modest graces of the humble Erythróniums, and the portly forms of the Yúccas are all attractions of which no good garden should be destitute. The species are all inhabitants of either cold or temperate latitudes.
771 Lílium $W$.
773 Fritillária $W$
782 Erythrónium $W$.
781 Yúcea $W$.

Order ClXiv. MELANTHACE无.

These, too, are pretty herbs, although destitute of the grandeur of the preceding, which, however, they far surpass in the potency of their virtues. The flowers of many are inconspicuous, and of a dull-green or yellow color, sometimes assuming a livid hue, which will bespeak the nature of their powers. A dangerous or poisonous acrid juice is their characteristic, which is particularly active in some of them, such as the Cólchicum and Verátrum. The roots of the former are the basis of the eau médicinale, and are now used in cases of gout with much success. The root of Verátrum is believed to have been the hellebore of the ancients, an active drug, which, administered in small doses, is a drastic purgative, in more abund ance a violent emetic. The root of Helónias dioíca, infused in water, is anthelmintic, but, steeped in spirits, yields a bitter and tonic tincture. The leaves of Cólchicum and Verátrum often produce vomiting and severe pain in the animals that eat them ; the flowers of the first are also said to be poisonous, and its seeds to possess the same properties as the roots, but in a milder degree. Groves and pastures in Europe and Siberia and North America are the most frequented by Melanthaceæ, several are found at the Cape, and Gloriósa is a native of the woods of middle Africa.

851 Cólchicum $W$.

78ł Bulbocódium $W$.

847 Xerophýllum Mich.

849 Androcýmbium $W . \quad 858$ Nolína Mich.

$8 \pm 5$ Melánthium $L$. 842 Lichtensteínia $W . \quad 844$ Tofiéldia Hud.

852 Helónias $I$.

2128 Verátrum $W$.

783 Glorićsa $W$.

\section{Order CLXV. BUTOMEe.}

Fine water plants, of which Bátomus, by general consent the most beautiful of British plants, has purple flowers; and Limnocháris, a native of the marshes of Brazil, has yellow ones.
939 Bútomus $W$
1175 Limnocháris Rich.

Order ClXVi. ALISMACEE.

Handsome water plants, with white flowers, and many ovaria. Some are common in our English ditches, others are found in similar situations in the tropics.
860 Actinocárpus $R, B r$.
1988 Sagittária $W$.
861 Alísma $W$.

\section{Order ClXVit. COMMELINEE.}

Mostly inhabitants of marshy ground, in either hemisphere, but not known in Europe except in cultivation. America is their grand station. Many are insignificant creeping plants, especially the Commelinas ; others, as the Pontedérias are very handsome; and the Dichorizándras are exceedingly noble caulescent plants, with large thyrses of blue flowers : this color is the prevailing one of the order.
84 Callísia $W$.
89 Aneiléma $B . P$.
730 Pontedéria $W$.
766 Dichorizándra Vand.
90 Cartonéma $R . B r$.
765 Tradescántia $W$

88 Commelina $B . P$.

Order ClXVili. JUNCEE.

Inconspicuous, rigid, worthless weeds, for the most part; Xýris and Philydrum, which have pretty yellow flowers, if belonging to the order, being exceptions. They clothe barren ground in most parts of the world, and are the first approach to the formation of a regular perianthium, as we ascend in the scale of vegetation. Xerótes has the habit of a low palm.
86 Xýris $L$.
760 Júncus $L$.
761 Lúzula Dec.
839 Flageliária $W$.
2076 Xerótes $R$. $B r$.
17? Philýdrum $R, B r$

Order ClXix. ERIOCAULE⿸.

Pretty interesting little bog plants, found in all parts of the world. The order consists of Eriocaúlon only, many of whose species are easily cultivated, though seldom seen in gardens. The Eriocaúlon septanguláre, found in a lake in the Isle of Skye, is, perhaps, the rarest of European plants. They are not known to possess any medical virtues.

223 Eriocaúlon $W$.

\section{Order ClXX. PANDANEE.}

With the habit of palms. and the inflorescence of Aroideæ, this fine order stands very distinctly separated from all others. The stem is an arborescent caudex, either growing to a considerable height, or weak, and lying on the ground. The leaves of some are formed into a coarse cordage ; the flowers of $\mathrm{P}$. odoratissimus, and the fruit of some others, are eaten. All are tropical.

2004 Carludóvica $\mathrm{Fl}$. per.

2041 Pandánus $W$.

Order CLXXI. NAIADES.

Floating uninteresting plants, scarcely susceptible of cultivation : they form a close approach to Cellulares, 1938 Zannichéllia $W$.

Order ClXXII. ReSTIACE无. Rigid, inelegant, often leafless plants, with split vaginæ, and the habit of some Cyperaceæ, or true Junceæ.
They are all inhabitants of the southern hemisphere, especially of the Cape of Good Hope and New Hollarid.
2046 Willdenóvia $T h$.
2047 Réstio $W$.
2048 Elégia $W$.
2110 Leptocárpus $\boldsymbol{R}$. $\boldsymbol{B r}$. 
Order CLXXIII. PALMA.

These were well named by Linnæus, the princes of the vegetable world; for they far surpass all other plants in the grandeur and majesty of their port. Their lofty stem, supported by a mass of fibrous roots, which frequently creep along the surface of the ground, consists of wood with longitudinal fibres, soft in the centre, but hard as horn itself at the circumference; it is almost always umbranched, bearing a tuft of leaves at the summit; in a very few cases it is dichotomous, always round, and it terminates by a single bud; by the fall of summit; in a very few cases it is dichotomous, always round, and it terminates by a single bud; by the fall of
the petioles of the leaves, which sheath it in a greater or less degree at the base, it is covered with large scars. The leaves, technically called fronds, are pinnate or flabelliform, never simple; and, in a young state, before they expand, they are folded up in plaits from the base to the apex. The flowers are small, with bracter at their base, either sessile or seated in some cavity, of a pallid color, and contained in a large bag called a spatha ; when they open, the mass of inflorescence, called a spadix, bursts suddenly through the under side of the spatha, generally evolving the most fragrant odors. Impregnation takes place rapidly, through the injection of the pollen upon the humid surface of the stigmas, which gape open to receive it. The fruit is perfected in a period varying from six months to a year; when ripe it is a drupe or berry, with either a fibrous or fleshy coat ; the mass of its kernel consists of oily albumen, which, in the case of the cocoa nut, is soft enough to be eiten, but which in most species is as hard as horn. Dr. von Martius, the celebrated traveller in Brazil, to whom the world is indebted for nearly all that is known of these plants, concludes his remarks upon the characters of the order in the following words:- "Palms, the noble offspring of Terra and Phœebus, are natives of those happy countries within the tropics, where the rays of the latter are ever beaming. In all such climates they are to be found, with this limitation, however, that in the southern hemisphere they do not overstep the 35 th degree of latitude, nor in the northern the 40th. Most species are confined within fixed and narrow bounds, for it comes to pass that wherever a district is characterized by striking peculiarities of soil or climate, those species exist which are not found elsewhere; but few, on the contrary, extend over a large extent of surface, as the Cócos nucífera, Acrocómia sclerocárpa, Borássus flabellifórmis, \&c. It is probable that the number of palms existing on the face of the earth, will be found by future travellers to amount to as many as a thousand species. Most of them love the margins of springs and streams, but few establish themselves on the shores of the ocean, and yet a smaller number ascend into the alpine regions of their country; some collect in large forests ; some are scattered singly or in clusters, among woods and plains. In the most ancient periods of the world, when the genera of plants were beginning to be formed, palms scarcely existed; they were preceded in the creation by the more ancient Ferns, Cycadeæ, Grasses, and Equisetaceæ. Some of their remains have, however, been found in variegated sandstone, and in limestone of the third order (fletzkalk), part of which belong to unknown species, and part to species still in existence. But in the times succeeding the deluge, they appear, from the written evidence of historians and poets, to have followed the footsteps of man, to whom their fruit yielded food, drink, and oil ; their stems houses, arms, utensils, flour, and wine; and their leaves cordage and roofs for habitations. In cultivation their soil should be slightly saline; they are propagated by seeds more readily than by truncheons of the stem; when cultivated they undergo no alteration, except in producing more fleshy or stemless fruit: it is extremely difficult to transplant them beyond their own country; naturally their migration is absolutely opposed by the barriers of the ocean."

\begin{tabular}{|c|c|c|c|c|}
\hline $\begin{array}{l}762 \text { Corýpha } W . \\
763 \text { Licuála } W . \\
764 \text { Thrínax } W . \\
855 \text { Sábal } P . S . \\
753 \text { Cálamus } W .\end{array}$ & $\cdot$ & $\begin{array}{l}1982 \text { Ságus } W \text {. } \\
1983 \text { Cócos } W_{.} \\
1984 \text { E'late } W . \\
1985 \text { Báctris } \dot{W} \text {. } \\
2007 \text { Caryóta } W_{\text {. }}\end{array}$ & $\begin{array}{l}2008 \text { Nipa } \boldsymbol{T h} . \\
2009 \text { Aréca } \boldsymbol{W} \text {. } \\
2049 \text { Pho'nix } W \text {. } \\
2077 \text { Eláis } W \text {. } \\
2078 \text { Chamæd rea } W \text {. }\end{array}$ & $\begin{array}{l}2079 \text { Borássus } W \text {. } \\
2080 \text { Mauritia } W \text {. } \\
2109 \text { Latánia } J . \\
2153 \text { Rhápis } W \text {. } \\
\text { 2154 Chamæ'rops } h\end{array}$ \\
\hline
\end{tabular}

\section{SECTION III. STAMENS HYPOGYNOUS.}

Order CLXXIV. GRAMINEE.

The order of grasses is beyond doubt the most natural of all that the ingenuity of systematic botanists has contrived; it is also the most numerous in species. The inflorescence is very much alike throughout the order, and the floral envelopes, which are bracteæ in a progressive state to the form of calyx and petals, offer few striking characters by which the genera can be characterized. Hence it is that the classification of the order, and its division into genera, has not only been found extremely difficult, but has given rise to much difference of opinion among botanists; some of whom, adhering to the synthetical arrangement of Linnæus, admit but a small number of genera, while others, admitting the analytical principles of modern science, divide it into a vast number. The middle course in this, as in most other cases, is probably the just one. A subdivision of the order into tribes, has been attempted by Palisot, Trinius, Dumortier, Raspail, Kunth, Iink, and others; that of M. Kunth is here adopted. The general habit of grasses is so familiar to every one, that it may be passed over in silence. They are remarkable for exhibiting, in no case, properties that are actually poisonous; possessing on the contrary, in almost all cases, wholesome and nutritive qualities. These latter are especially obvious in their seeds, which always contain a farinaceous substance, mixed with a certain proportion of glutinous matter. No one is ignorant of the various and important uses of the seeds of wheat, rye, barley, oats, maize, rice, and others, and in general of all the larger kinds of grass. It must however be remarked, that if the smaller sorts are not employed in like manner, it is merely on account of their minuteness, and not on account of any difference in their nature ; in fact, in times of scarcity, and in half cultivated countries, use has advantageously been made of Festúca fluítans, Zizánia aquática, Avéna fátua, Pánicum sanguinále, Avéna elátior, Brómus secalinus, and Elymus arenárius. It is also to be noted, that the particular use for which the seeds of certain grasses are employed, are not peculiar to them, but may be obtained from all the others, with slight modifications. Thus beer is made, not only from barley but also from wheat; spirituous liquors not only from our European cerealia, but also from rice. But it must he remarked, that a singular exception to the generally wholesome properties of grasses, appears to exist in Lólium temuléntum, the seed of which is reported to be narcotic and inebriating, and even poisonous; there is no doubt, however, that these qualities have been greatly exaggerated; for in the first place they disappear in bread or beer manufactured from Lólium temuléntum; and secondly, in times of scarcity, people have frequently lived upon it. But even supposing all that has been stated upon the subject to be true, this plant will still be found to be little different from wheat, when long exposed to wet; so well, indeed, is this known by country people, that a belief exists, that in wet summers wheat is actually transmuted into rye grass. The exciting properties of the oat, which are very unusual in this order, have been found to reside in the husk and not in the seed, and to depend upon the presence of a minute quantity of an aromatic principle, analogous to Vanílla, lying imbedded in the envelope of the seed, and capable of being extracted by aid of alcohol. As to the deleterious effects of the ergot of rye, these do not depend certainly upon any such property in the rye itself, but is caused either by the ergot disease, or, as is believed, by the parasitic fungus, from the attack of which it arises. Now let us pass from the seeds of Gramineæ to their stems, and we shall find a no less remarkable uniformity of nature in them. They all contain, especially before flowering, a sweet sugary mucilage, which varies in quantity in different species. The sugar cane, in which this is found in greatest abundance, not only constantly exists in the most favorable condition for producing it, as it rarely flowers, but is also one of the largest grasses known. The maize also abounds in sugar; and the same substance is secreted in such abundance by the Sorghum saccharátum, that attempts have actually been made in Italy to cultivate it as the sugar cane. The creeping roots of grasses, which are generally mucilaginous and demulcent, are sometimes used in medicine; but they are of more importance for retaining in banks the sand of the sen shore, so as to form artificial cliffs on flat coasts, to restrain the inroads of the sea. The stems of Andropógon schænanthus, the leaves of Andropógon citrátum, the roots of Andropógon nárdus, and the whole plant of all the species of Anthoxanthum, exhale an aromatic odor, and possess slightly tonic properties. To conclude, the epidermis of grasses has been found to contain a considerable quantity of silex 
139 Páspalum $W$.

140 Axónopus $P$. de $B$

141 Milium $W$

142 Knáppia $E . B$.
Tribe 1, Panicere.

143 Digitária $P$. $S$.

$14+$ Pánicum $B$. $P$

146 Echinochlóa $P$. de $B$

147 Orthopógon $\boldsymbol{P}$ de $B$.

143 Penicillária $P$. de $B$.
119 Lappágo $W$.

134 Cénchrus $P$. $S$.

150 Stipa $W$.

Tribe 2. Stipacex.

138 Oryzópsis Mick.

Tribe 3. Agrostidex.

151 Muhlenbérgia Schr.

152 Chatúrus $L k$.

153 Lagúrus $W$.

154 Polypúgon $W$. en

155 Gastridium $\boldsymbol{P}$. de $\boldsymbol{B}$.

169 Corynéphorus $P$. de $B$.

76 Anthoxánthum $W$

170 Aira $W$.

171 Avéna $\dot{P} . S$.

172 Trisétum $P$. $S$.

173 Danthónia $P$. de $\boldsymbol{B}$.

174 Gaudinia $P$. $d e B$.

175 Arúndo With.

199 Sclerochlóa $P$. de $B$.

200 Eleusíne $R . B r$.

206 Tríticum $W$.

208 E'lymus $\boldsymbol{W}$.

214 Perótis $H . K$.

217 Leérsia $R . B r$.

1950 Zéa $W$.

1951 Cóix $W$.

1952 Trípsacum $W$.

1953 Heteropúgon Rich.

218 Diarrhéna Mich.
156 Agróstis $W$

157 Trichódium $M i$

158 Tristegis Nees.

159 Sporóbolus $B . P$.

160 Airópsis Desv.
161 Cínna $\boldsymbol{P}$. de $\boldsymbol{B}$.

136 Spartína $\boldsymbol{W}$.

162 Psámma $P$. de $B$.

163 Crýpsis $W$.

133 Cornucópiæ $L$.
164. Alopecúrus $W$.

165 Phléum $W$.

166 Achnodónton $P$. de $B$

167 Chilochlóa $\boldsymbol{P}$ de $\boldsymbol{B}$.

168 Phálaris W.en.

\section{Tribe 4. BROMEA.}

\section{Chrysúrus $P$. S. 184 Brómus $W$.}

177 Sesléria $P$. de $B$. 185 Brachypódium $P$. de $B$.

178 Cynosúrus $P$. S. 186 Uníola $W$

179 Køeléria $P$. $S$. 187 Tricíspis $\boldsymbol{P}$. de $\boldsymbol{B}$.

180 Dáctylis $W . e n . \quad 188$ Dipláchne $\boldsymbol{P}$. de $\boldsymbol{B}$.

181 Glycéria $R$. Br. 189 Ceratochlóa $P$. de $B$.

182 Festúca $W . \quad 190$ Schísmus $P$. de $B$.

191 Triódia $R$. $B r$.

Tribe 5. Chlorides

201 Dactyloctérium $\boldsymbol{P}$.de $\boldsymbol{B} . \quad 203$ Cýnodon $\boldsymbol{P} . \boldsymbol{S}$

202 Leptochlóa $P$. de $B$. 204 Dinébra $P$. de $B$.

192 Beckmánnia Hov t.

193 Mélica $W$.

194 Molínia $P$. de $B$.

195 Briza $W$.

196 Póa $W$.

197 Eragróstis $P$ de $B$

198 Megastáchya $P$. de $B$.

205 Echinária Desv.

Tribe 6. Hordeace

209 Secále $\boldsymbol{W}$.

210 Hórdeum $W$

211 Microchlóa $\dot{R}$. $B r$.

212 Ophiúrus $\boldsymbol{P}$. de $\boldsymbol{B}$.

213 Monérma $P$. de $B$.

137 Nárdus $W$.

Tribe 7. Saccharined.

215 Sáccharum $W$.

216 Imperáta Cyr.

Tribe 8. Oryzea. 837 Orýza

754 Ehrhárta $W$.

Tribe 9. Olyrew.

1954 Olýra $I V$

1979 Zizánia $W$

1980 Phárus $\boldsymbol{W}$.

2129 Andropógon $W$.
2130 Chlóris $W$

2131 Sórghum $W$. en.

2133 Ischæ'mum $W$.
2132 Hólcus $W$. en.

2134 Æ'gilops $W$.

Tribe 10. Bambusacea.

131 Remiréa $A u b . \quad 219$ Arundinária $W . \quad 752$ Bambúsa $W$

Station Uncertain.

132 Lygéum $W$.

Order clXXV, cyperace.e.

The sedges, as these may be ca led in English, differ from grasses not only in their oomparative worthless. ness, and the different developement of the parts of fructification, but also in the sheath, at the base of the leaves, being closed up, not slit. As objects of ornament they are of no value, and as subjects of agricultural interest of but little; they are, moreover, of little utility to man. They are chiefly valuable for covering, with the appearance of herbage, waste, and barren, marshy, or sandy tracts, in which little else will thrive. The roots of Cárex arenária, dísticha, and hírta, possess diaphoretic and demulcent properties, whence they are sometimes called German sarsaparilla. Some of the Scírpuses and Cypéruses have eatable nutty roots; the stems of Scírpus lacústris, Eleócharis palústris, Cypérus téxtilis, and others, are manufactured into mats and the bottoms of chairs; the roots of Cypérus esculentus abound in oil, a very unusual circumstance; the papyrus of the ancients was manufactured from the stem of Cypérus papýrus ; finally, the roots of Cypérus lóngus, odorátus, and others, are fragrant.

74. Cládium $S c h r$.

119 Scho'nus $V a h l$

120 Rhynchospóra Vahl

122 Isolépis $R . B r$

123 Scírpus $R, B r$.

124 Eleócharis $R$. $B r$.

126 Trichóphorum $P . S$.

127 Cypérus $W$

128 Papýrus $L k$.

129 Kylínga $W$.

130 Maríscus Vah

1947 Cárex $W$

1948 Cobrésia $W$

1949 Uncínia Rich.

Order ClXXVi. aroideze.

Herbaceous, stemless, or caulescent plants, with broad fleshy leaves, approaching very nearly to those of Dicotyledons. Their flowers are enclosed within a spatha, and are imbedded on a simple cylindrical spadix. Some are natives of Europe and of similar latitudes, but the greater number inhabit the tropics, where they often climb by their rooting stems to the tops of lofty trees. They have thick fleshy roots, which, when fresh, contain an acrid stimulating principle, which is so volatile that it passes off freely upon the application of heat; whence the roasted roots of many species are among the most common articles of negro food. The heat; whence the roasted roots of many species are among the most common articles of negro food. The
leaves of $A^{\prime}$ rum seguinum are so paralyzing, that if chewed they deprive one of the power of utterance; whence in the West Indies it is called the dumb cane; the leaves of Dracóntium pertúsum are acrid; fresh gathered, and applied all over the surface of the body, they produce a slight inflammation and blistering, and are used in Demerara, by the natives, in dropsical cases. The root of A'rum triphýllum, boiled in milk, has been found efficacious in consumption. The flowers of many species are highly fetid. Typhineæ, or bullrushes are very like Cyperaceæ in habit. Pistiaceæ are floating plants, in which the organs of fructification are reduced to the very simplest state. Juncagineæ are obscure marsh or river plants.

252 Pothos $W$.

755 A'corus $W$.

756 Oróntium $W$.
Tribe 1. Genuine

758 Tácca $W$.

2006 A'rum $W$

2005 Caládium $\boldsymbol{W}$.
868 Dracóntium $\boldsymbol{W}$.

869 Cálla $W$.
876 Roxbúrghia $\mathrm{Dr}$. 769 Aspidístra $\mathrm{Ker}$ 757 Tupistra $B$. M. 
1945 Týpha $W$.

Tribe 2. TrPHINEe.

Tribe 3. Pistiacea.

1939 Lémna $\boldsymbol{W}$

109 Leptánthus Mich. 854 Aponogéton $W$.
Tribe 4. Juncaginea.

840) Scheuchzéria $W$. 317 Potamogéton $W$.
1946 Spargánium $\boldsymbol{W}$.

841 Triglóchin $W$.

Order ClXXVII. FLUVIALES.

With these the Vasculares and Monocotyledones terminate : it has long been apparent that we have been descending in the scale of vegetation; and hence, the last order exhibited a structure the most simple of all vascular plants. In the present order, Zostéra and Rúppia are so closely allied to Algæ, that they may be mistaken for them.

\section{CELlulares.}

The characteristics of this division have already been explained in the preliminary observations upon the natural orders; and the remarks which were required for each natural order of Cellulares have already been given in Cryptogamia in the body of the work. It has, therefore, been thought advisable to adopt from Professor Agardh such observations as he has made upon the orders, as a sort of contrast to those already given.

\section{CLass 1. FOLIACE}

\section{Order i. Filices.}

Of these the stem is perennial, often subterraneous and creeping, and occasionally becoming arborescent and leafy above the ground. The fronds or leaves are usually pinnatifid, and more or less compound; sometimes nearly simple and entire, with reticulated veins. The capsules are minute, one-celled, seldom manycelled, brown, membranous, and surrounded by a thick articulated elastic ring, irregularly bursting, and either clustered on the lower surface of the frond, or compound in spikes. Their vernation is circinate, and some are propagated by bulbs. The old botanists denied any fruit whatever to Ferns; believing the seeds of these plants to be so rare as to invest any body with invisibility who could collect them. Afterwards, their capsules were believed to be their seeds. Linnæus, and some others, doubted whether their fructification were seeds or pollen. Finally, the experiments of Ehrhart and Lindsay proved, beyond all cavil, that they were really seeds. As to the male organs nothing is known; some suppose them to be glands of the frond, others the elastic ring, some the indusium, and others the pores of the epidermis; lastly, Martius has supposed them to be the membrane including the spiral vessels. Ferns are chiefly inhabitants of the torrid zone, becoming rarer as we approach the poles. They delight in a humid soil, and they often grow parasitically upon trees. The medicinal virtues of some are highly astringent, of others anthelmintic, of others purgative; some have acquired celebrity for their pectoral, others for their corroborant qualities. The young leaves and roots of some constitute an article of food; beer is obtained from the roots of others, and, finally, Aspídium frágrans has been used as tea.

2168 Polybótrya $H . \& B$. 2169 Acróstichum $L$. 2170 Hemionitis $L$

2171 Gymnográmma Desv. 2172 Meníscium Schreb. 2173 Xiphópteris Kaulf. 2174 Céterach $W$. 2175 Polypódium $L$. 2176 Tæ'nitis $S w z$.

2204 Tódea $\boldsymbol{W}$.
Tribe 1. Polypodrace

2177 Nothochle'na $R . B r .2186$ Asplénium $L$. 2187 Allantódia $R$. Br. 2179 Struthiópteris $W . \quad 2188$ Scolopéndrium $\mathrm{Sm}$ us Bernh. 2181 Ellobocárpus Kaulf. 2182 Lomária $W$. 2183 Bléchnum $\dot{L}$. 2184. Woodwárdia Sm. 2185 Doódia R. Br.
189 Diplázium Swz.

2190 Ptèris $L$

2191 Vittária $S m$.

2192 Lonchítis $L$.

2193 Antróphyum Kaulf.

2194 Adiántum $\boldsymbol{W}$.
2195 Cheilánthes Swz. 2196 Davállia Sm 2197 Dicksónia L'Her. 2198 Balántium Kaulf 2199 Aspídium Swz. 2200 Woódsia $R$. Br. 2201 Cyathéa $\mathrm{Sm}$. 2203 Hymenophýllum Sm.

\section{Tribe 2. Osmundacere.}

2205 Osmúnda $L$. $\quad 2206$ Lygódium Swz.

2207 Anémia Swz.

2208 Botrýchium Swz.

Tribe 3. Ophioglosseze.

2209 Ophioglóssum $\boldsymbol{L}$.

2210 Maráttia Swz.

Order II. EQUISETACEA.

: Marsh plants, with a verticillate arrangement of their branches, and a highly indurated epidermis. Their Marsh plants, with a verticillate arrangement of their a hygrometrical movement. The quality of some is said to be hurtful to cattle, eeds are remarkable for a hygrometrical movement. The quality of some is said to be hurtful to cattle,
which is denied by others. Formerly they were used in medicine as astringents and diuretics. Equisétum hyemále has been employed for tea, and as a polishing material for furniture, under the name of Dutch rushes.

\footnotetext{
2211 Equisétum $L$.
}

Order III. LYCOPODINEE.

With the habits of mosses they have the seeds of ferns. They are herbaceous prostrate plants, with imbricated simple leaves. Lycopódium complanátum, Selágo, and clavátum as used as dyes; the sporules of Lycopódium clavátum are said to be employed for ameliorating wine, and are also used in making fire-works, on account of their inflammable nature. The herb of Lycopódium clavátum and Selágo is emetic, and produces abortion. Lycopódium phlegmária is reputed an aphrodisiac.

2212 Lycopódium $L$.

2213 Psilótum Stuz

Order IV, MARSILEACEA.

Floating or erect simple-leaved plants of no known use. The Marsileas, which are to some countries what Lémna is to this, are not known in cultivation. 


\section{Chass II. APHYLLA}

Order V. MUSCI.

Winter plants, reviving in humid air, abundant about the poles, rare at the equator. They cover the moun. tains of the earth as high as the limits of perpetual snow; growing in patches, they clothe the most barren spots with verdure, preserve trees from heat and cold, prepare the earth for nourishing more perfect plants, and fill up bogs and morasses with vegetable matter. To the economy of nature they are, therefore, more subservient than to the purposes of man. Medicinal astringent properties were formerly ascribed to some few, but they are now neglected or forgotten.

Tribe 1. Evaginulati.

2216 Sp̣hágnum $L$.

Tribe 2. Vaginulati Olocarpi.

2217 Pháscum $L$. 2219 chistostéga Mohır. 2227 Cinclidótus P. de B. 2236 Buxbaúmia L. 2219 Gymıóstomum Hedw. 2228 Tórtula $E h r$. 2220 HymenóstomumR.Br. 2229 Pterogónium Swz. 2221 Tétraphis Hedw. 2230 Didýmodon Hedw. 2020 2223 Grimmia Hedw. 2224 Weíssia Hedw. 2225 Dicránum Hediv. 2226 Trichóstomum Hedw. 2235 Diphýscium Mol 2231 Spláchnum $L$. 2232 Conóstomum Swz. 2233 Orthótrichum Hedw. 2234 Zýgodon Hook.

2238 Rartrámia Hedw.

2239 Púhlia Hedw.

2240 Brýum Hedw.

2241 Polýtrichum $I$.

2242 Anictángium Hedw. 2251 Hýpnum $L$.

2244 Leúcodon Schwagr. $22+5$ Fontinális $L$. 2246 Anómodon Hook.

2247 Neckéra Hedw.

2248 Daltónia Hook.

2249 Hookéria $S m$

Tribe 3. Vaginulati Schistocarpi. 2252 Andræ'a Hedw.

Order VI. HEPATICE.

Creeping small plants, with their leaves arranged in an imbricated manner. They differ from Lichens in structure, color, and fruit ; from Musci, in the dehiscence of their capsule. Their qualities are mild, if any; some of them are fragrant.

2253 Jungermánnia $L$.

2255 Ríccia $E . B$.

2257 Targiónia $E . B$.

$225+$ Marchántia Mich.

2256 Anthóceros $E . B$.

2258 Sphærocárpus $\boldsymbol{E}$. $\boldsymbol{B}$.

Order VII. ALG IE.

Plants ascending from the simplest form known in vegetation to a very compound state. The lowest are filiform, leafless, with their fructification immersed; the highest are leafy, with the fructification included in an indehiscent wart-like pericarpium. Some copulate like animals, others have a spontaneous motion like worms. Their color is lively, in the lowest grades green, in the highest red or purple. Some are ephemwral and microscopical, annual or perennial, and others extend to the length of many fathoms. They grow at the bottom of the sea, or in fresh water, the depths of which they clothe with vegetation, as the higher orders of plants cover the earth with forests. They grow on stems in the water oniy, or on each other. Sorne exhale oxygen, others are scented like violets. 'Their taste is mild; their substance gelatinous, membranous, or coriaceous, usually covered externally with mucus. The structure of the lowest is articulated; of the highest fibrous.

Tribe 1. Diatomex. 2259 Achnánthes $\mathrm{Ag}$.
2260 Diátoma $\mathrm{Ag}$.

2263 Desmídium $\mathrm{Ag}$.

2264 Schizonéma Ag.

Tribe 2. Nostochinde.
2265 Palmélla $\mathrm{Ag}$.
2266 Echinélla $\mathrm{Ag}$.
2267 Alcyonídium $\mathrm{Ag}$.
2269 Corynéphora $\mathrm{Ag}$.
2271 Chætóphora $\mathrm{Ag}$. 2268 Nóstoc $A$ 2270 Rivulária $\mathrm{Ag}$
2272 scythyménia $\mathrm{Ag}$.

Tribe 3. Confervoldes.

$\begin{array}{lll}2273 \text { Byssocládium } \mathrm{Ag} . & 2281 \text { Leptomitus } \mathrm{Ag} . & 2289 \mathrm{Zygnéma} \mathrm{Ag} . \\ 2274 \text { Mycinéma } \mathrm{Ag} . & 2282 \text { Mesoglóia } \mathrm{Ag} . & 2290 \text { Mougeótia } \mathrm{Ag} . \\ 2275 \text { Chroolépus } \mathrm{Ag} . & 2283 \text { Batrachospérmum } \mathrm{Ag} . & 2291 \text { Hydrodíctyon } \mathrm{Ag} . \\ \text { 2276 Trentepóhlia } \mathrm{Ag} & 2284 \text { Draparnáldia } \mathrm{Ag} . & 2292 \text { Conférva } \mathrm{Ag} . \\ \text { 2277 Scytonéma } \mathrm{Ag} . & 2285 \text { Oscillatória } \mathrm{Ag} . & 2293 \text { Bulbochæ'ta } \mathrm{Ag} . \\ 2278 \text { Stigonéma } \mathrm{Ag} . & 2286 \text { Cálothrix } \mathrm{Ag} . & 2294 \text { Nitélla } \mathrm{Ag} . \\ 2279 \text { Protonéma } \mathrm{Ag} . & \text { 2287 Lýngbya } \mathrm{Ag} . & 2295 \text { Chára } \mathrm{L} . \\ 2280 \text { Hygrocrócis } \mathrm{Ag} . & \text { 2288 Bángia } \mathrm{Ag} . & 2296 \text { Cerámium } \mathrm{Ag} .\end{array}$

2297 Griffithsia $\mathbf{\Lambda g}$. 2298 Chætospóra Ag. 2299 Polysiphónia Grev. 2300 Rytiphlæ'a $A$. 2301 Ectocárpus $A g$. 2302 Sphacellária $\mathrm{Ag}$. 2303 Cladostéphus $\boldsymbol{A g}$.

Tribe 4. Ulvaces.

\section{Vauchéria $A g$. 2306 Bryópsis $\boldsymbol{A g}$. \\ 2308 U'lva $\boldsymbol{L}$.} 2307 Solénia $A g$ 2309 Pórphyra $A g$

Tribe 5. FlorideE.
2310 Polyídes $A g$. 2311 Ptilóta $A g$.

\begin{abstract}
2312 Rhodoméla $\mathrm{Ag}$.
\end{abstract}
2314 Sphærocóccus $A g$.' 2315 Halyménia Ag.
2316 Bonnemaisónia Ag. 2317 Delesséria $\mathrm{Ag}$.
Tribe 6. Flcoidex.
2318 Lemánea $\mathrm{Ag}$. 2319 Chordária $\mathrm{Ag}$
2320 Scytosiphon $\mathbf{A g}$.
2321 Sporóchnus $\mathrm{Ag}$. 2322 Haliseris $\mathbf{A g}$. 2323 Encœ'lium $\boldsymbol{A g}$. 2324 Zonária $\mathrm{Ag}$. 2326 Lichína $A g$.
2327 Furcellária $A g$. 2328 Fúcus $L$ 2329 Cystoseíra $\mathrm{Ag}$.

\section{Order ViII. LICHENS.}

Lichens are not only most useful in the CEconomy of Nature, as preparing the surface of the earth for the reception of larger vegetables, but they are, moreover, of great utility to man. Many, as Cetrária islándica, are eatable, having a bitter principle, and giving out a styptic tincture, if immersed in alcohol. Others, steeped in urine or salts, are used for dying ; crustaceous species of this kind are Variolária oreina, Lecanóra tartárea, Leprária chlorína, \&c. ; foliaceous species, Parmélia saxátilis, Stícta pulmonácea, Solorína crócea, Gyróphora deústa and pustuláta, \&c. ; and branched kinds, Roccélla tinctória (the common Orchal), U'snea plicáta, Alectória jubáta, and others. In medicine, Cetrária islándica and nivális, Stícta pulmonácea, Alectória usneoídes are tonic and nutritive; Parmélia parietína, Borréra purpurácea, Evérnia prunástri, \&c., are astringent and febrifugal; Peltidéa aphthósa, anthelmintic; Evérnia vulpína, poisonous. Some yield a gum, as Evérnia prunástri; Stícta pulmonácea may be employed for bittering beer instead of hops, and Ramalína 
scopul6rum instead of scap. The various species give the grey hue to old walls and stones, cover desert heaths, and mottle the bark of ancient trees.

Tribe 1. Iniothalami.

2330 Spilóma Ach. 2331 Solorina Ach.
2332 Iecídea Ach.

2333 Calícium Ach.
2334 Gyróphora $A c h$.

2335 Endocárpon $A c h$.
2336 Thelotréma Ach. 2337 Pyrénula Ach. 2338 Variolária $A c h$ 2339 Urceolária Ach. 2340 Lecanóra Ach.
Tribe 2. Coenothalami.

2341 Parmélia Ach. 2346 Nephróma Ach. 2342 Borréra Ach. 2347 Roccélla Ach. 2343 Cetrária $A c h$. 2344 Stícta Ach. 2345 Peltidéa $A c h$.

\section{Evérnia $A c h$.}

2349 Cenómyce $A c h$.
2350 Bæomýces Ach.

2351 Isidium Ach.

2352 Stereocaúlon Ach.

2353 Sphæróphoron Ach.
2354 Alectória Ach. 2355 Ramalina Ach.

2360 Opégrapha $A c h$. 2361 Verrucária $A c h$.
Tribe 3. Homothalami

2356 Corniculária Ach. 2357 U'snea Ach.

Tribe 4. Athalami.

2359 Leprária Ach.

Tribe 5. Pseudo-Lichenes.

2362 Porína Ach.

2363 Arthónia Ach.
2358 Colléma Ach.

Order IX. FUNGI

We have now reached the lowest station of vegetable existence, in arriving where the vesicles which compose the vegetable fabric are combined in various forms, according to the contingent circumstances under which they are developed. The mould on the cheese, the ergot of corn, the rust of the rose, and the huge Bolétus, which, in Java, spreads out its many-handed body from the trunks of ancient trees like a vegetating demon, differ only in the number of the vesicles of which they are composed. Many species are eatable, as Agáricus campéstris; others are deadly, as Bolétus scáber; some are used medicinally, as Dædálea suavéolens in coughs; Agáricus túba regínæ in diarrhœe; Agáricus piperátus in calculous disorders; Phállus Mokúsin against cancer; Polypórus annósus against the bites of serpents. Some Coprini are used for healing ulcers; Polypórus officinális as a purgative; Polypórus igniárius as a styptic ; Polypórus destrúctor, and a number of others, constitute dry rot. For the poison of fungi, the roots of garlic, the leaves of parsley, and tincture of lacmus, are said to be remedies: so also is common spirit. Fungi swarm in all the coldest countries of the world, but as we approach the equator they are extremely rare; the place where they most flourish is Sweden, and the adjacent regions.

\section{Tribe 1. Hymenomycetes.}

1. Hymenini.

Div. 1. Pileati.

2365 Agáricus $\boldsymbol{I}$.

2366 Coprinus $L k$.

2369 Merúlius Haller. 2373 Bolétus Dill.

2367 Gómphus Fries. $\quad 2371$ Dædálea Pers. $\quad 2375$ Hýdnum $L$.

2368 Cantharéllus Adans. 2372 Polypórus Micheli.

Div. 2. Clavati.

2379 Clavária Vaill. 2381 Geoglóssum Pers. 2383 Mítrula Fries.

2380 Calócera Fries. $\quad 2382$ Spatulária Pers. $\quad 2384$ Týphula Fries.

2376 Sistostréma Fries. 2377 Phlébia Fries. 2378 Theléphora Ehr.

2385 Pistillária Fries.

\$ 2. Uterini $v$. Elvellaceæ.

Div. 1. Mitrati.

\section{Morchélla Dill. 2387 Helvélla $\boldsymbol{L}$. 2388 Vérpa Swz.}

\section{Leótia Hill.}

Div. 2. Cupulati.

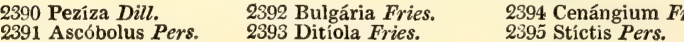

2396 Cryptomyces Fr.

\section{§3. Tremellini.}

2397 Tremélla $L$. ¿398 Exidia Fries.

2399 Dacrymýces Nees. 2400 Agýrium $\mathbf{F r}$.

84. Sclerotiacei.

2403 Acrospérmum Tode. 2404 Sclerótium Tode.

2405 Rhizoctónia Dec.

2406 Perióla Fr.

Tribe 2. Gasteromycetes.

$\S 1$. Angiogastres.

Div. 1. Phalloidece.

2409 Phállus Mich.

2410 Batárrea Pers.

Div. 2. Tuberacea.

2411 Túber Plin. 2412 Rhizopógon Fr.

Div. 3. Nidulariacee.

2413 Nidulária Bull.

2414 Myriocóccum $\operatorname{Tr}$.

2415 Polyángium $L k$.

Div. 4. Carpoboli.

2416 Atractóbolus Tode. 2417 Thelébolus Tode. 2418 Pilóbolus Tode. 2419 Sphæróbolus Tode.

\section{Pyrenomycetes.}

Div. 1. Sphariacei.

2420 Xylária Hill. 2422 Cucurbitária Gray. 2424 Heterosphæria Grev. 2426 Lóphium Fries

2421 Stromatosphæ'ria Grev.2423 Cryptosphæ'ria Grev. 2425 Sphæ'ria Haller.
2401 Hymenélla $F r$. 2402 Næmatélia Fr.

2407 Acínula $\mathrm{Fr}$.

2408 Erýsibe Rebentisch. 
2427 Sphæronæ'ma Fries.

Div. 2. Cytisporei.

Div. 3. Phacidiacei.

2431 Dothidéa Tr. 2432 Rhytísma Fries. 2433 Phacídium Fries. 2434 Hystérium Tode.

2430 Phóma Fr.

Div. 4. Xylomacei.

$\begin{array}{ll}2435 \text { Actinothýrium Kunz. } & \text { 2437 Xylóma Pers } \\ \text { 2436 Leptostróma Fr. } & \text { 2438 Lasiobótrys Kunz. }\end{array}$

2439 Asteróma Dec.

\$3. Trichospermi.

Div. 1. Lycoperdinei.

2440 Onygéna Pers.

2441 Tulostoma Pers.
2442 Sclerodérma Pers. 2443 Lycopérdon Mich.
2444 Bovista Pers. 2445 Geástrum Mich.

Div. 2. Trichocisti.

2446 Cratérium Trent. 2449 Dictýdium Schrad. 2452 Tríchia Pers.

2477 Stemonitis Pers. 2450 Arscýria Pers. 2453 Didérma Pers.

2454 Phýsarum Pers. 2455 Leocárpus Lk.

Div. 3. Fuliginoidei.

2456 Lycogála Mich. 2457 Spumária Pers.

Div. 4. Liceoidei. 2458 Dichospórium Nees. 2459 Lícea Schrad.

8. Mucoroidei.

2460 Múcor Pers. 2461 Thamnidium $L k$.

2462 Ascóphora Tode.

$$
\text { \$. Perisporia. }
$$

2463 Eurótium $L k$.

2464 Amphispórium $L k$.

Tribe 3. НурномчсETES.

1. Cephalotrichi.

2465 Cerátium Albertini. 2466 Isária Pers.

82. Stilboidei.

2467 Stílbum Tode.

\$. Inomycetes.

Div. 1. Byssacei.

2468 Tórula $L k$. 2470 Racódium Pers. 2472 Cladospórium $L k$. 2474 Ozónium $\boldsymbol{L} k$.

2469 Monília Pers. 2471 Demátium Pers. 2473 Helicospórium Nees. 2475 Rhizomórpha Roth.

Div. 2. Mucedines.

2476 Sepedónium $L k$. 2479 Trichothécium $L k$. 2482 Aspergíllus Mich 2477 Acremónium $L k$. 2480 Acrospórium Nees. 2483 Stachylídium $L k$.

2484 Penicíllium $L k$. 2485 Trichodérma Pers.

2478 Sporótrichum $L k$. 2481 Bótrytis Mich.

2486 Rubígo $L k$.

\$4. Phylleriacex.

Tribe 4. Coniomycetes.

1. Tuberculariæ.

2488 Tuberculária Tode.

2489 Fusárium $L k$.

\$2. Entophytæ.

Div. 1. Stilbosporei.

2491 Fusídium $L k$. 2493 Stilbospóra Hoffm. 2494 Sporidérmium $L k$.
2487 Eríneum Pers.
2492 Polythríncium Kunz.

2496 Cylindrospórium Grev. 2497 Urédo Pers.
Div. 2. Hypodermia. 2498 Ecídium Pers.
2490 Exospórium $L k$

2495 Næmaspóra Pers.

2499 Puccínia Mich.

After the most perfect classification which the present state of botanical knowledge renders practicable, there still remain a few genera which are incapable of having their true station assigned to them, either in consequence of their structure being incompletely known, or of their affinity not having yet been discovered. As far as this work is concerned, they are the following, all of which are Dicotyledones.
1966 Aúcuba $W$
1462 Aitónia $W$.
405 Bréxia Nor.
2121 Nepénthes $W$.
442 Vallésia $\mathrm{Fl}$. per.
2098 Eúclea $\boldsymbol{W}$.
2163 Laurophýllus $W$. 


\section{G L O S S A R Y}

OF

\section{TERMS USED IN THE GENERIC AND SPECLFIC DESCRIPTIONS, IN THE GENERAL OBSERVATIONS ON THE CLASSES, AND IN THE NOTES.}

The figures between parentheses ( ) refer to the engravings at the bottom of the page. After each term a reference is given to an example of its application in the body of the work: in these references, g. signifies genus, s. species, p. page.

\section{A.}

$A$, in composition, signifies without, as Aphyllus, without leaves ; Acaulis, without stem. s. 1339

Abbreviate (abbreviare, to shorten). Used in comparative descriptions, to indicate that one part is shorter than another. Sálvia crassifólia, s. 420.

Aberrant, deviating from the natural or direct way applied in Natural History to species or genera that deviate from the usual characters of their neighdeviate from

bours. p. 408 .
Abortion (1) signifies an imperfect developement of any given organ. Cephalánthus, g. 275 . p. 78.

Abraded, rubbed or worn off. Acácia, g. 2127. (note) Abstergent, cleansing, having a cleansing quality. Sapíndus, g. 926. (note.)

Accessory, something added to the usual number of organs, or their parts. Phálaris, g. 168. p. 32.

Accretion, the growing of one thing to another. p. 748 .

Accumbent, lying on, prostrate, supine; this term is employed in Crucíferæ, to signify a radicle, which lies upon the edge of the Cotyledons. p. 536.

Acerose, (2) needle-pointed; fine and slender, with a sharp point. Bánksia pulichélla, s. 1449.

Acescent, sour, tart, acid. Pinguícula, g. 52. (note)

Acetarious, any thing belonging to the salad tribes of vegetables. Lactúca, g. 1628. (note.)

Acetous, something that produces acidity. Tríticum, g. 206. (note.)

Acicular, (3) needle-shaped. Leptospérmum triloculáre, s. 6931 .

Acinaciform, (4) scimitar-shaped. Ehrhârta, g. 754 p. 238.

Acini, the small stones in grapes, strawberries, \&c. Cecrópia, g. 2043. (note.)

Aculeate, (5) being furnished with aculei or prickles, as distinguished from spines. Spartína polystáchya, s. 920 .

Aculei, prickles, sharp hard processes of the epidermis falling off when old; by which character they are distinguished from spines, which do not fall off Medicágo múrex, s. 10910.

Acuminate, (6) taper-pointed. Cánna índica, s. 2.

Acutangular, (7) having sharp angles. Cúrchorus acutángulus, s, 7722 .

Adnate, (8) adhering to a thing. Anthers are called adnate when they are attached to the filament by their whole length. Anthoxánthum amárum, s. 498 .

Adult, the full-grown of any thing : full-grown leayes are adult leaves. Prótea obtúsa, s. 1318.

Eruginous, having a color like that of ærugo or verdigris. Curcúma æruginósa, s. 82.

Agglomerated, collected in a heap or head. Ecidium Jacobæ'a, s. 16669.

Aggregate, (9) gathered together; usually applied to a dense sort of inflorescence. Calyménia aggregáta, s. 570 .

Agrumi, a name given by the Italians to any kind of lemons or oranges. Cítrus, g. 1615. (note.)

Akenium, (10) a hard pericarpium, containing a single
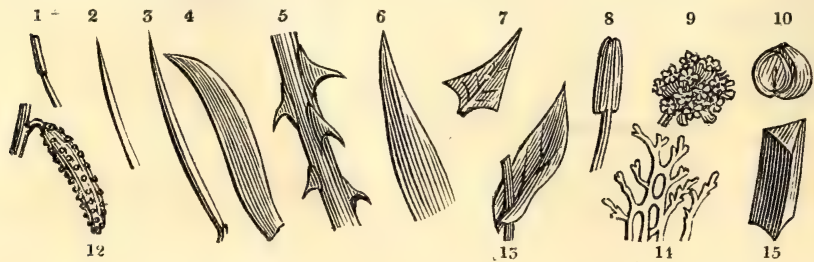

11

seed, which does not adhere to it ; it is the same the Linnæan nux. Hippophæ'a, g. 2058. p. 817.

Albumen, the substance under the inner coat of the testa, surrounding the embryo; it is sometimes ab. sent. Réserla, g. 1102. (note.)

Alembick, a vessel used in distilling, or acting like a still. Phœ'nix, g. 2049. (note.)

Alexipharmic, that which counteracts poisons, antidotal. Maránta, g. 2. (note.)

Alexiteric, having the power of doing away poisons. p. 1065 .

Alkalescent, having the properties or effects of alkali. Rímex aretósa, g. 856. (note.)

Alkali, any substance which, when mingled with acid, produces fermentation. Viola, g. 540. (note.)

Alveolate, (11) resembling a honeycomb. Borkhaúsia, g. 1637. p. 661.

Alvine, of or belonging to the intestines. Acácia, g. 2127 . (note.) nogéton, g. 854 . p. 240.

Amplexicaul, (13) stem-clasping : the base of the leat surrounding the stem. Céstrum auriculátum, s. 2465 .

Amylaceous, having the properties of starch. p. 1065. Anastomosing, (14) uniting, or inosculation, of vessels. Cinclidótus, g. 2227. p. 896.

Androgynous, producing both male and female sexes on the same root, or in the same flower. Uncinia, g. 1949. p. 768 .

Anfractuose, full of turnings and winding passages. Ochróma, g. 1458. p 560.

Angular, (15) composed of, or furnished with, angles. Lopézia coronáta, s. 103.

Angulo-dentate, (16) angularly tonthed, or angular and toothed. Lapsána commúnis, s. 11324.

Annulations, (17) rings or circles. Rivulária, g. 2270. p. 92.5.

Anterior, growing in front of some other thing. Hákea acanthophyylla, s. 1434 .

Anthelmintic, capable of killing worms. Geoffróya, g. 1517. (note.)

Antheriferous, (18) bearing anthers. Lopézia, g. 18. p. 1. Antiaphrodisiacal, any thing which checks the desire of sexual intercourse. Vitex, g. 1517. (note.)

Anti-pestilential, efficacious against pestilence. Angélica, g. 664. (note.)

Antiphrasis, the use of words in a sense opposite to that of some neighbouring parallel sentence. Globulária, g. 260. (note.)

Anti-scrophulous, antiscorbutic; efficacious against scurvy. Cynoglóssum, g. 336. (note.)

Antiseptic, efficacious against putrefaction. Artemisia, g. $172 \mathrm{~L}$. (note.)

Aperient, having a slight purgative quality. Curcúma, g. 14. (note.)

Apetalous, being without petals. p. 1.

Apex, (19) the summit; generally applied to any thing terminating in a point. Thália dealbáta, s. 26.

Aphrodisiacal, any thing which excites a desire for sexual intercourse. Justícia, g. 47. (note.)

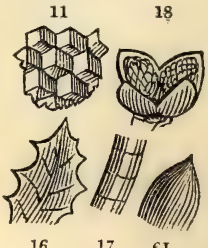

$\begin{array}{lll}16 & 17 & 6 \mathrm{I}\end{array}$ 
Aphthous, resembling something covered with little ulcers. Acácia, g. 2127. (note.)

Apiculate, (20) terminating in an apiculus or little point. Rósa microphýlla, s. 7512 .

Apiculus. (21) a small point. This term is generally used when the midrib projects beyond the leaf, form, ing a little point, or when a small point is very suddenly and abruptly formed. Tórtula unguiculáta, s. 14757.

Apophysis, (22) a swelling beneath the theca of a moss. Spláchnum, g. 2231. p. 896.

Appendix, (23) that which is attached. Sarracénia rúbra, s. 7675 .

Appense, being hung up as a hat is upon a pin; an approach to pendulous. Piménta, g. 1123. p. 409.

Appressed, placed close upon something else; when hairs lie flat upon the surface of a plant, they are said to be qppressed. Stachytárpheta hirsutíssima, s. 337 .

Approximated, near together. Sálvia truncáta, s. 445. Apterous, without wings, or the membranous margins which botanists call wings. Pinguícula, g.52. (note.)

Aquatics, growing in or belonging to water. p. 1 .

Arboreous, being a tree, as distinguished from frutes cent or shrubby. Pelargónium discípes, s. 9633.

Arborescent, having a tendency to become a tree. Píper tomentósum, s. 517.

Arcuate, curved or bent like a bow. Hypécoum procímbens, s. 1815

Areole, (24) little spaces or areas on the surface of a thing: the surface of crustaceous lichens is often cracked in every direction; the spaces between the cracks are the areolæ. Lecidéa coracína, s. 15378.

Areolated, the adjective of the last term. Solenia g. 2307. p. 925.

Aridity, dryness. Xerótes, g. 2076. (note.)

Arillate, having that peculiar appendage called the

Arillus. The term is only applied to seeds. p. 751 .

Arillus, (25) a process of the placenta adhering to the hilum of seeds, and sometimes enveloping them. Phrýnium, g. 5. p. 1.

Aristate, bearded, as the glumes of barley. Many grasses.

Aroma, the spicy quality of a thing. Justicia, g. 47. (note.)

Articulation, the place where one thing is joined with another, another word for joint. Corynéphorus, g. 169. (note.)

Asci, (26) small tubes in which the sporules of Cryptogamic plants are placed. p. 978

Ascigerous, having asci. p. 982 .

Assurgent, rising upward. Phlox amœ'na, s. 2113.

Attenuate, made thin or slender. Lopézia racemósa, s. 102.

Auriculated, (27) having an ear-like base. Jasminum auriculátum, s. 174 .

Awns, the beard or arista of corn. Salsolla muricáta, s. 3404 .

Axil-flowering, flowering in the axilla. Chionanthus axilláris, s. 154

Axilla, literally the armpit; in plants applied to the angle formed by the union of the leaf and stem. Dipsácus, g. 262. (note.)

Axillary, (28) placed in the axilla. Pollichia campéstris, s. 113.

Axis, the line, real or imaginary, that passes through any thing. Actinocárpus, g. 860. (note.)

\section{B.}

Baccate, berried, having a fleshy coat or covering, Gmélina, g. 1311. p. 493 .

Bagged, resembling a bag or sack. Ceanóthus, g. 510.

Bail, (29) the round central part of the flower of the Stapélia. p. 199

Bands, (30) or vittæ, are the spaces between the elevated lines or ribs of the fruit of umbelliferous plants. Búbon, g. 640. p. 116.

Barred, crossed by a paler color in spaces resembling bars. Sanseviéra glaúca, s. 4540.

20

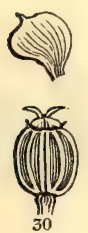

21

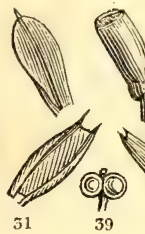

93

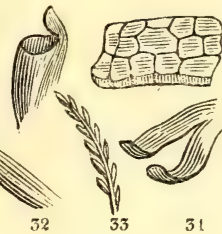

Beak, any thine which resembles the beak of a bird hard short points. Briza, g. 195. p. 33

Bearded, having long hair like a beard. Wulfénia, g. 50 . p. 9.

Beardletted, having small awns. Cínna arundinácea, s. 1010.

Bicuspidate, (31) twice pointed. Cárex lagopodioídes, s. 13081.

Bidentate, (32) double-toothed, or having two teeth. Alantódia axilláris, s. 14527.

Biennial, a plant is said to be biennial which requires two seasons to mature its fruit, and then dies. Phí lydrum, g. 17. (note.)

Bifarious, (33) placed in two rows. Alpínia tubuláta, s. 50 .

Bifid, (34) half divided in two; two cleft. Cánna lútea, s. 4.

Biglandular, double-glanded. Malpíghia glandulósa, s. 6.374 .

Bilabiate, (35) having two lips. Diclíptera, g. 48. p. 9. Bilobed, (36) divided into two lobes. O'xalis filicaúlis, s. 6.518 .

Binate, growing two together. Córnus suécica, s. 1791

Bipartible, capable of being parted in two. Prótea, g. 231. p. 77.

Bipinnate, (57) a mode of foliation; twice pinnate. Petróphila pulchélla, s. 1306.

Bipinnatifid, (38) twice pinnatifid, a mode of foliation. Verónica Jacquíni, s, 238.

Bisaccate, having two little sacks, bags, or pouches, Mathíola, g. 1381 p. 536

Biscutate, (39) resembling two bucklers (scuta) placed side by side. Biscutélla, g. 1413. p. 537.

Biternate, (40) divided in three twice over. Chæro. phýllum Claytóni, s. 3491.

Bi-tri-crenate, crenate twice or thrice. Jungermánnia pusilla, s. $1+958$.

Bi-tri-pinnatifid, pinnatifid twice or thrice over. Petróphila diversifólia, s. 1307.

Bi-tri-ternate, growing in threes twice or thrice over Actæ'a americána, s. 7650 .

Bivalved, two-valved, p. 877.

Blanching, made white by being grown in a dark

place. Lactúca, g. 1628. (note.)

Bland, fair, beautiful. Mesembryánthemum blándum s. 7348 .

Blight, a vague term, signifying a pestilence among plants caused by the attack of insects or of parasitical fungi, or by some endemical affection of the atmosphere. Húmulus, g. 2074. (note.)

Blistered, having the surface raised as the skin is when blistered. Sálvia micrántha, s. 393.

Bole, trunk of a tree. O'rnus, g. 69. (note.)

Boragineous, of or belonging to the natural order Boragineæ. Rhéxia, s.900. (note.)

Brachiate, (41) having arms or branches usually placed opposite to each other, nearly at right angles with the main stem, and crossing each other alternately Phillyréa angustifólia, s. 143.

Bracteate, furnished with bracteæ. p. 443

Bracteola, little bracteæ. Geropógon, g. 1620. p. 661.

Br actee, (42) small leaves placed near the calyx. Ma. ránta oblíqua, s. 19

Branchlets, small branches. Agróstis vulgáris, s. 993.

Bristles, rigid hairs. Ghinia, g. 65. p. 10.

Bulbiferous, bulb-bearing. Glóbba marantína, s. 96

Bulbous, having bulbs. Cypérus, g. 127. p. 31.

Bulbs, (43) underground buds resembling roots, and consisting of numerous fleshy scales placed one over the other. A'llium, g. 795. p. 272.

Burry, covered with hooked stiff hairs, like the heads of Bur or Burdock. Pisónia, g. 864. (note.)

Byssoid, having the appearance of Byssi. p. 979 ,

\section{C.}

Caàucous, falling off soon. Epimédium, g. 297. p. 79. Casious, grey. Curcúma cæ'sia, s. 84 .

Caspitose, growing in little tufts. Erínus alpínus, s. 8825 .

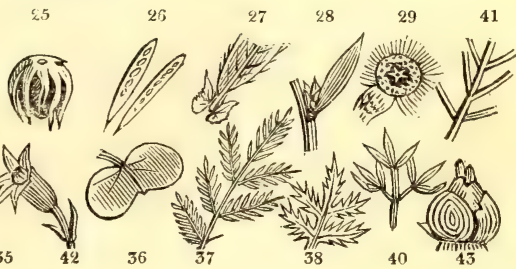


Calcarate, (44) spurred, or spur-shaped. Alpinia cardamómum, s. 48

Caicareous, chalky, or growing on chalk, O'lea, g. 32. (note.)

Calceiform, (45) formed like a little shoe. Pedilánthus, g. 1104. p. 393.

Calli, small callosities, or rough protuberances. Sálvia amaríssima, s. 397.

Callous, hardened. Brúnia ericoídes, s. 3005

Calycine, of or belonging to a calyx. Cartonéma, g. 90. p. 30 .

Calyculated, (46) having bracteolæ resembling an ex ternal or additional calyx. Myóseris, g. 1640. p. 661.

Calyptra, (47) literally an extinguisher; applied to the body which tips the theca of a moss, and the like. p. 895 .

Calyptrate, having a covering resembling an extinguisher. Eríca coarctáta, s. 5330.

Calyptrate, having a calyptra. Actinophýllum, g. 697. p. 117.

Calyptriformis, shaped like a calyptra. Marcgraávia, g. 1163. p. 456.

Campanulate, (48) bell-shaped. Cóstus, g. 11. p. 1.

Canaliculate, channelled or furrowed. Weíssia acúta, s. 14714 .

Cancellate, latticed; resembling lattice-work. Trigonélla cancelláta, s, 10882

Canescent, hoary, approaching to white. Selágo canéscens, s. 8662 .

Capillary, (49) very slender; resembling a hair. Trichóphorum, g. 126. p. 31.

Capitate, (50) growing in a head. Chloránthus, g. 25. p. 1.

Capitular, growing in small heads. Brýum, g. 2240. (note.)

Capituli, small heads. Réseda, g. 1102. (note.)

Capituliform, formed like a small head. Cenomýce,

g. 2349. p. 949 .

Carbonised, burned to a coal. Quércus súber, g. 2000. (note.)

Carina, (51) a keel like that of a boat; also the two lower petals of papilionaceous flowers. Pongámia, g. 1514. p. 598 .

Carinate, keel-shaped. Utriculária mínor, s. 329.

Cariopsis, (52) a one-celled, small, indehiscent pericarpium adhering to the seed which it contains, as the grain of grasses. Hydrástis, g. 1241. p. 459.

Carious, decayed. Juníperus, g. 2113. (note.)

Carminative, medicines which promote perspiration. Pimpinélla ánisum, s. 3562.

Carnose, fleshy. Gymnóstomum Griffithsiánum, s. 14671 .

Carpella, (53) the small parts out of which compound fruit are formed. Actinocárpus, g. 860. (note.)

Carpology, the science which treats of the structure of fruits and seeds. p. 1056

Cartilage, gristle. Róchea odoratíssima, s. 3868.

Cartilaginous, gristly. Aspicárpa, g. 29. p. 1.

Cataplasm, a plaster, or more properly a poultice. Zíngiber, g. 10. (note.)

Catarrhal, of or belonging to a cold. Acácia, g 2127. (note.)

Cathartic, purgative. Gratíola, g. 43. (note.)

Catkin, (12) inflorescence of the natural order Amentáceæ. Artocárpus, g. 1935. p. 768.

Caudate, tailed, being like a tail. Strophánthus, $g$. 416 . p. 111.

Caudex, the trunk or stem. Cócos aculeáta, s. 13321. Caudicula, (54) a small membranous process on which the pollen of orchideous plants is fixed. Rodriguézia, g. 1883 . p. 749.

Caulescent, acquiring a stem. Trichónema cauléscens, s. 642.

Cauline, produced on the stem. Centránthus calcitrápa, s. 112

Causticity, having a burning quality. Plumbágo, g. 324. (note.)

Cautery, that which burns. Artemisia, g. 1721. (note.)

Cellular, composed of cells. Eriocaulon septanguláre, s. 1295 .

Centimetre (55) is a French measure equal to 4 lines $\frac{432}{1000}$ or near $4 \frac{1}{2}$ lines. Palmélla, g. 2265, (note.)

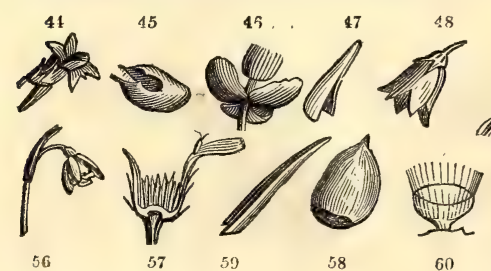

Centuria, hundreds. Buxbaúmia, g. 2236. (note.) Cephalic, medicinal to the head. Kæmpféria, g. 12 (note.)

Ceraceous, wax-like. Pezíza erúmpens, s. 16273

Cernuous, (56) nodding, drooping, or pendulous. Cánna iridiflóra, s. 17.

C'haffy, (57) bearing processes resembling chaff. Erióphorum, g. 125. p. 31.

Chalaza, (58) a spot on the seed, indicating where the vessels of the raphe terminate. Eriobótrya, g. 1137. p. 409.

Channel-leaved, (59) folded together so as to resemble a channel for conducting water. Trichonéma bul bocódium, s. 640 .

Charlatanry, quackery. Mandragóra, g. 447. (note.) Charring, blackening by fire. Quércus, g. 2000. (note.)

Chlorosis, the green sickness, a disease so called. A'nthemis, g. 1778. (note.)

Cilia, (60) hairs like those of the eyelash. Plantágo subuláta, s. 1707.

Ciliary processes, like eyelash hairs. p. 907.

Ciliated, eyelash-haired. Lopézia cordáta, s. 104.

Ciliato-dentate, toothed and fringed with hairs like

eyelashes. Cnícus heterophýllus, s. 11405.

Cinereous, ash-colored, grey. Grevillea cinérea, s. 1417.

Cingalese, inhabitants of, or belonging to, Ceylon. Plumbágo zeylánica, s. 1861

Circinately, (61) curled round like a sharp crook. p. 539 Cirrhiferous, bearing tendrils. Gloriósa supérba, s. 4574 .

Cirrhose, or Cirrhous, (62) tendrilled. Bignónia únguis, s. 8531 .

Clammy, viscid, sticky. Boerhaávia viscósa, s. 109.

Clathrate, latticed, divided like latticework. Solénia

compréssa, s. 15270

Clavate, club-shaped. Curcúma comósa, s. 85.

Clavellose, clubbed, or having club-like processes.

Chóndria clavellósa, s. 15290 .

Clavus, a name for the ergot, a disease in corn. Fes. túca duriúscula, g. 182. (note.)

Claws, (269) the taper base of a petal. Cánna limbáta, s. 8 .

Clinandrium, (63) that part of the column of orchi deous plants in which the anther lies. Listéra g. 1876. p. 749

Clypeate, (64) shaped like a Roman buckler. Tupistra, g. 757 . p. 238.

Cobwebbed, covered with loose hairs, as if with a cobweb. Anacámpseros arachnoídes, s. 6630.

Cochleate, (65) resembling the shell of a snail Rhéxia, g. 900 . p. 300.

Cohering, connected. Prótea, g. 231. p. 77

Collapsion, the act of closing or falling together. Sphæ'ria hydróphora, s. 16436

Columella, (66) the axis of the fruit of mosses. p. 874 Columnar, formed like columns. I'xia fucáta, s. 623 Comminuted, pulverised or pounded. Línum, g. 701. (note.)

Comose, this term is used to express a kind of inflo rescence, which is terminated by sterile bractea. Maránta comósa, s. 24.

Compact, close, solid. Cypérus vegétus, s. 895.

Complicate, folded together. Rhopála dentata, s. 1447.

Complicato-carinate, folded together so as to form a sort of keel. Fontinális antipyrética, s. 14848 .

Compound, used in botany to express the union of several things in one: thus, a compound umbel is formed by several simple umbels, a compound flower by several simple flowers, \&c. Alpinia nútans, s. 43.

Compressed, pressed together. Salicórnia, g. 22. p. 1

Concave, hollow. Zingiber mióga, s. 54

Concentric, points or lines at equal distances from a common centre. Eárycles amboinénsis, s. 4077.

Concrete, hardened or formed into one mass. O'rnus, g. 69. (note.)

Cone, (67) a particular kind of compound fruit. $\mathbf{P e}$ tróphila, g. 229. p. 76.

Conferruminate, united together, so as to be undistin guishable. Olýnthia, g. 1124. p. 409.

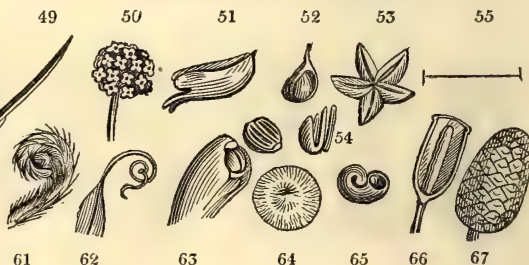


Confervoid, like confervæ. Sporóchnus, g. 2321. p. 926.

Confluent, running into one another. Jasmínum grandiffórum, S. 181

Conglobated, collected into a spherical form. Dacrymýces morifórmis, s. 16300

Conical, (68) resembling a cone. Hedýchium heteromállum, s. 16300. Brýum cuspidátum, s. 14830.

Conico-ovate, $(70)$ between conical and ovate. Pinus sylvéstris, s. 13502

Conjugate, (71) joined in pairs : a term chiefly applied to leaves. Piper cuneifólium, s. 524.

Connate, (72) joined together at the base. Calceolaria parália, s. 320 .

Connivent, (73) converging. Lœflíngia, g. 82. p. 30.

Conoid, cone-like. Siléne conoídea, s. 6223

Constricted, (74) tightened or contracted in some particular place. Sálix lanceoláta, s. 13691. s. 2164 .

Convex, rising in a circular form. Píper rubéllum, s. 543.

Convexo-plane, plane on one side, convex on the other.

Convolute, (75) rolled together. Crócus, g. 93. p. 30. Coralloid, like coral. Chóndria kalifórmis, s. 15291. Cordate, heart-shaped. Cánna variábilis, s. 9.

Coriaceous, leathery. Chionánthus virgínicus, s. 152.

Corneous, horny, of the consistence of horn. Sphærocóccus córneus, s. 15301.

Corniculate, having processes like small horns. Mesembryánthemum procúmbens, s. 7251.

Cornute, horned. Eucalýptus cornúta, s. 7003. crowr-like cup which is found at the orifice of the tube of the corolla in Narcíssus, Pancrátium, and others. Brodiæ'a, g. 114. p. 31.

Corpuscle, a small body; a particle of any thing. Secamóne, g. 577. p. 114.

Corroborant, strengthening, having the power to give strength. Melíssa, g. 1278. (note.)

Corrosive, having the power of wearing away. Sapíndus, g. 926. (note.)

Corrugated, wrinkled or shrivelled. Páspalum stoloniferum, s. 926.

Cortical, of or belonging to the bark. Linum, g. 701. (note.)

Corymb, (77) a raceme or panicle in which the stalks of the lower flowers are longer than those of the upper, so that the flowers themselves are all on the same level. Centránthus rúber, s. 110. corymb. Lopézia coronáta, s. 103.

Corymbulose, formed or arranged in many small corymbs. Crássula corymbulósa, s. 3887.

Cosmetii, beautifying. Dipsácus, g. 262. (note.)

Coste literally ribs: applied by botanists sometimes to the midrib of a leaf, and sometimes to any projecting round elevations having the same direction as the axis of the fruit. Morchélla, g. 2386. (note.)

Costate, ribbed. Jungermánnia furcáta, s, 15004.

Cotyledons, (78) seed leaves. Hórdeum, g. 210. (note.)

Cowled-leaved, a thing is said to be cowled or cucullate when its end is curved inwards in such a manner as to represent the cowl or hood of a monk. Lachenália bifólia, s. 4898.

Crence, notches. Saxífraga umbrósa, s. 6063.

Crenate, (79) notched. Cánna limbáta, s. 8.

Crenulate, full of notches. Sálvia pomífera, s. 370.

Crest, (80) applied to some elevated appendage terminating a particular organ: a stamen is crested when the filament projects beyond the anther, and becomes dilated. Kæmpféria, g. 12. p. 1. cribrósa, s. 16265. p. 297.

Crisp, when leaves are very much undulated at the
Conico-hemispherical, (69) between conical and round.

Converging, approaching together. Datúra férox, Cárex vulpína, s. 13084

Corona, (76) literally a crown : applied in botany to the

Corymbose, formed or arranged after the manner of a

Crenature, the notching. Prásium mínus, s. 8518.

Cribriform, riddled with holes like a sieve. Pezíza

Cribrose, perforated like a sieve. Parinárium, g. 870

margin, they are called crisp or curled. Cóstus villosíssimus, s. 66 .

Cruciate, (81) shaped like a Maltese cross : a flower is said to be cruciate when four equal petals are placed opposite each other at right angles. Gentiána septemfida, s. 3360.

Cruciferous, the name of a particular family of plants bearing cruciate flowers. p. 536 .

Crustaceous, having a hard brittle shell. Hellénia, g. 9. p. 1.

Crystalline, consisting of, or resembling, crystals. Mesembryánthemum lanceolátum, s. 7389

Cucullate, (82) hooded, cowled; see Cowled. Calathéa,

g. 3. p. 1 .
Culm, the stem of grasses, scitamineous plants, and the like. Maránta arundinácea, s. 18.

Culmiferous, producing culms. Tríticum spélta, s. 1235.

Cultrate, (83) shaped like a pruning-knife. Crássula cultráta, s. 3880 .

Cuneate, wedge-shaped. Teúcrium cubénse, s. 8117. Cup, the same as corona; see that word, g. 711 p. 236.

Cupule, (84) the cup of an acorn, and of all amentaceous plants. p. 1017

Cupuliform, or Cupulate, shaped like a reversed bell. p. 982.

Cuspidate, (85) like the point of a spear, a leaf is cuspidate, when it is suddenly tapered to a point Tritónia rósea, s. 664 .

Cutaneous, relating to the skin. Scabiosa, g. 264. (note.)

Cuticle, the scarf skin, or epidermis. Chára, g. 2295. (note.)

Cut-toothed, (86) cut and toothed at the same time. Plantágo macrorhíza, s. 1708 .

Cyathiform, cup-shaped, concave. Narcíssus pulchéllus, s. 4025 .

Cylindraceous, having the form of a cylinder. Dicránum Scottiánum, s. 14724 .

Cylindrical, cylinder-shaped. Salicórnia rádicans, s. 116.

Cylindrico-campanulate, cylindrically bell-shaped. Encalýpta, g. 2222. p. 896 .

Cymbiform, (87) boat-shaped. Vallésia glábra, s. 2456.

Cyme, (88) a mode of inflorescence, resembling a flattened panicle. Scírpus lacústris, s. 861

Cymose, flowering in cymes. Róchea cymósa, s. 3866.

D.

Decandrous, having ten stamens. Phytolácca abyssínica, s. 6573 .

Deciduous, falling off. Leaves which are shed annually are said to be deciduous : as are also trees that annually lose their leaves. O'lea excélsa, s. 141.

Declinate, curved downwards. Zíngiber zerúmbet, s. 56 .

ecoction, a preparation or digest by boiling water Cúnila, g. 58. (note.)

Decompound, (89) a leaf is said to be decompound when it is twice pinnated; a panicle when its branche are also panicled. Linociéra compácta, s. 474.

Decorticated, disbarked. Amýgdalus, g. 1128. (note.) Decumbent, lying down. Chloránthus inconspícuus, s. 121.

Decurrent, (90) running down. Lopézia coronáta, s.103. Decursive, having a tendency to run down. Actinótus heliánthi, s. 3591 .

Decussated, when two right lines cross each other at right angles they are said to decussate; leaves are often placed in this position. Ixóra parviflóra, s. 1746 .

Deflexed, turned downwards. Schizánthus pinnátus, s. 272 .

Dehiscent, (91) gaping; an expression applied to the mode in which the anthers or the fruit burst open and discharge their contents. p. 896.

Deliquescent, melting away upon exposure to air. p. 979.

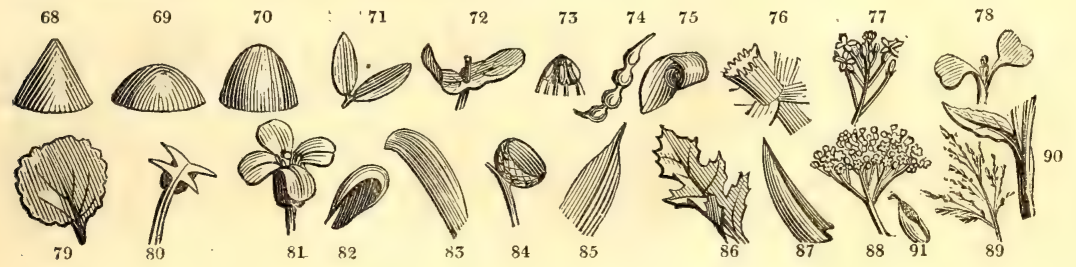


Delta-leaved, Deltoid, (92) shaped like the Greek $\Delta$. Mesembryánthemum, g. 1146. p. 437.

Demulcent, having the property of softening any thing. Málva, g. 1472. (note.)

Dentate, (93) having the margin divided into incisıons resembling teeth. Verónica acúta, s. 196.

Dentato-ciliate, having the margin dentate and tipped with ciliæ. Sónchus arvénsis, s. 11106.

Dentato-sinuate, (94) scolloped and toothed. Hypochæ'ris glábra, s. 11319.

Denticulate, being finely dentate. Circæ'a lutetiána, s. 487.

Denticulations, small toothings. Bossiæ'a scolopéndrium, s. 10121.

Dentiform, tooth-shaped. Barbaréa plantagínea, s. 8980

Dentrifice, powder made to scour the teeth. Acácia, g. 2127. (note.)

Deobstruent, having the power of removing obstructions, a term of medicine. Agrimónia, g. 1101. (note.)

Dependent, hanging dowr. Moræ'a spathácea. s. 826 . Depressed, pressed downward. Thálıa, g. 4. p. 1 .

Depurated, puritied, cleansed. O'xalis, g. 1065. (note.) Despumate, to throw off in froth or scum. Cecrópia, g. 2043. (note.)

Detergent, Detersive, having the power of cleansing. Physalis, g. 448. (note.)

Diandrous, having two stamens. Boerhaávia hirsúta, s. 107. Diaphanous, transparent. Encalýpta ciliáta $\beta$ alpína,
s. $1468 \tilde{\text {. }}$.

Diaphoretic, promoting perspiration. Sambúcus, g. 680. (note.)

Dichotomous, (95) a stem that ramifies in pairs. Phrýnium dichótomum, s. 28.

Dicoccous, having two cocci. p. 78

Didymous, two united. Priva mexicána, s. 8675.

Didynamous, (96) having two long stamens and two short ones in the same flower, each pair being collateral. Stenochílus, g. 1333. p. 493.

Dietetics, relating to food or diet. Sáccharum, g. 215. (note.)

Difform, two forms; used to express irregularity. An acámpseros rotundifólia, s. 6629 .

Diffiuse, scattered, widely spread. Verónica saxátilis, s. 226.

Diffusible, such as may be spread. Amýgdalus, g.1128 inote.)

Digitated, (97) fingered, shaped like the hand spread open. Verónica digitáta, s. 255.

Digitiform, formed like fingers. Mesembryánthemum incimptum, s. 7408 .

Digynous, two styles or female organs. Sálvia crética, s. 401 .

Diluent, something diluting. Melissa, g. 1278. (note.)

Dimidiate, (98) halved, divided into two parts. p. 895.

Dicecious, when a plant bears female flowers on one indiviuual, and males on another, it is called diœ. cious. Valeriána dioíca, s. 544.

Discoid. (99) When in Compósitæ the florets are all tubular, the head of flowers is said to be discoid. In other cases, when the florets of the centre of a head of flowers are more perfect than the rest, they are called discoid. Finally, when any thing is dilated into something which may be compared to a disk, the term discoid is also made use of Valerianélla discoídea, s. 563.

Discus, or Disk, the fleshy annular process that surrounds the ovarium of many flowers: also the surface of a leaf; also the centre of a head of flowers of Compósitæ. Enóplia, g. 504. p. 113.

Discutient, having the power to scatter the matter of tumours. Artemísia, g. 1721. (note.)

Disseviment, $(100)$ the partitions by which a seed vessel is divided internally. Elytrária, g. 45. p. 9.

Distichous, (101) two-rowed: producing leaves or flowers in two opposite rows. Schce nus, g. 119 p. 31 .

Ditrichotomous, (102) divided in twos or threes; a stem continually dividing into double or treble ra mifications. Trichódium canínum, s. 1001.

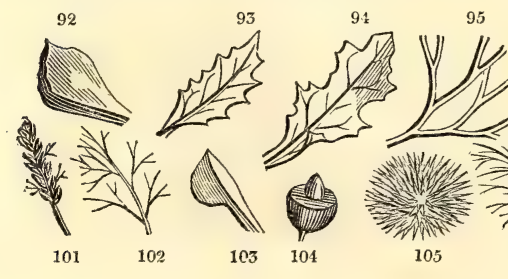

95

Diuretic, having the power of promoting the flow of urine. Bromélia, g. 726. (note)

Divaricate, growing in a straggling manner. Verónica pinnáta, s. 219.

Dodecandrous, having twelve stamens. Rivína dodecándra, s. 1511.

Dolabriform, (103) axe-shaped. Stizolóbium, g. 1551.

p. $59 y$.
Dorsal, growing on the back. Kæmpféria rotúnda, s. 67 .

Drastic, applied to medicines which act violently. Dictámnus, g. 997. (note.)

Drupe, (104) a kind of fruit consisting of a fleshy succulent rind, and containing a hard stone in the middle. $O^{\prime}$ lea, g. 52 . p. 9.

Dyspepsia, difficulty of digestion. Artemísia, g. 1721. (note.)

\section{E.}

Echinated, (105) covered with prickles like an echinus or hedgehog. Amómum súbulátum, s. 79.

Edible, eatable. Eleusíne, g. 200. (note.)

Effruse, (106) literally poured forth; applied to inflorescence, it means a kind of panicle with a very loose one-sided arrangement. Júncus effúsus, s. 4327.

Electuaries, a medicine of conserves and powders in the consistence of honey. Prúnus doméstica, s. 7045 .

Elephantiasis, a disease in which the limbs become prodigiously swollen and finally fall off. Smílax, g. 2081. (note)

Ellipsoid, (107) like an ellipsis. Nastúrtium amphíbium, s. 8970.

Elliptic-lanceolate, (108) a form between elliptical and lanceolate. O'lea americúna, s. 140.

Elongated, lengthened. Cánna gigantéa, s. 6.

Emarginate, (109) having a small notch in the end. Cánna coccínea, s. 3.

Embossed, (110) projecting in the centre like the boss or umbo of a round shield or target. Prótea umbonális, s. 1327.

Embracing, (13) a leaf is said to embrace a stem when it clasps it round with its base. Sálvia amplexicaúlis, s. 428.

Emetic, that which produces vomiting. Primula vulgáris, s. 2020

Emmenagogue, any medicine that promotes menstruation. Ligústicum, g. 665. (note.)

Emollient, softening. Triumfétta, g. 1087. (note.)

Emulsions, medicines made of bruised oily seeds and water. Amýgdalus, g. 1128. (note.)

Ensate, or Ensiform, (111) shaped like a sword with a straight blade. A'loe cándicans, s. 4444.

Epidermis, the outer skin of the bark. Lasirus, g. 934. (note.)

Epiphyllous, (112) growing upon a leaf. Jungermánnia epipliýlla, s. 15003.

Epiphytes, plants which grow upon other plants with. out deriving any nutriment from them. Catasétum, g. 1889. (note.)

Equidistant, equally distant. Egopódium, g. 652. p. 116.

Equikateral, having equal sides. A'loe reticuláta, s. 4392 .

Equitant, (113) a mode of vernation, or of arrangement of leaves with respect to each other, in which the sides or edges alternately overlap each other. Moræ'a iridioides, s. 827.

Erecto-patent, between erect and spreading. Dicránum glaúcum, s. 14715

Eroded, (114) gnawed, bitten; a term used to express a particular kind of irregular denticulation. Sálvia pinnáta, s. 377.

Eroso-dentate, the toothing being eroded. Iycopódium clavátum, s. 14632.

Errhine, promoting a discharge of mucus from the nostrils. A'sarum, g. 1072. (note.)

Escharotic, having the power to scar or burn the skin. Juníperus, g. 2113 . (note.)

Esculent, good for food. Oxystélma esculéntum, s. 3226 .

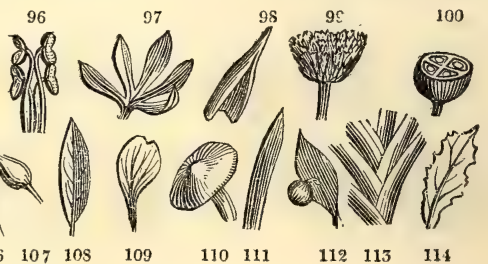


Estuaries, arms of the sea, mouths of a river. Polýgonum amphíbium, s. 5568 .

Etiolated, whitened by being kept from air and light. Tríticum spélta, p. 70. (note.)

Evanescent, quickly vanishing. Herácleum, g. 672 p. 117.

Évolved, unfolded. Aneiléma, g. 89. (note.)

Excavated, hollowed out. Borágo, g. 340. p. 109.

Excentrical, (115) flying off from the centre. Agáricus ulmárius, s. 15924.

Excoriate, stripped of the bark or skin. Bromélia Karátas, g. 726 . (note.)

Excurrent, projecting or running beyond the edge or point of any thing. Tórtula subuláta, s. 14751 .

Exotic, foreign. p. 1 .

Expectorant, any thing that promotes the discharge of mucus from the chest. Sambucus nigra, p. 225. (note.)

Exserted, (116) projecting beyond something else. Jasminum revolútum, s. 179.

Exsiccated, dried up. Papáver, g. 1170. (note.)

Extra-axillary, above or on the outside of the axils. Mesembryánthemum, g. 1146. (note.)

Extra-foliaceous, away from the leaves, or inserted in a different place from them. Echítes bispinósa, s. 2360 .

Exuvice, whatever is cast off by plants or animals. Cáctus, g. 1111. (note.)

\section{F.}

Facula, the nutritious powder of wheat or of other things. Codárium, g. 30 . p. 8 .

Falcate, or Falciform, (117) bent like a sickle. Dactylocténium, g. 201. p. 33.

Falcato-secund, bent on one side like a sickle. Dicrá num longifólium, s. 14717.

Falsely two-valved, having two valves which are not of the same nature as other valves. Hákea, g. 240 p. 77.

Farinaceous, full of flour. Tríticum, g. 206. (note.)

Fascicles, parcels or bundles. Maránta oblíqua, s. 19

Fasciculate, (118) arranged in bundles or parcels. Aspálathus, g. 1528. (note.)

Fastigiate, (119) tapering to a narrow point like a pyramid. Salicórnia procúmbens, s. 118

Fauces, (120) the jaws; the gaping part or orifice of a monopetalous flower, Acácia, g. 2127. (note.)

Favose, (11) pitted or excavated like the cells of a honeycomb. Thríncia, g. 1633. p. 661 .

Feathery, resembling a feather. Arundinària, g. 219 p. 35 .

Febrifuge, efficacious in moderating fever. Swieténia febrifúga, s. 5867 .

Feculent, muddy, thick with sediment. A'loe, g. 770 (note.)

Fecundation, the act of making fruitful. Jasione, g. 547 . (note.)

Feroces, (121) thickly set with spines, p. 443.

Ferruginous, iron-colored, rusty. Sidéritis, g. 1252 (note.)

Fibrillose, (122) covered with little strings or fibres. p. 989 .

Fibrous, (123) being composed of fibres. Scírpus mul ticaúlis, s. 858 .

Fiddle-lipped, (124) having a lip resembling the figure of a fiddle. Zingiber pandurátum, s. 53 .

Filiform, shaped like a thread. Mantísia, g. 16. p. 1.

Fimbriate, (125) fringed. Eleusine, g. 200. p. 33.

Finger-parted, (97) divided into lobes having a fancifu resemblance to the five fingers of a human hand. Verúnica vérna, s. 254.

Fistular, or Fistulous, hollow like a pipe. Monárda média, s. 356.

Flaccid, feeble, weak. Cánna fiáccida, s. 15

Flexile, capable of being bent in different directions, pliable. Paullínia, g. 923. (note.)

Flexuose, having a bent or undulating direction. Alpínia cardamómum, s. 48.

Flexiose-recurved, bent backward in a flexuose or undulated manner. Dicránum críspum, s. 14723.
Flocci, little tufts like wool. p. 983.

Flore horologice, flowers which expand at particular hours, whence they are a sort of timekeepers. Anagállis, g. 357. (note.)

Floral envelopes, the caly $\mathrm{x}$, bracteæ, and corolla, which envelope the inrier parts of the flower are all so called. p. 1 .

Florets, (126) little flowers; chiefly applied to those which constitute what were formerly called com pound flowers. Festúca vivípara, s. 1093.

Floriferous, that which bears flowers. Cólchicum, g. 851. (note.)

Flosculous, compound flowers, consisting of many tubulose monopetalous florets. Cárduus, g. 1663. p. 680 .

Foliaceous, (127) having the form of leaves. Pincknéya, g. 492. p. 113.

Follicle, (128) a particular kind of seed-vessel. Hákea, g. 240 . p. 177 .

Footstalks, (129) the stalks of either flowers or leaves. Avéna, g. 171. (note.)

Fornicate, (130) arched. Roscóea, g. 7. p. 1

Fragmentary, composed of fragments. Lecidéa microphýlla, s. 15440 .

Fringed, (125) having a border like a fringe. Cánna glaúca, s. 16

Frond, the leaves of palms. Sábal, g. 855 . p. 292.

Frontal, that which is in front. Kæmpféria rotúnda, s. 67.

Frosted, (131) covered with glittering particles, as if fine dew had been congealed upon it. Anomathéca, g. 106. p. 31.

Fructification, all those parts composing the fiower and fruit of plants. Póa alpína. p. 67. (note.)

Frutescent, or Fruticose, shrubby. Piper, g. 77. (note.)

Fugacious, that which lasts but for a short time Utriculária, g. 53. (note.)

Fulvous, tawny yellow or fox-colored. Sanseviéra fulvo cíncta, s. 4545 .

Fungous, having the substance of fungi or mushrooms. Cáchrys, g. 677. p. 177

Funicle, (132) the little stalk by which a seed is at tached to the placenta. Cardámine, g. 1392. p. 536. Furcate, forked. A'juga furcáta, s. 8099.

Furfuraceous, scaly, mealy, scurfy: Agáricus granulósus, s. 15745 .

Fuscous, blackish-brown. Brúnia ericoídes, s. 3005 .

Fusiform, (133) spindle-shaped. Selínum palústre, s. 3669 .

\section{G.}

Galeate, (134) helmeted; the upper lip of a ringent corolla is the galea of that corolla. Touréttia, g. 1299 . p. 492 .

Gelatine, jelly; a term of chemistry. p. 924

Gelatinous, consisting of jelly. Chrysophyllum, g. 424 (note.)

Geminate, doubled. Didýmodon, g. 2230: (note.)

Gemmce, (135) leafy buds as distinguished from alabastra or flower buds. Brýum, g. 2240. (note.)

Geoponic, relating to agriculture. Columéllia, g. 1785. (note.)

Germ, or Germen, the old name of the ovarium. Muscári, g. 821. (note.)

Germen inferior, (136) fruit below the flower. p. 1.

Germination, the first act of vegetation in a seed.

Tríticum spélta, p. 70. (note.)

Gibbous, protuberant. Maránta gíbba, s. 23

Glabrous, smooth. Aspérula lævigáta, s. 1611.

Gladiate, (111) shaped like a short straight sword.

Erýngium aquáticum, s. 3495 .

Glandular, having glands. Schwénckia, g. 42. p. 9.

Glaucescent, or Glaucine, having something of a

bluish hoary appearance. Mesembryánthemum glaucéscens, s. 7273 .

Glaucous, having a decided hoary grey surface. Cánna glaúca, s. 16

Globose, or Globular, (136) round or spherical. Pinguícula lusitánica, s. 322.

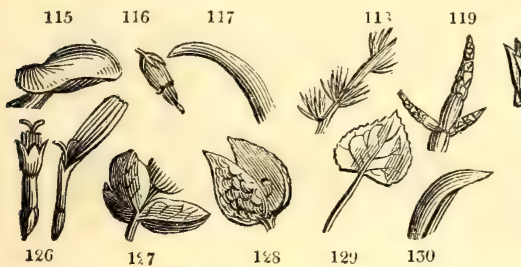

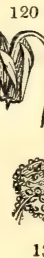

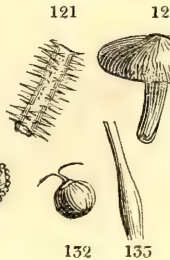

122

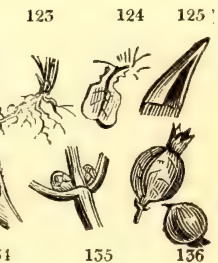


Glochidate, having hairs, the ends of which are split and hooked back, so that the hook is double. Thrincia híspida, s. 11175 .

Glomerate, (137) gathered into a round heap or head. Conýza glomeráta, s. 11850.

Glottis, the throat. Acácia, g. 2127. (note.)

Glumaceous, plants are said to be glumaceous when their flowers are like those of grasses. Cládium, g. 74. p. 11.

Glume, (138) a part of the floral envelopes of a grass. Anthoxánthum, g. 76. p. 11.

Gluten, a chemical principle. Tríticum, g. 206. (note.)

Glutinous, adhesive. Sálvia glutinósa, s. 398.

Grained, (139) the segments of the flowers of Rumex have tubercles which are called grains. Rúmex patiéntia, s. 4997.

Graniform, formed like grains of corn. Mesembryánthemum parvifólium, s. 7441

Granular, covered as if with grains. Gálium ánglicum, s. 1616 .

Gregarious, herding together. Agáricus fúsipes, s. 15857 .

Grooved, furrowed, channelled, marked with grooves. Caúcalis, g. 626. p. 115.

Grumous, clubbed, knotted, contracted at interval into knots. Aconítum napéllus, g. 1205. (note.)

Gynandrous, (140) having the stamens and style combined in one body. O'rchis, g. 1859

Gyrose, turned round like a crook. Urédo gyrósa, s. 16640 .

\section{H.}

Habit, features or general appearance of a plant. Diclíptera, g. 48, p. 9 .

Hamorrhages, copious bleeding. Acácia, g. 2127. (note.)

Hemorrhoid, a kind of disease. Ornithógalum, g. 802. (note.)

Hastate, (141) formed like the head of a halbert. Sálvia canariénsis, s. 372.

Hastato-lanceolate, between halbert shaped and lanceolate. Dicránum várium, s. 14728 .

Hastato-sagittate, between halbert-shaped and arrowshaped. A'rum maculátum, s. 13472.

Haulm, dead stems of herbs. Dioscórea, g. 2085. (note.)

Helmet, (134) the same as Galea; see Galeate. Monárda, g. 60 , p. 10.

Herbaceous, a plant the stem of which perishes annually. Maránta arundinácea, s. 18

Hermaphrodite, consisting of two sexes. Hippúris, g. 23. (note.)

Hexagonal, six-sided. I'ris ochroleúca, s. 782

Hexandrous, (142) having six stamens. Gardénia hexándra, s. 2834.

Hexangular, six-angled. I'ris gramínea, s. 795.

Hexapetalous, having six petals. Furcræ'a cubénsis, s. 4105 .

Hilum, (143) the scar or mark on a seed which indicates the place by which it adhered to the placenta. A'chras, g. 427. p. 111

Hirsute, rough with soft hairs. Pánicum miliáceum, s. 948 .

Hispid, rough with stiff hairs. Justícia ciliáris, s. 288.

Hoary, covered with white down. O'lea oleáster, s. 135 .

Homogeneous, having a uniform nature, or principle, or composition. Draparnáldia ténuis, s. 15105.

Honey-pore, (144) the pore in flowers which secretes honey. Geissorhiza rochénsis, s. 646.

Honey-scales, (145) the scales in flowers which secrete honey. Cotylédon, g. 1060. p. 341.

Honey-spots, the spots in flowers which secrete honey. Rúta, g. 998. p. 339 .

Hooded, (130) being curved or hollowed at the end into the form of a hood. Hippocratéa, g. 83. p. 30.

Horn, (146) any long subulate process in a flower is called a horn. Zíngiber, g. 10. p. 1.
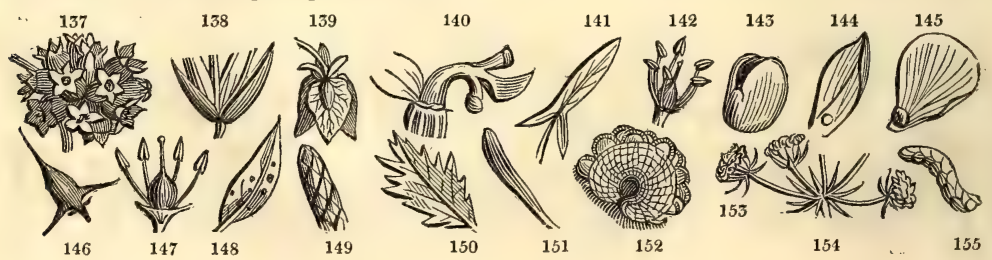

150

151

152

154

155
Husks, the dry envelopes of either flowers or fruits. Sporóbolus, g. 159. (note.)

yaline, crystalline, transparent. Diatóma, g. 2260. p. 924 . Syringa chinénsis $\delta$ rothomagénsis, s. 161

agogue, that which removes dropsy. Euphórbia, g. 1103: (note.)

ndicating the approach of moisture.

Hypocrateriform, salver-shaped. Galipéa, g. 41. p. 9 pogynous, (147) situated below the ovarium. Serúria, g. 234. p. 77.

ypophyllous, (148) under the leaf. Eríneum griseum, s. 16592 .

\section{I.}

Iced, (131) covered with particles like icicles. Me sembryanthemum pisifórme, s. 7210 .

ce-drops, transparent processes resembling icicles.

(149) laid one over another like tiles.

Maranta oblíqua, s. 19 .

traphis Browniána, s. 14682

Incurved, bending inward. Roscóea, g. 7. p. 1.

Incurve-recurved, bending inwards and then back

wards. Mesembryánthemum lineolátum, s. 7302

Indigenous, native of a country. Crócus, g. 93. (note.)

Indurated, hardened. Mílium, g. 141. p. 32

Indusium, (152) the membrane that encloses the thecæ

or ferns. Polybótrya, g. 2168. p. 876.

Inflexed, bending inward. Diclíptera, 9.78.

Inflorescence, disposition of flowers. Chloránthos, g. 25. (note.)

s. Tritónia fenestráta,

s. 672 .

Inspissated, thickened; spoken of sap or other liquor.

A'tropa, g. 446. (note.)

Intenerating, having the power of making tender or softening. Cárica, g. 2095. (note.) Bambusa, g. 752. (note.)

petiolar, between the petioles or leafstalks. Microloma, g. 578. (note.)

Intramarginal, within the margin. Listéra, g. 1876. p. 749.

Sántalum, g. 307. p. 79.

Involucels, (153) the partial involucra of umbelliferous

plants. Caúcalis platycárpos, s. 3528.

Involucral, having an involucre. Ammóbium, g. 1681 (note.) g. 148. p. 32

solucre, or Involucrum, (154) the bracteæ which surround the flowers of Umbelliferæ in a whorl

Caucalis platycárpos, s. 3528.

J.

Joints, the places at which the pieces of the stem are articulated with each other. Boerhaávia erécta, s. 105 .

uliform, (155) formed like an amentum or catkin. Brýum iuláceum, s. 14816. Mesembryanthemum glaciále, s. 7377. 
$\mathbf{K}$

Kaliform, formed like Sálsola káli, a sea-coast plant. Chóndria kalifórmis, s. 15291.

Keel, (51) when the midrib of a leaf or petal is sharp and elevated externally it is called a keel. p. 31.

Kneed, or Knee-jointed, bent like the knee-joint. Aconítum tortuósum, s. 7867.

\section{L.}

Labellum, (156) the front segment of an orchideous or other flower. Ionópsis, g. 1919. p. 750.

Lacinice, segments of any thing. Parmélia cyclosélis, s. 15581 .

Laciniate, cut or divided into segments. Phlómis laciniáta, s. 8365 .

Lactescent, yielding milky juice. Maclúra aurantíaca, s. 13256.

Lacuna, jittle pits or depressions. p. 948.

Lacunose, covered with little pits or depressions. Helvélla crispa, s. 16200

Lavigated, smoothed. Enothéra glaúca, s.. 5459.

Lamellated, (157) divided by plates internally. Músa, g. 721. (note.)

Lamina, literally a plate; it is mostly applied to the leaf of a plant considered without its petiole. Béta cícla. p. 207. (note.)

Lanceolate, (158) lance or spear shaped. Cóstus, g. 11. p. 1

Lanceolato-subulate, between lanceolate and subulate Sphágnum cuspidátum, s. 14653.

Lateral, on one side. Alpínia nútans, s. 43.

Lax, loose, not compact. Zingiber róseum, s. 59.

Leaflets, (159) small parts of compound leaves. Codárium acutifólium, s. 133.

Legume, or Legumen; $(160)$ a pod ; the fruit of leguminous plants. Gompholóbium, g. 954. (note.)

Leguminous, plants which bear legumes, such as the pea, the bean, the kidneybean. p. 8 .

Lenticular, shaped like a lens. Kyllinga, g. 129. p. 31.

Lentiform, in form like a lens. Rivina, g. 253.

p. 78.
Leprous, covered with spots or scales. Rhododendron ferrugíneum, s. 5923.

Lid, (161) the calyx which falls off from the flower in a single piece. Eucalýptus, g. 1126. p. 409.

Ligula, (162) the membrane at the top of the petiole of grasses and other plants. Zingiber pandurátum, s. 53.

Ligulate, (163) strap-shaped. Aneiléma sínicum, s. 595.

Limbate, having a colored or dilated surface. Eríca oppositifólia, s. 5265 .

Lirear, when the two sides are parallel. Cánna, g. 1. p. 1.

Linear-ensate, long sword-shaped. Márica califórnica, s. 833.

Linguiform, or Lingulate, (164) tongue-shaped. Hæmánthus coccíneus, s. 4149.

Lipped, (156) having a distinct lip or labellum Roscóea, g. 7. p. 1.

Lithontriptic, having the power of breaking the stone in the bladder. p. 1075.

Lobelets, (165) small lobes. Geránium sanguíneum, s. 9644

Lochial, relating to the natural discharges conse quient upon childbirth. Aristolóchia, g. 1934. (note.) Loccmotion, motion from place to place. Mimósa g. 2124. (note.)

Loculaments, partitions or cells of a seed vessel Cystoséira, g. 2329. p. 927.

Locular, (166) a fruit is called unilocular if it contains but one cell $(a)$, bilocular if two cells $(b)$, trilocular if three $(c)$, and so on. Fédia, g. 72. p. 11.

Loment, (167) a kind of legume falling in pieces when ripe. Mulléra, g. 1567. p. 597.

Lomentaceous, bearing pericarpia, called lomenta. Erucária, g. 1445. p. 539.

Lorate, (163) shaped like a thong or strap. Pancrátium littorále, s. 4062.

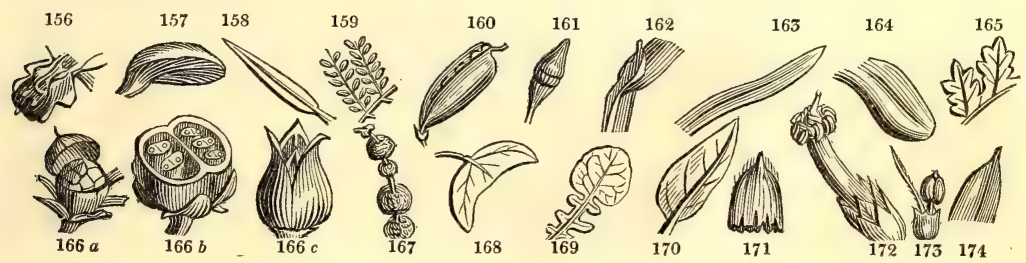

Lubricate, to make slippery. Acácia, g. 2127. (note.)

Lucid, bright, shining. Sálvia lineatifólia, s. 399.

Lunate, or Lunulate, (168) shaped like a half moon. Céstrum auriculátum, s. 2465.

Lurid, a color between purple, yellow, and grey. Moræ'a lúrida, s. 828 .

Lymphatic, of or belonging to lymph or sap. p. 874.

Lyrate, (169) lyre-shaped. Sálvia lyràta, s. 450.

\section{M.}

Macerate, to decompose by steeping in water or other liquid. Méntha, g. 1254. (note.)

Marginal, relating to the margin. Hellenia, g. 9. p. 1. Pimpinéla, g. 635. (note.)

Math, an old term for crop. Alopecurus, g. 164. (note)

Matrix, a place where any thing is generated or formed, Cálothrix, g. 2286. p. 925.

Medulla, the pith of a plant. p. 1053

Medullary, relating to the pith of plants. Mimósa, g. 2124. (note)

Melastomaceous, partaking of the nature or appearance of Melástoma. p. 300.

Melliferous, honey-bearing. Anchúsa, g. 332 . (note.) Membranaceous, or Membranous, having the texture of a membrane. Chionánthus marítima, s. 153.

Menstruum, a liquor used as a dissolvent. Ranúnculus, g. 1233. (note)

Meshes, the openings in any tissue. Mougeótia, g. 2290 . p. 925 .

Micacious, glittering, shining. Watsónia, g. 101 (note.)

Midrib, (170) the large vein which passes from the pe-

tiole to the apex of a leaf. Póthos, g. 252. (note.) médica, p. 655. (note.)

Mobility, the power of motion. Mimósa, g. 2124. (note.)

Monadelphous, (172) having the filaments cohering in a tube. I'xia monadélpha, s. 629 .

Monandrous, (173) having one stamen. Alchemílla A'phanes, s. 1519.

Moniliform, formed like a necklace, that is to say, with alternate swellings resembling beads and con.

tractions. Helióphila amplexicaúlis, s. 9312

Monocotyledons, having one seed leaf. p. 236.

Moncecious, having the one sex in one flower, and the other in another. Schœ'nus monoícus, s. 847.

Monopetalous, having one petal p. 9.

Monosepalous, having one sepal or division of the calyx. Pontedéria, g. 730 . p. 237.

Mordant, that which enables vegetable matter or tissue to receive dyes or coloring matter, and to retain them. p. 1064 .

Mottled, marked with blotches of color of unequal intensity passing insensibly into each other. Syringa pérsica, s. 162.

Mucilage, a turbid slimy fluid. Sálvia, g. 62. (note.)

Mucronate, (174) pointed sharp. Corispérmum in termédium, s. 127.

Mucronulate, having a little hard point. Bánksia integrifólia, s. 1459.

Mulch, a gardener's term for the placing manure about the roots of trees on the surface of the ground. Rósa, g. 1148. (note.)

Multifarious, very numerous; or arranged in many rows. A'loe rígida, s. 4387 .

Multipartite, much divided. Pterónia strícta. s. 11409

Multiplex, much multiplied. Selágo fasciculáta, s. 8657.

Muricated, covered with short sharp points. Pánicum muricátum, s. 949.

Muricato-hispid, covered with short sharp points and rigid hairs or bristles. Bryónia scabrélla, s. 13588.
Masticatory, grinding or chewing with the teeth.

Miliary, granulate resembling many seeds. Cítrus

Mitriform, (171) formed like a mitre. p. 895 . 
N.

Naiades, nymphs of the springs and fountains; a particular order of Monocotyledonous plants. p. 772 Narcotic, producing sleep or torpor. Brómus, g. 181. (note.)

Navicular, (175) boat-shaped. Airópsis, g. 160. p. 32

$\mathrm{Neck}$, the upper tapering end of bulbs is called the neck. Crínum sumatránum, s. 4184.

Nectariferous, bearing honey. Swértia, g. 599. p. 115.

Nectary, or Nectarium, $(144,145$.$) that part of a$ flower which produces honey. Alpinia Allúghas, s. 51 .

Nerves, the strong veins upon leaves or flowers. Cánna rubricaúlis, s. 11.

Nervimotion, the power of motion in leaves. Mimósa, g. 2124. (note.)

Nervose, or Nervine, composed of nerves. Eránthemum pulchéllum, s. 312 .

Neuter, neither male or female. Anthoxánthum, g. 76. p. 11

Nidulant, nestling; lying among any thing as a bird in its nest. Samýda, g. 1034. p. 340.

Nidus, the nest of any thing. Alcyonidium, g. 2267. (note)

Nodding, (177) having a drooping position. Verónica complicáta, s. 190

Nodi, (178) the articulations of plants: the place where one joint is articulated with another. Sporóchnus villósus, s. 15333.

Nodose, having many nodi or knots. Póa serótina, s. 1187.

Nodules, small hard knots. Ischæ'mum aristátum, s. 14230 .

Notch-flowered, having the flower notched at the margin. Verónica crenuláta, s. 185.

Nucamentaceous, producing nuts. Púnias, g. 1444.

p. 539.
Nucleus, the kernel. Myrica Fáya, s. 13869.

\section{O.}

$O b$ is used in the composition of Latin technical terms, to indicate that a thing is inverted ; for instance, obovate is inversely ovate, obcordate inversely cordate, and so on.

Occidental, coming from the west. Alpinia occidentális, s. 42 .

Ochraceous, having the color of clay or yellow ochre. Oscillatória ochrácea, s. 15118.

Octandrous, (179) having eight stamens. Rivina octándira, s. 1511

Octo ynous, (180) having eight styles. Phytolácca octándra, s. $65 \% 2$.

Officinal, any thing that is, or has been, used in the shops. Kæmpféria Galánga, s. 68.

Oleaginous, having the qualities of oil. Rivina, g. 253. (note.)

Oleraceous, esculent, eatable. Ranúnculus, g. 1233. (note.)

Olivaceous, having the qualities of olives. p. 924.

Opercular, (161) covered with a lid. p. 749 .

Operculiform, having the figure and position of a round lid of something. Operculáriá, g. 250 . p. 78

operculum, (161) a lid. p. 874

Opiate, having the power of opium. Dictámnus, g. 997 . (note.)

Orbicular, or Orbiculate, a plane surface circumscribed by a circle. Farsétia, g. 1397. p. 586.

Orchideous, of or belonging to the natural order of Orchídeæ. p. 748 .

Orifice, an opening. Schwénkia, g. 42. p. 9.

Ossified, become like bone. Cóix, g. 1951. p. 768

Ova, the eggs of any thing. Palmélia, g. 2265. (note.)

Oval, having the figure of an ellipse. Corispermum, g. 26. p. 1 .

Ovarium, or Ovary, (176) the part of the flower in which the young seeds are contained. Hæmodó rum, g. 111 . p. 31

Ovate, (181) egg-shaped. Maránta Tónchat, s. 22.

Ovato-acuminate, (182) egg-shaped, and tapering to a point. Cárex ovális, s. 13080.

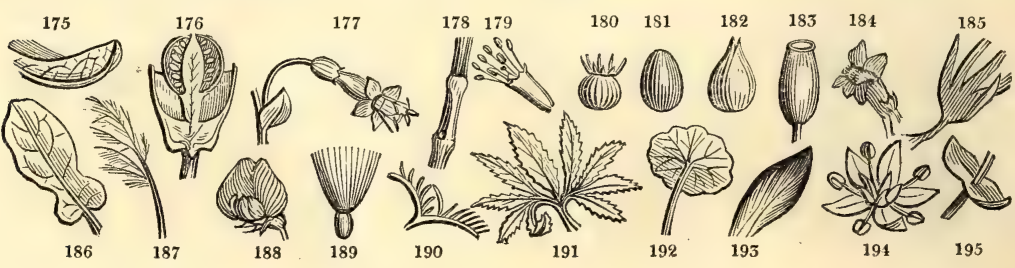

Ovato-cylindraceous, (183) egg-shaped, with a convolute cylindrical figure. Didýmodon purpúreum, s. 14762. Ovato-deltoid, triangularly egg-shaped. Bétula álba, s. 13188.

Ovato-rotundate, roundly egg-shaped. Pháscum múticum, s. 14660 .

Overlapping, when the margin of one thing lies upon that of another, it is said to overlap. Cýclamen vérnum, s. 2051.

Ovoid, (181) egg-like. Psorálea Lupinéllus, s. 10758.

Ovules, (176) the young seeds of plants contained in the ovarium. Nemóphila, g. 386. p. 110.

Palate, (184) the mouth of a ringent flower. Pinguícula edéntula, s. 327.

Paleaceous, abounding with chaffy scales. Bromélia

Palmated, or Palmatifid, (185) divided so as to resemble a hand. Curcáma Zedoária, s. 80.

Panduriform, (186) having the figure of a fiddle. Kæmpféria panduráta, s. 70 .

Panicled, (187) loose-spiked. Maránta, g. 2. p. 1.

Pannary, useful for making bread. Triticum, g. 206. (note.)

Papilionaceous, (188) butterfly-shaped flowers. p. 338 Papillose, producing small glandular excrescences like nipples. Onosmódium hispidum, s. 1930.

Pappus, (189) the crown of the fruit of Compósitæ, and similar plants. Centránthus, g. 20. p. 1

Papulose, producing small glands like pimples. Mesembryanthemum parvifólium, s. 7442.

Parabolically, in form like a parabola. A'loe brevifólia, s. 4435 .

Parenchyma, all the parts of plants which consist of cellular tissue only. Solorína, g. 2331. p. 948.

Parietal, being attached to the sides of an ovarium instead of its axis. Glóbba, g. 15. p. 1.

Patent, spread out or expanded. Lycopódıum annótinum, s. 14636 .

Patenti-reflexed, spread out and turned back. Cárex pauciflóra, s. 13069.

Patulous, slightly spreading. Centauréa babylónica, s. 12613

Pectirate, (190) resembling the teeth of a comb. Verónica orientális, s. 237.

Pectoral, relating to the breast. Trápa, g. 308. (note.) Pedatifid, (191) cut into lobes, the lateral ones of which do not radiate from the petiole like the rest. Saxifraga pedatífida, s. 6089 .

Pedicellate, slightly stalked. Céstrum tinctórium, s. 2475 .

Pedicels, small footstalks of flowers. Commelína coléstis, s. 592.

Peduncle, the common footstalk of flowers. Cánna Lambérti, s. 5

Pellicle, a thin skin. Papýrus, g. 128. (note.)

Pellucid, bright, transparent. Mesembryánthemum réptans, s. 7278 .

Peltate, (192) when the petiole is fixed in the disk instead of the margin. Píper peltátum, s. 514.

Pencilled, (193) marked in lines as if with a pencil. Crócus lagenæflórus $\gamma$ penicillátus, s. 612.

Pendulous, drooping, hanging down. Curcáma angustifólia, s. 91.

Pentagonal, having five angles. Piquéria, g. 1704. p. 663.

Pentagynous, (194) having five styles. Phytolácca abyssinica, s. 6573

Pentandrous, (194) having five stamens. Portlándia grandiftóra, s. 2622 .

Pentapetalous, (194) having five petals. p. 115

Perennial, lasting many years without perishing. Aspicárpa úrens, s. 132

Perfoliate, (195) when the stem passes through the base of the leaf. Verónica perfoliáta, s. 25l.

Perianthium, the envelope that surrounds the flower; this term is applied when the calyx cannot be distinguished from the corolla. Gomphréna perénnis, s. 3178 . 19 Karátas, s. 4114. (note.) 
Pericarp, the seed vessel. Deeringia, g. 563. (note.) Perichatial, (196) leaves which in mosses surround the base of the stalk of the theca. p. 895 .

Perigynous, (197) inserted into the calyx. Larbræ'a, g. 1064 . p. 341 .

Peristome, (198) the rim which surrounds the orifice of the theca of a moss. p. 895 .

Perithecium, Peridium, or Perisporium, different kinds of envelopes of the reproductive organs of Fúngi. Pyrénula, g. 2337. p. 948.

Persistent, remaining, not falling off. Codárium, g. 30 . p. 8.

Pervious, having a passage through which anything can be transmitted. Primula, g. 350. p. 110.

Petaloid, like a petal. Damasónium, g. 859. p. 241

Petals, (194) divisions of the corolla. p. 1.

Petiolate, having footstalks. Alpínia malaccénsis, s. 46 .

Petioles, footstalks of leaves. Císsus heterophýlla, s. 1780 .

Petiolules, little petioles. Erythrína, g. 1521. (note.)

Pezizoid, like a Pezíza ; a kind of fungus resembling a cup in figure. p. 1021.

Phenogamous, such plants as are visibly furnished with sexual organs. p: 108

Phagedenic, eating, corroding; a gnawing of the stomach ; also applied to ulcerous sores. A'nthemis, g. 1778. (note.)

Pharmaceutical, relating to the art of pharmacy. Astrágalus Tragacántha, p. 637. (note)

Phthisis pulmonalis, consumption of the lungs. Acácia, g. 2127. (note.)

Pileate, (199) having a cap or lid like the cap of a mushroom. Cúscuta chilénsis, s. 1811.

Pileus, the cap of a mushroom, p. 9i8.

Piliferous, bearing hairs. Sphenógyne dentáta, s. 12528 .

Piliform, formed like down or hairs. Grímmia pulvináta, s. 14690

Pilose, slightly hairy. Monárda Kalmiána, s. 363.

Pimpled, covered with minute pustules resembling pimples. Saxífraga liguláta, s. 6051.

Pinnce, or Pinnula, the segments of a pinnated leaf. Calceolária pinnáta, s. 315 .

Pinnate, (200) a leaf is so called when it is divided into numerous smaller leaves or leaflets. Codárium acutifólium, s. 133

Pinnatifid, (201) a leaf is so called when it is divided into lobes from the margin nearly to the midrib. Centránthus calcitrápa, s. 112.

Piquancy, sharpness, pungency. Spilánthes, g. 1605. (note.)

Pisiform, formed like peas. Lagétta, g. 909. p. 300.

Pistillum, or Pistil, (202) the columnar body situate in the centre of a flower, consisting commonly of three parts, viz. the ovarium, style, and stigma. Knáppia, g. 142 , p. 32

Pitchers, (203) hollow leaves so called. Nepénthes distillatória, s. 14077

Pith, medulla occupying the centre of a stem or shoot. Mélicá, g. 193. (note)

Pituitous, discharging mucus. Pánax, g. 2166. (note.)

Plane, flat. Matricária, g. 1771. p. 664 .

Plano-compressed, compressed down to a flattish surface. Poinciána, g. 977. p. 339 .

Plethoric, having a full habit. Juníperus, g. 2113. (note.)

Plicate, (204) plaited. Nicotiána repánda, s. 2206

Plumose, (205) feathery, resembling feathers. Centránthus, g. 20. p. 1

Plumula, (206) the young leaves in the embryo. p. 1053.

Plurilocular, (207) having many cells. p. 1085 .

$P o d,(160)$ a kind of seed vessel such as that of the pea tribe. Epimédium, g. 297. p. 79.

Polyandrous, (208) having more stamens than 20 Royéna ambigua, s. 6037 .

Polygamous, a plant is said to be polygamous when some flowers are male, others female, and other hermaphrodite. Rhagódia, g. 562. p. 114.

Polygynous, (208) having numerous styles. Royéna ambigua, s. 6037.

Polypetalous, (209) having many separate petals. p. 10.

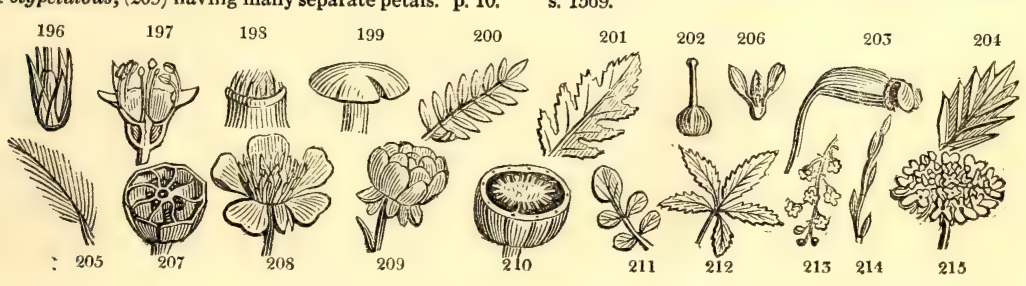

Polyspermous, (210) having many seeds. p. 1066.

Pome, an apple. Pýrus, g. 1133.

Pores, apertures in the cuticle through which p. 113 .

Porrect, extended forward. Bauhinia aurita, s. 5768

Pouch, a little sack or bag at the base of some petals and sepals. Nigritélla, g. 1860.

Prenomen, the first name of several; in plants it is the same as the generic name. Crócus, g. 93. (note.)

Precocity, ripe before the usual time. Dáphne Mezéreum, p. 3บS. (note.)

Prismatic, formed as a prism. Polycnémum arvénse, s. 599

Processes, protrusions either natural or monstrous. Orthotríchum, g. 2233. p. 896.

Proliferous, a plant is said to be proliferous when it forms young plants in abundance about its roots.

Scírpus Lázulæ, s. 867.

Prominences, protuberant risings from the surface. Colutéa arboréscens, s. 10484.

Propendent, hanging forward and downward. Cæ'sia vittáta, s. 4831.

Prurient, stinging. p. 1061

Pubescence, down, closely pressed to the surface Fragária vésca, s. 7566

Pullulating, budding. Conférva pátens $\beta$ prolífera, s. 15177.

Pulverised, reduced to powder. Crócus, g. 93. (note.) Pulvinate, become cushion-shaped. Grímmia pul

Pulvinuli, little cushions. p. 948.

Punctiform, formed like points. Pezíza punctáta, s. 16267.

Pungent, stinging or pricking. Corispérmum Redowskii, s. 126.

Pustular, or Pustulate, covered with glandular excres. cences like pustules. Pelargónium pustulósum, s. 9621 .

Pustules, pimples or little blisters. Brunsvigia Rádula, s. 4215.

Pyriform, shaped like the fruit of a pear. Paullinia pinnáta, s. 5612

\section{Q.}

Quadrangular, four-angled. Dorsténia Houstóni, s. 1526.

Quadrifarious, arranged in four rows or ranks.

Struthíola imbricáta, s. 1487.

Quadrifid, divided four times. Plantágo, g. 278. p. 78. Quadriglandular, having four glands. Malpighia glandulifera, s. 6373 .

Quartz, a species of stone. Laúrus cinnamómum, s. 5640 .

Quaternary, succeeding by fours. p. 76 .

Quaternate-pinnate, (211) pinnate; the pinnæ being arranged in fours. Anthýllis tetraphýlla, s 10211.

Quinate, in fives. Póthos pentaphýlla, s. 1506.

Quinquefid, (212) divided into tive. Císsus, g. 305. (note)

Quintuple, five times multiplied. Ephédra, g. 2115 p. 819

R.

Racemes, (213) a particular arrangement of flowers, when they are arranged around a filiform simple axis, each particular flower being stalked. Alpinia nútans, s. 43 .

Racemose, flowering in racemes. Verónica Barreliérı, s. 212 .

Rachis, (214) that part of a culm which runs up through the ear of corn, and consequently the part that bears the flowers in other plants. Páspalum, g. 139. p. 31 .

Radiant, or Radiate, (215) a flower is said to be radiant, when, in a cluster or head of florets, those of the circumference or ray are long and spreading, and unlike those of the disk. Scabiósa canéscens, s. 1569. vináta, s. 14640 
Radical, proceeding from the root. Phrýnium capitátum, s. 27.

Radicant, producing roots from the stem. Marc graávia, g. 1163. (note.)

Radicule, (216) that end of the embryo which is op. posite to the cotyledons. p. 537

Radius, (217) the ray of compound flowers. Solidágo canadénsis, s. 12066.

Ramenta, little brown withered scales with which the stems of some plants, especially ferris, are covered. Rhodoméla lycopodioídes, s. 15280.

Ramentaceous, (218) covered with ramenta. Euphórbia fragífera, s. 6793 .

Ramifications, subdivision of roots or branches. Eragróstis pilósa, s. 1207.

Ramose, branchy. I'lex, g. 315. (note.)

Ramuli, twigs or small branches. Draparnáldia g. 2284 . p. 925 .

Raphe, in seeds this is the channel of vessels which connects the chalaza with the hilum; in umbelliferous plants it is the line of junction of the two halves of which their fruit is composed. Búbon, g. 640 . p. 116.

Rationale, the reason of a thing. Solanum, g. 451. (note.)

Receptacle, (219) that part of the fructification which supports the other parts. Pollichia, g. 21. p. 1.

Recesses, the bays or sinuses of lobed leaves. Sisýmbrium obtusángulum, s, 9169 .

Rectangular, right-angled. Teácrium asiáticum, s. 8114 .

Rectilinear, right-lined. Bómbax eriánthos, s. 9942.

Rectum, an intestine. A'nthemis, g. 1778. (note.)

Recurved, bent backward. Zíngiber, g. 10. p. 1.

Recurvo-patent, bent back and spreading. Grímmia apocárpa, s. 14687.

Reflexed, bent backward. Cánna gigantéa, s. 6 .

Reflexed recesses, sinuses of leaves which are ben backward from the ordinary direction of the surface of a leaf. p. 165 .

Refrigerant, producing coolness. Oxális, g. 1065. (note.)

Reniform, (220) kidney-shaped. Leptánthus renifórmis, s. 736

Repand, (221) a leaf having a margin undulated and unequally dilated is said to be repand. Eránthemum bícolor, s. 313 .

Repando-dentate, repand and toothed. Dorónicum Pardaliánches, s. 12189.

Repellant, that which turns you away from any thing. $A^{\prime}$ tropa, g. 446. (note.)

Replicate, folded back. Cyclópia, g. 946. (note.)

Resolutive, or Resolvative, having the power to dissolve. Argemóne, g. 1172. (note.)

Resolvent, having the power of dissolving. Curcúma, g. 14. (note.)

Restringent, astringent. Bérberis, g. 829. (note.)

Resupinate, inverted in position, so that that which was in front becomes at back. Hedýchium, g. 6 p. 1.

Reticulated, resembling a net. Hákea unduláta, s. 1435 .

Retuse, (222) abruptly blunt. Hedýchium flávum, s. 36 Revolute, rolled back. Cánna speciósa, s. 13.

Rhomboidal, (225) like a rhombus. Sálvia mexicána, s. 385 .

Rhomboid-ovate, rhomboidally egg-shaped. Chenopódium atríplicis, s. 3416

$R i b,(170)$ the projecting vein of any thing. Curcúma rubéscens, s. 83 .

Rigid, stiff. Notelæ'a rígida, s. 157.

Ringent, (223) gaping. Justícia, g. 47. p. 9

Ringing, making an incision resembling a ring al round a branch. Liriodéndron, g. 1216. (note.)

Rotate, (224) a monopetalous corolla, the limb of which is flat and the tube very short, is called rotate. Valerianélla discoídea, s. 563 .

Rotundo-ovate, roundly egg-shaped. Cárex fulva, s. 13123.

Rubefacient, any thing which reddens the skin, or raises slight cutaneous inflammation. Euphórbia g. 1103. (note.)

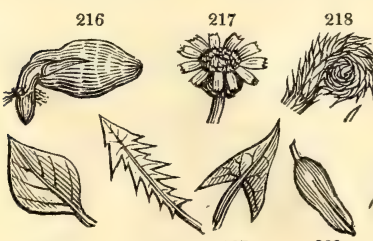

225

226

227

228

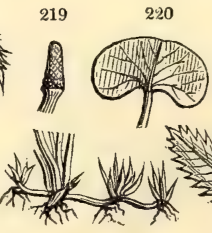

229

Rudiment, when an organ is imperfectly developed, botanists call such developement a rudiment. Molínia, g. 194. p. 33 .

Rufou's, reddish orange-colored, or rusty. Cánna glaúca $\beta$ rúfa, s. 16.

Rugose, rough or coarsely wrinkled. Calceolária rugósa, s. 317.

Rugulose, finely wrinkled. Sálvia chamædryoídes, s. 386 .

Runcinate, (226) hooked back, applied to the lobes of leaves. Hésperis runcináta, s, 9161

Runcinato-dentate, hooked back and toothed. Apárgia taráxaci, s. 11166.

Runners, (22.9) procumbent shoots which root at their extremity. Ranúnculus salsuginósus, s. 8037.

Rusty, rust-colored. Curcúma ferrugínea, s. 87.

\section{S.}

Saccate, bagged; having a bag or pouch; as many petals. Calótropis, g. 584. p. 115.

Sagittate, (227) shapedlike an arrow-head. Dorsténia arifólia, s. 1528

Salivation, a discharge of saliva from the glands of the mouth. Plumbágo, g. 324. (note))

Samara, (228) a kind of winged seed vessel ; the same as what the English call key. O'rnus, g. 69. p. 11. Sapid, agreeable to the palate. Nelúmbium, g. 1213. (note.)

Saponaceous, soapy. E'sculus, g. 866. p. 296

Sarmentose, (229) producing sarmenta or runners. Echítes biflóra, s. 2355 .

Sawed, resembling the teeth of a saw. Coldénia procúmbens, s. 1833.

Scabrous, rough with little asperities. Salvia runcináta, s. 459 .

Scales, any small processes resembling minute leaves; also the leaves of the involucrum of Compósitæ. Pollíchia, g. 21. p. 1.

Scandent, climbing. Píper, g. 77. (note.)

Scape, (231) a stem rising from the root and bearing nothing but flowers. Maránta comósa, s. 24

Scariose, or Scarious, membranous and dry. Bufónia tenuifólia, s. 1813

Schistous, rocky, formed of the rock called schist. O'lea, g. 32. (note.)

Scion, a shoot intended for a graft. Caméllia, g. 1476. (note.)

Scorice, cinders. Caméllia, g. 1476. (note.)

Scrobiculate, excavated into little pits or hollows. Antennária, g. 1725 . p. 663.

Scrotiform, formed like a double bag. Ellisia, g. 432. p. 111.

Scurfy, covered with scales resembling scurf. Eastoma, g. 365. p. 110.

Scutate, formed like an ancient round buckler. Ptilóta, g. 2311. p. 925.

Secund, (232) arranged on one side only : the same as unilateral, which is better. p. 917 .

Sedges, a tribe of marsh plants so called. p. 31.

Segments, parts of any thing. p. 1

Semi-, half.

Seminal, belonging to the seed. Scabiósa, g. 264. (note.)

Semination, seeding. Crócus, g. 93. (note.)

Sepals, (233) the segments of the calyx. Sebæ'a, g. 281. p. 98.

Septa, (166) the partitions that divide the interior of the fruit. Rulíngia, g. 704. p. 118.

Septiferous, bearing septa. Ramónda, g. 374. p. 110.

Serrated, (230) like the teeth of a saw. Mayténus boária, s. 134 .

Serrulations, notchings like those of a saw. Agáve yuccæfólia, s. 4093 .

Sessile, without footstalks. Zostera, g. 24, p, 1.

Setaceo-rostrate, having a beak with the figure of a bristle. Cárex ampullácea, s. 13162

Sctaceous, resembling a bristle in shape. Justícia nígricans, s. 282.

Seta, bristles. Schœ'nus nígricans, s. 845.

Setiform, (234) formed like a bristle. Rósa hibérnica, s. 7501 . 
Setigerous, or Setose, covered with bristles. Knáppia, g. 142 . p. 32 .

Sheath, the lower part of the leaf that surrounds the stem. Zostéra, g. 24, p. 1.

Sherds, the fragments of potting employed by gar deners to drain their flower-pots. Prótea, g. 231 (note.)

Shield, (29) a broad table-like process in the flower o Stapélia and its allies. Huérnia clavígera, s. 3351. Sialagogue, having the power of exciting saliva. p. 536 .

Silicated, coated or mixed with flint. Astrágalus tragacántha, p. 637. (note.)

Siliceous, flinty. Laúrus cinnamómum, g. 934. (note.) Silicle, (235) the small round pod of Crucíferæ. Lunária, g. 1395 . p. 536 .

Silique, (236) the long taper pod of Crucíferæ. Brássica, g. 1432

Simple, the reverse of compound. p. 1

Sinuate, or Sinuose, (237) bending in and out. Lycó pus europæ'us, s. 338.

Sinuato-dentate, sinuate and toothed. Leóntodon palústris, s. 11156 .

Sinus, the bays or recesses formed by the lobes of leaves or other bodies. Hamamélis virgínica s. 1814 .

Soboliferous, (238) producing young plants from the root. A'loe brévis, s. 4415 .

Soddened, soaked. Prótea, g. 231. (note.)

Somniferous, causing sleep. Primula véris, s. 2029

Soporific, causing sleep. Húmulus, g. 2074. (note.)

Sorediferous, (239) bearing soredia. Ramalina g. 2355 . p. 949.

Sori, (152) the patches of fructification on the back of the ironds of ferns. p. 925.

Spadix, (240) a spike protracted from a spatha. Zostéra, g. 24. p. 1.

Spatha, a broad sheathing leaf enclosing flowers arranged upon a spadix. Hedýchium spicátum, s. 34 Spathaceous, furnished with a spatha. p. 1.

Spathulate, (241) shaped like a spatula, a knife so called. Cánna gigantéa, s. 6.

Sphacelate, withered or dead. Senécio ægýntius, s. 11911.

Spherical, round like a sphere. Alpínia nutans, s. 4.3.

Spheroidal, almost like a sphere. Cáctus latispínus, s. 6850 .

Spherules, (242) minute spheres. Stromatosphæ'ria concéntrica, s. 16360

Spike, (214) flowers sessile upon a long rachis. Maránta lútea, s. 20.

Spines, indurated branches or processes formed of woody fibre, and not falling off from the part that bears them. Ancístrum, g. 68. p. 10.

Spiniform, formed like a spine. Mesembryánthemum spinifórme, s. 7363.

Spinous, full of spines. Alpínia cérnua, s. 44.

Spinulescent, having a tendency to produce small spines. Mesembryánthemum spinuliferum, s. 7421

Spinulose, covered with small spines. Rhéum Ríbes, s. 5667 .

Spiral, (253) circularly involved. Cóstus spirális, s. 65.

Sporules, that part in Cryptogamous plants which answers to the seeds of other plants. p. 874.

Spornliferous, bearing sporules. Phállus impudícus, s. 16936 .

Spurious, counterfeit. I'ris spúria, s. 781.

Spurs, (243) long processes resembling horns produced by various parts of the flower. Curcúma, g. 14. p. 1. Squamiform, like scales. Sántalum, g. 307. p. 79.

Squarrose, (244) spreading rigidly at right angles, or in a greater degree Zingiber squarrósum, $s, 60$.

Squinancy, an inflammation in the throat. Aspérula, g. 268. (note.)

Stamen, (245) the male organ of a flower. p. 1

Staminiferous, producing stamina. Campánula, g. 463. p. 112.

Standard, (188) the upper segment of the flower of Leguminósæ. Thermópsis, g. 944 , p. 338 Stellate, in the manner of a star. Schwénkia, g 42.

$$
\text { p. }
$$

235

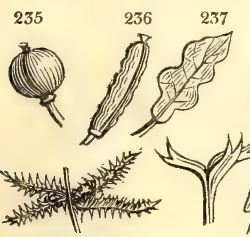

244

246245

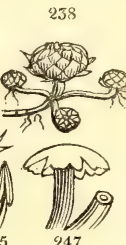

247

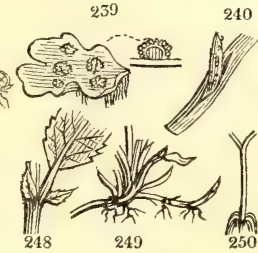

$4 \mathrm{~B}$
Stellulate, resembling little stars. Onósma taúricum, s. 1907.

Sterile, barren. Amómum grandiflórum, s. 74

Sternutatory, qualities which provoke sneezing. Prí mula vulgáris, g. 350. (note.)

Stigma, (246) the female organ of a flower. Cánna, g. 1. p. 1.

Stimulating, exciting. Cínna, g. 161. (note.)

Stimuli, stinging hairs. U'rtica árdens, s. 13230.

Stipes, $\left(24^{7}\right)$ the stalk of Fungi. p. 978.

Stipitate, having a short stalk, Aspidistra, g. 759. p. 238 .

Stipulaceous, having appendages called stipulæ. Solánurr peruviánum, s. 2516.

Stipulary, occupying the place of stipulæ. Paliúrus austrălis, s. 2896.

Stipules, (248) small scales at the base of the petiole of certain leaves. Spermacóce stylósa, s. 1653.

Stoloniferous, (249) having creeping roots. Sesleria elongáta, s. 1075 .

Stolons, root shoots. Agróstis, g. 156. (note.)

Stomachic, relating or agreeable to the stomach. Kæmpféria, g. 12. (note.)

Strangury, a disease, and produced on plants by tight ligatures. Ornithógalum, g. 802. (note.)

Strata, layers, beds. Cápsicum, g. 45.3. (note.)

Strice, small streaks, channels, or furrows. p. 877.

Striated, having striæ. Alpínia racemúsa, s. 41.

Strige, little, rigid, unequal, irregular hairs. Chára

hispida, s. 15199

Strigose, having strigæ. Lithospérmum arvénse, s. 1895.

Strophiolate, surrounded by protuberances. Hóvea, g. 1536. p. 599.

Struma, a wen or protuberance. p. 903.

Strumose, or Strumous, covered with strumæ. Me. sembryánthemum gróssum, s. 7422

Style, $(250)$ the stalk which intervenes between the ovarium and stigma, bearing the latter. p. 1 .

Styptic, having the power to staunch blood. Rhús, g. 681. (note.)

$S u b$, in composition, signifies subordinate, or somewhat.

Succedaneum, coming in the place of another. Tácca, g. 758. (note.)

Succulent fleshy and filled with juice. Blitum, g. 28 (note.)

Sudorific, having the power of producing perspiration. Sálvia, g. 62. (note.)

Suffiruticose, shrubby in a slight degree. Spermacóce suffruticósa, s. 1656

Sulcate, furrowed. Vibórgia, g. 1523. p. 599.

Supernatant, floating on the surface of any thing. Aloe, g. 770. (note.)

Suppurate, to generate matter. Rhús, g. 681. (note.) Supra-decompound, doubly compounded. Scírpus sylváticus, s. 868 .

Surculi, young shoots. Erythrónium, g. 782. (note.)

Suture, the line formed by the cohesion of two parts. Mirbélia, g. 967. p. 338.

Syngenesious, (251) belonging to the nineteenth class of the sexial system. Phlox, g. 369. (note.)

Synthetical, combining; opposed to analytical. Gillénia, g. 1142. (note.)

Syphilitic, useful in the cure of syphilis. Chenopódium, g. 611. (note.)

\section{T.}

Tails, (252) the long feathery or hairy terminations of certain fruits. Clématis chinénsis, s. 7968.

Tap-root, a root which penetrates deep and perpendicularly into the ground without dividing. Crinum defixum, s. 4182

Tartareous, consisting of tartar. Lecidéa cónfluens, s. 15384 .

Teated, resembling the figure of the teat of animals. A'chras, g. 427. p. 111.

Tendrils, (253) the curling twining organs by which some plants lay hold of others. Vitis indica s. 2858 .
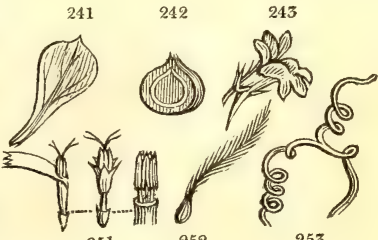

252

253 
Tenesmus, a disposition to go to stool, without the power of evacuation. $\mathbf{A}^{\prime}$ nthemis, g. 1778. (note.) Tepid, lukewarm. A'nthemis, g. 1778. (note.)

Terebinthinate, consisting of turpentine. A'bies bal sámea, p. 805 . (note.)

Terete, taper, round and long. Hákea oblíqua, s. 1423 Terminal, ending, or at the top. Maránta látea, s. 20.

Ternary, consisting of threes. Valeriána, g. 78. (note.) Ternate, (254) growing together in threes. Hedýchium elátum, s. 31.

Tessellated, variegated by squares. Sarcocéphalus, g. 498. p. 113.

Testa, the skin or integument of the seed. Psídium, g. 1118. p. 409

Testaceous, having a pale brown color. Mesembryánthemum testáceum, s. 7430.

Tetrachotomous, (255) a stem that ramifies in fours. Euphúrbia, g. 1103. (note.)

Tetrandrous, (256) having four stamens. Collinsónia anisáta, s. 469.

Tetrapetalous, (256) having four petals. p. 1069

Tetrasepalous, (256) having four sepals. p. 1069.

Thalamus, (258) that part of a flower which rises from below the ovarium and sometimes supports the outer envelopes, p. 539.

Thallus, (257) that part which bears the fructification of Lichens. p. 874 .

Thece, the cases that contain the sporules of Cryp. togamic plants. p. 874 .

Threads, long delicate hairs. Anacámpseros filamentúsa, s. 6632 .

Throat, $(120)$ the orifice of a flower. Justicia picta, s. 285 .

Thyrse, (259) a kind of dense panicle like that of the lilac. A'juga furcáta, s. 8099.

Thyrsoid, resembling a particular kind of panicle called a thyrsus. p. 85 .

Tomentose, densely and closely hairy. Thýmus tomentúsus, s. 8414.

Tomentum, dense close hair. Grevíllea buxifólia, s. 1418.

Tonic, bracing, corroborative. Sálvia, g. 62. (note.)

Toothed, (260) divided so as to resemble teeth. Pol. líchia, g. 21. p. 1

Toothletted, furnished with little teeth. Sálvia paniculáta, s. 402

Topical, local, confined to some particular place. Papáver, g. 1170. (note.)

Torose, uneven; alternately elevated and depressed. Papáver hýbridum, s 7659 .

Tortuose, twisted. Heliánthemum Fumána, s. 7773.

Torulose, slightly torose. Echítes torósa, s. 2357.

Torus, (258) the same as thalamus, which see. Sisýmbriurn, g. 1422 . p. 537.

Trapeziform, in the shape of a trapezium. Borónia serruláta, s. 5091.

Trapezoid, like a trapezium. Adiántum villósum, s. 14554 .

Triandrous, (261) having three stamens, p. $\delta 0$.

Trichotomous, (102) branches divided in threes. Tri chódium decúmbens, s. 1000.

Tricuspidate, (262) having three points. Allium Púrrum, s. 4617 .

Trifarious, arranged in triple rank. A'loe tortuósa, s. 4386.

Trifid, divided in three. Mantísia, g. 16. p. 1.

Trilocular, (166) having three cells. Leptospérmum triloculáre, s. 6931.

Tripetaloid, appearing as if furnished with three petals. Tillándsia xiphioídes, s. 4144.

Tripetalous, having three petals. Elatine hydropiper, s. 5635 .

Triquetrous, having three sides or angles. A'loe reticuláta, s. 4392 .

Triturated, reduced to powder by pounding, Amýgdalus, g. 1128. (note.)

Tropical, belonging to the torrid zone. Conocárpus, g. 544. (note.)

Truncate, (263) blunt, as if cut off. Hedýchiurn spicátum, s. 34 .

mubrculate, covered with knobs or tubercles. Ranúnculus parviflórus, s. 8073.
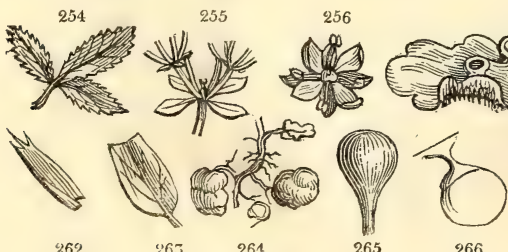

266
Tuberous, (264) bearing solid fleshy roundish roots like the potato. Cánna edulis, s. 12.

Tubers, roots so called. Curcúma, g. 14. (note.)

Tumid, swelling. Secále orientále, s. 1267.

Tunic, a coat. Crócus pusillus. s. 606.

Tunicated, having a coat. A'llium Pórrum, s. 4617.

Turbinate, (265) having the figure of a top. Salicórnia, g. 22. p. 1.

Turgid, swollen, puffed up. Brómus praténsis, s. 1132

U.

Umbellules, (153) divisions of an umbel. Caúcalis daucoídes, s. 3524

Umbels, (154) the round tuft of flowers produced by the carrot, \&c. Boerhaávia scándens, s. 108

Umbilicus, (266) the cord which attaches the seed to the receptacle. Bérberis, g. 829. p. 239.

Umbonate, (267) having a top in the centre like that of

the ancient shield. Cucúrbita Melopépo, s. 13566

Unarmed, destitute of prickles or spines, which are

the arms of plants. Corispérmum hyssopifúlium s. 124.

Uncinate, (268) hooked. Píper adúncum, s. 502.

Unctuous, fat, oily. Anchúsa, g. 333. (note.)

Undulate, waved. Sálvia pomifera, s. 370.

Undulato-rugose, rugose or rugged and waved. Stromatosphæ'ria deústa, s. 16361 .

Unguiculated, furnished with a short unguis. Alpínia galánga, s. 40.

Unguis, (269) the taper base of a petal. Diantlıus, p. 372. (note)

Unilateral, one-sided. Brachypódium loliáceum, s. 1147

Unilocular, (166) one-celled. Calepína, g. 1441. (note.) Unisexual, being of one sex. Próckia, g. 1179. (note.)

Urceolate, (270) pitcher-shaped. Camphorósma, g. 254 p. 78 .

Uterine, belonging to the womb. Acácia, g. 2127. (note.)

Uterus, the womb. p. 981.

Utricle, or Utriculus, a little bottle or bladder. Salicúrnia, g. 22. p. 1 .

Uvula, the gland of the throat. Acácia, g. 2127. (note.)

V.

Valvular, (271) or Valved, consisting of valves or seed cells. p. 895 .

Varicose, (272) swollen here and there. Pterocárpus, g. 1515 . p. 598

Vascular, (273) consisting of tissue in a very succulent enlarged state. Potamogéton, g. 317. (note.)

Vaulted, (274) formed or placed like the roof of a vault. Gladiolus namaquénsis, s. 709.

Veneering, the art of covering one kind of wood with thin plates of another kind. Spártium scopárium, p. 611. (note)

Ventricose, (275) inflated. Gastridium, g. 155. p. 32.

Veratrine, the active principle of Verátrum. Verátrum, g. 2128. (note.)

Vermifuge, that which expels worms. Helléborus, g. 1237. (note.)

Vernacular, native, Zingiber, g. 10, (note.)

Vernal, belonging to the spring. Verúnica vérna s. $25 t$.

Ver-satile, (276) swinging lightly on a stalk so as to be continually changing direction. Sternbérgia, g. 742 p. 237.

Vertex, the uppermost point. Röméria, g. 1168. p. 456 .

Vertical, perpendicular. Nivénia, g. 235. p. 77.

Vertically compressed, that is depressed. Salicórnia, g. 22. p. 1 .

Vertilinear, the same as rectilinear; in a straight line. Viola campéstris, s. 3037.

I'esicatories, blistering plasters. Ranúnculus g.1233. (note.)

257
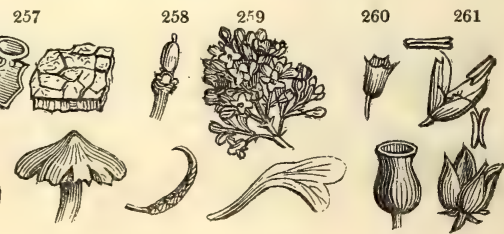

267

268

269

$270 \quad 271$ 
Vesicles, (277) hollow excrescences resembling bladders, g. 310. (note.)

Vexillum, (188) a standard ; the upper petal of a papilionaceous flower. Petalostémum, g. 1501. p. 598. Villons, (278) shaggy, with long loose hair. Cóstus villosíssimus, s. 66 .

Virescent, green, flourishing. Mesembryánthemum viréscens, s. 7275

Virgate, twiggy. Verbáscum cúpreum, s. 2152.

Viscid, or Viscous, adhesive, clammy. Boerhaávia viscúsa, s. 109.

Vivacious, lively. Cárduus, g. 1663. (note.)

Viviparous, (279) bearing young plants in the place of nowers and seed. Márica cærúlea, s. 841 .

Vuinerary, useful in the cure of wounds. Sýmphytum, g. 334. (note.)

Vulvijorm, like a cleft with projecting edges. Melampódium, g. 1828. p. 665.

\section{- signifies wanting or"absent. p. 79.}

$\mathrm{O}$, very numerous.

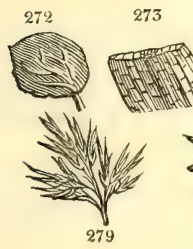

273

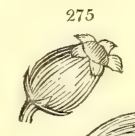

W.

Wattled, having processes like the wattles of a cock. Rhinánthus alectorolóphus, s. 8746.

Welted, flaccid, drooping. Cárduus acanthoídes, s. 11375 .

porls, (280) leaves inserted round a stern. Hip

Wing, (281) in botany, signifies a membranous border, wherewith many seeds are supported in the air when floating from place to place. Amómum dealbátum, s. 77 .

\section{$\mathbf{z}$}

Zones, (282) stripes or belts. Zonária pavónia, s. 15338.
274

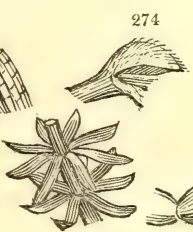

280

\begin{abstract}
276
\end{abstract}

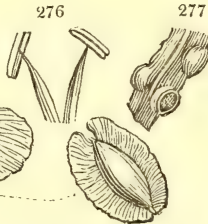

281
278

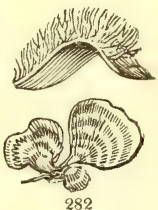




\section{TABLE OF SUCH}

\section{AS HAVE SYNONYMES IN}

IN this Index, the systematic names in col. 1. are distinguished as classical, i. e. names memorative, by the terminating letter or letters being in Italic, as Banksia; and as the other names are formed, in almost every case, from the Greek, but sometimes from

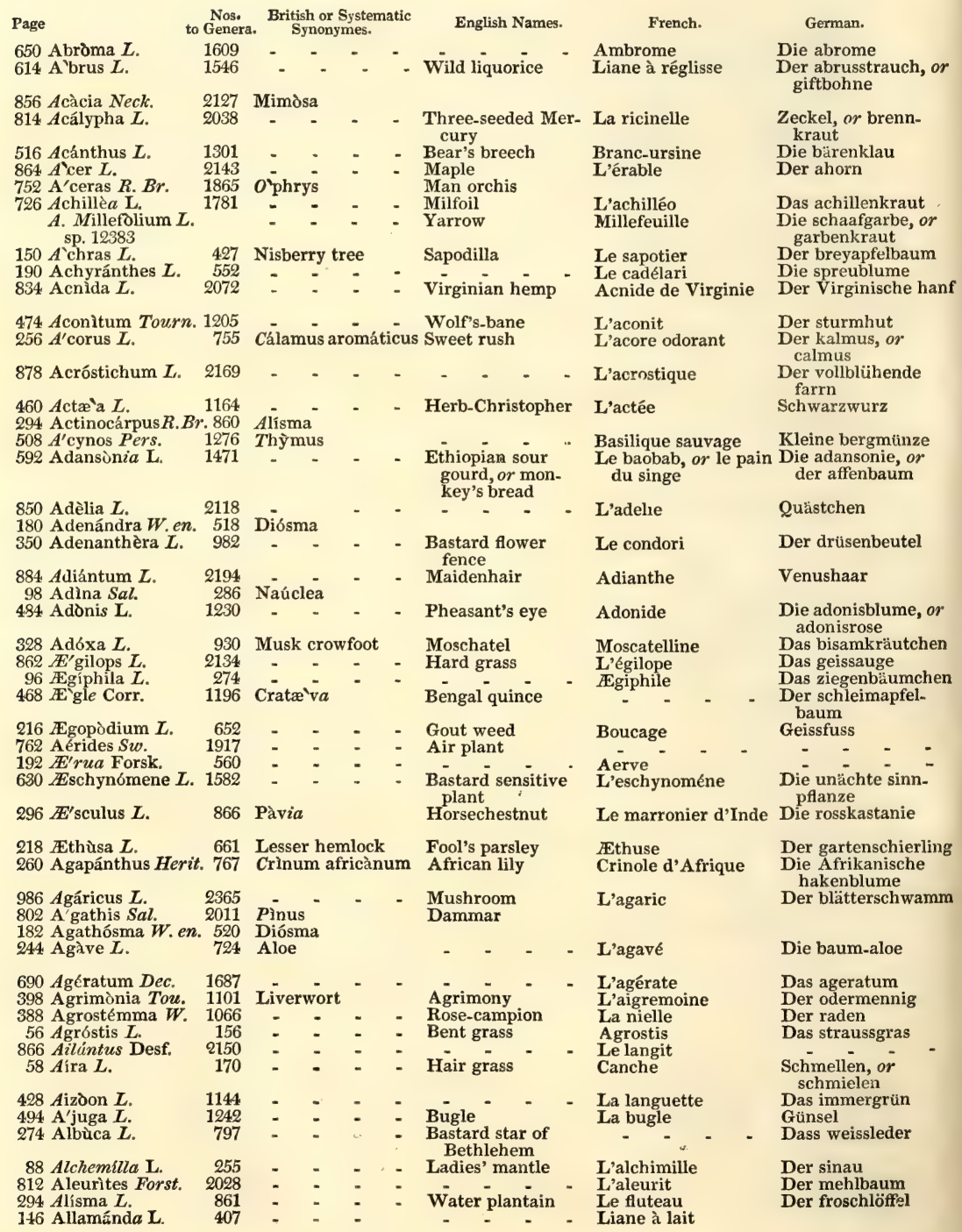




\section{OF THE GENERA,}

\section{DIFFERENT LANGUAGES.}

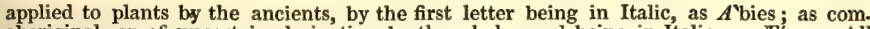
aboriginal, or of uncertain derivation, by the whole word being in Italic, as $\mathcal{E}^{\prime} r u a$. All the Greek and Latin.

Page Dutch.
614 Weegboontjes
814 Netelkruid
516 Beerenklaauw
864 Ahorn
726 Duizendblad
Hetgemeene dui-
zenblad
150 Sapodilleboom
190 Kafbloem
834 Kennip
474 Monnikskappen
256 Kalmus
878 Plakvaren
460 Kristoffelkruid
508 Vold mynte
592 Meloenboom, aa-
penbrood boom, or
baobaboom
Italian.
Spanish.
Portuguese, Danish, Russian, Polish, South American,
- - - Abro de cuentas Berdeebeedeo Otaheite. Olinda Ceylon. Konni Malab. de rosario

\begin{tabular}{|c|c|c|c|}
\hline $\begin{array}{l}\text { Acanto } \\
\text { Acero }\end{array}$ & & $\begin{array}{l}\text { Acanto } \\
\text { Arce }\end{array}$ & $\begin{array}{l}\text { Acanto Port. } \\
\text { Acero Port. }\end{array}$ \\
\hline $\begin{array}{l}\text { Achillea } \\
\text { Millefoglie }\end{array}$ & & Aquilea & \\
\hline$-\quad-$ & - & Sapote & Zapota menor Port. Sapotilletræ Dan. \\
\hline - $\quad-$ & - & $\underset{\text { ginia }}{\text { Cañamo de Vir- }}$ & \\
\hline $\begin{array}{l}\text { Aconito } \\
\text { Ácoro }\end{array}$ & & Aconito & $\begin{array}{l}\text { Aconito Port. } \\
\text { Acoro calamo Port. Waembu Malab. Cassabel } \\
\text { Egypt. }\end{array}$ \\
\hline Acrostico & & Acrostico & Acrostico Port. Pletbrægne Dan. \\
\hline Actea & & Actea & Actea Port. \\
\hline$: \quad:$ & - & Albahaca menor & $\begin{array}{l}\text { Serpao Port. } \\
\text { Iciboicica Brazil. }\end{array}$ \\
\hline
\end{tabular}

350 Klierenbloem

884 Venushaair

484 Adonisbloem

328 Muskuskruid

862 Geitenoog

96 Het geitenboompje 468 Slymappelboom

216 Gerardskruid

192

630 Schaamboom

296 Paardenkarstengeboom

218 Tuinscheerling

260 Afrikaanse haaklelie

986 Kampernoelje

\section{Boomaloe}

690 Geurkruid

398 Agrimonie

388 Koornvlam

56 Struisgras

866

58 Rietgras

428

494 Senegroen

274. Stiftbloem

88 Leeuwenvoet

294 Water weegbree

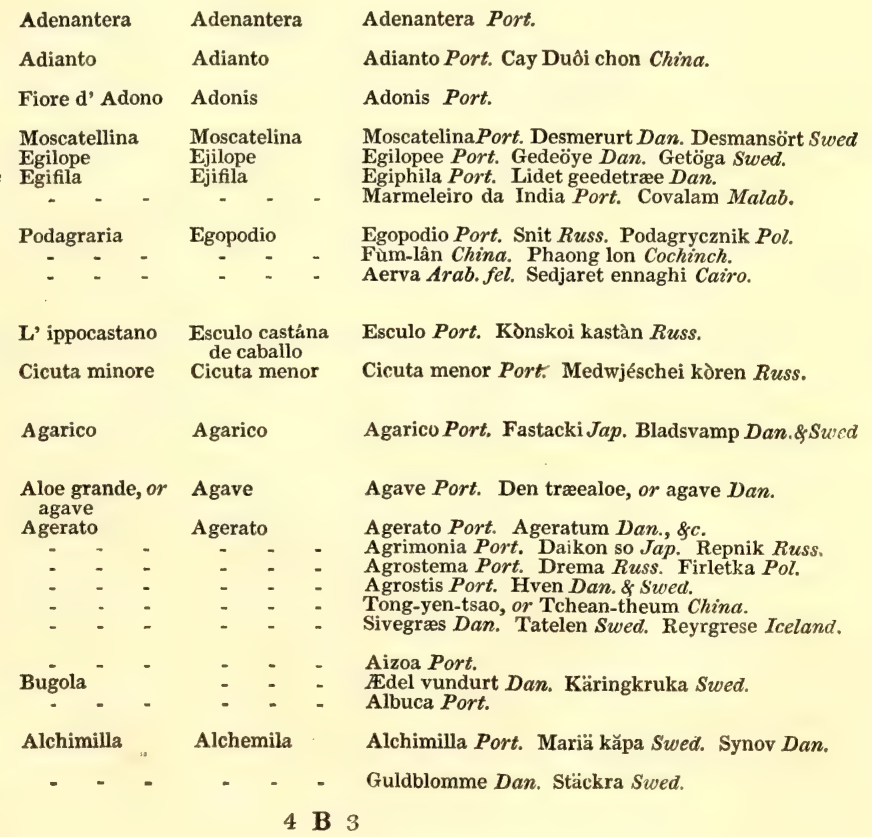



TABLE OF SUCH AS HAVE SYNONYMES IN

IN this Index, the systematic names in col. 1. are distinguished as classical, i. e. names memorative, by the terminating letter or letters beng in ltalic, as Bínksia; and as
the other names are formed, in almost every case, from the Greek, but sometimes from

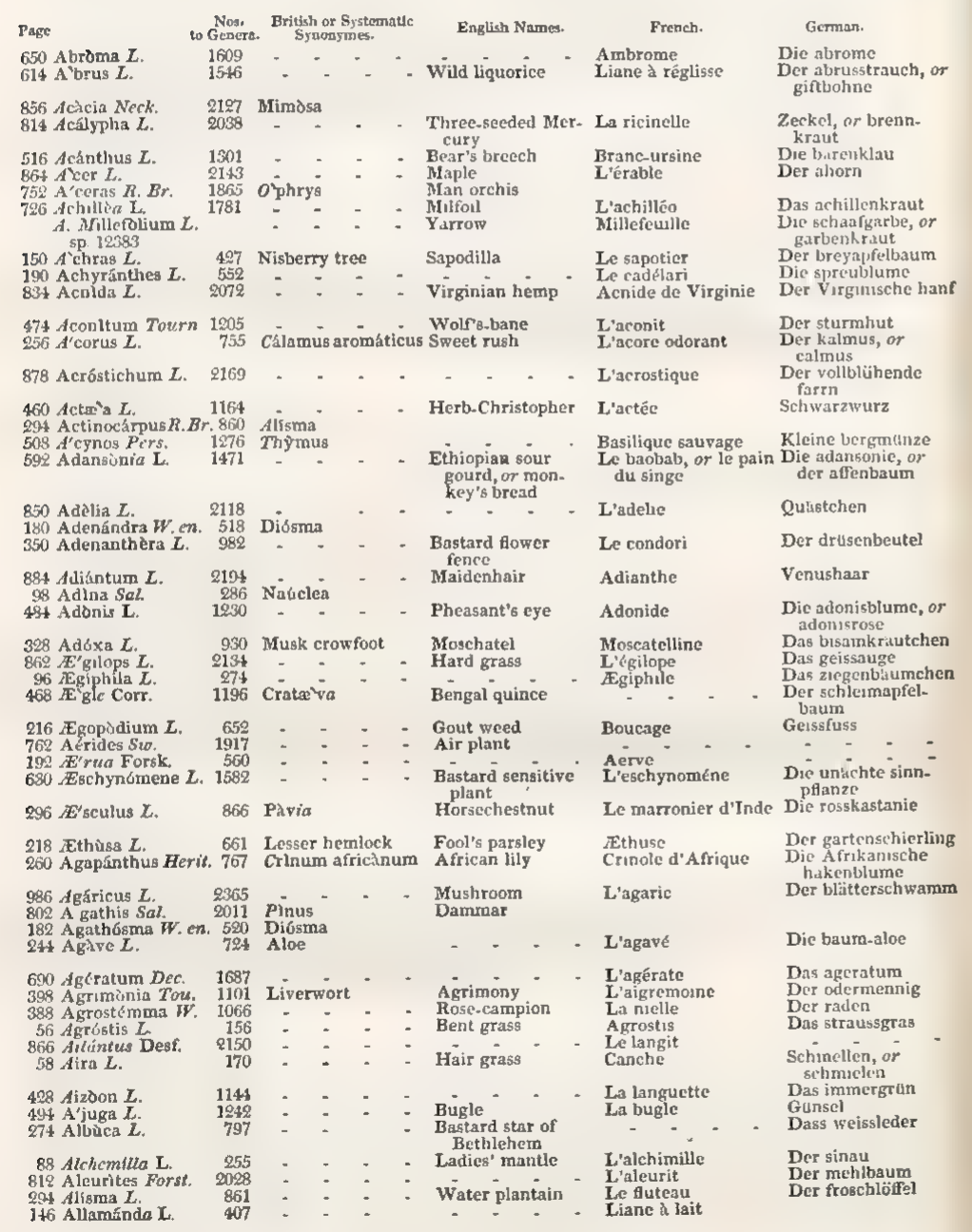

\section{OF THE GENERA,}

\section{DIFFERENT LANGUAGES.} prled to plants by the ancients, by the first letter being in Italic, as $A$ "bies; as com

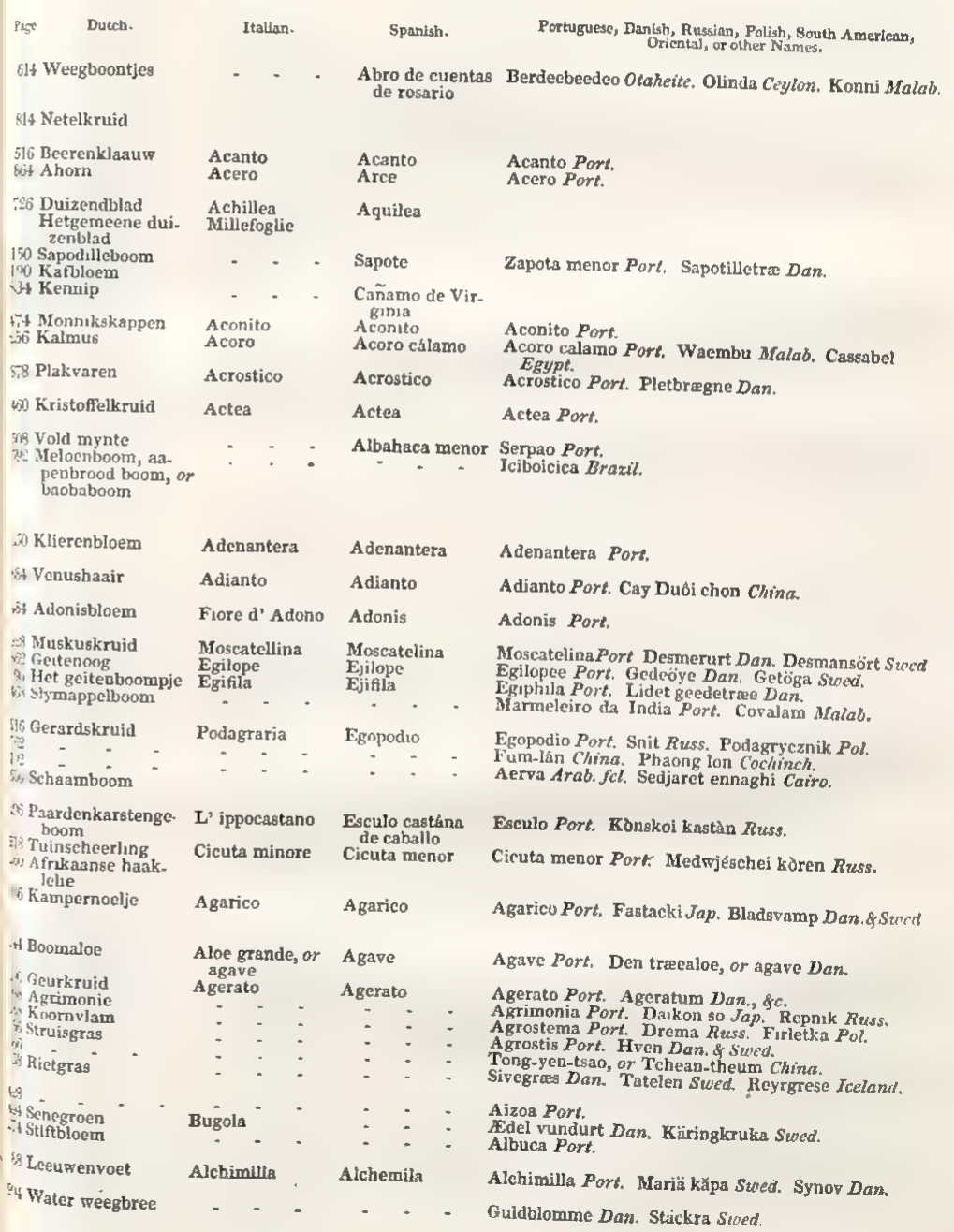




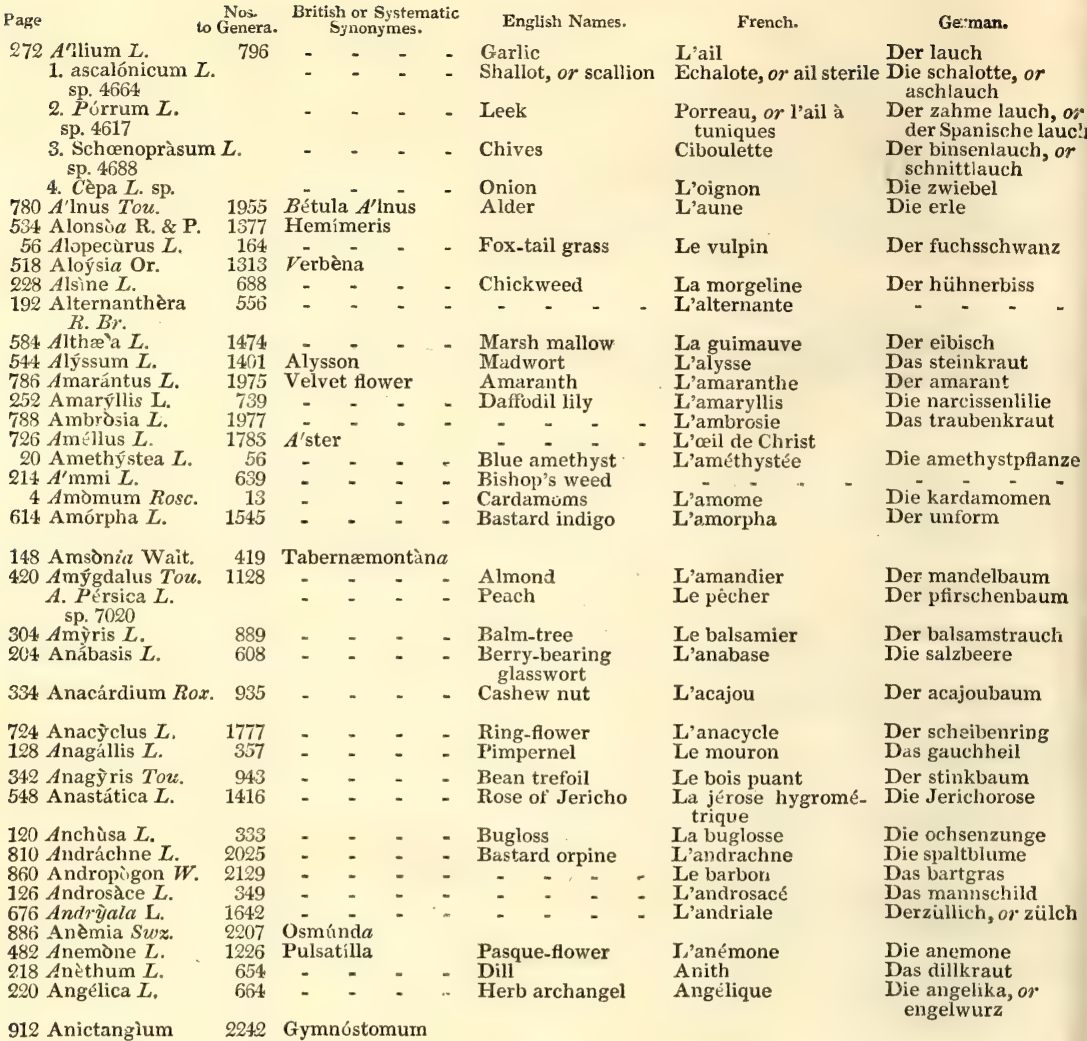

Hedw.
494 Anisómeles $R . B r .1243$ Népeta

180 Annina Adan 1200

912 Anómodon Hook. 2246

724 A nthemis $L$. $\quad 1778$

$\begin{array}{rr}280 \text { Anthéricum } L . & 809 \\ \text { 44. Antholỳza L. } & 107\end{array}$

8.32 Anthospérmum L. 2062

28 Anthoxánthum $L .76$

208 Anthriscus Pers. $\quad 620$

Hýpuüm

-

$=$

612 Anthýllis $L$.

834 Antidésma $L$. 2068

526 Antirrhinum L. 1343 T- -

882 Antrophyum 2193 Vittaria

$$
\text { Kaulf }
$$

2193 Vittaria

518 Aphelándra $R . B r .1306$ Justícia

272 Aphyllánthes $L$.
A. monspeliénsis $L$.

6 A pium 4614

$A$. gravè èlens $L$.

sp. 3618

194. Apúcynum $L$. 572

292 Aponogèton Thun. 854

476 Aquilègia $L$. 1208

$540 A^{\prime}$ rabis $L_{0} . \quad 1390$

614. $A$ rachis $L$

230 Aralia $L$.

360 A'rbutus $L$

$680 A \operatorname{retium} L$.

872 Arctopus $L$

734 Arctothica 2165

Wnl. 1815

800 Arica

1543 Pinda

$$
\begin{gathered}
\text { Justícia } \\
-\quad- \\
-
\end{gathered}
$$

$$
\text { - - - - Parsley }
$$

- - - - Dog's bane

nuts

378 Arenæria $L$.

696 - Én -

1660 Clot-burr

2165

Arrtùtis

1831

62 Arenaria $L$. $\quad 1050$

$\begin{array}{ll}462 & \text { Argemòne Tou. } \\ 766 \text { Aristolochia } L . & 1934\end{array}$

234 Armèria $\boldsymbol{W}$, en.

705 Státice Armèria

Columbine

Wall cress

Angeìica tree

Strawberry tree Burdock

Le corossol

La camomille

L'anthéric

L'antholise

L'anthosperme

La flouve

Cerfeuil à fruits

courts

L'anthyllide

L'antidesme

Le muflier

Jonciole

Bragalou de Mont

pellier

Le persil

Céléri

L'apocin

L'aponoget

Ancolie

J'arabette

L'arachide

L'aralie

L'arbousier

Bardane

L'arctope

Bear's ear

Cabbage tree

Sandwort

Prickly poppy

Birthwort

Thrift
L'arctotide

L'arec, $0 r^{\circ}$ chou pal miste

La sablonière

L'aristoloche

Statice
L'argemone
Der flaschenbaum

Die kamille

Das spinnkraut

Die steinblume

Der amberstrauch

Das ruchgras

Der rauhe kerbel

Die wollblume

Die schlangenbeere

Der doranít

\section{Die blattlose}

Die petersilie

Der celeri

Der hundekoh!

Der schwimmer

Der ackeley

Der gänsekraut

Die erdnuss

Die aralie

Der erdbeerbaum

Die klette

Der bärenfuss

Das bärenohr

Das sandkraut

Der stachelmohn

Die osterluzey

Das seegras 


\begin{tabular}{|c|c|c|}
\hline Dutch. & Italian. & Soanish. \\
\hline $\begin{array}{l}272 \text { Look } \\
\text { 1. Chalotte }\end{array}$ & $\begin{array}{l}\text { Aglio } \\
\text { Scalogni, or } \\
\text { cipolle malige }\end{array}$ & $\begin{array}{l}\text { Ajo } \\
\text { Escalónia, or } \\
\text { chalote }\end{array}$ \\
\hline
\end{tabular}

2. Prey, or porreye Porro, or porreta Puerro

3. Bieslook, $o r$ sny- Cipolletta maligia Cibollino de prey

780 Eizeboc

780 Elzeboom

56 Vossestaart

228 Muur

192 .

584 De heemst

544 Tanddraad

786 Amaranth

252 Lelie-narcis

788 Druifkruid

20 Amethystkruid

214

4. Kardāiomom

614 Amorpha, or bastaard indigo

420 Amandelboom Persikboom

304. Balsemboom 204. Zoutdruif

334 Catsjoe-appelboom

724. Ringbloem

128 Het guichelheil

342 Stinkboompje

548 Roos van Jericho

120 Ossetong

810 Andrachne

860 Baardgras

126

676 Woldistel

482 Anemone

218 Dille

220 Engelwortel

480 Annona

724 Kamille

280 Anthericum

44. Antholyza

832 Amberstruik

28 Geelbloem

208 Wilde kervel

612 Wundkruid

83+ Vlaschboom

526 Leeuwebek

272 Bies-anjelier

216 Peterselie Sellery

\section{Hondsdood}

476 Akeley

540 Honigschub

614 Aardeikel

230 Aralia

360 Arbutus

680 Klissen

872 Gedoornd

740 Beerenoor 800 De koolboom

378 Zandmuur

462 Klepheul

766 Osterlucie

234 Zeegras

Cipolla
Ontano

Inglaterra

Cebolla

Aliso

$\begin{array}{ll}\text { Alopecuro } & \text { Alopecuro } \\ \text { Morgellina } & \text { Alsine } \\ - & - \\ \text { Altea } & \text { Althea } \\ \text { Alisso } & \text { Aliso } \\ \text { Amaranto } & \text { Amaranto } \\ \text { Giglio narciso } & \text { Amarylis }\end{array}$

Cardamomo- Cardamomo bastardo

Il mandorlo Almendro

Pesco, or persico El melocoton

Il balsamino El balsamo

Il albero acaju dental

Anaciclo Anaciclo

Anagailide Anagalide

Ancusa

Andropogon -

Anchusa

Andropögon

Cantarillos

Anemone

Aneto

Anemone

Eneldo

Angelica

Anjelica

Annona

La camomilla

Anterico

Antospermo

Antoxanto

Antospermo

Antoxanto

Antillide

Antillide

Antirrino

Antirrino
Petroselino

Appio

Apocino

Acquilegia

Pistacchio di terra

\section{Arbuto}

Lappola

- .

$-$

Arenaria

Aristolochia

Statice
Pereiil

Apio hortense

Apocino

Mani

Madroño

Lampazo

Arctotis

Arenaria

Aristolochia

Statice Portuguese, Danish, Russian, Polish, South American,
Oriental, or other Names.

Alho Port. 'Tum Indian. Sir Pers. Tschesnok liuss. Scalotlögen Dan. Chalottenlök Swcd. Ossleych Boh. Mogyoró-hagyma Hung. Cay-nen Cochinch.

Alho porro Port. Purio Swed. Pras Russ. Plodziszek Pol. Pár-hagyma Hung. Chazir Heb. Korrat Cairo. Cebolinha de Ingalaterra Port. Graslög Dan. Luczer lupny, or Szczypiorek $P o L$.

Bhazal Hebr. Pias Pers. Sochan Turk. Sogan Tatar. Alemo Port. Olcha Russ. Olsza Pol. Ell Dan.

Alopecuro Port. Ræverumpe Dan. Raffvants Swed.

Kávar el abìd Arab.fel. Hámel, in Rosetta.

Althéa Port.

Alisso Port.

Amaranto Port. Krowawlek Russ.

Amarylis Port. Amaryllis Dan.\& Swed.

Ambrosia-Urt Dan. Ambrosia-ört Swed.

Indaco bastardo Indigo, or anil

Asperokephalos Tenedos. Chælle Egypt.

Cardamono menor Port.

Anileira bastarda Port. Bastard Indigo Dan.

Him ho gin Chin. Mindalnoe derevo Russ.

Scheptals Russ. Baratsk-fa Hung.

O balsamo Port. Abu scham Arab.

Anacardio occi-

Anagiride Leño hediondo

Rosa di Jerico Rosa de Jericó

La manzanilla
Cundurt Dan. Ullbomster Swed.

Antirrino Port.
Guanambao Port.

A macella Port.

Anterico Port. Kosatki Pol.

AntospermoPort. AmbratræDan. AmbrabuskeSwed. Guul ax Dan. Vărbrădd Swed.
Anaciclo Port. Ringblomster Dan. Ringsk fvan Swed. Poj. Kurjatschja noga trawa Russ.

Anagyro de Hespanha Port. Bob kamienny Pol. Rosa de Jerico Port. Kaf marjam Egypt. Roza

Andrachne Dan. \& Swed.

Andropogon Port. Skæggegræs Dan.

Pereloinaja trawa Rus. Rzesa skalna Pol. Hilsko Sw.

Anemone Port. Ollina gusa Jap. Wjetreniza Russ.

Angelica Port. Angelika Russ. Dziegiel ogrodiny $\boldsymbol{P o l}$.

Baqdunis Egypt. Petruschka Russ. Pietruszka Pol.

Kerafs Egypt. Selderi Russ, Zelerya Pol.

Hundedöd Dan.

Odamaki Jap. Kolokòltschiki Russ, Orlik Pol.

Gaaseurt Dan. Akerleukojer Swed.

Amenduinas Port. Mundubi Brazil. Cay dau phung Cochinch.

Ljesnàja jablon Russ. Jezowka wloska Pol.

Lapa Port. Lapuschnik Russ. Lopian Pol.

Biörneföd Dan.

Arctotis Port. Biörneore Dan. Björnöra Swed

Arenaria Port. Sandurt Dan. Sandört Swed.

Pigvalmue Dan. Piggvalmoge Swed.

Liden biergnellike Dan. Strandblomster Swed. 
Page

716 A'rnica $L$ tish or Systematic

696 Artemisia L A. Dracúnculus $L$. sp. 11739 1749 280 Arthropodium R. Br.

770 Artocárpus $L$ 800 A rum $L$

74. Arundinària $M x$. 219 60 Arúndo With.

$392 A$ sarum $L$.

196 Asclèpias L.

$658 A^{\prime}$ scyrum $L$.

480 Asímina Adan.

506 Aspálathus $L$.

282 Aspáragus $L$.

124. $A$ sperùgo $L$.

94 Aspérula $L$.

$A$. luteus $L$. sp. 4793

$A$. ramòsus $L$ sp. 4795

884 Aspidium Swz. 2199

880 Asplènium $L$.

$706 I^{\prime}$ 'ster $L$.

636 Astrágalus $L$

222 Astrántia $L$

212 Athamánta $L$.

$696 A$ thanasia $L$.

686 Atráctylis $L$.

288 Atrapháxis $L$.

$862 A$ triplex $J$

154 A tropa L.

828 Aúlax Berg.

58 Avena $L$.

380) Averrhòa $\mathbf{L}$.

144 Azàlea $L$

42 Babiàna Ker.

702 Báccharis $L$

2186

1739

1594

634

1717
1670

838

2138

446

2052
171

171
1058

10 Anthéricum

884. Balántium Kaulf. 2198 Dicksònia

504 Ballota $L$

696 Balsamita Desf. 1718 Tanacètum

956 Bambìsa Schr.

752 Arúndo Bámibos

342 Baptísia Ven.

540 Barbarè $a$ R. Br.

Podalýric

Erýsimum

596 Barringtònia Forst.1497 Butónica

752 Bartholìna R. Br. 1862 Arethùsa

524 Bártsia I

228 Basélla I

346 Bauhínia Pluk. 97

66 Beckmánnia Hort. 19

802 Bèlis Sal.

2010

286 Bérberis L

206 Bèta $L$.

502 Betónica $L$

780 Bétula $L$.

692 Bìdens $L$.

514 Bignonia L

546 Biscutéila $Z$.

638 Bisérrula $L$

164. Bixa-L.

1667
829

829

612
1262

1956

1697

1294

880 Bléchnum $L$

518 Blèchum $J$.

762 Bletia R. \& P.

302 Blìghia H. K

$8 B$ litum $L$.

392 Boccònia L.

6 Boerhaavia L.

1008 Boletus Di

592 Bómbax $L$

524. Bóntia L

122 Boràgo $L$.

836 Borássus $I$

826 Bòrya W.

206 Bdsea L. 61

1413

1595
1178

2183

1305

1911
885

885

1073

19

1472

1334

340

7079

2044

152 Bourrèria Gae.

98 Bouvárdia Sal.

864. Brabèium $L$.

762 Brasavola R. Br. 1914

756 Brássea R, Br.
431
287

2142

1914
1886
Cynosùru

Pinus

Rúllia

imodirum

Adèlia, Bigelòvia

s-pidéndrum
English Names.

French

Le doronic

L'absinthe

Wormwood
Tarragon

Bread fruit

Wake robin

Cane-brake

Reed

Asarabacca

Swallow-wort

- -

Sparrowgrass

German madwort

Woodruff

Asphodel

King's rod

Shield fern

Spleenwort

Starwort

Milk vetch

Masterwort

Spignel

Distaff thistle

Orache

Dwale

Oat grass

- -

L'azalée

Le jaquier
Le gouet

Le roseau

L'asaret

L'asclépiade

L'aspalat

L'asperge

Le porte-feuille

L'aspérule

Bâton-de_Jacob

Bâton royal

La doradille

L'astere

L'astragale

L'astrance

L'athamante

'athanasie

La quenouillette

L'atraphace

La belladone

L'avoine

Carambolier à fruits Zuurknoopboom

Der felsenstrauch

Plowman's spike- La bacchante nard

Stinkıng horehound La ballote

Costmary Coq des jardins

Bamboo cane

Le roseau d'Inde

Winter cress

La barbarée

Der streifeniarren

Die sternblume

Tragant

Die hirschwurz

Die athanasie

Das spindelkraut

Die melde

Die wolfskirsche

Der hafer

Die baccharis

Die zahnlose

Die frauenmünze

Das bambus-rohr

Die winterkresse

Le butonic

Cocrête

Mälabār nigh̀tshäe Baselle

Mountain Ebony Bauhine

- - - Daisy

Barberry

Beet

Betony

Birch

Trumpet föwer

La paquerette

L'épine-vinette

Bette, or betterave

Betoine

Ke bouleau

Le bident

Buckler mustard

Hatchet vetch

Anotta

La bignone

La lunetière

La pélécine

Le rocurier des

Indes

Strawberry blite

Celandine tree

Hogweed

Spunk

Silk cotton tree

Barbadoes wild

olive

Borage

Fan palm

- - - - Golden rod

Golden rod
Moonwort

Bléte, or blite

La tassole

La morille

Le fromager

Le daphnot des An-

tilles

Le rondier

Die beerblums

Die bergebenholz

Maslieben

Der sauerdorn

Mangold

Die l,etonik

Die birke

Der zweyzahn

Die trompeten-

blume

Das doppelschild

Das sägekraut

Der Orleansbaum

Der rippenfarrn

Die beermelde

Die burhavie

Der löcherschwamm

Der wollsame

Der wilde oliven-

baum von Barbados

Borago

Die weinpalme

Bosé

Lunaire

Der goldruthenbaum

Die mondraute

African almond

Brabei

Der scepterbaum 
TABLE OF SYNONYMES.

\section{Page Dutcin. \\ 716 Valkruid \\ 696 Alsem} Dragon

770 Broodboom 800 Kalfsvoet

60 Riet

392 Mans-oor

396 Zydevrught

658

282 Aspergie

124 Scherpkruid

94. Ruuwkruid

280 Affodil

880 Miltkruid

706 Sterrebloem

636 Kootkruid

222 Sterrekruid

212 Beerwortel

696 Duurbloen

686 Staalkop

288 Atraphaxis

862 Melde

154 Doodkruid

58 Havor

380 Zuurknoopboom

144 Azalea

702 Roerkruid

504 Ballote

696 Tuinbalsam

256 Bamboesriet

540 Winterkers

524

228 Beetklim

346 Bauhinia

718 Madelieven

286 Berberis

206 Beete

502 Betonic

780 Berk

692 Tandzaad

514 Bignonia

546 Brilkruid

638 Zaagpeu

464 Orleane

880 Ribvaren

\section{Bes-melde}

1008 Zwam

592 Kapokboom

524 Barbadoesche wilde olyfboom

122 Bernagie

836 Wyngeevende palmboom

206 Bosea

886 Maankruid

864 Kransboom

\begin{tabular}{ll}
\multicolumn{1}{c}{ Italian. } & \multicolumn{1}{c}{ Spanish. } \\
$\begin{array}{l}\text { Assenzio } \\
\text { Dragoncello }\end{array}$ & $\begin{array}{l}\text { Ajenjo } \\
\text { Estragon }\end{array}$ \\
$\begin{array}{ll}\text { Artocarpo } \\
\text { Aro }\end{array}$ & $\begin{array}{l}\text { Zueco } \\
\text { Yaro }\end{array}$ \\
$\begin{array}{ll}\text { Canna } \\
\text { Asaro } \\
\text { Asclepiade }\end{array}$ & $\begin{array}{l}\text { Cana } \\
\text { Asaro } \\
\text { Asclepiada }\end{array}$ \\
\hline
\end{tabular}

\begin{tabular}{|c|c|}
\hline Sparagio & Esparrago \\
\hline Asperugine & Asperugo \\
\hline
\end{tabular}

Asplenio

Astero

Astragalo

Atamanta

Atanasia

Atrattile

Atrepice

Atropa

Vena

-

- - -

Asplenio

Aster

Astragalo

Atamanta

Atanasia

- -

Armuelles

Atropa

A vena

-

$+$
Portuguese, Danish, Russian, Poli.h, South American,
Oriental, or other Names.

Volverley Dan. Fibler Swed.

Polin Russ. Malurt Dan.

Torun Pol. Kígyótiang Hung.

Eoroo Otaheite, Brödtræe Dan.

Munskesvands Dan.

Trost Russ. Trcina Pol. Rör Dan. \& Swed. Wodolei Russ. Kopytnick Pol.

Ascyro Port.

Sparsa Russ.

Rapette, or brevtaske Dan. Ormögen Swed.

Schwedopetschenaja trawa Russ. Myseka Dan.

Asfalt liuss, Kozle jayka Pol. Beenbrud Dan.

Stiernblomst Dan. Stjernört Swed.

Hvirvelurt Dan. Strutschkowaja trawa Russ.

Astrancia Port. Zápótza Hung.

Hiorterod Dan. Säfferot Swed.

Atanasia Port.

Acarna de Creta Port. Spindelurt Dan.

Atraphaxis Dan. \& Swed.

Lebeda Russ. Loboda Pol. Molla Swed.

Belladonna Port. Beschenaja wischnja Russ.

Avea Port. Owès Russ. Owies Pul.

Cheramela Port. Bilimbi Malab. Billinghas Cey.

Tsususi Jap. Odur rshawnoi Russ. Azalea Dan.

Marrobio

Marrubia Marroyo Port. Szanta czarna $P_{0}$.

Costo ortense Hierba de Santa Balsamita Port. Hanegræs Dan. Svensk salvia Swed.

Canna bambu Cana bambos E, owhe Otaheite. Ily Malab. Bambusör Dan.

Barbarea

Hierba de Santa Barbara

Dan.

Bergskälle Swed. Lokasiods broder Iceland

Murasakki Jap. LoqueiChin. Cay boung toiCochinch.

$\begin{array}{ll}\text { Margheritina } & \text { Maya } \\ \text { Crespino } & \text { Berberis } \\ \text { Bieta } & \text { Acelga } \\ \text { Betonico } & \text { Betonica } \\ \text { Betulla } & \text { El abedul } \\ \text { Bidente } & \text { Bidente } \\ \text { Bignonia } & \text { Bignonia }\end{array}$

Bonina Port. Barchatnaja zwietòschka Russ.

Tomara soo Jap. Barbariss Russ. Ciernie biale Pol. Acelga Port. Sweklà Russ. Cwikla Pol.

Betonica Port. Bukwiza Russ.

Berésa Russ. Brzoza Pol. Birk Dan. Biork Swed.

Brönsel Dan. Brunskiàr Sw.

Bignonia Port. Jacaranda Brazil.

Urucu Port. Achiotl Mexico. Bixa Dan. \& Swed.

Zminda Pol. Bærmeld Dan. Bärmolla Swed.

Folhas de pitao Port. Nuna-nunaOtah. Vuddjef Arab. Boleto Port. Grib Russ. Grzyb Pol.

Osttræe Dan. Ostträd Swed.

Boleto
Bombasi

BorragemPort. Oguretschnaja trawa Russ. BorakPol.

Borraggine Borraja

Palmeira macha brava Port. Ampana Malab.

$-\quad-\quad$ Hierba-mora

Bosea Dan. \& Swed.

Lunaria minore Lunaria menor Lunaria bastardaPort.Bogoroditschka rutschka Russ. 
Page Nos. British or Systematic

552 Brássica $L$ 1432 Cole, colewort

English Names.

$B$. o. c. capitàt

$B$. o. b. c. rùbra

B. o. $\gamma$. bullita

B. o. c. bullata

B. o. $\delta$. acéphala

B. o. . Butrytis

B. o. ל.

B. $N$ ipus L. sp. 9247

$B$. Eruca

B. o. vaccìna

$B$. o. fimbriàta

$B$. Nàpo-brássica

$B$. rutabàga

$B$ o. campéstris

B. Nàpus sylvéstris

B. Ràna L. sp. 9246

66 Briza $L$

246 Promelia

$6 \pm$ Brómus $L$

760 Broughtonia R Br 1905

13+ Brugmánsia Pers. 377

250 Brunsvigia Heir. 737

810 Bryimia L. 2024

214 Bibon $L$.

650 Bubròma $W$

364 Bucìda $L$.

Wild hops

1608 Theobròma

Guaxima

270 Bulbocodium $L . \quad 784$

$558 \mathrm{Bùnias} L$. $\quad 1444$

212 Bùnium $L$. 631

728 Buphthálmum L. 1797

218 Bupleùrum $L . \quad 657$

182 Bursaria Cav. $\quad 530$

872 Bursèra Jac.

336 Bùtomus $L$

$780 B$ úxus $L$.

692 Cacàlia $L$

224 Cachrys $L$.

410 Cáctus $L$.

2164

350 Càdia Forsk.

939 Water gladiole

1957

$17(0) \mathrm{L}$

677
1111

983

(brasi- 978

liénsis) Pluk.

$14 \overline{17}$ Bùnias

798 Calìdiur.: Ven. $2005 A^{*}$ rum

508 Calamintha $P h .1277$ Melissa

256 Ćlamus $L$

18 Calceolària $L$.

$\left.\begin{array}{l}1482 \\ 520\end{array}\right\}$ Caldàsia W.

740 Caléndula $L$.

298 Cálla $L$.

96 Callicárpa $L$.

406 Calligonum $\dot{L}$

36 Callísia $L$

8 Callitriche $W$.

753 Rotang

$\left\{\begin{array}{c}51 \\ 422 \\ 1324\end{array}\right\}$ Bonplándia

869
272

272
1106
87

89

- -

- $\quad-\quad$

Vèrnal star-h̄ ckweed

466 Calophýllum $L . \quad 1189$

Limodirum

756 Calopigon $R . B r \cdot 1878$ Limodirum
196 Calítropis $R . B r$.
584 Asclèpias

490 Cáltha $L$.

1239

454 Calycánthus $L$. 1157

764. Calýpso $S a l$.

1929 Limodiorum

140 Calystègia $R$. Br. 387 Convólvulus

5:50 Camelina Crz. 1425 Mỹagrum

592 Caméllia L.

1476 Japan rose

148 Camer̀̀i $x$ I.

162 Campánula $L$.

88 Camphorósma $L$

288 Canarina $L$.

$39+$ Canélla $P . B r$.

2 Cúnna $L$.

834 Cánnabis $L$.

458 Cápparis $L$.

532 Caprària $L$

1169

\& \& $S, 474$ Lonicèr

546 Capsélla Moen. 1409 Thláspi

160 Cápsicum $L$.

453

417

254

834
1085

1 Flowering reed

626 Caragàna Lam. 1569 Robínia 202 Carallùma R. Br. 598 Stapèlia
Cabbage

White

Red

Savoy

Brussels sprouts

Borecole

Cauliflower

Broccoli

$-$

-

$-$

$-$

$\div$

- - -

Quaking grass

Pine-apple

Brome grass

Bread nut

Bryony

Bästard cedär

Le chou

German.

Chou cabus blanc

Chou cabus rouge

Chou de Milan

Chou de Bruxelles à

jets

Choux verts

Chou-fleur

Chou-

Roquette

Chou cavalier

Chou frisé du nord

Chou-naver,

Chou-rutabaga

Chou-colza

Navette

Navet turnep

Brize

Das zittergras

L'ananas

Brome, or droue

Der kohl

Die ananas

Die trespe

Bryone, or couleavrée Die zaumrübe

Der steineppich

Orme d'Amerique Der guazumabaum

Olive-bark tree, Le grignon

or black olive - Campanette

Die kützchentra

gende mangle

Die uchtblume

Sea rocket

Earth nut

Ox eye

La terre-noix

Le bupthalme

Le buplèvre

Hare's ear

La bursaire

Jamaica birch tree Le gomart d'Ame-

Flowering rush rique

Butome

Box tree . - Le buis

- - - - - Larmarinte

Cöhineal fig

Le cactier

Brasiletto

Le brésillet

Caquille

Das zackenkraut

Die erdnuss

Das rindsauge

Das hafenöhrchen

Der beutelwurm

Die gummitragende

bursere

Die blumenbinse

Der buchs

Die pestwurze

Die nussdol le

Die koschenillenpflanze

Das brasilienholz

Der meersenf

Calamint

Le calament

Slipperwort - - Le rotin

Der kalamint

Der rotang

Die schuhblume

Marigold

Le souci de jardin

Calle

Callicarpe

Le calligon

Callise

Le callitric

Le calaba

Die ringelblume

Das schlangenkraut

Die wirbelbeere

Der hackenknopf

Der zärtling

Der wasserstern

Der kalababaum

Die sumpf-dotterblume

Die kelchblume

Allspice

Le calycant

Bearbind

Gold of pleasure

Le liseron des haies

La cameline

Die zaunwinde

Der leindotter

Dic sinesische, or

Bastard manchineel

Bell flower

La campanule

Canary bell-flower

- -

La camphrée

Die glockenblume

Die kampferpflanze

Indian shot

Cannclle blanche

Der weisse zimmet

Le balisier

Le cáprier

Das blumenrohr

Der hanf (hampf)

Die kapernstaude

Dic herzblume

Honeysuckle

Shepherd's purse

Guinea or Indian

Pepper

Siberian pea-tree

Le piment

Der Spanische pfeffet 
Page Dutch

552 Kaal
Italian.

Cavolo
Spanish.

Berza Portuguese, Danish, Russian, Polish, South American, VerçaPort. KapustaRuss.\&Pol. Kaal Dan. Kál Swed.
66 Trilgras

246 Ananas

$64 Z$ wenkgras
Briza

Pina de Indias

Bromo
Bevegræs Dan. Bäfvegräs Swed.

Ananas Port. Kapa-tsjakka Malab.

Bromo Port. Kosterj Russ. Hejre Dan.
810 Bryone
214 Gomeppe
650 Bastard-ceder

364 Leertouwersboom

270 Klokbol

\section{Knodsvrugt}

212 Aardnoot

728 Koe-oog

218 Haazenoor

182 Gom elemniboom

336 Zwaanebloem

780 Palm

692 Dokkeblad

224 Nootekroon

410 Cocheniljedraa-

350 gende vygplant

350 Brasilie-hout boom

548 Europische

knodsvrugt

508 Berg-kalaminth

256 Rottinggewas

18 Klompbloem

740 Goudbloem

298 Slangekruid

\section{Sterrekruid}

466 Geele gom-appelboom

490 Moerassig geel-

$$
\text { bloem }
$$

454 Kelkbloem

140 Haagwinde

550 Vlaschdotter

592 Chineesche roos

162 Klokjes

88 Kamferkruid

\section{Bloemriet}

834 Hennip

458 Kappers

532 Geitenkruid

160 Spaanschepeper

626
Ananas

Brionia

Nueza

Bubon

Norca branca Port. Przestep bialy Pol.

Mangle bastarda Port.

Colchico de la primavera

Castagna di terra Castano de tierra Castanha de terraPort. JordoldenDan. Jordnöt Swed.

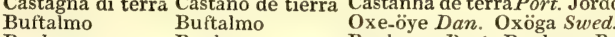

Bupleuro Buplero Bupleuro Port. Buplewr Russ.

- - - $\quad-\quad$ Pungen Dan

- Almacigo ame-

Butomo Butomo Susak Russ. Sit kwitnacy Pol. Blomstersiv Dan.

Busso El box Schimschat Persia. Samschit Russ. Bukspan Pol.

Cacalia Cacalia $\quad$ Pestrod Dan Pestrot Swed.

Plänta di - Tuero Nöddkrone Dan. Nöthrona Swed.

- - Kadi Arab

Legno di Fer- Fernambuco- $\quad$ Pao Brasil Port. Ibiri-pitanga Brazil.

Cachile Cakile Strandkarse Dan. Strandsenap Swed.

Calaminta Calaminto Melissa Russ. Melisa Pol.

- - - _ Rotang Drn.\& Swed. Rotan Malej.

Calendula Calendula Nogotki Russ. Nogietek Pol.

Calla Calla CallaPort. Smei trawaRus. MysseDan. Drakröt Swe.

Callitrica Calitriche Callitriche Port. Kaldunowa trawa Russ.

Sposa del sole Hierba centella Nogietek Pol. Kabeleye Dan. Kalfleka Swed. Malmequer dos brejos Port.

Il vilucchio Correguela Trepadeira Port.

Miagro Miagro RyschikRuss. KrowiaPol. HörrurtDan. DodraSwed. - - - Tsubakki Jap.

\section{Campanella Campanula Kolokoltschik Russ.}

Canforata Canforada

Campherplante Dan. Kampherväsk Swed.

$\begin{array}{ll}\text { Canna } & \text { Caña } \\ \text { Canapa } & \text { Cañamo } \\ \text { Cappari } & \text { Alcaparro } \\ \text { Capraria } & \text { Capraria }\end{array}$

Cana Port. Racua-canga Brczil. Katu-bala Malab.

Canhamo Port. Konapli Russ.

Alcapparra Port. Kapersowoy kust Russ

CaprariaPort. HierteblomsterDan. HjertblomsterSwe.

\section{Il peberone}

El pimentero
Pimentao Port. Vallia-Capo-Molago Malab. Perez Russ.

Gorochownik Russ. Karagan Tartar 


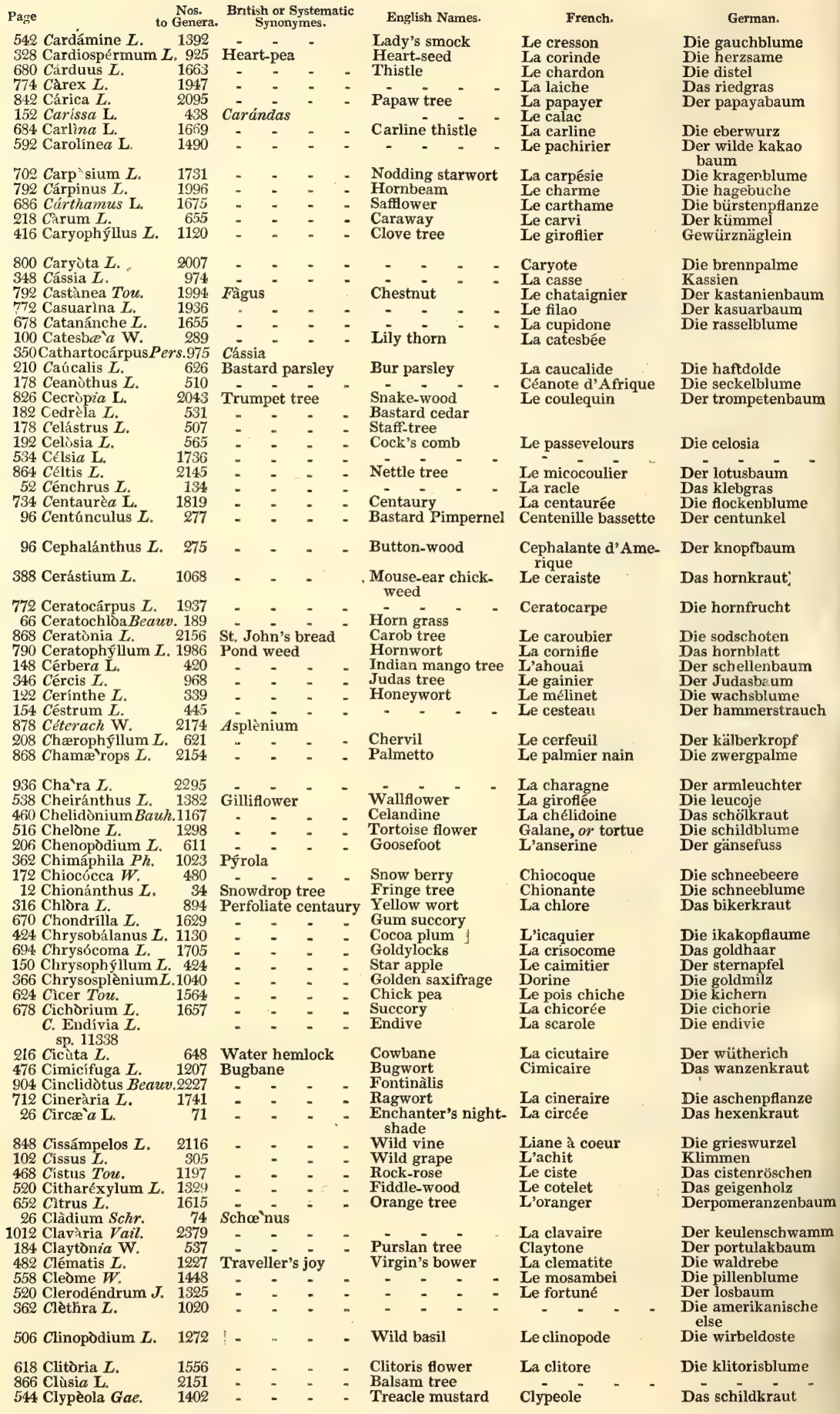


Page Dutch

542 Schuimblad

328 Hartvrugt

680 Distel

774 Rietgras

842 Papajaboom

684 Everwortel 592

702 Kraagbloem

792 Haagbeuk

686 Saftloer

218 Karwey

416 Kruidnagel-boom

800 Sagueerboom

318 Kassie

792 Kastanjeboom

678 Dwangkruid

\section{Doornzaad}

826 Trompetboom

192 Dèr hahnenkamm

864 Lotusbom

52 Kleefgras

734 Santorie

96 Zeer klein guichel

$$
\text { muur }
$$

96 Kogelboom

388 Hoornbloem

772 Hoornvrugt

868 Karobenboom

790 Hoornblad

148 Rinkelboom

346 Judasboom

122 Waschkruid

\section{Kervel}

868 Laage palmboom

936 Kaarskroon

538 Violier

460 Schelkruid

516 Schildbloem

206 Ganzevoet

172 Sneeuwbesie

12 Sneeuwbloem

424 Icacopruim

694 Pronkbloem

150 Star-appelboom

366 Goudveil

624 Cicers

678 Suikerey

Endivie

216 Water-scheerling

476 Wantsdryver

712 Aschkruid

26 St. Stevenskruid

848 Touwdruif

102 Boschtouw

468 Veldroosje

520 Vedelhoutboom

652 Oranjeboom

1012 Knodszwam

482 Clematis

558 Hederik

520 Lotboom

362 Clethra

506 Borstelkrans

618 Kittelbloem

866 Lymboom

544 Schildzaad

\begin{tabular}{l}
\multicolumn{1}{c}{ Italian. } \\
Cardamindo \\
Cardiospermo \\
Cardo \\
La caretta \\
Il papaio \\
Carlina \\
- - \\
Carpesio \\
Carpino \\
Cartamo \\
Il carvi \\
Il garofano aro- \\
matico \\
- - \\
Cassia - \\
Castagno \\
- - - \\
Catananche
\end{tabular}

Spanish.

Cardamina

Cardiospermo

Cardo

El carex

El papayo

Carlina

Carpesio
Charmilla
Cartamo
Alcaravea

Alcaravea

El clavo aroma-$$
\text { tico }
$$

Cassia

Castaño

Catananche

\begin{tabular}{|c|c|}
\hline Caucali & Caucalide \\
\hline Ambaiba & Ambaiba \\
\hline Celosia - - & $\begin{array}{l}\text { Celastro } \\
\text { Celosia }\end{array}$ \\
\hline $\begin{array}{l}\text { Arturo di Candia } \\
\text { Il loto } \\
\text { Cencro } \\
\text { Centaurea }\end{array}$ & $\begin{array}{l}\text { El almez } \\
\text { Cencro } \\
\text { Centaurea }\end{array}$ \\
\hline
\end{tabular}

Portuguese, Danish, Russian, Yolish, South American,
Orit ntal, or other Names.

Lugobüi kres Russ. Rzezucha polna Pol.

Blære-erter Dan.

Oset Russ. \& Pol. Tidsel Dan.

O carriço Port. Stærgræs Dan. Starr Swed.

Papayo Port. Pino-guacu Brazil. Papaya-maram Mal.

Koliutschka Russ, Lepczyca Pol. Korstorn Dan.

Xiloxochitl Mexico.

CarpesioPort. KraveblomsterDan. KrageblomsterSw.

Carpe Port. AsadPers. GrabRuss.\& Pol. AvenuögDan.

CartamoPort. Chartam Avab. PolewoiRus. KrokosPol.

AlcaraviaPost. TimonRuss. Karny Pol. KommenDan.

Cravoaria Port. Chanke Java. Gwosditschka Russ.

Schunda-panna Malab. Nibun Malej. Kettule Cey.

Chaiarxambar Egypt. Cassie Dan.

Riits Jap. Keschtan Russ. Kasztan owoc Pol.

Kajo tsjammara Malej.

Catananche Port.

Beterluus Dan. Kaukalis Swed.

Trompettræe Dan. Trumpetträd Swed.

Kuro gani Jap. Celastertræe Dan. Celasterträd Swed. Hanekam Dan. Hankam Swed.

Temur-agatsch Pers. Lotustræ Dan. Lotusträd Swed. Cencro Port. Burregræs Dan. Borregräs S'wed.

\section{Knaptræe Dan. Knappträd Swed.}

Hornurt Dan. Hornört Swed.

Ceratocarpo Ceratocarpo

Carobola Algarrobo

Ceratofilo Ceratofila

Siliquastro Algarrobo loco

Cerinte

Ceriflor

$\begin{array}{ll}\text { Cerfoglio } & \text { Perifollo } \\ \text { Palma di S. Pier } & \text { Palmitos }\end{array}$

Palma di S. Pier

Chara Chara

Celidonia $\quad$ Celidonia

Albero di neve Arb̈ol de nieve

Ustelipole Russ. Hornfrugt Dan. \& Swed.

Alfarroba Port. Johannisbröd Dan. \& Swed. Ceratofilo Port. Hornblad Dan. \& Swed.

Siliquastre Port. Fanna suwo Jap. Judastræe Dan.

Chupamel Port. Voxurt Dan. Vaxört Swed.

Cerofolho Port

Palmeira des vassoiras Port. Dvergpalme Dan Dvärgpalm Swed.

Chara Port. Armstage Dan. Ljusarm Swed.

GoiveiroPor. Nægeisi Arab.Gwosditschnüja tialke Rus.

Svaleurt $D$ an

Skiolblomster Dan. Sköldblomster Swed.

Guasefod Dan.

Sneebær Dan. Snöbär Swed.

Sneeblomster Dan. Snöblomster Swed.

Albero icaco Icaco arbol

Crisocoma Crisocoma

Crisofilo Chrysophyllo

Ceci - - Garbanzo

Achicoria

Endibia

Endivia

Ikakoblomme Dan. Ikakoplommon Swed.

Guldhaar Dan.

ChrysophylloPort. StierneæbleDan. StjernäpleSwed.

Gylden steenbrek Dan. Gul stenbrâcka Swed.

FrvançoPort. Ciecierzyca ogrodnaPol. MuseærtDan.

Zikorija Russ.

Endibia Port. Andiwija Russ. Sterbák Boh.

Cegude Por. Omeg Rus, Vand-skarntyde Dan.

Tægeurt Dan.

Aske-urt Dan. Ask-ört Swed.

Kaldunowa trawa Russ. Czarownik Pol.

Caapeba Port.

Cisto Port. Cistusrose Dan Cistusros Swed.

Fiolintræe Dan. Fioltrâd Swed.

Cay cam Cochinch. Pomeranez Russ.

Melarañin

Jara

Klubban Swed. Köllesop Dar.

Clematite Clematide

- - - $\quad$ - Tarenaya Port.

Pinna Cey.

Clinopodio

Albahaca sil-

vestre

Clitoria

Clinopodio Port. Bloschinza Russ, Storzyszek Pol.

Clitoria Port. Clitorisblomster Dan. \& Swed.

Rotella Hierba rodela
Escudinha Port. Skiold-urt Dan. Skôld-ört Swed. 
Page

36 Cneorum $L$.

682 Cnìcus $W$.

778 Cobrèsia W.

326 Coccolósa $L$.

844 Cócculus Bauh.

546 Cochlèria Tou.

$788 \operatorname{Cò} \cos \mathrm{L}$.

10 Codirium Vahl.

170 Coffè L

$778 C$ oix $L$.

476 Colbértia Sal. 292 Cúlchicum $L$. 2+ Collinsónia $\mathrm{L}$ 626 Colutea $L$.

452 Cómarum $L$.

36 Comoclàdia $L$.

934 Conférva $\boldsymbol{A g}$.

216 inium $L$

188 Conocárpus Jac.

270 Convaliària $L$.

140 Convólvulus $L$.

702 Conỳza $L$.

356 Coúkia Sonn.

350 Copaifera $\mathbf{L}$.

488 Cóptis Sal.

756 Corallorrhiza R. $B$ r.

466 Cúrchorus $L$

150 Cúrdia L.

732 Coreópsis Jac.

208 Coriándrum $L$.

482 Coriària $L$.

130 C)ris $I$

8 Corispérmum $L$ 52 Cornucòpiæ $L$.

102 Córnus $L$.

520 Cornùtia L.

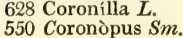

228 Corrigìola $\boldsymbol{L}$.

128 Cortus $a$ L.

600 Corýdalis Dec.

792 Córylus $L$.

58 Corynéphorus Beauv.

258 Córypha $L$.

722 Cútula $L$.

382 Cotyledon $L$.

556 Crámbe Tou.

230 Crássula $L$.

424. Cratæ'gus $L$.

396 Cratæ'va L.

674 Crèpis $W$.

524 Crescénti $a$

250 Crìnum $L$.

212 Crithmum $L$

36 Crocus $L$

608 Crotalària $L$

812 Crìton $L$

94 Crucianélla $L$. R. Br.

372 Cucubalus $L$.

808 Cùcumis $L$.

81)8 Cucúrbita $\dot{L}$

732 Cullumia $\mathbf{R}$. Br.

214. Cuminum $L$.

806 Cupréssus $L$.

6 Curcìma I.

100 Curtísia H. K

104 Cuiscuta L.

286 Cyanélla $I$.

$846 C$ ỳcas $L$.

128 Cýclamen $L$.

426 Cydonia Tou.

534 Cymbària $L$.

196 Cynánchum $L$

$684 C \bar{y}$ nara $L$.

$C$. Cardúnculus $L$ sp. 11458

122 Cynoglóssum $\boldsymbol{L}$.

348 Cynomètra $L$.

62 Cymosirus

50 Cypèrus $L$.

Cypèrus $L$. esculéntus $L$. sp. 896

690
Nos. British or Systematic

Genera. Synonymes.

84

4 -

- Widow wail Càrex

22 Ménispérmüm

1407 - - - - Scurvy grass

1983 - - - - Cocoa-nut tree

1951

Coffee tree

1211 Hibbértia

851

63
1573

1152

85

2292

649
544

787

384
1734

1734

986

1238 Helléborus

$1882 O^{\prime}$ phrys

1187

428

1804

Sebesten

091

360

26
133

306

1318

1576

351

1502

169

762
1775

1775
1060

1442

699
1132

1132

1638

1336

633

93

1530 Cáscarilla

271 Petty madder

1814 Arctòtis

1047

2022

2021

641
2017

14

300

310
824

2107

354

1134

1668

336

178

127

Job's tears

Meadow saffron

Aniseed tree

Bladder senna

Maiden plum

Hèmlock

Button tree

Bind weed

Flea-bane

Wampee tree

Tickseed suñ

flower

Coriander

Myrtle-leaved

sumach

the earth

Club grass

Fan palm

Mayweed

Navel-wort

Sea Kail

Hawthorn

Garlic pear

Succory hawk

African lily

Samphire

Saffron

Crosswort

Gourd

Cypress

Turmeric

Hassagay tree

Dodder

Sägo tree

Sow bread

Quince

Dö's bane

Artichoke

Cardoons
Marsh cinquefoil

Lily of the valley

Balsam of capevi

Le copaier

French.

German.

La camelée

Der zeyland

Le cnichaut Das kratzkraut

Le raisinier de mer Die seetraube

Le cranson Das lösselkraut

Le cocotier Die kakospalme

Le caffayer Der kaffebaum

Larmille Das thränengras

Colchique d'automne Die zeitlose

Le baguenaudier Der blasenbaum

Le comaret Das funfolatt

Comoclade a feuilles Die astlose

$$
\text { entières }
$$

La conferve

La cigue

Der wasserfaden

Le liseron

Der schierling

Die mayblume

Die winde

Die dürrwurz

Der kopaivabaum

Jew's mallow Ia corete

Le sebestier

La coriope

La coriandre

Le redoul

Le coris

Tickseed - Le corisperme

Horn of plenty grass Le coqueluchiole

Dogwood Le cornouiller

Scorpión - - L'agnanthe

Wart cress, star of

Strapwort La corrigiole

Bear's-ear sanicle La cortuse

Nut tree Le noisetier

Die muspflanze

Der sebestenbaum

Das käppchen

Der koriander

Der gerberstrauch

Der erdkiefer

Der wanzensame

Das füllhorngras

Der kornelbaum

Die kronwicke

Das lingenkraut

Die kortuse

Die haselstaude

Coryphe

Le cotylet, or cotyli

Le crambé

La crassule

L'aubépine Der hagedorn

Le tapier

Der tapiabauxi

Pippau

Der kürbisbaum

Die hakenlilie

Le calabassier

La crinole

La bacille

Le safran

Der meerfenchel

Die safranpflanze

Die klapperschote

La crucianelle

Das kreuzblatt

Bladder campion Le behen

Cucumber Le concombre

La courge

Le cumin

Le cyprès

Cuscute

La cyanelle

Le cycas des Indes

Cyclame

Coignassier

Cymbaire

La cynanque

L'artichaut

Cardon

Hound's tongue

Cynoglosse

Le cynomètre

Dö's-tail grass - Crêtelle

Le souchet

Amande-de-terre 
Page Dutch. 36 Chamaelea 682 Distel

326 Druiveboom

546 Lepelkruid 788 Kokosboom

170 Koffyboom 778 Traangras

\section{Wildi saffraan}

626 Senneboom

45. Rood waterbezie 36 Maagden-pruim. boom

934 Flap

216 Scheerling

188 Knopboom

270 Lelietjes van den dale

140 Winde

702 Tonderkruid

350 Balsem copayveboom

466 Moeskruid

150 Sebestenboom

732 Wantszaad

208 Koriander

482 Lederboom

130 Zeethym

8 Wantz-zaader

52 Trechtergras

102 Kornoeljeboom

628 Kroonkruid

228 Riempjes

128 Kortusa

792 Hazelaar

2.58 Sariboeboom

722 Koedille

382 Navilkruid

556 Zeekool

2:30 Dikblad

424. Haagdoorn

396 Stinkappelboom

674 Hondsbloem

$524 \mathrm{Kalabasboom}$

250) Haaklelie

212 Zeevenkel

56 Saffran

608 Rammelaar

94 Kruisblad

372 Wit been

808 Komkommer

8 (8) Kauwoerde

214. Komyn

806 Cypresseboom

6 Kurkuma

104 Warkruid

846 Sagoeboom

128 Varkensbrood

$426 \mathrm{~K}$ weeboom

$53+$ Bootjesvrught

196 Worgkruid

68t Artisjok

\section{Hondstong \\ 348 Teef jes-klink \\ 62 Vingerpluim \\ 50 Cypergras}

Italian

Camelea

Grappoliere

Olivilla

Spanish

Coccoloba

Coclearia

Cochlearia

Albero del cocco El coco
Il caffè
Lacrime di
Giobbe

Colchico

El café

Lagrimas de

Moises

Solatro

Cicuta - -

Il mughetto

Il vilucchio

La conizza

Copaiba

\section{Villorita}

Espanta-lobcs

Ceguda $^{-}$

Azücenà del

valle

La correguela

La coniza

Copai

\begin{tabular}{|c|c|c|}
\hline Il sebesten & - & El sebesto \\
\hline - & - & - \\
\hline Coriandro & & $\begin{array}{l}\text { Cilantro } \\
\text { Rulda }\end{array}$ \\
\hline $\begin{array}{l}\text { Il cori } \\
\text { Corisperma } \\
\text { Cornucopia } \\
\text { Il corniola }\end{array}$ & & $\begin{array}{l}\text { Hierba pinul } \\
\text { Corispermo } \\
\text { Cornucopia } \\
\text { El cornizo }\end{array}$ \\
\hline
\end{tabular}

Coronilla Coronilla

La coregiuola La correguela

El nocciuolo El avellano

Cotiledone -

Crambe Ombligüra

Bianco spino- Espino blancö

\section{Cuiete}

Crino

Critmo

Zafferano

Crotalaria

\section{Cuiete}

Crino

Hinojo marino

Azatian

Crotalaria

\section{Il been bianco Colleja \\ Cetriuolo Pepino}

La zucca Calabaza

Comino

Cypresso

-

\section{Comino}

Ciprés

Il sago

Ciclamine

Cotogno

Cinanco

Carciofo

Cinoglossa

Cipero

El sagú

Panporcino

Membrillero

Cinanco

Alcachofa
Portuguese, Danish, Russian, Polish, South American, Oriental, or other Names.

Citocacio Port. Chamaelea Dan. \& Swed.

Kradstidsel Dan. Kratstistel Swcd.

Druetrae Dan. Drusveträd Swed.

Skee-urt Dan

Inaiaguacuiba Brasil. Cay dua Cochinch.

Cay càphe Cochinch. Kofé Russ. Kawa Pol.

Lagrymas de N. Senhora Port. Jobs taarer Dan.

ColchicoPort. Beswrémennoi zwjetRuss, RozsiadPol.

Colutea Port. Linsetræe Dan. Linsetrüd Sued.

Sabelnik Russ. Pieciornik Pol. Krakfottis Swed.

Thachhoa Cochinch. Vandträd Dan.

Boligolow Russ. Swinia wesz Pol. Skarntyde Dan.

Knavtrae Dan. Knappträd Swed.

Landisch Russ, Konwalia Pol.

O liserâo Port. Snerli Dan.

A conizaPort. Cattuschiragum Malab. Troldurt Dan.

Copiba Port. Covaiba Brasil. Copaivatræe Dan.
Melochia Arab. Madurt Dan.

Sebesteira Port. Vidi-maram Malab. Sebestentræe Dan. Tægefrö Dan. Vägglusfrö Swed.

Coentro Port. Koriander Russ. Ghad Hebr. Lædertræe Dan. Läderträd Swed.

A corea Port. Korisurt Dan. Korisört Swed. Vorggeluussaed Dan.

Frugthorn-græs Dan. Fruckthorn-gräs Swed. Cornisolo Port. Kuroslejepnik Russ.

Kroneurt Dan. Kronört Swed.

\section{A correjola Port. Remurt Dan. Remört Swed.}

Avelleira Port. Frandik Turk. Oreschnik Russ.

Arvore dos sombreiros Port. Codda-panna Malab.

Luudblomster Dan.

Cotyledone Port. Rzesa wietrzna Pol

Strandkaal Dan. \& Norv.

Tykblad Dan. Tjockblad Swed.

Bodlak Pol. Bojarischnik Russ.

Tapia do Brasil Port. Tapia Brasil. Nurrvala Malab.

Cuiete Port. Kalabastræe Dan. Kalabastrăd Swed. Crino Port. Kroglilie Dan.

Funcho marinhoPort SöefenkelDan. SjöfenkălSwcd. AçafraoPort.Zatiphra Arab. Schafran Rus. Szafran Pol. CrotalariaPort. KlapperbælgeDan. SkallerskidaSwed.

Korsblad Dan. \& Swed.

Herva traqueira Port. Skum-neglike Dan.

Pepino Port. Kira Indian. Ogurzi Russ. Ogorek Pol. Abobara Port. Kabak Pers. Tikwa Russ. Tykwia Pol.

CuminhoPort. Timon Russ, Kmin Pol. Kummen Dan. CyprestePort. Elhanni drab. Kyparisnoe derewo Rus.s. Mangella-kua Malab. Gurgumeye Dan.

Pawiliza Russ. Kania przedza Pol.

O sagûeiro Port. Todda-panna Malab. Sagutræe Dan. Pao de porco Port. Galteknappe Dan. Svinbröd Swed. MarmeleiroPort. Haivah Pers. ArmudRus. PigwaPol.

CinancoPort. HundemorderDan.HundstrypareSwed. Artitschok Russ. Karciof Pol. Erteskok Dan.

Lingua de câo'Port. Tscherednik Russ. Psi iezik Pol.

Hanekamsgræs Dan. Kam-exing Swed.

Cipergræs Dan. Cipergräs Swed. 
English Names.

Ladies' slipper

766 Cypripèdium $L$. 19

$624 C$ ýtisus $L$.

718 Dáhlia Cav. Schreb.

322 Dáphne $\boldsymbol{L}$.

844 Datisca W.

134 Datùra L.

210 Daúcus $L$.

384 Davállia Sm.

Synonymes.

192 Deeringia R. Br. 2196 Trichúmane

472 Delphinia R. Br. 563 Celosia

370 Diánthus $\boldsymbol{L}$. $\quad 1046$

904. Didýmodon Hedw 2230

530 Digitàlis $\boldsymbol{L}$

52 Digitària $S c o$.

478 Dillèni $a \mathrm{~L}$

838 Dioscòrea $\mathbf{L}$

180 Diósma $W n l$.

870 Diospỳros $L$

908 Diphýscium 2159

604. Dipterix Schreb. 1518

324. Dírca $L$

128 Dodecátheon $L$.

616 Dólichos $L$

716 Dorónicum L

88 Dorstènia L

544 Dràba $L$

266 Dracæ'na $L$

510 Dracocéphalum $L .1279$

298 Dracóntium $L$. $\quad 868$

232 Drósera $L$.

454 Drỳas $L$.

" 11 . 1 . 687

210 Echinóphora $L$. 69

746 Echinops $L$. 1850

146 Echites $L$.

124 $E$ "chium $I$

340 Edwárdsia Sal

152 Ehrètia L

90 Elæágnus $L$

468 Elæocárpus $L$

836 Elà is Jac.

$790 \mathrm{E}$ late $L$

790 Elate L.

L. 931

48 Eleócharis $R . B r . \quad 124$

744 Elephantipus $L$. 1843

68 Eleusine Gae. 200

700 Elichrỳsum Pers. 1730 Cynosùrus

880 Ellobocárpus 2181 Ptèris

$$
\text { Kault. }
$$

72 E'lymus $L$

826 Empètrum $L$

848 Ephedra $L$.

2045

2115

760 Epidéndrum L. 1907 Vanílla

358 Epigæ'a $L$.

318 Epildbium $I$

100 Epimèdium $L$.

1015 - .

903
297

68 Eragróstis Beauv. 197

18 Eránthemum $R . B r .49$

488 Eránthis Sal. $\quad 123$

304. Erica $L . \quad 173$

704 Erigeron $L$. 173

426 Eriobótrya Lindl. 113

742 Eriocéphalus $L . \quad 1837$

50 Erióphorum $L . \quad r . \quad 125$

$556^{\circ}$ Erùca Tou.

624. E'rvum $L$

E. Léns $L$. sp. 10421

558 Erucària $G a$

210 Erýngium $L$.

550 Erýsimum $\boldsymbol{L}$.

604 Erythrina $L$.

\section{2}

Hëlléborus

Ling

Mespilus

-

$$
=\quad-\quad-
$$

True bitter vetch

1445 Condylocárpus

622 Holly

1424

1521

\section{Cytisus}

Spurge-laurel

Thorn apple

Carrot

Larkspur

Pink

Fraxinélla

St. Peter's wort

Fox-glove

Finger-grass

Litchi

Yam

Bucku plant

Date plum

Teasel

Tonquin bean

Leather wood

Leopard's bane

Whitlow grass

Dragon tree

Dragon's head

Dragon

Sundew

- $\quad$

Sea-parsnep

Globe-thistle

Viper's bugloss

oleaster

olive wood

Oily palm

waterwort

Spike rush

Elephant's foot

Barrenwor

Horse tail

Heath

Loquat

Pipewort

Cotton grass

Heron's bill

Rocket

Tare
Cock's-foot grass

Venus's fly-trap

American cowslip

Horse-eye bean

Sabot de la Vierge, or Der Venusschuh Soulier de Notre

Dame

Der geissklee

Le dactile

Der knauelgras

Fluteau

Der froschloffel

Laureole

Der seidelbast

La cannabine

Das streichkraut

Stramoine

Der stechapfel

La carote

Die möhre

La dauphinelle

Der rittersporn

L'oeillet

Die nelke

Dictame blanc

Der diptam

La dierville

La digitale

Die akadische

lonizere

Der fingerhut

Der rosenapfel

L'attrape-mouche

Igname

Le plaqueminier

Cardere à foullon

Der pseudolotus

Le bois de cuir

Die kardendistel

Gyroselle de Virginie Die göttergabe

Le dolic

Dorstène

La drave

Le dragonier

Dracocéphale

Draconte

Le rossoli

Driade

L'echinophore

Echinope

L'echite

Faseln

Gemsenwurz

Die contrayerva

Das hungerblümchen

Der drachenbaum

Der drachenkopf

Zehrwurz

Der sonnenthau

Das silberkraut

Das kronenkraut

Die stacheldolde

Die kugeldistel

Der klammerstrauch

Der natterkopf

Le cabrillet

L'olivier de Bohéme Der wilde oelbaum

Le ganitre

Die ganiterbaum

L'avoira de Guinée Die oelpalme

L'indel asiatique Die tannenpalme

'elephantope

Der elephantenfuss

Elyme des sables

Camarine

Das haargrass

Die rauchbeere

Die seetraube

Shrubby horse-tail L'uvette

Der grundstrauch

L'epigée L'épilobe Der weiderich

Le chapeau d'evêque Die bischofsmütze

Das kannenkraut

L'eranthème

Die frühblume

winter aconite

La bruyère

La vergerette

La joncinelle

Die heide

Das scharfe

Der kantenhalm

La linaigrette

wollkopf

L'ers ervillier

Die erve

Die linse

Die krausdistel

Der hederich

Der korallenbaum 
TABLE OF SYNONYMES.

Page Dutch

766 Vrouweschoen

624 Cytisus

62 Krop-aair

294 Water-weegbree

$322 \mathrm{Zwart}$ peper-

boompje

844. Weedaart

134 Doornappel

210 Peen

472 Ridderspoor

370 Anjelier

354 Diptam

Italian.

Spanish.

Pantoffola

Zueco

Citiso

Il dattilo

Citiso

El dactilo

Damasonio

Laureola maschio Laureola macho Loireola macho Port.

Stramonio Estramonio

Carota

Zanahoria

Estramonia Port. Durman Russ.

Speronella

Garofano

Dittamo bianco

Espuela de caballero

Clavél

Chitan

170 Akadische lonicera Madreselva

530 Vingerhoed :

Digitale

Madreselva

478 Roosappelboom

356 Vliegenknip

838

870 Basterd-lotus

90 Vollers kaarden

Dissaco

Dijital

$-$

$-\quad-$

$-+\cdot$

Cardencha poschki Russ.

Madresylva Port.

Digital Port. Naperstok Russ.

Fruta estrellada Port. Syalita Malab.
Portuguese, Danish, Russian, Polish, South American, Oriental, or other Names.

Calçado de Nuessa Senhora Port. Kokuschkiny Sa-

O dactylo Port. Hvasgræs Dan. Exing Swed.

Damasonio Port.

324. Lederstruik

128 Afgodskruid

616 Slingerboon

716 Wolverley

88 Contrajerva

544 Taschkruid

266Draakboom

510 Draakskop

298 Speerwortel

232 Zonnedaauw

454. Hertenkruid

228 Kroondoorn

210 Stekelkroon

746 Morgenster

146 Rooswinde

124 Slangekruid

$\begin{array}{ll}\text { Doronico } & \begin{array}{l}\text { Doronico } \\ \text { Contrayerba } \\ \text { Draba } \\ \text { Draba }\end{array} \\ \begin{array}{l}\text { Dragone } \\ \text { Dragocefalo }\end{array} & \begin{array}{l}\text { Drago } \\ \text { Dragocefalo }\end{array}\end{array}$

Doronico Port. Geede-urt Dan. Vildget_ört Swed. Contraerva Port.

Hungersblomst Dan. Hungerblomster Swed.

Dragoneiro Port. Dragetræe Dan.

DragocefaloPort. Cay co coCochinch. DragehovedDan.

Rugiada del sole Rociada

A rossolina Port. Solneznaja trawa Russ.

Pol.

Dictamo branco Port. Badan Russ. Dyptan Pol.

Echinofora

Echinopo

-

Echinofora

Echinopo

Echite

Echinofora Port.

Echinopo Port. Klottistel Swed.

Echite Port.

Echite
Echio

Hierba de la vi- Viperina Port. Rumian Russ.

bora

Olivo di Boemia Arbol de paraiso Kalaf Pers. Lochowina Russ. Oliwa lésna polna Pol.

90 Olyfwilg

468 Ganiterboom

836 Palmietboom

790 Wilde daadelboom

- - . Perin-kara Malab.

744 Olyphants-poot

72 Zandig koorngras

826 Besheide

848 Zeedruif

358

358

318 Basterd-wederik

100 Muiltjesbloem

890 Akkerig paardestaart

18 Vroegbloem

304 Heide

704 Scherp fynstraal

76 Kanthalm

50 Wolgras

6

\section{Erven}

Lins

210 Kruisdistel

550 Steenraket

604 Koraalboom

Elimo

- - - Elimo

Hierba de las

coyunturas

Epilobio

Epimedio

Equiseto

Erantemo

Epilobio

Epimedio

Equiseto

Erantemo

Erica

Brezo

Olivardilla

Erioforo

Erioforo

Ervo

Lenticchia

Yero

Lenteja

Eringio

Erisamo

Arvore corallo
Cardo corredor

Jaramago

Arbol der coral
Elimo Part. Sandhavre Dan. Strandrog Swed.

Camarinhas do reyno Port. Wodäniza Russ.

Stepnaja malina Russ. Kirsik Kalmuk.

Memecylo da Canada Port.

Kipreı Russ. Karamuk Tartar. Abragärest Lapl.

Epimedio Port. Ikaniso Jap.

Equiseto Port. Ma hoang Cochinch. Chwostch Russ.

Erantemo Port.

Weresk Russ. Wrzos Pol. Lyng Dan. Liung Swed. Blaa troldurt Dan.

Erioforo Port. Ageruld Dan. ängull Swed.

Lentilha Port. Tschetschewiza Russ. Soczewika Pol.

Sinaja golownik Russ.

Gortschitza polewaja Russ. Gorczyca polna $\mathbf{P o l}$.

$4 \mathrm{C}$ 
English Names.

French

270 Erythrònium $\boldsymbol{L} . \quad 789$

4) 8 Eucalýptus Herit. 1126

842 Euclea $L$. 2098

416 Eugènia L. 1119

178 Euónymus Tou. 509

688 Eupatorium L. 1685

400 Euphórbia L. $\quad 1103$

526 Euphràsia $L$. $\quad 134$

208 Evólvulus

$98 E^{\prime}$ xacum $L$.

850 Excæcària $L$.

102 Fagàra L.

354 Fagònia Tou.

792 Fàgus $L$.

542 Farsèti $a$ Turra

26 Fèdia Moen.

866 Ferònia Corr.

220 Férula $L$.

62 Festiuca L.

484 Ficària Dil.

872 Ficus $L$.

742 Filàgo $L$.

912 Físsidens Hedw.

290 Flagellària $L$.

630 Flemíngia Rox.

912 Fontinalis $L$.

452 Fragdria Tou.

288 Frankèni $a$ L.

868 Fráxinus $L$.

266 Fritillària $L$.

F. imperiàlis $L$. sp. 4513

$946 \mathrm{~F}$ ucus $I$.

602 Fumària Tou.

246 Furcrœ'a Ven.

276 Gàgea Sal.

618 Galáctia $B r$.

248 Galánthus $L$

634 Galega Tou.

502 Galeóbdolon Sm. 126

502 Galeópsis $\boldsymbol{L}$.

1260

92 Gàlium $L$.

394 Garcínia L

172 Gardènia $\mathrm{L}$.

380 Garidélla Tou.

40 Geissorhiza Ker

172 Genipa Tou.

610 Genista $L$.

202 Gentiàna $\mathbf{L}$.

578 Gerànium Herit. 146

666 Geropògon $L$.

1620

54. Gèum L.

105

42 Gladiolus $L$.

1169

460 Glaúcium Tou.

194 Glaúx $L$.

502 Gléchoma $L$

868 Gledítschia I

406 Glìnus $L$.

6 Glóbba Rosc

90 Globulària $L$

270 Gloriosa $L$

618 Glýcine $L$

628 Glycyrrhiza Tou. 157

518 Gmelina

698 Gnaphàlium $L$. $\quad 179$

324 Gnidia $L$.

196 Gomphocárpus R. $B r$.

194 Gomphrèna $L$.

568
1258

1258

-

Dog's-tooth violet

Red gum tree

Elephant apple

Cüdweè

Dicrànum

Hédýsärum

-

73

2328

Earth-smoke

Agàve

Ornithógalum

Clitoria

- - - - - Snowdrop

Gäleópsis

Dead nettle

266 Ladies' bed-straw

587 Asclèpias

754 Goodyèra R. Br. 1870 Neóttia

592 Gordonia El. $\quad 147$

588 Gossýpium $L$. $\quad 1481$

866 Gouània $\mathbf{L}$. $\quad 2146$

16 Gratiola $L$.

166 Grìas $L$.

384 Grièlum $L$.

352 Guaiacum $\mathbf{L}$.

304 Guàrea L.

788 Guettárda L.

43
1188
1063

1063

350 Guilandina J. 979

482 Gymnoclàdus Lam.2094
79 Yellow bonduc

$O$ 'rchis

Guilandino
Rose apple

Spindle tree

Hemp agrimony

Spurge

Eye-bright

$$
\text { - }
$$$$
-
$$

Beech

Giant-fennel

Fescue-grass

Pilewort

Fig tree

Cotton rose

Water-moss

Strawberry

Ash tree

Fritillary

Sea wrack

Fumitory

Hemp nettle

Bed-straw

Mangosteen

Cape jasmine

Tile-roōt

Genip tree

Broom

Gentian

Bastard cabbage tree

Crane's bill

Old man's beard

Avens

Corn fiag

Horn-poppy

Black saltwort

Ground ivy - - Le févier à

er à trois

épines

Däncing girls - La glinole

Madwort Globulaire

Superb lily La méthoniqu

Kidneybean tree Glycine

- - - - Réglisse

- - - - Gmelin

Everlasting Gnaphale

Gnidienne

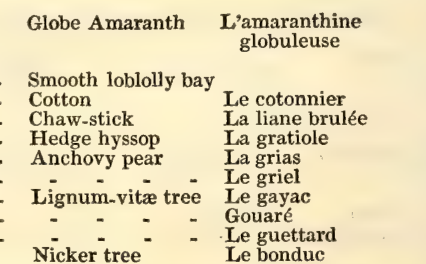

Die peitschenpflanze

Der jambusenbaum

Der spindelbaum

Abkraut

Das euphorbium

Der augentrost

Die kriechende winde

Die kugelröhre

Der blendbaum

Der fagara

Die buche

Der ackersalat

Das ruthenkraut

Schwingel

Feigen-ranunkel

Der feigenbaum

Das filzkraut

Das hüllmos

Die erdbeerpflanze

Die esche

Das kiebitzey

Tang

Der erdrauch

Schneetröpfchen

Die geisraute

L'ortie morte des bois Die gelbe hanfnessel

Die taube nessel

Das labkraut

Der mangostanbaum

Die garidelle

Der genipabaum

Der ginster

Der enzian

Dēr stöchschnabel

Der weissbart

Das nelkenkraut

Der schwertel

Das gehörnte schöl

kraut

Milchkraut

Gundelreben

Der honigdorn

Der glinus

Die kugelblume

Die prachtlilie

Die glycine

Süssholz

Die ruhrpflanze

Das schnabelkorn

Der kugelamaranth

Die baumwolle

Das gnadenkraut

Die anschojebirn

Die kronranunkel

Das franzosenholz

Der schüsserbaum 
Page Dutch

270 Hondstand

842

416 Jamboesboot -

178 Paapenhout

688 Boelkenskruid

400 Euphorbium

526 Oogentroost

228 Kruipwinde

98 Kogelpyp

850 Verblindboom

102 Zadelboom

354 - -

792 Buikeboom

26 Sprinkhaandkruid

220 Holstok

62 Dravik

484. Speenkruid

872 Vygeboom

742 Beurkruid

290

912 Fonteinmoos

452 Aardbezie

868 Escheboom

266 Kievitsbloem

Keiserskroon

946 Zeeruy

602 Duivekervel

246 Boomaloe

248 Wittertje

634 Vlakkenkruid

502 Geelbloemige hondsnetel

502 Knoopige hondsnetel

92 Walstroo

172

610 Brem

202 Gentiaan

604

578 Oijevaärsbek

666 Grysbaard

454 Gemeen nagelwortel

42 Gladiolus

460 Gehoorud schelkruid

194 Melkkruid

502 Aaardveil

406

90 Köolkruid

270 Pragtige-leliepraal

618 Pragtige-le

618 Kruipboor

628 Zoethout

698 Droogbloem

191 Rondbloem

\section{Katoen}

16 Genadekruid

384 Grootbloem

352 Pokhout

304 -

350 Balletjestruik

Italian.

Spanish.

Portuguese, Danish, Russian, Polish, South American,

Dente di cane

Diente de perro Dente de câoPort. Kandik Russ. HundetandDan.\&S Sw.

Giambosa - Jambosa

Fusaggine Bonetero

Eupatorio Eupatorio

Euforbio Euforbio

Eufrasia Eufrasia

Esaco

Fagara

Il faggio

Valerianella

Ferula

Festuca

idonia minore Ficaria

Esaco

Fagara

La haya"

Canonigos

Canaheja

Higuéra

Fontinale Fontinal

Fragaria Fresera

Frassino

Fritillaria

Fuco

Fummosterno

Fresno

La fritilaria

Galanto

Galega

Ortica morta

Gaglio

Ginestra

La genziana

Jinesta

La jenciana

Geranio

Geropogon

Erba benedetta

Ghiagguiolo

Islera

Espadaña
Xe lin tsu Chin. Cay nhaoe Cochinch.

Bieslen Bohm. Swida Russ. Ukurgol Tatar.

Eupatorio Port. Griwa konskaja Russ. Sadziec Pol. Euphorbio Port.

EuphrasiaPort.Otschnaja pomotsch Rus. SwieczkiPol.

\section{Esaco Port.}

Fagara Port.

Djæmdæ, Schoki $A r a b$.

A faya Port. Buk Russ. \& Pol.

Balderjan Russ. Kozlki Pol.

Canafrecha Port. Riisurt Dan. Risört Swed.

Mannagraes $D$ cin. Svingel Sw'ed.

Celidonia menor Port. Tschisttak menschoi Russ.

Figueira Port. Tin Arab. Finik Russ. Figa Pol.

Panambu valli Malab. May boac Cochinch.

Fontinal Port. Aaemoos Dan. Lonkemossa Swed. Morangueiro Port. Semljaniza Russ.

Freixo Port. Jas Russ. Jesion Pol. Ask Dan.\&Swcd. A fritilaria Port. VibeægDan. Vipaagg Swed.

Fuco Port. Si sj Jap. Tang Dan. \& Swed.

Fumaria Port. Fingosakf Jap. Semlanja orech Russ.

Hó virág Hung.

Gallega Por. Pestilentsrod Dan. Pestilentsrot Swed.

Ortiga morta Port. Rasnozwetnaja kropiwa Russ.

Calhaleite Port. Roschodnik Boh.

Cay deanh tau Cochinch. Cha tsu Chin.

Giesta Port. Genista Dan. \& Swed.

Goretschafka Russ.

Camarinhas, Camarinheira de Brazil Port.

Geranio Port. Schuratelinei nosRuss.Pychawiec Pol.

Cravoilha Port. Grebnik Russ, Zarzyczka Pol. Nellikerod Dan.

Schpaschnaja trawa Russ, Mieczyk ziele Pol.

Melecznik Pol. Melkurt Dan. Mjölkört Swed.

Ellera terrestre Hiedra terrestre Krotowik Russ. Bluszcz poziemny Pol.

Globularia

Siempre enjü

Haschfe $A r a b$.

Jamma mjoga Jap.

Globularia Port. KugleblomstDan. BergskubbaSwed. Methonika Malab. Junglang Java. Nienghala Cey.

Regolizia

Gnäalio

Regaliz

Gnafalio

Cam thaoCochinc. Dubez solotkoi Rus. LakrycyaPol.

Tani Malab. Dematha Cey. Doery radak Java.

Perpetua roxa Port. Wadapu Malab. Hoa nua ngai Cochinch.

Kopa Indian. Chloptscha taja bumaga Russ.

Licharodotschnaja trawa Russ. Konjtrud $\boldsymbol{P}$ ol

Guaiaco Port. Bakazt Russ. Franzostræe Dan

Jito Brazil. Guara Java.

Tawhannov Otaheite. Rava pou Malab. 
Page Nos. British or Systematic
Symonymes.

English Names.

French.

German.

878 Gymnográmma 2171 Grammitis

$$
\text { Desv. }
$$

368 Gypsóphila $L$

752 Habenària $R . B r .1861 \quad O^{\prime}$ 'rchis

248 Hæmánthus $L$. 731 African tulip

$\begin{array}{ll}- & - \\ \text { Blood flower } & \text { La gypsophie } \\ \text { Logwoomanthe } & \text { Le campeche }\end{array}$

Die gypsflanze

350 Hæmatóxylon $L .985$ Campeachy wood

Snowdrop tree L'halesier

394 Halèsia $\mathbf{L}$.
524. Hallèria $\mathbf{L}$.

108

1338

630 Hállia Thun.

1584 Hedýsarum

Hamamelis $L . \quad 312$ Black Virginian

870 Hamiltònia Mhl. 2162 pistachia

188 Hédera $L$. 549

2 Hedýchium Kon.

630 Hedýsarum $L$.

$H$. Onobry chis $L$. sp. 10597

716 Helènium L. 1755

470 Heliánthemum 1198 Cistu Tou.

730 Heliánthus $\boldsymbol{L}$.
H. tuberòsus $\boldsymbol{L}$. sp. 12439

194 Helicònia $L$.

194 Heliconia $L$. $\quad \quad 570$

558 Helióphila $L$. $\quad 1446$

$\begin{array}{lr}118 \text { Heliotròpium } L \text {. } & 325 \\ 488 \text { Helléborus } L . & 1237\end{array}$

1014 Helvélla $L$.

260 Hemerocállis $L$.

878 Hemionitis $I$

480 Hepática $D i l$

African fly honey. L'haller suckle

Witch-hazel

L'hamamelis

Die blutblume

Das campescheholz

Die hallerie

Die zauberstrauch

Oil nut

Ivy Le lierre

Garland flower Le gandasuli

Sainfoin

Le sainfoin

Der epheu

Die sulla

Esparzette

Willow-leaved sun- L'helenie flower

Sun rose

222 Heraclèum L. - 672 Hogweed

814 Heritièr $\boldsymbol{a}$ H. K. 2037

866 Hérmas Thun. 2147

754 Herminium R. Br. 1868

772 Hernándia L. $\quad 194$

208 Herniària $L$. 614

532 Herpéstis $R . B r . \quad 1367$

40 Hesperántha Ker 98

548 Hésperis $L$. $\quad 142$

584 Hibiscus $L$

672 Hieràcium $L$. $\quad 1635$

628 Hippocrèpis $I$. 1577

812 Hippómane $L . \quad 2030$

832 Hippóphae $\boldsymbol{L} . \quad 2058$

6 Hippuris $L$

174 Hirtélla $W$.

860 Hólcus $L$.

74 Holósteum $L$

72 Hórdeum $L$.

128 Hottònia I

198 Hóya R. Br.

202 Huérnia R. Br.

834 Hùmulus $L$

814 Hura L.

Sallow thorn

499

2132

210

355 Water milfoil

592 Asclèpias

596 Stapèlia

66 Hutchínsia R. Br. 1410 Cardámine

284 Hyacínthus L. 182 Hyænánche $\boldsymbol{H}$. K. 209

182 Hyænánche $H \cdot K .2097$

$\begin{array}{cc}1010 \text { Hýdnum } L & 2375 \\ 490 \text { Hydrástis } L . & 1241\end{array}$

842 Hydrócharis $L . \quad 2089$

208 Hydrocótyle $L . \quad 658$

204. Hydrolea $L$.

490 Hydropéltis $L . \quad 1240$

132 Hydrophýllum $L .372$

346 Hymena' $a \mathrm{~L}$. 972

886 Hymenophýllum 2203

$$
\text { Sm. }
$$

898 Hymenóstomum 2220 Gymnóstomum

$$
\text { R. Brown }
$$

136 Hyoscỳamus $L . \quad 381$

676 Hyóseris $L$. $\quad 1645$

104 Hypécoum $\boldsymbol{L} . \quad 313$

350 Hyperanthèra $\mathrm{Vahl} 98$

656 Hypericum

$914 H$ ypnum $L$

676 Hypochæ'ris $L$. 1650

254 Hypóxis $L$.

496 Hyssòus $L$

$546 \mathrm{I}$ bèris $L$.

Hyæna poison

- - -

Frog-bit

Pennywort

- -

Water-leaf

Locust-tree

Filmy leaf

Gymnostomum

- - - - Henbane

Swine's succory

La jusquiame

Hyoséride

Le cumin corn

Le ben oléifère

Le millepertuis

St. John's wort

Feather moss

Cat's ear

L'hypne

La porcelle

- - - - L'hypoxi

$\begin{array}{ll}\text { Hyssop } \\ \text { Candy tuft }\end{array}-\quad-\quad \begin{aligned} & \text { Hysope } \\ & \text { L'ibéride }\end{aligned}$

La jacinte

L'erinace

Morene
L'helianthe

Le bihai

'heliotrope

L'hémerocalle

La berce

'hernandier

La julienne

chere

L'épervière

Le mancenillier

L'argoussier

L'hirtelle

Holosté

Die sonnenblume

Die erdapfel

Der schraubenbaum

Die sonnenfreundin

Die sonnenwende

Die nieswurz

Der faltenschwamm

Die lilienaffodil

Der gitterfarrn

Die leberblume

Das heilkraut

Die hernandie

Das bruchkraut

Die nachtviole

Hibiskus

Das habichtskraut

Die hufeisenpflanze

Der manschinell-

baum

Der haftdorn

Der schafthalm

Der kräusler

Das darrgras

Spurre

Die gasserviole

Houblon

Coutarde enineuse

Der hopfen

Der streubuichsen. baum

Die hyacinthe

Der stachelschamm

Der froschbiss

Der wassernabel

Kleber

Das wasserblatt

Der heuschrecken baum

Das bilsenkraut

Der schweinsalat

Die lappenblume

Der behenbaum

Das Johanniskraut

Das astmos

Das saukraut

Der härling

Der isop

Die iberpflanze 
Page

Dutch.

talian.

Spanish.
Portuguese, Danish, Russian, Polish, South American, Oriental, or other Names.
368 Gipsminner

248 Tulp van de Kaap Emanto der Goede Hoope

350 Kampéchehout

Legno di Campeggio

\section{Afrikaansche kamperfölie}

104 Toverhazelaar

188 Klimop

630 Sierlyk haanekop Haanekammetjes

\section{Edera}

La sulla

La cedrangola
Hiedra

Sulla

Esparsita
Perekatipole Russ. Gipsurt Dan. Gipsört Swed.

Flor de la sangre Flor do sangue Port.

Palo de Campeche
Campecheeiro Port. Campeschetræe Dan. Campes. cheträd Swed.
730 Zonnebloem Aardpeeren

580 Schroevenboom

118 Zonnewende 488 Nieskruid 1014 Tolzwam

\section{Dagschoon 878 Oorvaaren 480 Leverkruid} 222 Heilkruid

272 Duizendgrein

\section{Damast}

584. Hibiscus

672 Havikskruid

628 Hoefyzer

812 Manceniljeboom

832 Duinbessen

6 Kattestaart

860 Zorghzaad

74 Heelbeen

72 Gerst

128 Waterviolier

284 Hyacinth

1010 Stekelzwamm

842 Vorschenbeet

208 Waternavel

204. Waterolyf

132 Waterblad

346 Gom animé boom
Girasole

Eliotropio
Elleboro
Pasta sciringa
terrestre
Emerocale
$-\quad-$
Anemone fega-
tella
Sfondilio

Girasol

Heliotropio

Eleboro

Lirio-asfodelo

Mularia

Anemone hepa- Hepatica nobre Port. Solotnikowa trawa Russ.

tica

Esfondilio
Tornesol Port. Sakrân Egypt.

Heleboro Port. Nyseurt Dan. Prustrot Swed.

Hemerocallia Port. Bolschoi lädüsch Russ.

Canabraz Port. Kulupär Pers. Putschki Russ.
Hera Port. Bjcullu Pers. Bljustsch Russ. BluszczPol.

Pipirigallo Port. Esparset Dan. \& Swed.

\section{Hoppe \\ 814 Ratelboom}

- - - - - Tooneenna Otaheite.

Erniaria Milgranos Herniaria Port. Sporyz trzeci Pol. Bridurt Dan.

Esperide Hespero Hesperina Port. Natfiol Dan. Nattfiol Swed.

Ibisco Hibisco HibiscoPort.

Ibisco

Ieracia Hieracio Hieracio Port.

Ferro di cavallo Hierba de la her- Ferradurina Port. Hesteskoe Dan. Hästsko Swcd. redura

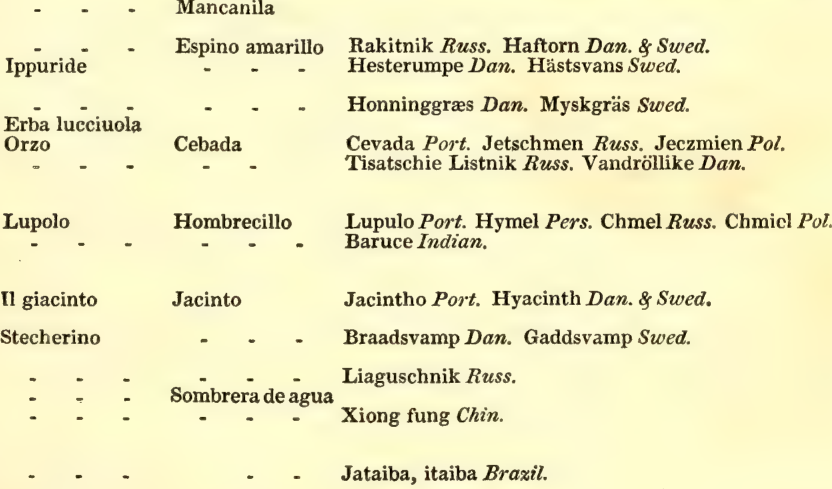

\footnotetext{
136 Bilsenskruid

676 Zwynenslaa

104 Lappenbloem

350 Kellerboom

656 St. Jans kruid

914 Takmos

676 Biggenkruid

496 Hysop

546 Bitter scheef bloem
}

\section{'T}

Giusquiamo

rinciatella

Beleño

MeimendroPort. BelenaRuss. BielunPol.BulmeDan.

- $\quad-\quad$ Z Zadorija

Corazoncillo

Ipno Hipno Hypno Port. Vægmosse Dan. Väg

Moringa Port

Melfurada Port. Sweroboi Russ.

- - - Hierba del alcon Kongpenne Dan. Véres lapu Hung.

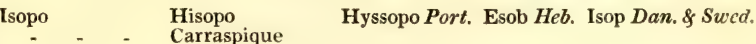


146 Ichnocárpus $R, B r .414$ Apócynum

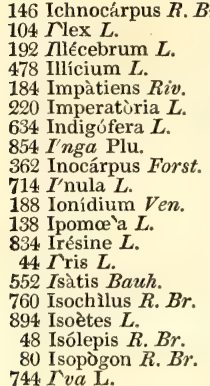

744 rva L.

188 Jasiòne $L$.

12 Jasminum $L$.

812 Játropha $L$.

298 Jonèsia W.

794 Juglans $L$.

258 Júncus $L$

849 Juníperus $L$.

18 Justícia L.

4 Kæmpfèria L.

356 Kálmia L.

618 Kennèdia Ven.

668 Lactùca $L$.

322 Lagétta J.

188 Lagø'cia $L$

54 Lagirus $L$

502 Làmium $\boldsymbol{L}$.

518 Lantàna $L$.

42 Lapeyroúsia Ker

315 Hulver

555 Whitloe wort

1215

- -

Touch me not

Mimòsá

2123

1024

1744

541 Vìola

1430

2214.

-

230 Scho'nus

1841 Bastard Jesuit's

bark tree

547

39

867
1999

1999
760
9113

2113

47

12

1011

1553 Gíýcine

1628

909 Dáphnè

548

153

1259

1312
103

678 Lapsàna $L$.

1651

806 Làrix Sal.

220 Laserpitium $L$.

846 Latania Com

524 Lathræ'a $L$.

332 Laúrus $L$.

498 Lavándula $L$.

584 Lavatèr $a \mathrm{~L}$.

316 Lawsonia L

358 Ledum $L$.

772 Lémna $L$.

2014 Pinus

669

2109

1339

1558 - -

etchling

1251

1475

898

1012

1939

506 Leonotis $R$. B

286 Leóntice $\boldsymbol{L}$.

670 Leóntodon $L$.

700 Leontopòdium R. Br.

506 Leonurus $L$.

552 Lepidium $L$.

$$
\text { L. sativum }
$$

912 Léske $\alpha$ Ehrh.

626 Lessértia Dec. $\quad \mathbf{1 5 7 2}$ Colùtea

192 Lestibudèsia R. Br. 561 Celosia

830 Leucadéndron $L .2053$ Prote $a$

506 Leùcas $R . B r . \quad 1269$ Phlòmis

912 Leùcodon Schwa. 2244 Dicrànum

248 Leucojum L. ${ }_{144}$ Leucopògon $R . B 33$ Br. 401 Styphèlia

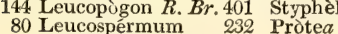
R. Br.

188 Lightfoótia Herit.
220 Ligusticum $L$. 665 - -

220 Ligústicum $L$

-

12 Ligústrum $L$.

264. Lilium $L$.

$298 L$ ímeum $L$

356 Limònia $\mathbf{L}$.

532 Limosélla $L$.

526 Linària Tou.

514 Linnæ' $a$ Gro.

232 Linum Bauh.

36 Primprint

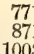

100

1359 Bastard plantain

1344 Antirrhinum

$\quad 701$

2001

628 Liquorítia Mönch. 1575
478 Liriodéndron $W .1216$

754 Listèr $a \mathrm{~B} . \mathrm{Br}$. 187

120 Lithospérmum L. 330

$O$ p̈prys
Holly

Knot-grass

Aniseed tree

Balsam

Masterwort

Indigo

Otaheite chestnut

Elecampane

- $\quad-$

Woad

Quillwort

Sheep's scabious

Jasmine

Physic nut

Asoca tree

Walnut

Rush

Juniper

Malabar nut

Galangale

Lettuce

Lace-bark tree

Hare's-tail grass

Archangel

Nipplewort

Larch

Laserwort

Bourbon palm

Toothwort

Tare

Laurel

Tree mallow

Henna bush

Wild rosemary

Duckweed

Lion's-tail

Lion's leaf

Dandelion

Lion's-foot

Motherwort

Pepperwort

Garden cress

L'agripaume

Cresson alenois

Das herzgespann

Die kresse

Die gartenkresse

Le badian de la Chine Der sternanis

Labalsamine Der springsame

L'indigotier $\quad$ Die indigopflanze

L'inule aunée

Der alant

Le quamoclit

L'iresine

Le pastel

trichterwinde

ie straussblume

Die iris

Der färberwaid

Der brachsemfarrn

Der jesuitische rindenbaum

Die jasione

La jasione

Le medicinier

Le noyer

Le génévrier

Die wallnuss

Die binse

Der wachholderstrauch

carmentine Die malabarische

Zedoaire à feuilles Der grosse galgant obrondes

La laitue

Der löffelbaum

Lagocie

Lagure

Le camara

Das sammetoras

Die taubnessel

Der Surinamsche The

com- Der rainkohl

La clandestine

La gesse

Le laurier

Lavatere

'henn

La lenticule

Der lärchenbaum

Die laserpflanze

Die schuppenwurz

Die platterbse

Der lorbeerbaum

Der malvenbaum

Dér porsch

Die teichlinse

Queue de lion

a leontice

or löwenschwanz

Das löwenblatt

Der löwenzahn

L'arbre d'argent

Der silberbaum

Snow-flake

Perce neige

Das weisse veilchen

L'angelique à feuilles Libstöckel

d'ache

Privet

Lily

Mudwört

Toadflax

Flax

Sweet gum

Glycyrrhiza - $\quad \begin{aligned} & \text { Liquorice } \\ & \text { Tulip tree }\end{aligned}$

Gromwell
Troëne

Le lis

Limeole

Le limonellier

La limoselle

La linaire

Le lin

La réglisse

Le tulipier

Le gremil

Der liguste

Die lilie

Der randknoten

Limonelle

Das sumpfkraut

Das flackskraut

Dèr flachs

Der amberbaum

Süssholz

Der tulpenbaum

Der steinsame
Le liquidambar 
Italian.

Spanish.

Portuguese, Danish, Russian, Polish, South American, Oriental, or other Names.

104 Schubbig härdkeіk 478 Sterany

184 Springzaad

184 Springzaad

220 Meeste

362

714 Gewoon alañ

Agrifoglio

Anice stellato

Acebo

Nevadilla

Azevinho Port. Waesoscheld Russ.

Anis de la China $\mathbf{P a}$ co huei hiam Chin Stierneanis $D a n$.

Balsamina gialla BaIsama amarilla Melindre naô me toques Port. Springurt Dan

Imperatoria Imperatoria Imperatoria Port. Mestarurt Dan. Mästererot Swed.

Indaco

Indigo Anileira Port. Houer Arab. Indigo Dan. \& Swed.

Enüla

138 Trechterwinde

Ipomea

Iride

Guado

Hi Otaheite

Enula campana Dewjatschik Russ,

Ipomea

Jpomea Port.

Iris

552 Verfweede

-

Iris

Ljetnjak Russ. Sinilo PoL

894 Priemkruid

188 Schaapskruid

12 Jasmyn

812 Purgeernooten

794 Ockernootenboom
258 Biezen

848 Geneverboom

18 Adhatoda

4 Sineesche galanga 356

668 Salade

188 Wilde komyn

54. Haazestaart

502 Doove netel 518

\section{כ78 Akkermoes}

806 Lorchenboom 220 Laserkruid

524. Schubwortel

620 Lathyrus

332 Laurierboom

498 Lavendel

584

$316-\cdots$

358 Wilde rosmaryn

772 Kroos

506 Leeuwestaart

286 Leeuwenblad

670 Paardebloem

506 Hartgespan

552 Peperkruid

Tuinkers

830 Zilverboom
Lattuga

11 gelsomino

Il noce

Giunco

Il ginepro

Ortica morta

Lampsana

Larice

Laserpizio

Latiro
Alloro
Lavendola
-
Ledo -
Lenticchia
d'acqua

Piscia in letto

Agripalma

Lepidio

Crescione
Lechuga

Jasione

El jazmin

Jasione Port. Monke Swed.

O jasmim Port. Jasmin Arab. Jasmin Dan. \& Swcd.

de Indias Pinhoes do Brasil Port. Munduy guacu Brazil.

Nogal

Junco

El enebro

Cay Hach dao Cochinch. Grezkiä orechi Russ.

Junco Port. Trostnik Russ. Sit Pol.

Moschewelnik Russ.

- - - Wanaepala Malab. Adhatoda Cey.

Katssula kelengu Malab. Thien lien Cochinch̆.

Skedträd Swed.

Alface Port. Handibe Arab. Laktuk Russ. SalataPol.

Cuminho bastardo Port.

Ortiga muerta

Lampsana

Alerce

Laserpicio

La madrona

Latiro

Laurel

Espliego

I

Lentejueala

acuatica

Aguavientos

Amargon

Agripalma

Lepidio

Mastuerzo
Kargasina Pers. Rasnozwietnaja kopriwa Russ. Camara Brazil.

Brzoskiew polna $\mathrm{Pol}$.

Listweniza Russ. Lerketræe Dan

Laserpicio Port. Laserurt Dan. Laserört Swed.

Dentaria bastarda Port. Petrow krest Russ.

Latiro Port.

Bobek drzevo Pol. Dafnä Tart.

Alfazema Port. Lawendul Russ.

Malvaiscaô Port.

Alhenna Arab.

Bagulnik Russ. Rozmarin Pol. Vild rosmarin Dan.

Lentilha aquaticaPort. RiäskaRuss. Rzesa wodnaPol.

Molotschai trawa Russ. Papawa ziele Pol.

AgripalmaPort. Dikaja kropiwaRuss. Serdecznik $P$ ol.

Mastruço Port. Kres Russ. Nasturcya Pol.

\section{Tydeloos}

220 Lavaskruid

\section{Liguster}

264 Lelie

356

532 Slykertje

526

514

232 Vlasch

798 Amberboom

628 Zoethout

478 Tulpboom

120 Steenzaad
Leucoio

Leucoio

Ligustico

Ligustic

Ligustro

Giglio

Alheña

Azucena

Linaria
Lino -
Régolizia

\section{Linaria}

Lino

Leucoio Port. Tözek viola Hung.

Ligustico Port. Loestilk Dan.

Alfena Port. Ibata Jap. SchostRuss. Ptasza zob Pol. Lilieja Russ. Lilia Pol.

Catutsjeri-Narregam Malab. San peng lac Chin.

Linaria Port. Dikol len Russ.

Marislegræe Dan. Vindgräs Swed.

Bad Hebr. Len Russ. \& Pol. Hör Dan. Lin Swed.

- - - Liquidambreiro Port. Xochiocotzo-quahuitl Mexico

Regaliz Lakrycya $\mathrm{Pol}$

Lithospermo Aljofar Port. Worobiewa trawa Russ. 


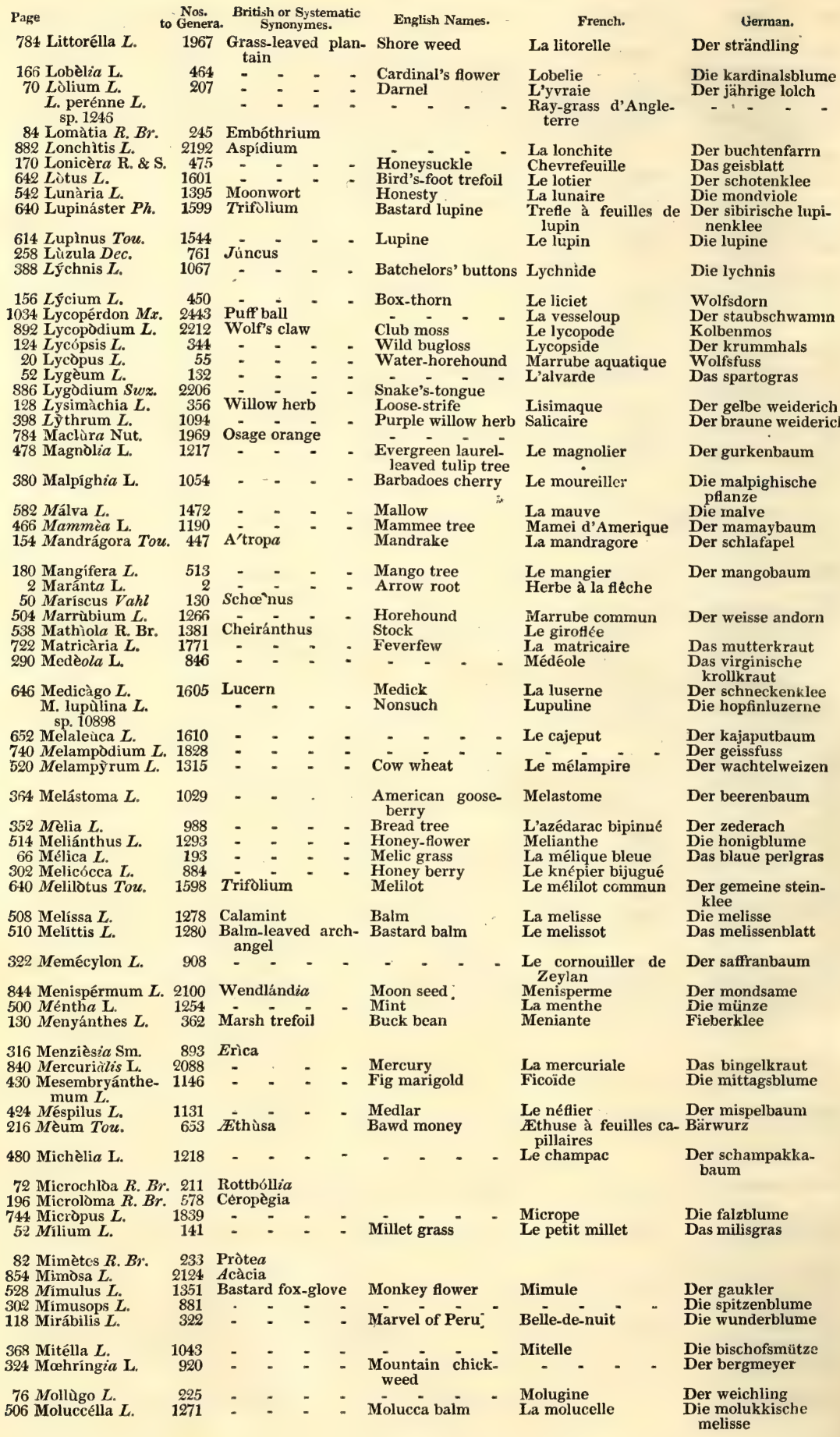


Page Dutch

784 Oevergras

166 Kardinaalsbloem

.70 Dolyk

170 Kamperfolie

642 Rolklaver

542 Maankruid

614 Vygeboon

388 Lychnis

156 Boksdoorn

1034. Stuifzwamm

892 Wolfsklaauw

124 Wolfschyn

20 Wolfspoot

52 Nootgras

128 Weiderick

398 Partyke

.478

380 Barbados kersen

\section{Maluwe \\ 466 Mammeboom \\ 154 Appeldraagend doodkruid}

180 Mangasboom

504 Gemeene malrove

722 Maartel

646 Rupsklaver

Hoppige rupsklaver

652 Kajapoetie

\section{Akkerig zwart- koorn}

364 Bessenboom

352 Azedarach

514 Honigbloem

66 Blaauwhavergras

640 Melote

508 Melisse

510 Melissebladig kruisbloem

322 Saffraanboom

844 Gulpzaad

500 Munt

130 Driebladige ruigbloem

840 Bingelkruid

430 Middagbloem

424 Mespelboom

216 Beerwortel

480 Sampaccaboom

\section{Kleinpoot}

52 Hirsgras

\section{Potze}

118 Wondërbloèm

368 Ruigbloem

324 Mosachtig muur

76 Zagtblad

506 Molukje
Italian.

Spanish.

Litospermo

Fior cardinale

Loglio

$\begin{array}{ll}\text { Madreselva } & \text { Madreselva } \\ \text { Jl loto } & \text { El loto } \\ \text { Lunaria } & \text { Lunaria }\end{array}$

Lupino

Licnide

$\begin{array}{ll}\text { Licoperdo } & \text { Espino africano } \\ \text { Licoperdo }\end{array}$

Licopodio $\quad$ Licopodio

Licopo - Licopo

- $\quad$ - Albardin

Lisimachia Lisimaquia

Salicaria

Salicaria

$\begin{array}{ll}\text { Malva } & \text { Malva } \\ \text { Mandragola } & - \\ & \text { Mandragora }\end{array}$

Mamoeira Port

Koldunowa trawa Russ. Pokrzyk ziele Pol.

Mangueira Port. Amb Arab. Can xu Chin. Po Java.

loteiro Port. Kierringtand Dan.

Lunaria Port. Maaneviol Dan. Manefioler Swed.

Tremoço Port. Temis Arab LupineDan. LupinSwed.

Cruz de Malta Port. Tatarskajo muilo Russ.

Licoperdo Port. Stövsvamp Dan. Klotsvamp Swed.

Licopodio Port. Ulvefoed Dan.

Liden oxetunge Dan. Aakerstik, Stikgras Norw.

Esparto bastardo Port.

Lysimachia Port. Werbuinik Russ.

Salicaria Port. Plakun_Russ. Sju Jap. Wroina Bohem

Köbus Jap.

Marrobio bianco Marrubio blanco Maroyo branco Port. Marrub ili schandra Russ.

Matricaria

Maruna ziele Pol. Moderurt Dan.

Medica Mielga

Medicagem Port. Gunscha Pers. Snegleklever Dan.

Malampiro

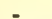

Trigo de vaca

Caju-kelan Java. Cay flam Cochinch.

Trigo de vacca Port. Pwan Russ. Koehvede Dan. Skälle Swed.

Fruta da Gralha Port. Muiva Brazil. Kadali Malab.

\section{Azedarac El cinamomo}

- - - Flor de miel

- -

Meliloto

Meliloto

Melissa

$-$

Melisa

-

- $\quad$ Wap.

Menta

Meniante

Mercorella Mercurial

Menta

Amargoseira Port. Zænzalacht Arab. Jussura Jap.

Juki no fato Jap.

Blaaetoppet græsDan.BlaaebunkeNorw.BláslokSwe.

MelilotoPort. TschimaeuPers. Gretscha dikajaRuss.

Melissa Port. Melissa Russ. Melisa Pol.

Melissa bastarda Port. Vild hiertensfryd Dan. Sjuvo

Walikaku Cey.

Ficoide Ficoide

Nespolo Nispero

Meu Meu

Grämigna mig- Mijo esparcidö

Leonpodio do reyno Port.

liaria

Mimulo

Fiór di notte

Mimulo

Märavillas de

Elengi Malab. Munamal Cey. Kauki Java. noche

Miata Russ. Mietka Pol.

Mercurial Port. Proleska Russ.

Ficoide Port. Ghasul Arab. JisplanteDan. IsörtSwed.

NespereiraPort. AigilPers.TschiskiRuss. Niesplik Pol. Meon Port. Medwjéschei kören Russ. Olesnik Pol.

Hapuphaha Cey. Hoa su nam Cochinch. 
Page Nos. British or Systematic

808 Momórdica

20 Monárd $a \mathbf{L}$.

356 Monótropa $\boldsymbol{L}$.

76 Móntia L.

174. Morínda $L$

782 Morus $L$

464 Muntíngia $\mathrm{I}$

244. Musa $\mathrm{L}$

284. Muscàri Des

$552 M$ ỳagrum $L$

64. Mygalùrus $L k$.

362 Mylocàryum $W$.en 1021

$119 M$ yosotis $L$.

326

23* Myosùrus $L$.

707

830 Myrìca $L$.

2055

790 Myriophýllum L. 1987

850 Myristica $L$

212 Mýrrhis Mor.

870 Myrsine $L$

2120

630

2160

$416 M$ ýrtus $L$.

832 Nagèia Gae.

240 Narcíssus $L$

52 Nárdus $L$.

1121 Myrica

711

538 Nastúrtium $R . B r .1383$ Sisýmbrium

182 Naúclea $I$

521

912 Neckèra Hedw. 2247 Hýpnü

864 Negúndium Dec. 2144 A'cer

476 Nelúmbium J. 1213 Cỳamus

526 Nemèsia Ven. 1346 Antirrhinum

850 Nepénthes $\boldsymbol{L}$.

498 Népeta $L$.

2121

1249 Nep

786 Nephèlium $\boldsymbol{W} . \quad 1971$

411 Rose bà

1710 Rose bay

694 Neurolæ'na

476 Nigélla Tou.

396 Nitrària $L$.

382 - - -

1209 Devil in a bush

1090

82 Nivènia $\mathrm{R}$. Br.

Pròtea

880 Nothochlæ'na 2177 Acróstichum

$$
\text { R. } B r \text {. }
$$

540 Notóceras $R . B r, 1385$ Erýsimum

464 Nühar Sm. 1176 Nymphæ'a

12 Nyctánthes $L$.

38 Jasminum

462 Nymphæ'a Neck. 1174. Water rose

870 Nýssa L.

2161 Water rose

620 O'chrus Pers.

$1559 P$ isum

762 Octomèria $R . B r .1913$ Dendròbium

$510 O^{\prime}$ cymum $L$

212 Enánthe $L$

318 Enothèra $L$

632 Wild parsley

901 Broad-leaved tree

100 'lea $L$. primrose

122 Omphalodes Leh. 337 Cynoglóssum

758 Oncídium Swz. 1895 Epidendrum

880 Onoclèa $L$.

612 Onònis $L$.

1541 Cammock

684 Onopórdum $L, \quad 1666$ Woolly thistle

120 Onósma $L$. 332

888 Ophioglóssum L. 2209

272 Ophiopdgon Ker. 790

144. Ophiorhiza $L$. 406

866 Ophióxylon $L$. 2152

72 Ophiùrus Beauv. 21

7520 phrys $L$.

$750 O^{\prime}$ rchis $L$.

L. 1274

760 Ornithídium Sal. 190

276 Ornithógalum $\boldsymbol{L}$. 80

628 Ornithopus $L$

$26 \boldsymbol{O}^{\prime}$ rnus Pers.

524 Orobánche $L$.

618 O'robus Tou.

256 Oróntium $L$.

54. Orthopogon $\boldsymbol{R} . \mathrm{Br} .147$

288 Orỳza $L$.

886 Osmúnda $\mathrm{L}$.

$792 O^{\prime}$ strya $M x$.

828 Osỳris Lam.
1578
69

Strangle-weed

756
147

147 Pánicum

837 -

1995 Cárpinüs
English Names.

French.

Male balsam apple Momordique

Oswego tea

Yellow bird's-nest Le sucepin

Chickweed

Montie

Indian mulberry

Morinde

Mulberry

Plantain -

Grape hyacinth

Gold of pleasure

Mouse-tail

Buckwheat tree

Scorpion grass

Mouse-tail

Candleberry-myrtle

Water-milfoil

Nutmeg

Myrrh

$-$

Myrtle

üa -

Lancashire asphodel

Water-cress

Le mûrier

Calabure soyeux

Le bananier

Jacinte botride

La caméline

Gremillet ou scor- Vergiss mein nicht pionne

Queue de souris

Le cirier

Le volant d'eau

Le muscadier

Myrsine d'Afrique

Le myrthe

Narcisse

Le nard serré

Le brise-os

Cresson de fontaine

L'erable à feuilles de Der aeschenahorn frêne

Sacred bean

Pitcher plant

Catmint

Rambutan

Oleander

Halberd weed

Tobacco

Fennel flower

Salt tree

epenthe

Chataire

Le laurose

Le tabac

La nielle

Nitrée

Das mäusechwänzchen

Der wachsbaum

Der federball

Die muskatmuss

Die afrikanische

Die myrte

Die narcisse

Das borstengras

Das beinbrechgras

Die brunnenkresse

Der kannenträger

Die nepte

Der oleander

Dez tabak

Der schwarzkümme

Der salpeterstrauch

Yellow water lily

Water jily - - L'arbre triste

Le nenuphar

Le tupélo

Der traurige baum

Die seeblume

Der tupelobaum

Die ochererbse

Basilikum

Die rebendolde

Die nachtkerze

Water dropwort Oenanth

Evening primrose L'onagre

Olive

Liolivier

Der oelbaum

Venus's navelwort

Rest härow

Cotton thistle

L'orcanette sensible

Bugrane

Le chardon commun

Der fühlfarrn

Die hauheche

Die zellblume

Die ochsenzunge

Adder's tongue

Langue de serpent

Natterzünglein

Snake's beard

Snake root

Snake-wood

Hard grass

Insect orchis

Dogstones

Marjoram

Star of Bethlehem

Bird's foot

Flowering ash

Broom rape

Bitter vetch

Floating arum

Rice

King fern

Hop hornbeam

Poet's cassia
Racine de serpent

Bois de couleuvre

Ophrise

La marjolaine

Ornithogale

Pied d'oiseau

Le frêne à fleur

Orobanche

L'orobe

L'oronce

Die schlangenwurzel

Das schlangenholz

Die ophrys

Die orchis

Der majoran

Die vogelmilch

Der vogelfuss

Die blühende esche

Der erbsenwürger

Die bergerbse

Die schwimmaron

Le ris

Der reiss

L'osmonde Der traubenfarrn

Charme à fruit de Deritalienische hag. houblon buche

Le rouvet

Die poetenkasia 
Page Dutch

808 Balsemappel

356 Europische bladloos

76 Bronminnende montia

174. Braamboozenboom

782 Moerbezieboom

464 Shaftbloem

244 Pisang

284 Druifhyacinth

552 Vlaschdotter

$\begin{array}{lll}\text { Moro } & & \text { Moral } \\ - & - & - \\ \text { Il giacinto } & - & \begin{array}{l}\text { Bananas } \\ \text { Jacinto } \\ \text { Miagro }\end{array}\end{array}$

118 Kruidig muizenoor Orecchio di topo Miosota

234. Muizenstaartje

Corda di topo

Cola de raton

830 Waschboompje

790 Vederkruid

850 Nooten moskaat

Noce moscada

Moscada

Mirto

Narciso

Nardo

Anterico ossi-

frago

Berro
Mirto

Nardo

Anterico ossi-

frago

Portuguese, Danish, Russian, Polish, South American,

Oriental, or other Names.

538 Waterkers

182 Bankalboom
850 Kanaraager 498 Kattekruid

\section{Oleander}

136 Tabak

476 Nigelle

396 Salpeterstruik

$\begin{array}{ll}\text { Gattaria } & \text { Gatera } \\ \text { Oleandro } & \text { Adelfa } \\ \text { Tabacco } & \text { Tabaco } \\ \text { Nigella } & \text { Arañuela } \\ - & -\end{array}$

Bandura Cey.

Kurka Malab. Koschitza mehta Russ.

Loendro Port. Tiflæ Arab. Oleander Dan. \& Swed.

PetumeBrazil. TamakaIndian. Tabac Russ.\& Pol. \&c Nigella Port. Ozarnucha ziele Pol.

Solotucha Russ. Diesengir Kirgis. Sugak Turcoman.
464
12

462 Plompē

870 Amerikaansche waterboom

620 Italische erwt

510 Basilicum

212 Druivebloem

318 Tweejaarige

10 Olyfboom

880 Gevoelig welkvaren 612 Stalkruid

654 Witte wegdistel

120 Ezelsreuk

888 Adderstong

144 Slangenwortel 566 Slangenhout

752 Tweeblad 750 Standelkruid 506 Mariolein

276 Vogelmelk 628 Vogelpoot 26 - 256 Drven

288 Ryst
886 Trosvaren
792 Italiaansche juk-
boom
828 Witte osyris

Ononide Onopordo

\section{Lingua serpen-} tina

Radice di serps Legno di serpe

\section{Ofri}

Orchide

Maggiorana

Ornitogalo Piede d'uccello

Orobanche Orobo

Riso

Osmunda

Carpino nero

Carpino nero

Neekblad Swed. Lekuta Bohem.

Arvore triste Port. Manja pumeram Malab.

Naufar Egypt. Wodanoi lelei Russ.

Nenufar

Tapizot

Albahaca

Enante

Alfavaca Port. RehanPers. WasilikRuss. BazylikaPol. Enante Port. Vand-steenbrek Dan.

Idegen Sárga Viola Hung.

Olivo

Sejtun Arab. Oliva Russ. Oliwne drzewo Pol.

Detiene-buey Restaboy Port. Iglischnik Russ. Lisi ogon Pol.

Onopordo Onopordo Port. Tatarnik Russ. Oset poyloczny Pol. Onopordo Port. Tatarnik Russ. Oset poyloczny Pol.
- - $\quad$ Bung. Lengua de sierpe Lingua de serpentePort.SlangetungeDan.Läketuriga

Raiz de serpiente Hampaddu-tanah Malay.

Leño serpentino Raiz de mongo Port. Ekawerya Cey. SlangetræeDan.

Ophris

Orchis

Mejorana

Ornitogalo

Serradilla

Orobanca

Orobo

Arroz

Osmunda

Carpe

Retama blanca
Ofrio Port.

Mardakusj Arab. Maeran Russ. Maieran Pol.

Ornitogale Russ.

Pé de passaro Port. Fuglefod Dan. Fogelfot Swed.

Orneiro Port.

Zaraza $P$ ol. Löverumpe Dan. Skierffrö Swed.

Museerter Dan.

Arroz Port. Dschjawat Ind. Ptscheno Russ, Ryz Pol. CarpePort. AsadPers, GrabRuss.\&Pol. AvenbögDan.

Mamaku Jap. 
Page

384 $O^{\prime}$ xalis $L$. Nos. British or Systematic
to Genera.

172 Oxyánthus Dec. $\quad 489$ Gädènia

636 Oxýtropis Dec. 1593 Astrágalus 152 Pædèria $L$

472 Pædnia $\mathbf{L}$. $178 P$ aliùrus $T o u$. 242 Pancràtium $L$ 820 Pandànus $\mathrm{L}$. 52 Pánicum $L$. 460 Papàver Tou. 48 Pardánthus Ker. 862 Parietària $L$ 328 Pàris $L$.

350 Parkinsònia I

228 Parnássia $\boldsymbol{L}$.

744 Parthèni $\quad 694$

52 Páspalum $L$.

24 Passerìna $L$.

564 Passiflora $L$

222 Pastinàca $L$

100 Pavétta I.

524 Pedàlium L. 1331

528 Pediculàris $L . \quad 1349$

406 Pedilánthus Neck. 1104

396 Péganum $L$. $\quad 1088$

568 Pelargònium Herit.1461

544 Peltària $L$. 1403

52 Pennisètum Rich. 135

580 Pentapètes $L$. 1468

384 Penthorum $\boldsymbol{W} . \quad 1062$

514 Pentstèmon $W . \quad 1297$ 696 Péntzia Thun. 1719 288 Péplis $L$.

716 Perdícium Dec. 1759

198 Pergulària $L$

502 Perilla W.

1255

194 Periploca $L$.

574

296 Petivèria I

865

694 Petrobium $R$. Br. 1709

544 Petrocállis $R . B \% .1404$

80 Petróphila $R$. Br. 229

222 Peucédanum $L$. $\quad 670$

1016 Peziza Dil

36 Phàca $L$

58 Phálaris $L$.

1022 Phállus $M x$

896 Pháscum $L$.

614. Phasèolus $L$.

214 Phellándrium $L$. 636

414 Philadélphus $L$. 1114 Mock orange

192 Philóxerus $R$. Br. 553 Gomphrèna

58 Phlèum $L$. $\quad 165$ Timothy grass

$506 P$ hlomis $L$

$132 P$ hlóx $L$.

828 Phœ'nix $L$

286 Phórmium $L$.

810 Phyllánthus $L$

208 Phýllis $L$.

156 Phýsalis $\dot{L}$

168 Phyteùma $L$.

390 Phytolácca $L$.

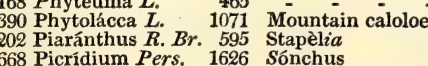

672 Picris $L$.

782 Pílea Lindl.

894 Pilulària $L$.

212 Pimpinélla $L$.

20 Pinguícula $L$.

$802 P$ inus $L$.

28 Piper $L$.

606 Piscídia $L$

832 Pistàcia $L$.

620 Pisum Tou.

96 Plantàgo $L$

798 Plátanus $L$

606 Platylobium Sm. 152

510 Plectránthus Herit.1282
Yellow succory

961 Urtìca

369 Bastard Lychnis

823

2027

448

15 Pepper grass

635 Anise

52 Yorkshire sanicle

77
1524
9065

1560

Bütton wood

$o^{\prime c y m u m}$
- -
English Names.

Wood sorrel

Cranberry

$-$

Pæony

Christ's thorn

Sea daffodil

Screw pine

Panic grass

Poppy

Pellitory

True love

-

Grass of Parnassus

Bastard feverfew

Sparrow wort

Passion flower

Parsnep

Supple Jack

- : -

Lousewort

Slipper plant

Wild Syrian rue

Stork's bill

- - - - Pellette alliaire

St. Helena red wood

American night.

shade

Water purslane

Péplide

Pérgulair

- - - - $\quad$ - Perille

Virginian silk

Guinea henweed

White wood

Sulphurwort

Jew's ears

Bastard vetch

Canary grass

Morel

Beard moss

Kidneybean

Water hemlock

Syringa

Cat's-tail grass

Jerusalem sage

Lychnidea

Date palm

Bästard hare's-ear

Winter cherry

Rampion
Virginian poke

Periploque

La pivoine

Narcisse de me

Le baquois

Le panic

La pariétaire

arisette

genet epineux

leur du Parnassus

Le paspal

La passerine

La grenadille

Le panais

iane a persil

Pedale

La pédiculaire

Harmale

-

Peucedane

Oreille de Judas

Phaque

Alpiste de Canaire

Morille

Häricot commun

La cicutaire des

marais

Le seringat

Fléole des pres

Phlomide

Le phlox

Le dattier

Phyllide-

Coqueret

La raponcule

Morelle à grappes

Picride

Ox tongue

Pilúlair

Pillwor

Burnet saxifrage

Boucage

\section{Butterwort}

Pine or fir

Pepper

Pistachia -

Pea

Plantain

Plane tree

Flat pea
Grassette

Le pin

Le poivrier

Le boisivrant

Le pistachier

Pois

Plantain

Le platane
German.

Der sauerklee

Die moosbeere

Die knackbere

Die päonie

Der Christdorn

Die machtlilie

Das panikgräs

Der mohn

Das glaskraut

Die einbeere

Der stachlichte gin. sterbaum

Das einblatt

Die meidblume

Das pfannengras

Der vogelkopf

Die passionsblume

Die pastinake

Der ostindische

fussangel

Das läusekraut

Die harmelstaude

Das scheibenkraut

Der scharlachrothe

flügelsame

Die fünfspitze

Die zipfelblume

Bürsten

Der laubenstrauch

Die Indianische

melisse

Schlingen

Haarstrang

Der becherschwamm

Das knollenkraut

Kanariengras

Die morchel

Das bartmos

Die gemeine bohne, or phaseole

Pferdesaamen

Der pfeifenstrauch

Das wiesen-lieschgras Die strauchartige phlomis

Die flammenblume

Der dattelbaum

Die blätterblume

Die schöne phyllis

Die judenkirsche

Der rapunzel

Die scharlachbere

Das bitterkraut;

Der pillenfarn

Kleine bibernel

Das fettkraut

Die kiefer

Der pfeffer

Der fischfänger

Der pistazienbaum

Die erbse

Wegerich

Der platanus 
Page Duten.

384 Klaverzuuring

320 Veenbessen

152 Stinkende knapbessen

472 Peonie

178 Christdoorn

242 Trosnarcis

820 Panik -

460 Maankop

862 Glaskruid

328 Wolfsbezie

350 Doornbremboom

228 Parnaskruid

744. Maagdebloem

52 Raspgras

324. Passerina

564 Passiebloem

222 Pinsternakel

328 Praatjes

100 Scheelkoorn

524 Oostindisch minkyzer

528 Luiskruid

396 Harmel

544 Schyfzaad

580

384 Vyfpunt

288 Kleine moerasmuur

716 Patryskruid

198 Luiffelbloem

502

194. Slingerplant

222 Haairstreng
1016 Judas-oor
636 Bootpeul
58 Kanary
1022 Morilje
896 Baardmoos
614 Turksche boonen
214. Waterkervel

414 Welriekende philadelphus

58 Weidig doddegras 506 Heesterig vitlkruid

132 Vlambloem

828 Dadelboom

810 Bladbloem

208 Kanarische phyllis

156 Blaaskruid

168 Raponsje

390 Lakplant

672 Bitterkruid

894. Pillenkruid

212 Kleine bevernel

20 Smeerblad

802 Pynboom

28 Peper

606 Vischboom

832 Pistacheboom

620 Erwt

96 Weegbree

798 Platanus
Peucedano Peucedano

Orecchio diGuida Oreja de Juda

Falari Alpiste

Spugnola Murguras

Fagiuolo $\quad$ Fasoles

Felandro acuatico

Italian

Ossicocco

Peonia

Giglio marino

Pañico

Papavero

Parietaria

Parnasia

Parnasia

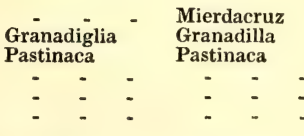

Pidocchiera

Alharma

Armora

Geringuilla

Aguavientos

Palma dattilifera Palma

Alchechengi

Raperonzolo

Rapunculo

Hierba carmin
Portuguese, Danish, Russian, Polish, South American,
Oriental, or other Names.

Koganne gusa Jap. Saitschaitschawel Russ.

Glukwa Russ. Tranbär Swed.

Fakobokon, Feifuri kadsura, Kusa panja Jap.

PeoniaPort. Thuoc duocCochinch.Pionnaja rosa Russ. Tæken-ágatch Tart.

Kaida Malab. Cay jua Coch. Kadi Arab.

Proso Russ. \& Pol. Panikgræs Dan.

Papoila Port. Post Ind. Mak Russ.\&Pol. Valmue Dan.

ParietariaPort. Noc i dzien Pol.

Parisetta Port. Woronei glas Russ.

Parnasia Port. Pereloi trawa Russ. Jednolist Pol.

Passionsblomster Dan. Passionsblomma Swed.

Pustarnak Russ. Pasternak Pol. Pastinak Dan.

Cururu-ape Braz. Kaka-toddaly Mal.

Pavate Cey. Pavetra Malab. Ta sa Chin.

Patiraja Cey. Kaki-mullu Malab.

Piolheira Port. Luusurt Dan.

Harmala Port. Hornaia routa Russ.

Sjasmin Malab.
Huo muon, Fi si than Chin.

Cottam Malab.

Sar modam Tart. \& Kalm.
Alcuequenjo

Peucedano Port. Wolosjanka Russ. Wieprzyniec Pol. Orelha de Judas Port.

Arai Jap. Kanariegræs Dan. Kanariefrö Swed.

Morilha Port. Smortschok Russ.

Feijaô Port. Torok mame Jap. Bobü turezkie Russ. Fazoli Pol.

Kruszykamien-ziele Pol. Stäkra Swed.

Philadelpho Port. Tschubuschnik Russ. Hvit schers. min Swed.

Arjanétz Russ. Donhammergræs Dan.

Wetrenaja sapja Russ.

Palmeira de igreja Port. Nachl Arab. Palma Pol.

Miachounha Russ. Boborelka Boh.

Rapunculo Port. Rapunzel Dan. \& Swed.

Kalalio Surinam.

\section{Libbæjn Arab.}

Pilularia Port.

Pimpinella branca Port. Bedrenez Russ.

Pimpinella sassi- Pimpinella

fraga blanca

fraga
Pinguicola Grassila

$\begin{array}{ll}\text { Pinguicola } & \text { Grassila } \\ \text { Il pino } & \text { El pino }\end{array}$

Pepe

Pimienta

Pistacchio

Piselli
Piantaggine

Alfocigo

Pesoles

Llanten

$\begin{array}{ll}\text { Platano } & \text { Platano }\end{array}$
Grassetta Port. Vibefit Dan. Tetört Swed.

Sosna Russ.
Pimenteira Port. Pilpil Pers. Perez Russ.

Alfostigo Port. Fistuk Arab.

Ervilhas Port. Wan Jap. Goroch Russ. Groch Pol.

Kamasch Pers. Uschik Russ. Babka Pol.

Platano Port. Tschinar Russ. Tschandary Georg. 
Nos. British or Systematic

758 Pleurothállis R.Br.1894 Epidéndrum

118 Plumbàgo $L$. 324 epidendrum

66 Poa $L$

$415=-$

342 Podalýria Lam. 948 Söhòra

460 Podophýllum $L$. 1166 May apple

756 Pogonia $R . B r . \quad 1879$ Arethùs $a$

908 Pòhlia Hedw. 2239 Brỳum

350 Poinciàna L. $\quad 977$ Cæsalpínia

132 Polemonium $L . \quad 370$ Jacob's ladder

254 Poliánthes $L$. $\quad 747$

876 Polybutrya

$47 \quad-\quad-$

74 Polycárpon $L$. 221 Linum

602 Polýgala Tou. 1508 Rattlesnake root

270 Polygónatum Desf. 789 Convallària

326 Polýgonum $L$

56 Polypodium L. 217

56 Polypogon Desf. 15

910 Polýtrichum $L$. 2241

754 Ponthièva R. Br. 840 Pópulus $L$

396 Portulàca $L$

Q28 Portulactir. 1091

106 Potamogeton $L$.

452 Potentílla $L$.

790 Potèrium $L$.

88 Pòthos L.

512 Pràsium $L$

670 Prenánthes $L$

126 Prímula $W$

286 Prinos $L$.

80 Protea L.

512 Prunélla L.

422 Prùnus Tou.

$P$. Armeniaca

$P$. Cérasus
$P$. Padus

416 Psídium $L$

638 Psoràlea $L$

100 Ptèlea $L$

882 Ptèris $L$.

122 Pulmonària $L$.

420 Punica $W$.

722 Pyrèthrum Sm. 17

362 Pýrola

$424 P$ ỹrus $L$

$$
\begin{aligned}
& P \text { ỳrus } L \text {. } \\
& P \text {. Malus } L \text {. } \\
& \text { sp. } 7090
\end{aligned}
$$

uássia $W$

794 Quércus $L$

364 Quisquàlis $I$

132 Ramónda Mx.

174 Rándia L. 486 .

$556 R$ áphanus $L$. $\mathbf{1 4 4}$

426 Raphiolèpis Lindl.1136

154 Rauwólfía L.

398 Resèda $L$.

$R$. Lutèola $L$. sp. 6658

828 Réstio $L$.

334 Rhèum

$318 R$ héxia $L$

524 Rhinánthus $L . \quad 1340$ Cök's comb

414 Rhipsalis Gae. 1112 Cáctus

358 Rhododéndron $L .101$

224 Rhús Tou.

48 Rhynchóspora

$$
\text { Vahl }
$$

190 Ribes L.

\section{R. Grossulària}

814 Ricinus $L$.

626 Robinia I

442 Risa Tou.

22 Rosmarinus $L$.

94 $R$ ubia $L$.

$450 R$ ùbus $L$.

$R$. Idæ'us $L$. sp. 7524

$292 R$ ùmex $L$

$846 R$ úscus $L$.

35t Rùta Tou.

130 Sabbàtia Adan.

74. Sáccharum $L$.

106 Sagina $L$.

Agróstis

Neóttia

Abele tree

692 Claytionia

1153

252

1288

350

231

1086

129 Cérasus

1181

298

2190

338 Bugloss cowslip

127 Matricària

1022

$\div \quad-\quad-$

- -

Verbáscum

Gardenia

Buttercups

441
1102

Dyer's weed

856 Sorrel

English Names.

French.

German.

Leadwort

Meadow grass

Duck's-foot

Dentelaire

Le franchipanier

Bleywurz

Paturin

Der rothe jasmin

Viehgras

Entenfuss

Greek valerian - La valériane grecque Das speerkraut

Poincillade

Der pfauenschwanz

La tubéreuse Die tuberose

All-seed

Milkwort

Solomon's seal

Persicaria

Polypody

Great golden

maidenhair

Poplar

Purslane

Purslane tree

Pond-weed

Cinquefoi

Burnet

Hëdge-nettle

Wall lettuce

Primrose

Winter berry

Seilf-heal

Plum

Apricot

Cherry

Bird cherry

Guava

Shrubby tréfoil

Brake

Lungwort

Pomegranate

Feverfew

Winter-green

Pear

$$
\text { Apple }
$$

Quassi wood

Oak

Crowfoot

Radish

Indian hawthorn

$\begin{array}{ll}\text { Mignonette - - Le boislait } & \text { Le réséda }\end{array}$

- - - - Laudéd

Gaude

Le persicaire
Le polypode

La perce-mousse

Le peuplier

pourpier

Ouintefeuil

La pimprenelle

Cöndrille de $\overline{\text { s murs }}$

La primevère

Apalanche

L'arbre d'argent

Brunelle

L'abricotie

Le cerisier

Le putiet

goyavier rouge

Fougere femelle

La pulmonaire

Le grenadier

a matricaire offi. cinale

Pyrole

La poirier

Bois de quassie

Le chene

Le quisqualier

Renoncule

Raifort

\section{Rope grass}

Buckthorn

Rhubarb

Virginian soapwort

Yellow rattle

Le nerprun

Rhubarbe

Ouadrette

Cocréte des prés

Die kreuzblume

Die weisswurz

Flöhkraut

Der tüpfelfarren

Das haarmos

Die pappel

Der portulak

Das saamkraut

Das fünffingerkraut

Die pimpernell 8

Anhängsel

Die nesselstande

Die mauerprenanthe

Die schlüsselblume

Die winterbeere

Der silberbaum

Die prunelle

Der pflaumenbaum

Der aprikosenbaum

Der kirschbaum

Die traubenkirsche

Der kujava-apfel

Der harzklee

Der saumfarren

Das lungenkraut

Der granatbaum

Das mutterkraut

Das wintergrün

Der birnbaum

Der apfelbaum

Die quassie

Die eiche

Der sonderling

Die ranunkel

Der rettig

Die reseda

Der wau

Der kreuzdorn

Rhabarber

Die ankerblume

Der hahnenkamm

Dwarf rosebay

Le rosage

Alprosen

Le sumach ordinaire Der sumach

Le grosseiller com- Die Johannisbeere mun

Le groseiller épineux Die stachelbeere

Le ricin ordinaire Der wunderbaum

Acacie commun Der acacienbaum

Le rosier

Romarin

La garance

La ronce

Framboisier

Die rose

Locust tree

Rose

61 - - - - Rosemary

1149 Blackberry Bramble

Raspberry

2111 Knee holly

Dock

L'oseille

Le fragon piquant

La rue

Der brombeerstrauch

Butcher's broom

- - Rue

215 - - - Sugar-cane

319 Chickweed break- Pearlwort stone 
Italian.

Spanish.

118 Loodkruid

66 Beemdgras

Piombaggine

Veleza

Poa

Poa

460 Eendenpoot

350 Paauwekuif

132 Speerkruid

254 Tuberoos

602 Kruisbloem

270 Salomons zegel

326 Persenkruid

878 Boomvaren

910 Haairmos

840 Abeelboom

396 Porselein

106 Fonteinkruid

452 Vyfvingerkruid

452 Vyfvingerkruid Cinquefoglio

88 Hangbast

670 Muurig knikbloem

126 Sleutelbloem

80 Zilverboom

512 Bruinelle

422 Pruimboom

Abrikoos

Kersenboom

Vogelkersen

416 Gojaves-appe

638

\section{Randvaren}

122 Longekruid

420 Granaatboom

722 Maartel

362 Wintergroen

424 Peereboom

Appelboom

354 Kwassiehout

794 Eik

364 Warstruik

486 Ranonkel

556 Tamme radys

398 Reseda

Wouw

17s Wegedoorn

334 Rhabarber

318 Ankerbloem

521 Haanekam

228 Roozelaar

224. Sunuak

\section{Aalbezie}

Kruisbezie

814. Wonderboom

626 Zoethoutboom

422 Roozeboom

22 Rosmaryn

94. Mee

450 Braamen

Braamboos

292 Veldzuuring

846 Muisdoorn

354 Ruite

74 Suikerriet

106 Vetmuur
Polemonio

Tuberoso

Poligala

Il ginocchietto

Persicaria

Polipodio

Politrico

Pioppo

Porcellana

Potamogeto

Primavera

$\begin{array}{ll}\begin{array}{l}\text { Brunella } \\ \text { Prugno }\end{array} & \begin{array}{l}\text { Brunela } \\ \text { Ciruelo }\end{array} \\ \text { Albercocco } & \text { Albarico-queira } \\ \text { Ciriegio } & \text { Cerezo } \\ \text { Pado } & \text { Pado }\end{array}$

Culeno

Felce feminina Helecho femi-

Polmonaria Pulmonaria

Granato Granado

Matricaria Matricaria

Pirola Pirola

Il pero El peral

Melo Manzano

Legno di quassia Leño de quassia

Quercia Roble

-

Ranuncolo Ranunculo

Rafano

Reseda Miñoneta

Guadarella Gualdu

Ranno Ramno

Rabarbaro Ruibarbo

Cresta di gallo Cresta de gallo

Sommaco - Zumaque

Ribes rosso Ribes rojo

Uva spina Uva espina

Ricino Ricino

Rosajo - - Falsa acacia

Rosmarino Romero

Robbia Granza

Rovo Zarza

Rovo ideo Zarza idea

Acetosa Acedera

Rusco Brusco

Ruta

Ruda

Cannamele Caña de azuca Portuguese, Danish, Russian, Polish, South American,

Dentellaria Port. Liigtorneurt Dan. Blyrot Swed.

Faaregræs Dan. fröe Swed.

Tsietti-mandaru Malab. Hoa phung Cochinch.

Valeriana grega Port. Grezkoe balderjan Russ.

Hoa hue Cochinch. Tuberose Dan. Tuberos Swed.

Fima fagi"Jap. Iztod Russ. Wyczka konicza Pol.

O scello de Salomâo Port. Kupena Russ.

Ramasch Pers. Potschednaja trawa Russ.

Panna kalengo Malab. Osokor Russ. Paproc Pol.

Politrico Port. Kokuschnik lenn Russ. Jomfruehaar Dan.

Topol Russ. Topola Pol. Poppel Dan

Beldroega Port. Cholsa Pers. Schruka Russ.

Medwesche ucho Russ. Rdest wodny Pol.

Schabnik Russ.

Pimpinella Dan. Pimpernella Swed.

Potha Cey. Ana-parua Malab. Cay ray leo Cochinch.

Vild latuk Dan.\& Norw.

Primavera Port. Bukwiza Russ.

Prunella Port. Kago noso Jap. Gortanaja trawa Russ. $\Delta$ mexieiraPor Barkuk Arab. Sliwnik $R u$ s. Sliwina $P o l$.

Kuriga Russ, Morela Pol.

Wischnaija Russ. Wisnia Pol

Tocheremucha Russ.

Xalxocotl Mexico. Malacca pela Malab.

Culeno Chili.

Feto femea Port. Warabi Jap. Wodianoi poporctnik Russ.

Pulmonaria Port. Meduniza Russ. Plucnik Pol.

Romeira Port. Rumman Arab. Granatnik Russ.

Matricaria Port. Matoschnaja trawa Russ.

Pirola Port. Gruscha dikaja Russ. Vintergrön Dan.

Kummitri Arab. Gruscha Russ. Gruszka Pol.

Maceira Port. Iablon Russ. Tgffah Arab.

Quassiatræe Dan. Quassiaträd Swed.

Pélut Pers. Dub Russ. Dab Pol. Eeg Dan. Ek Swed.

Xi kiun ssu Chin. Cay tlun Cochinch.

Rainunculo Port. Lutik Russ. Ranunkel Dan.\&Swed. Daikon Jap. Reddikke Dan. Rattika Swed.

\section{Gauda Port. Vau Dan.}

Escambroeiro Port. Getappel Swed.

Ruibarbo Port. Rhewen Russ.

Klopownik Russ. Hanekam Dan. Skallergräs Swed

Pjanischnik Russ. Schei Tart.

Sumagre Port. Koschewnoe derewo Russ.

Groselheira vermelha Port. Smorodina krasnaja Russ.

Groselheira Port. Krischownik Russ.

Nhambu guacu Braxil. Charua Arab.

Acacia bastarda Port.

Roseira Port. Kim anh tu Coch. Rosa Russ. Roza Pol. Rosmarinho Port. Klîl Arab. Rosmarin Dan. \& Swed. Mariona Russ. Marzana Pol.

Jaschewika Russ. Iezyny $\boldsymbol{P o l}$.

Malinik Russ. Maliny Pol.

Azedeira Port. Konnewoi schawel Russ.

Menschoi myschei tern Russ. Musetorne Dan.

Schedab Arab. Ruta Russ. Rude Dan. Vinruta Swed.

Cana de assucar Port. Viba Brazit.

Takanostme Jap. Grasarv Norw. 
Page

Nos. British or Systematic

English Names.

French.

German.

790 Sagittària $\boldsymbol{L}$. S. sagittifòl 1988 Adder's tongue Arrow-head

Sagittaire Das pfeilkraut sp. 13330 6 Salicórnia $L$. 798 Salisbùria $\mathrm{Sm}$ 820 Sàlix $L$.

204 Salsola $\dot{L}$.

22 Sálvia $L$.

224 Sambùcus $L$.

168 Samolus $L$.

460 Sanguinària $L$.
88 Sanguisórba $L$.

1982 Saltwort - - Sago palm

$\begin{array}{rcl}22 & \text { Saltwort } \\ 2003 & - & -\end{array} \quad-\quad \begin{aligned} & \text { Glasswort } \\ & \text { Gingko tree }\end{aligned}$

2042 - - - - Willow

609 Glasswort Saltwort

62 - - - - Sage

471 Pimpernel - Brook-weed

165 - - - - Puccoon

210 Sanícula $L$.

694 Santolina $L$.

328 Sapindus $L$.

370 Saponària $L$

Great burnet

174 Sarcocéphalus Afz. 498

462 Sarracenia L. 117

496 Saturèja $\mathbf{L} . \quad 1246$

750 Satýrium $L$

298 Saurùrus $L$.

1856

623 Saunders - - Sanicle
307 Saundal

Sandal wood

Lavender cotton

Soap-berry

soapwort

Guinea peach

- Side-saddle flower

298 Saururus $L$.

Savory

Fléchière commune

Le cycas des Indes Salicorne

Der sagoubaum

Le saule

La soude

La sauge

Samole

Glasschmalz

Le grande pim

prenelle des prés

La sanicle

Santal

Santoline

La savonnie

Die weide

Die sodapflanze

Die salbey

Der hohlunder

Das samoskraut

366 Saxífraga L.

90 Scabiosa $V$ Va
208 Scándix $L$.

482 Schìnus $L$.

1041
264
619

264

$o^{\prime}$ rehis

Lizard's tail

Sarriette

Le satyrion

Saxifrage

Cicely

808 tree

48 Schœ'nus $L$.

806 Schubértia Mir. 2015

48 Scírpus $R$. Br. $\quad 123$

366 Scleránthus $L$. 103

68 Sclerochlòa Beauv. 199

882 Scolopéndrium Sm.2188

$\begin{array}{rr}678 \text { Scólymus } L . & 1659 \\ 96 & \text { Scopària } L\end{array}$

$\begin{array}{rr}96 \text { Scopària } L \text {. } & 276 \\ 628 \text { Scorpiùrus } L . & 1579\end{array}$

666 Scorzonèra L. 1625

530 Scrophulària $L . \quad 1356$

512 Scutellària $L . \quad 1285$

72 Secàle $L$

209

382 Sèdum $L$.

$S$. álbum $L$ sp. 6451

406 Sempervivum $L .1110$

704 Sentcio

754 Seràpias L.

680 Serrátula $L$.

Cupréssus - - Bog-rush

Büll-rüh

Squill

Club-rush

- - - Knawel

Hard grass

Hart's-tongue

- - - - - - Wolden-thistle

Wild liquo

Viper's grass

- Figwort

Hooded willow. Skull-cap

herb

82 Serrùria R. Br.

514 Sésamum $W$

630 Sesbània Pers. 158

214 Séseli $L$.

60 Seslèria Sco.

177
2057

1 :

Rye

Lézardelle

Saxifrage

La scabieuse

Le mollé

Le choin

Cyprès distique

La scille

Le scirpe

Gnavelle annuelle

Der wiesenknopf

Der sanickel

Der santelbaum

Das cypressenkraut

Die seisenbeere

Das seisenkraut

L'épine jaune

Le balai

Chenille

Scorsonere

La scrophulaire

La toque

Die saturei

Bocksgeilen

Der eidechsensch wanz

Der steinbrech

Die skabiose

Der gartenkerbel

Der mollebaum

Das knopfgras

Die meerzwiebel

Die binse

Der wilde knauel

Le seigle

La joubarbe

Trique-madame

Die golddistel

Das besenkraut

Der skorpionschwanz

Die skorzonere

Die braunwurz

Das schildkraut

Der roggen

Das sedum

Le persil de marais Die sumpfsilge

Joubarbe

Le seneçon

Milk-parsle

Groundsel

L'elleborine

Saw-wort - - $\begin{aligned} & \text { L'ellebo } \\ & \text { Sarrette }\end{aligned}$

Die hauswurz

Die kreuzpflanze

Die serapie

Die färberscharte

Sésame

Der sesam

Der sesel

832 Shephérdia Nut. 2057 Hippóphae

94 Sherárdia L. 269

810 Sícyos $L$

2023

588 Sida $L$

498 Sideritis $L$

100 Siderodéndrum $\quad \begin{array}{r}1252 \\ 292\end{array}$ Jac

150 Sideróxylon $\boldsymbol{L}$

374 Silène $\boldsymbol{L}$.

554 Sinàpis Tou.

216 Sison $\boldsymbol{L}$.

425

1048

1433
647

Protea

Ėschynómene

Oily-grain

Le seseli

Field-madder

Single-seeded cu-

cumber

214 Sìum $L$.

$S$. Sísarum $L$.

646.

sp. 3598

270 Smilacina Desf.

836 Smilax $L$. 2081

628 Smithia H. K.

081 Convallaria

1580 Eschynómene

156 Solànum $L$.

451

- - - - - Nightshade

S. Lycopérsicum $W$.

sp. 2517

$S$. tuberosum $\boldsymbol{L}$.

sp. 2521

128 Soldanélla $L$.

710 Solidàgo $L$

82 Sorocéphalus

1627

- - - - Love apple

Potato

L'abutilon

La crapaudine

Ironwort

Iron-woôd

L'argan

Silene

La moutarde

Berle aromatique

Berle

Chervis

Water parsnep

Le smilace

Le maceron

Morelle

Tomate

Pomme-de-terre

Das eisenholz

Die silene

Amömlein

Wassermerk

Die zuckerwurzel

Die stechwinde

Das smyrnenkraut

Der schwarze nacht

schatten

Liebes apfel

Die kartoffeln

Soldanelle

La verge d'or

Die drattelblume

Gölden-rod

Le laiteron

Die goldruthe

Die saudistel $R, B r$. 
Page Dutch

790 Pylkruid

778 Sagoeboom

6 Zoudkruid

820 Wilg

204 Loogkruid

22 Salie

224 Vlierboom

168 Strandpungen

88 Sorbenkruid

210 Sanikel

102 Sandelboom

694 Cypreskruid

328 Zeepboom

370 Zeepkruid

$496 \mathrm{Keul}$

750 Bokskulletjes

366 Steenbreek

90 Schurftkruid

208 Tuinkervel

482 Heilboom

48 Biesgras

278 Zeeajuin

48 Bies

366 Jaarlyks hardbloem

678 Varkensdistel

96 Bezemkruid

628 Scorpioenstaart

666 Skorzoneere

530 Skrofelkruid

512 Helmkruid

72 Rog

382 Huislook

220 Wilde eppe

406 Donderbaard

704 Kruikskruid

754 Niesblad

680 Zaagblad

514. Vygboonen

214 Bergvenkel

94 -

588 Hoornheemst

498 Yzerkruid

Scorpioide

Scorza nera

Scrofolaria

Terzanaria

Segale

Sedo bianco

Semprevivo

Senecione

Elleborina

Serratola

Sesamo

Seseli

\section{Yzerboom}

374. Veldkaars

554 . Mosterd

216 Kruiderige steeneppe

214. Watereppe

Suikerwortel

Senepa -

Sio

Sisaro

836 Steekende winde

Smilace

216 Veldeppe

Macerone

$156 \mathrm{Zwarte}$ nagtschade Solatro nero

\section{Appeltjes der liefde Albergamo}

Aardappelen

Tartufibianci

128 Soutenelle

710 Goudroede

G0ิ8 Haazenlatuw

Spanish.

Sacta

El sagú

Salicor

Sauce

Sosa

Salvia

Sauco

Pimpinela de

Italia

Sanicula

Santolina-

Santolina

Jabonerä

Ajedrea

Satyrio

Saxifragia

Escabiosa

Perifollo

Falso pimiento

Escheno

Escila

Cirpo

Cardillo

Escolymo Port

Eassoirinha do Brasil Fort. Tupeicava Brazil.

Escorpioa Port.

Escrofular

Tercianaria

Centeno

Uvas de gato

Apio lechal

Siempreviva

Hierba cana

Eleborina

Serratula de los Serratula Port. Serp Russ. Jelenì trank Pol.

tintoreros

Ajonjole

Seseli

Gergelim Port. Kunschut Pers. Sesam Dan.\& Swed.

Seseli Port. Seselurt Dan. Seselört Swed.

Blaameader Norw.

Abutilo

Abutilo Port.

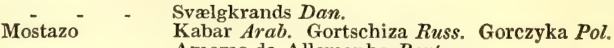

- - - Amomo da Allemanha Port.

Berrera Rabaça maior ou des rios Port

Chirivia tordesca Sokkerod Dan.

Esmilace

Apio caballar

Hierba mora

Tomates

Batatas inglezas

Vara de oro

Cerraja
Salsaparilha Port.

Olusatro Port.

Herva moira Port. Enabeddib Arab.

Tomateiro Port.

Batata da terra Port.

Vara d'oiro Port. Senbli Jap. Solotoschnik Russ. Tschistotél Russ. Mleczne Pol. Svinetidsel Dan. 
$\begin{array}{cr}218 & \text { Spanánthe Jac. } \quad 659 \text { Hydroc ćtyle } \\ 40 \text { Sparáxis Ker. } & 99 \\ I^{\prime} \text { xia }\end{array}$

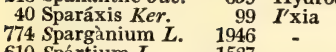

$I^{\prime} \times$.

82 Spatálla $R$. Br.

237 Protea

390 Spérgula $L$.

94 Spermacòce $L$. 270

$\begin{array}{rc}237 & \text { Protea } \\ 1070 & -\end{array}$

734 Sphenógyne $\boldsymbol{R} . B r .181$

134 Spigèlia L.

690 Spilánthes $L$.

834 Spinàcia $L$.

428 Spiræ'a $L$.

- - - - Spurrey

Arctiotis

1816
379

Arctiotis

2070 - :

- - - Spinage dows

906 Spláchnum $L$. 223 382 Spóndias $L$. ${ }_{56} 105$

$\begin{array}{cc}56 \text { Sporb́bolus } R . B r & 159 \\ 504 \text { Stàchys } L \text {. } & 1263\end{array}$

- -

159 Áróstis

20 Stachytárpheta $\quad 54$ Verbèna Vahl

226 Staphylèa $L$.

234 Státice $L$.

376 Stellària $L$

324 Stellèr $a$ L.

814. Stercùlia $L$.

828 Stilàgo $L$

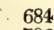

684
706
1049

1049
913

54 Stìpa $L$.

2036

2050

616 Stizolòbium $P$. S. 1551

482 Stratiòtes $L$.

1551 Dólichō

2096 Water alo

270 Streptòpus $M x$. 786 Uvulària

152 Strýchnos $L$. $\quad 437$ Núx Vómica

362 Styे rax

362 Stỳ rax $L$. $\quad 109$

658 Subulària $L$. Sutherlándia H.K. 1447

352 Swietenia $\mathbf{L} . \quad 990$

170 Symphòria $P \boldsymbol{h} . \quad \mathbf{4 7 6}$

122 Sýmphytum $L$. $\quad 334$

728 Synedrélla Gae.

12 Syrínga $\mathbf{L}$.

880 Tænitis Swx.

1791 Verbesìna

2176

718 Tagètes L.

1760

Ptèris

562 Tamarindus $L . \quad 1449$

$228 T$ tamarix $L$. $\quad 685$

838 Tàmus $L . \quad 2082$

696 Tanacètum $L$. $\quad 1720$

694 Tarchonánthus $L .1706$

848 Táxus $L$.

2114

Colùtea

-

Lonicèra

46 Teesdàlia

421 Indian -

1411 Ibèris

84. Telopèa $R$. Br.

244

634 Tephrosia Pers. 1590

864 Terminalia $L$. $\quad 2140$

494. Teùcrium L. 1244

484. Thalíctrum $L$

Grímmia

- - - - Germander

Feathered colum- Meadow rue bine

214 Thápsia $L$

643

650 Theobroma $L . \quad 1607$

342 Thermópsis $R . B r .944$
194. Thesium $L$. 569

546 Thláspi Dil.

806 Thùja $L$.

508 Thymus $L$.

562 Tigridia Jac.

466 Tilia $L$.

886 Tòde $a$ W.

1408 Treacle-mustard

2018 Tree of life

1275

1275

1452 Linden tree -

2204 Osmúnd $a$

222 Tordýlium $L$. $\quad 673$ Hedge parsley

454 Tormentílla $L$. 1154 Tormentil

516 Tourréttia Domb. 1299 Dombèya

168 Trachèlium $L$. $\quad 466$

260 Tradescántia L. $\quad 765$

666 Tragopògon $L$. 1621

104 Tràpa $L$

1020 Tremélla $L$. $\quad 2397$

532 Treviràn $\boldsymbol{a}$ W. en. 1362

354 Tríbulus Tou. $\quad 966$

122 Trichodésma $R . B r .341$

56 Trichòdium $M x$ : 157

40 Trichonèma Ker.

50 Trichóphorum Pers.

- - - - Throatwort

Spiderwort

Goat's beard

Water caltrops

-

Cỹrilla

Böràgo

Agróstis

Caltrops

808 Trichosánthes $L .2019$

Snake-gourd

296 Trientàlis $L$

640 Trifolium Tou.

862

290 Triglòchin $L$.

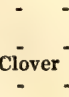

Winter-green

Trefoil

Arrow grass
Le rubannier

Le genêt

Spergule

Sphaigne

Abécédaire

L'épinard

La reine des prés

Le splane

Le monbain

Stachyde

Staphilier

Statice

La stellaire

Die sperlingszunge

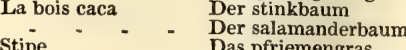

Stipe

Aloïdes

Die wasserfeder

Noix vomique

Alibousier

Subulaire

Le mahagon

La consoude

Lilas

Oeillet d'Inde

Le tamarinier

Tamarisc

Le tamier

Tanaisie

If

$-$

Krähenaugen

Der storax

Wasserpfriemen

Der mahagonibaum

Der beinwell

Der syringa

Die sammetblume

Der tamarindenbaum

Tamarisken

Schwarzwurzel

Der rheinfarrn

Der taxus

Der thekabaum

Le badamier de

Malabar

Germandrée

Rue des prés

Bathengel

Die wiesenraute

Tapsie

Le cacaoyer

Thesium

Bourse de pasteur

L'arbre de vie

Le thym

Tilīeul

Le seseli de Crete

La tormentille

Herbe aux trachées

Ephémérine

Sersifi

Macre flottante

La tremelle

Tribule

Dē kakaobaüm

Das leinblatt

Die hirtentasche

Der baum des lebens

Der thimian

Die linde

Das drehkraut

Tormentil

Das halskraut

Der bocksbart

Die stachelnuss

Die gallerte

Burzeldorn

Anguine à fruits

longs

Trientale

Trefle

Troscart
Der sinésische kürbis

Das sternblümchen

Der klee

Das salzgras 


\section{Egelknop}

610 Bezembrem

390 Akker-spurrie

896 Veenmoss

834 Spinagie

428 Reynette

906 Parasolmos

382 Varkensprium

504 Andoorn

\section{Pimpernooten \\ 234 Zeegras \\ 376 Oogentroostgras \\ 324 \\ 814 Stinkboom \\ 828 Salamanderboom \\ $54 \mathrm{~K}$ wispelgras}

482 Ruiterskruid

\section{Braaknooten \\ 362 Styraxboom}

558 Elskruid

352 Nieuwblad-boom

122 Smeerwortel

12 Syring

718 Afrikaan

562 Tamarindenboom

228 Tamarisch

838 Vrouwenzegel

696 Reinevaren

848 Taxisboom

14
Sparganio Sparzio

Spergola

Spinaci

Ulmaria

Splaeno

Stachi

Staffilodendro Statice

- - -

$-$

Noce vomica

Storace

Consolida

Siringa

Tagete

Tamarindo

Tamarisco

Brionia nera

Tanaceto

Tasso
Platanaria bas

Espergula

$-$

Espináca

Ulmaria

Splacno

Estaquis

-

Statice

Esparto

Mataperros

Estoraque

-
Pindsvünknoppe Dan. Träggan Swed.

Giesteira menor Port. GyelDan. PingstblommaSwed. Toriza Russ. Knægræs Dan. Fryle Swed.

Rödmus Dan. Rödmossa Swed.

Espinafre Port.SpinaschRuss. SzpinakPol.SpinatDan. Medunischnik Russ.

Spacno Port. Skyggeknop Dan. Parasolmossa Swed. Acaja; Ibametara Brazil. Oubou Carib.

Ortiga morta dos bosques Port.

Klekotschka Russ, Klokocina lesna krzak $P$ ol.

Strandblomster Swed.

Ojentröst Dan. Perer Swed.

Moujik-koréne Russ. Rudzik Tungus.

Satiriâo Port.

Esparto Port. Kawil Russ. Fejér árva Hung.

Mudores bolschoiRus. VandaloeDan. Vattu-aloeSwcd.

Noz vomica Port. Caniram Malab. Bræknödd Dan.

Storaque Port. Storax Dan. \& Swed.

Sylblad Dan. Frytilje Norw.

Consuelda major Consolda majorPort.Solnoi korenRuss. ZywokostPol.

Lila Lilaz Port. Serik Russ. Syreen Swed.

Clavel de muerto Tagecia Port. Sammetsros Swed.

Tamarindo

Taray

Tamo

Tanaceto

Tejo

Tammer bendi Arab. Tamarintræ Dan.

Tamargueira Port. Atl Arab. Grebenschik Russ.

Norça preta Port.

Tanasia Port. Dikaja riabina Russ. Wrotecz Pol.

Teixo Port. Kja raboku Jap. Tis Rus. Cis Pol. Id Sw.

Theka Malab. Cay sao Cochinch.

$-$

Germandrina

Camedrio

484. Waterruit

214

650 Kakauboom

194. Vlaschblad

546 Herders-taschjes

806 Boom des levens

508 Gemeene thym

562

466 Linde

222 Gemeen krielzaad

454 Tormentil

168 Halskruid

666 Boksbaard

104. Waternooten

1020 Lilmos

354 Voetangel

\section{Zumillo}

Cacahual

\section{- - - Hermosilla}

Adamaram Malab.

Carvalhinha Port. Ozanka Pol.

Zolotoucha Russ. Wrzodowiec Pol

Cucuhuaquahuitl Mexico. Kakaotræe Dan.

Linossisty tési Russ. Hörbladet naalebæger Dan.

Borsa di pastore Bolsa de pastor $\quad$ Linossisty tési Russ. Hörbladet naalebæger Dan.

Albero di vita Arbol de la vida Arvore da vidaPort. Livets træe Dan Lifvets trädSwe. Teino Tomillo Tomilho Port. Fimiane Russ. Tym Pol. Timian Dan. - - - - - Oceloxochitl Mexico.

Tilo - - $\quad \begin{aligned} & \text { Oceloxochitl Mexico. } \\ & \text { Uglamur Arab. Lipa Russ., Pol., Bohem., Siber., \&c. }\end{aligned}$

\section{- - - _ _ - _ Seseli de Creta Port.}

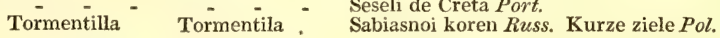

Barba di becco Barba cabruna Barba de bode Port. Kozlowa boroda Russ.

Tribolo acquatico Tribulo acuatico Tribulo aquatico Port. Panover-tsjeraua Malab.

- - - _ - - Levrehinde Dan. Skyfall Swed.

Tribolo terrestre Tribulo terrestre Tribulo Port. Kotewki Pol. 


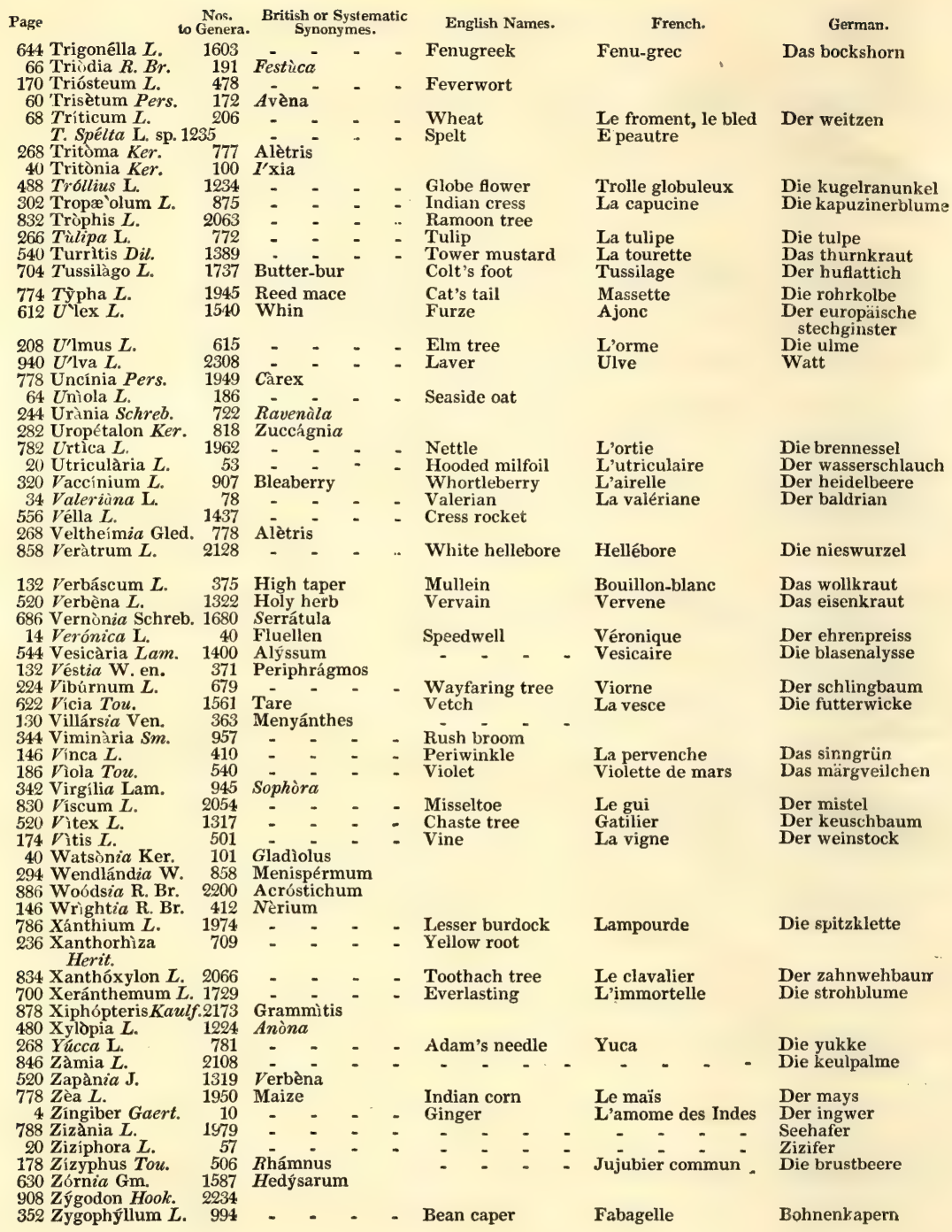


TABLE OF SYNONYMES.

Page Dutch.

644 Hoornklaver

68 Tarw

488 Drolbloem 302 Spaansche kers

266 Tulp

540 Turrekruid

704 Hoefblad

774 Lischdodde

612 Heybrem

208 Olm

940 Watervlies

782 Brandenetel
20 Neetekruid
320 Blaauwbessen
34 Valeriaan

8.58 Nieswortel

132 Wollekruid 520 Yzerhard

14. Eerenprys 544 Blaazig tanddraad

224 Viorne

622 Tamme vitsen

146 Maagdepalm

$186^{\circ}$ Tamme viool

830 Marentakken;

520 Kuischboon

174 Wyngaard

786 Kleine klissen

700 Straalbloem

778 Mays

4 Gember

788 Wild koorn

178 Jobenboom

352 Haauwkappers
Italian.

Fienogreco

Grano

Trigo

Iforva

Portuguese, Danish, Russian, Polish, South American,

Alforvas Port. Græskhöe Dan. Fenugrek Swed.

Ptscheniza Rus. Búza Hun. Budai Tar. Hvete Swe.
Fior - - - Kupalniza Russ. EngblommeDan.BullerblomsterSwe Fior cappucino Capuchinas - Mastruço do Peru Port. Indiansk karse Dan.

Tulipano Tulipan

Tossilaggine - Tusilago

Tifa Espadaña

- - - Aliaga

Olmo Olmo

\section{Ortica Ortiga Ortiga Port. Pokrzywa Pol.}

- - - _ _ _ _ Vandröllike Dan. Vassröllike Norw.

Mirtillo Mirtilo Myrtillo Port. Tscherniza Russ. Borrowkı czarne Pol.

Valeriana Valeriana ValerianaPort. Fai soJap. BalderjanRuss. KozlkiPol.

Elleboro bianco Vedegambre Helleboro branco Port. Tschemeriza Russ. Hvit Elleboro bianco

Tassobarbasso Gordolobo

Verbena $\quad$ Verbena

Veronica Veronica

Viburno Viburno

Veccie "Alverjanas

Pervinca Pervinca

Viola marzia Violeta

Vischio

Agnocasto

Liga

Sauzgatillo

Vid prustrot Swed.

Verbasco branco Port. Zaarskii skipetr Russ.

VerbenaPort. Co roi nguaCochinch. ScheelsnikRuss.

Veronica Port. Weronika Russ. Erenpriis Dan.

Germeschek Turk. Gordowina Russ. Hordewid Pol. Myschei goroch Russ. Wyka Pol.

Congossa Port. Barwinek Pol. Singrön Dan. Pachutschaja fialko Russ.

Visgo Port. Oméla Russ. Jemiel Pol.

AnhocastoPort. Dikoi perezRus. Kydskhedstræe Dan. Ænæb Arab. Winograd Russ. Winna macica Pol.

Lappola minore Lampazo pequeño Bardana menor Port. DurkomanKus.

$\begin{array}{lll}\begin{array}{l}\text { Gran turco } \\ \text { Zenzero }\end{array} & \begin{array}{l}\text { Maiz } \\ \text { Jeniibre }\end{array} & \begin{array}{l}\text { Tlaoilli Mexico. Tyrkisk korn Dan. } \\ \text { Zenjebél Arab.fel. Inbir Russ. Imbier Pol }\end{array} \\ \text { Giuggiolo } & \text { Azufaso } & \text { Maceira de anafegaPort. UnapTurk.FrangulinaRuss. }\end{array}$

Azufaso

Stroutschkowatye kapérsy Russ. 



\title{
GENERAL INDEX,
}

\author{
COMPREHENDING
}

THE SYSTEMATIC AND ENGLISH GENERIC NAMES, AND THE ENGLISH AND SYSTEMATIC SYNONYMES IN COMMON USE

IN this Index, the systematic names are distinguished as classical, i. e. names applied to plants by the ancients, by the first letter being in Italic, as $A$ bies; as commemorative, by the terminating letter or letters being in Italic, as Bánksia ; and as aboriginal, or of uncertain derivation, by the whole word being in Italic, as A'rua. All the other names are formed, in almost every case, from the Greek, but sometimes from the Greek and Latin. Where $n$. is added after the name, it refers to the note.

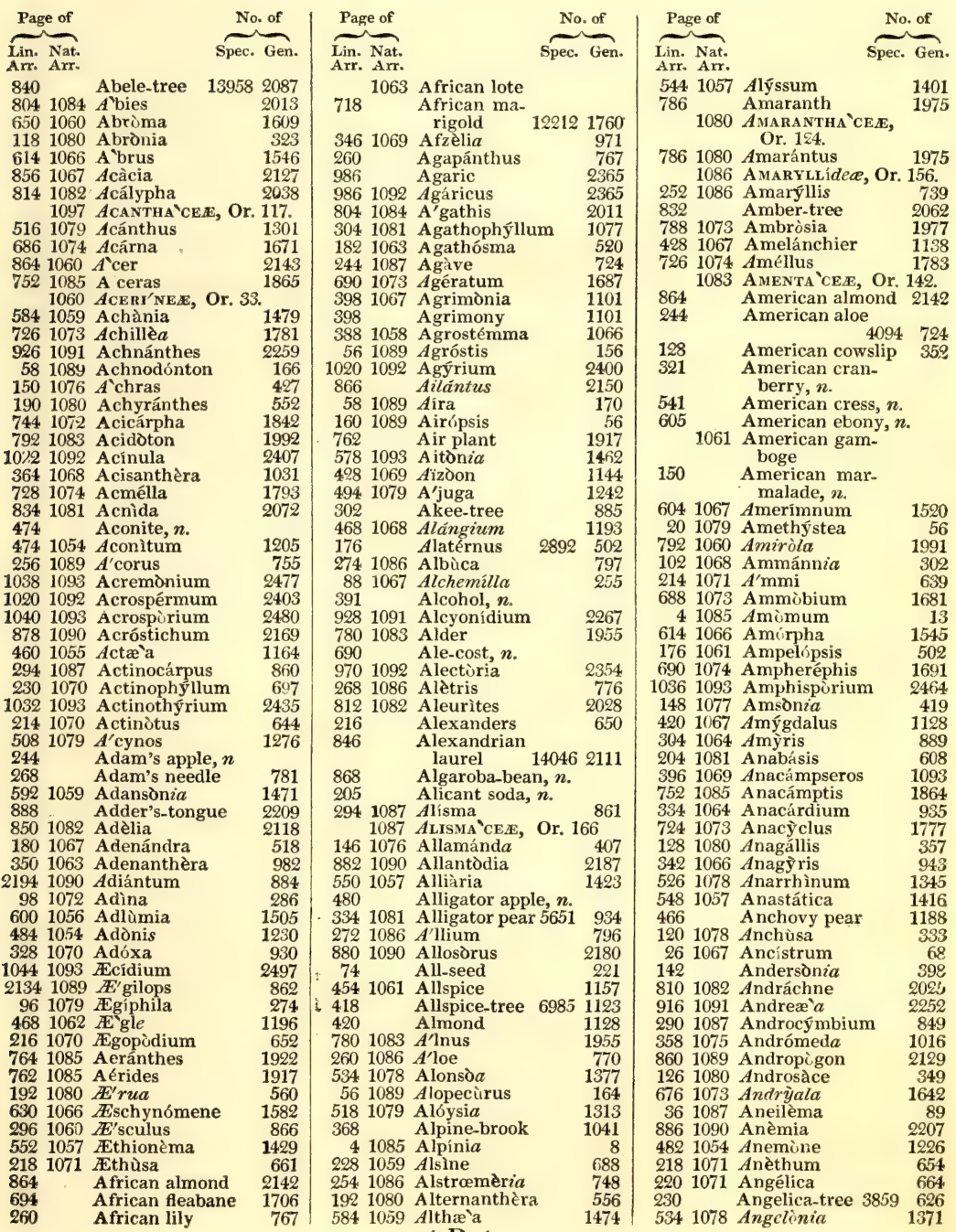


Iin. $\mathrm{Nat}$

$$
1062 \text { Angostura-bark }
$$

764. 1085 Angre'cum

7721069 Angùria

59 Angus oat, $n$

9121091 Anictangìum

2441085 Anigozánthos

60 Animal oat, 1054

212 Anise

$478 \quad$ Aniseed tree

4941079 Anisoméles

7581085 Anisopétalum

4801055 Annòna

1055 Annona'cea, Or. 4

5881059 Anòda

421086 Anomathèca

9121091 Anúmodon

7021073 Antennària

724 1073 A'nthemis

2801086 Anthéricum

5341078 Anthocérci

9221091 Anthóceros

44. 1086 Antholỳza

8321072 Anthospérmum

281089 Anthoxánthum

2081071 Anthriscus

6121066 Anthýllis

8341093 Antidésma

5261078 Antirrhìnum

8821090 Antrophyum

584. Antwerp holly

$$
\begin{gathered}
\text { Antwerp holly- } \\
\text { hock }
\end{gathered} 9776 \quad 147
$$

1921080 Anýchia

3441066 Aotus

6701073 Apárgia

4641060 Aperba

3241080 Aphanánthe

5181079 A phelándra

1091 A PHY LL E, Cl. 2.

2721086 Aphyllánthes

$2161070 A$ pium

$1076 A$ POCY'NEAE, Or. $101 .^{\prime}$

1941077 Apócynum

2921090 Aponogèton 85

466 Apothecaries' boxes, $n$

180
4261067 Apple-tree $7090 \quad 1133$

$\begin{array}{llll}4261067 & \text { Apple-tree } & 7090 & 1133 \\ 4221067 \text { Apricot } & 70561129\end{array}$

4761054 Aquilègia

$5401057 A^{\prime}$ rabis

614 $1067 A^{\prime}$ rachi

2301070 Aràlia

1070 A RaLIA'ce Or.

8461084 Arauciria

8061064 A'rbor Vitæ

$3601075 A^{\prime}$ rbutus

502 Archange

$6801074 A^{\prime}$ rctium

8721070 Arctòpus

7341073 Arctothèca

7401073 Arctòtis

1521075 Ardísia

1521077 Arduine

8001088 Arèca

3781059 Arenària

754 1084 Arethùsa

124. 1080 Arèti $a$

4621056 Argemine

967 Argol, $n$.

244 1085 Argolàsia

1401077 Argyrèia

44. 1086 Aristèa

7661082 Aristolochia

1082 A RISTolichue, Or 13

3941064 Aristotèlia 1084

394 1080 Aristotelia

716 1074 A'rnica

6661073 Arnopogon

4641058 Arnotta

$1089 A$ roíde $£$, Or. 176.

290 Arrow-grass

21685 Arrow-root

1034 1093 Arscýria .

480 Artabotrys

2201071 Artèdia

6961073 Artemísia

9761092 Arthrònia

2801086 Arthrop'dium

684 1072 Artichoke

7701083 Artocárpus

8001089 A'rum

74. 1089 Arundinària

601089 Arúndo
Lin. Nat.

$392 \quad$ Asarabacca

$3921082 A$ sarum

1077 Asclepia'dea, Or. 102.

1961077 Asclepias

10181092 Asclepias

10361093 Ascóphora

$6581061 A^{\prime}$ scyrum

8681076 Ash-tree

4801055 Asimina

6061066 Aspálathus

2821086 Aspáragus

840

Aspen

10401093 Aspergíllus

124 1078 Asperùgo

94 1072 Asperula

1086 Asprod 808

2801086 Asphódelus

81061 Aspicárpa

2581089 Aspidistra

884 1092 Aspidium

1090 Asplenium 2186

2201070 Assa-fœetida 3702668

617 Asses' eyes, $\boldsymbol{n}$.

7061074 Astelma

100 1074 A'ster

10321093 Asteroma

$636106 \%$ Astrágalus

2981064 Astránthus

2221070 Astrántia

5801060 Astrapæ'a

142 Astrolìma

6961073 Athamanta

1073 Athanàsia THEROSPE'RMEE,

Or. 139

1024 1092 Atractóbolu

6861074 Atráctylis

2881081 Atrapháxis

$8621081 A^{\prime}$ triplex

1078 A'tropa

$$
1078 \text { Attar, } \boldsymbol{n} \text {. }
$$

544 1057 Aubrietia

784. 1093 Á́cuba

8281081 Álax

1062 Aurantia' 1966

126 Auricula CEN, Or. 45.

581089 Avèna

454. Avens

3801061 Averrhoa

5901079 Avicennia

1771079 Avicénnia Avignon berries, $\boldsymbol{n}$.

558 Awlwort

521089 Axónopus

7721081 Axỳris

1072 Ayapana of Brazil

1821060 Ayènia

144 1075 Azàlea

421086 Babiàna

6781074 Bacàzia

7021074 Báccharis

7901088 Báctris

304 1068 Bæ ckia

9701092 Bæómyces

$176 \quad \begin{gathered}\text { Bahama } \\ \text { wood }\end{gathered}$

wood

5041079 Ballota

508 10"9 Balm

1728

2416

2416
1670

838

$38 \quad 810$

Bastard pimpernel 277

Bastard quince 7104 1133

$194 \quad$ Bastard toadflax 569

$636 \quad$ Bastard vetch 1592

$\begin{array}{rlll}2410 & 1092 & \text { Batárrea } & 1022 \\ 932 & 1091 & \text { Batrachospérmum } 2283\end{array}$

1201078 Bátschia

4701070 Bauèra 1199

3461067 Bauhínia 970

$216 \quad$ Bawd money 653

831 Bayberry-bush, $\boldsymbol{n}$.

3321081 Bay-tree 5646934

352 Bead-tree 988

425 Beam-tree, $n$.

6221065 Bean 104201561

$352 \quad$ Bean-caper 994

342 Bean-trefoil 943

$360 \quad$ Bear-berry 59671019

$\begin{array}{llr}140 & \text { Bear-bind } & 387 \\ 516 & \text { Bear's breech } & 1301\end{array}$

128 Bear's-ear sanicle 351

488 Bear's foot 80851237

6521068 Beaufórtia 1613

479 Beaver-tree, $n$

661089 Beckmánnia 199

92 Bed-straw 266

$\begin{array}{llr}792 & \text { Beech } & 1996 \\ 206 & 1081 \text { Beet } & 612\end{array}$

7901081 Begìnia 1989

1081 BEGoniàcea, Or. 128.

394 1075 Bejaria 1076

8021084 Bèlis

$252 \quad$ Belladonna lily 4255739

$540 \quad$ Belleisle cress 89781386

$162 \quad$ Bell-flower 463

7181074 Béllis 1756

7181074 Béllium $\quad 1757$

$468 \quad$ Bengal quince 1196

334 Benjamin-tree 5656934

56 Bent-grass

3631068 Benzoin, $n$.

6841074 Berárdia 1667

1055 Berberidea, Or. 6.

2861055 Bérberis 829

$286 \quad$ Berberry 829

7321073 Berckhèy $a \quad 1810$

848 Bermudas ce- 140502113

544 1057 Berteròa $\quad 1398$ 


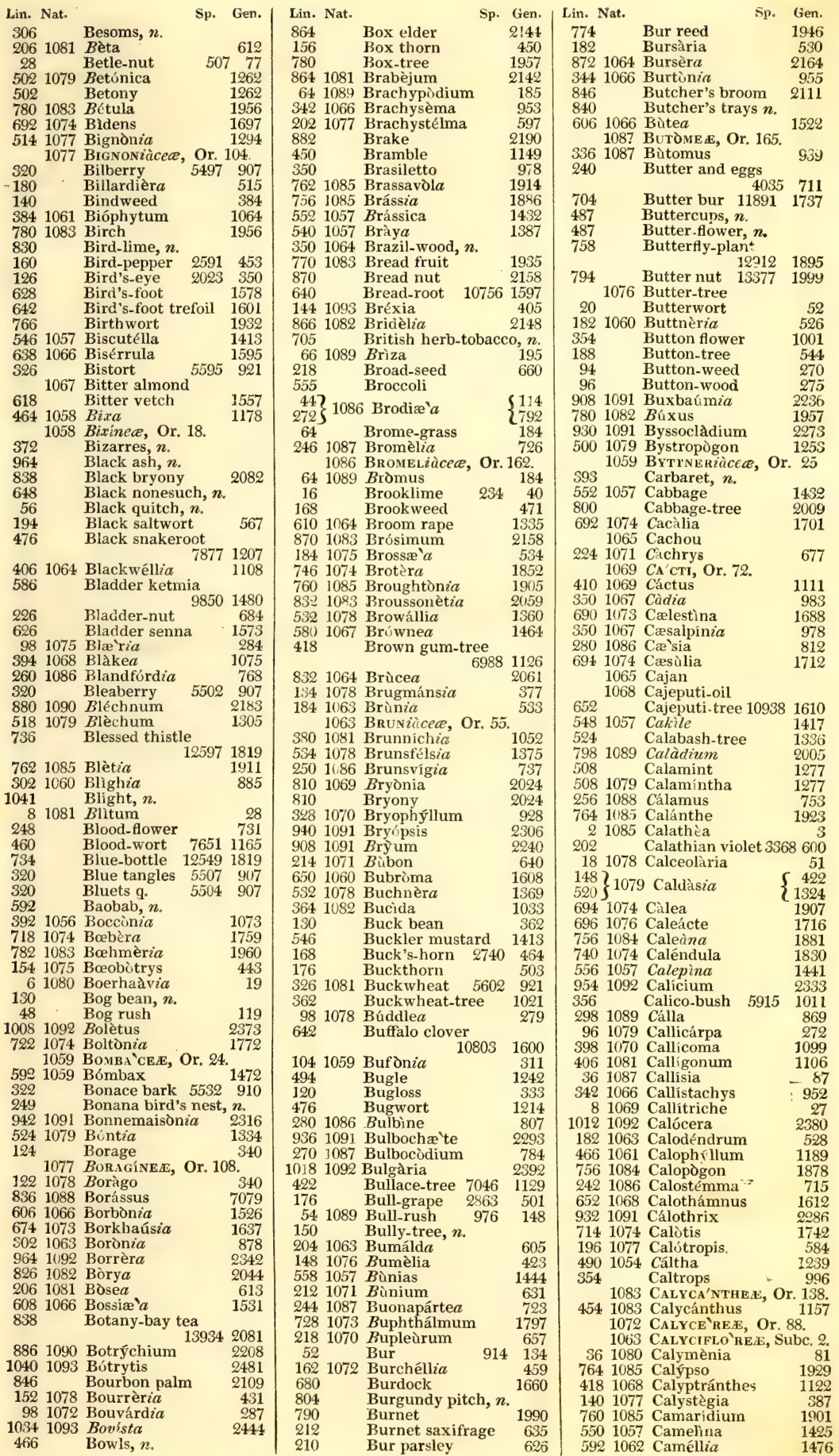


Lin. Nat Sp. Gen. 1062 Camellièa, Or. 47

1481077 Camerària

1621075 Campánula

1075 Campanula 463 3321081 Camphire-tree 5643 934 3331081 Camphor, $n$.

881081 Camphorósma

372 Campion 1047

$788 \quad$ Canada rice 133131979

2881075 Canarìna $\quad 834$

$\begin{array}{rlr}58 & \text { Canary-grass } & 168 \\ 830 & \text { Candleberry myrtle } 2055\end{array}$

$830 \quad$ Candleberry myrtle 2055

5461057 Candy-tuft

74 Cane-brake

1061 Canélla

1085 Cánna

834 1083 Cánnabis

1085 CA'NNEA, Or. 152

164 Canterbury bells

10061092 Cantharéllus $\begin{array}{rr}2675 & 463 \\ 2368\end{array}$

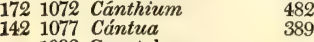

1082 Caoutchouc

389

$172 \quad$ Cape jasmine $2826 \quad 487$

$226 \quad$ Cape phillyrea 3817682

4021058 Caper $\quad 67481103$

$458 \quad$ Caper-tree 1162

1058 CAPPA RíDEE, Or. 14.

$\begin{array}{lll}458 & 1058 \text { Capparis } & 1162 \\ 532 & 1078 \text { Caprària } & 1368\end{array}$

1071 Caprifolia'cea, Or. 82.

1701071 Caprifolium $\quad 474$

5461057 Capsella

1601078 Cápsicum

6261066 Caragàna

202 Caralluma

218 Caraway

5421057 Cardámine

41085 Cardamom
$166 \quad$ Cardinal-flower

1409

453
1569

598

655

1392

2715464

3281060 Cardiospérmum 925

$\begin{array}{llll}684 & 1072 \text { Cardoon } & 11458 & 1668 \\ 686 & 1074 & \text { Cardopàtum } & 1676\end{array}$

6861074 Cardopàtum $\quad 1676$

1089 Càrex

5961068 Càreya

1521077 Caríssa

684 1074 Carlina

684 Carlina

7981087 Carludóvica

372 Carnation

$868 \quad$ Carob-tree

plant, $\boldsymbol{n}$.

5921059 Carolínea

7021073 Carpèsium

7921083 Cárpinus

6161066 Carpopogon

5561057 Carrichtèra

2101070 Carrot

1947

1499

2095
438

1669

1669

2004

1046

2156

1490

1731

1996

1549

1438

420 Carthagenian apple, $n$.

6861074 Cárthamus 1675

361087 Cartonèma

2181070 Càrum

90
655

1059 Caryophy'Llese, Or. 20.

4161068 Caryophýllus $\quad 1120$

8001088 Caryòta 2007

813 Cascarilla-bark, $\boldsymbol{n}$.

3341064 Cashew nut 935

814 1082 Cassava 136492033

3481067 Cássia

333 Cassia-buds, $\boldsymbol{n}$.

3261063 Cassine

7441073 Cassinia

224 Cassioberry-bush

3341081 Cassỳtha

079

7921083 Castànea

5241078 Castillèja

$814 \quad$ Castor-oil plant 136522034

936
1994

1337

7721083 Casuarina 1936

1083 Casuarínee, Or. 144.

261077 Catálpa

6781073 Catanánche $\quad 1655$

7561085 Catasètum

374 Catchfly

93 Catch-weed, $n$

1889
Lin. Nat.

628 Caterpillar

1001072 Catesbre' $a$

3501067 Cathartocárpus

Cathartocárpus $\quad 975$

854 Cat's-claw mimosa, $n$

676

774

58

Cat's-ear mimosa, $n$.

Cat's-tail 1945

Cat's-tail grass 81091944

7601085 Cáttleya $\quad 81091244$

7601085 Cáttley

${ }_{555} 1071$ Caúcalis

2861055 Caulophýllum

161 Cayenne butter, $\boldsymbol{n}$.

161 Cayenne pepper, $\boldsymbol{n}$.

1781063 Ceanòthus

8261083 Cecropia

510
2043

806 Cedar of Le.

banon Le- 135372014

1821062 Ceỏrèla

1062 Cedre'lee, Or. 44.

460 Celandine 1167

1063 Celastríneas, Or. 53.
1063 Celástrus

217 Celeriac, $n$

2161070 Celery $\quad 3618651$

1090 Cellula 'res, Div. 2

1921080 Celosia

534 1078 Célsi $a$

864 1083 Céltis

10181092 Cenangium

521089 Cénchrus

22 1073 Cenia

7341074 Centaurèa

734 Centaury

61072 Centránthus

724 1074 Centrospérmum

961080 Centúnculus

1741072 Cephaèlis

961072 Cephalánthus

901072 Cephalària

6901074 Cephalóphora

9361091 Ceràmium

10361059 Cerástium

10361093 Ceràtium

7721081 Ceratocárpus

1054 Ceratocéphalus

661089 Ceratochloa

8681067 Ceratònia

7901093 Ceratophýllum

1481077 Cérbera

3461067 Cércis

410 Cereuses, $n$

1221078 Cerinthe

1981077 Ceropègia

1541078 Céstrum

8781090 Céterach

9641092 Cetrària

2081071 Chærophýllum

716 1074 Chætanthèra

9281091 Chætóphora

9381091 Chætóspora

54. 1089 Chætùrus

8361088 Chamædòrea

144 1075 Chamælèdon

8681088 Chamæ'rops

754 1085 Chamórchis

724 1072 Chamomile

1004 Champignon, $\boldsymbol{n}$.

7401073 Chaptalia

9361091 Chàra

5201079 Chaste-tree

866 Chawstick

565

1376
2145

2145

134

1819

1819

20

1779
277

497

263

263
1690

2296

2465

2465

708

189

2156

1986
420

968

339

593
445

445
2174

234

621
1748

2271

2298

152
7078

404
2154

1867

1778

2368

1829

2295
1317

465 Cheese-colouring, $n$.

92 Cheese rennet 1604266

884 1090 Cheilánthes 2195

5381057 Cheiránthus $\quad 1382$

5161078 Chelone

$\begin{array}{ll}1081 \text { Chendlea } & 558 \\ 1080 \text { Chenopònex, } & \text { Or. } 126 .\end{array}$

2061081 Chenopodium 611

4801055 Cherimoyer 79211220

3801059 Cherlèria 1051

$\begin{array}{llr}422 & \text { Cherry } & 1129 \\ 160 & \text { Cherry pepper } & 2596 \quad 453\end{array}$

2081070 Chervil

7921083 Chestnut

6241065 Chick pea

Lin. Nat.

sp. Gen.

$\left.\begin{array}{r}76 \\ 288\end{array}\right\} \quad$ Chickweed $\quad\left\{\begin{array}{l}224 \\ 688\end{array}\right.$

581089 Chilochloa $\quad 167$

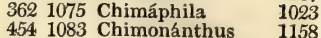

586 China rose 98191480

423 Chinese cherry, $\boldsymbol{n}$.

1721072 Chirocócca 480

121076 Chionánthus $\quad 34$

833 Chio turpentine, $n$.

1301077 Chironia

274 Chives 4688796

2421086 Chlidánthus $\quad 716$

3161077 Chlora 894

1084 ChLORA'NTHE E, Or. 146.

81084 Chloránthus 25

8601089 Chloris 2130

2801086 Chloróphytum $\quad 811$

981072 Chomelate nut $\quad 1607$

9421091 Chóndria 2313

6701073 Chondrílla $\quad 1629$

9441091 Chordaria $\quad 2319$

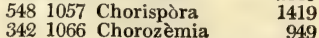

9801091 Chroolèpus $\quad 2275$

708 Christmas daisies, $\boldsymbol{n}$.

$488 \quad$ Christmas rose 80801237

178 Christ's thorn 505

7281073 Chrysanthéllum 1788

$\begin{array}{ll}7201073 \text { Chrysánthemum } & 1769 \\ 2421086 & \text { Chrysiphiala }\end{array}$

424 1067 Chrysobálanus $\quad 1130$

694 1074 Chrysócoma 1705

7401074 Chrysógonum 1827

1501076 Chrysophýllum $\quad 424$

3661070 Chrysosplènium $\quad 1040$

$\begin{array}{rrr}60 & 1089 \text { Chrysùrus } & 176 \\ 782 & 1082 \text { Cícca } & 1958\end{array}$

624 1066 Cicer 1564

6781073 Cichorium

2161071 Cicuta

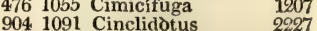

7121074 Cineraria $\quad 1741$

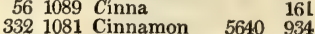

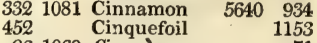

261069 Circæ'a 71

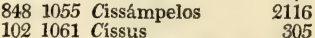

1058 Cistínea, Or. 19.

4681058 Cístus 1197

$358 \quad C$ ístus Lèdum, $n$.

5201079 Citharéxylum 1329

$654 \quad$ Citron $\quad 109791615$

1062 Citrus

261089 Clàdium 74

10381093 Cladospdrium $\quad 2472$

9401091 Cladostèphus 2303

151 Clammy cherry, $n$. 
Lin. Nat.

1421077 Cobe' 1077 Сов àcea, Or. 105. 7781089 Cobrèsia 1001072 Coccocýpsilum 3261081 Coccoloba

8441055 Cócculus

$12 \quad$ Cochineal fig 6888111

5461057 Cochleària $\quad 1407$

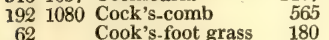

651 Cocoa-nut, $n$.

788 Cocoa-nut-tree

24 Cocoa plum

7881088 Còcos

101067 Codàrium

9401091 Codium

320 Codlins and cream

3541078 Còdon

7581085 Coelógyne

1701072 Cofféa

1701072 Coffee-tree Cog-wood-tree 564

7781089 Coix

4761055 Colbértia

2921087 Cólchicum

1061078 Coldènia

9721092 Collèma

24. 1079 Collinsonia Colombo-root, $n$

8091068 Coloquintida gourd, $\boldsymbol{n}$. 1068 Colocinth resin

\begin{tabular}{|c|c|c|c|}
\hline & & & \\
\hline & & & 2141 \\
\hline 226 & & Colpoon-tree & 682 \\
\hline 704 & & Colt's-foot & 1738 \\
\hline 476 & & Columbine & 1208 \\
\hline & 1055 & Columbo-root & \\
\hline 72 & 1073 & Columéllia & 1785 \\
\hline 5 & 1078 & Colúmnea & 136 \\
\hline & 1067 & Colùria & 11 \\
\hline & 1066 & Colùtea & 15 \\
\hline & 1067 & Cómarum & 1152 \\
\hline & 1068 & COMBRETA 'CE $\bar{E}$, & Or. 64. \\
\hline & 1068 & Combrètum & 916 \\
\hline & & Comfrey & 33 \\
\hline & 1087 & Commelin $a$ & \\
\hline & 1087 & Commelínea, & 167. \\
\hline & & Com & \\
\hline
\end{tabular}

626 Common aca. cia 104601118

361064 Comoclàdia 1.

1083 Comptònia

254 1086 Conanthèra 749

934 1091 Conférva $\quad 949$

1083 Conífere, Or. 145.

2161071 Conium

1881068 Conocárpus

9061091 Conóstomum 2232

88 Contrajerva $\begin{array}{lll}\text { Contrajerva } & & \\ \text { root } & 1527 & 257\end{array}$

2701086 Convallària 1077 CONVOLVUla'CE E, Or. 117

1401077 Convólvulus $\quad 384$

7021073 Conỳza 1734

3561062 Coskic

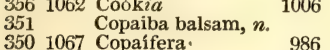

3501067 Copaífera

10041092 Coprìnus

4881239 Cóptis

2366

7561085 Coquaine parsnep, $\boldsymbol{n}$.

1882

1519

1501078 Córdia $\quad 428$ 1078 Condiàcea, Or. 109.

732 1074 Coreópsis 1804

$208 \quad$ Coriander $\quad 618$

4821063 Coriària 2091 1063 Coriarie'E, Or. 50.

1301080 Coris 360

81081 Corispérmum 26

$\begin{array}{llr}794 & \text { Cork-tree } & 133952000 \\ 480 & \text { Corkwood } & 79251220\end{array}$

102 Cormier, $n$

$388 \quad$ Corn cockle 65351066

102 Cornelian cherry

$42 \quad$ Corn flag $\quad 1794 \quad 306$ 970
532 $\quad \begin{aligned} & \text { Corniculària } \\ & \text { Cornish moneywort }\end{aligned}$
Lin. Nat.

072 Corn salad

521089 Cornucòpi

1021071 Córnus

1075 Corolliflora, Subc.

6281066 Coronílla

5501057 Corónopus

3021063 Corra' $a$

2281069 Corrigìola

1281080 Cortùsa

6001056 Corýdalis

7921083 Córylus

9281091 Corynéphora

581089 Corynéphorus

2581088 Córypha

7321074 Cósmea

2861060 Cossígnia

41085 Cóstus

4281067 Cotoneáster

$588 \quad$ Cotton

$50 \quad$ Cotton grass

$\begin{array}{ll}742 & \text { Cotton rose } \\ 684 & \text { Cotton thistle }\end{array}$

7221073 Cótula

3821070 Cotylèdon

$70 \quad$ Couch grass 12391060

1621072 Coutarèa

$616 \quad$ Cowage or cowitch 1551

216 Cowbane 648

$322 \quad$ Cowberry 5519907

802 Cow parsnep 672

1261080 Cowslip $2022 \quad 350$

1076 Cow tree of South America

520 Cow wheat

466 Cradles, $n$

5561057 Crámbe

320 : Cranberry

2301070 Crássula

424 1067 Cratæ'gus

3961058 Cratæ'v $\alpha$

1034 1093 Cratèrium

674 1073 Crèpis

5241078 Crescénti $\alpha$

552 Cress

$556 \quad$ Cress rocket

1034 1093 Cribrària

2501086 Crìnum

1059 Cristaria

361085 Crìcus

5181079 Crossándra

94 Crosswort

6081066 Crotalària

8121082 Crùton

826 Crowberry

3541063 Cròwe $a$

486 1054 Crowfoot $\quad 999$

388 Crown of the field, $n$.

94. 1072 Crucianélla

1056 CruCi'fers, Or. 12.

561089 Crýpsis

7601085 Cryptarrhèna 1909

8741090 Cryptoga'mia, Cl. 24

8761090 C. FI'LICES, Or. 1

8901090 C. EQUISETA 'CE

8921090 C. LYCOPODI'NEA, Or. 3.

8941090 C. Marsileacee, Or. 4

8941091 C. MU'sCI, Or. 5

9,81091 C. HEPA'TICE, Or, 6

9241091 C. $A^{\prime}$ LGE, Or. 7.

9481091 C. LICHE'NES, Or. 8.

9781092 C. Fu'NGI, Or. 9.

$858 \quad$ Cuckold-tree 141872127

yellow hue, $n$.

3721059 Cucubalus $\quad 1047$
10201092 Cryptomỳces

881072 Cryptospermum

1961077 Cryptostègia

7341073 Cryptostémma

480 Cubebs, $n$.

$794 \quad$ Cuckold 133731998

487 Cuckoo buds of

$542 \quad$ Cuckoo flower 90261392

8081068 Cucumber 2022

479 Cucumber-tree, $n$.

8081069 Cùcumis

2022

8081069 Cucrubita 2021

2396

2423

814

88871358
Lin. Nat.

Sp. Gen.

10261092 Cucurbitària 2422

$\begin{array}{llrr}960 & \text { Cudbear } & 15524 & 2340 \\ 332 & \text { Culilaban } & 5647 & 934\end{array}$

7321073 Cullùmia $\quad 1809$

$\left.\begin{array}{l}188 \\ 214\end{array}\right\}$ Cumin $\quad\left\{\begin{array}{l}548 \\ 641\end{array}\right.$

214 1071 Cuminum $\quad 641$

201079 Cùnila 58

3661070 Cunònia $\quad 1038$

1070 Cunoniacea, Or. 77

3981068 Cùphea

806 1084 Cupréssus $\quad 1097$

4721055 Curatélla $\quad 1201$

2561086 Curculigo $\quad 751$

61085 Curcùma 14

$\begin{array}{ll}1901069 \text { Currant } & 55 \mathrm{C} \\ 1001063 \text { Curtísia } & 300\end{array}$

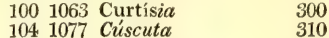

2041070 Cussònia $\quad 607$

$480 \quad$ Custard apple $\quad 1220$

2861086 Cyanélla 824

8861090 Cyathea 2201

1084. CYCA'DEE, Or. 148.

8461084 Cỳcas

1281080 Cýclamen $\quad 354$

3421066 Cyclòpia $\quad 946$

4261067 Cydònia 1134

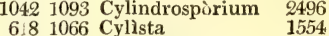

534 1078 Cymbària $\quad 1379$

7561085 Cymbídium $\quad \mathbf{1 8 8 5}$

1961077 Cynánchum $\quad 581$

684 1074 Cýnara 1668

681089 Cýnodon 203

1221078 Cynoglóssum 336

3481067 Cynomètra 973

621089 Cynosùrus 178

501089 Cyperus

1881075 Cýphia $\quad .545$

$806 \quad$ Cypress 9017

800 Cypress powder, $\boldsymbol{n}$.

8331085 Cypress turpentine, $\boldsymbol{n}$.

184. 1075 Cyrill $\alpha$.

1931
536

2501086 Cyrtánthus $\quad 736$

7581085 Cyrtopòdium $\quad 1896$

6001056 Cysticápnos $\quad 1503$

9461091 Cystoseíra $\quad 2329$

10301093 Cytispòra $\quad 2429$

6241066 Cýtisus $\quad 1566^{\circ}$

621089 Dáctylis 180

681089 Dactyloctènium $\quad 201$

10061092 Drdàlea 2371

$\begin{array}{rrr}196 & 1077 \text { De'mia } & 580 \\ 242 & \text { Daffodil } & 4040\end{array}$

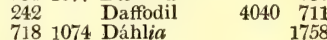

3641082 Dàis 1032

718 Daisy $\quad 1756$

604 1067 Dalbérgia $\quad 1513$

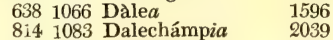

4521067 Dalibárda

$9] 21091$ Daltònia 2248

2941084 Damasònium 859

802 Dammar pine 2011

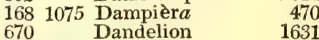

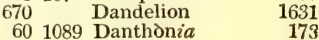

3221082 Daphne $\quad 910$

$70 \quad$ Darnel 207

$\begin{array}{lll}828 & \text { Date palm } & 2049 \\ 870 & \text { Date plum } & 2159\end{array}$

8441083 Datisca 2099

134 1078 Datura 376

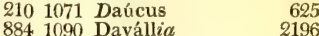

3461066 Davièsia 966

$260 \quad$ Day lily 769

214 Deadly carrot 643

$\begin{array}{lll}\text { Deadly night- } & \text { shade } & \\ \text { sh79 } & 446\end{array}$

502 Dead nettle 1261

802 Deal-wood, $n$.

338 DECA'NDRIA, CI. 10.

340 D. MONOGY'NIA, Or. 1

364 D. DiGY'N1A, Or. 2.

D. TRIGY'NIA, Or. 3.

D. Pentagy'nia, Or. 4.

D. DecagY'Nia, Or. 5 .

Deciduous

cypress 135382015 
Lin. Nat.

3941068 Decumària

1921080 Deeríngia

9441091 Delesseria

4721054 Delphinium

10381093 Demàtium

7581085 Dendrobium

5421057 Dentària

1621072 Dentélla

8561067 Desmànthus

9261091 Desmídium

1921080 Desmochæ'ta

Sp. Gen. Lin. Nat.

\begin{tabular}{r|ll}
1082 & 754 & 1084 \\
563 & 292 & Diùris \\
Dock
\end{tabular}

\begin{tabular}{r|ll}
563 & 292 & Dock \\
2317 & 532 & 1078 Dodártia
\end{tabular}

$1204104 \quad$ Dodder

$2471 \quad 392$

$1900 \quad 392$

$1394 \quad 398$

$456 \quad 398$

\begin{tabular}{l|l}
2126 & 406 \\
2263 & 406
\end{tabular}

DODECA'NDRIA, Cl. 11.

D. MonogY'NIA, Or. 1

D. DigY NIA, Or. 2.

D. TRIGY'NIA, Or. 3.

D. Tetragi'nia, Or. 4

D. Penagy nia, Or. 5 .

D. DODECAGY'NiA,$$
\text { Or. } 6
$$

1281080 Dodecàtheon

316 1000 Dodonæ' $a$

598 Diade'LPHIA, Cl. 17 .

600 D. Penta'ndria, Or. 1.

600
602
D. HeXa'ndria, Or. 2.

604 D. DECA'NDRIA, Or. 4.

D. DECA' NDRIA,

10 D. MonOGY'NiA, Or. 1.

28 D. DigY'NiA, Or. 2.

281086 Dianélla 282 . Trigy' Or. 3.

3701059 Diánthus

1301077 Diapénsia

74 1089 Diarrhèna

9261691 Diátoma

1691 Diátoma 2269

204 1077 Dichóndra

2601087 Dichorizándra

10361093 Dichosporium

884 1090 Dicksùnia

181079 Diclíptera

6001056 Diclỳtra

1054 DICOTYLE'DONES, Cl. 1.

9021091 Dicrànum

3541063 Dictámnus

1034 1093 Dictýdium

7321073 Didélta

10341093 Didérma

904. 1091 Didýmodon

1046

358

219
194

194

Dog-parsley, $n$.

Dog's-cab-

bage
Sp. Gen

1871
856
1365
310
1.
1.

.4.

270 Dog's-tail grass 178

1021071 Dogwood 306

10161066 D́lichos

5801060 Dombèy $a$

2141070 Dóndia

8801090 Doódia

7161074 Dorónicum

1083 Dorstènia

2541086 Doryánthes

644 1066 Dorýcnium

10301093 Dothidèa

589 Down, $\boldsymbol{n}$.

5441057 Dràba

2661086 Dracæ'na

5101079 Dracocéphalum

2981089 Dracóntium

298 Dragon

$5101065 \begin{aligned} & \text { Dragon's blood } \\ & \text { Dragon's head }\end{aligned}$

266 Dragon-tree

9321091 Draparnáldia

2821086 Drimia

428 Dropwort

2321058 Drúsera

(17. 17.

861081 Dryándra

Or. 1.

512 D. Angiospe'rmia,Or.2.

1701071 Diervílla

5301078 Digitàlis

521089 Digitària

4i. 1085 Dilatris

418
478

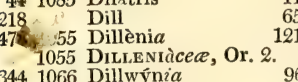

909 1060 Dimýára $\quad 960$

681089 Dinèbra

$816 \quad 204$

820 D. MONA'NDRIA, Or. 1.

820 D. Dia'NDRIA, Or. 2.

826 D. Tria'ndria, Or. 3.

828 D. TETRA'NDRia, Or. 4.

832 D. Penta'ndria, Cr. 5.

836 D. HEXA NDRIA, Or. 6.

840 D. OCTA'NDRIA, Or. 7.

840 D. ENNEA' NDRIA, Or. 8.

842 D. DECA'NDRIA, Or. 9.

842 D. DODECA'NDRIA, Or. 10.

844

D. ICOSA'NDRIA, Or. 11.

D. PolYA'NDRIA, Or. 12.

846 D. MONADE'LPHIA Or. 13.

3561058 Dionæ'a

8381086 Dioscorea $\quad 2085$ 1086 Droscorea, Or. 158

1801063 Diósma

$8701076 D$ iospỳros

7841081 Diotis

2861055 Diphylleia

9081091 Diphýscium

641089 Dipláchne

8821090 Diplàzium

5541057 Diplotáxis

1072 DIPSA'CE

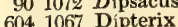

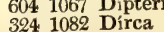

3241082 Dirca

2961078 Disándra

1961077 Dischídia

466 Dishes, $\boldsymbol{n}$.

10181092 Ditìla

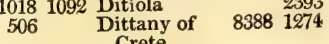

208 1067 Drỳas

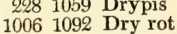

460 Tuck's-foot

353

637

1751

275

1604

942 Dulse 2315

7981089 Dumb carre 134512005

6901074 Dumerília 168

${ }_{529} 1069$ Duránta straw, $n$. 1330

208 Dutch elm, $\boldsymbol{n}$.

424 Dutch medlar, $n$

399 Dutch pink, $\boldsymbol{n}$.

8901090 Dutch rush 146312211

868 Dwarf fan-palm

$398 \quad$ Dyer's-weed 143192154

$398 \quad$ Dyer's-weed 66581102

1012 Earth tongue 2381

$\left.\begin{array}{cl}212 \\ 614\end{array}\right\} \begin{aligned} & \text { Earth-nut } \\ & \begin{array}{r}631 \\ 1543\end{array}\end{aligned}$

1087 Eau médicinale

$326 \begin{aligned} & 1076 \text { EBENA CEA, Or. } 98 . \\ & \text { Easter giant, } \boldsymbol{n} \text {. }\end{aligned}$ 1076 Ebony

604. 1067 Ecastaphýllum 1516

681089 Echinària

9281091 Echinélla

54 1089 Echinochlòa

2101070 Echinóphor

746 1074 Echìnops

124 1078 E'chium

7281074 Eclípta

9381091 Ectocárpus $\quad 2301$

3401066 Edwárdsia $\quad 9565 \quad 940$

$160 \quad$ Egg-plant $2565 \quad 451$

$462 \quad$ Egyptian lotus7681 1174

1521078 Ehretia

2561089 Ehrhárta $\quad 754$

3521062 Ekebérgia 1982

1082 ELAE'GNEE, Or. 134.

901082 Elæágnus 1259

1801068 Elæocárpus $\quad 1192$

671063 Elæodéndrum

8361088 Elàis

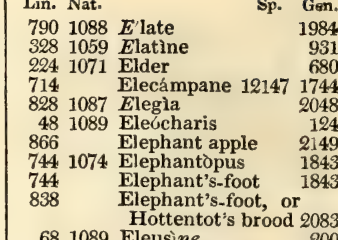

681089 Eleusine

7001073 Elichrỳsum $\quad 1730$

1521078 Ellísia 432

8801090 Ellobocárpus 2181

2081083 Elm-tree 615

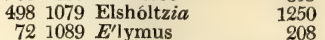

181079 Elytrària

1083 EMPE'TREE, Or. 140.

9261083 Empètrum 2045

784. 1063 Empleùrum $\quad 1965$

9001091 Encalýpta 2229

7321074 Encèlia 1807

shade

71

9441091 Encœ'lium 2323

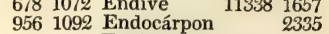

206 English mercury

3601075 Enkiánthus $\begin{array}{rr}3414 \quad 611 \\ 10 \% 7\end{array}$

332 ENNEA NIDRIA, Cl. 9.

332 E. MonogY' Nia, Or. 1.

334 E. TrigY'nia, Or. 2.

336 E. HeXaGr'NIA, Or. 3.

4641060 Entelèa 1183

$\begin{array}{lll}142 & \text { Epàcris } & 393 \\ 848 & 1083 & \text { Ephèdra }\end{array}$

7601085 Epidéndrum $\quad 2115$

3581075 Epiga'a $\quad \mathbf{1 0 1 5}$

3181069 Epilobium $\quad 903$

1001055 Epimedium $\quad 297$

756 1084 Epipáctis 1880

8901090 Equisètum $\quad 2211$

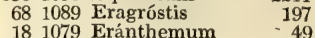

488 1054 Eránthis

2781086 Eremurus $\quad 806$

10221092 Ergot 2407

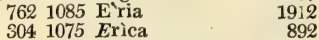

3041075 Erìca
1075 ERI'CEE, Or. 94.

704 1074 Erígeron

0401093 Erineum

5281078 Erìnus $\quad 1350$

4261067 Eriobótrya 1137

1087 Eriocau'lex, Or. 169.

$\begin{array}{rrr}76 & 1087 \text { Eriocaúlon } & 223 \\ 742 & 1073 \text { Eriocéphalus } & 1837\end{array}$

3341081 Eriógonum - 937

501089 Frióphorum $\quad 125$

2761086 Eriospérmum 800

174 1072 Eríthalis 493

1001072 Ernòdea $\quad 291$

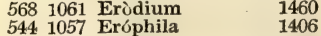

5561057 Eruca 1436

5581057 Erucària $\quad \mathbf{1 4 4 5}$

6241066 Ervília

$6241066 E^{\prime}$ rvum

2101070 Erýngium $\quad 622$

10221092 Erýsibe $\quad 2408$

5501057 Erýsimum

$\begin{array}{lll}130 & 1077 & \text { Erythra'a } \\ 604 & 1066 \text { Erythrina } & 152\end{array}$

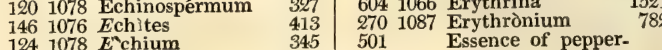

Essential oil of roses, $n$

mons, $\boldsymbol{n}$.

694 1074 Ethulia

344 1066 Euchilus

8421093 Eùclea

5481057 Euclídium $\quad \mathbf{1 4 1 4}$

2721086 Eùcomis

2421086 Eucrosia 713

4161068 Eugènia $\quad 1119$

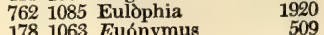




\begin{tabular}{|c|c|c|c|c|c|}
\hline Lin. & $\begin{array}{l}\text { Nat. } \\
1073\end{array}$ & Eupatorium & $\begin{array}{l}\text { Gen. } \\
1685\end{array}$ & $\begin{array}{l}\text { Lin. } \\
470\end{array}$ & Nat. \\
\hline 400 & 1083 & Euphórbia & 1103 & 118 & \\
\hline & 1082 & EupHorbiacea, Or. & 136 & 530 & \\
\hline 526 & 1078 & Euphràsia & 1342 & 174 & \\
\hline 1036 & 1093 & Eurotium & 2463 & 56 & \\
\hline 394 & 1062 & Eùrya & 1083 & 452 & 1067 \\
\hline 464 & 1056 & Eurỳale & 1177 & 926 & 1091 \\
\hline 242 & 1086 & Eùrycles & 714 & 288 & 1059 \\
\hline 130 & 1077 & Eustòma & 365 & & 1059 \\
\hline 282 & 1086 & Eùstrephus & 815 & & 1064 \\
\hline 344 & 1066 & Eutáxia & 961 & & \\
\hline 168 & 1075 & Euthales & 469 & 786 & 1083 \\
\hline 746 & 1074 & Euxènia & 1854 & 98 & 1077 \\
\hline 700 & 1073 & E'vax & 1724 & 354 & \\
\hline 40 & & Evening flower & 98 & 868 & 1076 \\
\hline 698 & & Everlasting & 1722 & & 1065 \\
\hline 966 & 1092 & Evérnia & 2348 & 177 & \\
\hline 228 & 1077 & Evólvulus & 695 & 632 & \\
\hline 98 & 1077 & $E^{\prime} \mathrm{X}$ & 280 & & \\
\hline 850 & 1083 & Excæcària & 2117 & 718 & \\
\hline 1020 & 1092 & Exídia & 2398 & & \\
\hline 786 & 1084 & Exocárpus & 1970 & 998 & \\
\hline 1042 & & Exospòrium & 2490 & & \\
\hline 162 & 1072 & Exostémma & 458 & 26 & \\
\hline 526 & & Eye-bright & 1347 & & 1081 \\
\hline 414 & 1068 & Fabríci $a$ & 1116 & 800 & \\
\hline 102 & 1063 & Fagàra & 303 & 60 & \\
\hline 354 & 1062 & Fagdnia & 995 & & 1086 \\
\hline 792 & 003 & $F$ àgus & 1997 & & \\
\hline 991 & & Fairy rings, $n$. & & 12 & \\
\hline 204 & 1077 & Fálki a & 602 & 266 & 1087 \\
\hline 258 & & Fan palm & 762 & 266 & \\
\hline 542 & 1057 & Farsétia & 1397 & 842 & \\
\hline 54 & & Feather-grass & 150 & 870 & \\
\hline 26 & 1072 & Fèdia & 72 & 60 & \\
\hline 202 & & Felwort & 599 & 320 & 1069 \\
\hline 218 & & Fennel & 654 & 946 & 1091 \\
\hline 476 & & Fennel flower & 1209 & 602 & 1056 \\
\hline 644 & & Fenugreek & 1603 & & 1056 \\
\hline 876 & 1090 & Ferns & & 602 & \\
\hline 866 & 1062 & Fer & 2149 & 908 & 1091 \\
\hline 562 & 1086 & Fer & 1451 & 978 & \\
\hline 220 & 1071 & Fér & 668 & 946 & 1091 \\
\hline 62 & & Fescue-grass & 182 & 246 & 1087 \\
\hline 62 & 1089 & Festùca & 182 & 612 & 1064 \\
\hline 722 & & Fev & 1770 & 864 & 1082 \\
\hline 170 & & Feverwort & 478 & 1042 & 1093 \\
\hline 484 & 1054 & Ficària & 1232 & 1042 & 1093 \\
\hline & 1069 & FicoídeE, Or. 70. & & 782 & \\
\hline 872 & 1083 & $F$ icus & 2167 & 356 & 1061 \\
\hline 292 & & Fiddle & 856 & 276 & 1086 \\
\hline 522 & & Fiddle-wood & 1329 & 618 & 1066 \\
\hline 94 & & nadder & 269 & 738 & 1074 \\
\hline 430 & & Fig marygold & 1146 & 4 & 1085 \\
\hline 872 & 1083 & Fig-tree & 2167 & 248 & 1056 \\
\hline 530 & & Figwort & 1356 & 732 & 1073 \\
\hline 742 & 1073 & Filàgo & 3838 & 130 & 1070 \\
\hline 792 & & Filbert & 1998 & 562 & 1086 \\
\hline 886 & & Filmy leaf & 2203 & & 1070 \\
\hline 48 & 1089 & Fimbristylis & 121 & 634 & 1066 \\
\hline 52 & & Finger-grass & 143 & 324 & 1081 \\
\hline 56 & & Fiorin & 156 & 502 & 1079 \\
\hline 804 & & Fir & 2013 & 502 & 1079 \\
\hline 706 & & Fire-weed, $n$. & & 728 & 1074 \\
\hline 793 & & Fishing-rods, $n$. & & 16 & 1063 \\
\hline 552 & & Fish-poison 9224 & 1428 & 92 & 1072 \\
\hline 912 & 1091 & Físsidens & 2243 & 669 & \\
\hline 1008 & 1092 & Fistulìna & 2374 & & 1061 \\
\hline 844 & 1058 & Flacoúrtia & 2101 & 394 & 1061 \\
\hline & 1058 & Flacourtia'nea, Or & r. 23. & 18 & \\
\hline 290 & 1087 & lària & 839 & 61 & \\
\hline 372 & & Flakes, $n$. & & 172 & 1072 \\
\hline 606 & & Flat pea & 1525 & 380 & 1054 \\
\hline 744 & 1074 & Flavèria & 1845 & 2 & \\
\hline 232 & 1059 & Flax & 701 & $27 \tilde{2}$ & \\
\hline 286 & & Flax lily & 823 & 396 & \\
\hline 702 & & Flea bane & 1754 & 356 & 1064 \\
\hline 98 & & Fleawort & 278 & 406 & 1070 \\
\hline 630 & 1066 & Flemíngia & 1586 & 56 & 1089 \\
\hline 550 & & Flix-weed & 1422 & 344 & 1066 \\
\hline 350 & & Flower-fence 5840 & 977 & 60 & 1089 \\
\hline 26 & & Flowering ash & 69 & 360 & 1075 \\
\hline 886 & & Flowering fern & & 318 & 1069 \\
\hline & & 14607 & 2205 & 734 & 1073 \\
\hline 336 & & Flowering rush & 939 & 1034 & 1093 \\
\hline 834 & 1082 & & 2071 & 40 & 1085 \\
\hline & 1090 & Fluvia'les, & & 84 & 1083 \\
\hline & 1090 & Folia'cea, Cl. & iv. 2. & 154 & 1077 \\
\hline 26 & 1076 & Fontanèsia & 66 & 172 & 1072 \\
\hline 912 & 1091 & Fon & 2245 & 172 & \\
\hline 218 & & Fool's parsley & 661 & 6.0 & 1066 \\
\hline 119 & & Forget-me-not, $n$ & & 202 & 1077 \\
\hline 320 & 1083 & Forskohlea & 933 & 202 & 1077 \\
\hline
\end{tabular}




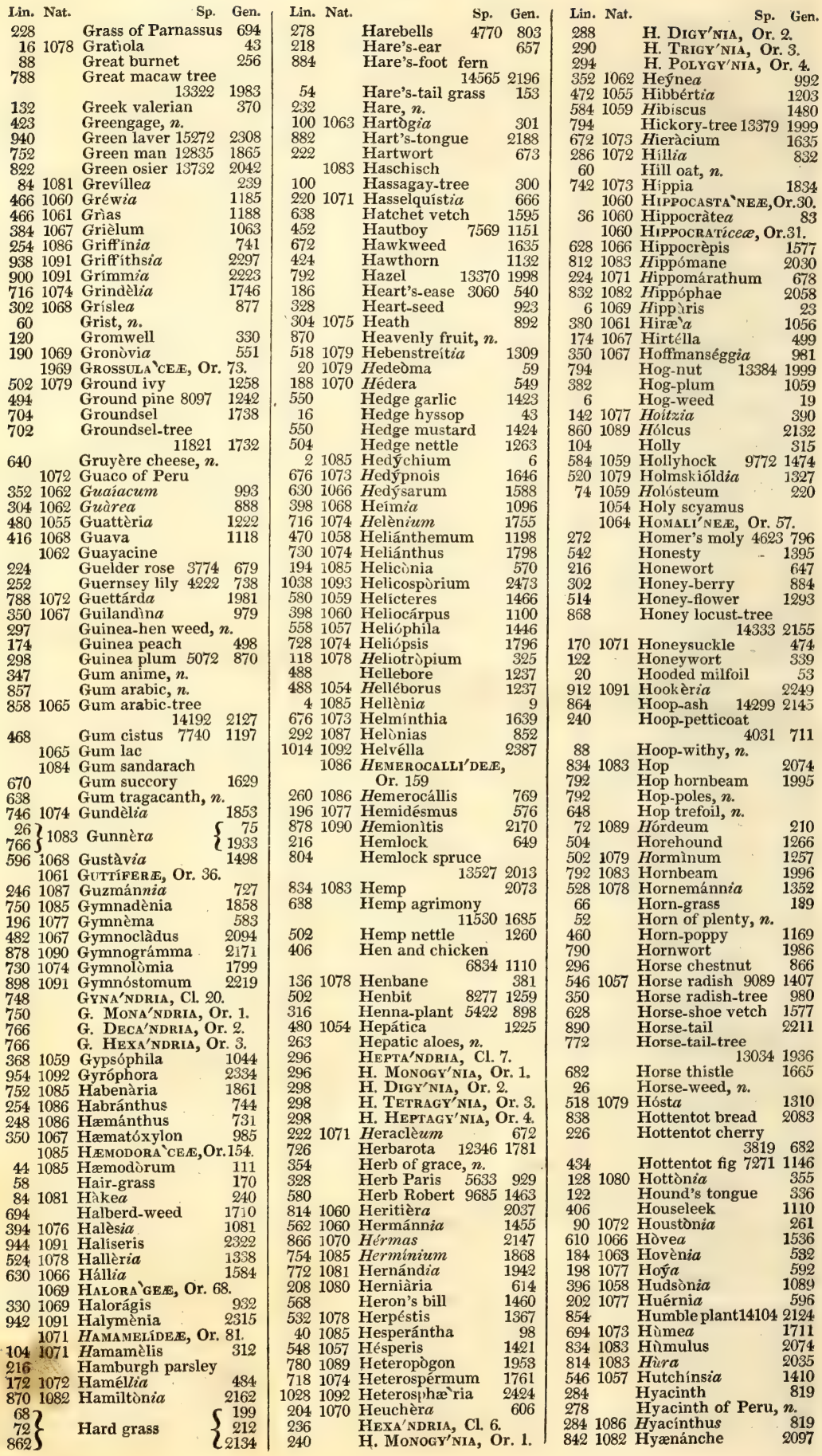




\begin{tabular}{|c|c|c|c|c|c|c|c|c|}
\hline $\begin{array}{l}\text { Lin. } \\
849\end{array}$ & Nat. & Sp. & $\begin{array}{l}\text { Gen. } \\
9097\end{array}$ & Lin. & Nat. & Sp. & Gen. & Lin. \\
\hline 1010 & 1092 & Hýdnum & 2375 & 694 & $\begin{array}{l}1069 \\
1074\end{array}$ & $\begin{array}{l}\text { Isnárda } \\
\text { Isocárpha }\end{array}$ & $\begin{array}{r}258 \\
1708\end{array}$ & $\begin{array}{l}358 \\
624\end{array}$ \\
\hline 366 & 1070 & Hydrángea & 1039 & 760 & 1085 & Isochìlus & 1903 & 322 \\
\hline 490 & 1054 & Hydrástis & 1241 & 894 & 1090 & Isoètes & 2214 & 284 \\
\hline & 1084 & HYDHOCHARI'DEE, & & 48 & 1089 & Isó & $12 Q$ & \\
\hline & & $\begin{array}{r}\text { Or. } 1 \\
\text { Hydró }\end{array}$ & & $\begin{array}{r}528 \\
80\end{array}$ & 1078 & gléxis & 135 & 668 \\
\hline & $\begin{array}{l}1084 \\
1070\end{array}$ & Hydrocótyle & $\begin{array}{r}2089 \\
658\end{array}$ & $\begin{array}{r}80 \\
488\end{array}$ & 10 & $\begin{array}{l}\text { Isopogon } \\
\text { Isopỹrum }\end{array}$ & $\begin{array}{r}230 \\
1235\end{array}$ & 670 \\
\hline 934 & 1091 & Hy & 2291 & 184 & 1075 & $I^{\prime}$ tea & 535 & $\begin{array}{l}359 \\
228\end{array}$ \\
\hline 204 & 1977 & Hydrolea & 601 & 744 & 1073 & $I v a$ & 1841 & \\
\hline & 1055 & HYDROPELTIDE $\&$, & Or. 8. & 188 & 1070 & Ivy & 549 & 88 \\
\hline 490 & 1055 & Hy & 1240 & 38 & 1085 & $I$ xia & 95 & 766 \\
\hline & 1078 & llum & 372 & 694 & 1073 & Ixodia & 1713 & 754 \\
\hline 930 & 1091 & Hyg & 2280 & 100 & 1072 & Ixòra & 288 & \\
\hline 346 & 1067 & Hy & 972 & 514 & 1077 & Jacaránda & 1295 & 884 \\
\hline 1020 & & Hy & 2401 & 770 & & 13033 & 1935 & 542 \\
\hline 648 & 66 & irpus & 1606 & 772 & & Jack in a box & 1942 & 692 \\
\hline & 069 & H & 1147 & 344 & 1066 & nia & 956 & 468 \\
\hline & 74 & Hy & 1692 & 252 & & a lily & 739 & 322 \\
\hline 8 & 90 & llum & 2203 & 150 & 1076 & dínia & 426 & 8 \\
\hline & 91 & mum & 2220 & 801 & & y, $n$. & & 674 \\
\hline & 78 & $H_{y}$ & 381 & 138 & 1077 & 2231 & 383 & 592 \\
\hline & 73 & $H \mathrm{y}$ & 1645 & 606 & & Jamaica dog- & & 4 \\
\hline & 56 & $\mathrm{Hy}_{1}$ & 313 & & & 10048 & 1524 & \\
\hline 3 & & hèra & 980 & 604 & & Jan & & \\
\hline & 1061 & NEAE, Or. 3 & 35. & & & 10034 & 1520 & 944 \\
\hline 656 & 1061 & $H y$ & 1617 & 870 & & Jan & & 502 \\
\hline 9 & 1 & $H \bar{y}$ & 2251 & & & milkwood 14363 & 2158 & \\
\hline 6 & 073 & HyI & 1650 & 418 & & Jamaica pepper, $n$. & & 506 \\
\hline 18 & 1079 & Hyp & 46 & 418 & & olana- & & 280 \\
\hline 254 & 86 & $\begin{array}{l}\mathrm{Hy} \\
\mathrm{Hy}\end{array}$ & 57. 75 & 320 & 1062 & $\mathrm{ra}$ & 1122 & 480 \\
\hline 502 & 79 & Hý & 1256 & $\begin{array}{l}320 \\
188\end{array}$ & 1075 & Jas & 547 & $\begin{array}{l}400 \\
518\end{array}$ \\
\hline 496 & & Hy & 1248 & 12 & 1076 & Jasr & 39 & 42 \\
\hline 496 & 79 & $H_{\mathrm{y}}$ & 1248 & & 1076 & INEA, Or. 100. & & 54 \\
\hline 1030 & 93 & um & 2434 & 12 & 1076 & num & 39 & 678 \\
\hline 546 & 57 & Ibèris & 1412 & 812 & 1082 & Ját & 2033 & 388 \\
\hline 966 & & Iceland moss 15596 & 2343 & 418 & & lum, $n$. & & 806 \\
\hline 438 & & Ice-plant & 1146 & 316 & 1055 & onia & $\delta 96$ & 806 \\
\hline 146 & 1076 & Ich & 414 & 736 & & thistle 12592 & 1819 & 472 \\
\hline 408 & & A, Cl. 12. & & 730 & & $\mathrm{~m}$ ar- & & 220 \\
\hline 410 & & 'NIA, Or. & 1. & & & 12439 & 1798 & 220 \\
\hline 424 & & I. Di-PentagY'nia, C & Or.2. & 506 & & alem & & 1032 \\
\hline 442 & & 'NIA, Or. & & & & 8355 & 1268 & 182 \\
\hline 104 & 1063 & $I$ 'lex & 315 & 104 & & Jesuit's nuts, $n$. & & 846 \\
\hline & 1080 & $\mathbf{E} \mathbf{E}$, Or. 1 & 125. & 778 & & ears & 1951 & 524 \\
\hline 192 & 1080 & Ille & 555 & 479 & & r's planes, $\boldsymbol{n}$. & & 620 \\
\hline 478 & 055 & & 1215 & 298 & 1067 & Jon & 867 & 332 \\
\hline 184 & 1061 & & 538 & 240 & & 4021 & 711 & \\
\hline 74 & 1089 & Im & 216 & 346 & & -tree & 968 & 224 \\
\hline 220 & 1071 & dria & 662 & 794 & 1064 & Júglans & 1999 & \\
\hline & & ow root & & & 1087 & EE, Or. 168. & & 870 \\
\hline 790 & & dage, $n$. & . & 258 & 1087 & Jú & 760 & 332 \\
\hline 77 & & Ind & 1950 & 918 & 1091 & mánnia & 225 & 498 \\
\hline 30 & & Ind & 875 & 848 & & & 21 & 584 \\
\hline 290 & & Indian cucum- & & 848 & 1084 & erus & 2113 & 493 \\
\hline & & ber & 846 & 614 & & Ju & & 694 \\
\hline 562 & & Indian date, $n$. & & & & 10218 & 1542 & 692 \\
\hline 41 & & n fig $\quad 6884$ & 1111 & 362 & 1069 & & 102 & 316 \\
\hline 42 & & wthorn & 1136 & 18 & 1079 & & 47 & \\
\hline 46 & & us 7682 & 1174 & 4 & 1085 & fèria & 12 & 1034 \\
\hline 10 & & madder & 295 & 356 & 1075 & Ká & 1011 & 324 \\
\hline 860 & & let 14220 & 2131 & 102 & & iru vine 1779 & 305 & 2 \\
\hline 174 & & eerry, $n$. & & 246 & & 4114 & & 958 \\
\hline & 1058 & $\operatorname{lin}$ & & 714 & 1074 & ssia & 174 & \\
\hline 328 & & $n$. & & 216 & & sies, $n$. & & 950 \\
\hline 2 & & & 1 & & 947 & & & \\
\hline 875 & & rubber, $n$. & & 618 & 1066 & èdia & 15 & \\
\hline 63 & 1065 & & 1589 & 454 & 1067 & Ké & 11 & \\
\hline & 1066 & fera & 1589 & 1004 & & $\mathbf{K}$ & & \\
\hline 8 & 7 & $I^{\prime} \gamma$ & 2123 & & & an & 15 & \\
\hline 36 & & irpus & 1024 & 612 & & vetch & 1542 & 74 \\
\hline 7 & 10 & & 1744 & 482 & 1082 & Kiggellària & 2092 & 71 \\
\hline & & & 541 & 487 & & ups, $n$. & & \\
\hline 7 & 1085 & Ion & 1919 & 2) & & $\mathrm{Ki}$ & & 94 \\
\hline 402 & & uanha 6739 & 1103 & & & fff, $n$. & & 772 \\
\hline 13 & 1077 & & 383 & 5 & 1059 & & & 652 \\
\hline & 1080 & Ire & 2069 & 3. & 1060 & ofia & & 860 \\
\hline & 1085 & E, Or. 155. & & $6 \mathrm{~S}$ & 1074 & & 17 & \\
\hline & & & 115 & 52 & 1089 & & 14 & 624 \\
\hline 3 & & Iris & 28 & 734 & & eed & 18 i & 1036 \\
\hline 6 & & Irish whin, $n$. & & 92 & 1072 & & & 50 \\
\hline & & Ir & 292 & 366 & & $\mathrm{Kr} \mathbf{r}$ & 1037 & 286 \\
\hline & & & & 19 & & grass & 555 & 670 \\
\hline 416 & & Iron-wood & 425 & 508 & & ed marj & & 700 \\
\hline & & & & & & Itònia & 1231 & 506 \\
\hline & & Iro & 1252 & 204 & 1081 & & 610 & 716 \\
\hline 103 & 1093 & Isà & 2466 & & 1089 & & & 1016 \\
\hline & 1057 & Isà & 1430 & 76 & 1081 & Kœ & 228 & 552 \\
\hline & 1089 & num & 2133 & 304 & 1060 & Kölreutèria & 887 & 974 \\
\hline & 1092 & Isidium & 2351 & 67 & 1073 & Krigia & 1644 & 44 \\
\hline & & $\begin{array}{l}\text { Isle of France } \\
\text { namon }\end{array}$ & & & $\begin{array}{l}1089 \\
1079\end{array}$ & Kyllinga & & 540 \\
\hline
\end{tabular}


Lin. Nat.

681089 Leptochlò

9301091 Leptomitus

414 1068 Leptospérmum

10321093 Leptostroma

9121091 Léskea

6301066 Lespedèza

6261066 Lessértia

1921080 Lestibudèsia

6681072 Lettuce

8301081 Leucadéndron

5061079 Leùcas

9121091 Leùcodon

2481086 Leucòjum

144 Leucopògon

801081 Leucospérmum

734 1074 Leùza

792 Lever-wood, $n$.

7201073 Leysèra

6881073 Liàtris

10361093 Lícea

9461091 Lichìna

2901087 Lichtensteínia

2601088 Licuàla

7221073 Lidbéckia

1881075 Lightfoútia

352 Lignum-vitæ-tree

2201071 Ligústicum

121076 Ligústrum

121076 Lilac

1087 LILIA 'CEIE, Or. 163

1086 Lilies of the field

264 1087 Lílium

264 1087 Lily

2701086 Lily of the valley

272 Iily pink

$100 \quad$ Lily pink

652 Lime

4661060 Lime-tree

2981069 Límeum

464 1087 Limnochàris

3561062 Limònia

5321078 Limosélla

5261078 Linària

5321078 Lindérnia

1059 Línes, Or. 21.

232 Linen cloth, $\boldsymbol{n}$

303 Ling, $\boldsymbol{n}$.

5.4. 1071 I.innæ' $\alpha$

261076 Linocièra

232 Lint, $\boldsymbol{n}$.

2321059 Linum

$\begin{array}{ll}700 & \text { Lion's-foot } \\ 286 & \text { Lion's-leaf }\end{array}$

$\begin{array}{ll}286 & \text { Lion's-leaf } \\ 506 & \text { Lion's -tail }\end{array}$

624 1066 Lipària

764 1085 Liparis

5181079 Lippia

7981083 Liquidámbar

6281065 Liquorice

6281066 Liquorítia

4781055 Liriodéndron

134 1077 Lisiánthus

142 Lissánthe

7561085 Lissochllus

754 1084 Listèr $\alpha$

1201078 Lithospérmum

784 1080 Littorélla

68 Live_grass

298 Lizard's-tail

75 Loaf sugar, $\boldsymbol{n}$

6581069 Loàsa

1069 Loàsece, Or. 67

1661075 Lobèlia

346 Locust-tree

6101066 Loddigèsia

361080 Loeflíngia

1301077 Logania

$350 \quad$ Logwood

701089 Lolium

8801090 Lomària

84 1081 Lomàtia

8821090 Lonchitis

Sp. Gen. Lin. Nat.

\begin{tabular}{r|rrl}
202 & 4261067 Loquat & 1137 \\
2281 & \multicolumn{1}{c}{1071 Lora'NTHEx, Or. 83.} \\
1115 & 610 & Lord Anson's
\end{tabular}

2436

1585

1572

516
1628

2053

1269

2244
733

\section{1}

232
1818

1765

1682

2459

842
763

1773

546
993 66
36
37

\section{1}

771

794
289

109741615

1615
1186
871

871

1175

1003

1344

1366

366 2199

$\begin{array}{ll}366 & \text { London pride } 60631041 \\ 550 & \text { I.ondon rocket } 91721429\end{array}$

302 Longan 5102883

7181073 Longchámpsia $\quad 1764$

$\begin{array}{lll}170 & 1071 & \text { Lonicèr } \boldsymbol{a} \\ 814 & & 475 \\ \text { Looking-glass plant } 2037\end{array}$

$\begin{array}{lll}814 & \text { Looking-glass plant } 2037 \\ 128 & \text { Loose-strife }\end{array}$

61069 Lopezia

2441085 Lophiola

1030 1092 Lophium
1292

701

$13 \quad 825$

1270

1928

1314

1575

1575
1216

378
395

1887

1876

330

1967
197

872

1619

464

1535

82
368

985

207

81

814 Mandioca, $\boldsymbol{n}$.

1541078 Mandrake

161 Man-dram, $\boldsymbol{n}$.

1001072 Manéttia

1801064 Mangífera

1521076 Manglílla

6 Mango-ginger 94

394 Mangosteen

1801064 Mango-tree

3941071 Mangrove Madeira mahogany, $n$.

Madwort

1055 MaGnoliàcea, Or. 3.

1055 Mahonias
Maiden-hai

Maiden-hair-tree

134412003

2281088 Maize $\quad$ Malabar nightshade 693

rala

1059 Málva
154 1078 Mandrágora

$\begin{array}{rr}10368 & 1558 \\ 2897 & 506\end{array}$

506
1601

2119

665

4517451

$12: 0 \quad 198$ eed.

133021975

108921605

309
1976

1395

338
1599

1544
1544

1544
761

369
1067

369
1067
450

2456

2456

2443
2212

2212
344
55

55
132

2206

208

2287
356

356
399

1094

2086

1076 Mabolo-fruit 143732159

1081 Mace, $\boldsymbol{n}$.

7581085 Macradènia

1969

1969
1898

1391

(1391

1077

$\begin{array}{llll}\text { 160 } 1071 & \text { Mad apple } & 2566 & 451 \\ 9 \text { Madder } & & 267\end{array}$

$n$.

1401

1217

2194

85

Malabar nut $\quad 302 \quad 47$

$\begin{array}{lrr}\text { Malcomia } & 1420 \\ \text { Male-fern } & 14590 & 2199\end{array}$

1472
1471

1054

1060 MaLPIGHIàceœ, Or. 34.

1059 Málva 1472

23.1472

$409 \begin{array}{r}1190 \\ 427\end{array}$

2030

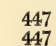

447
447

296

434

14
1079

1079
513
1078

Lin. Nat.

Sp, Gen.

8621089 Manisùris $\quad 2135$

$\begin{array}{llll}26 & 1076 & \text { Manna, } n \text {. } \\ 26 & \text { Manna ash } & 484 & 69\end{array}$

62 Manna seeds, $\boldsymbol{n}$.

631 Manna trungebeen, $n$.

61085 Mantísia

5321078 Manùlea $\quad 1370$

864 i085 Maránta

8881090 Maráttia 2210

4581060 Marcgraàvia 1163

1060 MarcGraAviàcea, Or.32.

9221091 Marchántia 2254

6 Mare's-tail 23

461086 Márica 117

5061079 Marjoram $\quad 1274$

173 Marmalade box, $n$.

504 1079 Marrubium 1266

57 Marrum,

1981077 Marsdenia 591

6901074 Marshállia 1694

452 Marsh cinquefoil

$584 \quad$ Marsh mallow 75751152

$490 \quad$ Marsh marygold 1239

218 Marsh pennywort

7 Marsh $3656 \quad 658$

264 Marsh samphire, $n$.

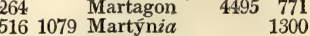
1079 Marum

1181080 Marvel of Peru 322

$740 \quad$ Marygold 1830

2781086 Massonia $\quad 805$

$220\}$ Masterwort $\left\{\begin{array}{l}662 \\ 674\end{array}\right.$

$508 \quad$ Mastick 84111275

8341064 Mastick-tree 138932065

$52\}$ Mat-grass $\{137$

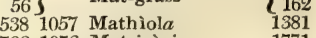

7221073 Matricària $\quad 1771$

$\begin{array}{lll}120 & 1078 \text { Máttia } & 328 \\ 528 & 1078 \text { Maurándya } & 1347\end{array}$

8381088 Maurítia 2080

7581085 Maxillària 1892

$460 \quad\}$ May apple 76521166

$\begin{array}{rrr}10 & 1063 \text { Maytènus } & 31 \\ 528 & 1078 \text { Mànus } & 1353\end{array}$

128 Meádia,

$66 \quad$ Meadow grass $\quad 196$

$484 \quad$ Meadow rue 1229

214 Meadow saxifrage 642

428 Meadow sweet

60 Meal, $n$.

4621056 Meconópsis $\quad 1171$

2901086 Medèola $\quad 846$

6461066 Medicàgo $\quad 1605$

$\begin{array}{lll}646 & \text { Medick } & 1605 \\ 4241067 & \text { Medlar } & 1131\end{array}$

402 Medusa's-head

681089 Megastàchya 66971103

6521068 Melaleùca $\quad 1610$

740 1074 Melampìdium 1828

5201078 Melampỳrum $\quad \mathbf{1 3 1 5}$

6901074 Melananthera 1693

2901087 Melánthium

421086 Melasphæ'rula 104

364 1068 Melástoma 1029

$\begin{array}{lr}5641060 \text { Melhània } & 1457 \\ 359 & 988\end{array}$

3521062 Mèlia 1962 MELIA 'CE在, Or. 43. 
Lin. Nat.

\section{Memécylon}

8781090 Meníscium

1055 MENisPe'rMeE, Or

8441055 Menispérmum 2100

5001079 Méntha

4681069 Mentzelia

1301077 Menyánthes

3161075 Menzièsia

8401082 Mercuriàlis

840 Mercury

10061092 Merùlius

4301069 Mesembryánthemum

9321091 Mesoglòia

424 1067 Méspilus

304. 1060 Metaiba

7001073 Metalàsia

4161068 Metrosidèros

$\begin{array}{lllr}216 & 1070 & \text { Mèm } & 653 \\ 252 & & \text { Mexican lily } 4239 & 739 \\ 638 & & \text { Mexican tea } 10750 & 1597 \\ 562 & & \text { Mexican tiger- } & \end{array}$

562 Mexican tiger flower 93431452

$\begin{array}{lllr}728 & 1074 & \text { Meyèr } \alpha & 1787 \\ 322 & \text { Mezèreon } & 5526 & 910\end{array}$

$\begin{array}{ll}322 & \text { Mezèreon } 5526 \\ 710 & \text { Michaelmas daisy }\end{array}$

3161075 Michaúxia

4801055 Michèli $a$

721089 Microchloa

1961077 Microlòma

7441073 Micròpus

7641085 Micrústylis

$400 \quad$ Mignonette

6881073 Mikania

1022 n. $\}$ Mildew

726 Milfoil

521089 Milium

$220 \quad$ Milk parsley

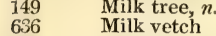

$636 \quad$ Milk vetch $\quad 1594$

$602 \quad$ Milk wort

120371739

895

1218

578
1839

1927

66761102

1683

1781

141

738 1074 Millèria

52 Millet grass

821081 Mimètes

854 1067 Mimòsa

5281078 Mimulus

3021076 Mímusops

5001079 Mint

761080 Minuártia

1181080 Mirábilis

3461066 Mirbèlia

8301071 Misletoe

1001072 Mitchélla

3681070 Mitélla

1014 1092 Mitrula

794 Mocker nut, $n$.

8361068 Modécca

3241059 Mœhríngia

510 Moldavian balm

702 1074 Molìna

661089 Molínia

194 1080 Móllia

761059 Mollùgo

506 Molucca balm

5061079 Moluccélla

8081069 Momórdica

1508
1822

141

233

2124

1351

881
1254

226

322

2054

294

1043

2075

920

84461279

1733
194

194
567

225

1271

2020

560 MONADE'LPHIA, Cl. 16.

562

562
568 M. PENTA'NDRIA, Or. 2
5 HePtA'NDRIA, Or. 3

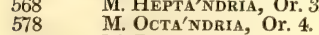

578 M. DECA'NDRIA, Or. 5.

589 M. DODECA'NDRIA,

582 M. POLYA'NDRIA, Or. 7

Mona'NDRIa, Cl. 1 .

M. MONOGY'NiA, Or. 1

M. DIGY'NIA, Or. 2.

201079 Monárd $a$

721089 Monérma

$128 \quad$ Money-wort $2068 \quad 356$

10381093 Monília 2469

$528 \quad$ Monkey-flower 135

592 Monkies'-bread, $\boldsymbol{n}$.

474. Monk's hood 7872 1205

6001063 Monnièrio

1080 MONOCHLAMY'DEE. Subd. 2.
Lin. Nat.

1084. Monocotrle'dones,

Cl. 2.

MoneE'CIA, Cl. 21.

M. Mona'ndria, Or. 1

M. DIA'NDRIA, Or. 2 .

M. TRIA'NDRIA, Or. 3.

M. Tetra'Ndia, Or. 4.

M. Pentándria, Or. 5 .

M. HEXA'NDRIA, Or. 6.

M. Polya'ndria, Or. 7.

M. Monade'lphia, Or. 8 .

Monotoca

3561075 Monótropa

5801061 Monsònia

761069 Móntia

8321069 Montínia

844 Moon-seed

646 Moon-trefoil 108901605

Moon-wort

1014 1092 More'a

1014 Morel

554 1057 Moricándia

261072 Morìn $a$

$\begin{array}{ll}174 & 1072 \text { Morinda } \\ 462 & \text { Morphia, }\end{array}$

7821083 Morus

678 ¿073 Moscària

328 Moschatel

892
506

Mosses

934. 1091 Mouceron, $n$

10401092 Mouldiness

$426 \quad$ Mountain ash 7101 1133

Mountain damson, $n$. Mountain ebony

1065 Mountain liquorice

$294 \quad$ Mountain sorrel 857

863 Mountain spinage, $n$.

672 Mouse ear 11184 1635

Mouse ear chick-

weed

$\left.\begin{array}{l}64 \\ 234\end{array}\right\}$

632

699

1036
532
608

Mudwort 2460

Mugwort 117331721

1089 Muhlenbérgia

7821083 Mulberry

6261066 Mullèra

6021058 Múndia

464 1060 Muntíngia

6021058 Muráltia

3561062 Murràya

1085 Mùsa

1085 Musa'cea, Or, 153.

2841086 Muscàri

423 Muscle plum, $n$.

75 Muscovado sugar, $n$.

$1002 \quad$ Mushroom 160132365

98391480

550 1057 Mustard

9301091 Mycinèma

64 1089 Mygalùrus

104 1063 Myginda

3621075 Mylocárpum

1079 MYopopín 1021

524. 1079 Myopòrum 1339

6761073 Myóseris

1181078 Myosòtis

234 1054 Myosùrus

8301083 Myrica

10241092 Myriocóccum

7901069 Myriophýllum

8501081 Myrística

4221081 MYrobTI'CE E, O

5921059 Myròdia $\quad 70471129$

212 Myrrh

2121071 Mýrrhis

8701075 Myrsine

1075 MYrsínea, Or. 95.

2901086 Myrsiphýllum 843

1068 MYRTA CEE, Or. 63.

4161068 Myrtle

4161068 Mýrtus

4 E

Lin. Nat.

Sp. Gien.

2495

$\begin{array}{ll}10201092 \text { Næmatèlia } & 2402 \\ 8321083 & \text { Nagèia }\end{array}$

1087 NAI'ADES, Or. 171.

60 Naked oat, $n$.

2861055 Nandina

830

2401084 Naravèlia $\quad 1228$

521089 Nárdus 137

2801086 Narthècium 813

$150 \quad$ Naseberry-tree 2411427

5381057 Nastúrtium 1583

353 Native gum, $n$.

151 Natural marmalade, $\boldsymbol{n}$.

7441074 Nauenbéroia $\quad 521$

3821074 Navelwort

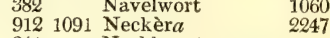

341 Necklace-tree, $n$.

4201067 Nectarine 70201128

860 Negro guinea corn,

8641060 Negundium 2144

476 Nelumbo

4761056 Nelúmbium $\quad 1213$

5261078 Nemèsia 1346

1401078 Nemóphila $\quad 386$

8501093 Nepénthes $\quad 2121$

4981079 Népeta $\quad 1249$

7861060 Nephèlium $\quad 1971$

9661092 Nephroma $\quad 2346$

2521086 Nerìne $\quad 738$

1461076 Nèrium $\quad 411$

3501057 Néslia 1426

7821057 Nestia 1426

$864 \quad$ Nettle-tree $\quad 2145$

6941073 Neurola'na ' 1710

1781062 New Holland cedar

New Jersey tea

1086 New Zealand 2918

430 New Zealand spinage

$414 \quad$ New Zealand tea

134 1078 Nicándra 69181115

$350 \quad$ Nicker-tree $\quad 979$

1361078 Nicotiàna 382

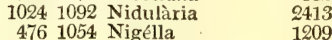

13 Night-flower, $n$.

318 Night-primrose, $\boldsymbol{n}$

1561078 Nightshade 451

7521085 Nigritélla $\quad 1860$

8001088 Nipa 2008

$678 \quad$ Nipplewort $\quad 1651$

9361091 Nitélla

3961069 Nitrària $\quad 1090$

821081 Nivènia 235

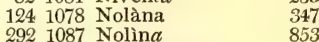

1851087 Nolitangere, $n$.

1241078 Nònea 343

$646 \quad$ Nonesuch 108981605

846 Norfolk island pine

$804 \quad$ Norway deal, 140482112

804 Norway spruce

9281091 Nóstoc

135502013

121076 Notelæ'a

8801090 Nothochlæ'na $\quad 2177$

5401057 Notóceras 1385

7581085 Notýlia 1893

4641056 Nùphar $\quad 1176$

Nut-tree

1076 Nux vomica tree

1080 NYCTAGI'NeE, Or. 123.

121076 Nyctánthes 38

1601078 Nyctèrium $\quad 452$

4621056 Nympha'a 1174

8701082 Nýssa

7741083 Oak 2000

1083 Oak gal

581088 Oat-grass

4681063 O'chna 171

1063 OCHNA'CEA, Or. 51.

564 1059 Ochròma 1458

6201066 O'chrus 
Lin Nat

Sp. Gen. Lin. Nat. 1415

5481057 Ochthodium

OCTA'NDRIA, Cl. 8.

302

O. DigY'NIA, Or. 2 .

O. TrigY'NIA, Or. 3.

$328 \quad$ O. TetragY'Nia, Or. 4.

7621085 Octomeria

1913

5101079 O'cymum

210 1070 OEn

1761063 Enóplia

3181069 Enothèra

$870 \quad$ Ogechee-lime

1844

1844
632

870

Oil-nut

143852161

504

901

1065 Oil of ben

333 Oil of camphor, $\boldsymbol{n}$.

$\left.\begin{array}{l}333 \\ 417\end{array}\right\} 1068$ Oil of cloves, $n$.

342 Oil of roses, $n$.

514 Oily grain $n$. 1296

836 Oily palm 18

1001072 Oldenlándia Or. 48. 295

$666 \quad \begin{array}{r}1620 \\ 10\end{array}$

101076 O'lea

1461076 Oleander

90 Oleaster

1076 OLEìn, Or. 99.

849 Olibanum, $n$

$\begin{array}{rrr}10 & 1076 \text { Olive } & 32 \\ 364 & \text { Olive bark-tree } & 1033\end{array}$

2121071 Olivèria

180 Olive-wood

4181068 Olýnthia

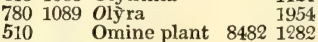
2162

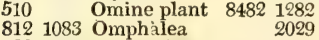

1221078 Omphalodes $\quad 337$

1069 ONAGRA'RtA, Or. 69.

7581085 Oncídium 1895

686 1074 Onobroma

880100

8801090 Onocl

$\begin{array}{lll}612 & 1066 & \text { Ondnis } \\ 684 & 1074 & \text { Onopórdum }\end{array}$

1201078 Onósma

1221078 Onosmðdium

10321093 Onygèna

974 1092 Opégrapha

6 Opera girls

881072 Operculària

1072 Opercularínea, Or. 85.

8881090 Ophioglóssum

2721086 Ophiopògon

1441072 Ophiorhiza

8661077 Ophióxylon

721089 Ophiùrus

$7521085 O$ phrys

4611056 Opium, $n$

8621070 Opopanax

8621062 Orache 1062 Orange-

1084. ORCHÍdea, Or. 150.

$7501085 O^{\prime}$ rchis

5061079 Oríganum

3401066 Ormòsia

7601085 Ornithídium

7621085 Ornithocéphalus

2761086 Ornithógalum

6281066 Ornithopus

3021060 Ornítrophe

$261070 O^{\prime}$ rnus

524 1078 Orobánche

1078 Orobs' 1335

$6181066 O^{\prime}$ robus 111.

2561089 Oróntium

756
689

46 Orrice-root, $n$.

361059 Ortègia

541089 Orthopdgon

9061091 Orthótrichum

2881089 Orỳza

521089 Oryzópsis

784 Osage orange

3161068 Osbéckia

9321091 Oscillatoria

826

Osier

1674
2178

$\mathbf{1 5 4 1}$

332

2440

2360

16
250

250

2209

79 )

406
2150

2152

1866

$7921083 O^{\prime}$ 'strya

Sp. Gen. Lin. Nat.

828 -082 Osỳris

1995

2051

$\begin{array}{rrr}6402 & 1059 \\ 362 & \text { Otaheite chestnut } 1024\end{array}$

$788 \quad$ Otaheite myrtle 1978

7407 Otanthus

1061 Oxalídes, Or. 39.

1833

384. 1061 Oxalis 1065

$\begin{array}{lll}728 & \text { Ox-eye } & 1797 \\ 720 & \text { Ox-eye daisy } 12238 & 1769\end{array}$

$720 \quad$ Ox-eye daisy 128381769

126 Ox-lip $2021 \quad 350$

1721079 Oxyánthus

3201075 Oxycóccus

3421066 Oxylobium

294. 108i Oxýria

1961077 Oxystélma

6361066 Oxýtropis

10381093 OzJnium

7841082 Pachysándra

1527072 Predèria

4721055 Pæònia
472

6861073 Palafóxia

5881059 Palàvia

1781053 Paliurus

814 Palma Christi

2591088 Palm, $\boldsymbol{n}$.

1088 PA'LMA, Or. 173.

9261091 Palmélla

790 Palm oil, $n$.

8721070 Pànax

2421086 Pancràtium $\quad 712$

1087 Pandànea, Or. 170.

8201087 Pandànus 2041

52 Panic-grass

521089 Pánicum

1170

$832 \quad$ Paper mulberry

$501089 \boldsymbol{P}$ apỳrus

1063 Paraguay tea

481086 Pardánthus 118

8481055 Pareira brava root 2116

789 Pariah arrack, $n$.

2981067 Parinàrium

3281086 Pàris

604 1067 Parivòa

3501067 Parkinsùia

9521092 Parmèlia

2281061 Parnássia

1921080 Paronŷchia

5401057 Párrya
216

Parsley 651

88 1070 Parsh

7447074 Parth

7281074 Pascàlia

$482 \quad$ Pasque flower7957 1226

324. 1082 Passerina

564 1068 Passifiùra

1459

1274

1902

5641068 Passion flower 65.

2221071 Pastinaca 671

5621086 Patersònia 1450

$292 \quad$ Patience 4997856

326 Patience dock, $n$.

34 1072 Patrinia

3281060 Paullinia

1001072 Pavétta

1060 Pavia

584 1059 Pavonia

6201065 Pea

4201067 Peach

70201128

70861130

73 Pearl-barley, $n$.

\begin{tabular}{r|rl}
147 & 73 & Pearl-barley, \\
2233 & 106 & Pearlwort
\end{tabular}

7181074 Péctis

1381079 Pedalìne, Or. 114.

524. 1079 Pedàlium

5281078 Pediculàris

4061083 Pedilánthus

60 Peel corn, $n$.

3961062 Péganum

794 Pekan-nut, $n$

8861090 Osmúnda

1806

7421074 Osteospérmum

1832

5681061 Pelargònium

1331

1104

1088

2721086 Peliosánthes $\quad$ Sp. Gen.

724 Pellitory of Spain

$\begin{array}{lll}5441057 \text { Peltària } & 123301778 \\ & 1403\end{array}$

9661092 Peltidèa $\quad 2345$

58 1089 Penæ' $a$ Penicillària $\quad 283$

10401093 Penicillum 2484

521089 Pennisètum 135

546 Penny cress 90991408

$500 \quad$ Pennyroyal 82541254

81571246

218 Pennywort 6

118 P. MONOGY'NIA, Or. 1.

P. MONOGY'NIA, Or.

P. DigY'NIA, Or. 2.
P. TrigY'NIA, Or. 3.

P. Tetragy'Nia, Or. 4.

P. Polygy'nia, Or. 6.

5801060 Pentapètes $\quad 1468$

$\begin{array}{lll}\text { 384 } 1070 & \text { Penthorum } & 1062 \\ 514 & 1078 \text { Pentstèmon } & 1297\end{array}$

6961073 Péntzia $\quad 1719$

2881068 Péplis $\quad 836$

281084 Pepper 77

942 Pepper-dulse 152852313

894. Pepper-grass 146492215

$500 \quad$ Peppermint 82291254

418 Peppermint-tree

Peppermint water, 112

543 Pepper-root, $n$.

176 Pepper-vine 2867502

$552 \quad$ Pepperwort 1428

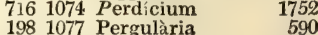

5021079 Perilla $\quad 1255$

10221092 Periola . 2406

1941077 Periploca $\quad 574$

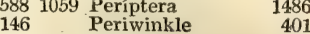

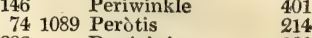

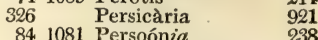

1081 Peruvian cinnamon

705 Pestilent-wort, $\boldsymbol{n}$.

3641068 Petalòma 1030

6001066 Petalostèmum $\quad 1501$

2961081 Petivèria 865

5201079 Petrè $a \quad 1328$

544 1074 Petrobium

801081 Petróphila

612 Petty-whin 101761538

2221071 Peucédanum 670

8441083 Peimus 2103

10161092 Peziza $\quad 2390$

6361066 Phàca $\quad 1592$

10301093 Phacídium 2433

581089 Phálaris $\quad 168$

10221092 Phállus $\quad 2409$

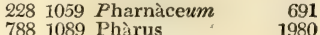

8961091 Pháscum

6141066 Phasèolus $\quad 1547$

5161079 Phaylópsis $\quad$ I303

$484 \quad$ Pheasant's-eye 1230

214 1070 Phellándrium - 636

1070 Philade'lphea, Or. 76.

414 1070 Philadélphus 1114

121076 Phillýrea 33

1921080 Philóxerus $\quad 553$

61087 Philỳdrum $\quad 17$

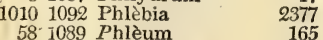

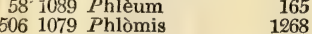

1321077 Phlóx $\quad 369$

8281088 Phœ'nix 2049

760085 Pholidota 1904

10301093 Phoma 2430

2861086 Phórmium 823

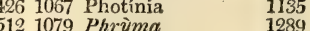

21085 Phrýnium

1881063 Phylica

8101082 Phyllánthus $\quad 542$

2081072 Phýllis $\quad 617$

2681086 Phylloma 
Lin. Nat.

1561078 Phýsalis

10341093 Phýsarum

$812 \quad$ Physic-nut

1681075 Phyteùma

3901081 Phytolácca

2021077 Piaránthu

111081 Pichurim-bean

Pickled olives, $\boldsymbol{n}$.

390 Pickpurse, $n$

372 Picotees, $n$

834 1064 Picrámnia

$\begin{array}{ll}668 & 1073 \\ 672 & 1073 \text { Picrídium }\end{array}$

6241073 Picris vea 101431566

7821083 Pílea pea 10143 156

484 Pilewort

$894 \quad$ Pillwort

1024 1092 Pilóbolus

8941090 Pilulària

261082 Pimelèa

4181069 Piménta

128 Pimpernel

2121070 Pimpinélla

174 1072 Pinckneya

802 Pine

2461086 Pine-apple

201097 Pinguícula

370 Pink

412 Pin-pillow

8021083 Pinus

281084 Pìper

1084 Pipera'cese, Or. 147

76 Pipewort

6061066 Piqueria

296 1080 Pisonia

832 1064 Pistachia-tree

832 1064 Pistàcia

10141092 Pistillària

6201065 Pìsum

2461087 Pitcaírnia

1084 Pitch

850 Pitcher-plant

182 Pittósporum

2081083 Planè $a$

7981083 Plane.tree

1232

2415
2215
73

1123

635

492

2012

726
52

68971111

2012

77

223

1524

2065

065

2385
1560
728

728

2121

522

616

Plank-plant 101211531

1080 PLantagínede, Or. 122

961080 Plantàgo

961083 Plantain

244 Plantain tree 278

103 Plant of gluttony, $n$.

7501085 Platanthèra 1857

7981083 Plátanus

6061066 Platylòbium

692 1074 Platýpteris

5101079 Plectránthus

1881063 Plectrònia

7581085 Pleurothállis

1741072 Plócama

70

Plowman's spikenard

8161082 Plukenètia $\quad \begin{array}{ll}1732 \\ \end{array}$

4221067 Plum

1080 Plumbagínese, Or. 121

1181080 Plumbàgo

1481076 Plumièria

$661089 \mathrm{Poa}$

3421066 Podalýri

880

Pod fern

8061084 Podocárpus

7161073 Podolèis

3421066 Podolòbium

1055 PODOPHYLLA'CEE, Or. 7

4601055 Podophýllum

6661073 Podospérmum

7561084 Pot's

9081091 Pihlia

3501067 Poinciàna

$250 \quad$ Poison-bulb $\quad 977$

152 Poison-nut 2446437 Poison-oak 3801681

1077 Polemonia'cees, Or. 106

1321077 Polemonium $\quad 370$

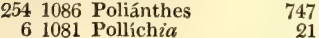

496 Poly 81371244

650 Polyade'llphia, Cl. 18.

650 P. DECA'NDRIA, Or. 1

652 P. POLYA'NDRIA, Or. 2

P. POLYa'ndria, Or. 2
PolYa'ndria, Cl. 13.
Lin. Nat.

P. Monogi,

470 P. PI

474 P. PentagY'NIA, Or. 3

476 P. PolYG'́nis, Or. 4.

10241092 Polyangium

$240 \quad$ Polyanthus $4008 \quad 711$

8761090 Polybótrya

6021058 Polýgala

221

1058 Polyga'Lee, Or. 16.

852 Polyga'mia, Cl. 23.

854 P. Mono'cia, Or. 1.

868 P. Die'cia, Or. 2.

1086 Polygónatum 789

1081 POLYGONeE, Or. 127

3261081 Polýgonum

9401091 Polyides

8781090 Polýmni $a$

878 Polypody

561089 Polypògon

10061092 Polyporus

9381091 Polysiphònia

7601085 Polystachya

0421093 Polythríncium

9101091 Polýtrichum

420 1068 Pomegranate

$\left.\begin{array}{l}106 \\ 772\end{array}\right\}$ Pond-weed

604 1067 Pongamia

2481087 Pontedèria

754 108t Ponthièv $a$

674 Poor Robin's plan

8401083 Poplar

4601056 Poppy

8401083 Pópulus

9761092 Porina

9401091 Pórphyra

1621072 Portlándia

$\begin{array}{ll}800 & \text { Portland sago, } n . \\ 422 & \text { Portugal laurel }\end{array}$

3961069 Portulìca 70301129

2281069 Portulacària $\quad 699$

1069 Portula'cee, Or. 71.

$\begin{array}{lll}172 & 1072 \text { Posoquèria } & 485 \\ 106 & 1090 \text { Potamogèton } & 317\end{array}$

205947 Potash, $n$.

1561078 Potato $n .2521451$

$59 \quad$ Potato oat, $n$.

73 Pot-barley, $n$

4521067 Potentilla

881089 Pìthos

848 Pounce, $\boldsymbol{n}$.

5121079 Pràsium

670 1(173 Prenánthes

764 1084 Prescitia

54 Prickly-grass

413 Prickly pear, $n$.

1261080 Primrose

1261080 Primula

7861080 Primula 'cea, Or. 119.

2861063 Prìnos

5201079 Priva

12 Privet

4641058 Próckia

3501067 Prósopis

5121079 Prostanthèra

801081 Protea

132991975

1975
828
1320

36

1179
984

984
1284

181 Proteàcee, Or. 131

927 Protocóccus, $n$

9301091 Protonèma

5121079 Prunélla

4221067 Prùnus

1067 Prussic acid

561089 Psámma

742 1074 Psiàdia

$4161068 P$ sídium

8921090 Psilùtum

6381066 Psoràlea

1721072 Psychótria

1001064 Ptelea

604 1067 Pterocárpus

904 1091 Ptelogònium

5421057 Pteroneùron

4 E 2

1836

1181

2213

1597
483

489

2190

1515

2229
1893

Lin. Nat.

Sp. Gen.

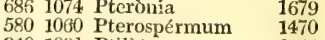

9401091 Ptiluta $\quad 2311$

10461093 Puccínia 2498

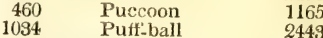

7161079 Pulicària $\quad 174$

1221078 Pulmonària $\quad 338$

1064 Pulse

$\begin{array}{llr}\text { 344 } 1066 & \begin{array}{l}\text { Pultenæ' } a \\ \text { 808 }\end{array} & 965 \\ \text { Pumpkin } & 135632021\end{array}$

4201068 Pìnica 1350327

3961069 Purslane 109

2781086 Puschkínic

506 1079 Pycnánthemum 1273

$424 \quad P$ Pracántha 70721132

9561092 Pyrénula 2337

7221073 Pyrèthrum $\quad 1770$

3621075 Pýrola ... 1022

4241067 Pỳrus

1054 Pythagorean bean of antiquity

1301077 Pyxidanthèra

$\begin{array}{rll}66 & \text { Quaking-grass } & 195 \\ 278 & \text { Orat }\end{array}$

3541063 Ouássia 4773

7941083 Quércus $\quad 2000$

761080 Queria 227

56 Quick, $n$

894 Quillwort 2214

4261067 Quince 113

3641068 Quisquàlis $\quad 1028$

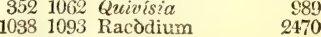

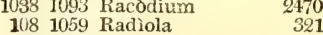

5561057 Radish 1443

6061066 Ráfnia 1527

$388 \quad$ Ragged Robin 6540106

8381086 Rajania $\quad 2084$

9701092 Ramalìna $\quad 2355$

$\begin{array}{lll}970 & 1092 \text { Ramalina } & 2355 \\ 786 & \text { Rambutan } & \mathbf{1 9 7 1}\end{array}$

1321078 Ramónda $\quad 374$

1681075 Rampion 465

274. Ramson $4671 \quad 796$

174 1072 Rándia 490

1054 $R$ anuncula'ce 2 , Or. 1 .

486 1054 Ranúnculus 1233

5561057 Ráphanus $\quad 144$

4261067 Raphiolèpis $\quad 1136$

5481057 Rapistrum 1418

450 Raspberry 7524 1149

256 Ratían-cane, $n$.

Rattlesnake-fern 146192208

602 Rattlesnake-root

154 1077 Rauwólfia 100051508

75 Raw sugar, $n$.

4761069 Reaumuria $\quad 1210$

$33 \pm \quad$ Red bay $5653 \quad 934$

793 Red beech, $n$

848 Red cedar 140562118

802 Red deal, $n$

1043 Red gum, $n$.

$418 \quad$ Red gum-tree 69921126

$226 \quad$ Red lac $\quad 3792 \quad 68$

5881059 Redoutè $a \quad 1482$

604. Red Saunder's-wood

927 Red snow plant, $n$.

586 Red sorrel, $n$.

Red-top, $n$.

Red-wood 2872503

60 Reed 175

7201073 Relhània $\quad 1767$

501089 Remirèa $\quad 131$

7621085 Renanthèra $\quad 1918$

3981083 Reseda 1102 
Lin. Nat.

1211058 Rhatany-root, $n$

$3341081 R$ hèum

$3181068 R$ héxia

524 1078 Rhinánthus

414 1069 Rhípsalis

10221092 Rhizoctonia

10381093 Rhizomórpha

394 1071 Rhizúphora 1071 RiHIzopHòre, Or. 80

1024 1092 Rhizopògon

3581075 Rhododéndron $\mathbf{1 0 1 4}$

9421091 Rhodomèla 2312

$3581075 R$ hodora

861081 Rhopàla

3341081 Rhubarb

2L4 106̆ Rhús

481 1C89 Rhynchóspora

10301093 Rhytísma

1901069 Ribes

961080 Rib-grass

9221091 Rícci $a$

2881088 Rice

2881072 Richárdia

8141082 Rícinus

5421057 Ricòtia

881081 Rivina

9 9.8 1091 Rivulària

6761073 Robértia

6261066 Robinia

274 Rocambole

9661092 Roccélla

2301070 Rìchea

$548\} \quad$ Rocket

4681058 Rock rose

7561085 Rodriguèzia

1681075 Roéll $a$

7461074 Rolándra

4601056 Römèria

1621072 Rondelètia

828 Rope-grass

$4421067 R$ osa

1067 Rosa'Cee, Or. 60

1085 Rosè̀ea

4401067

Sp. Gen.

938

900

1340

2412

1013
246

938

681

2432

550

$1687 \quad 278$

2255

837
833

833

2270

1647

1568

4648796

2347

51421

$\left\{\begin{array}{l}1421 \\ 1436\end{array}\right.$

1197

1883

467

1851

2047

1148

7

1148

$626 \quad$ Rose acacia 104651568

$1068 \begin{aligned} & \text { Rose apple } \\ & \text { Rose bay }\end{aligned}$ 5474 903
Rose

388 Rose campion 1066

$\begin{array}{rrr}22 & 1079 & \text { Rosemary } \\ 548 & \text { Rose of Jericho } & \mathbf{1 4 1 6}\end{array}$

443 Rose water, $n$.

221079 Rosmarinus
$233 \quad$ Rossoli, $n$.

$676\left\{\begin{array}{l}1066 \\ 1073\end{array}\right\}$ Rothia

844 1082 Rottlèra

464 Roucon, $n$.

208 Rough chervil

3021089 Roxbúrghia

$334 \quad$ Royal bay $5648 \quad 934$

3641076 Royèn $a$

1071 Rubia'ceE, Or. 84.

10401093 Rubigo

4501067 Rùbus $L$.

7301074 Rudbéckia

354

Rue

5161079 Ruéllia

5921060 Ruízia

234 1060 Rulíngia

75 Rum, $n$.

2921081 Rùmex

$2221071 R$ ùmia

1061090 Ruppi $a$

208 Rupture-

258 Rush

344 Rush-broom

50 532 1078 Russèlia

1060 Russian mats

1092 Rust

354. $1062 R$ ùta

1062 RUTA'CE ${ }^{\prime}$, Or. 49

721088 Rye

$70 \quad$ Rye-grass 1246

9381091 Rytiphlæ’a

2921088 Sábal

1301077 Sabbàtia

741089 Sáccharum

476 Sacred bean

381085 Saffron

$614 \quad 9313$
Lin. Nat.

221079 Sage

23 Sage-apple, $n$.

1059 Sagina

901087 Sagittària

$846 \quad$ Sago, $n$.

7881088 Sàgus

658 St. Andrew's cros

736 St. Barnaby's thistle

Sp. Gen. Lin. Nat.

Sp. Gen

$632 \quad$ Saintfoin 125981819

868 St. John's bread

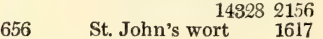

$170 \quad$ St. Peter's wort 476

$752, n$.$\} Salep \quad 4321 \quad 758$

1068 Salica'rie, Or, 61.

61081 Salicórnia

820 Sàlix

6901074 Sálmea

1084 Salop

6661072 Salsafy

388 Salt of lemon,

388 - Salt of lem

221079 Sálvia

224 1071 Sambùcus

210 Samolus

3641063 Samỳ da

1063 SAMY'DE , Or. 56.

1065 Sandal

102 Sandal-wood

848 Sandarach, $\boldsymbol{n}$.

814 Sandbox-tree

4601056 Santwort

881067 Sanguisórba

$210 \quad$ Sanicle

2101070 Sanícula

1082 Santalàcea, Or. 133

694. 1073 Santolìna

724. 1074. Sanvitàlia

177 Sap-green, $n$.

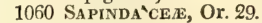

3281060 Sapindus

8121083 Sàpium

3701059 Saponària

501076 Sapòta

1076 Sapòtee, Or. 96

1561078 Sarach $a$

7621085 Sarcánthus

6021056 Sarcocápnos

174 1072 Sarcocéphalus

6081066 Sarcophýllum

1961077 Sarcostémma

621056 Sarracènia

1086 Sarsaparilla

3341081 Sassafras-tree $5657 \quad 934$

4961079 Satur'èja

7501085 Satýrium

2981084 Saurùrus

6801074 Saussùrea

1861058 Sauvagèsia

146 Savanna-flower

22

2003
2042
1696

96

(62

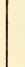

.

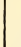

1

$\begin{array}{ll}994 & \text { Scotch barley, } n . \\ 608 & \text { Scotch bonnets, } n .\end{array}$

63
93 Scratch-weed, $\boldsymbol{n}$.

$\begin{aligned} 93 & \text { Scratch-weed, } \boldsymbol{n} \text {. } \\ 820 & \text { Screw pine }\end{aligned}$

$\begin{array}{lll}820 & \text { Screw pine } & 2041 \\ 580 & \text { Screw-tree } & 1460\end{array}$

5301078 Scrophularia $\quad 1356$

1078 ScrophularíneE,

2035

1050

$88 \quad$ Scunkweed 1504 252

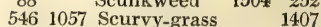

5121079 Scutellaria $\quad 1285$

9281091 Scythymenia $\quad 2272$

9301091 Scytonema $\quad 2977$

9441091 Scytosìphon 2320

206 Sea blite 3443611

$\begin{array}{lll}.832 & \text { Sea buckthorn } & 2058 \\ .380 & \text { Sea chickweed } & 105 \mathrm{u}\end{array}$

$\begin{array}{llr}380 & \text { Sea chickweed } & 1050 \\ 288 & \text { Sea heath } & 835\end{array}$

$210 \quad$ Sea holly $3502 \quad 622$

$\begin{array}{llr}556 & \text { Sea kail } & 1442\end{array}$

$\begin{array}{lll}234 & \text { Sea lavender } & 706 \\ 561 & \text { Sea matgrass } 1011 & 162\end{array}$

$\begin{array}{lll}561 & \text { Sea matgrass } 1011 & 162 \\ 210 & \text { Sea parsnep } & 624\end{array}$

714 Sea ragwort 121381741

$\begin{array}{llrl}548 & \text { Sea rocket } 9144 & 1417\end{array}$

Seaside balsam

136322032

1915

1506

498

3261081 Seaside grape . 922

812 Seaside laurel

Seaside laurel

64 Seaside oat

945 Sea trumpet, $n$.

Sea wrackgras: 24

981077 Sebæ' $\alpha \quad 281$

791089 Secile

1961077 Secamine

6021058 Securidàca $\quad 1511$

7881082 Securinèga $\quad 1578$

7441089 Sedge 1947

3821070 Sedum $\quad 1061$

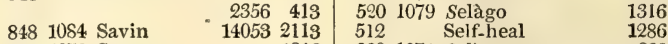

4961079 Savory 1246

$554 \quad$ Savoy

$260 \quad$ Savoy spiderwort

2201071 Selinum $\quad 663$

7201074 Sellò 1766

1069 Sempervívee, Or. 74.

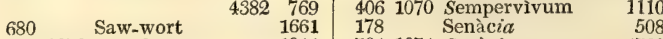

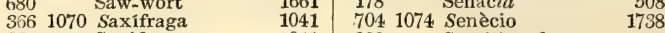

$366 \quad$ Saxifrage 1041

1070 SAXIFRA'GEE, Or. 75.

901072 Scabiosa

90 Scabious

1681075 Scæ'vola

1401077 Scammony $2260 \quad 384$

2081071 Scíndix

8921063 Schæffèria

2901090 Scheuchzèria

482 1064. Schinus

661089 Schísmus

8981091 Schistostèga

16
534 1078 Schizánthus

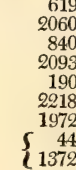

880 Sensitive ferm

8541064 Sensitive-plant

10381093 Sepedinium 141012124

10301093 Septànium $\quad 2476$

2981070 S $́$ ptas $\quad 2428$

$454 \quad$ Septfoil 1154

754 1085 Serapias $\quad 1869$

3281060 Seriana 924

1821060 Seríngia $\quad 525$

6761073 Seriola 1648

866 Serpent-wood

143162152 
Lin. Nat.

784. 1069 Serpícula

$628 \quad$ Serradilla

6801074 Serrátula

821081 Serrùria

1521076 Sersalísia

426 Service

6301066 Sésamum

214 1070 Śseli

601089 Seslèria

4281069 Sesùvium

54. 1089 Setària

654 Shaddock

274 Shallot

Shallot

356 Sheep laurel 59161011

666 Sheep's beard 1629

$\begin{array}{llr}666 & \text { Sheep's beard } & \mathbf{1 6 2 3} \\ \mathbf{1 8 8} & \text { Sheep's scabious } & 547\end{array}$

294 Sheep's sorrel 856

794 Shell bark hickory, $\boldsymbol{n}$.

132 Shepherd's club

$2133 \quad 375$

$546 \quad$ Shepherd's purse $\left\{\begin{array}{r}1408 \\ 9\end{array}\right.$

941072 Sherárdia $\quad 269$

884 Shield fern

$\begin{array}{lll}353 & \text { Ship-blocks, } n . \\ 784 & \text { Shore-weed } & 1967\end{array}$

184 Shore-weed $\quad$ Shrubby trefoil $\quad 298$

$588 \quad$ Shuttlecock 98651486

2361067 Sibbáldia $\quad 710$

426 Siberian crab 70921133

5321078 Sibthórpia 1358

8101069 Sicyos

5881067 Sida

4981079 Sideritis

1001072 Siderodéndrum $\quad 292$

1501076 Sideróxylon 425

728 1074 Siegesbéckia $\quad 1789$

374 1059 Silene

$\mathbf{1 0 4 8}$

856 Silk-cotton-tree

7381074 Silphium

6821074 Sílybum

$830 \quad$ Silver-tree 138402053

$140 \quad$ Silver-weed 385 1063 Simarubàcea, Or. 52.

7321074 Símsia

554. 1057 Sinàpis

810 Single-seeded cu-

1433

846 Sir Joseph Banks's pine 140472112

$2161070 S$ ison

10101092 Sistostrèma

5501057 Sisýmbrium

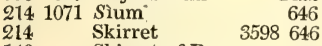

140 Skirret of Peru, $n$.

512 Skullcap

Slipper-plant $\quad 1285$

Slipperwort

1060 Sloànea

422 Sloe-tree 70521189

1086 SMILA'CEA, Or. 161.

2701086 Smilacina

8361086 Smilax

6281066 Smíthia

2161071 Smýrnium

$616 \quad$ Snail-flower 102561547

808 Snake-gourd 2019

144 1076 Snake-root $\quad 406$

$272 \quad$ Snake's-beard 790

886 Snake's tongue 2206

$\begin{array}{llr}326 & \text { Snake's-weed } & 5594921 \\ 826 & \text { Snake-wood } & 204\end{array}$

526, Snap-dragon $\quad 1343$

18 Snap-tree 304 47

Sneezewort 123481781

Snowball-tree 3774679

Snowberry

Snowdrop

394 1076 Snowdrop-tree

Snowflake

Soap-berry

Soapwort

Soda, $\boldsymbol{n}$.

541078 Solándra
Nat. Sp.
1078 SOLA'NEE, Or. 110.

1561078 Solànum

1281080 Soldanélla

6761073 Soldevílla

854 Soldier-wood

9401091 Solènia

7101074 Solidàgo

7421073 Solìv $\alpha$

$270 \quad$ Solomon's seal

9501092 Solorìna

6681073 Sónchus

3401066 Sophòra

8601089 Sórghum

821081 Sorocéphalus

294 1081 Sorrel

587 Sorrel cool drink, $n$

$360 \quad$ Sorrel-tree 59521016

$\begin{array}{lll}\text { Sorrel-tree } & 59521016 \\ \text { Sour gourd } & 99411491\end{array}$

$\begin{array}{lrr}\text { Sour gourd } & 9941 & 1491 \\ \text { Sour gum } & 14381 & 2161\end{array}$

Soursop $\quad 79201220$

Southernwood

116851721

$\begin{array}{lll}106 & \text { South Sea tea } 1831315 \\ 272 & 1086 \text { Sowerbæ' } \alpha & 795\end{array}$

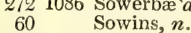

$668 \quad$ Sow-thistle

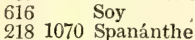

$550 \quad 659$

$150 \quad$ Spanish elm 92211428

$\begin{array}{rrr}150 & \text { Spanish elm } & 2415428 \\ 46 & \text { Spanish nut } & 82446\end{array}$

140 Spanish potato, $n$.

205 Spanish soda, $n$.

401085 Sparáxis

774. 1090 Spargànium

688 1074. Sparganóphorus 1684

464 1060 Sparmánnia 1182

324 Sparrow-wort

521059 Spartina

6101066 Spártium

821081 Spatálla

2261064 Spathèlia

1014 1092 Spatulària

500 Spearmint, $\boldsymbol{n}$.

486 Spearwort

14 Speedwe

3901059 Spérgula

94 1072 spermacice

1621072 Spermadictyon

9401091 Sphacellària

7441073 Sphæránthus

10281092 Sphæ'ria

10241092 Sphæróbolus

9221091 Sphærocárpus

9421091 Sphærocóccus

3441066 Sphærolobium

10301093 Sphæronæ'ma

9701092 Sphæróphoron

8961091 Sphágnum

734 1073 Sphenógyne

$752 \begin{array}{ll}1081 & \text { Spice } \\ \text { Spider ophrys }\end{array}$

$260 \quad$ Spiderwort

128381866

5201079 Spielmánnia $\quad 1321$

134 1077 Spigèlia

212 Spignell

$\begin{array}{rr}48 & \text { 1074 Spike-rush } \\ 690 & \text { Spilánthes }\end{array}$

9501092 Spiloma

8341081 Spinàcia

834. 1081 Spinage

178 Spindle-tree

4281067 Spiræ'a

7541084 Spiránthes

9061091 Spláchnum

$880 \quad$ Spleenwor

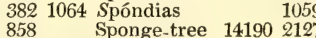

10421093 Sporidérmium 2494

561089 Sporóbolus

944 1091 Sporóchnus

10381093 Sporótrichum

142 Sprengelia

Spring-grass

275 Spring salad onion, $\boldsymbol{n}$.

804 Spruce-beer, $n$

10361093 Spumària

Spurge

Spurge laurel $5530 \quad 110$

\begin{tabular}{r|r}
2332 & 390 \\
444 & 278
\end{tabular}

Spurrey

Squill
Lin. Nat

73 Squirrel grass, 0. Gen.

8081068 Squirting cucumber

$$
56 \text { Squitch, } n . \quad 135592020
$$

1781063 Stà vid

10401093 Stachylídium

511

5041079 Stichys

6861074 Strehelina

$178 \quad$ Staff-tree $\quad 507$

1981077 Stapèlia

2261063 Staphylèa

1501076 Star-apple

198 Star-fish

59

684

424

276 Star of Bethlehem 802

98 Star of the earth

$736 \quad$ Star-thistle $\quad \begin{array}{ll}1710 & 278 \\ 7065 & 1819\end{array}$

234 1080 Státice 1739

764. 1085 Stèlis 1924

3761059 Stellària $\quad \mathbf{1 0 4 9}$

324 1082 Stellèra

5321078 Stemòdia $\quad 136$

10341093 Stemonitis $\quad 2447$

144. Stenanthèra 402

84. 1081 Stenocárpus 241

524 1079 Stenochilus $\quad 1333$

7541084 Stenorhýnchus 1875

8141060 Stercùlia 2036

9701092 Stereocaúlon $\quad 2352$

2541086 Sternbérgia 742

Stèvia 168

9661092 Stícta 2344

9301091 Stigonèma $\quad 2278$

8281083 Stilàgo

10421093 Stilbospòra $\quad 2493$

10381093 Stílbum

1083 Stinging nettle

504 Stinking horehound1265

541089 Stìpa 150

$376 \quad$ Stitchwort $\quad 1049$

6161066 Stizolibbium $\quad 1551$

5381057 Stock

7441073 Stove 1846

6861074 Stokèsia $\quad 1679$

$382 \quad$ Stonecrop 1061

$362 \quad$ Storax 1025

$568 \quad$ Stork's-bill 1461

$\begin{array}{lll}134 & \text { Stramoniuin } & 2165376 \\ 228 & \text { Strapwort } & 690\end{array}$

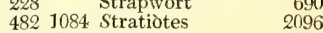

4181068 Stravàdium $\quad 1125$

$452 \quad$ Strawberry 1151

$412 \quad$ Strawberry pear, $n$.

$360 \quad$ Strawberry-tree 1019

194 1085 Strelítzia $\quad 571$

2701086 Streptopus $\quad 786$

10261092 Stromatosphæ'ria 2421

1481076 Strophánthus $\quad 416$

2501086 Strumària $\quad 734$

Struthiola $\quad 249$

$\begin{array}{lll}880 & 1090 & \text { Struthiópteris } \\ 152 & 1077 \text { Strýchnos } & 2179\end{array}$

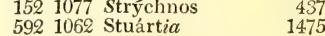

1075 STylídea, Or. 92.

7661075 Stylídium 1932

6301066 Stylosánthes $\quad 1583$

142 Styphelia 34

3621076 Stỹrax 1025

$\begin{array}{lll}558 & 1058 \text { Subularia } & 1447 \\ 678 & 1072 \text { Succory } & 1657\end{array}$

263 Succotrine aloe, $\boldsymbol{n}$.

5561057 Succówia 1439

75 Sugar, $n$

75 Sugar candy, $n$.

741088 Sugar-cane 215

$\begin{array}{lll}222 & \text { Sulphurwort } & 670 \\ 224 & \text { Sumach } & 681\end{array}$

206 Summer cypress

2391058 Sundew $\quad 2413 \quad 610$

$\begin{array}{llr}232 & 1058 & \text { Sundew } \\ 730 & \text { Sunflower } & 1792\end{array}$

$470 \quad$ Sun rose 1198

$\begin{array}{lll}328 & \text { Supple jack } 5615 & 029 \\ 626 & 1066 & \text { Sutherlándia } \\ & 1571\end{array}$

6261066 Swainsonia $\quad 1571$

$196 \quad$ Swallow-wort $\quad 588$ 


\begin{tabular}{|c|c|c|c|c|c|c|c|c|}
\hline $\begin{array}{l}\text { Lin. } \\
868\end{array}$ & Nat. & $\begin{array}{c}\text { Sp. } \\
\text { Swamp locust-tree }\end{array}$ & Gen. & Lin. & Nat. & Sp. & Gen. & Lin. \\
\hline & & 14325 & & & 1091 & Tetrùphis & 2221 & 930 \\
\hline 479 & & Swamp sassafras, $n$. & & 302 & 1060 & Tetrathèca & 879 & 532 \\
\hline & & Swedish beam-tree & 1133 & 494 & $\begin{array}{l}1079 \\
1054\end{array}$ & Teùcrium & 1244 & $\begin{array}{l}30 \\
34\end{array}$ \\
\hline 554 & & Swedish turnip & & & & $\begin{array}{l}\text { Subc. } 1 . \\
\text { Thàlia }\end{array}$ & & $\begin{array}{l}34 \\
52 \\
74\end{array}$ \\
\hline 20 & & Sweet bay $\quad 5646$ & 934 & $48 \tilde{4}$ & 1054 & Thalictrum & 1229 & 192 \\
\hline & & Sweet briar 7503 & 1148 & 1036 & 1093 & Thamnídium & 2461 & 366 \\
\hline & & Sweet calabash & & 214 & 1071 & Thá & 643 & 354 \\
\hline & & 9394 & 1459 & 1024 & & Th & 2417 & 1034 \\
\hline & & Sweet flag & & 1010 & & The & 2378 & 352 \\
\hline & & Sweet gale 13865 & 2055 & 956 & & The & 2336 & 1040 \\
\hline & & Sweet gum 13435 & 2001 & 792 & & Th & 1993 & 122 \\
\hline & 1076 & Sweet leaf & & 650 & 10 & Theo & 1607 & 56 \\
\hline 726 & & Sweet maudlin & & 146 & & Theo & 408 & 886 \\
\hline & & 12350 & 1781 & 342 & & Th & 944 & 40 \\
\hline & & Sweet pea & 1558 & 194 & 1082 & $T h$ & 569 & 50 \\
\hline & 1077 & Sweet potato 2264 & 384 & 680 & & Thi & 1663 & 808 \\
\hline & & Sweet sop & 1220 & 546 & 1057 & Th & 1408 & 512 \\
\hline & & Sweet sultan 12627 & $18 i 9$ & 182 & 1060 & The & 524 & 902 \\
\hline & & Sweet William & & 134 & & apple & 376 & 1040 \\
\hline & & 6140 & 1046 & 218 & & Thorough-wax & & 64 \\
\hline & 077 & Swé & 599 & & & 3684 & 657 & 726 \\
\hline & & ia & 990 & 234 & & Th & 705 & 296 \\
\hline & & Swine's succory & 1645 & 260 & 1088 & Th & 764 & 640 \\
\hline & & Sword fern & 2173 & 672 & 1073 & & 1633 & 290 \\
\hline & & 4279 & 2143 & 168 & & twort & 466 & 644 \\
\hline & 1071 & Sym & 476 & 806 & 1084 & $T h$ & 2018 & 290 \\
\hline & 78 & tum & 334 & 518 & 1079 & bérgia & 1308 & 214 \\
\hline & & $A^{\prime} \mathrm{CE} A$, Or. & 97. & 496 & 1079 & $T h$ & 1247 & 66 \\
\hline & & Sýn & $16: 4$ & 508 & 1079 & Thy & 1279 & 170 \\
\hline & 74 & Synedrélla & 1791 & & 1082 & THYMELE'E, Or. 13 & 32. & 174 \\
\hline 0 & & SYNGENE'SIA, Cl. 19 & & 508 & 1079 & Thy & 1275 & 482 \\
\hline & & 'uIs, Or. 1. & & 276 & 10 & $\mathrm{Th}$ & 799 & 780 \\
\hline & & 'RFLUA, Or. & & 368 & 1070 & & 1042 & 678 \\
\hline & & S. Frustra'nea, Or & r. 3. & 120 & 1078 & ium & 329 & 60 \\
\hline & & S. Necessa'ria, Or & r. 4. & 623 & & Tic & & 652 \\
\hline & & S. SEgrega'ta, Or. & 5 & 8 & & Tic & 26 & 56 \\
\hline & & 6611 & 1088 & 562 & & ower & 1452 & 68 \\
\hline & 976 & & 37 & 562 & 1086 & $\mathrm{Ti}$ & 1452 & 268 \\
\hline & 7 & æmontàn $a$ & 418 & 40 & & Til & 97 & 40 \\
\hline & 83 & nahac 13970 & 2087 & 466 & 1060 & Tilia & 1186 & 396 \\
\hline & 9 & $T$ & 758 & & 1060 & TILIA 'CEAE, Or. 27. & & 740 \\
\hline & 90 & & 2176 & 108 & 1070 & & 320 & 758 \\
\hline & 1074 & Tagetes & 1760 & 246 & 1087 & adsi $a$ & 729 & 488 \\
\hline & & palm 4358 & 762 & 58 & & y grass, $n$. & & \\
\hline & 69 & Talin & 1092 & 732 & 1074 & Tit & 1802 & 302 \\
\hline & & palm, $n$. & & 526 & & & 1344 & 832 \\
\hline & & ub, $n$. & & 136 & 1078 & To & 382 & 666 \\
\hline & & e 13603 & 2026 & 182 & 1064 & To & 529 & 426 \\
\hline & & -tree & 1449 & 789 & & To & & 2 \\
\hline & 1067 & $T a n$ & 1449 & 886 & 1090 & To & 2204 & 14 \\
\hline & & $\mathrm{T}$ & 6 & 290 & 87 & To & 844 & 1022 \\
\hline & 069 & $T$ á & 68 & 676 & 1073 & Tó & 164 & 1040 \\
\hline & 86 & & 2082 & & 1078 & To & & 254 \\
\hline & 73 & $\mathrm{um}$ & 17 & 604 & 1065 & bean & 15 & 68 \\
\hline & & pea 10365 & 155 & 834 & & e-tree & 2066 & 266 \\
\hline 6 & & Tar & 1720 & 524 & & Toc & 1335 & 266 \\
\hline & & $\mathbf{T}$ & & 410 & & histle, $n$. & & 478 \\
\hline & 074 & lánthus & 1706 & 222 & 1071 & To & 673 & 0 \\
\hline & & & & 212 & 1071 & Tc & 627 & 1032 \\
\hline & 091 & $\mathrm{Ta}$ & 2257 & 454 & 1067 & ntílla & 115 & 256 \\
\hline & 1072 & & & 904 & 1091 & & 222 & 151 \\
\hline 55 & & bread & & 1038 & 1093 & Tór & 2468 & $35 \overline{4}$ \\
\hline & 81 & arb & & 184 & & Touch-me-not & & \\
\hline & 1084 & & 2114 & & & 3019 & 53 & 228 \\
\hline & 079 & & 42 & 124. & 10 & tia & & 554 \\
\hline 90 & & & 262 & 516 & 1078 & éttia & 1299 & 118 \\
\hline 592 & & & 1496 & 232 & & Tor & & 804 \\
\hline & 1079 & & 4 & 540 & & stard & 1389 & 832 \\
\hline & 1078 & $T e$ & 137 & 168 & 1075 & $\operatorname{Tr}$ & 466 & \\
\hline & & & 14 & 214 & 1071 & mum & 0 & 54 \\
\hline & 1069 & $T$ & 6 & 474 & 1055 & & 12 & \\
\hline & 10 & & & 260 & 1087 & $\mathrm{~T}$ & 76 & 65 \\
\hline & & nia & & 774 & 10 & & 194 & 754 \\
\hline & & & & 666 & & opùgon & 1621 & \\
\hline & 1066 & us & 154 & 104 & 5 & 9 Tràpa & 308 & 1014 \\
\hline & 1064 & THA'CEE, & & & & & & 610 \\
\hline & & & & 484 & & Travel & & \\
\hline & 10 & & 2140 & & & 7983 & & \\
\hline & & iàcea, Or & & 544 & & $\operatorname{Tr}$ & 1402 & 218 \\
\hline & & a. $n$ & & 392 & & Tree celandine & & 940 \\
\hline & 1086 & ària & 2083 & & & 658 & 1073 & \\
\hline 72 & & Tet & & 884 & & $n$, $n$. & & 47 \\
\hline & 1055 & Tet & 1212 & 584 & & Tree mallow 9777 & 1475 & \\
\hline & & TET & 1.15. & 274 & & Tree & 796 & 36 \\
\hline & 10 & & 1145 & 294 & & $\operatorname{Tr}$ & 85 & 778 \\
\hline & 10 & ólobus & 1602 & 640 & & Trefoil & 1600 & 275 \\
\hline & 10 & otheca & 1753 & & 1060 & TREMANDRE'E, & 96 & 2) 64 \\
\hline $\begin{array}{l}7 \\
8\end{array}$ & & $\begin{array}{l}\text { TET } \\
\text { T. N }\end{array}$ & & & & Ame- & & 2 \\
\hline & & T. DIGY'NIA, Cl. 2. & & 1020 & 1092 & Tremélla & 2391 & 958 \\
\hline
\end{tabular}


Cin. Nat.

10491093

1059 Urèna

1086 Uropétalon

7821083 Urtica

1083 URTI'CEA, Or. 141

9721092 U'snea

201079 Ultriculària

4801055 Uvària

2701086 Uvulària

3201075 Vaccínium

8621072 Valántia

341072 Valerian

34. 1072 Valeriàna

1072 Valericinea, Or. 86

341072 Valerianélla

1541093 Vallèsi $a$

2521086 Vallota

7621085 Vínda

5301078 Vandéllia

1721072 Vanguièra

7641084 Vanilla

9561092 Variolària

1054. VAScula'res, Div

9401091 Vauchìria

2041059 Velezia 604

5561057 Vella

1681075 Vellèia

2681086 Veltheímia

$1084\}$ Venetian turpentine

208

Venus's comb $3478 \quad 619$

356 Venus'sflytrap59131009

166 Venus's look.

ing-glass $2695 \quad 463$

122 Venus's navelwort 337

8581087 Veràtrum 2128

1321078 Verbáscum $\quad 375$

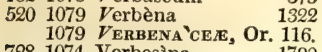

7281074 Verbesina

3281070 Vère $a$

6861074 Vernonia

141078 Verónice

1014. 1092 Vérpa

9741092 Verruciria

5201079 Vervain

5441057 Vesicaria

1321078 Véstia

622 Vetch

Vetchling

6061066 Vibórgia

224 1071 Vibúrnum

6221066 Vicia

1301077 Villársia

3441066 Viminària

1461076 Vinca

174. 1061 Vine

1061 Vinífere, Or. 37

1790
927

1680

40
2388

2361

371 1561

103491558

1523

679

1561

363

410

501

1861058 Viola

1058 VIOLARIE' ${ }^{2}$, Or. 15.

1861058 Violet 540

$\begin{array}{llr}124 & \text { Viper's bugloss } & 345 \\ 666 & \text { Viper's grass } & 1625\end{array}$

666 Viper's grass $\quad \mathbf{1 6 2 5}$

$\begin{array}{ll}342 & 1066 \\ 176 & \text { Virgília } \\ \text { Virginian creeper }\end{array}$

$834 \quad$ Virginian hemp 2868502

390 Virginian poke

$482 \quad$ Virgin's bower $\quad 1227$

$8301071 V_{\text {iscum }}^{\prime}$

4061076 Vísnea

$5201079 V$ itex

1741061 Vitis

8821090 Vittària

5201079 Volkamèria

441985 Wachendor

Waistcoat buttons, 11

4281067 Waldsteínia 1140

892 Walking ferm

Walking fern 146462212

Walking-stick, $\boldsymbol{n}$.

1390

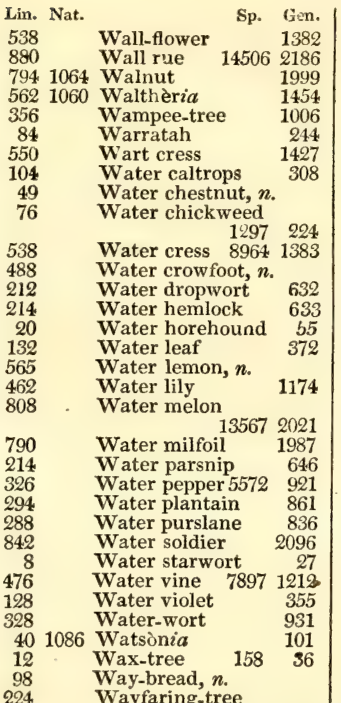

224 Wayfaring-tre

$\begin{array}{rrr}174 & 1072 \text { Webèr } \alpha & 3771 \\ 738 & 6794 \\ \text { Wedèlia } & 1821\end{array}$

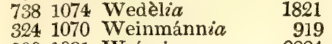

9001091 Weíssia

Welsh onion $4687^{2224}$

294 1055 Wendlándia 858

4961079 Westringia $\quad 1245$

681088 Wheat 206

71 Wheat starch, $n$.

426 Whitebeam-tree

70961133

$806 \quad$ White cedar 135452017

804 White deal, $n$

860 White hellebore, $\boldsymbol{n}$.

479 White laurel, $n$

White spruce

135312013

White wood $\quad 1709$

$\begin{array}{lr} & 1405 \\ \text { Whortle-berry } & 907\end{array}$

Widow-wail

Wild basil

Wild bugloss 84
1272

Wild chamomile 132911771

4 Wild cinnamon, $n$.

418

188

614

2

360

424

10

Wild clove-tree

69781121

Wild cumin $3104 \quad 548$

Wild liquorice $\quad 1546$

Wild oat 1058171

Wild plantain, $\boldsymbol{n}$.

Wild rosemary

Wild service 59441016

Wild tamarind 30

8281087 Willdendvia 2046

8201083 Willow 2042

$318 \quad$ Willow-herb 903

798 Willow oak, $n$.

Winesour, $\boldsymbol{n}$.

Winged pea 108671602

Winter aconite $\quad 1236$

Winter berry $\quad 828$

Winter cherry $\quad 448$

Winter cress $\quad 1386$

$\begin{array}{lr}\text { Winter grape 2861 } & 501\end{array}$
Lin. Nat.

sp. Gen,

$\left.\begin{array}{l}296 \\ 362\end{array}\right\} \quad$ Winter green 8621022

Witch-hazel 312

961078 Witheringia 273

5521085 Witsènia

$\begin{array}{lll}552 & \text { Woad } & 1430 \\ 474 & \text { Wolf's-bane } & 1205\end{array}$

170 Woodbine $2787 \quad 474$

85 Wooden apple, $n$.

620 Wood everlast

ing pea 103731558 496 Woodroof 268 8961090 Woód sage 81231244

Woodsia 2200

8801090 Woodwárdia $n$.

134 Worm-grass $\quad 379$

$696 \quad$ Wormwood 1721

$\begin{array}{rrr}146 & 1076 \text { Wrightia } & 412 \\ 18 & \text { Wulfènia } & 50\end{array}$

2901087 Wurmbèa $\quad 848$

208 Wych $3464 \quad 615$

7861073 Xánthium 1974

6561061 Xanthochỳmus $\quad 1616$

2361051 Xanthorhiza $\quad 709$

2761086 Xanthorrhæ'a $\quad 798$

8341063 Xanthúxylum 2066

7001074 Xeránthemum $\quad 1729$

2901087 Xerophýllum $\quad 847$

8361087 Xerotes 2076

7161074 Ximenèsia $\quad 1754$

304.1062 Ximènia $\quad 890$

441085 Xiphídium $\quad 108$

10241092 X Xlària

7581085 Xylobium $\quad 1891$

841081 Xylomelum $\quad 243$

10321093 Xyloma 2437

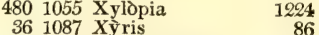

1961077 Xysmalobium 586

8381086 Yam 2085

390 Yarn, $n$

726 Yarrow 123831781

Yellow bachelors'

buttons, $n$.

356 Yellow bird's-nest 1008

502 Yellow dead-

nettle 82831261

Yellew deal,

Yellow rattle $\quad 1340$

Yellow-root 709

Yellow sultan

126301819

$316 \quad$ Yellow-wort 894

$848 \quad$ Yew-tree 2114

2681087 Yícca 781

6781073 Zacintha

728 1074 Zaluzània

8461084 Zàmia 2108

7721087 Zannichéllia 1938

5201079 Zapània 1319

7781089 Zèa 1950

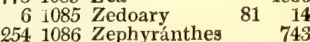

1021063 Ziéria 304

5041079 Zietènia 1264

55610 G Zilla

41085 Zingiber $\quad 10$

7201074 Zínnia $\quad 1768$

7881089 Zizània $\quad 1979$

1781063 Zizyphus

734. 1074. Zœ'gia 1817

944 1091 Zonària

6301066 Zórnia $\quad 1587$

2221071 Zosimia 675

8. 1090 Zostèra 1086 Zuccáni $a$

934. 1091 Zygnèma $\quad 2289$

9081091 Zýgodon 2234

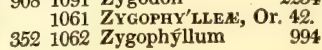


LoNDON :

Printed by A. \& R. Spottiswoorle, New-Strtet Square.

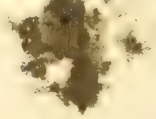





H.

4.

15.

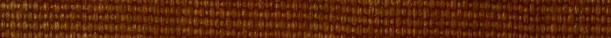

C67.

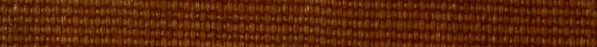

2.

4.

20.

(5)

per

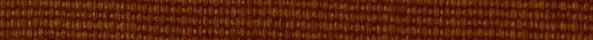

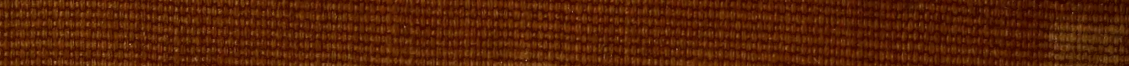

4.

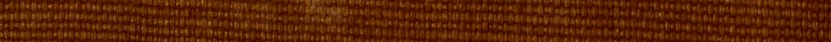
201 H.

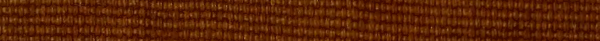

(4)

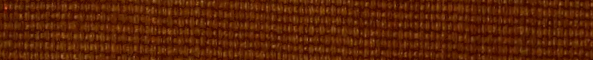

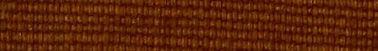

H.

W.

Wh

Whet

Hothenting

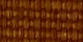

45.

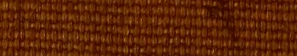

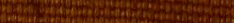

3.

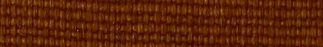

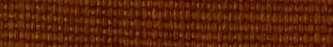

The

2.

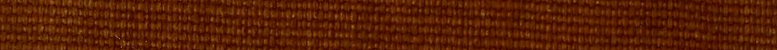

5. 